$710=$

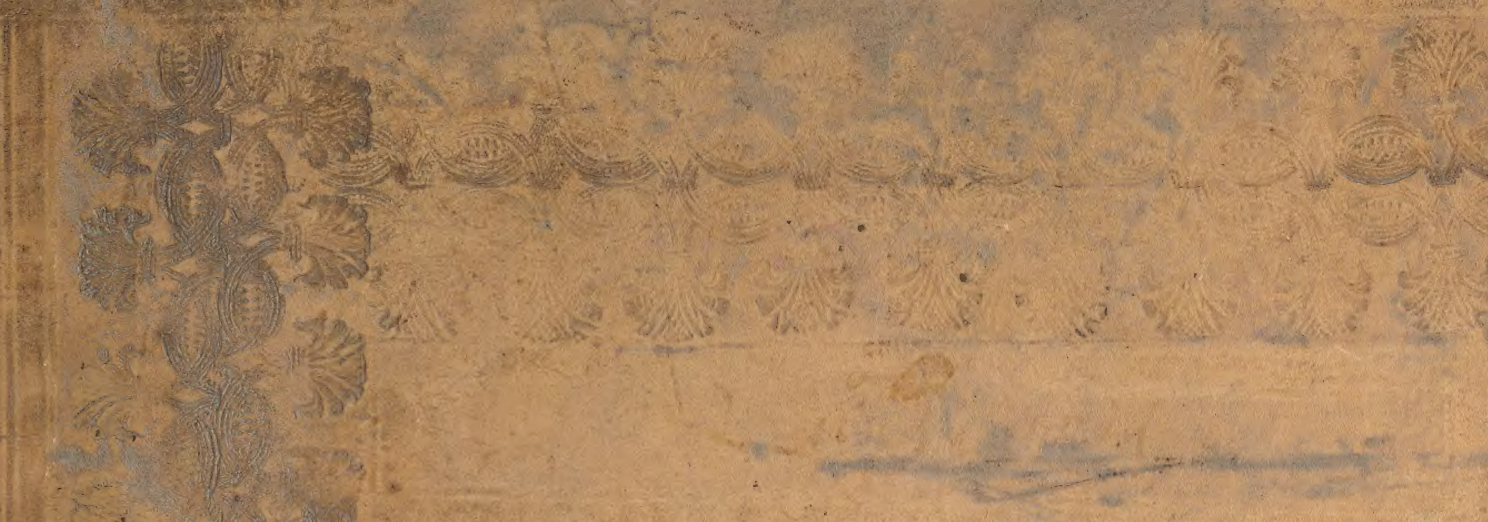
$1-34$ $1 x^{2} 2=$

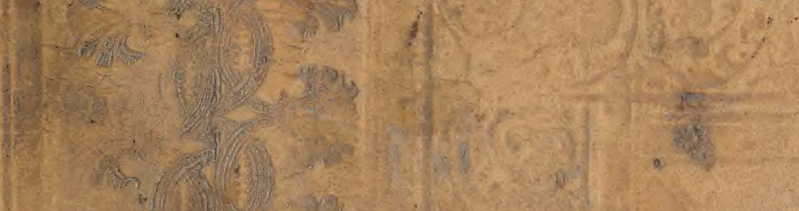

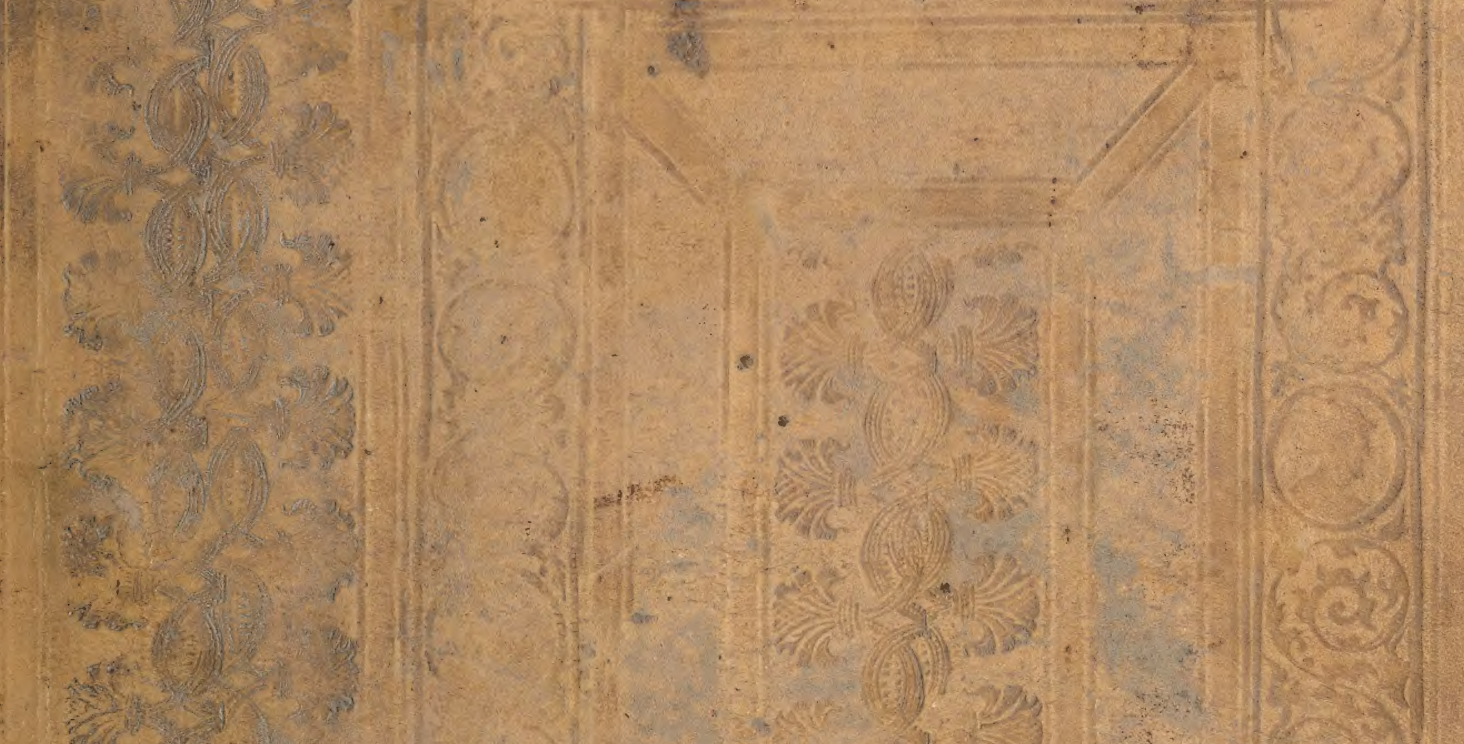

(1) $-x=2$

(2)

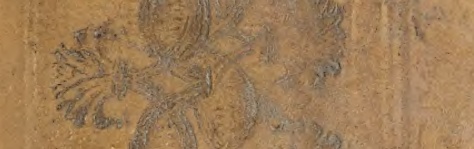

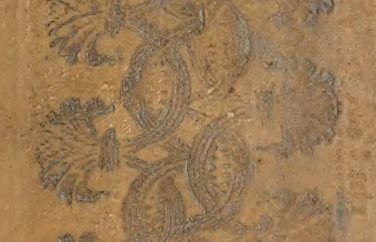

(ix)

$\log _{i=1}(3)>y^{2}$

1. Thet

$\left.-x^{2}+6\right)+50$

- $16(5)=13$

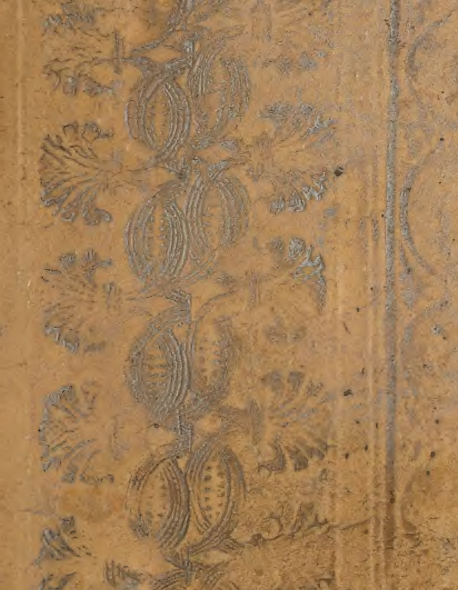

Mitis.

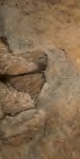

4a th $=37$

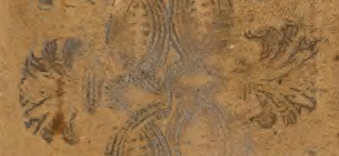

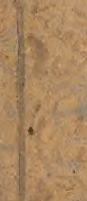

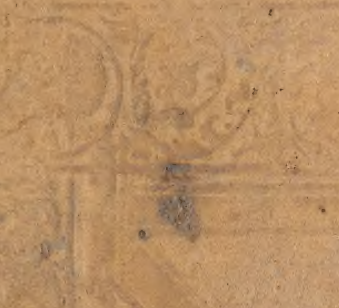

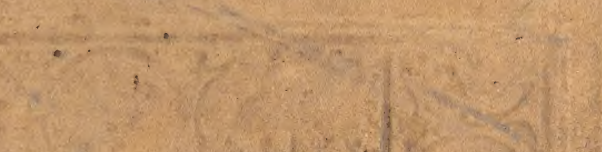

(ectis)
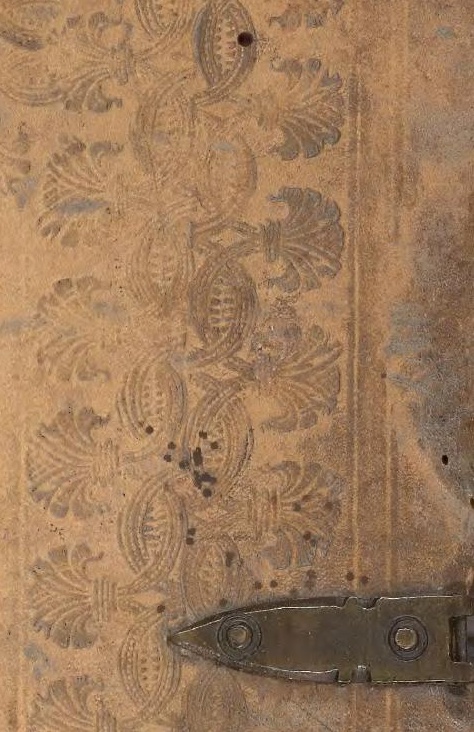

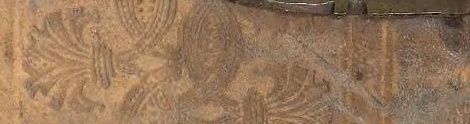

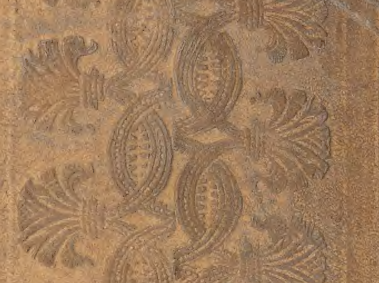

Rac.

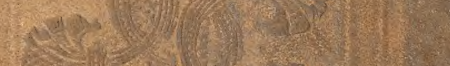

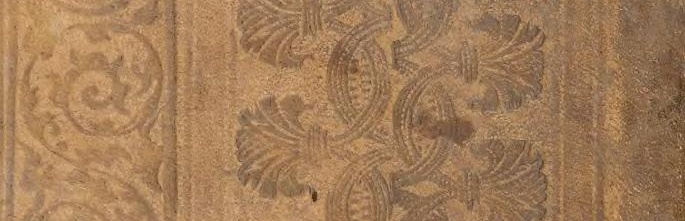

and

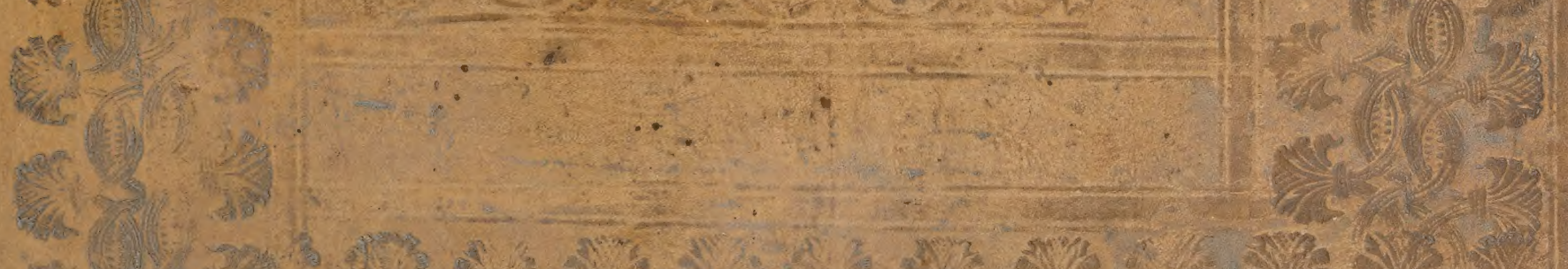

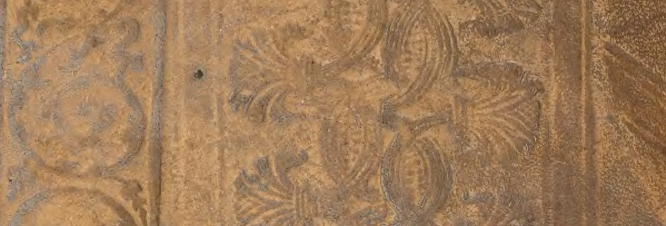

$+\sqrt{2}-5$

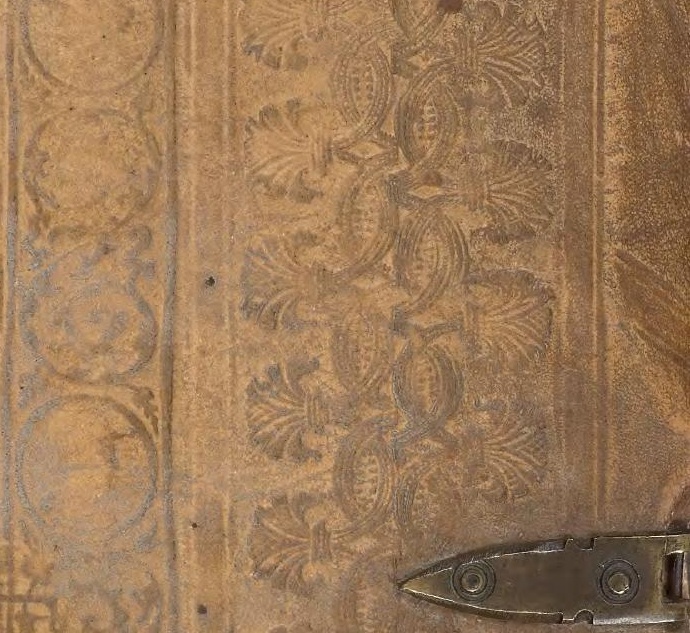

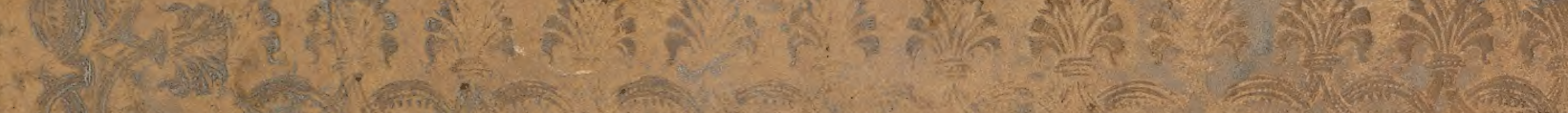




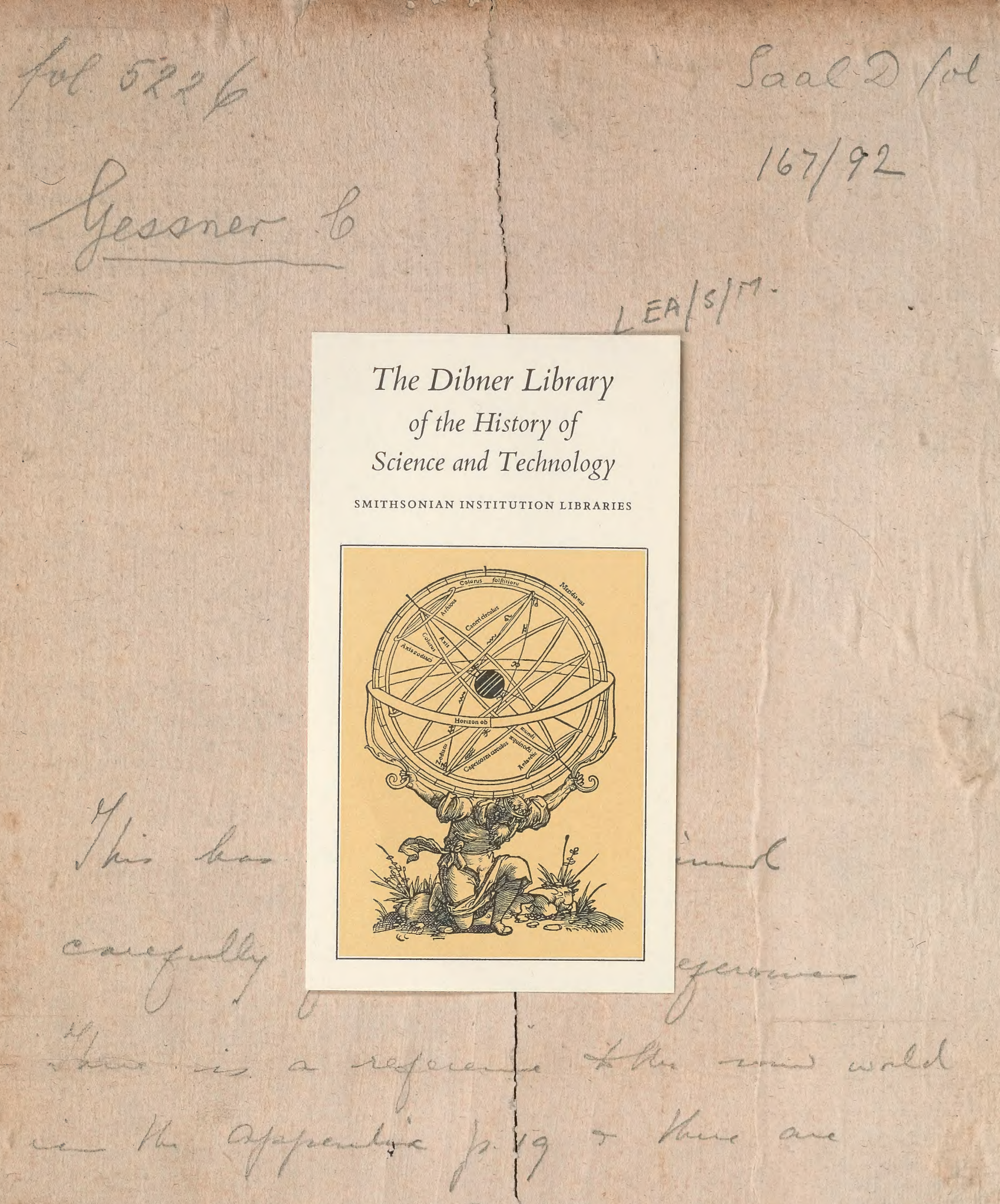

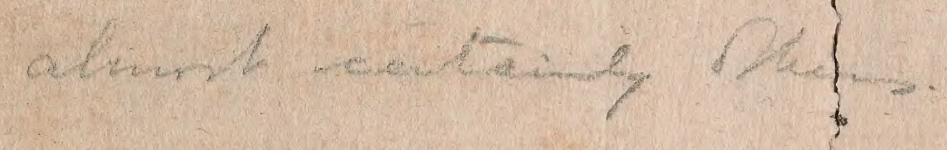

$*$

he Dibner Library of the History of

Sience and Technology

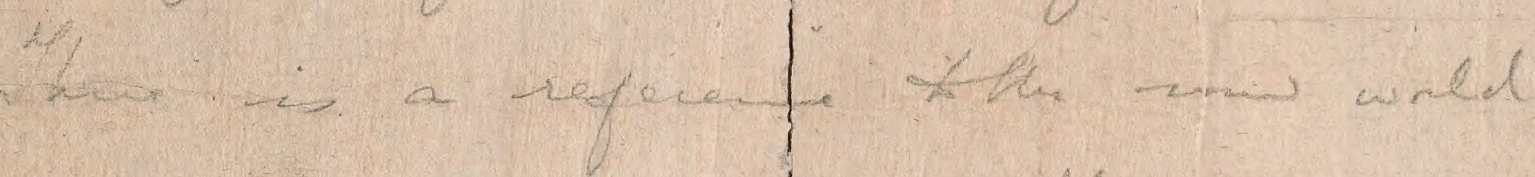

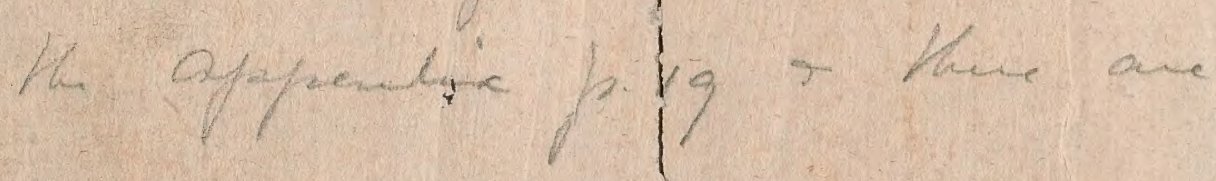

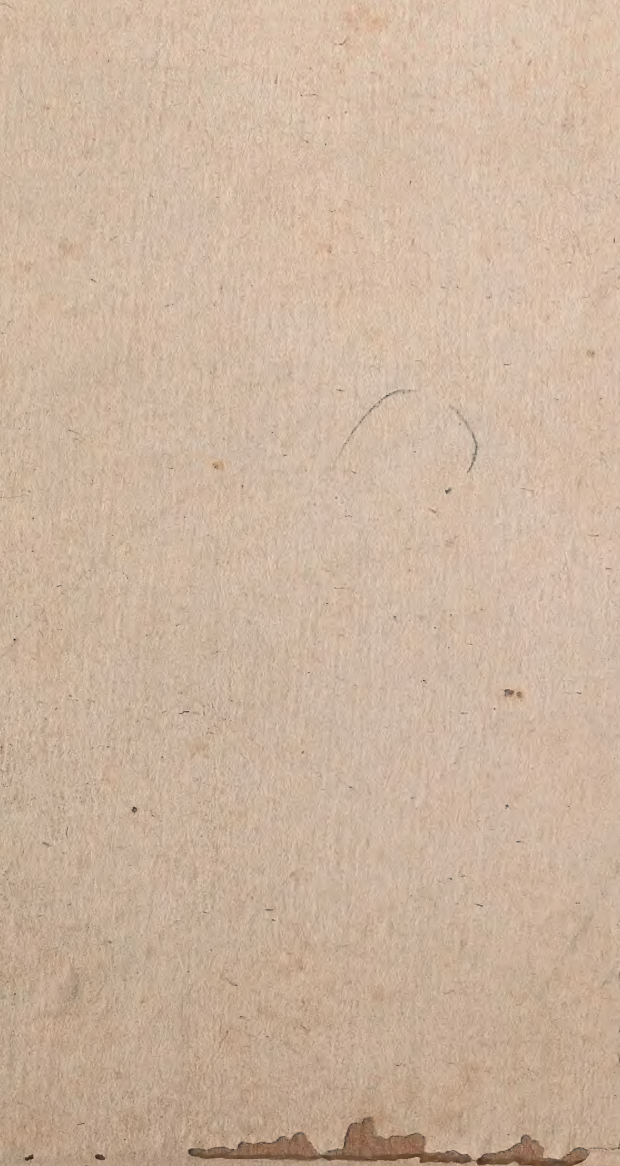




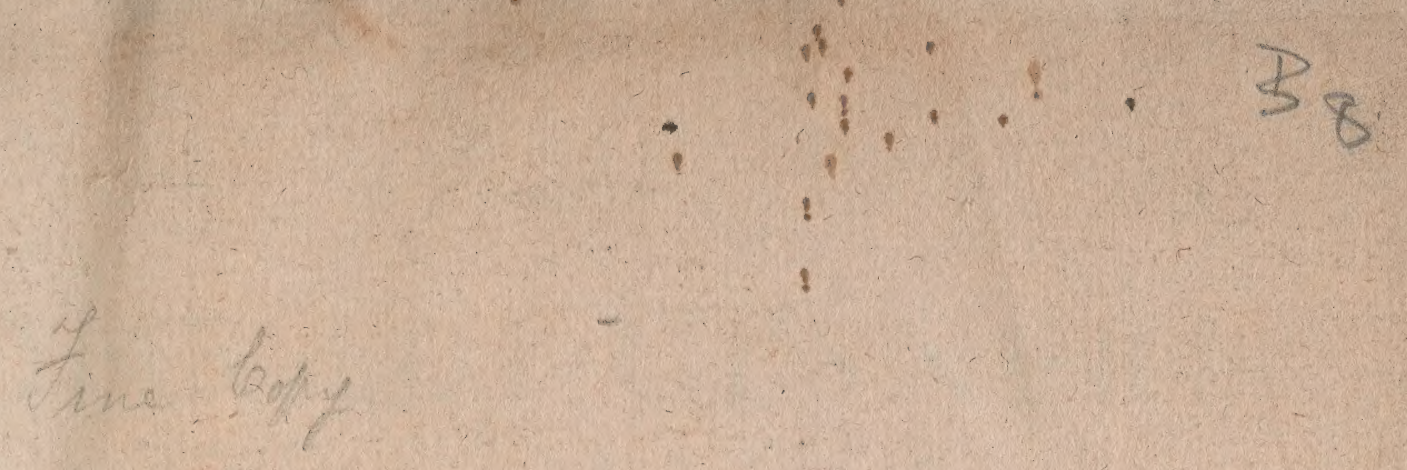

Pravere III 67

Wrth alutondic (rosit) 


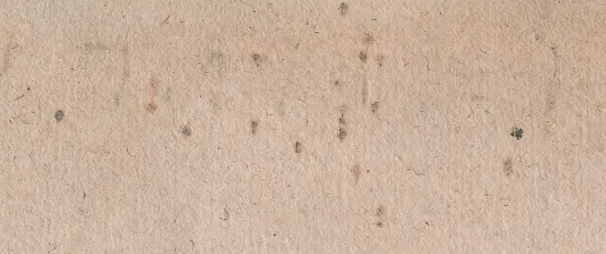

$\therefore$

a.

2.

s

?

?

1. 


\section{CONRADI GESNERI}

\section{medici TiguriniHiforix Anima}

lium Lib. I. de Quadru pedibusuiuiparis.

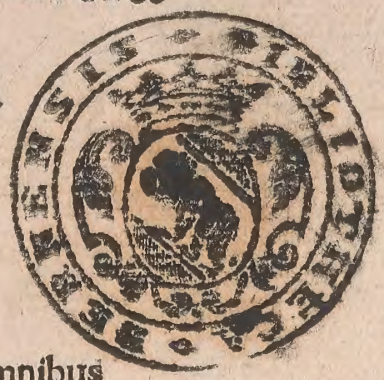

- P v S Philofophis, Medicis, Grammaticis, Philologis, Poêtis, 2 omnibus rerum linguarumćg trariarum ftudiofis, utiliffimum fi= mul iucundiffimumọ́ futurưm.

\section{A D IE C T O R E M.}

F. A B E B I S in hoc volumine, optime Lector, non folum fimplicem animalium biftoriam, fed etiam ueluticoni: mentarios copiofos, or caftigationes plurinas in ueterum ac recentiorum de animalibus frripta qua uidere bactenus nobis licuit omnia:precipuè uerò in Ariftotelis, Plinij, Aeliani, Oppiani, authorumi rei ruftice, Alberti Magni, erc, de animalibus lucubrationes. Tuum erit,candide Lector, diligentißimum $v$ laboriofißimuin Opus, quod non minori tempore quàn quidam de elephantis fabulantur, conceptum efformatumóg; nobis, diuino auxilio nunc tandenzi in lucem adimus, non modo boni confulere, fed etiam tantis conatibus (ut alterum quoq; Tomum citius ov alacrius abfoluamus) $c x$ animo fauere ac be=

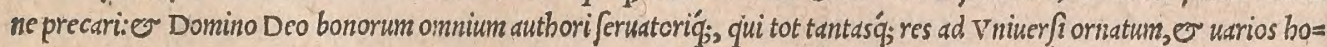
minum ufus creauit,ac nobis ut ea contemplaremur uitam, ualetudinem, otium $\sigma$ ingenium donauit, gratias agere maximas;

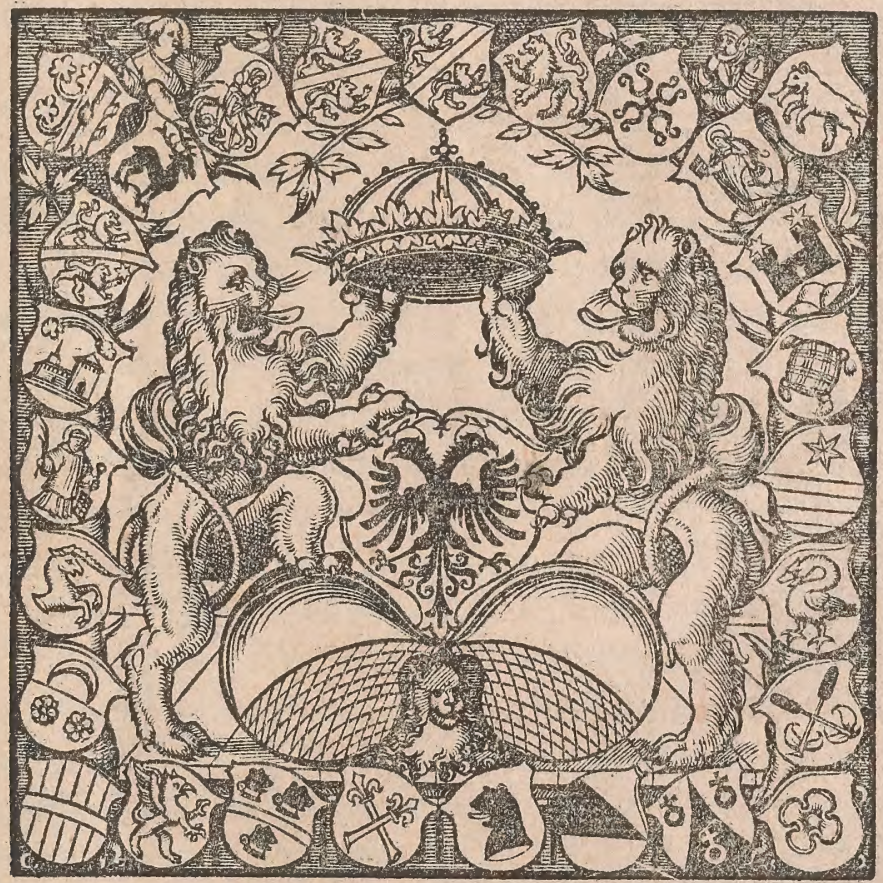

TIGVRI APVD CHRIST, FROSCHOVERVM, A.NO M, D, II. 
$-11,2$

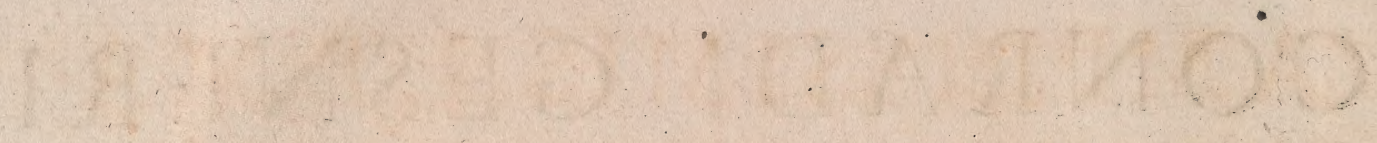

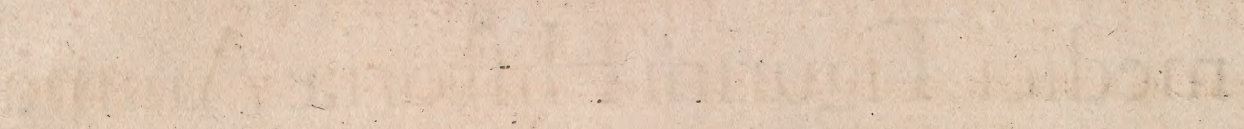
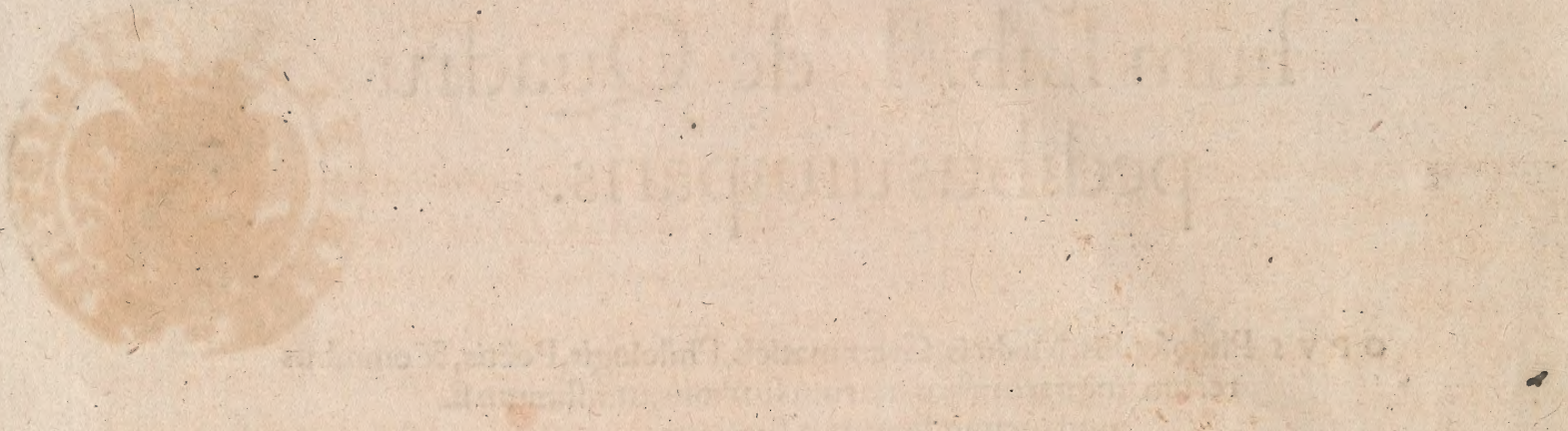

ity

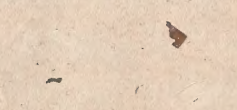




\section{AMPLISSIMIS ET MA}

\section{GNIFICIS VIRIS, PIET A TE, PR VDENTIA,}

omniọ uirtutum genere fpectatiffimis, Confulibus \& Senatoribus Reipub.

Tigurinæ, Dominis fuis uenerandis, Conradus

Gefnerus Tigurinus S, D, P.

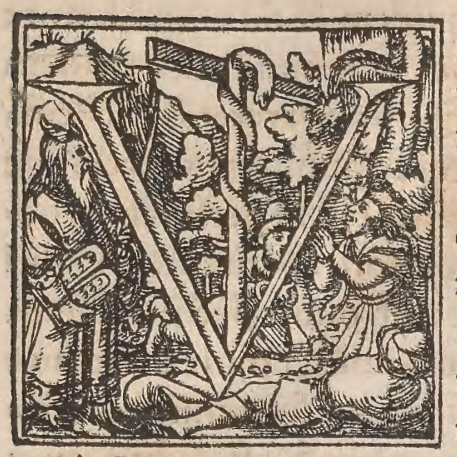

N I v E R A quidẽ Philofophia, Ampliffimi uiri, undíquaqs octafio or its optima \& pulcherrima, omnibus fui partibus amore culcúq crementum 0 . mortalium, ceu clientum \& amatorum, digniffima eft, ut opti periso mi \& fapientiffimi quique omnibus feculis iudicarunt, Sed quoniam ingenia hominum diffident, \& multas in nobis opi nionum uarietates, educatio, conuerfatio, confuetudo, \& uitæ uiçus '́g commoditas, \& aliæ forfitan complures caufæ, effici= unt, quæ fuis plerunç praiudicijs mentes humanas, non in lis teris tantum $\&$ religione, led feré nufquam nô occupant : hinc adeò fic ut aly̆ aliam partem literarum fequantur, quam fcilicet uel omnino, uel pro occa: fione \& ftatu rerum prafenti commodiorem fibi ftatuerint. Sicfactum eft ut ipfeà puero, à cognato rei medicaeftudiofo educatus, profeffionis iftius amorẽ ab adolefcen= tia imbiberim, Etquanquam progreffu xtatis uariarum rerum cognitionem degufta= $\mathrm{rem}$, nonnullis etiam immoratus rem medicam plus quàm par erat relinquerem, redij t2 men poftea,requirente id etiam rei domefticæ cura, ad medicinæ ftudiû. Cum uerò ma= ximam huius fcientix cum naturali philofophia cognationem animaduerterem, necule lum egregium aut certe doetum medicum haberi, qui non altius prima methodi meden= di rudimenta ex libris de natura tanquam fonte haufiflet, coepi $\&$ ipfe philofophorum qui de rebus naturalibus commentati funt feripta cognofcere: In quibus illa femper in primis me delectabant, qux de metallis, plantis \& animalibus tractata reperiebam. Idć; duplici nomine: Primum, quia certior de iftis fcientia haberi poteft, quàm de meteoris, \& alijs quibufdam, uel nimium fubtilibus $\&$ argutis, ac procul a fenfu remotis, uel eiufmos di ut firmam eorum cognitionem nec ratione nec fenfu fatis fperare liceat. Deinde quòd non folum ad medicinam, fed rem familiarem quogz adminiftrandam \& alias artes, mul to utilior \& propemodum neceffaria, mediocris faltem iftarum rerum contemplatio uile deretur. Itaqs plurimum hoc in ftudio temporis pofui, ita ut fuccifuis horis (quibus uuls gus hominû, \& literati etiam multi,otiofé abutuntur, deambulant, ludunt, côpotant) $8 \%$ quotiefcun $q \beta$ ab alijs ftudịs aut negotijs recreari defiderabam, ad iftos tanquam amores meos cupidè multis iam annis defexerim, Et quanquã de plantis permulta obferuarim, alïs ante me non animaduerfa, certe in lucem à nemine me priore prodita, (indicio fuerie Catalogus plantarum nofter quatuor linguis, ueluti rudimentum quoddam \& progym nafma iufti aliquando uoluminis parandi, ante decennium editus : \& paffim hoc ipfo in Opere digreffiones) minus tamen neceffarium uidebatur in prafentia de eis conforibes re,cum multi hodie crudité \& utiliter de plantis feripierint \& etiamnum feribant, ut de metallis etiã doctiffimé utiliffiméq̧́ Ge. Agricola, uir uel eo nomine multa laude dignif̌ fimus. Quamobrem ad animalium hiftoriam perpaucis noftri feculi, \& ferè per partes tancum tractatam, animum adieci. Hîc cum uiderem parum me praftiturum, nifi do= mefticis ftudips \& lectionibus peregrinationes quoque adiungerem, aliquot Germanix loca (non multa quidem illa) primum adri, mox etiam ltalix pauca, non hoc tantum no. mine, fed infuper Bibliothecx noftrx, quarn tum in manibus habebam, ut omne feripto rum genus enumerarem, locupletandx. Quòd fi Mecoenas aliquis contigiffet, uel maior fortuna mea fuiftet, multa profectò maris terræćs remotillima loca, animalium in primis hiftoriæ, deinde plantarum pariter aliarumọ́p rerũ cognitionis pofteritati tradendæ grae 


\section{Epiftola}

tia, etfi non firm xualetudinis homo, Deo fecundante, iam peragraffem. Id quoniam nö licebat, feci quod potui, aliquot in diuerfis Europæe regionibus mihi comparaui amicos, qui benigne, candide, liberaliter, multas animantiũ omne genus effigies ad uiuum repræe fentatas, quarundã etiam nomina in diuerfis linguis $\&$ hiftorias, mecum cômunicarunt 。 Ego interim non folum á uulgo, \& quibufuis percgrinis, qui ex uarnis nationibus ad nos uentitabant, aut hac fortè rranfibant, plurima fubinde quafita annotaui : \& fimul omnia ueterum acrecentiorum, quxcunq; de animalibus multis $\&$ diuerfis linguis, fiue ex pros feffo, fiue etiam obiter edita poteram nancifci, conferebam diligenter $\&$ in unum quafi corpús componebam. Ita paulatim creuit opus, magno quidem \& diuturno labore meo, nec parclo pro meis fortunis fumptu. Hoc cum ad iuftam magnitudinem tandem aliqquando perueniffe iam uideretur (quamuis opus propé infinitū appareret, $\& \mathrm{cui} f \mathrm{fms}$ per accedere multa poffent) excolere tan dem quicquid haberem \& publicare decreui? ne fi diutius differrem, plura potius inquirendo quàm qux adeptus effem perficiendo oc= cupatus, humanitus aliquid mihi accideret, ac tot tantiós labores noftri perirent. Volui autem primo loco Librum de quadrupedibus uiuiparis (qua non ouum, fed perfectum animal $\&$ concipiunt $\delta$ in lucem edunt ) emittere : qui fimul maximus, fimul caterorum utiliffimus uidetur, poftulante id etiam ipforum animalium dignitate. funt enim hæc cæa teris fine dubio digniora, perfectiora, $\&$ homini tũ corporis partibus $\&$ affectibus, tum animi facultatibus ac moribus propinquiora. De reliquis omnibus (hoc eft quadrupedi bus ouiparis, auibus, pifcibus, ferpentibus $\&$ infectis) alterum Tomum huic, ut conijcio, magnitudine parem futurum, fi diuina fauerint, breui dabo, materiam enim omnem in promptu iam habeo. Hac de Operis prima occafione, incremẽto editionéǵg dixerim. Pruftus ope đSed mirabitur forté non nemo, \& quos fructus, quantum operæpretium, tantũ uo rapretium. lumen, tantilabores fecum ferant, inquiret. Cuirefponderim: Primum hanc naturalis Adrem medică. philofo phį̧ partem plurimum prodeffe medicinx, id q́p uarijs modis. Vno, in genere fes rè circa plerafós animantes, quoniam plurimæ uel integræ, uel ex parte aliqua in cibofu= muntur, aut ad medicamenta intra extráue corpus humanum requiruntur. altero, priuae tim circa quadrupedes uiuiparas, qux propter fimilitudinem temperamenti \& corporis humani multos eofdem cum homine morbos patiuntur, quos in pecoribus armentis itse mentisós paftores acuetérinarij curant, $f e d \&$ animalium quædã feipfa, multa enim mor borū auxilia ab eis inuenta conftat. hinc multa ad hominis quoog falutem medicus non indoctus transferre potelt. lam ferpentium \& lacertorü ferè genus, \& infeEta qua dã, \& quadrupedes etiam nonnullx, præfertim in rabie, nec non pifces, morfu fuo ictúue, aut fí in cibo fumantur, feu quauis, feu certa aliqua parte fui, hominẽ aut uehementer la dunt, aut interimunt, hic maxima medicorum diligentia opus eft. neq̧enim par omniũ curan= di ratio. Præeterea circa cibum, potũ, fomnũu, uigiliam, motum, quierem \& animi affectus, a lias'́p res naturales, quarũ ufu decente fanitas conferuatur, fecus corrumpitur, plurima paffim à brutorum exemplis in ufum hominis eft deriuare. Ego certe maximã medicina partẽ in ter prima huius artis rudimenta à brutis tranfumpta uideo, tum ab ïs rebus quas illa per naturam faciebant, aut fortuito patiebantur, tum illis quas homines in ipfis expe: riẹbantur. Nam tuto \& citra impietatẽ periculum remedỉ noui dubriúe in beftia facere conceditur, in homine non item. Poftremó cum uaria medicamenta ex plerifop (ut dixi) animalibus habeantur, qua nos in fingulorum hiftorijs uno in loco ordine recenfemus, hac cômoditate fruetur medicus, ut cum aliquod animal ad manus eius peruenerit, quas nam eius partes precipuè ad ufum medicũ referuare debeat, infpecta illa ex partibus fin. Ad appartum gulis remediorü enumeratione, intelligat. Idem 8 coquus in uniufcuiufog hiftoriales ciborum. gent, quęnamad cibũ \& quomodo, quo apparatu, \& quàm falubriter veniant. Quod Ad uarias artes fifingulatim confiderare libet, permul tx fe offerent a d uitam homini fuftinendã neceffa= rix artes, qux omnes circa animalia earúmue partes occupantur. Nempe cibi gratia pifca tores omne aquatiliū genus uenãtur, partim fibi, partim ut uêdant, Rei pecuarię ftudiofi, omne pecorü genus emunt, alunt, diuendunt; \& qui Lacharị uocantur, cafeos, butyrü, \& 


\section{Nuncupatoria.}

ălia ex lacte pecorūopera cổiciunt, qui maximus montanæ Heluetix ímó neceffarłus uls ctus \& quartus eft, hic fcientia de curan dis bobus, ouibus \& capris requiritur. in alins qui dem regionibus alizetiam animantes, equi,afini, alces, rangiferi,cameli, lactis \& qui inde fiunt ciborum gratia nutriuntur. Venatores feras capiunt diuerfas. Sunt qui corpus mu niendi caufa coria \& pelles elaborant, alutarij, pelliones, coriarï, calceolarï, \& qui thora ces aliasóp pelliceas ueftes, \& qui ephippia, marfupia, \& huiufmodi côficiunt. Quidam ue nà cum pilis diuerfarum quadrupedữ pelles ad ueftimenta hyberna parant. Alị lanas $\&$ pilos tondent curant'́, fimiliter ad ueftes \& ftragula, ut ouium, caprarû, camelorū. Bo= bus 8 iumentis agricolæ utuntur. lumentorũ quidem ufus, præfertim equorü, latiffime patet, neceffarius agricolis, ut dixi,ad arandü : ijfdem \& alijs hominibus ad uecturas, ad itinera in pace belloóg cofficienda, Eft enim equitatus res in pace ciuitatibus \& principi $=$ bus decora, in bello neceffaria, terribilis, \& ubi camporū planicies patet, planè magni mo menti. Sunt $\&$ in ædifictïs, \& alịs operibus multa, ubi nifí iumenta uehendi aliosó̧ labo= res obirent, (equos dico, mulos, afinos, camelos, elephantos, alces $\&$ rangiferos $_{3}$ ) nónne hominũ opera, nec fatisfactura tamen, pro beftís requireretur. lam canum ${ }^{\circ}$ multiplex fit utilitas quis nefcir: Domos, pecora, homines, cuftodiunt, defendunt, amầt. Venantur ïdem, \& feras aut fugant, aut retinent, aut occidunt. Sed quid in fingulis hrereo, in re mi= nime obfcura: Sat fuerit in fumma affirmaffe, ad multas $\&$ diuerfas artes multorũ anima lium magnü imo neceffarium ufum effe, \& poffe tractari unumquodos melius, $\&$ ad us fum felicius conuerti,ab eo qui naturẩ eius tum alins in rebus, tum nís quas naturales (ut dí xi)medici appellant, plené perfpectã habuerit. Sedin ipfo Opere qui nam è fingulis animantibus homini ufus contingere poffint, ad remedia, ad cibuni, ad ueftes, ad uectu=

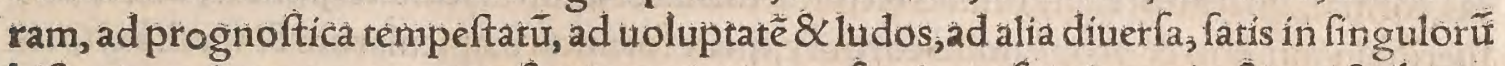
hiftoria explicatur, nec opus eft minutatim in præefentia perfequi omnia, \& quafi obtru= dereLectori. Quinetiã mores acuirtutes in homine formandi exempla \& documenta Ád ́bilosophia $a b$ animalibus abunde fuppetunt, quod quidem cum alin quidẫ eruditi, tum longé docấ te moribus. fimus ille Theodorus Gaza ubiin Ariftotelis de animalibus libros à fe conuerfos prafa tur, copiofe \& eloquenter declarat. Vnde nos eius tuetba prafationi noftręad Lectorem

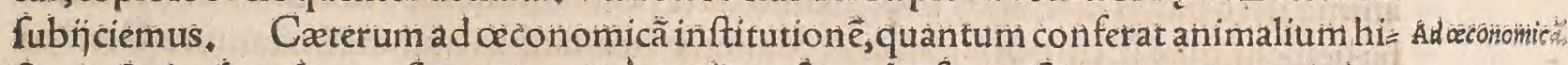
ftoria, fi pluribus demonftrarem, merito prolixus \& uerbofus exiftimarer, nam cumian antea agriculturæ, rei rufticæ, pecuariæ \& coquinaríx, ut íta uocem, quibus res familiaris côferuatur fimul \& augetur, longé tutilifímam hanc cognitionem effe docuerim, eadem opera oeconomiz utilem effe oftendi.

đPorrò quanquam non magnæe nec multæu utilitates ab animalibus ad hominễ redi= Dignitas er ho

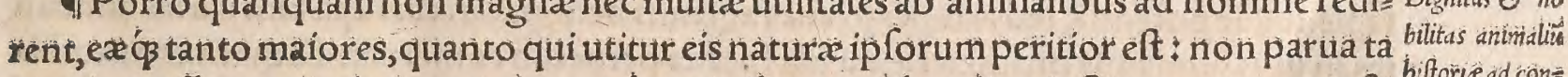
men in eorũ contemplatione uoluptas, homini bene ac liberaliter inftituto, tam uaria $\&$ hiftorie ad conn mira animaliư difcrimina inter fe confideranti oboritur: fiue ea in corpore, fiue animo \& 8 emplationètr utriufog actionibus fpectes, Quid admirandū magis quarundam auicularü extempora = operum Detis neo cantư cuius fuauitatê ne numerofiffimus quidè Muficorum hominü uocibus fimul $\&$ inftrumêtis quibufuis fumma arte utentiữ chorus nelongo quidẽ interuallo attigerit. Quantus eft in unius lufcinix admiratione fummus ille \& exquifitæ in huiufmodi rebus doctrinæ uir Plinius: Quis formicularü mirífica \& apicularü corpufcula, ingenia, opera, $\&$ in tantillis membris tantas animas, fatis digne uel admiretur uel prædicet: A tqui nullư eft animal in quo non aliquid fữu, illuftre, rarü:imò non aliquid, utita dicam, diuinitatis fpectetur.Quamobrēineptus fim, fi pluribus in præfatione ea tractẽ , qux paffim in ípfo opere copiofiffime refero. Ariftoteles ille philofophorü princèps, inter cxtera generofi $\&$ liberalis animi argumenta, hoc etiã ponit, animalibus, pracipue rari,íucundi aut a dmì rândi quippiã præferentibus, oblectari.lliberalis hercle \& fordidus eft animus, quifquis ubiq̧s utilitatê \& lucrữ fpectat. Quàm plưima enim \& pulcherrima nullưn de fe emolü mentü afferunt poffidenti, fed ipfa fui pulchritudine fola placent, \& animos fibi deuin: ciunt. Sic gemmx pretiofiffima, adamantes, topazij, hyacinthi, fmaragdi, chryfolithi, \& 


\section{Epiftola}

alix innumeræ, non quòd morbos geftatæ aut alia quędam pericula auertant, (quiod quí dam fuperftitiofe ne dicã impie credūt,) fed fola illa fplendoris \& luminís in qưocũog cos lore puriffima pulchritudine, quã in minimo codẽóp folidiffimo corpore illibatã ppetuò feruare uidentur, $\tan \not{\phi}$ coeleft is materiæ quædã particulæ aut ftellæ quędã terrenæ, in ho minum thefauros ueniunt, \& ipf fibi pretium funt, nec alium de fe fructũ præbent. Inte: rim faxa uulgaria æedificijs, molares piftrinis, cotes ferro acuendo, quãuis non utilem tan tum fed neceffariü uitæ ufum pręftent, ftupidiffimus tamen habeatur \& gallo Aefopi fis milis, qui ea gemmis nobilitate aut prætulerit aut etiã $æ$ quârit. At qui hęc inanimata funt corpora, immobilia, ignaua, inertí. Longe plus admirationis animalibus debetur : \& inter animalia plurimû illis, qux in anguftiffimo corpore tam multiplex organorum ges nus, qua ad motus \& actiones corporis requiruntur, conclufum habent. Nam \& pracla riartifices ingení uim in exigua magis quàm ampla materia oftentant. Alexander $\mathrm{Ma}=$ gnus(ut Solinus refert) lliadem ita fubtiliter in membranis fcriptam habuit, ut tefta nu= cis clauderetur. MyrmecidæMileffj \& Callicratis Lacedæmonī opera (ut fcribit Aelia = nus)propter nimiã exilitatem in admiratione habentur. quadrigas enim fecerūt quæ fub mufca poffent $a b$ fcondi, \& in fefamo diftichon elegeîum literis aureis infcripferunt, Soli nus Callicratê formicas ex ebore ita fcalpfiffe fcribit, ut portio earũà creteris fecerni ne" quiuerit. Sic natura in paruis quibufdam \& inutilibus(ut uidetur)animalculis, maiori ni= fu \& côtentione quantū preftare poffit, \& experiri ipfa \& nobis oftẽtare uidetur. Nam in omni re quæe ex materia et forma cōponitur, præeftãtior huius, uiliorillius dignitas eft, At corpus materiæ rationê habet:anima uerò eiusóģ fentiendi, mouendi, \& a gendi facul tas, formæ, quare ubi caedẽ omnes fecundũ formã \& animã facultates, motus, actiones ṣ́ fuerint in minimo \& propé nullo corpore, quale formicarü, apicularum \& fimiliū eft, na= turam fe quantũ fieri potuit à materia abftrahere uoluiffe, \& ueluti nudã oftentando for mam, fi nô utile opus, dignû̃ tamen admiratione côtemplationéóp efficere, omnino ueri= fimile eft. Hi tanquã ludi quidam naturæe nô côtemnen di nobis fed fpectandi proponun tur. Quód fị hominê miramur, qui paruo corpore omniũ in natura rerũ imaginẽ gerat, animo uerò patris \& opificis Dei, pximo certe poft hominê loco in admirationẽ anima= lia uenient, quæ $\&$ corporis partibus $\&$ animæ facultatibus homine imitantur. Certéna tura rexū omnium parens, (ut inquit Plinius, non recté naturä pro Deo nominans)nullūu animal ad hoc tantũ ut pafceretur, aut alia fatiaret, nafci uoluit, artesọ́ falutares inferuit $\&$ uifceribus, quippe cum furdis etiã rebus inferuerit, Iam fi qua animaliū homini utilia funt, ut pecora, iumenta, \& alia multa, in illis non tantũ côtemplabimur naturæ imó Dei fapientiã ac potentiā, fed infuper gratias agemus benignitati cius qui tam uarias animan tes in ufus humanos produxerit, earưúģ fpecies perpetuò conferuet. Si qua uero inutilia uidebuntur, in illis tantü admirationi accedere, quantũ utilitati decedit, exiftimare debes mus, Non enim cômunes folum aními corporisóp motus, uires $\&$ fenfus, in minutis illis animalculis habẽtur omnibus, nõ minus $\widetilde{\phi}$ in boue aut elephanto, quod ipfum per $f e f a=$ tis magnã admirationẽ mereretur: $f$ d infuper in quibufdã eorũ longe excellentiora inge

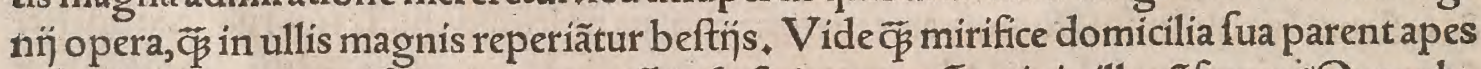
et fimilia eis genera, et formicæ. quantũ induftrix, quantũ artis in illa côferunt: Qux ob= fecro eloquentia fatis infectorũ iftorum affiduitatê, prouidentiam, \& ciuilêillam ac pers petuò concordẽ unius operís adminiftrationẽ, aliasqúp uirtutes, fiute à ratione aliqua pro= feĉas, fiue naturales potius, edifferat $₫$ Nõ eft autẽ quod ideo minus aliquis admirationi habenda hrec animalcula putet, fi uirtutes iftr non propriæ, hoc eft, non ex ratione \& uo luntate ipforum oriri uideãtur:neọ enim ideo minus mirabimur opera Dei, quibus per naturam indidit, ut illius fponte eadem multa prrficiãt, qua homines uix longo tempore đocti exercitatíç præftare poffunt. Luculêta certe hæc omnia diuinitatis nihil non ubiq̧ replentis teftimonia funt $\$ \&$ mirabilis eft Dominus Deus in operibus fuis, fiue per natu= ram, fiue per rationẽ aut uoluntatem, (qux utraq̧ etiam ab ipfo pendent,) fiue nullo in= tercedente medio moueat, Quomodo uerò ufquam abeffent potentia, fapientia \& boni 


\section{Nuncupatoria.}

Eas diuna, uel quomo do ufquam in mundo ceffarent, nedum in homine, quax in contem prifrimis iftis $\&$ minimis corpufculis, fepe tantillis ut uifum fallãt, necabfunt, necceffant, fed illuftria prafentix fux indicia edunt $\%$ Nam quòd mouentur \& agunt, potentia eft: quod fenfibus utuntur, \& inde utilia fibi cognita fequuntur, con traria uitant, quod domi cilia ftruunt, quod prouident de uictu, fapientix eft: quòd foetus fouent \& alunt, quòd fé intricem amant aut amare uidentur, dum degunt gregatim, dum omnes ad unũ opus con fentiunt, dum hoftes aut fures côiunctis uiribus repellunt, bonitatis. Harum uirtutū, aut quomodocunq̧ appelles, primū $\&$ perfectiffimum exemplum, aut ut philofophi loquiun tur, prima idea, caufa \& origo in Deo eft. Hæc igitur tam miranda in uiliffimis etiã \& $f_{\mathfrak{x}}$ pe ex putredine nafcentibus animalculis Deum opt. max. non fortuito aut temere nobis exhibuiffe credemus, fed ut hocargumẽto nobis conftaret, omnia diuinitatis effe plena, (cum ne pafferculus quidẽ ullus fit cuius non meminerit, aut qui citra tioluntatem ipfius

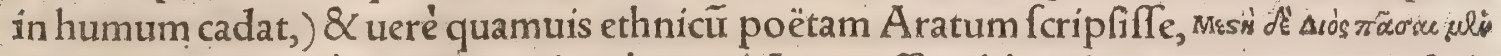

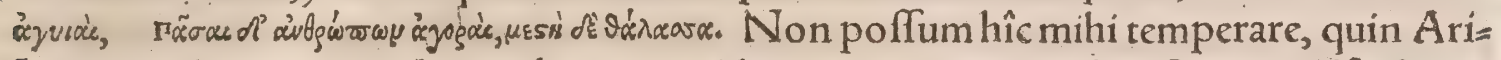
ftotelis uerba ex primo de partibus anim. libro, quoniã optine huc faciunt, adfcribam: nę̧ tritio mihi dabit aliquis, fi quid recté quanquam alienis uerbis protulerim; non enimi tam fpectãdum eft quis dicat, quàm quid dicatur, quamón cõmode \& opportune, Sicigi= tur fcribit: In ịs etiam qux in animantium genere minus grata noftro occurrunt fenfui, is natura parens \& author omniū miras excitat uoluptates hominibus, qui intelligunt caus ss fas, atç ingenue philofophantur, abfurdum enim, nullaọ́p ratione probandum eft; fi îma, , gines quidem rerum naturaliū, non fine delectatione propterea infpectamus, quod inge ss nium unà contemplamur quod illas condiderit, id eft, artẽ pingendi aut fingendi. Rerū,s,

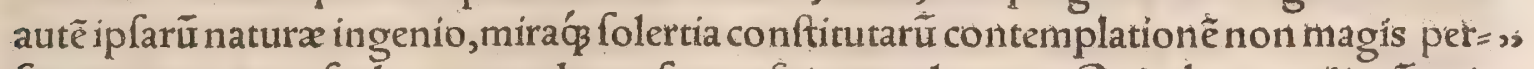
fequamur atç̧ exofculemur, modo caufas perfpicere ualeamus, Quã ob rem uiliorü ani=",

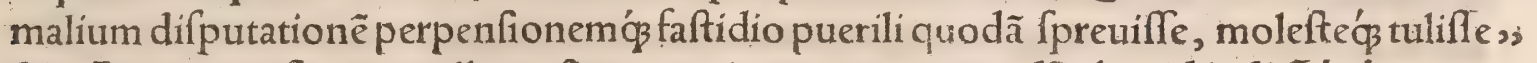

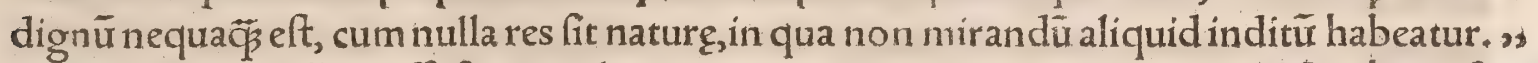
Et quod Heraclitũ dixiffe ferunt ad eos, qui cum alloqui cum uellent, quod forté in cafa"s furnaria quadã caloris gratia fedentẽ uidiffent, accedere temperarunt, ingredi eninm eos is fidenter iuffit, quoniam, inquit, ne huic quidem loco dị defunt immortales. Hocidem in s, indaganda quoç natura animantiū faciendũ eft. Aggredi ením quxo̧ fine ullo pudore », debemus, cü in omnibus naturæ numen, \& honeftü, pulchrumọ́̂ infí ingeniü. Quippe ss cum naturæ operibus iunctũ illud præcipue fit, ubi nihil temere, uicéģ fortuita cồmitta=

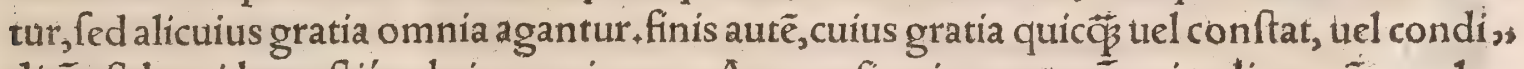
ditũ eft, boni, honeftiọ́ obtinet rationem. At uero fi quis caterorü animalium cốtempla ss tionem ignobilẽ, abiectamọ́ putat, iam hic de fe quo q̧ idem arbitrari debet. Non enim ;s fieri potelt, utea fine magna abominatione infpiciamus, ex quibus corpus conftat huma ss num, ut fanguinẽ, carnê, offa, uenas, reliqua generis eiufdẽ. Omnino ita cenfendũ, ut qui, de quauis corporis parte, aut de uafe aliquo difputat, nô de materià, aut eius materix gra = tia doceat, fed formæ totius ratione, ficut $\&$ cum de æedibus agitur, nổ de lateribus, hỗ de ;s luto, nô de lignis, fed de forma ipfarū $x$ dium docemus. Pari ratione, qui de natura agit, de côpofitione, totaḉp fubftantia traçet, nô de î́s, qux nunquã euenit ut à fubftãtia fep̣a= ss rentur, Hæcex Ariftotele, prolixé quide, , $\mathrm{e}$ d non præter inftitutữ noftruni, qui omnia il = s; lius de animalibus fcripta in hoc Opus cõgerenda ppofui, quamobrê ea etiam qux pras=

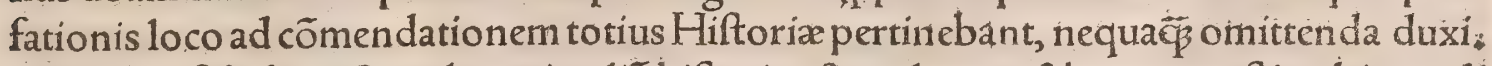
Hæc cữ ita fe habeãt, fingulas animaliũ hiftorias, fingulos quafi hymnos æxímabimus di uinæ fapientiæ $\&$ bonitatis, à qua tanquã perenni $\&$ purifíma faturigine, quicqd ufquã bene, pulchre, \& fapiẽter fit emanat,per mentes primú coeleftes \& fpirituũ angelorướz or dines, deinde hominũ animos, à præeftãtiffimis ad ínfimos progrediendo, (nam in homi nibus etiâ donorz Dei \& excellentix non una ratio eft, ) \& ab homine defcẽdendo per di uerfos animaliú gradus ad zoophyta \& plantas ad inanimiatä ur q $_{3}$ corpora $;$ ita ut ínferio

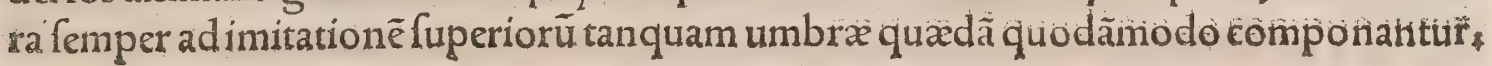




\section{Epiftola}

Sic quidẽ diuinitas in res tum fupra naturã fitas tum naturales defcendit:nos uerò ad eius contemplationê uice uerfa per eofdem gradus côfcendimus. Ipfa interim diuinitas perpe tuó una eademóg \& fibi nunquä non fimilis perfeuerat, necin feipfa decrefcie:fed in cor=

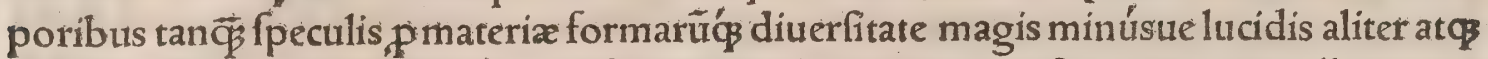
aliter refulget. Sicin corporibus noftris anima, licet tota toti infit corpori, nec ulla pars ea careat, illuftrius tamen facultates alias in alĭs exercet partibus. Verũ anima ita cõnexa eft corpori, idóg mouet ac perficit, ut aliquid ab eo uiciffím patiatur, \& damna eius nônulla fentiat, \& corpore fuo ceu loco \& domicilio circữfcribatur, quokż nihil in Deü cadit : qui ita omnibus fe cômunicat, ut neq̧ fubftantia neq pars corum ulla fit, nec afficiatur ab eis quicquã, neq̧ includatur, fed ita fitubiog \& omnia in omnibus ut extra omnia emineat, mundũ uniuerfum ac coelos omnes fuperior ip fe terminet ac côcludat. Verũ hęeneq̧̧ uer bis neç cogitatione humana, fatis exprimíaut cogitari poffunt, nổideo tamen ab omni côtemplatiốe abfterreri \& abftinere nos côuenit. Quin potius aliquiouf ỏ cổtemplando progreffos, potentiã eius humiliter agnofcere, infirmitatể noftram boni confulendo: $\mathfrak{f a s}_{2}$ pientiã eius admirari, noftram infcitiam emendando : deníg bonitati eius gratias agere, malitia noftram deprecando oportet. Quod fi ita affecti, círca inferiora ifta \& ueluti pos fteriora Dei, pio \& fimplici animo uerfernur, omnia hæc diuiritus nobis producta cum gratiarz actione agn of centes, necimmoremur tamen, fed fubinde ad ipfum opificê erigas mur, \& rebus alins omnibus occafionis tantũ $\&$ admonitionis loco aut tan calcaribus de authore ipfarũ cogitandi utamur, q̊niam tales fumus in hioc mundítheatro ut admoneri \&incitariad côtemplationê rerum diuinarum femper indigeamus : relictis pauló poft aut certe poft hanc mortale uitam externis iftis $\&$ inferioribus $\&$ pofteriori bus, per gratiã Dei patris duce domino noftro lefu Chrifto, qui primus $\&$ unus hanc uiã nobis morte fua praparauit $\&$ oftendit, ad ineffabilis illius intimi, ${ }_{2}$ fummi $\&$ primi boni confortiü admitremur. Atç hic eft finis $\&$ fcopus tum rerum omniư naturaliü confide $=$ rationís, tum uniuerfa hominü uitæ. Sed ne fortaffis quifquã arbitretur', not tra hæc tantü aut philofophorü gentilium diefa effe, nec ullis Sacra fcripturæ teftimonijs defen= di, pauca quædam ex facris literis mibi adferenda funt. Primum igitur in ipfo mundi ex= ordio, Deus hominem creaturus, qui in hoc mundo quafi theatro quodam fpectaret om nia,omnibus uteretur, omne prius animalium genus produxit, ut in domicilium undi= qua ơs inftruetum $\&$ abfolutũ homo ingrederetur. Deinde omnibus animalibus ad eum adductis, nomina fingulis ab eo imponi uoluit. \& quanquam credimus nỏ a nimalia tan= tum fed reliqua etiam omnia ab homine, fuo quod ç nomine duraturo in pofterum, aps pellata, Scriptura tamen per excellentiam quandam de folis animalibus hoc pradicat. Exprimit etiam diferte, omne animalium gernus, pifces; autes, pecora fiue quadrupedes, \& reptilia, in eum firem productum effe, ut hominis imperio, (non fruftra fcilicet, necirius tili, ) fubifceretur. Idem mox in benedictione, quam Deus in hominem confert, repetitur" Et iterum poft diluuium in benedictione Nox \& filiorum eius : Tímore (inquít Deus) \& metu ueftri afficietur omne animal, terrenum 8 uolucre, \& quodcung terra produs cit, aut in mari dégit. Omnia iuris ueftri funt. Quicquid mouretur \& uiuit, ad cibum uos bis permittitur. Et iam inftante diluuio iuffus eft Noas omne anirnalium genus, quod in aqua uitam degere non poteft, in arcam inducere, de auibus quidem \& animalibus pu ris, feptena fingulorum coniugia, de impuris uerò fingula, nimirüut ut fpecies eorum cons feruarentur, quas hominis caufa Deus produxerat. Vbi illud animaduertendum ims. pura etiam animalia, non contempta fuiffe.'Porrò in hiftoria Regum de Salomone les gimus, contuliffe ei Deum tantam fapientiæ facultatem, ut doctifimos qưof op \& celec berrimos uiros longo à fe interuallo relinqueret.mox inter fructus \& opera fapieritix ile lius commemorantur Parabolarum tria millia, Carmina quinque fupra mille, Hiftoria plantarum à cedro ufós ad hyffopum, poftremò Hiftoria animalium, auium, reptilium \& pifcium. Quid eft homo(inquit Dauid Pfalmo 8.) ut memoriam eius habeas? Prafe. ciftiillum operibus manuum tuarum, \& omnia fubiecifti pedibus eius: oues \& boues \& animalia 


\section{Nuncupatoria.}

animalia ruris, wolucres quoque \& pifces maris, \& quicquid per æquor tranfit. Et rurs fus Pfalmo i48, Laudate Dominum de terra, dracones $\&$ omnes abyffi, feræ $\&$ cuncta pecora, reptilia \& aues alatæ, \&c. A A tqui beftix Deum agnofcere uel laudarenon pof funt: nos igitur admonemur, Deum propter illas laudare, \& gratias ei agere, bonitatê \& fapientiam eius in omnibus iftis rebus quas ad uniuerfi ornatum, noftrumó́ ufum pro: duxit agnofcentes. Hinc eft quodD,Paulus ad Romanos fcribit, ethnicos etiam inexcue fabiles effe, quòd cum Deum agnoucrint ex operibus eius, quantum inde fcilicet homini cognofcere datur, non tamen ut Deum coluerint, neq grati fuerint. Siquidem qux funt inuifibilia Dei(inquit)ex creatione mundi, dum per opera intelliguntur, peruidentur, ip= fáq́ acterna eius potentia ac diuinitas. Poftremò locus extat copiofiffimus $\&$ luculen $=$ Introgrum bune tus de prouidentia Dei, qua animalia bruta dignatur ac profequitur, hiftoriæ lobi capite locum poft pre 38.8 39. quem ne fim prolixior hoc in loco omittam. Hæchactenus de dignitate \& exs fattionem adLs. cellentia hiftorix animalium : quibus ubi fubiecero clariffimorũ uirorum circa eandem forem ponea ftudij exempla, ut non modo homine liberali, fed principe etiam dignam, imó regiam hanc cognitionem effe appareat, finem prefandi faciam.

I Alexandro Magno regeinflammato cupidine animalium naturas no

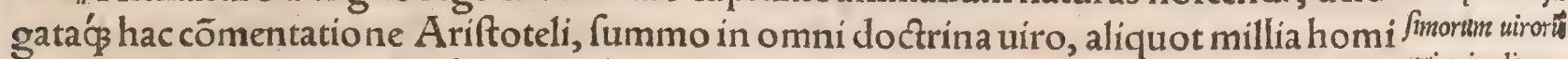

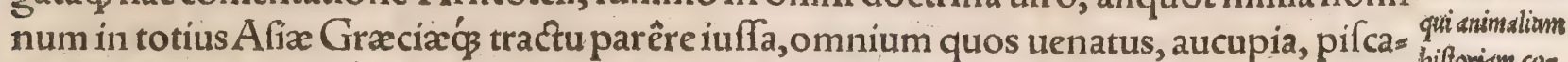

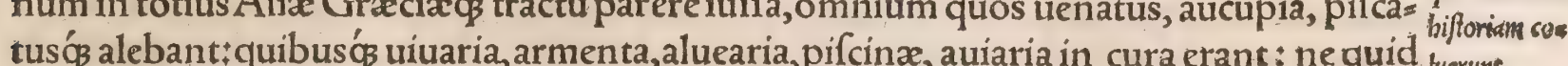
ufquam genitum (aliâs, gentium) ignoraretur $\mathrm{ab}$ eo : quos percontando, quinquaginta fermè uolumina illa præclara de animalibus condidit: qux à me collecta (inquit Plinius) in arctum cum ins quæ ignorauerat, quafo ut legentes boni côfulant, in uniuerfis rerum naturæe operibus, mediợ́ clariffimi regũ omniũ defiderio cura noftra breuiter peregrì nantes, Haecille. Alexander Macedo Ariftoteli hiftoriam animalium ei offerentife

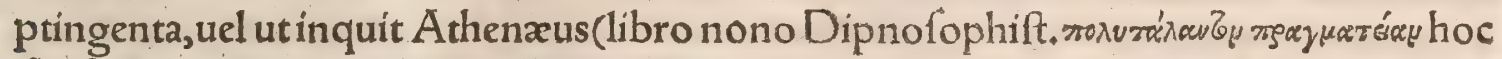
Ariftotel is opus appellans)octingenta talenta rependit. Regium enim munus eam ideo exiftimauit, quòd inter plurima regia quæ hîc traduntur, pręcipué colligi poffint, \& equi tandi, \& uenandi, \& aucupandi rationes, qux funt regix exercitationes, Niphus, Ales xander Magnus dono dedit Ariftoteli octoginta, ( Viues etiam octoginta legit, malim

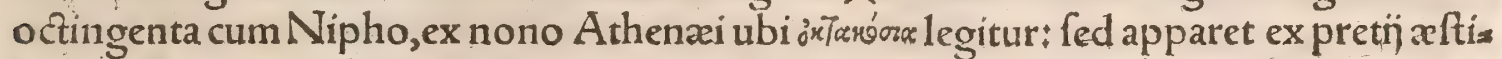
matione, quæ mox fubincitur, erratum effe librarij non authoris, quód octoginta hoclo. co legitur) talenta ( auri, ) quadringentis octogin ta coronatorum millibus æeftimanda. Hec autem xftimatio ita colligitur: Centum enim talenta Attica ex abaco ualent fexa= ginta coronatorum millia : qua multiplicata ogdoade, numerum conftituunt hoc loco repofitum, Robertus Cenalis, Eadem Guil.Budxi xeftimatio eft libro fecundo de Affe. Quod fi hodie uiueret Alexander, intelligeret profecto $8<$ miraretur inter innumera eius regia opera, nullius merito tantam ad pofteros gloriam \& famam ipfius tranfmiffam, quantam ex hoc uno apud uulgus hominum contempto opere. Orbem ferè terrarum uicit, ampliffima regna fubegit, urbes ingentes condidit. fed regnum eius in multas par, tes eo defuncto diuifum, in poteftatem Romanorum, aliorumóg regum uenit, urbes aut deletæ, aut mutatis nominibus, aut barbaris incolis habitatæ literarum \& hiftoriarum os mnium imperitis, conditorem fuum non agnofcunt. Interciderunt etiam quàm plurimi fcriptores, qui gefta cius literis mandarunt, ut uix unus aut alter ex poftremis extet. At animalium hiftoria, cura \& fumptu eius perfcripta, conferuata tot hactenus feculis, annis ferèmille nongentis, maximo femper apud omnes bonos \&eruditos in pretio fuit, \& magnæ femper glorix cum ipfi regi tum conditori eius A riftoteli, Non folum uero glo: ria maior ex hacin philofophum regis liberalitate ad pofteritatem manauit, fed etiam fru ćtus longè uberior, quàm ex multis illis uictorịj $\&$ regnis ab co partis. quid enim inde adiuuari pofteri potuiffent, quod illius etiam feculi homines uehemêter fibi damnofum experiebantur. Multa hominum millia ut fuum pro libidineimperium unus Alexander propagaret fubinde occidebantur, refpublicæ mutabantur, uaftabantur regiones, \& 


\section{Epiftola}

alia multa publica pruatać̣ mala, ut folent in bellis, mulitis magnisç̣ regnis obureniebãt. Nihil igitur tam honeftum \& gloriofum, nihil tam utile quod ad noftram durärit memo ríam, rexille regum perfecit, quàm quòd elegantiffimos illos de animalibus libros con* feribendiliberaliffimus author Ariftoteli fuit. Omnem ferè animaliü hiftoriam (in. quit Petrus Gillius ) uel à regibus ftudiofe animaduerfam, uel ab ịs qui hanc ipfam con. fripfiffent, ïfdem religiofe dicatam \& confecratam uideo. Nam ut onittam alios nobis liffimos reges, non optimos folum 8 diligentiffimos pecuarios habitos, uerum etiam cu riofos in exquirendis animalium naturis fuiffe:luba, Hieron, A ttalus, Philometor, Ar. chelaus reges de ui naturá́p animalium diligenter perferipferunt, Haxcille, Qua ueró no ftra fuper regum iftorum foriptis fententia fit, exponam in fine Catalogi ueterum nõ exe tantium, qui de animalibus fcripferunt. Oppianus Anazarbenfis poëta longédoctif fimus, cum fua de animalibus poëmata Antonino imperatori Seueri flitio Romeobtulifs fet, poftulare iuffus quod uellet, non reditum modo patris exulantis, quem folum pete= bat, facile impetrauit, fed etram pro fingulis uerfibus fingulos numos aureos accepit, quo dono exhilaratus poëmata fua aureis literis exarauit, ut meritò aurea appellentur. Sunt autem duorum eius poëmatum, de pifcibus \& de uenatione, quorum utrü ó ad Antoninum fripfit, circiter quinquies mille $\&$ octingenti uerfus. C. Plinius Secundus Hifto riam mundi, in qua cæetera breuiter, plantas \& animalia copiafiffime tractat, Vefpafiano imperatori dedicauit, cui chariffimus \& familiaris erat. Auicenna uir in re medica \& omni fcientiarum genere excellens $V$ ziro Perfarum regi à confilịs fuit, à qua dignitate pleriçeum principem nominarunt, non dubitauit tamen aliquot de animalibus libros edere, \& multa de ijfdem Ariftotelis fcripta interpretari. Non mírum autem maius olim cognitionis animalium ac totius corum natura ftudium fuiffe: fiquidem(ut Varro feribit lib.2, de re ruft. ) de antiquis illuftriffimus quifque paftor erat, ut oftendit Graca

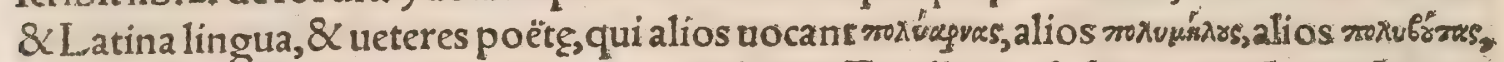
qui ip fas pecudes propter caritatem aureas habuiffe pelles tradiderunt, ut Argís Atreus, ut in Colchide Aeetes, \&c. Romanorum uerö populum à paftoribus effe ortum quis non dicir:quis Fauftulum nefcit paftorem fuiffe nutricium, quiRomulum \& Remum educauir? non ip fos quoque fuiffe paftores obtinebit, quod Parilibus potiffimum con. didếre urbemen non idem, quod mulkta etiamnum ex uetere inftituto bubus \& ouibus dicitur: \& quód $x$ s, antiquiffimum quod conflatum, pecore eft notatum: Er quòd nomi na multa habemus ab utroq̧ pecoréá maiore, \& à minore, ut funt, Porcius, Ouinius, Caprilius, Equitius, Taurus:item cognomina, ut Annij Capra, Statili Tauri, Pompos nij Vituli, Hacille. In facris quidem literis Abrahamum pecoris ditifimum fuiffele gimus, \& Dauidem patris fui greges pauiffe. Huc pertinet etian quod proditum eft, fummos olim uiros anatomes, hoceft diffectionis partium corporis humani perquam ftudiofos fuiffe, \& pueros etiamnum inter prima mathemata literarum in ea exercuiffe. Petebant autem cognitionem illam partium corporis noftri, non ex ipfis ftatim huma= nis corporibus, fed aliarum animantium, ut fimiarum, porcorum, canum, 8 aliarum quadrupedum infpectis, ut his rudimentis imbuti, promptius deindeas certius in diffes cando humano corpore uerfarentur. In primis autem Marcus Romanorum imperator, corporum confectionis, 8 fingularum partium natura peritus fuiffe memoratur. Alegy ptị reges fuis ipfi manibus anatomen adminiftrare non dubitarunt. Iam Boëthus \& Paulus Sergius Romanorum confules, \& alï quidam principes uiri, Galeno animalia diffecanti fxpeadfuiffeleguntur.

Dedicatio. Hocigitur \& huiufmodi Opus, \& tantorum uirorum ftudñs nobilitatum, Hifto: riaminquam animalium cum elaborarem, $\&$ primam eius partem de quadrupedibus uir uiparis hoc tempore in publicum darem, Excellentix ueftræ clariffimi \& prudentiffimi uiri, ommino multis de caufis confecran dum exiftimaui. Primum publico nomine, quòd omnes bonas literas fau ore ueftro dignemini, \& ftudia tum facra, tum qua illis fubfer. uiunt linguarum \& philofophiæ, liberaliter in repub. ueftra iuuetis atque promoueatis. 


\title{
Nuncupatoria.
}

Deinde meo prỉuatim, quòd ciuis fum uefter, quòd Academix ueftrx à puero alumntus, \& nunc in eadẽ philofophiæ naturalis profeffor, quòd hæcomnia in ciuitaté ueftra muls tis fubinde beneficijs per uos affectus, con fcripfi \& $x$ denda curaui. Has omnes ob caufas xquiffimum uidebatur, ut Opus meorum operum, nifi fallor, praftantifimum, fub no= minis ueftri aufpicio in lucem ueniret. Vos pro beneuolentia ueftra $\&$ humanitate, ita accipietis hanc dedicationem, (qua ut uobis honefta $\&$ gloriofa effet, quantum ingenio \&labore efficere potui, nihil ferè intermifi) ut externi etiam homines qui pietatem, pru= dentiam $\&$ fortitudinem ueftram mirantur, propenfum animum ueftrum in bonas lite= ras quoque earumóq cultores patrocinium non uulgare intelligant. Quod fi feceritis, \& me amplitudini ueftræ commendatum habebitis, ad reliquos etiam animalium hiftoriæ libros maiore animo \& alacritate abfoluendos accedam. Valete. Tigurianno Salutis M. D. LI. Menfe Auguito.

\begin{abstract}
T A I M V s breui, fi deo placuerit, Epitomen hurus Operis, omiffis fcilicet ìs qux ad Philo logiam \& Linguas pertinent, ut illis etiam quorum tenuior eft fortuna, ac î́s qui occupatiores funt alijs grauioribus ftudijs, quàm ut in iftis oblectari eis liceat aut libeat, per nos confulatur. Et, ut hoc obiter dicam, dediffemus forte etiam primi TomiBibliothecx ex officina noftra fuperioribus an nis publicatx Epitomen, nifi iam à nefcio quo infrins nobis id fieri audiremus, qui noftris in compen dium redactis, aut potius plurimis quæ in uolumine noftro crant, (ut funt præfationes, cenfuræ, ar gumenta, \&c.) Omillis, aliquor authorum nomina adiecit, quę quidem per fe ædi $\&$ paticis folijs com prehendi potuerant. Verum nos eadem omnia feorfim cum alijs quamplurimis ueterum recentio rumós foriptorum nominibus, primo quog; tempore in lucem dabimus, quod ad hoc uf́s tempus di fulimus ut eó copiofiorem A ppendicem iftam colligeremus. Vale, \& faue illis potius qui magnis fumpribus primi in publicum alicuius operis æedendi author es extiterunt, quàm qui lucri fpe belíris no more aliena inuolant, preter hominis Chriftiani officium, (quo quidem inter nos, fi boni uiri effes mus, uel citra leges \& priuilegia fponte nos uti oportebar $)$ quafi in tanta rerum \& literarum copia omnis aliahonefti lucri ratio $\&$ occafio defit, nifi qua cum iniuria $\&$ damno aliorum fufcipitur.
Iterum $V$ ale.
\end{abstract}




\section{QVAE ANTE OPERIS INGRESSVM \\ T R $\triangle$ C T A T T R.}

1. DE Operis ratione ad Lectorem admonitio.

- Deprouidentia Dei circa animalia, exhiftoria lobi.

3 Defručtu ex animaliū hiftoria percipiendo, ex Theodori Gazx præfatione in con uerfionem fuam Ariftotelis dẹ animalibus librorum.

4 Catalogus ueterum non extantium, qui de animalibus fcripferunt.

s Catalogilibrorum extantium, quibus ad hoc Opus ufi fumus.

6 Catalogus doctorum uirorum noftri fæculi,qui aliquid ad animaliü hiftoriam(ima gines, nomina in diuerfis linguis, defcriptiones)nobifcum communicarunt, gra titudinis ergò inftitutus.

7 Ordinis ratio, quem perfingulas ferè animalium hiftorias in capitum partitionefe cuti fumus,

8 Enumeratio quadrupedum uiuiparoru,, eo ordine quo in hoc uolumine defcribun tur, cum numeris paginarum,

9 Eorundem copiofior indexalphabeticus.

10 Eorundem indices aliquot alphabetici in diuerfis linguis, Hebraica, Chaldaica, Ara bica:Perfica, Graca, Italica, Hifpanica, Gallica, Germanica, Anglica,lllyrica,

\section{N O PERIS FINE.}

Paralipomena quædam cum figuris aliquot.

Additiones \& caftigationes. 


\section{CONRADVS GESNERVS CANDIDIS LECTORIBVS S.}

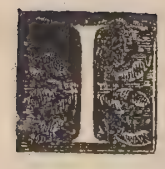

s epiftola nuncupatoria, qua occafione ad hoc Opus accefferim, quantum in eo elaboras uerim, qui inde fructus fperari poffint, $\&$ quanto ftudio tum reges $\&$ principes, tum imuld magni $\$$ doctiffimi uiri animalium hiftoriam excoluerint, fatis milii iam explicatum eft. Hîc reliqua de quibus admonendum Leçorem in Operis ingreffu duxi, feparatim propo nam.neq̧enim in dedicatione ad Reip.noftræ uiros principes facta, prolixiorem me effe decebat.

Et quoniam ipfa libri magnitudo, antequam legatur quicquam, de prolixitate apud multos me accufatura uidetur, hacc ante omnia mihi excufanda fuerit. gnum euafiffe Volumen, in quod omnia omnium, quotquot habere potui ante nos de animalibus cufatur. cripta fummo ftudio referre conatus fim $\div$ ueterum inquam $\&$ recentiorum, philofophorum, medi= corum, grammaticorum, poëtarum, hiftoricorum, \& cuiufuis omnino authorũ generisł nec eorum duntaxat qui Latinéaut Grarcé, fed quorundam etiam qui Germanicè, Gallicé aut Italicé lucubrał tiones fuas æadiderunt: Et diligentiffimé quidem illorum, qui de animalibus ex profeffo aliquid fcri= pểre, minori uero cura aliorum qui obiter tantum, ut hiftorici \& poếtæa, nónunquam de hịf́dem me: minerunt. His plurimas obfertationes proprias adieci,cum nullo pudore à quibufuis, doctis, indo, Ctis, ciutibus, peregrinis, uenatoribus, pifcatoribus, aucupibus, paftoribus, \& omni hominũ genere, multa fubinde interrogando colligerem. Per literas etiam ab hominibus doctis, quas illi ex diuerfis regionibus ad me dederunt non pauca cognoui. Imagines quogs animantium, operis molem auxe. runt. Præcipué uerò primus liber, quem nunc damus, de quadrupedibus uiutiparis, excreuit immo: dicèqquoniam hoc animaliũ̃ genus, ut homini familiarius, ita notius (pracipué noftro orbi) 8 utiliuss 8 multi de fingullis libellos aut etiam libros iuftos fcripferunt, ut de equis Hippiatri Gracè, Latinè, $\&$ alins in linguis recentiores, \&c. De canibus etiam multi multa prodiderunt; de pecoribus \& armen tis, bubus, capris, ouibus, fuibus, plurima rei rufticæ conditores Gracé Latinég. Dicat aliquis non fuiffe ex omnibus fed ex optimis tantum libris confcribendam hiftoriam. Ego uerò nullius fcri pta contemnere uclui, cum nullius tam malus fit liber, ex quo non aliquid haurire boni liceat, fi quis iudicium adhibeat:quod potiffimum fit, collatis melioris notæ frriptoribus, Græcis cum Latinis, ue = teribus cum nouis. Itaç̧ licet nullum genus foriptorum praterierim, \& à barbaris eriam $\&$ obfcuris in diuerfis linguis non pauca excerplerim, non temere tamen id fecitita ut neque negligentior iudi cari polfim, qui temere fidem quibufuis habuerim: neq arrogans aut parum modeftus, quil ullius lucubrationes contempferim. Ea fané quæ falfa aut quouis modo abfurda occurrebant, uel prorfus omifi, uel ita pofui ut arg trerem: aut fi quando id non feci, fiue per ignorãtiam, fitue aliam ob caufam, quod tamen rarius commiffum puto, (praterquàm in î́s quę ad medicinã pertinent, ubi fxpe multa tum falfa tum fuperftitiofa retulimus, ut amuleta forte $\mathcal{Q}$ alia, qua eitumodi funt, ut à mediocriter etiam eruditis uiris bonis facile agnofcantur ) ex ipfo atthoris nomine quanturm quid $\$$; fidei merea tur ferè iudicabit Lecfor.neqzenim ego fidem meam ubiç aftringo, contentus aliơrum uerba $\&<$ fen tèntias recitaffe. Quamobrem diligêter \& religiofé caui, ne ufquam nomen authoris omitterể, quan quam in paruís etiam $\&$ uulgò notis rebus:ut licet dubitationis nibil rebus ineffer, de uerbis tamen \& locutionibus conftaret, à qưo proficifeerentur authore, fi quis imitari uellet. Itaq copiofior fape fui,ut non folum rerữ cognitione prodeffem : fed ijs etiam qui foluta aut numerofa oratione Grace Latinéue differêre aut feribere utellent, fyluam uocabulorum locutionumós fuppeditatem. Cęterum ut omnia Latinè $\&$ purè fcriberêtur fieri fatis cómodè non potuit, cum quaxdã ex barbaris defumpta iiffeê penè uerbis recitârim, præfertim fí quæ obfcura uel dubia eranțreliqua uerò ab illis defcripta, ad mediocrem lingura Latina ufum deflexi, non quod melius non poffem, fed qutod tales authores talis elocutio magis decere uideretur. Quax uero ex bonis \& Latinis authoribus tranferipfi, illorum nihil mutaui . De meo quidem ftilo, non alittd dicam, quàm hoc pracipuè mihi curax fuiffe, ut fi non eleganter $\&$ gratiter, nec ad ueteris alicuius imitationem, mediocriter tamế Latinè \& clarè dicerem. Nam neç othum erat ftilum excolendi, cum in rebus ipfis tam uarijs tam innumeris occupatiffrmus effem $\div \&$ feré ad pralum defcriberem ea quaz annis aliquot prius congefta repofueram, ut fi excidí contingeret, non res amplitus inquitend $x$ admodum, fed fcriptio ferè tantữ, \& ordo, \& curä ne quiid fruftra repeteretur, me detinerent. Quin $\&$ argumentum operis non gratrem $\&$ ornatum fillum, fed perfpicuum $\&$ mediocrem requirebat, $\&$ plerunģ grammaticum, hoc eft interpretationi aptü. Non enim recitare tantum uerba author um uolưi, fed plerüq̧ etiam, ubi opurs uidebatưr, ex plicationem adieci,ita ut hoc Volumen nó tanturm Hiftoria fit aninalium, fed etiam expofitionis loco in plerof omnes qui de animalibus aliquid prodiderunt, futurum. Nam qui librum aliquem explicandum fü fcipiunt, duo præcipue curant, ut uerba \& $Y$ fenfus authoris declarent, $\&$ aliorum fimiles locos confe, rấr.quorum pofteriıs quoniam in hoc opere fummo fudio perfeci, collatis tum aliorutum tưm tunius authoris eadem de re ditterfis in locis dicta, minus operapretium fuit pluribus declarati authorum therba, cum ipfi inter fe loci tam diligenter collati mutuam lucem afferant, Sicubi tamen opus uidea 


\section{Prefatio}

batur, urerba etiam \& fententias pro mediocritate mea, tum aliâs, tưm per parenthefes, ưt urocant, $\mathrm{Ex}_{\mathrm{z}}$ pofui. Accedit praterea quod natura à nimio ftili cultu $\&$ omniaffectatione fím alienus, liac cura i lis relicta quibus uerba magis quàm res funt cordi. Sed ut copiofius dicta paucis repetam, prolixum hunc librum fieri oportuit, primum quod ex innumeris authoribus confectus eft; deinde quod fape multa de meo declarandi caufa adieci. Poterat tamen fic quoga multò breuior effe, fi Philologram non attigiffem, in qua me nimium fuiffe fateorłfed hanc quoç diligentiam, fi nó admodum utilem, iucundam tamen grammaticis \& alịs quibufdam fore fpero, mihi certe magno labore, multis uigi $=$ lifs confitit. Philologiam autem appello, quicquid ad grammaticam, \& linguas diuerfas, proserbia; fimilia, apologos, poêtarum diça, deniç ad uerba magis quàm res ipfas pertinet. Hæc \& huicúmodi magna ex parte ad ociauum fiue ultimum de unoquoç animante caput reieci : aliquoties tamen in priora etiam capita irrepferunt, partim quod ego uoluptate quadam ad digreffiones ciufmodi leut occafione inuritabar, partim quod lucis nonnihil authorum locis commode illic recitatis afferre uide $=$ rentur:ut cum alibi tum fecundo capite, ubi de partibus animalium fribebam, ex grammaticis, me. dicis $\&$ alịs fape plufcula attuli. In tertio, ubi de cibis animalium $\&$ morbis agendum erat, fre ad plantas (quibus illa uel nutriuntur falubriter, uel fortuito guftatis læduntur aut etiam necantur) co. piofius defcribendas diuerti: \& fimiliter in quinto capite, fi qux tales erant ftirpes, ut ïs per uenato res cum aliqua efca obiectis animalia perírent. Ex profeffo trerò in ipfa philologia, plantas illas nomi nare $\&$ interdum multis defcribere folitus fum, qux quouis modo nomen futum ab aliquo animali traxerunt.lam capite feptimo, quod eft de remedijs exanimalibus, $\&$ noxis quas morfu ictúue aut in cibo fumpta inferre folent curandis, non raro multa altius repeto, rei medíc illufträdx fudio. ER ubiloca authorum deprauata $\&$ reftituenda, digrediendi occafione preburerunt. Breuiter, ubicunç rarum aliquid, aut alips indictum, fe offerebat, quod explicatum communes literas illuftrare uidere $=$ tur, facilius ad id enarrandum ab inftituto deceffi. Nam cum à puero in grammaticæ $\&$ philologia ftudijs Græcis Latiniś́ ćs educatus fim, 8 adolefcens adhuc eadem profiteri coperim:donec adultus ad maturiorem philofophiæ præfertim naturalis $\&$ rei medicæ profeffionem acceffi, quanquam ex illis quoc philologiam non parum auxi ac folidiorem effeci: $\mathcal{X}$ auidiffimè femper uarís lectionibus me exercuerim, poffe me aliquid amplius in rerum $\&$ dictionum uariarum explicationibus quàm uulgus fudioforum præfertim ætate inferiorum, $\&$ alins occupatorum ftudijs, mihi perfuaferam. Quanobrem liberius fape $\&$ copiofius multa fcripfi, ueteres ac recentiores reprehendi, nullo pro= fecto uel obtrectandi aliena, uel mea oftentandi animo, fed candidè \& fimpliciter, ut quantum in me effet publica ftudia promouerem. Quòd fi nemo improbat illorum libros, qui nullo ordine ut quidç in mentem uenerit, uariorum authorum uerba $\&$ locutiones in utraģ lingua enucleant, utapud ure reres Macrobius, Gellius, Caftiodorus, \& quicunq uaria fcripferunt, quorum plurimos in fecunda Bibliothecæ noftræ parterecenfui: $\mathbb{Q}$ apud recentiores cum alí multi, trum præcipuè Guil,Budæus, Cælius R hodiginus \& Calcagninus, Politianus, Erafmus Rot, \&c, fed tanquam optimémeritis quícungs uir bonus $\&$ uel mediocriter doctus, magnas agit gratiastnon uideo quo iure uituperetur no. fter hic labor, in quo multa quidem ab alijs dicta, fed confufe, multa à me primum prodita, ita digeff $\&$ difpofui, ut propemodum nihil non furo loco redditum fit. Siquidem omnium non folum fura funt capita, fed capitũ etiam partes, 8 certi ordines, priores, polferiores, medix, uno ferè \& perpetuo per uniuerfum Opus ordine feruato. Et quoniam non rarenter incidebat, ut aliquid diuerfos in locos ex illis quos inftitueram referri poffe uideretur, ne nimius effem repetendo, fere ab uno loco ad alte. rum lectorem remifi, nifi res tota paucis repeti poffet. Hæe $\&$ alia quædam (ut diuerforum author uerba, $\&$ ftili uarietas) inaquale, interruptum, \& falebrofum ut ita dicam Opus, \& (ut aliquis forte obíciet) fcopis fimile diffolutís reddiderũt: quod vitium ego etfi animaduerterem, committere tame non recufaui, dum ita prodeffem. Erit autem hoc quicquid eft uitÿ multò minus, fi quis fecum repu. tet, me ifta omnia non eo inftitu to com pofuife, ut continua lectionis ferie cognofcerentur à ftudio. fis ${ }_{+}$fed ita temperaffe, ut quicquid aliquís fuper quouis animante noffe defyderârit, id fuo ftatim loco repertum, per fe etiam legere $\&$ claré intelligere poffit. Ita $\phi_{3}$ fi quis tantum ad inquirendum per in. terualla hoc Opere uti uoluerit, quí Dictionariorum $\&$ aliorum huiufmodi communium librorum ufus eft, hoc rectè facere poterí. quod fi perpetuò ferè nobis obferuati ordinis non meminerit, indi= cem alphabeticum confulat, quem in totius Operis, id eft fíne fecundi Tomi, utriç Tomo commtra nem ædemus, fi nihil interim aliud, ut homines fumus, acciderit. Idem feréPlinius in Naturæ hifto ria caurit:nam in præfatione ad Vefpafianum, Quia occupationibus tuis (inquit) publico bono par cendum erat, quid fingulis contineatur libris huic epiftolæ fubiunxi, fummaós, cura ne perlegendos hos libros haberes operam dedi. Tu per hoc $\&$ alïs praftabis ne perlegant: fed ut quifọ defideraurea rit aliquid,id tantum quarat, $8<$ fciat quoloco inueniat. Hoc ante me fecit in liser is Valerius Sora nus in libris quos tronj id $\omega$ e infcripfit, Hac Plinius. Qui in arte grammatica proficere cupiunt, $\&$ alicurius linguæ ufum fibi comparare, illi ab optimis grammaticis qui methodo compofitiua (ut uo cant)artem tradunt, à literis \& fyllabis ad dictiones \& octo fermonis partes, \& poltremo fermonem ipfum, \& fyntaxin progreffi, artis notitiam petunt, interim tamen Lexicorum ( ín quibus fingula dí ćtiones locutioneśćs erumerantur longe aliter quàm in pręceptis artis, ubi nec omnia fingillatim nec. codem ordine recenfebantur ) utilitatem non negligit, non ut à principio ad finem perlegat, quod 


\section{Ad Lectorem.}

operofius quàm utillius fieree, fed ut confulat ea per interualla, Ita qui animalium hiftoriam congnitưt. rus eft, \& continua ferie perlecturus, petat illam ab Ariftotele; \& fi qui fimiliter fripferunt ; noftro uero Volumine tanquam Onomaftico aut Lexico utatur. Non enim me latet quod Ariftoteles do: cet de partibus animalium I+4. multo præftare (ad philofophicam defcriptionem ) \& eruditius effe, de animalibus ita fcribere, ut tum partes tum affectus pluribus communes fimul tractentur, per $10=$ cos quofdam communes explicata corum hiftoria, primum ea perfequendo qua communiffima funt, ac paulatim ad minus communia, poftremo ad ea qux certis tantum generibus ac fpeciebus in. fimis propria fuerint, defcendendo.nam fi in fingulis animalibus partes 8 affectus aliquis fingula= tim confideret, multa fubinde repetenda erunt, quod perablurdum (inquit) $\&$ prolixum fuerit. Hoc ego difcrimen quamuis (ut dixi)animaduerterem, uolui tamẽ animalium hiftoriam fingulatim per= fequi, quod id noftro tempore, quo nomina plurimorum non amplius intelliguntur, multo irtilius futurum iudicarem $; \&$ nonnulla frequentius repeti minus abfurdum putarem, propter ordinem eiufmodi inftitutum, ut inquifitioni magis quàm continux lectioni feruiat hoc Opus, nô tamen oma nia qua communiter alicui generi infunt, in fingulis etiam animalibus pofui, tum quod quxdam nulli non nota fint, ut communiffimæ quadrupedũ partes : tum quod in quibufdam fí quis dubita= uerit, facile ad Ariftotelis locos, in quibus generatim illa tractantur, recurrere poffit. $8 \mathrm{C}$ fortafis nos etiam aliquando de animalibus fecundum genera $\&$ fpecies nónihil commentabimur. Adde quod commodius erat per fingula animalia hiftoriam à nobis condi eo etiam nomine, quod non phyficé

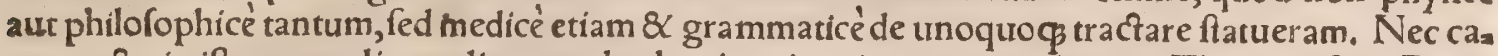
ret tractatio ifta exemplis eruditorum. de plantis enim uix unus aut alter, ut Theophraftus, Ruel. lius, iuxta methodum illam quæ cómunibus partibus $\&$ affectibus plantas fingulas fubỉcit, aliquid prodidit: fingulas uero feparatim plurimi delcripferunt $\&$ olim $\&$ noftro feculo, pracipué medici. Vnus Ruellius feré In utroģ; elaborauit, ut Galenus quoç;, fed in facultatibus tantum defcribẽdis. Fateor equidem potuiffe me quamuis inftituto meo manente, in multis multó breuiorem effe, nifi prater cxtera exquifitum etiam iftud diligentia mex ftudium me oblectaffet. Vbi in mentem uenit

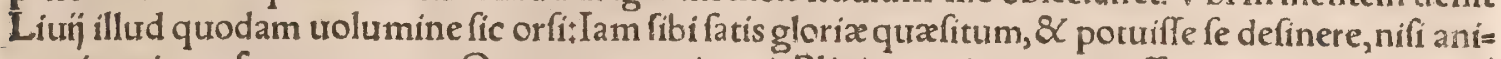
mus inquies pafceretur opere.Quanquam, ut inquit Plinius, maius meritü effet, operis amore (quod ipfum non fuæ fed Romani nominis gloriæ compofuiffe decuit) nó animi caufa perfetreraffe: \& hoc populo Romano præftitiffe non fibi. Ego quamus Liuium non folum uel animi gratia uel quaren= dx fibi gloria, fed magis etiam hiftoria ueritatis $\&$ populi Rom. illuftrandi caufa, fribendi labores fuftinuiffe exiftimo:modeftius tamen dixiffe iudico, ita ut dixit: ne fi eo modo quem Plinius requirit dixiffet, arrogantior uideri potuiffet, ut qui clariffimo totius orbis populo 8 gentium uiciori orna= menti quippiam fuis fcriptis acceffurum defe pradicaftet. Ego fimiliter etfi totum hoc Opus quale. cunç eft, non mihi fed Reip. \& A cademiæ noftræ moderatoribus(qui me à puero fua liberalitate fo uerunt, fouentóg etiamñ̃̃, et ad ea quę copi alacriter perficienda hortantur)uniurerfum deberi urolo, ac fi quid inde gloriæ nafci poteft, ad illos potifimum recidere : modeftius tamen, ni fallor, hac re ticeo, \& aliorum relinquo iudicís, an laudis $\&$ gloriofa famæe ex opere quanquam non illaudabili, Senatui \& Academix inulto iam tempore multis nominibus pietatis, doctrin $\&$ uariarữ uirtutum clariflimis, accedere quicquam poffit.

đSed nimium forte hîc etiam prolixus fum, dum Operis prolixitatem excufo, quianquam obiter fimul alia quędam egi, ut commoditates quafdam eius oftenderem, ac fiylum noftrum qualemcun qs excufarem. Pergo ad reliqua. Et quanquam de immenfo labore noftro ex antedictis fa tis cóftare poffit, ac ipfa Voluminis tum magnitudo, tum uarietas $\&$ difficultas explicatarum in eo rerum pro me loquatur, addam tamen nonnulla, fi ita fortaffis aquiores ac benigniores mihi cenfores contin. gant homines docti, ( nam de indoctis parum cura, ) ficubi me offendiffe animaduerterint. Magni enim $\&$ ardui conatus, etfi non per omnia réfpondeant, ureniam merentur $\$ \&$ (ut ille ait) opere in ma= gno fas eft obrepere fomnum. Plinius fe naturalem hiftoriam fuam confeciffe fribit ex exquifi. cis authoribus centum, adiectis rebus plurimis, quas autignorauerût, aut poftea intienerat uita $¥$ nec dubitamus(inquit)multa effe quę $\&$ nos præterierint. Eadem de hoc noftro uolumine accipi uelim: quamuis non folum ex authoribus centum, fed multó pluribus id mihi concinnatum fit, ut facile eft computare ex catalogo eorum quem infra pofui. Erat autem primò perquam laboriofum omnia dia ligenter $\&$ cum iudicio legere, deinde excerpere, $\&$ ad fuos redigere ordines $¥$ ac rurfus inter Opus feribendứ conferre, cum permulti eadem dicerent, alij ab alijs mutuati expreffis authorum nominis bus, alij fuffurati fuppreffis. Quàm uero $\&$ difficile $\&$ tædio plenum fit authorum fcripta fic inter fe conferre, ut omnia in unum quafi corpus redigantur, nihil omittatur, nihil repetatur temere, nemo facile intelligit nifi expertus, hoc quidem ita contingit, urel duos aut tres tancum libros conferendo; multò maximè uero complutres ut nos fecimussidéćs tam diligenter, ut ad alios authores fuper n̈fdem rebus minimé pofthac fit recurrendum, fed qui Volumen noftrum habuerit, omnia de ififem feripta

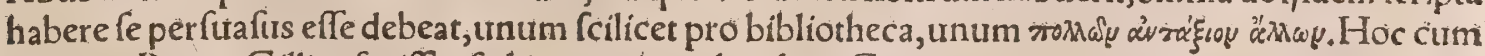
ante nos Petrus Gillius feciffet, fed in paucis authoribus, Gracos, inquit, qui de animalibus ferip fe: runt, non modo Latinos fecimus, quod facillimum fuiffet:fed Diony fium etiam Caffum, qui Mago nem conuertit, imitati, ordinem \& iudicium adhibuimus.Sed hac ego multo iuftius de noftris dixe 


\section{Præfatio}

rim, quit 8 ordinem nutito commodiorem fequutus fim, 8 longé plura contulerín inter authortm frripta, tum alia (ut fupra dixi)tum pleraç ex Gracis translata, \& ab alị̆s \& ab ipfo Gillio. Itaq fä pius Grxca appofui, ubi uel interpretes lapfi uidebãtur: aut uocabula loquutionésue rarum alicuid aut pulchrum, aut rei prafenti peculiare continebant, Multa etiam ipfe conuerti, uel quod transhata hactenus non effent, uel quod obuium in Gracis locum ipfe potius transferre, quàm apud interpre tem diutius inquirere uolebam. Ex Germanicis etiam, Gallicis, \& Iralicis quadam Latina feci. Hos lucubrandi labores, legendo, colligendo, conferendo, tranfcribendo, multis annis fuftinui $\div$ qui certe quales $\&$ quanti fuerint, non facile credi poteft, nifi ab expertis. effi an quifquam rem fimilem tentârit, ut omnia omnium, quotquot haberi poffent unius argumenti fcriptores, in unum corpus redigeres, non facile dixerim. nam quí ex multis quædam conferipferint quofdam noui, qui ex om: nibus neminem. Quamobrem poffum illud de laboribus meis dicere, quod Ariftides de elegantia

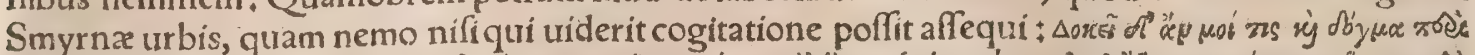

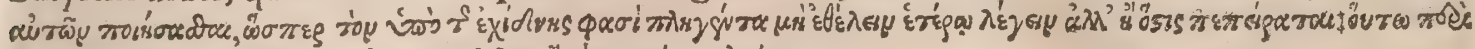

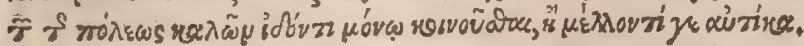

TQuod ad ftilum attinet, etfi in præcedentibus quædam dixerim, obiter digreflus, hic prituatim quadam adijciam. V fus fum igitur dictione humili $\mathcal{X}$ minimè affectata, ob caufas fuperius enume: ratas. Nam in his friptis in quibus rerum cognitio quaritur (ut Maffarius inquit in fimili argumen$t_{2}$ ) non luculenta orationis lepos, fed incorrupta ueritas exprimenda eft. Certe huiufmodi lucubra tiones(ut cum Plinio dicam)nec ingení funt capaces, quod alioqui nobis perquàm mediocre erat: nec admittunt exceffus aut orationes, fermonésue, aut cafus mirabiles, uel euentus uarios, aut alia iucunda dictu, aut legentibus blanda. Sterili materia rerum natura, hoc eft uita narratur, \& hac for didiffima quoque fui parte, ut plurimarum rerum aut rufticis uocabulis aut externis, imò barbaris, etiam cum honoris præfatione ponendis, Hæc Plinius, Quod fi ille homo doctiffimus idemás onan iudicio eloquentiffimus, quiḉ̧ caftitatem linguæ Latinæ cum laçe hauferat, $\mathcal{Q}$ alh̆s commodisatibus ufus, $\&$ unde plurimum excitari feruor ingenif poterat Meccenate adiutus imperatore Vefpafiano, de ftili anguftia $\&$ ruditate, in fimili ferè argumẽto excufationem inftituere uoluit ipfe hoc facerem multas ob caufas, quas ne fim prolixior non enumero. Cur quædam paffirn in hoc Opere diuerfis in locis reperantur, rationem reddidi iam ante, nempe quod ita pofularet infti= tutus à nobis ordo, \& capitum partiumç in fingulis diuifiołut non negligentix noftræ, fed accurate potius curiofx́ç interdum diligentix id adfcribendum fit. Sed repetuntur quædam aliquando eodem in loco, qux uiderí eadem poffunt obiter cognofcentifí quis uerò preffius confideret, nonni hil(quantulumcunģ) intereffe intelliget, uel in re, uel in uerbis. nam loquutio quandogs peculiaris, aut elegantia uerbor um, ut id facerem, inuitabat:ut haber et etiam quod dicendo imitaretur, fi quis eadem de re aliquid quouis modo dicere aut fcribere conaretur. Parenthées quoç (ut uocant grammatici)ad filum pertinent, qux paffim in toto Opere plurimæ funt, id'śs plures ob caufas, aut quia uaria erat lectio; aut fr ribendi modus diflidebat, aut noftra aliorúmue caftigatio adédebatur, aut ut interpretarer, aut ut de meo explerem, fi quid deeffer:aut ut Graca adderem, fiue quod elegantía fua placerent, aut peculiariter ad rem præfentem facerent, fitre qutod Latina ex eis non fatis benered dita uiderentur: denicg fimplíciter ad clariorem intellectum illorum quibus interfertintur, Quan. tum ad orthographiam, non femper eadem uocabula eodem modo fcripfi, fed fecundum authores quorum uerba recitabam nonnunquam uariaui.

- Hæc de filo \& elocutione. Quod ad res ipfas, earumás ueritatem \& certitudine, fidem meam in plurimis non aftringo, authorum(penes quos ea efto)nomina pofuiffe contentus. Ea certe magna ex parte fidem merentur, qux multorum \& eruditorum multis iam feculis confenfu muniuntur, ut hac etiam gratia authores à nobis complures nominatos, 8 quadam fortaffis non magno alio qui fru ctu repetita non fit poenitendum, A multis enim teftibus res una fi uerbis ïfidem dicatur, cò fide dis gnior eft. Fateor nonnulla leuicula effe, (ut Gillius etiam in A eliano fuo, quem nos in noftrum Cpus tranftulimus, ) red ea non multa funt, \& cum alịs infinitis grauibus $\&$ doctis comperifantur: actanquam næui in articulo pueri delectabunt Alcæos, hoc eft non ftultos alieni operis æeftimato. res. Ego uitilitigatores non curo.tales enim potifimum funt, ut Cato pronunciat, homines uera lau dis expertes. Quodfi non ad plenum fatisfecerim, ( utor îfdem uerbis, quibus in fua de pifcibus fcripta Maffarius)non erit culpa defiderï mei, quod fané ardentifimum eft, fed quod plus facere hoc tempore non potui. A equilectores boni cófulent tam diffufx materix quam fúcepimus maximam partem à nobis traditam $\in \mathbb{f l e}$, neç̧ enim tantæ rei fatisfaçurũ me unquam fperaui. Quin prius quan tum nos in iuuandis bonis artibus fecimus, alij tantum quocs faciant, ac deinde blaterent. Nec enim animo feremus, iniquo, fi ad hanc immenfam difficillimamós à nobis fufceptam prouinciam in atixi= lium peritiores aduenerint, nosç̧ etiam fuperauerint, Pædaretưm ferũt egregium illum uirum, qui quum in trecentorum numero lectus non effet, qui ordo apud Lacedamonios honore praftabat, abiretćs hilar is ac fubridens, reuocatur ab Ephoris interrogatusq̧́ quid rideret, répódit: Quoniam equidem ciuitatigratulor, qux ciues trecentos habeat meipfo meliores. Iam etfi profefius fum omnia ferè omnium hactenus qux ad manus meas peruenerunt de animalibus fcripta, in noftris lư = cubrationibus comprehendi:nö tamen idcirco fuperfluos aut inutiles pofthac aliorum libros haberi

uelima $_{2}$ 


\section{Ad Lectorem.}

uélim, neç enim id ut efficerem unquam cogitaui. Quin omnibus furum locum, furum honorem nàa nere \& xquum eft, cum prodeffe omnes uoluerint, \& ipfe omnino cupio. Merêtur enim alï propter antiquítatem, religiofe ut obferuentur:alij etiam propter methodum philofophicam $\&$ dialecticam, 2ut aliam à noftra diuerfam, alij propter elocutionem, qutidam propter hæc omnia. Græcos fané im: primis lingux ipforum fauentes obferuabimus. Sunt qui Ariftotelem, Plinium, $\&$ alios ueteres (inquit Gillius)omnem animalírm naturam feriptis comprehendife prædicabunt, à quibus adeò diffentio, ut ab eis pręclarè inchoatam multam animalium uím, non plané perfeçam audeam dicere Cur enim tot tantisć̣ religiofiffimis authoribus de ui \& natura animalium extincís, non amplum locum homínibus minimé inertibus ad nouram commentationem relictum effe arbitremur fum fex centis apium fcriptoribus nondum perditis, Ariftarchum Solenfem conftet duodequadraginta an: nos tihil aliud egiffe, quàm earum mores tum obferuaffe, tum foriptis mandaffe.

TRes ardua (cum Plinio loquor) ueruftis nouritatem dare, nouis authoritatem, obfoletis nito. Epilogus, rem, obfcur is lucem, faftiditis gratiam, dubijs fidem:omnibus uerò naturam, \& naturæ fuæ omnia. Itaģ ctiam non affecutis, uoluiffe, abunde pulchrum atç magnificum eft. Certe peculiaris in ftudijs caufa eorum eft, qui difficultatibus uictis, utilitatem iutrandi prattulerunt gratix placêdi. Quíd uerô laudabilius ex omni humanitatis ftudio quàm fufcipere tam liberale tamq́ uand uetuftatis, uel ab interitu potius uendicand $x, \&$ nomina rebus, $\&$ res nominibus reddendi Magna debetur gratia ïs qui úas publicas curant, fternunt, muniunt, repurgant, aperiunt, compla= nant, explent, dirigunt, ut faciles uiatoribus, iumentis \& curribus fint, ac fine impedimentis fine pe riculo perägantur:etfi inon omnia illi impedimenta, fed maiora tantum fuftulerint. Nec parum in re literaria merentur, qui Opus aliquod publice utilitatis ergô fufceptum ita excolunt, ut reliquis in eodem argumento nihil aut minimum difficultatis in poiterum fit futurum. Quod egoficirca infti. tutum meum, ut uolebam furm confequutus, ualde gaudeo: fin minus, aliquid eft magnam me par: tem praftitiffe, ut non magno negotio excitatià nobis homines doci quod reliquum eft aliquando abfoluant. Fauete igitur optimi \& aquiffimi Lectores Operilaboriofo, honefto, iucundo, utili, uario: \& Deo opt. max. gratias agite, \& orate ut fi diutius in hac mortali uita degen dũ fit, quoniam otiari non prodeft, in natura potius indagatione $\&$ operum Dei ac patris noftrigrata celebratione,

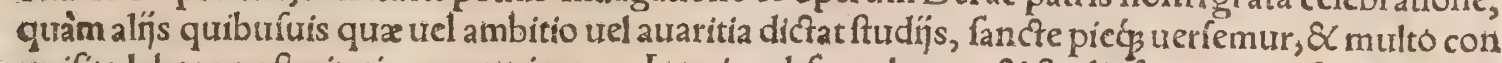
quifita labore pofteritati communicemus, Interim obfecro bonos \& ftudiofos omnes, fi qui habue. rint quicquam quod ad huius Operis perfectionem momenti aliquid afferre poffit, ut funt, cuiufuis generis animalium imagines, aut hiftoria, hoc eft quicquid ad earum naturam plenius cognofcen= dam facit:aut reprehenfiones corum in quibus nos hallucinati fumus, qux certe multa elle, qui ho. mo fim, non dubito, ingenuè $\&$ candidè nobifcum ut communicent, \& tanquam publicum Opus ac in medio pofitum illuftrent: quares $\&$ ipfis glorio $a, \&$ mihi iucunda, 8 hominibus ftudiofis per. petuo utilis eft futura . Certe Operis egregị, quantulumcunģ iutreris, participem fuiffe, in gloria ducetur. Ego etfi in pauciffimis uel una tantum in re, aut admonitus de errore, fuero, candide mox êtnendabo: aut aliquíd noui edoctus, adịciam, fiue ad fecũdum de reliquis animalibus Tomum, fiue feorfim in Appendice + Et ne ingratus in illos uidear qui aliquid contulerint, præter amorem quo il= los perpetuó profequar, fi aliud nihil ( ut tenuis eft fortuna noftra) beneficí in eos referre dabitur, candida faltem commemoratione nominibus ipforum in catalogo illorum per quos profeci enume: ratis, animum meum declarabo. Quòd fi qui uel deftituti occafione ad nos fcribendi mittendiure aliz quid, aut alia caufa affectúue impulfi, publicè etiam errata aliqua noftra caftigare uoluerint, quod fcio multos facere poffe grauter fimul $\&$ docie, at $\$$ ut faciant opto, illis quoc gratias habebo, hoc unum oro, ut candidè $8<$ modefte fcribant, quicquíd aduerfum me fcribere uilưm fuerit, atçs ita ut rempub.literariam promouendi magis, quám uel fuam ambiendi gloriam, uè nos reprehendendi caufa id feciffe, ut uiros decet magnanimos, uerè uideantur, Ego omnino ex qutorumuis iuftis cafti: gationibus mea emendare, nec fua laude quenquam priuare paratus fum. Spero enim, abfit inui: dia, ad omnem polteritatem duraturum hunc laborem noftrum, non quidem doctrinæ noftr $x$, qux exigua eft, fed diligentiæ merito, quæ tot tantaś́plucubrationes ex innumeris authoribus in unum! quafi thefaurum accuratiffimé coniunxit. Valete. 


\title{
DE CVRA ET PROVIDENTIA QVA
}

DEVS BESTIAS RATIONIS EXPERTES

dignatur $\&$ profequitur, locus lectu dignifl=

mus ex Iobi capitibus $38.83 \%$

Cap. 38: NVm tutrenaberis L E O N I pradam, \& paftum catulis eius fuppeditabis? Quis c o $R$ V 0 1 de cibo prof picit, cum pulli eius famelici ad Deum clamantes oberrant?

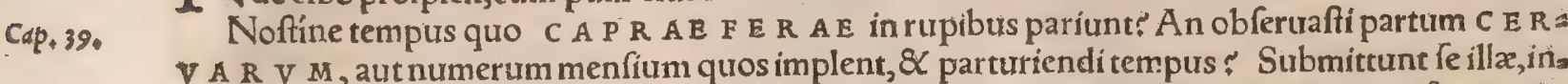
curuatæós foetum magnis doloribus æedunt. Tum hinnuli adolefcunt, 8 pabubo iam confirmati re. licta matre non redeunt. Quis A $S$ IN V M fylueftrem(pere)liberum dimifit, aut quis O N A G R I (arud, Hebrei tum pere tum arud a finum ferum interpretantur) uincula foluit? Ego domicilium eius in folitudine po= fui, \& cubile in loco fterili. Itaç ridet turbam oppidanam, nec audit clamores agafonis, Pafcua fibi in montibus difquirit, \& firpes omnegenus uirentes fectatur. Volétne M ONOC E R O $S$ tibi feruire, aut morari ad prafepe tuũ? An loro ipfum uíncies, ut fequendo te fulcos aratro imprimere, aut glebas frangere uelit? Aufisne illi credere, tantoós robore praftanti tưm permittere laborem? Sperabísne meffem tuam ab eo conuehendã, ut condatur in horreum? En pulcherrimas $S$ T R V T H I O N I $S$ (pauonis fecundum alios, aut galli fyimeftris)alas, quantũ fuperant pennas, $\&$ alas C I C O N I AE: (Quidam uertit: An [dedfiii] alas plaufibiles pauonibus, aut pennas ciconia o plumas?) Sed deferit in terra oua fua, ut in pul uere foureantur:nec cogitat pedibus ea diffipari, $\&$ à beftïs conculcari poffe. Ita immitis eft in pullos fuos, ac fi fui non effent: $S C$ ita pro eis folicita nó eft, ut peperiffe fruftra uideatur. Nullam enim men tem aut intelleçum diuinitus accepit. Quo tempore uerò fublimis euolat, ridet equũ fimul $\&$ equir tem. Túne E QV O dabis ut generofus $\&$ bellator fit? $u t$ alta ceruice ferociat, $\&$ hinnitum ædat? An fperes te illum excitare aut terrere poffe inftar locufta? A tqui nares eius ferociam fpirant:calcibus folum fodicat, \& fortiturdine fua fuperbus armatis occurrit. Metum omnem contemnit, nõ fran gitur animo, non expauefcit micantem gladium. Non pharetra fonitum, non haftam uibratam, non lanceam aut cufpidem curat. Dumćç fremitus $\&$ tumultus cietur, terram fodit, nec tubæ fono mo.

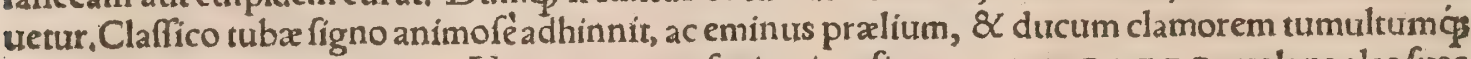
canquam odorans percipit. Num per tuam fapientiam fit, ut A C C I P I T E R uolans alas fuas uentis committat? Tuóne iuffu fublimis A QV I L A fertur, \& nidum in alto ftruit ? Incolic illa (Vultur incolit petras, erc.LXXX. Sed cadaucribus pafci Matthei etiam cap. 14. aquila non uulturi adfcribitur) petras, \& inacceffas rupium ueluti arces: inde fibi de efca prouidet, longe laté́s perfpicacifíma circumfpectans. Pulla eius fanguinem forbent:ipfa cadaueribus ubicungs fuerint, aduolat.

\section{DE FRVCTV EX ANIMALIVM HISTORIA}

\author{
PERCIPIENDO, EX THEODORI GAZAE
} prafatione in conuerfionem fuam Ariftotelis

de animalibus librorum.

Phyficus quo= Mnis philofophandi ratio naturalis, ubi à primis illis naturæ inithis, materiam dico, formam, modoucrfetur finem, agens, \& motum(ut ita loquar)emerferit, hic uerfatur, ac diutiffime immoratur, hic fuas in biforia anie uires exercet; atç multiplicem, uariam, $\&$ admirabilem rerum conftitutionem ampliffime explicat, malium, $\odot$ in Perfequitur ordine difcrimina omnia, quibus natura fuas animantes differre inter $f e$ uoluit; colligit quem finem. fumma genera, reliqua figillatim exponit: partitur in fpecies genera; \& fingula, qua circiter quin $\Rightarrow$ genta numero in his continentur libris, defcribıt:pergit quạ̧ explanans, quemadmodum oriâtur, fire terreftria, fiue aquaticatquibus nam conftent membris, quibus uefcantur alimentis, quibus affi. ciantur rebus; quibus moribus prædita fint, quantum uiuendi fpacium datum cuiç, eft, quanta cor poris magnitudo, quod maximum, quod mínimum eft : qux forma, quis color, qua uox, qux inge nia, quæ officia:deniqg nihil cmittit, quod in animalium genere natura gignat, alat, augeat, $\&$ tuéa= tur. Quæ omnia eó fpeçant, ut, quod fanctiffimus quǫ̧ author ille, quem deus fibi ueluti fuppelle ctilem quandam preciofam elegerat, admonet, ex îs, quæà natura proueniunt, deum immortalem, ex quo ipfa pendet natura, intelligamus, admiremur, atç colamus:qua re nihil pulchrius, nihil graa Minutorum ani urius, nihil dignius homini effe poteft. Tantus fructus horum librorum eft. Nec audiendi funt, quil mallum contem inquiút: Multa Ariftoteles de mufca, de apicula, de uermiculo, pauca de deo. Permulta enim de deo platio non per is tractat, qui doctrina rerũ conditarũ exquifitiffma, conditorẽ ipfurm declarat: nec trero mufca, nec nendx. uermiculus omittêdus eft, ubi de naturæ mira folertia agitur. Vt enim artificis curufuris, fic naturę in Caufarü cogni= genium in minutiffimis potius contemplandũ eft. Quinetiam cum rerũ caufas cognofcere pul. caufaru cogni= generrimũ fit (hac enim una cognitione, homo perfici,abfoluíṕp poreft, ur deo immorcali fimilis, quo. bilis. ad eius fieri porelt, euadat) his fané libris plene docemur, cur quæ q’ tes in animalium genere ita fit: planéǵg felicitatem affequimur illam nobiliorem, qux in actione animi confiftic, quam fapiens quog 
poêta prađicans: Felix, inquit, qui rerum pötuít cognof́cere caufas, Quid de anima loquar, dè qua toties publice, pritiatimós difputatur Nufquam fuorum librorum, tam a perte philofophus hic fuam opinionem exponit, quàm in his libris, quid anima fit, undép in corpus recipitur. Ad hac vititus biflo= mores illi, \& uir tutum officia, quibus uirum appellamus bonum, laudéç profequimur, longe mee rie aninalï ą lius hinc accipi poffunt, đa trel àrhetore, quem Graci fophiftam tuocant, uel à pradicatore, nomine mores er uirtis iam trito Latinis auribus, Lis enim fapenumero uita difcrepar à praceptis, $\&$ melius hortantur alios, tum officit. quàm ipfi officio fungantur: ut interdũ fruftra illa uirtutis egregia laus recitata fit, prolixaćç corum praceptio uacet, \& iaceat, cum exempla defiderentur uitæ praceptoris \& authoritas, quam qui re fpicir, facilius $\&$ motretur ad uirtutem, 8 in officio tenetur. At uero in contemplandis animalium moribus exempla fuppetunt omnium officiorum, \& effigies offeruntur uirtutum fumma cum au. thoritate naturæ omnium parentis, non fimulatx, non commentírix, non inconftantes \& labiles: fed uere ingenux atçs perpetux. Quis enim tam peruerfa natura hoftis fui generis eft, quín emen. detur, $\&$ mitigetur, cum nullum animal occidia fui generis beftia uideatur ?Quis tam in parentes im pius, ne cum ciconia auis, aut meropis pietatem erga parentes intelligat, pientior efficiatur Q Quis adeò inhumanus, illiberalisćs eft, quem offifragæ benignitas ín pullos aquilæ non faciat benignio. rem?Quis tam piger, iners, \& fegnis eft, quin excitetur ad uitæ munera, cum formicarum, ato apum labores, atque induftriam intuetur $?$ Quem non pudeat per metum peccare, cum nón folum leonis animum inuictum cogitat, fed etiam reguli auicula, qux cum aquila pugnat, certatćs de imperio? Quis principem bonum non colat atç̧ obferuet, cum fi rex a pũ in itinere aberrauerit, omnes eum inquirere, odor ratú́ fagaci perfequi, donec ínuenerint, cognitum habeat geftari: etiam regem à ple be, cum uolare non poteft, \& fi perierit, omnes difcedere $\%$ Nunquid parum exemplia d boni princi. pis fiue defiderium, fiue obferuantiam datur? Quis princeps non ad clemẽtiam facile inuitetur, cum reges apum armari quidem aculeo, fed eo nūquam utí intelligat? Quæ fídes, quis amor in canibus? Quanta in elephantis manfuetudo? Qux in anfere uerecundia? Quantum ftudium ornatus, ac $p o=$

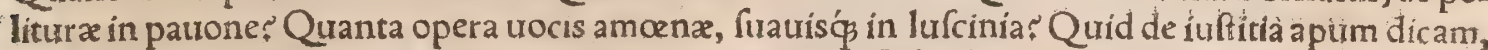
quæ colligunt quidem ex îs, quibus aliquid dulcedinis inef, fed fine ullo fructuũ detrimento: Quid de caftitate elephantis, qui quam impleueric coitu, eam rurfus non tangit? Aut columba, qua neç coire cum pluribus patitur, ne $\beta$ coniugium iam inde à primo or tu initum deferit, nifi uidua, aut coß lebs:Difciplina autem \& eruditio elephanti, quem non faciat fudiofiorem? Omnino nulla pars uitæ humanæe eft, quæ non furorum officiorum exempla commodiffime hine accipiat. Nam, tit omit= Adualetidititents tam artes illiberales, quæ $\&$ ipґ ingenn̆s animaliũ non partum iưuantur, ualetudínis exempla quæ. tuendam. fo unde commodius peti, quàm ex animalibus poffint Loca pro temporis conditione folent illa mut: tare: non plus edunt, aut bibunt, quàm fibi falubre fitt non diutius dormiunt, quâm ratio ualetudi=

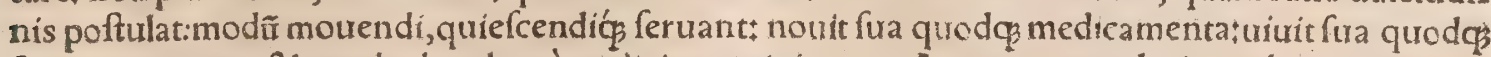
forte contentum, \& gaudet.hac late à medicis pracipiuntur. A tuero exempla, ín quibus tuis maior.

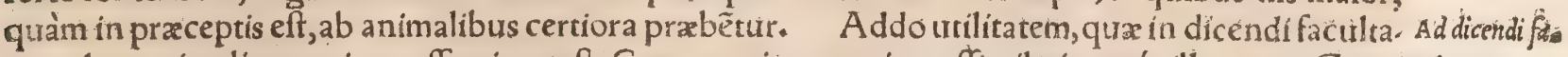
te ex hac animalium ratione afferri poteft. Comparationes enim, affimilarionesćs illæ, quas Græci cultatem. parabolas uocant, quæ plurimum or ationem exornant, auditoremó́s ténent, hinc cuarie, copiofe, ap= tifiméćp accipi poffunt: ut fiue oras, fiute cómunem partiris cum alĭs fermonem, eloquens, aptus,

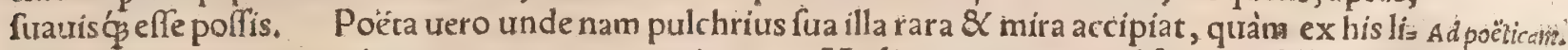
bris, qui natura arcana rimantur, enarrant, aperiunt? Medicus autem, quod fatetur, fe fura inde Adrem medic., ordiri, ubi philofophus definit, nufquam plenius, quàm hic uiderit ₹ quodćç à Galeno medicorum propter ariza principe traditur, A riftotelem primum anatomen, hoc eft, membrorum diffectionem fcripfiffe, hic tomen. agnofcet: $\&$ quod idem \& primus, \& optimus fuerit author, percipiet. Iam \& philofophi noftra Ad prima phys xtatis, qui quadrifariam rerum caufam ex prima illa librorum naturalis aufcultationis inflitutione, fice partizi dé accipiunt quidem communi quadam ratione: fed quemadmodum his natura utatur, in conftitutio= caufis. ne,generationés animalium, parum, authore Ariftotele, uident, inopia fcilicet exemplaris Ariftote lici quod legere poffint, hic uidiffe aliquandogaudebunt, $\&$ Phyfici, quos fe appellant, dignius de cae tero profitebuntur. Rationes enim ideo quærımus uniuerfales, ut demum res particulares, \& fenfï les teneamus. Accedit ad hæc uoluptas, qua iuuari, ac perfici quamuis actionem Ariftoteles ait, volughtus quam in contemplandis rebus naturæ auidiffime capimus. Nam fi pictor nos uehementer oblectat, cum animal frite pinxerit : quanto uehementius natura ipfa afficiet uoluptate, cum eius tam multa $\&$ uaria animalia, mira membrorum conuenientia, inauditaç moderatione \& elegantia facta cerna mus!Cum hos legimus libros, côtemplamur profectò quàm uarius, ac pulcherrimus fructưs horum librorum $\&$ utilitas amplior, quàm ut uerbis exprimi poffit, Hac Theodorus Gaza, 


\section{Catalogi}

\section{CATALOGVS VETERVM}

NON EXTANTIVM, QVI de animalibus fcrípferunt.

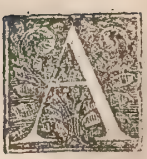

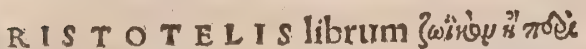
ixtúw, Athenaus alicubi citat, non pe= culiarem ullum puto librũ quo carea. mus intelligens, fed partem aliquam hi ftoria animalium, in qua de pifcibus tractatur. Nam \& libro feptimo Ariftotelis uerba de pifce

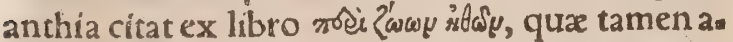
pud A riftotelem leguntur hiftoria animalium li= bro 9. cap +37.quod caput Gaza aut alius Latinè infcripfit de ingenio marinorum $\&$ flutuatilium pifcium pro ratione commodior is uitæ. Circa fi= nem quidem librifeptimi A thenæus, ex Ariftote lis libro quinto hiftorix animalium uerba hac re

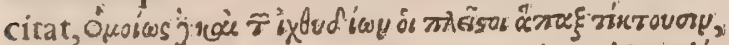

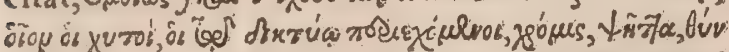
$v \Theta, \& c$. qua uerba eo in libro, capite nono a pud Ariftotelem inuenio, Alibi tamê eodem ín libro: A.then $x u s$ citat Ariftotelis uerba qua legantur

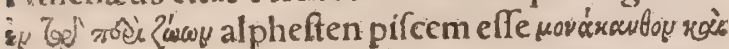

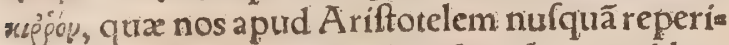
mus, ut fufpicemur quadã ipfius de animalibus fcripta, prafertim de pifcibus, nobis a miffa. Plia nius libro octauo Ariftotelem quinquaginta pra clara uolumina de animalibus condidiffe affir. mat, atqui Theodorus Gaza libros de animalie: bus ocfodecim effe ait, nouem feilicet de hiftoria a nimalium, quatuor de partibus, quínq de gene ratione, his Pliniun libros etiam de anima, 8 par ya naturalia (ut uocant) adnumeraffe apparet. fic enim omnes erũt quinquaginta, Niphus, $\mathrm{Ni}$ candri Scholiaftes in Alexipharmacis in aconiti mêtione, Arriftotelis ex libro decimonono de ani= malibus uerba citat de panthera, quod fumpto $2=$ conito ad excrementum humanum in arbore fu fpenfum à uenatoribus affultando tanquam ad remedium exhaufta tandem extinguatur, Quod Ariftoteles nó alibi quàm nono libro cap, 6. hifto rię animalium refert, quamuis etiam in Mirabilis bus meminerit. Diogenes Laêrtitis author eft fcripfiffe A riforelem, etiam de compolitis anima libus librû unum, item de fabulofis animalibus librum r.\& Anatomicos ocio, \& Selectum anato tomicum unum. hi omnes nobis interciderunt. Cæterum cópofita animalia intellexerim, quę ex parentibus genere aut fpecie diuerfis nafcuntur.

Alexandri Mynd froria iumentorü, memorantur ab Athenæo. $\sigma$ Antipatri librum de animalibus citat Plutar chus in libro de caufis nat. probl. 38 .

Antiphorhetor feripfit de paurnib. A thenęus.

A. Archeftratus de uarịs a nimalibus ad cibum aptis, eorumós ad gulam $\&$ uoluptatem appa ratu carminibus fripfit, quæ perfape recitat Athenaus.

Caclus Argiuus de pifcibus fcripfit carmine, Athenarus.

ब Callifhenis librum ter tium de uenatione citat
Fiutarchus in libro de fluuñs.

T Epicharmus Syracufanus pecudum medicis nas diliyentifímé conforipfir, Columella,

Theonides Byzantius fcripfitt de pifcibus oratio ne foluta, A thenxus.

ब Numenif librum Theriacum citant Scholia in Nicandrum,

đNumenius Heracleotes de pífibus poëma có. didit, Athenaus.

đPetrichi Ophiaca adducit Scholiáftes Nicans dri.

बPancratius Arcas Halieutica reliquit carmine: item Pofidonius Corinthius, A thenæus.

Seleucus. Tarfenfis Halieutica æedidit profa, A. then:us,

đSoltratus feripfit de natura animaliti, ut $\bar{A}$ the næus \& Nicandri Scholiaftes citãt: Eiufdem recundum de uenatione librũ citat Stobrus in Sermone quo Venus uituperatur.

-1 Strato Lampracenus phyficus fripfit de gene ratione animaliũ. item de animalibus, de quis bus dubitatur, $\&$ de fabulofis animalibus, Läértitus.

TTheophraftus: Ereffius (Laêrtio tefte) fcripfit de diuerfitate tiocis animalium eiufdem gene ris lib ${ }_{\star}$. De animalibus qux fapere dicun. tur, unum. De his qua in ficco morantur, duos, De animalibus, feptem. De his qua colores immutant, unum. De his qua lati. bula faciunt, unum. De automatis (fic pu. to uocat, qux non ex coitu, fed ex putredi. ne nafcuntur)animalibus, unum. Compen= dij ex Ariftotele de animalibus libros 6. De animalium prudentia $\&$ moribus, unû. De fructibus $\&$ animalibus uerfus mille centum 8 octogintaduos: Horum nonnullos etiá

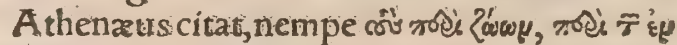

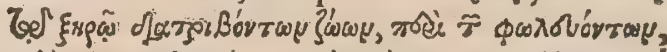

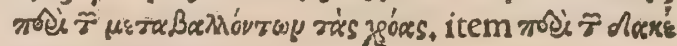

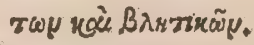

TXenocratis librum de utilitate qua ab anima: libus capitur citat Galenus libro 10,cap, 4 , de fimplicibus.

I Auguftinus Niphuis ín pręfatione commenta. riorum quos in Ariftotelis de animalibus li. bros ędidit, complures alios authores ueteres, quorum libri de animalibus feripti non ex. têt, enumerat, mutuatus ex Indice Plinif qui loco primi libri habetur. Authores enim ali= quot quos octauo pracipuélibro Plinius no. minat, tanquam omnes de animalibus fimpli citer fcripferint à Nipho numerantur, cum il. liobiter tantum in operibus fuis uel res ge. ftas uel rem rufticam continentibus, anima lium quorundam meminerint. Itxba, Hie: ron, Attalus, Philometor \& Archelaus reges de ui naturág animalium diligenter perferi prerunt, Gillius, Ego regum iftorum nomina citari quidem apud Plinium reperio, de ani. malibus uerò ex profefto eos icripfiffe nuffo quam legere memini. Hiero quidem, Philo. metor, Attalus \& Archelaus de cultura agri fcriple. 


\section{Authorim.}

feriperunt, ut refert Plinits 18.3. Iuba uero tum alia, tum de Arabia fiue Arabica expedi tione, codem tefte $6.27 .8 \times 12.14$. in quibus libris multa cos de animalibus feripfiffe cone ijcio, ex profeffo nifquam.

\section{CATALOGVS AVTHO=}

R V M EXTA TIV M, QV O= rum fcriptis ad hoc Opus ufi

fumus.

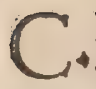
Plinius Secundus in fuo de natura Volure mine authorum quos fequitur nomina, $\&$ paffim adijcere, $\&$ in fronte Operis ad finem ca. pirum cuiufós libri pratexere troluit. Eft enim be nignum (inquit) ut arbitror, \& plenum ingenui pudorís, fateri per quos profeceris. nó ut pleriq̧ exijs, quos attigi, feccrũr. Scito enim conferente me authores, deprehendiffe à iuratiflimis et pro= ximis ucteres tranfcriptos ad uerbum, neç no= minatos. Obnoxij profecto animi, \& infelicis in. gevip eft, deprehendi in furto malle, quàm mus tuum reddere, cum præfertim fors fiat ex ufura: Hac Plinius, quem nos eriam fecuti authorü per quos profecimus caralogum adfcribemus. Enu. incrabuntur autem illi tantum quorum feripta extant nam fi illos etiam nominare uelle $m$, qui ab alijs, prafertim ueteribus citantur, etfi non $\mathrm{fi}_{\mathrm{s}}{ }^{\text {" }}$ ne exemplo id facerem, tamen catalogum nimis augerem, \& hominis ambitiofiac oftentantis fu. fpicionem de me* elinquerem. * Afterifco no rauimus illos, ex quibus omnia qua de animalie bus habebãt defumpfimus, fiure quòd toti de ani. malium hiftoria confcripti effent, fiue multa paf. fim ex inftituto, aut etiam obiter de animalibus paruca continebant:ita ut nihil amplius ad parti= culares animantium fingulortm hiforias $a b$ ịs perendum fit. Nam ex hiftoricis, poétis \& alïs au horibus, non omnia quacungs de animalibus apud cos haberentur excerpfi, quòd id prolixius quàm urilius futurum uideretur, (cum nuhil ferè roui in rebus ipfis apud illos tradatur, fed elocu. tio tantum urarier, ) red ea tantum qua fortuitò fi= ue in ipforum libris, fiue apud grammaticos $\mathrm{Ci}_{3}$ tantes occurrebant. Si qux tamen ad resipfas fa cere iudicabam, ex omni genere authorum ledu lo tranícripfi.

$$
\text { L I B R I H EBRAICI. }
$$

1. T) Vetus Teftamentum cum annotationibus Seb.Munfteri.

2. Eiufdẽ Munfteri Dictionaria, Hebraicola. tinum, 8 quadrilingue.

3. Epiftola presbyteri Ioannis, ut uocant, hoc elt Aethiopiç regis ad Pontificem Rom. de rebus Aethiopicis.

G ARAB I COS, hoc eft ex A rabica lingua tranf: latos, nominabo inferius inter obfcuros.

G R AECI,

4. * Actuarýliber de Serpentibus $\&$ uenenis, breuiter ex Diofcoride contractus eft. 5. * Adamantij Phyfiognomica.

6. A efchyli tragoedia.

7. Aétĭ non omnia fed pleraş euolui $\&$ ex: cerpfi : integrum uerolibrum iz. qui ett de uenenis $\&$ uenenatis animalibus.

8. * Aeliani hiftoria animalium, Petro Gillio in. terprete, cum eiufdem additionibus ex Oppiano, Plutarcho, Porphyrio $\& \mathrm{H}_{\mathrm{e}}=$ liodoro, ut libri titulus habet. Sic autem Aclianiomnia adicefa funt, ur nihil ad rem pertinens omitteretur. nam fi quan do filus luxuriari uidebatur, \& leuirer euagari, aut hominem cum brutis confe rendo reprehendere, (quod f̧̨pius facir, ut qui profelfione rhetor fuerit) plerụ̂ contraximus.

* Eiufdem uaria hiftorix libri i 4 .

* Eiufdem de ínftruendis aciebus liber.

9. * Alexandri Magni epiftola ad Ariftotelem de rebus Indicis Cornelio Nepote in terprete.

10. * Alexandri A phrodifienfis problematum li. bri 2.

11. Alexander Trallianus medicus.

12. Ammonius de differentís uocum.

13. * Annonis Pcriplus.

14. Apollonï Argonautica,cum Scholins.

15. Apofrolin Byzantí paræmix.

16. Appianus tiftoricus,

17. Aratus, cum Scholijs.

18. Ariftides rhetor.

19. Ariftophanis comcedix, cum Scholihs.

20. Ariftotelis hibri integri, quod particulares hiftorias atrinet, * Dehiftoria, degene. ratione $\&$ de pariburs animalium. Phy. fiognomica, De mirabilibus. De colori= bus. Parua naturalia, ut uocant. Proble mata.In cateris libris, aut nullum aut ra riffimum ullius animants nomen $0 c$ : curret.

21. Michaëlis Echefï Scholia in libros de gene ratione, qux loannis Philoponi nomine publicata funt. Niphus foribit Michaë: lis Ephefin Scholia in libros de genera= tione extare, expofitionem non extare.

22. * Arriani Periplus Euxini Ponti.

* Eiufdem Periplus rubri maris.

Eiufdem de rebus geftis Alexandri hiftorię.

* Eiufdem Indica.

23. * Athenai Dipnofophifta.

24. Biblia facra, hoc eft Vetus \& Nourum Tefta mentum Grace.

25 Callimachi poémata quadam.

26. C1. Galenilibrit alij quidem multi fparfimà nobis cogníti i integri ueró propter anis malium hiftor iam qui fequintur.

* Libri de fimpliciũ facultacibus. De anti* dotis. De iheriaca ad Pifonem. Deci bis boni $\&$ malifurri. De alimentoru facultatibus terrius. De parabilibus lia bri tres, quorü primus incipir, Cum ars 


\section{Catalogi}

medica circa nullas unquam urbes. Secundus, ad Solonem, acephalus. Ter. tius Galeno adfcriptus, incipit : De gur. gulionis uitñs.

17. Diodorus Sículus hiftoricus.

18. Diogenes Laértius de uitis philofophorũ.

29. Dion hiftoricus.

30. Dionyfius Afer defitu orbis, et Euftathius interpres.

$3^{1+}$ * Diofcorides.

32. Epigrammatum Gracorum authores di. uerfi.

33. Epiftolarum Græcarum authores diuerfi, quos Aldus olim uno uolumine con. iunxit.

34. Etymologicon.

35. Euripidis tragcedix.

36. Euftathius in priores quing Iliadis libros.

37. * Geoponicorum, id eft de re ruftica ad Con. ftantinum Cafarem librorum authores diuerfi.

38. * Hcliodori Aethiopica hiftorięlibri decem.

39. * Heraclidis defcriptiones rerumpub.

40. Herodoti hiftorix.

41. Hefiodi poëmata, cum Scholins.

42. * Hefychí Lexicon.

43. * Hippiatri Græci, Ablyrtus, Hierocles, Pee lagonius 8 alị uno uolumine coniûcti.

44. Hippocrates, præcipuèlibri de natura mu= liebri, de morbis muliebribus, de internis affectionibus.

45. Homerus, cum Scholijs.

46. Iofephus.

47. Ioannis Tzetzx uaria hiftoria.

48. *Iulius Pollux.

49. Lucianus,

5e. Lycophron cum Scholiafte.

51. * Nicãdri Theriaca \& Alexipharmaca, cum Scholg's.

52. Nicolai Myrepfi medicamenta compofita fe cundum genera, Leonharto Fuchfio in. terprete.

53.* Oppiani libri de pifcibus, 8 de uenatione.

* In eiufdem libros de aucupio para phrafis,

$54 . *$ Orpheus.

$55^{*}$ Ori uel Hori Hieroglyphica.

56. $*$ Palxphatus de fabulis.

57. Paulus Alegineta medicus.

Succidanea cum eiufdem, \& cum Galenio: peribus coniungi folita,

58. Paufanix libri de regionibus Græcix.

59. Philes qui de animalibus fenarios iambicos condidit, omnia ab Aeliano mutuatus.

60. Philoftratilcones.

*Eutdem libri de uita Apollonï.

$61 *$ Phurnutus de dijs.

62. Pindarus, cum Scholins.

63. Plato.

64. Plutarchi uirę, et alij uarí libelli:integri uerò,

* Vtrum terreftria aut aquatilia animalia fint fapientiora.

* Gryllus, uel quod bruta ratione utantur.
* Liber de Ifide 2 Ofiride.

*Caufa naturales.

65 . Polyani ftrategemata.

66. Polybius hiftoricus.

67.Procopius Gazaus fophifta in octateuchum ueteris Teftamenti.

68. Q. Calaber poëta.

69. Theophraftiopera.

70. Theocritus.

71. Xenophontis opera diuerfa.

*De uenatione.

* De re equeftri.

* Hipparchicus.

\section{IATINIA T T H RES Veteres。}

72. Āel. Lampridus,

73. Ael.Spartianus,

74. Alb, Tíbullus.

75. Ammianus Marcellinus.

76. Aulus Gellius.

77. Aulus Perfius

78. Aur, Cornelius Celfus.

79. $*$ Cal. A picius dere culinaria.

8o, C. Iul, Caíar.

81. C.Iulius Solinus.

81. *C.Plinï Secundi Hiftoria mund.

83. C.Suetonius Tranquillus.

84. C.Val.Catullus.

85. Decius Aufonius,

86. Fl. Vegetius Renatus de remilitari,

* Eiufdem Mulomedicina.

87. Fl. Vopif́cus hiftoricus,

88. Gratí liber de uenatione.

89. Iul. Capitolinus hiftoricus.

90. Iunius lutrenalis poêta Satyricus.

91. L.Annaus Seneca.

92. L.Apuleius.

93. L. Iunius Moderatus Columella de re ruft. 8 hortenfi.

94. Macrobius Ambrofius Aur.

95. * Marcellus medicus Empiricus, quem fim: pliciter Marcelli nomine citato inter re. media ex animalibus intelligi uolo, non Marcellum Vergilium illum noftri fecu li qui Diofcoridem tranftulit, \& annota mentis illuftrauit.

96. M.Actius Plautus Comicus.

97. M.AnneiLucani Pharfalia.

98. M.Aur elí Olympí Nemefiani poétze deue natione liber.

99. M.Cato de reruft.

100. M.Manilị Aftronomicôn libri.

101. * M. Terentius Varro de reruft.

* Idem de lingua Lat.

102. M.Valerï Martialis epigrammata,

103. M. Vitrutuius de architectura.

104. Nonius Marcellus delingua Lat.

105. Palladius de reruft.

106. Pomponius Mela.

107. P. Vergilï Maronis Bucolica \& Aeneis.

*Eiul 


\section{Authorum.}

* Eiufdem Georgica:

iv8. P. Ouidij opera.

* Eidem falfo adfcripta, Philomela de uoci" bus animalium, $\mathbb{Q} \mathrm{Pulex}$.

* Eiufdem Halieutica.

1og. Quintus Horatius Flaccus.

$110_{+}^{*} \mathrm{Q}$. Serenus Samonicus.

11. Seruius in Vergilium.

112. * Sextus Platonicus de remedins ex animalib.

113. Sexti Aurelij Propertí Elegix.

11. Sextus Pompeius Fefus de lingua Lat,

115. Sexti Iulï Frontini Strategemata.

116. Silius Italícus poéta.

1: Statius Papinius Neapol.poéta.

18. Titi Calphurnị Siculi Bucolica

119. T.Liuius hiftoricus,

120. Valerius Maximus,

IIBRI LA TINE QVIDEM EDITI, fed admodum impuré, ut ex Arabica lingua con uerfi plerig fuperioribus feculis, \& illorum qui tales authores imitantur: in quibus frequentifa

fima etiam circa res ipfas errata funt, par: tim authorum, partim inter. pretum imperitia.

121. Aefculapius nefcio quris, ex animalibus re: media defcripfit, quę pleraçs eadẽ apud Sextum Platonicum reperio.

122. *Alberti Magni de animalib.libri, innumeris errorib, inquiriati, ita ut Niphus totide ferè errores ineffe fcribat quot uerba.

123. A lexander quidã author obícurus, ab alịps eiufdem farinæ authoribus citatur, ipfe non uidi; ut \& Rodolphus in Leuiticũ.

124. Arnoldus de Villa nour, in ịs qua de ani= malibus fcribit, ut in libro de theriaca, Arabum eorúmue interpretum tum no= mina tum errores fequitur.

125. *Bartolemai Anglici de proprietatibus rer libri 19.

126. Auerrois libros Āriftotelis de generatione $\&$ de partibus paraphraftice reddidit, $l i$ cet meo iudicio perperã interpretet, $\mathrm{N} i=$ phus, Ego cum ex his foriptis nihil egre. gi) fperarem, necs apud nos reperirem; accerfere nolui, ut necs Auicenna de a. nimalibus libros, in quibus pleracs om= nia Ariftotelis effe puto $\& \&$ fi quid pra $=$ ter illa adiectũ eft, in Alberti lucubratio nibus, (quibus nos ufi fumus,) cótíneri.

157. *Auicennx opera medica. De eíufdem li. bris animalium in Alberti Magni men. tione iam dixi.

128. Elluchafem Elimichar medici de Baldath Tacuini.

129. *Ferdinandus à Ponzeto cardinalis, de ue. nenis.

130. ${ }^{*}$ Iacobus Dondus Patauinus; quem uulgó Aggregatorem uocant.

131. Iorachi cuiurdã liber de animalib, ab Àlber to Magno fape citatur, ( $\mathcal{X}$ ab alijs obfcu ris.) ait autê eû trequrenter falfa fcribere.

132. Kiranides etiam nefcio quís ab Aggregató re \& alijs recentiotibus, in remeớtís pras cipue $\mathrm{ex}$ animalibus fubinde citattr.

133. * Matthæi Syluatici Pandectæ inedicinales.

134. R. Mores.

135. * Petrus Aponenfis de uenenis.

136. * Rafis in libro de fexaginta animal ibus.

137. Semeryon uel Haren Semeryon; ab Alber. to Magno in hiftoria animaliư frequen 138. Serapio, (ter citatur.

139. Vincentï Belluacenfis de animalibus libr 7.nempe decimusfeptimus Speculina= turalis cum fex fequentibus. Speculi do cfrinalis etiam libro decimofexto rurfus de ñfdem breuiter agic.

140, Liber de natura rerum authoris innomina. ti, paffim apud recentiores illos quorum impurus fermo Latinus eft citatur, Vin: centium, n̂lbertum: ex quibits nos om. nia qua non prorfurs abfurda erant mu* tuati fumus,

141. Andreæ Bellunenfis Gloffemata in Auicen nam, utilia fané $\&$ erudita, quãuis dictio nis nõadmodữ puræe. fuit enim lingua Árabicę peritus, ita ut orthographię ctiấ friptarum ab co dictionum maior fit ha benda fides, quàm ab alins quorum plè riçs mífere illam corruperunt.

142. Laürentius Rufius Hippiatrica peritiffime fcripfit, quanquam ftilo nố fatis Latino.

143. Ifidorus Etymologici futi libro 12, de anima. libus quadam foripfit non inutilia, me= retur autem medium ferèlocum, ni fals lor, inter clafficos 8 barbaros authores.

144. ut \&Monachi illi quorum commentarij in Meíuen ante annos circiter offo $V e$ : netijs excufi funt.

145. Eiufdem ordinis fuerint 8 Petri Crefcen. tienfis de re ruft, libri.

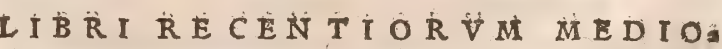
cri aut etiam egregio ftilo Latine editi, quorim authores aut noftra memoria uixerunt uel etiami num uiuunt, aut paucis ante noftram me, moriam annis e uita ex= cefferunt

146. * Ánex Syluỉ Árix \& Europa defcriptio. 147. * Alexandri ab Alexãdris 1.C.Neapol.Dies geniales.

148. Alexandri Benèdichi Veroneñ. de morbis curandis opus.

149. *Aloiff Cadamufti naúigatio.

150.*Aloifij Mundellæ epiftolæe medicitiales:

151. * Americi Véputij naulgationes;

152.* Andrex Alciati Emblemata,

153. * Andrex Vefalí opus Anatomicitim,

154. *Angeli Politiani opera:

$155 .{ }^{*}$ Antoni Murx Brafauoli libri de mè dicàa mentis ufitatis fimplicibus $\&$ cópofitis.

ig6: Antonius Thylefius: 
157. * A ugurfini Niphi commentarī in libros $\mathrm{A}=$ riftotelis de animalium hiftoria, genera, tione, $\&$ partibus.

* Eiurdem de augurn̈s liber.

158. * Baptifta Fieræ Mantuani cona.

159. Baptifta Platinæ Cremonenfis de honefta uoluptate \& ualecudine libri.

160. Baffianus Landus Placentinus de humana hiftoria.

161. * Belifarius Aquiuiuus Aragoneus Neritinorum dux de uenatione, ex Oppiano

* Eiufdem de aucupio liber. (ferè.

161. * Brocardus monachus de Terra fancta.

163. * Calń Calcagnini opera.

164.*Calif Rhodigini Antiquarum lectionum uolumen:quod frequentiffime in Opere noftro Calin fimpliciter nomine citatur.

165. Calius Aurelianus Siccenfis, (hic pertinet ad ordinem ueterum.)

166.* Calî Secundi Curionis Āraneus.

167. * Caroli Figuli dialogi, alter de muftelis,alter de pifcibus in Morella Aufonク̈.

168. * Caroli Stephani fcripta de uocabulis rei hortenfis, Seminarï \& Vineti.

$169 . *$ Chriftophori Columbi Naúgatio.

$170,{ }^{*}$ Chriftophori Orefcí Hifpani Annotatio nes in Aëtium \& eius interpretes.

171. * Defiderij Erafmi Rotopera.

* Eiufdem Chiliades adagiorum.

172. * Erafmus Stella de Boruffix antiquitatibus .

173. * Francifci Marí Grapaldi Parmenfis de par tibus redium libri 2. Tractat autem de animalibus librí primi capitibus, 6.7 .8 .9

174. * Francifci Maffarĭ Veneti in nonum Pliní de naturali hiftoria Caftigationes $\&$ An notationes.

875. Francifci Nigri Baffianatis Rhætia.

176. Francifcus Robortellus Vtinenfis.

177. Gabrielis Humelbergi̋ commentarị in $\mathrm{Sa}$ monicum, in Sextum demedicinis ani= malium, $\&$ in A picium.

178. Gafparis Heldelini ciconiz encomium.

179.* Georgn̈ Agricolæ libri de metallis.De pon deribus $\&$ menfuris.

* Eiurdem liber de animãtibus fubterraneis.

180. * Georgí Alexandrini prifcarum apud aus thores rei ruftica enarratio.

181. Guilielmi Budxi Commentarn̈ lingux Græcx.

*Eiufdem Philologia.

182. * Gul. Philandri Caftilionij Galli in Vitru. urum annotationes.

183. * Guilielmi Turneri Angli liber de auibus. $184^{*}$ * Gyberri Longolī dialogus de auibus.

185 * Hermolai Barbari Caftigationes in Plinit.

*Corollarium in Diofcoridem, * Phyfica.

186. * Hieronymi Cardani de fubtilítate libri.

187. * Hieronymi Vidæ poëma de bombycibus.

188. * Iacobi Syluin libri de medicamentis fimpli= cibus deligendis $\&$ præparandis.

189. * Iani Cornarí Annotationes in Galenũ de comp.pharm, fecíndum locos.
190. * Ioachimi Camerarï Hippocomus, Rheto. rica.

191. * Ioachimi Vadiani Commẽtarī in Melam. 192. * Io.Agricolx Ammonij de fimplicibus mea dicamentis libri 2

193. * Io، Boémus Aubanus de moribus omnium gentium.

194. Io. Brodxi annotationes in epigrammata Graca.

195. * Io. Fernelius Ambianus de abditis rerum caufis.

196. Io.Kufnerus medicus Germanus,

197. Io, Iouinianus Pontanus.

198. * Io. Manardi Ferrarienfis epiftolx medict nales.

$1999^{*}$ Io, Raurify Textoris Officina.

$200 *{ }^{*}$ Io. Ruellí hiftoria plantarum.

201. Io. Vrfini profopopocia animalium carmis ne, cum annotationibus Iac, Oliuarij.

202. *Iodoci V uillichï Annotationes in Georgi ca Vergilin.

203. *Iulianus Aurelius Leffignienfis de cognoe minibus deorum gentilium.

204. * Lazarus Bayfius de re ueftiaria, de renau. tica, de uafculis.

205. Leonelli Fatuentini de Vicforïs, de meden dis morbis liber.

206 * Lilij Gregorị Gyraldi Syntagmata de dịjs.

207. *Ludouici V artomãni Romani patritri Nas uigationum libri V II.

108. *Marcelli Vergilip in Diofcoridem Annos tiones.

209. * MarciPauli Veneti de regionibus Oriet tislibriz.

110* Matthias à Michou de Sarmatia Afíana at. que Europæa.

211. Medicorum recẽtiorum cum aliorum tum qui parum Latíné de curãdis morbis fin gulatim foripferunt libri diuerfi.

212. * Michaël Angelus Blondus de canibus 82 uenatione.

113. * NicolaíErythrai Index in Vergilíum.

114. Nicolai Leoniceni opera.

215. * Nicolai Leonici Thomai Varia hiftoria.

216. Nicolai Perotri Sipontíni Cornucopiz.

217. Othonis Brunfelf́ Pandectx medicinales.

218. * Parrlus lourius de pífcibus.

219. * Idem de Mofchouitarum legation:

220 *Petrus Crinitus,

211.* Petri Galliffardi Araquaí pulícís Enco. mium.

212. *Petri Gyllï Galli Additiones ad A elianili. bros de animalibus à fe translatos.

* Eiufdem liber de Gallicis nominibus pí frium.

123. *Petri Martyris Oceanex decades, de nauiga tionibus noui Orbis.

124. *Philippi Beroaldi Annotationes in Colu. mellam.

225. Pinzoni nauigationes: \& Magellaniad in fulas Moluchas.

226. *Polydorus Vergilius de Anglia, 


\section{Authorum.}

*Idem de rerum inurentoribus,

227.*Raph. Volaterranus,

228. $*$ Robertus $C e n a l i s$ de ponderibus $\&$ men= furis.

229.*Roberti Stephani Appendix ad Dictiona. rium Gallicolatinum.

$23^{\circ}$ * Scribonius Largus *

231. * Sebaftiani Munfteri Cofmographia uni= uerfalis.

232. *Sebaftiani Sigmarỉ cicadx Encomium.

233. Strozí poêtæx, pater \& filius.

234. Theodofitus Trebellius Foroiulienfis, con= cinnator Dictionarí quod Promptuas rium infcripfit.

235. *Valerius Cordus de medicamentis compo= fitis apud Pharmacopolas ufitatis .

G E R M A N I C I.

236. Balthafaris Steindel Dillingenfis Opfarty: tica.

237. Eberhardus Tappius Lunë̈lis de accipitrib.

* Eiufdem prouerbia Germanica cum Latí nis \& Græcis collata.

238. *Hieronymi Tragi hiftoría plantarium,

239. Ioannis Elię fcripta de uocabulis uenatorñs in libro eius de fcientia fribarum publi corum,

240, *Io.Stumpfin Chronica Heluetix.

241. *Michaél Herus de quadrupedibus.

242. Olai Magni tabula \& libellus de infulis $\&$ regionibus Oceani Septentrionalis Eu. ropxi.

243. Varï libelli Hippiatrici, Medicinales, et alï; partim excufi, partim manufcriptí.

\section{T I I C I}

144. Francífci Älunni(nó Ảrlưnni, ut fape fcri pfimus in hoc Opere) Ferrarienfis $\mathrm{Fa}$. brica mundi.

245: Petrí Andrex Matthxoli Senenfis cổmen: tarî in Diofcoridem.

246. Terr $x$ fanctx defcriptio authoris innomi. nati.

GALICE

247. Gulielmus Tardiuus de accipitribus 8 cà nibus uenaticis.

248. Ȧndrea Furnerī liber de decoratione hư manx natura.

249. Io. Goeurotus, de Conferuatione uita.

250. TThomæ Eliota Díctionarium Anglicola. tinum.

251. Sigímundi Gelenğ Lexicon fymphonũ La tinæ, Gracæ, Germanicæ \& lllyrica lin. guarum,
CATALOGVS DOCTO

R V M VIROR VM, QVI VT OPVS hoc noftrum $\&$ rempub.literariam illuftrarent; trel aliunde imagines animalium, aut nomina $\&$ defcriptiones miferunt; uel præfentes communi= carunt, Herũ nonnulli fuperius quoọ no. minati funt, quòd infuper fcriptis corum publicatis adiu= tus firin.

A Chilles P.Gaffarus medicus Germanus, Alexander Peiner Scaphufianus.

Aloifius Mundella Brixienfís medicus,

Andreas Martinus Roftochienfis.

Äntonius Eparchus Corcyræus, Græè língü profeffor Venetris.

Antonius Mufa Brafauolus illuftriffimi Ferra riæ ducis Herculis Eftenfis archiatros.

Ȧntonitis Stuppa Rhrtus.

Arnoldus Peraxylus Arlenius Germanưs.

Bartolemaeus à Caftromuro canonicus Cutrièn: fis in Rhatia.

Calíus Secundius Curro Italuss.

Calius Sozinus Senenfis.

Cafpar Hedio ecclefiaftes Ärgentinenfis.

Chriftophorus Clauferus Tigurinus archiatros, Cornelius Sittardus medicus Germanus,

Dominicus Monthefaurus medicus Veronêfis, Florianus Surz Rolitz à Varíhauia, Polonus.

Francifcus Belinchettus mercator Bergomenfis، Ge. Agricolla conful Kempnícin.

Ge. Fabricius poéta, Scholæe rector Mî́ienx.

Gisbertus Horftius Ämfterodam medicus Ro: Gregorius Mangolt Conftantienfis, $\quad\left(\mathrm{mx}_{*}\right.$ Guilielmus Gratarolus Bergomenfis; medicus. Gurilielmus Turnerus Ànglus medicus.

Henricius Stẹphanus Robertifílius, Pàrifienfís.

Hieronymus Fracaftoritus Veronenfis medicus. Hieronymus Frobenius Bafiliêfis typographus, Hieronymus Tragus Germantis

Io. Altus Heffus.

Io.Culmannus Goppingenfis.

Io. Dernifchwa mermanus,

Io, Eft wycus Ànglùs,

Io. Falconerus medicus Ànglus.

Io. Kentmannus Dréfdenfis medicuss.

Io.Oporinus Bafilienfis typographus,

Io. Ribittus facrarum literarum interprès Lâü. fannaz.

Iuftinus Goblerus İ C. \&̀ principi Naffatiènfià confilin's.

Lucas Gynus medicus Italuis,

Michaél Alyfius Gallus Trecenfis medicus,

Nicolaus Gerbelius Phorcenfis I. C.

Petrus Dafypodius Græcarum literaruini profer for Argentorati, præceptor meus.

Petrus Gyillius Galluss.

Petrus Merbelius Germanus, Carolo vi a à confí lips Médiolani.

Petrus de Mérnil Gallus.

Petrus Paulus Vergerius, olim epifcopus Iuftim inopolitanus: 
Sebaftianus Munfterus Hebraica lingua profef for Bafilex.

Sigifmundus Gelenius Bohemus.

Simon Lithonius Valefius.

Theodorus Bibliander facrarum literarum apud nos proferfor.

Thomas Gybfon Anglus, medicus.

Valentinus Grauius uir docqus \& fenator Mi. fenar.

Vincentius Valgrifius Germanus, typographus Venetïs,
đLucas Schân piçor A rgentoratenlis aures plurimas aduiuum nobis expreffit, $\&$ quaruma dam hiftorias quoç addidit, uir piciura firnul $\& C$ aucupin peritus.

of Hi ferè funt quorum diligentix beneuolen tiæćs erga me pariter $\&$ bonas literas, tü ipfe plu. rimum debeo, tum omnis fudiofort pofteritas debitura eft. Quòd fi forte alicuius per quẽ pro= feci nomen in præfentia præterij, id ille obliuion: potius 8 extemporanex fcriptioni, quàm ingra titudini ut adfcribat etiam atø̧ etiam oro.

\section{ORDINIS RATIO, QVEM PER SIN GVLAS FERE ANIMALIVM HISTO. rias fecuti fumus,}

DE PICTVRIS ANIMAIIVM in hoc Opere.

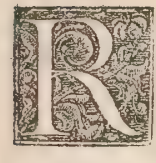

O A A I imperï principes olim adhuc maxima orbis terrartum partis domini, multa pe. regrina fubinde animalia populo fpectanda offerebant, ut ita illius animos fibi deuincire $t_{*}$ Atqui illa non nifi breui tempore, quo fcilicet durabant fpectacula, infpici et confiderari poterant. Noftræuero icones, quas omnes ad uiuum fieri aut ipfe curaui, aut ab amicis fide dignis ita factas accepi, (nifi aliter admonuerim, quod rarum eft,) quouis tempore $\&$ perpetuo fe fpectandas uolentibus, $a b f q$ labore, $a b f q \beta$ periculo, offerẽt. Nam animalia quædam uiua, propter periculum ex crudelitate ipforum aut ui ueneni, quis comminus infpicere fuftineat? ut fauos leo. nes, urfos immanes, crudeliffimas tigres, rabidas pantheras, infeftiffimos crocodilos, $\mathcal{Q}$ in marica. nes, filuros, lamias, cete:deniç uenenata uiperarum, afpidum, chelydrorum, et alia ferpentium fera= rumós genera, qua uel folo atpectu, cornibus, riçu, dentibus, unguibus, calcibus, aut aliter uulnera \& mortes minitantia, protinus homini fe inimica declarant. Atqui eadem picta non modo fine terro re, trerum $\&$ iucundé fpectamus: $\&$ tanto maiori quàm innoxias animantes uoltuptate, quanto mi= ners uiua accuratè $\&$ de proximo infpicere fuftinemus : Cuius rei caufam Ariftoteles etiam in pros blematis inquirit. Optaffem equidem cum fuis coloribus excudi potuiffe effigies: quod quoniam fieri non potuit, typogra phus pro ịs qui fumptum facere aliquanto maiorem non recufabunt, exem plaria aliquot pictoris manu coloribus illuftranda ad archetypum noftrum curauit. Minora ani malia, inter aues, pifces, \& infecta pracipue, ea qua uiuunt magnitudine plerun $q$ expreffa funt, fi It bri uel chartæe fpatium admittebat, Maiora uero neceffario imminuta funt ¿ quod fi non fatis certa proportione inter ea feruata ubíģ facta eft imminutio illa, excufare me poterit, partim pictorum di= uerfitas quibus ufifumus, id $\not$ diuerfis temporibus $\&$ locisłpartim occupationes plurimæ, qux me tum libro confcribendo tum aliâs intricabant, ut picturis operam dare fatis non poffem, eamç̧ cu. ram ferè in typographos rë̈cerem. Sed de magnitudine, $8<$ magnitudinum inter fe proportione nó admodum refert, dum catera bene habeant, in quo quidem curando pro mea parte diligentias nihil intermifi,

\section{DE P R I M O C A P I T E A.}

S IN G V L O R V M ferèanimalium hiftoriam, (perpaucis exceptis ubiid commodé fieri non poterat, ut ab initio ftatim in Alce, propter multas diuerfasḉs authorum de ea fententias) per octo ca pita, octo prioribus AIphabeti Latini literis maiufculis infignita partiti fumus, ut A fit primum ca= put, $B$. fecundum, \& fic deinceps. Vltimum uerò caput $H$, rurfus in totidem partes per minores lite ras diuifi, ut Philologia quoģ eodem ordine tractaretur, per a,b.c.d,e.f,g. \& ' h. literas, quanquả g; quæ pars de medicamentis eit, perrarò in Philologiam uenit, cum aliquod forte G, maioris id eft fe primi capitis paralipomenon fe offerebat. Sed fingulor um capitü argumenta ordine profequanur.

A. igitur quamuis cæteris collatum capitibus breuiffimum fit, plurimum tamen plerungs in eo laborandum erat. continet enim nomina diuerfarum gentium, Hebraica feré prinum: \& Hebraicis finitima, (ut Arab ca, Chaldaica, Saracenica ${ }_{\ddagger}$ )deinde Perfica, Græca, Italica, Hifpanica, Gallica, Ger manica, Anglica, lllyrica, ubi haec omnia habere porui, quod in quadrupedibus facilius fuit. In aui. bus fąné muliss, \& pif́cibus, ferpentibus, ac infectis, aliquando unius tantum aut alterius lingua nomina reperi, \& forte aliquando nullius, ut uel innominatum fureritrelinquendum animal, uel no men ei fingendum. Initio quidem ftatim de Latino nomine conftituendo laborandum erat, id quod 


\section{Capitum.}

perdifficile eft hoc feculo. Neç mirũ hoc uidebitur hominibus doctis, cum Plinius uir tantus $8 \mathbf{Q}$ in

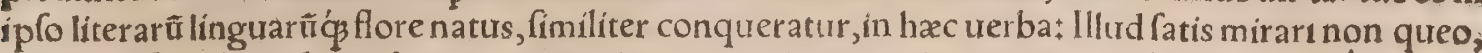
incercidiffe quarundam arborum memoriam, atq̧̧ etiam nominum, qux authores prodidêre, notis tiam. Quis enim non communicato orbe terrarum maieftate Romani imperï, profeciffe uitam putet cómercio rerum ac focietate feftæ pacis, omniaç etiam qua occulta ante fuerant, in promifcuo ufu facta? At hercule non reperiuntur qui norint multa ab antiquis prodita, defidia rerum internitione memorix inducta. Huius quidem ignorantix præcipua uideri caufa debet linguarum mutatio. neç enim Italia iam Latinè loquitur, Gothorum \& Langobardorum ut bellis oppreffa, \& colonịs occupata,fic uocabulis inquinata. Græcia Turcarum feruitio premitur, nec amplius Gracè fed bar bare loquitur, adeò ut non rerum modo, fed etiam locorum illuftrium nomina fint nouata.Quam obrem nemo nobis uitio dabit, fi aliquando uocabulis deftituti noura finxerimus, tum in uernacula lingua, tum Latina, aut Gręca, quod tamen nifiadmonito lectore, ut par eft, nufquam fies, in aurum, pifcium, ferpentium $\&$ infectorum duntaxat hiftorijs, \& in illis quoç raro $_{*}$ in quadrupedibus nun: quam aut rariffimé.

Hebraica uocabula, curm fuis interpretationibus præceptor nofter Theodorus Bibliander facrà rum literarum in gymnafio noftro profeffor, magnæ doctrin $\&$ incredibilis diligentiæ uir, pleraç nobis fuppeditauit. Inquifiui autem \& ipfe nonnulla,cum aliunde, tum ex Arabum libris qui in re medica extant, \& multa animalium nomina continent, qux ex Græcis tranftulerunt, quamuis Gra: ca nomina perfape retineant ita plerunq̧ detorta \& deprauata ut uix agnof́cantur, qualia plurima ex Ariftotele Auicenna tranftulit, ut apud Albertum legimus: quod indicium illius etiam feculi in. fcitiæ eft; ut non fit mirum doctiffimos etiam ludæorum hodie nihil certi de rerum nominibus, ut $a=$ nimalium, plantarum, metallorum, ueftium, inftumentorum, 8 c. docere poffe. Certe $R$ : Abraham aben Eżra, qui claruit anno Salurís 1217 , huiufmodi rerum nomina Hebraica prorfus obfcura effe alicubi fcribit, quòd in rebus naturalibus diuerfa regiones diuerfa proferant, in îs uerò qux artes faciunt longinquitas temporis plurimum immutet. Reliquarum linguarũ trocabula partim ipfe ufu cognoui, Gallica enim \& Italica mediocriter intelligo, partim ex dictionarïs, partim ex amicis diuerfis didici,

\section{DE}

c A P V T fecundum docet quibus in regionibus animalia quar ç reperiătur, 8 quómodo fecunt. dum illas differant: $\&$ fifpecies eius diuer fx $^{\prime}$ eperiuntur, aut aliæ quædam differentiæ, ut in equis fecundum greffum \& celeritatem, \&c. illas eciam explicar. Präcipuè uerò corpus defcribit, \& primü corporis magnitudinem: deinde partes fingulas, fimplices primum, externas internasćç, folidas $\&$ li quidas, ut funt, pellis, pili, (\& qui accidit eis color,) ranguis, adeps, medilla, offa, uenæ, nerui, \&c.de= inde compofitas à capite ad pedes, ut caput, cornua, cerebrum, oculos, aures, nafum, os, linguä, den. tes, pectus, dorfum, cor, pulmones, uentriculum, hepar, fel, liene, inteftina, genitalia, crura, pedes, un gues uel ungulas, \&c. ( quanquam cornua $\&$ ungues; $\&$ alia quxdam ex prædictis fimplices effe partes non ignoro, hoc ordine tamen collocaui propter fitum.) In quiburdam qux ab hominibus aluntur, ut pecoribus, iumentis, canibus, electionis eciam notas in hoc caput inferui,

\section{E C. L IT E R A i}

TER TIO capite comprehenduntur naturales corporis actiones, qux ử ad uita conferuatio= nem, uel fpeciei propagationem pertinent, fingulatim urero, Animantis cuíufq, Vox, Senfurs, Ci= bus, Potus, Somnus, Somnia:Excrementa alui, ueficx, genitalium, fudor, menfes, lac : Loci in quia bus uerfantur, ut montes, fylux, paludes, frigidi, calidi, \&c.latibula: Actiones corporis quod ad mo. tum \& quietem, ingreffus, curfus, uolatus, ferptio, natatio, cubatio $\$$ Sanitas, $\&$ eius figna, \& confer $=$ uatio, præcipué circa pecora, $\mathcal{Q}$ ea quiæ ab homine aluntur animalia, (quanquam hanc tiendæ $f_{a n i}$ tatis parrem qua fita eft in hominis cura, ad quintum feré caput reieci, ) Libido, Coitus, Conceptirs Geftatio $\&$ prægnantium cura, A bortus, Partus, Foetarum cura, Foetus eiứć́ educatio, Actas, \& éus dignotio. Vitæ fpatium. Morbi, eorứç caufa, figna, præcautiones, remedia. Et ex illis cômunes primum toti corpori, fiue quòd uniuerfum occupent, ut febres, peltis, uenena, fiue quòd in quatris eius parte fieri poffint, ut uulnera, ulcera, fcabies, abfceffus : deinde particulares à capite ad pedes, Qux ad ornatưm magis quàm fanitatem pèrtinent, ferè ad quintum caput differuntur.

\section{DE LITER A D。}

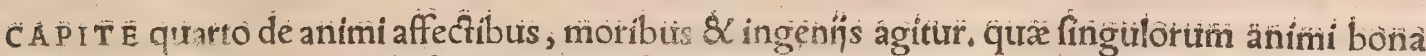
aự uírtutes, qux mala aut uitia fint, tum inter fe, tum erga foetus fuios, erga homínem. Sympathia $\&$ antipathix, hoc eft naturales quadam concordia $\&$ diflenifones fingulorum, primuin ad alias ani mantes, deinde ad res inanimatas.

$$
\text { D E } \quad \text { I I T E E R A E E }
$$

CAPV T quintum eft de ufu ex animalibus percipiendo, extrà cibum tamen ac remedia, 


\section{Ordo}

uenatione animalium, \& quomodo capiantur.Quomodo domentur uel cicurentur.Quomodotrat cientur fiue curentur, \& nutriantur, \& fanitatis tuendx præcepta $\$ \&$ in pecoribus quæad paftores greges \& ftabula pertinent. De inftrumentis quibus ad ufum corum homini preftandun opus eft, ut in boue de aratro, in e uo de re curuli, qua muis illam in Equo ad e. id eft quintam partem Philo. logia retulimus. Exhibitio eorum ín ludis $\&$ fpectaculis. Precium $\&$ pecunia qua ex ipfis eo rumue partibus uendendis habetur. Vfus diuerfi hominibus utiles ex fingulis partibus, ut pelliu ad ueftes, cornurum aut ungularum fuffitus ad fugandos ferpentes, excrementorum ad ftercoran dam terram, \&c. Prognoftica tempeftatum, 8 alia fi qua ex ipfis habentur commoda.

D E F. LIT ERA.

$S$ E X T O capite tractatur de alimēto ex animalibus, tum integris, tum per fingulas partes: fim: pliciter primum qua in cibum admittantur, aut non. deinde medice quàm falubriter id fiat, \& qua le alimentum ex fingulis corpori accedat, \& fi quid aliud huiufmodi medici fcriptum reliquerunt. Tertio de apparatu \& condimentis fingulorum, ex A picio, Platina, A thenæo, uulgo, \& $c_{*}$. Opfar tytica, id eft cibos $\&$ obfonia parandi condiendió̧ artẽ apud ueteres Græcos fcripferũt, Ácefias qui $\Rightarrow$ dam, Mithæcus, duo Heraclida Syracufani, Glaucus Locrus, Diony fus, A gis, Epænetus, Hegefip pus, Erafiftratus, Euthydemus, Criton,Stephanus, Archytas, Aceftius, Diocles, \& Philiftion, enume rati ab A thenæo libro 12. Idẽ frepiffimé multos Archeftrati uerfus recitat, ex poëmate eius quod Gaftrologiam uel Dipnologiam uel Opfopociam infcribunt, de trarñs cibis ad uoluptatem $\&$ gulam

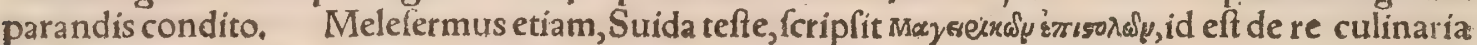
epiftolarum librum unum. Sed hos omnes intercidiffe non eft quod magnopere doleamus, plus fatis enim huius uoluptuaria artis, 8 multorum tum animi tum corporis uitiorum cauf $x$, non locu* pletes folum fed pleriģ etiam è uulgo periti funt: \& extant paffim huius argumenti libellí in uulga: ribus linguis, Italicè, Gallicè, Germanice, quos ipfe uidi, nec dubito quin alix etiam omnes lingux hodie ufitatæ fimiles habeant, cum pleriog non edant ut uiuant, fed uice uerfa. De alimẽtis ex ani malibus multa quídem diligenter, fed parum Latine, confcripfit Antonius Gazius medicus, in Co rona fua florida, ut infcribit, fed magna ex parte ueterum tantum teftimonia affert, qua nos exipfis fontibus petere maluimus.

D E LITERA Gं.

S E P T I M V M caputremedia ex animalibus homini utilia comprehendit; idás ordine, prít mum ex integris animalibus, deinde ipforum partibus tum fimplicibus tum compofitis, eadem fere ferie quam in partibus enumerandis capite fecundo fequor. Et quoniam fape ab una parte multa ua riaç medicamenta fumuntur, in morbis etiam quibus refiftunt percenfendis, ordine certo utor, ut prius communes morbi, deinde particulares à capite ad pedes progreffu facto commemorentur. Authores fermé citantur ifti, Plinius, Marcellus, Sextus, $R$ afis de fexaginta animalibus, Galenus \&

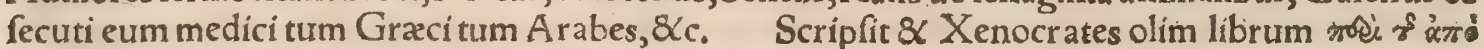

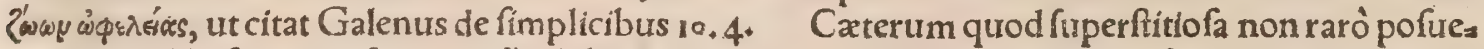
rim, cum alibi fape, prafertim in Philologia,tum hoc in capite imprimis, excufatione utar, fi quis re prehendat, partim communi, omnia omnium congerere me uoluriffe:partim quod cum quadã eiuf= modi fint, ut non omnibus, etiam eruditis forte, fuperftitiofa uideantur, fimpliciter omnia mihi reci. randa, iudicium lecfori relinquiendurn exiftimarim . Ego quidem amuleta omnia \& huiufmodi fü perftitiofa in uniuerfum damno, ita ut réjciendo potius modum excedere uelim, ac fimul etiam non inutilia quxdam fed fuperftitiofis fimilia excludere, quàm ex reuera fuperftitiofis (qualia certe innu mera funt, qua uulgus eiufmodi effe non putat) uel unum aut alterum duntaxat admittere. Ses cundo poft remedia ex animalibus loco, de morfibus uel ictibus animalium in homine curandis tra cfo: \& methodum medendi primum in genere prafcribo, deinde per fingula medicamenta diligen tiffimé apud authores obferuata,

DE H, IITERA, HOC EST DE PHILO

logia eiusó́s partibus.

O C T A V V M caput, quod totum philologicum $\&$ grammaticum ef, (nifi forte cum paralipo mena quæ̉am præcedentium capitum inferuntur, quod rarò fit, ) ex Græcis Latiniş́́ dictionarịs inter fe collatis, \& alijs lectionibus uarïs confectum, fimilicer in totidem partes diffecui, minoribus notatas literis, a,b,c,d.e.f.g.h. a. id eft prima pars Philologia, in fectiones feptem plerunç dí ftrahitur. Prima nomina habet, Latina 8 Græca præcipue, qua frilicet minus ufitata funt, ut poẻ tis aut a licui dialecto peculiaria, aut etiam ficta $\&$ ridicula, \& nominum etymologias, ex Gracis La-

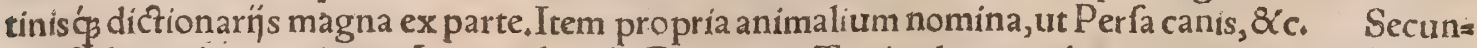
da eft de epithetis, primum Latinis, deinde Gracis. Tertia, de metaphorico nominum ufu, dećç deriuax 


\section{Capitum.}

deriuatis Latinis, \& Gracis feparatim, fubftantiuis etiam $\&$ adiectiuls ferè felunctls. Quarta, dè imaginibus animalium alicubi pictis, fculptis, fufis, aut aliter expreffis. Poterant huc ctiam emble mata quadam Alciati referri, quæ ad finem Philologia differre placuit. Quinta, de lapidıbus, fed potiffimum de plantis, qux ab aliquo animali denominantur. Sexta, de animalibus alijs, qua no= men à prafenti deducunt:aut aliqua ex parte ei conferuntur, quod pofterius tamen aliquando ad b. retulimus. Septima, de nominibus proprĭs ab animalis prafentis nomine fumptis, aut certe ita $\mathrm{fi}_{3}$ milbus, ut inde fumpta uideri poffint, hominum primo, uirorum $\&$ mulierum in utraç lingua feor fim, deinde regionum, oppidorum, fluuiorum, \&c.

b. c. d. e. f. g, eiufdem argumenti funt, quibus eifdem literis notata, fed maioribus, præcedentia capita: hoc tantum intereft, quòd hic grammatica folum, philologica \& poêtica, in e.uero \& $\mathrm{g}$. etiam fuperftitiola quadan attigimus; $\mathbb{Z}$ aliquando pracedentium paralipomena. Pars quidem $\mathrm{g}$. hoc elt de medicamentis, rarò inuenitur, quod omnia huius argumenti ferè femper ad feprímum caput rè lata fint.

h. hoc eft ultima pars Philologiæ, uraria continet, ea maximé quæ ad nullam partem pracedentem commodé referri poterant, Diuiditur autem feré in quinq̧̧ fectiones, Prima habet hiftorias tum ueras tum fabulofas. Secunda ad pradictiones pertinet, de prodigins, oftentis, portentis, mon ftris, (quanquam in c, etiam ubi de partu, aliquando monftra pofuimus,) ominibus, aufpicijs, augut: rịs. Tertia ad religionem: De animalium quorundam fepulturis, qux quibus dị́s facra fint, de $\mathrm{fa}=$ crificips ex eis, \& fi quíd huiufmodi eft, cum aliunde, tum ex Gyraldi Opere de dịs $s$ \& obferuationi= bus proprins. Quarta enumerat prouerbia ab eis fumpta, ordine literarum feré + ubi fæe pe quadam adiecimus ab Erafmo non anímaduerfa, quadam prolixius, quædam breuius quàm ille reddimus; quædam caftigamus. His fubáciuntur quandoģ prourbia quędam aut eis affinia, ex uulgaribus linguís aut Sacris defumpta literis. Quinta $\&$ ultima complectitur interdum paucas fimilitudia nes, Alciati emblemata, \& apologos fi qui apud authores alios occurriffent. Illos enim qui Aefopl nomine circunferuntur, ne prolixior effem, omifi.

Hactenus enumeraui fingula capita, eorumíg partes \& fectiones triginta aut amplius fi minu= tius diuidas, qux in magnis \& communibus animalibus, ut quadrupedibus ferè, pleræç reperiun= tur; quibufdam plures, alị̂s pauciores defunt, ubi nibil ad eas referendum occurrebat. funt quibus integra defint capita. quze dam fortaffis unum duntaxat $\&$ alterum, ut de nominibus, $\&$ corporis de. fcriptione caput habebunt, fi modo nomina mihi ulla cognita fint, nam corporis defcriptio femper aliqua futura eft. Huius uarietatis gratia literis ut capita eorumćp partes defignarem uti uolui po= tius quàm numeris. abfurdum enim uidebatur, quartum caput nominare ubi tertium deeffet, nec placebat quod in una hiftoria tertium fuiffet de corporis actionibus, id in alia de ingenio $82 \mathrm{mo}$ ribus aut alio diffimili argumento fub eodem numero proponere : cum ftatuiffem fub eadem litera aut eodem numero, idem femper argumentum afferre. Sed neque capitum partiumós fingula rum infcriptiones integras apponere libuit, ut uerbis parcerem in opere alioqui fatis uerboro. In literis uerò aliquam ponere, pracedente omiffa, minus abfurdum quàm in numerís tridebatur. Quòd fi non ubiç propofitam hîc partitionem exacté fecutus fum, quod fortè in prioribus quibufdam quadrupedibus, antequam prorfus hunc ordinem milí confirmaffem, non multis tamen commiffum eft tin nonnullis uerò propter uarias $\&$ confurfas fcriptorum opiniones, ut ab initio ftatim in Alce, feruari rectenon potuit: eft quando uoluptas ftudiorum me quafi oblitum mei ad dígreffio. nes \& philologiam, non fuo loco, ut prioribus feptem capitibus, admifcendam inuitauit + in omnit

bus tamen aliquam ordinis rationem fecutus fum, ut facile à bonis \& eruditis Lectoribus, qui operis molem \& materiam adeó coplofam reçe difponendi difficul

tatem xeftimauerint, ueniam mihi benigne datum iri perfuafus acquiefcam. 


\section{ENVMERATIO QVADRVPEDVM VIVIPA}

ROR VM, EO ORDINE QVO IN HOC VOLVMINE defcribuntur. Numerus adiectus paginam defignat.

A.

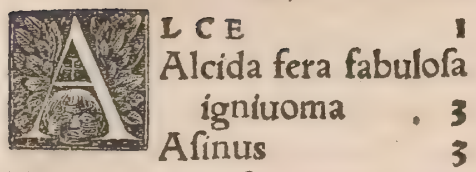

Hinnus,innus, $\&$ ginnus 18

5. Onager

Afinus uel onager Indicus 22

Onocentaurus

Axis fera Indica, maculofa, hin nulipelle, necaliud $\quad 23$ B.

Boryes \& pantheræ in Africa, nec aliud

10. De Boue in genere, \& Vacca priuatim

Taurus

Vitulus

Bubalus qui uulgò buffalus 139

Boues feri diuerfi $\quad 14^{2}$

15. Bifon 143

Bonafus

145

Catoblepon, Libyca fera tauro uel uitulo fimilis $\quad$ I5.

Boures feri Indiæ

Libyciboures

20. Tarandus

Vrus

C.

154

I5)

156

137

Cacus 159

Calopus 160, recentioribus bar baris memorata fera, ignota.

Camelopardalis

25. Camelus

Camelus dromas

Canis in genere

Canes diuerfi 235.82 inter ros de Cerbero quo $\beta_{3}$.

Canes uenatici in genere 139

30. Canis uenaticus robuftus aduerfus magnas aut fortes feras

247

De cane fagace, $\&$ animalium inueltigatione

Canis uelox

250

Canes aucupio feruientes, $\&$ a. quatici

259

Canes mixti uel bigeneres 259

35. Canis focius $\&$ fidelis ue poft mortem domini 260

Canis defenfor hominis $8 \mathrm{Cbel}$ licofus

263

Canes cuftodes, $\&$ primum de paftorali 265

Canis uillaticus $\&$ năuticus 267
Canes priuatarum $\&$ publicas rum adium cuftodes: $8 \mathrm{C}$ pri= mum de cuftodibus quadã in genere

40. Canis inutilis, 8 ædium priuatarumcuftos $\quad 269$

Canis mimicus

Capra

Hœdus

45. Capra fylueftres: \& Ru. picapra figura

Strepficeros

323

Caprea,capreolus, dorcas 324

Pygargus

$33^{\circ}$

Bubalus caprearũ generis $33^{\circ}$

5o. Ibex, uulgó capricornus 331

Dama Plinï, cornibus in aduer furm curuatis

334

Dama recentiorum, id eft dor= cas feu caprea platyceros 335

Caltor feu fiber

Catus feu feles

55. Catus fylueftris

Ceruus

Colos

Cuniculus

Dictys

D.

E.

Lamia $\quad 63^{8}$

Leo $\quad 642$

Lepus 681

Luca uel luci boues, id eft ele. phantes $\quad 410$

75. Lupus $\quad 717$

Lupo congeneres, Thos, Pan= ther, Lycopantheros, Lupus Armenius, Cicalus, Lupus canarius, Lycaon, Pathio, 766.8 deínceps.

Lupus ceruarius, Chaus, Lynx 769

Lupus Scythicus

775

Lutra

778

80. Lutræ cógeneres, Latax, Satyrium, Satheriữ,Porcos, 777

M.

Mxfolus, animal quadrupes in India, uitulo fimile, nec $\mathrm{a}=$ liud

Meles, uulgò taxus $\quad \quad 778$

Monoceros 78

Morchi capreolus $\quad 786$

85. Mulus 798

Mus $\quad 808$

Mures diuerfi $\quad \mathbf{8 2 8}$

Mus maior domefticus, uulgò rattus

60. Echinus feu erinaceus 400

Eale

Elephas

Equus

Genetha

$G$.

65. Glis

Gulo

Hyana$$
\mathrm{H}_{\text {. }}
$$

Hyænæ partim cógeneres, par tim nominibus tantum diffe rêtes, Alzabo, Ana, Belbus, Lacta, Lupus uefpertinus, Zilio, Crocuta, Lamia, Leu= crocuta, Mantichora, 629.8 deinceps.

Ad hyænam accedere uidetur \&lupus aureus $\quad 717$

Hyfrix

I.

70. Ichneumon

L.
399

410

399
410

443

631

Mus aquaticus

Meregrinus $\quad 830$

Mures agreltes $\quad 83^{\circ}$

Mus fyluaticus $\quad 833$

Mus auellanarum $\quad 833$

Mus napelli $\quad 834$

95. Sorex 834

Mus Noricus uel Citellus 835

619 Cricetus 836

619 Mures diuerfi fecundum regio

623 nes, ordine literarum 837

Póticus feu Venetus mus, uuls gò Varius

100, Mus alpinus

Mus Lafficius $84^{\circ}$

Musaraneus $\quad 844$

Muftela

Muftela fylueftres diuer $x+\&$ primum de muftela fylueftri feu ruftica in genere, mox de Viuerra, Furone, Ictide, 862,8 deinceps. Putorius, iltiffus uulgò $\quad 868$

635 Muftela Sobella, Noërza, Vor mela, Chiurca 869

Neades
105. Martes 865 
N.

Jeades uel Neides

O.

$\begin{array}{ll}\text { Oryx } & 870 \\ 210, \text { Ouis } & 872 \\ \text { Aries } & 912 \\ \text { Vercex } & 925 \\ \text { Agnus } & 927\end{array}$

Murmon uel mufimon, fera nó abfimilis oui, caprino uillo, 8xc. 934. Oues feræ, lbid. $\mathrm{P}$.

115. Panthera feu Pardalis, Par dus, leopardus

Feles zibethi

Poéphagus

Rangifer uel raingus

935

Raphius

120. Rhinoceros

Sciurus 955

Simia diuerfa

S.

Simia caudata, cercopithecus,

125. Cépus $969 \quad 667$.

Callithrix fimia caudata $b a r b a=$ taq̧́

969

De fimpis uel cercopithecis Pra fianis \& aln̈s magnis $97^{\circ}$

Cynocephalus 971

De fatyro fimia, dećp Satyris dæ monibus

974

130. Monftrum in ditione epi= fcopi Salceburgenfis in faltu Hanesbergio captum, anno Salutis 1531.

De Sphinge fimia

De Sphinge fabulora

978

Símiuulpa

Subus

13y. Sus

Aper

Talpa

$\mathbf{T}$

Tigris

Vrfus

140. Vulpes

V.

979

lbid.

981

982

881

$104^{\circ}$

1055

1060

Paralipomena, in quibus có, tinentur,

Dealce $\& 4$ uris quxdam.

Capra Indica imagines, item

Capreoli, Ibicis, Damæ feur cas prex platycerotis.

Tragelaphi,cum hiftoria.

Genethæ pellis.

Melis feur taxi figura.

Appendix de cornumonocero

Muris agreftís icon.

(tis.

SVM M A hiforiarum, centum quadraginta.
INDEX EORVN=

DEM ANIMALIVM AL

phabeticus, \& copiofior, infer =

tis etiam alijs parum Latinis

nominibus, qux recen: tiores quídam us. furpant.

A.

FRICANA,id eft,pä= thera

126.2. Agnus

Alce 1.8 quadam in Paralipo menis.

Alpinus mus

Alzabo,id eft hyæna

Âna

Anabula 160 Aper 1040

Araneusmus $\quad 844$

Aries $\quad 912$

Armelini

Afinus

A fini cornuti in Scythia \& A. frica

A finus Indicus

Axis

\section{Belbus, id elt hyæna} $12 \&>81$.

Bifon

Bonafus

Boryes

Bos

Boues feri diuerfi

Botres feri Indici

Boues Libyci

Boues Pæonici

Boures Trogladytici

$84^{\circ}$

625

629

trenatici in genere 139

Canis uenaticus robuftus, ad= uerius magnas aut fortes fe= ras

Canis uillaticus

247

$27^{\circ}$

apra Indica imagines, in $\mathrm{Pa}=$ ralipom.

Capra fylueftres

13 Caprea,capreolus

Capreoli figura in Paralip.

630 Capreolus mofchi $\quad 786$

143 Capricornus, uide Ibex.

145 Cartazonus

23 Caftor

24 Catoblepon

142

154

158

Bubalus de genere boum, uul. gò buffalus

Bubalus ueterum, de genere ca prearum

Burdo ig. \& 894. in $B$.

Cacurs

Callithrix fimia

Calopus

159

969

160

Camelus fimpliciter,uel Baciria

na 163

Camelus dromas urel Ārabica 171

Camelopardalis, uel Camelus Indica

Campe

160

Caniceps, id eft cynocephalus,

Canis 173 (971

Canes diuerfi 255

Canes aduatici, hoc eft in aquis mergi \& natare cófueti 259

Canes aucupio feruientes 159

Canes bellicof $\quad 263$

Canes bigeneres uel mixti 259

Canes cuftodes ingenere 165
344

Catus fylueftris

Centauri s5o, $\&$ deinceps

Cêpus $\quad 969$

Cercopithecus $\quad 967$

Cercopitheci Prafiani et alí ma gni $\quad 970$

Ceruus 354

Ceruus fubulo 355

Ceruus Achaines Ibid.

Chaus $\quad 769$

Chiurca muftelarum generis,

Chœropitheci 966. (870.

Cicalus $\quad 766$

Citellus uel mus Noricus 835

Colos 303

Cricetus de genere muriũ $8 ; 6$

Crocuta 6:0

Cunicultus $\quad 394$

Cynocephalus

D.

Dama Plinï, cui cornua in ad. uerfum adunca 334

Dama recentiorum, id eft $\mathrm{cas}$ preaplatyceros 335

Dama tel damula pro muftela,

Dictys 399 (8)

Dorcas, id eft caprea $\quad 324$

Dromas camelus, uulgò dro. 
medarius

Eale

Echinus terreftris

Elephas 410 Emptra

Equus

Erinaceus uel echinus

$\mathrm{F}$.

Feles feu catus

Feles ziberhi

Fiber feu caftor

Furo 862 aliâs fưrettus furun. culus, fretta.

G.

Genetha G.

Genethx pellis expreffa in $\mathrm{P}_{2}$.

Ginnus 18 (ralip.

Giraffa 161 Glis 619

Gorgon $152 \&$ deinceps.

Gulo

$\mathrm{H}_{\text {。 }}$

623

Hinnus

Hippardium

Hippelaphus 311, 312. 55०.

Hircoboues

$\begin{array}{lll}\text { Hircoboues } & 334 \\ \text { Hircus } 301 \text { Hoedus } & 314\end{array}$

Hyftrix

I.

18

$120^{2}$

631

Ibex 331 Ibicis figura maior in

Ichneumon 635 (Paralip.

ICtis 862 Innus 18

Lacta

L.

$63^{\circ}$

Lamia

$630,8 \times 638$

Lardironi

$87^{\circ}$

Lafficius mus

Latax

844
777

Lauzanum 937 Leo 642 Leopardus 935.8 priuatim de Lepus $\quad 681 \quad(60958$ Leucrocuta 630 Lupus 717 Lupus Arabix

Lupus Armenius

Lupus canarius

Lupusceruarius $769,8<767$

Lupus uefpertinus

Lutra

Lutræ congeneres

Lycaon

Lycopantheros

Lynx

Mrfolus

M.

Mantichora 631 Martes 865

Meles, uulgò taxus 778 . Eiuf= dem effigies in Paralip.

Monoceros 781. Appendix de cornu eiufde in Paralip.

Monops 152

Monftum in ditione epifcopi Salceburgeñ.captum 978 Mofchicapreolus 786
Mulus 793 Mus $\varepsilon 08$

Mures agreftes $83^{\circ}$

Muris agreftis maioris icon, in Paralip.

Mus alpinus

Mus aquaticus

Mus araneus

Mus auellanarum

840

$83^{\circ}$

844

Mus cæcus, qui $\&$ araneus, 844. accipitur etiam protal pa

1015

Mures diuerfi

828

Mures diuerfi fecundum regio nes ordine literarum $\quad 837$

Mus Indicus 655

Mus maior domefticus, uulgo ratturs

Mus Lafficius

819

Mus napelli

844

834

Mus Noricus uel Citellus 835

Mus peregrinus $\quad 830$

Mus Pharaonis 635

Mus Póticus feu Venetus, uul. gè Varius

Mus fyluaticus

Mus Venetus

Mufmon uel Mufimon

Muftela

Muftela ruftica 862

Muftel $x$ fylueftres diuer $¥ 862$

Muftela Sobella

Nabis

N.

Neades uel Neides

Nitedula.i. mus agreftis $83^{\circ}$

Noérza muftelarû̃ generis 869

Onager

Onager Indicus O.

Onocentaurus

Oraflus uel Orafius

Oryx

Ouis

19
22.8781
23
161
870
872

Oues ferx $935,8<161$, ouris fera procamelopardali.

P.

Panther

766

Panthera uel pardalis, pardus

Pathio $768 \quad$ (935)

Pirolus

Poéphagus

Porcos

Putorius unilgó diçus 868

Pygargus caprearum generis

Pygmai 966 (330

R.

Rangifer uel raingus 95०

Rhinocephalus 955

Rhinoceros $97^{2}$

Rhizes

159

Rupicapræ figura 319, hiftoria 321
8.

777

lbid.

Satyrus fimia 974

$\begin{array}{lr}\text { Satyridxmones } & \text { Ibid. } \\ \text { Scifmi } & 867\end{array}$

Sciurus 958

Serapha 161

Sefquiuolus $\quad 778$

Simia 957

Simia callithrix $\quad 969$

Simia caudata 967

Simiz diuerfa $\quad 966$

Simia Prafianx 8 alix magna 970

Simiuulpa

981

Singularis pro apro I×40

Sobella è genere muftelarum 869

Sorex

Sphinx fimia

979

Sphinx fabulora Ibidem

Spiriolus $\quad 956$

Strepficeros $\quad 323$

Subus 982

Suillus proichneumone 635

Sus 982

$T$.

Talpa 1058

Tarandus 156.8 in Rangifero $95^{\circ}$

Taurus

Taxus, uide Meles

103

Thos

Thuro 156,in Tarando

Tigris 1060

Tragelaphus 311. 8 311. Eutude pictura cum hiftorix appen dice in Paralipom,

V.

Vacca

24

Varia,ideft panthera $\quad 936$

Varius, id eft mus uel fciurus Póticus aut Venetus 839

Veruex 925 Vitultus 124

Viuerra 862

Vormela uulgò dicta égenere muftelarum $86 \mathrm{Gg}$

Vncia $\quad 937$

Vrfus 1065

Vius is7. Et quadam in Para lipomenis.

Vulpes $\mathrm{X}$.

Xandarus 157

Zabo, id efthyxna 625

Zilio 630

Ziberhifeles $\quad 9+8$

Zobella generis muftelarû 869

Zubro. 15

$1 \mathrm{~N}$ 


\section{Hebraica.}

TNDICES alphabetici nominum quiburs animalia in diuerfis linguis appellantur. Numerùs págí nam defignat, qua quaç hoc in Opere reperiuntur. Non eft autem ullus tam copiofus aut perfe. cius animalium catalogus \& index, quàm Latinus iam prius à nobis pofitus, in Gracis enim ưoca. bulis quanquam xqué copiofurs effe poterat, nō uifum eft tamen neceffarium cum adeò extendere, cum rariora ut poética \& dialectis peculiaria, ad Indicem toti Operi communem differre liberet. In carteris linguis, partim infcitia mea, partim eartum inopia, quòd multis præertim peregrinis anima* Whis nomina defint, indices nominum imperfecios facit. Germanicus etiam, ut uernaculus, cæteris. præfextim barbaris, copiofior à me confici potuit. In reliquis externi homines fui quífo patrí fermo nis uocabula, fi qux omifimus adijcict, $\mathcal{X}$ in n̈s qux pofuimus orthographix errata emendabit. Hoc etiam quif̧́ fecum æfímabit, multas cuiuf $\beta$ linguæ dialectos effe: $\&$ in eadem etiam dialecio, bar baros praccipuè homines, hoc eft, alia quàm Graca aut Latina lingua utentes, alios aliter fcribere: ideoḉ facilius mereri mé ureniam, qui à diuerfis $\&$ maxime peregrinis hominibus diuerfa nomina conquifui, fi non per omnia fatisfecerim.

\section{INDEX NOMINVM HEBRAICAE LINGVAE}

ET AFFINIVM, CHALDAICAE,ARABICAE, SARACENICAE: qux frepe articulo tantum, (al. articulum Arabes praponere folent) aut terminatione fo. la, (Chaldæi ferè aleph in fine adịciunt) aliáue exigura mutationo uariant. Apponemus autem difcernendigratia Chaldaicis $\mathrm{Ch}, \mathrm{S}$ Arabicis Ar, Saracenica paucà tan. tum \& Latinis literis fcripta habemus, (puto aũr eadem Arabica effe.)

Cætera Hebraica funt. Syriacã quoç̧inguam à Chals daica in paucis differre audio.

\section{$N$}

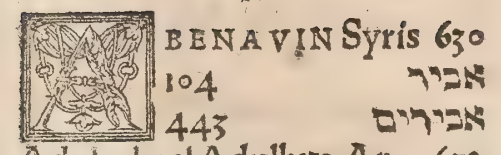

Adubul uelAdulbus Ar. $_{3} \quad 652$

851,968

$8 \sqrt{11}$

162,794 .

23

23

23. 353.

$354 \cdot 873.912$

354

355

873

872

912

Alierha

26

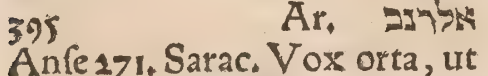
L. uidetur, ab Hebr. ; uel 1. Chald, NY

$336 \cdot 2$

401

\& 844

642

331

957

$33^{\circ}$

642

$64^{2}$

642 Ch. Mrcha Ar. Alberto prorhinoce rote. (uox corrupta mihi uj-

Ch, xym

Ch. 7นตัต

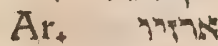

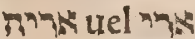

Ch. detur à karas, שาp. ) qุưan= quã alibi trocem Grxcan ra cit, ut fic animal dicât quafi archos, id eft princeps, fed rídiculè.

681 Ar. 23 Arnephlepus Saracen. Ibid. 681 Ch, $\mathrm{Ch}, \mathrm{s}$ 681 1055

3

3

Ar. Shat

bN 400

632409

957

787

443

162. 325

Bakera

เดมา

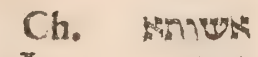

Ar. ikn

Ar. กากล

912

8กา

(1)

Baccara Saracenis

787

794

$4: 9$

TFस 25

$\mathrm{Cl}_{\text {, napk }}$

873

783

301

301162

nes:e 162

Ar, ponz 872

hat:

กรมา

cexpe

Àr.

ba

หา:

26

26

도.

tow?

Ar.

Cb.

मp.

Ar. $\$ 4972$

Ar.

fribitur \&

Beruet Perficum aut Ar,vide=

tur, 766 .pro thöë apud $A$ ui. cennam.
787

ows

Gazel,gazella,Ar, 325. 332 Sed Arabice cö́jcio by feri. bi.nam ain literam aliqui per gamma pronunciant, ut ab 1y, id eft capra, defcenderit, quoniá capreoli genus eft.

16.

Ar. arasid

314.927

Gadeia

643

Algiazar

162

872

$716 \mathrm{Ch}$

Ch.

$97 x$

abha uel dahab Syris $\quad 630$

$778 \quad A r$.

716 Ar.

Adib Ar. 717

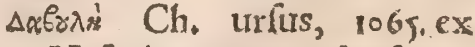

Hefychio, wox tranfpofita ui detur pro aldube.

Aldub Ar. 1068

$1065 \quad 37$

Dubbe Ar. \& Saracenice, 1064

160. $\& 716 . \mathrm{Ch}_{6} \quad \mathrm{~N}$

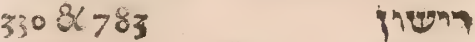

812 Ch.

$409 \mathrm{Ch}$. Sำ

4018844

กPIx 
Hanub Syltuatico, hircus $301 \quad 162$ nefcio cuius linguę. Anubin 356 quidem Aegyptị colunt $\mathrm{Ca}_{2} 957$ pite canino, Sunt qui lingua 173 Aegyptia anubin canem dici affirment.

Alhauar, 164, Ar. puto. Bellu= nenfis camelum exponit.

Alhamel,Ar.puto. Bellunenfis arietem interpretatur.

Hefel Sarac, uitulus, fi rectèlegitur.Hebraicèquidem bxy egel, fcribitur.

162 ;"口⿰幺幺

His $\&$ hyrzus, uoces Perficx uel Ar.pro muftela, apud $\bar{A}_{\text {. }}$ uicennam.

395
331
401
716
716
Alfebha Ar
19
18160,83200
160
395
9838110390
983
983
851
851
851
3
1055

Ar.

$$
\text { Ar. }
$$

Ar. 3

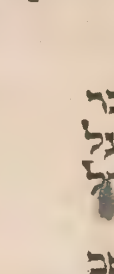

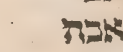

173

Kepb uel kolb Sarac.

รามารา

895

643

$3018<>83.82012$

Ar. בעזיר

רับ

Alchercheden ( $\overline{A r}_{\text {. }}$ ) id eft uni= 162 cornis, Bellunenfis

873

344

642

642

642

$23 \& 639$

$642 \& 1060$

642

173

$643 \quad 271$ กา 26

7 רז 19

.

$n$

การ

oxt

วาx

Ch.

กา

Anלn Alneme

Ch. ה 936

7nan 442

กาบ 442

Ar,

324

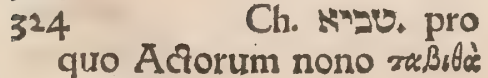
legitur.

967

873

395

Ch. Dו1

$268 \alpha_{124}$
873

Sufuatha

778

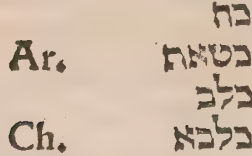

173

บ

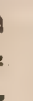

409
794

7831055.

มาว 642

26

3 בהול

Ch. 735794

194
794
162

לำ

ning

चי

$\mathrm{Ch}$.

לח

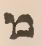

למר

פדרים

sogécold Iudxis, quod tigris Gra cis, Hefych, 1060. Ego hanc uocem factã effe puto à 7 ต Hebr. quod mulum, non ti= grim fignificat.

$16^{\text {פרז }}$

Ar. 394

Ch. ผาหาด

787

872

625

164 Ar.

Zabo \& alzabo Ar.

*

חדיפ

324

se fomininum

(l)

2718871

138967

Ar. $\quad 936$ 1055

Ch. Nרน 872

- 301

301
271

กั0

Ch.

$\mathrm{Ch}_{\text {。 }}$

443

ผมาก

8518957.896

4 이

400

395

Ar. $\quad \begin{array}{ll}4 & 400 \\ \text { Ax } & \text { Kipod }\end{array}$

עגלו

400

Ch.

(y)

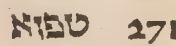

Ch.

19.81140 .82320$.

lachmura Ch.

401

401

is 8794

$33^{2}$

$3318 \times 33^{2}$

myan

มกา 271

19 Azel, tride Gazel fuperius.

सेत्र 271

xim 23

व"מ⿰" 3

3

Ch. אלy 6208808

2 .

Katt Saracenis

Acbera Ch.

872

912

nis 1060

$344 \quad 872$

บ2ב 325

872

794

살ㄹ 19

กษบว 19

794

Ar.

לy 19

Ch. Nมา1 2718301

400

401

7838952

873

$\mathrm{Cb}$. 추y

$\mathrm{Ch}$.

E"1y 7838952

872

783

บว9y $33^{\circ}$

Ibid. 783

x+y 794

Ch.

Niy 8442 Syris

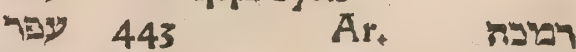

सר 395 Ar.

Ch.

พาו 27

7าม 1055

Ar.

Fise

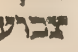

625

bid.

กมx

7ำ

Ch. тาตร

P

MP

C6. N"ม

Ar.

IIP

ทา

775

רap

Nep

IEP

קטיר
즌

577

מער

7า

nNe

שית

.643 


\section{Perfica. Linguæ diuer $x_{\text {, }}$}




GR AE C A.

s I quax rariora, poética, $8<$ alicui dialecto peculiaria erất, exclufimus ab hoc catalogo.

\section{A.}

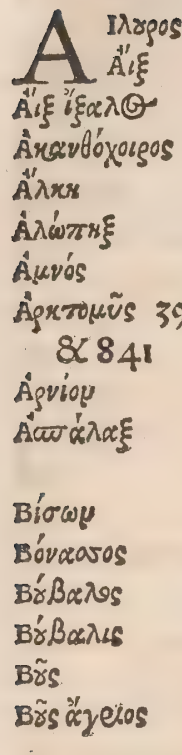

rerdsi retotridlos raxác ćzyexwe

rávos

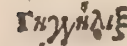

ríringos

rivyos

rnávos

rúreos

$\Delta$ sepexis

$\triangle x \sigma \cos ^{\prime}$

$\Delta x^{\prime}+$ iros

$\triangle$ ixtus

$\Delta o$ opxies

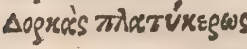

Ënacos

Èreis

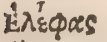

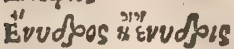

Eerpos

Exiัขos Xegoxíos

zegreias

Hínovos

ows

I"xors

I'vyos

ITHos

Imrogos

İxvéuผ

$\Delta$

B.

r.

$330.8 \times 14$

H.

๑.

$$
8
$$

862,8
344

271

320.82332

$401.8<633$

I. Kegros:

1081 KisBos

925 Kĩmos

$8 \times 778.8 \times 836$

Kónes

$1055 \mathrm{~K}$ Кокөच̃

Kvvokí $\phi \alpha \lambda e s$

$143 \quad \mathrm{~K}^{\prime \prime} \cos$

145 Kं́n norríguos:

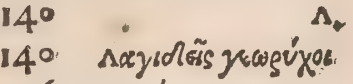

26 sayózigess

42. ^xyós

sám

851 Аर́ख

862 ArBseidlss pro cuniculis

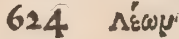

$831.8 \times 833 \quad \Lambda \dot{y}^{\prime} \xi$

Ibidem suráus

18.19 Аบrotrívomes.

624 súros

633

682 Mxprióga

395 Movios

399 Movóxegos

319,8324 Moguir

335 Mógos mógr bogersès

354 мथух

620 Mukos

4०9 Mvogós

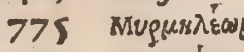

314 roरह่

Mũs ajjrgä́os

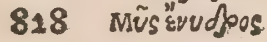

M.

N。

794 Nxitoles

o.
925 Keio's rourises

399 Mũ

K.

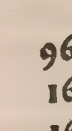

969

rapóares

160 rejóss

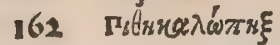

171 I'thros

956 Torqúzos

$104^{\circ}$ rógderiss

344 rógros

152 P

969

67

I

rúraglos

vquásos

Posins

836 P'tvórepos

969

Ibidem

píare genus murium

$p$

393

912

925

$63^{\circ}$

9.71

173

775

Expleciop

Extúeiop

- $\Sigma_{*}$

Eárupos

Eíucuj è genere murium

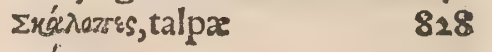

Exírpos:

$\Sigma \tilde{\delta}$ Bos

$\Sigma \pi 0 v d$ víns

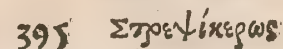

620 Euarypos

$681 \Sigma \tilde{s}$

638 इeiyg

777

682.

642

767.799

767

766

- 717

778 Yques:

$631 \dot{x}^{\prime \prime} \rho \alpha \xi$

Ibidem

$19.81104^{\circ}$

$78 \mathrm{v}$

640

124

786

844

620

Ibid.

Ys

Y̌sers

Dtṕrotrbs:

xirónss

Xnźrus 1040 633.8681

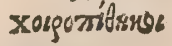

T.

Xoĭgos

$\checkmark$ o c E $s$ aliquot quibus

Græci hodie utuntur.

Ájéú, dama

831

$83^{\circ}$

870 Ä

Ágrö̈?cavós, al. xẹproblicuós, fimia

873,958

19 Áví,agnus

Eeier, hordus

K'ázzs, catus .

18.19 व"

442 deciopays

956

635 rónting
638

766.936
Axjós,lepus
966

335

936

937

981

936

778

$33^{\circ}$

966

829

952

8

id.

74

955

851

323

0.40

279

156

103

1060

30 요

624

985

631

864

983

\section{5}

25

314

344

688

354

717

Min⿴囗十 
Italica.

Nisucisy, fimia

Msớćáci, uitulus

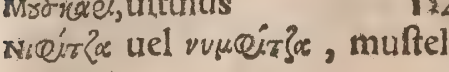

$$
852
$$

rovarios, mus

Trooßatro, ouis

Exires, canis

\section{T A L I C A.}

$A$ Gno

A Alicorno

Lafino

A finibaftardiuel nani

Ballortula

Beccho

Bertuccía

Biuaro uel betrero

Bue

Bufalo

Caméllo

Cane

Capra

Capretto

Capriolo uel cauriolo .

Cantoreo

Caftrone uel caftrato

Cauallo

Cauretto uel capretto

Ceruo

Ciacco Florentinus

Ciauarello

Cinghiale

Conigli

Daino uel danio

Donnola

Dromedario

Foino

Galero 621. glis

Garto

Gatro maimone

Ghiro uel gliero

Hiftrice

Iftrice

Lardirono uel lardirolo

Leocorno

Leofante

Leone

Leonpardo

Lepre

Lieuora

Liocorno

Lionfante

Lodra lodria uel lontra

Lonza

Lupo

Lupo certrarío

Maiale

Marturo, uel martaro, uel 98

$$
\text { turello } \quad 8648865
$$

Montone uelariete $913 \& 925$

Mulo

$3 \geqslant 6$

968

621

633

633

409

643

936

682

Ibid.

783

409

775

937

717

767

983

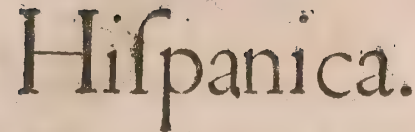

787

57 Mufico

124 Muferain urel muzeraigne Rh

tis

845

Muftela Rhatis Latinũ nomen

808 retinet

873 Orfo

106

173 Pantegana Venetis, mus ma. ior domefticus

Pardo

Pecora

9.7 Porca fattrice

783 Porco

Porco caftrato

18 Porco fyluatico

852 Porco fpinofo

301 Rato dicala

958 Ríccio uel rizo

336 Schiriuolouel f́chirato

26 Scrofa

39 Simia

164 Sorgomorgange

174 Sorgio molchardino

271 Sorice aliâs forgio

314 Sourco

324 Stainbucc

336 Talpa

925 Tafro 778 . Rhatís tafch.

442 Tigre uel tigra

314 Topo

$3 \$ 4$ Topuragno

93 Toro

314 Troia uel troiata

$04^{\circ}$ Vacca

335331

Es Vítello

17I Vlzol

852 Volpe

Vnicorno

344 Zebelli uel zibell

$6: 1$
783

ars

HIS P A NI CA.

$A_{\text {Bue }}^{\text {Sno }}$

Bufano

Cábra

Cabrito

Cabron

Cabronzillomontes

Camello

Carnéro

Cauallo

Cieruo

Comadreia

Conéio

Cordero

Córza

Dromedario

Elephante

Erizo
808 Iauali $104^{\circ}$, aper

938 León

Leonpardo,uellén 643

873 Leonpardo, uel leon pardál 9,6

983 Liebre 682

983 Liron 621

983 Lóbo 787

$104^{\circ}$ Marta 865

633 Móna 958

808 Mulo 794

401 Mufro 787

956 Nútria 776 . lutra

983 Orfouel ofo, uel offo 1065

958 Ouéia 873

$83^{\circ}$ Pérro 174

$83^{\circ}$ Puerro 984

808 Puérco filueftro, uel Puérco

8,8 montés $104^{\circ}$

331 Puérco efpin . 635

lo5s Rapófa 108

Rat $\quad 808$

1060 Ratón 808

8.8 Raton pequénno 834. in So2 rice, 82845

104 Sorce

983 Tafugo 778. meles

16 Ternera 124 , uitulus

834

Texón 778 , neles

Tópo

124 Vaca

314 Vnicornio 183

783 Zorlite 324

869

\section{GA L LICA.}

$A$ Gneau $\quad 927$

-Afne

Babion

3

26

Baccal circa Metas muftela ur cant, (Gallice puto.) 852

Bedouro 778. meles

Belette, belotte,balotte $\quad 852$

$\begin{array}{ll}361 \text { Belier } & 915 \\ 324 & \text { Beuf } \\ & 26\end{array}$

164 Beuffle 141

913 Biche 43 Bieure 336. fiber i35s

3i) Blaireau, aliâs blaureati 778, 852 meles.

396 Bouc 301

927 Brebis 873

335 Caion 984

171 Cerf 355

409 Chameat 164

401 Chat 344

4

(1)

4

.




\section{Gallica.}

$\begin{array}{lrlr}\text { Cheual } & 445 & \text { Souris } & 808 \\ \text { Cheureuel chieure } & 271 & \text { Taffon, taiffon, taixon, teffon } \\ \text { Cheureau } & 314 & 778 & \\ \text { Cheureul } & 324 & \text { Taulpe } & 1056 \\ \text { Chien } & 174 & \text { Tigre } & 1060 \\ \text { Chiens augues } & 247 & \text { Toreau } & 104 \\ \text { Chien limier } & 247 & \text { Truye } & 984 \\ \text { Coche } & 984 & \text { Vache } & 26 \\ \text { Cochon } & 984 & \text { Veau } & 114 \\ \text { Connin } & 396 & \text { Verrat } & 984 \\ \text { Dain uel daim } & 335 & \text { TCeltica uetus lingua cercos } \\ \text { Dromedere } & 171 & \text { pithecos uocabat áBgéryos: } \\ \text { Elephant } & 409 & 968\end{array}$

Efcurieu uel efcureau $\quad 956$

Foina uel fouina 865

Furon, furet, uel fufon, furet

$\begin{array}{lr}863 & 778 \\ \text { Grifart } & 852 \\ \text { Herminne } & 936 \\ \text { Leopard uel lyopard } & 833 \\ \text { Lerot } & 776 \\ \text { Leure Sabaudis lutra } & 621 \\ \text { Loir } & 717 \\ \text { Loup } & 767 \\ \text { Loup ceruier } & \text { Loup chatt, } 770 .(\text { Vide in Ad. } \\ \text { ditionibus } 8 \text { caftig, fuper ea: } \\ \text { dem pagina.) } \\ \text { Loutre } \\ \text { Lieure } & 776 \\ \text { Licorne } & 682 \\ \text { Lyon } & 185 \\ \text { Liron urel rat liron } & 643 \\ \text { Martre } & 621 \\ \text { Martes foublines } & 865 \\ \text { Mouton } & 869 \\ \text { Mute } & 925\end{array}$

Mulet, mulus, fomina, mule.

$\begin{array}{lr}794 & \\ \text { Mullot } & 831 \\ \text { Mufc } & 787\end{array}$

Muferain,uel muzeraigne 845 mus araneus

Mufet, uel mufette,idem Sabau - dis 845

Ours

Porc chaftre

Porc fanglier

Porcefpic

Porceau

Porcelet

Poutois uel poytois

Pouttet

Ran

Rangier uel ranglier $913+$ aries

Rat : $\quad 808$

Ratd'eau $\quad \therefore 830$

Rat liron uel rat ueul $\quad 62$

Regnard

Sanglier

1081

Sery Burgundis mus araneus 845

Singe
$95^{8}$

GERMANICA.

21.

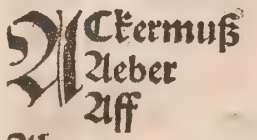

alp

2luwerads:

25 abion

3 atr oper beer

barg

25 iber

Żilcbmus

251 emitbier

3ock

3ogner

Zoll

25oummtarder

Soumrüter

Bracten

23randbirs.

25 iuffel 39 - moiloegroftebuif fe

Jithntarder

S.

Sam/Dantmlin/oambirt/bañ birs

Saps

Soznfowein

984

$104^{\circ}$

LE.

335.1100

778.1103

建icbort uel eycborn

LEinborit

K2/b/ellent

建的

促llens

进romuß

建

forlesoer vorle

farr oder vart

feeb oder veed

felomarder

felontuf

fiedtmarder

frette o ver frettel

frtloling

867

33

831

867

925 fuchs

1081

Suchnaff

982

furette

6.

Falis

(beif 271. Intijde geifen $1097+1098$

(5e)

Genitblats

Sinse

Grauwerct

Dreul.

hislemlit

คื.

619. 1102

314

839

621

Saggen

Sammel 913.925

852

104

Samfer ober bamefter $8 ; 6$

harnball 844

fafober baas 682

คhafelmußs 833. Froffeba felrutus

621.836

Jheilwiber 913

felfant 409

Sermelin 852

人रesbü: 258

1065 Sônn 355

984 Śinde/bintealb 35s

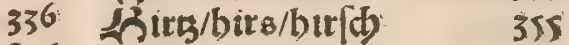

836 Lopenwider 913

787 Sotutbot 1065

301 Rीuns 174

921 frunbigel 401

ro4. Anufnarder. 865

Jaghing

$25 \%$

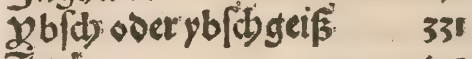

Jgel 401

fltis $\quad 864.868$

Xieren vat th 401

Thalb 124

TRamed oder Estneltbier 164

TKas 344. DOiloetars 393

Thisleini 314

Thütcher 925

TRozinfsitle 836

Tkunele/Eünigle/tunlein 396

Kii 26

TKurß̧̧ün 248. Corfici cas nes

Lamb

1.

Zaffits

Zefrat

844

984 Labtbuino 25

104 Lentroder lemmer muriũ ge=

839 gus in Norduegia uocatur 828

Leppars

936

Iew

643

Ziechtmarber 867

Lodbuanole 255 


\section{Germanica.}

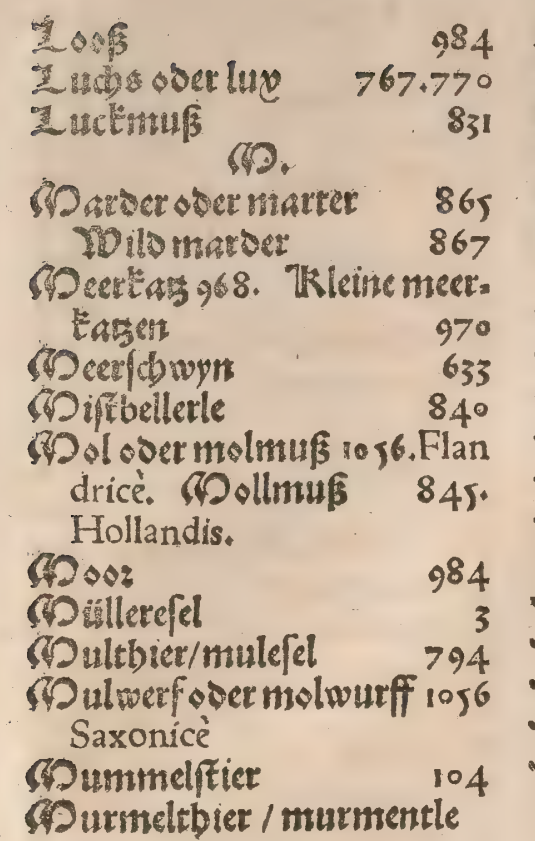

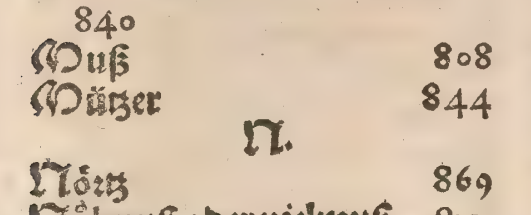

rïltmus obernielmuß 831 . 1104

D.

DW

Ditter

pantbertbier

776

pile

Poscopict

pundert

Ziambert

วิธี

Ereinbock

Steinnarder

Grier

Stofmus

Suw//u/faw

Eewigel

Tadmarder

Cads

Taran

Tbannmarder

Tbierwolf

Tigertbier

Darr/farr

D firle/firte/vert

Ded $/$ feeb

Dilfurâs 624 Gotebucke

331. 1099 Calfe
865 Camel

Anglica.

865 Camel 124

104 Cat 344. Catum montantum

831 Angli pro leopardo dicunt

$984 \quad 938$.

4 인

Cony

396

3 Dogge 174

633 Dormufz 833

867 Erdhrew, Vide Shrew.

767.770 Faloune deere 335

1060 Feret uel ferrette 865

Fífche 868

104 Foxe 1081

984 Geldid fit 984

839 Gore

(ent) 139.144. 159. Erofle Hare 682 vifent 158 Harte 355

Vogelbiins 259 Heffar 124

Dozifend bïnd 259 Heggehogg 401

D०8 1081. Vulpes Flandrice Hogg, hogge, hog 927. 984

Drods 158 Horfe 444

314

19aferbints 19 Lambe

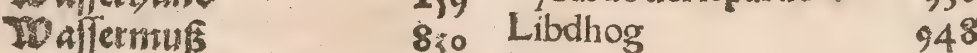

Wercte 839 Libdfu

Diser 913.925 Marmolet 968

Tillpactit 25. cerua Mineuer 852

Winsfpil 258. Tuirckifbe Molle

wino 258 Mows uel moure 808

Wifele 852 Mule 794

70 ol 1 if 717 Munkai 968

$9132 V_{0 i n t u i n t} \quad 869$ Murke katte

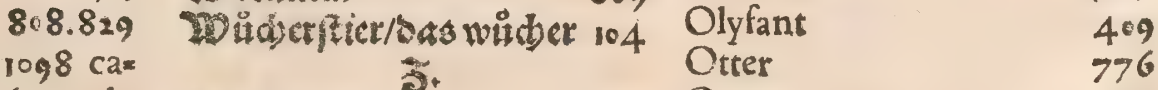

3ibetbetat at 948 Oxe 16

3yfilover jeifel 835.845. Pygge

Jifmeifs sie groflen 836. Pork 984

$845 \quad$ Porkepyne 633

3rté 124 Ram 913

$\begin{array}{lllll}3 & 124 & \text { Ratuel ratte } & 808, & 829\end{array}$

Jiinomarber $\quad 867$ Roo 324

Sheepe 873

Shrew, fhrewe, fhrow, erd.

A NGLICA. fhrew 845

Squyrrell 956

$\begin{array}{lll}P E & 958 & \text { Suluel fowe }\end{array}$

Babons $\quad 3$ Tup 915

Badger uel bagert $\quad 971$ Vnycorne $\quad 783$

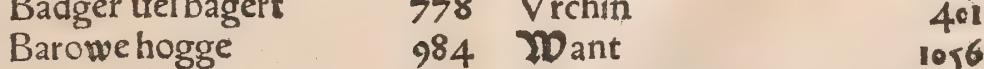

Baufon $\quad 778 \quad$ Datterratte 830

Beer uel beare $\quad 1065$ Wefel, uel wefyll, uel weafyll,

$336 \quad 852$

Werher Thepe 925

Dolfe 717
Betrer 336

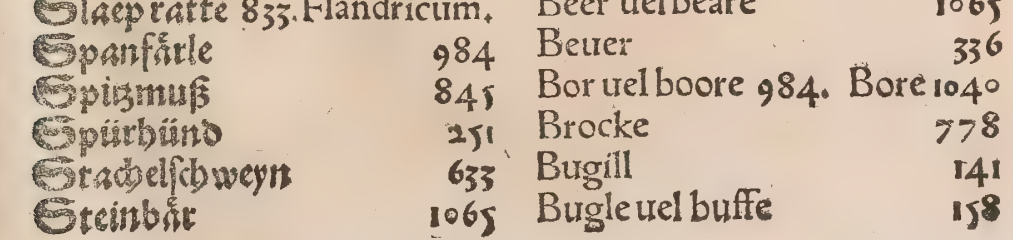

i

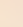




\section{Illyrica.}

\begin{tabular}{|c|c|c|c|c|c|}
\hline \multirow{2}{*}{\multicolumn{2}{|c|}{ IL L Y R ICA }} & oziecz & 331 & nos $\&$ Mofcourtas & 23 \\
\hline & & Kralik uel krolijk & 396 & Sarna & 324 \\
\hline \multirow{2}{*}{\multicolumn{2}{|c|}{$\begin{array}{l}\text { Extenditur autrem hac lingua } \\
\text { hodie per innurmerasgêtes, Bo } \\
\text { hemi, Poloni } \& \text { Mofcoutix pe }\end{array}$}} & Krticze & 1056 & Sczurek Polonicum & 621 \\
\hline & & Kun Bohemicum & 444 & Sczurcz & 829 \\
\hline \multirow{2}{*}{\multicolumn{2}{|c|}{$\begin{array}{l}\text { hemi, Poloni } 8 \mathrm{Mof} \text { Moutitx pe= } \\
\text { culiaria quxdam habent nomi= }\end{array}$}} & Lanị & 335 & Syfel Bohemice & 836 \\
\hline & & Lanị́(cerua)Polonicum & 355 & Skop & 873 \\
\hline \multirow{2}{*}{\multicolumn{2}{|c|}{ na in hac lingua, ut ple. }} & Lafica Polonicum & 844 & Skrzecziek & 836 \\
\hline \multirow{2}{*}{\multicolumn{2}{|c|}{$\begin{array}{l}\text { runç notauis } \\
\text { mus. }\end{array}$}} & Lew & 643 & Slon & 409 \\
\hline & & $\begin{array}{l}\text { Lewhart } \\
\text { Liska }\end{array}$ & $\begin{aligned} 936 \\
1081\end{aligned}$ & $\begin{array}{l}\text { Sniatky Mofcouriticum } \\
\text { Sobol uel Soból }\end{array}$ & $\begin{array}{l}393 \\
860\end{array}$ \\
\hline RAbion & 971 & Loni 152. Bohemicum. & & Srna & 324 \\
\hline DBaur & 141 & Los & 1 & Swinie & 984 \\
\hline Beram & 925 & $\mathrm{Ma}$ & 401 & Tchorz & 868 \\
\hline br & 336 & Me & 794 & Tur uel thuro Polonicum & 156 \\
\hline ertuiro & 770 & M & 808 & Tzuunerz & 401 \\
\hline aynus Bruffis mart & 867 & koczka & 968 & VijdraPolo & 868 \\
\hline Gednorozecz & 183 & Bohemice & 1065 & Vislij canes robuftiffimi & Polo: \\
\hline elen & $3 \pi 5$ & Nier & 845 & nis & 248 \\
\hline Gels & 401 & rodelá Polonicü & 844 & Vuelblud & 164 \\
\hline Gezwecz & 778 & Opicze & $95^{8}$ & Weprz & $104^{\circ}$ \\
\hline Polonicum & $3 \pi 5$ & Ofel & & Dewer Polonicum & 1065 \\
\hline & 104 & Otzïfchax & $4 \cdot 1$ & Dewerka uel wijewijerk & ka 956 \\
\hline Polonicum & 845 & Owcze & 873 & Vuydra & 776 \\
\hline & 344 & Pes & 174 & Mika & 717 \\
\hline zawa & 852 & d Polonicum & & 20ul & 26 \\
\hline onīj & 444 & Porcolpino & 633 & Zagicz. & $68:$ \\
\hline oza & .271 & Prafe & 984 & Zubr uel zubro & $x_{159}$ \\
\hline & 301 & Rys & $770^{\circ}$ & & \\
\hline & 314 & Roffomakanimal apurd & Litua. & I I I 50 & \\
\hline
\end{tabular}




\section{CONRADI GESNERI TI"}

GVRINI HISTORIAE ANIMALIVM

IIBER I. DE QVADRVPEDIBVS

VIVIPARIS.

DE ALCE.

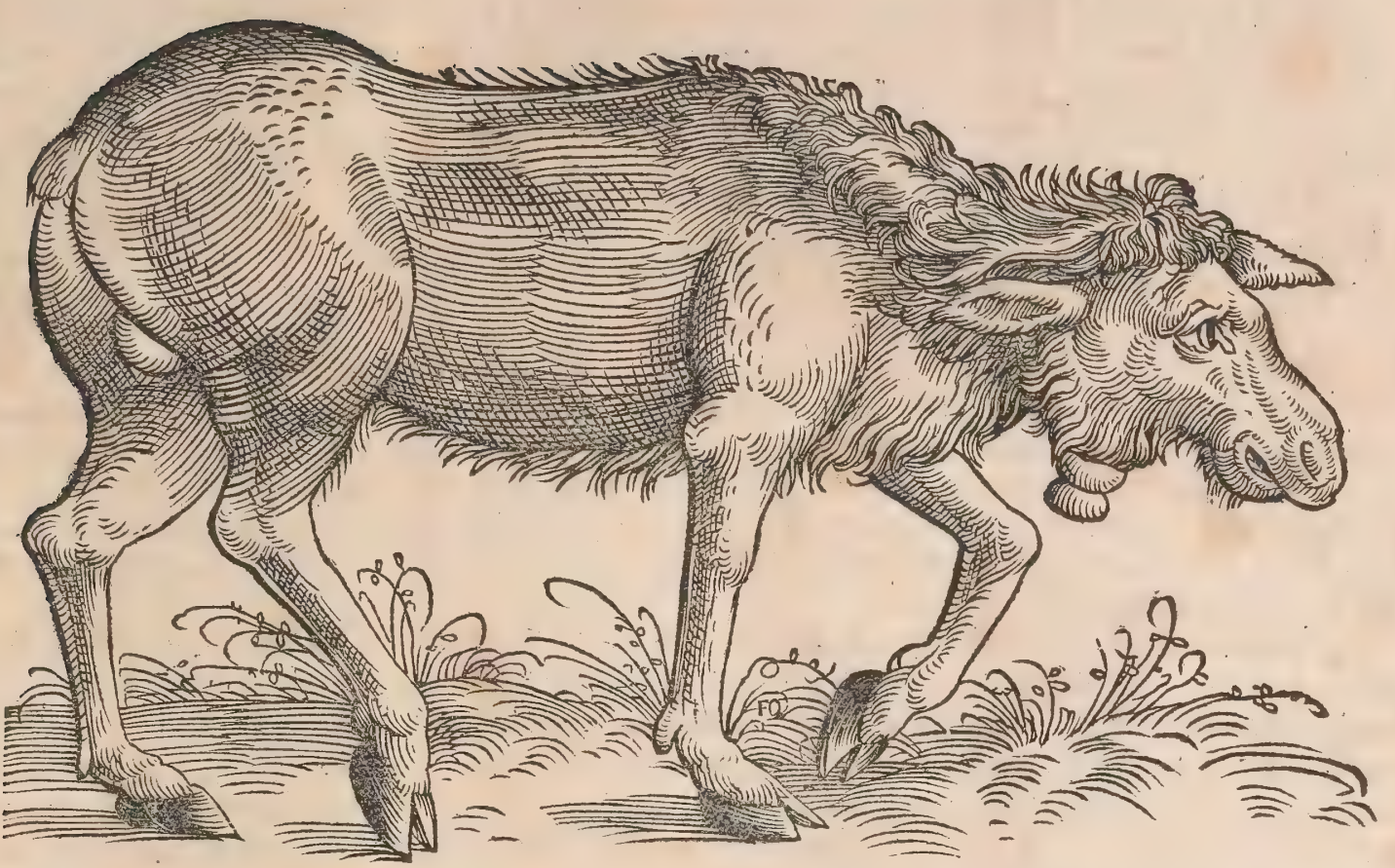

Pifturam banc d̀ pictore quodam accepi, quam ueram effe teftantur oculati teffes: ut etiam cornua, qque gemina habet. Nos urumb bic Forfim pinximus.

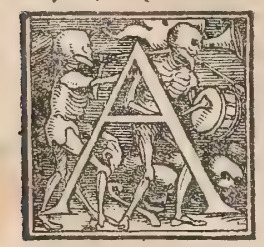

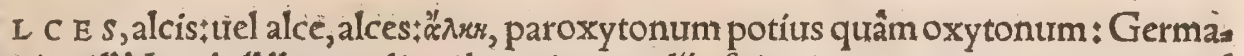

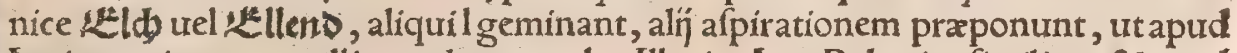
Latinos etiam nonnulli, quod non probo, Illyrice Los, Polonice fimiliter, $\&$ apud alios Pouuod, ut ex indigena quodam nuper accepi. Illyrï etiam ceruum Gelen uocant, \& fieri poteft ut inde nomen huius animantis ad Germanos translatũ fit, propter fimilitudinem eius cum genere ceruino. Nullum huius animalis nomen aliægentes habent, cum peregrinum omnibus fit praterquam Scandinauia, quod fciam: proinde

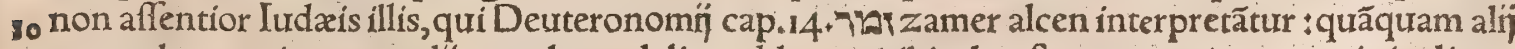
pro eadem rupicapram, alif camelopardalin reddunt : mihi ad poftremam animus magis inclinat. In tam rara igitur $\&$ longinqui foli fera authores inter fe uariare, minus mirabimur. Ego fingule= rum uerba apponam feorfim, cum alioqui fatis commode conciliari non poffint. Inter Gracos $\mathrm{fo}_{\mathrm{O}}$ lus Paufanias (qui A ntonini tempore claruit)in Eliacis differens de elephanti uulgo creditis den. tiburs, quod cornura fint nó dentes, haud omnibus enim eodem loco cornua nafci:argumento funt, inquit, Aethiopici tauri, $\&$ alca fera Celticx, ex quibus mares cornua in fupercilips habent, foes mina caret. Sed forte hoc loco Paufanias alcen confundit cum quadrupede illa quam hodie ran. giferum uocant, cui cornu è media fronte procedit, ut fuo loco dicemus, Eiufdem in Bocoticis uer. ba hac funt: Alce nominata fera, fpecie inter ceruum \& camelum eft, nafcitur apud Celtas, explo= 20 rari inueftigariós ab hominibus animalium fol a non poteft:fed obiter aliquando, dum alias uxenan tur feras, hæc etiam incidit. Sagacifimam effe aiunt; 8 hominis odore per longinquim interual. lum percepto, in foueas $\mathcal{Q}$ profundiffimos fpecus fefe abdere. Venatores montem uel campum ad mille ftadia circundant, \& contracto fubinde ambitu, nifi intra illum fera delitef cat, non alia ratio ne eam capere poffunt. $\mathrm{H} x \mathrm{c}$ Paufanias, qui ut plęriç ueteres Germaniam totam \& Septentriona. les finitimas regiones uno Celticæ nomine comprehendit.

ब. Cxar lib.6. Commentariorum de bello GallicołSunt item in Hercynia fylua qua appellan= tur Alces, harum eft confimilis capris figura, \& uarietas pellium ; fed magnitudine paulo antece dunt, mutilęḉ funt cornibus: $\mathcal{X}$ crura fine nodis articulis ç habẽt:neq̧ quietis caufa procumbunt 
neç fi quo affichax cafu coneiderunt, erigere fefe aut fubleuare poffunt, His funt arbores pro cuble libus, ad eas fe applicant:ato ita paulum modo reclinatæ quietem capiunt, quarũ ex ueftigh̆́s cum eft animaduerfum à uenatoribus, quiò fe recipere confureuerint, omnes eo loco, aut à radicibus fub. rutunt, aut abfcindunt arbores tantum, ut fumma fpecies earum ftantium relinquatur: huc cum fe confuetudine reclinatuerint, infirmas arbores pondere affligunt, atç unà ipfa concidunt, Sub Gordiano Romæ fuerunt Älces decem, Iulio Capitolino tefte:qui totidem quoque fuiffe frribit in Gordiani fylua memorabili picta in domo roftrata Cn.Pompeï.C.Plinius natural.hiftorię li.8.cap. 15. Septentrio fert Alcen, ni proceritas autriữ $\&$ certricis diftinguat, iumento fimilem. Item notam in Scandinatria infula, nec unquam uifam in hoc orbe, multis tamen narratam, machlin, haud difimia lem illi,fed nullo fuffraginum flexu:ideoćp non cubãtem, fed accliuem arbori in fomno, eáḉ́ inciráa in ad infidias capitur, aliàs uelocitatis memoratæ. Labrum ei fuperius prægrande; ob id retrogi aditur in pafcendo, ne in priora tendens introluatur. Hæc Plinius, \& apparet eum de alce \& $\&$ machli tan quam diuerfis animalibus frripfiffe ea, quæ Cafar in unam Alcen coniunxit. Sunt qui coníciant machlin feram illam effe, qux uulgo remer appellatur : de qua in Rangifero dicemus : alij uero ta. randum. In figura quam damus alcis etiam labrum fuperius perquiam craffirm apparet; $\&$ Olaus Magnưs Gotthus uir propter eruditionẽ ac regionis uicinitatẽ fíde dignus, uelociflimas effe alces teftatur, ut paulo poft dicam. Quramobrêcum folus quod fciam Plinius machlin feram nominauez rit, nee de ea quicquam fcripferit, quod alĭ authores alcibus non attribuant, animus mihi inclinat non animalis fed nominis tantum differentiam effe; nifi fortelectio corrupta eft, quod potius credia derim'; in quibufdam enim codicibus hon machlin fed iterum alcen legitur:quanquam propter prę 20 cedentia uerba fic legi non poffit. loannes Ammonius Agricola legit, multis tamẽ narratam alcen, haud diffimilem bubus fylueftribus, $\mathbb{Z}$ nullo fuffraginum flexux.Solinus fimia Pliní fic fcribitcap. 23. Sunt $\&$ alces mullis comparand $æ$, adeò propenfo labro fuperiore, ut nifi recedentes in pofterio ra ueftigia pafcínon queant. Scandinauia infula è regione Germanix mittit animal quale Alces, fed cui fuffrägines, ut elephantis, flecti nequeunt:propterea non cubat cum dormiendum eft. Taz men fomnolentum arbor fuftinet, quæ propé cafura fecatur, ut fera, dum affuetis fulcimentis inni. titur, faciat ruinam, Ita capitur:alioqui difficile eft eam manu capi, Nam in illo rigore poplítum in comprehenfibili fuga pollet.

-Nunc ueterum fcriptis fubdam recentiora.Matthæus Michauanus in defcriptione Sarmatia rum:A pud Mofchos Bifontes funt \& Alces, quarum crura abfg articulis pralonga. Mófchi appel 30 lantLozzos, \& Germani fiellend. Erafmus Stella in libro de Origine Brufforum:Ibidem inquitit funt Alce, non tamen ex afinorum agreftium genere:nam illi tantum in Africa $\&$ Afia reperiun. tur. Alce autem quafi medium genus inter equos $\&$ certros, cornua quotannis amittit, \& propter cimiditatem gregarium eft. A pud Albertum Magnum, uirum in rerum cógnitione non infelicis ter uerfatum, nominibus uero imperitifimé abutentem, libro hiftorix animalium 22, ubi quadru. pedum hiftoriam ordine literarum exponit, pro alce primum Alches fcribitur, deínde Aloy,poftea in Elitera, Equiceruum duorum generum facit, unum quem Germani uocitant LE Eent, cuius tas men nomenclaturæ teftem nullum producit: $\mathcal{Q}$ alterũ à Solino defcriptum, de quo infra dicemus. Cæterum libro 2, eiufdem operis de Aĺce in hanc fententiam fcribit, \& uexe ut ego iudico: Equicer uus nobis cognitus equo fimilis eft, fed altior, uulgo 佳lent, $\&$ ad equitandi ufum cicuratur : tan= 40 tundem enim uno die fpacĭ, quantum equus triduro perficit, Cornua eius folida 86 ramofa funt,

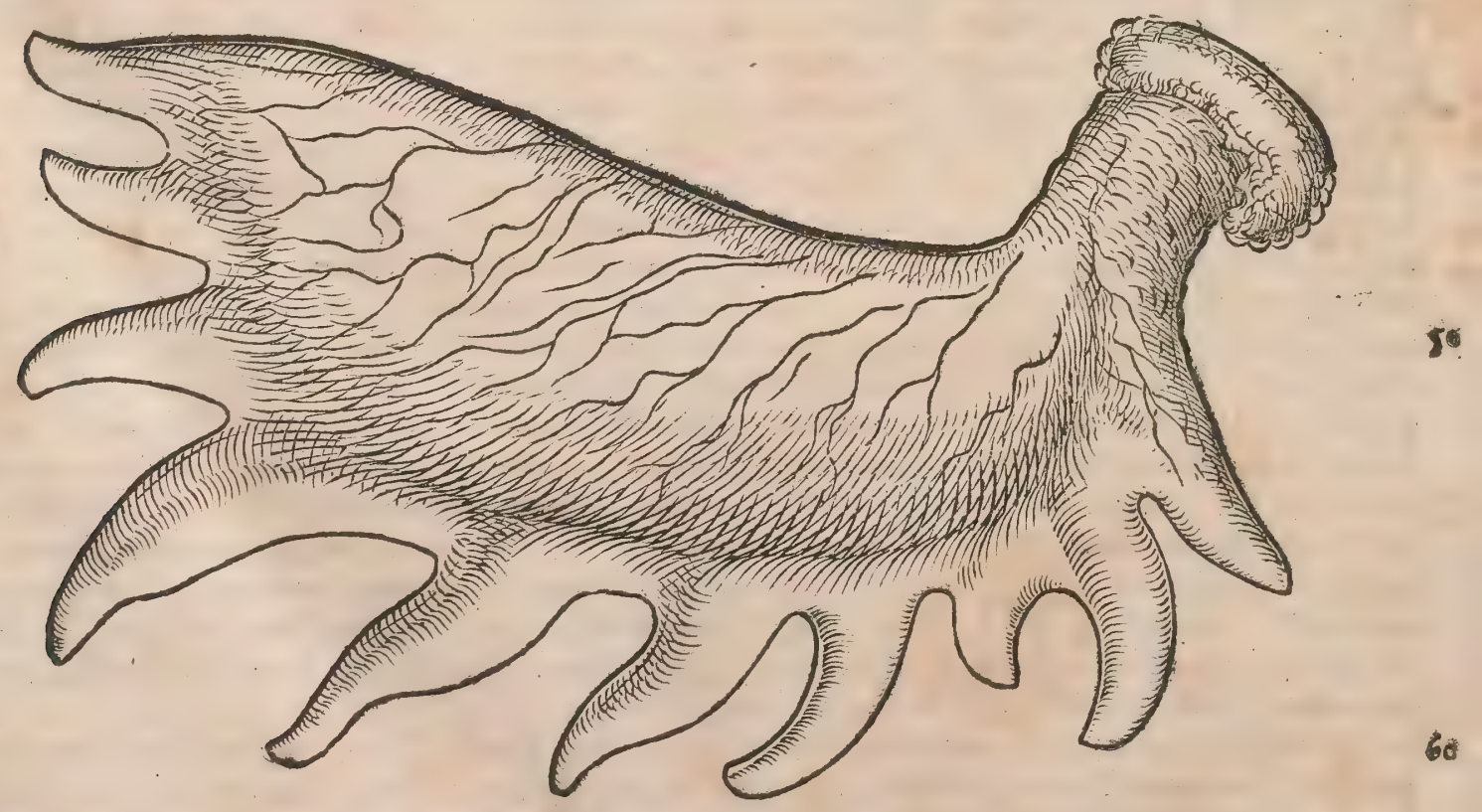




\section{De Alce. Lib. I.}

colore quo cerui, $\mathrm{Ab}$ initio ubi enafcuntur ad tres uel quattior digitos rotunda funt, deinceps lac ca 8 tenuia afferis inftar, \& circa finem multos producunt ramos. Facit hac latitudo ut fcabellis idonea fint, Pondus cornuum ingens. Magnus horum animaliưm nưmerus êf in fyluís Pruffix; Vngaria, \& Illyrix, Maiora funt certuís 8 hirfutiora, fimili tamen pilo, in cæeteris cauda folum cer = uis fimilia.Frontis latitido ad dios palmos, Hæc Albert. Videtur ạũt palmũ pro dodrante dicere.

I Nunc reliqua addam, qux uulgo apud nos feruntur. Cornua fingula libras círciter duode= cim appendunt, longitudine ferè duorum pedum, non ramofà irt ceruorum, mưcronibus tamen as liquot diuifa, dodrantem lata, armi potiưs quàm cornu figura, aduehuntur ex Lituania. Germa= nicum nomen miferiam fignificat: \& uerè miferum eft animal, fi credendirm eft qued fape auidiuí= io mus, quotidianum ei morbum cómitialem ingruere, à quo non prius leuetur quàm dextric (fi bene memini) pofterioris pedis ungulam auriculæ finiftræ immiferit ; quod ego fi fit fortuito fieri fufpi= cor, conuulfis $\&$ diftortis morbi magnitudine membris. Vingulam habet ut bos bifulcam.Illam, uel partem eius, aut annulum inde factum, eiufdem morbi amuletum geftant: unde fit ut maximo pre. tio uteneat. Scio id non raro profuiffe, fapius tamen fruftra tentatum : caufam alip in morbi difcrim men rẹ̄ciant, ego animi perfuafionem fuperftitiofis rebus magis minúsue aut nullo mơdo confi= fam effectus rerum maxime uariare crediderim. Capta uel modico utulnere lafa, expirat ftatim, prae timiditate nímírum. Pro ungula eius argyrta nonnulli bouinam uendunt, probatur odore, raditur enim $\&$ bene olet, ut fertur, bouis foztet. Alutarij pellem eius ad thoraces pifcium adipe (ad hunc ufum alumini præferendo) præparant, it imbres arceat, Veneunt fingule, ut audio, tribus aut qua 20 tuor denarịs autreis, A ceruina, cui fimilis eft, infpirata difcernitur, fertur enim tranfmittere fpiri= tum ut ab oppofita manu percipiatur, cum fit plena meatibus $\&$ pili in ea concauii. Ego ungulam integram cum ima tibia parte pilofa tiidi, nec ullam in pilis cauitatem reperi : quamuis fieri poteft ut meatưs quidam quí in uiuis erant, mortuis collabantur, priefertim longo poft tempore. Denfa \& folida eft adeó, ut uehementes etiam ictus punction crefim $\not \beta$ factos auertat, \& ferrei thoracis inftar hodie expetatur:quod Aelianus Tarando etiam attribuit, qui ex boum fylueftriũ genere eft quan quam \& Alces medici quidam \& feplafiarn̆ hodie tarandulos tocitent, ut Ioannes Agricola Am. monius fcribit; qui etiam de ungulis huius feræ prodidit; fufpenfas ita ut nudã cutem attingãt, epie lepfiam curare, $\&$ ab acceffione cius liberare hominem, quamuis iam óre fumantem. Audio præx. terea ramenta uel frobem ungula aduerfus eandem noxam in Polonía propinari.In Scandinauia; 30 ut dixi, plurimæ funt Alces, quæ gregatim degunt, \& fupra aquas gelu aftrictas, irruentes in eas montanos lupos excipiunt; hanc pugnam uenatores obferuant, 8 partem uictam perfequuntur. Trahuntur à cicuratis homines in uehiculis per niures $\&$ glaciem in Stredia:quod in Gotthia non 1 i cet, ne tanta uelocitatejexploratores frui poflint. Alces uituæ captæ principibus aliquãdo inter mu nera mittuntur. Elegans $\&$ argutum eft Andrex Alciati epigramma ; ideóç hurc adfribendum: Alciatæ gentis infignia fuftinet alce, Conftat Alexandrum fic refpondifferoganti, Quî tot obiuiffet tempore gefta breui:

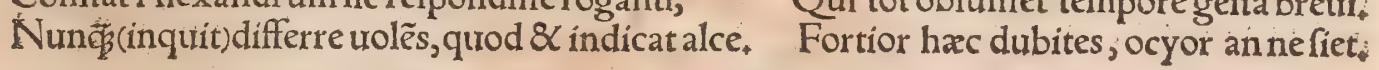

\section{ALCIDA FERA PABVLOSA.}

D IOD O R v S Siculus lib.4. de fabúlofis ántiquiorum geltis: Mineruã ferû́t alcidam peremiflé feram ftupendam, ex terra natam, $\&$ antea, ut qux natura plurimum ignis ex ore euromeret, infupe rabilem pugna. Ea primum in Phrygia apparuit,regionem quandam comburens, qua hucufog ex: ufta Phrygia dicta eft. Deinde ad montem Taurum trãfcendens, fylưas continuas ufọ ad Indos in cendio uaftauit, Poftmodum per mare in Phonician reuerfa, fyluas Libani incendit : perós. Aegy= ptum in Libyam profecta, ad loca peruenit occidua. Poftremó fyluis circa Ceraunia deftructis, om nígs incenfa regione, cum homines partím flamma abfúmpti effent, partim timore patriam lin. quentes ad remotiora diffugerent loca, Mineruam ferunt eam ferã necaffe, pellem pectori circun: dediffe. At ueroalcidæ morte terra commota, deorum hoftis, gigantes peperit, Hac ille; Liuius libbs 2.Decadis 5. Mineruam Alciden cognominatam fcribit,

\section{DE A S INO.}

\section{A;}

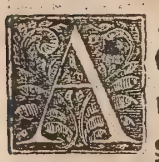

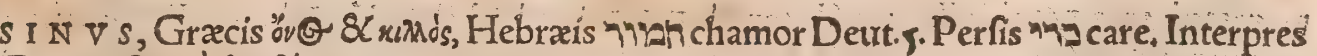
Græcus fermé '́roo?úy

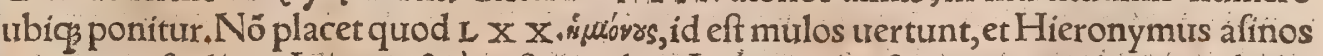
genere mafculino, Intrenio $\&$ à pofterioribus Iudxis pro afino poni tria hac uocabula,

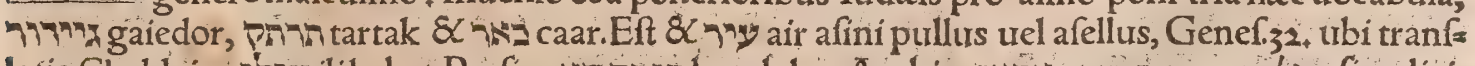

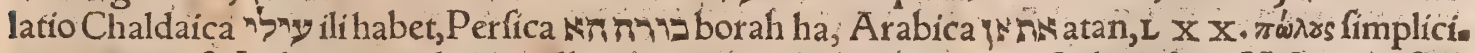
so ter uertunt: $Q$ Iudicum ro. aliqui pullos equorum etiam exponunt. Italis lafino, Hifpanis afno,

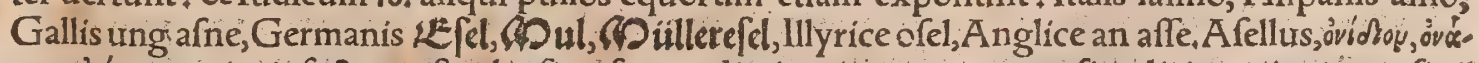
esp (óviore- enim infectum eft) ab afino forma diminutiua quanquam fimpliciter etiam pro afino 


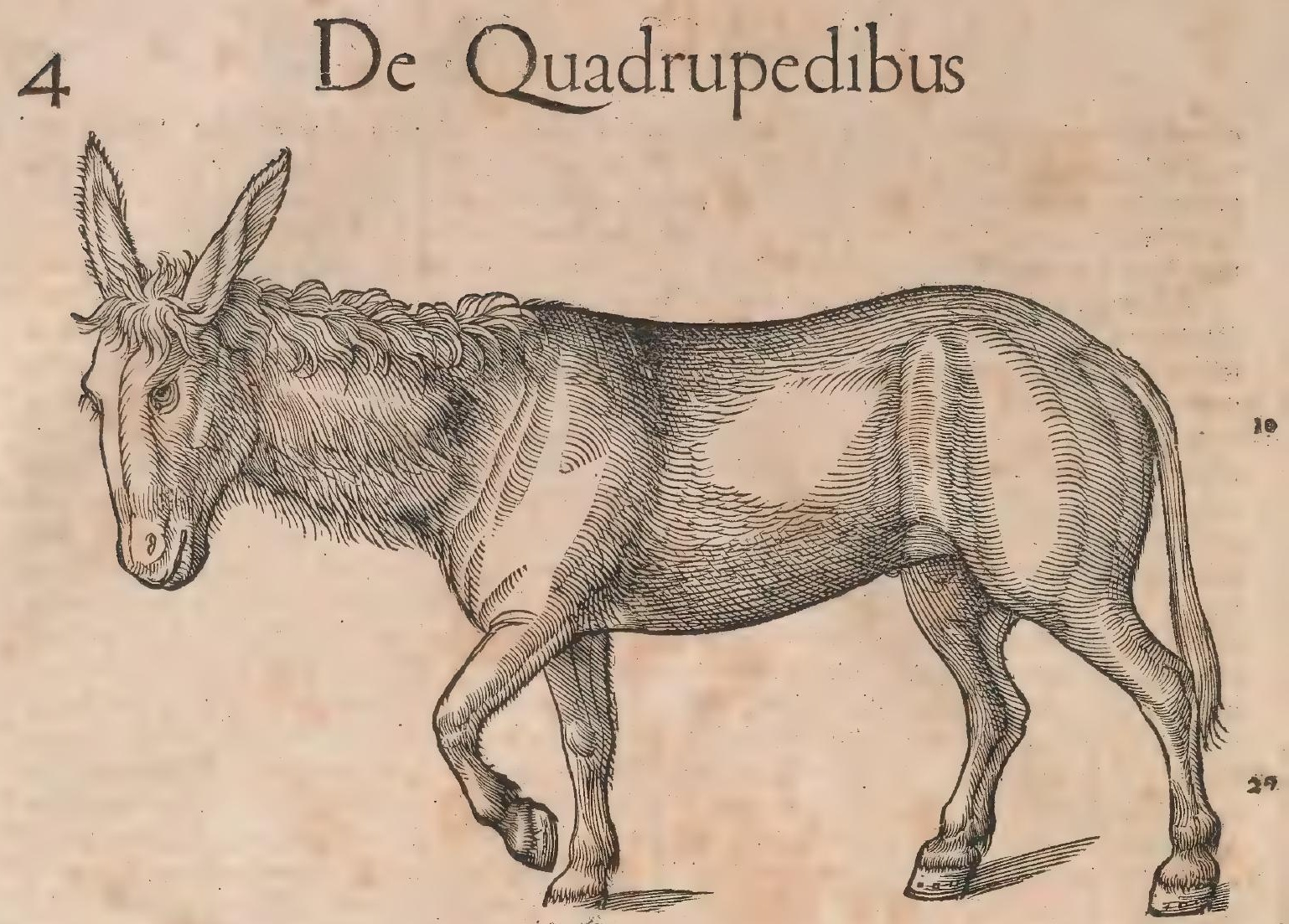

per contemptum ponatur. Nafcinntur aũt parui, trel uteri uitio, wel aliam ob caufam prater natur. ram, uel propter loci frigiditatem. Colımella ab initio lib. 7.Principiú (inquit) tenebit minor Arca dia, uilis hiç, uulgarisḉ̧ a fellus,Minor Arcadia, id eft Ârcadico afino, qui \& maior $\&$ pretiofus eft. $3^{\circ}$

$B$.

Afints animal gerulum, plagarum \& penuriæ inter itrmenta tolerantiffimus, tardius reliquis armentis deficit, laboris $\&$ famis maxime patiens, corpore macilêto $\&$ deformi. Frigoris impatiens eft:quapropter Pontica \& Scythica terra \& finitimæ afinis carent, ut etiam Celtica ( Gallia fupra Hífpaniam fita)propter immodicû frigus.Parui funt in Illyria, Thracia, \& Epiro, cum cæeterasqua= drupedes Epirotica terra magnas ferat. II In mulis etiam, afinis communia quædam dicemus. Afi ni fpeciofi $\&$ mularum generi feminando commedifsimi forma, in mulis infra defcribetur. Ab afpe ćlu(inquit)non aliter probari debet, quàm ut fit amplifsimi corporis, ceruice ualida, robuftis ac la=. tis coftis, pectoremufculofo \& uafto, feminibus lacertofis, cruribus compactis, coloris nigri uel ma culofi, aut etiam rubei, fecundum Palladium. Nam murinus cum fit in afino uulgaris, tum etiam $4^{\circ}$ non optime refpondet in mula,Murius apud Varronem:Ego, inquit, de afinis potiffimum dicam, quod frrm Reatinus, ubi optimi $\&$ maximi fiunt, è quo feminio ego hic procuraui pullos, \& ipfis Arcadibus uendidi aliquoties. Igitur afinorum gregem qui facere uult bonũ, primum uidendum ut mares, foeminas ś́p bona ętate fưmat, utíq̧̧ ut quàm diutiffime fruçum ferre poffint, firmos, omni bus partibus heneftos, corpore amplo, feminio bono, ex his locis, unde optimi exeunt:quod faciunt Peloponnenfes, cum potiffimum eos ex Arcadia emebant, in Italia ex agro Reatino. Non enim fi murenæ optimæ flutæ funt in Sicilia $\&$ helops in $R$ hodo, continuo hi pifces cmni mari fimiles na= fcuntur. Et alibi apud Varronem:Quòd fimiles parentum gignantur, eligendi, $\mathcal{Q}$ mas $\&$ formina cum dignitate ut fint.In mercando item ( ut cæteræ pecudes) emptionibus, \& traditionibus domis nium mutant, $\mathcal{Q}$ de fanitate ac noxa folet caureri. IA fino $\&$ tauro inter ea qua animal generant $\varsigma^{\circ}$ craffiffimus $\&$ nigerrimus fanguis eft. Plinius afinis pinguiffimum, homini tenuiffimum effe frri=

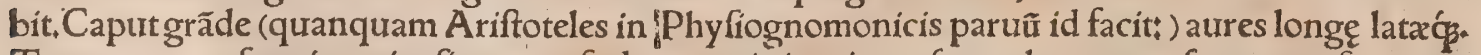
Tum mas, tum formina trigefimo menfe dentes mittit priores:fecundos autem fexto menfe, atque etiam tertios quartosíg eodem:gnomonas hos quartos à díu udicanda æatate nuncupant, Quo dfinō prius peperêre quàm decidant poftremi, flerilitas certa, Cor ei pro portione maximum, ut omnibus timidis, aut propter metum maleficis. Venter unicus, ut $\&$ reliquis qux folidas habent ungulas Felle caret, ut folipeda omnía. Mammas binas gerit inter femora, in anteriore dorfi parte circa feas pulas debilior, ubi $\mathcal{Q}$ crucis figura in $e 0$ apparet:pofterius $\&<$ circa lumbos ualidior. Caudam habet quàm equus longiorem. Cur pili è cicatrice nafcantur eis, in ${ }^{\prime}$ c candidi, Ariftoteles quærit Problema te 29.8 31. fectionis 10. Corpore afinorum exanimato fcarabeos gigni putant, बS Stygis aqua ex pe=60 tra profluẽs infigni frigiditate eft, diffilientibus urafis omnibus, afini modo ungula excepta, aut mutr lax, ficuti alí prodidere, ni mendofa funt Græcortim exemplatia, Certe in libro de primo frigido Plư 


\section{DeAfino B.C. Lib. I.}

tarchus de afini ungula intellexit, quod facit in hiftorñs item Ioãnes monachus in Alexandri men. rione. A tibro tricefimo Plinius, mularum ungulis contineri modo Stygís aquam prodit, facilis $l_{3}=$

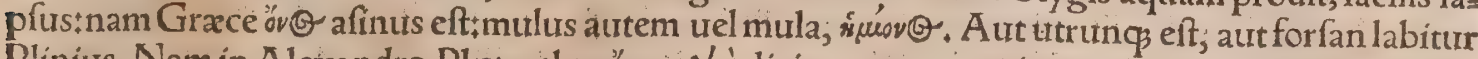

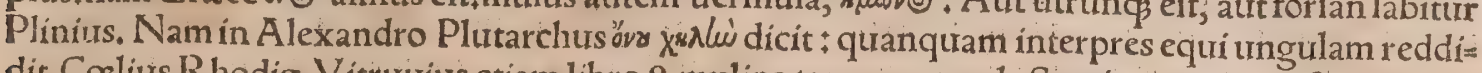
dit, Colius R hodig. Vitruuius etiam libro 8, mulina tantum ungula Stygis aquam confertrari pof re dicit: Iuftinus lib, 17 , feu Trogus, equi, Curtius autem lib, io, dum iumenti ait; in mediã relinquit, Aeliantus non ungulis fed cornibus afinorum Scythicorum contineri fribic,

C.

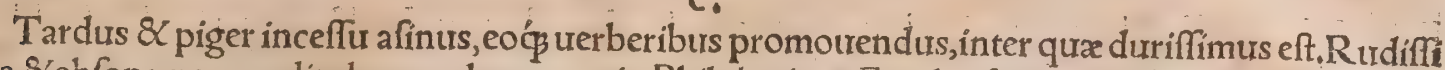
10 ma \&abfona uoce rudit, de qua plura mox ín Philología. बFFerulę afinis gratifimę funt in pabulo, cateris uero iumẽtis præfentaneo ueneno:qua de caufa id animal Libero patri affignatur, cui $\& \mathrm{fe}$ rula. Ocimum Venerẽ ftimulat, ideo etiã equis afinisḉ̧s admiflurę tempore ingeritur. Spinis quoō̧ adhuc teneris ucfcitur afinus, \& fructibus arboruึ. Quin $\&$ co rure (Columella tefte) quod pafcuo caret, côtineri poreft exíguro, \& qualicunqp pabulo côtentus. Quippe uel folijs fpiniśḉ, uel perticis falignis alitur, uel obiecto fafce farmentorũ.Paleis uero, quibus fere omnes regiones abundant, etiã glícit. Q. Hortenfius maiorẽ curam fibi habet ne eius efuriant mulli in pifcinis \$ quã ego habeo ne mei in Rofea efuriant afini, \&c. Ego enim uno feruulo, ordeo, non multa aqua domeftica; meos multinumos alo afinos, Varro: 8 alibi, Commode(ait)paf́cuntur farre $\&$ furfuribus ordeaceís. Ea= dem ferè in paftur obferuantur qua in equis, A qua potur pingurefcere eos ferunt, $\&$ ex cibo eò magis 20 proficere quo plus biberint.Pullum a finæa à partu recêtem fubïciunt equx, curius lacte amplior fit, $\&$ hippothelas uocatur: præterea educant eum paleis, fœno, hordeo. Non nifi affuetos potant fon= tes, qui funt in pecuarijs, atq̧; ita ut ficco tramite ad potum eant. Nec pontes tranfeũt per raritatem cortum translucentibus fluunjs. (Hic pro corum aliâs legitur plancarũ in Plinio:qux uox etiam Gal lica eft, \& pontium tabulas fignificat ut non approbemus illos qui placarum, aut ut Hermolaus phalangarum legere malunt.) Mirumḉ diçu, fitiunt: 8 fi immutẽtur aqua, ut bibant, cogende ex onerandæúte funt, Plinius. A pud Afros paftorales afini reperiuntur impoti, id eft, qui nunquam bi bunt, Herodotus lib, 4. Deafini paftu $\&$ potu uide etiam in equis. IN Non nifi fpaciofa incubitant laxitate. Varia nan p̧ fomnio uifa concipiunt, ictu pedum crebro: qui nifi per inane emicuerit, re= pulfur durioris materiæe clauditatẽ illico affert. Afinicur plus excrementi ficci egerant quàm hu= 30 midi Ariftoteles inquirit Problemate 8 . fectionis 10. Afinæ tenuiorem reddunt urinam quàm ma res. Purgantur menfibus, amplius quidem quàm oues $\&$ capræ, fed multó ex proportione minus: Anna focer Efau primus equis afinos copulauit, ut ludxi afferunt, Ifiodorus, Multus eft in coitu afinus, minus tame quàm equus. Tam mas quàm formina menfe tricefimo coít‘fed magna ex parte n€queunt generare:uerum in bimatu, aut trimatu $\&$ femiffe. Sed iam uel anniculã uentrem geffiffe afellam aiunt, ita ut quod pepererat, educariac perfici potuerit; Ariftoteles. Et Plinius fimiliter; Partus(inquit)à tricefimo menfe ocyffimus, fed à trimatu legitimustotidẽ qưo equę \& eifdem men fibus, \& fimili modo. De afinis ad coitum idoneis lege Conftantinum lib, 16 . cap, 20, item cur equa in Elide cx afinis concipere non potuerint, Leonicenum 1,62. A finus nifiả prima dentíum mutatio ne generare incipiat, nunquam poft generat, fed fterilis omnino perdurat, A riftot. Superftitiofè 40 quibufdam proditum eft, afinas non concipere tot annis, qurot grana hordei muliebris purgationis fanguíne contacia ederint, Non ęquinoctio uerno, ut equx \& cæatera pecura, admiffarís iunguntur afina:fed æftiuo folfitío, propter naturæ frigiditatem, ut tempore calido pulli nafcantur, endẽ enim tempore parit, quo coierit, Ariftot. Admittuntur ante folftitium, ut codem tempore alternis annis pariant, duodecimo enim menfe conceptum femen reddunt, Varro. Mares in remiffione operis de reriores ad generationem funt, quamobrem ab opere non difiungunt. A finus equam fuperueniens citius implet quàm equus. Si equus fuperuenerit afinam, quam inierít afinus, non peruertet afini initum: fed fiafinus fuperuenerit equam, quam equis inierit, peruertet (ita ut abortus fequatur, Plin.spropter feminis fui frigiditatem, Ariftot.Et alibi, A finus quidem equigenituram corrumpit, fed equus afini minimé, cum equa iam afini initu conceperit. Cum uel equus cum afina, uel afinus

5o cum equa inierit, multo magis abortus confequitur, quàm cum unigenæ inter fe iungantur : uterbi gratia, equa cum equo, aut afina cum afino. Euenit etiam tempus gerendi uteri, cum equus cum afino coierit, maris norma:id eft, ut quanto fpacio temporis mas perficitur furo in genere, tã to etiam foetus, quem ipfe procreat,abfoluatur, At magnitudine corporis, fpecie, \& uiribus, magis fomine, quàm mari fimile euadit quod nafciturt fi frequenter coeant, neç ullo interpofito tempore ceffen, qux ita iunguntur, breui foemina fterilefcit: qua de caufa non frequenter ita coniungunt, qui cu= ram huic adhibent rei, fed tempus aliquod interponunt. Non afinum equa, ut afina equumreci= pit, nifi afinus fit, qui equam fuxerit, Admittunt de induftria quos hippothelas tocant, ac fiequis mulgos cognomines, qui in pafcuís modo equerum uiribus bonis furperantes coeant. Reijcit afina' femen à coitu nifi interpelletur: quamobrem fatim â coitu uerberãt infeçanturó́s; Ariftot, Plínius

$60 \mathrm{rem}$ eandem his uerbis exprimit, Incontinens uterus urinam genitalem reddit, ni cogatur in cur fum uerberibus à coitu. Parit duodecimo menfe (annû uterum fert $\&$ afina $\&$ equa) fingùlatín ma gna ex parte procreat prolem; ea nanç natura eft, ut unum parias, fed nónunquam gemellos etiam' 
ædit, rariffime tamen. Mulus ex afina \& onagro genitus omnes antecellit, Parereud ín confpeciu hominis, uel in luce nolit fed tenebras quxrit(aliâs in tenebras ducitur)cum parturit. A parti die fe ptimo mari iungitur, eoǵs dieiuncta maxime recipit initum, fed poftmodum etiam patitur. Soles hxe, nifi priufquam gnomonem amittat,peperit, nunquam poftea initum recipere: fin antea pepe. rerit, parere tota fua xtate poteft. Gignit tota uita(tefte Pliniv)qux eft ei ad trigefimum annum. Ad mularum maximé partus, aurium referre in his 8 palpebrarum pilos aiunt: quamuis enim unico. lor reliquo corpore, totidem tamen colores quot ibi fuêre, reddit. Pręgnantes opere leuant. Venter enim labore nationem reddit deteriorem. Marem non difiungunt ab opere, quod remiffione labo. ris fit deterior.Secundum partum pullos anno non remouent à matre. Proximo anno noéribus pa tiuntur effe cum his, \& leuiter capiftris, aliaúe qua re habēt uinços. A dmittuntur ante folftitium, rt ut eodem tempore alternis annis pariant: duodecimo enim menfe conceptum femen reddunt. In paftu eadem ferè obferuant qux in equis. Partus charitas fumma, fed aquarum tædium maius ignes ad foetus tendunt. Exdem, fi riuus minimus interfit, horrent, ita ut pedes omnino caueant tin gere. Dolent eis à foetu mamma:ideo fexto menfe arcent partus, cum equx anno propé toto prabea ant. Lac grauidæ habent menfe decimo, uel ut Plinius fcribit, prægnantes continuo lactefcunt. Pul lis earum, ubi píngue pabulum, biduoà partu maternum lac guftaffe latale eft. Genus mali yocatur. coloftratio. Crafliffimum arinæ lac eft, ut quo coaguli uice utantur: tenuius equa, tenuiffimum ca. meli,Hac Plinius, quomodo autem craffiffimum fit afinæ lac paulò poft differemus. Vita afinis ad trigefimũ annum(aliâs amplior annis triginta) fomina uiuacior mare eft. đVno maxime morbo. laborant,quem malida uocant, quod uitium in capite oritur, facitós ut per nares piruita nultsa, ruf $=2$ faćs effluat, quæ fi ad pulmonem defcenderit, moriuntur: fed fi in capite folum eft, non infertinteri tum.Soli inter animalia pilofa, non à pediculo tantum, uerum etiam rediuo immunes funt. Plinius oues etiam à pediculis infeftari negat. TA fino moriente uifo celerrime deficiũt:rarò alioqui mor bis afficiuntur. Grammatici Gracci maliafmon effe dicunt catarrhum per nares in afinis: $\mathcal{Q}$ tormina etiam eis accidere:à neutro morbo eos euradere. Malie, $\mu a \lambda$ is, a pud cof́dem, affeçus iumentort̃ cum ruffiunt: 8 malis, aphtha, id eft, oris ulcus, inflammatio. A blyrtus de morbis equorum cap. 2. Maxi ma (inquit) agritudo eft, à quo equi non facile conualefcunt, quam pleriq̧ malin, alin catarrhum, Romani fumperium rocant, eft aurem reuera articularis morbus, deirde eius figna $\&$ curationem rubricit. Nos plura de hoc morbi genere in Boue dicemus. Si oues utantur ftabulo, in quo mulę, aut equi, aut afini fteterunt, facile incidunt fcabiem, Columella. Circa Abderam \& limitem qui Diome dis trocatur, equi nafcentibus illic herbis pafti, inflammantur rabie, circa Potnias uero afini, Pli= nius. A fini in Thufcia depafticicutam, tam graui fomno premuntur, ut ftupidi fenfućs priuati, ca* dauera uideantur. Et fxpe accidit, ut dum à rufticis propter pellem excoriarentur, iam dimidia par te detraĉa, tum primum expergif́cerentur, excoriantibus inde uehementer cöfternatis, Petrus An dreas Mattha olus. Ad urinx difficultatem alini, ut Suidas frribit, fuperftitiofi quidam hac uerba immurmurabant, Gallus bibit $\&$ non meïr, myxus non bibit $\&$ meït. Ego pro myxo hîc myoxum id eft bufonem accipio, ut fuo loco reperam copiofius. Ad mortos particulares in equis, alinis, $\&$ mulis, fanguinis detractione utendum eft, Hippocrates in Geoponicis. Eidem feré morbi afinis \& equis infefti funt, \& fimiliter curantur:proinde afinos curaturus ad equos tranfibit.

A finus ineptiffimis eft moribus, \& degenere animo, in primis thanfuetus,ingenñ placidi,ftoli. dus, nec ulla utcunģ magna 8 iniqua onera detrectat. Obuṇs in uia cedere nefcit. Vocẽ hominis confuetam intelligit $8 \mathrm{~m}$ minir irer quod aliquoties ingreffus eft. Maurufín afini primum ut fe in uiam dederunt, incredibiliter incitata celeritate iter conficiunt, ut euolare, non excurrere uidean. tur. Deinde eos cito felfos de uia, $\&$ pedes $\&$ fpiritus defic unt, ac pedũ tarditate ad currendũ con: fricti infiftunt, $\&$ acerrimas profundunt lachrymas, non tantopere, meo iudicio, ob futuram mor tem, quàm ob pedum infirmitatem; quare ut captiui ad equos alligati trahuntur, A elian. đAfino $\&$ tauro cortuus aduerfatur, quippe qui aduolans feriat, \& corum oculos laceret. Cum falo etiam auicula pralium ei eft:Spinetis enim fe feabendi caufa atterens, nidos eius diffipat:item cum fpino, cui uiçus à uepribus, quas afinus tenellas adhuc pafcit. Sunt $\&$ lupi eis inimici, ut qui carne alan= go rur, itaç ab illis circumueniuntur. Cum lupum afinus prafentem uiderit, caput in latus uertit, ne afpiciat, \& uifu auerfo inuaditur. Praterea colote hoftis eft:dormit enim colora in prafcpibus, \& $n a$ rem fubiens afini, ne comedat, impedit. Plura de colota lib. 2. in Stellione docebo. Quęrunt afini af. plenon herbam, ut minuant atram bilem. TAmmonianus Syriano cognatus, poetarum interpre. tationi $\&$ Gracx lingux elegantix deditus crat, atç afinum fapientix auditorem polfidebat, Sui. das. Qurod afini etiam difcernant genus; fpeciem ac indiuiduum, Galenus cófirmat lib. 2. Methodi, his urerbis: Adeoćs (inquit) eft euidens, ac omnibus natura infitum, tum hominibus, tum brutis, ut aliud quid ceu in fubftantia fubieçum, aliud ceu fpecie unum intelligãt:ut uel afinorum (qui tame omnium brutorum ftupidiffimi uidentur) aliud effe fpecie unum, aliud numero, notitiam non fus. giat. Confpecta nanç camelo, afinus fe retrahit, $\&$ fugit, ac timet, fi nunquam antecamelum con: 60 ipexitıfin autẽ uidere iam affueuit, quamuis aliam aliam $\not \beta \beta$ illi demonfres, tumen propter confuretu dinem non amplius timet, fed ueluti unam fpeciem intuecur, \& illam cui infueuit, \& hane quę nune 


\section{DeAfino. D.E. Lib I $_{+}$}

primum apparet. Ad eundem modum nec homines timet propter confuetudinem: fed hos quroquie uelut unam fpeciem uidet. Verum fi curatorem infpexit, nó folum ut hominem, fed etiam ut hunc hominem agnofcit, \& $\mathrm{X}$ micat auribus, \& caudam quatit; $\&$ rudit, $\&$ lafciuit, cum eum afpexit, utic indicans.fe familiarem agnofere. Hunc itaç tum ut hominem, tum ut familiarem nofcit. Eum aut tem quem primum iam uidet, ut hominem fimiliter, ut familiarem non fimiliter. Et paulo poft. Eo. dem modo ưiã norunt, non tantû̃ abfolute ut ưiam, fed etiã ut hanc aliquam uiam. Nam in ingreffur uix quam non nouit, afinum ftatue; attendég ut illam perambulet, ac totam peragat, in ncutram partem declinans, nifi ficubi in diterfa fcinditur, utigs declarans fe fpeciem ipfam uix meminiffe $\&$ claré agnofcere, Quippe inambulat eam, qux trita elt: quatenus autem ignorat, fallitur. Neqsenim so ex recordatione eius; qua infectilis unaç̧ numero eft, hanc quam nố nouit, peragere poteft: 8 qua fequuntur reliqua* GHirius loci funt etiam qux in Phyfiognomonicis Ariftotelis legimus, ubi ex aliqua hominis $\&$ partium eius ad afinum fimilitudine de ingenio pronunciat, A finis, inquit, $\&$ fuibus communis eft intemperantia circa Venerê: Afinis propriũ, cura $\&$ folicitudine carere. Qui afinos referũt capite paruo, ferè funt ftupidi:Qui facie carnofa, timidi:eadẽ magna, tardi:Qui fronte rotüda, ftupidi:Qui eminentib,oculis, fimplicesłmagnis, afiníni : Qui labn̈s craffis, \& fuperioribus

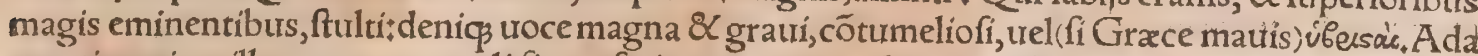
mantius etiam illos quorum oculi ficut afinis prominent, dementes $\&$ contumeliofos effe conṕcit. E.

Tertio anno domare íncipiưt ad eas res, ad quas quif́ç eos unilt habere in ufu. Greges eorunt 20 tion fané fiunt, nifi ï, qui onera portent, ideo quod pleríg deducuntur ad molas, aut ad agriculturam, ubi quid uehendum eft, aut etiam ad arãdum, ubi leuis eft terra, ut in Campania. Greges fiunt ferèmercatorum, ut eorum qui é Brundufio aut Apulia afellis doffuarịs comportant ad mare oleũ, aut utinum, item $\not ́ s$ frumentû́, aut quid aliud, Varro. Caterum Columella lib. 7. initio:Principium (inquit)tenebit minor Arcadiæ, uilis hic uulgarisćp afellus; cuius pleriçs rufticartim rerum autores

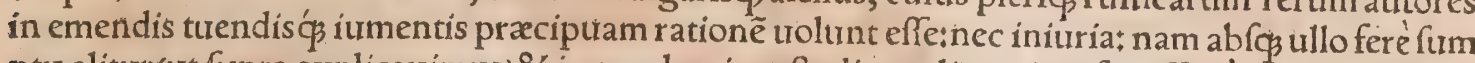
ptu alitur(ut fupra explicauimus) \& imprudentis cuftodis negligentiam fortifimè fuftinet. Huius animalis tam exiguæ tutelæ plurima $\&$ neceffaria opera fipra portionem refpondent:cum $\&$ facís lem terram, qualis in Batica totaćp Libye fit, leuibus aratris prof́cindat. In Byzacio A frica illũ cen tena $\&$ quinquagena fruge fertilem campum,nullis cum ficcurs eft arabilem tauris, poft imbres uili 30 afello, \& à parte altera iugi anu uomerem trahente, uidimus f́indi, Plinius. Ad hac uehicula non nímio pondere trahit. Sxpe etiam ut celeberrimus poeta memorat, Tardi coftas agitator afelli, Vilibus aut onerat pomis, lapidemós reuertens Incuffum, aut atre maffam picis urbe reportat. Iam urò molarum $\&$ conficiendi frumenti pené folennis eft huius pecoris labor, Quare omne rus tanquam maximé neceffariư defyderat afellum: qui, ut dixi, pleraçz utenfilia, \& uehere in urbem; 8 reportare collo, uel dorfo commodé poteft, Columella. A pud nos molitores maximé afellis utun tur, \& ruftici ad lignationem, \& rebus fuis uehendis mendici. Quicquid per afellum fieri poteft urliffimé conftat, Plin. Mulis, equis, afinis ferize nulla, nifi fi in familia funt, Cato.Quotiuga boũ, mu lorum, afinorum habebis, totidem ploftra effe oportet, $I \mathrm{dem}$. Alibi quoç afinos ploftrarios, $\&$ af num molarium: \& iugum afinarium apud Catenem nominari ieperio, A finum 400.nummû́m em. 40 ptum Q. Axio Senatori, autor eft $M$. V arro, haud fcio an cinnium pretio animalium uicto, Plin. Quxfus ex ĭs opima prædia exuperat. Notum eft in Celtiberia fingulas quadragenis milibus nut: morũ enixas(aliấs emi)Plin. Afini Arcadici in Gracia nobilitati, in ltalia Reatini, uf̧̧́ cò ut mea me mo:ia afinus uenierit feftertijs millibus fexaginta, \& unæ quadrigæ Romæ conftiterint quadrin= gentis millibus, Varro. Et alibi, Optimum eft (inquit) Reatinum feminium, ubi tricenís ac quadra genis millibus H s.admiffarn̈ aliquot uenierunt. Quadraginta feftertia ualent ære Gallico bis mils le libras Turonicas, hoc eft mille folatos bilibres. Tanti comparatã referunt afinam Reatinam geru $1 \mathrm{~mm}$, aratricem $8<$ prolificam, Quo fit ut fexaginta milia feftertiorum nummorũ, quibu's afinum fua memoria emptum V arro miratur, folatorum mille quingentorum compleant aftimationem, ut $R o$ bertus Cenalis calculauit. Et quroniam afini propter mulorum generationem pracipué utiles ac pre so tiofi funt, multa hic quæ ad eam $\&$ afinos admiffarios pertinent, dici poterant, nifi commodius uide retur in mulorum uffog mentionem ea differri. Ex onagro $\&$ afina genitus omnes antecellit, Plinius, Carmani propter equorum inopiam afinis in bello plurimum ututtur : \& afinum Martifacrificant; quem folum Perf $x$ ex omnibus dịs colunt, 8 bellicofi funt, Strabo $1 i b_{+} 15$. I Afininum lac mifcent adPhrygium cafeum conficiendum, A riftot. TStercus afinorum primum eft maximé hortiśdein̈ de ouillum, \& caprinum, $\&$ iumentorum, Palladius. Brafficis fimum afininum maxime conuenit, Plin.Quidam bubulo iumentorum fimum præferunt, ouillumó̧ caprino:omnibus uero afininum, quoniam lentiffimé mandanté contrario ufus aduerfus utrunç pronunciat, Idem. ITíbiæ ludi: cræ nunc è loto offibusć́ 3 afini $\&$ argento fiunt, Plinius: $\&$ alibi, Afinorum(inquit)offa ad tibias ca. nora funt. Tibiarum artifices ceruinis offibus, quorum olim ufus erat, afinina pręponunt, tanquam 60 argutiora: 8 A fefopus apud Plutarchum in fapientum conuiuio miratur tam craftum $8 \times 21$ Mufis alienum animal offa maxime tenuia $\&$ mufica habere. Niloxenus etiam eodem in libro: Bufirita inquit Naucratitas nos accufant, quod ex afinis offa tibijs adhibere copimus, cum ipfis uel tubanx 
audire nefas fit, qurod afini uncem afsimilet, qui propter Typhonem eis exofus eft.Coly fanemas co gnominatus eft Empedocles Laertio tefte: Nam cum Agrigentíni uento infeftarentur, illum auero tiffe dicitur circumpofitis urbi pellibus afinorum innumeris. Apud Cumanos mulier in adulte, rio deprehenfa ducebatur in forum, ut illic lapidi infiftens omnibus effet confpicura , Deinde impo= fitam afino, atç ita per totam ciuitatem circumductam, reducebant ad lapidem, ut ibi rurfus effet omnibus fpectaculo. His actis habebatur infamis per omnem uitam, 8 ignominia gratia òvobázis dicebatur, quod afinum equitaffet. Lapis autem nefaftus ac deteftabilis habebatur in quo fteterat mulier,Plutarchus in Problematis , Quadrabit hæc nomenclatura adagî inftar in quamuis proftia tutæ famæ, In Varini Camertis Lexico onoboftides $\mathcal{Q}$ onobatides eodem fenfulegimus, Oneaba* tes, Stephano òveGidxrus, A egypti urbs eft. Maxima etiă apud Parthos ignominia ducebatur, nudum to afino inuehi, Suid. Mesha Arabice nominatur pannus contextus ex pilis afinorum \& capra= rum, uel caprinis tantum: unde A rabes folitudinum incolx tentoria $\&$ faccos fibi conficiunt, An = dreas Belluneñ. Equx caluaria, fed non uirginis, intra hortum ponenda eft, uel etianı afinę.Credun tur enim íra prafentia foccundare qua fpectant, Palladius, Columella lib, so, inter rufticortum reme dia aduerfus tempeftates, fic frribit; Hinc caput Arcadici nudum cute fertur afellii Tyxhenus fixiffe Tages in limite ruris.

pullos afinarum epulari Mecœenas inftituit, multum eo tempore pralatos onagris : poft eum intern̈t autoritas faporis, Plin. Ariftophanis interpres in Vefpis fcribit afinos A thenis in cibum ure

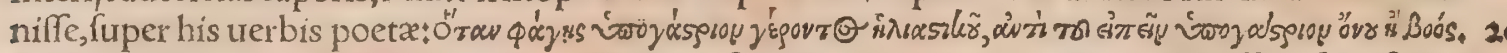
बा Sunt qui afinorum domefficorum, etiam cum fenuerunt,carnes mandất: qux peffimi funt fucci, ac concoctu difficillimæ, ftomachumćs lędunt, \& præterea inter edendum funt infuaues:quemad. modum equorum ac camelorum carnes, quibus etiam ipfis homines, animo $\&$ corpore afinini ac. camelini, uefcuntur, Galenus lib.3.de alimẽtorum facultatibus. G Lac muliebre temperatifimum eft, mox caprillum, hinc afininum, ouillumós, poftremo uaccinum, Aegineta, Archigenes $\&$ Phila 'grius omne lac incommodum effe calculofis pronunciất,præter afininum, quod fubftantia tenuif: fimum eft, \& facultatis facillimè diffoluentis . Igitur mirabiliter articulorum tumores \& nodos (quos ad callofx duritiei modum ex uitiofil lactis ufu pueri fuftinere cogũutur) leuigat $\&$ delet:unde admonendum duxi ut ipfum calculofis affiduè heminæ menfura exhibeatur, poft matutinas deam= bulationes, atç̧ id præferuandi à lapidis generatione gratia, præ omnibus alips fiat, Meminit horum 30 Aetius in curatione lapidis ueficæ. Idem fcriptor alibi de furppuratis renibus tractans, his uerbis uti tur: Lac itaç cum melle poft puris eruptionem eis prabendum $: \&$ primum quidem afininum aut equinum, ad ulcera enim repurganda conducit: quum uero repurgatione amplius opus non ha* bent, $\&$ morfus fiunt obtufiores, indigetós æoger nutrimento, tunc etiam bubulum lac eis exhiben. dum duarum aut trium heminarum menfura. Bubulum, afininum, \& equinum lac, utentri magis idonea funt, fed ipfum turbant, Diofcorides, Maxime perpurgat lac equinum, tum afininum, deinz de bubulum, tum caprinum, Varro. Pullum afininum à partu recentem fubijciunt equra, cuiurs la çe ampliores fiunt:çuod id lac quàm afininum, ac alia omnia dicũt effe melius, Idem. Dulcifímum ab hominis lacte camelinum, efficaciffimum ex afinis, Plin. Bubulum lac pinguiffinu ễ ett, ouinum S c caprinum multo minus, afinarum minimum pingue habet. Quamobrem perraro alicui in uen $=40^{\circ}$ tre coagulatur, fir recens mulfum $\&$ calidum adhuc bibatur: quod fi fal $\&$ mel adijciantur, fieri non poterit ut amplius coaguletur in trentre. Eandem ob caufam aluum magis fubducit, quód ferum ei copiofius infit, minus autem de cafei natura, cuius ratione lac aluum fiftit, Galenus lib.z.de alimen torum facultat, Et alibi , Equinum lac ocyus defcendit, fimiliós modo afininum, Quæritur apud recentiores medicos, an afininum lac fit omni alio tentius : quoniam Galenus fecum etiam in hoc pugnare uridetur, lib, 6 .de fanitate tuenda inter omnia laçis genera tenuiffimum dicens : tertio aus tem de alimentorum facultat. paulò ante citatum iam locum camelinum \& equinum ei in tenuita= te præferens, Ariftotelem tertio de animalium hiftoria fecuttus. Hos locos Ioan.Manardus in epifto lis ita conciliat:Sexto de fanitate tuenda, inquit, Galenus afininum lac leptomereftaton, id eft, ma= ximé tenuium partium affirmat:in tertio uero de alimentis, camelinum afinino, non in tenuitate fed in humiditate prafert,hygrotaton enim dicit, Quare nifi fateri uroluerimus Ariftotelê aliud fena fiffe quàm Galenum, dicere oportebit, quod per tentriffimum non intellexerit tenuiffimarum pars tium, fed maxíme humidarum, Hac ille. Ego Galeni uerba fic accípio, afininum lac tenuiffimum re će dici, fi comparetur animalium lacti quæ apud nos $\&$ plæraíp̧ gentes mulgeri folent, uaccarum nempe, ouium, \& caprarum:fimpliciter uero, $\&$ comparatione ad animalia quorum inufitatum fe rèad cibum \& potum in Europa lac eft, ut cameli \& equi non tenuiffimum, fed craffius. Sic etiam Plinitus tenuiflimum lac camelis effe frribit, mox equabus, craffiffimum afinæ, ut coaguli uice utan tur. Craffiffimum dixiffe uidetur, pro craffius quàm cameli \& equa. Leptomeres, id eft, tenuiü par: tium uocatur, quod non craffis neq̧ uifcofis partibus conftat, $\&$ cito ac facile corporum meatus fur bit:id quod lacti cò magís conuenit, quò liquidius eft, minus'́g cafeofę fubftantí habet, ut Galenus 60 ipfe exponit, Sed ne fim longior, \& fi plura hoc in loco contra Manardum dicenda haberem, ad re media tranfeo qua ex afino \& dituerfis eitus partibus apud fcriptores celebrantur. 
G.

Ex eadein aqua, de qua bos aut afinus biberit paululurm fumptum $\&$ potatum, tollit efficacitet capitis dolorem, Marcellus \& Plin. Ad comitialem prodeft afini cerebrum ex aqua mulfa, infuma: tum prius in folijs, femuncia per dies potum, Plinius lib, 28. cap,16. Numerus dierum in exemplari bus uulgatis non eft expreffus: ex fequentibus tamen conftat non pauciores effe quàm 30 . Rídicu= lum eft quod apud eundem legitur:Si quis afino (inquit) in aurem percuffum à fcorpione fe dicat; tranfire malumm protinus tradunt. Eft genus febrium quod amphemerínum uocẩt, hoc liberari tra= dunt, fi quis è uena auris afini tres guttas fanguinis in duabus hemínis aquả hauferit: item uenena ta omnia accenfo afini pulmone fugere, Plin, Idem fi tritus bibatur ad anhelitum $\&$ tuffim commen - datur ab Haly Arabe. Sunt qui ex afino mare nigró́s cor edendum cum pane fub dio prima aut fecunda luna pracipiant contra morbum comitialem, Plín. Ierur inaffatum efur comitialibus pro deft, fed ieiunis edendum pracipitur, Diofcorides, Alị admixta modice panace, orí inftillandũ do. cent, idḉs diebus quadragintałfic à comitialibus morbis $\&$ alips infantes tueri, Plíx. Aridum tritum cum petrofelini partibus duaburs, \& nucibirs iuglãdibus tribus purgatis ac melle illitis (aliâs ac mel le tritum) in cibo datum hepatico ieiuno mirabile eft, Plinius $\&$ Marcellus. Cínis ex eo cum oleo ad fcrophulas utilis eft; item ex hepate 8 carne eius cinis ad fiffuras frigore côtractas, ut A uicenna frri bit:ego Diofcoridem magis approbo, qui utraç hæc remedia ungularum cineri attribuit, ut etiam Rafis. Adlienis uitium efficaciffime datur inueteratus lien afini, ita ut in tríduro fentiatur utilitas; Plin.Si lienofus de fplene afini arefacto quotidie ieiunus pauxillum manducet, ita potenter fanabi20 tur, ut intra triduum utilitas remedij huius appareat, Marcel. Splen contritus \& ex aqua ímpofitus mamillis lac prouocat; Sextus. Lien inueteratus ex aqua illitus, mammis abundantiam facit, uuluas fuffitu corrigit, Plin. Splenis afinini leuiffinus puluis, cum feuo urfino $\&$ oleo ad mellis craffitiem redactus, \& illitus, fupercilịs pilos reftituít, $R$ afis. Renes inueterati tritíq

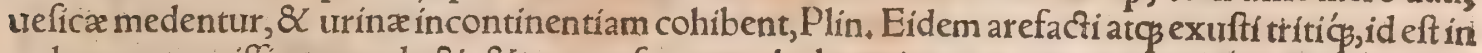
puluerem tenuifimum redacti, 8 ex menfura conchula unius cum uini meri cyathis duobus ftran guriofo poturi dati efficaciter medentur, Marcellus. Cinere genitalis afini fpiffari capillũ purtant; \& è canicie uindicari fi rafis illinatur, plumboóstritis cum oleo, Plinitus. Coitus ftimulat dexter afini teftis in uino potus pro portione, uel adalligatus brachiali: nec non eiufdem à coitu fpuma collecta rofeo panno, \& inclufa argento, ut Ofthanes tradit, Salpe genitale(afini)in oleum feruens mergi iu: 30 bet fepties, eoć perungi pertinentes partes:Bialcon cinerem ex eodem bibi. Teftes fale afferuaz ti, \& afperfi potioni, in afinarum maxime lacte uel ex aqua, ad comitialem profunt, Plinius، $\mathrm{Fel}$ tauri uel afini utrum per fefe aqua infractum, maculas in facie tollit, euitatis folibus ac uentis poft detractam cutem. Sanguis afini fedat fluxum fanguinis ex uelamine (id eft, cerebri tunica, ni fal. lor) Barbarts quidam: (Diofcorides hanc uim cereturo gallinaceorum attribuit) Eiufdem tres uel quatuor guttæ cum uino haufta, febres quotidianas fanant, A éfculapius quidam, Plinius, ut paulò ante retuli,idem fcribit de tribus guttis fanguinis ex trena auris, in duabus heminis aqua hauftis. Sanguis afínini pulli ex uino, regio morbo medetur, Plin. Adipem tradunt cicatríces corpori cớn colores reddere, Diofcorides:uel ut alip, ueftigia cutis abolet; ut Plinius, cicatrices nigras reducit ad colorem, Sanat \& uuluarum exulcerationes idem inueteratus, \& in uellere appofittrs duriciem uul 40 uarum emollit:per fe ucro recens $\&$ inueteratus ex aqua illitus, prilothri uim obtinet, Plin. Sime dulla afini aut feuo, is qui comitialem patitur, loco calido inungatur plurimum iutrabitur, Rafis. Scabiem hominis afinina medulla maxime abolent, Plin. Seuro cicatricibus ac lichenileprisćs. maximè color redditur:Sole adufta eodem aptiffime curantur, Plin. Coitus ftimulat anferis maf́culi adipe permix to illitum, $P$ lin. Sextus fimiliter, qui non feuum fed adipem rectius uocat, $\&$ ad anum hocmedicamentum apponi iubet. Pellis iniecta impauidos infantes facit,Plin. Offa confracta $\&$ decocta contra leporis marini uenenum dantur. Vngularum afini cínis per dies multos(toto men $f e$, Plinius) binis cochlearibus (urel ut $R$ afis habet, pondere trium aureorum $\&$ dimidí) potus, prodi. tur comitiales adiuuare:eædem oleo fubactæ ftrumas difcutiunt: $\mathcal{Q}$ illitæ (puluis ficcus illitus) per. nionibus medentur, Diofcorid. \& Galenus lib.ıi. de fimplicibus pharmacis , Perniones Graci chijo metla uocant, aliquí in iam citato Galení loco non recté phygetla legunt, Strumas dífcutit ungula afini uel equi cinis, ex oleo aqua illitus, \& urina calefacta, Plin. Curat etiam ea qua ferpunt ulce. $r a$, infperfus, Idem. Vngulæa afininæ fuffitæ partum maturant, ut uel abortus eurocetur: nec aliter ad hibetur, quoniam uiuentem partum necant, Plin. Cinis ex eifdem cum afínælacte inunctus, cicatri ces oculorum \& albugines tollit. Vt leucomata oculorum efficaciter difcutias, ungulas afini uiuen tis lima, \& f cobe earum quàm tenuiffimo, qui leuitate fua oculos non offendat, cum lacte mullëbri mixto, frequenter inungito, Marcellus. Annulum ex ungula afini, in quo nigri nihil fit, ab epileptico geftatum, prohibere aiunt ne concidat. Hodie idem pollicentur de annulo ex ungula alc̈es. $\mathrm{Ca}$ pilli $\&$ barbæ nafcentur etiam glabro, fi lichenem afini, id eft collectionem duram quæ eft circa crú ra eius, comburas, $\&$ teras, $\&$ puluerem illum ex oleo uetere imponas:hoc ita ualidum eft, ut fi mus:

60 lieri inde maxillam unxeris, barbas ei nafci fcias, Idem. Lethargicos excitat illitus ex aceto, Plin; Ex quacunç caufa grauedinem capitis exortam, qua intempeftiuum concitet fomnum, fine dolox re difcutit, fi quis impetigines in afini cruribus naturaliter natas detrahat, easćş in fcobe delimatas, 
immixto aceto naribus penitus obftipet, Marcell. Carnes ex iure fumptre phthificis medentur, Hoc genere maximè in Achaia curantid malum, Plinius. Simile quíd apud Auicennam legitur. Sunt qui carnem afini, fanguinem alíp aceto dilutum, per dies 40 , bibendum contra morbum comitialem pract piunt, Plin. TA Afininum lac cum melle pottri datum, uentrem facile \& fine periculo foluit, Marcel. Diofcorides $\&$ alij fimpliciter aluum mollire feribunt, Bubulum, afininum, \& equinum lac, uentri ma gis idonea funt, fed ipfum turbant; Diofcorid. Afininum peculiariter collutos dentes gingiuasḉ̧ fta. bilit, Idem. Eodem lacte percuffu uexatos dentes, aut dentium eiufdem cinere, confirmari notum eft, Plin. Non folum enim dentibus innoxium eft, fed ob tenuitatem etiam abftergendo conducit. Comi. tialibus morbis utiles tradût tefticulos arietinos inueteratos tritośç dimidio denarị pondere in aqua, uel lactis afinini hemina. Interdicitur uini potus quinis diebus ante $\&$ poftea, Plin, Ad comitiales(ut di 10 ximus)coagulum uituli marini bibunt, cum lacte equino afininóue, aut cum punici fucco:quidam ex aceto mulfo:nec non aliqui per fe pilulas deuorant, Idem. Lac afininum melle mixtum Galenus iuuez ni, qui feré cótaburerat, à balneo ftatim exhibuit, Sứpiriofis antè omnia efficax eft potus equiferorum. fanguis:proxime lactis afinini tepidi cum bulbis decocti, ita ut ferum ex eo bibatur, addito in tres he. minas cyatho nafturtij albi, perfufi aqua, deinde melle diluti,Plin. Si dolent ubera, lactis afinini potu: mulcentur: quod addito melle fumptum \& purgationes mulierum adiuuat, Idem. Stomachium exulce ratumlactis eiurdem potus reficit, item bubuli, Plin, Ariftolochia uel agaricum; obolis ternis ex aqua calida, aut lacte afini pota, ftomachi uitia fanat, Idẽ . Heraclides orthopnoicis dedit anifi feminis, quod ternis digitis prehenderit, tantundem hyofcyami cum lacte afinino, Plin. Cốmèndatur etiarn àd tuf. fim, extenuationem, (putum fanguinis, hydropem $\&$ duritiem fplenis. Capiti tamèn infirmo, \& iterti- 10 gine aut tinnitu laboranti non conuenit. Priuatim prodeft contra gypfum, 8 cerufam, $\&$ fulphur, 86 argentum uiuum; Item duræ aluo in febri. Gargarizatur quogg faucibus exulceratis utiliffime: $8 \mathrm{Cbibi}$ tur ab imbecillitate uires recolligentibus, quos atrophos uocant. In febri etiam qua careat dolorè capitis. Pureris ante cibum lactis afinini heminam dari, aut fi in exitu cibi rolionem fentirent, antiqui in arcanis habuerunt; fi hoc non effet, haburerunt è caprino, Plin. Eiufdem potus utilis eft coeliacis $\&$ dyfen rericis, addito melle, Plin. Tenefmus (id eft crebra $\&$ inanis uoluntas egerendi)tollitur poto lacte afinino, item bubulo, Idem. Sunt inter exempla qui lac afininũ bibendo liberati funt podagra chiragrá ue: Alij uero feriafinini potu eof dem morbos prorfus euafere, Plin. Aqua mulfa contra hyofcyamum fa lutaris eft cum lacte, maxime afinino, Idem. Afinino lacte poto uenena reftinguuntur. Peculiariter f hyof cyamum potum fit, aut uifcum(chamęleon ixias potius)aut cicuta, aut lepus marinurs, aut opocar zo pathum, aut pharicon, aut dorycnium: $\&$ fi coagulum alicui nocuerit: nam id quocg uenenum eft in prima lactis coagulatione. Sed meminiffe oporter recenti utendum, aut non multo poftea tepefacto. Nullum enim celerius euranefcit, Plin. Cancri fluuiatiles triti potićs ex aqua recentes, feu cinere adfer uato, contra uenena omnia profunt, pritratim côtra fcorpionum içus cum laçe afinino: uel fi non fit, caprino, uel qưocung: A ddi $\&$ uinum oportet, Idem. Rupta, conuulfa, cancri fluuiatiles triti in afininolacte maxime fanant, Idem. Afinintrm lac conferre aliquid candori in mulierum cute exiftimatur. Poppea certe Domití Neronis coniunx, quingentas per omnia fecum fơtas trahens, balnearû́ etiam folio totum corpus illo lactemacerabat, extendi quog; cutem credens, Plinius: $\&$ rurfus alibi, Cutem

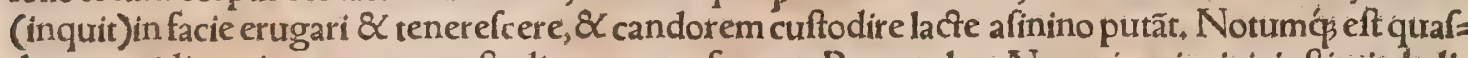
dam quotidie quingentarum cuftodito numero fouere: Poppea hoc Neronis principis inftituit, bali= 40 nearum quoģ fic folio temperato, afinarum gregibus ob hoc eam comitantibus. IV rina afini attri= tus calciamentorum cum luto furo illita fanat;item fcabiem hominis, \& ungures fcabros, Plin. Lepras ac furfures tollit tauri, uel addito nitro urina afini circa canis ortum, Plin. Afini urina traditur nephriticis fitue renum uitrijs mederi in potu, Diofcorides, Eadem cum melanthio prodeft contra omnes impetus \& fuppurationes fiue panos $\&$ apoftemata, Plin. Alij ulceribus exedentibus \& hưmidis utilem priz= dicant. Sideratis urina pulli afinini nardo admixto perunctione prodeffe dicitur, Plinius. Eadeni ca. pillum denfari putant, admifcentḉ nardum faftidí gratia, Idem. Vrina muli uel mulæ ưl afini cum fuo luto illita, \& clauos abolet, \& callis medetur, Marcel. đFimum afini recens cum rofaceo in graui tate aurium tepidum inftillatur, Plin. Vlcera capitis fubito nata fanantur, fi afini ftercoris fucco, \& $\mathrm{fcil}$ la contritæ quantum fatis uidebitur, \& bubulæadipis tantundem mifcueris, atç ad capitis ulcera ue luti ceroto ufus fueris, Marcel. Tam afinorum quám equorum fimum, fiue crudum, fiue crematum, addito aceto, fanguinis eruptiones cohibet, Diofcorid. Stercus afinæ aridum naribus infrictum fangui nem fine intermiffione fluentem cito compefcit, Plin.Idem firecens imponatur, profluuia fanguinis mire fedare dicitur : item cinis ex eo. Qui uulux etiam prodeft impofitus, Plin. Ad fanguinem une decungs fluentem adhibetur:fiè naribus profluat, fuccus expreffus inftillatur ac retinetur. Si obftruantur eo uenarum uel arteriarum aperta of cula, fangtris continetur, Fimus afini calidus uino mifce. tur, cuí íntinça utaffatim fuccum combibant linamenta goffampina, ad fluxum fangưinis coércen= dumlocis affectis immittũtur, $R_{2}$ fils. Emplaftrum ex eodem fronti impofitum fluxionem auertit, $R_{2}$ fis. Armentarij equi uel afini, qui herba pafcitur, ficcum fimum liquatum in uino, mox potum, contra fcorpionum ictus magnopere auxiliatur, Diofcorid. A finini fimi cinis ex uino cœllacis $\&$ dy féntericis 60 confert, Plin. Fimum afinini pulli, quod primum æedidit à partu, polean uocant Syri, dant in aceto mul fo contra lienis uitium; Idem colliacis ' $\alpha$ dy fentericis confert In fapa decoctum, colo magnopere pro. 


\section{DeAfino.H. Lib. I.}

deft: Datum fabxe magnitudine é uino medetur morbo regio intra diem tertium: Eadem et ex equind pullo fimiliterọ́, uis elt, Pliníus, Eruptionibus pituitæa afininifimi cinis illinitur cum butyro, Plinius; Equarữ uirus à coitu Anaxilaus pdiditin lychnis accenfum equinorum capitum uifus reprafentare monftrifice:fimiliter ex afinis, Plin.,Membrana partus earum, praccipue fi marem pepererint, olf $a_{2} t_{j}$ arcedente morbo comitialium refiftit, Plinius.

\section{H. Philologia de afino.}

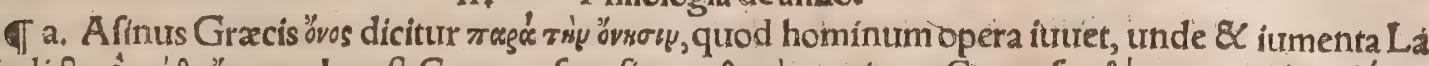

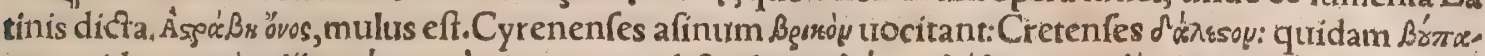

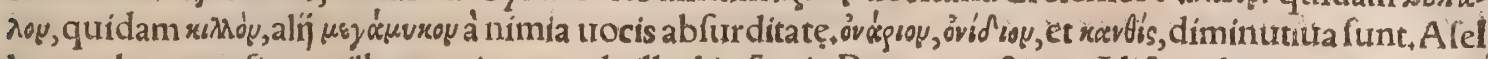
10 la pro ala quoç fiue axilla reperitur, unde illud in facris, Prouer ${ }_{4} 19 . \& 26$, Abfcondit piger manư fub afella:fic à qualo quafillum dicimus. Kwotúnous Varinus afinos interpretatur, qux uox ad canthelios accedit. Inueniuntur $\&$ hac nomina apud Graecos, $x \dot{\alpha} v \theta \omega \nu$, unde uocatus cantharus, id eft fearabeus,

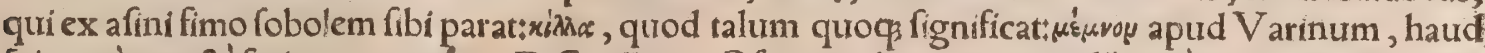
f́cio quàm recié fcriptum, Moviós, ut D. Cyrillus in Ofee propheta exponit, alî́ uerò magnam belluam, qux propter feritatem folitaria pafcatur, proprie tamen aprum fignificat, qui folitarius degit. Suidas

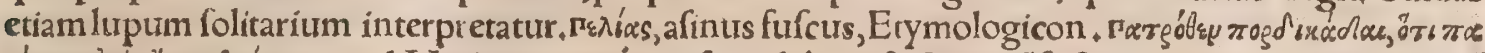

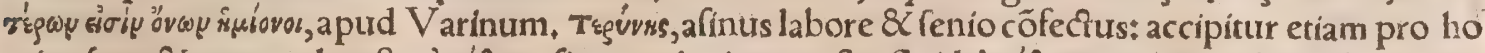

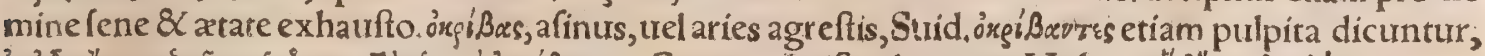

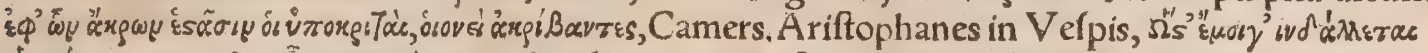

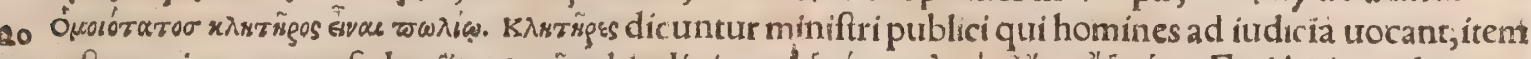

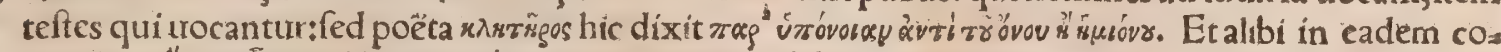

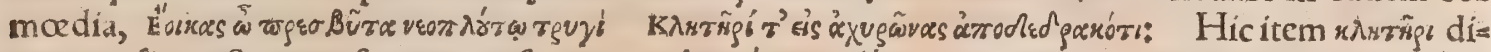

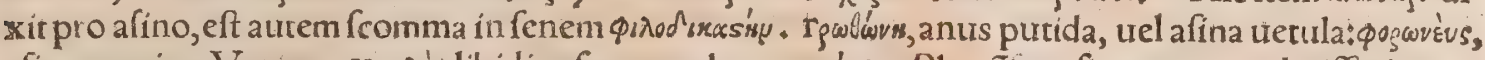

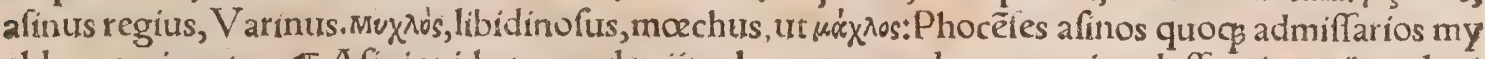
chlos nominant. Af Afiniepiaheta apud poétas leguntur, tardus, onerarius, doffuarius, uilis, platl= frarius, molarius, piger, pandus, utulgaris, Arcadicus, Mænalius, ignauus, léncégradiens, auritus, iners, rudens, fegnis, horripilus, turpis, clitellarius, lentipes, quadrupes; infulfus, miferanda fortis. Et à

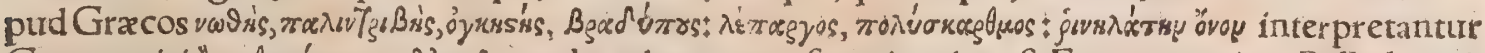

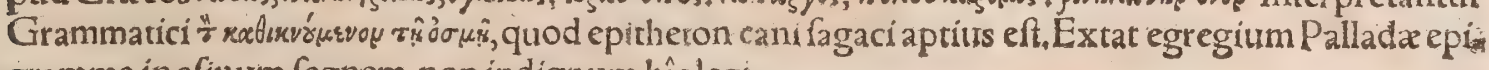
3० gramma in afinum fegnem, non indignum hîc legi.

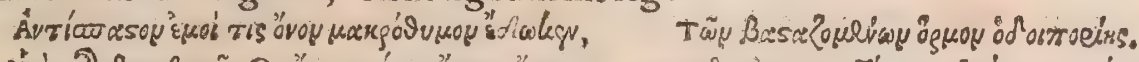

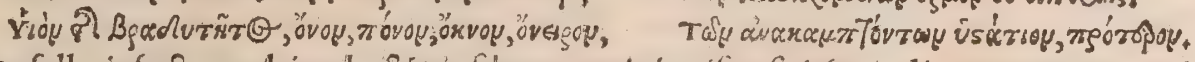

De afello infecto multipede, \& eiufdem nominis pifce, fuis focis dicetur:utrumģ eliam Graci onõ uel onif́n uocant:utríg à cinered (quem Gerınani eiam afininum uocant)colore nomen. A finius 8 A fellius nomina propria uirorum leguntur, Heratia infula ef, qux antea dicebatur Otius; Plin. Afine, Árivr, Fe'oponncfi uel Achaix urbs iuxta Mefieniam, unde finus Afinxus: Lucanits, Quas Afine cautes, \& quas Chios á́perat undas. Eft \& Laconica urbs dicta ab A fine filia Lacedæmonis; item Cypri \& Cilicia. Præeterea uafis genus eftovos apud A riftotelicos inter exempla homonymix, quod à fígura fic dictum conijcio, ur orcham à bellua marina. In figno cancri duæ funt ftel æx para 40 ure A felli appellata, Plinius libro i8. Exiguum inter illas fpatium obrinet nubecula, qued prafepe dé citur, Lactantius, In cancri deformationis parce; ut Hyginus feribit, funt quidam qui afini appellana tur, à Libero in tefta cancri duabus ftellis figurati Liber enim à lunone furore obiecto, dicitur mente captur fugiffe per' Thefprotiam, cogia âs ad louis Dudonæi templum peruenire, unde peter et répon fum, quo facilius ad priftinum ftatum mentis rediret:fed cum ueniffet ad quandam paludem magñ quam tranfire non poffet, de quiburdam duobus afellis obuïs factis dicitur unum deprehendifle eo rum, \& ita effe tranfuecium, ur omnino aquam non tet gerir. I taç cum ueniffet ad templũ louis Do donæi, ftatim dicitur à furore liberatus, \& a fellis gratiam retuliffe, \& inter aftra eos collocaffe. Non. nulli etiam dixerũt afino illi quo fuerat ueçus, uocem humanam dediffe Itạ̧ poftea eum cum Pria po de natura contendiffe, $\&$ uíchum ab eo inter fectum. Pro quo Liberum eitus mifertũ, in fideribus annumeraffe. Et ut friretur id pro deo, non pro honine timido(quia Iunonem fugerit) fecifle, fupra cancrum conftituit, qui dex beneficio fuerat affixus aftris. Dicitur etiam alia hiftoria de afellis, utait Eratof thenes: Quro tempore Iupiter bellogigantibus indicto, ad eos oppugnandos omnes deos conuocauit, ueniffe Liberum patrem, Vulcanum, Satyros, Silenos, afellis uectos: qui cum non longe ab hoftiburs abeffent, dicuntur a felli pertimuiffe, $\mathcal{Q}$ i a pro fe quifos magnum clamorem $\mathcal{Q}$ inauditum gigantibus feciffe, ut omnes hoftes eorum clamore in fugam fe cóiecerint, \& ita fint furperati, Hæec Hyginus. Poftremam fabulam Varinus etiam in Lexico fuo in afini mentione affert: $\&$ hanc ob cact fam afinis hunc honerem habitum inquit, ut in cancrifydere occafum uerfus collocarêtur. Achar

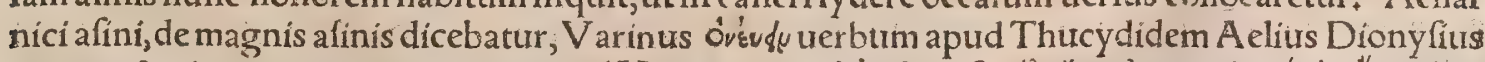

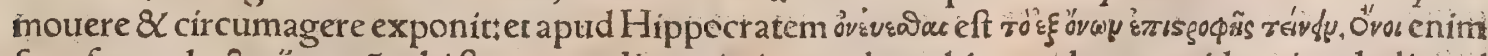
6o funt funes ductarỉ ex cãnabi fuppa aut lino, nimirum ad machinas uel ergatas idonei, uel alioqui ad trahendum aliquid. $\operatorname{Nam} \&$ cameli funes magni uocantur, à quibus anchor $æ$ fufpendũtur. A'gurs etiam, id eft uectes machinarum, oैvo nominantur.Lacini fuculas wocant tractorn̈ generis machinas 
qux conftant tereti ligno duobus aut pluribus uectibus traiecto, utrin $q 3$ xqua extantibus longituri dine: qux dum uerfantur funis ducfarius circa eas obuoluitur. Galli turnos dicũt, Germani ba|pel,

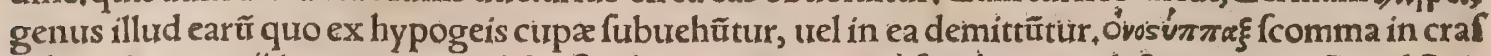
Ii \& rudis ingenĭ hominem apud A riftophanem, nimirum à funibus iam dictis tractum. A pud Sui=

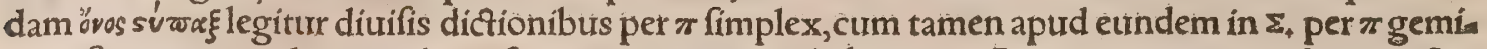
num ftyppax (quod magis placet) fine interpretatione habeatur, Cæeterum ergata machina tracto= ria uel hoc à fucula differt quod axe eft recfo. Nam etiam uectibus ficut fucula uerfatur, nonid quil dem brachiorum ductu, fed obnitentibưs 8 ambientibus uectiarị̂: Itali arganum uocât, ut Guliel. Philander fcribit in Vitruuium: Germani ein winden. Ad hęce̋vos unitas eft in cubis uel tefferis, Pol luce tefte(ut canis in talis) qua etiam cubus dicebatur, eodem nomine quo integra ipla teffera \& $\&$

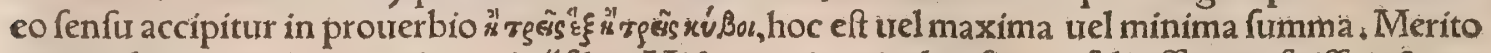
autem aliquis per iocum miretur in n̈fdem Midam, curi autricula afininx, feliciflimum fuiffeiactum,

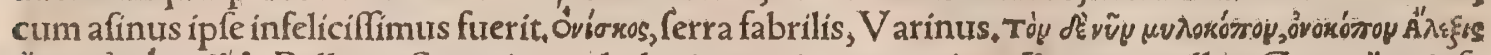
ส้

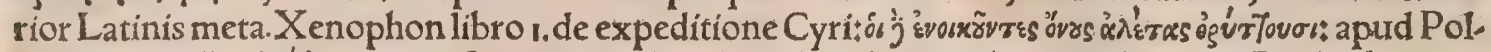

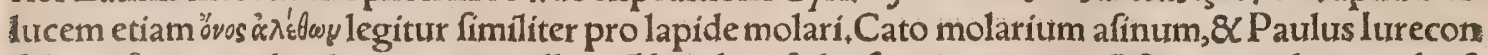
fultus afinum molendinarium appellat, nó lapidem, fed ipfum iumentum. Afinaria mola, qux ab af no circumagitur: ut Matt. 18. Qui offenderit unum de pufillis iftis, qui in me credunt, praftaret ei fu

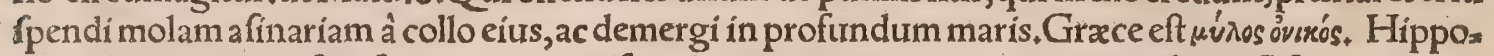
crati chirurgicum eft inftrumentum onifçus, luxatorum curationi accommodum. A fininomen in 20 ludis literarñ illi imponitur, qui in ftudịs uel moribus deliquerit; is enim protenfís indice $\&$ auricur lari digitis afinum uendere iubetur:hoc eft tantífper hac ignominia notari, donec in alium propter fimile peccatum eam transferat. Sunt quié collo ftipitem, afini uel nomine tantum, uel etiam figura onocephalum, candem ob caufam pueris appendant. Similiter et alĭ quandoq derifuri quempiam, digitis ut dixi protenfis auriculas afini imitantur, \& fibilum addunt. Hinc Perfius:

O Iane, à tergo quem nulla ciconia pinfit, Nec manus auriculas imitata eft mobilis albas.

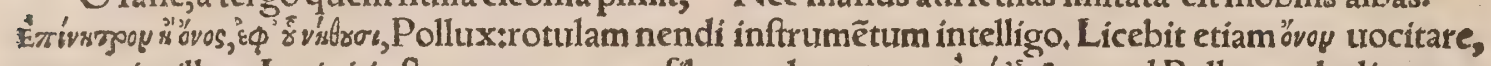

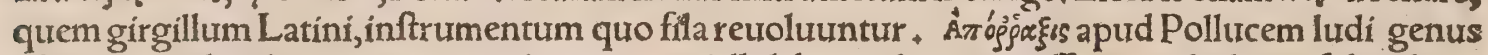
eft, in quo pila ad patrimentum uel parietem ui illidebatur, \& repercuffa manu ludentis fubindere. î́ciebatur, cui plures continui pila faltur fucceffiffent, rex appellabatur, \& imperabat:uictus autem 30 afinus, 8 imperata quęuis exequebatur. Alius apud eundem ludus puerilis oftracinda defcribitur, in quo deprehêfus in fuga fimiliter afinus dicebatur. Tefta erat ab interiori parte pice illita:eã aliqgs ad lineam in terra ductã eminus prójcicbat, fimul pronunciâs, nox, dies, propter colores tefta diuer fos, quorum alterum altera fibifactio eligebat:perfequebatur illa fugientem alteram, cuius in proie

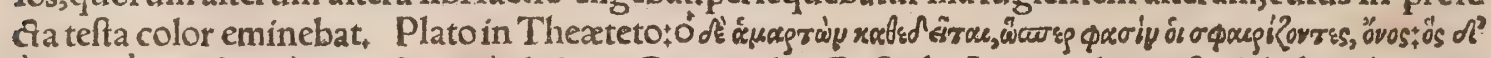

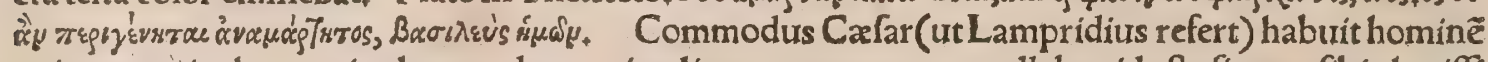
cuius proninebat penis ultra modum animalium, quem onon appellabat, id eft afinum, fibi chariffi mum, quem \& ditauit, \& facerdotio Herculis ruftici propofuit. Hincetiam onobelos díci coniectât: funt autem hi qui uiriliores uidentur, ut in Heliogabalo fentit Lampridius, uelut afini telum praferentes, Calius. Euclio ille Plautinus paupertatem fimulans adMegadorum diuitem filiam eius am 40 bientẽ in Aulularia fic loquitur: Nunc fi filiam locaffim meã tibi, in mentẽ uenit, Te bouêe effe, $\&$. me efre afellư, ubi tecum cóiunçus fiem, Vbi onus nequeam ferre pariter, iaceã ego afinus in luto. Tu bos me haud magis refpicias, gnatus quàm fi nun $\$$ fiem: Et te utar iniquiore, $8 \times$ me meus ordo irrideat: Neutrobi habeã ftabile ftabulût fi quid diurortin fuat, Afini mordicib, fcindãt, boues incur fent cornibus. Hoc magnũ eft perículü me ab afinis ad boures tranfẽ̃dere. Chriftiani cur afinarï per ignominiã nominati fint, 8 Chriftus onochelus, mox in onagris docebimus. De Ariftone Ephe fio 2 Onofcelide eius filia abfurdior eft hiftoria in Plutarchi Parallelis, $\bar{\phi}$ ut hîc referri debeat, $A b_{2}$.

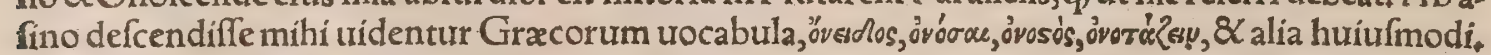
Lapis fpecularis in quibufdam Italiz locis uulgo fpeculum afini dicitur, TOnopordon herbam fi comederint afini, crepitus reddere dicuntur. Trahit urinas $\&$ menfes, aluum fiftit, fuppurationes \& 50 collectiones difcutit, Plinius:nec alibi aliud, ut ignota fit hodie, ficut etiam onocichla, cui flos diutur nior per partes florenti apud eundem. Inter uuras damnantur uifu cinerea, $\&$ rabufcula $\&$ afinifca colore nimirum dicta:cui eadem forte fuerit óvíjds Varino memorata, Afinaftra, fi benememini, in ter ficorum genera nominantur. Pruna feriora maiorás, afinina cognominata à uilitate, eodem co. lore funt quo hordearia, Plin.A Auriculam afini Galli quidam uulgo uocant fymphytum alterũ : $\mathrm{Sa}_{a}$ baudi lotû̃ pratenfem, panem afini. Inter ftirpium nomenclaturas Diofcoridi attributas, onomordö helxine eft:afini fanguis Á egyptn̈s, filix + afinus ichrei Magis, fampfuchum. Onitis etiam herba ex o.

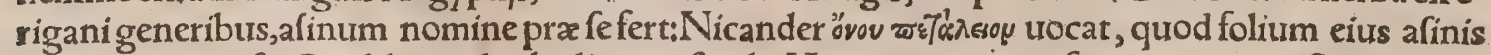
pabulo gratum fit, Onobletum herba lingura fimilis Hippocrati contra faminarum profluuia in uel lere apponitur. Onopyxus folio 8 caule fpinofus eft, Plin. Anonin quidá ononida malunt uocare, 60

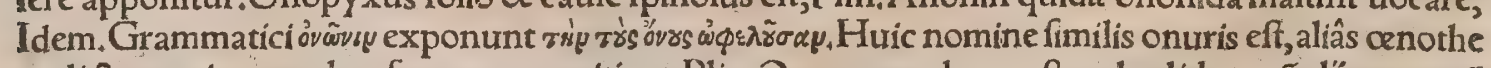
ra dicta, quęin potu data feras quoç mitigat, $P$ lin, Onogyrus planta eft male olida, quãalin anagyrứ นосลีเ, 
hocant, prouerbio etiam celebristitem uiri nomẽ. A bubus A thenis Buzuges nobilitatus, Ärgis $\mathrm{O}$. nogyrus, Varro, Onophyllon eadem anchirfe eft, qư Arabicæ lingux autoribus etiam afini lactu= ca uocatur. A nchirfam ipfam quog, Graci onocleam ưocant, 8 foln s lactuca defcribüt: Lycopfis e. tiam à nonnullis anchufa uocatur, lactucæ folijs + qux et onofmati herbæ apud Diofcoridem triburun tur.Anchufa genus alterum apud Diofcoridem onochiles appellatur, alị onochiló uel onochelim fcribunt, Eadem eft Alcibiadion Diofcoridis contra ferpentes, pracipue triperas, efficax : nec aliud Alcibion Plinï lib.25. cap. 5. quamuis ille qualis ea herba effet apud authores fibi repertum neget. Barbara \& Arabica quæ anchufx fiue lactucæ afininæ \& generibus eitfdem triburuntur nónina; qử in Arabicorum nominum interpretatione in Auicênam Andrex Bellunenfis, $\&$ antiquioris o cuiufdam innominati reperiutur, hac funt: Achatini, hearphilus, fefula, almiphar, anfadius' fenuat, fenchat, fengiar, alfangiar:fimarem tiel fincarem genus anchufæ cxteris maius:ahugilife, lactucella maior:abingilefa, argialefús, abtichaleła, achafunas. Cęterü onocardió, dipfacus intelligitur (quafi afi ninius carduus, ille nimirư qui in prouerbiư abö $t$,Símiles habêt labra lactucas:)à quo lógè díftat anà cardium fructus arborís Indicx. Dipfacum nonnulli etiam uirgã paftorís uocãt, \& laçucam afini cữ ea confundũt. Onobrychis folia habet lentis, \&c. Diofcorỉdes : Onocecidas Galenus à rufticis frría bit appellari gallas eas, qux grandefeunt fungof $x$, quafi afininas, quod ignaux fint $\&$ minus effica= ces. Afinaria feftum erat Syracufis mẽfe Maio, ab Afinaro fluuio appellatione ducta, apud quem A thenienfium imperatores Nicias 8 Demofthenes capti. Eiufdem nominis comoedia extat Plauti. na,in qua mercator pro afinis emptís pretium numerare introducitur Leonida feruo, qui Sauriam 30 atrienfem, cui numerari debuerat, fe fíngebat: De hac poéta in prologo fcribit; à Demophilo prius Gracè editam onagri nomine, Onofander philofophus fuit Platonicus, cuítis librum de optimo im.

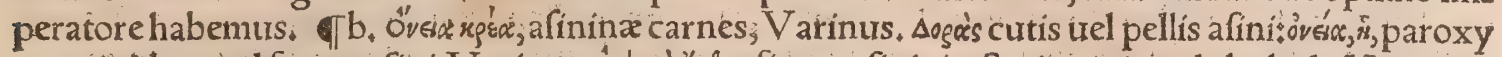
tonum, idem, itel forma afini, Varinus. Óv's ry ö ôos, fimus afini : polterius etiam de bubulo Homerus

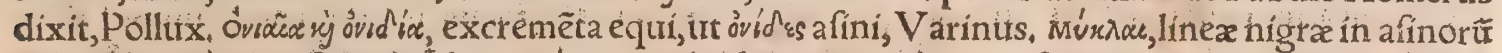
collis $\&$ pediburs nafcentes, Idem : wurros, reduplicatio quadam in afinorum \& boum collo; Idem. Afini colorem refert tarandus, cum ei libuit fui coloris effe:quem fape immutat. Cercopithecus pi= loeft afinino. Leucrocuta afini ferè magnitudine eft, Plin. plerioglegunt afini feri, id eft onagri. Ad Cadaram rubri maris peninfulam belluæ exeunt quædam afinorũ capitibus, aliæ alịjs, 8 depafcun tur fata, Plin. $\sigma c$. Vox afino apprime rudis, ut merito rudere Latinis dicantur:hinc $\&$ Gręcorum

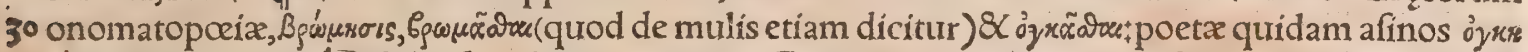

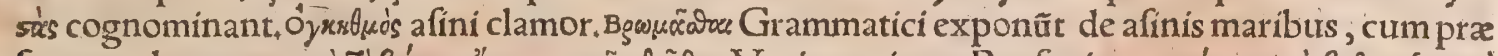

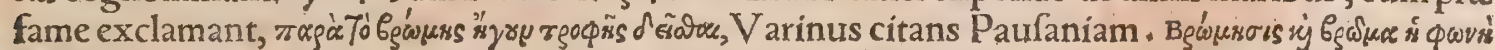

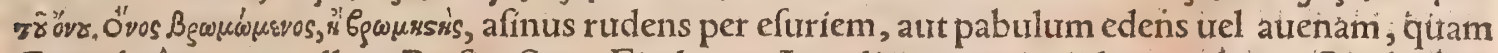
Graci brômon appellant.Perfius Sat.z. Findor, ut Arcadia pecuaria rirdere credas. Oivid líb. 3 . de Arte: Vtrudità fcabra turpis afella mola. Abufiue etiam de leonibus $\&$ de hóminibus dicitur apud Vergilium. In Philomela poemate obfcuri authoris hic tierfus legitur, Quirritat tiérrěs dus ridit, oncat afellus. Oncare urocem Gracam effe dixi, nec apird ullum Latinorum legiffenemi

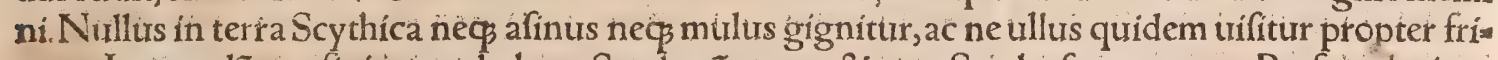
gora. Itą̧ rudẽtes afini perturbabant Scy tharũ equos: \& cum Scy thę fapenumero Perfas adoriren 40 tur, eorim equi exaudita afinorum uoce, côfternati auertebantur, arrectis auribus ftipefacti, utpo te infolentia tưm uocís, quẩ prius non audiffent tữ forma; quam nunquã infpexiffent, Herodotus lib, 4. Onocrotali aues ab afinino clamore nominãtur. ovobar Ejy de afínis proprie dicitur cum equas infendunt, Pollux. Homerus ut afini tardum $8 \times$ ne per itim quidem celeritatis capacem inceffum fí

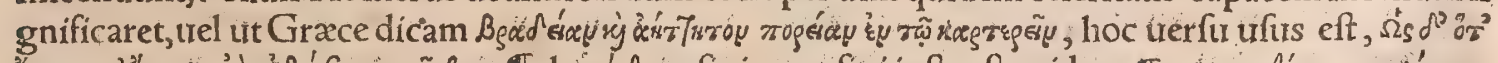

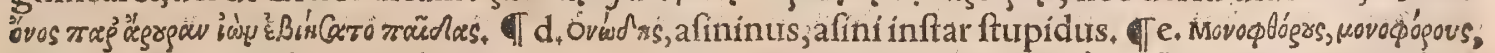

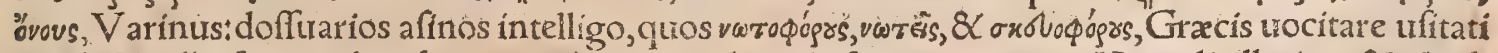
us elt, Clitellæ funt quibus farcinæ colligatæ mulis uel afinis portantur. Hínc clitellarium \& clitel. latumiumentum dicunt. Cato cap.10. Afinos inftratos, clitellarios, qui ftercus uectent, tres. Et Plaus tus in Moftell. Nam muliones mulos clitellarios Habent:ego homines habeo clitellarios: Magni 5o funt oneris, qưicquid imponas, tehunt. Sed quas homines baiuli gerínt clítellæ, muli İariani po tius dicuntur:furculæ fcilicet, quíbus religatas farcinas uiatores geftant. Frótinus libro 4. Stratege: matum:C.Marius recidendorim impedimentorum gratia, quibus maximé exercitis agmen chera tur, uafa \& cibaria militum in fafciculos aptata furcis impofuit, fub quibus $\&$ habile oncis $\&$ facilis

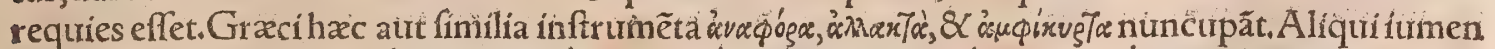

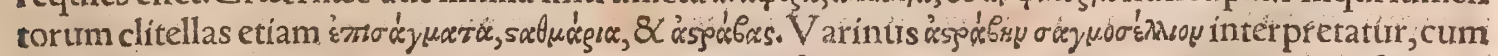
dubitatione tamen an totum potius iumentum, non folæc clitella, hoc nomine accipiendum fit apud Demofthenem contra Midiam; cum alioqui mulum femper fignificet. Mulorum, equrorum, afino=

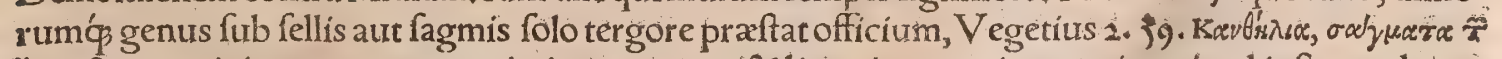

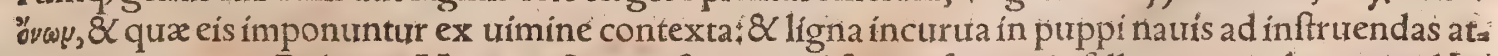
bo tegias: \& montes Bithynie, Varinus. Sagma, fagma:uel fagma fagmatis, fella quam uulgus (apud Ira los \& Gallos)baftum uocat, fuper quo componuntur farcina fed et profarcina quando $\$$ ponitur, Calius libro 11 . Forte hinc etiam patrio fermone equos $\&$ afis 
nos clitellarios uocant foumroff; \& foume fcl:ut Graci Latinióp Tagmarios: \& farcinam iumentí cin foum(ut ltali fomam: Graci puto etiam jóop) \& fellam ipfam etn fountaftel. Palmæ in Babylone. adiugeri fpatium extenduntur, \& pondere depreffa fuperius curuantur ueluti afini canthelñ, Xę. nophon. Varinus canthelios magnos afinos interpretatur: $\&$ prouerbialiter canthelium pro fupie.

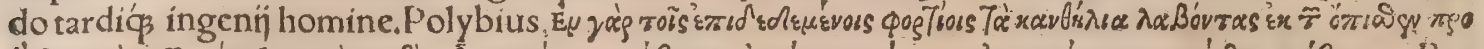

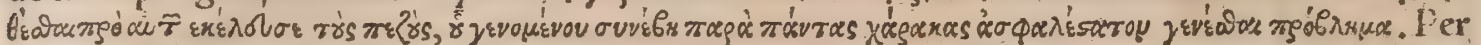

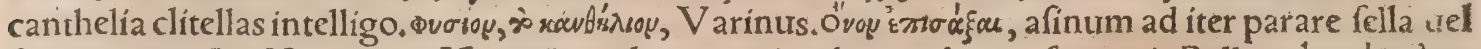

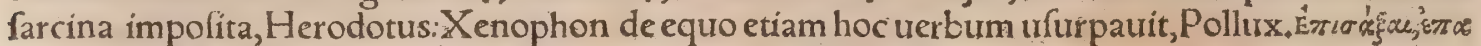

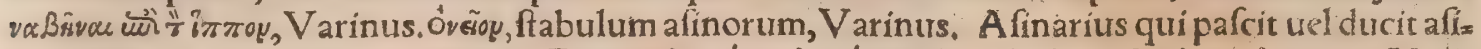

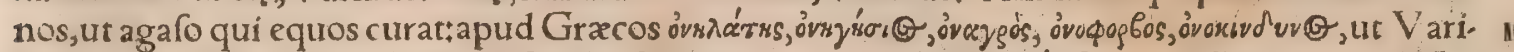

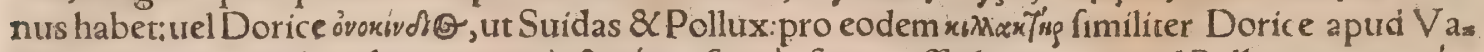

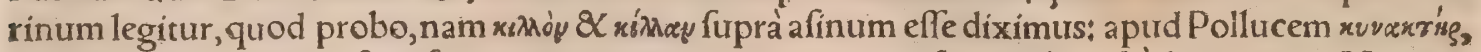
quod non placet in hac fignificatione:pro uenatore tamen, qui \& xuysyós, recté dici puto:ut $V$ arinus

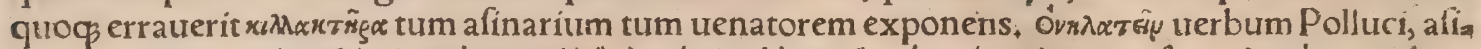

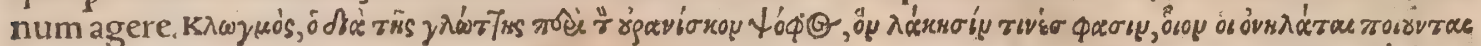

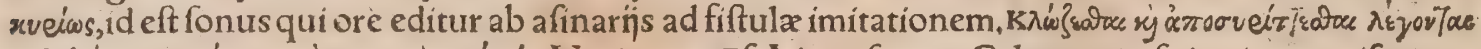

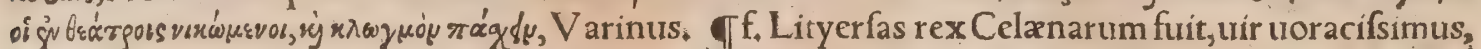

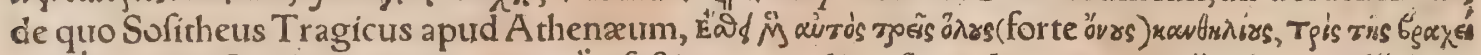

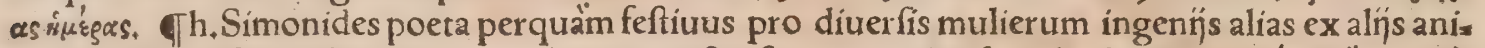

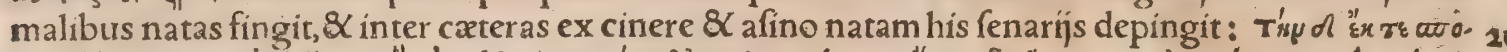

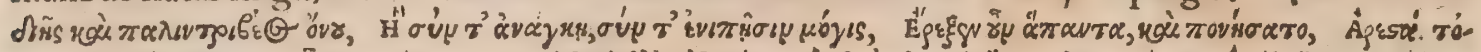

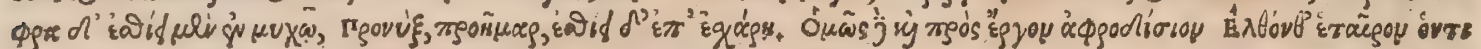

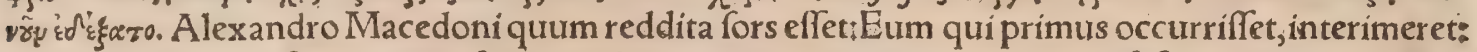
ubi quendam præfe agentem afellum uidit,arripi hominem ex oraculo confeftim imperauit. At is iam iam iugulandus, intellecta mortis ratione, proclamauit: Anteambulonem fuum nô fe peti ex re fporifo, quando is obuiam latus effet prior. Perquàm lepida apud Nicandrum de afino fabula le. gitur, qui iuuentutem à loue hominibus donatam, \& fibi impcfitã, cum ualde fitiret, dipfadi ad fon tem moranti, ut ad potum innoxius admitteretur, tradidit. Hinc eft quod dipfas feneciute exuta itx venefcit, \& propter afini deriuat $m$ in fe fitim, eandem hominibus morfu infligit . Sed ipfos poetze

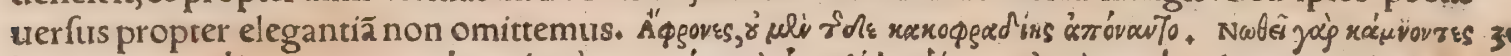

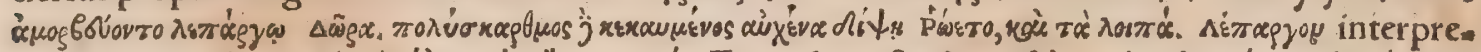

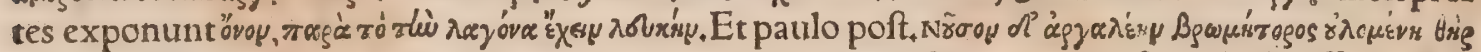
$\triangle \varepsilon \xi \alpha r 0$. A finum Coptitæ apurd Aegyptios præcipitem agunt, 8 homines rufos iniurins afficiunt in contumeliam Typhonis, quem rufi \& afinini coloris fuiffe ferunt: Bufiritæ \& Lycopolitæ tubas nó admittunt, ut qua fonum rudentis inftar afini edant. In fumma, afinum impurum $\&$ damonicum animal effe credunt propter fimilitudinem cum Typhone, tum colore tum animi ftultitia \& improbi tate: $\&$ cum placentas faciunt in facrificins Payni \& Phaophi menfium, infigniunt eas nota afini li. gati.Perfarum etiam regem Cchum uehementer eis inuifum, afini cognomine notauerunt(aliâs, $A r$ taxerxx cognomen fuit $O$ chi) unde commotus ille, A tqui afinus ifte(dixit) bourem ueftrum uorabit \& A pin mactauít.llii uero qui dicunt Typhonem fuper afino ex pugna euafiffe, \& cum feptem die rum itinere aufugiffer, filios procreaffe Hierofolymum \& Iudxum, res Iudaicas manifeftis fabulis implicant, Hac Flutarchus, ut nos tranfulimus ex libro de Ifide:paulò aliter Aclianus, qui Petro Gyllio interprete ita fcribit:Bufiritx, Abydus, Lycopolis, idcírco tuba fonitum ab auditione fua de teftantur, at $\$$ execrantur, quòd ab afino rudente eius clangor difsimilitudinem non habet: $\&$ fimul eis qui Serapidis religionem obferuât, odio eft afinus, atø̧ acerbitati. Cuius rei non ignarus Ochus Perfes, A pim quidem interfecit, afinum autem \& confecrauit, \& fanctiffima religione coli iufsit, $A e$ gyptios ut moleftia afficeret. Sed is fané tant fceleris facro boui perfoluit ponas, nec iniuftas, neç minus graueis, quàm Cambyfes dediffet, qui primus bello facrilego religionibus indiśo eiufmodi impietatem commiferat, Hactenus Aelianus, Cur in Confualibus feftis equos $\&$ a finos coronant 8 otiari finunt? An quia Neptuno equeftri feftum hoc peragunt, 8 afinus cum equo libertate com jo muni fruitur? Aut quies ifta iumentis conceffa eft, quod mare tranquillum \& nauigationi commo. dum fe præbuiffet? Plutarchus in quæftionibus Romanis cap. 47. Onofreli dæmones funt inaquo. fa $\&$ arida corporibus arefcentibus frequentantes, afininis cruribus. Hi fefe mares plurimum exh: bent,interdum quoqs leonem 8 canem induere uidentur, Cælius, Lectum in hiftoria eft ab Hyper

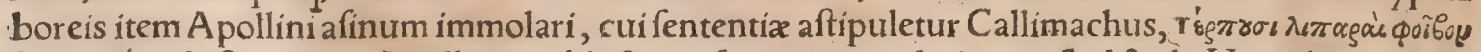
ôvoo фay iac,id eft pingues A pollinem oblectant afinorum iugulationes . Sed \& de Hyperboreis Pin.

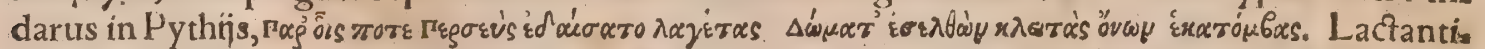
us lib.1.de falfa religione cap.21. ait Lampfacenos Priapo afinum in ultionem etludibrium mactare confueuiffe:quod quum is deus Veft dormientis pudicitix infidiaretur, illa intempeftitio afelli cla more fit excitata, $8 x$ detecta infidiatoris libido. Ouidius Faftorum 6. prolixius hanc fabulam perfe= 6o: quitur, \& afinum in deæ Vacunæ fefto feriari, \& é pane monilibus floribusćs coronari folitum tefta tur in Vefta gratiam, Idem Faftorum I fimillimam de Sileno eiusćs afello et Lotide nympha fabellä 


\section{DeAfino. H. Lib, I, 15}

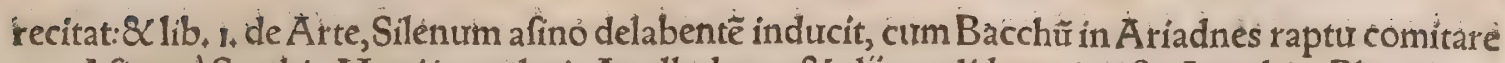
tur. Afinos à Scythis Marti immolari, A pollodorus $8<$ alin prodiderunt, tefte Arnobio, Phornutus fcribit propter bellicum clamorẽ uociferationemọ́ afinos Marti immolatos. Gentes quadã olim, ut ait $D_{4} A$ thanafius; in dịs fuis humana cum brutis mifcebant, 8 qux in natiura diffimilia erant, deos fuos fecertunt, cynocephalos, ophiocephalos, onocephalos, criocephalos:hoc eft; qui canis; ferpẽtis, afini; 8 arietis effent capitibus, Non eft hic filentio pratereunda mirabilis illa Bileami afina in fa cris libris Numerorum cap.22. celebrata, cui $\&$ angelum Dei uidére, $\&$ dominum infídentèm allo. quí diuinitus datum eft. An non etiam ipfe rerum dominus Chriftus, dum furum ipfe ingeniùim ab omni faftu alieniffimum oftendit, $\mathcal{X}$ indomito adhuc afello uehitur, ut diuus Zacharias olim futua so rum pradixerat,maximam huic quadrupedi gloriam adiecit : Extat Luciani liber Lucri utel Afini citulo, \&L. A puleỉ libri undecim A fini aurei:idem uthif̧́ argumentum; fed Apuleius omnia co, piofius tractat $\&$ multa intermifcet. Inftitưtum eft naturã mortalium $\&$ mores humanos obiter dè. fignare, ut admoneremur ex hominibus afinos fieri, quando uoluptatibus belluinis immerfi afinali ftoliditate brutefcunt, nec ulla rationis tuirtutis ćs fcintilla in eis elucefcit. Sic enim homo, ut docet Origenes in libris periarchôn, fit equus $\&$ mulus: fic tranfmutatur humanum corpus in corpora pe cuina, Rurfus ex afino in hominem reformatio fignificat calcatis uoluptatibus exutis ć̣ corporali= bus delicins rationem refipifcere, \& hominem interiorem, quí uerus eft homo, ex ergaftulo illo cœ: nofo ad lucidum habitaculum uirtutibus $\&$ religione ducibus remigraffe, ita ut dicere poffimus iu uenes illicio uoluptatum poffeffos in afinos tranfinutari; mox fenefcentes, oculo mentis uigente, c cü 20 uirtutés iam maturefcunt, exuta britti effigie humanam refumere. Proclus nobilis Platonicus mò net multos effe in uita lupos, multos porcos, plurimos alia quadam bruti fpecie circumfuros, Quod minimè mirari nos oportet, cum terrenus locus Circes ipfius fit diuerforium, in quo anima aut un: guentis delibutx, aut pharmacis epotis inebriatę, transfigurrentur in brutas animâtes. Pharmaca au tem funt obliuio, error, infcitia:Quibus anima confopita brutèfcit, donec guftatis rofis, hoc eft fcien tia(qux mentis illuftratio eft, curusş̧́ odor fuautrifimus)auidè haufta in himanã formam, hoc eft ra. tionalè intelligentiã, reuertatur: Hæc Beroaldus in Apulen̆ A finum, A fini encomium frripfit Hen, Cornelius Agrippa, in poftrema parte libri de uanitate fcientiarum. Aegyptí in Hieroglyphicis onocephalum pingunt, hominem rudem 8 nunquam peregrinaturn fignificãtes, ut qui nec hiftori

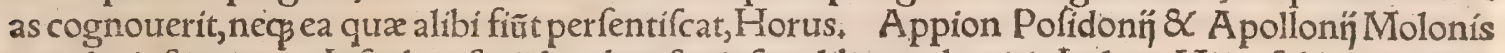
30 mendacia fecutus, ut Iófephus fecû̃do aduerfuss iprum libro redarginit; ludaos Hierofolymis in templo aureum afini caput ingentis pretĭ coluife fcribit:idós deprehenfum effe ab Antiocho Epiphane cum templum fpoliaret, A tqui cum uarï cafus (inquit lofephus) noftram ciuitatem uexauerint, \& Theos ac Pompeius magnus ac Licinius Craflus, $\mathbb{X}$ poftremo Titus Cafar cititatem ceperint, ni= hil huiufmodi illic inuenêre, fed puriffimam pietatem. Antiochus uero pecuniarum inops, cum non effet hoftis, fed foedere iunetus, focios $\&$ amicos nos aggreffus eft, nec aliquid in templo derifione di gnum inuenit, ut multi $\&$ fide digni fcriptores teftantur, Polybius Megalopolitanus, Strabo Cappa dox, Nicolaus Damafcenits; Timagenes; Caftor Chronographus \& Apollodorus: qui omnes An= tiochum pecunịs indigentem \& fódera uiolafle, \& templum auro argentóǵs plentim fpoliaffe fcri= bunt, Hæc A egyptitus A ppion cö́fýderare debuerat, nifi cor afini ipfe potius habuiffet, \& impuden. 40 tiam canis; quí in À egypto affolet coli,Hæc lofephus. Meminit hiftoria hưius Nic. Leonicenus eti am lib. 3. cap. 3o. Plutarchus Sympofiacorum lib 4 problemate y. Probabile uídetur(inquiit)Iudęos fuem colere, utpote feminandi $\&$ arandi magiftram, ut afinum quoos colunt, quod aqua fontem eis aperuerit. Hure facit Petri Criniti ex primolibro de honefta dif́ciplina caput 9 . Verba funt(iriquit) Cornelij Taciti, quo loco hiftoriã de ludæorum origine 8 moribus fcribit, Âfenfere Iudæi Mof du ci, (atç omnium ignari fortuitum iter incipiunt : fed nihil æque quàm inopia aqua fatigabat: Iamç haud procul exitio totis campis procubuerant, cum grex afinorum agreftium,é paftu rupem nemo re opacam confcendit. Secutus Mofes, coniectura herbidi foli,largas aquarum urenas aperít. Hic uul gatifimi codices deprauati funt: fed ita legendum effe conftat ex Apologetico Tertullianí; ubi ille, Refert(inquit) Tacitur Iưdæos A egypto expeditos, fiue(ut putauit)extorres, uaftis Arabia aquarü so locis egentiffimos, cum fiti macerarentur, onagris, qui forte de paftu potum petituri exiftimaban. tur, indicibus fontium ufos, ob eamós gratiam confimilis beftiæ fuperfíciem confécraffe. Sed hac me ra mendacia funt. Nos in facris legimus Genefeos 36 . quòd Ana focer Efau dum pafcit afinos patris

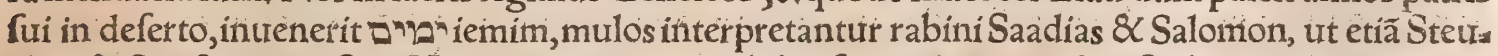
chus $\&$ Sanctes ex noftris, Hieronymus aquas calidas, fecutus quorundam Iudaorum opinionem, Sic enim fcribit in Quaftionibus: Alý putant ímim maria appellata, \& uolunt illum aquarum con= gregationes repériffe, quix iuxta idioma língux Hebraica maria nuncupantur. Et pauló poft:Nona nulli putant aquas calidas iuxta Punicæ lingux uiciniam, fita Hebręæ contermina eft, hoc uocabif lo fignari. Sunt qui arbitrentur onagros ab hoc admiffos efie ad afinas, \& ipfum iftiufmodi repérif: fe concubitumitut uelocifimi ex his afini nafcerentur, qui uccantur iamim. Pleriç putant gutod è. 60 quarum greges ab afinis in deferto ipfé curauerit primus infendi; ut mulorum inde noura contra naturam animalia nafcerentur. A quila, Symmachus, Theodotion $\&$ L XX.uocem Ebraicam reli:

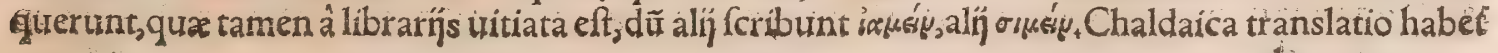




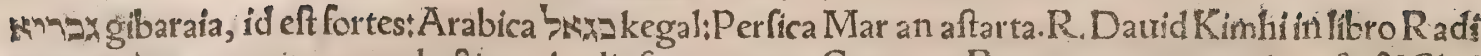
cum nulos exponit, quem doctiores hodie fequuntur. Caterum Romansueteres pari caufa \& Chri ftianos aque ac ludeos afinarios uocarunt, obftinato uidelicet in Chrifi nomen odio, quem per igno miniam etiam Chreftum per e literã appellabant. Sed et figuris picturis çß Chriftianis illudebant, quan do infando eriam picturx genere Deum noftrum fic depictum fpectanti populo propofuerunt, ut is foret auribus afininis, pede alrero inungulatus, librum geftans $\&$ togatus . Cui flagitio ut fcelus adde.

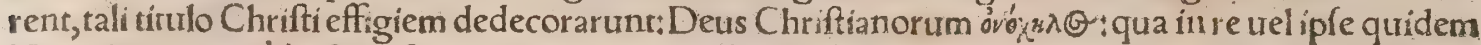
Tertullianus agrè à rifu abftinuit, cum nomen ipfum \& formam confpicer et, Hac Crinitus . Non oo mittenda eft hoc loco Simfonis hiftoria, quæ in facris Biblíps libro ludicum cap. 15. proponitur. Sim* Ion uir apud Iudæos omnium fortiffimus, cum in ipfum inermen Philiftæi irrucrent, maxilla afini ar. re repta quamuis iam marcida hoftes mille proftrauit:inderum nimia fiti laborarer, proiecta maxilla, pre= ces ad Deum fudit, \& aqua ex dente molari profluentis fcaturiginem impetrauit. Sunt qui uocem He braicam שnว"an hamactefch, non uerum dentem molarem, fed faxum dentis fpecie interpreientur, quod fuerit in loco illo tum recẽs à re gefta Lçhi, id eft maxilla; appellato. Notum eft lapides quiordam molares uocitari, non folum qui iam in ufu molx funt, fed quoniam illius funt generis, ex quo praftan tiores fiunt molares fiue catilli, quos afinos etiam Graci nominant.

Andrex Alciati Emblema in auaros.

Septitius populos inter ditifimus omnes;

Defraudans geniumọ̧́̂

Cư fimilẽ dicã hunc, inopẽ quẽ copla reddit?

Nanç afinus dorfo pretiofa obfonia geftat,

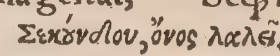

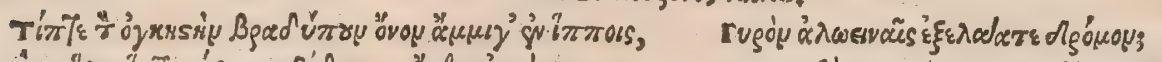

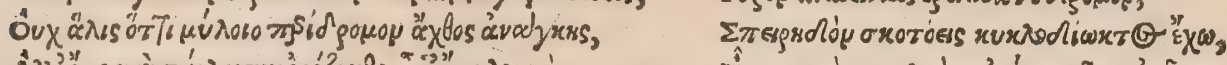

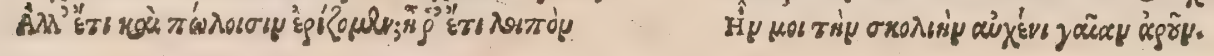

Arua fenex nullus quo magis ampia tenet,

Nil præter betas, durá̧́ rapa uorat.

An' ne afino: Sic eft:indtar hic eius habet.

P ROVER BIA.

Áfinus Ảegyptius, pro co quil derifui fit omnibus; quemós omnes infeçentur, contrellant, lacerët, Calius Rhod. A fellam agas. Afinus alia portat, alia Lacon. Antronius afinus. Afinus inter apes, de ins qui in mala inciderunt, Erafmus \& Surdas. Sus ful pulcher, afinus alino, Afinus auis, Eraf. \& Suid.

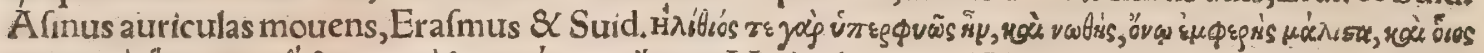

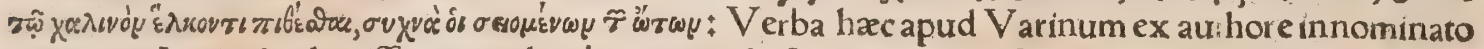
citannur. Auriculis demiffis, prouerbiũ à iumentis ductum, cui aduerfari uidetur illud, Auribus arre. ćtis. Horatius Serm,1. Demitto auriculas, ut iniquæ mẽtis alellus Quum grauius dorfo fubritonus.

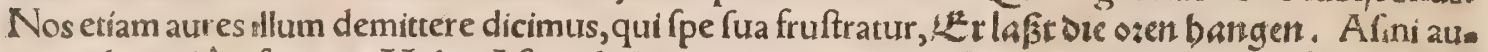
res, uide paulò inferius in Mida. A finus balneatoris, in eos qui ex fuis laboribus ipfi nihil fructus capi unt:fic Germani, KE in Karger reyder ifts $\mathbf{S a l o m e n}$ efel. A b afinis ad boues tranfcendere, eft ex humilior e conditione ad ditior um partes tranfire, apud Plautum in Aul, ut fupra recitaumus. Afini ho mines proftupidis $S$ ftolidis apud eundem in Pfeud. Camelus uel fcabiofa complurium afinorum ge

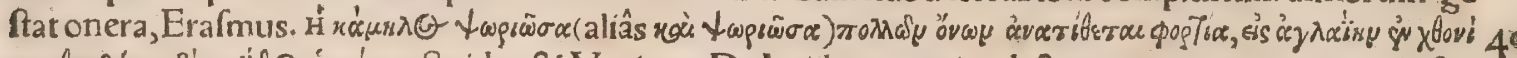

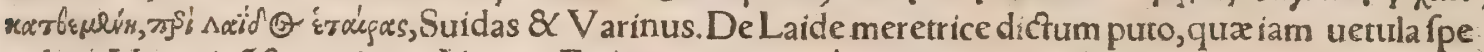
culum Veneri côfecraurit, ut Alciatus Emblemate perquàm lepido expreffit. Si uiel afinus canem mor

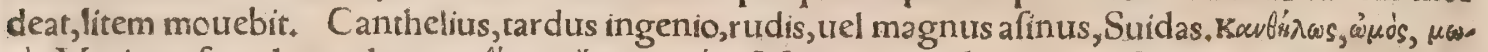

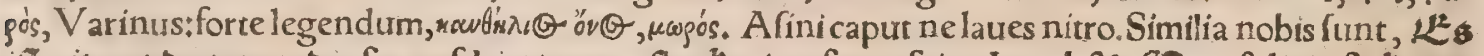
ift nit not Das man bie fauw foirt/man p fucte oder fengt frood wol \&, SDan fol bie fact nitt

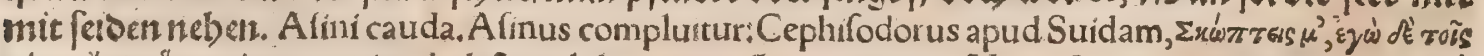

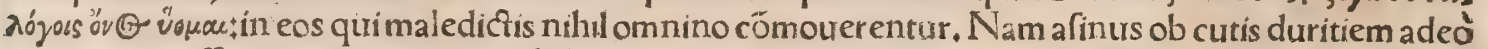
plutuia nihil offenditur, ut uix etiam fuftem fentiat. Huic affinia funt apud nos, $\exists \mathrm{db}$ bin fo naffs als idb

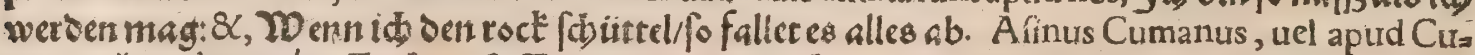

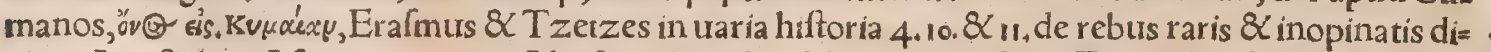
citur, A poftolius. A finos non curo, A bafino delapfus, A b equis ad afinos. Equus ex afino. A finus efu

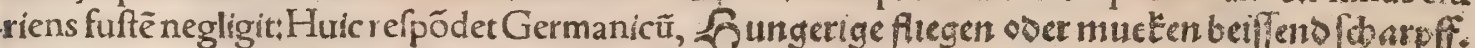

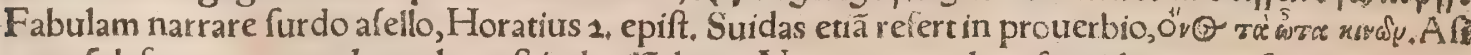
num fub freno currere doces, hoc eft indocile doces. Nam equus ad curfum idoneus, afinus ad eque. frem curfum inutilis. Horatius, Infelix operam perdas; ut fi quis afellum In campum doceat paren.

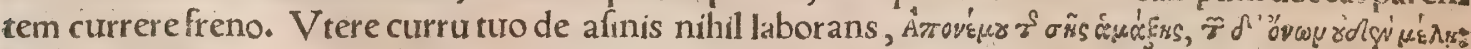
hoc eft, Cura res tuas hisç̧ fruere, nihil inquirens de alienis. Nam cui plauftrum eft domi, non optis ha bet deportandis oneribus afinos aliunde conducere. Afini lana, Ab afino lanam, \& A finum tondes,

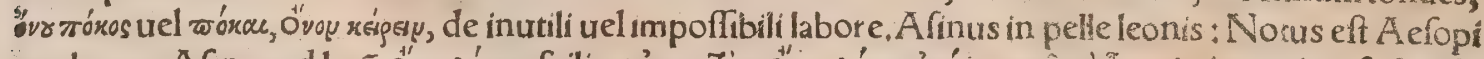

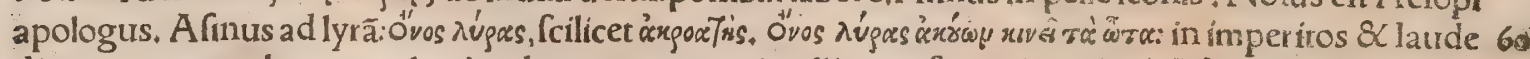
digna non approbantes, uel ea laudantes quæ non intelligunt, fecundum illurd, A finus auriculas mo.

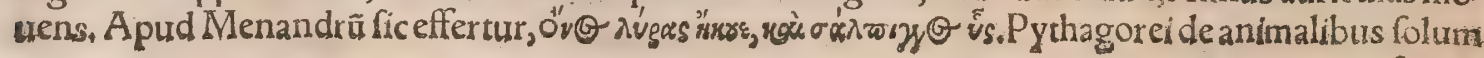


afinum afferunt ad harmoniam non factum effe, proinde abfurdam beftiam nullo fenfu ad lyræ $\mathrm{fo}$ nitum affici, A elianus. Miretur fanéaliquis cum natura aưriculas longiores illis addiderit animan: tibus, quas auditu præcellere opertebar, \& fonos promptiffime apprehendere, cur non exdem fos nos fimul argittius difcernant \$ certus enim difcernit $\&$ afficitur, afinus hon item. An non tam ad cognítionem $\&$ uoluptatem aurita funt animalia quædam, quàm ad corporis incolưmítätem tuen. dampprafertim cum timida ea omnia fint, Proinde in fupidum \& ea quæ non intelligit fe intellíge=

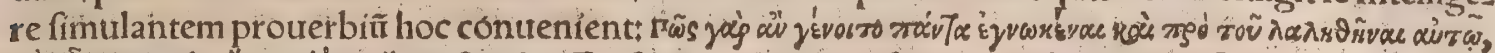

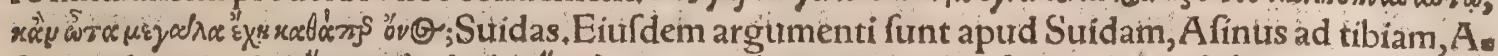
finus tubam audit, O"v 10 $v Q$, in eum cui res funt patum fecund $x$; felices enim eximijs equis infidere gaudent: nec infcite ias: cietur iti hominem parum feliciter coniugatum. Simile eft illud Vueftphalorum, fe rytt eyn gect

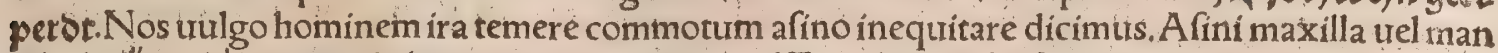
dibula, Ö'you grátos, iocus in hominem uoracem apưd Eupolidem. Eiufdẽ nominis Laconiz promone torium eft, quod ftadijs ab A fopo ducentis diftat; Paufania tefte, à figura forfitan appellatũ. Midas

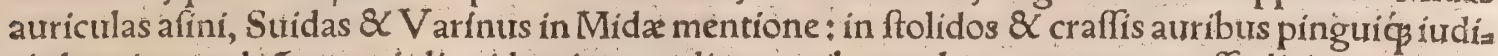
cio homines:uel cōtra, qui aliquid eminits audiunt, quibus uulgo aures tenues effe dicimus; tyrannos præfertím, quí corycæos \& aufcultatores quafi oblongas aures habent, qua prouerbí figura longxe etiam regum manus dicuntur. Nullum aliud animal acrius afino audire ferữt, mure tantum excepto. Lucianus in libello cui titulus, non effe facile credendum delatoribus, Calumnize depine 20 gens imaginem, Midx aures illi tribuit. Argo poëtx complures oculos attribuunt, quod homo fo=

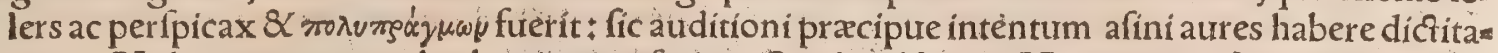
mus. Mida aures quomodo abierint in afininas Ouidiuts libro ti. Metamorphofeon graphice de=

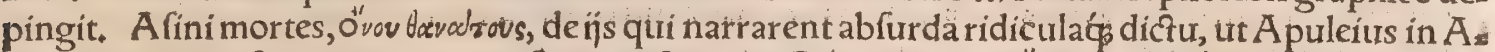

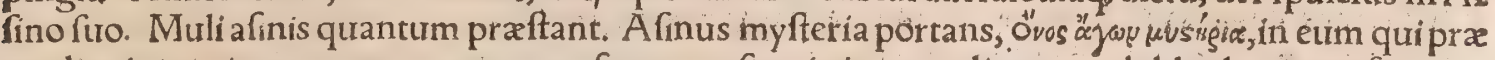
ter dignitatem in munere quopiam uerfatur: ut fi quis ignarus literarum bibliothecæ praficiatur. Athenis olim res quibus ad peragenda facra Eleufinra opus erat, afino impofita deportabätur. Huc pertinet apologus ille, quem Alciatus inter Emblemata uerfibus illuftrauit, fub titulo, Non tibi, fed religioni,

Ifidis eff giem tardus geftabat afellus, Pando uerenda dorfo habens myfteria

30 Obuius ergo deam quifquis reuerenter adorat, Piasḉs genibus concipit flexis preces

Aft afinus tantum prxftari credit honorem Sibi, 8 intumefcit admodum fuperbiens:

Donec eum flagris compefcens dixitagafo, Non es deus tu(afelle) fed deum uehis.

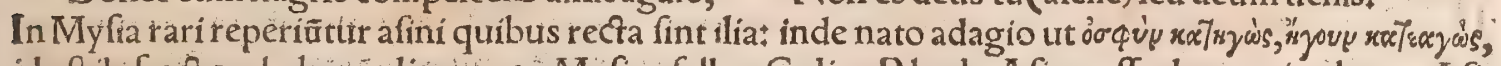
id eft ile fractum habénš, dicatur, ex Myfia afellus, Calius R hod. Afino offa das, cani paleas, Afi.,

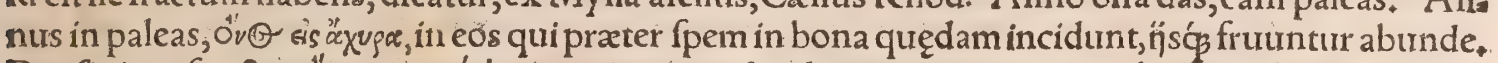
Deafini profpectu, övou masexúvecos, in eos qui ridendo titulo quempiam calumniantur, aut de fris uolis rebus aliquem in iưs ưcănt. Prouerbij occafionem alij aliam referunt, utErafmus recenfet, ego ne nimius fím, ad reliqua pergo. Rex âut afinus:id eft uictor aut uictus: Tractum eft adagium à

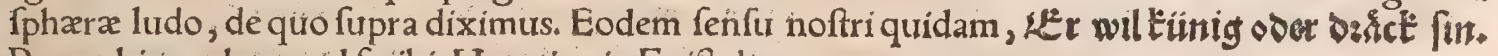
40. Prouerbium olet quod fribit Horatius in Epiftolis:

Qui male parentem in rupes protrufit afellum, Et merito:quis enim inuitũ feruare laboret Quadrabitin quofdam peruerfo natos ingenio, qui cum ipfi non fapiant, nolint tamen bene confir lentium monitis obtemperare: Afinus inter fimias, ubi ftolidus aliquis incidit in homines nafu-

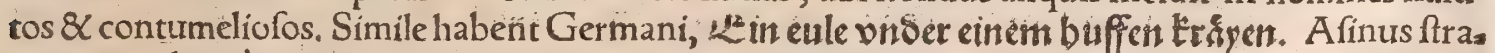
men mauult quàm aurum. De afini umbra, rodi ơvov o xiäs : in illos qui temere quamuis ob caúam fine fructu contendunt, quiod noftrí dicunt, $O$ mbein tubenos šck baberent. Ridiculam hiftoriam ex qua ortum eft prouerbium parœmiographi referunt. Archippus comöediam foripfit titulo Vimbra

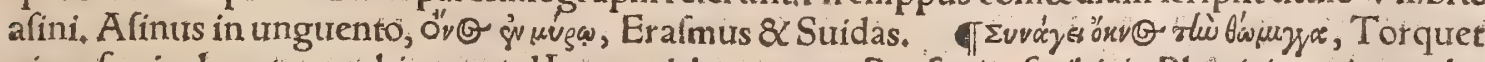
piger funicultum, prouerbium apud Ionas celebratum, ut Paufanias fcribit in Phócicis, cuius uerba 50 pauló aliter quàm ab Eräfnos translata fubfribam. Ex Polygnoti pićuris (inquit) hęc ctiam eft. Vir quidam (apud inferos) redet, quem titulus Ocnon effe indicat. Factus eft autem ad hunc modum, ut iple funiculũ torqueat, aftante afella, qux quod tortum fuerit affidue abrodat. Hunc Ocnitm aiunt hominem fuiffe induftrium operíg intentum, fed uxorem habuilfe fumptuofam \& prodigam, qux omnia illius labore corrafa mox abfumpferit. Cegnitum autem eft mihi etiam ab lonibus dici fole. re, fi quem confpexiffent in re quapiam elaborantem, qua nihil adferret emolumenti, Hic homo fir niculum Ocni contorquet, Picturæ hoc genus Delphis confecratum fuit, Plinius inter Socratis picforis argumenta, Et piger, inquit, qui appellatur Ocnos, fpartum torquens quod afellus arrodit ${ }^{\text {Er }}$ : rat $V$ arro qui defidem \& ignauum hac pictura fignificari putauit, cum laboriofus potius $\&$ iriduftrius, fed cui uxor prodiga lit, defignetur, quamobrem afina, non afinus, in piciura eft: quod Paufa. 60 nias de induftria annotauit, authores reliqui neglexerunt. Idem argumentum marmore calatum, $R o$ mæ duobus uifitari locis, neppe in Capitolio $\&$ in hortis Vaticanis Hermolaus Barbarus teftis eft. Hoc interim admirandum, non folum cur Plinius, ut Erafmus purat, fed $P$ aufanias etiam $\&$ alïj,ipfum hô 
minem Ocnon, id eft pigrum appellauerint potius quàm afinum, cui conuenit tum res ipfa nempe pigritia, tum nomen, cum onos \& 0 cnos una tantum litera differant: \& Propertius non Ocnon tor. quere funem, fed illum ipfi toqueri his uerfibus confirmet: Dignior obliquo funem qui torqueat Oe

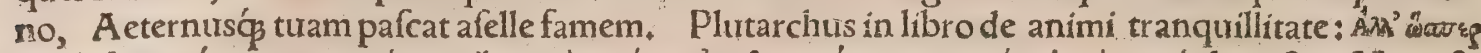

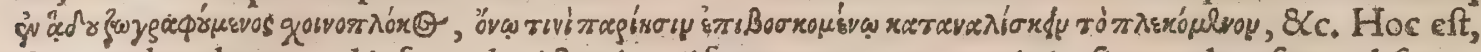
Quemodmodum apud inferos depictus is qui funem torquet, permittit afino ut depafcens abfumat id quod tortum fuerit:ita plerics rudes obliuiofi \& ftupidi homines, nulla prateritorum ratione ha. bita, futura femper expectant, \& prafentia abolent. Hæe prolixius adịcio ut qux Eraf́mus nec Græ cerectè legit, nec apté Latine reddidit, emendentur.Sunt qui ex hoc figmento(referente Suida, Eraf mus enim præterït) prourerbium övou rórae de rebus nullo fine perficiendis interpretentur, ut zórac io non ip fa afini uellera fint, fed funiculi quos abrodere $\&$ quafi tondere fingitur. Quinetiam prouer = bium rà gुv "x̣̂̉ ov, id eft, Qux apud inferos, Arriftophanis interpres ad eandem fabulā refert : quafi nó in genere ad omnia pertineat, quæ de inferis poétæ nugantur, ut omnia inanía fomnijs ćs limilia ap* té líc nominemus. Mihi fané qui primi hac confinxerunt, Cratinus \& Ariftophanes, ueterum poe. tarum \& Homeri maxime fabulas imitati uidẽtur, qui alias quoģ apud inferos poenas fimilıter per petuas 8 infinitas celebrarunt, ut cribra Danaidum, Sifyphi faxum, \& Tityi iecur, \& in Caucafo Promethei:ut hic ipfe perpeturus in torquendis funibus labor, pœna illius fuerit, qui uiuus uel in u. xorem luxuriofam, uel in meretricem prodigus fuiffet. Extat Alciati Emblema hoc titulo: Ocni effi* gies: De his qui meretricibus donant, quod in bonos ufus uerti debeat.

Impiger haud ceffat funem contexere fparto, Humidaçs artifici iungere fila mant?

Sed quantũ multis uix torquet ftrenuus horis, Protinus ignaui uentris afella uorat.

Foemina iners animal, facili congefta marito Lucra rapit, mundum prodigit inćs furum.

Sed defino tandem Ocní funẽ torquere, fi prius monuero ocnon etiã dici Gręcis auem ex ardearum genere maximam \& $\mathcal{X}$ pulcherrimam, tefte Paufania, quam Ariftoteles ftellarem uocat, \& olím è feruo in auem tranfíffe fabulam narrari feribit, quoniam ut cognomen fonat iners otiofaćs fit. Empufa mutabilior, prouerbij loco ab Erafmo refertur. Ariftophanes enim meminitin uarias eã formas mus rari, ut bouis, muli,canis, \& rurfus mulieris formofa. Interpres fribit fpectrum quoddam efre quod ab Hecate foleat emitti uidendum miferis \& calamitofis, Quidam exiftimant meridianis horis appa rere folitum n̈s qui parentant manibus. Fit autem in facris etiam Pfalmis mentio meridiani damonï. Sunt qui hanc ipfam Hecaten affirmant effe: narrant autem uno uideri pede, unde $\&$ nomen additũ $30^{\circ}$

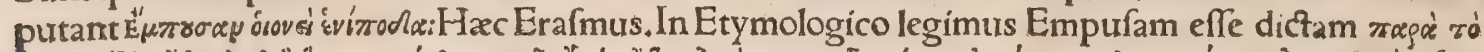

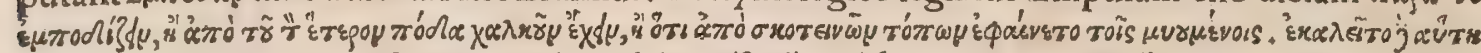

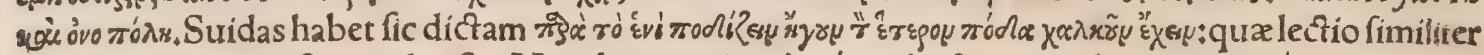

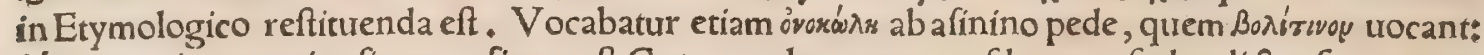
Bórbro enim proprie afinorum fimus eft. Cxterum dxmones quofdam onof́celos dicfos fupra anno tauimus, $\mathbb{1}$ Nunc Germanica quędam adagia, in quibus afini mentio fít fubnectemus, \& qua eis re fpondent Latina, nulla tamen eiufdem animãtis mentione, 进in efel beiffet Den an beren facketracter, id eft, A finus afinum faccigerulum uocat: quo fenfu illud ufurpatur, Loripedem rectus deridet. "Si fteln fin ১ ১es efcls falar treüter/id eft, Cardui afino acetarijloco funt; cui conuenit, Similes habent labra lactucas. Dillect fint ১es efels toot/id eft, Multi facciafinum opprimutt uel enecant: Huiuf= 40 modi eft, Cedendum multitudini. (San riffe ben efel nit jü bofe/er fol Dann fecte tragen, id eft, Afinus non uocatur ad aulam nifi pro faccis portandis: Latini fimiliter monent, Porrò à loure atç ful

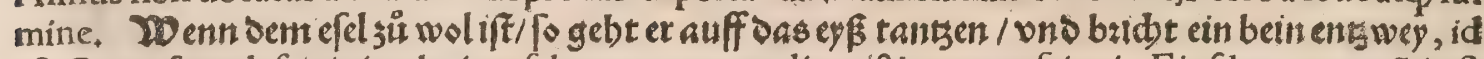
eft, Cum afinus lafciuit, in glaciem faltaturus progreditur, $\&$ crus perfringit, Eiufdem argumẽti eft illud, Virc Lydo negotium non erat, fed ipfe egreffus emit.

\section{DE HINNO, INNO, ET GINNO.}

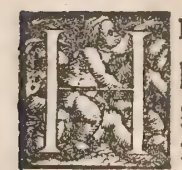

I N N V S, innus, \& ginnus, animalia nobis per Germaniam ignota funt(nifi, quis uiles 8 paruos afellos etiam fic nominare uelit, uteri uitio nanos)quanquam ne aliarum quidem gentium nomina præter Gręca reperio, à quibus Latini quoģ mutuati funt. Nam I tali quí so nanos $\&$ baftardos afinos uocant, circumloquuntur, Qui ex equo \& afina concepti ges nerantur, quamuis à patre nomẽ traxerint quod hinni uocâtur, matri per omnia magis fimiles funt, Columel. Equo $\&$ afina genitos mares, hinnulos antiqui uocabant: córrá̧́ mulos quos afini $\&$ equæ generarent, Plin. Hinnulus, foctura capreolorũ, caprarum, damarũ, leporum, fimiliumọ́:itẽ ex equo $\&$ afina genitus, Idem. Inulos accipiunt nônulli certuinos pullos : hinnos aũt $\&$ hinnulos cũ flatili ac duplíci cófonante, ex afina cócepros mares equi feminio, Calius R hod. Muli $\&$ hinni bigeneri aţ̣ infitrĭ, nõ furopte genere ab radicibus: ex equa enim \& afino, fit mulus:cótrà ex equo $\&$ afina hinnus, uterq̧ corũ ad ufum utilis, partu, fruću, uentre. Et pauló poft+ Hinnus minor eft quàm mulus corpo: re, plerung rubicundior, auribus ut equi, iubam $\&$ caudã fimilem afini habet. Item in uentre eft, ut e. quus, menfes duodecim. Hofce itẽ ut equulos $\&$ educant $\&$ alunt, $\&$ atatẽ eorũ ex dentibus cognof $=$ 6a cunt, Varro. Himus, hima, 8 himulus, \& himula uocãtur, qui ex equo \& afina nafcunt, quos quidã burdones appellant,Perot, Ego in quatuor his dictionibus librariorum culpa factũ puto; ut m pro 


\section{DeHinno. Lib. I.}

duplici nlegatur. Burdo autem dictus uidetur àr ḋ quordam recentiores í фógrwy legiturłuel quòd bardum, id eft fupidum \& fatuum fit animal; aut for fan ab Hebraica uoce pered quæ mulum fignificat, ut pirdah mulam. Sunt enim hinnictiam muli quidam, cum sisiovos, id eft, ex altero parente afini fint, Latini grammatici hominem bardum dici pit tant à Graco Bpad v's, qui tardus ingenio fit. Manni feu mannuli equi dicebantur, haud ita magni, ac pramites, uulgus (uti fribit Porphyrio)burdos uocabat: Burdones dici uidentur quocs ab lure confulto, Digeftorum tricefimofecundo, ac De legatǐs tertio, Cæliuss Rhodig. Peculiare quoddã mu lorum genus in Gallia circa Gratianopolin haberi audire aliquando memini, quod ex afina $\&$ tau. ro natum uernacula lingua iumar appellant. In Heluetiz alpibus fupra Curiam ad pagũ Spelugam 10 ex equa $\&$ tauro natum equum ex uíris fide dignis accepi. Hoc tempore in aula regis Galliarú ani= mal nutriri aiunt ab anteriore parte afini, pofteriore ouis fpecie. Sed præter inftitutum eft bigenera hîc omnia perfequi. Ferrarix in aula principis inter peregrina animalia afelli etiam ptrmili aluntur. De mulis pomilijs Martialis diftichon extat:

His tibi de mulis non eft metuenda ruina; đ Mulus cum equa coniunctus innum procreautit: poft deinde fuperuenire nō folet, Ariftoteles in terprete Gaza: Graci codices yívoy habent cum gamma $8 C$ hic, $8<$ mox de equo nano. Plinius $8+4,4$ hac ita reddit:In plurium Gracorum eft monumentis, cum equa muli coitu natum, quern urocaue. rint hinum, id eft paruum mulum. Hinum fribit per $n$ fimplex. Prodeunt quos ginnos uocant ex equa, cum in gerendo utero agrotauit, more pumilionum in ordine hominum, aut porcorum quos 20 pofthumos uocant: \& quidem ut pumilio, fic ginnus modum furo genítali excedit. Ariftot, 6, 24, hi ftorix animalium, Et alibi in libris de partibus animalium: Ex equo $Q$ afino ginni proureniunt, $\mathrm{cum}$ conceptus in utero ægrotauit. Aliqui non ginnum fed ivvó fcribunt pro manno uel equo pumilo. Ginni apud Ariftotelem deminuta forma equi dicuntur: quos $\&$ gygenios ab Strabone nuncupa ri, putant nonnulli: quanquam $\&$ mulorû̉ genus fic in Liguria uocetur, Calius R hod, ivıs apud Græ cos filiũ uel nepotẽ fignificat: $\&$ fieri poteft ut ab hac uoce iumenta nana quæuis Græce "ैvvou $\&$ yivyot dicantur, quod pullorum magnitıdinem nunquã excedant: $\&$ apud Latinos hinni \& hinnuli, $\&$ for té ginni quoç. Quanquam apud eos complurium quadrupedum fotus, fimiliter, ut fupra diximus, fic appellentur. Etymologiam literatores afferunt quod hinniant $\$$ uocem reddant equine fimilem; quam ego nō probo: neq̧ enim in ceruis \& leporibus, \& alïs huiufmodi talem percipimus uocem:

$3^{\circ} \&$ Græcæ magis quàm Latinæ originis uocabulum apparet. Vt mulus fic \& burdo fterilis eft. Hic equum magis refert, \& uocem edit equi:ille afinum, Albertus Mag:

\section{DE ONAGRO SIVE ASINO SYLVESTRI.}

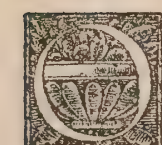

N A G R V S apud Varronem, imitatione Gręca, „veryfor :Latinis ufitatius onager diciture, afinus eft ferus aut fylueftris: regionibus noftris ignotus, dici tamen poteft uernacula lin.

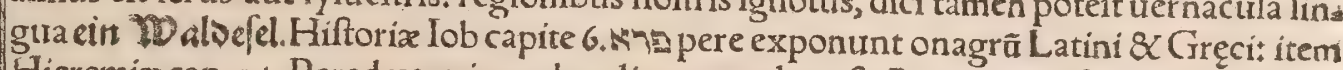
Hieremia cap. 14. Pered uero in eadem lingua mulus eft. Prophetæ Ofeæ cap. 8. legitur th lum hic animal nominant. Varinus meminit Cyrillum in huius propheta interpretatione $\mu_{0 v i}$ a $_{\text {a }} i_{z}$ $4^{\circ}$ num exponere:alios uero magnam belluam, qua ob ferocitatem fola pafcatur. Moviós alioquí aprum folitarium fignificat, Ego hanc uocem in translatione $\mathrm{L}$ XX. interpretum fiue uulgata Græca non reperio:fi in aliqua alia reperitur, ad hunc omnino locum capitis 8 . pertinere puto. Non cótrenit atr. tem onagrum gregarium animal folitarium trocarit nifi quis ita accipiat, quod licet gregatim in folitudine tamen degat. Et forté direrfa onagri genera funt. Ego præter hoc genus monocerotem ona grum legi, de quo paulò polz dicemus. Dictio $\leqslant$ m pere, ponitur etiam adiectiue pro fylueftri, ut

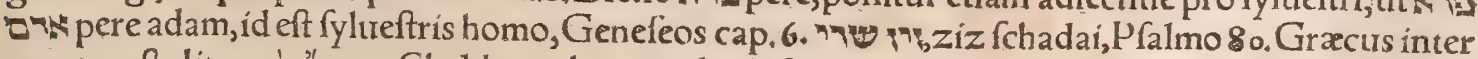

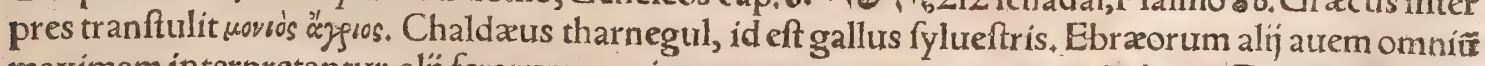

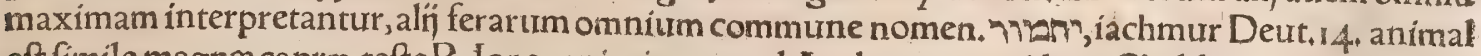
eft fimile magnæ capræ, tefte R. Iona, cui etiam apud A rabes nomen idem. Chaldaica translatio has so bet iachmura, Perfica kutz cohi. Septuaginta \& Lofephús, bubalus. Eft autem bubalus etiam de caprearum genere. Sunt ex noftris qui fufpicentur afinum ferü fignificari, $77 y$ y arod cöftanter omnes onagrum uertunt:8X y ere etiam Iob39. De uoce iemim, quam in Genefi quidam mulos ex ona

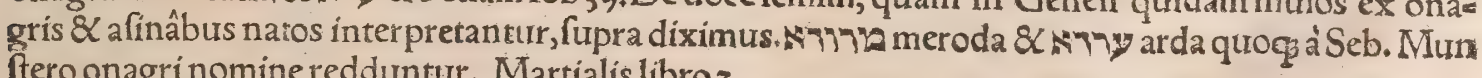
ftero onagri nomine redduntur. Martialís libro3.

Dum tener eft onager, folaç lalifio matre $\quad P_{a}$ fcitur, hoc infans, fed breue nomen habet. Noftra memoria rex Saracenortum, qui apud Tunim in A frica imperitat, Ferdinando regi Neapoli. tano afinum ingentem, forma confpicua ac uaria dono mifit, $R$ aph. Volaterranus. Onagri in Phry gia \& Lycaonia pracipui funt, fed pullis eorum tanquam fapore praftantibus Africa gloriatur : hos lalifiones appellant, Plin. Onagrorum in Phrygia \& Lycaonia funt greges multi, Varro, Angerman 60 nix ducatus, tenet feptentrionalia ad confinia Laponix:eius tractus eft totus fyluofus, \& ibi in praz cipuis feris uenantur uros $\&$ bifontes, quos patria lingua dicunt elg; $j \mathrm{~d}$ eft afinos fylueftres, Iacobus Zieglerus in Schondia, Alces feras quoldam inepte onagros interpretari reprehenfum eft fupra. 
Fuerunt fub Gordiano Romæ præter alias feras onagri uiginti : \& triginta in Sylua Gordiani primi (depicti tantum puto)lulius Capitolinus. A finorum greges ferorum Afia fert \& Africa, Plin. In Ly cia onagri non tranfeunt montem qui Cappadociam à Lycia diuridit. Amant locos excelfos $\&$ ru* pes. Hiere, 14. Onagri(peraim Heb.) Iteterunt in locis excelfis, \& attraxerunt auram ficut dracones,

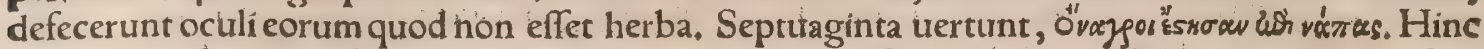
fumpta occafione obfctiri quidam authóres onagrum beneficio uentorum abfquie aquis uiuere fcri bunt, tanquam propheta per naturam id ipfum facere dicat, non potius necelfitate 8 inopia aqua: hoc enim multis animalibus per fitim cömmtine eft, ut ore hiante frigidum captent aerem . Ifidorus $\&$ lorath quidam fcribunt onagrum æquinoctio uerno, trel 25 . die Martï, per fingulas noctis $\&$ diei horas femel rugire, $\&$ inde aquinoctium cognof ci:item terram pedibus terere $\&$ fodere, atque inde ad fitim \& fugam prouocari. A pparet autem iftos orygem tiel cynocephalum pro onagro fomniare. Errant $\&$ alin recentiores qui fcribunt domari non poffe hoc animal $8 \alpha$ hominum confuetudinem ei intolerabilem effe. Nam, ut M. Varro teftatur, onagrus ad feminationem idoneus eft, quod è fero fit manfuetus facile, \& è manfueto ferus nunquam. Sed illi forfan Indicum \& unicornẽ onagrum cum uulgari confundunt. Epitheta onagri reperiuntur afininus, timidus (Verg. lib.z.Georg. ubi canes 20 lendos confulit, Sape etiam curfu timidos agitabis onagros) 3 (egnis, At fide dighi authores, minio méregnem, fed uelociffimum faciunt:ut claret his Oppiani uerfibus, quos libentius propter alia e. tiam epitheta adfcribo,

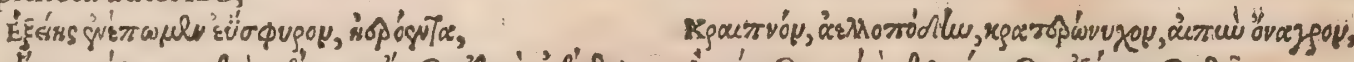

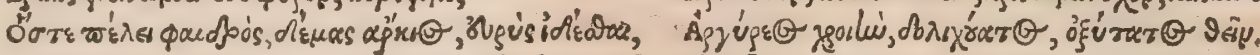

In his carminibus attribuuntur ei ungulæ bonæ $\&$ robuftæ, uelocitas uento comparanda, corpus fatis amplum, latum, \& pulchrum afpectu, aures longa, color argenti : ego cinereum fplendidum intelligo, ut ropógu eodem pertineat: nif quis ita accipiat ut Vergilij aeripedem ceruam, qued minus probo: neqg enim quenquã hoc fenfu ufurpaffe memini. Grẩmatici apud Græcos poetas aereũ exponunt obfcurum, nigrum, nebulofum Nebulæ color utpote cinereits afino conuenit:uidetur au tem idem afini $\&$ onagri color effe, ut conijcio ex Polluce, cuius hæec uerba funt, kìisp color eft ue. fium, quem nunc onagrium uncant. Dores enim afinum cillon uocant. Quod autem onager non

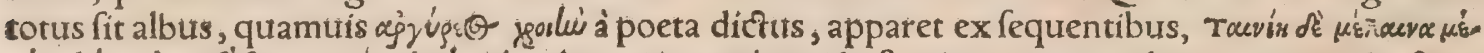

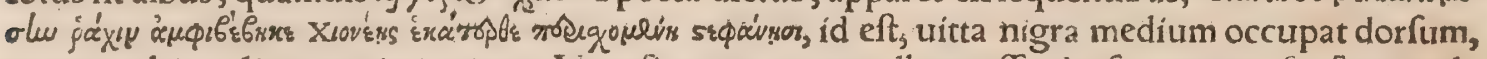
quam ambiunt linex utrings niuex. Nam fi totum corpus album effet dorfo excepto fruftra candi- 30 dæ illæ linex memorarentur. Magnus tamen ille $\&$ unicornis Indicus onager, ut Philes teftatur, to. to corpore albet, capite tantum rubet. Sed adjuciam reliqua etiam ex Oppiano, íta fèrè uttà Petro Gyl lio Latine expreffa funt. Cnagri paftu aluntur herbarum, quas abunde fundit terra, fortibus feris opima præda ræpe fiunt, magna forminarum multitudine gaudent, quoquò maritus ducit, forminæ requuntur, fiue is ad paftiones, fiue ad fontes proficifitur, atç ad uefperam unà cum ipfo ad dome. fticam fedem redeunt. Ex æmulatione $\&$ riualıtate tantopere laborat, ut fui pulli de matre fintei fue fpecti. I taç foeminæ parienti proximus affidẽs partum expectat, ac fi fomina editur, amat partum, $\&$ lambens ipfum lingua conform $t$ : Sin autem edirum marem uidet, tum fané animo incitatur, \& ex ægritudine laborare incipit, quòd alter mas natus fit, qui matre aliquando potiri poffit, quamob rem furenti animo \& prompto pullorum te iculos aggreditur abfcindere: Mater etfí pariendi dolo= 40 ribus debilit ta, fuo tamen infelici filio cótra patrem auxiliari molitur: \& quemadmodum in bello cum hoftes filio interfecto matrem retrahunt, quæ gnatum adhuc cæde palpitãtem amplexa magno gemitu plorat, genasós lacerans infra mamillas fanguinem effundit:Sic illa uidens pullum uícinum ad moriendum, miferabiliter lamentatur, \& lugenti perfimilis eft. Diceres miferam fuum partum cir cumeuntem fuaui \& fupplici locutione dicere: Marite, cur tuus afpeçus tam truculêtus ? Cur oculi tui, qui ante lucidi effent, fanguinei apparent ? An' ne Medufæ faciem uides, qux homines in faxa conuertitran immanis draconis uirulentum foetum ? an lexnæcatulum montiuagx ?Itá ne filium communi fufceptum uoto caftrabis ? O me miferam qux partũ edidi infelicem ob f́celus paternum. O filium hoc miferiorem, quod non unguibus leonum, fed plus quàm hoftilibus patris dentibus ob riualem inuidiam caftraris, Poft hxc elegantiffima eft epiphonefis poetæ in æmulationis $\& z \mathrm{clo}$ z je typix uim, cuius partem quin fubfcribam temperare mihi non poffum:

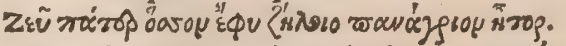

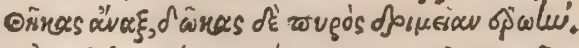

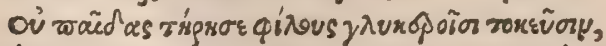
Kẽvop rà фं

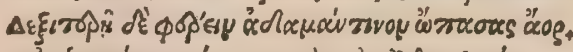

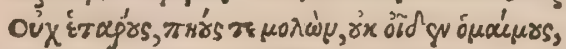

Pfalmo C 1 II I. Dominus, inquit pfaltes, fontes immittit flutins, utinter montes pratermeent:bibût inde animalia cuncta, \& fitim fuam extinguunt ฮ bus calidis ficciş́ tantum reperiatur, 8 ob timiditatem fubinde locum mutet magna cum celerita. te, prafertim cum natura corpore ficco fit, afinini nempe temperamenti ( funt enim fylueftria eadem qua urbana temperie, fed ficciora ferécalidioraćş)neceffe eft fepe fitim pari. Videndum eit tamen ne 60 oryx, quem phyfiologi ueteres $\&$ boniauthores perpetua fiti ardere fcribunt, non item onagrum, à recentioribus $\&$ imperitis cum onagro hac in re confundatur. Vtrunģ̧ fané Africa fiticulof r regio. 
nis peculiate animal eft, fed magis oryx, Metuit $\&$ fugit feras omnes carnituoras, idecḉ, ut plerag? tímida, urelocitate ualet. Venatioleonis onager in folitudine, 8 pafcua diuitum pauperes, sirach

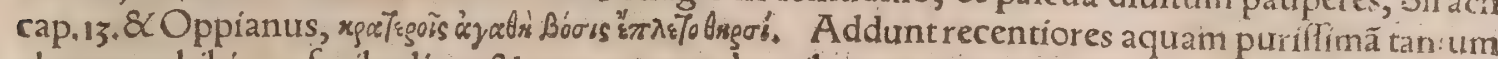
ab onagro bibi, nec facile aliam: $\&$ cum urgetur à canibus, excrementũ alui odoratum reddere, circa quod illis detentis ipfum effugere: Forminam nimis libidinofam effe, eó̧́ nomine mari fape móę ftam: Mares libidine accenfos, fi foemina defint, montes fcandere, uentum nar ibus hatrire, \& uoce terribili rugire: Cor onagri pinguiffimum effe: Feram ipfam quanto magis capta manfuécí, tanto efferatiorem effe antequam capiatur. Sed horum omnium grauem authorem habeo neminem : nifi quod Plinius teftatur fominas gaudere copia libidinis. In hoc genere finguli impericant gregibus 10 foeminarum. Aemulos libidinis fur metuunt. Inde eft quod grauidas fuas feruant, ut in editis mar ia bus, fi qua facultas fuerit, generandi fpem morfu detruncent : quod ca:sentes formina, in feceffibus partus occulunt, $\&$ parere furto cupiunt, Solinus $\&$ Plinius, Afini feri gregatim pafrunt̃ tur eos, equites perfequuntur, ac deféfos tàndem anhelos $\alpha_{\beta}, \&$ plurimo puluere excitato impeditos, partim iaculis conficiunt, partim uítos capiunt $\&$ catenis uinciunt: partim nimia perfecutione per culfos attonitoş́́ equis alligant, quos illi pracurrentes fequuntur, Poillux. Martialis libro i,

Pulcher adeft onager, mitti uenatio debet, Dentis Erythrai iam remouere finus. Aelianus fribit onagros in Maurianía curfú pernices effe, citó́g defiftentes $\&$ anielos à uenatori. bus capi, $R$ aph. Volaterranus, Generantur ex equa $\&$ onagris manfurefactis mulx ueloces in cur. fu, duricia eximia pedum, uerum ftrigofo corpore, indomito animo, fed generóo, Plínius 8 . 44 . Hi 20 forté funt muli quos Ariftoteles Syrix peculiares fribit, celeritate præetantes, nec fteriles ut proprie difi muli:quibus tamen commune nomen fortiti funt propter formæe finilitudinem: ut afini feri ure banorum nomen accepere, quibus tamen longe praftant celeritate. Onagro $\&$ afina genitus mulus omnes antecellit, Plin. TPullos afinorum epulari Meconas inftituit; multum eo tempore pralatos onagris: poft eum interït autoriras faporis, Plin. Galenus libro 3. de alimentorum facultatibus; Ceruina caro, inquit, non minus quàm bribula \& ouilla, fuccum uitiofum generat ac cócoftr difficilem: His fylueftrium afinorum, bono habiur praditorũ ac iuuenum, caro eft propinqua. बा Pinius cum ex afinino lacte \& offibusiemedia contra uenena quxdam recenfuiffet: omnia eadem onagris effica ciora efle fubiungit. Ad panos $\$<$ apoftemata in quacungs parte pracipuum remedium traditur in calculo onagri:quem diciur cum interticiatur reddei e, urinam liquidiorẽ initio, fed in terra fpiffan 30 tem $f e$. Hic adalligatus femini, omnes imperus difcurit, omniḉg fuppuratione liberar. Elt autem rarus inuenru, nec ex omni onagro, fed celebri remedio, Plinius 28. 1r. Fel eius extirpat morum, \& fuper abfceffum ueftigia urili er illinicur: Admifcetur etiam emplaftris contra ignes facros, quos curaie dicitur: priuarim ad elephantiafin $\&$ uarices adhibetur: Adeps rum oleo coftino cómendatur ad ie:num $\&$ dorfi dolorem, quem craffiflatus produxerint $\$$ illinitur quoqs ad panos falubriter, $A$ tif ene na. Caro contra dolorem fpina dorfi \& coxendicun iuuat, Rafis. Caro dorfiafini fylueftris cum oleo cataplafmatis inftar articulis dolentibus applicatur, A uicenna. Vrina eius la piden in uelica trangit, Galeno tefte, ut Auicenna citat. Vngula cremara cinis comirial bus prodeft: ide oleo admixtus firu mas diffoluit, \& alopeciam emendat fi cataplaímazis inítar adhibeacur, Vincentius Bell. Medulla in. uncta, podagras curat, $\&$ dolorem exringuit: Funum uirello out permixtum fronti illinicur, ur fan. 40 guis erumpens fiftatur: Idem crifpat capillos cum felle boúno inunctum: Aridum cum uỉio hauftũ

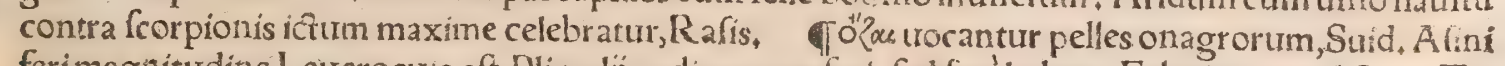
feri magnitudine Leucrocuı eft, Plin, alí codices non feri, feu feré habent. Fabulam apud Corn. Ta citum ludxos onagris indicibus fontium ufos cum in defertis Arabix firi macerarentur, in Philolo= gia de afino fupra retulimus. Onagrum fabulam infcripfit Demophilus, quam Plautus tranftulit A. finariæ nomine, ut fupra dixumus. Onagri item machin $x$ funt qux $\mathfrak{X}$ harpages uocantur, quibus iniectis accedentes quoluis arripere $\&^{\prime}$ attrahere licebat, Suidas. Harpagem alioqui uocant $\&^{\prime} \lambda \lambda^{\prime}$ uro

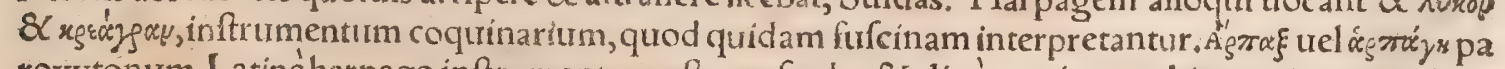
roxy tonum, Latiné harpago inftrumentum eft quo fitulas $\&$ alia é puteis extrahimus : item quod na. uibus in bello nauali inijcitur, ficut coruus \& manus ferrea. Licebit \& uncum à figura nominare. Ve

5o getius $4 \cdot \mathbf{2 3}$. lupum inftumentum quoddam delcribic in modum forficis dentatum, quo contra arie tes in oppuggnationibus oppidani funibus alligato utantur. Onagri nomen, ficut $\alpha^{\prime}$ creagra $8^{x}$ po=

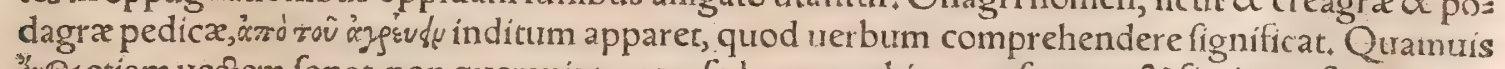
औै \& etiam uectem fonat, non quemuis tamen, fed quo machina uerfantur : \& fieri poteft ut impro

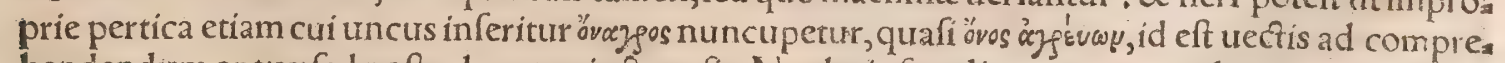
hendendurm aptus: fed noftra hæc conicctura fit. Nos huiufmodi onagros certis locis per ciuiatem publice expofitos habemus, ut cum incendiorum calamitas poftulauerit, omnibus ad manum fint Nunc de alio eiufdem nominis infrumento dicendum. Flauius Vegetius libro 4 c'e re militarica pite 22. poft defcriptionem baliftæ quæ funibus, neruis, chordisćs tenditur, $\&$ quanto maior furerit, tanto fpicula longius mittit: Onager autem, inquit, dírigit lapides: fed pro neruorum craffitudine 8

60 magnitudine, faxorum pondera iaculatur. Nam quan to amplior fueric, tanto mainra faxa fulminis more contorquet. His duobus generibus nulla tormen torum fpecies uehementior intrenitur. Saxis enim grauioribus per onagrum deftinatis, nö folum equi eliduntur $\&$ homines, fed etiam hof tutur 
machinamenta franguntur. Caterum forpiones dicebantur, quas nunc manubaliftas urocant, ideo fic nuncupati, quod paruis fubtilibusḉ f piculis inferant mortem, Hæc Vegetius. Ammianus Mara cellinus libro 23, diligentiffime hæc $\&$ alia bellica inftrumenta defcribit: onagrum tamen à fcorpio ne non diftinguit. Idem enim inftrumentum, tormentum(inquit) appellatur, quod ex co omnis ex. plicatio tor quetur: fcorpio autem, quoniam aculeum defuper habet erectum; cui etiam onagri uos cabulũ indidit atas nourlla, ea re, quod afini feri cum uenatibus agitantur, ita eminus lapides poft terga calcitrando emittunt, ut perforent pectora fequentiü, aut perfractis offibus capita ipfa difplo. dant, Hæc Marcellinus: Formam qui quxrit ex ipfo petat ; ego hoc tantum adferam fummitati eius uncos ferreos copulari, ê quibus pendet ftupea uel ferrea funda: \& quioniam uncos, ut ex Suida do cuimus, onagros aliqui uocant, inde aliquis potius quàm à lapidum reiectione nomen inftrumento : factũ coniecerit. ôvxy gós axytonũ, pro afinario exponitur: \& ỏvaygóborte, loca pafcendis afinis apta.

DE A SINIS SCXTHICIS, ET A RICANIS.

I N S C Y T H I A afini cornibus præditi nafcuntur, quorum cornua Árcadix fluminis Stygis aquam continent, qux tranfmittit uafa omnia, etiam fi fint ex ferro, Hæc cornua à Sopatro appor: tata fuiffe aiunt Alexandro Macedoni, \& illum admiratum mififfe Delphos, ut dedicarentur $\mathrm{Py}$. thia, Aelianus, Vide fupra in Bide afino, Proprie dictos afinos fupra ex Ariftotele in Scythia repe riri negauimus, Apud Afros, qui Aratores cognominantur s afinos cornutos reperiri, Herodotus author eft libro 4 .

DEASINIS, VEL'ONAGRIS POTIVS, INDICIS.

S Y L V E S T R E S afinos equis magnitudine non inferiores apud Indos naf́ciaccepi, cosḉ liquro corpore albos, capite uero purpureo, ocưlisóp nigris (cæruleis uertít Raph. Volat,) effe, cors núq̧́ in fronte gerere unicum: (Volaterranus addit fefquicubitale) cuius fuperius puniceum,infe: rius autem album, medium uero nigrum fit:atç nó omnes quidemindos, fed potentiores, cum tan. quam armillis quibufdam brachia, fic cornua auro, certis fpatijs ornarunt, ex his ipfis bibere folere Exhoc cornu bibentem ab infanabilibus morbis tutum fieri, neque eum ipfum côulfionibus cor: ripi, neqg facro morbo tentari, neq̧ uenenis ullis ferunt. Quinetiam fir quid prius peftilens biberit,

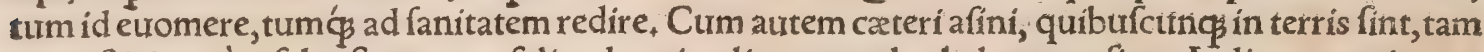
domeftici, quàm fylueftres, tum folipeda animalia, non talos habeant, afinos Indicos cornigeros 3

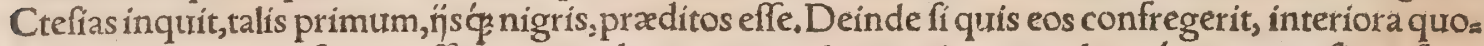
que nigra deprehenfurum effe: neqs modo corporis uelocitate longe multum rare, fed \& uelocitate eadem multo equis \& elephantis praftare. Cum autem in uiam fe dederunt, tardius primo ingrediuntur, deinde paulatim tantum confirmantur ad contendendum iter, eos qui dem ut fequi operofum fit, eorum uero curfum tranfcurrere nulli concedatur. Poftea autem quàm fominæ pepererunt, patres circum pullos à partu recentes fumma cuftodia uerfantur, eorũó̧ com. morationes locis Indix defertiffimis funt. Cum à uenatoribus Indis inuaduntur, pullos furos adhuc atate infirmos à tergo furo pafcentes habent, ato̧ pro eis propugnant; contra equites audent uenire, cosćs ferire. Tanto fané hi robore exiftunt, nihil eis ut obfiftere queat, quin ftatim \& concidat, $\&$ perdatur, equorumó incurfulatera difcerpunt, ac lacerant, \& uifcera difrumpunt:ex quo fit,ut ad eos equi appropinquare ualde metuant, appropinquatio enim capitalem utrif ç mulctam miferabi liter infert. Ex eo nanç cóflictu non equi modó, fed \& $\alpha$ afini pereût : pergrauiter calcibus pugnanit; corum morfus eatenus acerbiores exiftunt, ut quicquid comprehenderint, funditus diripiant: ex his uero qui funt confirmata atate incomprehenfibiles funt. Carnes corum quod amariflima fint, haudquaquam efculenta $*$ Hæc A elianus Petro Gyllio interprete, Raph. Volaterranus male tranftu lit hanc feram felle carere: $\&$ potionem ex hoc poculo ad ignem facrum conferre. Nam $\&$ fellis ue. ficam habet $\&$ potio illa contra morbum facrum, id eft, comitialem, non ignem facrum pradicatur:

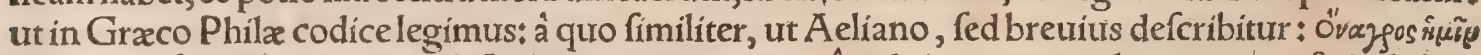
z'ś фy

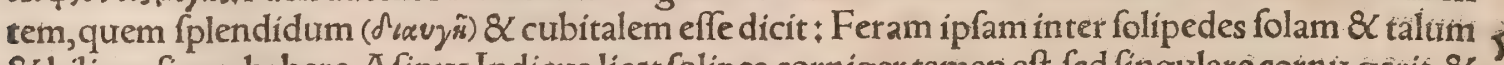
$\&$ bilis ueficam habere, Afinus Indicus licet folipes corniger tamen eft, fed fingulare cornu gerit, \& folus in folipedum genere talum poffidet, Ariftoteles, \& Plinius, Cornigera feré bifulca. Solida un. gula $\&$ bicorne nullum $\div$ Vnicorne afinus tantum Indicus. Vnicorne bifulcum; oryx. Talos afinus Indicus unus folidipedum habet, Plinius: 8 alibi, Cornua folidipedum nulli, excepto áfino Indico qui uno armatus eft cornu, Recentiores quidam obfcuri, onagrum Indicum, magnam $\&$ crudelem feram defcribunt, cornu unico, duro, acuto $8 \times$ longo: Robur ei tantum effe, ut ingentia faxa de ru: pibus euellat, idọ́̆ tantũ uím furam experiundi gratia. Monocerơs alius eft fimpliciter diçus, quem Indi Cartazonư uocant, nifi authores erraurerint, quod in rebưs adeò peregrinis facile fit: alius item rhinoceros; quem fxpe cum monocerote quidam confundunt:alius deniq̧ oryx, omnes unicornes. Cornu quiod tanto pretio hodie contra morbos quordam $\&$ utenena celebratur, plariç hodie rhino $=60$ cerotis effe aiunt, alí monocerotis fimpliciter: Aelianus \& 1 ilü fecutus Philes, fcriptores Græci, non alterius unicornis quâm afini Indici, ut diximus,dotibus iftis prędicant, in hiftorị́s fané horũ trium, 


\section{De Onosentauro. Lib. I. 23}

afini Indici, monocerotis, \& rhinocerotis, plurima communia reperio: paurca diuerfa: ut fufpicctur aliquis duo tantum díterfa animalia effe, unum rhinocerotem, $\&$ aliud monocercs ex media frons quod alij aliter nominauerint, \& cum rhinoceroté imperiti quidam confuderint. Plura uide infra an Monocerote. Magnus Indorum rex quotannis diem unum proponit, tum hominum tum beftia rum certaminibus:committuntur autem pugnatura inter fe beftia, feri tauri $i_{2}$ arietes manfueti, alini uno armati cornu, hyænæ, poltremo elephanti, Äelianus,

DE ONOCENTA R O:

O N O C E N T A V R V i quifquis uidit, non incredibile ducet, quod fama peruagatu elt, Ceni. in tauros fuiffe, neq fictores at $q_{3}$ pictores in eorum defcriptione erraffe. Verum fiue reurera fuerint, fi. ire omni cera flexibilior, \& ad fingendum habilior, fama illos finxerit, pratereo. Qua uero de ono: centauro fama accepi, hac funt. Eum homini ore \& promiffa barba fimilem effe, fimul $\&$ collum, \& pectus, humanam fpeciem gerere: mammas diftantes tanquam mulieris ex pectore pendere; hume ros, brachia, digitos, humanam figuram habere: dorfum, uentrem, latera, pofteriores pedes, afino perfimiles: \& quemadmodum afinum, fic cinereo colore effe:imum uentrem leuiter exalbefcere: du plicem ufum ei manus præftare: nam celeritate ubi fit opus eæ manus præcurrunt ante pofterioies pedes: ex quo fit ut non cæterorum quadiripedum curfu fuperetur: $A$ c ubi rurfus habet neceffe, tre cibum capere, uel aliud quiddam tollere, qui antea pedes effent, manus éfficiuntur: tumón non gra ditur, fed in feffione quiefcit. A nimal eft graui animi acerbitate. nam fi capiatur, non ferens feruitu. 10 tem, liber tatis defyderio ab omni cibo abhorret, \& fame fibi mortê confcifcit, licet pullus adhuc fure. rit. Hac de onocentauro Pythagoram narrare teftatur Crates ex Myfio Pergamo profecius, A clianus 2 Philes. Raph. Volaterranus feribit quod anticam corporis partem fimile humana habeat, pofticam afinina, colore fit albo, idç ex A eliano fe tranftuliffe ; exquo nos iam interprete P. Gyllio cincreum colorem ei tribuimus, imo uentri tantummodo albicantem. Ignobiles quidam authores onocentaurum aiunt monftrofum animal effe, quod non cum cateris ab initio creatum, fed poftea temere ex adulterina commixtione prognatum fit : uocem articulatam aliquatenus fonare, non tan men humanam+in perfecutores ligna uel lapides reijcere; (ed nihil horum authoritate muniunt. La. pidum certe reiectio onagris conuenit, ut fupra docuimus, óvox'svraugor, apud Aquilam trichiones, id eft, pilofi dicti, dxmones quidam corporei, fuperficie obfcura, $\sigma$ ḱmy quidã ex. Hebraica uoce tran 3․ ftulerunt, Varinus, Efaia capite 34. Hebraica uerba ארקר

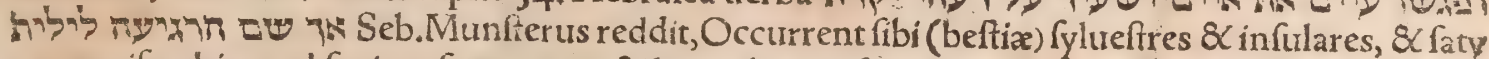
rus uociferabitur ad focium futsm: quin \& lamia ibi quiefcec, Vulgata translatio, Et occurrent da.

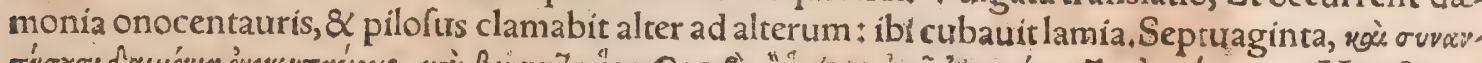

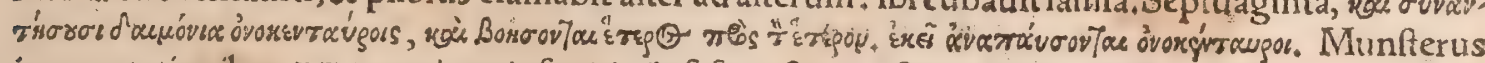

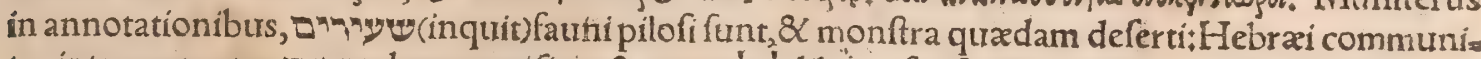

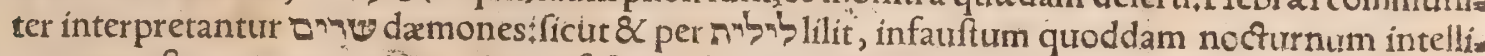
gunt monftrum, puerperis maxime infeftum : 2 multa fultiffime de co fibi perfuaferunt. Porrò per

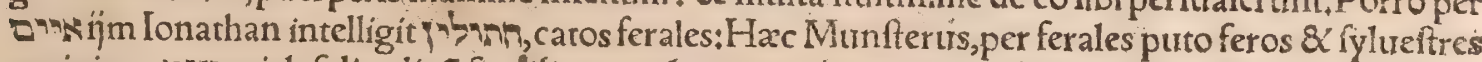
accipiens. $n$ y $t z i a h$ folitudine fignificat, unde $\square 9 n y$ tzím incolx deferti, qui funt $A$ ethiopes: $\&$ ani

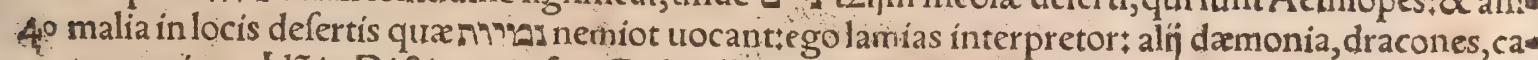
tos marỉros, Idẽ in Dictionario fuo. De lamís laruis, ex illarũ genere quas Empufas \& Mormolys cias uocất, mirabilem hiftoriam recenfet $C$ Xlius R hodiginus libro 29 cap.5. ferunt eas in amor $\tilde{\mathcal{C}} \&$ Venerem procliues effe, $\&$ humanas carnes uchementer expetere, Venereorứćs cupidine allicere multos, quos deglutiant mox. Dicuntur \& Libyca feræ quadam effe eiufdem nominis, de quibus in litera $L$. Onofcelos dæmonum quoddam gents fupra nominauimus : \& Empufam quocs afinino pede fingi diximus: ex quorum genere forfan $\&$ onocentauri fuerint. Credibile eft enim fítultos $\&$ fuperftitiofos quondam homines, uarias apparitiones $\&$ damonum fpecies naturali animalium ge. neri temere adnumeraffe. Quod fi qui in rerum natura onocentauri, fatyri, lamix \& fimiles fer $x$ ex: tant, ex fimiarum genere eas omnes effe crediderim : ut fuo loco copiofius exequemur. Vlulx, in 5o Efaia cap. 13 ab omni translatione, nomine ipfo Hebrxo ijm appellantur $\$$ pro his Septuaginta tantü onccentauros in translatione pofuerunt, Eucherius. Eruditi quídam per in in bubonem intelligunt, â uoce querula dictum:nam $\&$ dolentis interiectio eft. Dauid Kimhi etiam $\pi{ }^{\prime}$ aia, id eft, vulturem uel miluum effe fufpicatur. Vlulæ fané apud Hebraos etiam aliud nomen habent.Idem R. Dauid li. lit exponit animal folitarium $\&$ nocfu clamofum. Sunt qui auem magnam interpretentir, qua uena to uictitet, \& alio nomine j9"

$$
\text { DE A } \times \text { i: }
$$

C T E I A s in Indianafi fribit feram nomine axín, hinnuli pelle, pluribus candidioribusç maculis, facram Liberi patris, Plinius,

B O R Y E S.

B O R Y E $S$, panthera, thóes, \& alia fera diuerfa in Africa apud $\mathrm{P}$ aftorales populos Orientem uerfus gignuntur, Herodot, libro 4 . 


\section{De Quadrupedibus \\ DE BOVE SIMVL IN GENERE ET \\ VACCA PRIVATISA}

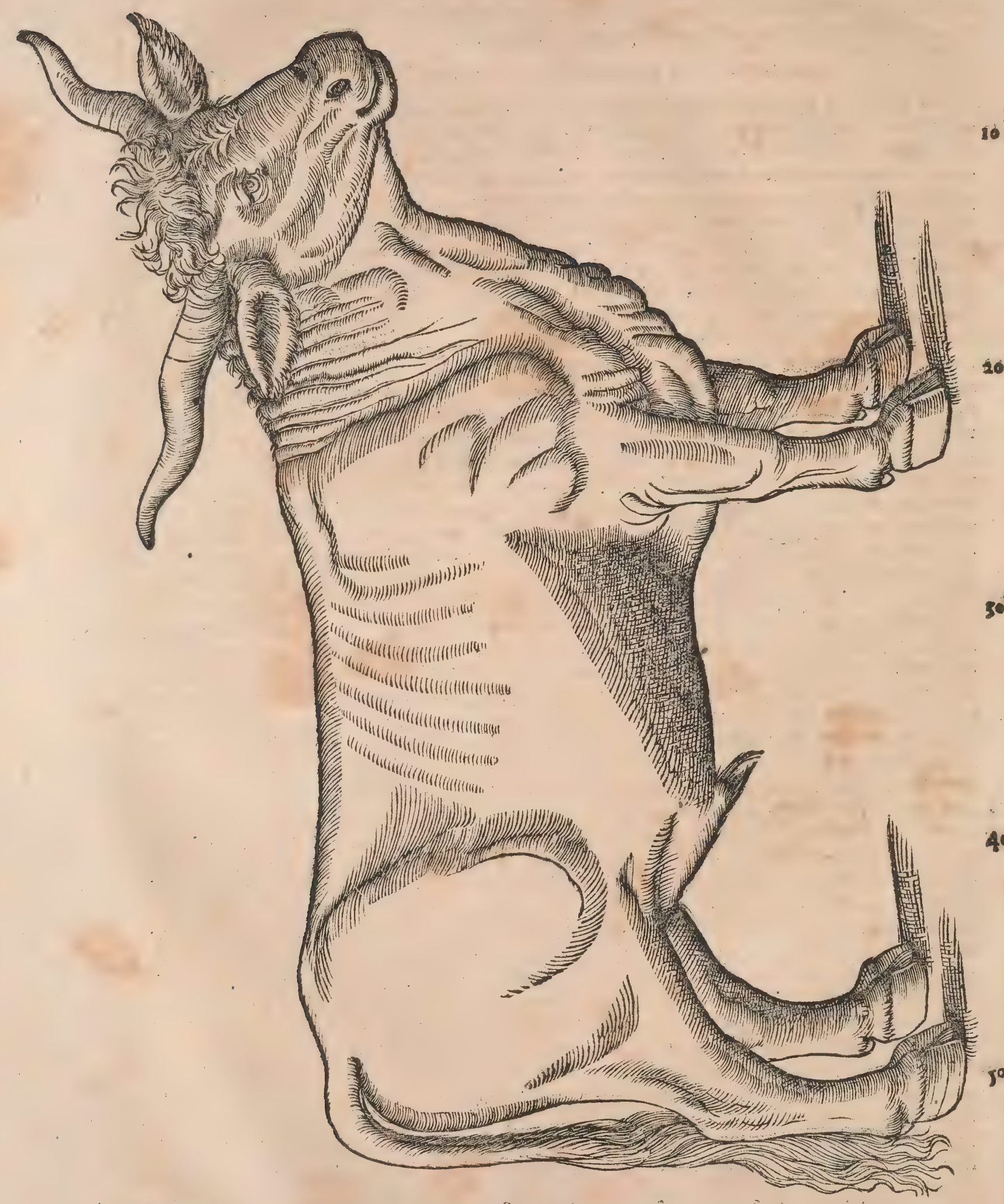

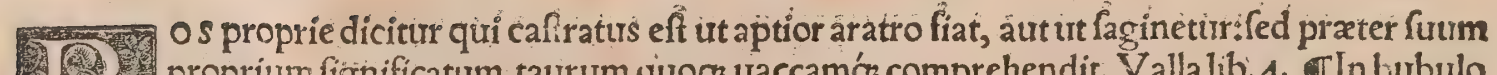

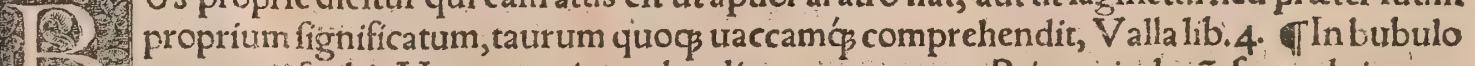

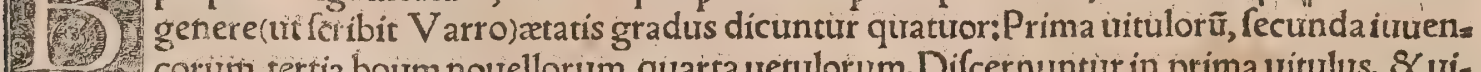
2. corim, tertia boum nouellorum, quarta uetulorum. Difcernuntur in prima uitulus, \& uia sula: in fecunda iutuencus \& iutuenca: in tertia \& quarta, taurrus \& uracca: Quxe fterilis eft uacca,tau= 60 ra appellatur: qux praegnans, horda. Ab eo in faftis dies hordicalia nominantur, qurod tunc hordx

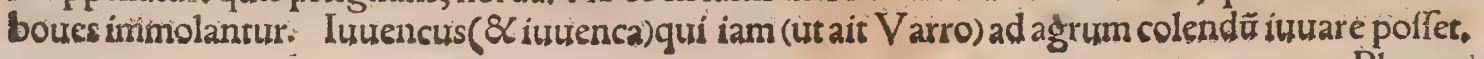




\section{Bos \& Vacca A. Lib. I. 25}

Plautus Trux. Vidi equidem iurtencum ex indomito domitum Fieri,atogalias belluas, Plinius lib.8. Optime cum domito iuuencus imbuitur.

2

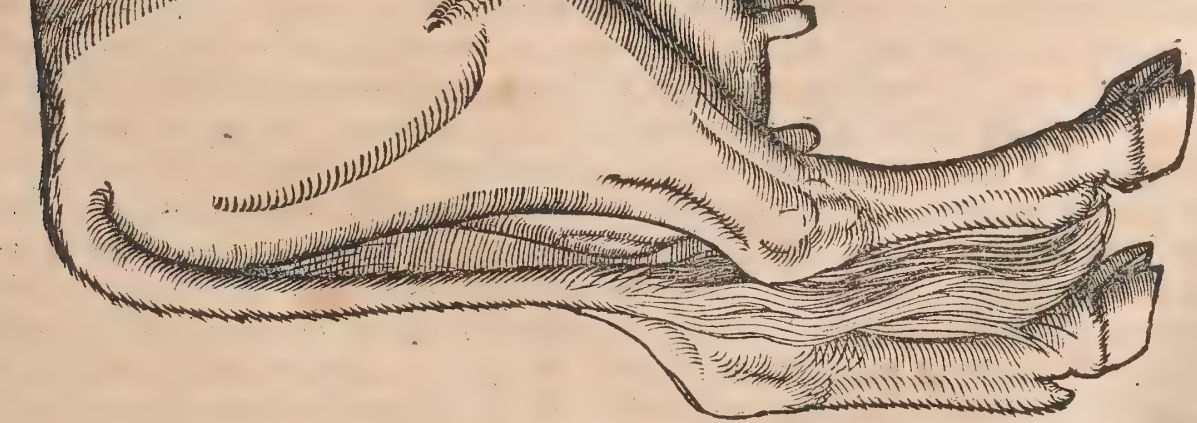

Vaccula, diminit. Verg. Vaccula nonnunquã fecreta cubilia captanș. Bucula, diminut. Boiddıge. Verg. I. Georg. Aut bucula coelum. Sufpiciens patulis captauit naribuis auras, Plinius lib. 34. cap.8. Myronem Eleutheris natum, \& ipfum Ageladis difcipulum, burcula maximénobilitatuit, \& $c_{\text {. }}$ Er Cicero 6. Verr. Aut ex are Myronis buculam? Idem i.de Diuinat, Itaq, ex eo auro quod exterebratum effet, buculam curaffe faciendam, \& eam in fumma columna collocauifie. Verg.i.Ge60 org. Aut errans bucula campo. Buculus(aliâs bucolus)nouellus toos \& tyrunculus, Columell, ilb. 6. Quum deinde buculos comprehenderis, extra ftabulium producito. THebraice fchor nomi

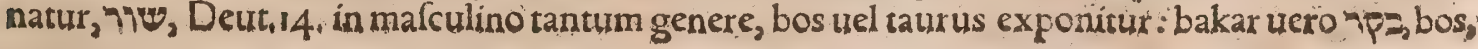


armentum, aut uacca. Thor Chaldaice, ideın quod fchor Hebręis, Danielis 4. inde nimirum Graci et Latini taurum dixerunt. Inuenitur \& tora apud recentiores, $\leqslant$ - mafculini generis, ut torata fomi=. nini. Aleph etiam $n$ bxà docilitate $\&$ affuefactione ad labores dictus uidetur.P falmo 8.pro alaphim, id eft boues, Chaldæus reddit tore, id eft tauri, Gracus Bós, Latinus armenta:A rabs bakar. Alpha eti am Graci grammatici caput bouris exponunt. Sacræ literæ diftinguunt pecus in duo genera, ut 0 .

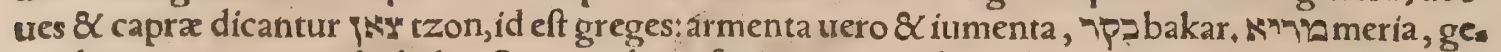
nus boum magnorum, bubalus, Sunt qui bene faginatas pecudes, ut boues $\&$ oues, intelligant: nam uox nา marah faginare fignificat, ut fcribunt rabini Kimhi \& Salomon in commentarijs Amos s. Hieronymus pinguia uertit. A braham ex fententia R. Saadiax, animal effe dicit maius bour, quod in

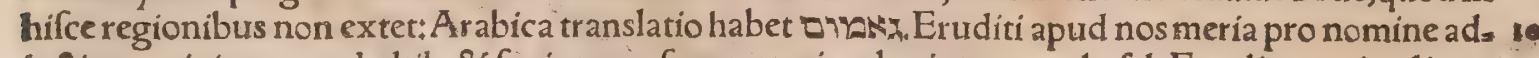
iectiuo accipiunt, quod altile \& faginatum fonet, ut etiam baria. Eas tachafch Exodi 25 , animalis no men uarïs coloribus diftinc?um. Onkelus uertit fafgona.R. Salomon Ezechix cap.16.taxum expo* nit,quod eruditi feré noftri temporis approbant: quanquam Hebrai quidam bouem expofuerint. Caterum egela ribsy Gene.15. \& Ierem.46.iutuencam potius quàm uaccam uerterim, cum bxy egel situlum fignificet. Exodi ca.32,pro egel Hebraico Chaldaus \& Arabs habent egela: Perfa gofalai: Septuaginta $\mu \circ x$ cosı uem bakar uocant, ut uaccam Saraceni hodie baccara, qua 8 para nm $\mathrm{Hebraice}$ dicitur, ut par $า \unrhd$ ítuencus, aut uitulus, cum additur ben bakar:fimpliciter autem bos in genere. Genefeos cap. 32. pro Hebraico parim, Chaldzus uertit tore: Arabs bakera, Perfa nadgaucha, uel madagaueha, aut bos in genere. Br̃s apud Gracos communis generis habetur, ut apud Latinos etiam, Italice bue, 10 Gallice beuf, Hifpanice buey, Germanice $₫ d) \beta 3$ \& rin' in mafculino genere tantum:Anglice ope, Il= lyrice wul.Baulbulis pro urina bouis apud Syluaticum legi,ceu Arabicam uocem. of $V$ acca, Italice etiamnum uacca, Gallice uache, Hifpanice uaca, Germanice Thì uel Tkübe, Anglice cow. Simili troce in Italia quondam Altinæ regionis incolæuaccas humilis ftaturæ 8 lacis abundantes ceuas appellabant, tefte Columella. Iunix, iunicis, teneræ atatis bos foemina, qux iam ceffauit uitula effe, necdum tamen ad fummam magnitudinem peruenit. Perfius Sat, 2. Tot tibi quum in flamma iuni. cum omenta liquefcãt. Plautus Milite, Quam mox ad ftabulum iunix recipiat féé pabulo, wóstı̊s

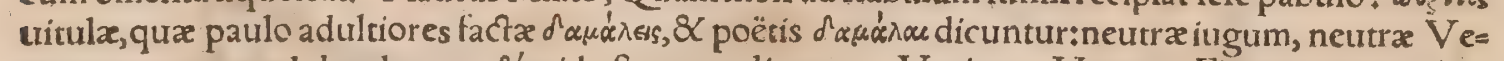
nerem experta; adultx demum Boss, id eft uacc $x$ dicuntur, Varinus. Vaccam Florentinus author Gracus brtí $\lambda$ saç aut damalin reddit.

B.

Bos in lege Mofaica animal eft facrificṭ̆s $\&$ cibo conceffum, quoniam ruminat $\&$ ungulam ha. bet bifidam. De antiquis illuftriflimus quifque paftor erat, ut oftendit Græca \& Latina lingua, qui $\pi \oplus \lambda \nu$ Bŕrres cognominant aliquos. Bos certe in pecuaria maxima debec effe authoritate: nee dubium, quin(ut ait $V$ arro) cæteras pecudes honore fuperare debcat, präffertim autem in Italia, qux ab hoc

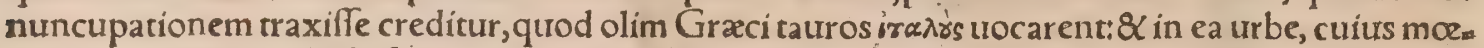
nibus condendis mas $\&$ foemina aratro terminum fignauerunt:uelut pecus, quod item $A$ thenis $C e$ reris $\&$ Triptolemi fertur minifter:quod inter fulgentiffima fydera particeps coeli, quod deinde laboriofifimus adhuc hominis focius in agricultura:cuius tanta fuit apud antiquos ueneratio, ut tam capicale effet bouem necaffe, quàm ciuem, $\mathrm{H} x \mathrm{c}$ Varro. Hoc animal, tantæa pud priores curæ fuir, 40 ut fit inter exempla damnatus à populo Ro.die dicta, qui concubino procaci rure omafum ediffe fe negante, occiderit bourem, a fưsós in exilium tanquam colono fuo interempto. Quare dicam de but bulo pecore, quam acceperim frientiam, utfi quis quid ignorat, difcat:fi quis fcit, ubi nunc labar ob feruet.Quod ad laudes $\&$ excellentiam boum, alia etiam quadam infra dicemus. Qua in emendis bubus fequenda, quaxọ̧ uitanda fint, non ex facili dixerim, cum pecudes pro regionis ccelićp fatu, et habitum corporis, $\&$ ingenium animi, $\&$ pili colorem gerant:alia formæ funt Afiaticis, alię Gallicis, Epiroticis alia:nec tantum diuerfitas prouinciarũ, fed ipfa qucog ltalia partibus fuis difcrepat. Cam pania plerungs boues progenerat albos $\&$ exiles, laboritamen $\&$ cultura patrî foli non inhabiles. $\checkmark$ mbria uấos, et albos, eadem ćp rubros:nec minus probabiles animis, quàm corporibus. Hetruria 8. Latium compacros, fed ad opera fortes. Apenninus durifímos, omnemq́ tes, nec ab afpectu decoros. Qux cum tam uaria \& diuerfa fint, tamen quadam quafi communia, $\&$ certa pracepta in emendis iuuẽcis arator fequi debet, ea $c_{\beta}^{\prime}$ Mago Carthaginenfis ita prodidit, ut nos deinreps memorabimus. Martio menfe comparandi funt boules, qui tamen five de noftris capian. tur armentis, fiue emantur, idcirco nunc comparabuntur utilius, quia necdum fagina ten poris ple ni, aut cælare poffunt fallaciam trenditoris, \& uitia fua, aut repugnando domitura contumacem ple ni roboris exercere fiduciam. Hac figna fpectanda funt in bobus, feu de noftrofeu de alieno gre. ge fuerint comparandi, ut fint boures nouclli, quadratis $\&$ gzandibus membris, \& folidocorpore, denfo breuiǵ: mufculis, ac toris ubiq̧ furgẽtibus, colore rubeo, uel fufco, ractu corporis mollifimo: cornibus proceris ac nigrantibus $\&$ robuftis, ac fine curtuatura prauitate lunatis (camuris, Vergil.) frontelaca \& crifpa, magnis $\&$ hirtis auribus:oculis $\&$ labijs nigris (fubnigris, nigrantibus)naribus. (6o refimis patulisó́, ceruice longa, torofa $\&$ compacta(cui plurima ceruix, Verg.)palearibus amplis $\&$ penè ad genua promillis(circa genua fluentibus)pectore magno, armis uaftis:capaci et tanquam im 
plente utero(uentre non paruo)lateribus porrecitis, lumbis latis, dorfo recto planóg, uel etiam fubfi dente, clunibus rotundis: cruribus neruofis, folidis, côpactis ac rectis, fed breuioribus potius quàn longis:nec genibus improbis, ungulis magnis, caudis longiffimis \& fetofis pilofisớ. Magni interefł cuiurmodi quxकs pecus fit ad fructum: Itą̧ potius bouem emúnt cornibus nigrantibus quàm albis, Varro. Nec mihi dif pliceat maculis infignis $\&$ albo: Aut iuga detrectans, interdumćp afpera cor nu: Et faciem tauro propior, qux́́ ardua tota, Verg. Optima torux Forma bouis, cui turpe caput,Idem. đVaccas etiam mente Martio maxime parabimus : \& quanquã eadem feré in ipfis defyderentur qua 8 in maribus, priuatim tamen earum figna referemus, ut ueterum etiam aliquife cerunt. Ergo qui uaccas aut gregem armentortum emere uult; obferuare debet primum, ut fint hae 10 pecudes atate nourella; \& potius ad fructus ferendos integra quàm iam expertæ: ut fint bene com. pofitx(corpore bene compacix) ut integris membris, oblong $x$, ampla, magnitudine commoderata, forma altiffima, atatis maxime trimæ, faltem non minores anniculis: quia uf́p ad decenniũ foetura ex his procedet utilior: bima aut trima fructum ferre incipit: corium attactu non fit a perum ac dus. rum:colore potiffimum nigro, deinde rubeo, tertio heluo, quarto albo. Mollifimus enim hic, ut du= riffimus primus, De medijs durobus prior quàm pofterior melior, utriq̧ pluris quàm nigri $\&$ albi، Probantur item uaccæ ceu maxime generofæ, flaurefentes colore, nigriş́́ cruribus. Ad hæc per fingulas partes commendantur, fi fuerint cornibus nigrantibus uenuftis \& lęuibus: latis (latifimis uel altis)frontibus: oculis magnis, patentibus \& nigris: pilofis uel fetofis auribus: compreffis malis

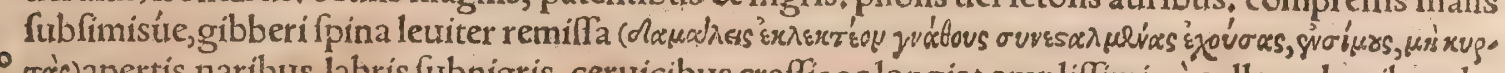
20 ra's)apertis naribus, labris fubnigris, ceruicibus craffis ac longis ampliffimis à collo palearibus de.

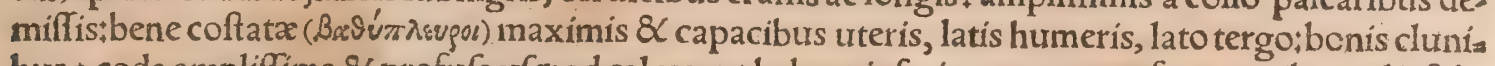
bus ; coda amplifima $\&$ profufa ufg ad calces, ut habeat inferiorem partem frequentibus pilis fub.

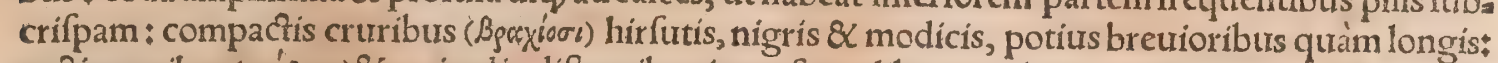
rectis genibus $\left(\sigma x_{i}^{\prime} \lambda \varepsilon \sigma\right) \&$ eninulis, diftantibus inter fe, pedibus non latis, neos ingredientibus qui $\mathrm{d} i$

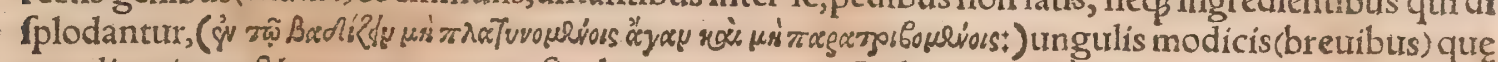
non diuaricent, \& quarum ungtes fint laues ac pares; Pulchrum fane fuerit decorari fignis omni= bus naturalibus fin minus; at certe pluribus, Omnis bos indigena longé melior eft quàm peregria nus: nam neq aqua, nec pabuli, nec cœli mutatione tentatur, neqg infeftatur conditione regionis, $\sqrt{1}-$ $3^{\circ}$ cutille, qui ex planis, \& campeftribus locis, in montana $\&$ afpera perducius eft, uel ex montanis in campeftria : itaq̧ etiam, cum cogimur ex longinquo boues accerfere, curandum eft, ut ex fimiliburs patrijs locis traducantur. Illud ante uniuerfa curandum eft, ut uiribus ad trahendum comparentur xquales, ne ualentioris robur alteri procuret exitium. Dentes bimus emittit bos, nec uniuerfos, ut equus, Nerui bubus prac cæteris animalibus durił tauro duriores quàm boui caftrato, Caro eis ficca Q atribiliaria. Cornua tauris robuftiora quàm uaccis, Ariftot circa finem libri 4. de hiftor. animalium:quo in loco Albertus Magnus contrarium habet, his uerbis; Cornura uaccarum fortiora $8 \mathrm{ma}$ iora \& longiora funt cornibus taurorum: deceptus forte Plinij uerbis, qui tauris minora quàm bu bus tenuioráq̧́ effe cornua fcribit, cum Plinius boum nomine non uaccas, fed boues exectos intelli. gat. Similiter $\&$ Rafis errat cornu robuftius uaccis attribuens. Gerunt autem boues ectomix, id eft caftrati, cornua maiora, eadem ratione qua fpadones ralui effici nequeứt. Nam coítus cerebrum ma

$4^{\circ}$ xime debilitat 8 imminuit. Bubulo pecori caftrato Democritus ait tortuofa, gracilia, longa nafci cornua. Contrâ teftibus prædito enafci fecundum radicem, craffa, recta, multọ́́s minus prolixa, eof demóg latiori, quàm alteros fronte effe: Nam hic ibidem cum multæ urenæ funt, ab ïs offa dilatantur, fimul \& cornumm eruptio quoniam craffior exiftat, frontem huic in latitudinem proferunt. Caftra. to uero quod fedes cornuum $\&$ initium enafcendi perparuum habeat circulum, minus dilatantur. Pars catra cornuum in bubus, ut alijs etiam ferè omnibus, ex cute potius oritur, quam folidum quid: dam offe enafcens fubit, impletós totam. Cornıra uaccæ calefacta facile in quamuis partem flectun= tur. Cornua iuniorum tepefacta in cera flecquntur, ducunturó́p facile quò uolueris, Ariftotel, Boum attritis ungulis, cornura unguendo aruina, medentur agricolx: A deoćs fequax natura eft, ut in ipfis

uiuentium corporibus feruenti cera flectantur, atģ incifa nafcentium in diuerfas partes torquean.
tur, urt fingulis capitibus quaterna fiant, Plinius. Plura de cornumum natura, uide paulo poft in bus bus Nomadiburs. Mutili dicuntur boues qui cornibus carent, Columella lib, 7.cap. 3. Lapillum ha. bent in capite, ut fertur, quem expuunt fi necem timeant. Dentes eis continui, 8 bis mutantur. Ru minant, nam fuperiore dentium ordine carent, id ef, primoribus quatuor, ut oures etiam 8 omnia quar ruminant. Oculi boum nigri funt, Ariftoteles; item lati planiós. Cor fine offe omnium, qua nos nourerimus, praterquam equi, \& generis boum cuiurdam, quod in corde cfficulum continere aiunt, Ariftot, In equorum corde $\&$ boum offa reperiuntur interdum, Plinius. Neruofam uero cordis bus, buli effe naturam, fignificatur uel eo offe quod in nonnullis gignitur:maxime uero taurorũ cor eiufa modi eft. Palearia à pelle dicuntur, quæ cum laxa prolixáç à collo dependet, generofitatis fignum in boue eft. Seneca in Hippolyto, Mufco tenaci pectus ac palear uiret, Ouidius Metamorph, 7. Pen. 60 dula palearia dixit, Palearium uero locus eft ubi conditur palea. Vaccęmammas binas inter femora habent:capra etiam $\&$ cerua $\&$ reliqua generis eiufdem mammas parte eadem gerunt:Cuius rei cau

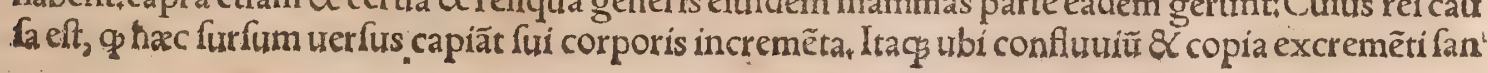


guinis, quilocus fanè infra eft, \& circa eftluentis materix oftia, ibi mammæà natura pofitę funt, Qura enim parte motus agitur alimenti, inde etiã capi alimentĩ poteft, Ariftot Boures in feminibus mãmas habent quaternas, Plin. Vaccis papilla quaternæ funt, Arift. De uentribus eorũ dicendi locus erie alius, ubi deruminantibus in genere agetur , Lapidem etiam qui reperitur in felle bouis, ad taurifel differemus. Vmbilicum uenæ contentæ in puramine complent, plures in maioribus animalibus, ut boue, cæeterisćs generis eiufdem: binæ in mediocribus: fingulæ in minimis, A riftot. Suum pili craf. fiores funt quam bubus $\&$ elephantis: quamuis tenuiorem quàm boues $\&$ elephanti cutem habeant, Idem. Vaccinum lac craffum eft, unde facile coagulatur, Albertus . Animalia quadam colore ua= ria funt:idós uel genere, ut pauo: uel non genere toto, fed parte, ut boues $\&$ capræ interdum urariæ ge nerantur, Ariftot, Boum caudx tenor longus, pili funt breues: equís contra, Ariftor. Horum caudis 10 eft longifimus caulis, atç in una parte hirtus; Plin. Et paulo mox, Leoni infima parte fetofus, ut bus bus $\&$ forici. Huic tantum animali omnium quibus procerior cauda non ftatim nato confunmata, ut cateris, menfuræ:crefcit uni, donec ad ueftigia ima perueniat. Camelopardalis pedibus $8 \mathrm{cruri}$. bus boui fimilis eft. Boum profua magnitudine auctior in longitudinem lien eft: cateris omnibus bi fulcis cornigeris rotundus . Bubulis fímiles funt renes uituli marini, fed folidi non caui:Item homi. num renes, quippe qui tanquam compoliti ex multis renibus exiguis conftent, neģ æquabiles funt quomodo renes ourum caterarumćs quadrupedum, A riftot.

TBoum multa funt genera, $\&$ uarĭ mores: A egyptí qui accolunt Nilum, \& colore niuei funt, \& magnitudine omnium præftantifimi. Veruntamen mites, $8<$ ad hominum genus manfueti, facile im perio audientes funt, Aelianus. Ariftoteles etiam boues in Aegypto maiores quàm in Gracia nafci 20

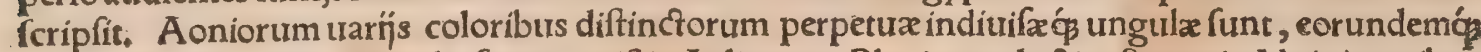
unicum cornu, quod ex media fronte exiftit, Aelianus. Plurimum lactis eft uaccis Alpinis, quibus minimum corporis, plurimum laboris, capite non ceruice iunctis, Plinius, Columella idem feribit de Altinis per $t$, quas incolæe eius regionis ceuas appellent: id quod magis probo. Altinum enim urbs olim in littore Venetiæ florentiffima fuit iuxta Aquileiam, á qua Altinares populi dici. Vaccæ $A_{\text {. }}$ rabicæ propter alentium humorum confluxum, qui permultum generofę propagationis nutrimen tum cornibus præftat, eifdem excellunt: qua uero cornibus carent, os humorem capere folitum, $\mathrm{fo}_{2}$ lidius habent, 8 haurdquaquam huncipfum fibi humorem recipere poteft. Quare incrementi caufa cornibus exiftit influentia, quam fané plurimæe ct craffifimæ uenæ humore, quantum ferre poffunt, grauidatæ infundunt, A elianus. Armenís duplex cornu fic erraticis flexionibus tanquam hedera zo retorquetur: Ac fi mucrone appetitur, ob corneam duritatem, non fine damno ferrum retunditur, Aelianus. Inquirendum eft an genus hoc monocerotis fit (ut etiam A oní boues) propter cornua in fereuoluta 8 mucronem eorum duriffimum. Circa Bcotix urbem Pœmandriam, qua \& Tanagra dicitur, optimi boues nafcuntur, Varinus: Apparet inde factum Pœmandria nomen. Carici in parte Afia for di uifu, tuhere fuper armos à ceruicibus eminente, luxatis cornibus, excellentes in ope re narrantur:cateri nigri coloris candidiûe, ad laborem damnantur, Plin. (Similia uide mox in Scy thi cis.) Boues pracipure magnos fert Epirotica terra: quas incola Pyrhicas uocant : paftum enim as bunde prabet, 8 loca fingulis anni temporibus accommodata habet, Ariftot. In noftro orbe (inquít Plinius) Epiroticis laus magna, à Pyrrhí(ut ferunt)iam inde regis cura, Id cófecutus eft , nó ante qua drimatum ad partus uocando. Prxgrandes itaç fuere, $\delta$ C hodiéǵs reliquix flirpium durant. At nunc $4^{\circ}$ annicula ad foccunditatem pofcûtur, toler antius tamen bimx, Plinius. Theodorus exA riftotele tran fulit Pyrrhicas uaccas ab incolis per annos nouem intactas Venere feruari: ego cum Plínio annos quatuor potius quàm nouem legerim: facilis lapfus ex $d$ in $\theta$. Has numero quadringentås effe, et pro prias regis accipimus, nec poffe uiuere locis alin's, quan quam tentatum ab aliquibus eft, A riftot. Fure. re in Epiro Pyrrhica boues, quas atauros uocabant, intactas Venere, ut incrementum ampliter ca perent, quafi fetauras dicas. Sic uero creduntur dicła ab ignea mobilitate, aut à colore: funt qui di. minutiuum putent ex forma Aeolica. Alí Pyrrhicas intelligunt Epiroticas, de regis Pyrrhi nomine, Calius, Scribunt Græci Epiroticos boutes Larinos dici ab Larino paftore, cuitus meminit Athenęus quo $\beta$, qui ab Hercule redeunte ab Geryonis nece, exceperit educaueritóg: unde Epirotica mox ar. menta fint celebrata. Etiamfi funt qui ab narium magnitudine dicilarinos uelint, ut eft ab interpre $\zeta^{\circ}$ te Ariftophanis adnotatum, fi quidem $\lambda x$ particula intendendi uim habeat, fíves uero nares fint. Cate rum Ceftrini quooß uocâtur, qui Larini,Cælius. A thenæus libro g. Larini boues (inquit) diçi funtà

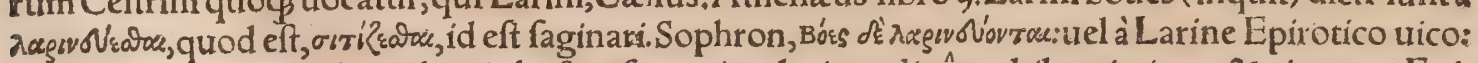
uel à Larino paftore. Hinc aliqui abufiue fures etiam larinos dixêre, altiles nimirum \& pingues. Epi. roticæ uaccæ præ fua præcipua magnitudine, amphoras fingulas fingulæ implent lactis, menítrác eius dimidium mammis duabus præftant. Erectus qui mulget, aut paululum fe inclinat: quoniam fedendo ubera contingere nequeat, Cæateras etiam quadrupedes magnas terra eadem Epirtis gig: nit, excepto afino: fed præcipue boures $\delta$ canes, atop etiam oues Pyrrhicas, à Pyrrho rege cognomi. natas, Ariftot, Erythrai boures mobilia fimiliter cornuta ut aures habent, A elianus:idem alị de Phry= gịs fcribunt. Argiuum Herculem miffum effe ad Geryonem ut boues abigeret, Hecatæus frribit, 60 non quidem ad terram Hifpaniam, nec ad Erythiam ullam infulam:fed loca circa Ambraciam atç Amphilochos Geryonem imperio tenuiffe:indeç̧ abactas boues, qua mira fpecie in illis comperian 
utr locis, herbida regione \& pafcuis admodum læta, Cælius. Vaccæ in Frifia ${ }_{j}$ Hollandia \& Selan= dia, propter abundantiam pabuli in regionibus illis magna corpora habent: $\mathcal{Q}$ omnes ferè quarum maculofx funt pelles, lacte abundant, tefte Alberto Magno. Boues quidam carniuori funt infar luporum, Rafis, In India boues folidis ungulis unicornes Ctefias nafci frribit, Plinius. Aliqui eti. am tricornes. Bubus Indicis camelorum altitudo traditur, cornua in latitudinem quaternorum $\mathrm{pe}_{\text {. }}$ dum, Plin. Ptolemæo fecundo ex India cornu allatum ferint, quod tres amphoras caperet. Vnde conícere poffumus, bourem illum, à quo eiufmodi tantum cornu extitiffet, maximum fuiffe, A elía nuss, In bubulo pecore, quod incitato curfu ualet, curam Indi ponunt: $\& C$ fimul de eorum uélocitate rex $\&$ permulti principes decertẩ, neq̧ turpe ducũt pro huiurúcemodi animaliú génere auro argen. 10 tourefponfionem facere, Currendi meta bobus hac conftituitur, ut inter fe nexi \& itrgati triginta fta dia currãt, Aequales et pares boues equis currũt, neq̧ uelocitate boues ab equis internof cas : Ac fi quando rex de fuis bobus cum quopiam fponfionem fecerit, in tantum contentionis ftudium proce dit, ut is ipfe in curru fequatur, atque adeo aurigam incitet. Is fané quidem equos ftimulis cruentat, â bubus uero manus abftinet, fiquidem ip nullis admotis ftimulis incitatifimo curfu feruntur: Ac ni mirum tam ambitiofa eft bubuli certaminis contentio, ut non diuites modò, fed inferioris ftatus ho, mines in eiufmodiconcertaminibus permultum uerfentur. Sunt item apud Indos alij boures, qui maximos hircos magnitudine non fuperare tridentur, Ii uel coniugati uelociffime currunt, nec mi: nus ftrentre quàm Getici equi curfum conficiunt, Aelianus. Arifteteles ait Leuctricorum boim cornua atç̧ aures, ex una ftirpe cognata $\&$ fimul contexta effe, Aelian, Garamantum armenta ob 20 liquis ceruicibus pabulantur. Nam fi reiecta(recta forte)ad paftum ora dirigant, officiunt prona in humum cornua \& obnixa,Solinus: Vide in Troglodyticis mox. In Africa regio eft (Garamantum aut uicina quædam) ubi boues prapofteré pafcuntur, quod cornua inflexa anterius habent, et ob id ceffim euntes pafcuntur. Nam offenfantibus in terra cornibus, progrediendo pafci nequeunt; alio= quí nihil differentes à cæteris bobus, præter craffitudinem pellis atç duritiam, Herodotus $1 i b .4$. In Libya Indis finitima retrouerfus paf́centium boum effe armenta auditione accepi. Caufa cur fic pa. fcantur eft, quód ante oculos cornua habent, \& quix ante pedes funt, tuidere non queant. Ex quo fit: ut ingreffionem ad caudam retorquentes, herbam depafcantur, Aelianus: ante quem primus 86 fo= lus opinor Herodotus in Libya boues iftos opithonomos reperiri fripfit, id exprimêtibus cornibus qua adnuunt proclinantur $\not ̧$ in ima:eius hiftoriam conuellit $A$ thenęus fub aliena perfona, quioniã $3^{\circ}$ à nullo præterea hiftoricorum fit cóprobata, Cẹlius. A pud Myfios, boues cornuum expertes funt, non item in Scythia, ubi minime cornibus boures mutili funt. Nec mihi moleftus quifpiam effe debe bit, quòd contrà fcribam atque Herodotus, cum ait bubulo generi non effe in Scythia corntia: Iccir cọ́́ cornibus mutilum eft, quòd uniuerfum caluariæ os nullas commiffuras habeat, nihilós humo= rum confluentium propter durítiem refiftentem capiat, \& uero uenæe per hoc ipfum os pertinentes, propterea graciliores $\&$ debiliores, quia minus alantur.Itemó corundem quià cornibus nudi funt, eóficciorem ceruicem, ac minus fortem effe neceffe eft, quòd ipforum pertenues uenę fint. In $\mathrm{No}=$ madibus, qui ad Męoticas paludes hyemant, 8 dies æeftitos in camporum ęquoribus uituunt, ex bo bus partim fine cornibus nafcuntur, partim ferrula ideo exfecantur, quod hæc pars uim frigoris fuf ferrenon queat, Aelian. Pufilla bucula quas Phafiana regio fert, fingula abunde beneficio pabus. 40 li mulgentur, Ariftot. Phœnicum libri teftantur, indigenas uaccas ea effe magnitudine, ur uél pro ceriffimi paftores cum mulgent ftare, atque adeo in fcabellum afcendere habeant neceffe, ubera ut poffint pertingere, A elianus:idem Ariftoteles de Epiroticis, Boues in Phrygia et alibi funt qui cor nua perinde ut auriculas moueãt, Ariftoteles $\&$ Plin. A elianus idẽ de Erythrẹis tradit. Boires Phrÿ= gị rubro colore \& flammeo, altá̧̧ \& torofa certuice praftant. Eorum ab alịs cornua longe diuerfa funt: neque enim confifunt, fed flexibilia huc illuc flectuntur, Aelianus. Scythici in quorum dor: fo gibber eft, \& proceriffimi \& ex omni parte albi, perparuis cornibus funt, \& minime acutis; fimili= terć $\beta$ ut cameli eminenti dorfo exiftunt: fimul $\&$ cưm dorfo clitellæ imponuntur, perínde ut cameli genu flectunt, rurfum ćs fufcepto onere furgunt, quod ipfum hominum, quir ijs ad grauifimorum o. nerum uectiones utuntur, difciplina facere folent. Quęrendum num quid differant â Caricis, de qui

$5^{\circ}$ bus paulo ante diximus ex Plinio: nec diffimilia de Syriacis nunc adferemus, ut fufficari quis por fet authores confudiffe. Syriacis non funt palearia, fed gibber in dorfo, Plin. Nodos fcapularum flex ctunt ut cameli. A elianus abfós ulla gibberis mentione, hæc fcribit:Syrí bellicofi funt, magno robo re, \& lata fronte, cornibus robuftis, afpectu truculento, non obefo corpore, neque rurfus macilento, ad curfum \& pugnam præftant, Aelian. Troglodytarum armentis cornua in terram directa funt; qua de caufa obliqua ceruice pafcuntur, ${ }_{3}$ Plin. Idem Solinus de bubus Garamantum prodit.

c.

Boures dentibus fuperficiem tantum herbartum carpunt, radices non lædunt. Ànimalium foli 8 retro ambulantes pafcuntur, apud Garamantas quidem hatid aliter, Laudantur multi cibi eda. ces, uerũ in eo conficiendolenti:nam hí melitis côcoquunt:ideọ́̂́ robora corporû́ citra maciế cốfer

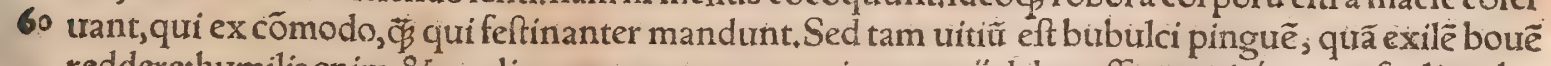

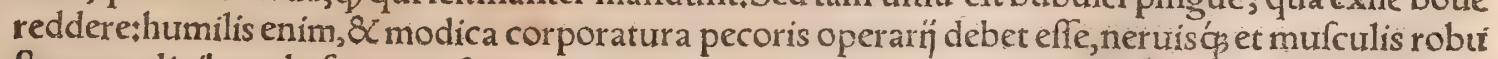
ftasnon adipibus obefa, ut nec fui tergoris mole, nec labore operis degrauet. Vaccas pafci oportet in 
locis uiridibus \& aquofistamant enim pafcua locorum irriguorum. Quamuis butyrum, irt audio, co lore faporé́́ praftantius fit ex pafcuís ficcioribus, quàm paluftribus. Si regionis ratio patitur, nuilus melior cibus eft quàm uiride pabulum. Vbi uero deef, eo ordine miniftretuti, guro pabuli copia \& la borum coget acceffro. Maritima \& aprica hyberna hoc armentum defyderat, quia melius frutetis \& his herba internafcente faturatur: $x$ ftate in opaciffimis nemorum commonde pafcetur, ubiuingulta $\&$ frons multa: $\&$ in montium altis frondofiş́ magis quàm planis pafcuis. Narn mciius nemoribus herbidis $\&$ frutetis $\&$ carecis, quàm lapidofis locis durantur ungula. Nec tam fluuios riuośç defyz derant quàm lacus manu factos:quoniam fluuialis aqua, quæ fere frigidior eft, partum abigit, $8 \mathrm{c}$ co = leftis iucundior eft, Columella, Quamuis circa fluuios recte propter amona loca pafcanturt foctura tamen aquis tepidioribus adiuuatur, unde magis utilius habentur, ubi plutialis aqua tepentes for. 10 mat lacunas, Palladius. Omnis extremi frigoris tolerantior equino armento uacca eft, ideoḉ, facile fub dio hybernat. Boues autem recte pafcendi non una ratio eft : nam fi ubertas regienis uiride pabulum fumminiftrat, nemo dubitat, quin id genus cibi cæteris præponendum fit:quod tamen nili ri guis, aut rofcidis locis non contingir:itaç in ijs ipfis uel maximum commodum eft, quod fufficit una opera duobus iugis, qua codem die alterna temporũ uice uel arant, uel pafcuntur: ficcioribus agrís ad prafepia boues alendi funt, quibus pro conditione regionum cibi prabentur, Columella. Boues \& fruge $\&$ herba uefcuntur: pinguefcunt ỉs, qux flatum cient, ut eruo, \& faba frefa, atç, etiam ipfa fabarum herba. Et feniores, fi cure incífa fpiritum adigas, deinde prabeas pabulum, pingtres facies. Ad hac hordeo urel integro, uel pinfito, \& à gluma feparato pinguefcunt, \& dulcibus, ut ficu, \& paf= fatuino etiam \& frondibus ulmi:fed pracipue fole, $\&$ lotione calidx aqux, Ariftot.

Cytifum in agro effe quàm plurimum maxime refert, quod bubus $\&$ omni generi pecudum uti liffimus eft, quod ex eo cito pinguefcit, \& lactis plurimũ prabet ouibus: tum etiam quòd octo mens fibus uiridi eo pabulo uti, $\&$ poftea arido poffis: prater ea in quolibet agro, quamuis macerrimo cele riter comprehendit : omnem iniuriam fine noxa patitur. Satio autem cytifi uel autumno circa idus Ocfob. uel uere fieri poteft. Cum terram bene fubegeris, areolas facito, ibićs uelut ocymi femen cy" tifi autumno ferito. Plantas deinde uere difponito, ita ut inter fe quoquourerfus quatuor pedum fina tia diftent. Si femen non habueris, cacumina cy tiforum uere deponito, \& ftercoratam terram circum aggerato. Si pluuia non inceflerit, rigato quindecim proximis diebus fimulatćs nouam frondem age re coperit, farrito, \& poft triennium deinde cædito $\&$ pecori prabeto, Equo abunde eft uiridis pondo $\mathrm{XV}$. bubus pondo uícena, cæteriş́́ pecoribus pro portione uírium. Poteft etiam ante Septem $30^{\circ}$ brem fatis commode ramis cytifus feri, quoniam facile comprehendit, \& iniuriam fuftinet, Aridum fi dabis, parcius prabeto, quoniá uires maiores habet, prius'́s aqua macerato, \& exemptum paleis per. mifceto, cytifum cum aridum facere uoles, circa menfem Septembrem, ubifemen eius grandefcere incipiet, cæedito, pauciş́́ hor is, dum flaccefcat, in fole habeto: deínde in umbra exficcato, 81 ita condito, Columella.Serenda in tenuiore terra qux non multo indigent fucco, ut cytifus $\&$ cicer, Plinius *

TQuoniam uero tam falutarem non omni folum pecudum generi, fed etiam homini fruticem, $\&$ non medicis modo, fed poétís quo $\beta_{3}$ Gracis Latinis ç celebratum, quinam hodie \& ubieffet, nemo adhuc ex eruditis, quorum ego fripta legerim, nos docuiț cómodum hine digreffus ea de re fudio. fis candide quod habeo communicabo: recitabo autem primum aliorum opiniones, Primum igitur Marcellus Vergilius (qui Florentia in Italia uixit) in commentarijs fuis in Diofcoridem, cytifum ho $=40$ die in Italia nufquam apparere, $\mathbb{Q}$ in antiquum ac natale fibi folum reuerfum, non paruum antiqua amantibus defiderium fui reliquiffe: aut fifit, incognitum fine honore iacere conqueritur. Poft hune Ioan. Ruellius Gallus cytifum hedie in fegetibus pracipue hordeaceis inueniri fribit, fruticem albi cantem, cui omnes ex defcriptione Diofcoridis nota conueniant:Sed alio in loco hunc cytifum fuum meliloto tam fimilem facit, ut difficillimé difcernatur: diftinguit autem hoc modo, Cytífi (inquit) folia digitis friata fubolent erucam, melilotus magis crocũ iucundo fequitur odore. Guftus quoç di frim $\tilde{e}$ facile prodet:nangs cytifus manfu cicer refipit. Hieronymus Tragus Germanus trifolium pra tenfe maius, afperiusćs, folins durioribus, oblongis, \& mucronatis (in Italia nonnulli trifolium lunatũ uocant) pro cytifo accipit. Poftremo Petrus Andreas Mathęolus Senenfis, in Italicis fuis ad Diofcori dem commentarḯs, fic fcribit, ut nos tranfulimus: Cytifus hoc tempore copiofiffimus per omnem Ita jo liam protrenit, Diofcoridis ac Plin̈̈ defcriptionibus undiquaç refpondens. Sunt quiuernacula lin gua trifolium caballinum uocant, alip tribolum. Ramos primum cubitales producit, ac fre maio. res, qui folīs ueri trifolín ueftiuntur, cum cofta è medio fatis prominente. Frondes cius albicant, $\&$ fi manu fricentur, acrem ceu erucæ odorem fpirant, fi mandas ciceris recentis guftum repręentẫt. Flores mufcofí racematim hærent, aliâs flauí, aliâs candidi. Hæ notæ cytifum adeò exprimunt, tt quín ipfiffimus fit negare poffit nemo. Caballinum autem trifolium urocãt, eò quod plurimum eius pabulo delectentur equi, qui liberi ęftate pafcuntur:id quod fententia noftre confirmand accedit: nam(ut Plinius inquit)cytifus equis tam gratus eft, ut pra co hordeum negligant. Fuchfius \& $\mathrm{Mo}=$ nachi qui commentarios in:Mefuen ediderunt, cum hanc firpem uerum cytifum effe nefirent, tri= folý odorati fpeciem fecerunt, Hacfenus Pet. Matthçolus . Prater illos quinoftra tempeftate ullam 60 cytifi mentionem faciat, reperio neminem, Eft autem communis hic Ruellï, Tragi \& Mattlixolier, ror, quòd cytifum arborefcere non anima duerterunt, id ćs non modo proceritate, fed materia quoqs 


\section{Bos \&Vacca. C. Lib. I.}

lignof, imo offea. Sic cnim Plinius fcribit, Tota offea eft ilex, cornuts, robur, cytifus, morus, ebenus, lotus, \& qua fine medulla effe diximus, Et quanquam alibi fruticem appellet, arbuftis tamen potius adnumerare debuerat. Ruellius quidem cytifum fuum fruticem nominat, fed cum laboret in diftin= guendo eo à meliloto herba, fruticis nomine eum abufum, ut fape fit, non eft dubium. Ebeni duo genera facit Plinius, unum arboreum, alterum fruticofum cytifi modo, \& tota India difperfum. Agit autem de cytifo inter peregrinas arbores: Frutex eft, inquit, intuentus in Cychno infula, inde translatus in omnes Cycladas, mox in urbes Gręcas, magno cafei prourentu * pptér quiod maximé miror rarum. effe in Italia.Quid eft igitur qưod Matthęolus per omnem Italiam copiofiffimùm effe fribit $\div$ Ego cur anno Salutis Chriftianx i s 4 2. Italiam ingreffus Patauium treniffem, in horto PetriBembi Cardi 10 nalis arbufculam nunquam prius à me uifam, \& omnibus qui mecum aderant ignotam, ut primum lia(quxa adhuc feruo)ubiq terna, omninoloti fitre trifolï pratenfis, minora tantum:guftu dulcia 8 glurinofa, malue propemodum inftar:id quod de cytifo Galenus ( $\&$ poft eum Aeginera)prodidit: $\mathrm{Cy}$ tifi(inquit)folia uim habêt difcuttiendi, fed aquofo tepidó́p fucco dilutam, quemadmodurm etiam mal. ux. Deinde cum per alpes in Germaniam redirem, non procul Tridento, idem omnino genus fyluéa ftre reperi, longe minus \& fruticofius fatiuo. Io. Quintinus, qui de infula Melite libellum adidit, cytifum in ea abundare teftatus nullam eius defcriptionem adiưxit. Nos, ut à ftudiofis diligentius pofthae animaduertatur, plura qua tum formam tum facultates eius attinent, ex ueteribus repetemus, 8 primum ex Diofcoride. Cytifus frutex eft albus in totum, ut rhamnus, ramos fpargens cubitales, maio= 20 resć interdum, in quibus folia foenigręci, aut loti trifolia, minora tantum, dorfo medio prominente: ea digitis trita erucam olent, guftatá̧ cicer(aliâs cicer uiride) rapiunt. Folia refrigerant, tumor és inter initia difcutiunt, fi cum pane trita illinãturłdecocfum cortum potu urinam ciet. Nonnulli, quòd apes alliciat, propéaluearia ferunt, Hæc Diofcorides:in cuius etiam codicibus nonnullis noménclaturæcy tifo ifta attribuuntur, teline, lotus grandis, trifolium, $\&$ apud Romanos trifolium maitus omnes fili cet à foliorum fimilitudine ducta: nam telis focnumgręcum eft. Columella cytifum $\&$ zeas, \& carni: cin, \& trifarin trocari fcribit: \& effe geminam, hoc eft fatiuam, \& alteram fux fpontis. Paulus Aegine. ta comain cytifí iubet pracordijs pragnantium contra tomitiones ex uretere uino imponi. Plinitis libro 13, Cap+14. Frutex eft(inquit) \& cytifus; ab Ariftomacho A thenienfi mir is laudibus predicatus pa bulo ouium, aridus uero etiam fuum;:fpondétós iugero eius annua H S. M. M, uel mediocri folo redi30 tus. Vtilitas qua eruo, fed ocyor fatietas, perquâm modico pinguefcente quadrupede, ita ut fümenta hordeum fpernant. Non ex alio pabulo lactis maior copia, autmelior, fuper omnia pecorum medici. na à morbis omni ufu pręfante. Quin $\&$ nutricibus in defectu lactis aridum, atqs in aqua decoc?um, potur cum uino dari iubet;fírmiores celfioresćs infantes fore. Viridem etiam gallinis, aut fi aruerit ma defactum. Apes quoç nunquam defore cytifi pabulo contingente, promittunt Democritus 8 Ar Ara. fomachus. Nec aliud minoris impendin eft. Seritur cum hordeo, aut uere femine ut porrum, uel cat:s le autumno ante brumam. Sifemine, madidum. Et fi defint imbres, fatum fpargitur. Planta cubitales feruntur fcrobe pedali. Seritur poft aquinoctia tenero frutice. Perficitur triennio. Demetitur uerno aquinoctio cum florere definit, uel pueti, uel anus utilifima (forte iriliffima) opera. Canus afpectur, breuterós fí quis exprimere fimilitudinem uelit,anguftioris trifolí frutex. Datur animalibus pon bi. 40 duum femper: Hyeme tero quod inaruit, madidum. Satiant equos denalibra, 82 ex portione mino ra animalia, obiter ćs inter ordines allium $\&$ cepe feri fertile eft. Non ęftuum, non frigorum, nô gran. dinum, aut niuis iniuriam expatrefcit. Adijcit Hyginus, ne hoftum quidem, propter nullam gratiàm ligni, Hucufos Plinius. Idem alibi: Glaux cytifo \&lenticula folijs fimilis ( quod Diofcorides quó̧ fcribit) \& c, coquitur in forbitione fimilaginis, ad excitandum ubertatem lactis, eamós quí hauferint, balineis uti conuenit. Et alio in loco: Glaucio quogs(inquit)lactis ubertas intermiffa reftituitur: fumi: turr eius rei caufa ex aqua. Hîc ego nó glaucio, fe d glauce legerim. Glaucí enim ufus eft extra corpus tantũ applicati(cum fit odore tetro, \& guftu amara)ad ophthalmiam maximé à principio, Sxignes fas cros nô ualidos, Diofcoride $\&$ Aegineta teftibus. Folia ramulofa funt ulmo $\&$ cytifo, Plinius.Quid autem hîc fibi uelit uox ramulofa non fatis mihi conftat : nec uideo quid ulmus cum cytifo circa foso lia cómune habeat; digeruntur enim ulmi folia fingula alternis ad ramulorum latera. Cornelius Cels fus lib, 4+cap.9, in curationelienis:inter ea qua urinam mouent $\&$ lieni profunt, ut trifolí femen, cu= minum, apium, ferpyllum, portulacam, \& reliqua, cytifum quoç connumerat. A cytífo dulce \& pin gue lac producitur. Mulieres quidem, filactis inopia premuntur, cytifum aridum in aquam mace rarioportet, \& cum tota nocte permaduerit, poftero die expreffi fucci ternas heminas permifceri mo dico uíno, atç ita potandum dari:fic $\&$ ipf $x$ ualebunt, $\&$ pueri abundantia lactis confirmabuntur, Columella 5.11. Fimum ad agros Iæetificandos alin aliud pręferunt: quidam cuiufcung quadrupedis ex cytifo. Molefta arboribus eft $\&$ hedera adnafcens, $\&$ uinciens : moleftus $\&$ cytifus, nam omnia fermè necat:fed eo ualentior auro(alimó frutex) eft hic enim uel cytifum ipfum interimit, Theophira fus interprete $\mathrm{G}_{a z a}$. Et alibi, Spiffa \& roboris medulla, quod atrum cognominant:atç etiam magis 60 cytifi, quippe cum hac proxima ad ebenum accedere uideatur. Principatus quidem ei in pabulis da tur, propter lactis inde copiam bonitatemós:incommodum tamen tantifper dum foret, utinquit $\mathrm{A}_{\text {. }}$ xiftoteles, apium examina eliciuntur: quanquam Democritus pradicet, nunquam de fore cyufifi pa. 
bulum contingere. Hederæ modo uincit $\&$ ftrangulat, Ruellius. A pparet eum erroris huius oce cafionem ex Theophrafto fumpfiffe, qui loco iam citato libri 4. cap. ultimo fic fcribit: \$logàe fé xy ú um"

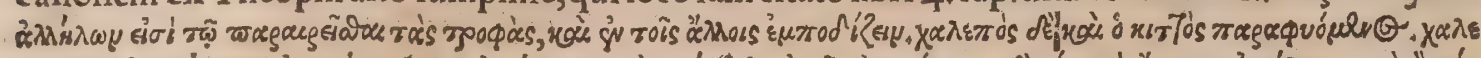

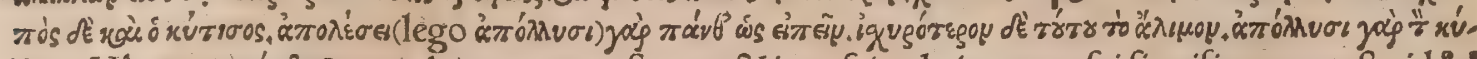

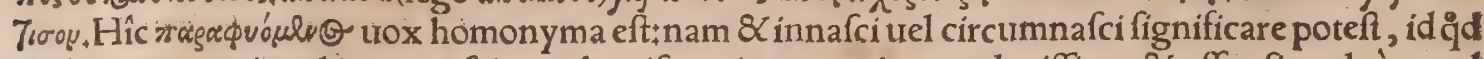
hedera contuenit: uel iuxta nafci, quod cytifo, cuius materia cum duriffima \& offea fit, adeò ut uel hebenum prouocet, minimé apta eft flecti $\&$ uincire. Sed iuxta nafcens radicibus fuis alimentum arboribus præripit, guftanti enim ut malua fucci plenus apparet, ut plurimum attrahere opus fit. Sic orobanche uicina ftrangulat, nó fuperficie circumuoluta, ut fciunt qui herbam nouerunt (quan quam Theophraftus alicubi per imperitiam proximis herbis cóuolui eam fcribat, ut etiam Pet. $A n_{*}$ 10 dreas Matthęolus recté obfertrauit)fed radicibus, fiưe fuccum duntaxat terręomnem attrahentibus illis, fiue etiam circumurolutis. Sic \& alimon frutex propinquum necat cytifum, non aliter quàm fal fugine fua, cuitus ui præfens cæeteris affertur calamitas. Nam proxima inuadere $\&$ inuolui alimon,

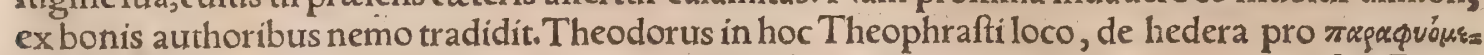

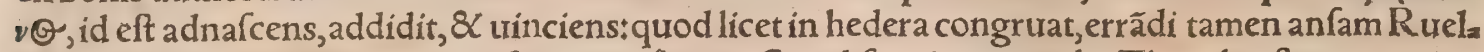
lio dedit, ut idem uerbum ad cytífum transferret. Qurod fi quis contendat Theophraftum omnino fenfiffe cytifum arbores iuxta fe ramis fuis amplecti,erraffe etiam in cytifo eum dicam fimiliter ut in orobanche, In Myfia, qua parte noftra prouincia fínitima eft, tractus oecurrit, quem Britum no minant, in quo mel A ttico fimile penitus magna cum admiratione confpexi : quanquam deteriora plané mella ibi quoç proueniant. Extabat autem ibi monticulus quidam non magnus, faxofus to: 20 tus, thymo $\&$ origano plenus, ad curius radices agri cytifo quamplurimo abundabãtt ex eo collis do= minus mel ufo̧ adeó colligebat, ut hac in parte Atticum etiam fuperaret, acre tamen ut Atticum nó erat, ftatimọ́ iccirco fe guftantes auertebat, \& naufeam cito commouebat, fi pauló liberalius come. ftum fuiffet. Hoc fiquidem de cytifo fcriptores uno ore tradunt, apes excytififloribus plurimum mellis excerperc. Frutic of uero planta cytifus eft, eam altitudinem attingens $s_{3}$ ad quam myrtus cre. fcit: Hæc Galenus libro I, de Antidotis, ubi optimi mellis indicia recenfet.Necant inuiceminter fefe umbra, ucl denfitate, at ${ }^{2}$ alimenti rapina. Necat $\&$ edera uinciens. Nec uifcum prodeft $\&$ cytifurs, Plinius libro 17.cap.24, circa finem, de morbis arborum loquens:tranftulit autem ad uerbum pene Græca Theophrafti uerba qux paulo ante pofuimus, hoc tantum intereft, quod uifci mentionem addit:ut non immerito aliquis conịciat diuerfam huius loci Theophrafti lectionem fuiffe, eamáçab zo aliquo in margine uel uerfuum interftitio annotatam, in textum afcitam. Ego certe Theophrafti

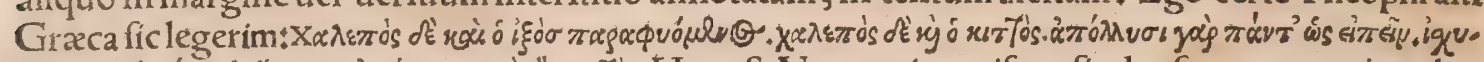

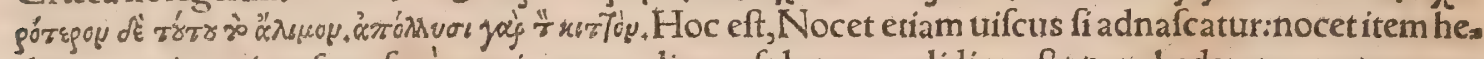
dera, qux in uniuerfum feré omnia necat:alimon folum ea ualidius eft ‡ nam hederam quo $\$$ necat.

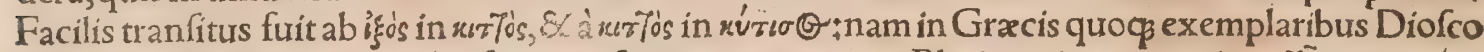

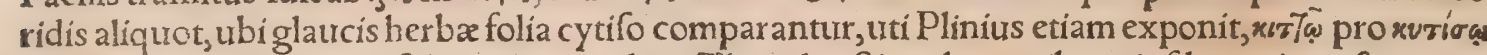
legitur. Huic lectioni confirmand $x$ accedunt Theophrafti uerba, quibus eiufdem rei caufam enue cleat lib. y. de caufis plantarum capite 22.quæ ex Theodori translatione huc apponam : conferendo enim recié conuerfa animaduerri, Qua autem (inquit) uicinitate iuxta fatorum, aut contagione fponte fe affociantium, corruptiones cóferuntur, has alimenti prorfus rapina folet committerełeoć celerius, quò ualidiora pluraćs fint qux infeftant, ceu qua fylueftria funt, qux radice numerofa co= harent, quęmulto indigent alimento, qux abrcindere, amplecti,ftrangulare atç irrepere apta funt, ut edera. Nam uifcum quoos, 8 omnino qua aliquam plantam profede capiunt, interimere por, funt, Edera \& auro, nimio pabuli defiderio, falfuginȩ́́ fibi ingenita, arbores necant; fed auro perni= ciofior eft, quòd plus habet falfuginis, Hæc ille. Nulla hîc cytifi mentio, ut uel cxco appareat, rectéa nobis emendatum effe tum Plini locum, tum Theophrafti fuperiorem. Obtinuimus itaç reçam nó inuolutam plantam effe cytifum. Hoc uel corollarijloco addam, non cytifon, fed citton, id eft hedea ram, omnia corrumpere, a Theophrafto hic friptum effe. Nam libro 3 .hiftor. cap. ultimo, ïfdem uer

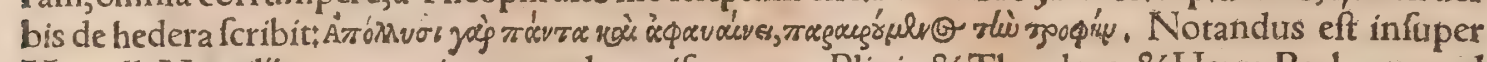
Marcelli Vergilin error, qui non modo cytifum cum Plinio \& Theodore \& Herm. Barbaro apud jo Theophraftum ineptelegit, quod tantis authoribus eum facere tolerandum erat:fed infuper ita urer tit: Theophraftus (ait)teftatur hederam alias arbores, hederam tero cytifum, cytifum tandem hali.

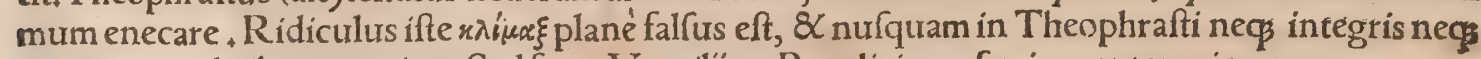
corruptis codicibus reperitur, Sed forte Vergilin ex Bucolicis uerfus in mentem ei uenerunt,

Torua leana lupum fequitur, lupus ipfe capellam, Florentẽ cytifum fequitur lafciua capella:

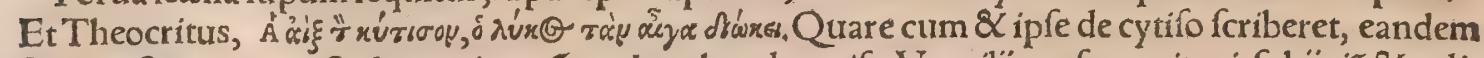
figurã eft imitatus. Sed quoniam cómodum hos de cytifo Vergilï uerfus recitaui, fubïciã \& relí quos eiufdem, in quibus cytifi mentionem facit. Aeglo.1. Non me parcente capellx, Florentem cy tifum, \& falices carpetis amaras, Seruius fuper hoc loco cytifum genus fruticis uel herbam effe me minit, qua nafcatur inter campos \& fyluas in Cytiza ciuitate : fic enim fcribitur, fiue per authoris 60 imperitiam, fiue librariorum uitio: nos ex. Plinio fupra docuimus in Cythno infula una Cycladum primuminuentum hunc fruticem. Scribitur autem Cythnus rectè per $t$ afpiratum, kv'tv@ apud 
Steph,cutửsetiam Ouidius meminit libro 7. Metamorphor. Florentemás Syrö, Cythnon,pla

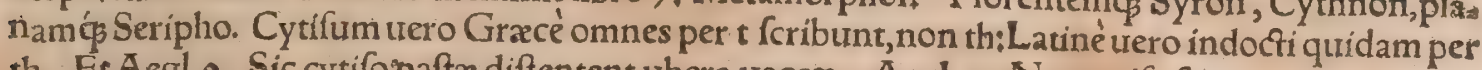
th. Et Aegl, 9. Sic cytifo paftre diftentent ubera uacca. Aegl, 10. Nec cytifo faturantur apes, nec
fronde capella. Et Georg. 2. Tondentur cytifi, tadas fylua alta miniftrat. Poftremo Georg. 3.

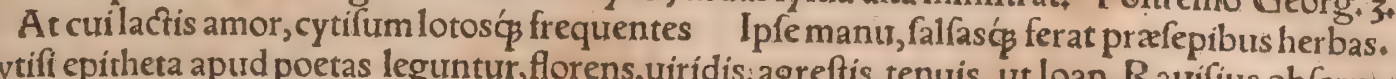

Cytifi epitheta apud poetas leguntur, florens, uiridis; agreftis, tenuis, ut loan. Rauifius obferuauit. Eupolis poeta in fabula qua infcribitur Aeges, inducit capras de cibis fuis \& alia quadam iactan.

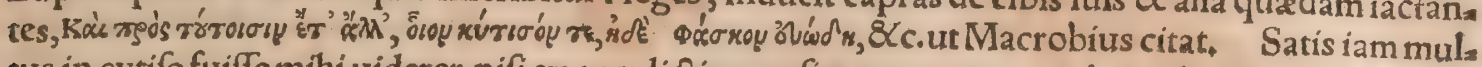
tus in cytifo fuiffe mihi uiderer, nifi ex prædictis occafionem pauca quadam adiungendi haberem. 10 Nam quod fupra diximus Democritum pradicare nunquam de flore cytifi pabulum contingere apes:admonet me laburni de qua Plinius lib.16.cap.18. Laburnum (inquit) aquas odit: Alpina 8 hac arbor, nec uulgò nota, dura ac candida materie, cuius florem cubitalem longitudine apes non attingunt, Hac Plinius:nec alibi apud ullum authorem laburni mentionem reperias. Nos arborem uidimus dependente flore luteo pedem longiore, forma qua piforum flores : nam 8 filiqux fubna. fcũtur. Florem autẽ appellamus oblongam ex multis floribus pendulam congeriem. Folia ei terna, ficut in loto pratenfi aut cytifo, fed maiora.Ruftici prope Orthodorum inter ortum R hodani \& Le mannum lacum leuít, aut lebit, fua lingua indigetant: \& florem teftantur apibus infeftum, quo uel aluearibus impofito diffugiant, fimiliter chauo ex arboris materia impacfo. Materiam ne fub terra quidem in æedificins putredinem fentire. Reperitur etiam in montibus circa Toggenburgum Helue= 20 tiæ regionem $\neq$ nec procul Bononia in A pennino. Hanc arborem fi quis Alpinum cytifum nominet, propter foliorum materixás fimilitudinem, \& eundem aduerfus apes effeçum (fi modo ueré fcribit Democritus)meo quidem iudicio non errauerit, Cytifus auget lac, ut eruum:fed dum floret incon: modus eft, urit enim tantifper \& extinguit lac, Ariftot, lib, 3 . hift. animal, cap, 21. Non mirum igitur fi eo tantifper abftineant apes. Albertus Mag, eo in loco, ut folet inepte omnia, pro cytifo cocturema ie. git, \& adhuc ineptius uiciam interpretatur. Prater cytifum \& laburnum, arborem qux folia fimilia, fimiliterós digefta, hoc eft terna habeat, anagyrin folam in monafierï cuiufdam hor to Venerïs ui= di. Har etiam fruticola eft arboris inftar, \& femen in corniculis gignit oblongis:fed graui tetróf o. dore à laburno ac cytifo facile diftinguetur, Fruticofum iliud arbultum, quod Galli uocant bagenaulde, Germani alicubi (Bafilea enim in hortis uidi) verbsintne Eid le: fic autem proprie nominant $3^{\circ}$ placentarum genus turgidum $\&$ rotundum, ípongiolum intus $\&$ imagine fauacea. Ifis enim pla centulis fiue globulis figura $\&$ inanitate fruticis huius folliculi bellé refpondent, Folia tamen ei non terna, fed bina, è regione, qualia in cicere, pifis, $\&$ alijs mulris:neq̧ facultas ulla qux in guftu malua compararipolfit.Quanquam autem Diofcorides glaucis folia tam cytifo quàm lenticula compaz rat: lenticula autem bina effe non terna conftat, non tamen neceffe eft cy tifi quogs bina effe, figu $r=$ ram enim fingulorum foliorum, non quo digeruntur ordinem, Diofcorides in ifta comparationere fpexit. AtPlinius trifolio tam fímilem fecit cytifum, ut abfog fimilitudinis nota ipfum trifolí nomen ei tribuerit:breuiter enim(inquit) fi quis exprimere fimiliturdine uelit, anguftioris trifolij frutex eft Hoc eft, finge trifoliü (anguftiorib.tantũ folījs) lignefcere et a dolefcere in fruticẽ , cytifum habes. Sic alibi de liguftro: Eadê(inquit)arbor eft qux in oriente cypros, cum non eandem reuera, fed undiqua 40 que fimillimam indicaturus effet. Sed redeo ad bagenauldam Gallorum, qua hic $\&$ propter gene ris cum cytifo affinitatem, \& ufum ad pecora, fi modo colutea Theophrafti eft, omitti nó debuit.Co* lutea(inquit Theophraftus libro 3 , hiftoriæ plantarum cap, 17.) Liparæ propria traditur, arbos ma gnitudine præftans, fructurm in filiqua ferens, magnitudine lentis, qui oues mirum in modum pin: guefacit. Nafcitur fermine, \& fimo pracipué ouillo. Tempus ferendi, cum Arciurus occídit: ferendü femine præmadefacto, cum iam in aqua pullulare in copperit, Habet folium non abfimile foenogræ: co:germinat primo unicaulis, triennio maxime:quo quidem tempore baculos decidunr. Elegantes enim illos proferre uidetur: $\mathbb{C}$ fi ita quis(Ruellius ñ̂́ recte legit, fi quis nimis, quafi ad baculos tan tum referret, non ad cacumen)decurtauerit, mox arbor emoriecur:haud enim latere plantigera cốa ftat,Spargit deinde in ramos, quartó́ so us)iam etiam in Gallia prouenit,omnibus nota bagenaulde nomine. Nanç frutex eft quadriennio fe in arborem efferens, ramis exilibus, folio foenogræci, membraneo folliculo, pellucente, prætumi: do, \& ueluti quodam fpiritu diftendente turgido, ita ut digitis fi prematur, crepitans diffiliat: in quo femen atrum, durum, latû, lentis magnitudine, pifi guftu. Mauritani fermone fuo uernaculo fe. ne nominant, duoóg eius fáciunt genera, fux pontis, $\&$ hortenfe. Nam $\&$ femine nafcitur, in fimo præcipuè ouillo. Addunt ubiog filiguas oblongas, quibus femina in ordinem utring digefta claus, duntur, tenui pendere pediculo. $\mathrm{Ob}$ id facile uentorum impetu deturbari, hærenteść pertinacius perticis decuti. Caducas opiliones legunt, faginandis oubus perquam utiles, Hac Ruellius : cuius fententiam Leonardus Fuchfius etiâ fequitur, nempe coluteam Theophrafti \& fene Arabum ean: dem effe plantam. Manifeftum autem illis eft qui utranq infpexerunt, ftirpes toto genere diucr.

60 fas effe. Nam colutea frutex eft anno quarto arborefens: fena uero herba cubitalis tantum $\delta$ an: nua:folliculis etiam multum difcrepant, Folips forte aliquo modo conueniunt, $\mathcal{Q}$ ur quidam fcribũ purgandi uiribus, Defcribitur fena à Serapione, quod autem filiqua tenacius hrentes perticis dét 
cutiantur, ut Ruellius tanquam ex Mauritanis fcribit, nufquam reperio.Petrus Andr.Matthaolus Senenfis in commentarịs Italicis fuper Delphinio Diofcoridis, fenam diligentiffime defcribit, $8<$ Ruellin errorem refellit. Quamobrem non immorabor hîc prolixius: fat fuerit hoc indicaffe in pra: fentia, fenam Græcis Latiniş̧́ ueteribus fuiffe incognitam \ bagenauldam uerò coluteam effe etiă

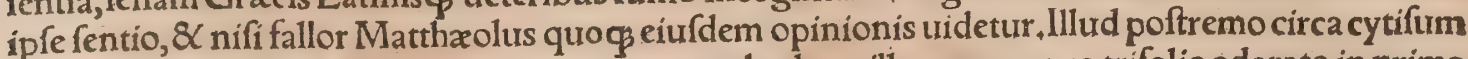
adjiciemus, uideri nobis Matthæolum errare,cum herbam illam quam pro trifolio odorato in prima editione Fuchfius pinxit, eandem effe putat cum illa planta quam ipfe pro uero cytifo accipit, flauis aut albis floribus, Nam trifolium illud Fuchfí)(quod ille à me admonitus trifolium Diofcoridis non effe fed lotum fylueftrem potius, in fecunda editione qux folas imagines habet, in lotum urbanam

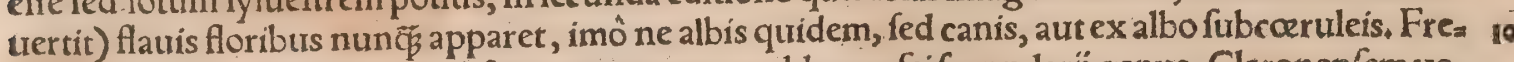
quentiffimum autem apud nos feritur propter quoddam cafei fecundarï genus, Claronenfem uo. cant, quod noftri hac potiffimum herba condire folent: De qua egi in Libello noftro de operibus la ctarịj: \& agam forfitan aliâs copiofius. Haçenus de cytifo \& alịs quibufdã cytifi occafione her bis, prolixius quidem fcripfi, non tamen prater inftitutu, quod ad animalium hiftoriam. Non enim bubus folum, fed omni pecori, pracipué autem oubus, capris, equis, apibus, gallinis, \& ipfi etiam homini, maximus cytifí ufus à maximæauthoritatis fcriptoribus promittitur : \& quæ híc uerbofius dicta funt, in animalibus cęteris repeti nihil opus erit. Non difficile autem fuerit cytifum aliunde ac cerfitam plantare, cum nullam regionem afpernetur : interim loco eius frondibus ulmeis potiffimũ utemur. Nam \& Columella illam cateris prafert frondibus, ut mox ex eius uerbis patebit : Et Ari. foteles ulmum apibus gratam, $\&$ frondibus eius boues pinguefcere teftatur + Iucundiffimum bu= 10 bus pabulum adfert ulmus:capra etiam $\&$ oues id appetunt. Varijs generibus foli prouenit: quam obrem à plerif̧́ feriur. Maxime autem commendatur Attinia, qua procerior latior ḉ quàm noftras eft.

(Cytifo aut Medica herba nutrimus boures lactantes; fic enim plus continebuntlactis, Sotion in Geoponicis Gręcis. Ariftoteles contra, lib.9.hiftor, anim.cap.21.Pabuli genus (inquit)aliud copiã la cis extinguit, urMedica he ba, \& praccipue ruminantibus:aliud auget, ut cytifus 8 cruum. Idem libro 8, cap.8. Herbæ Mzdicæ prima falx uitio datur, \& cum fortida aqua rigatur, incommoda eft. Et libro 9.cap.40. Expedit confeuiffe apud aluearia, piros, fabas, Medicam herbam, furiam, \& $c_{c}$ $D$ iofcorides, pratenfi trifolio(inquit)fimilis Medica recens nata eft: crefcenti deinde contrahitur $\&$ a ngufius fit folium, profertíp fimiles trifolio caules, in quibus femen lenticulæe fimile, inflexumćs zo corniculorum modo:quod ficcatum fuauitatis gratia condimentario fali mifcetur. Id uiride empla. fri modo impofitum, prodeft his qua refrigeranda func. Tota autem herba pro gramine utuntur, qui quadrupedes $\&$ iumenta pafcunt, Hæc ille ex translatione Marcelli Vergilÿ, qui mitllum cor. ruptumó hunc de filiquis $\&$ feminibus locum fufpicatur.Ruellius $\&$ Matthzolus ita tranftulerunt: Medica filliquas habet corniculorum modo intortas, in quibus femen lentis magnitudine dependet. Ex Hifpania(fribit Marcellus in Annotationibus)integros herbę quam illi Medicam cenfent, cum furo femine caules afferri nobis curauimus, Eft autem illius in Hifpania quotidianus in iumentor pabulo ufus:caules cubitales geniculatoś́ profert, trifolio undiq̧̧ fimiles. Audiumusḉ ab ịs qui in Hifpania rem obferuarunt, quod de ea ab antiquis fertur, quicquid in caule affurgit, in folís con trahiłnullo cibo prius magiś́ latari \& pinguefere iumenta pecusćg omne: parcius dari, quoniam inflet 8. multum creet fanguinem, quem ducere poftea neceffe fit:deniq nihil non ab antiquis tra = ditum de ea nunc etiam inueniri. Quod non conuenit feriptori huic, femen eft; quod hic lentis ma. gnitudine indicat, $\&$ intortum maius, cum rotunditate oblongum, colore flauefcente uidetur: quorum nihil in Diofcoridis Medice femine eft. Siliquam non licuit uidere, fed ut conj̈cere ex feminis quantitate facile eft, gracilem \&

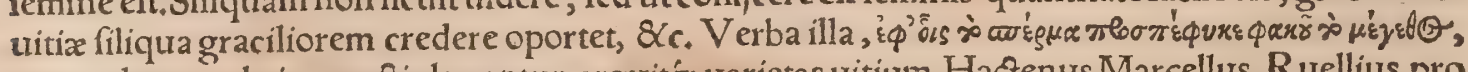
non endem modo in cunćtis leguntur, arguitó̧ uarietas uitium, Hactenus Marcellus, Ruellius pro

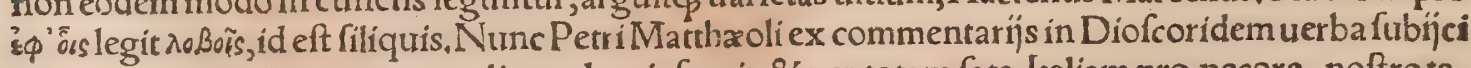
am:Medica(inquit)quanquam olim uulgaris furerit, $\&$ per totam fata Italiam pro pecore, noftrota= men tempore prorfus nos defertriffe uidetur. A bundat hodie (ut quidam fribunt, in Hifpania, $\&$ go fumma diligentia propter pecora colitur:uernacula lingua alfalfa uocant, qua quidem uox origi nis eft Arabica. Nam apud Auicennam in capite Cot,alfafáfat(aliâs, al afelet:aliâs, aliftifcat) nomina tur, Hæc Matthæolus, Ego his diebus ab Hifpano accepi patrio fermone alfalles uocari hanc herbã, ad duos aut tres ad fummum cubitos excrefcere, folia terna loti pratenfis inftar proferre. Io. Roderi. cus Lufitanus, qui annotationes quafdam in Diofcoridem reliquit, Medicam Hifpanice melguas uocitari author eft. Alalfeft, authore Ebenbitar, tox Perfica, idem fignificat quod farfafa, qux eft fpecies trifol'h, quod datur equis faginandis, $\&$ in Syria pabulum ef pecorum omnium : ficcum ap: pellant cot, recens alrathbe, Andreas Bellun. Nunc Plinij uerba apponemus ex lib.18.cap.16. Medi ca(inquit) externa, etiam Græciæ, ut à Medis aduecta per bella Perfarum, quæ Darius intulit, fed uel in primis dicenda: Tanta dos eius eft,cum uno fatu amplius quàm tricenis annis duret. Similis 60 eft trifolio caule folípśçs, geniculata:quicquid in caule affurgit, folia contrahuntur. V num de ea 8 cytifo uolumen Amphilochus fecit confufim. Solum in quo feratur, elapidatum purgatumós fubigi- 


\section{Bos \& Vacca. C. Lib. I.}

ntr autumno:mex aratum $\&$ occatum integitur crate iterum $\&$ tertium, quinis diebus interpofitis, $8 x$ fimo addito.Pofcit autem ficcum furccofumós, uel riguum. Ita praparato feritur menfe Maio, ali. âs pruinis obnoxia.Opus eft denfitate feminis omnia occupari, internafcenteş́́́ herbas excludi: id praftant in iugera modia uicena. Caurendum ne aduratur, terrạ́ protinus integi debet. Sífí humi
dum folum herbofumúe, uincitur, $\&$ defir dum folum herbofumúe, uincitur, $\&$ defcifcit in pratum. Ideo protinus altitudine unciali herbis $0=$ Innibus liberanda eft mantr potius quàm farculo. Secatur incipiens florere, 8 qurotiens refloruit. Id fexies eurnit per annos, cum minimum quater. In femen maturefcere prohibendum ef, quia pas bulum utilius eft ufq̧ ad trímatum. Verno feri debet, liberaríq cateris herbis: ad trimatum marris ad folum radi. Itaq reliqua herbx intereunt fine ipfius damno, propter altitudinem radicum . Si $c_{3}$ 10 uicerint herba, remedium unicum eft aratro, frepius uertendo; donec omnes aliæ radices intereant. Dari non ad fatietatem debet, ne repellere fanguinem neceffe fit: $\&$ uiridis utilior eft. Arefcit furcu lore, ac poftremo in puluerem inutilem extenuatur. De cytifo cui $\&$ ipfi principatus datur in pabu lis, affatim diximus inter frutices, Hactenus Plinius. Medica herba ftercoris \& urinæcaufa perit, ut quidam dixere, Theophrafus. Et alibi:Herbæ quædam diminutæ tonfę́́ meliores euadunt, ceur porrum, braffica, Medica, \&c. tollitur enim acredo $\&$ ficcitas, 8 radices talidiores redduntur. Mul= tis regicnibus Medica natu fatis morofa, alijs cumulatim emergit ; cum feritur decem annis durat: per annum deinde quater recté, interdum fexies demetitur:agrum ftercorat, omne emaciatum ar. mentum ex ea pinguefcit:çgrotanti pecori remedium eft. A d maciem equorum, ut Columelia pros didit, nulla res tantữ quantumMedica poteft. Flos in purpureum colorê fpectat. Hac herba (Ruellij 2o uerbis utor)plerios tractus Gallix uirent, quam uernacula confuetudine grande treflon, quafi tri folium uocant. Alī quod allatum fit à Burgundionibus femen auorum noftrorum memoria, Bur: gundienfe foenum agricolæ nominant. Rura quædam etiam apud nos foenaciam fermone patrio di cunt, Ruris difciplinæ prudentes Medicam iacta to femine ferunt, adiecta noftratis aurenæ portiun. cula:eam fiquidem radiculis fundamenta iacere putant, quibus comprehendens firmius nitatur. Sed 8 pleraqs prata featent apud nos Medica, qua uel naturę fponte, uel coli conditione nata eft: nifi quadam olim illic fata reliquiarum ueftigia reftent, quę herbofo(uti folet)cefpite uicfa, defciut in pratum. HancMarcellus Vergilius dum in lucem reuocare conatur, magis eius obliterauit $c 0=$ nnirionem. Vereor fané ne cytifum ille pro Medica uiderit:nam hac ferè facie, quam explicat, repre fentatur, \& Hifpanijs etiam frequens. Fieri oleum ex Medica tradunt ad neruorum tremores effi. $30 \mathrm{cax}$, Hactenus Ruellius. Quod autem oleum alcot ad tremorem maxime commendetur, author eft Aucenna. Egoliquorem ex alfalfes Hifpanorum ui ignis elicitum per inftumenta, egregiam ad uerfus calculum opem ferre audio. Medica herbę genus effe crediderim quam in Heluetia noftra quidam trifolium maius trocant, groffen Elee, Hieronymus Tragus foenogracum fylueftre : folia ei loti pratenfis, fed bina:ternis aut quaternis per fingulos ramulos binorum foliorũ ordiniburs : quo: rum in guftu dulcedo tanta, ut uel glycyrrhizam prouocent. Coliculicubitales, \& aliquando bicus= bitales, ab una radice plures exeunt, tranfuerfi fere per terram fparfi, fubruffi,geniculati, multis ala rum cauis. Flores candicant. Siliqux modice incurux \&lunatę in mucronem exeunt, triangulax, $e_{=}$ minente $a b$ una parte angulo per longitudinem qua duorum digitorum eft, ab altera carinata : in quibus femina foenograco minora paulo, angulofa, fpecie renum, colore lutea, fapcre uicix. Radix 40 alba, cubiti aut fefquicubiti etiam altitudine defcendit, crafitudine pollicari, lenta 8 tenax, uetur ftate ruffefcit; minus dulcis quàm fuperficies, imó fubamara ferè. Naf́citur iuxta uias, \& locis ficcis; ut montanis uel arenofis interdum. Herba omnino in multos annos uiuaciffima. Hieronymus Tra. gus lotum fylueftrem fiue Libycam effe fufpicatur: fed fapor medicatus abeft. Ego iam olim \& no: fro faculo primus fylueftrem lotum illam effe oftendi, quam noftri uocant funstraut.Ruftici qui dam apud nos folia trifolij maioris fui ad uomitum prouocandum edunt, aduerfus crapulam pra:

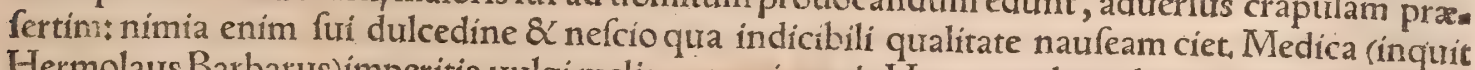
Hermolaus Barbarus)imperitia unlgi melica uocari cœpit. Hac quondam plena erat Venetia, fed pridem perịt:nunc in eandem prouinciam reuerti eam quafi poftliminio curauimus, ab annis mul tis ferè non uifam in Italia, fed ne intellectam quidem magnopere qualis effet, allatam ex Africa in - so Campaniam. Semen eius fub dente phafeoli recentis faporem prafentat, Hæc Hermolatus. Impulit eum opinor in hunc errorem Albertus Magnus, qui circa finem libri 3. de animalibus, Quadam pafcua(inquit)lac mínuunt, ut granum quod melega vocatur, $8 x$ à nonnullis furigum. Ariftoteles hoc Medica attribuerat: Alberto nominis uicinitas impofuit. Culmos melega (uel forgi, ut Fuchfi. us appellat:cuius hæc uerba funt)quaturor aut quing habet, altos, craffos, geniculatos, rubicundos, foli’s ueftitos longis, latis $\&$ in fummitate acuminatis, harundini non dillimilibus: fpicam quàn' panicum maiorem ac denfiorem, rufam $\&$ barbatam, in qua femen rufum, rotundum, lentis magn sudine, \& acuminatum. Florem luteum. Radicem multis fibris capillatam. Semen dulce eft, $\&$ gir ftu planè panicum refert, Hac Fuchfius. Exiubis eius fcopa ueftiaria fiunt. Errat Rucllius cum fcribit panicum in Italia melegam uocitari. Nielega enim Longobardorum, non alia eft quàm forgo 60 alibi dicta, \& in Hetruria fagina (nimirum à faginando pecore) Panicum uero per omnem Italiam

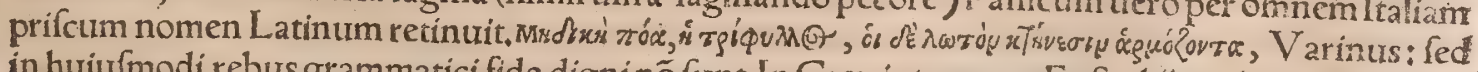
in huiufmodi rebus grammatici fide digni nô funt, In Gracia tempore Eufrathï archiepífopi The 
falonicx Medica herba nomen uetus adhuc feruabat, ut ipfe fcribit in commentarịs in Dionyfium: nec dubito quin hodiéç feruet. Hxc hactenus de Medica. BBubus frondem populneam, ulmeam,

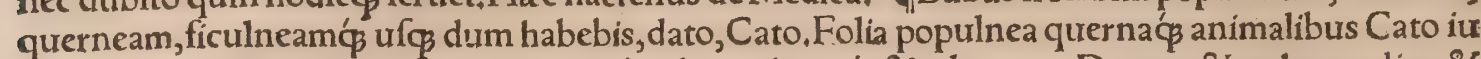
bet dari non perarida: bubus quidem $\&$ ficulnea, ilignaćs \& ederacea : Dantur $\&$ ex harundine $\&$ lauro, Plinius $+q u i$ alibi etiam eruum bubus iumentisó̧ utilifimum effe fribit. Ex cibis nemo dubi $=$ tat, quin optimi fint, uicia in fafcem ligata, \& cicercula, itemćs pratenfe foenum. Minus commode tuemur armentum paleis, quæubiq $\&$ quibufdam regionibus folæ præfidic funt, ex probantur ma xime ex milio, tum ex ordeo, mox etiam ex tritico:fed iumêtis iuftam operam reddentibus, ordeum prater has prabetur. Quibus alimentis potiffimum quæque pecudum pafcatur habenda ratio: nec folum quod foeno fatura fit equa, aut bos, cum fues hoc uitent, \& quarant glandem: fed quod or: deum, \& faba interdum fit quibufdam obícien dum, $\&$ dandum bubus lupinum, \& lactarïs Medi. ca, \& cytifum, Varro. Fabęlargius datæ copiam efficiunt lactis, Ariftot. Miratus fum aliquando cicuta eriam non abftinere boues, nec uiridi, nec arida, uidi enim magnos cicuta fafes ex pratis col lectos pro cibo uaccis offerri. Noftri hanc herbam uocant rofftumi

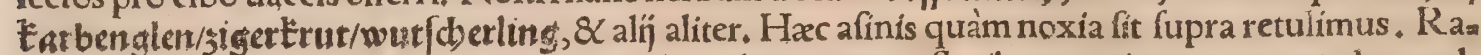
nunculo fimilem herbam, quam coronopodem aliqui putant, floribus aureis, inter uerna olera uula garem, butyri colorem commendare credunt fià uaccis depafta fuerit:eam ob caufam Germani in feriores nominant buttetblimen, noftrià fplendore gly f̧blimten, 8 alpblinten, quòd in alpibus uaccis pergrata fit. Eft $\&$ alia in paluftribus nafcens flore fimili maiore, folio rotundo, crenato, ra=

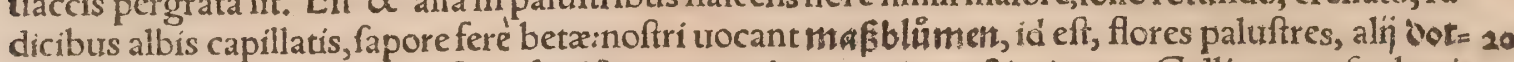
reiblimmen, à colore uitelli, alī fobmêtrblin nos: Nos idem genus in hortis dafypodion, id eft denfis conferctisḉp forum folịs salimus. Ruelius chamæleucen interpretatur:cui ego non affenferim. Chamæleuce enim uerius eadem qux tuffilago eft. Putomon planta fimilis eft arundini, quã boures edunt, Suidas; de quo plura mox in H.dicemus, Galion herba cft cubitalis, foliolis anguftis $\&$ per genicula radiatis fimul pluribus: flore flauo, con. fercto, mufcofo, odorato, abftinent eo boues: ut et urtic fimili herba foetida, 8 r marrubij quodam ge nerefoetido, quod in artris $\&$ noualibus naficitur, aliud quàm ballote, longioribus $\&$ in acutum exe. untibus folins, crenatis. De alịs quibufdam herbis qua bubus noxix aut uenenof $x$ funt, mox in mor bis eorum dicemus, Bobus (inquit Columella) pro têporibus anni pabula difpenfantur. Iantra, rio menfe fingulis frefi, \& aqua macerati erui quaternos fextarios miftos paieis dare conuenit, tuel lu $3^{\circ}$ pini macerati modios, uel cicerculæ maceratæ femodium, \& fuper hæc affatim paleas: licet etiam, fi fit leguminum inopia, $8<$ elata, \& ficcata uinacea, quę de lora eximuntur, cum paleis mífcere. Nec du bium eft, quin ea longe melius cum fuis folliculis antequam eluantur, præberi poffint: nam \& ribi; $\&$ uini uires habent, nitidumó,$\&$ hilare, $8 \mathrm{C}$ corpulentum pecus faciunt:grano abftinemus. Frondis aridx corbis pabulatoria mod orum uiginti fufficit, tel foeni pondo triginta, uel fi non, modius uiridis laurex, $\mathcal{Q}$ ilignex frondis: $f e d$ his, fi regionis copia permittat, glans adj̈citur, qua nifiad fatietatein detur, frabiem parit:potełt etiam fi prouentus utilitatê facit, lemodius fabæfrefæ pręberi. Mẽfe Februario plerunque eadem cibaria fufficiunt. Martio, \& A prili debet ad fani pondus adijci, quía terra prof cinditur: fat autem crit pondo quadragena fingulis dari: ab Idibus tamen menfis A prilis uf̧́ in Idus Iunias uiride pabuilum recte fecatur:poteft etiã in Calen. Iulias frigidioribus locis idem 4 præftari:à quo tempore in Calen. Nouremb. tota æeltate, $\&$ deinde autumno fatientur fronde, qua ta: men nô ante eft utilis, quàm cum maturuerit uel imbribus, uel affiduis roribus: probaturọ́ maxime ulmea, poft fraxinea, $\&$ ab hac populnea:ultimæ funt ilignea, \& quernea, $\&$ laurea, fed poft æftatem neceffarie deficientibus cateris, poffunt eriam $\&$ folia ficulnea probe dari, fi fit eorư copia, aut ftringere arbores expediat:ilignea tamen uel melior eft quernea, fed eius generis, quod fpinas nó habet: nam id quoque uti iuniperus refpuitur â pecore propter aculeos. Nouemb. menfe ac Decembri,per fementem, quantum appetit bos, tantum prabendum eft : plerunç tamen fufficiunt fingulis modí glandis, \& palex ad fatietatem datæ, uel lupini macerati modĭ, uel erui aqua confperfi fextarï $\vee 11$. permifti paleis, uel cicerculæ fimiliter confperf $x$ fextarí $x$ I I , mifti paleis, uel finguli modij uinaceo rum, fi ñis, ut fupra dixi, large palex adịciantur, uel fi nihil horũ eft, per fe foeni pondo quadraginta, jo Hæc Columella. Fonum alibi bis tantum, alibi ter aut quater etiam anno fecatur. Armentorum id cura, iumentorumáç progeneratio furum cuíc confilium dabit optímum, maximé quadrigarum quæeftus, Plinius. Sufficiunt fingulis boum iugis erui modñ quini fati.Martio menfe fatum, noxium effe bubus aiunt:item autumno grauedinofum: innoxium autem fieri primo uere fatum, Idem. Bu. bus glandem circa brumam afpergi conuenit, in iuga fingula modios 240 . Largior ualetudinem in feftat: $\mathcal{S}$ quocuncs, tempore detur, fi minus triginta diebus continuis data fit, narrant uerna fabie pœnitere, Plinius, Lupini modỉ finguli bouem unum fatiant, ualidumọ́ præftant, Idem. Palea plü

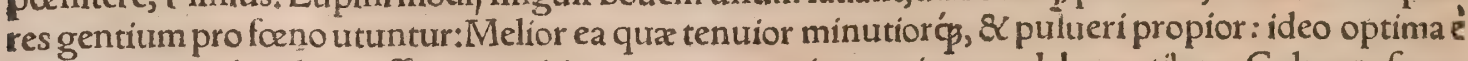
milio, proxima hordeo, peffima ex trítico, praterquam iumentis opere laborantibus. Culmum faxo= fis locis cum inaruit, baculo frangunt fubftratu animalium. Si palea defecit, \& culmus teritur, Ratio 60 hæc, maturius defectus muria diu refperfus, dehine ficcatus in manipulos conuoluitur, atque ita pro foenobubus datur, Plin. Vinaceos per autumnữ quotidie recentes fuccernito: Lectos exficcato, reftibus 
reftibus fubtentis, cribro illi rei parato, ficcos conculcato in dolia picata, uel in lacum uinarium pi. catum, id bene operito, iubetó́s oblini, uti habeas quod des bubus per hyemem, Cato. Hordei ftipur lam bubus gratifimant fertunt, Plin. Maxime ftudendum eft ut competentibus redũdantibusć faturi femper habeantur \& pingues, Omnis enim agritudo exordium fumit ex macie. Exhauftum animal celerius. labor frangit, altus uexat, frigus penetrat. Non folum enim aftiuis menfibus pafcu. um fufficit, ubi frondes diuerfi generis addantur, \& minirat uarietas ípfa faftidium. Hyeme non tall. tum paleis, fed foeno quo $\$$ \& hordeo, \& frepius eruo fagínandi funt boutes, Nullus autem uberiores ciborum repudiabit expenfas, qui confiderare uroluerit boum per inopiam pereuntium quàm cario rafunt pretia; Vegetius zil.M. V arro turdorum fimo ex auriarijs ad agros lectificandos principatum 10 dat:quod etiam pabulo boum fuum q́ Boues quidam lüporut inftar carnituori funt, $R$ afis. Theophraftus prodidit boues quocs pifce uefci; fed non nifi tuitente. A pud Paones qui Prafiadem paludem habitant, equis \& fubiugalibus pifces pro pabulo præbent, Herodotus, In Narbonenfi prouincia nobilis fons Orge nomine eft:in eo herbę nafcuntur ín tantum expetita bubuts, ut inerfis capitibus totis eas quarant. In remotiffimis ad Sep= tentrionem Oeeani Germanici infulis boues a deo pinguefcunt, ut periculum eis fit ne moriãtur pra pinguitudine. Facile faginantur, fi labore abftineant, Augentur iuuencæ amplius cum plus tempoz ris expertes Veneris degunt, ut iam in Epiroticis diximus, Ariftot.

40ues $Q$ equi forbendo bibunt, ut $\&$ reliqua animalia quorum dentes continui funt, Âriftot.

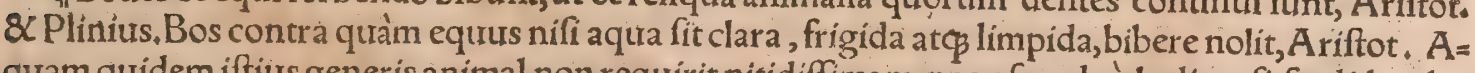
20 quam quidem iftius generis animal non requirit nitidiffimam, nec uf̧́ adeó laditur fi fordidam bi. berit:Sed tamen bubulci diligentis eft procurare, ut mundam femper $\&$ optimam bibat, Vegetius, Per aftatem boures aquam bonam $\&$ liquidam bibant, femper curato, ut tialeant refert, Cato. Theo. phraftus in Thurijs Crathin, candorem facere tradit, Sybarin nigritiam bobus ac pecoribus, Plin, Aeftate ad aquam appellendum bis, hyeme femel, Varro.

đBubus tantum foeminis uox grauior, in alio omni genere exilior (tenuior \& acutior) quàm mari. bus, quod maxime in homine pater, Ariftot. \& Plin. Vitulis etiam uox grautor quàm adultis, perfe ctisç:q quamobrem his caftratis uox è contrario mitatur: tranfeunt enim quæ caftrantur in forminã. In cateris animalibus uox maribus grauiò, foeminis acutior eft, Ariftot, Albertus Magnus uaccam ait eò quod corpore atribiliario, id ef frigid $\& \alpha$ craff $æ$ cóftitutionis fit, grauius fonare: tauros autem 30 beneficio fexus magis ad temperamentum accedere, eius ́́ gratia uocem habere acutiorem. Cátera omnia(inquit Ariftot, )cum natu minora füt, uocem mittunt acutiorem ; uituli autem bubuli gra, uiorem, ut $\&$ uaccæ quàm tauri. Vituli enim $\&$ uaccæ partem quam mourent non habent ualidam, al teri propter atatem, altere propter foeminei fexus naturam. Vas nempe per quod primum Ipiritus fertur, amplưm in îs eft, multumó́ aéris mouere cogitur:multum autem, prafertim fi tardè mourea $\vec{t}_{\text {s }}$ graue fonat.Cæteris animalibus uas illud anguifius eft.

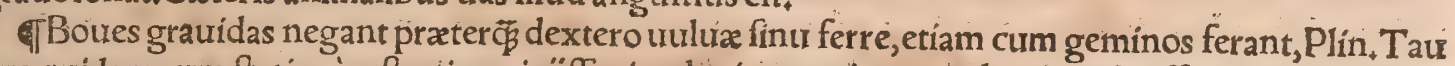
rus quidam cum ftatim à caftratione inïfRet, impleuit:quoniam nondum execti effent meatus, Arift.

Boues etiam fomniare palàm eft:ut omnia feré quir animal pariunt. Impendentem peftem, \& ter. ræ motum, \& coeli falubritatem, \& frugum fertilitatem pręfentiunt: Neq, tametfiratione carent, ab 4o eorum qua fibi aut falutem, aut perniciem afferre queunt, intelligentia aberrant, Aelianus, Vita foe. minis quindecim annis longifima:maribus uigintitrobur in quimatu, Plinius. Viuunt magna ex parte formina annos quindecim, atç etiam mares excifi;nonnullis atas, 'uel ad uiginti annos, atç e. tiam plures, fi corpore bene habito fint: $n$ nam excifos affuefaciunt, $\&$ duces conftituunt boum, ut ouium, qui plus temporis quàm cateri uiuunt ufu exercitï, 8 copia pabuli. Vigent quinquiennes maxi me:quocirca Homerum quidam recte dixiffe aiunt, Quinquennem taurum, \& bouís luftro for $\tilde{e}_{\mathbf{e}}$ tis. Idem nanq fignificari arbitrantur, Ariftotel. Aetas boum dignofcitur ex dentiburs : mutãtenim anteriores anno euoluto $\&$ decem uel octo menfibus: deinde poft fex menfes paulatim amittunt pro ximos, donec intra triennium omnes mutauerint. Quo quidem tempore optimé habiti funt, $\&$ in u $i_{m}$ gore ad decem uf̧̧́ uel duodecim annos perfeuerant. Viuunt ad quaturordecim uf́ç uel quindecím jo annos. In ftatu dentes habent pulchros, longos $\&$ aquales; qui per fenectutem eis imminuuntur, ni= grefcunt, \& corroduntur, Pet. Crefcentienfis. Noftri ex circulis quibufdam qui circa uaccarum cor nua nafcuntur fuperné feré, de atate iudicant;illi.in quimatu ferè terni funt, poftea plures. Sunt qui quoties fœt a fuerit, toties fingulos adnafci circulos exiftiment. Bubulum lac fertilius cafeo eft, quàm caprínum. Cum enim ex amphora lactis caprini formagines obola undeuiginti conficiantur, bubu= lum eadem menfura triginta facir, ut paftores confirmant, Ariftot. Bouris lac craffiffimum eft; cur aus. tem paucius proportione fui corpcris fit, in caprini mentione infra dicemus ex Ariftotele. Puffllæ bu culæ quas Phafiana regio fert, fingulæ abunde beneficio pabuli mulgentur: \& Epiroticæ uaccæ præfua præcipua magnitudine, amphoras fingulas fingulæ implent lactis, menfuréć eitus dimidium mammis duabus praftant.Quantum lactis prouenerit primum concrefcens, perinde ut lapis dure. 60 fcit:quod ita accidít, nifi aqua admifreatur. Lac à partu utile eft:antequam peperit, carèt lacte, Arift.

Vaccæ purgantur menftruis menfura quidem amplius quàm oues $\&$ capra : proportione autem multòminus, Ariftot. In uaccis interdum purgatio menftua quinto quoge menfe apparet in regio= 
nibus ualde calidis, reliquo tempore cum urina excernitur tcuius rei indicium eft, quod urina fomin narum omnium animaliũ tenuior eft cum grauida funt quàm aliâs, A riftot. Vaccæ acriorem quàm. tauri reddunt urinam, Idem. Menfes $\&$ uaccis fiunt, ut equabus, $f e d$ minus, Idem. Bos formina cum coittum affectat, leuiter purgatur menfibus, quantum heminx dimidium, aut pauló plus. Tempus aus: tem cö̈undi tunc potifimum eft cum purgatur, Ariftot . Adferemus 8 infra nonnihil de libidine $\&$ : coitu tatrorum prater ea quax hic dicuntur. In A egypti uico Schuffa nuncupato, non magno quide $\tilde{e}_{\text {, }}$ fed certe eleganti, qui in Hermopolitæ prafecturam cenfetur, Venerem religiofe $\&$ fancimfime $\mathrm{CO}_{3}$ lunt, quam Vraniam appellant: Á tọ uaccam etiam ideo uenerantur, quia affinitatem $\&$ conuenien tiam cum dea ipfa habere exiftimetur. Etenim huiufcemodi beftia tãtopere ad Venerem incitata eft, ut cum maris mugitum aurdit, ad coitum uehemêtiffime exardefcat. At perientes confirmant, taurum à triginta ftadịjs ipfo mugitu amatoriam fignificationem, quafi tefferã Veneris dantem, exaudiat, Itemó 1 Ilim bubulis cornibus A egyptï \& fingunt, \& pingunt, Aelianus. Vacca cum appetit coitum (appetit autem non diutius quàm tres horas)tum quàm maximum potef, mugitum edit, A c nifi hoc trium horarum fpatio taurus accurrerit, in aliud certum tempus, quod per. raro accidit, naturam claudit, Taurus autem uel longo loci interuallo, ex clamore illius appetitionem auribus concipiens, celerrime ad coitum accurrere feftinat, A elianus. Vaccæ ex forminis potiffim $\tilde{\text {, }}$ poft equas, libidine incenduntur. Tauriunt enim \& efferantur adeò, ut bubulci eas tenere aut capere nequeant. Indicium tum equx tum uaccæ fux libidinis praftant, genitalis fpecie prominẽtiore. Vac cæe etiam mingunt crebrius more equarum. Ad hxc, uacca tauros fuperueniunt, \& fequuntur fedu= $1 \dot{1}, \&$ affiftunt. Turgent ad coitum prius minores natu, quàm maiores, tum in equorum genere, tum 20 in boum, Ariftot. Menfem unum uel triginta dies ante admiffuram obferuari folet, ne foemina cibo 8 potione fe impleant:quamobrem pabull pars eis fubtrahenda eft: quòd exiftimatur facilius graciliores $8 \mathrm{~L}$ macr $x$ (macefcentes) concipere, ac femen attrahere: nimia uerò corporis obefitas fteriles red dit. Contrà tauros, durobus menfibus ante admiffuram herba $\&$ palea ac foeno pleniores facere conue. nit, \& à forminis fecernere, ut uires habeant \& fortius ineant. Hoc et armentarï \& opiliones obfer. uant. V num marem quindecim uaccis fufficere abunde eft, Columel. Varro habere fe tauros totide fcribit, quot Atticus, ad matrices feptuaginta, duos, unum anniculum, alterum bimũ. Hoc fecundũ aftri exortum fe facere, quod Graci uocant lyram, fidem Latini:tum deniq̧ tauros in gregem redige re. Iuuenca aliquando annicula peperit, ut educari augerígés, quantum genus exigeret, licuerit. $R e=$ centior ueró quàm annicula non patitur Venerem, nifi oftento. Iam enim uel quarto ætatis menfe ro 30 iffe perfpectum eft, Ârifot, Non minores oportet iniri quàm bimas, ut trimę pariant, eo melius fi qua drimx. Pleræo, pariunt in decemannos, quadam etiam in plures, Varro, Cum excefferint annos de cem foetibus inutiles funt.Si tamẽ ante bimatum conceperint, partum earum remoureri placet, ac per triduum, ne laborent, ubera exprimi, poftea mulctra prohiberi. Nec ante xtatem trimam tauros his oportet admitti.Sed erit furdium diligentis, amotis fenioribus, nouellas fubinde conducere, \& fteriles aratro ac laboribus deputare, $\mathrm{P}$ allad. Coitus à delphini exortu ad pridie nonas Ianurarí diebus trigin ta, aliquibus $\&$ autumno:gentibus quidem qua lacte uiuunt ita difpenfatus, ut omni tempore anni fuperfit id alimentum, Plin. Maximé idoneum tempus ad concipiendum à delphini exortu ufque ad dies quadraginta aut pauló pluss. Qua enim ita conceperint, temperatifimo anni tempore pariunt, Varro. Tempus admiffurze optimum, 'fecundum alios, medium ueris exiftit . Initium coitus pluri $4^{\circ}$ mis quidem menfe Aprili \& Maio:fed nónullæe etiam ad autưmnum uf̧́ tempus coéundi deducũt, Ariftot.Menfe lulio foeminæ maribus plerunģ (maximé)permittendę, (fubmittend $x$ ) ut co tempore conceptos proximo uere adultis iam pabulis edant: quia decem menfium partus fic poterit maturo uere concludi. Nam decem menfibus uentrem perferunt, neç ex imperio magiftri, fed Cuz fponte marem patiuntur. Âtç in id feré,quod dixi, tempurs, naturalia congruunt defyderia, quoniam poft uernam pinguedinẽ geftientes, \& pabuli nimietate exhilaratx lafciuiunt, Columel, \& $\mathrm{P}$ allad.Qurod fi aut foemina recufat, aut non appetit taurus (eadem ratione qua faftidientibus equis mox præcipie. mus) elicitur cupiditas odore genitalium admoto naribus, Columel, Si autem uaccæ non exceperint tauros, præcordium fquill $x$, hoc eft tenerrim $x$ fquilla partes, atç (ut quifpiam dixerit)pingue ipfum aqua tundendum eft, ex eoós, ubi furerint abfterfi, uaccarum finus ungendi, Quintilij. De tauris ad li- jo bidinem excitandis feorfim etiam infra dicemus. In uaccis equabusọ́ maximé conceptus indicium fit, cum menfes ceffârunt, fpacio temporis bimeftri, trimeftri, quadrimeftri, femeftri: fed id percipe. re difficile eft, nifi quis iandudum fecurtus; affuetusó̧ admodum fit; quamobrẽ non defunt, qui men: fes in his animalibus negent, Âriftot. Hoc admirandum, quod fertur, ex boure caftrato etiam, fi fita timadmiferis, uaccam concipere.Si abundantia pabuli eft in regione, qua pafcimus, poteft annis om nibus in foeturam uacca fubmitti. Si tero indigetur hoc genere, alternis temporibus oneranda funt; maximéćs, fi eædem uaccæ alicuri operi feruire confueuerunt, $\mathrm{Palladius.} \mathrm{Sed} \mathrm{non} \mathrm{dubium} \mathrm{ef,} \mathrm{ubi} \mathrm{pa}$ buli fit latitia, poffe omnibus annis partum educari:at ubi penuria eft, alternis fummitti: quod maxi me in operaríjs fieri placet, ut $\&$ uituli annui temporis (patio lacte fatientur, nec forda fimul operis, \& uteri grauretur onere. Vacca cum partum edidit, nifi cibis fulta eft, quamuis bona nutrix labo 60 re fatigata nato fubtrahit alimentum. Itaç \& foetæ cytifus uiridis, $\&$ torrefactum ordeum, maceratumós eruum prabetur, uel tenero olere commifto, torrido, molitós milio, \& per unam noctem la. 


\section{Bos\&Vacca C. Lib. I.}

ce macerato faliuatur. Melius etiam in hos ufus Altinæuaccæ probantur quas eius regionis inco. læc ceuas appellant: $e x$ funt humilis ftaturæ, lactis abundantes, propter quod remotis earum foetibus, generofum pecus alienis educatur uberibus $\ddagger$ iuel fi hoc prafidium non adeft, faba frefa, $\&$ uinum re: cte colerat, id ḉ̧ præcipue in magnis gregibius fieri oportet, Columella. Boues foetæ pinguefcunt dũ gerunt uterum, eduntó̧ amplius, ut etiam aliz quadrupedes. Boues círca Toronam, paucis ante par tum diebus, lacte carent:reliquo tempore habent perpeturo. Ventrem ferunt decem menfes, Varro. Pariunt menfe decimo: quicquid ante genitum, inutile eft, \& non iritale. Sunt authores, ipfo comple te decimum menfem die, parere,Plinius, $Q$ uandiu uiuunt $\&$ coire folent $\&$ parere. Pariunt fingu. los, geminos raro, Ariftot. Ferunt uterium mêfes nouem, decimo pariunt. Sunt qui decem totos men 10 fes, exceptis paucis diebus, affirment. Quiod autem in lucem pracurrerit hæc tempora, id abortiuum eft, uritaléçs minime, etiamfi paulò maturauerit partum; præmolli nançs, imperféçaćç ungula pro. dit, Ariftot. Mas ubi iutuencam fuperurenit, certis fignis comprehendere licet, quem lexum genera. uerit, quoniam fi parte dextra defiliuit, marem feminaffemanifeftum eft; fi læua, foeminam; id tamen uerum effè non aliter apparet quàm ubi poft unum coitum forda non admittit taurum: quod $\&$ ip, fum raro accidit. Nam quamuis plena foetu nó expletur libidine, adeo ultra naturæ terminos etiam. in pecudibus plurimum pollent blandx uoluptatis illecebræ, Cclumella, Varro, \& Afrícanưs. Cæ. terum fi defyderes utid quod orietur fit mafculus, quo tempore coéundum eft, uinculo finiftritm te ftem excipito. Sin autem fœemina, dextrum fimiliter deligato. A t nónullli id ipfum naturaliter faciũt: quí quidem fi mafculum nafci uolunt, fpirante Borea congreffus praparant: fin contra, foeminam; 20 aére exiftente Auftrino, Africanus. A prili menfe uituli nafci folent, quorum matres abundantia pa= buli iuuentur, ut fufficere polfint tributo laboris, \& lactis.I pfis autem uitulis toftum molitumós mi lium cum lacte mifceatur, faluiati more prabendum, Palladius. Cum parere coperint, fecundum fta bula pabulum feruari oportet integrum, quod egredientes deguftare poffint, faftidiof enim fiunt, Varro.V accæ per æftatem forcundiores pluuiofam inftare hyemem indicãt, Aliâs, Cum uaccæ plü. res grauida funt, $\&$ facile initum patiuntur, nimirum pro figno hyemis $\&$ imbrium id accipitur, A r $i$ ftot. Neq̧ enim fieri poffet, ut $\bar{A}$ lberto placet, animal fíccum foecứdo $\&$ genitali humore abundare, nifi iam à coelefti influxu ftellarum, qux annum regũt, humor in eis commoueretur. Tolerat frigus hoc armenti genus, et poteft facile hybernare fub dio:prouridendum tamen quo recipiunt fe frigidus locus ne fit: algor enim eas $\&$ fames macrefcere cogit. Calore igitur fub dio, frigoribus intra tecium 30 manere oportet.Sed laxo fpatio confepta facienda funt, ne in anguftís ftent, aut feriantur; aut con. currant, \& ut inualida fortior is ictus effugiat, nec iniuria fiat grauidarum, \& conceptum altera alte. rius elidat. Propter tabanos etiam $\&$ beftiolas quafdam minutas, aliqui folent includere feptis ne cố citentur. Ofto pedes ad fpatium ftandi fingulis boum paribus abundant, $8 \mathrm{C}$ in porrectione quinde. cim. Stabula equorum uel boum meridianas plagas refpiciant, non tamen egeant feptentrionis lu= minibus, qux per hyemem claufa nihil noceant, per æftatem patefacta refrigerent. Optima funt $f_{a}=$ xo aut glarea(glareis)ftrata, non incommoda tamen etiam fabulofa: (arenis ftrata)illa, quod imbres refpuant:hæc, quod celeriter forbeant tranfmittantćp: Sed utraç deuexa fint ( propter ungulas ani. malium ab omni humore fứpenfa) ut humorem effundant, fpeçentó̧ ad meridiem, ut facile ficcen. tur, $\&$ frigidis uentís non fint obnoxia (uel, propter flatus glaciales, quibus aliquis refiftere debet ob 40 iectus.) Subfterni oportet frondem aliudúe quid in cubilia, quo mollius conquiefcât, Boures nitidio res fient, fi focum proxime habeant, $\&$ ignis lumen intendant. Prafepium oportet extructum effe

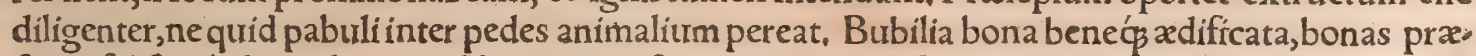
fepes, falifcas habeãt clatratas, Clatros inter fe oportet pede diftare. Si ita feceris, pabulum boures nō eícient, Cato. In incendijs fi fimi aliquid egeratur è ftabulis, facilius extrahi, nec recurrere oures bo. uesḉs fertur, Plinius, Hybernæ ftabulationi boum praparanda funt ftramenta, quæ menfe Augu. fto intra dies triginta fublatæmeffis præcifa, in aceruum extrui debent:horum defectio cum pecori, tum agro eft utilis $\downarrow$ liberantur arua fentibus, qui aftiuo tempore per canicula ortum recifi, plerū radicitus intereunt, $Q$ ftramentis pecoris fubiecti plurimum fter coris efficiunt. $\mathrm{Hac}$ cum ita curaue rimus, tum $\&$ omnegenus pabuli præparabimus, dabímuş̧́́ operam, ne penuria cibi macrefcat pe. so cus. Leuis autem cura pafcui eft:nam ut latior herba confurgat, ferè ultimo tempore aftatis incen. ditur: ea res $\&$ teneriora pabula recreat, $\&$ fentibus uftis fruticem furrecturum in altitudinem com pefcit. Ipfis uero corporibus affert falubritatem, iuxta confeptum faxis $\&$ canalibus fal fuperiectus, ad quem fature pabulo libenter recurrunt, cum paftorali figno quafi receptui canitur: nam id quogs femper crepufculo fieri debet, ut ad fonum buccinz pecus, fi quod in fyluis fubftiterit, fepta repete. re confuefcat:fic enim recognof ci grex poterit, numerusás cenferi, fi ueluti ex militari dif́ciplina intra ftabularij caftra manferint, Columella.

TDeboum fanitate tuenda complura funt, quæ exfçripta ex Magonis libris, armentarius fuus crebro ut legeret M.Varro curabat, Laborant armenta urehementius pruina folicitata quàm niue. Quocunģ autem tempore, fed maximè xftate, fi boures concitentur ad curfum, aut aluus eorum ad 60 perniciem foluitur, aut febriculacommouentur. Natura enim pigrum animal bos, \& labori potius quâm uelocitati accommodum, uehementer læditur fi ad opus cogatur infuetum, Colum. \& V ege. tius. Plantæ oliuarum primo furculari debent, ita ut fimplex fiylus altitudinem maximi fcrobis 


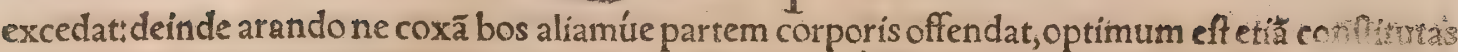
plantas circũmunire caucis, Columella. Cauendũ pręcipuè eft, ne aut curfu nimio, aut lenge inivere fatigentur, uel ullis grauioribus certe oneribus affligantur:nimiam enim laffitudinem fequifur crê tudo, \& omne animal eft debile fi rumpitur, Veget, Vt longxui \& fani fint boutes, bubuîn côuc nit prouridere uel dominum, ut à frigoribus calidiffimo cubili muniantur, \& fi fieri potefi, femper foco uicini fint boures. Quodam em beneficio naturali eiufmodi animalibus femper ignis ccmmodñ tf riue $q$ inutilis \& peftifer humor exudat, fiue cóceptũ ex paftu uel opere frigus expelliț, fiuc in fam.

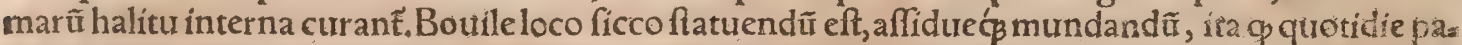

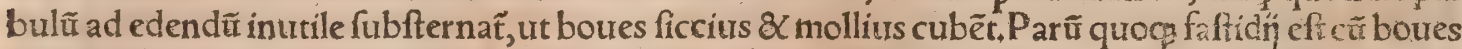

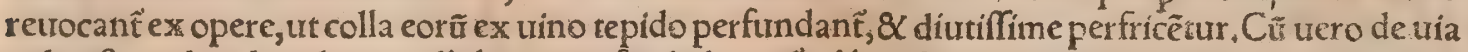

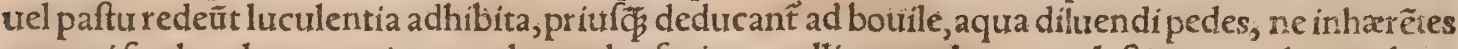
corpori fordes ulcera generent, uel ungulas faciant molliores, uel certe molefiam manducantiburs, uel inquietudinẽ afferant dormituris. Sed hyeme omni folertia frigus eft prohibendũ, uelut æfriuis menfibus pura aura quærenda.Per diem igitur fub umbra, per noctem fub diuo boues ftare conue nit. Non enim patciores fi aftuauerint, quàm fi alferint, colligunt morbos, Veget. Omnes ferè incer ti funt obfcuriç̧ animaliũ affecturs, Quî enim difcere aliquis poffit, aut à quo percontari, quonã affe cीu aut morbo ipfum animal cófliçeț? Si igit filphiû̉ cótufum ex uino meraco et nigro in nares illis

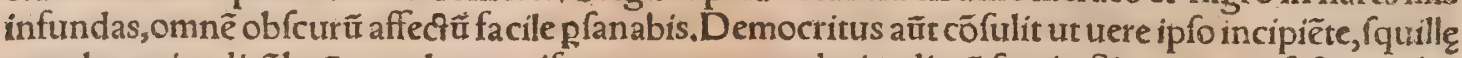
atç̧ rhamni radicê boũ poculo permifceamus, quatuordecim diert̃ fpatio. Si uero manifefto morbo laborent, elelif́phacũ (id eft faluriã)montano ex loco collectũ, prafium ḉ, in aqua, quã bibiturifunt bo 20

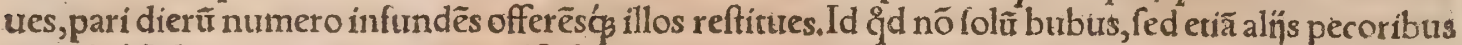
opitulaț.Sal præterea nutrimêtis côfufum, cōducit mire. (Multi largo fale mifcẽt pabula, Columel, ) Iutuat et Medica herba,Paxamus. Inter exordia tadiãti boui aduerfus omnes morbos potio ifta fue currit: Tres femuncias fquillæ minutatim cócifas, præterea radices teneræ popinũ ( uox ut apparet corrupta)effoffas $\&$ diligenter lotas, côtundes in pila, et tria ex eis pondera(forte pondo)addito fex tario falis, in uini feptē fextarios mittes, etper feptẽ dies p os bobus fingulos fextarios digteres. Quod fi toto anno aduerfus omnes agritudines defperatas, boues ftagnare(lego feruare, ttel faluiare, uel fa liuare) uolueris incipiẽte uere, id eft ab idib. Februarị quindecim diebus cōtinuis hanc potionẽ dà bis, qua ufq̧ adeò falutaris eft, ut approbatĩ fit integro anno boues fic curatos nullius morbi cótagi one tentari; Veget, in cap, de malide $\&$ morbis cótagiofis boũ. Non pderit cibis fatiari pecora, nili 3

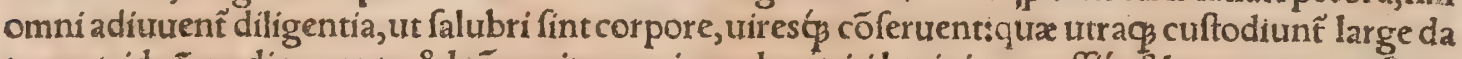

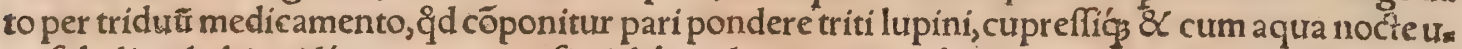
na fub diuo habito:idọ́ quater anno fieri debet ultimis temporibus ueris, xitatis, autumni, liyemis, Columel. Idem fermè remedium Vegetius fic defcribit: Foliorũ lupini(fic enim lego, non caprina) foliorũ myrti fylueftris, foliorum cypreffi, fingulorum uncias tres diligentifime deteres, \& infun: des in congium aquæ, \& una nocte fub diuo manere patiếris, $\&$ inde unicuiós tepefactos per trie duum fingulos fextarios dabis, idç̧ quater in anno, ut prædictum eft. Sxpe etiam langor \& naufea difcutitur, fi integrum gallinaceum crudum ouum ieiunis faucibus inferas, ac poftero die fpicas ul. pici uel allí cum uino conteras $\&$ in naribus infundas, Columel. Outum crudum cum hemina falis \& fextario uini per fingula capita(feptimo)diffundi percommodum eft, Vegetius, Bos fi agrotare coperit, dato continuo ei oum unum gallinaceum crudum, integrñ facito: poftridie caput unum ulpici conterito, \& id uafe ligneo terito, \& cum hemina uini facito bibat fublimiter † Bosḉ̧ ipfurs, $\&$ qui dabit, fublimiter ftet, leiunus ieiuno boui dato, Cato. Inuat etiam fi allium tunfum hircino mi fceas fepo, herbam quoç uerbenam additam deteras, rutam herbam, etiam pollinem iniungas, $\&$ cum uino per os digeras, Vegetius, Boum morbis commendatur feutum, fulphur uiuum, allium fyluefre, ouum coctum: omnia hac trita in uino danda, aut uulpis adipem, Plinius, Quidam mar rubium dederunt cum oleo \& uino, Vegetius id mane infundendum ait. Quidam porri fibras, alí grana thuris, alị́ fabinam herbam rutamḉ cum mero diluunt: eaç medicamenta potanda præ: bent, Columella. Thuris puluerem cum mero fite per nares inieceris, fitre per os dederis prodeft, Veget. Nec minores medicina bobus horum copia(malim, per illorum inopiä)fubminifiranț. Nam jo porros, rutam, apium, \& herbam fauinam, fi quis large deterat et mifceat uino, ternasíg heminas pre

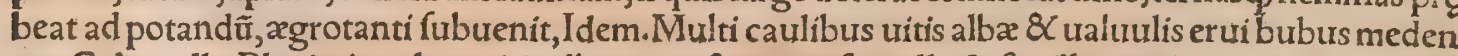
tur, Columella. Plurimí caulem uitis albx concifum, atç ferpyllũ \& fquillx partẽ in aqua macerant, ternasḉ heminas per tridữ digerũt, qua potio uentre purgat, uires quoģ cōfirmat, Veger. Ne bo ues debilitent̂,orobũ (id eft eruũ) cốminutum aqua diftemperans, propina fingulis mêfibus, Cõ tan tinus, Bubus fi morbum metues, fanis dato falis micas tres, laurea folia tria, porrifibras tres, ulpici fpicas tres, allif fpicas tres, thuris grana tria, herbæ fabinæ plantas tres, rutæ folia tria, uitis albæ cau les tres, uini fextarios tres. Hac omnia fublimiter legi, teri, darićs oportet. Ieiunus fiet, qui da= bit. Per triduum de ea potione unicuique boui dato. Ita diuidito, cum ter unicuique dederis, omnem abfumas: Boś́p ipfus, \& qui dabit, facito ut uterque fublimiter ftent: uafe ligneo da. 60 to, Cato. Nonnulli pellem ferpentis obtritam cum uino mifrent , Columella, Anguina pelle $\&$

\section{0}

(1) 
fale \& farre cum ferpyllo contritis uno die, deiectisḉ curm uino in fauces boum uua maturafcente; toto anno cos ualere quidam fcripferunt: Vel fihirundinum pulli tres tribus offis dentur, Plinius, Similiter Cato, fed alijs uerbis: Vbi uuæ(inquit)uariæ coperint fieri, bubus medicamentum dato quotannis, uti ualeant, Pellem angtrinam ubi trideris, tollito, $\&$ condito, ne quęras cum opus fier Eam pellem, \& far, \& falem, \& ferpyllum, hæc omnia unà conterito,cum uino dato bubus omnibus ut bibant, Eft etiam remedio cum dulci uino tritum ferpyllum, $\&$ concifa $8 \times$ in aqua macerata fcila 1a. Quæ omnes prædictę potiones trium heminarum (menfura) fingulis diebus per triduum da: ta, aluum purgant, depulfisḉ suitijs, recreant uires.Maxime tamen habetur falutaris amurca, fi tan. tundem aquæ mifceas, \& ea pecus infuefcas:quia protinus dari non poteft, fed primo cibi afpergun io tur: deinde exigua portione medicatur aqua, mox pari menfura mifta datur ad fatietatem, Columel la, Vegetius, Paxamus, De eadem Cato fic fcribit; Boues uti ualeant, $\&$ curatibene fient; 8 qui faft: dient cibum, uti magis cupide appetant; pabulum, quod dabis, amurca fpargito, primo paululum, dum confuefcant, poftea magis; $\&<$ dato rarenter bibere, commiftam cum aqua aquabiliter quarto quintóç die:hoc fi feceris, ita boues \& corporecuratiores erunt, \& morbus aberit. Votum pro bur bus, ut ualeant, fic facito. Marti Syluano in fylua interdius, in capita fingula boum uotum facito:far ris adorei libras tres, \& lardi pondo quaturor, pulpæe pondo quatuor femis, tini fextarios tres femis Id in urnas liceto conícere, 8 crinum idem in unum uas liceto conïcere. Eam rem diuinam uel fer nus, uel liber licebit faciat. Vbi res diuina facta erit, ftatim ibidem confumito. Mulier ad eam rem di uinam ne adfit, né ue uideat quomodo fiat. Hoc uotum in annos fingulos, fi uoles, licebit uourere;

20 Cato.Idem alibi, Dapem (inquit) pro bubus pyro florente facito. Eam hoc modo fieri oportet: loui dapali culignam uini quantum uis poluceto. Eo die feria bubus $\&$ bubulcis, \& qui dapem facient. Cum polucere oportebit, fic facies. Iupiter dapalis, quod tibi fieri oportet, in domo familiáćp mea cus lignam uini dapi eius rei ergó, Macte uino inferiori efto. Macte hac illace dape polucenda efto, Maa nus interluito:poftea uinum fumito. Iupiter dapalis, macte iftace dape polucenda efto. Macte uíno inferiori efto. Veftæ fi uoles dato + daps Ioui affaria pecuina urnæ uini louí cafte. Profanato fine con tagione, Poftea dape facta ferito milium, panicum, lentim, allium, Hac ex M. Catone utcunģ fuperftitiofa tranfcripfi:qui uolet obelifcum inducat. Non omittendum eft etiam illud ex Vegetio remedium, quod diapente uocari poteft, quoniam uno tantum pharmaco, betonica nempe, theria cam diateffaron apud ueteres antidotum excedit: Tres uncias baccarum lauri, gentianæ, ariftolo. $3^{\circ}$ chia longa, myrrh $x_{\text {, }} \alpha$ betonica, diligentifime detere $\&$ mifce cum mero, ex quo trinas heminas triduo iugiter iumento per os dabis:Morbos agritudinesq̧̣ depellit. Auris uulneratur, \& fanguis eius in os datur æogrotanti boui، Sili uel fefeli Creticum quadrupedum quoç altum fiftit, fitue tri. rum potui infufum, fiue mandendo commanducatum è fale :Boum morbis tritum infunditur, Plin.

Druidx Gallorum famolum herbam nominauere nafcentem in humidis: 8 hanc finiftra mants legi à ieiunis contra morbos futum boumćç iuffere, nec refpicere legentem, nec alibi quàm ín canali

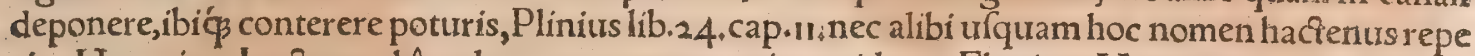
ri. Hoc etiam Lectorem hîc admonere operæ pretium uidetur, Flauium Vegetium, qui boum re. media tradidit libro tertio Veterinarix per quatuor capita, omnia ferè ad uerbum \& eodem ordine (paucis ab initio exceptis) tranfcripfiffe ex libro fexto Columella, à capite quarto illius libri ufģ ad 40 uícefimum, copiofius tamen fæpe quàm apud Columellam legantur. Codex Vegetï Bafileæolim excufus multis modis deprauatus eft. Curantur $\&$ fanguinis detractione quando fis iuxta caudam $\&$ in roftro uenis. Noftratium quidam aridas iuniperi baccas $\&$ urticarum folia te runt, \& pabulo aut fono intermifcêt, ad uifcerum incolumitatem, pulmonis \& iecinoris præcipue, conducere perfuafi. Sunt qui pueri impubis urinam infundant. Ablutuntur aliquando boures deco co ueratri albi in aqua cum fauina \& axungia uetere, ut cum alīs fordibus ac moleftīs tum pedicut lis liberentur:Lutuencas tamen hoc decocto tanquam uehementiơre contingi uetant. Porrò ne infe. ftentur à mufcis, lauri fructum contundens oleoćs incoquens, ex eo boues inungito:aut bubula etiam faliua illine, A fricanus, Bubus multæ æegritudines accidunt, tum occultæ, tum manifefta: \&. laffiturdines, qux proueniunt ex nimio labore atç calore, qux cognof cuntur ex faftidio cibi, ud 50 modo edendi mutato, $\&$ frequenti decubitu, $\&$ lingua ob calorem exerta, alijs ḉ mutationibus, quas facile animaduertût illi qui fanos $\&$ incolumes cos prius cognouerint, Caterum boues fani, fortes, $\&$ agiles nofcuntur, fi facile fe moureant cum tanguntur aut punguntur:membra eifdem plena, $\&$ auricula erectx. Pulchros fimul $\&$ ualidos iudicabis, quibus membra tum plena fuerint, tum pro portione inuicẽ bene refpẽ derint, Pet. Crefcent. A pud antiquos erat pabuli genus, quod Cato ocy mum uocat, quo fiftebant(lego citabant)aluum bubus, Id erat $\grave{e}$ pabulis fegete uiridi defecta ante gelaret. Sura Manilius id aliter interpretatur, $\&$ tradit fabæ modios decem; uiciæ duros, tantundem \& eruilia in iugero autumno mifceri \& feri folitos: Melius \& auena Græca,cui non cadit femẽ, ad. mixta. Hoc uocitatum ocymum, boum q́s caufa feri folitum. Varro appellatum à celeritate proueni endi,à Graco quod w̉xus dicunt(Plinius)quod ualet cito: fimiliter quoque ocymum (lego ocimum) 60 in horto. Hoc amplius dictum ocymum, quod citat aluum bubus, Varro: nimirum intelligens de ocymo Suræ Manilị. Ocimum per iôta herba illa odorata eft, quam uulgo nomine Graco bafili.

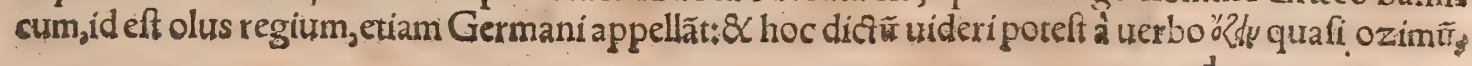


ppter odoris in co fuauitate. Ocymũ uero per y, uel qu cito pueniat dictũ, uel $q$ citet altư bobus, qui bus purgãdi gratia datur, farraginis uel pabuli genus eft, nempe fegetes fectæ trirides antequã fili. quêtur. Cótrà, ex fegete, ubi fata admifta, hordeư, \& uicia, \& legumina, pabuli caufa funt: Inde quod far ferro cafum, farrago dictũ : aut quod primum in farracea fegete feri coptum. Ea equijiumenta, uerno tempore purgantur, ac etiam faginantur, Varro. Plinius ocymum antiquos appellaffe tradit pabulum, umbra patiens, quod celerrime (tertio ftatimà fatu die) proueniat. Cato in uinea uetere feri iubet, nifi macra fit. Quod fecale atç farrago appellatur ( Gallis fegle, Germanis roggein) occari cantum defiderat. Taurini fub alpibus afiam uocant, deterrimum, \& tantưm ad arcendam famem utile. Duplici ratione apud nos(inquit Ruellius)(ecale feritur, aut fimplex, uel triticum aut far mifce cur æquis ferè partibus. Mifcellaneam hanc fegetem Galli miftellam quafi mifcellam nominãt: Con. ditiuamć

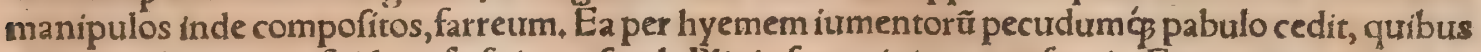
etiam pro latamine eft:id caufa fuit cur fecale Plinio farraginis genus fuerit. Farrago ex recrenen. tis farris prædenfa feritur, admifta aliquando \& uicia. Eade in A frica fit ex hordeo, undehordeacea farrago dicitur. Farragini qux ex hordeo eft, Columella pabulorum fecundas partes tribuit eam in reftibili fter coratiffimo loco \& altero fulco ferere cóuenit. Fit optima cum cantherini hordei decem modịs iugerum obferitur circa æquinoftium autumnale, fed impendentibus plưựs, ut cófita riga. taćs imbribus celeriter prodeat, $\&$ confirmetur ante hyemis uiolentiã. Nam frigoribus cum alia pa: bula defecerunt, ea bubus cateris ́́p pecudibus optime diffecta prabetur, \& fi depafcere fapius uo: les, ufçin menfem Maium fufficit. Quòd fi etiam femen ex ea uoles percipere, à Calendis Martrïs pe cora depellenda, $\&$ ab omni noxa defendenda eft, ut fit idonea frugibus: Hactenus Ruellius. Hine colligimus farraginis uocabulum ad diuerfa tum pabula, tum remedia, tưm fimplicia, quàm compo. fita pertinere. Farrago fimplex eft, ut fecale, hordeum, ocymum, far aut farris recrementa potius;mi. xta,cum triticum, uel auena, uel quauis legumina alicui iam dicfor um mifcentur in fatione. Grack mixtam farraginem ad equos purgandos graftin uocant:fed quæ circa farraginem ad equos priua: cim fpectant, in illis dicemus fuo loco: Hic enim communia quadam libet de farragine adferre, quòd ea non bubus folum, fed omni pecudi conueniat. Sementim facito ita, ocymum, uiciam, foenum gracum, fabam, eruum, pabulum bubus ferito, Cato cap. 27. Plinius lib.17.cap.22, circa finem, ocy mum ipfum à ueteribus pabulum appellatum fribit, cum $C_{\text {ato }} \&$ hîc diftinguat, \& rurfus cap، 54 . his uerbis, Per uer cum arabitur antequam ocymum nafcatur, des quod edant bubus pabulum. Id jo

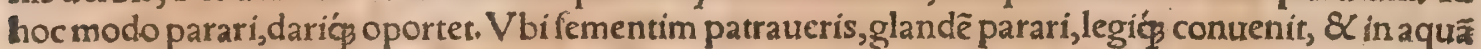
conịci, Inde femodios, fingulis bubus indies dari oportet, aut modium uinaceorum, quos in dolium condideris. At fi non laborabunt, pafcantur, fatius erit. Interdiu pafcito, noctu foeni pondo xx v. uni boui dato. Si foenum non erit, frondem iligneam \& ederaceam dato. Paleas triticeas, \& ordez ceas, uriciam, ‘cus fabaginum, uel de lupino, item de cxteris frugibus omnia condito. Cum framen. ta condes, qua herbolifima erunt in tecfo condito, 8 fale fuperfpargito. Deinde ea pro fono dato: $V$ bi uerno dare cœperis, modium glandis aut uinaceorum dato, aut modium lupini macerati, \& fae ni pondo $\mathrm{x}$ V. Vbi ocymum tempeftiuum erit,dato primum, Manibus carpito, id renafcetur : quod falcula fecueris, non renafcetur. V/f̧̧ ocymum da to, donec arefcat, ita temperato, poft uiciam dato, poftea panicum dato, fecundum panicimm frondem ulmeam dato. Si populneã habueris, admífceto, 4 ut ulmea fatis fiet. V bi ulmeam non habebis, querneam \& ficulneam dato. Nihil eft quod magis ex. pediat, quàm boures bene curare. Boues nifi per hyemem cum non arabunt, pafci nô oportet. Nam uiride cum edunt, femper id expectant: Et fifcellas habere oportet, ne herbam fectentur cum arabüt, Hæc Cato: 8 alibi capite 6o. Bubus cibaria annua in iuga fingula lupini modios $c$ x x. ac glandis modio C C XL, foeni pondo L XX1.ocymi tantundem:fabx modios XX.uicix modios XXX. Præte rea peneratim uideto uti fatis uicix feras. Pabulum cum feres, multas fationes facito. Omne pabue I un primum, ocymum, farraginem, uiciam, nouiffime foenum fecari oportet, Varro 1 .31. Ecdem in loco Varronis erratum effe puto, quood ocymum in horto, hoc eft bafilicum, ut ego interpretor, fimi: liter per ypfilon feribat, $\&$ ab eodem uocabulü w̉u's, quod ualet cito, deducat: Quod etfi admittam, per iôta tamen differentix caufa fcribi debuit, utueteres Græci omnes fcribunt. Exiftimo certe ocy = jo mum fur generis plantam effe : deinde etiam quafuis fegetes fiue unius fiue diuerforum generũ qua uirides fecabantur pecudum uel pabuli uel purgationis caufa eodem nomine dictas apud Varrone. Tertio etiam farraginem proprie diftam, hoc eft feminum $\&$ leguminum diterforum mifcelam:po fremo bafilicum olus, quod recentiorum quidam cum ocymo pabulo cófundit;et ocymum interpre. eatus genus illud frumenti, quod uulgo betoentosm, id eft paganicum frumentum appellatur, ( $n o n$ alia ratione motus, quàm quod pecudiburs faginandis utile fir, in eumós ufum in nonnullis Germà nix locis feratur ) eadem ei attribuit qux fcriprores ocimo oleri $\&$ herbæ odorat $x$, à qua id prorfus non diftinguit, ac per imperitiam illos reprehendit qui bafilicon ocimum Diofcoridis faciunt. Sed nimis operofum foret omnes omnium prafertinn noftri temporis errores reprehendere. Io. Ruellius idem frumentum paganicum, ueterum eryfimon cereale uel irionem Plinï effe contendit:fed impro 60 batur à Matthæolo Senenfi, inde quod irione uirente nullum animal uefcatur, \& folia ei fanguinea tribuantur: frumenti uero Turcici non folia fed caulis rubeat;nec co abftinçant pecudes, imo auide uefrantur: 


\section{Bos\&Vacca. C. Lib. I. 43}

tuelcầtur: deniç quod nihil fefamo cominune aut fimile habeat. Idem ab Italis circa Tridentum For imentone, \& alibi Saracinum uocari fcribit, Ruellius apud Gallos uelarum qutondam, nunc ireon, \& frumentum Turcicum, quod auorum ætare é Gracia uel Afia uenerit, Folitum ei hederacium, fca pus grandis per faftigium paniculas exerit,triangulis rariufcule coaceruatis granis, quae foliaceis membranis concepta detinẽtur. Ea pecudem omnem cateráqú ueterina quàm optimé faginant : $8<$ in candidiffimam teruntur molunturúe farinam, qux cum annona premit inopia in panificia fubs inde cogitur. Cum ematuruit granum fuis apludis explicitũ fagina glandis nucleo fimile nofcitur; quod incoquunt ruftici, ut bubus, iumentis pecudibusćs cedat in pabulum, cuius ufu uehementer glifcit fagina:mire enim ab eifdem expetitur. Iam agri pleriç in Gallia hac fruge rubent. Trionum io conftat ubiqs non irionem à Theodoro uterti, forfitan quod ei femen triangulum. Plinius herba ole raç̨a, qua eryfimon quoø̧ Gręcis ntmcupatur à cereali longe diffidẽs, uires permiftim affignauit, Hac Ruellius. Et quanquam hac ad fuperiorem locum de pabulo quadrare uideantur, irrepferune $\operatorname{tame} \tilde{e}$ huc nobis ocymi \& farraginis ratione, quibus ueteres ad medicădos boutes \& iumêta urebant:

Limeum herba appellatur à Gallis, qua fagittas in uenati tingunt medicamento qutod uene: num ceruarium uocant. Ex hac in tres modios faliuati additur, quantum in una fagitta addi foler: ita offa demittitur in boum faucibus in morbis. Alligari poftea ad prafepia oportet, donec purgen= tur. Infanire enim folent. Si fudor infequitur, aqua frigida perfundi, Plinius. Herbæ limei mentione nufquam alibi ullam reperi:exiftimo autem de generibus aconiti effe, quod Ariftoteles in Miris nar rationibus xenicum appellet, Nam id quog uenenum effe fcribit quo Celtr fagittas inficiant; cer, co uos aliaś́ feras uenaturi. Toram hodie uocant, ut in Lupis occafione aconiti docebímus. In Gallia fané ante non multos annos aconiti coerulei radicibus ad purgationes etiam hominum periculofá \& capitali infeitia utebantur:quod \& 10. Syluius in Gallis fuis reprehendit, \& ipfe in Sabaudia fieri obferuaui. 『In Galeni libello de medicinis parabilibus cap, 100. fuperftitiofam curam ut ne bo: ures ægrotẽt hurufmodi legimus: Cerui cornu fuper Panis dei facellum ponito, candelam accendito, \& ne interdiu accenfam obliuione demittito: \& in tempore fançum Demufarim inuoca to ac tollito:armenta tua \& uitam cuftodient. Noftrates quidam ualetudinis gratia bubus confer uandx pridie diui Martini, hoc eft quarto idus Nouembris cepas prabent aut ingerunt. Sunt quit ad omnes occultos morbos, uifcerum pratertim, ut pulmonis 8 iecoris, tam hominum quàm pecoz rum,edendas offerant radiculas rubix fyluatica, quam uulgò uocamus walomeiffer ab excellen3o tia, \& lỉberth raut, id eft iecorariam. Nafcicur in fyluis tantum \& umbrofis locis:alia quàm uulgaris rubia agreftis, congener tamen:breuior ea, caulibus rectis, folijs maioribus, fimiliter per genicula ra diatis, candidis flofculorum corymbis, de qua plura in Cane rabido dicemus, ubi alyfí mentio incidet. Peritiores quidam noftratium, feptimo quog die, fi domifit pecus: fin abfit in montibus, per fingulos menfes femel remedium hoc cum linctu(falem fic uocât)uorandum exhibent: quod ex he. dera terreftri uuigo dicta, baccis iuniperi, uifco de pyro arbore, $\&$ pulmonaria arboribus ad́nafcen. te conficiunt:praferuatà morbis uifcerum. Ingeritur eis etiam contra omnes morbofas fufpiciones gentianæ quædam fpecies, flore coruleo, radicibus albis amariftimis, \& quafi de induftria decuffa. tim incifis, unde aliqui uernacula lingua radicẽ cruciatã uocitant, alị moselgeer. Nafcitur in ficcis, afperis, \& faxofis collibus. Celebratur eius praconiũ, mobelgeet, iff aller treuter ein eer. Priuatim 40 uero aduẹrfus lumbricos \& peftilentix luem laudatur. Tempore uerno, \& apud nos menfe Maio potiffimum, ros mellitus interdum cadit, Græci aëromeli \& drofomeli uocant, Ebrai mannam; nos ftri oas bimmelbung, id eft mel coelefte, hoc rore madidas herbas fi pecora pafcant, multi peftem fé qui perfuafi funt. Chamaleontis nigri fuccus iuuencas necat anginæ modo: quare à quibufdam ulophonon uocatur, Plinius. Helleboro nigro equi, boues, fues necantur:itacs cauent id, cum can. dido uefcantur, Idem, Circa Scytharum \& Medorum dictam Thraciæ regionem, locưm effe aiũe uiginti feréftadiorum fpacio, qui hordeum producit, quo homines uéfcuntur, equi yerò $\&$ boues cæeteraç animalia abftinent, Ariftoteles in Mirabilibus, Gramen quod nafcitur in Cilicia, ab in colis cinna dictum, inflammat boues qux id frequenter comedunt dum eft uiride, Diofcorides. For fan $\&$ hą aconiti aliqua fpecies eft:nã Theophraftus aconitũ defcribit herbã breı̃e qux nihil fuper o uacui habeat, frumento fimilem, femine tamen non fpiceo. Quod fi ita eft, nihil impedit quin etiam gramini fimile, aut quadã eius fpecies dicatur. Nam (ut obiter moneã)aconiti nomen ad uarias for* mis q́plurimum differentes herbas uagum uidetur, cum aliud cyclamini, aliud platani, aliud feridis aut iridis potius folijs aconitum ab antiquis commemoretur, Sola inexpugnabilis ueneni uis tabifi= ca omnibus illis, ut uideo, communis eft. TProuenit apud nos noxia quxdã herba, qua non ip. fa folum boures abftinent, led etiã gramine circumcirca nafcente, licet eodem equi uefcantur. $R$ us ftici quidã apud nos malum Horem, alij malum Henricum appellât: ut atriplicis quoddã fylueftre ge nus bonum Henricum, Caulis ei albus, pedalis, folidus, \& fubftantia quadam humida mollí́ sinfar çus. Flores hirfuti, purpuraifcentes, in fpicâ congefti ut in tefticulo canis ferè, femina rotundả inftar milī. Guftu fubaftringit. Ra dice albiflima, nodis quibufdã exafperata $\&$ ueluri fquamata (ut faxifrà

60 ga alpina, cui folia quina funt fimilia fraxini folijs: $\&$ ut fanicula alba Hefforum)longiflima, ad quin que uel fex cubitos defcendente:quãmuis raro integra effodiatur:recens plané frigida humidać̣ ta ctu percipitur. Vites uicinas corrumpit \& frigore fuo ladit. Quamobrem diligencer à uinitoriburs 
effoffa in aquam reijcitur, ne in terra denuo compreliendere poffit. Plurimum circa eam graminis abundat. Folijs caret. Vis enafcenti tanta, ut uel per paurimentum, fi quod obfiftat, eluctetur. Vere tantum prodit. Flos folis impatiens, craffus, aquofus, intra triduum ui folis marcefcit. Natales ei ui nea collinę, \& prata fyluis proxima. Aưumno, ut audio, rurfus erumpit. Eadêe, nifi fallor, eggolethros Plinĭ fuerit, de qua ille lib,11.cap.13. Herba eft(inquit) ab exitio $\&$ iumentorũ quide , fed pracipue caprarū, appellata ęgolethros, Huius flores concipiunt noxíum uirus aquofo uere marcefcentes. Ita fitut non omnibus annis fentiatur hoc malum, Ex his floribus apes Heraclex in Ponto mel uenena: tum conficiunt; Hęc Plinitus: Nec alibi quícquam de ea aliud proditum legi,Mel Heracleoticum(ut fcribit Ruellius lib.3.cap.21.) ex herba fieri candida commemorant, qua agolethros uocetur: Símili ter etiam Hermolaus Barbarus legit, tan $\not$ ex Plinio. Quanquam autem illius noftra fuperficies ex albo palleat, radix albiffima fit:ex Plinio tamen de colore eius nihil cognoui: fed alia Plinï libro 18. ca.17. herba alba uídet̆, panico fímilis, occupãs arua, pecori quoģ mortifera, Forfan $\&$ hac aconito Theophrafti, quod frumento fimile facit, congener fuerit. Hieronymus Tragus lib.2. cap. 35. inter uitia frugum fexto loco defcribit herbam panico culmis nodis ̧́ ac foliorum uaginis fimilem, pror. fus inutilem $\&$ uitiofam, inter milium $\&$ panicum nafcentem. Et mox aliam fuperiori non diffimilem, fed longè maiorem:cuius folia ab initio planè milium referant, longis \& afperis ariftis armatã, quæ lapparum inftar ueftibus hæreant:in aruis milio $8 \mathrm{~L}$ hordeo confitis frequentem.Hanc ait ualde ncxiam effe, \& euritari à bubus. Harum altera proculdubio erit illa Plinï herba alba panico fimilis. Hicronymus ipfe alteram phalaridem Diofcoridis effe conịcit, quod nefim prolixior in præfentia non refutabołalteram miliariam Plinin, quã ille milium implicando enecare fcribit, cum ex duabus 20 illis ab Hieronymo defcriptis neutra implicet. Forfitan autem illa pofterior non aliam ob caufam bubus noxia eft, quàm quod interiora partium fuarum afperitate lædat, đHerbæ iam diçææ, quã agolethron reor, perquàm fimilis orobanche eft, nifi radice differret: $\&$ caule magis purpurafcente: $\&$ quoniam ea quó $\$$ ad boires $\mathcal{X}$ alia quædam animalia pertinet, diligentius eam defcribemus. Orobãche(inquit Diofcorides) cauliculus eft fefquipedalis, \& interdum maior, fubruber, hirfutus, tener, fine folio, pinguis, flore fubalbido, \& (aliâs uel) in luteũ uergente, radice digiti craffitudine, \& cum ariditate flaccefcit caulis, fiftulofa (cum radix ariditate flaccefcit fcapus dehifens in rimas diff? lit, Ruellius.) Hanc inter quædam legumina nafci conftat, \& ea ftrangulare, unde orobãchæ fibi co gnomẽtum ufurpauit, Eftur, ut olus, cruda, 8 in patinis, afparagi modo(dum tenera eft, Plinius)de cocta:legumentis addita, coctionem accelerare creditur, Hæc Diofcorides, \& $\&$ Plinius fimiliter feré. In quiburdam cedicibus adduntur $\&$ ifte nomenclatura: Sunt qui cynomorion, qui leonem appel. lent,Cyprị thyrfinen, lingua communis lupum,Plinius etiã libro 22.ca.ultimo aít à fimilitudine ca. nini genitalis cynomorion ab aliquibus nominari: non mala neqs inconcinna fimilitudine, fi plant $\bar{z}$ contempletur aliquis: qux à radice furgens, nudo, glabro fingulariç caule, in fummo folia aliquor confercta, \& inter ea emergentes habet flores fimul, \& quafi in glomerem collecta omnia:qua forma caninum genitale in fummo eft, craffius $\&$ quafi galerítum. Vidimus nos eruianginã, nec quícquã inter fegetes 8 legumina per æeftatem frequentius inuenitur, Marcellus Vergilius. Miror autem $\$$ cum orobanchen fibi notam profiteatur, nihil interim dicat in Theophraftum, cuius uerba citat, qui non recte de orobanche fcribit quod circumligãdo fe herbas adnatas ftrãgulet(Marcellus etiã inep= rius effert, cirris quibufdã circumligãdo fe, frribens)id quod Plinius quoç Theophraftum, ut folet, 40 imitatus, libro 18. cap +17 , his uerbis fcribit, Eft herba qua cicer enecat $\&$ eruum circumligãdo $f e$, ue catur orobãche. Quãuis Matthaolus fe aliquid huiufmodi apud Plinium legiffe neget: qui 8 ipfe fur per hoc errore Theophraftum non immerito arguit. Nam Theophraftus libro s. de Caufis, cap. 12 .

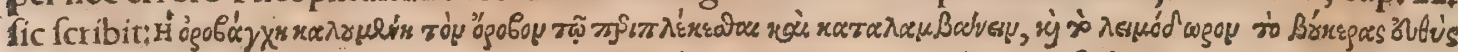
rî fi? $\pi$ aca quvoulwov. Hac Grace apponere malui, ne quis non authorem, fed interpretem erroris in. cufaret. Orobanche certe, ut fciunt oculati teftes, nequaça amplexicaulis eft : fed fola prafentia fua non attaças etiã necat, ut Matthæolus fentit:ego radicis hoc maleficium effe putauerim, aut quia ali mentum omne uicinis fubtrahit, ut apparet ex eo quod fucci pleniffima eft. Naf́citur autem non in. rer legumina folum, fed etiã in aruis frumento et cannabi confitis. Flores etiã ut caulis ad rubicundữ

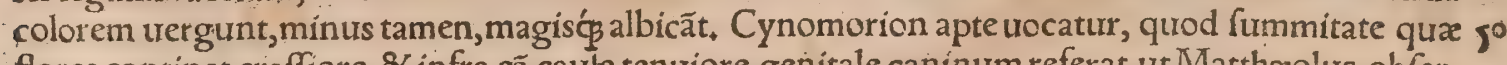
flores continet craffiore, $\mathcal{X}$ infra ea caule tenuiore, genitale caninum referat, ut Matthacolurs obfer. uauit:qui hac etiã addit, à rufticis in Italia hancherbã uocari lupã, eo quod plantas uicinas deuora. re uideatur:alibi caudã leonis:alibi torã, quoniã certò conftet ut primum uacca hanc herbã guftaue rint, tauros ab eis requiri. Alias herbas toræ nominæ in Lupo infra demonftrabo in mentione aco. niti.Orobãchen frigidã \& ficcã effe in primo ordine Galenus \& Aegineta frribunt. A recenti Gra= cia of prioleon, quafí legumen leoninum, aut leonteos botane (aliâs leontobotanon) quod eft herba leonina dicitur. In Parifienfi agro tenia, à tenendo, ut arbitror(inquit Ruclius)quod tenaci noxa

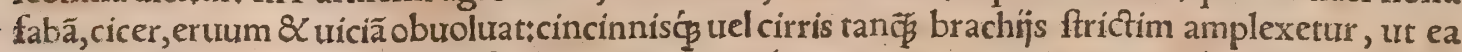
penitus obftrãgulet+uel quod peftis hæc pertinacius hæreat, ut manantia capitis ulcera, qux uulgus appeliat tineas, in pueris. In aruis (ut aiunt)non prodibit, fi in quatuor corum angulis, 8 medio, rho 60 dodaphnæ ramuli pangãtur:hoc eodem remedio putã́t legumen omne à noxa uindicari. Qui uolũ hanc frugum peftem prorfus aboleri, quinque teftas creta depingunt, Herculis effigiem leonem 


\section{Bos \&Vacca C. Lib. I.}

Itrangulantis referentes, $\&$ in quaturor agrorum angulis at $\$$ in medio collocant. Sunt qui delineata co modo teftam in area tantum media; ut hanc amoliantur perniciem, iubeãt obrui, Dernocritus affirmat orobanchen herbã confeftim abigi,fi mulier quà in menftruis ef, folutis crinibus $\&$ nido corpore, gallum in manibus tenens, aream circumeat, Ita tralidiora coalefcere legumina teftantur, qui hac fuperftitione funt imbutíquippe cum herba gallinaceum terens gallum delitefcat, Hac Ruellius, Âpparet autem non recté cognitã ei orobanchen fuiffe, cum leguminibùs eam obutolui, fuiş̧́ ea brachị́s amplexari, Plinium \& Theophraftũ fecutus, , fcribat: quod aut falfum eft, aut alia Diofcoridis, alia Thieophrafti orobanche fuerit, quod mihi uerifimile non fit:feré cnim una unius re: eadem ubiqg noxa eft.Idem Rurellius libro 1.cap, 8, orobanchę folia pínguía tríbuit,cum Diofcorides io eam fine folńs faciat:fed excufari poteft quod omnino breuifima cauliç̧ harêtia $\&$ alternis digefta habeat, ut nulla uideri polfint nifi quis de proximo intueatur quod autem in fummo caule folia ali quot ei confercta fint, ut Marcellus teftatur, nufquam uidi. Hoc infuper obfertrauí guftu fubdulcem. effe, ut non fitmirum in cibis recipi folitam: floribus fuatuiter odoratis, cauis, oblongis, in cacumine fpicatim hærentibus, ficut in cynoforchi:eundem radici thyrfo ac floribus colorē elfe êluteo candé dumiradicem craffam, nodofam, plurimis capillatam fibris, Cyprios thyrfinen appellafle fuŕpicor, quod tota ferè thyrfus fit, id eft fcapus planè rectus, Ab imperitis quibufdam falfo hypocifthidis no: mine appellatam olím audire memini. Qui picturam eius defiderat, in Germanico de plantis libro Hicronymi Tragi reperiet, inter fatyria (ut uocat) nono loco: in quo mireris cur fores ei neget, cum cofdem imago adiecta depictos exhibeat: $N a f$ ítur(inquit)in humidis $\&$ umbrofis fyluis mêfe $M a o_{3}$ 2o catile pingui fatyrio fimili, coloreligni aut fungortm in fyluis nafcentitum, radicemultis intricata fif bris, ut in Phu $8 \mathrm{C}$ elleboro nigro: Vitium omnino inter herbas, ut apparet; Hac Tragus。 to nullum pecus, nullum animal pafcitur: etfi fructum $\&$ folium nil nocere pradicent; uin mortife ram in radice tantum haberi, Boues, oues, iumenta, omnem '́s quadrupedem necat, impofita ueren= dis fominei fexus radice, folio quidem intra eundem diem, Ruellius. Ego in mótibus circa ip a uac carum ftabula \& tuguría paftorum magnam fape cœrulei præcipue aconiti copiam uidi, nam cuma à bubus non attingatur, copiofiffimum prouenit, Quemadmodum 8 alia quadam herba mire fre: quens circa eadem uiret, qua fímiliter boues abftinent, bonam uel bòne Germanice tiocãt, cubitali aut altiore caule,erecto: folijs incanis lapathi quodammodo (fi bene memini) figura, floribus luteis, odoratis, fed parum grato odore, calendulæ fimilibus, minoribus tamen \& anguftioribus in capituli

30 circuitur folíjs. Herbam lixiuio injiciunt, ut flatuo colore id commendet: Hanc caltham alpinam uro: care licebit, donec alius aliud nomen adferat. Eft $\&$ alia qua boues abhorrent, amplexicaulis, an nua, conuoluolo fimilis natura folíş́s, qua etiam proxime ad paganicum frumentũ hederę folịs fur pra defcriptum accedunt, acutiora tantum nigrioraç funt: cuius $\&$ femen refert figura triangula, fed minus eo ac nigrius eft: Hinc quoos lingua uernacula for wart wintocn, id eft uolixcrum nigrum appellatur:ab alihs fpin, eo quod coliculis fuis tanquam filis tenubus proxima quaç intricet, \& ir= retita in folum deprimat. Radix palmi longitudinẹn non excedit, fimplex, rotũda, Luxuria omnis in coliculos abit, quibus color f padiceus, genicula ut in polygono. Flores plurimi, albí, exigui, in: odori, infipidi. Nafcitur cum alibi, tum inter cannabin, eamç inuadit. Hanc Hieronymus Tragus libro 2.cap.33.0robanchen propter fimile maleficium effe fufpicatur, non affirmat tamen cum deficri 40 ptio ueterum longe diffideat. Poftremo quxdam blatken Germanis dicta, ut audio(perfonatam elfe conício)folins latis, cum rore madida â bubus depafcitur, inflat eas adeò, ut aliquandơ rumpantur, nifi curfu agitati incalefcant, \& per aluum rëjciant. In Burgundia frequentius hoc malum euenire aiunt, quod maior eius herbx illic copia fit. Cum rore non madet, obeffe negant, \& appeti alioqui ab ipfis, TConuenit huric loco etiam machinæ def criptio, quãquam communis omnium maiorưm quadrupedum, qua claufa iumenta boureśç curentur. Machina igitur (inquít Columella) fabrican da eft, ut \& propior tutusć́ acceffus ad pecudem medentibus fit, nec in ipfa curatione quadrupes re luctando remedia refpuat. Eft autem talis machina forma: Roboreis axibus(affibus) compingitur fo lum, quod habet in longitudinem pedes nourem, $\&$ in latitudinem pars prior dupondium femifem (pedes duos \& $\mathrm{femis}$, Vegetius)pars pofterior quatuor pedes. Huic folofeptenum pedum fipites re so cti ab utrogs latere quaterni applicantur: î̀ autem quaturor angulis affixi funt, omneśq tranfuerfis fex temonibus quafi uacerra inter feligantur, ita utà pofteriore parte, quęlation eft, uelut in cauream quadrupes poffit induci, nec exire alia parte prohibentibus aduerfis axiculis:primis autem duobus ftatuminibus imponitur firmum iugum ( $\operatorname{cranfuerfum}$ tigillum ad modum iugi, ad quod equorum capita uel boum cornua religantur, Vegetius)ad quod iumenta capiftrantur, uel boum cornua reljgantur:ubi poffunt etiam numelli fabricari, ut inferto capite defcendentibus per foramina regulis ceruix teneatur:cæeterum corpus laqueatum, \& -diftentum temonibus obligatur, fićḉ ímmotum ani mal medentis arbitrio eft expofitum. Hachactenus.

Deinceps de morbis fingillatim dicemus, generalibus primum 8 contagiofis, poltea réliquis. Morbus qui appellatur malis (de quo etiam in A fino iam diximus) diuerfo genere paffionum emis 60 grans, equini generis perplures contagione confumit, boues quoq idem interficit, fed à diuerfis dis. uerfo nomine uocatur. Si quando bouem tentauerit, iftis agnofcitur fignis: Erit bos pilo horridus $Q$ triftis, ftupentibus oculis, ceruice deiecta, faliuis aflidue per os fluentibus, inceffus pigrior, f pina riz 
gidior, faftidium maximum, pauca ruminatio cui fi inter initia fubuenire tentaueris, difcrimen eua det:fi per negligentiam adhibeatur tardior cura, uretuftioris morbi non poteft fuperari pernicies ro. borata. Inter exordia igitur adhibebis remedia qua fupra defcripfimus tanquam aduerfus omnes morbos, qua parantur ex filla, uel lupino \& cupreflo, uel allio, trel marrubio, uel amurca: urel theria cam diapente, \&c. Si porcinum ftercus, præfertim fuis ægræ; bos deuorauerit; ftatim peftilentiam contagionis folius mallei(malidis)fuftinet morbi. Qui cum femel in gregem uel armentorum uel do. mitorum incefferit iumentorum, ftatim omnia animalia qua leuem fufpitionem habuerint, de pol. feffione tollenda funt, $\&$ diftriburenda illis locis, ubi nullum pecus pafcitur, ut nec fibi inuicem nee alp̈s noceant. Confeftim(inquit Columella)mutandus eft coli ftatus $\&$ in plures diftributo pecore lóginqua regiones petẽdx funt, atç̧ ita fegregãdi à fanis morbidi, nè quis intericuniat qui cōtagione 10 cateros labefaciat. Nã pafcendo herbas inficiunt, bibendo fontes, ftabulo prafepiałet quamuis fani boues odore morbidorum afflante depereunt. V fog eò etiam mortua cadauera ultra fines uillix pro ijcienda funt, $\&$ altiflime obruenda fub terris, ne forte ipforum corporum(halitu ) interna fanorum contingantur S\& pereant.

TV no quidem uocabulo peftilentia appellatur, fed habet plurimas fpecies quas enumerare nó licet:facilius ipla principia à diligentibus intelligi poffint. Eft itaç humidus humor (humida malis) quoties per os \& nares humor effluit bobus, \& faftidium agritudóc confequitur. Eft ficcus, quoties nullus humor apparet, fed animal quotidie macefcit \& fit deterius, neciuxta confuetudinem ap. petit cibos, Eft articularis, quoties interdum de prioribus, interdum de pofterioribus pedibus clau dicant boues, cum habeant ungulas fanas. Eft \& fubrenalis, quoties à pofterioribus debilitas appa 20 ret, $\&$ lumbi dolere creduntur. Eft farciminofus, quoties per totum cor pus bobus tubercula exe= unt, aperiunt fe, \& quafi fanantur, \& iterum in alijs locis exeunt. Eft \& fubtercutaneus, quoties hu mor peffimus in diuerfís partibus corporis bobus erumpit $\&$ decurrit. Eft elephantiafis quoties uelut fcabies minutæ cicatrices exeunt extra corium, $\&$ ad fimilitudinêlenticula. EAt mania, qua infectis bobus eripit fenfum, ut nec audiant more folito, nec uideant:ex qua paffione celerrime mo riuntur, quamuis hilares pingueş́́ uideantur. Hi omnes morbi contagionefunt pleni, \& fi unum animal apprehenderint, celeriter ad omnia tranfeunt, \& fic interdum aut integris armentis, aut om nibus domitis afferunt interitus, Sed de malide morbo, eiusq́ nominibus, differentrijs $\&$ remedn̄js plura dicemus in Equis, nunc ex Vegetio \& Columella boum contra hanc peftem remedia fubiun gamus, Euincendi funt igitur quamuis peftiferi morbi, \& exquifitis remedís propulfandi,Panacis $3^{\circ}$ $\&$ eryngî̉ radices foniculi feminibus mifcend $x, \&$ cum defruti ac moliti tritici farina, candentíç a. qua confpergendæ, eoćp medicamine faliuandum agrotum pecus, Columella.'Panacemà feplalia= rins compara. Eryngion autem herba dicitur, qua in littore nafcitur prope undam maris, florem habet quafi aureum uel galbineum, folia eius funt quafi folia cardui fylueftris, inter arenas littorum largifime fpargitur thas effodies, $8 \mathrm{C}$ in umbra ficcatas feruabis, aduerfus morbum tam equorum boum plurimum profunt. Potio ex eis componitur ifta: $R$ adicum panacis \& eryngị \& feminis foz. niculi, fingulorum uncias ternas pariter deteras diligenter, addasó̧ farina triticeæ fextarium, ita ut prius frumentum frangas \& molas:quæ omnia de calida feruente confperges, \& cum melle uel fa= pa nourenas offas fingulis diebus digeres, Vegetius. Tum paribus cafia myrrhæcós $\&$ thuris ponde ribus, ac tantundem fanguinis marina teftudinis mifcetur potio, cum uini ueteris fextarñs tribus, 4 . $\&$ ita parua res infinditur. Sed ipfum medicamentum pondere fex unciarum diuifum, portione $\mathcal{E}_{=}$ qua per triduum cum uino dediffe fat erit, Columella.Sanguinẽ marinæ teftudinis colliges, $8 \times$ cum uino per os dabis:quã quia inuenire difficile eft, uulgarium teftudinum prodefle $x$ ftimant: Quod utrum bene opinẽtur, ufus uriderit. Nam aucfores de terreftri(marina legendum puto)teftudine tra cfauerunt, Puluerem etiá cafia fiftula, nec non etiam thuris pro aqua parte admífcbis, ex eo unã femunciã cum fextario uini ueteris in die per nares bouis infundes:Quod medicamentum per tri= duum facies. Morbi quoç quos fuperius nominauimus amari funt, 8 nō nifi amaris potionibus fuperantur. Nam contraria contrarńs potionibus curantur ratione medicinæ, ideós puluerem her.

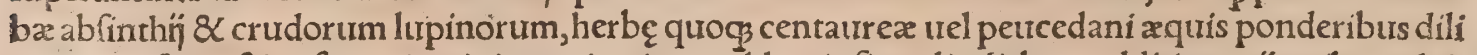
genter mif́ceto, $\&$ in fextario unini ueteris trina cochlearia fingulis diebus, additis uncris tribus olei, jo per os dato, Veget. Noftri etiam paftores \& opiliones abfinthïflores aridos contritos faliģ́ permis ftos, ouibus ac bubus prębent, quotidiana experientia edocti, omne genus interiores morbos abfin thio curari, dolores fedari, \& excrementa purgari, Hieron. Tragus, Prafens aduerfus peftem re medium cognouimus radicula, quam paftores cófiliginem uocant(alin pulmonariá, alij tantundem radiculam, Vegetius.) Ea in Marfís montibus plurimum nafcitur, omníós pecori maximé eft faluta ris, Lxua manu effoditur ante folis ortum:fic enim lecta maiorem uim creditur habere. V fus eitus uraditur talis:A enea fubula(acu urel acuto cuprino)pars auriculę latilfima circumfcribitur(quafi in circulo fignatur)ita ut manante fanguine tanquã o literæ ductus appareat orbiculus. Hoc $\&$ intrin fecus \& ex fuperiore parte auricula cum factum eft, media pars defcripti orbiculi eadé fubula tran fuitur, \& facto foramini pradicta radicula inferitur:quam cum recens plaga comprehendit, ita con 60 tinet, ut elabi non poffit. In eam deinde auricula momnis uis morbi, peftilens ćs urirus elicitur, donec pars qua fubula circumfcripta eft, demortua excidat, \& minima partis iaciura caput conferuatur. 
Eft autem confiligo herba illa quam Germanileustrut, id eft pediculariam uocant ( nam hac quocg ut ueratro albo contra pedículos pecorum utuntur)aliqui fol langenwursel: Galli pedem leonis, uel pomeleam, id eft pulmonariam, Sabaudi Marficam herbam : Graci recẽtiores ueterinarï diapyron, id eft feruidam \& ignex facultatis herbam. Eft enim temperaméto calidifimo, per omnia feréifidem quibus ueratrum nigrum uiribus pradita, Plinius à Marfis repertam fcribit, \& inde Sabaudicum nomen factum uidecur. Cum filigine nihil planè commune habet, ut fufpicer Latinos cum Gracam trocem diapyron imitari tellent, $\dot{\alpha} \pi \dot{\partial}$ mon $\pi v \rho \tilde{u}$, id eft tritico, cuius fpecies filigo eft, uocem compolitam credidiffe:cum ab igne potius defcenderit, ut iam oftedi. Ineft autem feruor ille radici $\&$ femini pres

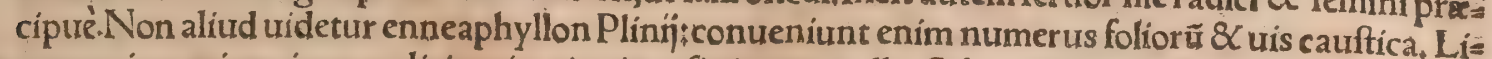
10 quore eius qui per ignem elicitur in uitreis uafis, in nonnullis Sabaudix locis aduerfus peftem hom nibus quoop propinant, ut fudores moueat. Catera qua de hac herba cognoui, quia nihil ad anima. lium hiftoriam pertinent, in aliud tempus differo. Confiligo fi defit, ellebori nigri radicibus codé fuc. ceflu, non bubus folum; fed equis etiam $\&$ fuibus medicandis utemur. In equis tamen cuti pectoris forata radicem inferunt, non auriculæu ut in bubus $\&$ fuibus, Cornelius Celfus etiam uifci folia cum uino trita per nares infundere iubet, Columella. Suffimenta quogs plurimum iutant, fulphur, bitu men, allium, origanum, femen coriandri, carbonibus infperge, \& cooperta boum(capita)fupra uas, in quo fuffimenta incenderis, diutifimé continebis, ut fumus eorum capiat, ac nares impleat, atç ita ad cerebrum \& interna falutari remedio penetret. Sed \& totum fuffire percommodum eft, $u t a b$ co. dem morbo pernicies expellatur, \& catera peftilentia contagio non coinquínet. Vergilius in Ge. 10 orgicis boum peftem his carminibus defcribit:

Ecceautem duro fumans fub tomere taurus Concidit: \& miftum fpumis tromit ore cruorem:

Extremosq̧́ cier gemitus:it tfiftis arator Moerentemabiungens fraterna morte iutuencum: Atø̧ opere in medio defixa relinquit aratra. Non umbra altorum nemorũ, non mollia polfunt Prata mouere animû̃ non qui per faxa tolutus Purior eleciro campum petit amnis:at ima Soluunt latera, atఢ̧ oculos ftupor urget inerteis: Ad terramḉ̧ fluit deuexo pondere ceruix

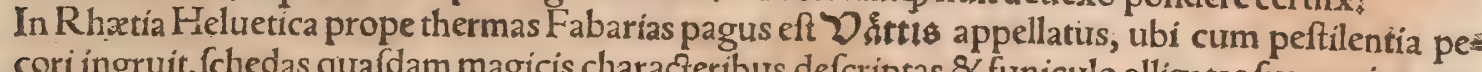
cori ingruit, fchedas quafdam magicis characteribus defcriptas $\&$ funiculo alligatas fupra uiam ex: tendunt, \& pecudes ut fubtus tranfeant impellunt: Sic peftem illico finiri aiunt. Schedas illas à mago quodam anteannos centum dono fe accepiffe teftantur, ut reconciliarentur, cum ille à uicino monte 30 deducto dracone herbas \& fruges qua duxerat proftrauiffet. Peftilentem in quadrupedibus luem

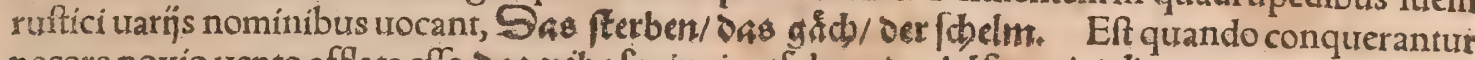
pecora noxio uento afflata effe,, $\mathrm{ab}$ vibefye in ein gfelter ser bofen wins Eommen, quod ex info. lito tremore apparet: Huic malo medentur aftrantia fiuc imperatorix herba radice, qua luna cre. fcente effoffa fit. TDeceftro quo boues infeftantur, 8 in furorem aguntur nonnunquam, inter in fecta traćabimus. TGeneralia igitur remedia aduerfus morbos generales cótagiofośģ retulimus, nunc aduerfus ualetudines, quęfingulis animalibus accidunt, nec in alia tranfeunt, remedia fubiun. gemurs, Vegetius, 6 Hactenus ex Vegetio \& Columella de malide \& peftilëtibus morbis diximus: quibus adhuc addẽdum uidetur malum quod Ariftoteles ręcúgou uocautit, quam Theodorus Gaza, nefcio qua ratione ftrumam tranftulit: Euenit fruma(inquit) ut calidius frequêtítusćp fpiretur:quod 40 denigg in homine febris, idem in boure ftruma eft:indicium morbi, ut demifle aures flacceant, 8 ut comedere nequeant:bréui moriuntur, adapertisḉs pulmo infpicitur putris, Hæc Gaza ex Arifto,

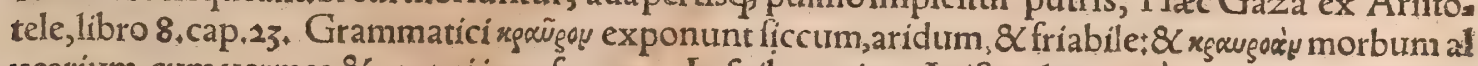
uearium,, $\mathrm{cum}$ uermes $\&$ aranei innafcuntur. In fuibus etiam Ariftoteles pauló ante de eodem mor= bo ksaw yea dixerat(fi recte habent codices excufi) capitis dolorem \& grauitatem definiens, qui plir. res fimul inuadat, $\&$ tribus uel quatuor diebus perimaț, interdum tamen uino per nares infufo cure tur. Ventris etiam profluuium incurabile eodem nomine uocari fcribit.Branchum etiam(Gaza raus cedinem reddit)in fuibus morbum effe Ariftoteles ibidem prodit, in quo maxillax pracipue $\&$ par: res circa branchias inflammentur:eumćs in alịs quoc corporis partibus fieri, ut pede uel aure inter dum:putrefcere protinus membrum 8 ulcus ferpere, donec ad pulmonem deueniat, quo taeto, mor so tem fequi:crefcere hoc uitium celeriter, nec poffe fuem quicquam edere cum ira ęgrotast curari à por carn̈́s cum malum adhuc modicum fenferint, haud alio modo quàm tota parte abfciffa qua copperit. Albertus Magnus Graca troce corrupta crocharon inepte nominauit, ineptior etiam cum uocem Arabicam effe ait:recté uerò, ut iudico, mali origine facit à defluxu capitis: addit experimento confta re, heptaphyllon(uel ut uulgus uocat, tormentillam) tum bubus tum equis faluberrime contra hane luem in potu paftúue dari. Hæc omnia hoc loco referre placuit : quoniam egañgos Ariftoteli dicfus morbus, tum in bubus tum fuibus, non alius mihi uidetur quàm malis humida à V egetio $\&$ recentio ribus Gracis appellatus : quibus cum etiam branchus propter periculum, eiuśćc celeritatem \& pul. monis noxam côuenit, differt autem quod in quibufuis etiam extremis partibus incipiat, jịśç fectis curetur. Non alius etiam quàm malis humida uidetur morbus ille boum, quem Itali uulgo, ut Pe: 60 trus Crefcentienfis fcribit, guttam robeam uocant, Is inuadit ex pabulo potúue nimio, pręcipure por humidas depaftas herbas, \& propter otium $\&$ aëris humiditatem. Vultus $\&$ oculi inflantur: \&, niff curetur, bos moritur. Curatur aût detracto fanguine fub lingua, hoc modo: Duę glandulę fub lingtia 
cultri acuti mucrone pluribus in locis fecantur, \& fanguis copiofe demitur. Fit etiam fuffitus curm thure ad nares bouis. N Nullo autem tempore, 8 minime æeftate, utile eft boues in curfum conci. tari:nam ea res aut cit aluum, aut mouet febrem. Sunt autem febricitantis bouis figna, calor totius corporis, maximè circa os, linguam, \& aures, manantes lachrymæ; caput grauatum, \& nutans, oculi lippi, compreffi(femiclaufi)et introrfum ceu in fouream recôditi:fluidum faliuis os:calidus, longior, \& cum quodam impedimento traçus fpiritus, interdum \& cum gemitu; uenarum inquíetudo, cibi faftidium, Caufa funt, immoderatus labor aut calor. Ferè enim agrotant boues cum laborauerint propter $æ$ ftus, aut propter frigora, aut propter nimium laborem, aut otium diuturnum, aut fi cum exercueris ftatim fine interuallo cibum potumúe dederis. Conuenit autem febricitantiabfineri ci= bo uno die:Poftero deinde exigutum fanguinem ieiuno fub cauda emitti, atç interpófita hor $\mathrm{mo}=10$ dica magnitudinis coctos braflica coliculos triginta ex oleo \& garo (liquamine) faluiati more de. mitti(digeri;)eamós efcam per quinç̧ dies ieiuno dari. Præterea cactrminalentifci aut olex, uel te nerrimam quanç frondem, aut pampinos uitis obịci, tum etiam fpongia labra detergeri, \& aquam frigídam ter die praberi potandam:Qux medicina fub tecto fieri deber, nec ante fanitatê bos emit. ti, Columella. Ex umbrofis locis accipiens gramen \& lauans, febrienti boui uorandum porrigito: aut uiris fimiliter folia.Aqua autem illi frigidiffima danda eft, eaćs in loco maximé umbratili, fed ex pofito fub dio. Quinetiam fpongia perfufa aqua, tum aures tum nares ipf $x$ perfrigerandæ funt.Alij faciem bouis, easć̣ partes qux fub oculis collocantur, ftiģnate inurunt : quas poftea fpongia lotio calido \& veteri madidata, bis fourent fingulis diebus, donèc decidant ipfa efcharæ, ulceribuş́́ cicatrix inducta furerit, Aures etiam exalperantur, donec fanguis uideatur effluere. Sunt quilæuigan= 20 tes farinam uino, eam comedendam apponant. Alij ubi lauerunt muria, bouem amiculís tegunt $\&$ calefaciunt. Alï cytifum ex uino porrigunt, Didymus. Conducit eis uictus ratio frigida :quamobrē à labore ceffent, $\mathscr{X}$ in loco frigido contineãtur falicum frondibus $\$<$ pampinis obtecti. In cibo ctiam falicum frondes conueniunt, $\&$ qua refrigerent herbæ, $\&$ hordeum infrigidatum. Si pleniores uide buntur, detrahatur fanguis. Aquam bibãt de malis acidis $\&$ prunis, ipfá̧̧ mala $\&$ pruna comedãt, Petr. Crefcentienfis. Bos febricitans perfunditur aqua, \& perungitur oleo \& uino tepefacto.Sitien= ti datur frigida. Si hâc non proficitur, demitur fanguis maximè à capite, Varro ut Petrus Crefcent. citat:Ego hæc nufquam apud Varronem reperi:negs in his qui publicati funt libris Varronis ulla pecoris remedia leguntur, nę̧ in Geoponicis Gracis ex eo quicquam inter remedia profertur.

Bubus perfrigeratis uinum nigrum infundendum eft, Florentinus, $\quad$ Bos offa non deuora $=30$ bit, fi lupi caudam ad præfepe fufpender is, Paxamus. Suis fimum fi forte deuoretur à bubus, læa dit mirum in modum. Præcipue autẽ quod egerit fus agra peftilentiam facere ualet, ut fuprà diximus: procul igitur à prafepibus fues arceantur:nec minus gallinæ. Nam bos cum gallinæ fimum inter pa bula fumpferit, ftatim nimio uentris dolore torquetur, inflatusós moritur : Cui hac ratione fuccurri conuenit. A píf feminis uncias tres, cumini fextarium femis, $\&$ duas libras mellis commifce, $\&$ tepi. dum per os infunde, ac tam diu ambulare compelle, \& confricandum cura manibus plurimorum, donec uentrem potio moueat, Gifni (uox corrupta uidetur)'quoç cum uino deterere, 8 per os dare creditur falutare remedium, Lixiuium quo $\mathrm{g}_{3} \mathrm{x}$ arbore ulmi uel cuiufcungs generis ligni cinerem, dummodo bene coctum, cum oleo mifcere, 8 liquidum ac tepidum diffundere per fauces, aduerfus ftercus(gallina)plurimum prodeft, Vegetius, Pro Gifni forte legendum folia fici, nam $\bar{A}$ bfyrtus $e=4^{\circ}$ quis hoc ueneno periclitantibus folia caprifici triduro ex aqua tepida bibenda prabet. Alia etiam có tra hoc malum remedia equis adhiberi folita apud Veterinarios leges. Miretur autem aliquis cum adeó noxium fit ftercus fuillum, iumento tamen cui natura exciderit loco remedí in potu darià Ve getio libro 3 , cap.9. If Bupreftin infectum fi bubulum pecus deuorauerit, tantopere inflammatio. nibus torquetur, ut \& rumpatur, \& non ita multò poft efflet halitum extremum, Aelianus, In Gra:

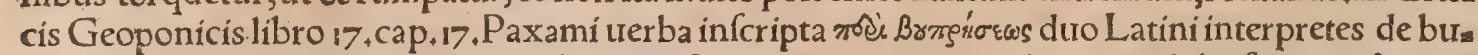
prefti uertunt, ego potius de uentris boum inflatione uertendum iudico: ut nihil referat an Br par. ticula hîc intenfiua fit, an ad boues proprie pertineat.Quanquam enim ex buprefti infecio uorato turgeat $\&$ infletur vienter, idem tamen affectus alias quog ob caufas interdum inuadit:Mulomedi=

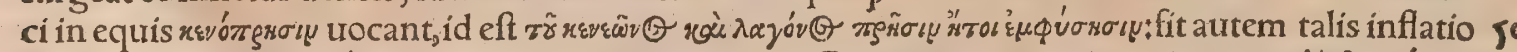

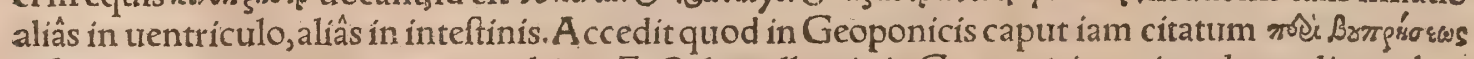
infcribitur per $\sigma$ non per sin penultima: Et Columella tria in Geoponicis capita, de cruditate, bu= prefti, \& torminibus infcripta, fub uno de cruditate comprehendit, nulla bupreftis mentione facta, fonitum autem uentris $\&$ inflationem tanquam figna $\&$ fymptomata cruditatis non omittir. Sed idem fortaffis remedium utríğ malo conueniet, quod Paxamus ita præf cribit: Ad duerfus hanc noxā quidam oleum in nares infundunt bubus:alị caprifici groffos aqua diluunt $\&$ naribus infundunt. Diofcorides certe poft uomitiones 8 clyfteres, caricas in cibo prodeffe docet, 8 cum uino potum earum decoctum aduerfus bupreftin infectum: Caterum oleum bubus per nares infundi donec ru. ctent ad inflationem fedandam, in Plinio legitur: Nec tamen negauerim oleum contra omnia uene. na bibi cum aliâs, tưm ad uromitum proritandum. Bupreftim herbam magna inconftantia Græci in 60 laudibus ciborum etiam habuere. Iidemós remedium tanquam contra urenenum prodiderunt: Ex ipfum nomen indicio eft, boum certe uenenum effe, quos diffilire deyuftata fatentur: Quapropter 


\section{Bos \&Vacca. C. Lib. I.}

nec de hac plura dicemus; Hæc Plinius. Videtur autem animal bupreftin, quod bubus ueneriofim eft,cum herba eiufdem nominis confundere, ideoćs Gracorum inconftantiam reprehendere, Legis rur fane apud Hippocratem bupreftis nomen oleris fylueftris: \& grammatici quidam finapi fimile faciunt, Rarum in Italia(inquit Plinius)animal bupreftis éf, longipedi fcarabeo fimillimum. Fallit inter herbas boúem maxime, ttnde $\&$ nomen inuenit: deuroratumç racfo fellè ita inflammat, ut rum pat. Nouerunt nunc etiam (ut in commentarp̈s in Diofcoridis librum 2, fcribit Marcéllit’s Vergills us) Italiæ rura hoc malum: tuidimusç nos peremptum aliquando eo ueneno bourem, Non fátis ta. men oftendunt ruftici eius animalis formam, diuerfis oppellationibus diuerfis locis \& diuerfa for ma defcribitur \& appellatur, Hac ille. Ex rurfus in librum 6. Bupreftis (inquit)nunc frequentior Ita lix eft, quàm agreftis fortuna \& res patiatur, interempto quotidie boue inueniri agricola lamentan tur.Sed de buprefti fuo loco plura, IEft ctiam paruarana in arundinetis \& herbis maxime ui. uens; mita ac fine uoce, uiridis, fi forte hauriatur, uentres boum difténdens, Plinius. IMagnam etiam perniciem fape affert hirudo haufta cum aqua:ea adhærens faucibuis fanguinem ducit(trahit) 8 incremento fuo tranfitum cibis pracludit:fi tam difficili loco eft(interius) ut manu detrahí non poffit, fiftulam, uel arundinem inferito, \& ita calidum oleum infundito: nam co contaçu anímal có feftim decidit. Poteft etiam per fiftulam deufti cimicis nidor immitti, qui ubi fuperponitur igni, fü mum emittit, \& conceptum nidorem fiftula ufó ad hirudinem perfert, is ćs nidor depellit hêrentem, Si tamen uel ftomachum, uel inteftinum tenet, calido aceto per cornu infufo necatur. Has medicis nas quamuis bubus adhiberi praceperimus, poffe tamen ex his plurima etiam omni maióri pecori 20 conuenire, nihil dubium eft, Columella. A duerfus hirudinem ab equis hauftã plura uide a pud $H i p=$ piatros, \& infra in Hírudine inter aquatica animalia. Incauti quiogs trorant interdum araneos, \& re. uomunt. Eft etiam mortifer îs ferpentis icfus, eft $\&$ magnorum animalium noxium uirus, nam $\&$ uipera, \& cacilia fxpe cum in pafcua bos improuide fupercubuit, laceffita onere morfum imprimit: Musç̧ araneus, quem Graci $\mu \nu y \dot{\alpha} \lambda \star y$ appellant, quamuris exiguis dentibus (partri quidem corporis Veget, non exiguam peftem molitur. Venena uiper $x$ depellit fuper fcarificationem ferrofactã her ba, quam uocant perfonatam, trita \& cum fale impofita: plus etiam eiufdem radix contufa prodeft: Vel Symonianum trifolium(carer eo Germania)quod inuenitur confragofis locis, efficaciffimum,

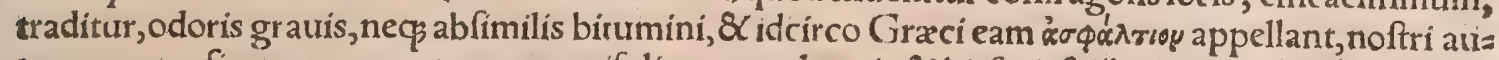
tem propter figuram uocant acutum trifolium:nam longis, \& hirfutis folins uiret, caulemćç robuftio 30 rem facit, quàm pratenfe. Huius herbæx fuccus uino miftus infunditur faucibus, atç $\beta$ ipfa folíjs, cum fale trita malagmatis more, fcarificationi intenditur(ipfa folia cum fale trita imponuntur, Veget.) uel fi hanc herbam uiridem tempus anni negat, femina eius collecia, \& leuigata cum uino dantur potanda, radicesḉ́ cum furo caule tritæ, \& farina (cum fucco caulis \& farinahordeacea, Veget,) \& fale commifta ex aqua mulfa fcarificationi fuperponuntur, Eft etiam præfens remedium, fi conte. ras fraxini tenera cacumina quin $q_{3}$ librarum cum totidẽ ríni, \& dưbus fextarị̂s olei, expreffumćç fuccum faucibus infundas:item Caciliæ morfus tumorẽ, fuppurationemḉ molitur. Idem fací etiam muris aranei. Sed illius fanatur noxa fubula ænea, fi locum larum compungas, cretáç cimolia ex aceto linas. Mus perniciem, quam intulit, fuo corpore luit: nam animal ipfum oleo merfum necatur, et cum imputruit, conteritur, eoćs - medicamine morfus muris aranei linitur(confricatur.) Vel fi id non adeft, humorḉs oftendit iniuriam dentium, cuminum conteritur, eiḉ̧ adịcitur exiguum picis liquidx, et axungiæa, ut lentorem ma lagmatis habeat, Id impofitum perniciem fubmouet. Vel fi antequam tumor difcutiatur, in fuppura tionem conuertitur, optimum eft ignea lamina (uel cauterio collectionem aperire, Veget.) refecare,

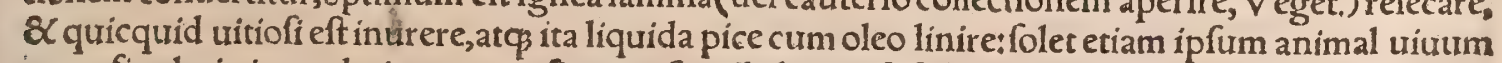
creta figulari circundari:qua cum ficcata eft, collo boum fufpenditur:ea res innoxium pecus à mor fu muris aranei præbet, Columella.Mures aranei, urtà rufticis noftris audio, apud nos quidem mi. nus uenen ofi funt morfur: fed aliud malum inferunc, ungulas boum in ftabulis erodentes. Quodad morfum, magis conquerüturi de muftelis:à quibus uulneratas partes, pelle muftelina eum in ufum referuata demulcent. Viperæ \& colubri iniurias Vergilius in Georgicis exprimit, hifce uerfibus: 50 Sxpe fub immotis præfepibus, aut mala taĉu Vipera delituit:coelumós exterrita fugit: Aut tecto affuctus coluber fuccedere, et umbrę, Peftis acerba boum, pecoríćs afpergere uirus; Fouit humũtcape faxa manu,cape robora paftor, Tollentem Derijce:iamós fuga timidum caput abdidit alte, Cum medij nexus, extremæćs agmina cauda Soluuntur, tardosóp trahit finus ultimus orbes. Si boure aut aliam quamuis quadrupedẽ ferpens momorderit, melanth na.Id per nares indito, $\&$ ad ipfum morfum ftercus fuillum apponito: Et idem hoc (fi ufus etienerit) homini facito, Cato. Non defunt hodie qui allium cum butyro coctum in aqua pecori à ferpentibus morfo exhibeant. Infeftant̂̉ boues tum rediuis, et pediculis, Arift. Ricinus nun $\bar{\not}$ in iumentis gignit, in bubus frequens, Plin. TEft $\mathcal{X}$ infefta peftis bubulo pecori, coriaginem ruftici appellant, cum 60 pellis ita tergori(dorfo)adhæret, ut apprehenfa manibus deduci àcoftis non poffit. Ea res non aliter accidit:quàm fibos aut ex langưore aliquo ad maciem perdukfus eft, aut fudans in opere faciendo refrixit, aut fi fub onere plutia madefactus eft. Quix quioniam perniciofá funt, cuftodien dum elt, ut 
cum $\mathrm{ab}$ opere botres redierint, a dhuc $x$ ftuantes anhelantes $\phi_{5}$ uino afpergantur, $\&$ off $x$ adipis (of fula panis uino infufa, Veget,) faucibus corum inferantur, Quod fi prædictum uitium inliaferit, proderit decoquere laurư, \& ea calda ( $\&$ cum calida, Veget.) fourere terga, multó́: oleo \& uino con feftim fubigere, ac per omnes partes apprehendere, $\&$ attrahere pellem(et uelut à coftis feparare, Ve getius,) Id ós optime fit fub dio fole feruente, (aut in loco calidiffimo, Veget.) Quidam fraces uino, $\&$ adipe (axungia, Veget.)commifcent, eoćs medicamento(repido, Vegetiuss)poft fomenta prædicta utuntur. TS Scabies extenuatur trito allio defrictołeodemás remedio curatur rabiof $a$ canis, uel lupi morfus, qui tamen 8 ipfe impofito uulneri uetere falfamento, aque bene fanatur. Et ad frabiem pr fentior alia medicina eft, cunila bubula, \& fulfur conterunẗ, admiftáq̧ amurca cum oleo, aqua (aliâs atç ) aceto incoquuntur. Deinde tepefactis fcifum alumen tritum fpargitur, Id medicamentum, candente fole illitum maxime prodeft, Columella. Glans largior ualetudinem infeftat, \& uernã ferè - fabiem efficit, ut fupra diximus: noftrilumbricos etiam inde generari autumant. Scabies atç exan. themata boum, urina ueteri atç butyro illita curantur. Alij ex refina $\&$ humida pice uino fimul uni tis ungunt, ac fic medentur, Florentinus, Sal pecorum fcabiem $\&$ boum illitus tollit:datur dus, \& oculis iumentorum infpuitur, Plinius, Corchoro Alexandrini cibi herba boum fcabiem ce lerrime fanari intrenio, Idem, $\Phi$ V ulnera boum curabis maluam arborefcentem contundens admo uenś́, ${ }_{3}$ Democritus. Frutex quidam periclymeno non diffimilis tum folịjs tum floribus, in fxpibus locisçafperis \& faxofis nafcitur, ramulis albicantibus. Floribus acíni rotundi omnes gemini fubnafcuntur, colore rubro:hunc gemellum appellemus licet: folia eius contufa boum ulceribus, ut audio, ruftici imponunt. TVlceribus gallæ tritæremedio funt, nec minus fuccus marrubij cum fuligine, 20 Columella. Si in ulcere fit pus collectum, ulcus ipfum eft abftergendum, urináç calida prouectı bo. ứs lauandum, laná́s molli fouendum, ac deniq̧ ex tenui fale \& $\alpha$ pice humida imponendum empla ftrum,Didymus, Suppuratio melius ferro refcindiẗ, quã medicamento. Expreffus deinde finus iple, qui eam continebat, calida bubula urina elutitur, atç linamentis pice liquida, $\&$ olco imbutis colliga tur. Vel fi collui(colligari, Vegetius)ea pars non potef, lamina candenti feuum caprinum aut bubur fum inftillatur.Quidam, cum uitiofam partem inufferunt, urina uetere(humana Veget. )eluunt, 2t: que ita æquis ponderibus incocta pice liquida cum uetere axungia linunt, Columella. Malis farcimi nofa, quoties per totum corpus bobus tubercula exeunt, aperiunt $f e, \&$ quafi fanantur, 8 iter urm in alijs locis exeunt, dicta fuperius, ut etiam Elephantiafis, TSolent etiam neglecta ulcera fcatere uer. mibus, qui fi mane perfunduntur aqua frigida, rigore contracti decidunt : uel fi hac ratione non pof= funt eximi, marrubium, aut porrum conteritur, 8 admifto fale imponitur:id celerrime necat prædi= cta animalia: (urel calcis uiux puluis infpergitur, aut cucurbitę uiridis fuccus cum ar eto mittitur, Ve getius. ) Sed expurgatis ulceribus, confeftim adhibenda funt linamenta cum pice, $8 C$ oleo ueterẹ́ axungia: $\&$ extra uulnera eodem medicamento circumlinienda, ne infeftentur à mufcis, qua ubi ul ceribus infederunt, uermes creant, Columella. In Geoponicis Græcis rectélegitur audác pro uermi. bus ulcerum, ut Cornarius etiam reddidit: Andreas á Lacuna inepte legit, 8 transfert $\gamma^{2} \lambda e^{\prime} s_{3}$ id eft cís catrices.Puluis ueratri intritus fuppurationibus cum oleo uel butyro, aut per fe etiã necat uermes. Sunt qui hyof cyamum imponant ut excidant uermes. Commendattur 8 chelidonium eodem ufir, $\&$ perficaria: A liqui abfinthï, marrubï, \& phu decocto uerminantia loca abluũt, Sunt qui folia $\mathrm{Per}$, fici contufa cum fuo fucco uulneribus indant: Alij caftrangulam herbam urtica fimilem (Germani 4 braunwurts uocant) foetidam, nodofis radicibus, pecoriuerminanti appendunt. Aliud item genus mali noftri uulgò tuermem tocant, Ser wurmt ons ber vngnampt : eft autem gentis ulceris ma= ligni, \& contumacifimi, quod artus pracipue extremos infeftat, fed \& alias partes, \& offa quo $\$$ ui. tiat:cuius plurimas differentias faciunt. Id in Equo etiam memorabirur : Hic fatis fit monuiffe in bu. bus contra hoc uitium herbas côtufas imponi, chelidoniam: uel clymenum, cui uulgo nomen grinne nadt fobatt:uel gentianæ illam fpeciem quam paulo ante cruciatam à radicis incif figura nomina, ui. Alin aliter medentur:quidam incantationes adhibent, ut ad paronychias etiam hominũ, quas uul. gư eodem urocabulc appellat. IFerè omnis dolor corporis, fi fine uulnere eft, recens melius fomen tis difcuritur:uetus uritur, \& fupra uftum, butyrum, uel caprinus infillatur adeps, Columella. ISI pecori fanguris per anum, aut uterum aut nares profluat, farinam triticeam cum ouo $\&$ butyro $\&$ so lotio ex equili haufto permifce, \& maffam inde coactam in cíneribus calidis coques ac pecori dabis. Sunt qui herbam, quam Germani columba ingluuiem uocant in aqua decoquunt, ac infundunt. De fanguine fiftendo, qui cum urina aut lacte profluit, inferius dicam. I Si qui boum artus luxati fue rint, in aqua natare compelluntur, ut commotione illa reftituantur, ISxpe etiam uel grauitate lon gioris ( uel ab afperitate itineris, Veget.)uel cum in profcindendo, aut duriorifolo, aut obuize radici obluctatur conuellit armos. Qurod cum accidit, $\ddot{e}$ prioribus cruribus fanguis mittendus eft fi dextru armum læfit, in finiftro:filæuum, in dextro:fi uehementius utrunç uitiauit, item(etiam Veg.)in po. fterioribus cruribus uenæ foluent̂. Pręfractis (Perfractis, Vege.) cornibus linteola fale, atఢ̧ aceto, 8 oleo imbuta fuperponuntur, ligatiş̧́ per triduum eadem infunduntur, Quarto demum axungia pari pondere cum pice liquida(arida, V eget.) \& cortice pineo, leuigatuóp imponitur : Et ad ultimum 60 cum iam cicatricem ducunt, fuligo infricatur, Columella. TSi in opere collum contufum erit, prae fentiffimum eft remedium fanguis de aure emiflus:aut fi id faciũ non crit, hexba, qua uocatur auia, 
cum fale trita, \& impofita. Si ceruix mota \& deiecta ef, confyderabimus quam in partem declinet; $\&$ ex diuerfa auricula fanguiriem detrahemus. Ea porrô urena, qua in autre uídetur effe ampliffima, farmento prius uerberatur: deinde cum ad icium intumuit, cultello foliuitur, $\&$ poftero die iterú ex codem loco fanguis emittitur, ac bidio ab opere datur iracatio. Tertio deinde die leuis iniungitur la bor, \& paulatim ad iufta perduciț.Quod fi ceruix in neirùram partem deieça elt, mediá́s intumuit; ex utraq̧̧ aưricula fanguis emittitur, qui cum intra bidưum (triduũu, Veget, ) quàm bos uitiữ coppit, $e=$ miffus non eft, intumefcit collü, netuí̧ tendunt, $\&$ inde nata duricies iugũ non patitur. Tali uitio comperimus aureum elfe medicamentũ ex picéliquída, $\&$ bubula medulla $\&$ hircino feuo, $\&$ uete. reoleo(Vegetiù's axungiam quiog ueterem addit)aquis ponderibus compofitư ; atos incoctũ . Hac 10 compofitione fic utrendư eft, cû̃ difítngiț ab opere, in ea pifcina, ex qua bibit, tumor ceruicís aqua ma

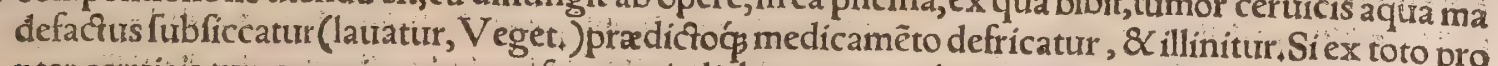
pter ceriticis tumorem iugum recufet, paucis diebus requies ab opere danda eft; Tum cerulx aqua frigida défricanda, \& fpuma argenti illinienda eft. Celfus quidem tumenti ceruici herbam, qux ro catur auia (ama; Vegetialiâs amati \& amaticum, Veget, )ut fupra dixi, contundi, \& imponi iubet.

Olauorum, qui feré ceruicem infeftant,minor moleftía eft:nam facile operanti lucerna inftillaz tur. (nam facile fanantir per'ardentem lucernam oleo inftillato, Veget ${ }_{i}$ ) Potior tamen ratio eft cu= ftodiendi, ne naf cantur: Néue colla caluefcant, qux non aliter glabra fiunt; nifi cum fudore, aut plu= ura ceritix in opere madefacfa eft:itaque cum id accidit, ureteri lateri later conteritur, eoćs in trito pri us quảm difiungantur(puluere lateritio trito priufquam deiugantur, Veget, id eft à iugo foluunt, 20 colla conifpergi oportet; deinde cum id ficcum erit, fubindè oleo imbui, Columella, Laditur colliur nimio iùgi pondere, \& maximè fi plutuia accefferit, Interdum etíam collectis humoribus exulcera= tur locus affectus, pharmacis qua confolident cutimóp generẽt curandus, qualia in equis etiam ufita ta funt:quamuis $\&$ peculiaria quadam habent qui bubus medentir, qualia feré funt ex quibus un genturm Agrippx dictum componititr; Petrus Créfcentienfis.

1Cum bos aures demittens non comedit, rephalalgia torquetur. Quare thymo uino commace rato, allins śs \& fale, ipfa lingua fricanda ef. Hordeurn etiam crudum ex uino fumptum opitulatur. Quinetiam foliorum lauri quantum manu apprehendi poffit,in os inferens, aut tantundem corticis mali $P_{u n i c i}$ miré contuleris. Myrrham præterea ad magnitudinem fabæ cum duabus fimiliter hemi nis uni diftemperans, infundenş́́s per nares, dolorem exterminabis, Paxamus, đMania bobus 30 eripit fenfum; ut nec audiant more folito, nec uideant, dicta fuperius inter fpecies malidis; Noftra tes infanix quoddam genus uocant birnnutitig, à cerebri uitio, cui uertigo fiue in orbem difcurfus adiungatur. Iuniores frequentius hoc morbo uexari putant, prefertim fi inter cornua fapius aut use hementius feriantur:uel cornua nondum confirmata nimium contrectentur. Sic affectos fi macta= uerint lanij, carnem uendere non licet.Plures moriưtur, nonnulli uerociurantur terebello iuxta cor nua frontem uerfus ad craneum ufक̧ adaço, ita ut fanguís effluat:funt qui uermẽ etiam uiuum ali= quando ex uulnere illo egredi affeuerent, ut ex paronychịs hominum: Mihi quidem neutrum ueri fimile fit, Oeftra fiue afili pungendo refonandóq̧ boues in furorem adigunt:minime autem ace cedent eis, fi quis contufas lauribaccas $\&$ aqua incoctas, per loca in quibus pafcuntur boues eas di. fperferit; mox enim diffugient nefcio quia naturæ iri. Qưd fi adhuc infeftare nen définant, cerufam 40 bubus aqua leuigatam inungunt, Soton. Plura de oeftris inter infecta: đIMalis humida vocatur quoties per os \& nares humor effluit, \& faftidium agritudo ôs confequitur, de quia fupra dictum eft copiofius inter reliquias malidis differentias. Pituita pecoris curatur furculo hellebori nigri per au rem maturé traiecio, \& poftridie eadem hora exempto. OOculorum uitia plering melle fanan. turinam fiue intumuerunt, aqua mulfa triticea farina confpergitur, 82 imponitur: fiue album in o. culo eft, montanus(foffilis V eget,) fal, Hifpanus, uel Ammoniacus, uel etiam Cappadocus minute tritus, \& iminiftus melli uítium extenuat: facit idem trita fepia tefta, \& per fiftulam ter die oculo in= fpirata:facit $\mathcal{Q}$ radix, quam Graci $\sigma i \lambda \phi i o j$ uocant, uulgus autem noftra confuetudine laferpitium ap pellat; huius quantocunqs ponderi decem partes falis Ammoniaci adńjciuntur, éaçs pariter trita ocu lo fimiliter infunduntur (cum fiftula infufflãtur; V eget.) (uel eadem radi 1 contufa, \& 8 cum oleo lenti.

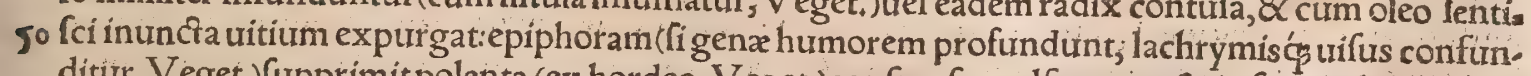
diturr, Veget.) fupprimit polenta (ex hordeo, Veget.) confperfa mulfa aqua, $\&$ in fúpercilia genasó impofita:paftinacæé́ agreftis femina; \& fuccus armoraceæ, cum melle collinita oculorum fedant do lorem(paftinaca quoģ agreftis, quam armoraceam uocãt; cum melle trită oculorum fedat dolorem, Veger, ) fed quotiescunç mel, aliusue fuccus remedíns adhibetur, circumliniendirs érit oculus pice liquida cum oleo, ne à mufcis infeftetur: nam $\&$ ad dulcedinem mellis, aliorumó́ medicamentorum non hæx folę, fed $\&$ apes aduolant $(\&$ uefpæ, Veget.) Columella. Iumentorum et bourm oculis Tŕa gafaum \& Baticum falem antiquilaudabant, Plinius, Interdum $\&$ tumore palati cibos refpuit,

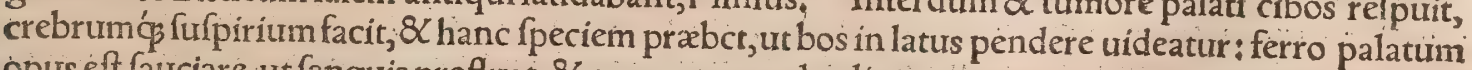
opus eft fauciare, ut fanguis profluat, \& exemptum ualuulis eruum maceratum, uiridem ́́́ frondé, Go iel aliud molle pabulum, dum fanetur prabere, Columella. Hunc morbum recéntiores hippiatri lampafcum, ut conn̈cio, in equis uocauerunt. Interdum duriufculus tumor, qui poftea fuppura: tur, ruftici apud nos uocant bie liedyte, maxillis adnafcitur, $\&$ mandentes impedit adeó ut emacien'? 
tur:proinde hanc ob caufam nonnunquam mactantur; aut lanijs ad cultrum uend hantur.

T Solent etiam(periculofa addit Veget.)faftídia cibi afferre uitiofa incrementa lingua quas tav nas ueterinarij uocant. Hac ferro reciduntur, \& fale cum allio pariter trito uulnera defricantur, do. nec lacelfita pituita decidit. Tum uino perluitur os, (melius creditur fi ad acutam cannam execes ra nulam, poft uino os lauatur, \&c. Veget, \& interpofito unius horæ fpatio uirides herba, uel frondes dantur, dum facta ulcera cicatrices ducant. Si neç ranæ furerint, neç aluus citata, $\&$ nihilo minus cibos non appetet, proderit allium pinfitum cum oleo per nares infundere, uel fale, uel cunila defri care fauces, trel eandem partem allio tonfo (tunfo) 8 halecula linire, Sed hrec his folum faftidiü eft, Columella, Ranæuitiữ (ut à noftris accipio)inftar lati ulceris lingtram occupat, fubnigrũ, \& no, no die nifi curet interimit: fignum eft faliua defluens: Curatur cufpide lignea, qua rana rubeța tranf : io fixa fit, melius uero fi in eadem aruerit, Sanatur etiam ftercore canino candido, fale, ruta, fuligine, $\&$ faluia pariter contritis, \& exertælingux infricatis. Caterum lingux puftulis ita medeberis:Bour oportet collocare fupinum, \& capite reclinato linguam, an puftulas habeat, infpicere : quas quidem candenti ferro acutó́ exurere conuenit. Dein uerò agreftis olex foln̈s contufis, faléćs etiam, ulcera inungenda funt:aut fale tenuiffimo $\&$ oleo aut butyro $\&$ fale : Aut cucumeris agreftis radix ficca contufa unà cum ficubus in paftum eft apponenda: A ut etiam farinæ hordeaceæ, triticiộ torrefa cti pollinis, fingulorum heminas duas uino madidatas offerto, Florentinus. बPutrida oris ulcera,

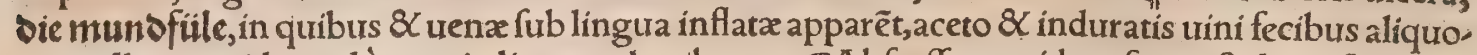
ties colluunt:uide paulò ante in lingux ulceribus, $\Phi$ Abfceffus quidam feu puftula in faucibus nafcuntur, unde locus multó angultior fit, quidam noftra lingua uocant ১as ttłet blìt : illas uel digitis uel ligno inferto comprimunt, repurgantó̧ locum affectũ:fanguis $\&$ humor fortidus effluit; nifi curarentur interituris:Quidam ad incantationes confugiunt. Haud fcio an idem malum fit; uel coniun furm fuperiori, uel omnino diuerfum, quod aliqui nominant sas g\$d blìt, hoc eft fubi tum fanguinem: $\&$ de pecude fic affecta dicunt, $\$ a s$ blit b bes angeftoffen, uidetur autem nihil ali. ud efle quàm inflatio fubita, 8 cruditatis fpecies (de qua nōnihil fupra in buprefti dixi, 8 dicam et: am plura paulò poft) quamuis imperitia uulgi nefcio quem fanguinis impetum caufetur. Huic mor bo urt medeantur manum aliqui in aluum adigưt, uel ftatim, uel uirga præmiffa, $\&$ ficca excremen ta proruunt, interdum \& grumos quofdam tanquam fanguinis, ut audio. Alíj culinarię colluruiei a, quam eis infundunt, \& ad curfum propellunt, quo calefact $x$ ftercus liquidum emittunt, \& alleuan.

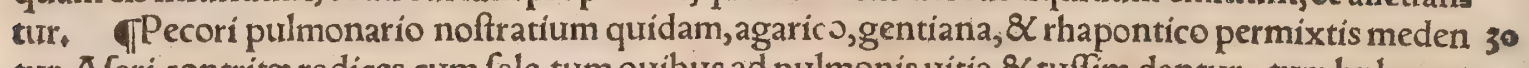
tur. A fari contritæ radices cum fale tum ouibus ad pulmonis uítia $\&$ tuffim dantur, tum bubus ut purgentur, Hieron. Tragus. Tuffim $\&$ anhelitus anguftiam nonnulli trinaceis aut iuniperi baccis fali admixtis in hoc animali curant. Alí aduerfus eafdem caufas 82 lentam pulmonum pituitam beronica herbx, cui uulgo nomen eerenprey $\beta$, pollinem fali immifcent, Hieron. Tragus : Qui eandẽ herbam Teucrion ueterum Græcorum effe conijcit, partim alịs rationibus id ut crederet adducitus, partim $q$ mira eius uis ad remedium lienis explorata fit, fi quis uinum in quo maceretur per dies ali quot bibat. Ego quan कृ́, ueronicam noftram recté pro Teucrio ufurpari poffe admitto, nec admodũ repugnauerim iudicio Tragi: magis tamen animus mihi inclinat ad illam herbam quam Leonardus Fuchfius primus fic appellauit, cuius hic uerba fubfcribam: Teucriũ(inquit)officinis ignotũ Germa nis gro $\beta$ batbengel(id eft betonica maior, quod nomen puto ipfe confinxit) dicitur $+A$ Diofcoride 4 chamædrys etiam nominatur, utpote chamædryi fimillima, adeo ut uiciffim etiam chamædrys hoc nomine diça fit Teucrion.Maius tamen quâm chamæedrys Teucrion eft, ut merito Germanis beto nica maior nuncupari queat. Nufö̧ quod fciam fponte in Germania prourenit, In Cilicia, Diofcori. de tefte, abundat. Ego id ante annos aliquot in hortis qừibufdam Italia uidi, nec unçßalibi, Iunio ac Iulio menfibus floret, Incidendi $\&$ tenuium partium facultatis eft, quare lienes fanat, 8 ordine fecundo calida, tertio ficca exiftimari poteft, ut Galenus fcribit. Herba eft, inquit Diofcorides, uir = gareferens effigiem, chamędryi fimilis, tenui folio, non multũ ciceri diffimile. A pud Pliniũ hemioni tis quo $\$$ Teucrium cognominatur, nimirũ $q$ fimiliter lienofis medeatur, Inuenit $\&$ Teucer eadem atate (qua Achilleon A chilles) Teucrion, quam quidam hermion uocẫ, fpargentem iuncos tenues, folia parua, afperis locis nafcentem, auftero fapore, nunक̧ florentem: Neqs femen gignit, Medetur yo lienibus. Conftató fic inuentam:Cum exta fuper cam proiecta effent, adhafiffe lieni, eumós exina niffe. Ob id à quibufdam fplenion uocatur. Narrant fues, qui radicem eius edunt, fine fplene in. ueniri. Quidam ramis hyffopi furculofam, folio fabx, eodem nomine appellant, \& colligi florentem adhuc iubent, adeó florere non dubitant, maximȩ́́ ex Cilicijs \& Pifidiæmontibus laudant, Hac Plinius 25.5. A pparet autem Teucrion illud quod priore loco defcripfit, 8 hermion à quibufdam uo cari prodidit(codices quidam impreffi non hermion, fed hermemon habent, Hermolaus recie refti= tuit hemionionthermion uero inter eryngị nomenclaturas apud Diofcoridem legimus, non etiam afpleni quod Hermolaus in Plinium fcribit)omnino Diofcoridis hemionitin effe ( utcung refrage tur Maffarius) quam \& ipfe fplenion cognominat \& fimiliter fine flore, ac fine femine defcribit, pe= trofis nafcentem locis, guftu aftringête; cum aceto ad minuen dos lienes bibi. In folins folum non có 60

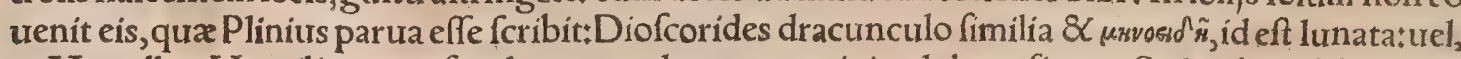
utMarcellus Vergilius transfert, lunæ nondum tumentis in globum figura, Sed uidetur Plinius cü 
herba feorfim tanquam ab afpleno diuerf meminit. Quramobrem nouam Fr, Maffarï opinionẽ ne

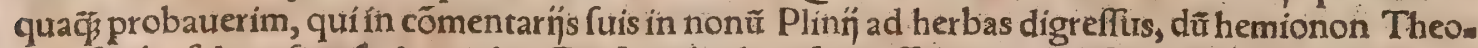
phrafti ab afpleno fiue f́ folnpendrio Diofcoridis diuerfam effe contendit, Theophrafti uerba, non Graca, fed ex translatione Theodori fuis confirmandis adducit:ubi Theodorus hemionon radice nu

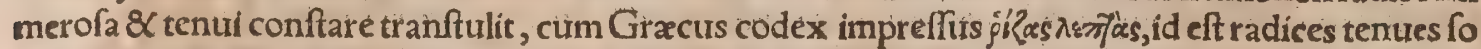
lum commemcret, non etiam numerofas, Deinde Diofcoridis uerba, cum ait afpleno multa effe folia

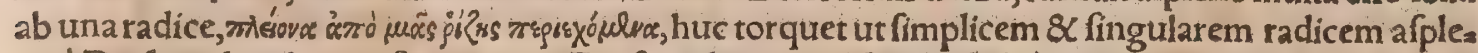
no à Diofcoride tribui exiftimet, cum Diofcorides non id fentiat,fed ab'una radice, id eft uno radicis fummo principlo(quod in plarifo plantis unim $\&$ fingulare reperitur, licet inferiora in diuerfas a $=$ beant partes) plura ftatim enafci folia, quod $\&$ in filice toemina fieri uidemus, Sed hemionios, inquit, quam modo citherach recentiores appellant, ut res ipfa monftrat, radice eft nigra, numerofa, tenui, ut capillamenti fpeciem referat:afpleno trero(qux in omnibus feré cum hemionio praterquam in ra. dice conuenir)limofa, cauternofa, ficut filicis, candida, hirfuta (qux omnia Plinius ei tribuit) itaç dia uerfam effe neceffe eft. Addimus etiam (inquit) quod Diofcorides ipfe myofotida radicem unam di. giti craflitudinis multis capillamentis fibratam habentem, in totum fcolopendrio comparauterit, Hęc duo poltrema Maffarí argumenta non difficile eft refellere; niam quod colorê attinet, uariant aliquan do authores, $\&$ colores ipí pro natalibus ac atate uariant: $\&$ cum fuperficies tantum inius coloris, interior uero pars tota alterius eft, nil mirum fi difideant authores, prafertim cum fape contingat ra dices non recêter effolfas, fed purgatas intueri. Poftremo quod hemionon tenues radices habere fcri bit Theophraftus, de capillamentis quibus fibrata eft accipi poteft, prafertim cum ex tam numerofa 10 fint, ut maior fiure una fiue plures, ijs inuoluta occultetur. Obtinuimus igitur nifi fallor hemionon Theophrafti non effe aliam quam Diofcoridis afplenon. Hemionitin uero Diofcoridis aliam quam hemionon effe, Maffarius recté fatetur. In Theodori translatione hoc etiam mihi difplicet, qued he. mionon montanas planicies amare conuertit. In Graco legimus ỏ montana $\&$ faxofa: neç enim ut plana fintrequiritur. Adcò difficile eft hominem in rebus iplis non exercitatum, utcunģ linguarum peritia polleat, boniinterpretis officio fatisfacere. Sic proxime ante

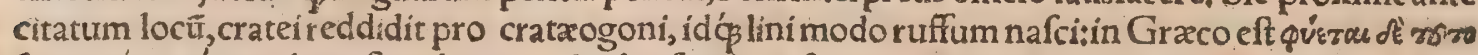

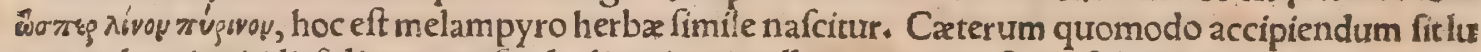
natum hemionitidis folium, non facile dixerim ; intelligi enim poteft uel folio ad totum latus alteru= trum in dimidiatum circulum contracfo:trel qua latiffimum eft folium circa primum à pede ortum, 30 ut in aro confpicitur $\&$ anaxyride ob candem figuram fic dicto rumicis genere, eminentibus utrinq canquam cornibus A Alio modolunata funt dracunculimaioris folia, ratione caulis cui harent incur. erati, Linguam ceruinam uulgo diçam quamuis aliquâdo hemionitin effe credidi, (enafcentia enim primum folia lunata funt)nunc phyllitin potius elfe perfuafus furm? partim doctiffimorum hominum Euricị Cordi, PetriMatthzoli, \& Franc. Maffar fententiam fecutus (quanquam Leonicenus, Ma. nardus, Ruellius \&Fuchf:us aliter fentiãt)partin uerbis Galeni commotus, qui phyllitidi acerbitatē, ideft, uehementem aftrictionem tribuit, ut optima ratione diarrhœa \& dyfenteria eius potu iuuen. tưr : hemionitidi uero, quam nulli hodie cognitam puto, aftriçlonem unâ cum amaritudine, ideoć̣ cum aceto potam fplenicis prodefte. A tqui in lingua ceruina noftra amaritudinis nihil percipimus. Quamobrem non fubferibam Hieronymo Trago phyllitin 8Chemionitin unam \& eandem herbam $4^{\circ}$ â Diofcoride pro diuerfis defcriptas afierenti, eamćs linguam ceruinam noftram effe. Idem cum ge. nus quoddam montana filicis polypodio fimile longioribus folins $\&$ acutioribus, ac pluribus circa unam radicem (qux forte altera lonchitis Diofcoridis fuerit) werum fcolopendrion effe afferuiffet, mox ceterac etiam Italis dictum, herbã longè diuerfam fimiliter fcolopendrion uerum facit. Matthęo lus fcribit fe à quibufdam rei herbaria peritis $\&$ fide dignis hominibus accepiffe, hemionitin ueram abunde prourenire in agro Romano, unde ipfi erutam in hortis plantauterint. Hemionitidi con. numeranda uidetur filicula illa quam Hieronymus 'Tragus defcribit libro 2, ca, 184, rara inuentu, in fyluis aliquando inter faxa prominet, radice capillata ${ }_{3}$ ex qua plurimi iunci fetarum inftar tenues enafcuntur, trientales feré, finguli fingula folia in cacumine erigunt, angufta, breuia, $\&$ ab altera parte friabili quodam puluere, ut filicum genus folet, obfita : horum quadam modicé lunata funt, so alia corniculorum inftar finduntur, Objiciet aliquis, Quid harc ad boum remedia? Refpondeo, Quoniam ueronicam uulgò dictam, celeberrimi in medicandis bubus experimenti herbam, non. nulli ueterum Teucrion effe credunt, \& Plinius Teucrion à Diofcoridis hemionitide non fatis di= finguit, $\&$ aliphemionitin cum phyllitide et fcolopendrio uel afpleno confundunt, de omnibus una eadếç̧ opera dicendi occafionẽ me naciữ exiftimaffe, prafertim cum omnes ad animalia quędã per tinerent. Proinde qua hic de fcolopendrio herba attulimus, in fcolopendra infecio non repetentur: neç in mulo, qux de hemiono \& hemioniride:neģ in ceruo, qua de lingua cervina. Ad de quód a $f_{\text {. }}$ plenos ad animalium omnium, non fưum \& pecorum duntaxat lienem agrum, uim habet maximã bubulo etiam pecori proculdubio profururam. Sed redeo ad uerenicam noftram et Teucrion. In Ira lia quidam circa Tridentum abrorono etiam ueronica nomen attribuunt. Sed nofrra ueronica à 60 uetonicx (alï per u, aln̈ per b fribunt:Latini per t fimplex, Graciper duplex)quadam fimilitudine nomen factum fufpicor;neģ enim una folum uxtonica eft, qux uxulgo apud omnes feré gentes no. 
men retintitífed etiam altera Paúli Á eginetx, quamille his tuerbis defcribit:Bettonica ramulos put legî fpargit, tenuiores, guftu ferè infipido, nafcitur maximé in petrofis. Vfus eft eius inter nephriti.

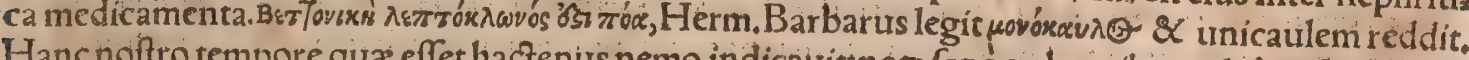
Hanc noftro temporé qua effet hactenus nemo indicautit neç fane ex breuibus adeò deferíptioni. bus fatis certum aliquid indicari poteft. Orit apud nos in parietibus, et in afperis montanis locis her bula odorata pulegio fimilis adeo, ut pulegium petratr appellari poffit:minor; tenuior, flofculis fub cariulei coloris, guftu ferè fatua. Hac fane uideri poffet A egineta bettonica, licet in nullo apuid nos ufu \& anonymos negligatur. Proxima quidem A eginetę deforiptionietiam pfeudochamadrys ef? qua multi liactenus falfo pro chamadrye uff funt:fimilis enim eft, flore corulex anagallidis: unde 10 coruleam aut fatuam aut inodoram chamædryn nuncupare licebit. Germani tocan blaumtent ln/sergif meinnit/belft/fraumenbiß̧ \& fbafferaut;quod nomen poftremum ab oubus ei indi tum eft, quibus ægris, in tulfi prafertim, hac herba medentur. Mirum in ea quod ad latera tantữ flo res aperiat, nunquam in medfi caulis cacumine, Caule eft recto, fed altera fpecies eius in yluis repe ritur \& faxis, quod pulegĭ inftar per humum fe extendit. Quemadmodum \& ueronica, inda recia, al tera fupina eft:qux $\&$ ipfa fortaffis alicui ad Aeginetx bettonicam proxime accedere uidebitur. Ego ex tribus iftis generibus ad nominis huius authoritatem primo loco à me defcriptum pra cate ris admiferim. Chamadryñ fatuam fiute coeruleam Hieronymus Tragus à Teucrio Diofcoridis non excludit:in qua fententia Matthæolus etiam fuiffe uidetur, cum fribit uulgarem quandam $\&$ ubiq nafcentem herbam, cliamadryi tam fimilem ut eam mentiri poffit homini partum exercitato, fapius

2o fe cogitalle Diofcoridis Teticrion èffe. Sed de nominibus ueterum qua quibus noftris plantis ac commodari débeant, non ego cuiquam ualde contenderim: 8 uoluptatis gratia magis qua ex ifto fudiorum genere mihi accedit; quàm feriò uel tanquam contentiofus in cis immorari foleo. Duo tantum neceffaria funt, primum ut qua de re fermo fit nobis conftet; quacun ${ }^{3}$ tandem illa uetere aur nouo aut inter nos ficto nomine ueniat:alter um ut certam de uniufcuiufģ, facultate iưdicandi methodum: ex faporum, odorum, ac cæeteris qualitatum formis calleamus. Namplirinti prorfus ame thodi,imperiti $\mathcal{Q}$ audaciffini homines de plantarum nominibus prolixe ac impudenter contenciüt, Quippe ut aliud nihil nunc adferam, tales omnino funt qui fatuam chamadryn, non folum nomine fed authoritate ac uiribus cum uera coniungunt.

q Redeo tandem ad boum circa thoracem morbos, additurus primü reliqua de tuffi \& afthmate 30 ut incoperam. Recens tuffis optime faluiato farinæordeaceæ difcutitur. (Si recens fuerit, fextariz us farinæ hordeacea cum uno ouo crudo 8 chemina paffi per os datur ieiuno, Veget.)Interdum ma gis profunt gramina concifa(tunfaçs, Veget.) \& his admilta frefa faba:Lentes quoç tualuulis exem ptæ, \& minute molitx; mifcētur aqux calidx fextarī duo, factáç̧ forbitio per cornu infunditur ، Ve terem tuffim fanant duæ libra hyffopi macerati fextarijs aquæ tribus. Nam id medicamentum teria tur, \& cum lentis minute, ut dixi, molita fextarịs quatior more faluiati datur, ac poftea aqua hyffo pi per cornu infunditir. Porri etiam fuccus cum ol $\mathrm{co}_{0}$ uel ipfa fibra cum ordeacea farina contrita re

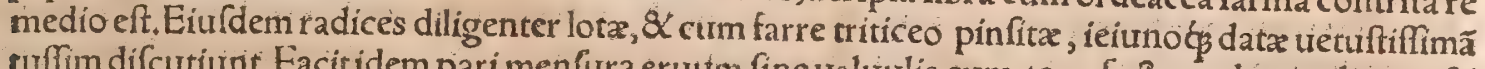
tuffun difcutiurit, Facitidem pari menfura eruutm fine ualuulis cum torrefacto ordeo molitum, \& faluiati more in fatices demiffumi, Columella. Hordeum redactum in pollinem madefacieris, atog pa 4 learum partes tenerrimas optime repurgatas, cum illiş́́s farinæo orobimifcens heminas treis, diuti. denş́ totum in partes ternas, bubus tuifientibus tributs uicibus edendưm dato. Quidam Artemi* liam herban purgantes, macerentes ç aqua, ex ea exprimunt fuccum, quem quidem ante aliud pa. bulum fpatio fèptem dierum infundunt, Didymus. Pulmonariam qua arboribus adnafcitur, cum fale edendam bubus anhelofis $\&$ tufficntibus uulgus noftrum commendat, maximé cum pulmo tur gidior excreuerit, \& ut ipfi loquiuntur collum fubiuerit. Nullam huius herbxapud ueteres mentio nem reperimus: pulmoni exulcerato $\&$ fanguinis fputo conferre creditur:ficcat enim $\&$ aftringit, ut Matchrolus teftatur. Sunt qui infuper facultatem ei adfcribant uulnera fanandi, \& ulcera geni. talium: \& fluxiones uteri tum pituitofas tum cruentas, nec non dyfenteriã $8 C$ uomitus biliofó fiften di. Eft \& altera eiufdem nominis, folijs ferèborraginis, hirfutis \& $\&$ afperis, fed acutioribits figura, jo maculis paffim albis, guftu etiam borraginis. Natales ei fylux $\&$ montes, lociós opaci. Primo uere cauliculi dodrantales fubcoruleos fores in corymbis proferunt, cynogloffa floribus fpecie fimiles, Radices ei plures, nigr $x, \&$ glutinof $x$. Hanc etiam ad explenda pulmonis ulcèra eruditi celebrant. In Italiæ hortis maculofa uidi folia, apud nos uero femper abfọ maculis: cætero nihil diftabant, Eas dem aut eiufdem generis proculdubio eft Plinï pulmonaria, quam aliqui (inquit)pepanim uocant, buglolfi folio, fed promiffo magis atģ læuicri, colore infuper dilutiore, albicantibus maculis notato, inftar pulmonis, inde nomen: nafcitur in humidis. Volunt aduerfus morbos uíferis fur nominis pe culiarieffe remedio, in cibo fumptam, uel potam, Hac Plinius, In Helfia, ut audio, quidam Germa. nice uocant blawen augentreft, id eft cuphrafian coruleam. In Gallia quidam fecundum genus atricula muris apud Diofcoridem effe putant: Videntur autem falli : nam folia oblonga \& angu60 fta non habet, quanquam qua fuperius cauli adnafcuntur taliaferéfint:inferiora oblonga quidem, fed palmi plerung, latitudine, circa extremiratem demum angufta in mucronem exeunt, fubtus als bicant, plurima ab una radice, pediculis oblongis, per quos neruus tranfit, diftraciis etiam iplis ini- 
teger, ut in pimpinella urulgo dicła. Ego ex omnium partium infpectione, \& qualitatibus omnibus, collatis, certo afferere polfum, hanc ftirpem fymphyti fpeciem effe, non petręi,fed alterius, nee aliud ab eo diftare, nifi quod undequaç minor eftideó́s non erraturum qui in medendo alteram in alteri us locum fubftituerit. Huc etiã referri debet herba in Hifpanỉs frequens, prẹcipue in Galitia \& ' circa Compoftellam, cui folia funt afpera, uerbafci communis uel fymphyti potius folins fimillima, longio ra quàm borraginis, floribus $\&$ radicibus bugloffo noftr fimilibus: bubus gratifimam effe aiunt. Monachi qui in ltalia commentarios in Diofcoridem nuper ediderunt, hanc ueram bugloffum effe contendunt;licet borraginem quog eiufdem nominis commercio non excludant, cum \& fapor $S$. herba fpecies conueniant. Vernacula lingua marrubium quogs pulmonis herbam uocat. Eft pra. terea ex lactuc $x$ feu fonchi fylueftris genere herba cubitalis, lacte manans, florum corymbis luteis, 10 quorum calyces nigricant, folinjs hirfutis, angulofis maculofis ́́;:afperis \& faxofis locis \& in parietibus emicat:eam quogs docti in Gallia pulmonariam uocitant. Mirifica eitis præconia frepe audiui cir ca uulnera glutinanda, $\&$ reduuiam hominum curandam. TPerdicium, id eft parietariam uulgare ueteres tumiumentis tum bubus ad tuffim $\&$ anhelandi difficultatem dederũt, Hieron. Tragus, Mulieres qua bubus medentur, parthenї, id eft matricariæ uulgo dicta, pollinem fali admifcenc uefperi ut lingant: Eo medicamento boues purgantur, refpirandiḉ difficultate \& inflatione liberantur, Idē. Lienem quo ob obfructum $\&$ turgıdum tuffis comitatur, pracipué cum ad curfum adiguntur pecu. des. Afthma Græci uocant anguftiam \& difficultatem refpirationis, quam ferè fonıtus quidam comitatur:Germani in quadrupedibus, ut equo \& boue ore bynfd, per onomatopœian fortaffis: In de 8 herbis quibufdam, qua remedium aduerfus hanc noxam praftare creduntur, impofitum no $2 a$ men byn/btraut, ut ariftolochię longx: \& folano perpetuo, quod boum ceruicibus aduerfus hoc ma lum paftores appendunt. Perpetuum autem à recentioribus genus hoc folani uocatum conício, in. de quòd licet folia amittat, non tamen etiam caules ut reliqua folani genera, fed toto anno uirides ure getosḉ conferuet, Vbiç̧illã noftris appellari audio yelenger yelieber ; quanquam $\&$ chamxpiryi nuper quidam nomen idem communicauerint, quod minime probo:neq̧ enim ratio nominis eadem ei conuenit.Quippe folani perpetui cortscem autradicem quó quis mandit diutius, eò dulciorê fụbs inde fentit, unde nomen ei impofitum:chamæe pitys uero ut ab initio amara $\&$ infuauis eft guftu, ita nihilo fuauior fit quantumcunq immoreris mandendo. Audio etiam mortale à quibufdam cogno. minari, cum ueneni minus quàm ullum folani genus habeat, ut ipfe perfuafus fum, nec unquam ab eius ufu incommodi quicquam uel homini trel quadrupedi natum audiui. Et cum cæetera folani ges za nera, qua Gręci ueteres nobis defcripfere(hor tenfe, uefficarium, fomnıferum \& infanum, ex quibus duo priora tartum nobis cognita funt)omnia, tefte Galeno, refrigerent, ideoǵs noxia fint, prafertim copiofius fumpta, ut frig:da venena folent: illud de quo hic agimus, cum dulcifimum fit, \& puimø. nis iecorisḉs obftuciones expediat, ac piruira lentorem incidat, quod multis experimentis certum eft, nequaquam refrigerare dicem us. Succum uero acinorum refrigerare, cum fubacidis fit, \& 2 diffe care, ut Matthacolus refert, non nega uerim: Additidem ad maligna \& contumacia ulcera, ac uulne. rum ir.flam mationes, egregiam huius fucci uim fefe expertum. Damnauerunt in eo fortaffis odor is grauitatem, qux in folys $\&$ baccis percipitur, qui primi mortalis cognomen addiderunt. Acini quis dem omnibus folani generibus communes funt, 8 foliorum ferè figura. Quod olim hortenfe fuit, in hortis iam coli defít, iponte uero natum palfim circa hortos fatis copiofum habetur. $N e c \beta$ enim $2 f=40$ fentior Hierony mo Trago, quifotanum illud fylueftre, radice maxima, acinis halicaccabi, fed nigris 8 nudis, quod inter cognita nobis folani genera nocentiffimum eft (in Italia folanum maius uel bella donna uocant, nos fbla affbeere) pro hortenfi capiendum docer: de quo plura inter fuum remedia dis cemus. Carerum folani noftri perpetui nomen apud ueteres, nifi malacociffus Plinï fuerit, nullum agnofco. Malacociffus(inquít Plinius)Demecritus aquilex mollibus hederæ folp̈s depingit,caule tene ro, hefe cuicunç quod fuerit nacfus inuoluente. Subeffe aquam ubi reperitur affirmat. Hac defcris. ptio quamuis etiam conuoluolo conueniat, qui aquas $8 \times$ ip fe amat, $8 \mathrm{C}$ heder $x$ folís fimilior uidetur, malo tamen folanum noftrã antiquo ifto nomine interim donare, donec aliunde certiora dífcamus. Nam Ruelln̈fententiam de frutice illo amplexicaule, quem figillum D. Mariæ aliqui uocant, \& ipfe alibi malacociffum, alibi cyclaminon alterum facit, Matthaolus iam reprehendit, cui nos libenter fub go fcribimus. Præeterea ueratri nigri fpeciem, abrotoni folńs, quam Hieronymus Tragus defcribitlib.1. cap. 135, itidem à fimili effecीu contra afthma quidam uocant bynfdbtraut:nec non gnaphalitum her. bam, quam aliqui rürteaut:quoniam torminibus medeatur:defcribitur autem ab eodem Trago lib. 1. cap. 109. ubi id polium alterum Diofcoridis effe con̈̈cit, fed falfó. IIudxi hodie cum proprer di. uerfos alios affectus carnem non fani bouis abominantur, de quibus in libris corum Thalmudicis per multa præcipi audio, tum fi pulmones coftis adhæerint, ucl omentum peritonæo : quos quidem ad: hrefus partium exulcerationem interdum fequi crediderim. Eft autem \& illa grauis pernicies, $\mathrm{cum}$ pulmones exulcerantur:inde tuffis $\&$ macies, \& ad ultimum phthifis inuadit. Qux ne mortem affe: rant, radix coryli inufta ita, ut fupra docuimus, perforatæa auriculæ inferitur, tum porri fuccus inftar heminæ pari olei menfuræ mifcetur, \& cum uini fextario potandus datur diebus compluribus, Colu 60 mella. A pud Vegetium uero fic legitur:radix confiliginis, fuccus porri,omnium hemina part men fura oleimifcetur, \&c. Ego Columellęlectionem prẹtulerim, De crauro fiue ftruma(ut Theod. Gaza 


\section{Bos \&Vacca. C. Lib. I.}

reddidit) affectu ut uidetur peftilente, cum tabe pulmonís coniuncio, in præcedentibus dictum eft:

TCruditatis figna funt crebri ructus, ac uentris fonitus, faftidia cibi, neruorum intentio, hebetes oculi:Propter qux bos neç ruminat, neqj lingua fe deterget, Remedio erunt aqua calidx duo con: gị, \& mox triginta braffic caules modice cocti, 8 ex aceto dati. Sed uno die abftinendum eft alio ci bo,Quidam claufum intra tecta continent; ne pafci poffit: Tum lentifci, oleaftríq́ cacumínum pon do III. S libra mellis una trita permifcent aquæcongio, quam nocte una fub dio habent, atç ita fauk cibus infundunt. Deinde interpofita hora macerati eruí quatuor libras obịciữt, aliáç potione (alio cibo uel potione, Veget, )prohibent. Hoc per triduum fieri, dum omnis caufa languoris difcutiatur. Nam fi negleça cruditas eft, \& inflatio uentris \& inteftinorum maior dolor infequitur; qui nec ca= so pere cibos finit, gemitus exprimit, locóǵ ftare non patitur, fape decumbere, 8 agitare caput ( $V \mathrm{e}_{\mathbf{i}}$ getius non agitare caput habet, fed trolutare cogit,) caudamćp crebrius agere (commouere, Veget, ) Manifeftum remedium eft proximam clunibus partem caudx uinculo(refticula uel lino, Vegetius) utehementer obftríngere, uiniḉs fextarium cum olei hemina faucibus infundere, atọs ita citatum per mille \& quingentos paffus agere ( bouem currentem trahere, Veget. ) Si dolor permanet, ungulas circumfecare, \& uncta manu per anum inferta fimum extrahere, rurfusćs agere currentê. Si nec hęe profuit res, caprifici aridæ conteruntur, \& cum dodrante aqux calidæ dâtur, Columella. (Vegetius fic legit, Si tardius proficit, tres partes lauri diu conteruntur, $\&$ cũ duplici aquæ calidæ dantitr.) Vbi nec medicina proceffit, myrti fyliteftris foliorum dure libræ deligantur (tunduntur in pila, Veget,) totidemós fextarị (libræ, Veg.) calidæ aquæ mifti per uas ligneum faucibus infunduntur : Âtque ita 20 fub cauda fanguis emitritur(quaturor digitis ab ano percuffa uena) qui cum fatis profluxit, inhibe: tur papyri ligamine. Tum concitate agitur pecus eoufgs, dum anhelet. Sunt $\&$ ante detractioneni fanguinis illa remedia: tribus heminis uini, tres(quatuor, Veget; )unciæ pinfiti allif permifcentur, \& poft eam potionem currere cogitur. Vel falis fextans, cum cepis decem(decem uncijs ceparum, $V_{e_{1}}$ getius) conteritur, \& admifto melle decocto collyria (longiora, ut uentrem refoluant; $V$ eget, )immit tuntur aluo, atq̧ ita citatus bos agitur, Columella, Eadem fermé remedia ad ftrophos, id eft tormina; Paxamus prafcripfit, ut pauló poft referemus, etfiidem prius de cruditate feorfim agat. Bubus crux ditate laborantibus (inquít $P$ axamus) medebimur a quam calidam propinãtes; brafficæćç aceto per fuf $x$ apponentes fafciculum unum. Aliqui partes teneriores braffic $x$ elixantes $\&$ contundentes, ex oleo eas illis per cornu infundunt; ftragulis ćp fimul bouem laborantem calefacientes, lenta illum ex= 30 ercent deambulatione: Id quod non folum boues, fed omnía pecora iuruat. Alȳ rurfus agreftis olexe folia, aut coliculos aliarum arborum teneros contundentes, a quamó̧̧ infpergentes dífemperant; ac tandem una $\&$ altera die fex heminas infundunt, Hac Paxamus, Si cruditas $\&$ uentris diftentio male habeant bourem, caudam eius deorfum magna ui trahito $\&$ extendito. Plura de inflatione dixi mus retro in mẽtione bupreftis, \& rurfus ftatim poft puftulas faucium. Matricariam quog herbam; ut uocant, contra hoc malum cum fale mifceri iam ante dictum eft. Bos cum gallinæ fímum deuo: ratuerit, ftatim nimio uentris dolore torquetur, \& inflatus moritur : huius etiam uerieni remedia fú. pra requires: Hoc tamen hic adjiciemus, noftrates non tam de fimo quàm plumis gallinaceis cont queri, fi boues forté uorauerint. Inflantur boues(ut fribit Petrus Crefcent.)uentribus ipforum ob ftructis aut flatu repletis, fi manu uel digito feriantur partes circa ilia $\&$ coxas, tympani modo refo, 40 nant: uifu etiam inflati apparent $\&$ dolore torquentur, $\&$ quandogs in terram fe profternunt, ac libenter procumbunt. Curantur clyftere uel cannula, ut equi etiam: aut manu pueri oleo illita extra. huntur ftercora:aut uena caudx acuto cultello inciditur, qux parte inferiore quatuor ab ano dígixis diftat.Periculum \& hoc uití affert, qu uro uulgus inter dum queritur, boues ruminandi facultatem ami fiffe. Ruminantibus enim omnis fere cibus ore elabitur, unde totius corporis macies ftatim confequl tur. Curandum eft igitur, ut manu inferta in fauces ingeratur, fiue illud ipfum quod boui xgro ex: ciderat, fiue quod alteri ruminanti ex ore fubtractum fuerit:ita tamen ne nimium urel omne alimen: tum illi fubtrahatur, ac idem qui in agro curatur affectus, in fano creetur. Abfurdo ruftici quidam pharmaco ruminationem reftitui putant, fordibus uaginarum excuffis $\&$ buccella panis ori infe rendæi infperfis, Sí bos cibum faftidiat, pabulum eius amurcæ fufficienti portione infpergito: Ole: jo etiam, refinæaut terebinthin $x$, fingulorum $x q u i s$ partibus miftis, ad radicem uf $\$$ cornua bouis deungito, Florentinus, Plarrof $\beta$ fane affectus faftidîn fymptoma comitatur, ut malidem humidam, capi tis dolorem, crudditatem, tumorem palati, alui profluuium, tormina $\&$ uẽtris dolorê, \&c. Vide etiam fupra ubi de rảna fub lingua diximus. Nullo autem tempore, $\&$ minimé xftate, utile eft boues in curfum concitari: nam ea res aut cit aluum, aut mouet febrem, Cholera affectís crura cauterio ufque ad ungulas exurenda funt, pofteaćp lautacro calidæ aqua affidué fouenda, contegendaćs ftragulis, Florentinus, Ventris \& inteftinorum dolor fedatur uifu nantium (anferis, Veget.) et maxime anatis, quam fi confpexerit, cui inteftinum dolet, celeriter tormento liberatur. Eadem anas maiore profectur mulos, \& equinum genus confpectu fuo (celeriter) fanat, Sed interdum nulla prodeft medicina. Se. quitur torminum uitium:quorum fignum eft cruenta $8 X$ mucofa uentris proluuies. Remedia funt 60 cupreffini quíndecim coni, totidemćs gallæ, $\&$ utrorumç ponderum uetuftiflimus cafeus, quibus in unum tunfis admifcentur aufteri uini quatuor fextarin, qui pari menfura per quatriduum difpen. fati dantur:nec definit lentif́, myrtiós, \& oleaftri cacumina uiridis (ita ut lentifci myrtiós $\&$ oleaftri 
cacumina prabeantur, Veget.)Alutis corpus, ac uires carpit, operićs inutilem reddit:qur cum acci dent, prohibendus erit bos potione per triduum srimó̧ diecibo abftinendus. Sed mox (fecundo die)cacumina oleaftri, $\&$ arundinis (cannix fylueftris, $V$ eg.) irem baccx lentifci, $\&$ myrti dandx, nec poteftàs aqua (poft triduum etiam, Veg,)nifi quàm parciffime facienda eft. Sunt qui teneræ laurus caulium libram, cum abrotani macerati(aliâs hortenfís, Veg.)pari portione dent, cum aquả calida duobus fextarijs, atç ita faucibus infundant, eademóp pabula, tut fupra diximus; obịciant. Qùìidam uinaceorum duas libras torrefaciunt, $\&$ ita conterunt, \& cum totidem fextarijs uini aufteri, potan dum medicamentum prabent, omniq̧́ alio humore prohibent, nec minus cacưmina pradictarum arborum obijciunt.Quod fi neç uentris reftiterit citata prolutuies, neqzinteftiniorum ac uentrís do lor, ciboş́́ refpuet: \& prægrauato capite, fi frepius, quàm confureuít, lachrymà ab oculis, \& pituita 10 à naribus profluent:uf̣́ ad offa frons media urat, auresćç ferro fcindantur. Sed uuulnera facta igné, dum fanef́cunt, defricare bubula urina côuenit. At ferro refciffa meliuş pice \& oleo curranturir, Colu mella.Qui bos torminibus difcruciatur(inquit Paxamusłloquitur autem de illis quíos Graci şóps trocant)minime in uno loco confiftit, nec cibum tangit, fed mugit. Parum igitur nutrimenti illi offe: rendum eft, caró́ circa ungulas uf̧́ ad fanguinem perpungenda, Alị circa caudam folutionem fa cientes, donec effluat fanguis, poftea linteolo deligant. Alin cepas cum fale tundentes admouentesć fedi quàm penitifliméfieri poffít, poftea boues impellunt, eoś́ cogunt ad curfum . Alij terentes ni.

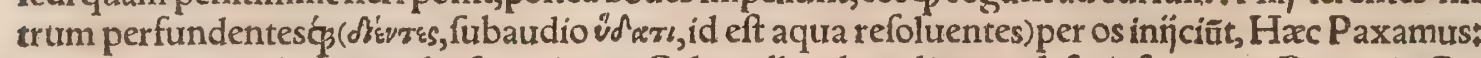
plera $\$$ autem eadem remedia fuperius ex Columella ad cruditatem defcripfimus Boues in Cy. pro contra tormina hominum excrementis fibi mederi ferunt, Plin. Aduerfus diarrhoram, rhamni 20 folia contundens, afphaltoós mifcens, da comedenda.Quidam folia mali Punica macerata farinæćq mifta offerunt. Alin farinæ hor dei cotylas duas, \& farinæ tritici torrefacti mediam cotyla partem mi feentés aqua, porrigunt, $\mathrm{Paxamus}$. Hodie quidam ex noftris ferpyllum contra uentris profluuium commendant:alij burfam paftoris. Quidam boures foriolos \& ftercore liquidolaborantes noftra lin gua uocant rennigt. ब Lien boum étiam quandoọ lentis craffisćç humoribus infarcitur, unde nó liberantur, $\mathcal{Q}$ diuturnus fit affecius: dignof cunturt ex tuffi, cum aliâs infeltante, tum maxime quan doad curfirm aguntur, Petrus Crefcent. qMalis fubrenalis uocatur quoties à pofterioribus debi litas apparet, $\&$ lumbi dolere credũtur, fuperius inter fpecies malidis memorata, Eiufdem, ni fallor; loci affectus eft, quemi noftrates uocant bie blatern vnoer sem trüt, 8 nefcio quíd concreti fan. guinis illic reperiri aiunt, for is nihil apparere:remedio effe irticx fafciculum cum radicibus, quem $z^{\circ}$ puto faucibus eorum ingerunt, ut rumpatur abfceffus, TCum fanguinem mingunt boures, , rarò euadunt. Aiunt autem cum prata pafcuis aperiuntur, propter nirniam pabúli pinginitudinem fole. re aliquando hunc morbum fequi, aucio nimirum fanguine ex alimenti copia: indé nomen etiam ei apud Germanos gtâfied, id êft morbus ex gramine:feré enim oborit cumà montibus uel macris pafcuis ad lætiora migrauerint. Remedia tentantur huiufmodi : hordeum in aqua decoquitur, $\mathrm{fi}$. mulćp lardum \& panis:decoctum iftud infundint. Aliqui blitım (quod circa fimeta $\&$ foló pingui prouenire folet, nomine fanguinariæ, caulibus $\&$ folīs rubris ) tufum falitumó $\$$ præbent. Nafcitur $8<$ herbula quædam in collium montium $q$ h humidis $\&$ glareofis locis, herba ipfa feffilis eft, fine cau= $\llbracket$ e, folijs ex uíridi pallidis, trium digitorum(fi bene memini) pinguibus ac fi oleo illita effent, flofculis colore \& figura ferè uiolarum, quas Martias dicimus, per fíngulos pediculos fingulis : hanc aliqui 40 noftrorum à loco natali uocantmofitgele, $\&$ ad fanguinis mictum commendant $\&$ mulierum quo que menfíbus fiftendis, Alí fecreto experimento iuglandiũ nucamẽta in ouo exhibẽda celebrant. Sunt qui ipfam cruentam urinam dum redditur excipiunt, ac riurfus ftatim per os infindint. Mu=

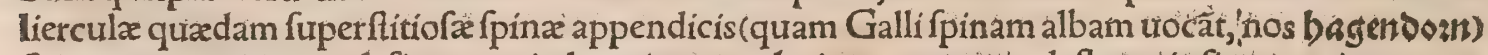
fpinami unam in terra defigunt eo in loco, in quem lotium cruentím defluxerit, fi cum primum cru enta efle incipit id fecerint, malum defiturû perfuafa, Prætêrea ad fiftendũ fangutinis mićum uix quicquam efficacius effe aiunt herba Roperti uel gratia Dei irulgo dicta, quam eam ob caufam paz ftores in montibus noftris uocant batnteraut, id eft urinalem. Quamuis enim uerbum batnen fim. pliciter urinam reddere fignificet: ruftici tamen apud nos aliquando priuatim de cruenta urina eo utuntur. Inferunt autem herbæRoperti manipulos aliquot contufos. Alij tormẽtilla herbam fimul jo $\&$ radicem terunt ac fali mifcent.Alij mufcum de nuce arbore in cibo prabent: $\&$ nifi profuerit, $b u=$ tyrum crudum admifcent. Allí(fi bene meminí) oxylapathi folia contứa falitaćs ori immittunt. Opor tet autem hoc morbo periclitantes boues, in ftabulo quiefcere, ne fubitaneus (ut uocant)fanguis fur perueniat: $\&$ foeno tum alio tum cordo falubri pafci. Si membrum coxendicis uitio, alimentum non fentiat, $\&$ contabefcat, frpe diứć illines hoc unguento, quod recipit ceram iuglandis magnitus: dine, axungiam de ruffo maiali, medullam fabuci arboris, bubulam medullam ac feuum \& falèm; qux omnia ad ignem bullire $\&$ mifceri debent. Alij de opima bubula carne, poftquam diu büllie: rit, innatantem pinguedinem auferunt, mox iure quod reliquum eft, locum affectum latiant, dein. de pinguedinem perfricando illinunt ad folem:aut fi folis copia non fit, afferem igne calefactũ mem bro admouêt . Alij inungi iubent, allio, axungia, herba fabina $\&$ fuligine tritis mixtisó̧, bobus fimul 60 $\&$ equis utilimedicamento.

IEft quando lac etiam cruentum excernitur:quo animaduerfo, muliercula lac omne emulfum 


\section{Bos\&Vacca. C. Lib. I.}

aqt: flutenti infundunt:aliæ mulctrali inuerfo id eft fundo immulgent, \& fignocrucis notant, Hẹc fcribo ut aniles fuperftitiones iftæ proditæ improbentur. Vaccam fuiffe Pirinthi aecepimus, cur: cibi excrementum extenuatum per ueficam tranfmittebatur, diffeçusḉs anus denuo propere coale, Icebat, nec refecando euincere uitium poterant, Ariftoteles. Boues gregales (ut Ariftoteles fcribit) morbis duobus tentantur, ftruma, de qua fupra dictum eft: \& podagra affectu egre currabili:facithęc utpedibus intumefcant: \& quamuis non intereant, tamen ungulas amittant; ualent melius corni: bus pice illitis calida, Hæe A riftot. Et alibi, Vngulas cum dolore articulortum laborat bos non amite tit, fed pedes tantummodo intumefcunt uehementer. Et rurfus alibi, Nec pedum dolores fentiūt bo: ưes, fi eorũ cornua illinantur cera, aut oleo, aut pice, Boû attritis ungulis cornua ungédo artuina me 10 dentur agricola;, Plinius. Non fubteri pedes boum fi prius cornua pice liquida perungantur, reper mus, Idem, Boues pedes ne fubterant, pritfquam in uiam quoquam agas, pice liquida cornua infima unguito, Cato, Per cornua hic ungularum fubftantiam intelligo, ut etiam uernacula lingua ap. pellamus:licet Plinius non ita accepiffe uideatur Strbtriti pedes eluuntur calefacta bubula urina:de inde fafce farmentorum incenfo, cum iam ignis in fauillam recidit, feruentibus cineriburs cogitur in fiftere, ac pice liquida cum oleo, uel axungia cornua eius linuntur, Columella. Sanguis dimifurs in pedes claudicationem affert:qued cum accidit, ftatim ungula infpicitur:tactus autem feruorem dez. monftrat:nec bos uitiatam partem uehementius premi patitur, Sed fi fanguis adhuc fupra ungulas in cruribus eft, fricatione affidua (ad triduum triti falis perfricatione, Veget,) difcuritur: uel cum ea nihil profuit, fcarificatione demitur. At fi iam in ungulis eft, inter dios ungues cultello leuiter (lenis 20 ter)aperies. ( 8 mundabis intus, Veget.)Poftea linamenta(ftuppa) fale ato; aceto imbuta applican, sur, ac folea fpartea pes induitur, maximé́ṕ datur opera, ne in aquam pedern mittat, $\&$ ut ficce ftabur letur. Hic idem fanguis nifi emiffus fuerit, faniem creabit, qui fi fuppurauerit, tarde procurabiutur:ac primo ferro circuncifus, $\mathcal{Q}$ expurgatus(expurgatur ad uiuum, Veget.) deinde pannis aceto $\&$ fale \& oleo madentibus inculcatis(aliâs impletur, Veg.)mox axungia uetere, \& feuo hircino pari pona dere decoêtis (aliâs ferro candenti ftillantibus, Veget.) ad fanitatem perducitur. Sifanguis in inferiore parte ungula eft (Veget. addit, nec aperturam facit, $8 \mathrm{C}$ tantum claudicat anima!,) extrema pars ip. fitus unguís ad uiuum refecatur, \& ita emittitur, ac lineamentis (fuppa trel linteolis cum fale \& oleo 8 aceto infufis, Veget,)pes introlutus f partea munitur, Mediam ungulam ab inferiore parte non ex. pedit aperire, nifi eo loco iam fuppuratio facta eft. Si dolore neruorum claudicat, oleo \& Fale genena, 30 poplites $q^{\prime}, 8 \alpha$ crura confricanda funt, donec fanetur. Sigenua intumtrerunt, calido aceto fourenda funt, 8clini femen, aut milium detritum, confperfumós (intufumós, Veget.) aqua mulfa imponendũt:

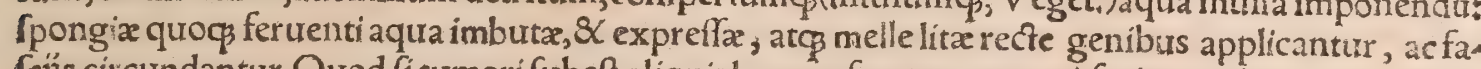
fcís circundantur.Quod fi tumorifubeft aliquis humor, fermentum, uel farina ordeacea ex paffo, aur aqua mulfa decocta imponitur: $\mathcal{E}$ cum maturuerit fuppuratio, refcinditur ferro:eá̧́ emiffa, ut fupra docuimus, linamentis curatur. Pofiunt etiam(ut Cornelius Celfus pracipit)lilí radix, aut fcyl. la cum fale tuel fanguinalis herba, quam noxúyovon Graci appellant, trel marrubium ferro reclufa fa, nare. Feré autem omnis dolor corporis, fi fine uulnere eft, recens fomentis melius difcutitur: uetus au temuritur, \& fupra uulnus butyrum urel caprinus inftillatur adeps, Columella, Si ob partis frigidita tem(inquir Florentinus) bos claudicet, pedem abluere contrenit, locumós affectum (ubi fcalpello fure 40 rit manifefratus) fourere ueteri urina.Dein uero fale côfpergere, atç ex fpongia peniculóue alio muñ dare. His factis, adeps hircina, aut bubula, probe contufa, parti dolenti ex ferro calido infillanda eff. Sin autem, q calcârit erectum palum, aut aliquid fimile, bos claudicare uideatur, cæatera quidem om nia fímiliter facienda funt,ceram aưt cum oleo ueteri, melle, $\mathcal{X}$ orobi farina, folutam refrigeratamíg ulceri imponere debes. Poftea uerò, accipiens incretam teftulam, ficuśća aut mala Punica tundens atç permífcens, ulceri circumponito: ac linteo aliquo deligato adeò curiofé, ut externarum rex î. ní hil fubingrediatur, donec bos ipfe firmiter poffit fare. Sic fiquidem percurabitur:tertia autem die fir mili medendi ratione fuccurrito. Si claudicet ob materix influxum, oleo $2 x$ paffo concociis, pars ipfa calefacienda eft, ac dein calida polenta hordeacea illi imponenda. Cærterum ubi pars ipfa tenera $\&$ mollis eft reddita, aperienda eft, extergenda ćp. Poftea ueró folia liliorum, aut fquillam ex fale, autr po so lygonon, aut deniç prafium contufum imponere expedit, Hactenus Florentinus. Si quid pedem at liamue partem bouis penetraterit, curandum eft ut extrahatur ctrm radicibus arundinis tritis, uel $\mathrm{rat}$ dicibus dictamni fuperpofitis $\&$ fafcia alligatis, uel alijs medicamentis qux fpinis extrahendis adh bentur in equis, ut in illorum hiftoria docuimus, Perrus Crefcent, Si talum, aut ungulam tromer lae ferit, picem duram, \& axungiam cum fulfure, \& lana fuccida inuolutam candente ferrofupra uul nus inurito. (aliâs inuroluito, $\&$ candente ferrofupra uulnts imponito, $\&$ ungito, Veget, ) Quod idẽ remedium optime facit exempta ftirpe, fi forte furculum calcarerit, aut acuta tefta, uell lapide ung ux lam pertuderit, qux tamen fi altius uulnerata eft, latius ferro circunciditur, $\&$ ita inurit ut fupra pre cepi:deinde f partea calceata per triduũ fuffufo aceto curațt. Iremi fi uomer crus fauciarit , marina la.

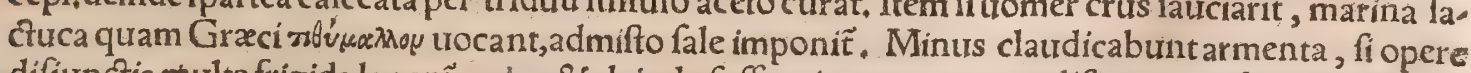
60 difiunctis multa frigida lauent pedes: $\mathcal{\alpha}$ deinde fuffragines, coron $æ$, ac difcrimen ipfum, quo diuifa

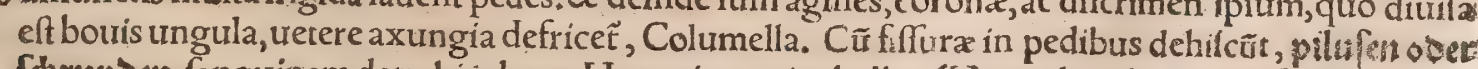
fobrunden, fanguinem detrahi iubent. Hetruxia myriophyllon (Hermolaus legit millefoliā)appellas 
herbam in pratis tenuem, à lateribus capillamenti modo foliofam, eximni ufus ad uulnera:boum ner tos abfcifos uomere folidari ea rurfusć iungi addita axưngia affirmans, Plín.

THis iam perfcriptis cum à remedins ad reliqua de bubulo pecore dicenda tranfiturus effem, in li. bellum quendam qui diuerfa remedia manufcripta Germanicé continebat, incidi: qua \& ipfa corol. larï uice pracedentibus adnecfere operapretium duxi. Sunt autem ifta. Si peftilentia bubus in. gruerit, radices afari in aqua decoquito $\&$ in potu exhibeto:uel ipfas contritas aquę infpergito \& fau cibus infundito:uel teltas limacum, fufficiunt autem fingulis bubus fingula. Alin herbam cruciatam gentianx fpeciem, ut fupra dixi, pariter cum limacum teftis terunt, \& per os infundunt. Alĭ trirgam auream (fic Itali uocant, nos betonifb wunstraut)contritam pani imponunt et ori inferunt. Forfian hæc Diofcoridis $P$ anaces Chironium eft, flore aureo, folio non amaraci, ut in Diofcoride legitur, fed so lapathi, ut in Plinio, maiore $\&$ hirfutiore: radix parta non alte demittitur, guftu acri : nafeirur m montanis, ficcis $\&$ afperis. Diofcorides ferpentium ueneno potam radicem, uel ilitam comarn, refi ftere docet.Afclepion panaces et Chironion Heracleo calidiora funt, (ego cum Galeno poruus minus calida legerim hinc floribus ipforum \& (emine ad malefica ulcera \& phymata utuntur, $P$ aulus \& $G a$ lenus. Arnoldus de Villa noura uirgam auream apprime laudat à uiribus urina ciendx $\&$ calculi res num frangendi: Italorum quidam herbam Iudaicam uel paganam uocant. Auicenna per herbam Iudaicam eruum intelligit:recentiores etiam unam fideritidis fpeciem eodem nomine uocitant, quam

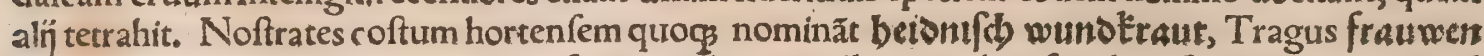
Eraut.Sic fit ut cum uel una res diuerfis nomintous appellatur, uel rurfus diuerfa uno, magna apud plerof s rerum inf́citia 8 confufio nafcatur. \Boues fi intumuerint, calendulæ fuccum cum aqua 20 potandum eis mifceto. Sanicula \& eupatorium (quod uulgus agrimoniam uocat)in trino decocia, boum uulneribus imponuntur. Sibos à ferpente morfus fuerit, butyrum de mêfe Martio cum fale ad focum permifce, \& illine: uel pelle muftelina locum demulce. Si ulcus malignâ, quod uulgo uer: mem appellamus, infeltat, carduos edendos apponito, tum bubus, tum equis pracipue: aut radicem $V$ aleriana ore commanfam fuperilligato, quod $\&$ hominibus prodeft. Boui pulmonario herbam pulmonariam arboribus adnafcentem, contritã, panićs cum fale infperfam in fauces demittito. A. $d=$ uerfus malum, quod noftrates fangurinem fubitaneum uocant, (de quo fupra, ubi de inflatione dixis = mus ) urticarum radices ex tribus plantis collectx, in cibo medentur. Cum fangtrinem ex uefica red dunt boues, quieti in ftabulo permittendifunt, ne forté fanguine fubitaneo corripiantur. Si boui aut uitulo aluus nimium fluat, toftam auren $x$ farinam faucibus immittes, $\&$ panem toftum infperfo fale: $3^{\circ}$ oxylapathi quogs femen in ciboiuuare certum eft. Contrà, fi excrementa alui retineantur, mufcerdam $\&$ cannabis femen in fauces inferito : uel uaccinum lac calidum, uel coquinariam colluuiem ue terem infundito. Boum $\&$ uitulor um lumbricos expelles infufo fucco quem exprefleris è folïs \& $r 2$ dicibus betærubea: Idem medicamentum pueris etiam conducit. Alï pollinem burfæe paftoris dictę aduerfus coldem commendant: quos ego errare iudico : alia enim herba.eft, quam uulgo Germani wurmtraut appellant, nafturtị fylueftris genus, cui fimillima feminum conceptacula burfe paftoris funt, ad lumbricos maximé commendata. Cumuacca foetauerit, ex auena fomentum ftatim admo uretor, ut prorfus liber etur. Si polt foeturam uiribus exhaufta erit, adeò ut confiftere uix queat, fo: res foeni facco falario infarcti $\&$ in aqua decocti, dorfolumbisćs bene calidi imponantur : bis die fal offeratur, 8 in folem progredi permittatur, ac cibus ibidem prabeatur. Si uaccam taurire uoles, fal 40 fam bouris carnem iuglandis magnitudine in os ei ingerito. Vel, Cum uitulus menfis unius atatem attigerit, falem uaccælingendum tam calefacito, quàm ferre calidiffimum manu potes, \& quater aut quinquies uacc $x$ offerto, mox taurum defyderabit. Pediculos boum $\&$ uitulorum hoc ungento $2=$ molieris, quod conftat cremæ lactis fefquifex tario, butyri menfura qux duas iuglandes aquet, 8C rea finæ pari,falem abunde addes, \& pariter feruefacies: cum opus erit illines. TSi quid noxỉ aut ue. nenofi boures deuroraffe uidebuntur, quod cum ex alijs fignis, tũ inflato corpore, facile eft conịcere: præftantiffimam antidotum $\&$ omnibus theriacis uulgaribus ( namillas quoç pecori uenenato quidam infundunt) longé præferendam, \& multis experimentis celebrem, ab amico quodam, dum hæc fcriberem, excepi huiufmodi:Gentianæradix in pollinem redacta, \& ftillatitio liqurori ex fecibus ui: ni (aquam ardentem uocant) permixta infunditur in fauces bouis: Aut fi gentiana defuerit, liquor so etiam folus. Idem pecori uehementer noxium effe aiebat genus illud glutinis aêrei(fic enim appello, cum nomen aliud ignorem ) quod colore fubflauo, molle, $\&$ coagulatum in muris interdum $\&$ her bis adhærens inuenitur. Ruftici quidam traịcientibus in aëreftellis id nafci aiunt: \& gramen etiam cui haferit, licet aquis pluunjs ablutum, uenenofam uim retinere afferunt. Non defunt qui ius in quo hordeum diutifímè coctum fuerit, unà cum cremore fue ipfo hordeo, bubus contra quemuis ignotum morbum infundant,

Non probat Plinius illos qui fubtilitatê animi conftare non tenuitate fanguinis putant, fed cute operimentis ̧́́ corporum magis aut minus bruta effe:boum tergora, fetas fuum obftare tenuitati im meantis fpiritus, nec purum liquidumós tran/mitti. Sunt fanéboues ingenio miti, remiffx, \& mini= 60 mé peruicaces, Ariftot. Agnofcunt uocem bubulci, uocatióg nominibus proprị̂s intelligunt, iuffisć̣ armentarij aut prafecti parent $\&$ obfecundant, Florentinus, Mores in operario boue quales proben 


\section{Bos $\&$ Vacca D.E. Lib. I. бI}

tur, infra dicemus. Boues coelum olfactantes, féç lambentes contra pilum, tempeftatem prafagi. unt,Plinius, Sufias boues numerandi fcientiam tenere Ctefias Gnidius fcribit. Nã Sufis regifingu la quotidie centum cados ad irrigandos hortos hauriunt. Quem quidem laborem, fitre quòd fit eis certus $\&$ conftitutus, fiue etiam quia diu multumós in eo fe exercuerint, promptifime obeunt: Nul. lam enim earum ad opus remollefcere uideres, neç ad alterum fupra quàm diximus cadum exhat. riendum, nec uerberibus, nec blanditn̈s inducere poffes, Aelianus. Plutarchus etiam in libro terre. ftríne an aquatica animalia plus fapiant, idem fribit in hac uerba:Boues Sufis hortos regios uer. fatili machina $\&$ modiolis hauftorïs numero certis rigant;centenos modiolos in dies fingulos fingu li boum ducunt. E natura etiam bouis ef, cum ex feritate ad manfuetudinem traductus ef, ut ad pa o rendum facilis fir. Enimuro ad feretrum portandum fub iugum miffus quietus manet, fitre uelis e. um erecfo capite quiefcere, fiue ad terram inclinato abijci, tum in ceruice $\&$ dorfo puerum puellám. ue geftari patitur. Equidem ipfe uidi, qui fupra níhil fe commouentes tauros faltarent. Item boues inftituti fefe in theatris inclinant, \& erigunt, \& motus uel homini ipfi difficiles faltant, Aelianus, Bo uem licet mańfuetû, nó facile tamẽ illius qui fibiftimulos admouer obliuio capit:at iniuriã animo ac memoria uel longiffimo interuallo cótínens, poenas pro maleficio fibi illato fumit. Nam cũ eft fub iu gum miffus, lorisés conftrictus, quodammodo fimilis eft homini in uincula coniecto, \& fe quidê tra. hi quò impellitur, acquiefcit. V tuero folutus eft, aliâs ad bubulcû̉ uerfus pedem fuum laxans, aliq̣d illius membrum contríuit:aliâs fxpe in cornua incitatus, in curfu illum interfecit: Cum tamen in cai teros fubito manfuetus exiftat, ac quietus in ftabulum ingrediat: neq enim ferus in eos exiftit, qui o iram fibi non mouent, Aelian. Boues $\&$ pafcunt per focietates atç confuetudines: $\& \alpha$ fi unus aberrâ rit, reliqui fequuntur:quapropter boarín nifi præuenerint, totum armentum requirant, neceffe eft, Ariftoteles. Eximia boum aratorum in focios pietas animaduerfa eft nam alter alterum, quo cum a. rare confueuit, fi forte defit, requirit, \& frequente mugitu defyderium teftatur. Quanto foetus fut. os amore profequantur uaccæ Oppianus his uerfibus prædicauit,

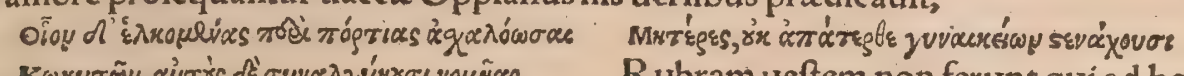

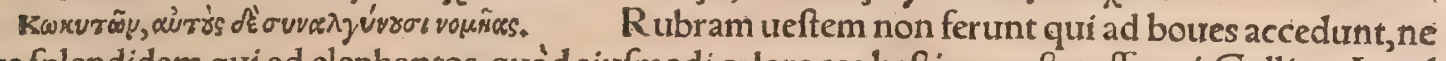
que fplendidam qui ad elephantos, quòd eiufmodi colore eas beftias conftet efferari, Gyllius. A pud nos cum exacta hyeme uaccx prinum in pafcua emittuntur, quauis proximam cornibus adoritur: qux tum uicfa fuerit, totam deinceps aftatem alteri cedit. Sunt qui allium cum fale uaccis fuis pri mum emíttendis in cibo prabeant, ut reliqux omnes propter odorem eas aurerfentur: fed minus pla. cidx inde fieri exiftimantur. Sunt qui nefcio an allium an aliud quidpiam bubus edendum ingerãt, irt à cæteris uitentur, \& ipfi herbis abunde fruantur. Boues lupus inuadit: alitur enim carne, Ari,

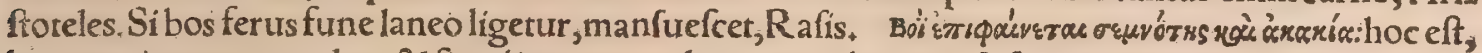
bos grauitatem quandam 8 fimplicitatem uultu ac moribus præ fe fert, Adamantius. Ariftoteles in phyfiognomonicis illos quibus facies carnofa eft, remiffi $\&$ negligentis animi effe cöñ cit: quibus magna, ignauros feu tardos:quibus oculi magni, fimiliter:quibus admodum caui, mites: \& illos etiä ignauos, quibus frons magna fit:poftremó querulos $\&$ indignabũdos, quibus uox primum grauis, in fine acusa fuerit:quod eadem omnia in bubus fimiliter fe habeant.

E.

40 Multiplicem ex bubus utilitatem capi Philes poêta recention iftis uerfibus complexus eft:

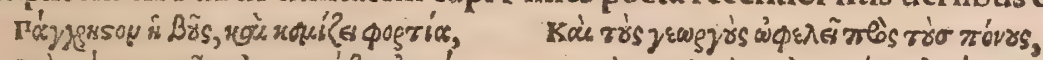

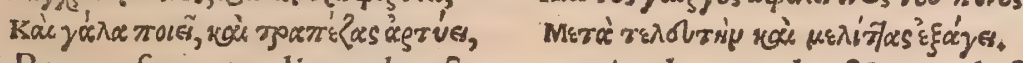

Hoc eft, Boum ufus extenditur ad uecturam, agri culturam, lac $\&$ opera lactaria, denís ad apum reftaurandam fobolem. Quid,Inquir Cicero, de bobus loquar q quorum ipfa terga declarant non effe ad onus accipiendum figurata:ceruices autem natæ ad iugum, tum uires humerorum \& latitu: dines ad aratra extrahenda, quibus quû̃ terræ fubigerentur fiffione glebarû, ab illo aureogenere, ut poëtæ loquuntur, uis nulla unquam afferebatur. Ferrea tum proles exorta repentè eft, Aufaç̧ funeftum prima fabricarier enfem, Etguftare manu uinctum domitumó́s iuuencum. Tanta puta batur utilitas percipi ex bobus, ut corum uifceribus uefci fcelus haberetur.

50 TCurandum eft omnibus annis in hoc æqué atos in reliquis gregibus pecoris, ut delecius habea tur:nam $\&$ enix $\&$ uetuftx, qux gignere defier unt, fummouend $x$ funt, $\&$ utiç tauræ, qua locum focundarim occupant, ablegand $x$, uel aratro domandx, quoniam laboris, $\&$ operis non minus quàm iuuenci propter uterifterilitatem patientes funt, Columella. Iutuencus caftratus aptior fit iu= go, \& manfuetior tractabilioróp, \& laboris focium mirifice diligit, ut fupra diximus. Boum uulgari tum quidam funt maiores, quorũ ufus eft in locis planis:alî́ minores, qui feréad montes remittûtur: thediocres utrifg, conueniunt locis : Oportet autem adultos boues non iuniores laboribus deftina. re, Petrus Crefcent. ब| Quæ in emendis bubus fequenda, quxḉ̧ uritanda fint, nō ex facili dixerim (inquít Columella)cum pecudes pro regionis coeliós ftatu \& habitum corporis, \& ingenium animi, $\&$ pili colorem gerant:alix forma funt A fiaticis, alix Gallicis, Epiroticis aliæ:nec tantum diuerfitas 60 prounciarum, fed ipfa quoos Italia partibus fuis difcrepat. Campania plerunç boures progenerat al bos $\&$ exiles, labori tamen $\&$ culturæ patrị foli non inhabiles. V mbria uaftos $\&$ albos, eademćs ru bros:nec minus probabiles animis quảm corporibus, Hetruria \&Latium compactos, fed ad opera 
fortes. Apentinus duriffimos, omnemọ́ difficultaten tolerantes, nec ab afpectu decoros: Quę cuin tam uaria $\&$ diuerfa fint, tamen quxdam quafi communia $\&$ certa præcepta in emendis iutuencis a. rator fequi debet:eaćs Mago Carthaginenfís ita prodidit, ut nos deinceps memorabimus. Parand funt boures nouelli, quadrati(uiribus magnis)grandibus membris, cornibus proceris(amplis)nigran tibus \& robuftis, fronte lata et crifpa, hirtis auribus, oculis \& labijs nigris, naribus refimis patuliş́, ceruice longa $8 x$ torcfa, palearibus amplis, \& penè ad genua promiffis, pectore magno(lato) armis uaftis, capaci $\&$ tanquam implente utero, lateribus porrectis, lumbis latis (craffis coxendiciburs) dor fo recto planóg, uel etiam fubfidente, clunibus rotundis, cruribus compactis ac rectis, fed breuiori bus potius $\bar{\phi}$ longís, nec genibus improbis, ungulis magnis, caudis longiffimis \& fetofis pilofisḉ̧, corpore denfo breuíg bouis aratoris electione, Bouem rubeum ab aratoribus probari difcimus $;$ qualis fortaffe eft, quem hodie Veneti agricolx lorum fuo uocabulo appellitant: Nec enim idem prorfus color eft rubeus, qui ruber à nobis, à Græcis égulgòs dicitur, Nic,Erythræus, Talis notæ uitulos, id eft íutrencos uel boures indomitos $\&$ rudes (inquit rurfus Columella)oportet cum adhuc teneri funt, confuefcere ma nu frequenter tractari, ad præfepia religari, ut exiguus in domitura labor eorum, $8 \mathrm{Cminus} \mathrm{fit} \mathrm{pericu}$ li. Verum neqs ante tertium, neç poft quintum (quartum, Varro)annum iuuencos domari placet: quoniam illa atas adhuc tenera eft, hæc iam prædura, Columella \& Pallad, Domitura boum in trima tu, poftea fera, ante præmatura,Plinius. Eos autem, qui de grege feri comprehenduntur, fic fubigi conuenit, Primum omnium fpatiofum ftabulum praparetur, ubi domitor facile uerfari, $\&<$ unde di= gredi fine periculo poflit. Ante ftabulum nulla anguftiz fint, fed aut campus, aut uia late patens, ut 20 cum producentur iutenci, liberum habeant excurfum, ne pauidi aut arboribus, aut obiacenti cuili. bet rei fe implicent, noxamós capiant. In ftabulo fint ampla pręfepia, fupraćs tranfuerfiafferes in mo dum iugorum à terra feptem pedibus elati configantur, ad quos religari polfint iuuenci(boues indo miti.) Diem deinde, quo domiturã aufpiceris, liberum à tempeftatibus, \& à religionibus(impedimen tis omnibus)matutínum eligito:(quo capti perducantur ad ftabulum ) canabinis ̧̧́́ funibus cornuą iutencorum ligato:fed iaculi, quibus copulantur, lanatis pellibus inuoluti fint, ne tenera fronte fub cornua lædantur:cum deinde bucoles comprehenderis, extra ftabulum producito, \& ad fípites re. ligato ita, ut exiguum laxamenti habeant, diftent'́s inter fe aliquanto fpacio, ne in colluctatione alter alteri noceat. Si nimis afperi erunt, patere unum diem noctem ćs defæuiant (inter uincula mitis

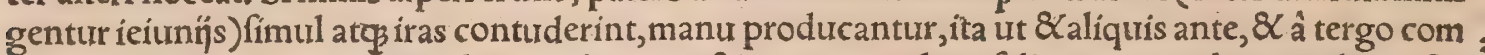
plures, qui fequantur, retinaculis eos cótineant: \& unus cum claua falignea procedens modicis icti. bus fubinde impetus eorum coérceat. Sin autem placidi $\&$ quieti boures erunt, uel eodem die, quo al ligaueris, ante uefperum licebit producere, $\&$ docere per mille paffus compofite, ac fine paurore am $=$ bulare:cum domum perduxeris, arcté ad ftipites religato, ita ne capite moueri poffint : tum demum ad alligatos boues, neç à pofteriore parte, neq̧à latere, fed aduerfus placide, \& cum quadam uocis adulatione(appellationibus blandis, \& illecebris oblatorum ciborum)uenito (bubulcus admulceat) ut accedentem confuefcant afpicere: deinde nares perfricato, ut hominem difcant odorari.Moxeti= an cóuenit tota tergora \& traĉare, \& refpergere mero, quo familiariores bubulco fíant: uentri quo que, \& fub femina manum fubijcere, ne ad eiufmodi tactum poftmodum pauefcant: \& $\mathcal{L}$ ut ricini, qui plarunç feminibus inharent, eximantur:idós cum fit à latere domitor ftare debet, ne calce (aut cor = 4 nu) cótingi poffit(quod uitium fi in primordijs effeçưi fibi ceffiffe fenferit, obtinebit,) Poft hęc didu ctis malis, educiro linguam, totumćs corum palatum fale defricato, libralesćs offas in præfulfæa adi= pis liquamine tinctas, lingula (in gulam, Pallad.) demittito, ac uini fingulos fextarios per cornu fatu= cibus infundito. Nam per hæc blandimenta triduo ferè manfuefcunt, iugumó̧ quarto die accipiût, cui ramus illigatur, $\&$ temonis uice trahitur:interdum $\&$ pondus aliquod (leue)iniungitur, ut maio re nifu laboris exploretur patientia, poft eiufmodi experimenta uacuo ploftro fubiungendi, $\&$ patr. latim longius cum oneribus producendi funt. Sic perdomiti mox ad aratrum inftituantur, fed in fub acto agro, ne ftatim difficultatem operis reformident, néure adhuc tenera colla, dura profciffione ter, ræ contundant. Quemadmodum autem bubulcus in arando bouem inftituat, primo (inquit Colus. mella)pracepi uolumine:curandum ne in domitura bos calce, aut cornu quenquam contingat:nam go nifi hre caueantur, nunquam eiufmodi uitia, quamuris fubacta, eximi poterunt. Verum ifta fic agen

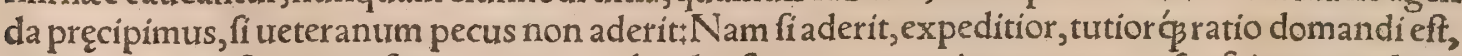
quam nos in noftris agris fequimur: nam ubi plauftro, aut aratro iutuencum confuefimus, ex dom: tis bubus ualentiffimum, eundemó placidiffimum cum indomito iungimus, qui $\&$ procurrentem retrahat, \& cunctantem producat, Si uero non pigeat iugum fabricare, quo tres iungantur, hac ma. chinatione confequemur, ut etiam contumaces boues grauiffima opera non recufent $\$$ nam ubi pi $;$ ger iuuencus medius inter duos ueteranos íungitur, aratrọ́́p iniuncto terram moliri cogitur, nulla eft imperium refpuendi facultas:fiue enim efferatus profilit, dtrorum arbitrio inhibetur : feu confi. ftit, duobus gradientibus etiam oblequitur: feu conatur decumbere, à ualentioribus fubleuatus tra hitur:propter qua undiqg neceffitate contumaciam deponit, \& ad patientiam laboris pauciffimis 60 uerberibus perducitur. Eft etiam poft domituram mollioris generis bos, qui decumbit in fulco; eũ non fatritiąfed ratione cenfeo emendandum+nam qui ftimulis, aut ignibus, alịsḉs tormentis id ui- 


\section{Bos \&Vacca. E. Lib. I. 63}

tium eximi melius iudicant, ueræ rationis ignari funt, quoniam peruicax contumacia plerunç fa: uientem fatigat. Propter quod utilius eft cirra corporis uexationem fame potius \& fiti cubitorem bouem eriendare: nam eum uehementius afficiunt naturalia defyderia, quam plagx. Itafg fi bos de= cubuit, utiliffimum eft fic pedes eiùs uinculis obligari, né aut infifteré, autr progredi; aut pafci poffit: quo facto inedia, \& fiti compulfus deponit ignauiam, quix tamen rarifima eft in pecore uernaculo: longés omnis bos indigena melior eft quàm peregrinus: nam neq aqux,nec pabuli, nec coli mua tatione tentatur, neç infeftatur conditione regionis, ficut ille, qui ex planis, \& campeftribus locis, in montana $\&$ afpera perductus eft juel ex montanis in campeftria:itan etiam, cum cogimur ex lon ginquo boues arceffere, curandum eft, ut ex fimilibus patrís locis traducantur:item cuftodiendum Io eft, ne in corpotatione (aliâs comparatione) uel ftatura, uel uiribus impar cum ualentiore iungatur: nam utraq̧ res inferiorí celeriter affert exitium. Mores hurius pecoris(bouis operarn̈)probabiles ha= bentur, qui funt propiores placidis quàm concitatis; fed non inertes (arguti, manfueti, Pallad.) qui funt uerentes plagarum, $\&$ acclamationum, fed fiducia uirium, nec auditu, nec uifu patridi, nec ad ingredienda flumina, aut pontes formidolofitmulti cibi edaces, uerum in eo conficiendo lenti: nam hi melius concoquunt, ideoḉ robora corporum citra maciem conferuant qui ex commodo, quàm qui feftinanter mandunt, Sed tam uitium eft bubulci pinguem, quàm exilem bouem reddere:humi lis enim \& modica corporatura pecoris operarij debet efle, neruis ć \& mufculis robufta: non adipibus obefa, ut nec fui tergoris mole, nec labore operís degrauetur, Hactenus Columella. Nourllos cum quis emerit iutuencos, fi eorum colla in furcas deftinata incluferit, ac dederit cibum, diebus pau 20 cis erunt manfueti, $\&$ ad domandum proni. Tum ita fubigendum ut minutatim affuefaciant, \& tiro nem cum ueterano adiungant: imitan do enim facilius domantur. Et primum eos aquo in loco, \& $\mathrm{fi}_{\text {- }}$ ne aratro, tum eo leui fimul arare faciant, $\&$ prineipio per arenam, aut molliorem terram dum con fuefcant. Quos ad ueciuras alimus item infituendum, ut inania primum ducant plauftra; \& fi por fis, per uicum, aut per oppidum, ubi creber crepitus fit, ac uarietas rerum cófuetudine celeberrima, ad utilitatem adducito. Neq pertinaciter quem feceris dexterum in eo manendum, Quod fi alternis fit finifter, fit laboranti in alterutra parte requies. V biterra leuis, ut in Campania, ibi inon bubus gra uibus, fed uaccis aut afinis quòd arant, eò facilius ad aratrum leure adduci poffunt, $\&$ ad molas, $\&$ ad ea, fi qua funt, qux in fundo conuehunt. In qua re alin afellis, alij uaccis ac mulis utuntur, exinde ut pabuli facultas eft. Nã facilius afellus $\bar{\phi}$ uacca alitur, fed fructuofior hæc. Cauto agricolæe hoc fpectã $30 \mathrm{dum}$, quo faftigio fit fundus:in confragolo enim ac difficili hac ualentiora parandum, $\&$ potius ea, qua plus frucrum reddere poffunt, cum idem operis faciunt, $V$ arro.Âraturos boues quàm aretiffi. mè iungi oportet, ut capitibus fublatis arent:fic minime colla contundunt:Si inter arbores uiteş́́ retur, fifcellis capiftrari, ne germinum tenera pracerpant: Securiculam infitiuam pendere, qua in. tercidãtur radices. Hoc melius quàm conuelli aratro, boues ćs luctari, Hæc Plín, apud quem plura ad arandi difciplinam lege libro 18,cap.18. \& deinceps: $\&$ apud Columellam libro 2, ca.2.3. \& 4. Bu= bulcus fiue arator nun $\ddot{\beta}$ ftimulo laceffat iuuencum, cuod detreçantem calcitrofitmó eum reddit: nonnunọ̧ tamen admoneat flagello, Columella. Fortifima bouis pars caput eft,ideoć̣ cornibus pre dita, qux iugo alligãtur. Ceruix etiam ei firma robuftxós carnis elt, quamobrem non defunt qui iťgum ceruici committant. Syria tenui fulco arat, cum multifariam in Italia octoni boues ad fingulos

40 uomeres anhelent, Plinius, $V$ no boum iugo cenferi anno facilis foli quadragena iugera: difficilis tri cena, iuftum eft, Idem. Saferna apud $V$ arronem ad iugera ducenta arui, boũ iuga duo fatis effe fcrí bit: Cato in oliuetis ducentorum quadraginta iugerum boutes ternos, ita fit ut Saferna dicat uerum, ad centum iugera, iugum opus effe, fi Cato ad octogena, Sed ego neutrum horum, inquit Varro, ad omnem agrum conuenire puto, \& utrụ̧̃ ad aliquem. Alia enim terra facilior aut difficilior eft alia. Terram duram profcindere nifi boues magnis uiribus non poffunt, \& fxpe fracta bura relinquum: uomeres in aruo. Ne boures operantes laffentur, oleã \& terebinthinam concoquens, ungito cornura, Democritus , Boures ferịs coniungere licet Hoclicet facere, trahant ligna, fabalia, frumentũ quod non daturus eris, Cato. Tribula uel tribulũ eft tabula faxo uel ferro afperata, qua frumenta tererent: in frequenti etiam nunc Italix ufu, Varro. E fpicis in aream excuti grana oportet, quod fit apud ali= so os iumentis iunctis $\&$ tribulo, $\&$ c. Varro i. ${ }^{2}$.

Ne boues in area ad trituram accommodata fpicas interim edant, dum proculcant, eorum bus. bulo fimo nares illinendx funt: Qux aftuta machinatio perficit, abillarum ut fefe efu abftineant. Hoc nimirũ animal huiufmodi tetri odoris afperfione deterritum, nihil, ne fi fame quidem acerrina premeretur, unquam ederet, Aelianus. 9 Vaccarum alix funt magna $8 \mathrm{mediocres}$, qua fobolis gratia nutriri folent, ut uituli mactandi, ac boures plaufruis \&aratris neceffarï, ex eis generent. Harũ lac, licet ad cibum \& conficiendum cafeũ utile fit, tolli tamen eis non debet, fed pro nutrimento uitu* lis relinqui. Aliz minores funt, qux lactis tantĩ \& cáé gratia nutriunt: ideóç uituli quindecim a partu diebus elapfis occidendi funt. Eligenda funt non nimiü partra, \& uberibus magnis $\$ \mathcal{X}$ caudis longis, ut aliqui addunt)Petr. Crefcent. Non degeneres exiftimandi etiam minus laudato afpectu: 60 plurimumlactis Alpinis, quibus minimũ corporis, plurimû laboris, Plinius:Altinas apud Columel. lam non $A$ lpinas legimus. Boues dicuntur matrices Varroni, quas $\mathcal{X}$ fructuarias recté appellâris. Cenomani \& Orobij quidã quotidiano fermone Bergaminos appellitãr, quos Vaccarios alị dicũ : 
Germani feñen: 8 bergaminas ipfas uaccas qua gregatim in montibus pafcuntur:bergư enim Gera mani montem uocant; unde $\&$ Bergonum dictum quod in montibus fitum fit ; uidentur \& Orobij populillius regionis inđe dictietymo Gręco, quod uitã in montibus agant: \& forte Cenomani Ger: manico, quafi fenumannen, id eft uiri uaccarij:uel ceuomani,à ceua, id eft uacca, ut Germani hodie \&olim in Italia Altini uocabant.

बNumerus de tauris, \& uaccis fic habe̋ urs, ut in fexaginta unus fit anniculus, alter bimus, Quim dam habent aut maiorem, aut minorem numerum gregum, Nam apud eum duo tauri in feptuagin ta matribus funt. Numerum gregum álius alium facit. Quidam centenarium modicum putant effe, ut ego, Atticus centumuiginti habet, ut Lucienus, Varro. Noftri Lactarí uaccas circiter triginta aut quadraginta ut plurimum in uno grege habent. Vtreliquis gregibus pecuarïs, fic $\&$ uaccis dele $=$ çus quotannis habendus, \& reijculæe rej̣ciundx, quòd locum occupant earum, qux ferre pofiutut fructus, Varro. Vaccæcum uel fterilefcunt, urel aratrum \& plauftrum renuunt, maçantur : \& cum uetulx iam dentibus amiffis non amplius bene aluntur, Boures euadent habitiores, fi calida fubinde lauentur: $\&$ fi quis incifa cute fpiritum in uifcera harundine adigat, Plinitus. Poft laberem pingue fcunt, at fi ante laborem uictu 8 otio abundent, citius moriuntur. Noftri prægnantes etiam uáccas ad mastandum faginant, idós optimé fieri aiunt circa medium geftationis tempus. Pinguefacies bo: ues ( ut Sotion docuit) fi prima die ubi redierint à paftu, comminuens brafficas, acetó́s acrí perfun. dens, eas illis porrexeris : $\&$ poftea paleis cribro tranfmiffis furfur triticeum permifcens, id in dies quinç fimiliter appofureris. Caterum fexta die hordei redacti in pollinem heminas quatuor appo= nens, paulatim curriculo dierum fex nutrimentum augebis, Sed tempus exhibendialimenti bobus, 10 hyeme erit, primò quidem, dum galli occinunt:fecundò autem, circa matutinum crepuf́culum : quo tempore etiam dandus eft potus; ac reliquum alimenti quod fupereft, id uefperi exhibendum eft. At xitate, primo quidem, diluculo nutriendi funt boues:fecundo autem, poft id, hoc eft meridie, ac futb= inde potus eft dandus. Quo quidem modo, circa horam nonam iam tertio cibans, denuo aquam ad. miniftrabis. Verum hyeme quidem potus fit illis calidior aqua:tepida autem aftate, Lotio etiam ipio rum buccas colluito, extrahens adnatam pítuitam : linguramós à uermibus repurgato, uolfella aufe. rens ( gignuntur fiquidem uermes in linguis boum ) ac fale deniçlinguam ipfam infpergito, Hxec Sotion. Varro memorat iutuencam quandam pinguitudine carnis adeo auctam effe, ut in eitis cor * pore forex exefa carne nidum fecerit, \& mures pepererit: Quod in fue etiam in Arcadia fpecratum fit, Eruum boures impinguat, Diofcorides. Eruum uerũ Lugduni uidi, ubi à rufticis feritur, ut Clau. 30 dius Milletus medicus illic mihi retulit;id fi fues nimium uoraterint, fanguinem per urinam eis mo ueri aiunt, quod ueteres etiam eruo attributunt in hominibus: accedit $\&$ color, qui cortice exteriori detracto inurs ruber, quod in Lugdunenfi illo legumine ipfe obferuaui, \& Actuarius de eruo fcribit: Hypoftafis orobea (inquit) à leguminis fimilitudine nomen habet in urina, cuius inftar eft globofa, ac eiufdem excorticati colorem refert, qui rubeus eft, uitello our rubeo fimilis, In Germania hactenus legumen hoc non uidi. Ciceris etiam genus alterum orobiaum trocant, ab erui fimilitudine, $\&$ quod fimiliter fubamarum fit. Ciceram Columella non tam leguminibus quàm pabuli generibus annume rat, qua bubus erui loco detur frefa in Betica, nec hominibus inutilis, fapore nihil differens à cicercu la: colore tantû̃ difcernitur, quo for det, obfoletior uidelicet $\&$ nigro propior, Hermolaus Barbartıs, Idem in Corollario ad Diofcoridis caput de lino, fic fribit: Olco feminibus lini expreffo fraces \& re trimenta quoq ipfa reponuntur, faginando iumentcrum generi, pracipuébubus, obefitate fola in: fignibus futuris:Quales ad nos Mediolano coronati ueniunt, principibus qurotannis officî̉ gratia do nantibus : uifceratione hinc folenni orta, magiftratibus diuifa carne globulis : quos quia feré pares funt, fociolos confuetudo appellat: quidam non focioles, fed fuccidulos à fuilla uifceratione uocare malunt, qua fingulis annis ante curiam uenationis die agitur, $\mathrm{H}$ c Hermolaus, Quidam braffic ca pitatæ folia, etiam ea qua tanquam inutilia feparantur, bubus plurimum alimenti conferre putant. Genus graminis in Cilicia nafcitur, quod indigenæ cinnam appellant, quod uiride obiectum boures inflammat. Sunt tamen qui boues inde pinguefcere contendant, nato alterutris errore, quòd alị triu.

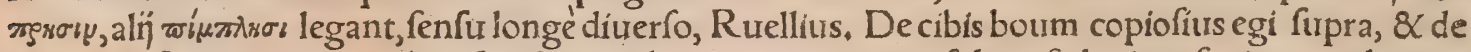
ccymo ac farraginis generibus feorfim, quibus non purgantur folum fed etiam faginantur bours.

TVerres, iturencos, arietes, hoedos decrefcente luna caftrato, Plinius. Menfe Maio caftrandifunt uituli,ficut Mago dicit, tenera ætate, ut fiffa ferula tefticuli comprimantur, \& paulatim confracta re. foluantur, Sed hoc luna decref́cente uerno, uel autumno fieri debere pracipit. Alin ligato ad machinam uitulo, duabus anguftis regulis ftagneis, ficut forcipibus ipfos neruos apprehendũt, qui Gręce

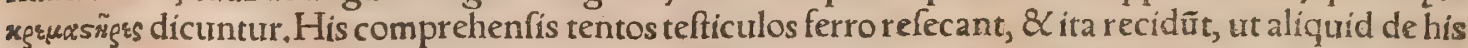
capiribus neruorum fuorum dimittatur hærere, quæ res $\&$ fanguinis nimictatem prohibet, $\&$ non omnino iuuencos fubducto robore uirilitatis efforminat. Nec admittendum eft, quod pleríg faciũt, ut ftatim caftratos coire compellant, nam certum eft ab eis generari, fed ipfos fluxu fanguinis interi re. Vulnera uero caftratura, cinere farmentorum $\&$ fpuma linentur argenti. Caftratus abftineatur à potu, \& cibis pafcatur exiguis, \& fequenti triduo præbeantur ei tener arborum fummitates, \& 60 fruteta mollia, $\&$ herbæuiridis coma: dulciora fagina roris, aut fluminis, Pice etiam liquida mifto cinere, $\&$ modico oleo poft triduum uulnera diligenter unguenda funt, Sed melius genus caftrationis 


\section{Bos\&Vacca. E. Lib. I. 65}

Fequens ufur inuenit, Alligato enim iutuenco, at deiecto, tefticuli fricta pelle clauduntur, at $\$$ ibili gnea regula premente, deciduntur ignitis fecuribus, uel dolabris, tuel, quod elt melius, formato ad hoe ferramento, ut gladí finílitudinem teneat. Ita ením circa ipfam regulam ferri acies ardentis im.

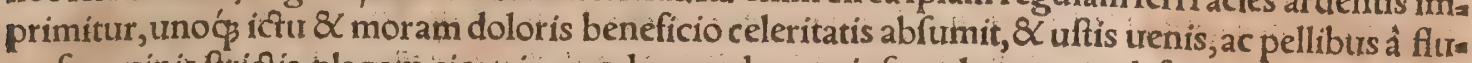
xu fanguinis ftrictis, plagam cicatrix quodammodo cum ipfo uulnere nata defendit, $P$ alladius. Ad copiamlactis melits Altinæ uacc probantur, quas eits regionis incolær ceuas appellant : ex funt humilis ftatura; lactis abũdantes; Columella. A pud nos etiam humiles $\&$ breutoribus cruribus urac cas tan $\ddot{p}$ lacie foecundiores magis probant. Ouillum lac caprinumós, mox bubulirm, commodũ eft

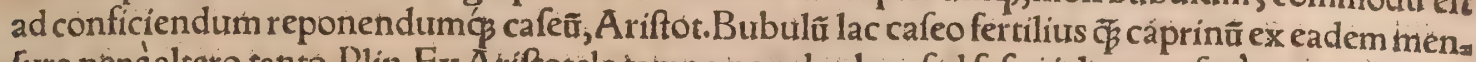
10 Iura penéaltero tanto, Plin. Ex A triftotele tamen non duplam, fed fefquialteram ferè proportionem colligimus, Cafei bubuli maximi funt cibi, $\&$ difficillimé tranfeunt funpti, Varró. Bos ante partum lac non habet, quo temporeà noftris dicitur jeguft gaan, per dies circiter decem, fub quod tempus lac denfius redditur, $\mathscr{Q}$ grauius olet:quas ob caufas, $\&$ ne fơtui iam grandiori alimentũ fubtrahatr, mulgere definunt, Ex primo femper à partu coloftra fiunt, ni admífceat aqua, in pumicis modũ coë unt dutritiä, Plin. Coloftrũ, id eft primumâ partu lac; Germani uocant bienfit, ruftici quidam ein p faffen. Improbari audio quod omniü primutim eft, illud uero quod ftatim fequî́ inter delicias cen. feri, utpote pinguius. Machid uaccinũ (apud Arabes)eft lac uaccinũ, à quo propter multam eíus in utre aut alio uafe concuffionem extractũ eft butyrum, Andreas Bellunenfis. Bubulci quidam fiue

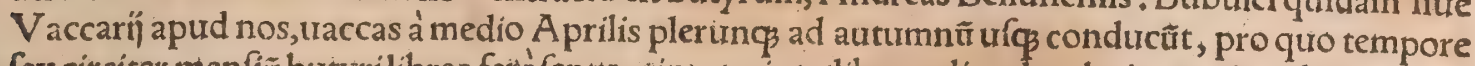
20 fex circiter menfiũ butyrilibras ferè feptuaginta quinç (libram dico duodecim unciarü)locatoribus pendunt. Vaccas nonnulli emût, \& ijfdem rurfus aut alijs locant nutriendas, propter fpem fobolis, quix ad dominũ 8 conductorem ex xquo pertinet. Quod fi foboles quotannis non protenit, certa pecunia à conductore numeratur. Si quid damni nulla conductoris negligentia inciderit, hoc etiam ex aquo ad utrof ó fpeciat. Pecudes armentaç; \& iumenta, fale maxime folicitant ad paftum, mul=

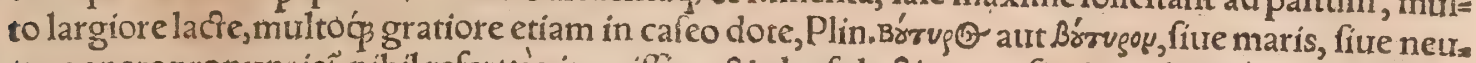
tro genere pronuncieț, nihil refert:é pinguifîma \& oleofa lastis parte fit, interdũ unà cum cafeis re: linquitur, feiuncto folum fero:unde cafei quandog tam opimi, ut adipofum humorem deftillent. $\mathrm{Bu}$ tyrum à boure nominatur, è cuius lacte copiofiffimũ confit, ut miret̉ Diofcoridem Galenus $\Phi$ ex cia. prino $\&$ ouillo confici lacte dixerit. Ex caprino tamen fieri folere teftis eft Pliníus, Hermolaus, Ego 30 butyri nomen quoties abfolute ponitur, de bubulo femper acceperim: quod $\&$ nominis ratio $\&$ pe cudis huius excellentia poftulant:optimũ enim plurimumó̧ ex uaccino lacie fit. Authores fi aliarũ pecudum butyrũ intelligant,nomen illarữ, ut caprinum aut ouillü, adịciunt : Inula in oleo difcocta (inquit Marcellus Empiricus) $\&$ contrita, $\&$ cũ butyro ouillo $\&$ melle impofita, cacoëthe maligna e. mendat. Sed quan đ̆⿱ buryiri nomen fimpliciter politã de bubulo femper accipiendũ mihi uideatur, non aliter tamen ín hoc Opere de butyro agam, nifi per fingula animalia ubi fingulorũ nomen addi tur: ut etiam delacie, fero, $\&$ cafeo. Nam qua de iftís in uniuerfum $\&$ communi quadam ratione di. ci poffunt, ea explicantin in Libello noftro, quem de laçe 8 operibus lactarn̈s priuatim adidimus, \& fi uita fuper fit, aliquando dabimus auctiorem.

TBoum cornur, magna præcipue \& feniorũ, apta funt pectinibus:offa tefferis \& cultellorũ mas 40 nubrî́s, Petrus Crefcent. Boũ cornibus ureteres pro poculis utebant, ut in Philologia dicemus, Cor nua dicebantur olim, quæ nunc tuba, ế $q$ ea qua iam funt ex ære, tunc fiebant ex bubulo cornu, Varro de Lingua Lat, R auco ftrepuerût cornua cantu, Vergil.Aeneid.8. Hinc cornicines dicti, V. titur hodiéćs cornu in bello, mugitu terribili, Heluetiorum pagus Vria.Qui bombardas, ut uocant, gerunt milites, puluerem accendendũ in cornibus pulchre adornatis reconditũ habent. $\in$ Boũ cos rijs glutinû̃ excoquitur, taurorû́ ó præcipuum, Plinius $\ddagger$ id Græci taurocollam urocant, ut in Tauro dicemus. Tergo bubulo lentor quidam mucofus abunde ineft, ex quo glucinum facere folent, A rift. Gummi albelat(ut Alchuinus \& Ebenbitar foribût)res eft compofita ex glutine(quiod é pellibus uac carum fit) \& marmore trito, Sunt qui interpretẽtur pharmacum quoddam fimplex quod ex India afferatur: $\{e d$ prima opinio uerior eft, Andreas Bellunenfis. Confectos cafix furculos corio bubulo so prafunnt, ut eo putrefcente enati uermes lignum erodant, Theophraft. Coria boumi adultorum fo leis calceamentorum conueniunt, Petrus Crefcent, Carbatinas Graci uocant, ut Xenophon, calce:

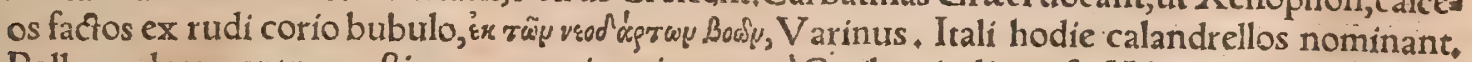
Pollux calceamentum rufticum exponit, cui nomen a Caribus inditum fit. Hermolaus Barbarus in Corollario ad faxifragam Diofcoridis, Carbatinis (inquit) legendũ in fecundo hiftoriæ animalium uolumine Ariftotelis cap.1. (ubi camelos qux per exercitum longiore itinere fatifcunt, carbatinis calceari fribit)non carbafinis eft Sunt autem carbatinz, quas Catullus ad Victium carpatinas cre pidas uocauit, calceamenti genus è Caria translatum, quod hodicéc uulgó fic uocatur, detractis uti que pofterioribus fyllabis, \& $\mathrm{r}$ litera principio adiecta, ut affolet. Nam \& carpifculus calceamenti genus eft, utFI. Vopícus ait in Aureliani Cafaris uita, Quídam tamen carbafa etiamnum uocant 6o boum coria, qux Cæéar alutas appellauit:nã, ut Suidas air, ubi defeciffent calcei, carbatinis uteban tur, ex crudis boum tergoribus recens detractis, ut illud Vergilianum: Veftigia nuda finiftri Infti tuere pedis, nudus tegit altera pero. Noltri hodie tergoribus bubulis utuntur etiam ad conficien 
dum puluerem tormentorum bellicorum, Nauigant Britanni umineis alueis, quos circundant am bitione tergorum bubulorũ (aliâs bubalorĩ) Solinus, Malth frigidarix compofitio taliș eft: fangui nem bubulü, florem calcis, fcoriam ferri, pilo uniuerfa contundes, \& ceroti inftar efficies, \& curabis adlinire, fícubi frigída balnei inter rimas labetur, $\mathrm{P}$ alladius:qui etiam paulò ante ad maltham calida riam fanguinem taurinum requifiterat. Eft $\&$ luxuriofa ratio uites ferendi, ut quaturor malleoli vehementi uinculo colligentur in parte luxuriofa: atçita uel per offa bubuli crưris, uel per colla fi. ctilia traiecti, obruant̂ binis eminentibus gemmis, 8c.Plin.17.21. Scabritia chartarũ leuígatur den. te cócháure, fed caducæ literæ fiunt, Plin. Noftri boũ præcipué dentibus ad chartã poliendã utuntur.

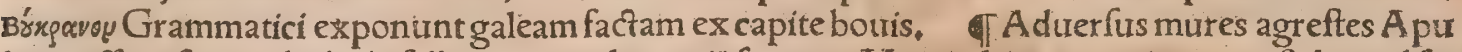
leius afferit femina bubulo felle maceranda ante ${ }^{\circ}$ fpargas. Mures abiguntur cinere muftela, uel fe to lis diluto, \& femine fparfo, uel decoctarû̃ aqua.Sed redolet(frumentum) uírus animaliut corț, etiã in pane $\div$ ob id felle bubulo femina attingi utilius putant, Plin. Si radici arborís fel uaccinû dlinatur, non accedent ad eam formicre, $R$ afis, Lycium adulteratur etiam amurca ac felle bubulo, Plin, Et alis bi:Lycitim In dicũ aliqui felle bubulo adulterant. Extinguuntur cimices amurca \& felle bubulo, le= ctis aut locis perunctis, $\mathrm{Pallad}$. Boures ne infeftentur à mufcis bubulam faliuam illine, A fricanurs Corni arborisflore deguftato, aluo concita moriuntur apes, remedium prabere eis urinam hominư viel boum: TCircumlini alueos apum fimo bubulo, utilifimum. Aluearia hyeme ftramento operi ri conducit, \& crebro fuffiri, maxime fimo bubulo. Cognatũ hoc ñs innafcentes beftiolas necat, ara= reos, papiliones, teredines ‘apesćs ipfas excitat, Plínius. Per trernos dies, ut Higinius ait ( círca calendas A priles, Palladius:)curand $x$ funt apes adapertis alueis, ut omnia purgamenta qux funt hy, 20 berno tempore congefta, eximantur, \& araneis qui fauos corrumpunt detractis, fumus immitta* tur, factus incenfo (\& ficco, $\mathrm{Pallad}$ ) bubulo fimo. Is enim quafi quadam cognatione generis, maxi. me eft apibus (apium faluti)aptus, Columella. Tinex 8 papiliones plerunç fauis adhærentes deci= dunt, fi fimo medullam bubulam mifceas, $\&$ his incenfis nidorem admoueas, Idem. Caftrandis al uearibus fumus admouetur ex arido fimo bubulo, quem in pultario factis carbonibus conuenit excitare, Palladius. Quidam xgris examinibus apum, ne intereant, bubulam uel hominis urinam (ficut Higinius affirmat) alueis apponunt. Campas nonnulli ficulneo cinere perfequuntur: fi per: manferint, urina bubula \& $\&$ amurca aqualiter mifta conferueant, \& ubi refrixerint, olera omnia hoc imbre confperge, $\mathrm{Pallad}$. A pes quomodo ex iuuenco perempto, uel(ut alíj uolunt) ex uentribus but bulis, uel(ut alị) offibus procreentur, explicabimus in hiftoria A pum + Fimus bubulus ftercoran= $30^{\circ}$ dis agris \& arboribus ac uineis utilis eft, Petrus Crefcent. Acerrimus hominis fimus eft, ut $\&$ Char todras, omnium optimum eum effe affeuerat:fecundum fuillum, tertium caprarum, quartum otriư, quintum boum, fextum iumentorum, Theophraftus: 8 Plinius feréfimiliter:qui tamê his omnibus

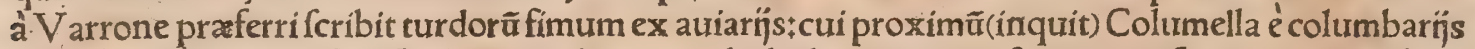
facit, mox gallinarïs, \&c. Et alibi, Quidam etiam bubulo iumentorũ finưum præferunt, ouillumćç ca prino. Ne quod animal paftu melefico decerpat frondem, fimo boum diluro afpergi folia iubent, quoties imber interueniat, quoniam ita abluatur uirus medicaminis, Plin. Area ad meffęm creta præparatur, Catonís fententia amurca temperata, Vergilin operofius. Maiore ex parte æquant tantum, $\&$ fimo bubulo dilutiore illinunt Id fatis ad pulueris remedium uidetur, Plin, Cato argilla

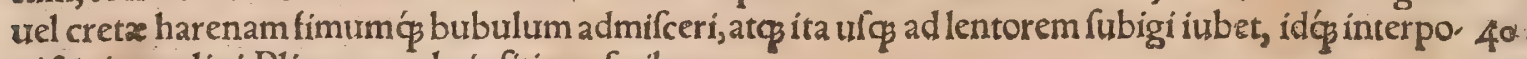
ni 8 circumlini, Plin, 17,14, de infitione fribens,

F.

Bubula caro multum nutrit, \& qui ab ea gignitur fanguis fupra menfuram craffior eft, propterea his qui temperamento funt melancholico, diurerfos $8 \times$ melancholicos morbos infert. Difficulter etia concoquitur $\&$ redditur. Sed fi concoquatur, abunde( $\&$ probe)nutrit: $\&$ fi cum ouilla carne com, parẹtur, frigida eft, fanguinẽéśs melancholicũ gignit,Si quis urero eam comedere expetat, uel cogat, eius læfionem quæ futura timeț, fic moderetur; cum aceto allïs \& ruta intingat, Solis hæc calidos( et ualentes)uentriculos habentibus cófert, $\&$ his infuper qui ualde \& cótinenter exercentur, Symeon Sethi. Hirci $\&$ boures carnem quidem habent minimum humidam, pituitofam ac lentam; nocent ta. men admodum ob duritiem, \& in alterando difficultatem, Galenus de attenurante uictur, Idem libro so 3. de alimentorum facultatibus cap.. . Carnes bubula (inquit)alimentum corpori fugger unt non me. diocre, neo diffipatu facile: Fanguinem tamen generant, $\bar{c}$ conueniat, craffiorem, Quod fi quis tem: peramento naturali melancholicus magis fuerit, affectu aliquo melancholico prehendetur, fi largius his uefcatur. Affectus autem melancholici funt, cancer, elephas, fcabies, lepra, febris quartana, $\&$ qua peculiari nomine melancholia nominatur. Lien item quibufdam à tali fucco intumuit : quã rem cachexia, id eft prauus habitus, $\&$ hydropes fapentumero funt confecutí . Cæterũ quantĩ carnes bubulæ totius fuæ fubftantiæ craffitie fuilla fuperant, tanto fuilla bubulas lentore antecedunt. Porrò quemadmodũ ex fuibus, qui atate funt florêti, ịs iưuenib.qui bono corporis funt habitu, $\overline{c o}=$

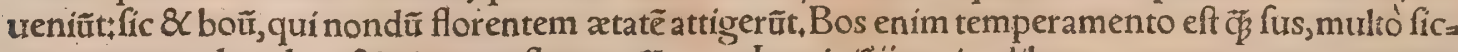
ciore: quemadmodum $\&$ uir $æ$ tate florens, $\overline{C B}$ puer, Iure igit ij 1 s a nimalibus, qua natura temperamen 60 to funt ficciore, adolefcens ætas ad mediocritatẽ ipfam confer:thumidiorî uerò natura, quod fibiad probam ac conuenientem temperiem deeft, ab atate florenti adfumit. Non modo itaç uituli carnes 


\section{Bos\&Vacca F.G. Lib. I.}

Habent ad conficiendum perfectis bubus praftantiores, fed etiam hoedicapris. Et paulo poft, Anima lia quz herbas è terra emergentes, aut arborưf furculos; aut germina depafcuntur; ea omnia, cum his abundant, habitiora funt, ac pinguia, nobisḉ̧ alendis accommodatiora: Quamobrem illa, quibus heé bas denfiores pafci eft naturale, hyeme, uere primo ac medio fiunt gracilia, ac praui fưcci: ut boutes, gui procedente tempore manifefto fiunt obefiores, fuccí́s melioris, cum herbæa augentur ac denfe. fcunt, $\mathcal{C}_{2}$ ad femen producendum feftinant, $Q$ ura urero exigua 8 gracili herba nutriri queunt, ea pria mo ac medio tiere praftant, ut oures:aftate prima ac media caprą, cirm fretticũ germina funt frequen tiffima. Etrurufus eodem libro, Caroleporum fanguinem quidem gignit craffiorem, fed melioris furcci quàm bubula \& ouilla. Itẽ in aphorifmos 2, 18. Caro bubula tardius \& paulatim alit. Frigidæ \& ficcæ 10 naturæ hac caro eft, impurum \& atribiliarium praftat alimentum, \& morbos eiufdẽ humoris alum= nos creat, quartanas, frabiem, lepram, fplenis uitia $\$$ hydropem, in illis prafertim quorü temperiem iftis affectibus aptam inuenerit:tardè à uentriculo defcendit, \& 2 aliuum fiftit, Ifaac \& Platina, Pracipué autem boum adultorum carnes uitlofum fuccum generant, \&Q contumaces funt coctioni, id́ç eò

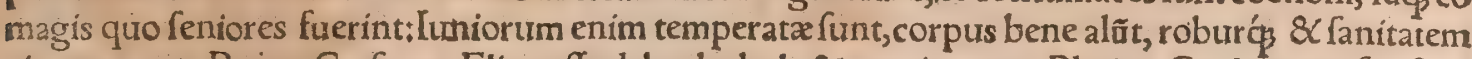
eitts tuentur, Petrus Crefcent. Elixa effe debet bubula \& $x$ uaccina caro, Platina. Caules caprifici fi ad dantur magno ligni compendio eam percoquunt, Plin. Quam ob caufam pleríç, cibos craffos atqué difficiles concoquere facilius poffunt, ut carnes bubulas : faciles \&r fucci compotes laudabilis, ut pifces faxatiles, egrè concoquunt: Rationem alin ad confuetudinem referunt; alin ad habitum quendam naturàlem ingenio hurmano inexplicabilem: alị̂ uentris calore immodico cibos eócoçu faciles ultra 1o modum pro fua facilitate concoqui, itaģ perfringicorrumpị́̂, (fubito corripi, deuri $8 \mathrm{C}$ fumigari, ut cruditatem penéquod accidit imitectur ) cenfent, difficile uero $\&$ quod modice immutatur, concoqui tăntum, non praterea quicquam uitiari: $\mathrm{Nam} \& \alpha$ paleæ quoniam perquam facile afficiuntur, in cines $\mathrm{rem}$ uertuntur ab igne largo $\&$ rapido:quod ligno querno accidere non poteft. Materiam enim pas tientem cauferefpondere efficienti conuenit : aliter fieri non poteft ut effectus is prodeat, quem uel

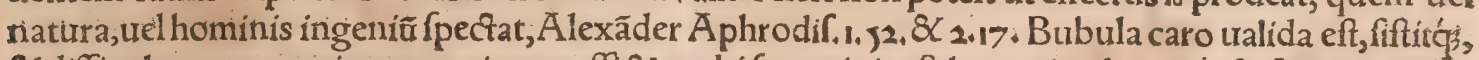
$\&$ difficulter concoquitur, quoniam craffi \& multi fanguinis eft hoc animal, caró́p \& fanguris \& lac graire eft: Qitorum lac tenue eft; fic $\alpha \mathcal{K}$ fanguis $\&$ caro, ut Hippocrates libro 2, de ratione urictus tefta tur. Celfus ex domefticis animalibus bubulam plurimi alimenti $\&$ ftomacho aptiflimam effe dicit, \&\& inter ea connumerat qux minimè intus corrumpantur. In titulinam fiue bubulam cum porris fuccê 30 daneis, uel cepis, uel colocafíps:liquamen, piper, lafer $\&$ olei modicum, A picius. Charis albachar Ara bice, ab Andrea Bellunenfi exponitur cibarium ex carne bouína、 TGenus farciminis eft, quod no ftri uocant birnwurfê, id eft cerebri farcimen, $\mathcal{Q}$ hoc ferè modo parant: Inteffinum rectum bouis aut uituli cum bona parte falis in aqua bullit, mox pulmo, lardum $\&$ aromata minutatim conciduntur; $\mathcal{Q}$ includuntur inteftino, unà cum cerebro, $\&$ ouis quaturor, $\mathcal{Q}$ lactis fextario $\mathcal{\&}$ apio: Sic paratum farcimen $\&$ fer tuefactum in cratícula torretur, unde uel ficcum, uel cum dulci $\&$ atomatibus condito iufculo apponitur. TPinguiffimum eft lac bubulum: Ouillum uero ac caprinum, habent quidem \& ipfa pinguedinis quidpiam, fed multòminus, Galenus. Bubulum, afininum equinumó́ lac, magis aluum emolliunt quàm ouillum, quod dulce, craffum \& pingue eft. Bubulum, afininum; \& equinum lac uentri magis idonea funt, fed ipfum turbant, Diofcorides. Lac \& cafeus ex uaccis non tam con$4^{0}$ ueniunt hominis nutrimento quàm ex ouribus, Petrus Crefcent, Lac quod maximè perpurget eft equinum, tum afininum, deinde bubulum, tum caprinum, Varro, Qurod praftat?'Capræ. Poft? Otris. Inde? Bouis, Bapt, Fiera Mantuanus delacte. Lac muliebre temperatiffimum eft, mox caprito

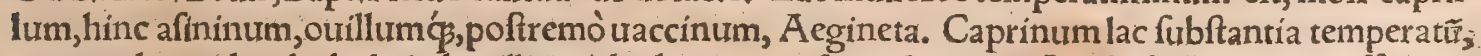
perrgando quidem bubuln imbecillius: ad reliqua uero fatis idoneum. Lacbubulum pinguifinum, cralfiffimum'ś, nutriendo 8 moderate penetrando idoneum. Quadam exiguo guftu famem ac fis timi fedant, conferuantós uires, ut butyrum, hippace, glycyrrhizon. Cafeorum maximi cibifuntbü buli, 8 qui difficillimè tranfeant fumpti, Varro. Equinus cafeus multum nutrit, \& bubulo qquodammodo fimilis eft.

$G$.

50. Ex cornu bubuli fummis partibus cinis, tuffim farlat, Plinits. Bubulicornus mucronem extra ftum duorum cochleariorum menfurra, addito melle, pilulis deuoratis, phthificis prodeffe tradunt; Idem. Cinis de cornu uaccæ cum aceto illitus, impetiginem ( morpheam foli contrapofitam) curat:\& naribis immiffus fanguinem profluentem fiftit, $R$ afis. Cornum bouis combures ex ea parte, qua cat piti adhæret, 8 in puluerem tenuiffimum redige, atqz ex eo pultuere cochlearia duo, cum aquæ calis $\mathrm{d} x$ cyathis triburs, \& paululo aceti, ieiuno fplenitico per triduum da bibendum, Marcellus. IBo. utis ungulia cinis ex aqua (illitus) frtumas difcutit, Plinius. Vngula uaccex ufta $\&$ pota à muliere cui lac defecerit, reftiturit lac, \& corpus laćantis corroborat, $R$ afis, T Coxæ boum uruntur bibunturćg ut fanguinem fluentem $\&$ menfes cohibeant, $R$ afis: Galentis taüiri femora ufta fanguinem fiftere for bit. Vaccarum femora cremata, fariguinis $\&$ alui quoģ proflutuium compefcunt, Auicenna $\ddagger$ Gales 6o nus de fcobe taurini cornu idem refert. If Scobs de T A L O bouis uino excepta \& dentibus mobi libus appofita eos confirmat, Galenưs: alị non frobem tali, fed crematicinerem, $\&$ dẽtes gingiuasḉp. laxas eo confricari iubent (ut Plinius $\$ \&$ R afis \& Haly quorum interpretes pro talocalcaneum \& $\&$ 


\section{De Quadrupedibus}

bourle imperite uerterunt) dentes ita firmandos $8 \mathrm{~m}$ mitigandum dolorem polliciti. Eiufdem cinis cuี myrrha dentifricium eft, Plin. Cum cera etiam et medulla ceruina ambuftis medetur. Scobs eius cum melle pota lumbricum rotundum educit, Galenus: Cum uino $\$$ melle perimit lumbricos cucurbi. tx granis fimiles, $R$ afis. $C u m$ aceto mulfo fcobs eadem (aliâs $O$ s bouis in cinerem redactum) fplene minuit tưrgidulum, Galenus, $R$ afis, Haly, Tollit præterea leucas, id eft impetiginem albam, Galen. Lepra prodeft,Haly.V enerem mediocriter excitat, Galen, \& Haly.Friuolum licet uideatur, non ta men omittendum propter defyderia mulierum: Talum candidi iuuenci quadraginta diebus nocti= busćs, donec refoluatur in liquorem, decoctum, \& illitum linteolo, candorem cutisćs erugationem praftare, Plin. बAriftolochia oblonga in fumma gloria eft, fi modo à conceptu admota uuluis in carne bubula, mares figurat, ut traditur, Plin. lus carnis bubulæe prapinguís coxendici boũ $\&$ equo= rum alimentum non fentiêti quomodo conferat, fupra in morbís explicaui. Ad hominis morfus car = nem bubulam decoctam imponi iubent:efficacius uituli, fi non ante quintum diem foluatur, Plin. Bubula caro impofita tumorem fanat, Idem. Calida impofita panos $8 \mathrm{C}$ apoftemata difcutit, ut fan. guis etiam \& fel eiufdem pecudis, Plin.Caro uaccína(bubula, Plin.) recens ureretro impofita, ulcera eius \& epiphoras miré perfanat, Marcellus, Eadem rancorem(rofiones, Plin.) ftomachi temperat ex uini \& aceti zqua portione difcocta \& cibo fumpta, Idem, Bubula carnis ius uentris fluxus ex flaua bile compef'cit, Symeon Sethi. Ius é carne uraccina, ut medulla etiam, ulcera oris $\&$ rimas fanãt, Plin.

TCorij bubuli cinis cum melle phagedænas in tulcerum genere adrodit, Plin. Veteris folex cre: matæ cinis calceamentorư attritus fanat, Plin. \& Diofcorides, qui ambuftis etiam $\&$ intertriginibus hunc cinerem mederi ait, fi illinatur: Hermol, Barbarus ex lini oleo illinendum tranftulit.Perniones 10 fanat corium combuftũ, melius fi ex uretere calceamêto, Plin. Deglutine ex corio bubulo eiusć̣ ufu medicinali, uíde infra in Tauro:nam Graci taurocollam uocant. TBoum medulla \& feuum ner= uis commotis conferunt, \& molliunt fi inungantur, $R$ afis, Medulla bubula ex dextro crure priore trita cum fuligine, pilis, \& palpebrarum titins , angulorû́ć occurrit: calliphlebarić modo fuligo in hoc ufu remperatur: optime ellychnio papyraceo, oleoćs fefamino, fuligine in nouo uaafe pennis de. terfa, Efficacifime tamen eurulfos ibi pilos coércet, Plin. Lucernam fictilẽ de papyro 8 medulla uaccina concinnato, atģ eius fumo fiue fuligine, pro calliphlebaro utere, quo palpebras exefas \& gla. bras fapius inungendo, decentifimas facies, Marcellus. Medulla bubulina (forte bubula aut bubalis na ábubalo legendum)uel taurina liquefacta, tepensí̧ infúáa auribus, plurimum prodeft, Marcel. Vlcera oris emendat ceruina trel uaccina medulla cum refina, Plin. Ceruix boum fi media íntumuit comperimus aureum effe medicamentum ex pice liquida $\&$ bubula medulla $\&$ hircino feuo, $\&$ ute $=$ tere oleo aquis ponderibus compofitum ato incoctum, \&c.Columella.Medulla uaccina cum farina tenui fubacta, \& uelut excoc̊us panis cibatui data, mirè dyfentericũ fanat, maximé fi \& cafeus bu bulus recens manducetur, Marcellus. Vituli aut bouis medull excoquũtur cum farina $8 \mathrm{C}$ cera, exi gưó́ Plura de medullis in genere ex Galeno dicemus infra in Vitulina.

TSeuum uítulinum feububulum contra uenena quxexulceratione enecant, auxiliatur, Plin. Clauos feuum bubulum fanat cum thuris polline, Plin, Lepras, furunculos, lichenes \& pforas fal $e_{\text {. }}$ mendat cum paffa uua exempto eius ligno, \& feuo bubulo atç origano ac fermento uel pane, ma. ximé Thebaicus, Plinius, Et alibi,In furunculis (inquit)illinitur feuum bubulữ cum fale, fimiliộ mo $4{ }^{\circ}$ do caprinum. Sole adufta feuo bubulo cã rofaceo aptiffime curant̆, Idem. Suppuratio in bubus fer. ro refcinditur, expreffus deinde finus ipfe, qui eam continebat, calida bubula urina elurit: uel fi collui ea pars non poteft, lamina candenti feuũ caprinum aut bubulũ inftillatur, Columella. Boum medul la \& feurum neruis commotis conferunt, $\&$ inuncta molliunt, $R$ a fis, Sanguis bubulus concoquit ab fceffus, fi cum feuro ad ignem emplaftrum fiat:emollit etiam tumores duros, $R$ afis. Vicera capitis fu. bito nata fanantur, fi afini ftercoris furcco, $\&$ fcilla contritæ quantũ fatis uidebitur, \& bubulæ adipis tantundem mifcueris, atç ad capitis ulcera ueluti ceroto ufus fueris, Marcellus. Oculorum epiphoras bubulo feuo cum oleo cocto illinunt, Plin, Seuũ bubulum cum adipe anferino tepefactum in auriũ grauitate infundunt, Idem, Seuũ uituli uel bouis, cum adipe anferino impofitum, rimas fcif furasḉ oris optimé iungit, Marcell, Vlcera oris ac rimas feuum uituli uel bouis cum adipe anferis et go ocimi fucco emendat, Plin. Rigores ceruicum bubulo feuo(quod 8 firumis prodeft cû oleo) optimè perfricantur: nam continuo mollefcunt $\&$ dolor omnis abfcedit, Plinius $\&$ Marcellus. Dattrr $8 \times f_{*}$ utum uitulinũ aut bubulum coliacis $\&$ dyfentericis, Plin, A deps bouis efficax eft uitris fedis, Plin. Taurinus adeps, bubulus, \& uítulinus aliquantum adftringunt, Diofcorides: Reprehenditur aute 2े Galeno libro undecimo de fimplicium pharm. facultatibus cap.4.quòd adftringendi uocabulo ab. utatur, ut cum caprinum adipem fuillo magis adfringere.fcribit, cum acriorem effe fcribere debuif fet:qux tamen interpretatio iam citato Diof coridis loco de tauri, botris, \& uituli adipe non conueni re uidetur. Porró bubulum feuum, renibus maxime detractum, exemptis membranis, aqua marina ex alto petita eluendum eft:moxin pila tundendum diligenter, affufa maris aqua. Cum uerò diffolu. tum fuerit, in fictilem ollam conïciendum, 8 marina aqua, qux non minus dodrante fuperemine $=60$ at, proluendum:decoquendum donec omnis aboleatur odor, additis ad fingulas feui Attícas minas, quaternis Tyrrhenicæ ceræ drachmis; excolatumḉs, detractis qua peffum ierant fordibus, in nouo 
fictilireponendum, opertumóp foli interdiu credendum, ut ad candorem reducatur, $\&$ odoris ui $z$ rus euanefcat, Diof corides: Ex quo infra etiam quomodo taurorum pingue priuatim curari debeat, prafcribemus. TSi angutis reijciatur, efficacem tradunt bubulum fanguinem, modicé $8 \mathrm{curm}$ as ceto fumptum. Nam de taurino credere temerarium eft, Plin. Sanguis uaccinus uulneri infufus, $e$ manantem fiftit fanguinem, Haly. Bubulus fanguis abfceffus concoquit, fi cum fetro ad ignem em= plaftrum fiat:emollit etiam tumores duros, $R$ afis, $P$ anos idem $\&$ apoftemata difcutit, ut fel quroç $\&$. caro bouis fi calida imponâtur, Plinius. Cantum f cabies fanantur bubulo fanguine recenti, iterumq̧́ cum inarefcat illito, \& poftero die abluto cinere lixiuio, Plin. TTradunt Arcades quidem non me

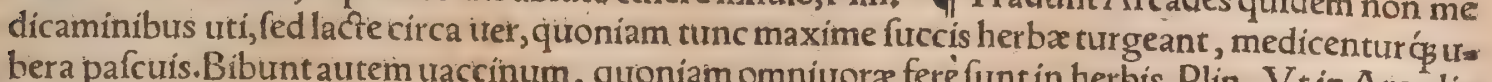
ro bera paicuis. Bibunt autem uaccinum, quoniam omniuoræ feréfunt in herbis, Plin. Vt in Arcadia bubulum biberent phthifici, fyntectici $\$$, 8 cachecta, diximus in ratione herbarum, Idem. Stoma. cho accommodatiffimum caprinum, bubulum medicatius, quo $8 \mathrm{C}$ aluus maximé foluitur, Plin. Bt: bulum lac prituatim prodeft his quí colchicon biberint, aut cicutam, aut dorycnium, autleporem marinum, Idem. Cuncta tienena expugnari eo tradunt Græci, maxime fupra dicta (id eft quar $\mathrm{ro}_{2}$ fiones uftiones inferunt) $\&$ fi ephemerum impactum fit, aut fi cantharides datæ, uomitione omnia egeri; Plinius \& Diofcorides, Cortex glandis(arboris, non fructus) decoctus lacteuaccino ferpentis plaga illinitur, Plin. Nitrum in facie exulcerationes fanat cum melle \& lacte bubulo, Plin. Lac bu. bulum oris uulnera recentia ad fanitatem reducit, ut quidam citat ex Diofcoride. Lacte bubulo aut caprino tonfillæ $\&$ arteriæ exulceratæ leuantur: gargarizatut tepidum, ut eft expreffum, aut calefa 20 çum : caprinum utilius cum malua decoctum \& fale exiguo, Plinius. Lac caprinum uel bubulum trel ouillum recens mulfum, dum calet, uel etiam calefactum gargarizatum, tonfillarum dolores $\&$ tumores cito fedat, Marcellus. Lac bubulum recens mulfum \& lento igne calefactum gargarifatî́ć arteriam conftrictam infufo catarrho, \& fauces exafperatas, priftina fanitati reftituta perfanat, Mar, cellus.Picem pracoquam, fiue quam uifcofam uocant, \& rubricam Scythicam, quam alij piffafphal tum uocant, cum feui ceruini remiffi cyatho uno, 8 lactis bubuli, uel ouilli pari menfura, fi quis iam periclitanti phthifico in potu uel in cibo quotidie dederit, mire ei fubuenit, Marcellus. Lac bubulūe tepidum incoctum fubinde fumprum, exulceratum quo $\$$, ftomachum fanabit, Marcellus. Stoma. chum exulceratum lactis afinini potus reficit, item bubuli, Plinius. Alui exulceratos fluores \& $\mathrm{te}$ nefmos, ouillum bubulúmure aut caprinum lac fiftit ignitis calculis (interpres addit, marinis) deco. 30 ctum, Diofcorides. Laborantibus tenefmo, id eft qui de perfrictione affidue federe cupiunt, \& nihil deijciunt, lac bubulum decoctum frequenter potum, maxime prodeft, Marcellus. Tenefmus, id eff erebra $\&$ inanis uoluntas egerendi, tollitur poto lacte afinino, item bubulo, Plin. In biliofis fluxioni bus lac bubulum aut caprinum tepidum recens mulctum auxiliatur in potu:aut ad ignem decoctĩ,

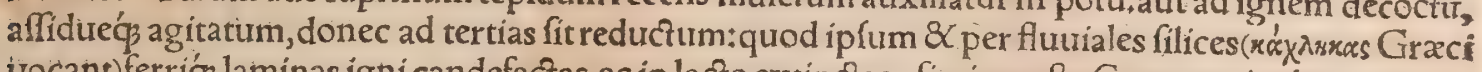
trocant) ferríg laminas igni candefactas ac in lacte extinctas, fieri potelt. Cæetertm in decoquendo fuperfantem concretionem fiue fpumam cochleari aut penna auferre oportet. Hoc enim nullum compendiofits remedium ad fluxiones biliofas reperire poffis. Quandoquidem autem febricitanti. bus lac ipfum in nidorem aut etiam acorem conuerti confueuit, maiusḉs nocumentum quàm com. moditatem inferre:tunc fanéin præfens, ipfum exhibere uitabimus: aquæ uero quarta parte ad lac 40 ipfum affufa, decocitionem faciemus, donec dimidium eius cófumatur, atọs hoc modo exhibebinus, Aétius:Quieadem ferè etiam in coliacorum dixta tradit, ita exhibitum fimul fiftere ac temperare ter coliacortum \& dyfentericorum remedia numeratur: dyfentericis addi mellis exigutum pracipi= unt: \& fi tormina fint, cornus ceruini cinerem, aut fel taurinum cumino mixtum, \& cucurbitæ car nes umbilico imponere, Plin. Contra rofiones inteftinorum à medicamentis factas lac infunditur Et fi urat dyfenteria, decoctum cum marínís lapillis, aut cum ptifana hordeacea. Item ad rofiones in teftinorum bubulum aut ourillum utilius, Plin. Nofiri ut dy enteriæ orcurrant in uaccino lacte tepi= do ftomoma fiute aciem ferri optimam nouies candefaçam extingurunt, idćs calídum propinant $x_{3}$ gro. Nonnulli in aqua etiam æaro bibenda aciem fimiliter extinguunt. Alih lac uaccinum in olla ad so ignem ponunt; $\&$ duos lapides nigros fluuiatiles fimul $\&$ aciem candefaciunt, $\&$ lacii imponunt, ac ne exundet ebulliendo caurent: Lac ita medicatũ quàm calidiffimũ bibi præcipiunt. Áétius de furp. puratis renibus tractans, Lac(inquit)cum melle poft puris eruptionem eis prabendum: $\&$ primum quidem afininum aut equinum; ad ulcera enim repurganda conducit:quum uero repurgatione am plius optis non habent, \& morfus fiunt obtufiores, indigeró̧́ æager nutrimento, tunc etiã bubulũ lac eis exhibendum duarum aut trium heminarum menfura.Conceptus adiutrari aiunt uaccini lactis potu, Plinius. Vulnerato inteftino refpiratio prodit inferné incốpicua iuxta uulnus, \& euacuan tur pectora: Dato igitur lac $\&$ uinum, pari aquæ menfura ammixta, Hippocrates libro 2, Epidemio rum fectione 6. Et alibi eodem libro, Capitis os (inquit)fi doleat fractúmue fit, lac uinumós pari mo

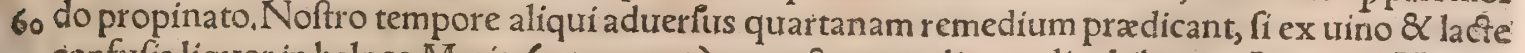
confufis liquor in balneo Marix (ut uocant) extractus per aliquot dies bibatur. Præterea Hippo crates in libro de natura muliebri, Cum fluxus albus obortus fuerit, qui uel uentris mouret profiuu* um, uel ad uterum uer titur, \&c. pharmacum bibi iubet, à quo fuperna purgentur, \&lac afininum, 
Poftquam autem(inquit)infra purgata fuerit, bubulum lac bibat ad dies quadraginta, fi poterit, me

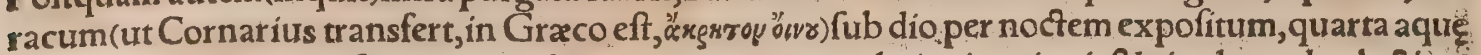
parte ammixta, 8 qua fequuntur:iubet autem aquam paulatim imminui, 8 eius loco plus lactis re pidi recens emulfi admifceri, donec rurfus ferè merum lac fiat. Nam ěxepstop non de uino folum dici tur, fed de quouis mero $8 x$ non mixto. Totus fane ille apud Hippocratem locus, difficilis mihi $\&$ ob. fcurus uidetur. Hoc faltem nobis fi non ex ifto loco, ex fuperioribus tamen conftat, uinum lacti per mixtum inter remedia quondam fuiffe. Sanos uero in cibo idem facere noftrates metris huic argu. mento accommodatis reprehendunt, quorum hic fenfus eft, Lac non Lyæo de iecore Eft abluen= dum, led liquidis Argenteiş́́ nymphis Ei, quidiu frui uolet Dextra ualetudine: Nimirum $q$ facile lac uino mixtum acefcat, \& fimul in uentriculo corrumpantur; aut etiam forte coagulandi in co lactis periculum fit. Auicenna certe Empiricos Indos alios ́́ docere feribit, lac cum acidis uel ace tofis edendum non effe, quoniam diuturni morbi inde oriâtur, ut lepra, \& alïp. Aétius de cura me. lancholia, V tile eft(inquit) lactis fero uentrem fubducere:ueruntamen id non fit quod ex cafeo fue rit expreffum:melius eft enim id, quod per decoctionem ex lacte feparatur, prafertim equino uel. bubulo, \&c. Serum de lacte bubulo, adiecfo melle \& fale, quantum fatis fit, potui fumptum,moran. tem aluum impellit, Marcellus. Idem ante omnia orthopnoicis prodeft cum nafturtio, Plin. Medul la uaccina cum farina tenui fubaća, \& uelut excoctus panis cibatui data, mirè dyfentericum fanat, maximé fi \& cafeus bubulus recens manducetur, Marcellus. Ad omnes epiphoras uentris, cafeum. uaccinum mollem calidum imponi oportet, quo tempore dy fentericis poriones ferro candenti cale. factas dari conuenit, Idem. Cafeus recens uaccinus coeliacis \& dyfentericis immittitur : Item buty= 20 rum heminis quatuor, cum refinæ terebinthinæ fextante, aut cum malua decoĉa, aut rofaceo. Sexti us cofdem effectus careo equino quos bubulo tradit, Plin.

-Bouis capiti lapillum tradunt inelfe, quem ab eo expui finecem timeat: inopinatis pracifoca: pite exemptum adalligatumḉ mirè prodeffe dentitioni: ltem cerebrum eiufdem ad eundem ufum adalligari iubent,Plin. Ex eadem aqua de qua bos aut afinus biberit paululum fumptum $\&$ potatu, tollit efficaciter capitis dolorem, Marcellus.In iuuencarum fecundo uentre pilæ rotunditate nigri: cans tophus reperitur, nullo pondere:fingulare(ut putant) remedium agre parientibus, fi tellurem non attigerit ${ }_{5} P$ lín. Et alibi lapillum memorans qui in ceruis reperiatur, fubdit: Nam de pumice, qui in uaccarum utero fimili modo inuenitur, diximus in natura boum: non aliũ quàm citatum ian lo= cum fignificans, Lingure exulcerationi $\&$ arteriarum prodeft ius omafigargarizatum, Plin, bubu li accipiendum puto, de illo enim lacie proxime dixerat, quan कृ̧ fimul etiam de caprino. Iecur uacs cinum coeliacis $\&$ dyfentericis medetur, Plin. lecur bouis uftum potumó, urentris \& fanguinis pro. flutum inhibet, Haly. GLyciû́ Indicum aliqui felle bubulo adulterant, Plin. Vaccinư fel ualidi. us eft quàm aliarû quadrupedũ̃: Mifcetur emplaftris ad ulcera qux eryfipelati \& dolori uchementi

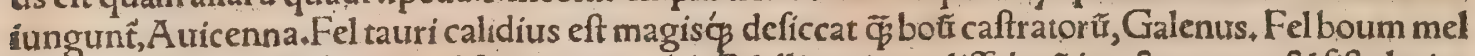
li admixtũ, ferrum infixum uel fpinam extrahit. Bdellium in co diffolutũ íuncto aceto, \& fiftula in. fufum, iutuat, Rafis. Permixto alumine $\&$ myrrha fel bubulũ ad crafitudinem mellis fubaciũ $\&$ illi: tum, ea qua ueretris ferpunt, mira celeritate perfanat : fupra etiam beta uino cocta recté imponit, Marcellus: apud Plinium uero li. 2 8.cap. 1 . fic legitur, Vitia qux in uerendis ferpunt, fel bubulâ $f_{a}=$ nat, cũ alumine A egyptio ac muria ad craffitudinẽ mellis fubaçû̃, infuper beta ex uino cocła impofi ta, ut caro quoq bubula, Panos $\&$ apoftemata in quacũ $q$ parte fel bubulũ difcutit, ut fanguis etiã \& caro bouis calida impofita, Plin. Strumas difcutit fel aprinum, uel bubulũ tepidum illitũ, Plin. Mar. cellus non aprinũ fed caprinũ ad firumas commendat, his uerbis: Fel bubulũ uel caprint̃ ad incipientes ftrumas optimé facere experimenta docuerũt. Nam penitus crefcere non finẽtur, fi eo adfiduè tangant. Cicatrices nigras reducit ad candorem, cum felle bubulo erucæ femen, Plin. Bubulũ fel cữ nitro \& cimolia furfures amolitur, fi caput inde lauet, A uicenna. In ufu eft etiam ad collyria contra ungues oculorû. Fel uaccæ nigræ, fi coillinanẗ oculi debiles, fcripturam amilli non percipientes, pros deft, $R$ afis; quid fibi uelit uox amilli non affequor:fenfus forfitan ef, ituari eos qui fcripta remotio. ra legere non poffunt, quos Græci $\mu$ vistas uocant, luf́ciofos uel luícitiofos Latini:Plinius tamen ny= calopas lufcióos interpretatur, eorû́ćs oculos felle capræà quibufdam inungi frribit. In felle bo: so um inuenit aliquid lapidi fimile, figura annuli, quod phlofophi vocant alcheron, quod tritû \& naribus attractum, aciem oculorũ promouet, $\&$ prohibet ne quis humor defcendens in oculis colligat: Item fi magnitudine lentis inde capiat cum fucco betæ, \& hauriatur naribus, comitialibus prodelt. Qued fi defit alcheron, fubftituat ei fefquidenarius de felle tauri nigri, Rafís. Hunclapidem in felle bouis repertum, aliqui etiam guers $\&$ maffat uocant, ut Matthxus Syluaticus fcribit, A rabica nimix rum dialecto: Vide in feile tauri infra. Fel bouis tinnitui $\&$ fonis auriư inteftinis medet,fi cum gof fipio imponatur: \& fi cũ oleo inftillet̂t, contraçũ ex frigiditate dolorem auriã lenit, Haly. Aduerfus grauitatem audiendi fel bubulũ cũ urina hirci, auricula quæ moleftiam furdiginis patitur, inftillabis. Itatimós fubuenies, Marcel. Si grauiras fit audiendi,fel bubulũ cum urina capra uel hirci medet, uel fi pus fit, Plin. Fel teftudinũ cum uernatione anguiư aceto admixto, unicé purulentis auribus pro. 6 deft:Quidam bubulư fel admifcent, decoctarứç carniũ teftudinis fuccũ, addita æque uernatione an guiû́:fed diu in uino teftudinem excoquût, Plin, Senectụs ferpentium (qua non uetuftior anno fit) 
feruente tefta ufta inftillatur auribus rofaceo admixto, contra omnia quidem uítia efficax, fed côttra graueolentiam pracipue; aut fi purulentr funt ex aceto, melius cum felle caprino uel bubulo aut reftudinis marina:Idem alibi, Aurium dolori \& uitīs medetur fel apri uel fuis uel bubulư, cum olco cicino $\&$ rofaceo æquis portionibus:præcipué uero taurinü, cum porrífucco tepidum, uel cum mel le fi fuppurent: contrá̧́ cdorem gratrem per fe tepefactũ in malicorio, Plin, Bouris felle palatum 11li= nitur ad prourocationem, Auicenna:forte apophlegmatífmum, id eft pituitæà capite detractionern proutocationis uocabulo accipere conuenit, Sunt qui morbum regiû́ pellicredät falcia línea in bu. bulo felle calido tincta, $8 \mathrm{C}$ corpori fub coftis incincta:quod triduro faciendum aiunt, ita ut quotidie renoưetur medicamentû. Si mulier diu non concepit, menfibus apparentibus tertia aut quarta die, io alumen tritum unguento dilutum, lana exceptum apponat, $\&$ per tres dies appofitum habeat: tertia uero die fel bouis radito, \& ramentum oleo dilutum ac fubactum, linteo exceptum apponito, \& tres dies appofitum habeat:fequenti uero cư uiro concumbat, Hippocrates in libro de natura muliebri. Induratam uuluam aperit fel bubulum rofaceo admixto, foris uellere cũ refina terebinthina impofi ta,Plin. Fel bouris mixtũ uino \& medullæ colocynthidis a melli, ano illito, aluum proritat; $\mathrm{Rafis}+\mathrm{He}$ morrhoides aperit, Auicenna:in quem ufum Galenus $\&$ alị taurino præcipue utunẗ. Marifcæaut fici, ut quidam fcribunt, fi felle bubulo linantur, indubitanter abolentur. Genus maligni $\&$ depafcen tis ulceris, in tibijs pracipue, quod noftri lupum uocant, fanari quidam promittunt, impofito cata: plafmate, ex fucco carlinæ (qui radice contufa expreffus fic) $\&$ chelidoni maioris $\&$ felle bubulo, ita ut partes fingulorũ æquales mifceantur. TLien bubulus in melle editur, $\&$ illinitur ad lienis dolo, 2o res:ad ulcera manantia cum melle, Plin. Inueteratus ex uino datur ad lienem fedandumtrecens aũt af fus uel elixus in cibo, Plin. T Vlcera in facie tolluntur membrana é partu bouis madida. IIn uefica bouis allif capita uiginti tufa cum aceti fextario imponuntur ad lienis dolorem, Plin+Aeris fo rem tritum bene cum finapi, aut etiam folũ, mittes in acetư, fimulćs in burcculari decoques: ita ut ali= quandiu illic bulliant, \& ad fimilitudinem pulticulę fpiffentur:poltea in uaccinam ueffican calida ea transferes, ita ut duobus digitis liquori huic ueffica maior fit, tum fpleni fatis calidũ medicamen ad= pones, ligabis fafcia, tertia die folues, mirabili gratulaberis remedio, Marcellus, A d colicam remediư ufu perfape comprobatum ab amico quodam nuper accepi huiufmodi: Later ignitus $\&$ fafcia ma. dente inuolutus, pedibus agri in lecto bene cooperti applicetur: Mox lac caprinum prius feruefaçum in ueficam bubulam infundes et umbilico impones quàm calidiffimũ. Hinc furdor copiofus ma 30 nabit:proinde ne aluus fiftatur, fimul etiam parum olei agro propinetur : quod et ipfum aliqui calio dum bibi uolunt. TBoues ne infeftentur à mufcis, bubulam faliuam illine, Africanus, TAiunt fi bouis caftrati urinæe cinis arboris myricæ immifceatur, trel in potu, uel in cibo, Venerem finiri: Car bóç ex eo genere urina ea reftinctus in umbra conditur:idém cum libeat accedere, refoluitur, Plín. Si quis fe infundat in urina bouis, ftomacho ob frigiditatem agro condicit : item ad hæmorrhoides, Haly. Noftro tempore quidam militibus quos dira oris ulcera populari lue per exercitum graflata uexabant(noftri uocant Dic bzïne) uaccarum lotium gargarifandü dedit, ac plerof $\xi^{\prime}$ magno lucrø furo curauit. Vulnera facta igne, dum fanefcunt, defricare bubula urina conuenit, Columella ubia. git de cauterïs boum ad epiphoras oculorư. Suppuratio boum melius ferro refcinditur quàm medi camento: Expreffus deinde finus ipfe, qui eam continebar, calida bubula urina eluitur, \&c. Columel

40 la. Corni arboris flore deguftato, aluo concita moriuntur apes, remedium prabere eis urinam hom num, uel boũ, Plínius.

đI Stercus animalium uim habet maximé digerentem. Verum ftercus humanũ ob foctorem abo. minandum eft. A tbubulú, caprinữ, \& ex alịjs quibufdam animalibus, neqg gratriter olet, $\&$ multa ex perientia non tantum nobis, fed $\&$ alijs medicis me natu maioribus comprobatum eft, Galentis de fimpl.medic, facultatibus libro 10, cap. 17. Etmox cap.23. Stercus bubulum (inquit) pro paftur uraio exiguam habet differentiam, eft'̧́ $\mathcal{Q}$ ipfum facultatis exiccatoriæ. Verum attractoriam etiam obti. net, ut monftrat dum apum uef parumćs morfus iuuat. Quanquam hac ut à proprietate fubftantia. totius iuuentur fieri poteft. Cærterum medicus quidam medicamentorum periturs, in Myfia quæ in Hellefponto eft, aqua inter cutem laborantes bubulo ftercore oblinens, in folem exponebat. At tque hic ipfe impofuit $\alpha$ partibur rufticorum phlegmone obfefís, humidum illud uere collectum, cum herbam boures pafcuntur.Manifeftum autem eft hoc effe alio moderationibus multò uiribus: dico autem aliud cum paleis uefcuntur. Nam hoc medium eft inter id quod modo diximus, \& quod pros uenit ab erui paftu. Liquet ergo, quemadmodum id quod ex pafcuo herbaceo prourenit, ad phleg. monas accommodatur, fic iftud aqua minfeftatis effe idoneum. Scire tamen oporter, omnia id genus medicamenta duris agreftium hominum corporibus aptari, nempe fofforibus $\&$ melforibus, \& qui opus obeunt tam ualidum:in quibus utic Mylius ille medicus $\&$ ad chorades adhibeat, $\&$ ad tumo res omnes fcirrhofos, ex aceto in cataplafmatis formam compofitum imponens, Hæc Galenus. Illis nitur in his qux rumpere opus eft, fimum bubulum in cinere calefactum, aut caprinum in uino uel aceto decoctum, Plin. Medetur aduerfus a pum \& uefparum ictus, $R$ afis: $\&$ Galenus, ut fupra recita= 60 urimus. Omnes tumores $\&$ abfceffus calidos cum acero impofitum fedat, Auicennat\& Galenus, ute paulòante dictum eft. Igni facro uitulinum fimum recens illinitur, uel bubulum, Plin. Armentaria: bouxs fimum firecens admoueatur, uulnerum inflammationes mitigat; Folijs autem inuoluitur ${ }_{8} \&$ 
calfactum cinere feruenti fuperponitur, Diofcorides, Illitum ex aceto duritias, panos, \& ftrumas difcutit, Idem. Abfceffus craffos diffoluit, Haly. Fimum bubulum cum melle recentia uulnera non patitur intumefcere,Plin.Quemuis tumorem fedari aiunt farina hordei cum ftercore bubulo uel capri no cocia, Author obfcurus.Ad ulcera antiqua tibiarum quidam hoc arido medicamento utuntur:te ftre ouorum, ueteres calceamentorum folex, \& bubulũ fimum de menfe Maio, arida teruntur, \& infpergũtur ulceri:fuperinditur etiam typha paluftris:fic ulcus exiccari aiunt. Fimum bubulư naribus inflatum, fanguinis profluuiû cohibet, $R$ afis. Aliqui ad eundem ufum acetum addunt; Aln̈ non ip= fum, fed eius cinerem inflari iubent, ut Haly, Fimus bouis folio inuolutus \& calefactus in cinere ua: ricibus applicatur, $R$ afis. Conuenit etiam abfceffibus qui poft aures fiunt, Auicenna, Bubulũ fimum feruens ex aceto decoctû, ftrumas difcutit, Plin. ftrumas $\&$ alios fcirrhofos tumores, urfupra ex $\mathrm{Gaz}$ 10 leno relatum eft. Magi fimi bubuli cinere confperfo puerorum urina illinût digiros pedũ, manibusć leporis cor adalligant, contra quartanam, Plin. Fimo bubulo ufto fuccũ betæ admifceri, atç̧ inde ca* put porriginofum lauari oportet, Marcel, Phthificis prodeffe tradunt, fimi aridi fed pabulo uiridi paPro boue fumã harundine hauftũ, Plin.Stercus uaccinũ eft ex medicamentis, quibus pulmoni, eiusç tabi, \& fimilibus noxis medemur, Auicenna, Potum uel clyftere infufum, uentri ob inteftinnrũ ulce= ra fluenti falubre eft, $R$ afis. Morbum arquatum pelli ferunt recentiores quidam, fi ébubulo fimo re= cente(aut uiridi, utrü enim ex lingua noftra transferri poteft)liquor in chymiftico inftrumento $e_{\text {: }}$ paratus potetur. Ad coli dolorem:Itercus bubulũ recens exprime per linteum mundum, \& fuccum eius in qualibet potione colico da bibendum, ftatim fubuenies:quod remediũ efficaciffimũ effe mul= ta experimenta docuerunt, Marcellus, Germani(prafertim noftri)colicam etiam matricis uocabulo 20 nominant, \& \&̊d abfurdius eft in uiris quọ̧:celebratur aût etiam apud nos medicamentũ illud Mar. celli iam dictum: Fimum uaccinû nempe uino permifcent, fuccumás linteo percolatum, agroto cali: dum propinant. Alị hoc fimũ magnitudine oui dimidiati quing unç̣̆s uini permixtum colant, $\&$ minutím incifa addunt aromata, zingiber, caryophyllos, macis, \& cinnamum: Hoc agrũ, ubi primû noxam fenferit, una potione haurire, $\&$ infuper fudare pracipiunt. Bouis ftercusaridum uftũ, tribus cochlearijis poturm hydropicos iuuat, Galenus ad Pifonem cap. 12, \&Rafis, Hydropicis auxiliat fimi ceruini, maximé fubulonis, fed \& bubuli(de armentinis loquor)quod bolbiton uocant, cinis cochicarior t̃ trium in mulfi hemina: bouis focminæin mulieribus, $\&$ ex altero fexu in uiris, quod uelu. ti myfterium occultarunt magi, Plin. Hydropicus illitus fimo bubulo iuuatur, fi diutius ad folem de= ficcetur, Antiquus quidam, \& Galenus ut fupra ex eo citaui . Hydropico plurimũ prodeft fimo bu= bulo inungi ad folê et confricari corpus totũ, $R$ afis. Ex eodem arido, aceto optimo \& aqua in morta rio diligenter admixtis, cataplafma toti uentri calidü contra aquam citrinam (id eft, hydropem) utilif. fimé imponitur, Rafis, Prodeft \& uituli fimû, ut infra docebimus. Bouis fimum coxendicis crucia. - tus fotu compelcit, Diofcorides, Ifchiadicis fimum bubulä imponunt, calfactum in folijs cinere fer. uenti,Plin. Fimum bubulũ feruentem, quem in cinere ardẽti calefeceris, coxarum dolori imponito, plurimũ prodeft, Marcell. Emplaftrum ex eo fit ifchiadi, Auicenna, Recens calidus podagram le. nit, Marcel. Recens cataplafmatis inftar podagram impofitus leurat, $R$ afis. Priuatim fuffitu fimi, quod àmafculo bout rediditum eft, procidentes uulua reprimuntur, Diofcorides. Maximum beneficium prệtat fimus mafculi bouis, hyftericis mulierũ fumigatus propendentibus, Antiquus quidam. Aiưt \&. fuffitu fimi è mare boure, procidentes unluas reprimi, partus adiuuari, Plin, Hippocrates in libro $4{ }^{\circ}$ de natura muliebri, ubi medicamenta refertmenfibus 8 fecundis detrahendis idonea, cum odora= menta quardam, (crocũ, calamũ,rofas, ftyracem, cneorũ paurco melle fubigenda) recenfuiffet, Hæxc (inquít)fuffiantur ftercore bubulo:id uelut acetabulũ oleariũ formetur, habeat'̧́ fưndũ tenure, \& fit

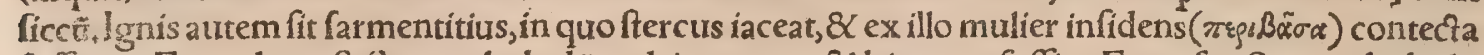
fufilatur. Et paulo poft, Stercus bubulü, cedri ramenta, $\&$ bitumen fuffito. Etr urfus, Stercus bubulü contufum ac cribratũ, aceti dimidia menfura, $\&$ decocti erui dimidia adiecta, leniter pro fomẽto ad hibeto, \&c. Et pauló poft initium eiufdem libri, aduerfus aquam intercutem uterl, pharmacum (in= quit)deorfum purgans bibendum dare oportet:poft pharmacữ uero, ureros bubuliftercoris fomen to fouere. बI Aqua pota, qua de bouis aut afini potu relicta eft, capitis dolores fanat, Plinius.

$$
\mathrm{H} \text {. }
$$

Bos, ô bos, $\&$ datiturus pluralis bobus, uel fecundũ ueteres bubus, primam fyllabam producuntste liqui cafus omnes corripiunt, Seruius. Fógrts $\&$ rógr $\alpha \xi($ inuenio $\& \pi$ ógus ) pro iutuenca dicitur à Græ-

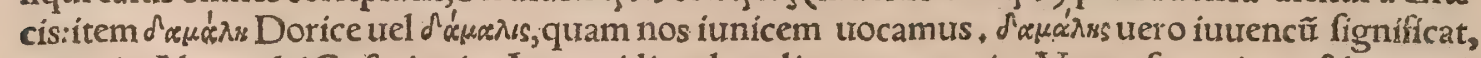
quem in Alexandri Cafaris urita Lampridius damalionem uocauit. Vrerç fexus in mofcho conti: netur. Photion damalin uocari omne animal exiftimat in iutrenta, Hermolaus Barb. \& Ariftopha

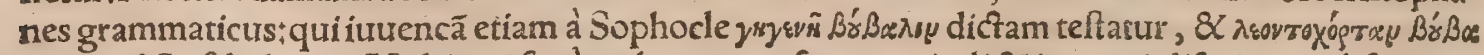
ᄀuy apud A efchylũ legi. Videntur fanẻ authores non femper uituli \& iuuenci difcrimen obferuare, quod ab atare eft, cum hic illo natumaior fit(ut diximus fupra in $\mathrm{A}$, circa principiü, \& rurfus circa

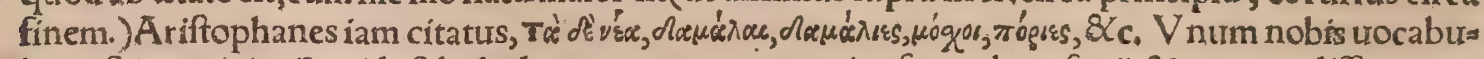
lum eft, $\$ a s$ rintouibe, id eft bubulü pecus, quo omnes eius fecundum fexû 8 xtatem differentias 60

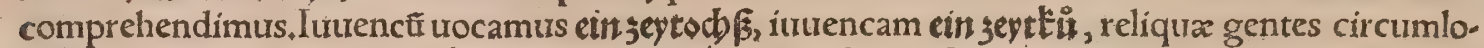

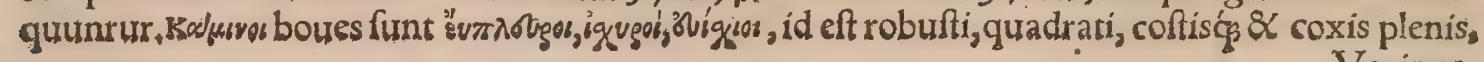




\section{Bos\&Vacca H. Lib. I. 73}

Varinus,ígejiọ, quoduis animal quod immolatur:per excellentiam autem bos, Idem + Dionyfius Siculus bourem nuncupabat garotan, Caliuss, Br̃s genitiuũ facit Boòs, uel Br̃ poeticé : accufatiuũ Bợ uel

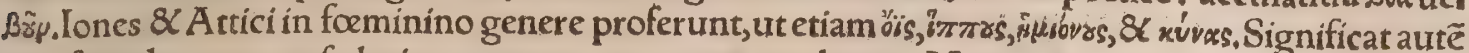
non fingulos tantum, fed etiam gregem aut armentum boưm; Varínus. Græci Br̈s nominari aiunt commiffuras futurarum in tunicis, Pollux. Bz̃y etiam appellare licebit chytropodem, qui anthracium

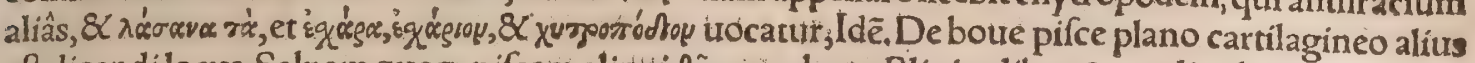
eft dicendi locus. Salpam quoq pifcem aliqui Br̃utiocabant. Plinius libro 8, tradit elephantes Italiã uidiffe primum Pyrrhi bello, 8 boues Lucas appellaffe, in Lucanis uifos. De boue placenta mox in ter prouerbia dicemus, Bẑs pro corio bubulo, totum pro parte, ut elephas etiam Gracis pro dente fo 10 lo, Euftathius. Bũs etiam, apud poëtas precipue, pro $\beta \tilde{s}$ s ponitur, $\mathcal{Q}$ â grammaticis exponitur, fcutû́,

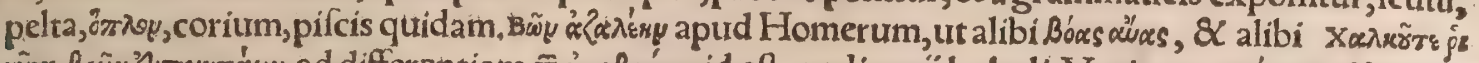

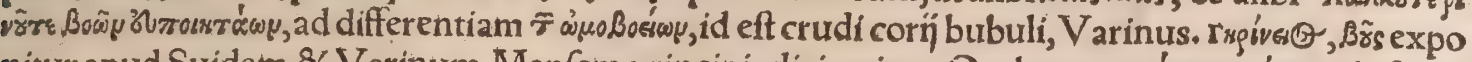

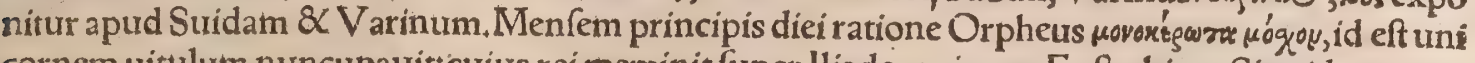
cornem uitulum nuncupauit:cuius rei meminit fuper lliados primum Euftathius. Siquidem menfis fimpliciter, utgenerationis effecter, bos appellatur. Quód uero habeat tunc primam fubftantiae

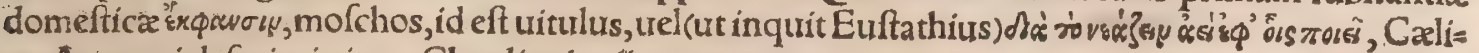
us. Armenti defcriptio inter Claudiani poémata extat.

1 Bubulus, idem quod bouinus, ut lac bubulum, Plin.libro 18. Stomachum exulceratum lactis afinini potus reficit:item bubuli. Sic bubulum pecus, Varro 2, de Re ruft. Bubulũ monumentũ ios co dixit Plaut, Sticho.Sunt qui $\&$ bouillũ recté dici putant, $\&$ citant Plinï locũ, Bouillæ carnis iure facile curatur, quem nos in Plinio nufȫ reperimus, Boidsoy bucula eft, trifyllabum pro teurafyllabo Boóidou. Ceruus eft animal adeò fimplex, ut equo aut bucula accedẽte propius, hominem iuxta uenan tem nố cernat:aut fi cernat, arcũ ipfurm fagittasć̣ miret, Plin. Vaccinus adiectiuũ nomẽ àuacca, lac เraccinû a pud Pliniñ. Quod fcorta paffim uacchas nuncupamus, ex antiquitate profluxit, in comca dị̆s quippe Ariftophanis comperitur fuiffe Athenis celebres meretriculas Cynnam \& Salauacchä,

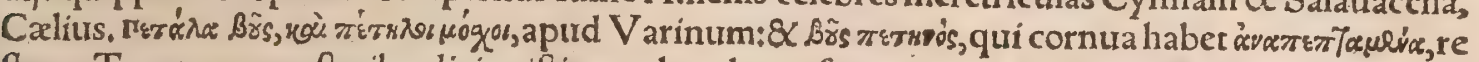
flexa. Tauras uaccas fteriles dici exiftimant, hac de caufa, $q$ non magis क tauri pariant, Feftus, Co= lumella lib.6. Et utíg tauræ qua locũ occupant foccundarumableganda. Varrolibro 2, de Reru ftica, Quxfterilis eft uacca, taura appellatur. TBouis $\&$ uaccæ epitheta hæc reperimus: Arator, - armofus, agreftis, agricola. Aeripes Ouidin, qui habeat pedes tan $\not$ ex 2 re folidos. Albus, Horatius

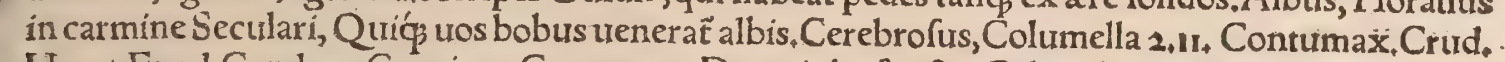
Horat.Epod.Candens. Corniger. Cornupeta, Decori ab afpectu, Colum, Durus. Duriffimi, Colum. Formofa, Otrid, 1 , de Arte. Ferus, Hirfutus, Immunis aratri, Ouid.Metam.3. Incuftoditæ, idem Faft. 1. Indigena, Ouid. Amor.3. Indomita, Valer, lib. 4. Argo. \& 2 Porphyr, Intacta, id eft iugũ non paffa, Horat,Epod, 9.Lectus, Ouid.Metam.6.Minaces, idem Metam, 1. Nitida \& niuea, Ouid. Omniuo= ra in herbis, Plin. 25.8. Opimi, Varro de Reruft. 2,1. Otiofus, Horat, Carm.3. Paffa iugum, Ouid. Metam. 3.Pafti, Verg. Aeg.5.Patuli, quorũ cornua in diuerfurm fupra modum patent, Plautus.Paui di, Claudian.Panegyr.3.Perdomiti,Colum.6.2.Piger, Horat, Epift.1.Tolerantes laborû, Colum.Ru ricolæ, Ouid.Faft. $\boldsymbol{y}_{\text {. }}$ Boures perpetuo epitheto toruos poetre trocant, $q$ pracipua frontis äperitas in 40 hoc pecore apparet:Claudianus, Vitulam non blandius ambit Torua parens, id eft uacca. Vne de Toruitas, ut Pompeio placet, quafi taurorū acerbitas duça. Tardi, Ouid. Amor.1. Trux. Tumi dus. Tutus, Horat, Carm, 4. Validus, Vetulus, Iuuenalis Sat, 10; Armenti epitheta, bucerũ, ualidũ, montanum, toruum, fpumans, lanigerũ, difcolor. Bucerię, boum greges. Lucret.lib.2. Buceriæáç gre ges, Nonius.Bucerus, a, um, ut Ouid. 6.Metam. Armẽta ós bucera pauit, id eft boures ipfos ualde cor nutos. Lucret, lib, y. Lanigerxós fimul pecudes, \& burcera fecla, hoc eft boues, Iuuenci 8 iuuenca epitheta, cornigera, formof $x$, fortes, laborifer, lunati fronte, petulans, torua fronte, pulcher, rudes 0 . perum, toruus, ualidus. Iuuencus de homine quocs iuuene, Horat.1ib.2. Carm, Te fuis matres me tuunt iutuencis, Tefenes proci,miferæćçnuper Virgínes nupta, Porphyrion,lutuenci ergo nú tantum boues dicunt, fed homines:quanuis in ufu fit, ut non nifi per diminutionem iutuenculos di

go camus, Catullus ad purum,Epigr. Qui flofculus es iunenculorum, Ouid, Epif, s. Graia iuruenca tienit. Plin.libro 10, Ex ijs iuuenca plura ä̧ ueteres, fed minora oua pariunt: de autibus. Ágyoi Bóss apud Homerum, non albi, cum nigri mortuis immolarent; nequeloces, hos enim ki $\lambda$ íroolos trocare folet poeta:fed qui iam excoriati propter pinguitudinem albi apparent. Öıotis, qui uini colorem re

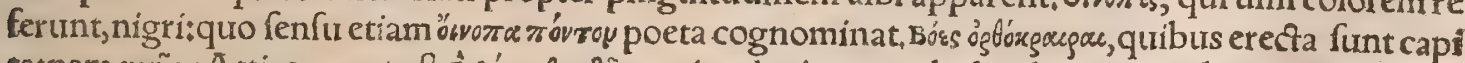

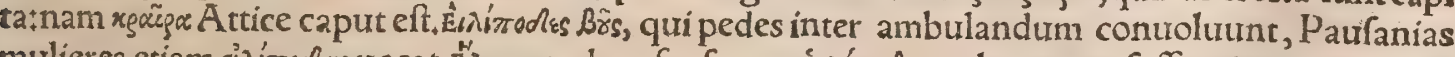

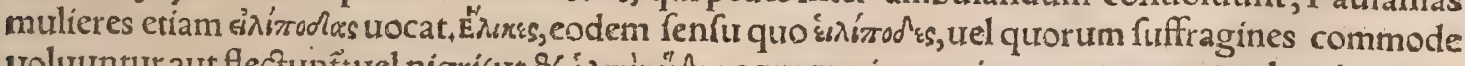

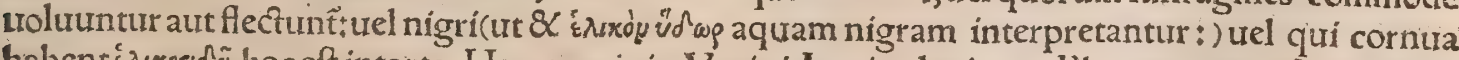

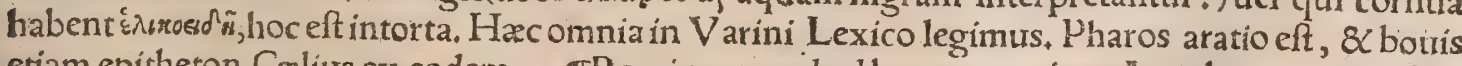
etiam epitheton, Cxlius ex eodem. TBoarium, quod ad bouem pertinet. Arua boaria, in quibus boarium forum Roma furic. Propert, lib, 4. Eleg. Aruá̧̧ mugitu fancite boaria longo. Feftus tas men boarium forum $R$ omæ dictum ait, $q$ ibi uenderentur boues: \& Plinius bouem areum ex $A$ egi na captum in eo confpici fcribit, \& Herculis cognominati Triumphalis ftatuam of Lappx boarix 
radix é uino pota articulis medetur, Plin. Ego hanc Diofcoridis Arcion effe iudico, quam à Roma nis perfonatiam 8 lappam uocari fcribit. Accedunt etiam uires fimiles: $R$ adix enim eius (eodem te. fte)concifa \& emplaftri modo impofita, obortos membrorũ fractis offibus circa articulos dolores fe. dat. Vulgo lappam maiorẽ \& bardanã appellant. Boariæ nomen ei factum crediderim, quod cũ pro cera fit, bubus facile adhæreat:ut lappa canaria canibus, qux à reliquis eiufdem nominis(Plinï uer bis utor)fola humilitate differt. Cunilam bubulam origanum fylueftre Gracorũ effe Io، Ruellius li: bro $3 . \mathrm{Ca}_{4} 25$. de ftirpibus ualidiffimis argumentis conuincit, Ego bubulam appellatam conịcio, $q$ in: ter boum remedia forte olim in ufu fuerit, quan $\not \mathbf{p}$ apud fcriptores in Hippiatrica folum mentionem eius inueniam; fic enim fcribit Columella lib,6.cap.30. Si bilis molefta iumento eft, trenter intume: fcit, nec emittit uentos. Manus uncta inferitur alue, \& obfeffi naturales exitus adaperiuntur, exem , ptó́ ftercore pofita cunila bubula, 8 herba pedicularis cum fale trita, $\&$ decocta, melli mifcentur, atçs ita facta collyria fubrịciuntur, qux uentrem mouent; bilem'́s omnem deducunt, Hac ille. Ef $\&<$ butes origanum apud Cydoniatas, idem nimirum bubulo, ut uel nomine proditur. Crateuas aptrd Græcos Ligufticũ fallo cunilã appellat:cæeteri ferè conizoides, cunilaginẽ , Plin. Nicander fylueftre origanum cunilam (rovi $\lambda$ sy) $\&$ panaces Heracleũ uocat.Paronychiam herbam Romani bouinalem uocabant. Femur bubulü appellatur herba, neruis utilis, recens in aceto $\&$ fale trita, Pli. Videndum an eadem fir, quam alibi fcribit myriophyllon dici, in Hetruria, qua boum nerui abfciffi addita axun

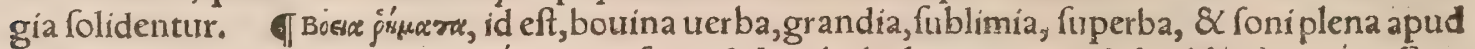

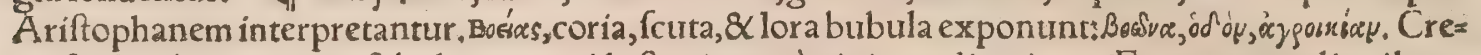
tenfes Bowviay urocant ueftibuli iantıam, id eft primam à uia ingredienti. TFœnogræcũ aliquíbuce 2 ras uocant, quoniam corniculis femen eft fímile, Plin. A libiapud eundem buceros legit, nimirum

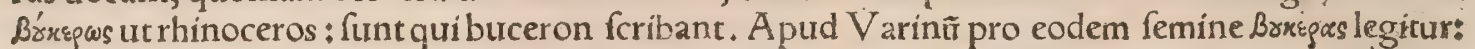
Buceraó appellari etiam anagallidem herbam Menetheus teftis eft, Galenus in Gloflis. Brxєpäís fons eft Platearûtitem Bórę̧ lacus fic olim dićfus, nunc uero genus herba. Vitem nigram aliqui bucras nion uocitant:idem nomen aliqui antirrhino tribuñ t. Bugloffos boum linguæ fimilis, Plin. Ego fimi litudinem iftam ad figuram pariter $\&$ afperitatem refero:utrun $q$ borragini noftræ cốuent: quan \&. alix quxdam herbx ad bugloffi defcriptionem accedant, omnes fere uiribus eifdem pracita, ui fupra oftendi. Cato cap. 4. de infitione loquens:Infuper(inquit)lingua bubula obregito, fi pluat, ne aqua in librũ permeet:eam linguam infuper librum alligato, ne cadat. Citar hunc locû etiam Plin. 17.14. \& herbæ genus interpretat́. A rabica \& Perfica nomina huius herbæ \& generũ eius inuenio, marmacor, marmues, fumufe, fcalue, alfafrens fumufe, meifidaf, keuzauguen. Syluaticus betonicx quoos tribuit lingua bubulæ uel equin $x$ nomen. Cirfio folia bouis linguæ fimilia, minora, fubcandi

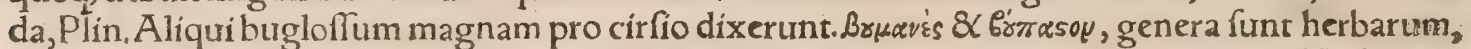
Varinus. Buphthalmus fimilis boum oculis, Plin. Romani olim boariam uocauerunt . Herba hace apud nos in cibũ uenit, V arin. A rabice chiaugefem nominat. Ebenfis in lib. de fimplicibus medic. albehar buphthalmũ facit:cum alij ocimi genus effe fcribant. Aizoon maitus alî́ buphthalmñ tocãt; alñ zoophthalmó, Plin. A pud Diofcoridẽ bubophthalmos inter eiufdẽ herbæ nomenclaturas legit. Boéphthalmō Ofthani fideritis. Boanthemō Galenus in Gloffis buphthalmó exponit, đ̊d \& chryઈan themô uocet. Bupleurû, genus oleris, Varin. Defcribit à Plinio herba fponte nafcens, caule cubitali folīs multis longis $q_{\text {s }}$, capite a nethi:laudata in cibis Hippocrati, et Nicandro in medicina iudicio inter paitinacas erraticas cenferi debet, quibus et defcriptione \& facultatibus fatret. Bupleu rum, bouis cofta, \& eft dulbub, Syluaticus. Dulbub autem quid fit nondum reperi. Bŕmexsıs uel bró mowsıs potius, genus oleris fylueftris fimile finapi, Varinus. De hoc pluribus in buprefti infecto. Brar zovo, trifolium berba, $V$ arinus. Butomo Theophraftus folium reddit arundinareum, angulare:caue lem inoffenfiffimum, qui malũ magnitudine fidx proximum in lacu producat: foeminam fterilem ef $f_{e}$,ad nexus utile e, \&c. Demecritus in Geoponicis eft author butomum in paludibus nafci, folia fere re irinis proxima; quibus boues iucundé uefcantur, unde nomen ei datum: ubicun lum excauandis aquilegîs idoneum faterur. Herbarï \& officina, ut Ruellio placet, uocant hodic iuncum cabacinum, quod folips eius tegetes $\&$ fportulæx, ficut \& f parto texuntur: nanque corbulas quibus ficus \& uuas paffas recondunt, corbas uel potius cabas folent appellare.

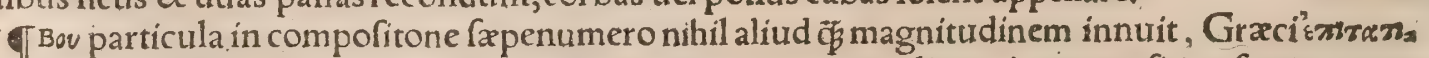

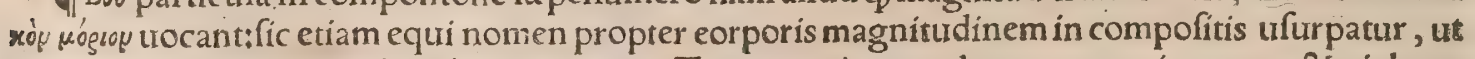
hippofelinon, hippolapathon, hippognomon. Tauri nomine apud ueteres omnia magna \& uiolenta fignificabantur, unde \& Bov particula, ut quiburdam uidetur, à boure dıcta eft, Euftathius. Lapatho rum generibus Solen bulapathon adiecit,radicis tantum altitudine differens, \& erga dyfentericos effectu, potu ex uino, Plin. Mihi quidẽ uerifimile fit eandẽ effe hippolapathon à Diofcoride dićam, quæ rumicum maxima locis prodit paluftribus, nec uiribus à cateris diffidet. Proeadem hydrolapx thum quoc $\beta$ acceperim, cuius loci natales nomine produntur. Diofcorides trium rumicum, agreftis oxylapathi, 8 uxalidis, femina in aqua uinóue contra inteftinorũ tormina utiliter bibi author eft.

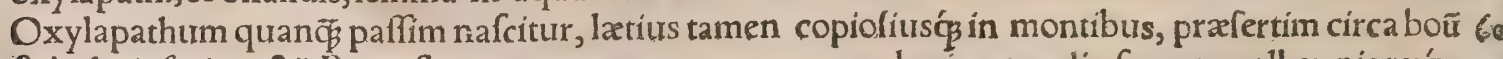
ftabula, ipfis intactũ. Bumafti uux tument mammarum modo, in pergulis feruntur albæ nigra'ç̧; Plin. Varro bumammas uertit,Macrobius bumammias circa finem libri z. Huius generis effe puto 


\section{Bos \&Vacca. H. Lib. I. 75}

quas Arabes \& uulgus hodie cibibas uel zibibas ưocant. Fraxinum ampliffimam lentifimamó́ bur meliam uocant in Macedonia, Plinius. Gaza apud Theophraftum bubulam fraxinum reddidit. Il fam effe puto ex qua menf elegantiores conficiuntur. Bufelinon prodidere quidam difierre bre. uitate caulis à fatiuo $\&$ radicís colore ruffo, eiufdem effectus, praualere contra ferpentes potum $\&$ litum, Plin. Menas apud Varronem, Noui (inquit) maieftatem boum, $\&$ ab his dici pleraç magna;

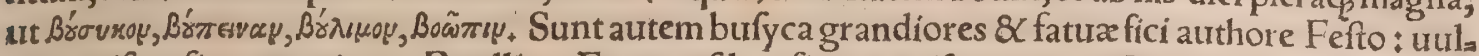
go marifcas ficus nominant, Ruellius, Ego quafdam ficos marifcas coniunctis uocibus in Plinï, Ca tonis, \& aliorum libris nominariinurenio.

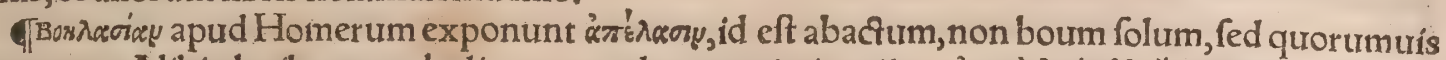

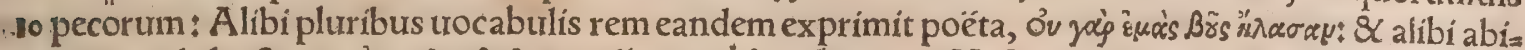

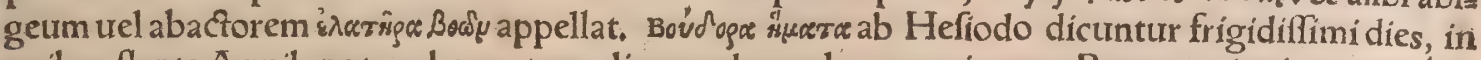
quibus flante Aquilone tum boues tum alix quadrupedes excoriantur : Boreas enim in uit, Káe

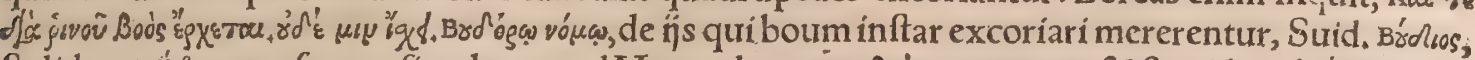
ftolidus, Boî́diss, manfuetus, fimplex, apudMenandrum. Bor Bodges, magnus $\&$ ftupidus, ávóća perbus, à nimia corporis mole dictus uidetur, \&c, uide Etymologicon, Bov Bày glandula in inguine

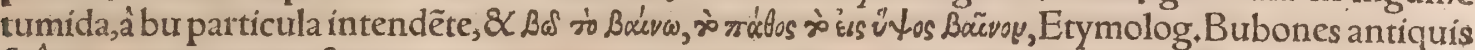
fuêre tumores uniuerfi prater naturam; mox ita priuatim nuncupati, qui in foemoribus, alis protu=

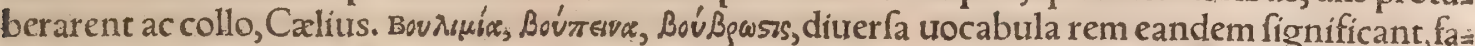
mem frilicet ingentem, $\mathcal{X}$ unitterfam : Indocitores fuperiore freculo medíci bolifmum \& famem uac

20 cinam uocarunt. Lud. Calius libro 26. ab initio, multa fcité de bulimo fcribit, tum alia, tum quid'ab

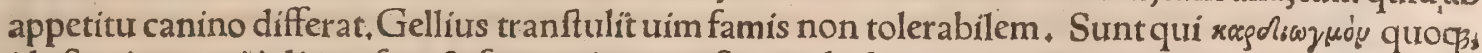

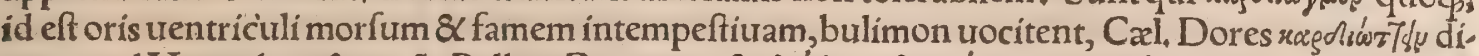

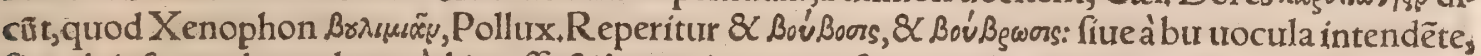
fitue ab ipfa quadrupede, quòd ita affecti boures integros efurire uideãtur(uel boures maçare cogan. tur)ut de Herculis uroracitate legimus, Sũt qui bubroftin dolorẽ aut triftitiã ingentem aut mifericor

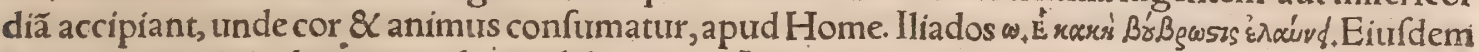
praterea nominis deam quandam uel damonem Ionum legimus, templo ei in Smyrna dedicato, a-

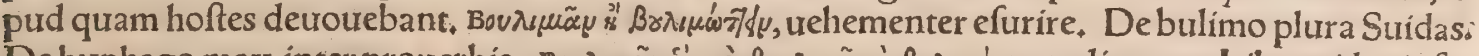

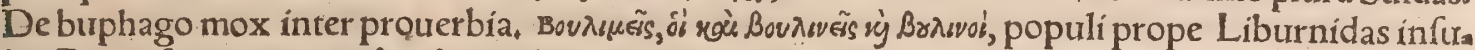

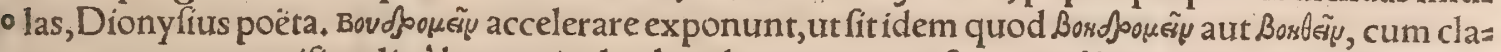
more accurrere : nifi malis à bu particula ob uehementem curfum, Bouf ṽrou aues quadam funt in Ixeuticis Oppiani. Dedit $\&$ noftra lingua auibus nonnullis nomen à bubus: nam fturnos uocatrin-

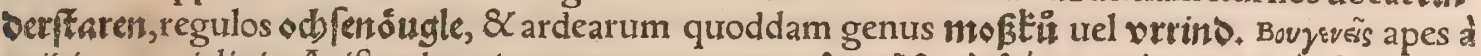

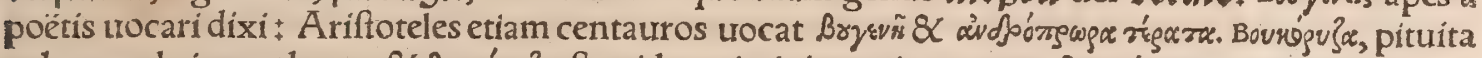

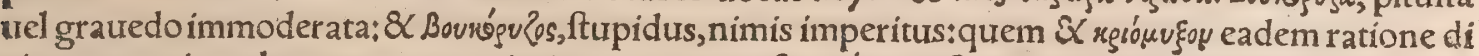
cimus, ut cui cerebrum muco ac pituita occupatum fit, Boviraus eft grandis puer, adoléfens ( qui ex

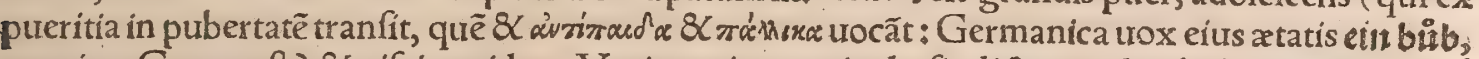
proxima Græcx eft ) \& pifcis quidam, Varinus; item apicula, fic dicta quiod ex bubus nafcatur. Bow

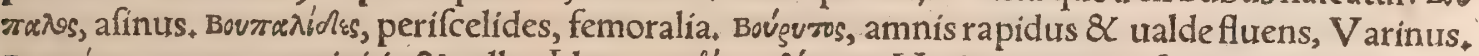

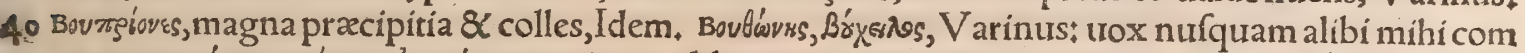
perta. Bouфógrwy xoigavo 'ยıxoóo

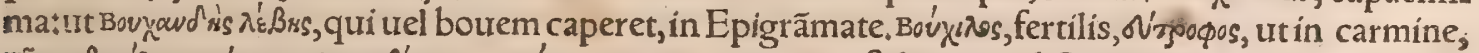

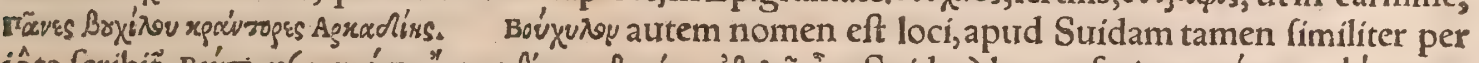

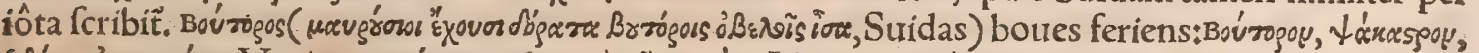

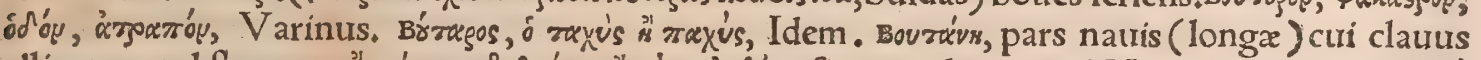

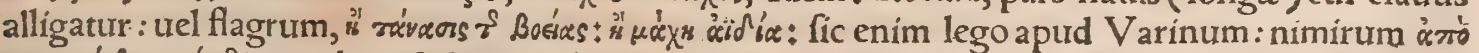
ro $\sigma$ ódsox révars, quod prædictis omnibus conuenit. Alexandri equum bucephalan uocarunt, fiue $a b$ afpectu toruo, fiue $a b$ infigni taurini capitis armo impreffi, Plinius. Dehoc plura dice mus in Equo, Bucephalum etiam inter tribuli nomenclaturas apud Diofcoridem legimus. Bupha. gus, urorax, helluo, \& leonis epitheton, fiure per hyperbolen, tanquam qui boues integros uoret, ut de Hercule fama eft: fiue à bu fimpliciter intendente particula. Nam $\&$ in alÿs quibufdam compofi. tis apud Gracos dubitari poteft, ab iṕis ne bubus, an qua diximus uocula, nominentur. Bupreftis fiue fcarabei genus boures inflantis, fiue alia uentris inflatio accipiatur, æque ad ipfos boues ac mor. bi magnitudinem, trocabuli etymon referri poteft. Sic $\&$ buryncho pifci cetaceo apud Varinũ,figt.. ráne roftri an amplitudo nominis caufa fuerit, dubites, Bovyouiou Iliadis lib.13. Grãmatici exponūt, bo:

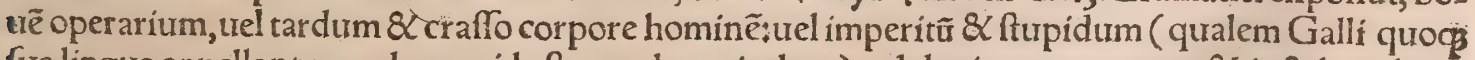
fua lingua appellant grand ueau, id eft grandem uitulum) uel deniç arrogantem $\&$ iactabundum;

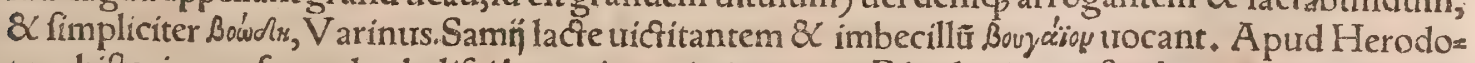
tum hiftoriarum fecunda obelifci burpori nominãtur: quos R hodopis quæetu ditata meretricio Del 60 phis dicauit, Nec ambigitur apud Græcos, quin magnos intelligere oporteat, etiamfi affandis bobus aptos Valia buporos accipit, ridiculé,ni fallor, Calius, Bufiris Aegypti rex (à quo ciuitati quooş no

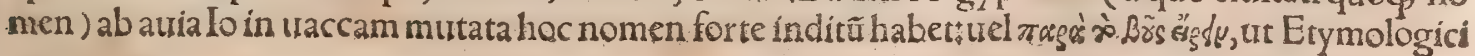


author conịcit,id eft à conferendis et iungen dis bobus, ut qui uel folus duos boures fúb iugữ include

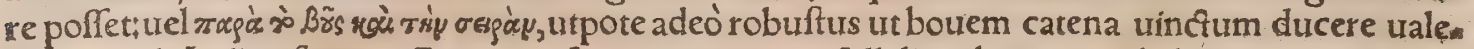
ret, ficuti de Laếrte fertur. Perpauca funt qux primam fyllabam bu purum habent, nec tamen cũ

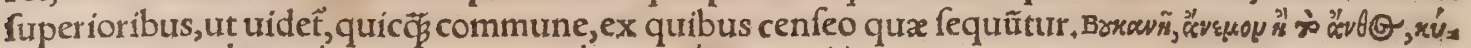

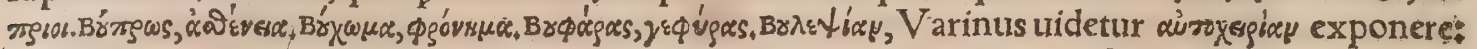
uocabulum rarum, nec alibi mihi repertum, apparet autem excoriationem fonare. Bouzgós zss, iqugós,

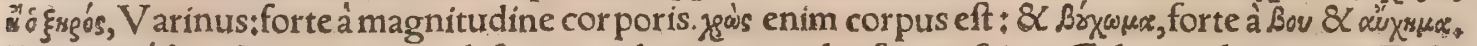
Budini, Bóó' เvot, Sarmatix populi funt, apud quos tarandus fera nafcitur, Gelonis adnumerati, Eufta thius in Dionyfium, Pannonï, fecundum aliquos Bŕyocen, Idem:Bulgari nimirum.

ब ¿́ं tantam magnitudinem exeunt, ut dito Claudio principe, occifre in Vaticano folidus in aluo fpe: ctatus fit infans. Aluntur primo bubulilactis fucco, unde nomen traxêre, Plin. A pud eundem boa appellatur morbus papularum, cum rubent corpora:is fambuci ramo uerberatur : fanatur etiam $e_{*}$ buli folins contritis $\&$ e uino uetere impofitis.

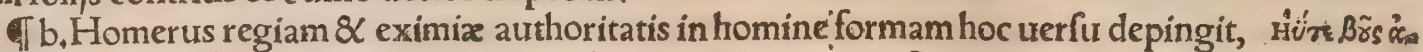

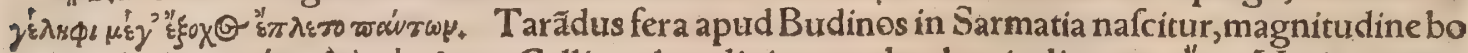

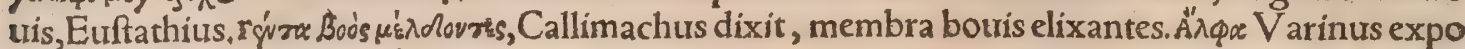
nit caput bouis:quod \& Bŕx̧̧ryoy una uoce dicitur, Bucephalus appellatur equus cuius coxis inuftē

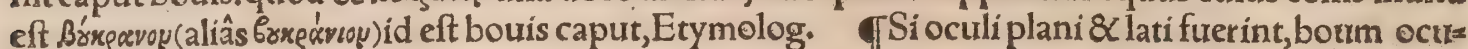
lis fimiles exiftimato, Adamantius. In Indico mari arbufculas nafci ferunt colore bubuli cornus, ram 1 mofas, 8c. Plin. Plutarchus in Sympofiacis Decade 7. Problem,2, docet homines prafractos 86 afperis moribus, \& intractabiles xє gсcб bón rs uocari folitos, quam uocem haud fatis commode uerteris Latine, Sumptam autem metaphoram ab agricolis, apud quos femina qux priufō̧ in terram deci,

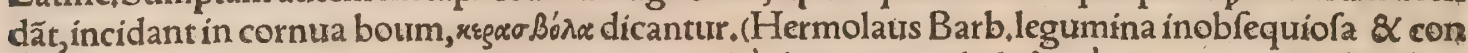

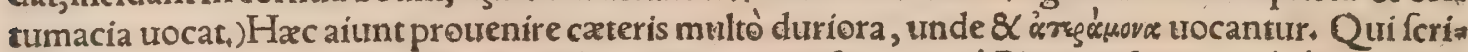
pfit Etymologicon indicat hanc tocê femel duntaxat ufurpatam à Platone, fumptamćsà legumini bus, quæ nec igni nec aqua mollefcant:cuiufmodi quædam uidemus admixta leguminibus minuta nigrać. Locus eft apudPlatonem libro de Legi.ø. ubi interpres inepte uertit fulminis tactu pradus. ra, quafi xescuvo Bór re dictum effet.Porrò cur id accidat, ut femina qux in cornua boum impegerint, aut non proueniant, aut proueniant ficciora durioraç̧, Plutarchus hanc adfert caufam: $q$ ea qæu à ; manu calida ftatim excepta terra fouẽtur, magis adiuuant calore, qui feminibus eft amicus. A $q u x$ in cornua incidant, proiecta magis uidentur quàm feminata, $8 \mathrm{C}$ mora frigus colligunt. Theophra ftus dubitat, num fritolum fit, quod de cerasbolis iactant agricolæ, Hæc Erafmus Roterod. in Chi-

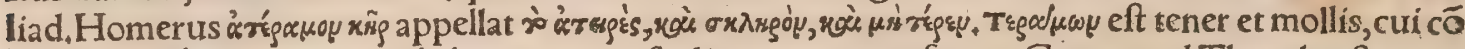

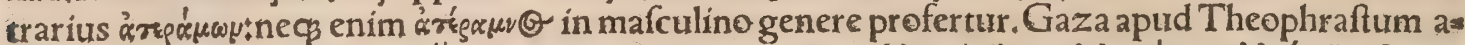

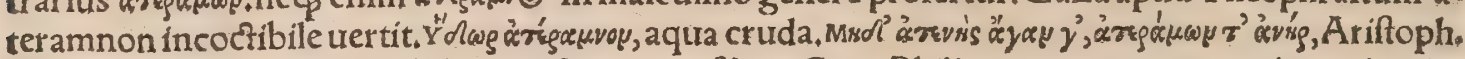
in Vefpis, pro uiro inexorabili, duro, \& cornea fibra. Circa Philippos ateramon nominant in pin. gui folo herbam, qua faba necatur:teramon, qua in macro, cum udam quidam uentus afflauit, Plin. Semina qux dum fparguntur boum cornibus attacta fuerint, non euadunt in bonam frugem, $8 \mathrm{gra}$ na producunt exigua, Rafis. Mihi quidem uerifimile fit ortam hanc perfuafionem de feminum duri $=40$ tate, quód qux dura $\&$ incoctilia funt, cornu duritiem ac tenacitatem \& infuper colorem pra fe fe rant, $\tan \tilde{\beta}$ uitio pericontagium nato. Similiter falfam illorum credulitatem reor, qui fatis ramentis de cornu arietis afparagos nafci tradiderunt: Nam illorum quoos femina cornu fubftantiam repra: fentant. Hermolaus Barbarus in Corollario ad fabam Diofcoridis, Plinius (inquit) Theophraftum intelligit, nonnun कै fieri ut teramos in ateramon tranfeat, cum uapore atos halitu terra madidam, indigena quidã uentus afflauerit. A liter Theodorus, qui duo illa, teramó $\&$ ateramon fiue ateramnố pro coctibili $\&$ incoctibili, non pro herbis ita nuncupatis accipir. Theophraftus certe alio loco facile fignificat ueriorem Thedori đ̆ $^{\circ}$ Plinip fenfum fuiffe: Tantum Hermolaus, apud quem pro his Plinif uerbis, teramon qua in macro folo, librarï fuppofuerunt, de qua in Macrobio. Macrobius certe quod fciam nullam huius rei mentionem fecit:non alienum tamen ab ifterum uocabulorum etymo so eft, quod idem ex Faborino fcribit terenum Sabinorum ligua molle fignificare, unde Terentios quo que dictos putat Varro: Hinc \& Horatium molle Tarentum dixiffe; \& Tarentínas oues nuceśç uo cari, quæ fint terentinæ, id eft.molles. A pparet fanè Gręcorum rég̨̧ Sabinos retinuilfe, Romanos au

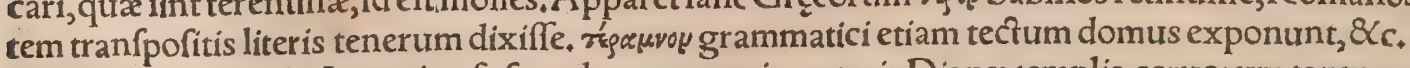

Boum cornua cur in Auentino fufpendantur, cum in cæteris Dianæ templis ceruor um tantummo. do cornua affigantur, lege apud Plutarchum Problem. Roman. 4.Boós régers apud Homerum effe aim unt cornu quod linexp pifcatoriæ iuxta hamum circumponitur, alij pilum, Varinus. Coronius ap.

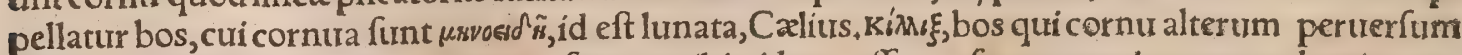
habet, Varinus. In Scythia maximum frigus mihi uidetur effe caufa, cur omnino cornua bouino ge= neri non fuccrefcant, aftipulante fententix meę Homeri carmine Odyffex quarto, quod ita habet: 60 Et Libyen, ubi funt cornuti protinus agni. Quod reçe dicuntin locis calidis mature cornua exift re. Nam in uehementibus frigoribus, aut non oriuntur ftatim pecoribus cornuataut fi oriuntur, uix oriuntur, 


\section{Bos \&Vacca. H. Lib. I.}

oriunturr, Herodotus libro 4.Vergilius fanè in Georgicis meminit boures in Scythia nimio frigore perire, cum non in ftabulis fed campis niuofis hyemem agant: Intereunt pecudes, ftant circumfufa pruinis Corpora magna boum. Cornu tox etiam ad ungulas propter fubftantia fimilitudinem transfertur, ut in uernacula lingua circa boues $\&$ equos, fic apud Latinos, Solido grauiter fonat un gula cornu, Verg. Georg.3. Hinc $\&$ equi cornipedes poërís diçi, Hoc non animaduerfo deceptus uidetur Plinius cum foribit:Boum attritis ungulis cornua unguendo aruina medẽtur agricola : $\mathrm{a}=$ deoóg fequax natura eft ut in ipfis uiuentium corporibus feruenti cera flectantur, \& c, ut fingulis capitibus quaterna fiant. A pparet eum ex diuerfisauthorum locis, qua alibi de proprie dictis in capite cornibus legerat, \& alibi de cornu, id eft cornea fubftantia ungularum, fine iudicio coniunxiffe, ${ }_{10}$ Quid enim ungulis cum cornibus capitis ita commune, ut hac illis attritis ungi debeant

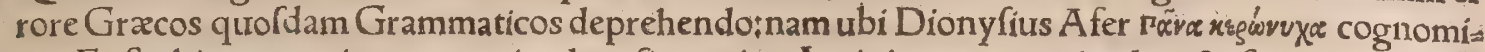
nat, Euftalhius exponit, non cornipedem(ficut etiam Latini poetx capripedem $\&$ femicaprum $\mathrm{P}_{\mathrm{a}}^{\mathrm{A}}$

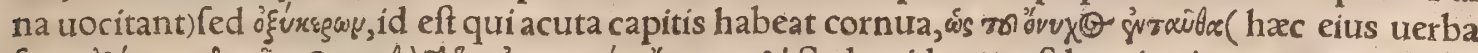

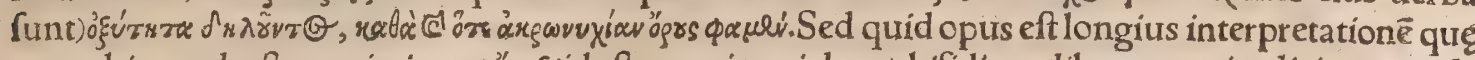

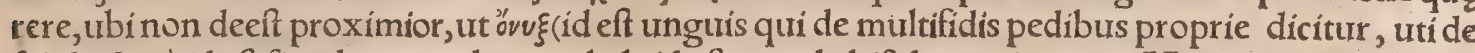
folidis óm $\lambda$ ' id eft fimplex ungula)pro chela id eft ungula bifulca accipiatur. Miretur autem aliquis - animal bifulcum, quale bos eft, Graci f'ixstoy uocent, cum illo numeri aduerbio nihil opus fuiffet: nam $\chi^{s} \lambda$ 's per fe de dionychis, id eft bifulcis tãtum dicitur, cuiufmodi pedem in cruftatis forcipem ap pellamus. Tún

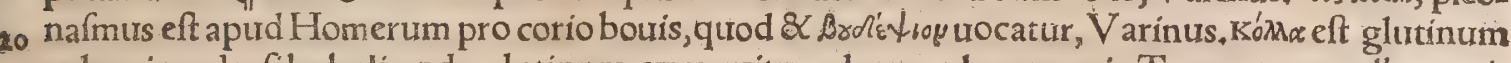
uel corium dorfi bubuli unde glutinum excoquitur, de quo plura mox in Tauro, taurocolla uocis occafione. Collopas uocant Græci coria duriora circa ceruicem fuum $\&$ boum, ex quibus fiunt xón $\lambda a$ Boi dicti,id eft clauiculi quibus intenduntur $\mathcal{Q}$ remittuntur fides in cithara, Varinus. Dionyfius

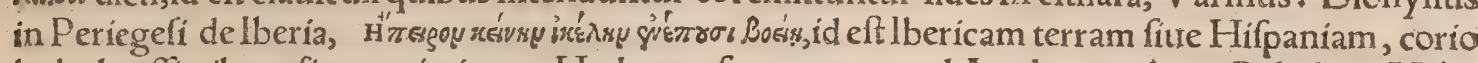
bubulo affimilant: figura nimírum. Hyda menfura terræ apud Anglos , authore Polydoro Vrbinate in Hiftoria Anglicana, uiginti iugera Anglicana comprehendens, nomen fortíta à corio bubulo (id Germani ferè hydam aut hutam appellant)quòd in tenuiffimas laminas fectum hydx quantitatem circumfcribere poffe uideatur: quod fi uerum eft, longè abeffet hyda à uiginti iugerum dimen. fione. Verum nihil prohibet eam dictionem ab una fignificatione in aliam fuiffe translatam, ut cen. zo turix etiam. Verùm authorem habeo Henricum archidiaconum Hintendunénfem, quí affeuerat hydam tot in fe capere iugera, quot uni aratro annuo cultu fufficere poffent. Quod fi uerum eft, ide foret hyda apud Anglos, quod manfum apud Iureconfultos, Robertus Cenalis. Dido foror Pyg。 malionis, Agenoris filia, cum Synchæo marito Tyrum habitabat: lllum Pygmalion ut pecunias eius obtineret in peregrinatione clam occidit. Occifus ille uxxorem in fomnis monet ut fuga fibi caueret à fratre impio, qui maioris pecunias quàm naturæ leges faceret. Itaçs is in Libyam fugit, affumptis alic quot Tyrins \& pecuniarum copia. Er cum Iarbas Nomadum rex non admitteret eam, tantum loci quantum bouis corium cccuparet fibi uendendum petịt. Hoc impetrato, corium difcidit in lorum angufum $\&$ oblongum, eó́p loci quantum potuit longèlatȩ́́ inclufit, ita ut maximam in eo ciuitatem conderet, qux primum noua ciuitas, deinde Carthago dicta eft: \& arx eius Byrfa, id eft corium; 40 Euftathius in Dionyfum. Cicerolibro 2. de Natura decrum, citritatem hanc à Carthagine Herculis filia dictam f́cribit, cum Byrfa prius diceretur. Reperitur $\&$ alia hiftoria ab Eufthio ibidem prodi. ta, quod cum Elif fiue Didonis comites urbem condituri terram foderent, capite bouis inuento; coe ptum reliquerint, perpetuos fibi labores et feruitutem illic futurã, quales boum funt, inde augurati: Poftea cum alio loco effolfo eqúinum caput inueniffent, bonum omen inter pretati, tanquam $\&$ oti= um \& urictus aliunde fuppeditandus defutura non effent, Carthaginem illic extruxerunt, qux eam

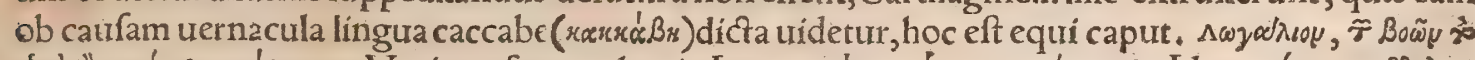

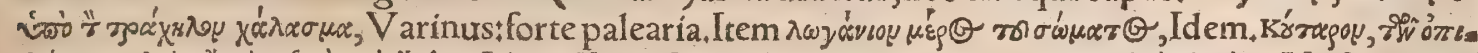
कें hanc uocem inuenio:conício autem effe partem illam carnofam, quam Latini lumbos, Graci ö $\sigma u^{u}$ so proprie uocant, eer fuludb bzater. Noftri bubulum uentrem multiplicem ruminationi deftinatum nominane menigfalt:quo nomine puto comprehendunt, omnes illos uentres numero tres, in qui. bus ruminando alimentum præparatur, quorum fingulos Græci fuis nominibus efferunt. Eorum primus (inquit Ariftoteles de partib. animalium 3.14.) cibum recipit inconfectum, fecundus aliquan tulum confectum, tertius plenius, quartus perquam plené confectum. Nomina hęc Graecé indita funt, noı ír , ter, arfineum fiue reticulum, omafum, abomafum. Sed de his alibiagendum erat, ubi de anímalibus in genere tractabitur. Qui Germanica eorum nomina defyderat, fi qux funt à bubularïs cognofcet: fic illos uơco qui inteftina diuendunt, $N$ am Grunnius Porcellus in teftamento ludicro bubularịs inteftina fura donat. Græci àd

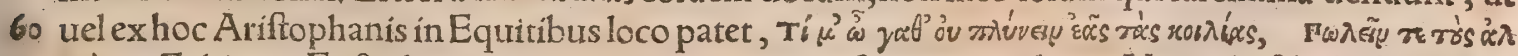
$\lambda x^{\prime} u r x s$ Echinum Euftathius exponit interna uentris feu uentriculum, Nicandrifcholiaftes bouis uentriculum propric hac uoce fignari ait;coniecerit autem aliquis eminentium partium afperitate 
caufam huius nominis fuiffe. Omafum grammatici exponunt pinguius atç craffius inteftinumi, quod nonnulli bubulum effe credunt, Horatius Serm,2, Seu pingur tentus omafo, Et rurfus is, epift: Patinas coenabat ornafi Vilis, \& agnini,tribus urfis quod fatis effet. De illo qui concubino procaci rure omafum ediffe fe negãti, bourem occidit, fupra diximus ex Plinio. Abomafi uocabulum â Gaza fiçum exiftimo, à fitu:R Reticulư uero imitatione uocis Græcæà figura eum dixiffe. TCæterü mem branas cum alias, tum diaphragma $\&$ peritonæum priuatim noftri appellant lyften: alin diaphragma priuatim Die Etre, id eft cornicem, nefcio quam ob caufam. Alia nomina uernacula partium illarum qux in laniena feorfim uçnire folent, paulo poft adferam in f,litera.

epulmo elephanti quadruplo maior bubulo,Plinius. Bucardia gemma bubulo cordi fímilis $\mathrm{Ba}$ bylone tantum naf citur, Idem. Homini renes bubulis fimiles, uelut è multis renibuts compofiti, Idem, Camelo tali fimiles bubulis, fed minores paulò, Idem, Boòs wó ó Attici bouis uiuentis pedem nomi=

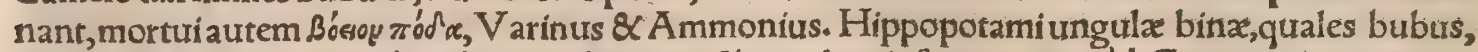

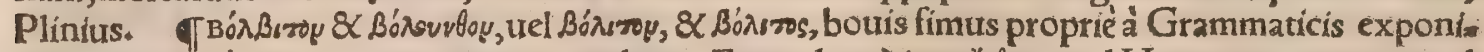
tur (improprié autem quorumuis animalium, Etymolog.) item ö oos apud Homerum, qua uox ad afinum magis pertinere uidetur, ut ovis etiam, author Pollux. Boliton afellorum proprie dici retrimen ta putant; fed $\&$ boum fuperfluitates ita uocantur. Quod uerò boliton pronunciant Attici, reliqua Gracia(prafertim lones, Etymologus)bolbiton, CaliusR hod. ex Arifophanis interprete in Batra. chos, ubi de Empufa legitur quod pedem alterum habeat BexBizrvop, id eft afininum. Agnof cunt tros cem Latini quoque: fiquidem Pompeius Feftus inde inflexum trerbum bulbitare putat, quod fignet

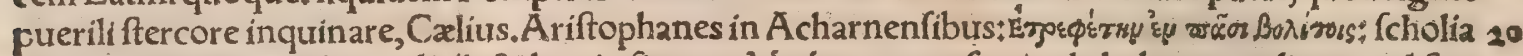

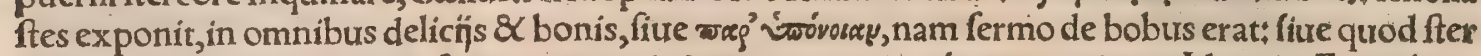
corata qux plantantur aut feruntur omnia latiora uegetiora $\not$ p proueniunt. Idem in Equitibus,

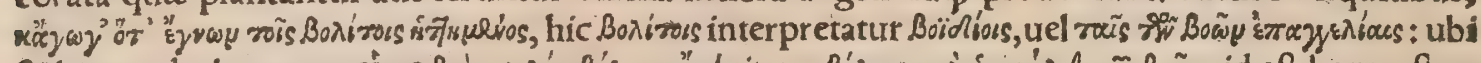

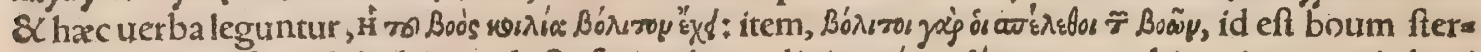
cora. De Empufa pede bolitino, id eft a finino fupra dixi. Borirou díxsy, prourerbium in eos qui ob mi nima delicła puniuntur: extabat enim Solonis lex etiam aduerfus fimi bubuli fures, Suidas, Arifto. phanis interpres, \& Erafmus in prouerbio Boliti poenam, ubi Boxízivoy oxínos ineptè exponit crus ue=

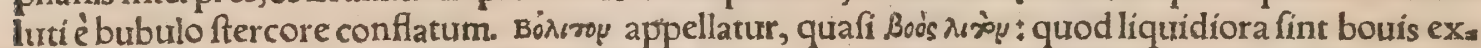
crementa quàm caterorum animalium, Etymolog. Citat autem \& Hipponactem, qui Bonírou ruoryú oxy dixerit, foeminam opinor extremé contemptam, In Phryfiorum agris uidere eft domos bolitinis $3^{\circ}$ parictibus:in alị̂s bubulum ftercus ad ignis materiam ( propter ligniinopiam ) ficcari : Quin $\&$ ho. die noftrates quem infigniter contemnunt, Bó

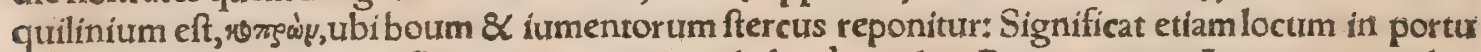
ubi alligatæ funt anchora, Bceotia regio nomen habet à rege loci Booto, quem Arne mater mulier Acolis enixa, ut patrem lateret, abiecit \&s Bodva (id eft ftabulû, ut ego interpretor: Cyrillo Bowy, ivvos, cuftodia eft apud Alexandreos ) unde nomen Bozoti illi impofitum, Ouidius, Metamorpho,libro 6. Te quocs mutatum toruo Neptune iutrenco Virgine in A eolia pofuit, Pallas fcilicer in tela fua

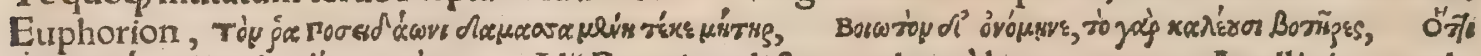

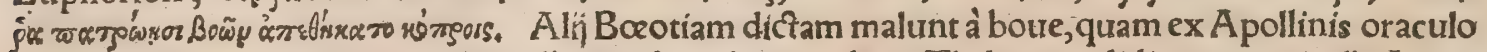
Cadmus fecutus eft, $8 \mathrm{C}$ quo in loco illa moribunda procubuit, Thebas condidit:cum regio illa Aonia 40. prius diceretur, Etymologicon. Huic fabulæ qui prolixius immorari uoluerit, legat Ouidium libro zertio Metamorph. Bolbitinum \& Bucolicum, duo funt ex hoftïs Nili, non genuina, fed efforfa, Euftathius in Dionyf.

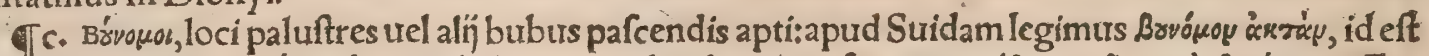

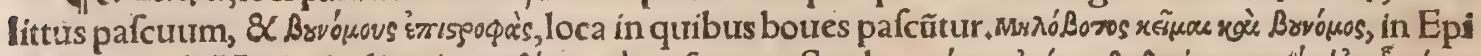

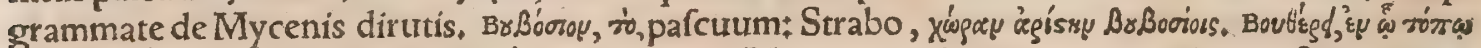

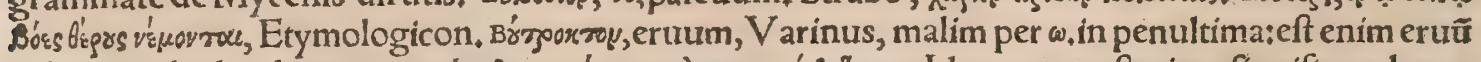

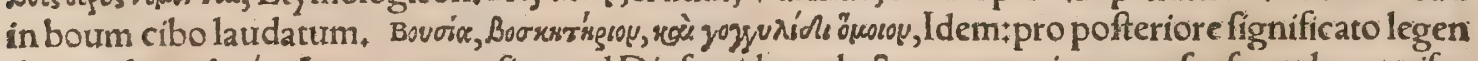
dum uidetur Brvic. Lotus pratenfis apud Diofcoridem, docforum omnium confenfu uulgare trifos lium eft, quo in quibufdam Italix locis, ut Brixix \& alibi, etiam agri conferuntur:cum pecori, tubus so præfertim, plurimum optimumós præftet alimentum; eft enim fubdulce $\&$ femel fatum reftibili per aliquot annos foccunditate germinat. Lotum arborem (ut obiter dicam) alị alia facie defcribunt, quam ego in Protincia Gallix fic priuatim nominata uidi circa montem Peffulanum, folijs refere. bat urticam maiorem feré, baccis nigricantibus rotundis, paulo minoribus quàm ceraforum, exigua carne, dulctfimis:arbor eft facis magna, uulgus illic ledonnier appellat. Gramen paffim cognofci. tur, geniculatis ramulis ferpens, radicesḉ ab ịs geniculatas \& dulces fpargens. Folia eius in tenuitatem cacuminata $\mathcal{Q}$ dura, ut arundinis paruz lata, bubus iumentis ć pabularium, Nec ulla ímentis herba gratior, fiue uiridis, fiue in foenoficcata, Ruellius, Vulgus noftrum graminis nomine plures ufu faciéć $\beta$ confimiles herbas appellat, $\&$ Plínius quoó tria facit genera, in quibus difcernendis nofri temporis medici contendunt: Diofcoridis autem \& ueterum medicorum gram $\widehat{e}_{\not}$ unum \& unius 60 generis eft, quod cum alips notis, tum denticulatis pracipue radicibus, fiue radicum mucronatis ger= minibus dif́ernitur, \& loca amat arenofa,Petrus Matthaolus reprchēedir Ruellium \& Leonicenum, 


\section{Bós\&Vacca H. Lib. I.}

qui gramints gientrs aculeatum à Plinio defcriptum, coronopodem Diofcoridis effe arbitrantur. Gra. men in officinis (inquit Ruellius)nomen feruauit, rura dentem canis $\&$ olítores appellant . Vulga* ris eft herba, nun oै $\mathrm{fe}$ ab humo attollens, flagellis teretibus articulatis, exilibus folís , \& in cacumen faftigiatis $s_{3}$ radice eciam geniculata, guftu non ingratæe dulcedinis. Gramen aculeatum rura nioftra etiam canarium dentem appellant:aliqui é uulgo capriolam, $\varphi$ capris grato fit pabulo ciu fanguinariam, quòd aculei foliorum quíni feniue in echinatum faftigium tinà conuoluti nares farciunt $t_{j}$ eliciendi fanguinis gratia cum extrahuntur, Crus galli etiam Latini appellauere, quód fly. lus è medins folips exurgens in pedem galli conformatus articuletur, reliquam exhibens cruris effigi. Em. Eadem ratione Gracis 8 CDiof coridi coronopus, id eft cornicis pes ab eadem figura nominatur. so Nante gramen aculeatum, crus galli, fangtínaria hæc, una $\&$ eadem eft herba, qux coronopus dici. tur Diofcoridi, Tantum Ruellius, Plura uide in Cornice infra libro 3 . De cunila bubula fitpra dixi: cuius mentionem hî́ repeto, ut Georgiutu Alexandrinú reprehendam, qui eandem effe qua nunc cotula \& bouis oculus appelleẗ imperitiffime fcribit, Polygoni fiue fanguinaria maris genus quod. dam eft pufillum, cui Germanicitm nomen thawel, \& frequentius reperitur æeftatibus pluurijs per arua,pracipué rapis confita. Herbula dodrantalis, fruticofa, pluribus ab una radicula alba inutili re cia defcendente cauliculis, qutorum geniculis folia adnafcuntur angufta, incana, \& in omnibus ala. rum cauis flofculi minimi numerofi fubuirides ftellatićs prodeunt. In pabulo mire expetitur bubus, quamobrem multis in locis fafces eis collectos offerunt, In uino cocta $8<$ pota calculos imminuit, $8<$ urina ftillicidium emendat. Defcribitur ab Hieronymo Trago li.1,cap.129 Quemadmodum \& alia 2o ei fimilis feré fed per omnia minor, femine pleniffima botryos inftar breuiffimis foliolis, à quibufdant herba cancri dicta(alia tamen ab heliotropio) eiuldem fere facultatis culus fuperior, eodem libro ca. pite 128. Germani uocant barntraut, id eff urinalem, in Gallia aliqui centigraniamiel millegrani= amíapore eft feré betæ, uinolo, linguam $\&$ os uellicante. Licebit hanc polygonon minimam, illam minnorem utel mediam appellare. Inter uítia frugum eft, quod triticum uaccinum uulgó ưocatur, fitweyffen, noftri blauw thaffen, nefcio qua nominis ratione: herba eft caule pedali uel altiore, folijs nigricantibus, binis, mucronatis: fpicam florum purpureã $x$ dit, fol'’’s etiam infertis eiufdem feré $\mathrm{CO}_{2}$ loris, afperfis maculis quibufdam flauis:radice breui inutili, mẹlfis tempore poftquam defloruit, in fingulis conceptaculis bina ternáue femina, tritici fimillima, colore tamen puniceo producit, Eodem colore panis, fi forte immifceatur, infici folet. Prouenit in agris qui triticum trel zeam alunt. Defcri. 30 bit eam Hieronymus Tragus libro 2. cap. 3 2. ufu nullo.

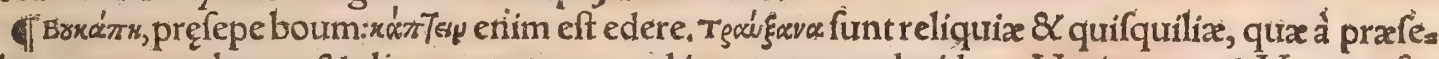
pibus equorum, boum, \& aliorum pecorum uel iumentorum decidunt, $V$ arinus. I $V$ accam foe tam Vergilius dixit:eft autem foeta \& grauida, \& partu liberata,Seruius. Antiqui etiam fordam di xerunt bourem pragnantem, Ouidius li. 4. Faft. Forda ferens bos eft foecundaç̧ dicta ferendo,

Et rurfus, Pontifices forda facra litate boure. Eandem hordam appellabant, undehordicalia Rox

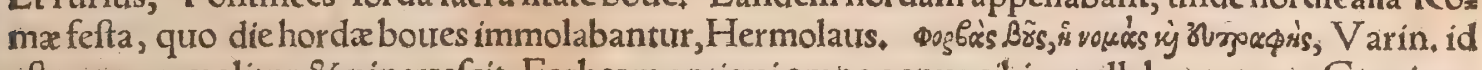
eft uacca qux alitur $\&$ pinguefcit. Forbeam antiqui omne genus cibi appellabant, quam Graci $\phi_{0}$; $B^{\prime}$ 's: His uocabulis propinquum eft Germanicum futter, \& Gallicum'fourrage, nifi quís à farragine potius deducat, De caprifico, quo ita boures(uel tauri)edomentur, ur prope immobiles confiftant, 40 res perquifita etiam Plutarcho in Sympofiacis, iniuria temporum defideratur.Si quis curiofior ratio nes aut coniefuras requirat, adeat $C$ zlĭ Calcagnini epiftolicarum quẹftionum libri 2, epiftolam is. Mutgio, fictitium uerbum à uoce boum, Ad Herenn, li.4, Imitationis hoc modo: Vt maiores rudere, uagire $\&$ mugire, $\&$ murmurare $\&$ fibilare appellauer unt.Litera mugiens, Quintil.1i.12. Inde cum actæ boures quædam, ad defiderium (ut fit)relictarum mugiffent; 8cc. Liurius 1, ab Vrbe. Protides implerunt falfis mugitibus agros, Verg. Aegloga 6.Dicitur etiam de alips animalibus, ut monocero. te apud Plinium:Etde inanimatis, Terram mugire uidebis, Verg, Aeneid.4. Malus mugit Africis

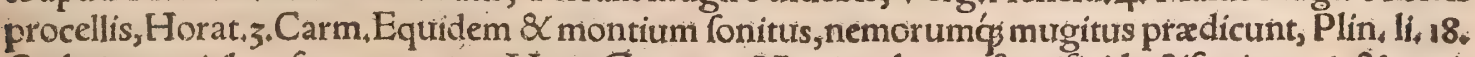
Crebris mugitibus fonant amnes, Verg, Gerorg, 3. Mugitus boüm fumifici, luctifoni, rauci, \& terri. ficià poetis nominantur, Diros uictima mugitus édidit, Ouid.Metam, 7. Et uox affenfui nemorum so ingeminata remugit, Verg. Geor $3+8$ in A eneide, Sequitur clamor columóć remugit, Eft auis quę boum mugitus imitetur in Arelatenfi agro taurus appellata, alioqui parua, Plinius, Gregés mugien tium, pro boum, Horatius. Boare, boum uidetur proprium, etiam ab ip ra uoce, quemadmodum bau bare canum: boire Pacuuio, Clamore $\&$ fonitu refonantes bount, fed hoc antiquum $\&$ inufitatum eft. Bourare dicuntur boues, cum uocem emittunt, tefte $V$ arroneli, 6 , de lingua Latina : boare tame

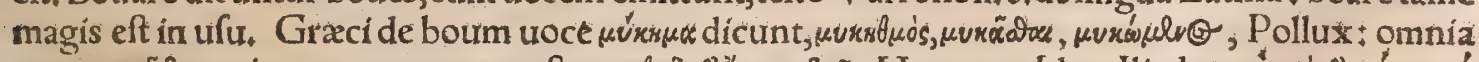

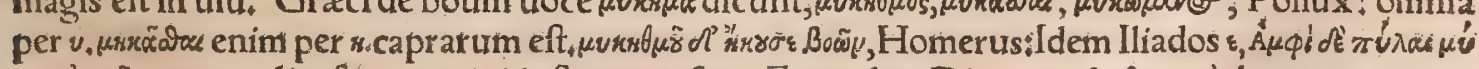

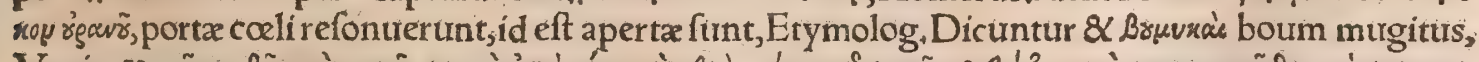
Varin. M⿻上ке̃

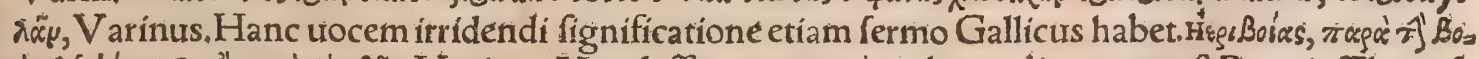

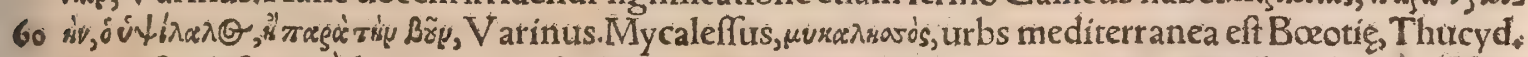
lib.6. fic dicta, quòd tuacca, qua Cadmum cũ exercitu Thebas duxit, mugiturm illic ediderit. Eft $\&$ alia Cariatitem mons éregione Sami,Stephanus. Mycale, mons quidam Didymo: Herodoto prò 
montorium in continenti fitum:Stephano utbs Carix. Nomen inde natum, quod reliqux Gorgos.

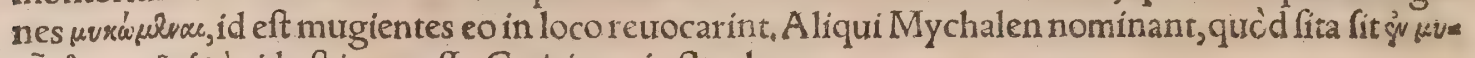

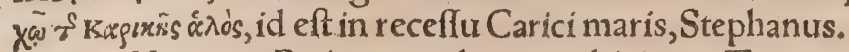

T. Narratur Pythagoras, bourem ubi prope Tarentum confpexiffet fabaciam fegetem morfica tim corrumpentem, tum etiam proterentem pedibus, bubulco infinuaffe, Bouem moneret, frugilus parcerct, Ridens bufequa:Ego(ínquit)bouatim non didici, tu qui uidêre fcholarum id genus expea riens, obeas uícem meam . Eueftigio Pythagoras auribus fefe admouens, fui artificí quapiam im. murmurauit.Res additur mira: Obedientiffimus bos, ut ab eo qui amplius faperet, ecoctus, lacerare mox fegetem deftitit:quin etiam in futurum eiufmodi pabulo abftinuit: fed $^{8} \mathrm{\alpha}$ bubulum defịt obfe= quium, factusćs de rureftri colono ambulator urbanus, Tarenti placide confenuit, de manibus homi io num uictitans, Calius.

đe. Cunctalegumina fitue frumenta bobus merito aratrisó̧ debentur : uinearum ipfarum ufus periret nifi eorum adminiculis fubuehendis carpenta fudarent, Quid de diuer forum orerum com. paratione referamus, dum inter mobilia \& quicquíd grauius eft, abfog uehiculis pene reddatur ima mobile? Reliqua quoģ animalia, ipfáç cohortales aues, ex eorum capiunt labore fubftantiam. Vn de enim equis hordeum, unde cibum canibus ; unde porcis pabulum dominorum folertia minifiraz ret, ni pararentur boum labore frumenta : Et ne longum faciam, bobus debet alimenta quicquid ali poteft. A pud alios genus mulorum, aptid alios camelorum, apud paucos elephantorum licet exi= guus ufus eft, nulla poteft natio effe fine bobus, Hæc Vegetius in prologo in librum z. Veterinarix. Multatio olim non nifi otrium boumós impendio dicebatur, non omitrenda prifcarum legum bene 10

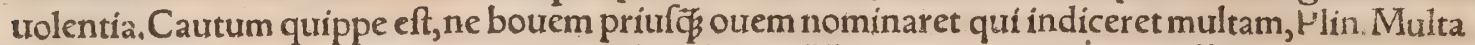
etiamnum ex uetere inftituto bubus \& ouibus dicitur, Varro. Aes quod antiquiffimum conflatum

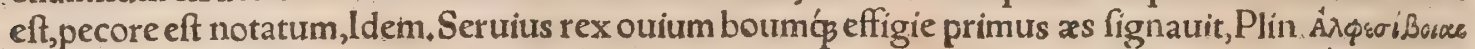

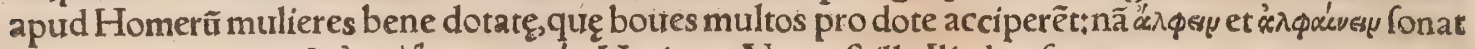

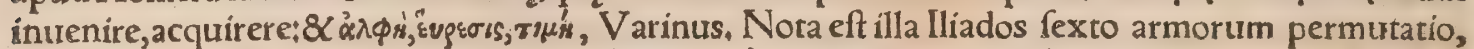

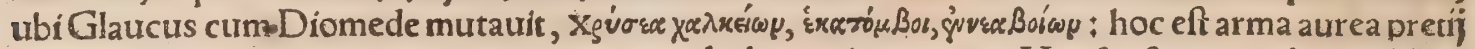
centum boum, pro armis æreis quæ uị nouem bubus redimerentur. Hoc fenfu etiam dvadiré $B_{0100}$ reperitur, quod duodecim boues pretio æquet, Bŕmuop, Bówyrzo, , bouis pretio redemptum, Varinus,

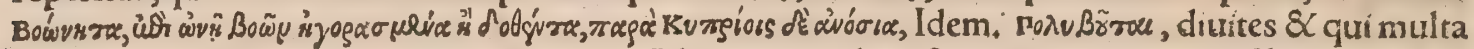
armenta poffideant, V arro \& $\mathrm{V}$ arinus. Vrbs cum condita eft, tauro \& uacca qui effent muri defi= zo nitum, Varro.

If Boues ad aratrum, Diodorus libro quarto \& quintojait Diony fium fecundum ex Ioue \& 2 Pro. Serpina genitum, uel ut alị fentiunt, ex Cerere, primum iunxiffe, cum terra prius manibus hominũ coleretur. Plinio uero libro 7.tefte, aratrum Briges Athenienfis inuenit, ut alij tradunt, Triptolemus, de quo Poëta in primo Georgicorum intellexit, cum dixit: Vnció̧ puer monftrator aratri. Qu® in loco Seruius:Alí, inquit, Triptolemum, alí Ofirim, quod uerius eft:nam Triptolemus frumenta di uifit, Tacuit aũt de nomine, quia nó unus in orbe monftrator aratri fuit, fed diuerfi in diuerfis locis. Ex quo Trogus prodidit Habidem Hifpaniæ regem barbarum populum primò docurffe boures ara tro domare, frumentaćs fulco ferere. De Ofiride ut oftendimus, fentit etiam Tibullus + Caterum o* mnia ferramenta ruftica, quibus terra uertitur, fimul, ut puto, cum aratro Cererem compe 40 riffe, Vergilius proculdubio hoc uerfu demonftrat: Prima Ceres ferro mortales uertere terram Inftituit. Quod uel Seruius approbat, dicens: Ceres prima omne genus agriculturæ hominibus indi* caurit:nam quamuis uel Ofirim, uel Triptolemum aratrum inueniffe dicant, illa tamen omnem agri. culturam docuit:quia ferrum dicendo, omnia agricultura ferramenta expreffic. Verû aut illi quos commemorauimus, nouiffmi, uel alị a libi hæc commonftrarunt: nam, utEufebrị atç Lactantị teft monio conftat, ante multas tempeftates quàm effet Ceres, frumenti ufus apud mortales erat, præfertim apud Hebraos $\&$ A egyptios, uti ex lofepho cognofere licet, \&c. Hac Polydorus Vergilius de rerum inuentoribus libro 2.rap.2.Baccho cornua attribui quidam iudicant, quòd primus coniun, gendorum boum author furerit, Diodorus Siculus. Buzyges, Hercules, quód bobus iunctis terram arauerit,à quo familia Buzygia, Varinus. Alĭ Buzygen quendam heroën, arationem inueniffe, \&\&fa milix nomen dediffe fcribunt. Iugatinus deus colebatur, quòd coniuges coniungeret, uel quòd iuga

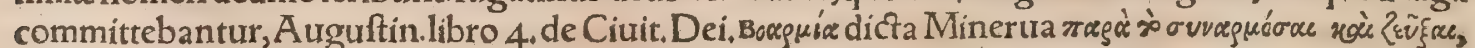
id eft quòd cóiunxerit in iugum $\&$ aratrum boues, Colitur autem hoc nomine apud Bocotos, Vari= nus.Pallas Bódexx cognominatur, quia humana excogitatum prudentia eft, boum opera terram cole $r e$, Cælius, Bobus terra aranda eft, \& nulla cum eis altera animalia iungenda funt:fed proprium boc genus fit ad arandum. Semina fint munda 8 impermixta, Iofephus libro 4 . Antiquitatum inter le.

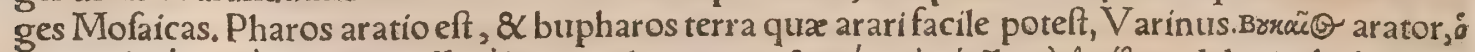

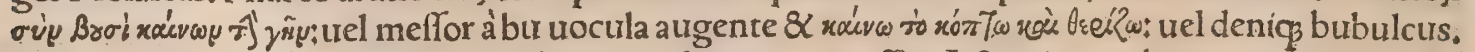
Iugerum uocabatur, quod uno.iugo boum in die exarari poffet, Açus, in quo boues agerentur, cum 6 aratur, uno impetu iufto. Hic erat $\mathrm{C} \mathbf{x} \mathbf{x}$. pedum, duplicatusḉ in longitudinem iugerum faciebat, Plinius. Manfum nonnulli terram effe affeurerant, culturæe annux unius aratri capacem : circiter ui= ginti iugera continentem, $Q$ C $c$ Robertus Cenalis. Bos jaüo dicitur ueluti colonus, à terra uidelicet: 


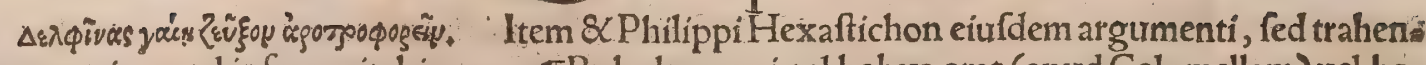
tibus tauris, quod infra recitabimus, Bubulcus, qui urel bobus arat (apud Columellam) uel bo. ues fundi aratorios pafcit. Cic, de Diuin. Eius âfpectu cum obftupuiffet bubulcus, clamoremćs, \&c. Ouid. 4, de Pon. Ipfe uides onerata ferox ut ducat Iacis Per medias Iftri plauftra bubulcus aquas. Sauromates bubulcus, Idem 3. Trift. Tardtus, Verg, Aegl.10,Iuniorum familia Bubulcum nomina uerunt, qui bubus optime utebatur, Plin. Alius eft opilio, alius arator:Nec fi poffit in agro pafci armentarius, non aliud ac bubulcus. Armentum enim id quod in agro natum non creat, fed tollit den tibus, Contrà, bos domitus caufa fit, ut commodius nafcatur frumentum in fegete, \& pabulum in nouali, Varro. Bubulcitari, bubulci officium facere, Plautus Moftel. Decet me amare, \& te bubulci tarier. Omnia fecum Armentarius A fer agit,tectumó, laremós, Armaćs, Amyclaumós canem, Creffamćs pharetram, Vergilius 、Venit $\&$ upilio, tardi uenere bubulci, Idem Aegl, 10 Seruius $\&$ alqu co in loco legunt fubulci, quos Nic. Ery thraus in Indice furo Vergiliano reprehendit, his uerbis: Tardi,id eft pigri, quod epitheton Bootx propriũ eft. Iutrenalis, Frigida circumeant pigri farraca boota. Ec Claudianus de Rapru Proferp.2. Pracipitat pigrum formido Booten:quan ö̉ hîc etiam mathematica adeft ratio. Potuit itaç hoc epitheton, quod bubulci proprium, fubmonere doctiffimü Seruium, \& alios, bubulci hoc loco legendum effe, non fubulci, quibus tardis effe non licet per pora corum celeritatem, quos fequuntur. Quorum paftorum etiam neglecta mentio confultò à uate fuit, cum nufȫ cos etiam Theocritus introducat: \& tria tantum fint, quod \& A elius Donatus fribit,paftorum genera, qux dignitatem in Burcolicis habeant, bucolici, opiliones, 8 omnium minimi xpoli, id eft caprarï. Quin \& ille ipfe Theocriti uerfus, quem Vergilius æmulatus eft, nullam fubulci men 20

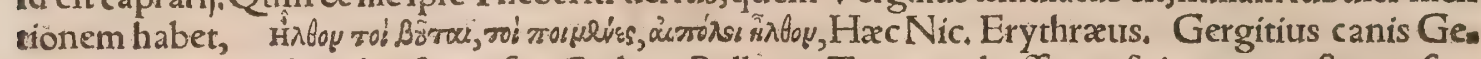
ryonis, qui boures feruabat frater fuit Cerberi, Pollix. Titormus buffequa fuit corpore ftaturofus,

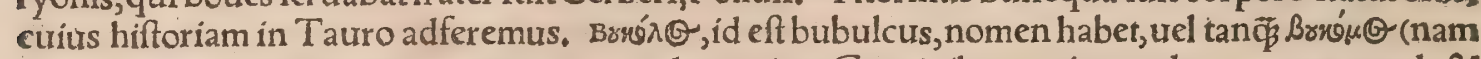
$\&$ hippocomum dicimus qui equos curat)uel quoniam Graci cibum etiam colon uocant : unde $\mathcal{Q}$

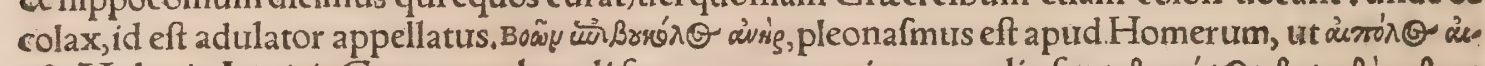

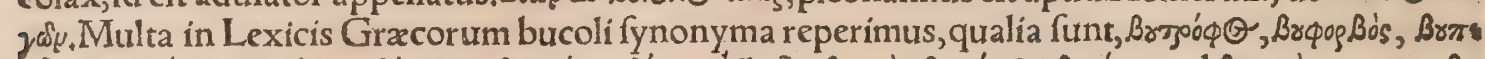

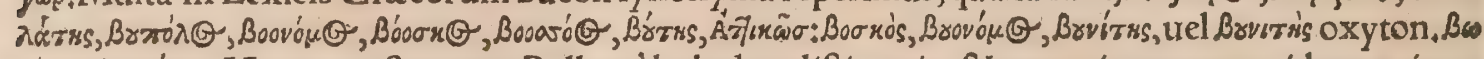

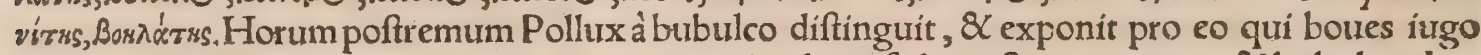
fubmittit: Videtur autem pro aratore magis accipiendum+ fed poteft pro utrocs, ut $Q$ bubulcus $L_{\text {a. }}$

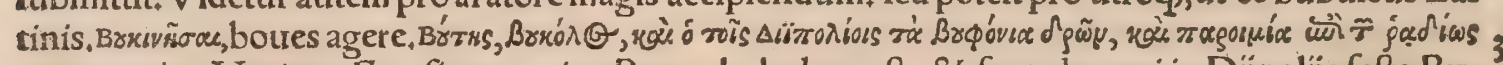

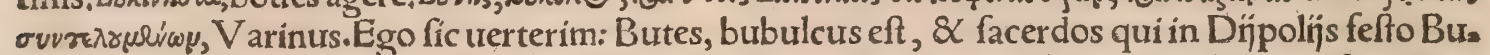
phonia celebrabat, id eft boure maçabat: quod in prouerbiü etiam abịt, de illis rebus quę fine appa

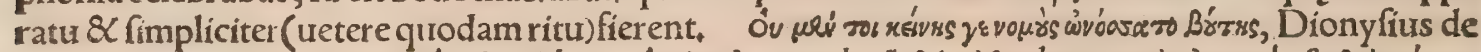

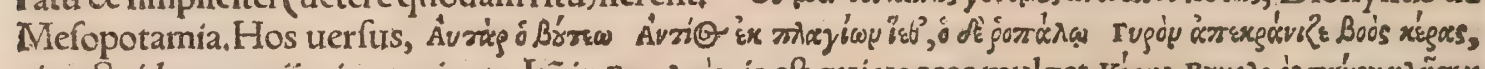

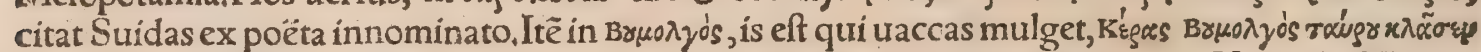

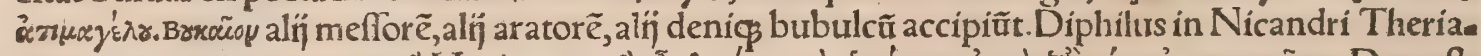

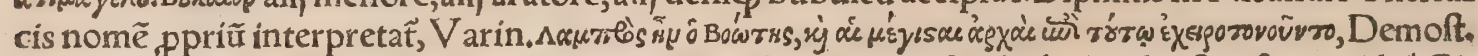

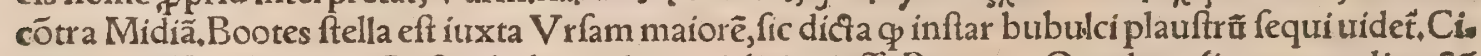
cero 2, de Nat.deorum: Arçophylax uulgo qui dicitur effe Bootes, Quod quafi temone adiunctã prafequatit Arctum. Ouidius, Arctophylax formam terga fequentis habet, Iutenal. Frigida 40 circumagunt pigri farraca Bootæ. Aratus, Tardus in occafum fequitur fua plauftra Bootes. Sunt qui Arcadem Iouis ex Califtone filium in Booten nutatum dicant: Pluribus tamen placet $\mathrm{Ca}_{a}$ liftonem in Vrfam maiorem, Arcadem in minorem conuerfum. Bowr sy, idem quod Bon $\lambda x r \tilde{\mu}$, id eft boues agere. Bucolion filius Laomedontis fuit, tefie Homero in Iliade. Guardalbia uel Guarum, id eft bubulcus caninus; apud Matthæum Syluraticum legitur, haud fcio quo fenfu, s'ir $\theta^{\prime} \delta \lambda_{\varepsilon}^{\prime} \pi \alpha \rho \jmath \Theta$, ac

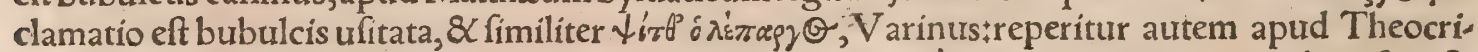

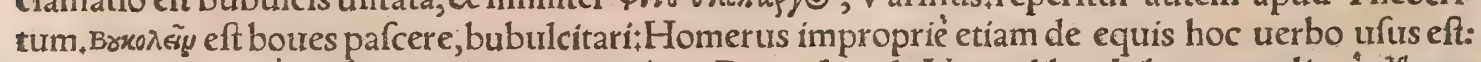

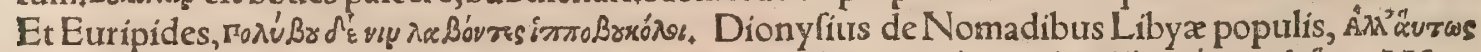

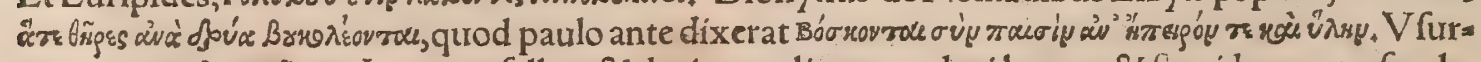

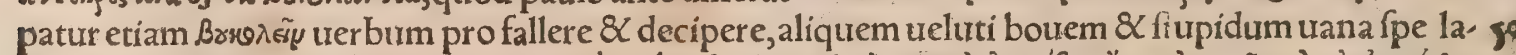

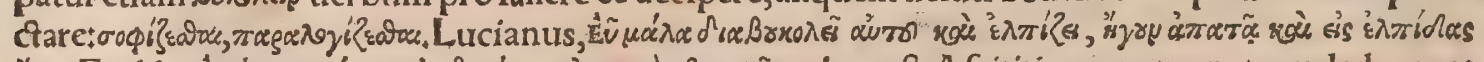

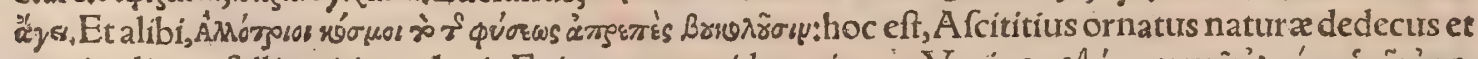

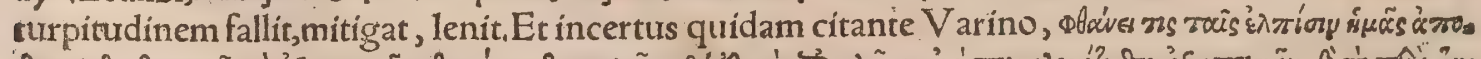

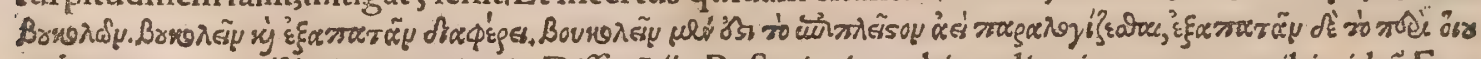

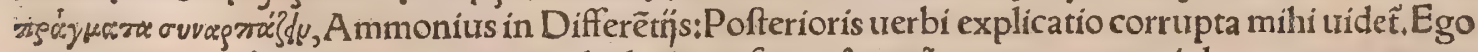

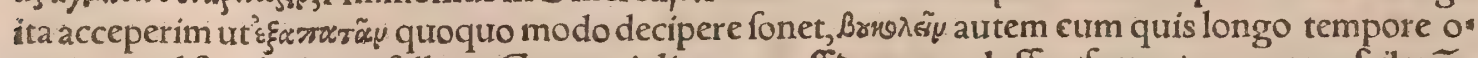
pinione uel fpeab aliquo fallitur:Germani dicunt, auff oem wonlaffen/fatsen/am martenfeil vmt.

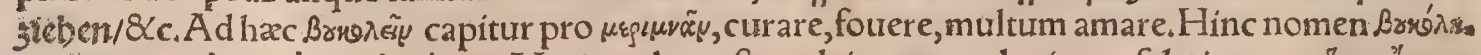
ïс,

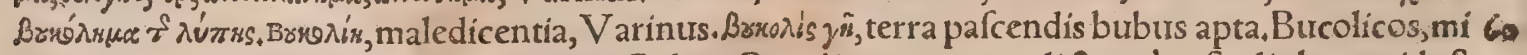
lites rufticos legimus apud $C$ apitolinum, $C$ alius. Bucolicum carmen dictum à cuftodia boum, ideft

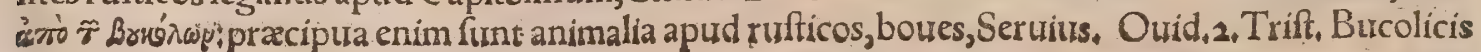




\section{Bos\&Vacca. H. Lib. I. 83}

feruenis luferat ante modis. Dianam Siculi Lyen cognominarunt, quoniam ab ea effent morbo in. fefto foluti:unde natum, ut ruftica multitudo theatrum ingreffa uictoriam caneret, quam de Syr acit ranis mox adeptus eft rex Hiero, quxa prima creditur Bucolicorum origo, quęomnium princeps car mine Daphnis celebrarit, mox Theocritus, Calius. Diomedes heroicum uerfum, etiam hexametrû́,

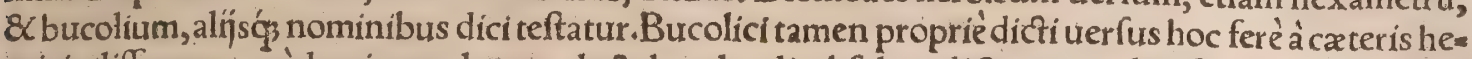
roicis differunt, quòd quintum locum dactylus claudit abfoluta dictione, qualis eft, Nos patria fí nes $\&$ dulcia linquimus artra. Bucolifmus uel bucoliafmus, genus melopozix, id eft cantionis $\&$ fal

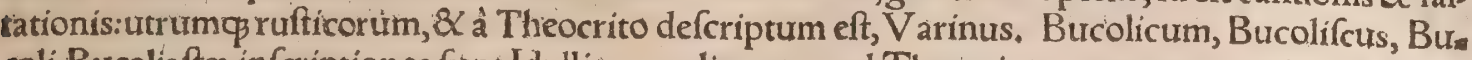
coli, Bucoliaftx, infriptiones funt Idylliorum aliquot apud Theocritum, nempe quarti, $6.8+9.24$. to Bolbitinum $\&$ bucolicum hioftia Nili funt manu effoffa, cum catera quings natura a peruerit, Euftas thius in Dionyfium. Bвx́rses uocabulum non bubulcos tantum fignificat, fed etian animalia qua dam, Etymologicon. Ego huius nominis animal nullum hactenus reperi ; nifi quod bucolinen cin= clum auem Varinus interpretatur. Panaces quod è Macedonia affertur, bucolicon trocant, armen: tarijs fponte erumpenrem fuccum excipientibust hoc celerrime euranefcit, Plinius. Diofrorides hoc panacis genus Heracleum uocat, ut ab Afflepio \& Chironio diftinguar: ex huius radice líquor den. fatus opppanax dictus nomen in officinis pharmacopolarum adhuc retinet. Herbam ipfam in hortis quibufdam Italize uidi, folio feré fici, \& per omnia fphondylio noftro ( quod aliqui brancham urfinã, qux acanthion eft, non recté uocant) fimillimam. Caterum panaces Heracleon Plinï, ne quís erret, planè diuerfum eft:ab Hercule (inquit) inuentum tradunt, alijoriganum Heracleoticum fylueftre 2o uocant, quoniam eft origano fimile, radice inutili. Brwàं, urbs Pharfalia aut Thracia, Varinus.

\Bubile, locus ubi boues murantur; Plaitr. Perf. Etenim metuo ne polfim In bubile reijcere, ne uagentur. Quxdam exemplaria hic legunt bubilem mafc,genere. Columella lib. ı.Domitis armen= tis duplicia bubilia fint, hyberna atç aftiua. Cato cap. 4 . Bubilia bona, bené́́ æedificata, $8 \mathrm{c}$. ut fus pra in C. Boftar, locus ubiboues ftare confureuerunt, Calepinus fine authore. Bouilia dicuntur in quibus boues morantur, ut Calepinus probat ex Columella loco libro 3 , in quo tamen nunc bubilia

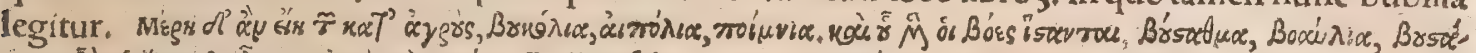

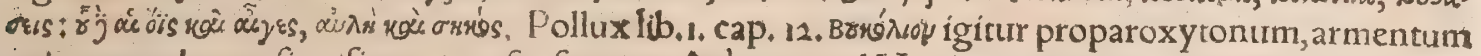

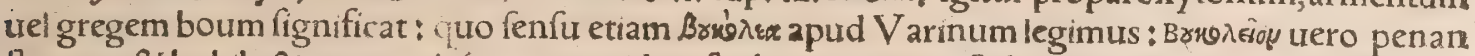
flexum, \& bubile \& gregem iplum, ut quidam feriburnt, ego proftabulo tantũ acceperim. Butcolia 30 in A egypto apud Hieronymum, ceu bubulcorum intelliguntur loca, Calius. Hippoftafium effe ui=

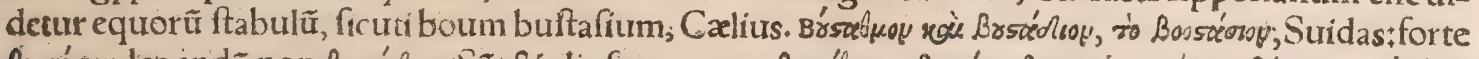

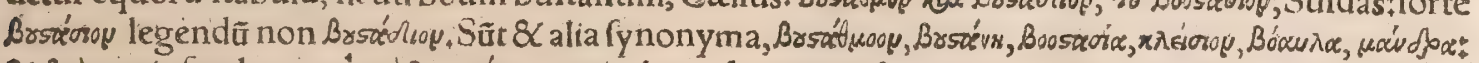

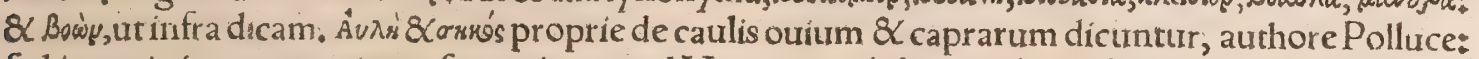

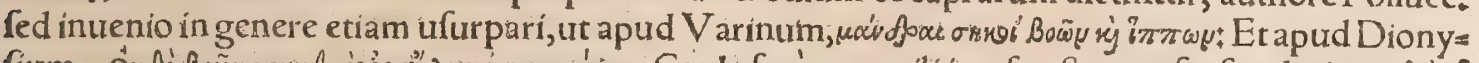

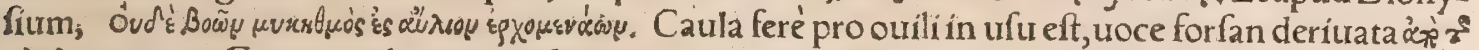

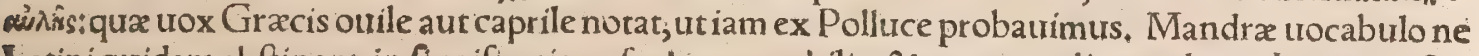
Latini quidem abftinent, in fignificatione fpeluncx, cubilis, \& r eceptaculi pecudum : Iturenalis $\mathrm{Sa}=$ tyratertia, Et ftantis conuicia mandræ Eripiunt fomnum Drufo. Tanagra Bocotiæmedirerra nex oppidum eft nobile; quod prius Poemandria dicebatur:producit autem boues præftantiffimos, 4. Stephanus 8 Varinus, बSibas Indicam gentem ab exercitu Herculis illic relictam aiunt : nam pellibus amicituntur, fcytalas (id eft baculos uel fcuticas) gerunt, 8 bubus clauæe notam inurunt, Arrianus lib.8. A piculam Græeci Bržry cognominant, quòd ex bubulis offibus gignantur, Varí: nus. Animas etiam in myftern̆́s gentilium theologorum melitfas \& Brysrếs appellatas; \& Buclopum deum qui generationem latenter audiret, Calius Rhod, prodit 22.3. In treterum friptis mentio fit de en faedere, quod inter Gabios $\&$ Romanos actum eft; Tarquinio Romanum imperium regen te: Vbi illud in primis notandum, quod in corio bubulo cius capita $\&$ conditionem exararunt priz fcis literis (ut refert Dionyfífus ) cumćç inftar clypei foret in templo louis locarunt. Qua in re Pom: peius Sextus Dionyfio acredıt, ut in euus commentarïs probatur, quos à Verrío Flacco collegit ‘ etf iuramentum Dionyfius urocat, in quo fanciendo eximium bouem immolarunt. Clypeum (inquir

so Pompeius) ob rotunditatem ueteres corium bouis appellarunt, in quo Romanorum foedus cum Ga bijs foret defcriptum, Petrus Crinitus 16.3. K'sos prima fignificatione cornu, fecundaria tum alia quadam tum poculum indicat. A ntiquitus enim cornuum bubulorum pro poculis ufus erat; ante quam inuenta effent alia. Eam ob caufam Bacchus quog cornutus fingebatur $\&$ taurus appellaba-

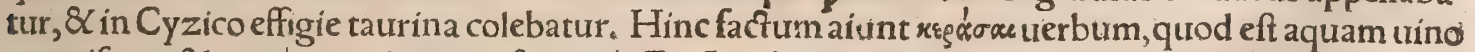
permifcere: \& n tur etiam Amalthex cornus quod utigaris fabula capra attribuit. Eiufdem generis poculum quod dam şutoutos, id eft annus dicebatur, à magnitudine nimirum \& fumma capacitate. Ingẽtia enim cor nua quæda.n prægrandium boum habentur:quales Pxonum $\&$ Molofforum fuerunt, ex quibus po cula conficiebant, labris eorum argento uel auro induĉis. Maxima capacitas, cógiorum Atticorum 60 quatuor, ut apud Athenaum \& Varinum legimus. Ariftoteles ab initio Mirabilium narrationum monopis fylueftris in Pxonia bours corpore ampliffimi cornua fingula dimidiati congrí menfuram

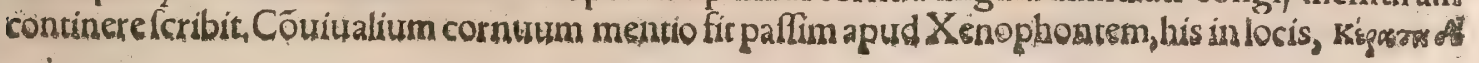




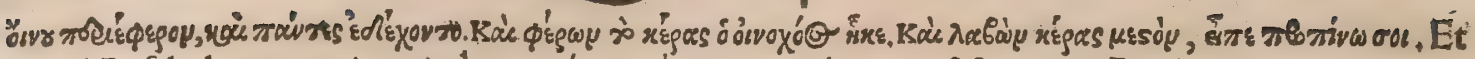
apud A efchylum, cum inquit:Ä gy

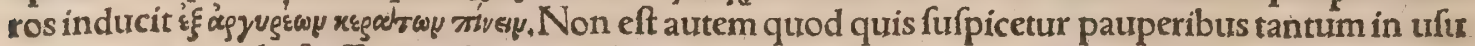
cornua pro poculis fuiffe: cum \& reges ïfdem uterentur: Philippum enim regem aiunt, illis quos be

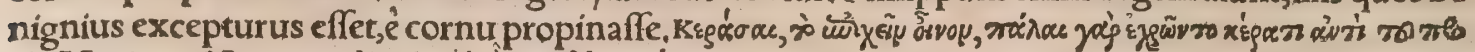

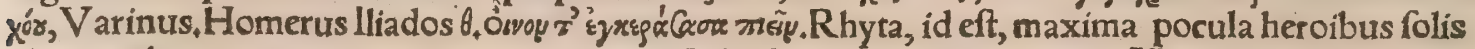
olim attribuerunt:nunc uero etiam ex cornu facta fic appellant, Athenaus, Xenophon defcribens

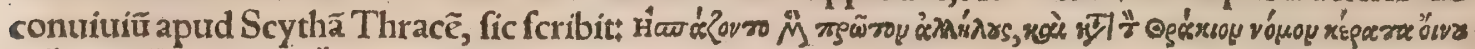

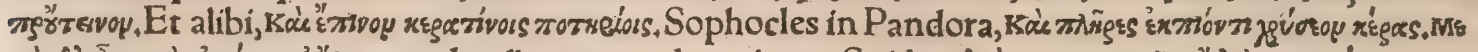

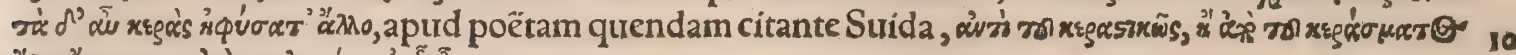

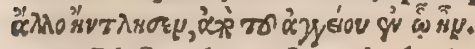

- A bftinebit cêfione bubula, Plautus in Aululariałid eft fcutica qua ex corio bubulo fiebat, Brsax́

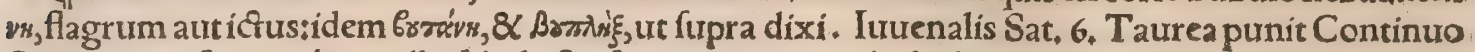
fexi crimen facinus ç capilli, fcholiaftæ f́cuticam ex corio bubulo exponunt. Zea uel zeteion uo catur locus quo feruitia punienda mittebantur, ad quod allufit poếta nofter comicus in A finaria(ni fallor)cum dixit:Qui polentam pranfitant, \& ubi uiuos homines mortui incurfant boutes, Hermol. Barbarus, Seuibubuli maximus ufus eft ad candelas $:$ laudatur pracipué exiuuencis \& circa. trimatum, TRura noftra uulgari dicfo uernum aut Maị menfis examen apum, uel boutis utilita.

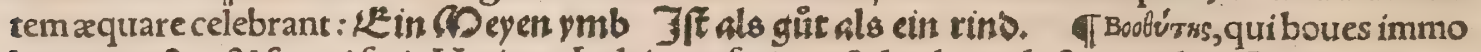
lat aut mactat, \& fecuri ferit, V arinus, Iudęi non feriunt, fed cultro adacto iugulant. Butypos Argo 20 nauticorum fecundo apud A pollonium dicitur, qui inter facrificandum fecurim boui impingit, Bŕs

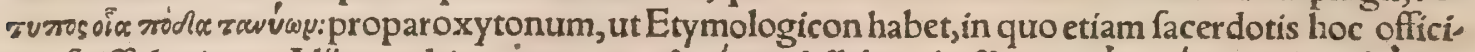

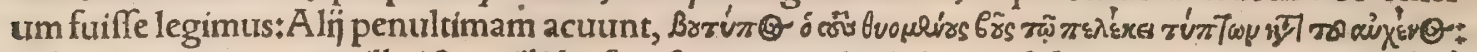

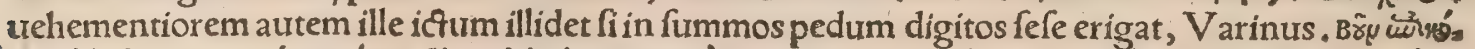

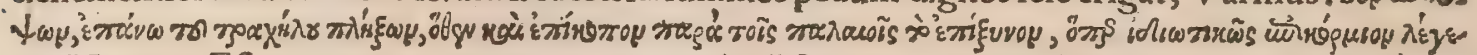
rou, Varinus. Eft autem truncus in quo coqui et lanï fecant carnes; woge ós quiuis truncus eft: Exifgvou

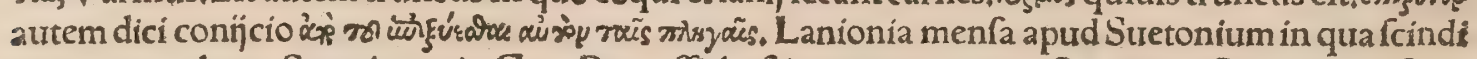
tur caro machara,Spartianus in Geta, Percuffic hoftiam popa nomine Antonius. Propertíus, Suce cinchíg calent ad noua facra(aliâs lucra)popx. Popx dicebantur qui uictimas habebant uenales, \& ligabant eas ad altare, feriebantós. Suetonius in Calig.Admota altaribus uíctima, fuccinctus Caligu zo la poparum habitur, elato altè malleo, cultrarium mactauit, Perfius Sat, 6.Mihi trama figuræe Sit relí, qua, aft illi tremat omento popa uenter, id eft crafrus $\&$ opimus, quales erant uictimarị. Lanius uel lanio, qui carnes in carnario uendit, $q$ pecora concidat, laniet ̣́́ dictus, Lanị qui ad cultrum bourem emunt, Varro. Laniena, officina in qua fiunt $\&$ uenduntur carnes. Qui fuccidiam in carnario fu= fpenderit potius ab laniario, quâm ex domeftico fundo, Varro li, 2, de Re ruft.Laniarium hic lanie. nam exponunt, mihi uidetur de lanio etiam accipi poffe. Cultrarius idem qui uictimarius, is qui ui: ctimam cultro immolat。 बा Apud Armenos nofiro tempore (ut fcribit Bartolemaus Georgeuits) mulier adultera fuper afina uicatim ducí̃ , \& nuda flagris cæeditur, \& tandem inteftina bouris in collo geftans lapidibus obruitur, Caterum uir adulter, iniectus carceribus, poft aliquot menfes pecunia redimitur.

TH.f.Heluetici boures commendant à tenerittudine carnis, curm alibi, tum iuxta Zofingam oppidũ agri Bernenfis, In Sueuía quoģ nobis uicina circa regionem Bar, pingues præcipue feuo habẽtur. Pinguiffimi Hungarici:qui hyemes etiam fub diuo tranfigunt, \& liberi pafcuntur, unde fit ut parû́ manfueti fint, \& minus tenera carne, Bubula abfolute, fubauditur caro, Plautus inAulularia:Agni.

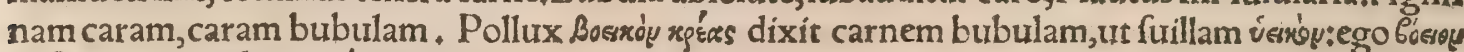

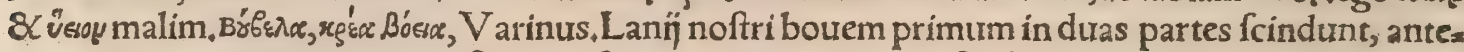
teriorem uocant ben votberen fbilt:pofteriorem, Den binderen follt. Deinde anteriorem, fiue tho. racem, trifariam diuidunt:primum feparant armos, $\&$ carnem adiunctam, ac in frufta aliquot fecãt.

- Reliqui thoracis partem pronam \& circa fpinam, appellantbozzuggen, hoc eft dorfum fuperius,

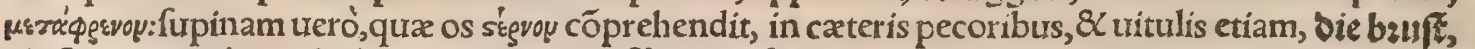

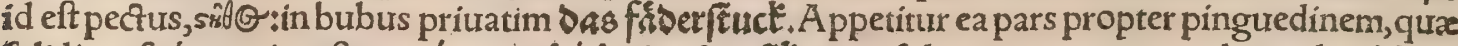

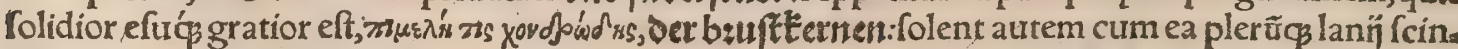
dendo relinquere iuguli partem cruentam 8 ingratam emptoribus, Den fidi. Caterum inferioris dorfi partem, qua renes continentur, ex cæeteris animalibus $\&$ uitulis, quoniam affati folet cum fua

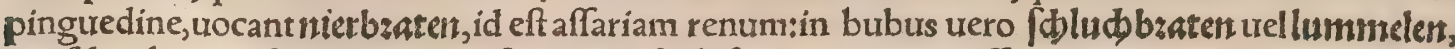
quafi lumbos, id eft partem carnofam \& mufculofam iuxta renes, offe uacuam: unde pingue uel fe = uum potius feparatur ad lucernas $\&$ alios ufus. Coxas cum natibus uocant $\$ a b$ ftotyle, $\&$ in duas partes diuidunt:alteram, cui ubera in uaccis adharent, $\nabla a s$ ober fpeltle : $\&$ alteram ab ea feparatam carnofam, $\searrow a \mathbf{s}$ pnderfpeltle. Pofterior hac pars, ficut \& lumborum caro, cum offibus careant, in ol= lis affari folent, hoc modo. Caro lota in uafe reponitur affuro aceto cum fale $8 \mathrm{i}$ iuniperi baccis, \& fic uel horis aliquot uel etiam diebus macerata,cum iure illo admixta aqua lixatur, donec modicum iu ris fuperfit:additur autem aliquid butyri cocti cum iuris pars ferè media confumpta uidetur. Sic $\&$ 


\section{Bos\&Vacca. H. Lib. I. 85}

tenerior \& palatogratior fit. Vbera elixa, mox incifa, torrentur in craticula, \& fale et aromatibus (pi pere \& carycphyllis maxime)infperguntur; Símilis $\&$ lingure apparatus eft: $\&$ pedum, $\&$ oris fiue buccæ, uel fi mauis, roftri. Alĭ tias partes, pedes inquam $\&$ buccas, qua ín carnario elixa emuntur; ex aceto frigida edere malunt cum cepitio \& pipere. Lingua etiam per mediû́ incifa, faliri ut reliqua caro \& infumari folet, cibo diuitibus etiam grato. Quibufdam in locis bubulas linguas príncipibus debent:tanta eartim zeftimatio Nouerunt n imirum etiam Mércurí olim facerdotes hanc lautitiam,

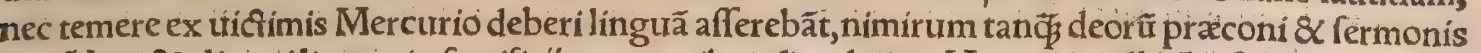
deo. Nam \& alioquti lingua in facrificrijs praconibus donabatur. Hinc iocus ille Ariftophanis in Plu

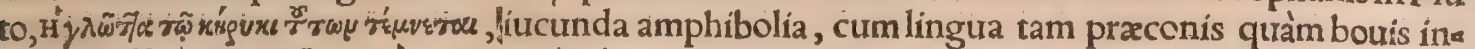

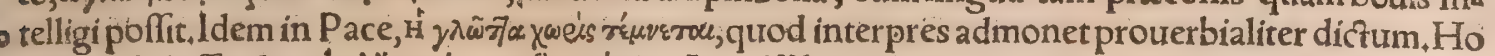

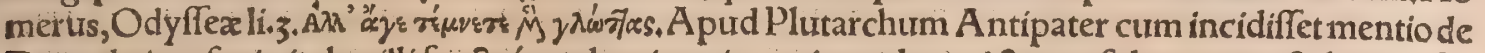
Demade iam fenio imbecilli fräctoćs, uelut, inquit, ex immolata uictima, folus uenter \& lingua fu. pereft. A pparet fanè linguam ceu profanum membrum facris adhiberi non folitum, quod ego quidem ad gulam hominum, præcipue facerdotum, religionem prætexentium, retulerim, Præfertur au. tem in cibo bubula cæeteris, $\mathcal{X}$ à nónullis operofius paratur:nam condimentis farctam in ueru affant. Aliarum pecudã quia minores funt, cum fuis capitibus relinqui folent, Pars circa ceruicem durio= re $\&$ tenaciore neruofaḉ carne conftat, difficilior concoctu. Inteftina etiam elixa adferuntur ex la=

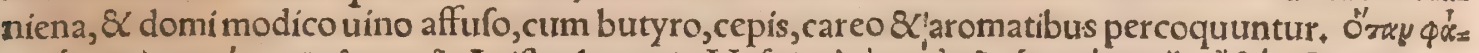

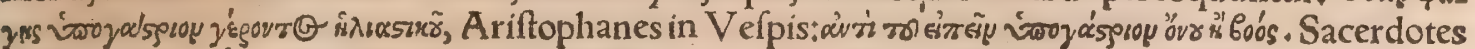
10 Alegyptị nihilère domeftica confumunt, fed eorum fingulis quotidie cibi facri cocti pręfo funt, \& carnis bubulæ $\&$ anferinæ fatis abundé, ${ }_{3}$, Herodotus. Antiquiflimos boure aratore \& immolando $\&$ comedendo abftinuiffe, paulò poft; ubi de facrificị́s boum, dicemus. Hercules cum in Dryopia fi lio Hylæe efurienti pauxillum cibià Theodamante peteret, nec ille quic đ̈ß daret, iratus beurem ei per uim abftulit, \& mactatum epulando confumpfit. Hanc hiftoriam fiue fabulam prolixius defcribit

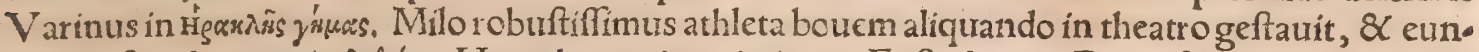
dem poftea deurorauit, Brfoivep Herculem ea in re imitatus, Euftathius in Dionyf. Hinc \& buphagus alterum Herculis cognomen. Olympia per ftadium ingreflus effe Milo dicitur, quum humeris fufti: neret bourem uiuum, Cicero de Senectute. Turcas in magnis epulis $\&$ nuptins boues integros affare audio, et bubus infertam fuem, fuigallinam, gallina cua. Verua fané maxima, in quibus etiam bo

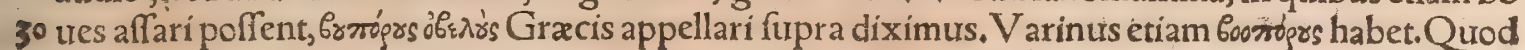
autem carnes bubulas uerubus transfixas ueteres affauerint, paulò poft in facrificips bourm oftende

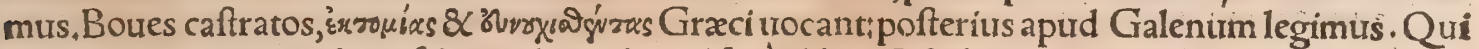
bubulam carnem apud nos fale condiunt (quod ferè idibus Octobris uel circa feftum D. Galli pri. mum faciunt, \& deinceps per hyemem tantum) in plenilunio incipiendum putant:fic énim maiore uegetioremós carnem permanfuram :ut magis fapidam, fi fub interlunium faliatur. Si diutius ferua= ri uelint(feruant autem multi integro anno) per dies circiter uiginti in uafe falitam relinquiunt, ac in: fumandam poftea in camino fufpendunt, ubi donec bene ficcetur dies plus minus duodecim relin. quitur, prout altius aut humilius pependit, $\&$ plus minûsue ignis ac fumi paffa $e f t$. Vbi primum fit $=$ fpenfa eft, accenfis iuniperi ramis $\&$ mox extinctis plæríp fumigant. Nonnulli carnis colorem com - mendari putant, \& rubefcere magis, fi aridis urtic $x$ fafcibus fuffiatur. Qui feruare nolunt, uno die cum fale relictam fufpendunt, $\&$ mox poft unum aut alterum diem elixant; fic enim plerifós tenere. fcere ac in cibo fapidior fieri uidetur. Anteö fufpendatur qua diutius in uafe falita fuit, muria fua, qux ex fale \& carnis fucco confluxit, diligenter abluũt; funt qui frigida lauare malint. Optima quæ de iuuencis aut uitulis fumitur, uetulorum nimis dura $\&$ ingrata, certe difficillima concoctu fit, cum fuftis inftar durefcat. Hoc etiam obferuari folet, ut caro falienda iuxta fornacem prius expofita aliz quandiu incalefcattinde falita opertáps in uafe in penus collocat. Carnes offibus adiuncta cateris fuperponuntur, ut ad ufum fubinde auferantur:feruatæenim deteriores fiunt.

ब Qui uaccas mulget, Bruoryòs Gracis eft:nos uaccarium aut lactarium appellare poffumus; st fuperius etian dixi:quanç Lampridius in Heliogabalo lactarios nominauit qui cibos ex laçe cô

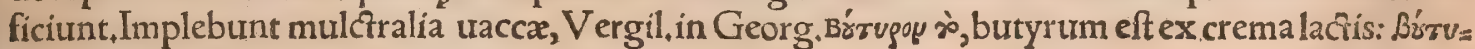
(⿶) autem herba quædam Dionyfio, $V$ arinus,

Th. A bobus dicta eft Bubona dea, ut â bello Bellona, D. A unguftinus, Paufanias in Meffenicis cir cafinem, quanto in pretio boues olim furerint, his uerbis exponit: In Pylo ciurtate agri Meffení fpes lunca eft, in qua Neftoris \& ante eum Nelei boures ftabulatas aiunt. Videtur autem genus hoc boum Theffalicum effe, \& ab Iphiclo Protefilai olim parte defcendiffe. Has enim Neleurs à procis filiz fux dono petebat: $\&$ harum caufa Melampus ut fratri Biantigratum faceret in Theffaliam vienit:ubi uin citus à bubulcis Iphicli, cum illi roganti uraticinium a periret, boures pro mercede accepit. Hoc fcilicet maximo fuit antiquis fudio, ut equorum et boum greges tanç illius freculi diuitias fibi compararêt, 6o Hinc eft quòd Neleus de acquirendis Iphicli bubus folicitus fuit: Et Euryftheus Herculi Geryonis armenta'ex Iberia, quorum percelebris erat fama, abigere præcepit. Videtur \& Eryx Sicilix prin, ceps tantopere boues ab Hercule ex Ery thia abductos amaffe, urt earum gratia cum Hercule luctaturus, uictor illius boues acquirere, uictus uerò regnum fuum amittere uoluerit, Homerus infuper 
in Iliade de Iphidamante Āntenoris filio refert, eum inter pracipua dona focero centum Eoures pro fponfa contuliffe. Quamobrem ueteres plurimum bubus delectatos fuiffe conftat , Pafrebantur au= tem, ut ego conjicio, Nelei boues ut plurimum extra Pylium agrum:qui ubigh fere arenofus eft, nec paf́cuis tam copiofis idoneus; id quod uel Homero tefie probauerim, qui Neltorem toties Pyli are. nofa regem cognominat, Hæc Paufanias, ut nos ex tempore conuertimus, Boomis epitheton Iuno, nis apud Homerum, $q$ boum inftar excelfos $\&$ rotundos oculos habear:uel ut alí, magnos, quodin muliebri facie laudabatur, \& inde etiam Europa nomen impofitum uidetur. Conuenit autem hae appellatio aëri, quem fub lunonis nomine tegebant, ut qui longélaté́g pellucidus \& uriui psruus

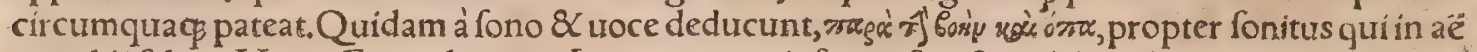
re reddi folent, Varin. Etymologus in Iunone exponit, formofam \& pulchris decoram oculis. Thra ces Dianam Bŕ $\beta a r o y$ appellant, Varinus. Qui myfteria gentilium tractant, Bryireis interpretaniur in generationem pergentes animas: $\&$ Buclopum deum qui generationem latenter audiat, Cxlius.

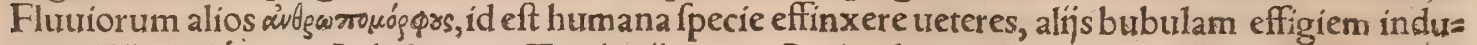

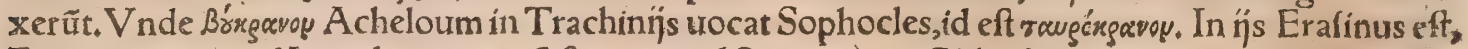
Eurotas item apudLacedæmonios, A fopus apud Sicyonios ac Phlyafios, apud Argiuos Cephifus, Hominis figuram prafert Alpheus, Cephifum Athenienfes hominem monftrant utiç, fed ita, uti promant fe nihilominus cornua. Auctor in Deorum natura Phurnutus, fluuios effingi pleruncs me.

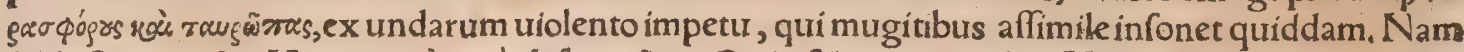

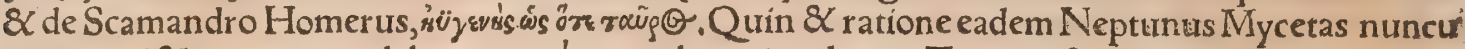

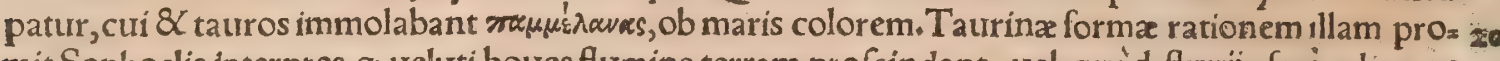
mit Sophoclis interpres, $q$ ureluti boures flumina terram profindant, uel quòd flưrịs fere adiacent pafcua,Calius. Cur Eleorum mulieres Dionyfium precentur utbouino ad fe pede ueniar, Plutar. chus explicat in Gracanicis problemate 36. De Ifide quam uacce forma Aegyptï colebant, iam fir. pra dixi ex Aeliano.

I Ex bobus uictimæ opimæ, \& lautiffima deorum placatio, Plin. Bouem uel boues facrificare Graci his uerbis efferunt, Brzs bú

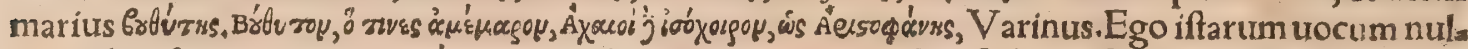
Iam alibi ufquam reperio. tiles ad facrifícia publica faginati dicuntur cpimi, Varro. Qui An athan munimentum, quod fluen= tis Eurphratis circumluitur, contra Iulianum \& Romanos defendebãt, cum Romanis fe dedidiffent, præfe bouem coronatumagentes, quod eft apud eos fufceptæ pacis indicium, defcendêtre fupplici. ter, Ammianus Marcellinus libro 24. TOuem aliqui, alfí bouem uictoria potiti immolare confue: ucrunt, ut fcribit Robertus V alturius de re militari libro 12,cap,2, Dećs triumphato uifcera tofta bo ue, hoc eft occifo in triumphi facrificio, Ouid. Faft.z.Prouerbium, Bouem facrificauit nemo un B be nefico prater Pyrrhiam, inferius require. Ceres ab Hermionenfibus eximia colitur ueneratione, er feftum eius Chthonium appellatum magnifice concelebrant. In his ferunt botres magnitudine uifen da $\&$ ferocia ad aram ex armento facile agi immolandos à Cereris facerdote, qux uetula plaruno eft, ac uiribus prætenuis. Super qua re carmina circumferuntur apud Græcos, qu $\&$ appofui, ath ctore corum Ariftocle:

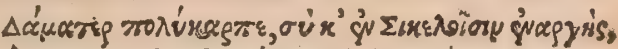

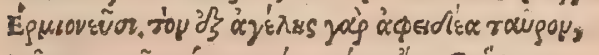

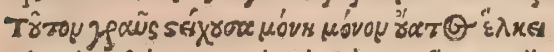

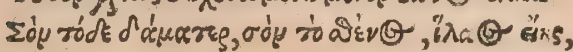

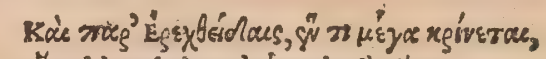

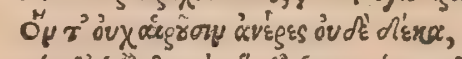

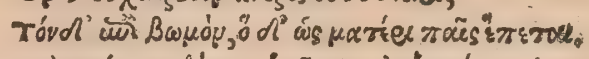

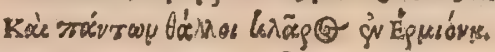

Taura, id eft fterilis uacca, inferis immolatur, Idç̧̧ merito propter infoccunditatem: fic \& ouis nö nigra tantum (ö̈ $\mu \dot{\varepsilon} \lambda \alpha s$, forte aries niger) fed nigerrima îfdem, propter tenebras inferorum, Varin. Pefte olim Lacedxmona diuexante redditum oraculum, ut Plutarchus refert, mali uim ceffaturam, fi nobilem tuirginem quotannis immolaffent. Quum obtemperarent Lacedamonï, ac forté macian. da duceretur fuo ornatu Helena, deuolans aquila gladium abreptum, \& ad armenta, qux Brrónıx uo cant, delatum fuper iutuencam denifit. Quo prodigio rapevvoxroviau, id eft uirginum immolationem defilfe:quod Ariftodemus auctor tradit. Idem obueniffe Roma in Valeria Luperca, ratione confimi li, uolumine 19. Italicarum rerũ Ariftides prodidit, Cælius:ex Parallelis Plutarchi minoriburs, quam. uis ipfe non citet, ut neç alios authores folet. Si quis Mineruæ bouem facrificaffet, oportebat etiam

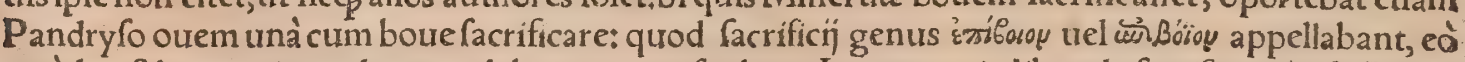
quòd poft bouem ímmolatum celebraretur, ut fcribunt $L$ ycurgus in libro de facrificando, \& Philo

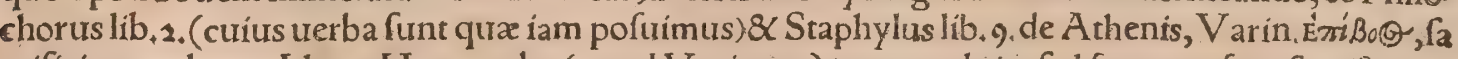
crificium ex boure, Idem. Hecatombe (apud Varinum) non quoduis, fed fumptuorum facrificium

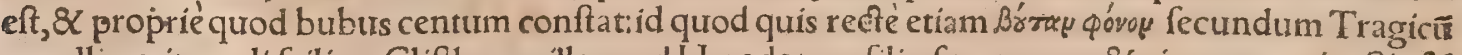
appellauerit:quali fcilicet Clifthenes ille apud Herodotum filia fur procos $\&$ citres excepit. Sic $\&$ chiliombeà millenario numero dicitur. Improprie uerò hecatombe dicitur etiam de alṇs animalibıs fiue pecoribus prater bourem:interim tamen per excellentiam tanç folis bobus confraret nomen re. tinuit. Numerus quog centenarius pro multitudine fimpliciter ponitur, ut cum dicimus ícivivuja vaüy, id eft multorum iugorum natem. Hecatombzon menfis dicebatur, qui apud Latinos lunius, 


\section{Bos \&Vacca. H. Lib. I. 87}

cò.quod plurimæ in eo hecatombx fierent, Varinus. Hic menfis apud A thenienfes Soli facer erat. cuius quia tunc magnus fit curfus, inde tempori factum nomen:quando numertis ध́ra rou fignare ma gniturdinem aduertitur plerungs:fiébat autem in eo folftitium æftiuum. İdem $\mathcal{X}$ Cronion dicebatur à facrificins quæ Saturno fierent, Cælius, Hecatombæus Iupiter ín Gortyna; tut Hefychius ait,appel. latus eft, \& à Caribus, \& à Cretenfibus, Sunt qui putent primum Græxcorum menfem Hecatombæô na uocatum ab Ioue, ut docuimus in libro de annis 8 menfibus, 8 c. Sed $\&$ hoc nomine A pollo nun cupatus ab A thenienfibus:quin Harpocration, aling $\oint_{\beta}$ libentius menfem ipfum A pollin attribuunt; Lilius Greg, Gyraldus, Idem alibi hunc menfem à Lacedæmonịs fic appellatum fcribit, \& Hiacyn. thia fefta in eo celebrata. Igitur fuit hoc facrum(inquit idem)interdum centum boum : fed $\&$ ouium o interdum, $\&$ caprarum, \& fuum. Fuerunt $\&$ qui ex omni genere hoc facrum peragerent, qui étiam fyfcion, id eft opacum $\&$ umbrofum nuncuparunt. Sunt qui centum pedum uictimarum dixerint Inuenimus $\&$ buproron facrificium quoddam, ex centum ouibus \& boue uno:alij \& Brópjxy dictunt; ut notat Hefychius, Sanè quidam non à uictimarum numero, fed quod centum Peloponnefi urbes

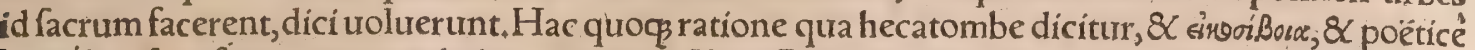

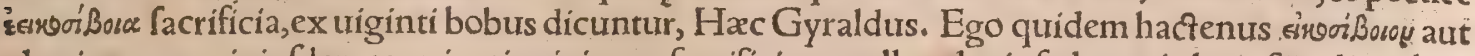
alterius numeri eiufdem terminationis in oov facrificium nullum legi: fed omnia huiurfmodi, ut éka=

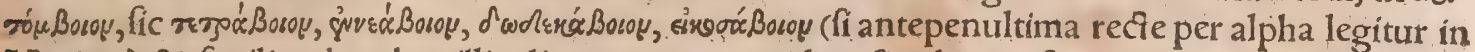
Varino ) \& fimilia, de rebus illis dicuntur qua totidem fiue boum fiue numorum pretia zequas rent, Varino tefte. Nam aureos quofdam numos, boues appellatos Etymologus refert in Hecatom 20 be. Sunt enim quibouem in trocabulis iftis compofitis numum intelligunt, cui propter æquale pre

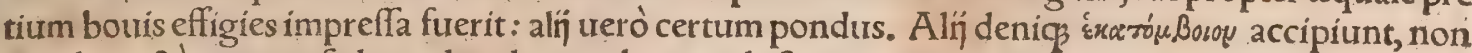
quod exactécentum, fed quod multorum boum, id eft quorumuis pecorum, per fynecdochen partis pro toto, pretio conftet, Varinus, Heræa ciuitas eft, qux \& Hecatombæa uocatur. Celebrantur aur= tem ab Argitris Hecatombæa centum bubus dex (nimirum Iunoni) immolatis, Præmium tunc cer taminis futum aneum proponebatur, \& corona myrtea. Vel urt alif, in certamine Hecatombęorum Argis, æs præmium datur, quoniam Archinus qui rex Argiuorum fuit $\&$ huius certaminis author, cum apparatus armorum cura ei delegata effet, arma etiam præmí loco donari uoluit. Nomen Heca rombais, inde quod in magna pompa boues centum pracederent, unde uifceratio ciubus cunctis dari folebat. Pindarus Diagor am in Hecatombais uicforem Argis maximé celebrat, Varinus. He

30 fychius ab Hecatombæo Apolline A thenis dicto Hecatombra celebritatem \& certamen nominata docet. Bovburic non folum facrificium ex bubus eft, fed quoduis regale $8 x$ magnificũ facrum:uel con= uiurum opiparum, \& magnificus apparatus, ut Erafmus etiam meminit in prouerbio, Nemo benë

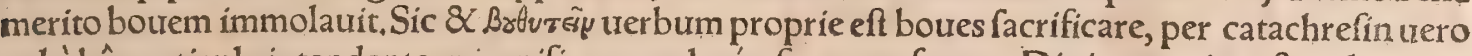
uel à bû particula intendente, magnificos amplość fumptus facere. Diuitum enim eft, uel regum

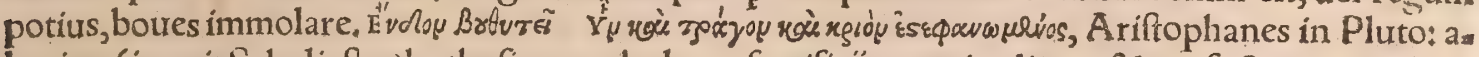
butitur(inquit Scholiaftes)buthyfiz uocabulo, ut facrificin magnitudinem $\&$ perfectionem indica. ret, quod hecatomben uocant. Perfectum enim facrificium fue, tauro, hirco \& ariete conftat, quod trittyn appellant: A thenienfes uero eodem nomine facrificium ex reliquis tribus etiam abfos boue,

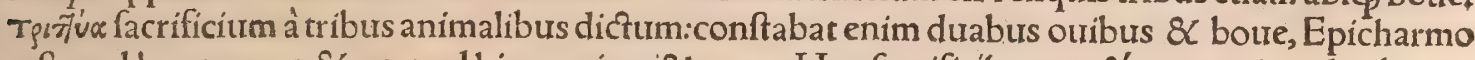

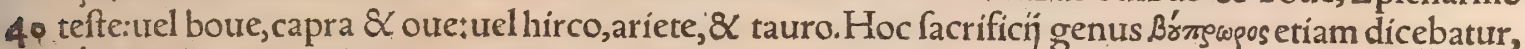
còquod bos pracederet, ut prora nauim. Videtur etiam trittyan quandam infinuare Ariftophanes,

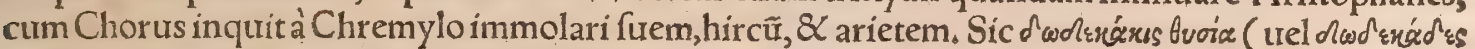

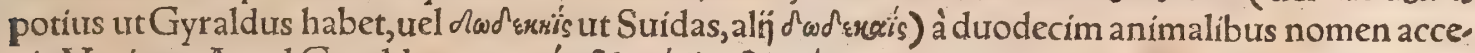

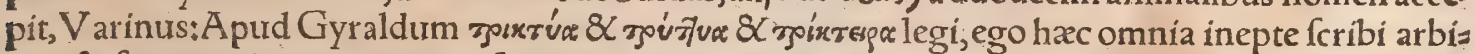
tror, \& femper trittys oxy tonum, foeminini generis frribendum, non in neutro plurali ut Gyraldus accipere uidetur. Nam cum à ternario dicatur, omnino iôta in prima fyllaba retinere deber ( librariorum, non Gyraldi, errorem exiftimo ) quemadmodum idem nomen cum tertiam partem tri. bus fignificat eodem plane modo zoı żús frribitur : 8 hoc poftulat etiam analogía : fic enim à quater=

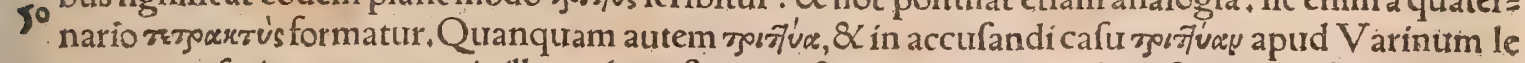
gatur, non fatis tamen grauis ille author eft quem fequamur: 8 apud Arifophanis fcholiaften in Plutum, loco quem ip fe citat, trittyn $\&$ trittys legimus:fic etiam apud Suidam \& Etymologum. Iam trittyn quocs pro tertia tribus parte, nonnulli per fimplex $t$, perperam fribunt. Sed redeo ad Gyral dum (quem ut tribus iftis modis, nec ullo recte trittyn fcriberet, Hefychius decepit \& fecutus eum Varinus ) hic ex Hefychio annotat facrificium hoc Enyalij, id eft Martis effe, quod tribus animalis bus cum tefticulis, id eft non caftratis fieret:uel ut alí tradũt (Callimachus apud Etymologum) rue, ariete, tauro, ferè Romanis Solítaurilibus fimile. Hoc ex Hefychio addendum, triadem alio nomine dicihoc facrificium, nimirum eadem ratione qua aliud dodecadem fupra trocari monuimus. Ifter quidam, ut Etymologus habet, ex bubus, capris, \& fuibus hoc facrificium perfici author eft:que quí

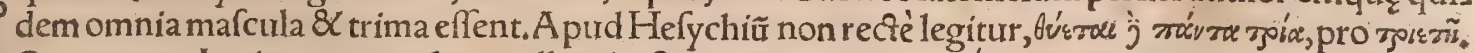
Quanquam Latinorum quidam nullam hoftiam maiorem minorémue bidente, id eft, bima effe de buiffe prodiderint. Sed nimis forte digredior, dum corrigenda authorum loca fequor auidius, Bŕzrope

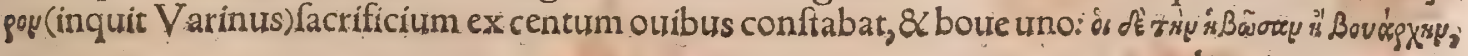




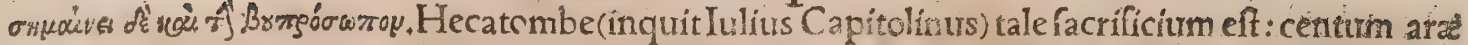
uno in loco cefpititix extrutuntur, $\mathcal{Q}$ ad eas centum fues, centum oues mactantur. Nam fi imperato rium facrificium fit, centum leones (uel ut aliquilegunt, oures, quod parum mihi placet, inquit Gy, raldus)centum aquilæ, \& cætera huiufmodi animalia centena feruntur. Quod quidem \& Græci quondam feciffe dicuntur, cum peftilentia laborarent, $Q$ à multis imperatoribus id celcbratum con

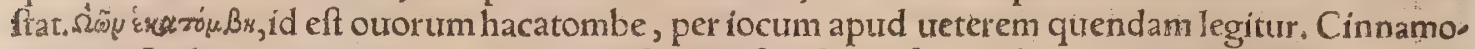
mum in Aethiopia gignitur, nec metitur nifi permiferit Deus: Iouem hunc intelligunt aliqui, Affabi num(aliâs Sabin) illi uocant, quadraginta quatuor boum caprarumós \& arietum extí impetratur

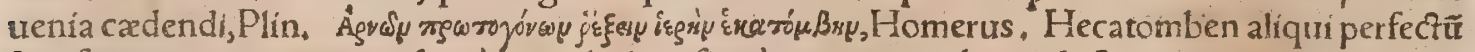
facrificium interpretantur, fiue à centû bubus, fiưe à centũ pecoribus, id eft triginti quinç anımali= bus, Etymologus, A pparet aũt legendũ effe, fiue à centũ pedib, pecorû uiginti quinq;. Huc pertinet

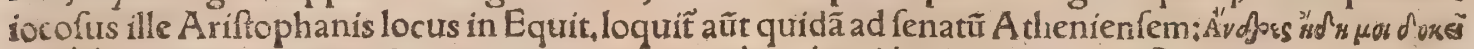
ह่

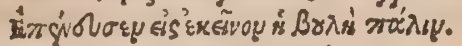

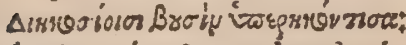

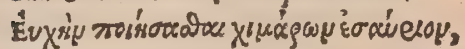

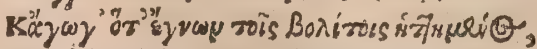

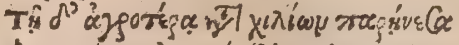

Addit hîc fcholiaftes Callimachum imperatorem Dianæuouiffe tot boues immolandos, quot bar: baros occidiffet in Marathone:cum wero ingens eorum numerus cecidiffet, nec ille tantum boum

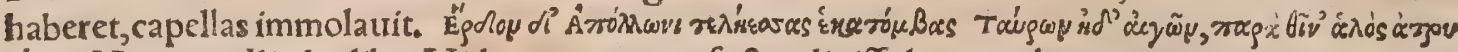
$\gamma^{\prime} \varepsilon \pi 10$, Homerus lliados lib. I. Videtur autem perfectas dixiffe hecatombas, qux omnino centum pe. cora complecterentur, non fimpliciter magnifica facrificia*Nifi quis ad uictimartum potius $\$$ nume ri perfectionem referre malit. Oportebatenim perfecta animalia, id eft integra \& non mutila immos Iari.Ef $\&$ alia ratio, qua trittyn fupradixi plenum perfectumćs facrificium appellarum fuiffe. Ho ftia fi maior erat, auratis cornibus plerũos immolabatur. s. C.extat deludis A pollinaribus primùm faciendis, quod Macrobius recitat primo Sat.in quo decemuiri pręceptum fuit, ut Gręco ritu hoftijs facrum facerent, A pollini boui aurato, \& capris duabus albis auratis! Latonæ boue fomina aurata: ludos in Circo populus coronatus fpectare iuffus eft:hinc Ouidius ait,Indutáćs cornibus auro Vi Efima uota facit, Et alioloco, Blandis indutæ cornibus aurum Conciderant ictæ niuea certrice ít

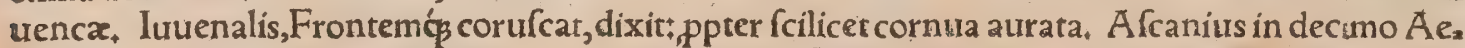

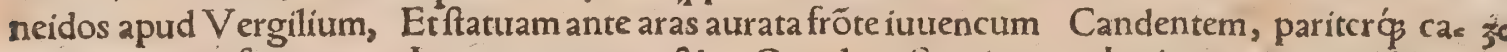
put cum matre ferentem, Iam cornu petat, \&c. Quo loco Seruius quæ loui conueniret uictima perbellé exponit, Tantum Gyraldus. T.Liuius lib, ı.quintæ Decadis, Quòd capưt iecinori defuif fet, tribus bubus perlitaffe nequiuit, fenatus maioribus hoftijs ufç ad litationem facrificare iuffit. Li tare uerò eft rité facrificare, \& impetrare, ut authorum teftimonins Gyraldus probat. Hoc nimirum

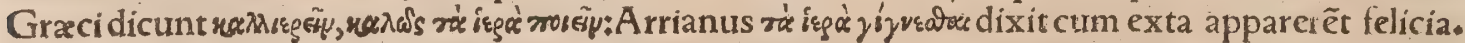
Xerxes in Pergamo Priami regia Minerux Iliadi malle boues immolauit, quarum libamene Magi heroibus parentauerunt, Herodotus libro 7. Hecatomphonia ex lege immolari à Meffenịs folita, in Septem fapientum conuiuio aucfor Plutarchus eft: tanö $\tilde{\beta}_{\beta} \mathrm{ex}$ hoftibus centum interemılfent, ut in quit Paufanias. Id facrum obijt A riftomenes Ioui Ithomatæ, Cælius. Epigrammatum Anthologí libro 1. fectione 33. extat Philippi cuiufdam epigramma in iuurencam, qux cû́ Dianx immolanda par- 4 turire, quoniam hæe dea parturiginum prafes eft, dimiffa fuit. बf Pythagoram proditur memorię cum noui quippiam excogitaffet in Geometria, Mufis bouem immolaffe:quod(inquit a pud Cicero. nem Cotta)non credo, quoniam ille ne Apollini quidem Delio hoftiam immolare uoluerit, ne aram Ianguine confpergeret, Calius. Iulitiam alunt propter iumentortm(boum) cædem triolentam dea reliciis terris ad fyderum remeaffe confortium, Veget. Ritus facrificandi uarios, \& quicquid de fa crificn̄s gentilium afferri poteft,copiofe doctiffiméç profecutus eft Lilius Greg. Gyraldus in Ope re fuo de dips:nos hic pauca quadam, non de facrificijs in genere, fed quæ ad boues facrificandos pri uatim faciunt a diungemus ex primo lliadis Homeri libro: ubi is hecatomben cum Chryfeide filia re miffam patri, \& A pollini immolandam his uerfibus defcribit:

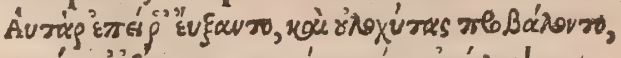

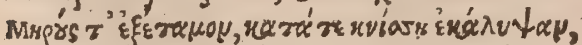

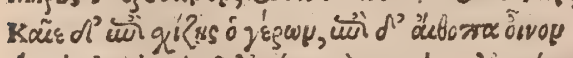

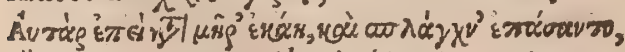

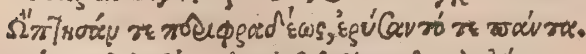

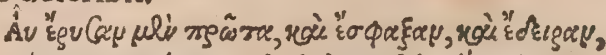

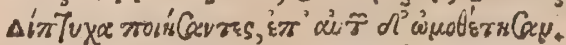

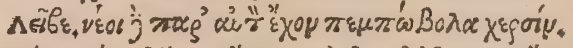

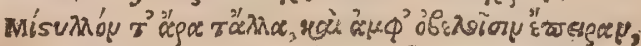

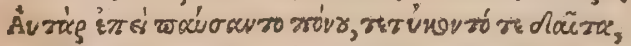

$\triangle a^{\prime}$

boures mactatos fcribit:addit aũt præterea,

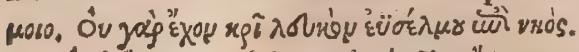

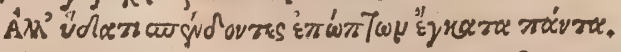

Eirde uerfibus Odyffex libro 12.ab Vlyffis focijs Solig

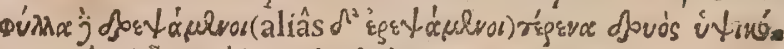

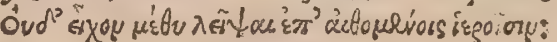

Conftat fanè, partim aliunde, partim ex his car. minibus, immolantes precari primum $\&$ uota deo facere folitos: Deinde prothymata celebrare : fic uocant quęante facrificium fieri confuetêre: ut eft uaporatio thuris, aut id genus primitix quxacun= 60 que, ut filigo, uel etiam placentulx:item ulochyta, id eft hordeum fale confperfum, quod ante facrifi cium aris infundebatur, de quo plura Calius Rhodig. 12,1.8 Gyraldus circa ultimă partem Operis 


\section{Bos\&Vacca H. Lib. I. 89}

fui de dńs. Vlochytas aliqui (ut Pollux)accipiunt ipfa uafa ex quibus ulæ fundebantưr. Peractis precibus, \& aliz quæedam ceremonix fiebant, utfacerdotis ad dextram, uel apud Gallos ad læ: uam conuerfio: 2 manuû ofculatio apud Græcos: $\&$ facrificulus fetas inter cornua uictimæ manux excerptas, tanç prima libamina in ignem mittebat: Tum uinum fimpullo circumferebat, ut aftan=

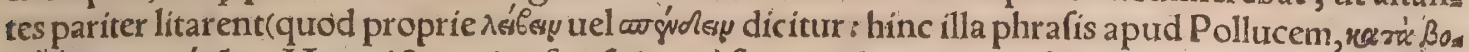

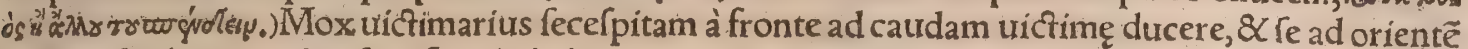
uertere folebat, quod in facrificio habebatur primũ. Secefpitã alị̉ cultrũ, alǐ fecurim, alỉ dolabrã ex ponunt. Ir quocung facro faces adhibebantur ex tedx ligno, quas folos mares ferre fas erat. Tum uictimam immolare fuccinctos miniftros facerdos iubebat. Hi autem uictimam fupra uerticem, ple .10 ritnç infra iugulum feriebant, idós pro dei uel animalis ratione. Graci quidem fícoelefibus deis

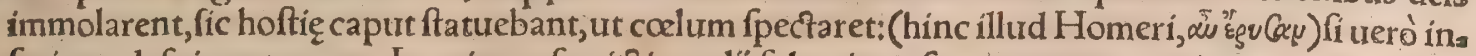
feris, ut def piceret terram. Interim cæefa uictima alin fphagia uafa, ut cruorem exciperent, cadenti ho ftia fupponebant:alin urictimam decoriabant,ạlia ó peragebant.Mox arufpex, flamen, aut facerdos, cultro ferreo uifcera \& exta rimabatur, \& extifpicium fiebat. Et tunc exta reddi dicebantur, cũ pro bata aræ fupponebantur, ut notat Seruius. Vergilius Georg.2.Lancibus \& pandis fumantia reddi mus exta. Eadem dicebătur profecta, cum aris dabantur ex fibris pecudum diffecta, Extis porrò ín. fpectis, ex omni uifcẻre \& membro primitias partes ós defectas farina farris inuolutas, in calathis $\mathrm{fa}_{2}$ crificanti offerebant: $8 \mathrm{C}$ tunc lioftia perfecta dicebatur. Has facerdos aris imponens accenfis, igne cumburebat, addito igni thure $\mathcal{X}$ cofto, alịsćs odoramentis, prout facrum ferebat $\mathcal{X}$ ritus, In mar timis facrificís, qux dijs marinis fiebant, exta in fluctus iactabantur, unde illud, Porricit in fluctus. Sané exta ueru affa apponebantur, prater $\not$ Barietis quxe elixare mos erat. Sed etiam coxas cum in. guinibus cniffa, id eft adipe operientes conburebant. Sic uictimarum quidem uifcera, licet nunquã . abluta, elixa per fefe fiebant: uinumó̧ aris poftea fundebatur, $8 X$ tunc porrici hoftia diccbatur. Ex quo emanauit prouerbium illud, Inter cæfa $\&$ porrecta, Ex reliquis autem hoftix partibus feu mem bris conam apparabant, quibus qui facris interfuiffent, uefci licebat, Hæc ex Gyraldo compendio quodam decerpfimus, - TApud Thuffas in Aegypto, ubi Venus cornuta colebatur, uacca illi im.

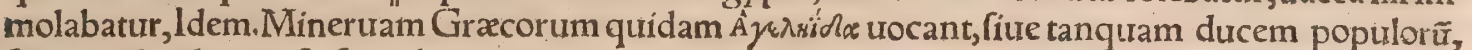
fitue quod indomita fit fiçuti boues armentinæ; quas etiam pracipue ei facrificabant, Phurnutus. In hoftịs quxdam fuêre quxiniuges urocabantur, id eft quæ nun $\bar{c}$. domitæ ac iugo fubditæ fuerunt. 30 Harum \& Vergilius meminit, Nune grege de intacto feptem mactare iutuencos Praftiterit, toti= dem lectas de more bidentes. Et ut iniuges euidentius exprimeret,adiecit, Et intacta totidem cer. uice iutuencas. Manilius Chreftus in libro de hymnis deorum, ait Minerux iniuges boures facrifica

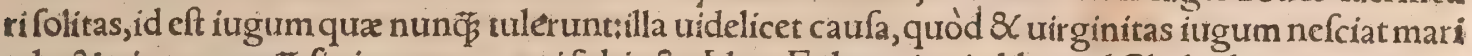

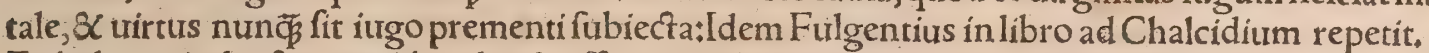
Ex bobus, uítulis, $\&$ pecudibus, laudatifim $æ$ uitulæ ad deorum placamenta habebantur. Idcirco $I_{0}$ uia à flamine omnibus idibus bos candidus, \& ex agro Falifco, aut Meuania immolabatur:illos enim ad facra faginabant, \& deorum fupplicị́s feruabant. Bos aurem qui iugo fubactus fuiffet, purus nó putabatur, Foetus bouis non ante tricefimum diem idoneus facris ac purus putabatur. Creditũ quo que bourem quinquennalem, infignem Ioui uictimam effe. A egyptí boues ruffas Typhoni mactare

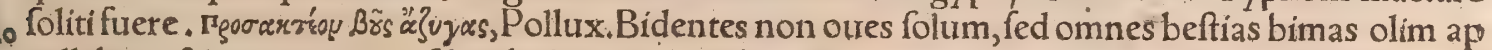
pellabant, \& antiquiores eafdem bidenes, quafi biennes, quia neç maiores aut minores licebat $\mathrm{ho}=$ ftias dare, Macrobius. Nos $\&$ boutem quinquennem Ioui immolari iam diximus: $8 \alpha$ pecora trima in facrificio quod trittyn uocauimus. Nullum etiam ex authoribus locum puto afferri poffe, unde bi= dentem bourem dictum aliquis intelligat: de ouibus uero plerofos omnes: Vnus Pomponị A ttellana rum poetæ locus Macrobio citatur, quo Marti uouet fe facturum bidente uerre. Debidentibus igis tur in Oure dicam: nam fi ueteres $\&$ quorum libri non extant, de alips etiam animalibus hac uoce uff funt, nihil ad nos. Lucianus in libello de facrificips uaria effe facrificia prodit pro perfonæ facrifican. tis qualitate: Agricola,inquit, de boue rem diuinam facit, opilio de agno, æpolus de capra , Bówuss a= pud Suidam trocatur qui bubus ad facrificia emendis publice praficiebatur : quod quidem hone. go ftifimum erat munus, $\mathcal{Q}$ imperatoribus præciptué deferri folitum. Diu feruatum apud A thenienfes $\&$ Solonis lege interdictum, Ne bouem, cuius opera, uel aratro uel currut uterentur, omnino immo:

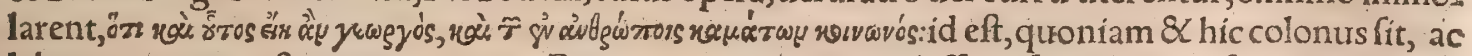
laborum quoģ noftrorum partíceps, Bourem aratorium immolaffe, nefas cêfebatur fummum. A the = nienfes autem primos hifce non abftinuiffe uel in cibis, auctor eft nobis Theon. Vlyffis quoç focios non temperaffe, cecinit Homerus: quo fit nomine indignatus Sol, quippe ut Solem intueamur, caus.

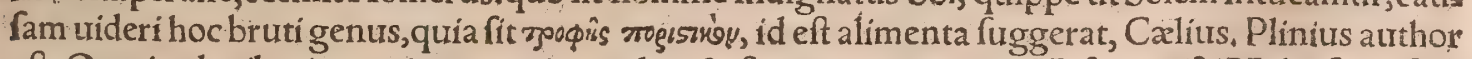
eft, Omnia plenilunio maria purgari:quædam \& ftato tempore:circa Mefanam \&IMylas fimo fimi lia expui in littus purgamenta. Vnde fabula, Solis boues illic ftabulari. Meminit \& loci \& boum A pollonij interpres libro 4. Myla (inquit)Siciliz Cherronefus, in qua Solis boues pafcebantur. Sed - \& rem quoqum fabula recenfuit in Naturalium Quæftionum libris Seneca. Has quidem Solis bo ues Homerus Odyffex primo uidetur nouffe. Verum feire conuenit, quandoç prioribus recepti fuiffe moris, Soli animalia dicare; quod apud claficos obferuatum authores eft, Nam \&' A pollons 
qua in finu Ionico eft, facras Soli oues fuiffe, Graci fcribunt, Calius. Memini alicubi legere per Sod lis boures à focipjs Vlyffis deưoratos, annos fignificari: tunc enim obịffe illos, cum omnes atatis anni; quos cis uiuere in fatis erat, exacti confumptićs effent. Sol enim atatis $\&$ temporis autor eft. Et ficut in fulcis aratro defignandis, boues ad certum progrefli terminum retrogrediuntur, ita Sol etiam ad utrunç folftitium, tanquam Brspoфxdioy, fuum peragit motum, ut uel hac ratione per noftram conie. cturam boues pro annis Soli tribuantur, Cxterum A pollinem bubus delectatum fuiffe, mox $\mathrm{P}_{\text {aufa }}$ nix uerbis declarabo, Supra etiam ex Euftathio docui menfem uritulum \& bouemappellatum. Hux facit fomnium Pharaonis, âMofe defcriptum libro Genefeos cap. 4r. Videbat ille in fomnis boues feprem egregias $\&$ opimas, quas totidem aliæ macie confect $\&$ turpes afpectu deuorabant. Accer: fitus lofephus, boures opimas feptem interpretatur annos totidem foecüdos $\&$ abundantes annonæ, 10

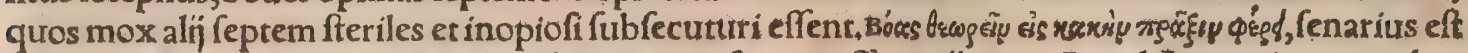
apud Studam, quo quarris de bubus fomnia inaufpicata efle conịcitur. A pud Aegyptios quoç bo. uem marem Soli facrum fuiffe, paulo inferius in A pidis bouis hiftoria dicam, Certe cum Luna pro. pter cornuum fpeciem, (qux ueluti minor Sol eft, fed forminex natura) boutes foemina confecraren tur:ratio poftulabat Soli tauros facros exiftimare: Quanquam Homerus de Solis bobus in fomini-

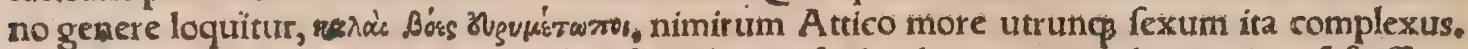

4 A purd Aegyptios $\&$ Phonices, ficut Porphyrius feribit, humanis carnibits potius ufi fuiffent, quàm uaccam comediffent: $\mathcal{C}$ quramuis tauris haudquaquatm abftinerent, tamẽ uaccarüm ufus non modo menfarum confuetudini, uerum etiam facrificationi interdictus fuit, A elianus, Ab Aegypto ad Tritonidem lacum Paftoritr A fri funt, carne uichtitantes ac lacte, nihil uaccinum gtiftàntes (quia 20

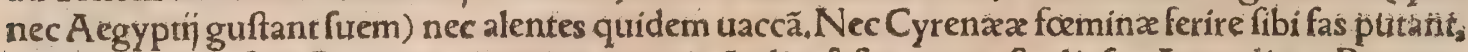
- ob Ifidem quareft in Aegypto, cui etiam ieiunia \& dies feftos agunt fudiofe. At mulieres Barcar, non modo guftu uaccinæ carnis, fed etiam fuilla abftinent, Herodotus libro 4, Inter exêpla eft dam natus à populo Romano die dicqa, qui concubino procaci rure omafum ediffe fe neganti, occiderit bourem: actus's in exilium, tanquam colono fuo interempto. Huc referenda funt etiam Ciceronis uerba, qua fupra pofui in E,circa initium. Animaloccidit primus Hyperbius İartis fitius, Prome. theus bourem, Plinius. TBuphonia feftum uetus, quod A thenienfes poft myfteria celebrabant per

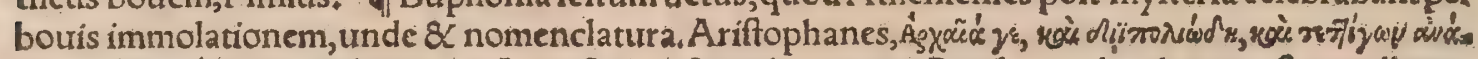
$\mu \varepsilon 5 x$, rou Kinxéd ov Bovqovíw. Sed \& Iouis Poliei facerdos, inquit Paufanias, buphonus eft appellatus; Callius: 8 alibi, Inuenio (inquit) in literis, Erechtheo imperante $A$ thenis, à Buphono prinum in $I_{0}=$ uis Polici ara immolatum bouem:quo peracto, fecurirelicta, mox fe è regione Buphonits prơripit. At in fudicium uocata fecuris eft, ac abfoluta:idós quotanthis ur fieret, feruatum tráditur. Meminit

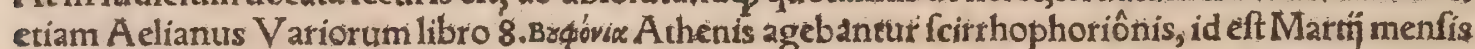
die quartodecimo, multis bubus immolatis, Etymologicon. A pud Varinum legimus Buphonia antie quiffimum feftum Athenis effe,inde orturn, quod in Dippolịs bos quíplacentam facrificio deftina. cam uorauerat à Batilone quodam, qưi forte cum fecuri aderat, occifus fit, idćs ut deinceps ita ferua retur inftitutum. Vocabatur autem Bórss qui in hoc fefto buphonia peragebat. De Butarum famis lia fupra diximus, Vide Erafmum in prouerbio Cecidis \& Buphoniorum: \& Gyraldum in Opere de dijs, ubi facrificia defcribit. $\Delta$ ós Bros, bos Iouri facer, feftum Milefiorum, Varinus. Boalia, ludi dins inferis confecrati, Sípontinus. Fiebant autem cum bubus, quemadmodum nunc quoç fieri $f_{0}=40$ let apud Italos Septuagefima tempore, quod rempus quidam Carnipriuium uocant. Bubetia fiue bubetī ludi, quos ueteres à bobus pecoréćs appellârunt, qui $\$<$ boalia, boum gratia inftituti, tefte Pli nio, In eo enim fefto folennis boum $\&$ taurorum uenatio fieri folebat, quemadmodum nune quoque Venetïs, \& feréper totam Italiam, fieri folet eo die, quem louedi graffo appellant.

बA pides díj erant apud A egyptios culti, uituli fcilicet qui per longün temporis interuallum ex fplendore lunx ( tes circa bouem naturm confecrati epulas publicas proponebant, Varinus, Fuit \& A pis A egyptio: rum rex Phoronei filius: \& codem nomine infula ante Cretam fita, Idem. Sed quoniam paffim apud authores A pidis bouis frequentifima mentio incidit, pleniorem eitus hiftoriam ex Plinif, A eliani, \& Herodoti fcriptis hic adiungemus, Primum igitur Plinius libro 8.cap.46. Bos(inquit)in Aegypto jo etiam numinis trice colitur, A pim urocant, Infigne ei in dextro latere candicans macula, cornibus lu næcrefcere incipientis. Nodus fublingua, quem cantharum appellant. Non eft fas eum certos uita

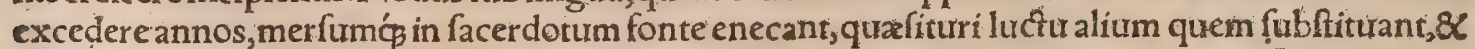
donec inuenerint morent, derafis etiam capitibus:nec tamen unquam diư quaritur. Intrentus de; ducitur Memphim à facerdotibus. Sunt delubra ei gemina, qua uocant Thalamos, auguria populo, rum. Alterum intraffel latum eft, in altero dira portendit. Refponfa prituatis dat, èmanu confulentiư cibum capiendo. Germanici Cæfaris manum auerfatus eft, haud multo poft extincti. Catero fecres: rus cum fe prọripuit in catus, incedit fummoto lictorum, grex ̧́ß puerorum comitatur carmẽ honorí cius canentium:intelligere uidetur, $\&$ adorari uelle. Hi greges repente lymphati furura pracinunt. Foemina bos femel ei anno ơftẽditur, fuis 8 ipfa infignibus, quanquam alijs:femperóp codem die $\alpha 6$ inueniri eam, \& extingui tradunt. Memphi eft locus in Nilo, quem à figura uocant Phialam, omnis: bus annis ibiauream pateram argenteamç mergentes, diebus quos habet natales Apis: feptem hì 


\section{Bos \& Vacca. H. Lib. I. gi}

funt,mirumón neminèm per eos à crocodilis attingi: octaươ port horam diel 6, redire belua feritate, Hrc Plinits. Loctum de cantharo fub lingua illuftrat Porphýrius in libro de abftinentia cartiitum fic frribens: Scarabeum animal rerum ditinarum indocti abominantur, quod Alegyptï fummopere

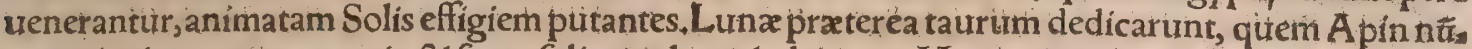
cupant, nigrum præ cæteris, \& figna folis atç lunæ habéntem, Mutuatur enim ex folé luna lumen. Solis fymbolum eft coloris nigredo (nam \& folis ardor, nigriora reddit humana corpora) \& qui fub lingua eft farabeus. Lunæ uero coloris dítuifio. Adijcit in Iffide Plutarchus, ita cantharos pilulam ex crementitiam fenfim in aduerfum protrudere, ficuti contrarium mundo fol curfum agat, dum ab occafu in exortum fertur: Hac ex Lodouici Calin Rhodigini obferuationibus.

Nunc $\&$ A liani uerba fubdamus. A pis (inquit)apud Aegyptios efficacifimus deus creditur, ex úacca qux fulgure afflata conceperit nafcitur, Epaphum Græeci uocant, A tọ huius generis anti. quam ftirpem repetentes, Io Argiuam Inachi filiam illius matrem fuiffe teftantur. Sed hunc fermo. nem Aegyptĭ ut mendacem renciunt, temporis longinquitatem teftem citantes. Epaphũ enim mul ris pòt freculis extitiffe ferunt, Primutm uero A pim permultis annorum milibus in homines trenif, fe. Infignes éius notas Herodotus; \& A riftagoras explicant:Quibus Aegyptn̈ non affentiuntur':no. uem enim \& uigintl eas huic facro boui aptas, et confentaneas effe dicunt. Qurenam fint, tum quieni admodum per corpus fparfæe, tum ut ipfis quafi Horibus infignitus fit, aliunde intelligendum. Cuiur nam autem ex fideribus naturam unumquod infigne per notas defignet, Aegy ptỉ fatis fitperó̧ de clarant: Etèim Nili afcenfum, unum infigne lignificare aiunt:aliaḉs infignia aliarium rerum fignifi cationes elfe, haud profecto prophanis, $\mathcal{Q}$ diuina hiftoria imperitis intellectu facilia. Cum autem fa ma emanaurit, Aegyptiorum deum exortum effe: ex fribis \& facerdotibus quidam, ut documentũ procreationi à patre traditum infignium notarum indicium accurate exquirant, eò ubi diua uacca partum ex fefe ediderit, accedunt, atque ibidem domum ad orientem folem, ubi fané alatur, quatuor menfes, excitant, Poftea autem quàm ibi nutritus eft exoriente luna, fcriba, facerdotess, \& prophetre eôdem proficifcuntur, \& fimul nauem huic facram inftruunt, eaćş ipfum Memphim tranfportant, ubi fedes huic funt $\&$ commorationes fuaues; tum curricula, puluerationes, exercitationes; \& uiacca rum formæ praftantia infignium æedes, tanquam thalami in quos ingredicur, quum qitam amat fux pertrenire appetit:Itemóg eft puteus, \& fons aqua potabilis. Nam eiufmodi hức fem per conducere miniftri \& facerdotes alferunt; non item ex Nili potione, ne propter dulcedinem in immenfam mo. $50 \mathrm{lem}$ pinguefcat, Iam tiero quias pómpas, qux factifícia Aegyptị conficiãt, cum noura allutrionis ad. uentum, tum dei exortum celebrantes, quas etiam faltationes tum agant, quos conuentus habeant, tum quemadmodum omnes urbes $\&$ uiri immortaliter gaudeant, longum effet explicare. Is autem ex cuits armento hre diuina beftia exorta fuerit, beatus habetur, fummamćs Á égytiorum admira tionem habet. Is bos prafenfione ualet: Nec fané uel puellas, uel aniculas ad tripodem feffitantes hà

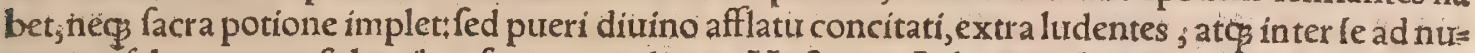
merüm faltantes, confulentibus futura pradicunt, Hactenus Aelianus. Caterum Herodotus libiro 2. de facro ifto Aegyptiorum boue in hac uerba fcribit; Sacerdotes in Aegypto boties mares Epaphi efle cenfent, eaćs de re hunc in modum explorant: Si pilum in eo nigrum uel unum uiderent, ne, quaquam mundum cenfent. Explorat autem hac facerdotum aliquis, ad id conftitutus, linguam pe cudis cum ftantis erecta, tum refupinatæexerendo, fi immunda fit, his fignis, qua ego alio referam in libro, Infpicit $\&$ caudx pilos; nunquid habeat fecundum naturam procreatos. Eam, fi fuerit his omnibus munda, notat alligato cornibus cannabo ( ú$\left.^{\prime} \lambda \omega\right)$ deinde applicata terra figillari anulo im. preffa, atç ita abducint. Nam immolare non notatam poena morte fancita eft. Et hunc quidem in moditm pecus probatur. Sacrificandiautem is eis eft ritus: Pecuide, que obfignata eft, ad aram ubi in

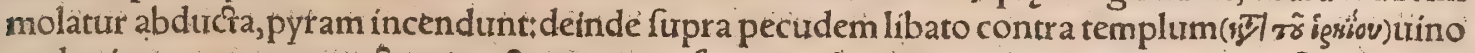
ac deo inutocato, eam mactant:maçatæ caputálportant, \& corpus reliquum excoriant. Caput autẽ multis uerbis execrati in forum fi nundinæ fint, \& eis Gręci negotiatores affuerint, ato $\$$ illis uendữt: quifi non affuerint, in flumen abijciunt. Execrantur autem capita in hac uerba:Si quid mali atit ip

50 fis immolantibus, autuniuterfa A egypto futurum fit, id in caput hoc conuertatur. Eodem ritu circa capita pecudum immolandarum, \& uini libamina, omnes pariter Aegyptij ad omnia templa(ipad)u tuntur. Atç ex hoc ritu nemo Aegyptiorum de capite ullius animantis deguftat. Eft tamen facrorũ delectus, $\&$ alius apud alia templa adolendi modus ab eís inftitutus, Quem uero dxmonem maxia mum putant, \& maximo fefto colunt, hunc pergam dicere. Poftea preces fuderunt, uaccam immolant, eamq̧́ corio exuunt, et to to aluo uactrant. Vifcera intra uentre adipemós linquưunt, crưra truncant, \& externos lumbos armosós ac ceruicem. His actis, reliqươn uacca corpus ftipant panibus puris, \& melle, \& irua paffa, \& ficis, \& thure, \& myrrha, at ribus, V bi hæc infarferunt, adolent, multum ưini, oléćç infundentes, ieiuni tamen priuf ç facrificêt. Dum facrificiũ ardet, omnes uerber antur, Pofteađ̆ uapulauerunt, dapes ex facrificị reliquịs propo: (40 nuntur. Boues mares eofdemćs mundos, ac uitulos uniuerfi Aegyptínimmolant. Forminas eis im. molare non licet, utpote Ifidi confecratas. Nam lfidis fimulacrum muliebre eft; bubulis præditum .

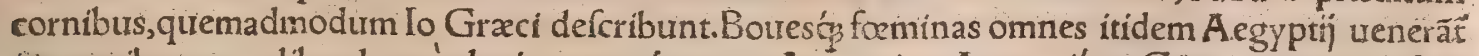
ex omibus pecudibus longé plurimum:coç nemo Aegyptius, Aegyptiáue, Graeci urí aut os fuat' 
uiarettrr, aut cultro, uerúue, uel olla, uel pura bouis carne Graco cultro incifa uterettre. Bottes quil demortui funt, hunc in modum fepeliunt:Fominas quidem in fiumen abijciunt, mares autề in fub. urbanis finguli defodiunt, uno aut altero cornu extante, figni gratia. V bi computruerunt, et fratum tempus aduenit, prafto eft ad fingulas urbes nauis, ex infula nomine Profopitide, quix eft in Delta, nouemćs fchoenorum ambitus. In qua cum alia funt frequentes urbes, tum ea unde proficifcuttur naues ad offa tollenda, nomine Atarbechis, ubi templum Veneris extructum eft. Exhac urbe ali permulti uagantur in alias urbes, Vbi effoderunt offa, afportant, eaćs uno in loco cuncti fepeliunt. Quem in modum boures, in eundem defuncta alia pecora fepeliunt, Ita enim apud cos circa hac legi bus comparatũ eft. Hactenus Herodotus li.2. Et rurfus in eodem : Pfammitichus potitus Aegypto, fecit in Memphim tum Vulcano ueftibula ad uentum auftum uergentia, tum é regione ueftibulo $=10$ rum aulam A pi, in qua, cum apparuit, A pis educaț, undiq̧ columnis cinctam, ac figuris refertam: in qua aula loca ftant columnarum coloffi dưodenûm cubitorum. A pis autem, Graca lingua Epaphus eft, Et rurfus libro 3. Cambyfe Memphim regreffo, parte copiarum amiffa, Apis apparuit. Aegyptij, ubi A pis extitit, ueftimenta quàm pulcherrima ferre, \& celebrando fefto operam dare . Id tunc facientes Aegyptios Cambyfes intuens, ratusć̣́, ob res à fe malè geftas, prorfus illòs effe in hís gaudijs, præpofitos accerfit Memphis, \& infolitæ ab îs lætitiæ caufam requirit: Qui cum refponde* rent, quo tempore deus illis appareret(longo autẽ interuallo apparere folitum)omnes Aegyptios fo lennem celebrare læcitiam;mentiri iuffos morte mulcrauit.Mox facerdotibus eadem referentibus, dixit, Si quis deus manfuetus adA egyptios ueniret, fore ut fe non lateret: 8 A pim eos adducere iuf fit.Eft autem hicA pis,idemóg Epaphus è uacca genitus, quæ nullumdum alium poteft concipere foe turm, quam A egyptị aiunt fügure ictam concipere ex eo A pim. Habet hic uitulus, qui appellatur A pis, hxc figna: Toto corpore eft niger, in fronte habens canderem figuræ quadratæ, in tergo effigi en aquila, cantharum in palato, duplices in cauda pilos, Poftea $\bar{\beta}$ A pim facerdotes adduxere, Cam byfes ueluti uecor dior, educto mucrone cưm uellet ferire urentrem, femur percuffit, cachinnã facerdotes inquit: $O$ capita nequam, huiufcemodi dỉ exiftunt, fanguine at $\not ̧$ carne pręditi, \& ferrum fentientes? dignus nimirum Aegyptīs hic deus. Nos certeludibrio habuiffe non iuuabit, Hxe locu. tus, imperauit his quorum munus erat, ut facerdotes quidem flagris caderent, Aegyptios autem(ut quenç feriantem adipifcerentur)occiderent, It feftum folutum eft.Sacerdotes mulctati : A pis fau ciatus femur, in templo iacens extabuit:quem é uulnere extinêũ tumulauêre facerdotes, clam Cam byfe. Ob hoc fcelus (ut A egyptĭ aiunt) continuo Cambyfes infanźt; cum ne compos mentis quidem 30 fuilfet, exorfus primum perpetrare facinus necando Smerdim germaní fratrem, \& fororem qua ei $\& 2$ uxor erat in Aegyptum uf̧̣ fecuta, Hactenus Herodotus, Porrò ficuti Memphitæ A pim bouem facrum habuere:ita \& Heliopolitani poft Solis templum Mneuin bouem pro deo coluerunt, quil in fepto quodam nutriebatur. Ammianus quoog Marcellinus inter multa quæ de Apide frribit lib. 22. hif. \& hoc feré ait: Inter animalia ab antiquis, confecrata Neumis \& A pis reponuntur. Neumis qui dem Soli, Apis uerò Lunæ dedicatus:qui diuerfis notarum figurís expreffus, \& $c$, quare confideran dum an Mneuis pro Neumis legendum apud Marcellinum, apud quem $\&$ longe plura inuenies. Veneri Vrania uaccam facram cuftodiebant in Hermopoli prafectura, in loco Scuffa nunctipato, Gyraldus in A pide:idem alibi, in Venere. Legimus quoos(inquie)apud Thuffas ( fic enim ibi feribit

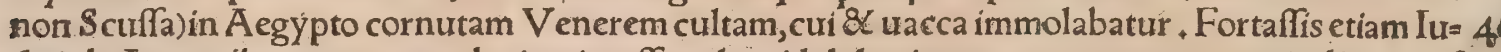
dai ab A egyptins, cum recens ab eis migraffent, hoc idololatrix genus acceperunt ut uituli aurei ef figiem fibi colendam proponerent; $\&$ fieri poteft ut inde occafio nata fit gentilibus calumniandi, aut reum afini caput ab eis adoratum fuiffe: fchor enim bouem fignificat literis uerò tranfpofitis rofch, caput.De boue lignea Mycerini in Aegypto culta,pauló poft dicemus, Cæterum an Serapis eade uocabuli origine nominatus fit, qua feraphim Ebraice angelorum genus ob ardorem amoris uel cla ritatem uifronis ita dictum, peritioribus huius lingux difcutiendum relinquo. Mihi quidem pulchre

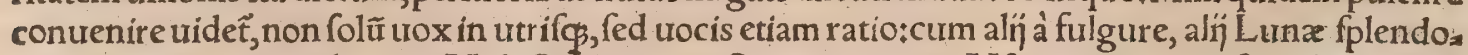
re Serapin concipi toluerint. Vide Suidam, qui Sarapim uocat. V furpatur atrtem farapls uerbum apud Ebræos pro ardere $\&$ urere; A eqưius fané eft Aegyptio deo Ebraicum $\&$ congeneris lingure nomen quàm Græcæattribuere. Quamobrem non fentio cum Varrone, qui Nymphodorum fecu= so tus, ut frequenter circa etyma nugari folet, cur A pis poft mortem Serapis appellatus fit, hanc ratio. nem reddit.Quia enim arca (inquit)in qua mortuus ponitur, oogos dicitur Gracé, \& ibi eurm uenera ri fepultum coperunt, priufó̧ templum eits effet extructum, uelut Sorapis primo, deínde una lite. ra commutata Serapis dictur eft, \& c. Ille atrem bos (fcribit hac Auguftinus lib, 18. de Ciuitate dei) quiem mirabili uanitate decepta A egyptus, in honorem eius delicịs affluentibus alebat, quoniã eum fine farcophago uituum uenerabã̈tur, A pis non Serapis trocaba tur: quo botte morturo quoniam que. rebatur $8 x$ reperiebatur uitulus coloris eiufdem, mirum quiddam diuinitus fibi procuratum effe cre

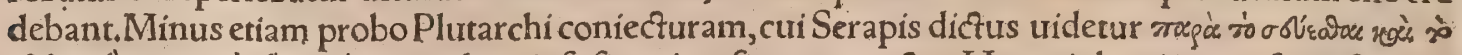

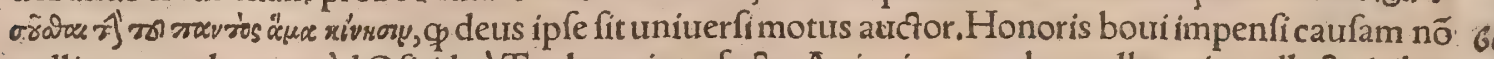
nulli eam tradunt, quòd Ofiridè̀ Typhone interfecto, A pis eius membra collegerit, collecta in bo: urem ligneum corio bouis albo circumtectum coniecerit, ideó́g ciuitatem Bufiridem appellatam, ut fcribit Diodorus:Alị aliam, Serapia príci medici uócabã̃, unde fyruporum ncmẽ ạd nos manauit, 


\section{Bos \&Vacca H. Lib. I. 93}

itt ego conjicio, qurod manifeftum fit ex Actuario: nimirum quòd xgri à Serapidis facerdotibus talia quxdam medicamenta didiciffent:unde etiam fimilia à pofteris eodem nomine dicta. Solebant atr. tem in Aegypto potiffimũ, uel in fomnis, uel per oracula, remedia à dijs accipere, ut ex locís aliqurot apurd Gale, deprehendimus:Non raro ením ęgros à deo, cuíus nomen non exprimit, monítos fcribic。

Memphis Aegyptiortm regia A pidis templum habet, qui idem eft quod Ofiris, Ibi bos A pis in repto quodam alitur \& prodeo habetur, albus frontem $\&$ quafdam paruas corporis partes, catera uero niger, quibus fignis iudicant, qui fit ad fucceffionem idoneus, alio uita functo. Ante íd reptum aula quędam iacet, in qua eft aliud leptum matris eitus, In hanc aulam nonnunquam A pis emittitur prafertim ut peregrinis oftendatur, Videtur enim per feneftram quandam in fepto, \& extra etiam fi 10 uelint. Vbiuero paululum lafciuierit, rurfum in propriam manfionem recipitur, Strabo libro 17. Taurum uero ad folem referri, multiplici ratione Aegyptius cultus oftendit, uel quia apud Heliopo. lim taurum Soli confecratum, quem Netiron(aliâs Neuton) cognominant, maximè colunt; uel quia bos A pis in ciuitate Memphi, Solis inftar excipitur: uel quia in oppido Hermunthi magnifico Apol= linis templo, confecratum Soli colunt taurum, Bacchin ( aliâs Bacin ) cognominantes, infignem mi raculis conuenientibus natura Solis, Nam $\&$ per fingulas horas mutare colores affirmatur, $\&$ hir futus fetis dicitur in aduerfum nafcentibus contra naturam omnium animalium: Vnde habetur ue. luri imago Solis ín aduerfam mundi partē nitentis, Macrobius Sat.1.21. De alio boure ligneo in Sai, in quo Mycerini regis Aegyptiorum filia fepulta fuit, cui etiam odores omnifarij quotidie infereban tur, inferius dicam. Bouem adorancetiam hodie in Lac regno idololatra Habraiam, in inlcima parte - India uerfurs meridiem. Eft frequens in prodigịs prifcorü bouem locutum : quo nunciato fena= tum fub diuo haberi folitum, Plinius. Tempore loannis Tzetzæ uulgo ferebatur oraculi inftar hoc diçum, Boũs Bośct roù raügos Conftantinopolin (qux ingenti exercitu Alemanorum, \&aliorum,à Romanis nimirum mifío tum temporis obfidebatur ) intelligat, qux à tauris, id eft Italis fiue Romanis condita efi:nam tatrrum (in quir) Latin etiam Italum uocabant:Exclamante autem boue, id eft Conftantinopoli, nimirum belli co \& claffico clamore, taurum, id eft I taliam repugnantem ploraturam in quit, Chiliadis o. cap. 277. Brox'é au uicus eft tribus Oeneidis in Attica(uel ut Stephanus, Aegeidis, Varinus uicum illum Brzixy appellat) cuius etiam incolæ Butadæ dicebantur, à Bute quodam facerdore, cuitus pofteri Butadæ $\&$ Eteobutadæ uocatifunt, Etymologicon.Scira feftum erat Mineruæ, uel ut alij Cer eris \& Proferping. $3^{\circ}$ In eo Erechthei facerdos umbellam ferebat albam, qux uocatur fciron. Agebatur autem Sciropho rionis, id eft Martī duodecíma. Sunt qui fcribant Palladis facerdotem ac Solis, cû fciro ex arce pro= dire in locum quem dicút Sciron. Vmbellam ferre lolitos, qui uocentur Eteobutada. I futere nobiles \& perilluftres Äthenis, à Bute facerdote propagati: Ex qua familia producebantur facerdores, Id ue rofymbolicéapudillos inftitutum, dum quenq̧ fummonerent tacité; tempus ædificandi, \& reçum aliquod fibi fuftruendi iam iam appetere, Calius. Bŕrss, inde patrony micum Brzionss, Nepruni filius; Etymologicon. Apud Stephanum uiri nomen legimus Bżros non Bŕriss, $P$ andionis non Pofídonis, id eft Nepruni, filî (quod magis placet) à quo Butadzo uic us in A egeide dichus fit. Fuerunt $8 \times$ alin Butæ,

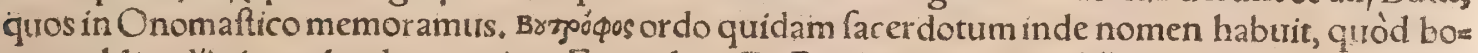
ues publice dijs immolandos nutriret, Etymolog. De Buphago in proucrbijs mox dicam. Buzuges - Athenis bubulo pecore nobilitatus eft, Argis Onogyros, Varro. Inuenio Buzygiam Athenís fuiffe familiam facerdotio præditam à Buzyge quodam heroë, ( alị Herculi Buzygi idem attribuunt) quỉ omnitm primus iunefis bobus araffe terram creditur, Cxlius \& Etymologicon. A thenienfes tres fa cras arationes relebrabant, primam in Sciro, ferundam in Rharia,tertiam fub Pelinto, quilocus But zygium uocabatur, Calius. Buzygaus mons eft Thelfalia, Plin.4.8. Anthermi Chị frulptoris filij fuerunt Bupalus \& Anthermus, clariflimi in ea fcientia, Olympiade fexagefima, Plin, Princeps omnium Bupalus Fortuna fimalacrum fecit polum in capise geftans, 82 manirum altera fuftinens Arrial thex cornu, Calius: Vide Onomafticon noftrum. Baffiadx celebrantur in Aegina, generis auctore Baffo:etiamfi apud Pindarum Budidas legir Didymus, de Budione progenitore, Calius.

TBoós virm, Hellefponti urbs, Germanicopolis poftea dicta, Plin. Boofura(bouis cauda) urbs Cy so pri infulæ, uicina $\mathrm{P}$ alapapho, Strabo. Pella urbs Macedoniæ, nomen acceptum refert boui,à quo in

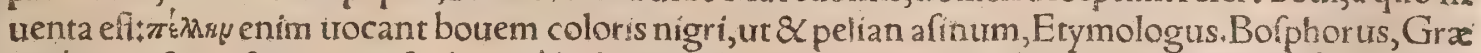
ci Bóusogou fine afpiratione fcribunt, à bubus meabili tranfitu dictus eft, propter anguftias freti, ut Pliw nius docet. Sunt autem duo Bofphori, alter iuxta Byzantium, qui Thracius dicitur, ommium angu= ftiffimus: cui nomen, ut Valerius Flaccus feribir, à craiectu lonus in uaccam defor mata:alter in introl tu Mrotidos paludis, per quem ipfa palus in Pontum defluit, qui Cimmerius \& Mroticus cognomis

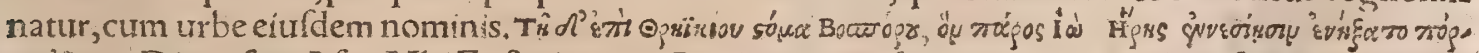

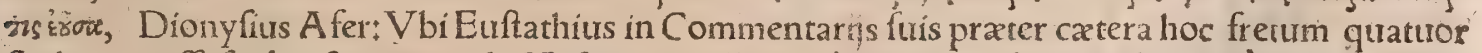
ftadiorum effe fribit, \& aliquando Myfium appellarum à minoris Afiæ populis, quiè regione Thra cum habitant; poftea uero Bofphorum Thracium difum fiue quod lo uacca oftro percita illic tra60 nauerit:fiue, ut alijs placet(Arriano tefte) quod aliz quadam uacca, quam Phryges monenteioracu lo fequebantur, ut eam ducem itineris haberent, intrepide anguftias illas maris inter Chalcedonem \&X Byzantiẽ traiecerit:quà \& illi tutó fecuti funt:ad cuius rei miemoriã bos enea apud Chalcedonios 
poftea conflata eft: \& eandem fortaffis ob caufam locus quidam illic Damalis etiamnum uocatur, Cæterum Ionis uaccæ traicctus ad Bofphorum Cimmerium ab alịs refertur. Elt $\&$ Indicus quidam Bofphorus. Et praterea eiufdem nominis portus iuxta Byzantium, quiliteris quibufdam mutatis perperam ita uocatus eft pro \$wo фóeioy. Nam cum Philippus in obfidione cuniculis actis locum ex

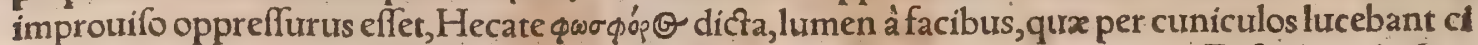
uibus oftendit;unde illi obfidione liberati Phofphorion ciuitatem nuncuparunt, Euftathius \& Ste: phanus, Plura uide illic in Euftathn̈ Commentarijs, 8 in Onomaftico noftro. Varro inter boum lau des recenfet, quoòd Bofphorus unus Thracius, alter Cimmerius ab eis dicti funt. Bóßacoss, uícus Alegy pti, $\&$ dea. Nam lo Inachi filia in bourem mutata, $\&$ poft multos terra mariḉ errores Aegyptum in. greffa, cum per humidum agrum incederet, ueftigia luto impreffit:qua cum regi illius loci ab ante rioribus pedibus iota literam, à pofterioribus o mega præferre uiderentur, Io nomen uacca impo=

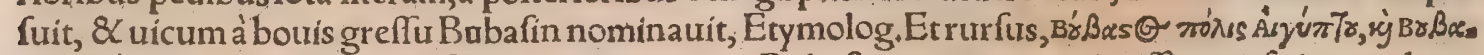

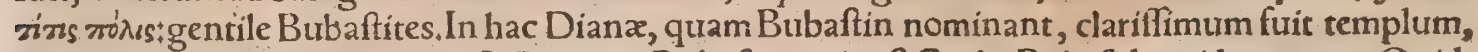
Sccut in Onomaftico dictum ef. Cæeterum Bubafus regio eft Cariæ, Bubafides uidere nurus, Ouid. Metamorphor. 4. Bubo ciuitas eft Lycix. Nafcitur 8 in Lycia Creta circa Bubonem, Plinius 3.5.

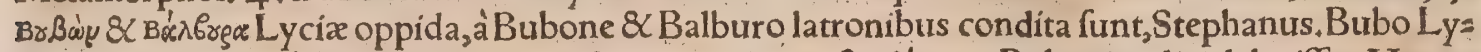

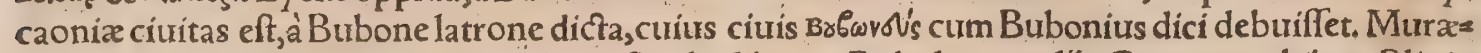
na Balburam \& Bubonem Lycís adiecit,Strabo libro 13 . Bubula cum alịs Cyrenes urbibus Plinio cómemoratur li, ,.ca, ,. Bubeium natio eft uel oppidum Cyrenes, Plinius ibidem, Bubetani, Campa nix populi Coriolanis uicini, Plinius 3.5. Bubulcorum ciuitas quadam in Alegypto nominatur, Stra 20 bolib.16. Bŕdwģ promontorium eft Salamini oppofitum. Iuxta Iftiæas $\&$ Cerinthum oppidulum in Acolia Budorus amnis eft, cuius appellationis montem habet Salamis in Atticam profpectantem, Straboli. 10.Ephorus caftellum in Salamine effe fcribit, fed pro caftelloBudaron per a apud Stepha num legitur. Sunt \& Budoræ infulx dux prope Cretam, Plinius 4.12, Brfór, ciuitas Illyria fic dicta, q. Cadmus è Thebis fugiens iugo boum inuectus celerrimé illuc peruenerit $\&$ ciuitatẽ condiderit,

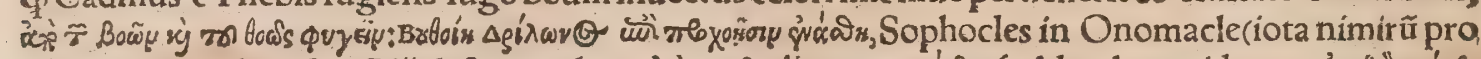

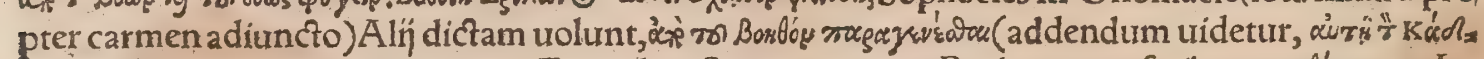

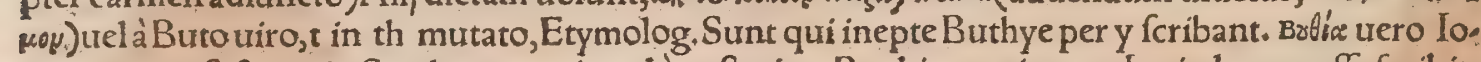
nix ciuitas eft \& regio,Stephanus:qui paulo poftetiam Buchiam exiguum Ionix locum effe fcribit. Buthrotum urbs ef Epiri in Thefprotịs (prope Oricum portum, ut Euftathius habet in Dionyfiü, uel ut Strabo Orchimum, quod nô probo in qua regnauit Helenus Priami filitus: uel Epiri colonia non longe ab Ambracio finu. Huic nominis caufa fuit, ut Teucer Cyzicenus fribit: quòd cum Hea lenus ex patria in Epirum ueniffet $\&$ bouem profoelice ingreffir immolare pararet, bos uulnere nó letali affectus aufugerit, \& finu quodam Epiri illic traiecto, in terram egreffus, mox collapfus obie. rit. Quo in loco Helenum aiunt religione motum urbem condidiffe, $\&$ ab euentu Butrotum nomi naffe, Etymologicon:plæriç per $\theta$ fcribunt:fed fi à bour uulnerato diçam uelímus, per $\tau$ fcribendi erit. Vide etiam in Stephano Grxco, Bóruex urbs eft Phocidis in Parnafo, fic dicła, inde quod cum Deucalió \& Pyrrho diluuio ingruẽte illuc fugiffent feruatiç̧ effent, incolæ quotannis magnũ boue

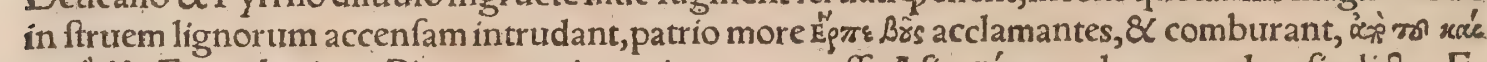

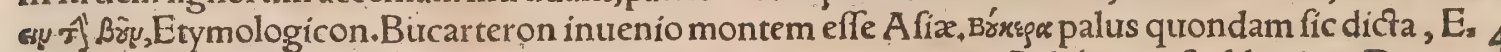
tymolog. Et rurfus, Brxesatis fons eft Platæis, fic appellatus:quoniam Polybus poft diluuium Deucaz lionis feculo ex Argis illuc ueniffe fertur, bouem ex oraculo ducem fecutus (ut quondam Cadmus. quoc(s)qui cum procumbens terram cornu feriret, fons emicuit, ut fribit Theon in commentarís in Callimachum, Etymolog, Brajsćcou regio eft Elidis Straboni:Stephanus non regionem folum Elidis

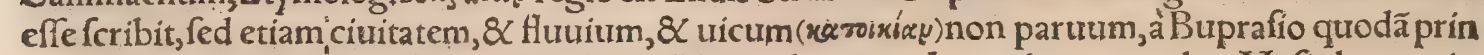
cipe.Buplanoctiftos a pud llium tumulos in Alexandra uocat Lycophron, quod ex Myfia bouem in fecutus Ilus, ibi demum urbem condiderit Ilium, ubi interquieuiffet ea, Calius . Burra, Bz̃gx, ciuitas Achaix mediterranex in finu Corinthio, haufta à mari, aliâs Buris diça: Ouidius Metam. 15. Si quę. ras Helicen \& Bûrin Achaidas urbes. Condidit eam Hexadius Centaurus, \& illic armentorum furo

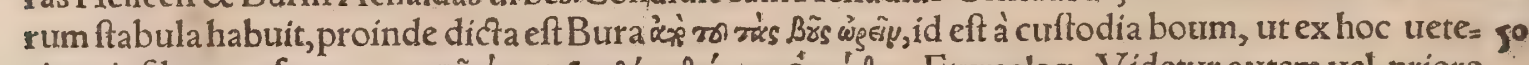

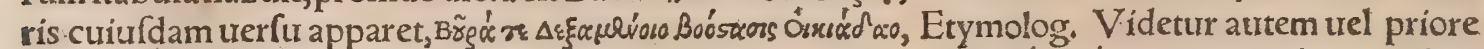

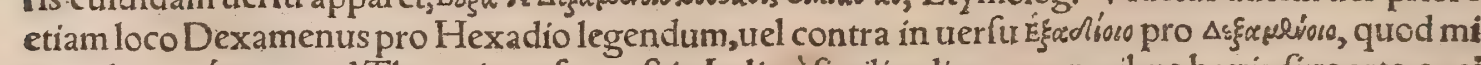
nus placet. Bresvo apud Theocritum fons eft in I talia, à fimilitudine cum naribus botris, fiuce arte exci fo lapide à Chalcone quodam ad bouini capitis fimilitudinem, ex cuius naribus aqua flueret: fiue lo

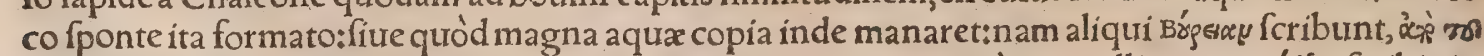
Br̃ й

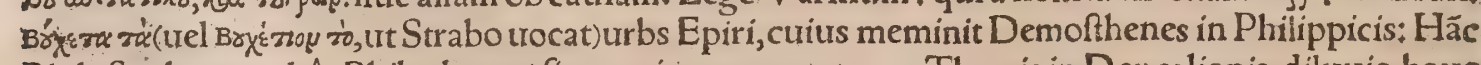
Philoftephanus(aliâs. Philochorus) fic nominatam putat eo $\Phi$ Themis in Deucalionis diluuio boure

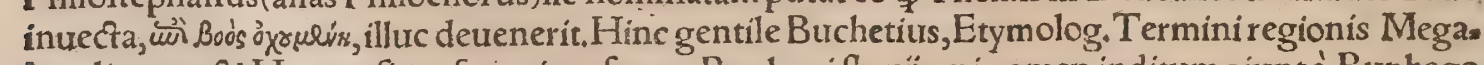
lopolitarum \& Heræenfium funt circa fontes Buphagi fluur̈:cui nomen inditum aiunt à Buphago co heroẹ, Iapeti \& Thornacis filio:quem in Pholoé monte pudicitia eius infidiantem Diana fagittis cō. foderit, Paufanias in Arcadicis. Bungę) idem quod bucephalus fonatieft autem nomen fluuij in Sa. 


\section{Bos \& Vaccà. H. Lib. I.}

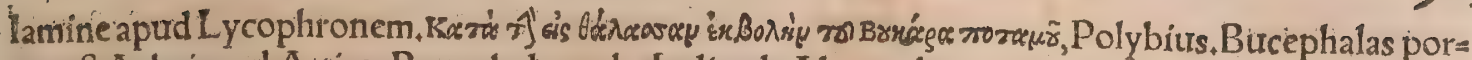
tus eft Achaix uel A trica: Bucephalea urbs India ab Alexandro condita, \& $<$ nomine equi fuíillic fe pulti appellata. Bouilla oppidum fuít ín Latio haud procul ab urbe Roma, uia qua Ariciam duce $=$ bat: Ouidius, Orta fuburbanis quadam fuit Anna Bouillis: fic diçum quafi bouis hillæa, q eò uulne

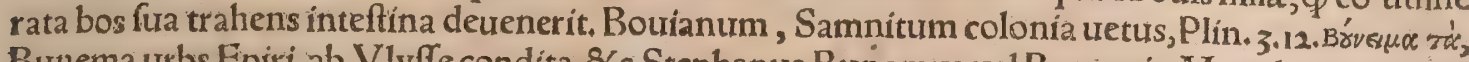
Bunema urbs Epiri ab Vlyffe condita, \&c.Stephanus. Bunomus uel Bunomia, Macedoniæ ciuitas; Pella poftea dicta,Idem, Bunartis, Libya ciuitas, Idem, Eubca infula A bantis olim dicebatur. Nam ut friptis affirmat Ariftoteles, profecti de A Ba Phocidis ciuitate Thraces, infulam incoluere: unde llius inquilini A bantes dicti. Sunt qui ab heroê Abante ita nominatam primum dicant, ficut herois - cx indolis matronam Euboam ei cognomen tradidiffe poftea. Fortaffis autem quemadmodum $8 C$ in littore fitum antrum quoddam in A egeum uergens Aula bouis uocatur, ubi Io Epaphum pepe riffe fertur, eadem ex caufa hoc nomen adepta fuit infula; quam Hellopiam quogs nominauere ab Ionis filio Hellope, fiue ab Aacli \& Cothi fratre, ut alí perhibent, qui aliam etiam condidiffe Hello piam dicitur in ea quae nominatur Oria Iftiza terra, Strabo libro 10, paulò poft initium libri. TDe iucenca ex Bafan furibunda $\&$ oftro percita Io. Tzetzes mentionem facit Chiliade 10, cap, 306, \&

Bafan fecundum aliquos Scytharum ciuitatem interpretatur:Sed uerfus eius aliquot recitabo:

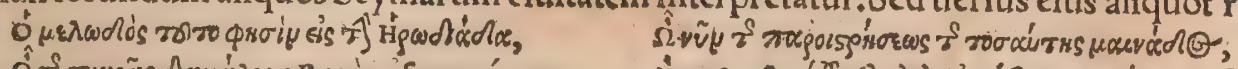

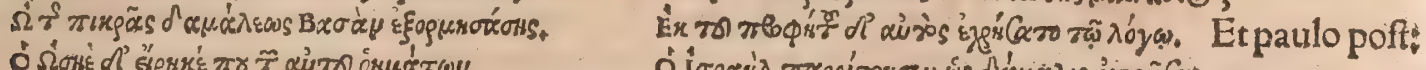

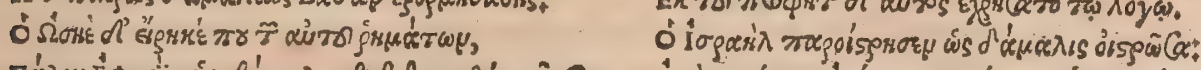

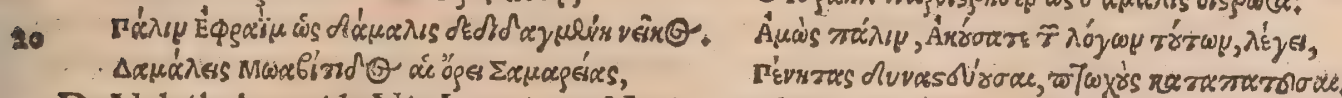

DeNelei bobus uide Nic. Leoniceni Varia,1,33, \& nos fupra quadam attulimus ex Paifania circa

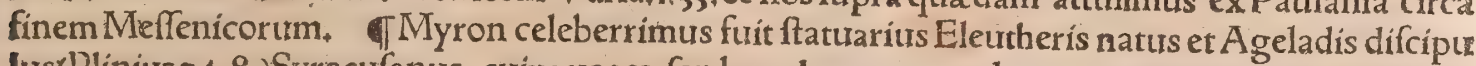
lus(Plinius 34.8.) Syracufanus, cuius uacca feu bucula ex are multorum poëtarum epigrammatis celebratur. Propertius, Atç aram circum fteterant armenta Myronis Quatuor artificis inuida fia gna, boures, \&c. A eginetico are Myron ufus eft, Deliaco Polycletus, aquales atç condifcipuli : $:=$ mulatio autem $\&$ in materia fuit; Plinius. Anthologï epigrammatum Græcorum libro 4. Sectione 7. difticha funt Elegiaca unum \& triginta diuerforum poétarum, omnia in Myronis buculam, tetra. fticha quatuor:hexaftichon iambicum unum: In eandem apud Aufonium epigrammata decem le. 50 gimus, ex quibus uel unum apponemus. Bucula loquitur: Vbera quid pulfas frigentia matris a henæe Ouitula, \& fuccum lactis ab xre petis. Hunc quocs preftarem, fi me pro parte paraffet Exteriore Myron; interiore Deus. Epigramma in bouem \& hircum calatos in orbe uel quadra ex.

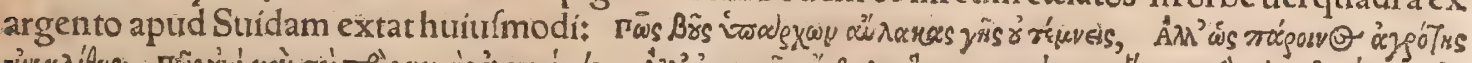

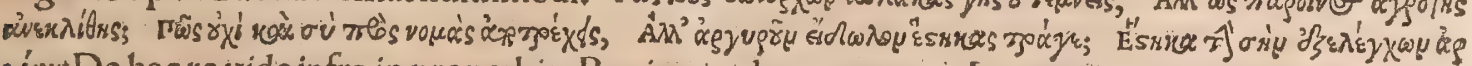
gía: De hac re uide infra in prouerbio, Bos in quadra argentea. Leguintur quandogs \& A tabyria boures, de montis Rhodï nomine fic nuncupatæ. Caterum ænex fuerunt ha, quas malo ingruente aliquo folitas mugire proditum eft, Calius 8 C lo. Tzetzes Chiliade 4, cap.138. Pindarum \& Callima chum authores citans.Meminit etiam Leonicenus in Varia hiftoria $3.10 \%$. In templo quodam Elidis boues arei duo dedicati uifuntur, alter à Corcyræis, ab Eretrienfibus alter. Quamobrem urero Cor. 40 cyrai bouem unum Olympips \& alter um Delphis confecrauterint, dicam cum de Phocenfibus fer. mo erit, Caterum de anathemate ipforum in Olympia rem fic habere a udio. Cum paruus puer fub hoc boue federet demiffo capite lufitans, 8 fubito caput erigeret, xri illifum confregit, \& non multis poft diebus ex uulnere obít. Quamobrem Eleis bouem tanquam homicidam ex Altí luco facro de portaturis, Delphicum oraculum redditum eft ut ritibus n̈s bouem expiarent, quibus circa cædem inuoluntariam Græci uterentur, Hæc Paufanias circa finem primi libri Eliacorum. Phalaris Agriz gentinorum tyrannus nimium crudelis admirandis $\&$ nouis tormentis homines cruciabat $\&$ torque bat:Quod animaduertens Perillus artifex iuuencam ex ære fabricatam à fe dono dedit regi, ur ho'pi tes in ipfam conieftos (fubdito igne) uiuentes exureret: aedebat autẽ iutuenca mugitum naturalicon. fimilem. At Phalaris eo folum tempore iuftus, ipfurm artificem primum iniecir, Dorotheus libro I, re, rum Sicularum, ut recitat Stobxus in Vituperio tyrannidis. Plutarchus in Parallelis minoribus, if $f=$ dem feré uerbis rem defcribitłutrif̧̧́ damalin, id ef iutencam fuiffe conuenit: Ouidius tamen libro 8. de Arte, taurum facit, his uerfibus: Er Phalaris tauro uiolentus membra Perilli Torruit, infelix imbuit author opus. Item Plinius lib.34.cap.8. Addunt quidam huic boui ianuam in latere fuiffe.

đMycerinum'A egyptiregem Cheopis filiũ ferunt, qu cum filiã defunctã excellentiori aliquo ge nere fepelire uellet, feciffe ligneam bouem uacuam, quam cum inauraffet, in ea filiam fepelifie de: functam. Neq̧ humo bos haec condita eft, fed ad meam ufç memoriam in propatulo fuit in urbe Sal apud regiam, in conclaui quodam exornato pofita: Cui fingulis diebus omnifarij odores inferuntur: noctibus autem perpetuo incenfa lucerna aftat, In altero contiguo conclaui ímagines ftant concus: binarum Mycerini, ut in urbe Saifacerdotes aiebant. Stant enim coloffi, id eft grandia fimulacra, cir 6o citer uiginti, éligno fabricati, nudi pleriq̧: qui quarum fint mulierum, non poffum dicere, prater quæ narrantur. Sunt qui de hac boure $\&$ coloflis hæc referant: Nycerinum amore filiæ fux captum, wim illintulife:deinde illam cum pra marore fe fufpendiffe, patrem in hac boue fepeliffe ; matrs 


\section{De Quadrupedibus}

autem manus miniftrarum, qux filiam patri prodidiffent, præcidiffe $\$ \&$ nunc earum hæc effe fimula cra eius mali, quod uiux paffe fuiffent. Hæc(ut ego opinor)dicunt nugatores, ut alia, ita et de mani bus colofforum:quippe quas ipfi uidimus temporis diurnitate delapfas, qux ad meam ufq $\mathfrak{\beta}$ xtatem ad pedes eorum ftratæ uifebantur, Bos quoç cum cæeterum corpus operta eft Phøeniceo pallio, tum uero ceruicem $8 x$ caput craffo admodum auro: Cuius inter media cornua circulus annexus inef, Soli affimilatus, Neq̧ ftans eft bos, fed in genura cubans, magnitudine quanta eft grandis uacca . Ef fertur autem é conclaui quotannis. Et poft đ̇ A egyptij uerberar unt deum quendam, quem in tali negotio non puto mihi nominandum, tunc $8<$ bouem in lucem proferunt. Aiunt enim eam oraffe patrem Myccrinum, utdefuncta quotannis femel folem intueretur, Hactenus Herod. đPafiphaê filia Solis, \& uxor Minois regis Cretæ(ut eft in fabulis)nefando tauri amore deflagrauit: cui opera 10 Dædali concubuit intra uaccam ligneam inclufa, \& fepta iutuencę corio: ex quo concubitu natus eft Minotaurus, medius fcilicet homo, medius q̧́ taurus, Seruius fcribit eam in domo Dxdali cum Tat: rofcriba regio con̈fle, 8 hinc datam fabula occafionem, Verg, Aegl.6. Et fortunatam fi nunç menta furflent, Pafiphaën niuei folatur amore iuuenci, Et copiolius lib.6. Aeneid. Hic crudelis amor tauri, \&c. Meminit etiam Ouiditus lib, 4.Metam. Minotaturus monftum fuit, partim hominis partim tauri forma:quod Minos inclufit Labyrintho(ut fcribit Homerus libro 8. Odyffę) \& cum uefceretur humanis carnibus, coëgit Athenienfes, qui Androgeum filium furum interfecerant, ut quotannis feptem filios ac totidem tilias in Cretam mitterent ad alendum monftrum. Quò demum cum ueniffet Thefeus filius Aegei regis Athenarum, beneficio Ariadnes Minotaurum occidit, \& e. greffus eft Labyrintho, De Pafiphä̈, Minoë, Minotauro, Dadalo \& Icaro multa fcribitIo. Tzetzes $2 \propto$ Chiliade 1.cap. iq. nos hæc pauca excerpfimus: Cum Cretenfes Minoi regnum non permitterent, $\mathrm{Ne}$ ptuno uouit, fi quid figni ad confirmationem eius ex mari appareret, fe immolaturum: \& cum ftatim taurus egregius apparuiffet, ad regnum admiffus eft. Ipfe uero taurum Neptuno alium immolauit, \& illum qui apparuerat armentis furis immifcuit : ex hoc \& Pafiphaé Minotaurum Bocífgwroy Oxeíoy natum aiunt. Cęterum hiftorię ueritas huiufmodi eft:Cum Cretenfes Minoi regnum negarent, Tau rus imperator cum claffe fupertuenit, $\&$ regnum ei confirmauit. Cum hoc imperatore, non in boure lignea, fed dome arte Dxdali fabricata, $\mathrm{P}$ afiphaë concubuit . Minotaurus in Creta facie bouis fuit, reliquo corpore uiri, Varinus in Scylla. Aquilam Romanis legionibus C.Marius in fectundo confus latu fuo proprié dicauit. Erat \& ante prima, cum quatuor alịs: Iupi, Minotauri, equi, a priộ, fingulos (aliâs, qua fingulos)ordines anteibant. Hinc egregium illud Alciati emblema:

Limine quod cçco, obfcura \& caligine monftrum Gnofiacis claufit Dadalus in latebris,

Depictum Romana phalanx in pręlia geftat, Semiurós nitent figna fuperbaboure:

Noś́s monent debere ducum fecreta latere Confilia:authori cognita techna nocet.

Sed I Mínotaurus cum hoc epigrammate, anteriore parte humanum pręferat corpus, pofteriore bo uinum, cû̃ contra'apud Phurnut. \& Varin. legat,, erratum forte fuerit. A riftoteles de generatione 2 * nimalium libro 4. cap. 3. Iam puerum(inquit)ortum capite arietis aut bouis referunt:idemós in cæate ris membrum nominãt animalis diuerfi : uitulum capite pueri , $\&$ ourem capite bouis natan affeue. rant. बा Motye, Morv́r, urbs uel maritimum caftellum Sicilia, à Motye muliere nomen habet, quae Herculi prodiditillos, qui boures eius abegerant, Stephanus, Boxtid as Hercules inde dicitus $q$ Geryo nis boues Ioui adduxerit, Etymologicon. Ouidius Faft.I. Ecce boures illuc Erythreidas applicat he 4 ros, id eft Hercules, qui Geryoni iuxta Gades regnanti eas abftulit. Dionyfius in Periegefi de Erya thea \& Geryone fic fribit:

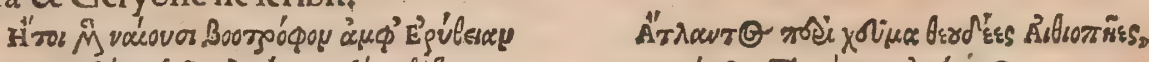

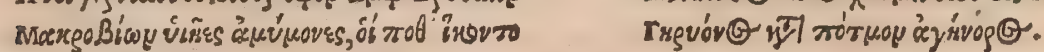

Hoceft, Aethiopes Macrobij circa Erytheam(uel etiam in ipfa) bubus abundantem infulam habie tant, iuxta A tlanticum mare, qui quidem illuc poft Geryonis mortem uenerunt. Nam dưm ipfe uia ueret(ut Euftathius fcholiaftes ait)inhabitabilis erat propter ipfius inhof pitalitatẽ. Fertur autem Her

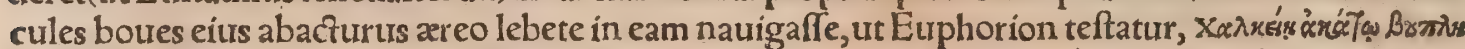

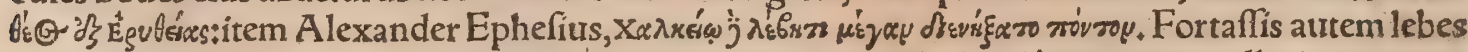
nauigị genus fuerit, cui etiam lembi piratici uocabulum colludit:idḉ: æereum appellari potuit, pro pter aliquid in eo ex ære factum, ut roftrum æratum, uel infigne aliquod æreum in prora puppiue. Sunt qui Erytheam infulam ipfas Gades interpretentur, contra Dionyfij fententiam : ali infulam quandam uícinam, qux à Gadibus freto unius ftadij tantum diftet : in quam fententiam eos addus: xit pafcuorũ illius loci ubertas:nã lac oưinû̃ illic ferum reddere negãt, \& \&adeo pingure uel craftum ef $f e, u t$ ad cafeum conficiendum aquam copiofam affundi defyderet, \& pecus intra dies triginta fuf focetur, nifi minuatur fanguis, Hucufç Euftathius, Idem alibi in eundê poêtam, Hercules (inquit) cum proficifceretur abactum boues Geryonis, in Scythiam peruenit, ubi ex uipera mixopartheno (cui fuperna pars corporis mulieris, inferna ferpentis erat) Gelonum, Agathyrfum \& Scytham tres filios fufcepit. Erythea uel Erythe, infula eft Geryonis in Oceano, fic dicta ab Erythea Geryonis \& Mercurï filia, tefte Paufania,Stephanus. Theogonia Hefiodicæ interpretes, Herculis nomine Sola 60 rem intelligût poteftatem: Geryonem uerò, cuius boues ab illo orbi terrarum illatas fabulantur, hye

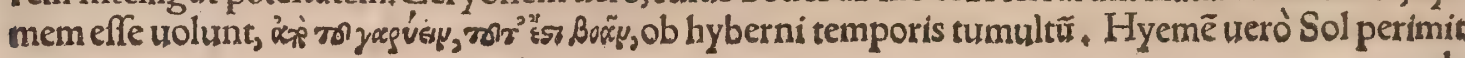




\section{Bos\&Vacca H. Lib. I. 97}

ab hyemali tropico ad uernum conuer futs æquinoctium. At boum nomine tonitrua intelligunt, qua dam foni fimilitudine:qua Geryonis dicuntur, quod hyeme quidem non fiant, fed illam ftatim con= fequantur:uel quia ex humecta eitus natura mox hac protieniant, Cảlits. Vnde nam Geryonis bo= ues Hercules adduxerit, ex Arriani fententia fupra dixi in B. litera, ubi de Epiroticis bubus , Plura de Geryone \& Erythea, uide in Onomaftico noftro, Orthus canis Geryonis fưit in Erythea, qui ca= nina capita duo habuit, draconum feptem, Varinus in Scylla, $\mathrm{Pal}$ aphatus Orum hức canem uocat: de Cerbero eiufdem Geryonis cane, infra in cane dicam. Gergittium quoç unum ex Gèryonis canibus fupra nominaui. Leonicenus in Varĭ's 1.33. de Geryonis bobus fcribit, quas Eryx habere cü piens ab Hercule fuitinterfectus: $\&$ nos idem paulò poft ex Paufania referemus, Plura uide in $\mathrm{Pa}_{a}$ pienato capite 26. Io filia fuit Inachi regis Argiuorum, quam cum Iupiter ob formæe elegantiam ma ximé diligeret, ab Inacho fluuio redeuntem tenebris fuperinductis detinuit \& oppreffit. Iuno autē cum ex al to tenebras uideret, fufpicata maritum furm alterius amore frui, in terras defcendit, tene.

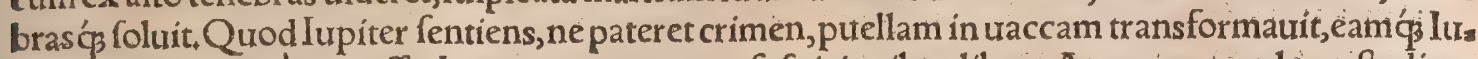
noni pof́centi agré conceffit. Iuno autem nec tum fufpicioniburs libera Árgo centoculo cuftodien. dam tradidit, quem Mercurius à loue miffus fopitum interfecit. Quapropter Iuno dolens, tracca ce. frum immifit, quo per multa loca agitata, tandem in Aegyptum uenit, ibiq̧́ prece Iouis à Iunone eidem forma reftituta eft, $\&$ ab Aegyptijs Ifis nominata Ofiridi regi ntipfit * poft mortem uero pro dea culta eft, cui anferem immolare, eiuśćs facra Ifiaca dicere folebant, Iuuenalis Satyra 6. Si candi. da iufferit Io, Ibit ad Aegypti finem, \&c. In fabula lús deferibenda prolixus eft Ouidius libro Metamorph.Meminit etiam Valerius Flaccus libro 4. Argonauticorum. Argis olea nunc etiam du rare dicitur, ad quam lo in uaccam mutatam Argus alligaurerit, Plinius. De Epapho fitre A pide filio paulò ante copiofiffime dictum eft, \& quxdam de ipfa exiam lône, Qui hiforicam interpretationem requirunt, legant Palxphatum capite quadragefimotertio. Violam idcirco dictam ion Graci pu= sant, quód cum Io in uaccam conuerfa effet, terra florem illum pabulobouis eius fuderit. No.

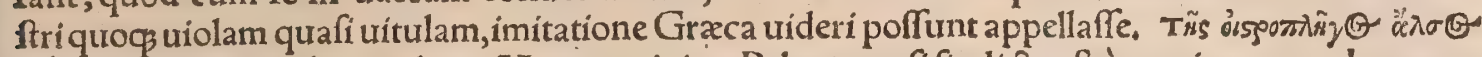
iváy ró jws, V arinus fine authore.Mycenæ ciuitas Peloponnefi fic dicta eft à mugitu, quem lo uacca, cum illuc ueniffet, edidit, quanç̄; alí alia etyma proferant, Stephanus, Europa filia fuit Agenoris re gis Phœnicum, quam Iupicer forma bouis aut iuuenci raptam, abduxit in Cretam : ibiḉ ex ea Minoëm,Radamanthum, \& Sarpedonem genuit. Vide Ouidium Metamorph. Iib, 2, Iuno ab Airgiuis 30 colebatur olim in templo quodam extra urbem:eo mulier facerdos currui bobus albis iuncto infia dens folenni die quotannis uchi folebat, Cum autem boures albi quondam deeflent, facerdos filiorû̃ mater duorum, iugo boum loco eos fubmifit, $\& \mathcal{C}$ fic ad templum inuecta eft. Cum autemà dea mune= ris aliquid pro hoc labore filips fuis petīffet, filí ea nocte in fomno è uiuis excefferunt, Palaphatus cap.ultimo, \& Stobaus ex Plutarcho in Sermone de laude mortis. Thebani (autor Paufanias in Ara cadicis) A pollini Polio, id eft cano, tauros olim immolabant. Et cum aliquando in fefto taurus deef fet, $\mathcal{Q}$ diutius cunctarentur qui miffi erant adducturi, de curru bubus iuncto, qui forte appulerat, alterum bouen deo immolauerưnt, 8 inde boues etíam operarios facrificădi mos eis inoleuit. Sunt qui narrent, $\mathrm{Cadmum}$ ex Delphis in Phocidem profectum boue duce itineris, qux ex Pelagontis ar mentis empta fuerit: $\&$ in utrog bouris latere fignum adhuc uifi album, lunæ orbi cum plena eft con - fimile, Hæc Paufanias. De Cadmi boue Ouidius initio libri z. Metamor. Noui (inquir Menas apud Varronem)maieftatem boum: \& bouem effe fcio, in quem potifimum Iupiter fe conuertit,cum ex: portauit per mare è Phœnice amans Europam. Hunc effe, qui filios Neptunià Menalippa feruẩit, ne in ftabulo infantes grex boum obtereret. Haud fcio an hae fucrit Menalippe illa Antiopes Ama zonum reginx foror, ab Hercule in bello capta. In Achaia(inquit Paufanias) templum eft Ápollinis \& fimulachrum eius nudi, calceos tamen pedibus induti:quorum altero bouis cranium calcat, $A$. pollinem enim bubus imprimis gaudere Alcæus fcribit in hymno in Mercurium, quem etiam Apol liniboues fuffurantem inducit: $\&$ longe ante Alcæum Homerus fingit Apollinem armenta Laome

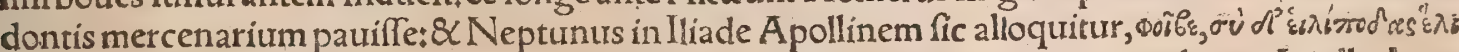
res Br̈s Brw 50 medonti féruierit, qua in re alï aliter fentiunt, explicatur à Varino in Báas Brvikêy. Apollo cur uocatus fit Nomius, uraria redduntur caura. Dicunt enim aliqui nomen hoc ideo tributum eí, quòd Cyclopibus interfectis, amilfáǵs diuinitate, regis Admeti armenta pauerit; 'vesey enim eft pafeere.

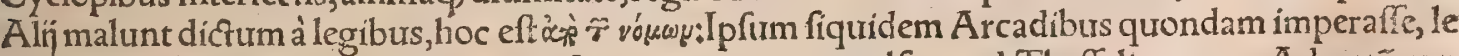
geśćs eís dediffe, uerû̃ ob nimiam earû feureritatem regno pulfurm, ad Theffaliæ regem Admetú con fugiffe, ab eó́s eam quę circa Amphryfum eft regionem impetraffełindeḉ factum effe, ut eius peco ra pauiffe creditus fit. Iuno in uaccã mutata alicubi ab Ouidio in Metamorphofi def cribitur, fi be: ne memini: \& iutuencus in ceruum. Prœtus A bantis regis Argiuorum filius fuít, eiç̧̧ fucceffit in re: gno. Hic tefte Homero lib، 11. Odyffex ex Antia uxore filias quatuor habuit:qua (tefte Pherecyde) quũ in forma feu pulchritudine fe lunoni pratuliffent, offenfa dea eís furorenn talem immifit, ut urac cas fe effe arbitrarentur, \& aratra timentes fyluas peterent. Hinc Vergil, in Sileno, Prcetides imple= runt fallis mugitibus agros. Harũ furorem emêdatũ ferunt elleboro à Melampode:à quo eliebori ge nus nigrum appellatur Melampodion. Eudoxius apud Stephanum, fontem quendã in Azania Ar 
cadix memorat, cuius aquam guftantibus uini ueniat tadium tantum, ut ne odor quidem cius fer ä tur, $q$ in eam aquam Melampus abieciffe credatur piamenta illa, quibus Protifilias furentes lufir urit. Ouid lib.ultimo Metam. fímiliter tradit, \& fonten yocat Clitorium.Meminit et Plin, lib.3r,ca. $0^{\circ}$ $\$$ Vibius Sequefter. Vide praterea Lactantium lib,3.Thebaidos Statĭ, fiue Lutatiũ ụt alï uolunt. P R O VER B A CIRCA BOVES.

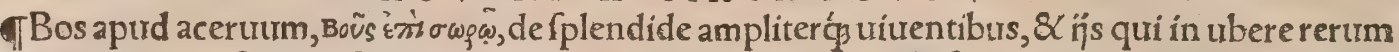
affluentia prolixius faciunt fumptum:Quo fenfu nofrates dicut, 20 ir in oen rozen fitst/oer fbnet. set int pfeiffen wo er wll. Suidas fcribit hoc adagium accipi poffe etiam de ŕs, qui in media rerum copia conftituti, non finuntur prafentibus bonis frui:per tranflationem à bubus ore obligato tritu= ram exercentibus; Id quod a pud Iudæos nefas erat. Si bourem non poffís, afinum agas; huic finiti=

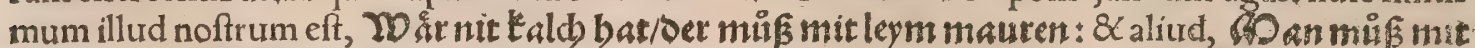
Dett p ferden pflitgen dieman bat. Equus in quadrigis, in aratro bos: Hoc eft, unufquifç ad id nes

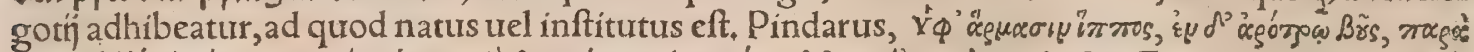

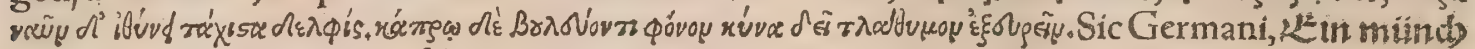
ift niergens beffer Dann int Elofter/ ein Dieb niergens Dann am galgen. Confine eft illi,Bos fub ita

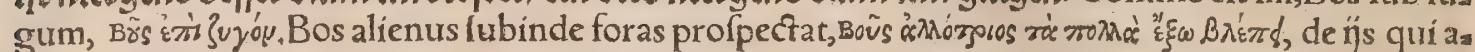
pud alienos non fatis ex animi fententia tractantur, eó́ fapius fuos defyderant : Huc allufife Plus

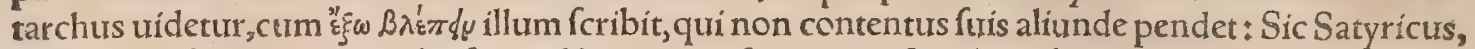
Nec te quafiueris extra. $\mathrm{A} b$ afinis ad boues tranfcendere, eft ex humiliori conditione ad ditionum

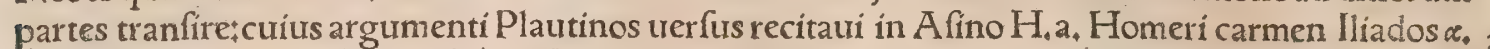

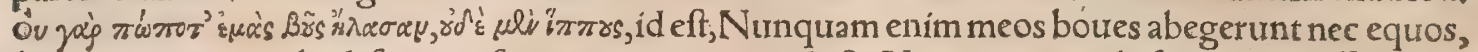
à Plutarcho prourerbiali figura ufurpatur, pro eo quod eft, Nunquam me laferunt aut affecerunt iniuria. Bos capite ultra Taygeton porrecto, uide inter prouerbia à taurofumpta. Oleum perdit 8 impenfas, qui bourem mittit ad ceroma, D. Hieronymus ad Pãmachium; Ceroma dicitur unguren tum quo dim ungebãtur a hletę: bos autem ad certamina inutilis eft. Itaç bourem ad ceroma mittere dici poteft, qui docet indecilem: aut ad id muneris quempiam afcifcit, ad quod obeüdum minime fir

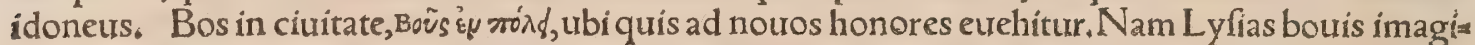
nem aream in arce collocauit Athenis + qux res in uulgi iocum ceffit. Nam in agris boum ufus, non in urbibus. Refipit huius prouerbij naturam Germanicum illud, Sieftil of die benck fejen. Et il Iud in indignéhonoratos, ein dieben vont galgen nemmen. Solidos éclibanoboues apponere, in

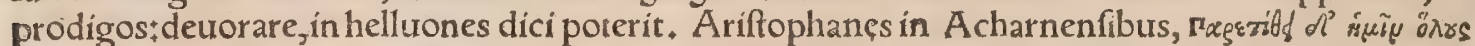
İx r rentem de frugalitate Gracorum, qui paululum carnium apponerent, quum maiores folerent totos boures, ceruos $\&$ arietes affos apponere, Et ibidem ex Herodoto tradit, apud Perfas diebus natalitís fuiffe morem, ut diuites bouem, afinum, equum, \& camelum apponerent, totos in clibano aut cami no coctos, Hac Erafmus Chiliade 3. Centuria i. \& rurfus Chiliade 4. Centuria s. fuper eodem pro uerbio feribit, per obliuionem nimirum. Quintilianus Inftitur. Orat.lib, j+paroemia, quam ait efle ceu bretrem apologum, hoc adfert exemplum: Non noftrum onus, bos clitellas? Satis conftat, inquit Erafmus, ex apologo fumptum:uerum quis fit is apologus, equidem nondum reperi. Poteritatrem hoc prouerbium duplici forma efferri:Boui clitella impofitx funt, ubi mandatum eft negotium pas 4 rum apto.Et, Bos clitellas ?ut fubaudias, ferat; ubi quis deprecatur prouinciam, curi parû fit idoneurs, aut quam fibi ducat indecoram. Boum fanè terga non effe ad onus accipiendum figurata, fupra in

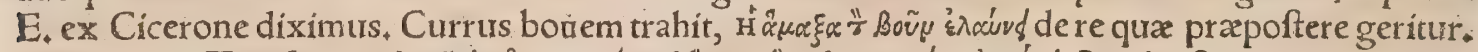

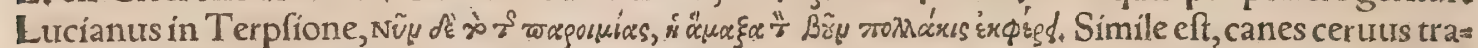
hit uel ducit: $\&$ apud Germanos, dieroffjbinbet ben wagen fpanten. Cyprioboui merendam, Verfum hunc Sotadicum ex Ennio Feftus Pompeius citat:oftenditćs conuenire, quoties conuiua fordidus $\&$ infipidus fordido a tos infipido accipitur conuiuio, Græci hoc prouerbium efferunt, $\mathrm{K}^{\prime}=$

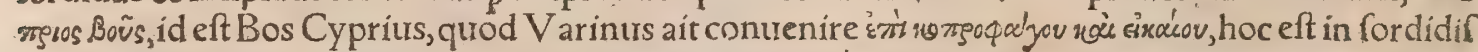

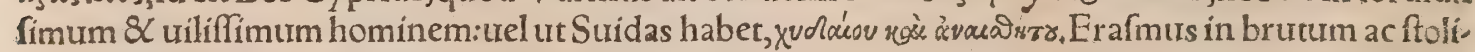
dum iaci folitum ait, propterea quod Cyprï boues magis bruti ferantur, quippe qui ftercore huma-s

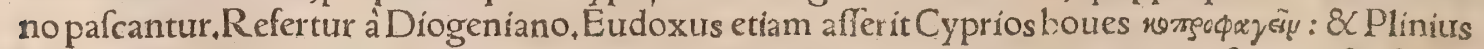
libro 28. cap.ultimo, narrat Cyprios boues hominum excrementa appetere, non paftus caufa, fed ut hoc remedio torminibus medeantur. Interpres Arifophanis in Plutum faibic Bocotios boures $\sigma$ kr фqáyous fuiffe, id eft oletum edentes. Ego fanè in Enníj uerbis non merendam legerim, ut Erafnus; fed merdam, utres ip a habet; $\&$ íenfus inde prouerbio fit clarior. Deinde quod ftolidos $\&$ brutos hoc nomine Cyprios boues Suidas \& cateri effe aiunt, quod ftercus urorent ego potius ad ingen $\ddot{\eta}$ ipforum Iagacitatem retulerim; qui torminibus latali fape morbo fic medeantur. Quís enim pardalin dixerit ftupidam, quod aduerfus aconiti uenenum eodem remedio utatur? Quinetiam homines ipfi cum colidolor $\&$ urentrís torfiones urgent, ad auxilium ab excrementis boum (ut fupra retuli) uel equorum, uel gallinarum fape confugiunt. Miranda potius hac ingenij folertia eft, certamillic 6 opem inuenire, ubi nemo f́peraffet. Redeo ad prouerbia. Expecta bos aliquando herbam, M've Br̃s

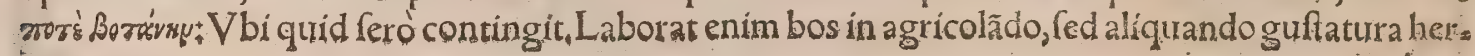



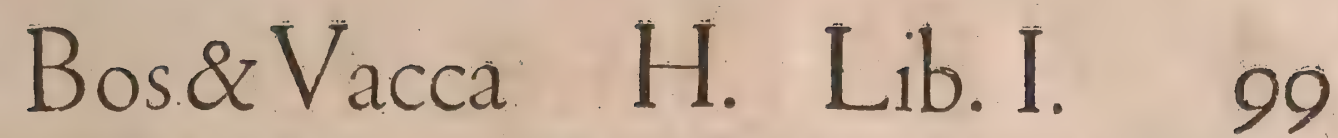

bam enatam. Finitimum illi, Ert adhuc tua meffis in herba eft. Boures meffis tempus expectantes, Boũs

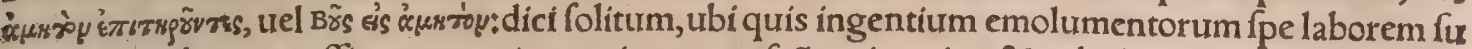
meret. Nam botres meffis tempore inter trituram pafcũtur interim, \& pabulum largius apponitur. Alịs ucro têporibus moleftior eft arandi labor, quod nullo pręfente fruçu leniatur. Bos in faucibus,

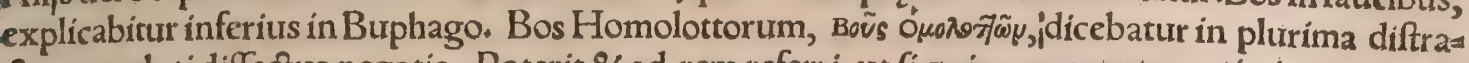
cius ac ueluti diffectus negotia. Poterit $\&$ ad rem referri, ut fi quis argumentum nimis minutatim diuidat. Zenodotus prodidit Homolottos populos, diffecto in minimas partes boue, foedus iügere. Quem morem Scythis fuiffe teftatur Lucianus in Toxaride: Haec Erafmus, qui errat quod Homolot tos facit populos, qui nulli funt. Accipiendum autem de Moloffis, \& $\delta$ articulum effe, clariffimurm eft apud Suidam. Non probo etiam quod de homine multis negotís diftracto prouerbium interpreta=

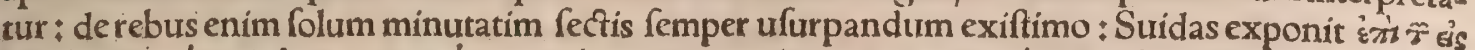

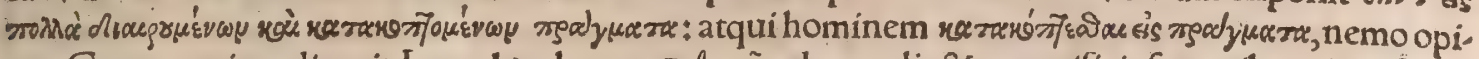
nor Græce peritus dixerit. Immoläre boues, Brbursin, de amplis $\&$ magnificis fumptibus, iam fupra copiofius explicatum nobis eft. Nemo bene merito bouem immolairit prater Pyrrhiam, óudeis

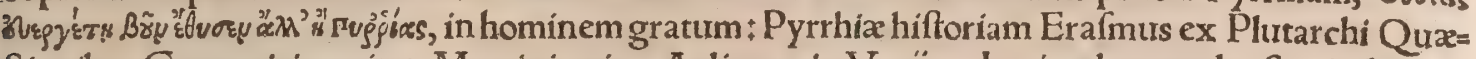
ftionibus Gracanicis recitat. Meminit etiam A elianus in Varïs. Inuitos boues plauftro inducere,

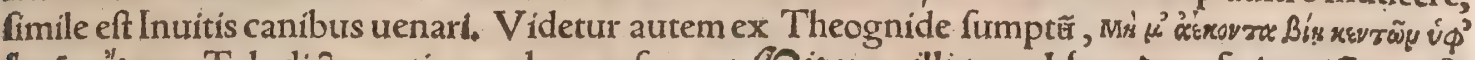

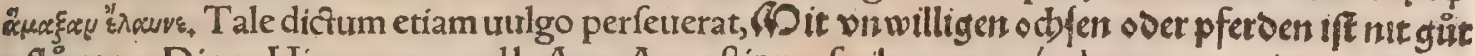
pflìgen. Diuus Hieronymus ad b.Aur. Auguftínum fcribens, eumćć deterrere cupiens, ne iuue. nis fenem prouocet;, Memento (inquit) Daretis \& Entelli, \& uulgaris protrerbï, quod bos laffus fortius figat pedem. A ueteri trituræ more ductum apparet, cum circumactis à bubus fuper manipulos plauftris grana excutiebantur:partim à rotis in hoc armatis, partim à taurorum ungulis. Huiuf= modi eft illud Germanorü, ID sir fid an vie alten teffel reibt/ser befderfit fich gern:nifi hoc forte magis ad reprehenfionem, illud ad laudem fenectutis facit. Necadmodum hinc abluditillud, Á.ré. rass Br̃s, id eft Lente (uel placide) bos, fubaudiendum incedit, uel mouret pedem:nam fenfim quidem mouet, at grauius premit. Congruet in illos, qui placide ac paulatim, citraćs tumultum, fed tamen als fiduitate rem conficiunt. In facris precibus tradit Plutarchus (in commentario de Ofiride $\&$ IIIde) mulieres Eleas publicis ac folennibus uotis ad hunc modum folitas Bacchum inuocare, ut accederet Bós nof', id eft bubulo pede, fiue quod huic animanti, cum fit uiribus immenfis praditum, deinde tanta corporis mole, tamen peculiare uideatur molliter, quafíćp pedetentim ingredi, nulló́s ftrepitu: uel quod bouis pedes arua calcatu reddunt meliora, quum reliquorum animantium noceant. Boue

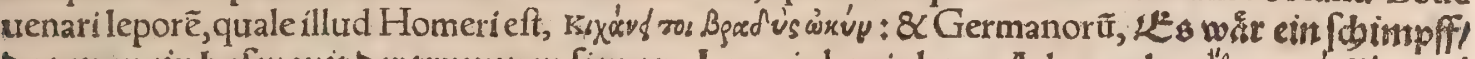

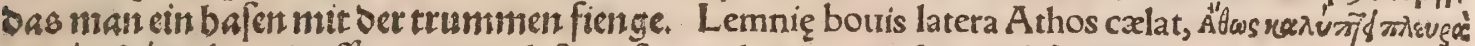
Aruvías Boós: ubi quis officit, aut moleftus eft, aut gloriam cuiufpiam obfcurat, aut-alioquin obfiftit. Tradunt in Lemno bouris fuiffe fimulacrum ingens, candido façum lapide: Id Athos Thraciæ mós, cametfilongo diffitus interuallo, tamen ob fummam celfitudinem obfcurat umbra fua. Nam, ut Ste. phanus fcribit, ad ftadia trecẽta umbram iacit:ut Plutarchus, per feptingenta fermé. Theocriti Scho

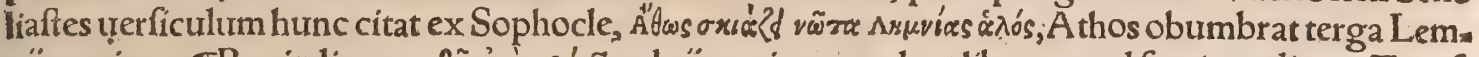

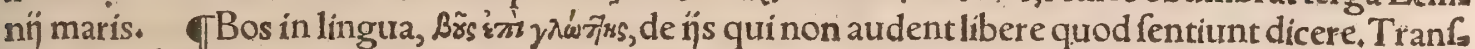
4o latum uel à robore animantis, quafilinguam opprimens non finat eam loqui : uel hinc quod Athe: nienfium numifma quondam bouis obtinuit figuram. Hinc iactatum nouimus, ut quicunç pecu= nia corrupticaufam filentio prodant (quod feciffe quum oratores alios, tum uerò Demofthenem,

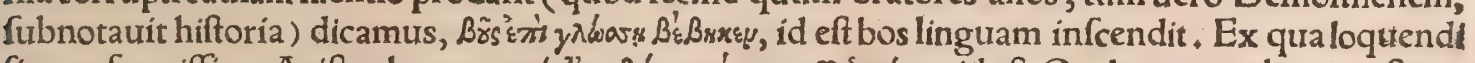

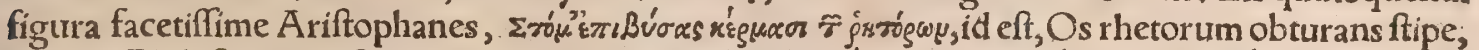

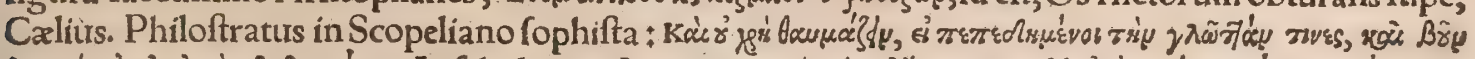

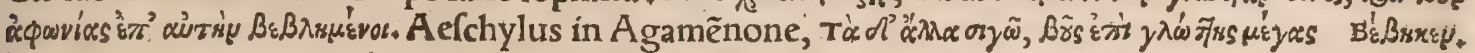
Ita corruptos homines, eleganter bugloffos appellabimus, ut apud Varinum obferuaui, qui fcribit,

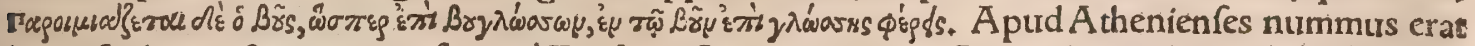
bouis fculptura \& nomine infignis, à Thefeo inftitutus primum, Plutarcho tradẽte, uel ob Maratho so nium taurum, uel ob Minois ducem, uel quod ad agricolationem perlicere uellet ciues. Iulius Pollux ctiam libro 9, fribit olim apud A thenienfes numifmatis genus à fculptura uulgo bourem dictum: ideoós in fpectaculo apud Delios, fi cui munus dandum erat, præconem pronunciare foliturm, tot bo ues illi donandos elfe. Bouem autem ualuiffe duabus drachmis Atticis! unde fuiffe qui crederêt hoc numifma Deliorum fưffe proprium, nó Athenienfium. A ddit item in Draconis legibuts extare men

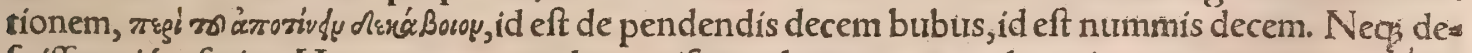
fuiffe qui fenferint, Homerum quoç de numifmate locutum, non de animante, cum ait: xpúres

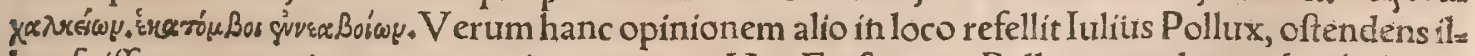
lam fuiffe commutationem rerum citra nummos; $\mathrm{Hxc}$ Erafmus ex Polluce, apud quem éresious

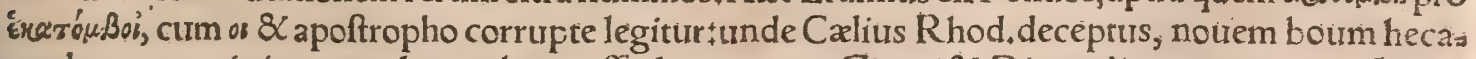
o tomben exponit, ignorans locum hunc effe de armorum Glauci $\mathcal{X}$ Diomedis permutatione. Philo

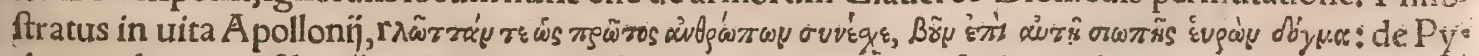
thagora loquitur filentij authore.Scholiaftes in Homerum lib, 2 , fribit prif́cos in altera parte numif 
matis bourem, in altera faciem regiam infculpfiffe. Seruius rex ouium boum $\$$ effigie primus as ff gnaurit, Plinius libro 18. . Hinc pecunia dicta, 9 pecudes fignatas haberet, quadam boures. Plautus in Perfa, Boures bini hic funt in crumena. Hxchactenus ex aliorum fcriptis: nunc noftram conic: cturam de bouis nummi pretio fubriciemus. Videtur fané eitus pretỉ hic nummus fuiffe, quo tum temporis boues finguli uęnire folebant. Quamobrem non æreum neç argenteum, fed aureum fuif fe colligimus, eiuśç fentẹtix teftimoniư ex Etymologo fupra citauimus, quí in Hecatombes men: tione hæe etiam fcribit:Bocóy alï ponderis nomen, alij pretium bouis interpretantur, alï didrachmi

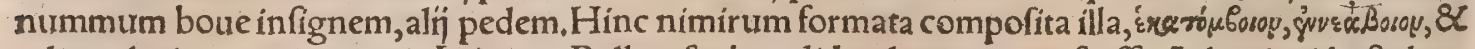
reliqua huius terminationis, Iam cum Pollux fcribat didrachmum eum fuiffe $A$ thenis, id eft duas drachmas appendiffe(quanquam de utro metallo fentiat non exprefferit, magisig de argento çau. ro fentire uideatur:quod tamen bouis pretio miniméconuenit)ex ipfo de pondere faltem, ex Etya mologo autem \& 2 re ipfa de metallo conftat. Nam qu didrachmus nummus non argenteus folum, fed etiam aureus fuerit, cum alị, tum Robertus Cenalis epifcopus Abrincenfis, uir in hoc argumêto ex ercitatiffimus, pluribus ueterum teftimonijs approbant. Valet autem (inquit Robertus) drachma auri fefcunciam argenti, hoc eft drachmas duodecim argenteas, qux Gallico numifmate æeftimandx funt libris Turonicis duabus, $\&$ folidis totidem. Nunc autem urgente auri inopia, uel hominum feu temporum iniquitate, fcutum coronatum ea xitimatione permutatur, pauloćc amplís. Et rurfus a= libi, triplicem olim aureum folidum fuiffe docet, unum drachmalem, alterum didrachmalem, tertī fextularem:eft autem fextula, uncix fexta pars. His confirmatis, Aureus ifte didrachmalis (inquit) zquabat pondere Philippeum nummum, qui olim apud nos erat: cui fucceffit apud Anglos num= mus Odoardeus, feu Nobilis ad rofam:nec obftat quod hodie pluris æeftimetur . Cur autem bos di. ctus fit nummus, triplex mihi ratio reddi poffe uidetur: una ab effigie, altera ab æquali pretio, \& ter. tia fortè à magnitudine nummi, qris inter aureos maximus furerit , Huiufmodi igitur bourem num. mum olim fuiffe, nec amplius etiam bours.communis pretium, hucuffs dixerim, Redeo ad prouerbi um, Bos in lingua, ut moneam fimilia à Germanis celebrari ifta : 过r Ift nit einer filberon biid) fers

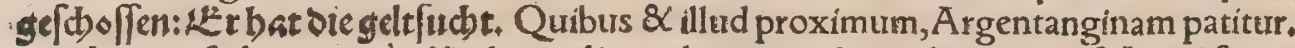

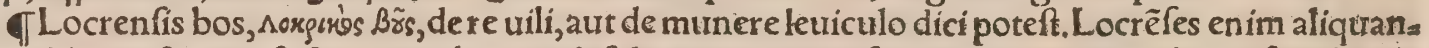
do publicum facrum facturi, cum bouem defiderarent, compofito ex minutis lignis bouis fimulacro, dijs rem diuinam fecerunt. Ex ipfo boue lora fumere, ' qui quo ladunt quempiam, ex ipfo quem lædunt accipiunt. Agricolæ enim lora ca duntẻ boum ter= goribus, quibus boures uinciunt. Afinus ad lyram prouerbium, in Afino retulimus, Caterum cum Cleon quifpiam, cui nomen inditum Boui,fcite caneret uoce, lyra uero non perinde titeretur: Strato nicus canentem audiens: Olim, inquit, a finus ad lyram dictus eft, nunc uerò bos ad lyram. Bos ma rinus, uide paulò poft Bos in ftabulo. Boues meflem expectantes, \& Bos Molottus, uide in prace.

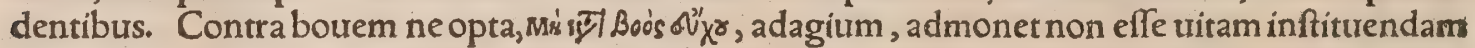
iuxta trotum animi, neç quiduis fperandum à fuperis, fed ut ea duntaxat fibi quif́s promittat, quar poffit induftria confequi.Refertur in Collectaneis Diogeniani. Videtur autem ducta metaphora ab agricola, qui negligens adhibere bouis operam in colendis agris, optat ut citra fuum laborem proure niat feges, Erafmus,Mihi quidem fenfus clarior uideretur, fi pro resck preppofitione legas ěvou, ut ita reddatur, Ne optes fine boue. Oppidò ôj eleganter Horatius hoc carmine, Optat ephippia bos pi 4 ger, optat ararecaballus, uitium illud fignificat humanis ingenins infitum, ut femper alienam fortem magis mirentur, fuam contemnant ac faftidiant, optent inexperta, experta damnent. Veteres bubus

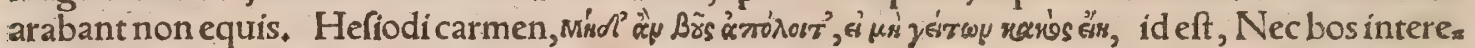

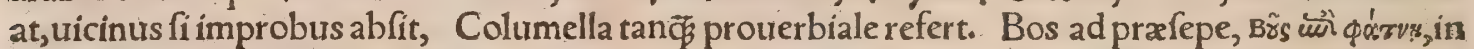
emeritos dici confueuit, quiç iam ob ætatem ocio atç abdomini feruiunt. Effertur item ad hunc mo

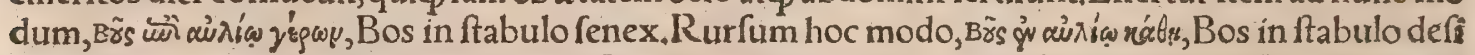
des, de ins qui molliter $\&$ in ocio uiuunt. Stratonicus inebriatus, dixit fe ab illo qui ipfum inuitaue: rat, tan $\not$ b bourem ad præfepe data cœena occifum, ut copiofius ex Athenęo Erafmus refert. Cógruet 8 in illos, qui in fuum aluntur exitium+quemadmodum n̈ qui fe uoluptatibus mundi explent, orco

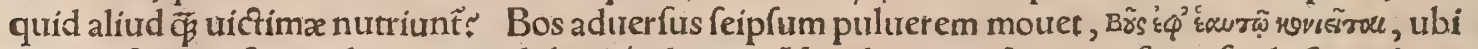
quis ad fuum ipfius malum uolens lubensós ducitur. Nam boues ut funt manfureti, facile fe prabent. uinciendos, necs grauatim obtemperant iugo. Kovıs. enim Gracis fignificat feftinandi ftudio ciere pulirerem.Quidam accommodant in eos, qui prudentes ac fcientes, femet in præuífum perículum inijciunt, bouis in morcm, qui fibi patitur iníci uincula, quibus ad cædem ducatur, refertur à Zeno.

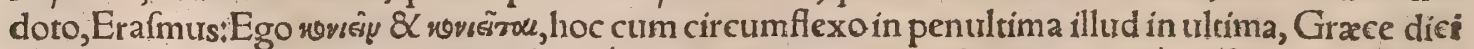

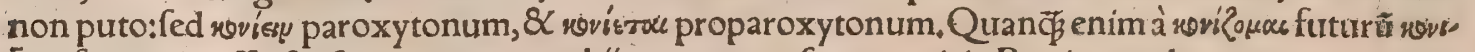
šou formari poffit, fenfus tamen prourerbij tempus prafens requirit. Bos in quadra argentea, in eos qui perfonam fuftinent officium aliquod egregitum pollicentem, nec ulli tamen funt ufui, nifi ad uo= luptatem aut faftum. Simillimum eft illi quod alibi retulimus Bos feptimus, Erafmus, Deinde recita=

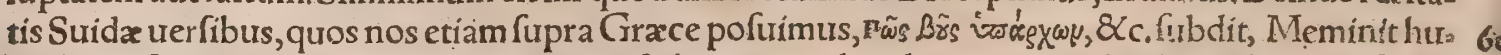
ius bours Iulius Pollux libro 6.cap.n.tan $\ddot{q} \&$ bos in quadra placentæa aut cibi aliquod genus fit, $f_{i=}$ militer ur bos feptimus. Vnde apparet ipfum uel non animaduertiffe, uel non intellexiffe Súvidz uer 


\section{Bos \&Vacca. H. Lib. I. tor}

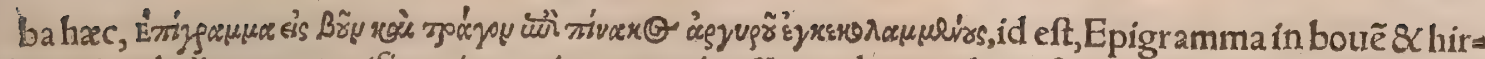
cum in tabella argentea (fic enim potius uerterim, ${ }_{\text {B }}$ quadram)cęlatos fiue fculptos . Quod fi ex epi. grammate uel apologo potius prouerbium facerelibet, conueniet in otiofos, \& ignauos, quićs exter na fpecie tantum, non re ipfa, munus furm exercent. Iulius Pollux loco citato nullam huius apolo= gi, fed feptimi bouis tantum, id eft placentæ, mentionem facít. Regia uaccula uel bucula, Bxorıı'่u Boildoy, de prodigiofa foecunditate ferebatur, natum è miraculo rei geftx. Aetate Ptolemæi iunioris uacca quadam eodem partu fex adidit uitulos, author Diogenianus. Bos fenex non lugetur, $\Gamma^{\prime} \dot{\rho} \omega \nu$

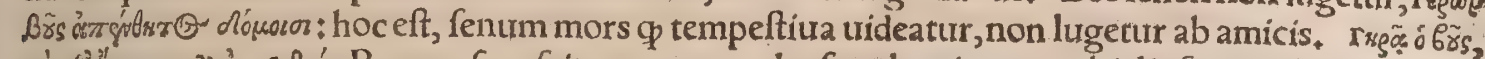

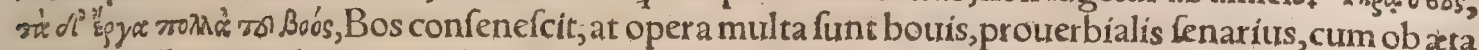
Io tis imbecillitatem aliquís inutilis redditur ad obeundum munus, Senarï fenfus clarius ita reddi pof fe mihi uidetur, Bos licet iam fenecta inutilis, merito tamen illorum operum, qux plurima iam olim

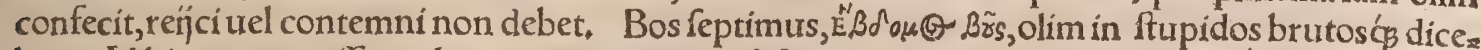
batur. Id hinc ortum efle tradunt, $q$ antiquitus pof fextam lunam bouis imaginem é farina pinfere confueuerint, qui feptimam lunam cornibus referret. Sunt qui malint hinc natum, $q$ cum apud ue. teres fex animantium genera mactari dïs folerent, ouis, fus, capra, bos, gallina, anfer:pauperes non habentes uiuum animal qued immolarent, bouts fimulachrum è farina fingere confueuerint: is quo niam fenfu uitaḉs careret, in ftoliditatis abrĭt prouerbium, Erafmus. Bos genus eft placentr, qua da batur antrum Trophoní fubituris:eò $\$$ in adyta décendentes mugitus audirent, Etymologus. Eraf mus dum ex Suida transfert, antiquos pof fextam lunam bouis imaginem è farina pinfere confue $a$ o uiffe, qui feptimam lunam cornibus referret, duplicem committit errorẽ. Scribit enim Suidas hanc

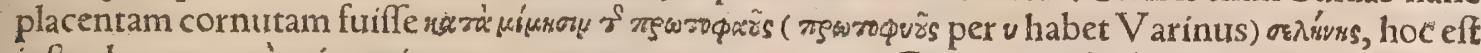

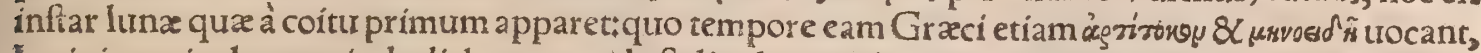
Latini corniculantem:inde dichotomos, id eft diuidua uel dimidio orbe cafa uocatur, primo fcilicet,

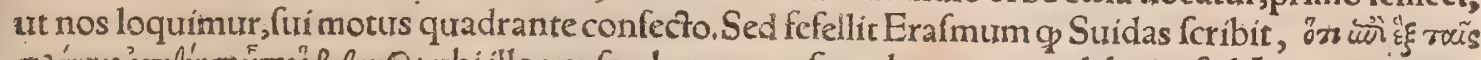

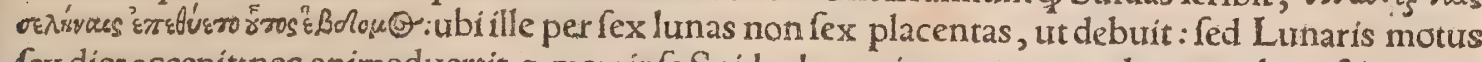
fex dies accepit;nec animaduertit $q$ mox ipfeSuidas lunas interpretatur placentas latas \& rotun das, quales noftri uocant flasen. Eafdem Paufania tefte $\pi \varepsilon \lambda \lambda^{\prime}$ rrs uocabant, ut Varinus citat, ex quo

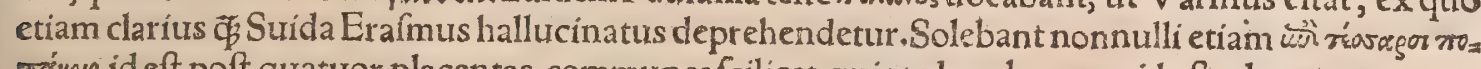
mívous, id eft poft quatuor placentas, communes f́ilicet, quinto loco bourem, id eft placentam unam 30 cornutam immolare, quan कु frequentius poft fex: proinde eodem fenfu prouerbiali quintum aut fe= ptimum bouem aliquis proferat, nịhil intereft. Pollux pelanos placêtas à bubus diftingurit: nam dịs omnibus eas communiter immolari folitas ait, bouem uero(id eft cornutam placentam)priuatim $\bar{A}=$ pollini, Diana, Hecatæ, \& Lunæ. Addit praterea pelanos à figura dictas effe, ut etiam boures:fed qua lis carum figura furerit, necipfe exprimit:nec alibi reperio, nifi quod Etymologus inter catcra pela= ni etyma, , ra, aut quantitatis potius, accidens. Ariftophanis interpres in Acharnenfibus, cum expofuiffer

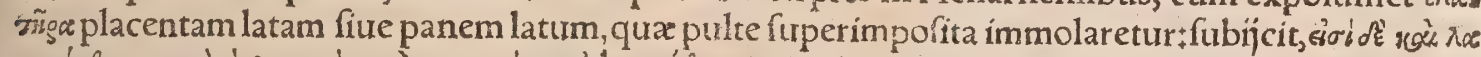

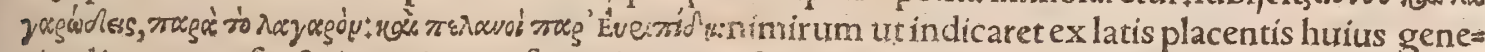
ris, alias uentrofas $\&$ intus inanes fieri, alias uero folidas. Empedoclem quoc ferunt, cum Olym= 40 pia uiciffet equis, $\Phi$ animatis ex præfripto abfineret, utpote Pythagoricus, ex myrrha, thure, $8 \times$ aro matibus alphs bouem concinnaffe, quem ad panegyrin conuenientibus diftribueritłquod paramix quadam imagine ururpari à nobis potent, in îs qux de faccaro panim coaptari cōformarićs animad.

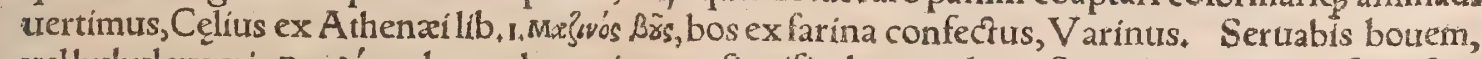

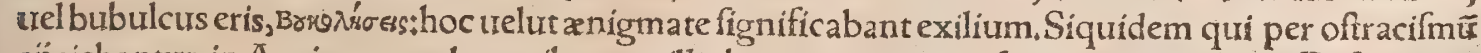
enjciebantur, in Argiuam exulatum ibantac illic bos erat æneus infigni magnitudine. Refertur in Plutarchi Collectaneis: Hefychius teftatur extiriffe in Phafmate Menandri. Bos in ftabulo, uide fu.

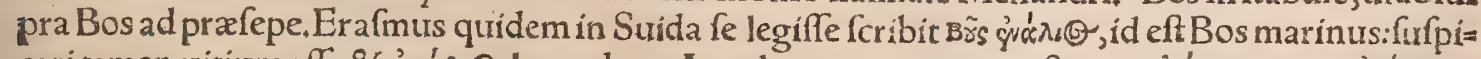

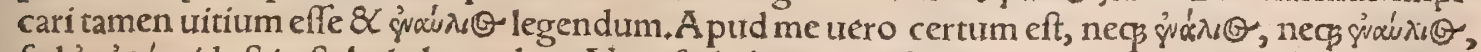
fed çu củi í, id eft in ftabulo legendum. Nam fic habent excufa Suidx, qua nos hoc tempore infpexis

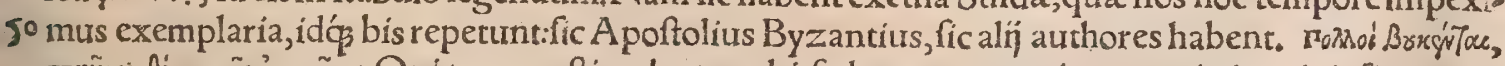

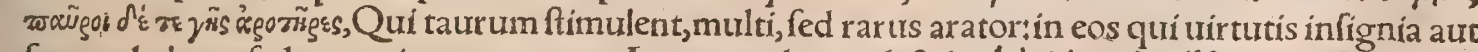

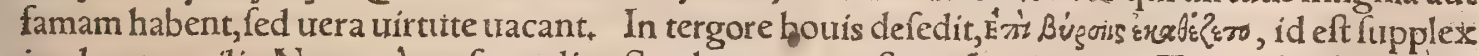
implorat auxilia. Natum à confureturdine Scytharum, ut teftatur Lucianus in Toxaride. Nam apud hos fi quis forte lafus effet, neç fuppeteret ulcifcendi facultas, immolato boure carnes minutin fe ctas coquebat, ipfe in tergore humi frato fedebat, manibus in tergum reductis. Id ó maximum furp: plícandigenus apud illos habebatur. Accedebat quicungs uellet opitulari, \& carnium portione gita ftata, dextroós pede tergori impolito, pollicebatur pro uiribus auxilio furturum. A top hoc foedus a.

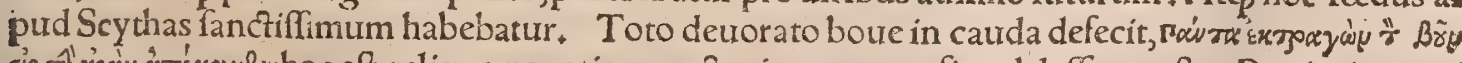

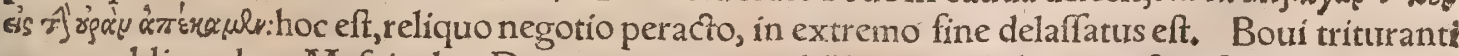
6o os non obligandum, Mofaica lex, Deuteron, 25 . prouerbij locum habebit, cum fignificabimus dignt effe mercede unumquenq̧ in quouis labore, \& illo pracipue fructu qui ex eiufdem laboris genere percipi poffit, priuarinon debere. Vide fupra in prouerbio, Bos apud aceruum. Boue uenari lepor 
rem, Plutarchus in commentario de animi tranquillitate, ueluti de re trehementer abfurda, fulls

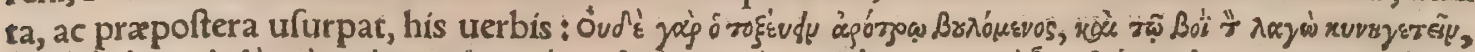

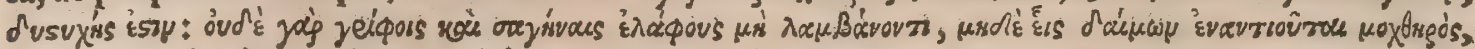

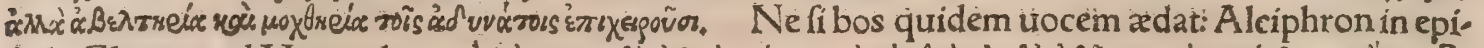

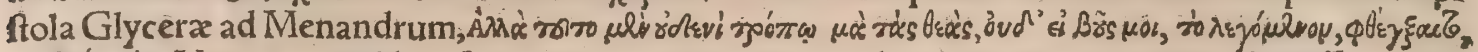

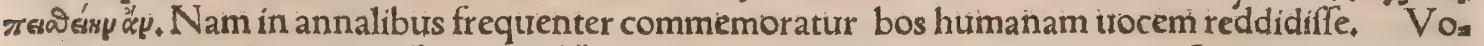

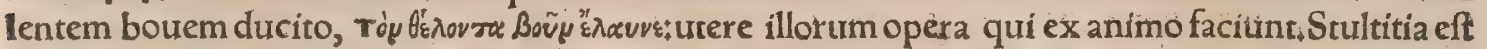
uenatum ducere inuitas canes, ut ait Plautus, $\Phi$ Sunt $\&$ alia quædam protierbia, qixæ in præceden tibus attigi, ut bulimia, buthyfia, budoro more; \& qua à bolito; id eft ftercore bubulo fumunrur : de quibus qui legere copiofius uoluerit, Chiliadas Erafmi adeat. De buphago tantum nonhihil adícia mus, quanquam \& fupra leonis id effe epithẹton monuerim, \& de homine uoraciffimo dici, uide $H$. b. \& Arcadiæ fluuium effe à Buphago lapeti filio nominatum, \& Herculem buiphagon uel büthœ: nan cognominari. Athenæus libro 10 . indicat larum auem Herculi attributamà prificis, quod \& ille

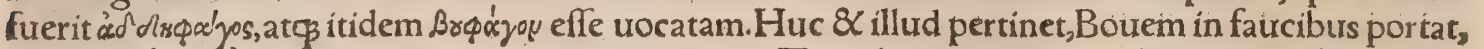

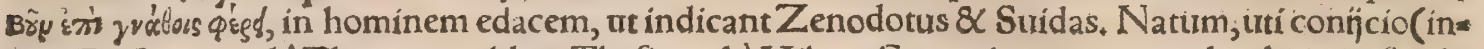
quit Erafmus ) uel à Theagene athleta Thafio, uel à Milone Croteniata, quiorum alter bouem folidư Colus comedit, tefte etiam Græco epigrammate, tum authore Pofidippo apurd Athenæum : alter, it narrat apud eundem Theodorus Hierapolites, in Olympijs taurum quadrimum htmeris fufteliti, eumç ésem die folus comedit:Cuius rei meminit \& A. Gellius. Caterum Hercules ut buphagüs, quod multi cibi effet, fic \& polyphagus, et addephagus, \& ab Orpheo in eius hymno pamphagus uo 20 catur: \& philopores quòd multum biberet, undeet fcyphum eidem dicarunt, ut gauiam propter eda citatem. A pud Lindios pium eft Buphagum, id eft Herculem execrari:quod in dei cederehonorem creditur, fi in eum multa conuicia dicantur, Gregorius Naz, aduerfus lulianum. De Buphonijs etiam multa retro dixi. Erafmus in prouerbio Cecidis $8 \times$ Buphoniorum Ariftophanis uerba in $\mathrm{Ne}$

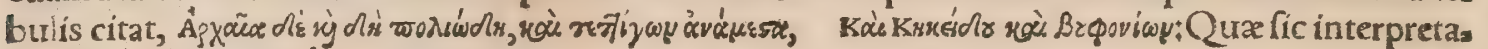
cur: Prifca hac fanè atç obfita canis, nec non oppleta cicadis, Ac Cecide cum Buphonị́s: cum

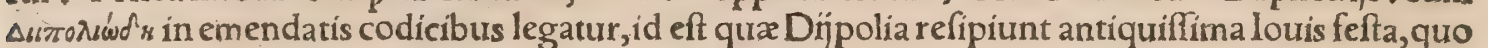
rum aliquories Gyraldus etiam meminit. Vfus prouerbin eft de re magnopere prifca, \& $\mathrm{C}$ ob uetuita. tem iampridem obfoleta defuetać. Buphonia feftum erat, \&c. Huiufmodil ludos adhuc durare uide mus apud Italos, præcipue Romanos, prifcæ uidelicet etiamnum infaniæ ueftigia, quos illi Taureos 3

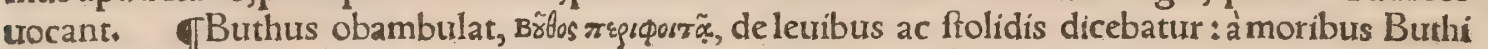
cuiurdam athletx, qui uicit in Pythịs ludis:meminit Hefychius, Fieri poreft ut ab edacitate id nomiz nis ei inditum fuerit, ut etiam Herculi Brloive: Vnde uiderur dici poffe in edaces quoque, Erafmus.

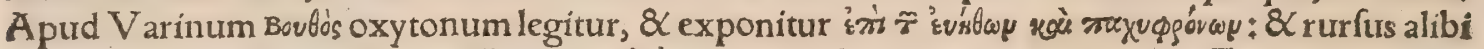

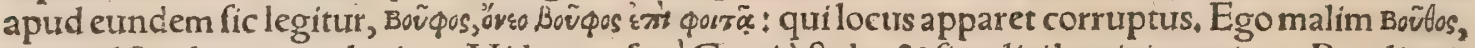
ut apud Suidam quoçlegitur. Videntur fané Grẹcià ftulto \& fimplicibouis ingenio, ut Butalionis

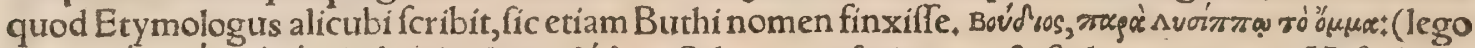

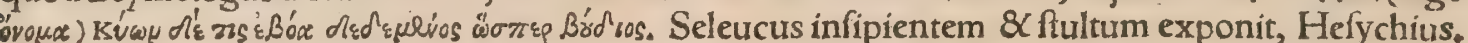

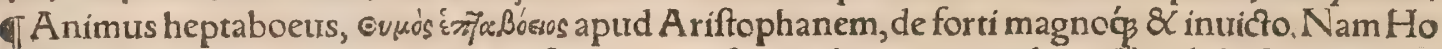
merus Aiacis clypeum hoc epitheto infignit, quod feptem boum tergoribus eflet obductus, ato $\$$ id impenetrabilis. Ouidius, Dominus clypei fepremplicis Aiax, Augix ftabulum, Ảvyésiou Brstiórix, in hominem, aut in rem maiorem in modum inquinatam. Lucianus in Pfeudomante oftẽdithuius ftabula tantum habuiffe congefti fimi, quantum ter mille boutes pluribus annis reddere potuerint, Seneca in libello de morte Claudin, In quos (inquit ) fi incidiffes, ualde fortis licet tibi uidearis, maa Iuffes cloacas Augię purgare, multo plus ego ftercoris exhaufi, Paufanias Eliacorum libro 1. paulò poft initium fic fcribit: Eleorum princeps furit Eleus filius Eurycyda Endymionis filię, patre Neptu no, fi quis credat. Pofteri Hixkiou nomen in Hixiou mutauerunt, \& Solis non Elei filiñ faciunt Augeam, ut fplendidius de eo loquantur. Augeas ifte boum caprarumón greges tam numerofos habuit, ut magna pars regionis propter fimum illorum inutilis iam effet. Proinde Herculi expurgãdum illum perfuadet, fiue regionis parte, fiue alio munere promiffo. Quod ille mox fluuio Minyeia immiffo perfecit. Cæterum Augeas, cum res arte magis quàm labore confecta uideretur, mercedem nega= uit; $\&$ Phyleum maiorem natu inter filios, à quo tanquam iniquus in hominem bene meritum repre hendebatur, eiecit, \&c. Graci hanc Augiæ ftabuli repurgationem, inter duodecim eius labores nu= merant. Extat Epigrammatum Græcorum libro 1, fectione 46. anigma elegantiffimum de numero

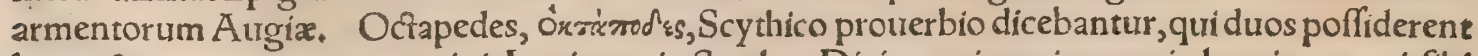
boures $\&$ currum unum:meminit Lucianus in Scytha. Dici poterit per iocum, in hominem qui fibi locuples uideatur:uel in eum cui rufticanre funt opes. Fornum habet in cornu, longè fuge, $\mathrm{Ho}$ ratius in Sermon, conuenit in homines maledicos $\&$ feroces. Inde translatũ, ut Acroni placer, quod antiquitus bubus cornipetis foenum profigno in cornu appenderetur, quo fibicauerent qui forte occurriffent.Id'ćs ideo fieri folitum Plutarchus in problematis Roman.71.autumat, quod copiofiore 60 pabulo, non modo bnues, fed $\&$ reliqux animantes ferociant. Hiclocus me admonet ut Ebręorum. etiam leges de boure cornupeta referam, ex Iolephi Antiquitaum lib.4. Bouem cornu percutiẽtem 


\section{Taurus. A. Lib. I. 103}

(feribit Iofephus, interprete Ruffino) dominus interficiat, Si uero aliquem interficiat percuitiens tau rus, ipfe quidem lapidatus moriatur; \& neç ad cibum utilis habeatur. Si uero cullpabilis etiam ap.

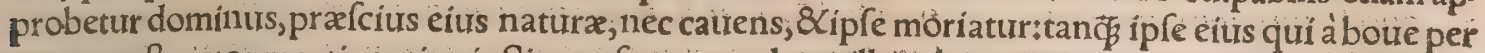
emptus eft, autor mortis extiterit. Si uero ferutum uel ancillain bos perimat; ipfe quidem lapidetur: triginta uero ficlos eius domino, lapidati dominus dare damnetur. Bos autem fi à boure percüfus mortuus fuerit, irendatur, \& qui mortuus eft, $\&$ qui percưflit: $\&$ pretium amborum eorum domini fibi diftribuant.

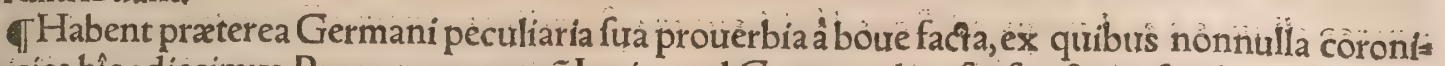
dis uíce hîc adiecimus. Præponemus autêL Latina uel Graca eodem fenfur ufitata, fine bouis mentio. 20 11e. Deo urolẽte, uel uimine nauigabis: Vueftphali dicunt, 10 ann Gott wil fo talbet out b wol ein - chfe:Si Deus uoluerit etiam bos uel taurus foetabit. Anus bacchatur : Vueftpháli, Sie olde Eoe wil by [šnt, Vacca uetula mordere urel morficatim ludere appetit, in prater ætatem indecorè lafciuí= entes. Camelus faltat:Germani, Vacca in grallis(ut quidam trocant) incedit. Dí bona laboribus uendunt: Germani, (5ott gibt etnem wolen od fen/aber nit bey den bözneren, Detis botiem ali. quando donat, fed non cornibus apprehendendum. Non témere eft quod uulgò dictitant: Germas

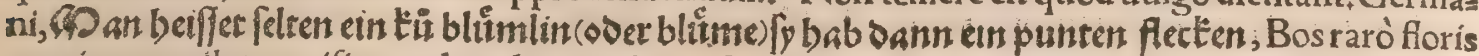
nomine appeilatur, nifi macula urel una infignis fit. Solent enim ruri maculofas uaccas flores appel.

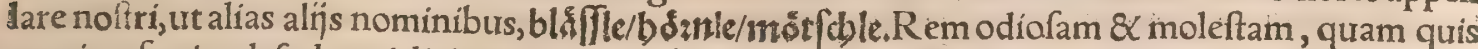

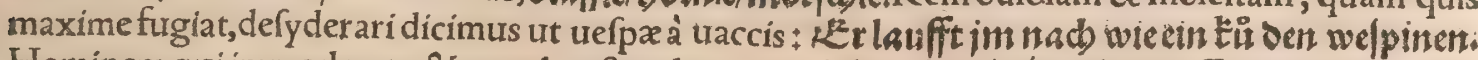

20. Hominem qui immoderate $\&$ uno haufu plurimum bibat, eevesi nivese dicunt Græci, noftri inftar uaccx, trincten wie ein

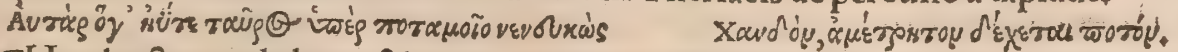

q Hæc haçenus de boue $\&$ uacca dixerim:quibus immorari plixius uolui : quoniâ bos principa tũ inter animalia homini utilia femper obtinuit: $\&$ cum Heluetia noftra boum armentis abundet, co piofius de eis fribendum mihi exiftimaui. Multo enim utilius iudico noftratiữ animaliữ naturas ha bere perfpectas, $\ddot{c}$ ịs neglectis aut parcius tractatis, moram in peregrinis facere.

\section{DE T A V R O.}
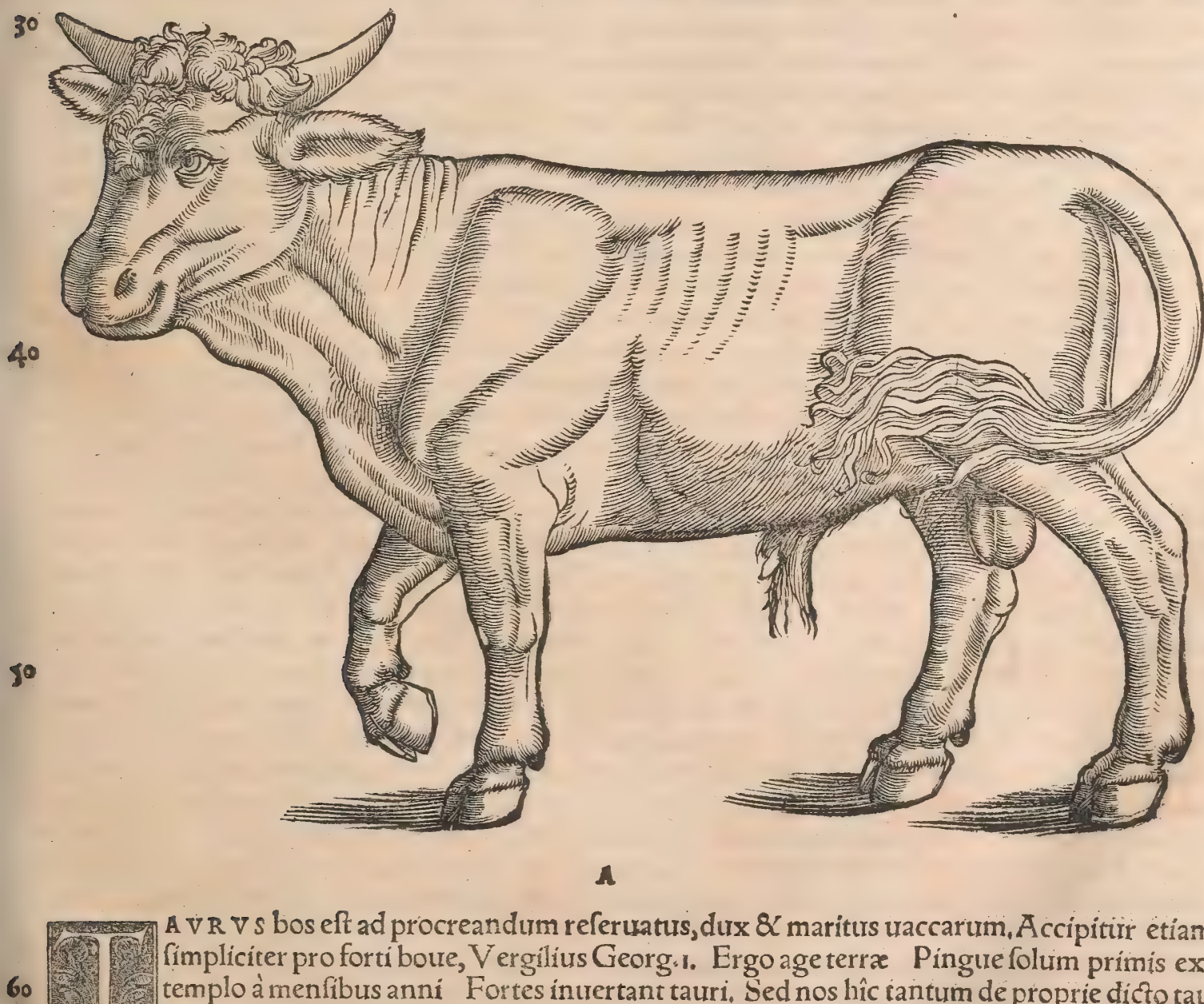

$\Lambda$

P V R V S bos eft ad procreandum referuatus, dux \& maritus uaccarum, Accipitir etiam fimpliciter pro forti boue, Vergilius Georg، I. Ergo age terra Pingue folum primis extemplo à menfibus anni Fortes inuertant tauri. Sed nos hîc iantum de proprie dicto tau roloquemur, non de boure caftrato. Quxcunq̧ de boure in genere afferri poffunt, quorum

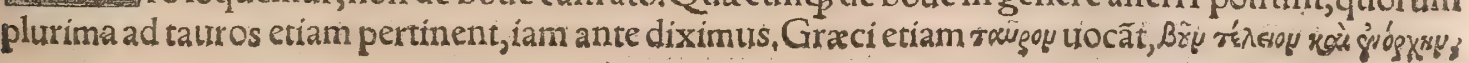


id eft bourem marem, adultum (utâ uitulo $\&$ iutuenco differat) $\&$ non caftraturm, Ebrai taưrìn ườ cant $7 \uparrow *$, aliquibouem fimpliciter interpretantur: Vide fupra in Ebraicis nominibus bouis, Mat. thaus Syluaticus taur exponit taurum, nimirum ex Arabica dialecto:nam \& Chaldari tor appellãt。 ר.s abir robuftum fignificat, $\&$ per excellentiam uel antonomafiam abirim numero multitudinis, pro tauris robuftis exponitur Pfal,22, alij caballos reddunt. Italicé toro, Gallice toreau. Germanice

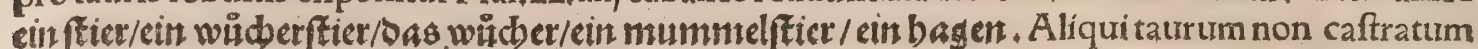
uocant eiit varten uel farr, forfan à par Ebraica uoce, qux \& iuuencum \& bouem fimpliciter fignifi cat:alï ein bollen:nam et Angli dicunt a bulle, ut lllyrín wul bouem in genere; lidem taurumiunecz quafiuuencum.

B.

Tatrus animal robuftiffimum, pracipue colli $\&$ capitis robore ualet: $\mathcal{Q}$ fronte ualidam pugné idoneam habet.Cornura eis infefta natura dedit, Plin, Ea ơ uaccis robuftiora funt, Ariftotele tefte minora etiam tenuioraćs 药 bubus, ut Plinius fcribit. Plura uide fupra in Boue in B. Homines caltra

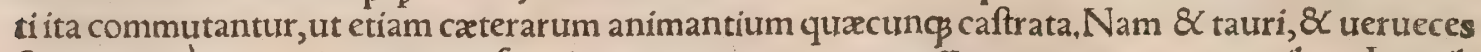
fua cornua é contrario gerunt: $q$ fơminæ quogs eorum contra, $\widetilde{c}$ mares armantur cornibus. Itaç if li maiora excifi gerunt, hi minora. A riftoteles fectione 10, problemate 38 . Et mox iterum eiufdem fe: crionis problemate 5 6.eandem dubitationem foluit cur boues caftrati maiora cornua gerant, Tauri potifimum neruofifunt, \& durioribus $\widetilde{\not}_{3}$ caftrati neruis, Cor etiam eorum neruofum effe in Boue dictum eft.Collopa Graci uocant pellem in ceruice bours, unde colla, id eft glutinum fit, ur mox ex plicabimus capite quinto. Taurorum fanguis fibris refertus eft:quare omnium celerrime coit $8 \mathrm{~d} d u=20$ ref́cit, Ariftot, Et alibi, Tauro \& afino, inquit, inter ea qux animal generant, craffiffimus $\&$ nigerri $=$ mus fanguis eft. Venenofam eius naturam, \& contra eam antidota capite $7+$ referemus. Arnobius libro 7 , ridens antiquorum fuperfitiofa facrificia:Non enim placet, inquit, carnem frebulam nomie nare, qua taurorum é coxendicibus demitur.Strebula authore Fefto, lingua Vmbrorum appellabã. tur partes carnium facrificatarum. Taurorum colla $\&$ truces in fublime iactus, tigrium rapinas, \&c.

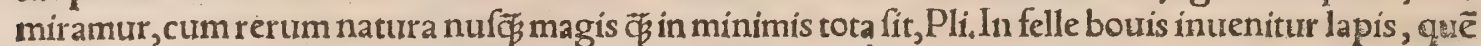

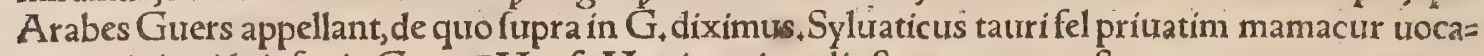
rimeminit:uideinfra in $G_{*}$ - TMenfe Martio, cui cordi eft armenta conftruere, tauros compara* bit, aut his fignis à tenera æate fummittet:ut fint alti, membris ampliffimis(ingentibus) moribus pla cidis, media atate ( $\&$ magis quæ iuuentute minor eft, $\tilde{\sigma}$ qux declinet in fenium, catera fere eadem zo omnia in his obferuabimus, quæ in bubus eligendis:neqs enim alio diftat bonus taurus à caftrato, ni ${ }^{\circ}$ fi quòd huic torua facies eft, uegetior af pectus, breuiora (parua) cornua, torofior ceruix, \& ita uafta, ut fit maxima portio corporis, uentre paulò fubftrictiore, qui magis reêtus, \& ad ineundas forminas habilis fit, Columella $\&$ Palladius. A ddunt alip, generofum taurum probari, fi facies fitminax: fi an. teriores pedes fortiter figat ac terrã fodiat:fi cauda ereĉa, fed modice incuruata fit: fí cornua in prom ptu adferiendum. Obieruandum eft,inquit Varro, ut boues mares feminis bonifint, quorum 86 forma eft fpectanda, \& qui ex his orti funt, ut refpondeant ad parentum fpeciem, Et pręterea quiburs regionibus nati funt, refert. Boni enim generis in Italia, pleriģ Galliciad opus. Contra iugatorĭ Li. guftici. Tranfmarini Epirotici non folum meliores totius Gracix, fed etiam Italix, tametfi quidam de Italicis, quos propter amplitudinem praftare dicunt, ad uictimas farciunt, atç ad deorum feruãt 40 fupplicia:Qui fine dubio ad res diuinas propter dignitatem amplitudinis, 8 coloris præponendi. Quod có magis fit, çalbi in Italia nó tam frequêtes đ̆ qui in Thracia, ubi alio colore pauci, Varro.

बDiuerfa boum genera propofuimus fupra in Boue cap, 2, Caterum Opplanus poëta Græecus if bro 2, de Venatione, ubi de tauris fcribit, non boum fed taurorum(tauri nimirum nomine tanquam digniore omne bubulum pecus complectens) diuerfa facit genera: \& primum Āegyptios comme morat tauros, non aliter $\widetilde{\beta}$ nos boues fupra: mox etiam Phrygios fimiliter, qui colore fint gouboí ze фiogepoir $\pi$, id eft flauro \& fiammeo. Deinde Aonios, Armenios, \& Syrios fimiliter ut nos fupra ex Ae. liano. Syrios quidem etiam Affyrios \& Pellaos uocat, \& in Cherronefo nafci fcribit:atç hos ipfos effe, quos Herculem Geryoni in Erythea abftuliffe fama fit. Eft autem Pella ciuitas Syrix, qux aliâs A pamea, à Pella Macedoniæe fic dicta, \& Berenice poftea, Stephanus. Idem Cherronefum Syriæ ciui so. tatem, eandem A pamex facit. Secundum alios, Pella Collefyria ciuritas elt, quę \& Bûtis uocabatur. Paufanias tamê fentire uidetur, Herculem boues ex Macedonica Pella abegiffe, cum loca circa Am braciam atç Amphilochos Geryonem imperio tenuiffe tradat. Aethiopici tauri non alij ${ }^{3}$ rhino cerotes funt:ut boues luci, elephanti: Vnde apparet bours $8 \times$ tauri nom $\tilde{e}$ ad quadrupedes fylueftres maiores diuerforum generum â ueteribiss applicatum fuiffe. Cibyratici tauri apud Suetonium in Gordianis, nominãtur à Cibyris. Stephanus Cabalidem urbem effe docet prope Cibyram, ituxta dor fum Mrandri, 8x Cibyriatas à Lydis ortos effe, qui regionẽ illã occupauerint. Meminit etiã Strabo. C.

Vita bubus foeminis quindecim annis longiffima, maribus uiginti:robur in quimatu, Plin. Gra cis facrificaturis moris erat, tauros explorare farina appofita. Nã fi guftare abnuiffent, concipiebant 60 inde, haud ualere fatis, Cælius, Lafer è filphio cauernis dentium in dolore indi cera inclufum, Plin̊̀ us non fuadet:quoniam tauros inflammet naribus illitum 2 \& ferpentes auidiffimas uini admixtum 


\section{Taurus. C. Lib. I. 105}

irmpat, Si tauris oleo rofaceo nares inuncta fuerint, obtenebrantur, A fricanus in Geoponicis. Cos ire tummares, tum forminæa anno ætatis primo peracto incipiunt, quoad facultas fit procreandi : ue. rum quod magna ex parte fit, uel anniculi, uel nacti ocfauum menfem Venerem adeunt. Sedenin quod maxime confeffum habemus, bimatu generant, Ariftot. Qui quadrimis minores funt (qui an

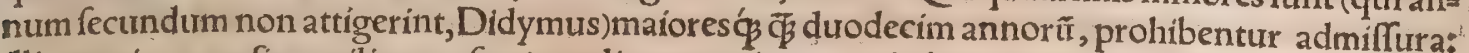
illi, quoniam quafi puerili atate feminandis armentis parum habentur idoneithi, quia fenio funt ef, foeti, Columella. Idem de uaccis intelligendum eft, Didymus. Generationem quadrimi implent, \& fingulis denæ eodem anno traduntur, Plinitus, Tauri duo fufficiunt matribus feu matricibus feptua ginta, uide fupra in Boue cap. 3. Duobus ante congreffum menfibus cum uaccis tauri páfi non de. bent: deinde admittendi funt, nec impetus eorum coërcendus. Sunt autem explendiherba. Quod fi paftura non fatis effe uideatur, cicera, aut orobos, aut hordeum macerare, 8 eis offerre conuenit, Didymurs, Tempus admiffuræ optimum,medium urerís. Neç enim omni anni tempore Veneris li.;

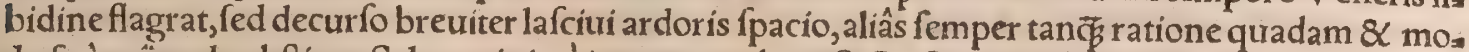
do fe à coêuundo abftinet. Salax minimé inter mares bos eft, Ariftot.Poft conceptum uraccæ, nunquã cum illa coit.Quamobrem Aegyptị uirum fortem eundemós temperatum fignificaturi, taurum in. tegra ualetudinis pingunt, Horus. Tauri non fapius $\widetilde{p}_{\mathrm{B}}$ bis die ineunt, Plinius . Seniores nec fapius quidem forminam eandem, eodem fuperueniunt die, nifi ex interuallo. A tiuniores, \& eandem frepi= us cogunt, $\&$ pluries petunt ac fuperueniunt, uigore fuçextatis, Ariftot. Taurus tanto ardore genita lem neruum contendit ad uaccam adiunctus, ur fine motu ullo femen emittat: ac fià muliebri genitá li neruus in aliam corporis partem aberrauerit, uaccam rigidiffima intentione uulnerat, Gyllius ex Horo A polline. Bos uno initu implețidḉ̧ merito, agit enim tam uehementer, ut foemina uix tolerãs furccumbat, Ariftot, Taurorum ceruorum conceptu, Plin. Boures laboriofius đ̆g equi coëunt, Ariftot.Si forte conceptio pererrauerit, uicefimo poft die marem foemina recipit, Ariftot, uel repetit, ut Plinius, $Q$ urod fi tauri ad coitus torpefcãt, caut dam ceruinam urens $\&$ conterens, atç latigans cum urino, pudendum tauri atç; tefticulos ungito: confeftimç̧ uel ad infaniam ufops pruriet in Venerem. Quod quidem haud in tauris duntaxat, fede. tiam in animalibus cateris, in ipfó̧̧ hominum genere fimiliter uftr ueniet. Soluit autem prurítum il lum exorbitantem, oleum inunctum. Iam uero polyfpermos, polygonuś́: trocata herba, animalia ip fa reddet multis numeris foecundiora, Quintilif. Ego unam \& eandem herbam utrifque nominibus o iftis intelligo:Quan $\ddot{B}$ cratæongonon quoç diuerfam à polygono herbam, \& polycarpon appellari, $\&$ foecunditatem augere inueniam. ॠT Turus tempore coitus tantum cum forminis pafcitur, cæa terosḉ oppugnat mares:temporibus cæreris mares inter fe côuer fantur : quod coarmentari dicitur. Iam Epiri prounciæ tauri fæpius trimeftri temporis fpacio non apparent, Ariftot. Per libidinê tau. ri efferantur, ut etiam arietes, $Q$ hirci. Qui enim fuperiore tempore focij iugi concordia pafceren. tur, coitus tempore diffident, $\&$ alter alterum libidinis rabie inuadir, Idem. Coit qui uicerit: cumós is Venere iam debilitatus languerit, aggreditur uictus ille languentem, \& plerun Hanc taurorum concertationem elegantifimus poëra Oppianus lib, 2. de Venatione pulcherrime defcribit, quem locum ut â Petro Gyllio translatus $\&$ Aeliani hiftoriæ de animalibus hiftorix infer tus eft, huc apponam. Sequitur (inquit)ut dicam, quemadmodum pro uaccis taurorum maxime ri. 40 ualis \& perpugnax natio, acerrime inter fe certet. Vnus præftantiffimus in minorum taurorum $\&$ uaccarum armentum dominatur. Hunc magnum regem perborret grex armentorum cornibus ar. matum, uacca hunc maritum fuum impotentiferocitate exultantem, eo maxime tempore timent, cum diuerforum armentorum tauri alij in alios mugiunt, $\&$ ab reliquis feparati, ceruicem iactantes inter fe minitantur. Tum fanéutrinc $\beta$ uehemés inftat pugna. Primum infefto obtutu inter fe intuen tur, at ${ }^{3}$ agrefti iracundia ardentes, ignem naribus fpirant, \& terram pedibus fpargunt, $\&$ pulueru= lenta iactatione, $8 \mathrm{C}$ martiali firitu contentiffime uociferans uterque prouvcat alterum. Ac poftea tuba fignum dederunt, ad pugnam acerbam effreni impetu ruentes, inter fe mutuis uulneribur ca: dunt. Et quemadmodum in pugna nauali duæ præftantes naues permultis militibus armatis fulgen tes, \& uehementi uento $\&$ remis propulf $x$, contrarÿs proris roftra inter fe mutua allidunt, \& concre pant armis, \& frepitu uirorum:fic taurorım in coelum tandiu fonitus fertur concurrentium, dum eorum alteruter ex certamine uictoriam retulerit. Viçus cum dolens de pugnaà fe male pưgnata, tum uerecundans in armento comparere, in fyluam proficifcitur, \& feparatim à cater is pafcitur, ac in montibus aliquandiu fe tanquam athleta quifpiam exercet, dum coilegerit uires, quibus cum fe confirmatum fentit, ftatim uociferatur, adeò ut fylua ad eius mugitus uchementer refonet: Ac po:

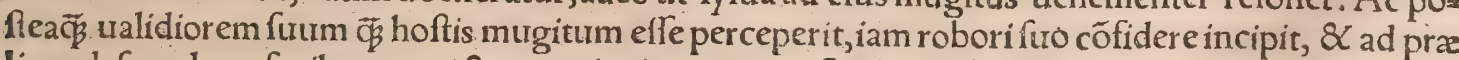
lium defcendens; facile ante uictorem uincit, ut qui paftionibus fe exercuerit, \& remotus ab omni Venere uirium eneruatrice uixerit, Hactenus Gyllius ex Oppiano: Nos pauca circa poftremam partem Gracis collata emendauimus. Rem eandem Vergilius Georgicorum libro 3, tanta uirtute poética defcribit, ut temperare mihi nequeam, quin ea quoç operi noftro afcifcam:

60 Sed nó ulla magis uires induftria firmat, (aYferuat) $Q_{2}^{*}$ Venerem, \& caciftimulos aucrere amoris: Siue boum, fitte eft cui gratior ufus equorum. Arç ideo tauros procul, atç3 in fola relegant Pafcua, poft montê oppofitũ, et trans flumina lata: Autrintus claufos fatura ad prafepia fer ianti: 


\section{6}

Carpit enim uíres patrlatim,uritós uidendo Dulcibus illa quidê illecebrís, et lępe fuperbos Pafcitur ín magna fylua formofa iuuenca: Vulneribus crebris: lauit ater corpora fanguis: Cũ gèmitu:reboãt fyluę́ç et magnus Olympus;

Victus abit,longéç ignotis exulat oris:

Victoris, tum quos amifit inultus amores: Ergo omni cura uires exercet; 8 inter Frondibus hirfutis, et carice paftus acuta: Arboris obnixus trunco, uentosćp laceflit Poft ubi collectum robur, uiresć receptæ, Flucto $u t$ in(aP uti)medio copit cũ albefcere
Ad terras, immane fonat per faxa:nec ipfo nte minor procumbit:at ima exxituat und \& \& longiffimo accurrat, in Boue fupra dictum eft cap.3. Graci afferunt, fi mares creari uelis, finiftrum tauri in coitu ligandum effe tefticulum:fi forminas, dextrum:tamẽ tauros diu ante abftinendos (Ve. nere) ut cum tempus eft acrius in caufas dilati feruoris incumbãr, Palladius in Martio: \& Africanus. in Geopon. Gracis:qui \& hxec addit: Vtmafculus nafcatur, fpirante Borea quidam congreffus pra parant:ut foemina, Auftro. Si tauri poft coitum ad dextram partem abeant, generatos mares effe tradunt:fi in laxuam, forminas, Plinitus: \& Horus in Hieroglyphicis, Quramobrem A egyptij, inquit, mulierem qua filiam pepererit, fignificaturi, taurum pingunt finiftorfum refpiciente: fin filium, tau rum qui fe uertat dextrorfum. In Gallia circa Gratianopolin muli uel ínni genus nafci audio ex afina 8 tauro, quod uulgò iumar appelletur. A pud nos etiam uriros fide dignosa affirmantes audiui, uifum fibi equũ ad pedem montis Spelugi(ut nos uocamus)in R hatia ex equa \& taurogeneratum,

D.

Tauris in afpectu generofitas, torua fronte, auribus fetofis, cornibus in procinctu dimicationem pofcentibuss. Sed tota cõminatio prioribus in pedibus ftat, ira glifcente alternos replicãs, fpargensḉ in alcum harenam, (infperfo puluere ad luctam procinguntur, Plutarchus) $\&$ folus animalium co ftimulo ardefcens. Vidimus de imperio dimicantes, $\&$ ideo demonftratos rotari, cornibus cadentes $3^{\circ}$ excipi, iterumás refurgere, modo iacentes ex humo tolli, bigarumó́ etiam curfu citato uelut aurigas infiftere, Plinius, Tatri animofi,iracundi, furibundió funt.Sanguis enim eorum fibris refertior eff, quare omnium celerrime coit $\&$ durefcit, Ariftotel, Contra, quorum fanguis tenuis $\&$ fine fibris eft, ut leporis $\&$ cerui, timida funt. Cur taurus iratus coftas per caudam uerberet, in Leone qui idem fa cit explicabimus. Taurus nifi caftretur, ferocit $\&$ infeftat cornibus: ad iracundiam facilis, prxcipue fi prouocetur, Extra armenta folitarius feré, non longè tamen à uaccis pafcit. Taurum color rubicun dus ad iram excitat, ut amplius in Philologia dicemus, Non eadem in tauros (qux in uaccas) exer. centur imperia, qui freti uiribus pèr nemora uagantur, liberosć egreffus reditusóg habent:nec reuo. cantur, nifi ad coitus foeminarum : Columella, cum dixiffet de uaccis crepufculo reuocandis fono buccinæ. Animalia fortia grauiorem habent uocem, ut taurus $\&$ leo:timida acutam, Arifoteles in 40 Phyfiognom. Nos in boure fupra, ex ipfo etiã Ariftotele, docuimus tauri uocem acutiorẽ effe quàm uaccx. Proinde illam hoc in loco comparatione aliorum animalium grauem dicemus, non item uac ce. Cui obiectioni forfan ut occurrat, mox addit: Verum præftiterit fortaffis non ex acumine aut gra uitate uocis, animal timidum aut forte iudicare:fed ualidam uoce fortitudinis, remiffam $\&$ infirmam timiditatis fignum faciemus, $\odot v \mu \circ \in \delta \tilde{H}$, id eft animofa funt, quorum craffa $\&$ plena ceruix eft:referun tur enim ad tauros animofos, A riftot, ibidem. Taurus animo incitatus, eo impetu cornibus appetit, ea impotentis animi effrenatione fertur, nihil ut eum, neq bubulcus, neque metus ullus reprimere queat. Atqui eum quidem ipfum homo fiftit, atç ab impetu continet, fi dextrum ipfius genu fafcia deligauerit, A elianus, Hinc eft forte quod $\mathrm{R}$ afis fcribit, bouem ferum fi fune laneoligetur, manfue fcere. Caprificus tauros quamlibet feroces collo corum circundata, in tantum mírabili natura com- 5 pefcit, ut immobiles pręftet, Plinius. Huius rei rationem Calius Calcagninus inquirit libro 2, epifto. larum. Gyllius ex Plutarcho citat fi ad ficum (non caprificum ut alij)alligetur, manfuefcere. Ego de caprifico intelligere malim : Nam \& caules caprifici, fi carni bubulæ inter elixandum addantur, ut Plinius alibi fribit, magno ligni compendio eam percoquunt. Hominem nouiffima calamitate cafti gatum defignaturi A egyptí, taurum pingût, caprifico illigatum:hic enim cum mugit, fi de caprifico ligetur, redditur manfuetus, Horus Apollo, Mithridates Ponticus cum fomnum caperet, fui cor poris cuftodiam non modo armis \& fatellitibus excubitoribus committebat: fed $\&$ tauro $\&$ equo $\&$ ceruo, quos manfuefactos habebat. Ii enim ad cuftodiam eius dormientis aduigilantes, fi quis accede ret,illius fenfum ex ipfa refpiratione quam mox percipiebant,atís ille mugitu, alter hinnitu, alius fura propria uoce, eum à fomno excitabant, A elianus, ITaurum urfis aperto Marte aggreditur, con= 60 ferta iam pugna, fternit fe refupinum, dumós taurus ferire conatur,ipfe fuis brachịjs amplectitur cor nua, ore morfum armis defigit, profternitç̧ aduerfarium, Ariftoteles. Vrfi tauros, ex ore cornibusç 


\section{Taurus. E.F.G. Lib. I. 107}

cortum pedibus omnibus fufpenfi, pondere fatigant: Nec alteri animalium in maleficio ftultitia folet tior, Plin. Tauri folent diuerfi affiftere clunibus continuati, \& cornibus facile propulfare lupos Varro. Tauricateris animantibus fatis manfuetos fe præbent, præter $\widetilde{c}$ illis, quæ rapacitate alias adoriuntur. Has uiribus coniunctis fxpe impugnant: $\&$ linguas in certamine exerunt, Author ob. fcurus. Tauro $\&$ afino aduerfarius eft coruusłquippe qui aduolans feriat, et eorum oculos laceret.

E。

Boum corịs glutinum excoquitur, taurorumç præcipuum. Præftantiffimum fít ex auribus tau

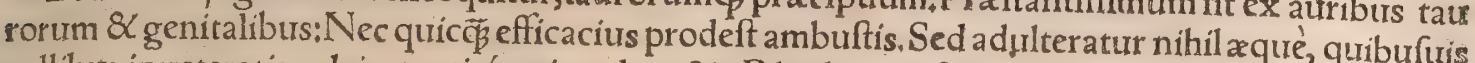
pellibus inueteratis, calciamentiş́́ etiam decoctis. $R$ hodiacum fidelifimum, eó́p pictores $\&$ medi. ci utuntur. Id quogs quo candidius, eó probatius. Nigrum 8 lignofum damnatur, Plíníusł Et alibi, Ichthyocollam (inquit) quidam ex uentre pifcis eiufdem nominis, non ex corio fieri dicunt; ut gluti= num taurinum. Collan, id eft glutinum, aliquí xylocollan uocant, $\phi$ in ligno ferruminando eius fit ufus, alin taurocollan. Probatiffimum R hodium eft. Ex boum corijs conficitur, colore candido, \& $\&$ lu cem tranfmittit:nigrum deterius, Diofcorides. Dxdalo inuentori prater ferram, afciam, perpendicis $\operatorname{lum}_{;} \&$ terebrum, glutinum quoçs debemus(telte Plinio)quo tenaci nexu hærerent fimul quæ alia ratione coniungi aptius non poterant, Ineft corịs omnibus mucofus lentor, alips minor, alijs copio= fior, ut in bubus: ex quo glutinum faciunt. Fabri affirmant, ubi conglutinata func ligna minus fran gi, quàm ubi continua. Collopa Graci uocant pellem taurina ceruicis (uel partis inferioris in cer= uice) unà cum pinguedine adhrente, unde prif́ci collabos faciebant. Alij furm $\&$ boum duriora co

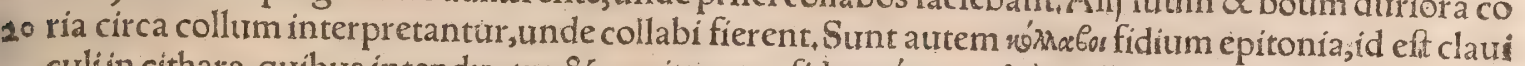
culi in cithara, quibus intenduntur \& remittuntur fides. Kódx a zo Boo's, pellis in dorTo bouris, unde glu ten conficiebant, Kólıkx, coriorum quảam fegmenta ex quibus glutinum coquitur. Syluaticus tria = felaicum (nef cio qualem urocem, crediderim autem à taurocolla corruptam) gluten taurinum expo nit. Deglutinandi ratione docet Plinius libro 16.cap. 43. Glutinum uulgare e pollinis fore tempera= tur feruête aqua, minimo aceti a perfu. Nã fabrile gummisçş fragilia funt,Plin. Et alibi, Scammoniã (inquit)laudatur Colophonium, Myfium, Prienenfe:fpecie autem nitidum $\&$ quàm fímillimum tau rinoglutini, TTaurorum felle aureus ducitur color, Plinius: Hermolaus addit, aramentis atque

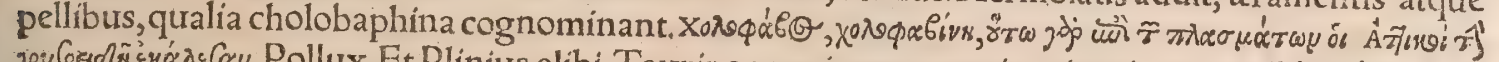

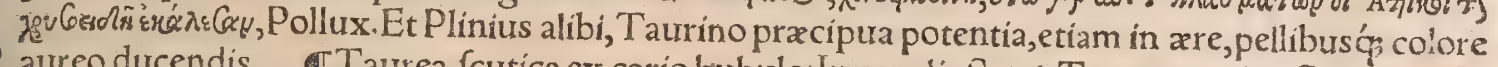
aureo ducendis, đTaurea, fcutica ex coriobubulo:Iuruenalis Sat. 6. Taurea punit Continuofe xi crimen facinusós capillí. TMalthæ calídariæ ad balnea compofitio huiufnodieft, Śanguinf tau rino $\&$ oleo florem calcis admifce, \& rimas coniundionis obducito. Irem ficum, \& picem duram, \&C oftrei teftas ficcas fimul tundes. Hís omnibus iunsturas diligenter adlines, Palladius libro 1. Tir. $41_{\text {t }}$ Ex codem frigidariæ malthæ compofitionẽ, qux cum cæteris fanguinem bubulum recipit, fupra po fuimus in Boue. Eft fané malthis aptus bubulus fanguis, quòd ç cæterorum animalium crafior fit, \& cito coëat dureturós: præcipué taurinus, qui co nomine eriam inter uenena eft: ideó́ is calidaria maltha, ubi craffior et firmior materia requiritur, frigidaria autẽ bubulus fimpliciter additur, $\uparrow \mathrm{E}_{*}$ pigrammatum Græcorum libro $1_{+}$fect 33 , extat epigramma Philippi in tauros, qui trahebant naures F.

Tauris Aegyptï uefcebantur; maccis non item, ut fupra diximus. Hircorum caro turm ad coquen dum, tum ad fuccum bonum generandum, eft deterrima: hanc fequitur, arietum: poft, taurorum, Porrò in ĭs omnibus carnes caftratorum funt præftantiores:uetulor um autem peffim quendum, tum ad fuccum bonum generandum, tum ad nutriendum, Galenus libro 3, de alimento. rum facultatibus,

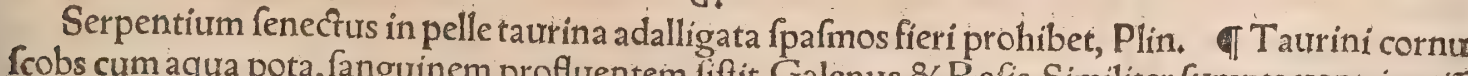
profluuium fapenumerite Galenus \& Rafis. Similiter fumpta uentris etiã proflutum fxpenumero cohibet, Galcnus. Taurini cornus ueterís ex parte ima cinis, infperfus $\mathrm{po}=$ tioni aqua, aluum fiftit, Plinius. Tauri cornu combures eo loco ubi ferpentes fuerint, \& fatim fugi. ent,Sextus \& Aefculapiurs. TSanguis taurinus difcutit mollitéc durities cum polenta illitus, Dio forides. Panos $\&$ apoftemata in quacunq parte taurinus fanguis aridus tritus difcutit, Plinitus; qui idem etiam de bubulo fimpliciter eodem in loco tradic. Galenus de medicam. fimplicium uiribus lia bro 1o.cap. 4. reprehendens curiofum uftrm ex fanguine animalium quorundam, quorum loco faci= liora paratu alia \& præftantiora medicamenta habemus: Vrforum(inquit)fanguis, fi abfeefribus im ponatur, fieri poteft ut concoquat, A dífciam uero etiam caprinum, hircinum, taurintm, Liceŕ́ tibi, fi uoles, prateritis fexcentis medicaminum parabilium, quibus concoquũtur abfceffus:urfos, tauros ac hircos mactare, quolibet fcilicet ufut:Nec enim quifpiam femel impofito in partem medicamento, promiffum eius exiget:nec etiam fí refrixerit ut iam cogatur. Taurifanguis ferpentes necat, $A$ efcu, lap.Maculas omnes illitus de facie tollit, Sextus \& A efculapius. Calidus offa fracta fomẽtat, Innominatus; fortèlegendum ferruminat. Si fanguis réjciatur, efficacem tradunt bubulum fanguinem, mo dice et cum ace to fumptum $+\mathrm{Nam}$ de taurino credere temerarium eft, Plin. Taurinus fanguis aridus Eritus contra parotidas prodeft, Plin, Magnificant quidam adizerfus podagras fanguinem tauri per 


\section{8}

fe,Plinitus, Aridus cum cotyledone herba phagedænis $\&$ fiftulis immittitur, Plinius. Āntidota aduer fus taurinifanguinis uenenum, ultimo hurius capitis loco proferam. T Taurinæ pinguedinis fre. quens medicis ufus eft, quamobrem quomodo ea præparetur, 8 odoramentis imbuatur, repetả hîc ex Diofcoride, prafertim cum ad aliorum quog animalium pinguedines idem appararus ex rquo pertineat. Priuatim(inquit)taurorum pingue fic curari debet:Renibus euulfum pingue profluente amnis aqua abluito, detractisćs tunicis, fictili nouo, poft đ̧ exiguum falem infperferis, liquefacito: de= in in nitentem aquam excolato, $\&$ ubi concrefcere copit, manibus iterum confricando uehementer lauato, aqua fæpius infufa refufać, donec quamoptime elotum uideatur, rurfus in olla cum pari mo do uini odorati decoquito; $\&$ cum iterum efferbuerit, dempto ab igni uafe, ibidem finito pernociaz re:poftridie fi grauiter adhuc oleat, noua olla repetitum, uino odorato perfundatur: eadem qux pri 10 us fiant, dum omne uirus euanefeat. Colliquatur $\&$ fine fale, præfertim affectionum earum caufa, quibus fal aduerfari folet, fed ita paratum non magnopere albefcit, Eodem modo pardorum ( $\pi \alpha$ d dee $\lambda \varepsilon \omega u$, id eft pantherarum, ut etiam Plinius habet, $\&$ capitis in Diofcoride titulus) ac leonum pinguia. curari oportet: (In Graco additur, \& apri, \& cameli, \& equi, \& fimilia $;$ quæ uerba interpretes nmit= tunt, eam nimirum ob caufam quod in titulo capitis non habeantur: Plinius tamen cameli adipem fimiliter curari teftatur) Hæe Diofcorides, ex quo fupra etiam bubuli feui curationem feorfim dedi mus. Nunc eadem de re Plinium audiamus: Qure ratio adipis(inquit) eadem in his quare ruminant, feui eft, alís modis non minoris potentiæ. Perficitur omne, exemptis uenis aqua marina uel falfa lua tum, mox in pila tufum, afperfum marina. Crebro poftea coquitur, donec odor omnis aboleatur. Mox affiduo fole ad candorem reducitur. A renibus autem omnelaudatiffimum eft. Si uero uetus 20 retrocetur ad curam, liquefieri prius iubent:mox frigida aqua latrari $x$ pius, dein liquefacere affufo uíno quamodoratiflimo. Eodemćs modo iterum ac læpius coquunt, donec uirus euanef́cat. Multi priuatim fic taurorũ, leonumós ac pantherarum, 8 camelorum pinguia curari iubent, Vfus dice. tur fuis locis, Plinius. Cæaterum odoramentis imbuendi, taurinum \& uitulinum nec non ceruinum pingue, $Q$ eiufdem animalis(cerui)medullam, ratio hac eft. Pingue quod odoratĩ reddi debet, dem. ptis, quo diximus modo, membranis, elotum \& uino quamodoratifimo, nulla maris aqua diluto, fer uefactum, pernoctare finitur:alterum id genus uinum eadem menfura infunditur, colliquatur, et ex quifite colatur:nouemó eius heminis, iunci Arabici feptem drachma adịciuntur . Quod fi ipium odoris fragrantioris fieri uoles, quadraginta floris eiufdem drachma, cum paribus palm $x$, calami, $\&$ cafia modis adduntur, \& xylobalfami, afpalathi fingula drachmæ, cinnamomi, cardamomi, \& nardi,fingulæ uncię. Omnia exactius tưnduntur, \& affufo uino odorato, in uafe operto, quod fupra car bones firmiter collocatum fit ter efferuefcunt, \& femoto ab igni uafe inibi pernonât: poftridie uinum effunditur, aliudós generis eiufdem adijcitur:ter fimili modo bene conferuefcat: deinde matuti nis exempto a dipe uinum effundatur: $\&$ abluto uafe, fi quid imo fubfidens hrfit, detergatur : poftre mò eliquatum pingue \& excolatum, ad ufus reconditur. Hoc autem modo odoramentis imbuitur, quod antea curatum eft:tuerum ante diça prius infpiffari folent, quò facilius fibi odoramêtorum ui res adfcifcant. Ita $\phi$ affumens quodcun $\phi$ horum uoles, cum uino feruefacito, impofitis unà myrti ra mulis, ferpyllo, cypero, item af palatho plenius tufo:aliquí tamen ad hunc ufum, uno duntaxat hor $\bar{u}$ contenti funt:cum autem ter efferbuit, exemptum leniter, \& linteo colatum, aromatis, uti expofis tum eft,imbuitur, Hactenus Diofcorides. Nunc de adipis fiue feui taurini facultatibus, in genere 4 primum agemus ex Galeno: deinde particulatim ex diuerfis authoribus, Galenus igitur libro I. de fimplicium pharmac, facultatibus cap.4. Taurorum adeps(inquit)fuillo multò calidior eft $\&$ ficci. or. Hoc interim addendum, marem foemina effe tum calidiorem, tum ficciorem; marem autem caftra tum adfimilari forminæ, uelut quicquid iutenilis eft ætatis . Et inter iutenilia foemina mare humi. dior eft, \& minus calida. Sic $8<$ adeps uítulinus taurino minus tum calidus eft, tum ficcus, Caterum quanto ficcior calidior $\phi_{\beta}$ fưillo eft taurinus adeps, tanto fuperatur à leonino. Itaç tan đ̈ß in medio có= fiftens, merito trtriqs medicamentorum mifcetur generi, \& ei f cilicet quod fcirtholis medetur : \& ei quod phlegmonas concoquit; cuítumodi eft tetrapharmacum quod uocant, ex cera, refina, pice, \& adipe conftans. Nam fiue in hoc taurinum, fiue uitulinum, fiue hircinum, fiue caprinum, fiue fuillü indideris, femper puri mouendo aptum, $\&$ concoctorium medicamen effeceris. Taurinus tamen for $y^{\circ}$ foribus $\&$ mefforibus, $\&$ omnibus carnem duram habentibus, fiue ob naturalem temperiem, fiue ex ratione ac forma uitæ, magis conuenit, $\mathrm{Hxc}_{\text {Galenus: } \&}$ alia quædam de adipe in genere: quibus explicatis reprehendit illos qui aftringendi uocabulo apud Gracos abutuntur : ex quibus etiam Diofcorides non recte caprinum adipem fuillo magis aftringere fribit:item taurinum, bubulum, 86 uitulinum aliquantum aftringere ( quan क̈̈ pofterioris huius dicti Galenus illic non meminit) cum potius aliquid caloris $\&$ acrimonix habere dicendum ei fuiffer: $\&$ caprinum fuillo acriorem effe, $\&$ calidiorem ficcioremćc. TVincit maculas in facie taurinum feutum uitulinúmue fel, cum femine cunilæ, ac cinere è cornut ceruino, fi canicula exoriente comburatur, Plinius. Sepum tauri cum re. fina \& creta Cimolia impone, omnem duritiem difcutit,Sextus:Aefculapius fimiliter, nifi $\phi$ procre ta Cimolia ceram habet:quod magis probo, cum ad Galeni iam dicfum tetrapharmacum accedat. 60 Arborum refinæ panos $\&$ fimilia cum feuo taurino $\&$ melle fanant, Plin. Parotides miro remedio comprimit adeps urfinus, pari pondere cum feuo taurino $\&$ cera permixtus, atç adpofitus, Plinius 


\section{Taurus. G. Lib. I. Iog}

\&Marcellus, Ruta emendat uitiligines, uerrucas, ftrumas, \& fimilia, cum ftrychno \& adipe fuillo ac taurino fetro, Plinius. A d foeminarum ftrumas cinis afpidum cum feuo taurino imponitur, Plin . Podagris medetur urfínus adeps, taurinum ç feumm, pari pondere \& ceræ: addunt quidam hypori Phidem \& gallam, Plin. Medicorum aliqui axungia ad podagras uti iubent, admixto anferis adipe, taurorumç feuo, \& œfypo, Plin. TTaurina medulla tertio loco poft certrinam \& uitulinan lauda tur: fequuntur eam caprina $\&$ outilla, Diofcorides. Ex medullis optimam femper expertus fum cer uinam, deinde tritulinam. A thircorum et taurorum, tum acrior eft, tum ficcior. Itaq 3 durities frir ho fas emollire nequit, fi qua etiam memoria manet corum, qux in quinto libro de his funt prodita, Ga. lenus de fimplicib,11+5. Tauri medulla in uino trita $\&$ potata, torminofos emendat, Sextus: Aef ula to pius non torminofos habet, fed tremulos, quod forte magis probandum eft, cum $R$ afis etiam ad ner uorum contractiones ea utatur, quan ${ }^{\circ}$ foris ilita, his uerbis:Medulla tauri a dignem líquata, fi mi= fceatur quarta pars myrihærubentis, \& olei laurini rantundem, manusćśs ac pedes inungantur dilu

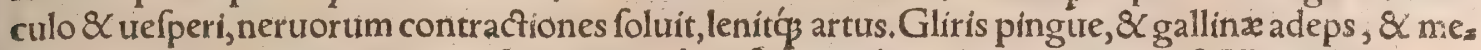
dulla bubulina,uel taurina, liquefaça tepensć, ,infuía auribus plurimum prodeft, Marcelluss,

T Taurinum fel Diofcorides ouillo, fuillo, hircino atos urfino prafert:\& poftea, Vrfinum (in. quit)ouillúmue, eadem taurino poteft, fed minore efficacia. Galenus de fimplicium pharmac, $1 b_{+} 10_{*}$ cap.12. Taurorum bilis(inquit) calidior \& ficcior $\mathrm{eft}$, के boum caftratorum. Et quorundam ego tauro rum bilem uidi coruleam, flaua nimirum fuperaffata (quod ob nimiam fatigationem, \& fitim fa= memós contingit)quam medicamento praparando inící uetui. Facile autem eft ex colore conïcce 20 re, qưodnam fel calidius acriusás fit, quod côtra. Taurinum fel mifcetur cưm melle ưulnerarị̆s em plaftris, theriacisós medicamentis qux foris inunguntur, Diofcorid. Melle mixtum ulcèra maligna fanat, Rafis. Vlcera cætera fanantur felle taurino cum cyprino oleo, Plinius cum de ulceribus cru= rum $\&$ tibiarum paulo ante locutus effet. Contra phagedænas cum inelle utiliter inungitur, Diofc. Phagedænis \& fiftulis immittitur cum fucco porri aut lacte mulierum, Plinius. Ambuftis prodeft fel tauri,Plin. Illitum fuper fimize mor fum, perfanat, Sextus. Vlcera in capite tanđF proprius morbus pracipuè infant bus nafcuntur, fed $S$ uriros \& mulieres grauter moleftant : hæc ergo felle taturino cum ace to tepefacto inlita, efficaci remedio fanantur, Marcellus. Mixtum cum nitro \& uino \&' oleo, quod fatis fit, ulcera capitis uel fertrefcentem fcabiem fanat, Marcellus. Alopecias felle taurino cum À gyprio alumine tepefactis illinunt, Plin. Cum nitro cretáuecimolia, lepras furfureśḉ efficacuîi= zo me exterí, Diofc. Fel tauri uel afini, utrumg̨ per fefe aqua infractum, euitatíş́ folibus ac uentis poft detractam cutem, maculas in facie uincit, Plin.In faciem illitum, lentigines purgat. Comitialia bus datur feurum caprarum cum felle taurino pari pondere decoctum, \& in folliculo fellis recondicit, ita ne terram attingat, potum uero fub limine ex aquia,Pli.Alcheron, id eft duram lapidis inftar fub= Itantiam, qua in felle bubulo reperitur, comitialibus prodeffe, \& aciem oculorum promourere, ac ne quid humoris in oculis colligatur prohibere, fupra in Boue docuimus ex Rafi: Quod fi defit alches ron, fubftituetur ei fefquidenarius de felle tauri nigri,èodem authore. Felle tauri cum oui albo colly= ria fitunt, aqu̇aóg diffoluta inunguntur per quatriduum, Plin, Cum melle \& balfamo oculorum uiria curat, Aefculapius. Ego, ut apud Sextum reperitur, potius legerim, hoc modo: Cum mulfo \& melle Attico inuncium, fuffufionem 8 caliginem oculorum fanat. Mulfo infufum, $\&$ aurribus inftillas to tum, fanat earum dolorem, Sextus. Aurium dolori \& uritijs medetur pręcipué fel taurinum, cum por ri fucco tepidưm:ưel cum melle fi fuppurent:contraćs odorem grauem, per fe tepefactum in mali co rio, Plin, Sanat purulentas aures, 8 in his rupta,cum caprino humanóue lacte inftillatum, Diof $c$.

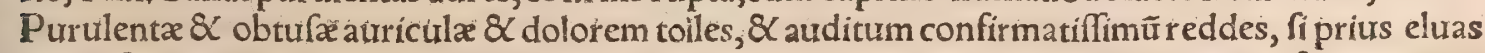
eam lafere cum recenti caprino aut mulieris lacte permixto, deinde inftilles tepidum fel taurinum cum oleo cedrino xquis portionibus mixto, Marcellus, Fel tauri confert ulceribus in aure recentis bus, Auicenna.Si duæ uel tres guttæ eius inftilientur auri tinnienti, conducit, $R$ afis. Cum porri fuc. cofibilis aurium medetur, Diofcor. Efficax habetur \& caprino lacte collui dentes; uel felle taurino; Plin. Contra anginas cum melle inungitur, Plinius $\&$ Diofcor. Melle permixtum $\&$ extrinfecus fau cibus appofitum, uel pro unguine inductum, anginas efficaciter fanat, Marcel, Fellis taurini, falis, a50 ceti, mellis, olei ueteris, aquas partes in unum miferioportet, 8 cum opus fuerit pinha perfricare fauces diutius laborantes, Marcellus, Bubuli lactis decocti potus, inter coeliacorum \& dýtenterico. rum remedia numeratur: dy fentericis addi mellis exiguum pracipiunt: \& fi tormina fint, cornis cer uini cinerem, aut fel taurinum cumino mixtum, \& cucurbitæ carnes umbilico imponere, Plinius, Ad lumbricos egerendes felle taurino madefactam lanam umbilico adpone, Marcellus . Sedis uitia

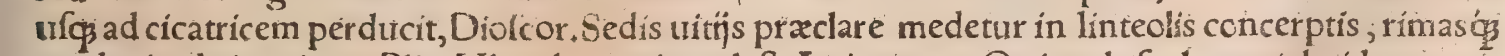
perducit ad cicarricem, Plin. Vlceribus ani prodelt, Auicenna Quiocclufas hæmorrhoides tauria

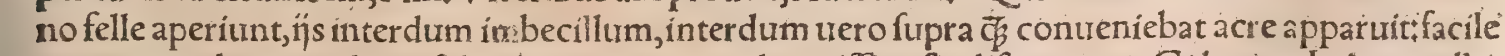
autem ex colore quodnam fel uehementius, quod remiflius fit, difcernetur, Gálenus. In lana collectum, \& fuppofitum ano, uentrem foluit:Idem facit $\&$ infantibus fuper umbilicum pofitum, $\&$ lum:

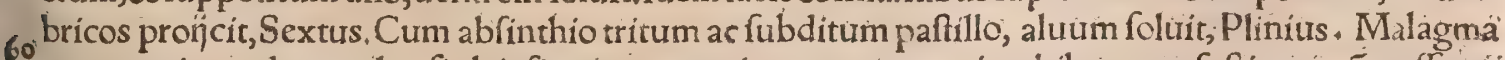
purgatorium ad paruulos, fi ob infirmitatem potionem purgatoriam bibere, aut fuftincre nó poffunts Lupinos crudos ficcos in ollam nouam miftos in furno torrebis, ficcatoś́s actunfos uel molitos câ 

felle taurino tuel uitulino mifcebis \& fubiges: $\&$ pro malagmate ad imum uentrem, ab umbilico de
orfum uerfus impones. Nam fi fuper umblicum impofueris, ftercus omne furfum uocabit: impofi. tum aût deorfurm uerfus, \& bilem detrahet, \& pituitam deducet, Marcellus. Contra genitalium \& froti dolores cum melle utiliter inungitur. Pterygia digitorum leuat aqua calida diffolutum : qui. dam adíciunt fulphur $\&$ alumen, pari pondere omnium, Plin. Butyro $\&$ medulla ceruina $\&$ felle taurino cum oleo cyprino aut laurino perfricta genua fanantur, Marcellus, Podagris (prodeffe aiũt magi)fpina hyæn $x$ cinerem, cum lingua $\&$ dex tro pede uituli marini, addito felle taurino, omnia pa riter cocta, atç illita hyænæ pelle, Plin,llinuntur felle taurino uuluæ in dolore, A wicenna. Muliertî purgationes adiuuat lana fuccida appofitum: Olympias Thebana addidit hyffopum \& nitrum:Cor nus ceruini cinis potus: item uuluas laborantes, illitu quo $q_{3}: \&$ fel taurinum cum opio appofitum $0_{*}$ bolis binis, Plin. Tauri fel trium dimidiorum obolorum Atticorum pondere, in uino iéunæ biberi. dum dato: 8 efformata quogs ex ipfo catapotia deuoranda, ut menfes detrahantur, Hippocrates de natura muliebri. Cum aqua colocynthidis recentis datum mulieri in partu laboranti, cito partum educit, $R$ afis, Sterilitatem ob partus uexationem fieri certum eft. Hanc emendari Olympias Thebas na affirmat felle taurino, $\&$ adipe ferpentium, $\&$ arugine, addito melle, medicatis locis ante coitus, Plin. $\quad$ Membrum tauri in aceto maceratum 8 illitum, fpendidam facit faciem, Sextus: fic \& 1 lu: tinum ex genitalibus tauri, ut infra dicetur. Genitale tauri rubri aridum tritum, et aurei pondere pro pinatum mulieri, faftidium coitus affert, $R$ afis. Recentiores quidam contrà ut in uiris Vener em exci tent, tauri membrum cateris huíus facultatis medicaminibus admifcent, बFFemora tauri (ut cor= nua etiam)ufta fanguinê cohibent, Galen. TTaurifimus tumores atç duritias foluit, Aef́culap: 20 Cum aqua calida potatus, omnes dolores fanat, Sextus, Calidum alopecips imponito, Sextus , Combuftus $\&$ afperfus uino aut aqua feruente, combuftum fanat, Sextus. Fimo taurino malas rubefce $=$ re aiunt, non crocodileam illini melius: $f e d$ fouri frigida $\&$ ante $\&$ poitea iubent, Plinius. Suffitu fi $\rightarrow$ mi,quodà mafculo boure redditum eft, procidentes uuluæ reprimuntur, Diof, $c_{*}$ Lepras ac furfix res tollit urina tauri, uel addito nitro afini circa canis ortum, Plinius \&Marcellus, Lotio taurino ca= put fi laueris, porriginem uetuftiffimam tollit,Marcellus.Ad porriginem, utọ́ non tędia animalium capillis increfcant, fel hircinum cum urina tauri prodeft, Plinius. Capitis ulcera manantia urina tau a ri efficaciter fanat: fi uero uetus fit, etiam furfures adiecto fulphure emendat, Plin. Vrina tauri ficum myrrha inftilletur, aurium dolores lenit, Diofcor, Si maior fit grauitas aurium, urina caprí uel tauri, uel fullonia(id eft humana)uetus calfacta prodeft, uapore per lagenæcollum fubeunte + admifcent et aceti tertiam partem, \& aliquid urinæ uituli, qui nondum herbam deguftauerit, Plin. Bialcon ad Ve nerem ftimulandam tauri à coitur urinam bibi iubet, lutoós ipfo illini pubem, Plin, Purgatorium fi mulier non concipiat, ex Hippocratis de natura muliebrilibro: Tauri urinam (inquit) collige trium heminarum menfura. Deinde artemifiam herbam, aut parthenium, $\&$ adiantum, et laurtrm uiridem, 8 cedri ramenta fimul contunde. Deinde in effoffa fcrobe carbones accende, $8 \times$ impofita olla urinã tauri infunde, $\&$ contufa in mor tario adijce : poftea fellam circumpone, $\&$ artemifiam herbam, auc hyffopum, aut origanum impone: 8 muliere fuper hæc collocata, donec fudet, foue. Vbi uerofudâa rit, laua cum calida, $\&$ in lauacrum artemifiam 8 laurum immitte. Deinde fubdititium medicamen. tum adhibe. Aut artemifiam, aut bulbium in uino albo tritum lanæ introlutum fubdat. Hac ad tres dies faciat, $\&$ deinde cum uiro dormiat. TDe taurino glutino, \& quodnam optimum fit; \& quo= modo adulteretur, fupra dixi cap. s. Praftantiffimũ fit ex auribus taurorum $\&$ genitalibus, nec quic: quam efficacius prodeft ambuftis, Plin. Cum melle $\&$ aceto ambuftis illini Auicenna iubet. Scabiem hominis abolet in aceto liquefactum, addita calce, Plin. Cum aceto illitum impetiginem tollit, \& fcabiem fi profunda non fuerit, Auicenna. A ceto remiffum, a diecfo fulphure uiuo leni igne decoctum;

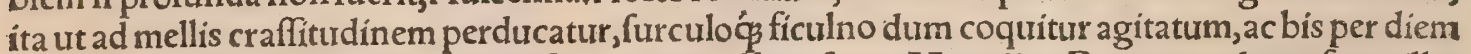
impofitum, impetigines agrias, id elt feras, potentiflime fanat, Marcellus. Recentes plagas ferro illatas fanat, liquefactum $\&$ tertio die folutum, Plinius, Cum melle $\&$ aceto mifcetur, eá̧̧ lotione len= des tolluntur, Auicenna. Membrum genitale tauri in aceto maceratum \& illitum fplendidam reddit faciem, ut fcribit Sextus: fit enim hoc modo glutinum candidand cuti, \& fcabiei tollendæ idone um. Medetur dentibus fabrile glutinum in aqua decocqum illitum $q$;, 8 mox paulo detraçum, ita ut confeftim colluantur uino, in quo decocti funt cortices mali punici dulcis, Plinitus, Glutinum tauri= num tribus obolis cum calida aqua bibitur in uetere fanguinis excreatione, Plin. Ad eundem ufum Marcellus Empiricus commendat glutinum quo charta glutinatur : hoc enim (inquit) calidum in modum forbitionis hauritur: uel ex aqua calida fanguinem excreantibus datur. Glus taurina aqua calida refoluta, coeliaci uentris inflationi utiliter imponitur, Marcellus: Ego magis probo Pliní leetio nem, qua huiufmodi eft, Infundunt dyfentericis \& glutinum taurinum aqua calida refolutum : In flationes autem difcutit uitulinum fimum in uino decoctum.

TSequitur ut de tauríni fanguinis maleficio, eiusć̣ fígnis \& antidotis, collatis authorum locis do: ceamus. Hic celerrimé coit atç durefcit(ut fupra diximus)ideo peftifer potu maximé, Plin. Miror au tem cur aduerbium maximé addiderit, quafi etiam aliter quàm potus ladere poffet, id quod authorũ 60 nemo tradidit, nec ratio indicat, Neq̧ enim tota fubftantia fua urenenofus eft hic fanguis, non magis

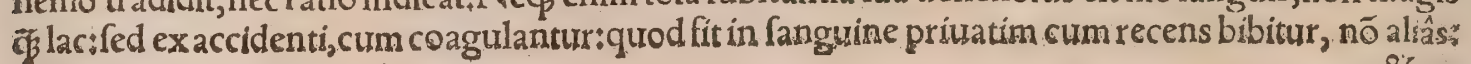




\section{Taurus. G. Lib. I. III}

\& ne tum quidem, exemptis fibris, quę cödenfationis caufam habent, Taurinus fanguis recens inter uenena eft, excepta A egira.Ibi enim facerdos Terræ uaticinatura tauri fanguinem bibit, priufquam defcendat in fpecus. Tantum potelt fympathia illa de qua loquimur, ut aliquando religione uel loco fiat, Plin. De Terra dea eius'́c oraculis Gyraldus foribit in Opere de dijs cum alibi,tum Syntagma= te is, in Themide, Simile gd fupra retulimus, nempe uaticinï caufa defcenfuris in Trophoní antrü bouem placentam dari folitam, cò quod intus mugitus quidam æederẽtur. Alegira urbs eft inter À to los \&Peloponnefiacos, Plinio \& Pomponio teftibus:eft \& Âegira infula apud Plinium. Äıyegpa (in= quit Stephanus) urbs eft Achaix ab Homero Hyperefia dicta:P Pilon Cilicix urbem facit Aegeiran. Midam illum ueterem multáq temporum fabulofitate inuolutum; Plittarchus in libro de fuperfti= Io tione fcribit, contracta ex fomniorum diritate animi xgritudine, cum mali nullưm fe promeret alle= uamen, tauri fanguine copiofius haufto, côceffiffe ab humanis: Qưod item Strabo teftat li 1 i. Taurini fanguinis uenenum deprehenderunt in diuina remortales, cum iugulatis ad facrificium tauris, qui aderant fuperftitiofiores calentem adhuc biberent, Nullus tamen clarius hoc genus mortis quã The miftocles fecit:quii poft pulfum è Græcia Xerxen exul à patrla, accepto ab Artaxerxe exercitux, fitue nolens, fiue defperans qua illi contra Græcos pollicitus fuerat praftare, in lonia Magnefia decepto cultrario ipfe taurum in facrificio tenens, (fimulato Dianx facro, quam Leucophryn uocãt, Calius )

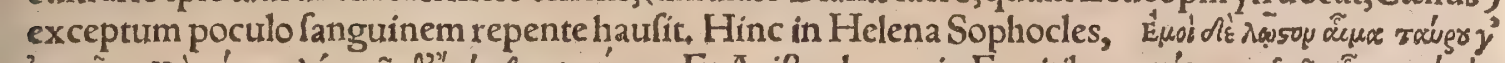

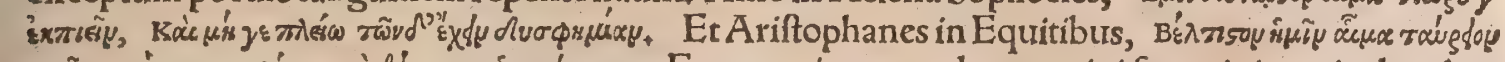

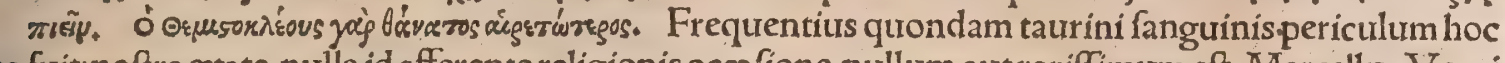
of fuit:noftra ætate, nulla id afferente religionis occafione, nullum aut rariffimum eft, Marcellus Vergi lius. Thucydides tamen Themiftoclem mortuum modò fribit, $\&$ in Attica clam hurmatum. Tauri recens iugulati fanguis epotus fpirandi difficultatem ftrangulatumó̧ cốcitat: faucium tonfillarumó̧ meatus pracludit cum neruorum diftentione, lingua rubefcit: dentes inficiuntur: quædam concreti fanguinis ueftigia, inter corum commiffuras reftant, Diofcorides. A gegineta omnia Diofcoridis uer. ba fuper hoc ueneno in fuum codicem transfcripfit:uariat autem in nonnullis, quax ut hęc fcribendo

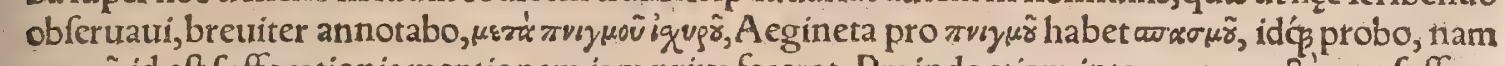
$\pi v i j \mu \tilde{z}$,id eft fuffocationis mentionem iam prius fecerat, Proinde etiam interpreces recte non fuffoca rionem, fed conuulfionem uel neruorum diftentionem uerterunt, EtNicander in Alexipharmacis,

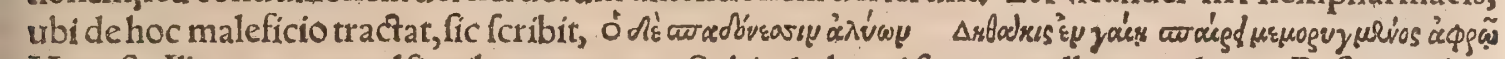
Hoc eft, Ille uero conuulfionibus uexatus Subinde humi fpuma pollutus palpitat. Pofterius hoc fignum de fpuma, quam ore nimirum reddit qui bibit, aliorum nullus commemorat. Sed non opus eft quod quis folicitus fit de fignis huius ueneni : neqg enim ita latere poteft, aut cibis potionibúsue immifceri ut alia quadam uenena: Euenire tamen polfet ut in fultis aut infanis hominibus, qui uel pponte uel oblatum bibiffent bunc fanguinem, aliquis horum fignorũ ufus effet. Rurfus ubi in Dio

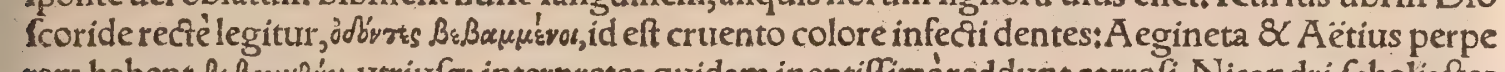
ram habent $B_{\varepsilon} \beta_{\text {poustiot, } u t r i u f o s}$ interpretes quidam ineptiffimè reddunt corrofi. Nicandri fcholiaftes

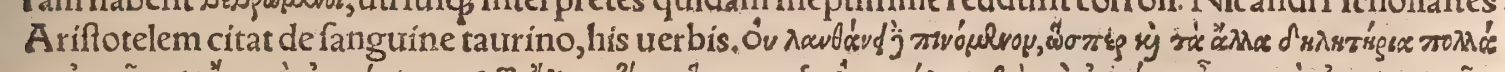

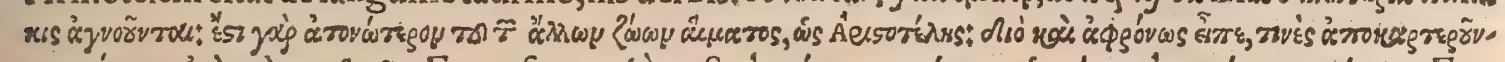

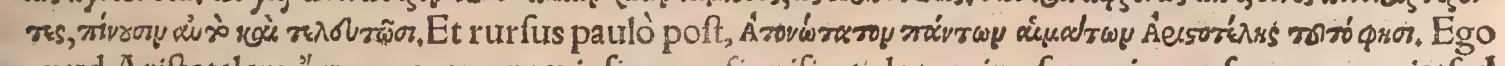
- apud Ariftotelem "*rovou uocem, quæ infirmum fignificat, de taurino fanguine nufquam reperio: fed

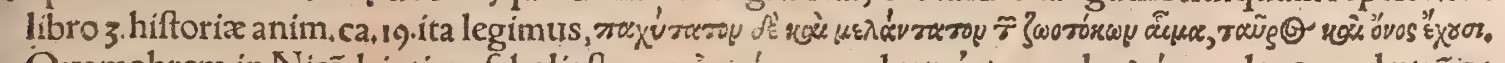

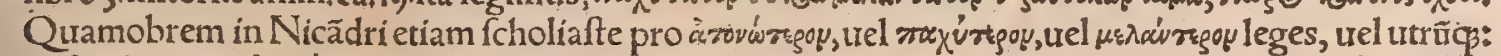
\& fimiliter pro \&rov'w zroto eadem uocabula in fuperlatito gradu. Hoc admiffo, ut neceffe eft, uerbo. rum qux ex fcholijs citauimus, hic fenfus erit: Cum cætera uenena frepe fallant, \& lateant, utuel ab inuiris cautisq̧́ fumantur: taurinus fanguis eịumodi eft, utpote nigerrimus 8 crafliffimus in toto fanguinis genere, Ariftotele etiam tefte, ut latere non poffit, nec nili a uolentibus fumi, quibuis fulti. tia aut defperatio hoc,faciendum perfuaferit:Quamobrem recté Nicander dixit, fi quis hoc uenenũ biberit à $\varphi \rho \sigma v^{\prime} v y_{\text {, }}$ id eft fuapte ftultitia, non fraude $\&$ dolo aut infidips. Tranfeo ad remedia. Vomi= tum à fanguinis iftius hauftu (monente Diofcoride) uitabimus: fanguinis enim globi feugrumi, at. - traçu illo in fublime relati, magis gulæ inculcantur.Idem Aëtius $\&$ Aegineta præcipiunt. Cærterum Galenus libro 2, de Antidotis cap.42.A duerfus taurinum fanguinem epotum, inquit, remedium eft acetum bibere et uomere. Mihi quidem Diofcorides \& alị uomitum rectè prohibere uidentur, illum fcilicet qualis poft cætera uenena moureri folet, nempe ab ufu dulcium pinguiumós, ut olei, hydrelæi, hydromelitis, \&c. Galenus probat, fed à folo aceto, ut quod grumos diffoluat, negs fimpliciter educat \& gulæ infarciat. Certe à lacte coagulato in uentriculo, fimiliter uomitiones uitandas Diofcorides, A egineta, \& Aétius præcipiunt, ne hærens in gulæa anguftís coagulatum lac ad exitum eluctando fuffocet. Hoc etiam obiter monuerim, eadem feré omnia quęlac in uentre coagulatum diffoluunt, \& qua fanguinem fuum cuiufgs in uentriculo uel alibi concretum difcutiunt, contra fanguinem tauri num quops antidoti locum obtinere. Statim autem (inquit Diofcorides) exhibenda funt medicas so menta, quæ concretum fanguinem difcutiunt, aluum fubducunt: $\&$ rurfus pauló poft aluum refol.

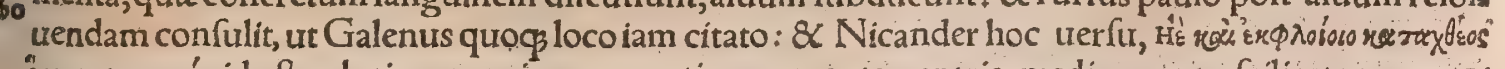
Egexertr yosgós, id eft uel etiam exprimas onerati excrementa uentris, medicamento fcilicet purgante; 


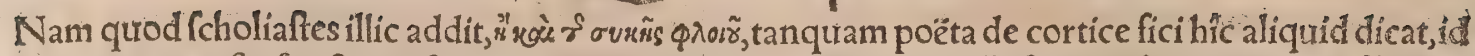
ita accipi neş fenfus \& conftuctio loci illius admittit, neq cum alís fcriptoribus conuenit. $1 \mathrm{bidem}$

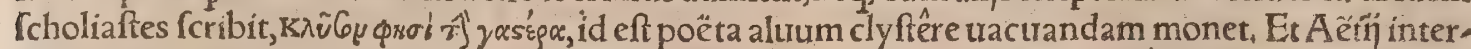
pres, Aluus (inquit)pinguribus \& lubricis infufis eluatur: Ego certe licet clyftêris ufum inter huits ueneni remedia non reprehendam, authores tamen nihil de eo pracepiffe contenderin. $\mathbb{N a m} \& \mathbb{N}$ candri uerba commodius de medicamento purgante per os fumęndo acceperis? \& Aētńl locus appa

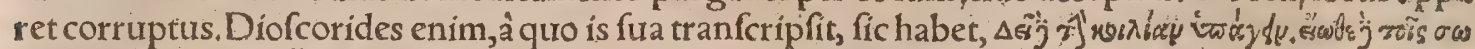

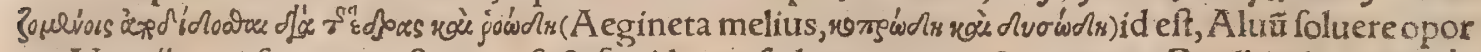

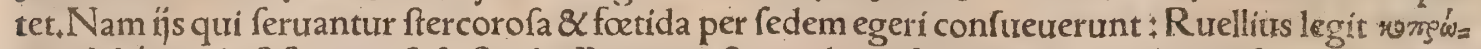

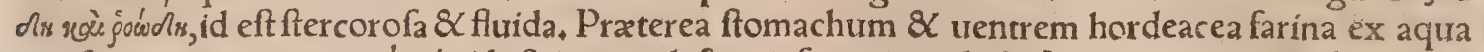

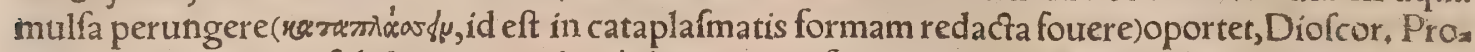
derit quogs uentrem fubducere, eundemós lupinorum farina $\&$ nitro in oxymelite decoctis conte. gere, Galenus:nimirum ut inde fluat, ut folet ab epomphalịs dicis medicamentis. Forfan $\&$ apud

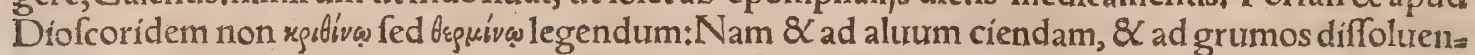
dos quantû lupini hordeo praftent, medici omnes fciunt, Meminit huius ueneni etiã Ferdinandus Ponzettus cardinalis, fed nihil adfert egregiư, ut neçalĭ recêtiores quorũ libros in prafentia adiui. Nune remedia qua particulatim apud authores inueni ordine literarum, fubnectam, ut inuenire $\&$ conferre facilius fit. Acetum per fe prodeft ad uomitum ciendum, ut ex Galeno dixi ; alin id ne. quaquam ad uomitum exhibent, fed uel mero uel aqua diluto (pofcam uocant) alia medicamenta qux fanguinis grumos diffoluere poffunt, admifcent. Ad lac quoc $\$$ coagulatum acetum per fe bibi Galenus confulit, non tamen ad uromitionem. Amarantus, Aëtio. Diolcorides hanc herbam helio= chryfon uel helichryfon urocat.Quænam uero hæc nobis fit, uel quo nomine hodie dicatur, medici contendunt, Eurycius Cordus $\&$ Leon. Fuchfius putant eandem effe qux hodie itulgo ftichas citri. na nominatur, in qua ego abrotoni folia defydero, \& potius ageraton Diofcoridis effe cońŕcio " Io, Ruellius cotulam non foetidam. Ego Matthxoli Senenfis fententix magis accefferim, qui helichry. fon apud Tufcos abunde nafci fcribit, locis incultis, $\&$ pratis ficcioribus, collibus, 8 arenofis flumia num ripis, altitudine cubiti, folips abrotoni, per interualla digeftis in caule quem rectum $\&$ folidum habet:umbella in cacumine aurea, qua uxlgaris millefol' aut eupatorị Mefuei fpeciem referat: flo. res uel aridi diutiffime uigent, $\&$ feruant colorem, quamobrem initio ueris anteç alí proureniant, ufus eorum ad corollas, Hæc exMatthæoli commentarĭs Italicé fcriptis , Rara apud nos hac herba eft, aut nulla:apparet autem athanafix uel tanaceti uulgo dictí generibus adnumerandam effe, ut etiam Mefuei eupatorium, quod Monfpeffuli herbam D. Marix uocant; in Italia quidam herbam Iu liam, contra lumbricos utentes. Omnibus una florum fpecies, umbellæx uidelicet aureæ, fiorum $\mathrm{CO}_{\mathbf{m}}$ rymbi ficci, quod pulchre cum Diofcoride facit: $\mathcal{X}$ hæc caufa eft, quod decerpti etiam longo tempo referuentur:nihil enim aut parum fucci amittunt, Omnibus fapor acris cum amaritudine quadam: omnibus odor quídam fuus eft, non ingratus, \& qui uel mofchi aliquid refipere uideatir. Quare minimam in hoc genere iuam mofchatam nonnulli appellant, quam ex agro Mefauci oppidi uallis Tellinæ, ut uocant, amicus quidam ante annos aliquot ad me mifit. llla quam defcribit Matthæolus, aut certe congener prorfus, Bafilex proxime urbem locis arenofis emicat, qua torrens influit . Nos tanacetum noftrum in aliorum locum non minore effectu, cum ad alia præftanda qua de helichry, fo ueteres promittunt, tum ad fanguinem ubicunç refolurendum, fubftituemus . Helichryfi Gale nus meminit in amaranto tantum, ut Aétius quroque : Aegineta in Amaranto primum ex Galeno, deinde in Helichryfo ex Diofcoride, quafi unam \& eandem herbam effe nefciret. Amarantum(in quit Galenus)incidit $\&$ attenuat:coma eius cum trino pota menfes detrahit(quod \& Plinius feribit) Creditur $\&$ fanguinis grumos non in uentre folum, fed etiam uefica liquefacere, in quem ufum cư uino mulfo bibendum eft. In fumma, fluxiones omnes potum exiccat, fed ftomacho nocet. Helichry fum Diofcorides etiam chryfanthemum \& amarantum uocari fcribit, eọ́ fimulacra deorum coroa nari*(quod diligentiffimé feruatrit P tolemæus rex A egypti, Plin.) Virga(inquit)eft candida, uirens, recta, firma uel folida. Folia habet ex interuallo angufta, abrotono fímilia:comam aurex lucis, in or: bem:umbellam circinatam, qux ficcis ueluti corymbis confat, (ad folis repercuffum, aurex lucis in so orbem ueluti corymbis dependentibus, qui nunquam marcefcunt, Plin.) radicem gracilem ( $\&$ in fu perficie terra, Theophr.)Nafcitur in afperis $\&$ torrentium alueis(yapedofoúdzon, aquofis conuallibus, Marcellus Verg Plinius in frutectis nafci fcribit.) Coma cum uino pota medetur anguftijs urina, rerpentium morfibus, coxendicis doloribus (lumborum uitijs, Plin.)\& ruptis. Menfes eadem trahit, concretumós in grumos in uefica \& uentre fangurinem cum mulfo pota abfumit. Catarrhum etiam fiftit, trium obolorum pondere ieiunis data in diluta uini albi potione. Mifcetur etiam ueftibus, ut in tegras ab erofionum noxis tueatur, (Plinitus addit, odore non ineleganti) Hæc Diofcorides. Duritias etiam $\&$ inflammationes difcutit, Plin.Marcellus Vergilius in fura translatione uirgam eibreurem

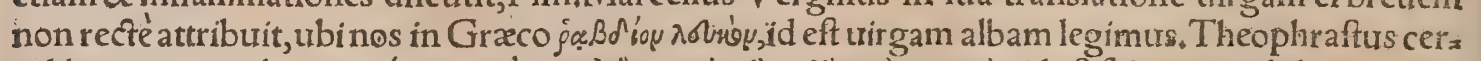

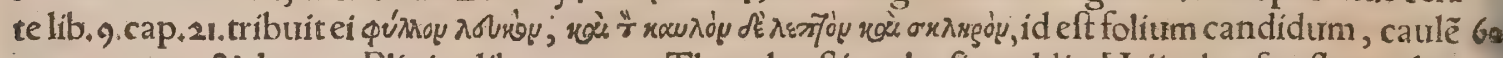
uero tenuem $\alpha$ durum. Plinius lib, 21, cap.11. Theophrafti uerba fic reddit, Heliochryfos florem haw bet auro fimilem, folium renue; cauliculum quoç gracilem, fed durum. Hoc coronare fe magi , fi \& unguenta fumantur ex auro, quod apyron uocant,ad gratiam quoç uitæ gloriam'ćs pertinere arbi 


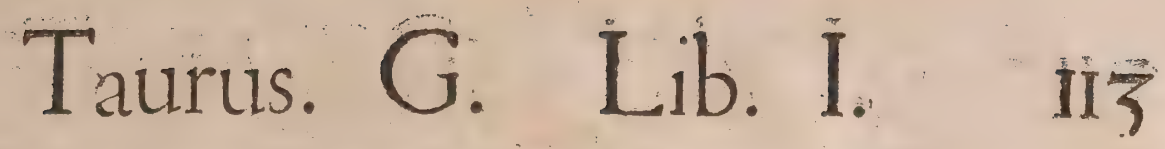

irantur. Hinc patet Plinium in Theophrafto neç caulem neç folium $\lambda$ ourop, id eft album, fed utrun

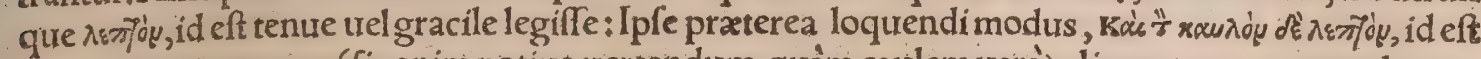
caulem quoç tentiem (fic enim potius uertendum, quàm caulem uerò) aliam quoçs partem de qua

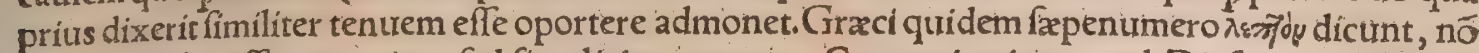
folum quod craffo opponitur, fed fimpliciter paruum. Conuenit etiam quod Diofcorides sevò, id

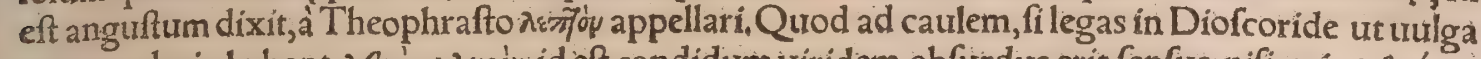

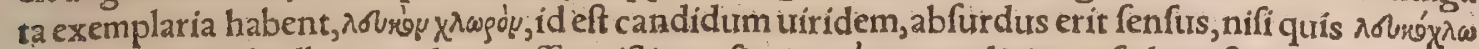

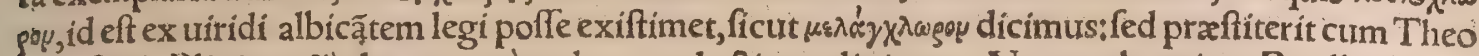
phrafto \&l Plinio $\lambda \varepsilon \pi$ fíu legere, quàm de noua lectione diuinare. Non proboetiam Ruellium qui paßs'ioy hic ex Diofcoride ramulum transfert, cum uirgam aut caulem deburifet:nam Theophraftus racuón habet, Plinius coliculum. Quanquam libro 21,cap.25. quod totum de heliochryfo eft, Plinius etiam fibi diffimilis, ita fcribit:Heliochryfum ramulos haber candidos, folia fubalbida, \& $<$. Sed nec illud quod reddit, ueluti ficcis corymbis depêdentibus, quan $\not$ alium Plinïlocum in hoc imitatus: neç enim in Gracis dependere eos legimus: $\mathcal{Z}$ res ipfa declarat in tanaceto \& fimilibus herbis, um. bellas fiue corymb os (ambigunt enim ferè inter utrunç) non pendulos fed rectos effe. Reprehen dendus eft etiam Theodorus, qui in Theophrafti loco iam citato, pro heliochrylo aureliam reddens, fic uertit:Aurelia folium habet candidum, fructum tenuen dirumó̧ : abfurdiffimus hic error eft; quo pro caule femen fuppofuit, Seminis enim mentionem nullus fcriptorum facit, caulem uero hu= iufmodieffe; omnibus conuenire fatis ex antedictis conftat. Venio ad uires amaranti: Vtuntur eo ad ferpentium morfús é uino $\& \mathcal{Q}$ ad ambufta cremato $\&$ melli mixto, Theophraft. (Plinius fimpli citer, ambuftis cum melle imponitur.) Hę uires ad herba fuperficiem, \& comam uel florem maxime pertinent:Theodorus uero ita tranftulit, ut herba ne an radix accipienda fit in dubio relinquatur.

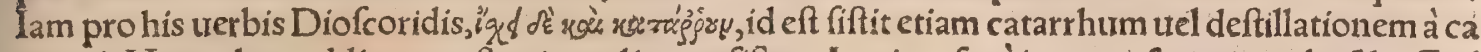
pite:ab Hermolao redditur, proflưuia mulierum fiftere. Legitur fanè in manuffriptis quiburdã Gra

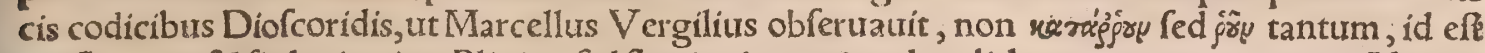
profluuium: \& fíc legit etiam Plinius, fed fluxionis uocem ad muliebrem tantum contraxit:Nam lit: bro 21. cap.25. Folia heliochryfi trium obolorum pondere mulierum profluuia in uino albo fiftere

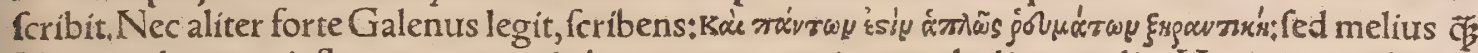
Plinius, ad quemuis fluxum non muliebrem tantum, uim uocabuli extendit. Hoc etiam melius on

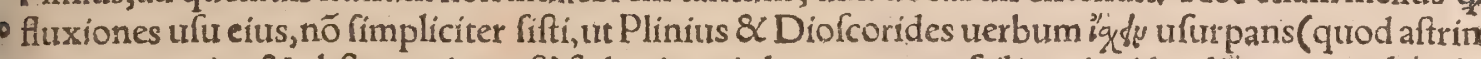
gentium potius $\&$ obftuentium eff) fed exiccari docet;memor fcilicet incidendi fattenurandićç $\&$ menfes prouocandifacultatem ei fe attribuiffe. A egineta helichryfum catarrhis fubuenire fcribit; Quod fi muliebria profluuia exiccat, de pituitofis pręcipue \&albis (ut uocant)intellexerim:ea enim \& diureticis $\&$ nenfes cientibus, ut afaro ac fimilibus, ab initio præfer tim adhibitis, multo felicius quàm aftringentibus folis curantur. Inter Diofcoridis nomenclaturas, chryfocoméetiam \& centau rium minus amaranti cognomen habent, \& ocimaftrum amarantis cognominatur; nihilominus ta men $\&$ inter $f e \&$ ab heliochryfo diuerf $x$ funt omnes hæ plantæ: ut improbandus fit A eginetæ inter pres Andernacus, qui amarantum Áeginetæ (quod \& Galeni amarantum, \& heliochryfos Diofco ridis eft)centaurium minus interpretatur, de quo tamen A egineta alibi feorfum agit, Plinius 21.11 ; 40 heliochryfon inter uernos flores commemorat:Sequitur (inquit)œnanthe, melanion, ex fylueftrit bus heliochryfos:quem locum ex Theophrafti hiftorix plantarum libro 6.cap.7,tranftulit, Eft $\&$ al $=$ terum amaranti genus, qurod Plinius libro 21, cap. 8 , ita defrribic, Amaranto non dubiears à natus tura uincitur(hoc eft nullum in ueftibus æque formofum purpuræe fplendorem ars ulla effingere poreft, ac in amaranto natura nobis exhibuít $t_{4}$ Eft autem fpica purpurea uierius, quàm flos aliguivis; \&iple fine odore. Mirumás in eo, gaudere decerpi, $\&$ latius renafci. Prourenit Augufto menfe, Du: rat ín autumnum. Alexandrino palma, qui decerptus afferuatur. Mirumóp,poftquam defecere cun cif flores, madefactus aqua reuiuifcit, \& hybernas coronas facit. Sunma eius natura in nomine eft, appellato, quoniam non marcefcar, $\mathrm{Hzc}$ Plinius: Cuius poftrema uerba, Summa eius natura in no= mine eft, fic interpretor, quafi medicinæ inutilem hunc amarantum dixiffet : nec ob aliud appeten.

go dum, quàm quia \& elegans flos eft, $\mathcal{Q}$ non marcefcit:qux fumma eius laus uel ex nomine deprehen ditur. Huius amaranti (quem Plinij, uel purpureum amarantum, cognominandum cenfeo, difcrim: nis gratia)nec alius quifquam ueterum, nec ipfe Plinius alibi, mentionem facit, Recentiores quidam florem amoris uocant, Germaniroce tólblin / aliqui taufentøơn: Galli ialoufiam, quafi zelotys pam, \& nobiles flores, \& paffeuelours, quod ferici uillofi purpuram uincat : Itali fiorueliuto, \& alip fior di grana, id eft florem ferici uillofi, \& 2 forem cocci, De quo pluribus fcriberem, fi quid ad medici nam faceret, effi iam nimis longé digreffum me uideo. Hoc faltem prætereundum non duxi, dipli cem in eo Matthæoli errorem elfe:primum, quòd Aêtij de amaranto uerba, quæ ille ex Galeno mu tuatus eft:non intelligit omnino ad aureum amarantum, id eft heliochryfum pertinere, \& $\&$ tanquam de purpureo accipi debeant, confidenter afferit:deinde, quòd Ruellium \& Fuchfium immerito re 6o prehendit, quòd amaranti potioneé tino fluxus omnes lifti feripferint, qux quidem non illorum, fed Galeni urerba funt, ut fupra oftendi. Accedit tertius error, quòd Aëtium teftem citat fluxiones omnes eo prousocari, cum ille non prouocari, fed contrà ficcari fcriplerit, Galenum in hoc fecurtuss 
Hieronymus Tragus amarantum purpureum Circeam effe fufpicatur, helichryfurm tieto linaria fpeciem quandam, quos errores. in præfentia alijs refellendos relinquo. Mihi fatis fit in unica planta cam multos uarioş́́ ueterum \& recentiorum errores aliud agendo indicaffe. Pergo tandem, tie coperam, remedia illa ordine al phabeti recenfere, qua contra taurinum fanguinem in uentre coa: gulatưm à̀ tueteriburs commendanturr. Brafficæ femen confert, Diofcor. Nicander idem cum aceto copiofo propinat. Braffica fylueftris femen toftum auxiliatur, Plin. Caprifici fructus (Latini grof: fos, Graci olynthos uocant)lacteo fucco turgentes, ex pofca, Diofc. Marcellus Vergilius pro olynthis eo in loco reddit fícorum caprificorúmure groffos: quoniam Graca uox(inquit)utriufó arboris immaturum adhuc pomum fignificet, \& Diofcorides lib, 1 , utriuf ${ }_{3}$ lac æqualem habere poteftatem tradiderit, Groffi caprifici cum pofca \& nitro, Aegineta, Caprifici grofli acero dilutx, Galenus, \&

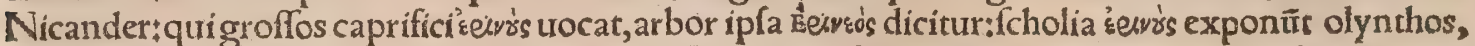
trel ramos fici, quod minus placet. Groffi caprifici potæ refiftunt fanguini taurino poto, \& lacti coa. gulato, Plinius. Groffi ex fíco maxime fylueftri liquore pleni, cum nitro \& pofca, Aétius. Aut fici fuccus eodem modo, Idem. Aut ramuli fici triti cum nitro \& $\mathrm{pofca}$, Idem. At uero fylueftris fici fuc. cus etiam ficcus comeftus, eueftigio grumos diffoluit, Idem. Aggregator cítat ex. Pliníl libro 2z. eti. am lignum caprifici fumptum prodeffe, ego eo ín libro cap. 7.ubi de caprifico agit Plinius, ex groffis rantum remedium inueni. Ex fici lignorum cinere lixiuium, Diofc. \& A Aétius. Prodeft autem etiam

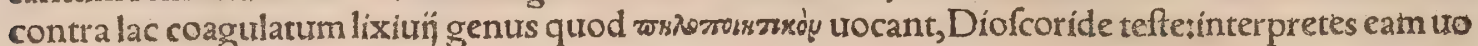
cem relinquunt, quidam luto traiectum aut uino factum reddit. Idem fic nominat Aegineta libro z. cap. 2. \& libro 5.cap. 57. \& alijs multis locis: \& Galenus circa finem libri 10. de compofirione medica. 20

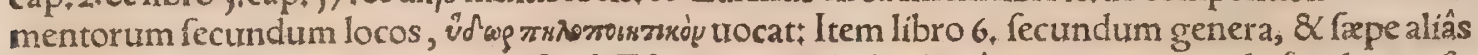
Gracis medicis hac appellatio in ufu eft. Eft autem nihil aliud quàm lixiuium, quale figulis in ufu eft Galenus libro 6.Methodi, Cum nullum medicamentum ad manum haterem, petiuiconian ftafen, id eft lixiuium liquidum, ubi uidiffem pelopcon, id eft figulum agro uicinum, Eadem eft sxuTh

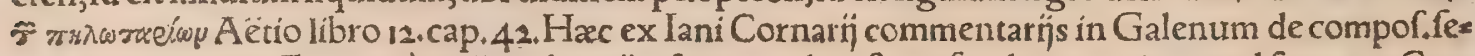
cundum locos, Ego uerò nullum lixiǘ ufum apud noftros figulos reperio: quod fi quem Cor. narius nourerat, quale id lixiuium effet indicare debuerat.Sed quorfum effet $?$ ' ad lutumne lauandũ? fruftra nimixum, quod uel prouerbium monet, quo laterem lauraxe pro inanem fumere operam di. cimus. Melius certe fecerunt, qui uocabulum hoc tanquam ignoetum praterierunt, $\&$ aquam lixiuã nobis fimpliciter reddiderunt, Decepit ipfum(ut Linacrum eriam ante, libro 6. Methodi Galeni uer tendo)quòd paflim omnes codices $\pi$ s

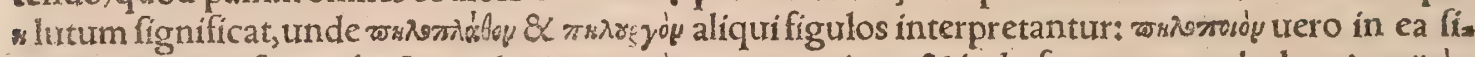

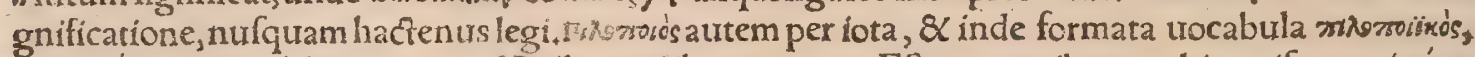

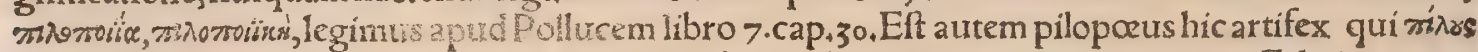

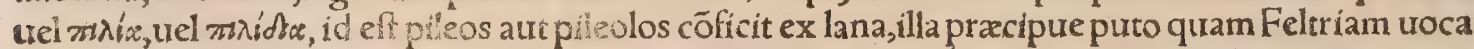

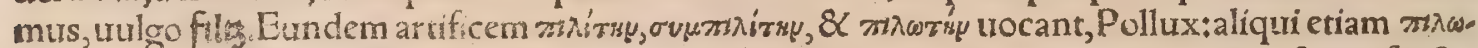

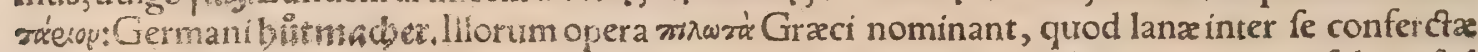

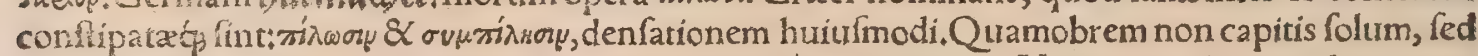
etiam pedum tegmina, tiel tibialia fic parata Graci zinzs nominant. Nam cum reliquiex lana pan= ni, à textoribus contexi foleart, hoc genus conftipando tantum fit. Pilotarï igitur ifti, præfertim cũ nubro uridiue colore la nas tingere uoluerint, lixiuio utuntur, ex cinere quem unlgo clauellatum uocant, noftri weto $\mathrm{f}$ b ch: qui combuftis animalium offibus fit, Audio alicubi pileos omnes iam facos, cuiufcunç coloris fint, tali lixiuio ab eis ablui, V tuntur eo \& alij tincfores, ad certa colorum ge ner a. Noftri praferunt cinerem illum qui ex face uini in maffas coaça cremataćs fit. Hæc lixiuñ ge nera quroniam plus acrimonix habent, $\&$ diffecantis abftergentisç facultatis funt, uulgari lixiuio non folum ad lactis aut fanguinis grumos in uentriculo concretos, fed ad alios etiam ufus extra cor pus, à medicis praferri debent, ut neruorum ulcera, fcabiem malignam, \&c. Hæc admonere opera. pretium uifum eft, cum fex aut feptem Diofcoridis, Galeni, \& Aeginetæinterpretes, hac in re om= nes hallucinati fint, A duerfus lac coagulatum quidem lixiuium pilotariorum auxilio effe folus Dio fcorides, \& imitatus eum Âegineta fcripferunt. Galenus, Aëtius \& Nicander, ubi de eodem uene: so no agunt, non meminere. Hoc omnino monendus ef medicinæ tyro, non temere lixiuium ullum, prafertim uehemens, intra corpus propinandum effe, cum erodendi $\&$ fepticam uim propemodum habeat: Et fi quando ufum eius neceffitas poftulârit, recuratione utendum per pinguia, \& abluentia vel obtundentia morfus, ut butyrum, $8 \mathrm{c}$. Coagulum omne cum aceto, radicéç filphí feu laferis, aut eiufdem liquore, taurini fanguinis grumos diffipat, Diofco. Ego A eginetalectionem prafero, qui coagulum ex aceto feor fim commendat, \& rurfus filphï radicem cum liquore feorfim : fic enim

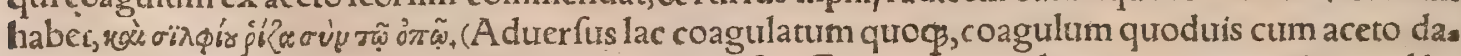
tur:aut filphị radix liquórue cum pofca, apud Diofco. Galenus coagulum ex aqua propinat, uel la.

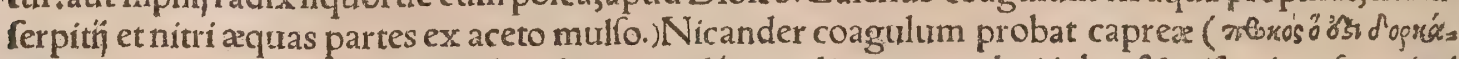
S(O) Scholia)uel hinnuli, uel hoedi, uel leporis:id'ç rarolinteo percolari iubet $8 \mathrm{~cm}$ if ceri, pof ca nimi 60 rum. Coagulum hædif fumitur contra fanguinem taurinum, contra quem $\&$ leporis coagulum ex 2ceto,Plinius.Calaminthæ, id elt nepeta arida folida, eorumós fuccum Diofcorides aduerírs lacicoa 


\section{Taurus.G. H. Lib. I. $\quad 115$}

gulatum auxiliari feribit:quamobrem crediderim in fanguinis taurini etiam periculo prodeffe; praz fertim cum remedia catera plarą̧ utrif

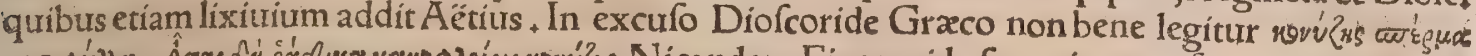

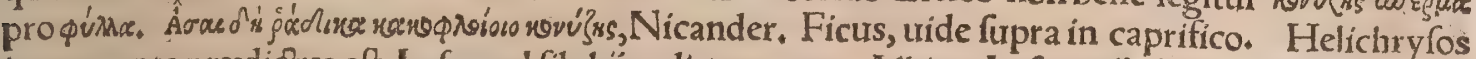
in amaranto predicius eft. Lafer uel filphí radix ex aceto, Aêtius, Laferpitij obolus femiobolúsue, Galenus. Vide etiam paulò ante in Coagulo. Nitrum per fe etiam prodeft, Diofcorid. Nitri ol oli

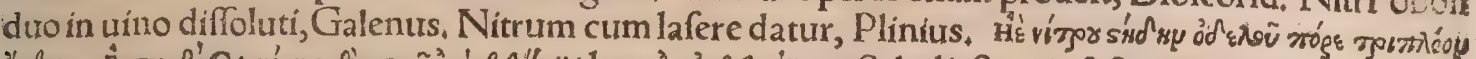

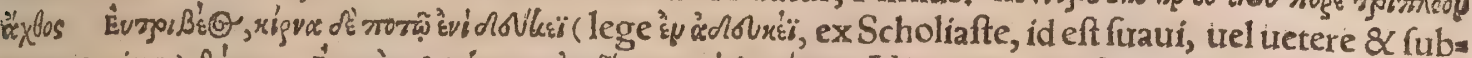

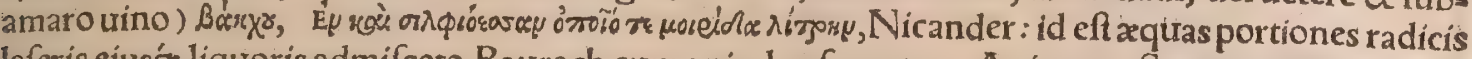
laferis eiusćp liquoris admifceto, Baurach cum aniuden fumptum, Auicenna. Spuma nitri cum aniu den, Serapio citans Galenum ur Aggregator habet, Piper apud Nicandrum per fe: Diofcorides co. nyzx folís admifcet. Porca, id eft aqua aceto permixta, uide fupra in Aceto. Petroleum recentio= res quidam laudãt ad fanguinis grumos diffoluendosłnec dubito quin ad taurinum quoç utile fit, Agathocles contra fanguinem tauri fonchi nigri fuccum demonftrat, Plin. Rubi fuccus ex aceto; Diofcorides $\&$ A egineta: Nicander rubi germina conteri iubet, nimirum ad fuccum quoque expri mendum: Loniceri translatio femina habet pro germina, uitio forte typographico. Thymus cum $\&$ fanguinem concreturn difcutere, $\&$ lac coagulatũ diffoluere pradicetur, in tauri quoģ fanguine re foluendo non ignauus exiftimandus eft.

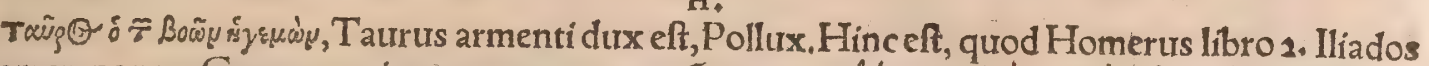

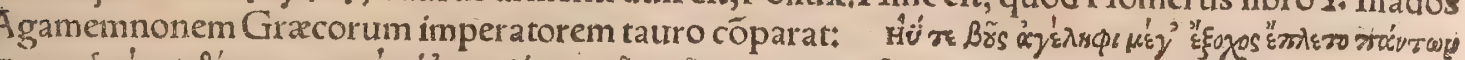

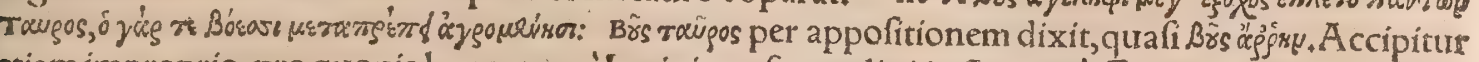
etiam improprie, pro quouis boure, tum à Latinis, ut fupra dixi in A. tumà Gracis; ut in hoc uerfu,

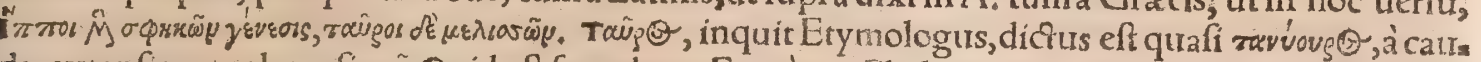
dax extenfione: urel quafi zoûpg, id eft fuperbus. Ego à ror Chaldaica troce appellatum potius fupra dixi. Italia à bubus nomen habere exiftimara eft. Gracia enim antiqua (ut fribit Timaus) tauros uocabat isun's's, à quorum multitudine $\&$ pulchritudine $\&$ foetu uitulorum Italiam dixerunt. Alif fcripferunt, quod é Sicilia Hercules perfecutus fit eo ncbilem taurum, qui diceretur Italus, Varro, Et alibi, Italia (inquic) à uitulis dicta eft, ut foribit Pifo. Tyrrhenortrm lingua taurus dicitur Italus: Propterea ab uno ex tauris Geryonis abductis ab Hercule, dicta eft Italia: quum prope Rhegium enataftetin Siciliam in Eryon campum, ac regn!m Neptuni filin peruaftaffet, Calius ex Gracis in. terpretibus ut ait. Italia olim armentofiffima iurt, Peretrus, Igsiy, taurus exponitur Hefychio $\& \mathrm{Va}$.

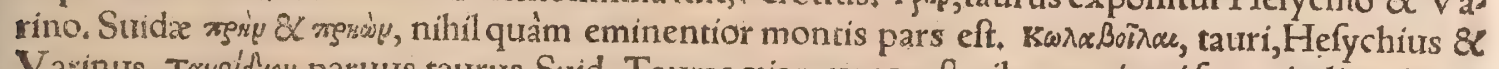
Varinus. Toueid' Omnia magna $\&$ uiolenta Grazci tauri nomine appellant, unde $\& \mathrm{Br}$ particula intendendi apud ipfos, ( de qua multa fuperius) Euftathius in Dionyf \& Stephanus in Tauri montis mentione, nam illum quoçà magnitudine aliqui fic dictum putant. Extat Ioachimi Camerarí in Exercitýs cius Rhetoricis de tauro elegãs anigma, hurufmodi: Mcechus eram regis fed lignea membra fequebar. Et Cilicum mons fum, fed mons fum nomine folo. Et uehor in coelo, fed in ipfis ambulo terris T Taurorum epitheta, Aeripedes, Ouidius, id eft pedes ære folidos habentes. Agreftes differñt àfylueftribus, Plin.lib.8. Alacres, Claudian.2.Paneg. Acer,Silius lib.23. Arator, Ouid.,.Fafto, rum. Bellator,Stat.3.Thebaid. Corniger, apud Cicer, de Nat, ex Poéta, \& Ouídius 15. Metamor. Eximij praftanti corpore tauri, Verg.4.Georg. Iners, Stat. 9. Thebaid. Ingens, Verg.2. Aeneid. Macer, Aegl.3. Nitens, Aeneid.3. Toruus, Ouid.8. Metam. Trux,9+Metam. Validus,7. Me-

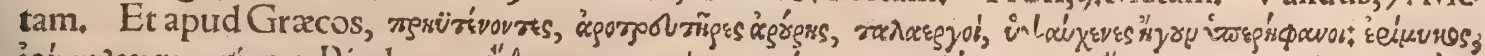

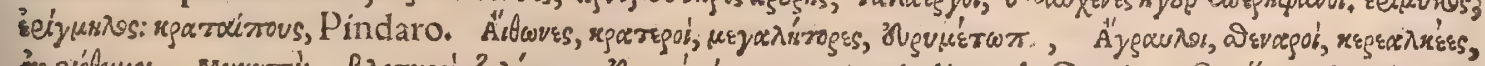

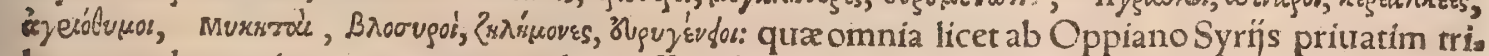

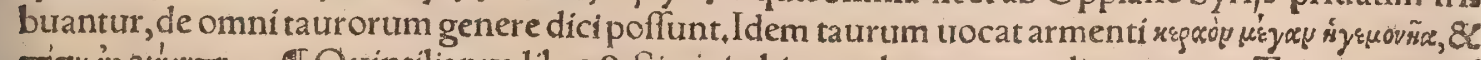

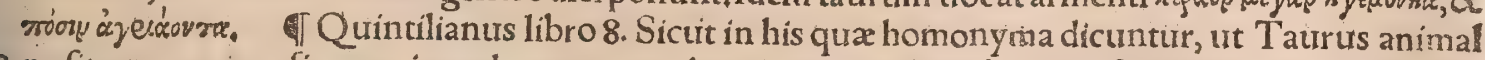
ne fit, an mons, an fignum in coelo, an nomen hominis, an radix arboris, nifi diftinctum non intelligi tur. De tauro fydere dicam infra in $h$. Ephefri pincernas appellare tauros folebant, Hefychius : non quoslibet tamen, nec ubiuis, fed in. Neptunitantum fefto, ut repetemus infra. Eft auis qua boum mugitus imitetur in Arelatenfi agro taurus appellata, alioquin paria, Plinius, Tauri urocantur fcarabei terreftres ricino fimiles, nomen cornicula dedere:alin pediculos terræuocant, $\mathrm{Plin}$. Taügo pars eft membri, \& pro ipfo membro per fynecdochen accipi uidetur. Taurum \& orrhon, ut foribit Ammonius, Graci eam uocant partem qua tefticulos interiacet, quam in aubus orrhopygion uom

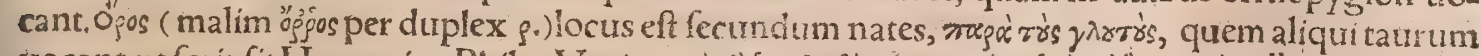

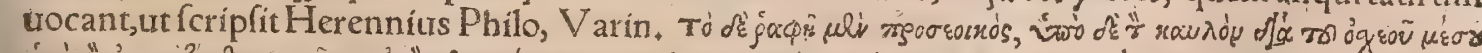

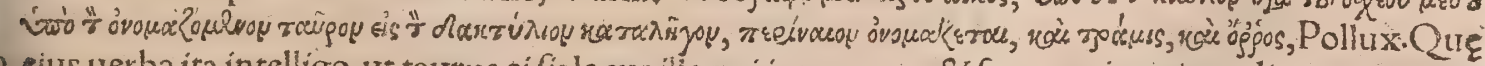
eius uerba ita intelligo, ut taurus ei fit locus ille qui inter anum \& fcrotum interiace, linea autem me dia qua fub cole ef, ac inde per fcrotum $\&$ taurum future inftar extenditur ad anum uf́p, tramis $\&$

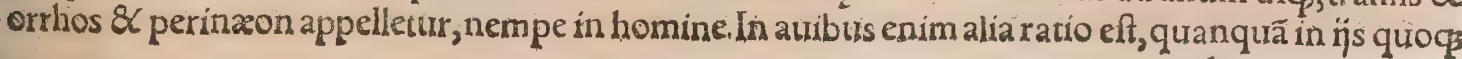


locus inter tefticulos medius, ttel potius finis loci illius eminentior orrhos nomineț. Sic igitur taurizs â cateris tribus nominibus differt, qux tamen aliqui cum tauro cöfundunt. Aliqui ir bunt:aliqui in mafculino, alij in neutro genere proferunt. In Gloffis Galeni hac uerbalegimus, $\mathbb{1}_{\varepsilon e s}$

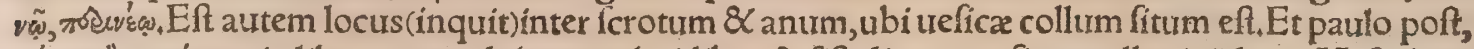

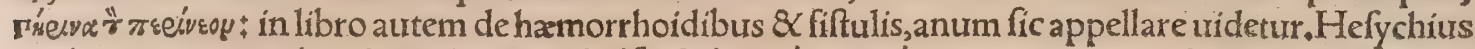

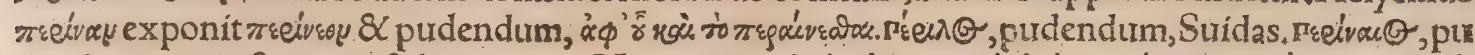

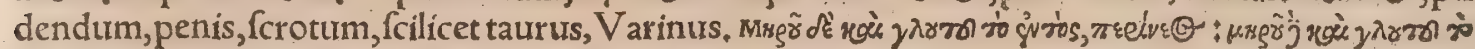

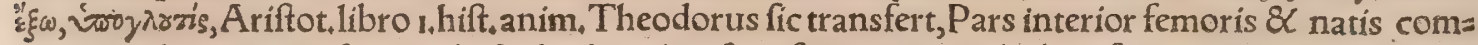
munis, coles: exterior fubnatale. Sed colis in hac fignificatione tocabulum fictum ab eo reor, ego in

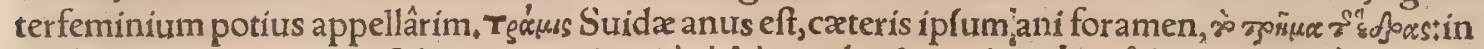

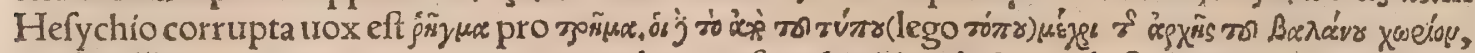
id eft, Al'y uero tramin exponunt partem ab ano ufos ad initium balani, id eft glandis:fic urocatur ex

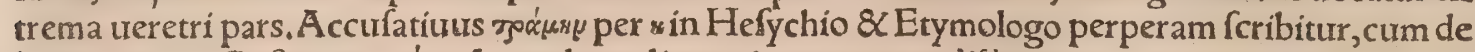
beret per iota.Poftremo zox́kurs fecundum aliquos interpretatur ỏgóò (quam urocem cum acuto in pe.

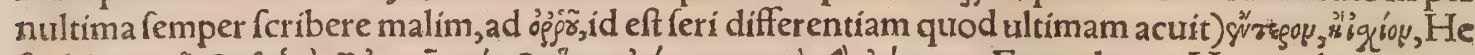

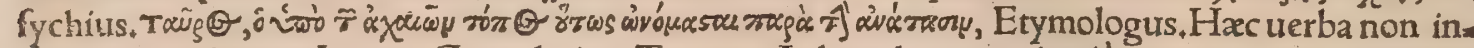
relligens quidam, in Lexico Græcolatino, Taurum A chaiæ locum ridicule interpretatur, cum non

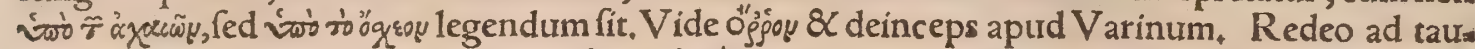

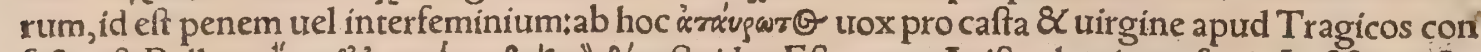

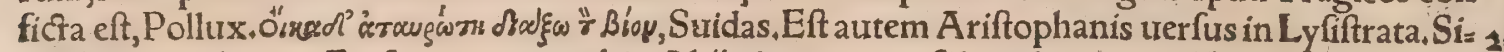
gnificaut eo (inquit Erafmus in prouerbio, $A$ bijt $\&$ taurus in fyluam) uitam colibem foeminx, ne: gligêtis taurum, id eft maritum. Sic \& Horatius pereat male quate Lefbia quarenti taurum, mon ftrauit inertem.Quod aũt Erafmus impudicam tauri fignificationem omittit, modeftix caufa magis

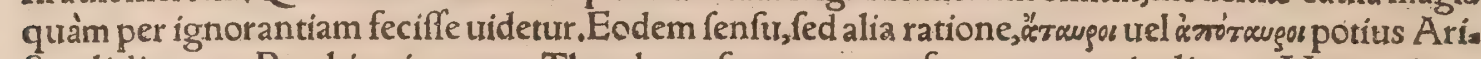
ftoteli dicuntur Pyrrhicæ iuuencæ, Theodorus fetauras transfert, quæ annis aliquot Venere inta= ctæ feruabantur, ut incrementum ampliter caperent. A tauro uidetur etiam uerbum raupzy forma=

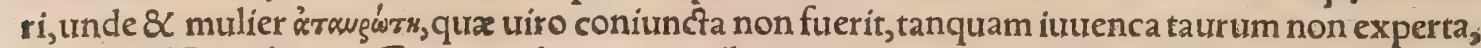
Varinus. Hippobinum Graci quidam uocant illum, qui meretricio amore debacchetur: aut qui inexplebiliter Venerea confectetur, quem Latinorum nonnulli etiam laftaurum dicunt, fed Grace ta men, ut ex Athenæo liquet. Nam eo uerbo Pompeius Leneus nobiliffimo hiftorico, uelut nauum zo inuffit. Id uero fignare hominem libidinis ualidx, in libro de grammaticis $\mathcal{Q}$ rhetoribus auctor Sue= tonius eft. Cuiufmodi narratur Proculus inter minufculos Romanorum tyrannos. Vocabuli ratio hæc, quia Græcorum lingua $\lambda \propto$ (Atticè, Etymologus)dictiones intendit; taurus uero eft pudendor $\tilde{u}$ pars, ficuti adnotatum à Galeno fcimus, nec non à Quintiliano. Eam fub ofcheo pofitam Euftatiuis

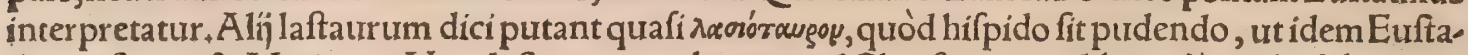

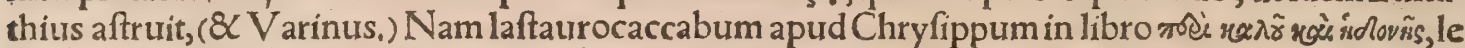

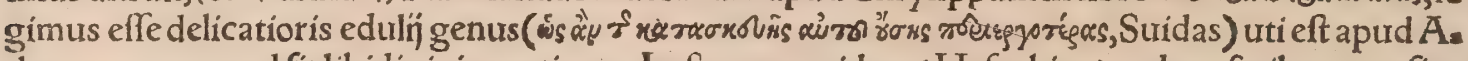
thenæum, ut quod fit libidinis incentiuum. Lafiarnos quidam (Hefychius) malunt fcribere, ut fint

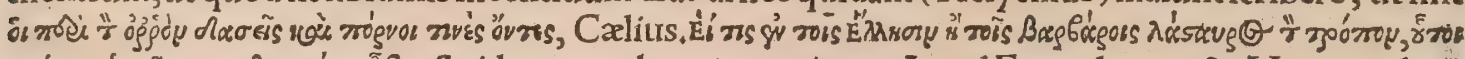

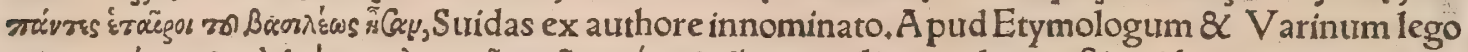

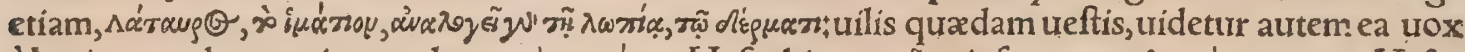

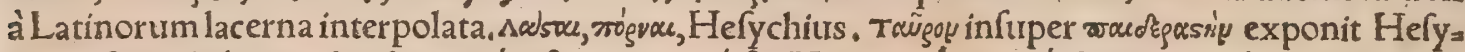

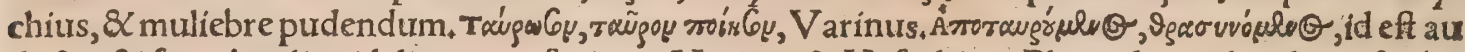
dacter $\&$ fuperbe aliquid dicens aut faciens, $V$ arinus $\&$ Hefychius. Phanodemus hordeum fcribit

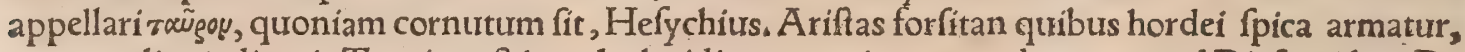
cornua aliquis dixerit. Taurion eft inter lychnidis coronariæ nomenclaturas apud Diofcoridem, De tora herba uulgó dicta apud Italos, quam Diofcorides orobanchen uocat, fupra differui in Boue ca. pite 3 . Eft $\&$ altera tora, uulgò dicta, prima fcilicet aconiti fpecies, de qua in lupo dicemus, Hoc fals tem in præfentia monendum lectorem duxi, lychnidi \& aconito non folum nomina communia ef: fe:cum illa taurion, hoc tora uel taura uocetur: fed etiam effectus, utrauis enim admota fcorpiones $\gamma$ tcrpefcere Diofcorides tradit: 8 licet aliud nihil eis commune exiftimem, ad philologiam tamen hęc non taceri pertinebat. Taurus apocathemenes Magis, lychnis fylueftris eft, Diofcorides. Eft \& alia taura, de qua Hermolai Barbari uerba hæc funt:Sunt qui oxyn putenteffe quam uulgus taturam $\&$ triada, hoc eft trinitatem, \& phragida, hoc eft figillum Salomonis appellauit * folio triplici, aut uno potius in terna difpofito, radice capillamentis multiplici;florecum maculis quiburdam sandidis coe ruleo. Aftringit, ad ftomachum diffolutum $\&$ enterocelas in cibo datur, Hermolaus Barb. of De nauigijs tauri nomine, infra dicam in $h$. TA maiore pecore nomina habemus, Equititis, Taurus: \&cognomina, Statilï Tauri, Pomponí Vituli, Varro. Taurus illequi Europam Phoniffam rapurit, Creia rex fuit, \& Gortynã cõdidit. Tauri cuiufdã quaftoris ad Armeniã mifît, meminit Ammianus Mar cellinus libro 14. Taurus medicus celebris in Creta fuit, \& alï quidã hoc nomine, Varinurs. Tau 60 rus Berytius philofophus Platonicus, uixit fub Antonino Pio, \&c. Suidas. De Tauro illo ex qưo Minotaurus natus fertur, dixi fupra in Boue cum $\mathrm{Pafiphaë.} \mathrm{Taurofthenes} \mathrm{propritum} \mathrm{uiri} \mathrm{nome} \mathrm{eft,}$ 


\section{Taurus. H. Lib. I. 117}

te quo A elianus in Varijs lib,9,ca,2. Taureas nomen propriú,Suidas, nec plura; Taurea Iubellin Campani, uiri memoranda fortitudine hiftoriá, defribit Liuius lib, 2. de bello Punico. Vide in Ono maftico noftro. Taurifcum fęuum tyrannum qui Gallias infeftabat, Herculem Amphitryonis filium occidiffe aiunt Galli, Ammianus Marcellinus libro is. Taurif́ci Cyziceni fculptoris meminit Plini us libro 34.cap. 12. Taurifcus pinxit Difcobolum, Clytamneftram, Panifcum, Polynicen regnum re petentem, \& Capanea, Idem libro 35. cap.11.Hermerotes Taurifri,non cælatoris illius, fed Trallianis inter monumenta fua fpectari uoluit Pollio A finius, Idem 36.5. Taurites quidam trir robuftus fuit;

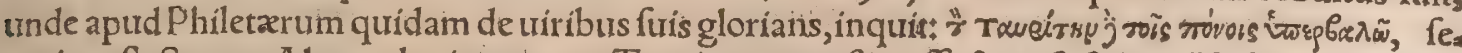
narius eft. Seurero Alexandro imperante; Taurinus auguftirs effeetus eft, S. Aur. Victor: Tauóórovos proparoxytonum, à tauro occifus ‘ paroxytonum autem is qui occidit; Ammonius \& Cyrillus. De tatrea, id eft futica alibi dixi: Eutropius autor eft Superbum Tarquinium excogitaffe primum uincula, taureas, fuftes, \& c. Et feriunt molles taurea terga manus, id eft tympana, Ouidius libro 4 . Faft, dixit autem taurea pro taurina,id eft ex corio taurino. Vergilius lib, 1. Aeneid. Taurino quantum poffent circundare tergo. Lucanus libro 1. Tauriferis ubi fe Lucania campís Explicat. Tor urus à tauro dicitur, afpectu feuerus $\mathcal{X}$ terribilis. Toraicas, ut Pompeio placet, quafi taurorum acer bitas dicitur. Eft autem toruus proprium bouis epitheton. Trux etiam quafi taurux dictus exifti= matur, id eft ferox, crudelis: unde trucitas, truculentus, \& trucido uerburm, Perottus:

(1) b. Tauǵs imagines bucrani, id eft boum capitibus, uel taurina forma, \& cornuti; ut fupra in Boure dixi. Flut uij cur taurocrani, id eft taurinis capitibus fingerentur, quatuor feré caúas affer unt:unam, ç ubi fe

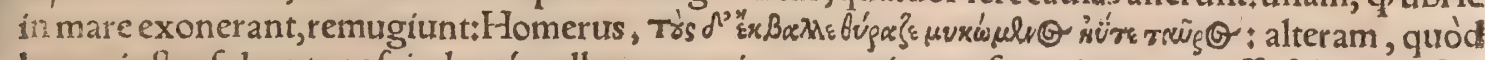
boum inftar fulcant profcinduntós tellurem:tertiam, quoniam pafcua circa ripas effe folent: poftre mò, quoniam curuis ambagibus cornua imitantur, V arinus, Taurus, ut idem habet, Alpheo fluuío immolabatur, ut Neptuno quoogs. In unitrerfum enim taurus amnium natura conuenit cum aliâs,

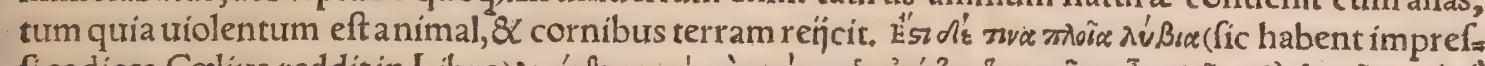

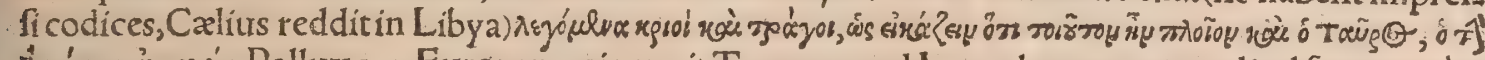

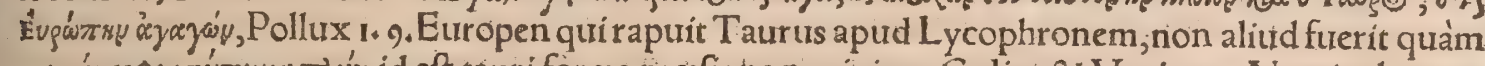

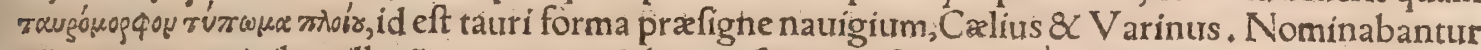
aũt naures nominibus illorũ qua prætendebant infignium: $\&$ maximé uerifimile eft, centaurum pi* frimć, \& cuncta id genus, ea ratione dicta prolata $\not ̧$ à Vergilio ín quinto, Bayfius. Hac de re copio fius frribit Nic, Erythræus in Indice fuo Vergiliano in Scylla. Taurocercuri, naues fluuíatiles, Sui das. Efr autem cercurus, genus natis breuioris, lembus, uide Bayfium. of Tougés, pellis tauri, Vari nus: \& galea ex pelle taurína, Hefychius. In uulgaribus Lexicis legitur rouǵçe, tegmina ex taurina

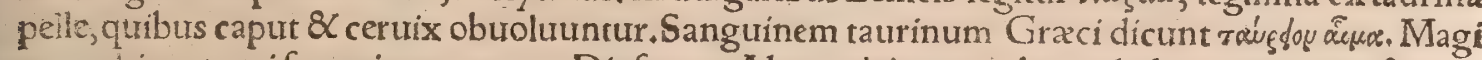
marrubium taurifanguinem uocant, Diofcor. Alexandri equum bucephalan tocarunt, fiue ab alpectu toruo, fiue ab infigni taurini capitis armo impreffi, Plinius. Ad Cadaram rubri maris pen. infulam exeunt pecori fímiles bellux in terram, paftáç radices fruticirm remeant: 8 quadam equo

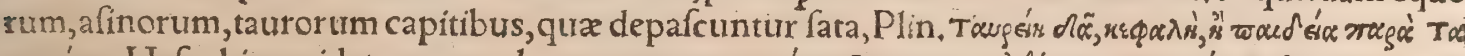

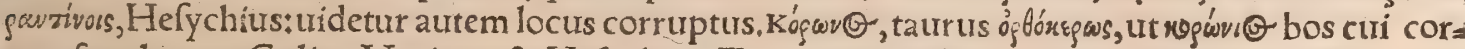
nua funt lunata:Cxlius, Varinus, 8 Hefychius. Tauroceros tribulus cognominatur aptid Diofcos

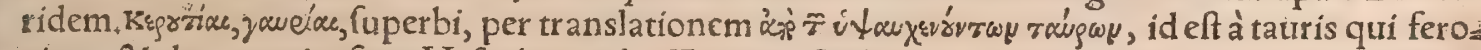
ciores \& elata ceruice funt, Herych. Tlo. Tzetzes Chiliade 11.cap.393 genus taurorum Scythico.

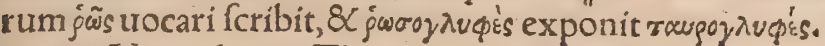

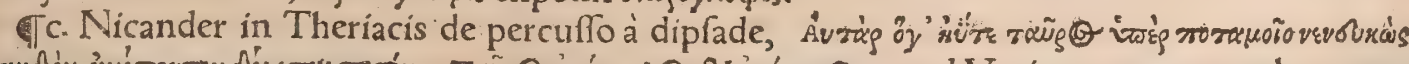

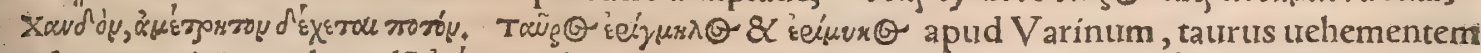

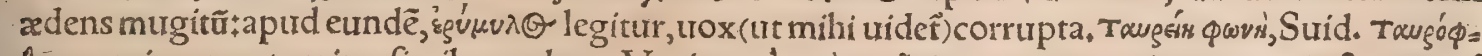

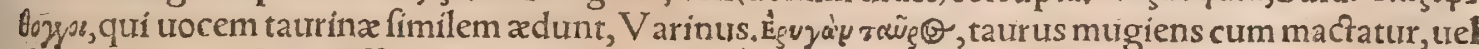

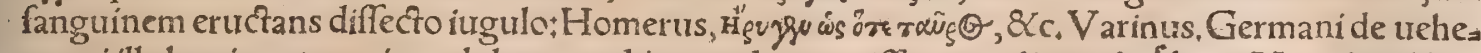
menti illa bouis aut tauri per dolorem uel iracundiam emiffa uoce, dicunt bzitlen. Vergilius libro duodecimo Aeneidos: Mugitus ueluti cum prima in prælia taurus Terrificos ciet: (atce irafci in cornua tentat Arboris obnixus trunco:uentosós laceffit I taibus: \& fparfa ad pugnam proludit a. rena.) Inclufa parenthefi leguntur etiam libro 3. Georgiccrum ut fupra citauimus, eadem prorfus, nifi quod pro tentat illic dif cit habetur. बT Tweiän uaccarum eft cum tauros appetunt, quafi tauri: re dicas:ficut namsãu, id eft fubare, cum fcropha libidine pruriunt $\&$ apros defiderant : utraqs enim

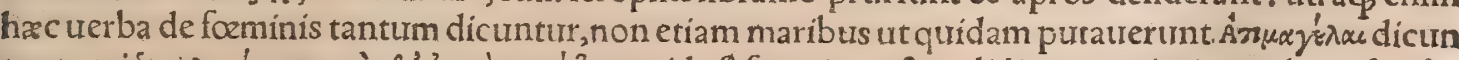

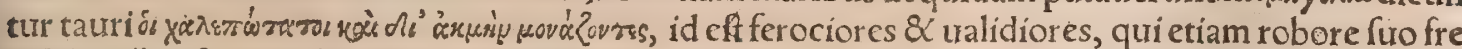

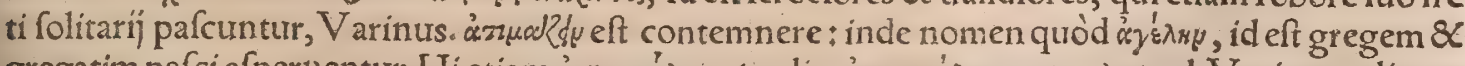

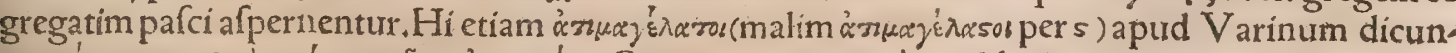

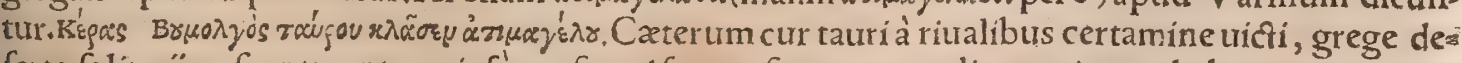

60 ferto folitarï pafcantur, ut copiofé profecuti fumus fupra cap.z. aliam rationem habet, neque recfe

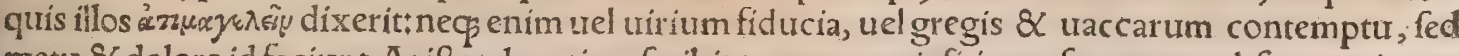
metu \& dolore id faciunt. Arifoteles etiam fcribit tatu os cum ipfi intex fe tantum abfog uaceis pa 


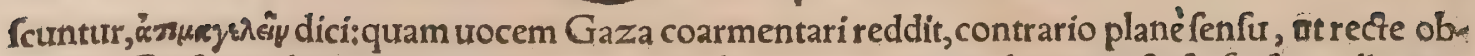
feruautit Erafmus: dearmentari enim potius uel abarmentari uertendum erat: $\&$ fic forfitan ille uer.

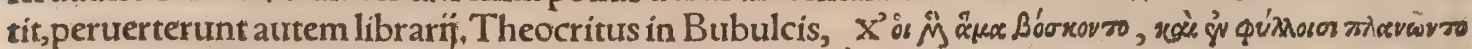

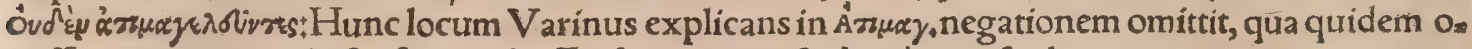

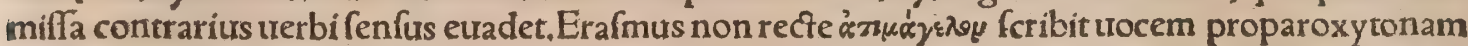

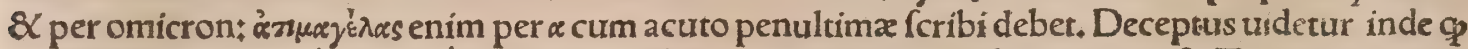

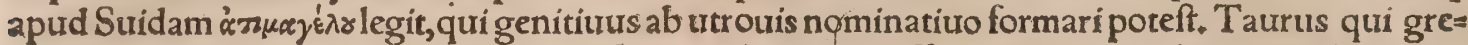
ge uaccarum fpreto $\&$ relicto feorfim pafcitur, in fyluam abïfle dicitur:id quod in prouerbium eti-

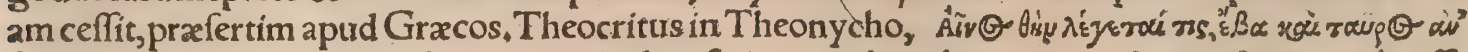
ỉ $\lambda x$ :queritur autem his uerbis amans quidam fe iam pridem ab amica reliçum, plurimumćs effe, temporis quo illa alịs amoribus indulgeat, neqs omnino curet ad prifinam redire confuetudinem. Licebit etiam ad alios diuerfos ufus prouerbium trahere, ut fi quis amicos priftinos, aut folita fitudia deferat:aut à conuiçu hominum abhorrens fecum uiuat.Scholia qua feruntur in Theocrirum, pro, uerbium interpretantur de his, qui abeffent non reuerfuri. Taurus enim fi femel aufugerit in ly! luã, capi non poteft. $V$ nde non inconcinne quis dixerit maritum diutius ab uxore fecubantem ázzuaxy $\lambda \epsilon^{*} u^{*}$ Tantum Erafmus, TBos initor, taurus eft procreationi refertuatus, Pafcite utante boures pue ri, fubmittite tauros, Vergilius A egl.ı.Submittere pro fubftituere accipit Palladius, \& Iuftinianus inftitutionum lib. 2, de Rerum diuifione: Sed fi gregis, inquit, ufumfructum quis habeat, in locum demortuorum capitum ex foetu fructuarius fummittere debet, ut \& Iuliano vifum eft : $\&$ in uinear demortuarum uel arborum locum, alias debet fubftituere. Megafthenes fcribit in India ferpentes 20 in tantam magnitudinem adolefcere, ut folidos hauriant ceruos tauros क́, Plinius.

dd, \& e. Odientis fignum eft limis oculis afpicere \& taurine, raupsolóy, ut inquit Plato: de qua uoce mox plura inter prouerbia. TTaurum color rubicundus excitat, urfos leoneś́g mappa pro ritat,Seneca libro 3. de ira.Rubram ueftem non ferunt qui ad boures accedunt, \&c. quód eiufmodi colore eos conftat efferari:Gyllius ex Plutarcho, qui tamen in libro de Alexandri fortuna, \& rurfus in connubij praceptis, tauros, non fimpliciter boures, hoc colore irritari fribit. Martialis in libro fpecfaculorum de rhinocerote, Quantus erat cornu cui pila taurus erat, Veftes uetuftate dilaben res ac laceras (in quit Calius)A Arifophanes lacidas unocauit:Latini id genus pilares dicere ueftes pof fent.Quod Martialis fignificat, quum Epigrammatum libro 2.de toga fua, quam pertritam confcif= famó̧ intelligi uolebat, ita fcribit: At me, qux paffa eft furiofi cornua tauri, Noluerit dici quam pi la prima furam. Erant fiquidem, ut Sextus Pompeius foribit, pilę uiriles effigies atç item muliebres ex lana, quę compitalibus fúpen debantur in compitis, quòd efle deortum inferorum putarent, quos rocant lares:quibus tot pilæ, quot capita liberorum, feruorum, mulierum círca compita habitabāt, ponebantur:ut effentịns pilis \& fimulacris contenti, uiuisḉs parcerent. Hifce uero imagínibus nulli us omnino pretij ueftes circumponebantur. Proinde pannofos etiam quandogB Martialis pilas uo. cat, ut Epigranmatum decimo in Laurum : Sed qui primus erat Iufor, dum floruit atas, Nunc poftquam defït ludere, prima pila eft. $\mathrm{Ab}$ hac pilarum fimilitudine, ut fribitMartialis interpres, ne ftes qux in fpectaculo tauris obịcerentur irritandis, pilę funt nuncupatæ: quòd à tauris peterentur, tanquam effigies hominum. Vel, inquit, pila dicebantur, quód in globum \& luforiæ pilæ fpeciem conuoluta iactabantur:Quanquam rudis antiquitas, ut $\mathrm{Pxdianus} \mathrm{aucfor} \mathrm{eft,} \mathrm{homines} \mathrm{è} \mathrm{ftramine} 40$ formaret ad eum ufum. Poftea, inquit, luxis in tantum aucfus ef, ut ueftes etiam purpurea obíce. rentur. Quod duodecimo Metamorphofeon fignificaffe Ouidius quoqg uidetur, quum ita canit, Haud fecus exarfit, quàm circo taurus aperto, Cum fua terribili petit irritamina cornu, Phoni: ceas ueftes, elufáģ uulnera fentit, Sed quod ille per luxum inftitutum ait ut phoenicex obijcerêtur: id minus ueritate connititur:nam ex nattra rerum oborta confuetudo eft: Quam \& iureconfultus Vlpianus Digeftis de furtis non ignoraffe tuidetur, ubi ait: Cum eo qui pannum rubrum oftendit, fu gauitćs pecus, ut in fures incideret, furti actio eft. Hoc 8 in Inftítutionibus relatum inuenies De ob ligationibus qux ex delicto nafcuntur, Hactenus Calius. Martialis in librofpectaculorum, de rhi nocerotefcribens, Nanģ gratrem gemino cornu fic extulit urfum Iactat ut impofitas taurus in as ftra pilas, Et mox de Carpophoro qui ceruum \& leonem in fpectaculo telis confecerat, Ille tulitge yo minos facili certice iutuencos, Extat in eodem libro Epigramma in Domitianum, quem Alciden uo cat:Quicum futurum colum \& immortalitatem fibi uellet repręfentare, tauro infidens fuperiores fcenæ partes in fpeciem cœli confectas petịt æmulatione Herculis, curirs nomen etiam fibi indide. rat:nam Alcides appellabatur. Qui taurum ex Creta in Atticam ducens eitus dorfo infediffe fertur, Domitius. Ornithônis oftum debet effe humile $\&$ anguftum, \& potiffimum eius generis, quod cochleam appellant, ut folet effe in cauea, in qua tauri pugnare folent, Varro. Theffalorum gentis inuentum eft equo iuxta quadrupedante cornu intorta ceruice tauros necare: primus id fpectacu.

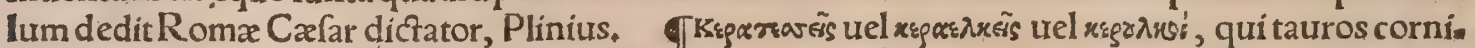

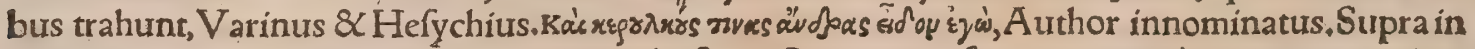

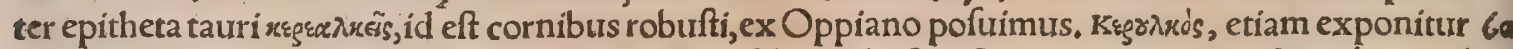

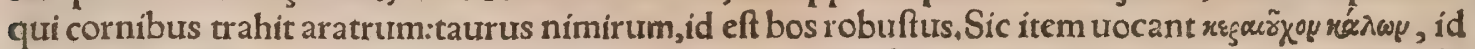
eft funem antennarum (funes opiferos Latini dicunt) Hefychius : idem A pollinis cognomen cft, 


\section{Taurus. H. Lib. I.}

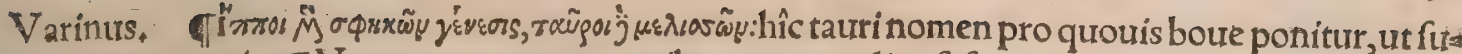
pra etiam monui. IV Veteres taurorum cornibus pro poculis uff funt, ut in boute fupra dixi, in H. $e_{*}$

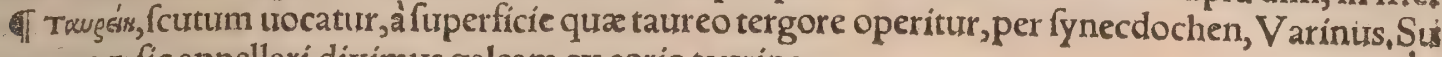
pra quoof fic appellarí diximus galeam ex corio taurino.

Gh. Afphaltites lacus animal non habet, nihil in eo immergi poteft:taurietiam camelićs impune

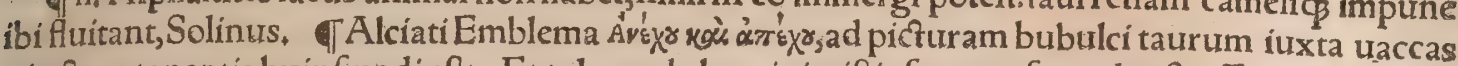
uinctum tenentis huiufmodi eft: Et toleranda homini triftis fortuna ferendo eft. Et nimium felix fape timenda fuit. Suftine(Epictetus dicebat) 8 abftine $e_{+}$oportet Multa pati, illicitis absćs tenere manus. Sic ducis imperium uinctus fert poplite taurus In dextro:fic fe continer â grauidis. TLa ctantius 4. Theb.comment. Hetrufcos confirmare ait, nympham qux cum nupta fuiffet, prædicafes $\mathrm{fe}$, maximi Dei nomen exaudire hominem per naturę fragilitatem pollutionemóǵ fas non effe: quod ut documentis affereret, conf́pectu cæterorum ad aurem Dei nomen nominaffe, quem illico ut de mentia correptum, \& nimio turbine coacium exanimaffe, \& reliqua. De Titormo buffequa Aeto 10 ferunt, quòd ftans in armento ferociffimi omníum maximiç taurri pede correpto, furentem ac inde fe proripere adnitentem fruftra, retinuerit conftantiffime : ac infuper manu altera prætereuntis forte tauri alterius pedem apprehenderit audaciffime, ac comprefferit ferociter. Id cum intueretur Milo Crotoniates, in coelum manibus fublatis, exclamaffe fertur: O lupiter, an alterum profemina. fti nobis Herculem hunc Hinc prouerbij demanaffe primordia memorant, Hic alter Hercules, Cæx. lius, Polydamas Herculis zmulator leonem in Olympo inermis confecit + idem boum ingreffus ar: o mentum, inibi taurum magnitudine infignem ac precipue fer um confpicatus, ex pofterioribus alte rum arripurit pedem, retinenş̣́ pertinaciffimè, ferocientem, ac impetu prarabido profilientem non dimifit prius, quàm indignabundus ac furens, tandem in Polydamantis manu chelam, id eft ungus lam reliquit, Cælitus, Milo quum quotidie uitulum geftaret, eundem taurum factum citra negotium geftaffe dicitur, De A pide tauro, \& Minotauro, \& tauro Minois(quem $\&$ Marathonium uocant, ex quo natum ferunt Minntaurum, uide plurain Onomaftico noftro in Marathone, \& ibidem in Hers

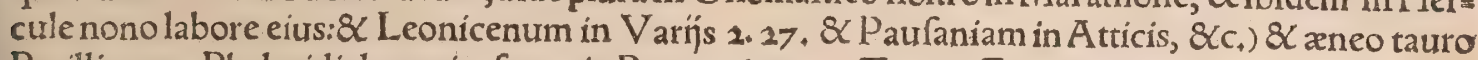
Perilli quem Phalaridi donauit, fupra in Boure egimus . Taurus Europa raptor rex Cretæ Gorty= nem condidit, Euftathius, De Ioue tauro raptore Europ lege Ouidium libro 2, Metamorphor. Nos iam prius oftendimus taurum iftum ab eruditis nauem taurina forma infignem exponi, Idem hic 30 taurus quod Europam incolumen tranfuexerit in Cretam, inter aftra confitutus fertur, Euripide tefte:de quo plura apud Hyginium \& aftrologos lege; alh hoc fignum effigiem Ionis in uaccam mutatz effe malunt, uide Varinum. Verfus iftos Vergilij ex primo Georgicorum, Candidus auratis aperit cum cornibus annum Taurus, $\mathcal{Q}$ aduerfo cedens canis occidit aftro, Macrobius exponitli. 1.cap.18.in Somnium Scipionis. Tauri fydus Veneri confecratum, Ibidem 1.21. Et Saturnalionum ca pite 12. Cum primum fignum aries (inquit)Marti affignatus fit, fequens mox Venerem, id eft taurus accepit:\& rurfus eiufdem libri cap.21. Taurum ad folem referri, multiplici ratione Aegyptius cultus oftendit,\&c.ut fupra in A pidis bouis hiftoria recitauimus. EIMedea apud Ouidium Metamor.li bro 7, iugulato Pelia pennatis ferpentibus per aërem fuper diuerfa loca inuehitur,et inter alia fuper Cycneia tempe, Quæ fubitus celebrauit olor:nam Phyllius illic Imperio pueri uolucres'̧́́s, ferũ č́p - leonem Tradiderat domitos: taurum quoqs uincere iuffus Vicerat:\& ftricio toties iratus amori, Premia pofcenti taurum fuprema negauit. Ille indignatus cupies dare, dixit: $\&$ alto Defiluit faxo cuncti cecidiffe putabant: Factus olor niueis pendebat in aére pennis, I Arnobius libro quín. to, de Cerere à loure deluffa in tauri forma:Parit, inquit,menfem poft feptimum, luculenti filiam cor: poris, quam ætas mortalium confequens, modo Liberam, modo Proferpinam nũcupaurit. Quam cữ uerueceus Iupiter bene ualidam, floridam, \& fucci effe confpiceret plenioris, \&cc, mox fubdit, In dra conis terribilem formam migrat, ingentibus fpiris pauefaciam colligat uirginem, \& fub obtentu fe. ro molliff.ludit at $q$ adulatur amplexibus:fit ut $\&$ ipfa de femine for tiff, compleatur louris; fed non ea dem conditione qua mater. Nam illa filiam reddidit lineamentis defrriptam fuis:at ex partu uirginis tauri fpecie fufa louialis monumenta pellacix. A uctorem aliquis defiderabit rei , tum illum citabi= so mus Tarentinum, notumó́ fenarium, quem antiquitas canit, dicens: Taurus draconem genurit, \& taurum draco. Ipfa nouiffimé facra, et ritus initiationis ipfius, quibus Sebadńs nomen eft, teftimonio effe poter unt ueritati,In quibus aureus coluber in finum demittitur confecratis, \& eximitur rurfus ab inferioribus partibus atç imis, Hæc quídem eruditè Arnobius. Porrò $\&$ Eurfebium audiamus de eadẽ re loquentem:Ceres, inquit, Perfephonen peperit, educatur puella, rósu frilicet (Pherephatten nonnulli appellant) cui lupiter, qui genuit, draco factus coniungitur. Vnde in Sabaziorum myftes $r$ ins draco in fpiram inuolutus, in facrificips, ad factorum memoriam, immo uero in teftimonium tan ta turpitudinis, ut fic dixerim, adhibet̂. Peperit $\&$ Pherephatte tauriformẽ filium, unde poếtæ quog:

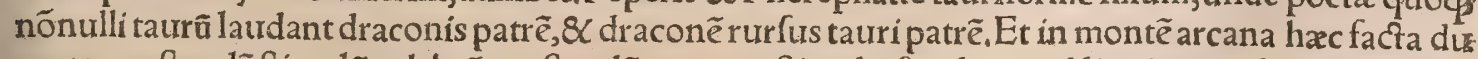
centes, paftoralêfftimuliũ celebrãt:paftoralēe(ut puto)ftimulü, ferulä, quod ligni genus bacchantes feso runt, appellấtesł Harc ex Arnobio \& Eufebio, ut à Gyraldo citant̃ Syntagmate 6.in Proferpina. Scri bit infuper Clemens louem commutatũ in anguẽ intuliffe Proferpinx tilię uitiư, unde fit natus Dio nyfius. Quo argumento etiam Sabaziorum myftica draconem praferunt in orbem complicatum; 
Hinc \& poëtx draconem tauri patrem dum concelebrant, fymbolice operté́s Iourem innuunt, ex quo $\&$ filia natus hic fit tauri fpecie.Quare ab Lycophrone taurum uocari fcimus, Calius. $T$ Ache lôus Epiri, uel ut alï Aetolix fluuius, nomen fub A cheloo rege mutauit, cum Thoas antea uocare tur, authore Stephano. Hic cum Hercule duello certauit pro Deianira Oenei Calydonix regis filia: fed uidens Herculem fortiorem, fe uertit primo in ferpentem, deinde in taurum, cui Hercules am: putauit cornu, quod Copia comiti Fortunx datum eft. Sed poftea A chelous Amalthex cornu Her: culi dedit, atcs ita fuum recepit. Tandem ab Hercule uictus fe in fui nominis fluuio gemino cornu infignito occultauit. Nam reuera A chelous Græciæ fluuius eft, duobus alueis, qui per fines Perrhe, biorum in Maliacum finum effunditur. Vide Otidium Metamorph, libro 9, de Acheloi transforma tione. Ceraftx incolx Amathûntis hofpites immolabant mutet cos, ad cornua uultum Flexit, $\&$ admonita eft hacillis poffe relinqui, Grandiaćs in toruos transformat membra iutuencos; Ouidius Metam.libro 10. Tauros in Colchide ignem effiantes, fuif fe fabulantur peétæa, quos uenefica ope Medex Iafon uicerit, de quibus Ouidius libro 7 . Meramor. Ecceadamanteis Vulcanum naribus efflant Acripides tauri, \& c utḉ́ folent pleni refonare camia ni: Pecfora fic intus claufas uoluentia flammas, Gutturaćs ufta fonant.tamen illis A efone natus Cbuius it. Vertere truces uenientis ad ora Terribiles uultus, præfixáḉ cornua ferro, Puluereúç folum pede pulfatrere bifulco, Fumificis

Tenetia fluuius Silis ex montibus Taurifanis fluit,Plin, lib.3, cap.18, \& mox cap 19. Taurifa. nos Iftrix populos facir. Et rurfus ibidem, In hoc fitu(inquit)interiere, Carnis, Segefte \& Ocra: Tati= rifcis Noreia.Et cap.20. Incolæ alpium multi populi,fed illuftres à Pola ad Tergeftis regionem, Secuffes, \&c.iuxtá́ Carnos quondam Taurif́ci appellati, nunc Norici. Lepontios \& Salafos Tauri= fcæ gentis Cato arbitratur, Taurif́, Taueiorot populi iuxta alpes (aliâs Taurini)Polybius lib. 3. Era=

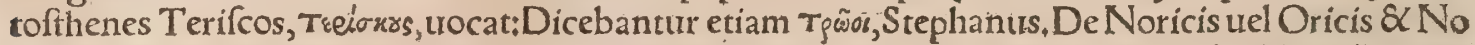
ricís plura fcribit Euf: athius in Dicnyfium: $\&$ Strabonem citat teftem, in Taurifcis Noricips iuxta Aquileiam, ad duos fub terra pedes ftatim aurum inueniri foffile. Orici (inquit idem Euftath,)iuxta Polybium habitant circa initium Adriatici maris + Norici uero uel Noricï iuxta intimum eiufdem re ceffum. Taturinum (ut hodie uocant) urbs Celtica eft Maffilienfium colonia, Tauǵess Stephano di.

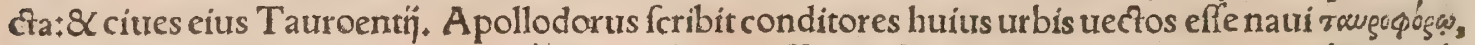
id eft cuitus infigne erat taurus:qui à Phocenfium claffe reiecti, ad terram appellentes, urbem inde nominatrerunt:Gentile Taurini, Stephanus. Taurini populi funt Italiæ Tranfpadanæ in Alpium ra dicibus, Plínius 3.7. Tranfpadanæ I taliæ colonia eft Augufta Taurinorum, antiqua Ligurum firpe, inde nauigabili $\mathrm{Pado}$, Plinius 3.17 . Præter mediam \& compendiariam nagiş́́ celebrem Alpium ui am (per alpes Cottias feilicet) funt etiam alix multo ante temporibus conftructx diner fis : primam Thebanus Hercules ad Geryonem extinguendum, ut relatum eft, \& Taurifum lenius gradiens, prope maritimas compofuit alpes: hićç̧ harum nomen indidit:Monøci fimiliter arcem \& portum, ad perennem fui memoriam confecrautit, Ammianus Marcellinus libro 15. Tauri populifunt Tats ricæ Septentrionalis regionis in Europa incolx, Iphigenix \& Oreftis aduentu maximè memorati: moribus funt immanes, immanemós famam habent, folere pro uictimis aduenas credere, Pomponi. us. Vide Onomafticum noftrum, Tauri Scythica gens ab A cgyptins colentibus bouem \& A pim o=

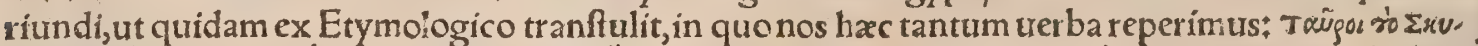

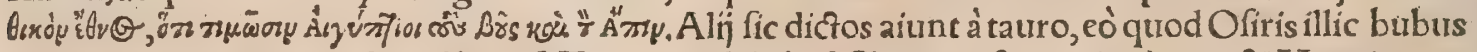
iunctis terram arauerit: A pud hos eft Taurica infula (uel Cherronefus potius) qua $8 \times$ Macotica no= minatur:habitãt quogs dictum A chillis curfum, \& c. Euftarh. Dionyfius poeta de Bofphoro Cimme.

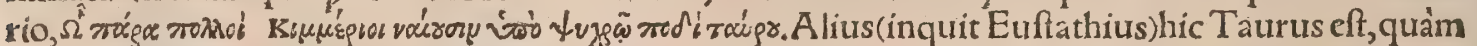
qui in Orientem uergit; aut Septentrionalis quadam eíus portio eft, fub qua Címmerỉ habitant, gens Scythica:\& Taurica Cherronefus ingens fita eft uerfus occafum Mæotidis faucibus adiacês, quam aliqui aiũt tum figura tum magnitudine Peloponnefo parem effe, Regionis illius incolx Tau rofeythæ uocantur à T auro monte qui illic eft:quod etiam. Herodotus non ignorauit, cum et ipfe de montibus Tauricis, id eft Scythicis mentionem faciat, Euftath. De Taurof cythis ab Antonino Pio uictis hiftoria refertur apud Iulium Capitolinum. Ad Syriam mons Taurus nomen à pecore has yo bet, Varro. Taurus mons A fia, ab Eois ureniens littoribus, Chelidonlo promontorio difterminatur: immenfus ipfe $\&$ innumerarum gentium arbiter, dextero latere feptentrionalis, ubi primum ab In: dico mari exurgit, \&c.Vide Onomafticum noftrum. Nomen ei uel à magnitudine: Nam ueteres tau ros urocabant omnia magna $\&$ uehementia: uel quòd eius pars ad mare prominens, tatrinam faci= em( qua magna uiolentaćs tauri dicuntur, ut Stephanus $\&$ Euftathius fcribunt, Tauro montinomen in ditum putat:〔ed contrà à Tatro monte magna uiolentá́ 3 omnia tauros appellari ait : quod egonon probo, \& Stephani Euftathríć uerba contrario quàm debebat fenfur eum accepiffe uideo. Dionyfius

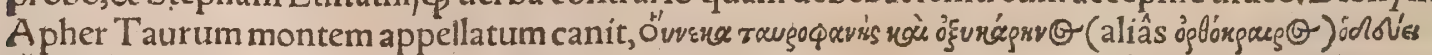

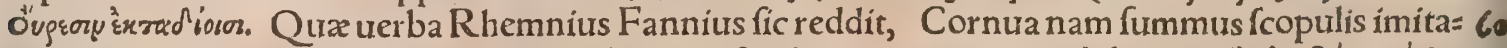

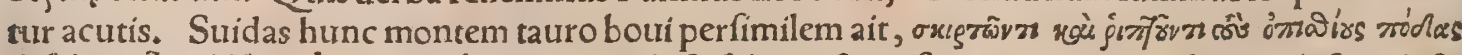

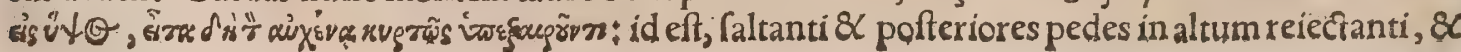




\section{Taurus. H. Lib. I.}

mox collum incuruatum attollenti. Alius praterea Taurus mons uidetur de quo apud Etymolo. gum \& V arinum legimus ex authore innominato, Taurts mons regionís illits glandes producit pabulum fuibus:pendebant etiam ex monte illo tributa, quä̀ redditus Tauricós appellabant. Tau. rominium, Taugourifoy, mons eft Sicilia multis bobis abundans; \& fupra êum urbs eiufdem nomi. nis, Perottus. Diodorus libro 16 , in Philippiregis hiftoria frribit, Andromachum Timai hiftorici pa= trem, coactis in unum qui cladi fuperfuerant, ab Dionyfio Naxoeuerfa, Taurum urbi uícinum col lem diutius incoluiffe:quare Tauromenï nomẻ loco conciliatum, qux mox opulentior fuit ciuitas. Taurominitanum littus cur Copria dictum fit, in Boue indicaui. Tauropolis, urbs Cariæ, Stepha. nus. Taurania, urbs Italiæ; Stephanus. In Campano agro intercidit Taurania,Plinius 3* 5. Tauria. num, Brutiorum oppidum in Italia iuxta R hegium, Mela lib. 2, AdBrutium littus in Italia, intus in peninfula Metaurus amnis eft, \& Taurahium oppidum, Plinius 3: 5. Taururum Ptolemæo 2,16 idem Taurunữ Plinio 3.25. alio nomine Alba Graca, Belgradum hodie, uulgo (5ried)ifb Deiffer burg, ubi Danubio mifcetur Sauus. Eft autem Vngarix urbs à Turca nuper expugnata. Tauri am phitheatrum apuid Suetonium nominatur, in quo C. Cæe far Caligula munera gladiatoria aliquot edi derit. Tyburtina porta Romæ alfquando Taurina diça eft, à capite tauri, quod illic infculptũ erat; Perottus, Alexandria Aegypti fallacibus iradis, tribus omnino aditur alueis, Tegamo, Pofidonio, Tauro, Plinius 5. 31. Taurus item fluuius eft apud Trozenem, ex quo apud Sophoclem nomina tur Tauria aqua, Táugssoy ṽowg, Varinus \& Euftathius Iliad, $\lambda$ \& \& A thenaus libro 3+addunt autem illi fontem etiam quendam Hyoëffan à Sophocle trocari:quæ uerba non intellexit Calius ineptè red

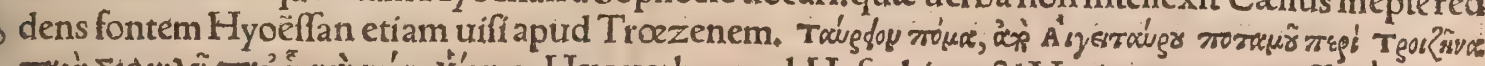

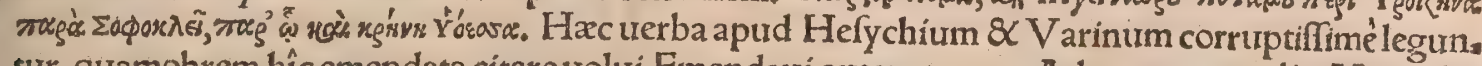
tur, quamobrem hic emendata citare uolui, Emendaui autem tum ex A thenæo, tum alio Varinilo= co cuius initium Taũge Avoía. Sic tauriformis uoluitur Aufidus, Horatius 4.Carm.

INunc de facrificís dicendum:Diximus autem iam in Boue prater alia quadam bubulo pecori facrificando communia, boutes mares ab A egyptís Epapho immolari, \& quomodo ab eis exploren=

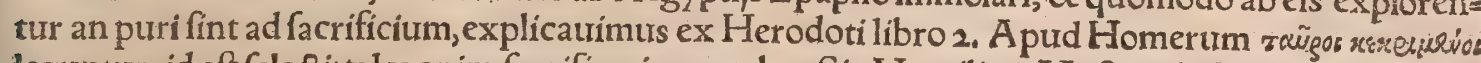
leguntur, id eft felecti;tales enim facrificari oportebat:Sic Vergilius, Mactant lectas de more biden tes. Gręcis facrificaturis moris erat tauros explorare farina appofita. Nam figuftare abnuiffent, con cipiebant inde haud ualere fatis, Calius \& Gyraldus. Druida uifcum omnia fanantem appellana - tes fuo urocabulo, facrificio epuliśḉs rite fub arbore praparatis, duos admouent candidi coloris tau ros, quorum cornua tunc primum uinciantur, $8 \mathrm{c}$, foecunditatem eo poto dari curicunç animali fte. rili arbitrantur, contráq́ uenena omnia effe remedio. Tanta gentium in rebus friuolis plerunç reli= gio eft, Plinius, Quoties aut thus, aut uinum fuper uictimam fundebatur, dicebant, Mactus eft tau rus, thure, uel uino:hoc eft, cumulata eft hoftia, $\&$ magis auctatid quod $\&$ Ifidorus libro 10. friptum

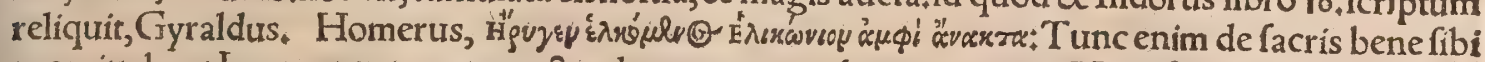
promittebant Iones, cum taurus mactandus magnum ęderet mugitum, Varinus in Helice. Meffe. nij taurum quetri manibus Ariftomenis mactaturi funt, columnæ qua in eius fepulchro eft alligãt: Quód fille, dum uinculum euadere conatur \& faliendo tumultuatur, columnam commovierit:lä tum omen interpretantur; fin minus, trifte, Paufanias in Meffenicis, Cum Agamemnón in Aülide o ceruum Dianx ignarus occidiffet, dea irata uentorum flatus amouit, ut nauigare non poffent. Ora culum confulentibus refponfum eft Agamemnonio fanguine deam effe placandam. Miffus igitur Vlyffes Iphigeniam filiam aftuà Clytæmneftra fub prętextu facti cum Achille matrimonî impetra tam àdduxit:cumć́s iam immolari pararetur, dea miferta illam fuftulit, ceruamćs pro ea fuppofuit, uirginem autem in Tauricam regionem tranftulit, \&c. Quidam in urfam fcribunt mutatam effe, alif in taurum, alij in anum, in ceruam alip.Sed hæ meræ fabulæ funt, res ipfa autem fic habet. Cum Iphi. genia iamiam immolanda effet, accidit forte ut unum aliquod ex pradictis animalibus $f e$ obtulerit, quod comprehenfum mox Iphigenia loco mactatum eft. Non eft autem abfurdum rem ita côtigiffe credere, cum in facris etiam literis Ifaaci immolandi loco arietem fe obtuliffe legamus, Varinus in Neoptolemo, ubi plura etiam de Iphigenia affert ex If aacij Tzetza in Lycophronem commentarijs - deprompta, \& Perottus in Cornucopia. Solitaurilium \& quo pacto fiant, meminit Cato de Re ru ftica cap. 141. Simile eis facrificium Graci trittyn uocant, de quo in Boue fupra dixi. Trittys uel trias facrificium conftabat ex hirco, ariete, $\&$ tauro, Varinus, Populus Romanus cum luftratur Solitaus rilibus circumaguntur uerres, aries, taurus, Varro, Perfectum facrificium fue, tauro, hirco \& ariete conftabat; hoc hecatomben Graci \& trittyn uocabant, ut fupra expofui. Solitaurilia facra fuere, que fingulo perfecto luftro per Cenfores celebrari mos fuit, ad luftrandam urbem, fue, oue, 8 tauro+ aut urerre, ariete, \& tauro, qui circum urbem ducebanturr, tumọ́ multa religione lưftrum condebatur. Solitaurilia, Feftus inquit, hoftiarum trium diuerfi generís immolationem fignant, tauri, arietis, uer ris, quod omnes integri folidió corporis fint: folum enim lingua Ofcorum fignificat totum, \& folidum:hæc Feftus, fed $\&$ Græci "orop dicunt totum $\&$ integrum. Porrò de Solitaurilibus meminit Li-

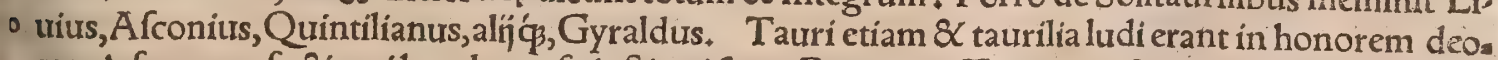
ram inferorum facii, qui hac de caufa inftituti funt. Regnante Tarquinio Superbo cum magna in= cidiffet peftilentia in mulieres grauidas, exiftimantes $R$ omani eam factam ex carne taurorũ diutius 
populo uendita, prohibuerunt ne amplius uenderetur, et ob hoc ludos dijs inferis inftituerunt: quos $8<$ boalia $\&$ bubetios aliquando uocatos inuenimus. Sed proprie hi ludi funt boum gratia celebrati, Perottus. Tauriludi dicebantur, qui deis inferis fiebant, Feftus. Sed de Taureis ludis fupra etiam in

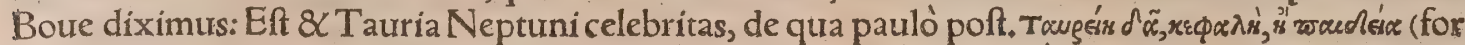

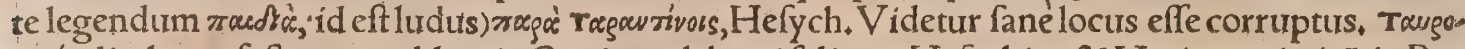
yoría dicebatur feftum quoddam in Cyzico celebrari folitum, Hefychius \& Varinus:nimiru in Bac chi honorem, qui in Cyzico tauriformis colebatur, ut mox repetemus: Ego raugozroxía potius lege rim, quanquam $\&$ Tauric $x$ Dianæ feftum fic nuncupatur.

T Taurum ut Neptuno fic etiam fluuips immolare lolebant: praccipué autem Alpheo taurum legi mus immolatum: habet enim quandam affinitatem taurus cum fluuijs, ut fupra in fecũda huius capitis parte ex Varino protulimus, Homerus de Chryfe fcribit, eum tauros \& capras Apollini immolaffe. Sunt enim tatri coloni quidam terræ, \& ad frugum prouêtum Solis effectum fuo labore adiuuant, De capris \& alịs animalibus cur Ápolliní immolarentur fuis dicemus locis. Supra in Bo. ue, ubi Cadmi mentio incidit, de taurorum etiam hoftýs A pollini facris nonnihil attuli. In Icaro infu la maris Perfici fplédidécolitur A pollo rouponìno, uel eodem cognomine Diana, Euftathius in Dio nyfium. A pollini taurum, Ioui non item immolabant, uide paulo mox in tauris Neptuno facris ex ITacrobio, Ex eodem fupra in Boure (ubi de A pide)taurũ ad Solem referri docuimus: $\alpha$ ubi armen=

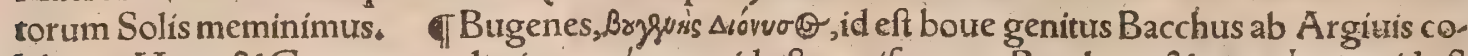

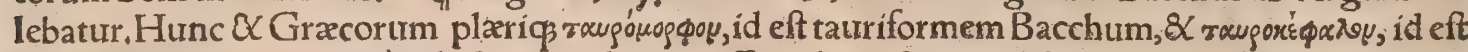
tauricipitem, item rougwrio ab Orpheo(dictum) effingebant, $\&$ appellabant: natumós ex Perfepho= 20 ne, ut Clemens in Strom. \& Eufebius in 2.Prap. Euang,tradunt (quorum uerba paulo ante adnus merauimus ) ut alios mittam. Quinimo etiam taurus dictus eft, \& illi cornua attributa, \& $\operatorname{cogno}=$ men etiam factum rougórє̧⿻s, id eft tauricornis, ut eft apud Nicandri commêt, in Alexipharm. Idem

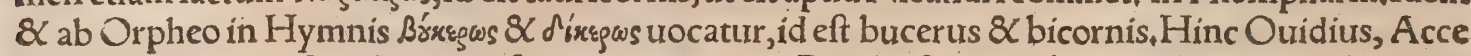
dant capiti cornua, Bacchus erís. Ideo autem cornua Baccho funt attributa, ut Diodorus lib. . . trae dit, quia primus boutes iugo iunxerit, \& Bacchus idem fit \& Ofiris, Idem tamen in quarto idcirco cornutum Dionyfium prodidit, quòd Ammonis filius fuerit, qui arietino capite cum cornibus fuiffe dicatur.Sunt qui cornua pro audacía fumunt, ut Phurnutus, quod audaces trucesḉ uinum faciac。 Hinc Ouidius, Tunc pauper cornua fumit. Sunt qui $\&$ fcribant cornua criftas uocari, $\& c_{*} \&$ cin= cinnos interpretentur: ac ideo Mofen cornutum Hebræis uifum putant, ut etiam Lyfimachum re: gem in eius nomifmatibus uidemus: $\int e d$ Armenios adhuc $\&$ Lydos facerdotes, cum huiufmodi cin. cinnis $\&$ capillis Romæ confpeximus, Porrò $\&$ illud item legimus, ueteres cornu bouis pro poculo ufos furffe: $\mathbb{X}$ in de factum effe, ut non folum cornua Dionyfio finxerit antiquitas, fed etiam taurus ipfe diceretur $\&$ tauriformis in Cyzico coleretur: $\&$ uspoü $\Theta$, id eft cornutus dicatur à Nicandro, Gy= raldus. Bacchus keparoqus's $\&$ taurus dicebatur, \&c, ut fupra monui cum dicerem ueteres cornibus pro poculis ufos. A thenzus libro 2.Plato(inquit)fecundo de Legibus uini ufum fanitatis gratia con ceffum ait. Verum ab ingenio hominum ebriorưm, Dionyfium tauro $\&$ pardali conferunt, eò quod

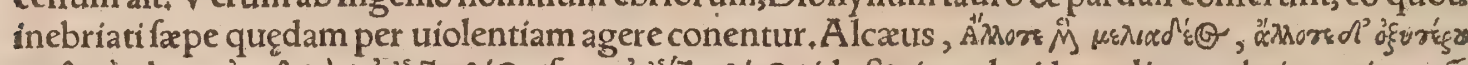

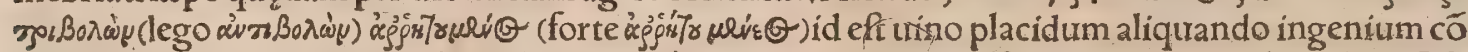
tingit, aliquando uehemens \& uiolentius quàm uerbis exprimi poffit, Quidam etiam Aveswoi, id eft fe

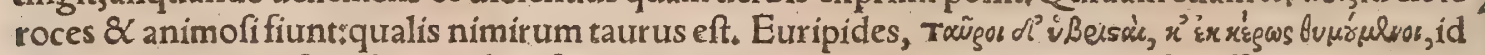
eft, Tauri proterui funt $\&$ cornibus ferociunt. Sunt qui natura pugnaces prorfus efferantur, ut par dalis effigies eis conueniat, Hæc A thenæus, Sophocles in tragœedia quæ infcribitur Tyro (Tereus perperam fecundum Varinum)taurophagum tocat Dionyfium, id interpretantur quia dithyram. borum poëtís in uictoria daretur bos, (in quo tamen aliqui Ariftarchum mendacï argutunt, Suid.)

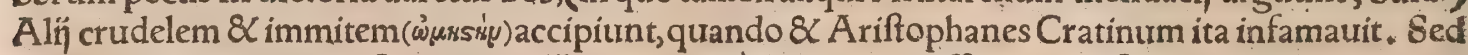
ad uinolentiam magis referendum alì'putant, quòd philoenus effer is, hoc eft uino indulgeret largia us, uel audax Baccharum inftar, Calius, Varinus, Suridas, Etymologus, At forfitan w̉ussisu hîc inter pretari conueniet, non fimpliciter crudelem $\&$ immitem, ut Calius tranftulit:fed wesoф́xyou, id eft quí cruda $\&$ non cocta uoret. Arnobius enim libró 5 , aduerfus Gentes, Bacchanalia etiam(inquit) præ: termittemus inania, quibus nomen Omophagïs Græcum eft, in quibus furore mentito, \& fequeftrata pectoris fanitate, circumplicatis uos anguibus:atç ut wos plenos dei numine ac maieftate do, ceatis, caprorum reclamantium uifcera cruentatis oriburs diffipatis , Stridas citat Ariftophanis ex $R$ anis uerfus, quibus Cratinum taurophagum uocat: $\&$ Bacchum eadem ratione mofchophagum cognominat. TDe tauro quem uetula Cereris apud Hermionenfes facerdos ducit $\&$ facrificat, in boure fupra diximus in $\mathrm{H}, \mathrm{h}$. TDiana Taurica dicitur, Grxcis etiam Taugé(ut habet Varinus)qux à Tauris populis colebatur:eadem Thoantea uel Thoantis, Oreftea ${ }_{3}$ Fafcelis, Aricina \& Nemoren= fis apud Romanos dicta eft.Nam Iphigenia iam immolanda, ut fupra narraui, numinis miferatione fubrraça, $\mathcal{X}$ ad Tauricam regionem translata, regi Thoanti tradita ef, fạcerdosḉ̧ facta Dianæ: ubi cum fecundum ftatutam confuretudinem humano fanguine numen placare, agnouit fratrem Ore $=60$ ftem:qui accepto oraculo carendi furoris caufa cum amico Pylade Colchos petierat: ct cum is occifo Thoante fimulacrũ fuftuliffet, abfconditũ fafce lignorum, unde $\&$ Fafcelis dicitur (ab alḡjs Facelis aut 


\section{Taurus. H. Lib. I.}

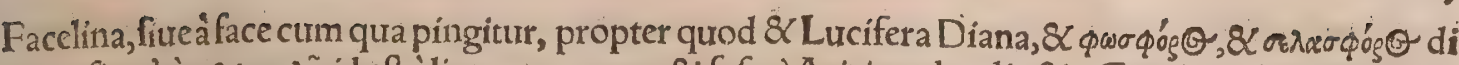

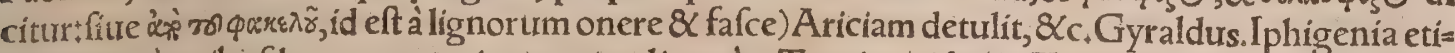
am Diana à quiburfam cognominata, nón alia quàm Taurica tídetur. Taüropoliz Dianæ meminit ctiam Diod.li, s.Idem $\&$ Tautropolia facrificia Dianæ \& Martis apud A mazonas uocari fcribit.Stra. bo quog; libro 14. ait in Icaria infula (Icaro Perfici maris infula, Dionyfius Afer) templum Dianæ fuiffe, (Stephanus id ex eodem Strabonis libro, in Samo fuiffe tradit)quod Tautropolium à dea dice. retur, id quod in decimolexto repetit, ubi fuit $\&$ oraculum. T. Liulus libro 4 .quintæ Decadis, Amphipolim cum iam fama pugnæx perueniffet, concurfuség matronarum in templum Dianæ, quam Tauropolon uocant, ad opem expofcendam fieret, \&c. Varinus, Tauropolon (inquit) Dianam dixe Irtnt, quoniam ut taurus circựmeat omniałuel quòd taurrum Neptunus immiferit Hippolyto, furens tem oeftro per omnem ferè terramituel quod Iphigenia é Scythia fugiens, in Attica fimulachrum Dia ñx conftituerit, \& Tauropolon Dianam appellarit; quod à Taurica gente tum primum ueniffet. Dionyfius Afer in fitu Orbis, non à gente tantum, fed à tauro, Tauropclon Dianam denominatam ait:quía, ut Euftathius, ea regio armentis abundet, quibus pręfit dea:feu quia Diana Linna credatur: quare \& Tauropuss, Taugwros, dicfa eft, quod fit ut taurus afpectu, Gyraldus. Cælius Euftathí locum melius ficreddit, irel quia cum Luna eadem fit, qux tauris uectatur, \& Tauropus dicitur. Sané Hefy chius non modo Tauropolam Dianam, fed \& Míneruam uocat. Alin Tauropolan dictam aiunt, drón

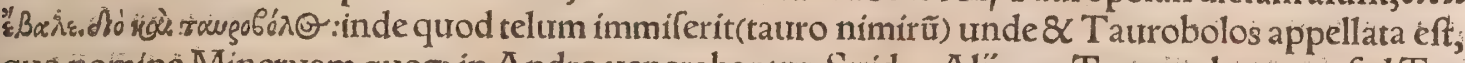
quo nominè Mineruam quoģ in Andro trenerabantur, Suidas.Alip non Taưropolon eam, fed Tau rophagon nominauerunt, quôd taurus pro Iphigenia in facrificio fuppofitus fit, Etymologuss, Taveíw vis, quix in Tauris Scychiæ colitur, fic diça tanquam gregum $\&$ pecorum prafes, per fynecdochen à

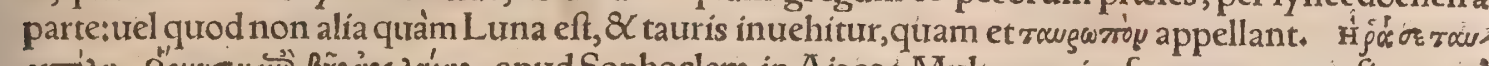

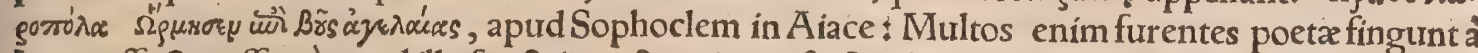
Luna affectos effe, cò quod illa fpectris nocturnis prafit,Suidas. Tloui taurum immolare nefas exi ftimatum, ut exponemus mox ex Macrobio. TMineriam quoos Tauropolam cognominari, ex Hefychio iam docui, Suidas eandem raugobónsy dictam in Andro coli frribitidcirco quod Anitus tau rum Atridis dederit, $Q$ ubicunç ille de natu exiliret, Minerua adem condendam iufferit, ita enim fe cundam fore nauigationem: Taurus autem in Andrum exilịt. De bubus Minerux immolari folitis, in Boure dixi. IMirabile eft Olympia facro certamine, nubes mufcarum immolato tauro deo quẽ

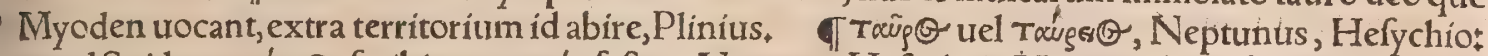

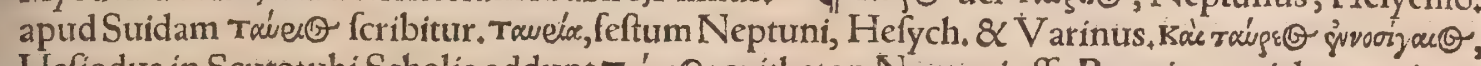
Hefiodus in Scuto:ubi Scholia addunt Tá $\alpha^{\prime} \in \Theta$ epitheton Neptuni effe, Bocotice, q ei deo tauri ma=

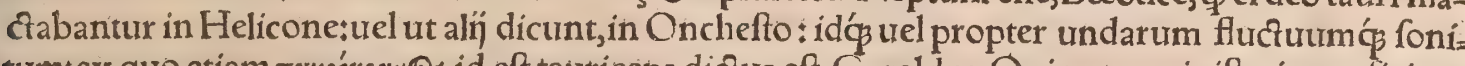
tum; ex quo etiam raugóngav $G$, id eft tatticeps diçus eft, Gyraldus. Qui potus minifterio praficiun: tur, dici quidem cenochoi folent:in Neptuni tamen fefto(apud Ephefios) etiam tauros fcio appella = tos, Cælitus ex A thenæo quem tamen non citat. Euangelus apud Macrobium libro z. cap, 10. Etcx his (inquit) quæ nota funt nobis, Maronem pontificï difciplinam iuris nefciffe conftabit. Quando e= nim diceret, Coelicolûm regi mactabam in littore taurum, fi taurum immolari huic deo uetitum? aut fi didiciffet, quodAtteius Capito comprehendit:Cuitus uterba ex libro ı. de iure facrificiorum hęc funt:İtaq̧ loui tauro, uerre, aricte immolari non licet.Labeo ucrolibro 68. intulit, nifi Neptuno, A. pollini \& Marti, taurum non immolari. Ad hac Pratextatus renidens, Quibus deorum immoletur tauro, fi tris cum Vergilio communicare, ipfe te docebit, Taurum Neptuno, taurum tibi pulcher A. pollo, Vides in opere poetæ uerba Labeonis? Igittrr ut hoc dociè, ita illud argute. Nam oftendit i= deo non litatum, ideo fecutum Horrendum dictu, \& uifu mirabile monftrum. Ergorefpiciens ad futura hoftiam contrariam fecit.Sed $\&$ noterat hunc errorem non effe in expiabilem. Atteius enim Capito, quem in acie contra Maronem locafti, adiecit hæc uerba:Si quis forte louri tauro fecerit, piaz culum dato, Committitur ergo res, non quidem impianda, infolita tamen. Et committitur non igno, rantia, fed ut monftro locum faceret fecuturo, Hucufç Macrobius, Paufanias in Corinthiacis men. tione Danai facta, eiusq́, fol'h, , Ibidem (inquit)Bitonis imago eft, humeris taurũ fuftinens: de quo $\mathrm{Ly}$. - ceas poeta fcripfit, quod cum Argitu facrificium loui in Nemeam ducerent, Biton uir admodum rọa buftus, humeris fublatum geftauerit, Taurus ut fluuins(caufam fuperius indicaui)fic etiam Neptu

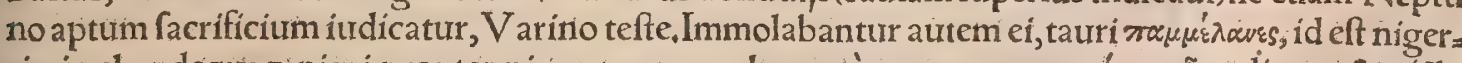

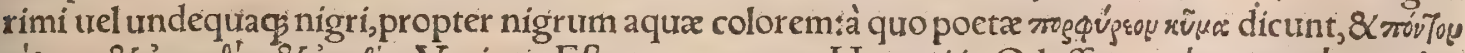

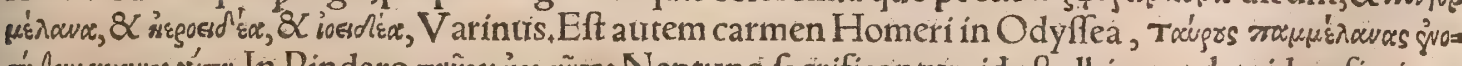

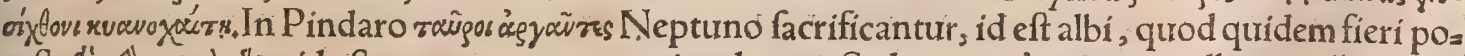

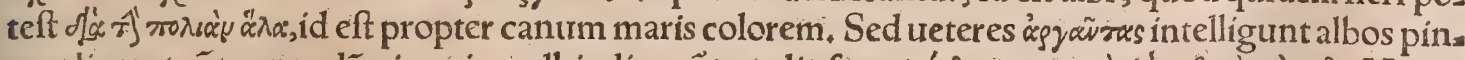

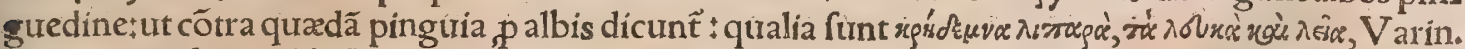
Pindarus infuper alibi Neptuno taurum immolandum cratapoda uocauit, qui fuiss fuit Delpho. rum mos, Calius, Homeri Scholiaftes, Tauros(inquit)ei immolabant, propter maris uiolentiam: ni. - gros uero,propter aq!zx colorem, ex maris profundo, Idem feré fcribit Phurnutus. Varínus in ieppi

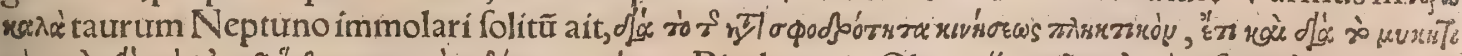

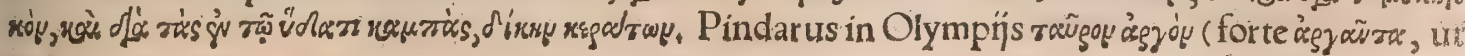


fupra ex Varino) illi afcribit:quidam album interpretantur, propter maris fpurmastali non alburn, fed florentem, feu nitentem, aut procerum interpretantur. Ego uelocem expono ; nam fic canes $\mathrm{CO}$ : gnominatos uidemus» Sed de hac uoce cum alibi, tum in Argiphônte Mercurio plura dixí, Gyrald. Iunoni de tauro albo antiqui rem facram faciebant, (ut in Boue fupra oftendi)uel de iuuenca potius alba ut docti autumant, quod Gyraldus poétarum tefimonïs comprobat. Pindarus in Nemeis in

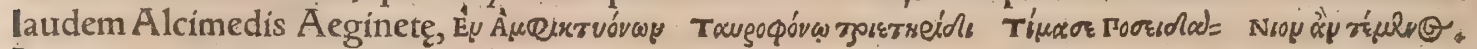
Interpres taurophonon trieteridem exponit, in qua tauri Neptuno ferirentur $\ddagger$ Repetebant autem If hmiorum certamen tertio quoģ anno. In maritimis facrificîs exta in flucius iactabantur, unde illud Silílibro 17. Cui numen pelagí placauerat hoftia taurus, lacłáç coeruleis innabant fluctibus exta. Graci aliquot Neptuno de cruribus taurorum rem facram faciebant: Vlyffes ariete, apro, \& tauro litauit. Non folos tamen tauros uel Neptuno uel Apollini, fed $\$$ alias quandoç uíctimas imz molabant. Heroibus tauro, capro, $\&$ ariete litabãt, Gyraldus, đ De lupo qui taurum confecit, quo aufpicio Danaus regnum obtinuit, in Lupo dicemus,

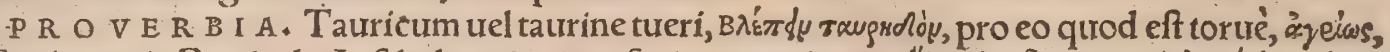

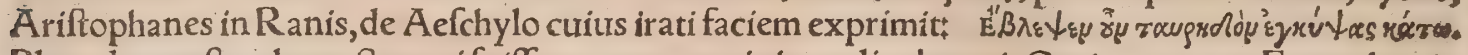
Plato demonftrat hunc Socrati fuiffe morem, taurinis oculis obtueri, Optima torux Forma bouis,

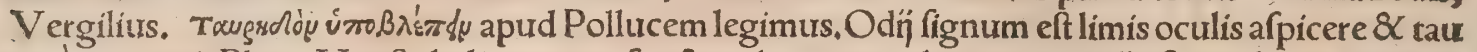
rine, ut inquit Plato. Vueftphali trucem afpectum hoc prouerbio notant, KËr fidt als cin od) s Der

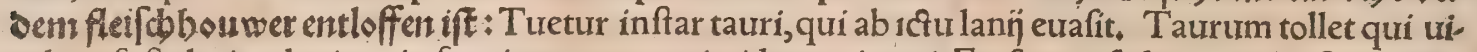
tulum fuftulerit:adagium in fornice natum, uti uidetur (inquit Erafmus) fed quod ad ufum uere= cundiorem commode torqueri poffit, fi quando fignificabimus maiora peccaturü adultum, qui puer uitijs minoribus affueuerit, In fragmentis Arbitri Petronị, Quartilla mulier omnium impudiciflima, Infans(inquit)cum paribus inquinata fum, 8 fubinde prodeuntibus annis, maioribus me pue. ris applicui,donec ad hanc atatem perueni. Hinc etiam puto natum prouerbium illud, ut poffe dicatur taurum tollere, qui uitulum fuftulerit, Hæc illa. Cæterum non abfurdum uidetur adagitum ad Milonis Crotoniatx factum referri, qui quotidie uirulum aliquot ftadijs geftare folitus, eundem tau. rum factum, citra negetium geftaffe legitur: Atç ita quadrabit in eos, qui paulatim rebus etiam ma

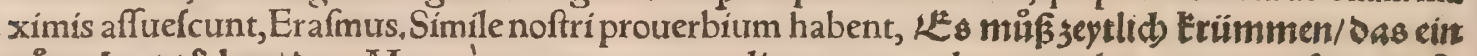
ginter bagg fol wetDen, Maturé curuetur oportet lignum, quod commodus uncus euafurum eft

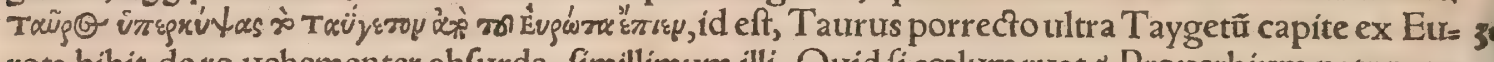
rota bibit, de re uehementer abfurda, fimillímum illi, Quid ficoelum ruat $\sim$ Prouerbium natum ex A pophthegmate Geradæ Lacedæmonī: is ab hofpite quopiam interrogatus, quæ pona foret adul teris apud Lacedęmonios, negauit ullos effe adulteros apud Lacedæmonios, At inftans ille, Quidfi quis exifteret,inquit, quam ponam daret $\mathrm{Is}$, inquit, taurum maximum dependeret, qui producio ultra Taygetum montem capite, biberet ex Eurota, Cumḉ hofpes arridens, Et unde taurus tam in. gens? Lacedæmonius uiciffim, At unde apud Lacedæmonios adulter ? Refertur à Plutarcho in uita

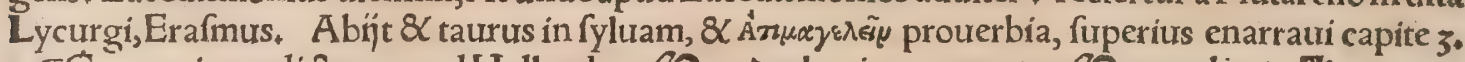
TGermanicum dictum apud Hollandos, (Pan orybe cin varren gen (Pontpelier/ Tumptet wiser er blybt ein fiter, hoc eft, Bouem etiamfi longiffime abducas, bos manet: Horatiani carminis fenfum habet, Coelum non animum mutant qui trans mare currunt, बProuerbium, Non fi teru peris, ex apologo natum, ad $R$ anam differetur.

\section{DE V I T V L O.}

\section{A.}

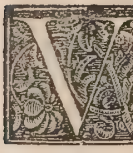

I T V L V s bosiunior dicitur. Difcernuntur in prima atate uitulus $\&$ uitula, in fecunda iutuencus \& iutrenca, Varro. Nos iuuencum \& iutuencam fupra comprehendimus in ge. nerali bouis uocabulo, hic de folis uitulis feorfim dicfuri. Attulimus autem fupra quoque nonnulla, qux ut bubulo generi in uniuerfum fic uitulis qurog conueniunt. TV Vitulum Ebrai uocant $ל x y$ egel, urel 7 par cum additur ben bakar: fimpliciter enim pofitum par, bouem in genere fignificat, ut fupra expofui in Boue, Rabi Salomon \& Abraham Efra egel interpretantur

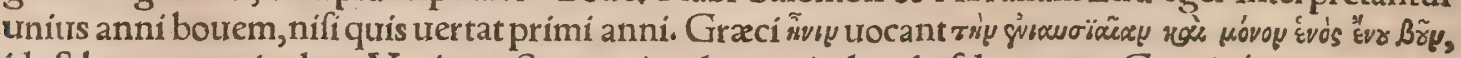

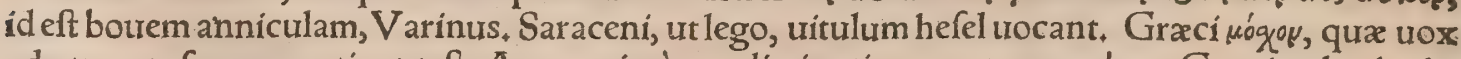

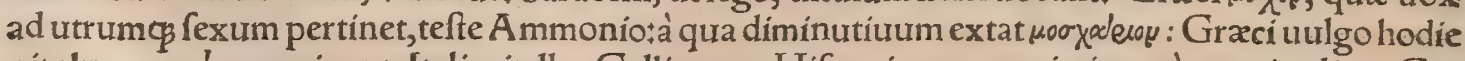
uítulum uroxúee nominant. Itali uitello, Galli ueau : Hifpani ternera, nimirum à teneritudine: Ger mani cirt kalb, Angli a calfe, Vitulus in mafculino genere dacúc $\lambda$ ss, raveí sop etiam dici poffe uide.

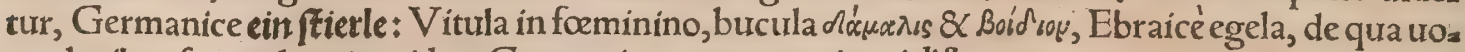
ce pluribus fupra docui:quidam Germanice exponunt ein jeittii, quae uox tamen ad iuuencam ui. tulo atate paulo fuperiorem pertinet:Anglis an heffar or yonge cowe.

B.

Vituli ungula fi in utero non abfoluatur, moritur, author obfcurus, Cętera quę ad partes corpo ris, fupra cum Boure requires. 
c.

De cibo potúćs uitulorum, tride mox quxdam in E. De foetura \& partur uaccarum etiam in BO. ure dixi. बIVituli item cur grauius mugiant quàm boues, cum animalia cæeterà nourella trocem a: cutiorem xdant, iam fupra explicatímus. TAdhac, remedia uitulorum non pauca, boum reme dïs pariter coniunximus. Prater catera, folent uitulis nocere lumbrici: qui fere nafcuntur crudira. tibus, Itaç moderandum eft, ut bene concoquant:aut fi iam tali uitio laborant, lupini femicrudicö teruntur, \& offæ faluiati more faucibus ingeruntur: Poteft etiam cum arida fico \& eruo conteri her. ba Santonica, \& formata in offam, ficut faluiatum demitti. Facit idem axungix pars una tribus par tibus hyffopi permifta. Marrubij quoq fuccus \& porri ualet eiufmodi necare animalia, Columella. to Vergilius in Georgicis peftem pecorum defcribens, Hinc latis uituli uulgo moriuntur in her bis Et dulces animas plena ad prarepia ponunt

Poft partum cura in tritulos traducitur omnis: Continuro ch notas $\&$ nomina gentis inurunt. Et quos aut pecori malint fubmittere habendo: Aut aris feruare facris, aut fcindere terram, Ec campum horrentem fractis inuertere glebis, Vergilius in Georgieis, Poft hac primum de domitui ra corum pracipit, de qua nos fupra etiam in Boue cap. . deinde de alimonia ipforum his uerfibus: Interea pubi indomitæ, non gramína tantum, Nec uefas falicum frondes, uluamćs paluftrem: Sed frumenta manu carpes fata. nec tibi foeta More patrum niuea implebuntmulçralia uacca: Sed tota in dulces confument ubera natos. Si qua (matrix) amífit uitulum, ei oportet fupponere ao eos, quibus non fatis lactis prabent matres. Semeftribus uitulis obijciunt furfures triticeos; \& fari: nam ordeaceam, \& teneram herbam: 8 ut bibant mane 8 uefperi curant, Varro, In alimonijs ar mentitium pecus fic contuendum:lactentes cum matribus ne cubent, obteruntur enim. Ad eas ma. ne adigi oportet, \& cum redierint é paftu:Cum creurerint uituli,léuanda matres, \& pabulum uíride obijciendum in præfepł́s. Item his, ut ferè in omnibus ftabulis, lapides fubfternendi, aut quid item, ne ungula putrefcant, Áb æquínoctio autumnali unà pafcuntur cum matribus, Varro. Menfe A: prili uitulí nafci folent, quorum matres abundantia pabuli iuuentur, ut fufficere poffint tríbuto labo ris \& lactis. Iplis autem uitulis toftum molitumós milium cum lacte mifceatur faluiati more praben= dum,Palladius.

Glunio menfe uituli recté, ut dictum eft ante, caftrantur, $P$ alladius:Qúómodo autem caftrari de

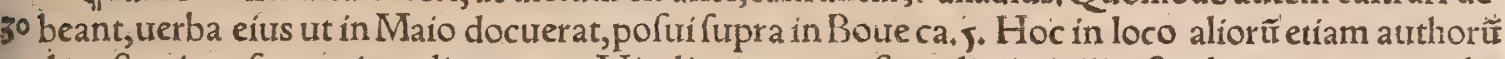
de caftratione fententias adiungam. Vitulis tempus caftrandi anniculis eft, alioquin minores des formioresćs euadunt, Ariftoteles, Caftrare non oporter ante bimatum; quòd difficulter, fi aliter fe. ceris, fe recipiunt. Qui autem poftea caftrantur; duri \& ínutiles fiunt, Varro \& Sotion in Geopon. Caftrare uitulos(inquit Columella)Mago cenfer, dum adhuc teneri funt; neos, id ferro facere, fed fif fa ferula comprimere tefticulos $\&$ paulatim confringere ( $\&$ paulatim confractis refoluere, $P$ allad.) Id's optimum genus caftrationum putat, quod adhíbetur ætati teneræ finé uulnere. Nam ubi iam in duruit, melius bimus, quàm anniculus caftratur. Idó̧ facere (uerno, ut recte addit $\mathrm{P}_{\text {allad }}$ ) uel autum no Luna decrefcente præcipit, tritulumḉ ad machinam deligare: deinde priufquam ferrum admo ureas, duabus anguftís ligneis(ftagneis, Pallad, fortè ftanneis, fed neutrum probo)regulis, uclutí for:

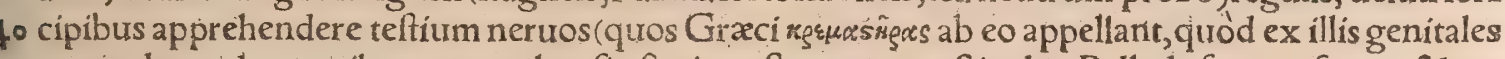
partes dependent)quibus comprehenfis, ftatim teftes (tentos tefticulos, Pallad, ferro refecare, \& ex. preffos(Palladius fimpliciter habet, ferro refecant, $\&$ ita recidunt)ita refcindere, ut extrema pars $e=$ rum adhærens prædictis neruis (capitibus neruorum fuorum) relinquatur. Nam hoc modo nec ertI ptione fanguinis periclitatur iuuencus, nec in totum efforminattur a dempta omni uirilitate, formaćs feruata maris, generandiuim depofuit, quam tamen ipfarin nố protinus amittit. Nam fi patiaris eum à recenti curatione focminam inire, conftat ex eo poffe generari; Sed minime id permittendum, ne profluuio fanguinis intereat. Verum uulnera cius famentitio cinere ( cinere fimpliciter, Sotion in Geopon.) cum argenti fpuma linenda funt:abfinendusíg eo die ab humore(potu, Pallad.) 8cexiguó cibo alendus.Sequenti triduo uelut xger cactiminibus arborum, 8 defecto uiridi pabulo oblectan50 dus(prębeantur ei têneræ arborum fummitates, \& fruteta mollia, \& herbæu uiridis coma, dulciora fa gina roris aut fluminis, $P$ allad.)prohibendus q́ multa potione. Placet etiam pice liquida, $\&$ cinere, $c \tilde{u}$ exiguo oleo (ut Sotion etiam habet)ulcera ipfa poft triduum(à caftraticne fcilicet)linire(uulnera dili genter ungere, Pallad.) quo \& celerius cicatricem ducant, nec à mufcis infeftentur, Hæc Columella \& Palladius. Sed melius genus caftrationis(iniquit Palladius) fequens ufus inițenit, \&c. quo fer. ramentis ignitis tefticuli deciduntur, ut fupra in Boure cap. s. recitaui. Vitulis (inquit Ariftor.lib.9. hiftoriæ anim. cap. jo.) tempus caftrandi anniculis èf, alioqui minores deformioresḉ euadunt. No dus caftrandi hic eft. Tractos deorfum teftes, atç obtentos, preffos śs in imurm fcorti, cultello adacto, extrudunt:mox fibras furfum, quoad maxime fieri poteft, reprimunt, $\&$ plagam infarciunt capilla. méntis, ut fanies effluere poffit: $\mathcal{Q}$ fi inflammatur, ignem adhibent fcorto, \& refpergunt $_{\text {Si }}$ bos à rea 60 centi caftratu ineat, procreare potef, Hac Ariftoteles interprete Gaza. Graca in codicibus impref

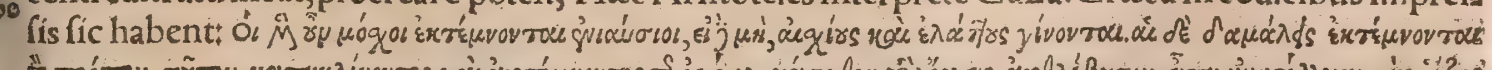

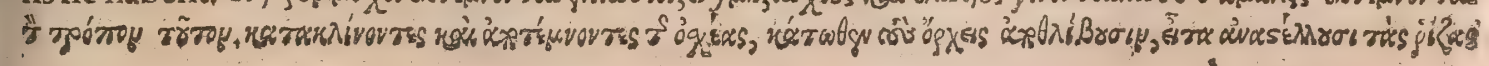




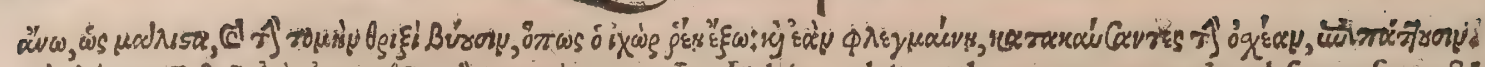

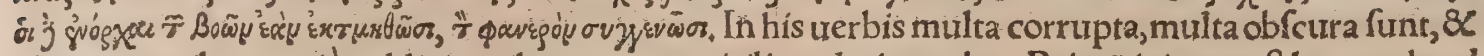
ab interpretibus uariè reddita quibus ego pro uirili mederi conabor.Primü igitur poft hac uerba,

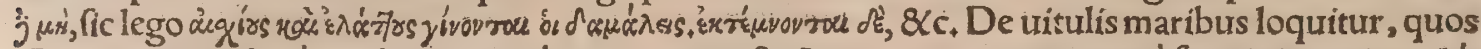

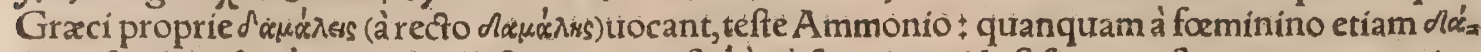

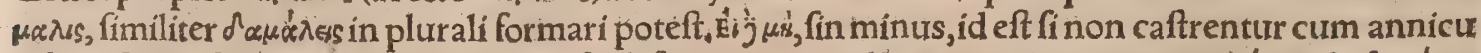

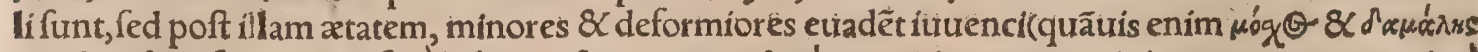

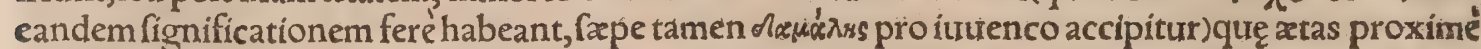
uitulum excipit, \& ita conuenit hic interpretari. Dixerät autem paulo ante, omnia animalia, fi dum crefcunt caftrentur, maiora \& elegantiora quàm non caftrata eiradere: fed fi pofteaç adoleuerunt, \& iam incremento conftiterunt, caftres, nihil praterea accedere ad magnitudinem poteft, Proinde non affentior Auguftino Nipho, qui ubi hunc Ariftotelis locum interpretatur, Minores(inquit) de. formioresćs euadunt, fcilicet fi infra annum caftrentur, Nam quod de cáftratione poft anni primi e. tatem, \& quo tempore iam crefcere definunt, non ante illam facta Ariftoteles loquatur, manifeftum eft ex iam dictis. Addit Niphus, fi autem furpra annum, non fine periculo agitur : at nos ex Sotione \& V arrone iam docuimus, non ante bimatum caftrandos effe: Sed efto ut pofterius dictum Niphi, pugnantibus inter fe authoribus, ue excufandum, uel etiam uerum fit: prius certe omnino Arifto. relis fententiæ aduerfatur, quod uel Albertus Magnus ipfum monere poterat, Genus illud caftratio nis, quo uitulorum, dum a dhuc tenerifunt, telticulos finfa ferula comprimere, $\&$ paulatim confringe re, Palladius \& Columella ex Magone docent:minus frangere uires, ideoćs tutius effe in tenera ara 20 te exiftimauerim, minus etiam effoeminare; cum teftes eis non omnino demantur, fed atteratitur can tum. Id quod teftibus iam ętatis progreffu durioribus, ut difficilius, ita nimio cum dolore fieret

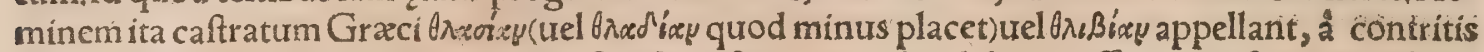
contufisḉs coleis. Hic modus quoniam fine ferro fit, nec tantum dolorem affert, nec fanguinem pro. fundit, non pugnat illis qui anniculos aut bimos demum caftrari uolunt: intelligunt enim illi de ca. fratione ferro aut cauterio facta. Varia fpadonum inter homines genera, Alciatus in libro de uerbo rum fignificatione proponit. Paulus A egineta libro 6.cap. 68, duplicem caftrandi modum explicat,

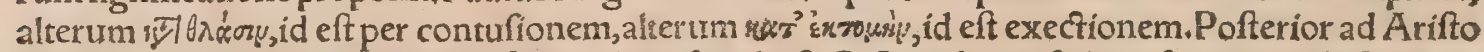
telis etiam uerba lucis nonnihil afferet, is huiufmodi eft: Caftrandus in fedili refupinatur, 86 frotum cum tefticulis finiftræ manus digitis premitur; 8 per frotum ita extenfum duas lineas rectas, per utrumgs teficulum unam, fcalpello incides: ubi exilierint tefticuli, cute detracta excidentur, ita ut tenuiffimum folum naturale uaforum commercium relinquatur. Atgs hic modus, eo qui per contu= fionem fit, magis probatur. Nam quibus teftes folum contufif funt, nonnunquam Verleremi appetût: nimirum quód pars aliqua tefticulorum contufionem fubterfugerit, Hac A gegineta:qui de contirfio

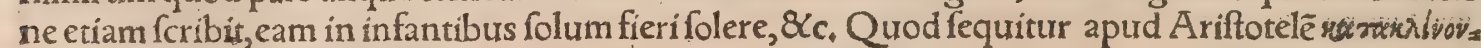

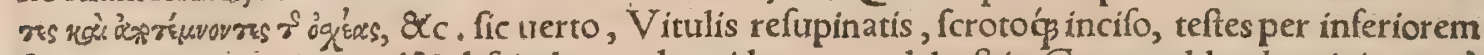
fcroti partem exprimunt ( $\&$ abfindunt uel excidunt, quod deeft in Græco:addendum igitur, wo:s 'หr fum recondunt. Quod Ariftoteles dixit, exporißron, id eft digitis uel inftrumento aliquo extrudunt,

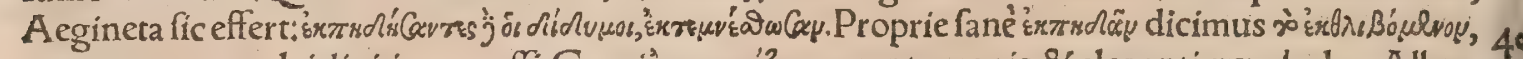

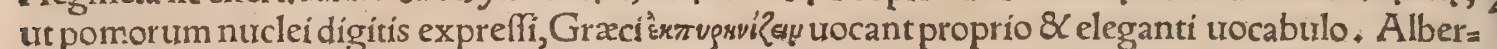
tus Magnus totum hunc locum fic reddidit, Profternitur ad terram uitulus, \& diuiditur corium o= fchei, \& exprimuntur tefticuli, \& ligantur nerui tefticulorum fortiter: \& tunc abfcinduntur tefticu. $\| i, 8$ eriguntur (id eft furfum reponuntur)radices neruorum, cineribus iniectis in uulnus; Et fi co quantur(id eft urantur)nerui, melius exit contra fanguinis fluxum. Qua pleraç ad Ariftotelis fen. tentiam quadrare puto:quanquam de fuo adiecit neruos(f́ilicet cremafteres)praligari, ex urulgi ex. perientia nimirum $+N$ am quòd cineres pro capillamentis fupponit, cum ueteres rei ruftica authores in hoc imitetur, facile condonabimus. Nam \& in libro de fimplicibus medicamentis ad Paternianü; qui inter nothos Galeni circumfertur, ita legimus cap.148. Cinis in recencia uulthera penitius infar

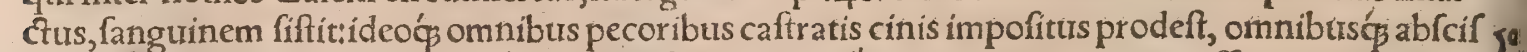

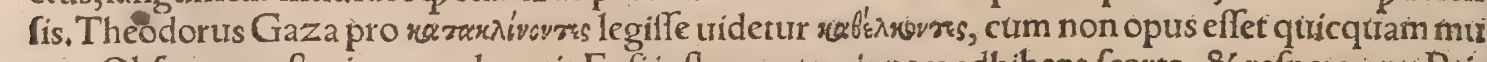
tare. Obfcurum eft etiam quod uertit, Et fi inflammatur, ignem adhibent fcorto, 8 refpergunt: Pris mum enim loco inflammato, ignem uel cauterium adhibere, uerè eft ignem igni addere, \& augere malum+deinde quod inflammationem refpergi ait, nec quifquam unde uel quonam medicamento ea refpergi debeat ex uerbis eius intelligere queat, reprehenfione dignum mihi uidetur.Paftores (in

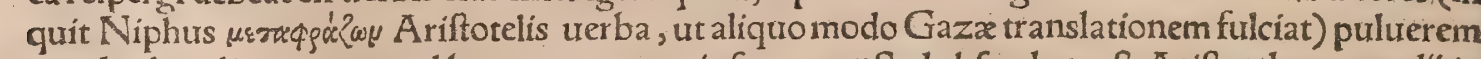
aut alitrd medicamentum ad hoc prxparatum infpergunt. Sed abfurdum eft Ariftotelem remedin in fpergendi nomen tacuiffe putare, prafertim cum eo omiffo, obfcura \& ineptæ conftructionis relin: quatur oratio. Albertus Magnus ridicule fimul $\&$ indocfe fic uertit:Si autem apoftema accideritin loco illo, puluerizatus tefticulus 8 loco fuprapofitus, erit conueniens cura ipfitus. Mihi poft nezte 60

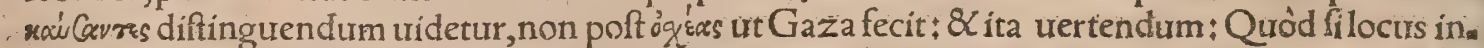
flammetur, urunt, \& C croto infpergunt,intelligo autem idem remedium quod proxime uulneri int. 


\section{Vitulus E. F. Lib. I.}

farciendum dixerat, nempe relyes, id eft capillamenta, aut lanas, Lanæe enim, Diolcöride tefte, uulné ribus à principio ftatim ex aceto, oleo, uinótie utiliter imponuntur, \&c, crematarum praterea cinis cruftas inducit, carnem excrefcentem cohibet, $\&$ ad cicatricem ulcera perducit. Ab initio igitur, ubi fiftere tantum fangunem oportet, lana mollis fimpliciter adhibetur : deinde ubi locus intumefcit,

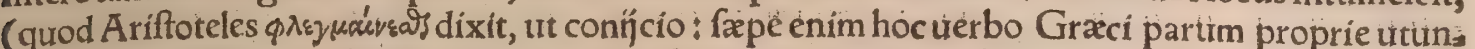
tur) \& pus colligitur, uehementiore remedio, ficcante expurgantéç opus eft, quod quidem non am

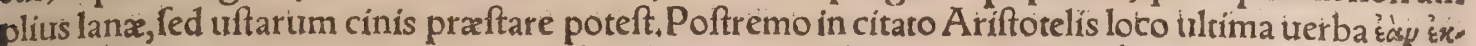

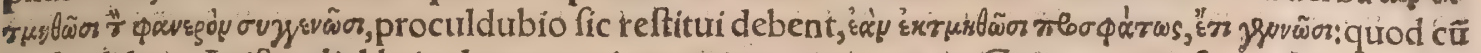
ex fimili loco Ariftotelis libri ı.de generatione ahim. cap. 4.tum ex Gazx conuerfione, \& Columel. $\mathrm{l}_{x}$ Palladĭ $\not$ cuerbis confirmari poteft. Hxc hactenuts dixerim fuper uitulorum caftratione, non tam reprehendendi $\&$ emendandi aliorum feripta, $\bar{c}$ negotium ipfum clarius explicandi inftituto.

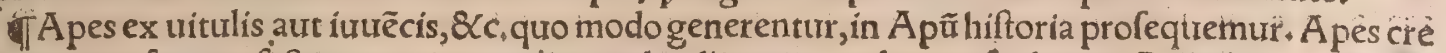
duntur non fugere, fi ftercus primogeniti uituli adlinamis oribus tuafculorum, Palladius; TCáfe us fit lacte coagulato, hoedino ímprimis uitulcrúmue coagulo, Plinius, Pelles uitulinæ ad tiarios tu= fus parantur, uel cum pilis, uel ijs detractis: \& uel diuerfis coloribus tincta, uel natiuo relicta, ad cus leos, peras, tibialia præértim mulierum in Germania:ueftuntur eifdem libri, mira elegantia, præ ca teris enim nitorem læuoremó politæ admittunt.

Vitulos lanñ ad cultrum emunt, Varro, In omni animalium genere, carnes uetulorim dura, fic: $c x, \&$ concoctu difficiles funt:iuniorum contra, humidx, $8 \times$ molles, at $q$ idcírco commodius conco= quuntur: his tamen exceptis, quæ ubi in lucem ædita funt, protinus in cibo fumuntur , Nanq; om. nes eiufrnodi muccof $x$ funt, ac præcipué quæ fuapte natura humidiore fint carne, ut agni \& fues:ue rtim hoedi $\&$ trituli, ut qui natura funt ficciores, multò melius concoqutuntur nutriuntós, Galenus in libro de boni $\&$ mali fucci cibis, Ex eiufdem libro 3 , de aliment, facult. fupra in Botre de ưitulina car= ne iudicium recitauimus, nempe quod bubulæ præftet $\&$ facilius concoquatur. Vituli uaccarum illarum, quas lactis tantư $\&$ cafei caufa nutrimus, quindecim à partu diebus elapfis occidendi funt:

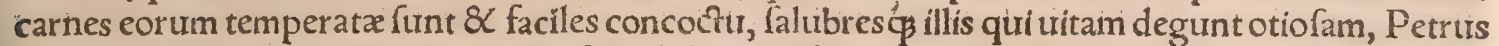
Crefcent, Hanc ítąs non iniuría menfre nobilitim crebro repetunt,Platina. Afliduos habeant ui= tulum tua prandia in ufurs, Cui madida $\&$ fapida iuncta tepore caro eft, Bapt. Fiera. Elixatirr uis tulína ut reliquorum pecorum caro:quidam ut apperitui confulant excitãdo, eodem ferè modo quo pifces coquiunt, in aqua primum elixant defpumantós, \& faliunt ( parcius autem ea falíri conuenit, in quibuis ius magna ex parte feruendo confumi debet) $\&$ cum femicocta uidetur, trinũ affundunt, deinde cepas per tranfuerfum concifas, poftremo cum parum iuris iam fupereft butyrum fertrefa cfum: aliqui butyro in fartagine farinæaliquid addãt, \& aceri modicum, $8<$ croceitm ex aromatibus pollinem, ipfaś́; cepas. Similiter etiam exta parantur, fic uoco arteriam cum pulmone corde \& ie.

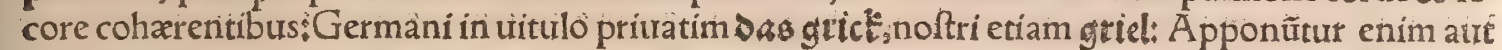
fimpliciter elixa, aut condimentario iure cum uino cocta, ut de carne iam diximits $\div$ fed ius illud cum carne femper coqui folet donec modicum fuperfit: cum extis uero interdum relinquítir copiofum, er aromatibus cum croco adiectis pani ga фavyolò diffecto in patinis infunditur (eirt grielfuppen)idç

40 inter lauta etiam primæ menfx fercula numeratur. Ventrem cum inteftinis uituli; Germani pritia:

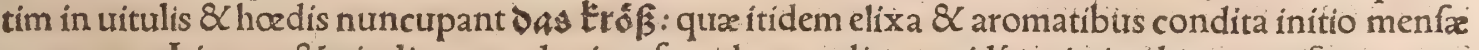
apponunt. Lixatur $\&$ uituli caput ad prima fercula prandiorum, idós arietino longe prafertur , pre tio fuperans fefquialtero, Cerebrum inde feorfim etiam in aqua modicé coctum, mox tunicis libera= tuim, in uino coquitur, \& infpergitur aromatibus; Sunt qui cum lacte mixtirm \& cepis minutatim in. cifis, butyro frigunt, \& aromiatibus condiunt. De uitulina carne falienda fupra in Boue dixitrelin: quitur autem cum fale in uafis ferè non ultra diem antequam fufpendatur in caminum. Gelu in pas tina fit tum ex pedibus uitulinis, tưm metaphreni feu dorfi fuperioris carnib.Pedes etiam elíxi cum aceto \& pipere edunturir:uel friguntur cum butrýro inuoluti confractis tudicula ouis, $T$ A picius li= bro 8.cap.5. títulinæ carnis uarios apparatus præf fribit, his uerbis; In uitellina fricta:Piper, Ligufti cum, apï femen, cuminum, origanum, cepam ficcam, uriam paffam mel, acetum, uinum, liquamen, oleum, defrutum. In uitulinam fiue bubulam cum porris fuccidaneis, uel cepis, uel colocáfíp:liqua men, piper, lafer \& olei modicum. In uitulinam elixam:Teres piper, ${ }_{j}$ ligufticum, careum, apí feme fuffundes mel, acetum, liquamen, oleum : calefacies, amylo obligas, \& carnem perfundes. Aliter in uitulina elixa:Piper, Ligufticum, foniculi fernen, origanum, nucleos, caryotam: mel; acerum, liquaz men, finapi 8 oleum. Elixum effe debet tituli pectus: Dorfum tamen feu fpina affaturam requí rit: Coxas eiufdem in pulpamentum rediges, Platina.

Artocreas quomodo paretur ex carne uituli, \&c. Platina libro 8.cap. 36 . his uerbis docet $\$$ Aut uituli aut hocdi aut capi carnem elixabis:elixam $\&$ eneruatam, minutatim concides, $\&$ in mortario tundes. Huic deinde parum cafei recentis, tantundèm tieteris $\&$ triti, parum petrofelíni $\&$ amaraci

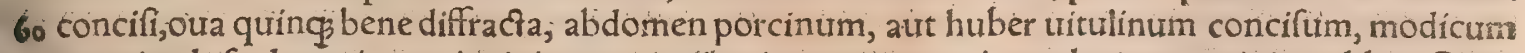
piperis, plufculum cinnami, minimum gingiberis, tantum croci ut colorem concipiat,addes: Ctra bis coquatur eo modo, quo albam diximus. Hoc edant Scaurus $\&$ Calius, qui nimiam macilentiam 
cum obefitate libenter permutarent: Vehementer enim alit, corpus obefat, hepar iuuat, obftruftio nem tamen $\&$ calculum facit. Et libro 6, cap. 9. Paftillum ex uitulo alinsue cicuribus animantibus hunc in modum parat:Cicures(inquit) appello, omnia quæ domialuntur, ut uitulum, capum, galli. nam, \& fimilia. Ex his paftillum fic facies: Carnis macræ quantum uoles fumito, minutatimć glas diolis concidito. Vitulinum adipem cum aromaribus huic carni bene mifeto, inuoluta cruftillis in furno coquito. Cocta ubi propé fuerint, duo uitella (uitella in plurali numero genere neutio fapenu mero profert) ab albore ouorum excreta cum modico agrefta, cumćs iure perpingui bene tudicula agitata, in paftillum infundes. Sunt qui modicum croci ad fpeciem addant. Fieri $\&$ hic paftillus in pa tella bene uncta, etiam fine crufta poteft: capum, pullaftram, \& quicquid uoles, integrum \& in frufta concifum, in paftillo pro uoluptate optímé coques. In hoc $\&$ multum alimenti ineft; tur, pauca recrementa in fe habet:cor, hepar, \& renes iuuat, obefat, ac uentrem *ciet. Et mox ibid. cap. 12. Paftillum (inquit) in olla fic facito: Carnem uitulinam cum adipe minutatim concifam, in ollam ponito:pipiones \& pullos, fi uoles, adijcito. Ollam ípfám ad carbones longè à flamma, ne concitaté efferueat, ponito. V bi ebullire occeperit, defpumato:paffulas deinde imponito. Cepam poftre mominutatim concifam, cum larido frigito:Frictam in ollam indito. Vbl omnia propê cocta exifti maueris, agreftam $\&$ aromata fuffundito. Sunt qui $\&$ duo uitella ourorum bene agitata cum agrefta infundant, Multum alet, tardè concoquetur, naufeam faciet, ftomacho nocebit, hepar $\&$ renes con, calefaciet, fperma augebit, caput \& oculos lædet. Idem Platina codem libro 6,cap, 18 , In pulpam ut tulinam: Ex coxa uitulina carnem macram abfindito, in frufta oblonga $\&$ fubtilia concidito tó́s cum gladioli cofta, ita ne refcindantur:ftatimós fale \& foeniculo trito fuffundito:amaracum de 20 inde ac petrofelinum cum larido bene concifum, $\&$ aromatibus fparfum fuper pulpas extendito: easḉ ftatim inuolutas in ueru ad ignem ponito:ne nimium deficcentur, caueto: coctas conuiuis ftatim appones. Multum alet, corpus folidum reddet, pauca recrementa relinquet. In pulpam Roma= nam, ca. 19. Carnem uitulinam in frufta non maiora ouro ita concidito, ne alterum ab altero refcinda. tur:falem'́ ac coriandrum, aut foeniculum tritum ftatim infpergito; afperfam, inter duas tabulas ali quãtulum opprimito. Veru deinde traieça cum teffella laridi, ne fe contingant, néure nimium defice centur, ad ignem uoluito, donec coquantur. Multi hoc eft $\&$ groffi alimenti, tardè etiam concoquis tur, $\&$ aluum aftringit. Etfubinde cap.20. Efitium ex pulpa: Ex coxa uitulina pulpam accipito, e. amćp uel cum adípe eiufdem, uel cum larido minutatim concídito. A maracum \& petrofelinum con tundito, uitellum our cum cafeo trito tudicula agitato, aromata infpergito, corpus unum facito, ac $\mathrm{O}=30^{\circ}$ mnia cum ipfa carne mifceto.In omentum deinde uel porcinum uel uitulinum teffellatim incifum, hoc pulmentum ad oui magnitudinem inuoluito, ad focum in ueru lento igne decoquito. Mortadellam uulgares hoc efitium uocant, quod certe parum incoc?um quàm nimium, fuauius eft, Tarde ob hanc rem concoquitur, obftruit, calculum creat, cor tamen $\mathcal{Q}$ hepar iuuat. Rurfus cap. 22. Farci. mina:Pulpa uitulin $x$ atç adipi fuill $x$ bene tunf $x$, tritum cafeum tum ueterem tum pinguem, ${ }_{j}$ aroma ta bene tunfa, duo aut tria oua tudicula agitata: falis tantum quantum res ipfa requiret, 8 croci quo crocea fint, admifcebis: admixtáque in inteftinum bene lotum, \&x perquam tenuatim produ z êum, inịcies. Cocturam in cacabo requirunt. Bona non nifi biduo durant, Seruari tamen in dies quindecim aut plures poterunt, fi plus falis $\&$ aromatum addideris, fiue ad fumum deficcaueris. Et cap. 30 . Caput uitulinum autbubulum, inquit, aqua calida depilato, ut fuem confurefti, fi elixum uo $=$ les:ubi coctum fuerit, in alliatum mergito; fi affum placuerit, repletum aromatibus, allio ac plerif odoriferis herbis, in furno decoquito. Et mox cap.31. In cerebrum uitulinum: Ex capite elixo ac co cीo cerebrum erues, cum quo duo uitella otiorum tudicula bene agitata, modicum píperis, parum a. greft $x$, falis quantum fat erit, mifcebis. Mixta hæc omnia in fartagine cum liquamine tantifper fri ges, donec, quod breui fiet, concreta fimul fuerint. Comedi cito hoc pulmentarium debet: ubi refri= xerit, nil infipidius, Item cap.35. In uentriculum uitulinum: Vitulinum uentrem in angulo leniter perforato, ftercusćs ac fordes omnes eximito:in lotum uentrem, haec qua dicam, indito: Ex cafeo ue teri oua quatuor bene facta(fracta) parum piperis leniter tunfi, croci modicum, paffulas integras, pe trofelinum, amaracum, mentam concifam. Mixta omnia et in uentriculum claufa, in cacabo bene co quantur. Et cap.26.Pulmentarium in carbone:Carnem macram ex coxa uitulina in buccellas non go nimium fubtiles concifam, cultri cofta contundito: fale deinde \& foeniculi femine bene trito utrin $\$$ afperfam, inter duas tabulas per dimidium horæ comprimito. Inde in craticula ad carbones conco. quito, in utranç partem crebro uertendo, addendóg teffellas laridi, ne igne inarefcat . Coqui non admodum hoc pulmentarium debet:calidum item conuius apponatur, quo magis appetentiam \& defiderium biben di excitet. Hoc Bibulus utatur, qui fitim in fe demortuam quarit. Idem 5.15. Non difplicuit mihi $P$ alelli holpitis noftri patina, qui pedes uitulinos bene lotos, 8 coctos cum iufculo aro matibus infperfo, in coenam more Romano attulit. Inditum quoç aliquíd ex aceto putấrim: ađèo appetentiam excitabant. A pponi hæc patina prima menfa confueuit. Boní \& facilis extat alimenti: pectori confert, tuffim lenit, meatus urinx exulceratos fanat, dyfentericis prodeft. A medicis tame anteriores magis quàm pofteriores, animalium partes probantur. Efitium ex abdomine porcino 60 aut uitulino parandum, ex eodem Platina referemus in Porco. Genus farciminis quod nof tri uo: cant cerebri farcimen(cerebrum enim cum condimentis recto inteftino bouis aut uituli infarcitur) 
Supra in Boure defcripfi, Circumfertur'liber quidam Germanicus coquínarius, ubi eduliorum ex ui

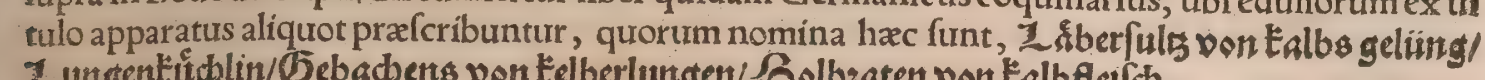
Lungentidblin/Gebad)ens von Eelberlungen/ Solbzaten von Ealb fletid.

G.

Caro uituli recentia uulnera non patitur intumefcere, Plin. Caro uitulina recens cum aceto cocta madidaç̧ alis impofita, foetorem hirci teterrimum tollit, Marcellus. Ad hominis morfus carnem bus bulam coctam imponunt:efficacius uituli, fi non ante quintum diem foluant, Plinius: 8 alibi, Canis rabidi morfu facta uulnera circuncidunt ad uiuas ufo̧ partes quidam, carnem ius ex eodem carnis decoctx dant potui:aut axungiam cum calce tufam, fcilicet admouent. Cornel. 1. Celfus lib.5.cap.27. agens de curatione communi aduerfus omnes morfus ferpentium + Si neq qui exugat(inquit)neq cucurbitula eft, forbere oportet ius anferinum, uel ouillum, uel uítulinum, $\&$ uro mere. Vituli ius uulgariter datum, inter auxilia coeliacorum $\&$ dyfentericorum tradunt, Plinius, Carnẽ uituli fí cũ ariftolochia inaffatã edãt mulieres circa conceptũ, mares parituras, pmittût, Plin.

TFeminum uituli cinis fordida ulcera, \& quæ cacoethe uocant, èlacte mulieris fanat, Plinius.

TMedullę animalium uim habent dura $\&$ f cirrho affecta corpora molliendi, fiue mufculi, fiue ten dines, fiue ligamenta, fiure deniq uifcera induruerint, Semper autem optimam expertus fum ceruinam, dein de iưuencorum feu uítulinam. Hircorum uero $8 \mathrm{x}$ taurorum acrior eft magiş́́ deficcat, un de fit ut firrhofas durities diffoluere non ualeat. Cæterum ex uitulina \& ceruina medulla, peffi eti am mollientes ad matricis quxdam uitia componuntur: $\&$ pharmaca ex medulla confecta mollien: dí́, ui pradita foris quoogs utero imponuntur. Accipitur autem non tantum offium medulla, qua uerémedulla eft, fed ex fpina quogs dorfi, qua reliqua ficcior fqualidioŕç eft, \& eam ob caufam feor fim utrafgs repono, Hæc Galenus lib.11. de facult, fimpl, cap. s. plura mox inferens de recondendi $\&$ feruandi medullas ratione. Communis ratio medullarum eft:(Plinïuerbis utor) Omnes molliunt,

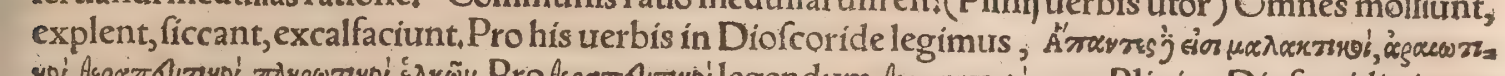

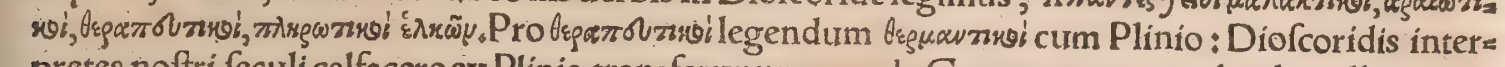
pretes noftri feculi calfacere ex Plinio transferunt:uerum de Graco textu emendando nullus memi

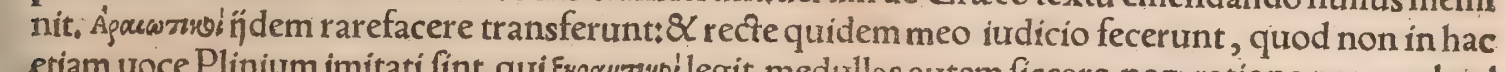

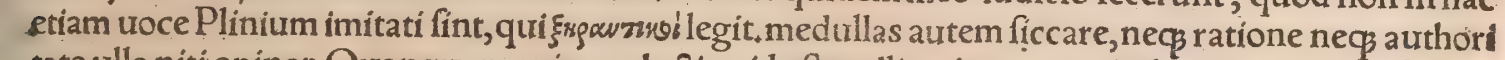
tate ulla niti opinor.Quanquam enim malactica, id eft mollientia ea proprie dicantur, qux calfaciứt, o exiccant, led utrumgs moderate, magis tamen calfaciendo ea quàm ficcando primi ordinis mødum excedere poffe fcio. Nam Galenus mollientia conferens pus mourentibus : hac aqualem calorem ei qui in homine fecundum naturam eft, efficere docet:illa multo maiorem, Proinde ut mollientia ple raq, ita medullas maxime, calfacere abfolutè dici poteft (quod meum eft iudicium) ficcare non item: nifi cum additione quod moderate omnino $\&$ in primo ordine. Nihil enim eorum qua fcirrhi in mo rem indurata funt(ingt Gal.) uel ualide ficcantibus, uel excalfacientibus talide, curari poteft. Simili-

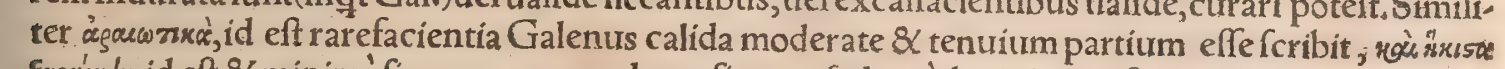
Expácydu, id eft 8 minimé ficcare:non quod non ficcent, fed quòd minimum ficcent, cuitts generis cha mæmalum effe ait, ordine primo calidum $\&$ ficcum. Verum Diofcorides, qui non raro Græcis uo. cabulis abutitur quod ad fecundas medicaminum facultates, hac etiam uoce rarefaciendi pro laxan - di abufus mihi uidetur in medullis:molliunt enim medullæ quæ dura funt, laxantóc intenfa, magis quàm rarefaciant denfa, aut obftructa aperiant, præfertim cum pinguiufculæ fint $\&$ emplaftic $f a=$ cultatis nonnihil habeant, recentes præcipué:accedunt enim medull natura in ruminantibus ad fe uum, in cæteris ad adipem. Quamobrem recté Galenus ubi de medullis agit, non calfacere, non fica care, non rarefacere aut aliud tale eas praftare fcribit, fed mollire tantum : quanquam $\&$ dscrú $\oint_{\omega}$, id eft diffoluere obiter eis tribuit, non fatis propria fignificatione. In translatione Serapionis:pro icgacese ziwi habetur refolutiux, 8 pro Asparsou zixol, fedatiux:unde hoc faltem cóftat olim etiam hunc locum

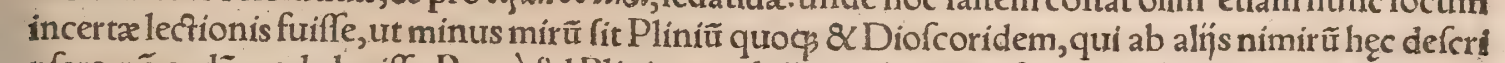
pfere, nó eodẽ modo legiffe. Porrò q̊d Plínius medullã explere, Diofcorides ulcera explere dixit, nee ipfe recte dictũ exiftimo, nec apud ullũ̃ ex probatis inuenio medicis. Nã quæ farcotica, id eft carnem - generare $\&$ ulcera explere proprie dícuntit, ficcare modice $\&$ abftergere fine morfu debent:ego uero nullam in medullis abfterfionem fentio. Fieri quidem poteft ut per accidens aliquando carnem indu cant, prafertim cum alins mixtæ. Multa enim per fe ladunt, alịs admifta eundem affectum fanant Quod farcoticis etiam contingit. Oleum fordes colligit, fic $\&$ cera:ærugo rodit: tria hæc mifta, carne regenerant, magis etiam fi quid farcotici adiungas. Scio Plinium commendare medullam ceruinam aut uaccinam ad ulcera oris, fed cum refina:item uituli uel bouris, ad dyfentericos, fed aln̈s admixtis: 8 uitulinam priuatim ad exulceratas uuluas cum feuo, quibus tamen alia ratione quàm farcotica prodeft: aưt fi illa quoç interdũ , per accídens tamẽ. Sed fatius eft hifce relictis, uerã medullarũ faculta tem ex Galeni uerbis fuperius recitatis addifcere:quibus hac addi poffunt, Medullis (ut etiam adipe)recentibus laxando, ueteribus infuper difcutiendo utendum effe. Medullarum(inquit Diofco rides)probatiffima eft ceruina, mox uitulina, poft hanc taurina, tum caprina 8 ouilla. Laudatiffi, ma(inquit Plinius) ceruina, mox uitulina, deín hircina $\&$ caprina. Curantur ante autumnum recen tes lotx, ficcatæáç in umbra per cribrum, Dein liquatæe per lintea exprimuntur, ac reponuntur in fín 
cili locis frigidis, Vide etiam Diofcoridem quomodo ad ufum parandx fint medulla. Vituli medullæ cum pari pondere ceræ $\&$ olei, uel rofacei, addito ouo, duritiæ genarum illinuntur, Plinius, Marceilus paulo aliter, Medulla(inquit) cum cera $\&$ oleo rofaceo æquis ponderibus liquefacta, $\&$ permixta, \& $\&$ ad emplaftri modum impofita, duritias palpebrarum, \& fi qua illic in modum pilularu nafcuntur, commollit ac difcutit, Marcel. Vituli medulla admixto cumino trito infura prodeft ín au rium dolore $\&$ grauitate, Plinius. Simile remedium uide mox in feuo, Recens uituli medulla cum cy mino contrita infufác, quamuis magnos dolores auricula ftatim releuat, \& intra triduum tollit, Marcellus:ex quo in Boure etiam dixi, bubulinam(fic legitur) uel taurinam medullam liquefactam, tepentemćs infufam auribus, plurimum prodefle. Medulla uituli, u̇el fi uaccina fit, ulcera oris ac ri. mas emendat, Plin. Vituli atut boutis medullæ excoquuntur cum farina \& cera, exiguoć́ oleo, ut for beri poffint, pro coeliacis $\&$ dy fentericis: Medulla etiam in pane fubigitur, Plinius + Marcellus item uaccinam,cum farina tenui fubactam, 8 inftar excocti panis in cibo datam, miré dyfenteriam fana. refcribit, maximè $f i \&$ cafeus bubulus recens manducetur. Manantia uerendorum ulcera fanat fe. uirm cum medulla uituli, Plin. Medulla uituli in uino ex aqua decocta cum feuo exulcerationibus uuluarum impofita prodeft, Plin. Componuntur ex ea medicamenta ad molliendum uterum, tum foris applicanda, tum peffis inditis, ut ex Galeno fupra recitaui.

बIVitulinũ pingue quomodo odoramentis imbui debeat, copiofé explicatũ eft fupra in Tauro ex Diofcoride. Idẽ quomodo à putredine conferueț, uide in Anferino ex Diofcor. Vitulinũ adipem ali quantĩ aftringere Diofcorides fcripfit, uide fupra in bubulo adipe. Seuñ uituli cũ fale fubactũ utilif= fime adhibet̃ pityriafi, Marcel,Cû fale tritũ capitis ulceribus utiliffimũ eft,Plin. A dipe uituli fi pal pebras craffiores perunxeris, extenuabis eas, \& ad fanitatē perduces, Marcel.Seuũ uituli cũ anferís adipe $\&$ ocimi fucco, genarũu(palpebrarũ) uitịs aptiffimũ eft, Plin.Idem remediũ alibi ad auriũ dolo rem \& grauitatem commendat, Plinius: \& Marcellus quoģ, qui tepidum infundi iubet, Et rurfus ali bi in Plinio idem remedium (nifi quod nihil differre ait, uituline an bouis feutum capiattir) ulcera 0 ris \& rimas emendare docet, Eft $\&$ alia mixtura(inquit)feuo uituli cum medulla cerui, \& albæ fpine folịs unà tritis:Idem præftat $\&$ medulla(uidelicet uitulina) cum refina, uel fi uaccina fit $\quad V i t u l i ~ a=$ dipem fucco ocimi adiecto, fi pariter tepefactam auricula infuderis, amariffimo incommodolabo= rantem continuo liberabis,Marcellus, Cuminum fylueftre auribus inftillatur ad fonitus atç tinni tus, cum feuo uitulino uel melle, Plinius:Quid filegas ? uel medulla, ut fupra habuimus ex codem autore, \& Marcello quog. Vituli adeps ex foemina(id eft uitula:fed malim ex femine, ut paulo poft exinguinibus)fublata, cum aqua cotylis tribus decocta, \& forbitionis more fumpta, coeliaco pluri= mum prodeft, Marcellus. Datur \& feuum uitulinum aut bubulum, dy fentericis \& coeliacis, Plinius, Manantia uerendorum ulcera fanat feuum cum medulla uituli in uino decocium, Plinius, Inflatio. nibus in fede feuum uituli auxịliatur, maximè ab inguinibus, cum ruta, Plin. Medulla uituli in uino exaqua decocta cum feuo, exulcerationibus uuluarum impofita prodeft,Plin. Teftium tumor, cum feuo uituli,addito nitro cohibetur, Plínius. De eodem remedio Marcellus, Adeps uituli (inquit) \& nitri modicum, unà permixta, 8 ceroti modo impofita tefticulis, tumores omnes $\&$ dolores perfana re dicuntur. Vngues fcabros feưum uituli emendat,Plinius. Sal prodeft contra incipientes uerru cas cum feuo uitulino,Plin. Author quidam obfcurus ex Plinio citat, feuum uitulinum podagricis $8 \times$ articularïs morbis prodeffe quod ego apud Plinium non de feuo, fed fimo uitulino, nec eo fim $=40$ pliciter, fed eitus cinere legi, ut inferius recitabo. -Teporino coagulo pares habent uires, hoedi, agni, \&c. \& uituli coagulum, Diofcor . Lethargicos coagultum uituli adiuuat in uino potum oboli pondere, Plinius libro 32 .qui totus êt de aquatilibus, proinde hoc in loco non uituli terreftris, fed marini,coagulum accipiendũ eft. T A recentibus $\mathcal{S}$ calídis adhuc uituli extis(id eft arteria,pulmo ne, corde \& iecore)minutatim concifis, liquor in uafis chymifticis elicitur, cui æquales partes faluix $\&$ meliffophylli liquorum fimiliter extractorum, admifcentur:inde membra frigida, uel refolita, urel tabida, mane $\&$ uefperi aliquandiu perfricantur, $\&$ mox calidis pannis inuoluuntur. Glecur ui= tuli mafculi, $\&$ tantundem foliorum faluiæ, minutatim pariter concidantur : collectus inde fillatiti= us liquor potui datur tum uiris tum mulieribus, qui durum tumorem tranfuerfum in imo uentre fur pra pudenda perceperint. TVincit lepras ac furfures uitulinum fel, cum femine cunilax, ac cinere so è cornu ceruino, fi canicula exoriente comburatur, Plinius. Felle uituli caput perunctum lendes exterminat,Marcellus. Alopecias fanat urina hominis uetus, fi cyclaminum a dịciatur, \& fulphur: efficacius tamen $\&$ uitulinum fel:quo cum aceto calefacio tolluntur $\&$ lendes,Plin. Fel uituli cale factum cicatrices extenurat: Medici adp̆ciunt myrrham $\&$ mel, $\&$ crocum, æreá́s pyxide condunt: aliqui $\&$ florem $æ r$ ris admifcent, Plinius libro 28.in fine capitis 18. imperitiflimé ad cicatrices cutis re ferens, cum ad oculorum cicatrices tantum pertineat, quod uel ipfa medicamentorum ocularium materia monere ípfum debuiffet, Idem medicamentum Marcellus Empiricus inter oculorum reme dia his uerbis defcribit:Fel uituli diligenter collectum ad cotylæ menfuram in uas æreum mittitur, tenuićs igne admoto ita excoquitur ut fpiffetur, deinde mellis boni tantum mittitur, quantum fellis illius decocti remanferit: a dijciuntur poftea myrrhæ tritx drachmæ duæ, \& croci una , \&. aris flos 60 pauxillum, ac poftea fimul omnia diu coagitata, ad tertias decoquuntur:quod medicamen in pyxi= de area debet reponi, fatis utile \& leucomatis $\&$ cicatricibus, \& omnibus uitïs oculorum, fi adfidue 


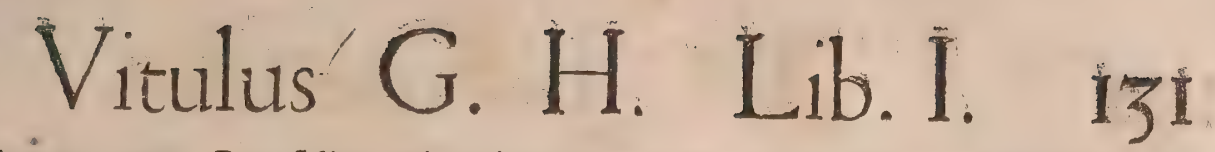

inde $\&$ opportune iningantur. Cum felle uitulino $\&$ aceto pari menfura ferpentis fenectüs, id eft exurix decoct $x, \mathcal{Q}$ lanula madefacta medicamentum auriculæ infertum, maximæ utilitatis effecre= ditur, fi prius fertrenti aqua de fpongia aurem foueris, Marcellus, Ex eodem malagma uentri fol= uendo de felle taurino uel uitulino parandum, iam in Tauro fcripfi. Vitulinum fel fi in purgatio nibus fuerit fub coitu afperfum uulux; , etiam duritiam uentris emollit, $\&$ profluuitum minuit umbi lico peruncto, atç in totum uulux prodeft. Modum ftatuunt fellis pondere denarï ad ap’̈ tertiam, ammix to amygdalino oleo, quantum effe fatis appareat hoc in uellere imponunt. Mafculi fel uituli cum mellis dimidio triturm, feruatur ad uuluas, Plinius. $\quad$ Thien uituli in uino decoctus, trituś́: $\&$ illitus, ulcufcula oris fanat, Plinius. Ad lienem fedandum, emi lienem uituli quanti indicatus fit, iu yo bent magi, nulla pretī cunctatione, quoniam hoc quoç religiofe pertineat: diuifumḉs per longitudi nem annecti tunicx utrincs, $\&$ induentem pati decidere ad pedes:dein collectum in umbra areface re: Cum hoc fiat, fimul refidere lienem agri uitiatũ, liberariḉ̧ eum morbo dicitur, Plinius. TGlus ten uítulinum aceto remiffum, admixta modica calce uíu, ut craffitudinem imellis habeat, illines lo. cis leprofis, atç illic ficcari medicamen permittes, efficaciter proderit, Marcellus. Lichenas oris pra: ftantiffimè uincit glutinum factum é genitalibus uitulorum, liquatum aceto cum fulphure uiuo ra mo ficulneo permixtum; ita ut bis die recens illinatur:item lepras, ex melle $\&$ aceto decoftum, Plin. Simile remedium in Tauro ex taurocolla diximus, quæ $\&$ ipfa ex genitali tauri fit. Auribus fractis glutinum è naturis uitulorum factum, $\&$ in aqua liquatum medetur, Plinitus, đFimo uituli fuffiri percuffos à fcorpione prodeft, Plinius. Sanguinem fítit fimi uitulorum cinis illitus ex aceto, Plin. to Vlcera quæ fordidata funt, fimi uitulini cinere $\&$ muliebrilacte purgantur, Marcellus. Igni facro uitulinum fimum recens, uel bubulum illinitur, Plinius. Varicum dolores fedat fimi uitulini cinis, cum lil'j bulbis decoctis addito melle modicołicemó̧ omnia inflammata \& fuppurationes minantia, Plinitss, Verrucas aufert uitulini fimi cinis ex aceto,Plinius. Aeftates, \& qua difcolorem faciǘt cutem, fimum uituli cum oleo $\&$ gummi manu fubactum emendat, Plinius. Oefypum cum melle Corficano tritum $\&$ appofitum, abolet de facie omnes maculas, quidam $\&$ butyrum addunt: fi uero $\&$ uítuli fimus, \& fel caninum mifceatur, medicamen utilius erit, ita ut pariter temperata omnia de coquantur, Marcellus. Melancholicis fimum uituli in uinodecoctum remedioeft, Plinius. Fimum uituli recentem fi quis ex uino potui dederit his quos Graci cholericos tocant, manifefto periculo liberabit, Marcellus. Hydropicis auxiliatur fimum uituli mafculi illitum : fimi uituli cinis cum fe5o mine ftaphylini, æqua portione ex uino, Plinius. Inteftinorum inflationes difcutit uitulinum fimum in uino decoctum, Plinius. Teftium tumor cohibetur uitulifimo ex aceto decoc?o, Plin. Manantia uerendorum ulcera feuum cum medulla uituli fanat; in uino decoctum, uel caprinum cum melle rubićp fucco:Vel fi ferpant, fimum etiam (uitulinum intelligo, quod fupra etiam ad fordidata ưlcera \& ignem facrum prodeffe oftendi, quanquam $\&$ capræifercus cancerofos cum melle mixtum $f a=$ nare apud Sextum legitur ) prodeffe cum melle dicunt, aut cum aceto, Plinius. Luxatis recens fimum aprinum uel fuillum, item uitulinum prodeft, Plinius. Vitulinum fimum recéntem articulis laborantibus illines, ftatim fubuenies, Marcellus, Podagris medetur bouis fimum cum acetifece: Magnificant \& uituliqui nondum herbam guftauerit fimum, Plinius. Articulorum attritis mede: tur uituli, qui nondum herbam guftauerit, fimum, Plinius. Fimi uitulini cinis, cum lilí bulbis deco - Ĉis addito melle modico, podagrís prodeft $\&$ articularńs morbis, è maribus præcípué uitulis, Plinius Si dolor fit \& grauitas aurium, urina capri medetur, uel tauri, uel fullonia uetus calfacta, uapore per lagenæ collum fubeunte; admifcent $\&$ aceti tertiam partem, $\&$ aliquid urina uituli qui nondum her bam guftauerit; Fimum etiam, mix to felle eiufdem, Plinius,

H.

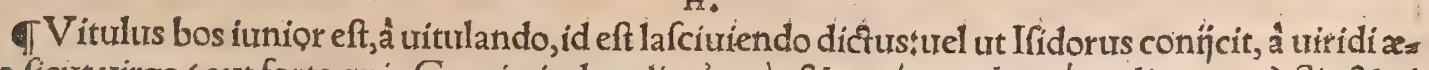

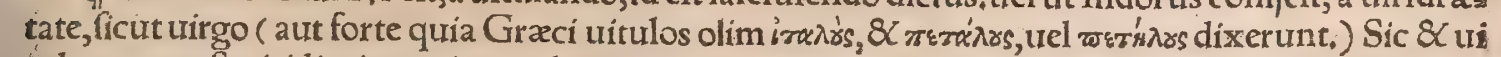
tula uacca eft uirídioris ætatis, necdum enixa: cum primum enim peperit nomine mutato iuuenca aut uacca dicitur. Sed hanc nominum proprietatem Latini non perpeturo feruant. Vergílius Aeglo ga tertia: Ego hanc uitulam ( ne forté recufes, Bis uenit ad mulctram, binos alit ubere foctur) De 10 pono, Et libro tertio Georgicorû, quos prius uitulos uocauerat, domitura iam idoneos, hoc uerfu Iam uítulos hortare uiamós infifte domandi, paulo poftiuuencos nominat, Iunge pares \& coge

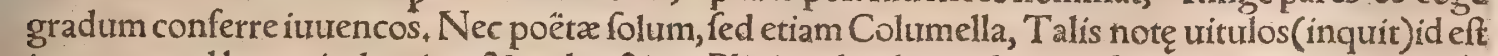
iuurencos uel boues indomitos $\&$ rudes, 8 c. Plinius alicubi uitulum mafculum dicit, tãquam aliâs de uitula etiam intelligi potuiffet: mihi quidem in cateris cafibus non opus uidetur fexus differen: tiam addere, cum inflectendi ratio uitulum à uitula ubiģ diftinguat, praterquam in datiuo $8 \mathrm{~K}$ abla tiuo pluralibus, proinde recte alibi Plinius uitulis maribus dixit;neqsenim ita uitulabus ut equabus apud authores reperitur. A purd Gracos etiam $\mu^{\prime}$ g $(0$ generis communis eft, authore Ammonio.

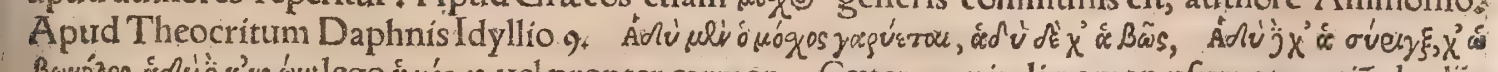

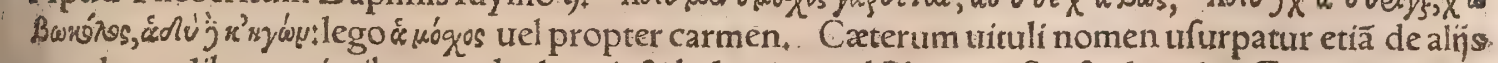
yo quadrupedibus maioribus, ut elephantis $\&$ balænis apud Plinium. Sic $8 x$ damalin Grace Photion omne animal urocari exiftimat in iuuenta. Stulté quidam in Dictionarị́s fuis Vergilium in carmine iam citato, lam uitulos hortare, $\&$ c, uitulos de equis interpretantur, cum proculdubio de boũ uitulis 
illic íntelligat poeta. Bõ uocamus \& uaccam, \& taurum, \& uitulum aliquando, Io, Tzetzes . Bös övos

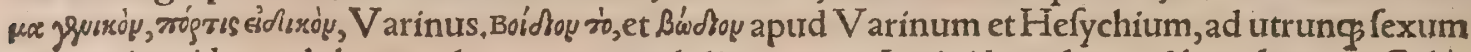
conuenire uidetur, de boue uel per æatatem urel aliter paruo; Latini buculum uel bucolum ( ut Colur. mella habet)de mare, de formina buculam dicunt, Móg $\odot$, inquit Etymologus, dictus eft uel quod $\mu \tilde{\omega}$

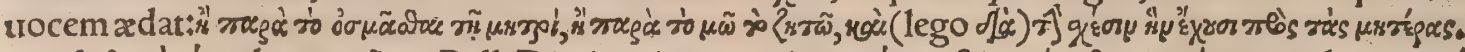

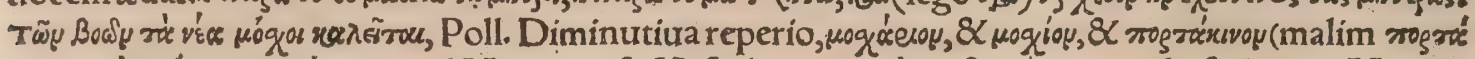

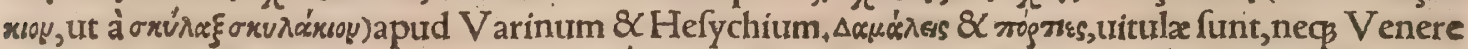

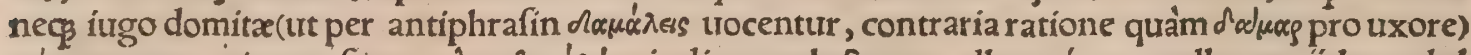

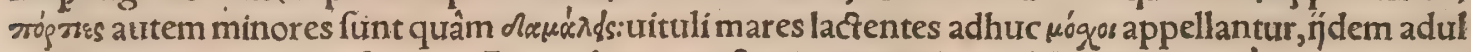
ti tauri, Varinus. Vide fupra in Boue, ab initio octaui capitis. A pud V arinum dasúcys uox corru=

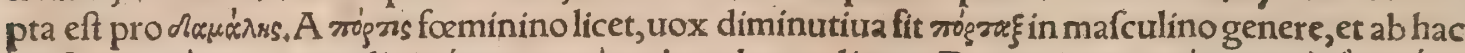

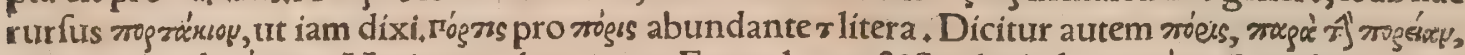

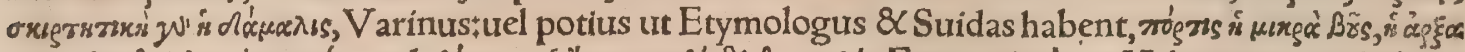

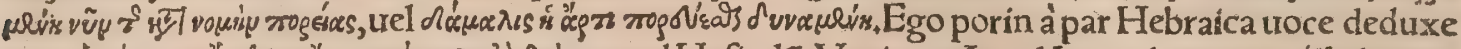

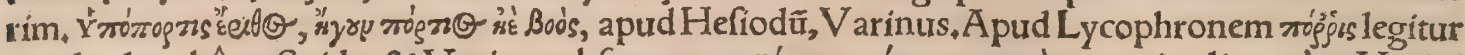

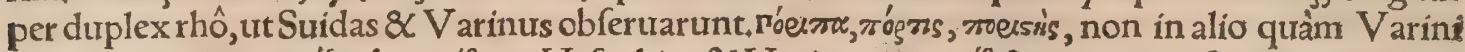

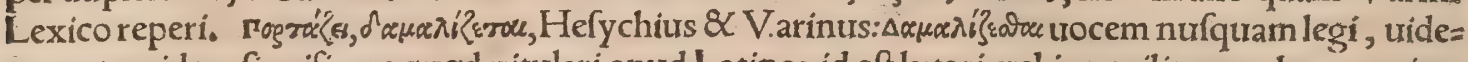
tur autem idem fignificare quơd uitulari apud Latinos, id eft lætari, uel iutreniliter exultare ut uitu.

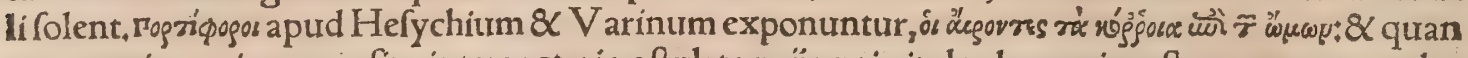
quam ratio uocis compofiræ interpretari poftulat pro ịs qui uitulos humeris geftant; tamen uocabu

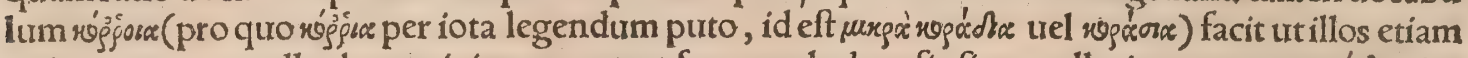

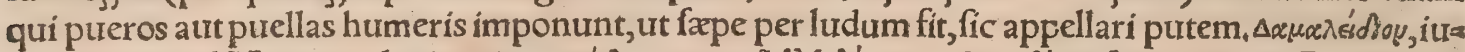

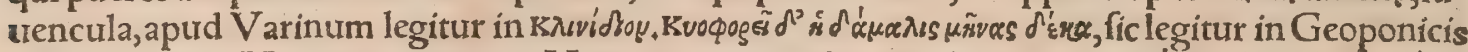

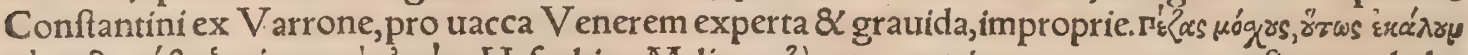

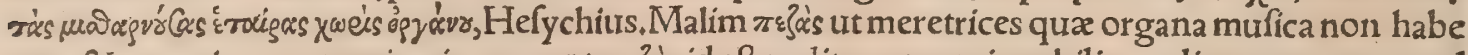
rent, $\&$ organis tanquam équis carerent, $\pi \xi \xi_{\text {jac, }}$ id eft pedites, uttpote ignobiliores dicerentur:quemad modum $8 \times \pi \varepsilon$ ¿o $\lambda_{0}$ jou, id eft orationem pedeftrem dicimus, cuius comparatione qua numeris liga.

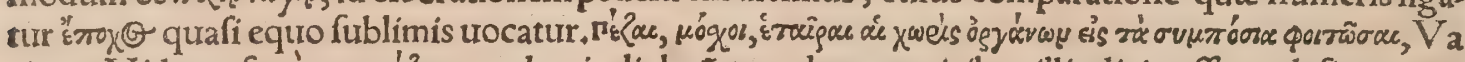
rinus. Videtur fanè uox $\pi^{\prime} \dot{\varepsilon}$ ?as tum de uitulis boũ,tum de meretricibus illis dici poffe, ut defit coniun

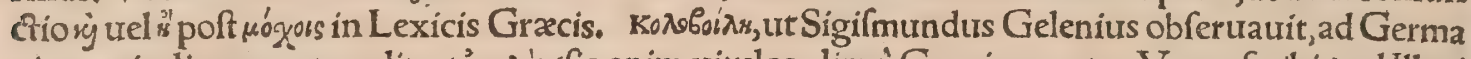
nicam uituli uocem accedit: ut irten ós (fic enim uitulos olim à Græcis uncatos Varro fribit) ad Illyri

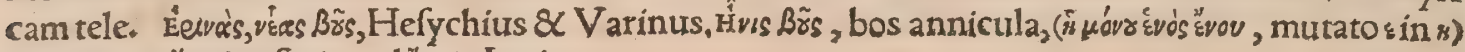

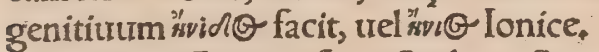

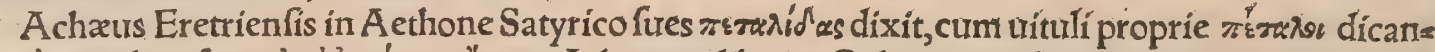
cur à cornibus, or parua exiliaća:ego pofteriorem interpretationem priori contrariam improbo. Nam ut $\pi \varepsilon r a \lambda o y$ pro

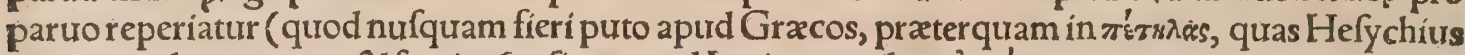

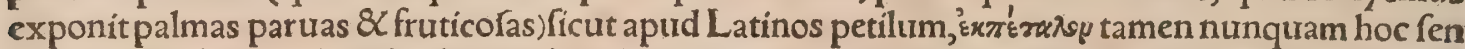
fu accipitur: fed patulum \& planum \& in latitudinem extenfum femper fignificat, proinde plana $\&$

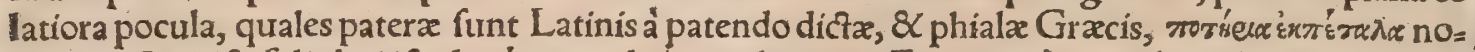

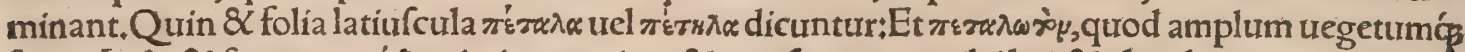
fuerit.Inde $\&$ futes weraiiós, nimirum opimę, $\&$ petafus genus pilei lati, $\&$ alia plurima, quæ omnia à uerbo $\pi \varepsilon r^{\prime} x^{\prime} \omega$ formantur, quod eft extendere $\&$ dilatare. Er quoniam plana latać, eadem fupino fi.

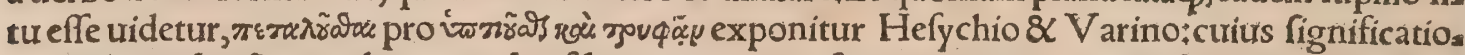

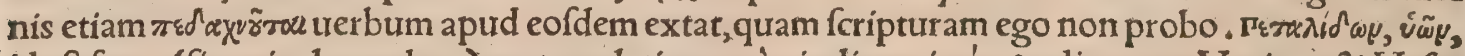

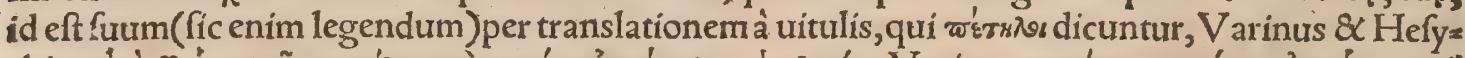

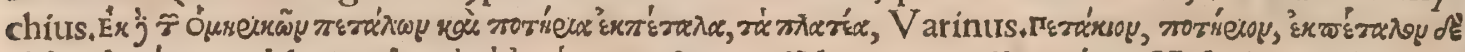

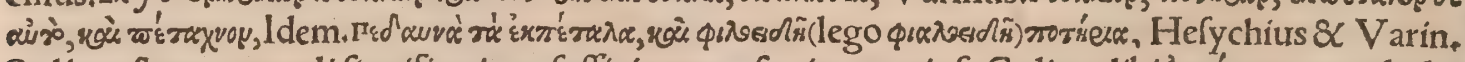
Sed hac fuper ecpetali fignificatione fufficiant:præfertim cum ipfe Calius alibi દ̌k tiora interpretetur, quoniam wéżax folia perampla fint. Debuerat fané eum res ipfa monere ne ec= so petala parua exiliać cornua redderet, autreddi poffe dubitaret, cum Athenæus fues petalides, id eft præpingues faginatoş́́ à petalis, id eft uitulis quorum ecpetala cornua funt translato nomine appellare teftetur. Pingue uero paruo 8 gracili contrarium eft. Aufus eft quidam in Lexico Gęrco. latino ecpetala cornua ramofa exponere, \& falfæinterpretationis illius A thenæum teftem mentiri. At poterant hominem utcunq Graci fermonis indoctum oculi fui docere, nunquam fibi ramofis

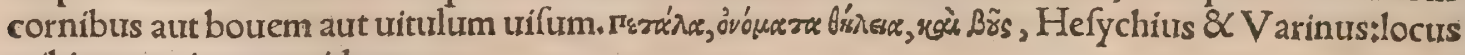
mihiparum integer uidetur.

TVituli epitheta, Ferox. Templis maturus, Iuurenal.Sat, 12. Imbelles, Stat,8.Theb. Lacten

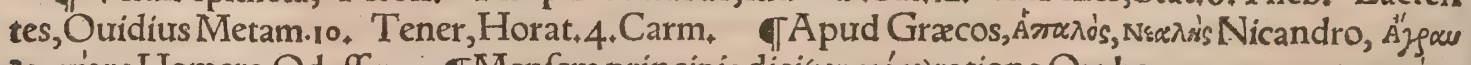

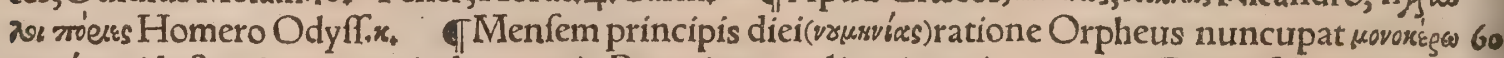

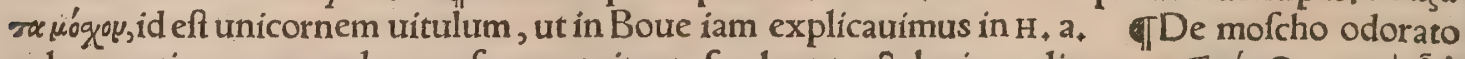
uel aromatico, quem uulgo mufcum uocitant, fuo loco tractabo in M, litera, 


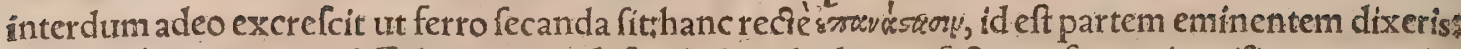

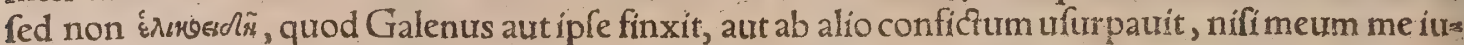
dicium fallit. ógtov autem eandem partem non à figura dixerim, ut Galenus: fed quoniam prominet,

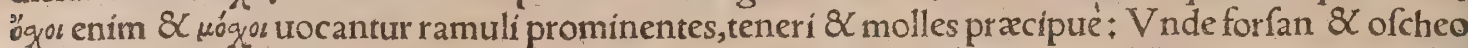
uirili, id eft fcroto nomen inditum, quod Etymologus dex ron ỏxovłu deducit. Videtur autem natura carnem illam quam in uiris circa fcrotum confumpfit, in mulieribus ad ipforum of chion quafi alterum ferotum tranftuliffe. Sed Galeno fi errauit, errare facilius fuit, quod tres iftę partes muliebris pu dendi omnes coniunct $x$ loco $\&$ circa extremum eius of culum habeantur. Ego Hippocratem uirum parci fermonis \& proprís urocabulis uti folitum, de re eadẽ tria diuerfa uocabula protuliffe uix cre= diderim. Tógopoeux celebritas feu feftum Athenis fuit, cuius apud auctores, $\&$ in primis Plutar $=$ cloum, crebra eft mentio. In Ofchophorijs pueri ingenui pubefcentes ( hi duo erant genere \& diui. tị́s eximin, ofchophori difti, Varinus ) eligebantur, qui ferrent öoxas, id eft ramos ac palmites cum fuis racemis (fic Hefychius \& V arinus interpretantur) in templum Mineruæ Sciriados. Fuit \& A thenis locus Ofchophorion nuncupatus, à Phalero non procul, ubi Minerux templum fuit, $\mathrm{He}_{\text {a }}$ fychitis $\&$ Nicandri interpres in Alexiph. Ab his Ofchophorica carmina dicta, de quibus in primo de Hiftoria poëtarũ egimus, Gyraldus. Galenus ögou $\&$ rógou fynonyma facit, ut fupra dixi, utrũ

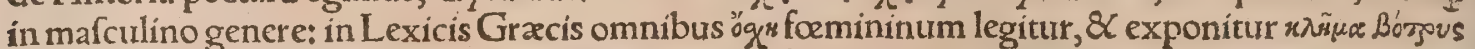

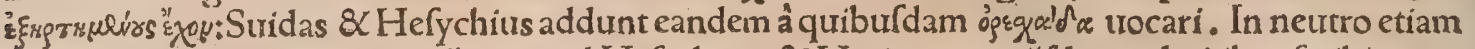
genere, multitudinis numero " $\mathrm{g} \varepsilon x$ apud Hefychium $\&$ V arinum pro ijfdem palmitibus fcribitur.

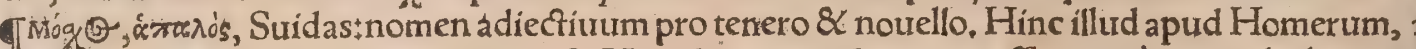

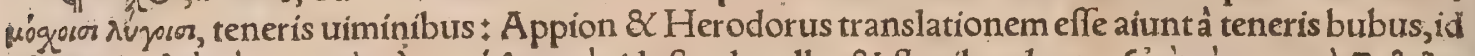

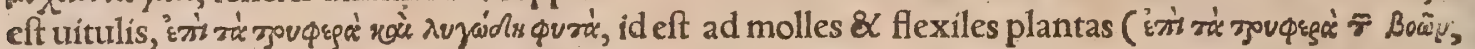

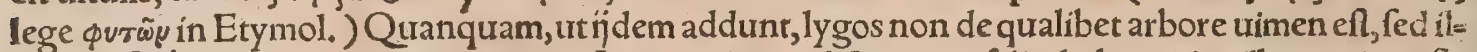
la præcipuréqux Græcis agnos uocatur, Latine vitex uel A merina falix: habet enim illa pręcipue fle xiles $\&$ uitiles ramulos. TDicuntur etiam per fe \& fubftantiue $\mu o ́ g o t$, nouelli ramuli ac teneri in

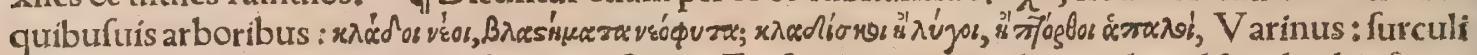
recens enati, annotína germina $\&$ apta infitioni, For fan $\&$ turiones aliquando reddere licebit:fic uro cat Columella teneritates fummas ipfarum arborum, qux pecori in cibo conueniunt, ut hominibus etiam ex fruticibus $\&$ herbis quos Græci afparagos nuncupãt, de quibus Galenus libro 2. de facultat. alim.Siue afpharagos (inquir) A ttico more, fiue afparagos dicas, nihil intereft. Sic autem uD=

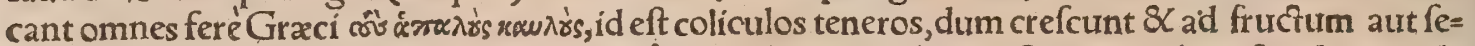

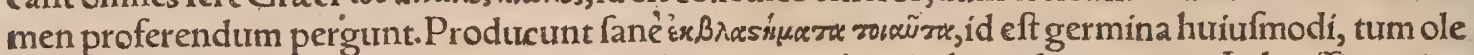
ra multa, turm ftirpes in genere, non ab omnibus tamen illis ad cibum decerpuntur. In braffica priua tim xúux quafi xưsux per fynærefin appellant:deinde de diuerforum olerum afparagis agếs, fubrjcit: Aliud af paragorum genus eft in fruticofis plantis, ut rufco, chamædaphne, 8 oxyacantha:à quibus differunt ( per excellentiam dicti afparagi) regius $\&$ paluftris (Latinécorruda) poftremobryonia, id eft uitis albxafparagi, Hæc Galenus, Cymas de braffica Latini etiam dicunt, Plinius libro i9. Brafs fica toto anno feritur, \&cc.cymas à prima fectione praftat proximo uere : hic eft quidam ipforû cau. lium delicatior tenerioŕç cauliculus, Itali etiamnum cymas aut cymolas urocant: hinc $\&$ Germanis natum uidetur furm Eyment 8 Eymle. Columella libro 10. Graccorum imitatione genere neutro pro $=4$ tulit, Frigoribus caules \& uericymata mittit. Quòd autem $\mu$ ógot de holeribus quoq̧ dicantur, ex

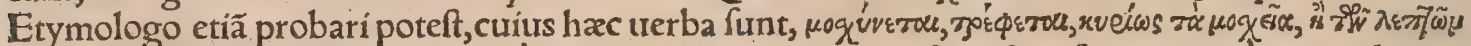

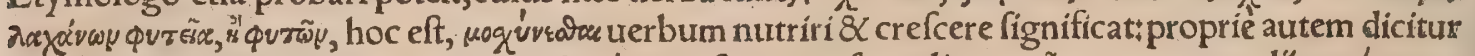

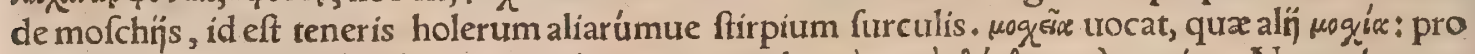

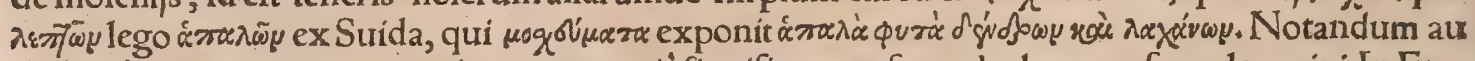
tem $ф u$ tou trocem qux totam plantam proprie fignificat, per fynecdochen pro furculo accipi. In Ety.

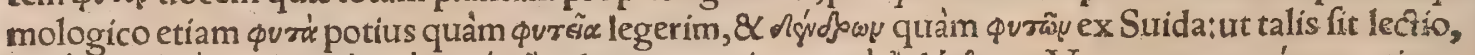

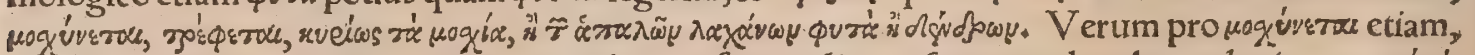

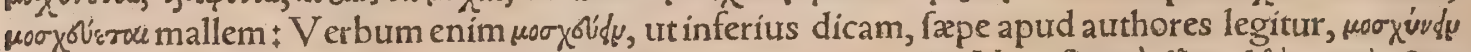

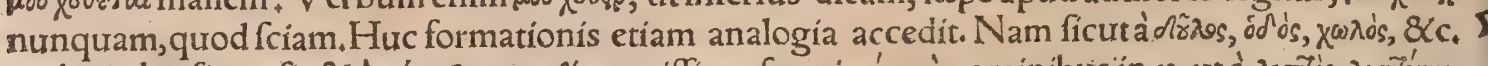

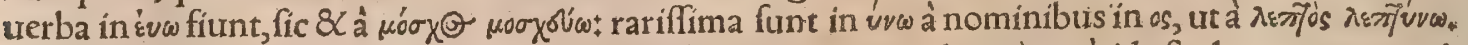

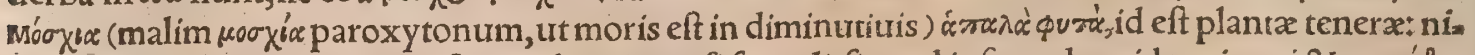

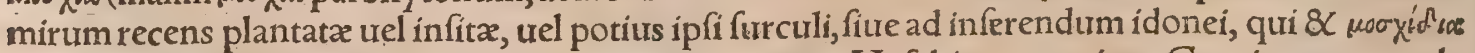

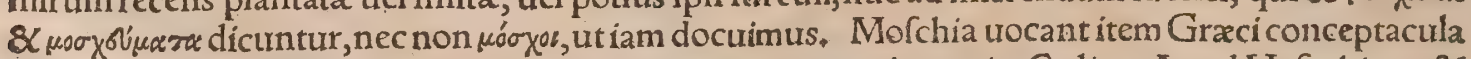
in cepis quxdam femen adferuantia, \& ad maturitatem perducentia, Calius: Apud Hefychium $\&$

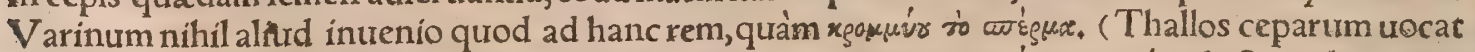

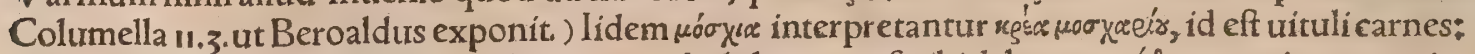

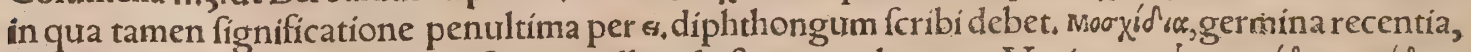

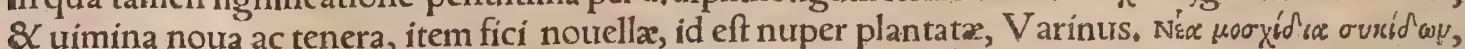

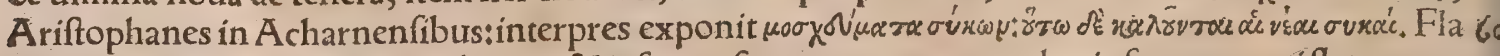
gella dicuntur Latinis cymæ arborum $\&$ ipfarum fummæ partes, quę ad cưiufcunçs urentiflatum mo uentur:unde etiã nomen traxerunt, ab eo quod flatibus perãtur, V crg. Néve.flagella Summa pete. 


\section{Vitulus. H. Lib. I. 135}

Mihi inde diça uidentur, quod flagellorũ inftar lenta flexiliaç̧ fint, Hac qưoç mof chos 8 mofchia Grace dixerim. Quód fi arbor inutili quadam fruticatione multos ueluti caudices emittere uidea= tur, cuiufmodi folent cerafus, prunus, corylus ! tantum is caudex iufté appellabitirr, qui eft medius \& robuftior:alij autem uicini ab eadem radice prodeuntes, qui quidem defecari $\&$ transplantari fo. lent, ut arbor craffior fit, \& ne foboles luxirrians parentem enecet, ftolones appellantur, à uulgo in Gallia reiectons quafi répiciendi: Ab his (inquit Varro ) Licinius Stolo primus cognominatus eft, quod nulli in eius fundo repériri poffent ftolones, quos circû́ arbores è radicibus effodiebat. Huiuf cemodiftolones uocantur etiam foboles ab olefcendo, Columella: In uineis appellantur pampinit unde pampinate uites, fuperfluos ftolones refecare. (In uite fobolem $8<$ ruftico uocabulo fuffragis $10 \mathrm{nem}$ uocant, Ruellius.) Eofdem Cato cap. jI.pullos arborum uocat? $\mathrm{Ab}$ arbore (inquit) abs terra pulli qui nafcentur, eos in terram deprimito, Pullulos quog nominauit Plinius libro 17 . Hinc pullu. lare \& pullutlafcere uerba, quafi pullulos emittere, Carolus Stephanus in Seminario. Ego iftos quo=

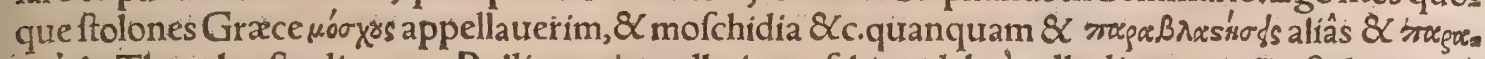

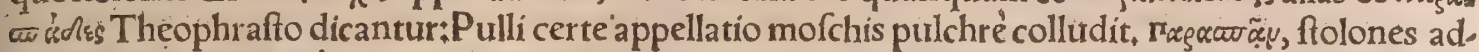

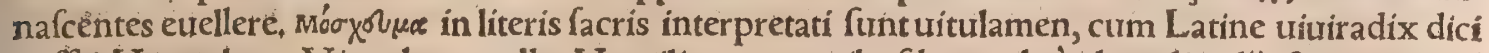
poflet, Hermolaus. Virgulta appellat Vergilius, qua quibufdam uulgó plantalia, alijs femina appel lari placuítnonnulli etiam palmites uocant:nempe furculos eos qui terra committuntur, ut in arbo reminfurgant, Virgas interdum appellant Plinius \& Columella, interdû ctiam uirgas malleolares.

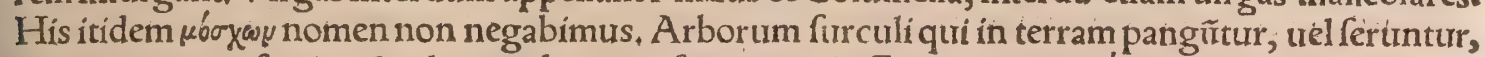

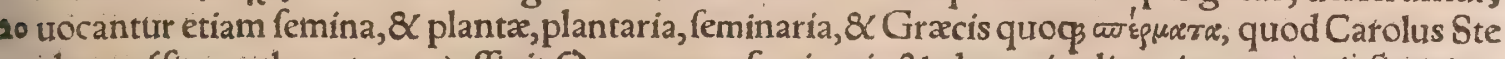
phanus(fine authore tamen)afferit. $Q$ uanquam feminaria \& plantaria alioqui uocantur ipfi agri no

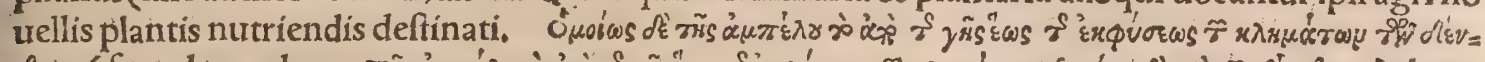

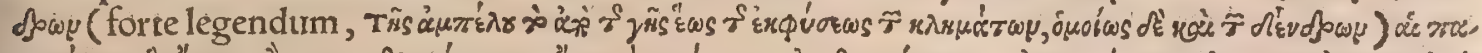

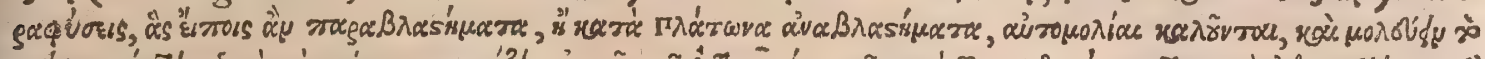

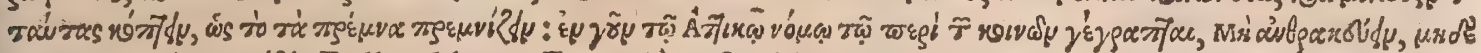

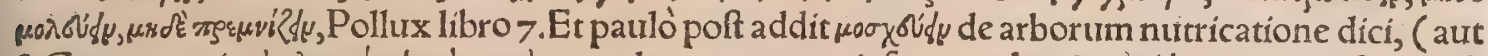

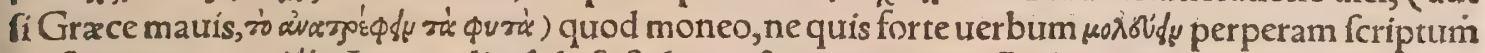

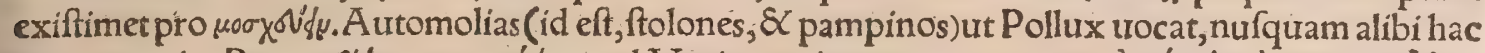

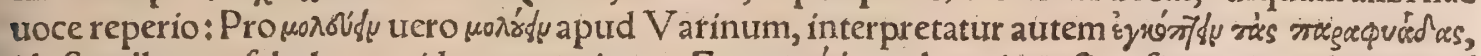
30 id eft pullorum fobolem recidere, pampinare. Ego woroúsu uerbum in ea fignificatione malim, quod

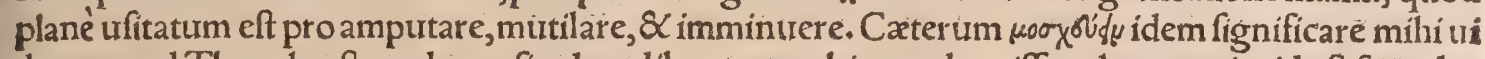
detur apud Theophraftum de caufis plant. lib.3.cap.3.ubi cum docuiffet phyteuteria, id eft furculos inferendos læues $8 \mathrm{~m}$ minimé fcabros effe debere, nec ullos habere nodos, fiue cæcos, fiure etiam fanos 8 germinantes: quoniam uis in germina abeat $\&$ fruticando difpergatur: fubdit, Eandem enim ob

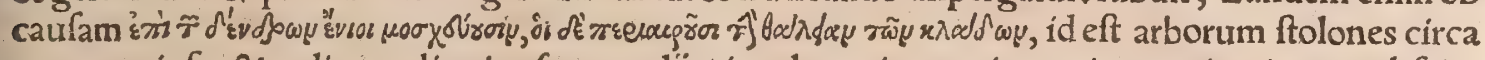
truncum infra $\&$ radicem, aliqui refecant, alijetiam luxuriantem in ramis germinationem abfcin. dunt, nempe in fuperiore parte arboris, Et paulò poft feminis, id eft furculi inferendi, infirmitati con fulendum monens: Ideo, inquit, qui inferunt curant, ut furculi ad eandem coeli regionem fpectent, quam prius in arbore fua, \& ut in fimili uel meliore folo infitio fiar, deniç ut à robuftiore parte arbo to ris furrculi auférantur:tales autem funt qui circa imum truncum $\&$ iuxta radices nafcuntur ( $p$ ullos

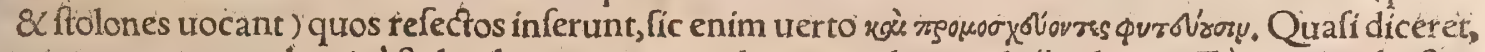
eó tempore quo arbores à folonibus purgant, eodem mox aliquos de ñs plantât. Eò autem robuftioa res funt omnes feré arborum furculi quo inferiores in trunco nafcuntur : habent enim illi tanquam

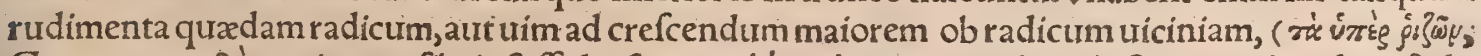

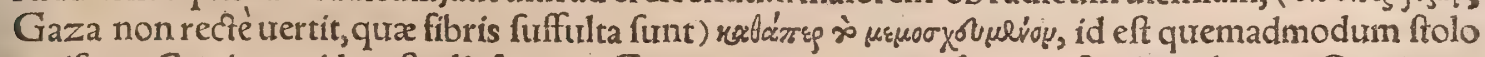
recifus. Cupio equidem fudiofos cum Gaza translatione conferre noftra $\&$ iudicare. Omnis au. tem illius errorinde mihi orturs uidetur, quòd $\mu_{0}$ xoúfe femper pro uiuira dices facere exponit; cum plarunç fimpliciter ftolones recidere fignificet. Sed quid fi uiuiradix de fola uite dicatur? ( eft enim hæc tritis furculus cum radice exemptus, quo ipfoà malleolis \& taleis differt) ut non Gaza folum, so fed Hermolaus, Budæus, \& alij recentiores hactenus circa hãc uocem decepti fint omnes : quod ego quidem in prafentia nondum affero, fed illis quibus orif plus eft $\&$ rei rufticæamor inquirendum propino: $\&$ hoc etiam inter cæera an Budæus uiuiradicem recté фurour'reup Grace nominatrerit,

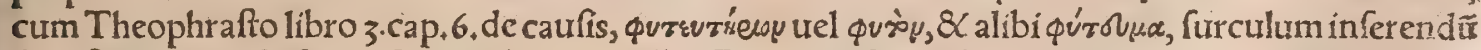
fignificet, quem \& femen Latini dicunt, ut illic Gaza tranftulit: Quanquam idem mox capite fepti=

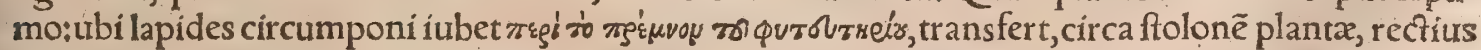
translaturus circa truncum (ut Palladius etiam uocat) cui infitus eft furculus. Mihi certe recte nos

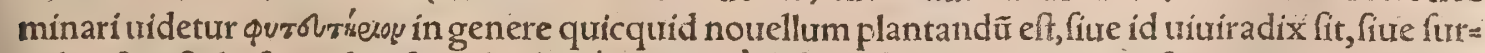
culus, fiue ftolo, fiure talea, fiue aliud quàm propriè dictum feme, ut apparer ex fine capitis 2.8 initio tertí, libri 2.hiftorix plantarum Theophrafti. Quin \& propagines forfitan tum uirum tim a bo

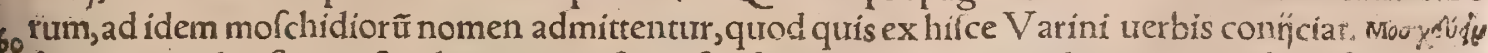
(inquit)apud rufticos eft palmites inuerfos in frobem ímponere ur radices mittant, $\&$ poftea trans $=$

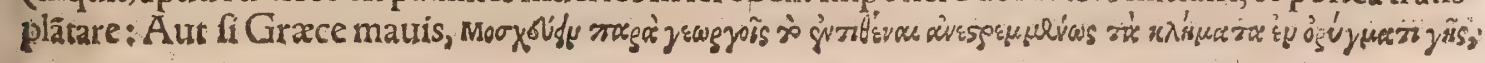




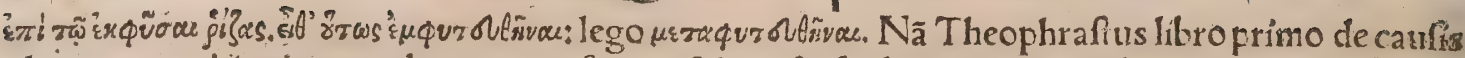

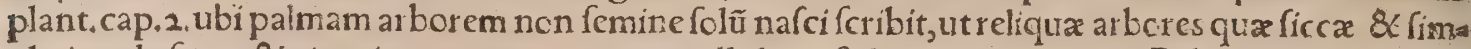
plici caule funt, \& circa imum truncum non pullulant, fed etiam uirgis eam Babylonios plantare,

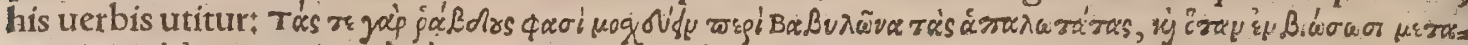

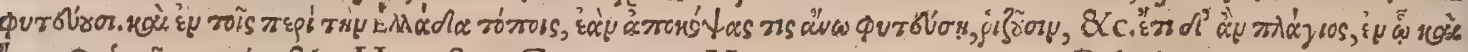

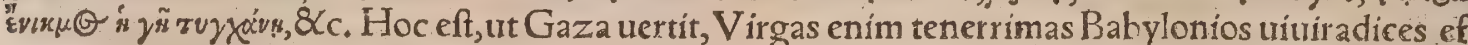
ficere, adultasḉ transferre accepimus. Quin \& Græcia fi quis ramos fuperne decifos ferat, radix de

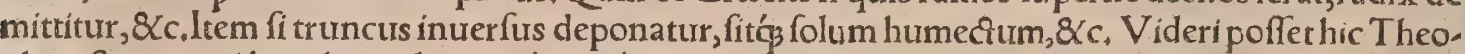
pharaftus $\mu 0 \sigma x$ oúqu uerbum aliter quàm aliàs unquam accipere, nempe pro eo quod eft ramos à fuperiore arboris parte recidere, cum pullos fiue ftolones inferius nullos habeat. Ego uero hunc locum . ita exponendum puto, palmam non femine folum nafci, fed aliter quog, in Babylone enim folones

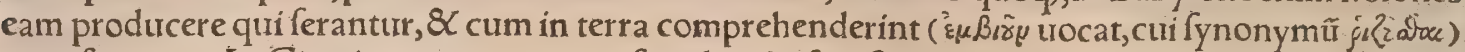
transferantur: In Græcía tuero quanquam fimplici $\&$ fine ftolonibus trunco proueniat, illic tamen quogg aliter quàm femine, nempe ramis fuperne refectis \& terræ commiffis plantari. Plinius certe libro $17 \cdot$ cap +10 , fruticationes à radicibus (à quibus ut etiam à trunco imo uirgulta plantanda fumun=

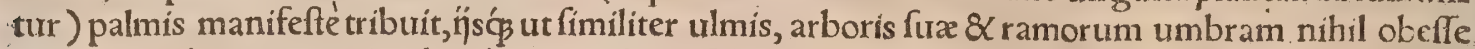
ait:cum exdem in cateris arboribus qux hanc fobolem habent, umbra plerungs pereant. Eandem

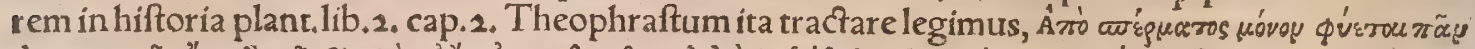

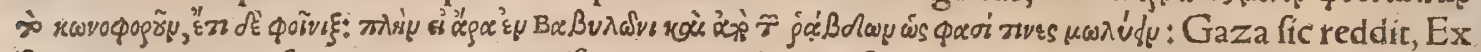
femine tantum nafcuntur cmnes coniferæ, item palma:ni forte apud Babylonem é uírgis quock $\mathrm{pro}=2$

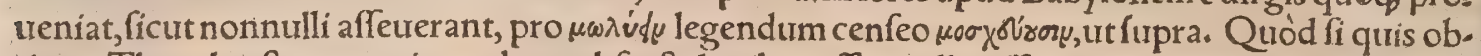

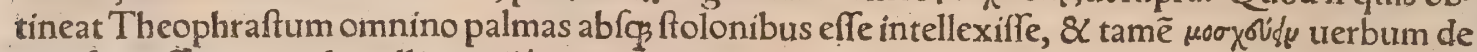

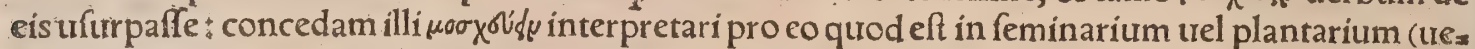
luti uitulum aut pullum ad nutricem ) pangere $\mathcal{Q}$ deponere ramum, ut iam adultus inde transfera= tur: quæ tamen expofitio à nullo hactenus clare prodita eft : mihi quidem fatis probatur. Eft autem

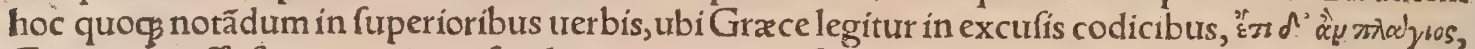
Gazam uertiffe, fi truncus inuerfus deponatur; cui uerfioni nonnihil aftipulantur Varini uerba hace

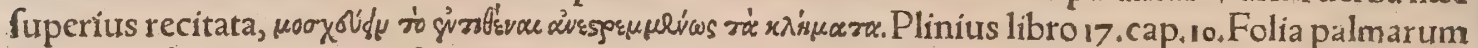
(inquit) apud Babylonios feri, at $\$$ ita arborem prouenire, "Trogum credidiffe demiror . At ego Pli= nium magis miror, qui cum ex illo Theophraftiloco ubi is de prouentu palmarum docer, multa in fuum opus tranftulerit, non obferuauerit Theophraftum hoc de uirgis palmænon folins ( quod ridi=

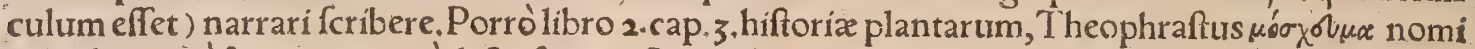
nat, plantamé femine propriè dicto fatam : A mygdala quocs, inquit, femine fata degenerat, tum $f_{a}=$ pore, tum quod dura ex molli redditur:idcirco adultam inferere, aut plantam fapius transferre pre cipiunt:hic pro mofcheuma Theodorus plantam recte conuertit, Quanquam igitur ut plurimum

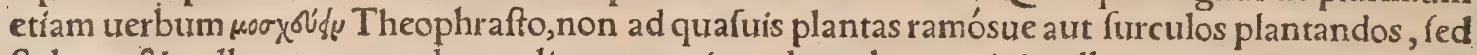
ftolones \& pullos accommodetur, aliter tamen interdum ab eo accipi, nulla contentione negauerim ( nam qua hic fcribo, dubitando magis $\&$ interim ipfe mecum addifcendo inter tot authorum difficultates, quàm docendo afferendóue fribo) de infitione certe nufquam ab eo ufurparí reperi . $\mathrm{Ha}_{*}$

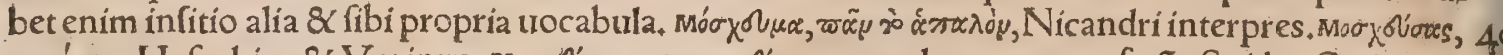

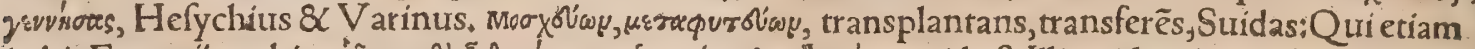

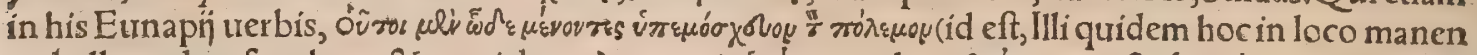

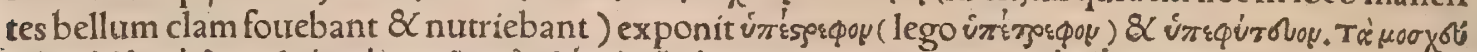

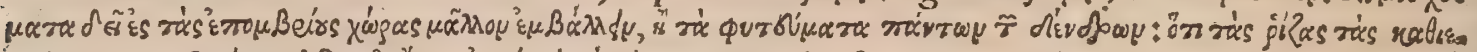

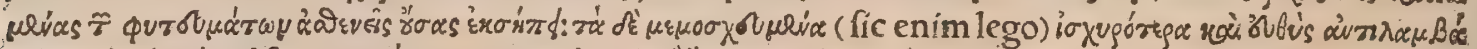

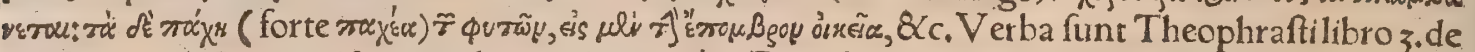
caufis cap. 17. Qux quidem ego longe aliter quàm Gaza fic uerterim, Commune hoc omnium arbo= rum eft, ut mofcheumata, id eft auulfi à trunco inferiore rami, magis quàm reliqui (id eft minores $8<$ fiperne decerpti furculi) folo humido mandentur. Ratio eft, quoniam humor radices furculorum quæ deorfum emittuntur infirm $x$, putrefacit: ftolonum uero uel autlfionum plantæ cum robuftio $=$. res fint, ftatim comprehendunt. Sunt autem crafficres plantæ humido folo aptiores. Artificiofas plantationes, qux non fponte natura, $f e d$ arte $\mathcal{Q}$ induftria fiunt, præter infitiones Theophraftus de

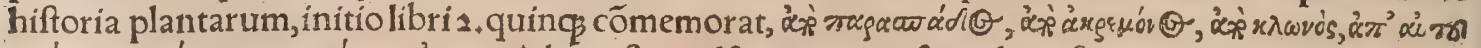

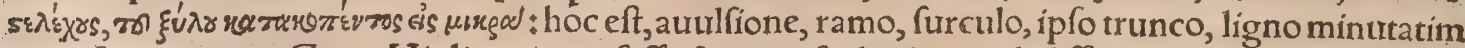
concifo, interprete $\mathrm{Gaza}$. Hic licet ex profeffo \& copiofe de plantandi differentís agatur, mofcheu. matum tame nulla mentio: unde apparet, mof cheumatis proprie dicti \& ex auulfione plantationem eandem effe. (Plinius 17.10. hunc Theophrafti de ligno minutatim concifo locum non intellexit, $\&$ manifefto errore ad infitionem illam tranftulit quæ filfo arboris tr unco fir.) Eft autem eius quod auellitur, differentia triplex, aut enim radicis aliquid fimul auellitur, aut faltem ftipitis, aut nec huius nec illius quicquam:quo poftremo modo punica et malus uerna exoriuntur, ut ibidem fcribit Theo 60

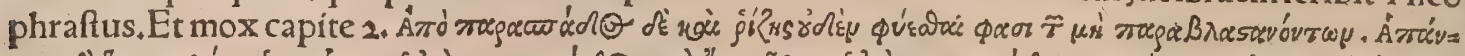

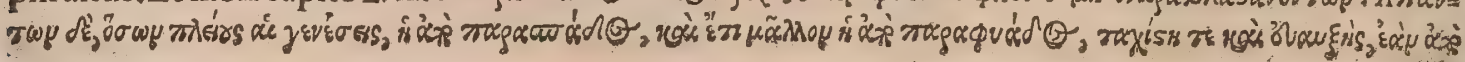




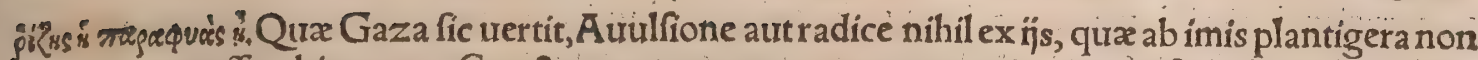
fint, exoriri poffe arbitrantur. Cunctorum autem, quorum generatio numerofior eft, ea qua autla fione, atç etiam magis qua fobole perfici poteft, ocyflima, $\mathcal{Q}$ auctu perfacilis êft; fi ab radice foboles accipiatur. Conftat igitur auilfiones trium generum effe, quia licet omnes parafpades \& mofcheu=

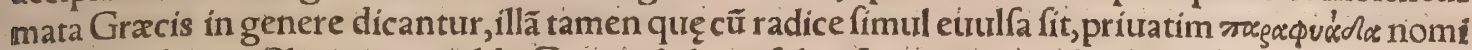
nari ( fobolem ex Plinio apte reddit Gaza: ) \& hanc folam Latinis tiuiradicem nominari, idćs in uis

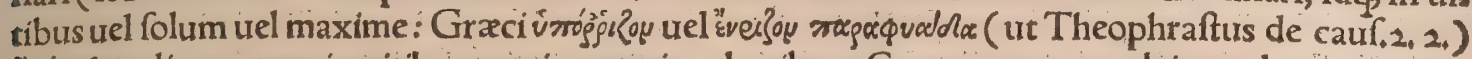

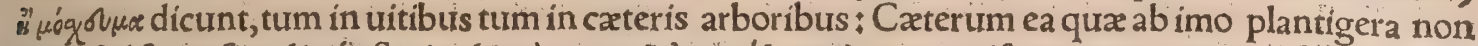

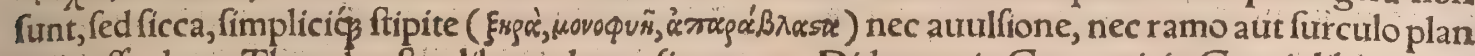
taripoffe; docet Theophraftus libro i, de caufis cap.16 Didymus in Geoponicis Græcis libro 5. qui

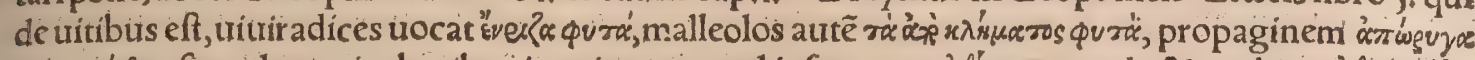

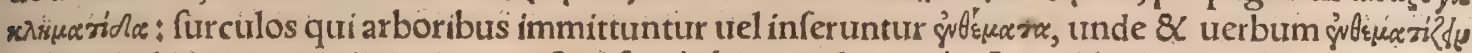

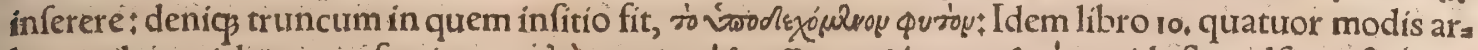

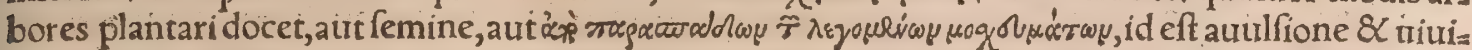
radicibus ( neq̧ enim diftinguit ut Hermolaus, qui differre quidem parum ait, fed quomodo differãt

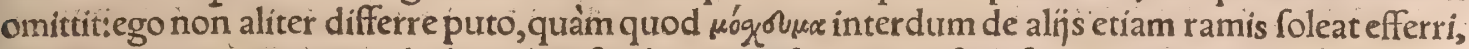
tanquam communius uocabulum:parafpades unam $\&$ certam fignificationem de imis circa trun=

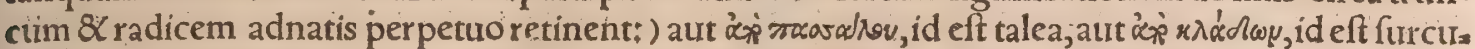
dis, Tranftulit hinc quadam Varro, libro ı.cap.39.8 40.8C parafpades uel mofcheumata uiuiradices uidetur interpretari. Plinius libro 17.cap +10 . Natura $\&$ plantaria demonftrauit, multarũ arborum radicibus pullulante fobole denfa, \& pariente matre quas enecer, $8 \mathrm{c}$. Nullis uero tales pulli proue= niunt, nifi quarum radices amore folis atç imbris in fumma tellure fpatiantir. Omnia ea non ftatim moris eft in fua locari, fed prius nutrici dari ( hoc etiam $\mu_{0 \sigma}$ you $\phi_{\mu}$ Theophraftus dicere uidetur) atc in feminarijs adolefcere, iterumćn migrare, $\mathrm{Hæc}$ Plinius: funt autem pulli illi ex radicibus paraphya des Theophrafti. Et mox pauló, Et aliud genus (inquit) fimile natura monftrauit, auulfićs arboribus ftolones uixere:quo in genere $\&$ cum perna fua auelluntur, partemćs aliquam è matrís quroç cor. pore auferunt fecum fimbriato corpore: Hx f́cilicet parafpades $\&$ moicheumata Theophrafti funt:

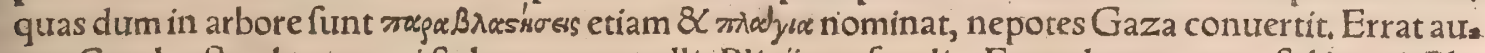
tem Carolus Stephanus qui ftolones cum pullis Plinij confundit. Ex eodem euentur eft (inquit Pli= - nius ibidem) furculos abfcilfos ferere. Viuiradicum certe in hac arborum plantatione nufquam me= minit. Cæterum ramorum \& furculorum plantaria ut Theophraftus, non diftinguit: (nam Theoph.

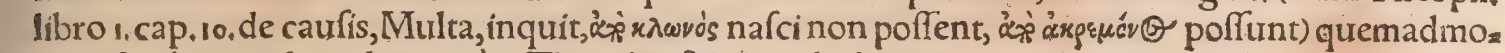
dum \& alia quadam aliter quàm Theophraftus quod ad hoc negotium attinet, eodem in loco tradit:

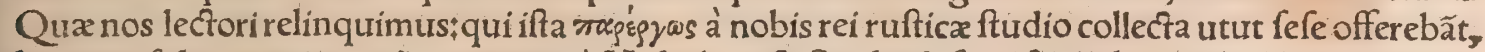

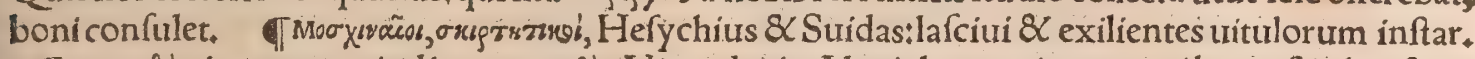

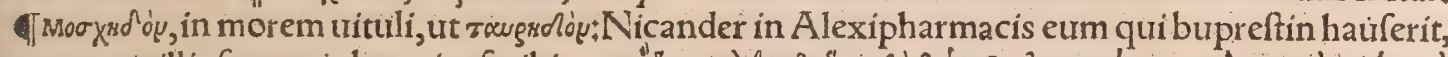

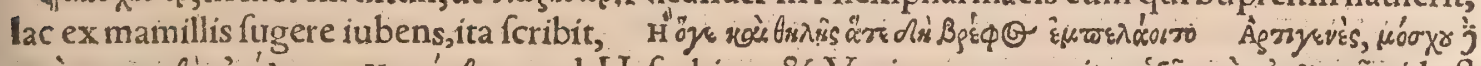

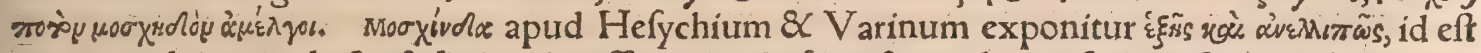
continuo deinceps ductu $\&$ fine intermiffione, qualis forte $\&$ uitulorum fuctus eft ex uberibus ina.

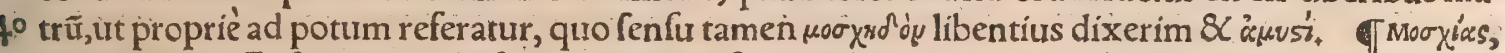
aries triennis, Euftathius: Mofchia lepores ueftigia habent odoratiora, quorum odore canes in $\mathrm{ft}=$ rorem aguntur,Polluxi. Violam idcirco dictam ion Graci putant, quod cum lo in uaccam à loure conuerfa effet, terra florem illum pabulo bouis eius fuderit. Noftri quoq uiolam quafi uirulam, imi=

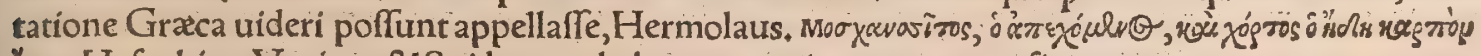
है $\omega_{0}$, Hefychius: Varinus \& Suidas non habent, nec mirum cum uox fit corrupta;

CPomponius Vitulus uiri nomen apud Varronem. Idem circa finê libri 2. Difcedimus (inquit) ego \& Scrofa in hortos ad Vitulum Nigrum Turannium. Mofchi fophifta hydropotæ meminit Calius Rhodig,lib.6, in fine capitis 4, ex Athenai libro6. Mofchus grammaticus Syracufanus, Ariftarchi familiaris, alter à Theocrito Bucolicortım poêta, Suidas. Antiquum de atomis dogma(fí 50 Pofidonio credimus) Mofchi eft,hominis Sidonï, qui ante Troianas res fuit, Strabolibroi6. Mo.

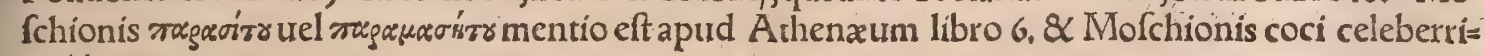
milibro 12 .

b. Más $\sigma$ res, animal quadrupes in India, uitulo fimile, Varinus, Hefychius. Elephanti pariunt fingulos magnitudine uituli trimeftris, Plinius. Bubalos proprie dictos gignit $A$ frica, trituli certíure

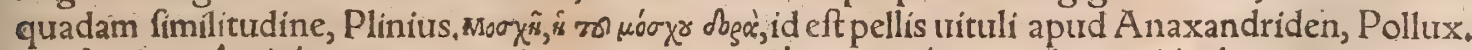

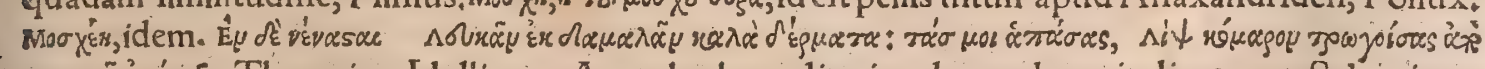
б Antirrhinon uocatur herba flore hyacinthi, femine uituli narium, Plinius: Hanc $\&$ bucranon uo cant, Galenus in Gloffis: Diofcorides etiam femen eius uituli naribus confert: Eft et inter hippogloffi nomina antirrhinon.

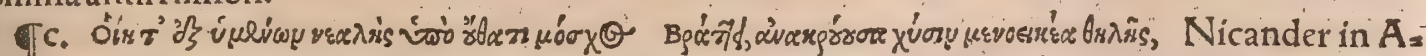
lexiphar, ubi contra Bupreftis uenenum lac ex uberibus fugendum confulit. Iofephus author eft 
in mutationelegis facrificiorum Hierofolymis in templo, uitulam inter manus facrificantitum pepes riffe agnam, Albertus Magnus, Vitulum aliquando capite pueri natum effe teftatur Ariftoteles de gener, animalium, libre quarto, capite tertio.

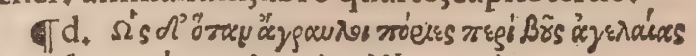

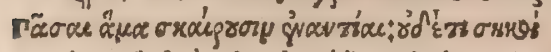

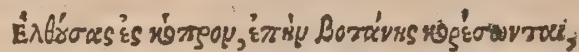

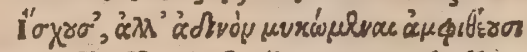

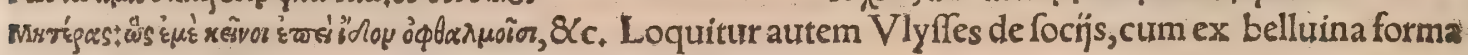
in homines redinffent, apud Homerum Odyflee libro 10.

बf. Caro uitulina nominatur Plauto in Aulul. Cicero libro 2, de Dirrin. Ān tu, inquit, caruncu la uitulinæ mauis, quàm imperatori ueteri credere? Idem Patolib. g. Integram famem ad ouum af= fero, itaq̧ ufo̧ ad affum uitulinum (quidam hîc uitellinum legunt, fed uetus exemplar uitulinum io

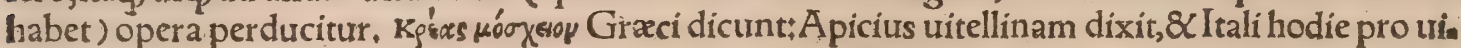
tulo uitellum, Imperator Valenslegem Orienti dixerat, Ne quis uitulinam efitaffe carnem uellet dum agricolationi confultum cuperet, Calius. Aegyptios. Agefilao uitulos faginatos mififfeapud A thenæum alicubilegimus. In uitulis pracipue mufculofam \& fuperiorẽ femoris partem, noftra! tes trocant ro:bzaten, quoniam os femoris in ea cannæ fpeciem refert.

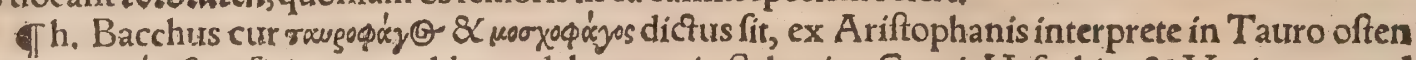

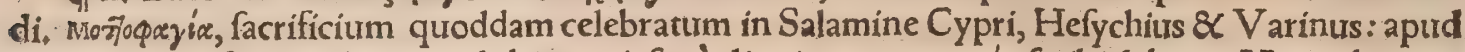

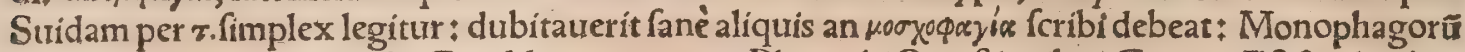
celebritatis apud A eginẽ les Gyraldus meminit ex Plutarchi Qux?tionibus Gracis : Eft \& alia wuen payíc dicia IVitulam deam Victoriam dici Pifo putatrit: cuitus rei hoc argumentum protulit, 20 quod poftridie nonas Iulias re bene gefta, cum pridie populus à Thufcis in fugam uerfus effet, unde Populifugia dicta funt, poft Victoriam certis facrificris fiebat uitulatio. Quidam interpretati funt quod potens effet uitæ tolerandę:hinc illi pro frugibus facra fiebant, quod obferuat Macrobius. Hyl lus in lib; de Deis, Vitulam deam ait quæ lætitix præeffet : unde etiam Vitulatio \& Vitulari, Varro in lib. Rerum diuinarum ait, quod pontifex in facris quibufdã uitulari foleat, quod Græci æauceví?de uocant(Hinc illud Vergilï, Latunnç choro pęâna canentes.) Títius uero uitulari interpretatus eft, uoce latari.Quidam de hac dea Vergilium intellexiffe uolüt,cum cecinit, Cum faciam uitula(pro uitulatione, facrificio ob latitiam facto) pro frugibus ipfe uenito, Hæc Gyraldus ex Macrobíl lib. 3. cap.2.Saturn. Vitulari ueteres dixerunt pro latari, teftibus Fefto \&Nonio, Plautus in Perfa, Commodantilubens, uitulor'̧́ merito. बDe A pide uitulo, copiofe in Tauro locuti fumus ₹ ubi \& uituli aurei à Iudaxis idololatris in Choreb confecrati mentionem fecimus. I Mactatos crederet illic Lactentes uitulos, Amathufiacasć̨̧ bidentes, Ouidius Metam.9. Dum faciam uitula pro fru. gibus, Vergil, Sic Seruius uidetur legere, \& Macrobius lib.3.cap.2.Sic Columella, Nifi prius catu. lo feceris. Alij malunt uitulam quarto cafu legere, ut dicimus rem diuinam facere: fed illi à doctiori. bus non approbantur. Circa uitulos dux facrificantibus dictr leges : Vitulum probari', fi articu. lum fuffraginis cauda contingat:breuiore non litari: Vitulos item ad aras humeris hominum alletos, non fere litare; ficuti nec claudicante, nec aliena hoftia deos placari, nec trahente $\int_{e} a b$ aris, Ca.

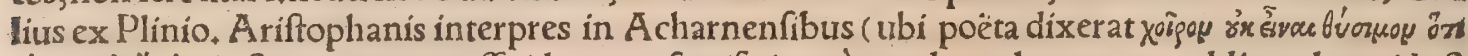

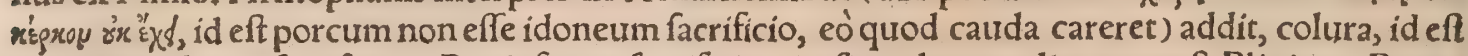
mutila non licere facrificari. Bouris foetus facrificio tricefimo demum die purus eft, Plinius. Boures 4 mares, eofdemó mundos \& uitulos, unitrerfi Aegyptỉ immolant, Herodotus. Vide nonnihil etiam fupra in facrificịjs ex boue. Ex bobus, uitulis, \& pecudibus laudatiffimæ uitulæa ad deorũ placamen ta habebantur, Gyraldus. Veteres Graci hoedorum, agnorum, uitulorum q́ infpectis inteftinis, fu tura prædicebant, Gyraldus, ex Paufania. In Lunæ deliquio Aemylius Paulus aduerfus Macedo= nas imperator, undecim ei uitulos, id eft mofchos, immolaffe narratur:etiamfi eo uocabulo tauros ac cepit interpres, Calius. De immolando porco, agno, uitulo, mentio fit apud Catonẽ cap, 141, Italiam à uitulis dictam Varro frribit, authorem citans Pifonem. Regionem tertiam Italiæ tenuerunt priua.

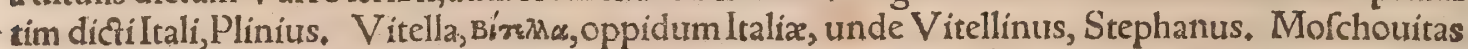
quidam interpretantur populos illos qui à Ptolemæo Hamaxobï,à Pomponio Mela Hamaxobita dicuntur, populi Sarmatiæ in Europa:qui ædium uice plauftris utebãtur:hamaxa enim Gracis plau jo frum eft:quamuis alio hodie loco quàm olim fiti uideantur.

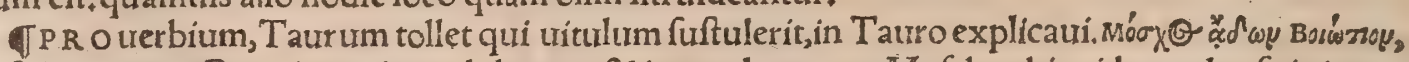
Mofchus canens Bozoticum, in multiloquos \& inepte loquaces, Mofchus hic citharodus fuit impe. ritus, qui citra refpirationem uocem in longum producebat, Bocoticum autem uocant cantionis ge. nus ueluti Phrygiữ aut Doricum, Erafmus, Suidas \& Apoftolius, Ariftophanes in Acharnenfibus,

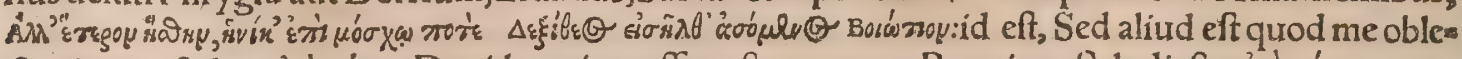

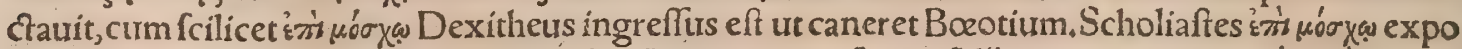
nit poft Mofchum, qui ineptus citharaedus Agrigentinus fuerit: Alip propter uitulum, eó quoód uicto ri pramium daretur uitulus, Bozoticum autem melos Terpandrum inueniffe ferunt, ficut $\&$ Phry $=$ gium . Cæterum Dexitheus optimus fuit citharœdus, \& uictor in Pythins : alij etrndem frigidum Go $\&$ ineptum fuiffe aiunt, Hac Ścholiaftes. Aliquid cito factum fignificaturi Vueftphali, dicunt, 2E be Damn \$ao kalb fein auge lectr, Antequam uítulus oculum lambat, ut Latini Citius quàm afpa 
ragi coquantur.: Lufciofum Latini lolio urictitare prouerbiali ioco dicunt, Germani quidam in. eundem, Wo at recbt in cin bauß fidht/Da wetpens sic Ealber blinbt, Si oculos in domum con. uertat, uitulos excreabit

\section{E B V B ALO.}

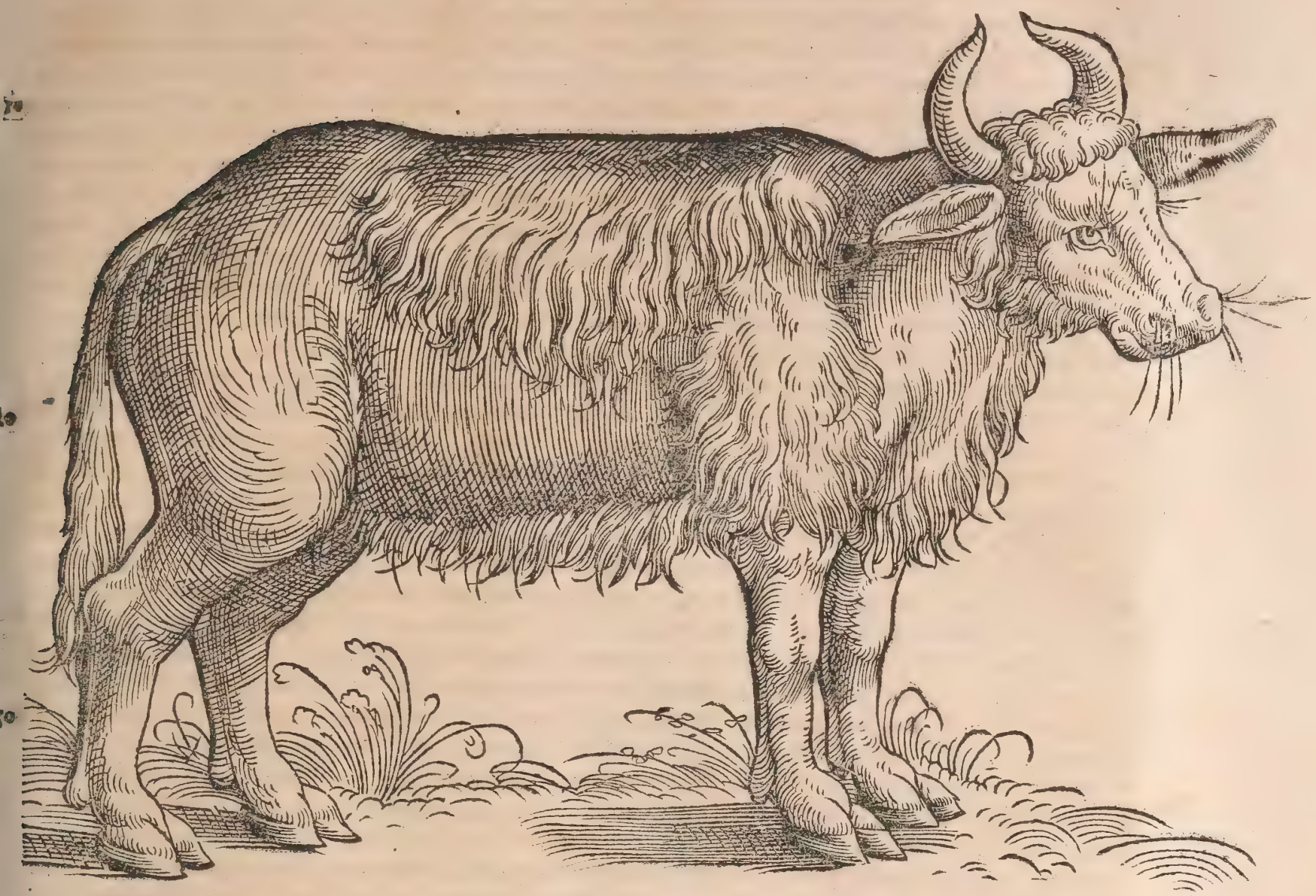

A.

\section{(2)}

V B A I I nomen omnino incertum eft, non hodie folum, fed iam Pliní feculo confufum: Alius enim Gracorum bubalus eft, cuí nullum aliud apud Latinos nomen contigit, ut pe: regrinis plerifq: de hoc alio loco inter capreas, quibus adnumeratur, docebo, Alius quem uulgobubalum uocant, qui de boum fylueftrium genere eft, nec ullú pecư iare apud Gra cos, qurod friam, nomen habet: Cum inter fylueftres alí quidam certa habeant nomina, fiue propria fiure à regionibus fumpta, ut bonali, bifontes, Indici, \&c. Accedic hoc etiam difficulatis, qurod diuerros fylueftres boues (ut Plinij tempore olim uros)hodie multi, prafertim in illis regionibus ad quas aliunde adducuntur)uulgus bubales appellat. Pauciffima anımalia( inquit Plinius libro 8.) Scythia gignit:pauca contermina illi Germania:infignia tamen boum ferorum genera, iubatos bifontes, ex* cellentiós \& ui \& uelocitate uros, quibus imperitum uulgus bubalorum nomen imponit: cum id gignat Africa uítuli potius ceruitue quadam fimilitudine, Hxc Plinius. Sed quanquam diuerfi bo ues fylueftres bubali nominentur à qubufdam, maximé tamen $\&$ à plurimis bos ille, cuius effigiem - appofurimus à praftantifimo medico Cornelio Sittarcio Norimberga ad me miffam, bubalus appel. latur:qui inter cicures \& fylueftres medius ferè mihi uidexur. Hunc Perottus apud ueteres in ufu fuife negat: $Q$ addit, ex Africa primum id animal allatum prodi. Ego Pliníf uerbis iam recitatis, qui bus proprie dictum, id eft Grecorum bubalum, in A frica gigni fcribit, hominem deceptum fúpicor, Quanquam bubali, quos priuatim fic uocitamus, ex quibus locis primum aduecti fint, certi nihil ha beam. Albertus Magnus meminit magnorum bubalorum fylueftrium, qui vifent apud Germanos appellentur, hos ego bifontes interpretor, de quibus pluribus dicam inferius. Erafmus $S$ tella in libro de origine Brufforum, Buffelus, inquit, quadrupes habet barbam ueluti capra, alioqui fimilis bout per omnia, \&c. Hunc ego urum effe docebo infra.Ifidor us etiam bubalos caprearum generis cũ bu= balis bubus confundit: Bubali ( inquit ) uocati funt cò quod funt fímiles boum, adeỏ indomíti, ut pra - feritate iugũ certicibus non recipiant:hos Africa proceat. At illi qui caprarum fylueftrum generis funt bubali, quos in A frica nafci conftat, neç bubus (uitulis tamen aliquo modo) fimiles effe, nil mi. rum fi iugum non recipiant, Quod autē de noftris non A fricanis agat bubalis Ifidorus, uel inde ap. 
paret, quod bifontibus eos coniungit. Martialis in Libro fpectaculorum, Carpophorum quendami laudans, . Illiceffit atrox bubalus ato bifon. Domitius interpres recte bubalum exponit urum, illum dico qui inter boues fylueftres omnium maximus eft, \& proprie urus dicitur. Plinius bubalum uulgaremintelligere uidetur, ubi fcribit è boue fylueftri nigro, fi fanguíne ricini lumbi perungantur mulieri tædium Veneris fieri dicit Ofthanes. Ariftoteles apud A rachotos (Indix ciuitatem)boues fyl ueftres effe tradit, qui differant $a b$ urbanis, quantum inter fues urbanos \& fylueftres intereft:colore atro, corpore robufto, ríctu leuiter adunco, cornua gerunt refupinatiora. Hi bubalis forte congene. res fuerint:confentiunt enim color, robur, \& cornuum etiam figura, ut paulò mox dicetur. De ricite iudicabunt illi qui prafentes habent bubalos, quibus noftra regio caret, $\Phi$ Sed relictis cateris, tum Africano bubalo, tum fylucftribus bubus, de illo folum agamus hoc in loco,cuius imaginem adiun: ximus. Huius igitur nomen apud Ebraxos nullum reperiri puto, nifi quis fub $\mathrm{n}$ in teo comprehendi arbitretur: Nam Dauid Kimhi exponit per cap.14. Chaldaica translatio pro to habet turebalah, (nam tor uel tor a taurum eis fignificat, balah(ni

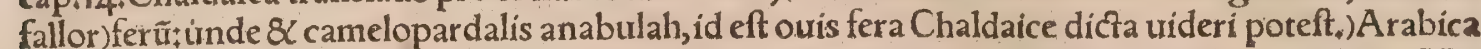
taietal, Perfica badek, Sepuaginta \& Hieronymus orygem, Sunt autem uerba legis eo in loco: Ve. femini bubus, ouibus \& capris:item ceruo, caprea, bubalo, capticorno, unicorne, boure fylueftri, \& alce, ut Sebaftianus. Munfterus tranftulit. Vnde apparet teo animal fuiffe purum, \& in cibis concef fim:quamobrem non poterit idem effe quod thôs, id eft lupus ceriarius, ut quídam coniecerüt pro pter nominis affinitatem. Idem nomen $k$ to feribitur Efaix cap. Si. Filly tui (inquit propheta, interpreteMunftero) iacuerunt mœrore affecti in capite omnium platearum, ficut bos fylueftris reti (cà. ptus, ) pleni furore Domini, increpatione Dei tui. Hieronymus hic orygem illaqueatum reddit, Se.

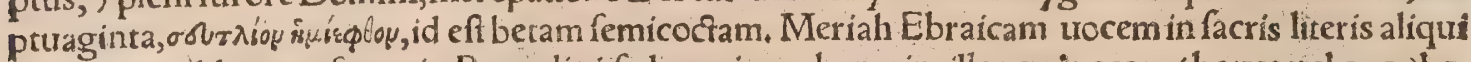
bubalum reddunt, ut fupra in Boue dixi:fed magis probauerim illos quipecora ( boures uel oues)be. ne faginata reddunt:nam marah faginare eft, Prophetx Amos capite 6. in translatione Hieronym! fic legitur, Nunquîd currere equi in petras queũt, aut arari poteft in bubalis? Error eft, nam Ebraice

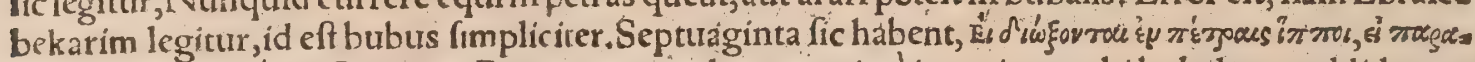

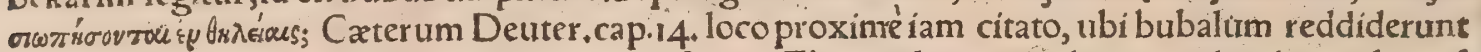
lofephus, Septuaginta, Hieronymus, \& Munfterus, Ebraice legitur iachemur uel iachmur (quod Arabes etiã \& Chaldai fimiliter reddiderũt, Perfæ kutzcohi) aliqui ex nớtris afinũ ferũ effe fứpicã tur, cum alia tamẽ onagror ũ nomina Ebraica habeamus, bubali Gracorum uero nullum fi iachmur demas. Ego certe iachmur bubalum proprie dictum à Gręcis effe crediderím, de caprearum genere. Nam R. Iona animal fimile magnæ capræ interpretatur: et Iudęi quidam, Munftero tefte, capram ru picolam reddunt. Hoc certum eft non effe bubalum uulgarem:primum quia lofephus $\&$ Septuagin ta Bŕßares Grace reddider unt, quem de genere fylueftrium caprarum effe eruditorum nemo dubio tat: deinde quia tertio Regum libro, cap.4 inter lautiores Salomonis regis cibos adnumeratur:Quo tidie enim confumebantur in aula Salomonis (ut illic legitur) decem boues faginati, \& uiginti gre: garï, atque centum oues, prater ceruos, capreas 8 capras fylueftres atq̧ aues caftratas: hîc Munfte. rus iachmur non bubalos uertit, ut in Deuteronomio, fed capras fylucftres: Hieronymus hîc quog bubalos:Septuaginta omiferunt. Bubali uero uulgares nequaquam poffunt inter lautos cibos cens feri.Sed tandem, ut copperam, concludo, aut nullum Ebrais nomen effe bubali uulgaris, aut fut to, 4 id eft boue fylueftri, tanquam fpeciem fub genere contineri. Syluaticus dicionem iamus bubalum exponit : uidetur autem corrupra à iachmur .Aufeac in ueteri Expofítione alphabetica uerborum Arabicorum Auicennæinterpretatur coagulum ceruinum, \& genitum buffali:apparet autem genitum uocem corruptam effe. ISed ne Gręci quidem, quiod fciam, quio bubalum noftum appellent, nomen habent : Nam $\beta_{\gamma}^{\prime} \beta a \lambda s s$ \& $B r \beta x \lambda$ is oxytonum fynonym $x$ uoces caprearum generis funt, quod fxpe iam repetī:Qux autem his animalibus etymi ratio fit, non facile dixerim : fed barbartim $8 \times$ pe: regrinum utpote A fricanis nomen effe puto:quod cum uulgus Italorum audiuiffet, \& uocis fimilis tudine deceptum bubuli pecoris genus effefibi perfuaderet, poftea boures fylueftres ad fpectacula adductos fic appellaffe uidetur, tanquam Latino nomine. Ariftophanes grammaticus fcribit dama:

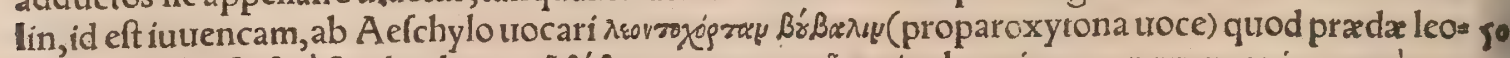
num expofita fit: $\&$ à Sophocle zry cem nufquam reperiam in Lexicis:dici tamen pofle exiftimo (ut poëtæ multa huiufmodi uocabula

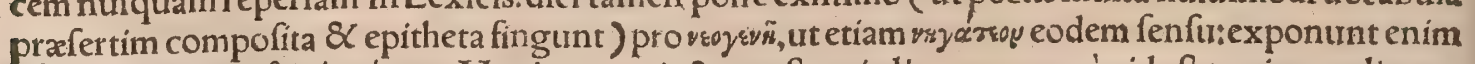

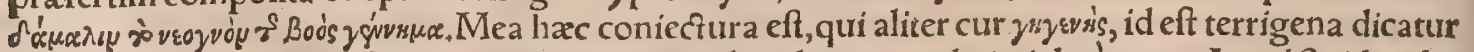
iutrenca, non uídeo:nifi forte quod ex terra $\&$ herbis alatur, quod nimis laté patet. A pud Suidam le gitur y'́z cum damalis alioqui omne animal in iutenta uocetur, Photione tefte. Sed hoc nihil ad utgarem bubalum, cum de uitula uel iutrenca tantum dicatur, ueluti uox diminutiua : uulgaris autem buba lus etiam adulto boue maior atç alcior fit: In Etymologico tamen in dictione Br Badocs, legimus Bŕsore

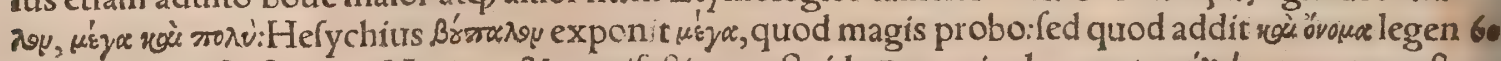
dum

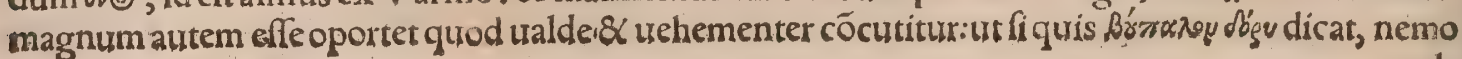




\section{Bub. A.B.C.D.E.F. Lib. I. i4t}

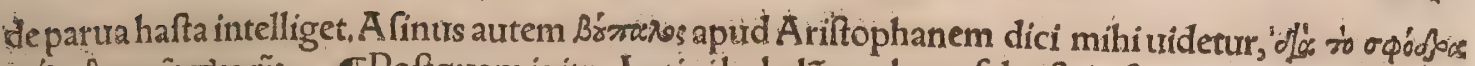

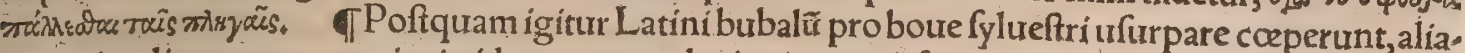
num etiam linguarum prouincix idem nomen ab eis mutuatx funt: neqz id mirum, cum perpaucís animalibus peregrínis alia nomina habeãtur, quàm à Latinis itel Graccis accepta, licet illi plurima prì mum à barbaris, id eft quibufuís alijs gentibus acce perint. Graci inquam, fiue futa fiue aliunde ac. cepta uocabula Romanis \& Latinis communicaurerunt, illi poltea nationibus cæateris præfertim à fe deuictis. TVifuntur Romx permulti, ut audio, bubali; unlgus adhuc uocat bufalos, Galli beuffle, Hifpani bufano, Germani büffel, Angli bugill, Lllyrica lingua baumol ${ }_{\downarrow}$

B.

Bubali uulgaris (fic enim appellabimus ad differentiam À fricani, \& uri, \& bifontis) defcriptio nem in libris Alberti Magni, Petri Crefcentienfis, \& recentiorum quorundam, huiufmodi reperio. Bubali ex genere boum fylueftrium funt, perquam robufti, $\&$ boue cômuni maiores altiores क́p:cor pore ualde craffo, cute duriffima, membris macilentis:pilis nigris; paucis \& paruis(minimis, ita urt in cauda fere nullífint, Albertus †) fronte afpera, crifpa \& intricata pilis : Capite ut plurimum prono ad terram, paruo fi conferas ad reliqui corporis modum, Albertus; etfi author libri de natura rerum, fimpliciter caput ingens eis attribuat. Intuitu fimplicitatem $\&$ manfuetudinem prafe fert. Cornúa eis longa, intorta, nigra: Albertus barbara dietione ualliculofa eis cornura tribuit, et nigra ficut capre Et rurfus, Cornua eorum (inquit)parua funt, ficut cornua ca pra domeftica, $\&$ aliâs interius iuxta collum dependent uerfus internam pectoris partem:aliâs erecta funt. Prateréa collum bubalis crafe fum eft, uel ut author quidam obfcurus habet, longum : Inferior dorfi pars caudam uerfus decliuis cauda breuis, parua, \& nullis fere pilis:crura craffa, robufta, \& reliqui corporis refpectu breuia.

Bubalus ungulis terram fpargit. Mugitus ei terribilis. Vaccæ $\&$ boures fylueftres, qux ruftice dicuntur bufala, lac habent \& tempore coitus, 8 in principio partus, Auguftinus Niphus. In hoc genere uacca alterius quàm fui generis uaccæ uritulum non a dmitric uberibus, fed odore agnitum re ijcit: fin autem uitulus uaccino ftercore illinatur, odore decepta lactat, et pro fuo educat, Albertus. In aquis morarigaudet, Petrus Cref

D.

Bubalurs quanquam remiffurs aliấs \& fatis manfuretus, fi tamen irritetur, perquiam iracundus $\&$ indomitus euadit: $P$ ugnat autem pracipue pedibus $\&$ ungulis, quas magno nifu defigit, $\&$ iterum iterumós conculcat ea quibus írafcitur, Perfequendo recia fertur, neq declinat, Albertus. Ira coma

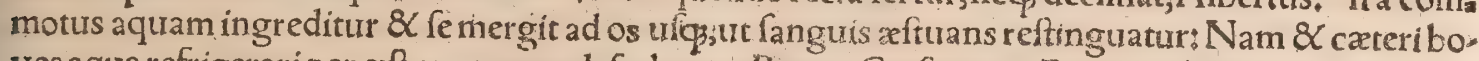
ues a qua refrigerari per aftum omnes defyderant, Perrus Crefent. Pueri multis in locis ludendo moleftifunt bubalis, qui infidentibus illis corum dorfo, aquam fi qua uicina fit ingreffi fe fubmitũut, unde pureri quandoos periclitantur. Colore uario $\&$ rubro prouocantur: qua de re pluribus egi in

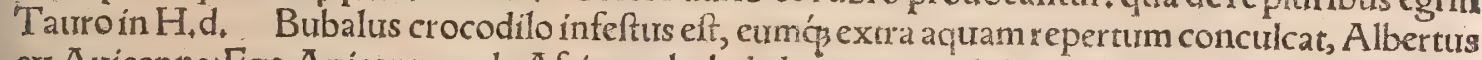
ex Auicenna: Ego Auicennam de Africano bubalo locutum crediderim, cum pleraç omnia fua ex Gracis defcripferit; accedit quod crocodilus Africa peculiaris eft.

E.

Bubalus quoniam robuftus eft \& patiens laboris, paffim ducendo currui, \& uehendis oneribus, ac etiam terræ arandæ coutuntur, Perottus. Ad plauftra \& aratra non fatis idoneífunt, fed in tra hendis per terram magnis ponderibus exercentur, ligati artificialiter quiburdam catenis, Petrus Cre fentienfis. Maximo conatú onera trahũt; adeó ut ad primi impetus nifum maiorem in gentra fe de: mittant, \& rurfus erecti pergant. Vnus tantundem ponderis, quantũ equi duo fermé, trahere ualer, Aibertus, Quod fi nimium fit onus in terram decumbit, $\&$ ne uerberibus quidem facilead furgen= dum cogitur, nifi leuato prius onere, Author obfcurus, Ferreus aut areus circuluis per nares ei tra ijcitur, cui alligato fune uel habena ducitur ac regitur, quo minus homini repugnare poffit. Coria bubalorum minus probantur quàm aliorum boum, etfi ualde craffa, Petrus Crelc. Nauigant Bri. tanni uimineis alueis, quos circundant ambitione tergorum bubalorum, Solinus:uide ne legendum fit bubulorum. In lege, Argumento funt:Sed ftragulas $\&$ bubolonicas, qux equís infterni folent: Sunt qui fentiât hoc in loco legendum, bubalinas, tut fubintelligatur pelles effe non ueftes : tanquani ex bubalorũ pellibus ftragulis ad equos fieri folitis. Ego uero (inquit Bayfius in libro de Vafculis) legenduni puto Babylonicas, quam lectionem mox teftimonijs fulcit.

Bubalus hinc abeat, néue intret prandia noftra; Non edat hunc quifquam, fub iuga femper eat; Baptifta Fiera. Carnes bubalinæ nimium melancholic $x$ funt, 8 ne boni quidem faporis, quare pa rum probantur:crudx adhuc forma $\&$ colore non adeo indecora funt, cocta uero omnino, Petrus Crefc, Cafeus de lacie bubali ualde folidus \& terreftris eft, Albertus,

G.

Ex ungulis uel cornibus bubali uulgaris, annuli fiunt, qui fi in digitis uel manuum uel pedunt fubinde geftentur, mirifice à quibufdam laudantur aduerfus neruorum conuulfiones feu fpafmos Sunt qui îfdem quaterna fila ex totidem metallis, auro, argento, zre $\mathbb{X}$ ferro fabricata innectanki 
tanquam efficacioribus fic futuris, tum ad fpafmos, tum ad alia quædam uítia. Aliqui tantundê fpe= rant ex annulo confecto de folis iftis filis inter fe contortis Non Nefunt qui infuper mentiantur an: nulos ex cornu uel ungula bubali in coitu diffilire, quod alioqui puto chryfolithis \& fmaragdis tri. buitur. Reliqua ex bubalo remedia quærecentiores ei adfcripferunt, ad bubulum Africanum perti. nent, de quo fuoloco.

Vulgare conuritium ef, ut craffi \& inepti homines, imiores prafertim \& ferui, bubali apud Ger manos appellentur.

\section{DE BOBVS FERIS ET SYLVESTRIBVS DIVERSIS.}

A.

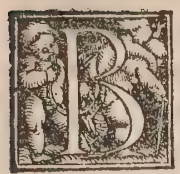

o v I s nomine ueteres multa peregrina \& fylueftria animalia, magna \& cornuta pracípue, quorum propria nomina ignorabant, appellauerunt; ut elephantos, boues lucas, rhi nocerotes, Acthiopicos boues: Cafar etiam alces $\&$ rangiferos boum nomine compre. hendere uidetur, nimirum propter animalium illorum magnitudinem \&lactis ufum.

बT Tauri agreftes differunt à fylueftribus:Plinius libro 8. Aethiopia, inquit, atrociffimos habet tau rosfylueftres, maiores agreftibus. Egofylueftres intelligo feros, ut funt uri, bifontes, \& alij, quos Graci àgpirs uocant, non tam à locis ab hominum confuetudine remotis, quàm natura fiute ingenio fero \& Iylueftri.Agreftes ịdem ảysaú $\lambda r$ suocant, qui quanquam manfueti fint, \& ex mafuetis nati, 20 liberi tamen folutió in agrorum, fyluarum, aut montium parcuis relinquuntur, nec ad ftabula reuo

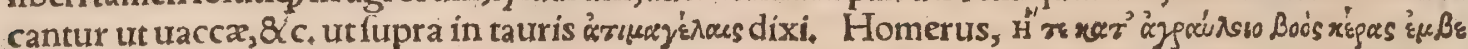

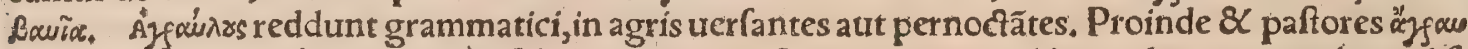
$\lambda_{s}$ cognominantur à poetis, quòd fub dio morentur. Oppianus tamen libro 2, de uenatione lianc difo

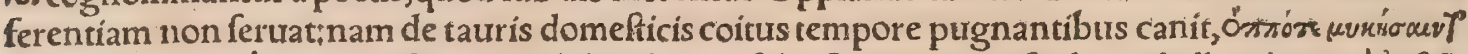

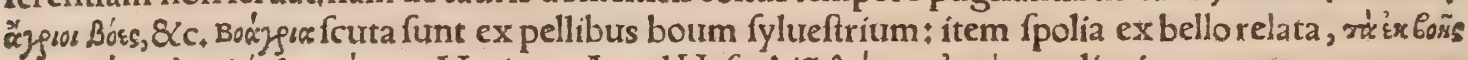

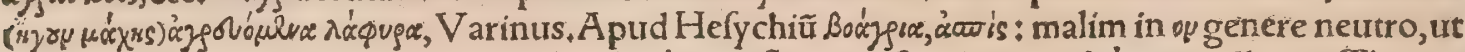

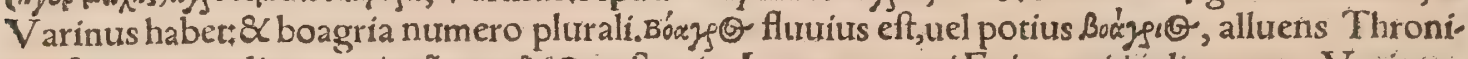

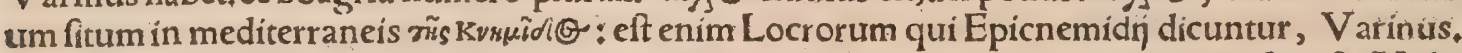
Meminit cius Homerus \& Strabo libro 1, \& pluribus libro q.unde fua Varinus transfcripfit. Vide. cur autem fic appellatus ab alluuione fubita : nam cum exigurus aliâs torrens fit, ut Strabo teftatur, quandog ad bina late iugera effunditur, ut recté impeturofo $\&$ fero bour comparetur. Karsó́ yovrss,

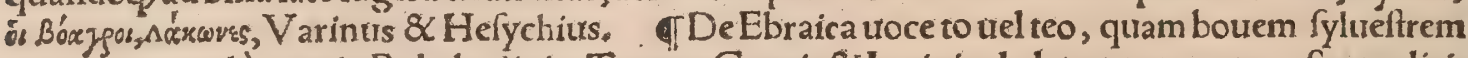
exponunt, pauló ante in Bubalo dixi. Taurus Gracis $\&$ Latinis de boue mare non caftrato dici.

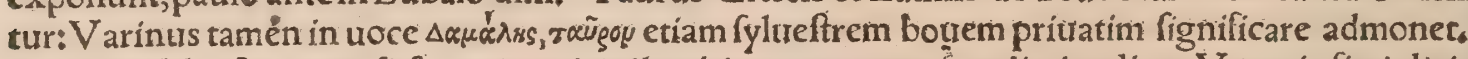
G Eoue fylueftri nigro fi fanguine ricinilumbi perungantur, mulieri tædium Veneris fieri dicit Ofthanes, Plinius. बSupra in Boum manfuetorum hiftoria cap.2, diuerfa boum genera enume. raui, quorum aliquot fera effe non dubito, ut Aonios \& Armenios, quos tamen ab alijs non fepara. ui, quoniam authores feríne an manfueti effent non fatis exprefferunt, GCirca Pæonium agrum atç Creftonicum fuper amnem Chidorumleones multi funt, \& boues agreftes pragrandibus corni bus qui ad Gracos ueniunt, Herodotus libro 7 . Hi mihi bonafi fite monopes uidentur, ut infra 0 .

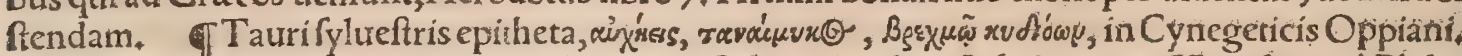

- In taurum fylueftrem qui Macedoniam uaftabat ad pedem Orbeli montis Macedonix à Philip

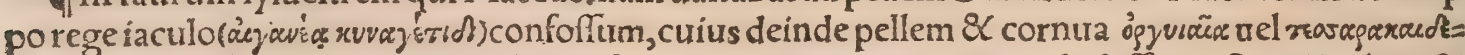
rés dlogex, in ueftibulo templi Herculis confecrauit: extant epigrammata doctifíma, Símmix duo, \&

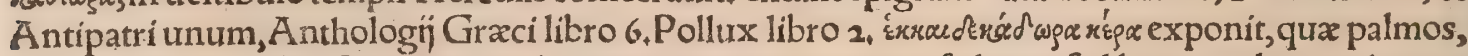
uel ut ipfe uocat, palaftas quatuor digitorum, aquent numero fedecim:fed hæe nondum attingunt orgyian, id eft ulnam. Dora uero quinq digitorum(palmum maiorem uel medium recentiores qui= dam uocant)numero fedecim, proxime ad ulnam accedunt, Sed non ef neceffe tam exacié has men furas refpondere, cum orgyiçon etiam fimpliciter magnum exponatur: $\mathcal{E}$ poetis maior in uocabulis $f^{\circ}$ licentia fit. De orgyia 8 palmo menfuris paulò poft in Bonafocopiofius agam. IT Taurus ille qurem Phyllius uiciffe fertur, ut fuperius retuli in Tauro ex Ouidï Metamor phofeon libro 7 . fylueftris fuif fe uidetur. De bubus opif honomis, id eft qui retrocedendo pafcuntur, meminit Ariftoteles $\mathrm{h}$. bro 2, de Partib,anim.cap.16, de elephantis frribens, quod nifi naris eorum mollis aptá̧́ ad flecten dum fuiffet, impedịffet eos in cibo capiẽdo lógitudine fua, ut boues opifthonomos fua cornura nif retrogrediantur:ubi autem illi reperiantur non meminit. Herodotus auctor eft in Libya bours opi fthonomos effe, id exprimentibus cornibus, qux adnutunt proclinantureq́; in ima, \& oculos obums brent, tametfi hiforiam conuellit Athenæus fub Vlpiani perfona, quoniam à nullo præterea hiftori corum fit comprobata, Calius. De alce etiam diximus, tam craffa ei promínere labra ut pafcendo re trogredi opus habeat. Sed opifthonomos boues non puto fylueftres effe cum armentorum nomen io â Plinio \& Solino eis tribuatur:\& Herodotus excepta cornuum figura nihilà cateris bobus differre ait prater craffitudinem pellis atç; duritiam, Solinus in Garamantum regione armenta obliquis cer 


\section{Boues fylueftres. A. Lib. I. I43}

uiciburs pafci fcribit propter prona in humum cornuta \& obnixa:Idem Plinius de Troglodyticis. He rodotus uero \& A Alianus Libycos boues propter eundem cornuum fitum, opif honomos, id eft re tropafcentes uocant. Ego omnes de pifdem bubus locutos puto Libyci enim omnes funt,nec pu= gnatobliquis fimul ceruicibus \& retrogrediendo pafci.Sunt \& alï Troglodytici feri, de quibus fta tim dicemus, TBoues quidam fylueftres habentur in Gallia iuxta mare mediterraneum prope Montempeffulanum, in parte loci quem $P$ alúdem urocant, mutis cincta. Manfuetis longè maiores funt, ut audio, \& capiuntur à uriris qui celerrimis equís infident cum haftilibus, hi uel fatim confici= unt boues, uel in anguftum quendam locum adactos includunt: Sua lingua uocant beufbrau, per onomatopociam. Aethiopici tauri ijdem qui rhinocerotes funt Paufanix in Eliacis, de quibus ro fcribit quod cornua in naribus producant, Errautit Angelus Politianus in Mifcellaneis cap, 56, tau. ros Aethiopicos quorum Paufanias in Boeoticis meminit, non ueros rhinocerotas effe afferens, fed per fimilitudinem tantum à quibufdam ita tocatos. Atqui Paufanias illic non folum rhinocerotas dictos tauros illos Aethiopicos feribit, fed addit fingulos fingula in naribus cornua habere; $\&$ infus: peraliud furperne exiguum, quod omnino proprie dicforum rhinocerotum eft, sut uel ex pictura; quam ad uiuum factam dabimus, inferius patebit. Immerito igitur Domítium Martialis interpretem reprehendit Politianus, reprehendendus ipfe. Quanquam enim $8 \times$ alï quidam Aethiopici tauri fy I: ueftres fint, à rhinocerotibus longe diuerfi, ut iam dicemus, Paufanias tamen nequaquam de illis in tellexit:quod quidem ita manifertum fit collatis Paufanix $\&$ aliorum fcriptis, ut ne minimum quídem dubitare quifquam poffit. Aethiopia(inquit Plinius)atrociffimos habet tauros fylueftres, ma 20 iores agreftibus, uelocitate ante omnes, colore fuluos, oculis cocruleis, pilo in contrarium uerfo, $\mathrm{ri}=$ cut ad aures dehifcente, iuxta cornua mobilia, tergori duricia filicis, omne refpuens uulnus. Feras omnes urenantur. Ipfi non aliter quàm foureis capti, feritate femper(malim, fua)intereunt. (Eadem o mnia fcribitSolinus cap. 5\%. de Indicis tauris.) De hifdem A eliani uerba in hiftoria animalium Petro Gyllio interprete, hac funt:Feri tauri A ethiopici, fi cum Gracorum bobus conferantur, duplam ha bent magnitudinem, ac uelocitate corporis fummé excellunt:tum rufis pilis ueftiuntur, tum carqus oculis ornantur: $\mathcal{X}$ aliàs quemadmodum aures, fic cornua mobilia habent. At enim in pugna ita ani mi feruore contendunt \& erígunt, pugna ut nulla flecti queant: Eius enim tergora tanto robore ftrint, ut nullis neç fpiculis, neq̧ telis penetrari poffint. In equorum 8 Coum armenta \& feras om neis inuadunt, Itaç paftores ad tuendum furum pecus, occultas fouear in magnam altitudinem de $3^{\circ}$ preffas, machinantes, moliuntur eis infidias. Hi cum deciderunt, acerbe ferunt, $\mathcal{Q}$ atroci animi $\mathrm{ex}_{\mathbf{1}}=$ candefcentia fuffocantur. De eodem \& ipfe Gyllius in Corollario, fic fcribit. Ferus taurus, ficut Oppianus ait, omnium animalium maxime carnibus uefcitur, $\&$ domefticis tauris maior eft, ac cum equo in uelocitatis comparatione coniungitur. Oris rictus ad aures ufque pertinet: tum rubro colo

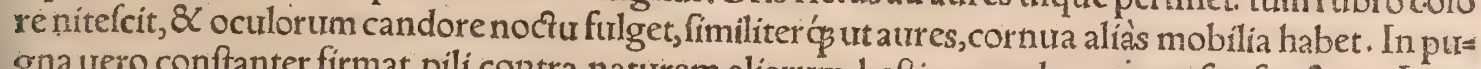
gna uero conftanter firmat, pili contra naturam aliarum beftiarum ad caput uerfus fpectant. Inui. cto robore cum alís animalibus belligeratur, qua poftquam deuicit, exedit \& conficit, egregiéćs paftorum uires \& canum multitudinem contemnit: eius pellis abictibus effe dicitur inuicta. Non uí comprehenditur, ac fi in foueam incidit, aliáue dolofa machinatione capitur, priftinæ libertatis re tinentiffimus, fibi mortem confcifcit. Troglodytæ, apud quos hurífcemodi belura nafcitur, praftan. bet, terro non concedit, $H x$ G uris, equi celeritas, tauri robur: \& quod magnam admirationem ha bet, ferro non concedit, Hxc Gyllius. Nil mirum autem fi idem taurus Troglodyticus appelletur, cum Aethiopia uicini fint Troglodyta, Quanquam $\&$ alios Troglodyticos ex Plinio fupra com= memoraui, qui propter inclinata terram uerfus cornua obliqua ceruice pafcantur. Ea quæ Gyllius fcribit, nufquam apud Oppianum reperio, quem ipfe teftem citat. Phrygios tamen boues defcribit Oppianus, qui ut Aethiopici iam defcripti tum cornua habent mobilia, auricularum inftar, tum fi.

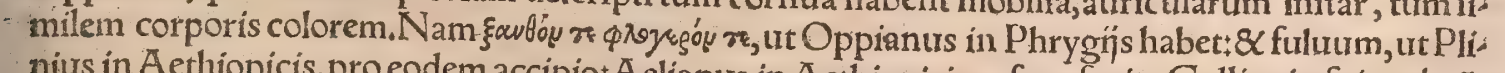
nius in Aethiopicis, pro eodem accipio + A elianus in Aethiopicis rufum facit, Gyllius in fuis rubrü. - Cornua quidem Phrygís mobilia etiam Plinius alibi tribuit, nec non Ariftoreles, A elianus Ery thrę= is: de quibus aliud nihil legiffe memini, Erythra urbs Ionum eft, alia Libyæ, alia Locridis, alia Bce= fix, $8<$ alia Cypri qux nunc Paphus, Stephanus. Phrygíns etiam prater mobilia cornua, \& altam to: rofamós ceruicem, nihil aliud attributum inuenio. Quod ad Aethiopicorum oculos, Plinius corule os effe Icribit, Aelianus glaucos, id eft cæefios, Gyllius in fuis noctu fulgentes, qua omnia facile con $=$ ciliantur, ut nihil diuerfum fit. TBoues quidam luporum inftar carniciori funt, $R$ afis: Idem Gylli us de Aethiopico, uel (ut ipfe uocat) Troglodytico fcribit:quamobrem merito ei richus ad aures uf́ que dehifcit, ut Plinius \& Gyllius teftantur:A elianus etiam omne genus animalium ab eis intradi T) Sưt \& rhizes apud Hefperios Aethiopes taurorũ generis fylueftriũ, de quib.in fine capitis de uro,

\section{DE BISONTE.}

I S O N T E M bourem effe fylueftrem conuenit omnibus, qualis uero is fit, $\&$ quo hodie no: mine appellandus, magna inter recentiores uarietas \& infcitia eft . Confundunt enim bi fontem alí cum bubalo, alí cum uro, alij cum rangifero appellato, alij deníç cum bonafo, uel tarando, uel uro. Ego quoad eius poffum haec genera diftinguam. Giscythia animas 
lia gignit pauciffima, inopia frućuum; pauca contermina illi Germania, infignia tamen boum fero. rumgenera, iubatos bifontes, excellentíq̧ \& ui \& uelecitate uros, quibus imperitum uulgus buba. lorum nomen imponit, Plinius, In his Plinị uerbis Raphaél Volaterranus $\& \mathcal{C}$ alĭ, pronomen quibus non ad uros folum referunt, fed etiam ad bifontes, quod ego non probo, \& ad uros tantum bubali nomenà uulgotum temporis translattm opinor: proinde Martialis in hoc uerfu, Illi ceffit atrox bubalus atos bifon, bubalum pro uro(ut Domitius reçé exponit)feorfim nominat. Sed idem euidentius contuincetur ex Solino, cuius hxc funt uerba cap + 23. In traftu faltus Hercynï, \& in omni Septentrionali plaga, bifontes frequentiffimi funt, boues feris fimiles, fetofi, colla iubis horridi, ulrra tauros pernicitate uigentes, capti affuefcere manu nequeunt, Sunt $\&$ uri, quos.imperitum uulgus uocat bubalos, Hæc Plinị fimia Solinus. Sed licet obtineamus uros tantum, non etiam bifontes, $\mathrm{O}=10$ lim bubalos à uulgo dicros, hodie tamen(ut fupra monui) aucta nominum confufione $\&$ inícítia re rum, bifontibus quoç bubalorum nomen apud quordam tribuitur:quemadmodum $\&$ bifontî no= men in lingua Germanica tum proprie dictis bifontibus tum uris, ut mox Alberti uerbis declarabia tur. Bifon cerui fpeciem fimilitudinemóg gerit, cuius à media fronte inter aures unum cornu in excelfitatem magis dirigitur, quàm ea qua nobis nota funt cornua, 8cc. Hac uerba Petrus Gyllius in Aclianum ftrum tranfcripfit ex libro 6. C. Iulin Cæearis de bello Gallico, nulla authoris, ut folet, mentione facta. Ego eo in loco nihil prorfus de bifonte reperio:fic enim habent exemplaria noftra, Eft (in Hercynia lylua) bos cerui figura, cuius à media fronte inter aures unum cornu exiftit excelfí us, magiş́́ direçum his, quæ nobis nota funt cornibusłab eius fummo ficut palmæ, ramićs laté diffunduntur:eadem eft fominæ maris ćp natura, eadem forma magnitudó̧́ cornuum, Hæc Cæár. 10 Hoc autem animal ego alibi docebo rangiferum hodie dictum effe. Nam quod non fit bifon, ex uete rum defcriptione, Oppiani prafertim, claret, In eodem errore uerfatum deprehendo 8 alios recentiores $\&$ Io. Pinicianum in Promptuario uerborum eius, in quo bifontem unum habere cornulferie bit ex media fronte. बA A pud Mofchourtas multifunt boues feri (aumerocb fert) quos aliqui uros, alı̈ bifontes tocitant, Olaus Magnus, Albertus magnus etiam urum cum bifonté confundere uide. turłnam libro 22. de animalibus, Vri(inquit:licet codices excurf habeant urni) quos nos Germani* cè vifentuocamus, cornua ingentia duogeftant, qux capaciffima funt, ita ut multi potum in ea in: fundant, $\&$ referuent etiam in eis, Idem alibibubalos fylueftres magnos vifent apud Germanos tro cari meminit. Vrfontes etiam apud eundem in $\mathrm{v}$ litera, ubi quadrupedes literarum ordine enume= rantur, corruptelegitur pro uifontes(uel utrecentiores quidam fcribũt, uefontes) $\&$ id rurfus probi fontes. Animal (inquit)eft toui fimile, collo fetofo $\&$ iubis ut equus, fed pernicius $\&$ truculentius, ut captum domari uix uel nunquam poffit: Hac cum ex Solino tranfcripfiffe apparet. Cæaterum libro ap. Intreniuntur (inquit)in genere boum nigri, magni, qui à quibufdam uocantur bubali, $8 \mathrm{a}_{2}$ pud Germanos voefent (fic enim illic fcribitur, melius Difent ut alibi habet) hi perquam robufi funt, adeò ut irritati equưm fimul \& equitem cornibus uentilent, magnitudine rquant magnum de xtrarium (fic egregium \& infignem equum Itali uocant) \& facies illorum boum (utor ipfius uerbis quan đ̈̈ barbaris, quoniam obfcuriora hoc in loco tidêtur) aliquantulum declinat inferius : ita quod habent eminentian fuper mediam lineam defcendentem inter oculos : \& declinatio artus illius eft uerfus os, \& uerfus frontem declinatio alia, \& eleuatio in medio, Cornua eis maxima $\&$ ad dorfum recurua, ut facilius cum eis eleuare $\&$ uentilare feu rejpcere poffint quod inuaferint . Plura corum 4 genera funt:quibufdam alta $\&$. longa cornua:alijs breuia, craffa \& robufta. Nota hae genera funt Sclauis \& V ngaris, \& finitimis Germanis. Ex his Alberti uerbis manifeftum eft vifent diuerfa fyl= ucfrium boum genera appellari, ex quibus ego minores bifontes dixerim, quod uocis etiam cogna tio declarat: maicres uero uros. Bonafi enim effe non poffunt, quibus cornua ad pugnam inutilia funt. Bifontes \& alces apudMorchos reperiuntur, Matthaus Michauanus in defcriptione Sarmatiarum. In Bruffia etiam bifontes funt, fed non admodum multi noftro faculo, tauris omnino adfia miles, \& iubas habentes proximé cornua, Erafmus Stella in libro de origine Brufforü. Angermana nix ducatus tenet feptentrionalia loca ad confinia Laponix; eius tracius eft totus fyluoftus, $8 \mathrm{ibi}$ in pracipuis feris uenantur uros $\&$ bifontes, quos patria lingua dicunt elg, id eft afinos fylueftres, tante proceritatis ut fummo dorfo æequent menfuram hominis porrecti in brachia elata, Sed hac altitudo , uris conuenit, non proprie dictis bifontibus, qui minores funt.

- Bifontes fiue bifones, Grace Bíwaves apud Paufaniam \& Oppianum, quanquam excufi codi: ces Oppiani Biswris habent, quod uel carminis ratione reprehenditur : manufcripti quidam Bíwras, fed omnino legeridum eft Bi iَwras nomen habẽt à Thracia, qua alio nomine Biftonia uocatur, unde \& Biftoniam gruem poetæ cognominant. Sunt enim Biftones Thraciæ populiàBiftone Ciconis filio dicti, Philoftephano tefte, Varinus . Eft $\mathcal{Q}$ bisovis $\lambda$ í $\mu v x$, id eft Biftonius lacus Dicęæ proximus in Thracia, Herodotus lib.7. Biftonia cithara, à Biftone filio Terpfichores, (fic enim legendũ, cum Ter pfichoræ Mufe cithara attribuatur) V arinus.Scribendum eft autem per omicron. Ouidius, Feffaćs Biftonia membra lauabis aqua Et alibi, Tuta tamen bello Biftonis ora fuit, Sunt qui uelint \& $\mathrm{ftag}$ num $\&$ prouinciam à Biftone rege nomen accepiffe, tride Stephanum. In Biftonio iuxta Abderam ftagno cuncta natantia demergilegimus. Turpes effeda quòd trahunt bifontes, Martialis libro 1. Tibi dant uariæ pectora tigres, Tibi uillofi terga bifontes, Latisḉs feri cornibus uri, Seneca in Hippolyto, Etrurfus in eadem tragoedia, Amat infani Bellua ponti, luciọ́ boues Vendicat $0=$ 


\section{DeBifonte. Lib.I. 145}

mnes natura fibi. Hic lureos boures quidam exponunt fylueftres; ut funt uri \& bifontes: ego potius elephantos intellexerim, quos in forminino genere boues lucas appellare ufitatius eft. TDe bifon re Oppianialiquot uerfus ex libro 2, de Venatione, hîc recitabimus, tưm quia perelegantes illifunt; tum ut ftudiofi eos cum Petri Gyllí translatione conferre poffinc,

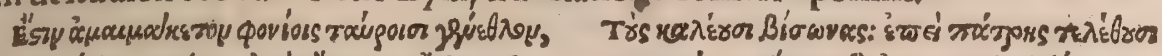

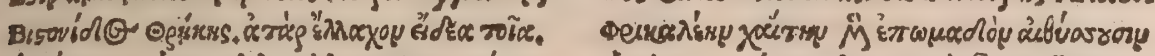

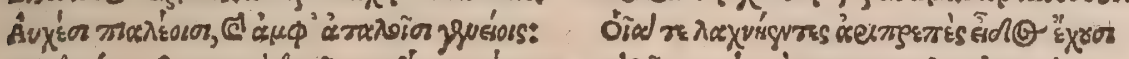

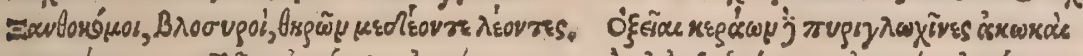

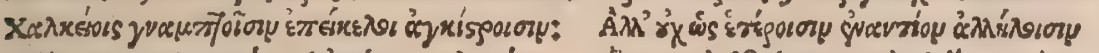

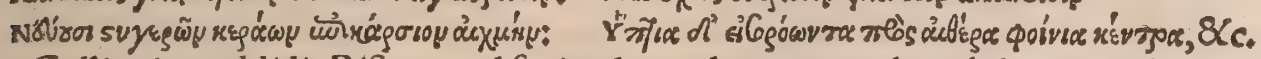

Hxc Gyllius ita reddidit, Biftones ad faciendas cædes prompti, horribiliceruice $\&$ pingui, rubro p lo, \& oculis terribilibus; cornuum mucronibus aduncis, \& hamatis, non inter fe reflexis, fed furfum uerfus furgentibus. Eos cum impegerunt uel in hominem uel feram, in fublime tollunt. Eorum lin. gua quidem angufta, fed afperrima, tanquam ferrum limare potef, ut cum lingit, fanguinem eliciat; Hxc qui cum Gracis conferet, facile deprehendet, primurm omiffa poëtx uerba, quibus bifontem iubam circa armos terribilem in craffa ceruice quatere aí, nec nó circa maxillas aut mentum, ut ita urocem, ut barbatus uideatur: Deinde ubi iubatis fiue hirfutis, \& fuluris, \& terribili afpectu leonibus bifontem comparat, hoc totum à Gyllio in bifontem congeri nulla interim leonis mentione: cũ poéta

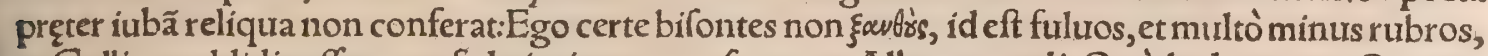
20 ut Gyllius reddidit, effe puto, fed nigricantes:ut fupra exAlberto,retuli, Quòd ad cornua, Oppiani uerborum fenfus hic mihi uidetur, ea non effe patula, uel extenfa, ut in cæeteris bobus, nec éregione in diuerfum ad latera abire uel extendi, (epicarfion enim tranfuerfum eft; ) fed rectà furgere, ita ta. men ut vै 7 be fint, id eft dorfum uerfus inclinent: $\&$ circa finem hami inftar turm recurua tum acuta effe: unde $\&$ rǵrspe uocat ab acumine. Talis cornuum fpecies, ut parua magnis conferam, in capreis noftris alpinis apparet, Gyllï uerba, non inter fe reflexis, nullam in Græcis rationem habent, Quod autem ad dorfum recurua bifontum cornua fint, ex. Alberti etiam uerbis paulò ante recitatis cốt tat.

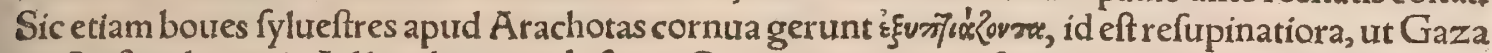
ex Ariftotele uertit. Ad hæc linguam bifontis Oppianus propter afperitatem linæ confert, non autë inftar ferri limare poffe dicit:ne quis forte intelligat, eam limarum quocs ufum praftare. Ego me ante paucos annos bifontis cornu uidere memini, quod aurifaber quidam habebat, ut labra argento includeret ad ufum poculi:nigredine fplendebat, duos dodrantes longum, aduncum inftar unguriô in rapacium auium genere, unde imperiti quidam gryphis pedem effeconíciebất:capiebat uini plus quàm duas libras. TReliquum eft, ut quo uenationis modo bifontes capiantur ex Paufania pera frribamus. Is igitur in Phocicis ita fcribit:Bifonis tauri Pxonici caput ex ære factum Dropion ( $\Delta \rho \circ=$

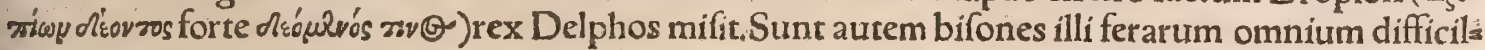
limi captu,nec ulla ui retium detineri poffent. Locum igitur decliuem ac deuexum fepimentis pri, mum uenatores circunclaudunt, deinde totam decliuitatem, $\mathbb{X}$ id quod ad primum eius ingrefum planiciem attingit pellibus recentibus detractis confternunt:ac firecentibus carent, ficca coria ut lit brica efficiantur, oleo madefaciunt:Pôft uero qui maxime equitandi periti funt, eiufmodi tauros in . loci illius anguftias undique compellunt:Ii autem ad primas pelles delabuntur, ato̧ per acclítitatem urfęs eò præcipites agunturr, quoad in planiciem delati fuerint: quo abiecti primó non curantưr:Dein de quarto aut quinto ad fummum poft die, cum iam fames $\&$ labor eorum pracipuum animi robur fregerit, homines qui ad manfuefaciendas beluas praftant, „̋̈s adhuc humi ftratis, pineos nucleos de. tractis inuolucris, nę̧ enim alium cibum ab initio admitterent, edendos obíciunt, ac denį́ uincu lis cóftrictos abducũ t, Hucufç̧ Paufanias, ut Petrus Gyl, ferécóuertit, Raphael Vola. li.7.eodẽ pla=

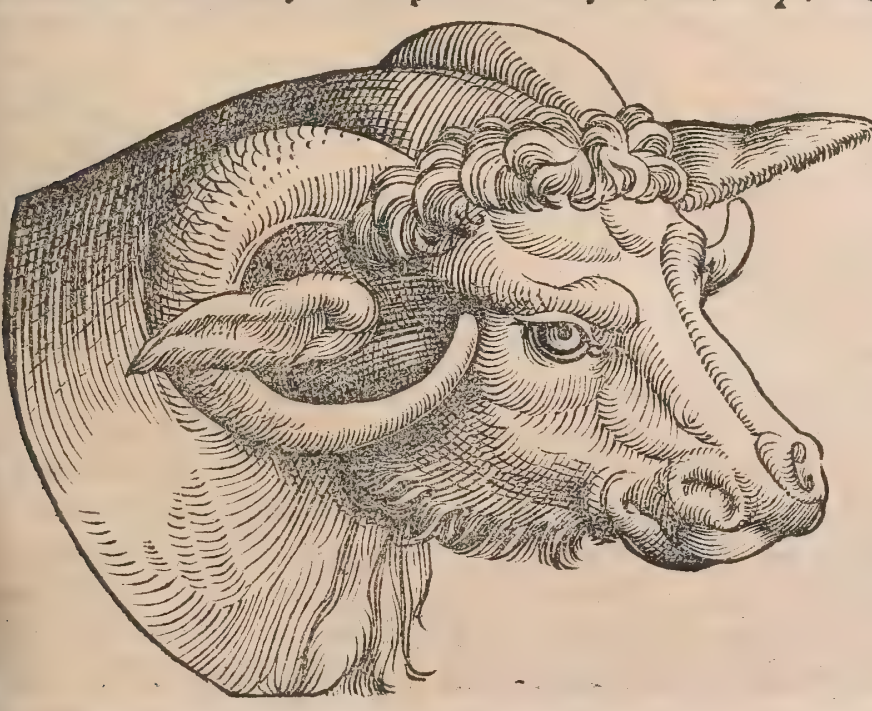
némodobonafos à Lituanis capi for bit, TVros \& bifontes Gręci in ex: perimentis non habuerũt, quanquä boue fero refertis Indię fyluis:portio ne tamen eadem, efficaciora omnia ( quã ex domefticis uel gregarĭs bu buis)ex his credi par eft, uridelicet q̊d ad medendi uim, Plin. Fortafís etiå thuro Polonorum, quem mox in $\mathrm{Ta}$ rando defcribam, bifontis genus eft:

DE BONASO.

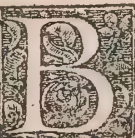

O N A S V S, Bóvarearo Arr ftoteli, per $n$. fimplex $\& \mathrm{f}$. duplex, alibi uero contra pernduplex, et f, fimplex, 
bos eft fylueftris, monops, uel monapios alio nomine dictus: de quo primum ueterf fripta recenfe bo, deinde recentiorum, A Ariftoteles de hiftoria animalium libro, cap. 45. Bonafus(inquit) gig. nitur in terra Pæonia, monte Meffapo, qui Pæoniæ, \& Mediç terræ collimitium eft, \& monapios ( $\mu \sigma_{\text {m }}$

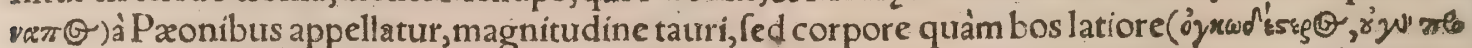

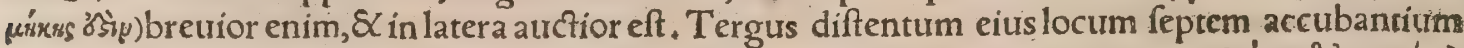

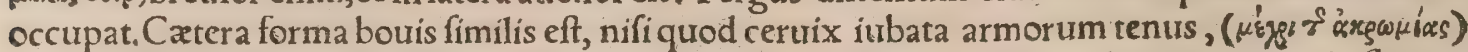
ut equi eft, fed uillo molliore, quàm iuba equina, $\&$ compofitiore: color pili totius corporis flauus:

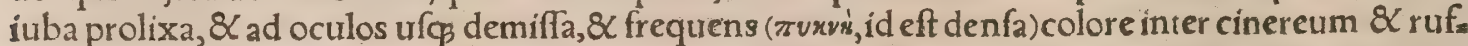
fum:non qualis equorum, quos partos uocant, eft, fed uillo iupra fquallidiore, fubter lanario, nigri aut admodum ruffi nulli funt:uocem fimilem boui emittunt:cornua adunca in fe flexa, 8 pugnæ in : utilia gerunt,magnitudine palmari, aut paulò maiora, amplitudine non multo arcitore, quàm ut fin-

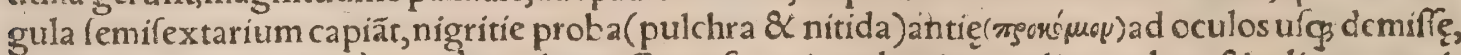
ita ut in latus potius quàm ante pendeant. Caret fuperiore dentium ordine, ut bos, \& reliqua corni. gera omnia:crura hirfuta, a tç bifulca habet:caudam minorem quàm pro fui corporis magnitudine, fimalem bubula: excitat puluerem, \& fodir, ut raurus:tergore contra ictus praualido eft. Carnem ha bet guftu fuauern: quamobrem in ufu uenädi eft. Cum percuffus eft fugit:nifi defatigatus nuffuam

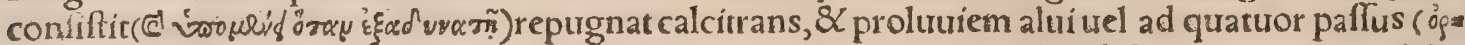
zurás) proijciens: quo prafidio facile utitur, \& plerunç̧ ita adurit, ur pili infectantium canum abfus mantur; fed runc ea uis eft in fimo, cum bellua excitatur, et metuit:nam fi quiefcit, nihil urere poteft:

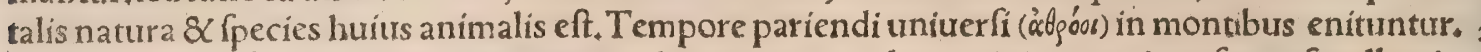
Sed priufquam foctum $x$ dant, excremento alui círciter cum locum in quo pariant, fe quafi uallo cir cundant $\&$ munitunt: largam enim quandam eius excrementi copiam hac bellua egerit, Hacienus Ariftoteles. Defcribit autem rurfur hoc animal n̈ldem ferè uerbis ab initio libri Mirabilium narratio num:cgo qua conferendo utu obiģ differre obferuaui, paucis notabo: In libro Mirab, narrat, ipfa fe ra non magnitudine tauri, fed boue maior $\&$ robuftior defcribitur : pro bonafo, legitur bolin thus:

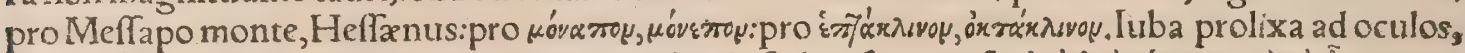

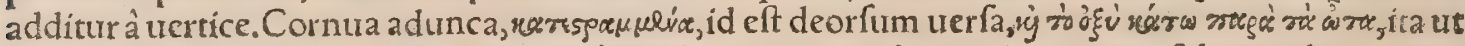
mucro inferne iuxta aures fit:contra quàm in hoc poétæ uerfu, patulæcamuris fub cornibus aures,

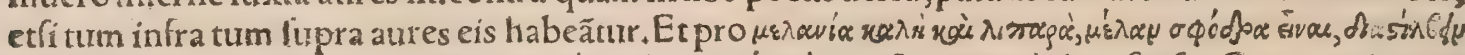

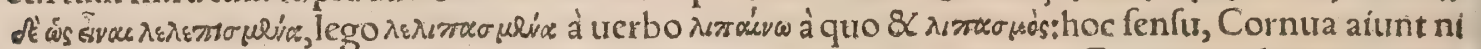
gro colore adcò faturata effe, ut tanquam peruncta fplendeant. Qtrod ad Gazæ translationē, miror

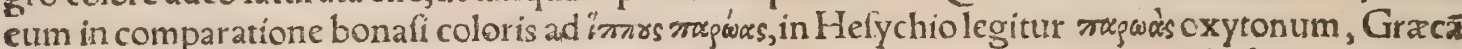
urocem reliquife(quamtis partos in uer fione corrupte legitur pro paroos)cum aliki femper, etiamfi

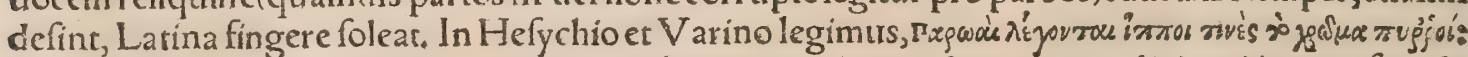
id eft, paroi dicuntur quidam equi colore rufi. Mihi animus inclinat paroos dici qui inter rufum $\&$ cincreum colure frnt equi, ut ż\negatio abundet:fic cnim multo cómodius cohærebit fenfus, hoc pa cto:Iuba bonafi inter cir ereum \& rufum colore eft, qui in parois diefis equis confpicitur: hoc tamen intereft, qurod fqualidior bonafis pilus eft iubx (Gaza recte addit fupra, id eft foris) infra uero, id eft intus, lanæ inftar mollis. Vetus translatio pro ré

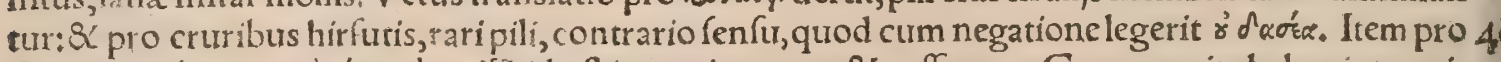

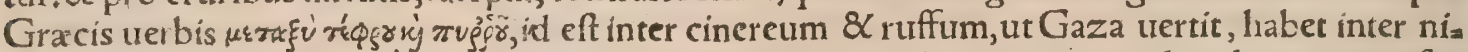
grum \& rufum:quod ferre probari poteft propter fequentia, ubi nę̧ nigros admodum neç rufos inueniri bonáos Ariftot. frribit:quafi cofdem colores femper in eis mifceri innuat. đIam quod

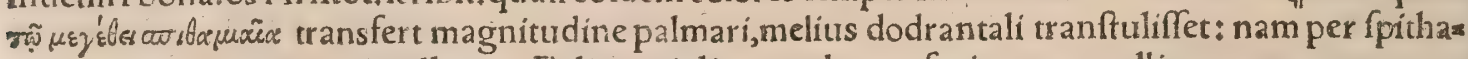
men eruditi dodrantem in telligunt. Et licet triplicem palmum faciant nonnulli, paruum, quatuor

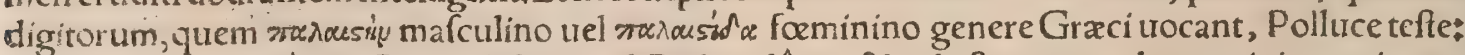
maiorem, quin q̧, dôron Græce dictum, etfi Pollux dôron \& palæften procodem accipit:maximum of?o digitorum: dodrans tamen tres minores $\&$ proprie dictos palmos continet, id eft digitos duode cim. Polluci fpithame extenfio eft à pollice ad minimi digiti finem, lichàs uero ad finem lichani, id eft indicis, Quamobrem partim uirandx gratia homonymiæ, præftiterit fpithamiæon reddere dodran $=50$ tale:partim ut proprie loquamur:nam produodecim digitorum menfura palmi nomen rariffimum eft, pro quatuor ufitatifímũ. Porrò dubitatuerit aliquis quo nã modo cornua magnitudine dodran talia fint, \&ad quã dimenfionẽ menfura ea pertineat, longitudiném ne an circumferentiã, an círcũfe rentix diametrum:quod fi quis capacitatem confideret quax dimidiati congí eft, omnino ad inræ cir cumferentix diametrum, qua cauitas orbicularis maximé patet, dodrantis menfuram pertinere intel liget. Neçenim alịs duobus modis bonafi communes botres excedunt:cum illis plerunq tum lon = giora dodrante tum ambitu ctiam ampliora cornua fint, diametro autem ima circumferentix do: drantali nunquam. TCaterum in eadem cornuum capacitate pro Graca uoce ñ dium congị fignificat, Gaza imperífiffime femifextarium uertit: cum chûs, id eft congius fextarium

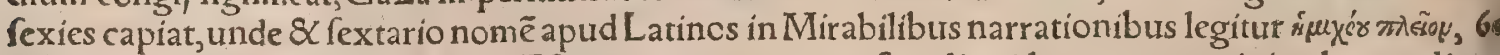
id eft plus quàm dimidium congị. Eft autem congius menfura liquidorum, qux uini uel aqux li:

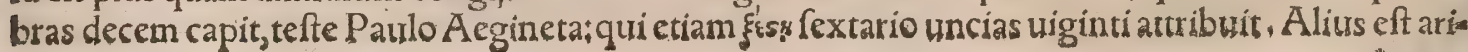




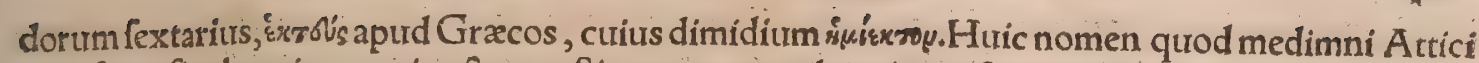
pars fexta fitchoenices capit octo: conftituunt autem chœenices octo modium Aegyptium uel Itall cum. Chonix xeftas(id eft fextarios liquidorum)duas capit.Quod fi quis de illo intelligat, femife xtarius choenices quatuor capiet, id eft fextarios liquidorum octo, quí uini uel aquę libras tredecim $\mathbb{Q}$ uncias quatuor caperent. Ita femifextarius aridorum ad femicongium liquidorum, duplus erit \& fupertripartiens quintas, ut uncias quatuor omittam. Sed chûs liquidorum eft menfura, $\&$ A Ari ftotelem de liquídis intellexiffe uerifimilius eft, quoniam cornibus huiufmodi pro poculis uteban= tur. Sed forte Gazam defenderit aliquis D. Hieronymi authoritate, qui commentariorum in Eze. chielem libro i, choả Atticum, fextarium Italicum effe fcribit. At hoc authorum alius nemo fcribit, ut omnino memoria uel rei infcitia lapfum Hieronymum aut librarium potius credam : qua de read uerfus Alciatum Hieronymo patrocinantem, Georgius Agricola libro 2, de ponderibus $\&$ menfu, ris doctiffime differit:ubi Plinium etiam erroris inculat; qui in uini nectaritis apparatu ubi Diofcori des choas, id eft congios fex habet, ipfe fiuc ex Diofcoride fiue alio Graco authore transferens, toti. dem fextarios reddit; quod ítidem uel ipfius uel librariorum negligentia factum conftat, cum alibi femper pro Græcorum fextario congium reponat, Sed Gazam fortaffis offendebat nimia capaci tas; fi dimidium congị reddidiffet. A tqui alia legimus longe capaciora cornua, qualia Pliníus uro= rum effe fribit, ex quibus barbari feptentrionales potant, urnaş́́ binas capitis unius cornua im. plent. Amphora duas capit urnas; urna congios quatuor, Volufio tefte, \& approbante Ge. Agrico 1a. Vnum igitur uribouis cornu congios quatuor capere poterat. A elianus Ptolemæo fecundo ex 20 India cornu allatum fribit, quod tres amphoras caperet, ut Aelianus tradit. Tres amphoræ congi= os uigintiquaturor efficiunt.

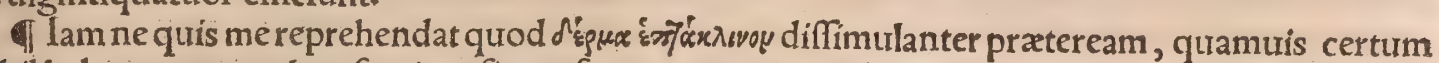
nihil habeo quantum hoc fpatium fit,proferam tamen in medium coniecturas meas, \& aliquot au

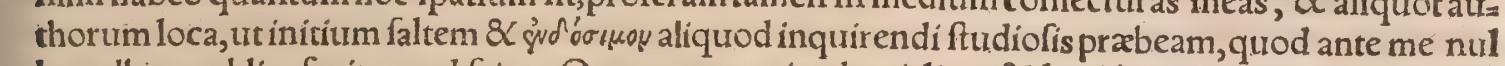
lus adhic publice fecit, quod fciam. Quanquam enim de triclinio $8<$ fimilibus uocabulis, \& tricliní forma; \& ueterum accumbendi more, primus (ut profitetur) Gulielmus Philander in Annotationj= bus fitis in librum fextum Vitruuhin diligêter quafiuerit:de fpatio tamen quod uel triclinon uel pen taclinó uel alịs hưiúmodi uocabulis dictum à ueteribus fit, quantum illud fuerit magnitudine, nul lus adhuc ne inquifiuit quidem,Quòd autem ueteres certam menfuram hifce uocabulis defignaue. rint, non minus quàm fi cubitos \& pedes nominafient, apparet, ex iam cítato Ariftotelis loco ubi

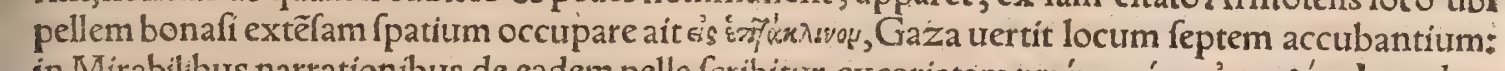

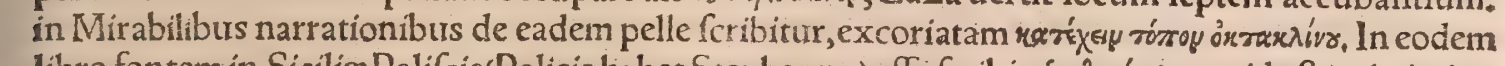

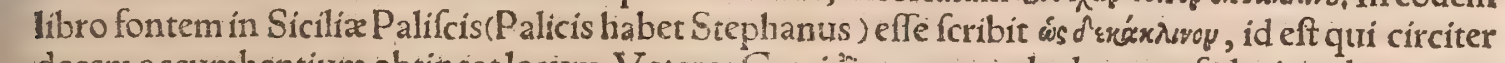
decem accumbentium obtineat locim. Veteres Grecci ốnoy non modo domum, fed etiam domus par res coenacula, uel coenationes (quanquam difingui hare fcio) \& cubicula uocabant; Hinc Pollix lib.

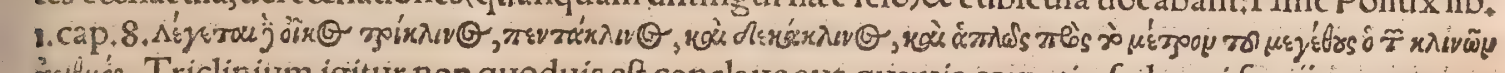
acbibus. Triclinium igitur non quoduis eft conclaue aut quaruis coenatio, fed certi f patij tantum: po fteriores tamen hoc uerbo abufi funt non ad quafuis modo conationes, fed etiam æedificia quando= que. Seruius Aeneidos 1, fribit antiquos ftratis tribus lectis epulari folitos:erraré́ł eos qui tricli. 10 nium dicunt ipfam bafilicam aut conationem:quam eius fententiam de triclinij fignificatione Gu. lielmus Philander non approbat, cum Vitruúj co ipfo in loco, quem illic exponit lib, 6.cap.5. uerba hæc fint, Tricliniorum quanta latitudo fuerit, bis tanta longitado fieri debebit: Altitudines omnium conclauiorum qux oblonga fuerint, \& $<$, \& paulo poft, Sin exedra aut œci quadrati fuerint, \&cat, Quibus quidem uerbis ut triclinium, conclauium, exedram $\& \propto$ œcon, fynonyma facerealicui parum animaduertenti uideri poteft: nam ósøy zoírxıvop ex Polluce iam diximus: De exedra uero apud eun

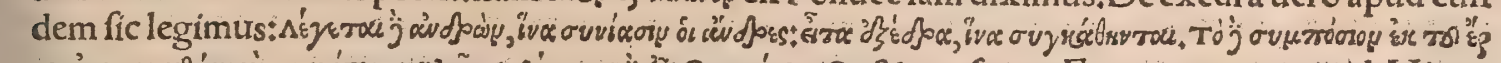

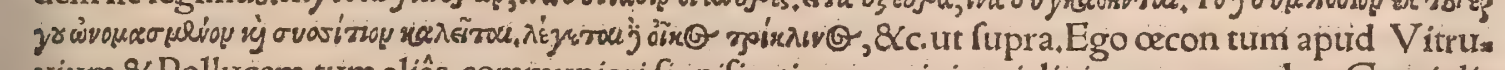
uium $\&$ Pollucem, tum aliâs, communiori fignificatione accipio:triclinium uero, uel ut Graci di= cunt zoír 10 tribus lectis, uel uno qui tres capiat, Vitruuius eodem in libro mox capite fexto, Fiunt autem (in quit)etiam non Italica confuetudinis œci, quos Græci Cyzicenos appellant, \&c, ita longi \& lati, uti duo tríclinia cum circuitionibus inter fe fpectantia poffint effe collocata, habeantós dextra \& fini ftra lumina feneftrarũ ualuata. Hunc Cyzicenũ œcó, quoniã duo triclinia capit, hexaclinon aliquis forte nominandum fufpicetur, \& fic recentiores nonnulili exponunt:mihi fecus uidetur, nam in hes xaclino fpatio menfam unam collocari affero, qua fex conuiuas cum furis lectis $\&$ circuitione recipi at:at œcus Cyzicenus duo triclinia inuicem fpectantia habet, utramq̧ cum futa circuitione. At iuxta unam menfam lectos duros triclinos ponere contiguos, aur hexaclinon unum, idem furerit, Triclinia hyberna, aftiua, \& autumnalia ad quam quxç coli regionem fpectare debeant, idem mox ibidem cap. 7. præf cribit, Pinacothecæ (rurfur cap. 5.) uti exedręamplis magnitudinibus funt conftituendę: - Oeci Corinthị tetraftylió̧, quió̧, A egyprój uocantur, longitudinis \& latítudinis, uti fupra triclinio= rum fymmetrix fcriptæ funt(id eft ut longitudo ad latitudinem dupla fit ) ita habeant rationem : fed propter columnarum interpofitiones, fpatiofiores conftituantur, Et paulo poif, in ocis Aegyptijs 
fupra columnarum epiftylia \& ornamenta, lacuriarịs ornantur, \& inter columnas fuperiotes fene ftræ collocantur, ita bafilicarum ea fimilitudo, non Corinthiorum tricliniorum uidetur effe. Hîc cri. clinia uocat, quæ pattlo ante occos Corinthios, Ec inferius ca. 10. ubi de Græcis ædificïjs loquitur, Cir cum a utem in porticibus, triclinia quotidiana, cubicula etiam $\&$ cella familiaricæ conftituuntur. . Et paulo poft: Græcorum domus habent triclinia Cyzicena, qux ad feptentrionem fpertant; ad meridi em uerò fectantes cecos quadratos tam ampla magnituéine, uti faciliter in eis, triclinìs quatuor ftratis, miniftrationum ludor umáç oper is, locus poffic elfe fpatiofus. In his œcis fiunt uirilia cöuiuias Non enim fucratinftitutum matres familiarum corum meribus accumbere. Hæc ferè nec plura a. pud Vitruuium de triclinịs reperio. Valer.Max.er Quintil, quod Cicerolib.2, de Orato, de Scopa loquens conclaue dixerat, triclinium interpretãtur. Veteres pranfuri aut coenaturi(ınquit Gul. Phi is lander)\{olebant lectos nonnunquam tres fternere accubitorios, dituerfos frilicet ab eis in quibus dor mirent:(Nam Heliogabalum tradit Lampridius folido argento habuiffe lectos triclinares $\&$ cubicu lares)unde uocatum triclinium : aliquando duos, inde Platutus quarto actu Bacchidum, biclinium

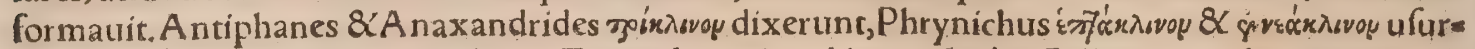

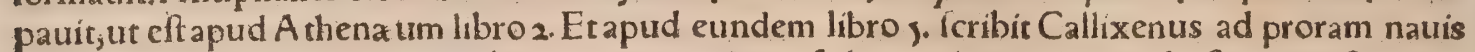

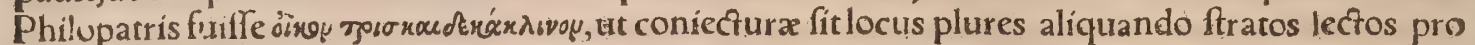
conuituarum numero: Nam in Platonis fympofio conuiux uiginticelebrantur. Confueutfie autem in lectis ueteres difcumbere $\&$ accumbere, uel ipfa nomina indicant, \& authorum alıquor teftum: nijs Philander comprobat. Sxpe tribus lectis uideas cœnare quaternos, Horatius, quem locum fic in terpretantur aliqui, ut conuiuatoris auaritia notetur, qui tribus lectis uoluerit conare duodecim, 2 potius quàm quartum lecium $\&$ menfam fternere, ceu non amplior effe deberet lectus quàm qui tres caperet nifi angufè. Ar mihi uidetur potuiffe quartus lectus addi, ut noua menfa non opus ef= ret, nifi alter a foret breuior. Lectis accumbere Germani etiam folitifunt, fed mos ille paulatim fol. uitur:funt autem illi fex feré pedum longitudine, ut finguli tres conuiuas capiant:quanquam fingư I tantum huiufmodilecti in lingulis zetis uel hypocauftis, ut uorant, noftr is habeantur. Sedilibus tamen, qux uel ftragulis uel etiam puluinis aut lectis fternantur, circa menfas, quas fer è quadratas aut rotun das habemus, pluribus aliqui utuntur:Eorum nonnulla fic fabric ata funt, ut afferes à dor fo modice inclinati accumbentes ac innitentes recipiant: Quidam fell is quoqs profundioribus inftra tisćs cum a naclintro, id cft parte quæ dorfi reclinationem excipiat, accumbunt magis quàm affident

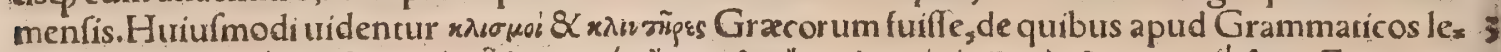

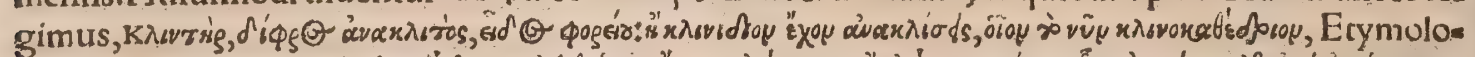

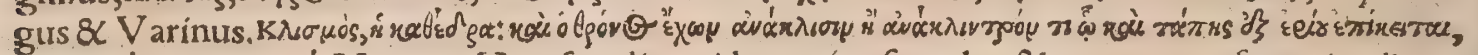

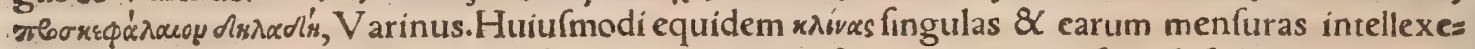
rim, à quibus zoir $\lambda$ เvoy $\&$ aliæ uoces formantur, ita ut in fingulis conuiuæ finguli federent, non au. tem quales aut quanti Romanis lecti quidam fuerunt, in quibus tres aut quattior difcumbebant, quit non clinæ fimpliciter, fed clinæ triclini uel tetraclini funt. Verifimile eft autem huiufmodi accubito rias fellas non ultra duos cum dimidio pedes latitudinem extendiffe, ne menfæ fpatia uacarent, cum amplitudo ifta difcumbenti fuficiat, lam fi fellas feptem ordine ponas deinceps contiguas, longitu= dinem omnes efficient pedum xvus.cum dimidio. Hxc quec; bonafi pellis longitudo uideri pote. rit, neç id mirum cum uri multò longiores defcribantur à noftris. A t A riftoteles quamuis pellcm

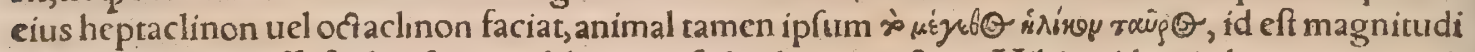
ne tauro xquale effe fcribit, 2 non oblongum fed in latera aucfum. Mihi quidem in hoc erratum uidetur: nam in Mirobilibus idem animal multò maius fimul $\&$ robuftius boure facit : deinde freri po: teft, ut caudx quocs longitudo fuperiori menfuræ adiêgen da fit. Heptaclinos igitur bonafi longitu. do non breuior erit pedibusfeptendecim;quæ uero latitudo fit, ex proportione longitudinis ad lati. tudinem in communium boum pellibus deprehendetur. Ego certe eandem omnium iftorum fpas tiorum, quà cline nomen habent, latitudinem fuiffe perfuadeor, \& longitudine folum differre: quod menfis oblongis uterentur, non ut noftri frequentius quadratis rotundisue, quod ex Vitruuï etiam uerbis patere poteft, qui triclinia propriè fic dicta longiora duplo quàm latiora effe uult. Cre. diderim infuper ab uno tantum latere menlæe ftratos fuiffe lectos, non utrinç̨ nec é regione. lubet é nim Vitruuius triclinia duo in ๔eco Cyziceno fe inuícem fpectare, ubi per triclinia côuiuas accum bentes fynecdochice accipio, uel lectos conuiuis paratos: quos ab utraç parteftratos, non reciefe fpectare, id eft è regione effe dicercs Commodius etiam erat miniftris mêf $x$ inferuire, ab alterolatere uacuo:adhæc commodius auferre menfam. Toties enim menfas quoties fercula $\&$ obfonia nuturi, 8 onuftas à duobus ferri, contriusć́s accubãtibus apponi folitum fuiffe, ex Alexi poeta apud A the næum libro 9. \& Plutarcho in uita F elopidæ coniecimus, inquit Philander. Pofterno fi Graci fuas clinas utrinc habuiffent, pari femper numero fpatium inde denominatum proferre debuiffent, ut di clinon, tetraclinon, hexaclinon: Nunc quoniam etiam impari numero triclinon, pertaclinon, \&c. di cunt, ab altero tantum men $x$ latere lectulos ordine pofitos conjicio, Suetonius in Augufto, Neç conauit unà, nifi ut in imo leço affiderent. Et poft, Incerto cafu fpem mercantium uel trufir ari uel explere folebat, ita ut per fingulos lectos licitatio fieret. Valerius lib. 2. Foeminx cum ur is cubantibus fedentes conitabãt.Romæ uidimus, inquit Philander, in æo de D. Euftathï, \& alins locis, Mutine 


\section{DeBonafo. Lib. I.}

etiam, fcalptum iti inarmoribus fingulis iacentem in lecto hominem fubiecto puluillo cubito; appoff tà à lectum tripede menfa, aliquando monopodio:Hanc deinde rem(id eft accumbendi apud uete res ritum)duabus picturis appolitis declarat. Soleas etiam(inquit)demere folitos effe, pultuinis $\phi_{B}$ inniti coenantes, prater marmora, multis Martialis \& aliorum locis probari poteft. Plures tribus aliz q trando in lecto accubitorio iacuiffe, indicat Martialis Epigram, lib, in Mamurram: Et teftudine. um menfus quater hexaclinon, Ingemirit citro non fatis effe fuo, Querebatur Mamurra quod le. ctus quem comparare urelle uíderi optabat, minus quadraret, cum fex tantum caperet, ipfius autem menfa amplior effet atç̧ capacior, Ex recentioribus quidã in Lexico Gręcolatino clinen menfam in terpretatur: quod fine authore puto fecit, Calius R hod. Antiquarum lect, 27.25. Obferuatum eft (in

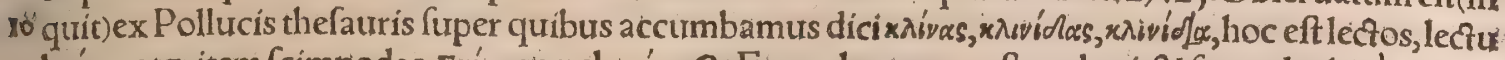

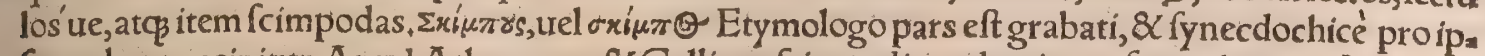
fo grabato accipitur. A pud A thenæum \& Gellium f́impodium deminuta forma legitur. Libanius in libro de fua ipfius uita, Quum domi (inquit)fum, iaceo in lecto tubi uero in fchola, in fcimpode, id eft in lectica, ut Càlius interpretandum putat; qui \& hoc à Gracis annotatum fcribit ; fcimpodion fi

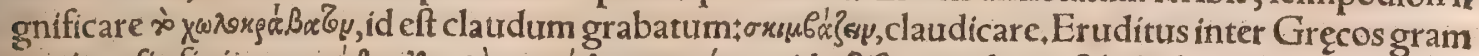

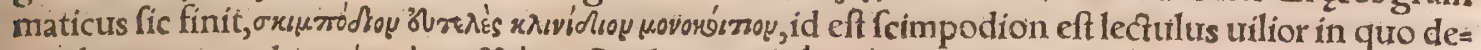

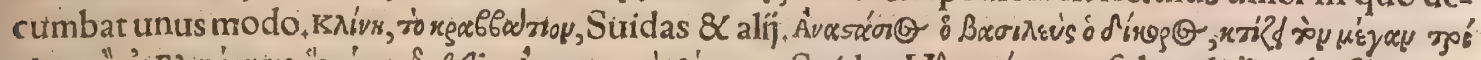

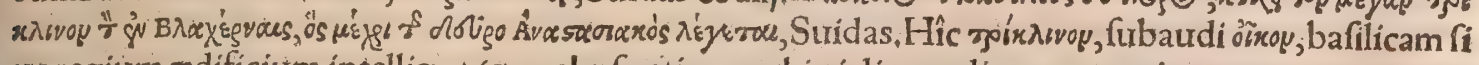
ue regium adificium intelligo : (quo abufu etiam architriclinum dixerunt, qui quantosung conui. so vio praeffer) nam cum proprie dicta triclinia diuites folum conftruerent, ut mihi uidetur, in quibus epulabantur, integras diuitum domos poftea per fynecdochen aliqui inepté triclinia uocauerunt, à parte totunitcontrà factum apparet in bafilica nomine, qux cum palatium aut integram domum, ut oiniay fubaudias, regiam aut regix fimilem proprie fignificet:aliqui ad partem domus tranftulerunt (ut ex Seruin fupra citatis uerbis aparet)fplendidiorem filicet, qualem pleriç hodie in diuerfis lin guis recepto uocabulo fallam appellant, fiue corrupto a bafilica nomine: fitue a falutatione. Eft enim bafilica, ut Sipontinus fribit, locus amplus, ubi à divitibus expectantur falutatores, \& conuiuia fi unt maxima, \& faltationes, \& ludi, Pofteriores æedem facram priuatim bafilicam nominarint. Ex noftris grammatici quidam triclinium interpretantur menfam quadratam, ad cuius tria latera fingu li fternantur lecti, quartum utero uacuum relinquatur: quod fi tale triclinium eft, quid heptaclinon - 2 enneaclinon efle dicent? menfas nimirum octo urel decem laterum, in quibus uacurum relinqua= tur unum, Scio Seruium, ut fupra citaui, antiquos ftratis tribus lectis epulari folitos fcribere : quod ut nulla authoritate munit, fic mihi ridiculum uidetur : nam pro conuiuarum numero uel tres uel plures fternebant: 8 locus ipfe, quamuis nullos haberet lectos aut menfas, pro magnitudinis tamen ratione triclinos aut tetraclinos, \&c, dicebatur:funt enim hęc nomina adiectiua, \& menfuræ, ac fi pe dalem aut cubitalem dicas. Proinde etiam menfam triclinon dicere licebit, non ipfam menfam, fed thagnitudinem eius fignificantes. Item lectum triclinon, uel tetraclinon, qui tantus fit ut tres uel qua tuor conuiuas capiat, Subftantiue uero ipfum loctm triclinium Latini dixiffe uidentur, in quo tres huiufmodi clinæ commodè ponerentur, ab uno fcilicet latere tantum. Recté igitur $\&$ leçum unum triclinon appellabimus, in quo tres difcum bant:locum trero aut fpatium triclinon, fiure qued unum

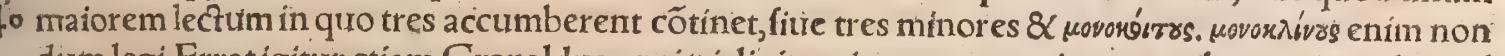
dum legi.Erratigitur etiam Grapaldus, qui triclinium interpretaturi in quio tribus toris, uel quod magis ridiculum eft, totidem menfis ftratis comedebant. Plautus in Bacchidibus, In biclíniocum amica fua uterçaccubitum eatís, Ita negotium eft; atç ibi in lectis ftratis potetis cito: Qui locum Ipfum biclinium hic accipere uolet, permittam+ego(ut Philander quoçs)leĉum in quo bini difcums berent intelligere malo:ut etiam in Heliogabali triclinís, quæ apud Lampridium uerfatilia fuiffe le gimus: in quibus (inquit) quandog amicos furos ponere confueuit, $\cos \oint_{\beta}$ uiolis $\&$ floribus obrutos opprimere, fic ut aliqui animam efflauerint, Cicéro ad Atti.lib, 13 . Villa ita completa militibuis eft, ut uix triclinitum, ubi coenaturus ipfe Cafar effet, uacaret. Plura apud Ciceronem loca, in quibus tricli nị̂ meminit, in Nizolï indice reperies. Lectos mulierum fcimus iam pridem totos operíri argen. to, 8 triclinia quædam, quiburs argentum addidiffe primus traditur Caruilius Pollio eques Roma. nus, non ut operiret, aut Deliaca fpecie faceret, fed Punica $I$ Idem $\&$ aureos fecit, Plin.33. 11 . Et paulo poft, Corneliưs Nepos tradit ante Syllæ uictoriam duo tantum triclinia Romæ fuifie argentea. Hîc ipre Plinitus triclinia lectos interpretatur:nam conationes totas argenteas furffe quis credat Item it bro 34 cap.2. Tricliniorum pedes \& fulcra Deliaco are exornari folita fcribit: \& mox cap.3. Tricli= nia arata $\mathrm{C}$. Manlium primum inuexiffe. Et libro 9 . Teftudinum putamina fecare in laminas, $l_{e=}$ ctosáp \& repofitoria his ueftire, Carbilius Pellio inftituit:hinc elt quod teftudineum hexaclinøn di. xit Martialis. Repofitorium grammatici interpretantur id quod fuper antiquortm menfa repone: batur ad fercula collocanda, quà fubinde unà cum ipfo repofitorio adferebantưr $\&$ auferebantur. Plinius lib, 28. Bibente conuiua menfan \& repofitorium tolli, inaufpicatiffimum iudicatur. Videtur autem per epexegefin addidiffe \& repofitorium, innuens non integram menfam, fed repofitori um tantum cum ferculis auferri folitum, Proinde cum ueteres afferri \& auferri menfas meminerût, perfynecdochen de repofitorịs tantum intelligo, Solent etiam noftri menfis repofitoria, id eft oper, 
cula lignea imponere, (qux commode eis demi reponićp poffunt, unde $\&$ appellata mihi uidentur) uel munimenti gratia, ut pretiofisłuel ufus, ut calculatio per cretam fuper eis fiat:uel ornatus, ut cư dituerfis coloribus florum alin' ue inducuntur:uel deniç ut latiufcula menfx fiant:funt enim repoff toria ipfis quas tegunt menfis latiora, ut conftat Plinij uerbis 33.11. Repofitor g̈s(inquit)argentum ad difua memoria coeptum Feneftella dicit, qui obijt nouiffimo Tiberij Cęraris principatu. Sed \& teftu dinea tum in ufum ueniffe. Ante fe autem paulo lignea rotunda folida, nec multọ maiora quàm men fas fuiffe. Se quidem puero quadrata $\&$ compacta, aut acere operta, aut citro copiffe: mox additum argentum in angulis, lineas ̧́ per commiffuras. Quod fi quis nec ufu nec figura repofitoria ueterum (quibus tamen nec ipfis certa figura fuit) noftris conuenire dicat, hoc certe conuenit (refpondebo) quod utraç menfis imponâtur: $\&$ poffent noftra, fi moris effet, eundem præftare ufum. Exrãt igítur to grammatici qui repofitorium fimpliciter exponunt loeulos uel reconditoria ubi aliquid reponatur uel recôdatur: Quod \& Bayfius ante nos animaduertit, qui in libro de uafculis repofitoria dicta pu tat non folum in quibus opfonia, fed etiam in quibus menfx collocarentur, citans uerba Flinif ex eo dem capite, quo nos alia iam fuperius citauimus, Iam uero \& $\alpha$ menfas(inquit Plíníus) repofitorns im ponimus, $\&$ ad fuftinenda op fonia interradimus latera (menfarum intellige, ut addit Bayfius ) $\mathcal{Q}^{\prime}$ in. tereft quàm plurimum lima perdideric. Ego fufpicor legendum menfis repolitoria, cum hac illis ma. iora fuerint. Repofitorium ex A thenæo túßwy appellatum, ibidem docet Bayfius: $\&$ id genus repoli= toria Gallicé chapeletz uocari, quiorum ufus fit ad fuftinendas lances $\&$ difcos : in quo quidem ipfe fibi parum conftare uidetur. Inuenio $\theta_{i} \beta$ k per iốa folium a pud grammaticos pro calatho ex folnhs có texto in arcæuel cifix formam. Tricliniarium, idem quod tricinium, uel quod ad triclinium perti 20 net. Varto i. de Reruft.Quoelaborant ut fpectent fua eftua tricliniaria ad frigas Orientis. Plinutus lib, 19. Qua purpura quis noniam tricliniaria facit. Tricliniar is etiam adiectiuum in ufu eft, pro quo alin triclinaris dicere maliunt, Plin.lib. 37 . Lectos tricliniares tres. Bellos contriutas \& conurictores fa ciles in candida, non pulla uefte accumbere decet: Tametfi conatoria \& triclinaria conuiuis darian tiqui moris fuit, Alexander ab Alex. Habentur $\&$ domeftic ac cibariæ ueftes, quales intra domeft cos parietes geftamus, quas triclinares $\&$ cœnatorias appellamus, Calius Calcagn . Periftromata cư ad triclinia \& coenacula accommodantur, triclinaria a ppellantur:qualia Plinizs triclinaria Bahylo. nica nuncupauit, Idem. In triclinio choa apud Quintilianum, æenigmatice dictum in bibacem arbi

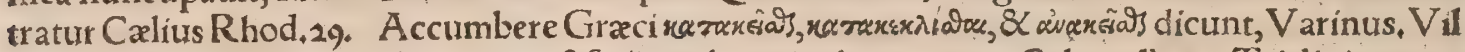
licus fit frugalitatis exemplum, nec nifi ferijs diebus accubans coner, Columella 2,1. Triclinium pro 31 lećo difcubitorio fitue accubitorio etiā $\mathrm{V}$ arro dixit lib, de $R$ e ruft.3, ca.13. Erat locus(inquit)celfus, ubi triclinio pofito cornabansus. Et 1i. I.ca. 59 in quo quidam etiã triclinium fternere folent coenandi caufa.Legi alicub: (nquit hilander)nec fucurrit locus, apud antiquos tres menfas fuife, unde $\&$ triclinitum uocatum effet: primam domini uxoris liberorum क́s: fecundam hofpitum: tertiam feruo. rum $\&$ domefticorum. Ego apud idoneum authorem de triclinio tale quid legi, uix crediderim. lus uenalis, Tertia ne uacuo ceffaret culcitra lecto, Vnà fimus ait, Apuleius lib.ro. Iam deníģ coenaz ti é triclinio domini deceffer amus. Quintilianus, Vix co limen egreffo, triclinium illud fupra conuia

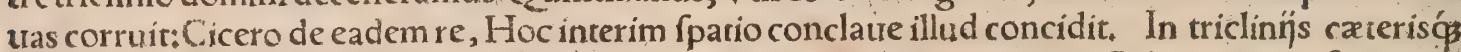
cóclaubus maximus eft ufus luminum, Vitruu. Conftat triclinium(inquit Calepinus, aut fi quis ad iecit) 8 leços difcubitorios, \& ipfam cœnationem, id eft locum ubi coenaturí dífumbebant, fignifi 4 care. Sed poftea triclinium per abufionem apparatus ad menfam factus dici confueuit, \& coacta in locum unum parandx paucorum cœnæ fuppellex neceffaria. Idèm triclinarium trocari dicit, in tria clinio miniftrũ. 4 Hac funt qua dum folicite inquiro de heptaclino pelle bonafi, obiter fe mihi ob. tulerunt: qux licet parerga, leciori communicanda iudicaui, ne labor hic nobis periret, in ea prafer tim re, de qua pleriç grammaticorum uel nihil uel perperam docent:cum quintuplicem zouxiira uro cabuli fignificationem (de quauis coenatione: de certx forma \& magnitudinis cornatione: de lecfo qui tres accumbentes capiat: de certa menfura cuiuslibetrei, ut fontis, it pellis: deniģ de toto conuia unj in triclinio apparatu) pauciffimi intelligant. Redeo ad bonafurm.

बNon placet quod orgyias Gaza uertit paffus : quanquam \& V alla apud Herodotum ita uer: terit, $8<$ uetus hoc in loco Ariftetelis translatio, ut apparee apud Albertum Magnum in Enchyto lis $\$$ bro 22. Licet enim paffus dictus uideri poffit à paffis, id eft extenfis manibus, fecundum grammati: cos:apud authores tamen in hac fignificatione nufquarn inueniri puto: proinde à pedibus paffis, id eft quàm maximéfine periculo poffunt diuaricatis extenfisḉż, nomẽ hoc potius factum credi erim. Eft enim ea menfura circiter quinç pedes, uel paulo maior. Quod autem paffum pro quings pedibus ueteres dixerint, facile eft calculare ex Plinijlibro 2.Stadium, inquit, $\mathrm{CXXV}$. noftros efficit paf fus, hoc eft pedes fexcentos $x \times \mathrm{x}$. Eft igítur paffus duorum greffuum, ut fit greffus cubitus unitus

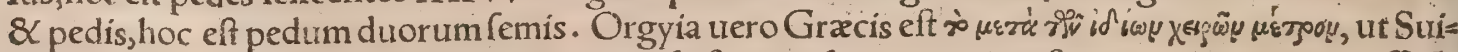
das docet, id eft menfura qux manibus extenfis fit, qux fua cuiç etiam ftatura uel proceritas effe fo let. Eft autem cubitorum quatuor, id eft pedum fex : hinc uerbum ó gyuży, brachịj extenfis metiri:

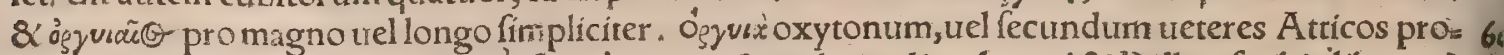
paroxytonum, extenfio manuum eftunà cum pectoris latitudine (quod \& Pollux fcribit libro 2.)

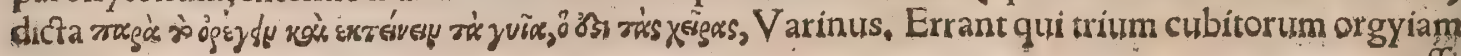




\section{DeBonafo. Lib. I.}

effe feribunt. Nos ulnam potius interpretabimur: Eft ènim ulna fpatium, ut Seruius inquit, quirañ= tum utraథ̧ extenditur mantus。 TTradunt in Pronia feram, inquit Plinius, qux bonafus uocetur. equina iuba, cætera tauro fimilem, cornibus ita in fe intlexis ut non fint utilia pughæ, quapropter fur ga fibi auxiliari, reddentem ea fimum, interdum \& trium iugerum longitudine : cuius contactus fe, quentes, ut ignis aliquis, amburat, Hæc Plinius; qui orgyias iugera exponit ineptiffimo fenfú. Quis enim credat ad tantum fpatium ftercus bonafos eiaculari Iugerum enim uocabatur, ut alibi fribit Plinius, quod uno die boum uno itgo exarari poffet, uel ut Columella libre s. Quadratus acius fi duplicetur, facit iugerum: $\mathcal{X}$ ab eo qurod erat iunctus, nomen iugeri ufurpauit. Elt autem actus qua dratus, latus pedes centum uiginti \& lögus totidem, Varro lib, I, de Re ruft, Sed fiue Plinị hic error 1o fit, fitre librariorum, aut illorum qui uocem non intellectam emendare uoluerunt, pro iugerum tum in Plinio tum Solino reponemis orgyiarum:quid enimi obftat quo minus uoce Graca utanurr : $\mathrm{So}=$ linus enim cap. 43, hunc bouem defcribens, ftatim poft Phrygix \& Lydia mentionem: In his locis, inquirit, animal nafcitur, quod bonafum dicunt, cui taurinum caput, ac deinceps corpus omne, tãtum suba equina: cornura autem ita multiplici flexu in fe recurrentia, ut fi quis in ea offendat, non uxulne, retur. Sed quicquid prafidnj monftro illi frons negat, aluus fufficit. Nam cum in fugam uertitur, pro luuie citi uentris fimum egerit per longiturdinem trium iugerum : cuius ardor quicquid attígerit, a durit. Ita egerie noxia fummouet infequentes, Hac Solinus, TMedi \& Pxones (inquit Hermo, laus in caftigationibus Plinianis) in Europa funt,à Pęone filio Endymionis Epei fratre, in Thraciam fiue Macedoniam ad amnem Axitum profecto: conuenerat autem inter fratres, ut qui curfu fupera. tus effet, imperium uictori cederet, ut fcribit Paufanias; meminit eorundem Trogus, Strabo, carteri. At Solinus animal hoc circa Lydiam Phrygiamóģ haberi tradit:quafi Męoniam uideatur legiffe,non Proniam. Sunt $\&$ Piones in A fia Myfia, qua fupra Caicum amnem fita eft:ab urbe dicti, quam Pio nis conditor Pioniam uocaurit, ut libro 5 , in Plinium expofui, qux omnia Solino erroris occafiones fuere, Hac ex Hermolao. Errores enim ueterum, quantumuis ipfe multis in locis animaduertam: ubicunq poffum tamen, alienis eos uerbis argurere quàm meis malo: quo minus ipfe facili ad repre= henfionem ingenio uidear.In manuferiptis quibufdam codicibus Plinĭ Moenia pro Pxonia reperi= tur, quali lectione forfan Solinus etiam ufus Mæoniam intellexit. Porrò quód idem bonafi cornua multiplici flexu in fe recurrere fcribit, fine authore facit:ego in unum folum circulum imperfectum ea conurerti puto, cuiurmodi in effigie apparent, quam adieci $\div$ Mifit autem eam ad nos Norimberga Cornelius Sittardus medicus, unà cum bubali uuigaris pictura fuperius collocata . Cæaterũ quod

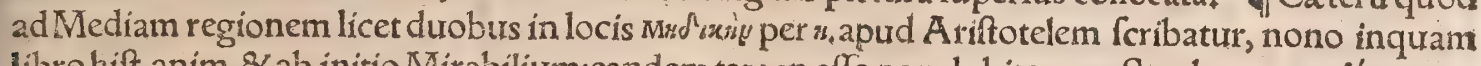
libro hift anim. \& ab initio Mirabilium:eandem tamen effe non dubito, quæ Stephano Maedíx per $\alpha i_{*}$ diphthongum fribitur. Media(inquit)ciuitas eft Thracix prope Macedoniam, à qua Maedi populi, diuerfà Medis A fix. Hinc præfectura Madica Thracix, uicina Pæonix. Horum nonnulli ad Mace. dones migrauterunt, Mædobithyni dicti. Eft \& alius Ariftotelis locus in Mirabilibus, in quo fic fori= bitur, Circa Scytharum et Medorum (Meoñuy, cum epfilo in prima fyllaba \& ô circumflexo in ultima) wirunt flutuium effe Pontum nomine, \&c. Hefeni, Hrásy, montis ut in Mirabilibus legitur, mentio. nem nufquâ inuenio:malim Mefiapi ut in Hiftanim. Gaza transfert, licet imprefli codices Ṁarazí habeant. A pud Stephanum Mróxino Eubor montem legimus, \&Nefapiam A puliam olím à Mefa 40 po rege dictam; fed hac nihil huc faciunt, I Bonafi Ariftoteles meminit etiam libro 3, cap, $_{2}$, de par: tibus anim, Bonnafis (inquit, fic enim illic fcribitur per $n$, duplex $\&$ f.fimplex ) quoniam cornua eis ad fefereflexafunt, excrementi profufionem natura pro auxilio dedit: hoc enim cum meturunt $f$ tuentur. Hac eadem profufione alia quogs feruari certum eff. In eoloco Gaza obfcurius uertit, qui bus pariaduncitate cornua reflexa inter feorbem colligunt:poffent enim accipi hæc uerba, tanqua de alijs quoç fimiliter aduncorum cornuum animalibus eo in loco tractaffet Ariftoteles, quod tame non apparet. Nam bubalis $\&$ capreis, de quibus proximé dixerat, licet adũca $\&$ parum utilia pugnzi cornua forte fint, non pari tamë aduncitate, fed longè alia quàm bonaforumi funt. Alijs item in locis; bonafum fcribit fylueftrem effe, bifulcum, capronatum equorum inftar, iubam habere, \& corntsa


dem translatio obfcurior eft, intelligi enim poteft ac fi cornua pariter incuruata ambo in orbem col. ligătur, ut fi quís brachia ante pectus extenfa in gyrum trertat:cum per fe utrumç fubtus aures cur. uatũ yau $\psi_{0}$, id eft aduncũ potius quàm orbiculare fit. Rurfus alibi bonafum interiora omnia bubus fimilia continere tradit Ariftoteles. बfA elianus libro 7. interprete Gyllio, hoc animal à Pronibus monopem uocari feribit, pilofo tauro magnitudine fimilem:et fercus eius, quod prę uexatione acre \& igneum reddit, fi in uenatorem quempiam infequentem inciderit, mortem afferre: cum Ariftoteles, Plinius $\&$ Solinus adurere tantum foripferint. Paufanias in Boeoticis Pconios tauros Rome in fpectaculis fibi uifos meminit, qui tưm reliquo corpore pilofi(dacốs) furerint, tưm maximé circả pectus \& genyn, id eft mandibulam. Hos egonon bonafos, fed bifontes effe crediderim: nam \& alibi in Phocicis bifontem taurum Pxonium uocat ipfe Paufanias: $\mathcal{X}$ Oppianus iubam eumgeftare

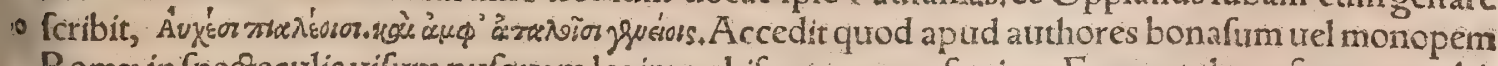
Roma in fpectaculis uifum nufquam legimus; bifontem uero fepius. Ego certe bonafum genus bia Contis crediderim:nam \& Albertus, ut fuperius retuli, boum quit unlgo pifent dicuntur, diuer fas fpe 
cies magnitudine folum differentes effe teftatur: quippe excepta cornutum figura, \& 2 reiectionefter coris, reliqua uidetur omnia cum bifonte cômunia habere. Bonafi certe folus Ariftoteles meminit, nam Aelianus $\&$ Plinius fua proculdubio ex Ariftotele defcripferunt, Solinus ex Plinio. Aliorum uero authorum quotquot bifon tis meminerunt, tum Græci turm Latini, bonafi nomen nun quam at tingunt: ut uerifimile uideatur boum fylueftrium maximos tantum uros ab eis nominatos uel buba los, minores uero omnes bifontes. Cornuum quidem necs magnitudo neç figura generis different am ftatuere poffunt, cum in domefticis cornutis pecudibus quantum, licet eiufdem generis uel fpe. ciei animantes cornibus differant, notiffimum fit. Iam quod ad ftercoris reiectionem, plaraç anima lium in curfu, prolixiore prafertim, id rẹijciunt, feruidius ftinis feilicet curfu calefactis, \& ob calorem flatibus excitatis, ut fit in humore: quibus inclufis uio to lenta per anguftum, magno impetu eruptio fit: Accedit $\&$ locorum compreffio ex uehementi mo= zu. Nonnulla etiam in metu, ut fepia fuum atramentum, excrementa emittunt. Hac adferrelibuit, it illi quibus occafio eff, \& propius illas regiones habitant, de boum iftorum differentia diligentius inquirant. Auguftinus Niphus bonafum fcribità recentioribus uaccam Indam uocaritin quo de repit eum Albertus Magnus, qui Solini de tauris Indicis $\& \subset$ bonafo diuerfis in locis fcripta, confundit. Albertus Magnus circa finem libri 22, uro quem zubronem uocat, fimílem fimi eiaculationem attribuit. Raphaêl Volaterranus libro 7 .bonafos eodem modoà Lituanis capi fcribit, quo nos $\mathrm{fu}=$ pra bifontes capi docuimus Paufanix uerbis. Bohemi, ut audio, monopem uccant loni. Germani iubam uocant móne(ut Angli etiam mane)inde factum monopis uel monapi nomen aliquis conie= cerit, utpote bouis iubati. Nam Ariftoteles certe nomen hoc non Gracum fed Pronicum effe fcris 2 bit, Pronum autem lingua eadem quæ Illyrica eft . A pud Albertum Magnum libro 22. bonachus pro bonafo corrupte fcribitur: $\&$ rurfus in eodem libro in $\mathrm{E}$. litera, Enchy tos, ubi omnia qux nos fu. pra recitatrimus Ariftotelis de bonafo trerba ex ueteri translatione recitantr:alij enchires fcribunt, nércio quibus tam barbarè $\&$ abfurdè fcribendi occafionibus alins, nifi quòd ex Arabícis translatio. nibus fumpta uidentur, qui Græcorum dictiones pleraf $\beta$ abfurdiffime corrumpunt, adeò ut originem amplitus non agnofcas. Alin tauro fylureftri, quem duram uel daran uocant, eadem qua bonafo Ariftoteles adfcribunt:cum harc nomina potius ad tarandum pertineảt, de quo paulo poft agemus. Superius in capite de diuerfis bubus fylueftribus bonafum mihi uideri dixi illum quem Philip= pus rex Macedonum ad pedem Orbeli montis in Macedonia iaculo confodit, \& cornua eius érkxe réedwęe, id eft fedecím palmorum in ueftibulo templi Herculis confecrauit:Sed forfitan urus fuerit 3 potius: nam fi bonaforum cornura in fefe, ut diximus reflectuntur, minus conuenire eis uidetur ifta menfura.

\title{
DE CATOBLEPA VEL CATOBLEPONTE LIBY=
}

\author{
CA FERA TAVRO VEL VITVIOSIMILI,
}

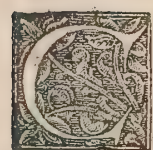

V M multiplices $\&$ uarias Africa procreat beftias, tum Catoblepontem fic nunctipatum parere exiftimatur . Tauro fimilis fpectatur, truculentus, terribilisćp afpectưalta ei $\mathcal{Q}$ den fa funt fupercilia:oculi non perinde quidem magni ut bubuli fub̈̈ciuntur; fanguine fuffu= fił non directè, fed terram uerfus intuetur:à uertice incipiens iuba, equinæ fimilis, per eitus frontem promittitur, qua fi uf̧̣ ad faciem pertinet, formidabiliorem eum reddit. Mortiferas depaz fcitur herbas; ac fimul ut taurino afpeciu confpexit, ftatim horret, \& iubam erigit: Ea autem in excelfum excitata, atç apertis labris per guttur quiddam uehementer acutum $\&$ horrendum emitrit, ut aêr fupra caput obdurcatur, 8 inficiatur:animalia autem a ppropinquantia, quæ hoc coelum hau riant, grautiter affligantur, \& uocis ufum amittant, in letaleśç conuulfiones incidant, Hęc Aelianus ab initio libri 7.Cæterum Plinius lib.8.cap.7. Apud Hefperios (inquít) Aethiopes fons eft, Nigris, ut plariç exiftimauere Nili caput, ut argumenta quæ diximus perfuadent. Iuxta hunc fera appellatur Catoblepas, modica alioquin, cæterisó membris iners, caput tantum prægraue ægre ferens, id deiectum femper in terram, aliâs internecio humani generís, omnibus qui oculos eius uidere confe ftim expirantibus, Hac Plinius: ex quo etiam Solinus tranfcripfit in furm Polyiftorem cap. 33. ubi so aliqui Tigrin pro Nigri fonte perperam legunt, ut Hermolaus annotauít. $\quad$ IIn Libya Gorgones

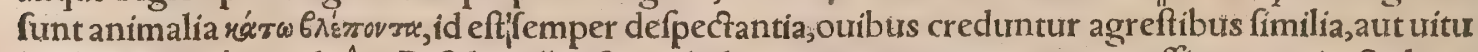
lis, ficuti quidam uoluêre. Peftilens ïs eft oris halitus, quippe intereunt mox afflata omnia. Sed nec innocentior ab oculis radius manans $s_{3}$ ubi concuffa, qux a fronte in oculos propendet, coma, fpecta= rint aliquíd. Cognitữ \& àMarỉ militibus aduerfus Iugurthã bellantibus, Cæl R hod, ex Athenęili. 5 .

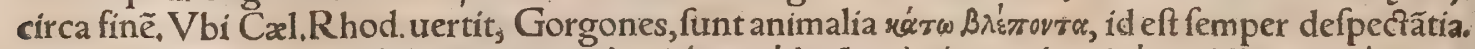

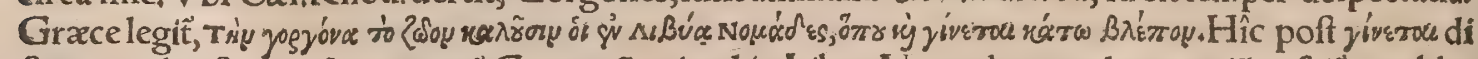
ftinguendũ eft, ut rectius uertât: Gorgonẽ animal in Libya Nomades, apud quos etiã nafciț, catoble: pon uracãt. Mirữ eft aû́t neç Pliniũ neç A elianũ in huitus animãtis defcriptione, eandẽ effe gorgon $\tilde{e}$ prodere:quod ne aliorum quidem feriptorum, quod fciam, ullus docuit, बCaterum quod halitu co eam occidere uertit, \& afflata omnia mox interire:quanquam ea Aeliani quocs fententia fuiffe uide tur, ex Athenęo tamen non recté conuerfum eft: Cuius uerba adnumerabo, ut eruditi iudicent: Éxey 


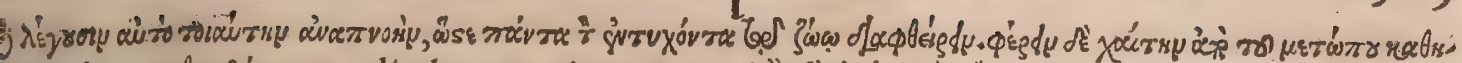

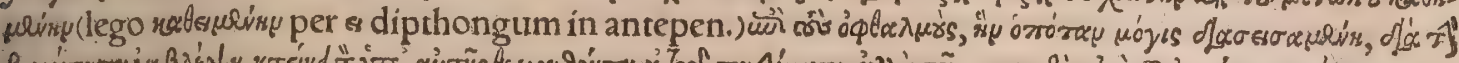

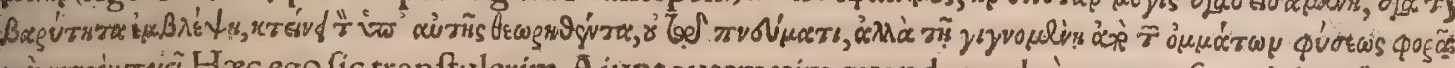

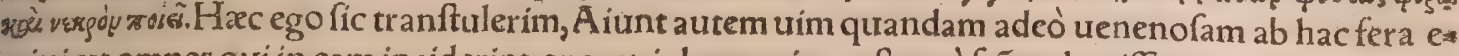
mitti, ut omnes qui in eam inciderint, enecet:iubam enim geftare à frōte demiffam qua oculi obum= brentur:qua difcuffa, quod quidem agre facit propter grauitatem, quemcunqs incuetur interimit; non fpiritu aut halitu(oris) fed nefcio qua ui ab oculis eius emiffa. Obijciet aliquis a'vartvoriv oris hali tum \& fpirationem fignificare: quod ut concedam, latius tamen pater, \& ne quis in hoc errare pof

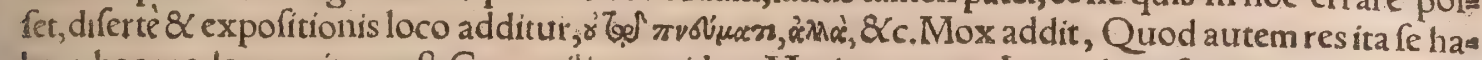
beat, hoc modo cognitum eft. Cum milites quidam Marium contra lugurtham fecuti, gorgone uifa oucm feram effe putarent, cum \& caput ad terram ei inclinaret, \& ipfa motu tardo procederet, gla. dijs confecturi in eam irruerunt. Vnde illa turbata, iubam orulis incumbentem difcuffit, $\&$ milites irruentes mox necauit. (Nulla hic fpirationis aut halitus ullius mentio.) Deinde cum iterum atcs ite rum quicunç aduerfus feram pergebant, interirent omnes:quidam fer $x$ naturam ab incolis didice. runt: unde Marij iuffu Nomades quidam equites eminus per infidias eam iaculis confecerunt, $8 \mathrm{im}$ peratori feram attulerunt, Quod autem talis, qualem defcripfimus, ea fuerit,pellis etiam, $\&$ Marï ex er citus, teftimonio funt. Hæc cum Vlpianus apud A thenæum dixiffet, Laurentius Romanus, qui dipnofophiftas excipiebat, affenfit, \& Marium ferarum illarum pelles Romam mifffe addidir, de quibus cuiufnam animantis effent propter formæ infolentiam conïcere nemo potuerit: fufpenfas autem eas effe in templo Herculis, in quo imperatores triumphances ciues epulo excipere foliti fưcrint, ut multiLatinorum poêtx \& hiftorici tradiderunt. TGorgonis uocabulum apud Gracos

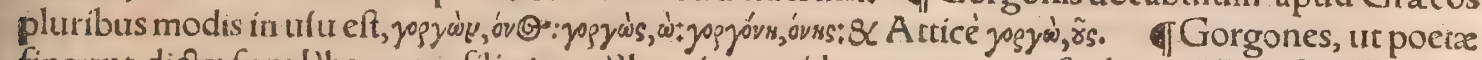
fingunt, dictx funt Phorcynis filia (non Phorci, ut quidam recentiores fcribunt. Medufam Phorcy, nidem Ouidius cognominat) \& Cerús, feilicet Medulá, Sthenio ( quam Hefiodus Sthenó uocar) \& Euryale, Quę Dorcades infulas in Oreano Aethiopico fitas habitaffe dicuntur, contra Hefperidum hortos. Scribit Diodorus libro 4. Biblioth forminas fuifle in Africa bellicofas, aduerfus quas Perfe, us bellum gefferit, et earum reginam Medufam debellaucrit ac interfecerit. Nominãtur autem foem næ iffx à Diodoro \& alịs A mazones, diuerfæab Amazonibus Sauromaticis uel Scythicis. Gorgo num \& Hefperidurm domicilia Strabolib, 7:obiter nominat. Perfeus laxua fupra aurigã tenet Gor: 30 goneum ad fummum capur, Vitruuius 9. 6. ubifydera à zodiaco Septentrionem uerfus defcribit, Gorgonum unam Perfeus interemit lonchodrepano, id elt hafta falcata, Suidas. Gorgonum capin ta draconum fquamis obfita fuiffe dicuntur: dentes maximi, fuum inftar: item manus \& alæ quibus per aëra ferri dicebantur: $8 \mathrm{C}$ in fe intuentes in faxa nertere. Ex tribus uero Medufa mortalis fertur fuife, ideóçà Perfeo decollata:reliqua dua forores immortales Perfeum nequiuere cófequi, quod Orcigalea obtectus (ut ait Hyginus) non cernebatur:hinc illæ tandem eum perfequi defiuere. My= cale urbs Cariæ eft, fic dicta quod reliqua Gorgones mycomenx, id eft mugientes, Medufx caput co in loco reuocarint, cum Perfeum infequerentur, Steph. Gorgonas Serufus, in extrema A fricę cír ca Atlanticum montem fuiffe frribit, unum q́s omnes oculum habuiffe, quo inuicem uterentur. Sere nus tamen ait puellas eas fuiffe unius pulchritudinis:quas cum uidiffent adolefcentes, ftupore torpe. 40 bant:unde fingitur, quod fi quis eas uridiffet, uertebatur in la pidem. Harum allegoriam in primo ex= plicat Fulgentius, \& co fubtilius lo. Zezes grammaticus in commentario in Hefiodum, Gyraldus. Græx quoq̧3(ut idem fcribit)Phorci(Phorcyis uel Phorcynis) \& Cetûs filiz in numero nympharum habitæfuere, tres, Pephredo, Enyo, \& Dinon:(Hefiodus Dinon non habet)fic nuncupatæ, quod fta tim ut natæ funt, anus fuiffe ferunt, \& unicum tribus oculum, unicumás dentem, quibus uicifim inter fe uterentur, Gyraldus. Has aliqui cum Gorgonibus confundunt, Plura de Gorgonibus uride apud Palaphatum cap. 33. cuius fuper his laruis omnia in librum fuum parcemiarum Apoftolius

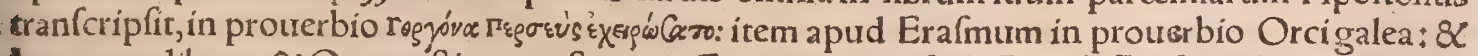
Lucanum libro 9.8 Onomafticon noftrum in Euryale, Medufa, \& Pegafo.Perfei \& Medufa fabu lam profequitur Ouidius Metam, lib, 4. Sané uidetur Gorgonis nomen ad puerilia terriculamenta confictum, ut etiam Lamix ex eadem Africa mulieris:nam monftrofa plera $\phi_{\beta}$ in Africam reijcieban tur. Sic noftri aliquando nocturnas mulieres pueris minantur, fic ludai de fua Lilith nugantur, ut

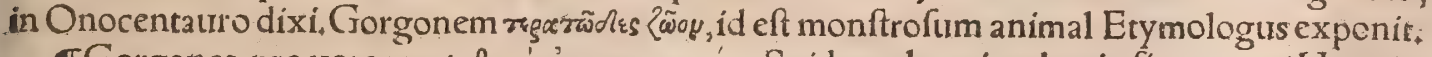

GGorgones, pro uoraces, фoßepoi sis yasgancegian, Suidas:tales etiam lamix finguntur: Horatius,

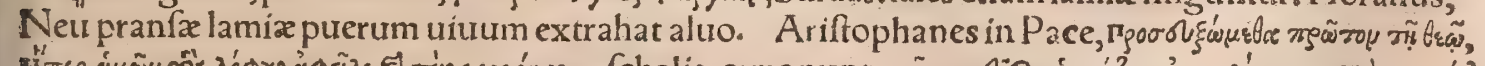

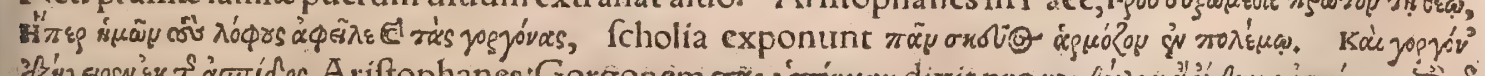

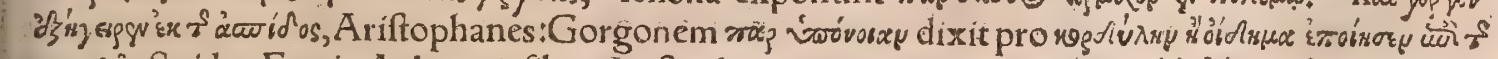

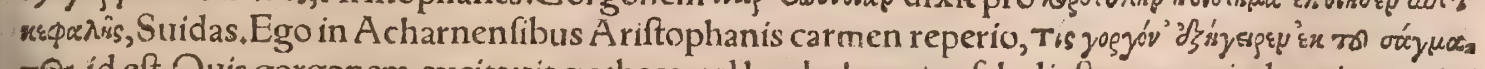
re-, id eft, Quis gorgonem excitauit ex theca uel hoplothecar ut fcholiaftes exponit: loquit!r enim

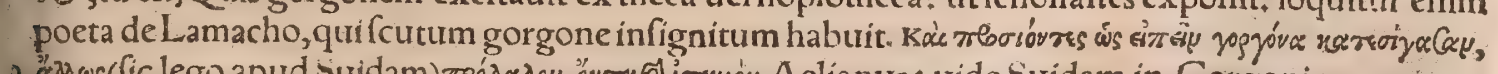

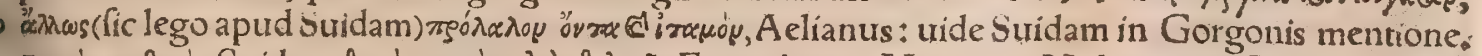

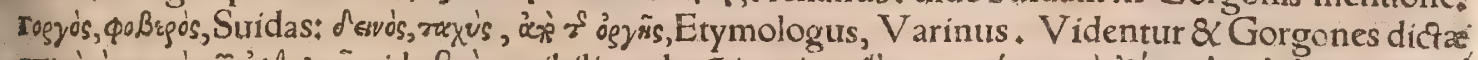

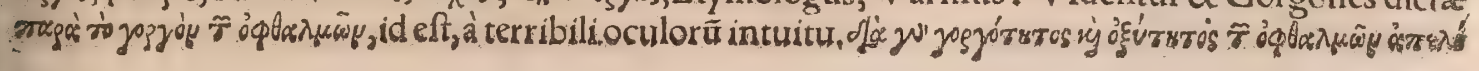




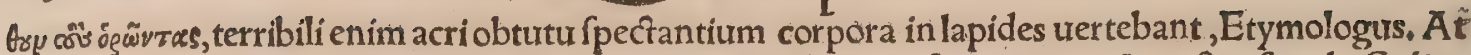
Latinorum quidam, ut Serenus, cuius opinionem ex Gyraldo fupra citaui, \& noftro faculo Calius Rhod,non horribili fed formofa facie intuentes ftupore quodam affectos aiunt:Hi fententiam à Gre

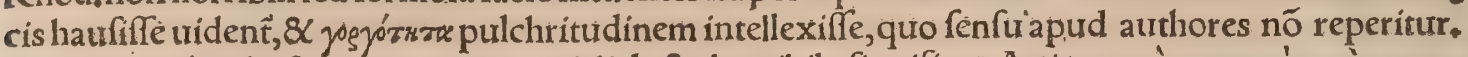

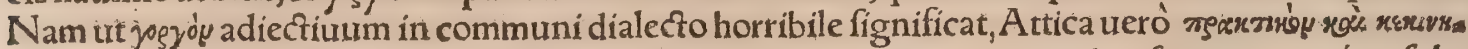
whiou, id eft agile uel actuofum ut ita dicam, 8 in actione promptum ac uelox:fic etiam jogyórns fub. ftantiuum utrogs fenfu capitur. Hermogenes libro 2, de ideis ab initio, yogyó twræe uocat illam formä orationis, quæ uitrida $\mathcal{Q}$ concitatior eft, $\&$ animos auditorum erigit atç excitat, remiff $x$ fupinæć $\beta$

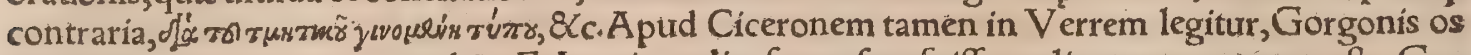
pulcherrimum cinctum anguibus: Et Lamiam olim formofam fuiffe mulierem annotatum eft. Gor gus, paroxytonum uiri nomen eft, cuius meminit Suidas. Gorgias rhetoris nomen fuit, à qua jogyıses

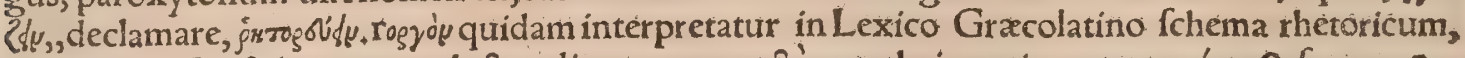

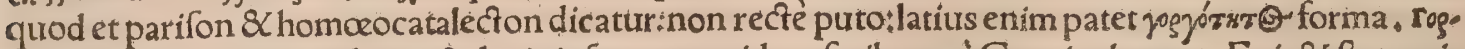
yıčou dicendi genus arduum $\&$ laciniofum, ut quidam fcribunt, à Gorgia rhetore. Fuit \& ftatuari us Gorgias apud Plinium. A pelles pinxit Alexandria Gorgothenem tragoedum, Plin.Plaftæ laum datilimi fuêre Damophilus $\&$ Gorgafus, ïdemćs pictores, $\mathrm{Plin}$. Paftillos Ruffillus olet, Gorgoni.

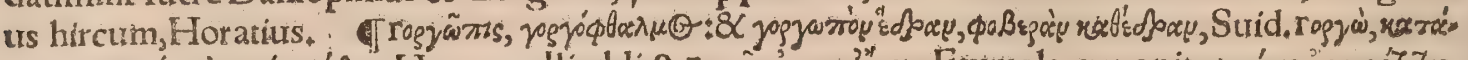

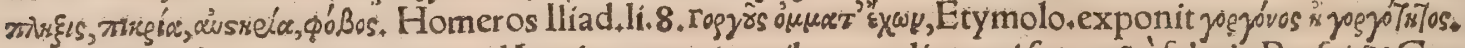

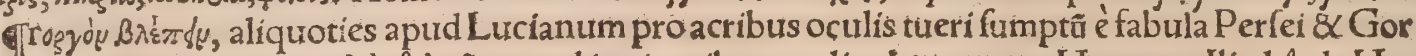

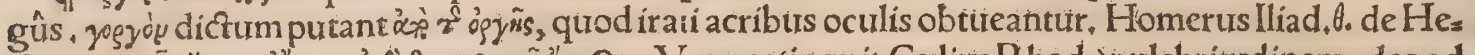

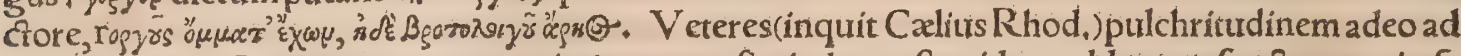
mirati funt, ut Gorgonem propter eximium tienuftatis decus, ftupidos reddentem fpectatores, in Ia

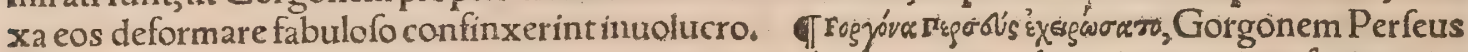
adortus eft, in Græcorum collectaneis ranquam prouerbium citatur, ubiquis egregium facinus incosptat, Erafmus. A poftolius hanc parcemiam exponit de ïs qui rem magnam \& infignem ftrenue

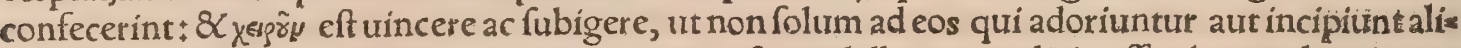
quid pertineat, ficut Erafmus interpretatur : etiamfi apud illos quoģ dici poffit, hortandi animäna

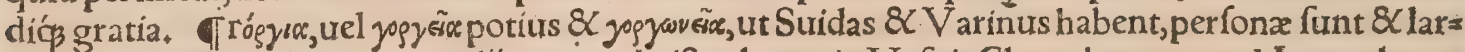
ux, quales hiftrionum in tragoxdips erant. Ariftophanes in Vefpis Choro loquente ad Lanachum,

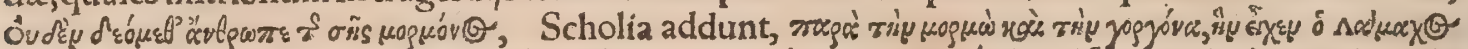

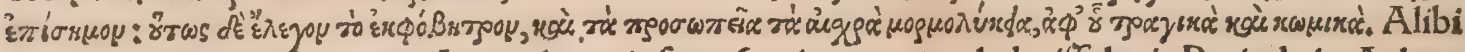
etiam in Scholịs huius poëtæ Lamachum infigne fcuti gorgonem habuiffelegi: Proinde in Achar=

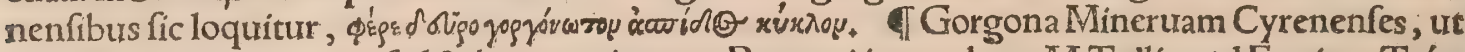
Graci grãmatici notant: fed \& hoc nomine eam Romani inuocabant.M.Tullius àd Equites: Téǵ, inquir, Tritonia armipotens Gorgona Pallas Minerua 2 \&c. Gyrald. Gorgonia autem Minerua dicta

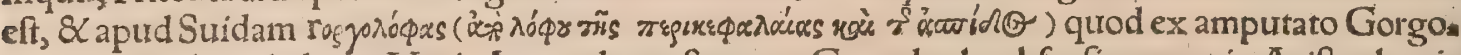
nis capite galeam habeat, Varin. Legendum eft autem Gorgolopha abfą figma, ut in Ariftophanis Equitibus habetur, item in Acharnenfibus, GGorgones infula obuerfafunt promontorio, quod uocamus Hefperionceras: has incoluerunt Gorgones monftra, \& fanè adhuc monftrofa gens habie tat:diftant à continenti bidui nauigatione. Prodidit deniç Xenophon Lampfacenus, Hannonem Pcenorum regem in eas permeauiffe, repertasós ibiforminas aliti pernicitate: atç ex omnibus quire apparuerant duas captas, tam hirto atc afpero corpore, ut ad argumentum fpectand $x$ rei, duaruim cutes miraculi gratia inter donaria lunonis fufpenderit, qux durauêre ufq in tempora excidij Car= thaginenfis, Solinus cap.ultimo;tranfcripfit autem ex Pliní lib.6.cap.31. Timomacho pictori ars pre cipue fauiffe in Gorgone uifa eft,Plinius, Gorgones Tithrafix apud Suidam cognominantur, à Ti thrafo fuuio aut loco Libya ubi habitabant. Gorgonia gemma nihil aliud eft quàm corallium, no. minis caufa, quod in duritiam lapidis mutatur, Plinius: Ouidius lib.4.Meta.coralij uirgas impofito Meduf $x$ capite in littore primum induruiffe fabulatur. Afpungitani populi ex Mrotis inter Pha.

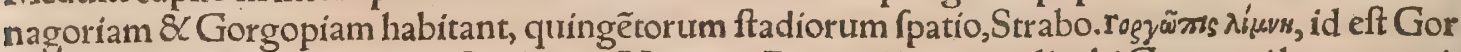
gôpís lacus, in Corintho a pud Cratinum, Varinus. Propertius etiam alicubi Gorgonei lacus memi- รe nit. Syndicus, urbs contigua Scythia cum portu, aliqui Gorgipen tocant, Stephanus, Gorgippla, urbs Indix, Idẽ. Gorgyia, locus in Samo ubi Dionyfius Gorgyienfis colitur, Gorgythion apud Ho. merum Iliad,8.Priami filius ex Caftianira,

\section{DE BOBVS FERIS INDIAE.}

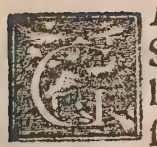

A R A M A N T V M bubus cornua in terram directa effe, ideó́s obliqua ceruice pafci, ut Solinus fcribit, \&c. fupra dixi inter diuerfos boures feros, I $D$ I a fyluas boure fero refertas habet,Plinius, . बI Magnus Indorum Rex quotannis diem unum proponit hominum cur 60 fibus $\&$ pugillationibus, tum luctationibus beftiarum, quæ fanè inter fe cornibus appeten tes, mirabili natura quadam eatenus ftrenue decertât, quøad aduerfarium funditus uicerint: Sicć̣ 


\section{Debobus Indicis. Lib. I. 155}

omni neruorum contentione, quemadmodum athletæ, ut aut maximo afficiantur præmio, aut glos riam capiant certaminis, nituntur. Rationis quidem expertes funt feri tauri, arietes manfueti, afini tno armati cornu, hyen $x$, poltremi in certamen ueniunt elephanti: in inter fe uulnerant, \& alter fape alterum uincit, atq̧ adeò in terimit : \{xpe etiam uterque uulneribus confecturs, fimul decumbir, Hace Aelianus, Cuius fupra etiam alium locum recitaui in Boue cap. 2 , de Indis qui bubus iunctis uelocif, fimo curfu in certaminibus ferantur:quoniam illic feri ne an manfueti effent hi boues non difinxe= rat: Hoc autem in loco omnino feros effe apparet: 84 res ipfa oftendit boures domefticos tanta ueio. citate minime pollere. IIndia generat boues folidis ungulis, unicornes, Plinius: Et proxime ante, Aethiopia Indicos boues (id eft Indicis fimiles, nempe unicornes) unicornes, tricornesćá gignir. Soli nus utrunq 3 locum coniunxit, nefcio quàm recte : Boures (inquit) unicornes $\&$ tricornes folidis un gulis, nec bifidis, in India reperiuntur. Bubus Indicis camelorum altitudo traditur, corntia in latitus dinem quaternorum pedum, Ptolemax fecundo ex India cornu allatum fertunt quod tres amphoras caperet, A elianus, Sunt item apud Indos alĭ boues qui maximos hircos magnitudine non fuperare uidentur : Ii uel coniugati uelocifimè currunt, nec minus ftrenué quàm Getici equi curfum confi. ciunt,Idem. Hos etiam fylueftres exiftimauerim. Rangiferum certe noftrum, \& boue fylueftrem ceffe, $\&$ omniũ in hoc genere uelociflimum, \& ad certamina curfusćs aptifímum, \& partím unicor= nem partim tricornem dici poffe, nec in Scandinauia folum; fed alịs etiam A fię ręgionibus inueniri, aliâs docebo:ut Indicos boues eiufdem generis credamus, Solinus nô reçe Indicos boues nominat, quos Aelianus Aethiopicos, \& Plinius etiam lib. 8.cap. 21. ut fupra ín Aethiopicis dixi, quibus cor 10 nura mobilia, \&c. Decepit eum fortaffis quod paulo polt fequítur apud Plinium, In India et boures fo lidis ungulis, \&c.quafi \& aliud antea quod in India nafceretur commemoraffet, quod fecit quidem fed uox eft corrupta:non enim eofdem legendum, fed Indos, in his uerbis, $A$ pud eofdem nafei $C$ te fias fcribit, quam mantichora appellat:quod conftat ex Arifotele de hift, anim,2,1. Errorcm hunc Hermolaus \& alị nó animaduerterunt. A A pud Arachotas(lego Arachotos)boures fylueftres funt, qui differunt ab urbanis, quantum inter fues urbanos $\&$ fylueftres intereft. Sunt colore atro, corpo

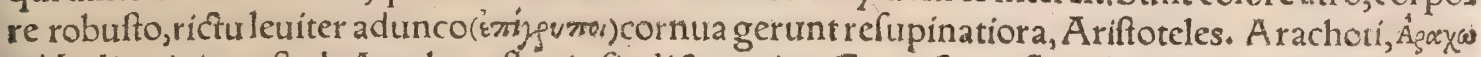
roi, Indix ciuitas eft, ab A rachoto fuucio fic dicta, qui ex Caucafo profluit. Sunt \& alï prope $\mathrm{Ma} \mathrm{fa}=$ getas, Stephanus. Sed Arachofia potius uocatur ciuitas illa Maffageris uicina, à Semiramide condiz ta, qux etiam Cophen appellabatur, Steph. Cornua refupinata, '2s vrifice?orra, qualia fint, in bifonte ex plicaui. Animalia qux Ariftoteles iskę uocat, id eft manfueta, Theodorus urbana urertere fo= let:quod mihi parum arridet. Nam ut de plantis ur bantum fylueftri contrarium dicatur (ficut Plinius arbores urbanas dicere folet)animal tamen urbanum ad oxy gro, id eft fylueftris difcrimen, an apud idoneum authorem ullum reperiatur, nefcio: manfuetum uero hac fignificatione poni fcio: Plinius

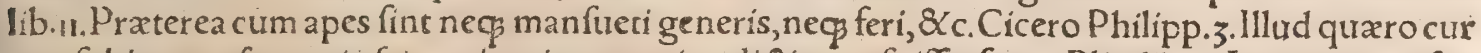
tam fubito manfuetus in fenatu tuerit, quum in edictis tam fuiffet ferus. Plin. lib. 9 . Lepores manfue fcunt rarò, cum feri dici iure non polfint. Complura nanç̧ funt nec placida, nec fera, fed medię in ter utrunç natura, ut in uolucribus hirundines, apes, in mari delphini. Cicur uero animal non tam manfuetum eft, quàm manfuefacium, quod prius fcilicet ferum fucrit:unde cicurare, manfuefacerc: uidetur tamen pro natura manfueto interdum abúfiue accipi.Cícero 2. de Nat. deorum, Qux uero Q quàm uaria genera beftiarum, uel cicurum uel ferarum? Hoc obiter addam, cicur à Gracis mihi

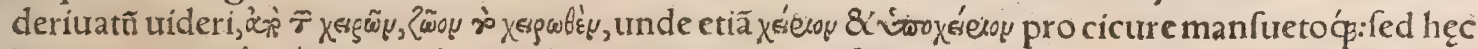
latius patent: ztdacaròy uero ad animalia proprie, cui oppofitum à ribecaroy. Legimus etiã domefticuni animal apud Plínium. Quamobrem miror cum uocabula propria Theodorum non deficerent, quí. bus redderet nurego, urbanum dicere uoluiffe:quod certe etiamfi de animalibus fimpliciter manfue. tis dici concefferim, poterit tamen tam de illis qua in urbe nutriuntur, quàm de manfuetis, qux ne ruri quidem defunt, intelligi. In plantis enim(ne quis illas mihi obijciat)alia ratio eft.

- TCynamolgi, quiab indigenis Agrï appellantur, comati $\&$ barbati funt. Hi canes maximos alũt; quibus Indicos boures urenanture uicina regione uenientes, fiure à feris pulfos, fiue pafcurorum ino pia,Strabo libro 16. Ctefias Cnidius in libro de rebus Indicis, apud Cynamolgos populos, innumeio ros boutes feros degere fcribit, qui quidem ab aftiuo folftitio ad hyemem ufg; mediam, gregatim hos mines inuadere foleãrt. Cynamolgi canes eis opponunt, cuos ea gratia plurimos alunt, Hyrcanis ma gnitudine pares. Hibubus feris immifli, facile eos debellant \& interemunt, Aelianus,

\section{DE LIBYCIS BVBVS.}

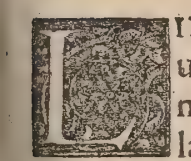

B Y COR VM boum tanta eft innumerabilitas, tanta item celeritas, ut unum infequentes uenatores interdum fallantur, quod nimitum ín alios feros incidant, 8 ille interim fub du meta, faltus ue fubiens fe fubducat, alị autem fimiles exoriantur, $\&$ uenatorum oculos fal: lant:quorum quempiam fi quis ingrediatur infequi, ne equo quidem, fed feffum longin: - quitate temporis comprehendet. Quòd fi quis uitulum adhuc tenerum cœperit, \& non ftatim occi. derit, ex eo duplici commodo afficietur : Nam praterquàm quod $\&$ iple commoditatem affert, mas rem fuam in captiuitatem inducit, Poftea enim quàm venator uitulum fune alligauit, ab eo fecediti 
Illa filin defiderio inflammata, tanquam afilo ftimulata fertur, cupiens diffoluta refte eum abducere: ac nimirum cornua compingit, ut uinculum laxet $\&$ diftrahat: At enim cornibus in funis complica tionem infertis, unà cum uitulo conftricta tenetur: Cuius uenator cum iecur detraxit, \& ubera excidit, $\&$ pellem exemit, carnes relinquit auibus $\&$ feris, Hæc A clianus. De Libycis bubus, quibus ter. ram uerfus diriguntur cornua, \& eam ob caufam retrocedendo pafcentibus, ex Herodoto $\&$ A elia: no dixi fuperius, in capite de diuerfis bobus fylueftribus. Philes feribit eos ideo retrogrados effe, quo niam cornua lata oculos eis obumbrent, ut ad progrediendum uifus eis inutilis fit, retro non item.

\section{E T A R A N D O.}

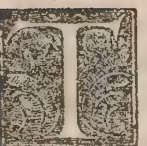

A R A N O magnitudo quæ boui, caput maius ceruino, nec abfimile: cornua ramofa, un= gula bifida, uillus magnitudine urforum (urfino colore, \& pariter uillo profundo, Solin.) Sed cum libuit fui coloris effe, afini fimilis eft. Tergori tanta duritia, ut thoraces ex eo facia ant. Colorem omnium arborum, fruticum, florum, locorumćs reddit meturens, in quibus latet:idcó́ raro capitur.Mirum effet habitum corpore(id eft cute)tam multiplicem dari, mirabilius \& uillo,Plinius. Et paulo ante,Mutat colores (inquit)Scytharum tarandus, nec aliud ex îs qua pilo ueftumtur, nifi in Indis lycaon, cui iubata traditur ceruix. Ruborem, pallorem, liuorem, hominiet befinj cutem mollem habentibus, 8 minime uillofis, accidere, nihil mirum: Tarando uero animali, cui eft tergus impenetrabile, \& uillus urforum magnitudine, admirabile uideri debet: feipfum enim cum uillis fuis hic uertit, millećs colorum fpecies cum fummo uidentium ftupore reddit,Scythicum animal eft, dorfo $8 \mathrm{r}$ magnitudine tauro fimile, eius corium ne f́piculo quidem penetrari potelt,Aclia nus, Caterum Solinus cap.33. cum lycaonem dixiffet Aethiopiam mittere, fubdit, Mittit \& tarandũ: cuius erroris occafionem prater of citantiam $\&$ negligentiam ipfius, nuilam uideo:cum Plinius dilu cidè Scytharum, id eft Scythicum tarandum appellet:lycaonem trero non in Aethiopia, ut Solinus, fed in Indis nafci ibidem fcribit. Hunc tarandum, addit Solinus, affirmant habitum metu uertere: \& cum delitefcat, fieri alfimilem cuicunç rei proximauerit, fiue illa faxo alba fit, feu fruteto uirens, fis ue quam aliam praferat qualitatem. Faciunt hoc idem in mari polypi, in terra chamæleontes. Sed $\&$ polypus \& chamaleon glabra funt, \& pronius eft cutis leuitate fpeculi modo proximantia æmulari: in hoc nouum eft ac fingulare, hirfutiam pili colorum uices facere, Solin. Tarandus, rógander, animal eft ceruo fimile, curius pellibus ad thoraces ( $x$ เrwoves)Scyth $x$ utuntur, Hefychius \& Varinus. Budini Sarmatie populi funt; apud hos tarandus nafcitur, animal admirabile, magnitudine bouis, facie

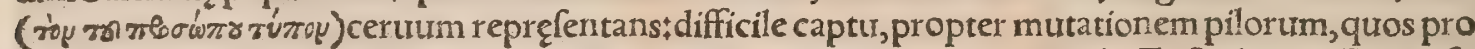

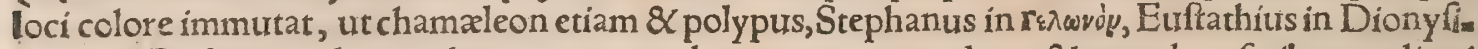
um. Barbariquidam authores pro tarando corrupte parandrum \& pyradum fcribunt : aliqui etiam tanquam diminutiua uoce tarandulum, quod ridiculum eff cum animal boui fimile fatean. tur: quidam adhuc abfurdius faciunt cum tarandum à tarandulo diftinguunt. Ioannes Agricola Am monius tarandulum interpretatur eleno, quam nos fupra alcen effe docuimus، Georgius Agricola rangíerum, cin reen. Et quanquam pleraqs tarando \& rangifero noftro cadem fint, libet tamen ab co dîfentie, nó certe dećtiffimum uirum reprehendendi animo, fed ut hominibus fud diofis diligen= tius inquirendioccafionem prabeam. Tarandum igitur effe exiftimo feram illam, quam Poloni tur uel huronem appellant, Inuenitur in una folum parte regni Polonici, in ducatu Mazouię inter Of= zezke \& Gartolÿn:maior bour manfueto, minor uro, ore diffimilis utriç, prapcutis in fine corni. bus, pernicifimo curfu, $\mathscr{X}$ ualde robufta. Defcriptionem hanc nobis communicauit, nobilitate do: frina \& omni uirtutum genere uir ornatifimus Florianus Sufliga Rolitzà Varshauia Polonus, Hac fera fi iubata effet, quod nondum certo fcio, bifonti adfcriberem: Nam recentiores quidam thu ronem Polonorum, zubronis, id eft urifpeciem faciunt. Caterum ut tarandum credam, plura cone currunt, primum magnitudo $\&$ fpecies bouris, fed caput uel os abfimile, deinde quód boum fylueftri um rarifima eft, \& in Sarmatia capitur uicina Gelonis, apud quos tarandum reperiri legimus?acce dit etiam nominis affinitas, nam in barbarorum quorundam recentiorum libris, daran huius bouis nomen legitur:quamuis alij duran uel durau fcribant, $\&$ bonafum interpretentur. Vnum eft quods obijci poteft, cornua thuroni non effe ramofa, qualia Plinius fuo tribuit tarando, Refpondeo, uideri mihi ueteres tarandum uel cum alce, uel cum rangifero forte confudifie:narn $\&$ alce $\&$ rangifer ramofa pratendunt cornua, Defcribunt autem alcen quoçs ueterum alij aliter:quòd in adeo peregri. nis animalibus mirum non eft: cum ea feré foleamus ut ex diuerfis auditu accepinus defcribere. Hæc ficui non fatisfaciunt, uel tarandũ pro rangifero accipiat, ut $\mathrm{Ge}$. A gricola \& ante ipfum Eliota Anglus, quibus cum ego fuper hac re non contenderim: aut fi quid melius inuenerit, in commus. ne proferat. Hoc addam pro corollario, ex Plinij defcriptione tarandum animal inter ceruum bo. uemć medium uideri poffe:cerui enim caput, cornua, $\&$ metum haber, cætera feré bouis. Thuro. nem fané taurum non meticulofum, fed taurorum omnium prafertím fylueftrium inftar, animo, fum effe crediderim, Iam quod Plinius frribit caput ei maius ceruino effe, $\&$ magnitudinem bouis, 6 rangifero fatis conuenit, quoniam in uniuef fum multo maior ceruo effe fertur. Capiuntur etiam apud Gelonos aut uicinos populos : quidam etiam colorem afininum ei tribuunt: praterea bifulcos 


\section{De Vro. Lib. I. $\quad 157$}

effe conftat. Hac tam multa cum conieniant, fi de coloris etiam mutatione certior fiam, fine cuncta. tione rangiferum pro tarando accipiam: $\&$ Polonicum thuronem bifontibus adiungam, Nam quod de corio fertur, ufum eius effe ad thoraces, ut quod ferrum non facile tranfmittat, nihil impediet:ple raf́g enim magnas feras in regionibus frígídis huiufmodi pelles habere crediderim, quales etiamial. res habent, qux ad hunc ufum in Germania communiores funt. Omnino quidem maiora minori. bus, fera domefticis, \& in frigidis regionum quàm calidis, animalia pelles craffiores folidiorêśćs ge runt. Sed rangiferi hiftoriam integram in R. litera dabimus:in præfentia fatis fuerit mihi non tam dif fentiendo quàm dubitando de eruditorum quorundam interpretatione, uel iplos, uel alios ad thuro nis fimul \& rangiferi hiftorias maiore ftudio inueftigandas excitaffe, \& fcepticorum inftar in utrã 10 partem rationes attuliffe.

ФDe T R oglodytarum bubuś, qui cornua terram uerfus habent directa, eamć ob caufam ob=

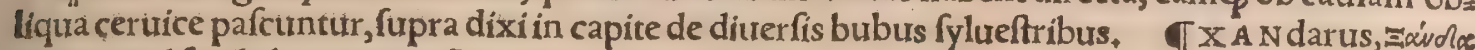
for, animal fimile boui, iuxta Atlanticum mare, Hefychius $\&$ Varinus, Omníno utox corrupta eft à carando: nec obftat quod tarandi nomen apud eofdem furo loco legatur; nã $\&$ alia huiufmodi errata innumera in ipforú Lexicis deprehendimus. Dicat aliquis xandarum à tarando diuerfum effe, quo niam ad Âtlanticum mare nafcatur, quod de rarando â nemine memoriæ proditum fit. Refpondeo tarandư în Scythia nafci, quæ Âfix, \& Europæ partim, maritimas ad Oceanum regiones complecta tur: Atlanticum mare autem dici, non felum occiduum illud $\&$ A phricani partem Oceani:fed uni nerfum etiam Oceanum apud ueteres, ut apparet ex his uerbis Ariftotelis in philofophix Compen.

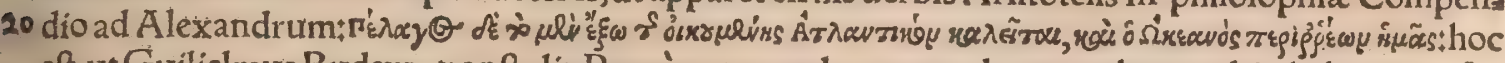
eft, ut Guilielmus Budaus tranftulit, Porrò autem pelagus quod extra orbem nobis habitatum fur. fum elt, \& Atlanticum dicitur, \& Oceanus, à quo ipfi circumluimur.

\section{E V R O.}

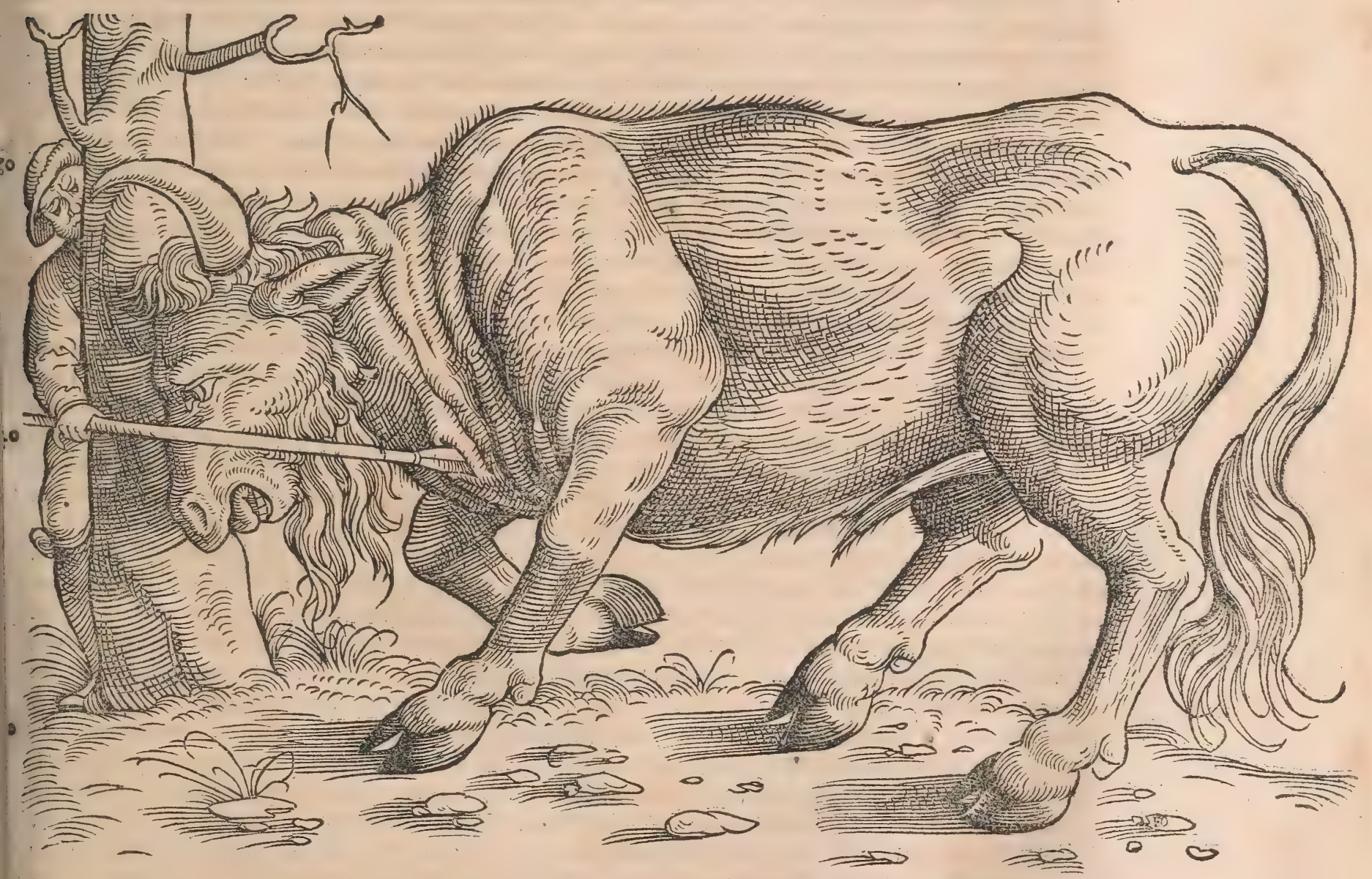

1. If fylua Hercynía nafcuntur, qui appellätur ưri.li funt magnitudine paulo infra elephan: tos, fpecie \& colore \& figura tauriłmagna uis eft corum, \& magna uelocitas:neç homini; neqs feræ, quam confpexerunt, parcunt. Hos ftudiofe foueis captos interficiunt. Hoc fe la bore durant a dolefcentes, atç hoc genere urenationis exercent: \& qui plurimos ex his in: terfecerunt, relatis in publicum corniburs, quę fint teftimonio, magnam ferunt laudẽ. Sed affitiefcere ad homines, \& inanfuefieri, ne paruuli quidem excepti pofunt. Amplitudo cornutim, \& figura, $\&$ fpecies multum à noltrorum boưm cornibuts differt, Hac ftudiofe conquifita ab labris argento ciri: 
cuncludunt, atog in ampliffimis epulis pro poculis utuntur, Cafar libro 6, belli Gall. Palrciffima $E_{c y}$ thia gignit inopia fruticum: pauca contermina illi Germania, infignia tamen boum ferorum genera, iubatos bifontes, excellentiós \& ui \& uelocitate uros, quibus imperitum uulgus bubalortim nomen imponit, cum id gignat Africa uituli porius ceruí ue quadam fimilitudine, Plinius, Vrorum corni* bus barbari Septentrionales potant, urnasḉ̧ binas capitis unius cornua implent. Alịs prafixa his pila cufpidant. A pud nos in laminas fecta translucent, atç etiam lumen inciufum latius fundunt,

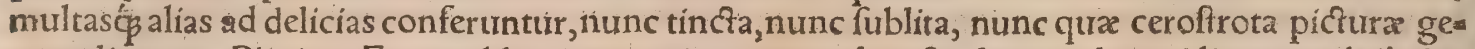
nere dicuntur, Plinius. (Ego cochlearia tum nigra, tum rubra, \& alia quadam uidi, qua ex bubalo= rum cornibus facta aiebant,). Iftis quos uros dicimus, taurina cornua in tantum modum proten= duntur, ut dempta ob infignem capacitatem inter regias menfas potuum gerula fiant, Solinus. V. ros $\&$ bifontes Gracl in experimentís non habuertint, quanquam boue fero refertis India fyluis: portione tamen eảem omnia ex his efficaciora(quàm ex bubus domefticis) credi par ef, Plin. Tibi dant uariæ pectora tigres, Tibi uillofi terga bifontes, Latisćg feri cornibus uri, Seneca in Hip * polyto. Et alibi in eadem tragoedia, Amatinfani Bellua ponti, lucićs boues; Hîc quidam lucos bo ues, fylueftres exponit, ut funt uri aut bifontes:ego pro elephantis potius acceperim, In carmineil. lo apud Martialem, Illi ceffit atrox bubalus, atq̧ bifon, bubalum pro uroexponunt ex Plinín uerbis proxime recitatis. Vergilius libro 2.Georgicorum, de uitium cultura, Texendx fapes etiam, \& pe cus omne tenendum: Pracipure cum frons tenera,imprudensç̧ laborum, Cui fuper indignäs hye mes, Solemó potentem, Sylueftres uri affidue, caprexó, fequaces Illudunt, \&c. Sylueftres uri (in quit Seruius) boues agreftes funt, qui in Pyrenæo nafcuntur monte, pofito inter Gallias \& Hifpa 2

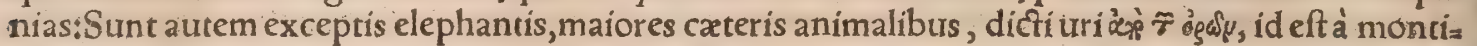
bus, quod Ifidor us etiam fcribit. Idem libroz. Georg, de peftilentia boum, Tempore non alio, dic üt, regionibus illis Quxfitas ad facra boues Iunonis: $\mathcal{X}$ uris Imparibus ductos alta ad donaria currus. Håc poëtx uerba interpretes referunt ad hiftoriam Cleobis \& Bitonis, quæ ab Herodoto narratur lib.s. \& à Cicerone libro I. Tufculanarum: Vide fupra in Boue $H$. h. Exponunt autem hîc quoģ $u_{a}$ ros, boues fylueftres:ego petius pro quibufuis magnis \& egregïs bobus acceperim hoc in loco, ut tauri nomen etiam ufurpatur: \& A chelo i pro qualibet aqua. In Græcorum enim foriptis Argiex Iu= noni, de qua bîc mentio, fimpliciter boues albos, facros fuiffe legimus; uide $\mathrm{P}$ alæa phatum cap. tultimo delunone, -Vergilius peregrina uerba non refpuit, ut in illo, Sylueftres uri affidué. Vri énim Gallica uox elt, qua feri boures fignificantur, Cæcinna Saturnal.Macrobri libro 6. Caterum uri urocabu= Ium in Gallica lingua, qux hodie fic uocatur, nufquam inuenio; in noftra ueró retinetur, nufquam tamen fimplex, fed in compofitione femper, pro fylueftri aut ueteri aut principali ¿dicimus enim Dzod 5 urum bouem, quem Sueui \&C Bauari \& alin quidam Germani u noftrum in au mutare foli= ti, auwero $b$; appellant: \& propter fimilem uocis mugitum auem quandam ardearum generis ali= qui varino, alij mo 3 ki nuncupant, Sic prban quafi gallum urum, id eft fylueftrem dicimus: pro ue teri autem uel principali, ut in nominibus $v 2 a l t / \nu$ z $D z$ in hoc fenfu factum per fyncopem à prapofitione voz. Apud Mof chouitas frequentes funt all: merod)fen, id eft boues fyluefties, quos aliqui uros, alij bifontes interpretantur; fed fupra docui uros Germanice dici groffe vifent, id eft bifontes: uel groffe wilbe biiffel; id eft bubalos fylueftres ma. gnos: ubi etiam Alberti Magni uerbis oftendi, in illorü præcipue cornibus (quæ maxima altífsimá̧̧́ (int)fingulas quotannịs rugas adnafci. Erafmus Stella in libro de origine Brufforum, Buffelus(in. quit)quadrupes, habet barbam ueluti capra, fimilis alioqui boui per omnia, $Q$ eft in Bruffia quidem ferociffimus. Caligula Cæefar hos primus Romæexhibuit in theatro, quos populus putauit effe taur. ros fylueftres, Sunt quifcribant boues fylueftres Germanicédictos auwerodb fen in Pruffia nafci,f miles ferèmanfuetis, nifi quod breuiora eis cornua fint, $8 \mathrm{C}$ barbx fub ore prolix $x$ : Hos perquam $a_{a}$ troces effe, non homini no fer is parcere: $\&$ fià uenatoribus, qui inter arbores fe continent, telis $\&$ iaculis petãtur, adeò exardefcere \& effer ari ubi fe cruentos uident, nec ulcifci fe poffe hoftem, ut cre bro in ip las arbores impetu fe ipfic conficiant. A ddunt, ea magnitudine effe, ut cornutum interuallu duos fedentes recipiat, Munfterus libro 3. Geographia fux in defcriptione Pruffix . Dubitet autem aliquis ad uru!' ne an bifontem defcriptũ his uerbis bouem potius referat. Vrienim magnitudo uía detur, $\&$ nomen Germanícum $\neq$ cornuum ueto breuitas, $\&$ barba, bifontis. Nam hominem $\&$ anima lia omnia inuadere, plerifos omnibus fylueftribus bubus commune eft. Barbatum uero effe bifonie

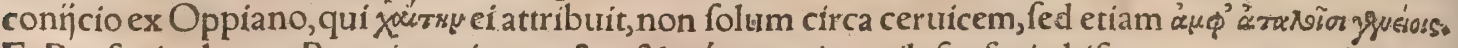
Et Paufanias boues Pæonicos circa pectus \& gruve maxime pilofos facit: bifontes autem ex Proni corum boum genere effe alibi dixerat. Ego certe fufpicor, quoniam ex diuerfis aduenis percunctari folemus, alium de alio, quem ipfe uiderit uel audiurerit, fylueftriboue refpondere, \& $\&$ ita in unum an mal congeri quod diuerforum eft.

TVrum lllyricalingua audio nocari zubr uel zubronem: Eliota Anglus uros fua lingura expos nit bugles uel buffes, tanquam hoc nomen à bubalo diuerfum fit, quem alibi a bugill interpretatur. In Angermannia ducatu Eurrop $x$ maxime Septentrionali $\&$ cófini Laponiæ, in præcipuis feris per to fyluas uros $\&$ bifontes uenantur, quos patria lingua dicunt elg, id eft afinos fylueftres, tantæ proce titatis ut fummo dorfo aquent menfurâ hominis porrecti in brachia elata, lac, Ziegler, in Schondia. 


\section{DeVro. Lib. I.}

fua. Tut uel thuronem Polonis nominaribouem fylueftrem domeftico maiorem, minorem uro, eti am fupra monui. T'Zubrones, ut fertur, boum funt generis, longitudine aliquando quindecim cubitorum: Cornibus maximis, trium cubitorum longitudine, colore fubnigris:tanta uelocitate, ut (cum impetui) reiectam alui proluuiem conurerfum ( retroactum) animal cornibus quandogs excipi at, antequam in terram cadat: (addunt quidam, \& cornibus exceptam longius proijciat in cares, ) In ryluis maxime feptentrionalibus degit, tanto robore ut equum cum equite (hominem 8 equum) cor nibus in altum proịciat, iterumós excipiat donec enecauerit. Capi aliter non poteft quầm foueis, aut uenatore circa craffiffimi trunci arborem circumeunte, \& $\propto$ fera infeftantis latera interim uenabulo perforantis. Alui excrementum tanto cum flatu eiaculatur, ut infequentem canem aut uenatorem inquinatum inutile reddat, uel ut alĭ, excacet : (quod item de bonafo Ariftoteles fcribit, fed adurere addit, 8 cornura eius pugnæ inepta facit; $) \mathrm{H}$ çc Albertus circa finem libri 22. parenthefin meis uerbis inferui. Ibidem paulo fuperius, Vrni (inquit:fic fribitur pro uri) funt boures quios Germanice vis fent(aliâs wifent)urocamus: cornua ingentia duo geftant copiofi liquoris capacia: proinde nonnulli pro poculis utuntur: His iracundihominem cum equo uentilant. Vide plura in Bifonte fupra.

- Alba Ruffia fiue Mofcouia, qua iungitur Lithuania, uros in Hercynia fylua producit, Antonius Vuied in tabula Mofcouia. Alibi etiam legimus in Lithuania multos effe uros, qui hominem cata= phractum etiam facile cornibus fublimem rapiant. Ifidorus arbores $\&$ armatos milites cornibus eos eleuare frribit. Ioannes Boémus urum in Pólonia reperiri, author quidam obfcurus in Boémia. Ego Moguntix \& Vuormacix, Germanix ad Rhenum ciutitatibus, ingentia boum fylueftritum capita, duplo(ut mihi uidebantur)domeftícis maiora, cum reliquïjs quibufdam cornuum, ædificińs publicis affixa(ante frcula aliquot, ut fertur) olim cum admiratione infpexi. Vrum aiunt quidam iuxta ar mos altiorem effe, parte pofteriore magis depreffum, pilis fubnigris. Ex corńs urorum apud Polo nos fiunt cingula cum ipfo pilo, qui nigerrimus eft (ut ex nobili Polono audiui;) $8 \mathrm{C}$ commendantur tanquam morborum quorundam amuleta, ornant ea nobiles auro \& argento,

IR H I $Z$ es urocantur, ut author eft I phicrates, bellux forma tauris perfimiles, uita uero \& magnis. tudine, pugnandi uiribus, elephantes referunt. Nafcuntur apud Hefperios Aethiopes, Strabo libro 17. Hi fortaffis rhinocerotes funt, qui $\&$ taûri Aethiopici appellantur, magnitudine etiam $\&$ uiri= bus elephantís fimiles:fed præftat diuerfos credere, quoniam rhinocerotum libro 16 , feorfim memis nit Strabo, urifum à fe defcribens,

\section{DE C A C O.}

A C V M recentiores quidam inepte animalibus adnumerauerunt, occafionefumpta ex Aeneidos Vergilianælibro 8.ubi poéta fic canit:

Hic fpelunca fuit uafto fubmota receffu Semihominis Caci:facies quam dira tegebat

Solis inaccenfam radijs, femperó̧ recenti Cęde tepebat humus: foribuş́́ affixa fuperbis Ora uirûm trifti pendebant pallida tabo. Huic monftroVulcanus erat pater, illius atros Ore uomens ignes, magna fe mole ferebat, \&c. Et paulo poft de cadauere éfpelunca ex ractiCaci, Nequeunt expleri corda tuendo, Terribiles oculos, uultum, uilloráćs fetis Pectora femiferi, atç extinços faucibus ignes, Grammatici aiunthunc Cacim Latium undiqglatrocinins 8 incendijs infeftaffe: demum Herculis quogs ex Hifpania, occifo Geryone rede untis 8 apud Euandrum hofpitantis $;$ boues noctu cauda traxiffe in antrum fuum. Has cun mane diminutas cerneret Hercules, nec quorfum erraffent fcire poffet, forté fortuna ad hoc antrum perue nit:fed cum ueftigia omnia foras uerfa uideret, cum reliquis abrijt. A beuntibus autem cæteris, occlu fa boues aliarum defiderio mugierunt. Hercules igitur audito mugitu, Caci fraudem cognouit, $\mathrm{raz}_{3}$ ptaćs claua iratus recurrit:fed Cacus fpelunca fretus in eadem fe abfcondit, claufis foribus ingêti $f a$ Xo, Qtrod Hercules uiden's, ad montis cacumen tendit, \&ad extremû deiecta maxima montis parte, in antrû̉ defiliens, Cacû ftrangulauit, bouesç̧ fuas recepit. Sunt qui affirmẽt hunc Cacũ Euãdri fuî́ fe feruû, qui in eo loco Italix omnia latrocinio \&incẽdio uaftauerit, 8 ob id Vulcani filiữ appellatũ. - Ouid, fabulatưr illũ tricipitê fuiffe cũ inquit, Męnalio iacuit fufus tria tempora ramo Cacus, \&cc.Ve ritas tamê fecundư philologos $\&$ hiftoricos hoc habet, Hũc fuiffe Euãdri nequiflimũ feruũ ac fure Nouimus aût malữ à Grecis rario dici, quem ita illo tempore Arcades appellabant:poftea translato

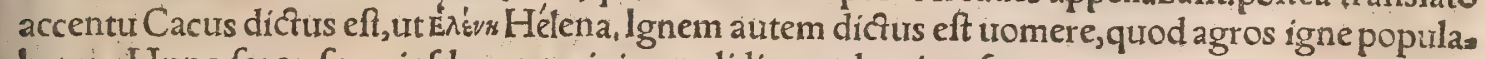
batur. Hunc foror fua eiufdem nominis prodidit : unde etiam facrum meruit, in quo ei per uir, gines Veftæ facrificabatur, Hæc Seruius enarrans iam citatum Vergilin locum. In huius rei memo riam Petití \& Pinarí Herculis facrificuli Roma conftituti funt, uide Macrobium Saturn. 3. cap. 6. Alberti Magni 8 imitatorum eius nugas de CaCo,tanquam fera naturali, ualde ridiculas prætereo; Similis feré huic eft alcida fera fabulofa, quam ex terra natam, infuperabilem pugna, plurimũ ignis ore uomuiffe, \& Phrygiã (quę inde nomen exuftę retinuit) combuffiffe ferunt, demuim à Minerua oé - cifam effe, ut fupra ex Diodoro Siculo recitaui. 


\title{
DE CALOPODE, SI QVAE EST, A RECENTIO.
}

\author{
RIBVS BARBARIS MEMORATA FEA:
}

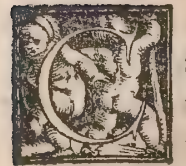

$A L O P$ V $S$ apud Albertum Magnum, \& eius imitatores, uel analopos, uel antaplon, uel aptalos(ut nominum corruptorum nullus eft modus)animal eft acutis, longis \& ferra. tis cornibus, quibus etiam arbores, licet magnas $\&$ altas, fecare fertur: fępius autem dum rami \& uirgulta cornibus adactis cedunt, eis intoluitur, recineturó: unde fit ut toce $\&$ clamore fe prodat uenatoribus.In Syria iuxta Euphrarem inuenitur, cuius aqux pou propter frigi ditatem gaudet, aftutum \& mira uelocitate, ut uenatores facile effugiat. Hac ferè Albertus author $\widetilde{e}$ citans nefcio quem Lorach,à quo tamen fapius tanquam parum probata fidei diffentit. Alij antapló fuum capreolo fimilem faciãt, corpore foetido, cui bina peracuta $\&$ falcata cornua fint: quibus poft. " potum ex Euphrate alacrior tanquam ludendo, arbores (urel, ut alin, frutices $\&$ dumeta) fecare foleat: effe autem genus quoddam fruticis, longis, tenuibus, lentisç̧ uiryis feu uiminibus, qux cum refeca re conatur, implicari inuroluriç eitus cornua: $\mathcal{Q}$ ita ex uoce, quam indignabundus emittit,à uenatori. bus deprehenfum occidi. TEgo apud ueteres $\&$ idoneos authores neq̧ hanc feram, neç fimilem ei ullam reperio, præter unum locum circa finem epiftolæ Alexandri Magni ad Ariftorelem de mira bilibus India, cuius translationem infcriptio Cornelio Nepoti tribuit: In illa ftatim poft Gangis $\&$ Euphratis riparum mentionem, fic legimus: Euri uenti flatus fecuti incidimus in malignas feras, de

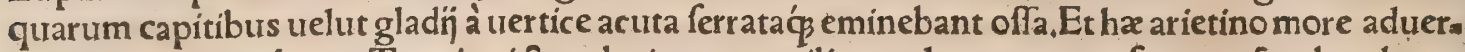
fus homines currebant: Tum intrictx plurimorum militum clypeos cornu fuo tranfuerberabant. Quarum occifis ad modum octo millibus quadringentis quinquaginta, fic inde ad Porum exercis ${ }^{2}$ tus meus cum fummo tandem labore ac periculo meo peruenit. Hic proculdubio illorum calopus fiue analopos eft.

\section{DE CAMELOPARDALI.}

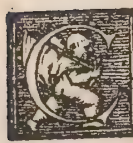

AMELOPARDA lin facræ literæ yo cant רar zamer, Deuteron, 14. ubi Chaldaica translatio habet אมา deba, Arabica กפหาห faraphah, Perfica ig phah, Septuaginta repeste. grápoladey, Hieronymus ca. melopardum. Dauid Kimhi præterea teftatur Rabi lonā frribere, zamer animal Ara bice uocari farapha, In tan. to igitur ueterum intepre. tum confenfu, nihil moura bunt nos recentiores, fiue Iudxi(qui merito magna re rum comnium infritia labo: rant) (itue alÿ; qui rupicaprã autalcen Ebraicam uocem zamer exponunt. Alces e. nim Syrix peregrinx funt, rupicapræ uerò alitud Ebrai. cum nomen habent, ut fuo loco dicemus. Numeratur autem zamer inter animalia cibohominum conceffa:nec obftat quod camelopardas lin nufquam in cibum uenif Se legerimus:raritas enim $\&$ peregrinitas facit ut cibo eã nemo experiatur, Camelo= pardalin Aethiopes nabin uocant,à qua uoce recentio res fortaflis Albertus $\&$ alin,

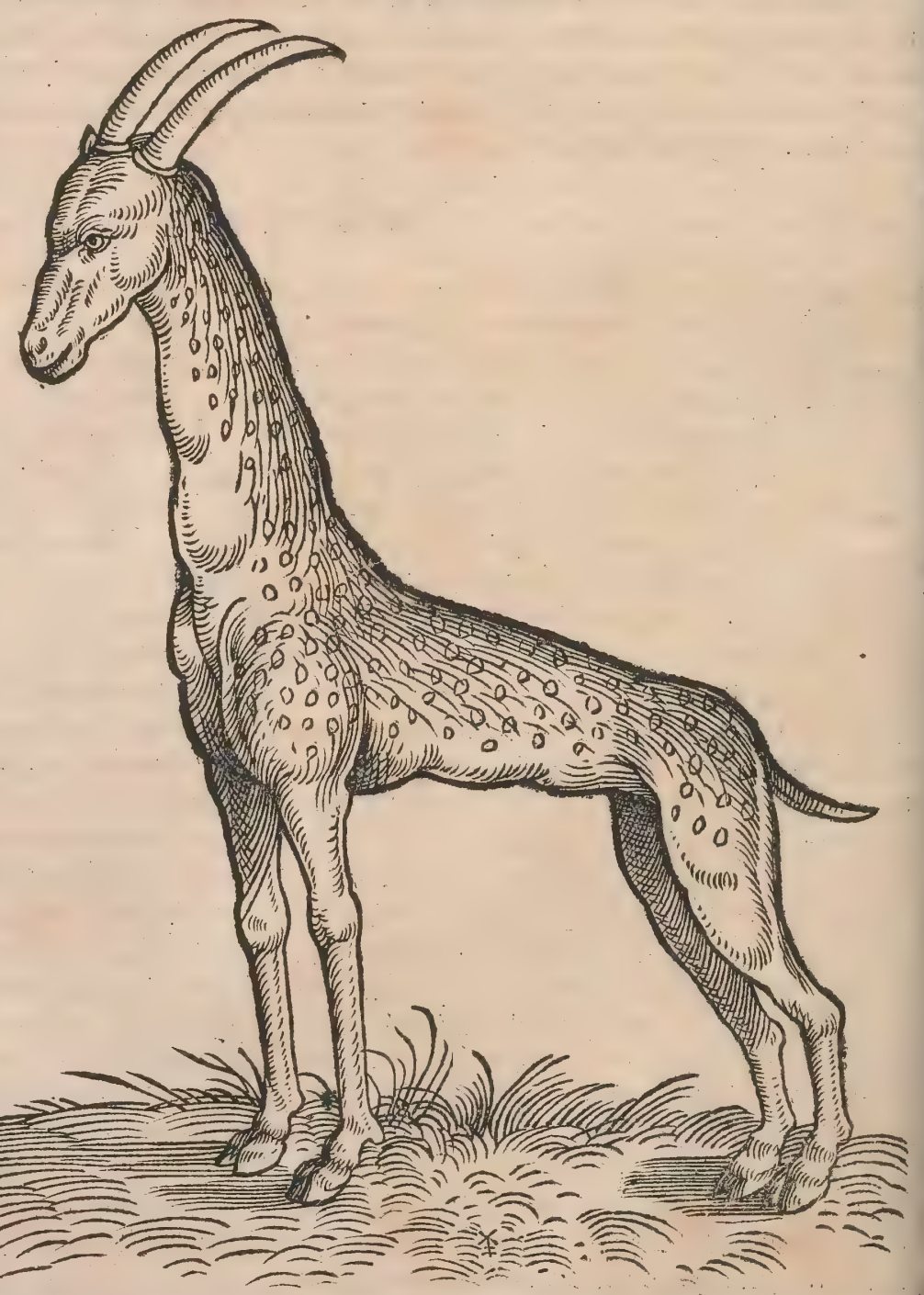

anabulam fuã detorferunt:fxpe enim in Arabicis dictionibus a uel ha prima fyllaba articuli ratione abundat,Paufanias camelum Indicam wocat, Reliqux gentes, quod fciam, omnes non alia quàm 


\section{De Camelopardali. Lib. I. IбI}

Ärabica troce ferapham appellant, fed alị aliter fcribunt gyrapham, giraffam, zirafam : Albertus ciusćs fimix, oraflum $\&$ orafium dicere aufi funt. Hieronymus, fi illius eft translatio uetus Biblica quam habemus, \& recentiores quidam indocfe camelopardum pro camelopardali efferunt. Fure: runt fub Gordiano Roma elephanti 32, \&c, camelopardali 1o. \& catera huiufmodi animalia innume ra \& diuerfa, qux onnia Philippus ludis fecularibus uel dedit uel occidit, Iulius Capitolinus: came. lopardalum dixit mafculino genere, inflexione fecunda ( nifi uitium librariorum eft) cum authores reliqui omnes, Gracos imitati, in forminino genere $\&$ inflexione tertia tantum protulerint. Politia= nus chamelum \& chamelopardalin per ch. (cribit, antiquo more fortaffis qui chenturionem pro cen turione dicebant.Latine etiam ouis fera dici poteft, ut ex Plinio patet:Perottus ín Plinio ouem fimpli 10 citer legit, feræ nomen omittit : codices quidam feré aduerbium habent, id accipi poffet pro plerunç uel apud multos camelopardalin ouem urocari, TCamelorum aliqua fimilitudo in duo transfertur animalia: Nabim Aethiopes uecant, collo fimilem equo, pedibus $\&$ cruribus boui (uel ceruo, Alber $=$ tus ) camelo capite, albis maculis rutilum colorem diftinguentibus: Vnde appellata camelopardalis, diçatoris Cęfaris Circenfibus ludis primû uifa Romæ. Ex eo fubinde cernitur; a arpectu magis quàm feritate confpicua:quare etiam ouris feræ nomen inuenit, Plinius 8,18 . Alias oues feras, quibus cor, poris $\&$ cornuum fpecies id nomen dedit, fuo dicemus loco:nam camelopardalis præter placidos $\&$ manfuetos mores nihil cum ouibus commune habet. In Lexico trilingui Sebaftiani Munfteri inue = nio $k$ yy ana pro oue poni, Chaldaicam uocem exiftimo:inde potius anabula hoc animal quibufdam dictum uidetur, quàm à nabi cum articulo, ut fuperius diưinabam. Quod fi anabara uel anabura di= ceretur potius quàm anabula,ouis feræ nomen ex integris duobus uocabulis Chaldaicis haberemus compofitum: fed balah etiam uidetur fylueftre fignificare: nam turebalah bouem fylueftrem Chals dai uocitant, ut fupra annotaui. Albertus Magnus apud Plinium non nabim fed anabulam legit: $\& \&$ codices quidam Pliniani nabuna habent, ut Ifidorus etiam legit : quanquám antiquior lecrio lit naa bin, qux apud Solinum quogs extat cap. 33. tefte Hermolao per $n$, in fine. Strabo libro 16. camelopar

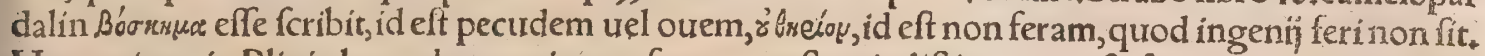
Hac ratione in Plinio legendum, ouis, non feræ* ut poft ouis diftinguatur, \& fera accipiatur fubran tiue. Porrò Plinị uerba hac camelorum aliqua fimilitudo in duo transfertur animalia, cum folius camelopardalis, cui cameli fimilitudo conueniat, mentio fubiungatur, obfcura funt: Prater camelo pardalin quidem ftruthiocamelum auem fcimus à fimilitudine cameli diçam, fed nulla hic eius men tio, fortaffis de equo $\&$ boue Plinius intelligi uoluit: huic enim cruribus, illi collo fimilis eft. Camelo pardi nafcuntur ex his durobus, à quibus nomen habent:camelis minores 8 breuiores collo:capite, oculis, colore, pilis, pardi fimiles: Vngula fiffura eadem quæ cameli, cauda longa ut pardi, Diodo rus libro 3. Biblioth.interprete Pogio.Græcum exemplar infpiciendum eft, pardum ne an pardalin habeat: Quod ad caudam, Oppianus paruam ei tribuit ut mox fubijciam.

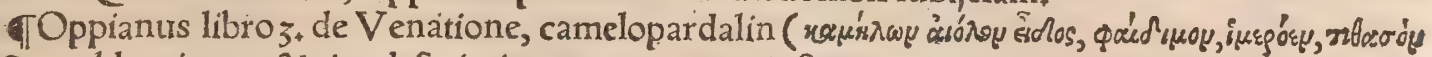

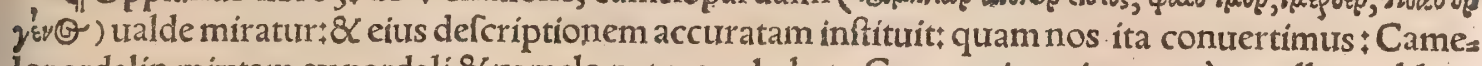
lopardalin mixtam ex pardali \& camelo naturam habet. Corpus ei uarium, stx.े̀: collum oblona

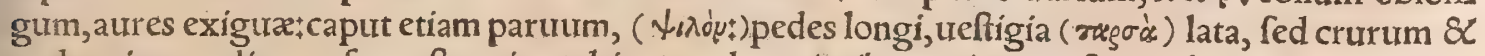
pedum inxqualis menfura eft, maior (altior) multo prioribus, minor pofterioribus, qui humiles $\&$ 10 ondá\}roy, id eft ad terram fe fubmittentibus fimiles funt. A medio capite itrxta aures utrincs in tempo

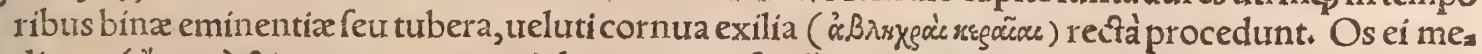

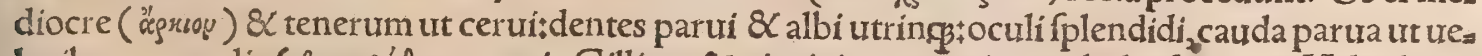

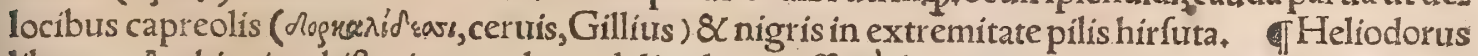
libro 10. Aethiopicæ hiftoriæ camelopardalin elegantiffimé depingit, nos íta conuertimus: Axiomi= tartm legati Hydafpi regi Aethiopum inter cæetera peregrinum $\&$ mirabilis naturæanimal dona= bant; cui proceritas $\&$ altitudo cameli erat:pellis color floridis uarius maculis, $\varphi 0 \lambda i \sigma:$ partes pofterio res $\&$ infra ilia, humiles $\&$ leoninæ formæ: anteriores uero circa armos $\&$ pectus, $\&$ pedes priores, aftiores multó quàm pro cæaterarum partium portione. Collum gracile, \& licetà relíquo corpore

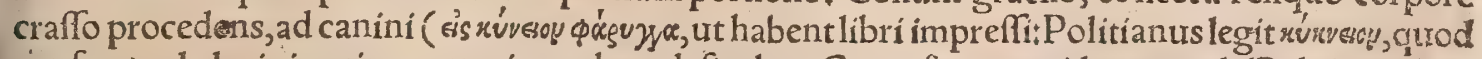
- prafero)uel olorini potius gutturis modum definebat, Caput forma quidem cameli(Politianus hac non rectélegit ) magnitudine uero paulo maiori quàm dupla ad ftruthiocameli caput. Oculís tan-

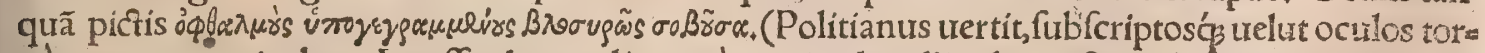
ué motans conniurebat.) Inceffus longe alius quàm animaliữ ulli uel terreftri uel aquaticoł neç, enin crura dextra $8<$ finiftra uicibus mouebat alternis, fed alterutra fimul:ut dextra pariter ambo, indefi-

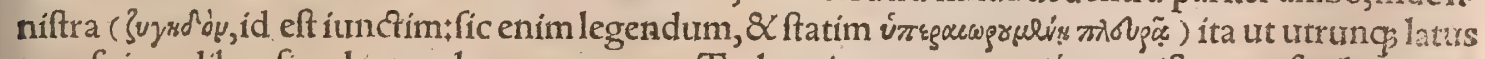
cum fuis pedibus fimul totumloco moureretur. Trahenti autem regentióp magiftro tam facile $8 \mathrm{r}$ mark fuetum fe dabat, ut tenui funiculo capiti circumuoluto, pro illius arbitrio quo modo 8 quocũ let ageretur, non minus ac fi robuftif́imo uinculo ducfũ fuiffet, Hæc Heliodorus: ex quo tranfule, runt hunc locum, Angelus Politianus Mifcellaneis, 8 Petrus Gylius cum A eliano fuo, utriçin furis - translationibus reprehendẽdi. Dion Prufenfis Romanæhiftorix lib, 43. Cæfarem hanc primo popix lo Romano fpectandam dediffe commemorat: $\&$ addit, ex ceterís quídem partiburs camelum uríderi* crura uero difparia habere, narn pofteriora prioribus breuiora funt, ut à clunibus, quafi confcenfio. 
nis gradur, eius excelfitas leuiter attollatur, corpusós reliqữ excelfum prioribus cruribur fuftineà tur. Colore fimiliter maculofo ut panthera diftinguitur. Apud Hefperios Aethiopes turm aliz fera tum camelopardales gignuntur; Strabolibro 17, item libro 16. In ïs locis (inquit, circa mare rubrum puto) Camelopardales nafcuntur, nullam cum pardali fimilitudinem habentes, Coloris enim irarie tate hinnulo fimillima eft, uirgatis pilis diftincto : pofteriora quoc cauda federe uideatur, ad bouris altitudinem. Anteriora uero crura à cameli cruribus non fuperan. tur,collum rectum eft, \& in alturm auectum, uerticem paulo fublimiorê camelo habet, unde propter hanc incommenfurationem, nec tantam celeritatem habere eam puto, quantam dixit Artemidorus, qui eam excellentem facit. At nec fera eft, Areioy : fed pecus, Bóorinjos, Camelos Indicas colore fimiles pardalibus Paufanias in fpectaculis Romanorum fibi uifas fribit in Bocoticis : ego non alias quàm camelopardales intelligo. đGyrapham, id eft camelopardalin Laurentio Medici à Sultano Aegy. ptio donatam, Italia longo poft uidit tempore, Egnatius. Hoc animal paucis ante annis in Hetruria uidimus, quod à rege Tunis ex A frica LaurentioMedici dono miffum fuerar, $R$ aph. Volaterranus. Diurerfum confufa genus panthera camelo, Horatius in epiftola ad Auguftum: quã ením uocamus pantheram, Graci pardalin. M. Varro in libro de lingua Latina ad Ciceronem, Cameius (inquit) fuo nomine Syriaco, in Latium uenit, ut Alexandrea camelopardalis nuper adducla, quod erat figura ut camelus, maculis ut panthera. Camelopardalin Laurẽtio Medici miffam miratifumus habe re cornicula, quanquam mas erat, quoniam de his nihil hac?enus in ueteribus memorijs legeramus, donec Heliodori fuper hac re uer ba legimus. Centum Gordiani principis ludis exhibitas feras oues accepimus, auctore Capitolino:Politianus, Videtur autem feras oues camelopardales exponere: de quo ut dubitem facit partim ipfe Capitolinus qui alio loco camelopardalos decem fub Gordiano Ro mæ fuiffe fcribit:partim quoniam alias ótes feras nouimus, de quibus aliâs. TOrafius anterior parte alturs, ualde eminet, ita ut extenfo capite uiginti cubitorum altitudinem poffit attingere. In po= fteriori uero parte demiffus eft inftar cerui . Collum habet extenfum, caput equinum, licet minus: pedes \& caudam ut ceruus: pellem uero fic omni colorum genere diuerfimodè uariatam, ut homo fruftra tentet artificio naturalem eius pulchritudinem imitari. Hoc animal noftris tempori. bus à Soldano Babyloniorum tranfmiffum eft imperatoriFriderico Romanorum augufto, Hac Ifi dorus: ex quo etiam Albertus Magnus defcripfit; fed addit præterea, quod licet multis coloribus in. fignis fic oraflus(fic legitur)album tamen $\&$ rubeum frequentiores habeat: $\&$ cum fe fpectantibus admirationi effe intelligit, huc illuc fe uertere, \& undiquaģ infpiciendum prabere. Hoc animal (in= quit)temporibus noftris uifum eft, \& Arabice feraph uocatur: Al'n quidam obfcuri authores anabu lam colore ualde rutilo, \& pellem eius propter ornatum in magno pretio effe fcribunt . Quidam in defcriptione Terræ fanctæ, ex qua etiam hanc imaginem mutuati fumus, girapham capræc compa rat, 8 pellem eius in uentre pifcatorio reti, ob uirgulas nimirum cancellatim digeftas * efFlorenti. nus in fuis Georgicis ait Romæ fe uidiffe olim camelopardalim, quod animal in Antiochia ego eriam uidi ab India translatum, Author Geoponicorum Gracorum.

\section{DE C A M E O}

\section{A.}

A M ELI nomen apud Äriftotelem \& ueteres abfolute pofitum, non ad Bactrianam folum quam hodie fimpliciter camielum nuncupamus:fed Arabicam etiam, quam Strabocames lum dromadem, recentiores dromedarium uocant, extenditur. Cum camelos quinquagin ta annos uitrere percepi, tum Bactrianos ad centefimum annum, A elianus; ex quibus uer bis apparet, cameli nomen commune effe, neq Bactrianis duntaxat, quibus geminum in dorfo gib. ber, proprium. Dicam igitur priore loco tum de camelo in genere, tum fimul etiam de Bactriana: po fteriore feorfim pauca de dromade, quoniam $\&$ figura dorfi pracipue differt, 8 cameli nominea purd recentiores non appellatur.

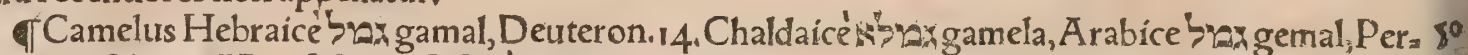

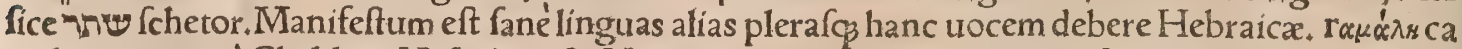
melus uocatur à Chaldaeis, Hefychíus $\& 2$ Varinns. Varro in libro de lingua Latina, Camelus inquit, fuo nomine Syriaco in Latium uenit and achaftranim, Efther 8. Dauid Kimbi milos inter pre tatur, animalia magna \& magni pretị ex equa $\&$ afino:Septuaginta pratermitunti:Híeronymus ue

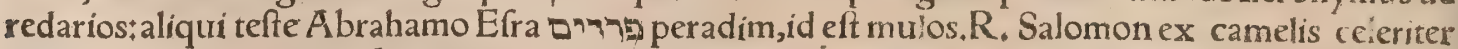
currentibus, nา 2 a bikra formininum: Efaix 60, bikre plurale mafculinum reperitur : ubi ab Hiero=

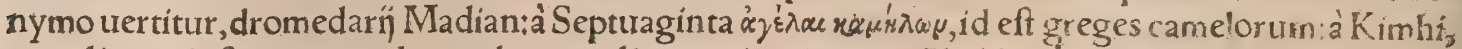
cameli parui, (funt autem dromades camelis cæteris minores:) Chaldaice, $p$ man h hugenain, id eft dro medarí. Rurfus uocem nבר Kimhi camelum paruam interpretatur, Heronymus capream : $a b A=$ quila Symmacho $\&$ Theodotione doourus redditur, id eft curfor, pi o dromace uei dromedario nimia rum:à Septuaginta ỏ $\chi_{\varepsilon}^{\prime}$,id eft fero. Nobis ex Theodori Biblianüri fententia camelus dromas fomina

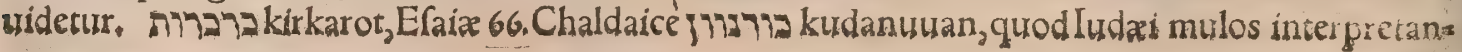




\section{DeCamelo. A. Lib. Is 163}

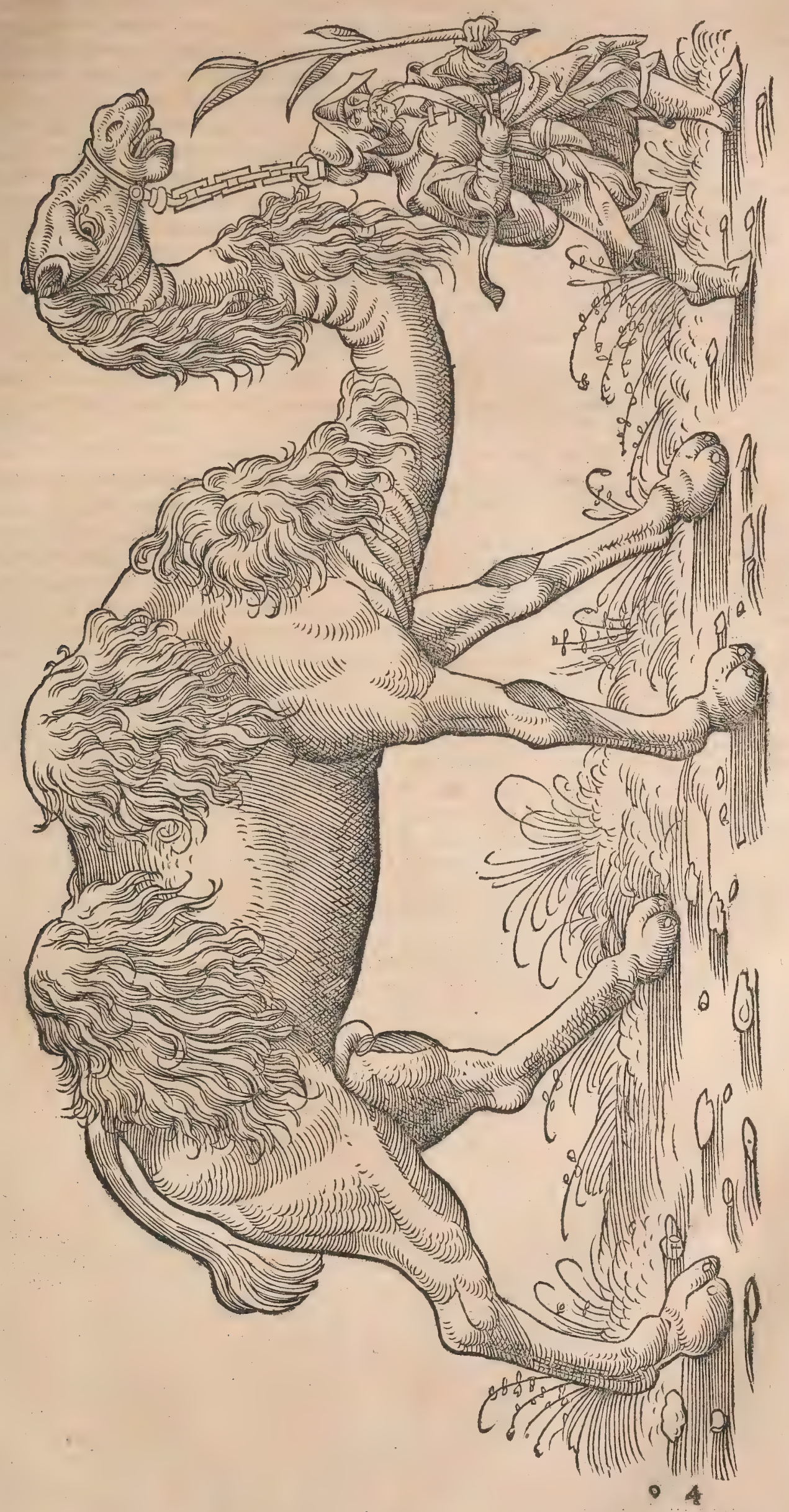


tur, item Septuraginta. A braham Efra genus camelorum excellens ${ }^{\prime}$. Salomon camelos aut alia animalia uelociffima: Eodem modo Kimhi explicat in libro radicum. Sed magis congruit interpretatio noftrortum hominum, ut currus aut carrucas intelligamus. Nam Hieronymus \& Symmachus car

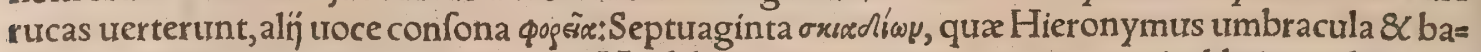
fternas interpretatur, $\&$ dormitoria. His fub iungam nomina quæ reperio in libris medicorum ex Arabica lingua, quanquam corrupta quxdam ex illis $\&$ ineptéfcripta uideantur. Gemel, came= lus eft, inde baul gemel, id eft urina cameli, Syluaticus: Antiqua expofitio uocabulorum Auicenna zemel habet per $z$. Camelus alnegib, id eft qui pafcitur in locis fylueftribus:fecundum alios uero eft camelus ualde uelox greffu $\&$ curfu fuo, quem Latini dromedarium appellant, Andreas Bellunen= fis in Auicennam, in Camelo $\&$ in Alnegib. In Pandectis Syluatici legitur anegibus (corrupté pro al negib)id eft camelus, Alhauar, camelus, Andreas Bell. Algiazar, id eft camelorum, Idem. Ebenars, camelus, Syluaticus, Aftergar feu aftergazi quid fit, inter authores Arabes non conuenit, Legitur enim in libro Benagi Albian quod fit radix aniuden(id eft filphí:) \& in libello de fimplicibus $A I_{c h}$ uin, aftergar effe uocabulum Perficum : quoniam aftir (nos רu fchetor fupra fcripfimus ex Per= fica translatione in Deuteronomion)Perfice idem fit quod camelus, 8 gar fpina, ut aftergar fit fpi na camelorum:Alij corticem radicis aniuden exponunt, Andreas Bell. Bartolemazis Georgieuitz camelum Saracenice fhymel uocari fribit, qux uox accedit ad zemel fupra dictam, ea rurfurs ad ge mel. IT Camelus Italice $\&$ Hifpanice caméllo, Gallice chameau, Germanice $\mathfrak{k}$ i̊meltbier, Anglice camel, Lllyrice Vuelblud.

B.

Camelos inter armenta pafcit Oriens, quorum duo genera, Bactriani \& Arabici: differtunt 'qurod ${ }^{2}$ 1 lli bina habent tubera in dorfo, hi fingula: $\mathcal{Q}$ in pectore alterum cui incumbant, $P$ lin. Camelus proa prium inter cæteras quadrupedes habet in dorfo, quod tuber appellant:fed ita, ut Bactrianæab Ara= bijs differant. Alteris enim bina, alterís fingula tubera habentur. Sunt etiam omnibus fingula parte ima, quale in dorfo, tubera, quibur incumbat reliquum corpus, \& firmetur, quoties in gentra indi=

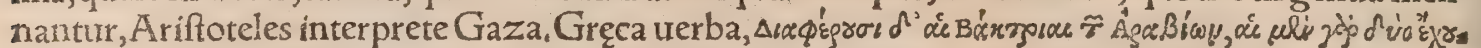

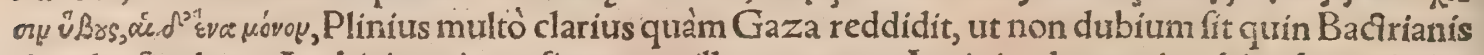
duo dor fi tubera, A rabicis unicum fit:nam ut ille pronomen Latinis ad remotius, híc ad proximius

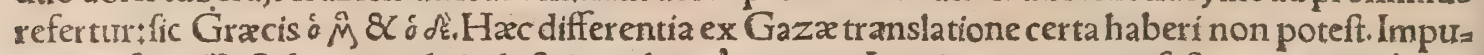
lit eum fortaffis Solinus, ut de induftria ambigué uerteret, Is enim errore manifefto contra quàm de buit, Arabicis tubera duo, Bactrianis unum attribuit, his uerbis cap. 51. Bactri (inquit) camelos for. tiffimos mitumt, licet \& A rabia plurimos gignat. Verum hoc differtunt, quod A rabici bina tubera in dorfo habent, fingula Bactriani. Errat etiam Sipontinus quiBactrias camelos, quibus bina tube. $\mathrm{ra}$, uulgo dromedarios urocari fcribit. Albertus magnus in diftinguendo à dromade camelum mecü fentit,Quod autemres contra fe habeat, quâm Solinus fcribit, facile Didymi etiam teftimonio com= probauerim. Is enim Bactrianam camelum in ijs montibus, qui ad lndicam pertinent, concipere

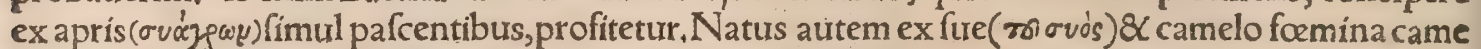
lus duplici gibbo eft. Verum quemadmodum in equis $\&$ afinis plurimas notas patris fert mulus: fic camelus ortus ex femine fuis tanquam indicium, uirtutis robur, pilorum ̧́ denfitudinem contra hit. Nec in luto eñ facile cameluss talis dilabiț, fed erigitur ftatim fuis uiribus, ponderisẹ́ fert duplü 4 quàm cęteri. Vocant aưt ipfos, \& meritò fané Bactrianos, quod primo fuerint in Bactris orti, Hęc ex Geoponicis Gracis in fine libri 16. 8 mox de dromadibus feorfim. Vocatautem fínuptop illum cui duofint tubera: pro qua uoce mẽdum eft Bibliotheces tertio apud Diodorum:ubi ditili fcriptum re perias pro dicyrti, Calius. Vide an dityli forte legi poffit, à tylo de quo paulo poft. Arabia multa $8<$ diuerfa camelorum prabet genera, tum pingưium tum macilentorum, quorum quidam ditili à gib bo duplici nominantur, \& c . Diodorus interprete Pogio. Camelin dorfo tuber Græci uocant hy= bon, quanquam \& eo nomine intelligitur collo qui eft obtorto, Cælius. बBoues Scythici fimiliter ut cameli eminenti dorfo exiftunt; fimul $\&$ cum dorfo clitellæ imponuntur, perinde ut cameli genu flectunt, Aelianus. Boues in Syria nodos fcapularum flectunt, ut cameli, Arriftoteles, Bubus Indis cis camelorum altitudo traditur, Plinitus. Nabim Aethiopes tocant animal collo fimile equro, came lo capite, \&c,Plinius. TCamelus inter bifulca maximum eft, Ariftoteles, Et alibi, Camelís opitula ta eft natura magnitudine corporis: fufficit enim hæc ad necem arcendam. Colorem habent cameli pullum atç natiuum, ob id uulgo pullum colorem camelinum uocant, Sípontinus, Buber, id eft las

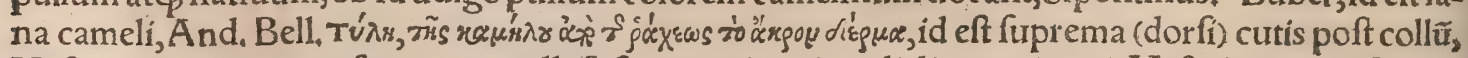
Hefychius $\& V$ arinus:forte quia callofa fit:proprie enim tyli dicûtur, inquir Hefychius, callofæ partes animalium doffuariorum circa humeros, trel fcapulas, ex frequenti afficicu nimirum $\& \&$ compref fione præter naturam. Poteft tamen tylos etiam fecundum naturam dici, ut apud Nicandrum caro protuberans, circum oculos anguium:inde rúnwe Grammatici etiam tuber exponunt, \& inferio rem pedis partem. Protagoras primus quam nuncupant $\tau \dot{u} \lambda z y$, in qua onera portant, intenit, Laërtí us libro 9. Nihil igitur obftat quin apud Diodorum legamus dizuภo, , id'ç elegantius meo iudicio, 6 quàm dírugroy, pro camelo cui geminum tuber. TCameli non funt utring dentati, quamuis cornibus careant; cuius rei caufam reddit Ariftoteles libro3, de partibus animalium, cap, 14. Camelus 


\section{DeCamelo.B.C. Lib. I. 165}

una ex ijs qux non funt cornigera, in fuperiori maxilla primores non habent dentes, Plinius, Et ali bi, Dentium(inquit)fuperiore ordine carent in utrocs genere, id eft tum Bactrianæe tum Arabiæ. Cameli adiusuantur proceritate collorum, Cicero de Nat. Anhar, id eft locus qui eft in inferiori par te gula, Latiné fonat uulneratio cum lancea: eò quod camelus ibi cum lancea percuffus, citius quàm unlo alio uulnere moritur, Syluaticus, Cameli ưenter cur multiplex fit, declarat Ariftoreles libro z. de partib.cap.14. Defenem, adeps zirbi,id eft omenti cameli;Syluaticus. Camelus fel non difcre tum, fed uenulis quibufdam confufum habet, Ariftot.lib; 4.cap.2. Et paulo poft, Camelus quia felle caret, diu uiuit. Plinius ètiam camelos felle carere feribit. In uentre(uel ut alibi,inter femora)mam mas duas cum papillis quatuor habet, modo uaccx, Ariftot. Genitale camelis neruofum eft, Arift. - Et alibi, Neruo(inquit)ita conftat, ut uel ex eo confici poffit(neruuss) quo arcus fidiffimé intendatur. Caprea, rangrae, funt in natura cameli prominentes carnes, Calius : nos clarius ex Strida dicemus mox capite s.ubi de caftratione cameli. Caudam habet camelus afino fimilem, genitale retro, Arift. Genua fingula in fingulis cruribus funt, \& flexus artum, non ut quidam perhibent plures: fed pro. pter alui interuallum plures effe uidentur. Habet etiam talum fimilem bubulo : clunes proportione magnitudinis paruos. Bifulcum id animal eft, nec utring dentatum. Sed bifulcum fic eft, ut pes par te fuperiore fciffus paululum fit ad flexum digiti fecundum: parte autem priore fumma, quadriparti to findatur difcrimine paruø, quantum primotenus digiti inflexu, $\propto$ quiddam inter fiffuras, perinde ut in anferum pedibus adiectum contexat. Pes ueftigio eft carnofus, ut urf $x$, qua de caufa eas qua per exercitum longiore itinere fatif́nt, caleeant carbatinis, A riftoteles. Camelo tali fimiles bubur lis, fed minores paulo. Eft enim bifulcus difcrimine exiguo pes imus cameli, ueftigio carnofo ut ur: $\mathrm{fi}$, qua de caufa in longiore itinere fine calciatu fatifcunt, Plinius. Coitus tota die eft camelis folis ex omnibus quibus folida ungula, Plinius. Carbatinas calceamenti genus effe ex rudi uel recente corio

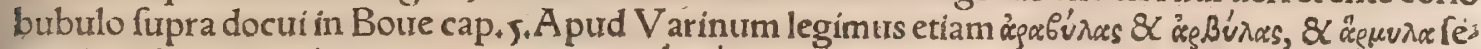

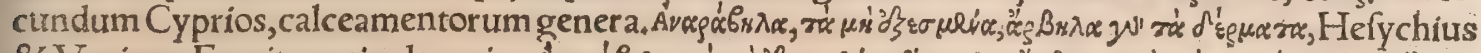

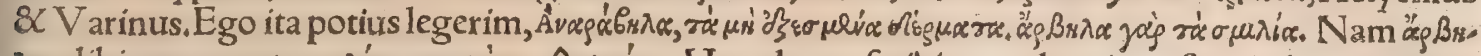

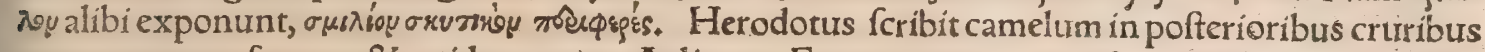
gerere quatuor femora, \& totidem genua, A elianus. Ego per genua articulos intelligo, per femora uero offa quæ inter articulos recta habentur. $\mathrm{Hæc}$ autem terna effe in prioribus cruribus, in pofteri oribus quaterna, ipfe dum hxc friberem in dromade obferuaui. Pedes nunquam atterunt; funt $e^{2}=$ zo nim illis reciprocis quibufdam pulmunculis ueftigia carnulenta, Vnde \& contraria eit labes (id eft lapfus uel lapfio) ambulantibus, nullo fauente prafidio ad nifum infiftendi, Solinus. Auicenna au* thor eft camelos quordam fiffos habere pedes, alios uero equí inftar folidos; Albertus, Camelus ani: maleft deforme, collo $\&$ cruribus longis, Idem,

C.

Genus camelorum utrum pes finifter non tranfit dextrum fed fubfequitur, Ariftot. Omnia animalia à dextris partibus ince dunt, finiftras incubant(id eft finiftris interim innituntur:) Reliqua ut libitum eft gradiuntur:1eo tan tum $\&$ camelus pedatim, hoc eft ut finifter pes non tranfeat dextrum, fed fubfequatur, Plinius. A p paret autem eum non intellexiffe locum Ariftotelis qui eft libro 2,cap.1, hiftoria anim, de greffu ani

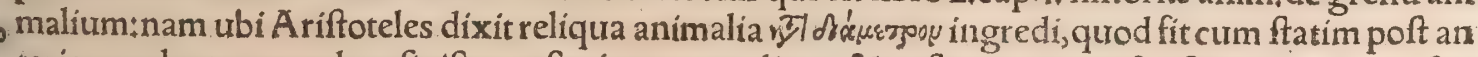
teriorem dextrum pedem finifter pofterior progreditur; \& poft anteriorem finiftrum dexter pofte. rior:Plinius uertit, ut libitum eft. TA A fefefeni, id eft. paftura camelorum, Antiqua expofitio in Aui cennam. Schornuanthos aliqui paftum uel fonum camelorum uocant:nam ubi nafcitur, longelaa té́q omnia occupat, ita ut pafcendi copiam abunde prabeat. A mant hordeum, cuius pabulư fubito glutiunt, 8 poftea tota nocteruminant:Si unus abfineat in ftabulo, cæteri tan ${ }^{2}$ condolentes in ftabulo fimul abftinent, Albertus. Quxdam præ fui corporis magnitudine, aut difficultate cibi non ad concoctionem idonei, fed fpinoli $\&$ lignei, multiplicem habent uentrem, ut camelus . Et hæc qui= dem quanquam cornibus caret, ideo non fuperne dentata eft, quiod ei magis neceffarium eft uentre talem habere, quàm dentes priores, \& $c_{+}$Ruminat etiam camel us more cornigerorum, quoniam uen - tres fimiles cornigeris habeat, Ariftot. Paftus columbarum 8 camelorum, eft herba habens granũ fimile grano myrti, qua pafcuntur cameli, nec indelæduntur quicquam, cum fit uenenum uermi. bus, Syluaticus $\&$ Antiqua exp.in Auic. Aftergar, id eft fpina camelorum, ut paulo ante dictum eft cap.1. Arabes Scenítæ pafcua omnis generis pecorum, præfertim camelorum, optima habent, Strabo. Schornuanthos quidam Arabice adcher appellant. If Cameli $\mathcal{X}$ equi turbulentam 8 craffam aquam fuauius bibunt, quippequa ne ex fluuio quidem prius hauriant, quàm pede inturbent, Poffunt uel ad quatuor dies tolerare fine potu, $\mathrm{m} \otimes x$ bibunt quàm multum, Ariftot. Sítim \& quatriduto tolerantrimplentur cum bibendioccafio eft, $\&$ in prateritum $\&$ in futurum, obturbata conculcatione prius aqua:aliter potu non gaudent, Plinius. Didymus in Georgicis ait triduum inte grum tolerare fitim camelum . Lutulētas aquas captant, puras refurgiunt: deniọ nifi coenofior liquor ' fuerit,ipfi affidua conculcatione limum excitant, ut turbetur, Solinus. Bactrij minus infeftantur fiti: ideóç laboris patientiores funt, Calius, Irati ftrident horribiliter, Author obfcurtss. In auerfum(ex

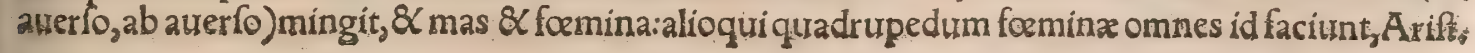


Feruidurm animal camelus eft, proindéćplafciuum: ex quo in Vefpis Ariftophanes feftuiffimè, Pho carum(inquir)odorem habebant, lamix uierò tefticulos illotos, cameli autem podicem. Coitus auer

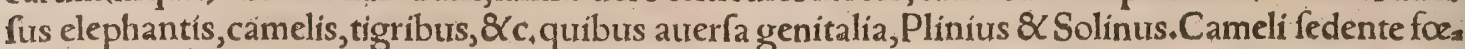

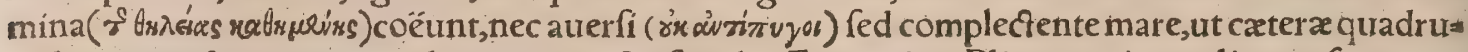
pedes agunt, \& coitum toto die exercent, A riftoteles. Errat igitur Plinius qui camelis auerfum pera gi coitum fribit, quod Hermolaus etiam in Caftigationibus Plínianis obferuauit. Interim miror quî tiat quiod auer $x$ non coëant more aliarúm omniũ quadrupédum, qux genitale retro urertúnt. Tem= pus coéundi in terra Arabia,menfe Septembri. Incipit \& mas \& formina coire in trimatt ; foemina poft partum uno inter pofito anno coit, Arift. A trimatu pariunt uere, iterumós poft annum implentur à partu, Plinius. Vere pariunt, Ariftot. Petunt receffum folitudines cum libet coire, nec aliquís cò potef tutò accedere, praterquam paftor armenti, Ariftot. Coituri folitudines aut fecreta certa pè tunt, neç interuenire datur fine pernicie. Coítus tota die elt tantum n̈s ex omnibus, quibus folidä un gula,Plinitrs. Genituræcupidine efferantur adeò, ut fæưiant cum Venerem requirunt, Solinus, $\mathrm{Ca}$ melus mas fauit tempore coítus, fiue homo, fiue camelus accedat; nam equís quidem odio naturali aduerfantur, Ariftot. Maffageta cum uxoribus in propatulo concumbunt, ut Herodotus fcribit: at cameli coéundam Veneris focietatem nunquam palàm inter fe ducunt:Quod quidem facríne ue recundia an admirabili naturæ munere faciant, Democrito álijsḉs difputandum relinquo. Cum au* tem inter eos coniunctionis appetitum paftor exorirí fentit, aliquò concedit, Aclianus. Nec matri nec forori mifcetur camelus, Didymus. Camelos in Ádmirabilium relatione tradit Áriftoteles nun quam coiffe cum matre. Obferuatum id S' in nono A uicennæ libro, qui eft de animalibus, Cælius. Camelus cum matre nunquam concumbit:Curius rei exemplo eft paftor quifpiam, is cum forminam quoad eius fieri poterat, exceptis geni talibus obtexiffet, deindéḉ filium matri fic opertæ admififfer: hic ex latebris coitus appetitione falfus, matrem imprudês fuperuenit furam, quod ubi intellexiffer, camelarium felerati coitus admiffarium, 8 mordicus premens, $8 \mathrm{~K}$ ad terram abiectum genibus af: fligens, cum fummis doloribus interfecit, atç feipfum pracipitem agens, uoluntariam mortem fibi confcitit. At inter homines Oedipum cum matre commififfe inceftum, conftat : $\&$ Telephum etiam commiffurum fuiffe, nifi eos diuino ductu draco diremiffet, A elianus ex Ariftotelis de hiftoria ani: malium lib.g.cap.47. Camelus uentrem fert menfes duodecim, parit fingulos, Ariftot. \& Plinius. Vniparum(fic legendum, non uiuiparum) nancs eft, A riftot.lib,5.cap.14. hiftorixanimal. Came-

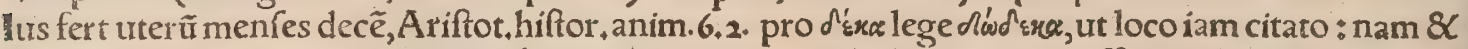
Plinius ita legit. Separant prolem à parenteanniculam, Ariftot. T Tenuiffimumlac camelis, mox equabus, Plinius. Tertio loco afinæ, Ariftot.Lac camelinum liquidiffimum, tenuiffimum ac minime pingure, licetós plurimo fero abundet, tardius tamen fecedere longa experientia compertũ eft. Came lilac habent, donec iterum grauefcant, Plin.Lac fuum uf̧́ eò feruant, quò iam conceperint, Árifto. Syluaticus aufa lac camelinum exponit. TCamelus quia felle caret, diu uiuit, Ariftoteles: Et alibi, Viuit diu,plus enim quàm quinquaginta annos. Et rurfus alibi, Viuit magna pars camelorum an. nos triginta, fed multo plures nonnulla: nam uel ad centefimum annum facultatem uiuendi protras

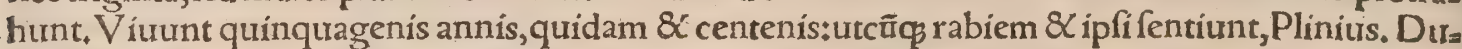
rant in annos centum, nifi forte tralati in peregrina, infolentia mutati aérís morbos trahant, Solinus. - Scabies cameli cedria curatur, Didymus, Rabiem 8 ipfi fentiunt aliquando, Ariftot, 8 Plinitus, Camelis accidit rabies \& podagra, unde facile moriuntur:quamuis enim non amittant ungulas, $\mathrm{do}_{=}$ lent tamen uehementer cum per itinera dura $\&<$ falebrofa incedunt, Albertus $\&$ alin recentiores, $\mathrm{Ca}$ melos necare traditur in Babylonis regione gramen id, quod iuxta uias nafcitur, Plinius, Iuba tradit cetaceo pingui 8 omnium pifcium adipe, negociatores in Arabia camelos perungere, ut afilos ab his fugent odore, Plinius,

D.

Quantopereinceftum cum matre fugiat camelus, paulo ante dixi. Odium aduerfus equos gea runt naturale, teitibus Ariftotele $\&$ Plinio. Cum Xerxes per Pxonium agrum atque Creftoni= cum iter faceret fuper amnem Chidorum, leones impetum dederunt in camelos, qui commeatum portabant. Sub nocient enim relictis locis confuetis è defcenderunt:nulloǵz alio neq̧iumento neģ homine tacto, in camelos graffati funt. Cuitus rei caufam admiror:quod leones quoties aliunde eis eit quo indigent, abftinent ab inuradendis camel is, quod animal nunquam antea nec experti fuerant il. lic, nec uiderant. Sunt autem per ea loca leones multi, Herodotus libro 7 . Onerandi cameli fí uel modice à camelario fuper genua calce percutiantur, ftatim flexis cruribus fe fubmittunt;

E.

Camelos inter armenta pafcit Oriens, Plin. Omnes iumentorum in ïs terris (Bactris \& Arabia) dorfo fungunt:atç etiã equitant̂t in prælị̂s. Velocitas in ter equos(id eft æqualis equor $\tilde{u}$ uelocitati) fed fua cuiqg menfura, ficuti uires. Nec ul tra affuetum procedit fpatium, nec plus inftituto onere re $=$ cipit,Plinius .Sunt alî̉ oneri ferendo accommodati, alij leues ad pernicitatem : fed nec illi ultra iuftû pondera recipiunt, nec ifti amplius quàm folita fpatia uolunt egredi, Solinus, Currunt Cameli celeri 60 us quàm equi Niffani, propter laxiore $\tilde{e}$ fui gradus glomeration $\tilde{e}$, A rift. Formicæ Indicæ Indos auru ab ipfis congeftum furantes, crebrolacerant, quamuis prauelocibus camelis fugientes, Plinius, Ca. 


\section{De Camelo. E. F. 167 :}

melis iunctis Indi tendunt ad auri furta, quod cuftodiriaiunt à formicis, quæ ưulpes excedant ma

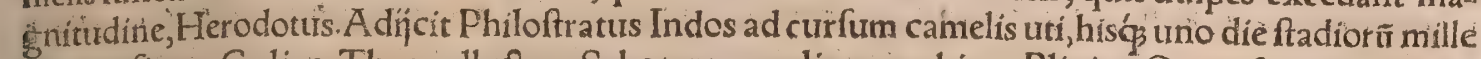
iter conficere, $C x$ lius. Thus collectum Sabotam camelis conuehitur, Plinius. Onera fexaginta came lorum memorantur in facris literis libro 4.Regum cap. 8. \& fex milia camelorum, Iob 42. \& rurfus quinque milia, primo Paralipomenon cap. y. Nonnulli fuperioris Afia incolę camelos uel ad tria mi lia poffident. Ex ditylis camelis(id eft quibus bina dorfitubera prominent) quidam ferendis oneri,

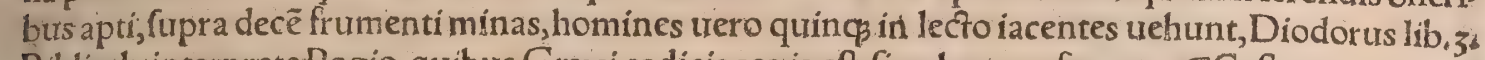
Biblioth, interprete Pogio, quibus Graci codicis copia eft, fi uolent conferant, qCaftrantur cameli mares, ut pugnacior es fint, à Bactris populis, fic petulantia excifa robuftiores fieri aiunt, (quod \& So linus fcribit:)Quinetiam foeminis uuluas ferro exulcerari, ut partibus illis qux ad furorem libidinis incitant aduftís, ad bellum aptiores exiftant, A elianus. Cameli etiom foeminæ caftrantur, cum eis uti in pralio libet, ne concipiant utero, A riftot. Caftrantur formina fues fic quoos uti cameli, polt biäu inediam, fufpenfa pernis prioribus, uulua recifa; Plinius. Caprex, ngregrac, carnes funt eminentes in tra pterygomata pudendi, quas excindũt cum ad bellum parantur, ne amplius coire poffint, Suriedas.

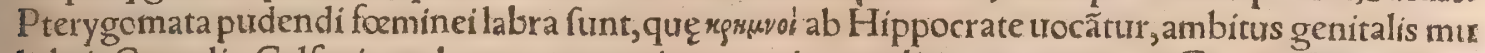
liebris Cornelio Celfo: intra hac qua prominet caro in camelis capreas uocant Graci, Hippocrates iia mulieribus ögisy, aliqui nymphã, Ad belli ufum, camelorum quoqs gerula opera expetitur $\ddagger$ ex $\mathrm{ca}=$ melis etiam Bactrí pugnãt, quod fint equis celeriores, \& magnitudinis ratione formidabiliores etiã, 8 hirfutiores; \& quia non infeftantur fiti, ac laboris patiétiores funt, ad diuerfos ufurs bellicos magis idonei, Calius ex Pollucis libro primo. Camelos aliquanta nationes (inquir Vegetius de re milit، $;$. 13.) in aciem produxerunt, ut Vrcilani in Aphrica, Mahetes hodie quogs producunt. Sed hocgenus animalium arenis 8 toleranda fiti aptum, confufas etiam in puluere uento uias abfop errore dirige: rememoratur. Caterum propter nouitatem, fiab infolitis uideatur, inefficax bello eft.

TVrinam camelorum fullonibus utiliffimam effe tradunt, Plinius. ILycion aptiffimum medis cinæ quod eft fumofum, Indi in utribus camelorum aut rhinocérotum id mittunt, Plinius. Ex pilis camelorum \& dromadum, quimediocriter molles crifpíq̧́ funt, ueftes audio confici, camelotas inde uulgo diças, Corulei coloris ueftis dicitur $\&$ cymarilis, inquit Bayfius. Hic undas imitatur, habet quooģ nomẽ ab undis, Ouidius: xúux enim fluctus eft. Nec me latet quofdam per cymatilem treftem apud Plautum intelligere undulatam, id eft de camelot:quod haud fcio an ridiculũ fir, Hæc Bayfius - Diurum Ioannem baptiftam legimus indutum fuiffe uefte ex pilis camelorum, contersta nimirum ex pilis, non camelota, id eft ipfa cameli pelle, ut pictores $\&$ ftatuarï fingunt. G Genitale camelis ita neruofum eft, ut uel nerutus ex eu confici poffit, quo arcus fidifime intendatur, Ariftoteles. Alha cab Arabice eft neruus camelorum contufus in uillis, quibus fimul cum colla inuoluuntur arcus !i gatione forti, ficut fit in Damafco hinc etiam in humane corpore offum ligamenta feu chordx alhas cab dicuntur; Andreas Bell,

F.

Camelus in facris literis animal in cibouetitum elt: quanquam enim ruminat, ungula tamen ton emnino diuidit, fed parum aliquouf $\beta$, \& fuperne tantum imum enim ueftigium omnino planuns folidumq̧́ eft:ita ut inter bifulca $\&$ folidipeda ambigere mihi uideatur: proinde \& Plinius alicubi fo - lidam ei ungulam triburit, ut ín B. fupra dicum eft. TS Sunt qui afinorum domefticorum mandunt carnes, peftimi fucci, ac concoctu difficilimas, nec non infúaues : ita etiam equorum ac camelorunt nonnulli, animó frilicet \& corpore afinini ac camelini homines, uefcũtur, Galenus libro z. de alimen torum facultatibus. Camcli tum lac tum caro, fuauiffima omnium eft : bibitur cius lac ad unam menfuram duabus aut tribus aquæ admixtis, Ariftoteles \&C Plinius:qui tamen lactis folum, nó iten carnis fuauitatem commendat:Etalibi, Dulcifimum ( inquit) ab hominis lacie camelinum eft. Ca

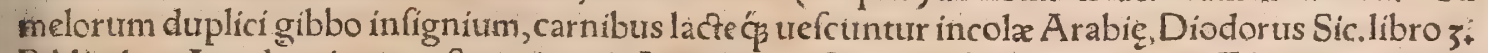
Biblioth. Apud maiores noftros, inquit Antiphanes Comicus, boues integros affabant, certros, a: gnos: deníg coquis quidam integrum monftum aflatum, nempe calidam camelum, magno (id eff Perfarum ) regi appofuí, A thenęus libro 4. Lac camelorum partui ticinarum butyri \& cafeofæ fubs. x fantix minus habet, ac tenue ef : Equarum lac eft ficur camelorum partui uicinarum, tenue, aquro: fum: Omne lac obftruit, iecur præfertim, excipinus camelorum foctarum lac $\&$ fimilium(afininum equinum)in quo parum cafeofieft, \& aquofitate fua abfrergit, Auicenna. In lacte camelino falfedo eft, inde quiod amant acetofuni, A uicenna: (fortelegendum, Salfum elfe camelinum lac, quioniam cameli appetunt falfa. Acetofum uero lac, \&cà nouro initio.) Lactis ufus fape inducit for des (alba: ras, id eft, uitiliginem profundiorem ) praterquam camelorum recenter foetarum: ex hoc enim raro tímentư albaras, A uícẽna. A lưum mollit lac equinum, camelinum, \& afininum, Idem. Camelinum lac omnium tenuifimum eft, \& meliorem tenuioremćs fuccum gignit:extenuat craffos humores ex crementitios:aluum mollit, \& obftructionibus liberat, propter uehementem calorem quí ei per nas utram inef, $\mathrm{Rafis}$. Arabes nouimus camelorum lacte uefci, à carnibus fuillis trero abftinere imprim mis, copiæ uel raritatis utrumqs ratione. At camelos deteltantur in Septentrionem reiecti, Calius. Heliogabalus comedit fapius ex A picij amulatione, ut Spartianus prodit, camelorum calcanea ${ }_{j}$ cri ftas gallinaceis demptas uiuentibus, \& 8 . 
Camelus calido \& ficco temperamento eft, Rafis. Veneno infectus, fineceffitas poftulet, colloce tur in uentrem muli uel cameli recens occifit fiquidem calor iftorũ animalium refoluit uenenum, 86 fpiritus parteś́s corporis omnes corroborat, Ponzettus cardin. Tharo cameli prouocat urinam, Auicenna:Bellunenfis cerui non cameli, legendum monet. Camelorum pingure quomodo curan. dum fit, ex Plinio $\&$ Diofcoride pradixi iam in Tauro, Adeps de gibbo cameli fuffita, iuuat hamo rhoides, Auicenna. Sanguis cameli fricatus(lege frixus)dyfenterize prodeft, \& diuturno alui pros fluuio, Haly.Síccatus \& frixus, fluxiones fiftit:cum uino potus, fagitzæ Armenz ueneno aduerfat, Auicenna.Poft purgationem uero menfium potum(hoc forte ad lac cameli pertinet) conceptû́ promouret, $\&$ prodeft prourocationi uteri, Auicennatut citat quidam author obfcurus:egó apud Auicen \& nam negs in fanguinis nec; in lactis mentione reperio. Medetur fanguis cameli epilepfix, Auicenna. TCameli cerebrum arefacum, potumós ex aceto, comitialibus morbis aiunt mederi, Plinius, \& $\mathrm{A}$. uicenna, \& Galenus in libro de theriaca ad Pifonem cap.12. TDentes quando fricantur, inteftinis excoriatis manifefte profunt: $\&$ hemorthoidas impofiti fanant:mifcentur item cum affagh, id eft un gento $\&$ livole cum aqua porrorum nabati, quo remedio inuncto efficaciter dolor harmorrhoidum rollitur, $R$ afis, TSpuma cameli cum aqua pota ab homine ebrio, reddit eum dęmoniacum, $R$ afis. TSi quis de pulmone cameli arido \& trito pondus aurei biberit,cacitatem incurret, $R$ afis. $\quad \tau \mathrm{Fel}$ cum melle potum comitialibus morbis aiunt mederi, item angina, Plinius. Solum per fe fronti illi= tum, prodeft aduerfum caliginem:fed ne omnino lippiatur, decoctum cum mellis optimicyathis tri bus, $\&$ croci uncia in unum mícebis, \& fic fuffufionem ad oculos facies, uel etiam fuperlines inde caligantes \& lippientes oculos:hoc medicamine etiam excrefcentes carnes in oculis \& cicatrices curantur, Marcellus. I Cauda cameli arefacia aluum folui aiunt, Plinius, Setas è cauda contortas, et finiftro brachio adalligatas, quartanis mederi, Idem. TLac camelorum recenter foetarum auxilia tur afthmati $\&$ anhelofis, Auicenna. Lac camelorum(quidam addunt, recenter foetarum ambulan tium) prodeft aduerfus hy dropem $\&$ duritiem lienis, ut caprinum eriam $\&$ afininum, Auicenna. $\mathrm{Ca}$ meli lac roborat iecur, obftructiones aperit, lienem craffum extenuat: $Q$ ituuat hydropicos, fi calidû bibattri, prefertim admixto ei faccharo alazur, Rafis. Lac camelorum recens foetarum cum oleo de alcanna(aliâs, alkerua)partibus internis induratis auxilio eft, Auricenna. Lac omne fpleneticis Q hepaticis, \& uictu attenuante indigentibus, infalubre, excepto camelorum foetarum lacie thoc es nim confert affectibus pleríf fplenis $\&$ hepatis, \& renourat(aliâs humectat, aliâs impinguat)hepar: Conducit prețterea in hydrope, maximè fi bibaț cum urina camelorum recens foetarum Arabicarũ: excitat etiam appetitum cibi, fed fitim facit, Auicenna. Protrocat menfes, et confert hæmorrhoidum aritijs, Idem, Epoto ueneno antidotum eft lac camelitidem corruptam temperiem corporis emendat, \& auget uentrem(id eft aluum de’hcit,) Haly. TFimi cameli cinere crifpari capillum cum oleo aiũu: $\&$ dy lentericis prodeft illitus cinis, potusíg̣ quantum trinis digitis capitur, \& comitialibus morbis, Plinius, Stercus cameli prohibet remanere ueftigia uariolarum, 8 tollituexrucas : $\&$ fluxum fane guínis è naribus fiftit, $\&$ cum medicamentis potum comitialibus confert, Auicennatauthor quidam obfcurus falló ex Plinio citat:Fimus camelialbus cum melle tritus $\&$ impofitus, tumores reprimit, \& $x$ tulnera deficcata expurgat: refoluit bothor ac ulcera, fcrophulas quoģ fortirer, \&c. Hxc ex Dío fcoride citata, neq̧ apud iplum, neq̧ apud Serapionem intrenio. A pud A uicennã uero fic legimus, Stercus cameli reloluit bothor \& ulcera: \& fimiliter ftercus pecudis fuper mellinum : ftercus capram rum refoluit frrofulas fortiter, $\mathcal{Q}$ fimiliter ftercus cameli:quod etiam articulorum dolores fedat $\& a b$ Iceffus eorum fanat, $\mathrm{H}$ æc Auicenna, TV rinam ulceribus manantibus utiliffimam effe tradunt, Barbaros eam fertrare quinquennio, $8 \mathrm{cheminis} \mathrm{pota} \mathrm{ciere} \mathrm{aluum,} \mathrm{Plinits.} \mathrm{Vrina} \mathrm{cameli} \mathrm{pulli} \mathrm{cum}$ à lacte feparatur, foluit uentrem: $\mathcal{Z}$ nifi folverit, medicamento aluo deíciendx apto utendum, $R$ afis. Vrinarum utiliffima eft, quam reddit camelus Arabica, quam alnegib uocant:furfures abftergit, $f$ caput ea abluatur:odoratui lafo prodeft (uetus translatio non recte habet, foetori narium) $\&$ obftrth curm os, quod colatorium trocant, efficaciter aperit, A uicenna. Vrina cameli, ut hominis etiam, ree medium eft hydropi:eadem illinitur fplen, pracipué cum lacte cameli,A uicenna. Sal Ämmoniacurs factitius hodie nobis affertur ex Germania plerung: licet nonnulliex urina camelorum arte quadã s denfata fieri credant, Petrus Matthrolus.

H.

Ta. Recentiores quidam chamelum per c afpirattrm fcribunt, ut Politianus \& Calepinus, forte ueteres imitati Latinos quichenturionem procenturione dicebant:aut propter etymologiam qua

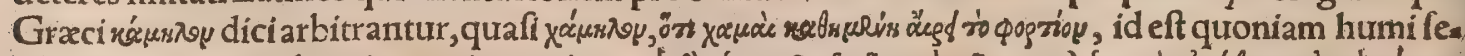

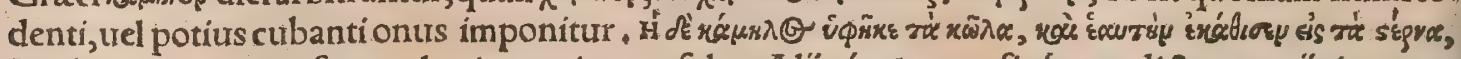

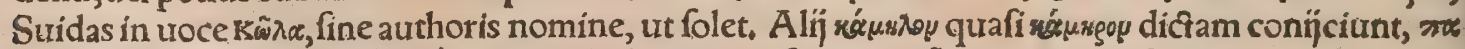

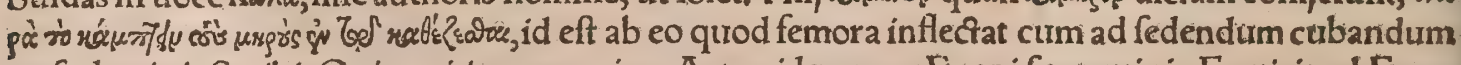
uefe demitrit.Scribit Onirocriticorum primo Artemidorus, ex Eueni fententia in Eroticis ad Euno

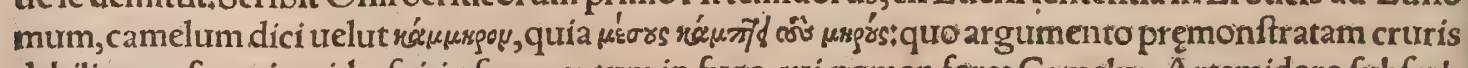
debilitatem fomnianti, hofpitio fe exceptum in fuga, cui nomen foret Camelus. Artemidorof fubferls. bit Horus, apud Aegyptios camelum inquiens, indicare hominem inceflu tardum: quoniam inter 


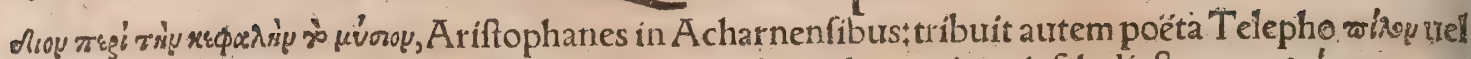
pilidion(quas uoces apud Pollucem quoç legimus) quod nunc, inquit fcholiaftes, rourcidewnsou noca. turi per epfilon, Calius galericulum inter pretarur. Vt camelaucion fic $\&$ caufia, rau oía, nomẽ habet, quod genus pilei lit mpgos ro rawux, id eft aduerfus aftum, idonei : de quo Antipater Theffalonicen, in

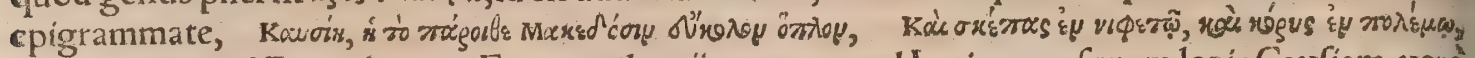
Hac Orus apud Etymologum, Ego camelaucï nomen apud Latinos nufquam legi : Caufiam uero regum Macedonum infigne furfieg ammatici tiadunt. Valerius Maximus lib. 5. Quemadmodum Antigonus caput Pyrrhi texit, caulia, qua uelatum caput more Macedonú habebat. Plautus in Mi lite, Facito ut uenias ornatu huc naucleriaco, caufiam 'Habeas ferrugineam. Kouvia aliqui eriam

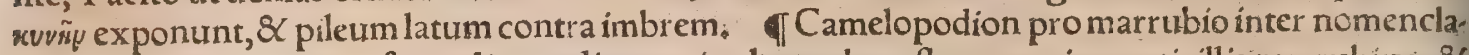
turas herbarum legimus; forte clinopodion potius legendum;florum enim uerticillis marrubium $B$ alia herba proprie clinopodion dicta, conueniunt, TCamelani Italia populi in fexta regione, $\mathrm{Nar}$ nienfibus \& Nucerinis uicini, Plinitus. Camelides, infula dux ignobiles Mileto utcina, in ora loa nia regionis, Plinius 5.31. Camelocomi, Kkess cura, ut apparet, nuncupati;meminit eorum Stephanus in Chatramotites uocabulo. Ali funt $\mathrm{Ca}_{2}$ melitæapud Strabonem libro 16. Ab Euphratis (inquit) fluminis tranfitu Scenas ufque, elt iter die rum uigintiquing: hîc funt Camelitæ, \&'c. Gamale, rákexax, urbs in ludaa uel Syria, Siephanus $\&$ Iofephus Antiquitatum libro 4.Suetonius in Tito, Tarrhachiam (inquit) \& Gamalen urbes uali. diffimas Iudax in poteftatem redegit. Videtur fanè hac etiam à camelo appellata, quam Hebræiga mal uocant. DeGangamela uico Perfidis paulo fuperius in hoc capite dixi.

b. Salluftium mirari foleo, qui Romanos fub Lucullo imperatore in Afia primum camelos uidiffe fcribit, arbitratum forte non eọs primum qui cum Scipione Antiochum deuicêre, neçs iterum qui cum Archelao ad Orchomenum \& Chæroneam nuper conferterunt, cognouiffe camelum, Plu

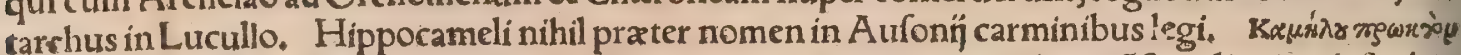
Ariftophanes in Vefpis Philocleoni attribuit, cuius cor poris partes ueluti môftri alicuius defcribit:

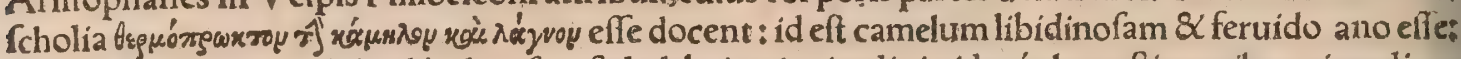
fpeciem habet prouerbī in libidinofos, fed plebeiæ tưrpitudinis, ideó̧́ honeftis auribus uitandi.

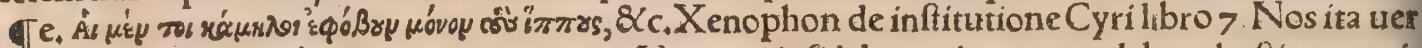
timus: Cameli nihil quàm terrori equis erant. Nam qui infidebant eis, neq cadebant hoftum equi= tes, nec ab ipfis cadebantur, cum equus nullus propius accederet. Hoc quanquam tunc urie urim eft,nullus tamen uir honeftus $\&$ ftrenuus camelum inequitandigratia alere uellet, neç eas in hoc exercere $\&$ inftuere eas ut pugnari ab ipfis poffit. Quamobrem priftino habitu refumpto, inter itu menta impedimentis deftinata degunt, Hac Xenophon. Idem libro 4. rertm Græcarum, Kàe áe sis

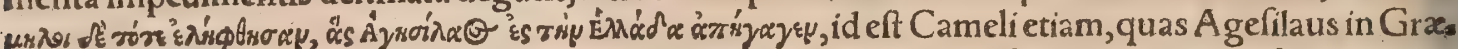

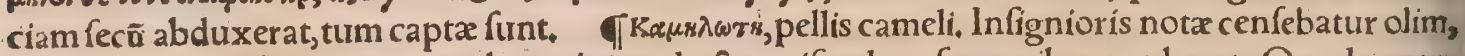
Ii quis camelo infidens, ac per urbem circumducturs, uifendum fe omnibus præberet. Quod contu. melix genus Byzantri in Arfacem Armenum, proditionis conuicium, promplit quandogs impera tor lultinianus, Cælius. Similem infamiæ notam in A fino fupra oftendi. Caput Gebanitarũ Thom na abeft à Gaza noftri littoris Iudax oppido $\llcorner$ XXX. XX XII, M. paff.qued diuiditur in manfio nes camelorum L.XII, Plinius 12, 14. circa finem : Et mox, Sumptus in fingulos camelos denarium D C L X XX. ad noftrum littus collig t. Manfio, inquit Sipontinus, iter eft unius diei, Idem iam cita tum Plinỉ locum fic legit, Abeft à Gaza \&C. M.D. X X X V II, millia paffuñ, quod diuiditur in man fiones camelorum fexaginta duas. Hinc percipi poteft iter cameli unius diei effe circiter quadragin ta aut paulò amplius millia paffưm, Hẹc Sipontinus; fecûdum cuius calculationem bis mille quin genta $\&$ trigintafeptem millia paffuum legendum mihi uidetur : aut minores manfiones facienda,

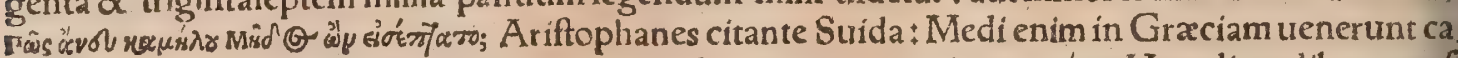

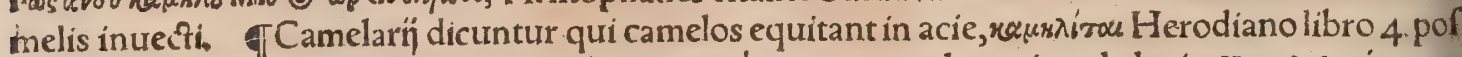

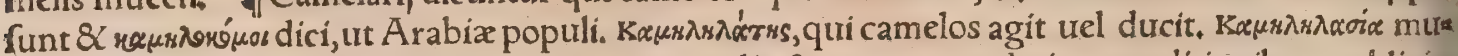
nus inftitutum erat impedimentis exercitus agendis $\&$ comportandis in expeditionibus publicis, Iureconfulti titulo De muneribus, camelariam dicunt camelorum curationem, qux publica pecunia alebantur, \& camelarios curatores ipfos. Quod munus, in quit Arcadius, perfonale eft. Sunt qui cas melafia dici arbitrentur camelorum prabendorum munus tabellarijs publicis transmittendis, Cali us. Camelafium eft apud Ammianum Marcellinum libro 17. Factum, inquit, tunc eft, \& deinde uni= us anni firmitate, ut prater folita nemo Gallis quícquam exprimere conaretur camelafí nomine iniqué:Apparet exactionis genus effe.

Th, Afphaltites lacus animal non habet:nihil in eo immergi poteft, tauri etiam cameliḉ impune ibi fluitant, Solinus. đArabes pingues ac faginatos camelos in ara Ignoti dei factificabant:nuptu ra uirgines camelis deos propitiabant, Gyraldus.

PROVER BIA. Cameli in fabulis dictum circumfertur ex Libaní declamationibus, Dum plu, ra affecto, etiã ịs qua habui fum excuffus, Calius. Camelus cornua defiderans, etiá aures perdidit,

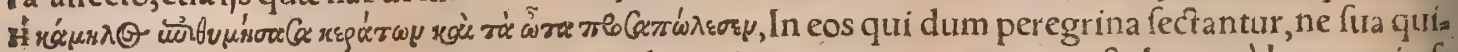
dem turentur; fumptum ab apologo de camelis, qui per oratorem cornua poftularunt à lous, qui of 


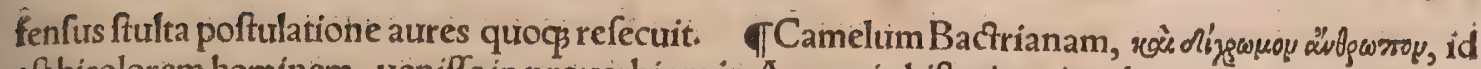
eft bicolorem hominem, ueniffe in prourerbium in Aegyptia hiftoria animaduertimusładuerfus cos quidem, qui ea promunt, qua admirationi putant furtura, re autem ipfa uel meticulofa funt uel plas né ridicula. Adagium rationem habet eiufmodi:P tolemaus Lagi duo quxdam inufitata in Aegyp; tum induxit, camelum Bactrianam infigniter nigram:bicolorem item hominem, ita ut medietas qui dem ex aquilibrio fummé foret nigra, reliqua portio albedinem praferret eximiã . Conuenientibus igitur in theatrum Aegyptís, alia utiog non pauca fpectaculo digna exhibuit:Demum fuporem no uitate rei, ac inufitata fpecie inuecturus, camelum produxit $\&$ femialbum hominem, Caterum Ae gyptï cameli afpectu territi, paulo minus profilientes mandarunt fugæe præfidium, etiamfi auro ef, - fet ornata egregié; ac purpura inftrata, freno quoç lapillis interlucentibus confpicuo, é the fauris $\mathrm{Da}$ rij regis, uel Cambyfæ, aut ipfius Cyri.Ad hominis autem illius ita coloribus diftincti, \& (ut fic dixe. rim)uariegati intuitum, partim fufius riferunt, partim ut monftrificum quiddam auerfatifunt. Hinc

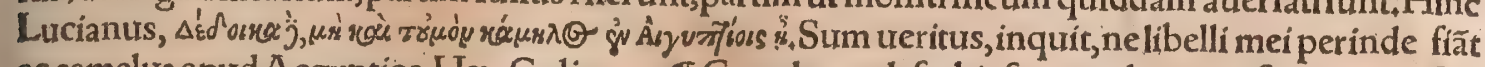
ac camelus apud Aegyptios, Hac Calius, I Camelus uel fcabiofa complurium afinorum geftat

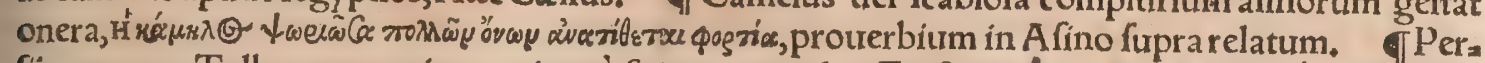

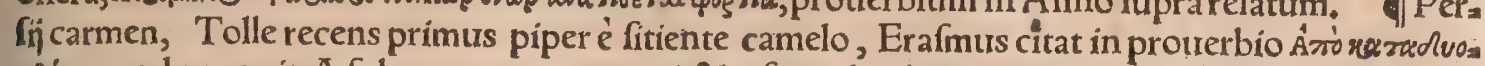
whins, quod exponit, A fubeunte portum naui, 8 refert ad celeritatem qux ad quaftum plurimum ualeat:tracto prouerbio, ut ipfe ait,à negotiatorum diligentia, qui merces ftatim emunt ab ipfis nait. tis in portum appellentibus: Non alium autem huius prouerbij authorem uel teftem citat, quàm Suri

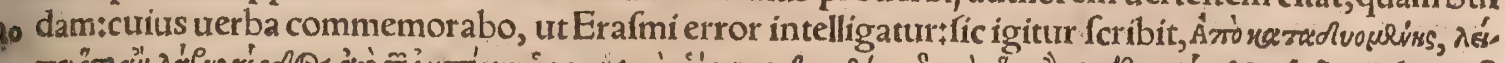

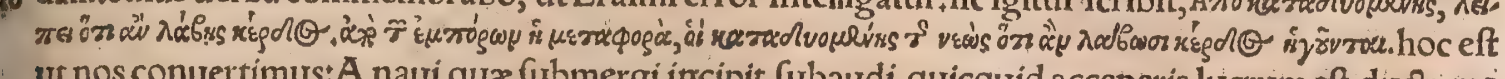
ut nos conuertimus: A naui quæ fubmergi incipit,fubaudi, quicquid acceperis lucrum eft: ducta me taphora à mercatoribus, qui è naui iamiam fubmergenda, quicquid abftulerint; inlucro ponunt. Fe fellit Erafmim rarro 'vearee uerbum, quod appellere exponit, \& portum fubire, quoniam aliquando fimpliciter fubire uel ingredi fignificat:cxterum de naui appellente plurima apud Pollucem libro : $_{\text {; }}$

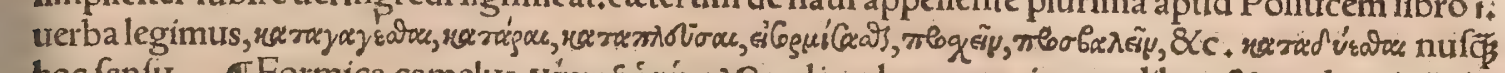

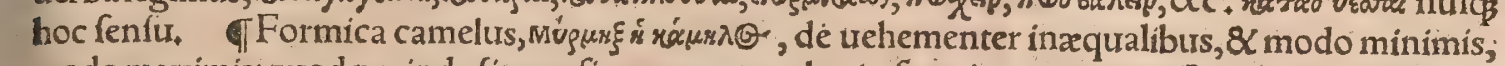
modo maximis:quod perinde lit, quafi repente camelus in formicam uertatur. Lucianus in prima es

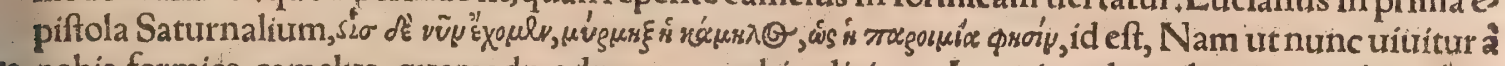
20 nobis, formica camelus, quemadmodum prouerbio dicitur. Loquitur de opibus inæqualiter inter mortales diftributis, ut huic plurimum fuperfit, huic multum defit. Neç intempeftitre dicetur in eos qui fibi non conftant, in utram qs partem immodici, Hæc Erafmus. Ego errorem furpicatus, locum in

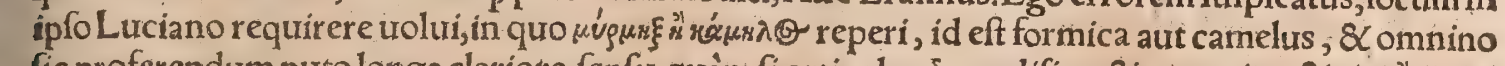
fic proferendum puto longe clariote fenfu quàm fi articulus î pro difiunctiua coniunctione is pona tur, ut Erafmus fecit. Similia huic puerbia funt, Rex aut afinus, bifdoff over bader, A ut ter fex aut tres teffera, Aut regem aut fatuum nafci oportet, Quod ad fignificationem prouerbï, Germani ele

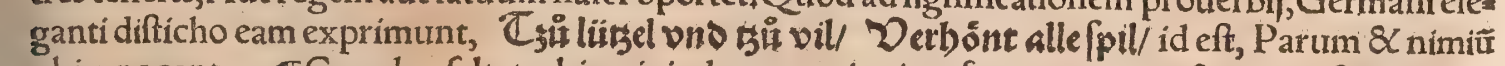
ubiq̧ nocent. TCamelus fal tat, ubi quis indecore quippiam facere conatur, \& inuita, ficut aiunt, Minerua. Veluti fi quis natura feuerus ac tetricus, affectet elegãs ac feftiuus uideri, natura geniọ́ fuo uim inferens, Hieronymus in Heluidium, Rifimus (inquit) in te protrerbium, Camelum uidi= mus faltitantem: Taxat autem hominis ineptiam, qui cum àMufis effet alieniffimus, tamen dífertus haberi uellet, Erafmus, Cælius hæc prouerbia, Lenticulam decoquens unguentum ne indideris, In oleribus piper, Camelus faltitans, omnia eiufdem ferè fignificationis facit, de quo uiderint quibus uacat:mihi non admodum probatur. Ad camelum faltantem proxime accedit Germanicum no. ftrum, Sie tư gaat auffiftelizen,id eft, Vacca grallis(ut uocant)incedit, Prouerbia à Domino no. fro in facris literis ufurpata, Facilius camelum per acum traíci, \& Camelum glutire, colare culicê,

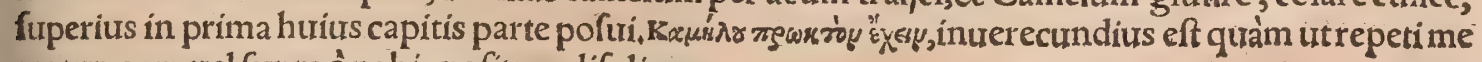
reatur, cum uel fupra à nobis pofiturm difpliceat.

\section{DE CAMELO DROMADE.}

A M EL V S dromas Græcisà curfu \& urelocitate diça, \& A Arabica camelus, omnia ferécumi fuperiore communia haber:priuatim tamen qux apud feriptores reperi aut ipfe obfertza. ui, de ea literis mandare uifum eft, cum figura etiam differat:utpote unico dorfi tubere, cî̉
fuperiori geminum fit, Dromedarĭ nomen pleręgs gentes ufurpant, Itali, Galli, Germani, Hifpani.Graci dromadem folum forminino genere dicunt, nec unquam quod fciam fine cameli no
Hits mine prxpofito. Plura qux ad nomina eius pertinent, $\&$ alia quxdam de hac quadrupede in came:

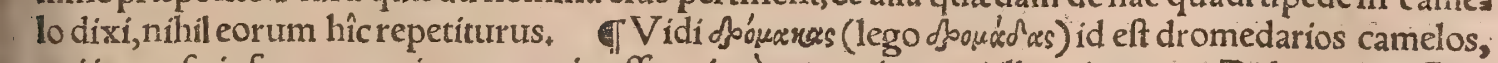
qui in curfu ipfo cum equis componi poffent, imó uero etiam qui illos uincerent, Didymus in Geo ' pon. Dromeda genus elf camelorum, minoris quidem ftatura, fed uelocius, unde $\&$ nomen habet; nam dromos Grace curfus $\&$ uelocitas appellatur:R Ruminat ficut bos $\&$ ouis $\&$ camelus, Ifidorus. Audio regi Gallorũ nuper duas camelos dromadas albas ab imperatore Turcarũ dono miffas effe: 
172 De Quadrupedibus



Dromas quam uidi dum hae friberem, altitudine erat quinquie cubitorum dodrante dempto, longitudine circiter fex: fuperius labrum in medio fciffum habet ut lepus: In pedibus duos ungures latos:bifulci apparent, fed diufio fuperne tanturm eft, nec penertat ad ima ueftigia:qua carnofa ei et plana latáç funt, orbis cibarị inftar. Tuber durum \& glabrum habet infra in pecrore cui incumbit, \& fingula in fingulis cruribus fuperius:reliqua ut Bactriana cameli. Camelos quinquaginta ane nos triuere percepi, Bactrianas ad centefimum ufop, A elianus, Litrius libro 7. belli Macedonici, $A$ n $=$ te hunc equitatum falcatæ quadrigæ, $\&$ cameli quos appellant dromadas. Et alibi apud eundem ni fallor, Dremades cameli inter dona erant uelocitatis eximia. Diodorus libo 3 . Bibliorheca de came lis ditylis, id eft gemina tubera habentibus, locurus, fubdit: Anacoli uero ligarió, qui dromaium funt forma, plurimum uia conficiunt: prafertim per deferta $\mathcal{X}$ a quis carenta loca, Ln bello quociue 
bulcus uxorem habuit nomine Cyno Graca lingua, id eft canis, Medica fpaco. Nam canem Med

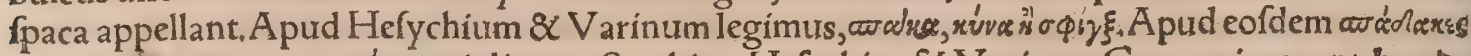
exponuntur canes. $\Gamma_{a c y} a^{\prime}$ s, canis lingura Scythica, Hefychius $\&$ Varinus. Germani uocant buns. Italicane, Galli chien. Hifpani perro. Illyrij pes uel pas, quod nomen Gelenio noftro ad fpaca uel as $\alpha$ in recro cafu, accedere uidetur. Angli, dogge.

Cani totum corpus hirtum eft, Ariftot. De diuerfis canũ generibus feorfim agemus poftea, ubi de canibus ea primum explicata furerint quæ omnibus ferè communia uídentur. Catulorum opti mus exiftimatur, qui ultimus uidere incipit, uel quem primum mater in cubile reportat, Alberus: ego idem in cane Venatico infra pluribus declarabo. Degeneres fub aluum reflectunt caudam, Ari ftoteles, Boni temperamenti in cane fignum eft, fi pilos mediocriter longos habet:excremẽta enim in pilos redundant, \& corpus expurgatur. Si uero nimium longi denfí̧́ fuerint pili, cutis feré fub. tus corrumpitur, foetori aut fabiei obnoxia, Albertus. đCanis ex proportione (id eft ex aquo) utriuf́ç partis incremẽta capit,Ariftot. Hybernum pilum amittit,Idem Sect,10.proble.23, Prona totius corporis hirfuta habet, Idem. TMedulla non eft nifi cauis offibus, nec cruribus iumentorum aut canum:Quare fracta non ferruminantur, quod deftuente euenit medulla, Plinius. đCanis cal ua nulla offea commiffura conftat, fed offis perpetuitate continetur, Ariftot. Aelianus. Generofis canibus imæ nares rotund $x$, folidę, \& feré obtufæe funt, Albertus ex Platone. Cani os refciffum eft, Ariftot, Serrati pectinatim coéuntes ne contrario occurfu conterantur dentes funt, canibus, ferpen tibus, pifcibus ${ }_{j}$ Plinius et Âriftoteles. Dentes canimutantur canini tantum appellati, ut eciam leoni, Plinius. Dentes canes non mutant, præterquam eos, quos uocant caninos, eos ćs quarto ętatis men fe tam foeminę, quàm mares. Vnde fit, ut diuerfa fit authorum fentẽtía. Alĭ enim quod duos tantum modo mutant, negant omnino ullos mutari, cum eos paucos reperire difficile fit:alí cum hos uide. rint, cæteros quoç pari ratione mutari exiftimant, Ariftoteles, Etrurfus alibi, De canibus (inquit)dis uerfa fententia eft, quippe cum alij nullum ijs decidere dentem opinentur, alij caninos tantum appel latos mutare uelint, quos etiam homo amittit:uerũ hoc latêre, propterea quia non ante mutant, quàm pares intus enafcantur. Quod idem uel in cæeteris fcilicet feris euenire uerifimile eft. Et quidem canim nos tantum mutare perhibentur.' Aetatis iudicium ex dentibur fumitur:quippe cum iunior es can didos habeant, $\&$ acutos: feniores nigros (fufcos $\&$ croceos, Alberttis ) \& hebeles, A riftot. \& A elian.

TCuncta interiora canis fimillima funt leonis uifceribus, ut quidam fcribunt. Caninus uentri= culus unus paruus $\&$ arçus eft, nec multò amplior inteftino, laxuis ós intus: habent autem omnia fere utrinç dentata uentriculum aut canino aut fuillo fimilem, Ariftoteles. Canibus inteftinum qua uentri iungitur, laxius eft: qua definit, arctius : quamobrem uehementi nixu, nec fine cruciatu eam partem leuant excremento, Ariftoteles $\&$ Plinius. Aluus anguftiffima canibus, Plinius. Pectus cani anguftum acuminatumǵg eft. Splenem habet longum ficut homo \& porcus, Ariftot, Teftes $\&$ men $_{\approx}$ tula cani foris dependent, intra pofteriores pedes, ut etiam leoni, Canum degeneres fub aluum refle. ciunt caudam, Arifoteles. Priores pedes flectũt ut homo brachia: \& uice brachiorum eifdem utun tur,Blondus.Pedes priores quinis diftinctos digitis habent, pofteriores quaternis, Ariftoteles. Qui=

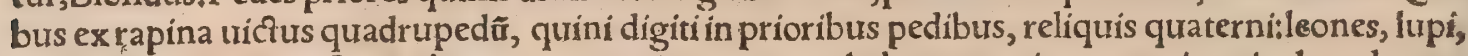
canes, \& pauca, in pofterioribus quoque quinos ungues habent, uno iuxta cruris articulum depen. dente, Plinius. Rapacibus unci funt ungues:cæter is recti, ut canibus, prater eum quià crure plerifg: dependet, Plinius, TCanes quoniam numerofo partu 8 multifida funt, mammas plures per uen = trem duplici or dine utro ${ }_{3}$ de latere gerunt, Ariftoteles. Quæ numerofo focunda partu, \& quibus digiti in pedibus, hæc plures habent mammas toto uêtre duplici ordine, ut fures: generof duodenas, uulgares binis minus; fimiliter canes, Plinius. Bipedes $\&$ quadrupedes qua animal procreant, omim nes uuluam aut uterum, infra feptum transuerfum continent, ut homo, canis, fus, Ariftor. Et alibi, Qux intra fe $\&$ foris animal generant, uterum habent in aluo, ut canis. Fimum cani ficcum eft, utlü po. Canis animal eft temperamenti calidi $\&$ ficci, fi ipfum per fe confideres : nam comparando alịs animalibus, contraria etiam temperamenta ei attribuerentur : Quippe ad hominem fi conferas, ficcus eft: ad formicam, humidus; Rurfus hominis refpectu calidus eft, leonis frigidus, Galenus.

C.

Somnus $\&$ uigilia,incrementum \& corruptio, \& uita \& mors, cæteraćs accidentia ex fenfibus, funt in canibus, ficut in equis $\&$ hominibus, Author obfcurus, Cani uita producitur ad decimum. quartum annum, A elianus, Viuunt Laconici annis denis, fominæ duodenís:cætera genera quinde cim annos, aliquando uiginti,Plinius. Laconici fanègeneris foeminæ, quía mints laborant, quàm mares, uiuaciores maribus funt:at uerò in cæeteris, \& fi non laté admodum cóftat, tamen mares uiùa. ciores funt, Ariftoteles. Et rurfus alibi, Cæteri canes (inquit, exceptis Laconicis) maxima ex parte ad annos quatuordecim, fed nonnulli uel ad uiginti protrahunt uitam. Quamobrem recté apud Ho merum canem Vlyffis uicefimo anno mori aliqui iudicant. Canis cum urocem ædit altiorem, latrare dicitur:quod uarias ob caufas facit: Eft $\&$ gannitus quidam eius fubmiffior, ut adulando, tride infra of in H. c. Canes etiam fomniare palàm eft, idóg fuo latratu declarant, quem per quietem agunt, Ari. ftoteles, \& Plinius. Cubile fuum luftrat canis $\&$ circuit antequam cubet;quod quidẽ non alia caufa 


\section{6}

primum fert in cubile foeta,Plinius, Catelli creci nafcuntur, à partứç tredecim primis diebus ita ocu lis affecti fưnt:poftea acerrimum oculorum fenfurm acquirunt, Aelianus, Vifurm catuli recipiũt die, bus uiginti,Fronto $\&$ Varro. Quxa ante iuftum tempus concepere, diutius cxcos habent catulos, nec omnes totidem diebus, Plinius. Q uomodo catulorum alị prius, alï tardius uifum acquirant, ex Ariftotelis fententia paulo ante expofui. Paritcanis duodecim complurimum, fed magna ex par re quings aut fex:unum etiam aliquam peperiffe certum eft, Ariftoteles. Cur fus $8<$ canis sint tam foe cund $x$, \& multiparz, Democritus eaufam affert, quod multiplicem uuluam, \& feminis cellas recep. tatrices multas habeant:Eas omnes femen non uno initu explet, fed iterû \& fapius ex profeminan. tur, ut frequentia feminis receptacula impleantur, A elianus . Nos ex Ariftotele \& Plinio fupra oftendimuss canem etiam uno initu impleri. Partus duodeni,quibus numerofiffimi, cextero quini, fe ni, aliquando finguli, quod prodigiofum putant:ficut omnes mares; aut omnes foeminas gigni. Pri* mos quog; mareș pariunt, in cæeteris alternant, fi ineant opportuno \& recto menfe, Pli. Albertus fori bit uifam fibi canem è genere maftinorum, quę fimul nouendecim catulos pepererit: $\&$ rurfus proxá mo poft partu ocfodecim, \& tertio tredesim:erat autem(inquit)nigra, et magno corpore.Singulos fe rè pariunt paruæ illæ catulæ quas mulieres in delicịs alunt, propter uteri exiguitatem, Alberus. Quadrupedum multifida, ut canis, leo, \&c,omnia crecos generant, poft palpebræx dehifcunt, A riftot. Multifidæ quæ pariunt imperfecta, omnes multiparæ funt:Quo fit, ut partum adhuc recentem alere poffint, auçum iam adeptumós magnitudinem nequeant:fed cum corpus ad nutriendum non fuffi ciat parum emittant, ut ea qux trermem partunt. Quadam enim ex ins catulos inarticulatos prope= modum pariunt, ut uulpes, urfa, leæna, \& alia nonnulla:fed omnia feré cæcos, ut ea quæ modo dixi: 2 atç etiam canis, lupa, lupus ceruarius, A riftot. Caprz \& oues, ut \& reliqua foecundiora \& multipa ra animalia, partus interdum monftrofos edunt, ut etiam multifida: multipara enim id genus anima

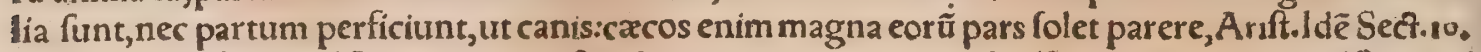

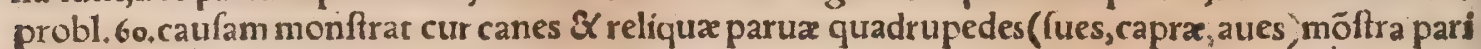
ant frequentius quàm maiores. Canis etfip permultos ex fefe parit catulos, horum tamen é numero primus prodiens in lucem patrem refert, omninoós fimilitudinem, fpeciemćs illius gerit: cæteri ut cafus tulerit, nafcuntur. Quod ftudio \& protidentia natura fieri uidetur, cum matri anteferentis pa trem, tum cater is catulis primigenium longe anteponentis. Coitus cani femper opportunus, Arift. Mares quarto annogignere incipiuntrlego incipiant, opera frilicet hominum admitrentium tunc primum robuftioris generandx fobolis gratia) foeminæ tertio ufç in nonum, Vetus quidam. Cas nes non per totam coëunt uitam, fed ufq̧ ad quendam xtatis uigorem:ad annos enim duodecim ma gna ex parte, \& coêunt, \& implentur. Verum iam aliquibus, tum foeminis, tum maribus, uel annü octauum $\&$ decimum, atq̧etiam uigefimum nactis facultas non defuit prolifici coitus : nam y̆s quio que fenectus utim generandi, pariendioǵ, ut \& cxteris tollit, Ariftotel. Non tota atate fua generant, ferèà duodecim definentes ${ }_{2}$ Plinius. T empus ad conceptum $\&$ procreationem, in mare optimum cum quadrimus effe iam copperit, idó, deinceps, fed non ultra ocłautum annum : foemina à triennio ad fexennium uf́p circa fobolem occupetur, Pollux. Mares iutueniliter ufg; in annos decem proge nerant:poft id tempus ineundis foeminis non uidentur habiles. quorum fenicrum pigra foholes exi= f́tit. Forminæ cõcipiunt úfö in annos nouẽe, nec funt utules poft decim um, Columella. In cane formi. na ætas hima ad procreationem probatur magis quàm minor, Tardiuus, Cum mares appetunt $\mathrm{coi}_{\mathbf{1}} 4$ tum, dies alíquot abftinendi funt, donec genitalia eis inflentur \& turgeant, Idem. Fominan: $\& \mathrm{mas}$ rem domi retinebis, fi mazam cum pauco fale uefperi eis obiereris, Idem. Si mas ad Venerem frigi dus fit, fuillam aut ouillam carnem pinguem unà cum iure ei appone, Tardiuus. Canes $\&$ fues ma res initum matutinum appetere, focminas autem poft meridiem blandiri, diligentiores tradunt, Pli. nitus: Canes à partu ualde fer ociunt, A riftoteles: qui \& caufam cur tum temporis fauiant inquirit Sect. 10. problemate 37. Mares libidinis copia placidiores fiunr, Idem. Prominetgenitale in foeminis cum ad coitum ftimulantur, \& locus humefcit, A riftot.Et alibi,Menftrua(inquit) huius animalis die bus feptem mouentur, finulǵ, euenit, ut genitale promineat:uerum nondum per id temporis coisû patiuntur, fed fequentibus feptem diebus: tempus enim quo toto canis libidine tenetur, diebus qua: tuordecim magna ex parte defcribitur. Verum nonnulla etiam ad fextumdecimum pruriunt. Pur, gatio autem qua coniuncta par tui eft, unà cum catellis nafcentibus prouenit, craffo pituitofọ́́ hu more:redduntur etiam tenuiores à partu, Arıfot. Lac ante diebus quinq̧ quàm pariant, ha. bent magna ex parte: trerum nonnullis etiam feptem aut quatuor diebus anticipat: V tile ftatim, ut peperint, eft, Ariftot. Craffius canum quàm caterorum animalium, lac eft, excepto fcrofax ac lepoe ris, Idem. Canes mifcentur coitu non inter fe folum generibus diuerfis, fed alịs etiam feris, ut infra docebo, ubi de Canibus mixtis agam. Oportet autem adæquare naturam ac ætatem $\&$ mafculi $\&$ foeminx: \& caue ne canes ex eadem matre prognati fimul ccểant, Varro in Gracis Geop.

- Primus effoctę partus amourendus eff:quoniam truncula, nec rectè nutrit, $\&$ educatio totius ha bitus aufert incrementum, Columella: apparet fanè eum loqui de cane qua primum peperit. In foes tura dandum potius ordeaceos quàm triticeos panes; magis enim eo aluntur, $8<$ lactis prębent maio. rem faculcatem, Varro. Sero quod à cafeo manautit quàm optime canes nutriuntur: plurimum $e_{3}$ nim cis alimentum pręttat, Diofcorides, \& Auicenna, Veloces Spartę catulos, acremǫ̣́ Moloffum 
Pafcelero pingui, Verg. Georg.3. Canes, feles, \& ichneumones uefcuntur eifdem cibis, Ariftot: Canis quoniam ficci temperamenti eft, humido nutrimento reficiendus eft, Albertus. Gratridas ca nies nutriemus non triticeis, fed hordeaceis panibus, ut qui maximi nutrimenti fint. Offa item ouitu éxuta carne apponemus, fed cocła, ut corum medulla temperet $\&$ pingtrefaciat ius ipfum:Quod eti am panibus comminutis poltea infundentes, tundentes ć $\beta$ rurfus, fimiliter offeremus . Enixis auten hordeacea farina, ca prillo bubulóue lacti permifta, offerếda eft; offumćs, ut diximus, elixorum, de coctũ ipfum erit potus quo utentur. Ipfis uerò catulis recens ortis opitulabinur! matris enim mam= ma non fufficit:ac proinde lacie bubulo iurég oflum imburentes panes, in pabulum eis offeramus. Sed apponenda etiã illis funt offa, ut tum roborent tum confirment, ac fimul exacuant dentes, Hæc Varroin Geopon. Gracis. Cibatus canis propior hominis, quàm ouis. Pafcitur enimè culina, $\&$ or fibus, non herbis, aut frondibus. Diligenter ut habeant cibaria prouidendum. Famesenim hos ad quxrendum cibum ducet, fi non prabebitur, $\&$ à pecore abducet. Nifi fi(ut putant quidam)etiam il

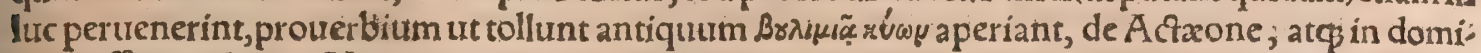
num afferant dentes. Nec non ita panem ordeaceum dandum, ut nó pótius eum in laçe des intritũ, quòd eo confueti cibo utijà pecore non cito defcifcunt. Morticina ouis non patiuntur uefci carne, the ducti fapore minus fe abltincant. Dant etiam ius ex offibus, \& ea ipfa offa contufa . dentes enin

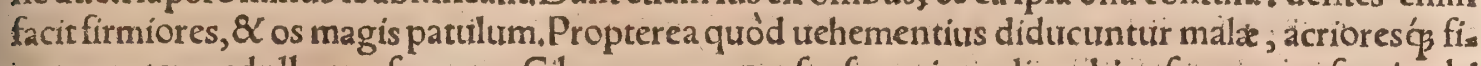
unt propter medullarum faporem. Cibum capere confuef́cunt interdiu, ubi pafcuntur:uefperi, ubi ftabulantur, $V$ arro in opere Latino de Reruft. V bi primum canis pepererít ftatim reijciédi funt de. o generes, aut uitio aliquo maculati. Ex feptem porrò feru andi funt tres aut quaturor:duo autem ex tri bus. Quibus quidem paleas fubfternunt, ut mollius incubent $\&$ calefiant, Eft enim impatiens frigo: ris huiufmodi animal. Catuli bímeftri fpatio cum matribus funt liquendi, Fronto in Geopon. Quan quam autem de paftorali cane priuatim illic loquatur, ut eriam Varro in loco iam recitato: uideban. tur tamen hac chuiufmodi effe, ut commode communi de cane tractationi adfcriberentur, ficut \& fé, quentium quxdam. Subfternitur eis åcus, aut quid aliud, quod meliore cubili facilius educantur; $\checkmark$ arro. Catulos fex menfibus primis, dum corroborentur, emitri non oportet nifiad matrem lufus aclafciuix caufa, poftea \& cathenis per diem continendi, \& noctibus foluendi, nec unquam eos, quorum generofam uolumus indolem conferuare, patiemur alienę nutricis uberibus educari; quo= niam femper \& lac, \& f firitus maternus longe magis ingenï, atø̧ incrementa corporis auget : quiod - fi efforta lacte deficiur, caprinum maxime conueniet praberi catulis, dum fiant menfium quattuor, Columella, agens de cane pecuario. Si plures funt catuli, fecundum partum fratim eligere oportet quos habere uelis, reliquos abrijcere. Quàm pauciffimos reliqueris, tam optimi in alendo fiunt prop. ter copiam lactis, Catuli lacte fiue maza, uel aqua lactís alendi funt:nec ullum alind alimentum of ferendum:quia laxus (largus) uictus folet efre maximo damno. Verum adulti ficcis uef cantur edu libus:panc uidelicet, $\mathcal{Q}$ offibuts, \& hoc fiat digeîtis horis, ut concoctio peragatur, \& potius famefcãt paululum, $\ddot{\xi}$ non exactis horis pafcantur, Blondus. Nemefianus etiã in Cynegeticis catulos cum ma tribus fero, 8 lacte, uel pane cum lacte pafcendos canit, à tempore uerno ad folftitium uf̣́: : nam cũ Sol in cancro fertur, confuetam minuiffe faginam Profuerit, tenueş́́ magis retincre cibatus: $\mathrm{Ne}$ grauis articulos deprauret pondere molles. Nam tum membrorum nexus nodoş̧́́ relaxant, \&c. (fic 40 enim legendum.) Mox cum iam fextum ætatis menfem agunt catuli, Tunc rurfus mifcere fero $\mathrm{Ce}$. realia dona Conueniet, fortemḉ dari de frugibus efcam. T Non permittendumeft ut nimium indulgeant fomno canes:nam cum natura calidi fint, calor internus per fomnum etiam auctior pra uos humores ad uentriculum attrahit, unde morbi fcaturiunt. Parum igitur à cibodormiant, quo: ad cibus mediocríter concoquatur, Albertus. Gani tanta fagacitas narium, ut nunquam canis nam carnem, ne uarietate quidem condimentorum falla cifima temperatam, deguftet, A elianus. Fel certro in cauda aut inteftinis effe putant:Ideo tantam habent amaritudinem, ut à canibus non attin gantur, Plinius. A Abftinent fraxini fructu, licet fues eo faginentur, quod dolorem uertebr $x$ coxar inde incurrant, Sunt $\&$ coprophagi canes:quamobrẽ Plinius, Venenati mellis, inquit, malũ (quo ho mo infectus fuerit) certum eft per excremēta, ad canes etiam peruenire, fimiliter'̣́ torqueri eos. Cor - ui \& canes inebriantur œnutta herba, Athenęus. Vinum auerfantur, unde caninum prandium dictum, ut infra explicabo:Panem tamen urino tinc?um deglutiunt. Canis aftate frequentius quàm hyeme cibandus eft, ut aftiuis diebus longis $\&$ calidis durare poffit. Infringatur ei panis in aquam. Si tamen freius quàm par eft cibetur, uentriculus ei fubuertitur. Lac aut panis lacte madidus opti: mè alunt, Si cumini tunfi cibarỉs eius modicum in j̈ciatur, uentris flatibus non erí obnoxius , Caro ficcata in cibo ei conuenit. Olei parum aqux bibendę fuperfufum, habitiorem fimul uelociorẽó̧̧ red. dit.Si cibũ faftidiat, panis atri micas aceto maceratas, in nares eius exprimes. In magna fame butyrũ recens cum pauco pane calido ei obịcies, paulò ante reliquum cibum, Tardiuus, बBBonum catulứ lactentem \& pręcæateris eligendum, ita cognofces.Praftat qui pondere uincit reliquos, proinde dili genter lactandum curabis: Vel ille, quem mater primum ore fuo reportat: Vel qui poftremus uome io re incipit. Alï prẹtantiorem hac induftria difcernunt, Locum fatis amplum circumqua ç farmentis aut cremin includunt, \& catulis impofitis accendunt, qui cum totus ardet in circuitu, matrem foris detentam dimittunt:quæ mox infiliens optimum quenģ̧ priorê effert, poftremó uilifimû, Tarciutiş 
Vidẽtur autem ex Nemefiani Cynegeticís hæc eligêdi indicia effe tranferipta: nam illud à loco ignè ambito fumptum, omnino fimiliter defcribit. Quơd uerò ad pondus, contra quàm Tardiuus, leuio: rem praferre uidetur, his uerbis: Pondere nam catuli poteris perpendere uires, Corporibusćp le• ues grauibus pranofcere curfu. Ego ita conciliârim, ut ad robur præferendi fint, grauiores:ad cele: ritatem, leuiores.

DE MOR B IS CANVM.

Offeres cani nonnunquam ius elixationis hedera: quoniam fi iftud exhibureris faltẽ per feptem dies, feruabis canis fynceritatem:quia et ouem paftus hederę fertuat, Blondusł:(per feptem dies, forte intelligit, feptimo quoq̧ die.) Ellebori tenuiffimæ radices breues ćş ac uelut decurtatę etiam ha legun tur. Nam fumma qux eft craffiffima, cepis fimilis, canibus tantum datur purgationis caufa, Plinius, Venter cani mollitur aut purgatur potu lactis caprini : aliqui falem contritum deglutiendum inge runt, aut cancros contritos cû̃ aqua mifcent, eamćp in potu exhibent; aut animalis alicuius uentrễ in cibo:alifi ftaphifagriam contritam cum pauco oleo in ouo prabent, et mox à purgatione lac mulfum, Tardiuus. Canes humidis potius quàm ficcis edulijs ales : cum enim natura ficci fint, accedẽte in. fuper $a b$ alimento ficcitate, aluo aftricta periclitantur fape ac pereunt. Obftructionis fignum eft, quod fubinde gemendo uociferantur, \& loco manere nefciunt, \& præ nimio déjciendi conatu febri citantium inftar tremunt. Hoc frequens eft in catellis mulierum, quarum plurima aluo moriuntur obftructa. Detur ergo eis maffa auenacea ex aqua calida, ut inftar denfx pultis edulium fiat; uel pa* ne auenaceo molli fermentato pafcantur, \& fero lactis interdum : fic ueloces $\&<$ bonæ ualetudinis euadent, ${ }_{2}$ Albertus, Ego auenam, præfertim in denfa pulte, aftringere magis quàm mollire aluû con= 1 tra Albertum dixerin. TCanes tribus laborant uitijs, rabie, angina,podagra:A riftoteles, Pollux, A clianus, Ego ex recentioribus longe plures infeftos canibus morbos cũ remedís fuis enumerabo,

T. Vulnerantur canes uel fuigeneris hoftium morfibus, uel alieni, à feris, ab hominibus, De uul. neribus eorum curandis Gratij ( uel ut Blondus citat,Maximi) elegantifima carmina hac funt:

Nec longe auxilium, licet alti uulneris or $\dot{a}$. Abftiterint, utrọ̧́̂ (lego uterọ́́) $)$ cadãt cũ fãguine Inde rape ex ipfo qui uulnus fecerit hofte Virofam eluuiê, laceriós per ulceris ora (fibra. Sparge manu, uenas dư fuccus cóprimat acer. Mortís enim patuêre uiiæ: tưm purtra monebo Circum labra fequi, tenuićs includere filo. At fi pernicies angufto pafcitur ore, Contrà pande uiam, fallenteiş́́ argue caufas. Morborum in uitio facilis medicina recenti. Sed taçu impofitis mulcêt pecuaria(.i,canes)palmis, (Id fatis)aut nigræx circũ picis unguine fignât Quòd fidiftricto letis eft in uulnere noxa, Ipfe habet auxilium ualidæ natale faliux.

Blondus hunc locum paraphrafi reddens, uifcera \& fibras reponi iubet, ac labra filo cófui, \& de. tractos pilos illius qui intulit uulnus fuperponi, aut trirofam eluuiem, donec fanguis fiftatur:inde ca nilambendum relinqui. Naturam enim canem ita dotaffe, ut lingua medeatur uulneribus: $\mathcal{X}$ fe bre ui tempore uulnus latifimum hoc modo confolidatum uidiffe: Idem fcribit A elianus, \& recentiores aliqui. Curare uulnera fua $\&$ aliena dicuntur lambendo, $\&$ fi uulnus attingerelingua nequeãt, pede faliuam ingerunt $\&$ fanant, Albertus. Si uulnus (inquit Blondus) lingua fua canis contingere non pollit, medicamentis \& methodo uti licebit, j̈fdem quibus in uulneribus humani corporis. Vulnus fimplex uel cani tantum lambendum dimittes, uel infperges cinerem de capite canis, qui maxime prodeft:uel falem tenuem torrefactum cum pice liquida impones, Blondus. Si canis à cane morfus fit, fquamæ ferri pollinem pice, excipe $\&$ inunge, Tardiuts: (qui errat picem liquidam Gallice uer. tendo poix fondue.) Canibus morfis anagallidem uenatores imponunt: qux etiam hominibus à ca. ne rabido morfis prodeft, Hieron. Tragus, Albertus anagallidem nó ad uulnera, fed uermes in uul. neribus canum adhibet, ut paùlò polt dicam. Canem à fera in uenatione morfum, cui roftrum ualde intumuerat, moribundum feré, citiffimè curauimus, primum extraço fanguíne (circa uulnus)cum incifione, fic enim uenenum euocatur:poftea oleo de hyperico illito, Blondus. Címices profunt cani à ferpente morfo, Plin. libro 29, TRemedia contra morfus quos canis rabidus homini inflixerit, infra docebo cap.7.8 mox ante illa, de morfibus canis non rabid in homine curandis. Aduerfus ri mas \& ulcera remedium Tardiuus prafcribit ex tefta urel ollæ fragmento, quod tritum acetọ́ forti mixtum imponatur : trel cum adipe anferis tercbinthinã. Senecio (fic uocat fifymbrium alterum, bzunnentreffid ) cum lardo recenti tritum $\&$ appofitum, tumorem in cane fedat, \& faniem fundi. tus extrahit, $\&$ ulcus ac uulnus confolidat, Albertus. Si canum urulnera intumuerint, butyro inum gito: hoc enim tumores depelli creduntur: fi maxime lingere uulnera confuefcant: (melius, fic con. fuefcent, quod perutile canibus eft; fenationibus (id eft fifymbrio altero ) prafertim tritis, cũ axun, gia uel hircino feuro appofitis, Aquiuiuus:qui ex Alberto defcripfiffe uidetur. Alberti uerba de fe. necione herba fupra pofui : is butyro quidem illini iubet ulcera uerminantia, ubi uermes in eis per alia medicamenta iam enecati fuerint: Butyro, in quit, men(é(Martio, addiderim)facto, inungantur* \& per hoc etiam ipfi tumores depelluntur : \& partes fic illitas canis lambet libentius, quod perutile eft. Si fpina uel aculeus in pede aliáue parte canem laferit, furfurefca cum lardo trita \& appofi= ta, extrahit, $\&$ faniem denudando aperit:Idem facit puluis hirundinellarum in olla noura cum parti= bus inteftinis combuftarum:quod medicamentum tanquam faluberrimum in pyxide referuandum eft, Albertus, Furfurefcam, ut uocat, herbam, uideo nō aliam effe quàm bechion, id eft tuffilaginem, 


\section{De Cane. C. Lib. 1. 179}

trulgor 0 [15bib: nam illam quog nonnulli ex ueteribus farfariam uocauerunt, forte quod folia als bis quibuîã̃, ceu furfurribus obducãtur thuius folia, ut a pud Ruelliũ legimus, tela omnia infixa cor. pori extrahunt, Quòd ad hirundines, (fic enim \& A quiuiuus etiã ex Alber to legír) hunc cineris i. pfarũ ufum apud ueteres in prafentia non reperio : cæeterũ harunidinis, quã phragmiten cognomi. nat, radicẽ concifam per $\{e, \&$ unà cư bulbis illitã,furculos $\&$ cufpides extrahere, Diof corides tradit: GVlceribus qux naf́ fi folent ex pratroñ̃ fuccorũ decurfu, maximérodentiư, medetur quoduis cor: rodens pharmacữ, \& ipfa lingura canis(lambendo fcilicet,)Blondus. Accidit etiã ur uermes innafcan tur in pofterioribus crutibus, quos ut eneces, prater unguentữ apof́tolorữ fiue A egyptiacũ ceratữ, inifýcies ulceri fuccũ foliorũ perfici:fic morturi confeftim exibunt:reliquã curã faliux canis permitte. 1o Sic enim qưodq̧ putridũ ulcus \& uerminofum curatur, quamuis quidã cófueuerunt \& fale fparge re, $\&$ dulci olitro inungere. Hxc nifi profuerint, utendũ ea ratione quã in humanorũ corporũ ulceri bus medici prafcribunt, Blondus. Vulnera uel ulcera uerminantia canû́ fucco hippiæ; quę uocàur: ranacetũ agrefte, perfundantur quoad extinguantur uermes. Venatores quidā experí affirmant; omnes huiufmodi uermes in omnibus brutis animalibus interire, fi fticas citrina collo eorũ furfpena daturr, ubi primũ aruerit.Porrô iam extinctis uermibus, butyro de mêfe Martio locũ inunges, quod $\&$ tumorẽ remittit, \& canes ad lambendũ inuitat, Alber tus. Hippiæe nomine anagallidẽ intelligo(fic enim uel Arabes, uel barbaros quofdâ appellare inuenio) cui cî́ tanaceto nihil commune eft, quàmi quod uermes fimiliter interimere poteft, nimirũ acri \& nitrofa facultate fua, qua betæ fimilis autetiẫ fuperior eft, quod ipfe ohferuaui:quamobrẽ idem ad apephlegmatifmos utriufq̧ ufus, De hac paus: lo ante etiă ex Hieron. Tragi fententia locutus fum. Contra uermes ulceribus innacos: Verminan tes partes aqua calida ablue, \& pofca:deinde píce, calce, \& fimo bouis in acetô mixtis, lautato locũ, et infperge puluerē ellebori nigri, Tardiuus. Vlcera in uentre canis oborta, pice liquida (de poix cle $r e$,id cft pice pura trel purgata)inunge: \& puluerem infperge quí recipít æquales partes opopanacis $\&$ radicum flammulx, Tardiuus.

- Si fcabies infeftabit, cytifi \& fefami tantundem conterito, 8 cum plce liquida permílceto; uitio كamós partem linito:quod medicamentum putatur etiam hominibus effe conueniens: Eadem peftis fi fuerit uehementior, cedrinoliquore aboletur, Columella. Si fcabies, impetigo aut lepra, quæ tria pro uno connumeramus, canem inuaferit : primium fanguis detrahatur à çuaturor cruribus è trena maiori, quæ in externa cruris parte defcendit:poftea fiat unguentum ex argento uiuo, fulphurc, 8 - fenine acalabis (urticam intelligo) trito:æ quales partes de cuobus (lego, tribus)cum duplo axurigie ueteris uel butyri míce, $\&$ inunge locos affectos, curabitur. Confert etiam lupini decoctio, $\&$ a qua falfa, Albertus. Decoctione lupinorum ablue canem fcabiofum, $R$ afis. Gratius poëta aduerfus ca= num frabiem remedium prafcribit, bitumine, pice, $\&$ amurca fimul ad ignem mixtis; Inde lauant $2=$ gros, forte linunt legendum, nifi intelligas inungendos primum canes, indelauandos. Hoc medica* mine illiti canes, plutuias \& frigora uritent: \& locis tranquilis, calidis apriciśćc contineantur, vt tuitiū exudent, \& medicamenti uis poros fubeat. Sunt qui fabiofos canes aqua marina mergant. In Si:i: lia f́pecus eft, ubi Stagna fedent uenis, oleoćs madentia uiuo(perroleum intelligo:)Huc pecudes mat la tabe affectx fxpe ducuntur, cum alia remedia non fuccefferint:facra Vulcano fiunt, \&c. Nec mo. ra (fic lego) fi medias exedit noxia fibras, His laue pręfidijs, \& $c$. Quòd primam fi fáletopem dis mifla facultas: At tu pręcipitem, qua fpes eft proxima, labem Adgredere, in fubito fubita eft medi cina tumultu. (forte, in fummo fumma eft, ut conueniat huc fententia Hippocratis, Extremis morbis extrema remedia tentanda.) Stringendx nares, fcindenda ligamin (articuli)ferro Armorum, ge mina ́c cruor ducendus ab aure. Hinc(à fanguine) uitium, hinc illa elt auida uchementia pefti. licet auxilijs feffum folabere corpus: Subfiduasćs fraces(id eft amurcam) diffúáç Maffica prifcó Sparge cado. Liber tenues é pectore curas Exiget eft morbo Liber medicina furenti, Hæc Gratius. Sepe icabies contagiofa plures fimul canes inficit, aut etiam perimit, Quin acidos Bacchilatices id eft acetû) Tritonide oliua Admifcere decet, catulosḉ̧ caneśq́ maritas Vngere profurerit, tepidoć oftendere Soli: Auribus \& tineas candenti pellere cultro, Nemefianus. Scabiem adufta feré bilis, aut falfa pituita generat. Comprimunt eam aliquando leuiora remedia, ut funt, decoctio fumaria, la - pathi, lupi faliçarij, borraginis, uel ferum lactis in quo eadem macerata fuerint. Prodeft etiam lauari lixiuio, uel aqua marina, uel garo temperato, uel aqua fabrorũ ferrariorum in quo ferrum candens extingurunt, uel deniģ, decoctione fumariæ cum radicibus inulæ \& lapathi. Aufertur \& fanguis nõ nunquıaam, uerum moderatius. Praftiterit autem ante omnia purgante medicamento bilem deịci, Blondus. Tardiuus ad fabiem commendat unguentum, quod conftat pice nigra, fulfure, lithargy= ric,oleo $\mathcal{Z}$ urina. Locus fcabiofus(inquít)tondendus eft, inde panno uel penicillo fricandus donec fanguis appareat:poftremò ungento iam dico calido inungendus, \& loco mundo continendus do necunguentum decidat; hinc iterum unges, fed abfos fricatione, \& iterum dum decidat loco mun do continebis. Canum fcabies fanantur bubulo fangurine recenti, iterumóq̧́ inarefcat illito, $\&$ pofte, ro die abluto cinere lixiuio, Plinius, Pix liquida praitantiffimum remedium eft ad canũ $\&$ iumentorum fcabiem, Plín. Diofcorides oleum lentífcinum \& cedriam quog commendar. Amurca frabio fis canibus auxiliatur, Theomneftus. TSi tumor in aliqua parte oriatur, remedium eft, alcæam cum aqua tritam, mifcere cum pafta(id eft maffa farinæ)\& fimul fubigere manibus, ac iam ceræ inftax tra 


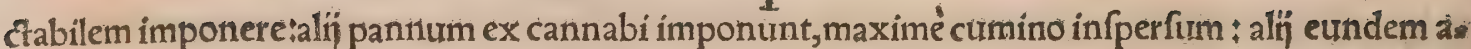
qua madidum pilis circa tumorem pritus rafis: Lac acidum quoģ bene agitatum $\&$ impofitum, dolo. rem fedat, \& reprimit tumorem: Item lini femen cum recenti fanguine coctum: Betula trita \&applica ta:Seneciones (id eft fifymbrium alterum)cum aqua lardo recenti triti $\&$ appoliti, tumorem fanant, \& faniem funditus extrahunt: \& ulcus ac uulnus confolidant, Albertus, Si tumor abfģ ulcere aut uulnere fuerit, de offe fepię puluerem emplaftri modo impone, Quòd fi etiam ueficæ(papulæuel exanthemata)adfuerint, coques finul galbanum, ftyracem, medullam cerui,ceram, oleum, falem amas: rum, \& mel; hoc pharmaco dorfun \& locos affectos canis per decem dies inunges. Tumori poft uul

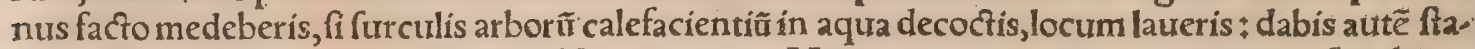
tim poftea edendũ butyrũ cum melle, Tardiuus. WVerrucas ita tolles:primü diligenter fricabis et purgabis, inde pinguedinẽ aliquam illines ut molliantur: deinde impones medicamentũ inftar em: plaftri ex puluere de cortice cucurbita, \& $\&$ fale minuto cum oleo $\&$ aceto.A Aut aloên tritẩ củ fina pin embammate mixtã, applicabis, ut ercdatur:Poftea decoctis in aceto folís falicis cû fcoria ferri ( id ef micis illis qua inter fabricandũ profiliunt, ut Tardiuus exponit, cum hac fquama potius fit quàm Icoria dicenda)etiam uerrucas colluito. IIdem aduerfus clatos(cloux Gallice) remediũ defcribir; quod componitur ex fimo arido, cortice cucurbita, 8 pane hordeaceo:quibus fimul crematis adda tur puluis ê plumbo, \& aftundatur acetũ, ut claui perfricentur:Quos etiã pofca prius abluere iubet, ac dicinde pręfcriptũ pharmacũ emplaftri inftar imponere. Gignuntur aliquando in canibus rì cini, urt pedes eriam $\&$ pulices, Plinius. TQuidam nucibus Græcis (amygdalis amaris, Fronto, quas Columella etiam contra mufcas commendat) in aqua tritis perungunt aures \& inter digitos, $\Phi_{2}$ mufca, \& ricini, \& pulices ( $\&$ pediculi, Fronto)foleant (fi hoc unguine non fis ufus) ea exulcerare, Varro.Aduerfus pediculos ftaphifagría contrita infpergatur:tuel totũ corpus lauetur calido decocto radicũ aceris contufarũ, Prodeft \& radix cedri,fed mandragoræ radix prafertur, Caurendũ eft in terim ne quid de his medicamentis, utpote uenenofis, in os canis perueniat, Tutius abluentur decot ço radicû̃ cyperi, quod pediculos omnes extinguit,Blondus, Pulicof cani remedia funt, cyminț tritum pari pondere cum ueratro aquaćs miftû:feu cucumeris anguini fuccus:uel fi håc non funt, uetus amurca per totũ corpus infufa, Columella. Pulices extingues ac perimes, aqua marina atque etiam muria perfundens canem, pofteạ̧́ inungens illum cyprino, cũ elleboro, aqua, cymino, \& uua immaturataut ex radicula fylueftris cucumeris aqua diftemperata: (Remedium fimile contra alcar den, id eft rícinos apud $\mathrm{R}$ afin legimus, Sed multò melius fuerit, amurca corpus inficere, quęetiam rcabiofis canibus auxiliabitur, Theomneftus: Tardiuus decocto ftaphifagriæ, aut foliorum \& fru ctuum cucumeris agreftis loca pulicofa lauari itubet: Albertus oleo ungi: fic receffuras pulices, nec citoredituras, Ganibus proprium ricini uitium eft, qui inde etiam nomen cynoraifta accepit, Ariftot. Non infeftari ricino locum amygdalis amaris illicum paulò ante dixi. Nemefianus oxelæo, inquit, fcabiem canum Vngere profuerit,tepidoć, oftendere Soli, Auribus $8<$ tineas candenti pel. lerecultro, ricinos puto tinearum nomine inteligens, Canis qui habet alcarden (id eft ricinos ) abs Iuatur cum aqua marina, aut aqua falfa, et deinde ungatur aceto uini $\&$ cymino, extinguentur alcar den, RaGs, Fcré per aftatem fic mufcis aur es canum exulcerantur, fxpeut totas amittant: quod ne fiat, amaris nucibus (amygdalis amaris, ut fupra)contritis linienda funt. Quòd fi ukeribus iam pra* occupatæ fuerint, cociam picem liquidam fuillo adipi uulneribusiftillari coueniet:hoc eodem medis camine contacti ricini decidunt. Nam manu non funt uellendi, ne ut ante prædixeram faciant ulce. $r a$, Columella.Plura de ricinis uide in libro de Infectis, tibi etiam de cynomyia, id eft mufca canina a = gemus. Amaris nucibus Gracis illita loca,à ricinis, mufcis, alịsós uitrins tuta effe, paulo fupra dictum eft. Chamæleontis fucco ricinos canum necant, Plinitus. ISi apes aut uefpæ, aut fimilia infecta canem pupugerint, remedio erit ruta ufta, \& ex aqua impofita:Quod fi punctura mufca maioris(ut crabronis)fuerit, aquam infuper tepidam adhibe, Tardiuus, $\sigma_{*}$ Canes $\&$ alix plerę̧̧ beftix impen dentem peftem, \& coli falubritatem prafentiunt, Aelianus. Si peftilentia ingruerit, uitandi conta. gij caufa canes adhuc incolumes in aliam regionem trãsferantur. Experimento autem probatum eft præferuari canem ab hac lue, fi uel puluis uentriculi ciconiæ, uel eiufdem partis in aqua decoctum in os canis apertum infundatur, Blondus. Gratius etiam in libro de uenatione canum peftem defcri $=$ bit, \& primum effe ait ad euitandum contagium, mutare coelum*fin illud fieri non poffit, fecundum ut medicamentis utamur: Sed uarin motus, nec in omnibus una poteftas, Difceuices, $\&$, qura tu= tela eft proxima, tenta.' Muli 8 canes apud Homerum libro $1 . I l i a d o s$, ingrtiente pefte primi infici untur: caufam inquirit Euftathius in commentarị"s, 8 Calius lib, 17.cap. 28. Heraclides Ponticus(in quit) putat iumenta pefte infici primum, quia deiecta in terram $\&$ prona in paftum, ¿zurs's trahant procliuius homine, cuius eft furrectum corpus, \& purrius fublimi infpirato aëre, \& c c.

ब A pocynum frutex eft folio heder $x$, molliore tamen, $\&$ minus longis uiticulis, femine acuto, di trifo, lanuginofo, graui odore:canes $\&$ omnes quadrupedes necat in cibo datum, Plinitus.Apud Dio fcoridē apocyni alia nomina legimus, ab eodem effectu, nempe cynanchen, cynomoron, cynocrama ben,cynoctonon,cynaricam, \& caninam : $\&$ apud Paulum Aeginetam cynoctonon, ut Marcellus 60 Vergilius legit:noftra exemplaria cynomoron habent, \& recté, cum apud Galenum quoç fic lega= vur, Caterum cur cynocrambe, quafi canina braffica, item braffica ruftica nominetur à quibufdam; 
copulatiua coniunctio) cum aqua $\&$ oleo, canes, fues $\&$ mures occidit, Diof corid. Chamęleonis cand didiradicis fuccus, occidit canes furesćs in polenta: addita aqua $\&$ oleo, cōtrahit in fe mures ac necar, nifi protinus aquam forbeant, Plinius. Auicenna idem de herba Mezereon fcribit, qux chamelaz Gracis eft:quod de chamaleonte Diofcorides, ut linguarum imperiti frepe tiocabulor ü fimilitudine decipiũtur. Blondus chamæleonem carduum uarium appellat: Gaza in Theophrafo urernilaginem transfert, quoniam inter Diofcoridis nomenclaturas à quibufdam fic appellari chamæleonem nigrtี legerat:ipfe commune utriç nomen fecit. Hoc fanè aliquis miretur, cur foli albo chamaleonti canes aliaş̧́́ quadrupedes necandi urenenum adfcribatur, cum nigrum longé perniciofiorem Galenus cae. teríç faciant: \& inter illius quoc $\$$ nomenclaturas cynomazon ( quafi maza cani obricienda) habea= tur, \& cynozolon propter grauitatem odoris, tefte Plinio: nam apud Diofcoridem malè fribitur cy= noxylon:quo etiam iutuen cæ pereunt anginæ modo, quareà quibufdam ulophonon uocatur, Plin.

बinziber canincm uel aquaticum, olus eft quód interficit canes, folia habet falignis fimilia fed pallidiora (magis citrina) ramulos rubentes fapore zinziberis, Syluaticus fine authore: defcriz ptio ad perficariam uulgo dictam uel hydropiper Diofcoridis accedit, qRhododaphnes(recentio. res oleandrum ap pellant) flos \& folia,canes, afinos, mulos, \& pleraf $\$$ quadrupedes perimunt, Dio fcoridès \& A Auícẽna. Idem facit elleborus albus apud Serapionem fecundum Eben Mef, \& A Auicen nam. Nuces uomicx etiam uenenum funt canibus. Chryfippus docet canes occidi, fi aqua eis detur in qua decoctus fuerit afparagus, Plinitus, Diofcorides, \& Auicenna. TPlumbi fumus canes occi. dit,Plinius libro 24. ut A ggregator citat. TVenenati mellis malum ( quo homo infectus fuerit)cer tum eft per excrementa, ad canes etiam peruenire, fimiliter'́s torqueri eos, Plinitus Circa Scythas rum \& Medorum dicfam Thracix regionem, locus eft uiginti fere ftadiorum fpatio, qui hordeum producit, quo homines uefcuntur: equi uero $\&$ boues abftinent: imó fues etiam $\&$ canes excremen ta hominum qui mazam aut panem ex hordeo illo comederint, auerfantur, tanquam mortis pericu. lo, Ariftoteles in Mirabilibus. TSi canis non cibi inopia, fed aliquo prater naturam affectu in ma ciem inciderit, ter aut quater butyro abunde eum nutries : unde nifi ftatim habitior fiat, fignum eft cum uermes fub lingua alere:illos igitur acu extrahes; Quod fi ne fic quidem corpulentior fiat, incu rabilem $\&$ breui periturum exiftimato, Albertus, Sunt qui fafcinatos etiam paulatim emaciari cre dant,ut proxime dicam. T Si ex pigro ignauoóg agilem \& uelocem reddere cupis, pane auenaceo accuraté cocto fermentatóǵ fubinde pafce, Albertus, Gratius quidem etiam ueterno quandoģ la borare canes author eft.

TDe rabie canum, îs'śg omnibus qux circa eam confiderari poffunt: \& quomodo in canibus cu rari debeat, $\&$ qua auxilia fint homini aduerfus morfum canis tum rabiofi tum non rabiofi,infra dif feram cap, 6. TBlondus nugatur quędam de fafcinó, qua ipfius omnino uerbis apponam, nó quòd probem, fed ne quid omittam. Canis ( inquit ) ut 8 infantulus, frequenter inficitur fafcino, ita ut de ueniat ad extremam maciem, Quorundã enim hominum oculi, aděo ligant, ut quem ligauerint non patiantur liberum effe, quinimó nec mentis compotem. Fafcinum autem dicimus effe genus incan tationis, ut patet apud Virg. Nefcio quis teneros oculus mihi fafcinat agnos. Morbus autem is oritur è fpiritu fafcinantis, Sed fafcini eft ingreffus per oculos fafcinati ad ipfurm cor uf́ç. Propterea cauendum eft ne catulus perfpiciatur ab inuidis hominibus donec adoleuerit, Quoniam hxc eft ma xima conferuatio falutis eius!quia remotis qua inficiunt, faluberrimus feruatur. Pleriç autem alï ex corallio baccatum monile circundant collo. Quidam $\&$ facris herbis prætegunt, \& cingunt frontem bacchare. Horum tamen ufus eft minus proficuus. Conclufio uerum prohibet fafcina, uelut far mentorum ignis, Hac Blondus. GLippitudini uel lachrymis canis medeberis, fi afpergas aquam

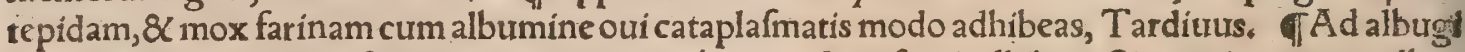
nen oculorum canis, os fepię crematum tritumćp mane \& uefperi adhibeto:Si uero inueterata albü go fuerit, illines medicamen compofitum, pari portione croci, fellis bubuli, furcci foeniculi, \& mellis, Tardiuus. TAd furditatem, quæ deprehendetur expigritie canis $\&$ tarditate, $\&$ omni alacritate amiffa, oleum rofaceum uino mero permixtum, ter die auribus immittes, Tardiuus, đInflatis uel tumidis auribus remedium præftant cortices granatorum oxelæo incocti, quod auribus inftillabis, Idem. Vulnus poft tumorem apparens, aceto latrabis, $\&$ mox infperges fpongiam tritam, Tard $i=$ uus. Vermes etiam in auribus occides, fpongia trita albo oui excepta \& cataplafmatis inftar'appli. cata,Idem. TCynicus fpafmus, id eft canina conuulfio in homine appellatum oris præter naturam diftentio, ita ut canis irati inftar ringi uideatur, quod feréfit mufculis ab altera parte remiflis, Celfus oris diftentionem, Auicenna torturam faciei uocauit. TSi calor nimius palatum canis inuaferit, butyrum melli commix tum in cibo dabis, Tardiuus. Eandem partem fi durities aliqua uel cancer in rederit, falem $\&$ myrrham teres, ac mifcebis aceto, utlocum affectum perfrices, Tardiuus.

I) Anginam barbari fquinantiam uocant, corrupto uocabuloà Grxco fynanche uel cynanche,

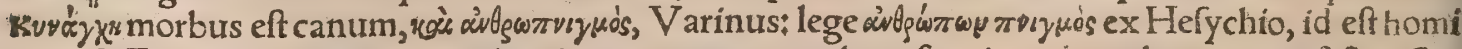
num fuffocatio.Quidam cynanchen interpretantur morbum faucium, à canibus quos infeftat. $\mathrm{Cv}$, nanche eft præfocatio nocturna, humore craffo $\&$ tenace ad bronchum, id eft arteriam delapfo, ma 6 ximè in pueris, Pollux:qui anchonen etiam (áyłérsu ) purulentum abfceffum inter epiglotridem $8<$ lingux radicem interpretatur.Synanche (ut ait $P$ aufanias citante Hermolao Barbaro) mufculis qui 


\section{DeCane: C. Lib. I. 183}

runt intrita fauces, inflammatis oritur:ficut ịs qui extra, parafynanche. Ad eundem modĩ cynan: che fit, cum mufculigutturis interiores accenduntur:paracynanche, cum exteriores. Galenus ta men libro 4. delocis affectis cap. , \& Prognoft, 3 , comment, 20 . hoc difcrimen reprehendit, Celfus

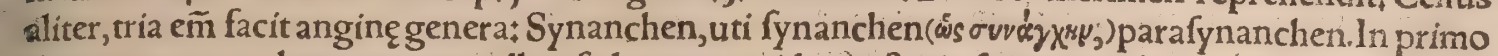
nec tumor nec rubor comparet ullus, fed corpus aridum eft, uix fpiritus trahitur; membra foluun tur. In fecundo lingua fauces ćs cum tumore intumefcunt, urox nihil fignificat, oculi uertuntur, fá es pallet, fingultusḉ eft. Illa communia funt, ager non cibum deuorare, non potionem potef, fpirí tus cius includitur. In tertio, quod leuius eft, tumor tantum \& rubor eft, catera non fequinntur. Hip pocrates $\&$ alï ueteres, ómnia mala quæ in gutture $\&$ faucibus accidunt, quas quidem fpirandi $c 0=$ - mitatur difficultas; angina nomine appellant. Cynanche, id eft angina interimit canes, A riftoteles, Pollux: Albertus addit intra fecundum, aut tertium, aut quartum diem, Ego innumeros uidi canes angina affectos, quorum nullus euafit, Aug.Niphus. TQuid dicam tuffis, quid moefti damna ueterni? Gratius de canibus. Tuffis clamofa, id eft canina, Syluaticus, Tuffis canum uenationem, \& cuftodiam indigentem taciturnitatemaximé impedit, Ideo ut paftores oui tuffienti per nares infun deré confueuerunt, ita $\&$ cani inïcies, uini cyathi diros fiue paulò minus, in quo dulces amygdala conituf $x$, ac mund $x$, fuerint foluta, Blond. Tardiuus pulegiü maius in oleo, melle $\&$ uino coctu, cani déglutiendũ offert. Anhelitus difficultas cani ingruit ab aére craffo: quamobrẽ in aërem puriorẽ du cendus eft $\$ \&$ nifi aére mutato curetur, aures eius ferro perforentur; ut fpiratio leuior fiat, Blondus,

qCaninus appetitus dicitur apud Galenum De locis affectis, ubi canum more, aut nil omnino, aut praui affectantur cibià mulieribus fecundo aut tertio poft conceptum menfe. Sic grammatici quidam in Dictionarịs furis falfò docent, \& fimul Galeno inituriam faciunt. Nam ille De locis affe= ctis libro s.cap. s.inter affectus oris uentriculi fic fribit: Conftat quod etiam cittæ uocatæ mulieri= bus accidunt, ubi hæc particula affecta eft. Qux enim aut canum more, aut nihil omnino, aut malos cibos appetunt, î́s appetentix inftrumentum laftum effe certũ eft, id urero os uentriculi effe demons fratum iam eft, Hęc Galenus, Et licet inde cittam fiue malaciam, aliquandoà canino appetitu nihil differre iudicari poffit, fape tamen ab eo differt: $\&$ mulieribus folum accidit, circa tertium geftatio. nis menfem pracipue(ut Galenus fcribit lib.1.cap.7. de Sympt.caufis, quood non pofit tum foctus; utpote imbecillus, quicquid ad uterum alimenti ratione fertur abfumere, Sed de hoc affectu in Pica

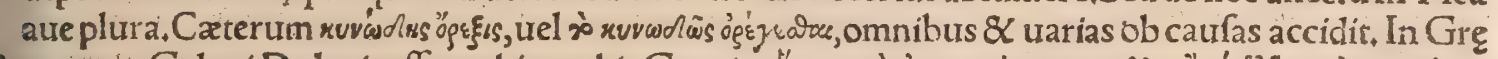

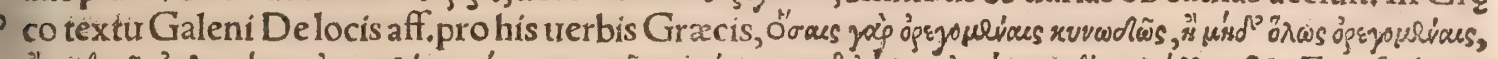

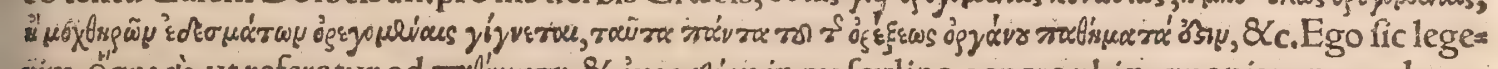

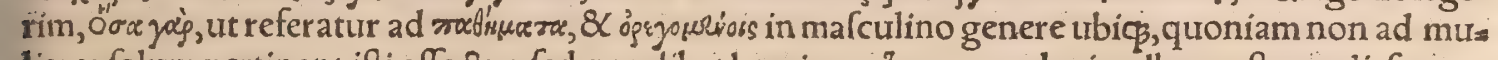
lieres folum pertinent ifti affectus, fed quoslibet homines: öraus certelegi nulla conftruendi fermo nis ratio patitur.Eft igitur fecundum Græecos medicos canina appetentia, contrarium amiffioni ap= petitus malum. Qui enim fic laborant, plures appeturnt cibos \& ingerunt:quorum deinde multitudi ne grauati, $\mathcal{X}$ affumptos cibos citra noxam ferre haud potentes, ad uomitum diuertunt. Poftea rurs fus cibo fe explentes, denuò ad tromitum reuertuntur, quemadmodum canes: unde etiam malumi hoc appellationẽ accepit, Aétius lib, 9. cap.21. Plura uide apud medicos. De bulimo in Boue dixi,ca pitis 8.parte 1. Caninum appetitum à bulimo fcire diftinguit Calius $R$ hod. initiolibri 26. cum prius - 25.9. confudiffet, In Hippocratis A phorifmum libro 2. Famem uini potio folurit, Galenus non quam libet famem, fed caninam fiue caninum appetitum intelligit:qua de re pluribus tractat Calius $25.90^{\circ}$ Sunt qui caninum prandium ad caninam appetitionem contra Gellium putent referendum, Cali= us. Si quod os gula canis impactum fuerít, nafum apprehende \& $\mathrm{collum}$ uerfus aliquandiu depri me: \& oleum faucibus infunde ut excites tuffim:tuffiendo enim os fxpe excutitur: A ut oleum aque tepidæe infufum paulatím immitte in gulam canis, ut remollito laxató̧́ loco os cedat, Tardiurs, Si hirudines adhareant gulæcanis, accipe quinç mufcas illius generis qux per xftatem ante equorü capita uolitant(Galli racines uocant) ex his crematis nidorem canis ore excipiat, \& hirudines ca. dent, Tardiuus. Alui in cane obftructx remedia iam fuperius propofui, of Vomitiones canis monftraffe homini uidetur, Plinius. Canes cum morbolaborant, herba(aliâs herba quadam)inge - fta euomunt, atçs ita purgantur, Ariftot, De canaria herba úide in $\mathrm{H}+\mathrm{a}$. Cum redundantia canis ue xatur, herbam in macerijs nafcéntem nourt, qua comefa, omne id, quo affigitur, cum multa pituita \& bile euomit, fibiós hæc uomitio falutem affert, fine ullius medici opera, quto a d expeliendam bilem nihil ei opus eft:rabiem hac nifi tollatur, facit, A elianus: Et rurfus alibi, Cum autem utrunç uentre exhaurire habent neceffe, herbam dicuntur quandam comeffe, cuius ui partim euomendo, partimi deñcienda aluo fuperfluentes cibos eijciunt. Vnde A egyptios aluos purgare didiciffe ferunt. Sica. nes parcius neqg craflis alimẽtis nutrias, non adigentur ad uomitum, Blondus. Si ftomachus debilis fuerit, \& cruditate ac tromiti laborârit, offa bouis in aceto coća rodenda obíciés, Tardiuus. Ven= trem fluentem fifter cafeus uetus ac durus in cibo, itein palumbes cocta $\&$ afperfa aceto, Tardiurs; Ad rormina uentris proderic cani, fi coopertum igni admoueris: \& gulæ eius inferueris allium tritũ oleo calido mixtum, Tardiuus. Ventris tormina cum frigidis ex caufis oriuntur, calidis iufculis, $\mathbb{C}$ potibus piperatis uincuntur, oleis etiam uel aliquo ex pinguibus oblatis. Forinfecus autem lauda = mus quodģ linimentum calidx uirturis, ut eft oleum liliaceum, ${ }_{2}$ utaceum, nardinum, \& laurinum;' 
ceratum dialthex, Marciaton, uel Agrippæ, 8 cineratis pannis dum circumuoluitur ctrrari pocent in frigidis affectibus. Tum etiam fi per os euomuerit fuccum é uentriculo, curatur, neglectis prafie dịs omnibus. Vana itaq erunt prafidia fi uirtus ualida fuerít ad expellendum nocua,Blondus.

TCanes cum lumbricis infeftantur, herbam tritici comedunt, Ariltot, fegetem herbefcentem depa. fti lumbricns expellunt, Aelianus. Podagra in canibus quanc̈ Pollux ex Ariftotele.Perraro ex ea conualefeunt, Aelianus, Lumbricos in uentre canis occides hoc medicamine, femen abfinthï, cornu cerui, \&lumbricos, arida tere $\&$ mifce butyro aut melli, Tardiuus, Cani fanguinem per urinam reddenti, remedium eft, coriandrum in lacte \& aqua coctu cum pauco oleo, \& duabus libris lenticul $x, \&$ quadraginta granis piperis contritis, quæ omnia com mixta ut edat curabis, Tardiuus. đAut incuruatæ fi qua eft tutela podagræ, Gratius de canibus. Podagra canum pedes extrorfum incuruat, Albertus, Auguftinus Niphus canes duos podagricos fecuraffe feribit, nunquam tamen efficere potuiffe quo minus poft unum aut ad plurimü duos curfus claudicarent.Podagra(Albertus addit calida)tentati pauci euadere poffunt, A riftot.

4. Cum plantx pedum canis ob terræ calorem feruidiores aut uft funt, cinerem lixiuium ( cen. dre paffee)mellí mixtum fuperilligabis. Plantas aut coxas propter laborem tumidas, oxelæo tepido inunge. Si pellis aut ungues à pede feparentur, farinam aquæ mixtam infuper deligato: Aut corti. ces mali punici $\&$ falem conterito, 84 cum aceto feruefacito injolla, cui canis pedes immittes quàm ferre poterit calidiffime: A ut gallas cum chalcantho contere ac mifce aceto, eóq́ tepido medicamẽ to canis pedes lauato, Tardiuius, बHi feré canum morbifunt, quos à fcriptoribus memoratos inue nio:quanquam $\&$ alĭ plures eis contingere poffunt.Nam ut (Gratius inquit) Mille tenent peftes, curaós potentia maior. बMorbilatentes præter iam dictos, fola ignis calefactione, \& graminis efu curantur, Albertus, TReliqua canum uitia, ficut in cæteris animalibus præcepimus, curanda funt, Columella. In Geoponicis Gracis libro 19, cap.3.ubi de morbis canum tractatio definit, ad

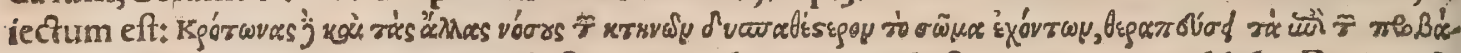

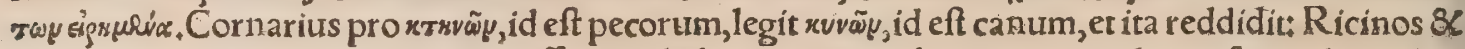
alios morbos canum, corpus peius affectum habentium, curabunt ea quæ ad oues funt relata: Andreas à Lacuna maluit uertere, Ricinos aliosés morbos pecorum, qua infeftantur ægrius aut difficl. lius, \&c. Ego cum Cornario fenferim, xuvw̃y, id eft canum omnino legendũ effe, flvau xt's uero quam. uris plerung fignificet id quod natiuo quodam robore praditum difficulter à noxijs caufis uincitur, uidetur tamen hoc loco poni pro male affecto ut Cornarius uertit:nam in Grammaticorum Lexicis

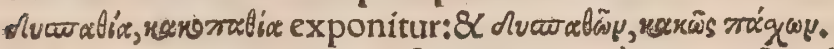

बCanem detenturus ne fugiat, butyro à capite ufós ad caudam illines, lingendumó butyrum da. bis, aut humida arundine à capite ufos ad caudam eum menfurabis, Fronto in Geopon. Gracis. Tat diuus alas tantum oleo illinendas fcribit, ut à curfu impediantur. Canis fequetur te, fi alterius canis fecundam obligatam panniculo, ipfi olfaciendam dederis, Fronto in Geopon. Canes non allatra.

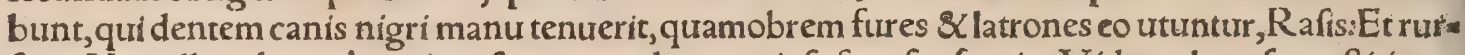
fus, Non allatrabitur à canibus fuper quo dens canis fufpenfus fuerit. Videtur hac fuperfitio ex Diofcoridis uerbis non intellectis nata, qux funt: Ad pracauendum etiam utuntur (morfífilicerà cane rabido, ne in metum aqux incidant; de quo proxime egerat)dente canino illius qui momorderit canis, folliculo ex aluta claudentes, \& ex brachio fufpendentes.Marcellus etiam in commentarips 2ddit,Diofcoridem fibi uideri loqui de pracautione metus aqua, non rabidi canis impetu : furum ta. men(inquit)relinquatur legentibus iudicium. Conftantinus in libello de incantatione, contra mor. fum canis a muletum facit, citans Diofcoridem. TCor canis fi quis fecum habuerit, canes ei molefti non erunt, Sextus. CoftanbenJuce fcribit, fi quis cor canis fupra fe habuerit, nô morderia à canibus: fed quamuis accefferint $\&$ olfecerint eum, ftatim refugere, Albertus. Blondo non fatis uidetur fecti habere, aut fupra fe canis cor, fed idem uorandum, aut (quod praftantius fit) tritum bibendum fura. det furibus $\&$ illis qui nociu ad amores fuos accedunt, fic à nullo cane allatrandis:quod furibus ( in. quit) $\&$ amantibus credendum dimittimus. Ego quifquis hrec credit, non caninum duntaxat habere cor, fed totum effe canem credo. Sed Blondum fefellit, quod cor canis potatum, pro portatum, ut $e_{*}$ go conício, apud Aefculapium legitur. Canis latratum auertit, linguam canis in calceo fubditam pollici portare, Plinius lib.29. Item ex fecundis canis membranam habere, Plin. lib. 30 . Et cor canis ficcum (fecum)habere uel linguam eius fummam pofitam fub pollice pedis, Sextus. In finiftra manu tenere linguam in panno ligatam, canes obmutefcere cogir, Kiramides. Leporis fimum uel pilos te. nere, Plinius lib. 3o.Muftelx uiuentis caudam abfciffam in pede portare, ficut dicitrm eft de lingua canis, Plinius libro 29, Rana uiua data in offa, Plinius libro 32 . Hac omnia ad cohibendos canumla. tratus, ex Plinio, Sexto, \& Kiramide ab Aggregatore citantur. A quo hac etiam canes fugantia re cenfentur, Cor canis portatum,Plin,2q. finiftra manu portandum Kiramides addit: aut lingua eius in panno ligata, Kiramid. Corpus inuncium lapathi $8 x$ cyclamini fucco, Theffalus. Nigidius fugere tota die canes confpectum eius, qui é fue ricinum euellerit ( 8 a dalligatum geftauerit nimirum) Icri purm reliquit,Plinius. TCanum morfus auertentia,cap.7,recenfebimus.

D.

Canis cateras rationis expertes animãtes cum alijs dotibus excellit, tum quod homines à quibus 
uxorem duceret, Aelianis. TCanis animal eft adeó docile, ut ad uarios ludos inftitui poffit . Mire uralet ingenio: \& per quandam difciplinæ ac obedientiæ formulam, timidus folicitus ḉs expectatione fufpendifolet, donec ad peragendi licentiam figno mittatur, ${ }_{2}$ Author obfcurus, Quicanes aut catu los domant ac erudiunt, obfequentes delinimento aliquo demulcent, reluctantes uirga compellunt, Blondus, Francifcus Marchio Mantux, parens Federici Ducis, comprehenfam uocem habens, morbi defectu, inftruxerat canem, ut tiocaret quem uolebat ex curialibus, is tandem utebatur cane, in aduocandis hominibus quos præcipue defideraffet, quemadmodum quis utitur officio optimi fer ui, Blondus. TPlutarchus frribit, fe non debere prateríre eam canis difciplinam, quam ipfe Ros mæ fpectaffet. Mini docentis nimirum fabulam, in qua uaria \& mültiplex perfona agebatur, nó mo do appofitè canis alios fubiecfos affectus imitatione confecutus eft:fed etiam cum ueneni(quod qui= dem tanquam mortiferum poèmati fubiectum effet, treruntamen tum dintaxat uim conciliādi fom: ni haberer) in eo ipro cane periculum fieret : is panem, ad quem uenenum adiniftum effet, fumpfit, \& deuorauit, ac quam mox præ fe trementis \& ebrietate oppreffi, animoó deficientis fimilitudinem fpeciemós geffit ${ }_{2}$ ac nimirum fe tandem ad terram abijciens, tanquam mortuus, hitmi ftratus iacuit, féć huc $\&$ illuc, ut fabular ratio ferebat, trahendum permifit, atque etiam cum ex dictis $\&$ actis intel lexit tempus effe excitandi, fefe fenfim primum tanquam ex arctiffimo fomno experrecitus miouris, $\&$ alleuato capite afpexit, deinde illinc furrexit, fimul $\&$ ad eum quem oportebat, \& neceffe erat cum gaudio profectus eft, ut omnium fanè fpectatorum, \& ipfius Cæefaris (nam aderat Vefpafianus fenex in Marcelli theatro ) admirationem $\&$ affenfionem commouerit. $T$ Canes fi excidantur, cef. fant à relinquendis heris: nec ad cuftodiam aut uenationem deteriores fiunt, Xenophon de infitu: tione Cyrilibro feptimo, Inter canes cibi nulla eft focietas, ut perfape de offe inter fe fic lace= rent $\&$ diftrahant, quemadmodum de Helena Paris $\&$ Menelaus. Solos uerò Memphiticos canes in medium auditione accepi rapinas proponere, \& communiter uiuere, Aelianus, of Canes hy= ana capit unmitionem hominis imitando, Ariftoteles. Hyænam traditur uomitionem hominis imitari ad follicitandos canes, quos inuadat: praterea umbra eius contaciu canes obmutefcere, Plinius.

E.

Canum, ficut ait Cicero, tam fída cuftodia, tamḉ amans dominorum adulatio, tantumó̧́ odium in externos, $Q X$ tam incredibilis ad inueftigandum fagacitas narium, tanta alacritas in uenãdo, quid fignificat aliud, nifi fe ad hominum commoditates effe generatos?" Sed de canum fagacitate, ac ue= natione, hominum minorum ufui canes feruire, $\&$ res domefticas his plané fciüt adminiftrare: $\&$ pauperi fatis ad fanu: latum eft, unum poffidere canem, A elíanus. Canes diuerfigeneris feris noftro tempore nó mícen turr, Pares iungendi funt paribus:Et admittendi qui primi lafciuierint, Blondus, * Catulorum cau das pof diem quadragefimum, quàm fint æditi, fic caftrare conuenietł neruus eft, qui per articulos

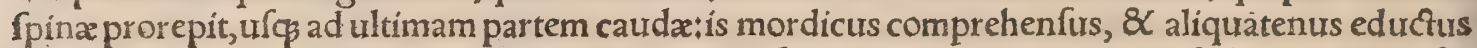
abrumpitur:quo facto neç in longitudinem cauda foedum capit incrementum, \& (ut plurimi pafto res affirmant) rabies arcetur letifer morbus huic generi, Columella. Equis \& canibus curatores illos prafecit Cyrus, quos exiftimabat reddituros hac pecora ad ufum fuum quàm optima, Xeno= phon. đCanis fimum cum urina putidiffima mifcetur, \& funditur circa plantas aut femina, qua à pecore tangi nolis, Democritus in Geopo, đEx canino fimo gluten quoddã faciunt, qui profitẽtur artem coriariam, ad glutinandas pelles, Blondus,

F。

Quid loquar de canibus, quos iutrenes ac pingues, \& potifimũ cum furerínt caftrati,apud quaf dam gentes frequentifime mandunt, cum multi fint qui pantheris uefcantur? Galenus libro 3 , de ahi ment, facul. Canum 8 uulpium carnem nunquam equidem guftaui, nec fanèguftare unquam fui adactus, neog in A fia, neç in Gracia, nees in Italia:aiunt tamen hanc quoģ mandi cöieçare tamen poffum uim ei ineffe carni leporum fimilem. Nam canis, \& uulpes, ut fummatim dicam, tempera mento funt ficco, Galenus de attenuante uictur. Plura de cane dici cogunt prifcorum mores:Catu= los lactentes adeo puros exiftimabant ad cibum, ut etiam placandis numinibus hoftiarum tice utes rentur his. Genito mane catulo res diuina fit, $\&$ in cœnis deûm etiamnum ponitur catulina: Adrijcialibus quidem epulis celebrem fuiffe, Plautifabulæ indicio funt, Plinius, Petrus Martyr Oceanica decadis prima libro 3.infulam quandam in nouo orbe effe foribit, in qua canes non latrabiles, afpe. ctus foediflimi, hozdorum inftar comedantur. बCynamolgi Indix populi canes mulgent $8 \mathrm{C}$ lacte uefcuntur, ut infra dicemus in Canibus diuerfis, A dhuc non uidentem catellum fi edas, nullum fen ties dolorem, Sextus.

$$
\text { G. }
$$

Pracordia uocamus uno nomine exta in homine, quorum in dolore cuiufcunç partis, fi catus. lus laçens admoureatur, apprimatur'ç his partibus, tranfire in eưm morbus dicitur, idćs exenterato perfufọ́ uíno deprehêdi, uitiato uifcere illo quod doluerit hominis, et obrui tales religio eft. Hi quo 6 que quos Melitæos uocamus, ftomachi dolorem fedant applic ati fæpius: Tranfiréq́ morbos ægritu dine corum intelligitur, plerunç $\&$ morte, Plinius, Plinio fubfcribit Serenus capite de pręcordins fa 


\section{DeCanic. G. Lib. İ. I87}

nandis, inqquiens, Quin etiam catulum lactentem apponere membris Conuenit, omne malư tranf currere fertur in illum, Cui tamen extincto munus debetur humandi, Humanos quia côtaçus mala tanta fequuntur, Et iunçus uitium ducit de coniuge coniunx. Idem remedium Marcelltus Empiricus ex Plinio, ut uidetur, defcripfit, cap. 21. Et Plinius ipfe rürfus alibi, Sunt occultí(inquit)in teraneorum morbi, de quibus mirum proditur: fi catuli priufquam trideant applicentur triduo fio. macho maxime ac pectori, \& ex ore xgri fuctum lactis accipiant, tranfire tim morbi, poftremo exa, nimari, difleçiś́s palam fiéri zgri caufas. Mori, $\mathbb{X}$ humari debere eos obrutos terra, Spleni dolenti quidam incifum fiffumć catulưm imponunt, Sexturs. Idem aduerfus omnem dolorem remedium de frribit, fi quis nondum uidentem catulum edat. Adurerfus rabiem, necantur catuli fratim in aqua, as 10 fexum eits qui momorderit, ut iecur crudum detoretur ex ijs, Plin, In Leonelli Fatientinilibro de curandis morbis, capite de paraly fi, ungenti catulini, ut uocat, deferiptionem iftam reperio: Catcl= li fubrufi exenterati in aqua decoquantur donec off feparentur, $\&$ in fuperficie prorfus nuda appa reant: deinde refrigerato uafe in quo bullierunt, quod liquatum elt (intelligo pingue fupernatans) colligi debet; 8 inde inungi fpina dorfi; 82 membra refoluta. Cibararium in Antidotario uirili un $=$ guentum chinarium ( ex cynarijs) à catulo canis dicfum, Syluaticus, Vermiculus ( fub lingư foim licet ) canis rabidi in collo furpenfus, fanat morfum à cane rabido, Sexturs. Aliqui morfís à cane ra. bido ừ à pauore aqua tuerentuir, uermem é cadauere canino adalligauểre, Plinius, Sanguis ricin euiulfi cani, pfilothrum eft; Plinius: Alÿ ipfum canis fanguinem pfilothrum faciunt. Canis cinere ex olco illito fupercilia nigrefcunt, Pliniuss. Aduerfus urinæ incontinentia Magi uerrini genitalis 10 cinere poto ex uino dulci, demonftrant urinam facere in canis cubili, ac uerba adijcere, ne ipfe uri nam faciat ut canis in fuo cubili,Plin, TDeftillationes fedat canina cutis curilibet digito círcum= data; Plinius, Corrigio canino(alibietiam in genere neutro utitur)rudi nec unquam uincto, quilibet digicus in quauis manu ligatus, remedium deftillantibus naribus præftat,Marcellus, Corrigiam ca ninam ter collo circumdatam remedio effe tradunt aduerfus anginam, Plinius : mire anginam rele. uat,Marcellus, Ad capítis dolorem pluribus femper'́s prodeft, limacis inter duas orbitas inurenta officulum per aurem cum ebore traiectum, uel in pellicula canina adalligatum, Plin. Corrigia ca= nina medius cingatur qui dolebit unentrem, ftatim remediabitur, Marcellus, đNeruofa caro canis pota, aduerfus canis morfum laudatur, Blondus: A efculapius ficum adijcit: Ego non neruofa, fed ra biofi canis caro legere malim. Saliuntur carnes canum qui rabidi fuerunt, morfis à cane rabido in ci bo dandx, Plin. Caninus fanguis commodéab his bibitur, quos efferata in rabiem beftia momorde rit:contra epotum toxicum auxilio eff, Diofcorid. Sanguine canino contra toxíca nihil praftantius putatir, Plinius. Sanguis canis nigri illitus(refperfus, Plin, ) omnibis parietibus domus in qua eft maleficium, tollit, Author obfcurus; Torminofi fanguinem canis bibant, miré fanantur, Sextus: Alfi ex A efculapio hac uerba citantes, tremulofos legunt: \& Blondus etiam tremori conferre hauftum fanguinem caninum fribit. Scabiem curat ante omnia fanguris caninus, Plinius. Auricenna Gale num citat qui fcripferit fanguinem canis pilos euulfos renafci prohibere + Plinius non canis, fed ricis ni cani euulfi fanguinem pfilothrum effe meminit; T Canis adeps cum oleo uetere 82 fucco abfinthï auribus (moderaté, |Sexturs)inftillata, quiacũ ç ex caufa exfurdatas aurres, miro modo reparare creditur, Marcellus \& Sextus.Canis adeps cum abfinthio \& olco uetere grauitatem aurium $\mathrm{Ce}_{\text {. }}$ 40 dat, Plinius. Canis adeps podagram $\&$ aurium dolorem fanat, Aefculapius, Lendes tolluntur a dipe canino,Plin, Caninum adipem cum alumine fcifto fabx magnitudine, ad urin $x$ incontinentí: am prodeffe tradunt, Plin, nifiquis potius ad hydrocelicos referat: non fatis diftinge enim de his ui= tips eo in loco agit Pliníus:Sed malim ad urinam cum Marcellus quoq̧ fic fribat, Vrinam continet lac caninum, 8 adeps eius cum allumine datus, ita ut fit fabx magnitudine globulus qui datur.

\Medullam canis ex uino uetere fubige, $8 \mathrm{emplaftri}$ modo impone condylomatis, potenter ea fanabis,Marcel, TPilos caninos panno adalligant capitis doloribus, Plin. Quidam ut tuerentur à pauore aqux, in morfu canis rabidi, pilos de cauda canis combuftos infuere uulneri, Plínitis, Pill canis in uulneribus quæ canis homini infixerit, applicati, \& fanguinem compefcunt, \& uulnus de fendunt quo minus ulcus tabidum fiat:debent autem mox ab inflicto uulnere adhiberi, Blondus. - Offibus fractis medetur caninum cerebrum linteolo illito fuperpofitis lanis, quxe fubinde fuffun, duntur ferè quaturordecím dieburs, folidat, Plin. Infandum diçu cunctis procul abfit amicis, Sed fortuna potens omen conuertatin hoftes, Vis indigna notio filparferit offa fragore, Conueniet cerebum blandi canis addere fractis, Lintea deinde fupeŕ́g induçu nectere lanas; Sapius \& fuce cus confpargere pinguis oliui, Bis feptem credunt reualefcere cuncta diebus, Serenus. Idem reme. dium apud Sextum legitur, qui addit, Fractura autem debet folida alligatione uti. Glaucomata dia cunt magi cerebro catuli feptem dierum emendari,fpecillo dimífo in dextram partem, fi dexter ocus lus curetur: in finiftram, fi finifter, Plinius. Caluaria canis finditur, \&. fi dexter oculus laborat, in dexteriorem partem fpicella demittitur: fin finifer, finiftram, Sextus. Marcellus glaucomata effica $=$ cifimè detergi foribit, fi catello dierum feptem, caput uiuenti diffindatur, $\&$ de dextra parte cerebri to oculus dexter, de finiftra finifter, intincto illic fpicillo inungatur.

TSumma uis in canini capitís cinere:excrefcentia omnia fpodin uice erodit ac perfanat, Plinitus. In ulceribus genitalium fpodíf uim fuperat, Marcellius, Canis non rabidi caput conbuftum, \& iden $^{3}$ 


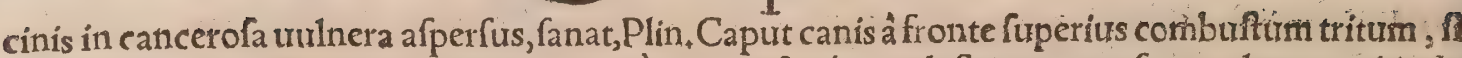
fuper fundatur oleum rofaceum, $8<$ accuratè teratur, fiatćs emplaftrum ex eo fuper ulcera capitis, de ficcat ea, $R$ afis, Albertus Galenum citat, quod caput canis combuftum, oleo infufum, \& fepo canis eitufdem, deficcat ulcera capitis \& fcabiem, Albertus ex $R$ afi. Ambuftis canini capitis cin is nede $\vec{t}_{\text {, }}$ Plin. Cum uulnere canis afficitur, cinerem capitis canis uulneri fuperfparges: aut fal tenuis torre. factus cum pice liquida imponatur, Capitis canini cinis à cane rabido morfos perfanat, sextus:uel

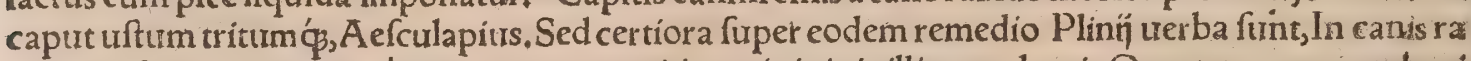
bidi morfu(inquit)tuetur â paưore aqua ca pitis canini cinis illitus uulneri: Oportet autem comburå omnia codem modo, ut femel dicamus, in uafe fictili nouo argilla circumlito, atç, ita in furnum inds to:Idem $\&$ in potione proficit:Quidam ob id edendum dederunt. Medetur teltibus farina ex offis bus canini capitis fine carne tufis, Plin. Caluaria canis trita 8 impofita, tumores tefliculor um mire fanat, Sextus. Tetris teftium tilceribus $\&$ manantibus auxiliantur canini capitis recentis cineres, Plin, Canini capitis recentis exufti cinis ueretri uel tefticulorum tabidis $\&$ humidis ulceribus in fperfus, aut cum accto adpofitus, adeo prodeft ut fpodium $\&$ utilitates eius, in hifce curationibus uin cat,Marcelluss. Sedis uitijs efficaciffimus eft canini capitis cinis, Plin.Ficus qui in ano nafcuntur, afperfus fanat, \& rhagades $\&$ omnem fpurcitiam, Sextur. R hagadas adfperfus adiungit, Marcellus. Sipili in caudis equorum defluant, capitis canini cinerem, loco prius butyro inuncto, infperges, $\mathrm{Pe}$ lagonius. Reduuias \& qux in digitis nafcuntur pterygia, tollunt canini capitis cinis aut uulua de. cocta in oleo, fuperillito butyro ouillo cum melle,Plinius, Idem cinis appofitus pterygia qua nafcũ tur in digitis, urit, $\&$ cicatrices tollit, Sextus. Omne iumentum( caput caninum uratur $\&$ fumum reddat fub capite eius, leuatur, $A$ bfyrtus, In mulfo medetur mor: boregio, Plinius, Rabídi canis caput contufum $\&$ commixtum cum uino, potatum mire fanat mor = bum regium, Sextus. Dentium doloribus, ut magi narrant, medetur canum qui rabiem præferunt, capitum crematorum cinis fine carnibus, inftillatus ex oleo Cyprio(lego cyprino ) per aurem cuíus épartedoleant, Plin. TSordes aurium canis cum uino mixtæ, ftatim inebriant, Albertus ex Rat fi. A pud ipfum tamen $R$ afin legimus, Si uinum in quo infufi fuerint alkarden, id eft ricini, propises alicui,inebriabis. Sordes aurium canis, fi eis peruncta licinia (ellychnia nimirum) de goffipio nouo in crucibulo (uafe teftaceo)uiridi extendantur cum zambac(oleo, Albertus) puro, ís accenfis capita prçfentium canina(calua, Albertus)uidebuntur, $R$ afis, Magorum quidam ricinum ex aure finiftra canis omnes dolores fedare adalligatum trädunt, \&c. Vide in Ricino. TCaninus dens finifter ma xímus, circumfcarificato eo qui doleat, medetur, Plinius, Colluunt dentes dolentes caninis dentibus décoetis in uino ad dimidias partes, Plin. Cinís eorum pueros tardé dentientes adiutrat cum melle: fit eodẽ modo $\&$ dentrifriciũ, Pli,Dens canis cóbuftus $\&$ cũ melle trîtus, gingiutas reprimit, ut dentes fine dolore crefcãt,Sext, Dens inde cótaçus cito emittiẗ, A efculap. Puleris dentiũ canis, dolores den tiü et gingiuas curat, Aefcul. Si infantiũ gingitræ canis dente conterant̂t (affricent́) citius euocantur

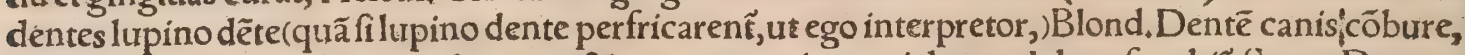
$\mathcal{Q}$ cinere eius in uini hemina decoque, $\mathcal{Q}$ ex eo gargarizet cui dentes dolent, fanabit, Sext. Dens ca nis cöbuftus et tritus impofitus, gingiuas(aliâs tumores gingiuarũ) \{anat, Sext, Idẽ cicatrices oculor $\tilde{u}$ extenuat, A efculapius; Blondus puluere dentium canis contacta cicatricum(fimpliciter) figna, pelli frribit, in quo eum erraffe puto, ut in permultis etiam alins, quod ueterum uerba attinet: de re ip ${ }^{2} \mathrm{e}=$ nim non difputo, quanquam $\&$ hoc ridiculum eft cicatricem folo contactu tolli. Molares dentes ca nis rabiofi qui momordit hominem, in corio alligati brachio, canis rabiofi morfum amoliuntur, $\mathrm{Se}$ rapio citante Syluatico, uide fupra in c . circa finem. Canis nigri dentem longiffimum in quartanis adalligariiubent, Plin. Dentes canini fufpenfi fupra ictericum, conferunt, $R$ afis lambendo \& fua \& aliena tum ulcera tum uulnera curat, ut fupra dixi cap. 3. Vulnus fi fimplex \& paruum fuerit, canis lingua lambendo, $\&$ natali faliuæ fucco emendat, Blondus. Vermes qui fub lingua rabidi canis inueniûtur, excifos $\&$ circum arborem fterilem ter latos \& datos, qui ab co mor fus fuerit, fanabitur, Sextus. Eft limus faliua fub lingura rabiofi canis, qui datus in potu fieri hydro phobos non patitur,Plin. Canis rabidi id quod fub lingua habet acceptum \& potatum cum aqua calida, uel ex ưino, mirifice fanat hydropicos, Sextus:lege hydrophobos ex Plinio : quos non fanat, fed tales fieri prohibet.

Si fumas de coagulo catuli parui \& conficias cum uino, diffoluit colicam folutione leui, \& alle. uatur æger eadem hora qua biberit, Rafis. Vomitus canum illitus uentri, aquam trahere promirtitur,Plinius, Vomitum canis hydropico fuper uentrem pone, ftatim incipit per feceffum aquam e. mittere, Sextus, Aduerfus aqua metum multò utiliffimè iecur eius, qui in rabie momorderit, das tur, fi poffit fieri,crudum mandendum: fi minus, quoquo modo cocium, aut itrs incoc?is carnibus, Plura uide infra circa finem remediorum ad morfos à cane rabido, ubi de metu aqua. Maculas in facie, œfypum cum melle Corfico, quod afperrimum habetur, extentat:item frobem cittis in facie cü rofaceo impofitum uellere:Quidam $\$<$ butyrum addunt. Si uero uitiligines fint, fel caninum prius acu compunctas, Plinius. Marcellus Empiricus idem remedium defcribit, fed uariat in quibufdam, proinde uerba eius apponam: Oefypum(inquit)cum melle Corficano tritum $\&$ appofitum, abolet de facie omnes maculas, quidam $\&$ butyrum addũt, Si uero $\&$ uituli fimus $\&$ fel caninum mícea 


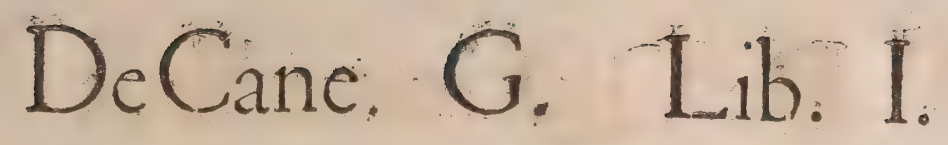

miedicämen utilius erit, ita ut pariter temperata omnia decoquantur, Hæc Marcellus . Qưod autem vituli fimus etiam aftates $\& \check{C}$ difcolorem cutem emendet, ex Plinio annotatimus in Vitulo : proinde dubito Marcelli ne an uulgatorum Pliníj codicum lestionem praferam. Fel canis cum melle curat oculos, A efculapius. Felle catelli dierum feptem oculi ex mells inunctí cito à leucomate liber abun. tur, Marcellus, Suffufionem oculorum canino felle malebat quàm hyænxe curari A pollonius Pita. naus cum melle: item albugines oculorum, Plinius. Fellis aut lactis canini forupulum unum, 86 mellis optimi tantundem mifcebis, conteres, 8 in ftrigili calefacies, 8 auriculæ infundes, 8 lana ob. rludes: Nihil potentius neç certius hoc medicamine, etiamfi intrinfecus cancerauerint aures, Maxcellus. Podagras lenit fel caninum, ita ne manu atringatur, fed penna illinatur; Plinius. Fel canis

10 aquatici aut canis rabidi lentis magnitudine fumptum, feptem diebus interficit, quibus fuperatis ef fe poteft (alutis fpes, Bertrutius. Fel canis nigti mafculi amuletum effe magi dicunt domus totius - fuffita eo purificatæe ue contra omnia mala medicamenta, Plin. TSplen canis in uino potatus, fple nem fanat, Sextus. Caninus lien fi uiuenti exprimatur, $\mathcal{Q}$ in cibo fumatur, lienis dolore liberat. Qui dam recentem fuperalligant. Alij duorum dierum catuli ex ageto fcyllitico dant ignoranti, uel heri= nacei lienem, Plin. Caninus fplen recens fupra fplenem hominis imponitur; dicente co qui adponit; remedium fe fpleni facere, poffea fplen intra parietem dormitorij cubicull tectorio, id eft capfella in: clufus, reponitur, \& defuper ter nouies fignatur,Marcellus. Splen uiuenti catulo exemptus, ciboć fed coetus fplenitico datus ignoranti,liberat eum quamuis grauiter laborantem,Marcel. Catellum lactentem de canna occide, $\&$ de ipfa canna fplenem eius tolle, ac nefcienti fplenitico, in carb. :ibus 20 coctum, uel affatum, manducandum dato, Marcel. TGenirale canis fub limine ianua del ....m, magi amuletum effe dicunt domus totius, contra omnia mala medicamenta, Plin. Corio uirgaca nis fi huoluatur terra fuper quam quis minxerit, \& ligetur, urinam emittere impediecur: \& quàn diu hoc ab aliquo feruatum ligatumç fuerit, non poterit ille urinam reddere, $R$ afis. TRedurias 8 qua in digitis nafcuntur prerygia, tollit canina uulua decocta in oleo, fuperillito butyro ouillo c $\bar{x}$ melle, Plin. Partus euocat membrana écanum fecundis, fi terram non attigerí, Plin. TQuidam in canis rabidi morfu, ut tuerentur à pauore aqua, menftrua canis in panno fubdidere calici, aut in tus ipfius C A VD A E pilos combuftos ínfuêr e uulneri, Plin. Vide circa finem huius capitis, inter re. media contra aqux metum. बMendacem magorum compofitionem qua inulictos faciunt, \& pre ter alia canis ungues a diabent cum cauda draconis; 8xcin dracone exponam.

T) Primiparæ canis lac potum, contra uenena anridoti uicem obtinet, Diofcorides, CInis cum la: 30 cfe canis primi partus, euulfis pilis quos renafci nolunt:uel nondum natis perunctis partibus, alij non furgunt, Rlin. Serenus etiam, Ergo locum crinis uulfi tange lacie car ino, Auulfam'̧́ uetá rurfus procrefcere fyluam. Pilos oculis moleftos diligentifimè uelles, atç eorum loca canino lacte continges, Marcel. Lac caninum euulfos pi os non pantur recrefcere, fi lucum fatim linicris unde fublati funt, Sext. Vt pilinon crefcant, \& decidan!: Lac caninum \& lachryma hedera \& lac tithy malli in uino mixtum, euulfos pilos non finit crefcere, fi mox linieris locum,Sext. Priniparac canis lacre perunctos, narrant glabrefcere, Diofrorid. Canis lac bihitum (lego illitum)pilos \& capillos crefrere prohibet, A fculap. De lacte canino quidam maniteftè mentiti funt, quod in palpebris pis los renaf́ci prohibeat, fi prioribus euulfis co loco foret illitum unde pilorum radices extractę effent: 40 Ad eundem modum qui fcripferunt, quod celerem pilorum in pudendis exortum reprimat; fi quis den foret ante pubertatem illitum; uićs quod foetus emortuos énceret potum, uerum non protules re. Sed \& alia quxdam praftigiaturis cuntaminata, tum de horum, tum de aliorum quorundam ani malium lacte confcribunt, qux me ab initio dicturum negaui, etiamfi experientia didiciffem uera di xiffe, $\mathrm{Hac}$ Galenus libro 10, de fimplicium facult cap.8. Albugines emendar canini lastis inftilla tio, ut quidam ex Plinio citat: nos fupra fel ad eafdem ex. Plinio ualere fcripfimtis, quod magis proba mus. Blondus ridicule de caninilactis albugine fomniat, tollere eam aurium dolores er pondus, $\& c_{*}$ Canini lactis inftillatio fedat dolorem au ium, Plin. Ex lacie aut felle canino remedium ad aures, paulò ante Marcelli uerbis defcripfi. Caninum lac inftillatum dolorem ergrauitatem auritum fedat, ut quidam citat ex Plinio:apud quem tamen fic legtrur: Canini lactis inftillatio fedat aurium dolor $\tilde{e}_{\text {: }}$ - grautritatem adeps cum abfinthio \& oleo uetere. Dolor aurium fedatur canino lacte, \& urfino, fire cens inftillecur, Marcellus. Lacte canino fi affiduè infanuibus gingiuas tangas, dentes eis fine dolo. recrefcunt, Sextus. Siferuentia os intus exulferint, lacfe canino ftatim fanabitur, Plin. Vrinam continet lac caninum, Marcellus. Caninum lac abortus mortuos expellit, Diofcorides: quod pau lò ante ex Galeno falfum effe oftendi, Lac canis eñciet mortum(foetum) fimulier continué biberít cum melle \& uino parimenfura, Sextus \& Aefculıpius, \& Rafis; qui ad difficilem quoç partum ide remedium pollere fcribit. Partus conceptos maturat caninum lac potum: Euocat membrana é ca. num fecundis, fi terram non attigerit:Lumbos parttrientium potus lactis (nefcio an de caninoads huc intelligat)reficit, Plinius. 즐 Canine lotio defluunt pili,Sextus. Lotitum caninum lutum fas ćum, in lana collectum, callos \& uerrucas mire fonat $\&$ tollit, Sextus. Verrucas omnium generum - fanat urina canis recens illita cum fuo luto, Plin. Auicenna, Marcellụs, Lotium caninum cum ni tro,lepras \& prurigines tollit, Diofcorid, Lotio canis fi addideris portiunculam Talis nitri, \& regio morbo \& prurigini apponetur. Recens lotium credimus quod omnem uerrucam toltat, Blondus 
puto. Qui in urinam canis fuam ingefferit, torporem lumborum dicitur fentire, Plinitrs; \& alibsi, ad Venerem pigrior fieri. Herba iuxta quam canes urinam fundunt, euulfa, ne ferro attingatur, lus xatis celerrime medetur, Plinius.

TStercus canum, ubi offibus duntaxat uefcuntur, neqg grauiter olet, 8 multa experientia, non tantum nobis, fed $\&$ alijs medicis me natu maioribus, comprobatum eft, Galenus libro ı. de facult. fimpl.cap, 18. 8 mox cap, 19. Sané ego memini ( inquit) me admirandam tum humani, tum canini fercoris expertum facultatem. Canino uti confueuit praceptorum noftrorum quidam, fola offa ca. ni edenda exhibens duobus continuỏ diebus, ex quibus durum, candidum ac minimè foxtens fier. cus prouenicbat. Hoc igitur acceptum deficcabat, ut cum poftea ufus effet, facile adleuorem polfet redigi. V tebatur eo ad anginam, dyfenteriam, \& fummé inueterata ulcera: Et pau!ò poft, In ulceri: bus extremé malignis multam experientiam habeoftercoris canini, cuius paulum quiddam medica mentis probatis mícui, 8 manifeftò feipfo ualentius reddirum eft medicamen, Hac Galenus. Ster= cus canis tritum cum fucco coriandri, rubentes abfceffus illitum fanat, $R a f_{i s}$. Gratius poéta in uul nere canis fanguinem fiftit fimo canino his uerfibus,

Nec longèauxilium; licet al ti uulneris ora Abftiterint, uteróǵs cadant cum fanguíne fibra: Inde rape exipfo qui uulnus fecerit hofte Virofam eluuiem, laceriós per ulceris ora Sparge manu, uenas dum fuccus comprimat acer. Blondus pilos caninos ad fanguinem fiftendum commendat. Verrucas omnium generum fanat fimi canini cinis cum cera, Plinius: Marcellus hũc cinerem impofirum etiam ablgis cera uerrucas curare fribit. Cinere fimi canini candidi cum rola. ceo, uerrucas efficacifrme tolli aiunt, Plinius. Ofribus in canino fimo inuentis, aduftio infantum, 1 qua uocatur firiafis, adalligatis emendatur, Plinius. Stercus canis album potatum ex cineris lixi. vio, caducos mire fanat, Sextus. Rana uitium linguam occupat uelut latum ulcus, fubnigrum: no no die necat nifi curetur: fignum eft faliua deftuens. Curatur fercore canino candido, fale, ruta, fus. ligine $\&$ faluia: quibus fimul contritis in pila, lingua exerta perfricatur, quod rufticorum experi menta docent. Caninum $\&$ humanum frercus gutturi impofitum anginis auxiliari, inter omnes conuenire inuenio, Diofcorides, Canino ftercore(quali iam dictum eft) ex praceptoribus meis quidam ad anginam utebatur rĭs admifcens qua alioquihuic affectui congruebant, Galenus. Ster cus canis ad fynanchen \& faucium abfeflus iam maruros, optimum eft reniedium, celeriter enim eaconftringit, Rafis, Recentiorum quidam ad anginz abfeeffus caninoffercore unà cum hirundi nis cinere utuntur, ut in Hirundine exponam. Canis fimum cum melle cppugnat anginã $\&$ glan. dularum ( tonfillarum ) inflammationes illitum, Blondus. Quidam ex chirurgis noftris a d iriam, hoc medicamentû aridum faucibus indunt, quod fit ex albo ftercore canino, pipere longo, litif mon tani lureis radicibus, 8 folano perpetuo. Caninum fimum album morbo regio mederur, Author obfurus. Idem flagrantiflimo canis fydere exceptum, cum uino aut a qua potum, fiftic aluum, Dio fcorides. Rafis pracipue ad hunc ufum commendat ftercus canum qui offa edunt. Stercus canis ficcatum, fumptum (collecium ) triginta diebus Iulin, \& in ortu Solis pondere aurei potum, cum de. cocfione gallarum (galli decrepiti, A bbertus: quod non placet) aut cum aqua malorum grana torum, Aringit naturam (uentrem, Alterus) folutam, Rafis. Ad dyfenteriam ftercore canino (quali pra. dictum efi) quidam ex praceptoribus Galeni utebatur: laffi tli admifrens, cui decocic calculos uos

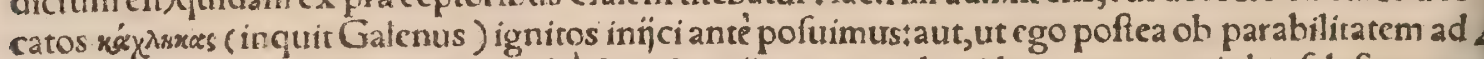
ferrum confugi, id candens lachi pi obé decocio inijciens, quod quidam non proprie lac fch fium ap pellant. Caterum praceptor ille meus, fiercus caninum lacti, in quo extincti erant calculi marini, clàm inifciebat, 8 id folum generofiflimos quof $\phi_{\beta}$ difcipulos docebat, In his ergo duobus (ad dyfen. teriam $\&$ anginam)multum expertus fum fiercus caninum, ceu medicamentum mirabile, Tantum Galenus. Stercus canis combuftum \& cum melle illitum, tineas infantium tollit, Sextus; tretrif for te 8 umbilico illinendum intelligens, Stercus canis ficcum $\&$ in potionem afperfum, hydropicos fa nat, Sextus, Ad uterinum dolorem (ut noftri appellant, fape etiam colicam improprie intelligen. tes)commendari inuenio fimum canis album \& à fuperfície repurgatum, ficcatumó̧, bibêdum cum liquore chymicis uafis collecto ex floribus liliorum. Ad ifchiadem remedium, Cera rubea, \& fter, cus canis quod eft album, hoc ficcatum in fole, 8 in modum farinę cribratum cum fuerit contufum, lento igni ceræ remiffie admifcecur per partes, $\&$ olei parum, tantum ut mollius idem efficiatur medi camen:fed antea tamen colocynthide $\&$ centaurio curetur cui medendum eft ( per clyfterem nimi rum ) ut(legoet ) fi non profecerit, curationem iterum adhibeas, Marcellus. Cinis fimi canini cana didi cum rofaceo rhagades curat, aiuntóp inuentum Aefculapị effe, Plinius. Stercus canis cum ru= faceo tri ium \& impofitum, rhagades ftatim fanat; Sextus. Stercoris albi canini \& betæ cinis in. fertus, rhagades adiungit, Marcellus. Ficos feu marifcas ani, ut ex chi urgis noftris quidam pollicenur, hoc modo curabis: Caninum fiercus albũ $\&$ folia allị fuper foco concremabis, ficos axungia inunges, deinde cínerem allí infperges, pofiea fimi experimento conflat. Aliqui fimul utrungs cine rem cum oleo fubigunt, $\mathcal{Q}$ inungunt. Si quis biberit uinum, cui iniechus fuerit lapis à canc mor. fus, exclamare cogetur, Rafis. 


\section{De Cane. G. Lib. I., igi}

G. id eft Capitis feptimi de Cane;pars I I.

ब1De morfibus canis non rabiofi. TDe rabie canum in genere, Quomodo in ipfis canibus caticatur aut curetur. TMethodus curandi morfos ab eis homines, TMe. dicamenta contra rabidi canis urenenum morfu inflictum foris admouenda, compofi ta primum, deinde fimplicia, ordiné literarum. Amuleta, \&c, TMedicamenta in. tra corpus fumerida, compofita \& fimplicia, eodem ordine.

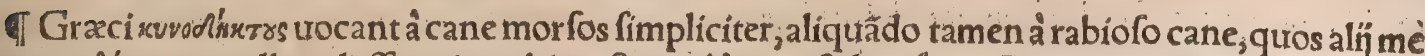

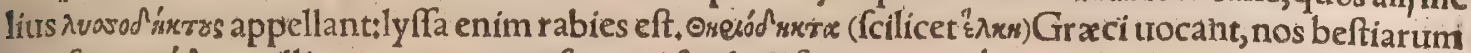

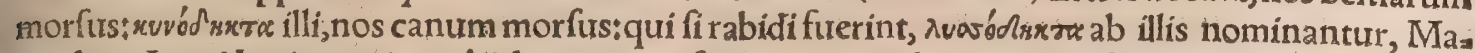
nardus. Apud Latinos etiam ubi de canis morfu mentio incidit, plexiç diftinctionis caufa, rabiofi; uel non rabiofi, addunt:quidam omittunt, ut Diofcorides cum frribit caninam urinam ad perfun dendos canis morfus idoneam effe, Ruellio interprete:nam Marcellus Vergilius rabidicanis mor fus contrertit: Et in commentario fuper Diof coridis de foeniculo capite, Qua Diofcorides(inquit)hic $\&$ alibi ruvó $\&$ жra fimpliciter trocat; non fimplex eius animalis utilnus fignificant, fed cum rabit $\&$ in rabie illatam homini fuo dente noxam:fiquidem non rabidi canis morfus ab alijs aliorum animaliti. morfibus $\&$ uulneribus non differt, $\mathrm{Ne}_{3}$ Diof coridem oportebat priuatim de eo in radicibus foen culi aliquid docere:communi enim aliorum uulnerum curatione non rabidi canis morfus curãdus eft, Hac Marcellus. Ego quanquam concefferim canis morfus fimpliciter pro rabiofi canís morfi: o bus apud authores aliquando ufurpari, non ubigs tamen nihil intereffe contra Marcellum affero. Nam Aétius de rabiofi canis morfu libro 6. cap.24.copiofe agit:de canis autem non rabidi morfu; lib. 13, cap, 2. ubi etiam de hominis $\&$ crocodili $\&$ aliarum ferarum extra rabiem morfibus curandis differit, Sic \& Plinius Valerian, expreffè cótra canis nó rabidi morfus medicamina aliquot profert: \& alia rurfus contra canem rabidum feorfim. Quamtuis enim non tantundem ueneni habeant, ac fi rabie tentarentur canes, non omnino tamen ueneno carent huiufmodi morfus, ut difertè, teftantur authores: Et ratio dictat, non inftar fimplicis uulneris curanda efle, qua dentibus inflicta funt, utpo te anguftiora $\& \&$ nonnunquam profunda. Iracundia quocs caput maximé petens animantis iratæ;

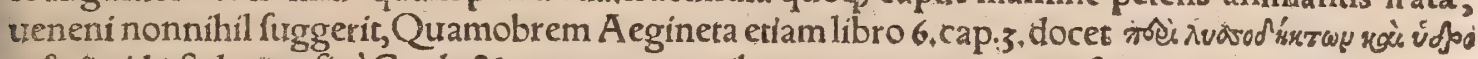

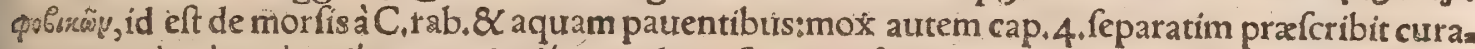

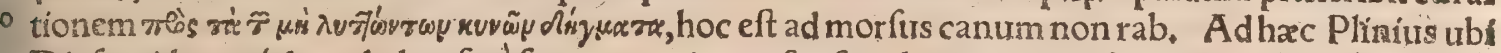

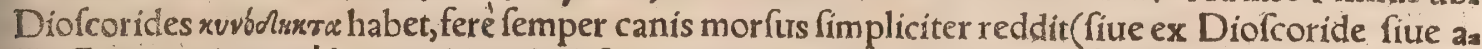

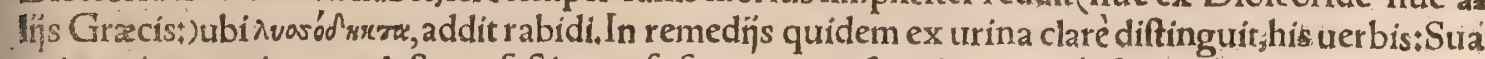
cuio̧ urina maxime prodeft, confeftim perfufo canis morfu, echinorumós fpinis inhar entibus, $\&$ in fpongia lanis' ue impofita : aut a duerfus canis rabidimorfus; cinere ex ea fubacto ₹ contrạ́ ferpenz

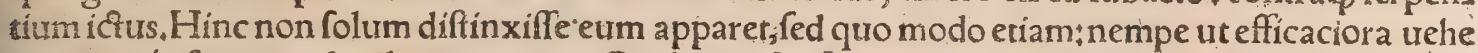
mentiorá̧́ fintremedia illa, qua contra C.rab, morfus faciunt, quamobrem hîc urinæ cinerem ad: dit, \& contra ferpentium etiam uirulentos morfus commendat qua quidém adiectionis nota admo

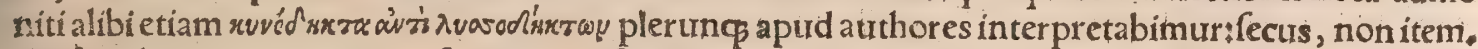
Ad fimplices uero canis morfus, urinam fimpliciter pollere fribit; quemadmodum etiam extrahen dis echinorum fpinis, qua nihil ueneni habent:quamuis morfus illi, non nihil, ut iam dixi, fed exie gurum uirus habeant. Nuces iuglandes cum cepa $\&$ fale $\&$ melle, canis hominisć́ morfui impon tur, Plinius. Hic facile apparet eum fentire de morfu canis non rabiofi, quoniam hominis morfum fimpliciter ei coniungit, A egineta quoq̧ idem remedium, nifi pro iuglandibus origanum poneret; ad morfus canis non rabidi commendat. At alio in $10 \mathrm{co} \mathrm{N}$ Nuclei iuglandium (inquit Pliniưs) à ieiuno homine commanducati illitićs, prafenti remedio effe dicuntur contra rabioficanis morfus. Mihi fa nè ita uidetur, quacungs morfibus canum rabidorum impofita iuuant, eadem fimplicibus etiam ca num morfibus profundioribus prafertim, ab initio prodeffe:quod \& Aêtius teftatur, libro $1 z_{*}$ cap. 2 , his uerbis, Si magnus fit morfus, quemadmodũ à magnis canibus infligi folet, prafcripta in fexto fer mone methodo curato, ueluti eos qui à rabido cane funt fauciati, Fieri etiam poteft ut efficaciora nô. - nunquam applicanda prafcribantur pharmaca ad fimpliciter morfos ; in caufa eft, quoniam nullis plerunç intra corpus fumendis, nec alịs feré foris illi remedís curantur : Leuiora autem interdum ad morfos à rabidis feris, non quod illa per fe fufficiant,cum multis uarïśćs aliphs intus $\&$ forís medi. camentis illi exerceantur:fed cater is $\&$ maioribus omiffis, fiue per imperitiam, fiue potius tanquiam àftudiofis rei medicæ per fe intelligendis, qui fura exaliorum feriptis colligunt, leuiora inter dium fola commemorant, ne toties uniuerfa curandimethodus repetenda ueniat. G. His ita confirmatis, re media aduerfus canis non rabidi morfus enumerabo, fi prius uniuerfalem eis medendi methodum ex Paulo \& Aétio Gracis medicis præf́cripfero. Paulus igitur libro 5.cap.4. Canis non rabiofi (ina quit)morfus, quum $\&$ ipfi uirulentæ cuiufdam fubftantiæ fint participes, ftatim aceto irrorans, Lata manumorfum ferito:infuper nitrum cum aceto tritum ab alto fuperinfundito:deinde fpongiam re centem aceto, aut ipfo nitrofo aceto madidam imponito, 8 codem medicamento uulnus per tridur

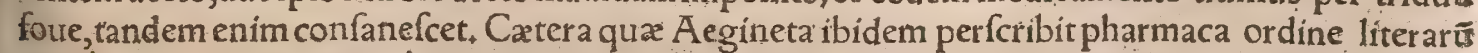
paulò poft fubiungam; unà cum cateris ex Gracis \& Latinis atsthoribus ad fimplices canis morfur 

remedịs. Sed $\AA$ ëtri prius uerba libro 13. cap.2. de morfu canis non rabidi in homine curando, ope.
rapretiưm uidetur adiungere, quoniam pleraç fcitu digna continêt, præfertim quod ad uniuerfa. lem curandi rationem, ab Ágineta omiffa. In his igitur(inquit)quos canis momordit; ftatim acetư irrorato, \& expaffa palma morfum percutito. Deinde nitrum cum aceto tritum ex alto fupra mor: fum deftillato $\&$ fpongiam nouam pofca aut aceto imbutam imponito, $\&$ ad tres dies obligato, ligamentó́g füperné ex pofca aut aceto prout trifum furerit, madefacito. Egregie ením auxiliatur. Poft hęc uero ut commune ulcus curato. Aut perdicium herbam cum fale tritam imponito, quotidic eam alterãdo donec excidat crufta. Deinde ubi ad cicatricem perducere uoluteris, ipfam per fe tritam im ponito, Qurod fi magnás fit morfus, quemadmodum à magnis canibus infligi folet, præfcripra in fexto fermone methodo curato, ueluti cos qui à rabido cane funt fauciati. Si uero cauus $\&$ angus so ftus appareat morfus, in principio cum aceto, ut dictum eft, irrorato: Detinde nitrum itidem cum a= ceto tritum ex alto fuperftillato, $\&$ anetho ficco ufto morfum expleto, $\&$ linteolum conuolutum ex ace to madefactum indito, $\&$ obligato, $P$ oft tríduum uerò foluito, $\&$ reperies morfum repurgatum. Idem facit $\&$ cuminum tritum morfui in ditum. Poftquam uerò ulcera fuerint repurgata, præedicto pharmaco utere liquefacto ad hominis morfurm relato, (Id conficitur, Mellis, terebinthina, butyri, adipis anferini, medulla cerui, aut uituli, æqualibus partibus liquefactis.) Sí uerò inflammatio fuxcce dat, lenticulam cum mali corio cocfam $\&$ tritam imponito: Vel rubi folia contrita emplaftri modo impone:aurt panis medullam in betæ fucco maceratam, tritamós pauco róaceo admixto, pro emplaz fro adhibeto. Ad uulnera uerò íam fuppurata, eruti farinam cum melle fubigito, 8 morfum exple to. Summé enim auxiliatur. Autirin cum melle 8 linamentis indito: ac fuperne lenticulam coctam tritam cum modico melle, \& rófaceo pauco imponito, Repurgatis uerò iam ipfis cum prędićo liquí do pharmaco expleto, ac deinde his qua cicatricem inducere poffunt, utitor. Emplaftra autem ad demorfos à cane; uel urffo, aut fimilibus animalibus, ftatim à principio commodé adhibentur, ex fale \& cerufa apparata. Etenim uenenofum humorem in morfibus ex dentibus relictunt expurgant, \& callofam ex impactis dentibus concretionem explanant, Hæc Aêtius.

If Foris imponenda aduerfus canum morfus, ubi rabidorum nomen authores non adiecerunt, hæc func.

TAcetum medetur canis morfibus, Plin.calidurm cum fpongia, Valerianus. Spongia aceto im. buta fimpliciter, Aegineta. aceto uel poíca, Âêtius, Linteolum conuolutum ex aceto madefactum indito uulneri, $\&$ obligato, fi cauus $\&$ anguftus furerit morfus $\div$ poft triduum foluito, $\&$ reperies mor $=$ fum repurgatum, Aêtius. Mifcetur $\&$ alịs diuerfis in hunc ufum medicamẽtis acetum, ut deinceps dicemus. Vide Spongia. Acetifex,Plinius lib.23. Eadẽ cum melanthio, Valerianus, Adianthon, Author obfcurus. A labaftrum,Plin.33. Alex in linteolis concerptis, Plinius: Valerianus addit cru da. Allium appofitum, Plinius 8 Macer, Cum melle tritum, V alerianus, In uulnera ex canũ mor. fibus cum melle imponitur, Plin. Allium illitum prodef, $8 \mathrm{C}$ intra corpus fumptum, Galenus de $\mathrm{pa}$ rabil. Ampeloprafon,Plin. lib.24. Amygdala, Plinius lib.23. Amygdalini nuclei cum melle triti, $\checkmark$ alerianus, Amygdalæa amaræ cum melle,Diofcorides $\&$ Plinius, A piaftrum, uide Meliffophyllon infra. Anetho ficcio ufto morfum expleto, fi cauus $\&$ anguftus fit, $A$ étius.

-Ballotes folia, Galenus. Ballote, id eft marrubium nigrum cum fale, Valerianus \& A egíneta: fo lia ex fale trita,Plin, Betæ fucco macerata panis medulla, tritá́ pauco rofaceo admix to pro empla fro adhibita,Aëtius, Bulbi cum melle triti,Plin.Bulbi omnes cum melle $\&$ piperis polline illiti, Dio for. Bulbus applicatus, Author obfcurus.

Canis urina perfy fa, Diofcor. Caprificus, uide ín fico, Cepa fuccus cum aceto, ruta, \& melle, Diofcor. Cepæ tritæ cum melle, Aegineta, Crudæ cum melle uel aceto, uel coctx cum melle \& ui. no appofitæ, Macer. Virides ex aceto illita, aut ficca cum melle $\&$ uino, ita ut poft diem tertium fol uantur, Plin, lib, 20. Cerri pifcis caro, non fecus atqs falfamentum, Diofcor. Cerufa, uide in Sale mox. Cinis uitium cum oleo,Plin, \& Valerianus: Ex aceto illitus, Diofcor. Cucumeris fatiui folia cum uino illita, Diofcor uride Pepones. Crocomagna,Plin.lib. 21. Cuminum tritum morfui indi= tum,Aétius. Cynoglofli folia cum fuillo adipe ueteri, Diofcorid.

TEbulus, Plin, 1ib, 24, Ebuli folia recentia 8 tenera cum polenta illita, Diofcorid, Samburcus uel chamaacte refrigerat canis morfum, cum polenta molliffimis foliorum ilitis, Plin, Erui farina cum oleo fubacta, A egineta, Erurum cum uino, Diofc.

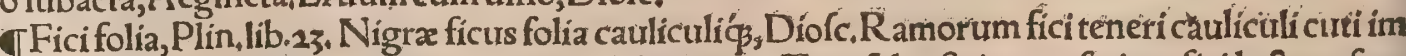
ponuntur,Plin. Cauliculi teneribene triti, Valerianus. Tum fylưeftris, tưm fatiux fici lacieus fuc, cus inftillàtus plagx, Diofcor. Caprificus aut lac eius, Plin. Groffi caprifici cum melle $\&$ folins, Plin, Fructus, frondes, \& folia cum melle, Plin. Foniculiradices trítæ cum melle, \& cataplafmatis mo do impofita, Diofc. Foniculi radice in fucco, uel cum melle, contra canis morfum utuntur, \& con. tramultipedem ex uino:Hippomarathron ad omnia uehementius, Plin. Fungifuilli canum morfie bus ex aqua illinuntur, Plin.

TGarum omne, Diofcor, Garum, Plin, lib, 3r, Gobius illitus contra ferpentium canưmós mor fus, Diofcorides, 


\section{DeCane. G. Lib. I. 193}

Heliotropium herba, Theffalus. Hippomarathrum, uide Foniculü. Hippofelini femen cum urino, Diofcorides apud Serapionem + in noftris codicibus non inuenio,

GI Iris ex oleo, Pliniuss. Iris gemma cremata, Plinius libro 37 .ut Aggregator citat.

- Lana fuccida, uide in Spongia. Lapathum cum melle \& aqua, Theffalus, Lafer cum aceto, Plinius libro 22. Lafer é filphio cum ruta,uel cum melle, uel per fe uif́co fuperlitum, ut hareat, Plin.

هMarrubium tunfum cum axungia ueteri imponitur, Plinius \& V alerianus, Síc autê refertur à Plinio ut uideatur ad utrunq̧ marrubium pertinere, magis tamen ad candidum. Marrubium ni. grum, uide Ballote. Melanthium cum aceti fece, Valerian. Meliffophyllon, id eft apiaftrum impoa fitum uel illitum, Galenus de parabil. Diofcorides, Cum fale tritum,Macer. Menta cum fale illita, - Diofcorid, \& Macer, Cum melle contrita, Valerianus, Mitulorum caro utiliffime imponitur, Dio. fcorides 8 Plin. Muria acida fotu prodeft, Diofcor. Myaces crematimorfus canum hominumós cum melle fanant,Plínius. Myacum carnes, Diofcorides.

Titrum addita refina, initís cum aceto illinitur, Plinius, $V$ alerianus axungiam addit, $\&$ aquis ponderibus mifcet. Nitrum cum aceto tritum ab alto fuperinfundatur : uel fpongia eodem imbuta imponatur. Nux iuglans cum cepa fale 8 melle ad canum hominứq̧́ morfus facit, Diof, Plin، $8 \times$ Valerianus. Nuces, Auicenna \& Plinius libro 23. Iuglandium carnes ab homine ieiuno commandu cata, Valerianus.

बOrigani coma, falis, cepa, pares fingulorum modi cum melle, Aegineta.

-T Peponis cortex cum uino, Plinius libro 10 . Folia peponum (ut cucumerum etiam) cum uino, Plinius, Perdicium herbam cum fale tritam imponito, quotidie eam alterando, donec excidat cru. fta': deinde ubi ad cicatricem perducere uolueris, ipfam per fe tritam imponito, Aëtius. Pifces falf maximé fardinc, Serapio ex Gal. Polygonos, uide Sangurinaria, Porrum, maximefylueftre, Plin. libro 24, nigrum, libro 27. Plantago, Macer \& Author obfcurus: Ex plantagine cataplafma cum fa le, Diofcorid. Pulegium recens cum uino bibendum, aut foris cum melle imponendum, Macer,

TRubi folia cum aceto tunfa cataplafmatís modo, Aegin, \& Aêtius.

IT Ex fale 8 ceruffa, ut fupra ex Aétio dictum eft. Salfamentum, uide Smaris, Samburcus, uide Ebulus, Sanguinaria cum axungia \& pane, Apuleius, Schiftos lapis, Plin, libro 36. Smaridis caro non fecus atç̧ falfamentum prodeft à cane demorfis, Diofcorides. Spongia porca aut aceto imbuta, Aëtius, Spongia recens, uel lana fuccida, aceto $\&$ oleo imbuta. Aegineta. Spongiæ minutè conci= duntur, \& imponuntur infuræ, trel ex aceto, aut ex aqua(frigida, Plin.) aut melle, abunde fubinde hu mectanda, Plinius \& V Valerianus، Spuma nitri cum pinguedine afini uel axungia, Diofcorides \& Galenus apud Serap, \& A uicenna, baurach nominans, Squillacum pice illita, Plin.lib.22.Stibiü tritum, Plin.lib, 32. Succida lana, uide in Spongía.

Thunni conditaneicaro, Diofcorides.

- Virorum capillus ex aceto, Plinius, Vitium cinis cum oleo, Plinius libro 23. \& Valerianus. Sua cuiq̧ urina maximè prodeft, confeftim perfufo canis morfu, echinorumć foinis inharentibus, $\mathcal{Q}$ in fpongia lanisúe impofita, Plinius. Vrina canis perfufa, Diofcorides. Ex uiticis(uel agni cafti, ut uulgò uocant) (emine, cataplafma, Auicenna, Vrtica cûf fale trita \& illita,Plinius, Valerianus, Macer, Auicenna, Diofcorides apud Serapionem, Cum fale combuft, Plinius lib, 22, ut Aggrega, tor cirat. Vrticæ femen emplaftri modo impofitum, Galenus de parabilib.

TQux potu aut efu intra corpus affumi medicamenta pracipiuntur, ad canis morfum fimplis citer, perpauca reperio: ut, Allium toftum potur efuićp datum, Galenus de parabilib. Calamintha fuccus potus, Auicenna. Caro canis neruofa pota, Aefculapius. Meliffophyllon ex uino potum,

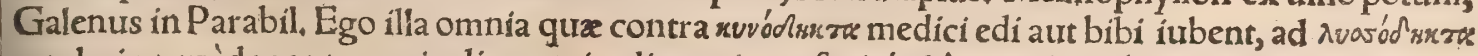
retulerim:quòd propter periculi magnitudinem, intus foris ćs, hîc attrahentibus, illic expellentibus, medicamentis impugnari defiderent.

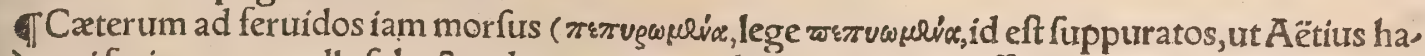
bet) erui farina cum melle fubacta admouetur:peculiariter enim his efficax eft. Inflammatione con flictantes, argenti fpuma trita ex aqua oblinito, Aegineta. đHrec aduerfus canis morfum fimpli citer pofita ab authoribus medicamenta, hacienus recenfuerim. Hoc non difimulabo qux A ggres gator enumerauít, ex Opere eius hîc repetita effe nam et ipfe remedia contra canís morfus abfolute, $\&$ contra rabidi canis morfus diftinguit: Otho Brunfelfitus, ut fparfim colligit, ita confundit.

बQumodo curandi fint morfus canum non rabidorum, quos ipfi inter fe intulerint, dictum eft fuperius cap.3.

- TRabies uel rabia apurd antiquos, morbus eft canum, quum ueluti furore quodam acti, huc atç illuc rapiuntur, nec ullum quietis locum inueniunt. Alij rabiem quafi rauiem dicí putant,à raucitate

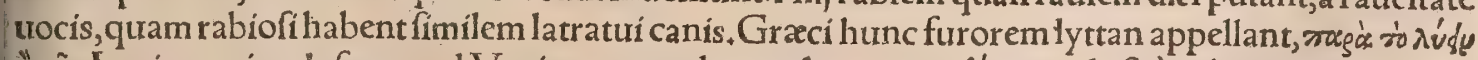

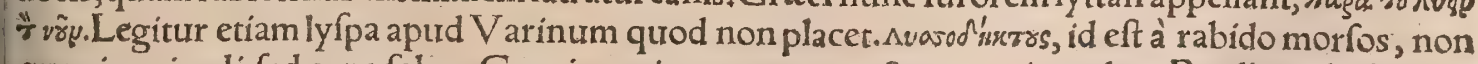
quouis animali, fed cane folium Graci nominant; ut non recte uertat interdum Ruellius, beftias ra= bie efferatas, \&c. Inuenio tamen de alịs etiam animalibus rabiei nomen pofitum. Murænæ etiam ra bie uexantur, ut caninum genus, Columella. Camelus etiam rabie tentatur, Ariftot. Circa Abdenå 
\& limitem qui Diomedis uocatur, equi pafi(nafcentibus illie herbis) inflammantirr rabie, circa Por nias uerò afini,Plinius. Rabiem, inquit Altertus, aliquí canitiem(quod barbai umi nemen eft) fiue caninam infaniam uocant. Excitat rabies in canibus furorem: 8 qux memorderint, omn:a rabiüt, exceptô homine: (quod pofteriores falfum effe deprehenderunt; nam $\&$ homines morfi fx pe rabiüt:

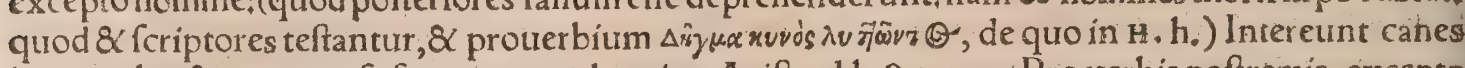
hoc morbo, 8 qua morfa funt, excepto homine, Ariftot.18b. 8.cap.22. Pro uerbis poftremis, excepto

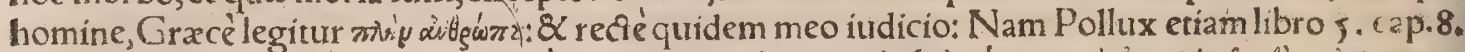

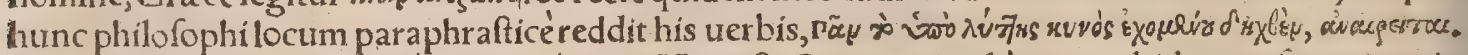

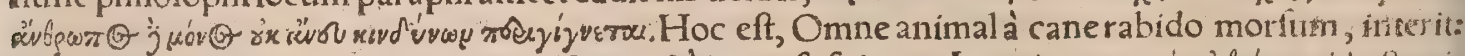

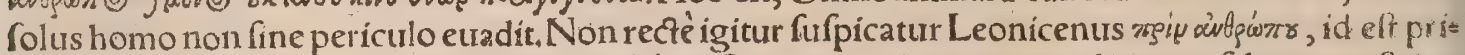

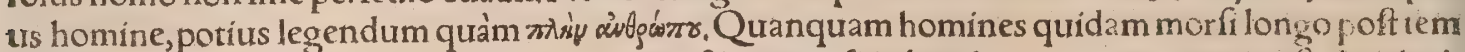
pore moriantur. Albertus refert hiftoriam cuíufdam morfi in brachio, cuicum anno poft duodecim

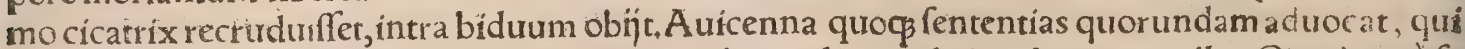
dicerent; poft duodecimum à morfu annum in rabiem aliquando incidere nonnullos.Quod uerò re rius quàm catera animalia tabificam rabiendi uim fentiant homines, efficitid natura difimiitudo. Nam $\&$ in contagiofis morbis, homines ab hominibus \& fanguine coniunctis afficiurtur facilius, Calius. Petrus Matthrolus narrat de Baldo quodam iurifperito, qui Tridenti cum cane fuo ludens leui er in labijs morfus eft, \& rë neglecta, cum rabidum fuiffe nefciret, poft quatuor menies rabie $S C$

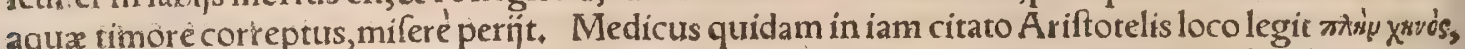
id eff excepto anfere, qui folus ex pedeftribis morfus, nec rabit, nec moritur ex morfu : Ec licet hoc reipfa uerum fit fortaffis, non facile tamen defendi poteft hac lectio, cum nulla urerborum inter fe fi= militudo appareat, Aug. Niphus. Non mirum eft autem, fi folus animalium homo à cane morfus $8:$ rabiem \& mortem euadat, non femper quidem, fed fapentumero:cum medicamentis ab utroq pra: reruari poffit:quæ cæteris animantibus non qué contingunt,ldem. Omne animal à rabiofo cane morum perimitur, Aelianus. Animalium quædam nullo præcedente morfu fua natura rabiunt, ut quibus dentes ferrati habentur; Michaële Ephefio tefte, ut lupi, uulpes $\&$ canes:alia nunquam ra: biunt nifimorfa, uel raro $\&$ non nifi ex magnis caufis, ut equi, $\&$ muli, $\&$ cætera id genus. Obferua tum eft animalia quædam à cane rabido morfa, rabiem non incidiffe:in caufa eft, quoniam ut rabies excitetur, canem eo folum dente, uel hịs dentibus, mordere oportet, quibus uis ineft ueneni : negs $e_{2}$ nim id ex $x$ quo omnibus ineft, Auy.Niphus. Homo morfus à rabido cane excitatur ad rabiem ab umbra forbi(corni, aliàs)quod nonnulli medici pro explorato tradunt, Idem. Cur folí animantiū canes rabiant per aftatem, caufam inquirit Alexander A phrodif. lib. 1. proble. 74. Vergilius in Georgicis peftilentem conftitutionem defcribens, Hinc(inquit)canibus blandis rabies uenic. Far. re uel triticeo pani, quo canes pafcentur, admifceatur liquor coctx fabx: fed tepidus, nam feruens rabiem creat, Columella. Pituit $\&$ bilis redundantiam, canis herba quadam detrorata uomitu le. uat:quæ nifi tolleretur, rabiem facerer, A elian, Rabiem canum fanguinis menftrui guftaru incipere fribit, Plinitus. Rabies canum Sirio ardente homini peftifera, $\&$ morfis letalis aqux metus, Plin.

Tanta uis mali eft, ut urina quog, calcata rabiofi canis noceat, maximé ulcus habentibus. Remediuี eft fimum caballinum afperfum aceto, \& calfactum in fico inspofitum. Minus hoc miretur, qui cogi tet lapidem à cane morfum, $u f(̧ ̧$ in prouerbium difcordiç ueniffe, Plin. Aggrauari uulnera conftat introitu eorum, quí unquam fuerint ferpentium canis'ue dente læfi, lidem gallinarum incubitus, pecorum foetus abortu uitiant. Tantum remanet uirus excepto femel malo, ut uenefici fiant uenena paffi Remedio eft ablui prius manus corum,aquaḉ illa eos quibus medearis infpergi,Plin. Quan tam habeat uim afficiendæ rei aptitudo, facile in telligitur in canibus: cum enim reliquorum animall um nullum rabie capiatur, folus canis eo affectu corripitur, atgs tanta fit in ipfo humorum corrue pto, ut fola eius faliua, fi humanum corpus contigerit, rabiem excitare polfit. Vt igitur ab exiguo initio, faliux uidelicet qualitate, aucta quadam in corpore affectio, quando ad magnitudinem notam tu dignam perurenerit, difcerni poteft, idḉs poft fex menfes, cum nonnunquam ante id tempus nulla nota deprehendatur:fic eodem modo uitiofo humore in anímalis corpore genito, paulatim tra ĉt temporis, principalium partium aliqua confentit, à qua deinde uniuerfum corpus celeriter alteratur, Galenus libro 6. de Locis affectis. Canis rabiofi fel lentis magnitudine fumptum, feptem die bus interficit, quibus fuperatis poteft efle falutis fpes, Berti utius. Cum igitur tanta fir ueneni uis ex rabido cane, quis fanæ mentis ad morbum regium rabidi canis caput contufum, mixtuníg uino, quod remedium apud Sextum legimus, propinauerit? Multò tutius ex Plinio canini capitis limplici ter cinerem ex mulfo ad eundem morbum aliquis biberit:licer ne hoc quidem probemus, inter alia ram multa liberaliffimæ naturæ, homini familiariora remedia. Quam ob caulam aquam eximefü: hydrophobi,quos à rabido cane morfos dicimus, \&í pudendum cum hypochondrips fimul illis intenditur:intremifcunt etiam, ac conuulfionem patıntur, adeó́p delirant, ut canum titu lat aturm $x=$ dant? Caffius problemate 73. đAd timentes canum impetum: Nerij radicem collocircundato, et liberabitur:quod fi experiri uolueris, cum canis in furorem uerfus fit, illi circumponito, fratimq̧́ fu. rorem deponet, Galenus de parabilib.cap.67. Qui edit allium \& fuperbibit uinum, turus creditur à morfurab.C.quia fugit odorem, Ponzettus, Caninus dens in corio alligatus brachio, aucr tit mor fuis 
canis, urel ut alin interpretantur, aqux meturm ut fupra in c. dixi, TRabidas canes includere opor's tet, illiş́́ in unam diem interdicere nutrimentum. Subinde autem ueratri aliquíd in potu mifcendü eft. Vbi uerò purgatz fuerint, hordeaceo pane nutrienda funt. Similiter curabis et eos quos rabidus canis morfu impetierit, Theomneftus in Geoponicis. Ellebori tenuiffimæradices breueś́s, ac uelut decurtatæ etiam hæ leguntur. Nam fumma qux eft craffiffima, cepis fimilis, canibus tantum datur purgationis caufa,Plinius. Eft uermiculus in lingua canum, qui uocatur ầ Gracis lytta, quo exem. pto infantibus catulis, nec rabidi fiunt, nec faftidium fentiunt, Plin.Sed hoc(inquit Ponzettus)nemi nem hactenus expertum legimus. Nanq fobit nodis qua lingua tenacibus hæret, Vermiculum dixếre, mala atç̧ incondita peltis, 8 cc. Iam teneris elementa mali, caufasíg recidunt, deinde falem 10 utlneri infpergunt $\&$ oleo permulcent, ut ftatim fanetur, Gratius. Catulorum caudas poft diem quadragefimum quàm fint $x$ diti,fic caftrar conueniet: Neruus eft qui per articulos fpina prorepit; uffg ad ultimam partem caudę:is mordicus comprehenfus, 8 aliquatenus educius abrumpitur:quơ facto necp in longitudinem cauda foedum capit incrementum: $\delta$ (ut plurimi paftores affirmant ) ras bies arcetur letifer morbus huic generi, Columella. Columella author eft, fi quadragefimo die quàm fit natus catulus, caftretur morfu cauda, fummusḉ eius articulus auferatur, fequenti neruo exem= pto, nec caudam crefcere, nec canes rabidos fieri, Plin. Mulieris qua marem peperit lacie guftato, canes rabiofos fieri negant, Plin, Rabies letale periculum in canibus, feu coelefti corrupto fydere manat, cum Sol uel in Cancro uel Leone mouretur,. Exhalat feu terra finus, feu noxius aér Caufa mali; feu cum gelidus non fufficit humor, Torrida per uenas concrefcunt femina flammæ. Quic. - quid id eft, medeberis canibus. Tunc uirofa tibi fumes, multumós domabis. Caftorea, adtritu filicis lentefcere cogens. Ex ebore huc rrito puluis, fectóue feratur, Admifcenśḉ diu facies concrefce. re utrung: Mox lactis liquídos fenfim fuperadde fluores, Vit non cunctantes hauftus infundere cornu Inferto poffis, furiaş́́ repellere triftes, Atģ̧ iterumblandas canibus componere mentes, Nemefianus. Sirio ardente rabies canum homini peftifera eft . Quapropter obuium itur per tri= ginta eos dies gallinaceo maxime fimo mix to canum cibis:aut fi prauenerit morbus, ueratro, Plin. Rabidicanes fi helleborum cum polenta comederint euomunt, ac ftatim foluti à rabie refipifcunt, Aëtius. Silymphaticus (inquit Albertus Magnus)aut rabiofus fueritcanis, ftatím ab alíps fepare. tur, ne in fanos quoç peltis hæc deriuetur, Arinetia rex $V$ alentia docet canem rabidum in aqua ca lida per longitudinem corporis mergendum effe diebus nourem, ita ut pofterioribus pedibus uix ter tam attingat, anterioribus furfum erectis. Poft hoc tempus extracto de aqua caput radatur, $\&$ dili- genter deglabretur, adeó ut cutis etiam cruentetur. Sic rafum fucco betz inungatur $\&$ perfundatur fipius: 8 cibi,fiquos admittit,eodem fucco tingantur. Danda eft etiam fambuci medulla, cuius ad= uerfus rabiem non exigua uis eft. Quod fi curatio intra feptem dies non proficiat, pro defperato oce cidatur, Hac Älbertus. Sunt qui rabidum canem ueneno quàm ferro necare malint: Mori autem ais unt fi cibo immíceatur rifagalli parum, cum hyof cyamo \& hermodactylis, Ponzettus. Cætera quae canes perimunt, fupra in c. recenfui. Tumorem quendam fub lingua canis rab.uermiculo albo fï milem, auferto cani ut primum in rabiem inciderit : deinde dabis eipanem edendum cum chelido= nio trito \& mixto adípi ueteri: \& uulnus inde factum illine folips ruta, fale contrito, axungia \& mel le commixtis, Tardiuus. Rabies eft morbus canis, ucl ira accenfa non differens à furore. Accendi. - ditur is morbus in uenis prope cor ipfum. Signum eft, quod canis agitur per fe $\&$ currit errãdoceu furore correptus; ut igitur is morbus comprimatur, ${ }_{2}$ tudẽdum eft quieti $8<$ fomno canis. Subducen: dus cibus, 8 liquida tantum ac forbilia offerenda funt: $\&$ ne hac quidem ad faturitatem: quoniam præftat fudere uentris lubricitati,negando offa $\&$ fanguinem gignentia biliofum. Poft tertium die . venæ turgentes tam in lateribus, quàm in cruribus etiam fecanda funt:fiue prö́piciendus eft in lacü in quo fuerit hirudinum copia, ut multum fanguinis polfint fugere. Poft hoc caput $\& 2$ corpus uni. uerfum oleo rofaceo omphacino, fiue unguento populeonis illinendum eft. Per os etiam cum opor 3 tuerit medicamen inijciendum eft, quod ipfam bilem educat. Poft hoc lauabis eum decocto lapathi acuti, rad,inula $\&$ fumarix, quoniam multum proficies. Cum uero canis iuuenculus patitur rabi $\mathrm{em}$, cani admittatur mafculus foemina, \& foemina mafculo, quoniam fic educi folet rabies, Blondus. - Quid prifcas arteis, inuentá́́ fimplicis anni Si referam non illa metus folatia falli Tam longam. traxêre fidem. Collaribus ergo Sunt qui lucifuga criftas inducere melis Iuffere, aut facris confer ta monilia conchis, Et uiuum lapiden, \& circa Melitefia nectunt Coralia, \& magicís adiutẫt can tibus herbas، Ac fic offectus, oculiḉs uenena maligni Vicit, tutela pax impetrata deorum, Gratius, TCanes rabidi frpenec uerbera nec uulnera curant, $8 x$ contra omne genurs armorü hominem mor dent: qưod ne fiat, quifos fecum geftet canis dentem, Nam Diofcorides exemptum cani dentem ca, ninum, $\&$ in ueficula brachịs alligatum, ad inhibendos canti impetus utilem facit, Blondus. Nos fut pra ad præcautendum potius aquæ timorem, Diofcoridis uerba ifta interpretati fumus. Molares den: tes canis rabiofi, qui momor dit hominem, in corio adalligati brachio, prohibent à morfu canis rabidi, Serapio apud Syluaticum: Videtur hac Serapio ex Diofcoride tranftuliffe, \& Serapionis interpres - procaninis dentibus reddidiffe molares.

II An canis qui momordit rabidus fuerit cognof ci refert:multi enim quia nihil graue ftatim $\mathrm{fe}$ quebatur morfum, neglectis mitio remedijs, $8 x$ uulnericicatrice inducta; incurabiles poltea obierǘt: 
Qamobrem nuces iuglandes bene contritas (commanfas, Ponzettus:) ulceri impone; \& poftridie (poft duas horas, Ponzettus) gallo aut gallinxedendas obrice; is uel $e_{j}$ initio quidem abltinebit : las me autem urgente fi deuorârit, obferua:nam fi canis qui momordit, non fuerit rabidus, uiuet auis: fecus, morietur poltridie. Quod fi fiat, ulcus aperire feftina: Et rurfus inter pofitis aliquot diebus, $f_{i}$ militer experire, ita ut cicatricem non prius inducas ulceri, quàm auis deuoratis nucibus iftis inco. Itumis degat, Aegineta ex Oribafio.Idem ab Aétio libro 6.def́cribitur, \& à Ponzetto Cardinali.Simi le experimentum(inquit Ponzettus)haberi poteft ex medulla panis ulceri adhibita, \& pofimodum alịs canibus oblata. Mícis ex triticeo pane morfum perfricabis, easós mox alteri cani porriges: quas ficomederit, indicium eft non rabere canem:tin abftinuerit, rabere. Exipfo quidem uulnere digno. fcere non datur, cum id fibi fimile lemper fit, nec ab alińs uiceribus $\&$ ferarum mor fibus diurerfum. Tritici grana undecim appofita uulneri donec humore mollita fe impleant, \& intumefcant, próncito gallina, qua fi faftidiat: rurfus alia obịcito aliàs, quibus fi fimiliter abftineat, periculófum \& leta. le fignum elt:fin effe coeperit, periculi fublati, A puleius ut Aggregator citat, Diofcorides, ut infra di cam, tritici grana fimpliciter canis rabidi morfibus inferi laudat.

- [Diolcorides fermonem de rabiofi canis morfu cateris prapofuit,quoniam id animal(inquir) domefticum ac frequẽs effe confueuit: $\propto$ in rabiem fapius agitur ac perit, ab eóç caueri difficile: in de periculum ineuitabile hominem manet, nifi multis utatur auxilijs. Plerunç autem fiagrantufi mis $æ$ ftibus (uel regionibus huiufmodi) in rabiem efferatur : interdum quoties frigora incefferunt,

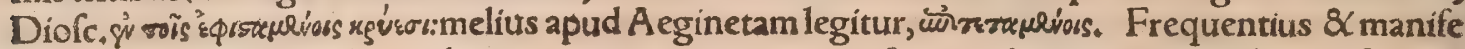
ftius quàm catera animalia rabiem patiuntur canes, quia uefcûtur cibis corruptis, cadatuera $\&$ n ul ta putrefaça lambunt:accedunt, penuria cibi, timor, latratus frequens, iracundia, $\&$ alia unde hu. mores ad rabiem excitandam exardefcunt, autumno prafertim. Quanquam catera animalia, ut lu: pi, uulpes, \&c. rabiem $x$ ftate potius quàm hyeme incurrant, Ponzettus. TCanis rabiofus potum $\&$ efcam aurerfatur:torué $\&$ folitò triftius intuetur, Diofcor. Corpus ei ftrigofum $\&$ folito compref: fius confpicitur, Acquarius.Largam fpumantemć pituitam naribus 8 ore prö́jcit, Diofcor. Hians quàm maximé anhelat, linguam exerit:languidx ei aures, cauda demiffa: inceffus fegnis, ac ueluzi fupidus: fi uerò currat, celerius folitò currit, id'ø̧ intempeftiuè $\&$ inæqualiter, Aëtiurs siticulofus eft, red potu ferè abftinet. Mutus ut plurimum, ac demens, ita ut ne fuos quidem familiares agnof cat, $A C$ gineta. In omnes paffim fine latratu irruit, xquè feras homines ̣́́, tam familiares quàm ignotos mor det:nec protinus infeftum quicquam infligit, nifi, ut uulnus, dolorem: Exinde morbus ille, qui ab a= qux metu bydrophobicus Graia eft uoce appellatus, contrahitur, Diofcor, Rabido cani caput ad terram nutat:ingua exeritur, idós adeò interdum ut retrahi non poffit:timore plenus elt, \& folitudi nem quarit, Ponzettus. Oculi rubent: caudam inter femina inferit; raucus eft, alienatur non folum à reliquis canibus, fed fuis etiam catulis: fugiunt eum cateri canes ( $\&$ allatrare folent)ac imbuto fan guine eius pane abftinent, Bertrutius, A qux metu afficiuntur, ut ea uifa pili plerunģ inhorrefcant, \& nonnunquam ex ea formidine emoriantur, Textor: Mihi ad hominem potius à cane morfum haec pertinere uidentur. Canis rabidi cauda demiffa eft:lingura porreça, $\&$ tanquam bile colorata : cirra rationem currit, deinde fubitò rurfus confiftit, Galenus ad Pifonem, Oculis uagis circumfpectat, et pratereuntes intuetur, Tardiuus. 『Caterum illis qui à rab. cane morfi funt corpus inarefcit, \& conuellitur interdum, ac febri intus acri uritur, animus delirat, Galenus ad Pifonem, Si uel modicũ aqua uiderint, tremunt $\&$ conuelluntur ftatim, \& uigilins delirịs'́s detenti uel breui tempore uitam finiunt, uel aliquanto poft, cum iam euafiffe uidentur, fubito rurfus tanquam à recenti morfu peri. clitantur, Damocrates in defcriptione antidoti diacarcinon apud Galenum lib.2, deantid. Somnia eis accidunt terribilia, puncturæ in corpore, fingultus $\&$ ficcitas oris, Galenus in Parabil. In ïfdem malum fignum eft, uox rauca. Quandiu uero inturendo fpeculum cognofcunt feipfos, fpes eft falur. eis. Cum per terram uolutantur inftar canum, nihil fperandum prater mortem : licet morfus adhue mente conftet. Eft quando rident. Interdum ager ipfe fibi uas uitreum uidetur, uel colum metuit ruiturum. Bertrutius addit, à rabido cane morfum intelligi, fi uulnus doleat magis quàm pro ratio. ne, affectus incidant a tribiliarị: his accedere anhelitus difficulta tem, aluum ficcari:urinam retineri, 8 cmitti quandoq nigram, uel lacteam, \& a deò craffam ut catuli ineffe uideanturł quando $\$$ contra tenuem \& aquof am:poftremo accidere fuffocationem cum fubitamorte. Voces creditæ audiri in rorpore morfi(quorum etiam Gariopontus memínit libro 1. cap. 11, in anteneafmo ) funtrugitus ua. porum:qui etiam ex cruditate augeri folent in corporibus infirmis, \& $\mathrm{ita}$ conuerti in fonum quen dam fimilem illi qui auditur in cauernis quando plures concertant, Ponzettus. Accidit eis aliquan. do gonorrhcea, id eft feminis profufio, Idem. Qui fanguinem in morfis ftatim congelari putant, fal luntur: nam ne parum quidem fuperuiuerent, Idem. TA rabidis canibus morfi, in aqua formidinem corruunt, pracipué qui prauis fuccis pleni fuerint, Aétrus. Euenit autem cum diftentione ner.

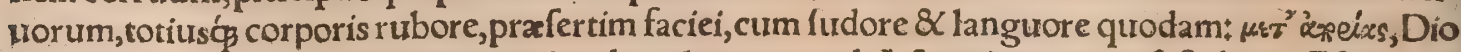
fcorides interprete Rutellio:qui aporian de eadem re apud Actuarium uertit faftidium. Eft artem aporia hoc loco proprie, anxietas \& præ dolore ac fpei inopia, corporis præter rationem iactatio.

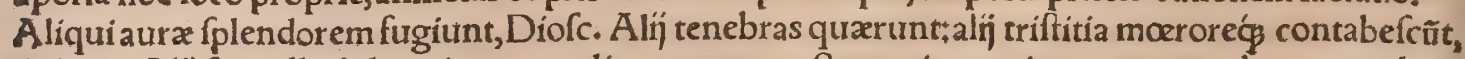
Actuar. Alí fine ulla doloris intercapedine urexantur. Sunt etiam giui canum more latratus adant, 
Quin à maioribus abfedentes carnes auferre(fecare)\& labia(labiorum margines)acie fcalpellicire cumfcribere, \& prehenfam hamulo aut uulfella ( $\mu \dot{v} \delta$ fow) carnem amputare oportet, In utrifg circum Itantia loca altioribus ulcufculis fearificanda, ut copiofior fanguinis uacuatio arceat, ne uenenum membratim infinuetur, Diofcor, Locus hic apud Á cीuarium (interpretẽ qutidem, nam Græca non uidi)turpiter corruptus ex Diofcoride emendari poteft. Cucurbitula cum multa flamma aggluti. natz, id iuuamenti praftant, ur treneni uis extrahatur, Diofcor.

TContra uirulentos içus uftio expeditifimum eft auxilium: Ignis enim qui uim omne fuperat, fimul $\&$ domat uirus, $\&$ ferri penitius non patitur: fimul etiam pars ignem experta, poftea nonuulgare fundamentuี curationi futur $x$ prabet, manente diutius exulceratione, Diofcorides interprete Ruellio:qui eandem fententiam apud A ćtuarium paulo aliter tranftulit, \& melius quidem mieo iue dicio, his uerbis: Simul uero pars ueneni aliqua intercepta fiftitur, qux non mediocre curationil futu rx iacit fundamentum:modò diu patens ulcus dehifcat: neq cito eius oræ coalefcant, Imponiuntur Falfamenta contra morfum canis rabidi: uel finon fine, ferro uft plagx, corporáç clyfteribus exina nita:hoc per fe fufficit,Plinius. Sunt qui ferreis cauterịs ullctus turant, A egineta.Efcharonica eriam pharmaca ignis uim obtinent, eiusç̣ loco ufurpantur, ut infra dicam in medicamentis cópolitis qua foris a dhibentur. Ridicula elt igitur Ludo.Calin fuperftitio fimul \& ignorantia, quã in humine tan. ræ doctrinæ 82 tam uarix lectionis non poffum fatis admirari. Nam cummedicioptimi quiç nullu remedium aduerfus canis rabidi morfus cauterio praferant, Cxlius uel id ignorans, uel ut fiens po tius cĩ uulgo infaniret, \& naturales caufas fictx religioni adfcriberet, libro :7.cap. 28. Nobis (inquic) potentius quam cynorrhodon Plinij, fuppetit medicamen, fed $\&$ ipfum coelitus petitum. Eft in Rho diginis paludibus $\mathrm{D}$, Bellini templum miraculorum frequentia celeberrimum, \& affuxu hominum etiam notifimum. Erećæ ædis caufa feré publica eft.Pullus is diuus Patauio, graftantibus nobilium

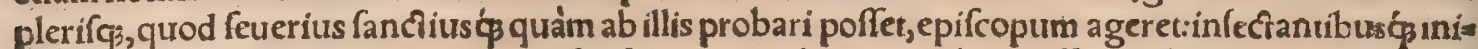
miciter aduerfarïs, in paluftre agri noltri foltum, quindecim millibus paffuum Rhodigio diftans, di. uertit.Quum manus hominum euafiffe uideretur, canum rabiem non cuafit, à quibus eueftigio con uulfus difcerptuś́, mox in diuorum indigitamenta relatus, templum in illis emeruit locis, in quo $\&$ arca marmorea ferreis occlufa cancellis, latet fanctiffumum eiufdem corpus. Templi uerò ex necis genere ea coeleftis eft proprietas, fi quis clauen fibi quæfierit, qua $x$ dis ualuæ recludantur, ac ea can dente, quicquid rabie agitari orfum fit, attigerit: prafentifimum eft remedium, \& nunquam non ue rum, Tantum Calius. Poft uftionem cum cruft $x$ decident, animaduertendum ne ulceris or $x$ coalefcant, \& c, Ruellius ex Diofcoride: Sic autem uertere debuerat, (ut reçe apud A cquarium uertit) Vftione peracia mox danda eft opera ut cruftæ decidant, ne ulceris ora claudantur. Et fifieri poteft

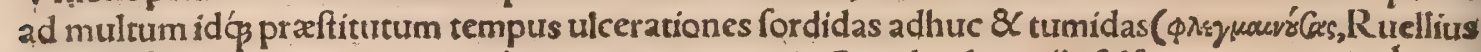
uertit inflammationem minantes) prorogari conuenit. Quod inditum n̈js falfamentum optimé prat ftabit, \& fylueftre allium detritum (intritze alliorum fpice, A etuarius: qui pro agrion, id eft fylueftre, aglithes legiffe uidetur:qux uox nucleos in capite allin fignificat:)irem cæepe: \& liquor, prafertim $C_{y}$ renaicus, aut qui Medicus, aut Parthicus appellatur: ad hac tritici genera pracipue commendané manfa uel non manfa impofita (ut in fimplicibus medic, foris applicãdis inferius repetam,) Hec Dio fcor. Poft cruft $x$ cafum uf $\not \beta$ ad dies quadraginta aut fexaginta, à cicatrice uulnus arcebis:ad quam fi feftinet, rurfus uitis aut ficulneo cinere aperies, Aërius. Sed quando tutum fit cicatrice claudere ulcus, ita ut nulla refidentis amplius latentisç ueneni fufpicio relinquatur, \& quo pacto hoc experi. ri oporteat iuglandium nucleis uel panis medulla tritis uulneri impofitis, \& poftea gallinæ aut cani obieçis, fatis explicatum eft fupra. Vlcus apertum utminimum per quadraginta duos dies feruet, Aegineta. TAbluendum eft etiam ulcus chamremali in 2qua decocio, \& radicis fylueftris rumicis, A egin, Locum fordidum lauant aqua cepa, Ponzertus. Noui ego fenem qui morfos ấ cane ra. bido, folo acido rumice (oxalide)curabat:primo enim ulcus eius decocto fouebat, deinde herbam ip. fam illinebat, eandēćs potandam exhibebat:quod quidem medicamentum tanquam efficaciffimum

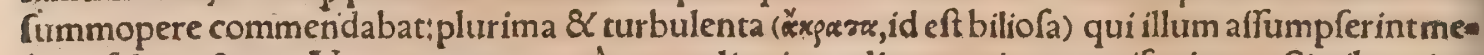
ijere folent, \&cat. Nos quo $\$$ non rarò cum reliquis medicamentis eum mifcuimus, Similes uires

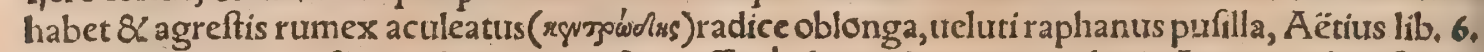
ca.24. Theriaca rofaceo diluta optime 8 tutiffimé ulcus ad cicatricem ducit, Aètius:uide infra in= ter compofita qua foris adponuntur. Obducta ulcericicatrice, ad integram morbi abolitionem, Ieborts albus propinetur. Si tamen quidpiam ab elleboro prohiberet, fatis effet hiera Rufi inferius

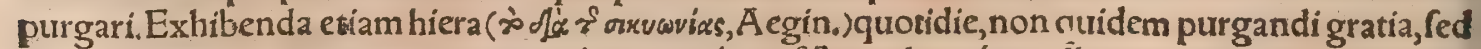
tanquam medicamentum proprietate huic morborefiftens, detur'ćs auellanę quantitas, cum cyatho decoctionis faluix (Â egineta, cum decocto falurix, fimpliciter) aut fideritidis herbæa, quam Heracleä uocant, qua etiam fola utuntur, aiuntćs non parum prodeffe, propterea $\&$ alyffum appellant, Ä̈ri. us. Dealyffo plura dicam moxinter medicamina foris adhibenda, licethoc etiam intra corpus fu matur. đSi uerò, quod perfape accidit, ante dies præfinitos cicatrices coirent, committerenturọ́, manum poftulabunt:nanģ eas diducere(redulcerare)rarnemó $\beta$ fcalpello circinare (carnes circum auferre, $\&$ diffecare ferro, Actuar.)aur iterum urere expediet. Vbi uero propofiturm tempus prate. rijt, ulcus ad cicatricem ducendum, \& emplaftro quod é falibus conficíur (dialôn dictun) locus 


\section{DeCane. G. Lib. I. 199}

comprehendendus:nec multó poft finapifimo utendum, Diofcorides. IQux ad partem ictam per tinent præfidia, ita fe habent. Cæterum uictus rationem ex ijs quæ ueneno aduerfantur, conftare 0 . portet, \& in eum tendere feopum, fimul ut ureneni uíres hebetét reftinguatós: fimul ut arceat, quo minus ad intima pernicies illabatur. Affumpta enim quadam pernicicfarum uirium penetrationi

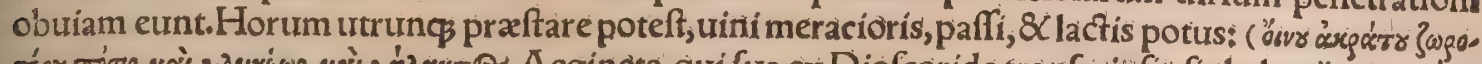

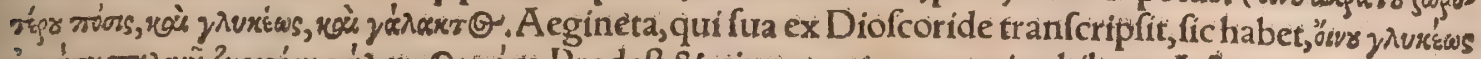

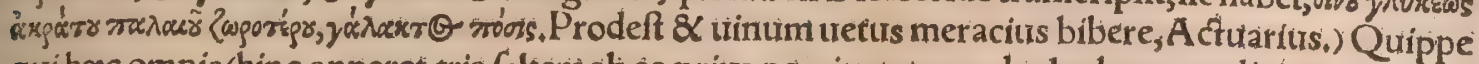
qui hac omnia(hinc apparet tria faltem ab eo prius nominatatnam de duobus non dicimus ominia:) capiunt ad curam, nonnilhil uenerio obijciunt, quod omnem eitis acrimoniam obcundat. Simili mo. to do alliorum, porrorim, ceparưmás cibus; quod ea difficulter conficiantur, uixó̧̧ aboleantur : nam multos dies huius cibi qualitates remanent, quo tempore nec euincuntur, nec permutantur à mor= tifera ui: ed contrarijs illa uis expugnatur, Cui rei antidotorum ufus accommodatur, \& $\&$ theriaces, 8 Mithridatif, \& eius quod eupatorio temperatur: (lego \& Mithridatij Eupatoris: hanc enim apud Galenum etiam morfis à C, rab, dari lego:antidotum uero ab Eupatorio nominatam nullam reperio) denís omnitum qua magnam aromatum partem fibi uendicant:quippe aromata omnía uiribus $\&$ fubftantijs ægre permutantuşquare in corporibus euincunt: Victus ratio hoc modo fe habet, Dio. fcorrs His adijciam Ruffi ex Aêttio uerba de uictus ratione circa cibum pracipuè feruanda، In uicíu (inquit)indigentia $\&$ fatietas etritanda +magis tamen indigentia hac enim furccortum prauitatem ad. áuget, quod nequaquam expedit malefico ulceri. Ergo alímentum moderari oportet, ut \& recté con ficiatur, \& laudabilem furccum corpori prabeat. Nec minus egeftioni $\&$ urinarum prouiocationi ftu dendum: quod quidem, tum ea quæ pradiximus, tum foeniculum \& fcandix comefta efficiunt.

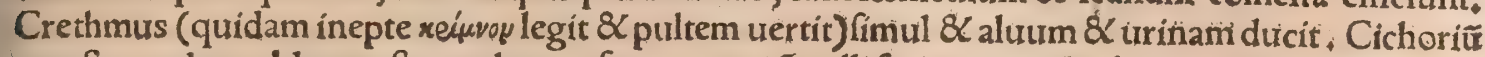
agrefte crudum oblatum ftomacho confert, quam nönulli ferin, nonnulli ab amaritudine picrin ap. pellant, Profunt $\&$ braffic cymx, \& paluftris afparagus, \& hortenfis rumex, agreftisćs $\&$ acidus (oxylaphathum:) \& é pifcibus qui teneras carnes habent, locufta, cancri, 8 echini recentes; $c u m$ ui $=$ no mulfo: $\chi$ carnium extremitates: auiculæç funt. Vinum album tenue, nec ualde antiquum. Intra annum uerơ praferuationis gratia, acceden te occafione, hiera purgari expedit, At inftante die tribus iugiter diebus theriaca accipienda eft, $\mathrm{Ha}_{2}$ çenus Ruffus, Inter principia demorforum à cane rabiofo curandi ratio talis eft. Verumenim uero fi ea quę retulimus auxilia, primis diebus prętermiffa fuerint, nec fcalprocarnem circinare, nee

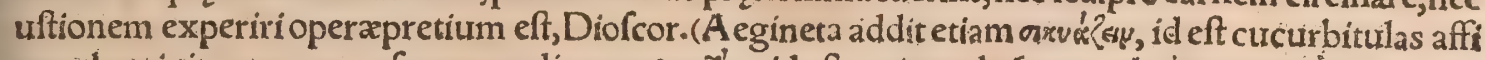

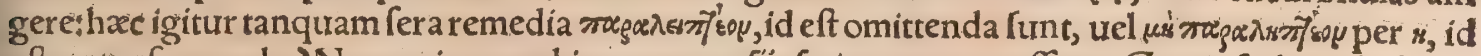
eft non ufurpanda.) Non enim quod iam pertranfít fatis euocare poffent. (Grace fic lego, $\gamma^{2} y_{j}^{\prime}$ inces

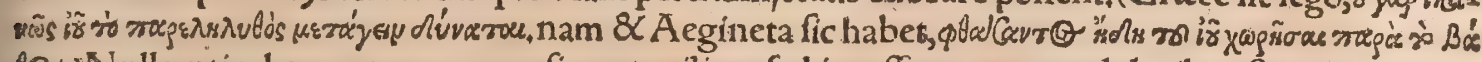
fo. Nulla utiqg harum rerum occafio aut utilitas, fed incaffum corpora doloribus fternentur,$A_{l}$ ter uero curationis modus accedat:deiectio magnum prabet iuuamentum, utpote cum mouendo

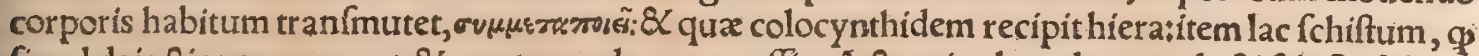
fimul deiectionem moureat, \& uenenum domare poffit. (Actuarius hxe duo non lacti fchifto folum, fed etiam hieræ tribuit,fi recté habet translatio.) Cibi acres, $\&$ meraculi potus, quibus uiis ueneni ue hementer retunditur, quotidie fumi debent. Cæterum fudores ante cibos, \& $\not$ poft etiam ciendi; dro. pacifmi, id eft picationes, finapifmićs alternatim per totum corpus adịciendi, (Ruellius ex A ćtuario uertit: dropacifmo \& finapifmo, unuerfo corpore \& particulatim ưtendum.)Sed longè omnium ef ficaciffimum auxilium helleborifmus cognofcitur:quo cum fiducia, non femel atçiterum, fed fre. quentius ante quadragefimum diem, uel poft hoc tempus, uti licet. Tantam enim uehementiam hoc auxilium habere fertur, ut quidam qui iam aqux metum fentirent, fumpto helleboro, fimulac primuี morbi impetum experirentur, fuerint feruati. Nam \& iam uitio tentatos, nemo unquam ferviare po: teft, Diofcorides: Egopoftremum membrum fic uerto, Nam eo iam uitio occupatos (rerequréris r'd?

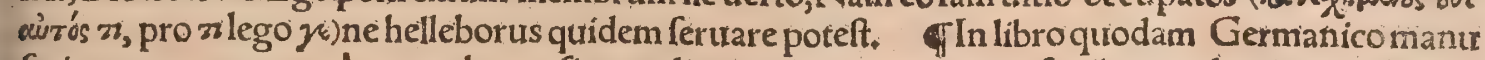
fcripto præter cætera à cane rab.morfi remedia quadam iam recitatis fimilia, quiadraginta diebus cô - tinuis balneo utendum reperio. TApud Io,Iouianum Pontanum in Antonio dialogo, Neapoli. tanus quidam refert fe ab Antonio quodam audiuiffe carmen, quo oppidatim uterentur Apuli, ad fanandum rabida canis morfum. Infomnes enim nouies fabbato luftrare oppidum, Vithum nefcio quem é diutorum numero implorantes:idǵg tribus fabbatis nocfư cum peregiffent, tolli rabiem om. nem, uenenum q́gextingui. Eft autem(inquit)carmen huiufmodi: Alme Vithe pellicane, Oram qui tenes A pulam, Littusç̧̧Polignanicum, Qui morfus rabidos leuas, Irasćçcanumi mitigas: Tur fancíe rabiem afperam, Riciusós canis lưridos, Tu fruam prohibeluem, I procul hínc rabies, procul hinc furor onnis abefto a Qui aquam expauefcunt, uidentur lymphatici etiam dici por fe.nympham enim, id eft aquam, Latini lympham uocant: \& lymphaticum exponunt furiofum, qui uitium ex aqua confpectu contraxerit. Vulgo memorix proditum eft, iriquit Feftis, quicurics fpe. - ciem quandam è fonte, id eft effigiem nymphx uiderint, furendi non feciffe finem, quos Graeci vujopo

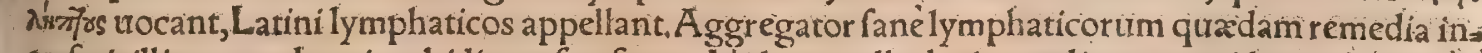
rerferit illis qua ad canis rabidi morfus fant. Nolumus illud etiam relinquere, uideri nobis quód: 
Diofcorides fcribit, nullum à metu a qux feruatum fciri, $\& c$, credidiffe aliquos de his intelligendum effe, qui non à rabido cane, fed rabiente $\&$ aquam iam timente homine morfi fuerint:Diofcerides ta men fimpliciter tradidiffe id uidetur, Marcellus Vergilius, Clyfteris mentionem ad morfos à C.rab. Plinius facit, ut fupra dixit:nec alius præterea quàm Galenus libro 2, de antidotis cap.68. Abfinthip decocro(inquit) agrum euacua, falisćş tantũ immittes, ut clyfter uehemens reddatur. đSi quis cô munem uenenatis morfibus cunćris medendi modum defyderat, à Diofcoride requirat: nos fatis pro lixi fuimus in peculiari ad canis rab.morfus curatione, tum ex Diofcoridis tum aliorum fcriptis col. latis hactenus expofita. A cituarius fua omnia huius argumenti ex Diofcoride, fed breuius defcrip: fit. Aegineta quadam addidit, quę fuo loco uel iam pofui, uel ponam deincepstut Pofidonĭ etiam $\&$ Rufi ex Aétio fcripta, \& aliorum,

đNunc poft uniuerfalem huic malo medendi methodum, ad particularia defcendam remedia, eo ordine feruato, ut primum $\mathrm{ea}$ qua for is adhibentur commemorem, deinde qua intrò fumuntur : $\& \subset$ in utrif̧́, compofita medicamenta prius quàm fimplicia:eáç omnia literarum ordine.

\section{CCompolita remedia qux morfui forinfecus adhibentur, hac funt,}

E Brutia pice medicamentum Menippi, quo ufus eft Pelops: Picis-Brutix libra, opopanacis uncię quatuor (tres, Aério \& A Átuario: \& ipfi Galenolib, 11 , de fimplicib,cap, 30, ubi Aefchrionem præcc = ptorem fuum hoc emplaftro ufum fcribit, propinantem interim per dies 40 , antidotum è cancris, ) aceti(acerrimi) fextarius(Italicus.) Opopanacem diffolue in cyathis quatuor aceti, \& quod fupereft aceti unà cum pice decoquito:ubi confumptum id uideris, tum opopanacem addito, fed caueto ne efferueat:cum fatis inter fe commifta uidebuntur, plagellas bene magnas(longa \& grandia fplenia, A cquar, )inde conficito, locọ́́ demorfo fuperindiro, Galenus lib, 2, de antidotis cap.74. Aërtius, ace. to cum pice decocto 8 confumpto, (inquit)deinde contrito in mortario opopanacifuperinfundens unito \& colligito: atç ita uulneri quadraginta aut fexaginta diebus applicato : prohiber enim cica. tricem. Vtendum eft anaftomoticis, id eft aperientibus(inquit Alegineta) ex quibus primarium eft; quod è pice \& aceto acerrimo \& opopanace conficitur, in tractatione de neruis iulneratis diligen= ter à nobis defcriptum: Quod fi morfus cutem babet teneriorem, dilui poteft irino aut balfamo, aut aliquo fimili. Hoc Actuarius etiam ex Galeno defcribit, ftatim poft mentionê antidoti diacarcinon. Loco morfo prius dilatato cucurbitula agglutinetur, \& poftea imponatur cataplafma ex allio \& ce $=$ pa fimul tritis fubactis $_{\beta}$ cum butyro:longé tamen praftat emplaftrum factum ex opopanace, arifro lochia, \& pice,Ponzettus، TE Echaroticon, id eft cruftam inducens, aridum medicamentum effica ciffimum, ab Äëtio \& Aegineta defcriptum:Salis foffilis drach.octo, chalcitidis, fcilla, fing, drach, fe decim, ruta uiridis, aruginis rafilis, fing, drach quatuor, feminis marrubij drach, una, Infoletur in pyxide ænca, \& aridum applicetur, quoufos ulceri crufta inducatur:deinde rofaceo temperetur, do nec crufta excidat, Aegineta infolationis non meminit. TEmplaftrum dialôn(quo locum dum ad cicatricem ducitur comprehendere iuber Diofcorides)nifi unum fuerit ex illis durobus, qux Gale nus defcribit libro 6, de compof, fecundum genera, cap.8. ad extrahendum, aliud iam non occurrit eiufdem nominis. Crediderim fanè ea recté huc facere, utraq̧ ením fale $\&$ ceruffa conftãt, $8 X$ alịps qự bufdam: fcribit autem Aétius libro 13.cap. 2, emplaftra ex ceruffa \& fale ftatim à principio commo. dè adhiberi morfis à cane, \&c. Solent autem Graci fales in plurali numero proferre etiam de uno tan tum falis genere. Aliud emplaftrum ad morfos à C, rab. Damocratis fenarijs defcriptum affert $\mathrm{Ga}=$ lenus libro 2, de antidotis, cap.119, quod conftat ex terra ampelitíde, bitumine, lithargyro, oleo, pro poli, ariftolochia, \& alijs pluribus. Eodem libro cap. 76:defcribitur Album Bafuli medicamentum, ad morfum C.rab.quod \& extrinfecus(inquit)ulceri imponitur, \& per os intrò affumitur, maximè ab n̈s quibus iam rabies dominatur, \&c.quod quidem non parum aliquis miretur, cum $\&$ empla= ftri formam habeat, $\&$ ceruffam $\&$ argenti fpumam uenena copiofe recipiat. Et mox cap. 77 . Bafil $c a, q u æ$ in aquarum formidinem(inquit) xgros incidere non permittit: hanc $A$ ugufta apud fe com: pofitam femper habuit. Habet autem emplaftri formam, utMenelai quoq̧ medicamentum ibidem cap.75. TTheríaca é uiperis cum rofacco diluta, \& ulccri appofita, confert, Aêtrius. Ego theriacã aliquando oleo ex rofis confecto dilui, \& ceu medicamentum, quod linteolis concerptis excipitur (emmoton Græci urocant)in uulnus indidi, ut cucurbitula cuiufdam modo exugerer, $8 \times$ ex alto ue. nenum extraheret, Galenus ad Pifonem.

$$
\begin{aligned}
& \text { Medicamenta finplicia ad morfum canis rabidiforis imponen. } \\
& \qquad \mathrm{da} \text {, ordine literarum. }
\end{aligned}
$$

đI Ácetum, Auicenna de agrefta. A damas, Plin.37. A diantum, uel capillus algol cum urino, $A$. uicenna, ut Aggregator citat: Ego apud Auicennam non reperio. Diofcorides uero adianti hei bx

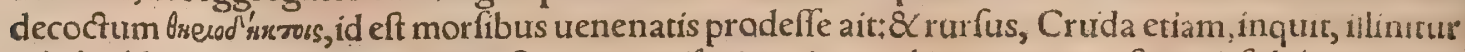

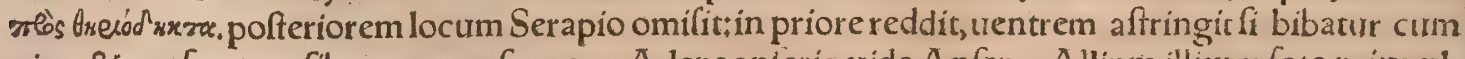
uno, 8 confert morfibus uenenoforum. Adeps anieris, uide Anfer. Allium illitum foto pritrs ul- 6 e cere, Aegineta, Ifaac, Sylueftris rofa radix pota, allio prafertim uulneri impofito, Aquiuiuus, Trito. allio rabiofa canis morfus curatur, Columella, Allum fylueftre detrítum, Diofcor, Amygdala, 
prazcipué amärà, Auicenna, Anagallidis folia, Āëtius: Succus quo abluatur uulnuts, Tragus. A na Ceris adeps cum melle, Plin,29. Affa, uide Lafer. After herba cum axungia uetere uiridis trita, Díofcorides, Axungia cum calce tufa, Plinius; Anguium fenectus cum cancro mafculo trita, Plinius.

TBetonica fuperilligata, Serapio fecundum Diofcor. Nos in Diofcoride Graco ad Axeiodíkr folum, id eft morfos à ferpèntibus commendari legimus. Trita applicata, Mufa, A puleius. Braffica folia cum lafere trita ex aceto. Per fe etiam braffica aduerfus rabidicanis morfus proficit, 8 ip fius decontum in potu, Galenus de Parabil.Caulis, id eft brafficx fuccus cũ uno, Serapiơ fecundû Dio

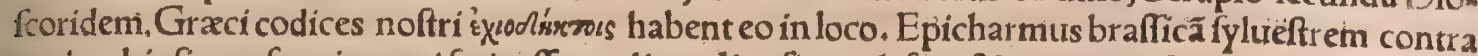
o canis rabiofi morfum imponi fatis effe tradit, melius ficum lafere $\&$ aceto acri,Plin.

đCalx tufa cum axungia,Plin. Cancrorum cinis é melle illitus, Aếtius:porus, Aurcenna.Cinis cancriafperfus aceto, Hali, Vide Anguium fenectus . Cinis teftarum marini cancri, Aggregator ex nefcio quo authore. Canis pili impofiti, Galenus in Parabil. Pili cauda canis combinfti,Aggrega tor. Quidam ulceri imponunt pilos eiufdem canis rabidi, Ponzettus, Canis uel draconis qui momor dit caput, abfciflum excoriatum ćs, cum pauco euphorbio applicatur, ac liberat in totum, ut quidant aiunt, Ponzettus. Cinis ufti canini capitis, à cane rabido morfos perfanat, Sextus: Aggregator intus \& extra prodeffe fribit. Capilli hominis cum aceto, Auicenna \& Sextus:cumbufticum aceto impo fiti, Haliabbas. Capilli hominis morfi aceto remolliti, Galenus in Parabil. Capilli Algol, uide Adian. tum paulo ante. Capreftercus cum uino; Plin. Caro arietis ufta cum uino, Aurcenna. Caftanex cum pauco fale \& melle, Ifaac: ego iuglandes potius quàm caftaneas adhibere $\tilde{e}_{\text {, }}$ aperiendũ enim non. aftringendum eft. Addunt autem alij authores iuglandibus quoç in hunc ufum falem $\&$ mel. Ce. px, Diofcor.Crudx cum melle uel aceto, Plin. lib. 20, uel cofta cum melle \& uino, Macer, Aếtius. Ex cepis cum fale 8 ruta cataplafma, A egineta, Auicenna, Haliabbas, \& Serapio fecundum Diofcori dem. Vide mox in Nucibus, Locum fordidũ lauant aqua cep̧̧, Ponzet. Chamęmalidécocto lauan dus eft locus, Aëtius. Cinis ficulneus ceroto exceptus, A eginet. Cinis uitium cum oleo, Aegineta: Si ulcus ad cícatricem feftinet, rurfus uitis aut ficulneo cinere aperies, Aétius. Cucumeris folia, $A$. uicenna:ego ad fimplices canis morfus cũ Diofcoride potius retulerim.

Eruum cum uino, Serapio fecundum Diofcor , cuitus Græci codices fimpliciter à cane morfis ipfum commendãt:lfaac, Auicenna, Colliget.Aliqui præter uinum mel etiã addunt. Oleum de oros o bo, id eft eruc, Galen, de Parabil. Euphorbium, Haliabbas: Vide paulò fuperius in Canis capite. E. qui fimus cum aceto calidus, Plin.

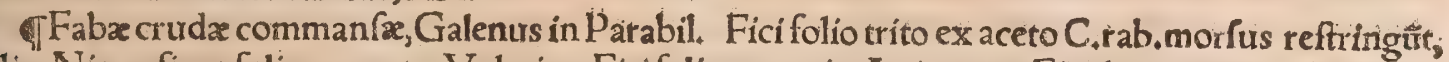
Plin. Nigra ficus folia ex aceto, Valerian. Fici folia recentia, Aurcenna. Ficulneus cinis, uide in Cit nere. Ficus immatura cum aceto, Plin, 23. Ifaac 8 Dioforides apud Serapionem : ego in codicibus nofiris non reperio. Foniculiradix, Auicenna:Diof́corides fimpliciter ad morfus canis refert. Fru mentum, uide Triticum.

GGallinaceum fimum duntaxat ruffum, ex aceto impofitum, Plin, Kiranides, Valerianus. Galli crifta contrita, Plin. 8 Kiranid, Gentiana, Auricenna, Habyx.

THir ci iecur impofitum, Plin.28.aqux metum auertit. Hirundinis pulli conibufti:uel glebula exhirundinum nido, illita ex aceto, Plin, De glebulis idem feribit Valerian. Hitundinis fimus, Pon zet. Hominis capilli, uide Capilli. Hominis uriria, uide Vrina.

Glris ruffa cum melle, Plinius.

Kakille herba marina, Auicenna.

1 Lana fuccida morfibus inculcata pof diem feptimirm foluitur, Plin. Lapathi, id eft rumicis, tum acidi, tum fylueftris, ufu's eft fouèndo aut abluendo locum, $\&$ illinendo, ut ex Aétio fupra do. cui in ratione curandi. Lafer urel filphin fuccus (barbari affam uocant) prafertim Cyrenaicus, atte qui Medicus, aut Parthicus appellatur, Diofcor. Afra cum oleo, Auicenna. Silphium cum fale, Alegie neta. Vide fuperius in Braffica fylueftri. Limacum caro \& tefta, Serapio citäs Galenũ, apud quem ego nihil tale repeirio,

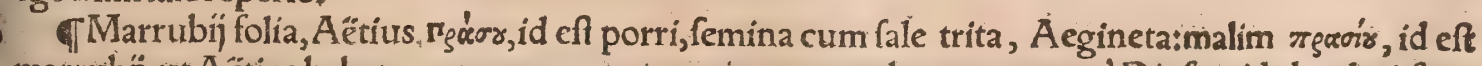
marrubh̆, tu Aëtius habet:quanquam porrum etiam contra hoc uenenum à Diofcoride laưdari fciã, fed in cibo.Marrubium fupra etiam contra fimplices canis morfưs cổmendauimurs, Prafium (id eft marrubium)cum fale, Serapio fecundum Paulư, \& $A$ ưicenna. Meliffophyllon per fe, uel cum fale, Aegineta. Menta, Aegineta, Auicenna. Muris aranei caudx cinis, ita uti ipfe cui abfciffus fit, uile uus dimittatur, Plinius,

TNuces(iuglandium nuclei, Plin,) à ieiưno commanfæ \& illitæ, Auticenna, Plin,23. Vide fupra ad morfus canis non rab.

TOrobus, tride Ertum. Olufatrum,Plin. Oftracorum carnes, Aticenna.

Pecudis ftercus uftum $\&$ illitum cum aceto, Auicenna. Perfonatix radix cum fale marino; A puleius, Pifces omnes, \& iura cor um, \& capita falfortrm ufta applicata, Auicenna : Vide Salfa. menta.Kamen pifcis marinus tritus impolitus, Serapiofecundum Galenum. Plantago tufa, Apü. leius, \&C Valerian.Lingua atietis cum fale contufa, A puleius, ut citat Aggregator. Porrum, tude 


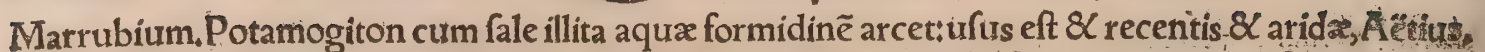
$\checkmark$ Rutæ folia trita uel commanducata inponuntur cum melle $\&$ fale, uel cum aceto $\&$ píce deco cta, Plinius. Rutæ folia cum melle, \& fale, $\mathcal{X}$ pice, A puleius. Ruta cum uino, A puleius ut Aggrega= tór citat.

Salpr fuccus perfufus, aut cinere ex falpa fubacto, Plinitrs. Salfamenta, Plinius. Salfamenta indita praftant ne ulceris oræ coalefcant, Diofcorides. $R$ abiof $x$ canis uel lưpi morfus, imporito uuula neri uetere falfamento fanatur in bubus, Columella.Vide Pifces, Sambuci folia, uide fupra ad mot: fus fimplices in Ebulo. Senecta, uide Anguis. Silphium, uide Lafer. Sefamum, Auicenna.

I Terra figillata (id eft Lemnia) fecundum Galenum apud Serapionem, illita, fuperpofitis ali= quibus folins:quorum pracipua funt allih fylueftris folia, póft centaurin maioris, demum prafin. Tri ticigrana, tam manfa, quàm non manfa imponantur, fiquidem fubacta piftáure ( $\delta^{\prime}$ bx $\phi$ véwulva, quafi fermentata, 8 turgida)à perfufione ( humore uel fanie manante ab ulcere) uulnera dilatant. Sunt qui à mandentium ieiunio fibi aliquid afcifcere arbitrentur, quod fuapte natura refiftat. Verum id certum non eft:caterum tempeftiuus eorum ưfus, minimè eft contemnendus, Diofcorides. Triticum coftum $\&$ commanfum, Ifaac. A puleius tritici granis appofitis $\&$ gallin $x$ obiectis, inde experiri doz cet rabidúsne fuerit canis qui nomomordit, ut fupra dictum eft.

- Verbena uel herba facra impofita, A puleius, Vituli marini adipe inungatur facies timentis aquam, Plinius 32. Vitium cinis, úide Vitis. Vrina hominis morfi goffipium intinctum, Galenus in Parabil. Vrina, cinere ex ea fubacto, Plinius, V rina cum nitro, Serapio fecundum Diofcoridem, \& Auicenna. Vrina pueri cum baurach (id eft fuma nitri) Hali. Vrinæ fex cum carbonibus ui. 1 tis uiridis trita appofita frequenter, abluto interim quem extrahit humore, A puleius ut citat Aggre. gator. THxc funt remedia qua ueteres aduerfus rabidi canis morfus foris imponenda celebrauce runt:Quafi cui non fatisfaciunt, augeat ea ex præcedentibus ad fimplicem canis morfum comme. moratis, efficacioribus prafertim. đHis fubijciemus amuleta quædã,id eft fuperftitiofa pharmaca, qua geftata folum abfç ulla ratione à nonnullis conducere creduntur: $8 \mathrm{C}$ his fimilia, qux caufas qui dem aliquas in natura habent, foris tamen ad auertendum aliquid ufurpantur, alligantur, inungun tur, fubfternuntur. TAd arcendos aqux pauores utuntur dente eo, qui caninus dicitur: hunc à cane qui momordit exemptum \& folliculo inditum, pro amuleto brachio adnectunt, Diofcorides. Arabes \& qui eos fequuntur, pro canino dente molarem reddunt, qui coxis alligatus, uel à brachio fúfpenfus, tueatur geftantem.Vermem è cadauere canino aliqui adalligant contra paurorem aquę, Plinius. Vermiculus canis mortui ín collo fufpenfus, fanat morfumà C.rab,Sex tus, Gentiana dicbus feptem cum hyænæ pelle amuleti loco geftatur, Actuarius. Hyænæ pellis utiliter fubfterni. zur morfís à C.rab. Aërius. đLupi uel lupufculi pellis fufpenfa ab eo qui à C.rab. morfus eft, aqua pauorem amolitur, Aggregator ex Haliabb. đLais \& Salpecanum rabioforũ morfus leniri aiunt, menftruo in lana arietis nigri, argenteo brachiali inclufo. Diotimus Thebanus ueftis omnino ita in. féfx portiuncula, ac uel licio brachiali infer ta, Plinius. Inter omnes contrenit, fi aqua potusóg for: midetur à morfu canis, fuppofíta tantum calici lacinia menftrưo tincia, ftatim metum eum dífcuri, ui delicet praualente fympathia illa Græcorum, Plinius. Iis qui iam aquam extimefcunt, ut bibant,

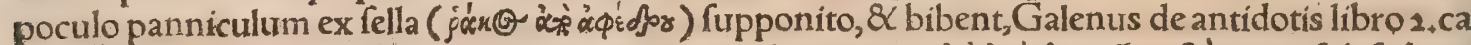

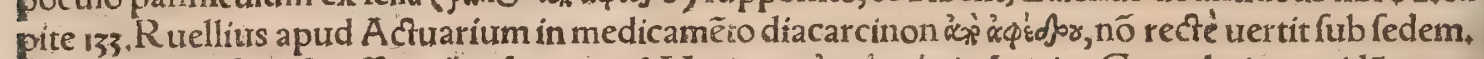

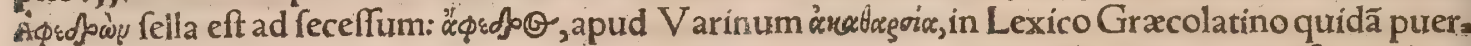
perium reddidit, fine teftimonio. TSuccorutie peruncios, aut etiam habentes, negant feriri ab his ueneficrïs (apibus, uefpis, \& cc.cane rabiofo) Plinius libro 20. Euitice baculus à canis $\&$ alińs mor ribus defendit, ut quidam ex Diofcoride citat:ego nihil tale in codicibus impreffis inuenio. Aggreg* tor quidem ex Auicenna citat, emplaftrum ex agno cafto morfis à cane prodeffe, IVrfi pellişau arituli marini, utiliter à $C$, rab, morfis fubfternitur, Aétius.

$$
\begin{aligned}
& \text { Antidoti } 8 \text { medicamenta compofita quax adueffus } C_{\text {.rab }} \text { mors } \\
& \text { fus (id eft ne in rabiem aut aquę metum qui morfi funt,incidant) } \\
& \text { intra corpus fumuntur. }
\end{aligned}
$$

TĀel Galli antidotus cum ad alia quædam, tưm morfis à C, rab. falubris, defcribitur à Galeno libro 2. de antidotis capite 54, conftat uarïs aromatibus cum opio, qua melle excipiuntur. Item alia ciufdem cap, 71 , uidetur autem \& ipfa ad morfos à C.rab,facere, propter antecedentia \& fequentia.

BBafuli Albũ \& foris imponitur, \& intro fumitur, \&c, uide firpra inter côpofita foris applicanda,

- E cancris paratur optimum aduerfus rabioforum canum morfus auxilium, quod $\&$ plerifg unum fatisfecit, eoćs curm fiducia utilicet. Eft autem huiufmodi. Cancros fluuiatiles in farmentis als ba uitis cremare oportet, 8 cinerem corum quamminutiffime tritum habere reconditût itidem gentianæ radicem tufam cribratamós reponere, quoties autem canis rabiofus morfum intulerit, in quas: ternos cyathos meraci uini, bina cineris cancrorum cochlearia, unumós gentianæ con̄́nciantur : haxc in polentre dilutioris modum fubacta, quatriduo bibantur. Inter principia medicamẽtum hoc modo detur:atqui fi ab illato morfu bini terni ue dies fluxerint,curationem aufpicabimur à triplicato pon: dere, fupra id quod ab initio retulimus, Diofc. Similis huic extat defcriptio Damocratis fenarijs iam. 


\section{DeCane. G. Lib. I. 203}

bicis, aputu Galenuint de antidotis libro 2.cap.116,in paucis quiburdam \& parui momenti rebus diffe rens: Codices Graci tamen corrupti funt, 8 interpretes quadam male transferunt. Eadem eft eíam Mithrea defcriptio eodem in libro cap. 70 . quo loco cum Damocratis uerfibus collato, qua doli me dicamenti utendưm fit illi, qui fecundo aut teitio dieả morfu demum uti incípí, clarius patebit:nem

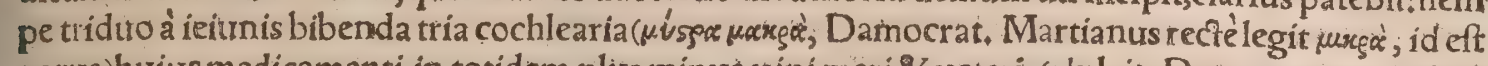
parua)huius medicamenti, in totidem plits minus uíni meri \& ueter is (dulcis, Damocrates) cyathis: ita ut qutotidie fumant cochleare untrm (ut Martianus recté urertit, licet Gracicodices noftri non ex primant)fcilicet paruum, cum tribus uini cyathis: idóg facere pergant per tres dies: uel quatuor, fi maior fuerit morfus. Si quis uero fecundo die antidoro uti incipiat, duplum medicamenti capiat; 10. nempe cochlearia bina, \& uini quantum prius. (tres enim cyathi uini, etiam duobus \& rribùs cochle

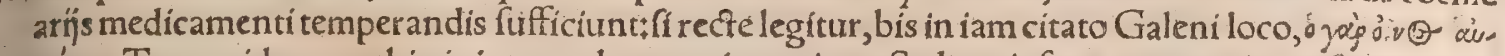
réprss. Tres quidem cyathi uini appendent uncias quin $\phi_{3}$. Sed res ipfa quantum uini mifceri conue niat ad commodam medicamentí potionem, fatis docebit.)Sequentibus autem duobus diebus, toc eft tertio \& quart à morfu, fat fuerit fingula quotidie medicaminis cochlearia, id eft drach, tres, ut infra dicam, ex pradicto uini modo haurire. At fi quis tertio à morfu die medicamento primum uta: tur, triplum, id eft tria cochlearia eo die bibat, \& fequentibus duobus quotidie fingula: ita en:m fier ut tantundem hauriat, qui tardius bibere incipit, ac qui primo ftatim die incopit, . Ex hac inter preta tione Diof cor etiam uerba clariora fient. Marcellus interpres apud Diofcor, dubitat utrum cineris cancrorum cochlearia duo, gentiana uero unum, meraci uini cyathis quatuor mixta, à prima die uf - quead quartam bibenda fint, ita ut quotidie hac menfura haturiantur: an fingulis diebus ufqga ad quare tam, quoniam uini cyathi quatuor funt, bibendus cyathus unus tantum fit. Nobis(inqutit) in prior $\overrightarrow{\mathbb{E}}$ illam rationem inclinat animus. Et merito quidem lle dubitat, cum necs, Diofcoridis hic locus intes ger mibi uideatur: ne ${ }_{5}$ alin eum fecuti, fatis aperte medicamenti ufum defcripferint. Multis omnino modis exemplaria Græca, tum Galeni dituerfis in locis, tum Aegineta, Aëcij, \& Actuarï uariant:interpretes etiam Latini alị aliter transferunt:ita ut ratione $\&$ iudicio magis quàm collatione cod icunt intelligêda fint omnia:ego in præfentia non omnia, fed ut fe obtulerint quædam, partim conferam; partim emendabo. In. Mithrex compofitione gentiana ad cancrorum cinerem dupla efts ut apud A çtuariũ etiā, contra quàm apud Diofcoridem \& Damocratem, In eadem, terebinthina etiā adịció tưr pari cum gentiana pondere:Martianus interpres eam trocem omittit, cui ego affentior, licet àve - prapofitio fequatur,quæ duo ut minimum ante fe nommata pharmaca poftulat. Videtur fanè hace

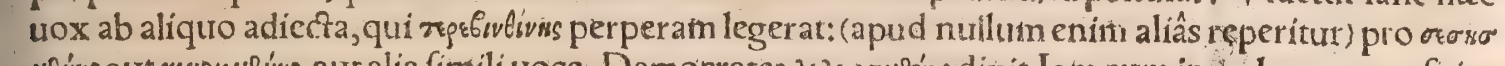

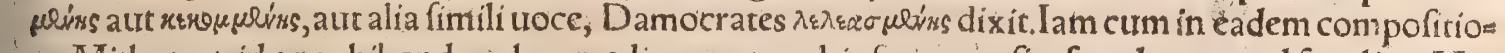
ne Mithrex, triduo exhibendum hoc medicamentum bis friptum fit, femel autem ad fex dies: Mar tianus fex tantum dicrum mentionem facit:apud A eginetam dies quatuor legimus, apud Diofcori: dem uffp ad quartum, id eft tres: A ëtius theriacam quoqs primis tribus diebus propinat. Quanquam A efchrionem Galenus fuum é cancris medicamentum per dies quadraginta propinaffe folitum feri bit:quod quidem ratione non caret, quoniam ad eum ufog diem feré aqua pauor timetur, Coctilea

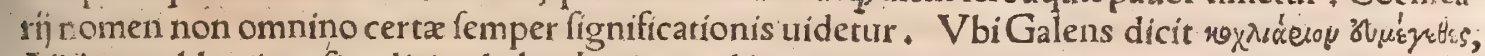
Aẹtïus cochlearium fimplicitcr haber. lam cũ cochleariũ magnum (quamuis id aliud uidetur quànt

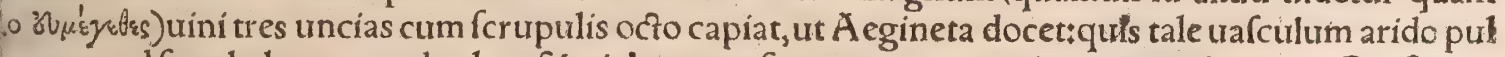
uere uel femel plenum, ut duplam $\&$ triplam menfuram taceam, unica potione hauriet

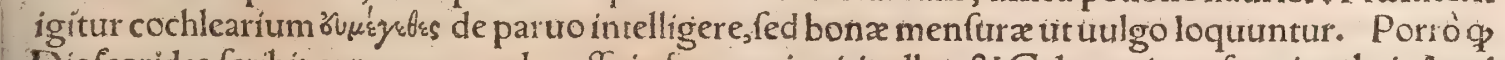
Diofcorides fribit cancros urendos effe in farmentis uitis alba, \& Galenus in uafe aris rubri, A egi

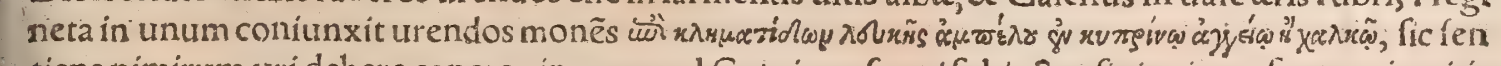
tiens nimirum uri debere cancros in æneo uel Cyprio uafe,cuifubiectu fit ignis ex. farmentis uritis

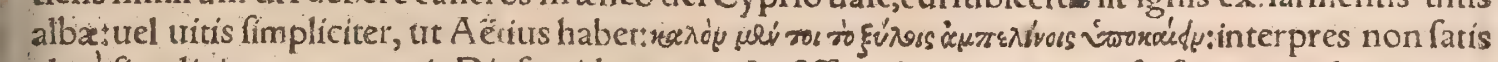
claré fimpliciter urere uertit. Diofcorides tamen fenfiffe uidetur cancros ipfis farmentis dum urun= tur, non uafi imponendos effe. Galenus parum curare uidetur ex qua materia fuccendatur ignis, poftulat autem uas aris rubri:nimirum quód ex ære etiam falutaris quædam contra uenenum uis - cancris accedat. Ex Cypro quidem(inquir Marcellus)in omnes medicinæufus as laudabatur. Huius medicamenti cochlearị menfuram quotidie cum aqua calida dabis uf̧̣ ad dies quadraginta : $q$ finon ab initio, fed poft dies demũ aliquor morfus uti incipiat, bina quotidie dabis, donec dies qua draginta expleas, Aëtius:Montanus interpres dierum numerum omifit, Facile quidem fieri poturit; ut negligentiores aliqui r'arepa pro rearapánovra fcriberent aut legerent. Aegineta prater ræteros docet cancros crefcente luna fumendos effe, id ç̣ ante Solis ortû. Diacarcinon antidotus, ex ficili= quo cineris cancrorum, \& drachma gentianæ contritar mixta, bis aut ter aut fapítus ex uino albo da turips uero qui iam horrent aquam, frequentius exhibere conueni: ut autem bibant, fuppone pocú lo lacerum pannum ex fella, (poteft autem hoc faciendum intelligi, uel ut medicamentum bibant uel fimpliciter utbibant, cum potum omnem abhorreant:)Açuarius. Gentiana etiam per fe inftar cochlearium trium ex aqua efficax eft, diebuis quadraginta uel fexaginta, Galénus \& A ćtuarius. In libro Secretorum, qui Galeno attribuitur, cap. 59 eadem feréleguntur quæ de fimplicium fa suttaté libro 11.cap, $3^{\circ} .8 \mathrm{r}$ medicamenti è canci is defcriptio talis, qualem ex Aécio infra recitabimus. Hujus 
medicamenti (inquit)cochlear unum magnưm ex aqua bibatur, nec minus quàm drachmæ tres bibatur. Myftrum fanè fiue cochlearium medicum drachmas tres continet, ut Ge. Agricola proz bat, apud quem plura reperies de cochlearn̈ diuerfis fignificationibus, tum aliâs, tum ín liquidoz rum $\&$ aridorum menfurís. Sed his omiffis Galeni de hac ex cancris antidoto uerba libro II . de rimplicib. capite 30 , afferam. Fluuiatilium cancrorum cinis (inquit) quanquam fimiliter prar. dictis (cochleis, echinis) exiccatorius eft, totius fubftantia tamen proprietate mirabilis eft ei. us in ijs qui à rabiente cane funt morfi, effectus, tum per fe, tum cum gentiana $S C$ thure multo pras ftantior. Thuris partem effe unam oportet, quinq̧ gentianæ, cancror ũ decem. Et rarò equidem alirer illis uftis nos fumus ufi; cxterum ad eum modum plerunq, quo Affchrion empiricus, medicamen. torum peritiffimus fenex, conciuis ac pręceptor meus. Patella erat aris rubri, in quam impolitis can cris uitentibus, eos haçenus uffit, dum facile ad leuorem redigi poffent. Hic Aefchrion paratũ fem per in $æ$ dibus hoc habebat medicamen, urens cancros $æ$ ftate poft ortum canis, quando Sol in LeO= nem tranfiffet, non nifi Luna decimaoctaua, Porrò bibendum hoc medicamen ìs qui à cane rabido fuiffent morfi prabebat quotidie diebus quadraginta, menfura cochlearn̈ magni ( fperfum. At fi non protinus ab initio, uerum aliquot polt dies curam cepiffet demorfi,tunc quotidie duo cochlearia aqua infpergebat. Interim uulneri emplaftrum è Brutia pice adhibebat. Haec tameth à præfenti infituto aliena (inquit Galenus) fribenda tamen cenfui, quia magnopere medicamento. - huic iple cófiderem, nimirum cum nullus unquam eorum, qui illo fuerint ufi, fit morturus. Poft hac Pelopem præceptorem fuum notat, qui cur cancri, "n̆ $\phi_{\beta}$ flusiatiles potius quàm marini, à C, rab, mor= fis mederentur, nihil proprietati fubftantięrribuens, caufas naturales ac certas afferre conabatur. $\mathrm{E}=2$ go(inquit)cancros opinor ex proprietate totius fubftantix prodeffe. Volui autem hoc in loco íd có= memorare, eò quod nullus eorũ qui cancris ufi funt, totis fcilicet eorũ corporibus, mortuus fit:quan quam præter huius operis inftitutũ, in quo de ñs quæ tota fubftantia agunt differere non propofue: ram. Hunc locum Latinus interpres perquam inepté \& obfcurè tranftulit, Quod fi eotempore, quo iam dixinus ex Galeno, paratum medicamentum non habueris, non ideo defiftes, fed quocũ pore præparabis, Aétius. Conficies autem hoc modo, Cancrorum fluuialium congrua magnitudi. nis, qui uiuentes in uafe rubri aris cremati fuerint, cineris uncias decem, gentiana uncias tres, (quin que in Graco, melius)fynceri thuris unciam unam, Aëtius. T Decancris per fe intra corpus fus: mendis, patilo poft fuo ordine dicam. TE凡t $\&$ aliud è cancris medicamentum Cratippi infcriptû viri egregị $\&$ canum nutritoris apud Galenum de antid. hb.2, cap. 71 . quod præter cancros \& gen tianam, myrrham recipit cum croco $\&$ pipere: $\&$ denarï pondere cum uini diluti cyathis tribus dax tur. Vide etiam Aggregatorem inter remedia morfus $\mathrm{C}$. rab, in Cancri $\&$ in gentianæmentione. Nicoftrati quoç a ntidetus eodem libro cap. 131. præter cancros \& gentianam, caftoreum ac lycium cum melle excipit. $\mathrm{Cl}$. A pollonï theriaca ad rabioforum morfus idonea defcribitur apud Gale num lib.2, de antid.cap.73. quæ prater cẹtera multa è f́nco \& cancris marinis exuftis conftituitur.

Cyphi, uide paulo poft in Antidoto è nucibus iugland.

ब) Efdra compofitio cum uino fumpta, \& illita cum fucco mentę, Nicolaus.

Heræ Cappadocis antidotus apud Galenũ li, 2, de antidot, ca,31,uidetur et ipfa efficax effe mor fis à C.rab. propter antecedéntía \& fequentia.Caterum quęibidem proximè fequitur Zenonis Lao

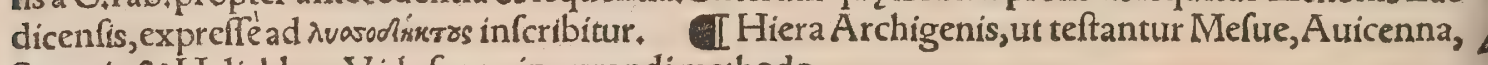
Serapio $\&$ Haliabbas. Vide fupra in curandi methodo.

q) Mithridatis Eupatoris diaf́cincu antidotus, Diofco, ut fupra emendaui, cum nullã ex eupatorio antidotum reperiam. Antidotus cum ad alia uenena, tum ad canum rab, morfus, à Mithridatio dia fcincu nihil ferè differens, prafertim illo quod carmine fcripfit Damocrates, praterquam paucis in fine adiectis, apud Galenum de antid.1ib.2.cap.127.

đE nucibus iuglandibus antidotum a pud Aétium lib.6.cap.24. morfis à C. rab.etiamfi febricitarecoperint, confert, quadam aduerfus hunc morbum refiftendi proprietate, fomnumó obiter con ciliat. Drachmam unam eius (inquit) ex aqua pluuiali calida in nocie poft febris uigorem dato, ita ut mane quidem confectio ex cancris exhibeatur, uefpere autem è iuglandibus: Quæ fi non affuerint, exhibeto quod cyphi appellatur, fiue illud habueris quod é trigintaquinģ rebus componitur, fiues quod è uigintiocto.

Theriaca diateffaron, Nicolaus. Theriaca magna, Auicenna,Aqua paurom morborum pef fimum hoc medicamentum fæpe tollere confureuit, \& mirabiliter tantorum malorum concurfui re. liftere, Galenus ad Pifonem.

GAd aqux metum antidotus fiue potio, \& catapotia, utraq̧ ex caftorio \& granis lathyridis com. pofita, apud Galentm de antidotis libro 2, cap.129. \& 130. Et cap.67. potio præferuans ne morfi in ra biem incidant, ualde generofa, Lycï Indicioboli tres cum exigua uerbena ex aqua dantur ad dies aliquot.

Medicamenta fimplicia, quæ intra corpus fumuntur à morfis à cane rabido.

Allia in cibo, Diofcorid.Aëtius, Abfinthium potum, Aëtius, Arietis caro aduffa cum uino, Auicenna: 


\section{DeCanc. G. Lib. I. 205}

Auicennałuidetur attem bibenda. đAlyffon herba contufa in edulio, rabiei canis mederi puta. tur, Diofcorides. Huíc plantá nomien, ut apparet, à pellenda rabie impofitum ef. Et quoniam nihil certi de ea noftri feculi hómínes docent, \& ueteres quoq alîa aliter defcribunt, qua ip obferíaue rim lectori communicabo. Alyffon (inquir Diofcorides libro3, cap, 96.8 apud alios 1o5.) exígtius frutex eft, unicaulis, fubafper, rotundis folīs : fructu duplicium fcutorurn êffigie, in quo elt femen quadantenus latum. In montibus $\&$ afperis locis emicat, Eius decocium fingultus fine febri, potu di fcutiti Idem efficit, fi quis eã aut teneat, aut odoretur:(poterit fanè hinc etiam alyffon quafi alygmon, id eft fine fingultu diçum uideri, quod eum pellat.) Cum melle trita, uitia ciitis in facie; \& lentigines emendat, Contufa in edulio, rabiei canis mederi putatur. Domibus appenfa falutaris effe creditur, $\& x$ hominibus atç animalibus fafcini amuletum. Purpureo linteo (ad collum) circimligata, pecorum morbos abigit, Hac Diofcorides interprete Rtrellio. Hîc primum notatu dignum eft, quiod Diofco= rides fcribit rabiem canis fanare hanc herbamin cibo ei datam, hoc alios ad homines à cane rabido. morfos tranftuliffe. Fieri tamen poteft, ut utrifos conireniat; quemadmodum de elleboro credítur. Movórou nomenclaturas loco ponitur, ut codices uulgati habent; Ruellius in contextum afciuit. Pro his uer

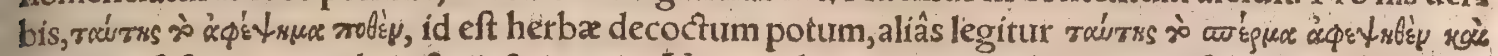
rodsy, id eft femen eius decoctum \& potum. Nomenclatura eius ilta leguntur, af pidion, haplophyl, lon, accyfeton, adefeton: \& monocaulon, nifi id potius ad cótextum, ut dixi, referri debeat. Ápidion diçum apparet à forma fructus, id eft pericarpì;, quo duplicem clypeolum refert. Atractylin etiam afpidion cognominari legimus. Plutarchus libro 3. Sympofiacôn, alyffon numerat inter hérbas qua folo contaciti halitúue, aut afpectit, prodeffe homini contra fingultum poffunt. Gregibus etiam(in. quit)ouium \& caprarum, fi circa ftabula plantetir, falubrem effe perhibent. Alyffon (inquit Gales nus libro 6. de fimplicib.) nuncupata eft, quơd mirifice iưuet morfos à cane rabido : Sed \& rabienti quocs data, frpe in totim fanauitiatç hoc ex totius fubftantix fimilitudine efficit: qua quidem fa= cultas fola percipitur experientia, Experiendo fanè ad inulta aliquis cognofcet, eam hiabere facultatem mediocriter fíccảntem, \& digerentem, \& fimul abfterforium nonnihil : eaćs ratione uitilíginem 8 ephelin expurgat. In Arabum libris alyffon inuenio nominari algacen, uel alguaficen Auicênæ, uel alufen: qux omnia à Graco corrupta fünt. Matthxus Syluaticus cap.36. Latine lilialeni dici fori bit, Lilialis (inquit) folia habet rubix, minora, fubafpera: per terram quocs rubia inftar extenditur: flore paruo, qualis in folano eft, lilï plané figtira. Deinde Auicennam citat, qui 8 ipfe florem eius li: lio fimilem faciat: $\&$ herbam ipfam calidam $\&$ ficcam in primo ordine, panaricix, id eft paronychia (aliâs panno)utilê, Pro lilio, ut Bellunenfis monet, Arabice legitur altors, id eft clypeurs, unde herba ipfa nominatur torfia, ut Gracis afpidion. Idem Syluaticus cap.27. Algacen, inquit, herba flos eft fi: milis lilio, exiguus, minor flore fambuci, caule \& folins rubix. Et alibi, Alahuch eft arbor magna, lilio alis dicta, qua caremus. Auerrois eluoxat appellat: \& renes quo $\$$ ab ea obftructioné liberarif cribit,

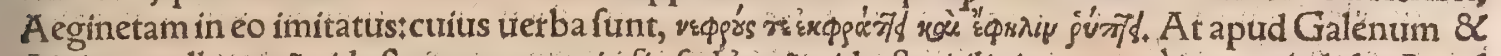

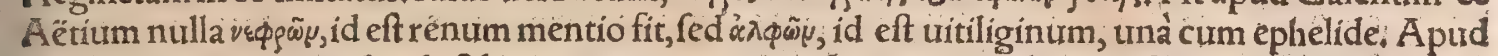
Diof coridem uero фax $\omega^{\dagger}$; id eft lentiginis, quam egolectionem omnibus prafero:quoniam $\&$ cxteri ex Diofcoride defcripferunt, aut faltem Galénits, alï ex Galéno: folet autem ut plurimum ephelidis o mentio фarroîs coniungi. Eandem effe uideo libro 2; cap. 25. apud Auicennam Árefeni, úel út Bellur nenfis caftigat, alfefani dictam, de qua infdem uerbis, quibus Aégineta fcribit, renes eam purgare, \& mederi morlis à C, rab, hoc tantum de fuo addit, exiftimare fe eam effe pafturam camelorum, uel cor uorum ut Bellunenfis emendat ${ }_{i}$ Vide hominis infritiam, duobus capitibus proximis eandem plan: tam nomine tantum uariante bis defcribentis. Io. Ruellius reprehendit eos qui alyffon Diofcoridis herbam crucialem irulgo dictan exiftimant, cui flos luteus eft, quaterna in geniculis folia titem illos quililiaginem rufticé dictam intelligunt, folio quadantenus $\&$ florelilí purpureo. Propius autem (inquit) accedere uidetur ad eam, quam rufticam cannabim uocant herbarif : qua fruticofa herbu la eft, unicaulis, folijs per initia fatis rotundis, ubi adoleuit oblongis, $\&$ per ambitum leuiter ferratis; fructu duplicium futorum effigie, in quo eft feinen quadantenus latum. Sed iri hoc rurfus eum er- roris notat Matthzolus Senenfis. Ego fané pèregrinam nobis $\&$ ignotam Diofcoridis alyffon reor, ut Matthazolus etiam:quod ut ita credam, Andrex Bellinenfis uerba in Arabicorum Auicenna uo cabulorum lexico præcipure mihi perfuadent.A aulufen (inquit) uel aalufen, fecundũ Ebenbitar fcri bitur per duplicem literam aleph: herba eft folins paruis, qux cito amittit:fructus folins maior eft, magnitudine feminís cucurbita, effigie clypei (appingit autem binos clypeos ouata feré figura collaren tes.) Geminæ fructus tunicæ ceur uaginæ, utrogg latere femina lenticulis paruis fimilia continent: $\&$ per fingưlos caules abundant huiufmodi fructus. If fere palmo altiores non funt. Vocant autem $\mathbb{A}_{\text {. }}$ rabes ipfas uaginas feu folliculos fructuum nomine. Et quoniam hi fructus referunt altors Arabice dictum, id eft clypeum, herba nominatur Arabice altorfia, id eft clypealis. Meminit eiưs Auicenna quarto canonis in capite de curatione morfus rabidi : $\alpha$ Ebenbitar in libro de fimplicibus praftan: tiam eius contra mor fum canis rabidi celebrat:Eft autem notiffima in Syria, Hæc Bellunenfis. Alia eft alyffos Galeni, uel potius Antonini Coi apud Galenum libro fecundo, de Antidotis cap.69. Aly f fum herbã côtufam (inquit) \& cribratam repone; huitis cữ opus fuerit à rabido cane morfis cochliter 
exhibebis ex aquax \& mulfx cyathis tribus Itatim à primo die uf́g ad quadraginta : fin minus, faite primis feptem diebus. Alyffus atrem herba eft marrubio fimilis, afperior tame \&' magis fpinofa cir

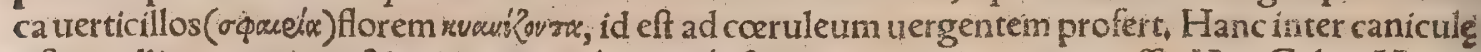
aftus colligere oportet, \& exiccatam cribratamóg feruare, It expirare non poffit, Hac Galen, Martia nus non recté uertit, alyffon orbes habere in fummitatibus ramulorum, quod Gręcè non legitur : 86 relpfa in marrubio ac fimilibus herbis uertichli huiufmodi to tos ramulos in geniculis ambiunt, non fummos tantum. Hęc eadem de alyffo apud $A$ ctuarium legimus, in mentione antidoti díacarcinon. De eadem libro 1. Aétius fic fcribit, Alyfion effe aiunt fideritin cognomine Heracleam, quæ paffim

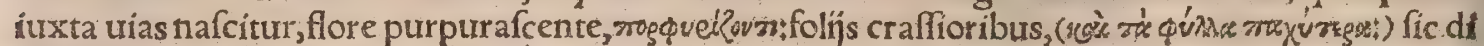
cta quod à cane rab. morfos mirifice iutuet: deínde eadem ei attribuit qua Diof corides firo alyffo, \&

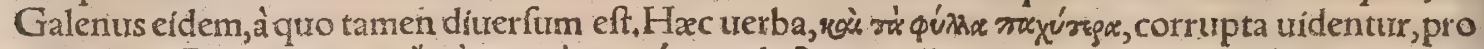
quibus ex Galeno legerim; 'Ły marrubium, cui fimilem effe, itidem ex Galeno addendum eft: Nam Diofcorides quoç fribit, fideritin Heracleam marrubio fimilia habere folia, fed longiora, ad faluix aut quercus figuram acce

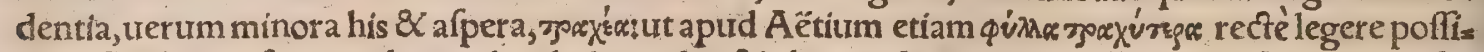
mus, Caules profert quadrangulos, dodrantales, $\&$ aliquando maiores, guftu non infuxaui, cum aftri ctione aliqua:in quibus per interualla uelut in marrubio in orbem circumacti uerticilli funt: 8 in his nigxum femen. Nafcittur lapidofis ( nare uulnera, \& a uulneribus inflammationes arcere, Hæc Diofcor, Ruellius \& fecutus eum Mat thaolus errant; hanc fideritin Heracleam effe putantes illam, qua tertia huius nominis à Diof coride

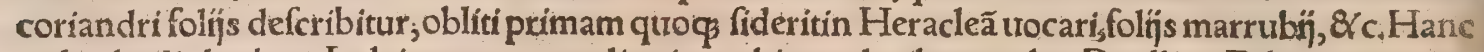
uulgo hodie herbam Iudaicam uocant, aliqui tetrahit, ut pluribus probat Ruellius. Diligentiores ina quirent num quæ ex urticæ mortux, ut uocant, generibus, huc faciat; qualis eft quxdam ballotæ fimilis, purpureis $\&$ dulcibus floribus, quam apes petunt præ cæeteris eius generis. Matthæolus alyfs fon in fecundo de antidotis a Galeno defcriptam, paffim in Italia uulgarem effe fcribit, fed nullũ eius nomẽ affert, ut neç defcriptionem. Cæterum herba Iudaica A uicennæ, nihil aliud quàm eruum eft. Herba paganica etiam, uirga aurea quibufdam dicta, ab alịs ludaica uocatur. Tetrahit herba vires ad matricem $\&$ urinæ meatus expurgandos, item ad fillicidium \& difficultatem urina Platearitis celebrat. A egineta morfis à cane rab, purgans è ficyonia pharmacum quotidie propinandum fcribit

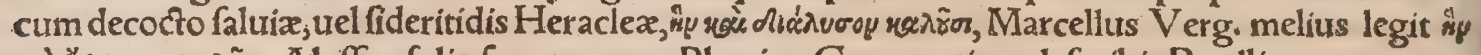

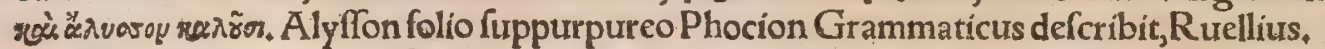

đVenio ad tertiam alyffi nomine herbam, de qua Plinius, Diftat(inquit)ab erythrodano(id eft ru bia)frutex alyffon uocatus, folijs tantum $\&$ ramis minoribus \& Quippe nomen accepit quód à cane commorfos rabiem fentire non patitur, potus ex aceto adalligatus q̧̧: Mirumóp eft quod additur infaniam(aliâs faniem, lego fingultum ex Diofcoride \& Plutarchn) confpecto omnino frutice eo fana ri, aliâs ficcari. Hanc Ruellius \&Matthæolưs rubiam minorem uulgo dictam interpretantur. Eiuf

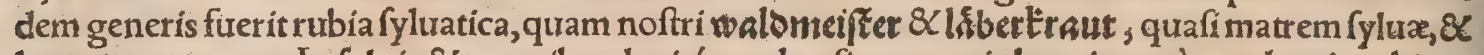
hepaticam, tocant, In fyluis \& montibus, locisḉ̧ umbrofís prouenit, breuior quàm uulgarís rubia a* greftis, fed uegetior afpectu; caulibus rectis dodrantalibus, foln̈s maioribus, minoribus tamen quàm fatiuæ: candidis $\&$ odoratis flofculorum corymbís; feminibus, ni fallor, gemellis: falutaris homini $\alpha$ pecoribus omnibus creditur, ad omnes occultos morbos, uifcerum prafertim, ut pulmonis $8 \mathrm{iecO}$ ris, fi radicula edantur, aut uino inịciantur, quo ufu etiam exhilarare putant helenị inftar Homeri ci, inde impofito nomine berbfreto: Hac habui de tribus alyfigeneribus,

A A nagallidis fuccus potus à $C_{*}$ rab, morfos turetur, Tragus, Aprinum iecur recens aridum cum vino potum, contra ferpentium \& $x$ canum morfus proficit ${ }_{j}$ Diofcor.lib, 2 .in Gracis codicibus habe

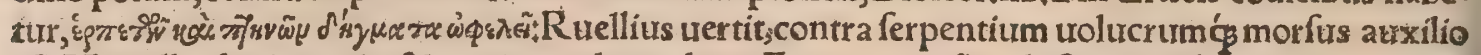

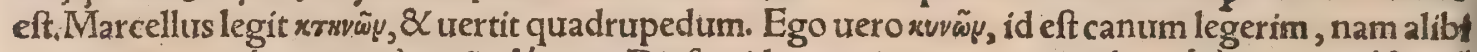

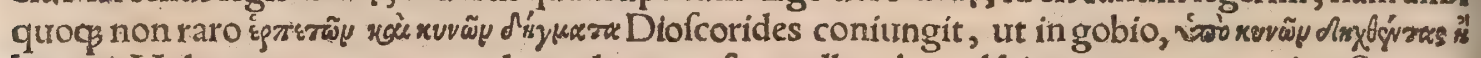

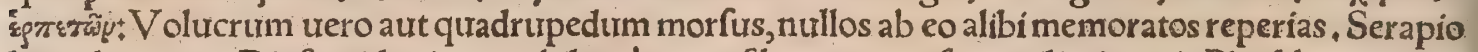
hunc locum ex Diofcoride citans, nihil quàm morfibus uenenofis auxiliari uertit, Plin.libro 28,cap. 10.A pri iecur(inquit)inueteratum cũ ruta potũ ex uino, contra ferpentes laudatur; fimili modo uerri num iecur, \& c. \& paulo poft de canis rabidi morfu agens, Laudant hirci iecur, qmo impofito, ne ten: tari quidem aquæ metu affirmant, Iecur hirci maturè fumptum, fubuenit, Ponzet. Surpicetur fané

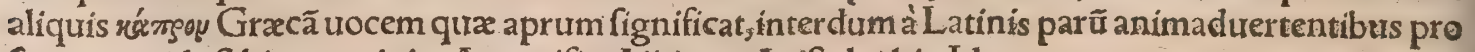
fuo capro, id eft hirco accipi, Artemifia, Aétius, Ariftolochia,Idem.

- Bitumen Iudaicum omnium utiliffimum eft,ex tribtrs aqua cyathis potû:datur pondere fcrtw puli uniứs, aliấs drachmæ unius, Aêt. Braflica, \& cius deccêtum in potu, Galenus de Parabil cap, 68. Britannica, uide inferius in Lycio.

TCepx \& porri in cibo, ut fupra ex Diofc, dictum eft. Cancrorum cinis epotus, Aétius, Plinits, Colliget, Albucafis:cum melle, Aurcenna. Cancrorum furuialium decocium, cum quibus copia ane 6 thi elixata fit, Idem. Caninus fanguis, Diofc, 2, 89. \& Galen, Sanguis rabidi C.illius qui momor. dit,Auicenna, Saliuntur $\&$ carnes canum, quirabidi fuerunt, in cibo dand $x_{2}$. Plin,2g, Aggregator 


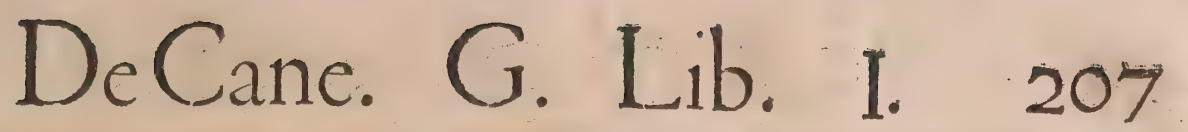

addit, eius pprie qui momordit. Vide paulò poft in iecore C. rab, ex Plin, Capitis caníni cinis, ufurs (ut fupra diximus)illitus uulneri:idem $\&$ in potione proficit:quidam ob id edendum dederunt: tue tura â pauore aqux, Plin, Sextus hunc cinerem fimpliciter à cane rabido morfos perfanare fcribit. Vermis qui fub lingua rabidi canis inuenituri excifus, $\&$ circum arborem fterilem ter latus $\&$ da tus illi qui ab co morfus fuerit, fanabit,Plinius eundem(exemptum infantibus catulis, quanquă eti am de alijs canib, exempto intelligi poteft)ter igni circumlatum dari fcribit morfis à rabiofo, ne rabi di fiant. Eft limus faliua fub lingua rabioficanis, qui datus in potu, fieri hydrophobos non patitur, Plin. Canis rabidi id quod fub lingua habet acceptum $\&$ potatum cum aqua calida uel ex uino, hy, drophobos(perperam feribitur hydropicos)mirificé fanat, Sext. Ego uermem uiuum in lingua uel fublingua canis reperirt nullum puto, fed uel limum, ut Plin, fcribituel uenam aliquam uermis in. ftar turgentem (Tardius tumorem uermi fimilem dixit:in homine quidem ranam appellant, Graci batrachon, tumorem fub lingua, qui maximè pueros infeftet:)à quali figura in cerebro etiam meatū quendam trermiformem appellant medici.Apparet autem etiam ueteres certi nihil hac de re habuif fe, ideoç̧ alios aliter, tuermem, limum faliuæ, trel fimpliciter id quod fub litigua eft nominaffe: quof dam ueroe cadatrere canis uermem. Videtur fané hare de uerme perfuafio à urilgo fumpta, quod in bubus etiám genere quodam infaniæ, quam noftri uocantbitnmitrig, terebello iuxta cornua ada= co uermem uiuum aliquando egredi affeuerat, ut ex reduuís hominum. Iecur canis qui rabie exa gitatur, toftum, $\&$ in cibo ab emorfis fumptum, ne tententur metu aqua tueri creditur, Diofcor. He. par canis qui momordic aliqui edendum dederunt, Aegineta, \& A Auicenna. Aërius addit affatũ : Se. - xtus, coctum. Multò utiliffimè iecur eius qui in rabie momorderit, datur, fi poffic fieri, crudum man= dendum: fi minus, quoquo modo coctum, aut ius incoctis carnibus. Scio certe quordam, qui iecur af fum C.rab.fumpfere, manfiffe fuperftites, uerum non illo duntaxat ufos, fed etiam alịs deinceps me dicamentis, qua huic ueneno refiftere experientia nouimus, Quofdam uero cum foli iecori fídem adhibuiffent, poftea mortuos audiui, Galenus de Simplic.11. 9. Necantur catuliftatim in aqua, ad fe= xum eius qui momorderit, ut iecur crudum deuroretur ex ís, Plin. Lactentis catuli iecur, \& eiufdem coạgulum, Plinius Valerian quoģ, commendat. Câtuli coagulũ ex aqua propinatum, efficaciffimũ eft:quod uel femel affumptum, aqua defiderium protinus excitat, ita ut $\&$ reliqua humida uniuerfa affatim appetantur:oportet autem catulum non prouectior is atatis effe, fed nuperrimè natum $\&$ ad huc laçentem, Aëtius, TCaprificicortex contufus $\&$ ex aqua potus, Aëtius. Cafor ei drachma - cum rofacei alıbi cyatho, Galen.de antid,cap.68. Centaurium minus potum, Aëtius. Chamædrys pota,Idem. Chamæmalum, uide Leucanthemis paulò poft.

TCynorhodon. Ad canis rab. mor fum(inquit Plinius) unicum remedium oraculo qurodam nưs per repertum eft, radix fylueftris rofa, quae cynorrhoda appellatur. Et alibi, Herbas alias inuenit ca= fus, alias (ut uere dixerim)deus. Infanabilis ad hofce annos fuit rabidi canis morfus, pauorem aquar, potusíg omnis afferens odium. Nuper cuiufdã militantis in prætorio mater uidit in quiete, ut radicẽ fylueftris rofxa, quã cynorrhodon uocant, blanditã fibiafpectu pridie in frutecto, mitteret filio biben dam in lacte. In Lacetania res gerebatur, Hípaniæ proxima parte:cafuććs accidit, ut milite à morfu cạ nis incipiente aquas expauefcere, fuperuenirec epiftola orantis, ut parêret religioni:feruatusćg eft ex infperato, \& poftea quíquis auxilium fimile tentauit. Aliâs apud authores cynorrhodi una medici= to na erat, fpongiolx, qux in medijs fpinis cius nafcitur, cinere cum melle alopecias capitis expleri, Hęc Plin. Sylueftris rofaradix medetur emorfis à C.rab,allio prafertim uulneri impofito, Aquiuiuus. Huius remedij excellentia, $\mathcal{X}$ impofitum â cane nomen, diutius huic plantæ immorari me cogunt. Cynosbatus idem \& cynorrhoda, id eft canis rofa, quôdam dictus eft, quoniam flos eius rofeus fit, \& rabidi canis morfibus medeatur: $R$ ura noftra paffim eum nouerunt, maximum inter rubos omnes, 8 qualem in cunctis Diofcorides defcripfit,Marcellus Vergilius. Reprehendit eum Petrus Matthęo lus, quod diuerfas(ut iple inquit)plantas, cynosbaton \& cynorrhodon confundat, \& pro eadem ac: cipiat. Sed antequam argumenta Matthæoli proferam $\&$ refellam, cynosbati ex ueteribus de= friptionem perpendamus, Cynosbaton(inquit Diofcorides)funt qui oxyacanthan dicunt: frutex rubo lóge maior eft, arboris inftar:folia habet longé quàm myrtus latiora. Spinas in uirgis robuftas,

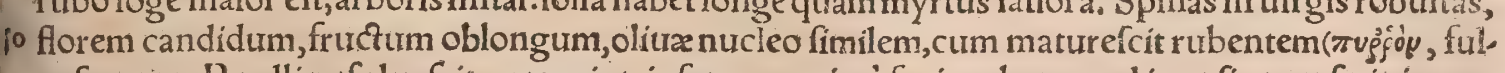
uefcentem, Ruellits: fuluefcit autem intrinfecus maximè, foris rubet:quod in rofis tum fatiuis tum fylueftribus apparet:) qui flocculos, uel quadam lanis fimilia intus continet. Altum fiftit aridus ei= us fructus in uino decoctus $\mathcal{Q}$ potus, fic ut fine interioribus lanis illis fumatur: faucibus enim $\&$ ar:

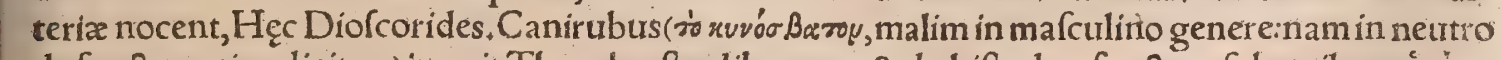

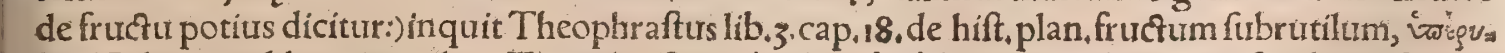

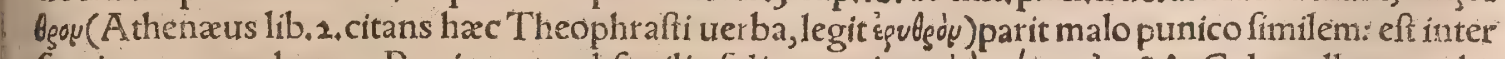

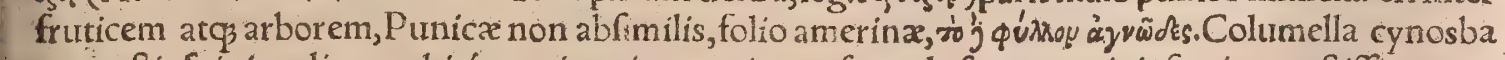
ton uaftis fpinis paliuro rubiś́s coniungit, cum in conferenda fepe præcipit femina uaftiffimarum fpinarum folo credenda effe: cuius generis etiam funt cynosbati, quos fua atas fentem canis appel - laurit, Marcel. Verg.Rubi alterum genus eft, in quo r ofa nafcitur:gignit pilulam caftanex fimilem, pracipuo remedio calculofis: Alia eft cynorrhoda, de qua proximo dicemus trolumine, Plinius li= bro 24,ca.13, Et mox cap.14. Cynosbatum, alij cynofpafton, alij ncurofpafton uocant folium habec 
ueftigio hominis fimile. Fert et uuam nigram in cuius acino neruum habet, unde neurofpaftos dic tur. Alia eft à cappari quam medicicynosbaton appellatrerunt. Huius thyrfus ad remedia iplenis \& inflationes códitus exaceto manditur. Neruus eius cum maftiche Chia commanducatus os purgat. Ruborum rofa alopecias cum axungia emendat, \&c. Caterum rofas fylueftres Theoph afus de hift plant. 6.7 feorfim nominat ac defcribit:Afperiores (inquit) tum uírgis tum folins conflat quàm fatiuæ, \& florem minus odoratum, minusḉ coloratum, nec tantũ magnitudine ferunt. Cynosbatı fruĉus (inquit Galenus libro 7.de Simplicib.)non parü aftringit, folia uero mediocriter . Itaç partio cularis eius ufus haud ignotus eft. Cauendum ab eo quod in fuctu eius lanx fpeciem habet, ceuar. teriam uitiante. Idem alibi cynosbata hulus fruticis fructus appellat, adnumerans eos alís agrèti= bus, qui ut minimum alimenti habent, ita praui funt fucci, ut cornis, moris rubi, arbuti er halicaccabi fructibus, diofpyris, \&c. Matthæolus Senenfis de rubo canino frribens, eum hodie ignotum arbitra tur, cynorrhodon uero rofam effe fylueftrem, quam Plinius ad rab.C. morfus celebrauit. Primum, in quí, li cynosbatus eadem rof fylueftri effet,nihil opus fuiffet eam pluribusà Diofcoride defcribi, fed uno uerbo rofam fylueftrem appellando fatisfeciffet lecforibus.Sed hoc argumentum leuius eft, quàm ut refelli debeat:cum $\&$ aliæ quadam fylueftres plantæ; nominibus ueniant proprüs, nec fem= per adiectione fylueitris circumfcribanturtfic fpinum pro pruno fylueftri dicimus: et ipfas fyiuea ftres rofas Germani fuo nomine, qued de fatiuis nemo diceret, bagenbutten uel banbiitrel nomina nutus: Galli efglantier. Deinde folia multum à myrti folïs differre ait, cum Diofcorides non fimplici. ter ea myr ti folÿs comparauerit, fed tantum multólatiora effe dixerit:mihi fanè quamuis ferrata, ta. menaliquo modo myrti folís fímilia uidentur, \& fimiliter per ramulos digefta, bina uidelicet è regis one. Fructus quãuis longe maior fit quàm nucleus oliux, figura tamen fimilitudo refpondet, de qua folum Diofcorides lóquitur. Plinius quidem alibi de cynorrhodo agit(quã rofam fylueftrem efle in. ter omnes conuenit:quan $\widetilde{\beta} \&$ \& lilï genus, ut poftea dicã, fic appelletur:) alsbi uero de cynosbato : fed hanc ita defcribit ut prorfus ei ignota fuiffe uideatur, 8 ipfe feipfum intricare. Sed non differre cy norrhodon à cynosbato, id eft rofam caninä à rubo canino, uel fuis uerbis ipfum aliquis conuincar. Vtrís à cane nomen:utriç̧ Plinius rofam attribuit, utrí̧̧ fpongiã ( licet in cynosbato pilulã caftae nex fumilem appellet) utriģ uim eandem in medicina contra alopecias, Nam libro 25. Aliâs apud au thores (inquit) cynorrhodi una medicina erat, fpongiol $x$, qux in mediṕs fpinis eius nafcitur, cinere cum melle alopecias capitis expleri, Libro autem 24 . Ruborum rofa (inquit)alopecias cum axungia emendat, Et quanç haecuerba ad proprie dictos rubos refert, in eo tamen errare mihi uidetur, cum hoc remedium cynorrhodo debeatur: de quo paulo ante dixerat, Alterum genus rubi eft in quo ro: fa nafcitur:gignit pilulā caftanex fimilem, pracipuo remedio calculofis. Certe rof fylueftris fpon: gia, pilula propter figurã recte dicetur, recte etiã caftanex echino fưo adhuc intectæ comparabitur. Erratigitur Hermolaus qui cynorrhodon à cynosbato non flore rofeo differre air, quẽ ferat utrũ fed fpongiolis, quas cynorrhodon habeat, cynosbatus non habeat. Galenus circa fituem cap. i* hib. Iv de compofitione fecundum locos, xuvómogơ uocem repertã in ænigmatico quodã medicamento ad alopeciã, cynosbatum exponit. A pud Diofcoridem rubum etiã proprie diêum, Grace Bodroy, cynof baton cognominari legítur: ut etiam capparin cynosbaton \& phileftaphylon. A ttribuuntur autem etiam cappari frutici apud Diofcoridem, fpina, ut rubi, in hami modum aduncæ; fructus olex fi. milis, qui cum dehifcens panditur florem candidum promit, quo excuffo, nonnihil glandis ob, longre figura inuenitur, quod a pertum grana acinis punicorum fimilia oftendit, parua, rubicunda, - Ex iftis notis multæ cynosbato etiã proprie dicto communes funt, qua Plinium uidentur intricafte. Vtcuncs,certum apud me eft, Plinium cynosbaton ignoraffe, \& quæ apud Græcos inuenerat nullo iudicio tranftuliffe. Paulo poft initium cap.14. $\mathrm{lib} .24$. Alia eft à cappari (inquit) quā medici cynosba. ton appellauerunc, huius shyrfus ad remedia fplenis $\&$ inflationes conditus ex aceto manditur. Ner uus eius cum maftiche Chía commanducatus, os purgat. Hac omnia de cappari intelligenda funtsou ius non fructus folum, fed etiã thyrfos $\&$ cauliculos ad remedia fplenis condirifcimus. Eiufdem fru.

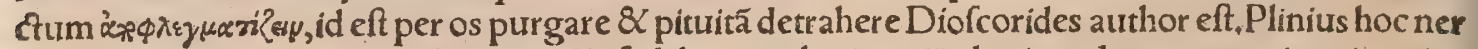
uo attribuit, cum prius non de capparis, fed de cynosbati tan $\not{\not}$ alterius plantæ neruo in acino eius contento, locutus effer. Proinde uel illa omnia ad capparin referre oportet, cui etiã uua conuenier (quã cynosbato nemo triburit) unde \& philoftaphylon Graci uocartunt, ac Plinius ipfe alibi opheofta

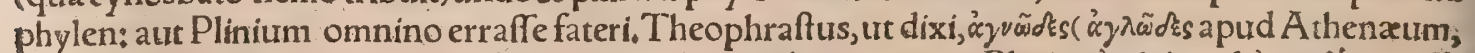

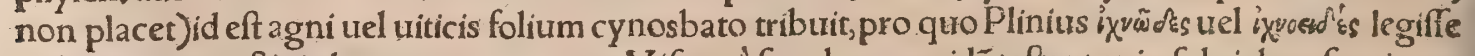
uidetur, cum ueftigio humano comparet. Vifưm à fe rubum quidă teftantur in fyltris hac fpecie, ut quafi folea effe uideretur, Hermolaus. Mihi animus inclinat mutilum effe hunc Theophrafti locum,

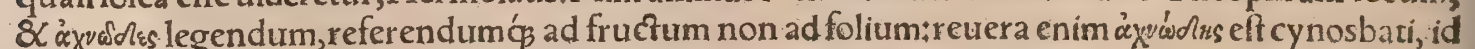

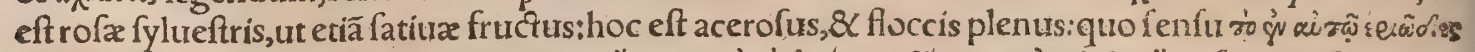

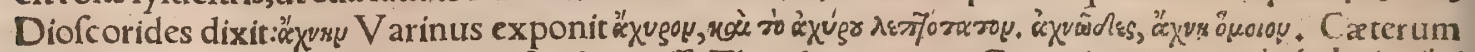

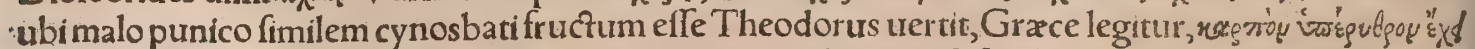

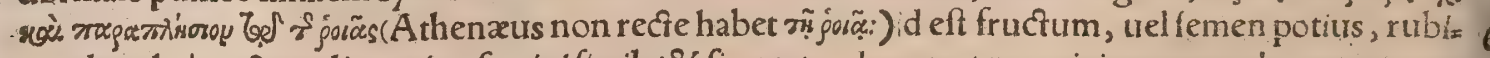
cundum habet, \& mali punicx femini fimile: $\&$ fic uertendum erat ne quis integro malo punico con ferri arbitraretur:quod ut caueret Marçellus Vergilius in alium errore ê incidit, transferendo, punicę 


\section{DeCane. G. Lib. I. 209}

eytino fimilem. Id licet quod ad rem ipfam defendi poffit:cytinus enim non folum appellatur flos fa tiua mali Punica apud Galenum libro 6, de Simplic, fed etiam prima poft Horem pomi ipfius rudi. menta; apud eundem libro 6. de compof. fecundũ loc. Theophraftus tamen omnino grana interiora fignificafte uridetur:qualicet alba fint in fructu cynosbati, fucco tamen rubente circumfunduntur, 8 magnitudine figuraós ad mali punicx grana quàm proxime accedunt: Eodem planè fenfu Dio fcorides de cappari feribit, fructum eius apertum grana acinis punicorum fimilia oftendere, partia, rubicunda, Errat $R$ uellius in hiftoria fua plantarû, circa finê capitis de rubo canis, cynosbaton ma gnitudine inter fruticem $\&$ arborem punica effe feribens: fefellit eum non bene diftincta translatio Gazx. Grace quidem clariffimé fcribitur, cynosbaton inter fruticem $8<$ arborem fimpliciter magni.

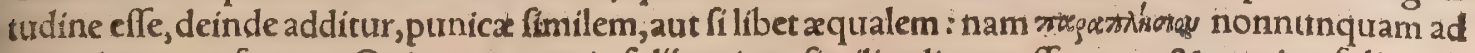
quantitatem refertur. Opinor autem in folijs etiam fimilitudinem effe: nam $8<$ punica folia, ut. pote gemina fibi oppofita \& angufta, myrto conferuntur. Capparis quamuis \& ipfa cynosbatus ap pellatur, propter fpinarum maximé fimilitudinem:longè diuerf $x$ tamen naturę eft, quàm noftra hẹe cynosbatus, nec ulla eius fpecies exiftimari debet, ut neçaconiti, quamuis hoc etiam nomen ei tri= buatur. Negg enim homonyma, id eft ea quibus idem nomen eft, ratio uero fubftantix dituerfa, ad tr. num genus referrí debent. Errat igitur duplici nomine Matthxolus, quí Pliniũ lib. 24. cap.14. duas cynosbati fpecies facere afferit, unath ueftigh humani folins, alteram folins capparis. Non enim fpeci. es duas cynosbati illic Plinius facit, fed prater cynosbaton eapparin quog fic appellari tradit:cappa ri uer ò folio fimilem, præter ipfam capparin(quam ipfam fibi fimilem effe nihil mirabimur)cynosba tum nullum facit. Sed quid opus eft pluribus?cum trel unica ifta nota, de floccis \& lanis in fructu fuf ficiat(quæ nulli alteri fructurum conuenit, quod ipfe legendo uel aliter obferuauerim) quam ur Dio fcorides folicynosbato attribuit, ita nos in folo cynorrhodo; id eft rofa fylueftri, quan ở in fatiua quo que, reperimus. Quod autem illi arteriam infeftent, faxpe periculo meo ipfe didici. Horum caufa for:

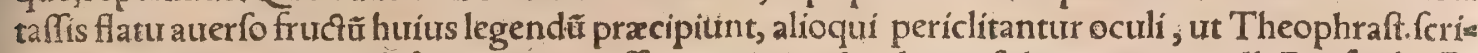
bit in hift. plant,9.9. Sed defcriptione omiffa uires in medendo confideremus:quas illi Diofc, $82 \mathrm{G}$; lenus aftringêdi ac aluum fiftendi tribuũt. At tui rofas fylueftres noftras cum alịs partibus, id ćs ma: gis कु fatiuas, tum præcipue fructu, ficcare, aftringere, fiftere, a pud omnes hodie in confeffo eft, \& gur ftus ipfe manifeftò oftendit. Nô eft autem quòd miremur quo pacto ưalidè aftringentia uenenis rế. frant,cum $\&$ alia nó pauca riufdẽ generis habeamus, ut pentaphyllon,tormentillä, terrã Lemniam, chalcanthum, \& c, fiute tota fubftãtia id agã̂t, fiue quia partes corporis roborãt, ita ut \& promptius ue nenũ repellãr, \& meatibus claufis minus ab eo afficiãrur. Hieronymus Tragus etiã dupliciter errat, primum $q$ cynosbatonà cynorrhodo feparat: deinde $\phi$ fpı̃ñ fepibus noftris uulgarem, quã pleriç hodie fpinã albam uocāt, cynosbató facit. In qua tamẽ, ut reliqua taceã, aculeorum f pecies ipfum dỏ cere poterat, cynosbati nomẽ ei nổ cóuenire:baton enim Græci rubưm appellât, fruticem uulgò no riflimum, cui aduncæ $\&$ hamatæ funt fpinæ:à quarũ fimilitudine nō in fruticũ genere folum plãtas diuerfas cynesbati, id eft rubi canini nomine uocauerüt Graci, ut cynorrhodon, capparin, rubuti ip fum, fmilacem afperã, cui rubi urel paliuri fpinas effé Diofcorides teftaț: ${ }^{2}$ inter animalia etiã baton

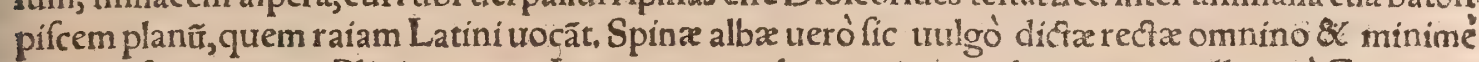
aduncæ fpin rigent. Plinius 24.14. Inter genera ruborum, inquit, rhamnos appellatur à Græcis, $\mathrm{ra}$ - mos fpargens reçtis aculeis, nố ut cæeteri aduncis:proximé autê de rubo prituatim dicto, \& cynosba= to locutus erat,ut uel inde côftet neutri illorû rectos effe aculeos, Rhamnũ certe Græci bati, id eft rubi generibus nó ad numerant.Plinio tamē uiro Latinæ \& patriæ lingux doctífímo, in fua língua

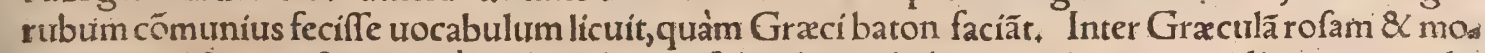
fcheuton diçã, qux fundítur è caule maluaceo, folia oleacea habens, media magnitudine autumnaks eft, quã coroneolam uocãt:omnes fine odore præeter coroneolã $\&$ in rubo natã, Plín. 21,4. Cum igit fua in rubo rofa fit, quid obftat quin illam nunc à rubo cynosbató, nunc à rofa cynorrhodon appelle mus, nulla interim rei ipfitis differentią Apparet etiã ex his Pliní uerbis rofam in rubo odor atã ef fe:quiod ideó dico ne quis imperite pro rubi rofa proprie dichi rubi flores accipiat; quod ipfe Plinius in remedijs ex rubo fecit, ut fupra dixi.Maxime aũt odoratum eft rof fylueftris genus montanũ, $\delta x$ - cateris minus, nó floribus tantum, fed frutice toto, noftri ob furauitatẽ odoris uinariã appellant: quã cum femel \& iterũ in horto plantaffem, ftatim degenerauit, 80 omnem qua prius undigh, folís maxi= me, fuauitate odoris fpirabat, exuit. Herm. Barbarus in proximè recitatis Plinñ uerbis legit, prater coroneolã in rubo natã, fine copulatiua coniunctione quã noftri codices habent, quos ego magis pi bo. Nouimus enim cynosbatum $\&$ rofam in rubo nafcente, quar tamen autumno apud nos quidem non floret: nifi raro fortaffis:nam $\&$ fatiuas interdũ autumno florere uidimus. Ad hæec cum alıbi etiã cynosbatum $\&$ rofam in rubo defcribat, coroneolam tamen uocari nufö meminit. Hermolaum $\&$ hac in re \& alijs omnibus ubi de cynosbato feribit fecutus eft $[0$. Ruellius: Idem, Coroneola (inquit) in rubo nata, iucundi odoris eft, fed angufti, R ofa uineæ uocatur flos fpinæa albæ, Syluaticus. Irinc er randi forte occafio nata quiburdã, ut f pinã albam cynosbatum facerent. Idem Syluaticus cifthum rò - fam caniná trocat, $\&$ aliã eius fpeciem (ledon forte)rofaginem. Recentiores(inquit R urellius)tum rom faginem tum rofam caninam uocant, fruticem thymo maiorem: folins ocymi,rotundioribus, flore ma li punica:flos mafculo rofaceus eft,forminæalbicans, Ego in fummis alpibus circa faxa odoratum 
fruticem, prorfus lignofum, humilem, \& copiofum ubi nafcitur :folips oleæ, pinguibus, duris, \& ruffis parte fupina:flore mali $P$ unicæ rofeo fape reperi, quam Heluetr etiam in alpibus roffterut (fi recte memini ) appellant,Sed rhododendron qquoqs in Gallia rofaginem uocari Ruel. meminit. बIQui dam fentem canis non recte pro uulgari rubo accipiunt. Cynacanthan in lexico Ambr. Calepini pro oxyacantha imperitiffime fcribi \& exponi reperio. Stephanis agria apud Aëtium corruptè legi tur pro ftaphifagria ad uitia pforas ć çapitis:nifi quis ftephanida putârit efle, quã à noftris coroneo:

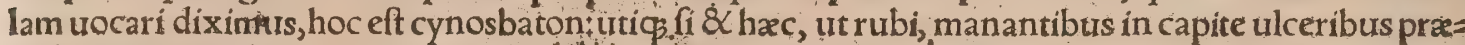
fidio effe poteft, Hermolaus in Staphidèn agrilam Diofcoridis. Phyfcius Locrus Amphictyonis filius, cum forte inter eum \& parentem obortum effet diffidium, multis ciuium acceptis de fedibus fta

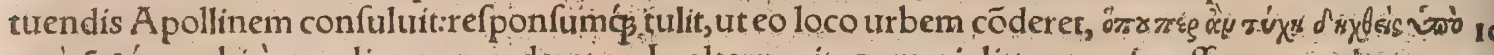

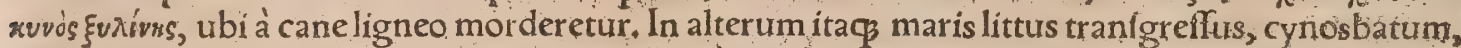
id eft caninum rubum pede compreflit:uexatus ós plufculos dies ulcere, eo loco ubi or aculium iuffe.

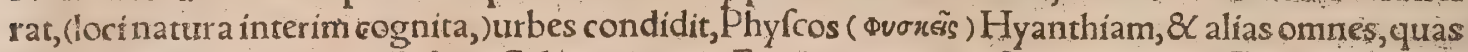
Locri Ozolæx coluerunt, Calius Calcagninus in Equitatione ; tranftulit autem ex Graccanicis Pltio tarchi, problemate 15. Errat autem ab initio:fic enim uertendum uidetur, Amphictyon filium habuit Phyfcium, is Locrum, Locrus Cabyen Locrum:quo cum orto diffidio, pater multis ciuium affum. ptis, \&x.Meminit etiam Athenæus libro 2, \& Calius R hod. 17.28. Canem ligneam Theophraftus cy nosbatum u,ocat, $V$ arinus. Illud fere præterierã quod fupra iam diçum oportuerat, quo fententia noftra cynorihodon non aliä à cynosbato effe, uelmaximé confirmat, ex eodem Varino: apud quẽ

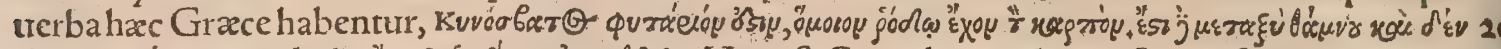

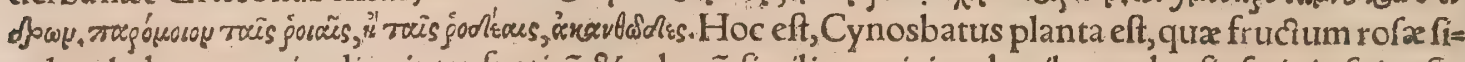
milem habet:magnitudine inter frutice $\&$ arborê;: fimilis punicis arboribus uel rofis fatiuis, Et paulo ante nomẽ et à cane impolitum foripferat, propter afperitatẽ \& fpinas, quibus ita uidelicet

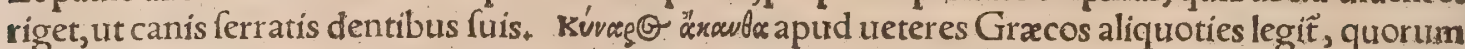

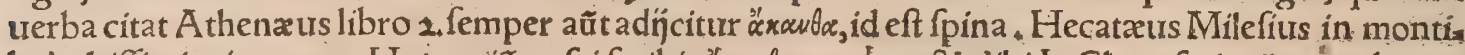

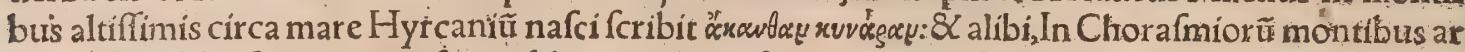
bores funt fylueftres, cynarà fpina, falix, myrica:nafcitur etiã circa Indum fluuium cynara. Et Scy" lax uelPolemon, In montibuis(inquit)proueniunt cynara, \& alix herbæ , Cęterum Didymus gram

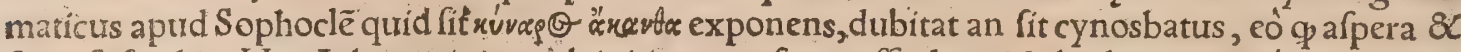

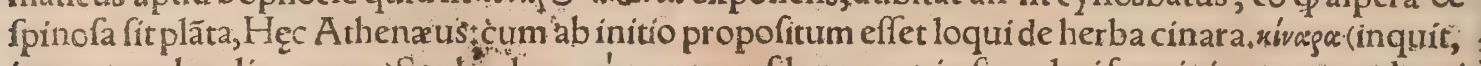
in neutro plurali numero) Sophöcles xuv'égeu per ypfilon uocat, in fingulari foeminino:quo modo eti am ipfe paulo poft per iôta fcribit uıvéscy, $\&$ eandem effe putat herbam qux carduus Romæ uocata fit, \& in Sicilia cactus:quan $\&$ caules eius cactos uocarent cibo idoneos, ut aliũ eiufdem caulem

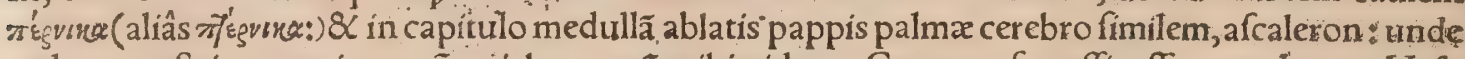
uulgare noftri temporis nome artichau natû́ mihi uidetur. Cynaron fortaffis effe cynosbaton, Hefy

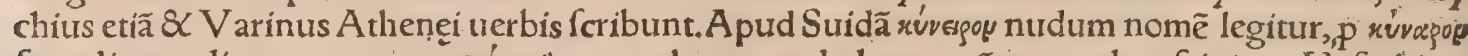
forte, licet ordine repugnante, Kúvadla, cynosba tum, uel planta quã capras depafci aiunt, Hefychius:

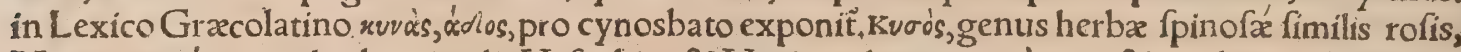

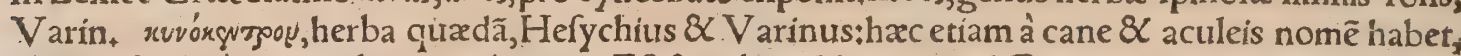
ut non alia quàm cynosbatus uideatur. Eft $\&$ rubens lilium, quod Græcicrinon uocât: alị florem eius cynorrhodon: Iaudatiffimum in Antiochia $\&$ Laodicea Syria, mox in Phafelide, Plin. Cynoro dón lifium eft hyacin tho fimile, Hefychius $\& V$ arinus. Eft et rubens liliũ, fatis apud nes frequens; dif ferens à purpureo: florem lilij nafcêtis in Italia cynorrhodon uocari Plinius eft author:quod \& Hip pocrates accepit, cum rubentia cynorrhoda forminarũ purgationibus commẽdat in uino, Ruellitiss. Ego cynoforchin hyacintho propiorem putauerim, flore purpureo, radicis bulbo gemino, qua al uum fiftit è uino pota:qua facultate etiam menfes fiftere poffe uidetur.

GEllebori \& elleborifmi uim fupra in curandi ratione ex Diofcoride docuí.

Gallinæ cerebellum potum cum aliquo liquore, Galenus in Parabilib. Ne morfi à rabiofo cane rabidi fiant, cerebello gallinaceo occurritur:fed id deuoratum anno tantũ eo prodeft, Plinius. Gentiana proprietate quadam itiuat pota $\&$ applicata, Auicenna, \& Serapio fecundum Habyx Quidã folius gentianæo obolos tres in tribus aut paulo amplius meri cyathis per dies duos \& triginti propinant, Galenus libro fecundo de antid.in uerfibus $D$ amocratis: \& in fine corundem cap, ni, fi. militer, fuccus autem(inquit)radici præetat. V fum certe eius præiftantiffimum effe, ex nobiliffima omnium è cancris antidoto, qưam fupra defcripfimus, facile eft conijcere.

बHelleborus, uide Ellebortrs. "Hinnuli $(v \varepsilon \beta \tilde{\gamma})$ coagulum bibendum, Damocrates apud Galez num libro fecundo de antid. Hippocampus marinus toftus, utiliter comedi proditur à rab.C. mor fis: quòd eius fanguis aquæ amorem inducat, \& propria quadam ui pauori aquæ refiftat; $Q$ uramob. rem bis ac ter hippocampum comedi cogunt:eundeníćpx acerrimo,aceto tritum uulneri applicãt, rabiemós hoc medicamento frequenter peruicerunt, $A$ étius. Hippofelinum, id eft olufatrum potum 8 illtum, Plinius. Hirundinis fimus illitus tuel potus, Ponzettus. Hirci iecur mature fumptum; 66 Ponzertus: Vide paulo fupra in A pri iecore. Hyana carnes in cibo, ut magi fcribunt, Plinius.

ILapathum tum acidum, tum agrefte, ut fupra explicauri in ratione curandi ex Ačtio, Lapathis 
bus cum Deo opem feret. Potiones quæcunģ cótra ứperarũ morfus defcriptæa å nobis funt, adtier fus rab.C. morfus etiã efficaces erunt, Damocrates apud Galenum lib.2, de antid. Morlis à croco: dilo conueniũt eadem remedia quæ ad morfos à cane ac ad reliquos relata funt; $A$ étius. Emplaftra ad demor fos à cane urel urfo aut fimilibus animalibus ftatim à principio commodè adhibentur ex fa. le 8 ceruffa apparata, $8 \mathrm{c}$. Idem. Et rurfus, Omnia ferè qux ad canis morfum dicia funt, eviam à fele morfis conducunt. Erit praterea, quod nemo ante nos monuit, non mediocris occafio ab hac curan diratione propter affectus $\&$ fymptomatum ac periculi fimilitudine $\tilde{e}$, ad febrim peftilentem eiusćs ul cera curanda tr anfeundi:Quod eruditi medici facile animaduertent:nobis ad fequentia properan

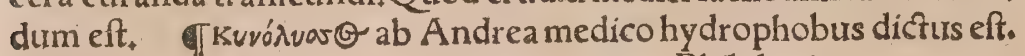

H. Philologia.

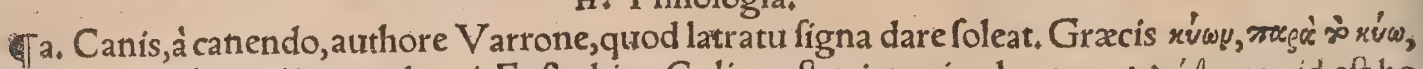
quod amare nobis indicat, ut docuit Euftathius, Calius; eft enim animal natura $\phi i \lambda \alpha^{\prime} \theta \rho \omega \omega r 0 y$, id eft ho minis amans, Varinus, Dubí generis eft apud Græcos pariter $\&$ Latinos, ita ut hos uel has canes uz

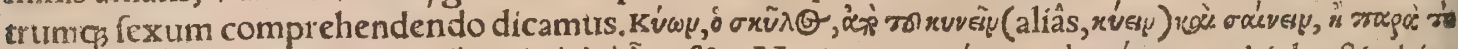

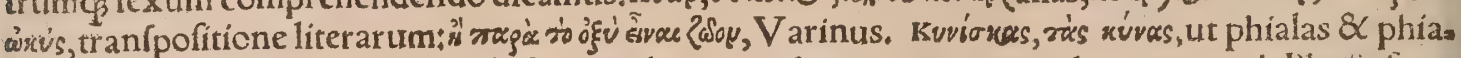
lifeas dicimus, Suidas, Varin. Noftri pecultari uoce be 5 in cane uocando uruntur, ab lilyrijs forte fumpta qui canem pes appellant. Naworg $\&$ axácuacu pro cane apud $V$ arinum leg! mus: pofterius etiā

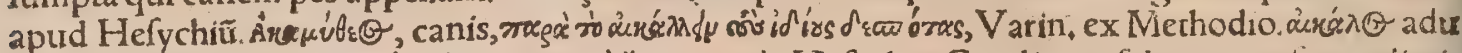

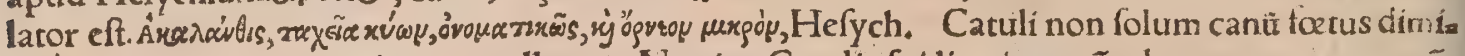
tiué,uerum omniữ animalium appellantur, Nonius: Catuli afpidis, uiperarũ , draconum, iacertarũ̃, fimia, tigridis, uulpium, muriũ, Plinio:ferpentis, Vergilio Georg. 3. leonis, Claudiano \& Vergulio, Egocum de canibus intelliguntur, abfolute poni puto, de cateris non nifi cum additione. Caturum canis Varro lib.4 de lingua Lat, dictum ait à fagaci fenfu $\&$ acuto. Sic canibus catulos fimiles, $f_{\text {c }}$ ma tribus hodos, Vergil. Chryfippus omnia in perfectis $\&$ maturis docet effe meliora, ut in equo o equulo, in cane ${ }^{\beta}$ in catulo, in uiro quàm in puero, Cicero. Graci plura habent uocabula : icy aces (inquit Varinus ex Polluce)catulicanum \& luporû dicuntur. A fcylace diminutriuũ fit f́llacion,ca

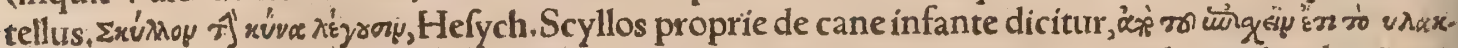

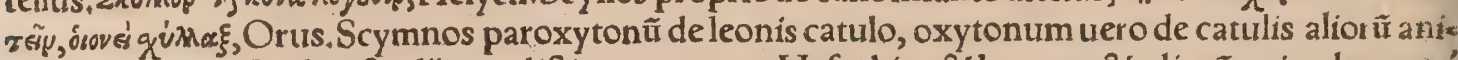
malium, Etymol.Polluxx \& alị non diftinguunt:nam Hefychíus $\&$ leonum $\&$ aliorũ animalium orú $\mu$ rrs paroxy tona dictione uocat: de canibus neutrũ inueniri puto. Catuli animalium illorũ quar pro. prium nomen non habent, fcylacia uel (cymnia dicunî, Pollux. Catellum Græci etiã cynidion \& cy narion uocãt, Varinus, Suid, non folum aũt ætate exiguos fic uocãt, qui proprie fcylaces dicuntur,

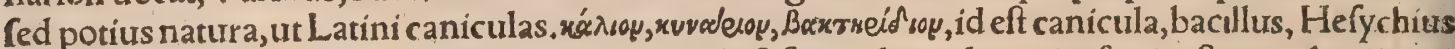
\& Varin. ego pro cynarion malim fchœnarion, id eft funiculus:calos enim funis eft, ut calon lign $\tilde{u}$, Tantillum lóci ubi catellus cubet, id mihi fat eft loci, Plautus in Sticho. Os \& labra tibi lingit Ma*

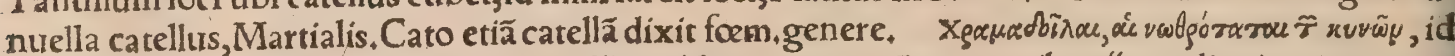
eft ignauiffimi canes:aliqui teftudines, aln̈ cochleas interpretãtur(omnibus îjs tarditatis nota conue

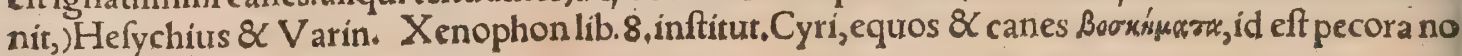
minat: $\&$ Gratius poeta, pecuaria.

Epitheta. Acer, Horat.Epod.12. Nec naribus acres Ire canes, Ouid, Amarus. Atrox. Ar= guti, Seneca in Hippolyt.id eft fonantes, Scindent auidi perfida corda canes, Ouid.in Ibin. Au= dax. Auritus. Blandi, Verg. Georg.3. Celeres, Ouid.Epift.4.8\%. Citi,Idem Epift.5. Clamoa fus, Emeriti,Stat,3:Syluarû. Ferus, Fidus. Fideles catuli, Horat, I, Carm. Acron exponit faga: ces, uel filentiũ inueftigãdo feruãtes. Horrendus. Horrifonus. Hirfutus. leituna,Horat. Epod, 5. Immanis. Immitis. Infeftus. Męnalius, Mordax. Ob́coeni, Verg, I. Georg. Obefus lacte, Claud,in Eutrop. Odori,Claud,2, de raptu Profer. Odorifequits, Pernix canis pecuarius, Colut mel. Peruigil,Senec, in Herc.fur. Properus. Rabidi,Sene.in Oedipo. Rabiofa, Horat. 2. Epift. Aut rapidis canibus fuccinctas femimarinis Corporibus Scyllas, Lucret. lib. 5. Raucus, Sagax.

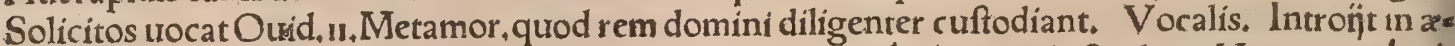
des ater alienus canis, Terent. Phorm. TEpitheta Graca, Ägrimoots, id eft celeres Homero. Ágyoi, celeres uel albi, Varin. Aiunt autem albos, ut quorum corpora molliora rarioráç fint prius pefte in

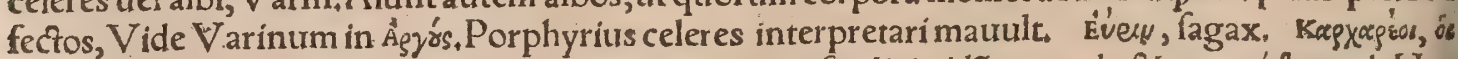

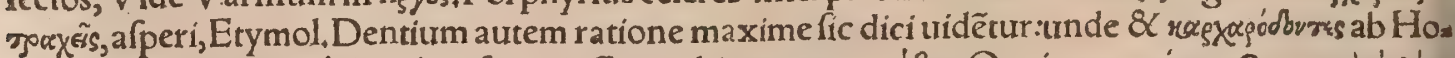

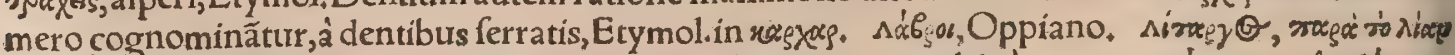

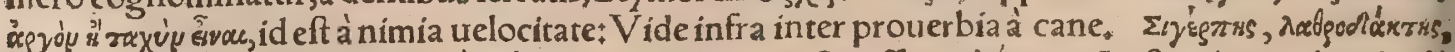

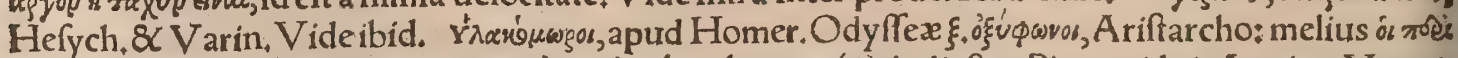

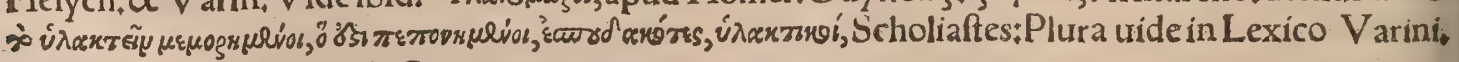

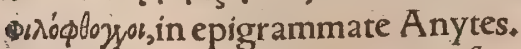

T Veneti paffim Patarinum frigus, nec non hominem canem Patarinum, fumma eius iniuria ap pellant,Nic.Erythraus. Canis uerbum eft, quo impudentibus inimicis conuicium fierifoler. Nam militare dictum eft in hoftem canis: $\&$ apud Homerum prograui contumelia in aduerfarium dicit.

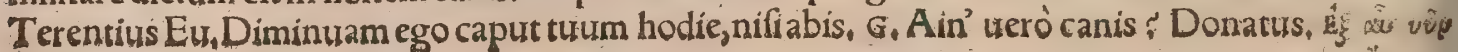




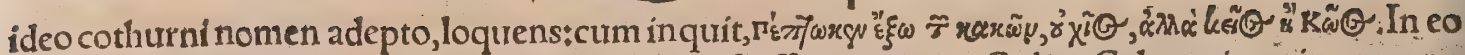
enim bella eft allufio, quod Theramenem Chium fuiffe accepimus; Calius Calcagninus in commen tario de talis;in quo præter cætera alium effe Galeni aftragalum inter os tibiæ $\&$ calcaneum often. dit, alium item Ariftotelis: \& paulo ante recitatum Ariftotel is locum Gręce \& Latine interprete Ga $z a$, diligenter examinat ac emendat. In talo figura in cadendo uicem habebat numeri. Monada figni ficans rocabatur canis, Perfio canicula:Quid dexter fenio ferret, Scire erat in uoto, damnofa cani. cula quantum Raderet. Semper damnólifubfiluêrecanes, Propertius. Damnofi faciro ftent tibi fape canes, Ouidius li, 2. De Arte. Vide Erafmum in proucrbio Chits ad Coum, Onos, id eft afinus, unitas eft in cubis uel tefferis, ut in talis cyon, Pollux. A pudV arinum tamen in k'vep legimus chium

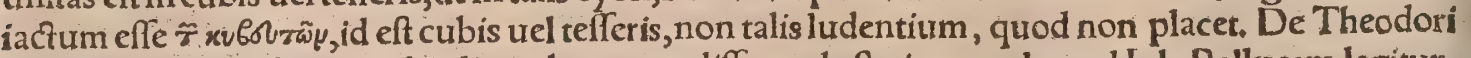
translatione quid fentiam alio dicam loco:non differendoftatim quod apud Iul. Pollucem legitur, qui non colon nec if chion in talo: fed coon \& chion uocari tradit, ut cous iactus idem fir qui fenio: \& chius idem, qui $\&$ canis. Alij tamen pauci(ut idem author eft)canem pro monade accipiunt: chium

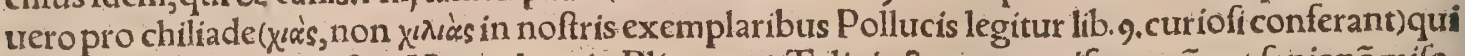

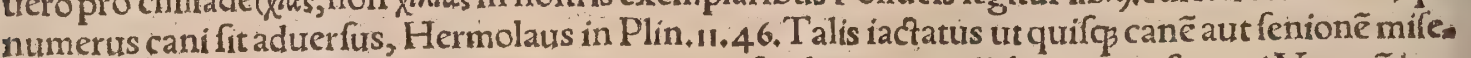
rat, in fingulos talos fingulos denarios in mediũ cöferebat:quos tollebat uniuerfos, qui Venerẽ iece

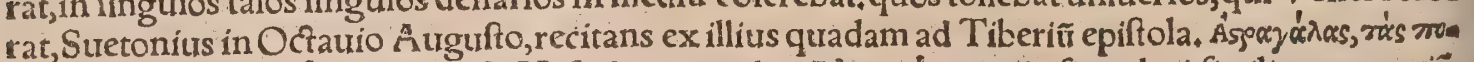

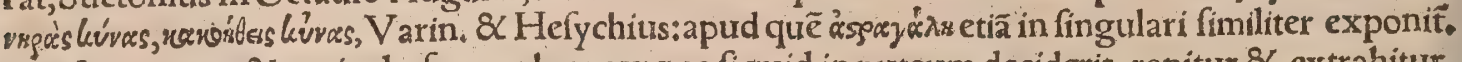
बLupus, qui \& canicula, ferreus harpax:quo fi quid in puteum deciderit, rapitur \& extrahitur,

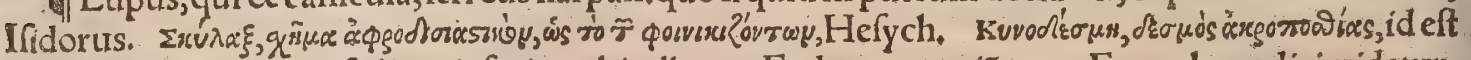
uinculư præputî́:pars fcilicet inferior, ubi adharet. Eadem pars etiã cyon Etymologo dici uidetur,

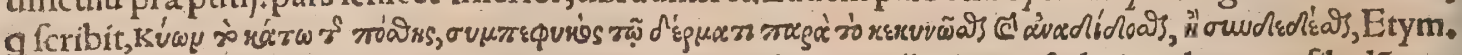
At Pollux li,2 cynodefmion interpretari uidetur, nó præputī partem, fed uinculum aut fibulã qua

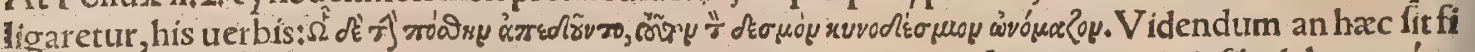
bula illa Cor. Celfi 7.25 . qua adolefcentes uocis aut ualetudinis caufa in praputio infibulabant. Kuvy

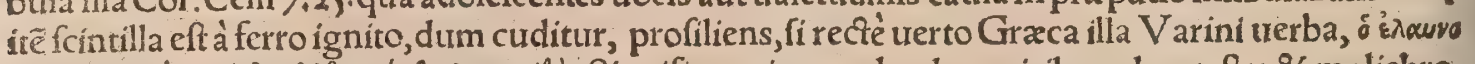

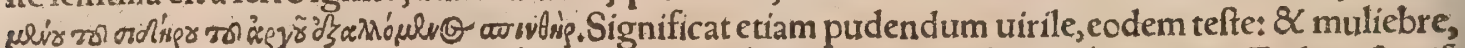

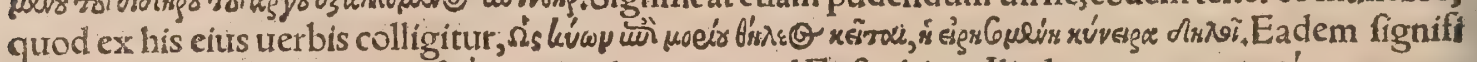

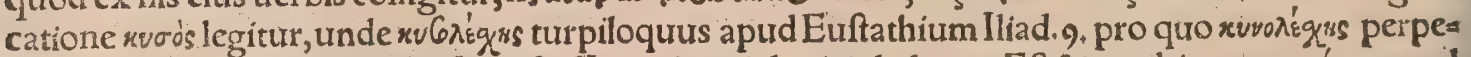
ram, ut puto, in Græcis quibufdam \& Græcolatinis lexicis habetur. Eft \& morbi genus xvey apud Varinum, quod quale fit non explicat:fuerit aŭt fortaffis cynanche, Item uinculum quo canum cer uices muniuntur, de quo pluribus dicam quinta parte huius capitis, Kúves, pars ungula equi, cla

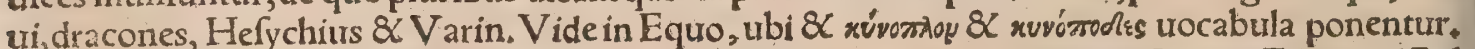
Equos quordam minus probandos cynepodas fuiffe nuncupatos inuenimus, Calius. Ego apudPol

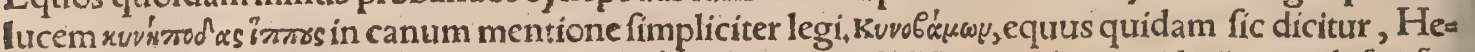

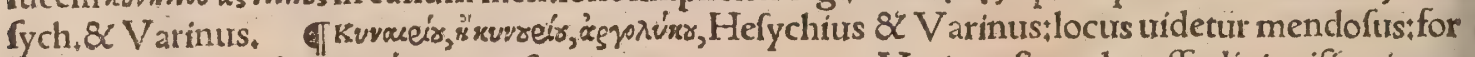

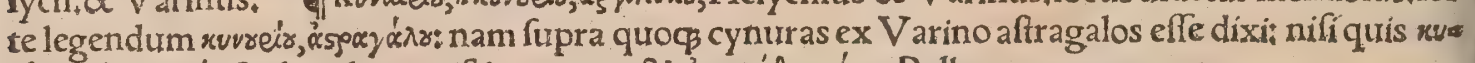

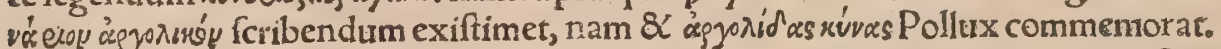

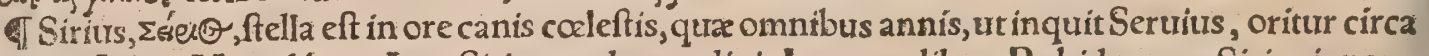
calendas Iulias, Verg. lib, 10, A en. Sirium ardorem dixit.Lucanus lib. 10. Rabidus qua Sirius ignes Excrit. Vide Onomafticon noftrum, Etymologicon, Hyginium, A ratum, \& alios aftronomos. Siriü Cato uocat catulum, Canicula ftella, qua $\&$ Sirius dicitur, in medio centro coeli $:$ ad quam quum Sol peruenerit, duplicatur xeftus, et nimio calore languent mor talium corpora:à qua dies caniculares uo cati: Vide Plinium 18,28.8 lib, 2.cap+27, \& $44^{\circ}$ Cicero, de Ditrin. Vt enim Ceos accepimus ortü C2 niculæ diligenter quotannis folere feruare, conieçuramós capere, ut foribit Ponticus Heraclides, $\Gamma_{a}$ lubrís ne an peltilens annus futurus fit. Vnde ab aftronomis uocãtur dies Caniculares, ab ortu ad oc cafum Canicula, quos periculofos effe aiunt. Sunt autem maximé circa triginta dies polt folftitium

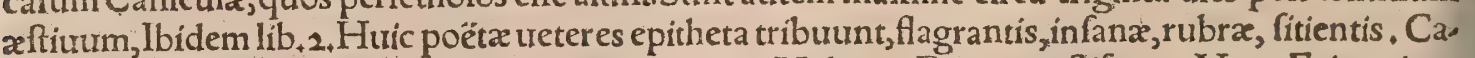
nem æfturum Tibullus dixit, acrem autumni canem Valerius Flaccus: æftiferum Verg. Erigonium \& Icarium Ouidius:Canis fydus inuifum agricolis Horatius. Plutarchus caniculares dies to

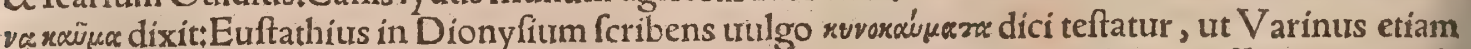
in xúwy, propter xftus illo tempore immodicos.Quamobrem, inquit, poeta Sirium effe ait malum fignum, Omultas inferre febrès inflammato aëre, Poetæe canem Orionis interdum cognominant, In fa bulis enim eft Orionem optimum uenatorem defunctum fyderibus adiunctum effe, \& fimul canem

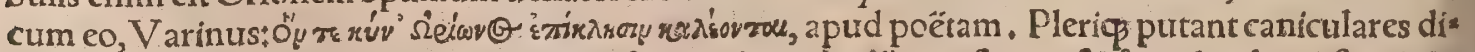
es caprifici dies efle, Gyraldus, Icarñ canis filiz cadauer lcarifi monftrauit: \& ficredendum eft poètís, hic Sirius eft, Pollux lib. 5. A cane fydereo, quen aftrocynon dicunt Gręci,at folechyn A egyptī, Cy nicum comperio annũ appellari, qui annis compleatur mille quadringentis fexaginta : Vifitation porrò id fydus facere quadriennio interiecto, Calius. De honoribus \& facrifič̉s cantum canicula fy deri exhibitis, infra dicam parte 8.huius capitis. Arctos, id eft urfas coe!eftes frribit Theon appel

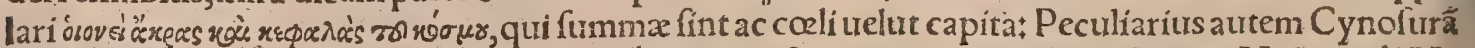

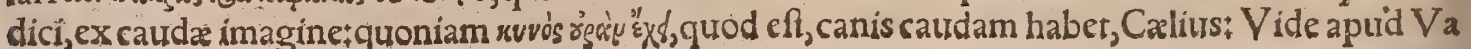


poft, Diofcorides unó genere contentus eft, recentiores duo ftatuerunt faftigia. Vnurm calamo exill \& longo, in cuius fipica continetur fermen pulicis colore $\&$ mägnitudine: alterum farmentofum , flo: ribus canino capiti fimilibus, fabaceis capitellis, femine pulićis effigie, radice tenui $\mathcal{Q}$ fuperuacua Accedit nominibus res ipfa, quod pfyllium quo 3 fpicatum cernitur : nec aliter nominatum TheO= phrafto reperitur.Itaç nihil apud me dubĭ reliquữ eft, quin Theiophrafticynops pfyllium fit: quod \&6 Pliniunt ignoraffe uideo, $\propto$ Theophrafti interpretem Gazam:imò (quod eruditorum pace dixez rimi)quicung frripferunt hactenus omnes, Obij ciat aliquis cynopem olus effe ex Hermolai uerbis: dicam illum de fuo hoc addidiffe. Theophraftus enim eo in loco, unide eius tierba Hermolaus citat, non folum de oleribus, fed ís omnibus qux in aruis nafcuntur, aruræa trocat, tractare inftituit: at pyllium quooģ in aruis terrenisć̣́(aliấs incultis)nafcitur, ut Ruellins ex. Diofcoride tranftulit. Ad. monendi tamen fumus, inquit Hermolaus in Plinitum 21,17, in Theophraftolegí quandog, conopa, quafi culicemtrion cynopa: $Q$ fanè culex nomen eft herbx Plinio, Hxcille.Plinius certe ficonopem apud Theophraftum in locis iam citatis legit,prorfus errauit:culicis quidē herbar femel $\&$ uno dun taxat uérbo meminit, ut fupra diçum eft, de macerädis in ea trita cucumeris feminibus. Cum igitur alia fit canaria Pliniñ quàm Theophrafti cynops, melitts fecit Gaza ubi cynopern ocultum caninum reddidit, quàm ubi canariam. Grammatici quidam anemonem quiogs kvvoxeqdidacove interpretantur. Antirrhinon A puleius cynocephalion \& cerebrum canis cognominat. Magi anethum cyniocephali genituram aiut capillos uocant, ut inter nomenclaturas apud Diofcorídem legitur. Cynia tion eft ea quam Theodorus canariam interpretatus eft, ut in culice docuimus, Hermolaus in Cor ollario, Nos de cynia illa Diofcoridis, qux \& cynocrambe uocatur, fatis prolixé fupra differúnimisis. Cæatèrum Pli nif canariam, quam ex foenigenere effe dixi, Ruellius his uerbis deferibit.Canaria (inquit) humilis eft herbula, folijs tritici, multo minoribus, calamulo tenui, geniculis pyxidatim cohærentibus articu lato, internodihs modo tibiarum in fe infar ĉtis, qua tracta fuis à uaginulis exeruntur, euanida fpica loco panicula, ita ut fohio \&x culmo triticum, cacumine arundinem æmuletur.Noftrates(Galli) herbã canis appellitant, quia guftata canés praféntaneam eliciunt tiomitionem, fic ut excuffo rurfum uen. tris onere, uorandi moliantur auiditatem, Hrec Ruelliứs. Idem alibi, Gramen(inquit) in officinis no men feruautit,rura dentem canis $\&$ olitores appellant. Vulgaris eft herba, nunquam fe ab humo at tollens, flagellis teretibus, articulatis, exxilibus folihs, \& in acurmén faftigiatis, radice etiam genicula= ta , gufftion non ingrata dulcedinis:Gramen aculeatum rirra noftra etiam canarium dentem appellẩ, aliquié uuulgo capriolam, quod capris grato fit pabuloł̣mtilti ab effectu fanguinariam, \&c. HęcR urel lius. Ego aliquando fúficatus furm canariam non cèrtum graminis genus effé, néc peculiari alligiua ui ad uomitum ciendum pollere:fed quoduis genus foenià cane tror atum, \& non bene commańfum (pracipue fi aut folia duriufcula, aut fpicam afperiorem habeat)faucés $\&$ gulam ftímulando nion $a=$ liter uomitum facere, quàm in homine digitus aut penna uel aliud quidpiam ficcirm (ut liniteolum) paulo profundius immiffum: prafertim cum neminem certi aliquid hac in re obferuaffe uiderem: 86 ueteres herbæa illius nullum nomen pofuiffe. Vide fupra dẻ Cane in $c$, in mentione uomitus canis, Nos fape canes per lufum etiam gramen obuium decerpere $Q \mathrm{C}$ mandere uidimus, Aliqui feles quo que detrorato gramine uomuiffe fibi obferuatum aiunt. Hyofcyamum Latini caniculatam uocât, Macer $\&$ Syluaticus:qui canicularem quog, dici meminit:nominis caufa forte eft odor qualis catulorum laćtentitum; cui fimilis ferè in cynogloffo etiam percipitur. Genus allí quod in aruis fponte. nafcítur, caninum à noftra gente diçum, ampeloprafum uidetur:canini autem nomen additum in conuicium uirofiodoris puto:defcribitur ab Hieron. Trago Tomo 2,cap.71, quanquam figuram ei= us pracedente capite appofiverit. Eodem capite 7 r.allitum caninum minus appellat, bulbi fylueftris quoddam genus, quod initio A prilis pulcherrimos flores coeruleos in pratis profert, unde in hortos etiam transferri cơpit $t_{s}$ folís paruis porraceis: ftofculis cauis $\&$ fpecie fimillimis lilif conuallium, ut uocant, floribus:proinde eodem nomine, addita corulei coloris differentia, à noftris nominatür b̆lø we meienry Ble. Iple hyacin thi fpeciem facit, quod \& etfi improbare poffum, in prafentia omittam. Violas Martias fylueftres coeruleas, quarum flores maiufculi fed parum odorati funt, Germani quil dam caninas urocitant, Tragus. Rubum minorem, curi odorata et rubéntia mora funt, noftri nominã̃e

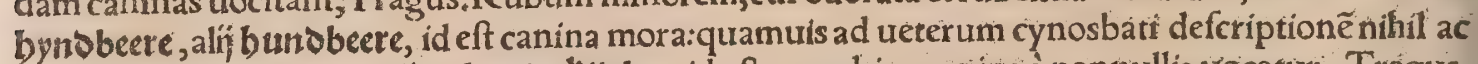
cedant, Bryonia feu uitis alba, bundskiurbs, id eft cucurbita canina a nonnullis ưocatur, Trágus. Syluaticus uitem canis faxifragam interpretatur. Squtillam aliqui cepam caninam dícunts alị̂ cepã muris, quòd mures interimat, Vetus expofitio uocabulorum Auicennax, Cepe caniis, uel aratillus, uel cepe fylueftre, Grace azit(uide ne ab hyacintho corrtiptum fit nomen) bulbum habet parưum, foris rubentem, intus album, folís croci, uenenofum, nutlitus in medicina ufus, $\&$ ideo non defcrip. tum authoribus, Syluaticus, Bulborum fylueftrium generis eft, \& forte Plinn̈ bulbina : cui fimiliter bulbus radicis rubet, intus candidus:abfog fquamis. Flos in fpicis uiọlaceus urel ferrugineus: Femen nigrum. Huius funt generis Fuchfif duo priores hyacinthi.Euafdalbiar, id eft bulbus caninus, V.es tus expofitio in Aurcennam. Gurardalbia, bubulcus (lego bulbus canininus)Syluaticus. Romani manis dragoram uocant caninum malum, ut legimus inter nomenclaturas apud Diofcoridem. Zinzibil " atchel, zinziber caninum, herba nota eft, fimilis hydropiperi, folís falicis(kalef)pallidioribus( magis citrinis) ramulis rubentibus; fapore zinziberisicanes occidit. Calidum eft in fectundo ordine, ficcum 


\section{DeCanc. H. Lib. I. 217}

in primo. Recens contritum cum femine abftergit maculas faciei, \& pannum, \& lentigines inireteratas:ac fimiliter impofitum abfeffus duros refoluit, Auicenna libro 2, tract.2, cap. 746 , in uectex exa pofitione Auicenna dictionum, fimiliter defcribitur zinziber Carmenum (uoce proculdubio cor rupta procaninum ) addit etiam auther credere fe perficariam effe. Aggregator quoq a nonnullis perficariă exponi ait, Nafcitur apud nos in montanis \& fylueftribus locis; iuxta riuos feré, herba ad hominis proceritatem; floribus purpureis, folijs falicis: flores filiquarum rudimentis prafixi harent: filiqux trium ferè digitorum longitudine floccis fiuc lanis albis plenæe funt, floret particulatim, caut. des $\&$ ramuli rubent:Ä nullo, quod fciam, qui noftro feculo plantarim hiftoriam cxcoluêre, defer pta. Ego propter elegantiam in hortum tranfuli, ubi uiuax iam áliquot annis uiret: hyeme fuperfia o ciem onnem faluís radicibus amittit, guftu acris eft:propter totam deniq̧ fpeciem rhododaphne mi nor appellari poffet, ni fallor. Aut hæc, aut perficaria uulgo dicta, Auicennæz zinziber caninum uia detur, Sed potius crediderim perficariam effe, 8 Diofcoridis hydropiper:quoniam id fimiliter cum femine illitum, tumores ac inueteratas durities difcutere ait, \& fuggillata abftergeré. Dé apocyno ftirpe tum proprie fic dicta, tum cognomine braffica ruftica, fupra fat copiofe docui. Eft $\&$ a pocynô officulum, in phryni feu rubeta aut buffonis latere compertum finiftro : quoniam canum impetus inhibeat, Calius ex Plinio. Caterum apocinon faltationis genus apud comicos fcriptura difingui tur; Hermolaus, Cynanchon etiam uel cynanchen apocynon dictam refertur inter nomenciaturas apuid Diofcor. Cynocardamon, nafturtium, Ibid, Cynochala, polygonum, Diofcor, Cynocto, non, apocynon, Idem. In Lexico Gracolatino uulgari cynoctonon aconitum expenitur. Cynoglof o fus urel cynoglofton herba uulgo nota eft, à foliorum fimilitudine ad caninam linguam appellata: Pli nius recté ei caulem tributit, quem Diofcorides negauit. Pläntagini etiam nomen idem attribuitur $\mathrm{a}=$ pud Diofcoridem, Cynoglofí pircis à bugloffo diuerfi Athenæus meminit libro 7 . Cynomazon,

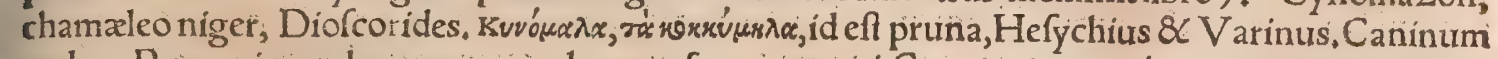

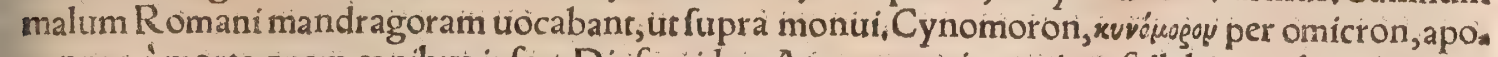
cynum, à morte quam canibus infert, Diofcorides. At cynomorion quinç fyllabis, orobanchen $\mathrm{co}_{2}$ gnominant Diofcorides \& Plinitisłà fimilitudine canini genitalis, it Plinius ait. Nos pliribus fupra in Botre cap.3. de hac herba egimis, hic pauca addiutri. Aegolethron herbameodem in loco docui perfimilem orobanchxeffe: quar quoniam ut capris, fic $\&$ alips nimirum animalibus exitio eft, for te cynomoron etiam dicta eft à canibits necandis: deinde idem nomen ad herbam ei fimilimam ab im. peritis translatum. Sed nominà rerum umbræ funt, de quibus minimé contendendum. A pud Syla o uaticim orobanche araris appellatur, $\&$ alibi altantik, ut ftatim ex defriptionibus apparet. Araris (in quit) herba caulem fine folịs æedit: nafcitur locis incultis; caule rubente $\&$ genitali canis fimili, La tiné cancellaria dicta. Galènus de compofitione fecundum locos 1,2, cynomoron (quatuor fyllabis) conijcit nó aliud quàn cynosbaton effe: Cornarius eo in loco per omega fcribere maluit, (nifi libra, riortum culpa eft ) in penultima, cum Græcus contextus Galeni omicron habeat duobus in locis: De cynocephalia herba fupra dictis in mentione canarix \& pfyllip, eft quod addam; Plinius cynoce phaliam herbam in Aegypto Ofiriten uocarifcribit:defcribitur autem ofiris herba à Diofcoride. Cy nocephalon herbam aliqui anemonen uocāt, Varinus 20 Hefychius; forte quod pericarpion fiue fé minum eius receptaculum canini capitis quandam referat fpeciem. Sebeften uulgo dicros früctus; - Syluaticus Perfice inquit mamillam canis appellari, uerfu etiam barbaro id confirmans : fed errat, $f_{i}$ febeften Perficam effe uocem putat. Græci enim myxa primum uocarunt; deinde in tionorem Aus gufti febaftos. Canis tefticulos noftrates Colchicon herbam uenenofam appellant, propter gemellos ferninum folliculos. Cynomorphos, crocus, Diofcorides. Cynoforchin(id eft canis tefticulum)ali qui orchin uccant, folijs olea, mollibus, ternis, per femipedê longitudinis in terra fratis: radice bul bofa, oblonga, duplici ordine, 8 c. Plinitus. Herba unulgó nota eft, cum multis $\&$ diuerfis eius generi, bus, Hippocrates radicem eius didymen, id eft gemellam appellauic. Cynozematitis, conyza maior; Diofcorides, Cynoxylon, chamaleo niger, Diof cor.fed malim cynozolon, ut Plinius habet lib. 22. cap.18. propter grauitatem odoris, quidam foctore eius ricinos é canum auribis decidere foribunt.

đNominibus non longiffimis appellandifunt canes, quo celeriưs quif - tamen breuioribus, quàm quax duabus fyllabis enuncientur, fictuti Græcum eft Scylax, Latinum Fe=

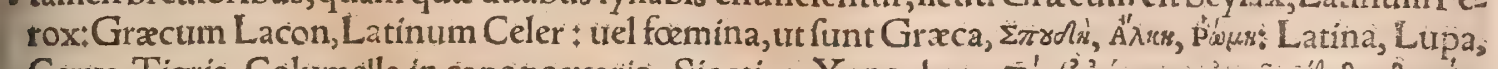

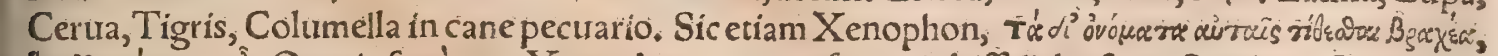

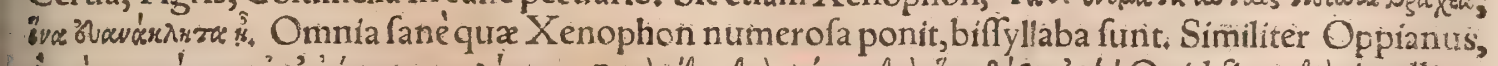

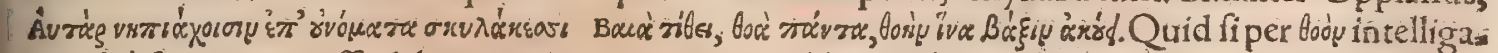

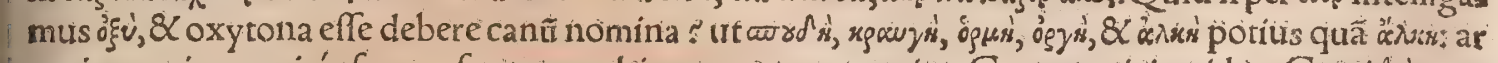
gutiora enim magis ás fonora funt quæ ultimam acuunt nomina. Grammatici quidem Greci doò acur

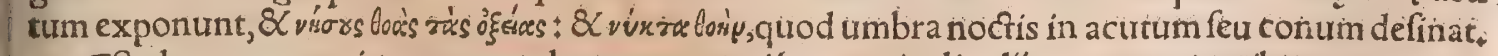

đSed canum nomina qua apud ueteres reperí(quamuis alia alips canum generibus magis conuenirent, ut celeribus, fagacibus, pugnacibus, cuftodibus, \& $c_{*}$ ) ex Xenophonte pracipue, \& Oưi. dïnetamorph, libro tertio, ubi Actaonis canes enumerat, or dine literarum enumerabo. X. litera' pro Xenophonte addetur, O. pro Ouidio. Poft ueteribus ufitata nomina, feorfim rëcentiora fubli: texam, 


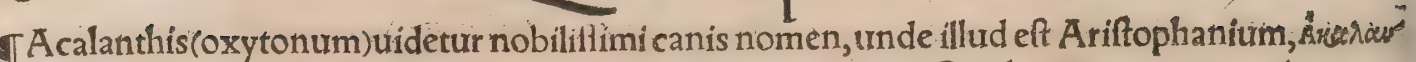

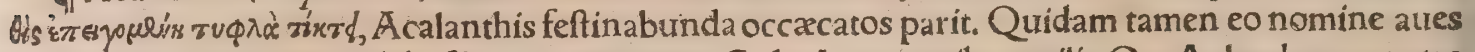
intelligunt, quas nonnulli bafilicas nuncurpant, $\mathrm{Cal}$. Agre naribus utilis, O. Aglaodos ex patre

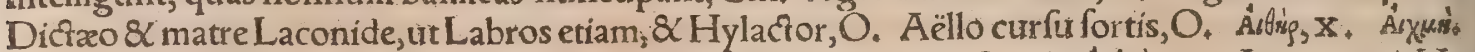

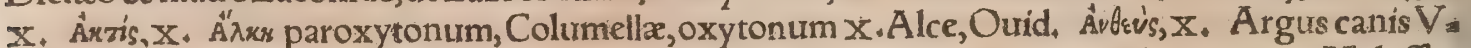
lyiffis, Polluce tefte, Ágyos. Afbolus atris uillis, $O$. Augeas canis Molotticus, de quo inter Moloffos

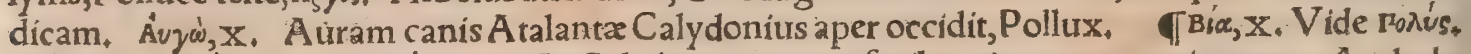

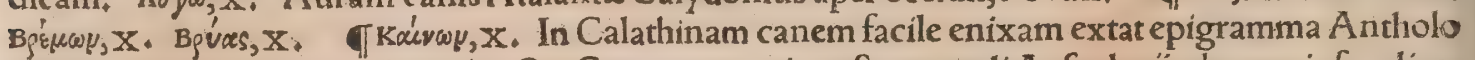
gí Graci lib, 1.Sect. 33. Canache, O. Capparus canis cuftos templi Aefculapí, de quo infra díce= mus. Cerberus, uide infra de canibus diuerfis cap +1 . Cerua, Columel. Xapa, X. Charon, Corax, Harpyia, \& Lycitas, canum A ctxonis nomina apud Aefchylum. Corax, uide Charon. Kawyi, X. Cyprio(aliàsCyprius)uelox cũ fratre Lycifca, O. đDorceurs Arcas, O, Dromas, O. đFerox, Colu

Gergittius canis Geryonis, Pollux, rstoús, $\mathrm{x}$, rv'wess, X. Omnibonus legit Gnomon. TEx ni= gram medio frontem diftincius $a b$ albo Harpalus, $O$. Harpyia una ex canbus Actxonis, O.et Ae fchylo, ut Pollux fribit. Heba, $t^{\prime \prime} \mathrm{C}_{2}, \mathrm{x}$. Xenophon Grylli filius fertur celebrem canem habuiffe,

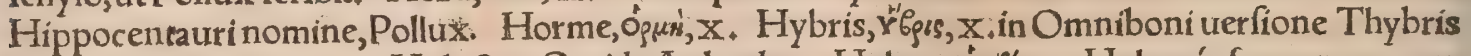

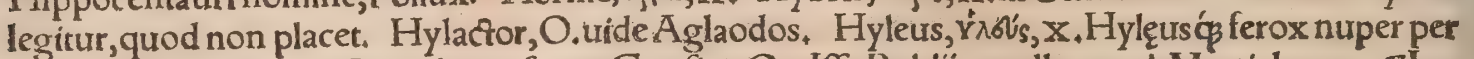

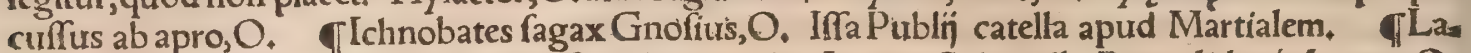
bros, $\mathrm{O}$. Vide Aglaodos. Lachne hirfuta corpore, $\mathrm{O}$. Lacon, Columella.Praualidusḉ Lacon, $\mathrm{O}$. Et fubftricfa gerens Sicyonius ilia Ladon, O. Lalaps, O. fuit $8 C$ Cephali canis hoc nomine. Lampu rus canis nomen apud Theocritum eft in Daphnide ac Menalca, ex ratione albicantis caudx, ut in =

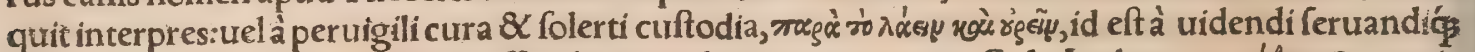
diligentia:uel quoniam fit uulpi affimilis quam lampuron uocant, Cæl. Lethargus, Aidecgy@, canis Hippamonis, Pollux. Leucon niueus, $\mathrm{O}$, ^⿻丷木wy, $\mathrm{x}$, nifiLeucon legendum fit. Locridem canem

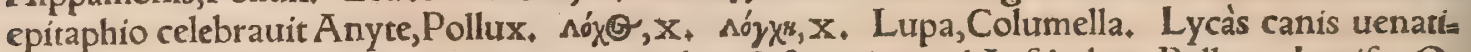
cus Simonidis, Pollux. Lycitas, unus ex canibus Actæonis apuid Aefchylum,Pollux. Lycifca, O. uide in Cyprio. Lydia ab apro peremptze epitaphion fcripfit Martialis. If Máęa canis Orionis, Cel. Mróses, X. Melampus Spartanus, $\mathrm{O}$. Melanchates, $\mathrm{O}$. Melaneus, $\mathrm{O}$. đDé́ lupo conce pta Nape, O. Nebrophonos, O. Nóss, X. đósvós, X. Omen,Cicero ı. de Diuinat. Tum ille arêi: us puellam complexus: Accipio om $\tilde{e}$, inquit, mea filia:erat autem mortuus catellus eo nomine. Ore fitrophus, O. O९gzis, x. Oribafus Arcas, O. đPamphagus Arcas, O. Perfa catellus L. Pauli có

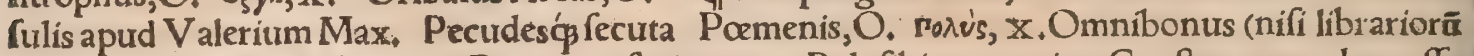
erratum eft) ex hoc \& fequente Bia unum fecit canem, Poly fibiam nomine: Conftat autem duos effe uel ex fyllabarum numero, cum catera omnia biffyllaba fint, $\&$ hunc numerum etiam Columella re

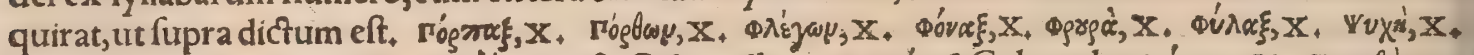

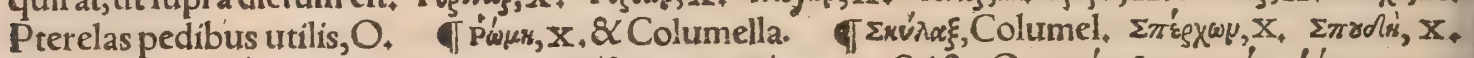

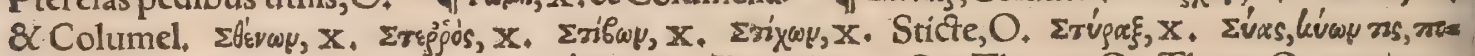

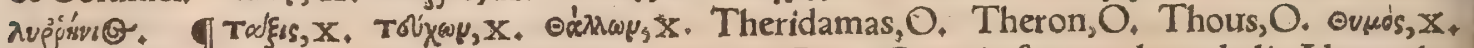
Tigris, O.\&Columel. Tgusxús canis Paonica, quam Panes Pæoniæ fatrapa dono dedit Alexandro regi,Pollux. Túpbas, $\mathrm{x}$. Xiфor, $\mathrm{x}$.malim per omega in ultima.

-Nunc qux apud recentiores reperiuntur nomina canum, fubiungam. TTurcus, $A$ ug. $\mathrm{Ni}=$ phus.Falco, leporarñ nomen apud eundem,Qux fequuntur,omnia ex Mich.Blondi de canibus li bro mutuatus fum, etfi quadam ex eis parum probem. A Pio(inquit) nobis olim familiarifimo $\mathrm{c}_{3}$ nis uocatus erat Scymnis. Mantuanus uero canes his nominibus uocitauit, Hylaxe (malim Hylax) Harpalagus, Tigrina, 8 alins iam recitatisłitem Ragonia, Serpens, Ichtia, Helor, Argus.Sunt $\&$ hxc canum nomina, Syagius(Syagrus potius)Menalcas, Graucis, Chiron, et Pilafter , Recêtiores etiam uarịs nominibus uocitant canes, ut Leonem, Lupum, Stellam, Quatroculum, Fulgur, Bellinam, $R u$ binum, A patria etiam uocant, ut Britannum, Gallum, Corficum, Croacum, Milanum à Mediolano: $\&$ Africano à Tuneto nomen imponunt. Alia deniç, Hifpanis, Gallis, Germanis, alia alịjs gentibus nomina funt. Nos noftram catellam Furiam appellamus, quod frequrenti rabie in furorempconcité, Hæc Blondus. Eft \& Satinus noftris non infrequens canis prafertim elegantioris nomen: \& à gente Phafianus, quod ex gentili in proprium tranfiuit, ut $\&$ alia quædam gentilia.

TVenio ad reliqua uocabula à cane deriuata:quędam enim eorum prima huius capitis parte iam recenfui. Canifera mulier nihil ad canem, ut prima fronte tridetur:fic enim uocatur mulier qua ca num, id eft qualum fert, quod eft ciftregenus, Gracis ravsфóg(G) dicta,Feftus Pompeius, Cynafones, acus funt quibus mulieres caput exornant, Idem. I Kuvódelas pro lergós dicunt Dores, $V$ arinus, $\mathrm{Ca}=$

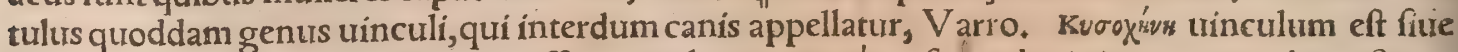
lignum, in quo fcorta, fi quid deliquiffent, tenebantur. Kvv'cy $y$ fecundum aliquos uinculum eft ma,

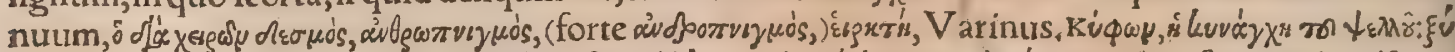

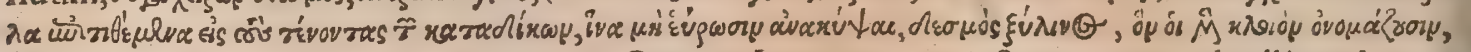
os $j$ renesó, \&c,plu: a uide apud Varinum. Cippum Latini trocant inftrumentum ad colligandos pe=

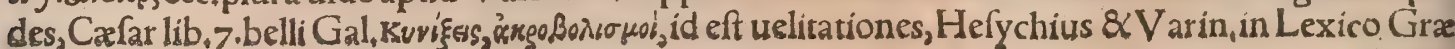


phalis apud Hyperboreos Simmix fcripta refert Io. Tzetzes Chiliade 7.ca, 14.4.De Canibalibus arted thropophagis multa paftim in hiftorịs Noui orbis Petrus Martyr et alij foribüt, Kuvos $k s q u \lambda d e$, id eft, Canis capita, collis eft Theffalia, 8 c parua regio Thebarum, patria Pindari, Sieph. Scotufla in Mace donia funt \& Theffalia, quarum altera infignis eft uicforia Romanorum contra Philippum regen ad Canis caput;ita locus à pellabatur, ubi T.Quinto Flaminio duce pugnatum eft, Hermol, in Pl, 31.2. Copias aduerfur Thebas egitubi foffis omnia ualliş́́ munita comperiens, fuperato loco, quem Canis capita urocant, agrum omnem ad oppidum ufç, deuaftutrit, Xenophon in Agefilai laudibus* meminit etiam alibi, qui locus iam non occurrit. Item Plitarchus in tita Pelopidæ, Cum autem is planam(inquit) procederent; atç uterq̧, ea promontoria, que Canis capita uocant, capere peditibus niteretur, \&c. Catularia porta Romæ dicta elt, quia non longè ad placandum canicula fydus frugi= bus inimicum, rufæ canes immolabantur. Cynæthium, kúvouta uel kuváddse, ciutitas in Arcadia. Hinc Cynathenfes populi, quos aliquià Cynætho Lycaonis filio putant appellatos, Steph. Cynatliaetiam urbs eft Thracix fub Nerito monte. Lufi Arcadix urbs eft in mótanis agri Clitorij, iuxta quos à Me lampode perhibentur curatæ Procti filix, in Dianx fano:inde haud proctl fontem effe aiumt in agro Cynathenfium uícino, cuius aqua pota morfos à rabida caneliberet, ob id Alyffon trocari, Hermo laus in Plinium, 31,2. Dionyfius Antiquitatum lib.1, tractum Cynæthium ab Aenex focio ibi defunco fepultós nominatum putat in Arcadia, Hermol. De loue Cynætheo quod à uenatione nominatus fit, cui Arcades \& Cynæthenfes uacabant, alibi quogs dicam. Cynæthus patria Chius ex rha= prodis poëtis maxime illuftris fuit, \& $c$. Cæli 7,29 . Cynethi uel Cynethufa infula meminit Hermola

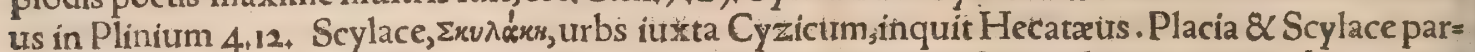
uæ Pelafgorum coloniæ, Pomponius, lib.1. Scyllaceim Athenienfium colonia in ultimo ltalix, corũ quiMnefthei comites fuere:hoc tempore Scylacium uocatur(uulgo Scilazo)Brutionũ ciuitas: Ver= gil.Aen,3. Cauloniśśs arces $8 \times$ nauifragum Scylacæum, uide Onomalt,noftrum, \& Nic. Erythræẽ

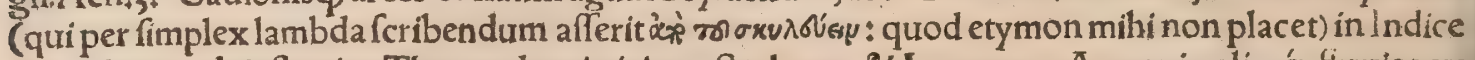
Vergiliano. Iris fluuius Thermodonti uicinus, Scylacem \& Lycum ex Armenia, aliosḉ fiuruios ex cipit, Euftathius in Dionyf. Cynadra, fons eft ex quo bibebant qui manumittebantur, unde natum

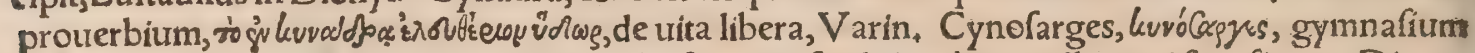
in Attica prope urbem \& templum Herculis, \& uicus fic diçus à cane albo, qui facrificante Diomo \& Herculi paratam uictimam oftendente rapta femora in hunc locum detulit, Stephan. Nomen aut tem inditum eft loco à canis uel albedine uel celeritate. Diomo territo propter abreptum facrificium refponfum contigit, aram illic condendam effe ubi canis femora dimififet. Didymus pro Diomo $a=$ pud Suidam perperam legitur, Exercebantur in eo gymnafio fpurî́ ( nam Hercules qưoç fpurrius fuiffe exiftimatur)qui neutro parente ciue nati erant ، Imprecatio In Cynofarges, fímilis eft illi, In coruos, Suidas, Hefych. Varin. Vide Cynofarges in Chiliadibus Erafmi. Examinabantur eo in loco fpurif, cum de patre controuerfia erat:fpurios autem(vódrs)A thenienfes etiam libertos uocabant, $V_{2}$ rinus exponens prouterbium Ess luvóGacy,s. Quidam acuunt ultimam, fed proparoxytonum ufitatius

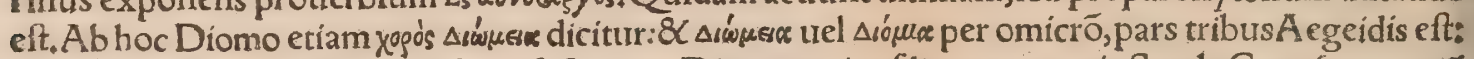
quod Hercules illic Colytti hof pitio fufceptus, Diomum eius filium amauerit, Steph, Cynolarges etiä Hercules cognominatus eft, ut meminit Herodotus $\&$ Plutarchus: $8<$ Cynofargis templi, in quo Her culis $\&$ Hebes aræ fuerint, Paufan, in A ttic,Plato non à cane alba, fed à Cynofargo quopiam, Cyno fargen (malim Cynofarges in neutro tantum genere:unde $\&$ datiuus şu luvoóégys profertur) diciam

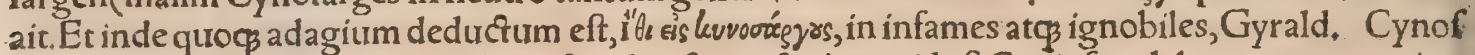
fema (luvos oñux, uel luvóassuop, alin per fimplex figma fcribunt) id eft Canis fepulchrum, quc nomine dictus eft tumulus Hecubx(tefte Plinio)uxoris Priami, qux doloris impatiens, poft cladem exitiữáş patria ac furorum, in canem conuerfa fertur. Tumulus Hecubx(inquit Pom. Mela lib.2.) fiuce ex figu ra canis, in quam conuerfa traditur(uide Ouidium $M$ Metam, 12, ) fiue ex fortuna in quam deciderat, humili nomine accepto. Eft autem promontorium Hellefponti, cuius etiam Thucydides libro 8. me minit:Stephano, locus Libyæ, \& alia quædam regio. Cynofemon locus eft Cherronnefi, in qurem He cuba captiua ducfa poft captum Ilium, in mare defilị $t, \&$ uitam finiuit, Varinus $\&$ Suidas. Vlyfles Ilio capro Maroneam praternauigans, cum Hecuba illic exercitui dira imprecaretur, ac tumultum moureret, lapidibus obruit, \& iuxta mare obtexit(fepeliuit)ac locum Cynoflếma nominauit, Suridas, Pollux lib. ร. Cynoffema in Hellefponto à celebri quodam cane diçum putat, nifi quis(inquit)crede. re malit,à tumulo Hecubx in canem uerfę, nomen ei impofitum. Aliud eft Cynoffema apud Calydo. nios, ubi Aura canis Atalantæà Calydonio apro occifus, fepultus eft, Idem. Aliud eft Cynofiêma in Salamine, fepulchrum canis Xanthippi Periclis patris:Sed de canum aliquot fepulchris plura dicã in ultima parte huius capitis. Cynna,kúvvo, oppidulum prope Herácleam, ab una A mazonum ap: pellatum : uelà Cynne fratre Cœi, Stephanus, Cynna, PhilippiMacedonum regis filia, Athenaus libro 13.

Tb. Kuvoesdr's, cani fimilis, afpectu canino.pfyllion fupra cynoides appellauimus. Canilus inte: riora omnia fimilia leones habent, A riftot, Felium $\&$ ichneumonum pleraq, ut canum, $P$ linius, $\mathrm{P}_{\mathrm{a}}, 6$

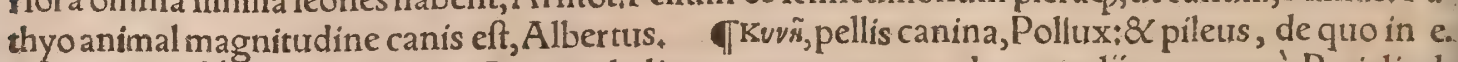
mox, Suidas kivreso oboxy dixit, Cynocephali cognomentum, quod quum alijs,tum uerò Pericli ad. 
roborat \& alit, Eodem tempore cibus eis ad fatiem concedendus eft:nam cum uenantur, cibo fatti: rari inutile eft. Conueniunt autem catulis qui nutriuntur, edulia uino madida, Pollux. sis jovíwy \&e

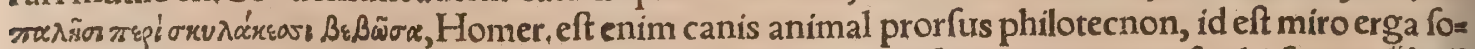

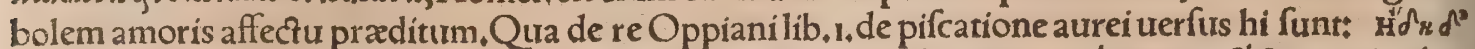
à

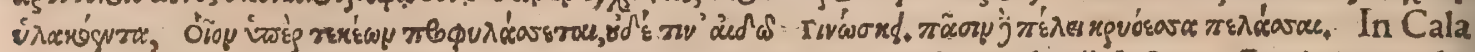
thinam caniculam facile enixam A dai epigramma extat lib, 1.Anthologî,, [ect.33. Canis iuxta die noftúç uidet, Calius Calcagn, in rebus A egypt. TCanibus inter quadrupedes, inter aures uulturi bus pracipua odorandi uis eft:Forte quòd animalia illa ficciora fint, nec aliorum modo humidum aut pituitæ obnoxium cerebrum habeant. Vigilantifimum natura canem effe, in æedium cuftode dicemus:

qLatrare propritm canis eft, cum impetum facit, \& uoce terret, Plautus, Etiamíne mex in me la. trant canes. Et alibi, Nec gannio,nec latro. Venaticus ex quo Tempore ceruinam pellem latrauit in aula, Militat in fyluis catulus, Horat.Epift. . pro allatrauit:Sic Plinius, Hanc habentes negane latrarià canibus.Latrator Anubis, Vergilio \& Ouid. Sxuit canum latratus in auras, Verg. A pud Hebraos uox na nabach, id eft latrauit, non alibi reperitur inBiblïs quàm Efaix cap. 56. A pud Pol

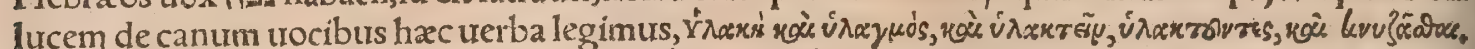

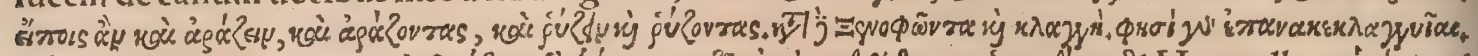

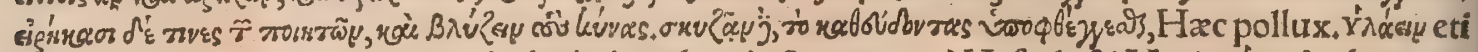

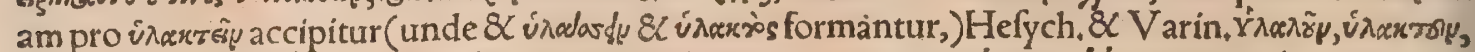

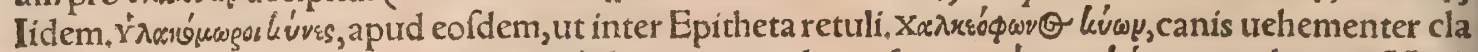

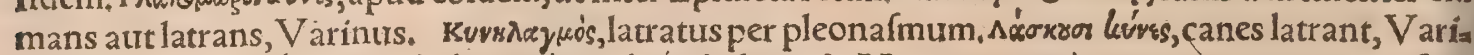

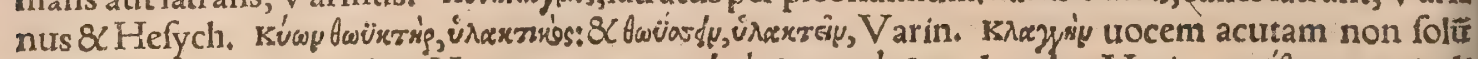

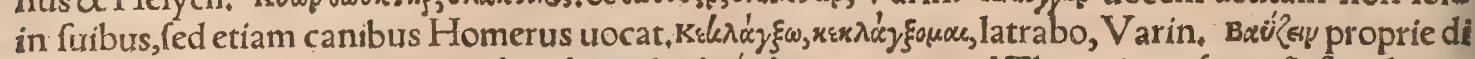

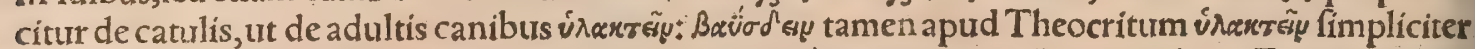
exponunt, V arin, Baubari, latrare:uerbum factitium à uoce canum, Lucret, lib, 5 . Et cum deferti

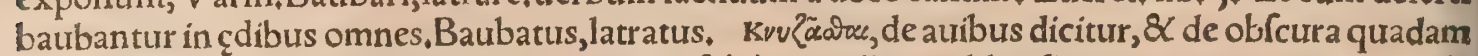
ac fubmifla canum uoce: qux ab hoc uerbo xvv $\}_{x} \theta \mu \dot{o}^{\prime}$ appellatur, blanda canum immurmuratio, $\&$

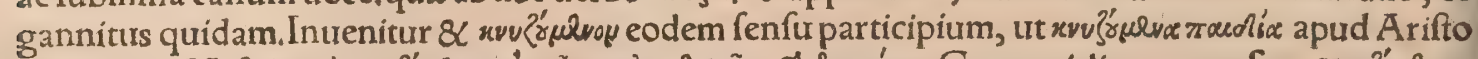

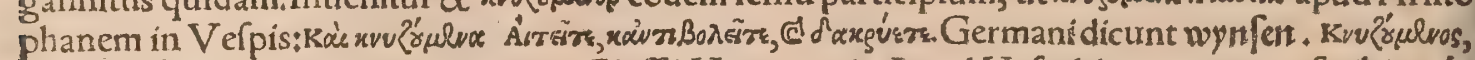

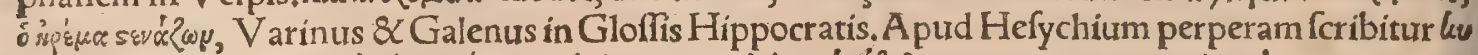

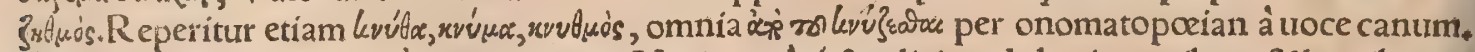

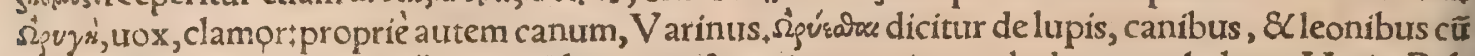
per famem ululant: $\&$ de alijs animalibus quæ proprium uocis uocabulum non habent, Varin.Pol= lux de minoribus tantum, ut uulpibus, thoibus, \& lupis, vi rum prius canibus, alterum lupis peculiariter tribuiffet. Vlulare dicuntur canes, quum lamentantibus fimiles lugubrem quandam $\&$ querulam ædũt uocem: Ouid. lib. Is. Metam, In $\phi_{\zeta}$ foro circumq́ domos \& templa deorum Noçurnos ululaffe canes, Manet Germanis quoq̧ eadē onomatopœia,

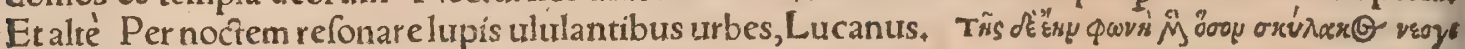
$\lambda \tilde{w}$, ,Homerus. Catulus glaucitat, Author Philomela. Canina eloquentia, Quintilianus 9.12. Vide inter prouerbia. Latrat $\mathcal{X}$ in toto uerba canina foro, Ouidius in lbin. Gutturaćs imbuerunt infan tia lacte canino, lbid. Hominem conuicijs $\&$ maledictis utentem canatim loqui(cui fimile aduerbi. um bouatim eft)aliquis dixerit. Aduerbio hoc obfoleto ufus eft Nigidius, tefte Nonio. Ringi, os torquere, quod canes faciunt latraturi, uel cum ex ira in rugas deducunt os. Ringi quidam à rhin, quod Græce nafum fignificat, \& ago deducunt:ut nares torqueri fignificet. Hinc rictus oris diften:

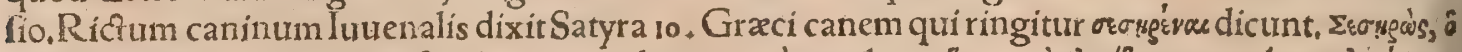

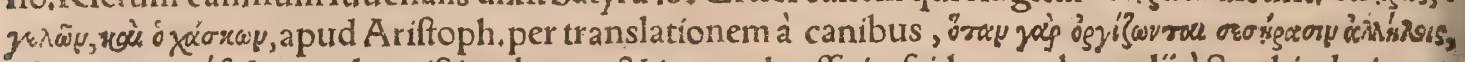

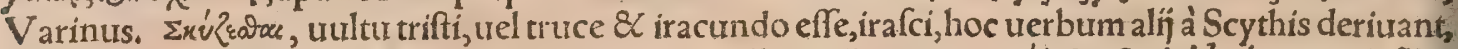

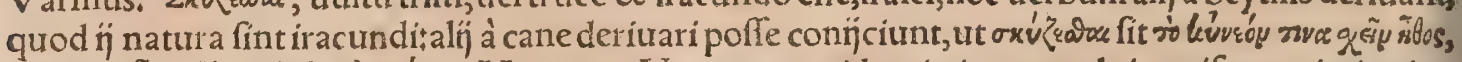

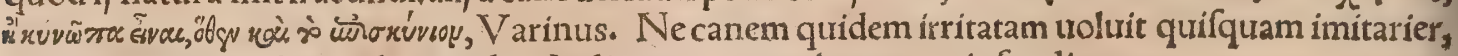
Plautus in Capt. Caniculæ quadam Indic nunquam latrant, ut infra dicetur.

4) Canica, furfures de farre à cibo canum uocatæ, Sex. Pompeius \& Nonius, Pleriçex ueteri bus ad manuum ablutionem ufi funt apomagdalia:id uerbum fignat, molle ( $\&$ medullam)panis:q̊d quia mox obícerent canibus Lacedæmonỉ cynada uocabant(Pollux 6.14,) Significare id ipfum uidetur Athenæus quo $\$$ : Poft coenam (ínquit) libationes obibant, nec abluentes manus, trerum abfter gentes buccella, $\mathcal{X}$ apomagdaliam afferebat unufquif $\$:$ id quod faciebant ob nocturnos in biujis metus. Idem libro 9. apomagdalia honores nuncupat.Meminit eius uocabuli Plutarchus in Lycutgo:fed ita, ut intellectum eius uocis neutiquam uideatur interpres animaduertiffe. Innuit ipfum hoc

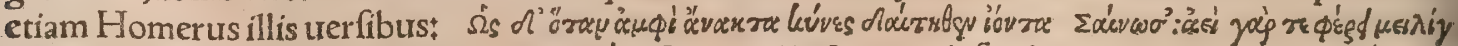

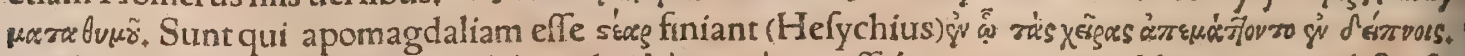
Auttor item Euffathius eft, magdaliam dici ỏ̉ cibariorum for dibus pinguioribus, inde canibus pararetur cibus, Haecomnia.Calius 18,1, Kuv'xedss, 


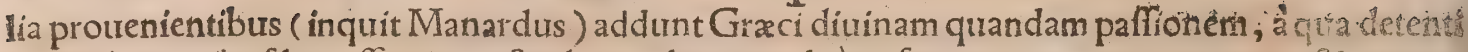
maioribus quibufdam efferri poteftatibus uidentur, adeò ut futura quocs pronuncient, \& proptes rea entheaftici uocantur, quafi deo pleni. Et paulo pof, Addiderant Arabes quam cutabutumap. pellant, deriuato nomine à beftiola, qua irrequieto quodam motu fuper aquas modo hurc modo if luc abfȩ ordine uagatur:Latini(ut quidam uolunt)tipulam id infectum uocant, in palureribus locis frequens. Hactenus putaui hunc morbum ab Arabibus, præcipue autem à $R_{a} z$, inuentum? nec efa fe eius mentionem apud Gracos. Dum urerò hac friberem, docente me fuprema ueritate, clarécoa gnoui effe quem Gracilycaonem, lycanthropiam, \& cynanthropiam uocant, nomine à lupis uel cas nibus deriuato. De his enim feribit Paulus, Nocte exeunt, ad diem ufges circa fepulchra plerungs uagantur, lupos canesḉ(canes non dicit Paulus, fed Aëtius:) per omnia imirantes, oculis concatis \& ficcis funt,craffe imbecilliter ć uident, linguam ficciffimam habent; ualde fitiunt, os falíta caret, cru= rág habent ob affidus offentiones infanabiliter ulcerata. Aëtius ferè eadem, unum addens, quod menfe Februario incipit. Qua fi conferantur his qua de cutabuto fribit Auicenna, nemo ambiget eum morbum ab co defcriptum, quem Graci(ut diximus)lycanthropiam uocant, id eft hominis in lupum conuer fionem, prafersim cum $S$ curatio, feré uerbum ex uerbo, à Paulo fit affumpta, Hucz uf́ç, Manardus. A canibus quidem \& lupis huic affectui nomen impofitum reor, fiue quod hæ anis mantes in rabie fimiliter afficiunt, fiuce quod à rabidis ipfis homines morfi unà cum hydrophobo in. terdum hoc affectu capiantur. W Canis feu in mortem incidit, feu in furorem, fplenis noxa in caufa eft, Calius ex Horo. Kúveroy fávorioy, id eft caninam mortem, apud Ärifophanem, difficilem in: terpretantur: quoniam difficulter animam efflare deprehenfum fit animal hoc, Hefychius, $V$ arinus, Calius. Morficatim inter fe 8 homini colludunt canes, $\&$ alia quxdam animalia.

đd. At illud non modo $110 n$ arrogantis, fed potius prudentis, intelligere fe habere fenfum \& ratio nem, hæc eadem \& caniculam non habere, Cicero lib 3 . de Nat. Nes tamen de ingenio $8<$ induftria canum, multa diximus fupra cap.4. De impudentia canum, uide parte 1. huius capicis. TDe fice canum complura exempla proferemus infra ubi de canibus focijs, defenforibus, \& cuftodibus aget. Canis albus fymbolum effe putatur fidei, unde Picus Mirandula cecinit, Signa quibus fubito ui= fum eft oftendier albis Exuillis animal, dominis domibusí̧̧ fidele. GHomines qui paruam 8 planam habent frontem, nempe fimilem canin $x$, ftolidi (a'va'io ${ }^{2} b$ )iudicabuntur: Item qui lerenam $\&$ exporrectam habent, affentatores:quod canes cum adulantur, frontem fimilem præ fe ferant, ut fu= pra copiofius dixi in D .ex Ariftotelis Phyfiognomonicis: Ex quibus reliquas etiam à canibus fumptas de hominum moribus pronunciandi coniecturas hic adfcribam. Animalia fortia, inquit, graue

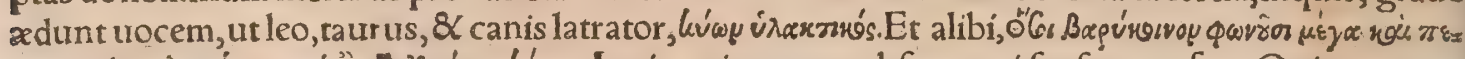

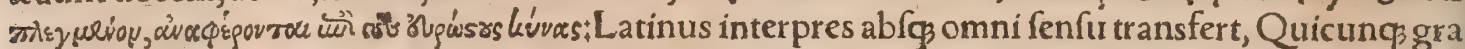
uiter uocant, magnum ac perplexum:reducuntur ad fortes canes. Adamantius de hoc uocis genere

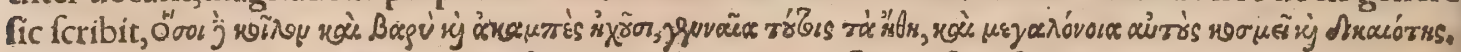
Cornarius uertit, Qui uero cauum $\&$ grauem, ac minime flexuofum fonum $x$ dunt, his gener ofi mo

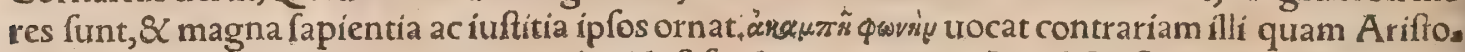
teles in cinæd is $\&$ mulieribus $\kappa \varepsilon \kappa \lambda \alpha \sigma \mu l \dot{w} w$, id eft fractam nuncupat. A pud A riffotelem igitur ex $A$ da

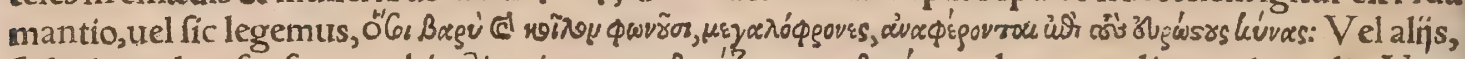
fed ad eundem fenfum, uerbis. Si quis tamen Bagúbvop pro Bagúroivou legere malit, non impedio. Nam

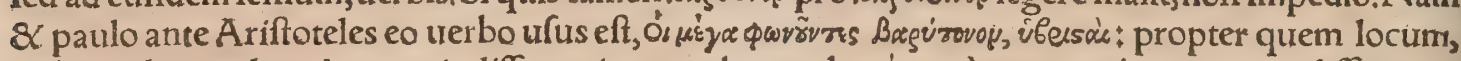

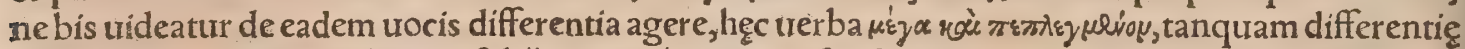

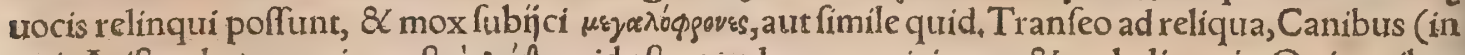

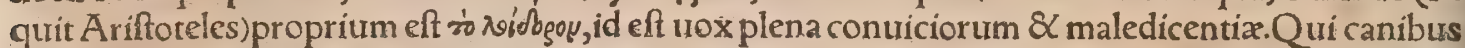
fimilẽ ædunt uocê, canini ingenï homines exiftimabunt̃̂, Ádamantius, Qui caput magnum habẽt,

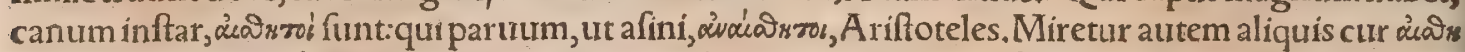

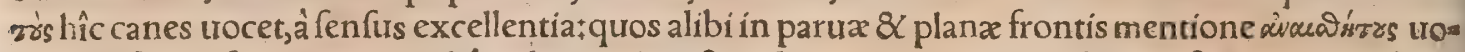
cauit:nifi ita difcernamus, ut aliâs ad ingenium $\&$ ueluti rationem animalium referamus tocabulũ fenfus:aliâs ad exteriorum fenfuum acumen \& fagacitatem. Rurfus, Quibus oculi, inquic, igniti funt, impudentes habeant, ob fimiles canum oculos. Et de labris, Quibus (inquit), labra tenuia funt,

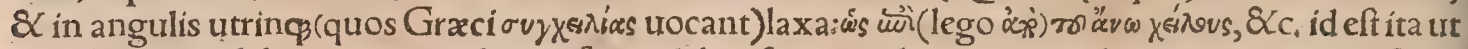
pars fuperioris labri iuxta angulum inferiori labro fuperimplicetur, ut ita dicam, magnanimi funt: hac enim fpecie leones, nec non magni robuftí canes apparent. Idem de huiufmodi labris iudicium

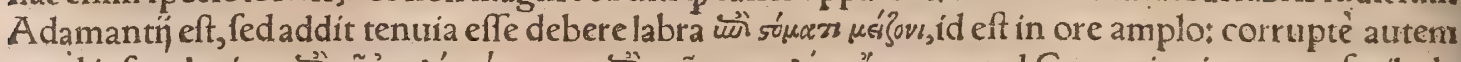

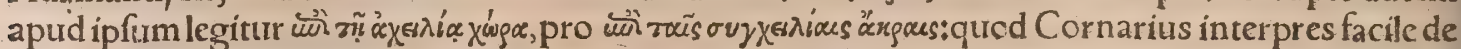
prehendiffet ex Ariftotele, nifi conferendi laborem fugiffet. Et paulo poft, Hoc etiam caninum eft, fi Iabrum fuperius \& gingiux promineant:hos ad conuicia \& maledicendum pronos conícito. Qui bus circa dentes caninos labia prominent (

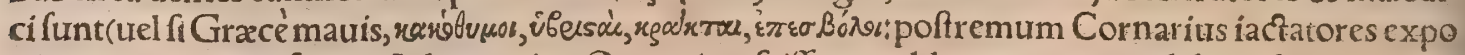
nit:) ut qui canes referant, A damantius, Os nimis refciffum, ualde uoracem, crudelem, demen:em ac

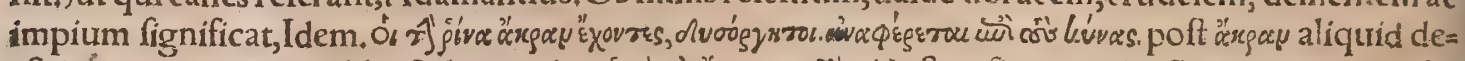

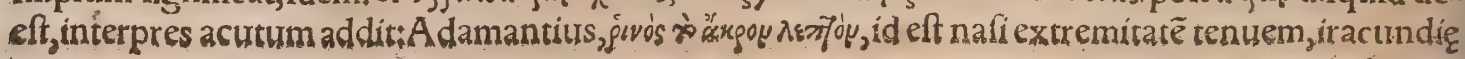
indicium 
thdicium facit. Eandem fi craffa, obtufa, rott̃da \& folida fit, qualis in leonibus \& generofis canibus fpectatur, fortibus $\&$ magnificis feu gloriofis uiris conuenire ait. Ó '̊̉

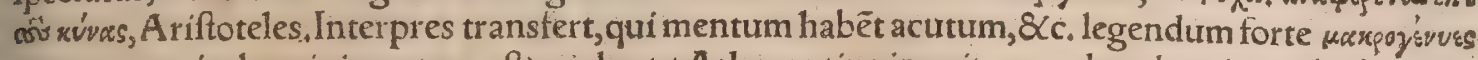
(mentum enim hominis tantum eft) quales, ut $A$ damantius inquit, non admodum improbi funt, fed loquaciores; rà voxauvórefor, \& fubmolliores, Cornarius: fed quoniam eo in loco Ariftot. de pilofis tantum partibus loquitur, eft quod dubitemus, Qui fupra lumbos in cinctu ( fic uoco partem qua

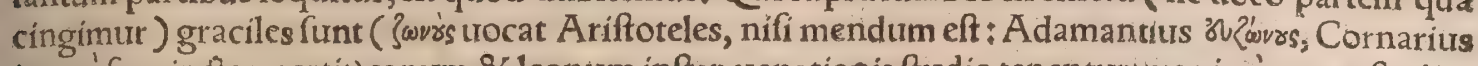
ineptéfuccinctos uertit)canum $\&$ leonum inftar, uenationis ftudio tenentur: maximè autem furdio fiffimi uenationum canes, eiufmodi funt; Asiftoteles. Phocylides poëta mulieres alias ex alịs ani.

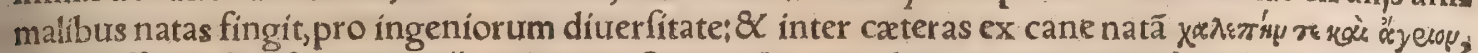
id eft difficilis $\&$ afperi ingenï mulierem. Simonides(qui idem argumentum fenarijs profequitur)

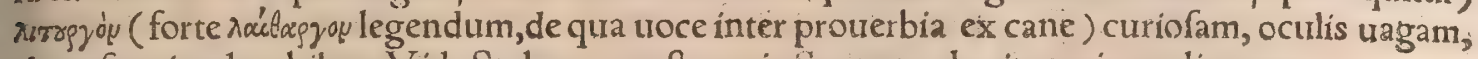
clamofam, implacabilem. Vide Stobxum noftrum in Sermone de uituperio mulierum.

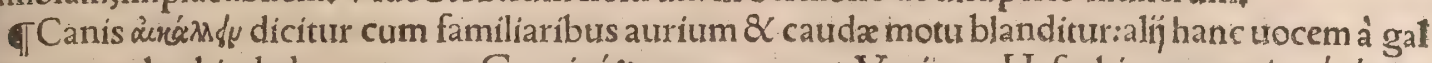

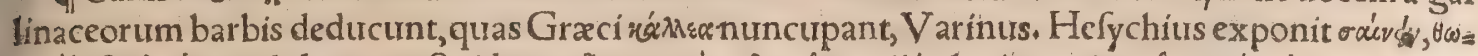

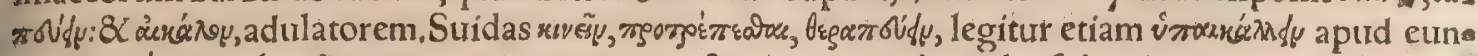

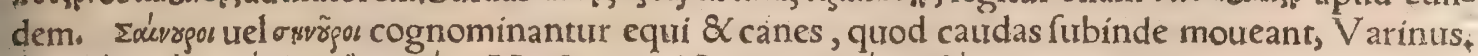

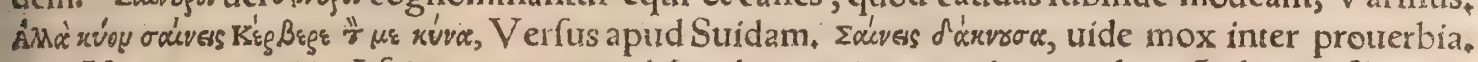

đNuper in naui in Africa, cum nautis ablentibus canis in amphoram oleo nô plenam filices in. ifceret, obftupui, quî in mentem ueniffet, ac unde fubijfet cani, graubus fubfidentibus leuiora tolli elidiç̧, Ariftotimus apud Plutarchum in libro Vtra animalium, \&:c. TImpetis canum amolitur nerij radix collo fufpenfatuel dens caninus in corio alligatus brachio, ut fupra dixi ubi de rabie canũ in genere egi: \& ibidem feorfim inter amuleta. A porynon officulum effe aiunt in finiftro latere ru= betæ, quo canum imperus cohibeantur, Plinius.Salpe negat canes latrare, quibus ín offa rana uira data fit, Plinius, Cor caninum habentem fugiunt canes: Non latrantuerò, lingtra canina in calcia. mento fubdita pollici: autcaudam muftela, qua abfciffa dimiffa fit, habentes, Plinius: Et alibi, mema branam ex fecundis canis habentem, aut leporis fimum uel pilos tenentem; aut qui hyanælinguam in calciamento fub pede habeant, ut magi pollicentur:aut qui periftereon(id eft uerbenacam herb habeant. Lapis in Nilo niger faba fimilis reperiť,quouifo canes non latrant:abigit idem dremonia, Thrafyllis in A egyptiacis ut Stobaus citat. Lugduni in Gallia uidi lapillos quordam albos, laıs, ro tundos, cochlea quadam fpecie, quas fabas marinas ( fi bene menini uocant) \& appenfas lac nutri cibus augere promittunt. Roma in adem Herculis in foro boario, nec mufca; nec canes intrant.

Te. Nunc ut fum pollicitus (inquit Columella)de mutis cuftcdibus loquar:quanquã canis fallo dicitur mutus cuftos. Nam quis hominum clarius, aut tanta uociferatione beftiam, uel furem prædi cat, quàm ifte latratu? quis famulus amátior domini quis fidelior comes? quis cuftos incorruptior ? quis excubitor inueniri potelt uigilantior? quis deniq̧ ultor aut uindex conftantior? Quare uel im primis hoc animal mercari, tueriós debet agricola:quod \& uillam, \& fruçus, familiamćs \& pecora cuftodit, Columella.Mox autem fubłjcí uenaticum canem agricolx inutilem elfe : ideoç diçurum fe de uillatico tantum \& paftorali, de quibus nos etiam infra leorfim. In emptionecanis, de fania tate \& noxa ftipulationes fiunt, exdem qua in pecore, nifi quod hic utiliter exceptum eft. Alij pre= tium faciunt in fingula capita canum: Alij ut catuli fequantur matrem: Alij ut bini catuli unitus nu* merum obtineant, ut folent bini agni unius ouis : pleriģ ut accedant canes, qui confueuerunt effe unà, Varro, Quo colore eligendi fint canes docet Pollux 5 . II. fed ita ut de uenatorio pracipuè lo: qui uideatur, quamobrem eoufąs differemus. Turce pilos in caudis canum inficiunt rubro colore, Blondus. Canis in fyluis à uenatoribus tefticulis alligatur, ut clamore pardalin fiue pantheram illi.

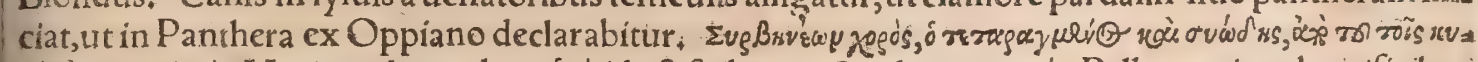

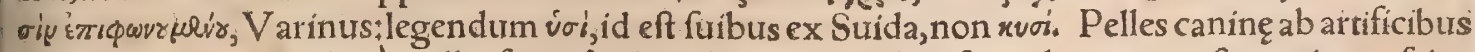
ita praparantur, ut plane molles fiant, 8 chirothecis aptæa aduerfus imbres:qua aftate etiam refrige rare exifimantur. Ex ïfdem ocrea fiunt corrigḧs tranfmifra, quibus utuntur qui tumida $\&$ ulce. rofa crura habent, duplici commoditate nam $\&$ aftricta pars minus influentes recipit humores: $\& 1$ la neis caligis, quarum fape moleftus eft contacius, non exafperatur, K'vvanias ( forte rvveriou per ac, )

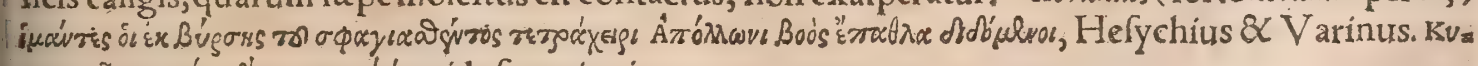

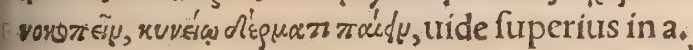

- Collaria canibus circundantur, pracipuè munimenti gratia aduerfus feràs, uenatorịs, maximé pugnantibus, neceffaria, nec non paftoralibus utilia:quibufdam pro ornamento, $\&$ difcernendigratia:\& pro amuletoaduerfus rabiem, quod Gratius poêta teftatur, his uerbis: Collaribus ergo Sunt quilucifugæe criftas inducere melis Iuffere, aut facris conferta monilia conchis: Et triutum lapide $\tilde{z}_{\vec{z}}$ 82 circa Melitefia neciunt Coralia, 82 magicis adiutant cantibus herbas. Quapropter hoc in loco, tanquam communi, de collaribus agere uolui, non in pecuarĭ́s aut uenatorís folum: $\&$ propter affi nitatem fimul etiam de loris, quæ uenaticis propria funt, quibus aduerfum feras muniuntur arman. tur'q́. Venaticis canibus(inquit Cælius 17,26.) collare munimenti caufa addifolitum, quo retun. diluporum impetus polfet ${ }_{2}$ nouimus ex Grammaticorum gloffematis , \& Pompen̈ præcipuéFeftit 
qui id etiam uecari millum fcribit, Sed M. Varro Reritn rufticarum libro 2, dicere mellum maluít: Is millus ex corio concinnabatur, ferreis confix us clauis. Inde factum, ut quicquíd prafidio nobis eft, proterbio quodam, id effe mutimento pronunciemiss, perinde ac fit millus cani.Poétæa armillas tos uidentur appellaffe canes ex hac ratione, quoniam millus fit n̆s armillarum uice. A pud Gracos deræamburs eft latum corium ( $\&$ firmum)ob canis collum. Dicitur $\&$ perideræum, at $\phi$ item peride.

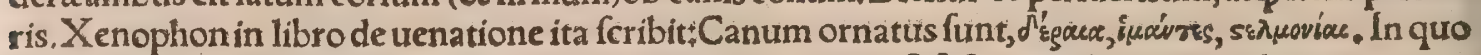
illud adurertendum, quas Xenophon ftelmonias uocauit, id eft fafcias quibuis canum latera pramu. niuntur:Pollux telamonias dixit, $\mathrm{H}_{\mathrm{C}}$ Calius. Canibus, ne uulnerentur à beftís, imponuntur col laria, qux uocantur mellum, id eft cingulum circum collum, ex corio firmo cum clauulis capitatis, qux intra capita infuitur pellis mollis, ne noceat collo duritia ferri. Quòd filupus, aliúsue quis his utulneratus eft, reliquos quogs canes facit, qui id non habent, ut fint in tuto, Varro. Atçarmillatos colla Moloffa canes, Propertius 4.Eleg, Ex pelle melis pharetras \& canum colla obregunt, inde me lium (aliqui per I duplex (cribunt)uel millium genere neutro, ut Varro:tuel millus mafculino, ut Fe.

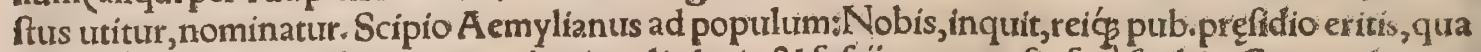
fi millus cani.Pollux libro 5. cap. 9 , de uinculis, loris, $\&$ fafcijs canum, fic fere fcribit: Canes ad urena:

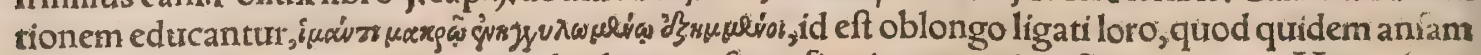
habeat, id eft in fummo reflexum \& duplicatum fit, ut firmius manu iniecta retineatur. Xenophon,

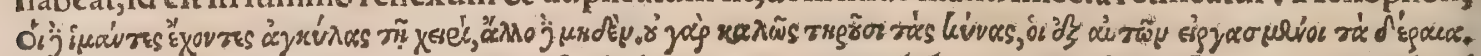
Omnibonus uertit, Lori manibus anfas habeant, præterèa nihil;neç enim bene fercuant canes, ficol Iaria ex ipfis cótexta fuerint. Ego rẽ ita intelligo, Retinacula fiuélora(Omnibonus mafculinogenereloros dicit, imitatione Græcorum puto)feorfim effe debere, $\&$ annexos tantũ collaribus, nion conti nuos: fed hæc ab illis certius petenda funt, qui urenationem experti callent. Quod ad uocabulum gुvury

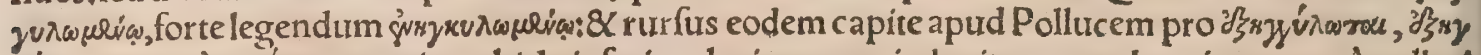

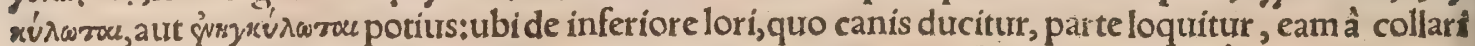
penderefcribens, \& iuxta cynanchum annecti:fiue quod annulo ferreo, quem ảyxúrsy appellare li.

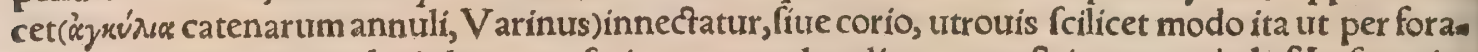
men in una extremitate lori altera tranfmittatur, quod nodi genus noftri uocant ein lit (ळ) : fic enim

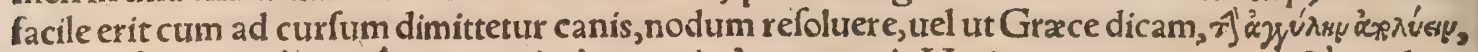

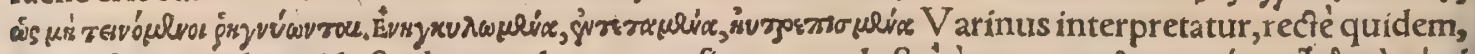

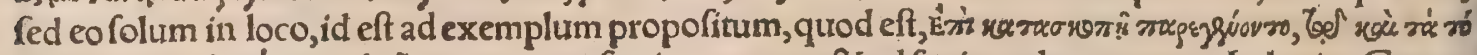

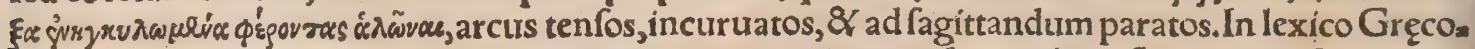

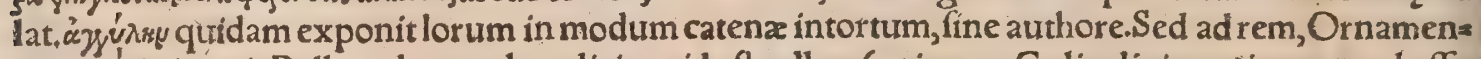
tum canis, inquit Pollux, deræambus dicitur, id eft collare (ut iam ex Calio diximus)intra quod affu ta effe debet agnina pellis, ne collum canis corio atteratur. Telamonia, $r$ rec $\mu$ curíc, fimiliter latum eft

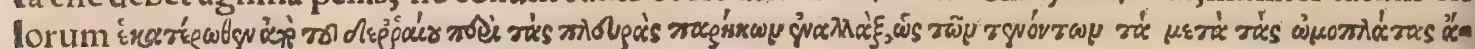

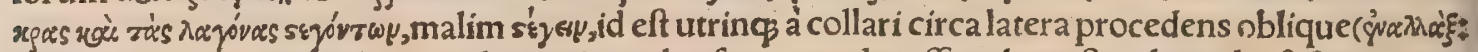
quod uerbum ita intelligo, ut telamonix ambr fe mutuo decuffent: hoc eft, ut lateralis fafcia ea qua à dextra collaris parte incipit,obliquè fer atur ilia finiftra uerfus:quęuerò à finiftra collaris parte pro cedit, ad ilia dextra)ita ut fumma dorfi pars, Graci tenontas dicunt propter latos illitus loci tendines;

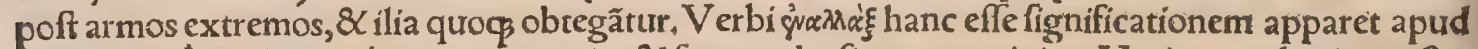

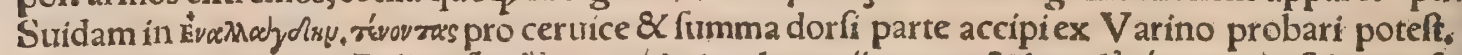

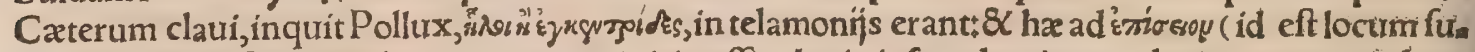
pra pudenda)uffos extenduntur, ne canis iniri poffit, clauis infcendentium audaciam reprimêtribus, ne ex ignobilibus concipere poffint. Porrò à collari longum $\&$ anguftum dependet lorum, quod iu xta cynanchum innectitur:eóç canis circunducitur. Sunt qui etiam terga canum ualidis corís $0_{\text {. }}$

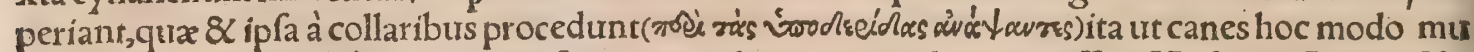
niti nequaquam facileà pugnacibus fer is, quas adoriuntur, uulnerari poffint, $\mathrm{Hactenus}$ Pollux, No

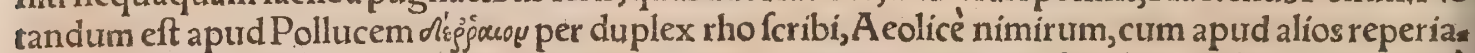
tur cum fimplicirhô communiter. A pud eundem perideræon primum fimplici, poftea duplici thô

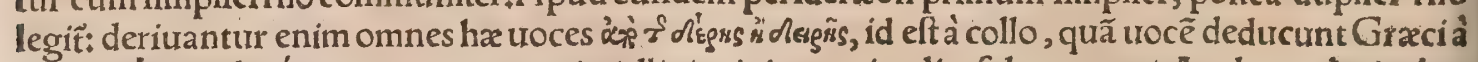

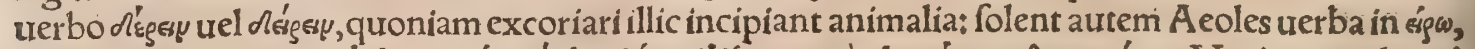

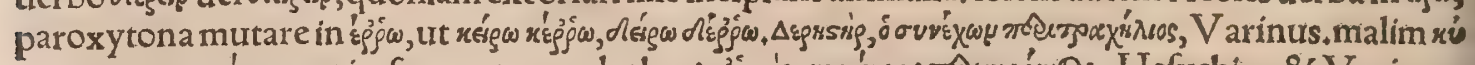

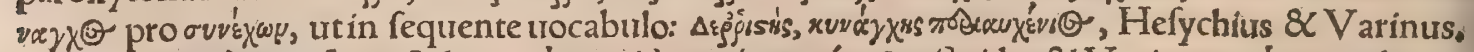

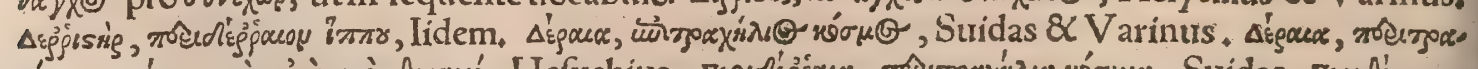

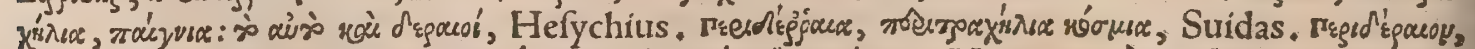

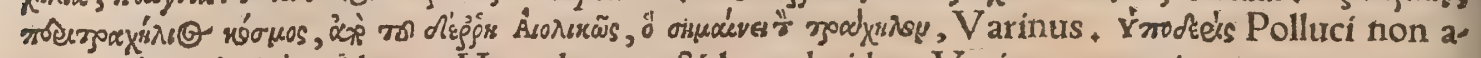
liud quàm nồdte's uidetur. Hypoderæon \& hypoderidem Varinus exponit ornamentum mus liebre, monile, murænulam. Deræa, id eft collaria (inquit Xenophon) fint lata \& mollia, ne atterant canum pilos. Stelmonix etiam (fafcias uertit Omnibonus ) loros habeant latiores, ne terant lagonas, id eft latera uel ilia canum : clauata fint etiam (encentridas, id eft clauos infu.

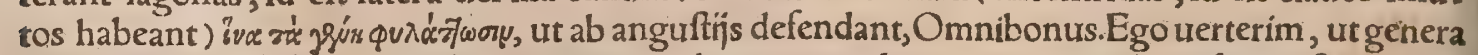
canum conferuentur, nec ignobiliorum coitu degenerent: clauos enim eam ob caufam pofterioribus 
rum celebritate, Phalanthus capiti cynam imponeret. Loquitur inquit, de infidijs quas Lacedamo. niorum helotes, id eft mancipia uocati, \& Parthenia popularibus ftruxerãt. Cynam paulo poft idem author ( ut opinor) ex Ephoro, pileum Laconicum appellat, licer aliter rem ipfam narrer, Hæc Вay. fius. Kuvery aliqui dictam putant à Cyne (áx kuvos) huius nominis artifice, qui primum id genus pi

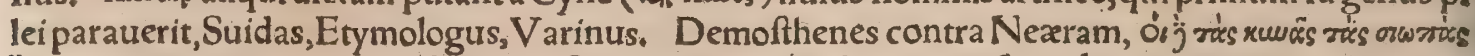
"xerzts. Mercurius arietem fub axilla ferens, \& capitigeftans impofitam luws̃u, \&C. anathema Arca. dum in templo quodam Hierocx farix, Paufanias in Eliacis, Cynæe diuerfa fiebant, fed pulcherrimæ in Bocotia, quas ruftici geftabant, Varinus. Theophraftus libroz. hift, plant, cap, 10, de abiete foe

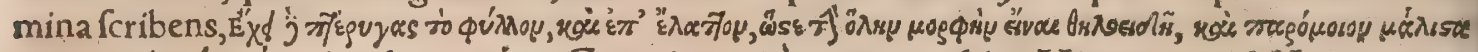
rois Borwzious kvaveres, \&c, lego xweres, Gaza imperite uertit cyathis. Minerua apud Homerum in Diomedis curru, ne uideretur à Marte Orci galeam ( Ádz xuñy) fubiuit: hanc aiunt onnium in ná tura rerum nigerrimam effe. Grammatici craffiffimam nubem interpretantur. Hinc prouerbialiter

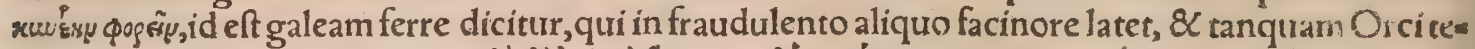

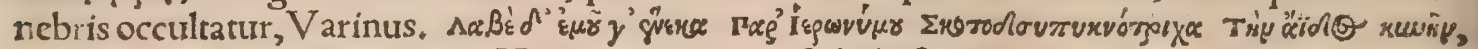
Arifophanes in A charnenfibus. Hieronymus, inquit Scholiaftes, in comoedris sirridebatur tanquarn nimis comatus : quapropter hic comico ioco Orci galeam ei attriburit, ceu qui fub rimia coma eaća deformi $\&$ fqualida (quo fenfu Graci uerbum xreiộu proferunt) propenodum lateret. Vide Erais

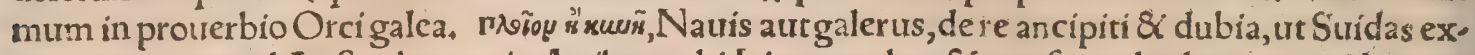
ponit: ex tat apud Ariftophanem in muibus: ubi Irin qux alata \& petafata adiolauerat, quidam in=

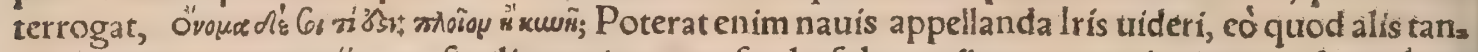
quam remis aérem traịjceret: fimilicer enim extenfa alæ fulcant aërem, ac remi aquam: uel quod ure: ftis cius in curfu ( uolatur ) finuata cffet, Kuwñ autem, uel galerus, propter petafum pilcum, qưo tan. quam nuncia utebatur, ut Mercurius quog: nam \& Sophocles in Inacho cynam Arcadicam Iridi

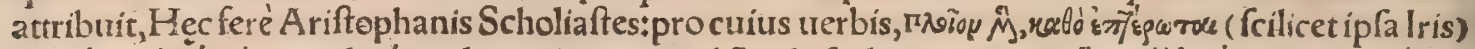

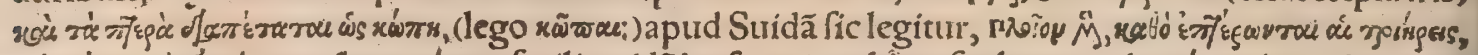

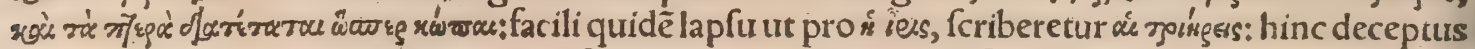
Erafmus multa de triremi \& malo petafata nugatur, nulla interim Iridis eiusó habitus mentione, à qua tamen primariò prouerbium hoc defcendit. Canautas capitis ornamenta ueteres dixêre, $\mathrm{Fe}$ ftus. Hefychius bis xwĩup exponit ỏsxíey, id eft domum:cuius interpretationis occalionem aliam non

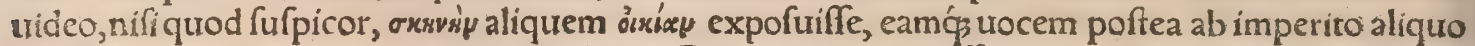

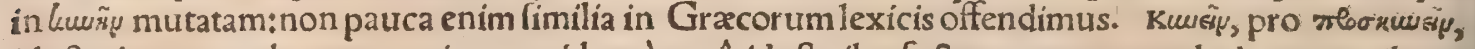
id clt adorare, uerbum recentiores quidam à cynâ, id elt pileo factum putant:quod adorantes pileum à capite dimoueant:fed huius etymi neminem ueterum, quod f́iam, authorem habent:kueș proprie

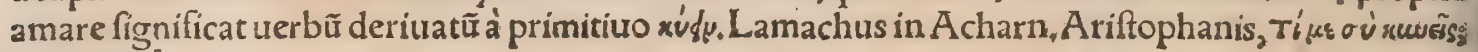
fcholia oruvess exponunt.

बf. Canarï circa Atlantem A frica montem dicti funt populi, quod uicius eius animalis rís pro. mifcuts fit, \& $\alpha$ uifcera ferarum diuidua, Plinius 5. I. Infelices Hifpanos, qui Nicuefam fecuti, Bera= guam habitandam elegerant, oppreffir egeftas tanta, ut neç àfcabiofis canibus, quos uenatus $\&$ tur telax caufa fecum habcbant ( $i v$ certaminibus nanq cum nudis incolis canum opera plurimum utebanturr) neque aliquando à peremptis incolis abftinuerint, Petrus Martyr in rebus Oceanicis. Et rurfus alibi, Váchim Nunnez quendam nefcio quo in loco Noui orbis ad tantam inopiam per= ueniffe ait, ut fcabiofas car.es \& coenofas bufones, ac huiufcemodi alia pro delicatis epulis edere fue rint coaki.

6i)h. De cane quem Vulcanus ex ære Monefio conflauit, inter uenaticos celeres dicam. Alciati Emblema in impetum inanem, Lunarem noçu (ut fpeculum) canis infpicit orbem: Séćs ui dens, alium credit ineffe canem, Et laurat: fed fruftra agitur uox irrita uentis, Et peragit curfus fur da Diana fuos, Arthologij Graci libro 4.inter epigrammata in imagines animalium, ultimum eft

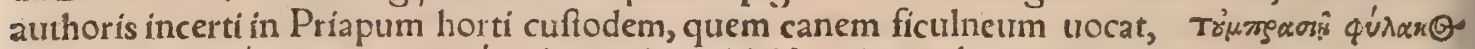

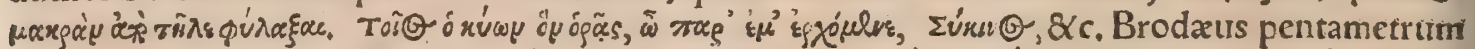

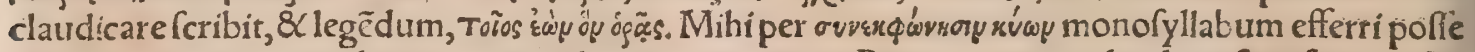
uidetur, quam uocem ideo retínere malim, quia conuenit Priapo, cum pudendum fignificet, $u t$ pra expofui, Epitaphia quędam canum diuerforum, in fuis infra generibus referam, ut uenatici in. ter uenaticos, \&c. TDe canum quorundam (Hecubæ in canem mutatæ, Auræ canis Atalantæ, Xanthippi ) fepulchris, unde locis etiam impofita nomina, fuperius dixi parte 1.huius capitis , A pud Moloffos canes inhumari folitos aiunt. Honori defuncti canis ciuitatem conftituiffe Magnum Ale. xandrum Theopompus feribit, Cælius. Bactriani, ut Oneficritus fcribit, eos quiiam fenio morbóue confecti fint, urituos canibus apponere folebant, ad hocipfum de induftria enutritis, quosí̧ illarum gentium uocabulo fepulchrales uocent, Calius. Diogenes dicebat, fi canes eum lacerarent Hyrca. niam hanc fibi fore fepulturam: fin urultures, Cafpiam, Stobxus: apud quem tamen non Cafpiam, in uulgatis fimul $\&$ manufcriptis codicibus, fed \&̊न7'soy reperi. Verum cum alij Indos, alí Iberos $\&$ Ca:

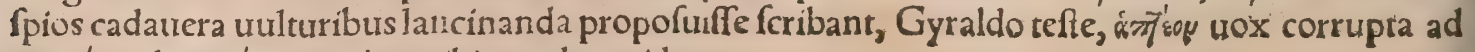
Kacusia uel Krowíny propius milhi accedere uidetur. 


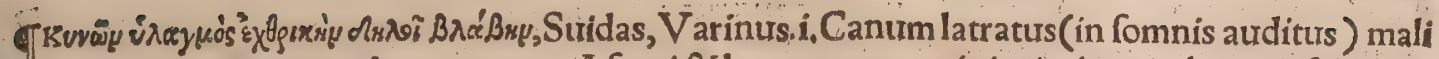
aliquid ab inimicis mettrendum monet. Afperi $\&$ latrantes canes iniurias hominibus prafagiunt, \& magna damna: Alieni canes fi blandiuntur, dolos 8 infidias nunciant, $8 \mathrm{c}$. A rtemidorus: Idem de uenaticis, cuftodibus, \& alïs, quid fignificent in fomnis; feorfim nugatur. TAerhiopes Sambris proximi fummam regix poteftatis cani tradunt, de cuius motibus quifnam imperitet, augurantur, Solinus. Natio Aethiopum eft qux canem, \& habet regem futum; \& illius etiam appetitui paret : fi adulatur, eum non iratum effe credunt: filatrat, iram agnofcunt: tum etiam uellicatiónes, uluilatus, difcurfus coniectantes, ei obtemperant, Aelianus, Apud Aethiopes gens(Nubas quidam uocant) in Africa Ptoemphanę fuere, quibus regis uice canis dominabatur, quem mirificé obferuabant; ex il - lius enim motú \& nutu imperla, $\&$ qua effent placita augurabantur, Gyraldus ex Plinio. Canem locutum in prodigijs, qutod equidem annotauérim, accepimus: $\&$ ferpentem latraffe, cum pulfus eft regno Tarquinius, Plinius. Equidé etiam uerba prif́cæ fignificationis admiror. Ita enim eft in com mentarńs Pontificum: Augurio canario agendo dies conftituantur, priufquam frumenta uaginas exeant, \& antequam in uaginas pertueniant, Plinitus, De facrificio canario(quamuis Gyraldus cana rium auguriùm $\&$ facrificium idem faciat) quod pro frugibus Canicula fyderi immolabatur, infe= rius dicam. Paufanias Eliacorum lib.2. fcribit de Thrafybulo (Gyraldus Thrafyllum uocat) quo= dam uate Iamida(ex Iami A pollinis filin familia) cuitus imago in Olympia fit; cui galeotes (id eft ftel= lio, not mufteilla aut feles ut Calius fufpicatur) ad dextrum hưmerum arrepat, \& canis affiftat, uer intercífis, a ciecur patefaciens, quod is primus extis canum infpectis uaticinium inftituerit quem lo o cum in Lectiones antiquas fuas tranftulit Calius 13.35. Scribam fignificaturi A egyptĭ, aut prophe= tam, aut fplenem, aut odoratum, aut rifum, autfternutationem, canem pingunt. Scribam guidem, quoniam eum qui debet effe perfectus feriba, oportet multa meditari, adlatrare omnes quodammo= do, agreftem effe, nemini gratificari, quemadmodum nec canes. Prophetam, quoniam pra cæer is animalibus admiratur canis, \& obtutu firmo intuetur fimulacra deorum, quemadmodum prophe tam.Splenem, quoniam leuifimum fplenem canis habet: $\&$ ex eo mors eft illi, \& rabies aliquando: $\&$ miniftri canem curantes, cum eft moriturus, ut plurimum fplenetici fiüt.Odoratum uero, rifum, \& fternutationem:quoniam qui planè funt f́plenetici,neq odorari, neq̧ ridere, neq̧ fternutare pof funt, Orus in Hieroglyph,interprete Bernardino Vicent. Magiftratum fcribentes iterum canem pingunt, cui addüt regiam ftolam nuda figuræe appofitam: Quoniam quemadmodum canis, ut ante dictum eft, in deorum fimulacra intentis oculis profpicit: fic $\&$ magiftratus antiquis temporibus in nudum regem prof́piciebant, cuius gratia uendicat fibiregiam ftolam, Orus ibidem. Et alibi, Canis auterfionem fignificat. In homine impudente etiam, pro quo ranam pingunt, canis meminit néfio qua ratione, nam cum ranam in oculis fanguinem habere dixiffet: 8 impudentes effe, quibus tales

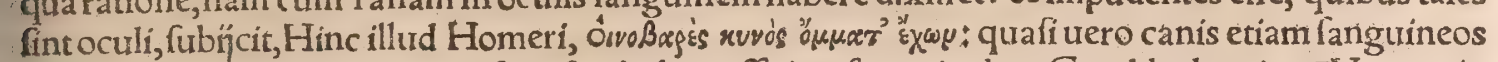
habeatoculos, Canem album fidei fymbolum effe iam fupra in d.ex Gyraldo docui. TV Teteres iu rabant per $\mathrm{canem}_{\text {, }}$ ut in Anfere dicemus. Cur facerdotem(Haminem dialem) cane \& capra abftine: re, \& ne tangere quidem aut nominare oportuerit, explicatur à Plutarcho in quæftionibus rerum Romanarum. De capra aliâs : Quod ad canem, inquit, minus quidem ille libidinofus, minus etiam quàm capra foctidus eft. Dicunt tamen aliqui non fas effe canem arcem $A$ thenis ingredi, ut neque - Delum infulam, eò quòd in propatulo coêant, tanquam boues fues $\&$ equi in thalamis, non autem publice $\&$ inuerecundè mifceantur. Sed illi ueram caufam ignorant; iccírco enimà facris $\&$ afylis templis canem arcent, utpote animal pugnax, ut tutum acceffum fupplices habeant. Videtur autem louis quoç facerdos, uiua quædam uel ædes uel imago Iouis exiftimatus, ad quam libere fupplices nemine prohibente aut terrente confugerent. Quamobrẽ lectulus eius in ueftibulo domus erat, \&uc. Ad hac canis animal impurum credebatur, nec ulli coeleftium deorum facrũ, fed Hecatę, Marti, \& c (ut inferius repetam, ) Hac Plutarchus.Canem alere in Delo nefas erat, Strabolib. 10. Panegyrin canum menfe Augufto ab Romanis folitam celebrari,aucfores Gręci funt, monumento urbis capte ab Gallis. Tuncueró cadebantur canes, qui \& ávínaxтot, id eft fine latratu agebant, anferibus ams pliter fonoréćs inclamantibus. Hoc ipfum arbitrơ à Plinio fignificatum libro 29, ubi canes ait annua pendere fupplicia inter ædem Iuuentutis $\&$ Sumani, in furcas uiuos arbore fixos fambucea, Calius. Viuæ canes cruci fambuceæ affigebantur à Romanis, $8 \mathrm{X}$ anfere infidente inter ædes Iutrentutis 8 Sumani deferebantur, Gyraldus. Sed hac dere etiam in Anfere dicam. Caribus exta canis deis of $=$ ferremos fuit, unde factum eft prourerbium Caricum facrificium:nam pro hirco canem mactabant, authores Diogenianus, Hefychius, Arnobius.Meminit etiam Suridas. Catulos lactentes adeo puros exiftimabant ad cibum, ut etiam placandis numinibus hoftiarum uice uterentur his, Plinius. A pud Boeotios expiatio fieri publicé folebat cane per medium duas in partes diffecto, inter quas tranfibãt, Plutarchus problemate iam citato. Vbi apud Græcos canis immolaretur, Leonicenus in Varia hifto ria 1.6. Romaní in Lycæis, qux Lupercalia uocant, Februario menfe canem immolant, cuius rei cau fam Plutarchus in quaftionibus Roman,inquirit:Canis facrificio, inquit,omnes ferè Græci uteban , tur, \& etiamnum quidam utuntur ad expiationes. Et Hecatæ catulos cum alijs ad expiationem pertinentibus exponunt: $\&$ eos qui expiari opus habent catellis luftrant, ( $\pi \varepsilon e \mu \mu f(7) \approx)$ hoc expiandi ge nus perif́cylacifmon uocantes, Aut quia canis lupo inimicus elt, ideo in Lupercalibus immolatur, 
Aut quia Lupercos in urbe difcurrentes canes latrant \& moleftant. Aut quoniam $P_{a n i}$ hoc facriff cium peragitur, cui canis propter caprarum greges gratus habetur, Hac Plutarchus, Idem in eo. dem cur canis in urbe non appareret cum rem diuinam Herculi faciebant, hãc rationem affert; quro. niam canis Hercull femper moleftus fuerit: ut Orthus (fic fufpicor legendum pro 8 rts) 8 Cerberus: \& cum Licymnī filius Oeonus propter canem occifus effet ab Hippocoontidis, praliaricum ipfis coactus, prater multos alios amicos lphiclum fratrem amifit. Plura de Lupercalibus eorumćs rú leges apud Plutarchum in uita Romuli, Vide ne non recté Gyraldus ex Plutarcho citet perifrylacifs mum facrum effe ex catulis : facrum enim uel facrificium ab expiatione differt. Cur Geneta manx

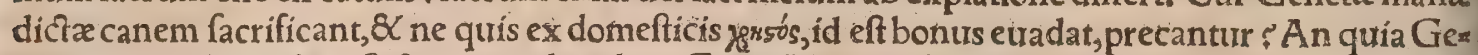
neta generationis dea eft $\$ 2$ quemadmodum Gräci Hecatæ; fic Genetæ Romani canem immolant pro domefticis? Socrates quidem Argiuos frribit llithyix, id eft Lucinæ canem facrificaffe facilioris puerperij gratia. An forte hæc precatio ne quis domefticorum bonus fiat, non ad homines, fed ca.

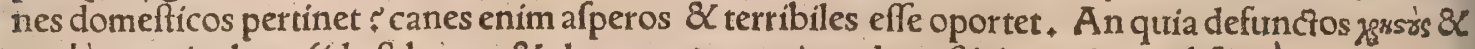
rou $\downarrow$ 's nominabant (id eft bonos \& elegantes) ne quis ex domefticis moriatur,obfcuré petunt

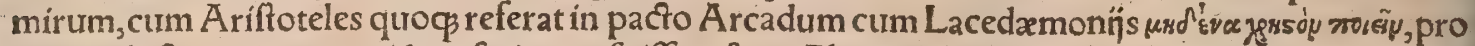
eo quod eft neminem occidere fcriptum fuiffe referat, Plutarchus in quxetionibus Rom. De Gynæ cea $\&$ Geneta deabus uíde Gyraldum Syntagmate 17. Genito mane catulo res diuina fit, 8 in coe= nis deûm etiamnum ponitur catulina, Plinius. Ego pro Genito mane legendum puto Genitoma.

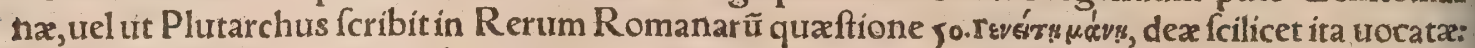
manum ueteres bonum uocabant, quanquam Gyraldus Bonam deam(qux $\&$ R hea uocatur et alio nomine Gynæcea, ut ipfe inquit,) à Geneta dea feparat Syntag, 17. Cynetiam, ruveria , Hefychius

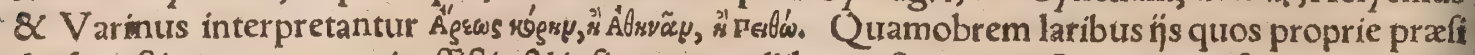
des(præftites)uocant, canis affiftit, \& ipfi canum pellibus ueftiuntur? An quia præfides domus cua ftodes effe conuenit, externis terribiles, quemadmodũ canis eft : domefticis ueró mites ac benignos: An potius uerum eft quod Romanorum quidam dícunt, $\&$ Chryfippo philofopho probatur, malos quoldam damones circuire, quorum opera dij tanquam lictorum \& carnificum utantur puniendis impris $\&$ iniuftis hominibus : \& ex horum numero etiam lares funt, noxí dæmones uitæ $\&$ familia rum infpectores: eam $\not$ s ob caufam caninis pellibus amiciuntur, 82 canem affiftentem habent, ut qui in malis hominibus inueftigandis puniendisḉ acres natura fint, Plutarchus in caufis $R$ om, Lar fami liaris ab antiquis, tefte Plauto, in canis figura efformabatur, Gyraldus; Et mox, $\mathrm{V}$ alde (inquit)confi. derandum puto, quid rãdem fibi Cornutus feu Probus grammaticus in Perfị Satyris uoluerit, cum fcribit:Succinctis laribus, inquit, quia Gabino habitu cynomia, id eft canina pelle dei penates for. mabantur, obuoluti toga fupra humerum finiftrum, \& fub dextro. De Serapidis cane in Cerbero dicam. Hecatæ canis immolabatur, ut qux Proferpina exiftimaretur, ut Plutarchus fcribit 8 \&yco

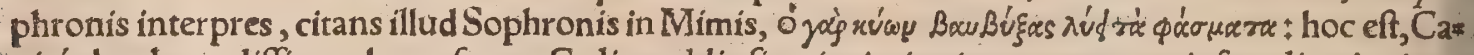
nisćs baubans diffipat phantafmata.Calius addit, ficuti ęris tinnitus quoç, aut eiufmodi quippiam. Huc refpexiffe uidetur Vergilius in Bucolicis, hoc uerfu, Nefcio quid certe eft, \& Hylax in limine latrat. A b Hebro flumine haud ita diffita eft ciuitas nomine Zona, poft quam habētur Orphei quer cus fub quibus eft Zerynthium antrum:quod tamen in Samothrace ftatuunt alij: $\&$ Lycophron effe

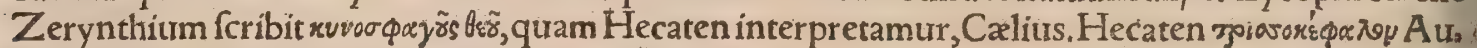
fonius tergeminam uocat, quod caput eius dextrum fit equi, finiftrum canis, medium hominis agre: ftis, ut fcribit Orpheus in Argonauticis, Cxlius 20.6. Hecatæ canes antiqui triburebant, Theocritus

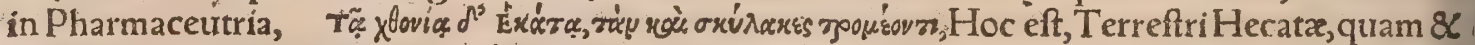
catuli metuunt. Scholia addunt à poéta id dictum quoniam catuli auferrent Hecatæe cœnam, Gyral

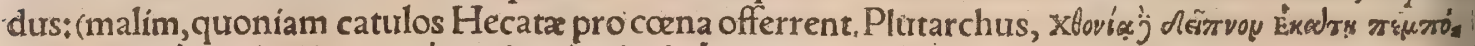

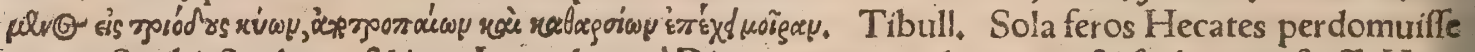
canes. Scribit Sophron, \& item Lycophron, à Diana canes iugularił quín \& fpeluncam fuiffe Heca

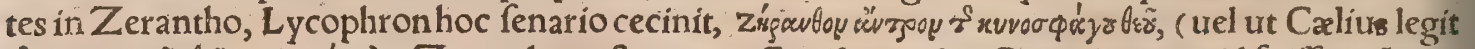

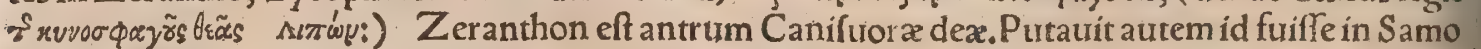
thracia:Stephanus citans hû́c fenarium, in 'Thracia : Nicandri interpres ibidem ad quercus Orphei.? Verum enimutero (inquit Gyraldus) fi eadem Hecate $\propto$ Diana fit, non mirum illi attribui canes, ut uenatrici. Hinc Liuius Andronicus in hymno, ut eft apud Terentianum, Dirige odorifequos ad certa cubilia canes $\ddagger$ uerfus eft myurus, Vergilius, Notior ut iam fit canibus non Delia noftris* Porrò aít etiam Phurnutus, canes ideo Triuiz facratos, quod illi iugulari folerent. Alï, propter ue. nationem ، Quidam etiam attributût, quod \& $<$ Proferpina putetur, curi canes, id eft Furiæ afcriberen.

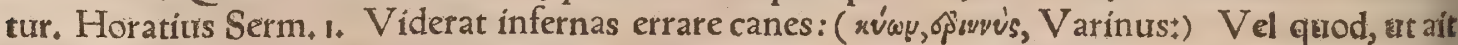
Vergilius, Nocturnis Hecate triuñs ululata per urbes. A d hac fcribit Hefyehius, fimulacrum He cates canem fuiffe, uel quod ei immolarentur canes : uel quod ipfam nónulli cum capite canino, hoc eft cynocephalon effingerent, Gyraldus. Exta canum Triuizuidi libare Sabxos, Et quicunque tuas accolit Aeme niues, Ouid. De facrificio Hecatæ celebrato Romaldibus Auguftis plura uide apud Gyraldum Syntag. 17. Canes adhibebantur Aefculapị templo, qưod is uberibus canis fit nu. rritus, Feftus. Cynetheus Iupiter fic cognominatus, qutoniam urenationem Arcades, utpote rudes 
(rufticioris uitæ homines)antiquitus exercebant:uenådi uerò ars cynegia \& cynegetice Grace tro.

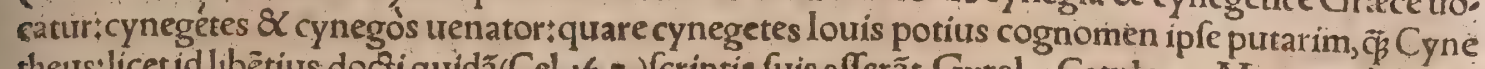

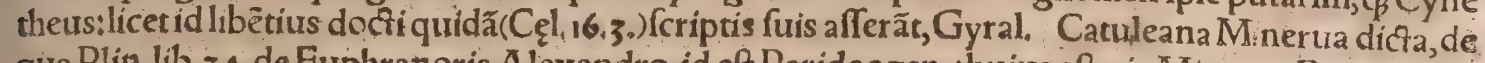
qua Plin, lib, 34, de Euphranoris Alexandro, id eft Paride agens; huius eft, ait, Minerua Roma, qua dicit Catuleana, infra Capitoliutm à Q Luefatio Catulo dicata. Sunt qui libentius Catulianã legãt, Gyrald. Canes à Caribus Marti immolari A pollodorus \& alip fripferunt, tefte Arnobio.Marti ue

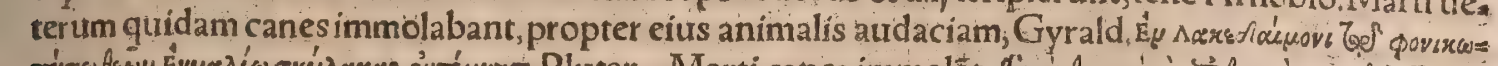

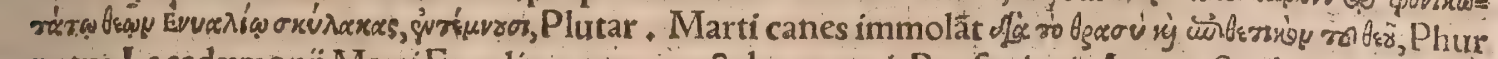
nutus. Lacedamonij Marti Enyalio canem mactabant, ut ait Paufanias in Lacon. Scribitenim ephe 10 bos Lacones cum pugnam efient inter fe inituri, Marti canis catulum nociu immolaffe, deo fcilicet ualidiffimo uictimam ualidiffimam ínter cicures dicare fe arbitrantes. Subdit idem, catulos quod fciat, non facrificari abalíjs Gracís, Colophonís exceptis, qui catellam nigram nociurno tempore

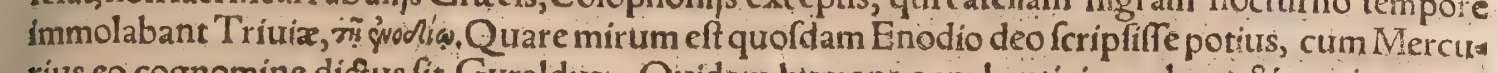
rius eo cognomine dicius fit, Gyraldus; Quidam humana cum brutis iungebant: $\&$ que in natura diffimilia erãt, ut ait $D$. A thanal, deos furos fecerüt, cynocephalos, ophiocephalos, \&c. Nec Anubin

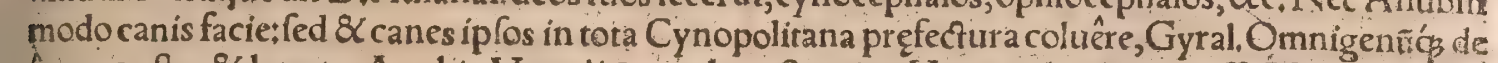

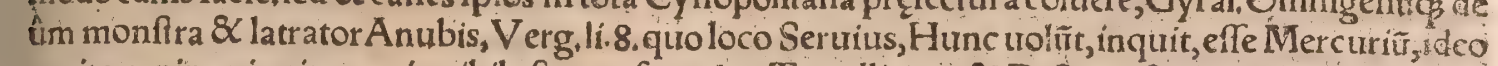
capite canino pingitur, quía nihil eft cane fagacius. Tertulianus \& D. Augultinus uidentur cynoce phalum pro A nubi deo ponere, quód fcilicet capite fit canino, non enim cynocephalum animal in. - telligunt. Nos in templa tuam Romana accepimus Ifin, Semicanesós deos, Lucan. Semihominern canem Sedulius dixit. Plura de Anubi, \& cur capite canino effictus fit, apud Gyraldü lege Syntag. 9. unde hæc ctiam defumpfimus. Aegyptus Harpocratem quegs habuit $\&$ cynocephalum ficie A nubim:quorum imagines digitis geftare, moris eciam Roinani fuit quandof, Calius. Canem (ali ad Anubin hoc referunt)A Aegyptị uenerantur, ex có́ç legem quampiã uocicarunt.cur id facianir; duplicem caufam afferunt; Alteram, quód cum lfis ufquequaç Ofyrim quareret, canes præcurren tes, partim unà cum ipfa purerum ínueftigare conarentui, partum feras reprimerent: Alterã, quód cũ ftella canis ( quem Orionis fuiffe fama celebratum eft) exoritur, tum cum ipfo pariter Nilus fere at tollens irrigationem in terram A egyptum inuehit, in agrosás redundat, Quamobrem canem ut fer tilis aquæ conciliatorem A cgyptij uenerantur; Aelian. Sunt quilingua Aegyptia Anubin canem - dici affíment. Aliqui eundem Mercuritim interpretantur, \& Hermanubin quós tocant. Straboli bro 17 , in templi Heliopolitani defcriptione, In ingreffu fani, inquit, cft paumentum, latitudine iu= geri aut paulo minus, longitudine uero tripla quadrupláue, $8 \mathrm{choc}$ Dromus dicitur, de quo Callima

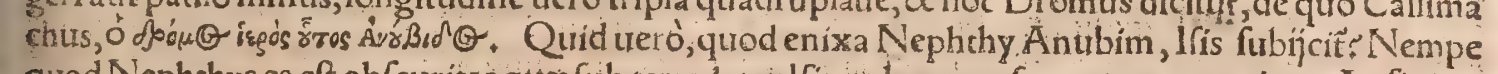
quod Nephthys ea eft obfcuritas qutæe fub terra later:I Iis ea lux qua fupra terram emicat. At finitor circulus, quem horizontem uocant, titrigg communis $A$ nubis dicitur: $Q$ iure cani comparatur. Iux.

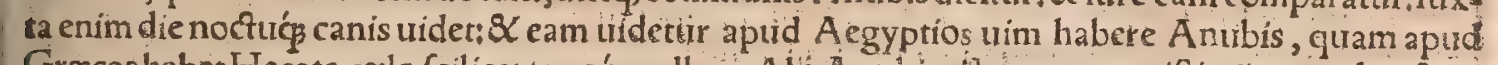

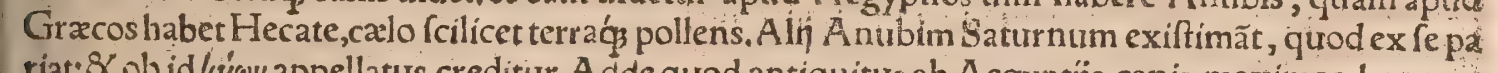
riat: \& ob id kúw appellatus creditur. A dde quod antiquitus ab Aegyptijs canis maximos honores meruit:quod occifo abiectọ́ A pi a Cambyfe, ex eo nihil omnino guftârit, Cxlíus Calcag. in Rebirs Aegypt. Onofreli damones, mares feut plurimum exhibent, interdum quoç leonem \& caneri in duerc uidentur, Caelius 1. 47. Cynades, kvvad dss, Neptunus, A thenis colebatur, Hefych. SC Varin. Meminit eius Gyraldus etiam. Canario augurio(ut fupra etiam dixi)conftituebantur dies, pritufis frumenta uaginis exirent, $\mathcal{Q}$ anté ${ }^{\circ}$ in uaginas peruenirent, à cane ducfo uocabulo. Siquidem rutile canes, id eft non procul à rubro colore immolabantur, ut ait Atteius Capito, canario facrificio pio f. ugibus, deprecandx fauitix caufa fyderis Canicula, (hoc, ut feribit Feftus, Iulio menfe ficbat. ) Le

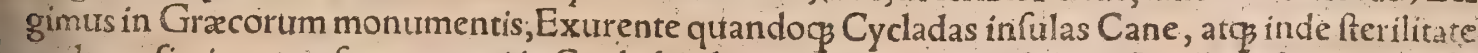
multa ac ficcitate confequuta, qui in Ceohabitabant; ex oraculo Ariftrum Apollinis \& Cyrenes fi lium accerfuerunt:aduenit is, ex Arcadia fecum quibufdam ductis , templum ćs ex exit louis, quent uocauti lcmaum, quafi tu pluurium dicas. Canem quoq̧ rebus diuinis operatus placauit, Ceisḉs le gem inftituit, fingulis annis eiufdem feruarent exortum cum armis, ac eidẽ rem obirent diuinam:

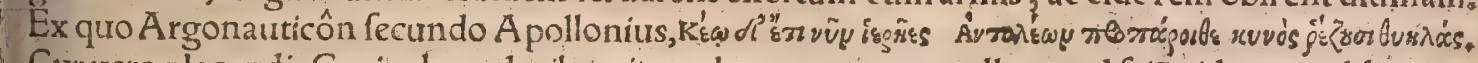
Cur urero placandis Caniculæa ardoribus immolarentur canes, nulla(quod fciā) idonea redditur ra. tio:nam \& Ouidius Faftorum 4 ita canit, Procane fydereo canis hic imponitur ara, Et quarefi at, nil nifi nomen habet. Cur autem rutilæ, forfan de A egyptiorum furperftitione duxerit initia, quã do boues ruffos gentium illarũ ritu immolare permittebatur, quod Typhoni perfímiles uiderentur \&.c.Calius. Ego propter fimilitudinem rutili Canículæ coloris id potius obferuatum coniecerim. Feftum quo ex canibus res diuina fiebat, recte à canum cæde nominari Cynophontis potef: cuitur modi apud Argos celebratum uidetur quando $\$$, Calius. Ceos folerter quotannis ortum Canicula obferuare, \&cc, fupra fcripfi ex Ciceronis lib. . de diuin. Rubigo deo uel Robigini dex, ad arcendã 1. ex fegetibus robiginem ueteres menfe A prili extis canis $\&$ ouis facrificabãt ư Ou Ouid in Faftis tefta tur , Gyrald, Nifi prius catulo feceris, Columella: 
P R V V R B IA.

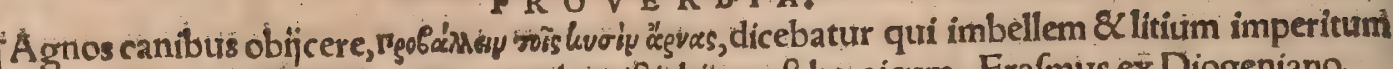
calumniatoribus $\&$ exetcitatis exponeret hemiftichitum eft heroicum, Erafmus ex Diogeniano. Agninis lactibis alligare canem, apưd Plautum in Pféudolo. Lactes dicuntur inteftina molliora. Qui canem alligat, inquit Erafmus, inteftinis agninis, is non modo canem amitrit, uerum \& pradā

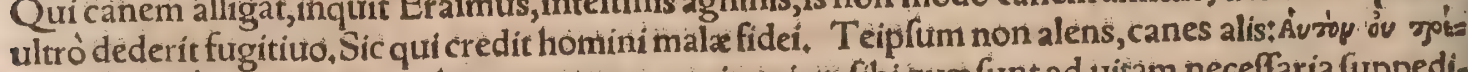
$\phi \omega \mu$, xúva's zo' $\phi$ sis, in eum dicebatur, qui cum per inopiam fibi qua funt ad uitam neceffaria fuppedi. tare non poffet, conaretur aut equos aut famulos habere domi, \&C. Si uel afinus canem mordeat. litem mouebit, Afino offa das, cani paleas. Attali canis, in homines nimium uoraces : nam Attali canis cibum glutiebat, non guftabat, $R$ auifius Textor. TQuid cani \& balneo? ri kotrón hwitiy Bee 10

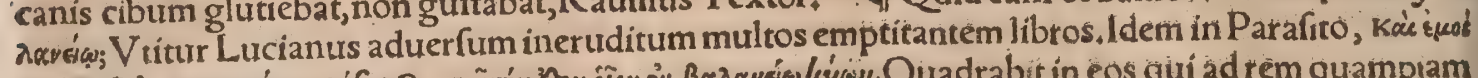

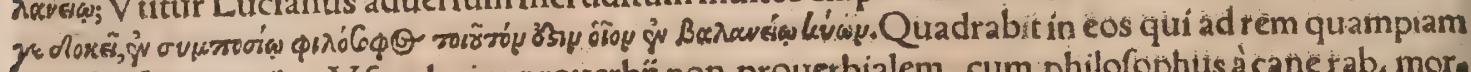
prorfus funt inutiles. V fum huius prourerbí non prouerbialem, cum philofophis à cane rab، mor. fus balneum ingrederetur, fupra oftendi, De ufu huius prouerbij uide plura apud Calium 30.19 . Vt canis è Nilo:Quileuiter a c cbirer artem quampiam, aut authorem deguftant, hiceu canis é Nilo deguftare dicêtur.Id a dagị natum eft ex apophthegmate quodã, cuius meminit Macrobius Satur. lib. 2.cap.2, id elt huiufmodi:Poft fugam Mutinenfem quarentibus quid ageret A ntonius, quidã $\mathrm{fa}_{2}$ miliaris eius refpondit: Quod canis in Aegypto, bibit \& fugit. Nam in illis regionibus conftat canes raptu crocodilorum exterritos, bibere $\&$ fugere(aliâs, currere $\&$ bibere.)Solinus ait, eos nó nific cur. rentes lambitare, ne deprehendantur. Certum eft iuxta Nilum amnem currentes lambere, ne croce: 2 dilorum auriditati occafionem prabeant, Plin. De quo dicam etiã infra cap.1. de diuerfís canibus, us bi de A egyptijs. Simile habent Germani, Ker louffi oarïber/als ein ban über sie beiffen Eolen.

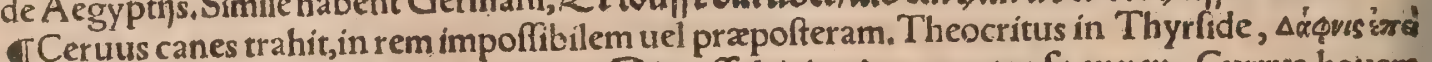

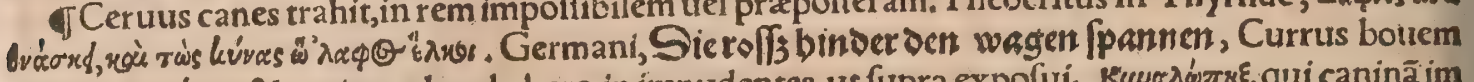

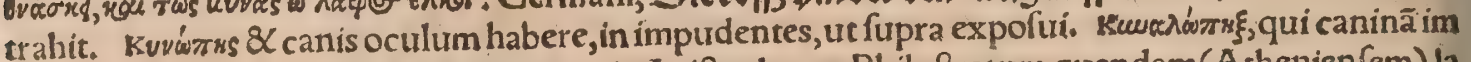
pudentiam cum uulpina aftutia coniunxit. A riftophanes Philoftratum quendam(Athenienfem) la fciuiufcule fe ornantem uocauit cynalopeca, ex cane \& uulpe concinnata dictione, nifi ad Cynnä fcortum referre malueris, Calitis: nam $\&$ rogvo Booróv fuiffe aiunt. Vocât item cynalopecas canes $\mathrm{La}_{\text {: }}$

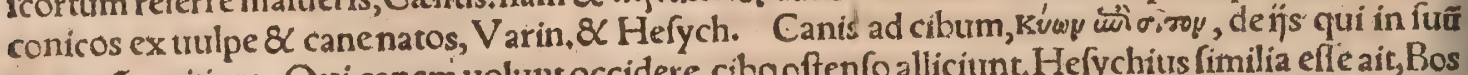
properät exitium. Qui canem uolunt occidere, cibo oftenfo alliciunt. Hefychitus fimilia efle ait, Bos ? ad mactationem, \& Sus in uincula: Vide infra,Canis in uincula. Canis corio affuetus: uide poft in

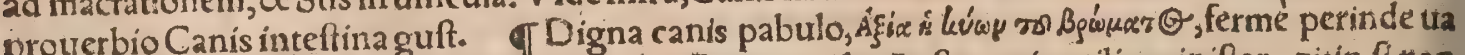
let acfi dicas, Dignus operarius mercede fua. Et uix quifquã eft tam inutilis minifter, quin fi tion amplo falario, certe uictu dignus effe uideatur. Referturà Suida . Simillimum illud Germanicum,

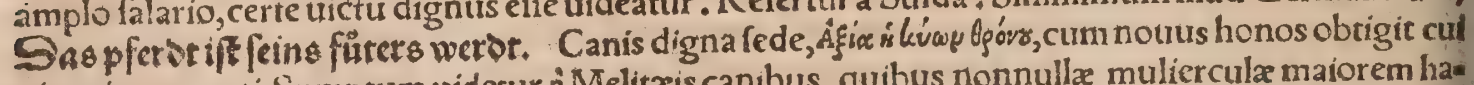
piam immerenti.Sumntum uidecur à Melitæis canibus, quibus nonnullæ mulierculæ maiorem ha. benthonorem quàm ipfis maritis. Nifi mauis referre ad Anubim Aegyptiorum deum. Refertur à Diogeniano. Canes uel catella dominas imitantes, ubi qui fubfunt eorum exprimunt mores ifcro ciam, arrogantiā, faftum, \&c, fub quorum imperio degunt. Videas autem \& Melitæas opulentarü mulierum delicias, faftum, la fciuiā, toramós fermè mor um imaginem reddere.Plato libro 8.de Re* pub. de ciuitate licentiofx libertatis loquens: Planè, inquit, etiâ beftiæ quæa ab hominibus nutriunt, quâto liberiores hac în ciuitate fint quàm alibi, nemo nifi expertus crediderit. Nam \& catella, ut ha. bet prouerbium, perinde ac her $x$ funt: $\&$ equi $\&$ afini tanta per uias libertate progredi confuef cũt, ut in obuium quenç ímpetum faciãt, nifi cefferic. Vna domus non alit dưos canes, Eis oirtos r' diuveroul

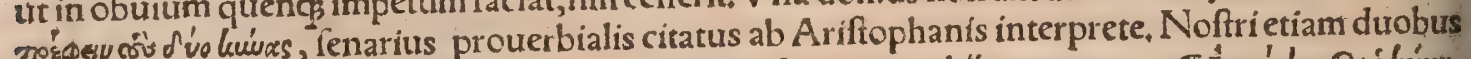

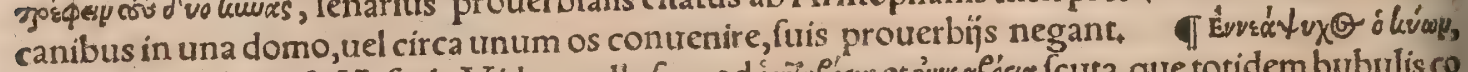

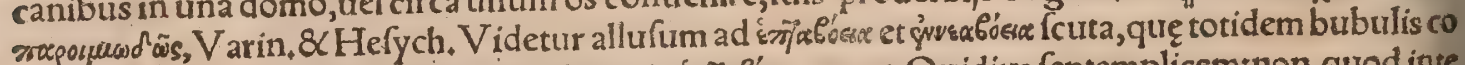
rijs obducta erant. Homerus Aiacis clypeum Ėj]atósoy uocat, Ouidius feptemplicem: non quod inte gra feptem boum haberet coria, fed quod quantocuncs corio fepties plicato conftar et. A riftophanes

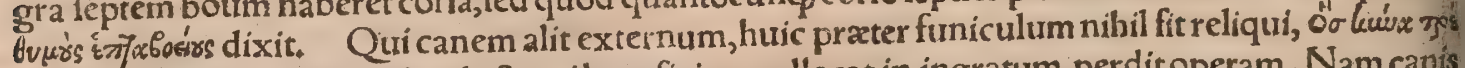

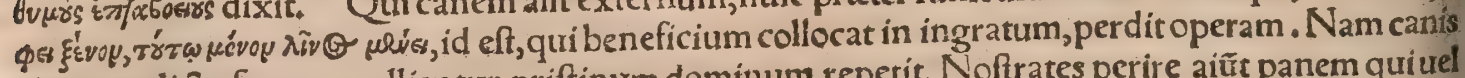
alienus relicto fune quo alligatur, priftinum dominum reperit. Noftrates perire aiưt panem qui urel pueris alienis uel caniburs externis detur. Canem excoriatã excoriare, Suidas ait dici folere de n̊s qui iterum ea patiuntur, quibus aliquando fuerunt afflicti, Ariftophanes in Lyfiftrata, Tó rô фug

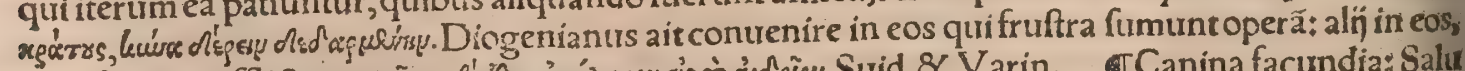

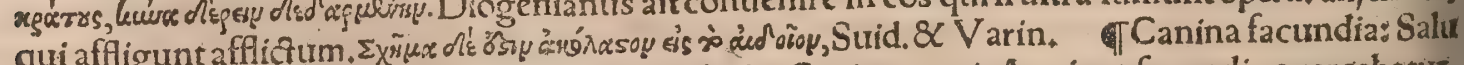
ftius apud Nonium Marcellum in dictione Rabula, Canina (ut ait Appius) facundia exercebatur. In cos qui tantum ad malcdicendum eloquentix ftudium exercercnt: à rixa canum \& oblastatu, fumpto epitheto. Siquidem $r$ litera, qux in rixando prima eft, canina uocatur. D. Hieronymus ine piftola ad Ruft.monachum, Pomparum ferculis procedunt in publicum, ut caninam exerceant fas cundiam.Idem obtrectatores fuos fubinde canes appellat. De canina eloquentia fuperius etiam in uoce canuma nonnihil; \& alibi in Cynicorummentione. Ariftophanes in Vefpis duos canes indua 


\section{4}

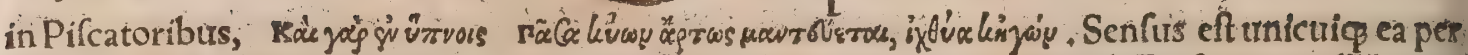
fomnü occurrere; quę impenfe defyderat, uel quibus magnopere deditus cft. Erafmus apud heocr tum pro "k riftotelem legatur; audire nos fapénumero canes dormientes tienationem fomniare. Ego ipfum dê hac fcriberet Eralmum fomniaffe puto:nhil enim huiufmodi apud Ariftotelem reperirur : cuíus de fomnḯs canum librò 4 . hiftoria animalium cap. 10.uerba hac funt: Item fomniare non folum homi nes, fed etiam equos, \& canes, \& boues palàm eft, \&c. Declarant id canes fío latratu quem per quie tem agunt:nec aliter Græca häbent, quæ cum Gazx translatione contulimus. Ad hac communius eft, 8 xque ad omnes pertinet canes panem fomniare: uenationem, non item. Quãobrem non eft ut cum Erafmo emendatiorem hac parte Theocriti codicem expeciemus. Pellem caninam rodere, prouerbiali metaphora dixiffe tridetur Martialis, proeo quod eft hominem maledicum \& improbũ conuicin's infectari. Sic enim fribit in obtrectatorem quendam \& oblatratorem: Non deerunt tam men hac in urbe forfan, Vntrs, uel dưo, trésue, quatuórue, Pellem rodere qui uelint caninam.

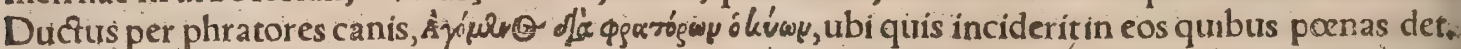
Phratria Athenis dicebat tertia pars tribus. In comitỷs auterfiquis canis intercurriffet, continuo pete

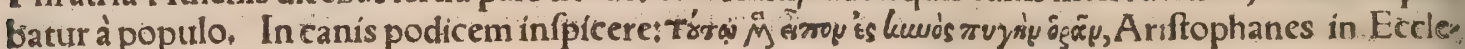

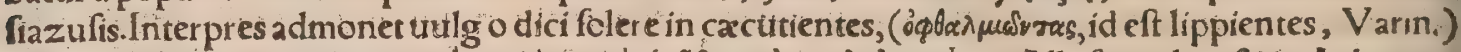

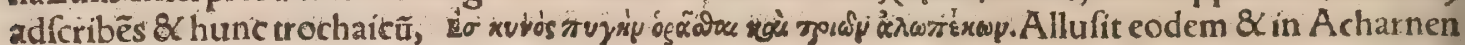

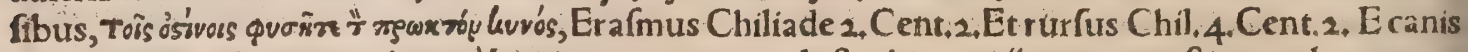
podice, dicqum (inquit)uidetur à Luciano, pro eo quod eft rebus anxíps atós anguftis, quod ea pars ar 2

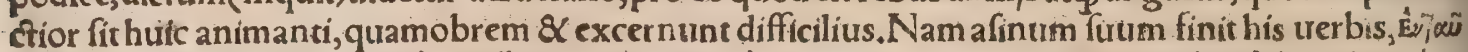

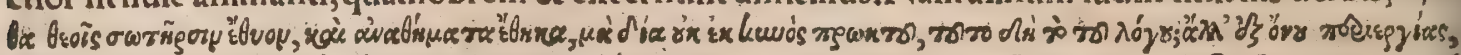

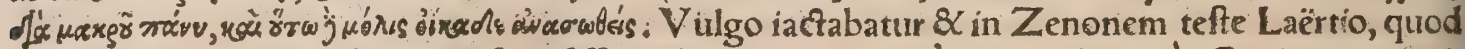
in canis poftico de republica confcripfiffet, trel quod nimis anxiè, uel quod inepté. Canis in pratepi,

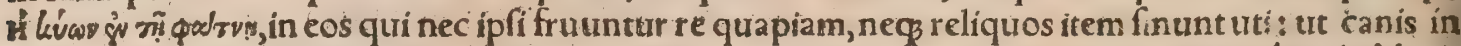
prafepi nec ipfe uefcitur hordeo, \& equum uetat uefci, Lucianus aduerfus indocium, Átà ro of luwis

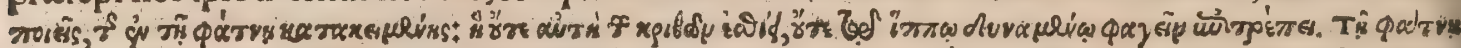

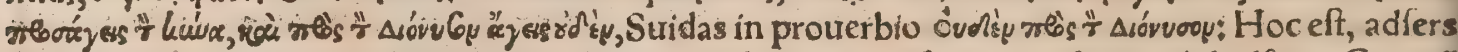
quie ad rem nihil attinent, ex his uero qux pertinebant ad caufam propofitatn nihil adfers. Caninư prandium, id eft abftemium, \& in quo nullum uinum biberetur : propterea quod peculari naturæ proprietate, canes à uitio abhorrent. A. Gellius libro iz. Cap, ultimo: Eius autem loci in quo id pi ouer.

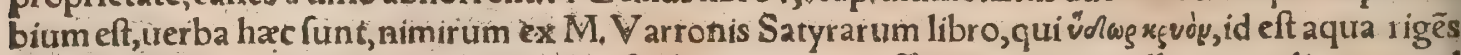
inforibitur. Non uides apud Mnefitheum frribi tria genera efle uini, nigrum, album, medium, quod

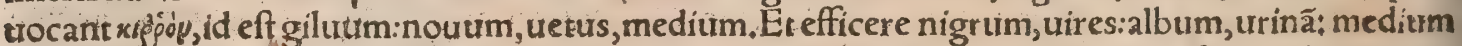
peplin, id eft concoctionem. Nouưm refrigerare, teetus calfacere, medium uero effe prandium caninum. Quid fignificet, inquit Gellius, rem leuiculam diu, $\&$ anxie qux fiuimus, Prandium aurem ab. ftemium, in quo nihil uini potatur, canínum dicittr, quoniam canis uino caret. Cum igitur medium tuinum appellaffet, qutod negs notuum, neç, treturs effer, \& plerungs homines ita loquantur, ut omne uinum aut noutum effe dicant, autuetiss, nullam uim habere fignificauit, neqg noui, neq̧ ueteris, q̊d medium effet. Idcirco pro uino non häbendt, quia ne $\beta$ refrigeraret, neos calfaceret, Hactenus Gel, 4 lius. Plauttis etiam in Cafina, caninam coenam uocat, qux abftemia \& fine trino fit. Sunt qui caninû prandium ad caninam appetitionem contra Gellium putent referendum, $C_{2}$ l. Vinum medium pro aqua ueteribus tuidetur accipi, quoníam tuinum omne aut muftum fit, aut uettr, Calius:qui ex Mne fithei uerbis iam recitatis id probare conatur, mihi non uidetur. Cynicum conuiuium, id eft, rynice. rum phulofophorum, ubi lentes feré cibus erat, aqua potus, A thenatus libro 4. defcribit. Promerica

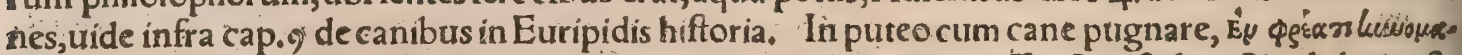
Xî, in eum cuíres effer cum improbo aliquo, quem declinare nó poffet, A poftolius. Simile heric eft,

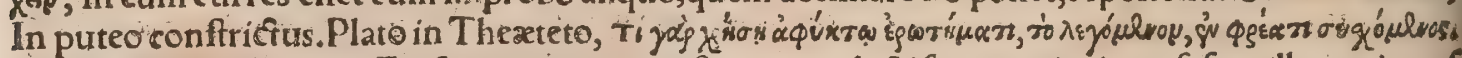
Quadrabit in eos, inquit Erafmus, qui in anguftias eas redacti funt, ut extricare fefe nullo modo por

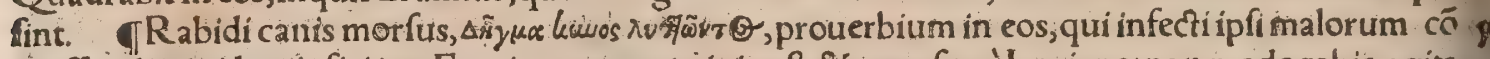
greflu, alios itidem inficiunt. Etenim recepta opinio eft, \& expofita à Luciano: non modo rabie agita ri $\propto$ aquam expatiefére, quos ita affeçus canis momorderit:fed $\&$ ipfos item retiner euim, eundem imprimendi morfum, atç ita deinceps fieri hydrophouicos omnes, ut fiat quadam rabidorum cate

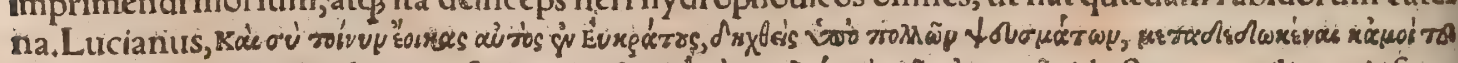

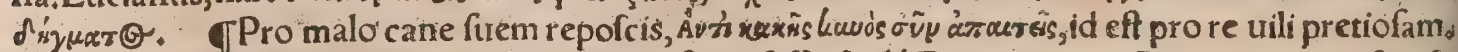
Sus enim efculentis, canis haudquaquiram trefcus eft: Refert à Diogeniano. Canis peccatum fus de

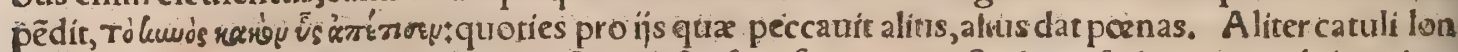
ge olent, aliter fues, Plaut.in Epidico:Quo dicto fignificat non uefte dignofci hominem ab homine uerum ineffe natiuum quiddam, genuinum ac proprium in unoquoq;, quod in ipfo uultu oculisḉs eluceat, quo hominum ingenia difcernas.Similiter Martialis, Omnia cum ferit, Thaida Thais olee.

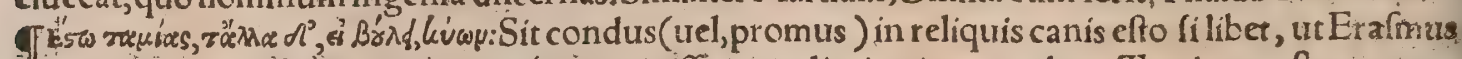
ier tit:In eum cuifolicítas immerenti contigiflet, peculiariter in eunuchos. Tamix quaftores erant 


\section{DeCane. H. Lib. I. 235}

Athenis, $\& c$, ut Suidas refert. Erant $\&$ tamix triremium. Is magiftratus interdum furacibus commic tebatur, non integris $\&$ incorruptis uiris. Per froniam dici poteft de eo, qui dignitatem inuadit, nihil laborans quam eruditionem, quósue mores poftulet ea dignitas. Canes timidiuehementius latrãt: Q.Curtius lib.7.demonftrat huiufmodi prouerbium apud Bactrianós uulgò iactatúm fuiffe, Canis cimidus uehementius latrat quàm mordet: Cui fimilem allegoriam fubijcit, altiffima quxés flumina minimo fono labi. Germani etiam vitranq

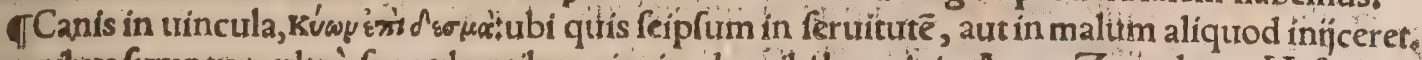
A canibus fumptum ultrò fe prabentibus trinciendos cibilenocinio, Autor Zenodotus, Hefychius 8. Suridas indicant in eandem fententiam dici Bos in uincula. Supra etiam ex Erafmo fímiliter expo to fui parcemiam Canis ad cibum. Canis uindictam surués nímsy, fubaudi paffus eft, aut aliud commo dits: Macedonicum adagium in eos; qui prater expectationem poenas dant ijs, quos aliquando laferunt:natum ex morte Euripidis, de qua infra de canibus diuer fis cap, 1 ; Canis reuerfus ad uomi-

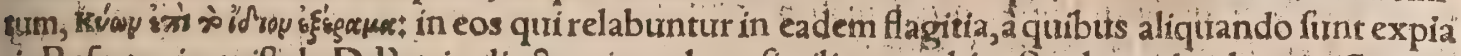
ti. Refertur in epiftola D.Petri, adiecto etiam altero fimili prouerbio, Sus lota ad uolutationẽ conni. In eandem fententiam. Hebraus ille Parcemiographus, Sicut canis(inquit) qui reuertituk ad uominum fuum, fic imprudens qui iterat ftultitiam. Nam hưc, ni fallor, locum Petrus defignautiti. Sumptả metaphora à canibus reforbentibus quod euromuerint.

TCynadra fons prourerbio occafronem dedit, ut fupra dixi parte iliuius capitis, Chius ad Coum:

hoc etiam fupra explicatum eft ibidem.
THis fubtexam Germanica quadam adagia, in quibus mentio canis fit, \& Latina quibus fenfư conueniunt adiungam. Wañ oet alte buno bellec/ fo fol nsan auffabeh + Profpectandum uetuló cane latrante: hoc eft, nequaquam negligendum quoties fenes periculum catiendum admonent. $\mathrm{C}_{2}$ nes enim uetuli non latrất temere, quemadmodum iutuenculi. Meminit Erafmus in prouerbio, Eum

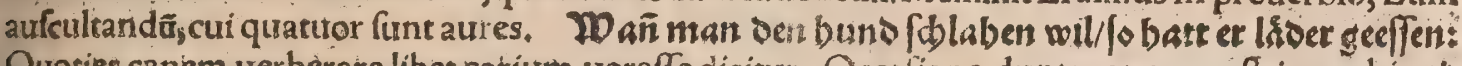
Quoties canem uerberare libet cotium uroraffe dicitur, Occalione duntaxat opus eff improbitati,

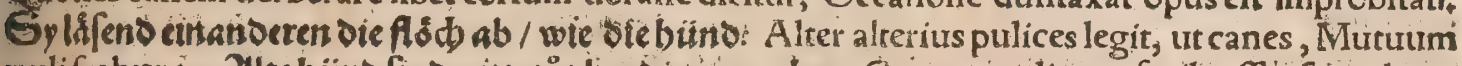

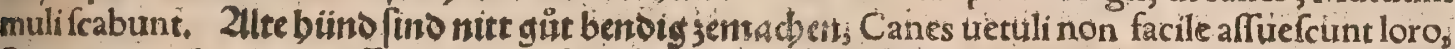

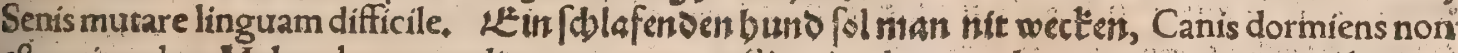
eft excitandus, Malum bene conditum ne moueast Sir ctiam leonem dormientem excitare adagium

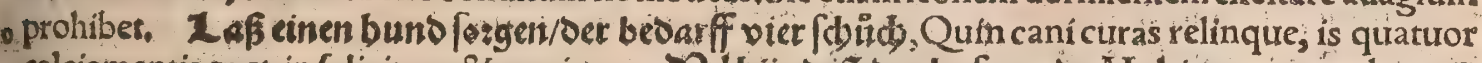
calciamentis eget, in folicitum $\&$ anxium, Dilbün ift oer ba. [ent toot, Multi canes mors leporu,

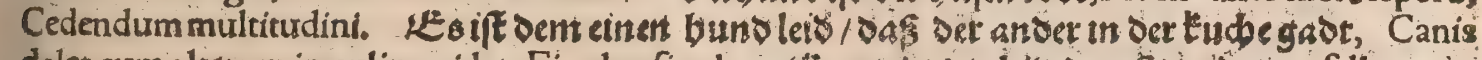

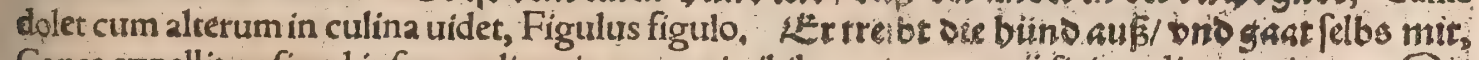
Canes expcllit, ac fimul ipfe egreditur:in eum cui nihil omnino negotif fit in aulis principum, Sic

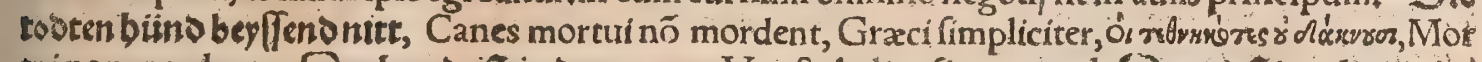
tui non mordent. Ser bund ift in dem potte, Vueftphalis ufitatum; uel, Su wirft den buno in potte firtoen, Canis in olla, ubi ne bolum quidem relictum effe intelligunt. 2in Der buns bincken/

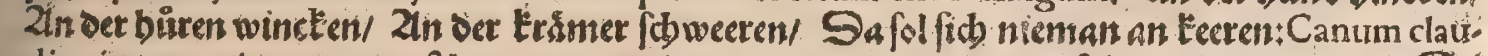
dicatio, meretricum nutus, \& mercatorum iuramenta, ex æquo omnia fidem non merentur. Sú wilt von dem buno/blager cin Eolben Euffen, Fuftem petis (autlicitaris) à canicida:Hoc eft, pe.

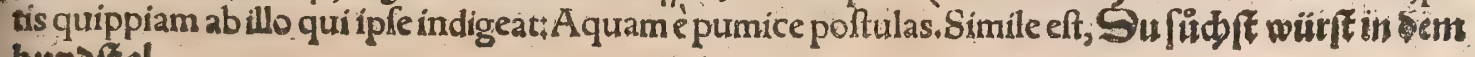
bundtal.

\section{DE C A I B V S I VERSIS.}

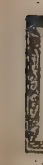

A C T E N V S decanibus dixi ea qua canibus communia omnibus uidebantur t eliquit eft ut quae fingulatim ad canes diuerfos pertinent confcribam. Itaqg primo loco ordine lite. rarum dicam de ijs canibus, quortum hiftorix extant aliqux, nec tamen ad ullum genus fe. quentiùm commodè referri poffunt. Nam quæ ad uenaticorum genera diuérfa, uél pafto. orales, uel focios, uel cuftodes, \&c.pertinent, feorfim poltea ad fuum qua q̧ genús refet am.

TCanes in Aegypto minores quàm in Gracia fiunt, Ariftot. Aegypti canes fugaciffimi funt, Nam cum ea qua in Nilo degunt, timeant, ab his admodum fugitiui funt, neq quamuis illuc fitis ad bibẽdum eos attrahat, ferarum Nilicarum metus quiete illos potione fe complere permittit. Ideo ne quid eorum, qua infra aquam degunt emineat foras, ip fos ćs obtorta gula de ripa in altitudinem ab. ripiat, non inclinatione corporis abie fa incumbunt ad bibendum, fed ut primum ad ripam acceffe. runt, feftinanter, 8 in tranfcurfu lingua lambentes, rapiunt, ac certe, ut ita dicam, potionem furan: tur, A elianus:Idem fcribit Varix hift.lib. 1. cap.4. Vide fupra in prouerbio, Vt canis è Nilo bibit, $\&$ fugit. Solos Memphiticos canes in medium auditione accepi rapinas proponere, 8 . comminiter viutere,Aelianus.

6. Alcibiades canem habuit fexaginta minis uenalem, mire formofum: curius caudam cum muti. tilaffet, illi qui formam canis ab eo corruptam reprehendebat:de induftria fe abfeidiffe refpondit,

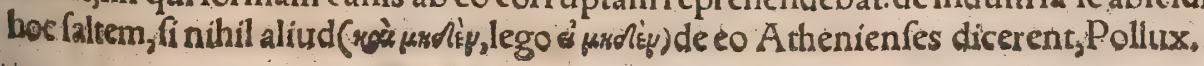


236 DeQuadrupedibus

IAttali canis inter prourerbia eft, in homines troraces:quod is tiçu ingenti cibum glutiret, norl guftaret, Textor.

TCelebris futit etiam Cerberus Epiroticus canis, Pollux 5 . 5. Inuenio hunc Alexandrifuiffeca. nem, adeò robuftum ut cum leonibus congrederetur, Calliusł quí Pollucis uerba malè perpendit, \& canes divierfos confudít. De hoc Alexandri cane inter robuftos dicam inferius.

TCarmanius uir, $Q$ canis eitufdem nationis, animo agrêfi atç a deo duro, immanfuetiac feriexi ftimantur, ut natura manfuefieri non queant, Á elian.

बCerberus alius fuit, quem poetæ fabulantur inferorum cuftodem furiffe, tricipitem, \& cum ab Hercule àd lucerri(tríplici catena trinçus) extraherétur ex fpuma eius natum effe aconitum, ut Nie cander canit. Cerberirm quafi kgrobógoy, id eft carnitiorum diçum grammaticorum conieçura eft. Fertur quiod hic fuerit férpens in Tæxnaro Laconix promontorio, cuitus uenerio môrtäles extingue: bantiri. Et quoniam in Txnaro ad inferos dicitur effe aditis', Dítis canem dixerunt:quem cum Her cules triucidaffet, nata eft fabula, canem tricipipiẽ inter emiffe: Aut quia omnes cupiditates \& cuncfa uitia terrena contempfit ac domuit. Ouidius tergeminum \& uipereum canem appellat, Seneca in tragcedijs triformem $\&$ Tartareum. Serapídis fymbölum canis eft, triceps ille feilicet, qui in aqua, ter $x a$, \& aëre, tribus his elementis uérfatur, pernicioffiffimuts dæmon, ut ait Porphyrius. Nam \& exitıan les dæmones opertè canes uocantur atri $i, \&$ furix canum nomine ueniunt. Serapidis fimulacro, in= quit Macrobius, fignum tricipitis animantis adiungunit, qutod exprimit medio eodemó̧ maximo ca pite, leonis effigiem:in dextra parte caput canis exoritur, manfueta fpecic blandientis: pars treròlae

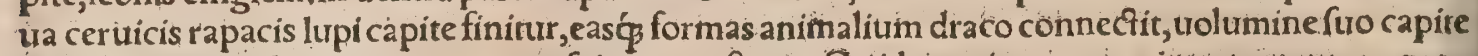
redeunte ad dei dextram, qua compéfitur monftrum. Quidam tria tempora interpretantur, prate

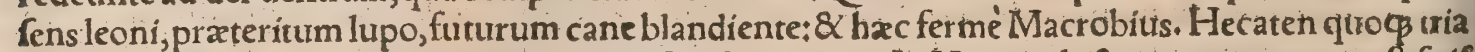
capita habuiffe, equi, canis, $\&$ hominis agreftis, fupra dixi. In Hecatzil lectum monumentis eft, fuif

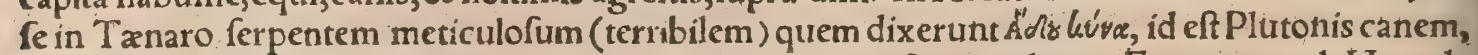
quoniam morfum eueftigio infequeretur mors, ureneni poteftate uiolenta. Eum támen ab Hercule ad Euryfthea fuiffe producium, unde irrepferit Cerberi fabella, quem princeps Homerus dixít Ás

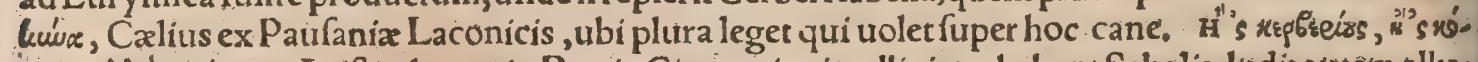

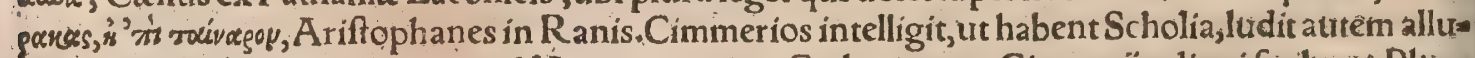

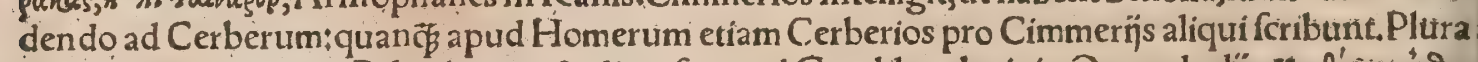

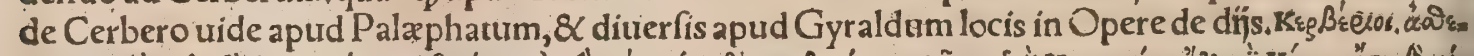

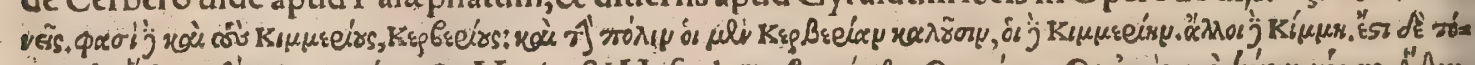

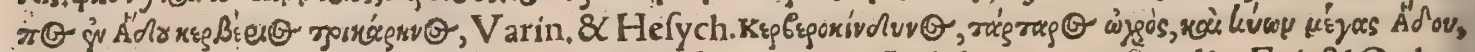
Iidem. DeGergittio cane Geryonis Cerberifratre, dicå nőnihil in cane paltorali. Fuit \& Orthus Geryonis canis in Erythea, cui canina capita duo, \& draconum feptem erant, Varinus in Scylla. - Plura de Cerbero cane uide apud Varinum.

I Cyrus commemorabat fe ab uxore Mirradatis bubulci, qux Cynò uocabatur, fuiffe educatum, remper eam laudibus profequens, ita ut in omni eius fermone effer $C y n o$. Quod nomen accipientes eitus parentes, ut diuinius uideretur Perfis filius eorum fuiffe feruatus, diunulgaruntà cane Cyrum, cum effer expofitus, fuiffe educatum: Vnde hac fabula emanauit, Herodotus lib. 1. Cyrum Manda. Ila filium àcane fuiffe enutritum fama refert, A elian.lib.12. Variorum.

- Diogenis Cynici feruius fugitiuus, captus $\&$ Delphos abduçus à canibus laniatus eft, fugę poe nàm hero perfoluens, A elian.in Varijs.lib.13.

T) Euripidem à canıbus profriffum interiffe, ferè omnes tradunt, ad locum Bormifcum, de montis Bormil nomine appellatum in Macedonia. Canes eas feribit Stephanus ab indigenis Efterincas(Ėsw

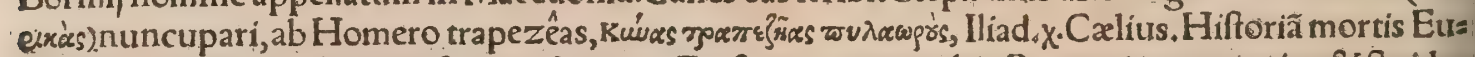
ripidis à canibus illatæ copiofius profequitur Erafmus in prouerbio Promericanes, cuitus $\&$ Suidas meminit; item in prouerbio Canis uindictam. Kuwòs ol'xsu, Canis uindictam, fcilicet paffus eft: Mace. donicum, inquit, adagium eft in eos, qui prater expectationem pơnas dant îs, quos aliquando lare runt, ab Euripidis interitu natum. In Macedoniæ uice; qui Thracum dicittrr, qued olim à Thracibus fit inhabitatus, cum canis quidam Archelai regis aberraffet, Thraces de more furo mactatumfas crificarunt, ac detorarunt. Quod ubi comperiffer Archelaus, talentum eis mulcfam dicit, Verum cum illi foluendo non effent, Eutripidem fubornarunt, qui regem exoraret ut fibi mulctam remitte. ret, ita ut fecit.Poftea uero cum Euripides in fyluta quadam felus effet, \& Archelaus à uenatur reuer zeretur, canes Euripidem cinçum difcerpferunt, deuorarunt'́g. Exiftimatum eft autem eos canes, ex eo prognatos fuiffe cane, quem Thraces facrificarant. Valer. Max. libro 9, cap.de morte non uulga: ri, refert Euripidem, cum ab Archelao rege Macedonum coenæa adhibitus fuiffet, dom umà contriuio repetentem, à canibus fuiffe difcerptum. Eos canes ab xmulo quopiam immiffos fuiffe confirmat A.Gellitus 15.20,Stridas (in Euripide) addithos zmulos fuiffe Arridęum Macedonem, \& Crateuam Theffalum poêtas, quos Euripidis' glơria urebat. Hi finxerunt eum à regïs canibus dilaceratum fuif - fe, Sunt qui narrent eum non à canibus, fed à mulieribus fuiffe dilaniatum, cum intempefta nocie Craterum adolefcentem peteret, Archelai amafium (uel ut alij, uxorem Nicodemi Arethufíj.) Accós. modari poterithoc prouerbium etiam in hunc fenfum, qucties author illati mali diffimulatur; teluti. 


\section{De Canibus diuer fis. Lib. I. 237}

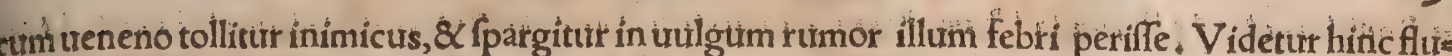
xiffe quod hodie paffim apud Germanos dictitant, ubi quid accidit incommodi certi, incerrto auttho: rê, quodís nemini poffis imputare, id canis accidiffe morfu, Hactenus Eraf. Sunt quil Promerumino ninatum dicant Archelai miniftrum, qui in Euripidem tralde fibi exofum, quod ab eo apud règem

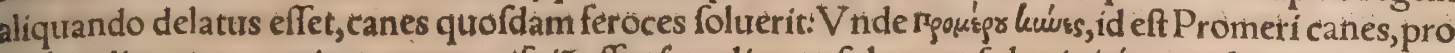
uerbio dicantur, quoties potens quifpiã offenfus, aliquos fubonnat fubmittitọ́, qui alicui negotium faceffant, Refertur à Diogeníano, Eraf,

बPrater Euripidem feruntur \& alif quidam celebres uirià canibus laniati, qios illius hiftoriæ oc cafione hoc ipfo in loco memorandos duxi, Thrafi, Actæonis, \& Lini, omnitm hoc mortis genere o defunctorum, meminit Ouidius in Ibin hoc tetrafticho: Pradaćp fis illis q quibùs eft Latonia Delos

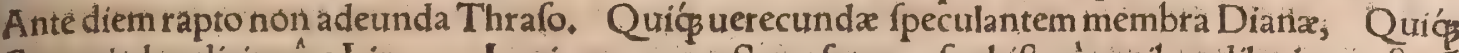
Crotopiaden diripuêre Linum. Lucianus quoos Samofatenus fophifta, à caniburs dilaniatus eft, nô fine diuinæ ultionis fufpicione: Nam Chriftianus primum cum à fide catholica defeciffet, animum \& fylum ad lacerandam religionem conuertit,Io.Rauifius, Medio Linus intertextus acantho; Letiferíç canes, Statius libro 6. Thebaidos. Milo(Crotoniates)à feris laniatus êf, uel (ut alị)à caní. bus, Varin. Heracletus Ephefius philofophus cum hydropicus effet, $\&$ medicorum operam recu= faret, fuo ipfe perijt medicamento. Nam quum feuo bubulo fe aliquando ut prius inunxiffet, ac dor. miens apricansćp foli.prabuiflet exíccandum, canum fato nęcio quo fuperuenientium morfu la niatus eft, $10 . R$ autifius.

10. Fericanes reperiuntur, Ariftoteles.

DeHecuba in canem mutata, nōnihil attuli fupra in ttoce Cynoflểma, inter nomina propria a cane facta. Vide Ouidium libro 13. Metamorph. Hippamon canem habuit Magnetem, nomine Lethargum, qui cum hero fuo fepultus eft, ut indicatur hoc epitaphio quod Pollux refert, Ávdsi uli

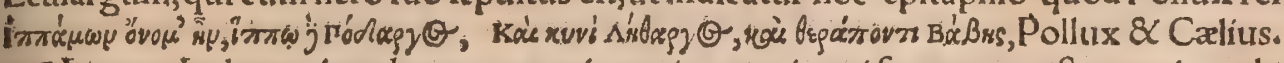

『. In terra Indorum haud prope mare inuen itur canis qui femper poteft uocari catulus. Is ć́ dome fticus eft canis, colore maculof $x$ lynci perfimilis. Pilofus itaç reperitur, ac depilis; ut tonfus. Nec ta. men latrat,nec gemere fcit, aut fufpirare, ut retulit nobis Hifpanus quidam, qui maximam partem Indixe peragrauit, Itaç3 nullam emittit uocem, cum etiam necatur : \& compar uidetur föturælupi: Edit autem ac bibit, ut alius canis, eftó̧ paulo minus mitior I talo cane: quibus eft doméfticus, mouet tantum caudam geftiens, \& faliens, quod eft indicium amoris in dominum, Blond. कDe Indicis canibus magnis \& robuftis; infra dicam inter Venaticos. Petrus Martyr etiam in defcriptione No ui orbis canum qưorundam non latrantium meminit, quí in cibum quoç̧ ueniant : Et alibi, canum non latrantium roftro utulpino.

q Palamedes agricola canem habuit quem Vlyffem áppellabat, \&c, Blondus, nefcio ex quo atr. thore. IL.Paulo confulli cum forte eueniffet, ut bellum cum regePerfa gereret, domũ è curia regref fus, filiolam fuam nomine Tertiam, qua tum erat admodum paruula, of culatus, \& triftem animad= uertens, interrogauit quid ita eo uultu effer:quæ refpondit Perfam periffe: decefferat autem catellus, quem puella in delicịs habuerat, nomine Perfa. Arripuit igitur omē Paulus, éćg forturito dićo, qua= fi certam fpem clarifimi triumphi animo præfumpfit, Val.Maxim.1.5. TPholyes, fului dicuntur

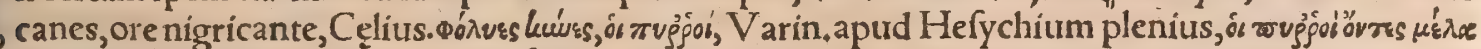

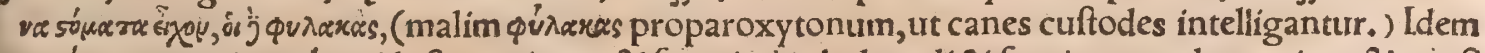

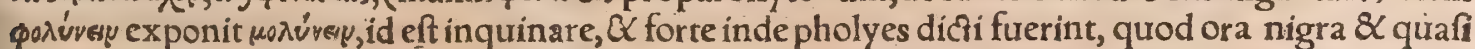
inquinata haberent:Nifi quis ab aliquo locofic dictos fuiffe malit, Pholon quidem urbs Arcadia eft: QPholoé eiurdem regionis mons fyluofus.

TSalentini canes à Varrone probantur in paftoralium mentione.

TScylla Phorci \& Cretheidos Nymphx(fecundum alios Hecates) filia fingitur à poetis. Ingtrina eius in canes mutata effe fabulatur Oridius Metamor, lib.14. Er Vergilius A eg.6.marinos canes di cirde Scylla loquens. Vide Onomafticon noftum, \& Gyraldum in fine hiftoriæ de marinis dijs. Il. lum Scylla rapax canibus fuccincta Moloftis, Vergilius in Culice.

- In Scythia canes cum afinis, in magnitudinis comparatione coniunguntur, quibus ad uehicula rotis carentia mercatores utuntur, ac duo homines in uno uehi poffunt:quod ipfum ad lutulenta cōa ficienda itinera inuentum eft. Sex igitur canes ad uehiculum ordine ligantur, in quocunģs $a b$ auriga qui unà cum mercåtore in uehiculo fedet, diríguntur, eò plauftrum euehunt, \& lutum tranimirtunt. $\checkmark$ num iam diem amplius laborem ferre non polfunt. Itaç his laffis recentes atc $\beta$ integri canes fuc: cedunt,neçiz tamen magna onera imponuntur, fed duntaxat negotiatorem, \& aurigam \& pellium fafciculum uehunt. Ergo unoquog; die negotiator habet tandiu neceffe commutare canes $\&$ auri. gas, quoad ad montes, ubi emat pelles peruenerit, Aelian.

T Turcarum imperatorem audio Gallorum regi, uno aut altero ante ç hęc fcriberem anno, canes dono mififfe pectore \& 4 uentre rubentes.

6) DE MELITAEIS CATVLIS, ET ALIIS

paruis qui in delicịs habentur.

I A С Y X N O Sicilix promontorio imminet Melita, de qua catelli portantur, quos Melítxos uo 
cant; Strabo libro 6. Erant olim in pretio \& delicijs mulierum catuli qui nafcebantur in Infula Meli: ta, fita in finu Adriatico non procul Ragufio ciuitate: Ea nunc pauperes pifcatores tantum haber in.

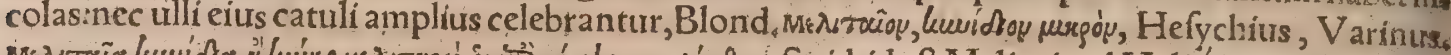

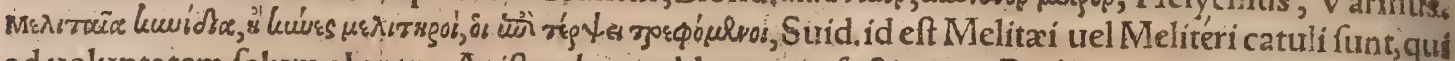
ad uoluptatem folum alintur. Ariftoteles problematum fectione io.Probl, 14 . inquirens cur in animantium genere alia parto; alia magno confiftant corpore: Caufa, inquit, duplex reddi poteft : Aut enim locus, aut alimentum id facit, Locus, fi anguftus eft: alimentum, fi exigurum: quod etiam partu iam edito nonnulli efficere conantur, ut qui catellos in caueolis occlufos educant. Et paulo poft, Fit

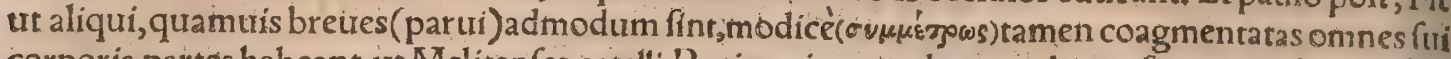
corporis partes habeant, itt Melitenfes catelli. Ratio enim, qtiod non ut locus, fic natura furum effice reopus foleat. Catelli Melitenfis magnitudine ictis eft (genus muftela ruffic $x$, quam uiuerram inter

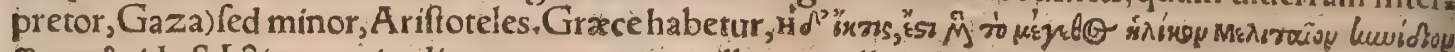

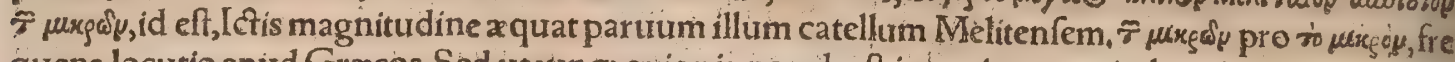
quens locutio apud Gracos. Sed utctin $\beta$ exiguis non deeft ingenium, nec in homines anor. Nam Theodori faltatoris Melitenfis catellus, ultro feipfum in heri tumulum inïciens, cum ipfo unà fepe liri uoluit, ut Aelianus prodidit. Catuli quos Meliteos uccant, ftomachí dolorem fedant applicati fa pius:tranfiréş morbos ægritudine eorum intelligitur, plerunq $\&$ morte,Plin, đCatella Melitæa,

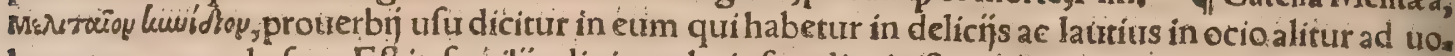
luptatem, non ad ufum. Eft in familins diuitum huiufmodi miniftrorum genus, quos illi non ad minifterium, fed animi caufa domi habêt, Erafmus Chiliad.3. Cent.z. Et rurfus Chiliad. 4.Cent. 4. eodem prouerbio repetito, Melitai catuli(inquit)fic uocantur nimirum ab infula Melita, inter Corcyram ni gram \& Illyricum fita, author Plin,lib.z. cap, vltimo.itidem Strabo \& Stephanus. A pud Lucianum

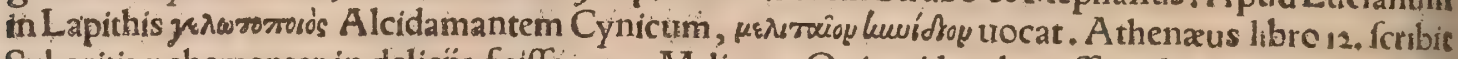
Sybaritis uehementer in delicips fuiffe canes Melitæos. Qui quidem hoc effe uidentur in genere cas num, quod nani 8 pumiliones inter homines, Hæe Eraf. Canis digna throno, adagium fun ptum, ut uidetur, à Melitais catulis, ut fupra dixi inter prouerbia in hiftoria Canis in genere.

đPręter Melitęos, qui hodie ex Melite, ut Blondưs refert, nulli funt:diuerfi alï catelli mulieribus pracipue delicatis \& oriofis nutriuntur. Membris omnibus pufilli \& graciles funt, quos nofirates uulgo bzacteri uocant, Eberhardus Tappius. Inferiores Germani, ut idem fcribit, huiufmodi canicu las nominantiunfern bünotgen, hincillud Vuefphalorum Su byüieft/alsein junffern bünDe=

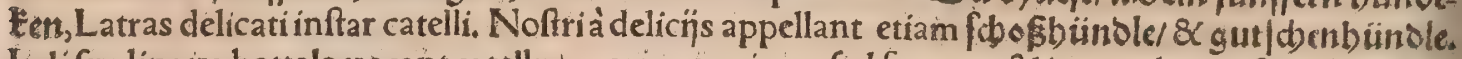
Itali fua lingua bottolo uocant catellum corpore exiguo, fed ferocem \& iracundum inftar rubeta, id eft ranæuenenofre, quam bottam dicunt. Nomina diminutiux formæà cane apud Latinos $\&$ Grę cos ufitata, fupra recenfui cap.8. de Cane parte 1. Martialis diftichon in catellam Gallicanam, De. litias paruæ fi uis audire catellat, Narranti breuis eft pagina tota mihi. Catellos perö̧ elegantes 86 pretiofos Lugduni in Gallia haberi audio, quorum finguli decem denarṇs fiue drachmis aureis, ali: quando uaneant. Catellus qui in delicn̈s habetur, inquit Blond. partiulus eft, pedalis uel femipeda lis: habetur autem in maiore pretio, fi adultus non maior fit mure. Eligitur quadratus corpore, non teftaceus(fic ille loquitur)capite etiam inftar capitis muris, roftro paruo, auribus non maioribus ctr niculi(abfurdum uidetur:)cruribus breuiffimis, pedibus anguftis, cauda oblonga. Laudatur eriam fi collum longiufculis pilis ad armos ufog ueluti iubatum fit, partes cateræe tonfis fimiles. Blandus fero ci prafertur. Color candidus uel niger præ cateris probatur. Sunt ex eis nonnulli hirfuti admodum prolixis pilis, alin breubus \& glabri propemodum, Hac ferè Blond, Et rurfus, Canis delicatulus, in quit, placet cum huc illuc faltitat, ac lenirer latrat, \& abf̧̧ morfu mordicat : pracipué fi mundus eft,

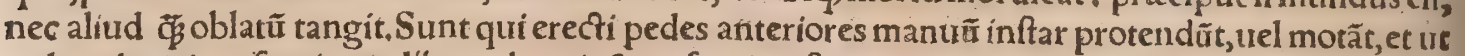
uulgus loquitur, feruiunt:alï quod proiectum fuerit roftro reportant, \&c. Lafciux mulieres praci: pué lectis admittunt, \& lambi gaudent,Blond. Et alibi, Catulos (inquit) quos principes $\&$ matrona in delicḯs fouent, pracipuros gignit Hifpania. Et rurfus: Catulis cingulum fericum collo apponune cupreis campanulis circumfeptum:fic nan $q$ matronæ plurimum afficiuntur. Sxpe iam uifum eft caniculas fingulos peperiffe fortus, exiguas prafertim catellas, quas in finu matronze fourent, pro. pter uteri anguftiam; nam cum plures concipiunt, frequenter moriuntur, Albert. Catellis matrona rum altuus frpe obftruitur, unde plæræç moriuntur, Albert. De catellis qux animi caufa nutriun

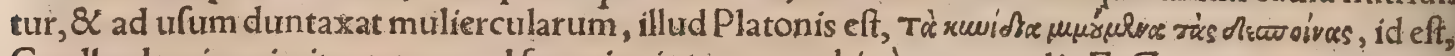
Catellx dominas imitantes, quod fuperius inter prouerbia à cane retuli. Er Gorgo apud Theocrie tum in Syracufýs profectura duo mandat famulax, ut infantem uagientem placaret, \& catellum rea uocaret intrò. Lucianus falfifimé ludit in Stoicum barbatum, cui in eodem fedentí uehiculo domi. na catellam committic, obteftans illum per ea qux funt in urita dulciffima, ut diligenter curet, Eraf, Martialis uerfus in Iffam catellam Publï, tam lepidi funt, ut omnino hic adfcribi mereantur.

Iffa eft putior of culo columba.

Iffa eft carior Indicis lapillis.

Hanc tu, fi q̨ueritur, loqui putabis.

Collonexa cubat, capitç̧ fomnos,

Iffa eft blandior omnibus puellis.

Iffa eft delíciæ catella Publi.

Sentit triftitiamós, gaudiumós.

Vtfufpiria nulla fentiantur: 


\section{De Canibusdiuerfis.Lib. I. $\quad 239$}

Et defiderio coacta uentris,

Sed blando pede fufcitat, toroús

Cafta tantus ineft pudor catelia.

Pictam Publius exprimit tabella:

$V$ fit tam fimilis fibi nec ipfa,

Aut utrancs putabis effe ueram,
Gutta pallia non fefellit utlla:

Deponi monet, \& rogat leurari.

Hanc ne lux rapiat fuprema totam

In qua tam fimilem uidebis Iffam;

Iffam deniqs pone cum tabella,

Aut utranç putabis effe pictam.

DePerfa catello, quem L.Pauli confulis filiola in delicijs habuerat præcedente capite dixi. FCor ticem caprificus arboris detrahes, \& dum recens eft, ad f plenem, uel etiam fi opus fuerit, a diecur pö nes: \& ubi tumor fiue duricies fplenis uel iecoris erit, ibi corticem diutius continebis : deinde in fu= mo eam fufpendes. Quod cum facies, rogabis, ut ficut cortex ille paulatim fumo ficcatus arefcit, fic fplen uel iecur laborantis arefcat. Hęc autem res tantum ualet, ut fi catulis recens natis fiat, dicantur omnino non crefcere, Marcellus Empiricus. In Anthologio Græco legitur A dxi epigramma in cas

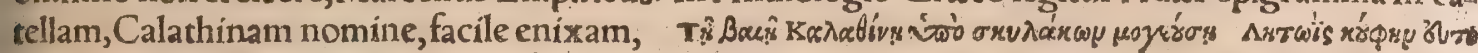

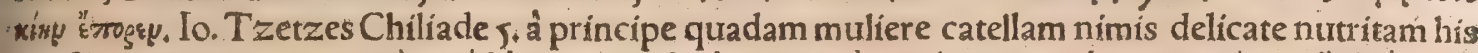

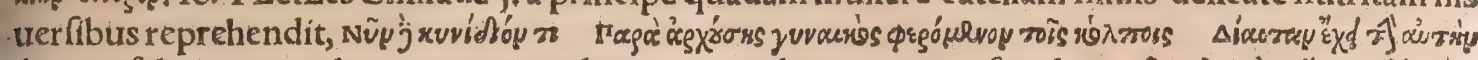
( quam feles reginx, de qua proxime dixerat, quod ex aureis uafis ederet, $8 \leqslant c_{i}$ )

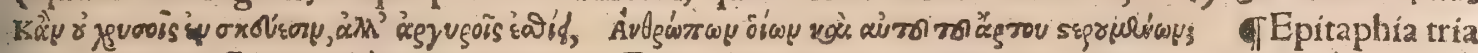
catellorum ex Blondo hîc apponam. बRoma, Corporis exigues cura dum cogor in artius, Suba ducto matris lacfe, mifer perń. Ne tamen \& fati nomen uís afpera tollat, Leucippicineres haec ca.

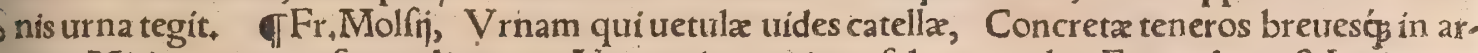
tus, Mitis ne renuas fauere lingua. Nam qui me exiguo folo recondit, Exemplum eft Iouris opti* mi fecutus, Quodante Erigones polorefulget, Ob fummum catulus decus fidemóg. of $R_{i} I n f r r i a$

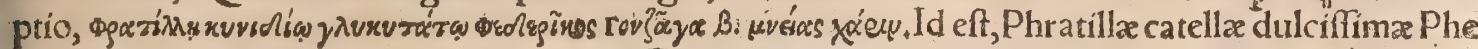
dericus Gonzaga II, memoria gratia, TRéperitur etiam catella diminutiuum nomen à catena, tefte Calio, (apurd Catonem.)

DE CANIBVS VENATICIS IN GENER E⿺辶.

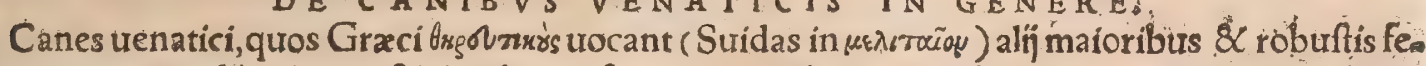
ris opponuntur, alin minores $\&$ timidas perfequuntur, uel ut comprehendant, uel ut in retia adigất: aln̈ fagacitate ualent; aliqui fagaces fimul \& celeres funt : alij \& celeres $\&$ mediocriter robuftitrobus fiffimi enim in fuo genere fimul \& celerrimi effe non poffunt. De robufto, celere, fagace, fingillatim dicam in fequentibus: hîc de uenatico in genere. Quamuis enim plaraç de uenaticis canibus in gen nere prolata, pracipue apud Xenophontem, Pollucem \& Nem fíanum \& Gratium, ad canes cele res, ut qui urel lepores, uel ceruos aliasḉs feras in retia adigunt, fpectare uideantur : funt tamen non nulli quos fimpliciter uenaticos dicas, quod celeritati uel robur uel fagacitatem uel utrumqs coniun xerint. Hinc illa Platonis comparatio eft libro 2, de Rep.ubi inquírit qua \& quales natura fintad urbem cuftodiendam idoneæ; his uerbis, Exiftimásne differre naturam generofi canis, \& generof adolefcentis ad cuftodiam agendam? Quorfum hac? V trung ipforum fagacem oportet effe ad fen tiendum, \& uelocem deinde ad infequendum, ac demum robuftũ curm affecutus furerit, ad pugnana dum capiendumćs. Audax etiam $\&$ fortis fit oportet, fiquidem bene pugnaturus fit: neutrum autem

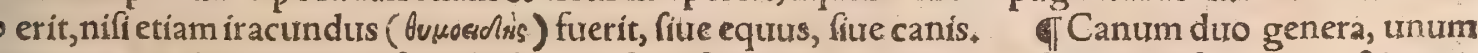
uenaticum, $\&$ pertinet ad feras beftias ac fylueftres: alterum quod cuftodiæ caufa paratur, $\&$ pertí. net ad paftorem; Varro. Mirandum in modum canes urenaticos diceres, ita odorabantur omnia $\$ \&$ perueftígabant, Cicero 6. Verr. Catulus uenaticus, Horat, I, epift. Turba uenatrix cảnum, Valeritis Argonaut. 3. Amphitheatrales inter nutrita magiftros Venatrix, fyluis afpera, bláda domi, Mar tialis in epítaphio canis Lydia. Ceu pernix cum denfa uagis latratibus implet Venator dumeta Lacon, Silius lib.3. TSed quoniam uenationis ufus latifime patet, quacung, ad eam in genere pertinent, differam in alium librum, ubi de animalibus generatim docere propofur, \& quę uel omnit bus uel pluribus communia funt certis locis ac ordinibus rerum digerere. Deferis etiam fingulis quomodo in uenatione canum opera capiantur, in fua cuiufc hiftoria dicam $_{\dot{j}}$ in prafentia non alia de uenatione dicturus, quàm qux canibus peculiaria uel rerum uel nominum ratione uidentur. de uenatione dicturus, quam qux canibus peculiaria uel rerum uel nominum ratione úd

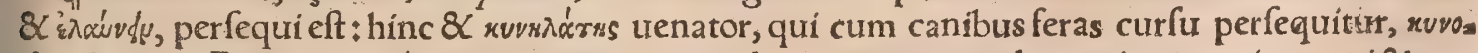

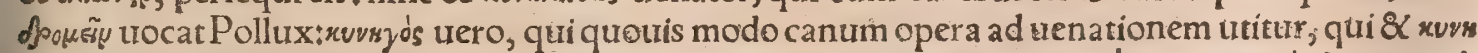

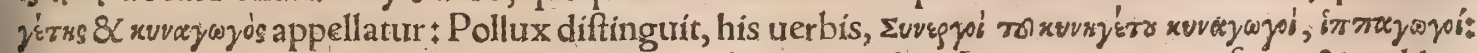
jimirum ut cynagogus cynegeta inferuiat, canibus ducendis. Incipiam captare feras, $\&$ reddere pinu Cornua, \& audaces ipre mourere canes, Propertius lib. 2. Kuvoasoos, Axpourou, Hefychius: apuxd

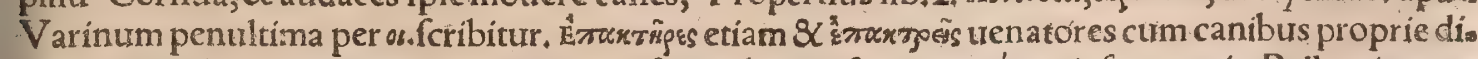

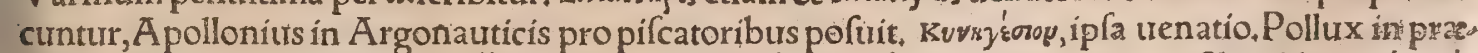

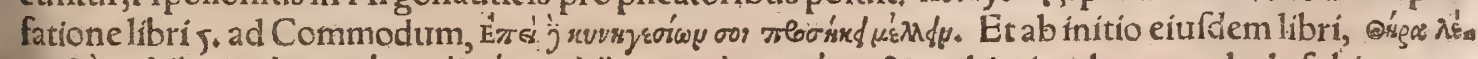

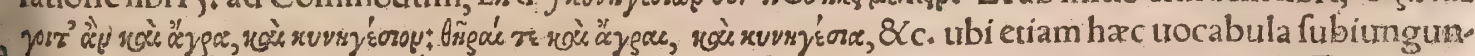

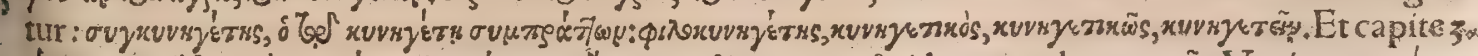

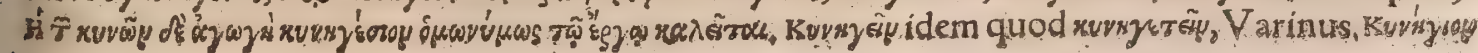




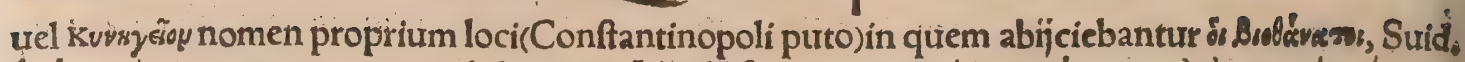

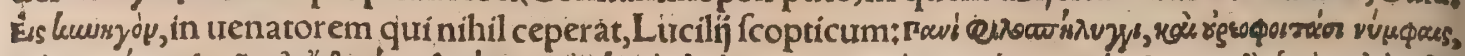

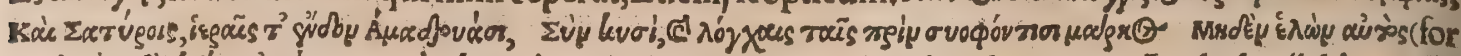

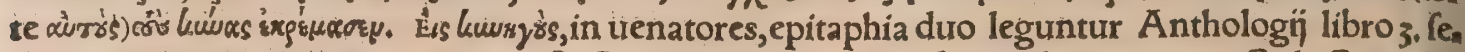
ctione 19, ham tertium in aucupem eft. Cynulchos uocant qui fecum ducant canes, Cæl. Cynæthei Iouis à uenatione dicti; quem Gyraldus Cynegeten appellare mallet, mentionë feci fupra, Eft \& kww

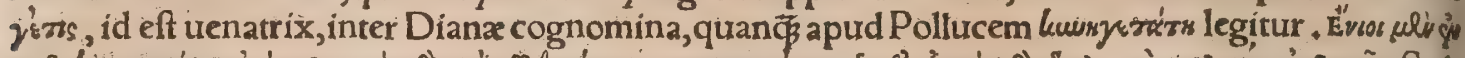

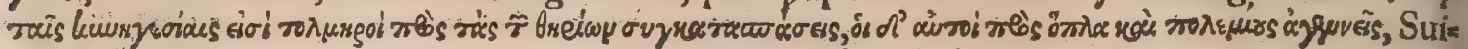

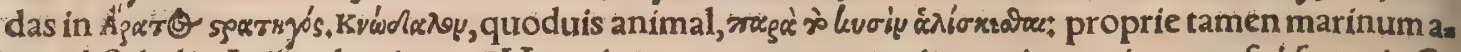
nimal,Scholia Ariftophanis; TVenaticorum canum, propria nomina uaria recenfui fupra in $\mathrm{C}_{2}$ ne in genere cap.8. TCanis alfeluchi, eft canis quo tenatores utuntur, ad capiendas aues aut qua. drupedes, Andreas Bellunenfis.

INunc canes uenaticos ordine literartm enitmerabo, tim fecundum regionim \& populorum apuid quos nafcuntur nomina; tum dominorum, \& c c.illos imprimis, qui ad certum aliquod uenatico rum genus, ut robuftum, celer, fagax, commodèreferri non poffunt: Sï tamen hic etiã illorum quof dam breuiter attigero, nihilominus fuís in locis repetam. Non tunc egregios tantium admirếre Moloffos; Cum parat (lego comparat, id ef, Canes hi uerfuti tantưndem dolo efficiúnt, quantum

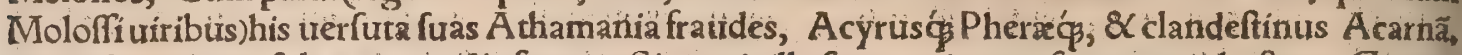
Sic \& A carnanes fubierunt prelia furto: Sic canis illa fuos taciturna fupertienit hoftes, Gratius in libro de Venatione. Pro Acyrus lego Acytus. Elt em̃ Acytos Plinio 4. 12, infula, de qua fic fcribit, ftatim poft Sporades: Melos cum oppido, quam Ariftides Biblida appellat , Ariftoteles Zèphyriam, Callimachus Mimallida, Heraclides Siphnum \& Acyton: Hac infularum rotundiffima eft. Hinc for

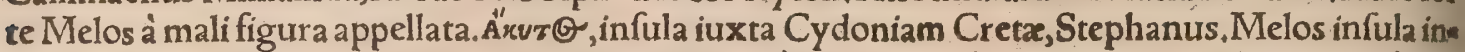
rer Cretam \& Peloponnefum interuallo æquali fita:à Peloponnefo promontorium Scyllæum,à Cre ra Diçynnzum habens, Strabo. Eft aũt Diçynnaum promontoriũ in Tityro Cydoniatarum mon. te, Hermol.Quod autem de hac infula Gratius intelligat, ex uicinis conftare uidetur : quod illarum quoos canes ad uenationem commendentur, ut Creta \& Amorgi. Vicina eft etiam Thera infula, quam alī inter Cyclades, alī inter Sporades numerãt, Plin. Stephanus óxpou per s prima longa feri bit. Gratius forte Theras in plurali numero dixit, ut legendum fit, Acytus Theræćp̧, \&c, de quo eru diti inquirant quibus otium eft. Si quis Pheras legere malit, ut $\Phi_{\text {egòs }}$ Theffalia oppidum intelligai mus:non pugnabo. Situm enim hoc oppidum eft in Pelafgicorum camporum termino ad Magninefi. am, ut Strabo docet:Laudantur autem ex Magnefia quoq canes.Accedit quod \& Athamania Thef falix regio fit, quan $\not$ alĭ Illyrix adfcribant, authore Stephano. Acarnania regio \& pars Epiri ef, merfa medio finu A mbracio, ut Plin. fcribit, Hanc ab Aetolia diuidit amnis Achelotis, aut Pindus mons ut Solino placet. Acytos igitur, Pheræ, Ácarnania, \& 2 A thamania, omnes ëiufdem ingení ca nes producunt uenaticos, tierfutos, fraudulentos, clandeftinos, taciturnos:Aetoli uero contra, latra

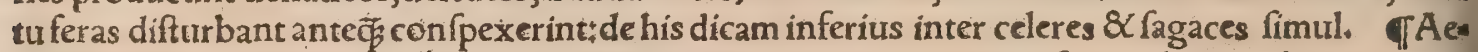

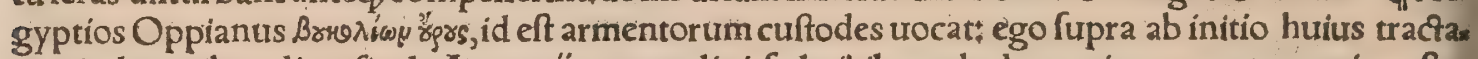
tionis de canibus diuerfis, de A egyptïs quoq̧ dixi, fed nihil quod ad uenationem, aut pecoris cufto: diam, TAlopecia, id eft uulpina canes, uide inter Mixtos infratitem ín Laconicis inter celeres, et mox in Caftorins. TAmorgi, Ausospoi, inter uenaticos numerantur ab Oppiano:poffent $\&$ Amor: gini dici, ab Amorgo infula una Cycladum Stephano. A Amyclaum canem non alium effe puto quàm Laconicum ab Amyclis Laconix ciuitate, in qua Caftor $\&$ Pollux educati funt. Vergilius pro paftorali cane pofuit, eo tropo(ni fallor)quo Acheloum pro quauis aqua. TArcades à Polluce $\&$

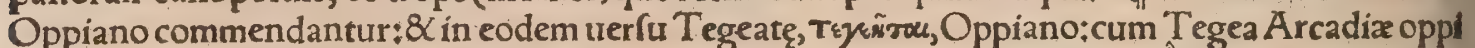
dum fit. Idem Arcades Eleis canibus commode mifceri frribit, cum Elis etiam, $\hat{i}_{\text {r }}$, Arcadię urbs fit, unde gentile Eleus:neç ením A egyptiam uel Hifpanicam Elidem, quarũ Stephanus meminit, poẻ

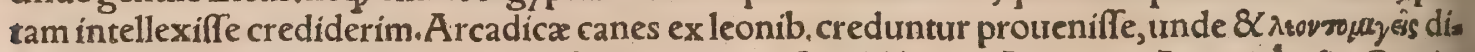

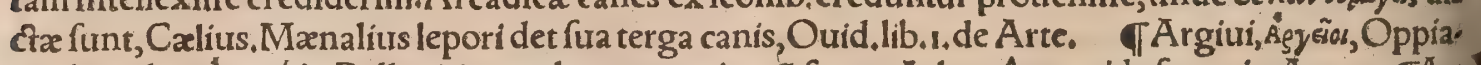
no: Argolici, Ágyoridts, Pollurci, in catalogo uenaticorư funt. A thamânes, uide fupra in Ácy to. đAu fonï, Oppiano:Idem Tyrrhenos canes Laconicis rectémifceri ait, non alios puto quàm Aufonios in telligens.

đDeBritannis canibus inter fagaces dicam ex Oppiano \& 2 Gratio.

ॠEt uanæ tantum Calydonia linguæ Exibit uitium patre emendata Molofo, Grat:

qCares, Oppiano:qui eofdem Thracijs commifceri poffe fribit, Carinæ, Kexiveu,Polluci celebran eur, non alix quàm Cares, aut in foeminino genere Cariæ urel Carica canes. Nam Ǩaéur gentile no men foeminini yeneris apud Stephanum reperio. Quamuis apud eundem in mentione Carnes ciui= tatis Phœnicix, à qua gentile fit Carnites, hic Lycophronis fenarius referatur, ö̀ Kagvirou lúuss, ubi ipfos nautas Carnitas canes appellare uidetur . Kossóeloc, Harmodī, \&Menelai* des,à dominis uel nutritoribus dicti funt, Pollux. Et rurfus, Caftorides A pollo Caftori donauit , Nis 6 cander eafdem alopecidas uocat, eò quod Caftor canes uulpibus mifcuerit. Xenophon, T'á jy j'vn ₹

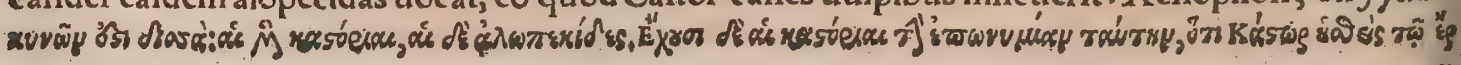


De Canibusdiuerfis. Lib: İ. 24 i

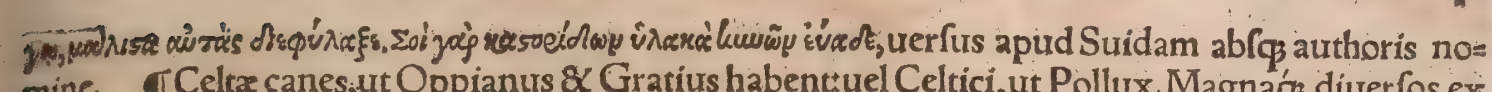
mine. TCeltz canes;ut Oppianus \& Gratius habent:uel Celtici,ut Pollux. Magná̧̧ diuerfos ex tollit gloria Celtas, Grat. Quondam inconfultis mater dabit Vmbrica Gallis Senfum agilem; Idẽ. De Gallico cane plura inter celeres. TChaonidas canes aliqui à Cephali cané, alij de chao luporü generis fera progenitas fufpicantur, Calius. Ego potius à Chaonia regione, quęin media Epiro eft, nominatas dixerim:hinc enim Chaonis gentile foèmininum fit, authore Stephano, Ex Epirotis qui.. dem populi celeberrimi fuerunt Chaones et Molofsi; commendabantur autem Moloffi quoç canes; ut infra dicemus:qui \& ipfi ex Cephali cane, ut Chaonides, nati primum exiftimabantur. of Cretici canes, Oppiano \& $x$ Polluci.Hos Oppianus ad fobolem cum Pxonibus commode iungi fcribit. Xe. 10 nophon Cretenfes canes etiam apris immitti ait. Ex Creticis canib, alios diaponos dici audio, alios pa rippos. Et illis quidem in uenando gloria plurima:nocies etiā feras impugnando adduntlabori, f $x_{3}$ pég feris affidentes dormiunt,mox orta luce depugnant.Parippi uero cum equis currere confureué re, tanta quoģ arte, ut nec pracedant un $\ddot{\beta}$ ferè, nec fubfequantur, Calius ex Polluce. Cretica canis expeditifíma eft, faltứç maximé ualet, ut Cretenfes teftantur, \& fama peruagatur, Aelian. Gnofus urbs Cretzeft, unde Gnofij canes inter fagaces dicendi. Et patre Dicłæo, fed matre Laconide nati Labros \& Aglaodos, Ouid. Dictaum Cretenfem intelligo : eft enim Dicte mons Creta, uel una ex quatuor pracipuis urbib. Cretæ. Dicłæus etiam Cephali canis fuit Martiali, Acron grammaticus Mo loffos etiam apud Horatium 2. Sermon.1. Cretæos interpretatur è Moloffia ciuitate Creta: (de qua ego nihil apud clafficos authores reperiri puto.)Sed paulo ante oftendi ab Epiri regíone Molofía, no 20 men his canibus inditum effe. Ichnobaten fagacem Gnofium Ouidius cognominat. बCypielli. cæ, uide Menelaides paulò poft, \& Pfyllici.

TElei cum Arcadibus ad fobolem uenaticam procreandam mifcentur, Oppian, TElymais nomen à gente fita in meditullio Bactrorum \& Hyrcanix, Calius ex Polluce. Stephanus eam regio nem Elymas, Plinius Elymaidem uocat. Caterum Elymix urbi Macedoniæ ab Elymo heroé nomen contigit, uel Elyma Thufcorum rege, De Elymxis Sicilix gente, \& Elymnio loco Eubcex, uide Var num. Quid fi Elymai ex Eubora potius oriundi fint, cum \& Erecrici inde commendentur ? ne tam procul petendi fint. Sunt $8<$ lepores Elymai, de quibus fuoloco, बClarus eft Epiroticus canis Cer berus nomine, Pollux. T Eretricas Eurytidxab A polline dono acceperunt ac nutríirerưt, Pollux: apud Calium non rectè legitur Eretrina. Eretria Euboex infula urbs eft, $\&$ alia Theffalia, Stephan.

đGallici, uide Celtæ fuperius, \& infra inter Celeres, đGeloni fagaces Martem odêre, Gratius, Traxêre animos de patre Gelonze Hyrcano, Idem. qGnofí, uide in Creticis

GHarmodỉ à nutritore dicti, Pollux, THyrcani,Pollux.Canes Hyrcana ex tigride concipit, ut dicam in Mixtis. Traxêre animos de patre Gelonæ Hyrcano, Grat.

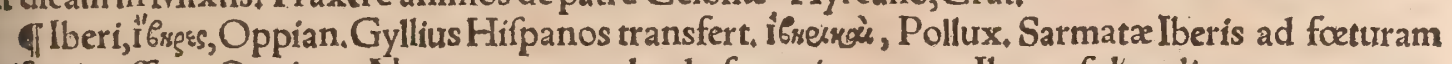
mifceri poffunt, Oppian. Nec quorum proles de fanguine manat Ibero, fubaudi contemnantur, Nemefian,Quærendum an de lberia Afiatica uel orientali accipere debeamus, qua regio fita eft iu. xta Ponturm inter Colchidem \& Armeniam, ut eædem canes forte fint Phafianæ, qua nomen etiam. num retinent. Phafis enim Colchorum fluuius eft. $P$ hafiana canis à partu non ante fextum menfem impletur, ferius uero in quàm plurimis obferuaui, Aug, Niphus, IIndica, uide inter Venaticos 10 fortes.

- Laconici, Lacanx, Lacedamonn̈, uide infra inter Celeres, đLibyci, Quinetiá ficca Libyes in finibus acres. Nafcuntur catuli, quorum non fpreueris ufum, Nemefian. Tl Locrides, Polluxi soxpoi, Oppian. Locrides canes Xenophon apris immitti fribit. If Gratius cum Seras canes intra: ctabilis iræ dixiffet, fubdit, At contra faciles, magniq́s Lycaones armis, id eft ea parte quam humeros in homine dicimus. Lycaonia regio Afię minoris eft prope Phrygiam:uel fecundum Stephanum Ly ciæ S Ifaurix regio. Alí partem Arcadiæ Lycaoniam uocant, Stephanus totam Arcadiam fic dictam fcribit:Gentilia, Lycaonius, Lycàn,8 Lycaon.

TIMagnetes, Oppian, De Hippamonis cane Magnete, cui nomen Lethargus fuit, fupra dixi. Magnefia Macedonix regio eft, Theffalix annexa, Eft etiam urbs $\&$ regio eiufdem nominis in Afia 50 adMrandrum fita,Stephan.Magnetes iuxta Mzandrum aiunt alere canes praliandi focios, mo $\lambda_{\varepsilon}^{\prime}$

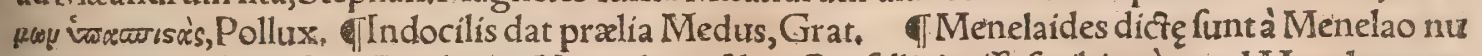
tritæ, Pollux, Et rurfurs, Menclaides Nicander eafdèm Cypfellicis effe frribit'eò quod Menelaus cas nes duos ex eo loco fratres circa Argolicam educauerit. Videmox in Pfyllicis. TMololfi, uide in ter Venaticos fortes.

- Paones, Oppian, Nec tibiPannonica ftirpis temnatur origo, Nemefian. Paones $8<$ Cretici ad foeturam recte mifcentur, Oppian. Vide inter canes robuftos infra. TPerfes fagax fimul $\propto$ pu gnax eft, Grat. बा Phafiana, uide in lberis paulò fuperius. T Pheræus, uide fupra in Acy tos, ef Pfyllici canes nomen habent ab urbe Achaica, Pollux. Calius dubitat an Cypfelici legendum fit: quoniam in Arcadia munitus locus Cyplela uocetur, cuius apud Thucydidem mentio fithiftoria 5. Eft $\&$ in Thracia nominis eiufdem adiacens Hebro ciurtas, Stephanus.

I Sauromata, Oppianus:idem Sarmaticum canem cum Iberide fomina coniungi polfe ait. Sar matix pars eft Polonia hodie dicta; ubi uenatorị canes lis nominibus habentur: Vislÿ a maximi 
omnium, adurerfus lurpos, urfos, 8 apros, Charczij, minores patulò. Pobicdniczị, parul, ad àres $\$ 2$ lepores.Pfï, medij magnitudine inter primum \& fecundum genus، TSunt qui Seras alant, genus intractabilis iræ, Gratius. TSpartani, uide Laconici inter Celeres infra.

IT Tegeatas fupra cum Arcadicis memoraui. T Thracij, Oppianus + idem Thracios \& Cares fo* bolis gratia mifceri ait . T Tyrrhenorum mentionem feci in Aufonijs + q Tufcos cum fagacibur memorabo.

- Veltrumì ưulgo in Italia uocant canem uenaticum, \& uelocifimum curfu, Fr. Arlunnus: V: de inter Celeres. I Vertagus, celer fimul \& fagax eft, de quo plura inferius, $9 \mathrm{Vmber}$ fidelis et ragax eft, ut inter fagaces referam.

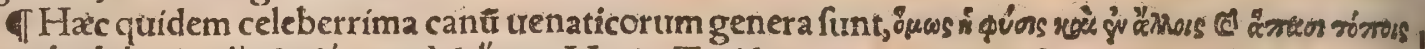

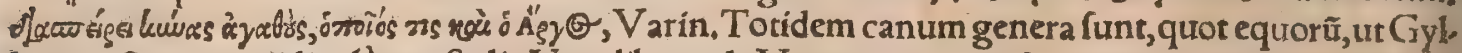
lius exOppiano ridiculè tranftulit, Nam libro i.de Venatione, cum de equis agere poéta defineres:

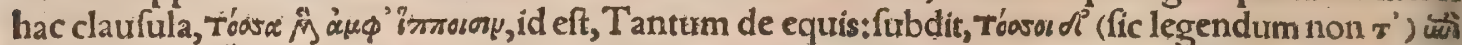

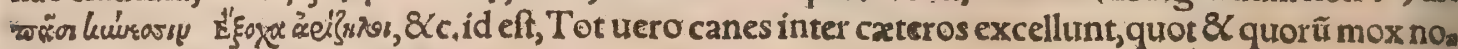
mina addit, Prones, Aufonï, \&ce.

I C A ES uenatici quales eligi debeant \& ad fobolem procreandam admitti, Gratius poëta his carminibus elegantiffime docet.

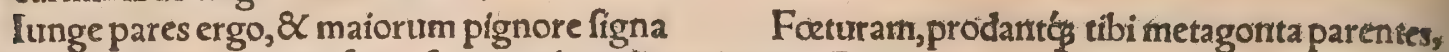

Qui tenuere(genuere forte)fua pecg hoc im̄ane iưẽta. Et primũ exptos aními, quę gratia prima eft,

In Venerem iungunt:tum fortis cura fecunda

Sint celfi uultus, fint hirtz frontibus aures, Spirent, aftricti fuccingant ilia uentris:

Cxiaries non pexa nimis, non frigoris illa

Quod magnos capiat motus, magnisç fuperfit.

Mollis in officio. ficcis ego dura lacertis

Sed fruftra longus properat labor, abdita finon

Fomiria, nec patie Veneris fub tempore magnos

Primi complexus, dulciflima prima uoluptas,

Si tenuit cunctos, \& $\mathrm{mater}$ adultera non eft,

Nerenuat fpecies, aut quxe detrectet honorem.

Os magnum: \& patulis agitatos morfibus ignes

Cauda breuis, longumós latus, difcreráç collo

Impatiens: ualidis tum furgat pecius ab armis;

Effuge quilata pandit ueftigia planta

Crura uelim, \& folidos hac in certamina calces.

Altas in latebras, unićs inclufa marito

Illa, neos emeritze feruat ueftigia laudis.

Hunc Veneri dedit impatiens natura furoreme Da requiem grauid $x$, folitos 6 ; remitte labores,

Vix oneri fuper illa fuo, Hæc Grat. Nemefiani de canibus uenaticis ad fobolem eligendis uerfus, in fra recitabo in Celere, de hoc enim ille potiflimum agere uidetur, T Canis uenatici (inquit Tardi, ) partium corporis omnium bona fit proportio: caputleure, cerebrum amplum : pili à capite $\& \subset$ fronte antrorfum dirigantur. Aures fintmolles, lax $x$, pendulx, longx, $8 \times$ multum diftantes. Ven $x$ frontis magnæ: oculi nigri, uifus acutus:nafus amplus:fauces largæ \& profundx. Pili circa os barbam refea rant, fimiles refectis. Multa $\&$ craffa in ore faliua:facies clara, collum longum $\&$ in fine plenum:pen ctus amplum \& craffum, coftx prominentes: dorfum breue \& planum, non acuminatum circa ter tebras,Catrda non feparata à coxis, breuris, mollis, nodis robuftis, Coxa fint amplar, \& fuperius tor an fa:pedes parui, digitis duris, $\&$ apte coniunetis, ne quid terra aut luti in uia admittant, Corporis po. fterior pars altior anteriore probatur. Si pars in crurib.prominens, calcar appellant, curfum impedi. at, fecari debet, Laudantur quilcrum aut catenam, qua uincti tenentur, fape $\&$ ualidé trahunt. Ex . colore nihil certi feré pronunciatur: fapius enim turpi colore canes, pulchrioribus praftant . Niger tolerantior frigoris eft quàm albus, Canis alba, oculis nigris aut albis, pecfore terram uerfis inclinam to, pelle longa inter coxas, deniq̧ cauda longa $\$$ craffa, alacris $\&$ animofa in urenatione eft, Hac Tard. A partu etiam catulorum delectus habeatur, de quo itidem Gratí uerba adicribam:

Tum deinde monebo

Ne matrem indocilis natorum turba fatiget,

Percenfere notis, iam ́́ inde excernere paruos, Signa dabunt ipf $x$, teneris uix artubus harę

Ille, turos olim non defecturús honores. Ia mós illum impatiens æquę uehementia fortis

Extulit:affectat materna regna fub aluo.

Dum tepida indulget terris clementia mundi. Verum ubi Caurino perftrinxit frígore uefper,

Ire placet, turbaćs potens operitur inerti. Illius è manib, uíres fit cura futuras

Perpenfare:leuis deducet pondere fratres: Nec me pignoribus, nec te mea carmina fallent,

(Vide qua fupra diximus de catuli electione in genere.) Nemefianus rem eandẽ clarius defribit,

Pondere nam catuli poterís perpendere uires, Corporibusćs leues graubib, prænofcere curfur.

Sed hæc ad celerem canem magis pertinent, quàm uenaticum in genere: quemadmodum \& illud for

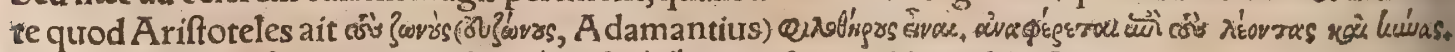

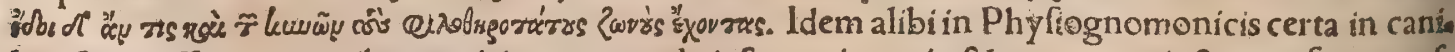
bus figna effe ait, ex quibus periti uenatores de ipfortm ingenio 2 natura coniecturam facere pof

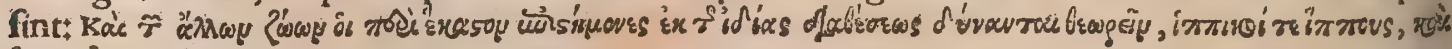
kussýroci lúwas.

Xenophon canis uenatici formam, $\&$ animi corporisç dotes, qur maximè probentur, his uer Bis depingit.Primum, inquit, magnas effe oportet, capite leui, fimo, articulato, \& fub fronte urenofo,

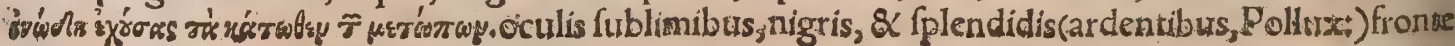


faturabis eos butyro, multo immixto cafeo recenti, \& finul per nouem dies includés, donec urideas cattulam concepiffe: nec ullo modo ante hoc tempus euagari permittes. Cum autem cöceperit fomi. na, dimiffo mare, grauidam retinebis, ira ur interdum, fed raro, inambulandi copiã ei concedas. mox iterum ad cubile ex framētis reuoces.Quò partui uicinior erit, eò copiofius ales, ut foctui poftéa lac fuppetat. Prabebis autem humida nutrimenta, ut lac $\&$ ferum cum parte butyri, quibus $\&$ panis aif quid $\&$ carnis cocta mifcebis. A partu pro numero catulorum eam nutries, ita ut nec obefior, nes macilenta fiat: ne uel lactis inopia propter maciem aut praua qualitas propter pinguetudine fequa. tur. Nam cum canum lac natura craffiffimum fit propter temperamenti iplarum calor em, in corpo. re obefo frigidius ac tenuius euadit. Catulı fuo tempore ablactandi, $\&$ cibar ut nec iufto fiant habitiores, nec alimentum quod incremento \&\& robort fufficiat, defiderent. Serum, igitur cum aliquãto laçe quod pinguiufculum fit, primo dandum eft eis, \& paulatim pofica cum iā

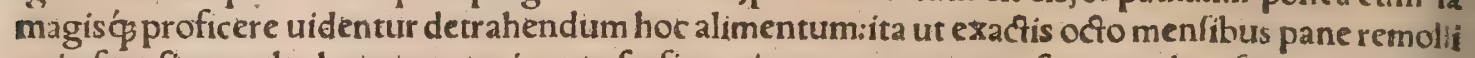
to in féro fine multo humore nutriantuir, fic fiet ut intra annum canes fanos, agiles, fortes atç faga ces habeas. Poft menfes ocfodecim exerceantur ad uenationem, idḉs primo moderaté, ut ultro indi. es magis magisć̣ fe exerceant. Nimius enim curfus \& labor ab initio, tenella adhuc membra exic cat, \& uenatıoni inualida ineptáq̧ reddit: Mediocri uero exercitio, excitatus calor in cruribus alimẽ cum attrashit, neque confumit:unde fit ut cruribus ualidi uenari fponte defiderent, Hac A ibert.

TMedia xefare, ex Nemefiani confilio, ranes tenuius alentur, ne gratris cibatus molles articulos pondere deprauet. TProtinus \& cultus alios, \& debita foetz Blandimenta feres, curạ̧́ fequếie merentem. llla perinde fuos itt erit delata minores, Ac longam praftabit cpem:tum deniç fotu Cum defunt operi, fregitóg induftria matres, Tranfeat in catulos omnis tutela relictos. Lacieno. uam pưbem, facilị̧́ tueberemaza. Necluxus alios, auidxésimpendia uita Nofrant:hacmagno redit indulgentia damno, Grat. Et paulo polt de uenatore, uel magiftro can burs pręficiende, Idcir co imperium catulis, unuṣ́́ magifter Additur, ille dapes, poenamós operamós miniftrans Tempe ret:hunc fpecter fyluas domitura iutuenrus \&c. TVenatici canes (ait Oppian.)à teneris affueicät equis uenaticis, \& cunctis hominib.blandi funto, folis infefti feris:non faciles ad latrandum:filentiü enim omnino uenationi conuenit, pracipué inter inueftigandum. Canibus tacitis mittite habenas, Seneca in Hippoly to. Pollux '̇xpareis canes laudat: quos intelligo, uel abftinentes latratt, uel qui fes ram captam ad domini adiventum conferuent, aut ore illafam afferant, ut trertagus leporem. Id́e pro

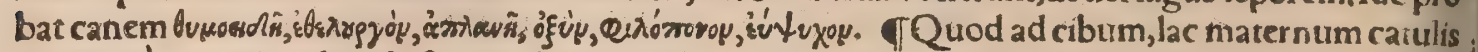
praccipuè conuenit: deinde fanguis animalium qua ceperint canes, tit paulatim uenatorio alimento affuefcant, Pollux. Oppianus ad uenationem educandos lactari pracipit, non domefticarum canû neç caprarum aut ourum uberibus, fegnes enim $\&$ debiles futuros:Sed cerux, aut leanę cicuris, uel dorcalidis aut lupæ, ut robufti ac ueloces fiant. De uiciu catulorum pracipué uenaticorum, ex Ne. mefiano docui fupra in Cane in genere. fSed neq conclufos(catulos)teneas, neç uincula collo Impatiens circundederis,noceas q́ futuris Curfib.imprudens:catulis nam faperemotis, Aut ue zare trabes, laceras aut pandere ualuas Mens erit, 8 teneros torquentronatibus artus, Obiuni dúntue nouros adrofo robore dentes, Aurteneros duris impingunt poftibus ungues, Nemefant. qCanes uenatici $\alpha$ alij quomodo procreandi fint, \& quib. parentibus, fupra ex Blondo dixi capite s.de cane in genere. đCaftrati canes ceffant à relinquendis heris: nec ramen ad cuftodiam aut ue nationem deceriores fiunt, Xenophon in Pxdia. Si canis inter uenandum nimia fiti laboret, duo aut tria oura confracta in gulam ei immittes: fíc enim fitim extingues, \& à periculo hecicax uel maraf : mi canem liberabis, Tard. Laudatur uenaticus canis, quilartus, alacris, \& animofus eft, qui auricu. las fubinde mouet, \& frontem uerfus dirigit:qui circumfpectat undequa $\$$ \& ferarum ueltigia, tra. cfus, $\&$ halitus fequitur $\&$ olfactat, Tard.

TCanum inter uenandum continentiam, obedientiam, fagacitatem Plutarchus extollit in libro Vtra animalium, \&c. Deadmirabili canum fide in Niciam uenatorem dicam in Cane focio. Mirz trenatici canis difciplina fpectatur, dum paret domino, nec illum relinquir, fed fufpenfus expectat, donec ad perfequendi licentiam mittatur figno: $\&$ comprehenfam feram dum feruat, uel ad dominû̉ refert,Blondus.

đ Omnis canis uenaticus ex eo quod ceperit feram, non mediocri uoluptate afficitur, \& tanquẩ pramio, fi dominus ei permittat, fic ea capta utitur. Si quidem non conceditur, beftiam feruat, quo: ad uenator aduentarit, de totá̧́ captura pro fuo arbitratu ftatuerit. Quod fi morttro uel apro uel cer uo inciderit, non attingit quidem, nec enim alienis fe laborib. adfcribit, nec qua a d fe non pertineät, fibi affumit:ex quo apparet æmulationum uirtutis natura eum non expertem effe. Nec enim carnes quærere, fed uictoriam amare uiderur, A elianus, Idem canis ingenium Plutar, in lib. Vtra animaliü, \&c.his uerbis defcribit: Venaticileporẽ cum infequuntur, fiquidem necaruntipfi, difcerpere $8<$ fan guinem auide lambere gaudent: fin, quod perfaepe fit, curfu confectum, ac fpiriribus quantu fupere rat, extrema contentione confumptis, exanimem afiequuntur, prorfus non attingune, aftant autem cauda tantum gefticulantes, quafinon pulpæ, fed uirtutis ergó certaffe uideri uelint.

I Equis 8 canibus Cyrus illos prafecit, quos exiftimahat reddiuros hiac pecora ad ufum fuum

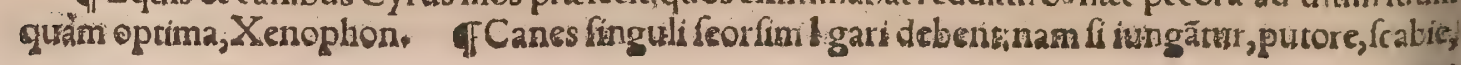


nea eius refrigerabit. Âlí aquam patrco aceto mifcent,cum micis panis atri: \& eo liquore collum ac dorfum canis illinunt, Tardiuurs. TQuomodo lupos, uulpes, urfos, ceruos, capreas, \& alias feras, canum opera uenatores capiant, in ipfis qua capiuntur feris fingulatim explicabimus. TVenatio cum genus canum, non folum nihil agricolam ituuat, $\int e d \&$ auocat, defidem $q$ ab opere fuo reddit, Columeila. TLepus $\&$ urulpes canum metu exhorrefunt, $\&$ interdum uel fola canis latrantis de. nunciatione ex loco undiģ fepto, uepribus \& dưmetis ueftito excitantur, Älianus, TNonnéui. des quod etiam uenatores, dum lepores partui xftimandam rem fectantur, multa machinẩtur? Dum

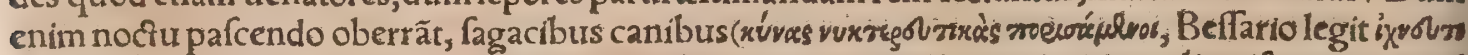
xós, quod non probo, ne denuo de njfdem agar) cos captant. Sed quoniam interdiu refugiunt, $8 \times 2 d$ cubile fe recipiunt, alios canes parant, qui qua redierint odor e percipiant, \& in cubili eos deprehendant. Quoniam uero celerrimi funt, ut à confpeçu etiam facile aufugiant, aliud genus canumin uelo. cium habent, quibus aurolantes intercipiunt, Et quia his etiam aliquando elabuntur, retia per trami... tes qua fugiunt, difponunt, quibus tandem irretiantur, Hac Socrates libro 3. A pomnemoneumatü cius apud Xenophontem, ad Theodotam mulierem formofam. Cui illa, Quonam horum, inquit; utar, ad meos captandos amatores? Si per louem, inquit ille, pro cane quempiam apud te habebis inueftigatorem huiufcemodi amatorum, atģ fortunatorum hominum, qui quidem ut primum eos compererit, doctus arte, efficiet ut tua in retia concidant. Retia funt, forma ifthec tua, atç inge: nium, \&c. बV terũ ferunt duobus menfibus:nć oportet autem grauidam uenatum educere, cum

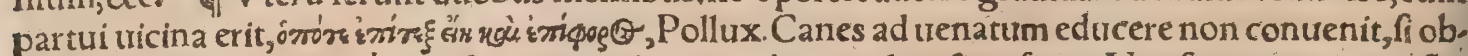
iectum cibum non auidè admiferint, quod eas non bene ualere fignificat. Nec fi urentus ingens fla uerit: tham ueftigia rapit, nec canes odorari, nec fagenas retiáue ftare permittit, Quod fi horum neu=

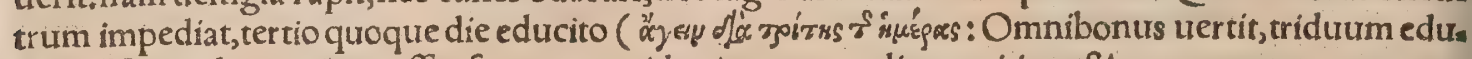
cito.) Nec uulpes agitare affuefcant canes:id enim non mediocre uitium, $8 \mathrm{cum}$ oportet, nunquam

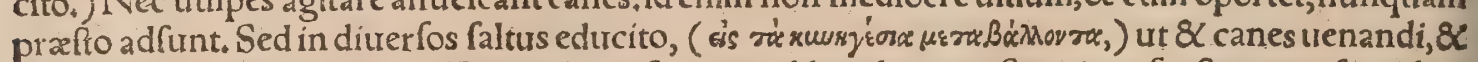
ipferegionis peritus euadas. Exeundum eft autem diluculo, ne ueftigatione fruftrentur: fiquidem tardiuf culis neç canes leporem inueniunt, nec ipfi fructum capiunt, Neq̧ enim diutius manet natu ra ueftigị, res plané euranida.

A A $2 x o n$ uenator Ariftxi filius, ira Dianx, quam nudam ín fonte laurantem uiderat, in cerutum mutatus, à fuis canibus laceratus eft, ut canit Ouidius libro z. Metamorphofeon : Canum Actæonis nomina fuperius recenfui inter alia diuerfa canum nomina. Scholiaftes in quartum Argonauticorũ A pollonï, A ctronem Meliffi filium facit, quem mulieres Bacchi Orgia celebrantes laniarint. Actço nem (inquit Fulgentius ex Anaximene) uenationem dilexiffe aiunt:is cum ad maturam peruenifiet xtatem, confideratis uenationum periculis, id eft, quafi nudam artis fux rationem uidens, timidus fa ctus eft. Et pauló poft, Sed cum uenandi periculum fugeret, affectum tamen canum non depofuit, quos inaniter pafcendo pené omnem fubftantiam perdidit. Ob hanc rem à fuis canibus deuratus eft. Pauló extra Megara (utfcribit Paufanias in Bceoticis) fons eft ad dextram : \& paulò ulteriu petra, quam $A$ Efæonis uocant, $\&$ in ea quiefcere aiunt $A$ cfæọnem folitum uenãdo defelfum. In fon. tem urero infpexiffe, cum Diana in eo lauaretur. Stefichorus Himerzus fcribit pellem ceruinãà dea Actxoni circumiectam effe, ut à canibus occideretur, nec uxorem duceret Semelen. Ego abfq̧ nu: mine A ctxonis canes rabiem paffas puto : in quo quidem furore etiam alium quemuis obuium lace raffent, Haxc ille. Plura de A ctæone uide in Fabulofis Palæphati hiftorïs, cap. 4. Actęonem, inquit, à proprín deuoratum canibus, falfum $\mathrm{eft}$. Canis enim herum imprimis diligit : \& peculiariter uena.

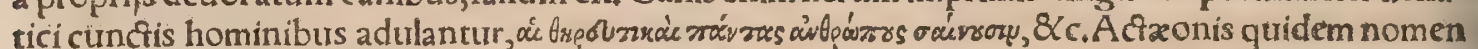
aptum uenatori mihi uidetur, \& eiufdem originis cuius smoxtrig, id eft uenator, apıd Gracos, â cani bus ducendis. Sunt qui fribant Indicos ex Actronis canibus prognatos:qui poft rabiem in fanitas tem redeuntes, Euphrate tranfmifo in India erraterint. TOrion maximus fuit uenator, qui cum uriribus fidens gloriaretur nullam effe feram, quam non conficeret: dịs infolens uerbum ulcifcenti-

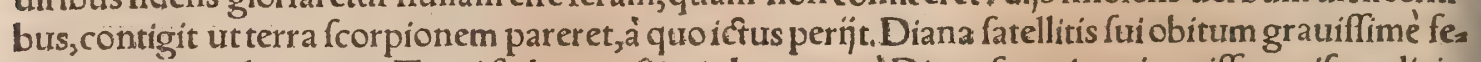
rens, eum in collum iuxta Tauri fydus confituit. Lucanus à Diana fcorpicne immiffo occifum dicit, 8 deorum miferatione in coelum fublatum. Horatius ab ipfa Diana fagitris confoffum tradit, cò quod ui uroluerit eam comprimere, \&c. Plura in Onomaftico neftro. Maram dicunt Orionis canem appellatum fuiffe, Calius, $\Phi$ A talanta Schonei filia fuit, qua Meleagri amore capta, aprum om: nes Aetolix agrns deuaftantem occidit, \&c. Vide Onomafticon in Meleagro. TLycadem nomine canem Theffalicam celebrem epicaphio, quod tumulo eius infcriptum fuit,Simonides fecit: quod ut

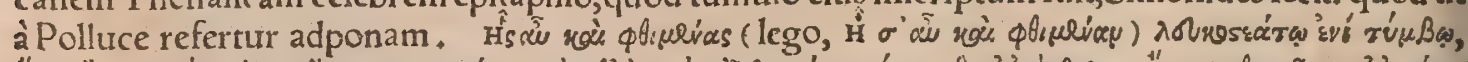

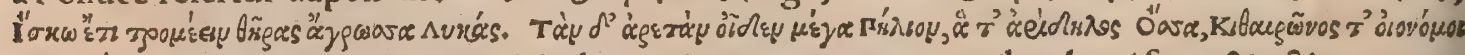
oromác. In fomnis canes uenatici a d uenationem exeuntes, omnibus boni funt, 8 actionum pra nuncri:uerum reis $\mathcal{Q}$ in ius uocatis, malli,Blondus ex Artemidoro. Et inferius, Qui igitur ad uenatio nem aluntur, ea qux foris comparantur bona fignificant, $\&$ actiones : quare bon um eft ipfos uidere uenantes. Canes uenatici dici poffunt, qui alios clam aufcultantes produnt, ut Corycai:item mi niftri magiftratuum, fa ellites, lictores. Tullius A ctione in Verrem fexta, Apponit de fuis canibus quendam, quìi dicat fe Diodorum Melitenfem rei capitalis reum uelle facere, lbidem aliquanto poft, 
fos, \& apros urtuntur, uislï nominantur, ut fupra dixi, TMoloffi apud Ariftotelem magni \& robił fti canes, duorum generum funt, alī pafforales, alï ad uenationem utiles, ut infra dican?. Albertus feremaftinos proMoloftis uertit:quod nomen ltali etiam \& Angli ufurpant, haud fcio cuius origin nis, nifi quis maftinum quafi maximum accipiat. Germani $X_{i i \nu e n}$ appellant, forte quod rudes $\&$ præcęteris hirfutif fint. De horum igitur genere paftorali infra dicam:de uenatico \& pugnace boc in loco:quan $\overline{\text { p }}$ paftoralibus etiam aduerfus lupos aliquando pugnandum eft. Ex canis cum lupo coitu gignitur magnus canis qui maftinus uocatur à nobis, Albert. Maftini canes funt grandes 81 morda cés, Francifc.Alunnus. Cahem uidi qux fimul undeuiginti catulos peperit, 8 alio partu ocfode. cim, tertio tredecim:erat autem nigra, corpore magno, ex illorum genere qui maftini dicuntur, $\mathrm{Al}$ bert. Ex leporario \& maftino nati catuli, robufti fimul \& ueloces fiunt, Albert. ubi Arifoteles haber ex Laconico \& Molofto. Maftinus lupo fimilis eft, \& circa generationem fimiliter fe habet ut lepura ritts: fed cum ablactatur nutrimentis ficciorib. \& crafficribus ali debet, Idem. Maftini (inquit Beli farius Aquiuiuus)ex illo genere canum funt,quigrauiores \& minus ueloces habentur:quos in $D$ al - matia puto plures intreniri. Nafci enim folent(ut fertur)in ea parte, quam lllyrij incolunt \& Lilurni quo . Eiufdem generis Albani uidentur, ex Plinio. In Corfica quidem plures funt, feroces in pri= mis, \& ad quarcunģ animalia inuadenda capiendaćs audaciffimi. Eligi debent, atroci tuultu r eruice \& capite maximo, labro fuperiori fuper inferius dependente, rubicundis oculis, apertis narib or quod ueluti flammam hiatu euomere uideatur:acutis dentibus, collo tumente, pectore amplo, ita ut leonis fimilitudinem pra fe ferant:magnis pedib. diferetiş́ digitis: duris ac curuis unguribus, ut $f_{0}=$ lo inharere magis poffint, quo ualidius feram profternant conculcentós. His enim canum generıburs uetratus omnes fuperare facilius curfer $\&$ capere uenatores poterunt, $H$ ęc Aquiuiu. Canum ex $C$ or fica(tur $\mathfrak{b}$ bünd)in Iralia, Romę pracipue, ufum effe aiunt aduerfus apros $\&$ boures feros.

A Alanum canem Hifpanice diçum Fr. Alunnus fcribit eũdem elfe quem Irali uulgò Moloffum uocent: $\mathbb{Q}$ alibi Alanum canem uertagum inter pretatur. De uertago dicam inferius, Alania regio eft Scythix Europę, qux ad Mactin paludem pertingit:cuius incolx Alani(propelftrum, Ptolem.) quorum meminit Plin. 4.12. ubi Alanum eriam Scythia fluuium faci. A mmianus fcribit Alanos uo cari, quos prifci Maffagetas dixerint. Et fequerer duros aterni Martis Alanos, Lucan. TDe Ata tali canib, dixi fupra in prouerbijs à Cane in genere.

Indiam petenti Alexandro Magno rex Albaniæ dono dederat inufitatæ magnitudinis canem: cuius fpecie deleciatus iuffit urfos, mox apros, 8 deinde damas emitti, cótemptu immobili iacente. Eáq, fegnicie tanti corpcris offenfus imperator generofífpiritus, eum interimi iuftit. Nunciaurit hoc fama regi. Iraç alterum mitrens, addidit mandata,ne in paruis experiri uellet, fed in leone elephan. to ue: duos fibi fuiffe, hoc interempto praterea nullum fore. Nec diftulit Alexander, leonem ́q fra cum protinus uidit. Poftea elephantum iuffit induci, haud alio magis fpectaculo laxtatus. Horrenti. bus quippe per totum corpus uillis, ingenti primum latratu intonuițmox ingruit affultás, contrạ̧ beluam exurgens hinc 8 illine, artifici dimicatione qua maximè opus effet infeftans, atç euitans, donec affidua rotatum uertigine afflixit, ad cafum eius tellure concuffa,Plin. A pud Albanos nati canes feris omnibus anteponuntur, frangunt tauros, leones perimunt, detinent quicquid obiectum eft, Solin. Et pauló mox, Hoc genus canum crefcit ad formam amplifimam, terrificis latratib. ultra leones rugitibus infonans. Albania eft regio Orientalis inter Colchon $\&$ A rmeniam, cuitus incola Albani:à quibus orti funt quorum pars in Peloponnefo, pars in Macedonia confeditiuxta Dyrrha. chium, quorum dux fuit Georgius Scanderbegus.

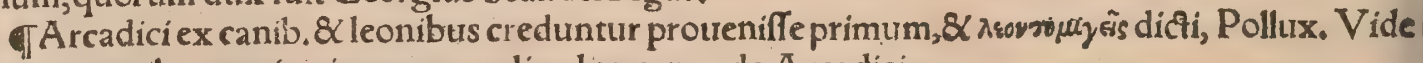
fupra in canib.uenatic is in genere ordine literartum, de Arcadicis.

C.anaria una ex Fortunatis infulis, repleta canib. (ingentibus)forma etiam eminentifimis: in. de etiam duo exhibiti lubx regi, Solin. \& Plin.6.32.

TCreticæ ranes, ut Xenophon feribit, apris opponuntur. Et pugnaces tendant Creffæ Fortia trito uincula collo, Seneca in Hippolyto. Hæ nimirum diaponi dicti funt: uide plura fuperius in Canib.urenat,in genere, inter Creticas.

बCynamolgos alij populos, alij canes cortum appellant. Reperio prope palưdes que ad meridiem funt, effe canes, qui dicuntur cynamolgi, quibus lac bubulum cibus gratifimus: Hi Indicos boues qui gentem illam æeftate inuadunt, expugnant, ut Crefias fcribit, Pollux, $\mathrm{C} æ l_{+}$Cynamolgos Aethio.

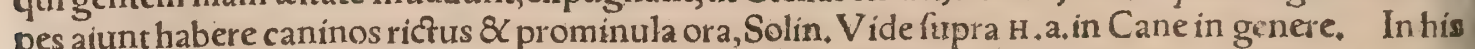
libris, quos Cnidius Ctefias de reb. Indícis cöfcripfit, Cynamolgorum gentem, ait canes pernultos, magnitudine Hyrcanis canib, pares, alere folere. Quamobrem fir haxc natio tam canum frudio fa, cau fam idem affert,Cum ab aftiuo folftítio ad mediam hyemem, tanquam apium examina, qua ad al ueos frequentes uerfantur, fic armenta numero ampliora boum ferorum eos cornib. wehen entcr in citata appetant $\&$ noceant, hi non aliter hac retundere ualentes, canes quos magna cura aluer unt, in ipfos immittunt, qui facile boues debellant, 8 interimunt. Deinde ante commemorats homines, quas efculentas carnes exiftimant, fibi auferunt, reliquas canib impertiunt, likenterọ́ communicãt, Reliquo anni tempore cum non amplius eò boures accedunt, ad uenandas alias feras fecum ducunt.

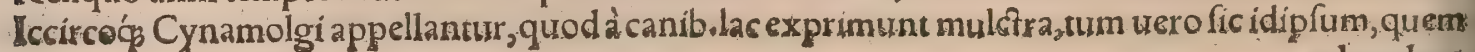
admodum 


\section{DeCanibus diuerfis. Lib. İ. 249}

admodum nos tuel ourillum urel caprinum, bibunt, A elianus, Cynamolgi, qui ab indigenis Agrñ ap. pellantur, comati $\&$ barbati func, Hi canes maximos alunt; quibus Indicos botres uenantur, é uicina regione uenientes, fiue à feris pulfos, fiue pafcuorum inopia, Strabolibro 16.

बEpirotica terra canes pracipue magnos fert, Ariftoreles, Clarus eft inter canes Epiroticus Cet berus, Pollux, Epiri regio eft Moloffia, de cuius canibus inferitus mox dicam. Chaonia etiam Epir pars elt, unde canes dicta Chaonides sde quibus fupra inter Venaticos in genere。

Hyrcanicanes robufti $\&$ feroces, ex cane qua conceperit ex tigri quanquam Plinius Indicas etiam ex tigribus concipere fcribit. Vide infra in Mixtis

Indicæ canes apros, certros 8 hinnulos uenantur, Xenophon, Indicos canes ex canibus $A$ c o nis propagatos fcribir Nicander Colophonizts qua à rabido furore refipifẽêtes, Euphrate tranfmiffo in Indos ufọ aberrarint, Pollux, Calius, A putd regem in Babylône canum Indicorum tanta alebatur multítudo, ut ad prębenda eis cibaria, quatuor in eadem planicie magni uici attributi effent, aliorum tributortm immunes, Herodotus libro I. Ariftuteles hos canes nafci fcribit ex cane \& tigride, alibi uero ex cane \& fera quadam non expreffo nomine, E tigribus canes (inquít Plinius) Indi uolút con. cipi: \& ob id in fyluis coitus tempore alligant foeminas. Primo \& fecundo foetu nimis feroces putant gigni, tertio demum educant. Sunt qui Hyrcanos etia canes è tigribus concipi fcribant, ut in Mixtis dicam. Ex Indicarum rertm foriptis de his qua fubfequuntur docemur: Canes forminas multò ge nerofiffimas, tum ad inueftigandas feras narium fagacitate praftantifimas, tum uero ad curfum tue locifimas in loca ubi tigridibus eft habitandi confuetudo, uenandirationibus eruditi, perductas ut

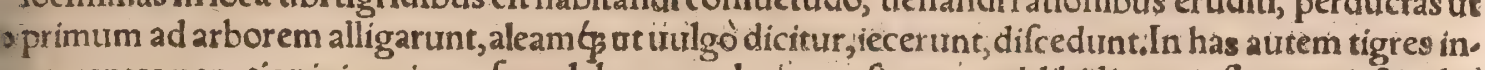
currentes uenationis inopia, ex famelaborantes lackrant:fiautem ad libidinem inflammati, \& cibo completi fint, cum canibus complexu uenereo iunguntur : nangs illi quo os cum funt exfatitrati, ue. ner em meminerunt. Ex hac tigridum confuetudine cum canibus $s_{j}$ tigris quidem non generatur, fed femen ad deterius delapfum, maternum genus referens, canis efficitur, licanes tigride patre nati, us uel cerui, uel apri uenatum præclare fpernunt, fic cum in leones incurrunt, gaudio uehementi exiliunt, Gylius ex Aeliano. TCelebris eft \& Alexandri canis, qui leones impugnaurit, alumnus In. dia, centum minis emptus, in cuius defuncti honorem Alexandrum chutatem cöftituiffe Theopom pus feribit, Pollux. Is etiam, quem Porus Alexādro donauit, duos leones uicit, Pollux. A pponam et A eliani de canibus Indicis A lexandro donatis quâtumuis prolixam hifroriam, quod non exiguum inde ad acuendam animi fortitudinem pro uirtute \& pietate retinenda argumentum triri boni tra here pofint: Summa igitur Indus, inquit, nobilicate homo, Alexandro Philippi regis filio, horum ro boris canum, fic periculum fecit, ut primo ceruum emirterer, canis ex eo loco, ubi quiefcebat, eum defpicatiflimum habens, nibil fe commouit:deinde ad aprum dimifum, quemadmodũ affectus fue. rat in ceruum, immotus permanfit:tum uero ubi urfus immiftus funfet, æque hunc, atç alios defpis catui ducens, ab eo inuadendo fe tenuit: Ad extremum hic leonem quem protuliffent in medium, ut uidit,cum ira exarfit, ac profecto tanquam iuftus hoftis in certamen defcendiffer, fine mora intrepidus inuafit, atç3 acerrima comprehenfione, leonem conftricium tenens, illius fauces premebat, $8 C$ fuffocabat. Tum Indus, qui hoc fperfaculum regi prabebat, quiḉ probe fciebat eius robur animi $\&$ conftãtiam, primum huic caudam abf́cindi iuffi, is præ ipfo leone, quem mordicus tenebat, fibi cau. , dam facile abfcindi patiebatur:deinde etiam crus unum fuffringi imperauit. Is uero aque ut à princi pio urgebat, $\&$ perinde nihil remittebat, quafi alienum crus, $8 \check{c}$ ad fé nihil pertinens fuffringeretur. Poft alrerum, unde quoç is nihil commotus arcté tenebat; tum tertium incidi præcepit, is fimiliter ut antè nihil fe relaxauit à retinendo leone:tum etiam quartum crus abfeindi uoluit, is nihilo remiffior facius, nihiloćs minus leonis retinens, maximo robore ad eius perniciem incumbebat. Deniq̧ etfic ca putà reliquo corpore abfiffum erat, illius tamen dentes, ex illa leonis parte, in quam primum defixi furiffent, pendebant fimul, \& quâuis is qui eos in initio defixiffet, iam mortutts effet, eitus tamen ipfius etiam nunc ex leone appenfum capur fublime fercbatur. Hic cum Alexander non mediocri dolore afficeretur, ipfius admiratione uirtutis obftupefactus, quod is qui tale uirtutis experimentum dedife fet è uita, quám ex robore animi cedere malurifet. Quare Indus uidens Alexandrum ex huius cafux dolorem non mediocrem cepiffe, quatuor canes huic fimillimos illius donauit ; ille cum grato $\& \mathrm{I}$ it. cundọ animo cos munere accepit:tum uero eum ipfum qui dediffer tanto precio, quanto par effee praftantifimum regem, remuneratus eft. Itaç horum quattior munere Alexander ex memoria do. lorem quem ex primo fufcepiffet, depofuit, Hactenus A elianus interprete Gyllio. Diodorus Sicu. lus $\&$ Strabo Sopithen regem fuiffe dicunt qui canes illos Alexandro donauit. A pud Pollucem li.

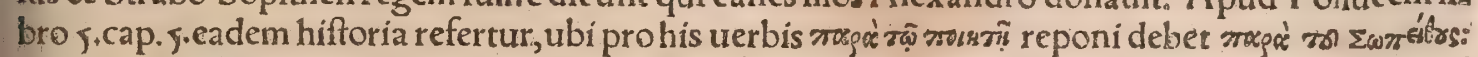
quidam inepte Sophiten fcribunt. Defcribitur etiam apud Strabonem libro !s. Fed copiofius apud Diodorum Sículum libro 17 . Sopithes rex(inquit)pręter multa \& fplendida dona alia dedit Alexan dro centum quinquaginta canes, qui pragrandes, robuftiffimi, alinśśp naturæe donis præftantes ual. de erant; atç cum tigribus commifceri dicebantur. Eorum uirturs ut Alexandro reipfa innotefceret' , leonem fortiffimum intra fepta quædam duci fecit Sopithes, duosḉ imbecilliores énumero canum;

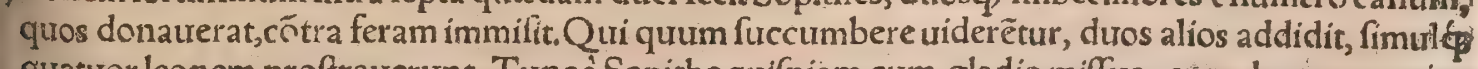
quatuor leonem proftraurerunt. Tunc à Sopithe quifpiam cum gladio miflus, c1us dextrum undus 
canis cop pit abfcindere. Ibi Alexandro inclamante, regî fpiculatores adcurrerunt, manumós homi nis retraxerunt, Iuffit Sopithes aquo animo.id ferrent pro eo cane tres(quatuor, Strabo: \& A elian.) ab fe dono accepturi. Igitur uenator reprehenfum crus paulatim concidere, neq unquam canis aut

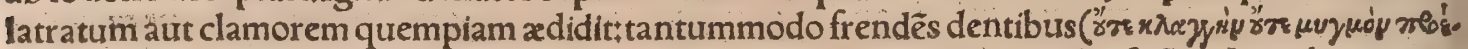

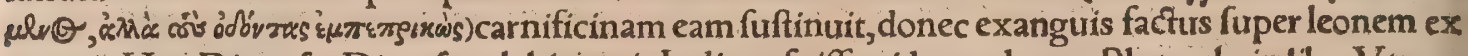
pirauit, Hac Dionyf. Diuerfus ab his canis Indicus fuiffe uidetur, de quo Plutarch, in lib. V tra 2 nimalium, \&cc.Canem, inquit, qui inter Indicos primas tenebat, quiḉ̧ aduerfus Alexandrum depu, gnârat, in harenam produĉtrm, quantifper ceruus aut aper urfúsue emitteretur, contemptim ima motum iacuiffe ferunt, Sedenim ubi leo confpectus eft, excitatum momento, pedib. harenam fparfif

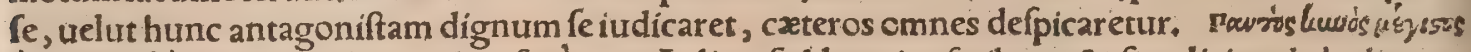

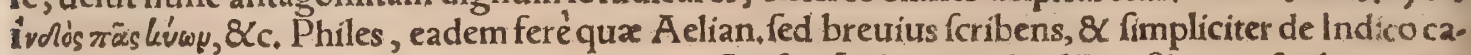
ne quolibet, non Alexandritantum. TApud Prafios Indiz populos Megafthenes fcribit, canes ualentiffimos effe, qui non ante morfum dimittant, quàm aqua narib; infundatur: Nonnullis pre fitu dio in morfu oculos difforqueri, nonnullis etiam excidere, leonem $\&$ taurum à cane derineri, taurū

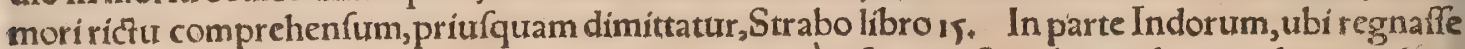
Sophites memoratur, $\&$ gentem effe fapientia præcipue infignem, \& $\&$ nobiles ad uenandum tradunt canes ₹quíģ latratu abftineant cum uidere feram, leonibus maxime infeftos, Calius abfque autho. ris nomine.

- Lacanæe canes uenatorib. etiam aduerfus apros feruiunt, Xenophon:fed de his infra in Celere,

I Locrenfes canes uenantur apros, Xenophon.

Indocilis dat pralia Medus, Grat.

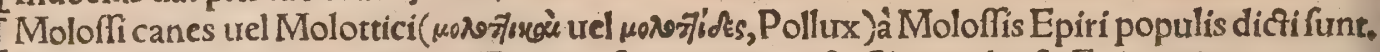
Nam $\&$ hi $\&$ Chaones celeberrimi ex Epirotis fuerunt:unde $\&$ Chaonides $\&$ Epirorici canes commendantur, Chaonides $\&$ Moloffi canes, ex Cephali cane (de quo inter celeres) natos primum fabu. Iantur, Acron interpres Horath̆ Moloffos canes à Moloffia ciuitate Creta nominatos fomniat, Ex canib,maximi animi eft Moloffus, quia acriter animofi funt Moloffi uiri, Aelian. Molotticum ge. nus uenaticum nihilo à cateris difcrepat:at pecuarium longe $\&$ magnitudine, et fortitudine contra belluas praftat. Infignes uero animo 8 induftria, (id eft forticudine $8 C$ curfu) qui ex utroq, Molotti= curm dico \& Laconicum, prodierint, Ariftot. Albertus ex maftino \& leporario natum commendat: hoc nomine Laconicũ, illo Moloffum intelligès.Maftinus hoc têpore, \& Germanis uulgo rudius di cfus, alius paftoralis ef, de quo infra: alius uenaticus, fed is quoģingens ut ex A quiuiuo iam retuli: cum Moloflos uenaticos nihil à cæateris uenaticis difcrepare fribat Âriftot. Molofius uel Molottus, canis nuagnus \& paftoralis, Varin. Suid. Vergilius etiam Georg. 3. pro paftorali accepit his uerfib. Veloces Spartæ catulos, acremó̧ Moloffum Pafce fero pingui, nunđ̈ cuftodib.illis Nocturnum Pabulis furem incurfusć̣ lupporum, Aut impacatos à tergo horrebis Iberos. A Apud Molofios populos ferunt canes inhumari folitos. I Canis Moloffus, magnus \& mordax elf, ut canis éCor fica, Fr, Alun. Mordacem dici puto, non quod temere mordeat, fed quod uehementer, 8 morfum fe. ris inflichum uix remittat, ut de Indicis diximus. Nam Corficanum etiam audio, cum apro aut bout fylueftri dentes infixit, non aliter abftrahi poffe, nifi uenator caudam eius mordicus apprehendat, Scoppa in dictionario fuo Latínoitalico Moloffum canem bracco uel uracco Italice dictum inter= pretatur, quod non placet. \Calydoniam canem Moloffo mifceri Gratius poéta probat. đXas, poroi $x$ Morsosoi, Oppian. Quando rure redierunt Moloffici, Odiofićs \& multum incommodeftici, Plaut in Captiuis, Incommodefticum quidã exponit, qui incommoda inferat: ego immodeftum ma= lim, \& modi nefcium. Exanimes trepidarefimul domus alta Moloflis Per Conuit canibus, Horat. Serm, 2.Sat.6. Teneant acres lora Moloffos, Seneca in Hippolyte. Atque armillatos colla Moloffa canes, Propert, Eleg.4. Illum Scylla rapax canib,fuccincta Moloffis, Verg.in Culice. De Nico* medis cane Moloffo dicam in cane defenfore: $\&$ ibidem de Eupolidis poëta cane Molottico, cui nomen fuit Autgeas.

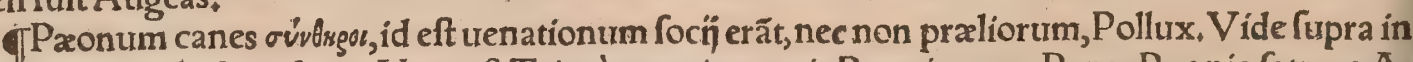
parte 1. de canib. diutrerfis. Nota eft Triacàs nomine canis Pæonica, qua Panes Pæonię fatrapa $A$. lexandrum regem donauit, Pollux.

๑Perfes, fagax fimul \& pugnax eft, Grat.

Inter canum nomina, qua apud Xenophontem legimus, robuftis pracipué conueniunt ifta:

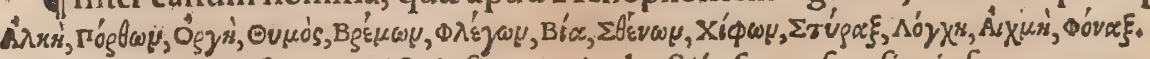

TCanes defenfores, qui \& ipfi magnirobuftí̧̧ funt, feorfim infra commemorabo, ut paftorales quioque.

\section{DE CANE SAGACE, ET ANIMA- lium inueftigatione.}

Sagacitas de odoratu pracipuré dicitur,Plinius deguftu etiam protulit, Seneca fagacitatem fenfuum corporis fimpliciter dixit, transfertur etiam ad ingenium. Hinc fagæ mulieres dict $x$, qux ( ut Cicero ait)multa fcire uolunt, item perita facrorum, diuina, incantatrices, maleficx. Plin, lib.8.de muribus, Quorum palatum in guftu fagaciffimum authores quó nam modo intellexerint, miror: 


\section{DeCanibusdiuerfis. Lib. I. 25i}

Sagax catulus, Ouid, I, de remed.am, Fideles catuli, Horat, 1.Carm; Ācron exponit fagaces, uel filen tium inueftigando feruantes, Naris fagax, Lucan.lib.7. Plautus in Curcul. Canem effe hanc quidë Magis par fuit:nafum ædepol fagax habet. Sagaces canes dicuntur authore Fefto, qui ferarum cubf lia prafentiunt, Anfer fagacior canibus, Ouid. 11, Metam. Acuto homine nobis opus ef, $S \mathbf{C}$ natt ra ufúç callido, qui fagaciter perueftiget, Cic.1, de Orat, Sagaciffrmé odorari, Ibid. lib.2. GOdori canes, Claudian. lib.2, de raptu. Et odora canum uis, Vergil, fic Lucret.lib, 4. Promiffa canum uis: \& lib.6. Cumprimis fida canum uis. Dirige odorifequos ad certa cubilia canes, uerfus eft my uruts Liun Andronici, Nec naribus acres Ire canes; Ouid.7.Metam. Et naribus utilis Agre, Ibid,li.;

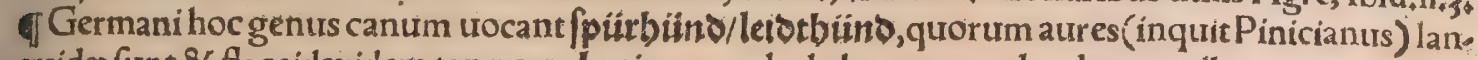
guida funt \& flaccidx:idem tanquam Latino uocabulo hos canes plaudos appellat, ex recentiori. bus puto barbaris. Noftrates príatim jagbiin $\diamond$, id elt uenaticos, fagaces nominant:alins enim uena. ticis alia nomina tribuũt. Angli, houndes uel fpaynelles, fagaces uocitanc. Horum maior hodie ufus eft quàm olim:indicatas enim feras aut exturbatas cubili, bombardis eminus petunt uenatores, us plerunq̧ canum celeritate aut robore, ac retibus etiam partum fit opus. TCarteiz in cetarïs poly pus émari exire affuetus in lacus apertos, atç̧ ibi falfamenta populari, deprehendi non potuit, nifi

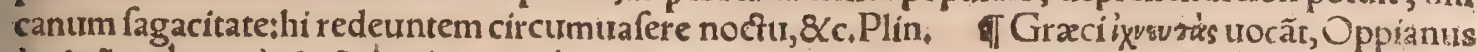

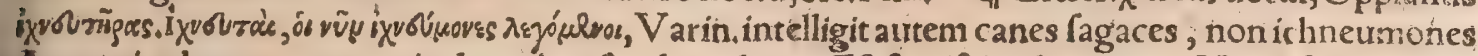
A egyptios lutrarum generis, de quibus fuo loco dicam. Eft $\&$ pifcis ichneumon, Varit1, Ichnos Gr $x$

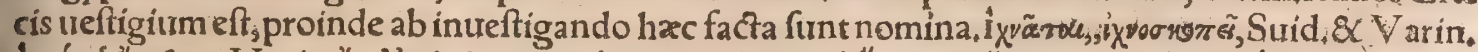

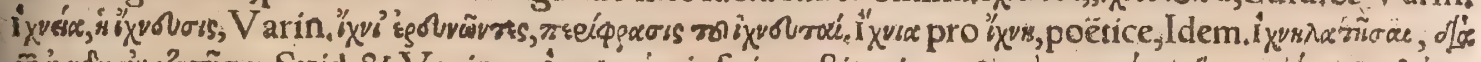

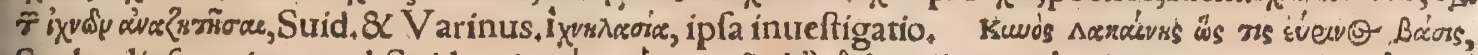

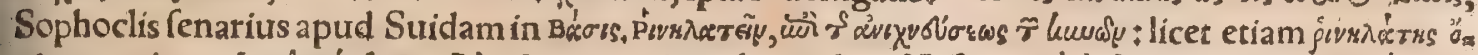

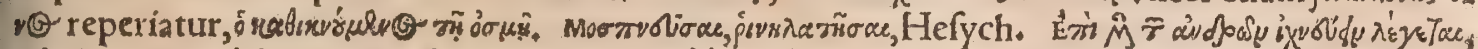

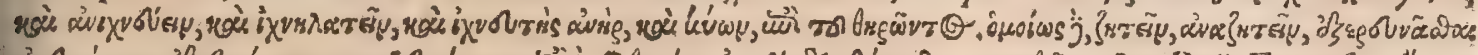

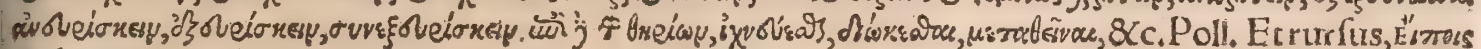

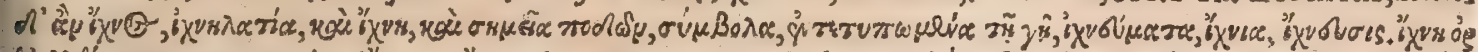

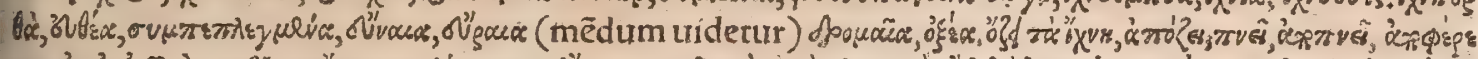

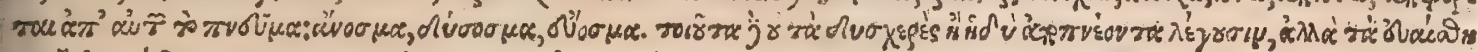

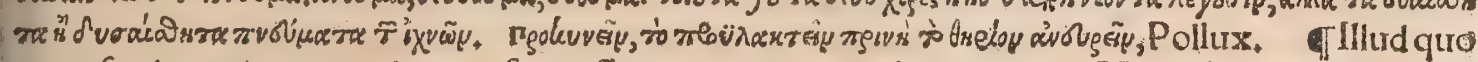
que ufus inuenit, ut acerrimos ac fagaciftimos canes in rurribus nutriant, Veger.libro 4 . de remilit; qCanes fagaces odore $\&$ importunis latratıbus feram infequuntur, coguntćs ad laffitudinem, do. nec eam in manus uenatorum uel leporariortum déṕciant: 8 quam iuflu uenatorum infequi coepe's rint, non relinquunt, etiamfi multas alias inuenerint, Author obfcurus:

TIndagare proprie fignificat locum aliquem retibus cingere, ut fera tibicung fit intra id fpatum reperiatur, fed improprie aliquando fimpliciter pro inquirere $\&$ inueftigare ponitur: hinc deducun tur, indagatio, indago, inis:indagatrix, indaganter. Omnibus ueftigĭs indagare aliquid, Cicero ad Atticũ lib. 2.Saltusó̧ indagine cingũt, Verg.4. A en. ¿d ef, ferie plagarum faltus cingentium. Syluis undiog impeditifimis, aut altiffimo flumine uel indagine munitum, Cafar 8. belli Gal.de campo quo dam. Et fyluas, uaftạ̧ feras indagine claudí, Lucan.li,6. Budxus indaginem metaphorice interpre tatur folfam, \& turrium munitarum feriem.

TV nius an uarị coloris indagatores fint canes (inquit Belifarius) parum referre uidetur : ut fta. tura etiam parux' ne an magnæ fint. Sat erit fi deiectis ac propendentib, auribus, retortis furfum na. ribus, odoratu acutiffimo fuerint, tut neç aliud quàm uenatum latratu indicent: quo quidem atroci

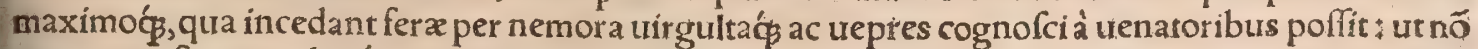
uen torum ftrepitu aliarúmue rerum ad latratum inuitentur, ne falfa fufpicione uenatores concitê. Debent autem uenatorũ uoci ita parere, ut nec longiffimè progredi aufint, nec prope ưenatores tantum manere uelint. Fit fanè non natura folum, fed etiam arte difciplinaćs, ut canes ad obediendum faciles efficiantur. Albi coloris indagatores praferuntur, quum ferarum generibus longe diffimilio res fint:nigri enim interdum apros, ruficapreas aut alias feras colore fuo referunt, unde uenatores decipiuntur, Hactenus Belifarius,

TCanem odorum (inquit Blond.) quidam autumant praftantiffimum quiradratum effe:querm nos etiam probamus, \& breuem; fimo potius quàm a dunco roftro, capite concinno:crurib. pofterioribus eadem ferè altitudine qua funt anteriora: pectore quod non fit maius uentre: dorfo plano $\$<$ porrè co ad caudam. Oculi fínt agiles $\&$ crebró moueantur, aures pendula arrigañtur fubinde: cauda mutilæ frequens motus, \& roftri per terram odorus error.Qui dutm prædam quærit, fentes ac fpine, ta diutius odoratur, fagacior eft, Laudatur imprimis qui prada inuenta, domini accurfum expectat ${ }_{d}$

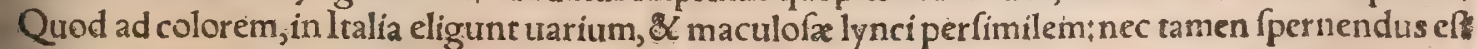
nigri coloris, Albus etiam ac fuluus color canem odorum decorat. Dirm non uenatirr, loris inftas

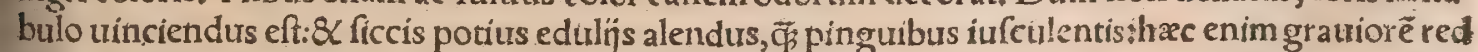
dunt, Educendus tamen nonnunquam eft é ftabulo uinctus, in uicos tantum, ut excrementis fee oneret promptius:mox iterum coércendus ufque ad tempus uenationis, Hæe Blond. Canis fagaz

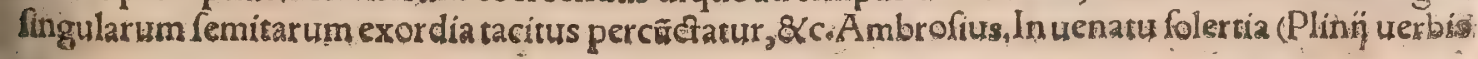


utor) $\&$ fagacitas präecipua eft.Scrutatur ueftigia atç perfequítur, comitantem ad feram inquifito rem loro trahens:qua uifa, quàm filens $\&$ occulta demonftratio eft, cauda primum, deinde roftro. Ergo etiam fenecta feffos, cacoś́ roftro cubilia, $\mathrm{Hzc}_{2}$ Plin, Canes pracipué fagaces, taciti $\&$ minimé prompti ad latrandum funto, $\mathrm{O}_{\mathrm{p}}$

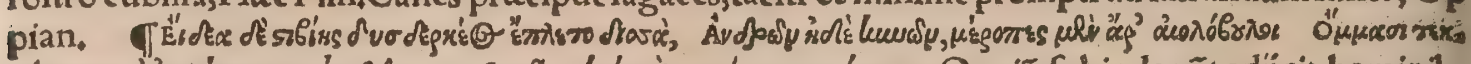

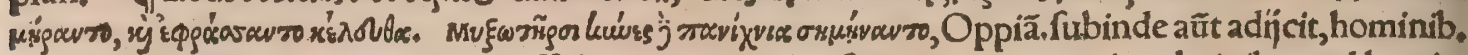
ad inueftigandum commodiorem effe hyemem, quod ueftigia tum temporis uel niubus uelluro im preffa liquidò appareant: uer canibus aduerfari propter uarios florum odores, aptifimum effe aus cumnum. In A etna Sicila(ait Ariftoteles in Mirabilib.) antrum quoddam effe fertur, \& circa id un diquaque magnam florum copiam toto anno prouenire: pracipué uero uiolis refertum effe locum amplifímum, qux fragrãtía fua locos uicinos adeò repleant, ut canes eo odore occupati, fruftra le. pores inueftigent, fFugiunt cerui latratu canum audito, aura femper fecunda, ut ueftigia cum ipfis abeant, Plin. INunc Xenophontis de inueftigatione uerba adfcribam, partim noftra, par= tim Omniboni translatione ufus, ubi ille non erraffe uidecur. Diuerfe igitur, inquit, canum indagis nes funt, Quadam ueftigijs deprehenfis, nihil fignificantes pergunt, ut an inueftigent nefcias : aliae auribus tantummodo micant, cauda immotx manent, Alix auribus immotis fummum caudx ui-

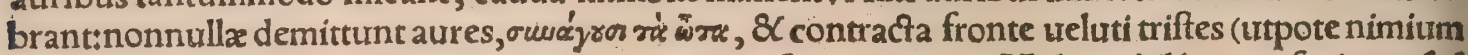
intentx) caudam quogg immobilem demittentes, curfum peragunt. Multæ nihil horum faciunt, fed infanientes obambulant: $8 x$ ueftigía circumlatrantes, cum in ea inciderint, temere figna confundüt. Sunt qux ambagibus multis ac erroribus ufæ, nec ueftigia rectà qua antrorfum ferunt fecuta, (viorx

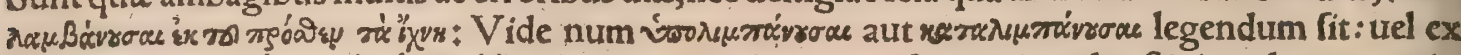

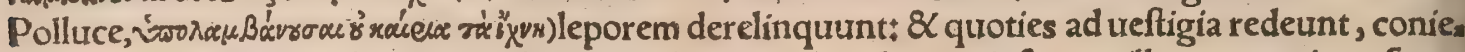
citram faciunt. At ubi leporem uident, trepidant:necinuadunt, priufquam illum moueri confpexe rint. Quæ uero inter indagandum $\&$ perfequendum, aliorum canum inuenta pracurrunt, \& fape refpeçant, fibi ipfr diffidunt; ut contra nimis autdaces 8 confidentes funt qux peritas laboris focl as ante fe progredi non finunt, fed interturbando impediunt, A lize falfa amplectuntur, \& quicquid nactx fuerint, plaudentes fibi $\&$ iactabundx procedunt, fux fibi fraudis confcix. Quxdam hoc ide

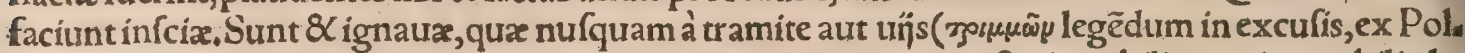
fuce) declinant, ueftigia recta ignorãtes. Damnantur etiam quæ ueftigia cubilium ( circa cubilia les porum)nö difcernunt:curfu uero impreffa, celeritex percurrunt. Sunt qua ab initio curfus magna

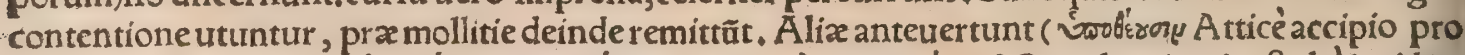

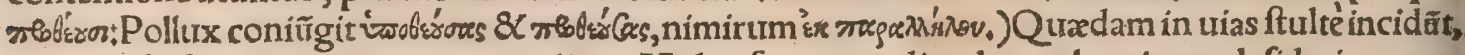

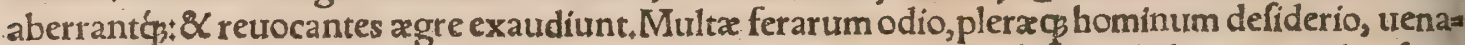

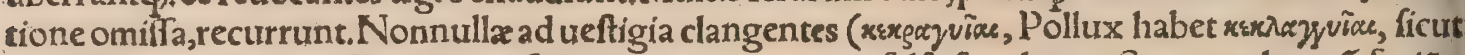
Omnibonus etiam legiffe uidetur) fallere tentant, pro ueris falfa fimulantes. Sunt quę hoc nô faciưt, fed inter currendum ficunde clamorem audierint, ad hũc relicto opere ferũtur. Alize temere fequun tur, aliz multum præueniưt.Quædam(reçè fe facere)putant, aliz fimulāt. Nonnulla inter currendum inuídia \& amulatione certãt,fȩ̣́ mutuo iuxta ueftigia irritant, ita ut alter ab altero nó abfce. dat, fed unà ferâtur. His quidem uitís canes partim natituis, partim ex mala inftitutione ortis prędi ti, inutiles euadũt: $\mathcal{X}$ homines etiam ftudiofos uenationis deterrere poffunt, ${ }_{3}$ actenus Xenophon; A quo ufurpatum ixкuн imperitius quidam eãdem interpretationem in Græcolatinum Lexicon retulit)certare $8<$ fe inuicem

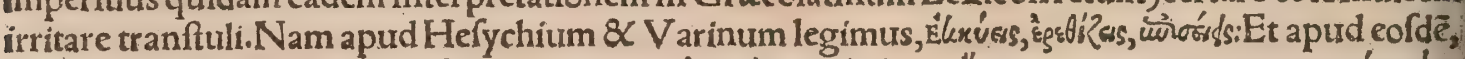

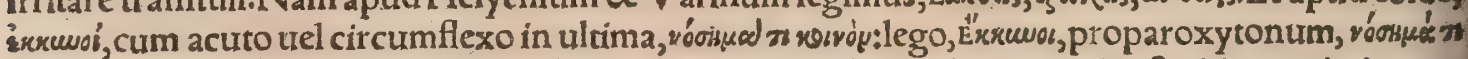

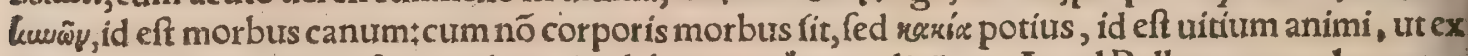
Xenophonte patet:ut ipfi canes hoc uirio laborantes घ̌k»uvor dicãtur. A pud Pollucem 5.11, leguntur

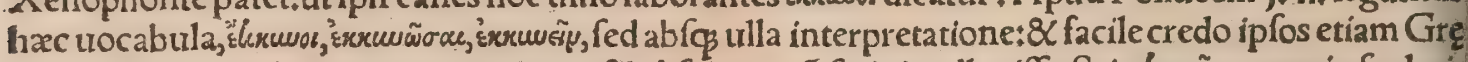
cos grammaticos has uroces ut antiquas \&ँ obfoletas nố fatis intellexiffe. Scio luwẽu exponi ofculari: ilkueveiy urero uocem quam Pollux à canibus factam effe ait, nemo quod legerim, in ea fignificatione ponit adde quod ф̧bovegas, id eft inuide apud Xenophontem adiungitur, (quamuis Omnibonus ima perite, ut folet ad pracedentia referat)côtuenit autem inuidia irritationi, ofculis minimé. Hoc clarius

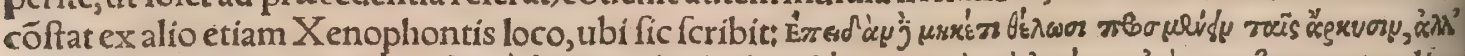

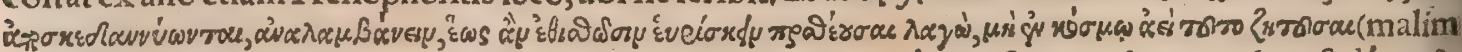

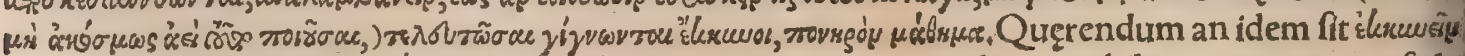

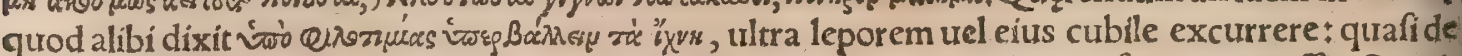
curfutantum contentio eis fit, non de lepore, $\&$ alter pręcurrentem alterum ferre non poffit. Omnis

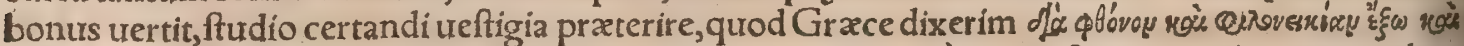
"wakgrég ranquam defertores, non ignauia aut metur, nec errore, qua alia canum uitia funt, fed inuidia mutua $\&$ contentione quadam ambitionéç.

बCanes ita ueftigent(inquit Xenophon).ut à uips \& tramitibus mox recedant, capita terræ obli. qua ( $\lambda$ sgías, ficlego) admouentes:ad ueftigia fubrideant, auresí̧ demittant, \& faciles fubinde ocu 


\section{4 . Dé Quadrúpedibus}

ueftigia:uerno autem confura. Nam lepus coitum quarit cưm aliâs femper, tưm hoc tempờe: quarañ obrem fimul uagantes neceffario ueftigia implicant.Subolent autem ueftigía cubilium (iuxta cubi. lia) diutius quàm curfu impreffa.llla enim lepus perambulat infiftendo, hac celeriter tranfcurrit: un de fit ut illis referciatur humus, his leuiter imbuatur. Syluofa item loca redolent magis quàm nuda. Siquidem modo percurrens lepus, modo procumbens, multa contingit: \& qux fequûtur, in leporis hiftoria referenda.

TBraccum canem tulgò dichum, alị canem fagacem \& odorum: alip aliter interpretantur, ut fur

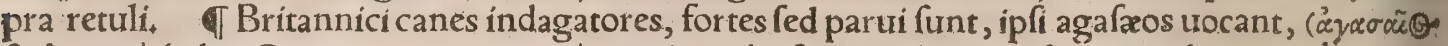

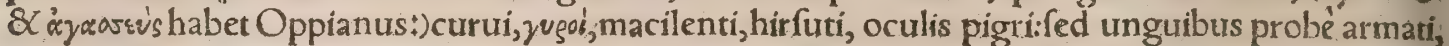
$\&$ dentibus multis acutis, odoratu $\mathcal{Q}$ indagatione præeftantiffimi, tum ad ueftigia deprehendenda, tum notandos aéris halitus. Hunc experturus uenator, leporem uiuum aut mortuum é domo rus. de fert, nố rectà, fed obliqué, modo ad dextrã modo ad lęuram procedens. Et cum longius abfuerit, fcro, be facta inhumat. Mox reurerfus caniem educit, ut fit prope initium uix Is percepto ftatim odore, nul lis apparentibus ueftigins anxius \& folicitus difcurrit, \& circum obuia quæq inquirit, lapides, col les, uias, arbores, uites, fępes, areas: tandem deprehenfo aéris tractu, qua delatus eft lepus, illac omni= no per omnes ruris ambages fequitur, donec ipfum attingat leporem. Quòd fi in ipfa uenatione ope ra eius uti uelis, uidebis quàm cauté ueftigia premat, quàm tacirè $\&$ infidiofè accedat, cum prę corpo ris partuitate facile inter uites aut arundines culmósue lateat. Cum uero prope leporem fuerit, incre dibili celeritate, fagittæ aut excitati è latibulo ferpentis inftar, \& $\mathrm{mira}$ alacritate prędam inuadit: qua partim unguiburs acutis, partim dentib. fubacta, utcunqs graue onus uix magno labore ad uenatore refert:Qui latus occurrens canem unà cum lepore à terra fublatum gremio reponit, Hæc Oppian, in fínelibri i, de uenatione. His Gratĭ quocs $\&$ Nemefiani de Britannicis canib. uerfus adiungam, Quiid freta fi Morinûm dubio refluentia ponto Veneris, atç̧ ipfos libeat penetrare Britannos? O quấta eft merces, \& quantũ impēdia fupra, Si nỗ ad fpeciem mentituroş́́́ decores Protinus, hęc una eft catulis iactura Britannis, Gratitıs.. Diuifa Britannia mittit Veloces, noftrićs orbis urenatib. aptos, Nèméfían.

ФMartem odêre Geloni, Sed natura fagax,Grat. Traxếre animos de patre Gelonę Hyrcano, Idem. Gnofij qtrog canes fagaces funt, quamobrem Ouidius inter canes Actxonis Ichnobate fagacen Gnofium fecir.Oppianus libro 4 de polypo fcribit, qui è mari egrediatur olearum, quarü

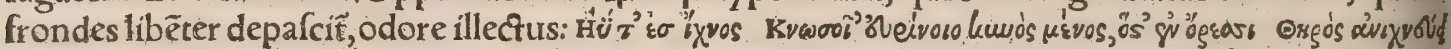

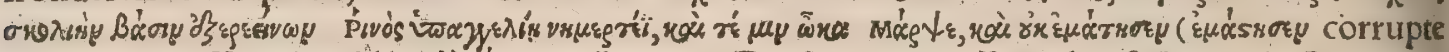

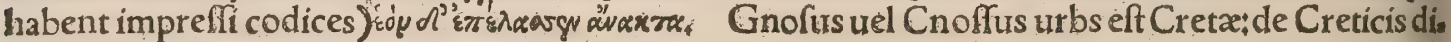
xi fupra in Venaticis diuerfis,

ه Hifpanici canes, ut atrdio, Gallis efpaigneul $x$ dicti, auriculis funt longis, minus tamen quàm bracchit lepores \& cuniculos excitant, pilis plerũ ģ nitidis, non hirfutis.

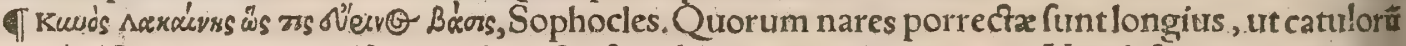
(Luvidíwe) Laconicorum, olfactu ualent, Ariftot,degeneratione anim. 5. 2. Nos de Laconicis mox in ter celeres dicemus:qui puto maiores funt, fagaces uero Laconici minorest nam Ariftoteles huvidiut uocauit.

TTufci cỏmendantà Nemefian, his uerfib, Quin \& Tufcorum non eft extrema troluptas Sape canũ:forma eft illis licet obfita uillo, .. Diffimileş́́ habeãt catulis uelocibùs artus, Haud tamẽ initucû́da dabũt tibi munera pręda. Nanģ \& odorato nof cunt ureftigia prato, Atos etiam leporum fecreta cubilia monftrant.

ब $V$ mber fagax, fed timidus eft.

Atfugit aduerfos idem quos repperit hofteis $V$ mber.quanta fídes, utinã $\&$ folertia naris, Tanta foret uírtus, $\&$ tantum uellet in armis, Grat.

Aut exigit Vmber Nare fagax écalle feras, Syllitus libro3. Quondam inconfultis mater dabit

Vmbrica Gallis Senfum agilem,Grat.

T. Canum diuerfa nomina ex Xenophonte fupra retulimus, inter ea funt qua fagacib, pracipue

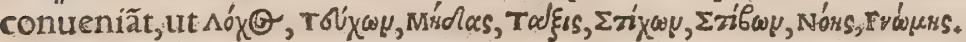

I V E N A T I cortum canum alị fagaces funt, in quibus tamen celeritatem defideres, ut quos dixis :

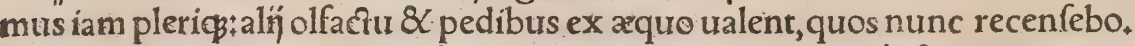

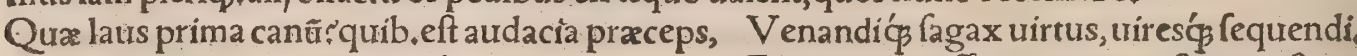

Quæ nunc elatis rimãtur naribus auras, Et nunc demiffo quarunt ueftigia roftro, Et produnt clamore feram, dominumós uocãdo, Increpitant:quem fi collatis effưgit armis: Infequî́t tumulos ọ́ canis, camposá̧̧ per omnes, Nofter in arte labor pofitus, fpes omnis in illa, Ouidius in Halieuticis.

- Aetoli celeres fagacesḉ funt, de quib.Grat. Āt clangore citat, quos nondúm côfpicit apros, Aetola quæcũç̧ canis de ftirpé(malignum nimius properat furor:Et ramé illud Ne uanum totas genus afpernere per arteis, Mirum quàm celeres, \& quantum nare merent:; Tum non eft uicti cui conceffere labori. - Britannicus canis fagax \& celer eft, ut fupra docuimus.

ICelcici canes ex Gallia Britanniaç̧ uenientes;odoratu curfúç funtinfignes, Textor, De Galls 


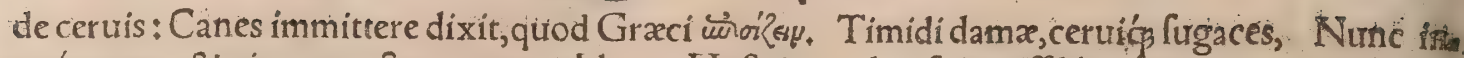
terós canes, \& circum teĉa uagantur, Idem. Hyftrix aculeis fuis miffilibus ora urgentium figit ca

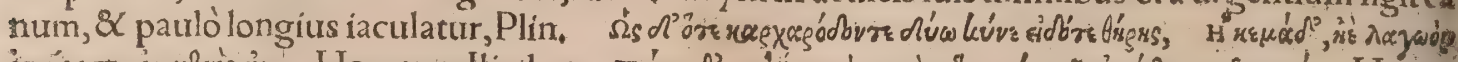

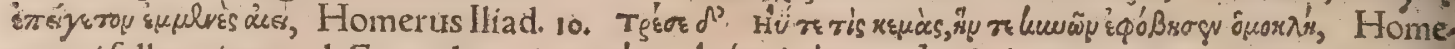

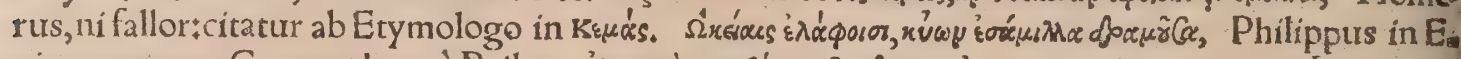

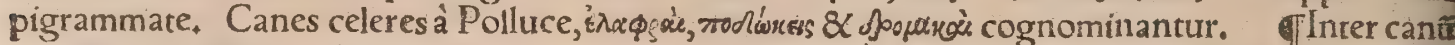
ncmina propria, qux fupra recenfui, uelocibus ifta maximé conueniunt, Aura, Lælaps : \& apud Xe

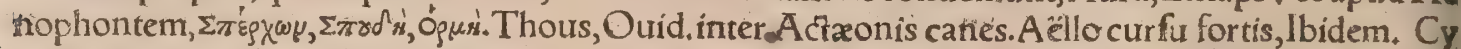
prio uelox cum fratre Lycifca, Ibidem. Volat acer Hylax, uolat ocyor Eurơ Harpalagus, Baptifta

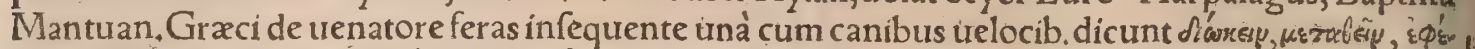

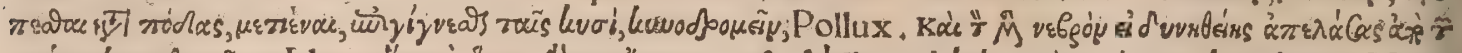

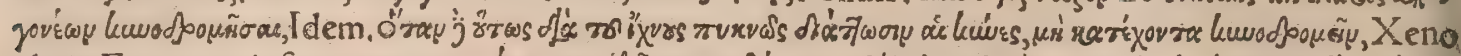

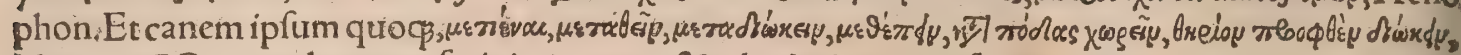
Idem. Quomodo canes feris ímittantur, $\&$ ad celéritatem ac fortitudinem acclamante uenato re animentưr, apud Xenophontem in libro de uenatione leges. TCanis uelox \& idoneus immit. ti in certros, lepores, ac damas, corpore fitlógo, ualido, mediocriter magno(fic à gnıov expono)capite le ul, nitido:in quo oculi fplendeant corulei, (nigri:) ore dentiburs afpero, oblongo : auriculis paruis, quarum tenues fint membranæ:collo procero, pectore robufto $\&$ lato:pedibus anteriorib, breuior bus rectis:crurib. longis 8 rectis:Icapulis latis: coftis laterum obliquis:lumbis non pingtuibus, fed be

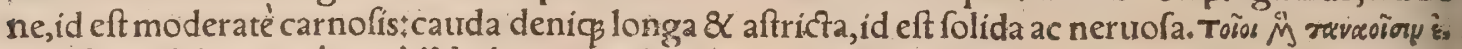

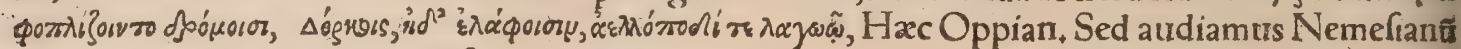
quoque de eligendis canib, ad focturam præcipue, quoniam de celeribus maxime loqui uidetur, cu ius hi funt uerfus.

Incipiat primo, cum fanus temporis atthor Elige tunc curfu facilem, facilemó̧ r recurfu,

Non humili de gente canem, fit crurib.altis, Coftarum fub fine decenter prona carinam,

Renibus ampla fatis ualidis, didućạ̧́̂ coxas:

Huic parilem fubmitte mare , fic omnia magn $\tilde{u}$, Corporis $\&$ uenis primaui fanguis abundat. Principio tibi ctrra canum non fegnis ab anno Pandit inocciduum biffenis menlib.æuum. Seu Lacedęmonio natam, feu rur e Moloffo Sit rigidis, multamćs gerat fub peçore lato Qua fenfim rurfus ficca fe colligat aluo:

Cưíç nimis molles fluitent in curfibus aures. Canis celer futurus, elígi debet, qui inter catulos? porrdere leuior fuerit, ut fupra dixi in cane in genere. TAliud canum genus eft(inquit Belifarius) qui ad magna animalia fortiaćs, ut apri funt $\mathcal{Q}$ huiufmodi, fuftinenda (impedienda) pti dicûtur, quo ufás fortiores grauiores $\phi_{\beta}$ canes aduenerint. Hi aprum fiftent, $\&$ in curfu aliquando mordendo im pedient. Eorum duo funt genera:unum ftrigofiorum, quifi perniciores fuerint, uelociffima etiam fe ctari poterunt animalia. Huiufmodi canis tum corpore toto, tum capite \& collo oblongis efto: pecto re acuro, coftis inferius longis, $\&$ ad ima paululum trahentibus tpræcordịs lateribusć $\$$ ita amplis, ut \$. ne difficultate canes fpiritum trahãt. Nam quo facilior refpiratio furerit, tantoexpeditiores ad cur fum erunt. Ilia fint angufta $\&$ compreffa:trenter exilis, nam craffus currentem grauat. Crura alta, bracłria nō xque, ne leporis capturam impediant. Anteriores pedes, ut in fele, rotundi potius quàm longi fint. Alterum uero medium(inter robuftos $8 \mathrm{i}$ iam dictos celeres)genus eft : cuius generis $\mathrm{ca}=4$ nes cum leuiorib, ftrigofioribus ç̧ morfumós cerui paruifacere uideãtur. Et hi quidem omnium generum canes, fi pedes uenator fure. vit, finiftra manu ducendifunt: dextera uero, fi eques, fi tamen lancea cartierit. Dexteris enim parti= bus tum feræ tum homines commodius pugnam committunt, Hactenus Belifarius, Leporarï quí maximé probentur, dicam ex Alberto inferius in catalogo celerum. Pedes celeris, pilos habeãt den fos, tenues, molles, Pollux ex Xenophonte. Pecuarius canis neque tam ftrigofas aut pernix debet effe, quàm qui damas certrosós, \& uelocifima féçatur animalıa, \&c. Columella. a Canem ex piz. gro treloce e reddes, fi pane aurenaceo bene cocto $\&$ fermẽtate, affrdue eum reficias, Alber. If Catuli ce ieres futuri cum iam quaturor menfium fuerint, Libera tune primum confurefcant colla ligari, Concordes \& ferregradus, claufíp teneri, lam cum bis denos Phobe reparauterit ortus, Incipe non longo catulos producerecurfu,

Sed parua uallis fpatio, feptó ure nouali.

His leporem præmitte manu, non tríribus aquisis, Nec curfus uirtute parem:fed tarda trahentern Membra, queant iã nunc faciles ut fumere prędã. Nec femel indulge catulis moderamine curfus, Sed, donec ualidos etiam præuertere fuefcant, Exerceto dit, tuenandi munere cogens Difcere, \& emeritz laudem uirtutis amare.

Exerceto dit, tlenandimunere cogens Seu curfus reuocent, iubeant feu tendere curfurs, Quinetiam doefi uictam contingere pradam? Exanimare uelint tantum, non carpere fumptam, Hre Nemefian, IV Enatorcanes(inquir Xe nophon)uenatum agat, foeminas menfium octo, mares decem; nec eas ad cubilium ueftgia foluat fed fubmiffas ( $\dot{\phi} \in \mu$ tixas, fubnexas)longis detinens lor is ueftigantes fublequatur, \& per ueftigia cur

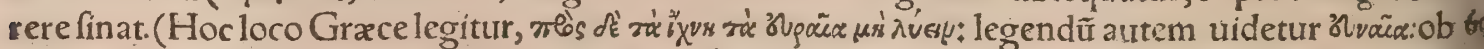

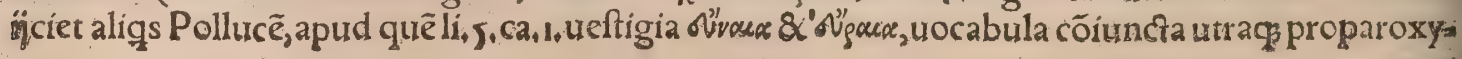


Curm fe plurimum (inquit) currendo exercuit, multo effufiorem ad Venerem effe ferunt, qaco nicigeneris foeminæ, quia minus laborant quàm mares, uiuaciores maribus funt: at uero in cære: $r$ is, \& fi non late admodum conftat, tamen mares uiuaciores funt, Ariftot. Viuit mas Laconicus ad annos decem, foemina ad durodecim, Ariftot, \& Plin, Propria in eo genere maribus laboris alacritas, Plin. TQuorum nares porrectre funt longius ut catulorũ Laconicorum, olfaçu prệtant, Ariftot, In genere cảnum Laconico foeminas effe fagaciores quàm mares, apertum eft. Infignes animo $\&$ in dultria canes funt, qui ex utroque genere, Molotticum dico $\&$ Laconicum, prodierint, Ariftot.Laco nici canes, inquit Aurg. Niph. uulgo bracce dicuntur. Albertus leporarios interpretatur. Sed bracci nomê hodie inconftans eft, ut frriptura quoque. Nam aliqui per c fimplex feribunt, alíf per c duplex, alị afpirationem addunt, bracus, braccus, bracchus, aut eadem in forminino genere in a. Sigrfmun dus Gelenius broccum fcribit per o, ut accommodet Graco uocabulo Bpénx Q Germacice biack, Il. lyrice praczieck. THaud fcio an aliquid huc faciant ifte uoces, brocus uel brochus $\&$ bronchus, quafi broche, id eft craffo \& prominẽte fit ore, quem canem brachum dicimus. Seneciutem in equis intelligi negant poffe, præterquam cum dentes facti funt brochi \& fupercilia cana, Varro. Seneçù in ueterinis intelligitur dentium brochitate, fuperciliorum canicie, Plin. Et ex eo enatis duobus den tibus, dextra $\&$ finiftra paulò eminulis fuperior $i b$, directis potius quâm brochis, $8 \times$ acutis, Varro de canib.loquens. Hinc patet brochos dentes dici prominentes ita ut adunci fint : quare hanc uocem ఝ bus prominentibus. A labris, inquit Plin, bronci labeones dicti funt:emendatiores codices broci ha. bent. Quidam brochum interpretãtur cuimentum $\&$ dentes inferiores magis quàm fuperiores pro. minent. Similiter à datum, \& implendis depler dis

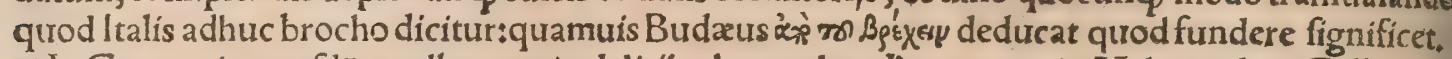
GIn Germania quofdã catellas qua in delicijs aluntur bzacten uocare in Melitxis dixi. Galli, ut au dio, braccham appellant uenaticam canem (celerem \& fagacem ) qux perpetuo curfu feram quam primum confpexerit(in quam luffu uenatoris immiffa fuerit) infequatur, utcunç plures fe offerant: eandem $\&$ aues excitare aiunt, corpore humilem, auriculis longis, ore craffo, Fr. Alunnus canê bra. co Iralice dicfum exponit fagacem $\&$ odorum. Canis altus retro in lumbis, ftricius $\&$ magnus in peciore, quileporarius uocatur, coire aliquando incipit octauo menfe, Albert. Quos Ariftoteles La conicos, nos Italicos dicimus, Blond. Aliqui uertagum leporarium exponunt, ut fupra dixi.

Teporarï canes (barbari leuerarios fcribunt)nobiliffimi funt, pectore ualent, latratus æedere ne fciunt: $\mathcal{Q}$ nifi producantur ad curfum, intra domum fe continent, Author obfcurus. GLeporari. us collo longo pulchrior \& melior erit.Longum autem etiam arte reddetur, fi in fcrobe prolongitus dine canis effolia, ipfum (nimirum dum corpus adhuc increfcit)quoties cibandus eft, colloces: \& $\mathrm{ct}$ bum fcrobis oræ imponas, ut canís nificollo bene extenfo affequi non poffic, GLeporarï (inquí Albert.)optimi funtlongis \& planis capitibus, non enormib. auriculis acutis retrorfum directis \& paruis:labro fuperiore fuper inferius non dependente, nifi minimum forte: collo longo, \& aliquantu lum turgidiore quàm caput, ea parte qua capiti iungitur:pectore enormi, $\mathcal{Q}$ bene acuto inferius: co. ftis longis \& ualidis: ilibus ftrictis:crurib, altis, macris potius quàm obefís:cauda non crafra, nec ad, modum longa, $R$ arò uel nunquam latrent, Proprium enim his canib. eft fuccenfere minoribus qui 4 procuftodia latrant. Non quíduis inuadunt, indignum id fe exiftimantes. Lacte magis quâm fero

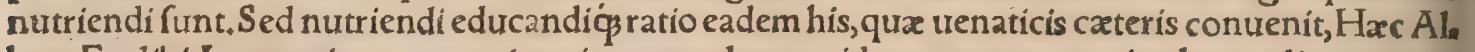
bert. Et alibi, Leporarios magnos, inquit, quos ueltres quidam uocant, ex coitu leopardi cum cane, ortos nõnulli dic ũt. Veltro Italice uulgó diçus canis, uenaticus $\&$ curfu uelociffimus eft, Fr. Alun. quærendum an idem uertagus fit, cum nomina colludant. Leuis ilia Falco, Mantuan. A pud Aug* Niphum Falco proprium nomen elt canis leporarij. TCanibus uenaticis dorfum integunt pan nis diuerforum colorum, aduerfus frigoris iniuriam, pracipué leporarijs: $\propto$ pedib. adhibent calcia menta, quo facilius illafi curfum exerceant, Blond.

TPodicnitzịP Polonis appellati canes, parui $\&$ celeres funt, quib. utuntur ad arres $\&$ lepores.

Thes ueloces quidam \& magni Germanicè anpellantur, 20 inofpil, nimirum à uelocitate ip rum uentis comparata: Alÿ funt qui nominantur Cürctifo wins, Turcici canes : utrique in lepos res, uulpes, ceruos, \& fimilia animalia immitunur, communi nomine beß̧bĭn dicłi, quod etiã de robuftis licet non uelocibus dicitur.

T Gallici canes fiue Celtici dicti, diuerfi funt:uide fupra in Celtis inter Venaticos ditrerfos, \& inter fagaces fimul acceleres in Vertago. Vt canis in uacuo leporẽ cũ Gallicus aruo Vidit, 8 hic pradã pedibus petit,ille fa!utem, Ouid.li, I. Meram. Leporêḉ̧ lafum Gallicicanis dente, Martial, Gratius Gallos canes inconfultos, id eft non fagaces uocat,ideó̧̧ ad prolem mifcêdos Vmbris. Gallicos quil dam leporarios interpretâtur, qui in locis montanis optimi proueniant; \& eam ob caufam commen dant Turcicos ex montib. Dalmatiz, \& régionibus ad orientem fitis . Laudantur in eis, pedes duri, auriculæ longx, caudx fetofx \& prolixiorib, pilis.

Et fubftricta gerens Sicyonius ilia Ladon, Ouid,inter canes Actaonis.

Locridis nomine canis Anyte poëtria Tegeatis, gloriam pofteris tranfinifit, hos tetrafticho it 


\section{De Canibus diuerfis. Lib. I. 259}

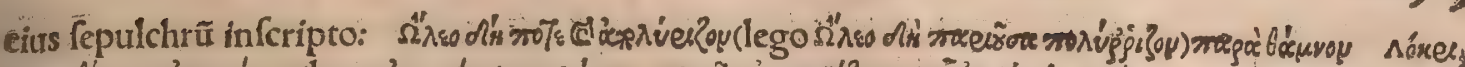

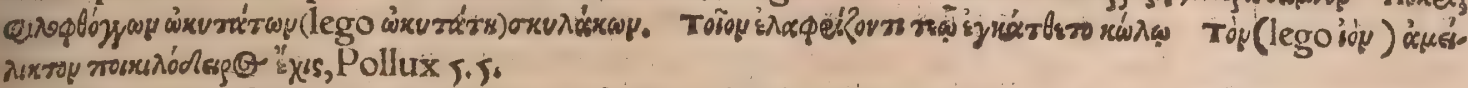

đ Chaonidas \&CMolottidas aliqui tradunt prolê effe eius canis, quiem àre Monefio ubi conflauic Vulcanus, immiffa quoq̧ anima, loui dedit dono:is ueró Europa, haec Minoi, Minos Procidi : illa uero Cephali effe uoluit munus, Necqui Dictaa Cephalum degente fecutus Luciferæ pariter ue nit ad aftra dex, Martial. Eius haec fuit natura, ut uitari non poffet, ubi infequeretur: ficuti Tets. mefia uulpes fuiffe narratur incomprehenfibilis. Qua ratio(ne ineuitabilem canem uulpes effurge. ret, aut uulpem incomprehenfibilem canis caperet)utrunç deformauit in lapidem, Cælius ex Pollit 10 cis lib. 5. cap. 5. Plura uide apud Tzetzen Chiliade 1.cap.20,80 Ouidium lib.7.Metam, qui Lxlapem hunc canem uocatum fcribir: \& Palæphatum cap.9. licet Telmefia apud eum legatur. Teumeffus Bozotia mons eft, unde uulpes Teumefia, Stephan. Telmiffus uero per iota in penult. Caria uel $\mathrm{L}_{y}$; cia urbs. Monefium as quod fuerit non reperio. Teumefliam uxulpem Dionyfín ir a in Thebanos ex citatam ferunt, quam cum canis à, Diana Procridi datus, capturus effet, utriç in lapides mutati fin. guntur, Blond.

बCanicula quadam cum uenaretur, quamuis uentrem ferret, leporem cepit, eaḉ iam capta prö da, ftatim domino cedens feceffit, atç quàm mox nourem catulos peperit, quos aluit poftea, A elian.

TAnthologij Græci libro 1 . Sect. 33 . legimus epigramma in canem celcrem cuí grauidæuterus uulneratus cicatrice concreuerat, partus autem tempore fectus eft ut poffet eniti : 8 aliud in canem 1. celerem fitimortuum.

$$
\begin{aligned}
& \text { DE CANIBVS INSTRVCTIS AD AVES } \\
& \text { capiendas, } 8 \text { aquaticis. }
\end{aligned}
$$

C A N E S arte \& difciplina potius inftructx, quàm fuopte ingenio \& fagacitate ad aurum captt. ram infertuiunt: quamuis odoratu etiã eas ualere oportet. Docentur autẽ hoc modo, Irretitis perdici. buts primo circumducuntur faxpius, \& per minas tandem affuefcunt undiquaç circuire. Deprehen. dunt autem perdices odorando, fi primò ueftigñs captarum fxpius imponantur, Albert. Noftrates \&Galli hos canes coturnicum appellant, quod corum opera hoc maxime auium genus capiant: Ita

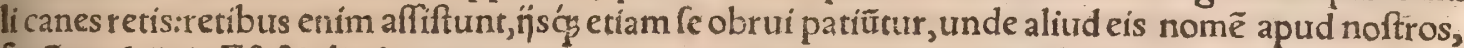
forfteno büno. Eft \& aliud canum genus, quos communi nomine vogelbün o uocitãt, id eft auium canes, quorum ufus eft ad uaria accipitrum genera. Canes coturnicum tota hyeme, ut audio, foluti \& liberi funt, primo uere legantur, \& per totam æftatem ad autumnum ufos, aut faltem refectas fege tes, detinentur. T Canis alfeluchi, eft canis quo uenatores utuntur in capiendis aubus aut qua. drupedibus, And,Bellunen. Auis nulla non canem parui facit : unam otidem excipio, quæ prop. ter corporis fui grauitatem $\&$ tarditatem, canem perhorrefcit, A elian. Genus canis quod in plerif́, regionibus hodie braccham appellant, auriculis longis, ore craffo, \& c cde quo fuperius feripfi inter fa gaces fimul \& celeres, auib, excitandis aptum eft, Poloni canibus, qui podicnitzï apud eos nuncu. pantur,ad aues $\&$ lepores utuntur. đNare fagax alius, campiş́́ undisćs uolucres Quærit, \& ad nutus huc indefeffus, \& illuc Difcurrit,Stroza filius in Epicedio canis.

TS Sunt quædam genera urforum alborum, canum, luporum, \& fimilium quorundam animaliu - qua uenantur $\&$ habitant tam in aqua, quam in terra, Albert. Aquaticos canes uoco, quos noftri wafferbind:quorum alips caftores, lutras, $\&$ anates fylueftres uenantur : alĭ fi quid in aquam inciderit, aut proiectum fuerit, reportant.Sunt autem aquatici canes plerunç uillofi. Haud fcío an aqua ticum intellexerit Bapt.Mantuan,cum fcribit, Ichthya regis Deliciæ, nomẽ patrix fortita marinę, DE CANIB VS MIXTIS VEL BIGENERIS.

MIX TI \& bigeneri canes uocari poffunt, tum qui ex utrocs parente cane, fed diuerforum gene: rum, ut ex Moloffo \& Laconico apud Ariftotelem celer fimul \& ualidus fururus nafcitur : tum qui parente altero cane, altero fera, ut lupo, leone, 8 c. nati funt. Excogitarunt hanc mixtionem uenato. res, prioris quidem generis, uel ut uitia quædam emendarent $\&$ præcauerent in fobole : uel ut dotes quafdam adincerent; Pofterior is uero, ut uel magis robufti ad uenandũ aduerfus maiores feras producerentur canes, uel certe callidiores, ex ingenio parentis:cum non corporum modo, fed animorü quoque bona maláue à parentib, in prolem deriuari conftet. Dicam igitur primum de priore $8<$ firm. pliciore genere.

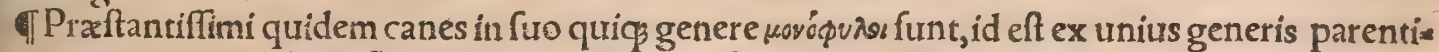
bus prognati:uerum fuperflua uenatorum cura mifcere etiam diuerfa genera, qua quidem innume rafunt, adinuenic, Si quis igitur mixcis delectabitur, coniungere poterit Arcades Eleis, Paronins Cre tenfes, Cares Thracijs, Tyrrhenos Laconicis, Sarmaticum Iberidi, Oppian. Iccirco uarijs mifcebo gentibus ufum. Quondam inconfultis mater dabit Vmbrica Gallis Senfum agilem, traxêre ani. mos de parte Gelonæ Hyrcano, \& uanæ tantum Calydonia lingux Exibit uítium patre emenda: ta Moloffo. Scilicet ex cmni florem uirtute capeffunt, Et fequirutr natura fauens, Grat, Etpatre 6. Dictæo, fed matre Laconide nati Labros \& Aglaodes, Ouidius inter canes Actronis. Vertagü ex cane Gallico \& alio quodam fagace mixtum effe, unde Galli uocant ung metif, ex quorundam fententia fupra retuli, 
ब Noftrís temporibus canes non admifcentur uruipibus, lupis, aut tigrib: quroniam tanta af \& feritate non egemus, Blond. Hos quidem canes recté aliquis femiferos appeilabit, a d reliquerum mixtorum differentiam. TCoêunt animalía, \& quorum genus diuerfum quidem, fed nitura nó multum diftat:fi modo par magnitudo fit, \& tempora aquent grauiditatis:raio id fit fed tamen fie ri $\&$ in canibus, $\mathcal{X}$ in uulpib. $\mathcal{Q}$ in lupis certum eft, A riftot.

qChaonidas canes aliqui à Cephali cane, alij de Chaoluporum generis fera, progenitaś fúpican tur, Calius.

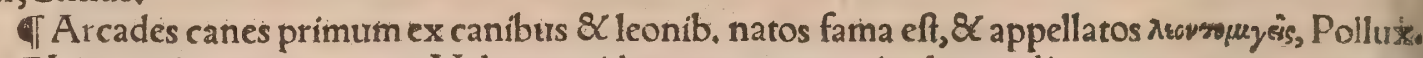

बI Leporarios magnos, quos Veltros quidam uocant, ex coitu leopardi cum cane procreatos qui dam dicunt, Albert.

TCum canibus lupi coéunt in Cyrenenfi agro; Ariftoteles, \& Pollux citans Aríftotelem. Cumi apudRoccam Vandream cum Federico Monfortio uenaremur, in itinere reditus, qtridam ex canibus, Muccius nømine, infectatus eft lupam magno nifu, quam affecuttrs canire deprehendit, $\delta$ cû̉ ca coiuit. Nam cum nos uøcib. \& cornibus reuocantes non curaret, inquirentes tandem inuenimus cum lupa coëuntem, féritate utriufas pra defiderio Veneris remiffa, Aug.Niph. E lupis canes Galli uolunt concipi, quorum greges futum quif $\beta$ ducforem è canib. $\&$ ducem habent. Illum in uenatu comitantur, illi parent, Nanç, inter fe exercent etiam magifteria, Plin. Ex canis cum lupo coitu gie gnitur magnus canis, qui maftintis trocatur à nobis, Albert. alibi fimpliciter maftinum lupo fimilem facit, Idem alibi inepte lincifitum uocat ex cane patre, \& lupa matre natum : fimiliter \& alij barbari friptores:quorum aliqui etiam lintifcum fcribunt, \& Ifidori uerba adducunt Plinium teftem citan tis canes ex lupis \& canib.natos, eum forte mífentur; lintifcos dici. Ego nihil tale apud Plinium re= perio. Videtur autem hæc uox deprauata prolycifco vel lycifca, quod canis nomen apud Vergiliû legimus, Multum latrante Lycífa; Aeg 3. Cyprio uelox cum fratre Lycifca, Ouid. inter Actxonis canes. Referenś́ lupum tortio ore Lycifea ; Mantuan. Fuit \& Lycas canis Simonidis epitaphio nobilitata, ut fupra retuli. Dećs lupo concepta Nape, Ouid. Crocuta appellarur fera, quam aliquí ex lupo \& cane nafci putant, tride infra in Crocuta, Dum hac feriberem canis in urbe noftra eras, lupo fimilis, \& ex lupo natus uulgo ferebatur.

T. Canis rufus ex genere cuftodum, catulus adhuc cum fimia tier fari confutetus multa ior of $\&$ ri fu digna facere confuefcit: $Q$ uòd fi etiam coierit cum ea, natus ex eis canis omnium aptifimus ad lu doserit, Albert.

đCanes ex thoibu's natos Grat, commendat, his iuerfib. Hic(Hagnon Bccotits quidam)\& femiferam thoum de fanguine prolem Seu nôrit uoces, feu nudi ad pignora Martis, Et fubiêre aftu, \& paruis domuêre lacertis. $\checkmark$ ulpina fpecie:tamen huc exacta uoluntas.

Finxit.non alio maior fua pectore uirtus. Thoës commiffos(clariffima fama)leones Nam genus exiguũ, \& 8 pudear क̧ informe uideri, Exercere uelis, \&\&c. In impreffis codícib. hic trerfus, Vulpina fpecie, \& c .cum fequentibus, fepara. tur à cane ex thoibus nato, fed confiderandum eft an pracedentib, cohæreat.

TI Ex tigride 8 cane gigni confirmant Indicos:uerum non ftatim, fed tertio coítu:primo cnim bel luinos adhuc catulos procreari aiunt, alligantur canes locis defertis, \& nifi bellua incenfa libidine fit, fapelacerantur, Ariftotel.Et alibi, Canes etiam Indici (inquic) ex bellua quadam fimili, \& cane generantur. Ex rigrib, canes Indi uolunt concipi: $8 \mathrm{ob}$ id in fyluis coitus tempore alligant foemi. nas. Primo \& fecundo fotu nimis feroces putant gigni, tertio demum educant, Plin. Plura de In. dicis canib. uide fupra in Venaticis robuftis. Grat, Hyrcanos canes ex tigride nafci feribir his uerfib. Sed non Hyrcanæ fatis eft uehementia genti Tanta: fuis petiêre ultro fera femina fyluis. Dat Venus acceffus, \& blando foedere iungit. Tunc \& manfuretis tutò ferus errat aduker In ftabulis, ultróçs grauis fuccedere tigrim Aufa canis,maiore tulit de fanguine foctum, Sed praceps uirtus ipfa uenabitur aula. Ille tibi $\&$ pecudum multo cum fanguine crefeet: Pafce tamen;quæcunç domi fibi crimina fecit, Excutiet fylua magnus pugnater adepta.

Bapt.Mantuan.Tigrinam canem nomine proprio propter macularum fimilitudinem nominauit, Et Tigrina notis tergum maculofa. Lacanas aiunt ab initio ex canib. 8 uulpibus natas, alopeci das appellatas effe, ut fupra dixi in Laconicis. Xenophon alopecidas canes uenaticus facit: \& fane uidentur uenatici quidam ueloces, ut leporar ̈̈ dicti,capite magis in acutum tendente $\&$ rof rri figu ra uulpem referre. Albertus non ad uenationem fed ad mimica \& ridicula opera inftruendum cas nem, ex tulpecula natum commendat, ut dicam in cane mimo.

$$
\text { DE CANE SOCIO ET FEDELI. }
$$

so CII hominum uocitari poffunt, omnes qui ab hominibus aituntur canes, non folum ur reliqua animalia manfueta, quæ Graci ouravegwroblov zxe, quod hominibus conuerfentur, appellant: fed quia laborum curarumó́ focios hominibus fe præbent. Verum canibus alijs præter ipfum hominem alĭ us etiam fcopus eft, ut uenandi opus, \& cuftodiendi dom.os, pecora, aliasós res.Quamobrem forium eanem per excellentiam hîc appello, qui ipfius tantum hominis caufa nutritur, praccipue ut èdcmo prodeuntibus $\&$ iter facientibus comesfit, fiue fimpliciter $S \mathcal{X}$ uoluptatis, aut etiam defenfionis gra:

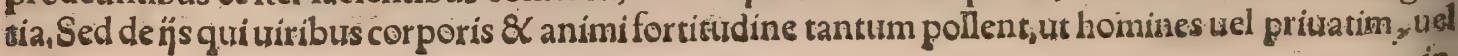




\section{De Canibusdiuerfis. Lib. I. $26 i$}

in bello defendant aduerfus hoftes, in fequentibus dicam, hoc prius loco de canibus focijs fimplici. ter acturus, Caterum canem animal elfe fummo in hominem amore fideḉ, dixi capite quinto, de Cá ne in genere.

ब Canis fodalis(inquit Blondus) eligatur magnitudine intèr canem \& catulum media, hirfutus, pilis oblongis, fiue crifpis, fiue protenfis:quadratus, capite ad roftrum uff̧ pilofo, placidus: \& qui do mino contínue affiftat, in itineribus indefeffus, 8 morantem expectet.

Codri poëtax canis apud Iuuenalem memoratur; nomine Chiron. Canum beneuolentiat pros prium in altores fuos illud de ttíro Colophonio teltatur:Is ad nundinas profícifcens, uti quadam ibi emeret, nam eius in mercaturis faciendis uerfabatur induftriat pecuniam, ferutim, \& canem fecum accepit. Ac quidem feruus, qui eam ipfam pecuniam ferebat, cum uix aliquantum proceffiffent, ad deñciendam aluum ex inftituto itinere diuertit, quem fecutus eft canis, is poftquam necefficari de diffet operam, è terra marfypium tollere oblitus, difceffit. At ưero canis ibi remanfit màrfypío incur bans: deinde fimul ut ad emporium, domítus \& feruus ueniffent, re infecta, cum nummi eis abef rent ad emendưm, eadem uia qua profecti fuiffent, reuerterunt:at $\$$ cum eò ueniffent, ùnde prius ille diuertiffet, de recta uia ab itinere fufcepto deflexerunt, $\mathrm{ec}^{\mathrm{t}} \mathrm{em}$ ubi fanènummos feruus reliquiffer: Vbicanem marfypio incubantem; pra făme uix fpirantem oltendunt; qui uix dim doninũ \& con= fertum fuum uiderat, cum à marfypio fe remourens uno $\&$ eodem tempore $\&$ cuftodia $\&$ uía excef fit, Aelianus. Eandem hiftoriam lo. Tzetzes narrat, Clíliade z.cap. izı hoc intereft, quod Anacreon, tem Teium, non uirum Colophonium, canis dominum fuife fribit. Gelon Syracufanus cum arctif 1o fime dormiret, fe icfum è colo cogitabat:Hoc quod el uidebatur, infomnium erat. Is etfi dormiebat, inter fomnium tamen contentifima uoce clamabar. Canis igitur quem ipfe alebat, fimul atç altoris amici fui uocem audiffet, tanquam quodpiam Geloni periculum crearetur, infidix́ćs compàràêtur, \& in leçum maximo impetu profiluit, \& circum dominum conuerfans, uehementiffime latrabat, ue lut infidiatorem ulcifci cupiens. Gelon cum rei funefta metu, tum canis clamore fomno quamuris ar cififimo teneretur, folutus eft, A elianus.

बTyrif aiunt Herculem captum fuife amore nympha citiufdam illius regionis, cui nomen fure. rit Tyro, (Túgos, lego Tupw.) Sequebatur atutem Herculem canis quoç, prifco more. Solebantenim canes ad conciones etiam comitari heroës. Herculeus igitur ifte canis cum ad faxum quoddam re. ptantem uidiffet purpuram, carnem prominentem mordicus apprehẽfam deuoratuit, \& labia cruore o tinxit. Hunc in cane colorem uirgo intuita, Herculem deinceps a dmiffuram fe negauit, nifi veltem ei caninis labris pulchriorem floridioremós afferret. Iraç Hercules hoc animali inuento, \& cruore collecto, munus puella attulit, primus ut apud Tyrios fama eft, Fhecnifix tinçuræ inuêtor, Pollux.

बT Tobiam canem habuiffe comitem in uetere teftamento legitur.

TXanthippicanes, eo tempore, quo ingentibello Perfarum in Gręciam exardefcente Athenien fes monentibus oraculis relicta patria in claffem demigrarũ ${ }^{*}$ dominum fecuta ex Artica in Salant ha traiecerunt, Aelianus. Tzetzes Chiliadez.cap. 130. Xanthippi, quiPericlis pater fuit, canem ut dominum fequereur nauigantem in Salaminem, in mare fe proiecifle feribit: $\&$ demum uribus na

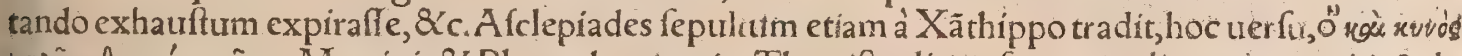

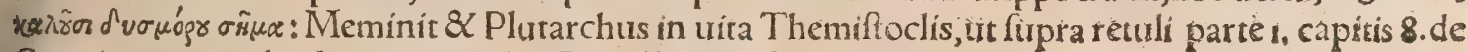
Cane in genere:ubi alios quoq locos Cynoffema dictos recenfiti.

HISTORIAE CANVM, QVI FIDEM DOMI

nis etiam poft mortem feruarunt.

Digna commemoratione funt canum exempla, qui in fide $\&$ amoreerga dominos poft mortem etiam dominorum, conftantiflimé perftiterunt, quod uel pro eis pugnando, uel rogis fponte infiliena tes commoriendo,tuel cadauteribus oftendendis, uel deniç, homicidąs prodendo mirificé declararâr. Primum igitur de illis dicam qui pro dominis certauerunt; mox or dine de reliquis.

TRoma bello quodam ciuili Caluus Romanus cum necatits effet, huius uíri caput ex hoftibus nemo abfcindere poterat, cum tamen fumma contentione fexcenticertarent, \& facinus iftud con fifcere pulchrum ducerent priufquam canem quem is aluiflet, interfeciffent, ei affidentem, $\&$ bene uolentiam erga illum ipfum fídiffme \& amantifíme fer uãtem, proćş codem humi ftrato, \& quí iam extremum fpiritum effudiffer, fic propugnantem, tanquam uirum commilitonem, \& contubernas lem bonum, \& ad extremum amicitix obferuantem, A elianus, \& T zetzes Chiliade s.cap. 13ı.ubi in terpres Galbam pro Caliro peruertit. Meminit \& Plutarchus in libro V tra animalium, \&c, fed omif: fo Calui nomine. đDario qui extremus regnaut apud Perfas, in ea pugna quam contra Alexan

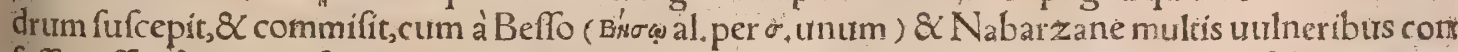
foffus effet, $\&$ iaceret fratus: omnibus mortuum relinquentibus, canis ab eo educatus folus perman fit fidelis, eumćs tametfi non amplius furum altorem, ficut tam $\vec{e}$ a dhuc uiuentem feruauit; A lianus; Tzetzes Chiliade 3. cap. 13r. Darí à Befo occifi canem itrx ta fepulchrum, ut Silanionis canem man

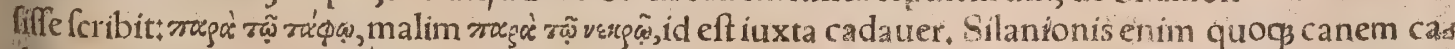
datreri adhafiffe, proximé ex eodem authore referemus. Pugnaffe aduerfus latrones canem prodo mino accepimus, confectumćç plagis à corpore non receffiffe, uolucres $\&$ feras abigentem, Plin ius $\alpha$ 4. Cum Silanion dux Romanus in pugna cecidiffet, cadauer eius canibus, feris, $\&$ aububus expos 
fitum, foluts canis omnium fideliffimus multis dieb. fertuatit, $\&$ partes eius pudendas operuit, doned aduenirent Romanorum duces, \& fepeliri curarent, Tzetżes Chiliade 3.cap.130, Syllanion nomen fuit ftatuarn̈ cuiufdam. TSed fuper omnia in noftro æuo actís populi Rom.teftatum, A ppio lunio, \&. P. Sillio coff, cum animaduerteretur ex caufa Neronis Germanici filin, in T. Sabinum \& feruitia ei us, unius ex his canem, nec à carcere abigi pottuiffe, nec à corpore receffiffe, abiecto in gradibus $\mathrm{Ge}_{\text {, }}$ motinjs moftos edentem ululatus, magna pop. Rom corona circumftante, ex qua cum quidam ei ci, bum obieciffet, ad os defuncti tuliffe. Innatauit idem in Tiberim cadauere abiecto fuftentare cona. tus, effúfa multitudine ad fpectandam animalis fidem, Plin, GCanis Iafone Lycio intertecto, cibü capere noluí, inediaćs confumptus eft, Plin. Daphnidem bubulcum Syracufanum canes quinque

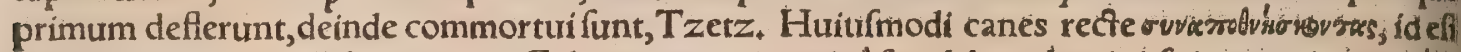
commorientes, appellabimus. TGelonis tyranni canis à fepulchro domini fui, hec ui, neec uillis blandimentis abfceffit, A clian. Gelone Syracufano in fomnis clamante, ut quiti fulmine ictus fibi ui. deretur, canis latrare nố defijt, donec excitauit, Tzetz. Hức canem Philifus, teftePlinio, Pýrthum apoellatum fcribit. Is uero, cui nomen Hyrcani reddidit Duris, accenfo regis Lyfimachi rógo, inie cit fe flammæ: fimiliterćp̧ Hieronis regis, Plin, De Lyfimachi cane idem fcribit Plutarch,inlib، V tra animalium, \&c.8 A A lian.Clarus eft Pyrrbi Epirotæ canis, qui cum Pyrrhus in fomnis exclamaffet, circumiens eum cuftodiebat; mortui autem cadauer cum cremaretur, in rogum infilijt, Pollux. E2. dem eodemćs modo feciffe canem, quuem Pyrrhus, non rex ille, fed priuatus homo educârat, fama eft:circum corpus exanime harentem, capulo cum efferretur affultantem, poftremo in rogum fefe ábïcientem ac comburentem, Plutarch.ibidem.Cum Polus tragœdus ( hiftrio Tragicus, Tzetz.) defunetus antiquo more cremaretur, canis eitus alumnius in medios rogos fefe immittens, uiuus una cum altore fuo exuftus eft: Idem deMentoris canib.fertur, Aelian, \& Tzetz. fed Tzetzes unum duntaxat Mentoris canem id feciffe fcribit. TTheodorum faltatorem(pfalten, Tzetz.) cum proz pinquí in fepulchrum impofuiffent, Melitenfis catellus eius, ultro feipfum in cadaueris tumilum in ïciens, pariter cum domino humari \& fepeliri uoluit, A elian.\& Tzetz. TNoftris temporib, in cin iritate Aftenfi, cum mulieris cuiufdam genere claræ funus procederet, canis facto impetu furper ca. dauer infilint, \& præ dolore difiectus eft defuper, tanquam ab aliqua fera laniatus; quoniam unià mo ri uoluit, Blond. Eurpolidis poétæe canis, defiderio domini defuncti, morore inediaćç contabuit, de quo plura moxinter defenfores. Nicias quifpiam ex uenatorib,cum de improúfifo in carbonax riam fornacem lapfus fuiffet, canes, qui cum eo erant hoc intuentes, non illinc difcefferunt, féd pria mo circa caminum ingemifcentes, \& ululantes commorabantur:tandem prætereuntes leuiter, ef fen fim morfu ueftim attrahebant ad id quod accidiffet, tanquam auxiliatores domino fuo implorantes homines. Vnus igitur uidens hoc idem, fufpicatus eft id quod erat, \& fecutus eft canes, inuenití Niciam in fornace defiagratum(deflagraffe potius dixerim) ex reliquis coniecrauit rem ipfam, Aeli. anus interprete Gyllio: \& Tzetz.Chil.z.cap.13ı.cuius hi funt uerfus:quos appono, quoniam Gylini

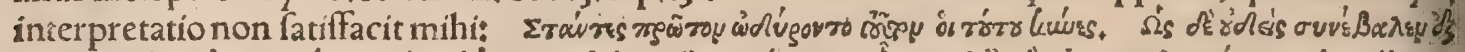

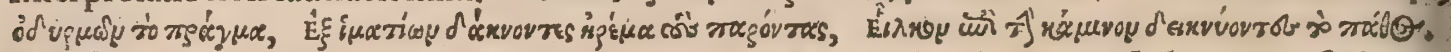
Scd clarius res intelligetur ex Calio, qui libro 23. cap.27. eundem locum ex Aeliano tranftulit, cu: ius ego pofteriorem tantum partem adfcribam, Id autem (inquít) intuitus quidam, canem infecus tus ducem, factum deprehendit, exuftumós in fornace fpirantem Niciam, re prorfum coniectata ex ijs quar in ignibus urifebantur reliquix. Similis eft hiftoria, quam Blondus refert, his feré uerbis: ' $M a$ rius Cæfarinus é patrítio genere R omæ tuenatơr acerrimus, dum equo infidens 8 canem ducens ad venationem exit, incidit in profundam foueam: quod uidens canis creberrimis ululatibus circumlas trabat fouteamteo audito ruftici quidam accurrerunt, 8 re cognita hominem extraxerunt è fourea, in qua ei inedia pereundum fuiffet, relicio mortuo equo. Anno poft hunc cafum euoluto, eodem die febri correptus, obritt. II Icarï Erigona filiz patris à rufticis interfecti cadauer canis oftendit:er fi credimus poétis, hic Sirius eft, Pollux \& alif Cum Bacchus uini ufum hominib, monftraffet, \& I. carius agricolis A thenienfib, id bibendum dediffer, illi inebriati, \& fe uenenum bibiffé fufpicati, ocs ciderunt Icarium. Huitus cadauer cum filia non inueniret, cane monftrante reperit. Huic etiam po. ftea morienti canis commortuus eft, Tzetz. Idem pulcherrimos fuper eadem re uerfus ex Orphei Georgicis commemorat. Erigonæ canis, fux dominx fepultura affectx immortuus eft, Aeliã. Qui non Erigones mallet habcre canem, Martialis in canis Lydia epitaphio. T Accepià uiris uerbo rum non prodigis, fyluam effe non procul Aurelia(urbe Gallię) ubi cum graffatores hominem quen dam interfeciffent:interfectum homicidij tegendi gratia inter frutices inhumaffent:canis ( quilatro num uirib, impar fuerat, neç his potuerat reluêari) domini fui domum propero curfu redierit; ac reiecfo, qưi offerebarur, cibo, uelut lachrymoftrs nunc egrediens, nunc reuertens, non prius latrare deftiterit, quàm praftita tanti infortuní cóięfura impetratrerit, ut redeunti fibi ad domini cadauer aliquis daretur comes. Hunc ergo cum fecutus effet unus ex domefticis famulus, fequentem reuolu tis ubique femitarum ueftigñs ad inhumati locum perduxit, ubi \& unguibus f́alpuriens, \& terram dentib,effodiens, occultum corpus indicauir,Io, $R$ auifius Textor, Gononiæ puer quidam catu= lum amabat, femper cum eo oberrare folitus. Hunc pòt in cella uinaria feipfum laqueo fufpendent cem intuens catulus, perterritus conftitit; deinde paulò poft immobilë uidens, parentes tanquam fú 


\section{DeCanibus diuerfis. Lib. I. $26 \%$}

perifi nuncitts latrando curfu adiuit: $\&$ fubinde furfum ac deorfum recurrens, latrare non deftitit, donec miferi parentes fecuti filium pendentem repererunt,Blond. THefiodicanes à mortuo non recedentes, latratu homicidas prodiderunt, Pollux.Plutarch.in lib, Vtra animalium, \&c. cum reci. taffet hiftoriam canis qui apud $\mathrm{P}_{y}$ rrhum regem homicidas prodidit, quam proximé fubriciam, Idem (inquit)Hefiodi fapiẽtis illius canem feciffe fama eft, cum Ganyctoris Naucletij filios, quorũ manib.

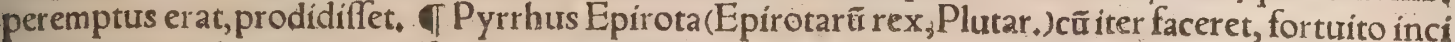

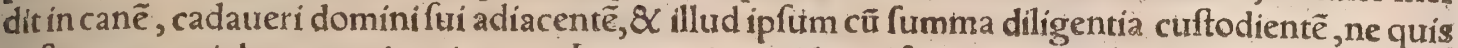
poft mortem uiolaret, at $\beta_{3}$ imminueret, Is autem iam triduum ferens inediam, diligenti cuftodia affie dutss illud feruabat. Hoc fimulatos Pyrrhus intellexiffet, hune quidem miferatus, fepttltura affici iuf fit:cani uero plentum cibum ad fe amandum allicientem dedit,paulatimós illum allectans abduxit, at que adeo attraxit. Sed hac quidem hactenus. Poft paulum cum exercitum luftraret Pyrrhus, ( $\left.{ }^{2}\right\} \xi z \pi{ }^{\prime}=$ कis \& uero canis adeffet: is non manfuetus folum, uerum catera quàm tacitus erat. Vtuero in recenfio ne militum interfectores domini animaduertiffet, tum non fe continuit, quin uafto latratu in eos $\mathrm{fe}_{\mathbf{z}}$

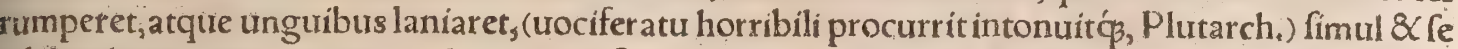
ad Pyrrhum conuertens quoad poterat, teftem in hancrem citabat, quod homicidas teneret. Latratum religioni habuit Pyrrhus, eíģ in fufpicionem \& circunıftantibus hi uenertunt de uiri morte. Ita qte quaftione adhibita, ea quorum accufarentir confeffi funt, A elian.8\& Plutarch. Meminit etiam

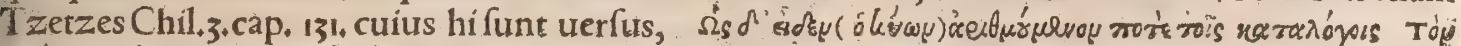

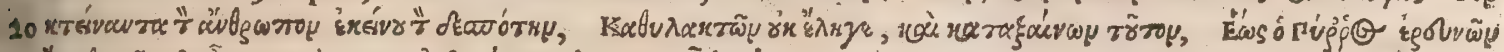

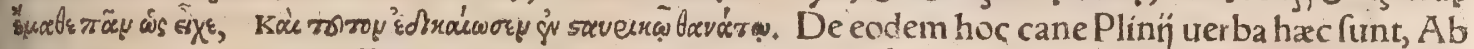
alio cane accepimus in Epiro agnitum in conuentu percufforem domini, laniatu $\&$ latratu coact $\tilde{\pi}_{3}$ ut cogereturr fateri fcelus. Simile eft (inquit Tzetzes)quod Chronicus quidam paucis ante nos an nis contigiffe annotauit; Nempe cauponem quendam fepeliffe cadauer (nimirum hominis à fécci. (i:)qui poftea proditus à cane, \& prafecto urbis flagitium confefiú, cruciaffixus fit. IIn Gallia duo mercatores ad nundinas proficifcebantur, quorum alter canem ducebat. Hunc alter nefanda auricupidine captus, cum per folitudinem quandam equitarent, iugulauit, 8 humo condidit. Caniș amiffo domino, nemora \& faltus illos latratibus implebat:quem accolze miferati in diuerforium du= xerunt \& cibo refecerunt. Refectus ille ad locum cadaueris fepulí redibat. Ita $\phi_{\beta}$ retentus eft ad redi tum mercatorum:quibus reuerfis canis in homicidam tanquam proprium hoftem conciratus, flagia tium eius prodidițquod ille captus confeflusḉ, laqueo fufpenfus, turpiffimo fine pro frelere dedit ponas, Blond. Memini etiamin Gallia (inquit idem) haud procul Parifís, contigiffe ut adole. fcens quídam mulierem amaret: ad quam dtrm accedit affumpto focio iutuene, \& comite cane, in mè dio nemoris à focio rualı traieçus gladio expiratut. Canis, qui gènere Britannus erat, duu locum fer. tratrit, in quo domınus erat occultatus. Et cum ex familia quidam adolefcentem perquirerent, cane folum repererunc iuxta fepulch um, quod tamen non agnofcebatur: quoniam tumulus terræ fuerat. Socius cadis author ubinam effer adolefcens interrogatus, ignorare profitebatur. Sed prodidit eum canis irruens tanquam in proprium hoftem. Itaque ad rectores urbis adductus eft, $\&$ cum caufan proferre non poffet, cur tantopere nunc infenfum haberet canem, haud aliter ei quàm domino blan diri prius folitum + iuffus eft duellum cum cane experiri. Canis pelle cocta integitur *ipfe mucronem geftans leui tantum linea uefte tecius, in duellum prodit. Canis gulam homicidx mordicus appre: hendit, eumḉ́ profternit: exclamat ille, Míferemini patres, cane auulfo fatebor omnia.Confelfus igis tur quod perpetrauerat fcelus, morte multatus eft, $\mathrm{Hæc}$ Blond.

\section{DE CANE HOMINIS DEFENSORE \\ $\&$ bellicofo.}

D E canibus robuftis, fed uenaticis, fupra differui: Nune de illis dicendum qui homines uel pritua

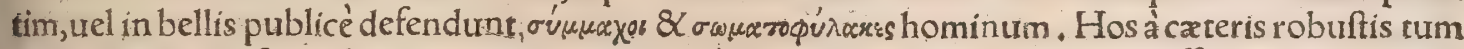
uenaticis tum paftoralibus, non alia re magis quàm educatione 8 inftitutione differre puto . Plurim mum fanè roboris, ferocix, $\&$ animi his, de quibus nunc agimus, adefle oportet, cum aduer fus hom c nes $\&$ armis munitos; $\mathcal{X}$ in iracundia ipfis feris ferociores, nonnunquam eis fit depugnandum. Si millimus ergo canis (inquit Blond.) in propellendis iniurn̈s hominum atç ferarum, operam furam præftabitidem fideliter ftabulum domi feruabit, $\propto$ pecora for is cuftodice. Canes tum defenfores tum alti, quomodo procreandi \& quibus parentibus, explicaui cap. 5. hiftoria de Cane in genere ex Blondo, Thanes uirorum nobitium cuftodes, pilofi hirfutiç̧ funt, \& ex Gallia petuntur, Blond. CAd latrones inueftigandos, non quilibet canis idoneus eft, fed eligi debet canis ferox, qui non die gnetur difcernere homines. Principio autem hoc modo inftituendus eft. Muniatur aliquis pelle den fa, quam canis lacerare nequeat aduerfus hunc canis incitetur, $\&$ is fugiens tandem à cane fe fna capi, \& cadens ante eum mordere patiatur: Poftridie fimiliter in alium immittatur canis, \& hoc fiat frequenter:tandem enim beneficio odoratus infequeturr eum, fuper cuius ueitigia ponitur. Eam ue. so ro ob caufam eligioportet canem, qui homines non-difcernat, nefi blandiri aliquibus affuefcat, $f_{e}$. quatur ueftigia illorum quos diligít. Sed etiam forma odoris eorum remanens apud canem, cerebrü eius confundit,adeò ut non dignof cat ueftigia eius queminfequi debet. Non pauciautem eiufnodi 
reperiuntur canés, quiu neininem fèrmè difcernere dignantưr. Qùod uel inde conftat: quoniam etia am canes uenatici aliquando confinduntur, curm fuper diuerfa ueftigia ferarum ponuntur, \& erra= reincipiunt, Hæc Albert TCanis defenforius horridus fit, \& femper pugnaturo fimilis, omnib. inimicus prater dominum ita ut ne tangi quidem fe patiatur à familiaribus : fed omnibus morfum minetur, tanquam hoftibus; dominum tame rectis cculis feruet, Blond: Et alibi, Defenforius(inquit) forma praftanti deligatur, qua terrorem intuêtibus inducat:laudatúr feuerus, minime blandus, quil $\&$ conferuos tanquam iratus infpiciat, $\&$ citius excandefcat in exteros, item qui uigilantior fit, et cir ctrmquaç profpiciat, ut folent animofi. Sed quoniam canis rarò natura defenfor bonus eft, ideo hac arte inftruendus erit. Infans eriamnum irritetur ad iracundiam à pueris. Anniculum lam $\&$ adultû, gladio laceffere $\&$ obruere oportet, ac impugnare donec feffus $\&$ uictor os cruentum reportet: fer. uus autem \& gladiator, uel lacer, uel uictus recedat.Poft pugnam uinciendus eft, neģ permittetid ut folutts uagetur: fed in uinculis pafcatur donec euaferit optimus defenfor. Aggredi autem eum oportet ftrictis mucronib. Hac ratione fortifimus fiet, \& contra hoftes duci, \& dominum ab infidips fecurum reddere idoneus. Hoc enim feruatur hac tempeftate etiam plerifg, in locis Hifpanix, ut per cepimus, Hactenus Blond. TAlexander Pheræus Theffalia tyrannus educaffe fertur canem in. folitx magnitudinis, atrocem 8 infeftum omnibus prater domêticos atç illos à quibus cibum ca. piebat. Hunc dormiens foribus cubiculi cuftodem adhibebat, ut quifibi metueret quod uarijs tor, mentis multos fubinde afficeret, Blond. đEupolidi poétre comico A ùgeas Eleufinius munere do nauit canem, non modo genere Molotticum, fed etiam forma praftantem:quem codem nomine Eu polis, quo A ugeas erat, appellauit. Canis iam nomine Augeas, cum longa confuetudine tum uero ci borum illecebris allectus, \& blandirijs, diligebat dominum, ut praclare oftendit, cum aliquando fer. uus nomine Ephialtes dramata quadam Eupclidis domini fui furriperet. Tum non fatuit canem fü rax feruus. Is itaç acerrimo impetu,crudeliḉ incurrit in hunc direptorem, mordicus ḉ̧ compretien dens interfecit: Poft autem aliquanto in Aegina Eupolis exceffit è uíta, ibiọ̧́ eius corpus ad fepultu ram datum fuit. Huius trero canis morte illius ingemifcens, non tantum ululatu primo fllius esicef fum è uita luxit, fed deinde mœrore inediá̧̧ extabuit, in odiumḉ̧ uritæa adductus ex altoris fui mor: te, extinctus eft. Ex eo locus hic, ad huius cafus memoriam conferuandam, Canis luctus appellatur, Aelian. Eadem fcribit Tzetzes Chil.z.cap. 1zı.Apud Suidam hæc uerba legimus, o" $\pi r$ r

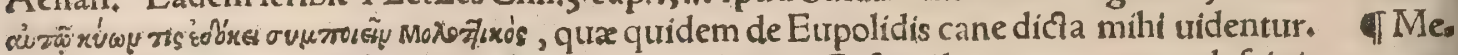
moratur \& Nicomedis Bithynia regis canis, uxore eitus Cofingilacerata, propter lafcitriorem cum marito iocum, Plin. Nicomedes rex maximû \& fidiffimum fibi charifimumó canem Molofum ha buit, huius conitugem Ditizelen(ex qua Prufiam, Zielum, \& Lyfandram fufceperat) regi colluden. $\mathrm{t} \mathrm{cm}$, canis hoftem arbitratus, inuafit, $\mathcal{Q}$ dextrüm humcrum morfu aưufit, carnes $\&$ offa dentib,com minuit. Illa moriens in ulnis mariti Nicomedię fepulta eft in fepulchro deaưrato:Quod quidam tem poribus Michaélis filh Theophili effodientes, faluum adhuc mulieris cadacter inuenerunt, uefte ex auro texta inuolutum:qua in fornace fufa, auri libras tredecim fupra centum repererunt. Caterum canem ipfum à regis confpectu femotũ,defiderío regis 8 mœrore propter necatam mulier $\widetilde{e}$, pleríg mortuư referũt, Hærc Tzetz, teftẽ citans Arrianũ in Bithynicis. Tं Orpheũ aucupio intentum draco inuafurus erat, quem interceptum canes occiderunt, ut ipfe recitat in poëmate delapidib. (quod eti= amnum extat,) Tzetz. बI A pud nos Volcatium nobilem, qui Cefelium ius ciuile docuit, afturco. ne éfuburbano redeuntem, cum aduefperauiffet, canis à graffatore defendit : Item Cælium fenato. rem $x$ grü Placentia ab armatis oppreffurm; nec prius ille uulneratus eft, $\bar{c}$ cane interempto, Plinius, G His auxêre fidem, qutos noftro fulua fub ęuo Miratur, nutritá̧ R hodos, cufodibus illis Arua, \& Carpathí defenditlittora ponti. It noctes animora phalanx, innexa trilici Pecfora thoracum tunica, facrumós profano Seligit, \& blande exceptum deducit ad urbem, Illum autem rapit, \& morfu difcerpit acerbo, Stroza filius in Epicedio canis. $\mid$ Adolefcens fpecta tæ uirtutisl inter Danaos canem habuit horrendæacerbitaris, qux fola plerunç bis fenos peremit triros,Blondus.

Garamantum regem canes ducenti ab exilio reduxếre, praliantes contra refiftentes, Própter bella Colophonï, itemćc Caftabalenfes, cohortes canum hiabuêr e: ex primæ dimicabant in acie, nun quam detrectantes. Hæe erant fidiffima auxilia, nec ftipendiorum indiga. Canés defendêre Cimbris crefis domus eorum plauftris impofitas, Plin. Cum Hyrcanis 8 Magnefins canes quafi focietatem bellorum gerendorum inire folebant, hisḉ maximo ad bella inferenda, adiumento erant. In pugna ad Marathonem ccmmiffa cuiufpiam A thenienfis canis, fumma contentione illi tulit auxilium, ac fi mul ex ea actione uterç in uarịs fcriptionibus honoris memoriam confecutus eft, $\mathrm{A}$ elian. Magne.

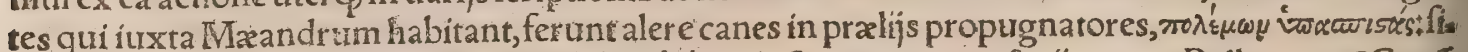
miles autem erant Paonum quogs or o'vivongo licúss, id eft uenationum focij canes, Pollux. बCertü eft ex uerbis Valerí Maximi Máfiniffam regem Numidarâ (quũ parũ fídei in hominum pectorib, reponeret)corporis fui cuftodiam canibus commififfe, Textor. ITale(ex canibus) tibiauxilium Colophion, tibi tale parafti Cafpia yens, partosá̧ æqué partiris honores, Stroza filius in Epicedio: canis. A pparet eum Cafpiam gentem apud Plinium legiffe, ubi codices noftri rectè habent Cafta: balenfes, Eft enim Caftabala Cilicix \& Phornicix ciuitas, qua $\&$ Perafia dicebatur, Stephanus ex 


\section{DeCanibus diuerfis. Lib. I. 265}

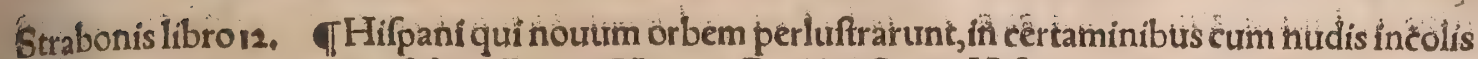
canum opera plurimum ufi funt, Petrus Martyr. Et alibi, Canes Hifpahorum (inquit) in homines nudos rabidi infiliebant, haud fecus ac in feros apros aurt fugaces ceruos : nec minus fidos Hifpani

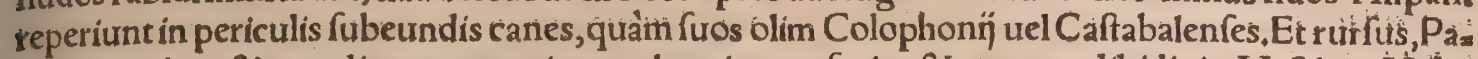
cram regulum \& tres alios eum comitantes, homines nefarios \& extremæ libídinis; Vafchus Hif̂́pa nus apud feaccufatos in bellatorum canum fauces coniecit, illorumós lacerata cadauera crèmarl iuffit.De canibus, cum quibus pralia ineunt, mira referuntur. Ad indigenas armatos haud fectis îr. ruunt pracipites ac in ceruos attr apros, fi digito monftrentur. Data quandoos teffera canibus folu= tis pręeuntibus agmen, toruo Moloffotum afpecłu atç infureto latratu pêrterriti hoftes hæefitantes;

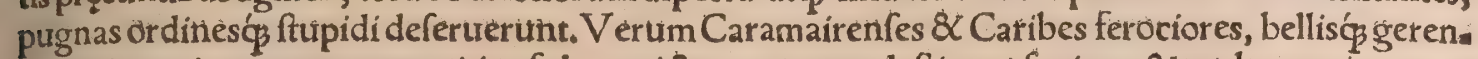
dis aptiores, in ruentes canes citiư fulgure ifo uenenatas deftinant fagittas, 8 multos perimunt.

DE C A N I B $S$ C V S T ODIBVS: ET PRIMV

de päftórali.

C A N V M qui cuftodes dicuntur, \& cuftodix caufa parätur, alí pécòra, alị uillas, alin domós prí uatas, alï publicas, ut templa, cuftodiunt. Apta cuftodum nomina apud Xenophontem funt Phylax \& Phrura. Plura de cuftodibus in genere, uide infra ab initio tractationis de cuftodibus ædium. Sed primum de pecuario, inde differamus de reliquis. TMolotticum genus uenaticum, nihil à cateris difcrepat: At pecuarium, longè \& magnitudine; \& fortitudine contra belluas praftar, A riftoteles.

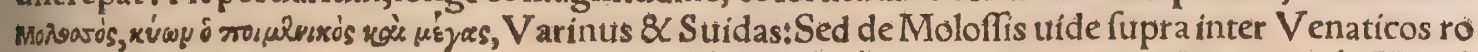
buftos. Nec tibicura canum fuerit poftrema : fed unà Veloces.Spartæe catulos, acremó́s Molofo fum Pafce fero pingui:nunquam cuftodibuts illis Nocturnum ftabulis furem, incurfusç̧̧ litporu, Aut impacatos à térgo horrebis Iberos; \&c. Vergilius in Georg. Pecurariü canem Aug. Niphus ma= ftinum interpretatur:Sunt autem maftini, ut fupra docui, quos Germani tii sen appellant。

Nufic de mutis cuftodibus loquar:quanquam canis falfo dicitur mutus cuftos, nam quis ho: minum clarius, aut tanta tociferatione beftiam, ttel furem pradicat, quàm ifte latratu? quis excubi= tor inueniri poteft uigilantior!" Quare uel imprimis hoc animal mercari tuerićs debet agricola‡quod $\&$ uillam, \& fructus, familiamós \& pecora cuftodit, Columella. Sed de uillatico alibi : hic de illo dices mus, quí ( ut Columella inquit) propellendis iniurins hominum ac ferarum comparatur: \& idem oba feruat domi ftabulum, foris pecora pafcentia. Relinquitur(inquit Atticus apud Varronê) de qua.i drupedibus quod ad canes attinet, maximè ad nos, qui pecus pafcimuts lanare. Canis enim ita cuftos eft pecoris, ut eius quod eo comite indiget ad fe defendendum. In quo genere funt maximè oues, de: inde capr $x$. Has enim lupus captare folet, cui opponimus canes defenfores. In fuillo pecore tamen funt, qux fe uindicent, fures, uerres, maiales, fcrof $x$ :propè enim hęc apris, qui in fylutis fape dentibus canes occiderunt.Quid dicam de pecore maiore? cum friam mulorum gregem cum pafceretur, eoćs teniffet lupus, ultro mulos citcunfluxiffe, \& ungulis cædendo eum occidifle? $\&$ tauros folere diuer fos affiftere clunibus continuatos, \& cornibus facile propulfare lupos? Hac ille.

đPecuarius canis (utor Columella uerbís)neç tam ftrigofus aut pernix debet effe, quàm quí damas, ceruośćs, \& uelociffima fectatur animalia:nec tam obefits aut grauis, quàm uillæa horreí́s cu: ftos: fed $\&$ robuftus níhilo minus, $\&$ aliquatenus promptus ac ftrenuus, quoniam $\&$ ad rixam, $\&<$ ad pugtiam, nec minus ad curfum comparatur, cum $\&$ lupi repellere infidias, \& raptorem ferum con.

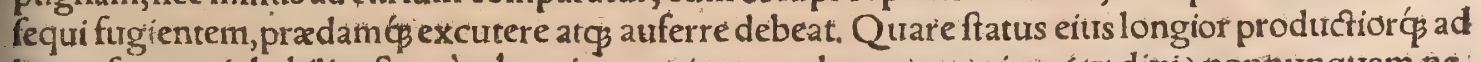
hos cafus magis habilis eft ${ }_{3}$ quàm breuis, aut etiam quadratusł quoniam (ut dixi) nonnunquam ne. ceflitas exigit celeritate beltiam confectandã. Cæateri artus fímiles membris uillatici canis, aquè pro. bantur, Hæc Columella, Canes ad pecorum cuftodiam (inquit Varro apud Conftantinum) præcipué generofi, corpore magno funt, uegetis uiribus, animo non deiecto, grauí latratu atф̧̧ formida bili utentes: Qui etiam in adeuntes non fruftra ac temere infiliunt, fed uires in fuum tempus refer:

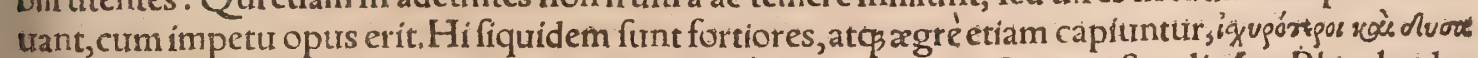
rwróreou: intelligo qui nón facile capi, id eft uincià feris queant. Canis paftoralis (ur Blondo plas cet) defenfori fimilis eligatur, educeturç fimiliter. Laudat in eo colorem album Columella, quí fi nö reperiatur, quemuis potius quàm uarium probabis:ut quem prifci ( Columella ) nec in uillaticis nec paftoralibus laudauerint. Non mirum eft autem ficandidi canes hac tempeftate probenzur à pafto: ribus, cum illi pra cæeteris facile dignof cantur à lupis:nati cæeteri in tenebris quandoğ non agniti à paftoribus, pro ipfis lupis petiti funt, (utfupra eriam in Venaticorum colore dictum eft,) Hac Blon. dus. Paftor album probat:quoniam eft fera diffimilis, magnoós opus interdum difcrimine eft in pro pulfandis lupis fub obfcuro mane, uel etiam crepufculo, ne fi non fit albo colore conf picutis, pro lu: pocanem feriat, Columella. Primunt ætate idonea parandi funt (inquit Varro) quod catuli $\&$ uetu li, neç fibi,neqs ouibus funt prafidio, \& fer is beftipjs nonnunquam pradx. Facie debent effe formofi,

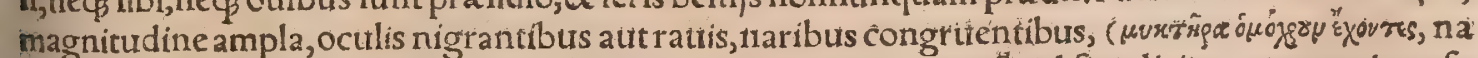
fum eiufdem coloris habêtes, Fronto: Eiufdem coloris intelligi poteft urel fimpliciter, ut unus in nafo - color fit:uel ut idem qui in reliquo corpore: uel idem qui in oculis, quos Fronto proxime nigros tan tum probauerat:)labris fubnigris aut rubicundis, neq refimis fuperioribus, neç pendulis fubtus: mento fuppreffo, \& ex co enatis duobus dentibus, directis potius qựàm brochis(tortis, Crefcêtienfis). 
$\&$ acutis, quos habent labro tecos. (Fronto fimpliciter dentes acuros requirit:) capitib. \& auticulís

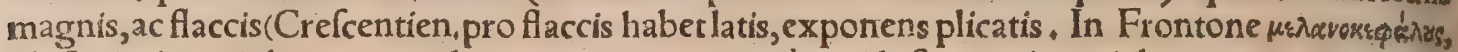

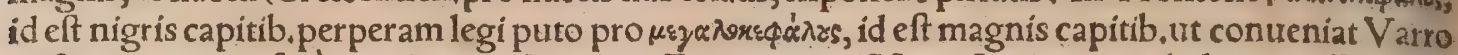
ini,ficut in cateris feré omnibus:pectore lato, Fronto:quod Varro Latinus non habet.) craffis cerui-

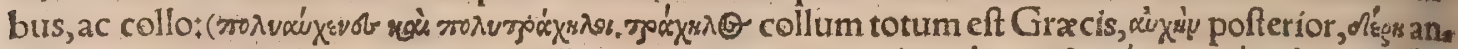
terior tantum pars, Fronto.)internodin's articulorum longis, ( rs, id eft, artubus longis, brachịs folidis $\alpha$ craffis; Fronto,) crurib.rectis, ac potius uaris quàm ua.

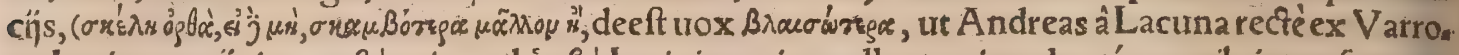

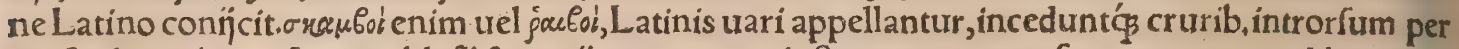
uerfis: $B \lambda$ au oi uero, Latínis blafij $S \mathcal{L}$ uacï, cancrorum inftar crura extrorfum curuant.) pedib.magnis

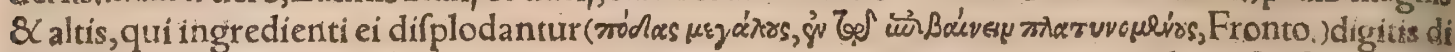
fcretis, diselfarulious: unguibus duris ac curuis:talo, nec ut corneo, nec nimium duro, fed fermentato

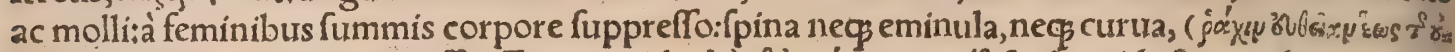

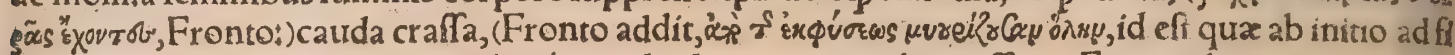

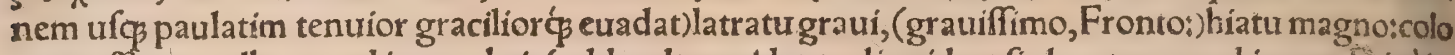
re potiffimum albo, quod in tenebris (addendum uidetur aliquid, ut fic legatur, quod in tenebris à lu po \& alịs feris facilius dignof cantur, ut fupra etiam docui:uel tale quid:) fpecie leonina, Hacienus $\checkmark$ arro.Poftrema eius uerba ex. Frontone dilucidius intelligentur Is canes probat albos colore, pra

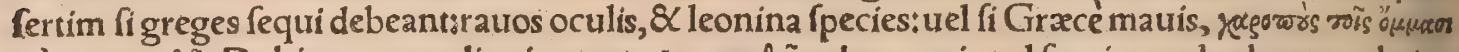

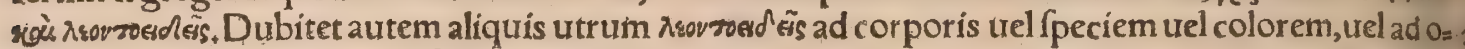
culorum tantum colorem referat:ego de oculorum tantum in eis colore acceperim, quem Graci in

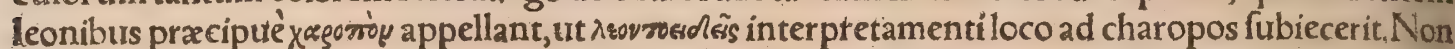
enim intelligi puto de reliqui corporis colore, quem album defyderat.Quod fi quis de corporis fpe: cie 8 figura accipere malit, illi non contenderim, ne Varronem quogs erraffe, aut locum effe corrus ptum defendendum mihi fit:quanquam pofterius iam proximè probaui.Crefcentienfis, cuius modí ca apud me authoritas ef, hunc V arronis locum ufurpans, colorem leoninum fimpliciter in cane $\mathrm{pa}$ ftorali laudat, nulla albi mentione. Oculis igitur charopis fite rauis $\&$ leoninis hoc genus canis de.

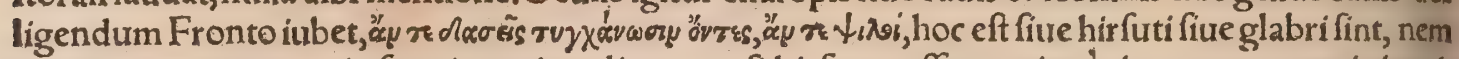
pe reliquo corpore, ut in formina etiam dicetur:etfi hirfutos effe pracipué circa armos magis leonis. num effer. TPraterea foeminas uolunt effe mammofas, æqualibus papillis, Varro. Fronto etiam in forminis tum pręcedẽtes maris notas defiderat, tum ut magnas habeant mamillas, 8 papillas in eis magnitudine pares:quoniam nonnulla canes marcidas mamillas, \& inftar ligni ficcas durasíq ha.

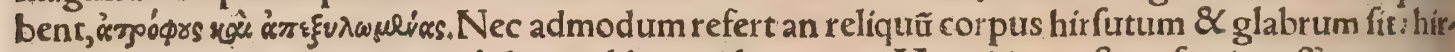
futies tamen canem magis terribilem reddere uidetur. TMagni intereft ex femine efie caneseor dem, quod cognati maximé inter fe funt prafidio, Varro. Canes funt nutriendi, affines affinib.iun cti:naturaliter enim illi fibi mutuò blandiuntur, ut Andr, â Lacuna uertit : ut Cornarius, mutuam

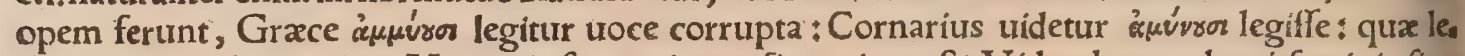
ctio ex pracedente etiam Varronis fententia confirmari poteft. Videndum ut boni feminis fint: itaçà regionibus appellantur, Lacones, Epirotici, Salentini, Varro. Videndum neà uenatoribus aut lanís canes emas: Alteri quòd ad pecirs fequendum inertes:alterl fi uiderint leporem, aut ceruñ quod eum potius quàm oues fequentur. Quare aut à paftoribus empta melior, qua oures fequi con= fueuit:aut fine ulla confuetudine qua fuerit:canis enim facilius quid affuefcit, eáq̧́ firmior confue sudo, qua fit ad paftores, quàm qua ad pecudes, Varro. IS Seruabimus eos collum corum crudo corio circumuallantes, gutturó $\not \mathcal{Q}$ totas fauces munientes, ab ipfo nimirum corio erigentes ferreos aculeos. Siquidem fi aliquam harum partium attigerit fera, canem occidet:fin trero aliã partem mos morderit, uulnus excitabit duntaxat, Varro in Conftantini Geoponicis. At ne in eos graftentur fes ræ, ut hyęnæ \& lupi, munire illis guttur at $\$$ collum oportet, ueluti ferratis thoracib, clauisápacumi natis transfixis, à fe inuicem latitudine digitorum duûm aculeis ipfis diftantib. Fronto ibidem. Sed de collarib. canum plura dixi parte 5. Cap.8. de Cane in genere. In locis faxofis $\&$ fenticofis, calcia: menta pedib. adhibenda funt, quibus prategantur ufç ad crura, ut integris pedib, canis ualidior ob fiftat contra impetus beftiarum, Blond. THos canes qui educant, collidunt, atog ad mutuam pur gnam impellunt, deprimi tamen non finunt, ne pufillanimes fiant animoós perculfi, fed in certamine audaces alijs minime cedant, Fronto. Educunt eos, plures in unum locum, \& irritant ad pugnandurin quo fiant acriores:neç defatigari patiuntur quo fiant fegniores, Varro, đPublitus Aufidius. Pon tianus Amiterninus non(lego,cum) greges ouium emiffet in Vmbria ultima, quibus gregibus line paftoribus canes acceffiffent:paftores ut deduxerüt in Metapontinos faltus, \& Heraclea emporiü, inde cum domum rediffent, qui ad locum deduxerãt: è dẹy derio hominum diebus paucis poftea cau nes fua fponte, cum dierum multorum uia intereffet, fibi ex agris cibaria quxfierunt, atgg in Vmbris am ad paftores redierunt:necg corum quifquam fecerat, quod in agricultura Salerna pracepit, qui uellet fe à cane fectari, uti ranam obrjciat coctam, Varro. Numerus canum pro pecoris multitudí ne folet parari. Feré modicum effe putant, ut finguli fequantur fingulos opiliones, de que numero alius alium modum conftituit. Quod fi funt regiones ubibeftia fint multa, debent effe plures:quod 


\section{DeCanibusdiuerfis. Lib. İ. 267}

aecidit ịs, qui per calles fylueftres longinquos folent comitari in xituia, $\&$ hyberna. Villatico uero gregi in fundum fatis effe dưos, 8 id marem \& foemitiam. Ita ènim fưnt affiduióres, quód cum alte: ro idem fit acrior: 8 fi altèr indéfinenter (Crefcentien, tuocem indefinenter omittit) ager ef, ne fine cane grex fit, Varro. T Catuli duob, menfibus primis à parti, non difiunguntur à matre; fed mi= nutatim defuefiunt, Varro \& Fronto, Confuefacitunt qüóq ut poffint alligari primum leurib; numel his (uinculis, Crefcent.) quas fi abrodere conantur, neid confuefcant facere, uerberib, deteriere foe tent, Varro, Affuefaciunt eos ưinctulis, primo quidem loro, dèin uero paulatim ferreà catenż, Fron to.Pluurijs diebus cubilia fubfternerida frónde, aut pabulo(palea Fronto;)duabus de caufis, ut ne ob linantur, aut perfrigefcant. Quidam eos caftrant, quod co minus putant relinquere gregem: Quidã non faciunt, quod eos credunt thinus acres fieri, Varro. TCanis paftoralis colludit paftori, grege agnofcit, infidiantes feras perfequítur:qua dotes fi ei nätiux $\&$ fpontanex fuerint, excellit in furo ge nere,Blond. Catuli quot educandi, \& alia quxdam ad procreationem, educationem $\&$ cibatum per sinentia, lege fupra in híltoria Canis in genere. Canes interdiu claufos effe oportet; ut noctu uigi: lantiores fint, Cato ca.124. qux eius uerba ad uillaticos $\&$ alios cultodes potius quàm paftorales per tinere mihi uidentur, \& f Petrus Crefcentien,in paftoralis hiftoria ea recitet. C Cibaria ferè eadẽ funt utri $\not$ generi (pecuario $\&$ uenatico)prabenda. Nam fi tam laxa rura funt, ut fuftineant pecoru greges, omnes fine difcrimine canes ordeacea farina cum fero commodé pafcint. Sin autem furcu= to confitus ager fine pafcuo eft, farreo uel triticeo pane faturandi funt, admifto tamen liquitore cocta faba, fed tepido:nam feruens rabiem creat, Collumella. Non permittunt illis mortua tangere peco , ra:ne in uiuencia etiam affuelcant impetum facere; reuocantur enim xgerrimé, ubi fëmel carnes cru das guftauerint, Fronto.

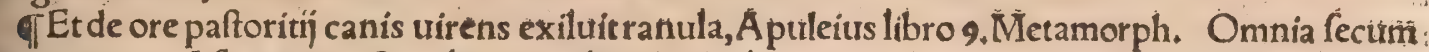

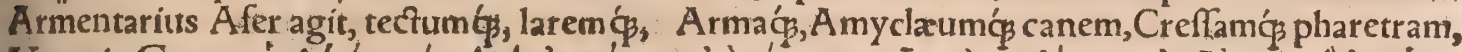

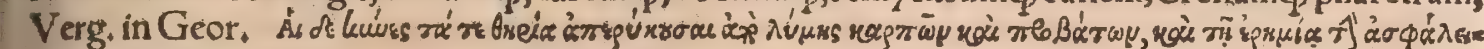

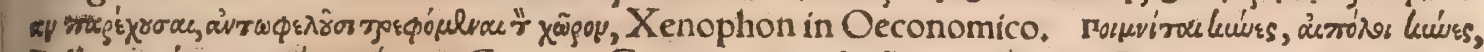
Pollix. Kúusb rotuvi

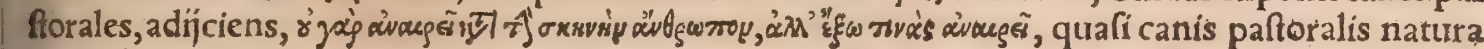
his uerbis declaretur, ut qui nulli familiarium noceat, externos uero quofdam (nimirum fures $\&$ pre dones)interimat. Pecudesćs fecuta Poemenis, Ouid,inter canes Actæonis, Aegyptî́ canes ab Op

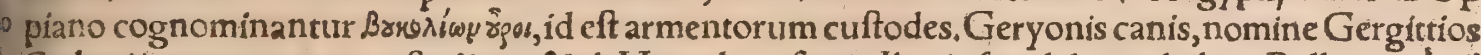
Cerberifrater, armenta cuftodiens, \& ab Hercule cæfus, in lberia fepulchrum habet, Pollux . is of

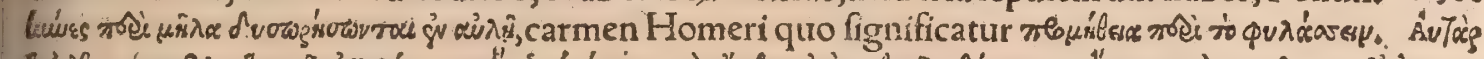

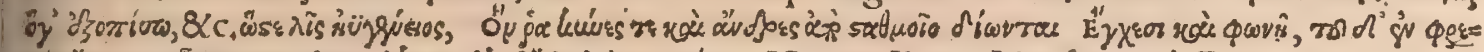

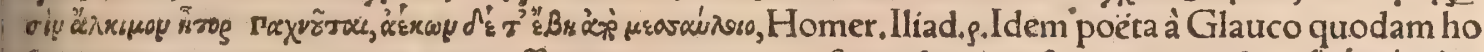

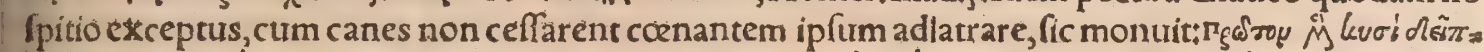

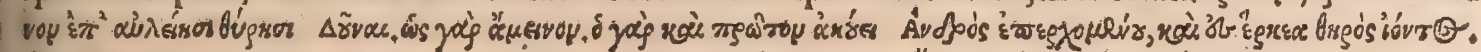

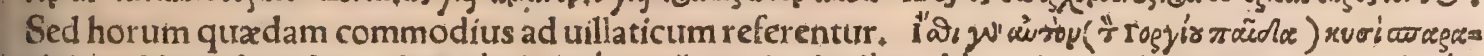

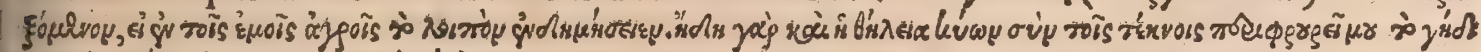

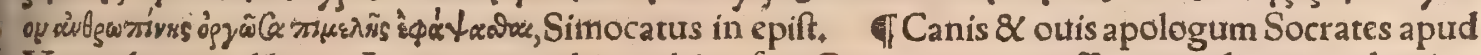
1. Xenophontem libro 2. A pomnemon, his uerbis referr:Cum animantia effent uocallia, ouem domino furo dixiffe ferunt: Mirtum facis profectó, qui cum nobis, à quib. lanam, agnos, cafeumóc habes, ni= hil des nifi quicquid à terra capiamus:canem, qui nihil tibi tảle prabet, de quo tu comedis pane participem facis, Canis uero cum hac audiffet, Non immeritò per louem, dixit:Ego nan $\$$ fum ille, quí \& uos ip fas faluas facio, at'̧ cuftodio, ut nec homines uos furêtur, nec lupi rapiant. Quòd fí ego uos non cuftodiam, nec ad pafcua uobis proficifcilicebit, timentibus ne pereatis. His ab éo dietís ; oues quoque fertur cani conceffiffe.

DE CANE VILLATICO, ET NAVTICO.

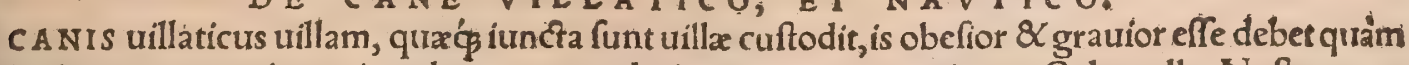
pecuarius, corpore etiam minus longo, cum celeritas in eo non requiratur, Columella. Noftrates ut paftorales, fic uillaticos etiam eius plerun $\$$ generis habent, quos rudios uocant, 2iüoen. Villacu ftos eligendus eft ampliffimi corporis, uafti latratus, canoriós, ut pritts autditu maleficum, deinde etis am confpectu terreat, \& tamen nonnuriquam ne uifus quidem horribili fremitu fuo fuget infidian= tem:fit aữt coloris unfus, isḉ magis eligatur albus in paftorali, niger in trillatico;nă uarius in neutro eft laudabilis. Villaticus, qui hominum malefichís opponitttr, fiue luce clara fur aduenerit; terribilior niger confpicitur, fiute nocte, ne confpicitur quidem propter umbr $¥$ fimilitudinem : quamobrem te ctus tenebris canis tutiorem acceffum habet ad infidiantem. Probatur quadratus potius, quàm lon* gus, autbreuistcapite tam magno, ut cor poris uideatur pars maxima: deiectis, 8 propendentib, alk ribus:nigris, uel glaucis oculis, acri lumine radiantibus: amplo, uillofó́ł pectore, latis armis, crurib.

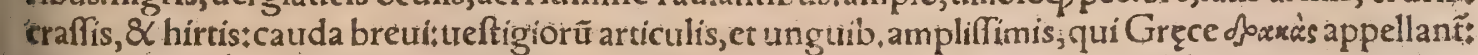

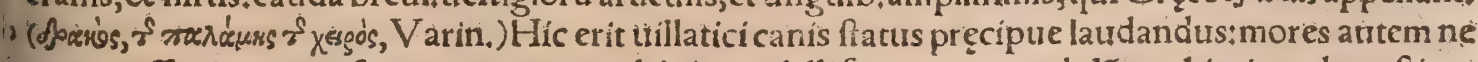
gque mitiffimi, neq̧ rurfus truces, atథ̧ crudeles, quod illi furem quoq̧ adulấtur, hi ctiam domefticos inuadunt: fatis eft feueros elfe, nec blandos, ut nonnunquam etiam conferuos íratius intueantur; 
remper excandefcant in exteros. Maxime autem debent in cuftodia itigilaces confpicitnec errone, fed affidui: $\&$ circunfpecti magis, quàm temerarï:nam illi, nifi quod certum compererunt; non indicant:hi uano ftrepitu, \& falfa fufpicione concitantur. Hæc idcirco memoranda credidi, quia non na* tura tantum, fed etiam difciplina mores facit, ut cum emendi poteftas fuerit, eiufmodi probemus : $\&$ cum educabimus domi natos, talib.inftitutis formemus. Nec multum refert an uillatici corporibus graues, $\mathcal{X}$ parum ueloces fint:plus enim comminus, $\&$ in gradu, quàm eminus, $\mathcal{Q}$ in $f_{\text {patiofo curfu }}$ facere debent: nam femper circa fepta, \& intra adificium confiftere, immó nelongius quidem rece.

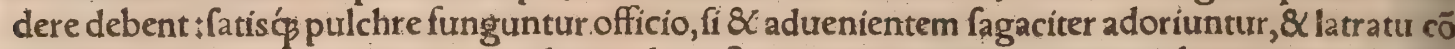
terrent:nec patiuntur prcpius accedere, uel conftantius' appropinquantem uiolenter inuadũt. Pri= mum eft enim, non adtentari:fecundum eft, laceffitum fortiter \& perfeueranter uindicari; atque hæe , de domefticis cuftodib.Columella. Blondus uillaticum laudat hirfutis contractisç pilis, ut ipfelo. quitur: qui corpus in gyrum colligat, altero oculo trígilet, altero dormiat : qui leuiffimum propter motum expergifcatur:aurib. \& cauda domino faueat, eiusós manibus caput fubíciat $\&$ dorfum, quam ita blandior domino, $\&$ in cuftodia uigilantior futurus; externis tamen, imó familiaribus quo que domini, terribilis efle debet. TCanes potius cum dignitate $\&$ acres paucos habendum,quàm multos:quos confurefacias potius nociu uigilare, $\&$ interdiu claufos dormire, \& catena uinctos effe, ut folutí acriores fiant, Varro 1.21. Canes interdiu claufos effe oportet, ut noctu uigilãtiores \& acrio res fint, Cato 124. Ad uillaticos referri poffunt etiam fuperius pofita quxdam circa finem hiftoria

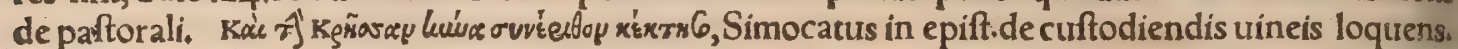

IIN A V T I C V S canis eft quià nautis uehitur, ut nauis \& rudentum merciumćg cuftos fit. Is eligi ? tur corpore maximo, terribili latratu, qualis eft canis Crouaticus, pilis $\&$ magnitudine lupo proximus, afpectu etiam atroce, Blond.

DE C A N B V S PRIVATARVM ET PVBLI. carum ædium cuftodibus. Et primum de cuftodi.

bus quardam in genere,

CA NES curtodes diurerfos effe fupra dixi ab initio hiftoriz canis paftoralis. Canes fi caftrentur, ceffant à relinquendis heris, ad cuftodiam \& uenationem nihilo deteriores facti, Xenophon. Erle. uifomna canum fido cum pectore corda, Lucret. libro 5.quod fomnifint modici ac parcé dormíant. Cuftos epitheton canis, quod domum altoris protegat, Textor. Exagitant $\&$ lar, \& turba Diania fures, Peruigilantó́ lares, peruigilantó́ canes, Ouid,li, s. Faftorum,canes turbam Dianiam uocat, Boffcum pugilem Theffalum longé aliter quàm canes tractare debetis: nam ferociores quidem $\mathrm{Ca}_{3}$ nes pleriq̧ interdiu uinciũt, noçu dimittunt: Hunc uos, fi quod ęquum eft feceritis, noctu uinçum tenebitis, interdiu folutum dimittetis, Xenophon in Expeditione Cyri ad finem libris. Vigil, epi theton canis, quod pro foribus excubias agat ut rem domini tueatur. Robuftę́q fores, \& uigilum|ca num Triftes excubiæ munierant fatis, Horat,libro z. Carminum, Ode 16. Tenebris ćs teguntur Omnia, iam uigiles conticuêre canes; Ouid. libro 4. Faftorum. Catenarium canem legimus apud

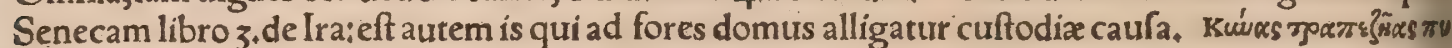

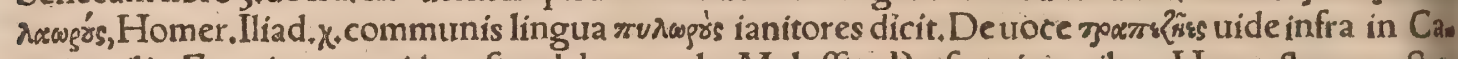
ne inutili. Exanimes trepidare fimul domus alta Mcloffis Perfonuit canibus, Horat. Serm. 2. Sat, 6. Illud quoqs ufus inuenit, ut acerrimos ac fagaciffimos canes in turribus nutriant, Veget. lib.4+ de re milit. đSi eximios cuftodes habere cupis, robuftos elige, eoş́́ lígatos inter diu femper inclu de, noctu folue. Erunt enim mirabiles in cuftodia, neminem omnium agnofcentes, nec admiffuri in domum quenquam, Albertus.

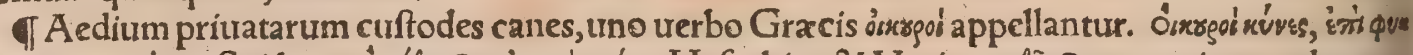

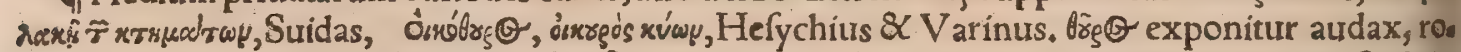

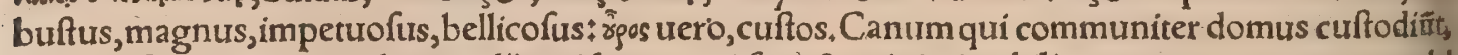
quidam funt magni, quidam medĭ, quidam parui:funt $\&$ minimi nobilium matronarum : omnes hi domos latratu defendunt, $\&$ alienis importuni funt, $A$ urhor obfcurus.' Rufus canis ex numero cut ftodum,idoneus eft ut mimicus fiat; Albertus. Genus canum ignobilius, quod ad cuftodiam deftis natur, ita ut plurimum ante menfam fe difponit, ut uno oculo oftium, altero largam domini manum infpiciat, Albertus. TA Anfer folertiorem cuftodiam præbet quàm canis, Columella, Eft \& anferi uigil cura, Capitolio teftata defenfo, per id tempus canum filentio proditis rebus, Plinius, đCanes domus cuftodes in fomnis uifi, uxores $\&$ famulos et quxfitas poffeffiones fignificant, Artemidorus,

TCanes etiam templis cuftodes $8 \times$ ædituos multis in locis gentiles adhibuerũt, qui fures $8<$ facri: legos arcerent ac proderent, Achæa Pallas cognominata eft, cuius templum ( ut A riftoteles fori bit in libro Mirabilium) in I talia apud $D$ aunios $A$ pulix populos, in quo antiquitus fuiffe tradit cum alia, tum fectures $\&$ enfes cateráç Diomedis eius $\not ́$ fociorum arma. Huius templi cuftodes canes fuife perhibentur, qui Gracis adeuntibus blandirentur, cæteris mortalibus agreftes $\&$ feri, Gyrals dus Syntag, „1, de dijs. Ex pauló poft, llias Minerua(inquit)cognominata eft in Daulia, cuius templo canes alebantur, quibus id erat inftituti ac moris, ut aduenientibus Græcis blandirentur : barbaris 6 uero fi aduenirent, latratu infefti erant. Scribit Dion Chryfoftomus Græcos à Troia abituros $\mathrm{p} 0 \mathrm{~s}$ pondiffe fe Minerux lliadi relicturos maximum ac pulcherrimum inos'ísoy. Hoc Minerua lliadis templum 


\section{De Canibus diuerfis. Lib. İ. 269}

remplum in Daulia effe Calius etiam meminit lib. 23+ cap. 30. Achæx uero Palladis apud Daunios, cum étudem illic ingenij canibus, Leonicenus in Varn̈s 1.91. Daunia dic?a eft Apulia, uel à Dauno Pilumni filio, Turni auro, qui in ea regnauit ‘ uel à Dauno Illyricæ gêtis claro uíro. Eius incola Daur ni dicti, \& flutrius in ea Daunus, Ef \& Daunium, urbs Italiz, \& murus Thraciæe, Stephan. Daulida uero uel Daulis, Phocidis oppidum, à Daulide nympha dictum, in quo Procne \& Philomela furerût, ut poêta fabulâtur. A pưd hos Daulienfes Mineruę templum, \& ftatua antiquiffima fuit, Stephanus.

T Vulcani templum in Aetna fuit cum igne perpetuo $\&$ inextingtibili: ad cuius templi $\&$ Iurci cuftodiam canes aftítiffe ferunt, qui a deuntibus cafté $\propto$ religiof ${ }^{\prime}$ blandiendo affociantes comitaban tur, uti dei familiaribus. In fceleftos uerò $\&$ contaminates, fi uel templum, uel lucum ingredi uellẽ 10 irruebant, \& mordicus cos appetentes lacerabant, ceteris allatrabant, Gyraldus:cuitus uerborum po ftrema clarius intelligentur appofitis Cellij $R$ hodigini uerbis, qui eandem rem libro 23, cap.29. defori bens, Quod fi manibus(inquit)non puris, fcelerég aliquo pollutior templum inuifat, uel lucum, ir rưunt mordicus, lacerant, conuellunt ́́s. Cateros ex coetu aliquo remeantes; lafciuiore intemperan tiorétue infectari modo, fatis fuperćs habêt.Idem huius rei caufam recté in immundorum fpiriturum fallaciofam fedulitatem reñcit. TScipionem Africanum ferunt folitauife noctis extremo, priuf= quam dilucularet, in Capitolium uentitare:ac iubere aperiri cellam louis, atos ibi folũ diu demorari quafi confultantem de rep. cum Ioue: ædituosḉ eius templi fxpe effe demiratus, quod folum id tem. poris in capitolium ingredientem canes femper in alio fauientes, neç latrarent eum, neç incurre. rent, Gellius 7.1. Quid tacitos linquam, quos ueri haud infria Crete. Nec femper mendax, ait aut 1o rea templa tuentes, Parceré́s haud ulli folitos (mirabile dictu) Docła Tyaneiftratos fenioris ad ora Non magicocantur, fed quod diuinitus ollis. Infita uis animo uirtutis gnara latentis, Stroza filius in Epicedio canis, IIftuc uerò(inquít Plutarchus in libro Vtra animalium, \& $c_{*}$ ) quod maio= res noftri A thenis iam tum agentes fe uidiffe narrare foliti funt, his quare diximus longe confpicuum eft magis. Aefculapij templum homo quidam clàm fubiens (nocte intempelta) magni ponderis aur argentíg donaria furripuit, ac latêre putans tacite fefe fubduxit. Canis autem quiturm cuffos erat templi, Capparus nomine, quoniam latratus ædituorum nemo curabat, facrilegum furgientem infe. cutus eft ip fe: ac primo quidem faxis petitus non deftititmox exorta iam luce, propé quidem nō ac ceffit, fed oculis diligenter hominem feruans fequebatur *cibum uero obiectum ne contingebat qui.. dem:iam ubicunç quieuiffet ille, excubabat hiciuxta: rurfus cum procederet, furgens infegieba. 30 tur item:uiatoribus etiam quicunç̧ fe obuiam tum fortè tuliffent, adulabatur, cum hunc infefte fern per allatraret, impeceretós. Hac cum qui furem perfequebantur ex obuị̂s colorem fimul $\& 2$ magnitudinem canis narrantibus fcífitando comperifient, auidius iam urgentes, prehenfum hominem a Crommyone ufog reduxerunt, Canis autem conuerfus exultans geftiensçş præuolabat, ueluti fuam prędam capturamó̧ facrileğum illum faceret. Ei ut alimentum publice daretur, tum ut facerdotibus cura huius perpetua incumberet, Athenienfes fciuerunt, Hactenus Plutarchus. Eandem hiforiam Aclianus defcribit, ex quo ea folum adfcribam in quibus nonnihilà Plutarcho diffidere uidetur. Fur primum, inquit, faxis lapidatione facta, canem appetebat: deinde ubi is latrare non defiferer, $i_{a}$ lum allicere conabatur, panem $\&$ offas canum illecebras obijciens: Verum cuftos incorruptus ca, nis, uel fur cum euaffret in domum furam, uel cum inde exiret, fe illi implacabilem inexpiabilemós 10 prabens, furem latrare non definebat. Tandem intellectum eft ubi canis effet, $\&$ in furem captum. A thenienfes uerberibus ac tormentis quafiuerunt:qui omnia confeffus $\&$ ex lege capite damnatus, extremum dedit fupplicium. Meminit etiam Io. Tzetzes Chiliade 3. cap, 131 , non unum, fed plures

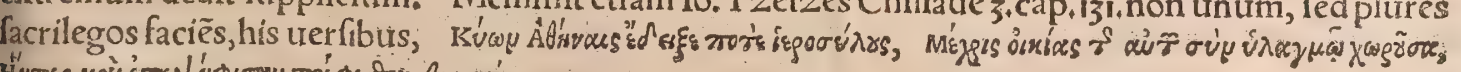

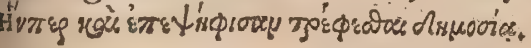

\section{DE INVTIL CANE, ET AEDIVM}

priuatarum cuftode.

IN $\vee$ T IL Is canis, qui ad nullum hacienus enumeratorum generim pertinet, temere latrat, $\&$ ci bo tantum urorando occupatur, quem fumit qualemcunç:mox fomno $\mathcal{X}$ inertix deditus, Blond. Ta

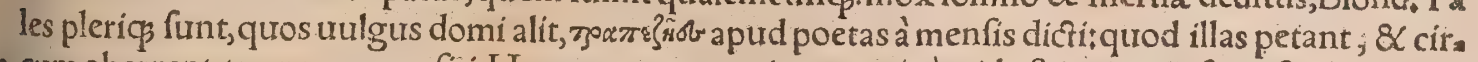
ro cum oberrent, tanquam parafiti. Homerus tamen etiam $\pi v \lambda x \omega \cos ^{\prime}$, , id eft ianitores $\&$ cuftodes porta.

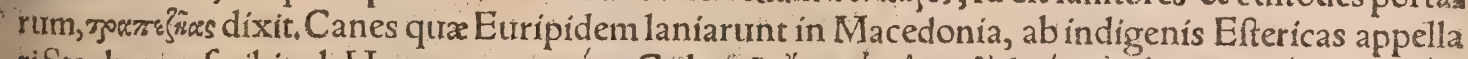

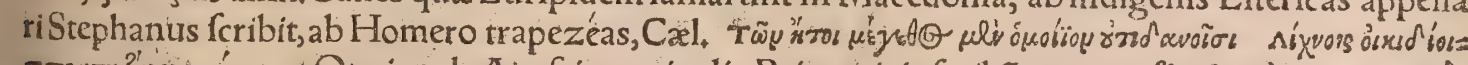

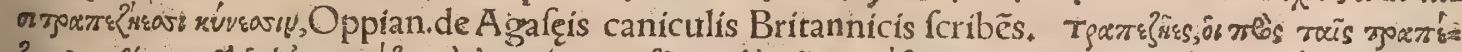

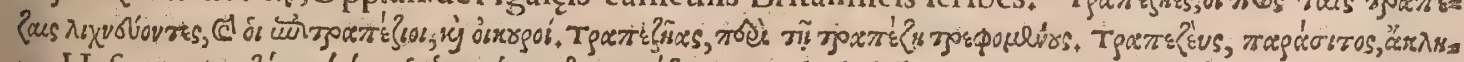

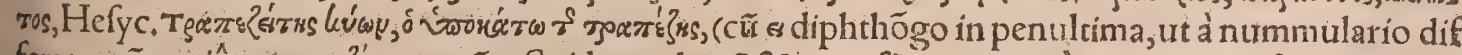

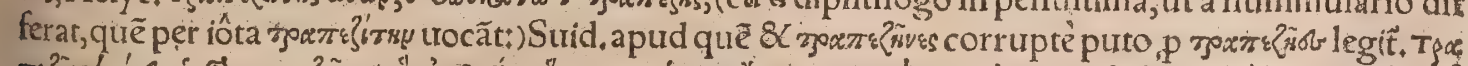

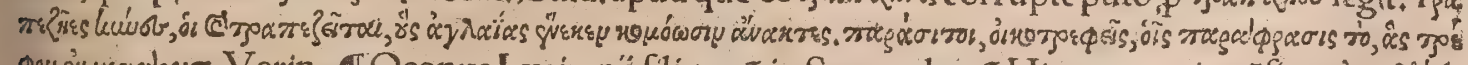

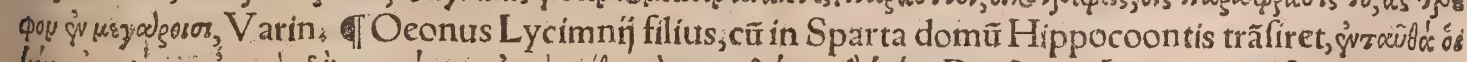

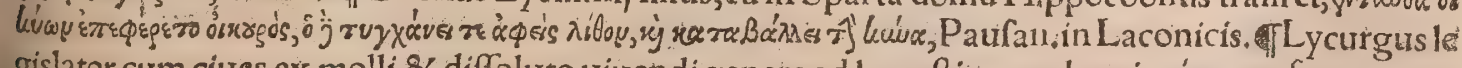
6 gislator cum ciues ex molli $\&$ diffoluto uiuendi genere ad honeftius moderatiusćçransferre cıpe. ret, catulos duos ïfdem parentib, natos educauit: quorum alterum domi reliquit, \& gulæ indulgere, liguriendo lingendóg uafa \& cibos permifit, alterum rus eduçum uenationi affuefecit. Poftea in 
concionem duxit, ubi fimul $\&$ cibarịs quibuifdam propofitis, \& lepore emiffo: hic ftatim leporem $\mathrm{fe}_{\text {. }}$

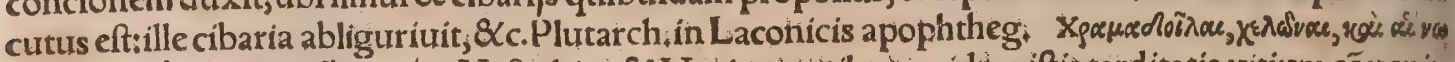

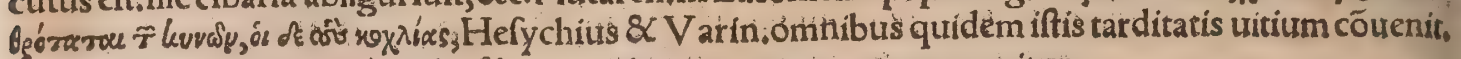

đI Lucernarius canis à quibufdam nohinatur tantum, nön exponitur.

$$
\text { DE MIMICO CANE: }
$$

Canis animal docile eft, \& 2 homini facile inftituendum fe prabet; qưamobrể agyrta \& circumfo. ranei homines quidâ, ad ludos diuerfos $\&$ mimica uel hiftrionum opera canes afluefaciunt. Optimi fané mimi fuerint, id eft ad imitationem aptiffimi, ex uulpé nati canes, Alber to tefte: quiti fi defint, rufi ex cuftodum numero deligantur, \& catuli adhuc cum fimia uerfentur: ex qua multa iocofa difcent. Quòd fi etiam ex coitu eius cum fimia natus fuerit canis, omnium in hoc genere praftantiflimus e: uadet. Apud Aegyptios tanta multis canib, docilitas fuiffe proditur, regnante Ptolemæo: ut lude." $\checkmark e$, faltare, \& molliter ad fymphonia cantum moureri edocti fint: ac uicem feruorum pauperibus do. mi aliquando praftiterint, Io.Textor, बIMemorabilem mimici canis hiftoriam retuli fupra cap.4. in Cane in genere.

\section{DE C A P R A.}

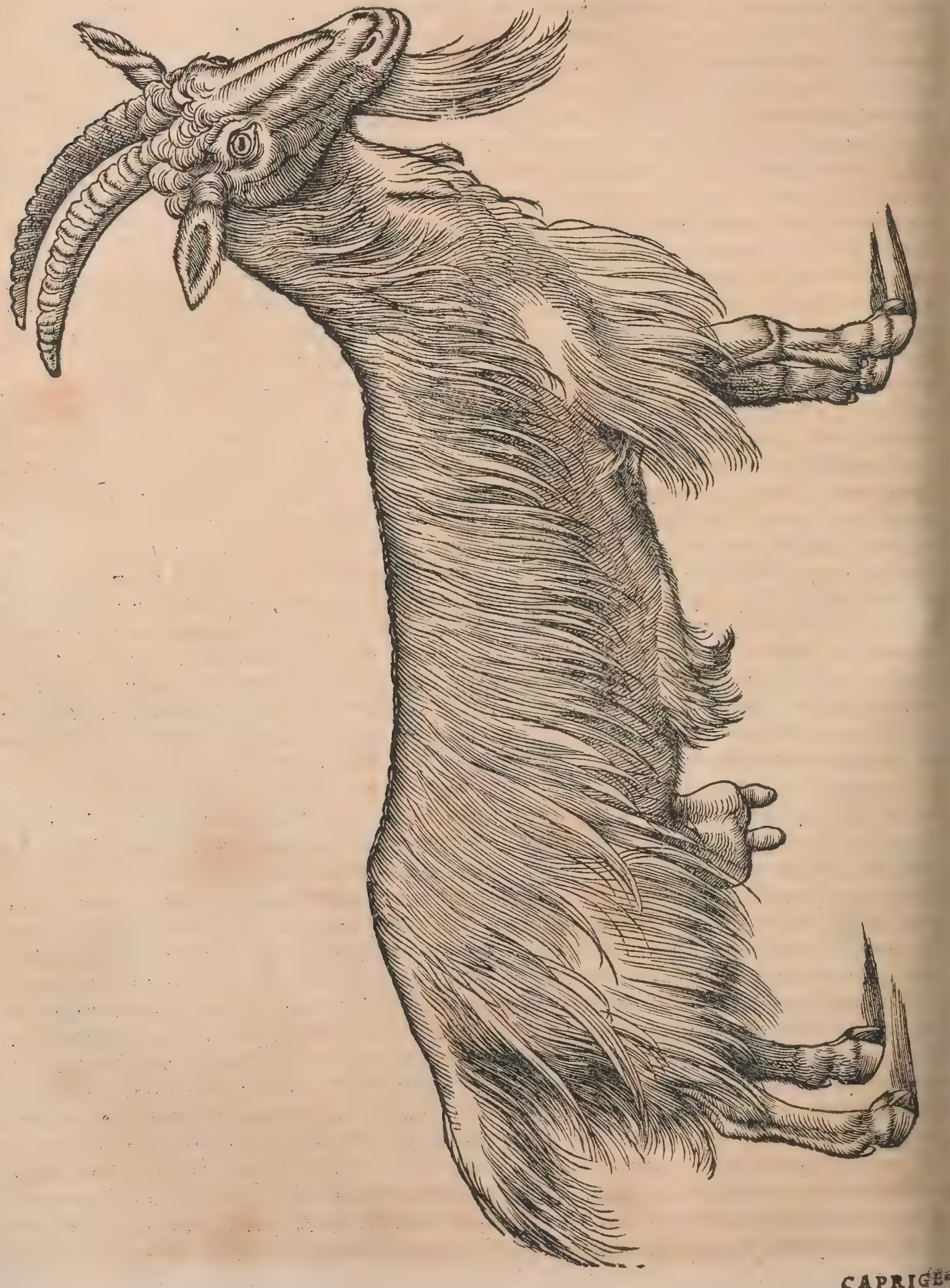




\section{De Capra. A.B. Lib. I. 271}

A.

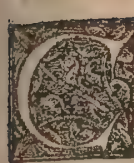

A. PRIGIE V M genus omne, capras, hírcos $\&$ hódos, Hebrei uocant eviy izim, à nomi.

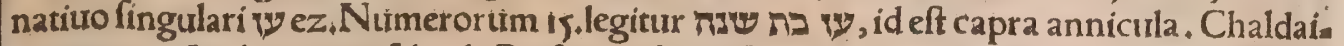

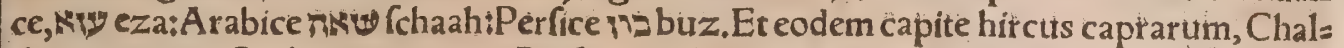

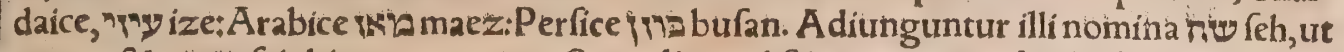
pecus caprarum, \& y yyu feir hircus caprarum, Sacræ literæe diftinguunt pecutdes in duo genera, ut

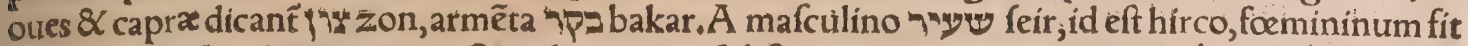
องทา feirah izim, capra. Seir alioqui non fubbfantiue tantum pro hirco, aliâs pilofo \& fatyro, aliâs dxmonio exponitur, fed adiectiue proprie hirfutum fignificat, Leuit. 16 , ubi pro capro accipit,

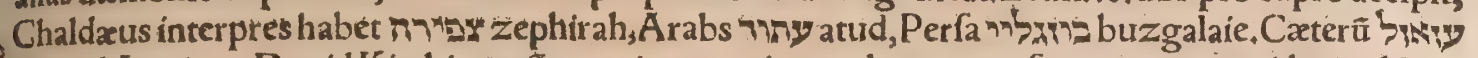
azazel. Leuit.16. Dauid Kimhi nomê montis exponit, quod eũ capra frequentent : quidam addunt

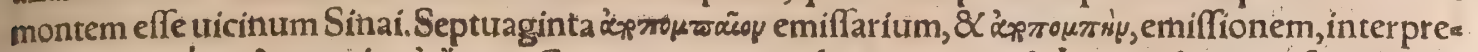
tantur: $\&$ Trájoy of piatorius, qui abit $\&$ aufert mala. Hieronymus caprum emiffarium interpretatur. Aquila ad confir matum deputatus: Chaldaica \& Perfica translatio uocem relinquũt: A rabica uertit, itis $\zeta_{2 x}$, mons

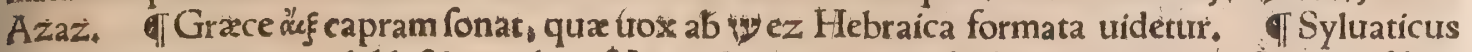
mier capram exponit : dakh \& metaham Vetus Auicentix uocabulorum intérprés ، Á pud eofdem nomina hæc reperio, Baualmaís, urína capræ: $\mathrm{Haramiem}_{3}$ fterctss captinum: Adalafi , ungula capri. na. I Saraceni capram appellant anfe. Itali nomen Latinum feruant, ut $\&$ Hifpani, nifip in b mu tarent, Galli cheure, uel chieure:Germani geifis:Angli a gore:Illyrï koza.

B.

đA egyptix capr $x$ fotus quinos parere feruntur:quod focundiflimas Nili aquas bibant. Quam quidem paftores etiam lactis inopibus pecudib. $\&$ infoccundis dare folent, A elian. If In Africa quadam parte tonfiles cajprafunt, ex quarum uillis nautæ rudentes conficiunt, Textor. Aegypin aftirmant capras fuas, quoties cum Sole eodem planè loco Sírius oritur, in ortum omnes conuerfas córefpicere, atç hoc fyderis eius reuolutionum argumentum certiffimum effe, Plutarch. in libro V. tra animalium. ब Cafpix capræ $\&$ albiffim $x$ funt, \& cornibus mutila, $\&$ ad maximorum equoru magnitudinem accedunt, Earum uilli adeo molles, cum Milefijs lanis ut mollitudine comparari pof

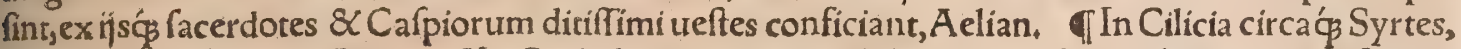
uillo tonfiliueftiuntur, Plin. IIn Cephalenia capra non bibunt quotidie, ut alia animalia : fed ad= uerfum fibi crentum ore híantes excipiunt, Ariftot, in Mirabilib, đCapras in Gimanti natas Alexã der Myndius feribit fex menfes non bibere, fed tantum in mare intueri, $\mathcal{Q}$ ore hiante illinc auras ex cipere, Aelian. Illyricx capræungulas quidem habent, fed non bifidas, Aelian.ex Alexandro Myndio. Apud Illyrios pecorz aiunt bis anno parere,geminos pleraç, nonnulla etiam ternos aut quaternos hoedos: alia quinos uel plures: praterea lactis fefquicongium reddere, Ariftoc, in Mirabi= lib. Or thragoras in libris qutos confcribit de rebus Indicis, inquit in Coytha uico fic nuncupato ab indigenis pifces capris comedendos obïci, Aelian. TLibycorum capræex pectore ubera ap. penfa babent, Idem. TCallifthenes Olynthitus, capras fcribit in Lycia denfiffimo \& prolixiffino hirfutas effe pilo, ut muliebres crines effe uideantur, \& paffim tanquam outes tonderi, ex eifdem nauium fabros rudentes contexere, A elian. I Sardiniam pecudum optimam effe parentẽ, Nyma

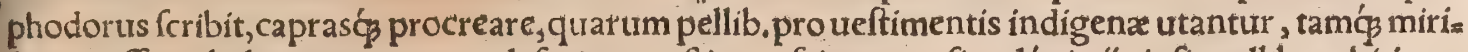
fica ui effe, ut hyberno tempore calefaciant, xftiuo refrigerent, fimulćs in ijs ipfis pellib. cubiti magnitudine pilos innafcitatç ei qui n̈s indutus furerit, fi commodum tideatur cum eft frigida tempe. itas, pilos ad corpus conurertit, ut ab îs calefcat:cum autem eft zeftas, inuertit, ne calore uexetur.

TScyrias capras, require cap.8, inter prouerbia. TCaprę in Syria funt auriculis menfura dodranta li \& palmari, ac nonnullæ demiffis ita, ut fpectent ad terră, Ariftot.Capræ Syriæ(forte Scyriæ) quan tum aliæ nullar lac habere dicuntur, Aelian. Capra Mambrina in regione Damiata dicta, fert equí tantem, fellam, frenum, \& catera quib. equi inftrui folent, admittit:auriculas ad terram uf̣́ 3 demiffas habet, cornua deorfum reuoluta fub ore: Haud fcio an fit ex capris fylueftrib. illius rëgionis, Italus 10 quidã innominatus in defcriptione terrę fançę. Recentiores quidam hanc Indicam capram uocant, (ut pleraç peregrina Indica) addũt cornua ei acuta effe, parum diftantia:corporis colorem eundem qui rupicapris:teftes ut equi:cxtero noftratib,capris non diffimiles: fylueftres tamen effe $\&$ in altis montib, reperiri, uifu acutiffimo, \& eam ob caufam a Gracis dorcades nominari. Séd illi in dorcadü nomine plurimum falluntur, ut patebit infra in hiftoria dorcadum. Mambre mons eft iuxxta Hebró, inde Mambrinæ factum cognomen fufpicor. In regione Nubia, quam nunc Mauritaniam uccant, oues latifimas habent caudas, \&c. Et inter auriculas caprorum \& caprarum illius terræ, palmi ferẻ (dodrantem intellige)menfura intercedit. Etcaprorum quidam caudas habent pendentes uf $\phi$ ad terram: \& auricula eorum feréterram attingunt, Albert.Magnusł:Sed locus omnino corruptus eft, cum ita legendum fit, ut fupra ex Artftotele citauimus. Oues India $\&$ capras ad maximorum ma gnitudinem afinorum audio accedere, $Q$ uatuor fortus plerunģ pariunt, tres uero cum minimum: Caprina cauda in eam procedit longitudinem, ut terram contingat, Aelian. बf Capra in Narbonen fiGallia, ut audio, auriculas latiores longioresḉs noftris habent, ut qux ad dodrantem longitudinís. 
accedant. TQui caprinum gregem(inquit Coffinius apud Varronem) conftituere urult, in eligen do animaduertat oportet:Primum atatem ut eam paret, qua iam ferre poffit fructum, \& de njs eam potius, qua diutius: nouella enim quàm uetus melior. De forma uidendum, ut fint firma, magnę(be ne compaćx; magnæ $\&$ mufculof $x$, corporisćs fuperficiem lenem \& $\&$ qualem habêtes, Flerentin.) cor pus lene ut habeant, pilo crebro, nifi figlabra funt, duo enim genera earum : fub roftro duas ut marnillas penfiles habeant, quod ha focundiores funt:ubere fint grandiore, ut \& lac multũ, \& pin gue babeant proportione. Capella, inquit Columella, pracipué probatur fimillima hírco(cuíts for mam laudabilem infra defcribam) fi étiam eft uberis maximi, 8 laçis abundãtiffimi. Capram am. plam quàm paruam potius eligunt, Varro.Caprarum generofitatis infignelacinia (mamilla, Var: ro ut iam portui:uel uerruculæ, ut in Hirco dicetur: Noncola, papillæ quæ ex faucib. capræ depens, dent,Felt.)corporibus è ceruice binz dependentes, Plin. TCapræcolorem mutant, ut feribit Ari froteles Sect.10.problenate 7. Capræ interdum uarix generantur, Idem. Longa \& acuta funt cor nua capris $\&$ hircis, frons robufta, Albert. Non omnibus capris cornua, fed quil, funt, in his $\&$ in. dicia annorum per incrementa nodorum, Plin. Mutilis lactis maior ubertas, $P$ lin. Corniger $8 \mathrm{C}$ bi. fulca funt,Ariftot, T Capræoculi in tenebris fplendent, lucemćç iaculantur, Plin. Conditos (quíbus opponuntur prominentes) in homine oculos, clariffimé cernere putant, ficut in colore caprinus, Idem. Hominum quibufdam oculi caprini funt, Ariftot, Oculos aliquando habet capra colore diffimi les, Author obfcur; Capræ fuperiores dentes non funt, prater primores geminos, Plin. Capris pauciores funt dentes quàm hircis, Ariftot.\& Plin. . TSpirillum uocari inuenio barbam caprz. Dependet omnium mento uillus, quem aruncum uocant. Hoc fi quis apprehenfam ex grege unam an trahat, cateræ ftupentes fpectant. Id etiam eueníre (aiunt)cum quandam herbam(eryngium, ut cap. 3. dicam)aliqua ex eis momorderit, Plin. In capris aruncum Äriftoteles cryngum appellaurit, Cęl. Bi nas in feminib, mammas habent, nee alibi, ficut 8 oues, Plin. Caufam eius rei reddit A riftoreles ut in Vacca expofui. GPilicraffiprodeunt bircis, forminis tenuiores. THoures \& capræ \& quacun que id genus cornigera funt, ob ficcitatem adipem plurimũ generant, Galen, de facult. alim. of Cer ui $\&$ capræ, \&c, fel non habent, Plin. Caprex potius legerim. Nam Græce legitur méness aptid A rifto relem. A pud Plin, \& alius locus eft, ceruortım \& caprarum fanguinem non fpiffari,fimiliter ex $A_{\text {. }}$ riftotele translatus:ubi iterum mónob legitur Grace:unde apparet Plinium mgónee uertufe capream, librarios autem corrupiffe. Hoc Gaza etiam uel non animaduertit, uel non probauit: mórá enim ex Ariftotele damam transfert, non de Pliní credo dama, fed de uulgari intelligens, qux proculdubio caprearum generis eft. Ouium $\&$ caprarum pars maxima habet fel: $\&$ quidem terris quibufdam ${ }^{3}$ adeò largè ut exuperantia prodigï loco, habeatur, ut in Naxo: fed alịs quiburdam locis omnino ca= ret, ut apud Chalcidem Euboicam parte quadam agri, Ariftot. qPlures habet uentres capra, quo niam ruminat, Ariftot. $\quad$ Lienem bifulca inter cornigera habent rotundum, ut capra, ouis, Arift. Cur capra inter femora mammas habeant, caufam affert Ariftoteles de Partib, 4.10.

c.

TCapras fpirare per aures falfo credidit Alcm fed Archelaus, legitur, ut apud Varronem quoq. Hoc idem (inquit Varro) paftores curiofiores alis quot dicunt. Paftores capras aurib. \& naribus ref pirare reftantur, Aelian, Philes fignum addit, quo= niam nafo obftructo, nihil offendantur. Huc facit quod Oppianus de ęgagris, id eft capr is fylueftrib. 4 frribit, meatum quẽdam à medio inter cornua loco ad pulmones peruenire, cui cera infufa fuffocen tur. Tradunt capras noctu non minus cernere quàm interdiu: ideo fi caprinum iecur uefcans tur, reftituit uefpertinam aciem his quos nyctalopas uocant, Plin. Et alibi, Quoniam capræx noftu es qué quoçs cernant, fanguíne hircino fanarilufciofos putant, nyctalopas à Gracis diços. Senfư aus diendi ex omnib. ungula bipartita pradítis animalib.acerrimo eas effe putant, A elian. Hominem as cuti auditus fignificare uolentes A egyptî́, capram pingunt:hæc enim \& aurib, \& quadam parte gut turis audit, Horus. Somniat etiam hoc animal, Ariftot. 8 Plin.

TCapra ruminant:carent enim fuperiore dentium ordine, A riftot, $\mathrm{Pafcũtur}$ urero fyluas, \& fum ńna Lycæi, Horrenteiś́s rubos, \& amantes ardua dumos, Verg.in Georg. Gaudent locis monta. nis, Florentin.Capræ in montofis potius locis $\&$ fruticib. quám herbidis campis pafcuntur, Varro, " Aluntur herbis, \& arborum ramúfculis quos ore poffunt attingere in montib. $\&$ conuallibus, $O b=$ fcurus. In pafcendo loca crebro permutant, fummaćs tantum contingunt, Ariftot. Nec multo alia ter tuendum hoc pecus in paftu, atcs ouillum:quod tamen habet fua propria quadam, quod poritrs fylueftrib. Faltibus delectantur quàm pratis. Studioféenim de agreftib. fruticibus pafcuntur, arque in locis cultis uirgulta carpunt, itaçà carpendo capræ nominata: ob hoc in lege locationis fundi excis pi folet, ne colonus capra natũ in fundo pafcat. Harũ enim dentes inimici fationis, Var. Vrentes cul ta capellas, Verg.Morfus earũ arbori exicialis. Olituã lambendo qưoque fterilem faciunt, eạ̧́ ex cau fa Mineruæ non immolantur, Plin. Et alibi, Oleam fi lambendo capra lingura contigerit, depaueritá primo germinatu, fterilefcere author eft $M$. Varro. Capras in orcafum decliui fole, in pafcuis ne. gant contueri inter fefe, fed auerfas iacere:reliquis autem horis aduerfas, 8 inter cognitiores (lege 6 cognatiores,)Plin, Hæc Plinị uerba malè intellexit Albert. ita fcribens, In die cum pafcuntur dicun tur refpicere ea, qux è regione funt oppofita:in fero autem refpiciunt ea qua iuxta funt pofita, 


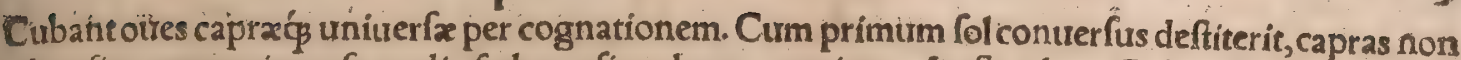
aduerfis praterea inter fe oculis, fed auerfis cubare accepimus, Ariftoteles. Cubant difficilius oues quàm capra, magis enim capr quiercunt, acceduntọ̧ ad hominem familiarius : fed funt frigoris im

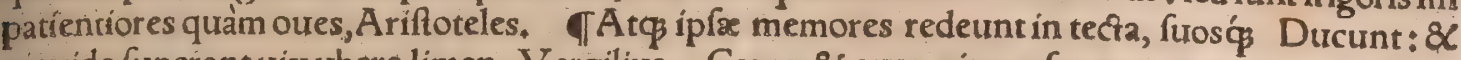
giauido fuperant uix ubere limen, Vergilius, Capræ $\&$ oures pinguefcunt cum gerunt partum, eduntí̧ amplius, ut \& cateræ quadrupedes, Ariftoteles.

đEupolis elegans ueteris comodize poéta, in fabula qux infcribitur Āegés, inducit capras deci-

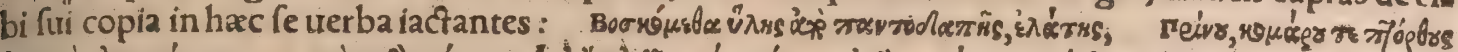

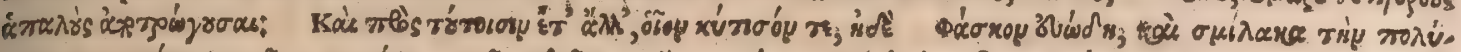

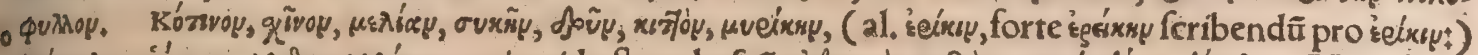

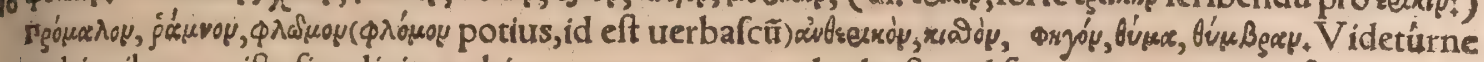
uobis ciborum ifta fimplicitas, ubi tot enumerantur uel arbufta uel frutices, non minus fucco diuer. fa quàm nomine? Haec Euftathius apud Macrobium contra Difarium, quí pecudes uti fimplici cibo, Q ideo expugnari difficilius eartum,quàm hominum fanitatem dixerat. Phafcon Theophraftus ưo, cat, quem alij fphagnon, fplanchnon, $\&$ bryon, penem (al, per $n$. duplex)incerro, id eft mufcum è ra.

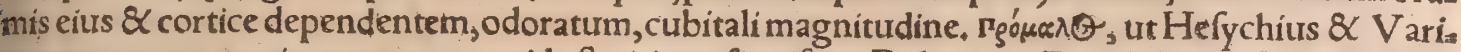
nus exponunt, myricam aut agnum id eft uiticem fignificat. Reliqua in Etipolidis uerfibus fatis no. tafunt, Tlubeo frondentia capris Arbuta fufficere, Vergilius. Arbutus, Gracis rópep@ $\Theta$, arbu= ftum eft quo Germania caret : frequens uidi in Gallix Narbonenfis nemoribus fructu omnium tar diffimo, tam fimili fragis, ut nifi maior effet, \& luteo intus colore, non difcerneres. T Caprinum pecus dumeta potius, quàm campeftrem fitun defiderat:afperiṣ́́ etiam locis ac fylueftribus optimé pafcitur. Nam nec rubos auerfatur, nec uepribus offenditur, \& arbufculis frutetiśćs maximè gau= det. Ea funt arbutus, atç̧ alaternus, cytífusḉs agreftis, Nec minus ilignei querneić frutices, quii in al titudinem non profiliunt, Columella. Alaternum qui notrerit nullius adhuc fcripta legi. Fruêtum arborum fola nullum ferunt, hoc eft ne femen quidem, tamarix fcopis tantum nafcens, populus, ale nus, ulmus attinea, alaternus, cui folia inter ilicem $\&$ oliuam, Plinius 16.26. Nafcitutr apud nos fru= tex, rariffimus alibi, iuxta fluuij Sili ripam, perfici arboris fapore foliorum ferè, fructu $\&$ femine nul lo quod obferuauerim:quem fruticem perficum appellare licebit donec aliud nomen reperiamus, nam alaternum effe nondum affirmauerim, quòd folia latiufcula uideantur. T Gramen aculeatum aliqui è uulgo capriolam uocant, quòd capris grato fit pabulo, Ruellius. Gramen etiam apud Gra cos agicon cognominari inuenio.

TCytifum in agro effe quâ plurimü refert, quòd $\&$ capris $\&$ omniû́ generi pecudẩ utiliffimus eft, $\mathrm{Col}$. Sed de cytifo in Boue copiofiffimé egi. Vbi etiã reprehêdi illorũ opinionẽ qui loti fiue trifolī pra têfis genus maius, durius, \& acutioribus foln̄s, cytifum effe purât, eò riuod loto fimíle foln̈s, $\&$ capris

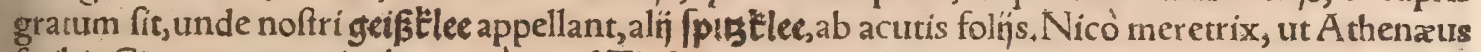
frribit, Capra cognominabatur, eo quod Thallum nomine dititem cauponem confumpfiffet, id eft ad paupertatẽ redegiffet: thallos enim Graci olex ramos appellant, quos auide petunt capra. If Pe riclymenon frutex eft apud Gracos, qui nunc caprifolium \& materfylua dicitur uulgò: quanquam Diofcorides matremfyluam pro hedera capit, cui periclymenon fimile eft, Hermolaus in Corollario, Clymeno \& periclymeno multa eadem turm in uíribus tum defcriptione Theophraftus \& Diofcoria des adfcribunt, ut Hermolaus itidem montrit:doctiores difcernant. Periclymeno aginæe etiam no: menclatura à capris facta apud Diofcoridem triburitur:certum eft id effe quod noftrates uocant gile genconforr/ waltlilgen/ seünling/ /pectlilgen/ geyfisblatt. Scribonius, \& qui eum in fura trãfcripfit Marcellus Empiricus, periclymenon fy̆luæ matrem interpretantur. TEdera dicitur, quod liben. ter à capris edatur: ut barba hircina etiam, 8 rofa canina, a b hircis appetuntur, Syluaticus. I Lada appellatur herba, ex qua ladanum fit in Cypro, barbis caprarum adhærefcens, Plinius. Arabia ladas nogloriatur:forte cafứç hoc, \& iniuria fieriodoris, plures tradidere. Capras maleficum aliàs frondi. bus animal, odoratorum uerò fruticum expetentius, tanquam intelligant pretia, carpere germinum caules praedulciliquor e turgẽtes, diftillantemća ab his ( cafus mixtura) fuccum improbo barbarum uillo abftergere. Hunc glomerari puluere, incoqui fole. Et ideo in ladano caprarũ pilos effe. Sed hoc non alibifieri quàm in Nabatæis, qui funt ex Arabia contermini Syriæ. Recentiores ex autoribus ftrobon hoc uocant: traduntó fyluas A rabum, paftu caprarum infringi, atø̧ ita fuccum uillis inh $x=$ refcere, uerum aû́t ladanum Cypri infula effe. Similiter hoc $\&$ ibi fieri tradunt, \& effe œfypum hir corum barbis genibusćs uillofis inhærens, fed ederæ flore derofo, paftibus maturinis, cum eft roru lenta Cypros:Deinde nebula fole difcuffa, puluerem madentibus uillis adhærefcere, arç ita ladanü depecti, Plinius. Errat autem quod ederæ flore derofo à capris ladanum fieri fribit, Græciederam ciffon appellant, cifton uero(uel cifthon potius cum a firatione)fruticem odoratum, cuius alterum genus ladon uel ledon dictum, illud eft ex quo fit ladanum, nec quicquam cum edera commune ha bet:qua de re plura leguntur apud Marcellum Vergilium in commentarijs in Diofcoridem. GCa.

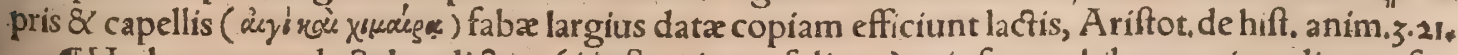

THerbam pentadactylon dictam (id eft quinquefolium ) priufquam bibant quinq̧ dierum fpa cio illis uorandam dato, fic plurimum lactis habebunt:In eundem ufum uentribus earum dicfamnus 


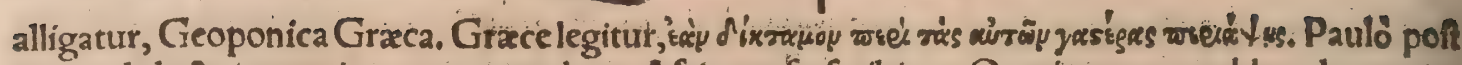
tamen de lacte in omni pecore augendo ex Africano fic feribitur, Omnia pecora reddent lac copio.

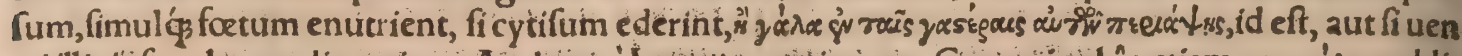
tri illis ípfum lac applicueris, ut Andreas a Lacunà uertit: nam Cornarius híc etiam pro zére reddit dictamnum. TCaprxin Creta ictze fagitta; quarunt tiafcentem illic dictamnum, \&c. Ariftoreles in Mirabilib, intellige feras capras, ut copiofius in illarum hiftoria dicètur. T Serapion in libro de Simplicib. citat Galenum fcribentem fe uidiffe capras lingentes (pafcentes) tamaricis frondes $;$ quae poltea finc fplene inuentz fint: Item alias lingentes ferpentes excoriatos, easćs póftè minuis fenefre re $\&$ albefcere, aliâs \& poft allefcentes minus fenefcere, Albert. \& alĭ quidam barbari, Ego hunc lo cum neó apurd Serapionem, neç apud Galenum reperio. Si caprę ex uafis tamaricis biterint aut ederint, non habebunt fplenem, Conftantin. Melioris notx anthores de fuibus hoc fribunt, minui corum lienes alueis ex tamarice factis. T Si ex caprarum (uel ouium ) grege quşpiam eryngium herbam ore fuimpferit, Plutarch.eam dicit primum, ac deinceps reliquum caprarum gregem tandiu à progrediendo fuftinere, quoad de cius ore herbam paftor decraxerit, Aelian. Si quis apprehenfam ar unco ex grege unam trahat, cater f̧ fupentes fpectant, dem eurenire aiuni cum quandam herbam (eryngium intelligo)aliqua ex eis momorderit. Vide Marcelli Vergilij commentarium in eryngiñ Diof oridis. Huic pecudi nocet $æ$ ftus, fed magis frigus, $\&$ præcipue for $x$, qux gelicidio hyemis conceptum fecir. Nec ea tamen fola creant abortus, fed etiam glans cum citra farietatem data efi. Ita. que nifi poteft affarim praberi, non eft gregi permittenda, Columella, TQuibus in loris pecora f cammoniam, ueratrum, clematidem, aut Mercurialem pafcuncur, lac omne uentrem er ftomachum fubuertit:quale in luftinis montib. effeà nobis proditum eft. Siquidem capræ, quibus candidum ue. ratrum pabulo fuerit, primo foliorum partu,euomunt: \& corum lac hauftum naufeam crèt", \& ftom machum in uomitiones effundit, Diofcorid.Alibi etiam in ueratri mentione idern de capris fr ribit. - Lafer multis iam annis in Cyrenaica prouincia non inuenitur:quoniam publicáni, qui paf́cua cô ducunt, maius ita lucrum fentientes, depopulantur pecor um pabulo, Si quẩdo incidıtpecus in fpem nafcentis, hor deprehenditur figno:oue cum comederir dormiête protin us, capra fternutante, Plin, बPoftea quàm capra proxima eft ut iuguletur, non amplius cibum attingit, A elian.

Herba eft ab exitio, pracipué caprarum, appellata agolethr os, \&c. Plin, de hac abunde differu⿰氵 in Boure. TSabina capris $\&$ ouib.uenenum eft, Plin.lib.16. T Rhododendron in iumentis, $\mathrm{Ca}^{4}$ priś́:,$\&$ ouibus, uenenum efi:idem homini contra ferpentium uenena remedio, Plin, Et alibi, Pe. cus \& caprafia quam biberint , in qua folia rhododendri maduerint, moridicuntur. IEunya mus arbor dicta, nafcitur cum alibi, tum in Lefbo infula, monte Orcynio, cui nomen Ordyno: ma. gnítudine mali punicæ, atç folio eitufdem, maiori quàm uincaperuinca (chamædaphne:) \& molli, ut punica. Germinaremenfe leptembri(Pofideône)incipit, Horer in uere, flos colorealba uiola fimiliss

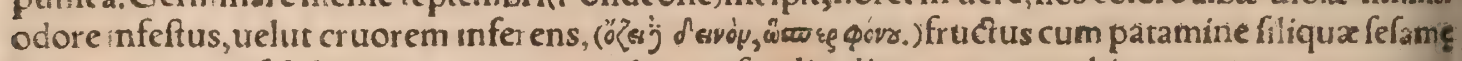
proximus, intus folidus, praterquam quod in tuerfus diudditur quaternos:hic pecus(oues)enecat gi ftatus:quinetiam folium idem facit: 8 potiffir òcapras, nifi purgentur, interimit. Purgantur atuem anocho(elleborum nigrum inıelligo: Hippori ates ecicmon uocat, apud Plinium enromon legittr, )

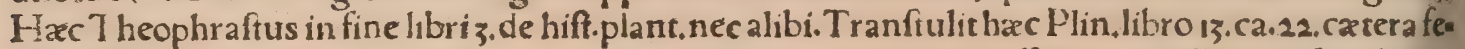
rêfimiliter, fed pro chamadaphne laurum reddidit: ávexoy cum quid effer non in relligeret, fimpliciter.

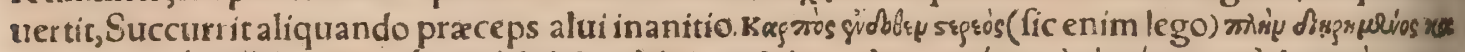

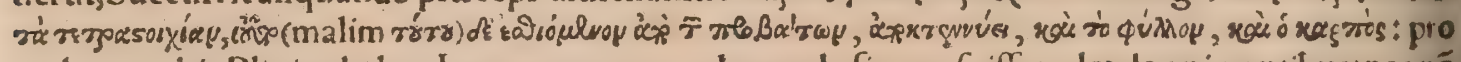
quibus uer bis Plinius haber, Intus granum quadrangula figura, fpiffum, letale animantibus:nec nó $\mathcal{Q}$ in folio eadē uis:nulla ouium aut caprarum mentione. Hanc arbufculam effe fufpicor illam qua uulgó apud barbaros, item Gallos $\&$ Italos, fufaria uel fufanus appellarur ab ufu fuforum, propter mareria foliditatem:à nonnullis Gallicé fcrcta facerdotum, à figura fruŝus: Germanice foblımpfort:

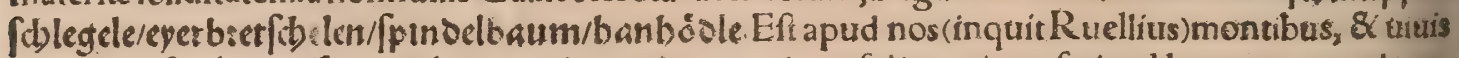
interdum fepibus nafcens artor, purica mali proceritate, folio maiore, fatis ad laureum accedente: flore luteo, albx uiolx non dıffimili:filiquis quadrangulis, per maruritasem purpureis : grano intus folido, crocata membrana claufo. Ar buficula grauter, cum delibratur, olet. Hanc neq peeus, neque? capra notellorum germinum etiam aud da prorfus at tingit, ligno intus buxeo, quam ad fufos neru muliebri celcbres ufurpant. Culing̨ transfigendis lardo carnibus pro ueruculo frequenter utunttr. Sed an fit euonymos, erfi multr deliniationes faueãt, non aufım affirmare. Fufanuśinquici Crefcen. tienfis) eft arbor parua qux in fepibus oritur, ex cuuts ligno fiunt fufr optimi, \& alia hor genus. Hie.

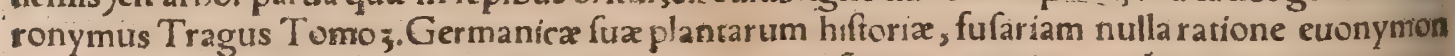
efle negans, carpinum facit, quod unico argumento confirmat, quoniam ex dura eius materie uas ria uaforum genera fiant. Veterum aliqui carpinum fub acere comprehendunt, alịg genus diuerfum faciunt.Sunc qui in montibus enat $m$ carpintm, in campeftribus gallicam torent. Car pino materies eft flaua crifpaćs, Theophraftus: A ceris genus tertium zygiam appellant quod ex ea materia iumen tis iuga comparant, rubentem, fiffili ligne, cortice liudo \& f cabro. Hinc fatis conftare poteft, fufati: am nequaquam effe carpinum aut zygiam, An opulus etiam arbufto gallico faciũdoidonea arbor, corno fumilis, ülmi proceritate adolelcens, frondibus ferè uitigineis, baccis racematim dependenti- 
bus à matưritate puniceis, \&c, aceris, uel gallicx, uel zygix genus fit(quoniam Gracum nomen ali ud ei hacfenus non inueni)doctis confyderandum relinquo. Opulus (inquit Crefcentienfis) arbor forte paropfides $\&$ f (forte paropfides) $\$$ affides (afferes forte)pro delicatis operibus. Redeo ad capras. TAegyptí ho minem oures \& capras perdentem fignificaturi, animalia ipfa pingunt conyzam pafcentia: hęc enim conyzam edentia moriuntur, fiti enecta, Horus; TOcymum Chryfippus dicit infaniam facere, 8 lethargos, \& iecinoris uitia:ideó́g capras id afpernari:hominibus quoog fugiendum cenfet, \&c. (ide in. Geoponicis Gracis legimuts.) Secuta ætas acriter defendit:nam id elfe capras, \&c.Plin, Capræ fan liuam humanam perniciofam effe nof cunt (ut quæ marinas etiam fcolopendras interficiat) itaç uia tant:nec unquam eas latet, A elian. TCapra multis herbis uenenatis \& ferpentibus utitur, \& pro ficit ex eis, Albert. At Plinius de capreis, non capris frribit; quòd urenenis pinguefcant, đHaufto melle capra ualde debilitantur, \& mori periclitantur, Albert.

TCapella per aftatem bis ad aquam duci debet, Columella; TCapra cum mourentur poft me. ridiem plus aqux potabunt, Albert. Iubeo frondentia capris Arbuta fufficere, 8 fluurios prabere
recentes, Vergilius.

TCapris in Aethiopia uita eft ufģ ad annos undecim, in orbe reliquo plurimum octo, Plin. Vita capris ad ocfonos complurimum annos, Ariftot. Idem non capras, fed oues Aethiopicas ad duode.
cim uel tredecim annos uiuere fcribit.

TCapræ coire incipiunt feptimo menfe, $\&$ adhuclactentcs, Mutilum in utroç fexu utilius. Pri. 10. mus in die coitus non implet, fequens efficacior, ac deinde concipiunt Nouembri menfe, ut Martio - pariant turgefcentibus uirgultis, aliquando annicula, femper bimę, in trimatu initules: pariunt octo nis annis, A bortus frigori obnoxius, Plin. Tempus admiffura per atutumnum fere ante menfem Decembrem pracipimus, ut propinquante uere gemmantibus frutetis, cuin primum fylua nour germinant fronde, partus $æ$ datur, Columella. Oues \& capræ annicula coëunt, atç uterum ferunt; fed capra potius; mares quo $\phi$ in ijs ípfis generibus eodem illo tempore ineunt:fed proles differt, qua tenus præftantior ea eft, quam fenefcentes mares $\&$ forminze procrearint, Ariftot. Oues \& capra terno aut quaterno coitu implentur; $\&$ fia coitu imber acceffit, abortum infert; pariunt maxima ex parte fingulos, fed aliquando $\&$ binos, 8 ternos, 8 quaternos; ferunt quíng menfibus tum oures tî. capra. Vnde fit ut locis nonnullis, quibus coli clementia, \& pabuli copia eit, bis pariant; Âriftot. VI tra oc?o annos non funt mares feruandi:quia genus hoc languore fterilefcit $\&$ atate, Pallad. libro 8. Capra oui fimilis eft multis nominibus, Lnitur quippen̈fdem temporibus. Quinģ menfibus ingrau fcir foetu, perinde ut oues. Geminos etiam parit ut plurimum, Florentin. Commodifimum tempus eft ut hac animalia coéant, quod hybernum folftitium pracedit, Idem. De maribus 8 focminis idẽ ferè difcrimen, ut alij ad denas capras fingulos parent hircos, ut ego:alif etiam ad quindecim, ut $\mathrm{Me}=$ nas:nonnulli etiam, utMurius, ad uiginti, Varro. Capris propriæ funt uoces ad Venereum coitû, Ariftoteles, Anima capris quàm ouibus ardentior, calidioresḉ concubitus, Plín, Capra tota uita coit: $\&$ gemellos parit, tum pabull beneficio, tum fi pater aut mater uim eam geminandi per naturã obtineat, Ariftot. Anniculæuel bimæ capellæ (nam utraç æas partum ædir) fubmitti hoedum nó oportet. Neq̧ enim educare, nifi trima debet:Sed annicula confeftim depellenda foboles (quod tene 1. riores matres generant tranfigendum eft, bima tandiu admittenda, dum poffit effe uendibilis. Nec ultra ocio annos matres (matrices) feruanda funt, quiod affiduo partu fatigatæe fteriles exiftant, Colu mella \& Palladius, Capra uentrem fert quinq̧ menfibus, Varro. Defeminio dico eadem, qua $A$ ticus in ouibus: hoc aliter, ouium femen tardius effe, quo hæe fint placidiores. Contra caprile mobilí, us effe: De quarum uelocitate in Originum libro Cato fcribit hæe, In Soracti Fifcelio capre fere funt, qua faliunt é faxo pedes plus fexagenos. Oues enim quas pafcimus, or ta funt ab ouibus feris: fic ca præ, quas alimus, à capris feris funt ortæ, Varro. Quod ad focturam pertinet, defiftente autumno exigunt à grege é campis hircos in caprilia.Item ut in arietibus dicfum, quaconcepit, poft quartum menfem reddit tempore uerno, Varro. Capra pariunt 8 quaternos, fed raròadmodum. Ferune quinque menfibus ut oures. Pinguedine fterilefcunt. Trimæ minus utiliter generant, $\mathcal{Q}$ in fenecta, - nec ultra quadriennium, Plinius. Parit autem, fi eft generola proles, frequenter duos, nónunquam trigeminos. Peflima eft fortura cum matres binæ, ternos hœdos efficiüt, Columella, Capræ \& oues (ut $\&$ reliqua fócurndiora $\&$ multipara animalia)partus interdum monftrofos $æ$ dunt, Ariftot. Idem

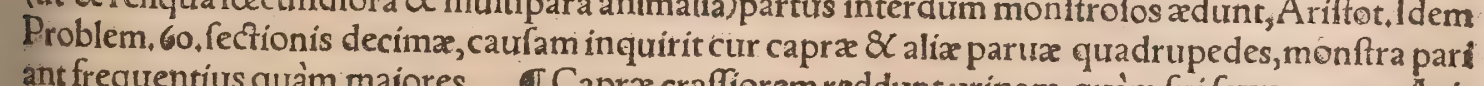
ant frequentius quàm maiores * TCapra craffiorem reddunt urinam, quàm fui fexus mares, Ari * ftot, TCapris 8 ouribus cur plurimum fit lactis proportione furi corporis, Ariftoteles quærit proble mate 6. fectionis 10. De menftruo caprarum fluxu, uide in Ouibus,

TOuibus quidem robuftiores funt capra, fed oues melius ualent, Ariftot. De emptione alitet atç de ouibus díco, quod capras fanas fanus nemo promittit:nunquam enim fine febri funt. Itaque ftipulantur paucis exceptis uerbis, ac Manilius fcriptum reliquit, fic: Illas capras hodie recte effe 86 bibere poffe, haberéǵ recte licere, hæc fpondés ne? Varro, Quid dicam de earum fanitate? quia nunquam funt fanx:nifi tamen illud unum, quod quædam remedia feripta oportet habere magis ftros pecoris, quibus utantur ad morbos quordam earum, ac uulneratum corpus, quod ufu frpe us. 
nit his, quod inter fe cornibus pügnant, atç in fpinofis locis pafcuntur, Varro, Graecis facrificatur ris moris erat, capras frigida aqua explorare nam fi guftare abnuiffent, concipiebant inde haud ua lere fatis, Cal. TAlyfion ficírca ftabula plantetur, gregib, ouium \& caprarum falubrem effe per. hibent, Plutarch.libroz. Sympor. De alyffo copiofé docui fupra, inter medicamenta fimplicia intra corpus fumenda ab ijs quos rabidus canis momordit. TCapras nunquam febri carere Archelaus author elt:ideọ̧́ fortaffis, quod anima his quàm ouibus ardentior, calidioresćp concubitus, Plin. Capra natura fua frigoris impatiens animal eft, utpote nunquam non naturaliter febriens: quód fi quando febris eam reliquerit, mox perit, Florentin. बCapr $\&$ alix quędam beftix, cum impen dentem peftem, tum tuero terręmotum, \& cơli falubritatem, $\&$ frugum fertilitatem prsefentiunt, Ae. lian. Nec capræ nec oures pefte inficientur, fi ex ciconia uéntriculo, aquia intrito, fingulis cochleare unum infuderis; Quintilï. . I Alia genera pecorum ctum peftilentia uexantur, prius morbo \& lan goribus macefcunt:folx capell $x$, quamuis opima atq hilares, fubito concidunt, uelut aliqua ruina gregatim profternantur. Id accideremaxime folet ubertate pabuli, Quamobrem ftatim cum unam, uel alteram peftis perculit, omnibus fanguis detrahendus. Nec tota dic pafcendar, fed medís quatum or horis intra fepta clatudend $x$. Sin alius langor infeltat, pabulo medicantur arundinis, \& albæ fpi: næ radicib, quas cum ferreis pilis diligenter contuderimus, admifcemus aquam pluuialem, folamć potandam pecori prabemurs. Quod fiea res agritudinem non depellit, uendenda funt pecora: uel fo negs id contingere poteft, ferro necanda, faliendaćs. Mox interpofito fpatio cenueniet alium gregem reparare: Nec tamê ante quàm peftilens tempus anni, ficue id fuít hyemis, uertatur ęftate: fiue autum. ni, uere mutetur, Columella . Otres \& caprà rediuos habent, pediculis uacant, Ariftot. In ouib. $8 x$ in capris ricini folum gignuntur,pediculi $\&$ pulices nulli,Plin. T Melampodis fama diuinatio nis artibus nota eft. A b hoc appellatur unum ellebori genus Melampodió. Aliqui paftorem eoden homine inueniffe tradunt, capras purgari pafto illo animaduertentem, datoós lacte earum fanaf́e Proetidas furentes, Plin, T Plutarchus(in quaetionib, rerum Rom.) capram prater catera ătis malia comitiali tẽtari morbo refert:proptereaḉ (uel propter fótorem, uel libidinem:) ưetéres facerdo tes ea uehementer, ut morbida, abftinuiffe: quoniam guftantib, attr tangentibus modo aliquid mor:

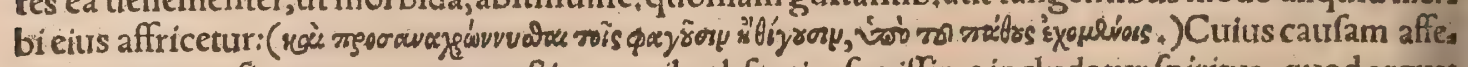
runt, pororum fiue meatuum anguftiam, quib, obfeptis, frepiffime includatur fpiritus, quod arguat uocis tenuitas. Nam qui eo affectionis genere tentantur, fimilem capella uocem xdunt, Cxl. 6. 9. In morbo comitiali cerebrum nimis humidum eft. Cognouerit autem hoc ipfưm quis maximé ex 0 , uibus, \& prafertim capris: hx enim frequentiffimè corripin:ntur; quod fi capur iplarum diffecueris, reperies cerebrum humidum $\&$ fudore refertum ac malè olens, Hippocrates in libro de morbo fa. cro. TOculos fuffufos capra, iunci puncto fanguine exonerat:caper rubi, Plin. Caliginem ocus lorum caprinum pecus probe curare fcit: Cum enim conturbatum oculum, 8 ' non probe affectum ad uidendum fentit, eum ad rubi fpinam $\&$ admouet, $\&$ referandum permittit:hæc ut pupugit, pitui ta ftatim euocat, ct nulla pupillax lafione facta, uidendi ufum recuperat. Hinc etiam homines hoc ct:

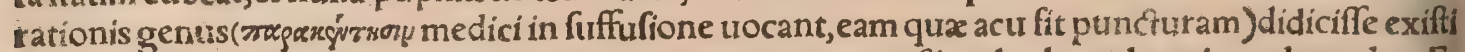
mantur, A clian. of Capras negant lippire, quoniam ex quafdam herbas edant: item dorcades. El ob id fimum earum cera circundatum noua luna deuorareiubent, Plin, 9 Capris quas aties cas primulgi dictæ mulrêre, cæcitas oboritur, Plin. ISi capra diftẽdatur aqua cutis, quod uitium Gra ci uocant hydropa, fub armo pellis leuriter incifa perniciofum tranfmittet humorem, tum factum uul nus pice liquida curetur, Columeila. TSefelis Maffilienfis femen capris,quadrupedibusḉ̧́ alịjs bi. bendum datur ut partus faciles reddat, Diofcorid. TCum efforta loca genitalia tumebunt, aut recund $x$ non refponderint, defruti fextarius: uel cum id defuerit, boni uin tantundem faucibus in: fundatur, \& naturalia cerato liquido repleantur, Columella. fI Idem cum de pelte dixiffet, qua to tos greges infeftat, fubdit:Cum uero fingulæ domo laborabunt, eadem remedia, qua etiam ouibus adhibebimus. Et ruirfus, Sed ne nunc fingula perfequar, ficurin ouillo pecore dictum eft, caprino me debimur.

\section{D.}

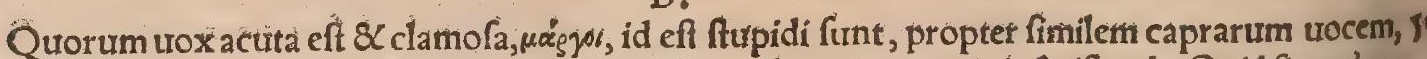

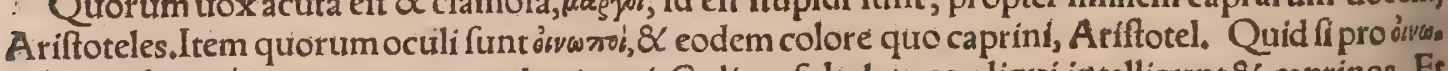
roilegas ácyarroi ? nam agopos oculos, inquit Calius, fubglaucos aliqui intelligunt $\&$ caprinos, Et A riftoteles iple libro quinto de generat. anim, ca.1.Oculi(inquit)quorundam animalium ruffi toto generefunt, aut cafí, nonnullorum caprini, utcaprarí generis : fic enim Gaza reddit hac Graca,

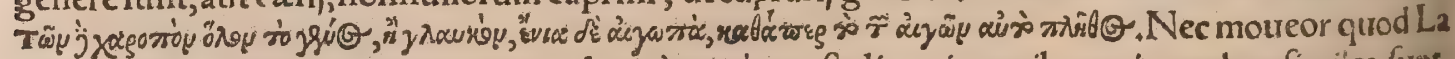
tinus interpres barbarus innominatus legit öswrob, tranftulit enim quibus uino colore fimiles funt, Apud Adamantium nihil reperio, quod huc faciat. Scio óvwrion in cenfu colorum effe: nam \& ouvente

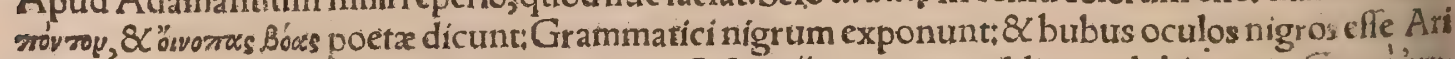
Aoteles loco iam citato fcribit. Vinea urina(ut A ctuarij interpres reddit, nec dubito quin Gracéosvroe róp legatur)hepatis colore exiftit, aut uini paulo quàm rubrum eft nigrioris, quale uel exigurum plus 6 rimæ aqua mixtum, adhuc rubicundo colore fpectatur. Vineo paffeus intenfior eft, maxime fimilis paffo quod ex uuia nigra confit; huiufmodi etiam cerafi fruchus color eft. Sed de nigris oculis A rifto 
téles proximè dixerat: \& nigricances colores non conueniunt capræ, qurum ad lucem noctu funden dam minimé idonei fint. TSolertiam caprarim Mutianus uifam fibi prodidit in ponte praienui; duabus obuins e diuerfo:cum circumacfum anguftia non caperent, nec reciprocationem longitud in exilitatem caca, torrente rapido minaciter fubterfluente, alteram decubuiffe, atç ita alteram pro culcatz fupergreffam, Plinius. TCapra indignum putans fe in extremo ouilli pecoris agmine in。 cedere, gregem quidem antegreditur, at ipfam hircus barbx fiducia antecedit; Aelianus. A Arun. coli quis apprehenfam ex grege unam trahat, cateræ ftupentes fpectant, Plinius. Idem eis accidere aiunt, fi qua earum eryngium momorderit, ut fuperius retuli, Sed confiderandum eff, an qui eryn. gio hoc attribuerunt, cryngi ( fic Graci aruncum uocant) nominis uicinitate decepti fint. Curiof 10 experiantur:ego quod ad eryngium, rationis nihil uideo:cryngo autem apprehenfa una ç cteras ftu pere minus mirum eft.

Caprarius, paffor, cuftos, exercitor $\not$ caprarum eft. Vruntur hac uoce Varro $\&$ Columella. Gra:

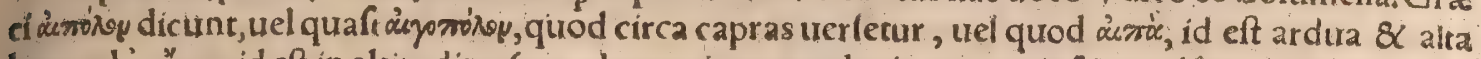

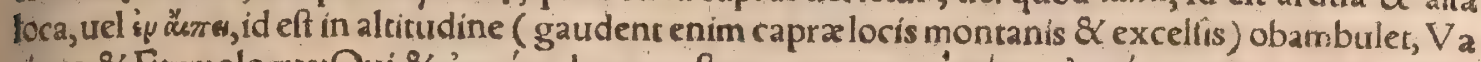

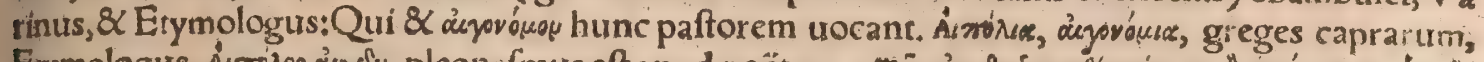

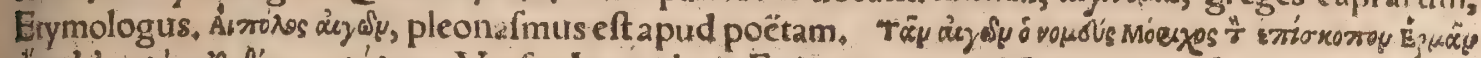

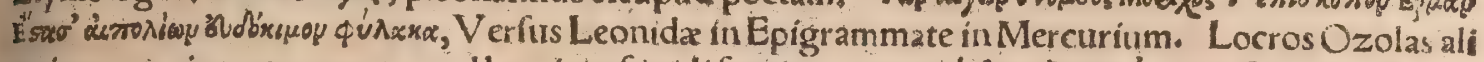

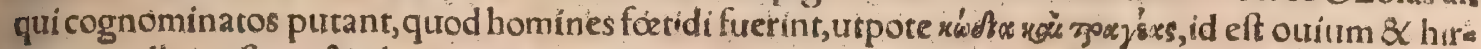
corum pelles geftare, \& plerung inter caprarumgreges uer fari folitos, Plutarchus in quaftionibus de rebus Gracorum. Tria tantum genera funt paftorum, qux dignitatem in Bucolicis apud poë tas habeant, bucolici, opitiones, \& omaium minime xuli, id eft caprarï, ut Ael. Donacus fcribic.

IMagiffer autem pecons acer, dur us, frenuus, laboris patientiffimus, alacer, atç audax effe de. bet, 8 qui per rupes, per folitudines, per uepres facile uadat, 8 non ut alterius generis paftores $\int_{e}$ quatur, fed plerunq̧ ur antecedat gregem. Qurare cum effe maxime ftrenuũ opus eft. Capella; duin dumeta pafcunt, capris cedưr, fubinde qua cedit compefci deber, ne procurrat. Sed placide, ac lence pabuletur, ut $\mathbb{Q}$ largi fit uberis, \& non ftrigofifimi corporis, Columelia. Caprarï leures $\mathfrak{X}$ ueloces finto, ut caprarum celeritatem affequantur, Geoponica Graca, GCanis cuitos eft pecoris, quod co comite indiget ad fe defendendũ in quo genere funt maximè oues, deinde capra, Varro. TCas prile, ftabulum eft ca prarum. Difficilius fe recolligentes à ferpencịm ictu, in caprifbus optimé con

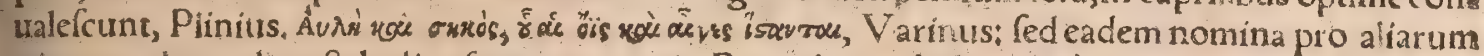
eviam quadrupedum fabu'is ufurpantur, ut in Boue dixi. I I fum uerò caprile uel naturali faxo, uel manu conftratum eligi debet:quoniam huic pecori nihil fiofternitur. Diligenş́́ paffor quotidie fabulum conuerrit:nec patitur ftercus; aut humorem confiftere, lutûnue fieri qua cunça funt cå pris inimica, Columella. Non tamen ita multa capræ, ut oues, una ftatione claudantur, quam luto \& ftercorecarere conuenier, Palladius, Stabulatur pects melius ad hybernos exortus fi fpectac, quod eft alfiofurn. Id utpleraq̧ la pide, aut refta fubfterni oporter, caprile quò minus fic uliginofum ac lutulentum. Foris cum eff pernoctandum,tem in eandem partem coeli, qux fpectent, fepra opor tet fubfterni uirguless, ne oblinantur, Varro. Et ftabula à uentis hyberno opponere Soli Ad me. 10 dium conuerfa dıem:cum frigidus olim lam cadit, extremoćs irrorat Aquarius anno, Vergilius,

बI Superius quadam explicata funt capite 3 qua huc referri poterant. In ouium hiftoria ctián nơ pauca dicemus, quax capris $\&$ ouibus conmunia funt. $\Phi$ Capræ natura mobiles $\&$ celeres funt; quamobrem paltores non pręficiunt eis ducem, Ariftot, TRelinquirur de numero, qui in gregi. bus eft, minor caprino, quàm un ouillo, quòd capra lafciux, \& qua difpergunt fe. Contra quód oues re congregant, \& condeniant in locum unum : itaque in agro Gallico greges plures potius faciunt, quàm magnos, quod in magnis cito exifunt peffilentix, qua ad perniciem eos perducunt. Satis mà gnum gregem putant effe circiter quinquagenas, quibus affentiri putant id, quod ufu uenit Gabe. rio equici Komano:is enim cum in fuburbano haberet agrum iugerum mille, $\&$ à caprario quoda qui adduxit capellas ad urbem, denarios fibi in dies fingulos dari audiffet, coégit mille caprarũ gre. - gem, fperans fe capturum de precdio in dies fingulos denarios mille. Tantum enim fefellit, ut breub omnes amiferit morbo: contra in Salentinis 8 in Cafinati ad centenas pafcunt, Varro. Melior fit grex, fi non eft ex collectis comparatus, fed ex confueris unà. Sed numerum gener is huius maio. tem, quàm centum capitum fub uno claulo non expedit habere, cum lanigera mille pariter commo deftabulentur. Atós ubi capræ primum comparantur, melius eft unum gregem tutum, quàm ex plu ribus particulacim mercari,ut nec in paftione leparatim lacinixe deducâtur, \& in caprili maiore con cordia quiete confiftant, Columella. Caprartim qua coitum non patiuntur ubera, paftores montis Oetæ urtica perfricant uchementer, ${ }_{3}$ ut dolor em infligant, itaç primum cruentũ humorem eliciunt mox purulentum, poftremo lac non minus, quàm ex ins, qux Venerem patiantur, Ariftoteles, Alt er tus feribit fe hoc uidiffe in mulieribus tum uiduis term uiiginibus, qua idem in fuis expertz mamils lis, lac abunde emiferint. Exanimalibus fibi quo plus prolis nafcatur, harum rerum curatores, \& paftores ouium, caprarum, \& equarum, gentalia cempore coirus, delibutis multo fale 8 nirro mas. nibus, perfricantiunde ijs uehementior coitus appetitio exoritur, Alij ca pipere, alij nitro perungũ $\hat{c}_{3}$ 
alip turtic $x$ frucfu: funt etiam quimyrtha \& nitro eadem inungant. Ex ea fane fricatione foeminx \& libidinofiores euadunt, \&C mares fuftinent, A elian. I De capris quod meliore femine ex, qua bis pariant, ex his potiffimum mares folent fummitti ad admiffuras: quidam etiam dant operam, ut ex infula Medica (Melo potius, ut Pollux habet:uide infra in hoedo cap.6.) capras habeant, quod ibi ma ximi ac pulcherrimi fieri exiftimantur hoedi, Varro. V tilitas ex pecore duplex, una eft tonfura, $a$ oures $\&$ capras detondent, aut uellunt;altera, qua latius patet, eft de lacte \& cafeo, quam fcriptores Graci feparatim tyropociam appellaruerunt, ac foripferunt de ea re permulta, Varro. ब $H_{x}$ quo que non cura nobis leuiore tuenda, (aliâs, Hac tuenda.) Nec minor ufús erit, quamuis Milefla ma gno. Vellera mutentur, Tyrios incocta rubores,(aliâs colores.) Denfior hinc foboles: hinclargico pialactis. Quò magis exhaufto fpumauerit ubere muletra, Lxta magis preffis manabunt ubera (flumina, Ald.)mammis. Nec minus interea barbas, incanaćs menta Cinyphn̆ tondent hirci, ft. tasç̧ comanteis V fum in caftrorum: 8 miferis uelamina nautis, Verg.libro 3. Georg. Serưius in cô

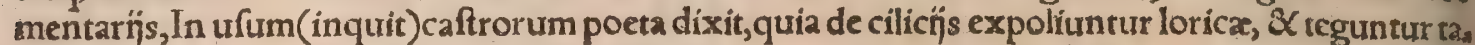
bulata turrium, ne iactis facibus ignis poffit adhaerere. Celfus ait retuliffe $V$ arronem, Cilicia fic apa pellari, quod ufus eorum in Cilicia ortus eft:fed de his iterum paulopof. T Capra, hoedo, lacie ö falubri,cafeo, pelle in caftrorum ufum, hominem iuuat. Vnde $\&$ hyemem continuare fub pellibus maiores dicebantur. (Sub pellibus, id eft in caftris ftatiuis. Cicero 4.Acad.Budaus, Militum enim ta bernacula apud antiquos pellibus conficiebantur. A pud Pollionem Trebellium legimus imperatori Claudio donatas pellium tentoriarum decurias triginta: Vide plura apud Calium 27.14.) His etiam nautæ utebantur: uilis enim aquam pluuiam rệciunt. Cinyphix capelix olim in pretio erant, quia maiores menfe quinto pariunt. In quibufdam lactis magna ubertas. Ex hís hordi lactentes efuri funt optimi,Platina, Illic iniufix ueniunt ad mulctra capella, Horat, in Epodis, Butyrumá borre no minatur, è cuius laçe copiofiffimum confit, ut miretur Diofcoridem Galenus, quod ex caprino et on uillo confici lacfe dixerit: ex caprino tamen fieri folere teftis eft Plin. Hermol. Pinguiffimum eft lae bubulum, ouillum uero ac caprinum, habent quidem \& ipfa pinguedinis quidpiam, fed multo minus, Galen. Caprinum lac tertia feré parte minus foccundum eft ad cafeum conficiendum bubulo, Ariftor. Bubulum cafeo fertilius eft quàm caprinum, ex eadem menfura pené altero tanto,Plin.Cum fal capris datur ante partum, multo lactis prouentu uigebunt, Albertus.

- Velabrenfes cafei diçi funt caprini, quod fumo apud Romanos in Velabro condirentur. Nó quencunç focum, nec fumum cafeus omnem, Sed Velabrenfem qui bibit,ipfe fapit, Martial, Et ca prarum gregibus fua laus eft, Agrigenti maximè, eam augente gratiam fumo, qualis in ipfa urbecó ficitur, cunctis praferendus. Nam Galliarum fapor medicamentium obtinet, Plin. Cafeum Sicua lum lulius Pollux meminit \& A riftoteles, ex ouillo \& caprino mixtum laçe: quod hodiéç fitubi utriufos copia habetur. Hunc A thenaus præferri putat omnibus, utic poft Achaicum ex oppido Tromilia, unde Tromilicus dicatur, \& à Simonide Stromilius, ex caprino lacte, Hermol. filn Pli nio legendum fit epityrum, an caprarum, in mentione cafei libro 11 . controuerfum diu fuit:Ipfe non epityrum (uerba funt Hermolai)fed caprarum lego:non quia epityrum oliuę fractx genus fit, ut qui dam putant:quandoquidem oliux genus illud pityrum $\&$ pityrida, non epityrum uocari confat: Sedilla ratione potius, quod nifi, caprarum gregib, fua laus eft, in recenti maximè eam augente fu. mo gratiam: \& reliqua, fic legamus, uix ftabit fenfus, nifi planè quis extor queat. Præterca cum de bubulo \& ouillo cafeo differuiffet author, maximé fequens erat, ut de caprino quoç; loqueretur: ne quia fit omnium feré deterrimus, improbari omnino itudicaretur. Adde quod infumari non alius ma

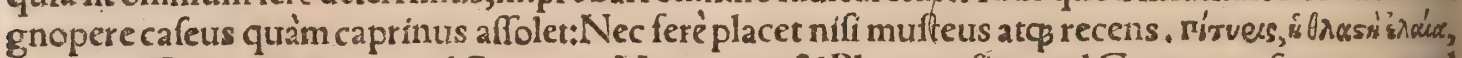
Varinus. Epityri mentio apud Catonem, Varronem, \& Plautum fit:apud Græcos nuf́quam, quod fciam, quod miror in compofitione uocis Graca, Caprini cafeoli praftantes in Rhatia Heluetica fiunt, pracipue(quod friam) ijs in locis qui circa thermas Fabarienfes montani funt:partim ex capri no mero, partim admixto bubulo lacte. Ex caprino 8 hircino feuo candelae apud nos fierifos lent. Caprino fanguine adamantem molliri Albertus fcribit, de quo in Hircini fanguinis men: tione dicam. Sanguíne caprino macula contactx abluuntur, Marcell. If Ad ferpentes fugandos quidam capræ ungulas urunt, Pallad. TCapræcornu uel pilis accenfis fugari, ferpentes dicunt, Plin. Caprina cornua conficiēdis arcubus idonea effe, apud Varinum legimus, in dictione taugus: Homerus Pandari arcum ex cornu capræ feræ concinnatum memorat, ut in Ibice dicam. Cornua caprarum tria circum arbuftum erecta infigito, acumine deorfum, alia parte furfum fpeçãte: $\&$ obs ruito, ut fumma cornuum pars paululum de terra promineat, quo pluuia delapfa deficendens, cor nua irriget. Hoc facto uitis ualde fertilis euadet, A fricanus in Geopon. Grac, lib.4. TFel capra in uafe aliquo in terra repofitum, capras ad fe allicere fer $\tilde{t}$, ac fi illa non parum inde iutếrur, Albert, Si pilos equi candidos producere uolueris, locum rafum felle caprino illine, A uthor obfcur.

§Caprina pellis, Cicero 1. de Nat.Et cincius uillofx tegmine capræ, Maro in Moreto. Peiles ca, prarum cum uillis fuis parant $\&$ expoliunt pelliones, quibus ueftitur uulgur prafertim muliertum, in Sueuia pracipuè, aduerfus iniuriam frigoris, Quamobrem $\&$ infantibus inde fiunt tunicax . Pel= les à mercatoribus rudes petuntur ex montanis Sabaudiæ locis circa Geneuam. A ptze funt pellicnखె operis, ex teneris rantum hor dis $\&$ capellis, quales uerno tempore mactantur, atate duorum plus mi 
nusंmenfurm:Vfurpant etiam ex illis qua ftatim à partư moriứtur, ut ouiư quog̣. Caprę pellis apưd

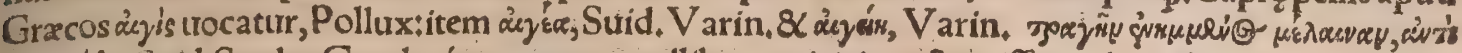

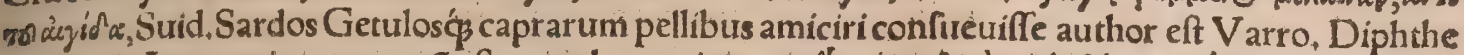

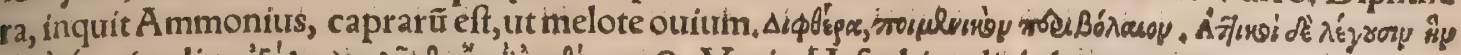


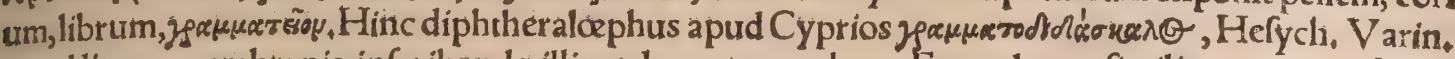
quod literas membranis infcribendo illinat dum pueros docet. Etymologus fimiliter exponit, $\&$ ad,

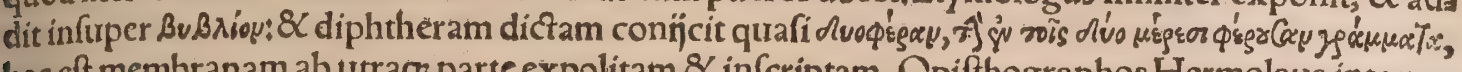
hoc eft membranam ab tutraç parte expolitam $\&$ infcriptam. Opifthographos Hermolaus inter pre tatur, quoniam utraqg pagina fcripti effent, aduerfa \& auerfa, minutis liceris $\&$ lituris pleni, ócerér

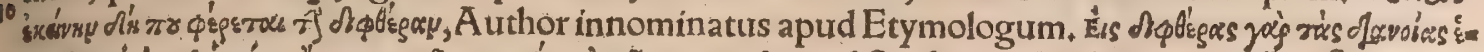

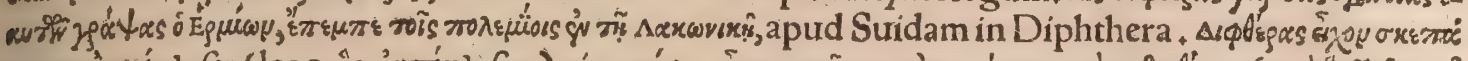

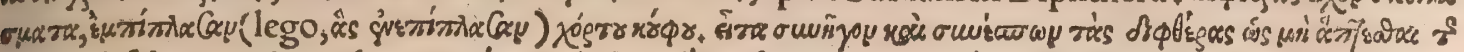

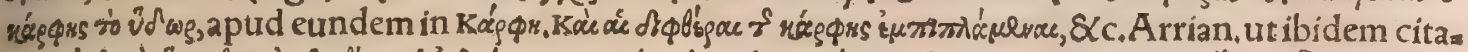

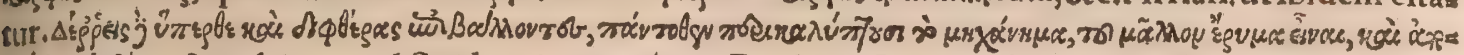
x chinas quafdam fuiffe fcribit, bubulis corịs intectas, quas perticis quibufdam fupra, fe geftabantmi

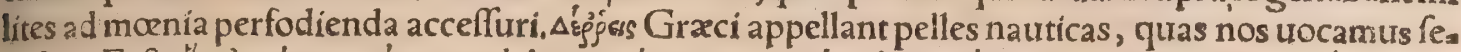

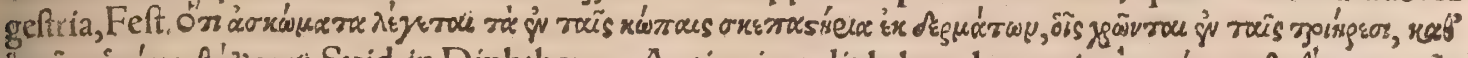

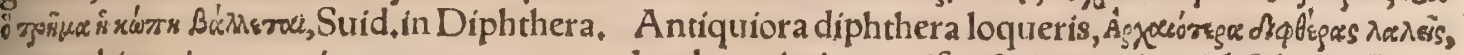
prouerbium in cos qui nugas narrant, aut de rebus nimium prifcis 2 iampridem obfoletis. Aiunt enim diphtheram pellem fuiffe cius capræ, quæ Iouem lactârit, in qua creditum eft antiquitus, illum

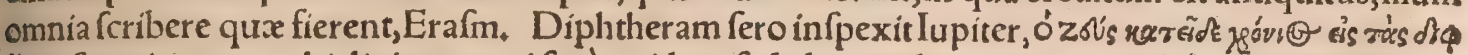
Ágass, fenarius prouerbialis in eos qui ferò quidem, fed aliquando tamen pro malefactis dant poenas,

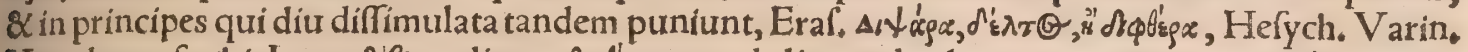
Herodotus fcribit lones Bibrous dicere of $\phi \theta_{\varepsilon}^{\prime}$ ess, quod aliquando ob penuriam papyri, pellib, uteren. tur, tum caprinis tum ouillis. Vel ut Calius citat, Herodotus fcribithircinas pelles \& ouillas biblos stiam dictos ueteribus, quod papyri uicem impleuerint quandogs. Citat etiam Pollux hunc locum in fine libri 8.8 addit diphtheras alio nomine ir/sses uocari:qux dictio cum alibi, quod fciam, non

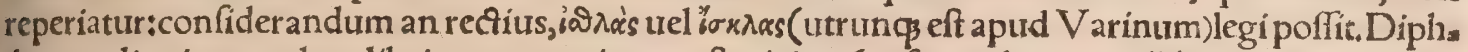
theram aliquioperculum libri exponunt:item paftoricium(ut fupra dixi)ex pellib,indumentum, đd quidam uocantrhenonem, fagum pelliceum. Scorta ueteres, pelles nominabant, unde penula fcor=

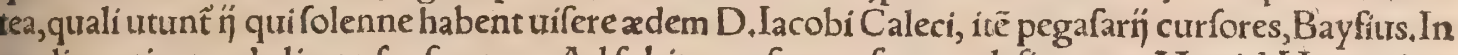
grediare uiam coelo licet ufa̧̧ fereno, Ad fubitas nufquam fcortea defit aquas, Martial, Hanc etiam recté puto Gracé diphtheran appellari. Rhenonem Grammatici quidam exponunt ueftem pellice. am, dictam quod calidos teneat renes; fiue quía jovós pellis dicitur, fiure quod Rhenani populi ca pe: culiariter utantur:Nam Cæfar lib.6.bel, Gall,fcribit, Germanos uti paruis rhenonum tegumentís. Sed hos Grammaticos Græece nef́ciulfe apparet:omnino enim rhenones ab ouibus dicuntur, quas

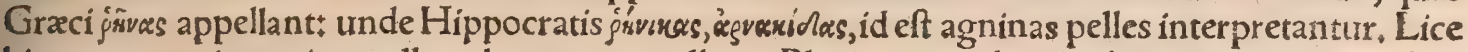
bit tamen caprinas etiam pelles, thenones appellare. Plurima enim his dubus pecorum generibus

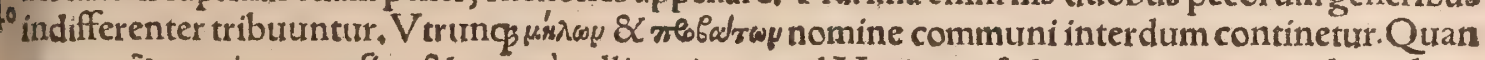
quam $\mu \tilde{n} \lambda x$ potius oures fint, \& $\mu$ riwzi pellis ouina:apud Varinum, fed etiam caprina apud eundem. Hefychius diphtheram exponit:Suidas non integram pellem aut ueftem, fed zonam pelliceam $\mu$ se

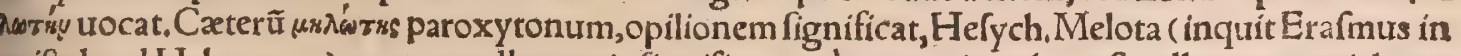
epiftola ad Hebr.ca.II.) non tam pellem ouis fignificat, quàm exuruium: hoc eft pellem corpori detra= ctam unà cum lana. Legímus item Daunïs ucl Calabris in more fuifte, pellibus incubare, quas melo tas dicunt, id eft ouillas, in Podalirï fepulchro:fićás per quietem oraculis inftrui. Qui Amphiarao fa crificant, facris peractis, arietis pellem fubfternebant, atç ita dormicbant captantes fomnia, ut aur thor eft Paufanias:ad quod allufit Vergil,ita de Latino canens libro 7. Aeneid. Pellibus incuburit

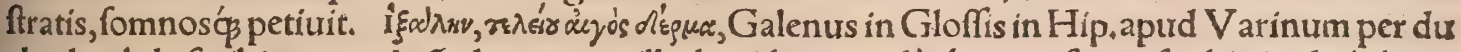
plex lambda fcribitur, quod nó placet:ut ne illud quidem quod wox́is sy per figma fcribit in diphthera

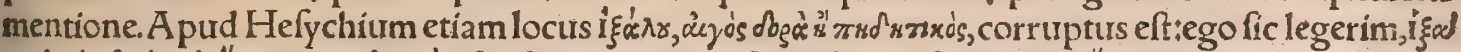

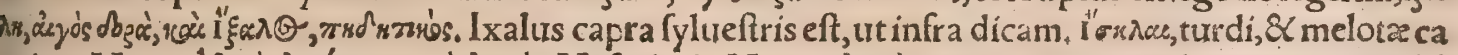

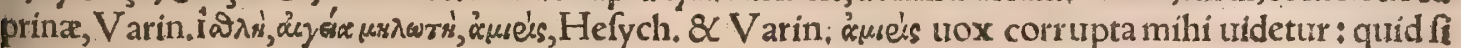

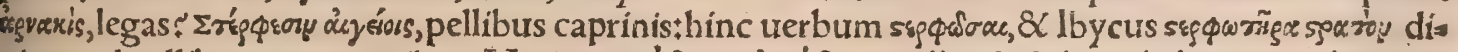
xit,quod pellibus utantur milites, Varinus, Mćdà $\lambda$ ràs $\mu$ ća

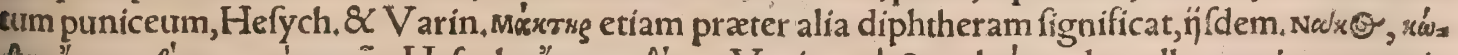

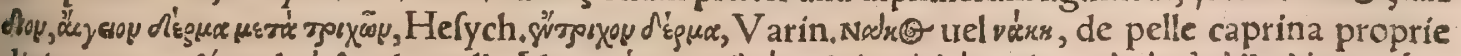

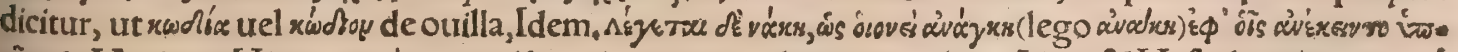

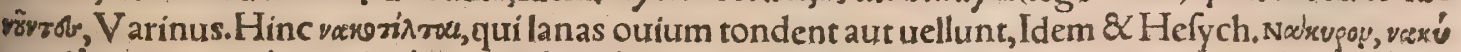

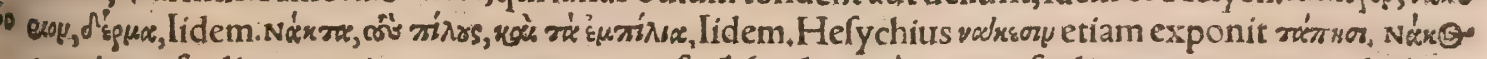
tum in mafculino, tum in neutro genere profert, (melius valkws in mafculino genere primæ declina 


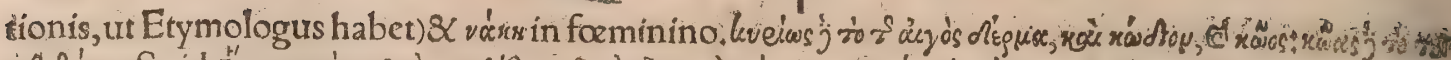

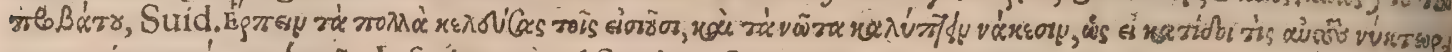

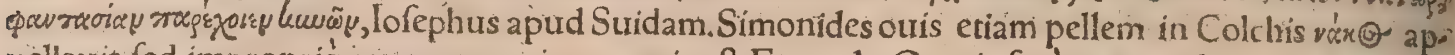
pellauit, fed improprié, caprarum cnim proprie eft; Etymol. Omnia feréopera ex lana, nacca dicun tur à Græcis, Feft. Hæc uox cum fua fignificatione ad yóxza magis quàm vóx $\theta$ aut vósxy, pertinere

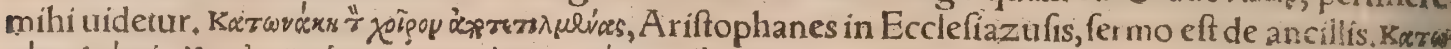

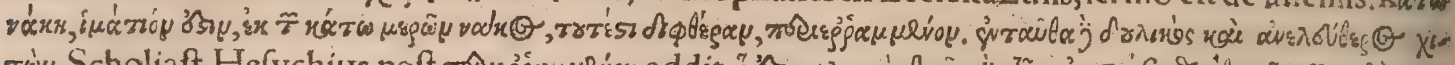

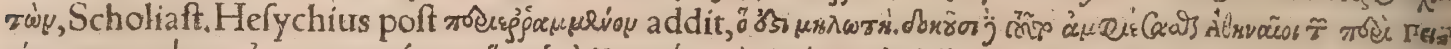

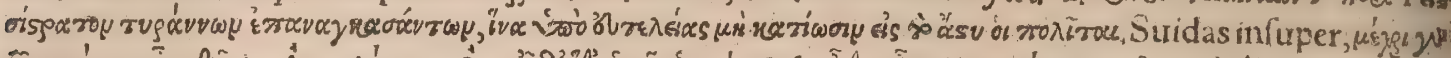

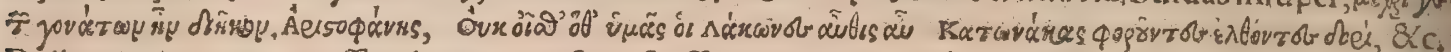
Pollux catonacam craffam laneam ueftem fuiffe ait, cuius oræ vón rit, Sicyonijs olim in ufu, tyrannide preffis: \& A thenis fub Pififtratidis, ut puderet eos urbem intra

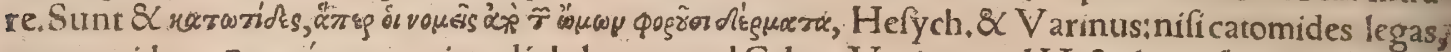

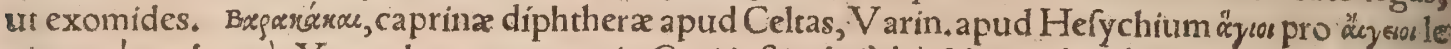

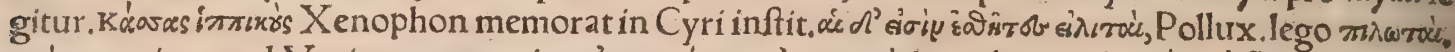

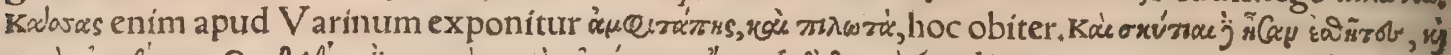

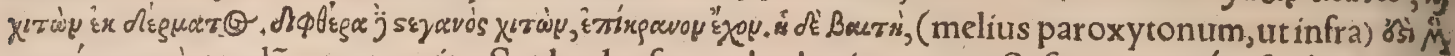

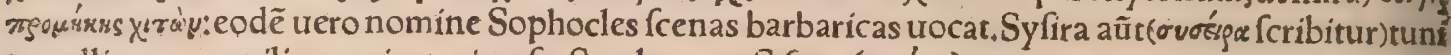
ca pellicea,cum pilis, manicata, in ufu Scytharum. Sifyra (orógex)uero, tegumentum ex diphthera. Ariftophanes, Ëu т⿻𨈑㇒́

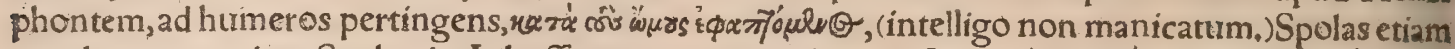

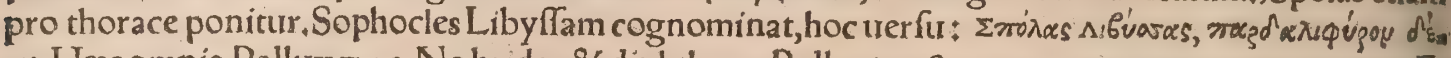
९os, Hæc omnia Pollux 7.15. Ne bridas $\&$ diphtheras Pollux 4+18.cum tragico apparatu numerat, Er

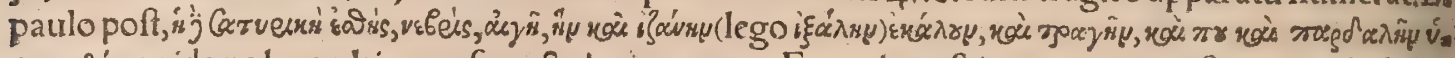

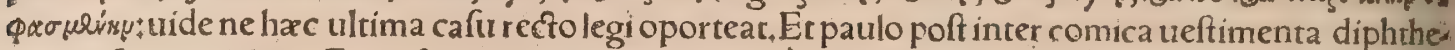

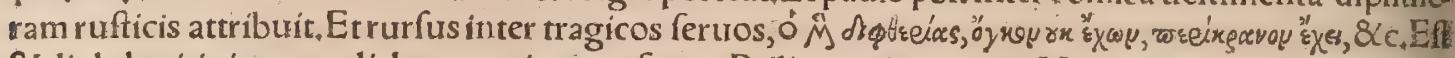
\& diphtheritis inter muliebres tragicas perfonas. Pellis caprinæ, inquit $V$ arro, apud antiquos quop Gracos ufum fuiffe apparet, quód in tragodijs fenes ab hac pelle uocantur diphtheria: $\mathcal{X}$ in comoes dịs qui in ruftico opere morantur, ut apud Cacilium in Hypobolimæo habet adolefcẽs, a pud Teren tium in Heautontimorumeno fenex. De fifyra, fifyrna, \& fify, ueftimentis ex pellibus caprinis fiue cum pilis, fue abfag, illis, multa legimus apud Varinum, Etymologum, \& alios qua breuitatis caufa pratereo. Bóctay, Varinus exponit melotam; diphtheram, fifyram. Bætan enim (inquic) nocant te:

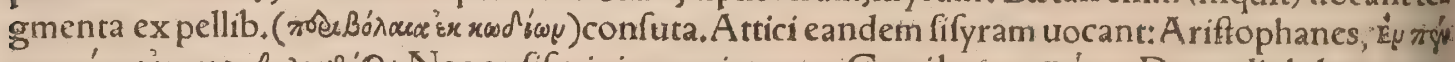

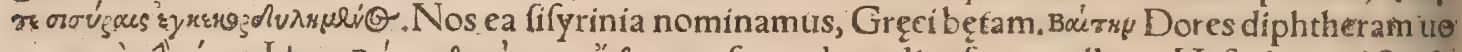

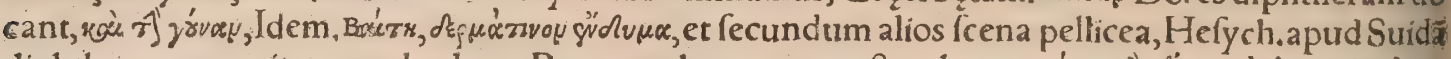

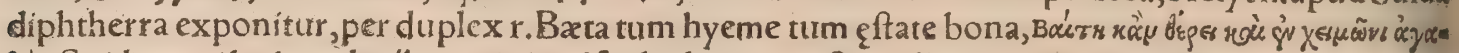

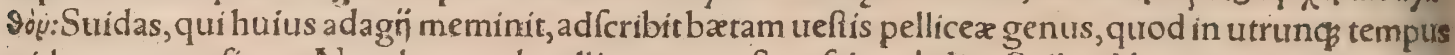
uideatur appofitum. Nam hyeme depellit uentos, eftate folem. Iulius Pollux lib. 7. meminit tunicam fuiffe pralongam, qux toterm contegeret corpus. Conuenit igitur de re ad multa ufui futura, Erafo Sophron in Mimis muliebribus rufticorum diphtheras, bretas nuncupauit, Follux lib. 10. ca.45. Et 4

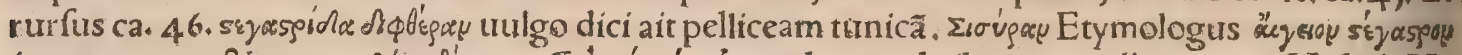

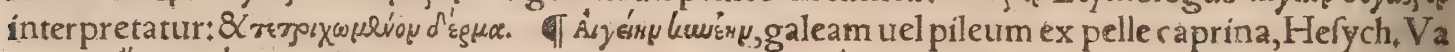

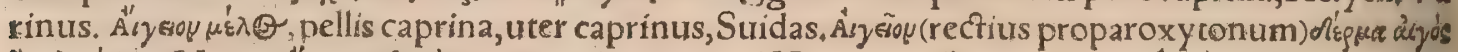

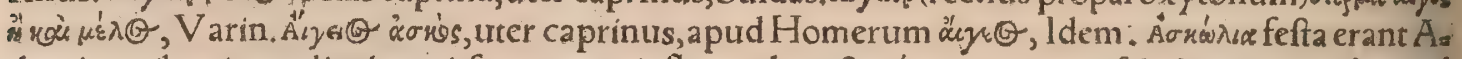

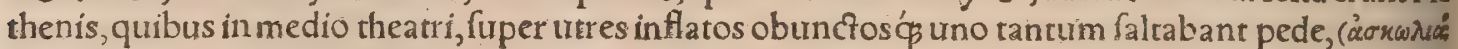

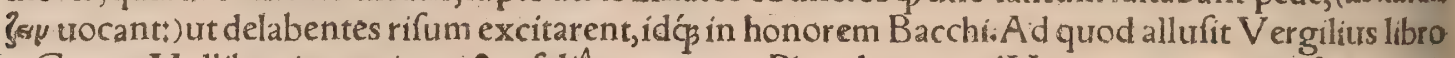
2. Georg. Mollibus in pratis unctos faliêre per utres. Plura lege apudV arinum, qui utres iftos capria nos fuiffe fribit. TLadani fruticem effe dicunt in Carmania quoqs, colligićs ut gummi incifo cor

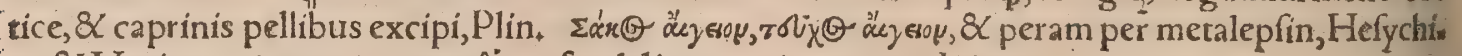

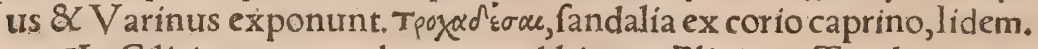

In Cilicia capræ tondentur, ut alibi oues, Plinius. Tondentur capræ, quod magnis uillis funt, in magna parte Phrygia: unde cilicia, \& catera eius generis fieri folent. Sed quod primum ea tonfu ra in Cilicia fit inftittrta, nomen id Cilicas adieciffe dicũt, $t_{3}$ arro. Aeneas Syluius zambelottum urls go diçum è caprarum pilis in Cypro fieri fcribit. Lana merhazi, eft lana capræfubtiliffima, ex qua fiunt zambeloti, \& alia uellera fubrilia, Andreas Bellunenfis. Mathahaze, pannus ex pilis capr $x, \nabla e$ tus expofitio in A uicennam. Mefha, pannus contextus ex pilis afinorum \& $\alpha$ caprarum; $\&$ interduna ex folis caprinis: Ex hoc enim rudis pannigenere qui deferta habitant Arabes, tentoria et faccos fibi conficiunt, Andreas Bellun. Tonfis caprarum uillis in A frica nautæ rudentes parant. Capra pilos miniftrat ad ufum nauticũ $\&$ ad bellica tormẽta, $\&$ fabrilia uafa, V arro. Caprini pili neceffarī funt, quum ad funes conficiendos, \& faccos, aliaćs his fimilima:tum uel maximé ad rudentes nauticos; quum neç rumpantur facile, nec naturaliter computrefcant, nifi admodum negligantur a Florenti- 


\section{De Capra. E. F. Lib. I. $28 \mathrm{~s}$}

nus. Arabum Scenitarum tentoria cilicina funt: ita nuncupant uelamenta é caprarum pilis textaj Solinus,

q Caprinum \& ouillư ftercus feduló conferuato, Cato. Qutidam hominis fimum $q$ fit acerrimū,

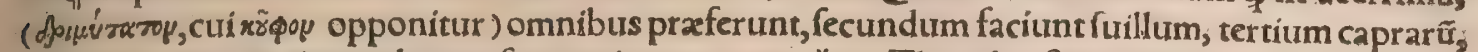
quartum ouium, quintum boum, fextum iumentorum,ővw, Theophraftus interprete Gaza; Huma ni fimi mentionem ad ftercorandum (quamuis noftrates eo utuntur) alï authores, quod nunc me. minerim, non faciunt. Afininum uero in fimili comparatione diuerforum fími generum, Palladius prxfert, \& Plinius idem ab aliquibus praferri fcribit. Facile autem fuit apud Gręcos hominis legere proafini, uel contrà. nam genitiưm ab afino frribuntärs, $a b$ homine äper cum nota abbreuiationis: - Obinci poteft, non poffelegiows, id eft afini,apud Theophraftum : quoniam fexto $\&$ ultimo loco afini ni meminerit. Refpondeo, Gazam non afinorum eo in loco, fed iumentorum uertiffe, imitatum fcili cetPlinium \& Palladium: \& quanquam afini quoq iumentorum nomine ueniant, hic tamen iumen

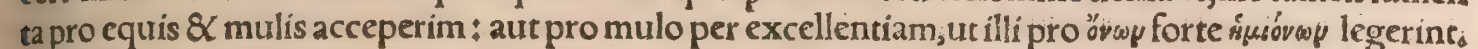
Nam de afinino \& equíno Plinius fuis tractat nominibus, de muli fimo non item, Stercuis afinorum primum eft, maximè hortis, deinde ouillum, \& caprinum, \& iumentorum, porcinum uerò peffịmû, cineres optimi, Palladius. Quidam bubulo iumentorum fimum præferunt, ouillumó́ caprino: omm nibus uerò afininum, quoniam lentiffimé mandant. E contrario ufus aduerfus utrun ç pronunciat; Plinius. Et alibi, Aliqui columbaria præferunt: proximum deinde caprarum eft; ab hoc ouíum, de: inde boum, nouiffimum iumentorum, TA Adeó́g, nihil omifit cura, ut carmine quoçs comprehen

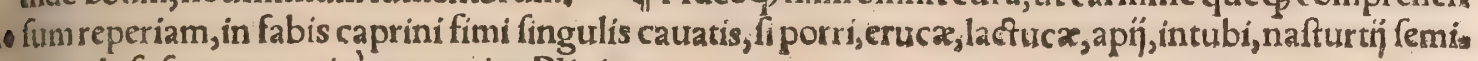
na inclufa ferantur, miréprouenire, Plinius,

TVtuitulicarnes habent ad conficiendum perfectis bobus pręttantiores, fic hodi capris. Capra nanģ temperamento, minus quàm bos, eft ficca:fi tamen homini \& fui comparetur, mulcum fupe. rat,Galenus libro 3, de aliment, facult.cap.1. Et proximé poft, Caprina prater fuccum uitiofum acri moniam etiam habet. Et ruifus, Aeftate prima ac media praftantiores funt capra, cum fcilicer fruti. cun germina, quibus uefci folent, abundant. Hodi(inquit Symeon Sethi) fi fex menfes excedant, capellæ iam urocantur. Capræ $\&$ hirci plurium annorum, cencoctu difficiles $\&$ mali fucci funt. Car nes caprinæ utiles funt patientibus puftulas $\&$ bothor, fi praparentur cum uino rubeo dulci. Hod o uocantur ufq 3 ad fex menfes, \& annales poft annum, \& duorum annorum poft biennium; cò dete. riores, quo maiores natu, Elluchafem author Tacuinorum. Capella atç hirci foetidi carnem ne de. guftato, Platina. Caprarum \& hircorum iecora fugito, ne m epulepfiam incurras, Idem. Caprina caro plurimum alit. Quamobrem Clitomachus Carthaginenfis noux Arademiax fectator pręclartis, Thebanum quendam athletam hac carne uefcentem, reliquos fua ataris athletas uiribus fuperafie foribit. Validus enim huius carnis fuccus $\&$ tenax eft, unde multum temporis in corporibus duras re potef: objiciebatur tamen ei fudoris graueolentia. At fuillx $\&$ agninæ carnes, cum in corporibus incoctæ manent, facillimé corrumpuntur propter pinguitudinem, Aihenæus. Caprinæ carnes que cunque bubulis infunt mala (hoc eft concoctu difficiles effe, $\&$ atribiliarias affectiones exacerbare) omnia habent, \& flatuofiores funt, \& ruchus ampliores faciunt, \& choleram generant. Sunt autem odor atiffim $x$, folid $x$ ac iucundiffim $x$, optim $x, 8<$ percosta, $\&$ frigid $x$. Verum iniucundiffim $x, \&$ graueolentes ac dura, peffimæ; imò etiam recentes. Cptimæ uerò funt æftatis tempore, peffiniæ au. tumno, Hippocrates in libro de uictus ratione in.morbis acutis. Mulier cui ulceratus eft uterus, ab. ftineat carnibus porcinis, bubulis, \& caprinis, edat autem panes, Hippocrates de morbís muliebrib Rafis ad Almanforem caprinam carnem magis quàm arietum (ouilam) reffigerare fcribit, $\&$ paru nutrire. Homines ruftici uentres caprarum fanguine earum unà cum adipe implent; uti Homerus ait folitos proces Penelopes, Galenus de fimpl.10,4.

T Aluum minus tentat caprinum lac:quoniam pecus hoc aftringẽtibus pabulis, quercu, lentifco \&olearyinis frondibus, \& terebintho magna ex parte uefcitur: indeftomacho accommodarifimum reddi folet, Diofcorides. Maximé alit quodcunç̧ humanum, mox caprinum : unde fortaffis'́fabulae louem ita nutriturm dixere. Idem ftomacho accommodatiffimum eft : quoniam capræ fronde magis quàm herba uefcuntur. Lac fchifton quomodo fiat ex caprino laćce aduerfus morbos diuerfos com mendatum, fequenti capite Plinif uerbis docebo. Multo minus pinguedinis habet quàm bubulum Galen. Si capra aut alterius animalis fcammoniam aut tithymallum depafti, lac cibi loco quis fum. prerit, omnino aluus illi fluet, Idem, Et in libro de boni $8 \mathrm{mali}$ fucci cibis $\mathrm{ca}_{+} 6$. Caprini(inquit) lactis ufus, frequens apud nos eft, apud alios bubuli. Caprinum inter cæetera lactis genera moderate fe ha= bet, cum non admodum pingue craffum ḉ fit, ob idç̧ medium quoģ effe cenfetur, quod in corporis bis noftris praftat, 8 c, fed cum inter cæera animantium genera capellæ mediocritatem adepta lint, inter fe tamen inuricem collatx, alio quàm diximus modo differre uidentur. Neqg enim harum partra dif́crimina funt $a b$ atate, à paftionibus, ab anni tempore ab eo ipfo fpatio quo à partu ædito cliftant: qux abunde tertio de facultate alimentorum libro diximus. Nunc uero id tantum referre fit fatis,caprinum lac fine melle fumptum periculofum effe: plerif $q_{3}$ enim qui purum illud hauferunt, coactum elt in uentriculo in fpeciem cafei, qued quidem cum accidit, mirum eft quàm aggrauet hẹ 
minem ac ftrangulet. Eam ob caufam lac ubi fumunt nonnulli, ne in uentriculo coaguletur, mellits aqux, \& falis nonnihil admifcent, Hæc Galen. Lac muliebre temperatiffimum eft, mox caprillum, hinc afininum ouillumós, poftremó uaccinum, Aegineta. Caprinum lac fubftantia temperatum, purgando quidem bubulo imbecillius ad reliqua uero fatis idoneum, \& 2 nutriendo non parum efficax. Quod praftat, Caprx. Poft? Ouis.Inde? Bouis,Baptift,Fiera.Mantuan,de lacte. Lac oma nium rerum, quas cibi caufa capimus, liquentium, maximé alibile eft, $\&$ id ouillum, inde caprinum, Quod autem maximè perpurger eft equinum, tum afininum, deinde bubulum, rum caprinum, $V_{a x}$ ro. - Cafei maxími cibi funt bubuli, \& qui difficillimè tranfeãt fumpti:fecundo ouilli: minimi ci bi, \& qui facillimè deỉ ciantur, caprini. Capræ Scyriæ lac augent, pręcipuè autem cafei(nimirum cx lacte earum)maximè commodi funt, Hippocr de morbis muliebr.

G.

TlMilia remediorum ex capra demonftrantur, ficut apparebit:quod quidem miror, cum felbri ne. getur carere. Amplior potentia fer is eiufdem generis, quod numerofiffimum effe diximus, Plin. Er alibi de anfere locutus, fubdit:Mulra pręterea remedia funt ex anfere, quod miror æqué quàm in $\mathrm{ca}$ pris: Nançanfer coruusćs, ab ętate in autumnum morbo conflictari dicuntur. đDifficilius fe re colligentes à ferpentium ictu, in caprilibus optimé conualefcunt, Plin. Omnium quadrupedum mor bis capram folidam cum corio \& ranam rubetam difcoctas, mederi reperimus, Plin. Lacerta uriridis uiux dextrum oculum effoffum mox,cum capite fuo decifo, in pellicula caprina, cötra quar tanas adalligari iubẽt magi,Plin. đCaprini corñ cinis ex olco illitus perniones primé abolet,Mar. cel. Iniurias è calceatu ex oleo corí caprini cinis fanat, Plin. Pelliculæ caprinæ ramenta cum pu mice trita, acetoćs permixta, exanthematis profunt, Marcel. Si foeminx fanguis ex narib. nimie dẹ fluat, mamilla eius uinciantur corrigio caprino, Marcell. Corium caprinum cum fuo pilo décon ctum, firco eporo, aluum fiftit, Plin.

of Pili caprini ufti, fluxus omnes fedant, A efculap. Veft $\&$ aceto permixti, fanguinem denarib, fluentem reprimunt, Sext, Combufti adiecta pice $\&$ aceto, inferti naribus cito fanguinem fiftunt, Marcel. Eodem modo in naribus appofiti, lethargicos excitant, Sext. Caprini cornus nidor aut pio lorum, lethargicos excitat,Plin. Finum caprarum in mulfo, calculos expellit: piliquog caprinicis nis, Plin. Combufti tritiớ \& in potione dati,ftranguriofos potenter emendant, Marcel. Caprarĩ cornu uel pilis accenfis fugari ferpentes dicunt; cineremás cor um potum uel illitum, contra ictus uạ lere,Plinius.

TComitialibus dantur carnes caprinx in rogo hominis toft $x$, ut uolunt magi, Plin. Caprina caro qua fuper focum, uel rogum hominis mortui af̣fațur, fumpta, caducis remedium eft, Sext. Lufcios Ios, quos Graci nyçalopas dicunt, quidam inaffaticaprini iecinoris fanie inungunt, aut felle capre; carnes $\dot{\beta}_{3}$ eas uelci, \& dum coquantur, cculos uaporari præcipiunt: id quoq̧ referre arbitrantur, fi rutili coloris fuerint, Plin. Ego hic non fimpliciter capra carnem lufciofis edendam intelligo, fed ie coris carnem:etfi ea minus proprie fic adpelletur, Graeci in uifceribus parenchyma uocant. Caprin noiure cantharides expugnari tradunt Graci Plin.

Drufus tribunus plebis traditur caprinum fanguinem bibiffe, cum pallore $\&$ inuidia ueneni fibi dati infimulare Q.Cepionem inimicum uellet,Plin. De curiofo ufu caprini hircinió̧ fanguinis ad abfreffus cócoquendos, in taurino fanguine Galeni uerba retuli. Sanguine caprino macula conta efxabluuntur, Marcel, Diof corides leporino calente ephelidas \& lentigines illini iubet. Caprinus fanguis contra toxicum bibitur, Diof corid. (qui cum uino bibendum monet) \& Galenus libro 2 . de antid. Venenum potus extinguit, Aef culap. Decocius cum medulla contra toxica urenena fumitur, Plin. Hircinum aut caprinum fanguinem aliqui terræ Lemnia mifceri folitum fcribunt: fed Galen nus id fuo tempore factum negat. Commendatur ad antidota hoedinus quoç fanguis à Diofcoride, Potus humores remediat, Sextus; forte per humores, uentris fluores intelligit: Quanquam Plinits fanguinem caprinum, uel medullam, uel iecur, aluum foltere fribit : fed maior apud me Galeni \& Diofcoridis authoritas eft, quorum hîc uerba adýciam:Sanguis hirci, uel capra, inteftinorum tormi na $8 \mathrm{~L}$ alui fluores fiftit, in quem ufum frixus in fartagine ftatim fumitur, Diofror. Sanguinem capra. rum hydropicis quidam cum melle exhibent:aliqui ad dyfenteriam eodem tofto $8 \mathrm{C}$ ad uentris fluxủ funt vifi: Videturós mihi quifpiam, craflam eius effentiam \& terream, cum caliditate exiccatoriam of re fufpicatus, ad hunc ufum perducfus, Galenus. Sanguis caprinus cum medulla, hydropicis auxilia rur:efficaciorem putant hircorum, utigg fi lentifco palcantur, Plin. Sanguis caprinus decoctus cum medulla dyfentericis fubuenit, Plin. Si fint tormina, fatis efferemedin in leporis coagulo poto é uis no tepido uel femel, ar bitrantur aliquitcautiores $\&$ fanguine caprino cum farina ordeacea $\&$ refin na uentrem illinunt, Plinius ubi de remedijs coeliacorum $\&$ dyfentericorum agit. Sanguinem ca。 prinum fi polentæ furfuribus, adiecta refina mífcueris, atç emplaftri modo ano uen trićs ad pofueris, pondus omne $\&$ libidinem deiectionis efficaciter reprimes, Marcel.Sextus non capra, fed capri fan guinem, cum refina $\&$ polline (malim polenta)mixtum, \& uentri fuperpofitum, torminofos fanare fribit. Sed an capra aut capri fit fanguis, parum refert, ut patet ex Galeni uerbis paulò ante pofitis. Inuenimus etian caprinum fanguinem renum calculos frangere, Marcel. Verg.de hoc plura in hir cino. Sanguis caprinus cum polenta impofitus, ani uitium omne perfanat, Marcel. Cateris uitîn 


\section{DeCapra. G. Lib. 1. 283}

redis(proxime de inflationibus eius dixerat)medetur fanguis caprinus cum polenta, Plin.

$\checkmark$ Adfringentior eft caprinus adeps (addunt aliqui, pafcuorum caufa, quamobrem dyfentericis datur, \& $\&$. ut infra dicetur, Diofcor. Boues $\&$ capra, $\&$ quacurnq̧ id genus cornigera, ob ficcitate adipem plurimum generant. Sed fiue adipem(feutm) fiue pinguedinem, totum oleof $\&$ pinguis fubitantix genus in animalibus appelles:non tamen licet citra mendacium adipem caprinuin humi= diorem effe dicere, quàm fuum, \& $c$. Caterum caprinum adipem in recto inteftino, aut in colo, potius quàm fuillum inịcimus: non quod acrimonias plus obtundat: fed quod ob craffitiem citius concrefeat, cum fuillus inftar olei defluat, Galenus de fimplicib. 11. 4. Et paulo poft:Hoedorum adeps(inquic)minus tum calidus tum ficcus eft, quàm caprarũ, fed $\&$ cupra= rum minus quàm hircorum. Et rurfus cum nonnullos aftringentia pro acribus dicere reprehendif fet, fubdit:Sed illi in uocabulis potius, quàm rebus ipfis hallucinari uidentur : 8 maximé illi quibus Graca lingua infureta eft, qualis eft Diofcorides A nazarbenfis, \&c. Hic enim cum air magis effe az ftrictorium adipem caprinum fuillo; fi quidem acriorem fignificare uelit per magis aftriciorium, ac cipimus fermonem ceu uerum:at fi illud, talem habentem qualitatem, qualem rhus, rheon, hypoci. fthis, balauftium, haud uerum effe fermonem dicemus, Hucufas Galen. Seurum capra adffringen: tius eft feuo boum, $R$ afis. Caprinus adeps datur utiliter his, qui cantharidum uenena hauferunt, Diofcor, Seutum caprinum cum cera, contra ictus ferpentium imponitur, Plin. Omni morfui $\&$ lae fioni fubuenit, A ef́culap. Feré omnis dolor corporis fi fine uulnere eft, recens melius fomentis di= fcutitur:uetus uritur, \& fupra uftum butyrum, uel caprinus inftillatur adeps, Columella in remedijs - boum. Et alibi, Suppuratio(inquit)in bubus ferro refcinditur : expreffus deinde finus ipfe, qui eam continebat, calida bubula urina eluitur:uel fi colluri ea pars nó poreft, lamina candenti feuum capri num aut bubulum inftillatur, Seuum caprinum perniones farcit, Plin. Cum calce ftrumas dif́cu tit, Plin. Adeps caprina cum calce fubacra $\&$ appofita, ftrumas ftatim diffoluit $\&$ fanat, Marcel. Ca prinum feuum admixta fandaracha ungues fcabros emendat, Plin. Ex fepo caprino admixta fanda racha cerotum, unguibus leprofis fuperpofitum, fine tormento fanat, Sext. Cantharides lichení ils litas cum fuccó taminix uux, \& feuo ouis uel capræ, prodeffe non dubium eft, Plin. Vlcera qua ferpunt, cohibet feutum cum cera:irem addira pice ac fulphure percurat,Idem. Manantia urerendo. rum ulcera fanat feurum caprinum cum melle rubió; fircco, Plin. In furunculis feuum bubulum cü fale ilinitur:aut fi dolor eft, intinçum oleo, liquefactum fine fale, fimilićs modo caprinum, Plinius. Adeps caprinus cum rofis mixtus, puftulas, qux in nocte grauefcunt, tollit, Aefculap. Hoc etiam aur ribus inftillatum furdos fanat, Idem. Of Comitialbus magi commendant feurm caprarum, cum felle taurino pari pondere decoctim, \& in folliculo fellis reconditum ita neterram attingat, biben= dum fub limine ex aqua, Plin, Zex farina ex uino rubro ad fcorpionum ictus tepida illinitur, tuffi cum caprino fetro aut butyro, Plin. Ius decocti caprini adipis, phrhificis in forbitionibus prodeft, Dio fcorid, Capræ feuo in pulte ex alica, \& phthifin $2 \times$ tuffim fanari, ucl recenti cum mulfoliquefacto, isa ut uncia in cyathum addatur, rutæéç ramo permifceatur, non pauci tradunt, Plin.Idem alibi rtrpica= pra feuo ex lacte phthificum liberatum fcribit, ut infra dicam. Ptifana cum adipe caprino cocta, tor minofis in declinatione conuenit, Marcel. Caprinus adeps decocfus cum polenta, rhoë $\&$ cafeo, dy fentericis datur, \& cum ptifanæfucco infunditur, Diofcor. $R$ afis ubi remedia ex capra defcribit, leo. to nis etiam feui(nifi interpres errauit, quod omnino fufpicor)mentionem immifcet, cum de leone tra. ctaffet ab initio libriillius de 60, animalibus, nec ullum tale ex eius feuo remediữ memoraftet: Sepü leonis, inquit,omnibus prefertur:ob hoc quum clyfter ex eo paratur cum aqua ordei toft : aut cum aqua farinæe tofta, \& fumach cocti( coctum) \& liquefactum cum cera, exulceratis inteftinis fummo: pereconducit. Seuum caprinum in forbitione aliqua inteftinorum uritris magnopere prodelt, ita uti protinus hauriatur frigida aqua,Plin. (Sexturs idem remedium hydropicis commendat, quod nó probo.) Seuo hirci aduerfus dylenteriam utuntur, in pane qui cinere cocžs fitłcapręà renibus maxi mé, ut per fe hauriatur, protinusḉs modicè frigidam forberi iubent. Aliqừ $\&$ in aqua decoctum fe. uum admixta polenta \& cymino, \& anetho, acetọ́́, Plín. A dipem caprinum de renibus fublatum; mifce cum polenta furfuribus, atçs adrice illic cyminum, \& anethum, $\&$ acetum, aquis portionibus, so atç ex aqua decoque, 8 colatum forbitionis more dy fenterico dato fumédum, mire celeriterós fub. uenies, Marcel. Helxine imponitur podagris cum caprino feuoceraćs Cypria, Plin. Seurum ( ca. pri, Albertus) cum ftercore caprarum coctum \& $\mathrm{Croco}_{\text {, }}$ ponitur (fricatur, Albertus) fuper podagrã, ut diffoluat(leniat, Albertus)dolorem, Rafis.

- Caprina medulla quar to loco poft certinam, uitulinam, 8 taurinam laudatur apud Diofcori: dem, poftrema eft ouilla. Laudatifima ceruína, inquit Plinius, mox uitulina, dein hircina \& capri. na. Vide fupra in Vitulina, ubi multa de medullis earumó̧ uiribus in generedixi. Sanguis capris nus decoctus cum medulla, contra toxica uenena fumitur, Plin. Idem remedium dyfentericis $\&$ hy dropicis prodeft, Idem. Er alibi cum ex caprino remedia quæadã docuifiet, fubdir, Nec abdicant fimur ex melle illitum epiphoris, contráç dolores medullā, item pulmonem leporis: ut dubitet aliquis le. 6o porinám ne an caprinam medullam accípiat:ego de caprina intelligo. Sanguis caprinus, trel mes dulla, uel iecur, aluũ foluit, Plin. Ego cötra fiftere potius dixerim, cum ficcandi modice $\&$ emplafticä ferł́faculcatem pleraģ omnes medulla habeant:Quamobrem ad dyfentericos etiá caprinz medullę 


\section{4

ufus eft, ut numc dicam.Quinetiam fanguinem caprinum, ahuum fiftere fupra dixi, idem de lecote mox confirmaturus, Sanguis caprinus decoctus cum medulla dy lentericis fubuenit, Plin. Sana guis caprinus cum medulla hydropicis auxiliatur:efficaciorem putant hircorum, utigg fi lentifico pa fcantur, Plinius.

TCornu caprinum dextrum in Athanafiam magnam, fic appellatam compofitionem apud lo: Mefuen requiritur:item in antidotorum defcriptionibus filin Serapionis $\& \mathrm{Hali}$, \& A uricennæ. A. pud Mefuen codiceş quidam uariam lectionem habent, Aliâs de cornibus cerui. Hanc reprelien: dunt monachi qui nuper in Mefuen fcripferunt, quoniam apud alios authores non habeatur.lo.Ma nardum quogg (fus Minerua) uituperant, qui fcripferit fuperftitiofè dextrum potius quàm finiftum cornu fumi: ipfi enim dextrum praferendum putant, fiue occulta nobis ratione illud praccellat, fiue quod pugnando magis exerceatur: \& alia multa multo rifu excipienda nugantur. Non ignoro ta= men ex cerui cornibus alios dextrum, alios finiftrum praferre, ut fuo loco dicetur, Caprarum cornu uel pilis accenfis fugarí ferpentes dicunt, cineremó corum potum uel illitum contra ictus ualere, Pli nius. Puluerem de cornu caprę, \& eíus lac cum origano, \& cum uini cyathis tribus, à ferpente mor fus bibat, urenenum excutiet, Sextus. Sed is confundit in unum remedium, quod Plinius triplex fecit, de cornu, de lacte, \& de cafeo capra: de cornu Plinï uerba iam retuli, de reliquts quogs mox fubiun. gam:uidẽtur etiam corrupta quæedam in Sexto, qux omitto, \& Pliní feruandam lectionem moneo. Sudores inhibet cornus caprini cinis èmyrteo oleo perunctis, Plin. Caprini cornus uel fimi cinis ex aceto illitus, fanguinem fiftit:hircind uero iecinoris diffecti fanies efficacior : Et cinis utriufos (uel cornus uel fimi caprini, ut hircini iecoris per parenthefin mentio inciderit) ex uino potus, uel nati bus exaceto illitus, Plin. Ad facrum ignem; Cornu caprinum in flamma uftulato, $\&$ cruftas qua: exurgunt excuties in uas nouum, donec confumatur:deinde conteres cum aceto fcillitico, $\&$ illinies facrum ignem, mirificè fanabitur, Sextus. Cornu caprinum capiti infirmi qui non dormit, fuppofi= tum, uigilias in fomnum conuertit,Sext. Capra cornu furfure mixto cum oleo myrtino, capillos fluentes retinet \& crefcere facit,Sext, Caprini cornus farina uel cinis, magiş́́s hírcini; addito nitro $\&$ tamaricis femine, $\mathcal{Q}$ butyro oleoó $\$$, prius capite rafo, mire continent ita fluentem capillum, Plin. Comitialem morbum deprehendit caprini cornus, uel ceruini ufti nidor, Plinius. Si caducus ueré ca ducus eft, caprinum cornu aduftum naribus fi fumplerit(fi ante nares eius teneatur.)mox cadet, $\mathrm{Se}_{\text {. }}$ xtus. Lethargicos excitat caprini cornus nidor, aut pilorum, Plin. Cornibus cerui \& caprę uftis ma ximè uturntur, ut $\&$ nos fape ufi fumus, tum ad candorem dentium, tum ad contrahendas mollitie fluidas gingiuas, Galenus.Cornu capræa ad albedinem uftum, dentes egregié abftergit, \& gingiuas corroborat, earum $q$ ́ tưrgentium dolorem reprimit, Âuicenna:item \& Rafis \& Ālbertus, qui dentes co confricandos fcribunt. Cornu capræ rafum in mel mixtum, $\&$ pifatum(contufum)medicatum(ex medicina malicia natum, ut Humelbergius exponit, ) uentris fluxum reprimit, Sextus. Caprino cornu fuffiri uuluam, utiliffimum putant, Plin. Ouiculæ aut capræ cornu tufum, $\mathcal{Q}$ ordeum toftum ac frefum oleo fubigito ac fuffito, Hippocrates in libro de morbis muliebribus, inter medicamenta muliebria diuerfa, \& ita confufa, ut de multis ad cuius facultatis titulum referri debeant dubitemus. Capræcornu, \& gallam, \& adipem fuillum, ac cedriam,fuffito, lbidem. Lotium caprinum cornu caprino inditum referuatur ad remedia quxdam, ut in lotij mentione dicam.

đ Capra ungulas ad ferpentes prohibendos $\mathrm{P}$ alladius uri iubet. Caprinarum ungularum cine. re perunctx ex aceto alopecix fanantur, Diofcorides $\& R$ afis. Albertus acetum urehemens requirit, \& malignam quoç alopeciam ita curari fcribir. Quidam ungues caprarum deuftos, mox́́ acero perfufos, alopecíjs illinunt:Itaq, fuerit $\&$ hic cinis facultatis extenuatorix, Galen. A efculapius ungu las uftas cum pice liquida teri \& illini iubet. Vngularũ cinis cum pice, fluentẽ capillũ continet, Plin,

IT Talorum capra recentium cinis dentifricio placet, \& omnium fere uillaticorum quadrupedum, ne fapius eadem dicantur,Plin.

TÁd rupta inteftina laudant caprini capitis cum fuis pilis decocti fuccum, Plin. Caprinum caput cum pilis decoctum $\&$ contritum, incifa inteltina folidat, Sext, Cum pilis fuis contufum, atç dif́co ćum, ciboç furmptum, rupta interius inteftina dicitur glutinare, Marcellus $\quad$ đCerebrum capræ (caprea, Sextus:)magi per annulum aureum traiectum, priufquam lac detur, infantibus infillant contra comitiales, cæeterosós infantium morbos, Plin. Capra cerebrum cum melle carbunculos in uentre fanat, Aefculap. Aqua qux è capra palato effunditur, $\&$ quicquid consedit, mifceatur cum melle $\&$ fale, $\&$ ex eo caput $\&$ corpus ferò fricetur, pediculi extinguentur, Sextus, Idem remedium eft ad uentris dolorem: fed $\&$ uentrem ftricium folvit, \& fi plus biberit, purgat, Idem. I Lingua exulcerationi $\&$ arteriarum prodeft ius omafi gargarizatu,Plin, omafum intelligo bubulum;de illo enim laçe proximé dixerat, quanquam fimul etiam de caprino.

TCaprinum iecur affum fi edatur, tum ad nyctalopas accommodari aiunt, tum eos qui comitiali morbo funt obnoxī, arguere, conuulfionemó̧ illis accerfere:Idem poteft hircinum, Galenus, $\Gamma_{2}$ pilio quocg lucernarum luminibus aduolans inter mala medicamenta numeratur: Huic contrari= um eft iecur caprinum, Plin。Caprini iecoris inaffati decidua fanie, inungi lufciofos (nyctalopas) prodeft: $\&$ dum coquitur apertos oculos halitu eius uaporari: prodeft in cibo toftum ad eadem, Dio* fcorid, \& Galenus. Capras tradunt noctu non minus cernere quàm interdiu;ideo fi caprinum iecur 


\section{DeCapra: G. Lib. I. 285}

hefcantureftrtitutituefpertinam aciem his quos nyctalopas uocant, Plinius. Et alibi, Et quioniam can pra noctu xqué queqs cernant, fanguine hircino fanari lufciolos purant nycialopas Gracis dictos: Capra uero iecincre in uino auftero decocto:Quidã inaffati iociner is fanie inungür; att felle capræ: earneş̧́ eas ( ipfum iecoris uifcus ) uefci, \& dum coquanur, oculos uaporari ijs praccupunt:Id quo= que referre arbitrantur, fi rútli coloris fuerint. Volunt $\&$ oculos fuffiri, iocinere in ollis decocio quidam inaffato, Plinius, Dum hepar caprac cum aqua $\&$ fale decoquitur, comprimac fe oculis aper tis fuper uaporem huius aqua, cui uifus deficit nocfur,multum iuuar, Rafis: Celfus medicina lib $\sigma_{\text {: }}$ pof multorum in oculis morborum curationes, de oculorum imbecillitate curanda fic prodit, Prx= tet harc imbecillitas oculorum eft, ex qua quidam interdiu fatis, noc?u nihil cernumt, quod in foemi. nam bene refpondentibus menftruis non cadit, Sed fic laboranies inungi oportet fanguine iocino. ris, maxime hircini, fin minis, caprini, ubi adaffum coquitur, excepto:atos edi quoç ipfum iecur de. bet, Sext.hac remedia ad nyctalopas caprex iecoriadfcribit, uide infra. Iecur affum capra coeliacís. fubuenít magiş̧́ etiam hírci,cum uino auftero decoĉum potumós, uel ex oleo myrteo umbilico inu pofium:Quidam uerò decoquuntà tribus fextarịs aqua ad heminam ( $a l_{+}$geminum) addica rutay. Plinius. Vini ueteris feces, \& iocineris caprini fruftum fufficiens in ollam rudem mitte, \& facito ut: bulliat, at fed quod fiftat, non foluat, conftat ex co quod coeliacis fubuenit, ut iam dictum eft, \&cc. Si pariens inflata fuerit, hepar ouillum aut caprinum, calido cinere obrutum, edendum dato meracius ad dies quatuor, \& uinum bibat uetus, Hippocrates de natura muliebri.

TFel caprinum ueneficijs ex muftela ruftica factis contrarium eft, Plinius. . Fellecaprarum pfim lothri uís efficitur, fi etrulfis pilis triduó feruetur illitum; Plinius; uide paulo poft in remedijs huius fellis ad palpebras \& fupercilia. Fel caprinum ad incipientes ftrumas optime facere experimenta docucrunt: nam penitus crefcere non finentur, fi eo affidué tangantur, Marcellus:apud Plinium nó caprinum, fed aprinum fel frumas difruterelegimus. Fel caprinum cum aluminis cinere fcabiem hominis abo'ct, Plinius. Lepras iecur hirci calıdum illitum tollit, ficut elephantiafin fel caprinum, Plinius: Diofcoridcs hircinum fel ad elephanciafis tumores commendat. Magi felle capra facrifica tx duntaxat illito oculis, uel fub puluino pofito, fomnum allicidicunt, Plinius. Ad porriginem pra deft cornus ceruini cinis è uinu, utọ́̂ non tredia animalium capillis increfcãt : item fel caprinum cum creta cimolia \& aceto, fic ut paululum capili inarefcant, Pliníus. Hyblazi mellis fuccicum felle ca= prino Subueniuntoculis dira caligine preffis, Serenus. Fel quidem caprinum plurbus modis af fumunt ad oculor um remedia:cum melle, contracaligines, (Sextus caprex fel cum melle mifcet ad, uerfus caliginem; Diofcotides in eundem ufum fel lylueftris capra commenda: ) cum treratricana didi tertia parte, contra glaucomata:cum uino, contra cicatrices, \& albugines, $\&$ caligines, \& ptery. gia, \& argema:ad palpebras ueı ó, euulfo prius pilo, cum lucco oleris; ita ut inunctio inarefcat con. tra ruptas tuniculas, cum lactemulieris: Ad onnia autem inueterata fel efficacius putant, Plinius: Eadem omnia Sextus de caprex felle fcribit, paucis uerbis uariantibus, uide infra. Sedat caliginem fel cum paffo aut melle, Idem: Caprinum intelligo, etfi propius nominatus fit lepus. Felle capra ny. ctalopas inungunt, uide fupra in iecoris ex hoc animali remedio ad eoldem. Diofcorides capræ fylue ftris fel ad oculos luf́ciofos \& uarios eorum affectus commendar. Collyrium ex felle caprarum iyla 10 ueftrium uel domefticaruin, telam cculorum fanat, $R$ afis $\&$ Albertus. Fel caprinum palpebris ue fupercilijs impofitum, pilos abolet:acerrimum enim eft, 8 forfan in aligs quoç locis pfilothrum, Al bertus. Domefticarum fuum bile utuntur quidam ad ulcera aurium, medicamento utios non reprom bo: \& u quoqs ubi com pofitorum nihi adfuerit, utitor:funt enim innumera. Sed \& pro affectus ma gnitudine, alia etiam atç clia alterius animalis bilis poteft congruere. Nam ubi ulcus diuturnum fue rit:multam q̧̧ faniem pusç̧ contineat, etiam ficciorem bilem præeferes; puta ouiũ, quę paulò eft acrior fuilla:hac etiam magis caprarum, cui adfimilis quodammodo ef urforum \& boum: taurina ualen= tior eft \&c. Galenus. Medicamentum quod recipic fellis caprini $\&$ mellis ana fercipulum unum; conteres $\&$ in frigilicalefacies $\&$ infundes, $\&$ lana obcludes aurem. Nihil hoc medicamine poren tius, neç certius, etiamfi intrinfecus cancerauerint aures, Marcellus. Senectus ferpentitum ufta, cum rolle caprino auribus purulentis inftillatur, ut in Senectute ferpentium dicam ex Plinio. Auriuan uítia fanantur tritis porri folïs cum felle caprino; trel pari menfura mulfi, Plin. Aurium uitijs mede tur fel caprinum cum rofaccotepido, aut porri fucco:aut fi fint rupta ibr aliqua, é lacte mulieris ${ }_{3}$ Plin Quorum auditus hebes eft, ex felle caprino, formicarum ouis, melle \& chelidonio mixtum medicamen auribusinftillent, Innominatus. Anginæ prodeft caprinum fel cum melle, Plin. Caprinum fel, uel taurinum, melle permixtum, \& extrinfecus faucibus adpofitum, trel pro unguine inductum, anginas efficaciter fanat, Marcellus. Ad ceruicum tumores fedandos, ouorum uitelli cocícum as dipe anferina illinuntur, felle caprino aquis ponderibus permixto, ato inde ceruices fricantur, Mar cellus. Capra fel cum cyclamini fucco $\&$ aluminis modico:aliquii $\&$ nitrum $\&$ aquam adiecifle ma lunt, aluum foluic, Plinius: fubditum paftillo intelligo:quod mox etiam de felle taurino dicit cum ab. o finthio trito: Simile remedium Sextus ex felle caprea defcribit, ut in Caprea dicam. Ad lumbricos egerendos felle caprino madefactam lanam umbilico adpone, Marcellus. Ani uitia \& côdylomata felle caprino perunci2, fanaricertiflimè conftar $x_{2}$ Marcellus. Fel caprinum per fe condylomatis fedie 
medetur, Plinius fi bene memini. Cum melle ueretri doloribus ulceribus'̧́ illitum prodef, Marcel, Caprarum fel callum uuluarum emollit infperfüm, \& à purgatione conceptus facit. Probatum re medium eft felle capritio, nori manu, led pinnà, pedes perunctos confeftim dolore releuari, Marcel。

बCapræhirci ue liene affo, coeliacis utuntur,; Plinius, Sextus tor minofis caprex lienem bibend commendat.

T Genuinum capra ftercori commifceas, \& factum quafi malagma, femora perunge, mirè fanae femorum dolorem, Sextus:Per genuinum(inquit Hurnelbergius)aut tefticulos, aut naturam, aut tale quid intelligendum putamus, ficuti de patella cerui etiam diximus.

QQ Qui urinam tenere non poterit, capræ ueficam comburat, $\&$ cinerem eitș ex aqua cum uini po tione bibat, Marcellus.

TCapra fecunda ex uino pota mulierum fecundas eĭciet, Sext. Membrana caprarum inqua partus æditus, inueterata potúg fumpta in uino, fecundas pellít,Plin.

TDe lacte caprino uide quxdam fupra ca.6. Scio Damocratem medicum in ualetudine Confidia M.Seruilï confularis filia, omnem curationem aufteram recufantis, díu efficaciter ufum lacte caprarum, quas lentifco pafcebat, Plin. Cancri fluuiales triti potíç ex aqua recentes, feu cinere ad. fer uato, contra uenena cmnia profunt, priuatim: contra fcorpionum icius cum lacte afinino: uelfi nen fit,caprino, uel quocung;:addi \& uinum oportet, Plinius. Abfyrtus idem ferè medicamenad cephalalgiam in equis commendat, ut dicam paulò inferius. Caprinum lac contra cantharides re, medio eft, Plinius \& Sext.\& contra ephemerum, potum cum taminia uua, Plin. Lactis (caprinu bau fus cum uua taminia, contra içus ferpentium ualet, Plin. Capræ lac quod primum mulgeiur le uiores facit acceffiones in quartanis, fi illud editur aut ex dulcibibatur, Sext. Magorum quidam fin mi hirundinum drachmamunam in lactis caprini uel ouillí uel paffi cyathis tribus aduerfus quarta nas ante acceffiones dant Plin. Agnis febricitantibus multi lacte caprino medentur, quod per cor niculum infunditur faucibus, Columella. A licx ufum ad fyntexes ex ouillo aut caprino lacte, in on uillo dicam ex Plinio. Fel herinacei pfilothrum eff, utiç mix to cerebro uefpertilionis, \& lacie caprino:item per fe cinis cum lacie, Plin. Vetonicx farina èlacte caprino pora fanguínem ex hubere fluentem fiftit,Plin. Sa er ignis morbus ouium infanabilis penè ad omnem tactum excandefcit, fo la tamen ea fomenta non afpernatur lactis caprini:quod infufum tantum ualet, ut blandiatur igneă fruitiam, differens magis occidionem gregis quàm prohibens, Columella . Frigidam uftionem no= ftrates uocant, in uulneribus $\&$ ulceribus quibufdam periculofum fymptoma, cum locus tanquam uftus nigrefcere $\mathcal{Q}$ fenfum amittere incípi, $\mathcal{Q}$ caro ipfa refolui ac decidere, ex putrilagine ni fallor, fphacelum aut gangręnam dicas: huic aliqui occurrunt, filicis maioris radice in lacte caprino deco. cta \& impofita calida:Alï anthemidis flores cum far ina tritici in lacte caprino coquunt \& imponüt. Lac caprinum potum pruriginem $\&$ morfus fanat, Aefculap. Si quid in membri alicuius arciculü deciderit, unde uel dolor uehemens oriatur, uel ligamenta lafa humorem remi tant(quem noftri uo cant tas glto waffex) quod magno tum dolore tum periculo fit, lini femen in lacte caprino decoques $\&$ impones, Author obfcurus, Lacte caprino lendes tolli tradunt,Plin. Lac caprinum incocium, fed non adulteratum aut uiriatum, recre alopechis infricatur, mirum ef,,Marcel. Cancros fluuiatiles feptem contritos mifce fextario lactis caprini, \& olei cyatho: diligenter percolatum equo ex capite dolentiper os infunde, A b fyrtus: Simile paulo ante recitaui ex Plinio aduer fus uenena. Philiftion opifihotonicis brafficz fuccum ex lacte caprino cum fale $\&$ melle bibendum cenfet, Plin. Dextro oculo chamaleontis, fi uiuenti eruatur, alburgines oculorum cum lacte caprino tolli', Demorritus narrat, Plin. Fel tauri fanat purulentas aures, $\mathcal{Q}$ in his rupra,cum caprino humanó ue lacte inftilla: tum, Diofcor. Purulentæ $\&$ obrunf $x$ auriculx $\&$ dolorem tolles, $\&$ atrditum confir matiffimum red des, fi pritus eluas eam lafere cum recenti caprino aut mulieris lacie permixto, deinde inftilles tepidû fel taurinum cum oleo cedrino $x$ quis portionibus mixto, Marcel. Idem remedium alibi etiam defcrit bit ab initio capitis noni. Lacte caprino peruncta gingiua, faciles dentitiones faciûr, Plin. Efficax habecur caprino lacte collui dentes, uel felle taurino, Idem. Dentes mobiles fapius colluendi funt lacie càprino, Sext. Caprino lacte recenti, ficut mulfuim fuerit, os affiduè collutut, laborantes ex içus dentes confirmat, Marcel. Lacie bubulo aut caprino ronfillæ $\&$ arterix exulceratzeleuantur: Gars garizatur repidum, ut eft expreffum, aut calefactum:Caprínum urilius, cum malua descetum \& fas le exiguo, Plinius \& Marcellus. A efculapius artericum haber, pro eo cui lafa fit arteria : arteriacum malim, quan $\tilde{\beta}_{\xi} \&$ arthriticis lac fchifton caprinum datur, ut mox dicemus. Lac caprinum, uel bubu lum, uel ouillum, recens mulfum dum calet, uel etiam calefactum gargarizatum, tonfillarum dolo: res \& tumores ciro fe $:$ at, Marcellus. Pectoris doloribus decoctum in lacte caprino prodeft naftur. in femen, Plin. Maximé perpurgat lac equinum, tum afininum, deinde bubulum, tum caprinum, Varro.Caprini lactis porus cum fale $\&$ melle aluum foluit,Plin. Purgatoritum efficax, quod nes fto machum trexat, nec captur gratrat, \& bilem deducir:lactis caprini fextarium, falis ammoniaci uncias duas, mellis optimi unciam unam, in unum omnia diu contrita \& permixta ieiuno potui dantur: fed poft potionem diu inambulare debet, ut ipfa potio melius motu corporis profit, Marcellus. Mute

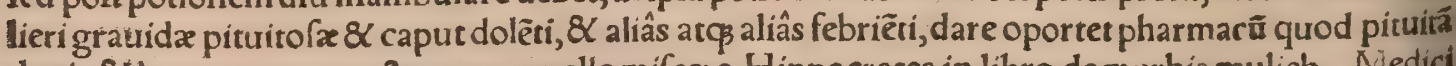
ducit, 86 lac caprinum coftum cum melle mifcere, Hippocrates in libro de murbis mulieb. Niedici 
peciem unam addidere lactis generibus, quod fchifon appellauere; id fit hoc modo: Fictili nouio fer uet, caprinum maximé, ramisḉ ficulneis recentibus mifcetur, additis totidem cyathis mulfi (acet! milifi, Diofcor, )quot fint heminz lactis. Cum feruet, ne circumfundatur praftat cyathus argenteus cum frigida aqua demiffus, ita ne quid fundatur. A blatum deinde igni refrigeratione diuiditur, \& difcedit ferum à lacie.Quidam \& ipfum ferum iam multò potentiffimum, decoquunt ad tertias pat tes, \& fub dio refrigerant. Bibitur autem efficaciffimè heminis per interualla, fingulis diebus, quinis (fingulis uf $q \beta$ ad quinas, Diofcor.) )melius à potu geftari. Datur comitialibus, melancholicis, paralyti. cis, in lepris, elephantiafi, articularibus morbis. Inteftínorum tritijs magnopere prodeft lactis caprint potus decoctus cum malua, exiguo fale addito: $\&$ fi coagulum addatur, maioribus emolumentis fiet; Plinius. Lac caprinum ex coagulo temperabis, \& dum tepet, antequam penitus conftringatur, dy. ienterico bibendum dabís, cito remediabitur, Marcel. Lactis caprini ftatím mulfi grandi potioni additur de coagulo hoedino fruftum, quantum auellana grandis eft:quod digitis, medicinali $\&$ pollice fublatum uel miffum, îfidem digitis contemperatur, \& datur laboranti đyfenterico dum adhuc ca letlac, antequam coagulo frringatur, per triduum: $\mathrm{H} x \mathrm{c}$ potio ieiuno dabitur contra orientem biben da, Marcel. Lac caprinum feruens, a diecto polenta quantum fatis fit, cum fuerit quafi tenuis pulti, cula, dyfenterico bibendum dabis, Marcel. Lac caprinum ad dimidias partes decoctum, dyfentericis \& coeliacis datur, Plin . Si torminofi uel coeliaci propter frequentes defurrectiones uiribus defi cientur, dandum erit eis ius gallinæ pinguis excoct $x$ cum butyro, uel lac caprinum aut ouillum te. pidum per fe, uel etiam decoctim cum butyro, Marcel. Iniectio ad dyfenteriam, Amyli uncias tres 10 in lactis caprini cocti pro modo quantum uifum fuerit, adïcies, \& ita iniectionem facies, Marcellus. Alti exulceratos fluores $\&$ tenefrnos, ouillum bubulúmue aut caprinum lac fiftit,ignitis calculis de cocfum, Diofcor.Polt clyfter is ufum, fi quidem ftercorum multitudo in caco inteftino fit:fin minus, polt fomenta pectini inguinibusćs admora, exhibendum eft lac caprinum recens mulćum hemina menfura, nequaquam minus; uerum non aceruatim, fed figillatim partitum. Sequenti deinde dielac ipfrm ad dimidium decoquatur, ablato eo quod in decoctione concretum fuperftat, atç ita exhis beatur, Aêtius in cura tenermi. Idem alibi docet quo paço lac cum calculis fuurialibus ignitis. fiue bubulum fiue caprinum, in biliofis alui fluxionibus, \& coliacorum alibi, parare conueniat, ut in bu bulilactis mentione fupra expofui. Panicum fiftit aluum in lacte caprino decoctum, $\&$ bis die hau flum: fic prodeft $\&$ ad tormina,Plin. Panis antiquus ex lacte caprino decocius, $\&$ more forbitionis go uentris fluxu laboranti bis ad diem datus, cito fuccurret, Marcel.Satiui fiferis priuatim fuccus cum lacte caprino potus, fiftit aluum, Plin. Caprino lactelienes fanantur, poft bidui inediam tertia die edera paftis capris, per triduum poto fine alio cibo, Plin. Vtiliffimum lienofis hoc remedium eft: Capra lactares abftinentur à cibo per triduum, tertia die hedera tantummodo faturantur, $8 \alpha$ mul. gentur antequam bibant:fr ex eo lacte fextarios tres per triduum calidos ftatim quomodo mulfi fue rint iciunus lienof us acceperit, ita ut nullos alios cibos illo triduo mãducet, potenter fanabitur, Mar. cellus. Qui cotidie ieiunus ferum caprinum, fed earum capellarum qux hedera pafcuntur, bibe. rit, fplene confumpto erit, Marcel. Lac caprinum femicoctum, fi caprætantummodo hedera pa. fantur, infantibus lienofis datur, Marcel. E caprino lacte adiecto coagulo, ur folet cafeus fieri, po tus detur hydropicis, elabuntur, Sextus. Remedium ad colicam ex lacte caprino calido in bubula ue 40 fica uentri admoto, fupra defcripfi in Boue: hic illud addam, aliquos non in ueficam lac infundere, Sed fpongiam eo grauidam imponere, 8 infuper uas ligneum, quo lac minus defluat. Lac caprinü potum lumbricos necat, Aefculap. Paffi Cretici cyathos tres, lactis caprini itidem, feminis cucume ris grana triginta tria , optimè trita fimul una potione qui biberit, abfoluet renium dolore, Marcel. Anatolits equis fanguinem per urinam excernentibus, lactis caprini cotylam cum amyli ea menfus ra, qua tribus ouis par effet, $\&$ olei uncịs tribus, omnia mixta per cornu infundi iubet: Pelagonius lac caprinum amylum, \&i oua tria, \& fuccum perdicĭ herbæ commifcet. Vettonicæ farina é lacte ca prino pota, fanguinem ex hubere fluentem fiftir, Plin. Medicamenta quxdam ad Venerem incitan tia medíci ex caprino lacte propinant, Marcel. Herbæ quam orchin uocant radicem alteram, qua mollior \& inferior eft, in lacte caprino uiri in Theffalia bibunt ad ftimulandos coitus, duriorem ue, so ro ad inhibendos, Plin. Ad eos quibus femen fuit, $\&$ non potentibus, $\&$ aquofum eft, unde efficit ut foemina non concipiat: Caprinum lác cum melle potum, remedium eft $\mathcal{X}$ ualde optimum ut con cipiat,Sext. Si fedis mufculus promineat, \& rimas patiatur, caprinum lac calefactum illinito, In. nominatus.

CCaprinus caleus recens, his qui uifcum biberint, remedio eft, Plin. Ad reliquos (prater canis rabidi)teftiarum morfus, caprinum cafeum ficcum cum crigano imponunt, 8 bibi iubent, Plin. Et alibi, Cafeum caprinum cum origano impofitum, contra ictus ferpentium ualere tradunt. Siccus exaceto ac melle purgat ulcera, Plinius. Contra quartanam datur cafeus caprinus recens cum me! le diligenter fero expreffo, Plin. Impofitus cafeus caprinus omnes punctiones $\&$ dolores reprimit, Aefculap. Mollis, id eft recens, cum melle fubactus impofitus ç, \& panno defuper tectus aut linteo, to fuggillationes liuoreśq́p celeriter abfterger, Marcellus. Cafeus caprínus ficcus cum porro igni facro illinitur, Plin. Siccus ex melle $\&$ aceto in balineis, oleo remoto, papulis nigris illinitur, Idem. Re cens coagulatus fupra oculos pofitus dolores cito lenit, Marcellus, Ad feruorem uel punctionem 
oculorum, capitis 82 pedum dolorem:Cafeus caprinus recens oculis fuperpofitus mintefubuenit: Itể fimili modo capiti dolenti fuperpone: Sic \& pedum dolorem medicare, Sextus, Cafeo caprino mol Ii impofito ex aqua calida epiphoræ fedanturtfi tumot fit $t_{3} \mathrm{x}$ melle:utrunç uero fero calido fouen dum,Plinitus. Ad ueretri dolorem, cafeum caprinum $8 \mathrm{~K}$ mel pari pondere in pultario fictili coque, $\&$ bis ad diem impone: fed ante uino uetere locum qui curandis eft eluas, Marcel. Geniralium car bunculis cafeus caprinus tritus $\&$ impofitus medetur; Plin. Si mulier cibos auerfans, uterc doleat, $\&$ febris ipfam ac rigor corripiat, pepli albi quintam dimidiæ chœnicis partem, 8 feminis urticæ tan turndem, \& cafei caprini rafi dimidiam chœenicem, fimul cum uino uetere mollito, deinde cocia for benda dato, Hippocrates in libro de morbis mulieb. Et paulo poft:Si ex partu alui profluuio corri. piatur, bibat uuam paffam nigram, \& punici dulcis malicorium, 86 internum nucleum, et coagulum , hoedí:brec uino nigro diluta, \& cafeo caprino ac polenta triticea infperfis, bibenda dato. Et alibi in eo dem libro, fi quid in uteris computruerit, item fi fanguis $\&$ pus exeant, cafeum caprinum uel dera fum affatumó, uel fimpliciter, cum æquali parte polentæ mifcer, $8<$ in uino ieiunæ propinat.

T Omnium creberrimé utimur caprino ftercore. Graci wugúders (foem.genere) propriè nonninãt, digerentis $\&$ acris facultatis; adeo ut et induratis fcirrhorum in modum tumoribus congruat, nõ tan tum lienis, fed etiam aliarum partium. Vftum tenuiöris effentix quidem, uerũ haud manifeftó red. ditur acrius:quamobrem fane ad alopecias congruit, $\&$ omnia adeo qua extergentia medicamenta defyderant, ut lepras, pforas, lichenas, \& id genus alia. Mifcetur \& digerentibus cataplafmatis; quas lia funt qua accommodantur ad paroridas $\&$ bubonas diuturniores, Eft enim uis cius tum uft, ttum non ufti, abfterforia, $\&$ digerens: nec eam paruam habet digerendi potentiam. Verum pro paftu ua rio nonnihil habuerit differentix : non tamen tantum, quantum ftercus humanum. Medicus quifo piam ex ịs qui in agris $\&$ uicis medicinam exercent, utebatur hoc fimo ex aceto ad uiperarum mor fus, $\&$ multó fané etiam magis aliarum beftiarum:ac profecto ex ïs complures feruauic. Et hic ipfe quoos medicus ad auriginem potandas ipfas fpyrathos ex uino prabuit; $\&$ ad profluuium mulie brecum thure appofuit, Qux omnia fane optimus medicus ignorare non debet: carerum potio. ra eligere, potiffimum ad urbanos $\&$ honoratos uiros, $\mathrm{Hac}$ omnia Galenus libro 10 . de facult. Fimpil cium ca,22. Caprinum fimum inquietos infantes adalligatum panno cohibet, maxime pueilas, Pli, nius. In aceto decocfum imponitur ferpentium morfibus, Diofcor. Et alibi, Cum uinoftudiofe im pofitum uiperarum morfibus auxiliatur. Fimum caprarum in aceto decoctum \& Allicum in ictus ferpentium ualere dicunt, placet $\&$ recentis cinis in uino: A tq̧̧ in totum difficilius fe recolligentes à 〔erpentium içu, in caprilibus optimè conualefcunt:Qui efficacius uolunt mederi occif $x$ capræalux̃ diffectam, cum fimo intus reperto ftatim illigant, Plin. Percuffis à fcorpione fimum capra efficacin us cum aceto decoctum auxiliatur,Plin. Ad canis rabidi morfum laudant capr fimum ex uino il. litum aut melle, Plin. Sanguinis impetus ex aceto cohibet, Diofcor. Caprini fimi cinis ex aceto illis zus, Plinius:uide fuperius in Cornu caprini mentione ad eundem ufum. Caprinum fercus impof tum non patitur confurgere tumorem, Sext. Farina hordei cum ftercore bouis uel capracocia, ad omnem tumorem ualet, Author obfcurus, Stercus caprinũ cum melle mixtum, fanat luxos, 8 rus mores difcutit, \& non patitur iterum cöfurgere, Sextus: Luxos intelligeluxatos, ut inferius dicam ex. Plinio. Fimum caprinum ex aceto decoctum ftrumas difcutit, Plinius. Fimum caprinum ad bu bones diuturnos ufurpari, ex Galeno iam dixi. Fimum bubulum in cinere calefactum, aut capris num in uino uel aceto decoctum, illinitur in his qua rumpere opus eft, Plin. In aceto decoctum im. ponitur, ulceribus quæ ferpunt, igni facro, paroridibus, Diofcor. Ex aceto fubferuefactum \& illittr, fanat ulcera qux ferpunt, Plinius. Et alibi, Manantia uierendorum ulcera fanat feutum caprinum cử melle rubíǵ fucco: uel fi ferpant, fimum etiam prodeffe cum melle dicunt, aut cum aceto. Prodeft ad lepras, pforas, lichenes, \& id genus alia, ut paulò ante ex Galeno dixi. Cum melle mixtum \& ap pofirum fanat cancerofos, Sextus. Cum melle commixtum \& fuperpofitum, carbunculos qui in uentre nafcuntur, difcutit,Idem. Fimus caprinus in aceto feruefactus $\&$ fubactus imponitur, quo o: minia crurum $\&$ tibiarum ulcera purgantur $\&$ perfanãtur, butyro bubulo cũ oleo cyprino aut laurí no poftmodum addito,Marcellus. Spin ac fimilia corpori extrahuntur excrementis capr ex ul. no, Plinius:apud Sextum capri non capralegitur, his uerbis, Stercus capri ex uino confperfum im. pofitum'q́, quod inhærebit, extrahet \& fanabit. Medicus quidam medicamentorum peritus in $M y$

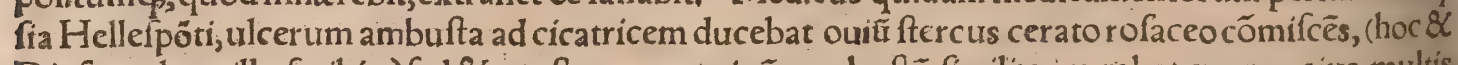
Diofcor, de ouillo fcribit:) fed \& per ftercus caprinũ combuftũ fimiliter curabat, parum eius multis. numeris maiori cerati(rofacei)moli admifcens, Galenus. Græecum exemplar noftrum habet, Ka's $\mu h^{\prime}=$

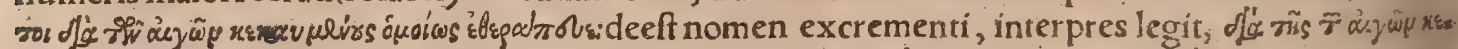

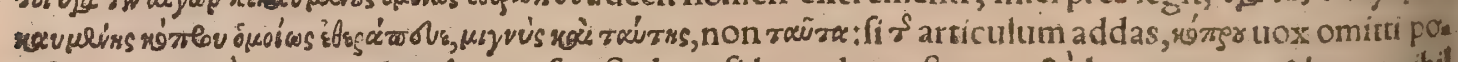
teft ut proximé in præcedentibus pofita.Sed confiderandum eft an recié leyatut uskaupuirs, ut nihil

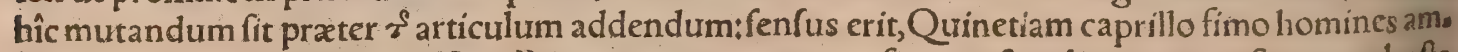
buftos fimiliter curabat, \&c. Nam Plinius quoog caprarum fimum (fimpliciter, non uftum ) ambufta fine cicatrice fanare dici, fcribit.A ggregator etiam ex Auicenna citat, capræ ftercus cum aceto, uel cerato rofaceo, ambuftis auxiliari. Deinde cum ouillo fter core non ufto ufus fit ille medicus, de quo Galenus frribit, quod minus acrimonix quàm caprinum habet, caprinum in eun dem ufum uffifle 


\section{De Capra: G. Lib. I.}

non eft uerifimile. Quanquam fi ufti quog hurius fimi (cum acrimonix ex igne nihil affumat, ut ex Galeno fupra dictum eft)modicum copiofo cerato aliquis mifceat, idoneum ambuftis medicamẽ red det.Scio $\&$ alia quadam (ut pilos, teftas purpurarum, $\&$ coria)in hunc ufum uri folita. Proinde rem in medio relinquo, ut quif́p pro arbitrio legat \& fentiat. Luxatis fimum caprinum cum melle illini: tur, Plinius; Luxum \& tumores difcutit cum melle, $\&$ non patitur iterum confurgere, Sextus, $C_{0}$ Itis fractis laudatur unicè caprinum fimum ex uino uetere, aperit, extrahit, perfanat, Plinitis. Neruorum doloribus fimum caprinum decoctum in aceto cum melle, utiliffimum putant, uel putrefcen te neruo, Plinius, Melle mixtum impofitumóq, fuppuratos neruos expurgat, \& ad fanitatem ufque perducit, Marcellus. Cum acerrimo aceto mixtum morbum articulorum fanat,Sextus: In dulci po tum, Idem ut Aggregator citat. Cum polenta $\&$ aceto in corporibus duris, ut rufticorum, Galenus ut Aggregator citat, Cum melle mixtum parotides miré fanat:item articuli cum eodẽ peruncti, $f_{2}=$ nantur, Sextus. Cum aceto mixtum \& fuperlinitum neruorum contractionem fanat $\&$ confirmat, Idem, Cum aceto coctum $\&$ fubacium, at $\phi \beta$ ad craffitudinem mellis impofitum, articulorum con. tractiones relaxat, \& tremulis prodeft, Marcellus, Cum melle in aceto decoctum articulorum attri= tis prodeft, Plinius.

Medetur alopecips exuftum, \& curm aceto aut oxymelite(melle, Albertus)illitum, Diofcorides \& Rafis: meminit etiam Galenus, ut fupra retuli. Caprino fimo cum melle alopecias expleri tra dunt, Plinius, Paulus Aleg, ubi de alopecia fcribit, tum caprino tum ouillo ad eam excremento uti. tur. Septem pilulas ftercoris caprini ex aceto tere, $\&$ fronti inline contra capitis dolorem, Marcels lus. Ceruicis dolor inflexibilis, quem opifthotonon Graci uocant, leuatur bulbo trito cum fimo cas præ ceruici illito, Plinius \& Marcel. Stercus caprinũ fimo(uino forte ) confperfum, tritumq̧́ $\&$ im pofitum oculis, a tq̧; obligatum, omnem dolorem tumoremós detergit, Marcellus. Nec abdicant fimum ex melle illitum epiphoris (oculorum, ) Plinius. Contra parotides in aceto decodum impo: nitur, Diofrorides : meminit etiam Galenus ut fupra dictum eft. Parotidibus prodeft urina capra calefacta inftillata auribus, fimumọ́ eiufdem cum axungia illitum, Plinitus, Cum melle cómixturm parotidas mire fanat,Sexuss. Baccas caprinas aridas terat, $\alpha$ ex uino generofo bibat quem tuffis malé habet:piruita ftatim reiecta fanabitur, Innominatus. Fimum caprarum, præfertim in montí bus degentium, potum in uino, regium morbum emendat, Diofcorides. Medicus quidam in agris aduerfus auriginem potandas ex uino prabebat caprinas fpyrathos, Galenus. Illinunt $\&$ uentrem coeliacis fimo cum melle decocto, Plinius,. Caprinum ftercus pro fomento impolitum, colicis pro: deffe dicimus, Sextus. Stercus caprinum recens in aqua remiffum colatumćp, cum mulficorylis tribus, \& piperis contriti granis fexaginta, in tres potiones diuifum per triduum datur:ita ut prius corpus eius colici,cui potio danda eft, acopo pe:ungatur, ut perfrictiones omnes coacto fudore difcedant, miro remedio fanabitur, Marcellis. Ad induratos lienis tumores medici non pauci creber simécaprinum ftercus applicant, Galenus: Et rurfus, Ad aquam intercutem, \& ad fplenicos, uarie caprino ftercore utimur. Aridum tritum adiecto melle potui datum ex aqua calida, mire produscit (educit) tineas, Marcellus. Calculos expellit fimum caprarum in mulfo, efficacius fylueftrium; Plinits. V tilem ifchiadici uftionem hunc in modum accipiunt:In eo interftitio ubi pollex brachiali committitur, caua ueluti lacuna fubfider, in qua lana oleo imbuta fubfternitur, deinde figillatim fers uentes ftercoris caprini pilula imponuntur, dum uapor per brachium ad coxam fentiatur perueni re, \& coxendicis dolorem mitigare: aduftio id genus Arabica appellatur, Diofcorides, Ego caum il lam lacunam in ipfo brachiali, interno eius latere, nempe fub pollice reperio:qux tamen non femper apparet; manum uerò ita tenenti, ut digitus minimus infimo loco fit, pollex fupremo, idem $\not \dot{\beta}$ furfum $\&$ retro tendatur, omnino confpicua fit inter duos neruos, figura prorfus idonea qua baccam reci= piat caprinam. Hxc admonere uolui, quoniam interpretes non fatis conueniunt, \& Diofcoridis te

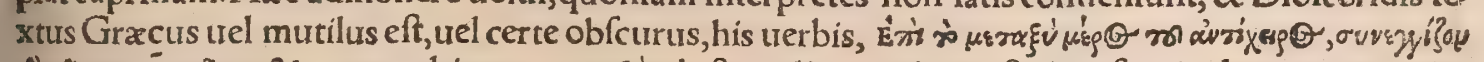

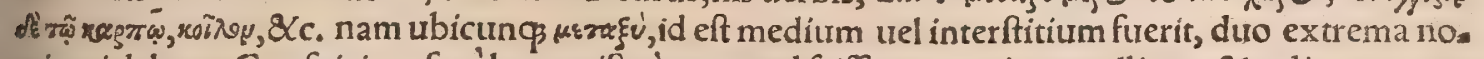
minari debent. Confpicitur fanélacuna ifta à parte uel fciffura qua inter pollicem \& reliquam ma.

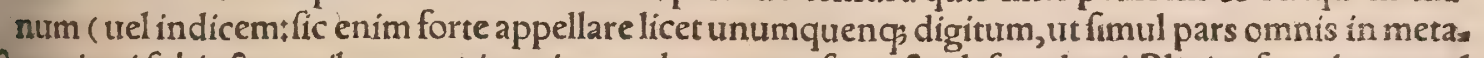
" carpio ei fubiecta attriburatur: ) interiacet, ad carpum uf 3 recta defcendenti.Plinius forte hac apud Gracos locutione non intelleça fimpliciter cauam manum reddidit, ubi idem remedium defcribit; his uerbis : A fierunt $\&$ magi fua commenta. Primum omnium rabiem hircorum, fi mulceatur bar: ba, mitigari. Eadem pracifa non abire eos in alienum gregê. Huic admifcent ( fenfus uidetur, huic commento alterum admifcent; neक̧ enim fimum barbx mifceri intellexerim) fimum caprinum, $\&$ fubdito lintedo uncto caua manu, quantum pati poffit feruens, fuftineri iubent : ita ut fi læua pars doleat, hxc medicina in dextra manu fiat, aut é contrario. Fimum quoque ad eum ufum acus area punctis tolli iubent. Modus curationis eft, donec uapor ad lumbos fentiatur peruenire. Poftea uero manum porro tufo illinunt;item lumbos ipfo fimo cum melle: fuxadentç in eodem dolore $\&$ teftes le poris deuorari, Hac Plinius. Simile remedium idem author alibi docer, in quo plus rationis(ut Mar cello Verg.etiam uidetur)minus fuperftitionis eft: If hiadicos, inquit, urifub pollicibus pedum( Ä gregator legit, fub poplite) fimo caprarum feruente utiliffimé tradunt. A rabica illa (inquir Marcel hus Verg, ) apud Diofcoridem uftio, noftra ætate, qued audierimus, in nullo ufu eft. Plutarchus qui. 
dèm in commentario Cur ferò fcelerati à numine puniantur, in ufu eam fuiffe uftionem ïs trexbis

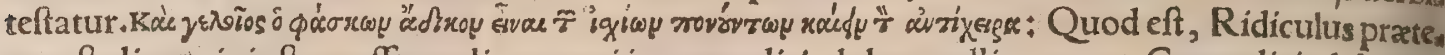
rea eft, dicens iniuftum effe medicum, qui in coxendicis dolore pollicem urat, Coxendicis dolor per femora,genua, tibias ̧́́ ad infímos talos pertiner, quod in fuperiore hominis parte non fit: quamob $\mathrm{rem}$ plus rationis effe uidetur curr pedum pars potius quàm manuum uratur. Pręterea qui aptiorem

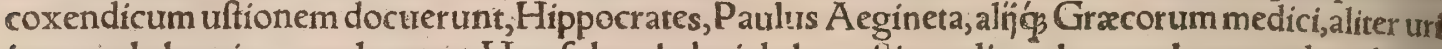
in eo malo hominem uoluerunt. Hre folum habui de hac ultione dicenda, nec plura apud authores reperiołut neq̧ cur Arabica diceretur:coníjcio tamenà gente nomen intentum, quoniam Arabes

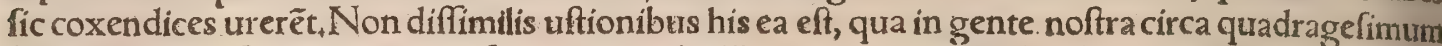

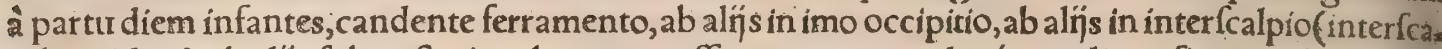
pilio malim ) ab alịs fub pofteriore humero paflim uruntur : uulgoć polfe feliciter primæ illius ætatis pericula infantes euadere, Hæc fere Marcellus.Mihi quidem hae infantium uftio nulla ex parte cum Arabica conferenda uidetur, cum preferuandi gratia \& ferro fiat, illa curandi \& fine ferro, \& c. His iam perfcriptis Aëtium adiui, qui libro 12,cap.3.ex Archigene \& Antyllo multa fuper hac re adfert digna memoratu, \& Diofcoridis etiam uerba repetit, qua ex Cornarín interpretatione nonnihil ab excufis Diofcoridis codícibus uariare uideo: Sed quoniam co dice Aêtrị Gracco deftituor, Cornari" translatione utar in ïs, ut digna funt,recenfendis. Veteres (in quit Archigenes)etiam trftione in if chiadicis ufifunt, alï aliter, \& $c$, Quidam ad propinqux cruriaf, fecto manus locum inter magnum digitum $\mathcal{Q}$ indicem medium, circa infernũ magni digisi fiue polli cis articulum, ${ }_{,}$caprinum ftercus feruens per forcipem imponunt, ftercoráćs permutant, donec fen fus uftionis ad locum affectum perferatur, Diofcorides hanc rem ita tradit, Caprinum, inquit, fter cus feruefacito, \& extenfo magno manus digito, cautum locum circa inferni eiufdem articuli finem nota, \&c, ut fuperius recitaui. Antyllus autem, nos(inquit)etiam huiufmodi trrendi modo utimur: ftercus caprinum ficcum ferurefacimus, eoćs uentrem magni digiti affecti pedis perurimus paulò in fra unguem, $u f(\beta)$ ad os ipfum uftione penetrante. Hxc ipfa uftio extremas coxendicum affectiones, $\&$ qux nullis alins prafidñs cedınt, diffoluit. Caterum polt uftiones porri folia cum fale trita impo nito, \&c. Fimum capra cum farina hordei $\&$ aceto impofitum, maximé in duris $\&$ rufticorum cor poribus, remedium eft ifchiadis, Serapio citans Galenum, Aggregator. Fímum caprinũ cum axun

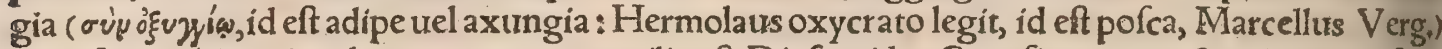
impofitum, his qui podagra tentantur, auxilio eft, Diof corides, Cum fimo capr $\&$ croco impofitus adeps hircinus, podagricis auxiliatur, Idem ut alicubi citatum reperi, Seuum capri cum fimo caprar rum coctum, \& croco,podagris impofitum dolorem foluit, $R$ a fis, Albertus crocum omittit. Poda gris medetur taurinum feuum, \& c a ali hircinum præferunt feurm, cum fimo capræ, \& croco fina: píce, cum caulibus ederæ tritis, ac perdicio uel flore cucumeris fylueftris : Magnificant alị fimi cat prini cinerem cum axungia,Plínius. Fimum caprinum cum aromate aliquo (cum fpica nardi, ue tus translatio ) hauftum, menfes cit, \& partus euocat:tritum in farinam, \& impofitum lanis cum thi re, forminarum profluuia fiftit, cæterosó̧̧ fanguinis impetus ex aceto cohibet, Diofcorides. Sterco, rís caprini pilulas, \&leporis pilos, pinguedine phocæ fubacta fuffito: Aliud, Stercis caprinũ \& pul monẽ phocęac cedri ramenta fuffito, Hippocrates in libro de natura muliebri,inter diuerfa uterorí remedia menfibus præcipué \& fecundis pellendis. Medicus quidam in agris fimum caprinum ad proflưuium muliebre fiftendum cum thure apponebat, Galenus. Profluuium quamuis immêfum urina capræ pota fifti obftetrices promittunt, \& fi fimum illinatur, Plínius,

बV rina caprarum cum aceto féllitico haufta contra ictus ferpentium ualet, Plinius. Panos $\alpha$ apoftemata (impetus $\&$ fuppurationes)in quacungs parte difcutit:ut fuum etiam in lana impofita, Plinius, Dolorem ceruicum inflexibilem, opifthotonon uocant, leuat urina capr $x$ auribus infurfa, aut fimum cum bulbis illitum ( bulbo trito cum fimo capra ceruici illito, Marcellus;)Plinits, OpiIthotonicis \& tetanicis lotium caprinum cum aqua mixtữ efficaciter prodeft, fi ieiunis potui detur, Marcellus. Vrina capræ aurium doloribus infillata medetur, Diofcorides. Sub eo momento quo egeritur, tepidam auri obtunf $x$ infundes, Marcellus. Lotium caprinum miffum in aures, dolorem fedat:fi cum mulfo mifceatur, fi pus habet, eijciet, Sextus. Inftillatum dolorem fedat, quod magis fuppuratis auribus adfirmatur:ob quam caufam prafentis auxilï plures exceptum \& cornu capri no inditum, in fumo fufpenfum, diligenter ad neceffarias nedelas referuant, Marcellus, Sigratin tas fit audiendi, fel bubulum cum urina capræ uel hirci medetur: uel fi pus fit: In quocunģ attem ufu putant hac efficaciora, in cornu caprino per dies uiginti infumata, Plinius. Vide infra etiam in hirci urina.Vrina capræ calefaça inftillata auribus, fimumós eiufdem cum axungia illitum, ad pas rotides profunt,Plinius. Vrina capra ad aquam qux cutem fubijt, cum nardi fpica quotidie binis cyathis cum aqua bibitur, urinamó per aluum extrahit, Diofçorides. Hydropicus forbeat locism capra, mirificé fanat, Sextus. Vide in lotio hircino. Hydropicis auxiliatur urina ueficæ capræ (codices quidam minus emendati habent apritpoterat \&, capri, legi: nam hircina qurogs prodeft, utin. fra oftendam ) paulatim data in potus : efficacius quæinaruerit cum uefica fua,Plinius. Ad urina difficultatem \& calculum lotium caprinum, red montanum (id cft caprartum qux in montibuspa: fcũtur) tepidum potari oportet, admixto uino cum aqua, b faftidium $_{2}$ Marcellus, Lotium caprin? 


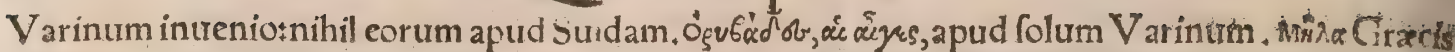
antiquis, Homero pralertim, omnia pecora, fignificât Nam Odyffex libro 17. procos maciantes fad

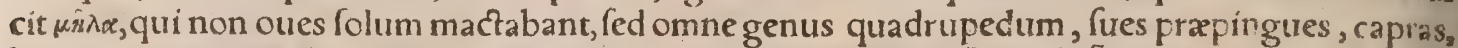

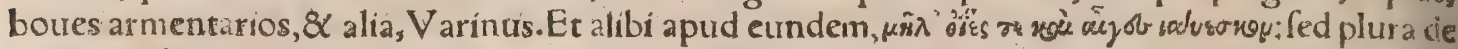

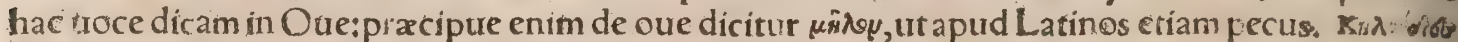

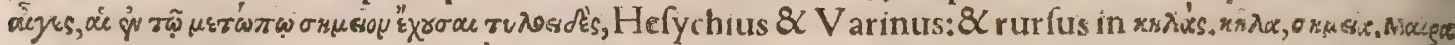

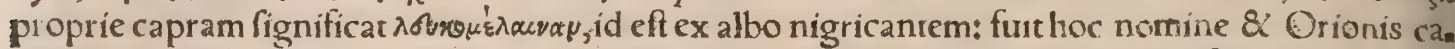
nis, Caxlitus. Furt \& Mara uxor Lycaonis apud Paufaniam in Arcadicis, Atlantis filia, quán Vly@ fes etiam apted inferos fe uidiffe narrat, fed hoc nomen oxyzonum eft. Gangra diéa capella in $P_{2}$ phlagonia nomen urbi dedit, ut infra dicam. Ciffatha, nonen capra apud it heocritum, Varinus.

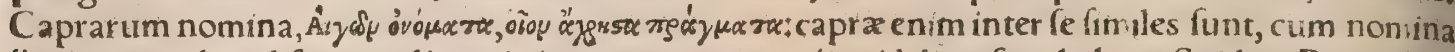
îs tantumn rebus difcernendi gratia imponantur, qux aliquid diuerfum habent, Suridas. Prouerbia Itter dicfum utideri poteft de rebus inutilibus, fiue ftudio circa nomina inutilia: quale fortaffis er hoc noftrum fuerit in ipfis caprarum nominibus, ut prouerbium aptiflime quadtet. Miror Erafmum nõ meminiffe. Caterum quod capra non differant, falfum eft: Color enim non omnibus idem, $\&$ alia

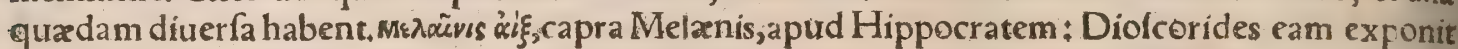
qux nata fit circa Melænas, qux urbs eft in campo Crifao ante Cirphium fita, \& pafcua habet optiz ma, unde lac laudatiffimum prouenit, Galenus in gloffis. If Sed nimis arefa premunt olidx conti uia capra ${ }_{3}$ Horatius ı.epift, id eft, føetor fub alis excitatur arcténimis difcumbentium: hunc $\&$ capi $\tilde{s}$ \& hircum appellare confueuerunt poêtz, ut in Hirco dicetur. À ys Dorice appellantur magni fus cfus, Suid.\&V arinus; hinc forte Aegaxum pelagus diefum, de quo mox inter propria. Capella !nter uirorum cognomina à capillor um hirfutie pofitum eft, Cælius. Eandem ob caufam fulianum adu'an di profeffores apud Conftantium Cafarem, capellam nuncupabant, Idem. Nicó fcortum, ut fupra ex Athenæo retuli, capra dicebatur, quod Thallum cauponem exhaufiflet: nam thailus proprie olex germen fignificat,qtro delectantur capræ. Stridas illam Nanon appellat, \& \&. quod nomen per n duplex fribi debet. Sed fallitur tum ipfe Suidas, tum Calius eum lecutus lib. 8. Nicò enim nominam sum hoc fcortum furt: de quo Athenætrs libro :3.ubi etram mox poft Nicûs mentionem de Nannio agit, unde deceptus eft Suidas, uel is ex quo ipfe defumprit. GCapra fignum eft coelefie. Quineo idus Septembris Cafari Capella oritur uefperi,Plinius 18.31. Decimo calendas lanuarias Capra orri dit mane, tempeftatem fignificat, Columella II.2.Meminit etiam Cicero de Nat. Poft infana caprafy dera frigidas Noctes, Horat. 3 .Carm. Videtur autem hoedos fignificare, quornum ortus \& orcalus concitat tempeftates, de quibus Verg., Georg. Hædorumós dies feruandi:ubi Seruius, A A ,rigæ fiu gnum eft haud longé à Septentrione:hic in manu finiftra fert hoedos, in humeris capram, qux aluffe

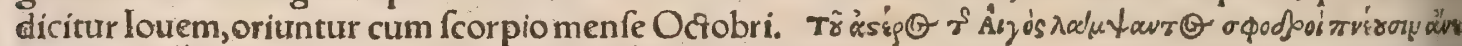

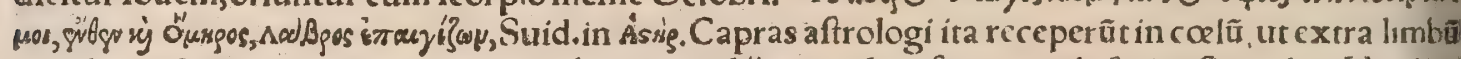
duodecim fignorum(ut noxium dentibus animal ịs qux depafcitur)excluferint. Sunt duo Hoediet Capra non longè Tauro, Varro. Apud Phliafios (inquic Paufanias in Corinthiacis)capra imago zrea in foroerecta fuit, multis fui partibus deaurata. Eam uero tum alins honoribus afficiun, tum at ro ornăt, nefydus quod Capram uocant, fuo exortu noxium fit, cum alioqui fubinde uineis noceat. Nafcitur Oleniæ fignum plutuiale Capella, Cuidius. Plura uide apud aftrologos, \& infra in capra

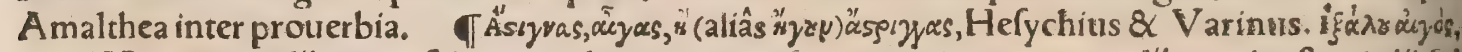
apud Homerum, alï caprz faltantis uel cum imperu fe mouentis exponunt, alì caprí caftratialij fyl rreltris, uide infra in Capra fylueftri, Ka àvтঞ, Hefychius \& Varinus. Vide ne Calydonia non epitheton capra fit, led eadem qua A.malthea, Eft enim Olenus urbs in Aetolia, iuxta quam fuit aper Calydonius:in qua nutritam fertunt capram

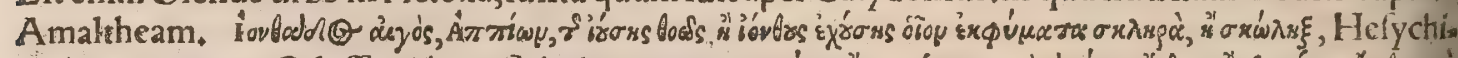

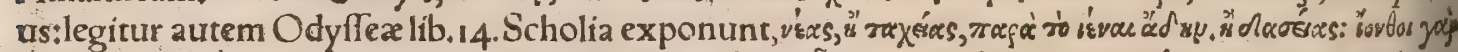

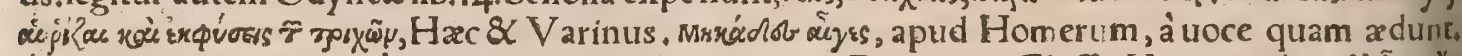

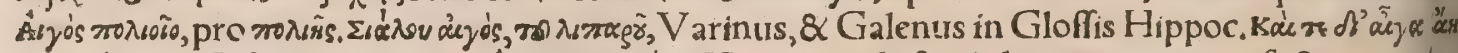

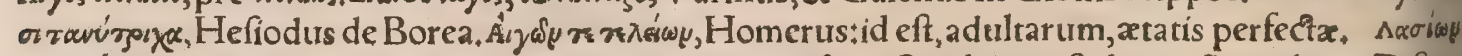

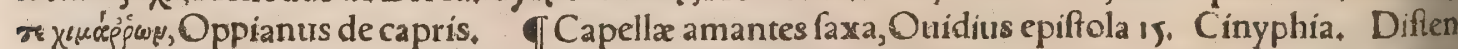
tx lacie, Vergil.Aeglog.7. Dumiuaga. Felix pecus, Vergil, Aeg.1. Frondipeta. Graciles, Ouix dius ı. Metam. Hirfuta. Hirtæ, Vergil.in Georg. 8 Iuuenal.Sat.5. Intonfa, Lafciua, Vergilitus Aeg. 2. Olida. Pauida. Petulca. Querula. Rorans lacie. Sequax. Simæ, Vergil.Ảeg 10. Te geatis. Timida. Villofa. Vrentes culta, Verg.2,Georg. Omne enim quod momorderint, urunt, Seruius. TA capra adiectiuum fit caprinus. Caprinus grex, Liuius 2. bellí Pun. Calepinus caprih lum etiam dici uult, quod probat ex Varrone de reruft.lib. 1.ubi nunc caprinum legimus. Sunt qui capreus adiectiua uoce proferant recentiores:hinc capreum uellus, Sipontinus. Caprile femen mo bilius eft, Varro de re ruft. Caperare frontem, rugis contrahere, \& afperitatem uultus ofiendere: quod à crifpis caprorum front bus traçum eft, authore Varrone libro 3. de lingua Lat, uel à cornut̂ caprinorum fimilitudine, refte Fefto. Vnde 8 caperatum rugofum dicitur. Vfus eft in paffiua fignir ficatione Plautus in Epid. Quid illuc eft, quòd illi caperat frons feueritedine Caprunculum, ua! 


\section{De Capra. H. Lib. I. 293}

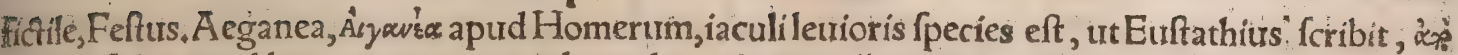
Tol kैy ye isaac, quod longius mittatur:uel quod ancyle ex pelle concinnaretur caprina : Signat uero

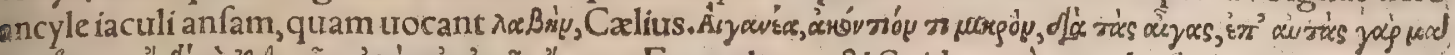

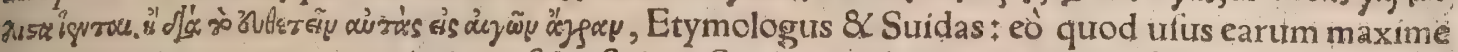
fit in uenatione caprarum, nimirum fylueftrium. Suidas iaculum exponit holofideron, id eft ex fer-

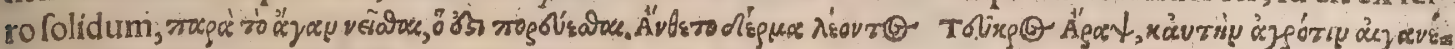
ap, in epigrammate quodam ut citat Suidas . Plura de hoc uocabulo lege apud Varinum. A Aly

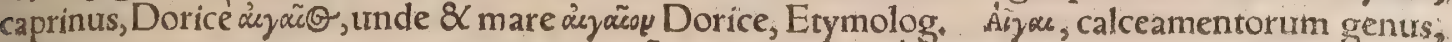

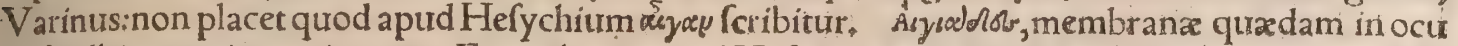
lis, \& albicantes in eis cicatrices, Etymologus:apud Hefychium \& Varinum áes senídiob, qutring, fylla bis legitur. Tharix forminam(lego formina)habet, quam Graci uocant agida, mellei coloris, Pii nius $16.390^{\circ}$ Quod $x$ gidem appellant, pinus foemina gignit. Id autem eft cor eius, 8Cc. Theophraftus dehiftoria plant, 3.10 . Et rurfus aliquanto poft, eodem capite, Habet ut pinus ægidem:ita abies albü, diçum luffon, ueluti xgidi refpondens, nifi quod hoc album, xgis gratius colorata eft, Arcades ams

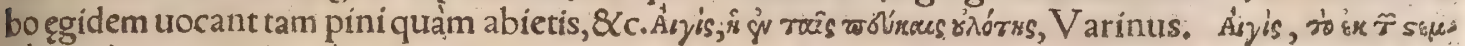

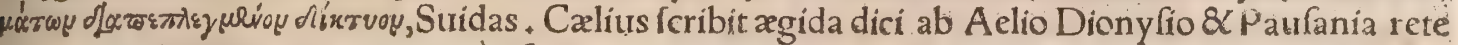
ex coronis contextum: quem uerö ufum habeat genus hoc, non explicant apertius:probabile tamen

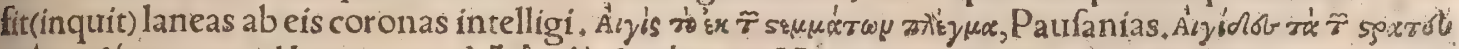

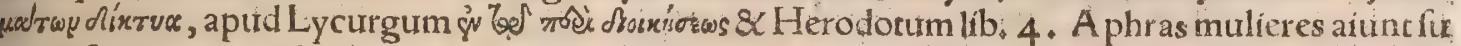
per ueltem nudas geftare caprarum pelles fimbriatas, ac rubrica litas, unde apud Græcos defluxe.

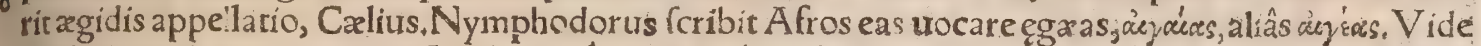

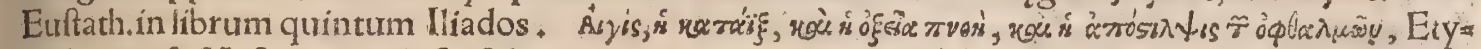
mologus, \& Hefychius: id eft, fubitis uenti motus uel impetus, oculi momentum cum fplendore.

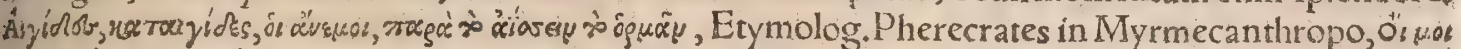

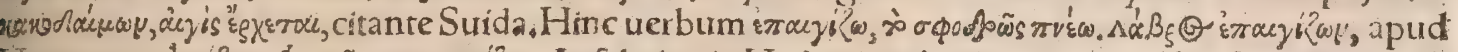

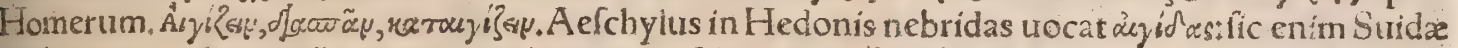

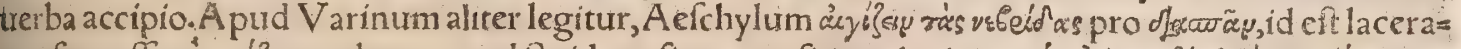
re ufurpaffe. År

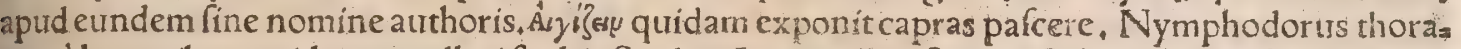
cem à Laconibus ægidem appellari fcribir, Suidas. A egis pellis eft quam Libyes (Libyfia mulie: es,

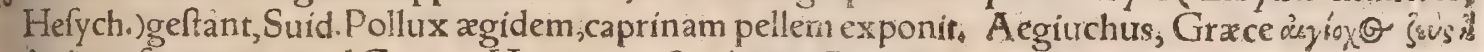

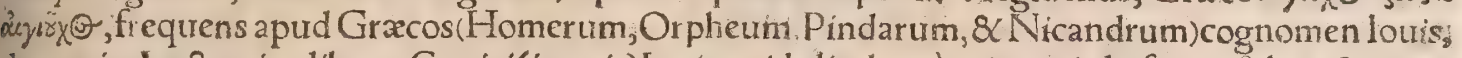
de quo ita Lactantius libro 1. Cretici(inquit) louis quid aliud, quàm quo modo fit aut fubtracius pas tri, aut nutritus, oftendunt? Capella enim A maltheæ nymphæ; quæ uberibus fuis aluit infantem, de qua Germanicus Carar in Arateo carmine fic ait; Ilia putatur Nutrix effe louis, fi trè èlupiter infans Vbera Cretex mulfit fidiffima capra, Sy ere quæe claro gratum teftatur alumnum. Hurius capellæ corio ufum effe pro fcuto louem contra Titanas dimicãtem, Mufxus aucfor eftunde à poé tis agiochus nominatur, Hacienus ex Lactantio, Hyginius uerò: Euhemerus inquit, A egam quan= dam fuife $\mathrm{Panos}$ uxorem, eam comprelfam à loue peperiffe, quem uri fui Panos diceret filium. Ita=

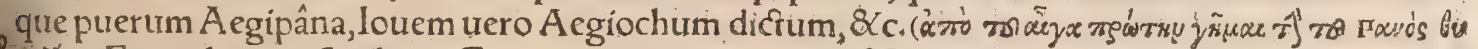
yätepa, Etymologus.) Scribunt Gręci grammatici quod poft louis natiutatem, ipée fic in Creta à cam. pra inuentus(uertendum erat; quod lupiter in Creta natus, nutrimentum ex capra inuenerit, id eft

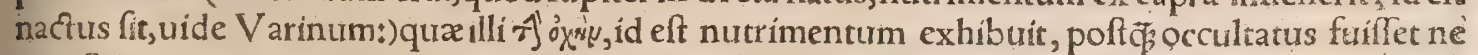
eum Saturnus pater toraret, cuius capræ cornu fit A malthex datum. Vel Iupiter egiochus appella

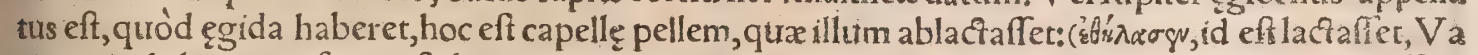
rinus unde hęc transfert:geftabat autem, inquiunt, hanc pellem Iupiter, in rei memoriam.) Efina gebatur uero ægis eius ex materia prétiofa, ad caprinę pellis fimilitudinem. Sunt qui à $V$ ulcano in Ió uis gratiam factam dicant. Alíj, inter quos Arpocration, egidas effe uolunt nexus \& plicaturas è co ronis, \& retia coronis implicatałatç hinc funt qui nomen (egiochi) deductum effe opinentur. Sed magis uerifimile uidetur, Iourem egiuchum nuncupatum à uentorum $\&$ turbinum conuerfionibus, (idem Varinus fribit) quas ipfe lupiter commoueat, Grece æagidas \& categidas appellatas $₫$ ut ex

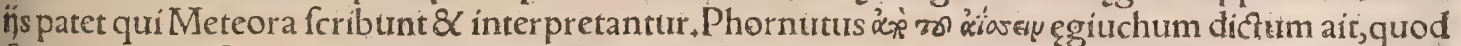
filicet impetu feratur, Hæc de egiocho Loue omnia ex Gyraldo. Phyfica allegoria (inquit Cælius) louris \& Pallados ęidem interpretamur:quando co nomine procellas afrectionesćp in fúblimi con:

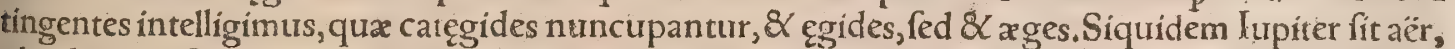
ubi id genus formidolofa concipi folent:Ad quem Pallada item referunt eruditiores. A egis eft mu nimentum pecforis æreum,(uerba funt Seruin)à Vulcano fabricatum, habens in medio Gorgonis caput, \&c. Hoc fi in pectore hominis fuerit, ficut in antiquis imperatorum ftatuis cernimus, lorica irocatur. Si uero in pectore numinis, nam $\&$ fcutum louis $\&$ Palladis ab Homero ita appellatur, $x$ gis dicitur. Vide Ouidium circa finem lib. 4. Metam. Aegifono quam nec fera pectore uirgo, Valerius

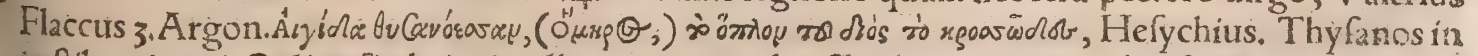
ireltibus(inquit Calius)fimbrias intellige, quas item broflos (ego nunquam broflum apud idoncos 
authores, fed femper croffum legi)uel croffos per omicron ucocitant:funt autem fchifmata, id eff fif furæ quædam. Qualís nam fuerit louis æagis, \& an Minerua propriã habuerit ægidem, uel à loue tan tum mutuata fit, uide apurd Varinum in Áty is zol doss. De Aegide quam induta facerdos notos nut

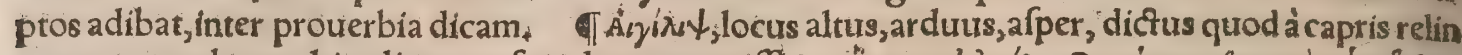

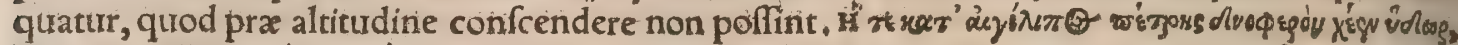

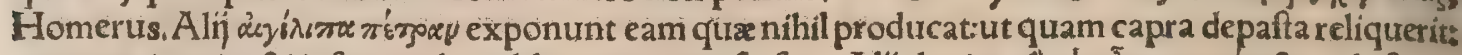

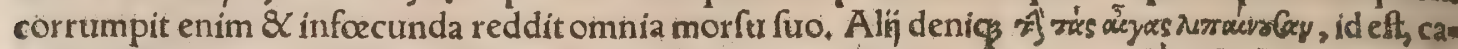
pras faginantem:poffunt enim etiam in faxofis \& afperis locis capræ commodé pafci, Varinus. Aise i in w $\psi$, abfceffus eft in maiore angulo oculi, uel inter illum et nares, per quem piruira affidué deftillat:

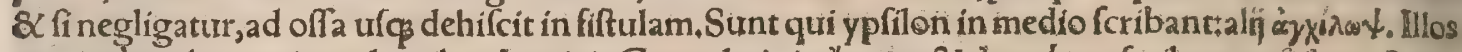
minime probo qul in uulgaribus Lexicis Græcolatinis, aڤy lops apud Suidam pupillæ paffio exponitur, fine authore. - IMachinx traciorix genus tripes, ar pud Vitruurium 10,2, his tterbis defcribitur: Tigna tria ad onerum magnitudinem ratione expediun tur, \& à capire à fibula coniuncta, $\mathcal{Q}$ in imo diuaricata eriguntur funibus in capitibus collocatis, $\$ C_{c}$, Hac machina hodie utuntur nauta (inquit Gul.Philander) capram uocantes, Pueri noftrates lignd tripes, quod capram trocant, in ludo quodam erigunt, 8 baculis eminus petunt.

of Caprificus, fylueftris eft ficus. Tithymallum noftri herbam lactariam uocant, alị lactucam capri nam, \&c. Plinitss, Et alibi, Lactuca, inquit, fponte nafcentis, primum eft genus eius quam caprinam uocant, qua pifces in mare deieça protinus necantur, qui funt in proximo. Hoc Diofcorides ultimo inter tithymallos uerbafci folip̧s attriburit. Caprariam rutam, ut medici recentiores uocant, in Gallia Narbonenfi uidi: Germania non habet:meminit eius Ântonius Brafautolus, \& cc. Manardus libri is. epiftola ultima non reçè fufpicatur polemoniam effe. Capra lien, malua fecundum magos, inter no menclaturas Diofcoridis. A egilops herba eft, quamVergilius auenam fterilem uocauit in Georg; Enecat hordeum feftuca qux urocatur ægilops,Plin.18,19. Galenus etiam fcribit feftucam, qux Gr ęa ce dicatur ægilops, in hordeo frequentiorem erumpere, præcipuécum imbecillius femen diutius hu mo conditum, infelici exortu nartum adoleuerit. Plinius auenam Gracam uocauit cui non caditfes men:tion nifi poft annum ex femine fuo gignitur, uere pilofum ei folium ut lolio, non tamen ut tili pingue, fi Theophrafto credimus, immitis alpeçu, \&c. hinc forte æegilops dici meruit, quemadmodir $\&$ oculi uitium inde dicfum uideri poteft:nam louis aut $P$ alladis $x$ gid a poéræ horriferam, terrificam Q iratam cognominant, Nifi quis malit ita diçam: quod fui nominis morbum oculorum fanet, ut Diofcorides frribit.Eandem ob caufam arbor xgilops fortaffe nomen hahet, cum glans illifit triftis,

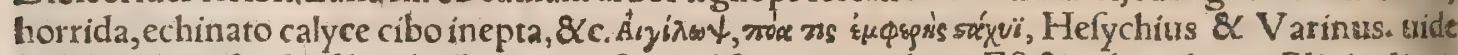
Diofcoridem. Quibufdam bulbi genus eft, haud fcio qro authore. Eft $\&$ arbor, de qua Plinius if. 16. Excelffilima agglops, incultis amica églandiferis fola, \&c. Gaza in Theophrafto Macedonicã afprin cerrum ucrtit:Plinitus eadem omnia agilopi cerro tribuit. A egithalus herba genus eft, Varinus:Sui

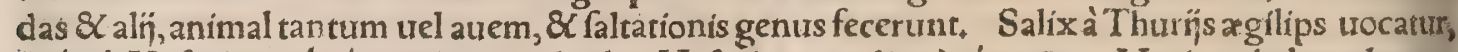

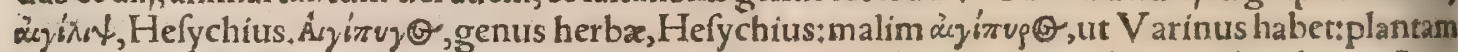
effe fpinofam fcribens:uel herbæe genus, folio lato, lenticula fimili, colore glauco, ulceribus inflama matis utilem. Videndum an fit anchufa, uel tribuli potius aliquod genus. Fieri poteft ut imperits grammatici diuerfas plantas confuderint. Meminit ægipyri Theocrirus, \& Ariftophanis Scholiaftes in Ranis, cuius hac funt uerba: Diony fri facerdotem, ut Eupolis inquit, æegipyron exiftimate, hoceft

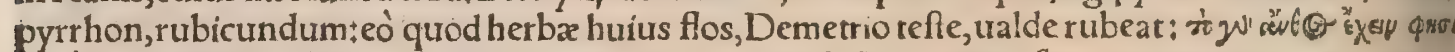

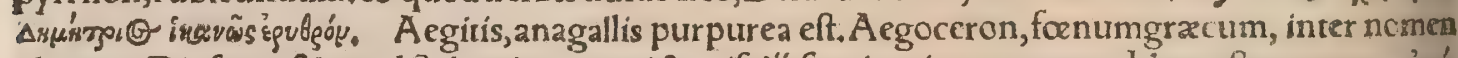

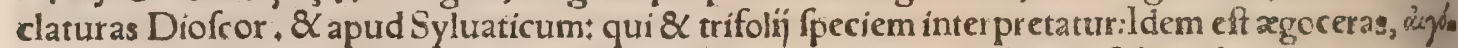
ecpos, ut habet Plinius \& Galenus in Gloffis Hipp.alio nomine, ififdem teftibus, buceras uocatur, Quoniam corniculis femen (filiqua) eft fimile, Plinius. A pud Hefychium non recie ferrbitur äyikspexp

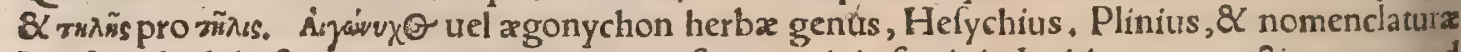
Diofcoridis, lithofpermon interpretantur:catfa nominis in feminis duritie, quam rectitus tamen ad lapidem, quàm ungulam referas: cum fragilis fit, non ut in afparagi femine cornu vel ungula inflax

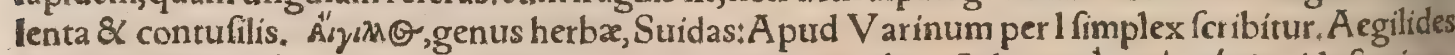

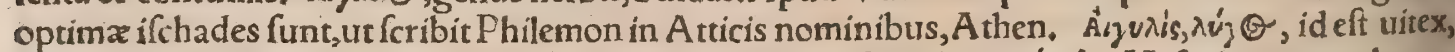
Etymologus. Aegynos, cicuta, inter nomenclaturas Diofcoridis. Kúvad $\alpha$, Hefychius cynosbatum interpretatur, tel plantam quam capras depafci aiunt. Phillyream Diofcoridis, hoc eft liguffrum, Germanorum quidam gei $\$$ b o 15 , hoc ef lignum caprinum uecant. Eft $\&$ herba fyluatica, flere can dido, mufcofo, odorato, oblongo $\mathcal{Q}$ barbx quandam referente fpeciem, quam recentiores quidam in fuis plantarum hiftorijs Germanico nomine gei f bart appellant, id eft barbam caprinam, ab hircina diuerfam:nullo haćenus in medicina ufu, nec ueteribus puto memorata. Hortenfi cultu digna uide tur, propter egregium $\&$ odoratum florem, apibus $\&$ omni infectorum uolucrium generi gratifli mum: facilimê prouenit tranfplantata, quod meo experimento dídici: $\&$;in multos annos ftiv ps una durat.

đMufrimones, uel Mufmones potius, caprino uillo animalia, inter Oures dicẽtur. Albertıs murfmo nem ex capra \& ariete nafci frribit. Asyóovoues, animalia fic dicta, Hefychius \& Varinus, auginevs $\theta$ 


\section{DeCapra. H. Lib. I. 295}

pro ăchrge, Etymologus $8 \times$ Varints, Caprimulgts auis nocht intrans paftortim ftabula, caprarum uberibus aduolat fuctum propter lactis:qua iniuria, uber emoritur, capriśḉ cæcitas quas ita mulfe re oboritur, Plinius. Græci hunc ægothelan nominant:å quo differt ægithalus, Gazæ parus. Alia eft \&. agithus auis minima, falum alicubi transfert $\mathrm{Gaza}+\mathrm{Caprimulgus} \mathrm{apudCatullum} \mathrm{dicitur} \mathrm{is} \mathrm{qui} \mathrm{ca}$

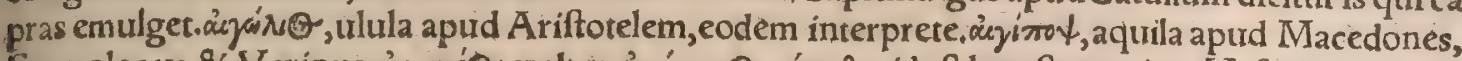

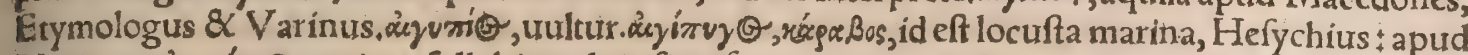

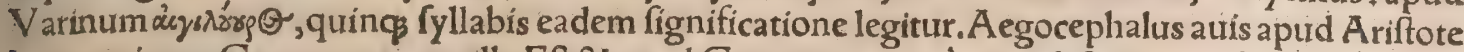
lem, capriceps, Gaza:ut ax capella. Eft \& apud Germanos auis à uoce dicta bimmelgeif́, id eft ä̌s ria capra.

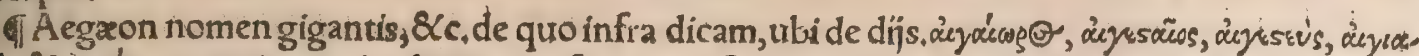
$\lambda s i s$, \& ácydi $\lambda s$, propria nomina hominum funt apud Suidam, de quibus tamen ille aliud nihil fcribic.

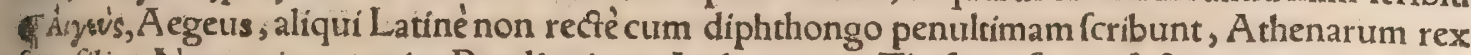
fuit, filius Neptuni(aut uerius $P$ andionis)ex Aethra uxore Thefeum filium fufcepit, quem Ouidius Aegidèm patronymicé cognominat, uide Onomafticon. Habuit \& Medeam uxorem. Huius \& The

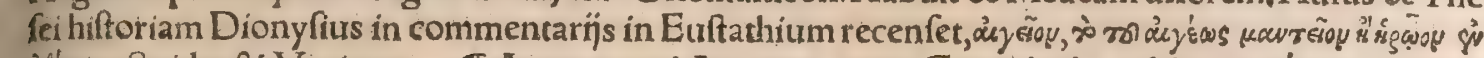

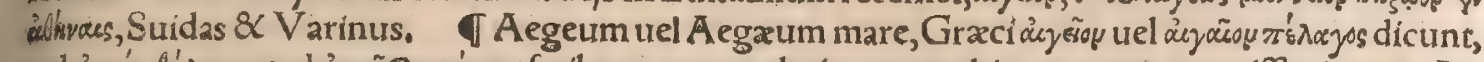

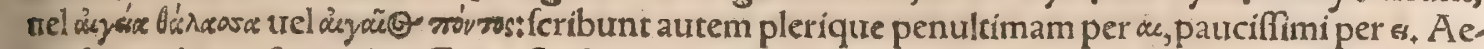
ges $\&$ xgides ut fupra dixi Græci fluctus, uel magnos fluctus exponunt: ab a้u g autem communiter

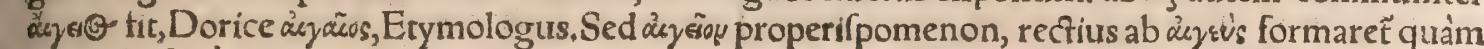
10 ab ớs. Eft fanè A egeum pelagus fluctibus \& nauigandi periculo terribile, Suidas $\&$ V arinus. Idem Dionyfus poéra teltatur, circa Sporades infulas frribens Aegeum pelagus furis fluctibus refonare: nec ullum effe alium maris meatum, cuius undx uehementius $\&$ altius agitentur. Aegri maris latũ æquor, ank ream uerfus Propontis anguftus meatus excipit, Euftathius in Dionyf. Etrurfus, Hoc mare aliqui dictum uolũt ab Aegaone, curius in Iliade meminit Homerus: Vel ab A egis loco Bceotia, in quo po ẽta Neptuni equos quíefcentes facit. Aliqui dictum malunt ab Aegeo Thefei patre, qui in illud mare re pracipitârit ab arce in Aegis infula, fic enim Etymologur fentire uidecur:trel (ut alij) ex Athena= rum arce. Vide Etymologicon, Varinum,Suidam, \& Cælium libro ız.circa finem ca. 9 .A Agæum rya re Cyclades alluit, Hefych. Sunt qui A egeam Amazonum reginam in eo peritffe referant. Acgro mari nomen dedic fcopulus inter Tenedum \& Chium uerius quàm infula, A ex nomine, à fpecię ca= præquæ à Gracis íta appellatur, repente in medio mari exiliens, Plin. Solinus hoc faxum Antandrũ nominat, quod procul uifentibus capræ fimile creditur. A capris nominauerunt Aegæum pelagus, Varro.Aegas Eubcex urbem Septentrionem uerfus memorat etiam Theophraftus in fine libri 9. hift.plant. Fuerunt $\&$ aliæ plures Aegæ, de quibus confule Stephanum: $\mathcal{X}$ inter cæteras Aegæ Ma,

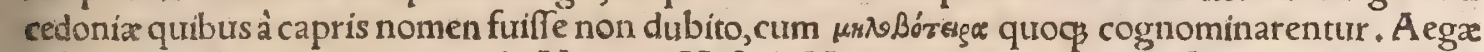
infula iuxta Euboeam, cum templo Neptuni,Hefych. Vide etiam Varinum \& Etymologữ in áuyces \& Strabonem libro 8, quíab Euboicis Aegis mari Aegxo nomen inditũ uerifimilius puțat. A chaí. cæuero A ega, hoc tempore, inquit, defertæ incolis funt, urbem habent Aegienfes. Aegion fatis in= colarum habet:quo in loco louem à capra laftatum fribunt, \& $c$. Vide Äzrop in Camerte \& Stepha=

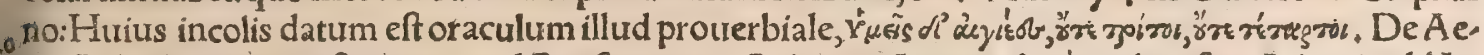
gis Achaicis mentio eft etiam apud Paufaniam in Achaicis. Aegeis, ácyriss, tribus fuit Athenis, ablAe geo Pandionis, filio dicta, tribules Aegidx, Stephanus, Suidas, Hefych.A pecore nomina habemus, Ouinius, Caprilius; item cognomina, ut Annï Capra, Statilï Tauri,8c. Varro. Aegaus finus eft

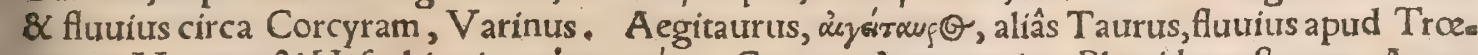
zenem, Varinus $\&$ Hefychius in Trévgen rojuce. Campus Aegaus circa Phocidem eft, quem Aegas fluuius alluit, Euftath. in Dionyf. Vide etiam Stephanum, apud quem legendum puto hoc modo,

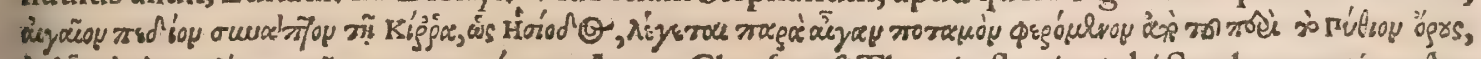

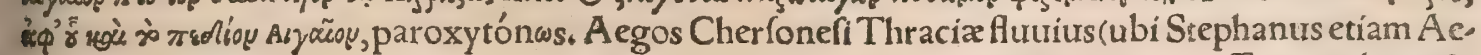
gas oppidum effe meminit)apud Strabonem, ut quidam feribunt:ego genitiuum effe puto ab $æ x, 8<$ - addendum potamós, id eft fuuium: ad huius oftia claffis Athenienfium à Lyfandro capta fuir, idón factum interdiu in Thracix parte ad A egos flumen. Alyós no rumoi, urbs Hellefponti, Steph. A egofthe=

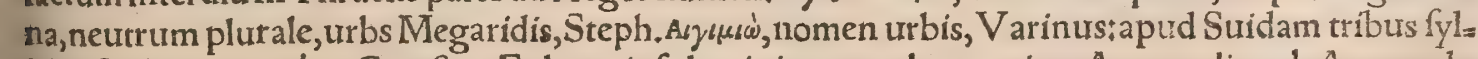

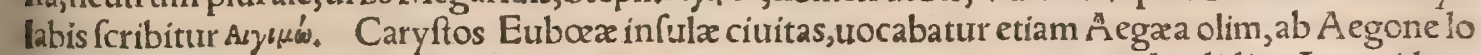
ci domino, à quo 8 mare Aegæum, Stephanus. Aegates, promontorium Acolidis: Artemidoro Aex dicitur in nominatiue, Steph. Aegiale ciuitas eft in A morgo una Cycladum:item unà Gratiart inquit Lactantius, alio nomine Thalia. De Aegiale Dicmedis uxore, uide Onomafticon. Aegiale us Medex frater fuit: $\mathcal{Q}$ alius A pidis frater, Phoronei filius, 8 c. A egeftæi, Thefproti, ab Aegefta quo dam imperatore dicti,Stephanus, Aegimus rex Dorienfium fuit circa Cetam, Stephanus in Dy màn. A egila, uicus fuit A tticæ, ab A egilo quodam heroë diçus, Philemon in Acticis dictiónibus, ut Äthenæus citat. Alyzerios Gracis eft littus maris, arenofum proprie $\mathcal{Q}$ calculofum : etymon adfe-

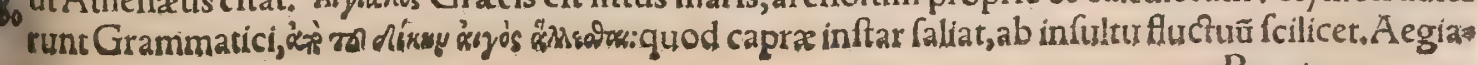




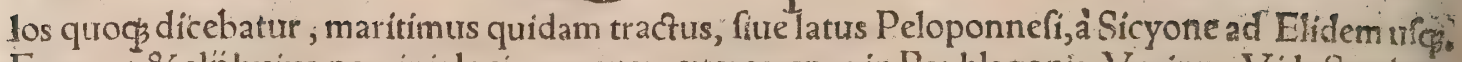
Fucrunt $\&$ alij huius nominis loci, ac præter cæeteros unus in Paphlagonia, $V$ arinus. Vide Stephan.

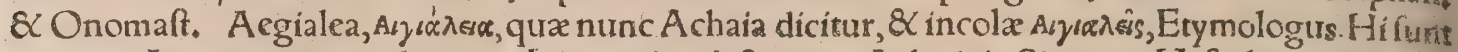
qui cum A gamemnone militarunt, lones prius dicti, nunc A $A$ chæi, in Sicyone, Hefychius \& $V$ arifi.

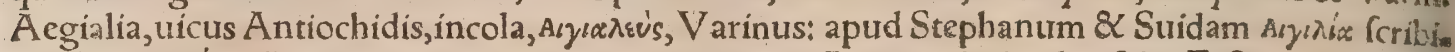

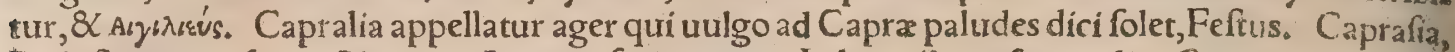
Padi fluminis oftium, Plin.3.16. A capris feris propter Italiam Caprafia ( $m a l i m$ Capraria) inivia eft nominata:à quibus ortæ funt capræ quas alimus, Varro. Capraria infula in mari Thuf́co feu Ligu ftico capris abundans, quam Graci Aegilon dicunt, ut forbit Plinius $3 \cdot 6.0$ Solinus ca.9. Alia eft Ae gilla uel Aegyla a pud Plinium 4.12. Aegimurum Sipontinus ob nominis fimilitudinem .Caprari. am effe fallo tradidit, \&c. Hermolaus in Plinium.5.7. Caprix uel Caprex, infula ultra Surrentum Campaniæ urbem, circiter ocio milia paffuum, nobilis coturnicum multitudine, qua ex ltălia uclain

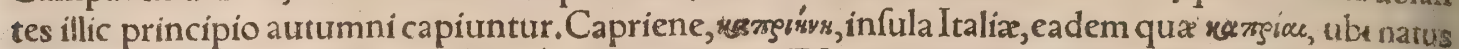
eft Blafus Capriata poëra avofogensíny, Stephanus. Eft autem una tantum infula, ni fallor, quam= uis in plurali Caprea dicta. A Surrento octo M. paff.diftant, Tibern̈ principis arce nobiles Capi ex, circuitu XL.M.paff.Plin.3.6. Sirenes primo iuxta Pelorim, poft in Capreis infula habitauerût, Serul us. Capraria uocatur una ex Fortunatis infulis, enormibus lacertis plus quàm referta, Solinus. A egimorus infula elt Libya:uel ut alĭ, ante Siciliam \& Africam, alì Aégimurum fribunt, per $u_{*}$ Vide Steph $\&$ Strabonem. De Aegimoris infulis, Plinius y.7. Eft \& Polyæga nonten infulæ Plinio.

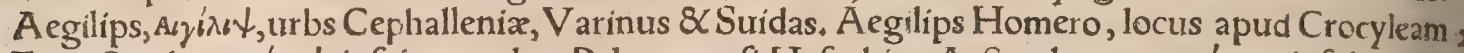

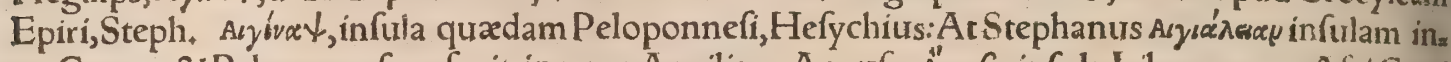
ter Cretam \&<Peloponnefum facit, in uoce Aegilia. Aegufa, ÄryzCa, infula Libyx, quam A fri Catri am uocãt,Steph. praftat per $\mathrm{fduplex}$ fcribere, cum gentule inde fieri dicat Alegufæus ut Scorufæus: nam hoc quogsper fduplex fcribendum eft, ut primitiuum Scotuffa, Aeguffx meminit Plinius 3.\&. Aegaufienfe uinum in Afia celebratur, Calius. Äzsege Achaia urbs eft, dicta nimirum ab alno ar, bore, quemadmodum ab ulmo Ptelea.Patranias tamen libro 6. (ut Steph, recitat) huius nominis ras tionem affert huiufmodi.Cum Sicyoniorum exercitus aduerfus $A$ egiratas ueniret, capris coliechis faces earum cornibus alligarunt nociu:Quibus confpectis Sicyonij exercitum auxiliarem Aegira tis uenire fufpicati, fugerunt. Vnde illi liberati urbem Hyperefiam prius dictam, Aegiram appellar

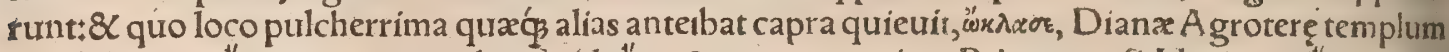

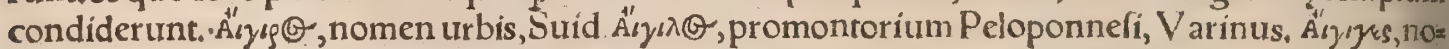
men gentis, Suid. Aexonia, urbs Magnefia, \& Aexone pars tribus Cecropidis, Steph. C aprullon portus prope montem A tho Pomp.Melæ lib. 2. Aegone uel Aegonea, nomen ui bis, Suidas: Stepha nus addit Melienfium effe. Aegoftis, urbs Locridis, Steph. Aegys, urbs Laconica, Steph. Gangra Paphlagonię urbs eft, cuius nominis originem Nicoftratus, referente Stephano, iftam facir: Cum caprarius quidam ruri capras adeffe omnes reperiret, domi uero unam deeffe: rem domino narrax uit. Iuffit ille diligenter quęnam fecederet obferuare. Deprehendit igitur unam in altum quendam collem afcendere, \& intra illum hoedorum uoces audiuit, quos illic capra enixa erat. Et cum commo dus is locus (dominø) uideretur, ciuitatem in eo conditam Gangram appellauit, quod capellix nos men fuerat

बb. Mefas eft radix corni capriní:Aly interpretantur partem cornu iuxta pedes animalis, $\bar{A}_{n}$ dr.Bellunen. Aegophthalmos gemmæ nomen eft apud Plinium lib.37. Gemmæ non paucx (inquit Ge.Agricola)lineis inter fe difcurrentibus, \& fæpenumero colore uariatis, effigies rerum expri= munt;oculi quidem humani, leucophthalmos:caprini, xgophthalmos, \&c.Mufmones arietes in Sar. dinia pilum habent caprinum,Strabo. Equiceruo cornua funt capræ proxima, Arifot. Caprarum barba firilum uocatur, Sipontinus, Nonnulla etiam duplicigenitali, altero maris, altero forminẹ na fcuntur: $\&$ in genere quidem hominum, fed maxime in caprarum: gignuntur enim quas uocane hir

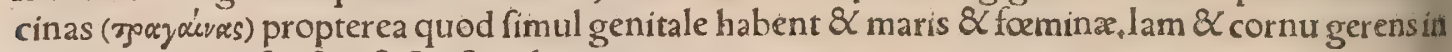
crure capra confpecta eft, Ariftot. de generat anim. $4.4^{*}$

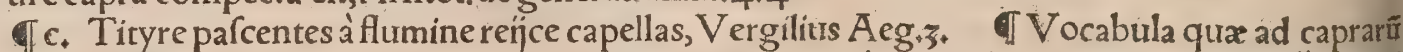

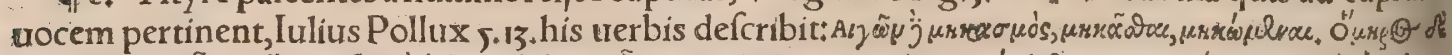

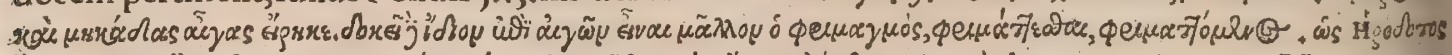

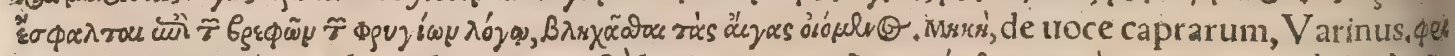

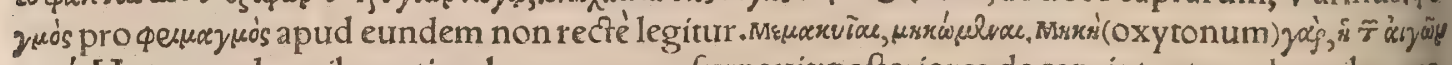
фwrú. Homerus de oubus etiam hanc uocem ufurpauit:pofteriores de capris tantum, de ouibus ven

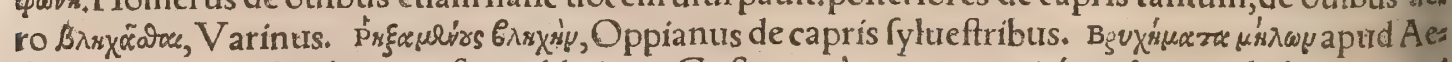
fchylum, ut citat Strabocirca finem libri ı 4. Guftatum à pecore capris ̧́ pulegium, balatum conci tat:unde quidam Græci literas mutantes blêchon uocauerunt, Plinius. Sed balare proprium ouitum eft. I Iam puerum ortum capite arietis aut bouis referunt, \& c. fed nihil ex n̈s, quæ nominant, eft: quamuis fimiliturdo quxdam generatur:quod euenit etiam non in monftrum perterfis : quamobre fapenumero per conuicium rionnulli deformes affimilantur, aut capræignem efflant, aut arietipe tulco, Ariftot, degenerat,animal,lib.4,cap.3. TCiborum in capris fuper fluitates, $\mathrm{P}$ alladius capri- 


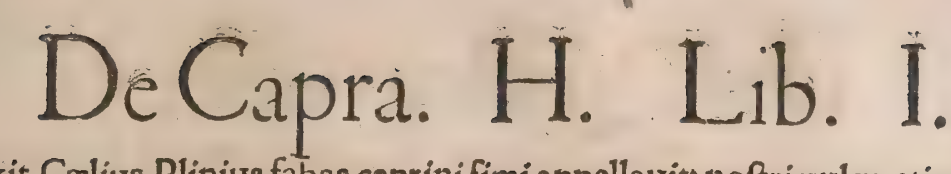

naas facetébaccas dixit, $\mathrm{C}$ xlius, Plinius fabas caprini fimi appellauit: noftri uulgo etiam caprartum fa bas:Marcellus Empiricus ftercoris caprini pilulas: Græci ఐuǵc $\theta$ rs genere forminino. Nicander in

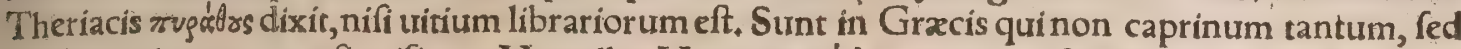
ouillum etiam ea uoce fignificent, Marcellus Verg. Irvegónéss, caprarum \& ouium excrementa, Ga.

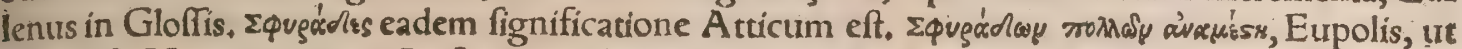

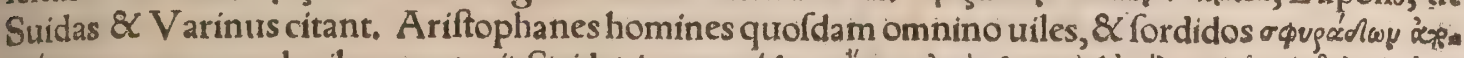

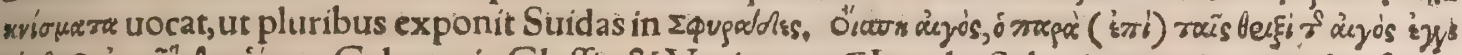

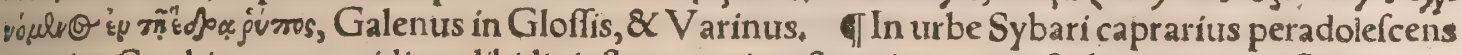
nomine Crathis, cum cupiditate libidinis flagraret, inceftum in capram fcelus exercuit: Quod qui. dem ipfum ut hircus gregis dux perfpexit, riualitate laborare, at $\beta_{\text {interea fuum occultare animum }}$ coxpit, quoad aliquando tandem eum fomnum capere deprehendiffet: tum enim omnibus reuocatis uíribus, facto in eum impetu, cerebrum diminuit. Cum eiufmodi facium ad indigenas per manaflet, non modo ei tumulum magnificum excitarunt, fed ex eo etiam flutuium Crathim nominarunt ( $\mathrm{Cra}$ this fluuius iuxta Aegas Achaicas à duobus fluminibus incrementa fufcipit, fic à mifcendis aquis ap pellatus:à quo $\&$ Italicus uocatus eft Crathis, Strabo: ) infantem autem puerum ex eius cum capra confuetudine fufceptum, caprina habentem crura, \& faciem humanã, in deos repofitum, deorumḉ honore affeçum fuiffe, \& Syluanum deum (Hylaum numen Napæumó́, Cælius:) effe in fermonē hominum uenit. In beluís igitur obtrectationem $\&$ riualitatem ineffe hircus docet. Eandem hifto:

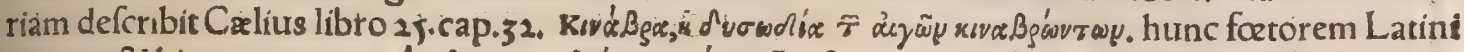

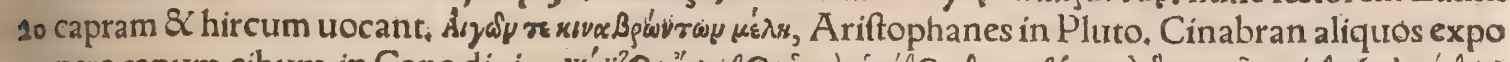

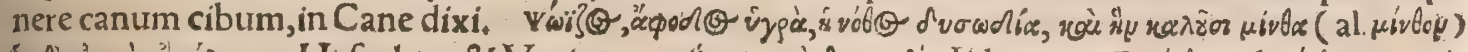

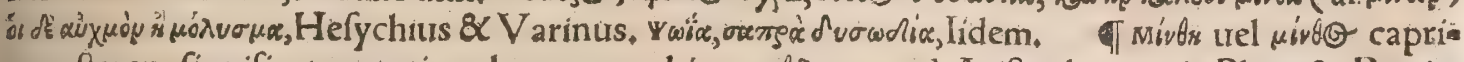

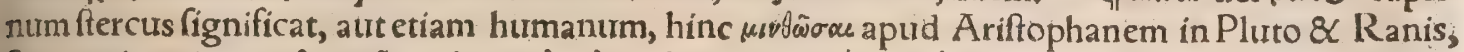

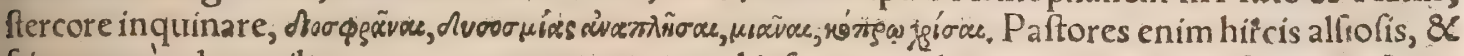
frigus ægrè tolerantibus nares excrementorum uel ipforum uel hominum inungere folebant: $\&$ eo foxtore ad fternutandum mouere, quod hoc pacto nimio frigoris fenfuliberentur. Minthon aliqui mentam herbam, alý thymum, alí iyngem exponunt: alï floris genus in ftercore nafcentis, quo hirci gaudeant, Varinus \& Scholia Ariftophanis.

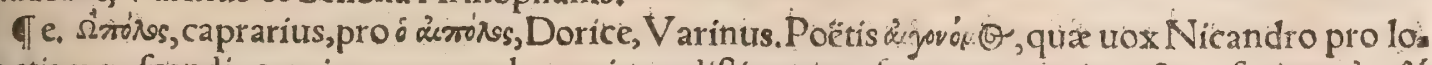
zo co etiam pafcendis capris accommodo ponitur : diftinguitur for te accentu in recto cafu:item áeys $B^{\prime}$

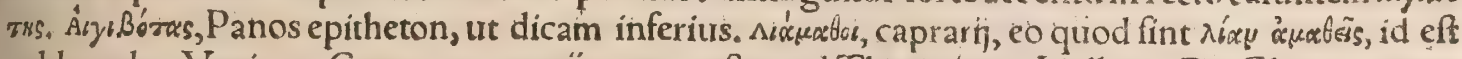
ualderudes, Varinus, Comatas caprary̆ nomen eft apud Theocritum Idyllio s. De Glauco capra-

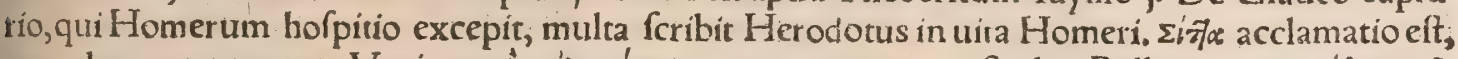
qua ad capras utuntur, Varinus. Ärroiner xúves, canes caprarum cuftodes; Polltix. If AryíBotos $\gamma \tilde{x}$, terra apta pafcendis capris, Suidas \& Hefychitis: proprie autem de montana dicitir; quam ácyiryouj

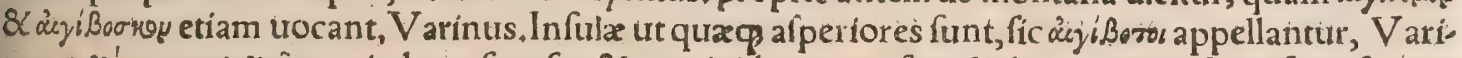

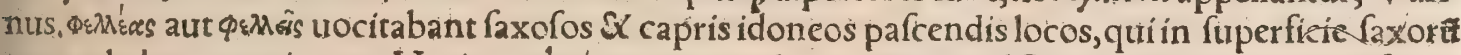

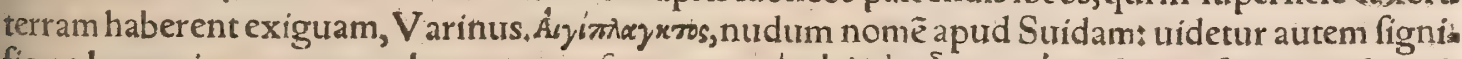

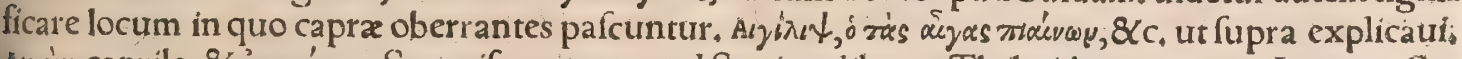

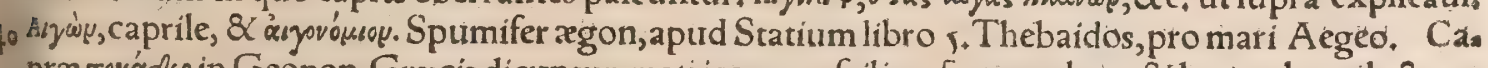
præ roxkedss in Geopon. Græcis dicuntur, matrices quæ fcilicet foetum alunt, \& lac præbent:lactares Marcellus Empiricus dixit:quæ tamen intelligi polfunt etiam abfos fortu, \& 8 cum à parti remotiores funt, In capram multo $\&$ dulci lacte abundantem, \& co nomine a Cafare quodam abductam epi.

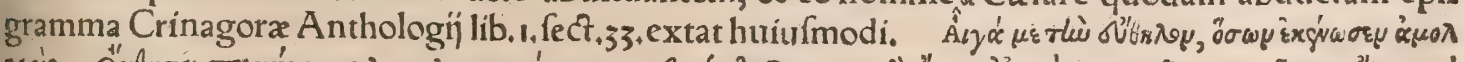

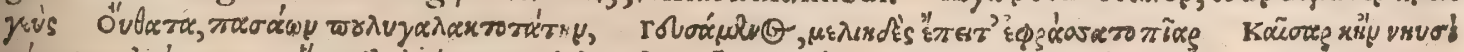

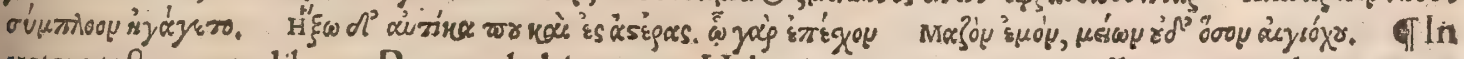
uetere teftamento, libro 1.Regum kebir uocem Hebraicam exponunt capillitium ex pilis caprinis inftar capitis criniti factum : Ionathan tamen uertit noda, id eft utrem ex pelle fcilicet caprina $\&$ pis lofa factum.

50 Tf. Aegitho Thyeftis \& Pelopia filio capra alimentum fuggeffit, Calius ex Aeliani Varijs,

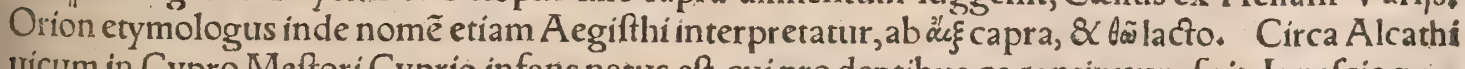
uicum in Cypro Meftori Cyprio infans natus eft,cui pre dentibus os continuum fuit, Is nefcio pro. pter quam fufpicionem expofitus, à capra nutritus eft: $\mathcal{Q}$ primum Aeginomas dictus, poftea Eury prolemus, \& Cyprins imperauit, Pollux libro fecundo. Antiphanes in Aceftria apud Ailienxum, atrarum qurendam illas tantum capras mactantem inducit, ex quibus nullum amplius fructum hó dorum aut cafei capiebat.

Th. Cur ueteres facerdotes capra fic abfinurerint, ttt neę tangerent aut ederent, neqs nominat rent, ex Plutarcho expofui fupra cap. 3. Capræ oliuam lambendo quó̧̧ fterilem faciunt, eaćs ex caufa Mineruæ non immolantur, Plinius. Capras in arcem alcendere A thenis non licet, neque om 60 nino facrificari Mineruæ, quod oleæ ramos uorent $\&$ lædant, $A$ thenæus. Obferuatum eft (inquiti Calius) capras A thenis in arcem non iungi, (admitti: ) praterquam femel ad neceffarium farrifí ciumsne olea ibi nata primum, poffit tangi:quarido ita proditum eft, cius animantis faliuam effe frü 
Ctuis uenenum, quo nomine nec dex immolatur. A egyptỉ qui Iouis Thebani templum incolunt, aut Thebani ritus funt,,$\not \circ$ omnes ab ouibus fe abftinentes, capras immolant.QuiMendetis templum obtinent, fiue Mendefij ritus funt, hi capris abftinentes, immolant oues. Itaç Thebani , \& quicune propter illos ouibus parcunt, aiunt ideo fibi conditam hanclegem ₹ quod lupiter cum ab Hercule cernere eum uolente, cerni nollet, tandem exoratus id commentus fit, ut amputato arietis capite, pel lẹ́ uxillofa, quam illi detraxerat, induta fibi, ita fefe Herculi oftẽderet:Et ob id Aegyptios inftituiffe Louis fimulacrum facere arietina facie: \& ab A egyptïs A mmonios accepiffe, qui funt Âegyptiorum atç Aechiopum coloni, $\&$ linguram inter utrof os ufurpantes. Qui etiam mihi uidentur ea dem re fe Ammonios cognominaffe, quod Aegypií Iouem Ammonem appellant. Ob hancrem arietes non mactantur à Thebanis, fed eis facrofancti funt. Certo tantum die quotannis in fefto louis, unum de. mum arietem amputant, cuíus pellem detractam, hunc in modum louis fimulacrum indurunt, ad il. lud'́s deinde aliud đưcunt Herculis fimulacrum. Hoc, acto, cuncti qui circa templum arietem uerbe rant, deinde facra eun dem urna fepeliunt, $\mathrm{Hac}$ Herodotus libro 2. A gricola de boure rern diuinam facit, opilio de agno, xpolus de capra, Lucianus, Graci facrificaturi capras frigida aqua ex. plorabant : Nam fi guftare abnuiffent, concipiebant inde, haud ualere fatis, Calius. Capclla pro bubus immolatæ : item capræ auratæ albx Apollini immolatx, uide fupra in Boue $\mathrm{H}, \mathrm{h}$.

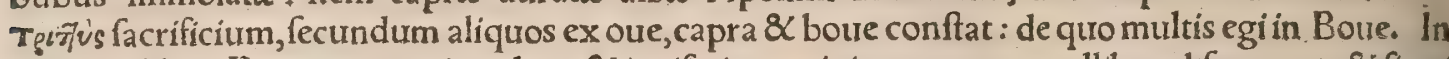
Lupercalibus Romæe capras iugulant, \& incifis in corrigias caprarum pellibus, difcurrunt : \& fi qui obftent, fcuticis cędunt, Plutarchus in Romulo. Embarus quidam, uel Barus, cum Diana Munyz chia ut regio à pefte liberaretur filiam alicuius immolandam requireret, ea conditione immolaturü fe fuam promifit, ut facerdotium familia eius perpetuó maneret; filia in adyto occultata, capram ei, us ueftimentis indutam mactauit:quæ res in prouerbium abït, ut in hominem prudentem et aftutü

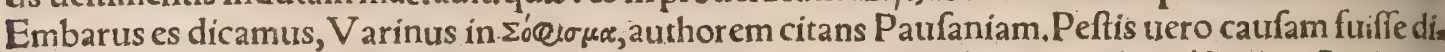

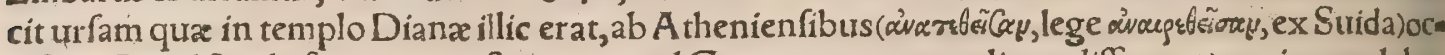
cifam. Apud Suidã fame non pefte (qux apud Gracos una tantum litera differunt) regionem labo: raffe fribitur Erafmus protrerbium Embarus fum, de homine infano, deliro \& demente inter preta tur, Suidam fecutus: qui Embarum filiam fuam uerę, non capram ei fubftitutam, immolaffe refert,

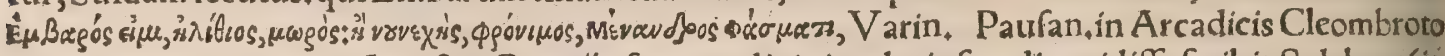
Lacedæmoniorũ regi in Leucrris Bœotr̄js fignum diunitus huiufmodi accidiffe fribit:Solebant(in quit)Lacedæmoniorum reges pecora fecum educere in bellum, ut dịs ante pręlia litarent \$ pręibant

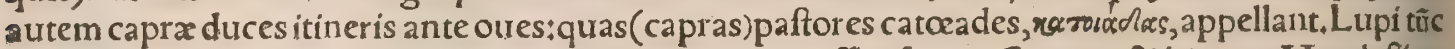
impetur in gregem facto, illafis ourbus in folas capras graffati funt. Capram \& hircum Mendefíco

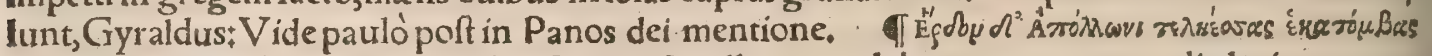

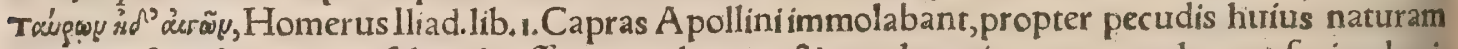
impetuofam, 8 in altum faltando efferri gaudentem: $\&$ quod caprina cornua ad arcus faciendos i. donea fint: A pollo autem toxotes ef, id eft arcubus $\mathcal{Q}$ fagittis oblectatur, V arinus in Táugrs đe aijas, ex Euftathio in Iliados I. Capra, qua nunquam fine febri eft, Aefculapio qui eft deus falutis, per cố trarietatem immolatur, Seruius. Aegazon, nomen gigantis, qui Coeli (aliâs Titanis) Terræọ́ filius fingitur: A egæeon qualis, centũ cui brachia dicunt, Centenas ós manus, \&c. Verg. 1i, 10. Seruius eum dem cum Briareo efle fcribit. Vide Onomafticon noftum $\&$ Varinum, \& Gyraldum in Opere de 4 dîs, Syntagmate quinto, duobus in locis. Hefychius Aegeonem exponit Briareon; \& deum maris

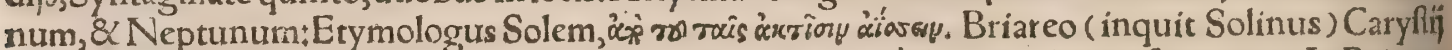
rem diunã faciunt, ficut A egæoni Chalcidêfes. Nã omnis ferè Eubıra Titanũ fuit regnũ. In Briareo (inquit Calius) quod oburium erat, fabulæ inuolucro factum cft obfcurius. Quippe prodir hiftoria effe in Afia tumulum A gronis nomine, abs quo fontium profiliens multitudo çircumiectos impin.

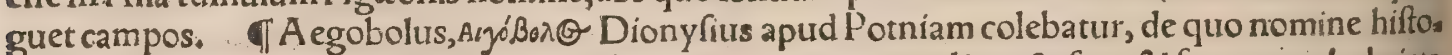
ria hac prodita clt. Cum ibi Dionylia celebrarent, ita in contumelias acti funt $\&$ furorem, ob ebrieta tem, ut Bacchifacerdotem interemerint,Quare dei ira graui peftilentia affecti funt. Ciues hac de re Apollínem confuluêre: à qưo refponfưm acceperunt, ur deo formofiffimum puerum immolarent, Quod cum Potnienfes per multos annos feciffent, capram demum à deo edocti pro puero fuppofue so runt:unde deo cognomen à capra uidelicet fuppofita, facium uidetur, Gyraldus. Cinnamomum in Aethiopia cafuri, quadraginta quatuor boum,caprarũćç \& arjetum extis, à loute impetrant ueniá metendi,Plinius. In Pedafia Cariæ(ut tradit Ariftoreles in Mirabilib, ) facrificium Ioui peragitur: in quo capra deducta ex Pedafis per ftadia feptuaginta magna fpectante turba procedit, nec pertur batur inuia, nec inde auertitur, funiculo uincta facerdotem pracedens. In eadem mírantur extras nei cornua eius quatuor congios capere. A egophagus, id eft capriuorus cognomínatur Iupiter a. pudNicandrum in Theriacis, Etymologus, \& Varinus:Mihi tamen, inquit Gyraldus, non fuccur rit, apud Nicandrumid nomen legiffe. In Laconicis Paufaniæ Iuno nominatur áuyoфáyos, apud La cedremonios tantum id adepta cognomentum, quando $\&$ dex capras immolant. Sacellum ab Hercu leprimò erectum ferunt, qui $\&$ princeps capras immolârit:quoniam pugnanti aduerfus Hippoco: ontem ac liberos, nullum a lunone fe ingeffiffet impedimentum, ficut fere affueurat: Ad rem uero diuinam adhibitaspotiffimum capras, quod aliarum uictimarum haud fuppeteret faculas. Verum 


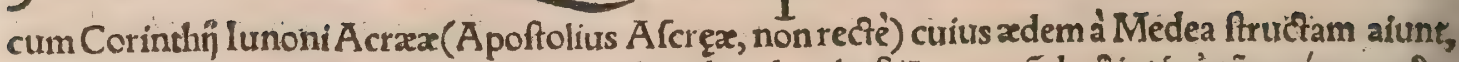

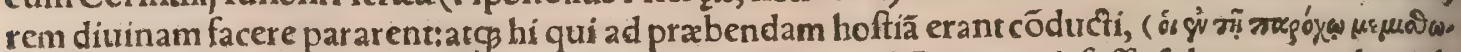

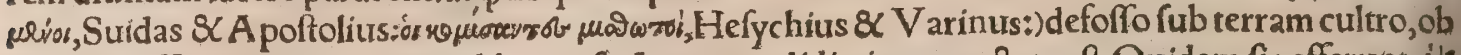
litos fefe aff!mularent, capra pedibus exfcalpens, prodidit, ita $\$$ mactata eft. Quidam fic effertint, Áks

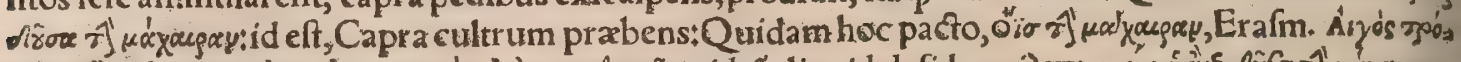

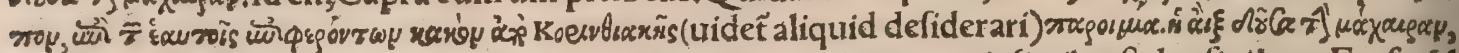
Suid. TDe lana caprina:hoc eft de re inutili $\&$ minimi momenti, fimile eft de afini lana,Eraf. Al rer tixatur de lana fæpe caprina, Propugnat nugis.armatus, Horat. GLiberæ capræab aratro,

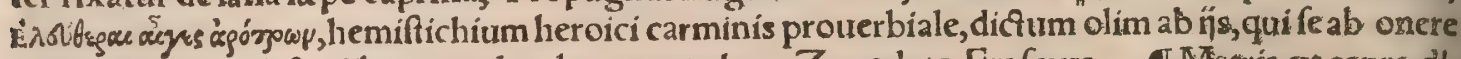
quopiam aut moleftia liberatos glorabantur, authore Zenodoto, Erafmus, q Matris ut capra di

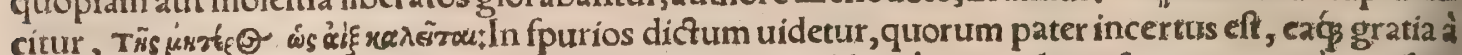
matre denominantur. Ductum ab hoedis, qui in caprilibus à matre dignofcuntur:nam à patribus haudquaquam poffis. Manet etiam hodie uulgl iocus (apud Germanos) quo dicunt, fapientem effe

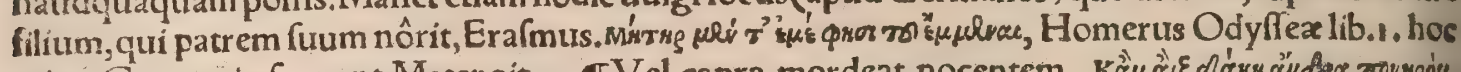

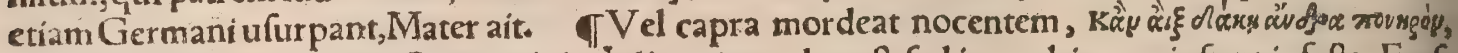
(hemiftichium heroicum:) Capra minime alioqui mordax eft, fed improbis omnia funt infefta, Erafi

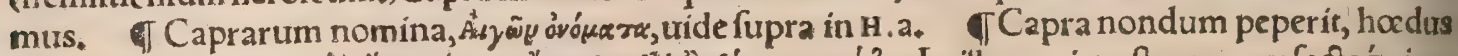

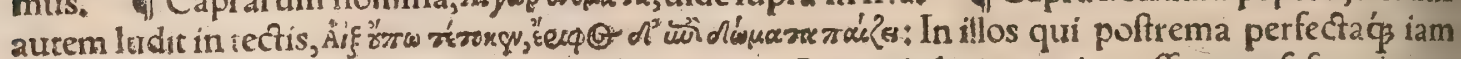
aggrediuntur, pratertis ifs qux pracefliffe oportuit:Aut qui gloriantur iam affecutos fefe, cuius ne fundamenta quidem fint ia $\mathrm{cta:Aut}$ qui rem agunt prapofteré. Prius eft enim peperiffe, quàm ut hoe dus ludat in tectis. Refertur à Zenodoto, Erafm. $\$$ Capram portare non poftum, 8 imponitis bo uem, (Melius, imponite mihi bourem, fine copula.)Plutarchus in commentario De non accipiendo

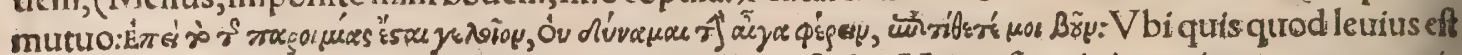
recufat, \& quod multó fít intolerabilius imponi fibi poftulat. Veluti fi quis impatientia paupertatis (nam ad id accommodat Erafmus) ufuris inuoluat fefe, quod onus uix diuitibus fit toler abile, Erafo

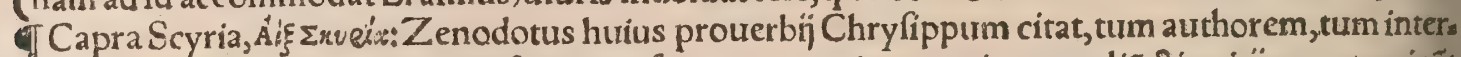
pretem. Conuenit in eos qui beneficiũ maleficio corrumpũt, aut uirtutes adiũctis uitijs contaminẳ

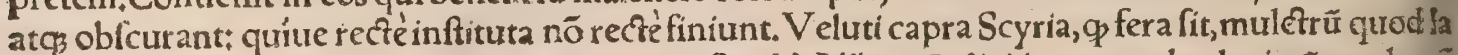
çe impleuerat, ip̣fa rurfus euertit. (Meminit etiã Suid.) Alńp putẫt dici in cos, unde plưrimü enolumê ti capitur, propterea quod cius regionis capr $¥$ maximam laçis uim reddere dicantur. Id quod aftir

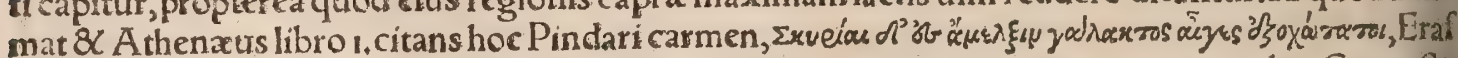
mus. Idem Â thenaus libro 12.capras ex Scyro \& Naxo tanquam pracipuas commendat. Capra Sy riæ(malim Scyriæ) quantum aliæ nullæ lac habere dicuntur, Gyllius ex A cliano. Eft autem Scyros u. na Cycladum. Dic de tribus capellis, in eum uidetur ceu protrerbio torqueri poffe, qui mulra, cxtra caufam qux funt $\&$ ad rem nihil attinent, dicit:ex hiftoria, quã Martialis lepidiffimo epigram. mate refert, Non de ui, neç cæde, nec ueneno, Sed lis eft mihi de tribus capellis, \&c. Huric fimillimü cf Lucilifi epigramma Græcum, quod recitat Erafmus in prouer bio Alia Menecles, alia porcellus

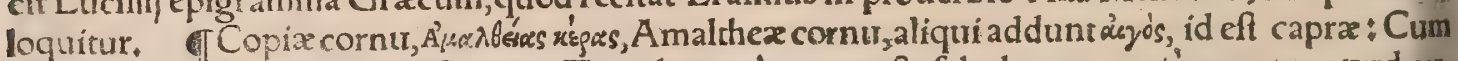
sifiatim omnia fuper effe fignificamus. Translatum à peruertufta fabula, qua uariè narratur apud aub hores, Quid am ad hû̃ modum narrant:R hea louem enixa metu patris infantem in Creta orculuit 1 rutriendum à duabus nymphis A draftea $\&$ Ida, Meliffi filiabus. (Ouidius unam fuiffe frribit, quam Naidem A maltheam uocat, )Ha nutricauerunt illum capra cuiufdam lacie, cuitus nomen fuerit

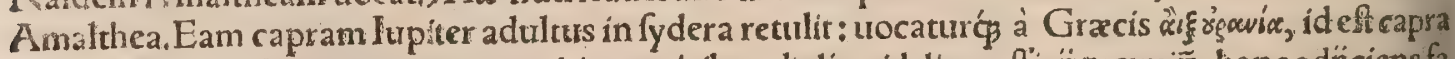
coleftís. Huius alterum cornu nymphis nutricibus dedit, uidelicet ofticĭ pramiư, hanc adj̈ciens fa cultatem, ut quicquid optaffent, id illis ex co cornu largiter fuppullularet. Ouidius capram cornual terum ad arborem fregiffe feribit, qtrod Amalthea nympha herbis cinefum, \& pomis repletum ad lo uis ora tulerit. Iupiter poftea regno poritus Sydera nutricem, nutricis fertile cornu Fecit, quod don minæ nunc quog nomen habet. Legimus \& Herculem Aetolis donaffe Copiz cornu, propter coërs citum cornu funinis A cheloi: quare regionem illam antea fterilem, fertliffimam reddidit:corni ni mirum laborum duritiem fignificante, frugibus feracitatem, Erafmus. Idem pluribus authorum ex \{ emplis, Plinï, Gellï, Luciani, Plutarchi, Horatï, ufum huius prouerbï explicat . Ego n̈s omilfis qua dam apud alios obferuata adíciam. Hanc capram Oleniam uocat Ouidius quinto Faftorum. Vide nonnihil fuperius in Aegiochi louis mentione: $\&$ Palaphatum cap.47. Aegium(inquit Straboli.8.) oppidum eft Achaia, ubi louem à capra lactatum fcribunt, ficut A rarus prodidit, As

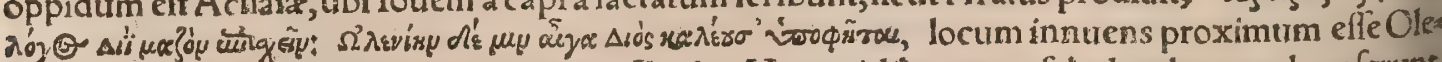
nx. Vide ảryés apud Varinum. Scholia in Iliados Homeri tibrum is, fabulam hoc modo referunt Cum Saturnus filios omnes natos fatim deuoraret, $R$ hea louem enixa, la pidem fafcís inuolutum Saturno uorandum tradidit:infantem uero in Creta Themidi \& A malthea, qua capra erat, commi. fit. Hanc Titanes quoties infpiciebant, terrebantur. Alebat ipfa fuis a dhibitis uberibus Ioue. Is adul tus parre expulit regno. Et cum impugnarent eum Titanes, confilio Thenidis capræillius pelle pro regmine induic: ut cui ppetuo terrendinatura ineffet:atcs ita uicit Titanes, et hanc ob caufamAlegio chus dictus eft. De pelle capra qua Louem aluit, nonnihil etiam fupra dixi ca, $;$, in mentione puerbi 


\section{DeHirco. A. Lib. I.}

Ântiquiora diphthera loqueris. Euftathius in Dionyfium de fitu orbis fcribens, ubi ille Ácheloi furü meminit, cuius finiftrum cornu cum Hercules confregiffet, Amalthea cornu bonis refertum omnibus pro illo recepiffe dicitur: uarias interpretationes affert, $\&$ multa fuper hoc cornu docte $\&$ egregie differit, qux breuitatis amore relinquo. Princeps omnium Bupalus Fortunæ fimulacrum fecit,polum in capite geftans, 8 manuum altera fuftinens Amalthex corni, Cal. Socrates Amal. thex cornu hoc pacto interpretabatur. A maltheam aiebat fignificare homin $\widetilde{e}$ qui minimé malthon; id eft mollis $\&$ diffolutus, fed gnauus $\&$ operarius effet. Per cornu uero bouis, quod animal eft labo= riofiffimum, uirum operarium innui.Botros autem $\&$ fimilia in cornu effe:quoniam omnia, quorü egemus, in agricultura infunt:quamobrem geftantes ipfum bonus Genius, bonaćp Fortuna introdu cuntur, Stobæus in Sermone de Agricultura. A purd eundem in Sermone de laude diuitiarum Phile. mon poéta, A malthea cornú non tale effe fribit, quale pictores depingunt, bubulum fcilicet, fed ip

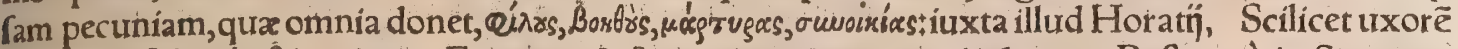
cum dote, fidem $q$, \& amicos, Et genus, \& formam reginá pecunia donat. Poftremò in Sermone defoelicitate, Hippodamus Thuriurs eunomiam, id eft bonam legum conftitutionem in rep. Amal= thex cornu interpretatur, Gentrs illưd poculi apud A thenęum libro ॥, (x'ses appellat) cui aggluti= nati erant cotylifci referti papauere albo, tritico, hordeo, 8 leguminibus, non temere aliquis cornú Amalthex nominauerit. I Prouerbium quod iam retuli, Copia cornu, uel Amalthex, uel Amal.

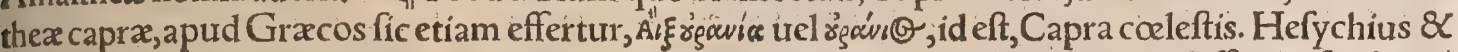
Varinus capram coeleftem interpretantur candida fabæ genera, qua calculos \& fuffragía ferebant: Similiter Suídas, 8 infuper,Cratinus(inquit)eos qui munera accipiunt ab ips nutriri ait, ut lupiter ab Amalthea capra nutritus eft. Alin res illas, ex quibus magna lucri \& pecunix augendx occafio fit, ita nominant, Capra coeleftis, de illo qui quę cupit confequitur omnia. Ferunt enim Iouis capram inter fyderá locatam qui primus orientem afpexerit,per omnia tuoti compotem futurum, Idem, Ca.

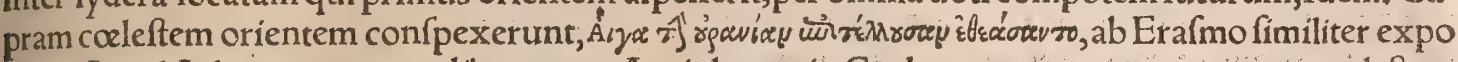
nitur. Apud A thenæum tamen libro nono Antiphanes in Cyclope conmemorat capram coeleftem

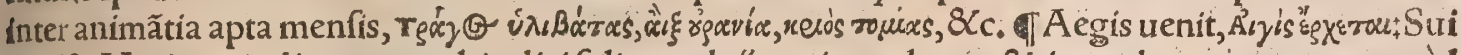
das ( $\&$ Varinus)indicat prouerbio dici folitum, de n̈s qui petulanter $\&$ impudenter agerent : quiòd Aegis dicta fuerit facerdos A thenís folita ferre facram agidem; $\&$ ita ingredi ad eos qui nuper dus

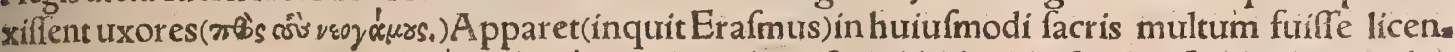

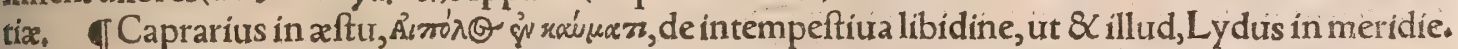
$\mathrm{Nam}$ his horis caprarî, dum feductis gregibus in umbra latitant, lafciuire foliti fcribuntur . Refer= tur àZenodoto \& Suida, Eraf, THis adíciam duoemblemata Alciati, quorum prius inferibitur In defcifcentes: Quòd fine egregios turpi maculaueris orfus, In noxaḿ́s tuum uerteris officium, Fecifi,quod capra,fui mulctraria lactis Cum ferit, 8 proprias calce profunditopes. Vide paulo ante in prouerbio Capra Scyria. Alterum, In eum qui fibi ipfi damnum apparat, Capra lupum non fponte, meo nunc ubere lacto, Quod male paftoris prouida cura iubet. Creuerit ille fimul, mea me poft ubera pafcet, Improbitas nullo flectitur obfequio. Aliud eiufdem in amatores mere tricum, ex aftutia pifcatoris caprinam pellem induti, $\&$ ita farges pifces allicientis:quòd in hoc pé. cus mirificé ament, in Sargo referam.

DE HIRCO.

A.

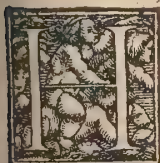

IR C V S duxeft \&̀ màtitus caprarum:Qui caltratus, caper nominatur, Martialis, Dum iugulas hircum, factus es ipfe caper. Caprum pro hirco improprie pofuit Vergilius A glog.7. Vir gregis ipfe caper. 7 yy atud Hebrais hircus eft, \& proprié maior:nam mi=

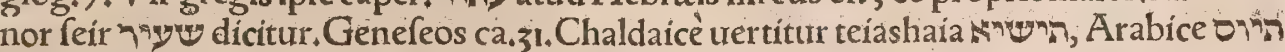

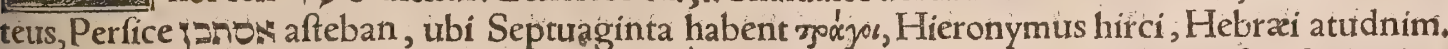
רעy fair etiam pro hirco ponitur, adiuncto feré caprarum nomine, hoc modo fheir iffim, Sed de hac

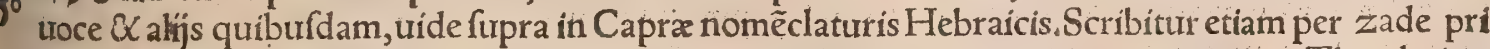
ma litera, zeir:quiam uocem Danielis 8 . Hieronymus hircum capiarum interpretatur, Theodotion

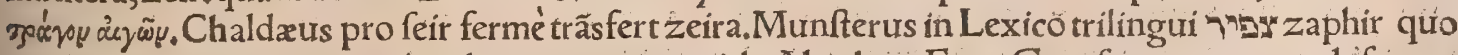

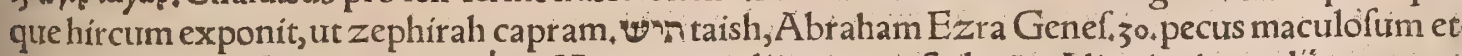
uarium intelligit:Septuaginta zó́cyos, Hieronymus hircos, tranffuler ät. Aliqui arietes, alip totum ge nus ouium inter pretãtur. Chaldzus reddit teiashaia, Arabs teus, Perfes aftarha. 1 zar, Dauid Kim hi agnum exponit, item arietem $\&$ hircum. Carim pfalmo 37 . Hieronymus monocerotes reddit, $\mathrm{Se}=$

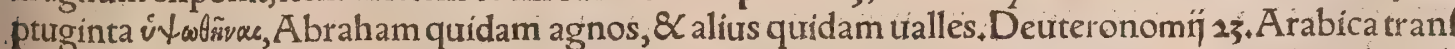
latio habet baraph,Perfica adbehan, Septuaginta ógiñu, Hieronymus agnorum. Syluaticus hanub hircum exponic. Hifpanicè Cabron uocatur, Germanice bockt, unde miturati funt Itali fuum beccho,

$60 \&$ Gallibouc, \& Angligote bucke, id eft caprarum hircum. Nam caprarum nomen Germani etiam

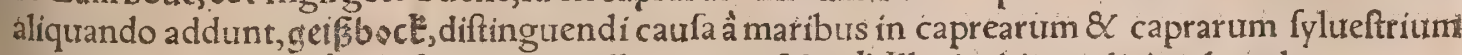
genere, quos item bock, id eft hircos appellant, ut reeb bock Illyrice hircus dicitur kozel. 


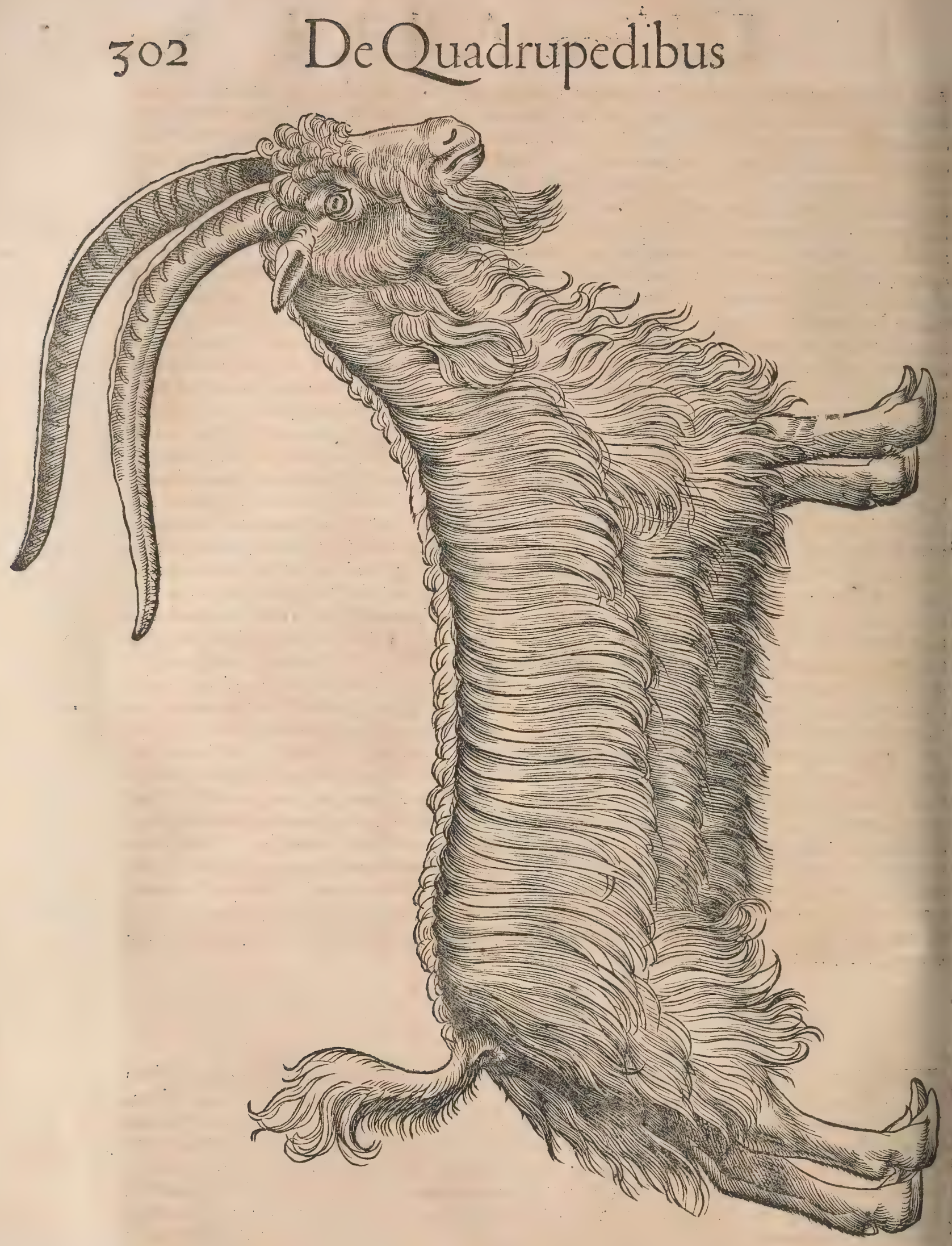

$\therefore$

B.

Caper etiam tondeture, Vfum in caftrorum ac miferis uelamina natrtis, Columella. Nec minus in terea barbas incanạ́̂ mêta Cinyphỉ tondent hirci,fetasós comanteis Vfum in caftrorum, \&c. Ver gilius in Georg. Cinyps(inquit Probus)oppidum eft \& flumen A fricæ regionis Garamantum, apud quos hirci uillofiffimi nafcuntur, quos tondent ad cilicia quibus nautæe utuntur. Quidam apud hữ

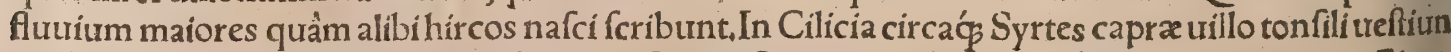
tur, Plinius 8. 5. Hermolaus eo in loco pro Syrias, Syrtes repofuir, Circa Syrtes enim(inquit) Ciny= phium pecus celebratur Vergilio, Silio,Martiali, Claudiano, cæteris, ut quinto libro(Caftigationum in Plinium)diximus. Cilicij hirci, id eft uillofi,Etymologus $\&$ Varinus:De cilicrís pannis fupra dixi

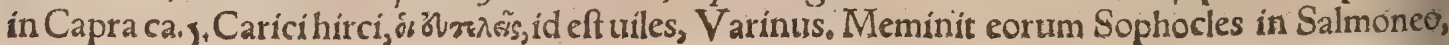




\section{De Hirco. B.C.D.E. Lib. I. 303}

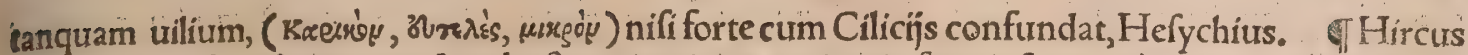
natura animofus eft, pugnax $\&$ robuftus: pracipux ci uires in fronte, $\&$ cornibus; qux longa $\&$ act ta haber, Albertus. Dentes capris pauciores funt quàm hircis, Ariftot. THanc pecudem murilan parabimus quicto coeli ftatu. Nam procellofo atçs imbrifero cornuta femper. Nam \& omni regione maritos gregum mutilos effe oportebit, quoniam cornuti feré perniciofi funt propter petulantiam: Columella. Nunc hirciadmittendi funt (inquit Palladius, in Noutembri) ut foetum primi ueris foure repoffic exortus, Sed caper eligendus eft magni ( ámpliffimi, Colum.) corporis, molliori pilo, \& po. tiffimum albo:(11itido, 1 piffo, \& longo capillo, $\mathrm{Pall}$ adius, nígro denfós \& nitido atos long:fimo pillo, Columella ) capite paruo:aurribus flexis $\&$ graubus, (longis auriculis intractis $\not$, Plinius : fiacidis \& pragraurantibus auribius, Columella: ) quàm maximé fimus, Plinius, cui fub maxillis duiz uiden. tur pendere(collo dependent, Columella : qua de re etiam in Capra dixi) uerrucula, bretri plenaç

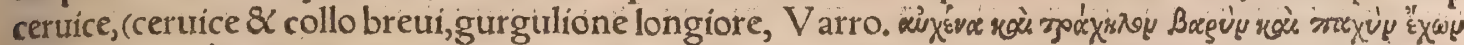

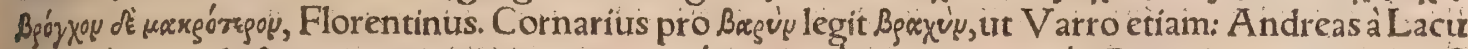

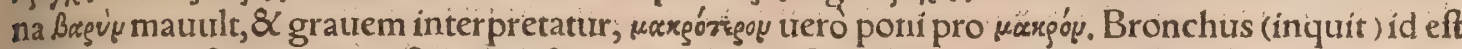
afpera arteria fieri non poteft ut löga fit, collo breui exiftente: curm uidelicet eius prolixior pars quiz pecius ipfum egreditur, femper adhareat collo, \& longitudinem eius neceffario adxquet, Gurgü lionem eruditi ferè Græcam uocem gargareôna, id eft uuam, reddunt : quod hic non conuenit, Sed forte hoc loco intelligemus fupremam partem arterix ex cartilaginibus aliquot conditam $\&$ promi=

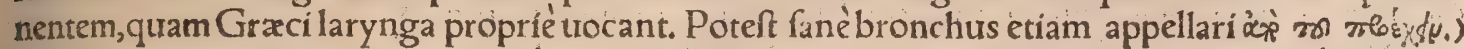

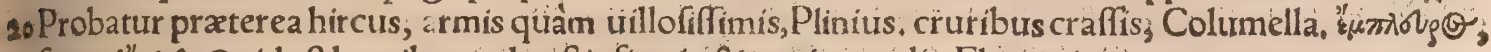

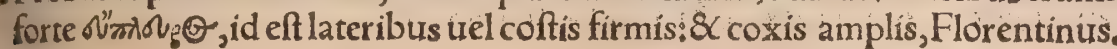

c:

Hircus cornibus ictu tam ualido ferit interdum, ut afferem etiam uel fcutum obtentum fcindat, \& profternat hominem, Author obfcurus. Capri petulci facuitiam qua aftutia paftores repellant, infra dicemus in Arietis petulci mentione ex Columella. Hircos aiunt fex menfes hybernos fupra Siniftrum latus iacere, quum dormiunt: ab aquinoctio hyberno totidem menfes fupra dextrum, Hirci delectantur in cibo barba hircina(de qua infra dicẩ in $\left.\mathrm{H}_{4} \mathrm{a}_{*}\right) \&$ rofa canina,Syluaticus. "Hir cus(inquit Ifidorus)animal eft lafciuum, $\&$ femper feriens ad coitum : cuíus oculi ob libidinem ín tranfuerfum afpiciunt, unde $\&$ nomen traxit. Nam hirci, lecundum Suetonium, funt oculorum an. guli:de quibus uide infra capitis 8 . parte 1 . Qui hirfuta crura habẽt, libidinofi fint, quemadmodum

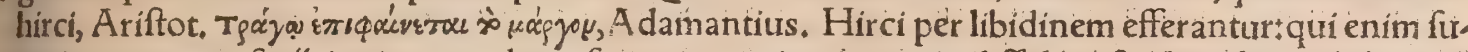
periore tempore focī, iugi concordia pafcerentur, coitus tempore diffident, $\&$ alter alterum libidinis rabie inuadit, Ariftot. Septimo poft die quàm in !urem editus hircus eft, coire incipit; \& quamuis fterile femen emittit, omnium tamen maturiflimé quadrupedüm ingrëditur coire, Aelianus: Hircus menfium feptem fatis habilis eft ad procreandunn:quioniẩ immodicus libidinis, dum adhuc ube= ribus alitur, matrem ftupro fuperuenit, \& ideo celericer, $\&$ ante fex annos confenefcit, quod imma tura Veneris cupidine primis pueritix temporibus exhauftus eft. Itaç quinquẽnis parum idoneus habetur fominis implendis, Columella. Ad ineuridas foeminas $\&$ ante anniculum congruus $\ddagger$ non autem durat ultra fexennium, Palladius. Hirci anniculicoêunt, fed praftantior ea proles eft quam 40 hatu maiores tum capra tum hirci generauerint, Ariftot. Hirci pingues minus foecundi funt: ue. rum cura extenuandi adhibita, efficitur ut coëant, atç̧ procreent, Ariftot, Et alibi, Hirci pinguefcen tes minus feminis habent:quamobrem eos folent ante admiffionem extenuare: Caprę etiam pingue dine fterilefcunt, ut ex Plinio fupra dixi. Satyrï genus erythraicon, arietibus quoç \& hircis ad Ve nerem fegnioribus in potu datur, Plinius. Hirci, tauri, $\mathcal{E}$ arietes pro foeminis pugnam ineunt, $\mathrm{Ae}$. lianus; Confiderandum igitur an uerum fit quod recẽtiores quidam non indocti, dũ caúfam eruere conantur, cur illi quorum uxores corpus inuulgent, hircorum appellatione deformentur paffim, in de fieri conficiunt, quod animalium foli(uti putant) hirci, fuigeneris formellas ipfis intuẽ cibus iniri, facile ferant, Cælius. De hirco qui riualem paftorem dormientem interemit, fupra in Capra dixi. Hirci maximè olidi funt, unde \& hircofos tocamus homines graueolentes, uide H.a. Hircis alfio= go fis ftercore fuo uel humiano nares oblinû̃t paftores, ut fuperius docui. Oculos fuffufos capra iunci puncto fanguine exonerat, caper rubi, Plinius.

Hircus gregem barba fiducia antecedit, A elianus. Afferunt $\&$ magi fua commenta $:$ Primum ontiutm, rabiem hircorim, fi mulceatur barba, mitigari $\uparrow$ eadem pracifa, non abire eos in alienum gregem, Plinius, Hircus non fugiet, barba eius deconfa, Florentinus in Geop. Græcis.

E.

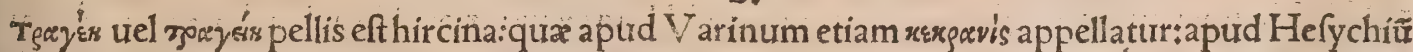
fimiliter fcribitur:fed eo in loco, qui ordinis ratione rexkpvis fcribendũ admoneat: 8 mihi quidem ea

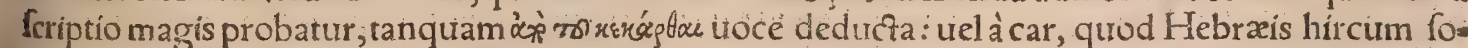

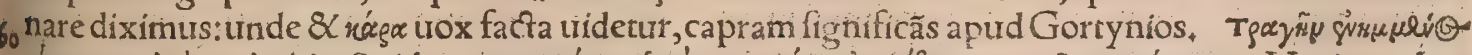

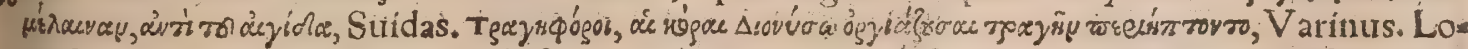
criOzola, ut nonnullis placet, dicti funt, quod homines fortidi fuerint, ut qui trageas, id eft hircinas 
pelles geftarent, ut fupra dixi ca. 5. hiftorix de capra, ubi $\&$ alia multa de caprinis pellibus attuli,qư̌ pleragg omnia ad hircinas ex aquo pertinent. Sabxi propter quotidianum ufum thuris \& myrrha lignorum, ad faftidium nidoris illius pellendum, urunt fyracem in pellibus hircinis, fuffuntọ́ :ecta, Plinius. Hircinas pelles $\&$ ouillas fcribit Herodotus biblos etiam dictas ueteribus, quod papyriui. cem impleuerint quandog, ${ }_{3}$ (xlius. THircorum fanguini tanta uis eff, ut ferramentorum fubtili tas non aliter induretur, fcabricia tollatur uchementius quàm lima, Plinius: Hermolaus pro lima, le, git fcobina fabri. Sanguis hircinus adamantem emollit, item leonínus. Eft enim inter cateros horũ fanguis calidiflimus: A damas autem cum frigidus ficcusç pracipué uincitur, Simocatus. Adamantís natura inuictiffima, $\&$ duarum rerum uiolentiffimarum contemptrix, ignis \& ferri:non alia rumpitur ui, quàm hircino fanguine macerata recenti $\&$ calido: etiamfi hoc gemmarí noftri falfum \& ridiculum exiftimant, Hermolaus. Caprinus (hircinus potiz us) ranguis bulliens de nouro calidus extractus mollit adamantem, Albertus. De Adamantis gemma natura $\&$ duritie, uide apud Erafmum in prouerbio Adamantinus: \& in Opere Ge. Agricolæ de na tura foffilium lib.6. THircinum feuum ad candelas praftantiffimũ eft, urquod folidius fir, nec fas cile liquatum diffluat. ब Amoris faftidium fieri pota hirci urina, admixto propter faftidium nar, do, Ofthanes dicit, Plin. Phileriphus in Epiftolis Theophylacti Simocati:Caftratio, inquit, feras etiam quietiores \& moderatiores reddit:Ego autem caftrãdi peritiffimus fum:nam uưhnus fale farcio, \& picem illino: unde mox ita coalefcit, ut cutis ricino \& cucurbita integrior fiat.

F.

Hircorum caro, tum ad coquendum, tum ad fuccum bonum generandum elt deterrima, Gale. nus \& Aegineta. Hanc fequitur arietum, poft taurorum caro: Porrò in n̈s omnibus carnes caftrarco rum funt praftantiores, uetulorum peflima, Galenus lib.3. de alim. facult. Idem in libro de attenuan re uictu, Hirci $\&$ boues (inquit)carnem quidem habent minimum humidam, pituitofam ac lentam: nocent tamen admodum ob duritiem, 8 in alterando difficultatem. Hircina abfolute mala eft, Auts cenna. Non recté quidam Auicennæ tribuunt, huius carnis ufu febrem quartanam induci : idenim Auicenna non de domeftícis, fed fylueftribus hircis feribit. Capellęatç̧ hirci foetidi carnem ne degu ftato, Platina. Hircina caro, tefte Ifaaco, deteriorem quàm caprina fuccum generat. Hircorum cas ro libidinis tempore uitiatur $\&$ foetet, A riftot. Bapt. Fiera cum hœedum in cibo commendaffet, fub. dit: Cum male olet, ficcat, fit iam caper improbus, abfit, Et cadat ante focos uictíma Bacche tuos. Capri cum coiuerunt, improbam habent carnem, minimé pinguem \& ficcam:quibus curęeft ut fua- 3 uior fiat caro, hircum adhuc tenerum caftrant:fic enim frigida et humida qualitate temperamentum eius emendatur, Albertus. Hircorum carnes traditur uirus non refipere, fi panem hordeaceum eo die quo interficiantur, ederint, la ferue dilutum biberint, Plinius. Hircorum tefticuli concoctioni te

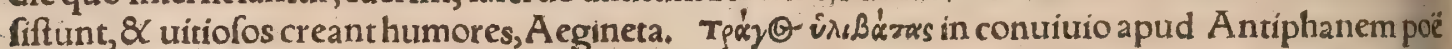
tam in Cyclope apponitur, ut Athenzus fcribit. De Hircina carne uide nonnilil etiam fupra in Cau prina, Caprarum 8 hircorum iecora fugito, ne in epilepfiam incurras, Platina. Noftri farciminis genus uocant Hlobwurft, quod hoc modo paratur: Hircinum iecur recẽs minutatim incifum, parla ter cum fex ouis, \& medulla panis albi, aromatibus \& croco conditur , inuolutumq́ omento torret, $\&$ menf apponendum in paropfide facchare rudiore confpergitur.

G.

Hircos apud nos caupones quidam in ftabulis equorum alunt, tan $\not$; ad corum fanitatê momenti nonnihil afferant: quod eò ucrifimilius eft, quoniam Plinius quoģ̧ à ferpentium iću difficilius fe re. colligentes, in caprilibus optimé cóualefcere fcribit. Mille remedia ex capris, ut ait Plinius, demon frantur:Amplior potentia feris eiufdem generis : Alia uerò ex hírcís : Democritus etiānum eftectus auget eius qui fingularis natus fit. $\mathrm{TH}$ Henx dentes, fi de finiftra parte roftri eruti fint, illigatos pecoris aut capri pelle,ftomachi crucianbus prodeffe aiunt magi,Plinitus. đEx pilis capri fumi gabis eum qui in inguine dolet, fanabitur, Sextus. Hircini utris uinarij duntaxat cinis, cum pari pon dere refina, fanguinem fiftit, $\&$ uulnus glutinat, Plín. đT Caprini cornus farina uel cinis, magiş́́ hircini, addito nitro $\&$ tamaricís femine, $\&$ butyro oleó $\$$, prius capite rafo, mire continent ita fluen tem capillum, Plinius, Cornu capri combuftum \& mixta farina impofitum; furfures (cabiemós in capite emendat, Sextus. Ad hircos uel alas fortentes remedium, Hirci maturioris cornu rafum uel exultum cum felle hirci mifcetur, $\mathcal{X}$ pondere aquo myrrha adrícitur: ato inde afcellæ, demptis pri. us pilis, affiduè perfricantur, Marcellus. II omnibus pharmacopolijs (inquit Matthacolus) loco fanguinis draconis uenditur res factitia, ex refina, ( $\&$ bolo Armenio, Syluius) fanguine hirci, forbis aridis, $\&$ alijs. permixtis. Hirci uel capra fanguis in fartagine frixus, \& in uino potus contra toxis ca efficax eft, Diofcorid. \& Auicenna, qui pro toxico Armenx fagitte nocumentum uertit: Ifaci in Diætis non recté citat Diofcoridem, tanquam is fcribat, fanguinem hirci calidum perunctum, araneas (fagittas Armenas) 8 mala trulnera curare. Abrceffirs calidos cito maturat, $\&$ applicatur poft congelationem, Auricenna. Galeni fententiam de fanguinis caprini hircinió̧ ad abfcefíus cons coquendos curiclo ufu, in taurino iam recitaui, Sanguis hircinus in cerato quodam poda. grico apud Aetium admifcetur. : Omnem lepram illitus hircinus fanguis emendat, Marcels lus. Pilos oculis moleftos diligentiffimé uelles, atọ eorum loca hircino fanguine recenti intines, Marcellus. Sanguine hircino fanari lufciofos putant, nyçalopas à Gracis diços, Plinius. Cui fan 
guris flutit(de naribus, irt infcriptio habet)fricetur fanguine capri, $\&$ reprimet, Sextus, Sanguis hir cinus cibo aptatus iocineris dolores reficit, Plinius, Calens adhuc fuper prunas excoctus $\&$ cibatui datus ieiuno, iocineróo mederi traditur, Marcellus. Hirci capraúe fanguis inaffatus fartagine, dya fenterias $\&$ coeliacorum profluuia fiftit, Diofcorides, ( Vide fupra in Caprini fanguinis remedris, ) Sanguis hircinus, in carbone decoftus, aluum fiftit, Plinius. Exceptus \& coagulatus, ac fuper carbo nes affatus, in cibo datus, mirabiliter profluuium uentris emendat, Marcellus, Sanguis capri( capr fecundum alios, ut in remedips ex capra dixi ) cum refina \& pollinemixtus, \& uentri fuperpofitus, torminofos fanat, Sextus, Sanguis caprinus cum medulla hydropicis auxiliatur: efficaciorem pu: tant hircorum, utiog filentifco pafcantur, Plinius. Sanguis hirci potus lapidem renum frangit, Aui cenna.Si hircus diuréticis nutriatur, fanguis eius cum petrofelino 8 unino fumptus aridus tritus'́, calculum in renibus \& uefica frangir, Albertus, Aëtius lib, 11, cap.12.Sanguis hircinus(inquit)tum ad nephriticos, tum ad calculofos pręfens eft remedium:nam \& lapides iam antea natos foluit, \& ita per lotium excerni facit, ut etiam alŷ́ deínde nó gignantur:dolorem infuper fedat, Colligitur autem hoc modo. Quum uua maturefcere coperit, ollam nouram accipito, $\alpha$ infufa in ipfam aqua, donec terreum depofurerit olla coquito: $\&$ accepto è grege hirco atate matura, plus minus quatuor anno. rum, elus maçati fangurinem medium olla excipiro:ita ut eum qui primum effluxit, itemós poftremuี penitus relinquas:medium autem infpiffari finito, $\&$ in olla fitum per acutam arundinem in multa frufta diffecato:indéģ́ reticulo denfo, aut linteolo raro, aut cribro arctiore conteçum fub dio expo nito ut infoletur, 8 rofcidus fiat ( rore iam decufo, poft hor am fecundam fub Sclem ponas, Marcellus, ut infra dicetur:) cauendo ne imbre commadelcat. Porrò ubi exiccatus furerit, diligenter tritum in pyxide adferuato: $Q$ remittente malo cochlearium plenum cum paffo Cretico exhibeto . Cogno minatur autem pharmacum hoc Diuina manus. Hurius $\&$ nos, inquit Philagrius, in breui tempore non afpernandum periculum fecimus. Aliquando autem odoris commendandi gratia parũ phylli, aut amomi, aut fimilium ammifcemus, Ego, inquit, hoc pharmacum cum troglodyte pafferculo per mixtum, cuidam penitus nihill lotij éj cienti polt magnos dolores exhibui, \& 8 permagnum lapidem attritum ab co expuli, Hucufọ Aétius, Cxterum hircinum fanguinem manum dei appellari, teftis efí etiam Alexander lib, 2, \& A uicenna decimaoctaua tertï, cap, 19, ut Chriftoph. Orofcius obferua. uit, Alexander Trallianus libro 8.cap.7.aduerfus calculum in uefica caprinum fanguinem cömen.

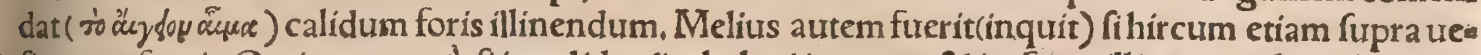
ficam pofueris. Optimum uerò, fi in calido aêre balnei inungas, 8 ita fuperilliges:quod quidem non femel tantum, fed frepius, \& per interualla faciendum eft. Torinus in paraphrafi fua innuere uidetur, fanguinem fupra ueficx regionem effundi debere (nimirum ex ipfo hirco iugulato, aut ex uafe adhuc calidum)atq̧ ita illini, Idem Trallianus ad dyfuriam medicamétum ex hircino fanguine com= mendat. Ad lapides de ueffica énciendos remedium fingulare, ut apud Marcellum empiricum cap. 26. defcribitur:Hircum fegregatum uel claufum(inquit) feptem diebus lauro pafces, \& poftmodum â puero inpubi occidi facies, \& fanguinem eius excipies munditer, ex eo dabis laboranti in uini cya thofcrupulos tres: at uerò ut eius rei experimentủ capłas, lapillos fluudales in uefficam mittes, in qua fanguis exceptus fuerit:nam in ueffica excipi debet, \& fignatam repone: intra dies feptẽ folutos penitus inuenies, Etrurfus eodem capite, Calculofis(inquii) expertus affirmat incredibiliter fuccurri o remedin tali, Si hircum, melius fi agreftem, melius fi anniculum, \& fi menfe Augufto claudas loco ficco per triduum, ut ei folas laurus edendas fumminiftres, \& a quæ nihil accipiat, ad poftremum ter tio die, id eft aut Iouis aut Solis occidas. Melius autem erit fi caftus purus q́ fuerit $\&$ qui occidit, $\&$ qui accipiet remedium. Exfecto igitur gutture eius fanguis excipitur, utilius fi ab inueftibus pueris excipiatur, comburitur in uafe fictiliufg ad cinerem. Vas autem in quo torrebitur, coopertum \& inlitum gypfo in furnum mittetur:quod cum uapori exemeris in puluerem conteres; nec non $\&$ po lypum marinum identidem ut dixi exuftum, in puluerem rediges. Confectio autem uniuerfi medicaminis hæc eft : Sanguinis huius hirci uncias tres, thymi unciam unam, pulegĭ unciam unam, po lypi exufti cineris uncias tres, piperis albi unciam unam:apü, feminis olufatri unciam unam. hęc om nia feparatim tunfa, \& ad leuiffimum puluerem redacta cômif́ces, $\&$ dabis infirmo, melius fi die So. lis aut louis, cochlearis menfuram in meri potione, aut curiufcunce dulcis poculi. Prouidereautem debes ut digefto ac iciuno potio detur: $\&$ rurfum ut eadem potione bene digefta, cibos accipiat: $\&$ eò melius erit, fi hanc potionem cum condito, polt balineum in fabanis adhuc conftitutus acceperit. Et fubinde, Supra omnia efficax (inquit) aliud ex eo facies medicamentum fic, fanguis hírcinus ea ob feruatione qua fupra excipitur in patella ferrea candente ut aduri poffit $\&$ Itringi continuo ipfe fan guis, ita ut poftea in puluerem redigatur: uel certe continuis aliquor diebus ad Solem ipfum fangui nem pones, ita ut rore iam decuffo, poft horam fecûdam ponas, $\mathbb{Q}$ ante nonam colligas: pofteaquam ita fuerit ficcatus fanguris, ut nullum humorem habeat, colliges eiurdem cruftulas 8 teres, atọ, ex co leuiffinum puluerem rediges: deinde accipies herbam tribolum; cuius herbæipfum tribolum, hoc eft femen fpinofum proịcies:ipfam autem herbam leciam de locis maritimis ficcabis, tundes et in pul verem rediges. Confectio autem medicaminis totius hæc eft: Herbæ triboli uncias duas, piperis un. cias duas, petrofelini Macedonici uncias duas, fuli fertulam id eft coronam fiure fphæram unam, hæc omnia feparatim tunfa, $\&$ ad leuiffimum puluerem redacta, cum fanguine hírcino mícebis: \& dabis 
infirmo die Solis aut louis cochlearum menfuram, in meri potione aut cuiufung dukis liquirohio Prouidere autem débes vit digefto ieiunoćs potio detur:quam cum acceperit qui calculum pattur, mox lapides folutos omnes per urina m emitret, Hactenus Marcellus, fubịciens etiam adamantem hoc fanguine perfufum folui. Sanguis hirci ut calculũ frangat quomodo praparetar, docetetiam lacobus Syluius in Methodo de componendis medicamentis, ab inizio capitis de animalib. \& corum partibus, ex Auicenna $\&$ cateris practicis, Sanguiníhircino, inquit, quamdiu ab animali calet, $c_{0}$ quendi abfeffus uim tantum tribuit Galenus : qualem caprino, taurino, \& creteris calidis humidis modice. Quód fi adamantem frangit, fed calidus tantum ab animali + fic lapidem calidus tantum epotus fregerit:Quod \& fanguinem uulpinum ex uena fecta potum praftare audio. Ne autem coa. guletur, Xenocratis exemplo, mifcere poffis acetum feruefactum aut coagulum. Hirci qunç, capri, cerui, leporis, fanguinem fartagine frixum dyfenterias \& coeliacorum profluuium fifiere tantuni docet Diofcorides, non addit calculum frangere, qua uis tenuibus conurenit, cum dictorum ani, malium fanguis fubftantia craila ; $Q$ terrea, \& cum calore ficcatoria dyfenterias fanet, Hac Syluitis. De fanguinis ibicis, id eft hirci fylureftris alpini ufu ad calculum, dicam inferius.

9) Hircorum carnes in aqua decoctx panos $8 \mathrm{X}$ apoftemata in quacuncs parte dif́cutiunt, Plinitus, GD Dedullis in genere quadam protuli ex Galeno, in mentione Vitulinz fupra:\& priuatim etiam de hírcina alins ć́. Laudatiffima ceruina medulla, mox uitulina, dein bircina 8 caprina, Plin. of Hoe dorum adeps minus tum calidus tum ficcus eft, quàm caprarum: $\int \mathrm{e} \&$ caprarum minus quàm hir corû: \& rurfus hircor û̃ minus 药leonũ, Galenus de fimplicib, 11.4 . Hircinus adeps ualidifimè difcus tit:huic proportione refpondet ouillus, Diofcorid,Magis refoluit quàm cęreri, A uicer, Seữ hircintี cum melanthio \& fulphure \& iride, lentigines \& maculas tollit:labrorum etiam fiffuris efficax cum adipe anferino, ac medulla ceruina refinaç $\&$ calce, Plin. Ceruix boum fi media intumuit, comperl mus aureum effe medicamentum ex pice liquida $\&$ bubula medulla $\&$ hircino fero $\&$ uetere oleo, aquis ponderibus compofitum at $q$ incoctum, \&c. Columella. Medicamen hoc tetrapharnacum di ci poteft, nam $\&$ uiribus refpondet Galeni tetrapharmaco, quod confit ex cera, refina, pice, \& levo hircino caprinóue aut alterius animalis, maturans $\&$ concoquens. Sanguis demifius in pedes bo um, nifi emittatur, faniem creabit. Locus primò ferro circuncifus $\&$ expurgaturs, deinde pannis a ceto $\&$ Iale $\&$ oleo madentibus inculcatis, mox axũgia uetere $\&$ feuo hircino pari pondere dec oçis? ad fanitatem perducitur, Columella. Bupreftis cum hircino feuro lichenas illita ex facie tollit mea fica(feptica) uí, ut fupra dicium eft, Plin. Pedes locuftarum cum feuro hircino triti, lepras fanant, Pli nius. Vnguium fabriciam tollunt locuft fricta cum feuo hircino, Plin. Seui hircini uncias duas olci uiridis fextarium dimidium : hac fimul in duplici uaferemiffa \& calefacta dyfenterico inícies, Marcellus. Similis \& caprini ufus eft, ut fupra dixi. Vtuntur \& feuo hirci in pane qui cinere coctus fit, capræà renibus maxímé, $\mathcal{X} \times$.Plinius inter dyfenterica $\&$ coliaca remedia, ut in Capra recitaui. Cum fimo capræ $\&$ croco impofitus adeps hircinus podagricis auxiliatur, Diofcor, \& Rafís. Poda= gris medetur taurinum feuum, \& c, alij hircinum praferunt feuum cum fimo capræ, \& croco, finapia me cum caulibus edera tritis, ac perdicio uel flore cucumeris fylueftris + Alij feuum hircinum mas gnificant cum helxines parte æqua, finapis tertia, Plinius. Etalibi, Podagris cum feuo hircino ue hementer profunt minoris fambuci cauliculi illiti. Heliotropï radix cum folins $\mathbb{X}$ hírcino feuro pos dagris illinitur, Plin. Hircinum feum, ouillum, ceruinumó ita curato. Elotum ex his quodcung, tunicis, ut in fuilli adipis mentione dicfurm eft, exemptis, pila enolliendum tradito, ac manibus frica to, affura paulatim aqua, donec ne amplius quidẽ cruentum uirus excernatur, aut pingure aliquod innatet, fed nitida fpec?etur:deinde in ollam fictilem conj̈cito, $\&$ adiecta aqua ut fuperemineat, leur pruna liqurefacito, \& mouteto, atç in aquam colato:cum \& qua anté ciximus facito;tertiò fine aqua liquefactum, in perfuram líquore pilam colato, refrige. ratumóp, ut in fuilli ratione diximus, recondito, Diofcorides.

TDe hircino iecore nonnihil reperies fupra in Caprino. Hirci iecur, inquit Galenus, eadem ca: prino efficere aiunt. Ad canis rabidi morfum laudant hírci iecur, quo impofito ne tentari quidem aqua metu affirmant, Plinitus, lecur hirci maturé fumptum ab n̈s quos canis in rabie momordit, atus xiliatur,Ponzettus, Sanguinem fiftit caprini cornus cinis, uel fimi, ex aceto, (frilicet illitus: ) hirci. ni uero iocineris diffecti fanies efficacior + Et cinis utriuff ex uino potus, uel naribus ex aceto illitus: hírcini quo $\xi_{3}$ utris uinarí duntaxat cinis, cum pari pondere refin $x$, fiftit fanguinem, $\&$ uulnus glu tinat, Plinius. Iecur hirci calidum illitum lepras tollit, Plinius. Ad nycralopes caprino praftat, Cet fo tefte: ut fupra retuli. Iecur affum capra coeliacis fuburenit, magisćç etiam hirci cum uino auffero decocłum potumón, uel ex oleo myrteo umbilico impofitum: Quidam uerò decoquunt à tribus fex. tarị̂s aqua ad heminam (aliâs geminam)addita ruta,Plinius, lecur hircinum mifum in ollam no. uam cum uini aufteri cotylis fex ad tertias decoctum, fed dum excoquitur compuncium, ut humor eius cum uino permifceatur, poftea dy fenterico potui datum efficaciter prodef?, Marcellus. Aluum fiftit iecur hircinũ decocłum in uini hemina, Plin. Tradunt hircini iocineris cibo comitiales deprehen di, Diofcor. THircinum fel imbecillius eft taurino, Diofcorid. Vide fupra in Taurino, ubi \& in gea nere quxdam de felle docuimus. Hircinum priuatim thymia abolet, \& luxuriantes elephanticorum. extuberationes illitu reprimit, Diof corid. Plinius caprino felli tribuit quod elephantiafin tollat. Fel 
tamé. Ānnofus, auidus, barbiger, celer, cinyps, corniger, dux pecoris, grauis, hirfutus, horricomus,; imbellis, immundus, olens, olidus, piger, procax, faliens, fetiger, uagus, uilis. Capri etiam feorfim ea pitheta hac reperio, Vir gregis, Vergil, Aleglog.7.Albus, Horatius 3. Carm, Bicornis, Ouidius is: IMetam.Libidinofus, Horatius Epod. Io, Setigeri, Silius lib. 3 . Et praterea apud Textorem, bifrons;

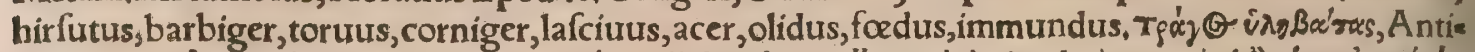

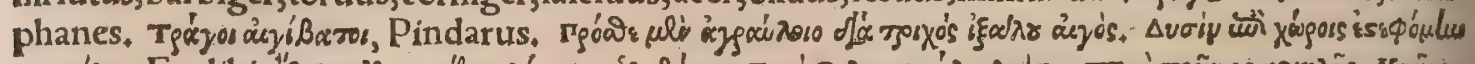

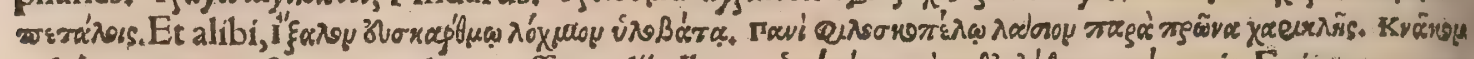

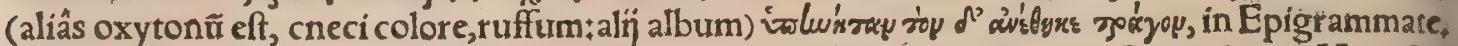
Caperare frontem, rugis contrahere, à crifpis caprorum frontibus, \&c. ut in Capra dixi in $H, a_{1} C_{2 .}$ pronex uocantur in equis comæ feu iubæ in frontem deuex $x$, TTragemata, bellaria fecundû $M a=10$

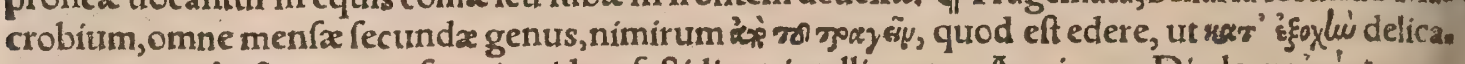

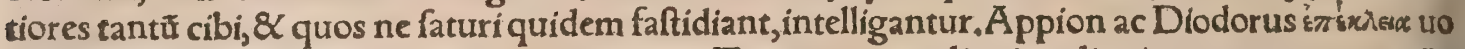
cari tradunt, quæ poft cœnã dantur tragemata. Tragematum reliquias aliqui apotragemata uocã́t, Calius. Tragemata uoco ea, qux polt conam uoluptatis ad bibendum excitanda gratia mane duntur: Sunt qui cannabis femine frixo cum alijs tragematis uefcantur, Galenus de aliment, facule,

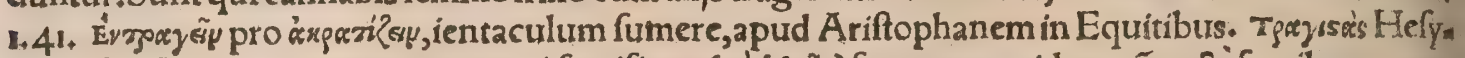

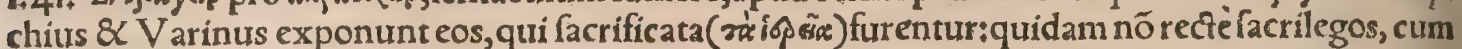
à uorando nomen factum uideatur. T $\rho^{\prime} y \in \Theta$, hircinus. Tragicum licet ut plurimum accipiatur pro co quod ad tragcediam pertinet, reperitur tamen pro hircino etiam; nam tragica cornua in Pyrrht galea hircina intelligunt, tefte Calio. Follibus hircinis conclufa auræ, Horat. I. Serm. Veteres hir. ${ }^{\prime}$ quinum pro hircino extulerunt. Plautus in Pfeud. Heus tu, qui cum hircquina ftas barba,refponde quod rogo. Hírcipilum quidam pro hirfuto ufurpant, uel eo qui duros pilos habet. of Hircus ani. mal eft libidinofum: \& quoniam libido oculos contrudit in angulorum anguftias, quos uocant hir, quos, authore Suetonio in uitijs corporalibus : inde à Vergilio feriptum uolunt, Tranfucrfa tuentibus hircis, quoniam libidinis, qux in hirco praferuida eft, illic promantur figna : etiamfi A puleits grammaticus, quod ilic hæreant oculi, hircquos dici opinatur, Alīh hircis defendunt, quoniă id ani.

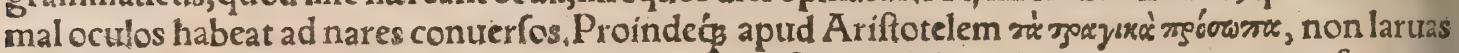
interpretamur, quod fecit Theodorus : fed tragicas facies, ad hanc hircorum naturam referentes: quoniam tragoedorum perfonæ nibil minus, quàm oculos ad nares ualeant inflectere, Calius, Ifido. rus ipfum animal hircum, ab oculis ad hircquos(id eft angulos in eis, Græcicanthos dicunt)cótrerr 3 fis, fic appellatữ autumat. In iam citato Vergilin hemiftichio, hircis an hircquis rectius legatur, uide Pontanum de A fpirat. lib. I. Nos quamobrem hircum animal (inquit Nic. Erythraus Italus) uulgo becco uocemus, unde beccari, beccarie, $\&$ uox illa infamis ab hiftoria eiufdem animantis deducia qua populus Venetus uicifím fe uf̧̧́ ad fabulam impetere folet, pluribus fanè in Stoico docuimus: Hac ille, fed Stoicus eius non extat. Eft intra aures neruus nomine tragos, èregione curius eft quë uocant antitragon, Cælius, THircum \& caprum (ut Catullus) poëtæa appellare confueuerunt gra. ueolentiam fub alis. Sed nimis arfa premunt olida conuiuia capr 2 , Horatius 1. epift, I, foctor fub

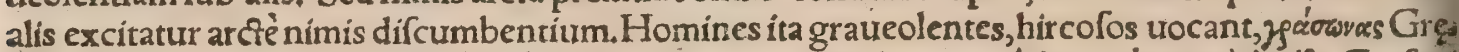

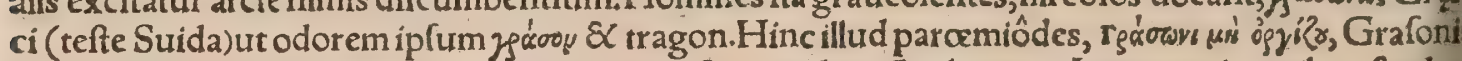
ne fuccenfeas. Sudorem corporis ac fordes grafoniam dixit Archigenes. Lanarum in ouibus fordes Græeci ut œfypum fic grafum appellant. Ariftoteles in A charnenfibus, tragafaum uocaurit malè o. lentem, \& alia fabula tragomafchalos eofdem dicit, Cxlius 24.18. ubi plura de hircini odoris ratione

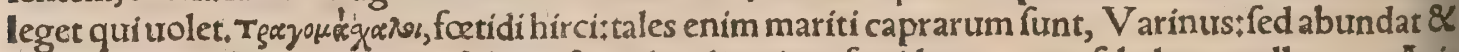
expungenda eft uox tragi, id eft, hirci:fiquidem homines foetidos tragomafchalos appellant, ut Aria ftophanes in Pace, ubi in Scholís uerba à Varino ufurpata leguntur, fed fine dictione tragi. Pollux, Hefychius $\mathcal{X}$ alin xuvdb docui.Plautus in Muftellaria, Te Iupiter d’̉'ćsomnes perdant, oboluifti allium. Germana illuuies, rufticus, hircus, hara fuis, ad hominem tranftulit immundum $\&$ libidinofum. Etin Afinaria, Pro, pter operam illius improbi hirci edentuli. Grauis hirfutis cubat hircus in alis, Horatius in Epodis, Plautus in Mercat.Quum fis iam ætatis plenus, anima foetida, Senex hircofus, tu ofculêre mulierê, \&c. Perfius Sat.5. Dixeris hac inter hircofos cẽturiones, id eft, rufticos, olidos, \& omnis nitoris ex pertes, Budæus: Nonnulli legunt V aricofos, Qui rem Venereã agunt, aut qui in æatate funt qua

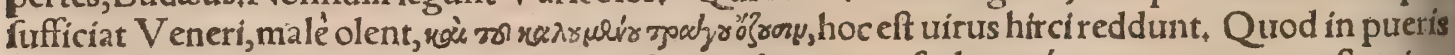
non fit:cuius ratio eft, quoniam puerorum fpiritus humorem fudoremćs concoquere poteft : uiro rum autem nequit. Proinde funt in n̈s humiditates crudx indigeftx́ģ, \& ad corruptione procliues: ideoćsfudores eorũ, \&C refoluti illinc fumi grauiter olent, idç̧̣ in al is præcipuè atఢ̧̧ ingurinibus, \&c. Ab hoc eurentu putant eruditi, ut Sext. Pompeius docuit cum Cêforino, pueros dici hirquitalos, ubi primum ad uirilitatem accedunt, fitćs Venereorum appetentia opportuna, Hxc Calius, Hirquítals lus, per 1. duplex, \& rurfus Irquitallus fine afpiratione, purer qui primò uirilitatem fuam experitur,à libidine foilicet hircorum dictus, Feftus, Hircipili, denforum pilorum homines, Idem. I Naues gutęa dam Libycæarietes 8 hirci dicuntur: unde conn̈cimus taurum etiam, quiEuropam abduxit, tale nauigium fuiffe, Pollux \& Calius. Tragi naues uidentur, fortè quod id genus animalium haberent 


\section{DeHirco. H. Lib. I.}

tanquam infigne, Bayfius. TVox immutatur, maribus maxime: fed forminis etiam idem accidit, quanquam obfcurius, quod quidam hircire appellant, cum uox mittitur inxqualis, poft ueró reftitui

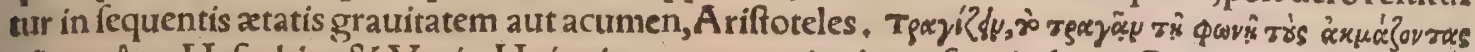

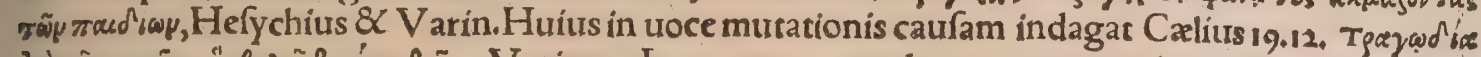
i Tragœediam alị quafi hírcinum cantum dictam uolunt: nam hircus præmiū dabatur tragœediarum authoribus, qui ruftici \& paftores erant. Carmine qui tragico uilem certabat ob hircum, Horatius in Arte. Alexander pubefcentes pueros hirciffare fcribit,ob uocis afperiratem raucam, ab hircis ita uo cem efferentibus producta uerbi ratione. Siquidem naturam tunc corpora diffociantem, multam re - pentinamq̧̧ atatis efficere mutationem, autgefcêtibus foeminarum uberibus, marium uero thorace, humeris, teftibus: Accedere item morborum mutationes, folutionésure, \&.c. Calius 19.21. Idem alibi rgxyi $i\{$, hircum olere exponit. THirci pinguefcentes minus feminis habent: hinc $\&$ uites cum ni - mia alimenti copia luxuriant, hircire dicuntur, A riftot, de generat, anima, 1, 18, interprete Gaza : qui 2 aliũ Ariftotelis locum in Hiftoria anim, fic tranftulit: Hirci pingues minus foc cundi funt: quorum argumento uites, quoties per nimiam alimenti copiam luxuriantes fructum non ferunt, hircefcere

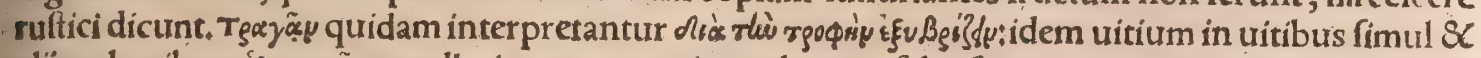

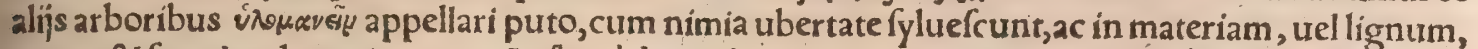

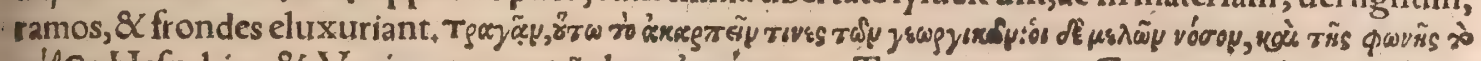

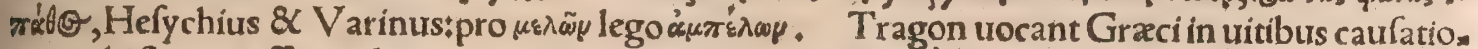
nem, ubi flatu graffante decutiuntur germina, hírculum Latinéqueas nuncupare, Calius: Alì fic uocant, fitue importuno uento germina à uiribus abfcindantur, fiue cultorum imperitia oblędantur, ur Hermolaus in Corollario in quintum Diofcoridis lub.cap. 1.ubi tanquã diuerfa uitis uitia hircum \& hircefcere uidetur accipere, cum unum fit: $\&$ cum infocunda fiunt uites hircefcere dici ait, cum hoc non fimpliciter fed adiecta caufa nimia ubertatis proferendum fit. Articulâtionem (inquit Caro lus Stephanus) eleganci uocabulo uocauit Gaza:quod uitis in ipfo articulo potifimum ladatur, In* de uero hircefcere fiuchircire dicuntur uites ab antiquis fcriptoribus, cum infoecunda propter arti. culationes oblafas redduntur: quoniam hircus animal(ut inquit Ariftot.)pinguredine fterilefcit, Hęc

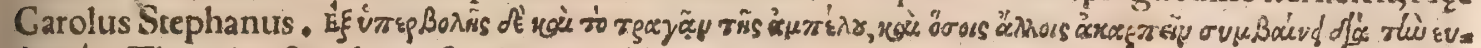
Bnessiey, Theophraftus de caufis plãtarum libro y.cap, 12. Ibidem fratim hurius uitri remedia adf cribit: \& mox cap. 13, eiufdem caufas: ubi Gaza fic uertir, Vitis aurem articulatio uenit, aut flatu ablatis ger minibus, aur imperitia culturæ concifis, aut tertio in fupinum excifis. Sic enim humor largius coiles efus, uehementer ad germinandum excurrit, ita ut nihil queat fructificare. Sufpicetur fane aliquis in duobus his locis non articulatio, fed hirculatio ab inter prete primum effe fcriptum: cum hoc uoca bulum Græco respondeat, $\&$ eiufdem operis libro , in frne capitis 21 , hirculatæ uites ab eo reddãtur,

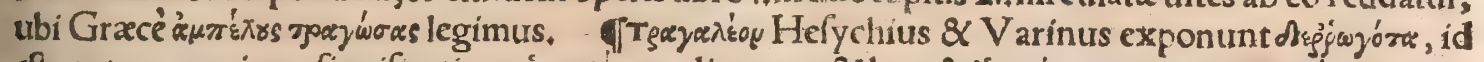

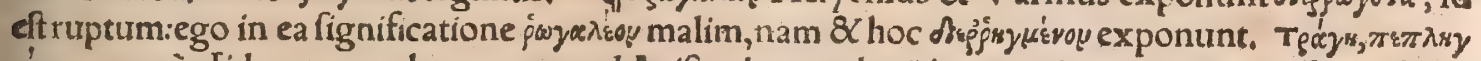

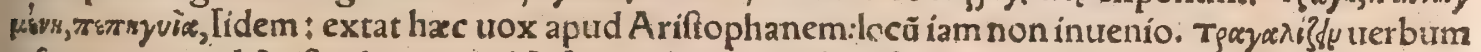
ufurpatur apud Ariftophanem in Vefpis, uidetur auté fignificare arrodère, uel paruis fubinde mor. fibus deuorare:interpretes uariant. Suídas Ariftophanis locum adducit, fed abfo̧ interpretatione:

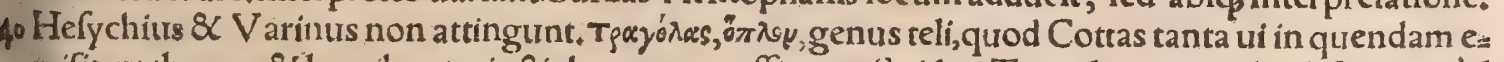
mifit, ut thorace $\&$ la teribus traiectis humo eum affigerer, Suidas. Tragula, genus teli, dictum quood fcuto infixum trahatur, Feftus, Tum T. Baluentio uiro forti utrung femur tragula trá́citur, Carar s.bell Gall. Eft \& retis pifcatorí genus eodem nomine apud Latinos. Tragos uidetur etiam panis nomen furffe, à figura nimirum:ut in Ceruo dicã capite fecundo, circa finem corum qua de Achęina

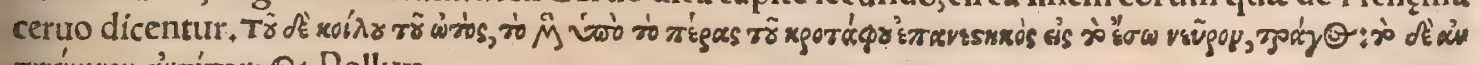
гикม́

đErineon, ut ex Paufanix thefauris (in Meffeniacis) percipi licet, Gracorum nonullli olynthon dicunt:tragum autem Meflenĭ, Id quod fymbolicéfignificauit Apollo Ariftomeni \& Theoclo uati

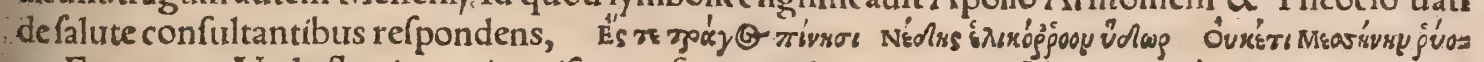
o $\mu$ er. Erat autem. Neda fluuius, cuius uifuntur fontes in Lycæro monte. Tragus uerò non hircus intelli gebatur: $\int e d$ erineos arbor in aquam Nedx prona, ac folijs humorem quodam modo hauriens, unde Theodo coniectatum ingruere Meffenịs fatale malum, Cellius. Idem paulò poft erineon negat effe fylueftrem ficum, fed fui generis haberi,à Dorica ciuitate fic nuncupatam, ex Lycophronis interpre.

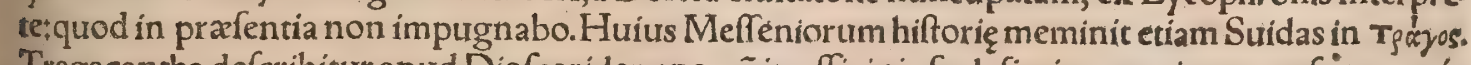
Tragacantha defcribitur apud Diof coridem:nomẽ in officinis feplafiariorum etiamnum féruat:utçs omnes lachrymam paffim nouerunt (inquit Marcellus Verg.) fic peregrinam Italia ftirpem, fi Theo phrafto credimus, pauci nouiffe nunc poffunt, in Creta, Arcadia, Peloponnefi Achaia, \& Afiæ Me. dia nafcentẽ. Et paulò poft, in uetuftiffimo Diofcoride Latino, Longobardis literis Icripto, repertum à fe fcribit, tragacantham compofito nomine à Gracis nominatam, quoniam fpinofa, \& $\&$ tragio, qua Creta peculiaris ftirps eft, congener $\&$ fimilis fit. Gaza apud Theophraftum, qui tribus quod fciam locis cius meminit, hirci fpinam transfert. Tragacanthen fert Creta, fpinæalbæradice, multû̃ præ: latã apud Medos aut in Achaia nafcẽti, Plinius, Abũdat hodiȩ̧́ in Crera,\& inde Venctias affertur, 
Antonius Brafauda. Tragion fruticem folä Creta infula gignit, terebintho fimilẽ \& femine, quod contra fagitrar um ictus efficaciffimum tradunt, Plinius, Tpayejoy penultima circumflexa, Hefychíus \&. Varinus nihil quàm herbæ genus effe docuerunt. Diofcorides libro 4.cap.47.tragion deicribit quod in fola Creta nafcatur, folịjs, uirgis $\&$ femine lentifco fimile. (Plinius alicubi his tribus partibus iunipero fimile facit tragion fiue tragonin, quod nor probo: lentifcus enim \& terebinthus ïfdem tribus fimiles fermé funt, utraç à iunipero longè diuerfał) fed minoribus omnibus, \&c. Ferunt, in; quit, fagittis uulneratas fylueftres capras hoc fibi frutice mederi,paftiş̧́ co decidere cufpides. Hine forte aliquis tragion dictum conïciat, quod hircis $\&$ capris fylueftribus medeatur. Sed mox apud eundem alterum tragion defcribitur:quod cum prióre puto nihil quàm nomen cömune habet, non etiam nominis rationem. Sic enim dictum ait, inde quod folia eius hirci odorem per autumnum fpi rent. Idem tragon, tragocerotem, 8 cornulacam $R$ otnanis appellari adfcribitur:item forpion, quod nomen trago herbx mox dicend $x$ magis conuenit, ut garganon quc ${ }_{\beta}$, fcribendũ traganon. Tra gonia herba qualis fit, non traditur, Credo $\&$ falfum efle promiffum Democriti(portentofum enim eft) adalligatam triduo abfumere lienes, Plinius, Ego hanc tragoniam alterum Diofcoridis tragion cíe crediderim:cui fcolopendrï feu afpleni folia tributuntur: $8 \mathrm{c}$ eam ob caufam forte etiã uires ex. dem à magis. Galenus alterum hor genus tragĭ multis in locis nafci fribit. Vel potius lonchitidem alteram, cui folia fcolopendrï \& f plenem minuendi uim Diofcorides tribuit. Fierietiam poteft, ut una her ba propter nomint ditterfitatem pro diuerfis habita fit à Diofcoride, \& eum fecutss alīs, Eft $\&$ alia herba tragos; quam aliqui frorpion uocant, femipedem alia, fruticofa, fine folijs, pufillis race, mis rubentibus, grano tritici acuio cacumirse, 8 ipfa in maritimis thafcens, Htrius ramorum decem aut duodecim cacumina trita ex uino pota, coliacis, dyfentericis fanguinem excreantibus, men. fium ç abundantiæ auxiliantur, Plinius, Eiufdem meminit lib. 13. cap, 21, Tragion, inquit(lego tra. gon) \& Afia fert, fiue fcorpionem, ueprem fine foln̈s, racemis rubentibus, ad medicinæ ufum. Dio. icorides etiam lib.4, eap. 49. hanc plantam defcribês, fcorpion $\&$ traganon à quibufdam nominari meminit. Nomen equidem tragi impofitum ei fufpicor à tritici granis, quibus á Plinio fimpliciter, à Diofcoride magnitudine tantum compar atur. Eft aurem tragos etiam tritici fiue frumenti genus, ut mox dicemus.Scorpion diçum apparet, quod acuminata granorû capita fint. In iuncorum gene re aliqui eam numerant, nec difimilem marino iunco in aliquibus faciunt, Marcellus Vergilius ex Hermolao $q$ ui hanc in litronbus I taliz gigni herbarios afferere fcribit, \& cb fimilitudine è muls tis iuncum marinum uocari. Idem monet racemos à Plinio dictos, quos Diofcorides jáy res uocat, id eft acinos:hi finguli ${ }_{j}$ acemi ex acinis pluribus collecti intelliguntur. Poffet fané aliquis acinos iftos foliorum loco tragi ramulis adbarere fufpicari, quemadmodum illecebra tertium fedí genus foliola

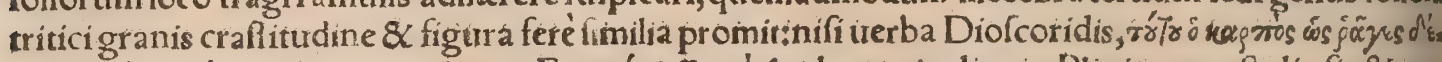

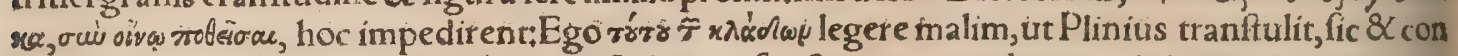
fructio melius confabit. Marcellurs tranftulit eius fructus numero decem acinicum uino poti, tan.

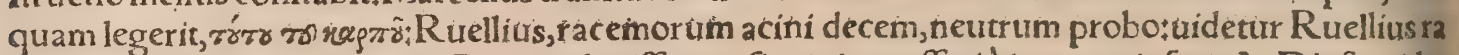
cemorum pro ramor um apud Plinium legiffe quafi acini neceffarió in racemis fint. Ac Diofcorides in trago non acinos, fèd ueluti acinos fpectari. frribit ‘ wos dinge, reddendum circiter decem. Tragon cerealem Diofcorides defcribens, libro 2.cap. 84 certum frumenti genus intelligit, alï paratam ex tritico ueluti halicam fic uocant. Tragos(inquit Diofcorid.) quandam chondri, id eft halica frugis 4 §iguram gerit:multó minus quàm zea nutrit, quod multum aceris habeat:quare agrius conficitur, aluum q $^{\prime}$ magis emollit.P tifanx conficienda uulgata ratio eft: fimili modo ex tritici femine tragum fit, in Campania duntaxat $\&$ Aegypto, Plinius. Alibi quog, tragum Italix peregrinum $\&$ ab Orien. te inuéctum meminir. Tragos cognomento arídins hoc eff cerealis, út ab herba trago diftinguatur; fumenti genus eft. In Hippocrate quid fit ftrygis, quod ipfe leuius effe tritico, \& uentrem magis fol uere teftatur, non comperi:nifi quis pro rrago ftrygite (forte, fitode) accipiat, Hermolatrs, Galenus de trago frumêto à Diofcoride dicfa repetir. A ddit lib. 1. de aliment.facult.) ex fplendida \& nobilifir ligine feu olyra, ut decet excorticata, tragum ronfici,cuius plerifg eff ufus. Primum in aqua coquis tur, mox effufa priore aqua mulfum, fapa, uel paffum infunditur:demum pinea nuces aqua pramäs ceratæ donec intumefcant, fuperinïciuntur. Sunt qui tragum non ęmulari tantüm afpeçi olyramin; fed idem effe genus defendunt, fpecie tantum differre. Farris apparatum docet Aetius lib. 9; cap. 45. Frumentum uel maturum uel uiride madéfit, cortice repurgatur, Sole ficcatur, craffiffime mo:

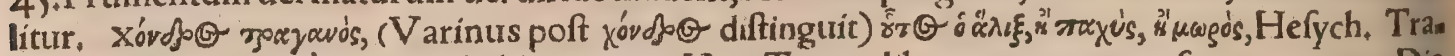
gum quidam Gallice exponit du ble turguet. Hier. Tragus lib, 2.c2, 23, tragum frumentaceum Dio fcoridis interpretatur farris genus, qued Columella uerriculum albü appellarit : ipfe Germanicun ei fingit $\mathcal{C}$ eut doen reif, id efforyza Germanica:quod oryzx inftar grana eius cum lacte coquan. tur:hordeo(inquit)fimile eft per omnia, uegetius tamen \& candidius, uere feritur, Ego de ea re certi in prafentia nihil habeo: Hcc tantum dicam, uideri mihi genus hoc frumenti tragos appellari Gra.

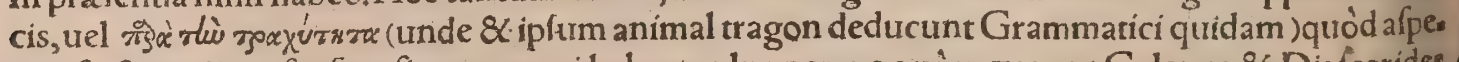
rius fit, \& multum furfurofi recrementi habeat, plus nempe quàm zea, ut Galenus $\&$ Diofcorides

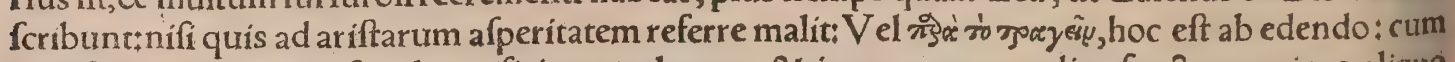
non folum grana per fe ad panificium molantur, \& integra aut modice fracta cum iure aliquo 


\section{DeHirco. H. Lib. I.}

decoquantur $₫$ fed infuper fui generis cibarium ex eis fiat, ut ex Galeno iam retull. Curm Gallico nardo femper nafcitur herba, que hirculus uocatur, à grauitate odoris \& fimilitudine, qua maxime adulteratur. Diftàt, quod fine cauliculo eft, $\&$ quod minoribus folins, quodó $\$$ radicis neç amare,ne= que cdorata, Plinius. Diofcorides tragon appellat, \& difcerni docet quod candidior fit, ac folijs mi

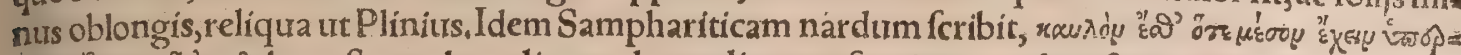

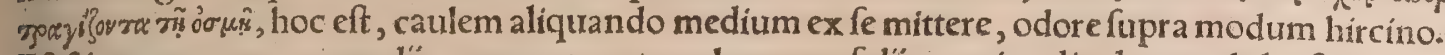
Ef \& tragopogon, quem alí comen uocant, caule paruo, folins croci, radicelonga, dulci, furper cau Iem calyce lato, nigro. Nafcitur in afperis, fine ufu, Plinius, Et alibi, Scãdix, quę ab alĭjs tragopogon uocatur, herba in cibo uulgaris apuó A egyptios. Tragopogon (inquit Hermolaus in Corollario) so hoc eft hirci barba, qua \& f candix à Plinio rocatur:nifi, quod fufpicor, deprauata lectio eft, defcri. bitur a' Theophrafto hiftor,plant, 7.7.in hunc modum: Radix longa, dulcis : folium croci, longius: caule paruo, (breui)furper quem caly x laturs, $\&$ barbula:quę fummo uertice incana $\&$ prolixa funditur. Acetarium quidam olus hanc effe falfó uolunt, quam unlgo barbam petra, \& in Gallia cifpa= dana barbulam hircinam uocent. Habetur \& quęgerontopogon, id eft fenis fiue presbyteribarba dicitur, tragopogoníferé tota fimilis, nifi quod lacte manat, $\&$ radice amara eft, non dulci, à Nican= drogeraós pogon fortafie nuncupata: $\{e d \&$ radice dulci carpitur Roma. Tragopogona uocari $\&$ in trago pifce, inuenio partem fub gula eius nigrantem, ut $A$ thenaus author eft, Hacc Hermolaus. Et alibi, Nicander(inquit) erigerontem intellexiffe uidetur, ctm geraon pogona dixit: nam $\&$ nos fe= necionem urocamus, aut tragopogonifimilem herbulam, qux uulgo barba fenis dicitur:aut chryfo do comen, quam $8<$ louis barbam appellamus. Tragopogon herba(ut apud Ruellium legimus)edens do eft, flore liteo:quę ueró alílis in hortis cref́cit, folio eft latiufculo, flore purpureo, Radices in al tum agit, quę hybernis diebus acetaria dulcedine fua commendat. A plurimis nunc Romana con. fuetudine dicitur petræ herba, quod afperis locis quafi è medịs faxis uideatur erumpere, à quo etia Hetruria faxificam appellat, Gerontopogon eadẽ efre creditur permultis, Alij diftinguũt, quoniam hircibarbula fit radice dulci oblonga, in f capo calyx ingens, flos purpureus $\&$ prolixa barba:In gerontopogone radix amara, flos luteus, in caulis uertice calyx longus, qui incanefcentes barbulas fa tifcat, Hac Ruellius, Ego tragopogonem in Montepeffulano uidi, in Germania 82 alibi hacienus nufquam:folins croci. Cater um barba fenis, quam recentiores pleriç pro hircina falfo accipiunt,

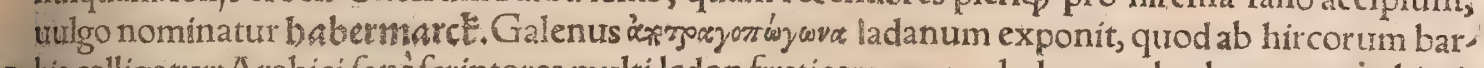
go bis colligatur; Arabici fané fcriptores multi ledon fruticem, ex quo ladanum, barbam uocant hirci nam. Barbahircina 8 rofa canina, ab hircis appetuntur, Syluaticus. Idem alcheratib, herbam hirci. nam interpretatur: \& alibi Lac de Serfi, herbam hircinam uel hypocifthidem: \& Crifomon, linguam hircinam, centumneruiam, Quidam chrifomon, chamamalum faciunt : centumneruiam, plantagi= nemmaiorem. Sed de Ladano quodè barbís caprarum \& hircorum depafcentium colligitur, dixi in Capra capite tertio. Alauim genus eft calamintha: $\&$ aliud quod calamintham hirci uocant, $V e$ tus expofitio uocabulontm A uricennas. Tragoriganum herba eft, qua in cibo libidinem ftimulat,

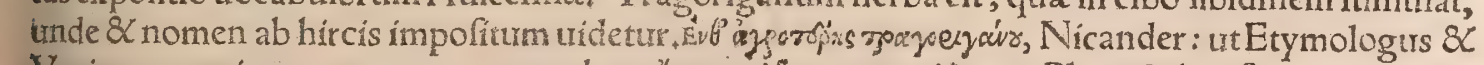
Varinus meminerunt + corrupta apud cosoecy uel opsy uox uidetur. Plura de hac ftirpe uide apud Ruellium. Tragonaton, lychnis fylueftris, in nomenclaturis apud Diofcorid. Vbi tragoceros etiam 40 anemone, 8 a loë cognominantur:item tragion altcrum, quod Romani inde facto nomine cornula cam appellaffe uidentur:quamuis in hiftoria cius nulla cornuum fimilitudo, fed odor tantum hírci. no fimilis exprimitur. Saxifragia hircina à quiburdam uocatur herba pimpinelle fimilis, propter of dorem radicis, Matthaolus. Germani hancipram pimpinellam vocant, cum à uicinis gentibus Gals lis $\&$ Italis, aliam pimpinellæ nomine appellanda ćffe conftet, que $\&$ in cibum uenit, $\&$ in hortis $\mathrm{CO}$. litur. Natrix uocatur herba cuius radix euulfa uirus hirci redolet, Plinius. Forfitan hae faxifragia iam dicta fuerit:quanquam dictamnus etiam uulgaris, ut audio, cum eruitur, radice hircum olet

Cinirus ex oue $\&$ hírco nafcitur, Albertus hibro 22 , in lbrida, fine authore, Plinius umbros $\mathrm{di}$ cos exmufimone(cui uillus caprinus, uel hircinus) SCoue nafci fribit. De capris traganis in $\mathrm{Ca}$ pra dixi, parte 3.capitis 8. $A$ Ab hirci fímilitudine 8 cerui, nomen tragelaphi factum eft. Eft eadem, so qua ceruus, fpecie, barba tantum \& armorum uillo diftans, quem tragelaphon trocant, non alibi quàm iuxta Phafin amnem nafcens, Plinius 8.33 .82 Solinus in fine capitis 22. Ge. Agricola trage= laphum interpretatur, Germanice dictam feram ein bannsbirfe/qux quidem mihi hactenus igno. ta eft. Tragelaphus, inquit, \& ceruus, in fyluis cubant. Tragelaphi \& bubali nafcuntur in Ara. bia, Diodorus lib.3. A pparet fané ab Ariftotele idem animal hippelaphum dici, (ut Raph. Volater. ranoetiam uidetur)quoniam $\&$ peregrinum facit, \& eadem quęPliníus tragelapho tribuit, barban nempe, $\&$ armos uillofos, \& cerui fimilitudinem, tum magnitudine corporis, tum quod formina in eogenere cornibus caret. Hippardium (inquit) \& hippelaphys tenuifímo iubre ordineà capite ad fummos armos crinefcunt. Proprium hippelapho uillus, qui eius gutturi, modo barbæ, dependet, Gerit cornua utrunç, excepta foemina hippelaphi: $\&$ pedes habet bifulcos. Magnitudo hippelaphi 60 non diffidet à ceruo:gignitur a purd Arachotas. Et alibi, Hippelaphus fatis iubr fummis concinet ar. mis, qui à forma equi $\&$ cerui, quam habet compofitam, nomen accepit, quafi equiceruus dici me. ruiffet, Et rurfus, Equiceruo cornua funt capra proxima, Gaza aliâs Gracum hippelaphinomen 
relinquit, aliâs equiceruum transfert. $\mathrm{A}$ lbertius ramofa \& ceruinis fimilia cornua tragelapho tribuit, fed fine authore.Cerui fimilitudinem utriq in hoc animali uiderunt, tum qui tragelaphum, tum quí hippelaphum nominarunt:fed hi propter iubam equiceruum dicere maluerunt, illi propter barbam fimul \& cornua hírcoceruum. Volaterranus tamen ex A eliano citat, tragelaphum cxtera fimilem ceruo effe, barba tantum 8 armorum uillo hirco propiorem. Pygargus, inquit Bartolemaus Angli, cus, animal eft cornutum $\&$ barbatum hirci inftar, minus ceruo, maius hirco, fimile hírcoceruo, led longè minus, ut legimus in Gloffa in Deuteronomị caput 14. TFk ako uocem Hebraicam Deute ron 14 . aliqui tragelaphum interpretãtur ; aln̈ ibicem autrupicapram. Vide infra in lbice. Trage. laphus aliquibus nominatur de re qux nitlla fit, nec ufquam in rerum natura reperiatur, ut $\&$ oruvdow

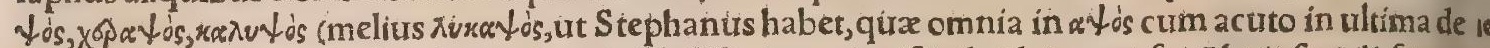

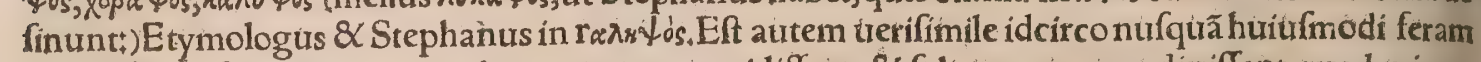
extare à plerifos creditum, quod nünquam eam uidiffent, \& folum nomen audiuiffent, quod mirum non eft, cum in Arabia \& apud Arachotos reperiri authores referant, A rachoti autem Indix ciuitas eft, ab Arachoto fluuio fic dicta, qui ex Caucafo profluit; Sunt $\&$ alï (alia huius nominis ciuitas, que 8 Arachofia)prope Maffagetas, Stephan, Athenæus libro undecimo tragelaphos pocula quadã di. cla, Alexidis \& Eubuli teftimonïs comprobat, qui fimpliciter hoc nomen inter pocula pofuerunt:ter

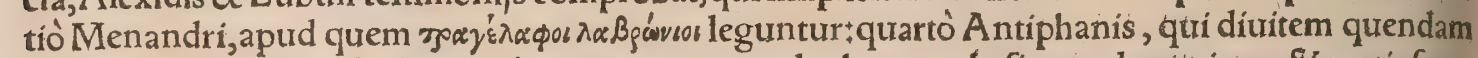
prater alia poffidere fcribit phialas, triremes, tragelaphos, carchefia, ampla nimirum \& pretiofa po cula. Satyros aliqui tragos, id eft, hírcos trocarunt, eó quod hircorum aures habeant, Hefychius $\&$ Varinus, Tragopanadem auem quam plures affirmant maiorem aquila, cornua in temporibus 1 curuata habentem, ferruginei coloris, tantum capite phoeniceo, Plinius fabulofam putat . Tragos

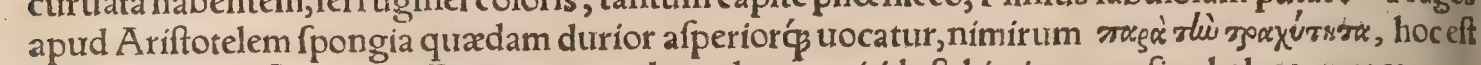
$\mathrm{ab}$ afperitate deflexa uoce. Dicuntur apud eundem tragi, id eft, hirci, mænæ fiue haleces mares cum foetu impleri formina incipit‘à libidine ut uidetur, qua hircus præcipuè infamis eft. Feftus docet etiã concha genus tragum dici, mali faporis : unde caufa nominis intelligitur. Alius item tragos pifcis exocœto, qui $\&$ adonis uocatur, fimilis defcribitur:nifi quod partē fub gula nigrantem habet, quam tragopogona uocant, Hermolaus.

T Caper grammatici nomen. Eft $\&$ Caper uel Caprus, fluuius, qui Laodiceam Cariæu urbẽ cum Lyco \& A fopo amnibus alluít,Strabo \& Plinius meminerunt:fed hęc uox ad capron Gracorum, id

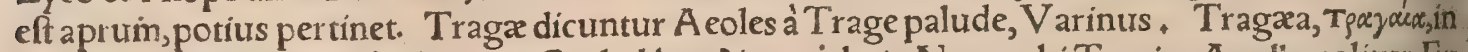
rula efr iuxta Cyclades, (uel una ex Cycladibus:)item urbs in Naxo, ubi Tragius A polio colitur, Eu polis per epfilon \& plurali numero fcribit T $\rho_{\rho} \alpha \xi \varepsilon \tau \alpha^{\prime} \epsilon_{\neq}$ciuis Trageates, Stephanus. Ante Miletum in proximo eft Lada infula circa Tragæas infulas, qux ftationes piraticas habent, Strabo libro i4. Tra gaf $x_{3} T_{\rho} \alpha_{y} x_{\varepsilon} \sigma \alpha$ proparoxytonum, regio Epíri, à Tragafo quodam, in cuius gratiam Neptunus falis denfationem fecit:unde fal Tragafxus. Hinc \& campus Halfius à fale dictus eft, Stephanus. A pud

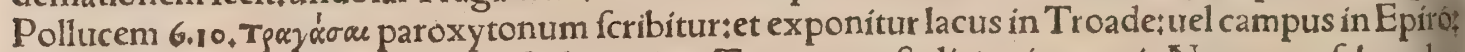
à Tragxo (lege tragafo, quamuis Calius etiam Tragęo tranfulit:)cuius gratia Neptunus falem den

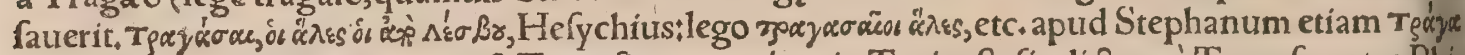

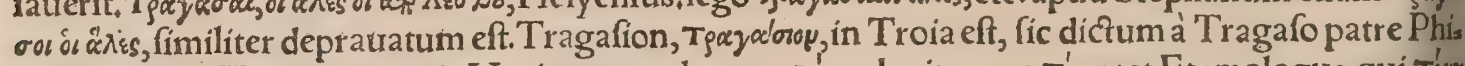

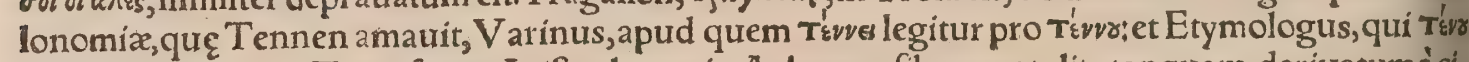
habet per $v$ fimplex. Tragafxum Ariftophanes in Acharnenfibus protulit, tanquam deriuatumàcis uitate nomen, cum per iocum ad hirci uirus magis refpiceret, Varinus. Tragafęum in Troade, falem intelligit A thenæus:cui quum reetigal iniunxiffet Lyfimachus, euranuit:mox dempto, fuccreuit, $C$ lius. Tragilus, $T_{f} d y \omega \lambda \theta$, urbs eft Thraciaxiuxta Cherfonnefum $\&$ Macedoniam, Steph. Tragu= rium, infula in mari Adriatico, adiacens Dalmatiæ, cum ciuitate eiufdem nominis, P tolemæur lib, 2 Plinius 4,21, marmor cius commendat. Ceraiftes, Kigaís's's, locus eft Mileti, dictus inde quòd A pol lo cornua hirci maris ab co mulfi, illic fixerit, ut Callimachus fcribit, Varinus,

Tb. In Delo infula confecratum aiunt hirci cornu bicubitale cum dodrante, ponderis librarim uigintifex, Varinus in K'́farte. Montanus hircus, quí in montanis pafcuis uerfatur, domefticus alioqui.Pafcali pecore, ac montano hirco atç foloce, Lucilius. Solox lana, craffa: \& pecus quod pafs fim pafcitur non tecfum. Titinnius in Barathro: Ego ab lana folocia ad puram data, Feftus.

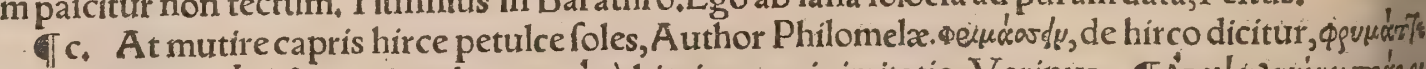

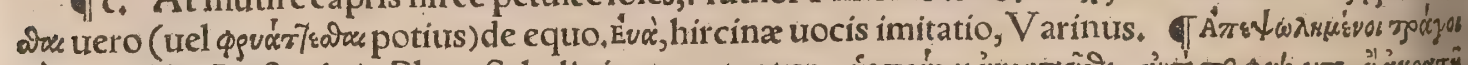

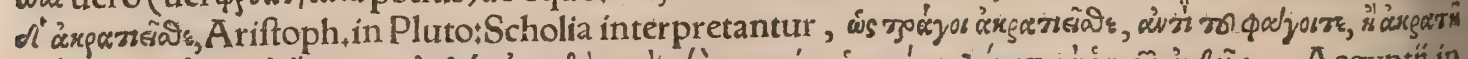

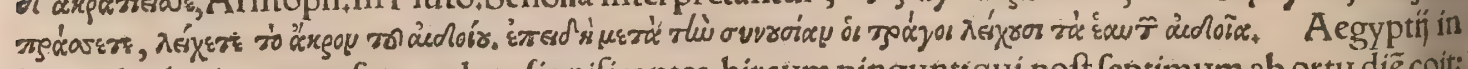
hieroglyphicis penem foccundum fignificantes, hircum pingunt: qui poft feptimum ab ortu diê coit: 8 quanquam inualidum $\&$ fterile femen emittit , coit tamen citius cæteris animalibus, Orus. In Mendefia Aegypti, hoc mea memoria prodigitum cổtigit: Hircus cum muliere cońt propalam, quod in oftentationem hominum peruenit, Herodotus lib. 2. Hac de re etiam Pindari uerfus Strabo citat

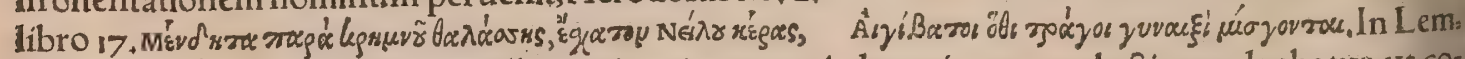
no infula ex mammis capri, quas ille geminas iuxta genitale gerit, tantum lactis enulgebatur, ut $\mathrm{CO}^{\circ}$ loftra inde conficerent; quod idẽ etiã proli mafcula capri illius eueniffe accepimus, Sed hac oftentis 
Gthiumeranda potiús ducunt. Nam \& Lemnio illi pecoris domino confulenti, deưs ampliús incre.

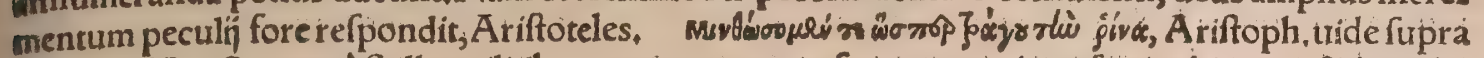
in Capra H.c. Satyrus à Sylla militibus captus, uocem afperam, equi prafertim hininitu, \& hirci ba latu permiftam ædidit, Plutarchus in Sylla. Et pauló poft, Pridie quảm Campaniam ingtederetứ; duo eximiz magnitudinis hirci iuxta Ephitum montem confererè confpecti funt; omnia quę inter pügnandum euenire mortalibus folent; nuth inferentès ${ }_{j}$ nưnc tolerantes. Erat autem uifio, quę paü latim à terra eleuata quaquauerfus per aërem difpergebatur, obfcuris idolis perquam fimilis:polta modium euanuit.

4d. Elephanti ex animalibus maximé exhorrent hircû́, ceraften, (arietem intelligo,) porcum: quibits fane machinamentis Romani elephantos Pyrrhi regis primum uertentes, uictoria funt po. titi, Volaterianus.

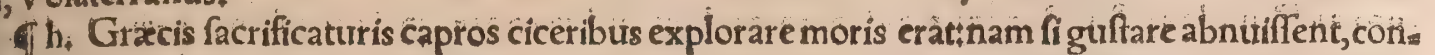
cipiébant inde haird ualere fatis, Cxlius. Perfectum facrificium fue, tauro, hirco, \& ariete confta bar:hor hecatomben $\&$ trittyn urocabant, ut expofuimus in Boure pluribus. Heroibus tauro, capro, $Q$ ariete litabant, Gyraldus, A pollini, Homero tefte, units tauro, alius ariete, aliquís hirco facrum $\mathrm{fe}=$ cit. Agathius Gottici belli lib. 2, author elt; ingritente Perfarum bello in Marathonís campis, troe uiffe hithenienfes, totidem fe hircos Dianæ immolaturos, quiot peremiffent hoftes. Quod cum im: ples e in primis ctuperent, tion quiffe tamen, etiam capris a diectis uel fuccidaneis, Càlitis, Capram $\&$ hircum Mendefí pro dijs fibi côfecrarunt, Gyraldus; \& Strabo lib. 17. İdem tum Pâna tưm hircum uno uocabulo Menden appellant; ut fupra dixi in prima parte huius capitis. In Capra etiam ex He= rodoto retuli quod Mendefí capras $\&$ hircos trenerentur: $\&$ de hircinis cruriburs $P$ anos, inde $\&$

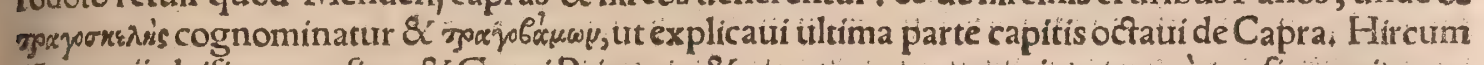
(Alegyptij)deificarunt, ficut \& Graeci Priapum: $\&$ propter eam corporis partem à qua fít omnitum or tus, pudendis non folum Aegyptï, fed alii plures facra faciunt, Diodortis Sicitus. Bacchi transfor mationem in caprum, Ouidius libro j. Metariorphofèon defcribit, Hircum Baccho facrificant, in= quit Phurnutus, eỏ quod uites $\&$ ficos ladere exiftimetur. Quamobrem excoriato etiã hírco in ü. trem infiliunt agricolę iuuenes in Atticis uicis. (Hưtic Afcoliorû̃ morễ in capra iam explicautit) Sed forte hac uictima Bacchus gaudet, quoniam \& iplëhircirs fit. Vergilius lib.2. Geor.cum quadrut. pêdes uitibus infeftas nominaffet, fubiungit: Non aliam ob culpam Baccho caper omnibus aris

Cæditur: $\&$ ueteres ineunt profcenia ludi, \&c. \& mox poft mentionem a fcoliorum, id eft, faltationis fuper tutres caprinos uel hircinos uino repletos, Et ductus cornu ftabit facer hircus ad aram+ Pin. guiáç in ueribus torrebimus exta colurnis. Vifima ntiminibus(inquiti Seruius in hunc Vergilí locum fribeins)aut per fimilitudinem, aut per contrarietatem immolantur:per fimilitudinem, ut nis grum pecius Plutoni: per contrarietatem, ut caper qui obeft uitibus, Libero. Aris autèm omnibus; nonfine caufa dixit. Nam cum numinibus cateris uarie pro qưalitate regionum facrificetur; $\& c_{*}$ Libero ubiç̧ caper immolatur. Prima exiftimatur hoftia(inquit Probus) fuiffe fus, quia terrã roftro protritdèndo femina erueret;fecunda caper, quia uitem laferat:quod \& Pythagoras etiam teftatur apud Ouidittm libro 15. Metamorph.Meminitetiam Varrolib, 2.cap.4. Icaro patri Erigones, Liber. pàrèr uinum \& utitèm, \& unam tradidit:qui cum feuiffet uitem ipfam, \& hircus in uineam fe conie yo ciffet, $\&$ quę ibi tenerrima folia uiderat decerpfiffer, ex pelle cius utrem fecit, ac uento plenum për. ligauit, $\&$ in medium mare proiecir, fuośç fodales circa eum faltare coëgit, Higinús. Incenfís iam altaribus, \& admoto hirco, id carmen quod facer chorus Libero patri reddebat, tragozdia dicebatur. hoc cft ab hirco uinearum höfte, \& à cantu, ut refert Donatus. Vel quiod uter ex eius pelle trini ple= mus, folenne præmium cantoribus fuerat:uel quod hirco donabatur eius carminis poëta. Ouidius lib.1.Faftorum: Sus dederat pönas:(propter agrum fcilicet roftro effoffum, \& fegetem uaftatam, Cereri ímmolata:) exemplo territus horum Palmite debureras abftinuiffecaper. Quém f́peçans aliquis dentes in uite prementẻm, Talia non tacito dicta dolore dedit. Rode caper ưitem; tamen hinc cum ftabis ad aras; In tua qutod fpargi cornua poffit, erit. Citat hunc Ouidij locim Politianiss in Mifcell. cap.26.8 adijcit eriam Eureni diftichon Gracum, ex quo Ouidium tranftuliffe apparet.

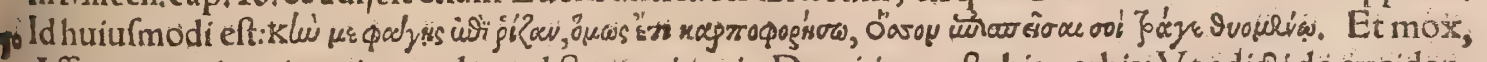
Afferamus etiam (inquit) quod apud Suetonium in Domitiano eft, his uerbis: Vt edicti de exciden= dis uineis propofiti gratiam faceret, nơn alia magis re compulfus creditur, quâm quóod fparfílibelli

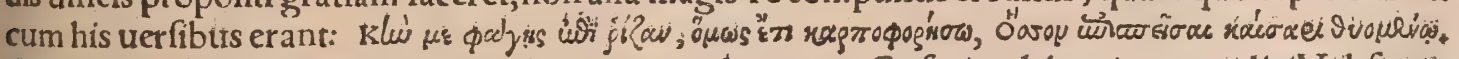
Quod enim fupra uitis capro minitabatur:hoc eaden nunc Cæfari, pulcherrima parodia: Vel fi me, inquiens,ad radicem comederis:tantum tamen tini producam, quantum immolando Cafari pof:

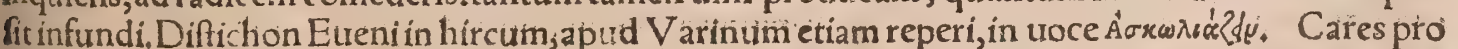
hirco canem immolabant, unde factam eft protierbitum Caricum facrificium, ut in Cane rètuli. Veit neris waud'sur, id eft, utulgaris dicfæe effigies ex ære hirco èriam æreo infidet, Scopæ ftatuarn̈ opus, a

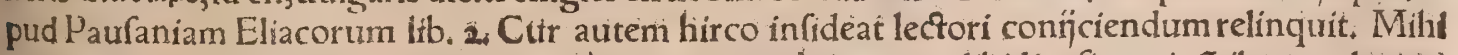
6o quidem ratio in promptu apparé, quod hirctus maximé obnoxius libidini fit: cui gẽtiles pandemion fuam Venerem præficiunt, quan̈i ad ưranix, id eft coleftis differentiã ita cognominant:nifi quis hîa

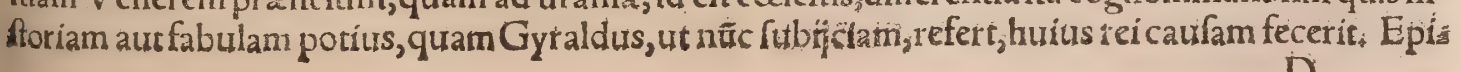


tragiam Venerem, inquit, Plutarchusin magnis $P_{a}$ rallelis fribit uocatam, rum A pollo Delphin (Deiphicus, Calius) Theíeo refpondiffet, naugaturo in Cretã, ut deligeret fibi nauigationis ducem

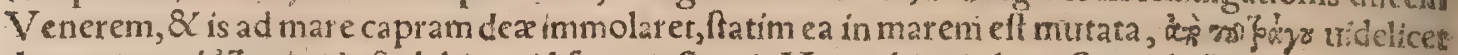

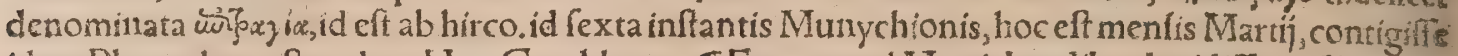
idem Plutarchus eft author, Hac Gyraldus. IExtat apud Martialem lib. s.lepidifinut Epigram ma, quo narrat hiftoriam facerdotis, qui cum hircum Baccho maciaret, agreftem \& rudem quen. dam hominem fibi inferuientem, tefticulos acuta falce fecare iuffit, Teter ut immunda carnis aburet oder. Interim occupati círca hircum inclinatió̧ facerdotis ferotum ap parens, rufticus re male intellecta fubito refecuit, antiquos facrorum ritus id poftulare exiftimans. Sic modo qui Tufcus fuer as, nunc Gallus harufpex, Dum iugulas hircum, factus es ipfe caper. Anytes epigramma in puer os

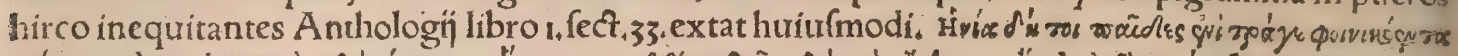

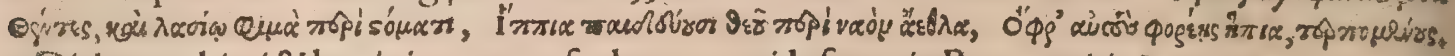
Dialogum hirci 2 bouis in argento fulptorum, uide fupra in Boue capitis 8.parte 8.

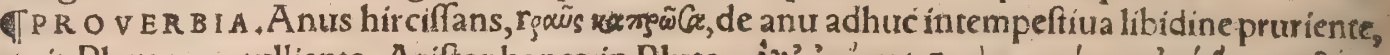

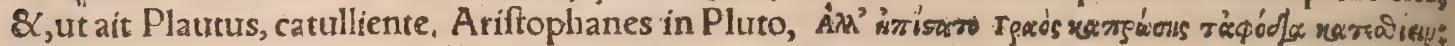
Verum nouerat Anus capriffantis uorare uiatica; de iuuene cui anus libidinofa omnia fuppedita. bat.Nota eft hircorum libido, odorós, qui \& fubantes confequitur, Hęc Erafmus. Impofuit ei uocum fimilitudo, ut récroy Gracorum(quibus ea uox a prum \& fuem marem fignificat)pro Latinorum ca. pro, id eft hirco transferret, Ka msoë fcropharum eft, cum libidine turgent $\&$ mares requirunt, ut in ipfar um hiftoria claré conftabit.Quamobrem Anus fubans, non hirciflans, ab Erafmo reddendum : fuerat. A d eundem ferè fenfurm à Germanis quibufdam effertur: 20 ann dic alten geul gebern wa:

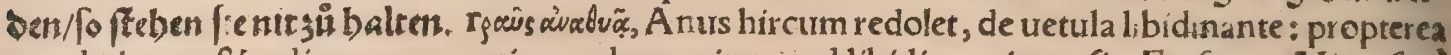
quod alarum \& reliquarum partium odor excitatur ad libidinem incenfis, Erafmus, Miror fane nullum ab eo huius protterhị authorem citari, neq̧ à quo Gracorum id decerpferit indicari.Quod ideo defidero, quoniam a'vatvax urox deprautata mihi uidetur. Ego nihil hircinum in ea urideo, fed àvas bées legendum affero, ut fenfus fit, A nus iutreniliter ludit aut laltat: in quem fenfum $\& \alpha$ hac profe.

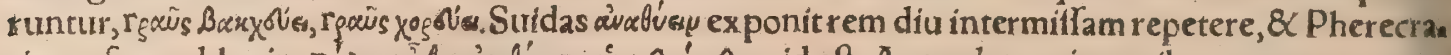

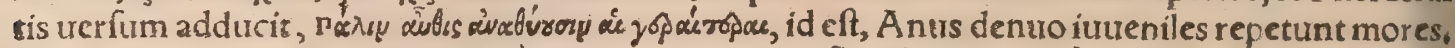

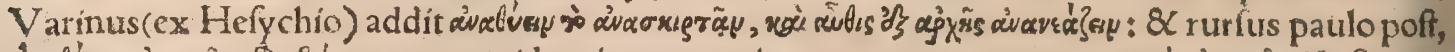

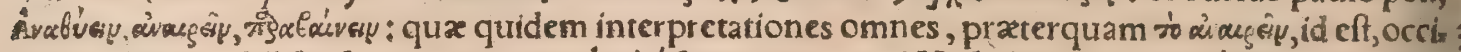

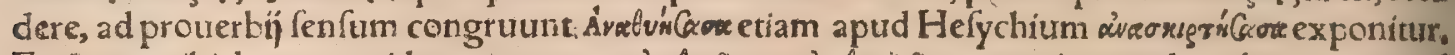

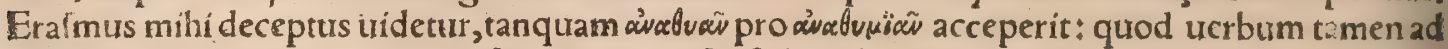
hircinum \& foetidum odorem referri non poteft, fed ad fuauem $\&$ gratum qualis aromatum eft: adde quod tranfitiuum femper eft, ut fuffire Latinis. TCaricus hircus, Ka'erís zoóz $\Theta$ : Dirge nianus indicat dictitatum de uilibus \& contemptis. Hefychius indicat ufurpatum à Sopliocie, \& ce Fieri poteft ut prouerbium eò refpiciat, quod Cares pro hirco folent immolare canem, ut indic atum eft in prouerbio Caricum facrificium, Erafmus. TQui Bauiũ non odit, amet tua carmina Maưt, Atqs idem iungat uulpes, \& mulgeat hircos, Vergilius in Palamone: de re palàm abfurda. Eft $e_{2}$ nim uulpes animal ab aratro uehementer alienũ. Lucianus de Dcmona çe in uira cius narrat, qurod cum confpiceret duros quofdam philofophos, utrof f̧̧ pariter indoefos, inter fe difceptantes, \& alte. rum quidem ridiculas quafdam quxftiones proponentem: alterum item aliena, neç quicquam ad rem facientia répondentem: Quid, inquit, amici, an non horum alter hircum mulger e videtur, al

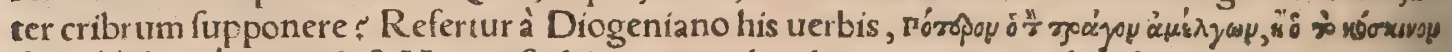

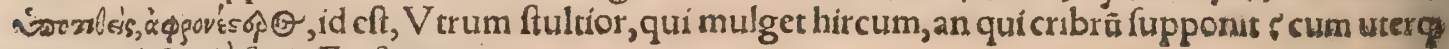
pariter abfurdè facit, Erafmus.

\section{DE HOEDO.}

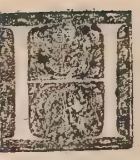

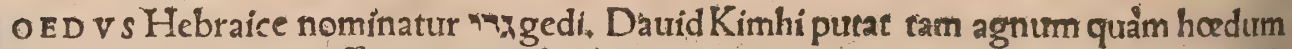
fic appellari, \& ideo differentiæ caufa plerun $\$$ caprarum nomen adïci, hoc n:odo. gedi haifiim, R. A braham folis capris hoc nomen attribuit, ut folet etiam Arabica lingua:plu rale mafculinum eft gedan̈m, formininum gedioth. Genefeos cap. 38. Chaldaica translat tio habet gadeia, A rabica gedi, Perfica bus kahale bufan. Septuaginta eriphon, Hieronymus hoedũ, Sair uel feir etiam Hebræis paruum hircum fignificare fupra dixi, aliqui hoedum interpi etantur,

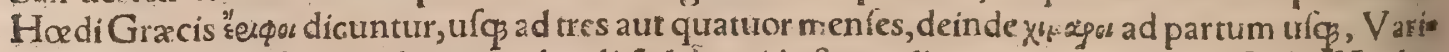
nus, Qui fex menfes excedunt, non hoedi,fed augs, id eft, capella uocantur, Symeon Sethi. Hoedus hodiȩ́́ uulgo apud Gracos opieu nominatur. Iralice cauretto, quafi capreolum dicas : quo nos mine barbari quidam etiam in Latina lingura pro hnedo abutuntur. Aliqui ctiam Italice capretto vio cant, alị ciauarello: R hęti qui Italice loquuntur ulzol. Hifpanicé, cabrito، Gallicé,cheureau, Ger=

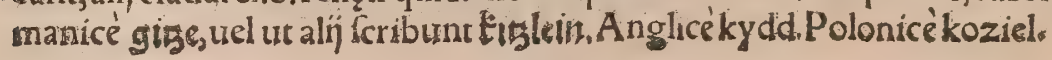




\section{DeHoedo. C.D.E.F. Lib.I. 315}

c.

Ferè ad tres menfes nồ difiunguntur hoedi, Varro, In nutricatu hoedi trimeftres cum funt fact: tum fubmittuntur, \& in grege incipiunt effe, Varro. Vbiediti funt,eodem modo quo agni edu= cantur:nifi quod magis hoedorum lafciuia compefcenda, \&arctius cohibenda eft. Tum fuper lactis abundantiam famera, uel cytifus, aut edera prabenda: uel etiam cacumina lentifci, ( $\&$ arbutui, $\mathrm{P}_{\text {all }}$ \&

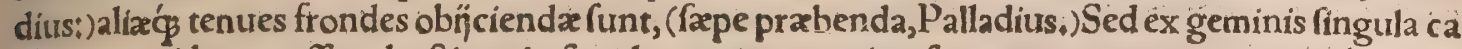
pita, quax uidentur effe robuftiora, in fupplementum gregis refertrantur; catera mercantibus tra duntur, Columella. De mentigine hoedorum mortifera lactentibus, dicam infra in Agnis ex Colum mella, \&c. Natura corporis partes fingês perficiensóg, fecit ut ipfę citra doêtrinam, proprias actio. nes aggrederentur:cuius rei exactiffimum aliquando fecimus periculum, hoedum alendo, fed ita alendo, ut matrem qua ipfum in titero geftauerat, nunquam uidıffet. Cum enim pragnnãtes capras diffecarem, hoedum à matre exolutum ita abftuli ut ipfam haudquaquam uideret: atç in domum quandam, ubi multæx pelues erant, depofui:quarum alix uini, aliz olei, alięmellis, alix lactis, aut ali

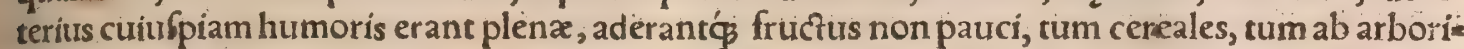
bus decerpti. Hunc itaqg hoedum confpeximus, in primis quidem pedibus incedentem, perinde ac fi audiuiffet crura incellits gratia fibi futffe conceffa: deinde excuffit quam à matre contraxerat hue miditatem. Poftea pede latus fcalpere, ac deinde fingula uafa olfacere tridimus : percepto itack fin: gulorum odore, lac tandem abforbuit, Quibus tifís, omnes exclamauimus, Hippocratem uerè di= xiffe,animalium naturas effe indoctas, ( $\&$ reliqua) Galenirs lib.6.de locis affectis, cap.6.

20 D. Splendídior uitro, tenero lafciuior hoedo, Oiridius.

TE. Cafeus fit lacte coagulato, hoedino imprimis uitulorúmue coagulo, Plinius. Maio menfe, inquit Palladius, cafeum coagulabimus fyncero lacte, coagulis uel agni, uel hoedi, \&k, II In iurife confultorum libris ubi tractatur de auro $\&$ argento legato, in lege Argumento funt, odonum lege: batur,Bayfius odorum legendum alferit: quod ex œedorum(fic fcribit fine a fpiratione)pellibus fies bant calciamenta, ut ex antiquis, inquit, marmoribus Romx coniecimus. Idem his Martialis poëtæx ad Phocbum uerfibus comprobat, Oedina tibi pelle contegenti Nudx témpora uerticemćs caliuę, Feftué tibi Phoebe dixit ille, Qui dixit caput elfe calciatum. Feftiue autem dixit, propterea quod Romani temporibus illis in calciamentis uterêtur pellibus oedinis, $\mathrm{H}$ æc Bayfius. De pellium caz

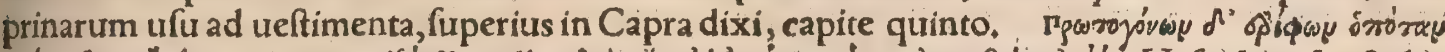

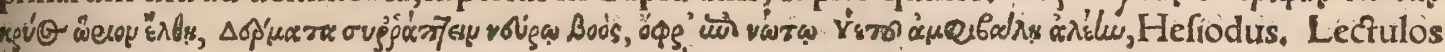
pellibus hoedinis fternere, Cicero lib. 2. de Legibus. Euphorbia incifa conto fubditur excipullus uentriculo hoedino, Plinius. A gni $\&$ hoedilarciuientes; $\&$ inter fe faltantes, latos(ferenos)dies pro= mittunt, Aelianus. Caurendum ne anferes hoedinos porcinósue pilos deuorent: exoluunt énim eos fi toraterint, Anatolius. TVerres, iutuencos, arietes, hoedos; decrefcente liuna caftrato, Plinius, Aliqui pilos hoedorum fuffiunt, \& eo nidore fugant ferpentes, Plinius.

Hcedus ab edendo diçus eft, inquit Ifidorus, tenerienim pinguiilsimi funt, \&̌ grati faporis.

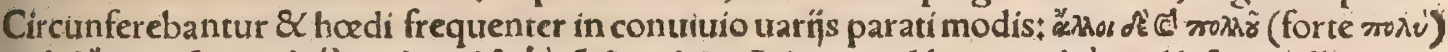
ms ärro हैy 40 conditi fuerint, uel potius lacfeum in uentriculis eortem concretum fuccum, quo ad cafeos coagus landos utuntur. Hoedi apud ueteres ex Melo(Medica infula, Varro de re ruftica; corruptèut iuddi. co)praciptrelautdabantur, ut fcribit Pollux:aut ex Ambracia, uti eft apud Gellium, Callits, Hox, dultus ad domini faltet,fed frigidus, aras。 Vix calet ille, xgris uda alimenta feret,Bapt. Fierä. Ex pedeftribus animãtibus fuilla caro probatifimus cibus eft, deinde hoedina, mox unitulina, Galenus

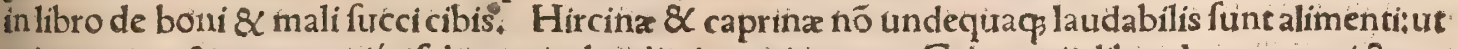
arietes etiam \& oures agniḉp:folis autem hoedis innoxie utare, Galenus in libro de attrenix. uictu. Hoedorum carnem, etiam ut primum in lucema diti funt, in cibo non illaudabilem effe, ex Galeño docui iam in Vitulina. Hoedorum cai o minus excrementi habet quàm arietum, Auicenna. Hoo. dortum carnes facile concoquuntur, \& modicé nutriünt ( ut Gyraldus uertit : Græce legimus fym.

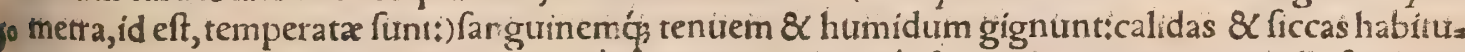
dines ac temperaturas iuuant. Sunt uerò meliores; melioriş̣́́ fucci, qui nec nimis tenelli fünt, nee nimis natu maiores. Nam qui fex menfes excedunt, non hoedi, fed capellla, aìiks, uocãtur. Rufi fané Q glauci, creteris melicres funt:fed colicis morbis nocent. Aiunt quoq; quiòd fi pulmo eorum(ante porum) edatur, ea die temulentiam atiertere, Symeon Sechi. Ebrietatem arcet hoedinus pulmo, Plinius. Hoedina carnes hyeme improbantur, conueniunt xftate, reliquis temporibus mediocres funt,Rafis ur in Tacuinis citatur. Hoedinam carnem, qua nulla inter domeftica animalia potior habetur, edito. Parum enim recrementi in fe habet, facillimè concoquitur, bene alit, fanguinem bo. num generat, calido \& frigido contempera tum. Hic cibus conuenit lautè urituentibus, Platina. Et paulo ante, Ex capris(inquit)hoedi laçentes éfui funt optimi。 Et alibi, Hơdi utrễlibet(affi uel elixi) 6o cocti, fuaues \& falubres funt: coxæ tamen aff $x$, melores habentur: Eadem $\&$ de agni coctura, 『Hoedus in allio:Integrum hoedum(inquit Platina) aut quartã parten, teffeliis latidi \& $*$ fpinacis

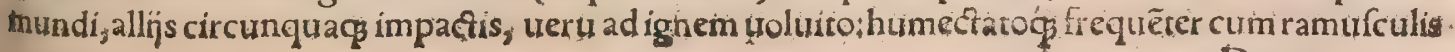


lauri aut rofmarini, ex hoc, quod nunc frribam, condimento : Cum agrefta, cumọ́ iufculo pingut duro uitella oui bene agitata, duas fpicas allij bene tunfas, modicum croci, parum piperis mifceto, in parellamós indito.Inde, ut dixi, qued coquitur, afpergito:coclum, in patinam ponito, partemćs con. ditura infundito, ac petrof elinum minutatim concifum infpergito. Hoc obfonium bene coctum cin to comedi debet, ne refrigefat:oculos hebetat, Venerem demortuam excitat. Ex eodē Plarina quo modo paretur artocreas ex hoedina carne, in Vitulina iam dixi, eft enim eadem ratio. TSanguis hoedi in cibum formatus, quem fanguiculum uocant, cœliacis $\&$ dy fentericis à qubbufdã commen. datur, Plinius. Aliqui fanguiculum, hoedi uel fuis fanguinem exponunt, in cibum formatum. Talis

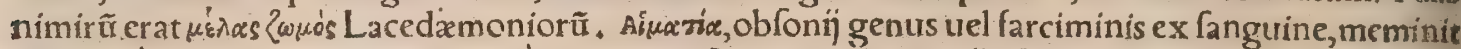
Pollux. Átudizroy, garum quoddam è thynni inteftinis cum branchīs, fanie ac cruore côfectum, quafi fanguiculü, Lexicon utilgare. flocinora, fiue pulmones: Iocinora hoedina uel agnina fic coques (uerba funt A picï 7.10.)Aquam mulfam facies, $\&$ oua, partem lactis admifces eis ut incifa iocinora forbeãt, coques: $\&$ œnogaro, pipere afperfo inferes. Aliter in pulmonibus:Ex lactelauas pulmones, $\&$ colas quod capere polfunt, $\&$ infringis oura duo cruda, falis grana pauca, mellis ligulam, \& fimul commifes \& imples pulmones: elixas, \& concidis: teres piper, fuffundis liquamen, paffum, merum, pulmones confringis, \& hoc œnogaro perfundis. I Copadia hoedina fiue agnina, (ut decet A picius 8.6.) Pipcre, liquamine, coques cum phafeolis paratarïs (aliâs faratarijs:) fuffundes liquamen, piper, lafer, cuminum tritum, buccellas panis, oleum modice. Aliter hoedinam fiue agninam cxcaldatam:Mirtes in cacabum copadia, cepam, coriandrum minutim fuccides. Teres piper, liguft:cum, cuminum:liquamen, oleum, uinum:coques; exinanies in patina, amylo obligas. Aliter hoedinam fi. ue agninam excaldatam: A gnina cruda trituram in mortario accipere debet. Caprina autem cum co quiur, accipit trituram . In hœdum fiue agnum affum: Hœdicoc oleo coxeris incifum, infundes in pipere, lafere, liquamine, oleo modicè: $\delta$ in craticula aftabis, ecdē iure continges:piper afperges, \& inferes . Aliter hoedus fiue agnus affus: Piperis femunciam, af a. reos fcrupulos fex,zingiberis modicum; petrofelini fcrupulos fex, laferis modictm, liquaminis opti mi heminam, olei acetabulī. Hodus fiue agnus fyringatus: Ex offatur diligenter à gula, fic ut uter fiat, $\&$ inteftina cius integra exinaniantur, ita ut in caput in teftina fufflentur, $\$<$ per nouifimam par tem ftercus exinanitur, aqua latantur diligenter, \& fic implentur admix to liquamine, \& ab humeris confuitur, $\$$ mittitur in clibanum:cum coctum fuerit, perfunditur ius bulliens lacte. Piper tritum, li quamen, carenum, defrurum modicé, fic $\&$ oleum ctiam: bullienti mittis a mylum; uel cere mitritur in retiaculo uel in fportella, $\&$ diligẽter confiringitur, $\&$ bullienti zyma curm modico falis fubmittitur: cum bene illis tres undas bullierit, leuatur, $\&$ denuo bullit cum humore fupra fcripto, bullienti condi cura perfunditur. Aliter hødus liue agnus fyringatus: Laetis fextarium unum, mellis uncias quan uror, pipcris unciam unam, falis modicü,laferis medicum, dactyles tritos ocło, ius in jpfius olei acetabulum, liquaminis acerabulum, mellis acetabulum, uini boniheminam, amylum modice. Hodus fiue agnus crudus: Oleo, pipere fricabis, et afperges foris falem purum mutto cum coriandri femine: in furnum mittis:affatum inferes. Hodus fiue agnus Tarpeianus: Antequam coquatur, ornatus confuitur. Piper, rutam, fatureiam, cepam, thymum modicum: \& liquamine collues. Hoedum mace rabis in furno in patella qua oleum habeat;cum percoxerit, perfundes in patella impenfarr; teres fa tureiam, cepam, rutam, dactylos;liquamen, uinum, carenum, oleum; cum bene duxerit, impenfam in difco pones:piper afperges $\&$ inferes. Hodus fiue agnus pafticus: Mittes in furnum, teres piper, rutam, cepam, fatureiã, damafcena enucleata, laferis modicû, tuinum, liquamẽ \& oleum:uinũ feruês colluitur in difco, ex accto fumitur. Hodus laureacus ex lacte: Hoedum curas, exoffas, interanea cius cum coagulo tolles, lauas: adijcies in mortarium piper, ligufticum, laferís radicem, baccas lauki duas, pyreth i modicum, cerebella duo uel tria: hac omnia teres, fuffundes liquamen, temperabis ex fale:fuper trituram colas lactis fextarios duos, mellis ligulas duas, hac impenfa inteftina repies, \& fu: per hoedum componis in giro (quidam legit zirbo, id eft omento:) 80 omentum charta cooperies, fur culas:in cacabum uel patellam compones hodum:adịcies liquamen, oleum, uinum; cũ ad mediam cocturam uenerit, teres piper, ligufticum, $\&$ ius de fuo fibi fuffundes, mittes in defrutri modicum, te. res, reexinanies in cacabum:cum percoctus fueri, exornas, amylo obligas $\$<$ inferes, Hucufop A pir cius lib.8, ut dixi,cap.6. \Pulmo hœdinus (ut fcribit Aerius in ratione uictus colicorum lib. q, ca, 30.) bis affatus ac in cibo acceptus, fuperabundans alimentum fubtrahere uidetur: Qui uero eumla cie replent, deindeç, coquunt, aut affant, uoluptatis gratia non utlitatis refpeçu id facrũt: multó̧ magis qui eum frultatim concifum in fartagine torrent. TVentrem cum inteftinis noftri in uitulis

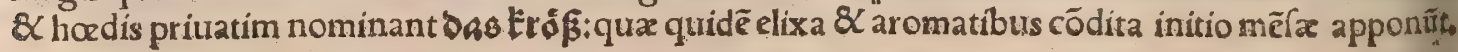

Celfus libro r.cap.7. docens curationem communem adurerfus omnes morfus ferpêtium:Si neq qui exugiat, inquir, neq cucurbitula eft, forbere oportet ius anferinum, uel ouillũ, uel uitulinum, \& uomere: Viuum autem gallinaceum pullum per medium diuidere, \& protinus calidum fuper uul= nus imponere, fic ut pars interior corpori iungatur $\$$ Facit id etiam hødus agnúusue difciffus, 8 cali= da eius caro ftatim fuper uulnus impofita . TAliqui carnem recentem hodorum, (uulneribus ex

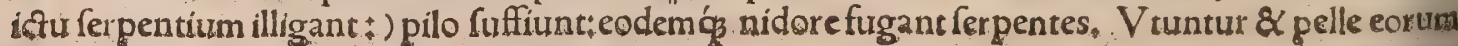


verente ad plagas,Plinius, Hoedorum pilis fuffiri uuluas utile putant, Plinitus, Àd inflammatio= nes tonfillarum \& anginas, gallinæ hoed'ue iufculo utere, Galenus Euporif, 2, 15:

T Hoedi fanguis (ficcus, apud Galenum lib.2.de antidotis) utiliffime in antidota mifcetur, Dío. fcorid. Sanguis caprinus decocius cum medulla contra toxica uenena fumitur, hoedinus contra reliqua, Plinius. Sanguinis excreationes reficit hoedinus fanguis recens ad cyathos terinos cum a - ceto acri pari modo, feruens potus, Plinius. Porró quod de hoedorum fanguine prodidit Xenocra tes, ratus id ob aceti miftionem poffe aliquid efficere, perfuafi cuidam in agro degenti; qui rei rufti: ca quide ftudiofus, fed primis difciplinis eruditus erat, ut experiri uellet, Is retulit fe in duobus fan. guinem expuentibus ufum, nonnullam utilitatem expertum. Cxterum illorum neuter, ex ijs qua o mihi narrabat, neqs ex arteria, neç ex larynge aut pulmone expuiffe uifus eft. Xenocrates igitur in primo libro De percipienda $\mathrm{ab}$ animantibuts utilitate, ubi de hoedis differit, fcribit in hęc uerba $\mathrm{Ad}$ hamoptoicos, hoc eft fanguinem fpuentes, admodum utilis eft hoedorum fangtris: oportet autem nondum(Marc, Vergilius perperam pro nondum habet nuper) concreto plus minus menfura fe= mirotylę tantundem admíceie aceti acris, id ćs ferucfactum trifariam partiri, 8 'in fingulos dies fin. gulas partes exorbendas dare. Itaç licebit tibi forte fortuna in agro deprehenfo, ubi reliquor ư fues rit inopia hoc uti, cum citr a periculum id experiri polfis, Galenus de facult, fimplic, 10, 4. Sanguia nis hoedini recentis, antequam congeletur, uncia cum aceto mixta, \& triduo pota, uomitui (malim excreationi uel fputo) ranguinis confert, itemćs agni,A Aricenna. Sanguine hoedi in cibum formato, qurem fanguiculü uocant, ad coeliacos $S$ dyfentericos affectus quidã utuntur, Plinius. T Hoz. go dorum adeps minus tum calidus tum ficcus eft çuàm cáprarum, Galenus. Noftri ex adipe de ox mento hodi fumpto, \& ftillatitio rofarum liquore macerato, in libras tribus urel quatuor caphurx drachmis admixtis, unguentum parant ad fiffuras labiorum $\&$ narium utile, $\&$ mulieribus tum a $=$ liâs tum ne facies à fole aduratur expetitum. Galli \& Itali pomatum uocant, quoniam odoris coin= mendandigratia poma adijciunt, hoc feré modo: Mala quinç̧ decorticata $\&$ in partes diuifa, \& ca. ryophyllis infercta, in rofarum liquore mof chato macerantur quatriduo. Deinde addũt adipis ho之. direcentis libram, \& fimul feruefaciunt in balneo Marię(ut uocant)donec omnia albeícant:mox cü pradicto rofarum liquore abluunt, ut totum fiat album, $8 \mathrm{X}$ in uafe uitreo reponunt. Sunt qui odo=

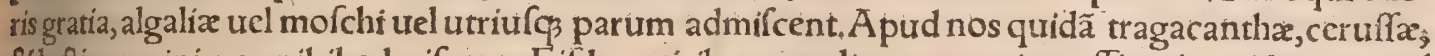
Slactiscaprini nonnihil admifcent. Eildem uiribus praditum aut etiam efficacius tidetur, quod 30 tulgo unguentum album caphuratum uocãt, olco róarum, cera alba, ceruffa, albis oưorum mixtís cumimodica caphura.Poffet $\&$ calx uiua, prafertim lota admifceri, ut in illo Sexti ad labiorum fif furas, Sepum caprex (tribuit autem caprex eadem feré omnia qua alï caprę) \& adipem anferinum, \&medullam cerui, \& cepe cumm refina fimul \& calce uiua, fac ut malagima : mirè fanat labiorum fif furas, Feminum hoedi cinis inteflina rupta farcire mire traditur, Plinius. Sanguinem fiftit, Idem. E lacte mulieris proficit ad cacoëthe, Idem. T/ Ariftoteles coagulum laudat ex inulo feu hin nulo. Nicoon(ut Nicandri Scholia citant, \& Hermolaus in Pliníym 11.41 , ) in libro de difficulta= tibus, optimum coagulum ait hinnuli, fecundum leporum, tertium hoedi. Marcellus Verg.non re. ce agni pro hoedi in huius authoris teftimonio pofurit. Coagulum hinnuli, leporis, hoedi, laurdatum. pracipuum tamen dafypodis, Plinius. Leporino coagulo pares habet tiires, coagulum hoedi, agni, hoinnuli,\&c.contra aconiti potum in uino, 8 concretum lac in aceto, conuenienter affumuntur, Diofcorid. Reliquas uires, utpote communes, fed leporino praciptias, in Leporis hiforia dicam.

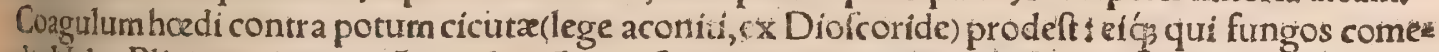

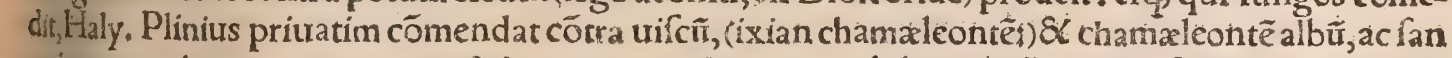
gưnem taurinum, contra quem \&leporis coagulü ex accto bibatur. Contra pafúnacã $\&$ omnitum marinorum ictus uel morfus coagulum leporis uel hoedi uel agni, drachmæ pondere ex trinofumi: tui, Plinitrs. In profluuio fanguinis hor di coagulum bibi urile putant, Plinitis, Et alibi, Coagulum hoedi tertia parte ex aceto potum fanguinis excreationes reficit. Ex aceto fanguinem fifit, Plinius. Magnitudine faba in uino myrteo remiffurm, \& iciuno coeliaco potui datü, efficaciter prodef, Mar: cellus. Coliacis \& dyfentericis coagulum hoedi in uino myrtite magnitudine fabæe quidam propia so nant,Plinius. Coagulum hoedi aduerfus alui profluuium Hippocrates laudat, ut dixi in remediǵs excafeocaprino, Acerrimo aceto maceratum aduerfus muliebre profluuium ieiunæ propinato, Galenus Parabilium 2.73. Ebrietatem arcet pulmo apri aut fuis affus, ieiuni cibo fumptus eo dieitem hœdinus, Plinius \& Symeó Sethi. Pulnonis hoedini combufti cinis prurigines oculorum difcutit, \& fcabras palpebras emendat, fi quafi fribium imponatur, Marcellus. Vrinæincontinen. tiam cohibet uefica foeminx fuis combufta ac pota: Item hoedi, uel pulmo, Plinius. IHcedorum lien impofitus lieni fedando prodef, Plinius. Impolitus lienem digerit, Galenus Parabilium 2.40\% Hodinus lien, fimiliter ut hircinus, fuper fplenem infantis adpolitus, \& tumores $8<$ dolorem eitrs emendabit,Marcellus. II monte Atlante Getuli, qui euphorbium legunt, hodino lacte adulterant,fed difcernitur igni. Id enim quod fyncerum non eft, faftidiendum odorem habet, Plin, $1 \mathrm{De}$ Golica paulò ante diximus in pulmone.

Hœdus animal eft ex capra genitum:quod nomẽ dociores plerí̧̧ cum ce diphthongo fributnt, 


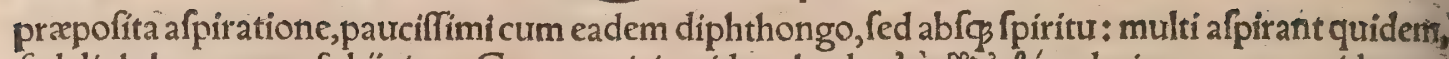

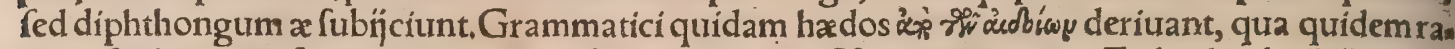
tione fcribendum foret ædus, quod nufquam reperitur. Ifidorus, ut dixi in F. ab edendo. Alin deniç hoedum dictum uolunt quafi foedum lingua Sabina, in qua F. litera in afpirationem uertitur. Ho: dulus etiã $\&$ høedillus diminutiualeguntur. Et Tyburtino ueniet pinguiffimus agro Hœdulus, Iuuenalis Sat, II + Dic igitur me tuum pafferculum, gallinam, coturnicem, Agnellum, hoedillum,

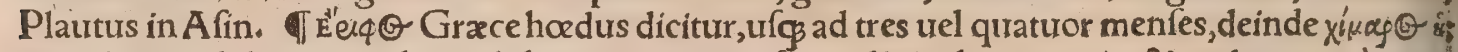
(quod etiam de hirco nondum adulto inuenitur, ut fupra dixi,) donec pariat $\&$ mulgeatur $¥$ à partu iam $\chi^{\prime} \mu \alpha \rho_{\alpha} \& \alpha \alpha^{\prime} \iota \xi$ nuncupatur : De mare uero op"

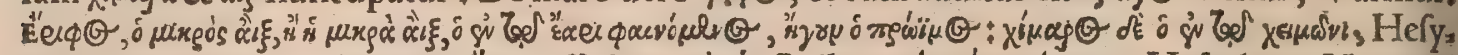

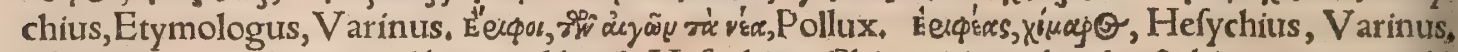
Xínajob, capræ hybernæ, uel hirci, uel hoedi, Hefychius. Chimari inter hoedos $\$$ hircos ætate medi2

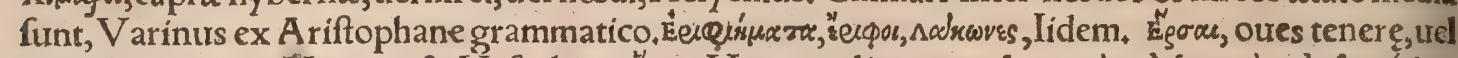

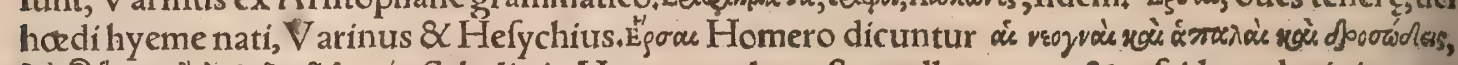

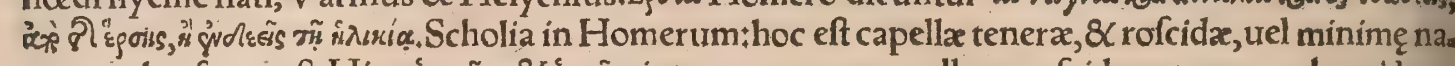

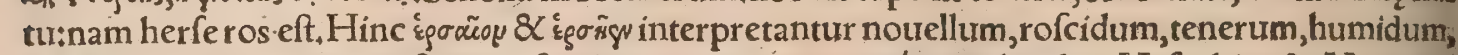

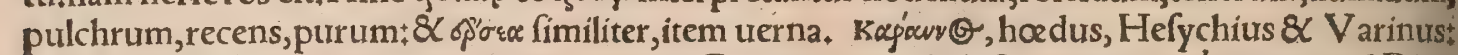

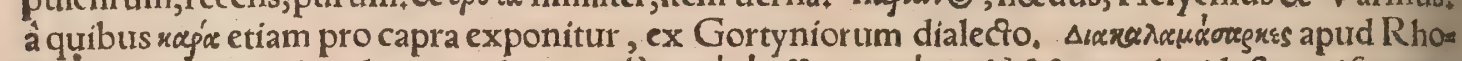

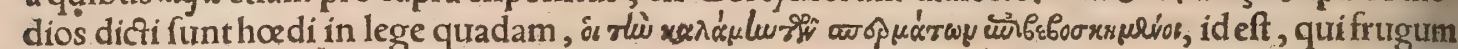
culmos iam depafcerentur, Hefychius $\&$ Varinus, đEpitheta: Neq oues, hœdiós petulci Flo ribus infultent, Vergilius. Splendidior uitro, tenero lafciuior hoedo, Ouidius 13. IMetam. Laf́iuum pecus, $\&$ uíridi nó utile Baccho, Dat ponnas:nocuitiam tener ille deo, Martialís, ApudRa uifium leguntur etiã ifta, Tenellulus, Petulans, Vagans, Corniger, Mollis, Lactens, Pinguis. IEri phiam herbam multi(magi)prodidere:Scarabeum hac in auena, (id eft, caule) habet, furfum deor: fum decurrentem cum fono hoedi, unde $\&$ nomen accepit. Hac ad uocem nihil praftantius effe tran dunt, Plinius. Videntur fanè magi hoc ex ea remedium ad uocem commêti, quòd uocalis aut fono. rus potius in ea fcarabeus(fi credere libet)difcurrat. Eriphia(ut habet Ruellius tanquam ex Plinio, mihi Pliní leeus iam non occurrit) feptem lanuginofis ramulis apị modo foliatur : purpureo flore, \& eo quidem perenni, femine fabaceo, totidem radiculis quot ramis. Vidimus (inquit Ruellius)in editifimis montibus inter faxa herbam apij folins, ramofam, leui lanugine pubefcentem, purpureo flore adhuc exitu autumni \& per hyemis initium emicante, femine fabaceo, ramulis pluribus, folia tis, rubentibus, radice craffa, longa.Sed nó animaduerti fi tot radiculis fibrata effet, quot eft ramulis brachiata, eam tamen crediderim ranunculigenus effe, qued flore purpureo à Diof coride notatur, Erificium (ut habet liber Galeno adfcriptus defimplicibus medicamentis ad Paternianum cap. 97.) herba eft qux in fummis montibus inuenitur, folins apï, thyrfulo oblongołin cuius fummo flofur lus quafi uiolaceus eft, \& $\mathrm{fem} e ̨ n$ in medio:radix ad magnitudinem $\&$ ualetudinẽ in fpecie cepæ obr longa, \& ueluti ad unũ extuatæ: habetọ́ radices alias qua fic radiculas minutas élateribus emittunt, nigro cortice claufas:hæc ipfa uiribus eft aconito fimilis $\&$ thapfix:proprio guftu omnes illas pro bare deuita. TEripha \& Parthenia, nomina equarum Marmacis proci Hippodamix ab Oeno. mao occifi, Calius. THordi,ftella duę funt, quas Auriga (quod fignum colefte eft fuper cornua Tauri)in manu tenet, Poetæ nimbofos $\&$ pluuiales cognominant, quod eor uiffimas excitet tẽpeftates. Quãtus ab occafu ueniẽs pluuialibus hoedis, Vergilius 9. Aeneid. Hoedi pridie nonas Octobris oriuntur uefpere, aries medius occidit, Columella lib.l1. Vide fupra in $\mathrm{Ca}_{2}$ prafydere. II Eriphus poeta comicus fuit, cuius fabula feruntur, Acolus, Peltafta, Melibca, refte Athenæo lib.14. Suidas. Phileriphos, nomen ruftici in epiftolis Aeliani.

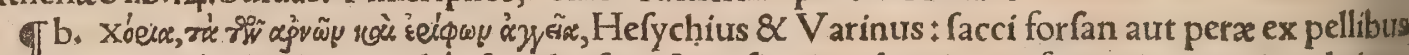
agninis hoedinisue. Chorion aliâs fecûddas fignificat, fiure inuolucrü quo foctus in utero inuoluiutur,

बic. Subrumari dicuntur hodi(uel agni, unde agnus fubrumus)cum ad mammam admourn. tur, quam alij dicunt rumim, (fic enim lego) uel quia rumine trahunt lac fugentes, Feftus.

बd. De hoedo qui tigridi familiaris fuit, in Tigride dicam. ब Captilus eft auis quam uenatur draco,cum debilitatur in uenando hoedos $\&$ arietes, \& c. Syluaticus.

qe. Strauit pelliculis hodinis lectulos Punicanos, Cicero pro Mur, of Hodile ftabulum how dorum eft. Nec uirides metuunt colubros, Nec Martiales hoedilia lupos, Horatius i.Carm. Ver mem qui in Indo flumine reperitur feptem cubitorum longitudine, capturi, agnum aut hodum in hamum implicant, Aelianus,

बा h. Veteres Græci hodorum, agnorum, uitulorumćs infpectis inteftinis futura prędicabant, Gyraldus ex Paufania. Bacchum eriphon dictũ fuiffe Hefychius 8 V V arinus meminerunt:Phur" nutus hircum fuiffe Bacchum, ut fupra narraui. TFaunores diuina nonis Decemb, de hoedo 82 uino fieri folebat. Horatius tertio libro Carm, ad Faunum ipfum canit, Si tener pleno cadit ha, dus anno, $8 \mathrm{c}$.

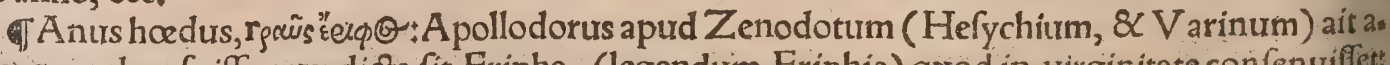
num quandam fuife qux dicta fit Eripha, (legendum Eriphia) quod in uirginitate confenuifet; 
nas capras apudRafim feras intelligas, aut domefticas in montibus pafcentes, q 7 ar famer $H_{e}$ brais camelopardalin effe docui fupra, quamuis nonnulli capream uel rupicapram exponant:qui dam adhuc ineptius alcen. 7han iachemur, lib. 3. Regum cap. 4. quidam capram fylueftem ex-

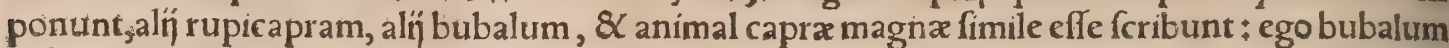
effe coniecerin, non bouem fylueftrem, fed ex caprarum fylueftrium genere, de quo infra dicam.

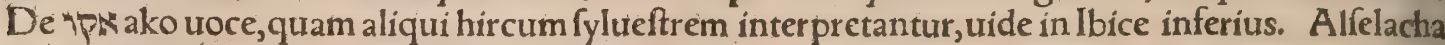
(uetus gloffarum interpres alfuledati habet)eft urina hircorum montanorum, ut patet apud $A$ ui cennam lib. 4, fen 4, tract. 2, ubi docet modum cọfectionis alfelaha, Andreas Bellunenfis, Ego in lo, co abeo citato nihil tale inuenio.

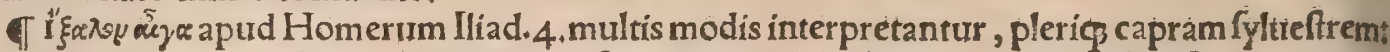
Porphyrius eandem caftratam, quia fæpius feræ capræ adultæ dum in uenationibus fugiunt, geni-

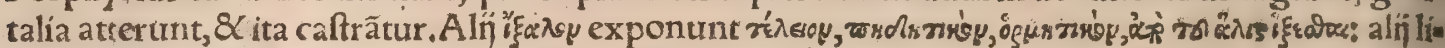

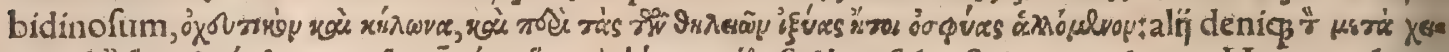

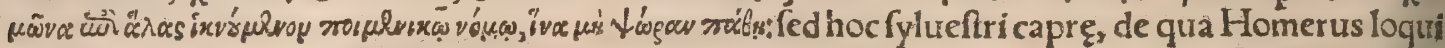

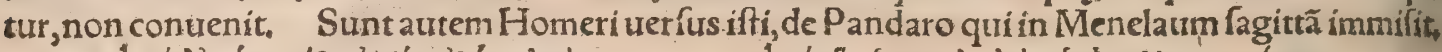

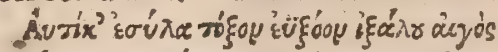

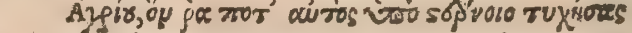

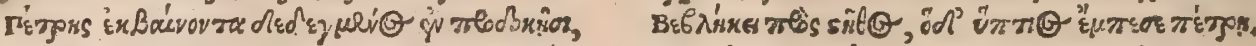

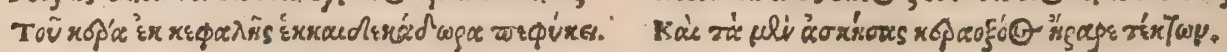

Éxrauderććcioja cornua Scholiaftes exponit, quax extendãtur ad fedecim palæeftas, id eft, palmos, reprchenfis illis qui à fedecim annis fic dicta ful picãtur, quod w̄or annus fic. Mihi quidem hoc fyl= ueftris capra genus, ibex uidetur, propter cornuum magnitudinem: de qua inferius, Eft $\&$ " $" \xi \alpha \lambda \theta$

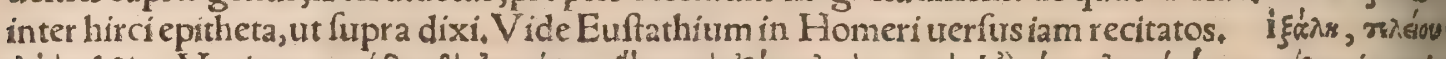

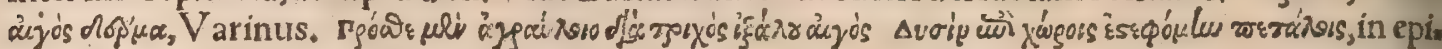
grammate quodam, ut citatur à Suida. Reperitur etiam hirci epitheton i $\xi^{\prime} \propto \lambda$ ir in epigrammax

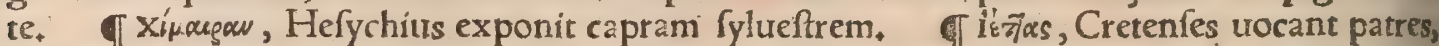
aut hircos fylueftres, Hefychius: apud Varinum afpiratur. T Yivat (O, capra fylueftris', $\mathrm{He}_{\mathbf{1}}$

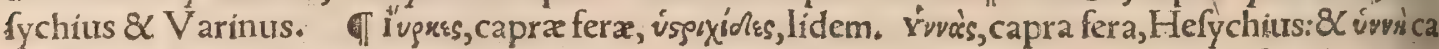
pra fimpliciter, \& uomer aratri, apud cundẽ. Cerui appellatione forte intelligit Ariftoteles etiam

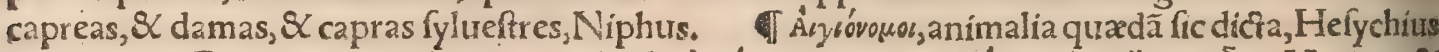

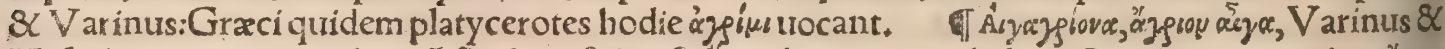

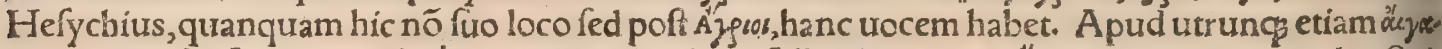

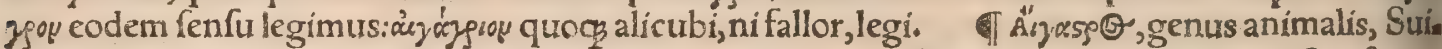
das $\&$ V arinus. Legitur \& ácy odspr in forminino genere apud Suidam, fed nudü nomen. Sigifmutr

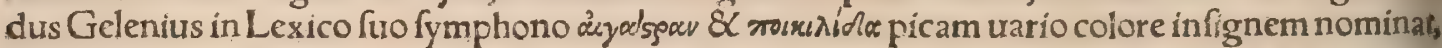
uocabulis ab eo repertis apud recentiores quof́dam Gręcos, quibus \& agriluftram ceu Latinam uo cem adiungit, qux ad æagaftran alludit.

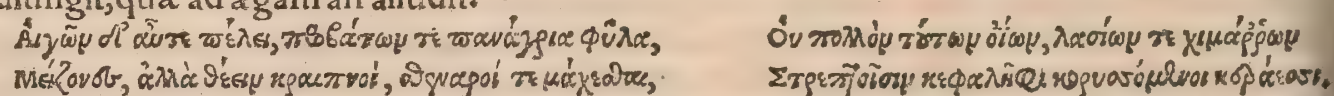

His uerfibus Oppianus lib.2. de uenatione ftrepficerotes dictas intelligere uidetur ex fylueftriti caprarum genere:qquanquam ita conftru fus fít fermo, tt omnia non minus ad oues quàm capras

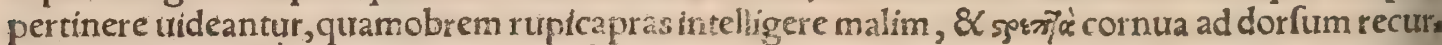

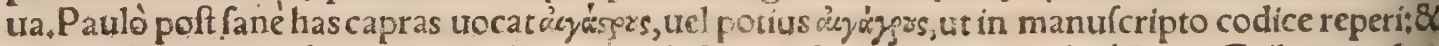
in excufis etiam poft paucos uelfus áyazys habetur. Sed Oppiani uerba à Petro Gyllio translata apponam. Feræcapre, inquit, noftris domeficis haud multo maiores, fed ad currendum urlociores funt, (tortis in capite armatæ cornibus, ) Ac fi quis cornibers fiparum ceram infundit, uitæ uiam, 8 fpiritus meatum intercludit, quòd tenuis fpiruus per media cornua ad cor ipfum proficifcitur. In hoc genere mater fuos pullos etiam atog etiam difigenter curat. Quam quidem maternam educax tionem filij cum pari ftudio compenfant. Et quemachodum homines parentem xtate affecfa infira mum alunt $8<$ laboriofę patrís educationi fatisfaciuncic caprarum pulli,charos parentes fenectute confectos traçant, pabulum nimirum fuo orecollecium eis porrigũt, \& ex fluuio hauftam aquam ad potioniem afferunt, ac nimirum eorum corpis horridum lingentes, nitidum reddunt. Quòd fifos Iam matrem comprehenderis, continuò etiam fuam capies teneram prolem. Eam fané exiftimares tanquam uerbis filios impellere ad fugam, procul ralibus gemitibus orantem: Fugite filij infeftos te natores, ne me miferam capti materno nomine priuate. Eos contra circum matrem crrantes, dice* res primum lucfuofum cantum occinere, deinde humana \& fupplici uoce loqui : Per Iouem uena tor te rogamus, per Dianam ipfam, charam matrem libera, $\&$ nos infelices præmium fufcipe: flecte tutum durum cor, uerere deorum iura, \& genitoris tui fenectutẽ. At enim cum uenatoris inexora bilem animum fentiunt, fua fponte in uincula incidunt, 8 cum matre capiuntur.

(1) Ef $\&$ aliud genus, quod ad ibicis feu capricorni noftri naturam, nifi quod maius eft, accede. re uidetur, ab Aeliano in heccuerba defcriptum: Capræ feræ ad fummos Libycorũ montium uerti: ces commorantur, ad boum magnitudinem accedunt, ipfarum armi \&rcrura luxuriofis pilis fluunf, tibri s paruis, frontibus.rotundis, oculis raris, $\&$ concauis, non ualde proiectis funt, Cornibus poft primum 


\section{DeCapris Sylueftribus. Lib. I. 32t}

prtmutrom exortum utrifọ ab alteris longe auerfis, \& aberrantibus, \& incuruis, non enim fimiliter atque aliarum caprarum recta exiftunt, fed eatenus retor quentur, ut ad armos pertingant. Ex cas pris longe maxima ad faliendum habilitate funt:nam ex cacumine in aliud longe diftans cacumen tranfiliunt, \& tametfi fape earum quapiam, dum ex uno uertice in alterum faltare contendit, ob ni miam interuallorum diftantiam per prarupta faxa praceps agitur, nihil tamen laeditur, fic eft ad uerfus faxorü duritiem membrorũ refiftenti firmitate, ut nec cornua frangat, nec capur diminuat. In fummis montibus plurimas, folertia quadam captãdi caprarī generis, nimirũ uel iaculis, uel re tibus, uel laqueis à docirina artis uenaticæ inftructi comprehendunt. Iam in patentium camporum æquoribus quilibet uel tardus pedibus eas, quód ibidem nonualent ad fugiendum, caperequeat. Earum pellis \& cornua aliquot commoditates habent, nam in frigidis tempeftatibus ad uim frigo rum atque hyemem excipiendam paftoribus $\&$ fabris materiarịs pelles mirifice profunt. Cornua adhauriendam de praterfluentium riuorum confluentibus, aut é fontibus potionem, ad depeller, dam fitim, nó minori ufuí habentur, quàm uel calices ipfi: tanta enim capacitate funt, ut in bibendo refpirare fit neceffe. $\mathrm{Ab}$ homine expoliendi bene perito cornu politum, tres méfuras capere poteft

fldem de feris in Aegypto capris', quas fcorpï non ladunt: In Copro, inquir, Aegyptia urbe \&magna conficiendorum aliorum facrorum religione Ifim A egyptï colunt, \& uero eodem cultu hanc ipfam uenerantur, quo aut coniuges aut liberi àlugentibus afficitmtur + Vbilfis hanc relí gionem pofidet, ibi acerrimi ad peftiferum uulnus inferendum fcorpï maximi uerfantur, qui ut percufferunt, ftatim interficiưt: ad quorum uitationem omne cautionis genus Aegyptij adhibent; o fexcentá̧̧ machinamenta moliuntư, ureruntame e lugentes ad Ifidis fanum capræ feræe ex omnibus tegumentis nudx inter forpios humi iacentes ab horum acerbitate integra incolumeśćs perma nent, ex quo fit, ut Coptitæ eius caprini generis forminas ad diuinitatem $\&$ religionẽ confecrent, 86 religiofifíme colant, eafdemó̧ lfidi in amore $\&$ deliç̣̆s effe exiftiment:contra aû́t mares immolant.

Pifces quidam nigri tenenati in Armenia reperiuntur:horũ farina ficus cöfpergunt, quas in ca loca qux maximé abundant feris diffeminant. Befilix primum ut ea attigerunt, fratim moriun.

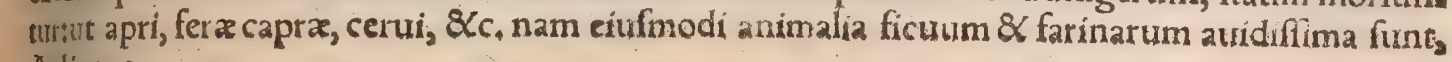
Aclianus.

TR V PICA P R s etiam(quartum figuram ab initio huius capitis dedimus) Plinio inter caprarum fylıeftrium genera nominatas, adnumerare hic liber: quoniam hoc nomen apud folü Plinium legimus, \& apud Grecos fimpliciter fera capra dicuntur, ut coninjcio:nam \& magnitudine \& figu ra tum cornuum tum reliqui corporis ad uillaticas proximius arcedũt, quàm ulla reliquarum. Hæ

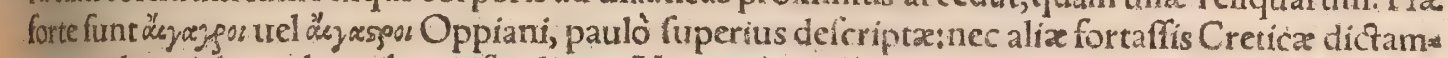
niremedic celebres, de quibus infra dicam. Nomenà rupibus inditum:in ijs enim per fummos uer fantur montes. Germani appellant gem uel ga Rhęi qui Italicé loquuntur, camuza. Hifpani capra montés, ni fallor. Angli uuilde goote, id eft, fyle uefrem capram, Poloni dzyka koza, id eft, ferani capr am. Bobemi melius korytanfky kozlik, quafi Carnicum, feu(ut nune loquuntur)Carinthacum hirculum : quod lla pars alpium ut uicinior Bo. hemis, ita eft notior. Capream forte Martialis pro rupicapra improprie pofuit in hoc difticho, Pendentem fumma capream de rupe uidebis: Cafuram fperes, decipit illa canes. - Capra genus fylueftre non magnum, curua ad modum unci habec cornua, quibus fe retinet cumper deuexa montium cadit, Albertus. Rupicapris cornua in dorfum adunca, Plinius. Anima. lia quadam infirma habent cornua, qux parum aut nihileis ad pugnam conferunt: qualia funtín capris montanis, quam gemteje Germani ưocant. Habent enim cornua parua $\mathcal{Q}$ ínualida, qux non tamad pugnam, quàm ad retinendum fe ceu unco, dum rupes fcandunt $\&$ cadunt interdum, a na. tura eis cóceffa uidentur, Albertus. Et rurfus, Animalium cornutorum qux apud nos apparent, minimum eft caper montanus:qui rubros haber oculos, \& cornu recuruum, acutifimum uifum, \&C gregatim pafcitur, lingua noftra gemete dictus. Cornua ei nigricant, notrem aut decem circiter dis gitos longa:multis nodofis circulis exafperata, minoribus paulatim, in unco nullis:is letris $\&$ acutus go eft, hami inftar, Parallela feré, hoc eft aquis undique interuallis furgunt, folida, ab initio tan. tum circiter pollicis menfuram caua, \& teretia magis quàm domefticis. Mares à forminis in hor genere nihil differunt, non cornibus, non colore, non reliquo corpore. Magnitudo qux capra uillati.

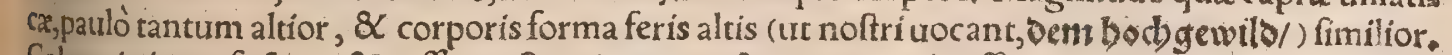
Color eis inter fufcum $\&$ ruffum eft:qui tamen aftate mag!s ad ruffum, hyene ad fufcum uergit. 'Memini partim albam, partim nigram diftinetis coloribus uidere. Certum eft colorem eis per ann' tempora mutari. Totæ albę interdum, fed rarifime confpiciuntur. Rupes montium colunt; ut dixi, non fummas tamen ut ibex, necs tam alte $\&$ longe faliunt. Defcendunt aliquando ad inferiora al pium iuga. Conueniunt fape circa petras quafdam arenofas, $\&$ arenã inde lingunt, ut uillatica pe: cora falem, quo lingux inertem pituitam defricent, \& excitent appetitum. Qui alpes incolunt $\mathrm{Hel}_{\text {. }}$ uetï, hos locos fura lingua fulgen, tanquam falarios uel halopegia, appellant. Circa hos occultant fe 6o trenatores cum bombardis, $\&$ pro more accedentes capras ex improuifo feriunt. Cum in uenatio ne urgentur, altius femper afcendunt, donec nullus ad eas canibus pateat acceffus: deinde cum ue natores per faxa manibus pedibusćs reptando fequi uident, de faxo in faxum tranfiliunt $;$ ac mon 
titum cacumina petunt, donec nulla fcandendi reliqua fit facultas:illic fe cornibus retinêt, \& quafî

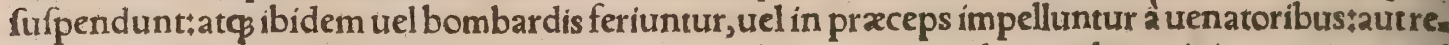
licta, interdum quod inde fe abfoluere nequeant, illic pereunt tandem, uel pracipites ruunt: quod circa ibices etiam euenit.Mox à diui lacobi die, qui oćauo calendas Âugufti notatur, frigídiores montium cliuos pettunt, ut paulatim adfuefcant frigori. Audio captas aliquando cicurari : pilus eis denfus eft, quamobrem pelles illarum quæ hyeme capta funt à pellionibus parantur, comodo quo lupinz:hx pilis extrorfum uerfis geftantur etiam pluuio tempore. Fiunt ex eifdem chirothecx pro equitantibus. Cornua in ędibus hominum lautiorum parietibus affiguntur, fingula unco deorfum uetfo:uel bina erecta ut in capite fuo erant, pelli \& parti caluæ adhuc harêtia:uel quod elegantius eft ligneo capiti ad huius animantis effigiem fculpto, inferta. TA rupicapris nomen indidere noftrates radici quam uocãt, gemfenwurb, alī muterwurs, quod affecqui colico mederi credant Rhætorum quidam graffoy, Sabaudi alacro: Pharmacopolæ uulgares doronicum. Hæc quanquam natales habeat ipfos montium trertices, niuofos \& faxofos pracipue: \& ipfas rupiü rimas, cubi ple. runģ femper ripicaprax uerfantur:ur, uel quod ïfdem locis nafcatur, uel co pafcãtur, dictum mihi urideatur:) facile tamen in hortos tranfplantata comprehendit. In Prouincia Gallix fponte ratum in planicie uidi, Radix eft omnium dulciffima ad faftidium fere:tranfuerfa, digito craffitudine minor, creberrimis confercta geniculis, ut polygonaton al pinü uocari poffit : huic binæ fibræ permul tx tanquam pedes ưtring fubnafcuntur, quatuor aut fex digitorum longitudine, alba, fed ficcęint fufcãtur. Tota radix fcolopendra infecti fígurã refert:fertrari per multos annos poteft:nullis (quod miror in tanta dulcedine)uermículorum iniürijs obnoxia : fuccus eitam lentus $\&$ pinguis, ut non prorfus arefcat, nec dura aut fragilis fiat, natiui perpetuó fucci tenax:quod idem in angelica uuigo dicta fieri animaduertimus. Flores aurei, circinati, hieracic maiori perfimiles, in fingulis coliculis, qui ferè dodrantales funt, finguli, odore grato, \& fubacri : folia hirfuta, trientalia, qux initiolatiora paulatim in mucronem fe colligût. Calfacere \& ficcarcitudico in fecundo gradu, Vulgus apud nos efficacem eius ufum contra uertiginem credit:ea forfitan ratione, quoniã capre montanx, qux fre quenter eam depafci folent, citra cmnem uer tiginem citato per aditas \& pracipites rupes feranttri curfu. Genera eius duo, maius, quod in noftris alpibus nafcitur, \& mollius eft:minus, quod Romas num uocant, durius $\&$ folidius. Longé aliud effe doronicum orientale, guftu feruête \& aromatico, in multa Arabum medicamenta requifitum, nunc non oftendam : plura uide apud Ruellium,

बA udio uenatores quofdam, ex recenti uulnere fcaturientem huius animalis fanguinem for: bere, tanquam infigne uertiginis remedium. Rupicapra feui cyatho \& lactis pari menfura de ploratum phthificum conualuiffe certus author affirmat, Plinius:aliâs legebatur, nó rupicapra, fed lupi \& capræ. Nos uillatic etiam capræx feuum phthifin fanare, \& c. fupra indicauimus.

I I Creta infula capras fylueftres fagitta transfixas dictamnum herbam quęrere aiunt, (ut de pafcantur, hoc enim fpicula ex corpore éṕci, A riftotel, in Hiftoria animal. \& in Mirabilibus. Din çamnum Cretæ infulæ proprium eft, ui mirabile, 8c.præcipué ad difficiles partus mulicrum. Aut enim facile poffe parere faciunt eius folia, aut certe dolores penitus fedant. Dantur bibẽda ex aqua. Rara hæc herba:locus enim qui fert exiguus admodũ eft, eumḉ caprą depafcunt capeffendæ caŭ fa uoluptatis. Verum etiam quod de telis fertur, affirmãt. Capras enim fagitta transfixas, dictamno deuorato telum eijcere, Theophraftus de hifto,9.16. Idem D:ofcorides fcribit in dictamni hifforia:

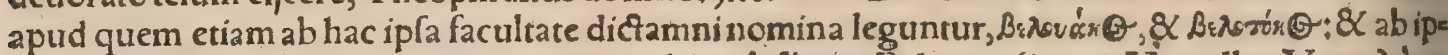
fis animalibus obenidsop, quod diminutitũu uidetur à dogn $\theta$. Beloacos (inquit Marcellus Verg.) àre lorum remedio uocatur, belotocos ob eandem caufam, \& é amplius quod parturs adiuurat: $\&$ ấ ue natrice dea Diana,Artemidion. Dictamnum herbam extrahendis fagittis cerui monftratere, percuffi eo telo, paftụ́ $\beta$ eius herbx eiccto (malim, cerui monftrauere percuffi, \& telo paftu eius herbx eiecto)Plinius 8.27 . Et rurfus 25.8. Dichamnum of endêre ut indicatimus, cerux uulneratx pafta, Ratim decidentibus telis. "Non eft alibi quàm in Creta. Et pauló poft, Et in Creta autem non fpas ciofe nafcitur, miré́ ̧́ capris expetitur, (quod ex eodem Theophrafti loco tranfulit, ubi ille agas, id eft capras fagittis uulneratas, hac herba in cibofibi mederi fcribit:)Hæc Plinius: Corruptò autem cer uos uel ceruas pro capris legi, uel inde apparet quod poftremo loco additum eft, mirȩ̧́́ capris expeti tur. A dde atuhores omnes, quorum hic teftimonia citamus, capras non ceruos effe conuenire, qua dictamno utantur. Plinius certe ipfe alibi fcribit ceruos in Creta infula, praterquẩ in Cydoniatarum regione non effe. Et Solinus, Ager Creticus (inquit) fylueftrim caprarum copiofus eft, ceruo eget, Lupos, uulpes, aliaćs quadrupedum noxia nufquam educat. Miror eruditos, Hermolaum præcipứ, hos locos apud Plinium non animaduertif́e. Cretic capra paftu dictamni telis eiectis, nónnegra uidis enjciendi partus uim huic plantæ ineffe oftenderunt? Huc properare uulneratas folum trideas, dictamnum quęrere, dictamnum fequi, Plutarchus in libro Vtra animalium etc. Cicerofcribit ca pras in Creta feras, cum effent confixæ uenenatis fagittis, herbam quxrere, qux dictamnus uocare tưr, quam cũ guftaffent, fagittas excidere é corpore dicưt. Cretenfes fagittandi peritú, iaculis petunt capras, qux in montium cacuminibus pafcuntur. Illa uerò percuffx, fatim comedunt herbam dis

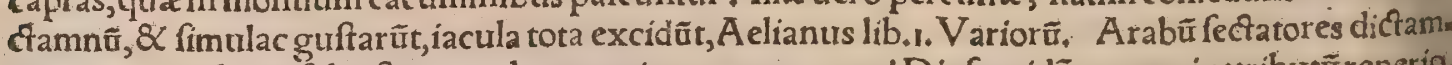
nũ uertunt pulegiũ fylueftre, quod nomen inter catera apud Diofcoridẽ quoç ei attributüreperio 


\section{Decapris fylueftribus.}

Commemorantur \& Cynthix capra fylueftres, à Cyntho móte Deli fic nominatx, de quibu:

Graci author is incerti epigramma extat Anthologíl libro 6. fect.15. huiufmodi.

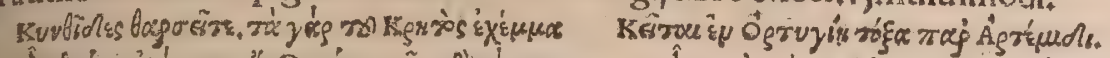

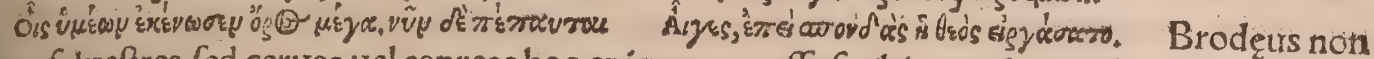
ad capras fylueftres, fed ceruas uel capreas hoc epigramma effe fcribit:quod ego nó probârín, cuin expreffe legatur a.ys. Idem docet uocabulum Ex gi, ut fit proprium nomen urenatoris Cretenfis in genitiuo cafu (quod nobis etiam placet:) in alijs ue-

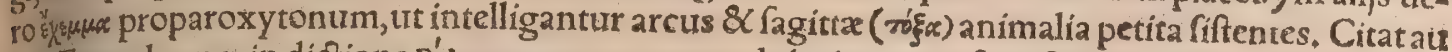
tem Etymologum in dictione $B_{\varepsilon}^{\prime} \lambda \xi \mu \nu \alpha$, ex quo tamen de huius uocis fignificatione ftatui nihil poteft, cum propter termination is fimilitudinem folum ab eo proferatur. Debebat enim (inquit) à Bir

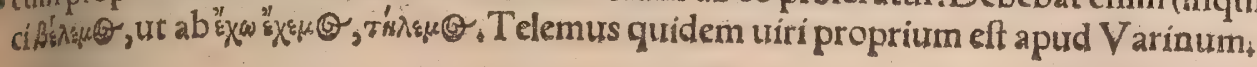

G.

De remedins ex capris fylueftribus.

Millia remediortm ex capra demonftrantur: quod quidem miror, cum febri negetur carere: $A m$ plior potentia feris eiufdem generis; quod numerofifimum effe diximus, Plinius. Caprearum uires medicas infra feorfim dicam: quanquam Sextus non alias feré capreis attribuir, quảm Plinius capris manfuetís. Sylueftrium caprarũ fanguis abfceffus maturat, Marcellus Verg. Ego apud Galenum caprino fanguini fimpliciter hanc uim adferibi inuenio, ut in Taurino fangune dictumeft. Sylue ofrium caprarum fanguis cum palma marina pilos detrahit,Plinius. I Collyrium ex feto caprarum fylueftrium, confert patientibus tclam oculorum, $R$ afis. Albertus collyrium (quamuis culmo depra tate apud eum legitur)non ex fimo, fed felle caprarum fylucftrium uel domefticarum, contra telam oculi prodeffe fcribit. Seuum montanarum caprarum confert pulmoni ulcerato, $R_{2}$ fis, I Caprx fyltaticx iecur carbonibus inaffatum, \& per fe fumptum coliacos remediat : idemós arefactum $\&$ tritum, \& cum tino potui datum, certiffime auxiliabitur, Marcellus. of Caprx fylueftris fel commens dat Diofcorides ad uarios oculorum affectus, Sextus caprea. Fel hircifylueftris eft theriaca monf bus uenenofis, Auicenna. Capra fylueftris fel priuatim prodeft contrafufufones incipientes, ocus lorum caligines, argema (albugtnes uertit Marcellus) \& genarum (palpebrarums ) fabritias, Dio. forides. Er rurfurs, Sylueftrium caprarum felle peculiariter peruncti lufciofi fanantur : idem poreft

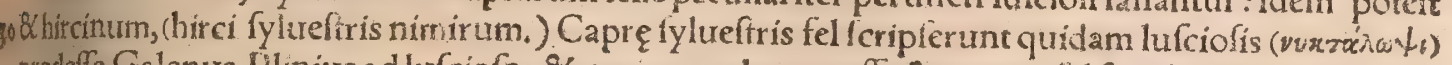
prodeffe, Galenus, Plinius ad lufciofos $\&$ uarios oculorum affectus caprę fel fimpliciter laudat. Col fyrim ex felle (feuro, $R_{a}$ fis:) caprarum fylueftrium uel domefticarum, contra telam oculi ualet, $A l_{\star}$ betus. Calculos expellit fimum caprarum in mulfo, efficacius fylueftrium, Plinius, R emedia qua

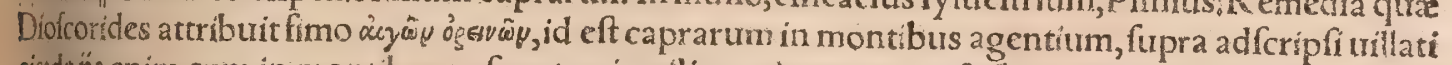
ciside f̈s enim cum in montiburs pafcuntur, intelligo, admonente ipfa fermonis ferie, qure talis ef:Ca pratumbaccę, pręfertim in montibus agyentium, etc. Nec moueor quod uctus Diofcoridis translatio hoclocofylueftrium caprarum habet

ब[H. Áryar'se, iaculum paruum \& leue, cui nomen ab ufu in uenatione caprarum, nimirum fyls ueftrim, ut dixi in Capra. Ambrofia apud D of coridem fecundum Romanos caper fyluaticus ap. lopellatur, \& ab alïs artemifia botrys : quiburs nominibus ad dictamnum accedit, qua \& ipfa artemifion, \& dorcidion uocatur. Vera etian artemifia toxotis trel toxerefia cognominatur, quafi \& ipfa fa gittas trahere poffir, dicfamni inftar. of Ca pellam fylueftrem Spartani immolartunt iam iam conflictu

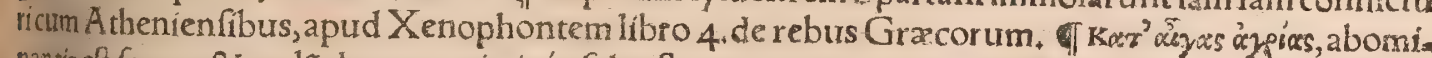
mantis eft fermo, \& malũ deprecantis, inḉ fylueftres capras auertentis. Vfus eft adagione A thenaus ib, 2 Myrtilus, inquit, affeuerabat, urelut ad capras fylueftres nos relegaris quarences, Hegefandrum Dejphum in commentarijs fuis eius dictionis meminiffe. Ad capras lyluefires pónir pro eo quod dificilimum effetinuentu, aut quod wiquam eft. Citauerat enim ex authore tefímonium, quod mox Plutarchus negat apud illum extare. As hoc prouerbium opinor allufit A puleius in A fino, fin gens Pfychen à Venere mitti ad arietes agreftes, Erafmus, Suidas $\&$ Varinus fribunt hoc prourex

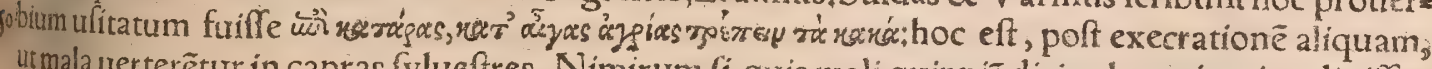
utmala uerterêtur in capras fylueftres. Nimirum fí quis mali quippiā dici uel nominari audiuiffer,

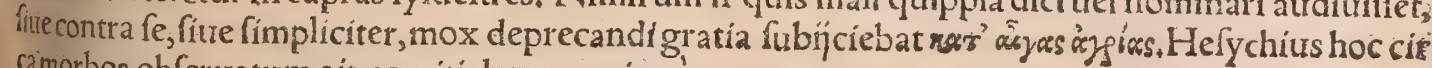
camorbos obferuatum ait, comitialem pracipue.

\section{DESTREPSEEROTE.}

EX caprarum fylueftrium genere ftrepficerotes funt: mittunt eos tranfmarini fitus, Pliniirs. Et alibi, Cornua erecta, rugarumó ambitu contorta, 8 in leue faftigium exacuta(ut lyras diceres) ftr $\epsilon_{2}$

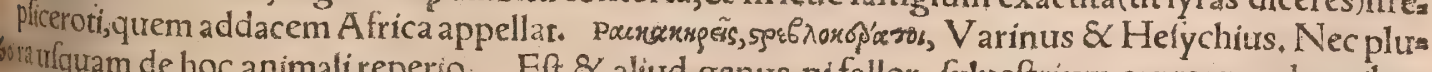
boratquam de hoc animali reperio, Eft \& aliud genus, ni fallor, fylueftrium caprarum, de quibus

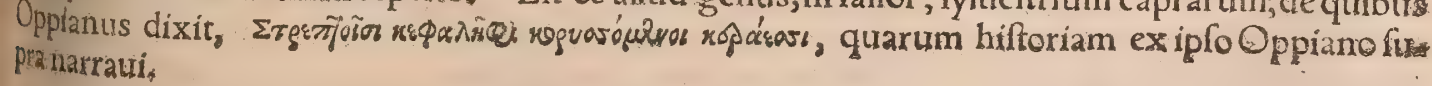




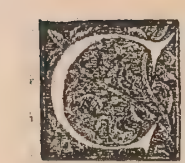

A P R E A,capreolus $\&$ dorcas, tria nomina, animal unum mea quidem opinione denotant: nam neqg Grammatici neç ali foriptores fatis exprefferunt quid de his nominibus fentirent, Dorcadis nomine Plinius $\&$ alij ueteres $u=$ turitur, tanquam nullum apud Latinos uocabulum ei refponderet. Leonicenus reprehendit Plinium quòd capream $\&$ dorcadem tan quam diuerrfa animalia diuerfis in locis memoret, ut uefpertilionem \& nyçeridem, \&c. Recentiorum plèiç, etiä doctifimi, ut Gaża, Hermolaus, \&c.capream uertunt, alï Gracum nomen retinent, Capream quogirecentiores non omnes codem modo interpretantur. đCaprea dicta eft, quod quañdam, it ait Varro, capref fimllitudinem habeat. Sunt autem fylueftres capra (Grammaticus quidam, non Varro) unde capreoll dicti. Capræu(fylueftres)in plurimas fimilitudines transfigurantur!funt caprex, funt rupicaprę, \&ce. Plinius. Ecce feræ faxi deiceta uertice capra, Vergilius 4. Aeneidos Seruius capras exponit, In Africa non funt capra fylueftres, ut Ariftoteles:ut Pliniuts, capreę. Ma rtialis etiam capream proru picapra accepiffe uidetur, non pro dorcade, ut infra dicam. Ego capreas quidem dé genere capran rum fylueftrium effe concedo, id ḉ propter reliqui corporis figuram; non item cornuum, qux ra mofa eis $\&$ ceruinis fimilia funt, ut media inter teras capras \& ceruos naturęe cếferi debeant, ut plaz tycerotes quoç. Rupicapra uero, ibex, dama, \& bubalus Africus, quae cornibus etiam capram au hircum referunt, magis proprié caprxx fylueftres mihi dici uidentur. Caprea igitur proprié dicta molis eft cornibus, paruis, nec de iduis (de quo pluribus infra dicam) tefte Plinio: Hane German!

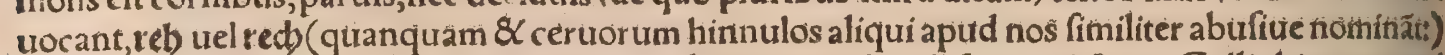
marem priuatim tedb beck, foeminam redsgeiß̧. Angli roo:Illyrí frna, uel farna: Galli chieutreàu uel cheureul fauuage. Hif pani zorlito, uel cabronzillo montés. Itali capriolo tiel caưriolo, \& in foemini no genere capriola u el cauriola. Licet pleriф̧, (in fua quíq̧ lingua)nô capream, féd capreolum, hifce nominibus interpretentu: :ego certe inter capream \& capreolum non aliam quàm uel àtatis, utel fes zus potius differentiam inuenio, ut a pud Gracos etiam inter dorcum; dorcadem, dorcalidem, $\mathcal{\alpha}_{c} c_{\text {, }}$ Quifuperiore feculo literas docuerunt, capreolum pro hordo per infcitiam interpretati funt, $\mathrm{C}_{2} \mathrm{z}$ preolus diminutiuum à capreus, animal fylueftr $e$, Grammaticus quidam. Corydon apud Vergiliú A egloga 2.A lexidi puero duos capreolos promittit, his uerfibus: Praterea duo nec tura mihi ualle reperri Capreoli, fparfis etiam nunc pellibus albo, Bina die ficcant ouis ubera, quos tibi feruo. Sparfos albo exponit Seruius, qui habent adhuc maculas à prima ætate uenientes. Acceffu enim temporis mutant colorem, \& eorum maculx effe gratix minoris incipiunt. TCapreolus (inquil Albertus)cornibus magis refer fpeciem cerui: ufu effeacuto fertur, uoce debili, (exile alibi dicit:) quam uenator fibilo folin imitatur, $\&$ allectum capreolum, quafiad fuigeneris animal profiliens in cerficit, aut capit. Et a!ibi, Capreoli, qui ceruis cormibus fimiles funt, non mutant dentes : qui cum craffefcunt cis, a tate prouectiores intelliguntur : oculi cis pulchri, uifus peracutus, abundantin A frica ultra mare Carthaginis, ur Auicenna fcrihit. Hos Auicennæ capreolos, dorcades intelligo, alterius generis quàm capras yylucftres, quas in Africa effe negauit Ariftoteles, ut Plinius nó recte capreas tranftulerit, fi illæ à capreolis nö differũt fpecie, quod nos afferimus. Capreolos in Aegypto capi teftis eft Marcellinus libro 22. Reperiuntur etiã in Germania permulti, Albertus, Cerui apo pellatione forte intelligit Ariftoteles capreas quo $\$, 8$ damas, $\&$ capras fylueftres, Niphis $313 . C_{20}$ preæ multa capiuntur in regionibus Heluetior um alpinis, colore ceruis nö diffimiles, fed mole core poris longé inferiores: qua u1x capras æquant: ex quarum eriam genere fylueftres exiftimantur, Mas cornua in capite gerir fenis plerunq̧̧ ramis diftincta. Si fomina fuus maritus capiatur, alium quarit zeumó fecum ad priftinæ habitation is fux locum adducit. Fơmina uero capta, maritus alio difcedit; \& aliam fequitur coniugem. Quamobrem callidi uenatores, forminas rarò capere folent, \& fortuitò captas inter dum dimittunt:quod una aliquädo foemina complures capiendos adducat mares, ut fribit loan. Stumpfius nofter in Chronicis Heluetia.

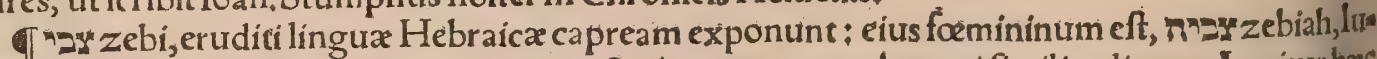
daus quidam ceruum mihi interpretatis eft, deceptus puto ob cerui fimilitudinem. Legitur hac uox Deuteronomin cap.14. inter animalia cibo permulfa : ubi Chaldaica translatio habet $\aleph^{n} \geq 0$ thar

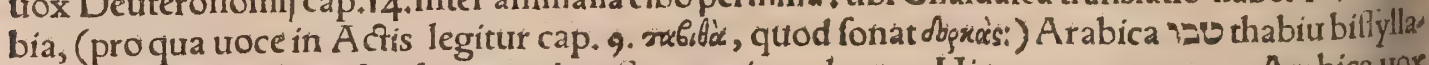
bum, ut ufit confona: Perfica $7 n$ s ahu: Septuaginta dorcas, Hieronymus caprea. Arabica uox 8 Chaldaica finitimæ mihi Hebraica uidentur; $z$ litera tantum in th uel $t$ conuerfa. In tanto ueterum $\&$ eruditorum confenfu, non dubitabimus quin zebi fit caprea, feu dorcas: ut minis me approbem recentiorum illos quí damam, aut hinnulum exponunt. Zebaoth numero plurali fơmininolegitur Canticorum cap. 2. ut zebaim in maf́culino 1. Paralip. 12. ubi Munfterus capreas ueloces curfu exponit. Libro 3 . Reg.cap، 4. zebaim numerâtur inter cibos lautior es regis Salomo sis, cum ceruis $\&$ bubalis, quos iachmur uocant, $\&$ ipfis ex caprarum fylueftrium genere. Equidem 

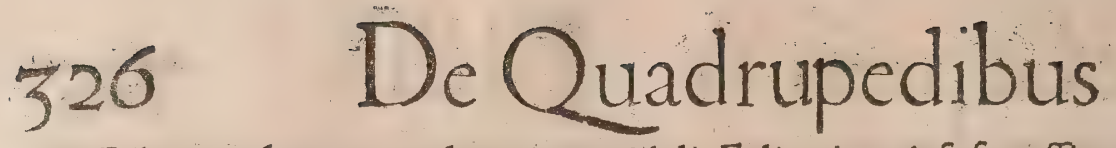

Hic Gillius eandem uocem damarum reddidit. Et licet in re ipfa fortaffis nihil interfit, negligentia ta men uocabulorum $\&$ inconftantia ueriẽdi uiros eruditos non decet, $\triangle$ ógrau, róvsd'ss, id eft lendes, Hefy

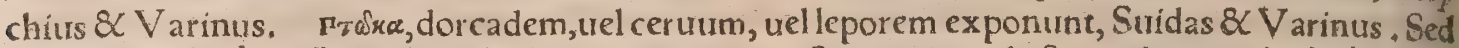

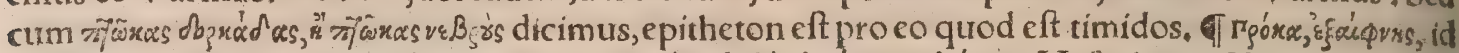

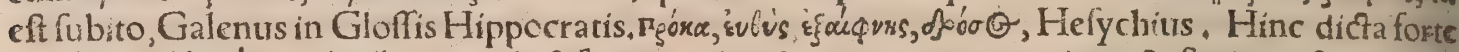

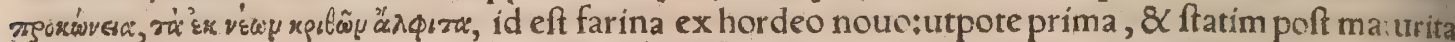

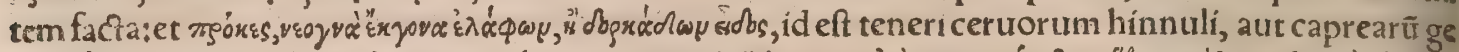

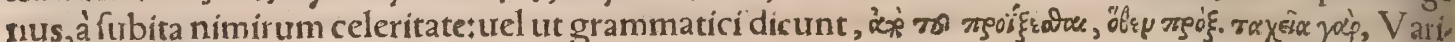
nus: Helychio limplíciter certî. Idẽ rojgras ceruos uel celeres interpretatur, quod minus placet. Iam cum prox Gracis etiam rorem fignificet, tenerum ceruæ foetum fic appellari inde cóiecerim eadem ratione, qua herfa îfidem hodi trocantur: nam herfe etiam uel erfe ros eft. Damam Graci proca tro cant:Arrftoteles $\&$ idonei fer è omnes, \& Dionyfius à ceruo non diftinguit. Philetas primigenios cer uos procas dici uoluit: $\mathrm{A} b$ hoc animali Proconnefus appellata eft, Hermolaus. Arifioteles ceruo \&

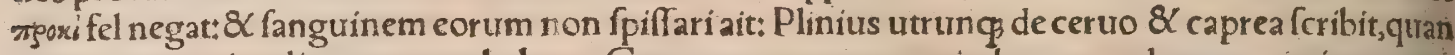
quam corrupti codices capram habent. Gaza tamen proca uertit damam, utulgarem nimirum, noa Pliní damam intelligens. Idem Gaza, A phrodifienfis problematum 1,27.8begras reddidit damas, ubl inquiritur cur dogrễy, \& aliorum quorundam animalitum excrementa paulifper aroma oleant. Ego quidem nullius animantis alui excrementum odoratum noui præterquam martis é muftelarumgen nere. A phrodifienfis forte de mofcho audierat, qui excrementum eft dorci feu capreoli peregrini, nen alui tamen, fed apoftematis círca umbilicum, ut alibi referemus. TOppianus libro 2, de viena= tione poft ceruorum hiftoriam eurycerotas, id eft platycerotes fubiũgit, de quibus fcribit per omnia ceruos effe, excepta cornuum latitudine, \& ftatim iógrzs ( pro ob́gros puto, carminis ratione: nam \& paulo poft, \& alibi dogrewp meminit fine ulla defcriptione propria)hifce uerfibus, Tŕs $d !$ ' «

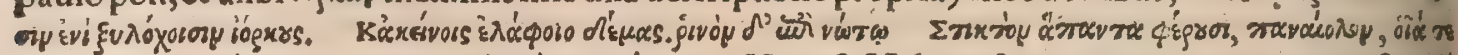

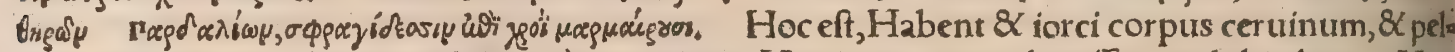
lem undiqz maculofam, non aliter quàm pantherx. Hos igitur capreolos effe non dubitabimus.Mox

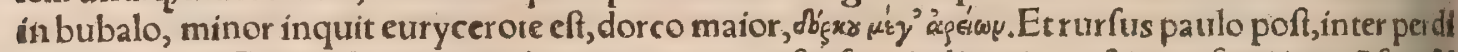
ces $\&$ dorcos (Gillius damas uertit)mirü naturæ confenfum indicat:ita ut $\&$ manfueti inurice fint, $\&$ in propinquo maneãt, $\& \mathrm{z}$ y̆fdẽ in locis pafcãtur. Quamobrem uenatores capto dorco propofito, pel. dices alliciunt, uel contra. Porrò circa finem libri quarti, uenatores monent ne pcft lengum $\&$ prolixum curfum dorco uel modicé refpirare $\&$ quiefcere permittant : pracipuéenim eis gratrem $\&$ mo: leftam effe in medio curfu urinam:quã fi refpirando excreuerint, longè uelociores poftea ferri. đCer rig genus eft, quod Achxinen Ariftoteles wocat, Albertus corrupte halzanen, \& dorcadem interpre, ratur. Alcheff eft animal quod dicitur gazella, \& eft simile capreolo, Andreas Bellunenfis. $\mathbb{f}$ Daz milla, id eft animal fimile capreolo de $\mathrm{Han}_{\mathrm{n}}$ :Damala, idem,Syluaticus. fln dorcadem, curius uber à uł pera iffum fugente hinnulo (v\&ßjòy uocant) unà cum matre perät, epigramma Polyæni, \& alterum Tibern̈ lli, A n thologin Gracilibro 1 fectione 33. Eft \& tertium ibidem Tiberï, in dorcadem in man!

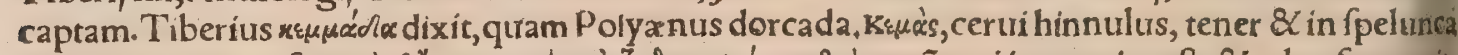

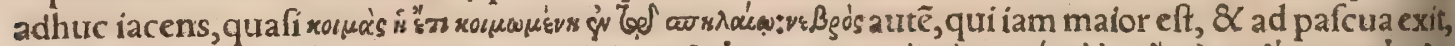

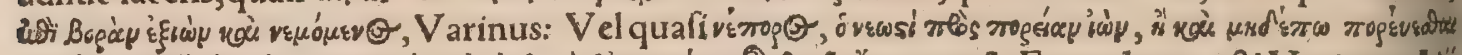

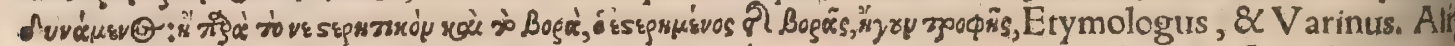
contra vißers hinnulos in prima etate uocant, xséás as uero in ea qua iam ceruis, id eft adulcis, proxis mi funt, Varinus. K\&ua's, hinnulus, uel ceruus, uel dorcas, Hefychius. Minus equidem miror ueteres Græcos unum uocabulum de duobus animalibus diuerfis ufurpaffe, cum Germani noftrates etiant utrunq animal una uoce reed appellent. Dorcas enim adulta cerui hinnulo fimilis, \& magnitudine

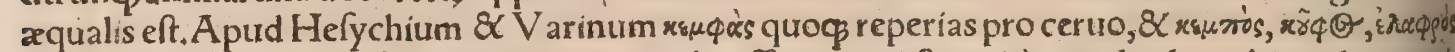

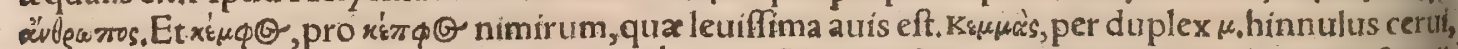

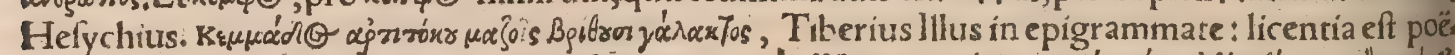

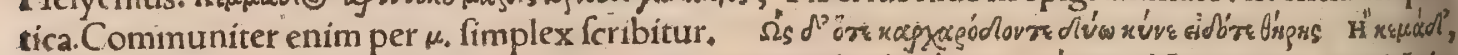

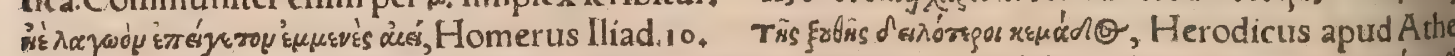
natum in fine libri quinti. Etymologus cemadem hinnulum reruri uel dorcadem exponit. Tfira d'

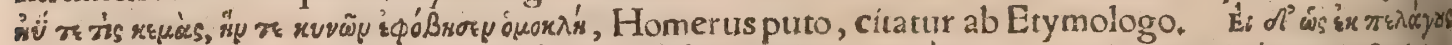

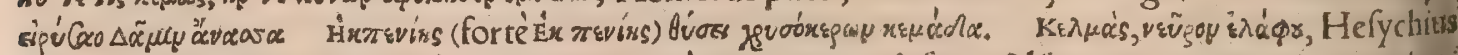

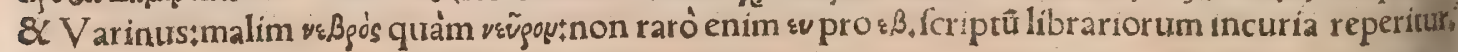
B.

De Libyco dorcadum \& cemadum genere Aelianus hęc tradit:Dorcades (in Libya) quanquam uelocitate funt mirabili, tamen inferiores funt in currendo equis Libycis:earum aluus nigris uittis di ftinguitur, reliqui corporis color rubet: $\mathcal{X}$ pedes quidem eis longi funt, cornibus caput ornatur, oct li nigri, longiffimæa aures habentur. Kquás à poetis nuncupata, turbinis inftar celerrime fertur, $\mathrm{Hla}$ uis pilis Ipectatur, cauda eft tum pilofiffima, tum exalbenti, eius oculi cyaneo colore tinéti uidentur, atres peraltis pilis refertæ, neç modo in terra pedum celeritatem oftendit, fed etiam cum in flutin confluentem inciderit, ungulis pedum remigans, fluçus perrüpit, \& uero in lacubus natare gauder, 


\section{De Capreis. B.C.D.E.F.Lib.I.}

inde fibi paftum comparat: uirides itrncos 8 cypertum depafcitur, Hac Álianius. Vitrà Catadit pa Nili procedens A pollonius ceruros \& capreas inuenit, Philoftratis;

Cornira animalium uracua funtiuxta caput, $8 \mathrm{C}$ ibi intrat corpus quoddam durũ , feré offeừi; poris refertum:prater cornu cerui, \& eorum animalium quxa fimilitudine quadam cum ceruo con ueniunt, ut funt dama (uulgaris; ) capreolus, \& equiceruus; (alcen intelligit:) qux omnia nobỉs co. uenita funt, \& cortum cornua folida effe conftat, fed poris intus plena, Albertus. Et ruirfus, Nullum animal nobis notum mutat cornt, prater ceruum; \& nobis (lego ei, nempe ceruo) cótrenientia anis malia.A tqui Plinius cornua capreis decidua effe negat. At Calius ex $P$ aufania ut certuorũ, fic dor. cadum quog cornua decidere \& renafci fcribit. Belifarius tufos canes colore capreas referre tra.

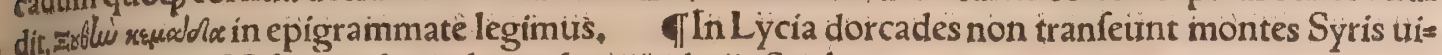
cinos,Plinius: Hifpania dorcades multas producit, Strabo.

『C. Venenis caprex; $\&$ cotirnices; ut diximus; pinguefcunt, placidiffima animalia, Pliníús:

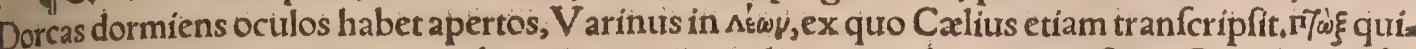
dem 8 lepus $\&$ dorcas exponitur, leporem autein oculis apertis dormire conftat: Capream noffu cernere loan. Textor fcribit:quod Plinitus de capris fcribit, de capreis (quod fciam)nemo. Nifi quis ita interpretetur hac Plinij uerba, Capras niegant lippire, quoniam ex quafdam herbas edant: item dorcades, Et ob id fimum earum cera circundatum noura luna deuorare iubent. É quoniam nochu aque quoç cernant, fanguine hircino fanaril lufciofos pittant, Hac Plinius; TPendentem fum: ma capream de rupe uidebis, Cafuram fperes, decipit illa canes, Martialis lib. 13. Videtur autem mon proprié dictam capream, fed ripicapram Plinü intelligere: qửa \& fummas rupes confcendit, $8 \mathrm{ab}$ ijs pendete folet cum uenatores urgent; 8 cornua ad hẩc rem idonea habet, caprea non item: accedit quod in proximo ante hoc difticho de dorcade (íd eft uera caprea)locutus fit, quod fuperius adfripfi, Blondus etiam, qui his proximis annis multa edidit Romæe, capreã pro rupicapra accipe. reuidetur:Caprea, inquit, faxa \& rupes altiffimas habitat; nimirum propter timiditatem: Vidimus tamen \& manfuetum hoc animal! nam inter homines deponit feritatem celerrimé, ut \& hinnulus cerui, Expelle eius fimbriantur mutlier ũ pellicea indumenta fiunt $\&$ chirotheca, \&c. Eandem Cre. ticam effe putat fylueftrem capram, qua dictamno (uel, ùt iple inepte fcribit, pulegio) depafto $\mathrm{Ia}_{2}$ gittas fibiexpellat.

ID. Tam difpar aquilix columba non eft, Necdorcas rigido fugax leoni, Martialis, Prouer = 30 bium, Caprea contra leonem, infra ponam.

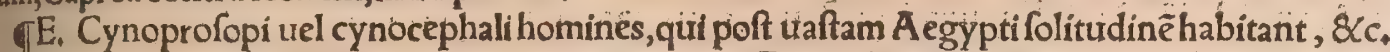
exuenatu dorcadum \& bubalorum uiuunt, A clianus. Dorcadum \& bubalorum, tanquã éiufdem reneris animalium, mentionem Simocatus etiam in epiftolis coniungit. Qualis eligendus fit canis qui uenetur dorcos, ceruos, \& lepores, ex Oppiano in Canécelere doctii. TCapreas, apros, \&Cle. pores in unum leporarium coniungi apitd $V$ arronẽ in opere de re ruft. legimus. Nunc ut habeant multos apros ac capras, (lege capreas)complura iugera macerís concludunt, Varro. In leporario tonlepores folum includuntur fylua, ut olini in iugero agelli, aut duobus:fed etiă cerui, aut capra (lege caprex)in iugeribus multis, Idem. Aprós in leporariơ pingtres folère fièri fcis Axi. Nam que funditm in Tufculano emit hic Varro à M. Pifone, ưidifti ad buccinan inflatã certo tempore apros 40 \& capreas conuenire ad pabulum, cum è fuperiore loce è palaftra effunderetur apris glans, capreis

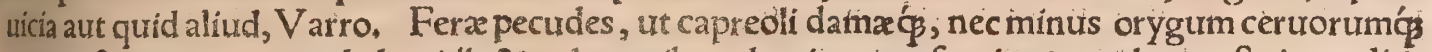
genera, $\&$ aprorum, modolautitins $\&$ uoluptatibus dominorim feruiunt; modo quafturi ac rediti. bus, Columella 9. ubi de uiuarịs faciendis fcribit.

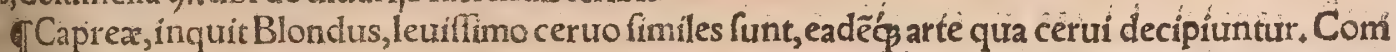
prehenduntur enim canibus, implicantur $\&$ retibus, at rarius quàm cerui : quoniam alpes $\&$ mon. tium culnina incolunt. Quamobrem infidia in montibus \& collibus ponendx funt. In fyluis citius capiuntur, Cauren dum eft ne uenantes ab eis uideantur:quia procul etiam agnofcunt uenatorem, $\&$ mox fuga elapfac occultantur. Cum uim canum $\&$ infidias uenantium propefenferint, exrupia bus quandogs prar cipitantur: quare $\&$ rupes funt obfidendar. Circa Romam nocturnis infidins ad lư men Lunæ; bombar dís aliquando traịciuntur, ut cerui etiam, \& urfi, aprí̧́, Hæc Blondus. Caprę certitíg, ut fępius experti funt uenatores, fiantem uentum petere currendo folent, ut téfrigerari fpi. ritus curfu laborantěs uento poffint:quiamobrem ad uenti flatum canes collocandi funt . Attrahi enimità ùento ceruí folent $\&$ capreę, ut nolentibus quando ç uénatoribus illa fugam arripere ad. nitantur, Belifarius. Síc etian certí latratu canum audito, ut Plinius fcribit, aura femper fecinda fugiunt, ut ueltigia cum ipfis abeant. Scythis $\&$ Sarmatis urenationes funt, intra paludes quidẽ ceré uorum aprorumóg, in campis autemi onagrorum \& dorcadum, Strabolibro 7. Dorciquantopere ament perdices, eisćs propofitis illicianturr, fuperłus ex Oppiano retuli. Capiuntur et folín fibilo allecti capreoli, quo uocem eorum uenator imitatur, ut fupra dixi ex Alberto, \& pluribus dicam in trenatione cerui.

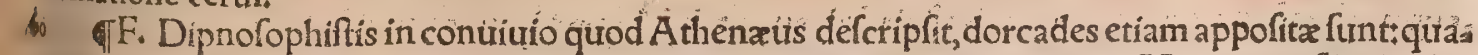
rüm carnem Palamedes Eleaticus onomatologos non infuautem effe dixic. Hic optata feret nobis fomenta calore Vda leui, modicis moxq́g coquenda focis; Bapt,Fiera de capreolo:pręerert auteini 
cum dama, quam magis aduftam (id eft, ficcioris alimenti, effe fcribit. Dorcadis caro melioris. fucci $e f t, q u a ̀ m$ cæterorum agreftium animalium, 8 ad humanum corpus quandam haber familiaria tarem, humidisḉ \& multas fuperfluitates habentibus corporibus prodeft Item morbis colicis \& $\mathrm{co}$ mitialibus, fed uentrem moratur, \& neruis fua ficcitate conducit, Symeon Sethi. Ex fylueftribus optima eft gazelli caro, deinde apri, Auicenna. Carnes ferinæ omnes prauæ funt, ut qua fangui nem ferinum \& melancholicum gignant:gazellorum tamen minus malx funt cxteristeas fequun: tur leporina, Ellucharem. Caro gazel parum excrementi gignit, utpote ficca, Rafis. Nutrimen: tum ex algazel frigidum \& ficcum eft, A rabs quidam. Caro caprearũ,authore Celfo, bon $\& \mathcal{O}$ plus rimi alimenri eft:fanguinem tamen atra bili confinem generat, बI lus in caprea, ut docet $A$ picus: Piper, ligufticum, careum, cuminum, petrofelinum, ruta femen : mel, finapi, acetum, liquamen $\&$, oleum. Aliter ius in caprea affa: Piper, condimentum, rutam,cepam, mel, liquamen, paffum, oleum modicè:amylas cum iam bullint. Aliter ius in caprea:Piper, condimentum, petrofelinum, origanum modicum, rutam, liquamen, mel, paffum \& olei modicum:amylo obligabis, Hactenus A picus $8 .{ }^{\circ}$

- Ex ceruo uel capreolo paftillus quomodo paretur, Platine uerbis dicetur in Certro. Ex capreo. lo item quomodo fiat ius cófumptum, ex eodem docebo in Gallina ubi de capo. Cerui anteriorem partem in iufculo laridario coques, lumbos affabișex coxis paftillos aut pulpaméta facies: Eadẽ \& capreoli, damę, ac caprę̧cociura,Platina. Cibarn̈ genus, quod Germani uocãt bofuneftel, hoc eft li gulas aulicas, hoc ferè mndo fieri inuenio. Capreoli pellis bulliat $\&$ depilata elixet́, deinde in ligulas feu tænias dodrãtales $\&$ féquidigitũ latas fciffa, coliquamine, quod gelu in patina uocãt, côdiatur. G. De remedĭs ex caprea \& dorcade.

Plinius maiore proparte fimpliciter $\&$ domefticis tribuit capris uires, (ut Humelbergius ob. (eruauit)quas Sextus peculiariter capreis:id quod non magni momenti eft:cum remedia ex eis nô differantgenere: fed in eo tantum quod fylueftria in plerifg efficaciora domefticis habeantur. $A m=$ plior potentia, inquit Plinius, feris eiufdem generis (caprini, ) quod numerofiffimum effe diximus. Sicui otium erit diligentius inter (e conferre poteft (nos obiter tantum contulimus) remedia qua $\mathrm{ab}$ authoribus collegimus, primum attributa uillaticis capris:fecûdò fylueftribus fimpliciter : tertiò fylueftribus illis quas dorcadas Græci,Latini capreas uocant, quæ hic in præfentem locum conge rimus. TCaprea torminofis in cibo profunt, Marcellus: dy fentericos intelligo:ficcat enim \& $\mathrm{res}$ rinet uentrem caro caprearum, ut Symeon Sethi prodidit. TCordis draconis pingue in pelie dor. cadum neruis ceruinis adalligatum in lacerto, conferre iudiciorum uictorix magi promittunt; $\mathrm{Pli}$ nius. Et poft pauca uerba, Dentes draconis illigatos pellibus caprearum ceruinis neruis, mites pra* ftare dominos poteftateś́ exorabiles:unde apparet eum dorcadem non eandẽ exiftimaffe cum cai prea, eadem nimirum ratione qua dafypodem à lepore differre putatit, Mulieri candida à pectore hyænæ caro, \& pili feptem; \& genitale cerui,fi illigentur dorcadis pelle collo fúfpenfa, côtinere par tus promittunt, Plinius. Inter remedia aduerfus comitialem morbü, Magis placet draconis cauda, in pelle dorca dis alligata ceruinis neruis. . T Sepum caprę, $\&$ adipem anferinũ, \& medullã certu $\&$ cepe, cum refina fimul \& calce uiua, fac ut malagma, mire fanant, Sextus. Cerebrum caprea (car pra Plinius) per annulum traiecfum fi dederis infanti ad glutiendum antequam lac fugat, efficit ut nec caducus fiat, nec phantafma incurrat, Sextus, GDorci coagulum eafdem leporino uires has bet, Diofcorides. Leporis, hinnuli, aut caprex coagulum potum ex uino, nec non immiffum cum oryzx cremore coliacos \& dyfentericos iuuat, Galenus Parabilium I. 13. . T. Cui oculi dolent,ils cur caprex contritum ex uino bibat cum aqua calida in feruore, fanabitur, Sextus, Idem remedium ad eos qui ab hora decima nō uident, id eft, nyctalopas feu luf ciofos, huíufmodi prafcribit:lecur ca. prex (alij capr $x$, uide fupra:) in aqua calida falfa coquatur, \& eius uaporem oculi excipiãt, \& ex eał dem aqua oculos foueant; fed $\&$ iecur edant, 8 ex liquefaço inungãrur, Quidam iecur eius affant in craticula, \& fluentem faporem colligunt, \& ex eo intunguntur. Quidam coctum uel affum is cur capreæ cum pane edunt, $\&$ idem bibunt. Caprex iecur combuftum $\&$ afperfum, fanguti nem fiftit, Sextus, Contritum, \& ex aceto in naribus offultum, fanguinem mire fiftit, Sextus.

Ad maculas de facie rollendas: Caprea fellis drachmam unam, farinxliupini 8 mellis drachmas quatuor commifces in unum, \& exinde faciem linies, limpidam faciem efficit, Sextus. Fel caprex cum aqua mixtum, illitum in faciem à fole uftam, fanat, Idem. Adlentigines in facie:Fel caprex feruatum illitum, lentigines de facie purgat, $\&$ omnes maculas extenuat. Item cum melle $\&$ nitro commixto, \& f pongia combufta \& fulphure uiuo ad mellis craffitudinem redactum, \& in $\{4$ ciem illitum, emendat, Sextus. Fel caprea(capra,Plinius) cum melle A ttico mixtum inunges, can liginem potenter difcutit, $\&$ claritatem praftat, Sextus. Fel caprex drachma una, \& modicum ui. ni cum melle ut poffit teri, inunges, \& fanabis oculorum caliginem. Idem facit $\&$ ad cicatricem ${ }_{3} \&$ argemata, \& nephelion, \& glaucomata, \& pterygia, li ex co felle inungantur. Item ex eo felle inutr gantur palpebra cum oleris fucco, extractos pilos non finit renafci. Facit $\&$ ad ruptiones ex icfur thi nicularum cum lacte mulieris tepido. Hoc autem fel quanto uetuftius fuerit, tanto melius erit, Sextur. Eadem omnia de capræa felle legimus apud Plinium, ut fupra recitaui, paucis quiluufdam ua: riantibus. Fel dorcados per $f e$ ad claritatem oculorum laudatur: Hippocratis, ut putant, aurhorita= ceadijcitur, quod in argentea pyxide id feruari iubent, Plinius. Afleruni dorcadi intra uffera hus 


\section{DeCapreis. G.H. Lib. I. 329}

inorem quendam ineffe, qui caliginẽ depellat oculorum, \& obtufiores quoģ uiftus exactrat, Origem nes in Cantica:ego non alium quàm bilis humorem intelligo. Ad tinnitum \& fonum auricularü: Fel caprea cum rofaceo aut fucco porri tere, \& tepefactum auribus inftillato, fanat, Sextus. Fel ca prea cum rofaceo, ut fupra, dentium dolorem fanat, Idem. Ad faucium dolorem : Fel caprex ctim melle Attico mifce; $\&$ fauces tange; mire fanar, Sextus. Ad omnia uitia qux in faucibus nafcũtur: Caprea fel cum melle Attico, adiecta myrrha, croco, \& pipere aquis ponderibus coques in trino do nec contrahatur, \& ex eo fauces quotidie tange, donec fanx fiant, Idem. Ad uentrem foluendum: Fel caprex fuppofitum ano cum fucco cyclamini herbx $\&$ alumine aliquantulum aut anetho (ni, Tro, Plinius)combuftum, inditotcaue ne hamorrhoides habeat,Sextus, Idem Plinius de felle capr fcribit, ut fupra dictum eft. Ad ueretri exulcerationem \$ Fel caprea mixtum cum melle aut fucco rubiappofitum, miré fanat, Idem. ISplen capreæ potatus torminofos mire fanat,Idem. Plinius coliacis capræ hirciue lienem affum commendat. đCapras negant lippire, quoniã ex quafdam herbas edant:item dorcades. Et ob id fimum earum(quarendum, an caprarum tantum, an etiã dor cadum) cera circundatum noua luna deuorare iubent, Plinius. Ad arquatos: Caprcæe ftercus aridur frítum cribratum, cochlearï mêfura ex uini odorati cyathis quatuor ieiuno \& loto exhibe: febricie tantiburs autem ex aqua eandem potionem, Galenus Parabilium 2.39.

H.

Quemadmodum capreolus apud Latinos diminutiuum eft à caprea, fic dorcalis 82 dorcadion

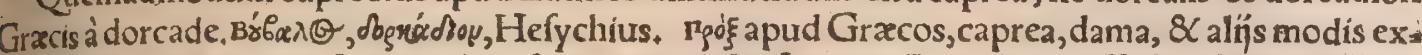
ponitur, ut fupra monui. Longe aliud fonat prox dictio Latina., Prox (inquit Feftus) bona tox, ue lut quidam uocant, fignificare uidetur, ut ait Labeo de iure Pontificio libro 12, Aliter proba uox; utatimo.

IEpitheta: Caprea pafcuis intenta, Horatius 4. Carm, Edules, Horatius 2. Serm. Imbelles; Ouidius I. Faft. Lafcitix fimilê ludere caprex, Horatius 3.Carm. Sequaces:Vergilius lib.2.Geor.

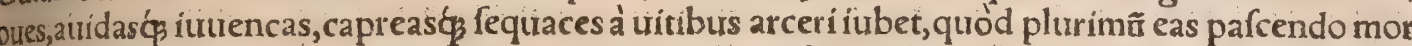
dendó̧̧ liedant. Servius perfecutrices exponit, ut fimile fit illi, Malę̧̨́ fequacibus undis:nimirum quoduineas perfequantut. Vitibu's à rupicapris nemo metuit ; quare hoc etiam argumento quo. modo hac dio genera fylueftrium caprarum differant, apparet. Ibices altiffima occupãt, \& parum defcendunt:rupicapræ defcendunt quidem, fed nön longe, ita certe ut loca culta nunquam attin. go ganticapreoli inferiora montium, \& colles, \& u ualles, fyluas q̧́ etiá circa planitiem colunt. Caprex celeres etiã, \& fylueftres dicuntur inter Textoris epichera. Fuyaces, Ouidius ı. Metam. \& Vergil.

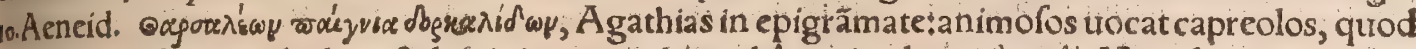

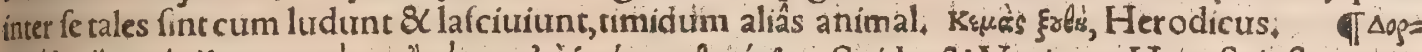

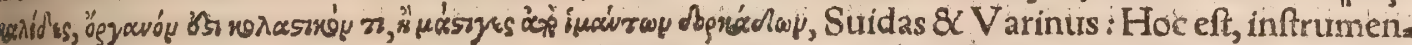

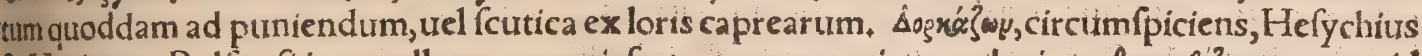

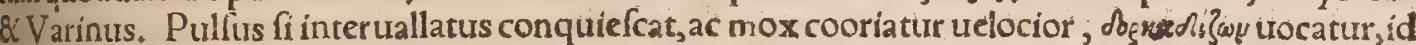
eft dorcadiffans:qux nuncupatio de animalis producta in curfut natura eft, Calius. Mentio eius fit aptrdGalenum, nonnullis saprifantem uertere placuit, बCapreoli uitium cincinnifunt intorti, quía ad locum capiendum tendunt appeilati,Pompeits lib.3. Vitis caprea dicta eft, quod parit ca= to preolum: is eft coliculus uiteus intortus, ut cincinnus: is enim uites ut teneat, ferpit ad locũ capiun. dirm, ex quo àcapiendo caprcolus dictus, Varro de re ruft. 1. 32. Noua circuncifís undiç capreolis fpargantur in tabulatis, Plinius lib.17. Graxci helica uocant, de quo multa dixi in Vitulo parte pris ma capitis octaui, Vere deinde priufquam coeperit germinare, capreolis; quod genus bicornis ferramenti eft, terra commoureatur, Columella 11.3 . Ego huic inftrumento nomen pofitum credide $=$ ím, uél quod capreoli cornua reprafentet, qux quidem puto in fummo bifida effe, diuaricatis raa mis, qualia \& ceruina fxpe uifuntur, Quod fi ambos huius ferramẽti mucrones, quos ab altero tan. tum parte habet, refpicias, capræuel rupicapræ cornuum quandam uidebis fpeciem: Velà fimilitu. dine ad illos uitiữ capreolos, quibifurcati fimpliciter funt, necdum in fefe retorquentur , German hac inftrumenta uocant jettboutwle, id eft farcula, ab ufu farriendi \& exherbandi. Capreolus; it yo quidam fcribit, dictio Tecronica: Cx far 2 , belli Ciuilis, Dux primum trabes in folo aque longx, di. fantes inter fe pedes quatuor, collocantur:inç̧ eis columnellæ pedũ in altitudinem quinos defígưt, has inter fé capreolis molli faftigio coniungunt. Vituuuitus lib.10. cap. 20.car dines uocat, extremas capreolorum partes qua in cauum indintur, \&xc.ut fribit Gul.Philander in Annotationibus fuís in Vitruuium. Spirulatím fignat, clauiculatim, \& capreolatim, Calius, Dicitur 8 Clebeti fubiecius capreolus, id eft helix, fplen, Idem: Mulieres ferè circulum ex ftramento nexum lebetibus \& curcu imis fubdunt:ut patellis \& fartaginibus tripodis genus illud quod furculas habet, quiburs fartaginû anfæ nitantur, fixam unam, alteram ambilatorian. Hoc forte capreolum Latinè dixeris;ífue quod tripes fit, ut \& machinam quandam tripedem, 8 ludi puerilis inftrumentum capram uulgò dici füpramonui:fitue propter furculas: nam ceruos etiam bacilla furcillata utocari Seruius fribic: \& Gre to ci helicas in uitibus capreolos uocãt, quos Germani furcillas. Eft $\&$ aliud inftrumentum cum anfa bidente feu furcillata, quod menfis imponitur, ut patellas fuftineat prafertim pauperum, in quibus inferunt pultem; hoc etiam capreolum nominarim, cil pfantienenedst. GDorcidion eadem di 
ctamno herba eft, ut fupra expofui. A pud Aêtium libro 10, cap. 2, aduerfus iecorts obftructionem dorcadiadis herba, qux $\&$ muf́cium appelletur, pars una, cum cofti dimidio, cochlearí menfura in potu datur. Hæe quxnam fit, certi nihil habeo: uidetur fané effe odorata aliqua herba, qux mofchum odoramentum recentioribus tantum Græcis notum, ex quibus Aetius quoç eft, odorefuo referat: cuiufmodi ego plures noui, fed iuam mofchatam uulgo dictam, chamxpityi fimilem, aut genus alte rum chamæpityos, obftrucfo iocineri proculdubio utilem, præ cæeteris hoc nomine donârim. De alïgs herbis qux mofchum olent, in Dorcade peregrina $\mathrm{ex}$ qua mofchus colligitur, in $M$. litera dicam. In uenio $\&$ mufcilion dici quandam herbam ab odore mufci, ut conijcio: quoniam \& dorcida uocant eam, naribus uitiolis \& foetentiburs accommodatam, ut $A$ ërius exiftimat, nifi quis pro dictamno acci piat, quod $\&$ dorcidiũ appellãt, Hermolaus. 1 Dorceus, unus ex canibus A ctęonis apud Ouidium, Dorcon, $\Delta$ ógrwy, nomen ruftici in epiftolis Simocati. Orynx (lego ory $\mathrm{x}$ ) animal colore dorcadifi= mile, Hefychius \& V Varinus. Antaplon, peregrinum animal capreolo fimile, uide fupra in Calo, pcde. A capreis Caprex dicłæ funt, infula ultra Surrentũ Campaniæcirciter octo millia paffuum, Tiberï principis arce quondam nobilis, nunc coturnicum multitudine, 8Cc. Sipontinus. Caprea no mine infula etiamnum eft in cófpectu Neapolis, Nic. Erythraus. Caprexab A thenæo abrupta, Stra bo lib.1, Et libro 5. Caprearum, inquit, duo antiquitus fuerant oppidula, nunc uero unum, quod Nea politani occupauere, \&c. Tiberium aliquando in Capreis habitaffe apud Iofephum quog legimus lib.18. Antiquitatum, cap, 12. Huius infula fupra etiã in Capra memini, capitis 8.parte 1. Dorcades infulas (ut quidam nominant, perperam fortaftis: nam apud Plinitum $\&$ Solinum Gorgones appela Iantur:) in Oceano Aethiopico fitas contra Hefperidũ hortos, Phorci filix Gorgones dicta inhabi= 1

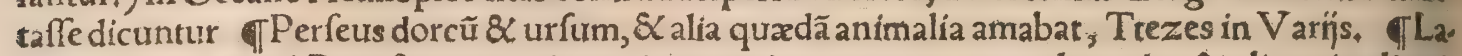
phria Diana apud $P$ atrêfes magno in ara igne excitato ceruos, apros, dorcades, $\&$ alia animalia ui. ua inịciunt, $\mathrm{Paufanias}$ in Achaicis . T Caprex prius iungentur lupis, de re incredibili, apud Hora.

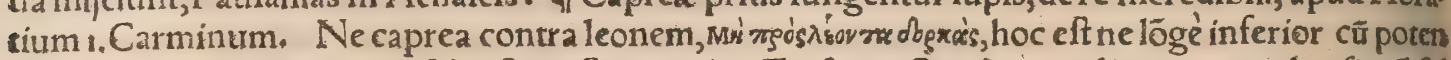
tiore decertes. Dorcas enim fylueftris eft capreolus, Erafmus:Quafi uero aliquis capreolus fit nó fyl

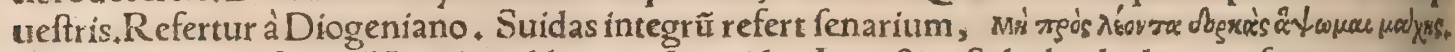
Huc pertinêt uerfus illi Vergilianilibro 10. Anneid. Impaftus ftabula altaleoceu fape peragiã̌s, (Suadet enim uefana fames) fi fortefagacem Confpexit capream, \& c. Sed prius A ppulis Iun gentur caprea lupis, Horatius, Cirat Erafmus in prouerbio, Prius lupus ouem ducat uxorem،

DE $Y$ G A R G O

PY GA R GI, tefte Plinio, ex caprarum fylueftrium genere funt, quas tranfmarini fitus mittứt.Qui dam pygargum capream fylueftrem exponunt, non diffimilem dam $x$, cuius interpretationis autho: rem non afferunt. Sumine cum magno lepus, atęs aper, atç pygarguis. Et Scythica uolucres, Iu

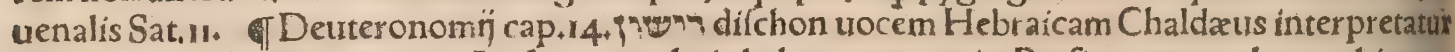

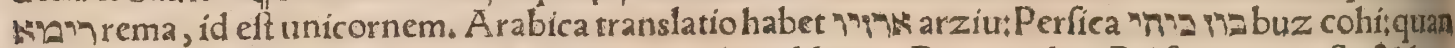
quam ctiam pro akko, id eft ibice, ibidem koz cohi redditur. Buz quidem Perfice capra eft, \& koz quoç fortaffis:nam \& lllyrice koza uocatur. Septuaginta múgreyosi Hieronymus pygargus. Numes ratur autem inter quadrupedes cibo hominum puras. Bartolematrs Anglicus author obfcurus, $\mathrm{Py}$, gargus (inquit) animal cornutum eft $\&$ barbatü inftar hirci, minus cerue, maius hirco:fimile hircos ceruo:miræ uelocitatis: loca frequentat fyluofa \& deferta. Gleffa etiam, inquit, in Deuteronomion, 4 animal hircoceruo fimile exponit. TEft $\&$ aquila gents apud Ariftocelem pygargi nomine $a b a b$ bicante cauda. Gręci grammatici zúyoesyu interpretãtur etiam pro homine timido \& imbelli, quodï quibus alba funt nates, uel potius totum corpus, ferè timidiores fint:melampygi uero, id eft nigris na tibus, qualem fuiffe Herculem ferunt, fortes ac intrepidi: Vide prouerbium, Ne in melampygum in cidas, apud Erafmum, cuíus mentionem Varintrs quoç facit:Item pro turpi \& libidinofo, ut pygars

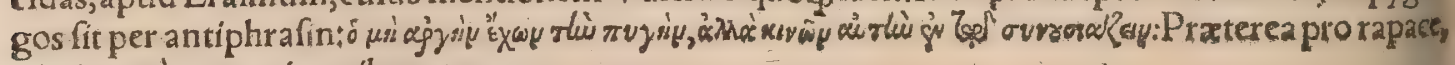
nimirum à pygargi aquila natura,

DE B V B A I O.

PA V C A animalia gignit Germania:infignia tamen boum ferorum genera, iubatos bifontes, ex, cellentiós $\&$ ui $\&$ uelocitate uros, quibus imperitum uulgus bubalorum nomen imponit: cum id gi s gnat Africa uituli potius ceruri ue quadam fimilitudine, Plinius. Bubali uulgaris, id eft uulgo fic apa pellati apud pleraf̧̧ Europæ gentes, hiftoriā fupra fatim poft Taurum defcripfi, \& obiter quadan de Afrícano bubalo immif́cui, prafertim capite primo, Apud Gracos tibicunģ, bubali mentio fit, de Africano femper intelligemus: \& fimiliter apud $L$ atinos ueteres: $N$ am recentiores omnes pro boiris

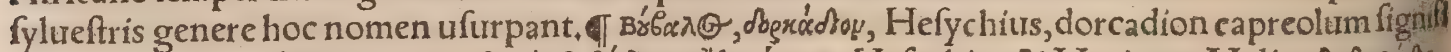

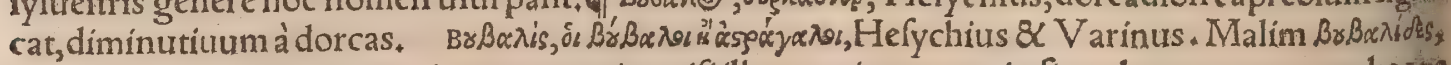
ut numerus cum interpretatione contreniat: nifi illam potius mutes in fingularem numer rm, hoc $\mathrm{pa}$ cto:Bubalis, $\&$ bubalum animal, $\&$ talum fignificat, Talum forfitan bubalum aliquis dictum furpice tur, à bú augente particula, $\&$ uerbo $B_{\alpha}^{\prime} \lambda \lambda \omega *$ è quòd ludentes frequenter eum proiectent. Ariftophas

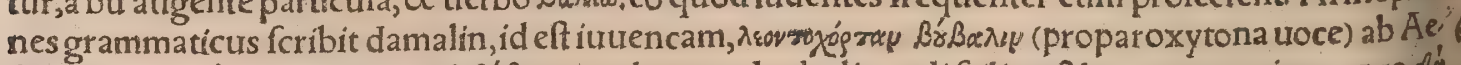

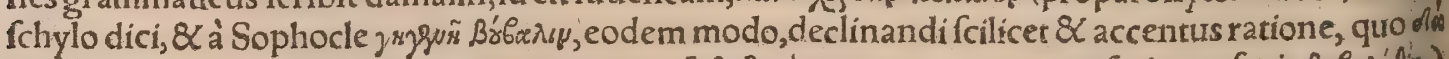

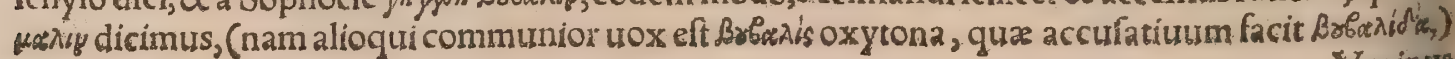




\section{DeBubaío. F.G.H. Lib. I.}

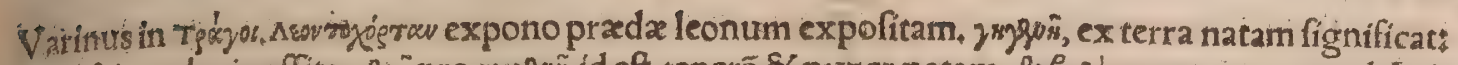

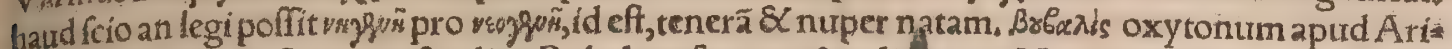

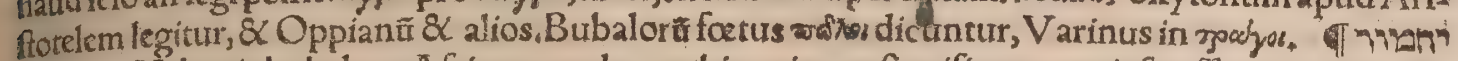
iachmur Hebrais bubalum Africanum, de quo hic agimus, fignificare, copiofe afferui in Bubalo deboum genere fupra. Caterum Deuteronomí capire 14، ubi Hebraice iachmur legitur, Perfica translatio habet mosk andaz. Tragelaphi \& bubalinafcuntur in Arabia, Diodorus siculus lib.z.

- Bubalus, inquir Oppianus lib.2, de Venatione, cor pore minor eft eurycerote (id eft dorcade platycerote: Gyllius non recté ceruum tranftulit:) dorco autem longe praftantior, (dama longé infe. rior Gyllius inepte uertít:)(plendidis eft oculis, fuaui colore, pulcher afpectu. Cornumm recti lon,

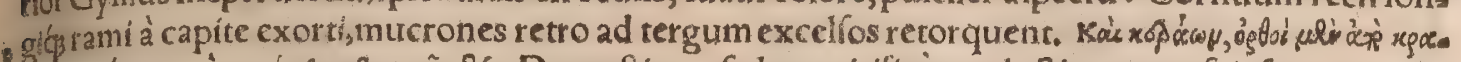

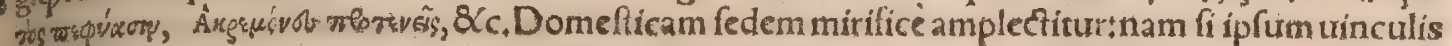
aftictum uenatores in alienum locum longinquum abduxerint, ac ibidem in paftionibus liberum \& folutum reliquerint, non obliuifcitur ad confueta loca redire, neqz diu patitur apud externos ut hofpes erret:ne $\zeta$ ením folis hominiburs amica patria eft, fed eius defiderio etian feræ tenentur, Hæc Oppianus. Idem lib.4 dePifcatione, fcianam pifcem bubalidi, \& ftruthiocamelo comparat; quod hac omnia in mett, occulta to tantum capite, tota fe fa tis latere putent.

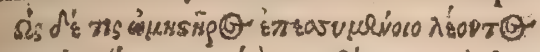

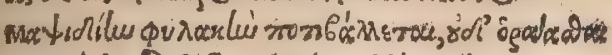

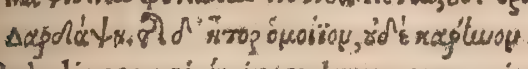

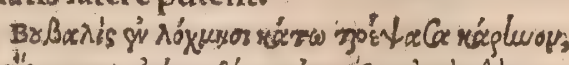

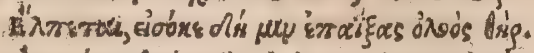

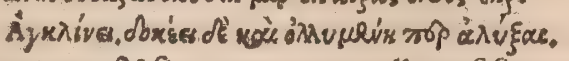

- TBubalis capreisćs interdum cornua inutilia funtınam \& fi contra nonnulla refiftunt, \& cor nibus fe defendunt, tamen feroces pugnaceş̧́ belluas fugiunt, Ariftotel, $3+2$. de Part, animal. Bu; baloum \& ceruorum fanguini fibra nulla infunt: quare fanguís eorum non fimifiter ut alior um concrefcit, Ariftot. Bubali fanguis aliquantulo amplius fpiffatur, quàm leporis 8 cerui, quippe quiproximé ouillo aut paulò minus conf́ftat, Idem. Bubalorum fanguis non fpiffatur, Plinius.

If. Bubali coagulum eafdem uires leporino haber, Diofcorides, Coagulum hinnuli bubali contra potum cicutæ prodeft, \& contra fungos, Haly. Barbari quidam remedia qua de bubulo fimo $\&$ tauri urina Diofcorides fcripfit, abfur drffime ad bubalum referunt.

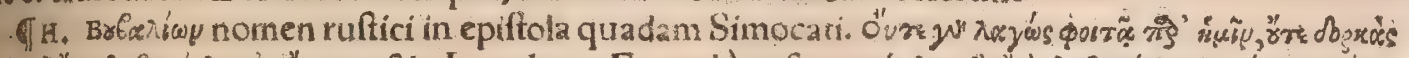

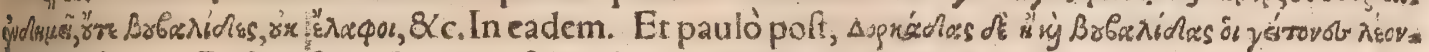

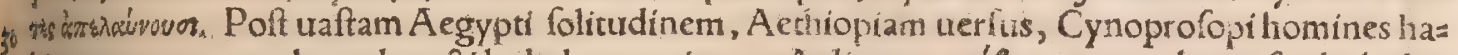
bitantes ex uenatu dorcadum \& bubalorum uiuunt, A elianus. Bóbinax, carnes bouts fe!r bubulx, Hefychius. Ornamenta qux circa manuum iuncturan ferunt, prafertin mulieres, Graci peri. carpia; \&c, \& bubalia uocant, Calius ex A theneco. Bubalion ornamentum aureum circa brachiale:

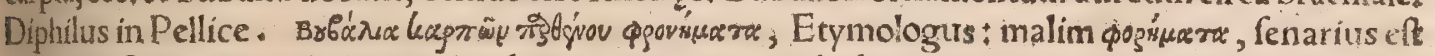
iambicus. Sunt qui muliebre pudendum exponāt, ut amphideon etiam pro utroø̧, ut fupra diçum eftin Vitulo cap.8. Brócice, cucumis agreftis, Galenus in Gloffis in Hippocratem:idem nomen a.

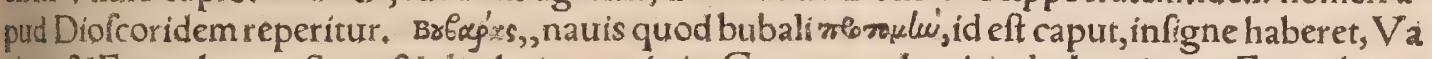
rinus $\&$ Etymologus. Sunt $\&$ alia buius uroris in Grxcorum Lexicis declarationes, Etymologus Bbibinop exponit magnũ $\&$ multum. Brfagins nomen nauis apud Philiftum:dici uidetur de oneraria

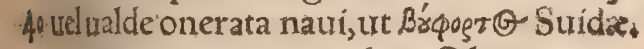

TDE ORYGE, uidein Olitera,

\section{DE I B ICE.}

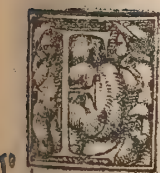
x. Caprarum fylueftrium genere funt eriam Ibices in alpibus, pernicitatis miranda, quanquiam onerato ca pite uaftis cornibus gladiortimó̧ uaginis, in hac feli brant, ut tormento aliquo rotati, in petras, potiffimum emonte aliquo in alium tranfilire quærentes, at $\mathrm{s}$ recuffu pernicius quo libuerit exultant, Plinius. Hoc genus Germani uocant ffeiri: bott:Galli quog Cifalpini qui Italice loquũtur circa Mediolanum, Germanicum nomen ufurpant: \& fimiliter funitimi eis $\mathrm{R}$ hęti, foemi nam tamen priuatim fux lingux urocabulo uefinam indigetant.

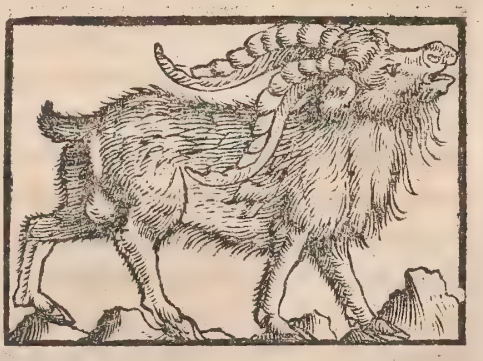
Scoppa ibicem foem. gen. facit, penul. breui, Plinius ibices rotati mafculino genere protulit. Iden Scoppa Italice camorciam interpretatur, fed hac rupicapra eft camuza Rhaticé dicta. Foeminam

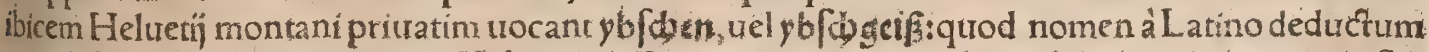
non dubito.llyrï kozoroziecz. Hebrain ps Deuter. 14 - inter quadrupedes puras : quanquam Sea ptuaginta illic tragelaphuten interpretantur, de quo fupra dixi:quod parum placer, quoniam trage. 6. laphum circa Phafin amnem folum reperiri Plinius frrihir, Diodorus Siculus eriã in Arabia, Chal

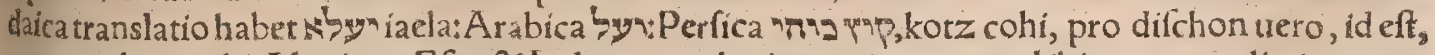
pygargo buz cohi, Abraham Efra, \& I udacorum plarig rupicapram uel ibicem, ut audio, interpre. 
tantur. RabiSalomon Germanica uoce feinboct, id eft ibicem : Kimhihircum fylueftrem $5 y m$ ial, unde formininum iaelah, plurale ieglim. Dauid Kimhi hircum ferum exponit. Hieronymus primo Reg.cap.24.8 Auguftinus luftinranus pralmo 104. ibices uertunt. Videtur fané nomẽ iaal à fcan dendo factum. Gręca translatio non rectè habet ina®aüs. Chaldaica iacla. Arabica gazaél uel gazal, quod nomen prodorcade tel caprea fuperius expofui. Vox iaal reperitur etiam lob 39.8 Prouer, 5. aliqui damam, alin hinnulum uel capream interpretantur. II Capricorni nomen apud Latinos authores, quorum quidem fermo probetur, pro animali pofitum nunquam legi, fed femper pro fy. dere, ut interius exemplis patcbit: \& fimiliter egocerota Græcortum, ad cuius imitationem capricor. iji uocem Latini formarunt:apud Suidam folum legimus, Acgoceros animalis genus, nec plura,

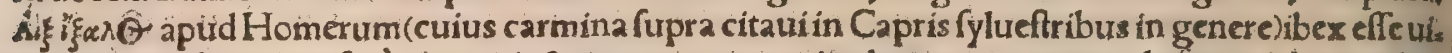
detur: $N$ am $\&$ nomen feréconuenir, \& cornuum magnitudo apta ut arcus inde fiant. Alize quidem fylueftres capra minus idonea arcubus cornua habere uidentir, quod uel minora fint, uel ramofa,

Quamobrem de féris capris, quas ixalos trocat Homerus, ex Euftathio hic auctariü adinciemts, fuperius omiftum. Capra fer $\boldsymbol{x}$, inquit, dum fugiunt uenatores attritis uehementius coleis, fape

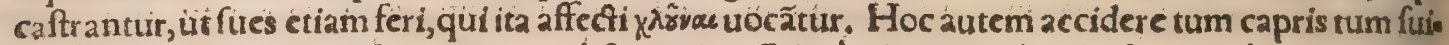
bus feris multi etiam niofiro tempore obferuarunt. Porró cornua ixali capri ixnoudknédouge, id eft fes decim palmorum, fiue dodrantum quini $\beta$ \& palmi unius, quidam ita intelligunt ut per fe utrumg dimidia tantum menfura fuerít, nempe duorum dodrantum cum dimidio. Sed hac magnitudo ni. Lil rarum aut mirum haberet, Atqui uel fingula quatuor dodrantum uifa funt, \& alia maiora ad fe= primum uf̧̣ dodrantem. In Delo certe iniula confecratũ aiunt cor nu aduectum ex locis circa nia. rerubrum, arietis bicubitale \& ocfo digitorum, librarum uiginti fex pondere: $\&$ alterum hirci, bicu bitale cum dodrante, ponderis eiufdem, Hac Euftathius. Habent al pes, ut Polybius tradidit, peet. liaris formæ beliuam, fpecie fimilem ceruo, ceruice $\&<$ uillis exceptis, qubus caprum refert, geritó fub mento aruncum dodrantalem, cuicrafficiés propulli equini cauda, 8 paulatim in mucronem

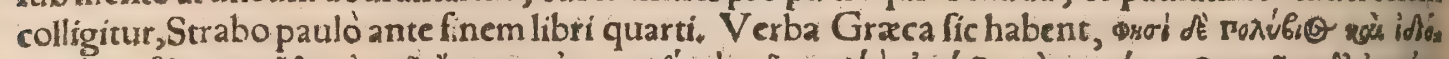

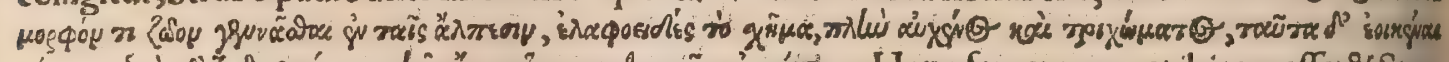

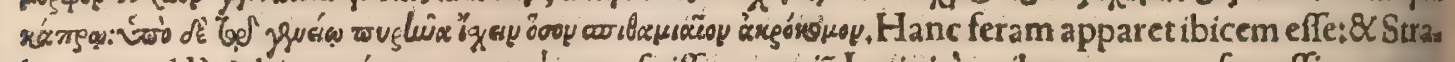
bonem uel Polybium rángou pro z̧á yop pofuiffe, quioniã Latini, à quibus accepere fortaffis, raprum hircum appellant: Graci uero a prum uel fuem marem, ciri cum ibice nihil commune. Iv fui Graeis nucleum fignificat, præcipué olıux: $\&$ ab eius figura quamuis congeriem feu ftrue, qux in acumen tendit, qualem Latini metam uocant, cuiufmodi eft foeni meta. Latinus Strabonis interpres carnis globum tranftulit. đ Ibix in uetere Teftamento cum $i$ in utrag; fyllaba fcribitur, $\&$ ab imperinit pro caprearum genere uel ariete exponitur, Ifidorus dorcades, capreas, \& ibices imperitiffimé confundit. lbices, inquit idem, quafi auicesieò quiod inftar auium ardua $\&<$ excelfa teneant $\&$ inhar bitent, ita ur de fublimi uix bumanis obtutibus pateant; unde $\mathcal{X}$ meridiana pars ibices aues uocant, qua Nili fluentis inhabitant. Ibides aues intelligere uidetur, nulla ratione', Similem uideo $R$. Ifaac ludai crrorem qui Hebraicam uocem ako, id eit ibicem, nomen auis facit. INofter Francifus Niger in R hxtia defcriptione, Rhętos Heluerís confoederatos, quoniam ibicem pro infigni gentis habeant, in uenationburs ei parcere ferrbit, his uerfibus: Parcitur hîc capricorne tamen tibi, $\mathrm{P}_{2}$ nos amice, Arma quòd exornes, \& pulchra infignia gentis. Hinc longum hic uitam urituens, ine 4 gentia iacias Cornua, perọ́p plicas rugofa,repandaç̧ in armos, Formofusć̣́, nigris uillis ín montia bus erras. Thapra fylueftris alterum genus eft caper montanus uel ibex, Albertus; duo enimge nera, prater capreolos, (qui minus proprie capris adnumerantur, ut fupra dixi) caprarum fylue frium Germanis nota funt, rupicapra \& bex. Ldem Albertus Creticas capras, quæ paftu dictamni infixas corpor ibus earum fagittas excernunt, ca pros montanos fite ibices interpretatur, quod ta: men nullis argumentis probat. Et alibi, Nullum (inquit) animal curfu $\&$ agilitate tantum pollet, \& fimul tam ingentia cornua habet, quàm caper montanus, quem Latine ibicem trocant:huitrs enim cormua à capite uf $q$ ad clunes protenduntur: $\&$ cadens ab alto totum corpus inter cornua protegit à collífione, 8 ictus lapidum magnorum excipit cornibus. Et in catalogo quadrupedum alphabis tico, lbex de genere capri animal, colore fuluum, in alpibus Germania abundans, magno etiam hir, co maius: fummas rupes afcendit, $\&$ cum altius frander e nequit, conuerfum aliquando uenatorem deijcere nititur:fed peritus uenator cr uribus diuaricatis dorfo cius infilit, 8 cornua manibus appre hendit, \& fic aliquando de rupe depofitus euadit. Extat Gordianifylua memorabilis picta in do mo roftrata $\mathrm{Cn}$. Pompeñ, in qua pictura etiam nunc continentur ibices $100.8 \mathrm{c}$. hac autem omnia populo rapienda conceffit die muneris, quod fextum adcbat, Iulius Capitolinus in Gordianopth mo. Ibicum generis mihi uidêtur ferx illa capra in fummis Libyx montibus, quas ex A eliano de fcripfifupra in Capris fylueftribus in genere. 9loannes Stumpfius nofter in Chronicis Heltre tix non pauca memoratu digna fuper huius animantis natura fcriplit, qua ego Latiné fic reddidí lbices in fummis apud Heluetios montibus abundant. Incolunt enim tertices alpium, ubiglacies nunquam folutur, nofri appellant fitr \& glett foder. Natura enim frigus requirit hoc animal, ca: 6 cum aliter futurum. Egregium eft \& corpulentum, fpecie ferẻ ceruina, minus tam $\bar{\varepsilon}$. Cruribus quie dem gracilibus, $X$ capire par to ceruum exprimit.Pulchros \& fplendidos oculos habet, Color pellis 


\section{DeIbice.F.G. Lib.I. 333}

fiftus eft. Vngula bifulcx \& acutæ, ut in rupicapris. Magni ponderis cornua eireclinanturad dor fum; alpera \& nodofa, có̧̧́ magis quo grandior $æ$ tas procefferit. A ungentur enim quotannis; donec iam uetulis tandem nodi circiter uiginti increuerint. Bina cornua ulkimi incrementi, ad pondus $f_{e}$ decim aut ocfodecim librarum accedunt. Libram dico pondus fedecim unciarum, quanưtram no fra octodecim implet, Ibex faliendo rupicapram longe fuperat: hoc tantum ualst, uinifiqui uide. rit, uix credat. Nulla montium tam praceps aut ędita rupes eft, quam non falt:bus aliquot fuperet:fi modo afpera fit, \& fpatia tanta promineant, quanta falientis ungulas excipere poifint. Parietem fcandit, fi afper fit \& nō incruftatus. Venatores impellunt eam ad rupes excelfas \& lartres, illic cum euadere nequeat, conficitur, uel ab homine funibus per rupem demiffo, uel ab rís qui f́andẽdo per rupium latera accedunt. Fera trenatorem expectat, \& folicite obferuar; an inter ipfum \& rupem uel minimtrm inter fit f patiũ:nam fi uifu duntaxat intertueri (ut ita loquar)poffit : impetu facio fe tranf

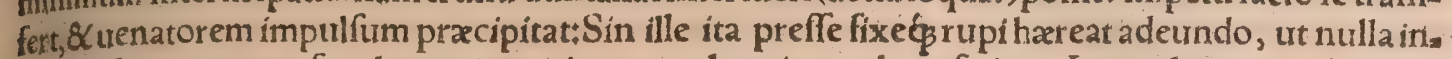
erualli fpes appareat, fera loco manet, in quo uel capitur uel conficitur. Iucunda quiden hac ues natlo, fed multis laboribus $\&$ periculis coniuncta:quamobrem faxpius bombardis feriuntur. Valefi qui circa Sedunum habitant, ibicem in prima atate captam omnino cicurari, \& cum uillaticis capris ad pafcua ire \& redire aiunt:progreffu tamen xtatis ferum ingenium nó prorfus exurere. Foc mina in hoc genere mare fuo minor eft, minusćp fufca:maior capra uillatica, rupicapræ non adcò difínilis. Cornua ei parua, \& ea quoģ rupicapra, aut uulgaris caprä, cornibus feréfímilia, Hucuf, que Stumpfius. Ariftotelis uerba de coitu ęlurorum, id eft felium, lib, 5, cap. 2, hift.ánimal. Aiber 6 tus ridicule transfert ad capri montani, fiue ibicis coitum, his uerbis: Mares furiomor û (barbarum hoc uocabulum ex Auicennax translatione ad eum perueniffe opinor) non coếunt cum forminis re trofuperfilientes: fed mas eleuatur in pedibus pofterioribus, $\&$ foemina applicat $f_{e}$ ei aquãdo, $\& c_{*}$ Viderat for tè uel ipfe, uel ab alịjs acceperar qui ipfi uiderãt, ibices inter fe colludentes, \& colluctan tes quodam modo: ut etiam capra felcnt: \& hunc corum lufum exiftimauic coitum effe. Er fi mas ximé ita coirent, quod mihi tamen in tali fuffraginû $\mathbb{X}$ reliqui corporis caprarũ fimiliumǵs quadrua pedum habitu, fieri nequaquam poffe uidetur:ridiculé tamen errat; ut dixi, pro fele ibicế interpreta tus. Albicem moriturum uenatores quidam narrant in al tifimam montis rupem afcender e:ac ibialtero cornut ad parietem feu latus rupis innitentem ambittr perpetư, ita ut nunquam conuerta ur, circuire: donec attrito iam cornu moribundus corrtiat. Etquoniam in alifirimis inacceflis gomoritur locis, nunquam feré cadauer eius inuenitur : contingit tamen aliquando ut magni niuium globi dum pracipites è uer ticibus ruunt, ipfa fubinde uolutarione auciores, oburios forte ibices ui iios, it $8 \times$ alia quauis animalia, arbores, faxa, tuguriá, corripiant, inuoluantós, \& ad imos montium pedes deferant.

G. Sanguinem ibicis aliqui commendant aduerfum calculum ueficx:hoc modo. Vini apiati (hoceft, in qüoadhuc multo apium aridum uel femina cius impofita fint) partes circiter fex: fangui nis partem unam, fimul feruefaciunt, mox in uafe referuant, $\&$ ter die potum inde prabent: mane, \& tum quidem in balnei folio fedenti:in meridie, uefperi : hoc triduo fieriiubent, futurum enim ut calculus in arenam comminutus cum urina excernarur: fin minus, execandum effe, tanquam extre mo remedio fruftra tentato. De hirci domeftici fanguinis ad eundem ufum praparatione, pluribus 4. dixifupra. Incredibile \& unicum remedium (inquit Marcellus Empiricus) if hiadicis \& ars thriticis hoceft, quo \& ipfe Aufonius medicus fanatus cft, \& multos ita iacentes, ut mourere fe fine cruciatu nequirent, intra quinç dies frare, ambulare aurem intra feptem dies fecit:Conficitur fic, $\mathrm{Ft}$ mum ibicum Luna feptimadecima colliges, quanquam \& alia Luna uetere collectum (fires urge. bit) fímili efficacia profit, dummodo medicamentum feptimadecíma Luna cóponatur. Ex eo ergo fimo quantum unius manus pugno pleno potuer is comprehendere, dummodo impar fir numerus pilularum, in mortarium mittes, (conteres ualidiffimè) atç adijcies piperis grana uiginti quinque diligentiflime trita:tunc addes mellis optimi heminam, \& uini ueterrimi optimi fextarios duos: (aliás fextarios quatuor $8 \alpha$ conditi more mifcebis porionem) 8 contritis prius pilulis uniuer $\{a$ mifcebis, \& repones in uafculo uitreo, ut cum fuerit opus paratum habeas medicamentirm ad fub otreniendum. Sed ut maior fit medicaminis efficacia. Luna feptimadecima id facere debebis: $\mathcal{S}$ cum daturus fueris remedium, à die louis incipe, \& per dics feptem continuros dato, ita ut qui remedian duseft, ftans in fcabello contra Orientem bibat. Quxe potio, fi ita ut foriptum eft; data \& obferuata fueric, etiamfi omnibus articulis \& coxa infirmus contractusç̧ fuerit, \& immobilis ac defperatus iacuerit, neceffe eft ut feptima die ambulet (ita fanabitur, ut nunquam paribus doloribus implice. tur,) Harc Marcellus cap. 25. Et rurfus cap.34. Intictam, inquir, potionem ad ifchiadicos \& arthriti. cos facientem, in titulo fuperiore de ifchiadicis pleniffimé f́cripfimus : fed quoniâ tam diuinus eitus effectus eft, iteran dam putaui, ne quis arthriticis remiedia requirens huitus ignoratione fallatcir. Fi= mus ergo ibicis in fylua uel in monte colligitur. of Coagulum ibicis eafdem leporino uires habet, Serapio citans Diof coridem: ego cum Græcis Diofcoridis uerbis contuli, nec inuenio nomen ullum 6 Gręcum cui ibicis nomen Latinum cöueniat, fed totus is locus apud Serapionem murilus eft:nam hinnuli, dorci; bubali, \& cerui nomina omiffa funt : unde conincio unum ex iftis Serapionis inter pretem expofuiffe ibicem, \& dorcum uel bubalü, potius quam hinnulü aur ceruum, itareddidiffe, 
बा H. Aegoceros, id eft capricornus, animal eft marinum, ut fcribunt Grammatici, in quod tra dunt fe Pana transformaffe, $\&$ in aquam fe deieciffe, cum in A egypto unà cum reliquis dăs Typhô. na gigantem acerrimum deorum hoftem fugeret. Sed Iupiter huius ingenium admixatur, inter aftra eum collocauit. Lucanus lib.8. Humidus Aegoceros, nec plus Leo tollitur urna , Lucrerius lib. 5. Quo pacto æftúis è partibus ægocerotis Brumales adeat flexus. Sunt qui æogocerotemà lo. ue inter fydera relatum fcribant, quod cum co nutritus furerit. Aly̆ Pâna exiftimant pofteriorem par tem in effigiem pifcis, príorem uero in formam hirci commutaffe: \& ea fpecie à loue in coelum effe translatum . Tum gelidum ualido de peçore frigus anhelans Corpore femifero magno Capricor nus in orbe, Cícero 2, de Nat Eadem lege in Arato, Lotis Hefperia Capricotnus aqua,Pro, pert, lib.4.Eleg, Tyrannus Hefperix Capricornus trida, Horatius 2,Carm. Plura lege apud Varinum, qui Á egocerota Pani fimilem, \& natutn exeo ait, \&c. Aegocerós humidus, gelidus, ce: ler, corniger, udus, nittofus, laniger, hirfutus, fetofus; cortiger, aurritus, horrendus, atrox, tropicus, aquofus, rigens, imbrifer, minax, frígidus, urniger, in Epithetis Textoris, Conueniunt autẽ hac epis thera omnia quidem fyderi, fed partim etiam ibici feræ. Cur per cancrum anima defcendere, per ca. pricornum a fendere dicatur, Porphyrius explicat in Antro nympharum, 8 Caelius 15.23. Capra afcendunt pafcendo, unde in zodiaco fignum, ubi Sol rurfus afcëdere incipit, hac potiffimum ratio. ne capricornum dixerunt.

M V S M O N Is hiftoriam poft Oués rëquire:etfi hoc etiấloco reponi potuiflet:funt enim iullo cà prino, \& à Paufania in Phocicis hircifylueftres uocantur.

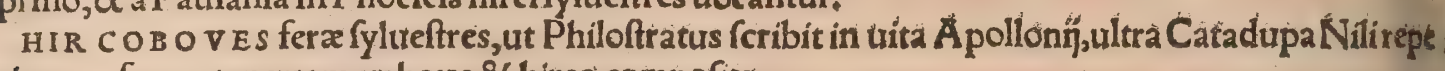
riuntur, forma tanquam ex boue $\&$ hirco compofita.

DE DAMA PLINII ET VETER V R:

C A PR A R V M fylueftrium generibus, qux tranfmarini fitus mittunt, Plinius damas quociad numerat: $\mathcal{X}$ alibi, Cornua (inquit) rupicapris in dorfum adunca, damis in aduerfum;ut dama torte nihil aliud aut parum à rupicapra differat, praterqua cornuum fitur. Quamobrem longe alia eft dan ma uulgaris, de qua proxime dícam,nempe dorcas platyceros Gracorum, cui nomen Latinum non inuenio:ut ne 9 Gracum dama Plinị. Sipontinus platycerotes ex damarum genere effe foribit, nul lo ad hãc rem teftimonio ufus. Certum eft platycerota uulgo damam trocari, neç uulgaris damà ge. nus, fed cam ipfam effe. Alị dorcadem fimpliciter damã interpretantur, ut Platina, 8 dorcem Gaza in problematibus A phrodifienfis, \& Albertus agazel uocem Arabicã, qux omnia ad capreas \& plaz rycerotes, $\&$ alias fortaffis caprarum fylueftrium fpecies, ut capreolum à quo mofchu's excernitur, tanquã generis uocabula, non ad folam damarum fpeciem pertinent. Theodorus ex Ariftotele rśn xx uertit damam, de qua troce plura dixi in Caprea.Strabonis interpres ?ogres facit damas. Gadilone tica regio (inquit Strabo libro 12.) polt Halyos oftia ad Armeniam ufqa extetiditur, tota campeftris; alit autem zorcas, quarum alibi raritas eft. Mario Grapaldo $v_{\varepsilon} \beta_{\rho} \partial_{y}$ damam reddere libuit, Hoc in uni, uerfum dixerim, recentiores omnes ubi damam uel ex Gracis uertunt, uel aliter eius meminerunt, eam quæ uulgò fic appellatur, hoc eft platycerotem, non Plinỉ damam intelligere. Primus noftrofe culo $\mathrm{Ge}$. Agricola difcrimen animaduertit. An uero uetuftiores damæ nomine Plinianã femper in: relligant, nec affero, neç nego. Recentiores quídam " nunt:nos capream effe lupra docuimus. Eft \& furi generis Auicennæagazel, quã Albertus damam nominat, libro 22, his uerbis: Dama beftia eft magnitudinis caprex, figuræ, \& pilifficut ceruus cor: nua habens, fed plana, longa $\&$ acuta. Eft autem curfu uelox, uita prouida, cornupeta in aduerfas fi bi beftias. Arabice uocatur agazel. T Damæ manfuefcunt rarò cum fera dici iure non poffint, Plis nius 8. 56.ut Vincentius Bell.\& Volaterranus alí '́s citant. Quin etiam Platina uidetur hanc lection nem fecutus, damam rarò manfuefieri poffe fcripfife : noftri codices melius, Hi manfuefcunt rarò, cum feri dici iure non poftint, proximé autem de leporibus loqurutus erat. Hâc lectionem Gelenitus in Caftigaticnibus fuis probatex archetypis manúfcriptis. Pecuarius canis negs tam ftrigofuis aus pernix debet effe, कृ qui damas ceruosá̧ \& uelociffima fectatur animalia, Columel. Nöomittendá funt etiã tria de damis epigrämata Martialis, quorum unũ lib, r.extat de pugna damarü hưiufmodi,

Frontibus adurerfis molles concurrere damas Vidimus, $\&$ fati forte iacere partí

Spectauere canes prædam, ftupuitḉ fuperbus Venator cultro nil fuperefféfuo,

Vndeleues animi tanto caluêre furore? Sic pugnãt tauri, fic cecidểe uiri. Et alterüli.

Afpicis imbelles tentent quam fortia damæ Pralia, tam timidis quanta fit ira feris?

In mortem paruis concurrere frontibus audent. Vis Cafar damis parcere?mitte canes:

Tertium in Xeripis: Dente timetur aper, defendunt cornua ceruum. Imbelles damæ quid niff prę da fumus? Fuluo tergore dama, Ouidius in Halieuticís numerans eas cum lepore $\&$ certro: TEt canibus leporem, canibus trenabere damas, Vergilius in Georg. Feræ pecudes, ut capreolida mæx́n, nec minus orygum ceruorumćs genera \& aprorum, modolautitijs \& uoluptati dominorum feruiunt, modo quaftui ac reditibus, Columella 9.1. Timidi dama ceruiḉ fugaces, Nunc interós canes $\&$ circum tecta uagantur, Verg.in Georg. Grammatici mafcalini aut forminini generis efie di cunt. Cum canibus timidi uenient ad pocula damæ, Vergilius A egl.8. Oculis capti talpa (inquiti Quintilianus 9;3.) \& timidi damæe dicuntur à Vergilio:Sed fubeft ratio, quia fexus uter क̧ altero fignd 
ficatur. Tam enim mares effe talpas damasç̧ quàm foeminas, certum eft. Et fuperiecto pauidę nà tartint Aequore dama, Horatits 1.Caim, Veloces dama, Seneca in Hippolyto, IDama epi. theta apud Textorê recenfentur hac, Agreftis, erräs, furgax, imbellis, leuis, pauens, pautidus, pronus in fugam, fpurcus, tener, territus, timidus. Poffunt fane 8 hrec epitheta, $\&$ alia pleraç de damis a pud authores memorata, tum platyceroti tum Plinị damæ (cornuum figura tantum excepta) com. munia effe, quando utraç fylueftrium caprarum generis funt. Indiam petenti Alexãdro Magnọ rex Albania dono dederat inufitata magnitudinis canem:cuius fpecie delectatus, iuffit urfos, mox apros, \& deinde damas emitti, contemptu immobili iacente, \& c. Plinius, IDama Pythagorz filia fuit, ingenio $\&$ doçrina in exponendis paternis fententiarum inuolucris excellens, $C_{2}$ lius. 1 Gordiani fylua memorabilis extat, in qua piçuræ etiam nunc continentur, damæ ducenta, \& $x_{c_{*}}$ lulitus Capitolinus in Gordiano primo, Recentiorum quidan dammam per m duplex fribunt, quod ego non probo.

\section{DE DAM A unlgari, fiue recentiorum.}

A I M A L IV M quorundam cornua in palmas finxit natura, digitoś̨́ emifit ex ins, unde platy, cerotas uocant, Plinius. Diofcorides dorcadem platycerotem nominat, quod dorcadi, id eft caprex,

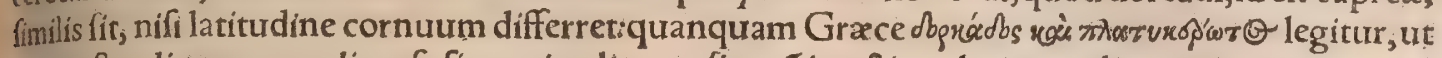
fupra oftendi, tan quam diuer fa fint animalia:ego fine cóiunctione legere malim, ut interpretes on

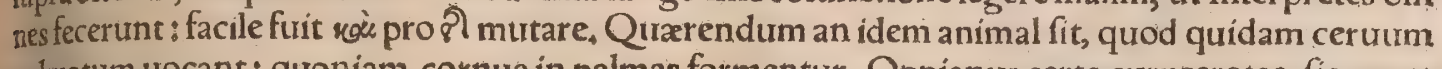
palmatum uocant: quoniam cornua in palmas formentur. Oppianus certe eurycerotas, fic uocat carminis gratia, ceruino generi adfcribit lib.1. de uenatione, his uerfibus:

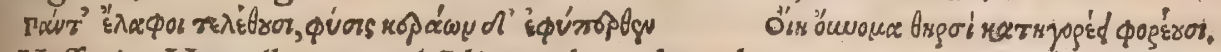

Fr. Maffarius Marcellum reprehẽdit qui dorcadem platycerotem, capreã à latitudine cornưum fic dictam apud Diofcoridem uerterit, quod caprea 8 platyceros genere omnino differant. Ego Marcellım fuperius defendi. Caterum platycerotem, damam uulgarem, id eft uulgo fic dictam, ap. pellare uolui, quòd alia quàm Plinï dama uideatur, cui cornua in aduerfum adunca effe ait ut rupi= capris in dorfum: $\&$ alibi ex tranfmarinis regionibus eam mitti Noftra uero dama $\&$ multis alins in

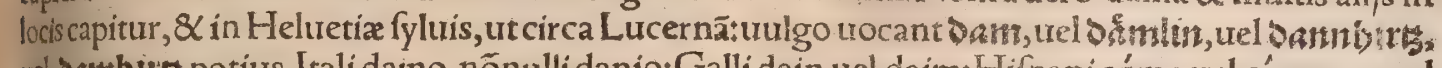
wel Dambith potius. Itali daino, nônulli danio: Galli dain uel daịm: Hifpani gámo uel córza, quod

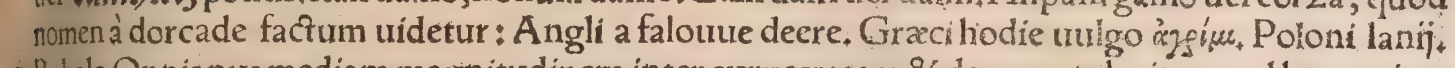
yo Bubalo Oppianus mediam magnitudinem inter eurycerorem 8 dorcum tribuit, qurod hoc maior; illominor fit. Cerui appellatione forte intelligit Arifteteles eciam capreas, 8 damas, 8 capras fyl veftres, Niphus. In Samothrace capræ funt feræ quas Latinè rotas appellant, Varro. Hermolaus legitquas platycerotas appellant. Damula tanquam à dama diminutiuum apud lfidorum $\mathcal{X}^{\prime}$ as liosrecentiores legitur. Multi (ut Vincentius Bell. Alberus, \& alij) cum muftela quam Itali uu!go donnolam uocant, damam (quam ipfi damulã appellant) confundune, tum aliâs, tum remedịs, quxx cx muftela funt, damę adfcriptis. Damula, inquit Ifidorus, uocata eft, quod de manu effugiat, ut. pote timida \& imbellis, \& cui pro armis fit fugx leuitas. बDamarum fanguini fibræ nullę infunt: quare fanguis earum non fimiliter ut aliorum concrefcit, Ariftor. Et alibi, Damæ timida funt:nam fanguis earum fibras non continet. Idem damam fel non habere ait:Etalibi, Fel(inquít)dama pror 4o fusnon habet. Cornua damæ folida funt, ut cerui Albertus. Cornua cerui $\&$ dama feré funt eiuf dem figuria, differentia in quantitate, Idem. Pinicianus cornuum fpecie deceptus platycerota in: terpretatur ein ellen», quam nos ab initio operis alcen effe oftendimus. Sunt autem dama uulgaris

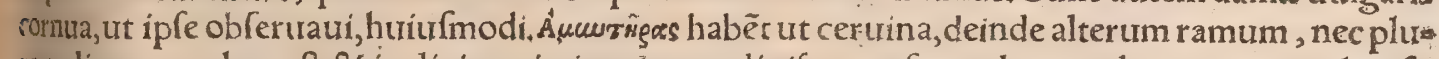
restreliqua pars lata eft, \& in digitos circiter decem diuifa, prorfus eodem modo quo corntr alces fut pradepictum dedimus. Totum cornu longum eft ducs dodrantes cum palmo: huius media pars fu. perior lata eft, ut dixi:inferior rotunda ut in ceruo, latiurdo ad quinç digitos. Galli pilulas excre: mentorum cerui, damæ, \& caprex, fumees appellant. of De uoce damarum uide in Ceruo.

f F. Dama,inquit Platina, cum capreolis feré in qualitatibus conuenit:bonum nangs alimen. tumeius caro uefcentibus praftat:modici quidem recrementi eft, fanguine tamen ad atram bilem so quoquo modo tendentem efficit. Baptifta Fiera poft mentionem capreolifubdit, Damula adua fta magis,fi matris ab ubere rapta eft; Huic prior in noftro forte erit orbelocus, I Decoctura. damx, ex Platina, uide in Ceruo capite fexto: $\&$ ibidem de conditura platycerotis ex Apicio. Caro algazel feræ, quam Albertus damam exponit, frigida $\&$ ficca eft, \& hamorrhoides mouret, nificum pipere, cinnamomo ac finapi paretur, Albertus:uel ut $R$ afis habet, nificum melle, pipere, galanga \& cinnamomo conficiatur. Et rurfus, Comedantur carnes algazel cum finapi $\&$ allins.

G. Dorcadis platycerotis coagulum eádem leporino uires habet, Diofcorides. Fimus alga. zel capillos auget, \& emẽdat eos, cum oleo (nyrtino) praparatus. Silingua eius arida fuffiatur gut tur, (locus trel membrum in quo eft fanguifuga)hirudines decidunt. Tali cinis impofitus in fiftus. lam, iutuat, Rafis \& Albertus : qui $\&$ alia quadam de fimo $\&$ felle (quo tamen carere putatur) hu bilus animantis ad coitum $\&$ conceptum pertinentia fuperfitiofa $\&$ illicita fribunt. 


\section{6 DeQuadrupedibus}

DE CASTORE.

A.

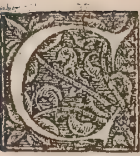

A STOR animal quadrupès eft amphibiũ : Latini fibrum, $\&$ ut Seruio placet cane Pon ticum uocant:Gracis nomis

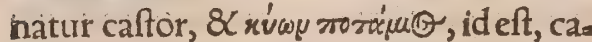
nis fuuiatilis, ut apud Syluaticum legin mus. Iralis, biuaro : uel beuero: Gallis; bieure, quanquãa Brafauola Gạllos $\mathrm{Ca}$. ftoris nome retinere fcribit id quơd $\mathrm{Hi}$. fpanos fecilfe putto:fieri tamen poteft ut Galli etiam in regionibus quibufdam re tinuerint, In Matthæooli Italica Diofco= ridis trâslatione fiber ipfe il caftoreo uo catur. Germanis biber:Anglis beuer:Il. lyrijs bobr : qua omnia à fibrouoce $\mathrm{La}$ tina deducta effe prima fronté ftatím ap paret, Syluaticus plurima paffincaftoris 8 caftorei in Arabum libris nomina re cenfet, quorum multa fcriptura folum $\&$ orthographia differũt, ego omnia ut. cunç corrupta adnumerabo, Albedue fter,caftoreum: ego ipfưm caforrem po: tius intelligo, nam pro tefticulis iutm uel iune uel fimilem uocem addere folent: Ium de beduft, Iuna da badufter: Angui de belduftor: Guidelarus: Quibar:In de bidifter: Zun de bedufter:luna da bau. fter: Iune de buftor: Gen de bedufter. Auicêna habet Giẽdedeftar, alsâs Gien. dibideftar.Reperio $\&$ alia quædam uo. cabula apud Syltraticum \& alios, qux tum inter fe tum à fuperioribus non pa rum differunt: ut, $C$ alcubas, $A$ mphima, urce corrupta forfan ab amphibio: 8 Anfinia fimiliter, nam ceu Gracam Syl uaticus exponititem A chiam, Anchian, Anchiani, Antín algil, Afufchelhar. Al= bertuslamyekyz barbaram uocem, ex Auicēna putto, caftorem interpresatur: qux uox fortaffis llyrica eft. Nam Po= lonis dama laníj dicitur, cuius diminu. tiuum lanïka. Caftoreum telticulus eft animalis , quod caftor appellat̃ uel deư, Platearius, Ex his tot f́cribendi modis quin maior pars corrupta fit, dubiữ non eft:ego quos quibus praferam incertus furm, Kipod Hebraicã urocem Efaix 34. $\&$ alibi in Sacris literis non caftorem, ut cuidam uideur, fed echinum terreftrem fignificare in eius hiftoria demonftrabo: T) cium, alī hirudinem interpretantur, aut thor concordantiarum reptile uolans. R. Salomon alibihericium, alibikn=s exponit, id eft fibrun, Gallica linguia (qua is uti folet) bieure díctum : fic etiam Munfterus legit. Nen placet legi uiuerras, quod id uocabulum lingua Gallica R.Salomoni familiari, aliter efferatur.

B.

Differt à lutra fiber cauda folum:cætero pilus utric pluma mollior:utrự co aquaticum, Plinitis. Surt qui fibrum meli comparent:\{ed corpus ei longius triburunt, \& pilum fubtiliorem. Pilos habet 


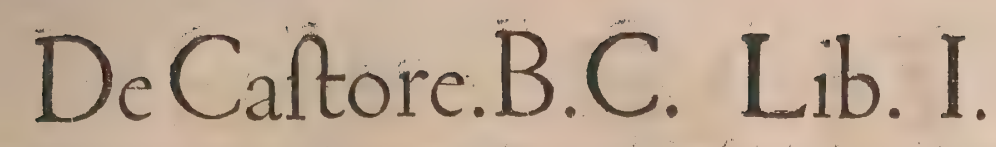

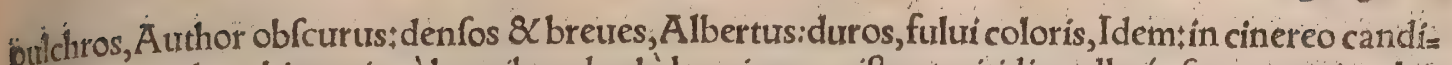

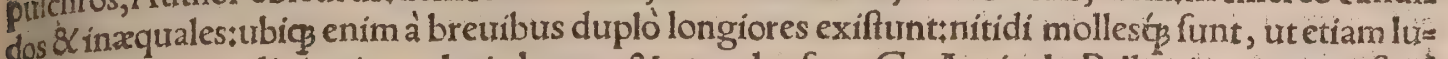
draturus tamen pili alterius coloris, breues $\&$ xquales funt, $\mathrm{Ge}$, Agricola. Pellis cius cinerea eftad nigredinem declinans, Albertus:quo nigrior eft, tanto pretiofior habetur, Author obfcurus. Pilo eft fiber fuperne canino, alibi lutræ, Syluius, Pellis ei mollis : \& ut Albertus art, ualde den $f_{a}$. Aures iminima, rotundx, Sylurius. Dens ualidiffimus, aduncus, pralongus, Idem:acutiffimus, Ego fibri a: fud nos capticaluam feruo, in qua dentium eius naturam pulchré perfpexithabet attê prominen: tes, longos, la tos, aduncos, in utra $\$$ maxilla binos coniunctos, qui inciforum loco funt, omnino int muritum genus inferiores extra maxillam tribus digitis prominent, fefquidigito fuperiores: utríque o in extremitate interiori, obliqua ueluti fectione cuneiformi magis magiś́pattenuantur, ut acies ex 3 trema tanquã cultri fit. Color eis qua foras fpectant ex flauo ruffus: his lefe defendũt, ligna fecant; \& pifces nimirum tanquam uncis iniectis apprehendunt. Alterum genus dentium, ore intimo habet, nempe octo molares in utraqg maxillathi breues $\&$ in fuperficie afperi funt, ạc plicis quibufdan eminentibus feu rugis, ad limæ ufum facii uidentur, ita ut corticibus arborum in cibo comminiren= dis molendisọ́ aptiffimi fint. Animal eft horrendi morfus, Plinius:Morfu potentifimum, adeò ư cum hominem inuadit, contrentum dentium non prius laxet, quàm concrepuiffe perfenferit offa fracta,Plinius \& Solinus. Morfum caftoris quidam dicunt non fanari, nifi læefus audiat fracturam offurm caftoris, Albertus : Ego hanc ftultam perfuafionem ex Plinn̆ aut Solini urerbis modò relatis; maléintellecis natam crediderim. Seta oris cornea, Syluius. De teftibus eius dicemus mox cap.4. ${ }_{20}$ Pedes priores caninis fimiles habet, pofteriores anferinis : etenim membranæ quadam digitis funt interiectatitaç hi ad natandum, illi ad eundum magis nati aptiós funt, frequenter enim in terram progreditur, Albertus \&CGe.Agricola.Pedes anteriores anferis, fed ungulati;pofteriores fimiaz, Syl uius:ubi librariorum la plum interpretor quod anteriores pro pofterioribus legitur, \& contra. Caur dalata, (palmum ferè, Ge, A gricola)longa dodrantem, Idem: obfcurus quidam author cubitalem effefcribit:Cauda pifcium, Plinius, non quod ad figuram caudx pifcium, fed quod pifcium corpoa ris fquamis obducta fit, \& pifcem fapiat. Pifcofa, folex amula, Syluius. Pilis caret uni forte quia drupedum. Cauda corio fquamofo regitur, prapinguis, hanc in aquam femper demittere foler, it 82 pedes pofteriores, reliquo corpore ficco. Sine aqua diu uiuere poffe negant. Apta eft ad natandum caửa, cum pifces infequitur, \& gubernaculi inftar eam ceu remigando mouet caftor. Falfò quí: go dam affirmant, quod nunquam retrahat eam ab aquatretrahit enim cum nimium frigida $8 \times$ glacia. lis aqua eft:quanquam Ge.Agricola fribit, etiam cum frigoribus conglaciat; fibrum in gradibus domicilh fui iacentem, caudam $\&$ poferiores pedes in flumen demittere. Falfum eft etiam quod aiunt lutram ab eo cogi, ut aquam hyeme circa caudam ipfius moueat, ne congeletur:uincít tamen lutram, \& expellit, uel acutifímo morfu occidit, Albertus. ब Per unitrerfum Pontum plurimus eff fiber, Solinus. Nafcitur \& in Hifpania fuminibis, ut inquit Strabo. Item in Italia, ubi Padus in marc fe exonerat. Nec inepti funt qui ad Matronam Gallix fluuiũ crebro capiuntur, Syluitus. Hel. retiamultos habet circa Arulam flumen, Vrfam, \& Limagum noftrum. Gaudent enim ripis ma. gnorum fluminum, cum animal fit amphibium:non folum ut reliqua quibus hoc nomen tribuitur; qura uictus tantum gratia aquas petunt: fed etiam quadam natura affinitate, ut iam in cauda $8<$ pedum pofteriorum mentione diximus, qua ad pifcium naturã accedunt. Abundat $\&$ relíqua Ger mania multís in locis : nec non Sclauorum regio; Polonia, Pruffia \& Ruffia, Albertus. Spectabilis naturæ potêtia in his quoq, quibus $\&$ in terris $\&$ in aqua uícius elt, ficut $\&$ fibris quos caftores uocant, Plinius. Die quidem in fluuios abditus ærtatèm agit, nocte in terra uagatur, Âelianus,

C.

Fiber $\&$ lutra egrediuntur ex riparum cauernis, in qubus latent, $2 x \mathrm{fe}$ in fuminibus mergunt, äpifices capiunt quibus uefcuntur: fed fructus quogs \& cortices arborum comedunt, Ge, A grico: la. Cibus eius melica (nomen barbarum $\&$ ignotum mihi)eft pifcis, \& arbortum cortices; Albertus. Multi aiunt caftorem pifcibus uefei inftar lutra: alij argumentum effe pifcofi fluminis, ubi cafto=

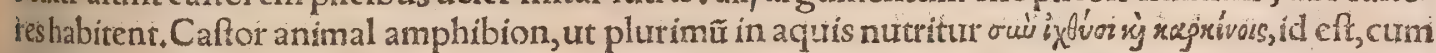
so pifcibus $\&$ cancris. Vetus interpretatio habet, fibrum uiucre ex pifcibus $\&$ cancris $¥$ item $M a r c e l l i$

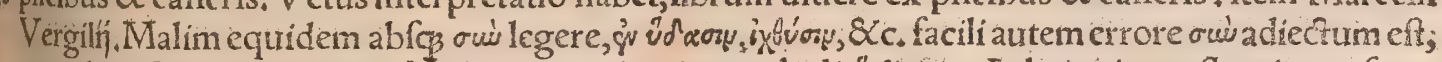
cum idem fontis fit ultimæ fyilabx pracedentis tocabuli údacou. Arbores iuxta fumina ut ferro cedit,Plinits. Cafur \& forturito obiectis urefcitur, A elianus. Imprimis prouridus eft, \& folers † etenim fruticibus $\&$ arbufculis dente tanquam ferro refectis, ante riparum cauernas cóftruit paruas quaf. dam cafas: $8 X$ in ijs duos trésure gradus, quafi quafdam cameras : ut cum aqua fluminis crefcens in undauerit ripas; afcendere pofitc cum decrefcit, defcendere, Ge. Agricola, Sxpe nocku prodit élati= butlo, \& amputatis arbortum ramis circa flutuios, conftruit fibi cafas ex eis cum folario (tabulato fut: periore) in quo habitat cum crefcit aquita, Albertus. Domicilia corum dimidia parte in aqua funt; \& dimidia fuperant: A gricola ea diligenter obfertaãt: $\&$ fi altius pofuerint, ferunt in montibus:fihut 6 milius, in uallibus, Olaus Magnus in deferiptione Septentrionalium regionum. Similis cbferuatio' eft in Aegypto, fi bene memini, circa crocodili cubilia. Fiber dentibus deñ cir mediocrís magnituí dinis(craffamento inter dũ femotis humani)arbores; $\alpha$ calas inde conftruit bicamerataș uel trica 
meratas, cum folarn̄s, ut aqua modo afcendere aut deicendere poffit, Albertus. Archíteçura in fo fa mirabili utitur, Syluius. Alnos, populos, \& falices infeltat: pracipué uero genus illud falicis fylue ftris latifolię, quod noftri uocant falwyoen/uel farmy oen. Sic me fubes quoridie quafi fiber falicem, Plautus. Amaris arborũ folijs \& corticibus caftor profummis delicins uefcitur, Author obficurus, D.

Fibri femper eadem femita ex aqua ad arborem aliquam procedunt: quam abrodunt totam, ni. hil tamen cum ceciderit præter corticem edunt. Cum arborem iã feréfecuit caftor, quoties içum facit, toties fufpiciens confiderat num fit cafura : timet enim ne fi eo ictu concidat, ab ea, priufquam recedere de loco poffit, incautus opprimatur. Nec uero minus eft cöftans in propofito qquàm folers; nam quam arborem ad ripas primo elegit fecandam, eam non mutat, etiamfi longo temporis fpatio diffecare non poffit, Ge.Ägricola. Ligna refecta ad ftructuram, de qua pracedenti capire dixi, ad, uehunt. Caffores gregatim ad fyluas lignatum pergunt:imponunt autem ligna fuper uentrem refus pinati unius, qui pro uchiculo fit, \& inter crura eius artificiofe componunt:qui ne delabantur com: preffis ea cruribus ante $\&$ retro fringit: hunc fic onuftum cateri cauda ad cafas uf́c pertrahunn Hanc iniuriam fieri negant nifi peregrino caftori, qui aliunde ad eos confugerit, aut fortuitò pertue nerit ad caftores loci alicuitus incolas:illum enim hoc pacfo in feruitutem ab eis redigi. Alij non pere grino, fed natu grandi $\&$ laboribus confecto, qui propter dentes obtufos lignis fecandis ineptus iam fir, hoc fieri aiunt. Ita ractati caftores in dorfo glabrefcunt, quo figno à uenatoribus fortem eorum miferentibus agniti, illafi interdum dimittuntur, Albertus Magnus à perito quodam uenatore rem ita narratam fe audiuife fcribens: \& ali quidam obfcuri authores: Sed mourent me, quo rem minus fabulofam exifímem, eruditi \& fide digni uiri Olai Magni eadem affeuerantis uerba in defcriptio. ne regionum Europa Septẽtrion. Accedit quod mures alpinos focnum hoc modo in cuniculos con uehere, etiam noftrates aiunt, Sed hoc in dubio relin quamus. TCeterum quod genitales partes fibri, fiue quilibet, fiue Pontici, ut Plinitus fcribit, ipfi fibi urgente periculo amputent, ob id fe peti gnari, noua refutatione noftra non eger, cum iam olim apud ueteres tanquam fabulofa hxc perfuatio ex, plofa fí. Marcellus Vergilius huiufmodi ueterum fabulis ignofcit, quod de induftria ab eis compof ta uideantur, ut bonas \& utiles res authoritate aliqua munitas uulgus hominum facilius \& libêrius admitteret, quod in religione \& ethnici factitarint, \& inter cæteros Plato philofophus. Ego contra ut bono uiro \& fapientiæ ftudiofo, cum philofophiæ finis fit uerítas, fabulas ubigg fugiendas exifti mo,illas inquam qua proueris credendx obtrudũtur, fic in religione potiffimum noxias. \& peftilen tes eas exiftimo: eam $\oint_{3}$ ob caufam cum Platonem $\&$ cxteres gentilium damnatrerim, qui tale quidin fuis fuperftitionibus aufi funt:tum omnes qui in noftra religione, qua puriffima \& fynceriffima effe debebat, idem moliuntur aut olim moliti funt, qua de re pro dignitate dicturo maximus fe campus aperiret:ego ad caftorem. Primum autem ponam illorum uerba, qui caftorem ípfum fe caftrareicrio pferunt, (unde etiam nomen eius grammatici quídam Latini deriuant; quod reçé fieri non poteft, cum dictio Graeca fit:) deinde aliorum qui redarguerunt. Tefticuli eius appetuntur in ufum me delarum;idcirco cum urgerife intelligit, ne captus profit, ipfe geminos (id eft teftes, ut Graci didy mos) fuos deuorat, Solinus:isćs folus opinor huius lententię: nam alij non per inuidiam teftes abeo reuelli, neq uorari : fed reuulios abijci ín urenator um confpectu redimendi fui gratia fripferunt, Quife Eunuchum ipfe facit, cupiens euadere damno Tefticuli:quoniam medicatum intelligitin. guen, Iutuenalis Sat,12. Idem teftatur Andromachus in Theriaca antidoto carmine defcripta, $\mathrm{H}_{0}$ minem ipfum fibi nocentem Aegyptï indicaturi, caftorem pingunt: hic enim uenatoribus infequen tibus refticulos fuos demordens, relinquit, Horus in Hieroglyph. Fibrorum teftes aptifunt medi camínibus, propter quos ubi fe requiri fenferunt, eos fecant, Seruius. Redimunt fe ea parte corpo. ris, propter quam maximé expetuntur, Cicero. Quod autem caufam abinfequentibus uenatorth bus cur tam cupide peratur non ignorat, idcirco mordicus premens uf $\phi$ incumbit ad elidendostes ftes, quioad ab fe abfciderit, \& fic eos abiecerit, tãquam homo fumma prudentia in latrones incurrês, quarunç portat ad fe redimendum exponit. Quòd fi poftea quàm exfecius $\&$ ex periculo fertattrs fuerit iniectantibus iterum urgeatur, hic fefe alleurãs, at $\$$ quamobrem infequi ulterius pergere non debeant, caufam oftendens, ad reuertendum, quod iam ea parte quam experunt car eat, uenatores in 1 ducit. Perfape etiam nunc tefticulis præditus cum à uenatorum confpeciu felongifimo curfuremo uerit, eam partem defideratam ita aftute cóprimit, 8 occultat, ut infectatores fallat, A elianus, IV Va, num eft quod traditur, teftes ab ipfis auelli, \& à fefe abrici, quum uenatu urgentur: fíquidem tangi nequeunt, ita, ut in fue fubftricti, Diofcorides. Amputari hos ab ipfis cum capiuntur, negat Sex. tius diligentiffimus medicinæ:Quinimo paruos effe, fubftrictosép, \&adbærentes fpina, nec adimili: ne urta animalis poffe, Plinius. Falfum eft quod agitatus à uenatore caftr et ferpfun dentibus, ac te ftes proíciat: $\&$ poftea fi ab alio uenatore urgeatur, erecto corpore caftratum fe oftẽdat, ut fape in re gionibus noftris compertum eft, Albertus. $T$ A nimal eft ualde manfuetum, Author obfcurus. Ego neq dífciplina manfuefieri poffe credo;ne⿻s manfuetum effe natura, cum plané mordax \& noxium dentibus fit, ut fupra dixi.

Volucra animal ferè prarodit teneros adhuc pampinos \& uuas : quod ne fiat,in ipfa putatione 


\section{DeCantore. E.F.G. Lib. I. 339}

firotics falcem acueris, fibri pelle aciem detergito, atç ita putare incipito, Columella. Volutocem as liqui appellant animal prarodens pubefcentes uuas:quod ne accidat,falces cum fint exacitæ, fibri-

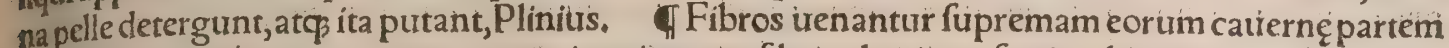
perforantes, perq̧́ eam paruium canem immittentes: fiber ad exitum fugit, ubỉirretitus fuftibus oc. ciditur. lidem hi canes, noftri aquaticos uocant, lutras $\&$ anates fylue ltres uenâtur. Canis ad hoc inftructus, in aquam proọcitur, qui ad cauernam caftoris pertueniens, ingreditur : nec cedit caftor mortibus, donec artificiofa illa cafre eius. ftructura refringatur; Author libri de nat, rerim. Cum canes perfequtntur caftorem, aiunt illum obuerfum uentrem ac tefticulos oftendere, quorum illi odoris diritate affecti fugiant, Author incertus: Tefticulos quidem, cum ad lumbos, trt dictum eft, fubfricti fint, oftendere nequeunt. In Pruffia, ut audio, naffis capiuntur, arborum corticibus in= efcati,ad hos irrepunt, \& ijs confumptis cum exitus non pateat, fuffocantur. Sed nố puto fieri poffé utcibum in ipfa aqua capiant, cum nullum eis fitinftrumentum quoreddant influentem cum cibo aquã,ut pífcibus branchia. Vrinari diu nó poffunt, fed refpirationis caufa caput fubinde exerũ $t_{;}$ Q fic bombardis impetuntur, tuel transfiguntur haftilibus. In aquis caftorem confpicatirs; pilofum pifcem putabam. Sequebantur eum nauta uenatores:unus in prora contum ferracum gerebat: alif paulatim nauèm ducebant uerfus eam partem, in qua fibrum fubmergi uiderãt : \& cum fiber motu exterritus captr exereret, qui contum tenébat illum confixit, Brafauola. T/Hoc animal urenamire non modo propter caudam quia uefcimur, \& pellem qua ueftimur: fed etiam propter teftes, quibus ut medicamentis utimur, Ge.Agricola. Venatores caftorẽ capiunt,pellis gratia magis quàm telti: 10 culorum, Platearius, Pellis caltoris aliquaindo pretiofa fuit, nunc in paruo pretio eft, Albertis. Mollis \& nobilis eft, eò pretiofior, quó nigrior; Aúthor obfcurus, Lutræ \& caftoris pellibus conci. fis, fimbrias ueftium ex pellibus nobilibus confectarum, folent exornare : quanquam lutrx pelles longé praftant fibri pellibus, Ge. Agricola, Ex canis fluuiatilis pelle cyna, id efl pilel primũ facti funt, ut in Cane dixi capitis 8.parte 5. Sed hoc ad lutram potius pertinet.

F;

Caftor quoniam amaris arborum folīs \& corticibus auidé uefcitur, tota eius caro \& fi bono, tae mert amaro odore perfunditur ${ }_{5}$ A Author obfcurus. Tota eius caro abominabilis eft prater cautdain? Albertus, Ego qui fibri carnem ederunt, laudantes eam audiui: fed multum intereft quomodo pa. retur, Sunt qui elixant primum, deinde affant in fartagine, uafís femper apertis, ut odor gratis ex: pírt, quod in alís etiam carnibus fit quæ gratiús olent, auium aut ferarum. Ipfe nihil eius præter caudam \& pedes polteriores guftaui, iure croceo conditos. Suaties, tenerra, \& prapingues funt hae partes, inftar thunni carnis, folida quadam tenaciós pinguedine: faporis feré cuius anguilla, quibis fimiliter etiam apparantur, ubi modice primum ebullierint. $A$ pipetunt has delicias ganeones, maxi: me autem ipfas inter digitos membranas. Memini alicubi apud Plutarchum legere,

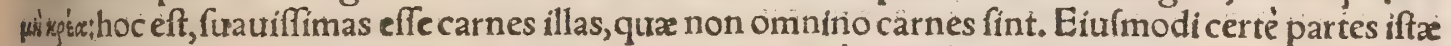
in fibro funt, ư quæ ad pifciũ naturam faporemq̧́ proximè accedăt: unde ieiunin etiam tempcribuss apud illos qui ea retinent concedũtur, ut apud Anglos quóg aưis quadam, quam puffin (uit audio)

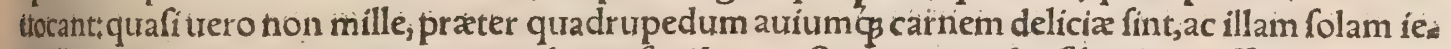
lunfís excipere oporteat, cateris pro arbitrio frui liceat. Sunt qui caudas fibrorum affas pauco zin 4o gibere confperfas apponant. Elixant alï, \& denfiufculo aliquo iurè condiunt,

G.

Pelle cáftoris paralyticos utiliter uteftiri aiunt, Albertus, Fibrinärưm pellium cum pice liqui. da combuftarum cinis, narium profluuia fiftit fucco porri mollitus; Plinius. Podagris utile elt fit brinis pellibus calciari, maximé Pontici fibri,Plinius. Apud Aetium idem remedium calciamentis ex pelle canis flutuiatilis triburitur : lutram intelligit, nam teftes eius ad eadem ualere ait, ad quæ ca. foris teftes, minore tantum efficacia, lib 2, cap، i78. dixerat autem de caftore pracedenti capite. TVrina fibri refiftit uenenis, $\& \mathrm{ob}$ id in antidota additur adferuatur autem optimè in fua uefica, it aliqui exiftimant,Plinius, đFel caftorís ad multa utile eft: Eiufdem coagulum fédat morbum ca= ducum, Auicēna, ut quidam citat. Ego apud Aưicennã in capite de caftoreo nihil tale reperio. Vì go tlliquidem marini coagulum caftorei uires habet, \& commendatur ad comitiales : fed hoc animal felle caret.

T Genitales caftoris partes caftoreum trocant medici,Plinius. Et alibi, Fibros (Graci) caf́tores uocant; 8 caftorea teftes eorum. Caftorea ex aqua mulfa drachmis binis aluum emolliunt, Idem.

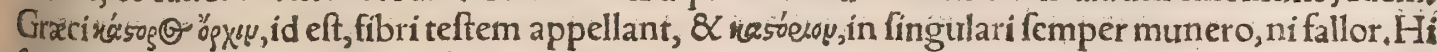
fpania etiam caftores procreat: $f e d$ caftorëum ex eis nó eam quam Ponticum habet uim:Pontico e.

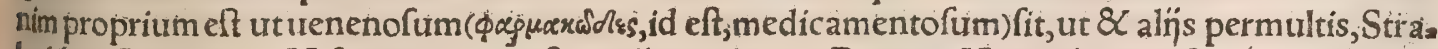
bolib; 3. Caftoreo in Hifpania non ineft uis illa medica, ut Pontico, Hermólaus ex Strabone. Caufé urr quis fortè aërem calidum, cuius uri medicamentofum illud uirus exhalet $\&$ digeratur. Nam in Heluetia noftra ${ }_{j}$ ut $\&$ in reliqua Germania, ubi frigidum coelum, nibil deterius, opinor, Pontico na 6 fiur. Effe autem Pontum quoģ frigidã regionem nemo ignorat. Efficacifimi caftoris teftes funt éPonto Galatix,mox A fricæ, Plinius, fi recte fic legitur. Eligi debent reftes qui ex uno ortu cori nexi funt:fieri enim non poteft ut gemini folliculi in una membrana coniuncti reperiantur : líquore 
intus ueluti cerofo, odore gratri $\&$ uirus redolente, gufu acri, mordente, ac friabili, naturalibus tit nicis circundato, (interfepto, ) Diofcorides interprete Ruellio. Grammatici quidã caftoreun odo rem putrem $\&$ acutum interpretantur: fed non eft putris boni caftorei odor : uerum gratuis $\$ f_{0,}$ tidus. Mihi quidẽ aridum frepe non iniucundo odore uifum eft. In afpalatho, inquit Plinius, inenar. rabilis quadam eft odoris fuauitas: \& paulo poft fubdit, odore caftoreo effe. Et alibi, onychem fuff: tum uulux ponis mire refiftere foribito odorem effe caftorei, meliusćs cum eo uftum proficere. Te. fículi abfcifi in umbra fufpenfi deficcantur, fic deficcatialbi $\&$ molles funt. Praferuntur ex maio ribus natu, uel qui in uigore atatis fint, nimium iuuenes $\$$ uetuli non placent, Platearius : quan. quam intricatiora eius hac de re uerba funt. Eligendum acri fapore mediocriter : nam çuod ualte acre eft $\&$ quafi terreum, adulteratum eft. Glutinofum etiam fit, \& neruos habeat intricatos, \& pel- n liculas adharentes, Per feptem(aliâs fex)annos in magna efficacia poteft feruariantefertu tamen rccentius, Pelliculis abiectis, quod in eis continetur, in medicamentis ponitur, Platearius. Opera, pretium eft diuifa pelle melleum liquorem cum eueftiente tunica affumere, \& ficcatum potui dare, Diofcorides, uc Ruellius uertit; ego fic potius, Quoniam fibri teftes non eminent, fed interius conv duntur aftricició̧ funt ut in fue:pellem fcindi oportet, $8 \mathrm{C}$ unà cum tunica melleum cótinente liquo rem cos eximi, atq̧ita ficcatos in potu dari. Caftoreum aliqui fraude corrumpunt, conincientes in follem gummi, aut Ánmoniacum, cum fanguine (Marcellus Verg,addit, eiufdem animalis;)\& caftor co fubactum, $\mathcal{X}$ ita exiccantes, Diofcorides. Sextius diligentiffimus medicina, friplit cafto $r$ is teftes adulser ari renibus eiufdem qui fint grandes, cum ueri teftes parui admodum reperiantur, Præterea ne ucficas quidem cife, cum fint geminæ, quot nulli animalium. In his folliculis inuenirili: 1 quorem, 8 afferuari fale. Itacs inter probationes falfi effe folliculos geminos ex uno nexu depen. dentes, quod iffum corrumpi fraude, conícientibus gummi cum fale Ammoniaco: quoniam Am. moniaci coloris effe debeant, tunicis circundati liquore ueluti mellis cerofi, odoris grauris, guftu as maro $S$ acri, friabiles, Hucuf̧̧́ Plinius: Nó probo quod pro (fanguíne aut Ammoniaco:)ut prius legebatur, aliqui fale A mmoniaco pofuerunt, cum Diofcorides etiam non falís, fed fanguinis men. tionem faciat: \& A mmoniaci lachrymæ, non falis : recte autem pro gummi Ammoniacũ inícietur, uel contra: quod utrungs tenax $\&$ uifcofum fit, quali fubftantia fi odor etiam caftoreus accedat, facile fallet in guftu:at fale quouis iniecto, uix quenquam falleret, cum genuinum caftoreum nihil ralis relipiat:fic igitur legam Plinị uerba, Cón̄cientibus gummi cum fanguine, aut A mmoniacum: 8 nihilà priftina lectione mutauero, nifi A mmoniacũ pro Ammoniaco. Caltoreũ, inquit Plateas rius, quidam hoc modo adulterant:Pellem, in qua caftoreum fuerit, uel alius tefticulus recens, im= plent fanguine $\&$ neruis, a ddito puluere caftorei, ne fuus odor abfit; alÿ fanguinem $\&$ terram com mifcent:alï callidius, fanguinem, fagapenum, \& neruos, adduntóp piper ut acrimoniam acquirak, Hac $\mathrm{Clatearius.} \mathrm{Caftoreum} \mathrm{non} \mathrm{fimile} \mathrm{noftro(id} \mathrm{eft} \mathrm{noftris} \mathrm{caftoribus} \mathrm{exempto)} \mathrm{Venetís} \mathrm{uendi}$ tur, Brafauola, Caftoris tefticulos qui hodie uendütur, longè maiores effe, quàm ur genuini \& ueri caftoris uideantur, copiofe fcribunt Monarhi ui nuper in Mefuen commêtarios effuderunt, Matit throlus fcribit ex fibris ucrum caftoreum fe habuiffe, quod magnitudine, colore, odore $\&$ facultate longe diffimile fuerit uulgari pharmacopolarum caftoreo. \Hac dum foriberem uerum caftor reum infpicere uolui, quod è caftore apud nos capto nuper exemptum erat. Pondus teftium am horum, libra cum femuncia, id eft uncia duodecim cum dimidia. Alter altero longé maior erat, fex digitos ?ongus, quatuor latus. Subfrantia qua in folliculo continetur, flaua folidaç \& 8 ceræ fimilis, acris, tenax: non terrea, nec fub dentibus, cum manditur, friabilis $\&$ afpera, quale fictitium feréca foreum eft. Ego euttandx fraudis caufa noftrate femper quàm peregrino utimalim. Sed plerique pharmacopolæ quoniam mincris emunt peregrinum, uerúme an falium id fit parum curant. $A b$ uno tefte ad alterum communis meatus pertinet, longus circiter decern digitos : in quo diffecto ge. nicale reperi, quod uno côftat officulo(ut in uiuerris quoç, ) carne, qua induitur, nigris quuburdam puncis cxafperata, Tefticulo utriç alter etiam folliculus adharet, plenus albo quodam \& pingul humore, fubftantia mellis, molli, \& foetida purris inftar cafei, longitudine interdum duorum pollis cum. Et forfan de hoc folliculo Diofcorides intellexit in fine capitis de caftoreo frribens, Oportet aut tem diffecia cute caforeum auferre, unà cum membrana quæ humorem melleum continet, \& ita ficcarum in potu dare, Nam proprié dichi caftorei fubflantiã paulò fuperius non melli fed ceræ com parauit.Sed hurnor ille melleus propter pinguitudinê non fatis idoneus eft qui ficcetur; odore etiam faporéç differt à folido caftoreo, utro $\beta$ ingratior:acris tamẽ $\&$ calidus \& tenuiffimarum partium, quamobrem ille potius extra corpus, uel per $f e$, uel cum oleis ungentisćç quibus caftor eum mifcere placueritutendum exífimo, folidiore uero intra corpus, Pharmacopol $x$ quidem nönulli reliquam etiam circa iftas partes pinguedinem partim in oleum de caftoreo inñ ciunt, partim pilcatoribus uen dunt, qui eam alins quibufdam mifcent ad inefcandos pifces, lidem cafiorei unciam denario indis cant plerunç. Sufpenfum in aëre ficcatumćs in abfinthio reponunt. Sunt quí ex foeminis etiam tè ftes haberi affirment, fed exiguos, \& qui trix unciam finguli appendant. If In antidoto nephritica éfexaginta rebus apurd Nicolaum Myrepfum, interprete Fuchfio, trium caftorei generum mentio fit, quæ autem \& qualia illa fint non exprimitur, nec alibi reperio. Proinde quarendum miht uides tur, an de rheo, quod proxime ante nominatur, tria hac genera intelligi debeani:diuerfa enim rhei 

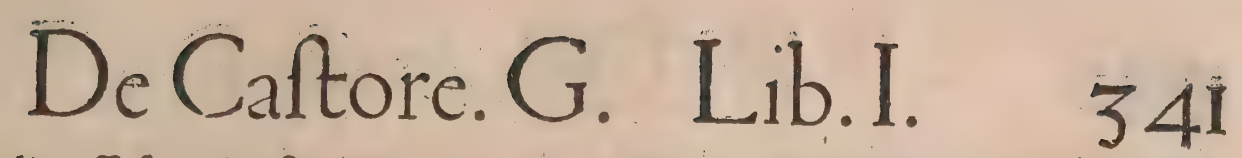

genera in ufu medico effe fcimus, caftorei non item. Caftorei odore femel imbuta, tenaciffima eius funt, \& uix un quam remittunt:imbưuntur autem eo etiam quar non tetigerint, in n̈fdem uafis aut caplis opertis condita. đCaftoreum é Perfide ferméadulteratum ad nos defertur:fyncerum enim tanta ui odoris eft præditum, ut olfacienti ueficam caftorï, fanguinem è naribus eliciat. Perfę autem adulterandis rebus funt exercitatiflimi. Seruatur annis decem, Syluius teftẽ citans Ludouicum pa. tritium Romanum:cuius ego librum Germanice tantum uidi, ubi hac omnia non de caftoreo, fed demofcho fcribuntur, haudfcio an per interpretis imperitiam. TAt Chalybes nudi ferrum, ui= rofág Pontus Caftorea, Verg, I. Georg. Seruitus uirofa uenenata exponit:nam licet fint multís ré medio, inquit, tamen pragnantes corum odore abijciunt, \& egerunt partum: Virofum autem deri. ua a b eo quod eft uirus ; alī fortia interptetantur à uiribus. Sed hi in etymologia uocis errant, ille

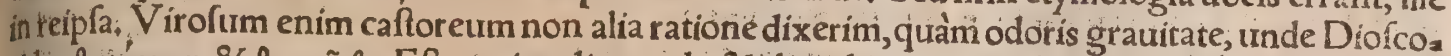

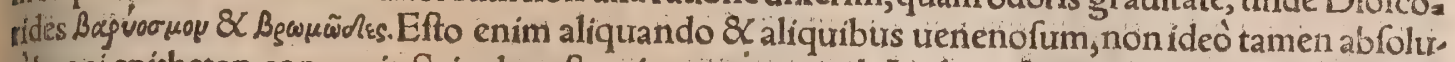
tehoc ei epitheton conuenit. Scio de caftorei ueneno apud Arabes ; 8 recentiortum qưordam qui fllog fequuntur, mentionem fieri:mihi tamen non alia magis ratione in caftoreum id cadere uidetur; quàm alia quauis putrida \& corrupta. Pleraq enim talia irenenatam \& contrariam hominis natuię facultatem obtinent, ut nuces rancida, \&c.facile autem corrumpi caftoriã uidetur, utpote folliculo inclufum, \& humidũ, nifi recté \& cömodo loco ficcetur. Caftoritum nigrum; foetidum; rancidum; die uno necare affirmat Auicenna, Syluius. Ponzettus cardinalis lib, 2, traci, 8.cap.z. Caftoreum, in. quit, corruptum, nimis calfacit, \& acutos pectori uapores fubmittens, partitu cotinuitatem foluit. ${ }_{20}$ Remedio eft lac afininum:cui quidam fyrupum de acido citri fucco admifcent: quiód fineceffitas po fulet Philonis antidoti drachma una aut altera ad fummum propinetur. Caftoreum corruptum, inquit Matthæolus ex Petro A ponenfi, infaniam \& furorem inducit, xger lingtam exerit, febri con fiçatur, \& uno plerungs die moritur, Curandi modus eft, ut butyro \& aqua muifa uomitus pro. tocetur, \& repetatur toties, donec nullum amplius caftorei odorem reddat: pofiea dandum eft me= dicamentum diamoron, (rob mororum aut limonum) uel fyrupus de limonim (ut uocant) citro, rúmue fucco:Peculiare ueró huius mali remediũ coriandro adf́cribitur, fi feminis tolti denarị diio exhibeantur. Auicēna caftorei uenenofi antidota effe fribit, aceturm, acidum citri liquorem, \& lac aftinum. Venenofum autem effe ait, quod uarium fit, uel (ut Belliunenfis emendat) puiluierulêtum, fubingrum: die una occidere: \& fi quis euadat, illũ incidere in birfen, quod uocabulum Beilunenfis 30 pleuritín exponit. Birfen eft apoftema capitis propter confenfüm diaphragmatís factum, Verus in pres gloffarum Auícenna, Biriferi aliquando pro pleuritide inuenitur, Idem. Ego phreniticut, non pleuritictum, eum qui prafens periculum euadat, fieri intelligo. Phrenes diaphragma uocatur, quo inflammato cerebrum etiam afficitur, ut phrenitis fiat, iuel ut quidam uxocant paraphrenitis. ${ }^{\mathrm{N}} \mathrm{Wa}=$ nardus in epiftolis 17.3.carabitum uel firfen (corrupte puto pro birfen) exponit phrenitin. If $\mathrm{Ca}$ foreum fi defit, tantundem acori $\&$ dimidium piperis fubftituetur, Aurcenna. Aetius, ut fupra dixi; canis fluuiatilis teftes ad eadem facere ait, ad qua caftoreum; recentiores idem de lutræ teftibus for bunt, Caterum fluuiatilem caneñ âlutura non differrè, in Lutra docebo. In Antiballomenis inter Galeni notha pro caftore agalochüim uel fiphitum ufurpari poffe legimusego non agalochum, fed

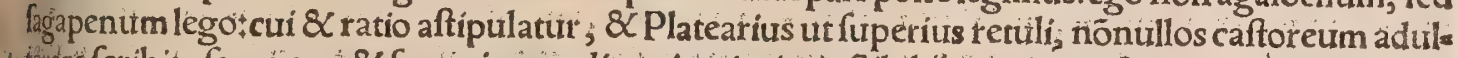
4 terare fcribit, fagapeno $\&$ fanguine modico piperimixtis. Sil phn̉ nomine caftoreo fübitituèndi, af fanfoetidan uulgo dictam intelligothæe enim melius quàm dulcis dicta caftoreo refpondet, cum aliâs tunt ad uteri pracipuémorbos. Eft enim uterus ín mulieribus uéluti animal quoddam; quod fraues cdores fequitur, foctentes fugit:fugari autem debét, cum nimium afcendit, foetidis fupra ad. hibitis, fuauiter odoratis infra:cum nimium defcendit, contra: $\&$ ad húnc quidem ufum quicquid gratiter ac uirus olet, caftorei locum implet:cuiufmodi funt diuerfa; quæ cum urintur grauifine dent, ut pennæa auiưm, ellychnium candela recéns éxtinçum, lanæ laciniæćç combúftæ; folex cal clamentorum, alliơruth aut ceparum cortices, capilli, capræe cornt, pix, galbanũ $\&$ alia grauris odo tis etiam non ufta, ut parthenium, quod inde matricariam urocant, \& fcrophularia urtice finllis, quam aliqui galcopfin Diofcoridis effe putant, $8 c$. Sunt qui ad fuffocationem ab utero potrim ex go raftoreo $\&$ alins medicamentis componant id malo obnoxijs, præferuandi maxime gratia. Compofitio eiufmodi eft $! R$ trtæ $\&$ meliffophylli folia: dauci, nigellę \& abfinthị Pontici(uel (ementinx)femina, fingula denarỉ femis pondere; caftorei de. harius, \& affa fotidx fcrupulus mifcentur, odoramentum hoc ut faluberrimum, ita etiam illis mus lieribus qua foctidũ nihil patiuntur nổ aque ingratum effe aiunt ut catera huius generis. IT Te. ficulos caftoris (inquit Galenus de fimplicib. 1i, 11.) nuncupant caftorium, medicamentum \& cé. lebre, $\mathbb{S}$ multi ufus, adeò ut Archigenes de caftorñ ufu totum confcripferit librû. Atç ille fanè par. ticilares eius facultates expofuit, nos more noftrogeneralem tantum facultatem dicemus; Itaque girod excalfaciat manifeltum eft. Nam fi uoles ipfum ad unguem leuigatum oleo maceratum parti cuipiam infricare, eúidenter illam incalefcere percipies. Iam cum caftorif confiftentia ficca quoque 6 fit, \& calfaciendi potentiam habeat adiunctam, meritò deficcat. Porò quoniam impenfe fubrilium eft partium, ob id efficacius eft quàm alia qux fimiliter ut ipfum $\&$ calcfaciunt $\&$ deficcant. Pene: thant enim tenuitum partium medicamenta, 8 in altum fubeunt admotorũ corporum, poiffimu 
ri ca denfa furerint, utt neruora. Sanéfi odori guftuiḉ aduertas animũ, fưpicaberis humano corponi aduerfiffimam habere fubftantiam:tametfi in natura nihil efficere comperiatur eorũ qux talia facere affolent, cum nullã omnino corporis partem intrò fumptũ ladat, Nam fiure corpori humido applices reficcarionë pofcenti, fiue frigido excalfactionẽ, fiue frigido fimul \& humido, magnã utio̧ experiere cómoditatem: potifímum fi febri uacet. Et corum fané multis qui non admodũ calidả patiebantur fe brim (fic enim uertere debuerat interpres) fed ut fic dicam tepidã, qualis accidit in cataphoris maxi. mé \& lethargis, caftorẽ̃ exhibuimus unà cum pipere albo, utrunģ menfura cochlearn̈ ex melicrato bibendum prabentes : nec quifquam ullam fenfit noxam. Quæ porrò in corpus intrò fumptum ius uat, ஜ̣̂f $\tilde{e}$ prodeft quog cuti impofitũ cum Sicyonio aut uetere oleo: Qux uero ampliori caliditate in digent, ijs etiam per fefe infricari debet. Iuuat etiam fi quis fuffitum eius in prunis impofiti infpira= 10 tione hauriat, maximè affectus in pulmone aut capite confiftentes. Attamen lethargicos 81 catapho ricos affectus, qui quidem adiunctam habent febrim, praftat non dicfortum (Sicyoní aut ueteris) on leorum quopiam macerantes curare, fed potius ex rofaceo capiti colló̧̧́ imponere, Haxc Galenus:re. liqua de caftoreo ex eodem, furo quact loco referam. If Caftoris teftes coquunt difpofitiones contu maces $\&$ fcirrhofas, Galenus de cópol, pharm.fec.locos. Caftoreum ualde calefacit, relaxat (fecun, dum alios, recorporat,) \& fic elimat diuturna neruorum uitia, quæ (forte qui, f́ilicet nerui) nimins doloribus contrahuntur, De fimplicib.ad Paternianum liber Galeno adferiptus. Diffoluit, attrahit (aliâs, confumit,) \& neruofa maximè loca roborat, Platearius. Idem in calfaciendo tertium ei gradurn attribuit, in ficcando fecundum, Calefacit (inquit Auicenna) in fine tertij uf $q$ ad quartum, ficcat in recundo.In fumma calfactoriam uim habet, \& in uniuerfum uarios obtinet ufus, Diofcorides.

TFibri teftes ferpentium uenenis aduerfantur: priuatim contra ixiam ex aceto bibuntur : faciũt etiam ad alia uenena, Diofcorides . Profunt contra uenena: Differentia tantum contra genera eft mixtura.Quippe aduerfus fcorpionem, ex uino bibûtur:aduerfus phalangia \& 2 araneos, ex mulfo, ita ut uomitione reddãtur’aut ut retineantưr, cum ruta:A duerfus Chalcidas (aliâs Chalcidicas, nem pe lacertas) cum myrtite: Ad duerfus ceraften $\&$ prefteras, cum panace, aut ruta ex uino: Aduerfus cæteras ferpentes, cum uino, Dari binas drachmas fatis eft, eorum qux adỉ ciãtur, fingulas. Auxilian ur priuatim contra uícum (ixiam, chamæleontem fcilicet, Diofcor, ) exaceto:aduerfus aconitum, ex lacte aut aqua: A duerfus helleborum album, ex aqua mulfa nitró s. $_{2}$ Plinius, Caftoreum confert morfui paruorum uenenatorum, Auicenna. A frigore laborantibus, caftori ternis obolis uti ex quatuor cyathis uini prodeft, Plin. Caftoreo cum melle pro pfilothro ufi pluribus diebus reperiun= 3 tur:In omni autem pfilothro uellendi pritus funt pili, Plinius, Ladanum cum caftoreo fiftulis medea cur, Plinius. Medetur abfceffibus frigidis, \& ulceribus malignis, Auicenna. đSternutamenta olfas ctu mouent, Plinius $\&$ Diofcor. Somnum conciliant cum rofaceo $\&$ peucedano peruncto capite; 8 per fe poti in aqua, ob id phreneticis utiles, Plinius. Caftoreọ́ graui mulier fopita recumbit, $\mathrm{Lu}$ cretius lib.6. Caftoreum cum peucedano $\&$ rofaceo capitis doloribus utiliter illinitur, Plínius. $C_{a}$ pitis affectionem frigidam \& flatibus coniunctam curat, emplaftri more impofitum, \& fuffitu, Auh $_{\text {, }}$ cenna. Galenus etiam fuffitum eius refpiratione hauftum ad capitis affectus utilem dixit. Capitis dolores ex utero fedat, Hippocr.Epidemiorum lib.7. Caftoreum in aceti mulfi cyathis tribus, aduer fus comitiales ieiunis datur: his uerò qui fapius corripiuntur clyftere infufum mirificè prodeft, $\mathrm{C}_{2}$ Itorei drachmæ dur effe debebunt, mellis $\&$ oleifextarius, $\&$ aquę tantundem: $A$ d præéns uero cor 4 repris, olfactu fubuenit cum aceto, Plinius. Caftoris teftes diuerfis neruorum alịs medentur:uel triti ad craffitudinem mellis cum femine uiticis, ex aceto aut rofaceo: Sic $\&$ contra co mitiales fumpti profunt, Plinius. Contra epilepfiam $\&$ alios frigidos affectus capitis, pondere frrus puli, ieel dưorum triúmue bibendi dantur cum rutæ fucco, aut uino in quo decocta fit ruta, Platea rius. Medentur $\&$ uertigini, inunci, uel triti ad craffitudinem mellis cum femine uiticis ex aceto aut rofaceo: Eodem modo opifthotonis, tremulis, fpafticis, neruorum uitḧs, ifchiadicis, ftomachicis, \&paralyticis fubueniunt; Plínius. Tl Lethargicos $\&$ utcun $\phi_{\beta}$ ueterno obdormifcentes excitantin fufi:cum aceto autem \& rofaceo, olfactu $\&$ odoris fuffitu, idem faciunt, Diofcorides, Plinius \& Aur cenna. Vide pauló fuperius in Galeni uerbis. Aduerfus lethargum (docente Plateario)prouocetur fternutatio cum caftoreo: cerebrum mouet ac roborat: Vel cum menta, fucco rutæ, \& $\propto$ pauco aceto \& decoctum, abrafo occipitio, infricetur, \& cataplafmatis modo imponatur. Puluis eius cum fuccoru= tæ naribus inificiatur, aut furmus recipiatur per nares. Qui poft xgritudines aliquas, ut lethargum aut peftilentiam, in obliuionem deciderint, eos maximé iuuat hiera R uffi: \& caftoreum cum oleo ocs cipiti illitum:poft purgationem ueró hieræ caftoreum drachmępondere cum melicrato porum: non parum iứare creditur, Aétius, Paralyticis medetur, Plínius, eo modo quem paulo ante retuli,la paralyfi totius corporis, da tur uinum in quo decocfum fit caftoreum, cum ruta et faluia, Platearius. Emplaftrû ex caftoreo ad refolutos, inferius apponam inter compofita pharmaca à caftoreo denomi nata. In lingux paralyfi,puluis caftorei fub lingua tenetur, donec per fe refoluatur $\&$ confumatur, Platearius. Contra paralyfin membrigenitalis, pecten frequenter foucatur uino in quo caftoreum decoctum fit: \& ex caftoreo cataplafma imponatur, Platearius. Potum \& illitum prodeft tremulis, conuulfionibus, (fpafticis, \& neruorum uitrís, Plin, uide etiam paulo inferius in mentione opifthoto. ni) $\&$ omnibus neruorum uitís, Diofcoríd, \& Plinius, eo modo quem fuperius ex eo recitaui. Potum 


\section{De Caltore. G. Lib. I. 343}

Epafmismedetur, Galenus de Theriaca ad Pifonê. Tremulos ituat, fi ex oleo perungatur, Plinius. Ceterim falluntur medicorum pleriģs(inquit Galenus)in ufu caftorei, cum id modo confiderant, partem quampiam aut tremere, aut conuelli, aut fenfu motúue priuatam effe, aut ægre fentire mo. ueriue: haud fientes id genus fymptomata ad diffimiles fequi corporis affectus, Quod fi ex plenitu: dine fiat conuulfio, utile fuerit caftoreum $\&$ potum \& impofitum: fin ex ficcitate uel inanitione, adurerffimum: $\&$ fimiliter in tremore. Caftoreum auxiliatur opifthotonis, eo modo quem fupra re. culi ex Plinio. Rigor ceruicis mollitur caftoreo poto cum pipere ex mulfo mixto ranis decoctis ex olco \& fale, ut forbeatur fuccus : Sic \& opifthotono medentur, tetano: fpafticis uerò pipere adiecfo, Plinius. Caftorcum cum melle claritati oculorum plurimum confeit, Plinius, Et alibi, Claritatem uríus facit cum melle Attico inunçư. Fel callionymi cum rofaceo infufurm, auribus utiliflimum eft, uel caftoreum cum papaueris fucco, Plinius, Cum oleo tritum aurium doloribus medetur, melius
ficum meconio, Idem.

I Si audiendi difficultas ex caufa frigida fiat, caftoreum medetur:eodem nihil utilitrs, cum fpis ritus includuntur auribus: debet autem magnitudine lentis oleo nardino diffolutum infundi, Aui. cenna. TMederur $\&$ dentibus infufum cum oleo triturm in aurem,à cuius parte doleant, Plinius. Afpaffi uxori dentis $\&$ maxillæ dolor uehemens : caftorium $\&$ piper colluens, ac in ore tenens, re. mifit; Hippocrates Epidem.7. Si quis fuffitur eius in prunis impofiti infpiratione hauriat, inuat af fectus in pulmone aut capite confiftentes, Galenus. Suffitus eius naribus attractus utilis eft ad ab= fceflus \& alia pulmonis uitia, Auicenna.Sufpiriofis caftoreum cum ammoniaci exigua portione ex 20 aceto mulfo ieiunis utilifime potatur, Plinits. TS Sitim facit, Auicennas Cohibet fingultus ex aceto, Plinius, Diofcorides, 8 Auticenna. Caftoreum cum ammoniaci exigua portione ex aceto mulfo calido potum, fpalmos ftomachi fedar, Plinitis. Singultus fi ex plenitudine ftomachi provex ueniat, ad caftorei ufum accedito: fin autem ab euacuatione, aut acrium humorum morfur prourene: rit,medicamen hoc fuggito, Galentss. Medetur ftomachicis, Pliniusteo modo, quẽ fupra prafcripfi aduerfus uertiginem, \&c. Tluuat contrainflationes $\&$ tormina, Plinius $\&$ Diofcorides. Dolorem itntris pungentem $\&$ flatus diffoluit, fi cum aceto bibatur, Auicentna. Ileos $\&$ inflationes pellic ca. floreum cum dauci femine \& petrofelini quantũ ternis digitis funatur ex mulfi calidi cyathis qua. atortormina uero cum aceto uino mixto. Quibus uenter ita flact diffenditur, ut agre curationem admittat, ac torminibus uexatur atç fingultu, idós ob frigidos craffos ós humores, aut craffos flatu. go lentosís f́piritus, eos caftorium ex oxycrato potum adiuuar, Galenus, Exapparatis in colica affectione pharmacis hocce nobis, inquit Archigenes, familiare eft Caftoriũ \& anifum tenutfimé trita, duorum cochlearium menfura præbemus ex aqua mulfa, Aêtius. Eribídem paulò ante, Caftoreum etiam(inquit)potum, totius affectionis molem demolitur, omnibuş́́ medicamentís prątare reper tum eft: datur eius drachma una in tribus cyathis optima aqua mulf $x$. बV fus inuenit ut anima lia (equi difficultate urinæ laborantes)à collo ufģ ad pedes inuoluantur de fagis, fuppofitis nitus uiuis, addito caftoreo, fuffumigentur, ut totưm uentrem telticulośç corum caftor ei fumus e: uaporet, \& confeftim detractis carbonibus cooperti deambulant 8 mingưt, Vegetius, " I Aluum emoliunt caftorea ex aqua mulfa drachmis binis: Qui uehementius uolunt uti, addunt cucumeris fatiui radicis ficcæ drachmam, 3 aphronitri duas, Plinius. Et alibi; Caftoreum ex mulfo potum pur 40 gationibus prodeft:Sed hic purgationes pro menfibus accipio. TSi gonorrhoea infeltat, caftorei in fucco uiticis \& pauciaceti decoctü,renibus, pectini, \& locis genitalıbus cataplafmatis inftar ap. plicetur, Platearius. TIfchiadicis medetur, Plinius:quo fupra dixi modo contra uertiginem, $8 c_{c}$ TVuluarum exanimationes pellit, uel fubdirum, Plinius. Inuenio apud quofdã oftracium uo: carí,quod aliqui onychem uocant; hoc fuffitum uulux poenis miré refiftere : odorem efie caftorei, meliuśás cum eo uftum proficere, Plinius. Caftoreum cum aceto $\&$ pice olfactum, contra uuluam prodeit, Plinius. De ufu caftorei contra hoc malum, fupra etiam dixi. Capitis dolores ex utero fedat Hippocrates Epidem, lib.7. Menfes ac fecũdas cier duabus drachmis ex aqua cum pulegio potum,

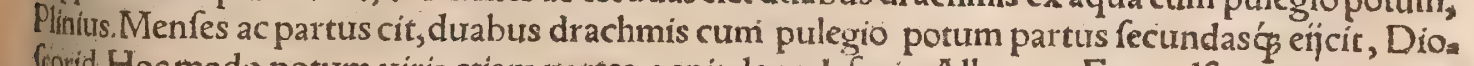
forid. Hoc modo potum uiris etiam partes genitales calefacit, Albertus. Ex mulfo potum purga so tionbus prodeft: Ad fecundas etiam uti eodem prodeft cum panace in quatuor cyathis uini: $\&$ à fri. gore laborantibus ternis obolis, Plinius. Menfibus retentis ubi per uenam qux in malleolo eft, mo dicéeuacuaffem, oblato caftorio unà cum pulegio aut calamintha, femper medicamen hoc expertus fum purgationem ciere fine hominis noxa. Praterea fecundas morantes ej̣cit, eaćg omnia ex me. licrato potum efficit, Galenus, Caftorí potus puerperij purgamentà à partu purgat, Hippocrat, de norb, mulieb. Si caftoreum fibrúmue fuppergrediatur grauida, abortum facere dicitur, \& periclio taripartus fifuperferatur, Plinius.

T Antidotus diacaftoriu, id eft è caftorio, à Nicolao Myrepfo defcribitur, utilis uertigínofis, co. mitialibus, apoplecticis, refolutis, \& paraplecticis, eft autem Sectionis prima antidotus 27.8 rurfus alia eiufdem nominis, numero 102, in qua cum caftoreum non recipi animaduerterem, ftatim diaco= 6f ftulegendum deprehêdi, \& hoc nomine eandem antidotum ab Actuaria defcriptã: quod Fuchfium non animaduertiffe miror. IDiacaftoriur emplaftrum ad refolutos, ab A CAtario defcribitur in ca pite de emplaftris 8 linimentis, Eadem defcriptio in paucis uariâs apud Nicolaũ legitur Sectionez. 
qua de unguentis eft, numero fecunda. IIn uulgaribus Nicolai Prapoliti, ut uocant, defcri ptionibus, (nam in Graco libro, quem Fuchfius tranftulit, non reperio) oleum de caftoreo contine. netur, ita ut uncia caftorei in libra olei decoquatur donec abfumaț pars tertia, \& poftea reponatur infpetfo caftorei puluere. Pharmacopolæ quidam huic oleo addunt pinguedinem qux circa iplos caftcris teftes reperitur. Extat etiam apud recentiores defcriptio olei de caftoreo Iacobi de Manlinss, quod præter caftoreum lachrymas aliquot calidas, 8 aromata, aliaćp recipit. Sunt qui diùerfis me dicamentis caftoreum addant, prafertim aduerfus comitiales. In n̈fdem Nicolai uulgaribus defcri ptionibus errhinon, id eft per nares purgans medicamentum reperio, curi à caftorio nomen, inter pin lulas nefcio qua occafione defcriptum: Inter Nicolai ex interpretatione Fuchfŕ errhina non inue thio. Mifcetitr caftoreum etiam medicamentis quæ ad excitanda fternutamenta componi folẽt, cum. helleboro albo \& pipere feré.

Fiber ab extrema ora ut Varroniplacet, it. uocartur: quoniam dextra \& finiftra fluminis maxime úideri foleat: $8<$ antiqui fibrum (inquit)dicebant extremum:unde fagis fibriæ (fimbriæ legendô pu. to, ut Feftus habet:) \& fibræ in auribus \& iecore. Canetri fituriatilem, lutrã effe fuo loco oftendam: qui caftorem exponint, decepti tridentur inde, qutod potamitum pro Ponticum legerint; nam caftor etiam, canis Ponticus appellatur. O९xise animal quadrupes, 8 herba, Hefychius $\&$ Varinus: Vide, tur autem caftor effe, cuius teftes maxime in ufu funt:hèrba uero non alia quàm orchís, id eft, tefticu Itrs Diofcoridis fuerit, Fiber, genus uefpa quadrupedis, Feftus:legẽdum beftix, nam de fibro, quem Graci caftorem ưocãt eum loqui, mox́ ćitatis ab co Plauti uerfus indicat. Vefpa quidem infecium eft, fed nullum infectum quadrupes. Interim non ignoro lutram fibro congenerem exiftimari, trax uero ichneumonem quadrupedem Á ǵgytiam : \& uefpre etiam genus apud Ariftpohanem uo, caríchneumonem, Caftor à caftrando dicitur, non quod feipfum caftret, ut foripfit lfidorus: fed

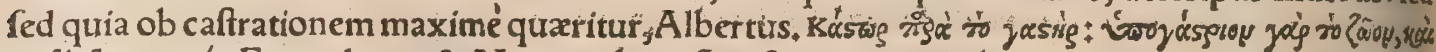

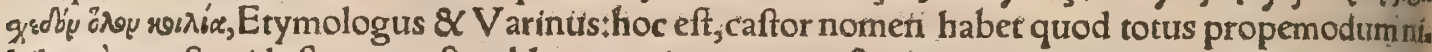
hil quàm gafter, id eft, uenter fit. oblongo enim corpore eft, cuius maxima pars in uentrem confus. mitur. If Auius fiber, Silius lib, 15. đFibrinus adiectiuum, ut pellis fibrina:Græece reścio, ut

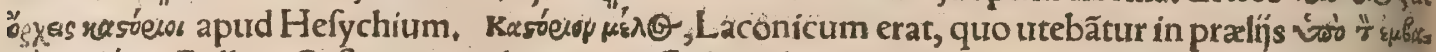

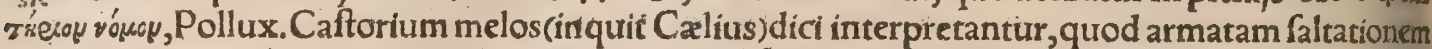
Diofcori cöpererint primi, cum ỏsxksswi forent plané. Meminit Pindarus in Pythïs ad Hieronêode

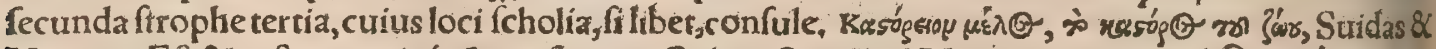

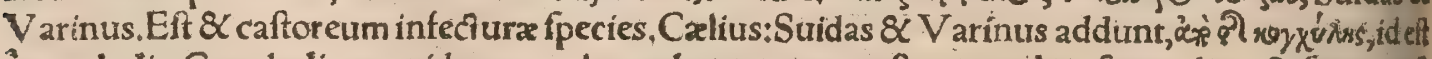
e conchylio. Conchylium quidem, quod onychem uocant, caftoreum olere fupra dixi, \& fieri poreft

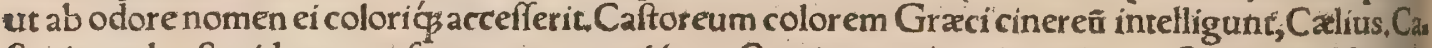
ftorias uel caftorides canes fupra memoraui inter Canes uenaticos in genere. Oppianus lib, i. de pifcatione meminit nefcio quarum caftoridum, qux amphibix fint, $\&$ in littoribùs coëant, $\&$ tamdi rum inaufpicatum'ś fam mortem abeffe eo tanquam nuncio exiftimare debeat. Aelianus interprete Gillio caftorides aui bus adnumerauic, Lutras é genere fibrorum nufquam mari accepimus mergi, Plinius. Vitulo ma rino uichus in mari ac terra: Simile fibre $\&$ ingenium, \&c.Plinius. Caftorem uitulo marino compä 4 rat, tum uicfus ratione, quia fimiliter amphibius fit, tum ingenio, quia uitulum aiunt euomere fel fuum ad multa medicamenta utile: item coagulum ad comitiales morbos: ut caftorem feipfumca firare. AAriftolochia longa apud Germanos biberwurs, id eft fibri radix appellatur, haud fcio quam ob caufam. TFalfa caftrationis, quam fibi ipfe caftor inferret, perfuafio, anfam dedit pluri bus amantibus ut picturas ex hoc animali fibi fingerent, Brafauola, I EmblemaAlciati,Aere quandoque falutem redimendam:

Etpedibus fegnis, tumida \& propendulus aluo,

Mordicus iple fibi medicara uirilia uellit,

Huius ab exemplo difces non parcere rebus,

Hac tamen infidias effugit arte fiber. Atçabijcit, fefegnarus ob illa peti. Et uitam ut redimas, holtibus ara darei

\section{DE CATO SEV FELE.}

A.

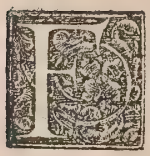

ELES animal eft familiare ac domefticum, omnibus notum: ưilgó catus nominatur, ut opinor,à folertia:nam catum fapientem dicunt \& acutưm, Græci elluron uocant, Phil, Beroalduis. Recentiores quidam Grammatici cati (uel uit alï fcribunt catti, per $t$ duplex) nomine abftinent, quod apud nullum idoneum, at ipfi aiunt, authorem reperiatur. A tqui utitur eo Palladius, \& Theodorus A riftotelis hiftorix animal. interpres eluron non aliter quàm ca. cum reddit. Sextus Platonicus catam genere focminino dixit: Martialis cattam t geminato, Catum 6

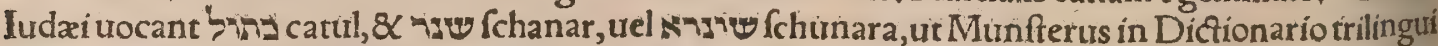

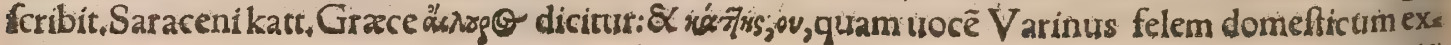


catum appellant, quoniam inter erudítos controurerfum effe urideo, relinquoo alị̂s ítudicandum, Hạ̀ ille: Quafi uerò feles $\&$ catus diuerfa fint anímalia : fed forte fequitur Columellam (inquit Car. Figir: lus) cui feles eft belua illa, quam fouinum appellant Galli,Germani cin wifele, muftelam autem for fitan capit pro ictide, At ego etiam Figulum errare dixerím, à Beroaldo $\&$ alījs Italis deceptum, in eo quod Columella felem fouinum facit,

Feles antiquitus non erant manfuefactx: uiuebant in agris, inde urbes $\&$ domos repleuere, Sed de cato fylueftri, dicam poltea feorfim. Pannonica cattælibro 12. Epigrammatum Martialis cele, brantur hoc difticho: Pannonicas nobis nunquam dedit, Vmbria cattas: Mauult hac domitra mittere dona Pudens، Feles Hifpanici diçi apud nos, agiliores rapacioresćg funt cęteris, maiores, nigriores, \& pelle molliffima; qux propterfplendidam nigredinem \& mollitiem alicubi etiam, ut in Gallia Narbonenfi $\&$ alibi, ad ueftes in ufu eft. A pud nos ex fylueftribus tantum pelles parantur:do mefticas enim excoriaffe parafféure pelliones noftri pro ignominia ducunt. Sunt \&R Romani qui, dam à noftrís dicit. Tartefia feles, tuide infra inter protierbia. In Pordofelena, uia interiacet, cu. ius ultra alterum latus gignitur catis, citra alterum gigni non poteft , Ariftoteles interprete Gaza: Grace legitur gale, id eft muftela. In Pordofelene infula uiam muftela non tranfeunt, Plinius 8. 58. Idem 5. 31. Porofelen nominat.Pordofelene, infula eft iuxta Lefbum, cum utrbe eiufdem nominis: Aliqui ut ciuilius loquantur (porde enim crepitum uentris fignificat) Porofelenen nominant, Ste: phanus, Feles (alures)in Aegypto effe meminit Strabo lib, 17 • qux quantopere ab Aegyptjjs colan tur dicam infra,

- Feles figura fimilis eft leoni, aut lext1 potius, ungubus ac dentibus fimiliter inftructa؛fed at. riculas acutiores feles habet, leęna rotundiores. Domeftici cati diuerfos habent colores, fylueftres omnes grifeum (id eft cinereum,) Albertus. Ex felibus domefticis qux dam alba funt, alix rufa, alix uraria, Sipontinus. Color feligrifeus, glaciei urehementer congelata fimilistatç̧ hic ei fecundum na turam eft, alif extrinfecus accedunt, ut ratione cibi, præcipué domefticis, Albertus, Caro eilaxa 86 mellis, Idem. Oculi catorum noçu lucent, non fine teriore inturentiü, prêfertim ex improuífo. No ćurnorum animalium, uelut felium, in tenebris fưlgent radiantó̧ oculi, ut contûeri non fit, Plinius, Perficos fmaragdos, Democritus refert, non translucidos, fed iucundi tenoris, uifum implere, quetin non admittant, felium pantherarumó oculis fimiles, Nan $\$$ \& illos radiare,nec perfpici: Eordem in Sole hebetari, umbris refulgere, 8 longius quàm cateros nitere, Plinius 37,5 . Oculi felis carbinn: culofi tam acuté cernunt, ut in cauernis etiam tenebrofis, tanquiam in luce, mures confpiciât, Alber, tus $\&$ alius autrhor obfcurus: A cluri, id eft cáti, hyænæ, \& uefpertiliones, cur nociu uidèant, Ales xander Aphrod, in quirit lib.. problemate $66.8 \mathrm{C}$ caufam affert tenuiffimum quem fortiti funt ưiden. di fpiritum. Noftri uitreos felitum oculos appellant, quioniam per noctem radiant, inclufo eis liumine tanquam uitro aut uitrex laternæe . Felem marem A egyptí dicunt pupillas ad Solis rationem uar riare:cum enim exoritur Sol, tum longæ fiùnt, in meridie rotundæ uidentur, ad uefperam autemob fcurantur, Gyllius:Plura de oculis felium lege infra cap. 8, proximè ante prouerbia. Leonibusas pardis, omnibuśḉ generis eius, etiă felibus, imbricatę af peritatis lingua, ac límę fimilis, attenuansó lambendo cutem hominis. Qux caufa etiam manfuefacta, ubiad uicinum fanguinem peruenitfalis tia, inuitat ad rabiem, Plinius. Dentes cati ferratos habent: $\&$ pilos (Albertus barbara uoce grano: nes uocat) circa os, quibus abfciffis audaciam perdũt, Albertus $Q$ alius atithor obfcurus * Vngules eis hamati, ut leonibus, $\&$ uaginis reconditi,

$$
\text { c. }
$$

Catus animal eft uelox, \& f́candendo, reptando, faliendoó mirx àgilitatis، Valde mordax, $\bar{A}$ ilber tus. Diuerfa murium genera, $\&$ aues uenantur, $u$ ut dicam capite quartc, $\&$ ideo natura beneficio etiam in tenebris cernunc. Vefcuntur ïfdem quibus canes, Ariftot. Pifces præcipué appetunt, $V$ ala de intemperantes funt circa cibum, eiusćs gratia non raro pericula fubeunt, Albertus. Foros; forna cés, \& loca calida diligunt: unde pilos fæpe adurunt.Purè \& molliter cubare gaudent ، TLibidinis tempore, mares pręcipué, efferanturtnoftri uocant ramlen. Cati per libidinem accenduntur, $\&$ domi bus fuis relictis uagantur:uel ut $A$ lberto placet, folitudinem petunt, quafi præu uerecundia homities relínquant:propria tưm eis $\&$ dira uox elt. Feles coêunt mare ftãtẹ, foemina fubiacẹnte, Plinius, Fe. les non parte pofteriore fe iungunt: fed mas ftat, foemina fubiacet, Sunt porrò in eo genere foemina ipfa natura libidinof $\&$ falaces $;$ ita $\$$ mares ad coitum ipfa frequentes alliciunt, inutitant, cog gunt; puniunt etiã nifi pareant, Ariftot.Puniunt, inquit Niphus, infectando fcilicet uerberandoç:. Græce

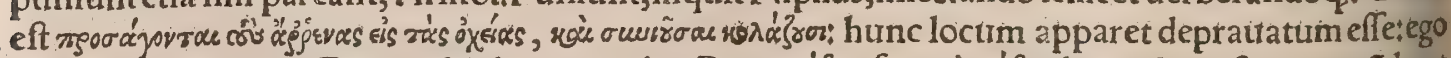
illum fenfum, quem Gaza reddidit, non uideo.Pro x fominæ mares ad coitum alliciunt, $\&$ dum coëunt, in terram fe fubmittunt: quo fenfur uerbum óxiné ¿ep in ufueft, \& fimile apud Germanos bocken. Albertus hic furrioz, id eft catü, ineptiffime caprum montanum exponens, Foeminx furiomorum, inquit, funt ualde obedientes ad coitum, $\&$ clamant al liciendo mares ad coitũ tempore coitus, Item lib, 22 in alphabetico quadrupedũ catalogo quódnam 6 animal fit non exponens, Furioz, inquit, in coitu maximé feruet; ita qưod in forminam graffari uides tur : 8 cum coitum perficere non poteft, clamat: exercet autem coitum, proftratum fuper foeminam 
in domicilịs ubi educati funt, plerunç manêt, etiamfi migrent à quibus nưtriti funt. Longius etiant in faccis afporrati, reuertû̉tur. Caftratur uter $\phi_{\beta}$ fexus, ni fallor, præcipué tamen mares, ut mitiores \& corpulenti fiant, minusḉ deferant domos \& euagentur. Auribus abfcilfis, facilius domi remanent, quod guttas auriculis apertis illabentes fuftinere non poffint, Albertus.

TOntie murium genus perfequitur catus: captos primo lufibus afficit, illufos urorat, Author obfcurus. Feles quidem quo filentio, quàm leuibus ueftigh̆s obrepunt auibus ? quàm occulto fpe, culatu in mufculos exiliunt cetn fui efie, Plinius. Pugnant cati obfidentes terminos fure uenationis, Albertus. Felis $8 \mathrm{i}$ ictis autes

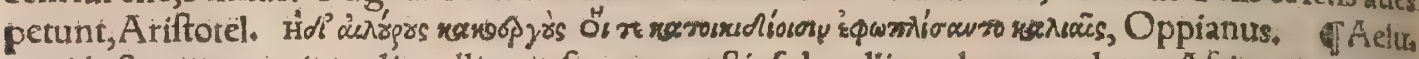
ros, id eft catus, non inuadit gallinam, fi ruta agreftis fub gallina ala appendatur, A fricanus in Geo,

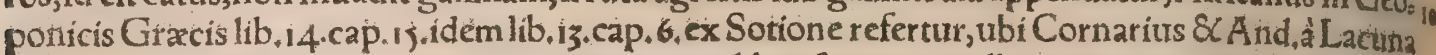
interpretes "ogitba fímpliciter aurem urerterunt, cum librö fequiente gallinã uerterint, quod magis pro bo, nam de gallinis illic ex profeffo agitur. Ne columbra a felibus infeftentur, ad feneftras acos adi.

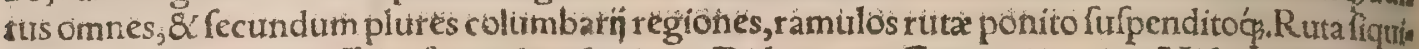
dem trim quandam poffider feris aduerfatricem, Didymus in Geoponicis i4.4. Vide etiam mox c2. pite quarto. Neflotrophin(id eft loci ubi anates alluntur) omnes parietes tectorio leuigantur, nefe. les, aliáue qux beftia introire ad nocendum poffit, Varro de re ruft, 3. 11. Etrurfús càp. 12. Septalea porarí è macerńs ita effe oporter ut teflor io tecta fint, ne feles atrt meles aliátie quix beftia intrare poffit. In anferum cellis, \& alijs generibus pullorum, cauendum eft ne coluber felèś́s aurtetiam muftela ponfit af pirare:quæ ferè pernicies ad internécionể profternunt teneros, Columêla. Nelios

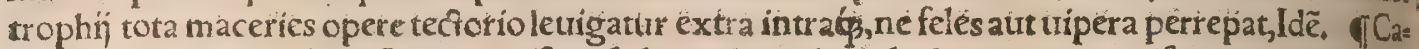
qus lerpentes etiam $\$$ bufones interficit, fed non comedit: $\$$ laditur ueneno, nifi mox aquam fuper biberit, Albertus. Bufonibus quoç pugnare diciturtquirurum licetuenenatis aculeis (ego nullêt bua fonis aculeum noui)repugnetur, non tamen necatur, Author oblcuris. Ariftoteles \& Plinits mu Itcllam in'micam effe feribunt cornici, fui, \& ferpenti: Hær, inquit Pcrottus, ad felẽ referri non pof Iunt, cum nec feli \& cornicialiquid commune fit, nec ferè multum feli \& ferpenti: contra uerò mu ftell $m \&$ cornicũ nidos fape diripit: $\&$ uifa eft frequenter cum ferpente pugnare. Cum monachi quidam fubinde agrotar erit, nec mali caufam intelligere poficnt, audiuerunt tandem à rufticooper rario qui catum monafterí cum ferpente ludentem uiderat. Non erat autem letale hoc ueneniun, quia latitia ferpentis ex ludo ueneni uim remittebat: Nec mirum, cum mures etiam ferpentibus cols ludant, Ponzettus, Cum feles fimiam in Acgypto infequerentur; hæc autem omni neruulortum contentione in fugam le impellens, rectà confcendıffet itı arborem, atç; illi ad eandén arborê afcen diffent, (ad corticem enim inhærentes furfum correpere fciunt) hac iànè ur fola à plüribus circum uenta ex arboribus trunco ad ramorum cacumina fe uertens diu multumç ex ịs extremis pepen dit:lli tum quòd eò accedere non quirent, ad aliam fe conuerterunt uenationem, A elianus.

E.

Poffum de ichnèmonimm utilitate, de crócodilorum, de felium dicere, fed nolo effelongior, $\mathrm{Cl}$ cero de Nat.lib.1. \& Tufculan.5. ब. Alo zlurum, qui aduerfus mures foriceś́ perpetuos $P_{a}$ alladis (ut Homerus fcribit)id eft Mufei ac bibliothecx mex hoftes excubet, $\&$ ftipendia faxit; cui non deli, cias modo, uérum etiam, figratus effe uolo, dimenfum \& annonæe autoramentum debeo, Cẹlius Cal is cag.in epittolis, Mures abiguntur cinere muftela, uel felis diluto, \& femine fparfo, uel decoctarum in aqua:Sed redoler(frumentum) uírus animalium corum ctiam in pane $\vdots$ ob id felle bubuloferitina attingi utilius putart, Plín. Nec feles, nec uulpes, nec aliud animal gallinas cótinget, fi ruta fyltieltris fub ala gallinis fufpendatur, $Q$ multò magis, fi uulpis, aut felis fel cữ cibo fubąư exhibueris; tre etî̉ Democritus confirmat, Cornarius in Geoponicis Gracis lib, 14. In Graco exemplari, ut Anditus à Lacuna citat, non ruta fylueftris, fed ruta fimpliciter legitur. Hac a pud Auicennam quoģ lib, 3 , fen 6.tract. 3. cap. 13. muftelas fugare dicitur:id quod mireris cum eadem contra ferpentem pugnatil ra rutã fttmat. Rutæ ramulos in columbarñs, pluribus locis oportet contra animalia inimica fufpetu dere, Palladius. Plura uide pracedenti capite. TCatos domefticos uicinorum cum moleftífint, facile quis capiet eirdem quibus mures maiores capiuntur caueis fue mufciptrlis : aut etiam laqueis qua domos ingrediuntur per feneftras alibiue difpofitis. In granarijs muffcipula difponantur ad mures capiendos, \& per foramina oftij felibus introeundi poteitas reliquatur ad murres frumentaro dentes fugandos, Grapaldus ex Varrone ut puto. Qui uulpes aut lupos capere uivlt, fóc dolo una tur: Carne fuilla pingui latitudine palmi, recens tofta, foleas calceorum inungat, exeundo interime fylua domum urerfus: \& fimul in ueftigia frufta fuilli iecoris affi $\&$ melle intincti renciat: $\&$ felis cada zier à tergo trahat. Vbi autem fera ueftigia fequens iam in propinquo fuerit; tecum habeas oportei hominem fagittandi peritum, qui fagittam immirtat, Author obfcurus.

i.

Muftela fel duntaxat contra afpidas eft efficax, cæetera funt ueneno, Perottus ex Plinio. Átfelis buts, inquit, multi boc tempore pro delicatiffimis epulis utuntur. Cuniculi caro dulcis eft: 84 fapore (ur quidam fcribit)felium carni proxima; Feles in quibufdam regionibus in cibum admitti, $\mathrm{pr}^{2} \mathrm{x}$ - ipué in Hifpania, aiunt, Noftratium aliquifeles fylueftres edunt, domefticas nulli. Hali carnes catti 


\section{DeCato. G. Lib.I.}

mederi hxmorthoidum doloribus fcribit, \&c, ut mox in G, dicam, Catos edunt quidam in Gallia Narbonenfi, ut audio, ubi prius uno aut altero die noctu fub dio expofuerint, quod ita teneriores fiant, \& odorem grauem exhalent.

Catus animal eft immundum $\&$ uenenofum, Author obfcurus, Muftela fel duntaxat contrà afpidas eft efficax, cætera funt uenenum, Perottus ex Plinio $¥$ At felibus, inquit, multi hoc tempore pro delicatiffimis epulis utuntur.A Alibietiam Plinius ueneficia quadam ex muftela ruftíca fieri mé= minit.Et alibi, Mures (inquit) abiguntur cinere muftela, uel felis diluto, \& femine fparfo, uel decocta rum aqua:Sed redolet(frumentum)uirus animalium eorũ etiam in pane. His Plinị uerbis muribus uenenofam effe felem aliquis confirmauerit, non item homini:uirus enim non tam uenenum, quàm odoris grauitatê \& foetorem fignificat. Sunt quifolum cati cerebrum uenenofum effe putent: de quio Ponzettus lib.2.tractatu 6.cap.5. Dicunt, inquit, quod qui ederit de cerebro cati mafculi, de. mentetur feré:eft enim ualde ficcumfi ad hominis temperiem conferas $\$ \&$ meatus cerebri obftruit, ita utimpediat fpiritus animales ne ad pofteriorem uentriculum tranfeant : inde exclufa memoria line mente uidecur quific affectus elt, Curatur propinando. bis menfe drachmã terra Lemnix cum aqua fampfuchi, aromata etiam cibis mifcenda funt, recreandi fpíritus gratia. Vinum bibendũ clam, rum, \& cum eo quandog drachma femis diamof chu dulcis, Sed forte fat fuerit, bonam uictus ration nem inftituiffe, Hæc ille. Cerebrum cati fumptum, inquir Matchæolus, uertiginofos \& ftupidos red. dit(ftolidos $\&$ quafi praftigñs obnoxios, Petrus A pon, $) \&$ is affectus agréctiratur, nec nifi paulatim 20 temporis progreffu. A egro uomitus prouocandus eft, poft terra Lemnix porum, id'̧́ bis aut ter in menie. Iutuat etiam quotidie fumpfiffe tribus aut quatuor ante cibum horis antidotum diamofich Sunt qui pracipuum hurus mali remedium effe fcribunt, fi dimidius fcrupulus mofchi contriti éui no bibatur. Quod fi uenenum eft cati cerebrum, apparet non eandem effe galen, id eft muftelam, cuius cerebrum aridum in comitialibus propinatur, ut fcripfit Galenus ad Pifonem.

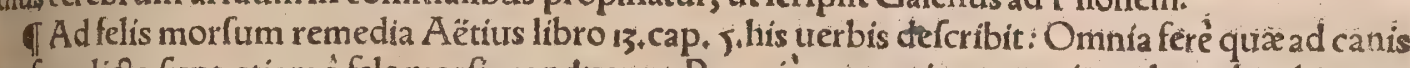
morfum dicia funt, etiam à fele morfis conducunt. Proprié autem eis conuenit, mel, terebinthina, $0=$ leum rofaceum, fimul eliquato ac utitor, Aut centauream tritam cum melle imponito. Aut galli fter

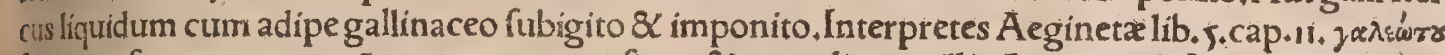
felis expofuerunt, perperã ut apparet;nam figna \& remedia quę illic Aegineta defcribit, eadê habet yo Aétils libro iam citato cap.12. Impofuit ipfis opinor, quod apud Aeginetam proximè antecedit re= medium ad morfum afcalabote, quem ftellionem reddiderunt. Atqui fieri poteft ut Aeginera nefciverit afcalaboten $\&$ galeoten idem effe animal, id medium hoc ad afcalabotæ morfum ab alio adiectum fic, cum nulla eius nofcendi figna ut in cate. ris habeantur, $\&$ unum duntaxat remedium breuiffime proponatur, nempe fefamum contritư ca: taplafmatis modo imponi, quod ipfum Aëtius inter remedia aduerfus galeotę morfum ponit, ut Aui renna quoq̧, quanquam mutila eius lectio uideatur cum Aëtio conferenti.Sed tam galeoten quàm afcalaboten ftellionem effe in Stellione pluribus probabo. Errauit etiam Auicennx interpres, qui Iib, , fen 6.tractatu 4, cap.13. cattũ proftellione tranftulit:eadem enim illic figna \& remedia leguntur qua Aêtius \& A egineta de galeote habẽt. Ponzettus lib.3.tractatu 4,cap. 4.cati morfus figna 4o eadem refert, quæ Aétius, Áegineta \& Auicenna galeotx, id eft ftellionis morfus, nempe dolorem magnum, \& uiridem(liuidum potius, ut Graci habent) circa uulnus colorem:remedia uero alia. $\mathrm{Cu}_{2}$ rantur(inquit)bona uicqus xatione: Quidam exhiberi iubent cerebra aliorum animalium, $\&$ uinum clarum odoratü dilutum : \& fæpe lauari ulcus urina hominis, ut qux uirus inflictum confumat;uel lafecaprino $\&$ origano. De morfu cati uide etiam Arnoldum in Breuiario 3.16. TCum quo. rumuis animalium pili,fi ab incautis deuorentur, arteria praclufa fuffocationis periculum miniten tur: pracipue tamen felium pilimaligni $8 \mathrm{Cuenenofi}$ funt, Matthrolus. बPrauus eft etiam an helitus felium:noui enim quoldam, qui cum noctu in lectis feles fecum habuiffent, 8 infectum ab eis aêrem infpiraffent, hectica febri $\&$ marafmo tandem confumpti perierunt. Nec ita pridem in mo nafterio quodã ubi permulti cati familiariter nutriebantur, $\&$ in coenaculis cubiculisḉ̧ \& lectis mo go nachorum frequentes erant, adeo plericg infectifunt monachi, ut intra breue tempus nec miffa nec uefpera eo in monafterio decantarentur, Idem. Alexander Benedictus in libro de pefte, cauendum confulit, ne canes $\&$ cati noftri tempore peftis, extra domum uagentur+facile enim ab eis aërem pe. filentem refpirando hauftum afferri, Hoc maximè mirum eft quod nonnullos fixooculorum obtutu ladant:alios uerò fola præefentia:Quod quidem non folum acciditex maligna aliqua aut ues nenofa ui in ipfis catis:fed accedente occulta quadam hominum qui ita afficiuntur qualitate fiue na= tura, colitus nimirum eis illapfa:quæ nifi prafente obiecto prouocante, ad affectum eiufmodi non mouerur. Huiufmodi ego homines Germanorum non paucos cognoui $\div$ qui nulla fimulatione pralentibus tantum catis, quanquam illi adeffe nefcirent nec prauidiffent, nec uocem eorü audiuiffent, mirum in modum lædebantur. Nam cum aliquando ad conuiuium uocatus in connaculo effem, $\&$ to expectaretur talis ingenï quidam, catum eo in loco occultarunt, illum mox ubi aduenit, fudare, pal. lere, \& ob metum tremere animaduerti, \& catum alicubi latere conquerentem audiui. Huius ego natura homines eifdem remedijs iuuari crediderim, quibus ï iuuantur qui cerebrum cati ederint; 
Matthaolus. Vidi \& ipfe qui prafentes catos ubi confpexiffent audiffénture, ferretion poterant,

Aelurorum, id eft felium falforum carnem, ad lauorem tritam, ligna (fcolopas) corpori infixa impofitam educere aiunt, utpote attrahendi ui præditam, Galcnus lib.1, de fimplic. Carnes cattica lidæ funt \& ficcæ: medentur hæmorrhoidum doloribus, renes calefaciunt, dorfi doloribus prolunt, Sumpta caro reprimit turgentes podice uenas, id eft hæmorrhoides, Vrfinus: Iacobus Oliuarius ad dit hoc remedium fe expertum effe. Et Eumbus lumbis praftat adefus opem, Vrfinus:idem Olita rius addit ueriffimum effe. Ego nifi in fumma omnium remediorum, quæ ratione aliqua nituntur, inopia, nunquam ad hæc abfurda experimenta defcenderim. Podagræ utilis fertur carocatta agre fis inuncta, Rafis $\&$ Albertus. बI Sanguinem cati paronychiæçuidam illigant, \& latentem in ea uer them (ut uulgus credit) eadem nocie extingtri promittunt, Innominatus , I Cati fylueftris feutum fi mile eft natura carnis eius: carnem autem calidam, mollem, \& podagræ utiliter illini dixerat, $R$ afis, Inter taurinum \& fuillum adipem fuerit felinus, Syluius. TOculorum uitio quod noftri uocant Aitcen uns fsil/hoc eft, ungues, nebulas $\&<$ leucomata fic medeberis: Caput cati nigri, quine mactr. lam quidem alterius coloris habeat, ures in olla figlina, intus (utuulgo loquuntur) urtreata, aut figu lo urendum committes : non eft periculum ne nimium uratur. Hunc cinerem per caulem penna in oculum inflabis ter die. Noctu fiquis ardor infeftet folia è quercu aqua madida, bina fimul aut terna oculo impones aut illigabis: Hoc tanquam egregium experimêtum furum medicus quidam mihi nar rauit : ego poftea in libro quodam manufcripto Germanico reperi, adiecta promiffione uifum refti. tuendi etiam poft anni unius cxcitatem, \& remedio ad authorem Hippocratem relato. $\Phi$ Felis iecur uftum tritumó $\beta$ ita ut bibi polfit, calculofis remedio eft, Galenus Euporifton 1,52, TQQuartanis magi excrementa felis cum digito bubonis adalligari iubent, $\&$ ne recidant, non remoueri tepteno circuia tu. Quis hoc quaro inuenire poturit? qux ue eft ifta mixtura? Cur digitus potifimû́ bubonis electus eft:Modeftiores iecur felis decrefcente Luna occifx inueteratum fale, ex uino bibendum ante acceffiones quartanæ dixêre, Plinius. Catæ ftercus cũ ungula bubonis in collo uel brachio fufpenfum, poff feptimam acceffionem, difcutit quartanam, Sextus. TCati agreftis fel ad oris torturam utilifí mum fertur:accipitur autem fellis catti nigri (cati fylueftres aptud nos non funt nigri, fed ex domefti cis quidam) dimidia drachma, (Albertus non rectè habet unciam) \& mifcetur cum zambach ponder re quaturor aureorum, \& fit fternutatorium, $\mathrm{R}$ afis \& Albertus. Fel cati, præcipue fylueftris, foctum mortuum ab utero extrahit, fi fubitus fuffiatur, mixtum cũ ftercore nigro alicuius cati , uel eiufdem cuius eft fel, Idem efficit fel eius, cum mifcetur aqux colocynthidis, $8 \mathrm{cmadidam}$ inde fpongiam (la: nam) mulier ori matricis indit, $R$ afis $\&$ Albertus, \& Pro ftercore felis, ftercus ichneumonis ufurpa ri polfe, in Antiballomenis Galeno adfcriptis legitur. Ad quartanam cata ftercus à fuperftitiolis alligari, paulo ante diçum eft. Cata (uel cati) ftercus ficcum cum finapi aquis ponderibus cum aceto cötritum $\&$ impofitum, capitis alopecias fanat,Sextus $\&$ Aefculapius. Spinam aliúculue quid faurcibus adhærens, felis extrinfecus fimo perfricatis, aut reddi aut delabi tradunt, Plinius. Cata fert cuš contritum recens purum illínitum faucibus fine difficultate extrahit fpinam, Sextus. Cumrefin na 8 rofaceo fuppofitum, profluuitum mulieris reprimit, Sextus: At Plinius hoc idem remediumex ulcerationibus uuluarum impofitum prodeffe fcribit, id quod magis placet : nam adipem uulpium quocs, 8 medullam uituli in uino ex aqua decoctam cum feuo idem praftare ait, Fimus carifuffi: tus $\&$ illitus fortum mortuum expellit, Author obfcurus,

H.

बa. Feles nomen, ut Grâmatici quildam ưolunt, tam mafulini quảm fominini generis: Valla in foeminino genere utitur: funt qui mafculini tantum generis faciất, manifefto errore. Mantuanus $T c$ ciurugos feles dixit. Felis aurea, 6,29. Ef $\&$ apud Calium Calcagninum $\&$ V allam Herodoti inter pretem hac felis:eft 8 meles foem.generis a pud grammaticos. Ne feles aut meles, aliáue qux beftia intrare poffit, Varro 3. "Ific etiam Ge.Alexandrinus legit:grammatici quidam recêtiores in Dictio narrís, felis \& melís legunt. Phil.Beroaldus quoç feles protulit. Catus uel cattus, à capiêdo dicuts uidetur recentioribus, ut qui mures $\&$ aures captet. Ego potius tanquam cautum $\&$ aftutữ ita dictum crediderim. Catos enim olim fapientes $\&$ callidos appellabunt, unde $\&$ Catones primum dictos $10=$ lunt. Sed homo catus nunquam terminat, nec magnitudinis, nec diuturnitatís modum, Cicero Tus

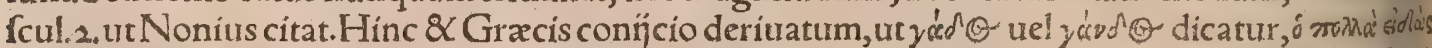

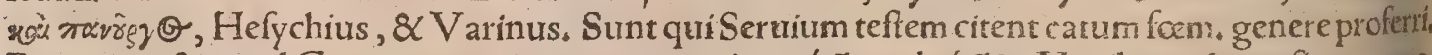
Reperitur \& apud Gręcos recentiores grammaticos náz:

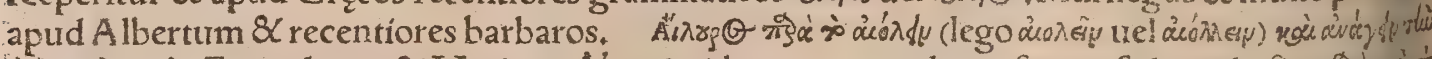

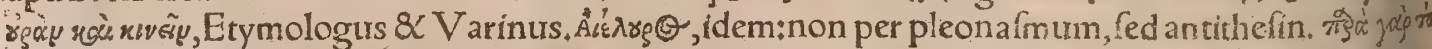

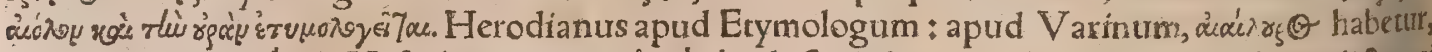

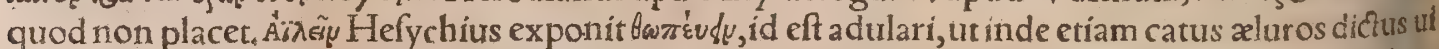

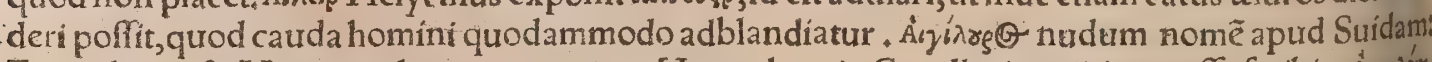

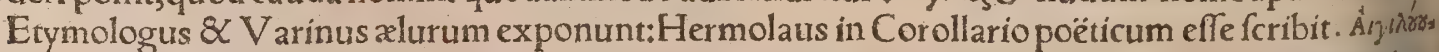
¡o quinç fyllabis, carabus, id eft locufta (ex oftracodermorum genere) exponitur:ut etiam xgipy =

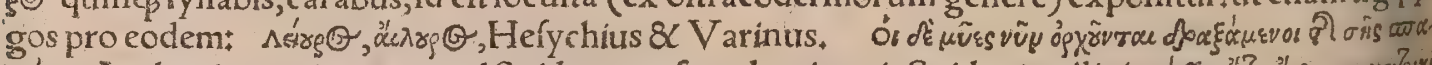

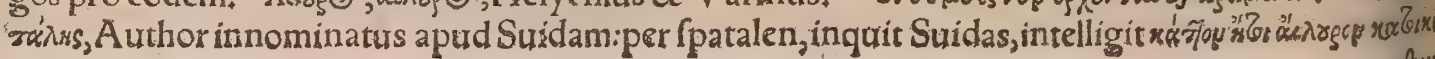


dicam $\& x$ de Z ibetti cato, in Panthera. Pifcen cattam, uel cattum algarium Itali uocant nuftelum leurem \& ftellarem. Tati fons, ex quo aqua Petronia in Tyberim fuit, dictus quod in agro cus iufdam fuerit Cati, Feftus. Cati, Germanix populi, Sicambris finitimi?hià Plinio 4.14. Chatti dicun

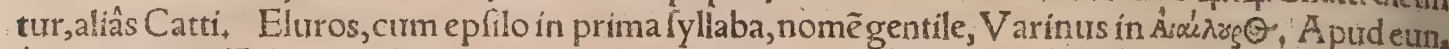
dem tamen in E. legitur Elluros per 1 duplex, nec aliter quàm nomen gentile exponitur: \& rurfus

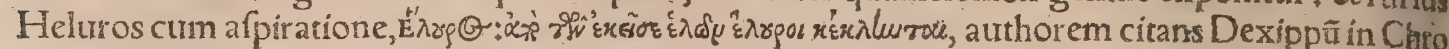
nicis, \& rurfus monens per epfilon fribendum cum gentile eft + cum animal fignificat per ar diphis thongum. Cum autem Heluri populi à paludibus dicantur, a fpirandũ effe hoc uocabulum, 81 fima plici frribendum ex Gracęlingua proprietate apparet. Erafmus in prouerbio Minerua felem, non rectè attribuit Etymologo quod in eo non legitur, pro animali fcribendum dicens "̈irpou per es quafi torquicaudam aut trahicaudam, fic enim iple loquitur.

i c. Qui multum fternutant, dicuntur à noftris cum catis ediffe. Pici fcandunt in fubrectum fe lium modo, Plinius. Et felis inftar exeuntes é rimulis mures uenatur, Aurelius citante Perotto, Sićḉs repugnabant uotis contraria uota: Non fecus ac muri catus, ille inuadere pernam Nititur; hic rimas oculis obfertuat acutis, Mantuanus in Bucolicis,

afd. Ibis in palmis ad euitandos feles nidificat : non enim facile in palma ob eminentem $\&$ culs tellatum trunci corricem ị fape repulfi \& reiecti, furfum correpere poffunt, Gillius ex Aeliano. Vulpanfer ab aquila $\&$ felis $\&$ caterorum hoftium fuorum iniurńs fe defendit $\&$ propulfat, A elia. nus. Beluas etiam in cos â quibus beneficia acceperunt, uehementer grata effe, teffimonio funturel Aegypti admodũ fera animalia, feles, ichneumones, crocodili, Idem. Iani Lafcaris epigramma ex, tat in caniculix fociam galen (felem intelligit ut uidetur ${ }_{5}$ ) 8 opem ei ferentem.

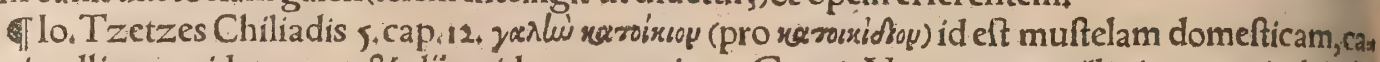
tum intelligere uidetur, ut \& alï quidam recentiores Graci. Narrat autem illic in quantis delicijs hoc animal fuerit apud Monomachi imperatoris uxorem: quæ indito ei barbaro nomine Mechlems

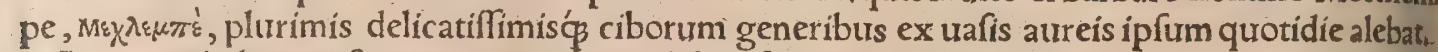
đCatus aut belua per foramen intrans quid fignificet per 12, figna Zodiaci, Luna in fingulis exia frente, explicatur ab Aug. Nipho de augurịs lib, 1, tabula feptima. TCum Gigantes adurerus deos pugnarent, deorũ alin alias fibi formas induêre, Fele foror Phoebi latuit, Ouidius lib. 5. Metam, A cfopus puellam fuiffe alurum fcripfit, \& quidem ita praftantem forma, ut inuidiam in $\mathrm{Ce}_{\text {Vene: }}$ ris concitarit:qua Venus percita priftinam formam abftulit, nouam intulit, nec eam tamen dege.

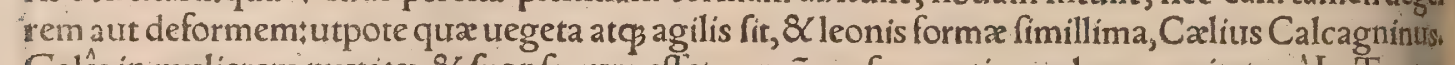
Galês in mulierem mutatx, \& fponfa cum effet murẽ perfequentis, apologus recitatur à lo. Tzetze C.hiliadis quartæ cap. 11 . Item uulpis \& felis colloquium apud Erafmum in prouerbio. Multa notil uulpes, ubi ingruente canum ui feles fubfilït, uulpes relicta capta eft.

Aegyptiorinm mores quis ignorat? quorum imbuta mentes prauitaturm crroribus, quamuis carnifícinam potis fubierint, quàm ibim, aut afpidem, aut felcm, aut canem, aut crocodilum uiolêt, Cicero. Et alıbi, Ipfi quorum uanitas ridetur Aegyptï, nullam belluam nifi ob aliquam utilitatem confecrauerunt, ueluti felem quod pelle eius fcuta contegant. Ego fuperftitionis gratia magis quàm utilitatis, felium pelles A egyptios fcutis induxiffe putarim: nam cum molliflima fint, ictibus refife re nequeunt ut bouina. Felem (inquit Herodotus lib. 2, interprete $V$ alla) incenfa ftrue diuina res

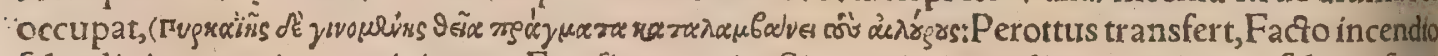
feles diuino numine corripiuntur: Ego fic uerterim, Si quando incendium contigerit, feles in furo"

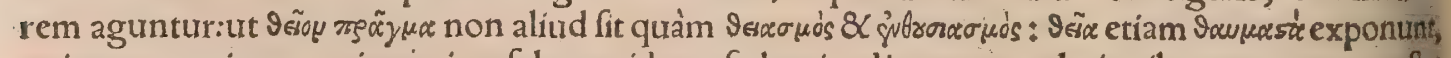
ut interpreteris rem miram circa feles accidere: fed ne in aliorum translationibus occuper, praftal ut reliqua ipfe transferam:) Nam Aegyptn̈ ab igne interuallo aliquo recedentes, extinguere neg gunt, feles tantum obferuant, (cuftodiunt, ne infiliant:) at illa uel fubeuntes uel fuperfilientes hio minum coetum in ignem ruunt. Hoc ubi fit, Aegyptus magno afficitur luctur. Cum uero in domo

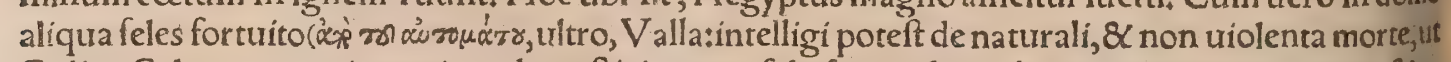
Calius Calcag.exponit)moritur, domeftici omnes fola fupercilia radunt:totum autem corpus \& $\alpha$ ca put, in quorü domibus fic moritur canis. Efferuntur feles mortux ad facra teça, ubi falf $x$ fepeliunts tur in urbe Bubafti:Hax Herodotus, Bubaftum A egyptia lingura felem nominari fupra dixi. Gen: tes aliquas qua felem auream pro deo habuerint circa Syenen fuiffelegimus, Gyraldus. In R hadata (oppido Libya circa Nilum ad Arabia latus)felis aurea pro deo colebatur, Plinius 6。29. Nibilme poenitet interdum (uerba funt Calí epiftolicarum quæftionum lib. ..) æluro, feu mauis felem appel. lare, blandiri.Cur enim mihi illud iocanti uitio detur, quod A egypcus ferium atque adeofacrum lia bet. Nam inter bruta quæ nimis fuperftitiofe colit, æluro tanfum tribuit, ut in eos qui reliqua fponte uolenteś́s interemerint, decretum fit fupplicium capitale: quod fi cafú aut certe nolentes fecerint, fcelus prafcripta mulcta poffe expiari putant. Sola felis inter quadrupedes (Herodotus libro 2 in terprete V alla, ibim 8 accipitrem adeò facras haberi ait, ut fiue tiolens fiue nolens aliquis necaure rit,neceffario morte afficiatur:) inter auitia ibis, nominatim excipitur:has nolens uolénsue quisle: 6 tho dederit, crimen non nifi capite luitur. Cuius rei tanta religio fuit, ut Diodorus in fecundo Bi: bliotheces fidem atque oculos fuos in teftimonium adducat: quum atate Ptolemæi, inita nuper ami 
serdum: fimiles domefticis per omnia, maiores tantum, denfioreḉs 8 oblongiore pilo: Colore fuffit, uel ut Albertus loquitur gríei, Quem ego circa finem Septembris apud nos captum confideraui, his iufmodi fuit. Longitudinis à fronte ad extremam caudã, dodrantes quatuor. Linea nigra per dor fum defcendebat; in pedibus etiam \& alibilineę erant nigræ. Inter pectus \& collum macula latiuffula ex pilis albifimis, Reliqui corporis color ubiq̧ fufcus, curi in dorfo paucus ruffus in unum colorem mi. fcebatur, ad latera dilutior, id eft cinereo propior;inter crura pofteriora circa clunes ruffus, Calli imat digitorum in pedibus nigri, $\&$ pili circunqua $\not$ concolores, $C$ auda craflior quàm domefticis, tres pal mos lóga, duobus aut tribus orbibus nigris diftinća: extrema pars palmi lógitudíne tota nigricabat,

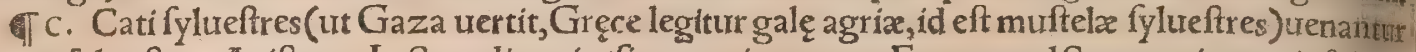
mures fylueftres, Ariftot. In Scandinauia (fic uoco ingentem Europa ad Septentrionem infulam) âlyncibus capti urorantur, Olaus Magnus.

TE. Canibus immiffis capiuntur, uel impetuntur bombardarum globis arboribus infidẽtes. Se pe ruftici plures arborem circumftant, \& felem defilire coactũ fuftibus caedunt. Felemóćn minacem Arboris in truncolongis prafigere telis, Nemefianus. I Pelles earum cum pilis ad ueftium ufum pa rantur, ut ex alijs etiam feris:priuatim uero tibialia \& manicæ inde fiunt, pilis introrfum uerfis, cum artus refrigerati aut arthritici funt. Pilus admodum mollis, fed pinguiufculus eft:ideọ̧́ facile côglo batur, \& minus placet in ueftitu. Catifylueftres fumum rutz $8 \mathrm{C}$ amygdalarum amararum fugiunt, Rafis. Muftelas quoç rutam fugere legimussitem catos domefticos, ut fupra fcripfimus.

I $F$. Cati agreftes temperamento propinqui funt leporibus, caro corum calida $\&$ mollis eft, $R_{a}$ fis. Apud nos etiam in cibum ueniunt aliquando, capite fere $Q$ cauda abfcifis. Sunt qui fatis lauts: tos affirment, alin abhorrent propter domefticorum fimilitudinem, quibus apud nos nemo vefcituri

đ G. Felis fylueftris pinguedo á quiburdam reponitur, calefaciens nimirũ, molliens \& difcutiês, magis quàm domeftici. V tuntur ea in morbo articulari, alias quoç pinguedines cum herbis ad eun dem affectũ facientibus contufas in anfere affantes, ut in Anfere dicemus, Ego excoriatũ aliquando hoc animal longè pinguiffimũ uidi. Diuerfa ex huius feræ partibus, carne, adipe, felle \& fimo, reme dia, ex fententia Rafis enumerauri fupra inter domeftici cati remedia, cũ non aliud intereffe uideatum quàm quod ex fylueftri omnia fint efficaciora. बSylueftres maximè feles ad morfos à crocodilis ob contrariam quandam affectionem accedere confueuerunt, Aétius 13,6. Galli lupum ceruatium quoç catum fylueftrem nominant, quem Itali quidam lupum catum.

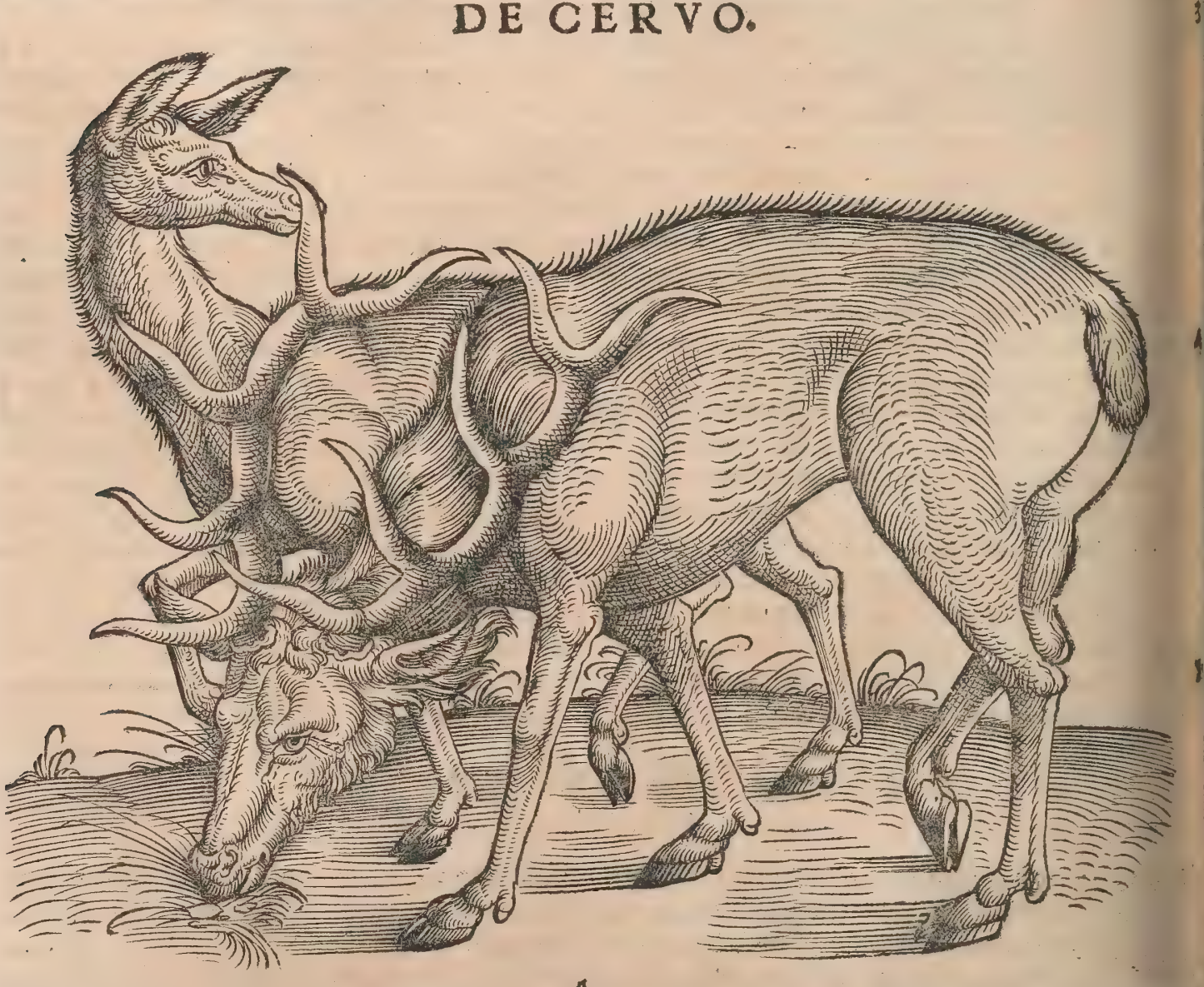

A.

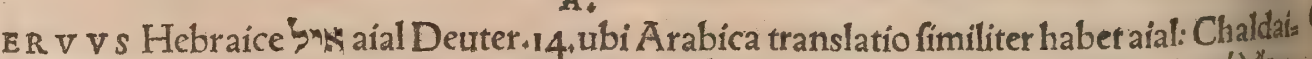

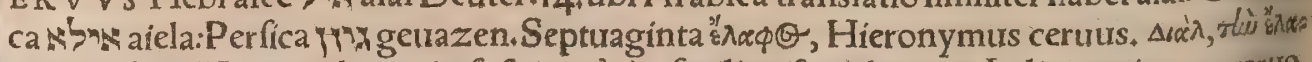

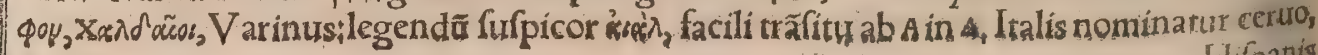




\section{De Ceruio. A. Lib. I.}

Hifpanis cieruo, Gallis cerf, Germanis birts uel birs, uel birfw: Anglis harte, Illyrijs gèlen+Polonis

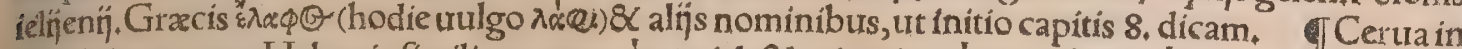
fominino genere Hebrais fimiliter utmas, ua, Hifpanis cierua, Gallis biche: Germanis \& Anglis binde uel bițin, quidam primam fyllabam pery alí per î fcribunt, quorum neutrü placet in lingua Germanica : In eadem certam alứ byn alî pithredit appellant. Poloni laní, quo nomine tamen damam quoq̧ interpretantur. ol In eodem

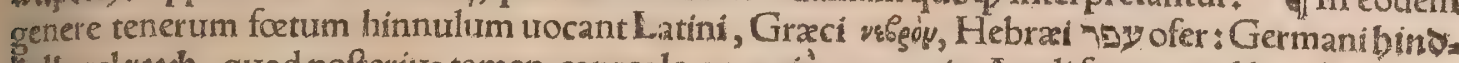
Ealb uel reeb, quod pofterius tamen capreolo propriè conuenít. Angli faurune uel hynde kalfe. Bimis cornua primum oriuntur fimplicia $\&$ recta, ad fubularum fimilitudin $\tilde{e}_{\text {; }}$ quamobrem fubus. lones per id temporis eos uocant, Ariftoteles 9. 5. hift. animal, interprete Gaza. Ariftoteles Grace

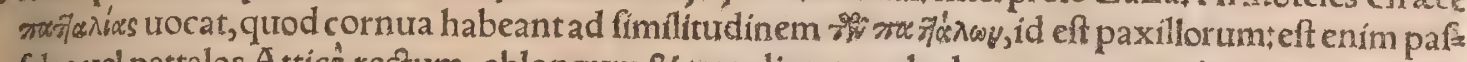
falos uel pattalos Atticé, rectum, oblongum \& teres lignum, ab altera parte acuminatum, ut parieti. bus infigatur (hinc etiam dictum uolunt ảe motraresy quod eft infigere) ut fufpendatur ab co alis quid. Eiufdem feré figuræ fubula inftrumentum cerdonum eft, qưo ad perforandos calceos ac fuen. dos utû̃tur. Hinc fubulones cerui, quibus cornua fimplicia, minimę́́ ramofa ad fubularum fimilí tudinem. Alijs fimplicia cornua natura tribuit, ut in ceruorum genere fubulonibus ex argumento dictis, Plinius lib.n1, Germani ceruum huiufmodi uocant fpifbirty, Angli fpyttarde. Cerui parui, fin bulones, Italis cerbiati, Arlunnus, Galli proprium uocabulum non habent, ipfa uero fubulonis 8 anniculi cerui cornua boflas, id eft tubera appellant, ut quidam fcribit, quæ apparent antequã ena 10 fcatur cornu:id quod non placet, nam fubulonibus ceruis cornua fubularum inftar iam apparent. Cerui pulmonem, maximé fubulonis, ficcatũ in fumo, tritum's in uino, phthifico quidam profuifle fcripferunt, Plinius, Et alibi, Efficacior eft ad id fubulo ceruorum generís, Sed de fubulone uoce pro sibicine cui libet plura leget apud Crinitum 18.13 . Vbi prater alia, De fubulis (inquit)notum eft om: nibus acceptas effe pro mucronatis fpiculis; quorum fit ufus in lanificḧs ad pectenda uellera:(Gera mani id inftrumentum uocant bedblet,; Itali pectinem) Hinc illud ab Anneo Seneca dicitur, indi; gnum effe pro dís hominibusís in aciem fufcepta fubula armatum defcendere. Sed hoc Seneca te ftimonium fubulam uel fubulas pro inftrumento lanis pectendis uel carminand is apto nó fufficit, fed proinftrumento cerdonum potius accipienda fubula (unde Germanica uoces defcendunt, fü luj per fyncopen, \& per metathéin alfen) in uerbis Senece uidetur cum fingulari numero protule 3o ritnam inftrumentum lanificio paratum ex plurimis in circulum fixis $S C$ rectà rigentibus confta fubulis, Subulæ etiam dici polfunt quauls mucronata ferramenta teretia, oblonga, qualia capulis infixa cum cultris femper in eadem uagina minimo loculamento condi folent. Emuthiss, genus cer. ui,uel certa ætas cerui, Hefychius \& Varinusteundem mozianiay effe conịcio: fpathe quidem gla dium $\&$ cultrum fignificat + uide mox in Achainis, Subulo eriam lingua Hetrufca dicitur tibicen: Ennius, Subulo quondam uicinas (aliâs marinas) propter aftabat aquas, aliâs plagas, Feftus.

TAchainis ceruis cognomine fel contineri in cauda creditur, Arifoteles 2,15 , hift, animal. Gra

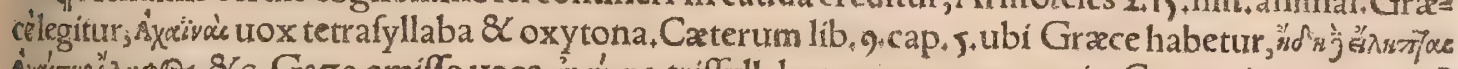

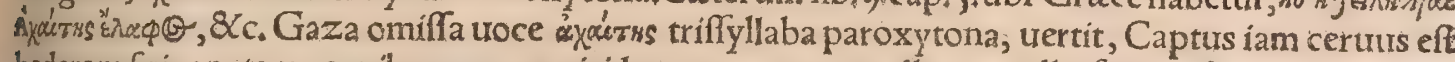
hederam fuis enatam cornibus gerens uíridem, quae cornu adhuc tenello forte inferta, quafi ligno

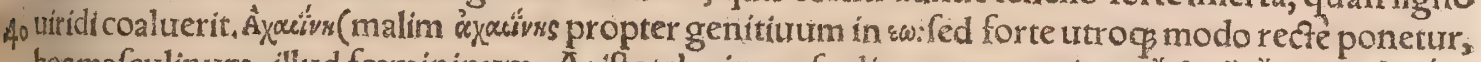

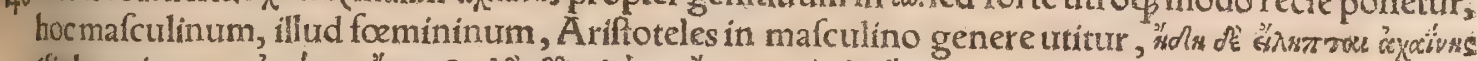

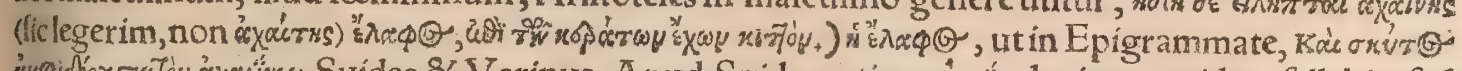

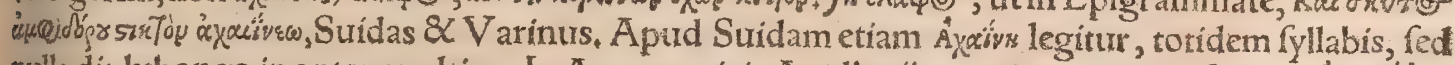

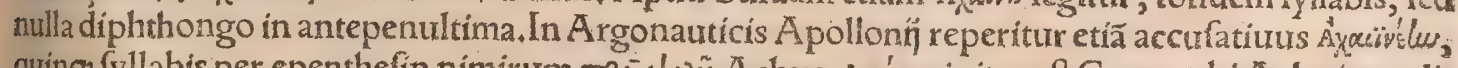

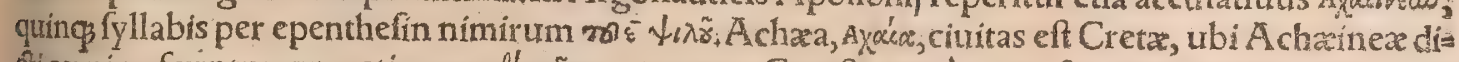

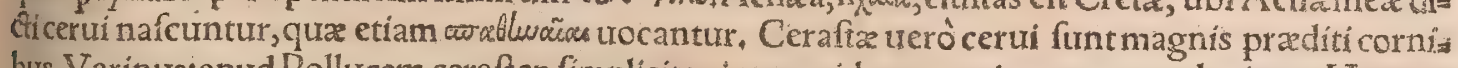
bus, Varinus:apud Pollucem ceraften fímpliciter inter epitheta cerui pro cornuto legimus, Hermo laus in Corollario, Genus ceruorum(inquit)prægrande, Græci Echæineas(lego Achæineas) ab op: pido uocant: Ariftoteles A chęnas(melius A chainas quatuor fyllabis)cognominat. Atqui Varinus so ceraftas, non Achaineas, ceruos magnis cornibus, non fimpliciter magnos, appellari fribit. Sed Her

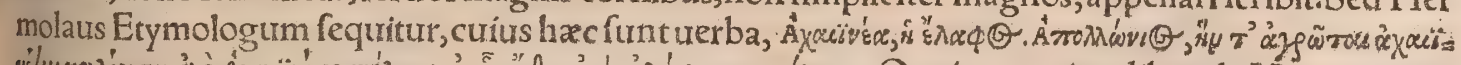

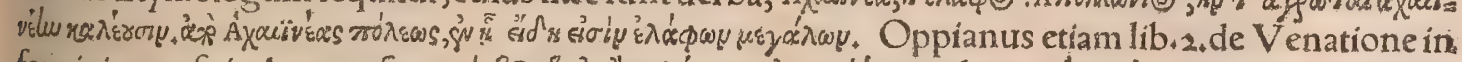

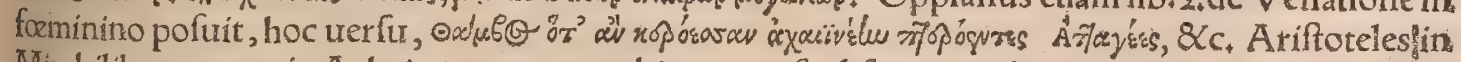
Mirabilibus ceruos in A chaia cum cornua abiecerunt, fe abicondere dicit, (quod lib. 9. cap. s. hiftor. animal.de ceruis in genere dixerat;) 8 multis in cornum loco hederam innatam apparere, ut Gaza

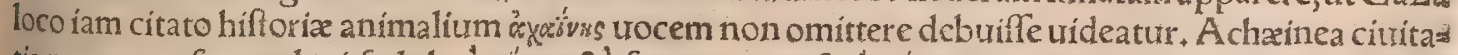

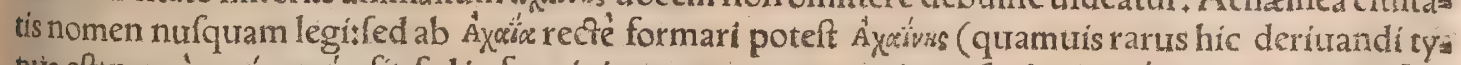
pus eftrnam à recíx rgeivs fit, fed in foeminino genere tantum, in mafculino roceirss, iuxta quam for

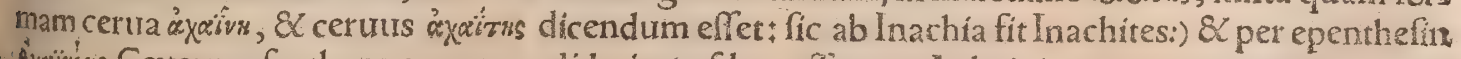
60 Axäiv kws. Cærerum fpathenæas non crediderim eofdem efle cum Achainis: cum certam cerui atatem eo unx denotet, \& a figura cornuum deriuata fit, ut fuperius docui. Cydoniata fuperioribus annis uicatim habitabant, poftea Lacones $\&$ Achai conuenientes habitauerunt, \&c. Strabolib; 10, Hine 
uerifimile eft locum aliquem apud Cydoniatas Achaiã ab incolis dictum effe:cum in reliqua Creta cerui effe negentur. Mirabile in Creta (inquit Plinius) ceruos præterquam in Cydoniatarum regio.

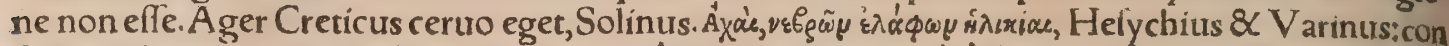

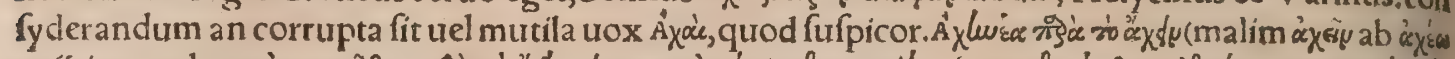

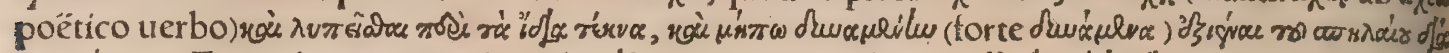

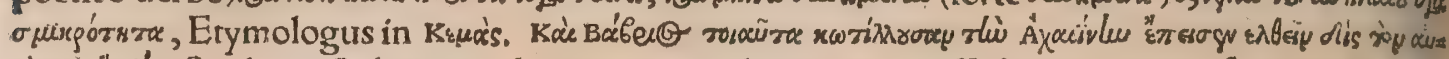

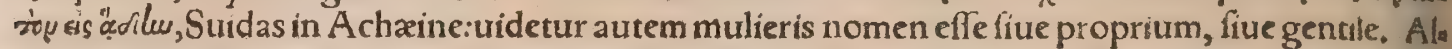
hertus \& alij barbari A kanes uel A hane fcribunt, tanquam diuerfum à ceruo genus: led hac india gna funt memorari. Axxaíy s apud A thenaum lib.3.genus eft magni panis quod in Thefmophorns tiebat, qux inde etiam Megalartia dicebantur, folebant autem adterentes dicere, Ayáchlu, staz

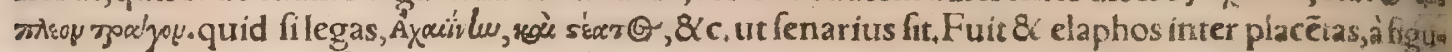

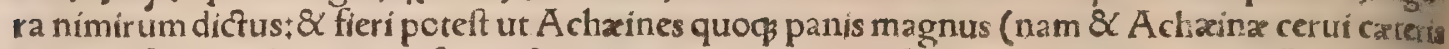
maiores feruntur) cornutus fuerit, 8 inde eriam tragos, id eft hircus appellatus. $\mid$ Gordtani iyh. ua memorabilis picła in domo roftrata $\mathrm{Cn}$. Pomperi picturas animaliü diuerfas continet, in:er qua funt cerui palmati ducenti mixtis Britannis, Iul. Capitolinus in Gordiano primo. Cerui palmati qui fint nufquam reperio + conício autem effe quos uulgo damas uocant, $\mathrm{G}$ i æci dor cadas platycerotas, Alia enim damæ fuerunt, ut fupra docui, quas Plinius \& alij nimir um ueteres ita appellarunt:pro inde non eft quod quis obriciar in eodem piciorum animalium catalogo damas etiam à Capirolino nominari. Quamobrem cum platycerotes cerui (nam ceruis Oppianus adnumerat) Latinum nomẽ aliud non habeant, $\&$ cornua eorum, ut Plinius frribic, natura in palmas finxerit, digitosós emiferít ex ił́s,ceruos palmatos appeilare non dubitabimus. Eadẽ ratione palmata grammaticis quibufdam dicta uidetur à latitudine clauorum, piça poftea a ppellata à genere piciuræ: alịs à palma in ea inte. $\mathbf{x t a}$. Hanc merebantur trium phantes, ut qui de hoftibus palmam reportaffent. De Britannicis etiam ceruis, quorum unà cum palnatis Capitolinus meminit, certi nihil habeo : audiui tamen $\&$ alhos \& nigros ceruos nuftro tempore in Britannia reperiri; Albos quidem etiã Romæ fibi uifos Paufanias fcribit, ut inferius recitabo. Et forfitan quoniam eodem numero utrun $\varphi_{p}$ genus comprehendere uo: luit $C$ a pitolinus, congeneres aut faltem ex peregrinis utriq̧ regionibus adducti fuerint, Inueniunis tur fané rangiferi hodie dicii, ad Europa Oceanum circa Septentrionem, ceruorum generis, quil palmata, ut audio, \& latiufcula habent cornua, quos Iulius Cafar fortaffis inteilexit, ib, 6, belli Gal, his uerbis. Ef (in Hercynia fylua Germanix) bos cerui figura, cuius à media fronte inter aur es unî̉ $3^{\circ}$ cornu exiftit excelfius, magis $\not ́$ direćum his quę nobis nota funt cornibus:ab eius fummo ficut pal ma ramićs late diffunduntur:Sed de hoc plura in Rangiferi hiforia. In Scythia natio quadamfer ror um hominum eft, qux ex feritate ceruos in eam manfuetudine traduxit, ut in cicuribus illis tath quam equis infideat, A elianus. Fortaffis etiam Scythici ifti cerui, rangiferifuerint. Habent $\&$ alces lata cornua \& digitis diffincta, feḍ Capitolınum de ịs non intellexiffe coniftat, quum paulo poft feor fim nominet. If Ceruns cicures equitant in Ocdor regione A fiæ ad Oceanum Septentrionalem. In Scythia plurimi cerui funt, Solinus. In Heluetia noftra minus hodie quàm olim ahundant, quiod fylux propter frequentiam incolarum indies minuantur, \& uenari cos minus inter dićtum propter demociatiam, quàm apud alıas gentes qua principibus parent, Ceruus nullus eft in Africa, Ariftoteles \& Herodotus lib.4 \& Plinius: Idem alibi, Ceruos A frica propemodum fola non gignit, $4^{\circ}$ A pud Philofratum tamen legimus A pollonium ultra Catadupa Nili ceruos \& capreas inuenife. Mirabile in Creta ceruos, praterquam in Cydoniatarum regione non efle, Plinius. A ger Creticus ceruo eget, Solinus. In Helleíponto in alienos fines non commeant cerui: $8 \mathrm{C}$ circa Arginuffam Ela tum (aliàs Elatium, quod probar Hermolaus in codicibus manu friptis repertum, non Elaphum, Arifloteles, inquit idem, Elatoenta uocari tradit, ex abietum, ut arbitror, frequentia : Grxci quidem

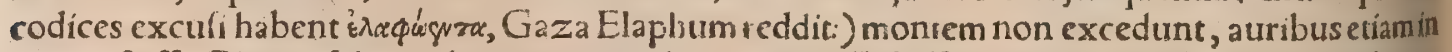
monte fciffis, Plinius. Idem alibi ceruis omnibus aures effe fciffas ac ueluti diufifas feribit. Aeliantu horum utrung ${ }_{3}$ (id eft loci in quo funt fines nó excedere, 8 auribus effe fciffis) ceruis Hellefpontia cis tribuit. Arifioteles îs qui circa Arginuffam funt, pofterius tantum, fed uerba eorum adíciam. Monte A fix Elapho nomine a pud Aryinuffam, quo loco Alcibiades mortem obít, cerux omnes y friffa aure funt: qua nota uel alibi, fi loca mutarint, dignof́cũtur : Et quidem foetus iam inde à primo ortu in utero idem contrahit fignum, Aruftotel.Ceruus (inquit A elia nus) prælentibus palcuis onni anni tempore contentus, alia non defider at. Nam in Hellefponto collis eft, ubi cerui, quorum aliera diffiffa eft auris, fic pafcuntur, illius extra fines ut nunquam progrediãtur. Sed cerui omnes natalis foli amantifimi funt, ut infra dicam cap. 4. Arginufx Straboni iib, 13. tres funt partux infula contis nenti proximæ, ante Afiam prope Lesbum, inter Mirylenen \& Methymnã. Plutarchus Alabiadem in quodam Phrygix oppido, curius nomen non fit expreffum, interemptum feribit.

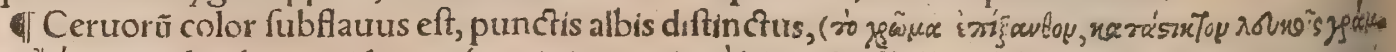

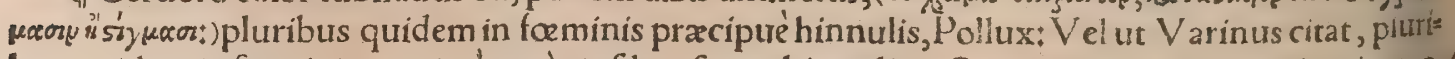
bus quidem in foeminis, maximéueró eiufdem fexus hínnulis. Ceruinus nominatur eciam incer e=6 quorum colores. Ceruus aliquando albus inuentus eft, \&c. Ariftot. in libello de coloribus: Ruellius Ariftotelis locum fic reddit, Animantes cuncix, quax fiue imbecillitatis caufa, fiue caco naturę nitio 


\section{De Ceruo. B. Lib. I.}

pracoci paurcó̧s uiciu fuftinentur, candidx proueniunt: fic lepus inuenitur candidus*item cerrus

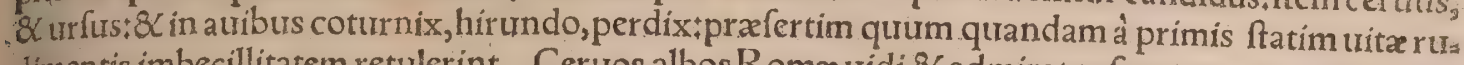
dimentis imbecillitatem retulerint. Ceruos albos $R$ oma uidi $\&$ admiratus fum, ex qua uero regio ne uel Continente, trel infulari aduectx effent, non uenit mihi in mentem interrogare, Paufanias in Arcadicis: Vide pauló fuperius in Britannicis. Apollonius \& comites $\mathrm{Paracã}$ Indiz urbem pra tergreffi, cum non multum adhuc proceffiffent, fiftulx fonitum audire uifi funt, quafi paftoris gre gem colligentis, ac fubinde paftorem uiderunt, qui albarum ceruarum gregem pafcebat. Mulgent autem ipfas Indi, quod earum lac maximum effe nutrimentư putant optimumó̧, Philoftratus lib. 3. Funt aliquando $\&$ candido colore, qualem fuife traditur Q. Sertorï ceruam, quam effe fatidicam Hípanixgentibus perfuaferat, Plinius. Alba cerua Sertorius quidam uír acer 8 egregius dux, ad barbarorum militum fuorũ animos continendos conciliandosćp utebatur. Siquidem hanc, qua à Lufitano quodain (in ipfa Lufitania capta)fibi dono data effet, oblatam diuinitus $\&$ inftinctam Dia næ numine, colloqui fecum moneré $\$$, \& docere qux utilia factu effent, mentiebatur: Ac fi quid du rius uidebatur, quod imperandum militibus foret, à cerua fefe monicum pradicabat, Vide Gellium lib.15. \& Plutarchum in uita Sertorí. Timida animalia pilum mollem habent; ut ceruus, lepus, oures, Ariftotel, in Phyfiog. Saginam uel pinguedinem cerui, Galliuocant uenaifon.

1. Ceruis cornua funt excelfa, oculi magni, collum debile, cauda exigua, crura perquam gracilia,

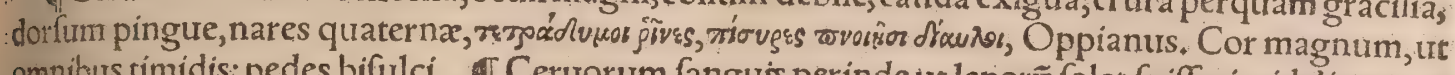
omnibus timidis: pedes bifulci. Ceruorum fangurs perinde ut leporũ folet fpiffari, uidelicet non 20 coitu firmiore, ut cæterorum, fed fuido, quale lac elt, quod fine coagulo fponte coierit, Ariftot. Cer= uorum fanguis non fpiffatur, Pliniưs, Ceruorum fanguini fibre nulla infunt, quare non fimiliter ut aliorum concrefcit, Ariftot, Idem quarto libro Meteororum, ceruínum fanguínem nó coire fcribił* quoniam aquæ naturam magis fapit; ac frigidifimus eft; $\&$ propterea fibris carer; qua opera terra funt folidæéç confiftunt, Calius.

Cerui pulcritudine $\&$ magnitudine cornuum ramofor omnibus feris facile antecellunt, $\mathrm{Op}$ pianus. Bifulcis (inquit Plinius) bina cornua natura tribuit; nulli eorum fuperné primores dentes. Quiputant eos in cornua abfumi, facile coarguuntur ceruarum natura, qua neç dentes habent, ut neq mares: nec tamen cornua. Cæterorum offibus adhare $\mathrm{e}$; ceruorum tantum curtibus enafentur. Cornua quadam in ramos fparfit natura, ut ceruorum, Plinius, Et alibi, Omnibus caua, 8 in mu 30 crone demum concreta funt:ceruis tantum folida, 8 omnibus annis decidua. Ceruo ex cornige= ris uni cornua tota folida, \& fparfa in ramos, \& quotannis decidua, tum utilitatis caufa, ut onere leventur, tum ex neceffitate præ pondere, Ariftos. Et rurfurs, Ceruis quoniam cornua præ ninio cx. ceftu fuperuacua funt, alterum h̋̉s auxilium natura adhibuit, nempe uelocitatem + grandis enim illa \& multifida cornum magnitudo potius obeft quàm prodef. Orpheus in 1ibello delapidibus cer uinum etiam, cornu celebrat, quod foliditate 8 duritic ad lapidum naturam accedat : Ques $y^{\prime} \mu \mu^{\prime}{ }^{*}$

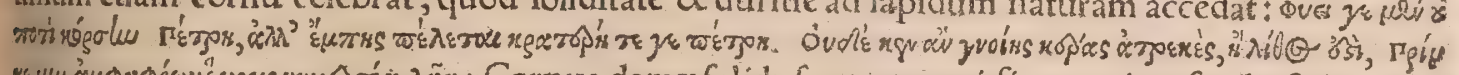

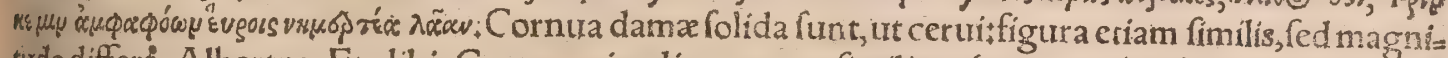
turdo differ', Albertus, Et alibi, Cornur animaliurm ceruo fimilium (ut capreoli, platycerotis, alces) interius rarum $\&$ meatibus exiguis peruium eft, inftar fubftantia qux aliorum cornibus infigitur. 10. Ceruinum quidem cum aruerit, perquam leue redditur, prafertim fi fub dio fuerit, ita ut nunc humeat nunc ficceat:inureteratum enim hocmodo tam leue redditur ut euanidum \& inane uideatur: quod ipfe deprehendi in cornibus qux per fyluas à ceruis abiecta reperi.Cerui igitur $\&$ fimilium $a=$ nimalium cornua, terrex funt natura, calore ualido coaĉra, 8 ad off is fubftãtiam accedunt. Cæetera tuero his collata humida funt, \& molliri apta, cartilaginis naturæ uicina, \& flexibilia calore: quamob= rem non calore fed frigore concreta uifentur, ut intelligitur ex p̈s qua in Meteorologia docentur, Hac Albertus, Cornua mares habent, foliçanimalium omnibus annis ftato ueris tempore amit= unt, Plinitus. Soli ceruo cornua omnibus annis decidua, initio à bimatu:cateris perpetua, nifi per uim aliquam amittant, Ariftotel. Et alibi, Anniculis nondum cornua nafcuntur, nifi quoad indicip gratia fit initium quoddam prętuberans, quod breue hirtum ́́ eft. Bimis cornua primum oriuntur It fimplicia, \& recia, ad fubularum fimilitudinem, quamobrem fubulones per id temporis eos urocant, Trimis bifida exeunt, quadrimis trifida, atç̧ deinceps ad hunc modum procedit numerus ufiç ad an num fextum. A b hoc fimilia femper prodeunt, ita ne fit dignof́cere atatem ramorum numero. Pro atate ramos augent:id incrementum per fex annos perfeurerat:deniç̧ numerofiora nö poffunt fier conua, poffunt craffiora, Solinus. Indicia atatis in cornibus gerunt, fingulos annis adícientibus ramos ufp ad fexennes: Ab eo tempore fimilia reuiuifcunt: nec poteft atas difcerni: fed dentibus fe

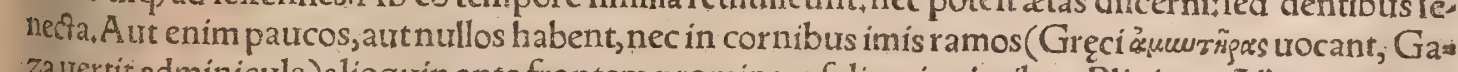
za uertit adminicula) alioquin ante frontem prominere folitos iunioribus, Plinius. Albertus incer tum effe fcribit quot ramos (ipfe culmos appellat) cornu certuinum producat: fe tridiffe quod unde= nos habuerit. Ceruos fenes (inquit Ariftot.) cum cornumu indicia defiêre, cognofcimus maxime 60 indicio duplici illo:dentes enim aut nullos, aut paucos habent, atç adminiculis carent:uocantur ad. minicula rami, qui imis cornibus prominent ante frontem, quibus in pugna utuntur iuniores: fenes autem carent:amitunt fingulis annis cornua menfe a prili, qua cum amifcrint, occultãt fefe inter. 
diu,ut fuperius dixi, idç̧ opacis faciunt locis, ut mufcarum tędio uacent:pafcuntur per id tempus nì ciu, donec recipiant cornua, qua primum quafi cute ueftita, $\&$ hirtiufcula emittunt: fed cum creue, tint, Soli exponunt, trt excoquantur, \& ficceant; ubi iam nihil attritu arborum, cum ea fcalpant, indo lent, tunc ea relinquunt loca, confifi habere iam quo repugnare poffint, cum res exigit : captus iam

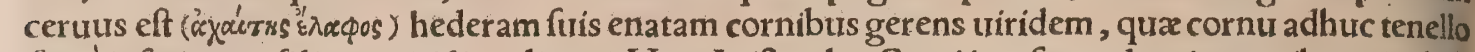
forté inferta, quafi ligno uiridi coaluerat, $\mathrm{Hac}$ Ariftoteles, Capti iam funt edera in cornibus uiridan. $t \hat{\epsilon}_{j}$ ex attritu arborum, ut in aliquo lignoteneris dum experiûtur innata, Plinius, A pud Âthenatum libro 8. quidam Ariftotelem reprehendit, tanquam incertum aut fabulofum hoc fit, quod hederam cornibus cerui adnatam fcribit. Audio Antuerpia cornua ceruina in pharmacopolio quodam fpectati, quorum fingula ramos circiter quindecim habeant, Erumpunt(ceruis cornua poftquam abiecerunt) renafcentiburs tuberibus primò aridæa cutis fimilia: eadem teneris increfcüt ferulis artin dineas in paniculas molli plumata lanugine. Quamdiu carent ĭs, nocibus procedunt ad pabula. In, crefcentia Solis uapore durant, ad arbores fubinde experientes : ubi placuerit robur, in aperta pro. deunt,Plinius. Exuuias illas anniuerfarias, quibus orbati latent cerui, quafi honore atco infignias miffo: non cornua, ut Latini, fed capur, quafi decus ferinû, appellant uenatores Galli (tefte de cerf, Cranij partes é quibus cornua enafcuntur Galli molas uocant. Stipitem corneum, quam materiem dicunt, aptè aiunt erumpere è molis fuis \& exiftere: qua fedimenta funt cornuum: (Gallicèle mara raín. Iecter fa tefte. Les meules:) tum tabulata ipfa fruticantia è molis concinnè in ramos effe expan, fa. Scapos è caudice pro portione enatos: é f́capis porrò cornicula educta in mucrones congrué defia nere:non contractiora ipfa quàm iuftum eft, non diffufiora, non abfurdè confornicata. Tum probe clauatum effe caput, (Gallice, tefte bien cheuillee;) $8<$ congruenter patulum, \& xquabili fruticatude corum (Gallicè, bien rengee, Ceruum egregium \& fpectandum fignificare uolentes, fic loquuntur, Capite præditus eft commodè nato, compactili, concinno, recté, ordine, decenter conftituto (Gallicè tefte bien nee, bien rengee.) Materiam ipfam caudicis pulchrè fulcatam effe, atọs inter fulcos ftriásue (quas quafi colliquias appellant atç ftillicidia) fcabritiem eminere aquabiliter unionatam: quod Bu dxo uerruculofam fignificare úifum eft. De ceruino capite quod ramos cornuum omnes habet, Galli dicunt tefte femee ou fommee. Iidem ceruum cum cornua iam nuda \& cute libera apparent, bruni trocitant, aut fynonymis (ni fallor) uocibus blond, ou faute. Infimi rami uerfus frontem re: cià procedunt, nec eriguntur : his enim pugnat ceruus (quamobrem Græci amyntêras uocant) reli quis uentilat, Albertus. Ramos cornuum qui è fuis tanquam ftipitibus prodeunt, Galli pritia: 3 tim cors appellant: $8<$ ex his primum, hoc eft amyntêra, prope molas enatum, endouiller uel entoils lier, urerbum quidem entouiller impedire eis fignificat: fecundum, furendouiller ou furentoilliet: reliquos, cheuilleures ( quafi clauos) ou cors : lupremos $\&$ in faftigio utriufos cornu, efpois : quos rurfus cum gemini tantum funt, nominant fourchie quafi partem bifurcam: cum terni aut qua terni, tronchure: cum quini aut plures, paulmure, quod palma inftar tanquam in digitos finda, tur (ut palmatus etian eiufcemodi ceruus dici poffit:) deniç cum perplures uerticis ramuli in or bem ambiunt, coronnee, id eft coronatam. Germani cornua cerui gemina uocant ein gebüth $8 \mathrm{c}$ ramos maiores fangen, eodem fenfu quo Galliperches, id eft perticas:minores, en De uel zincteth. Cornua adhuc tenera 8 . fimplicia mord i uel Eolben, qux in cibum nobilium 8 príncipum uenitut Cornua fi ramos impares protulerint, ipfa ramorum paria ab altero, quod plures habuerit, numerât, बQuadricornem ceruum Nicocreon Cyprius habuit, quem Pythio confecrauit, Aelianus. Cer uus cornua locis difficilibus amittit, \& qua inueniri nequeant; unde illud prourerbium ortum, Quá cerui amittunt cornua. Quafi enim fua amiferit arma, cauet ne inermis reperiatur. Cornu finiftum compertum effe à nemine adhuc fertur:occulit id enim tanquam quodam medicamento pradirum, Ariftor. Cornua cerui foliftato ueris tempore amittunt ; iøeo fub ipfa die quàm maximé inuia pe tunt, Latent amiffis uelut inermes, fed $\&$ hi bono fuo inuidentes. Dextrum cornu negant inueniri, ceumedicamento aliquo præditum. Id'̧̧ mirabilius fatendum eft, cum $\&$ in uiuarịs mutent omni bus annis:defodió $a b$ ịs putant, Plinius. Et alibi, Ceruus dextrum cornu terra obruit contra rubeta rum uenena neceffarium. Ego an abiecta cornua occultent, $\& \mathcal{L}$ dextrúmne magis, ut Plínius fcripfit, an finiftrum ut Ariftoteles, certi nihil habeo. Hoc unum addam conciliari forfan iftorum poffe diffi dium, dextri $\&$ finiftri acceptione uaria. Nam, ut A riftoteles docet lib.2, de coelo cap.2, dextrum uri, bus modis ufurpatur, uel propriè, ut in animalibus unde principium motus fit fecundum locum:uel ad fimilitudinem illius, ut in ftatuis: uel impropriè, quod rectà è regione dextro lateri noftro opponi tur dextrum, quod lauo lęuum:fic uates mundi uel coli dextra $8<$ finiftra accipiunt:hac ratione dex trum cornu ceruinum, ad nos quídem finiftrum dici poterit. Aiunt ceruos quoldã in Achaia, cum cornua abiecerunt, in loca illa fe conferre, ubi difficillimé inueniantur:idós eos facere, tum quia non habent quo fe defendant, tum quia dolent his partibus unde cornua exciderũt:multis uerò hederam in cornuum loco innatam uideri, A riftoteles in Mirabilibus. Eodem libro, Ceruos, inquir, in Epiro aiunt cornu dextrum (non finiftrum) humo obruere, id'ćs utile effe ad multa. Atqui hac ambo trim ipfe in hiftoria animalium, tum. Plinius, non Achaicis folum uel Achainis ceruis, fed quibufuis inge nere attriburunt. Cornua enciunt in aquas, ut quidam aiunt, ne dextrum inueniatur, tanquam ufum aliquem illius intelligant:Mihi tamen (inquit Albertus) compertum eft, hoc non in uniuerfun 


\section{Dc Ceruo.B. Lib. I.}

effe irerrim! intreni enim aliquando in fylua frondibus obrutum cornu finifrum. Ảegyptĭ longæetum fignificantes, ceruum pingunt: cò quod ceruis fingulo quoģ anno cornua germinent, Orus. A pud erndem legimus ceruum fuos dentes infodere, quod aliorñ, quod fciam, nemo tradidit. Cur aursem folis ceruis cornua decidant, multis rationibus explicari poteft. Primum ex materia qua con. ftant:quoniâ ficca \& terrea funt, ut ceruus iple totus, nempe hirco fimilis temperamento, calido fice cọ́̂çadunt autem facilius, ut in ftirpium quoç folís, qux ita funt arida ut nullũ habeant lentorem aut tenacem fuccum, qualis cæterorum cornibus ineft, cuitus gratia flecti molliríg̣p poffunt, Deinde ex loco, quoniam, ut diximus, non ex craneo nafcuntur ut reliquis, fed cuti tantum adh arent:tertio abefficientibus caufis:nam $\&$ calore æeftatis ficca duriora $q$ fiunt, $\&$ hyeme fubfecuta à frigore fimi:

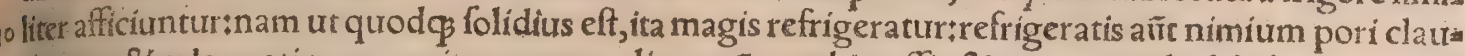
duntur, \& calor natiuus emoritur: ut neq alimentữ attrahi poffit, \& uix qua trahi debebat praclufre fint: quod in cęteris, cum omnium caua fint $\&$ uapores excipiant, non æque contingit, Sic igitur affe: ça cornua cadunt tantum, fitue offendentibus ipfis aut impellentibus ultro, aut inter ramos $\&$ uimina quandoģ implicatis, fiuc etiam fponte ipfo nimirum pondere depreffa $:$ non prius a titem hoc

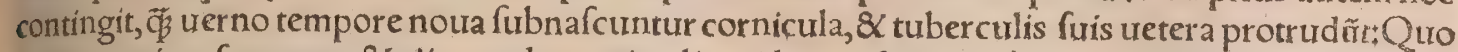
tempore etiam ferpentes $\&$ alia quędam animalia aridum induratumọ̧ ponưt extruiư, cuti noùa naz fente, Sed eadem de re Aelianû audiamus interprete Gyllio:Caufam(inquit)cer uis cur cornura re=nalcuntur, Democritus eam dicit, uentrem ijs calidifiimü effe, \& eorum uenas per uniuerfurm cors pus pertinentes effe rariffimas, \& $\mathcal{L}$ os quod cerebrum amplectitur, membranæ inftar tenuifimum \& 10 perrarum effe, indeḉ̧ ad fummum capitis uerticem craffifimas atq̧ opimas uenas exoriri : itaç ci= bum 8 huius nutrimentum minime concoctum, à natiuo calore in totum corpus eitusḉ́ parzeis dis firahi. Idemó̧ ait eis pinguitudinẽ extrinfecus circunfundi, fimul $8 \alpha$ cibi uim per uenas in caput re= torqueri, $Q$ reflecti, ex eo cornua permulto humore irrigata eñafci, Continenter enim uicinis ad ca: dendum fuccrefcentia $\&$ influentia funmouent, atque expelliñt priora, ac fané exortus humor ex= tra corpus durefcit ab aếre eum ipfum confolidante, \& in cornean durritatem confirmante. Humor autem qui etiam nunc intra cutem fubeft mollis, \& tener, partim ab exteriore refrigeratione durea fcit, partim ab interiore tepore tener manet, Quocirca recens cornu enafcens, \& intrinfecus premens, uetus tanquam alienum expellit, $\&$ fané humor concrefcens, ad depellendum antiquum ina frmuseft:at durefcens, priora extrudere poteft, quorum pleraç interno robore extrahuntur:non3onulla arborum ramis circumplicata $\& \mathrm{C}$ feram ad curfum incitatam ui impedientia abrumpuntur: Eo pacto uetera excidunt, recentia ad erumpendum parata, naturz munere proferuntur, Hacte= nus Aelianus. Cur ceruo quotannis cornua cadant $\&$ renafcantur, Hieronymus Garimbertus in libro Italicè frripto quaftione 43 . inquirit. Solet ceruus decus illud fuum quotannis extrere quart ternationem, reftibilíǵp fobole uelut materiam recidiuam paucis menfibus in integrum reftutuere,

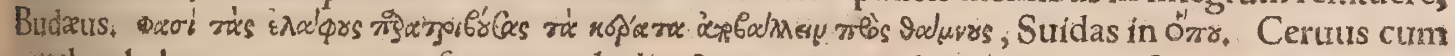
nondurm habet cornua, tamen fronte praludit, \& ea qua nondum expertus eft tela minatur, Ama brofius, - TCerui, ficum per ætatem nondum cornua gerunt,caftrentur, non ædunt cornua : fed ficornigeri exciduntur, non decidunt cornua, \& magninidine eadem feruantur, Arifot, Et alibi, Cervis tantummodo cornua omnibus annis decidua, nifi caftrentur. Non decidunt caftratis cor» 4ottira, nec nafcuntur, Plinius $\&$ Solinus. His ego auhhoribus potius crediderim quàm Oppiano, quà librode uenatione fecundo cerusis caftratis cornua defluere fcribit. Sed praftat uerba eius recitare,

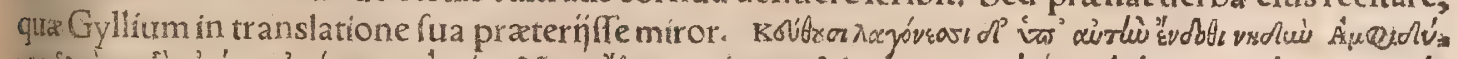

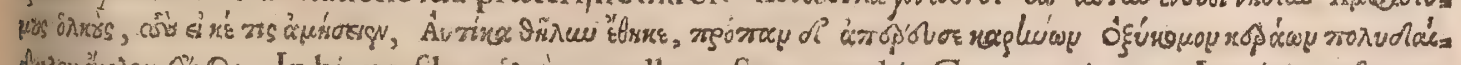

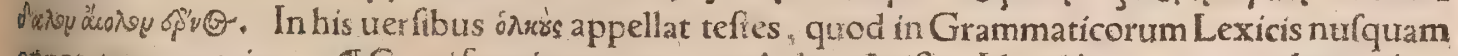
athotatum reperias. If Cerui foemina cornua non habet, Ariftot, Idem libro 3. cap, 2. de partibus animal,caufam afferens cur cerux cornibus careant, cum dentes fimiliter habeant atç mares, Eaz dem, inquit, utriufç fexus natura $8<$ cornigera eft $\$$ fed foeminis adempta funt cornua, quoniam ne maribus quidem utilia fint: fed uirium meliorum beneficio mares minus offenduntur. Pindarus in

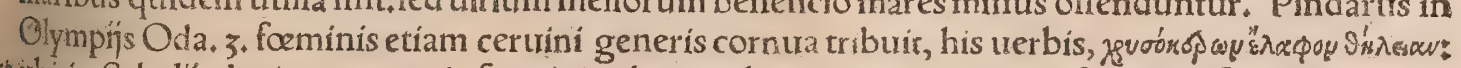
So ubi in Scholĭs legimus, ceruis foeminis ab omnibus poêtis cornua adfcribi: \& fieri poffe ut id

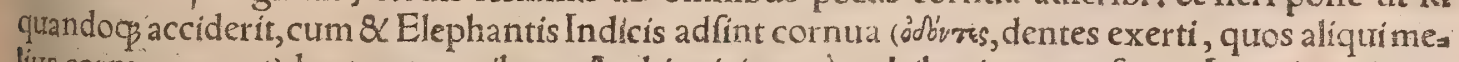
litrs cornua uocant)duntaxat maribus, Aethiopicis uerò ac Libycis utrọg fexu. Loquitur autem Pindarus de cerua, quam Hercules cepiffe fertur cornibus aureis. Pollux tamten in mafculino gene

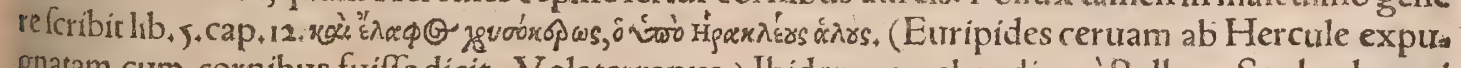
gnatam cum cornibus fuiffe dicit, Volaterranus.) Ibidem reprehenditur à Polluce Sophocles qui Telephi nutricem ceruam rop ósarav, id eft cornutam dixerit. Ceruam quax Telephum lactauit, picfo: res $\&$ plaftr cornutam faciunt, Scholia Pindari. Errat $\&$ Anacreon, inquit Pollux, qui cornutam

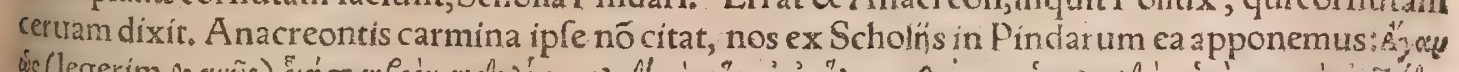

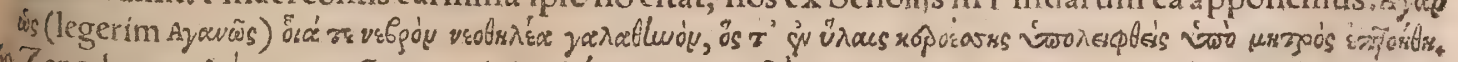

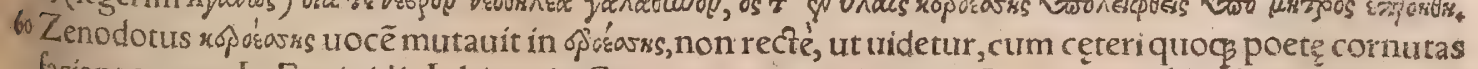
faciant ceruas. In Euripidis Iphigenia, Ceruam cornigerã (inquit Diana) manibus Achąorũ tradãa

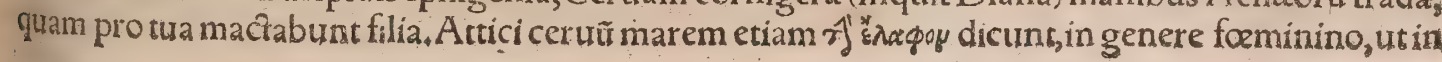




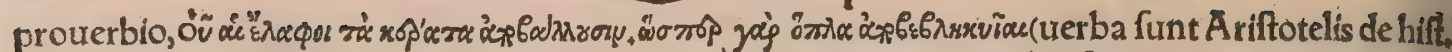
animal.9.5.qui focminas cornibus carere minime ignorauit, ut ex uerbis fuperius recitatis apparet:)

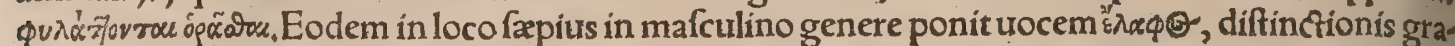
tia, qutoniam de foeminis quoç nonnulla priuatim in eo fcribit, Alijs uero in locis aut femper aur ut plurimum fiue aliquid fexui commune utriç, fiue mari proprium referat, formininam facit, ut in Mi

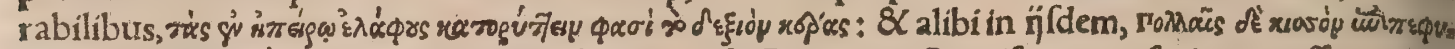

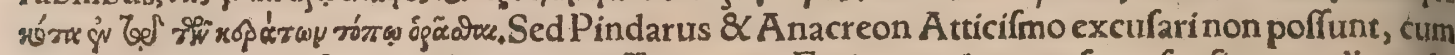
omnino fe de ceruis foeminis loqui exprefferint, TFacies ceruis carnof $a_{2}$ nafus fimus, collum ob. longum \& exile, Ariftoteles in Phyfiognom.

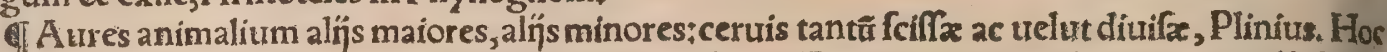
alibi non omnibus, fed ịs tantum qui circa Ärginuffam in Elapho monte uerfantur, aures effe fiffas fribit, ut Ariftoteles quog;: Aelianus Hellefpontiacis, ut fupra oftendi, GDedentibus etiã ceruo rum \& fenectutis ex eis indicio,nempe cum iam pauci uel nulli funt, in pracedentibus docui. Den. tes ceruo funt quatuor utrin ç tum fupra tum infra, quibus molit cibum: \& infuper alij duo magni, qui mari quàm formina maiores funt. Vergunt autem deorfum dentes cerui, ita utr repandi uidean, tur, Albertus 2.4. Vermes cerui continent omnes fuo in capite uiuos, qui nafci folent fub lingtrain concauo circiter uertebram, qua ceruicl innectitur caput, magnitudine haud minores ñs uermibus, quos maximos carnes putres adiderint. Gigni unituer fi at ̧̣ côtigui folent, numero adeò circiter ui, ginti, Ariftotel, Ego eos ita gigni \& coharere intelligo, ut uermes in lumbricolato, quos curcurbiti, nos appellantrecentiores, Ceruis in capite ineffe uermiculi fub lingux inanitate, \& circa artictl: lum qua caput iungitur, numero uiginti produntur, Plinius $\&$ Albertus. Ego dum hac friberem ab oculato tefte fide digno audiui, qui fe uidiffe affirmabat diffecto cerui capite recenti, non uigint tantum, fed plurimos omnino uermes, eoséf non cohærentes fed difcretos:funt qui dicant non om: nibus innafci. बPecius ceruinũ Galli peculiari uoce hampam trocant. ॠCerto cor magnum eft, Ariftorel. Maximum cor pro portione ceruo, muftelis, \& 8 , \& omnibus timidis, aut propter me tum maleficis, Plinius. TDe ofle ex cordecerui dicã cap, 7 , inter medicamenta ex ceruo. TCerı uus multiplicem uentrem habet, \& c. A riftoteles lib.3, de partibus : nimirum ut omnia ruminantia, ficut in Boue expofui, TCeruus non habet fel, A riftot. Et alibi, Ceruus felle caret, quare 8 longe, uus eft. Cerui fel non habent:quod hominum paucis nö eft, quorum ualetudo firmior \& uita lons gior, Plinius. Ceruus felle uacat:quanquam eius inteftinum amarum adeo eft, ut neà canibus quis dem attingatur, nific ceruus prapinguis fit, Ariftot. Etalibi, Ceruis Achainis cognomine fel condi neri in cauda creditur. Eft, quod ibi contineri aiunt, colore quidem fimile felli, fed non ita ut fel hus midum, fed lieni fimile parte interiore. Sunt qui certo(inquit Plinius)fel nó in iecore effe, fed in câts da aut inteftinis putent: Ideo tantam habent amaritudinem, ut à canibus non attingantur. Míror e quidem de Achainis ceruis nullam apud Plinium \& alios Latinos mentionem extare, cum Arifton reles diferte diftinguat. Hoc etiam nunc fubit, extremam cerui caudam fortaffis illam ob caufam tue nenatam effe, ut capite feptimo profequar, quod fel in ea contineatur. Fellis enim in multis anima lium uenenofam effe naturam traditur. Inteftina cerui perquam foxtida funt:quoniam, ut Plinitus ait, fel diffufum eft in eis : alíp tamen in auribus cerui id diffundi dicunt, al’’ in cauda, Albertus. II Brileto \& Tharne quaterni renes funt ceruis, Plinius. Apion, nifi nugatur, ceruos locis qui, buffam quatuor renes habere tradit,A elianus. đCeruo genitale neruofum eft, Ariftot. Cauda exigua, Idem. Cerui tefticulos Galli peculiariter daintres nominant, बBifulca animalia, utbos, ceruus, caprea, in pofterioribus pedibus talos habent, Suidas in $\Delta i x x^{\prime} \lambda \alpha_{*}$. बTGermani, pratertim lau tiores in loquendo, ut aulici, propria quadam de cerui partibus uocabula ufurpant:fanguinem tros

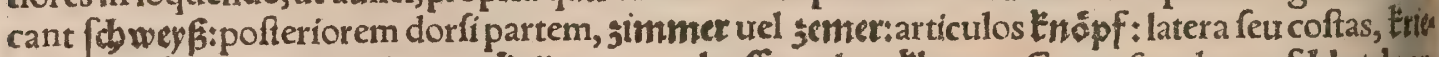
ben uel wâno: os in corde, Dab Erüs: crura, leuff: pedes, Hawen. Coxas feu clunes, fblegel : ar mos, bitg.

ब Cerua animal afpectu egregium eft, mutilum cornibus, ceruo minus, uifu acuto, miratuelocis tatis. Quaterna ubera habet, ut uacca, Ariftot, Ex eodem fupra in hiftoria uacca expofui cur mam mas binas inter femora habeat.

Cerurorum mira uelocitas eft, ut amplius patebit capite quinto, cum de uenatione ipforũ dicam, Fluuios etiam \& mare tranant, ut capite quarto explicabitur, बCerui mares, ut omnium feréanir malium, uocem grauiorem quàm foeminæ mittunt. Vox autem maribus in hoc genere, cum tempus coéundi eft, (de qua plura inferius:) forminis autem cum mettrerint : breuis uox foeminæeft, maris productior, Ariftot. Ceruus $\&$ lepus, utpote timida animalia acutam ædunt uocem, Idem in Phys fiognom. Ceruus unus cum pluribus ambulat fominis fui generis : rarò autem plures cerui mares fimul incedunt, nifiatate minores fuerint, quorum mulri quandog uetulum comitantur, eíg obe: diunr, $\&$ coitu in eius prafentia abftinent, Albertus. Ceruus fi erectas auriculas teneat, acerrime fentic, nec latêre eum infidiæ poffunt: fin demiffas, facile interimitur, Ariftot. Cum erexêre aures, acerrimi audítus:cum remifere, furdi, Plinius, Rectis auribus acutifimè audiunt, fummiffis trerò nihil, Solinus, Exafmus hæc Plinị \& Ariftotelis teltimonia citat in prouerbio, Auribus arrectis, quant 


\section{De Ceruo. C. Lib. I.}

Ğtram enim \& alix animantes (nam foli homini immobiles funt) fi quid eminus audierint aturiculas furrigant:certro tamen ijs arrectis peculiaris $\&$ acerrima auditu percipiendi uis eft. Cerui cum maría tranant, non uident terras, fed in odore earum natant, Plinius, TCeruum ruminare planum eft:degit enim aliquando cum hominibustalioquin ex feris nullum ruminare conftat, Ariftot. $R u_{\text {it. }}$ minant fylueftrium cerui, cum à nobis aluntur, Plinius. Fama eft elaphobofci pabulo ceruos refie ftereferpentibus, Plinius. Elaphobofci femen contra ferpentium ictus datur in uino: fama eft hoc pabulo ceruas ferpentum morfibus refiftere, Diofcorid. 3.78 . Hinc nimirum etiam ophioctonon, 8 ophigenion appellari meruit. Inuenio \& elaphicon appellari, \& Romanis cerui ocellum. Apud Hé

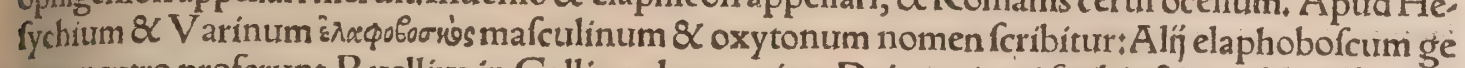
nere neutro proferunt. Ruellius in Gallia uulgo gratiam Dei nominari fcribit, $\&$ apud Streffionen. Ses herbam copariam, quod ea utantur ad uulfa, rupta.Defcribit autem eam lib, 3. cap. 48. Simpli= citrs (quàm canes herbam qua fibi contra ferpentes medentur) cerua monftrauere elaphobof con; Plinius. Herba in Montepeffulano auricula leporis dicta, cuius folia ad lithiafin pota cómendant; elaphobofcon ab aliquibus creditur : radice eft alba, fimplici, ut in apiorum generibus, non ino= dora,floribus luteis per umbellas digeftis, caule ramofo, cubitali, folin's quadrantalibus, fpecie quo= dammodo plantaginis minoris, fed minoribus, 8 cum primum erumpunt auriculas mufculor 亿̃ refé rentibus. Nafcitur locis afperis $\&$ ficcís, rara apud nos, circa Bafileam frequentior. Sed Hieron. Traz gus aliud elaphobofcon facit, paftinacx fcilicet hortenfis genus illud, fi bene memini, quod fylueftri fiferi(ut Fuchfius uocat)fimillimũ eft, Eft \& elaphofcorodi herba defcriptio apud Diofcoridem, fed non genuina illius authoris, A phrolcorodon quidem alio nomine allium Cyprium uel Vlpicum no minatur, pragrande, $\& \mathrm{c}$. Dictamnum herbam extrahendis fagittis cerui monftrauere, percuffico telo, paftúç eius herbx eiecto, Plinitus. Cretenfes iaculandi periti feras capras in uerticibus monx tirm pafcentes percutiunt:ex accepto uulnere, ftatim dictamnum herbam comedunt, \& eueftigio ia cula excidunt, Aelianus. Hinc forte qui de medícina Arabice fcripferunt puilegitum ceruinum ap= pellant hanc herbam,Pulegï hortenfis genus fylueftre eft, undiquiagi fimile aut idem potius hor= cếl, nifi tenuius \& acutioribus folijs prodiret. Id in Sabaudia circa Lemannũ lacum uidi copiofum; \& circa Montempeffulanum, ubi fi recté memini certuinum cognominant. Sed alia eft dictamnus; quanquam uires in medendo non diffimiles fortita. Mefcatramefir $\mathcal{X}$ deferulï, uettis interpres uo. cabulorum Auicennæ pulegium ceruinum interpretatur. Ariftoteles non cerutos; fed capras fylue= 30 fres in Creta dicamni paftu fagittis abfolui tradidit: Vide fupra in Capris fylueftribur Creticís. Smilacem afperam aliqui hodie in Italia uncant rubữ ceruinum. Spina ceruina uuilgo ab Italis no: minatur frutex fpinofus, cuius granis diuerfo tempore decerptis ad diuerfos colores noftri utưtur, fermo uernaculus appellat tritybecte. Hunc quidam rhamni generibus adnumerant, quos Matthaolus tepreliendit.R hamnum tamen à Romanis fpinam certralem dici, inter nomẽclaturas apúd Diofcoridem legitur, Sefeli monftrauere ceruæe enixæà partu, Plinius: Primum fefelis genus, quod Maffilienfe Diofcorid, uocat, intelligo. Sefeli Aethiopicum, ut mihi quidem uidetur \& Leonharto Fuchfio, noftrates radicem ceruinam albam appellant: ea perquam craffa, longa, $\&$ amara eft, $\&$ re finofa, Alia minor elt, radice foris nigra, fubdulci, refinofa, ceruinä radicem nigrã trocamus: Fuch= fits fefeli Peloponnefiacum facit: quod facilius crederem fi locis humidis nafceretur, ego femper 40 inficcis reperi. Cerui mares duntaxat, folani genus fyluaticum, noftri baccas foporiferas uocant, (dequo pluribus dicam in Surm hiftoria) \& fimiliter fambucum fyluaticam fiue montanam, cui in umbellis grana cocci inftar rubent, mirum in modum amant: $\&$ per aftatem illic plerun $\$$ s uerfantur ubihx plantæ uirent; folent enim ḧfdem feré locis nafci. Depafcuntur autem frondes tantum, non eriam baccas, Fomina utrifop(tum folano turm fambuco iam dictis) abftinet: nifi cum fortum mafcu lum geftat:tunc enim marium inftar eis delectatur, Hieronymus Tragus, Serpentes etiam à ceruis eduntur, fitre natura quodam odio, fiue ut morbis quibufdam medeantur, ut mox capite quarto di cam. Quin \& fuibus ferpentes in pabulo funt, Plinius 11,53 . Quanquam non ignoro(inquit Hermo lauts) diffidere ferpentes $\&$ fues, $\&$ c, quia tamen pars hæc ex Theophrafto fumitur libro eius quinto de ftirpium caufis, feréadducor ut ita fribendum putem. Quin $\&$ ceruis ferpentes in pabulo funt,

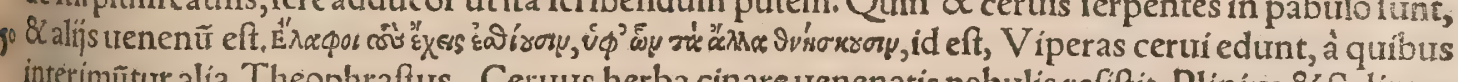
interimũtur alia, Theophraftus. Ceruus herba cinaręuenenatis pabulis refiftit, Plinius 2 Solinus, Cerui morfi uel à phalangio, uel à quouis generis eiurdem, cancros edunt: quod idem liomini etiam prodeffe putatur, fed non caret faftidio, Ariftot. \& Aelianus. Percuffi à phalangio, quod eft aranei genus, aut aliquo fimili,cancros edendo fibi medentur, Plinitus, f Cerui cornua abijciunt, ut fu. pra dixicap. 2 . Pilulas excrementorum cerui, dam $x_{2} \&$ capreoli, Galli fumees appellant. TCer urum lachryma cur falla $\&$ improba fit:aprorum uerò dulcis, Plutarchus in libro de caufis natú ralibus quaftione uicefima, his uerbis exponit. In caufa eft(inquit)temperamentum iftorum anima litum, quod in ceruo frigidum eft : in apro feruidum 8 igneum + quamobrem hic fe opponit perfe quentibus, ille fugit: quo quidem tempore pracipuè, propter iracundiam, moutertur lachryma. Nam

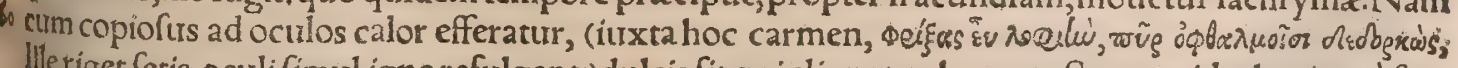
lileriget fetis, oculi fimul igne refulgent:)dulcis fit qui eliquatur humor. Sunt qui lachrymas à fanguine perturbato cxcitari feparariós tanquam ferumà lacte exiftiment; tit Empedocles : Quonian? 


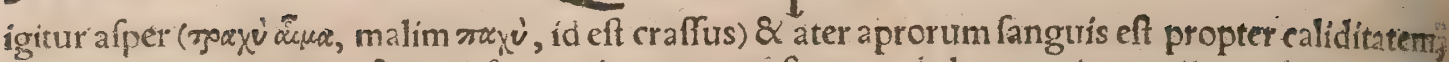
ceruorum contra tenuis $\&$ aquofus:conlentaneum eft ut quod ab eo per iracundiam uel metum ex cernitur, frmiliter fe habeat. Hunc locum etiam Calius tranftulit lib. 12, cap. 5. Idem mox ab iníio li, bri tricefími occultam 8 incogniram ait effe caufam cur ceruis falfuginofæ manêt la chrymæ, fuibus dulces dum capiuntur. Bezahar propriè eft lapis qui dicitur lachryma cerui, quę generatur in cer uris:quia cerui comedunt uiperas, maximè in Perfia: Et hic lapis eruitur etiam é terra et fodinis, ut tra dit Tiphafi Arabs in libello de gemmis cui ex A rabico in Latinum fermonem translatus eft. Quin. doç tamen bezahar appellatur quoduis antidotum ueneni, Andreas Bellunẽfis. Vide plura inferius capite feptimo. Cerui montes excelfos non afcendunt, ut qui nimitum corpulenti, ad planiciem maz gis quàm montes idonei fint:quamobrem fyluas $\&$ ualles, \& fuminibus uicina loca frequentus ha

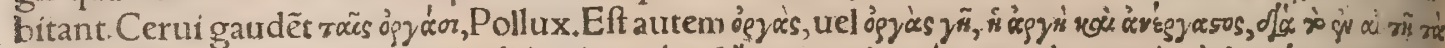

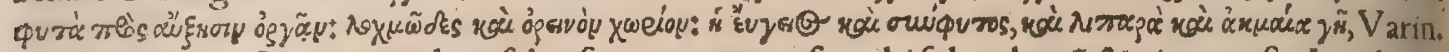
Hoc eft, Orgas eft locus incultus, fyluofus aut nemorofus, ubi folum bonũ $\&$ pingue eft. A pud eun,

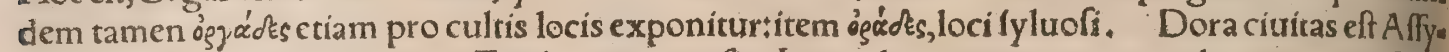
rię deferta, marginibus amnis (Euphratis) impofita:In quo loco greges certuorũ plures intrenti funt: quorum alĭ confixi mifflibus, alị ponderibus elifi remorũ ad fatietatem omnes pauerunt: $P$ ars ma xima natatu adfueta uelocialueo penetrato incohibilicurfu euafit ad folitudines notas, Ammianus Marcell. libro 24.

- Cerur tempore libidinis efferantur, $\&$ certant pro feeminis, féq mutuis interdum uulneribus uel mortis periculo conficiũt, idọ́ præcipué faciût in fine Augufti, quo tempore Arçuri iydus cum 2

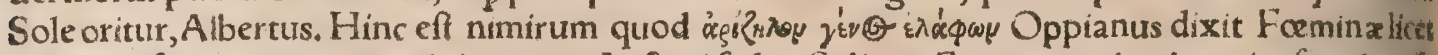
prius conferantur, non concipiunt ante Arefuri fydus, Solinus. Cum mares impleuerint foeminas, ,e parantur per fe ipfi, \& propter libidinis gratreolentiam quif $\phi$ folitarius fcrobes fodit: fotent ut hir ci:facies queq eorum nigrefcit afpergine, ut hircorum : degunt ita, quoufog imber accedat, cum pas f cua repetunt. Hac ideo ceruo accidunt, quia falax animal fuapte natura eft, atģ etiam quía pingui abund.it, A riftoteles. Mares generis huriufce cum ftatutum tempus Venerem incitauit, fauiunt trat bie libidinis efferati, Solinus. Foemina à conceptu feparant fe: At mares relicti rabie libidinis fruitit, fodiunt fcrobes, tunc roftra eorum nigrefcunt, donec aliquando (aliâs, aliqui) abluant imbres, Hint, Vehementi amoris libidine flagrant, ur tanquam gallinacei ( $\&$ reliqux aues) toros dies ad Venerem non ceffent incumbere, Gillius ex Oppiano, lam mares foluti defiderio libidinis, auide petunt $p a 3$ bula. Vbi fe prapingues fenfêre, latebras quarunt, fatentes incommodum pondus : $\&$ aliâs femper in fuga acquiefcunt, (ut in uenatione ipfor ũ dicam cap.5.) Plinius. Inter ca, qux animal generant, augentur ós magnitudine infigni, nec Ceruæ mares fuos patiuntur, nifi raro:nec uacca tauros: pros pter rigorén genitalis, nimiamós tentiginem, fed clunibus fubfidentibus femen recipiunt genitale: fic in ceruis manfuetis fieriuifum eft, A riftotel. Cerui non fimsliter atç alix feræcoèüt: neç enim Pantes, neç cubantes, fed magna celeritare currentes ineunt foeminas, fimul $\&$ tametíi properantes firgere uxores pedibus amplecturtur, non earum tamen curfum retardare poffunt: fed inexorabils illa ad confiftendum, maritos ferunt, \& fugere perfeuerant: $\not j$ autem duobus pedibus quantum pols funt, curfimós fequentes coiturm ab foluunt, Oppianus. Taurorum ceruorumćp foeminæ uimnon tolerant, ea de caufa ingrediuntur in conceptu, Plinits. Cerua plurimum fublidens coit, ut dictum 4 iam eft : marẽ enim fultinere nó poteft, ob eitus contentiffimû̃ impetũ. Veruntamen aliquando ctiam fuftinent modo ouium \& focias declinant, cum turgente iam Venere coitum appetunt.Mas non in eadem immoratur, fed muta t: breuiç's inter pofito tempore, aliam atos aliam fupergreditur, Ariftotel, Ceruit in coitu uriciffim ad alias tranteunt, $\&$ ad prior esredeun,, Plinitus. Coitus ab Arcturo, ment re Augufto $\&$ Septembri:implentur paucis diebus, $\&$ ab eodem mult $x$, Arifto:eles. Conceptus cet uarum pof Arcturi fydus, Plinius. Simi, libidinofi effe conjíciuntur, à ceruorum fimilitudine, Ant foreles. Ad decimumoct. cal. Octobris, cerui libidinari incipientes, catulientiű ceruarum concilia bula quærunt, $\mathcal{X}$ uelut ad forum Veneris undiç conueniunt, Budæus. Et rurfus, Libidine (quem in eis affectum Galli trocant le rut ou reut d'ung cerf; Germani brunft/id eft ardorem) flagrantifit ma admiffar ̈̈ ad menfem agitãtur, tunćç̧ rabie pruriginis efferati, $\&$ canes $\&$ homines atrociter in uadunt quũ primum afpexerût. Deinde paulatim defæưientes, alterum paulò minus menfemabit munt. Vox maribus cum tempus coéundi eft, foeminis aurem cum metuerint, Arifoteles. Rance. re (reer Gallicé) fićtitia uoce tunc dicuntur (cum libidinantur mares, \& foeminas uocant, fiue clato capite gutture pleno, fiue ad terram demiffo: $R$ ancentes autem ololygones tunc uocantur: $R$ ancor, ipfe clamor, Budars, Germanis briten. Ololygon apud Aríftotelem proprie dicitur de uoce ranan rum mariư libidinis tempore. Solet ceruus ex macie hyberna, ac tabe libidinofi temporis fub men fem uiciflim Maium cito in corpus ire, è gregarinsḉ cateruis aclocis abdiris $\&$ abftrufis, in quibusde lituit, emigrans, in loco delecto ftabulari, (gifter, Gallice) unde commoda \& propinqua fit pabulatio, (les uiandes, Gallicé:) illicós uelut in a Ptiuis inftauratiuủ decor ̃̃ ac faginã (uenaifon, Gallicé:)recipe re. Hac habiturdinũ uiciffitudine nunc flaccêtes, nûc ftrigofi:tũ eualef́centes, tũ̃ obefi:aliâs cornicuto fi $\&$ fublimes, aliâs mutili $\&$ inermes, $\&$ tanquã pudibũdi apparent. Phyfici referũ t ceruư purgatio nis indigũ apia comedere, A elianus in Varijs, Sed hoc ad ceruam pertinet, quex nó felino id eft apio, 


\section{De Ceruo. C. Lib. I. 363}

fed fefeli herba, ante partum purgationis gratia utitur:ut duplex in Āeliani codicibus error fit, fü authoris fiue librariorû, alter quod to no, alter quod felina pro fefeli. Forminx ante partum purgantur herba quadam, qua féfelis dicitur, faciliore ita utentes utero. A partu duas habent herbas, qux aros $\&$ fefelis appellantur : paftare deunt ad foctum, Illis imbui lactis primos uolunt fuccos; quacunque de caufa. Cícero dicit cer = uas pauló ante partum perpurgare fe quadam herbula qua fefelis dicitur, Gillius, Silis uel fea relis folia quoque utilia funt, ut qua partus adiuuent etiam quadrupedum : hoc maximé pafcí dicuntur cerua paritura, Plinius, Graci fefeli, ur finapi, neutro femper genere proferunt, nón fefelis in recto. Eius tria funt genera, fed ufitatiffimum quod ueteres Maffilienfe uocant: $\&$ uulgo ho die filer montanum. Id non alibi copiofius uidi, quàm in Gemmio uulgo dicto monte Sedunorum, circa thermas, Datur ut partus adiuuet capris quadrupedibusćpalīs bibendum, Diofcorid. Fomí næ per efum fileris uterum præparant, ut facilius concipiant; è quod propter duritiam uírgæ non accipiunt femen nifi fugiendo; Albertus, Sed cum authores omnes non ad conceptum, fed partum faciliorem ceruas hoc pabulo uti contreniant; Albertum erroris infimularenon dubitabo. Quæex ferismitígentur, non concipere tradunt, ut anferes : apros trerò tardè, \& ceruos, nec nifi ab infantia educatos, Plinius. Hinnuli uere nafcuntur, Xenophon. Vterum ferunt octo menfes:pariuntma. gna ex parte unum:fed noninullas etiam geminos peperiffe perfpectum ef, Ariftot. Octonis men. fibus ferunt partus; $\&$ interdum geminos, A conceptufeparant $f$, Plinius, Incrementum hinnuli celere.Purgatio cateris temporibus nulla euenitcerua:cum atrtem parit, pituitofo quodam humo 2o re purgatur, $P$ arere iuxta uias maximé folent metu belluarum, Ariftor, In pariendó femitas minus cauent, humanis ueftigịs tritas, quàm qua fecretæa a feris opportunæ, Plinius. Idẽ Plutarchus fcrí bit in libro $V$ tra animalium, 8 c. fed imperitus interpres pro ceruis elephantos pofuit. Ferarũ quas drupedum cerua maximé prudentia praftare uidetur, tim quia circa femitas pariat, quo filicet bel lux propter homines minus accedunt:tum etian quia cum peperit, inuolucrü primum exedit, mox feflim herbam petit, quam cum ederit, tedit ad prolem, Ariftot. Et alibi, Ceruæ(inquit)fratim à par tueduntinuolucrum, ut dictum eft, nec fieri poteft ut id accipiastprius enim quàm in terram demit.

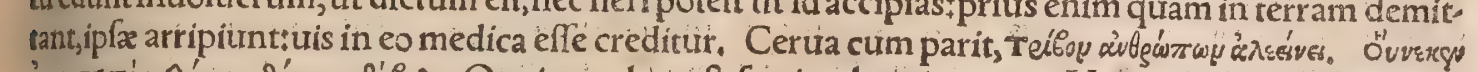

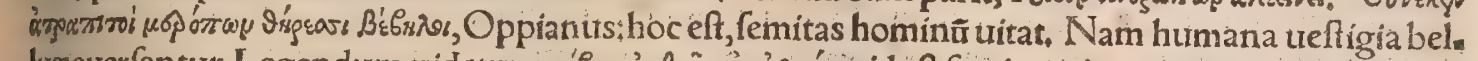

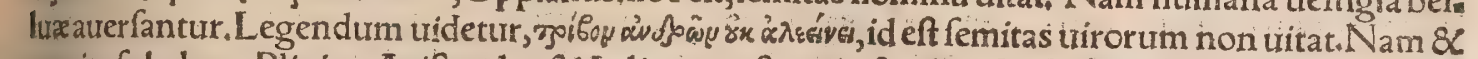
zo rem ita fe habere, Plinius, Ariftoteles, \& A elianus teftantur: $8 \alpha$ idem fenfiffé poétam, ex proxímo uer fir, quo caufam eius facii reddit, apparet. Inuolucrum foetus, quod ceriam mox trorare diximus, Graci chorion uocant:ut habet lib. 9 , hiftoriæanimal. cap: s. ex quo uerba eius iam fupra recitaui= mustudeo autem lapfum effe Plinium, qui non chorion fed aron legerit; $\&$ interpretatus fit nino enim illum Ariftotelis locum ab eo translatum apparet:in quo barbari etiam dragontex, ut ipfi trocant, mentionem faciunt, quod inter ari cognomina eft:quanquam fimul \& fecindina. Praterea hinnulum ducens in ftabula, affurefacit, quò refugere debeat, faxum hoc eft abruptum, (petra dif= rupta, alibi) uno aditu: quo loco eam fi quis inuadit, expectare repugnarȩ́́s affirmant; Ariftoteles. qui \& alibi idem repetit. Editos partus exercent curfu, \& figam meditari docent:ad prarupta ducunt,faltumćs denionftrant, Plinius. Secundum uias(inquit A elianus interprete Gillio)cerua pare 40 refolet, quod quidem ipfum fapienter facere uidetur, uel quòd hinnulis fuis infidias à feris timeat fieri,uel quia celeritatis fiducia homines egregie contemnat. Non enim, tametfi infirmior; dubitat coseffugere poffe:poftea autem quàm fe opimo corporis habitu affectam fentit, non amplius iuxta uias partum edit, quod lam fe minus accommodatam ad currendum intelligit:at enim uel in faltibus uel conuallibus parit, Hac Aelianus:Cui Graca ad manum funt, cum Gillij translatione conferat; Erraffe enim mihi uidetur uel interpres uel ipfe A elianus. Neçenim de cerua apud ullum bonú aut thorem legimus, quod ubi iam corpulẽtior eft, iuxta uias parere definat, $8 c_{*}$. Sed de ceruo mare hoc fertur, quod cû̃ pinguiorem fe fenferit, ídeoć, tar diorem, loca remota \& folitaria petat, Ariftoteles $\&$ Plutarchus in libro Vtra animalium, \&c. Exrecentioribus quidam fribit foetum à cerua occuli, ne a mare deprehendatur:quod cum neqs treterum authoritate, neq ulla obferuatione certa confirmet; 50 fidem apud me non meretur. Cerux non qualibet partus fuos educant, teneros ftudiofe occulunt: $\&$ abfconditos inter profunda fruticunt uel herbarum pedum uerbere caftigant ad latendum. Cum maturuerit ad fugà̃ robur, exercitio docent curfus, 8 affuefcunt falire per abrupta, Solinus. बI Hye= mextenuantur cerui, debilitanturósłuere autem urigent maximéad curfum, Ariftot. TSenectu. tem indicant dentes, cum aut pauci inueniuntur, aut nulli, Solinus, $\&$ alif, ut fupra diximis in cornuum mentione, quibus finguli anni ramum adijciunt, à biennio uf̧́ ad fextũ: $\mathcal{Q}$ cum abieĉa cormua renafcantur quotannis unà cum adminiculis, id eft infimis ramis: atate prouectioribus î nonz renafcuntur, \&c. Sunt qui tradunt ceruos fenecta graues ferpentium efu recreari, ut proximo cap. dicam. Dicûtin capite cerui annofi intra os oculi uefpas \& formicas gencrari $\&$ aliquấdo progredi, Albertus. Venatores afferũt, quod in ceruo natu grandi offe capiris fub oculo terebrato uerpa cons 6 treræ $\&$ formata interius ex humore fuperfluo, uel ut alí auturnant, ex medulla prodeant cutolan tes: \& tunc negãt eum poffe diutius uiuere, nifi efu ferpentium renouetur : Aliquando etiam eodem thodo uefpas dicunt prodire concretas è naribus cerui $i_{2}$ A uthor libri de naturis rerü. Apparet autem 
uel Albertum erraffe, qui pro formatæ legerit formicx, uel alterum qui contra : quod ad lectionem loquor:nam quod ad rem ipfam ncç uefpas equidem neç formicas in a nimãtis tiiua corpore nafc] crediderim: Et uerifimile eft ortum hunc errorem ex uerbis Ariftotelis fuxitan male rranslatis, qui lib. 2. hift, an. cap. 15. uermes, non uefpas, in capitibus ceruorum reperi: $i$ fcriplit, ut fupra recitaui,

- Vita effe perquàm longa hoc animal fertur, fed nibil certi ex ijs quax narrantur, uidemus: nes geftatio, aut incrementum hinnuli ita euenit, quafi uita effet pralonga, A riftoteles: Idem lib.4,cap, 2, de partibus animal.Ceruus, inquit, felle caret:quare $\&$ longæuus elt. Efre autẽ longrua quædam felle carentia, ut ceruum $\&$ delphinum, meminit etiam Cælius 4.17. Hefiodus (uerba func Plinî) cornici nourem noftras tribuit atates, quadruplum eius ceruis:id triplicatum coruis. Hefiodi tieritus

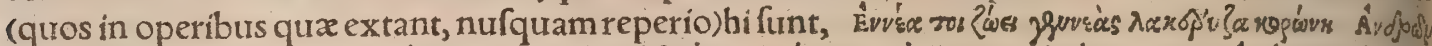

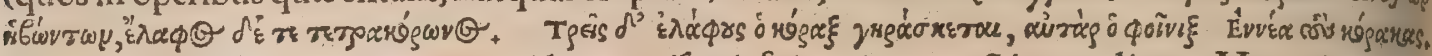
Hos uerfus Hefiodi interpretatus uidetur quifquis fuit, cuius carmẽ inter reliquas Maronis appen, dices extat:eftó̧ huiufmodi: Ter binos deciesḉ nouem fuperexit in annos lufta fenefcentû quos implet uita uirorum. Hos nouies fuperat uituendo garrula cornix, Et quater egreditur cornicis fecula ceruus, Alipedem ceruum ter uincit coruus : at illum Multiplicat nouies phonix reparas bilis ales. Meminit Erafmus in prouerbio Cornicibus uiuacior: Ariftoteles(inquit)homine nullum

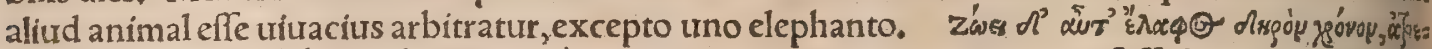

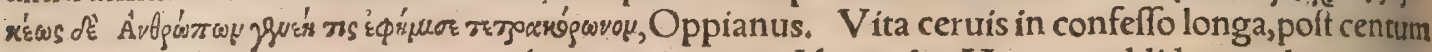
annos aliquibus captis cum torquibus aureis, quos Alexander Magnus addiderat, adopertisiam cute in magna obefitate, Plinius. Ad dignofcendam uiuacitatem Alexander Magnus torques plus rimis ceruis innexuit, qui poft annum centefimum capti, nec dum fenï indicium præferebant, Soli, nus. A pud Peucetinos(Peucetios potius dixerim)aiunt effe Dianæe templum, ubi dedicata dex un

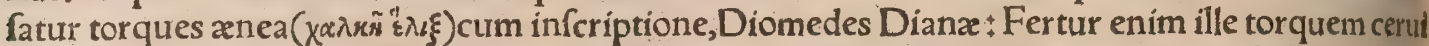
collo addidiffe, circa quam aucfa fit caro, 8 ceruus poftea captus ab A gathocle rege Síciliz in tema plo louis confecratus, Ariftoreles in Mirabilibus. Peucetia Italix regio eft, alips nominibus Calabria,

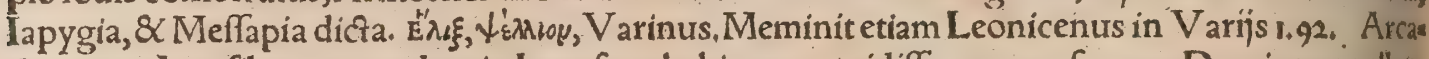
des aiunt Arcefilaum quendam in Lycofura habitantem, uidiffe ceruam facram Dominæappellat:

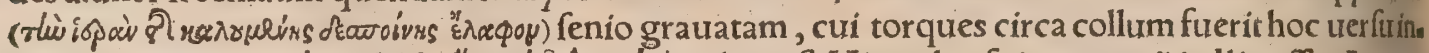

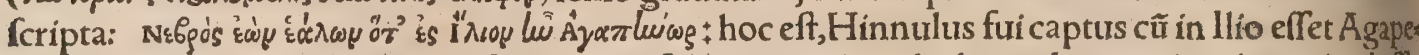
nor:quo quidem teftimonio confirmari poteft ceruum etiam elephanto longe uiuacius animaleffe, Paufanias in Arcadicis. Ceruus in uiuarn̈s compluribus annis fuftineri poteft : nam diu iutenis poffidetur, quod æuil longioris uitam fortitus eft, Columella.

बF Febrium morbos nô fentit hoc animal:quin \& medetur hức timori, (ut capite feptimo dicam,) Plinius, Patuit ceruros nunquam febrefcere, Solinus. Cerui ægri ramufculos oleæ comedunt, \& fan nantur, Ambrofius. Sed hoc remedium ad elephantos, nó elaphos, id eft ceruos, à ueteribus referrl uideo. Elephas olex flore uel oleo fibi medetur, Aelianus. Et chamaleonte deurorato, oleaftrofibl medetur, Plinius. Eodem remedio contra idem uenenum coruus etiam apud Plinium utitur. Pha langium non minus ceruis quàm hominibus perniciofum exiftit:à quo lafi celeriter pereunt, niffly ueftrem hederam comedant: qua quidem adefa, phalangï acerbitas nihil eis quicquam nocet, Gila lius ex Aeliani Varijs : in quibus tamen nos legimus ceruum à phalangïs icfum cancros edere, Qurod cerui omnes uíuos in capite uermes cótineant, \& c. fuperius ex Ariftotele \& Plinio dixi,Nam quod uefpas $\&$ formicas cis innafci Albertus fcribit, falfum exiftimo. Cerui in fuga inteftinodo, lent, quod eis tam infirmum eft (tenue $\&$ imbecille) ut ictu leui rumpatur intus cute adhuc integra, Ariftot, 8 Plinius. Cacqus eft genus fpinæ, qua hinnulus icius inutilia habebit offa ad tibias, $V$ as rinus. Ceruum Galli dicunt froyer, id eft prurire, cum caput eius f́cabie afficitur, \& pellis feparatur.

D.

De prudentia et ingenio cerui non pauca iam ante diximus, nō repetenda nifia admonendi forte gratia. Ferarum quadrupedum cerura maximé prudentia pręftare uidetur, tum quia circa femitas pariat, \&c.tum quia hinnulü ducens in ftabula, affuefacit quó refugere debeat, \&c, ut fupra diçum eft. Hinnulos tenellos a dhuc abfcondit:poftea ad curfum maturos affidué exercet, \& fruteta tranfilire docet, ne dum per loca fruticibus arbuftiş́́ confer ća currunt, cornibus hæreant $\&$ capianturr, Albertus. Cicures multis in locis Heluetia Germanixá̧ cerui publicè in follis circa monia alun tur, ut cum libuerit magiftratui habeant quod uenentur, li ad uocantium ex alto uoces accurrunt, maxime cum cibi prafertim panis deífciendi fpe alliciuntur. Mithridates Ponticus cum fomnúcar peret, fui corporis cuftodiam non modo fatellitibus cómittebat:fed $\&$ tauro, \& equo, \& certro, quios manfuefactos habebat. Ii enim ad cuftodiam eius dormientis aduigilantes, fi quis accederet, quod ex ipfa refpiratione ftatim percipiebant, ille mugitu, alter hinnitu, ceruus fua propría uoce, euméfom no excitabant, Aelianus. Ptolemaus fecundus, quem etiam Philadelphum appellant, cerui hinnulum munere accepit:quen cum aleret, fic ad Gracum fermonem affuefecerat, ut loquentes intellige ret, cum tamen ante hunc ipfum creditũ effet, folam Indorum linguam ceruos percipere, A elianus, \& ex eo Calius 23. 34. Cerui ingeniofi ac timidi funt; Ariftotel. Et alibi, Cerux (melius cerui,ut utrungs fexum comprehẽdamus:quod Attici etiam in fominino faciunt)timida funt;nam fanguis 


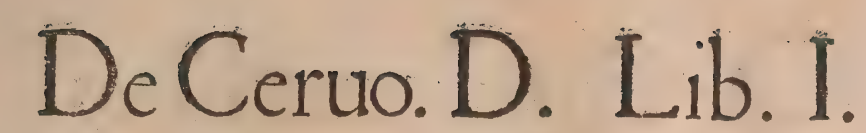

earum fibras non continet, ideoç non fpiffatur, Ariftotel. Fruftra ceruis tanta nafcuntur cornua, cum eis in pugna non folum contra feras aut canes, fed ne contra lepores quidem uti aufint, Oppia nus. Cerui timiditas ceruos pro fugituis dici, \& uirum ceruinum protimido, in caufa eft, uc expli. cabimus capite ociauo, parte prima : \& ultima inter prouerbia. Timidiffimum animal eft ceruus, lepus, oues, qua omnia pilum habentmolliffimư, Ariftoteles in Phyfiog. Timidi funt homines quo rum facies eft carnofa : item quorum collum eft tenue $\delta$ oblongum : $\&$ qui uocem $x$ dunt acuram: nam eadem in ceruis fimiliter reperias, Ibidem. Ceruorum quidam audaciores funt, qui homines tranfeuntes per fyluas inuadunt:alin fugiunt, Albertus. Ceruus non infcius dextrum fuuth cornu ufui magno hominibus effe, hoc ipfum inuidia flagrans, ne tanto bono homines fruantur, in terram occultat, Aelianus, Sed hac de re piura dixi capite tertio. Miro natalis foli defiderio tenentur, non Hellefpontiaci folum, ut Ä elianus prodidit:fed cerui omnes, ut audio, pulfi locis ubi educatifunt, $\&$ meliora quando $q$ paf́rua nacti, femper ad priftina redire folent. Mas cum pingurerit, quod ualde tcmpore fruchuum fit, nufquam apparet, fed longe fecedit; ut qui ponderefura corpulentix capi fe

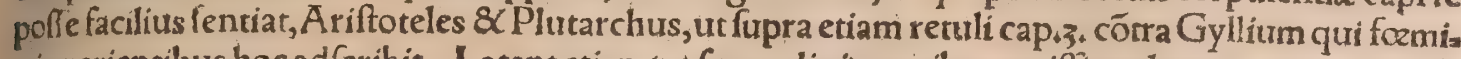
nis parientibus hoc adferibit. Latent etiam(ut fupra dixi)cornibus amifis, uel tanquam inermes fe

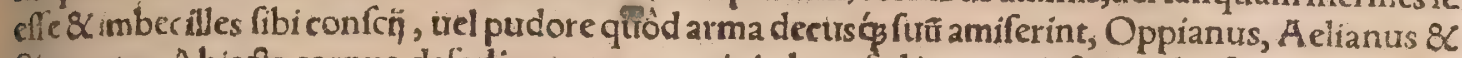
Simocatus. A biecta cornua defodiunt, non quouis in loco, led in remotis \& condenfis arbuftis:pra cipué alterum, fiue dextrum, fiure ut alì's placet finiftrum, tanquam ui medica efficacius, quam liomi= nibus inuideant. A pud Horum legimus ceruum fuos dentes, qui exciderint; humo infodere, quod quidem non cerui, fed elephanti eft, ut in hiftoria eius capite tertio dicam. Cauere etiam dicurur, ne quando in uulnera, qux acceperint recentia, iolis radius incumbens priufquam obducantur, cat nem putrefaciat, A elianus, Fugiunt uenenata: $\&$ fi iacula ueneno infeça in loca cis cófueta emi: tanur, recedunt, Albertus. Dictamnum ipfi prodiderunt, dum co paftiexcutiunt accepla teia, her bam quoq quam cynaren uocant contra noxia edunt gramina, Solinus. Animal eff fimplex, 82 om sium rerum miraculo ftupens + in tantum, ut equo aut bucula accedente propius, hominem iux ta ue nantem non cernant:aut fi cernant, arcum ipfun fogitcas ćs mirentur, Plinius. Mulcentur fiftula paftorali \& cantu, Plinus. Paftorum mufica fape ita oblectariferunt, ut interim negligant pafcua. Mirantur fibilưm fiftularum, Sclinus:Quamobrem fibilo \& cantu ueirantiü capiuntur; ut fequent capite dicam. TMaria tranant gregatim nantes porrecto ordine, $\$$ capita imponentes praceden 5o tium clunibus, uicibusḉs ad terga redeuntes: Hoc maximè notatur à Cilicia Cyprum traijcientibus: nec uident terras, fed in odore earum natant, Plinius. Si maria tranant, non afpectu petunt littora, Sed olfactu:infirmos ponunt in ultimo, \& lafforum capita clunibus per uices fuftinent,Solinus. Mo veclaffis nauium (Gyllius ex Oppiano) mare tranfnant, unus ante cęreros natat, dux ad tranfimitten dum; hunc alter capire innitens tergo, infequitur: \& fimiliter cæeteri deinceps fubfequuntur, Cum autem primus prænatando defatigatur,ad extremum agmẽ recurrit, \& capurt in alterum ind linans, paulum â labore recreatur. Secundus recens, defatigato fuccedens anteit, atç alï omnes in aliorum uicem fuccedenres, duces efficiunturtpedibus tan quam remis utuntur, cornua excelfa tanquam ue la uentis permittunt, Har Oppianus. Iden feribir lo. Tzetzes Chiliade 3, cap, 12 r. In A mano, Libas no, \&Carmeio, Syrię monubus(inquit A elianus) ceruri nafcuntur, qui cum in Cyprum tranfmirtere fo wolunt, gregatim ad lixtora peruesiunt, ibićz randiu fecundos uentos praftolantur, dum per placa thinam quietem belle 6 bi fare enterint, tum fidentianimo fefe traijcere mare ingreff, $\&$ ordine natant, \& uero in antecedentium tergo fubfequenies capita reponunt: ac nimirum dux idcirco re $=$ tocedit, quia non habet tb nitatur, \& pof on requieti fé dat, fimul \& extremum agmen ducit, In Cyprum ideo tranfnant, quód paftionum, qua illic amplifima effe dicuncur, defiderio tenenvur. Et profecto adeo feracem Cyprin fe incolere regio. nem teltantur, de agrorum ut bonitate Aegytut; non concedant. Eodem modo Epirotici cerui in Corcyram qua co nera Epirum eit, me tr as eunt, A elianus. Manifefta eft negligentia illius qui

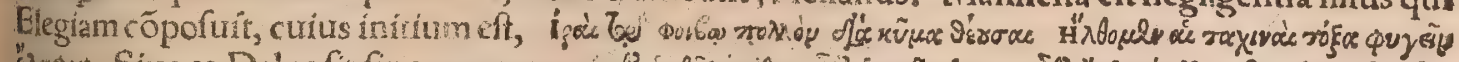

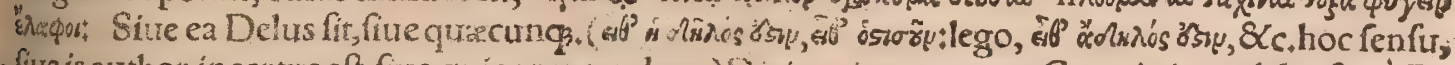
so fitre is author incertus eft, fiue quicung, tanden.) Dicit enim ceruas ex Corycio iugo delapfas, è $\mathrm{C} i=$

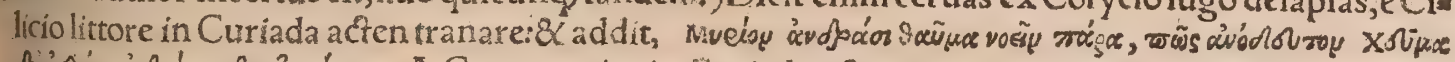

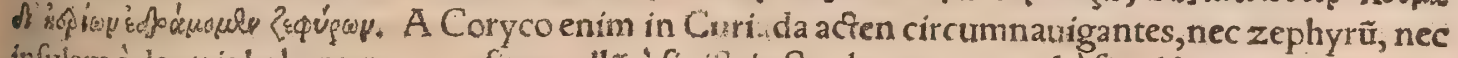
infulam à dextris habent, nec rranfitum ullü à finittris, Srrabo non procul à fine libri is. OP ugnan tes in pafcuis, uictori ut domino obediunt, A lbertus. Et alibi, In pugna tempore libidinis uictus om= nino paretuictori, \& fequitur ipfum tanquam herum.

Amantur ab attagenis, Ceruos cum lippis aggregari fabulantur in lucis Venetorum, ita illic manfuefcunt feræ,Strabolib.5. बCeruis quoce eft fua malignitas, quanquam placidifimo ani= malium:urgente ui canum, ultro confugiunt ad hornincs, Plinius. Aburfo nónunquam inuadun

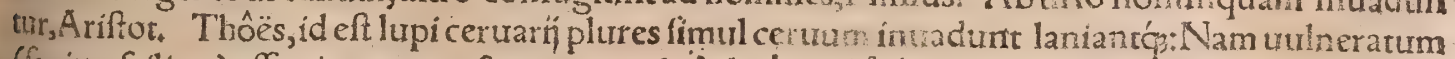

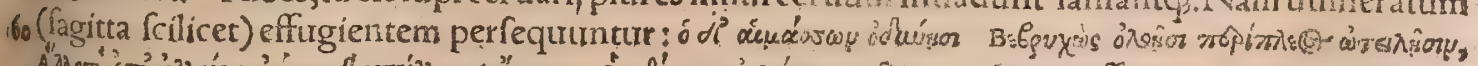

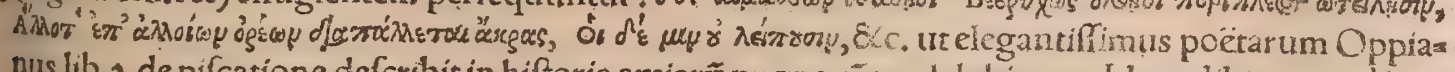
nus lib, 2, de pif́atione defcribit in hiftoria amiarũ pugnę cötra delphinum, Idem alibi ceruos à lyn 
cibus infeltari canit. Homeriuerfus, quomodo thôes faucium infequantur cerưum, ex libro ưndect. molliados, in Thôe poft Lupum recitabo. Fugit ceruus cum arietem uidet,Horus, Timentceruí gannitum uulpium, Albertus: Primo \& lecundo generi aquilarum, non minorum'tantum qua drupedum rapina, fed etram cum ceruis pralia. Multum puluerem uolutatu collectum, infidens corribus aquila excutit in oculos, pennis ora uerberans, donec pracipitet in rupes, Plinius. TEle. phantorum anima ferpentes extrahit: ceruorum item urit, Plinius. Eit alibi, Ceruís eft cum ferpen, te pugna : inueftigant cauernas, nariumộ fpiritu extrahunt renitentes. Serpentes hauriunt, \& fpiritu narium extrahunt de latebris cauernarum, Solinus, Exitio ferpentibus effe ceruos nea mo ignorat, \& fi qux funt extractas cauernis mandentes: Nec uero ipfi fpirantesćs tantum aduer fantur, fed membratim quoque, fugantur nidore cornus ceruinifi uratur : Pelles cerui fubftrata, recuros præftant ab eo metu fomnos, \&c.Plinius. . Mirifico quodam natura munere ceruus ferpets. tem funditus uincit:neç enim ipfum, tametfi hoftis in latebram abditus, effugere potef. Etenimille naribus fuis in ferpentis cauernam incumbens, uehementifimè infpirat, \& fpiritu fuxo quafi amato rio quodam alliciens extrahit,inuítumćs profert, ac nimirum procumbentem illam mandere ingred! tur:Quod hyeme facere maximé folet, A elian. Videtur fanè A elianus rationem qua ceruus ferpen. tem è latibulo extrahit ignoraffe, ideoćs philtro franc uim comparaffe:ac fí ita à certri fpiritu traheres tur, ut à magnete ferrum, à fuccino paleæ. Solet ením ad occultas huiufmodi caufas hominum infci: tia confugere, nempe ad totius fubftantia proprietatem tanquam ad facram imperitia anchoram. Quód fi eo tanquam philtro ferpens allicitur, non antipathia fed fympathia quxdam inter cerui \& ferpentis naturam fuerit, Sympathiam appelio tacitum quendam naturæ confenfum, \& ueluti amo rem mutum. Atqui ipfe A elianus hoftem cerui appellat ferpentem, \& alij authores, ur audiemus, ${ }_{1}$ omnes. Defendat aliquis fpiritum faltem cerui gratum effe ferpentibus, fiure caloris ratione, quo ut ualde egent propter naturę fuæ frigidiratem, ita ueliementer defiderant:fiue alia quadam ignota, un de hoc etiã eureniat, quod Plinius tradit, ut é fummo certri gutture (ex quo filicet fpiritus meat)uftis offiburs, ferpentes congregari dicantur. Refpondeo, Cum plurimę cerui partes ferpentibus aduerfen tur, ita ut uel auertant carum morfus (ut authores referunt, \& nos partim quinto partim leptimo cap.recitabimus) uel mor fis iam lafisḉs ueneno fingulari remedio fint: non uerifimile effe quod Plis nius de gutture ufto fcribit, prafertim cumid neos authoritate alia ulla, neç experimento conffet. Quamobrem non fpiritum cerui, quatenus à certo proficifcitur:fed coniunctum illi calorem, quate, nus calor eft, ferpentes fequi concefferim: pręfertim cum (ut A elianus fcribit) hyeme poriffimumita fieri contingat:quo tempore etiam reliqux animantes, fomno id temporis $\&$ frigido ueterno obno:

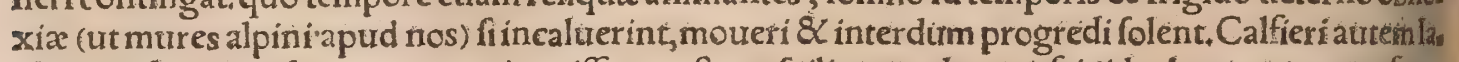
tibulum ferpentis fpiritu tantum immiffo poteft, co fćilicet modo quơ frigidas hyeme manus forr mus. Hinc fortaffis A eliantus dixit, certurm naribus admotis uehementiflimé in ferpentis cauernam inf́pirare. Simpliciter quidem infpiratio eft, cưm aér externus ab animâte attrahiturł expiratio uero, ctrm internus emittitur, A elianus atrem fentire uidetur ceruum expirantem, id eft emittentem halia tum fuum ${ }_{2}$ illum infpirare, hoc eft immittere in latibulum. Ego contrario modo ferpentem trahi exis fimo, certro nimírum non emitterite halitü, cóģ implente latibulum, fed potius aërem latibuli quan tum poteft exhauriente, ut refpirationis fuctu eo euacua to ferpens fequatur, nó aliter quàm uinum aut alius liquor canali immiffo, \& aére extracto : quo quidem modo etiam cucurbitula fanguinem hauriunt. Et fic proprié ferpentem trahere, licer inuitum $\&$ renitentem, ut ipfe Aelianus $\& x$ alịf fris bunt:fuperiore enim modo non intritus fed fponte progrederetur ferpens, gratum fibi calorem fecu tus, ut uerno folet cum Solis calorem percepit. Rurfus opponi poteft, quód Plinius inquitit, certuiani mam ferpentes urere: atqui extracto haufoç̧ aëre uri non poffunt, halitu autem fuo immiffo $\&$ in latibulum continuo ductu infpirato poffunt. Dicam non tanti apud me Pliní uerba effe, quantarei ipfius ratio certis argumentis confiderata. Aftipulatur opinioni mex fiue Oribafius fiue alits au thor, cuius commẽtarios in Hippocratis aphorifmos Io. Guinterius Andernacus primus noftro fect lo in lucem dedit, is in libri primi aphorifmum uicefimum nonum fcribens, ad quartionem qua ratio ne femen uiri genitale ad fundum ufog uteri perueniat, Sciendum (inquit) fic matricem illud exuge re, quemadmodum ceruus ad orificium cuniculi appofitis naribus, inde extrahit ferpẽtem, Qui Geo $\beta$ ponica Graca collegit, libro 19.cap. 5. Xenophontem teftem adducit, quod ceruus fpiritu fuo (iic ipfe uerto) ferpentem ceu uertígine affectam ad fefe adducat \& rapiat attrahendo: ubi Grace fic legitur,

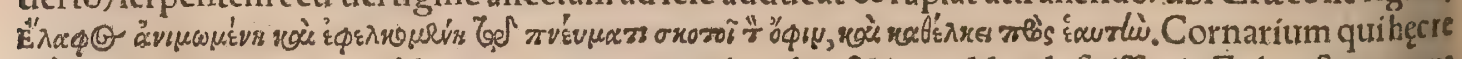
ctè conuerterat Andreas à Lacuna temere reprehendit, 8 ita reddenda fuiffe ait, Exhauftus cerurus ac uulneribus exafperatus, fuo fpiritu ferpentē obtenebrat, ad fefę́́ trahit: \& in caftigationibus feor

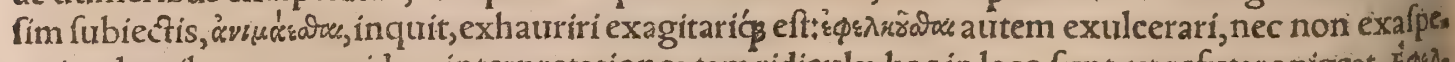
rari uulneribus:quar quidem interpretationes tam ridicula hoc in loco funt, ut refutare pigeat. Ėøฺn

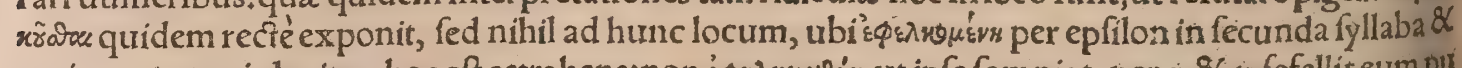

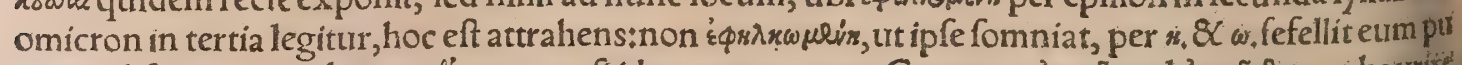

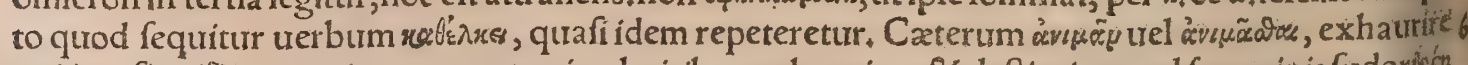
quidem fignificat: non ita tamen ut animal uiribus exhauritur $\&$ deftituitur, uel fanguinis fudorls $c^{\circ}$ fluxu, aut labore debilitatur: fed proprié a quã urel alium humorem alicưde, ut ex puteo, exhaurirt: 
uino fiunt tegmenta hominum, 8 rerum multarum operimenta, Blondus. Noftri has pelles parant; uel cum pilis, illas præfertim qua elegantiores $\&$ maculof $x$ funt, ut puluinis fediliũ inducantur : uxe] pilis demptis, ad caligas, femoralia, chirothecas, \&c, T Ex offibus ceruorum tibia fiunt. Cactus

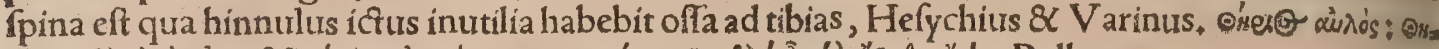

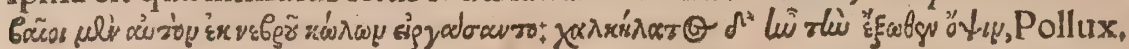

- Ceruis, ut dixi,cum ferpentibus pugna eft, quas etiam cauernis extractas mandût. Nec urerò ipfi, fpirantesćs tantum(inquit Plinius)aduerfantur, fed membratim quoq̧, E fummo cerui guttus re uftis offibus congregari ferpentes dicūtur, Plinius. Sanguine quoç̧ ceruino, fi unà urantur draa contion \& cunilago \& anchufa, lentifciligno, contrahi ferpentes dicunt: Diffipari deinde fi fangui, ne detracto adijciatur pyrethrum, Idem. Pelles cerui fubftratze fecuros praftant à ferpentium metu fomnos, Plinius. Aut tu ceruina per noctem in pelle quiefés, Serenus cap. 46. In ceruîna pellefi ia cuerit, nullus ad hominem ferpens accedit, Sextus. Medulla perunctos feuóue cerui aut hinnuli, fugiunt ferpentes, Plinius. Ceruina medulla prater cæteras, ferpentes inuncta fugat, Diofcorid, Medullam ceruinam incenfam tecum habens, cum eadem fuffumiga locum in quo es, \& effugat fer pentes, Sextus. Nicander in Theriacis unguentum quoddam prafcribit ex carne ferpentium, me dulla cerui, \& unguento rofaceo cum oleo ceraćs, quo inuncti à ferpentium morfu tuti fint. Adipe ceruino elephantino ó perunços, ferpentes fugiunt, Idem. Serpentes fugiunt omnino dentem cer ui habentes, Plin, Alia lectio erat, Fugiũt omnino aliquid cerui habentes, quę minus placet:Nam de dente Serenus etiam fcribit, Aut genere ex ipfo dentem portabis amicum. Coagulum hinnuliex aceto bibitur ab ictu ferpentium: \& fi omnino tractatũ fit, eo die non ferit ferpens, Plinius, qCer= uis cum ferpente pugna eft, $\&$ c. ideo fingulare abigendis ferpentibus, odor adufto ceruino cornu, Cornus ceruini odore(nidore, fumo, fuffitu, fuffimento, uftrina, incenf $u_{3}$ ) ferpentes fugãtur, Plinius, A elianus, Varro, Palladius, Rafis, Cornu cerui crudum fuffitu fugat ferpentes, Diofcor. Catren, dum ne pulli à ferpentibus afflentur : id uitatur fapius incenfo cornu ceruino, Columella. Etalibi, Vt exitiofis ferpentibus tecta liberentur, muliebres capillos, aut ceruina fapius ure cornua, quon rum odor maximé -non patitur ftabulis pradictam peftem confiftere. Accenfis utrislibet, (de, xtris uel finiftris cornibus, ) odore ferpentes fugantur, Plinitus $\&$ Solinus, Si quis ceruicornua in puluerem excidat, pofteaç excifos in ignem pulueres conn̈ciat, fumus inde nafcens undio que ferpentes fugat, Gyllius ex Aeliano. Serpentes fugiunt odorem cornucerui, fi inde $2 u n$ gue domus fuffumigetur, Albertus. Rafis tamen, à quo ille fua ex animalibus remedia tranforib pfit, fic habet: Si locus in quo culices funt, cornu ceruino 8 unguibus capræ fuffiatur, difcedent, Cornus ceruifacto incenfu plurima infectorum pars fugiunt, Ariftoteles, Quin \& ipfi cerui (tts ftes funt Etymologus $\&$ V arinus) ut ferpentes è cauternis propellant, cornu ad proximum faxum attrito concalfactóş, aërem nidore imburunt, quo percepto illa progrediuntur. đI Ex cornu cerul fiunt quadam ornamenta armorum, Blondus, Ceruina cornua, ligneo prafertim capiti inferta, parietibus diuitum \& nobilium affigurntur, tum ornamenti gratia, tum ut ufum prabeant fufpell. dendi à ramis qua quis uoluerit, Cordis draconis pingue in pelle dorcadum neruis cervinis adal. ligatum in lacerto, conferre iudiciorum uictoriæ magi promittunt: Primum fpondylum aditus pote ftatum mulcere: Dentes cius illigatos pellibus caprearum ceruinis neruis, mites pręftare dominos, poteftateś́ exorabiles. Sed fupereft compofitio, qua inuictos faciunt magorum mendacia: Cauda draconis \& capite, pilis leonis e fronte \& medulla eiufdem, equi uicforis fpuma, canis unguibusadalligatis ceruino corio, neruisḉ cerui alternatis \& dorcadis : Quæ arguiffe non minus refert, quàm contra ferpentes remedia demonftraffe, quoniam hac morborum ueneficia funt, Plinius,

$$
\text { DE VENA TIONE CER VI. }
$$

Ceruus animal eft fimplex, \& omnium rertm miraculo ftupens $;$ in tantum, ut equo aut buculi accedente propius, hominem iuxta uenantem non cernant : aut fi cernant, arcum ipfum fagittasị mirentur, Plinius. Stupent omnia, propterea facilius obuios fe prabent fagittantibus, Solinus, Cers

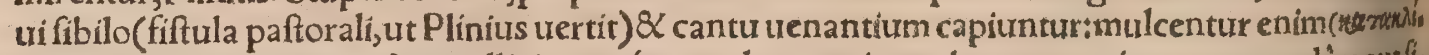

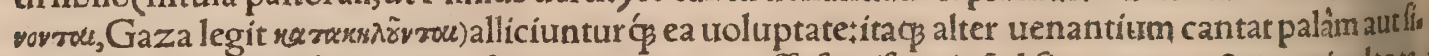
bilat,alter clam ferit à tergo, ubi focius tempus iam effe fignificarit:fed fi ceruus ereças auriculas tes neat, acerrimé fentit, nec latêre infidix poffunt: fin demiflas, facile interimitur, Ariftot. Albertus hunc uenationis modum fieri ait, cum aliquis folio fub ligna pofito fibilat, imitando uocem hinnull, ad quem fonum prodeat ceruus, pracipue uerò capreolus, \& reliqua ut Arifoteles. Si audierint cerui tibiam aliquam fiftulamćs concinnè fonantem, non fugiunt, fed expectantes capiuntur, ridea licet fuauitate Muficx allecti, Xenophon in Geopon. Grarcis. Hominem adulatione deceptim tis gnificantes Aegyptï cerutrm pingebant cum tubicine:mulcetur enim certus cantus modulamine, ac fic quodammodo oblitus fui capitur, Horus. In fundo quem in Thufculano emit hic Varroài Pifone, uidifti ad buccinam inflatam certo tempore apros $\&$ capreas conuenire ad pabulum: Et pat Ió poff, Ibi erat locus excelfus, ubi triclinio pofito coenabamus. Quintus Orphea uocari iuffit:qui cum eo ueniffet cum ftola, $\&$ cithara, $\&$ cantare effet iuffus, buccinam inflauit:ubi tanta circunflit xit nos ceruorum, a prorum, \& caterarum quadrupedum multitudo, ut non minus formof um mihi uifum fit fpectaculum, quàm in Círco maximo xdilum non fine Africanis beftịs cum fiunt urena 


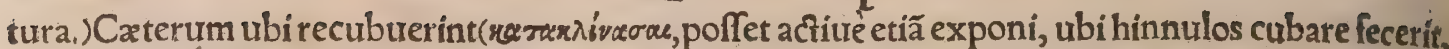

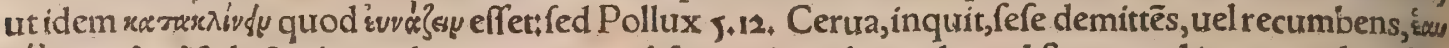

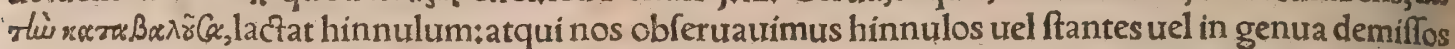
à matribus etiam ftantibus lactari;) \& lac prabuerint, ac ne ab ullo uideantur círcûfpexerint, fuum

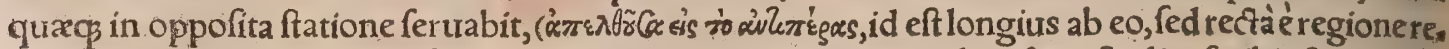
cedens: Pollux non ceruam, fed ceruum genitorem longius recedere $\&$ cuftodire fcribit, $\&$ acceden tes impugnare:quod non fecilfet puto, fi raraxi ivrorac apud Xenophontem actiuè accepiffet: nunc cum in neutra fignificatione ponat, $\&$ ceruam cubãtem faciat, non fimul etiam in oppolitum locum eam recedere dicere potuit, fed patri hoc tribuit, quod mihi minus placet. Ariftoteles enim mares à forminis extra tempus libidinis feparari tradit: $\&$ notum eft quod mares in quadrupedũ genere nula lam fobolis curam fufcipiant.) Hæc ubi uiderit uenator, canes foluat: ipfe uerofumptis iaculisad

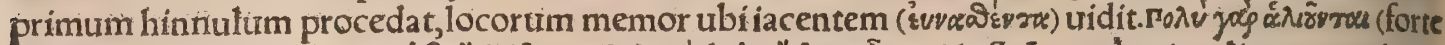

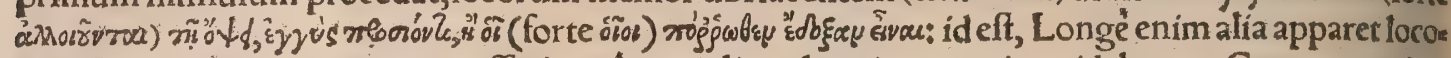
rum facies, cû̀ quis propius accefferit, quấm qualis ex longinquo prius uidebatur. Curm autem iam uiderit hinnulum, accedat propius. Ille immotus iacebit, ueluti terræ affixus, \& fe opprimi ('averíâre)

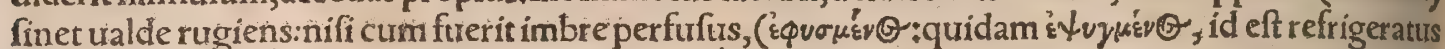
legit:ego ephyfménos, id eft imbre madidus rectêlegi uideo:) tunc enim haudquaquam manebit:ी quidem humor in ipfo (id eft hưmiditas pluuialis in cute eius) rigebit frigore; (nam cutis humida $f_{a}$ cile friget, prælertim matutino tempore:) qutod eurm fugere cogit. Capietur autem à canibus cum $l a$ bore infequentibus. Captum cuftodi retium tradat:rugiet ille. Cerua partim uidens, partim audiens,

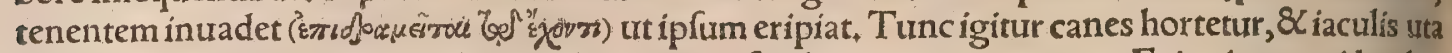
tur. Hunc ubi obtinuerit, ad alios tendat, in quos fimili uenatione utetur. Et iuniores quidem hin nuli hoc modo capienturțiam úerò grandiufculi difficilius:nam cum matribus alịjsḉs ceruis pấcun tur:quibus in medrjy cum agitantur, fugiunt: fæpe inter primos, raro inter poftremos: $\&$ pro illis pus gnantes cerua canes proterunt. Itaq̧ non facile capi poffunt, nifi quis inuadens fubito diffipet, utex ipfis quilpiam unus defituatur: quod ubi coactis eis acciderit, hinnulum fequuti canes primo curfu fuperantur. Nam trepidum illum facit abfentia ceruarum, \& hinnulorum in ea ętate celeritas incom parabilis eft. (Quafi dicat, Hinnuli iam grandiufculi,tum natura celerrimi funt, tum auget celeritax tem metus, quo foli relicti afficiuntur.) Secundo tamen tertióue ftatim capientur. Corpora enimillo= rum cum adhuc tenera fint, labori fufficere non poffunt, Quinetiam tendicula (podoftraba) cer: 30

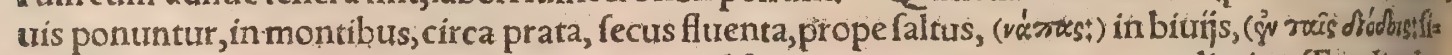
gnificat autem diodos etiam fimpliciter uiam uel femitam:) in arvis, qưocunç adierint. Tendiculas auten oportet ex fmilace plicari, \& delibrari (id eft cortice fpoliari) ne putrefcant. Harum coronafis ue Hexus (fpira Omnibono) pulchre rotundus fit, 8 infertos habeat clauos ferreos ac ligneos alter,

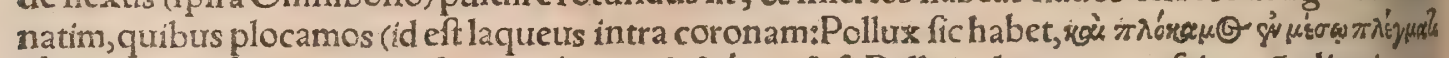

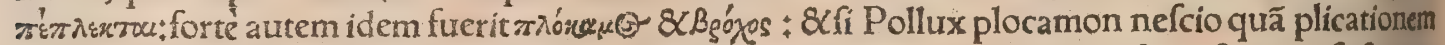
in ipfius plegmatis, id eft coronæ parte media dicere uidetur, ut non intra ipfam, fed in ipfa $\&$ pars iplius fit: Et forfan neipfe quidem Xenophontis fentëtiam affecutus eft, nam cưm uerba eitus tran. fcribat, hoc in loco aliter habet quàm in Xenophonte legatur:) implicetur. Debent autem ferrei clati robuftiores effe, ut fi lignei cefferint, hi pedem premant. Caterum laqueus funiculi, coronz fuperpo 4 nendus, \& funis ipfé é parto contextus fit:nã fparti materia putredini miniméobnoxia eft, Laqueus ipfe funiculusćs ualidi fint. Lignum à fune pendeat quernưm aut iligneum, longitudine trium dos drantum,craffitudine palæftæ, id eft palmi (Omnibonus uertit ulnæ) cum cortice. Porrótendicula ponendx funt aperta frobe quin $\phi_{\$}$ palmos profunda : ea fuperne rotunda fit, $\&$ coronis tendicula rum æqualis:interius uero fundum uerfus magis magisćs in anguftiam colligatur. Similiter funícu

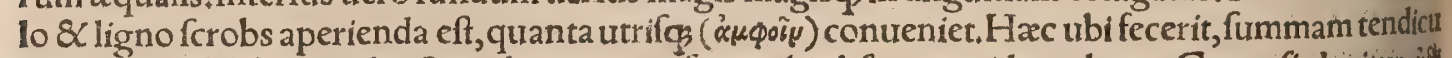
Ix fcrobem fubfternat, (ut Omnibonus transfert:mihi obfcurus uidetur locus: Grace fic legitur, iut

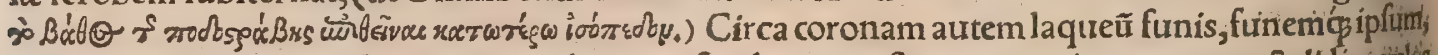
\& lignum deponat, in furm utrunç locum, (frrobem:) poftea coronx imponat atractylidis caulís tranfuerfos, (uirgulas enodes, Omnibonus:) qui non promineãt foras. His folia minuta iníciat, gữ tunc anni tempus habebit. Poftremo frobem terra implebit, ea primum quę ex fuperficie cum fodes reinciperer, ablata eft: deinde terra firma procul inde fumpta, ut ceruæ quàm maxime occultus fitlo cus.Qtiòd fupererit terræ, afportetur longèà tendicula. Quia fi recenter motæ terræ odorem certá fenferic, fentit autem fubitò, auertetur . Porrò ceruas montanas uenator cum canibus in aurora pos tiffimum, quanquam $\&$ reliquo die, obferuabit:campeftres ueró diluculo tantum. Nam in montibus non noctu foltrm capiuntur, fed etiam interdiu propter folitudinem $\div$ In agris autem nocte tantum:

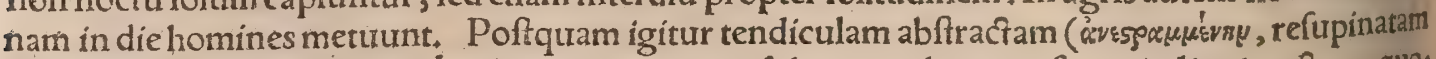

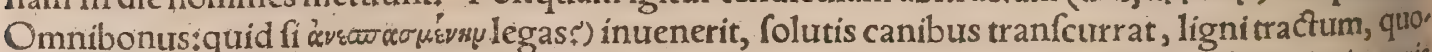
ctinc; ferat, obferuans. Erit enim plerunç non incertus, quippe motis lapidibus, \& limite in agris ducto, uia manifefta erit.Quód fi per afpera loca feratur, raptus de ligno cortex lapidibus harebit, \& fic facilior erit perfecutio. Iam fi pede uinctus fuerit anteriore, cito capietur : nam lignum inter cur rendum, corpus totum $\&$ ora ferit, Sin pofteriore, lignũ quod trahitur uniuerfum corpus impediet, 
ad alterum fylura latus falit, $\&$ in fubfyluana arbufta progreffus, manet. Idem frequentius calles an guftos fequitur. Foemina uerò cum à pafcuis difcedic, rectà in fyluam pergit, \& denfiora fequitur lo. $\mathrm{Ca}_{j} \mathrm{ab}$ uno ad alterum progrediens, donec in condenfo aliquo tandem remaneat, Author innomina tus * Circa Romanos agros inćp̧ fyluis fuburbanis, infidiatores nocfu ad lumen Lunæ , iaculis uel machina ferrea igni crcpitante transfigunt capreas, ceruos, urfos, $\&$ apros, Blondus, $\mid \mathrm{A}$ Apud Cel tas aiunt pharmacum(id eft herbam uenenofam, uel confectum ex eius fucco uenenum;nam $\&$ aco nitum pardalianches in Armenia nafcentem herbam uenenofam, fimpliciter pharmacon appellat) effe:quiod Xenicum ab ipfis appelletur, mira corrumpendi celeritate. Quamobrem urenatores cum ceruum aut aliam feram tinctis eo fagittis percufferint, mox accurrere $\&$ carnem circa uulnus $\mathrm{ex}$. cindere, ne urenenum fubeat. Eo enim infectum corpus putrefceret, $\&$ in cibo uenenofum effet, $\& c_{*}$. Ariftoteles in Mirabilibers. Nos in Lupi hiftoria de aconito dicturi, Xenicum docebimus primum aconiti genus effe, quod Galli alpini hodie toram urocitant. Licebit etiam toxicum hoc uenenumap, pellare: eò quod toxa, id eft fagittx (per fynecdochen) eo inficiantur:quanquam alterius toxici exiperarum fanguine apud Scythas confecti A riftoreles eodem in libromeminit. Toxicũ ex herba apto fimili(ranunculigentis eft, à qưo rifus Sardonius dictus) Hifpanis in ufu fuiffe, author eft Strabolib, 3.Plinitus toxico nomen ab arbore taxo factum putat:quod non placet, etiamfi taxo uenenum ineffe

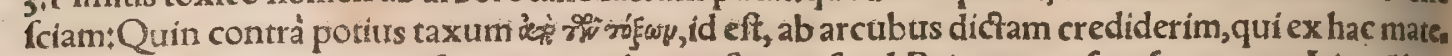
ria optimi fiunt. Quem in ufum in montibus noftris cæra ad Britannos uf̧̣ afportatur. Limeü her, ba appellatur â Gallis, qua fagittas in urenatư tingunt, quod uenenum ceruarium uocant, Plinitus; Idem uidetur quod Ariltotelis Xenicum, \& forte ita legendum erat. Nam cur limeum dicatur, ratio nulla fe offert, xenicum uero tanquam arfenicum ab eadem ueneni ui dictum aliquis coniecentt, Tofí quafi toxicum apud alpinos quofdam Gallos uocatur, fi rectè memini, ea herba quam in Boure confiliginem effe docui.In Arabicx fectæ medicorum libris toxicum uenenum fagittæ Armenæ no mine appellari obferuauimus: haud fcio quam ob caufam, nifi quod in Ariftotelis Mirabilibus legi, in Armenia pardalion diçum uenenum nafci, $\& \mathrm{c}$. Eft autem id non aliud quàm primum aconitige nus pardalianches Diofcoridi dictum, quod hodie quidam alpiũ incolar(ut dixi) toram uocant,eog fagittas inficiunt. Toxicum quidem apud Gracos medicos, non quoduis quo lagittis tingendisuea nenum diuerfa gentes utebantur fignificat, fed unum aliquod certumás genus, unde fit ut certa e. tiam remedia aduerfus ipfum defcribant, quod recté fieri nó poffet nifi unum \& certum aliquodué nenum intelligerent: quod quale fuerità nemine explicatur: fitue quoniam uulgo notum effer, quod mibi non fit uerífimile:fut potius quoniam ignorabant, ut quod ex alienis regionibus, Gallia \&A menia afferretur, unde etiam xenicum forfitan, quafi peregrinum, appellari potuit. Nes; enim aliud Diofcorides $\&$ alij de toxico quíd fit feribunt, nífi barbaros(id eft externas gentes) fagittas eo tinge re. Situe igitur toxicum herba ef, fitue ex herbæ fucco paratum uenenü, toram uulgo dictam effecre diderim, \& A riftotelis Xenicum, \& limeum (firectélegitur) Plinij. Aduerfus xenicum Celtarü (ina quit Ariltoteles)antipharmacum repertum effe aiunt corticem quercus: (ciufdem, uel fagi, uelith cis corticem Diofcorides contra toxicum commendat:)Alin aliud quoddam folium (forte pentaphyl lon, id eft quinquefolium, ut Diofcorides habet:) quod Celræ coracion uocểt(alludit ad coracion alis quo modo uocabulum tora, cuius antipharmacum hodie antoram, quafi antitoram, appellant, \& $\mathrm{q}_{\text {.) }}$ ) A conito uim effe fepticam, id eft putrefaciendi, omnibus conftat: eandem \& xenico tribuit Árifo, 4 teles. Quanquam 8 reliqua onnia toxica, feptica effe probabile eft. A coniti genus quod apudnos nafcitur, os \& fauces inflammare ip fe meo periculo didici, Nam cum imprudens aliquando eiusta dicem guftaffem, non deglutiuifem tamen, magnum paulò poft feruorem percepi, non continuum fed inxqualem tanquam mordentibus formicis. Os autem \& linguam inflammari à toxico quroqure Diofcorides prodit. Sed ha coniectura funt noftræ: plura de his uenenorum nominibus, in Lupi hiftoria, ut promifi, dicêtur. đFeræ pecudes, ut capreoli damæćs, nec minus orygum ceruoruníg genera, modo lautitís $\&$ uoluptatibus dominorum fertriuntmodo quaftui ac rediribus, Columella 9.1, ubi agit de uiuarijs faciendis. In leporario, inquir Varro, non folum lepores includuntur fyltra, ut olim, in iugero agelli, fed etiam cerui aut caprea in iugeribus multis . Pifces quidam nigri uenes nati in Armenia reperiuntur: horum farina ficus confperfas in ea loca qua maximé abundant fert is diffeminant. Beftiæ primum ut eas attigerunt, ftatim moriuntur : at $\$$ ea fraude apri, cerui, \&c, ne, cantur: nam eiufmodi animalia ficuum \& farinarum auidiflima funt, Aelianus, II Scythis $\&$ Sart matis uenationes funt, inter paludes quidem ceruorum aprorumóg, in campis autem onagrorum $\&$ caprearum, Strabolib. 17 .

A P PENDIX DE VENATIONE CERVI,

Ea quæ doctiffimus uir Guilielmus Budęus fecundo de Philologia libro de trenatione certuorum elegantiffimé fcripfit, cum reperirem Dictionario Gallicolatino Roberti Stephani, uiri de ominibus bonis literis optimé merití, in calce adiuncta, omnino digna exiftimaưi quax noftro huic operi corol. larn̈ inftar feorfim accederent, adiectis pariter, ut illic reperi, uocibus \& phrafibus Gallicis, quas pa" renthefeos fignis fparfim inclufi, Ea igitur huiufmodi funt.

- Fera fugax, fallax, lubrica, longis anfractibus interdum fruftratur urenatorem. Mæandros fiu ga implicare infignes cerui folent, quumillud Dianx latrabile fatellitium truciós riçu terribile cos 


\section{DeCeruo. E. Lib. I.}

etueftigio fequitur. Veftigatores artis uenatoria callentifimi, Moloffos, echemythos (limiers qui nè

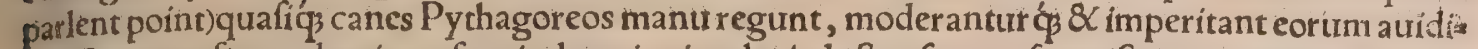
tati.Quorum fit prudentia, ut fera indagationis or be in luftro fuo(en fon gifte) circumuerta, canibus excurforibus(chiens courans) improuifo obïciatur, qui recentia perluftrent $\&$ odorata treftigia $f u=$

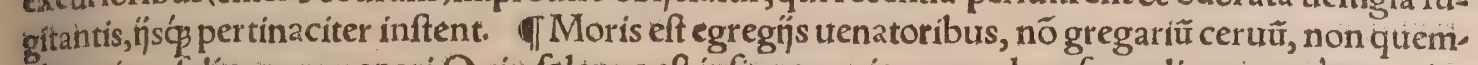
libet etiam folíuagum uenari.Quin folenne eft ipfis, non minorem ad curfum eligere, quàm qui itu= ftx proceritatis effe uideatur. Id autem non afpectu modo cerui, fed plexunq̧ ceruinis ueftigñ s, ex: crèmentorumç̧ ftercufculis (les fumees) iudicatur:qux inuêta uenatores diligenter colligere folent, atģ intra cornu uenaticum(la trompe) condere. Sunt $\&$ magnitudinis indicia: affriçus ad arborum oftipites, qui confpicui fape funt intra fines ftabulationis eiustum cubilis inuenti amplitudo, 8 fub. ftramenti laxitas ubi interquieuerit. Hęc enim \& alia renunciari in concilio venatico (a l’affemblee) à ueftigatoribus folent:quos reges habent uelut mancipes inftrumenti uenatorï atq̧ minifterï, eo= rumó̧ arbitrati, concilio faltuenfi dimiffo, uenatum committere folent: quod fermone peculiari dicirur ${ }_{3}$ ceruũ aut feram cuiufuis generis canibus permittere, (liurer aux chiens $s_{+}^{+}$) \& copulas canưm

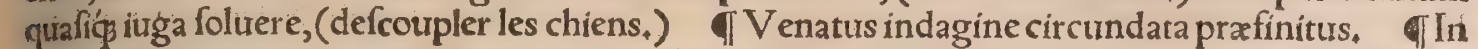
ipfa ferarữ exagitatione, omnia uenatoris munera exequi, pernici curfur uenatus fpatia permetien= do:contrás certuí uafri \& exercitati(cerf ruzè)ftrophas, uenatorias antiftrophas ex tempore commi

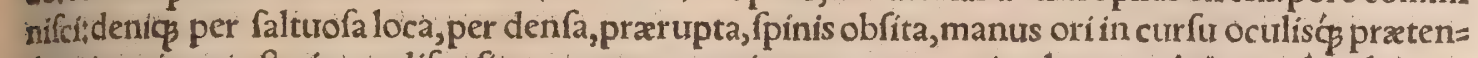
dere;interim per ftationes difpofitas ex equo exanimato recentem in alterum(chétuaux de relais)at= 10 que in alium nonnunquam affilire. TEgo interea tutus carbafeum feptim (les toiles) curriculo - ambibam in equo fedens:capitećs fupra carbafa eminens, certamé ipfum arbitrabar oculis, atç̧ fine difcrimine circumfpectabam. Ceruus grandis (grand cerf) urocatur is demum qui decem cornis culis, quod minimum fit, infignitus eft. Hunc ego (ait Budxus) eximium uoco \& decumanuminon quafi denarium, fed tanquam eminêtem $\&$ egregium. Eiufrnodi cerưus fape comitatus incedit uno minore ceruo, qui nondum tutela fux factus fit, quem uos armígertm eitus urocatis, l' efcuyer dur grand cerf) ego etiam optionem (optio $\&$ antea accenfuts uocabatur, quem decurio aut centurio re rum miniftrum fibi optabat, \&c. Feftus.) decumani, \&comitem, \& parafituin, atç emiffarium uroca. ri poffe credo. Qui cerui atate adhuc funt gregariatatrt licet foliuagi fint, indigni tamen trenatu iu dicantur, quafinondum annos ætatis impleuerint curricularis † réịculi â uenatörbus appellantur. 3o Miediocrem ceruum uenatores cum fignificare uolunt, aiunt ceruum effe uenabilem; tuenabili tha: gnitudine, uenatui iam adultum, fed ueluti tyronem $\&$ notitium. His enim tierbis utuntitr indaga= tores, quum indagationem antelucanam 8 matutinam renunciant in conuentu faltuenfi; fignifis rantes ceruum quafi fubdecumanum. T Conuentus fub diuo celebratur:ibiós coetum ómnê ftra turm per herbam, in ftibadịs menfam Principis: Confilia etiam agitari, quem potiffimum ceruum uenandum fufcipiãt ex ị́s qui digni uenatu effe renunciati funt. TDiuerfax prouincia mandari indagatoribus folêt, ita ut quir. que fuam obeat, in alienam pedem non inferat indagandi gratia, néue in ea quid obturbet, neu pro poteftate faciat. II Indagator ueftigin's cerui inftat, aut foleatis (la forme du pied) fi locus uligino= fus eft, uel pluuia antecefferunt:aut odoratis arente folo:ad qux fequenda Moloffo ueftigatore (le li 40 nifier) utitur, at $q \xi$ eò ufq $\$$ perfequitur, quoad decumanum recubuife in proximo certís fignis explos tatuerit. (V eftigia cerui Galli uocant erres ; ubi ueró forma pedis non apparet, trt fit ubi tuel nimia herbxe crefcunt, tiel nullæ, fed locus atidus ac durus eft, aut folia impediunt, aut aliud quiddam, fous= lees du cerfappellant.) Verum ne ille fortaffis, aut accelfu indagantis propinquiore, aut Molofi fremitu, aut panico (ut fit interdum)territus, inde excefferit: (tametfi enim eitufcemodi canes infignis. teauriti,generis fint Harpocratici, (chiens muts:) tamen quum propius acceflêre, nefcio quid pra feruore obloqui atog gannire plerunģ folent, máliś́s increpitare:) Ne igitur ceruus hưiufcemedi ali quo cafu aut culpa, e cubili matutino profilierit, indećs longius abierit, folennis eft cautionis inda gine latiore cubilis locum circumforibere: Moloffum numella (collier)regentem \& compefcentem, necinde difcedere, donec exploratum habeat, feram intra fpatium à fe circinatum iacere. Gyro clats yo dere ceruum uocant, \& ibidem fiftere . TRex Francifcus, huius notminis primus, hanc propemo= dum formulam uenatici proceffus inftituerat, Quum polt renunciationem circuitorum, de concilip fententia decumanum untm aut alcerum, ad eius diei fpectaculum delegiffet(nam interdum pomea ridianam etiam uenationem matutinæ addere folebat; quum fuccenturiatas copias canum haberet, geminumó̧ inftrumentum (double efquipage) conuentus foluebatur : ad uadimonị locum ibatur. Moloffus rur fus é loro numella (la longe ou laiffe du collier)cubilis indíciú faciebat. Feram inde im= petu facto excitabat, quod uulgò lancinare dicitur (lancer le cerf.) Tum decuria canum leuis excur fus(chiens courans) foluebantur: buccinis (trompes) fignum uenatts commifli dabatur, \& tanquam bellicum canebatur ad canes exhilarandos (pour resbaudir les chiens) \& acuencios. Subfidiaria ca. thum decurix ad locos deftinatos dimittebantur, qua feffis fuccederent, fi res ica ferret: $\&$ alié rurfus 60 ad pomeridianum miffum afferuabantur integrx. Decumanus ipfe ceruus canibus excurforibuis'; equis celeribus, buccinarum clangore, uenatorum clamore, concentu allatrantium canum urgebáa tux, Quod fi cafu aliquo eureniebat; ut ante uenatus aufpicatum indagator non liquere renunciar 
certamen in pofterum diem reỉciebatur, aut ceruus comperendinabatur. Nam ut diutius fpecfact. lo eximeretur \& certamini, rariffimè contingebat . Sin coli intemperie, aut antiquioris curra auoca mentis eureniebat:uelut reus ampliatus, primo quogz die uenatico ad curfum repetebatur impetur a, troci \& peruicaci. Fllud uero pracipua admiratione dignum eft, quod is eximitrs ceruus, quem ue nationideftinatũ, canibus peritis magiftri femel exagitandum dederunt, ita in pradam illis obiectus eft, ut interdictum fibi effe omnibus alips intelligant. In multiplicia autem frepe ueftigia medins in fal tibus ut incurrant neceffe eft: prafertim in quibus feri greges facrofancti furnt legum regiarum fancrionibus, quas aquarias faltuariasq́a dicimus, (Par les ordonnances fur le faiç des caures et foreftz.) In aufpicando uetiatu nonnunquam noxia admittitur, $\&$ ab ipfis ftatim quafi carceribus perperam. curfus inftituitur, fi impoftura fiat canibus:quam huiufmodi elfe frequenter $q$ accidere conftat. Infi: gnis ille ceruus æatate $\mathcal{Q}$ ufu ureterator (cerfruzè) folet fatellitem fuum cerumm, nunc pediffequim, nunc anteambulonem habere, quem armigerum dicunt, (l' efcuyer du cerf) quafi grandi ceruo fub. feruientem. Hunc ille infignis ín cubili fecum deprehenfum 8 repente emicâtem, interdum canum cæcæ auiditati obịcit, ueluti uxictimam uenatrici deę pro fe fuccidaneam, præftigia quadam fefe octr lis corum naribusćs fubducens. Verum hoc illicó animaduertere experientis eft uenatoris ${ }_{g}$ pracipi. tisç canum impetus errorem compefcere, \& fallaciam cerui irritam folertia fua facere. Id frangere canes appellant (rompre les chiens) quod fignificat cirrfurm illum male coptum fiftere. A gmine igi turr retro per ftatorem illum uenatorem inhibito (quod clamofo, crebro, caftigabundo uociferatulie ri folet) inftauratiua indagatione opus eft, 8 cane rurfus numellario (le limier) ut agmen excurfo= rium in ueftigium maior is cornigeri reponatur. Qua denuo arrepta, decumanus ille corniger praci, piti primum fuga, deinde ludificante rapitur, loquaci canum agmine certatim eum urgente, clangen, téćs comíatu, quoad diuturno curfur fraçus atq̧. exanimatus, tandem ab uniuerfo. Dianæ fatellitio circumueniri fe minaciter mordicusó patitur: qui exitus eft claufulá̧ ludicri.

- Vererator em ceruum uerfutumás un lgus uocat, qui multa \& exquifita perfugia atrocis fupp. plicí nouit, uitæx́s præfidia. At proceres maiorum (ut ita dicam) gentium exercitores ferarum, non ut alifi, planum \& uafrum ceruum, fed cordatum \& prudentem uocant (cerf fage) ob íncredibilem eius animantis folertiam, qua à natura munita eft; pręter uolucrem celeritatem \& corniculare propu gnaculum. Solere ceruos aiunt fimul ut fenfer unt rem fibi effe cum affeclis infeftis fimul \& fagaci

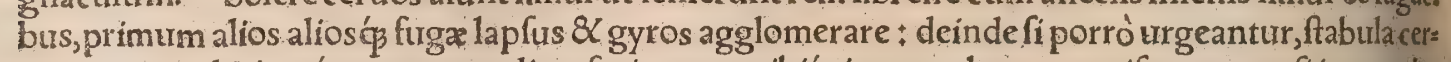

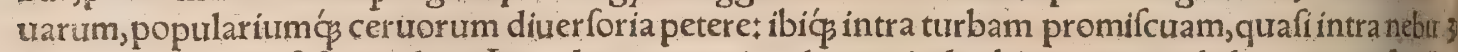
lam erroris canini fefe condere. Inter dum gregarios aliquot inde abigere, at $\varsigma^{*}$ ad aliquantum fati permixtim ueftigia facere, ad negotium canibus exhibendum, Quum autem aliquantifper hac ratio ne contechnati funt, ab illorum comitaturepente fe fubducentes, per tramitem deuium longiufule abfcedunt, deinde interfiftunt: ut interim canes ueftigia ceruulorum aut ceruarum excipientes, dia trerfi ab eis auferantur. Quum hrec fropharum commenta, canum experientiffimorum uis odoran di uicerit, circumfpiciêtia utí̧ uenatorum adiuta:ad alia denuó fe uertunt fubfidia falutisțtuiufrio: difunt, per fua quadamtenus recurrere ueftigia ; deinde fpiras furgæ intorquere multipliciter $\& 4$ ua riè, \& quàm fieri poteft perplexiffimé: tum raptim longius procurrere: qux omnia comminifcuntur aduerfus folertem canum fagacitatem. Ita $q_{\beta}$ interim dum canes intenti funt deducendis elapfibus $\&$. extricandis qui ab ipfis ceruis glomerati funt, fpatia magna illi permetiuntur ${ }_{+}$quum interea buccina 4 rum hortamenta, curfitantium canum híantem acuant auiditatem, $\Phi$ Solent cerui plerunç fecundo uento ferri, treis (ut perhibent) ob caufas. Príncipio, quum aduerfo uento feruntur, uentus ore \& na ribus irrumpens, fauces corum uehementer arefacit, animaćs duçum inhiber. Deínde fecüdo ven. to cedentes, quum canum uocem facile excipiunt, ex eaćp colligunt propinqui an remotifintumue rò olfactum fui fequaci turbar adimunt. (De hac cerui uento fecundo fuga, dixi etiam fuperiusex alins authoribus. ) Inter exẽpla huius animalis, ultima perfugia exquifitá̧̧ experientis, har finţ commemoratu digna: Vifum effe certum in armentum bubulum irrumpere : infilientemq́g in bo: uen, primoribus cruribus armiş̧́ complexum, ad longiứculum f patium uelut equo urehentem, po fremis tantum ungulis terram ftringere: ut odorem fui canibus, quoad fieri poffet, exile incertunç relinqueret,

- Ludouico rege huius nominis XII, uenatorix turma decurio, qui uenator maximus appella tur (le grand ueneur) ad durodecimum ab urbe lapidem uenabatur, uiro Præfidi id fpectaculumgta tificans, qui Budæum comitem fecum amicitix caufa eò duxerat. Ibi cum mentio huiufcemodimirift centiarum ceruinarum incídiffet, hoc affirmabat. Me (inquiebat) pridem uenante ceruũ quendam ab atate $\&$ experientia uafrum, euênit feruente uenatu $\&$ longé iam progreffo, fugitiuus ut ille non compareret: $Q$ tamen canes nec ultrà procedere uellẽt, nec in fua ueftigia redire. Ibi omnes fupere, circumfpicere, inter fe afpicere, lapidem (quod dicitur) omnem uenatorés 8 magifri mouere, Res erat miraculi plena, \& A pollonianæ præftigiæ fimilis, quafi fublimis fera alipes abịffet a ut terra di fcedente, rurfumóç coéunte, non compareret : aut oculos noftros canumọ́ praftrinxiffet. Tandent omnia (ut fit in tali cafu) à nobis perluftrando, deprehenfus eft planus ille cornipes in furto fui mas nifefto atç memorabili. Alba ibidem erat fpina enata in loco défo atç opaco, que ad magnitudinem abor eam excretrerat. In eam ceruus dolis folennibus confumptis, faltu fe coniecerar, Stabat auten 


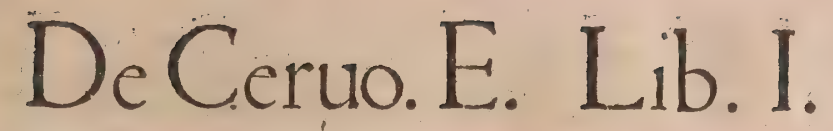

ille fublimis, ramis fruticis ipfo faltu diuaricatis: fic interceptus; inde ut defilire non poffet, fitre erat forte exanimatus: Ibi enim quafi compeditus imbelliş́́ confeçus eft. A tqui ut omnia ludificator illeceruus faciat, $\&$ urelut alter Proteus omnes fefe in facies uertat, nifi folum quoqs noctur irerterit, poftridie latrabiles illas manus ac refimas auribus ćs infignitas, minimé ad extremũ eluctabitur:non fi anhelu's \& aftuans in amnem fe coniecerit, undiş́ fecundis uehendum fe dederit: quod fape re frigerandi caufa facit:non fi amnem traiecerit, ut canum curfum intercidat; non fi incitatiore curfu diurnoç̧̧ profligatus, animum iam defpondẽs, undis potius perire, quàm laniari malit, - Mira eft certe agriophaga illius turba pertinacia:dirum autem fatum cornigera animantis, quum ad extre mum laffitưdinis adducta, opperiri cogitur atrocem illam clamofam - undigg fe riçu petentem minaciffimo at $\not$ infeftifimo. Qua tandem circumuenta, poft omnia falus: tis prafidia deplorata, repenté fàpé affiliens, primum quen ${ }^{3}$ uenantium in quem incurrit, cornu pe tere folet, nifi ferro protinus excipiatur; (Enferrer d'ung efpieu de chaffe, Quód ubi factũ eft, aut fi aliâs fera afflicta \& Itrata eft; (Eft abatue)tum demú receptui canitur ab eo qui primus in eam con fectam occurrerit. Tứn fimonũ chorus ille filonumón inclamatur, \& uenatores coëunt quoquo urer firs palantes:qux tanquam ouatio eft, ob rem bene \& feliciter geltam. Quam deinde ipfam excipic uiferatio(la curee, le droict des chiens, cum ceruo capto panis fanguine eius imbutus pelliós ipfius impolitus in cibum permittitur canibus $;$ interdum etiam aliquid de armis $\&$ collo cerui adijcitur, ) extemporalis, quå fic debetur ipfa canibus trenaticis, ut libamentum capturæaccipitribus in aucur. pio uolucri. Vifceratorem autem peritû effe oportet; quilanienam ferinam ưenatoria cum palaeftra - exequatur, qui fcitè feram deglubere nouerit, membratimḉs incidere, \& profecare incifam. Tergore autem detracto, caput abfcindendum elt, Molofiós therelencho porrigeridum $\&$ permittendum(le droict du limier) quem $Q$ indagatorem appellamus. Has enim ei primitias peculiares placita maio= rumlargiuntur ob indicium feræ: nimirum ut in capite ferino lacerando $\&$ obrodendo, fructum na

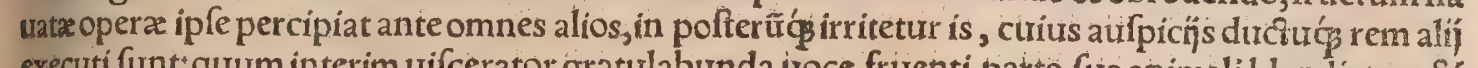
executi funt:quum interim uifcerator gratulabunda iroce fruenti parte fua animali blandiatur, \& tanquam maçum uirtute induftria çs therelenchica ipfum effe iubeat. Deinde uenatoria plebi infis móg minifterio uenationis, fuæ funt partes uifcerationis îfdem fcitis attributæ* + Epulurin cani= num omnibus in ünum euocatis uenatoribus, \& cunctis claffiburs canư decurñóş́ coéuntibus, fievi hoc modo folenne eft: Venatores intra tergus ferinum panis fragmêta fanguine feræa madentia mia go fent cum omafo, in minutas particulas concifo. Nónunquam praterea fi canes ftrigofi fint $8 \times$ ma. cicexhaufti, aut fi ftrenuaminfignite operam eo die natiauerint, liberalitatis eft uenatoria, opiparis cosimpenfius epulis accipere, ceruicem extis addentes, 8 nonnihil (ut ita loquar) é uriuo refecare. Hæc quum recté at tó ordine facta, concinnatæóp épula futerint éxerti manu uenatoris:tưn deniç lis culentos illos deæ uenatricis epulones ad epulum fui generis admittunt cum ouantium urociferatur; (la huree.) Nam antea \& interim dum epula illæ parabiles expediütur, coronæ geftientis ac canor rapacitas, culinæ circunfufx nidorem ç captantis , à miniftrís arcetur fuftes in manu geftantibus. Priore epulo peracto, fit $\&$ alterum eodém momento, fed non eodem loco: ex interaneis perpurgatis $\&$ dilutis(funt enim hac quoç Diana facra eiusóg fatellitio) non concifis fruftillatim aut profectis, fed integris;ita ut quưm aliquandiu illa uifcerator fublimia tenurerit \&oftentarit, ad irritandam eda, to cis agminis uoracitatem, tum ea demum repente in medium porriciat, Inter cæfa uerò \& porrecta cuncta uenatorum cohors cum auxilís \& calonibis, fublatis buccinis canere capturam quam uio cant(corner prinfe) debet, eo quo fupra dicium eft modo, quũ ceruus in poteftatem uenit agminis venatorï.Iam ueró buccinaturæ modos uenatores alios atç alios habent pro fignificationư uarie = tatequandoquidem indagatores non alio urocis commercio utuntur, interim dum in quęftione cer= ulfunt qui abfक co foret, aut inter fe ipfic cum noxa incurrerent, aut longius interdum euagarentur inquirendo, quĩu receptu opus effet. Nam fi unus forte(ut fit) fortuna, primore inquifitione ceruum decumanum indagine opportưna uadatus fuerit, côfeftim fignum receptus cateris buccina fura da» bit, ut illi ad contrentum extemplo fe recipiant.

I Ef interdum uenandi ratio ita conftituta, aut cafu comparata, prafenti ut cónfilio opius fit:ut fi diffufus dies hefternus fuerit, \& fifti tum cerüus certo loco nö poffit:aut fi ceruus qui ad quaftio: nem deftinatus éf, ftabulum certum nullum habeat : fi meticulofus $\&$ panico confternabilis, qui interquiefcere interdiú, cubiléç mutare identidem gaudeat: nam $\&$ íq qui recenti uenati exagitati fuerunt, ad omnem ftrepitum confternabiles, ftatarị feré nó funt. Sünt \& quil cubili excitati,illico in pedes ita fe conñciant, ut non per finitima fationis fura loca cứfitare, \& conmeare remearéćs foleant (quod pleriç ceruifaciunt) red recisis irineribus porrò femper excurrant. In hac igitur fpecie is quit canibus regendis prafectus eft, fimulacid comperit, fignum canore buccinæ dare folet, ut î qui in fubfid’́js locati funt, \& reliqui omnes uenatores at $\$ \beta$ auxiliarif, calonesḉ̧ uenatici, fui minifierî́ pro: tinus uafa colligant, quum ceruus caftra moverit. In fuperioribus autem fpeciebus fignum copulis foluendis canitur in femita treftigiali, fimul ut inuenta fera eft. . TTendiculis ac pedicis, reticula=

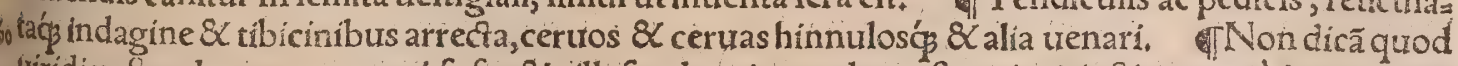
turidi uefte ad uenatum cerui, fufca \&uillofa ad apri, utendum eft, maiorũ inftítuto: quòd cer to quiò. dam modo amictũ effe oportet; qưòd enfé fuccinctum, \& cultro ad improuifa munitũ : cuòd ternos 
aut minimum binos equos uno die, eosó̧ pegafidas, oris morigeri ac ductilis habere, ad defultoriatin uiciffitudinem è feffo in recentem affilien di. Non uenatoris inlignia, non geftamina, non inftrumen tura enumerabo:Non genera canum, nó formas, non naturam, nô educationem, non inftitutionem, non probationem generoforum, non degenerum notas dicam;nó blateronum at ftigationem attingam. Omittam etiam quod ut pueris ingenuis pædagogi, fic canibus generofis cy, nagogifui attributifunt.

Quum poft coitionem illam fylueftrem de cerui nece coactam \& folutam, ad loctrm indaginis uentum eft à cohorte uenatoria:princeps ille uenator, qui ducfor effe canum moderator ḉ iuffus eft, 8 penes qृuem fafces(ut ita dicam)eius diei effe contigit: priufquam paria canum refoluuntur, fia = tuere folet quo loco grandiores canes ueloceś̨̧́ locandi fint: quos licebit ceruarios ( chiens cerfs, bauds, muts; id eft, ceruarin, quod ceruos tantũ uenentur:audaces: muti, quod cum ceruus uerfuram fecit, uocem \& latratum continent, donec eam relinquat)uocemus:quamuis cos in ordinem lepora riorum lingura uernacula redegerit, quomodo \& fuarios luparios ás:qui etiam ceruipetæ, apripera,

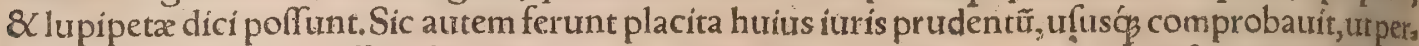

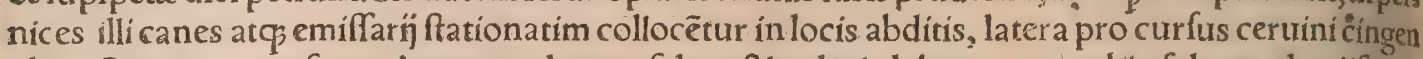
tibus, Quem procurfum ad apertum locum fylux; $\&$ ueluti glabrentem, uel in fyluam glandiferam proceram \& illuftrem pertinere oportet, ut natura habitusḉ locorũ tulerit, qua maximè uerifimile eft ceruum tandem tranfiurum:quia ea uia forfan fert ad amnem, aut ad aliud perfugium, aut fta: bulum ceruo notum $\&$ amœnũ. luftum effe aiunt ternas quidem ftationes difponere, fed geminas: fenos uerò in fingulis ceruarios, hoc eft utrinç ternos, medius ut ceruus tranfcurrẽs, utrin. ab ipfis, urgeatur. Senis autẽ ceruïpetis (qui terni ut dixi ex aduerfo fibi collocati funt) latrunculi bini é nuta mero minifterị aflignantur, quos tírularios appellare folent, qui numellis eos cohibeãt (qui tiennent les chiens en titre)quoad ceruus præterierit:tumós demum à latrunculis canes emiffi, illicet emicanı tes $\&$ improuifi, cerıum tanquam ex infidịs territum adoriuntur. Interdum etiam bini ternorû́ui: cem fupplent, fi fauces procurfus longiores fint, plures ó̧ latrunculorû ftatiunculas pofcere videanta tur. Procurfum autem ipfum confititutum effe oportet loco delecto, \& quàm fieri poteft apertiflimo: quippe in quo fyluaricum fpectaculum æditur trel principibus foeminis uel proceriburs, quorúgia tia interdum unius diei urenatus comparatus eft, quiós per fyluam euagarigrauantur, aut ceruum ureftigio perfequi. Perniciffimorum porrò canum latebra prime loco ltatuenda, $8 \mathrm{C}$ deinceps perni=ciorum ad ultimam procedendo, qux ipfa effe debet ualidiffimorum atç atrociffimorum, Id quod 3 ideo conftirutum eft, the primi qui funt uelociffimi, præcipiti curfu alipedem ipfum exerceant: tum deinde lecundi primis fuccedentes $\&$ accedentes, \& $<$ rertin rurfus fecundis, fi quatuor fint ftatiuncirs $1 x$, fractum iam\& exanimatum ad ultimos urgeant: fi quidem ad triarios (ut dicitur)res ipfa redierit, $8 \mathrm{~m}$ mus fupradictas ceruus eluctatus fit. Hæe porrò manus non à tergo, ut aliæ quæ uelocitate taa lent, fed a duerfæ feræ obïcienda:quia robore $\&$ ferocia præualens, fiftere eam poteft, $\&$ morfu relí nere, cæterisć́ lacerandam ociofe præberc. Cærterum non cuíuslibet miniftri latrunculariũ munus eft:nanç̧ nifi canes emiffarí tempeftiué emancipêtur \& appofitè, extemplo ínfidias fera fufpectanls, ac tergiuerfans, retrò recurret: aut tranfuer fo impetu aliqua erumper, ex anguftijs illis, ficubirinam nacta fuerit: aut clauftra curriculi perrumpet. Quod fi femel fecerit, nulla ui poftea fubigi poterit,in eandem ut curriculi naffam uel caput folum inferat. Id ne qua ratione eueniat,alarñs aftitibus latera procurfus frequentari folent: Quorum munus eft, fimul ut fer a carceres curriculi ingreffa eft, eam uociferatu \& equitatı utrings abfterrere, quo ipfa intra fepta curriculi compulfa, ad ultimũ tandem finum fatalemó irrumpat:quum regreffus nullus ei pateat,propter affeclas illos quadrupedes, tiocio feratores infeftifimos, Eft praterea fupradicti uenatoris, primarum partium actoris, fubfidiacar num ueftigatorum, qui excurfores uocantur, opportunis ftationibus deponere, miniftrisćs commit: tere. Ad hoc autem funt decurix canum integra comparatæ, quas relictas appellant(les relais)utdes curnjs iam fellis fuccedant, aut temere expatiaris; cerutum q́ qui fui fur tum fecerit, fi per fubfidiortm loca ueftigia duxerit, recenti uenatu profligant $\$$ exaniment. Secunda igitur tertiáç manus excur forum ea de caufa difpontûtur, ut fi res ad fubfidiarios a ut triarios deuenerit, ab ip fis uenatus dentó inftauretur. Verum hoc maximopere cauend ô, ne fubfidiarn̈ ipfi canes auerfa ueftigia protinus prose aduerfis ineant:quod tanquam in portu eft impingere, auerfá̧ (ut aiunt) aui cer tamen aufpicari.

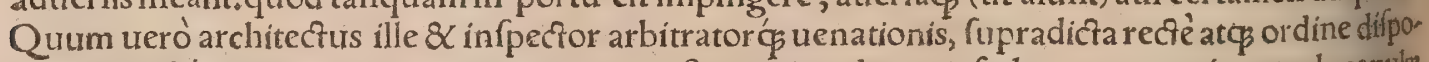
fuerit, quafí́; refoluendx funt, ceruuś́ a amini latrabili ad excurfum obrícíendus, \& exponendus ad pradami Sic autem rem temperant, ut ab ipro commiffu uenatus, hortamenta primùm remiffiora faciát: quia canes fuopte ipfi impetu ab initio ardentius feruntur. Leniter igitur uenator cogere agmen flaccorí gentis debet, fineréç cos certa ueftigia legere. Simulac uerò ceruus longius in pedes lefe dederí,gy roś́s quofdam circumferipferit, folet primum per ueftigia fua regredi, ut dereliça ftabulationismes mor, æftiuorumć furorum amoenitatẽ requirens blãdam atç̧ iucundam:quam tamẽ poftquam per= fentifcere copit fe retinere fine præfentanea certáç nece non poffe, tum deniç, falutem illi quafiul timam dicit, identidem reftitans, \& moftus folum uertit. Eft etiam quum praceieri fuga ingens lipas tium fylue pręcipiens, exin arbitratu furo alias atģ alias in alijs ftrophas cominifítur, Polcit autem 


\section{De Ceruo. E. Lib. I.}

Iffits urenatoris officium, ut ipfe agmini illi clangenti atç excurforio affeclam fée eureftigio prębeas quoad fieri poteft: \& ut dicere folent, ut acius canini tractum inoffenfo tenore perequitet. Actum ap pello uerbo quafi uenatorio $\&$ faltuenfi, femitam per quam canes ipfi ueftigatores agere ceruum dicuntur. Sin falebrarum montiumue occurfu homo inhibeatur quo minus id faciat: debet quàn citiffimép potêt, aut circuitu aut flexu cópendiofo canibus occurrere, id ́́s aduerfo uento:tum actum ab ec inter cifum illicó repetere qui nifi fub oculis identidem agmen fuum habuerit, mendofam corum excurfionem emendare non quibit. A tubi cóticuiffe canes fenferit, aut incertas uroces ambiguxásure edere, metuere iam à cerui dolo malo incipit, aut ab hallucinatione canũ ueftigia eius legentium ₹ ne aut femita excefferint actuaria, aut uenatum uerterint, \& ceruum ipfum decumanum temere pro 10 quolibet cer uro dereliquerint, Quod ut comperire poffic, receptui canere moris elt, \& Retror fus re trotfus, iterum atç̧ iterû ingeminare canoro uociferatu. बFecerint porrò uerfuram cerui canes, néene fecerint( $(\mathfrak{r}$ ils ont changè de cerf)hac ratione quifpiã maximé cópererit. Alicubi infíftat, unde canes arbitretur $\&$ obferuet commeantes. Nam fi dolus fugitiut in caufa eft illius repentini conticinij, omnis canum caterua eodem ftupore affici uidebitur. Sin uerfura temere ấ canibus arrepta ef (quod uenatores dicunt colligere, quafi agglomerare permutationis actum) claffis excurforiæ du= ctores, \& coryphxi caninæ fymphonia, qui a d huiufmodi fpecies ufu occalluerunt, actum uerfurz cum tyronibus nequaquam exequentur. (Chiens reftifs, canes qui cum uident ceruum qui petebastur alís fe immifcuffe, reftitantes manent loco, \& expectant magiftum.) Hurufmodi enim excurfo res uix unquam nuntium remittunt prad $x$ fibi ab initio defponf $x$ ac deftinata. Errore igitur intel20 lefo actuarius uenator eos retro inhibitos reducet, unde repetere priftinum actum certius legitie mumós poterunt, cum clangore fymphoniaco: aut fi crror oolo ferino admiftus eft, unde eos in gra, dum(ut ita dicam)reponere legitima excurfionis, ex adulterina aut fubdititia poterit, of Ecce au= tem rurfus aliud atç aliud incommodũ, quod fapenumero negotium illis exhibet, \& quafi uitium aufpicãtibus affert: Canes fic errore aut fraude lapfi, in integrumó̧ fubinde reftituti, in errorẽ non. nnmiquam denuro aqué grauem impingunt, auerfis ungulis uenatum illum ineuntes reperitũ:totá̧ adeo fylua quafi to to coelo(quod aiunt)aberrantes, excurrunt:nönunquam huc illuććntranfúter fi ra piuntur, ferarum gregariarum fequentes ueftigia, aut ceruorum etiam quorumuis abgregatorum, guibus fyluarum lemitę tramitesćs referti funt. In qua fpecie non modo urenatore circumfpecfo fed perínicaci opus eft, qui fugacis feræ ueftigia ungulata colligat cernurus ex ephippio, uel equũ habe 30 na poft fe trahés:alioquin inter artis magiftros prauaricari per inertiam dicítur. Et quide ut un cane unlturina fagaciras, fic acies aquilina in uenatore neceffaria. IIam uerò unius eiufdemós cornigeri ueftigia foleata, odorata, cubiliaria, fedentaria, \& curricularia, non eadem, non paria, nô fimilia ubiç funt: ex quo alia rurfus exiftit nec modica difficultas \& erratio, Interdum enim euenit, ut fele. chus certưs, naçus uiam quampiarn fqualidam \& pultuerulentam, tum diu, tum longé per eam ue. figia faciat:in quo canum fagacitas cum experientia fallitur. Nam pręterquam quòd canes turm exił

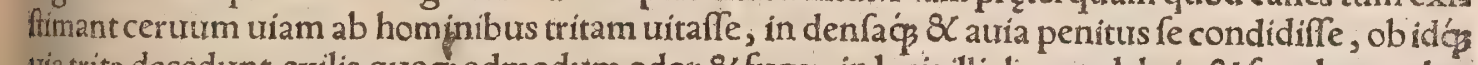
tia trita decedunt, exilis quo os admodum odor \& fugax in locis illis haret glabris, \& fqualore pulue rég obfitis:quum alioqui folis ardor in uniuerfum omnêftatim humorem, in quo ueftighy odor hae, ret, haurire \& abfumere foleat. Cótrà in locis herbidis et in uepreculis odoratioria ídeo funt ueltigia, 40 qtod non folo tantum pedum, fed $\&$ cruribus, $\&$ corporis affrictu, ueftigiaria femita odorata rema net, In locis etiam opacis odor minus furgere folet.lam paftores loca in fyluis caluentia, \& retorridis herbulis fcabrisç̧ uirgultis obfita, ob id fape incendunt, ut ex folo concalefacto herbida feges exo: riatur, qura at mentis perutilis eft. Ita quum per bufta (ut fic dixerim) illa, recentibus adhuc fauillis, ceruus uiam fecerit, canes odore fuliginis offenfi, ac crebrò fternutantes, ueftigationem defermit: qui fi etiã ipfi ibidem pertolerarint, tamen odorari ueftigia nequeunt, hebetante utiç fenfum $\&$ prę. iralente odore fuliginofo. Hoc ubi uenator actuarius animaduertit, lacunam illam (ut ita loquar) ue= ftigiorum, circumactu uitare debet:deinde intercifam ueftign̈ femiram farcire, $\&$ actũ repetere:dun= taxat nifi cerusus in fur retrorfus ueftigia cefferit. In fumma autẽ addubitatione harpocratidem illum labeonem é numella uenator ipfe confulit:quem therelenchum fupra ab in dicio fera diximus: so qui quafi quidam antiftes Diana, non uoce, fed caudx uerberatu atqs murmure \& gannitu dare re. fponfa folet;inon flexiloqua, non ambigua, omniós ueftigiali argumento indicióçs certiora. Solet eriam in huiufmodi cafu ducfor ipfe agminis ac moderator actus, quum fera per detrectationem ac dolum abeft, 8 buccinæ canore $\&$ inclamatu palabundos canes, fociosćs ludicri $\&$ miniftros iubiJatu euocare, \& celeufma requifitoritum adere, quod requeftam canere uocant'corner requefte.)Id eft fermè perinde, ac fi iurifcófultorum uerbo dicerem, ceruum requirendum adnotare, ut delatum ac reum doli mali,buccinæćs praconio peruulgare furtũ fui feciffe. Tum autem operae effe putant pretium, caninum comitatum fqualore, feruore, laffitudine confectũ, ob idćç imperia hortamentáç detrectantem, qux ito fonte recreare:ibiós pane $\&$ quafi curãdis corporibus reficere:tum cornutum clangore alacritati reftituere:plaufu \& $\&$ blandimentis ad uenatum ab integro ineundum exufcitare: $6_{0}$ interim etiam actum à capite denuro arceffere, quafíç ad carceres reuocari excurfo pené fpatio. ब Mos uerò certiorum eft, quum profligatos fe fentiunt $\&$ ex agitatu enectos, aut (ut loquintur uenatores)duré $\&$ atrociter actos (mal menez, rudement menez) fyluarũ opaca (le coutrert) relin. 
quere, atģ in campeftria (la champaigne) fe conijcere:interdum ad uicós uillasćs propius accedere. quod ferenon ante facit, quàm animum defponderit, omni fpe depofita folennium perfugiorum. Eo tamen pacto fape cuenit ut canibus fe fubducatin campeltri enim planitie, locis $\not$ profciftis $\&$ in

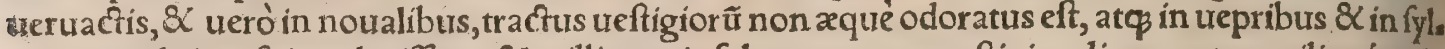
uarum ceduis, (efpines, butiffons, \& taillis:) quia foleata tantum ueftigia relinquuntur exiliterçs odo rata, nullo nec crurum contactu nec corporum. In recens autem inaratis eó amplius negotium exhi, bet canibus odor foli fubacti. Sed tum uenatoris eft officium nec inertís nec prauaricatoris, oculis ueftigia in mollibus locis legere: tum canum languorem impetumóp fenefcentem hortatur clafficoós fylueftri erigere \&' renouare, (resbaudir les chiens.)

TV enatoris ipfius, \& cantum calliditas $\&$ folertia, \& (ut loquuntur uenatores) fapientia, in uet: furris extricandis, $\&$ in emendanda canum hallucinatione, maximé uendibilis, ut fi in ulla uenationis parte. Verfur (la change) duplicem modum effe aiunt ; unum, fi ceruus felectus, \& curriculo pra. fentis diei deftinatus, aut fatelitem furum, aut uegrandem alium cerum fimonibus illis pediffequis ftris obiecerit, quafi profe piacularem hofiam: tumb̧ intorta uertigine impcforia protinus fe fub. duxerit, In qua fpecie urenator peritus \& ueterator non temere fallitur, fi modo canes pratereuntes obleruauerit, aut eorum tantum clangorem exatudierit. Quippe omnium cerui affectatorum troces notas habere debet, corum præcipue qưu claflis duefores appellantur, $8 \alpha$ naris emunctioris effe no. fcuntur. Sermone fyluatico fauces $\&$ a fum cuicufag canis noffe uenatorem dicunt. Alter modus eft, fi decumantrs, qui primum quenç certum in tuenatum, aut parafitum fuum in difcrimen,quafíg, in reatum tranferiplit, focium fuga fefe tranfcrípto illi adiunxit: quod idcirco interdum facit, ut maio= 1 re ftupore 8 perplexiore uenatu homines canesćs afficiat atog implicet. Id quod ubi accidit, dicere folentuenatores, lesitimum achum unà ferrí cum trerfura. Huiufcemodi impoftura duas indices no, tas minimé (ut peribibent) fallaces, à téchnologis uenationis proditas effe comperi: fí compertæ fidel auriti excurfores nec traniloquentix quoquo modo furfectit, repentẻ ita infiftant, ut nee progrediuis deantur nec regredi, fed quafi ftare in ueftigio:aut fi porro ita a gant, ut inerter id fe facere ac fine fpe pra fe ferant, ob id'́ç urocem baubantium non edant; nimirum quos ueluti deprehenfos pigeat \& pus deat incaffum porro progredi, quafi per cafiginent, Is cafus etiam præfentis confilï hominem pofcit, qui ftrategematibus aliquando uenaticis doctimenta luculenta folertię fux dederit:qui in eodem (ut dicitur) ueftigio, confilia expedire ftrategematica alia atç alia poffit. If Poftremò ceruus diu exercis tus $\&$ ian fatifcens, omnibus commentis fugx ac prafidin confumptis, folet (ut ante dicfum eft) att 3 flumen aut ftagnum perquirere, in idóg fe faltu conńcere. Quod interdum refrigerandi caufa farit, fxpius tamen Nympharum ædem, quafi afylum ultima fpei $\&$ deploratx perens; ob id́f́pinde ple rung non nifi captus eijci poteft. Ibi aurem modó aduerfa unda, modo fecunda fertur. Quò cumuer nator feftinus $\&$ curriculo urenit, in primis animaduertere folitus efr quo loco ceruus in flurnen infl lipt, locumíg animaduerfum deftricta fróde aut humi ftrata notare, aut ex arbore fufpenfa, Reliqua uix memoratu digna, quæ in utracg ripa facienda funt: quibus modis innatans corniger urgendus fit \& lancinandus: quomodo fugitiuus enatator perfequendus, fi ulteriorem ripam fuperauerit, aut fi per citeriorem retrocefferit. Hachactenus de uenatione cerui ex Philologia Budai : Erquath quam Germanis etiam non defint fure uoces ac phrafes uenaticx, eas tamen breuitatis caufa omifi, Gailicas uerò a diunxí,guod \& Budxi uerbis nonnihil addere lucis uiderentur, \& à fermone Latitio h non adeò abhorrere.

Mas cum pinguerit, quod ualde tempore fructurum fit, nufquam apparet, fed longê fecedit, Äri ftot. Caro ceruorum libidinis tempore uitiatur 8 foetet, perinde quafi hircorum, Ariftot, Blondus cerua grauida carnem hoc odore effe fcribir, haud fcio quàm uere." Quafdam nos principes formi: nas frimus, omnibus diebus maturinis carnem eam deguftare folitas, \& 1 logo auo caruifre fe bribus: quod ita demum exiftimant ratum, fi sulnere uno interierit, Plinius \& Solinus. Cerui, inquitlis dorus, carnes habent teneras $\&$ faciles concoctu (falfum eft) propter motus frequentiam : Et fic ${ }^{2}=$ frentur, antequam cornua crefcant, caro melior fiet, magis $\ell_{\beta}$ temperata in ficcitate $\&$ calore. Caro leporum fanguinem quidem gignit craffiorem, fed melioris fucci quàm bubula $\&$ ouilla:certinà au tem non minus ïs fuccum uitiofum generat, ac concoctu difficilem, Galenus lib +3 , de aliment, facul. Idem in libro de attenuante uictus ratione, Equorum (inquit) 8 afinorum efim, hominiburs afninis relinquo: Proximi afinis firnt cerui, eó̧́, ab eorum efu eft abfinendum. Ceruina caro bubula feré affimilís eft:tardé enim concoquitur, parum alit, ac bilem atram auget: efuri tamen ęftate, pręciprére romenfe Auguito, quàm hyeme fuauior eft, Platina:nimirum quia aftate pinguief cunt, hyeme exte, nuantưr. Ego contra quàm Platina, bubulam \& ceruinã fi concoquantur, mulữ alere dixerim:quod $\&$ Celfus teftatur. Duram coctúç difficilem prabet alimoniam, A egineta. Ceruorum carnes,inquit Symeon Sethi, mali fucci funt, \& difficilis concoctionis, \& bilem atram gignunt. Oportet autem cauere.ab îs qui çtate capiuntur, quod uidelicet eo tempore uipet is ac ferpentibus cerui uefcantur, unde fiticulofifiunt. Hoc fuapte natura norunt, quod fi aquam ante illorũ concocionem hauferint, intereant:propterea fitim tolerant, eá́; incenduntur. Ceruorum igitur carnes co anni tempore fums par, uenenofa funt, ac ualde noxia: ( $H$ Hoc fortaffis in alïs regionibus calidis acciditapud nos, quod 


\section{DeCeruo.F.G. Lib.I.}

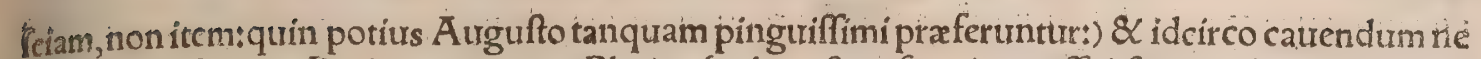
eis æftate uefcamur , Per hyemem uero(Platina feribit aftate fuauiores effe : funt qui hyeme etiă fér

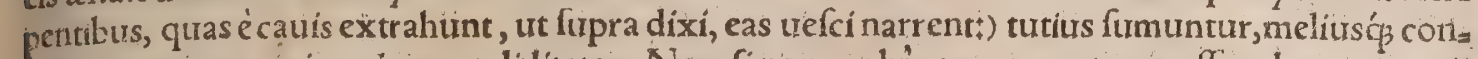
cogtuntur propter interiorem caliditatem. Nam fi non probé concoquantur, craffum humorem giz gnunt, iecurós \& lienem obftruunt. Quinetiam fertur fi crebrius $\&$ fine modo fumantur, corpurs tre mulum \& quod non confiftat facere, Hactenus Symeon Sethi. Ceruina dura eft concoctu \& me =

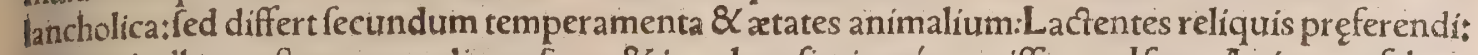
Si teneri adhuc caftrentur, meliores funt, \& in calore ficcitaté́s remiffiores, Ifaac. A uicenna febres quartanas huius carnis efu induci fcribit, Carnes ceruorum \& arietum montanorum, funt omnes - mala 8 nociux, Elluchafem in Tacuinis. Caro cerui calida eft $\&$ lenis, Rafis de Go. anímal. Cerui caro prouocat urinam, Auicenna. Seruathominem à calidis affectibus, Blondus fine authore:uide turr autem febres intelligere, à quibus præe eruat tefte Plinio, urt paưlò ante retuli. Patuít cos nun. quam febrefcere: quam ob caufam confecta ex medullis corum unguenta fedant calores hominum languentium,(febricitantium,) Solinus . I Hepar ceririomnino prautum eft, 8 malè températum, ut Vincentius Bell, ex A riftotele citat:ego nufquam apud Ariftotelem legere memini. of Cornua tenera $\&$ mollia adhưc (qua prioribus abiectis recens producuntur, $)$ in delicís appetuntir à nobili= bus: quod pretiofiffimum ex eis ferculum paretur. Magna enim $\&$ pretiofa ui aduerfus aconitum pollent, Blondus. Sciendũ eit aũt aconiti nomine indoctiores toxicum $\&$ uenenũ ferè quioduis comprehêdere. Tenera quidem certrinorũ cornuum tubera in principũ cibữ uenire dixi etiâ fupra cap, 2 . TCeruinæ caudæuenenum inefle dicemus proximo capite. If Achillem aliquífic nominatum

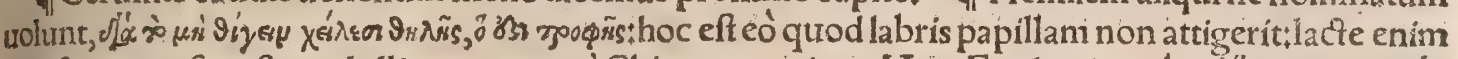

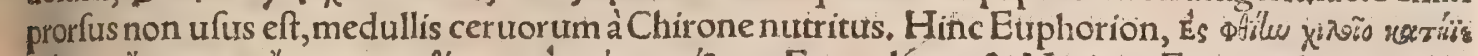

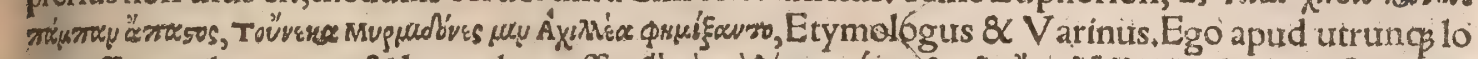

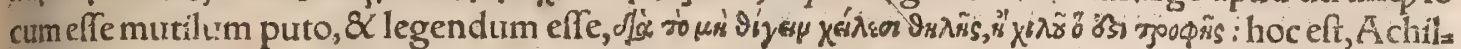
lem dicqum effe, uel quod papillam non attigerit, uel chilum, id eft alimentumit commune uocabur= lum $\chi i \lambda$ ós ad lactis alimentum infantibus proprium hic cótrahatur. Telephum etiam cerualactaffe fertur, ut in Phiiologia dicam. TA picius lib.8,cap, 2, uariưm cerui, id eft ceruinæ carnis, appara. tum docet his urerbis. I us in ceruum: Teres piper, Iiguficum, careum, origanum, apł femen, !aferis

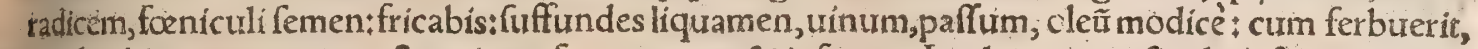
30 amylo obligas, ceruum coctum intro foras tanges, 8 inferes. In platycerote, fimiliter $8 \mathrm{~L}$ in omnege nus uenationis eadem conditura utêris. Aliter:Cerum elixabis \& fubaffabis: Teres piper, ligufti= cum, caretim, ar fi fèmen: fuffundes mel, acetû, liquamen, oleumi calefactũ : amylo obligas, 8 carnem perfundes. Ius in ceruo:Piper, liưufticum, cepullam, origanü, nucleos, caryotas : mel, liquamen, finape, acetum, oleum. Ceruina conditura:Piper, cuminum, condimentum, petrofelinứ, cepam, ru=

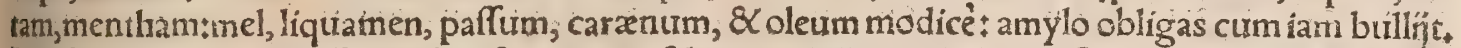
lura feruentia in ceruo: Piper, ligufticu, perrofelinum, curminư, nucleos toftos aut amygdala:fuffun= des mél,acetum, uinum, oleum modice, liquamen, \&agitabis embamma. In ceruinam affam:Piper, nardoftachyum, folium, api femen, repam aridam, rutam uíridem:mel, acetum, liquamen : adiectas caryotam, uuam paffan \& oleum. Aliter in ceruum affim iutra feruentia:Piper, liguftic olnum, damafcena macerata:uinum, mel, acetum, liquamen, oleữ modicé:agitabis porro \& fatureia, Hucufas A picius. TCeruianteriorem partem in iufculo laridario coques, lũbos affabistex coxis paftillos aut pulpamenta facies. Eadem \& capreoli, dama, ac caprex coctura eft, Platina:(quafi irero capreolus \& caprea aliter quàm fexu differant.) Idem lib.9. cap, 8. de honefta uolupt. Ex certro, in= quit, ucl capreolo, paftillî fic facies; In frufta haud magna carnem cócides : una bullitione cum aqua \& aceto faléş remollitam, ex cacabo eximes: finesç̧ in quadra, donec itis exinaniet cinnamum contritum fimul cum larido tunfo in modum placentæe fubiges, carnemós additis quís bufdam per longum laridi teffellis, hoc quafi foliato inuolues, indesćs circun quaçs caryoophylli gené ia: farinam deinde bene excretam fubiges : ex fubacia cruftam grofliorem unicuicg frufto circun

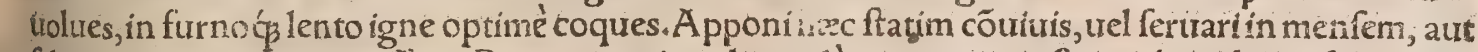
sofaltem dies quindecim polfunt, Parum onnino alit, tardè concoquitur, ftomachưm laxat, fpleneticis 8 hepaticis nocet, pectus exafperat, Hxc Platina. Sanguine cerui noftri utuntur ad itis nigrum, quod uulgò piperatum uocant, à colore puto, licet abfós pípere plerunç̧ paretur. Qui dearte co. quinaria Germanicé foripferunt, pracipuè Baltafar quidam Dillingenfis, ex ceruina paftillos, ut uo cant,parare docent:nec non pulnonis $\&$ hepatis apparatum $\&$ condimenta.

G.

Cerui natura omnia uenena abigi \& repelli confat, Alexander Benedictus : ex Plinio nimirum, cuitus hac de re uerba cap. 5. retuli, đCeruinus fanguis aluum fiftit, Plinius. Hirci,capra, rerui, \&leporis fanguis, inaffatus fartagine, dyfenterias \& collacorum profluuia finit, Diofcorid. Frixu's tưn oleo cerui fanguis, fi fiat ex co clyfter, fanat inteftinorum ulcera, \& remouet fluxũ antiquưm, 6o Alberus \& Rafis. Ego negs ceruinum neçalium fanguinem in clyfteribus à peritis medicis pon puto, fed uel bibi uel illini ad fluxiones firêdas, ut in Caprino dixi, Cum aceto mixtus 8 inunctus fitlothrum eff, Galenus Euporifton 2, 85. In uino potus contra toxica (fagittas uenenatas, Rafi, 
Albertus non reciè habet apoftemata uenenata, )efficax eft, Diofcorid, cui non cerui folum, red \& cuiufuris iam dicforum animalium fanguis eandem uim obtinet. Sanguis ceruinus vieficcatus $\&$ ttitus fumptus, à uenenatis belipjs morfos iuuare dicitur, Symeon Sethi, of Febrium morbos ceruts non fentit, quin \& medetur huic timori: Quafdam nos principes forminas f́cimus, omnibus diebus matutinis carnem eam degultare folitas, \& longo æuo caruiffe febribus : quod ita demum exiftinã ratum, fi uulnere uno intel ierit, Plinius $\&$ Solinus. Er alıbi, Febres arcet ceruor câ caro, ut diximus, Plinius. Caro ceruicalefacit $\&$ lenit, $R$ a fis. $\Phi$ De medulla in genere ex Galeno fupra diximus in Vitulina, ubi $\&$ Ceruinx facta mentio eft. Cerui pingue $\&$ medulla quomodo odoramentis im buantur, uide fupra in Taurino pingui ex Diofcoride. Ceruina medulla laudatiflima elt , Diofcor. \&.Plinius, Aétius in pharmaco quodam contra podagrã pro cervi medulla tantundem adipis cer= uini fubftituit. In Arabum fcriptis pro medulla cerui cerebrum quidam inepiè uertunt, Hebraica vocis homonymia decepti. Confecta ex medullis ceruorum unguenta, fedant calores hominũ lañ gurertium, Solinus: Immunem côfer uant à febribus, Albertus. Plinius id carni ceruinx in cibo furm. ptę attriburt, ut fuperius retuli. Cerui medulia pharmacum eft paregoricotaton, id eft mit:gando $8 \%$ eniendo dolores prętantiffimum, Galenus ad Pifonem.Dolores fedat, Aefculap. Serpentes inun. êa fugat, ut cap. , dixi: ubi $\&$ alia ex ceruo qux extrinfecus ferpentes arcent enumeraui. Sunt qui ceruinam medullam peculiare faciant remedium perfufis aqua alióue liquore feruido. Medulla \& pingue ceruorum dura carcinomata molliunt impofita,Symeon Sethi. Gyraldus in fua translatione difcutiendi uim etiã eis attribuit, quod in Graco codice impreffo non legitur. Vlcera catera praxterquam in tibrijs cruribusḉ (s) cornus ceruini cinere, uel medulla cerui explentur \& purgantuí, Pli, nius. Cotyledon cum medulla ceruina calefacta impofita, fiftulis medetur, Plinius. Et alibi, Cotyles don eciam purulētis auribus infunditur, \& cum medulla ceruina calefacta. Hirci feuum efficax eft labrorum fiffuris cum adipe anferino, ac medulla ceruina refinaḉ $8<$ calce, Plinius. Eadem uerba apud Sextum in paucis mutata legímus hoc modo, Sepum caprex $\&$ adipem anferinâ $\&$ medullam cerui $\&$ cepe cum refina fimul \& calce uiua, fac ut malagma, mirè fanat labiorum fiffuras. Seuum stituli cum medulla cerui $\&$ albæ fpin $x$ folńs unà tritis, ulcera oris 8 rimas emendat, Plinius. Mes dulla ceruina in aqua calida potui data, inteltinorû dolorem etfi tormina fuerint, mirè fanat, ${ }_{3}$ Sextus, Cellus inter alia ad dyfenteriam medicamenta, fi uetuftior morbus eft, ex inferioribus partibus in= fundere iuber medullam certinam, ut quæ dolorem leuet, \& mitiora ulcera efficiat. Butyro \& men dulla cer uina \& felle saurino cum oleo cyprino aut laurino perfricta genura fanãtur, Marcellus, Mes 3 dullam cerui $\&$ adipem liquefacito, \& in lana apponito, Hippocrates de natura muliebri inter fuba dititia medicamenta qux uterum emolliunt. Idem in libro de morbis muliebribus, medicamentum fubdititium purgatorium his uerbis defcribit, Medullam anfer is aut cerui magnitudine fabre affulo unguento rofaceo $\&$ lacte muliebri terito, uelut pharmacũ teri folet, \& cum hoc os uteríllinito, Ex uttulina $\&$ ceruina medulla peffi cōponuntur, uteros emollientes: $\&<$ extrinfecus uteris medicamen: ta imponuntur, quxe ex medulla præparantur, uim habentia emolliendi. Accipitur autem nó foium ue: a medulla ex offibus, uerũ et am ex f́pina dorfi, \&c, Galenus de fimplicib.11.5. A pud Rafin idern legimus, fed pro medulla perperam legitur cerebrum, uitio interpreris ut credo. Cerebrü(medulla, $\mathrm{R}$ afis ) cerui, prodeft contra dolorem coxarum $\&$ laterum: $\&$ in reftituenda fractura, quam etiam mi tigat, Albertus $\&$ Rafis: Albertus infuper addit ualere contra pulfum cordis, quod non probo, 10.4 Agricola menfibus euocandis peffum ex medulla ceruina cómendat: Huius medullę, inquit, drach mas duas aut ti es mulierculæ ratione babita, inuolue findone munda, \& fi libet de filo appende, $\mathrm{Cu}_{4}$ raridum eft tamen ut reliqua fatis refpondeant, corporis tidelicet praparatio, \& habitus conftitutio, uictus, \& atas: nec ita multum poftea fequetur menfium eruptio. Hoc noutum experimentũ trocat, curius admiranda facultacis, inquit, non reddidit nos certior es fcriptorum quifpiam. Atqui Hippos crates, ut fuperius recitaui, ex medulla anferis aut cerui medicamentum uteri purgatorium (hoceft quod mêfes aliośq̧́ eius humores euocet ) ex anferis aut cerui medulla parare docet, quo os uteri it linatur. Cochlea uuluam auerfam corrigunt cum medulla ceruina, ita ut uni cochlea denarij pon dus addatur 8 cyperi. Cerui pingue (adeps, feuum) quomodo odoramentis imbui debeat, $c^{\circ}$ piofe in Taurino docui ex Diofcoride: $\&$ quomodo fimpiciter curandum fit, in Hir cino ex eodem, Ceruino adipe perunctos ferpentes fugiunt, Diofcorides \& Plinius : ut fupra cap. 5. retuli. Aëcins in pharmaco quodam contra podagram pro ceruina medulla tantundem adipis ceruini injícipofic monet. Cerui adeps nu lo medicamentorum mollientium elt inferior, Gaienus de comp. ferund. gen. Seuum cerui calefacit \& lenit,Rafis. Medulla \& pingue ce uor:m dura carcinomata mols liunt impofita,Symeon Sethi. Capillis nigrandis infectio optima ex hirundinum ftercore paratur, ut in earum hiftoria recitabitur:oportet autem feuo ceruino fariem prius perungere, ne quid ex mes dicaméto diftillans eam commaculet, Marcellus. Seui ceruini ufum ad lentigines faciei, paulò poft in remedijs ex cornu a periam. Abfyrtus aduerfus tuffim equorum ex frigida caufa remedia pre" fcribens, poft purgationem \& fuffitum, in uno dulci liquare iuber adipem ceruinũ aut ouillum cum rera, \& lingua apprehenfa infundere. Picem præcoquam, fiue quam uifcofam uocant, \& rubricam 6 Scythicam, quam alíp piffal phaltum trocant, cum feui ceruini remiffi cyatho uno, 8 lactis bubutitiel ouilli pari menfura, fi quis iam periclitanti phthifico in potu uel in cibo cotidie dederit, mire ei fubs 
explentur \& purgantur, Plinius, Puftulis cornurs ceruini cinis ex aqua illinitur, Idem. Maculas in facie abolet taurinum feuum uitulinúmue fel, cum femine cunila, ac cinere é cornu ceruino, fi cani. cula exoriente comburatur, Plinius. Ad lentigines de facie tollendas, Lenticulam cum fobe tenus de cornu ceruino, \& feuum ceruinum pariter diuide, coque $\&$ tere: atcg inde faciem uel ante horam balnei, uel etiam in balneo frequenter inlinito, ita ut quafi pro pane molli utaris, efficaciffimum me. dicamen experieris, fed lenticula maior pars fit, cornus \& feui ęqualis menfura, Marcellus. Cornu ceruino combufto in Sole faciem line, \& deterfa fubinde renoua, $8<$ hoc in ortu Solis facies, mire tol lit lentigines de facie, Sextus. Articulorum fracturis cinis feminum pecudis peculiariter medeiur, efficacius cutm cera + Idem medicamentum fit exmaxillis (pecudis intelligo, id eft ouls) fimul uftis, cornućs ceruino $\&$ cera mollita rofaceo, Plinius. Combuftum ad drachmas tres, adiecta fpuma ars । genti duarum drachmarum, \& ceroto macerato mixtam, intertrigines dolentes miré fanat, Sextus, Ceruini corrius fcobes limata, \& ex uino potui datz (Plinius ullinendum ex uino fentire uidetur, ut etram ad porriginem, ut paulơ fuperius citaui) pedunculos in capitelendesćç nafci non finunt, Mar cellus. Cornus cer, cinis illitus front ( $\&$ témpơribus) ex aceto uel rofaceo (aut ex uino, Plin, )capi tis dolores fedat,Plinius, Marcellus \&C Galentrs Euporifton 2.91. Ad capitis dolorem, Cornư cer. ui in cinerem redactum, exinde drachmam cư ưint cyatho, 8 aqua cyathis duobus da bibat, Sextus, Comitialem morbum deprehendit caprini cornus, uel ceruini ufti nidor, Plinius. Et alibi, Cornibus ff ue dextris fiue finiftris accenfis, odore comitiales morbi deprehenduntur. Vftrina hac nidore ui. tium aperit ac detegit,fi curi ineft morbus comitialis, Solinus, Sunt $\&$ alia quxdam grauiter odora ta, qua fuffitu arguunt epilepticos \& concidere compellunt, ut bitumen, gagates lapis, cornu capri=: num capriniós iociner is affati odor, ipfumós iecur comeftum, ut fcribit Áétius libro 6.cap. 13. Âdul torum cornuum $\&$ in ramos diffuforum maxima dos eft in morbum comitialem, Blondus, Sunt q̨ư aridum hoc medicamentum comitialibus commendent, quod mifcetur ex urif́i querni uncia una: mucronum de cornibus cerui drachmis duabus, \& cordis lupini drachma una, quíbus addunt feo, bem tritam de occipitio cranei humaní. Qui poft argritudines aliquas, ut lethargum aut peftilêtiam in oblituionem deciderunt, eos maximè iutuat hiera Ruffi: $\&$ poft purgationem hiera, fcobem dentis elephantis circiter drachmam unam è mulfa potam non parum iuúare creditur, \& cornu ceruinum fimiliter, Ẩtius. Aduerfus fcrophulas gutturris, quidam certinum cornú tritum, cum fpongh̆s in quibus lapides reperiuntur æquali menfura, ex uino aut aqua quotidie mane à íciunis bibi iubent; fic aboleri, fi adhuc increfcant:fin iam conftiterint, non augeri. Cerui cornu uftum, \& cadmięmo 3 do elotum, ulceribus oculorum $\&$ defluxionibus falutare eft, Diofcorides. Mifcuerunt ipfumus ftum elotumó̧ nonnulli collyrị́s deficcantibus oculorum fluxiones eft enim omniũ talium uis exic catoria, Galenus $\mathbb{X}$ Sextus, Ceruini cornus cinere f cabricias octulorum inungutt:mucrones autem ipíos efficaciores putant,Plinius, A d polypum, Cornu cer, uftum \& fandaracham 12aribus inflato, Galenus Euporifton 1.26. Cerui cornu uftum elotumćc, infrictum dentes expưrgat. Crudumin aceto feruefactum, fi eo gingiux colluantur, maxillarum à dentitione dolorem adimit, Diofcor.Grat

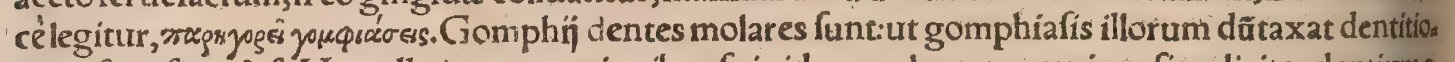
nem, fignificer:sxfi Marcello in annotationibus fuis id non placeat, omnium fimpliciter dentime miffionem hoc remedio faciliorem fieri exiftimãt Quoniam alij authores in remedrís ex cornu cẹ, gomphiafeos non meminerint, $\&$ dentes tantum mobiles confirmari, $\&$ gingiuas flaccidas compes 4 Icere fcripferint. Addit infuper nouam effe hanc uocem, $\&$ nefcire fe an iterum in toto Diofcoridis

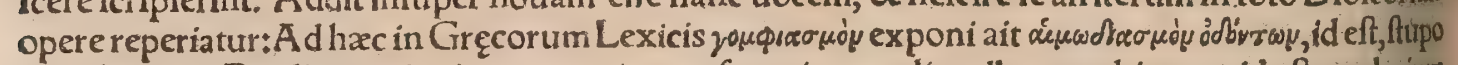
rem dentium. Ruellius cuius interpretationem fuperius retuli, nulla gomphiorum, id eft, molarium mentione facta, fimpliciter maxillarium à dẽtitione dolor ê hac collutione adimi fcribit. Et quãquam gomphiafis íta molarium emiffionê fonare uidetur, ut cdontiafis dentium fimpliciter, tamen ipla res medí facultas eiufmodi eft, ut neç molarium neç aliorum dentium producioni conueniat, ut quix gingiuas aftringere indurare $q$ ' $\beta$ poffit, quamobrem ufus eius eft, cum dentes confirmare mobiles, \& gingiuras laxas conftringere libuerit: cum illę molliri lenirió̧ opus habeant. Aetius libro quarto, cap: 9, de dentitione fcribens, nullum eiufdem aut fimilis facultatis remedium prafcribit, fed ea tanitum qua laxare poffint gingiuas, ut funt leporis agniue cerebrum, mel modicé decoctum, \& apud Ággis netam gallinaceus adeps. Sed neç ad dentium fuporem, hoc aut fimile remedium ab alio autiore pofitum inuenio: quanquam remedia aduerfus hunc affeçum plarigz putant non certa qualitate ula

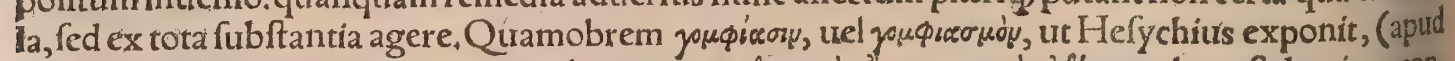
$\checkmark$ arinum SCCamertem no n reperias) accipio ow fraçionem, uel contritionem, qua feilicet uel ictu uel cafu fit. Hoc non animaduertiffe Marcellum

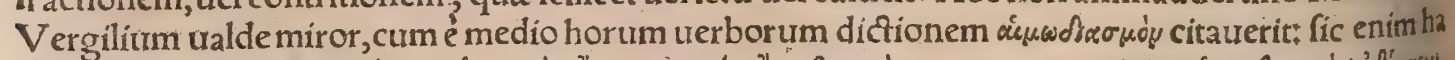

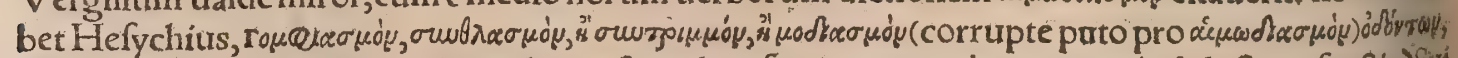

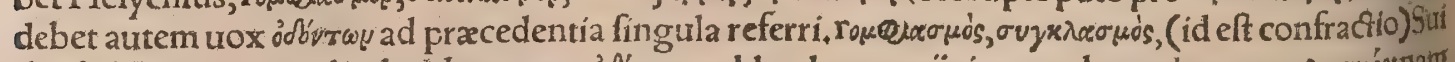

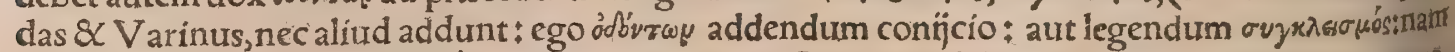

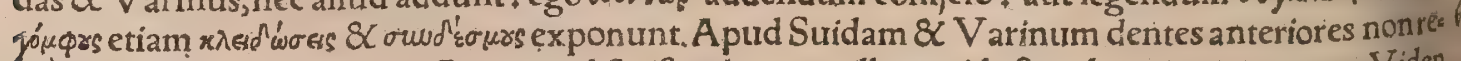
cié yó curr autem illi gomphï dicti, quod pluribus quafi gomphis, id eft, cuneis feu clauis, radicibưs nempe 


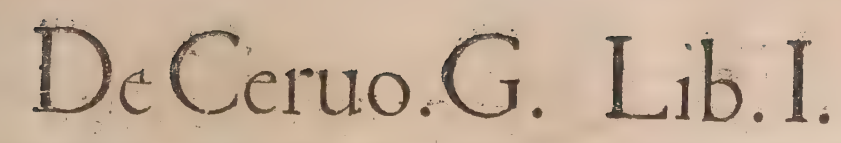

Stris in prafepia fua (fic enim Gręci dentiũ loculamenta uncant, quanquã Pollux 11 b. $\mathbf{z}_{\text {; }}$ aliter accipe revideatur) infiganturr. Vetus Diofcoridis interpres apud Serapionẽ pro gomphiafi fimplíciter den tirm dolori exponit. Qurod ad medicamenti naturam, utile id mihi uidetur tum ad dentes fimplicicer dolentes, tum etiam mobiles \& laxos, fitie fimpliciter, fiue externam ob caufam uiolentam, ut ît $\&$ cafum: ad dentitionem uerò fiure aliorum fiue molarium dentium, non tantum inutile, fed etiam no xium. Nonent enim medici non aftringendam effe gingiuam, ne callofior reddita nafcituros dentes impediat.Quod cum ita fe habeat, Hermolaum, Marcellum, \& Ruellium, Diofcoridis interpretes; pariter omnes erraffe fatebimur. Galenus lib. 5. de Compofitione medicamentorum fecund ̃̂́ locos medicamenta aliquot mylica defcribit, hoc eft ad molarium dolores. Sed fatis hac in re prolixus iam o fui. Dentes mobiles confirmat ceruini cornus cinis, dolores ́́ corum mitígat, fite infricentur, fítre colluantir: Quidam efficaciorem ad omnes eofdem ufus crudi cornus farinam arbitrantur. Denti= fricia utros mode fiunt, Plin. Cinis cornus cer, dentes dealbat; $\&$ dolores tollit, Galenus Eup $2 \cdot 12$ Cerui cornu in oxygaro decoquito, frepȩ́́ eo os abluito, Ibidem i, 8 . Quod urerò affumpit nomen de dentefricando Ceruino ex cornu cinis eft, Serenus, Cornibus cerui $\&$ capra uftis maxime utuntur, ut $\&$ nos fxpe ufi furmus, tum ad candorem dentium, tum ad contrahendas mollitie fluidas

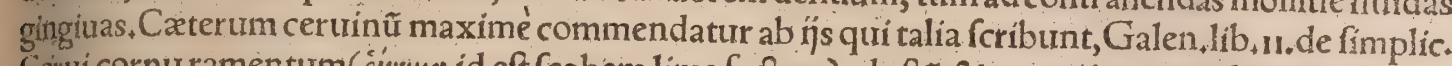
Cérui cornu ramentum ( tum, uacillantes dentes confírmat, ficut $\&$ bouis talus idem poffe traditur, Galenus ad Pifonem, \& Aegineta. Cornu cer. combuftũ dentes qui mouentur confirmat, fi eo pro dentifricio quis titatur; 10 Sextus, Cornu cer, decoctũ cum aceto, fi eo colluatur os, fedat dolorem dentium, \& confolidat gin gitas, $R$ afis $\&$ Albertus, Ex puluere eitus dentifricium fit expurgandis dentibur, lidem. Cornu cer. combuftum, tritum cum aceto, dentibus adpofitũ prodeft, Marcel. Sunt qui etiam modum mífen. dipraferibant, huiufmodi, ut acetifint uncia tres, cornu cerui ufti drachma dux, inde collui os iu= bent. Ramenta cornus ceruini uel frobem eius lima factam cum uino uetere ad tertias coque, $\mathbb{E}$ inde adfidué os elure:miré proderit roborandis dentibus,Marcel. Ad dentes mobiles $\&$ dolentes, $\&$ gingitrarum tumorem, remedium fict Cornus cer.combufti uncias duas, folih forupulum unum, falis Ammoniaci tantundem, piperis grana nouem, iris Illyricx fcrupulos nouem; ex his puluerẽ tenuilli mum facies, $\&$ co dentes cotidie perfricabis:fi mobiles erunt $\&$ dolebunt, facile cadent: $\&$ fi fine $d o=$ lore ualidifunt, confirmabuntur, $\&$ candidiores $\&$ odoratiores erunt;melius autem proficient, $f$ in tiuncturis aut radicibus aut cauaturis eorü, de hoc ipfo dentifricio aliquid refederit, Marcel. Cornutu

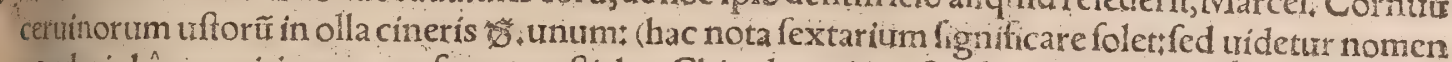
ponder is hic requiri, non menfuræ:) maftiches Chix denarios octo, falis Ammeniaci iemunciam: $d$ Lgenter hæc trita in ưnum concorporantur, 2 perfricandis dentibus adhibentur, Marcel. Centrine conus exufti cinis in potione datus empyicis uel hamoptoicis medetir, Marc. Symeon Sethi pule monem ufur cornus ceruiniladi fcribit. Cornus cer, cinis elotus excreantibus fanguinem prodef, Diofcor.Marcellus interpres addit, cum tragacãthæe lachryma duorum cochleariữ menfura:qued in Gracotextut non hoc in loco, fed mox in remedio ad dolorem uefica fubijcitur + fed nihil periculi ui deoetiamfi ad utrumgraffecium tragacantha adjiciatur. Vftum \& lotũ dyfenteriam, \& fangunis -excreationem, praterea coeliacos affectus fanat: $\alpha$ aurigini ittile effe dicunt:Porrò duo exhiberi co. ochlearia ad omnia ifta pracipiunt, Galenus, Sanguinem expuentes cer, cornu's cinis fanat, Plinitus. Ad uonitum nimium reprimendum fulphuris uiui pufillü, \& ramenti de cornu cerui tantundem, in olio forbili tritum \& permixtum bibi utile cf, Marcel. Stomachi rheumatifmos cornus ceruin cinis reficit, Plinius. Regio morbo cornus ceruini cinis prodeffe dicitur, Plinius, Galenus ut paư⿱宀' ante retuli, uftum \& lotum aduerfus hunc affectum laudari foripfit. Cineris cornu cerui drachma cum unini cyatho uno $\alpha$ a qua duobus, propina ad morbum regium, miraberis bonú effectum, Sext. Rafis contra hunc morbum circiter trium aureorum pondere bibi iubet. Lienem fedat cerurini cor nus cinis in aceto, Plin. Cornu cer, combuftum ex oxymelle detur potui, \& Pplenem ficcat, \& do lorem tollit,Sext, Galenus in libro de Theriaca ad Pifonem cap.12,cum fripfifet frobem (pivsuta)

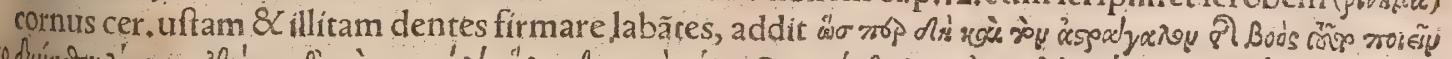

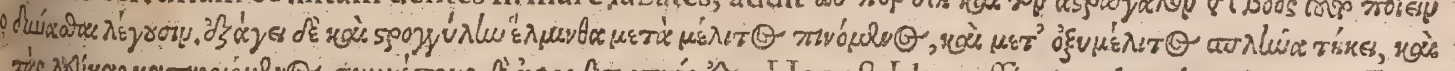

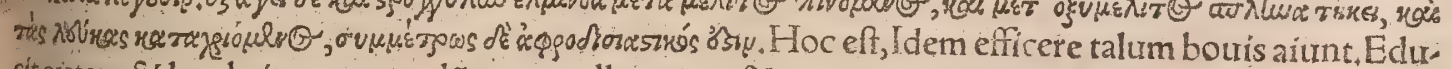
citautem \& lumbricum rotundũ cum melle potus, 8 cum oxymelite lienem minuit, \& uítiliginen albamillitus:deniç mediocriter Venereus eft, (ad Venerem excitat.)Qux omnia non ad cerui cors

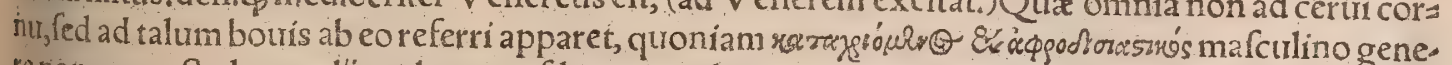
re ponuntur. Sed cum alij authores eafdem uires de cornu cer.prædicent, aut talum bubulũ \& cor

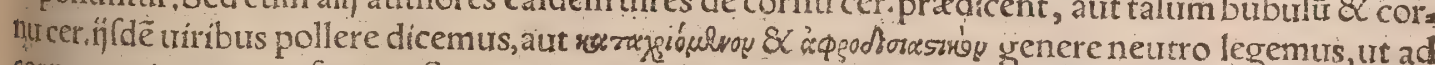
conu cerui tantum referãtur. Supra certe inter remedia ex boue, Rafin eriam 2 Haly Arabicos feria ptores, tali bubuli urm aduerfus lưmbricos, uitiliginen albam, \& fplenem turgẽtem ex aceto nutifo, denigh Venerem excitandi citauimus, Quamobrem præftiterit nihil in Galeni lectione mutaffe, fed eafdem utriç in plerifos facultates effe putare, etfi uim Veneris cienda ceruino cornu attriburi nuf= quam hactenus legerim. Cinis lotus, biniśćs ligulis (cochlearịs)epotus, dyfentericis \& coliacis pro deft, Diofcorid, \& Galenus ut fuperius citaui,lifdem cinerem huius cornus tribus digitis captumin 
potione aqux untilê effe Plinius annotauit. Vftum \& potum ad pondus trium aưreorü \& femis (ẩ pondus uncię $\&$ duorum aureorum, Albertus‡)reftringit fluxum fanguinis qui eft fine putredine: \& ualet contra ulcera intéftinorum \& fluxum uentris antiquum, $R$ afis \& Albertus. Ad dyfente: ricos, cochlearum integrarum uftarum uncia una, cornu cerui ufti uncia dux, uniantur fucco plan, taginis: fabæ magnitudine datur febre carentibus cum uino, cum aqua uero febricitãtibus, Galentis Euporiften 1.112. Cornu ceruinum mollius uftum cum gallæ pari portione in potum dato ad uén. tris profluuiư, Ibidem 2.46. Cineris hurius drachma ex uini cyatho $\&$ aqux duobus epota, fluxum (inferiptio habet, urentrís folutionem)omnem cohibet, 8 dolorem fedat, Sextus, Ceruini cornus de ipfis radicibus qux capiti hærêt, fcobes lima tenuiffimus façus, $\&$ ad drachmæ menfuram cum uini aufteri cyatho datus, fiftet nimios uentris fluores, fi uel triduo iugiter bibatur, Marcellus. \ Cornus ceruini teneri cinis cochleis A fricanis cũ tefta fua tufis mixtus in uini potione, colo magnopere pro def, Pliniuss. Hoc idem medicamentum apud Marcellum Empiricũ̃, quamuis prolixe expofitum, adf́cribam tamen, promiffi maghitudine adduçus, præfertim cưm cochlex etiã a dmícceantur, ut dů plici nomine animalium hiftoria dignû̉ uidètur: remittemus autem lecforem huc à cochlea, Âd coli dolorém (inquít Marcellus cap. 29.) faciunt quidem mirifice qua fuperius pofita funt, fed catera me

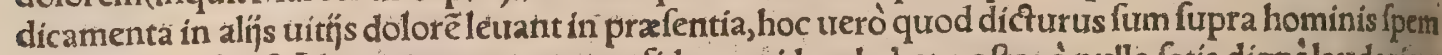
conditionemós eft. Ideo primo tempore ne fidem quidem habet, poftea à nullo fatis dignélaudarípo teft:nam \& in præfentia dolorem tollit, \& in futurum remediat, ne eum unquam repetat. Rarò enim quis iterum; uel ad fummứ tertió, hoc accepto médicamento uexatus eft:quamobrem fí quandore: petierit iterum dolor, dandæe erunt per triduum $\&$ tunc potiones, eodem modo quio prima data fuit, Interdum urerò 8 tertio in dolore eodem genetépotiones daburntur, quod rarò quidem accidet, ut poft primam potionem dolor redeat; fed fi admonente caufa iterum atģ iterũ data fuerit, in fururum quoģ ita remediabit, ut ne fufpicio quidế inlla hưic uitio relinquatur:fí quando tamen repetierit hor malum, frigus ex multitudine cibi pręcedit, gratritatemíq quandam \& torporem eius loci, ideft coli, fed fine ullo dolore fentiendum infert, plane ut tum intelligant, quanto malo caruerint, qui ilia mos leftia liberantur. Hoc medicamento prínü mutliercula quędam ex A phrica ueniens multos Romx remediaurit:pofiea nos per magnam curam compofitione eius accepta, id eft pretio dato ei quod de fiderauerat qui uenditabat, aliquot non humiles neç ignotos fanaúimus, quorum nomina fuperua cuum eft referre. Conftat autem medicamentum ex his rebus $¥$ Cerui cornua fumuntur dum tenera funt, \& quafi in tabulas uel partes breués $\&$ tenues dituifa in olla fictili componuntur, operculoóg 3 fuperpolito, \& argilla undiģ circundata, fornace aut furno urûtur, donec in cinerê candidiffimùm redigantur, atç ita trita in uafe uitreo mundo reponuntur. Cum dolorem coli habebit aliquis, ante diem abftinebitur quàm poturus eft medicamentum ab omni cibo, atģ ita poftera die dígefús atọ ieiunus accipiet ex hoc puluere cornuum exuftorum cochlearia tria cumulata, fatis ampla, quibus mifceri debent piperis albigrana nouem trita, 8 myrrhæ exiguum, quod odorem tantümodopiz fare poffit, Haxc in unũ commixta in mortario diligêter agitantur ac teruntur : deinde cochlea Irera A phricana, id eft inde allata,fumitur, quàm maculofiffma, \& cuitua fi fierí poteft, in alio mortario cum fua tefta cótunditur, atç ita teritur donec nullum ueftigium aut afpritudo appareat teftularũ:pofte? uini Falerni non faccati cyathus adijcitur : \& nihilominus rurfus teritur . magis enim tunc appare bunt afpritudines, fi qux refederint, quibus leuatis (forte proleuigatis) iter ũ adinciuntur duo cyathi eiufdem uini, atç ita cum priore compofitione bene admifcentur, poftea transfunduntur quafunt in mortario in calicem noữ : qui calix fuper aliud uas ponitur ad carbones, \& adfidurè moutetur con cleario liquor, ne quid fubfidat, aut peruratur. Vbi bene incaluerit, adijciuntur in eundem calicem, de his qua fupra foripta funt coclearia tria : 8 rurfus permouetur uniuerfa permixtio, Cum autem calore fufficienti temperata erit potio, dabitur epotanda uerfus orientem + ftatim dolor fine dubira tione cefrabitfed ur penitus a boleatur, dari potionem fimiliter oportebit per infequens biduum;ied quibus hoc remedium dabitur, cibum in prandio tantummodo, aut de tempore iti cozna exiguum capient, quo facile conficiant, ne crudi eam fumant:poftea uerò in confuetudinem uictus fui remlts tentur. Oportebit autem remediatos non intemperanter in futurum uinü bibere:tametfi enima àcoli dolore turi fuerint, metuere nihilominus debent, ne alia parte corporis aque adficiantur ob intems? perantiam, ob quam utiç; colo fuerant ante uexati, Hactenus Marcellus. Aëtius etiã lib.9, cap̧, 3lo inter colicorum pharmaca medicamentum hoc defcribit ex Afclepiade his uerbis : Cornu cernire cens enati adhuc pilofi, tenerrimíg ac ufti, cochlearia maioris modi tria , piperis albigrana nourem, myrrhæ exiguum ad commendandum odorem. Contere omnia, eisḉ cochlearum terreftriû́ magthá rum unà cum teftis fuis, quantum uifum fuerit a dịcé: omniaḉs fimul trita, \& urino Falerno marimi x to trium cyathorũ menfura permixta, \& ad mites prunas in uafe fictili calefacta, ac fedulò ne quid in fundo refideat, agitata, prabe bibenda, ita ut nihil reliqui maneat: atç̧ id maximé temporéaccel. fionis $\&$ ieiuno adhuc ægro fiat. Deinde uerò cibum qui facile conficitur præbe, atç hoc ex ordin ad̉ dies tres exhibe. His ueró qui cochleas fumere non poffunt, reliqua prabe ficca cum uino. A A Iumbricos uentris, Cornu cerui ramenta ex uino uetere potui dato à balneo, Galenus Euporiftonz. 188. Cornu cer, \& ebur mixta aliqui propinant, ut exigantur lumbrici. Tinearum genera pelli.

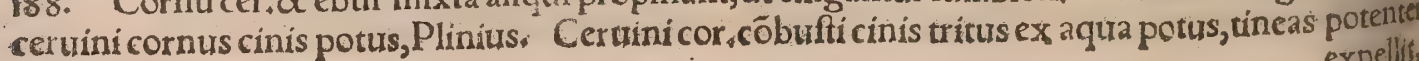


expellit, Marcellus, Cornus cer, limatilima lignaria fcobis quantum quaturor uel quinq cochlearia fint, ex aqua in qua decoctus fuerit ipfe fcobes potus ad cyathos tres, mirifice facit aduerfum lum bricos, Marcellus. Combuftum dasü in uino uel aqua calida, lumbricos necat \& ércit, Sext. Vftum potum cum modico melle expellit uermes, Albertus, Rafis. Sunt qui admifceant cretam, femen fan= fum, titellum affum, \& cum melle placentam fiue paftillum conficiant, unde modicum exhibent, tam pueris quàm adultis. Cornu cer.ad ftrangurias utûtur, Symeon Sethi. Ad aquofum ramicem; Acetum potui dato, \& cerui cornu uftum ad cataplafmatis modum imponito, Galenus Euporifton 3.159. Nonnulli remedís qua ad fanguinis micfum dantur, cornu ceruinũ admífcent. Vfum po. tumǵ pondere trium aureorum \& femis contra dolorem urefic $x$ prodeft, $R$ afis 8 Albertus. Eodem modo potum humiditates ex uteris manantes cohibet, lidem. Mulier proflutuo laborans uftum $\&$ mollifimè tritum cum uino bibat, fanabitur, Sextus. Ad muliebre profluuiũ, Cornu cer, uftum po. tui dato, Galenus Euporifton 2.73. Mulierũ purgationes adiuuat cornus cer, cinis potus:item uul. uas laborantes, illitu quoç, Plinius:in cuius uerbis adiuuare purgationes mulierum, menfes promo uere $8 \mathrm{C}$ ciere interpretor: quanquam abundantes etiam menfes, uel pituitofas potius fluxiones (irt paulòante dictum eft) fiftere poteft. Mulier fi offocatur à uulua, quod nequiffimum uritium Gracè

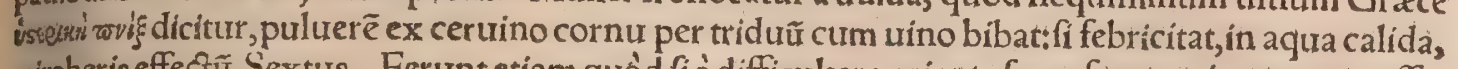
miraberis effectũ, Sextus. Ferunt etiam quód fi à difficulter pariente fuperferatur, iutuamento effe, ut Gyraldus uertit ex Symeone Sethi:cuius Gręca uerba nô integra mihi uidentur, nempe hęc, $\Phi x \sigma i$

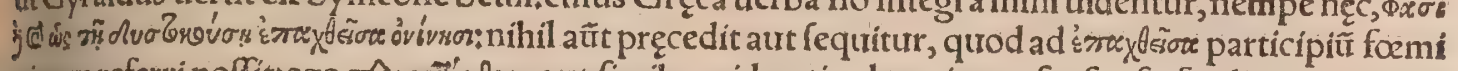

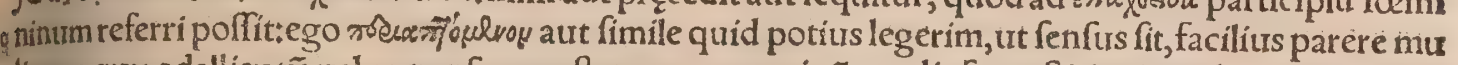
lierem qux adalligatũ urel appenfum geftet cornu ceruinũ, qualis fuperftitio circa alia quoģ multa eft,pracipurèuero aétiten lapidem. Cerui cornu $\&$ oliuas nondü habentes oleutm, fimul trita mixta fuftio, Hippoc, in libro de natura muliebri ad nefcio quos uteri affeĉus:nó fatis enim exprimitur.

Cerebrum cerui apud Albertũ $\&$ interpretem Rafis falfó pro medulla fcribitur, ut fupra mo= nui, ge bezahar lapide, qui dicitur la chryma cerui, Andrea Bellunenfis uerba retuli fupta ca. pite tertio. Belzahatd, inquit lo. Agricola, eft antidotum contra uenenũ epotum efficaciffimum \& prorfus diuinum. Siquidem probatiffimus medicus Auenzoar libro primo teftatur fe hoc uno ne. dicatum effe quendam qui perniciofiflimum uenenü fumpferat, quod cum biliofum effet, protinus uniterfo corpori auriginem induxerat, Dofis erat belzahardi trium granorum hordei pondus cimm uncips quin q̧ aquæ cucurbitæ, quæ nimiam ueneni caliditatem refrenaret. Cæterum hutiús medica. mentiorigo huiufmodi eft: Ceruus poftquam cum ferpentibus congreffus eas dectorauit, fiti corre: ptus, práertim in regionibus Orientem uerfus, ubi pragrandes reperiri conftat : mox ftagnum aut flumen aliquod quarit in quod fefe immergat:(iuxta lllud regij prophetæ, Sicut ceruus defiderat ad fontes aquarum, ita anima mea defiderat ad $\mathrm{re} \& \mathrm{cc}$.) Inde tamẽ natura ita docente, uelut $T$ antalis in medịs fitiens fluctibus, non bibit:nã ftatím concideret mortưs fi quid aqux deguftaret, Erumpunt

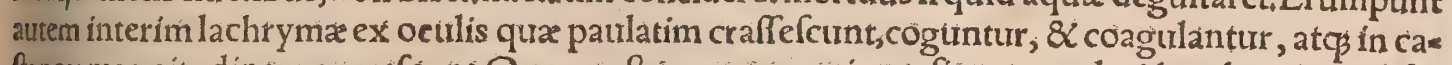
ftanex magnitudinem excrefcunt.Quas, poftquam ex aquís euafit ceruus, deciduas homines obfer uant, \& colligunt, Hoc illurd eft belzahard, tantax apud eos qui poffident altimationis, ut cuiuis ueneno tuel meditũ ungtrem oftendant, Hac ille. De codem Ferdinandi Ponzetri cardinalis uerba hẹc funt: Experientia cognitus eft ad omnia uenenorum genera pollens lapis quem uocant Kemne feu bezar, colore citrifplendens, odore tinit natus ex lachrymis certiorum. Infirmi enim atate flumen quoddam ingrediuntur in Oriente, $\&$ ftant in eo immerfiuf $\phi$ ad caput, donec emittant lachrymas, qua frigiditate aqux 8 aëris coagulatæ, uertuntur in lapidem magnitudine autellanæ: qui exeunti: bus â flumine decidit. Huitus triti, ut docti omnes teftantur, fi pondus duodecim granorum hordei fu matur, expellitur omne trenenũ $\&$ uirus per fudorem. Ceruorum lachryma collect $x$, cordis pulfu laborantibus auxilio funt, Phyfiologus author obfcurtus. Venenû Hebręi aut finitimę lingux prę

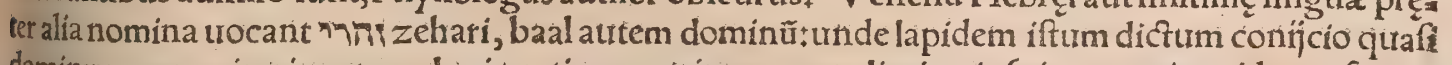
dominum ueneni:cuius etymologiz ratione merito pro peculiari cuiufuis ueneni antidoto ufurpa. tur. Hunc lapidem aliquibegaar uocant, uide plura in Pandectis Syluatici.

đPulmo ceruinus clauos $\&$ rimas callićp uitia fanat, fimiliter ut fimum fitis recens illitü, ac tertio diefolutum, Plin. Pulmo ceruinus impofitus $\&$ fape renouatus ex calciameto lafos pedes fine dolore perfanat: fed leporinus pulmo impofitus multó efficacius curat, Marcel, A pud Plinium quiden ftatim à ceruni pulmonis mentione remedium ad calceamentor uै attritus fubijcitur, unde for fan de. cepturs eft Marcellus.Quód autem ceruino pulmoni apud Plinium nihil cum attritibus calceamen: turũ fit, inde conftat, quia Plinius hoc obferuat, ut morbos $\&$ affectiones prius, remedia pofterius no minet, îs quidem in locis, ubi remedia fecundum affectionu genera partitur, ne qua poffit or iri cona fufio. Fecc de Pliniana lectione: nam quod ad naturam remedif, hoc eft ipfum cerui pulmonem, an ad alterum affectũ magis conueniat, an aque ad utrunģ, experturis iudicandum relinquo: quanquam inter tam multa $8<$ obuia remedia horum uitiorũ, neminem cerui pulmone opus habere puto. Tur fim fanat pulmo ceruinus cũ gula fua arefactus in fumo, dein tufưs ex melle qutotidiano ecligmate! Efficacior eft ad id fubulo ceruorũ generis, Plin. Et alibi, Sunt qui cerui pulmonem phthifico pro:
fuife fcripferint, maximé fubulonis, ficcatum in fummo, tritumó̧ in uino. Certui pulmones cumfutis 
gurgulionibus uirgulis tenfos, in fumo donec arefcant furpẽde, \& ex his aliquid contufurm tritumé diligenter adiecto melle, ecligmatis modo phthifico dato, quem fanari citiffimè uoles, Marcellus. As phthífim non perfectam fanandam, Pulmo cerui calamo extraçus $\mathcal{X}$ arefaçus côteratur: $\&$ cochle: ria cius tria ex mellis cyathis tribus cxhibeantur, deinde paucis diebus interpofitis iterum propine turr, Galenus Euporifton 2.27. Pulmonis cerui in olla fictili exufticinis datus multís ad fufpiritun uel dyípnceam profuit, Marcellus.

T'Tradunt ceruas, cum fenferint fe grauidas, lapillum deurorare, quem in excrementis reperum aut in uulua(nam \& ibi inuenitur)cultodire partus adalligatum: Intreniuntur $\&$ officula in corde 8 in uulua perquàm utilia grauidis parturientibusćs, Plinius. Lapis qui in uulua aut in uentriculi cerui inuenitur, phylacterium eft pręgnanti, \& perficit ut partum perferat, coós ratio colligit uelocil fimum effe illud animal, nec tamen aborfum facere. Simili ratione officula inueniuntur in corde ce vir,aut in uulua eius, qua idem præftant, Sextus. Vt mulicr non concipiat, Eadem offa in brachis fufpenfa efficiunt ne mulier concipiat, Idem. Os à corde cerui humanum cor totius fubftantix fimi litudine roborare $A$ çuarius cum A rabibus confentit: fed $a b$ aliorum animalium maiorũ corde $p_{0}$ tưs fuerint, qux tã multa proferunt pharmacopolæa, quàm à corde cerui, A n urerò cartilaginofa ha fubftantia magis praftare id qureat, quàm cordis aut arteriarum corpus, ipfi uiderint, Syluius. Vene tijs bubulum aut uaccinum quoddam os uenditur, quod uerè os eft, etiam ingêti pretio, pro offe de corde cerui. Ego duo corda ceruí aperui: unum ftatim à cerui morte, in quo neruus quidam aut carti lago neruea apparuit, non admodum dura, in crucis modum:alterum interfecti ante fex dies, curius ner urea cartilago multó durior crat, \& tenfa, tali feré figura, quali Venetịjs os de corde ceruí tễditur; bubullum illud inquam uel uaccinum. Illius nerui uis apud ueteres non memoratur, minusíg̣ in ro. borãdo corde ualere arbitror, Anton.Brafaurola. In corde cerui(inquit Platearius) reperitur quod dam os parte finiftra, ubi quadam concauitas eft, in quam fplen refpirat, \& excrementa emittit, (per uapores filicet, qux illic ob ficcitatem fuam in offeam uertantur fubftantiam. Eft autem hoc os de fanguine cordis, fubrufum, $8 \mathrm{C}$ melancholicum expellendi fumum uim haber:Datur etiam contra car diacam (fic uocat pulfum feu tremorem cordis) fyncopen, 8 hamorrhoides, Hac ille. Os cordis cerui tritum potui da mulierifterili, \& uidebis gloriam Dei, Galenus Euporifon 3.174 . Cor fine of. fe eft omnium qua nos nourerimus, praterquam equi $\&$ generis boum cuiufdam, A riftoteles. $\mathrm{Ne}_{e}$ gligenda eft illorum of citantia qui in cordis affectibus magno fupercilio os cordis cerui, nefcio quit. bus gemmis $\&$ auro mixtum, propinant: quum interim ceruo non aliud os, quàm uitulo aut caniaut fui infit,cartilagineæ nimírum magnæ arteriæ $\&$ uenæarterialis radices. Et officulum illud quode ceruorum cordibus exemptum pharmacopolarum officinæ mihi hactenus ementitæ funt, aliudni, hil effe cenfeo, quâm grãdius agni hyoidis offis officulum, quod continunum eft, $\& \lambda$. fimillimumtnin fi quod dextrum crus etiam tranfuerfím finiftrum decuffatim fecat, $8<$ alterum crus altero breuiur fit:quod etiam ouina lingua quoties menfx apponetur, lace clarius edocebit, Hæc And. Vefal Eft apud nos quidam rei uenatorix peritus, qui mihi affirmauic os ín corde cerui non alio temp intueniri quàm eo quod inter duos diux Virginis dies feftos intercedit, hoc eft à medio circiter $A$ fto ufg, ad idus Septembris. Cor cum pelle $\&$ cornu cerui combure, $\&$ ex oleo utulnus inung lenus Euporifton 3.184 . बHinnuli coagulum laudatifimum ef, Ariftoteles. Nicander leporis agulum contra uenenata laudaurit, quo loco Nicoon antiquiffimus medicinæ author, primum agulis honorem hinnulo tribuit, fecundum lepori, tertium uerò agno (hœedo, ut citat Hermolar Plinium:) Diofcorides leporino primum in coagulorum cenfu ordinē dedit, Marcellus Verg, quidem in Diofcoride mireris, quod primum hinnuli $\left(\nu_{\varepsilon}, \beta \tilde{\rho} \tilde{)}\right)$ coagulum nominet, \& rurfuspi poft cerui, qua de re fupra alicubi dixi. Pares autêuires habere frribit leporino coagula hoedi, a hinnuli, dorcadis, platycerotis, dorci, cerui, \&c. Coagultum hinnuli, leporis, hœe di laudatum:pr puum tamen dafypodis, \&c. Plinius. Contra morfus (ferpentium) præcipuum remedium ex gulo inuli in utero occifi,Plinius lib.8. Etrurfus libro 18. Summis remedïs præfertur inulico

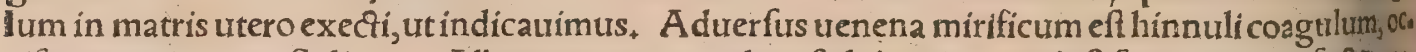
cifi in matris utero, Solinus. Albertus non coagulum fed abortiuum (id eft foetum imperfectâ)per peram legit. Coagulum cerui ex aceto potum ab ictu (ferpentium iuruat: \& fi omnino trac fit, eo die non ferit ferpens, Plinius, Vtiliter bibendum datur morfis à cane rabido, Damocrat pud Galenum libro 2, de antidotis. Contra potum cicut $\&$ fungorum efum prodeft, Haly . gulum cer. fitue leporinum, fitre hoedinum, in potione folutum bibitur utiliter a bempyicis uel hi ptoicis, Marcellus. Coagulum cerui ex aceto fanguinem fiftit, Plinius. Deglutitum fanguinê intimis profluentem facile ftringit: idem facit $\&$ coag. leporis, Marcellus. Leporis authinntli coas gulum ex uino potum, nec non immiffum cum oryzæ cremore coeliacos \& dy fentericos ituat, Gale mus Euporifton 1.113. Inteftinorum uitijs magnopere prodeft coagulum ceruorum decodum cum lente betaćs, atç ita in cibo fumptum, Plinius. Hinnuli coagulum priuatim tríduo à purgation bus admotum, partus fpem intercipit, Diofcnrides. TVentres ceruorum, uide mox in Tefrib - Teftes cerui inueterati, uel genitale maris, falutariter dantur in uino. Irem uentres qui centipellio nes trocantur, aduerfus ferpentium morfus, Plinius, Genitale cerui tritum (Aegineta ficcarip iubet, tum teri, additḉ mifceri remedị̂s; qux ad uiperarum morfus componũtur) $\alpha$ in uino 


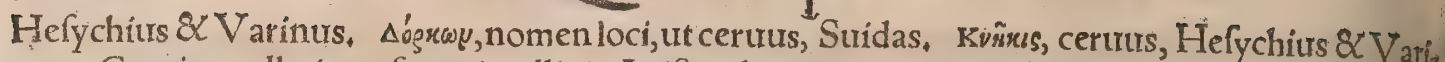
nus. Cerui a ppellatione forte intelligit Ariftoteles etiam capreas, \& damas, \& capras fylueftres,

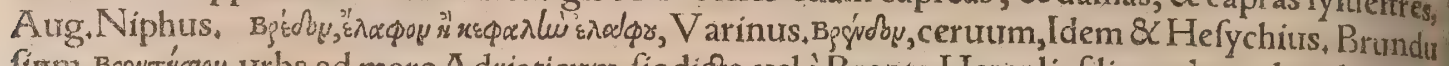
firm, Bsquŕsou, urbs ad mare A driaticum, fic dicta uel à Brento Herculis filio : uel quod multis por tibus uno in ore fitis opportuna fit, quibus cerui caput quodammodo refert. Vocant autem Meffas píceruinum caput brention, ut Seleucus fcribit in fecundo gloffarum, Brundufium (Bgsrrígoy, Strabo lib, 6.)Meffapiorum lingua cerui caput dicitur : Sic enim eft ciuitas cum portu capiti cerui. no perfimilis, cum cornua, \& caput $\&$ linguã habere uideatur, Onomafticon. Hinc forfan $\&$ Bret. totia dicta infula maris A driatici cum Brettio fuuio, quam Elaphuffam Græci uocant; aliqui Bret tanidem, apud Stephanum, quanquam \& Oceani infulaBritannicx, Græcis Brettanides dicuntur,

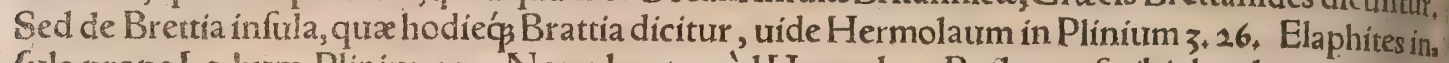
sula prope Lesbum, Plinius 5. 31 . Non placet quơd Hermolaus Barbarus fcribit bredon poêtas cer= uum aut caput cerui nominare, cum Meffapiorum non poétarum id ưocabulũ fit, qui brendon uel brention potius quàm bredon proferunt, licet $V$ arinus etiam bredon habeat. Non ftatim autẽ quic.

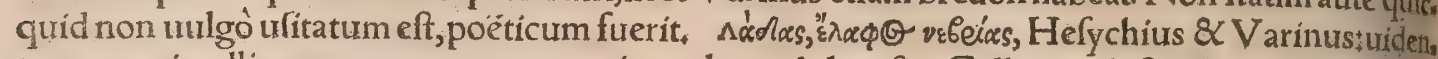
tur autem intelligere ceruum marem, qui nondum adultus fit. Gyllius in hiftoria camelopardalis, dorcalidas ceruos non reciè interpreta tur, ego capreolos uerterim. Aufeac, id eft coagulum cer. uinum, \& genitum bubali, Vetus expofitio in Auicennam. Aufeác alanerb, id eft coagulü ceruli.

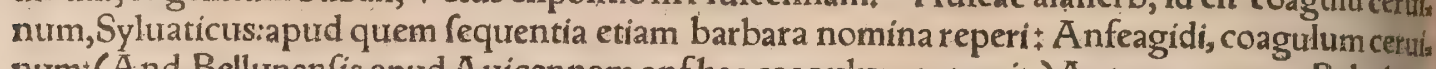
num:(And. Bellunenfis apud Auicennam anf haa coagulum exponit, )A uteros, ceruus: Belachim, ceruus.Meloffia,medulla ceruina. THinnulum uulgó uocant 8 fcribunt ceruum adhuc tenerü, quod nomen author quidam obfctrus ab hinniendo deducit. Eruditi quidam aliter fribunt, fedua riant Inulos per fimplex $n$; \& fine flatu pro ceruinis pullis rectius proferri Hermolaus putat hinnos autem $\&$ hinnulos per duplex $n . \&$ curm afpiratione, ex afina conceptos equi coitu, fed utiç fifint mares, ut Plinius adiecit:quanquam Nonius etiam hinnas uocat, \& $\mathrm{c}$. Hermolaus in Diofcoridis ca. put de certrino cornu. Idem ex Hermolao Calius exfcripfit. Cerui inulum fiue inuleum, nebròn

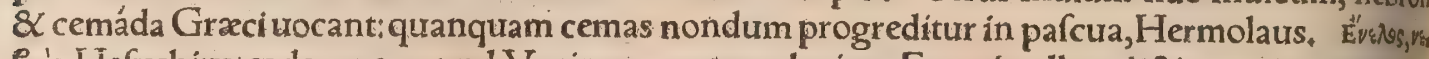
Bojs, Hefychiusteadem uox apud V arinum oxytona legitur. Ego uix ullam dictionem repeririputo, in qua tam multiplex fcribendi ratio fit apud Latinos pariter atç Græcos, $V^{\prime \prime} v Q G$, w voós

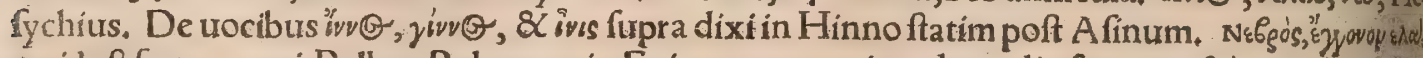
$\phi \gamma$, id eft foetus cerui, Pollux. Polyænus in Epigrammate etiam dorcadís foetum $v \varepsilon b_{\rho} \dot{y}$ a ppellat, $M_{2 a}$ rius Grapaldus nefcio unde motus veGgò damam interpretatur. Dorcas proprié caprea eft, ut fupra docui; Græci tamen grammatici etiam hinnulım, ঋे જી

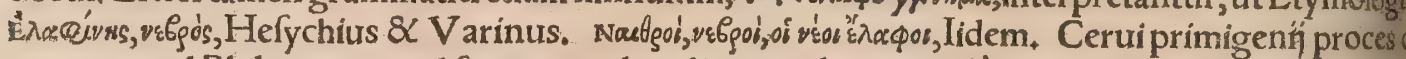
cuntur apud Philetam, (quod fupra reprehendi:) grandiores paulo iam dici cemades ualent : per cia demum æate ceruit Nifi eos item qui achæinæ nuncupentur, aut fpathinæ, quædam ætatis elf difcrimina coniectet aliquisł uel etiam generũ ex magnitudine, urel cornibus interftitia. Graci fchon

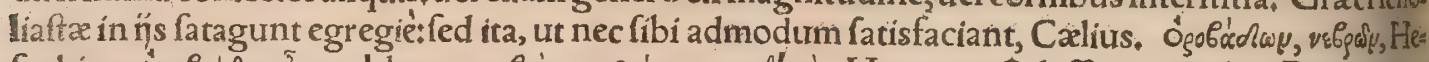

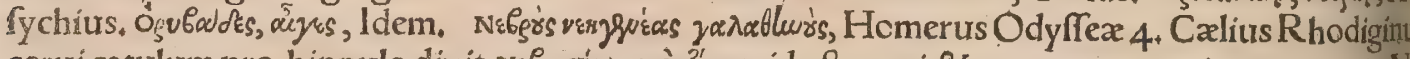

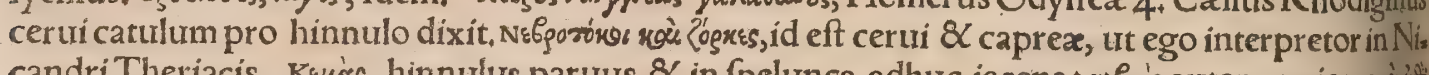

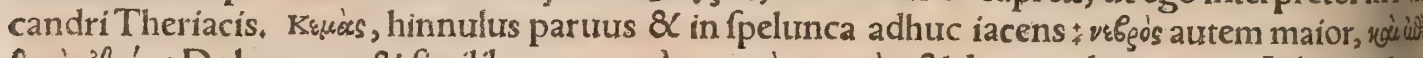

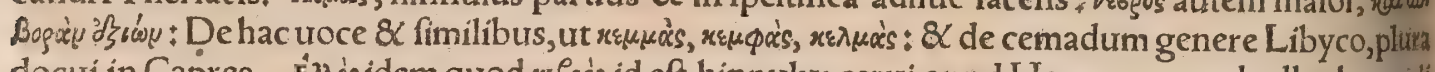

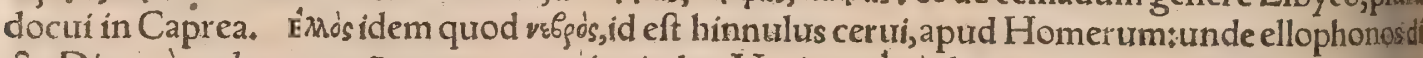
cta Diana à cæde certorû, utpote uenationis dea, Varinus, Ėßjós, leuris, celer, nuper natus, (tanquam epitheton ceruit) item mutus, humidus, marinus, (tanquam epitheton pifcium, quod mihi ellopspo

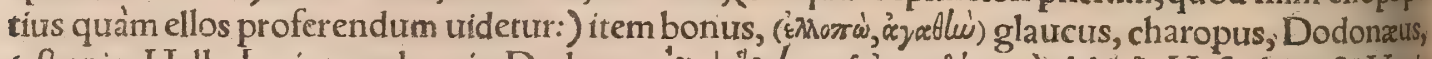

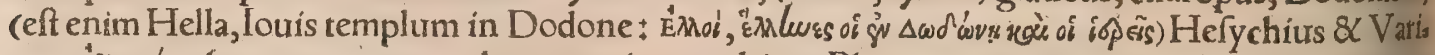

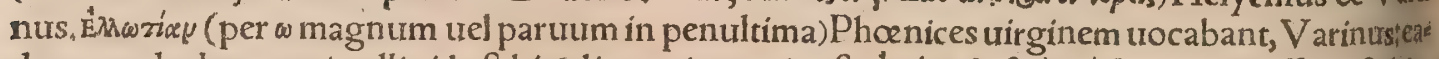

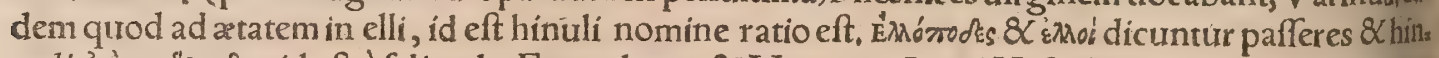

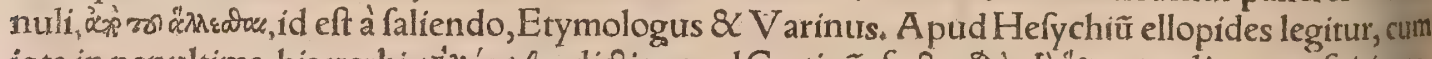

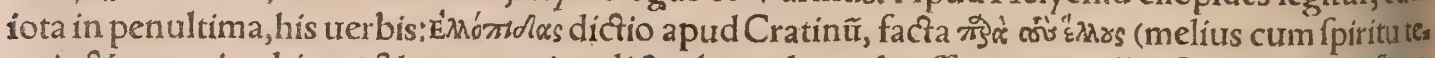
nui , \& acuto in ultimat) \& communiter dictos hinnulos, uel pafferes, uel pullos ferpentis fignificat;

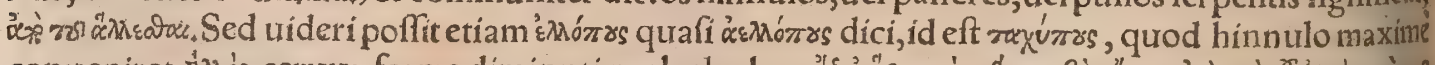

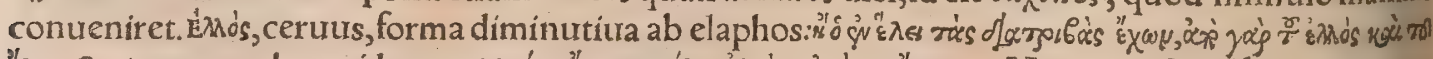

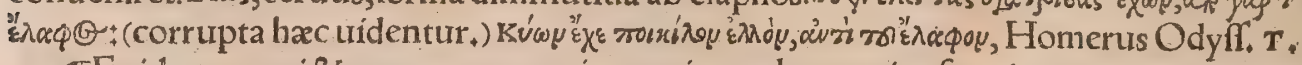

बा Epitheta cerui 8 cerua : conueniunt enim eadem utríg fexui prater cornigerum. Fixerit aripedem ceruam licet, Vergilius 6. Aeneid. Agilis, Alatus, Ouidius r. Metam. id eft uelociter cure rens. Alipedes cerui, Lucretius lib. 6. Annofus. Celeres, Stat. lib.6.Theb, Celeripes,Cornigeri, Lucret, lib.3. Aut furgentem in cornua ceruû, Verg, Aeneid, 10. Cornigera, ut habet Textor, fine 6 authoris nomine, fed fallò ‘ ut Graci etiam poëtæ pleriç nop órasay, id eft cornutam ceruam falfó $c^{\circ}=$ gnominauerunt, ut fupra oftendi cap. 2. Cretæa id eft Cretenfis, Seneca in Hippolyto, ubi Gram* 
hoftes, deinde in Spartam:à Cantharione uerò poftea cæteros omnes Lycæum ingreffos. Elaphos placenta nomen habet ab elaphebolijs facris in quibus fieri folebat ex fefamo $\&$ farinz flore (sxuros, farina pinfita, Ruel.) Cálius ex Athenæi lib, 14. Hermolaus à menfe (elaphebolion enim September eft) in quo fiebat, dictam ait. Erant autem elaphebolia facra codem in menfe, ut nibil interfit. Ineptits $\&$ obfcurius lo. Ruellius, hanc placentam ceruorum uenationibus dicatam fcribit.

a Ceruifca pirum à Cloatio inter reliqua pirorum genera nominatur apud Macrobium libro cap.19. Linguam ceruinam Romani uocant filicem foeminam: Noftri hodie uulgo hemionitin Dio fcoridis fic uocant, de qua pluribus dixi in Boue cap.z. inter remedia ad morbos buum. Elaphine, ueratrum nigrum, inter nomenclaturas Diofcoridi adiunctas. Elaphion, ocimaftrum, lbidem: $\mathrm{He}$. fychius tame \& Varinus interpretantur conion, id eft cicutam. Ceruịnum trifolium noftri uocãt, herbam bicubitalem aut proceriorem, locis nafcentem aquofis, odoratam, folips ternis, oblongis, cres natis, umbella purpurea, \&c. quam pleriç pharmacopola uulgo hactenus eupatorium uocarunt, Ruellius hydropiper effe credidit.

ब. Cerua, canis nomen apud Varronem, Tarando caput eft maíus ceruino, nec abfimile,Plin. Tarandus a nimal eft ceruo fimile, V arinus 8 Hefychius, Euftathius facie ( uum reprafentare fcribit. Bubalos A frica gignit uituli cerútre quadam fimilitudine, Plinius, Ef in Hercynia fylua bos cerui figura, Cafar lib. 6.belli Gall, Gyllius pro bos legit bifon, ut in bifontis hi ftoria oftendi. De caprea fiue capreolo, $\&$ platycerote, qux ceruini generis quadrupedes funt, fupe rius egi poft capras fylueftres. In Sardinia eft ephion animal ceruo minus, \& pilo demü fimile, nes alibi nafcenstid quanquam Plinius interĭfle arbirratur, mufimonem effe conijcio, muffonem uulgo: rocant, ut ftatim pof Ouis hiftoriam referemus. Ceruarius lupus, qui $\&$ hodie apud Iralos $8 \mathrm{Gal}$ los nomen retinet, ex cerua \& lupo, aut lupa \& ceruo genitum ac miftũ animal exiftimatur; de quo pof Lupum priuatim dicam. Ceruaria ouis, qura procerua immolabatur, Feftus. De hippelapho, id eft equiceruo, qui $\&$ tragelaphus dicitur, in Hirco docui capitis oftaui parte prima. Tragelaphum Ge.Agricola Germanica uoce mihi ignota branobirts interpretatur. Alberto alcen eriam equicer uum appellare placuit. Illud quogs animal quod Septentrionalis tantum regio producit, rangiferum uocant aliqui, ceruino generi adferibendum uidetur. Ex amico quodam accepi, uifum fibi in aula regis Gallia Francifci, equum pofteriore parte ceruum. Elaphis nomẽauis, quafi dicas certrariam, Oppiano in Ixeuticis, quòđ pennas pelliceruinæ fimiles habeat, colore nimirum \& maculis. Anía

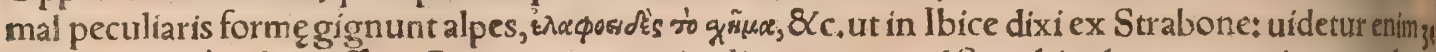
non aliud quàm ibex effe. Ceruorum magnitudine aues apud Struthiophagos reperiuntur, aliz quàm ftruthiocameli, in eorum tamen hiftoria nobis referendx. Ceruum uolantem Galliuulgoap pellantmaximum inter fcarabeos, \& ramofis cornibus, quibus ceruũ refert, infignem. Belluas quaf dam ex boue ceruoós compofitas A pollonius ultra Catadupa Nili procedens reperit, Philoftratus: Vide mox in fequenti parte $b$.

T De Elaphuffa \& Elaphite infulis fuperius dixi prima parte huius capitis. Eft \& Elaphonnefis, una Sporadum infularũ cum urbe eiufdem nominis, Stephanus. Ceruaria, locus ad Templun Ve neris, Galliæ A quitanicæ finis, inter Pyrenæi promontoria in finu falfo ad mediterraneum mare, me minit eius Mela libro 2. Thyatera, Ovod zesper, urbs eft Lydię, qua etiam Myforum uitima uocabattit.

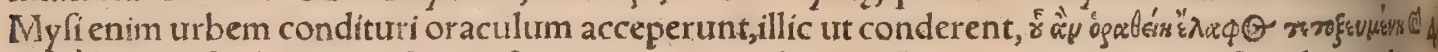

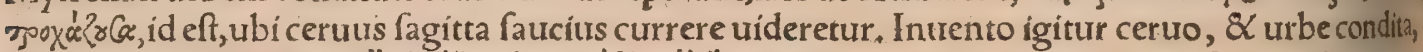

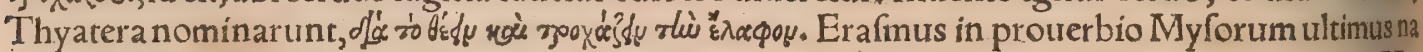
uigat, huius ciuitatis non meminit, fed Acolidem uel Teuthraniam fecundum alios, extremam My. fix partem oraculo fignificatam fcribit. Refert autem oracula duo diuerfa ab eo quod nos ex Stepha

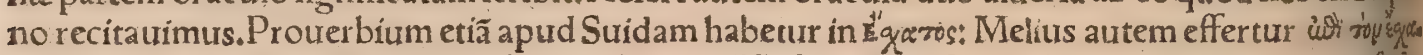

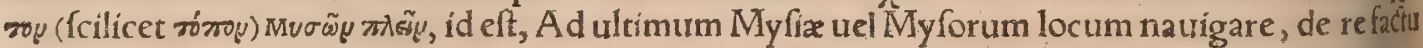
difficili $\&$ äjs qui dura quapiam imperant. Namfi cum Erafmo proferas, Myforum ultimus natigath nilis ad hunc fenfum, neç ad oracula. Simile illud Germanorum uidetur, Vbi piper prouenit,ideft in remotiffima aliqua regione. Telephi hiftoriam in hoc prouerbio longè aliter narrat Suidas, quàm Erafmus, qui ex nefcio quo authore uertendo, tum in alins tum quod фovsis pro yovess legit, deceptus ui 4 detur. Elauía, Ė $\lambda$ ḱvıc apud Stephanum, caftellum Sicilia, nihil ad ceruum.

I b. Orfei Indi monocerotem uenantur, capite ceruo fimilem, Plin. Boures ceruorum cothis bus præditos Ludouicus Vartomannus fibi uifos fcribit in Zeyla urbe Aethiopiæ, principi illits lo:

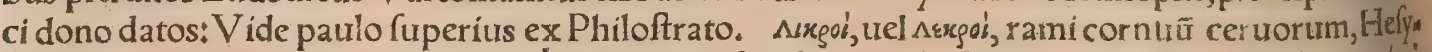
chius \& V arinus: forte quod obliqué uel per tranfuerfum enafel foleant: $\lambda$ ug

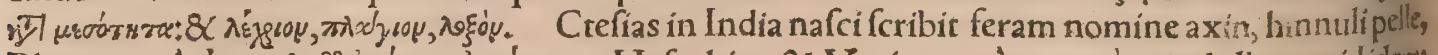

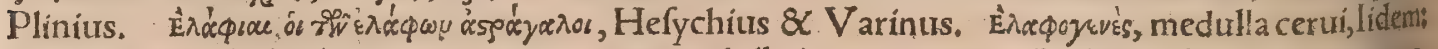
Syluaticus titafin barbaram uocem pro cerui medulla interpretatur. Aethiopia leucrocutam gene

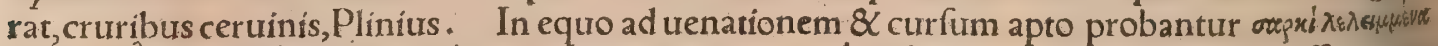

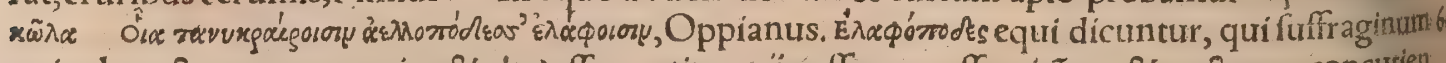
articulo recła (procera potius \& alta) offa continent:j peffimo greffu nitũtur, \& ueçor em concutien do fatigant, A bfyrtus cap.114. Equus habeat falces curuas $\&$ amplas tanquam ceruinas, Ruffus. 
Certros colore nigricantes in fylua Hercynia, uel ut aliqui uocant, Martiana, quidâ reperini aiunt:

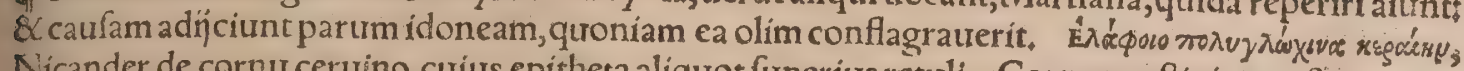
Nicander de cornu ceruino, curius epitheta aliquot fuperius retuli. Cornuum ftipites noftri uocant fangen/quafi perticas, é quibus rami enafcütur:quibus ftipitem unum adnumerare folent cưm rà morum cerui numerữ proferunt. Circa meffis tempus, ut audio, cute cornibus obducta, uermiculi quidam fubnafcuntur, qui cornus fuperficiem inaqualiter exedunt \& exafperant. Eo tempore uer miculos fentiens cer uus $\&$ pruriens, arboribus cornua affricat, quod noftrates dicunt firnent. Inter cerui craneum \& cornua, ur ipfe obferuaui, officula fiue tubera offea gemina protuberant lacuia, duos circiter digitos longa, eô breuiora quó ceruus natu maior eft:horû́ fingulis cornua fingirla ad= nafcuntur per lymphyfin quanda \& quafi articulationẽ. Subulonis cerui cornua uidi dodrantis cir. citer longitudine: furcarń uero uulgo dicii (cin $\$$ gabler $)$ qui trimus eft, durorư $\&$ amplius dodrantû. Obferuaui etiam in confummati cerui cornibus mucrones fiue ramulos fupremos, qui binialioqui plarunç aut terni fpectantur, feptenos, \& eodem in locoftipitis latitudinem fex digitorum:inferius autem erant $\&$ alĭ bini rami $\&$ adminicula. Cornua abïciunt (noftri reeren tocant) Martio, $\&$ cí tius etiã fi aêrris cenftitutio calida $\&$ fícca fuerit. Abịciunt autem aliâs pariter, aliâs unum polt alte= rum horis aliquot, duodecim interdum aut pluribus interpofitis. A biecta in uittarís quidem apud nos negligi ab eis, nec humo obrui aut aliter curari, obferuanum eft: Quin etiam in fyluis fxpenume. ro in aperto non occultata defoffáue reperiuntur, ut quod hac de re ueteres tradider unt omnino for
taffis fabulofum fit.

Tc. Cerui glocitant \& onagri, Authior Philomela İem catuls glaucitare tribuit. Glocíre uerơ \&glocidare apud Columellam \& Feftum, propríum eff gallinar um quũ ouis incubituræ funt. Gra= uiterćs rudentes Cxdunt, Vergilius in Georg, de cervis. Xenophion ceruorum hinnulos beãy di=

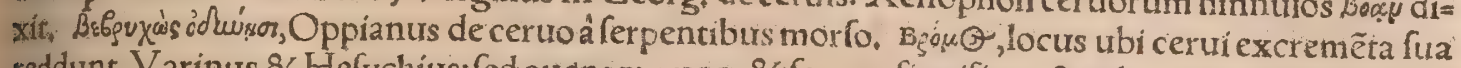
reddunt, Varinus \& Hefychius; fed auenam quoos \& fonum fignificat, \& odorem: atqui pro odore non quouis, fed uirofo tantum, per $\omega$ circumflexumi in penuirima foribitur: \& inde forfitan nomen loco excrementorum cerui, of Vinceres curfur ceruum, 8 grallatorem gradu, Plautus citante

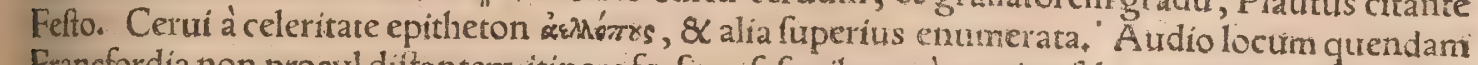
Francfordia non procul diítantem, itinere forfitan fefquihora, à cervino faltu nomen babere, in quo lapides duo erecti uifantur, interfitio pedum hominis mediocris feré fexaginta; tanto enim fpatio fa so liffe illic ceruum, idqg etiam firpra plautrum oneratum, cum uenatores inftarent. Nofriceruis, quos in uiuarn̈s alunt, præter foenum quoridie auenam quogs, offetint. Libidinari íncipiunt circa calendas Septembris, aut aliquando tardius, quod hyemis etiam tardioris fignum effe conijcitur. Cerua uterum gerit, ut uacca, feptimanis quadraginta, \& fíngulos itidem parit.

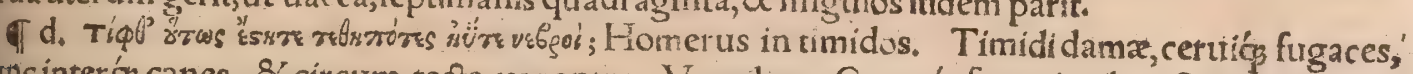

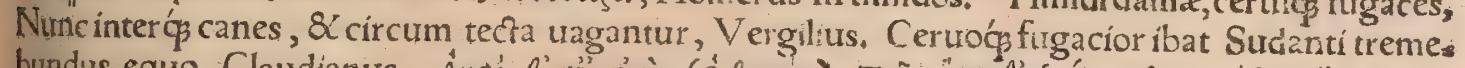

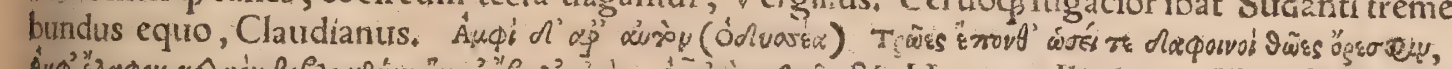

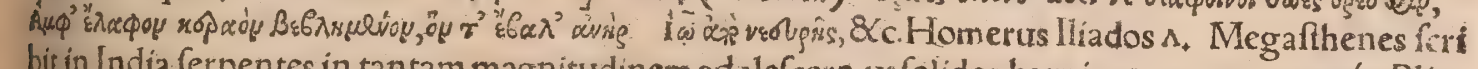
bit in India ferpentes in tantam magnitudinem adolefere, ur folidos hauriant ceruros tauros ćp, Plín.

đe. Mordent aurea quód lupata cerui, Marrialis 1.6 . I, enumerans animalia in fpectaculo quto: 40 dam exhibita. Orpheus in libello de lapidibus fponfum iubet cornu ceruinum geflare:fic enín perpetuam ei cum fponfa futuram concordiam. Cerui cornu fuper Panos dei facellú ponito, candelamós defuper accendito, \& ne interdiu accenfam obluione demittito, $\mathcal{S}$ in tempore fandû De: mufarim inuocato, ac tollito:armenta tua $\&$ uitam cuftouterst, Author libri Parabilium Galeno ad: feriptifunt autem hac uerba lib+3.cap.ico. Cerutpelins $\&$ pedes dextrifi infigantur portæe, prohi. bentingreffum cuiuslibet animalis uenenofi, Galenus Euporifton 2,143 . Nec equi nec boues mor bo premuntur aliquo, fi illis cornu ceruinum appenderis, Abfyrtus. T/ Cerui proprium eft sein;

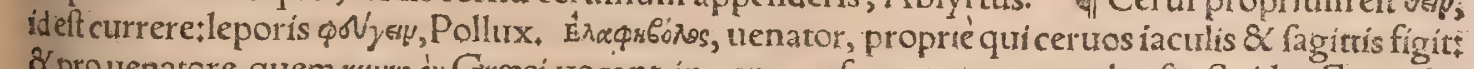
a pro uenatcre, quem xusryou Graci uocant, in genere ufur patur per catachrefin, Suridas, Erymolo.

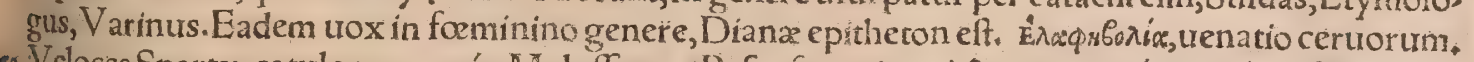

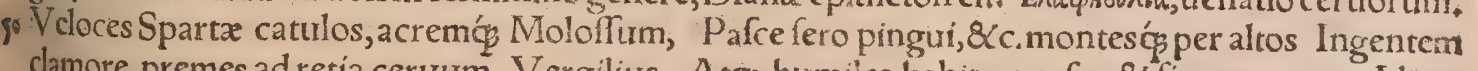
clamore premes ad retia ceruum, Vergilius. Atç humiles habitare cafas, \& figere ceruos, Idem: figere, id eft uenari \& iaculari ; quanquam per ceruos hic etiam bacilla furcillata intelligí poffunt; ut fupra dixi ex Seruio, Idem in Georgicis de pecoribus Scythix fcribens, qua non in ftabulis, fed campis niuofis hyemem tranfigant, deceruís etiamlic canit, Confertó̧́agmine cerui Tor pent mole nour, \& fummis uix cornibus exrant. Hos non immifis canibur, non caffibus ullis, $\mathrm{Pu}_{\mathrm{i}}$ nicexúe agitant pauidos formidine penna: Sed fruftra oppofitum trudentes pectore montem;

Comminus obtruncant ferro:grauiteŗ́́ rudentes Cxdunt, \& magno lati clamore reportant: qVenaticus ex quo tempore ceruinã peliể latratuit in aula, Militat in fyluis, Hora. epift.1. đI Leo. nidx uel Mnefalci tetraftichon in ceruum uenabulo occifurm, ex at n̂nthologị Græci fect. 15. Lib. 6.

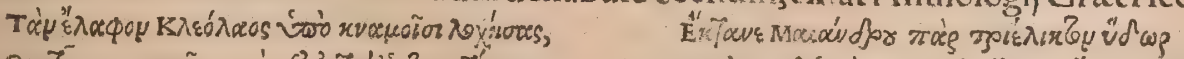

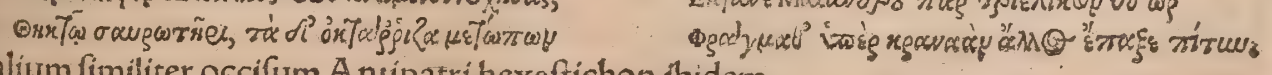

Etin alium fimiliter occifum Antipatri hexaftichon ibidem, 


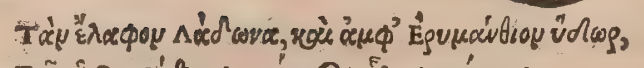

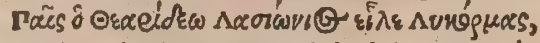

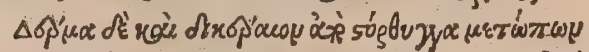

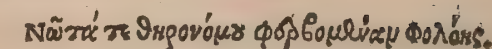

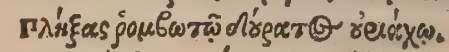

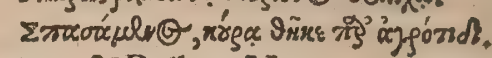

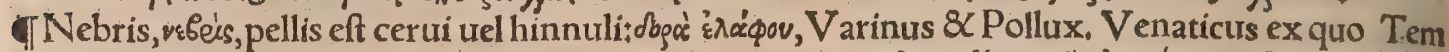

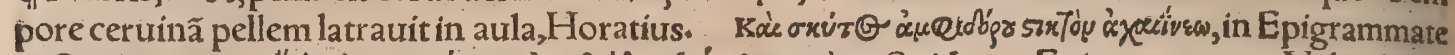

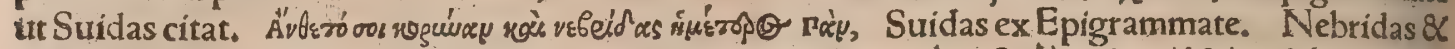

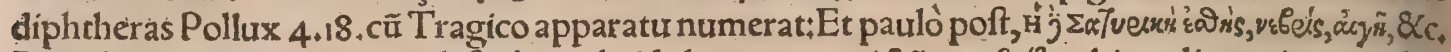

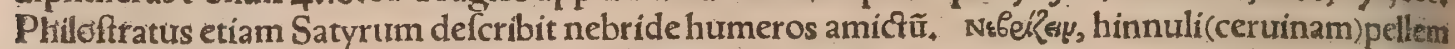
- geftare, Etymologus. Vtitur hoc uerbo Demofthenes pro Ctefiphonte, tanquam is qui facris initia

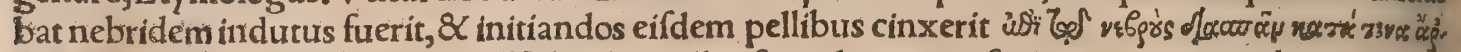

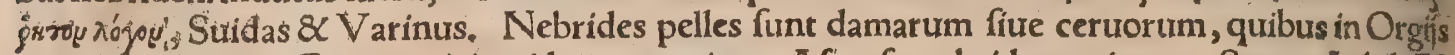
Bacchiutebantur, Grammatici quidam recentiores, Afperf nebrides uario auro, Stat.2. Achil, Fit \& nebrites gemma Libero patri facra, à nebridum pelliû́ fimilitudine, Plinius lib. 37. Huius gemma

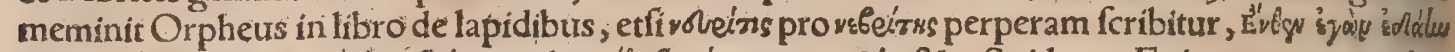

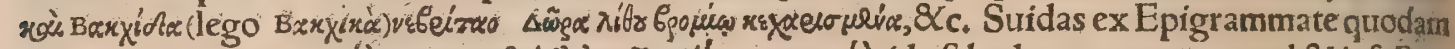

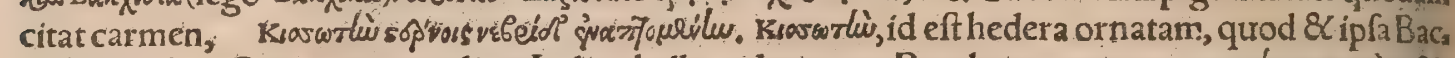
chofacra fit. Camaritz populi ex Indico bello rédeuntem Bacchưm exceperunt, z'

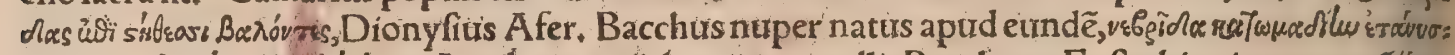

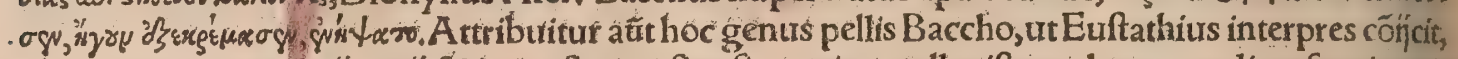
eo quod homines ebrị uarĭ $\&$ inconftantes fint,ficut etiam pelles iftat tiel propter diuerfum in turis 20 colorem: uel denic quod ebrietas infirmos \& timidos reddat, quemadmodum \& nebros fiure certuss animal imbelle $\&$ ad fugam natum eft. Nebrida ferre dicitur cleganter, qui timidior eft $\&$ uinolen. turs, quia illam geftaret Bacchús, Calius, Habebit fané protıerbỉ fípeciem, ut fi quis hominẽ aftutum

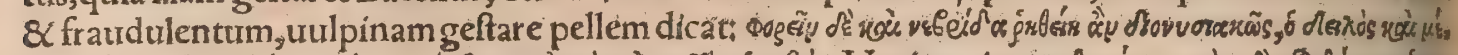

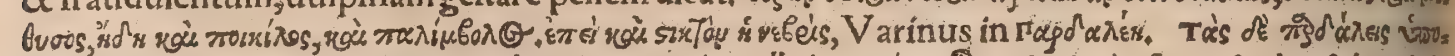

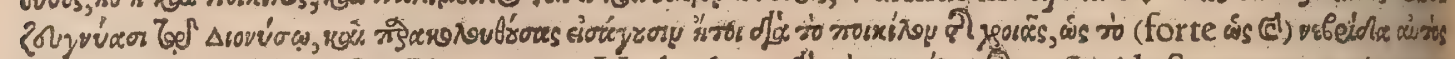

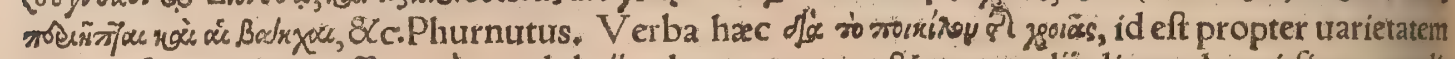
coloris, forte accipi poffunt eò quod ebrij colorem mutent. \& eorum alíp aliter color ati fiant : aut dí

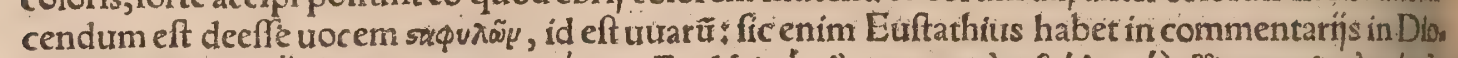

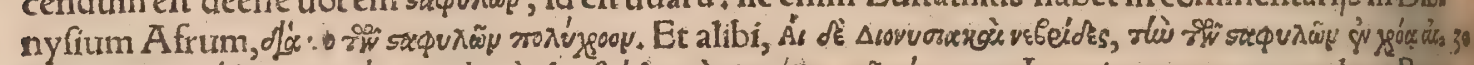

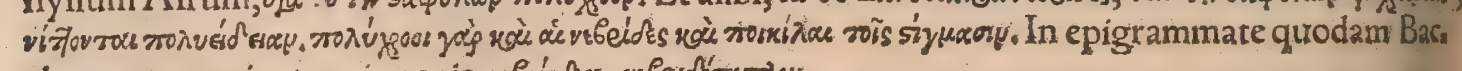

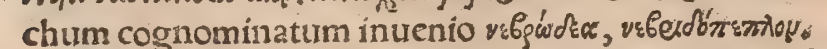

ब1 h. Certra nutriuit Telephum Agaues (A uges, Calius 2r.37.) \& Herculis filiũ̃, A elianus libro

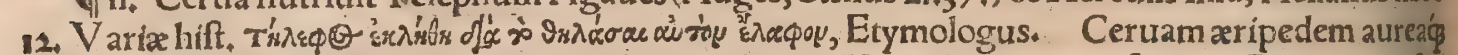

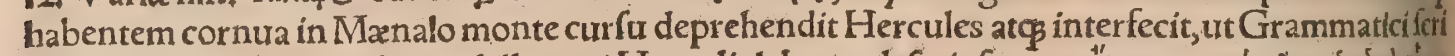

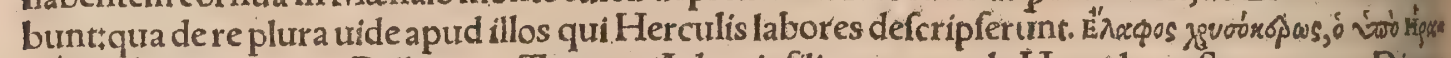
xíkrs áñrs, Varinus ex Polluce. Taygeta Atlantis fillia ceruam ab Hercule poftea captam Diañ confecrauit. Fertur autem quod cum Hercules eam Euryftheo traderet, collo eius infcriptum fuerit;

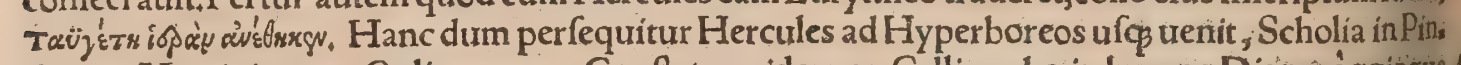
darum. Meminit etiam Calius 7.15. Conftat equidem ex Callimacho in hymno Dianzè quinque 4 ceruis fecus Parrhafíf montis radices inuentis, quarum è cornibus fplendebat aurü, quatuor ipiam fine canibus cepifle, currứģ adiunxiffe: fugientem aliam Iunonis uoluntate, Herculi ut certamen fieret, rupem excepiffe Cerauniam, Grapaldus. Sed de ceruo ab Hercule capto fupra etiam dixican pite fecundo, contra cos qui foeminam \& tamen cornutam fuife fcribunt. ApudMartialemEpig. lib.13. diftichon in ceruũ cicurem extat huiufmodi, Hic erat ille tuo domiturs Cypariffe capiftro, An magis ifte tuus Syluria ceruus erat? Cypariffus fuit Telephi filius, ab Apolline dilectus, urdon cet Ouidius lib. 10. Metamor.à Syluano uero, ut Seruius:qui cum puer ceruam mãfuetiffimani (fiue Apollinis, fiue Dianæ fuerit)occidiffet, præ nimio dolore expirauit, tandem in arborem fui nomitis permutatus. Nunc eques in tergo (cerui) refidens huc latus \& illuc Mollia purpureis frenabis ora capiftris, Ouidius de Cypariffo. De ceruo Syluix quem Afcanius fagitta peremit, lege Vérgi $5^{\circ}$ lium lib.7.Aeneidos. Silius poéta ceruam Campanam celebrat. Aegidius Âthenienfis(quen in. ter fanctos quidam colunt)ceruam in eremo familiarem habuiffe fertur, cuius lacte nutritus fit, utin uulgaribus fanctorum hiftorî̉s legitur. De A ctaonis mutatione in ceruum, lege Ouidium Metam, lib.3. De eadem nonnihil diximus fupra in Cane uenatico. Alciati Emblema in receptators ficariorum, Latronum furumç manus tibi Scæua per urbem It comes: 8 diris cincta cohors gla dỉs. Atque itate mentis generofum prodige cenfes, Quód tua complures allicit olla malos, En noutus Actron, qui poltquam cornua fumpfit, In pradam canibus fe dedit ipfe fris. - Idęumó̧ nemus, quo nati furta, iutuencum Occuluic Liber falfi fub imagine cerui, Ouidius lib. $\%$. Metam. Delphigenia Agamemnonis \& Clytęmneftræ filia ita fabulantur poéta:Quũ Agamem" non in Âlide ceruum Dianæ ignarus occidiffet, dea irata uentorũ flatus amouit, ut natuigare non 60 poffent.Quapropter cum oraculum cófulerent, refponfum eft, Agamemnonio fanguine deameffé placandam. Miffus ígitur Vlyfies Iphigeniam filiam aftu à Clytamneftra fub pratextu facticim 


\section{DeCeruo. H. Lib.I.}

Achille matrimonij impetratam adduxit:cumćç iam immolari parabatur, Dea miferta illam fuftulit, ceruamás pro ea fuppofuit, uirginiem autem in Tauricam regionem tranftulit, \&c. Vide Onomafti con propriorum nom.uel Gyraldum in Taurica Diana $\&$ Ouldium lib.12.Metam. \& Euripidis Iphi geniam in Aulide $8 \mathrm{~L}$ in Tauris. Aliqui non ceruam, fed taurum; pofitũ aíunt, ut fupra in Tauro capitis ocfaui parte ultima ex Varinooftendi. A chillis curfus, penin fula fiue cherfonnefus eft, quam Tauri habitãt iuxta Boryfthenem:quam A chilles dưm Iphígeniam in Scythiam ex Aulide abreptam perfequitur circunquaç curfu fertur emenfustinterim trero $D$ ia na ceruum facrificandum fubftituit, Euftathius in Dionyfium. बAegyptn̈ hominem adulatione deceptum fignificare trolentes, ceruum pingunt cum tubicine: mulcetur enim ceruus cantus modur lamine, ac fic quodammodo oblitus fuí capitur, Horus. Reliqua â ceruo fumpta hieroglyphica fur= perius fuis quą̧ locis collocaui. Cerui cornu dins gratum facit Orpheus in libello de lapidibus; Boum cornua cur in Auentino fufpendantur, cum in cæteris Dianæ templis ceruorũ tantummodo

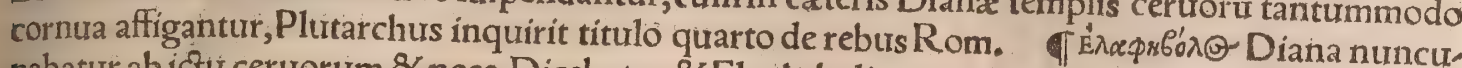
pabatur ab ictu ceruorum $\&$ nece. Dicebatur $\&$ Elaphebolia, quo nomine culta eft à Phocenfibus: qui cum à Theffalis obfeffi in fumma defperatione (qux etiam in prouerbium uenit) uictoriam obti=

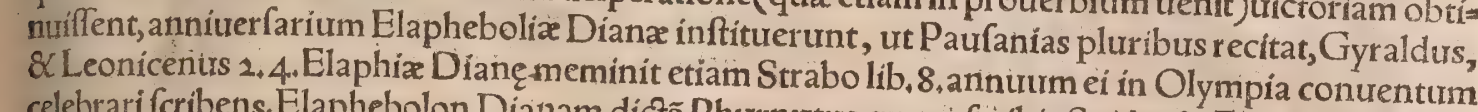
celebrari fcribens. Elaphebolon Dianam dictã Phurnutus quợ fcribit:Suidas \& Ellophonon+nam ellos ceruus eft. Eft enim uenationis dea. Theophilus Elaphebolon à ceruorum infectatione dictam putat, Meminit Orpheus in Hymnis. Elaphebolia fefta celebrantur menfe Februario ab A thenien. fibus, in quibus cerui Dianæ Elaphebolia facrificabantur:unde 8 menfis ipfe Elaphebolion dictus, Gyraldus, (Meminerunt etiam Etymologus \& Varinus.) Dianæ ceriros facrificabant:hac enim ei uichima prol lphigenia data fuiffe creditur, Hæc omnia fere Gyraldus obferuauit diuerfis in locis in Opere de dịjs. Laphria Dianza apud Patrenfes magno in ara igne excitato, apros, ceruos, $\&$ alia animalia urua injiciunt, \& facrata uirgo in poftremo agmine pompecurru ceruis iuncto inuehitur, Paufanias in Achaicis. Ceruaria ouis dicitur qua pro cerua immolabatur, Pompeius lib, 3 .

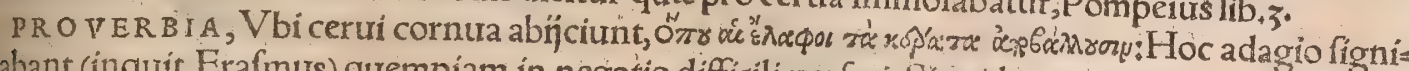
ficabant (inquit Erafmus) quempiam in negotio difficili uer \{ari. Siquidem cerui cornua depofituri fecedunt in loca afpera atgs inacceffa: (qua de refupra dixi, cum ex alĭs, tum Arítotele, qui ctiam prourbrị huitus meminit.) Conueniet $\&$ in eos qui à communi hominum conuictu fubducunt fefet item in locum uehementer abditum abftufumóp. Poftremó quod innuemus nufquam inueniri, illic effe dicemus ubi cerui cornua abíciunt. Plutarchus in Commentario de Pythijs oraculis oratione profa redditis, oftendit hoc oraculum aditum fuiffe de Procle tyranno; utilli fugere ac migrare lice= reteò ubi cerui cornu abíciunt, fignificante deout defoderetur, \& émedio prorfus tolleretur. Idem meminit huius adagn̈ Sympofiacon decade feptima, problemate fecundo. Suidas 8 muturatus ab

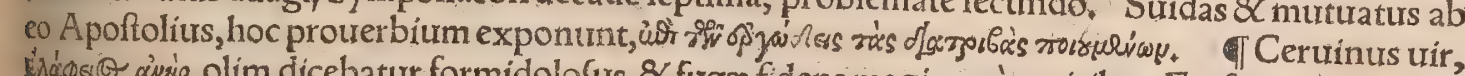
in cerutum aliquís prouerbialiter dixerit, \& cor cerui habere, $\&$ nebridem geftare, ut in præcedentibus docui, đI Ceruus canes trahit, cum ádúúxioy feu prępofterũ quippiam fignificamus, Prępofterum

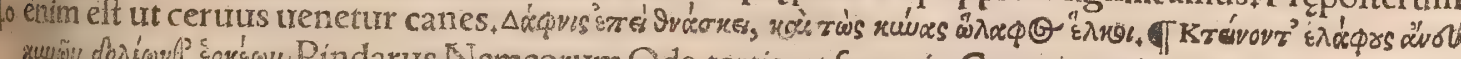

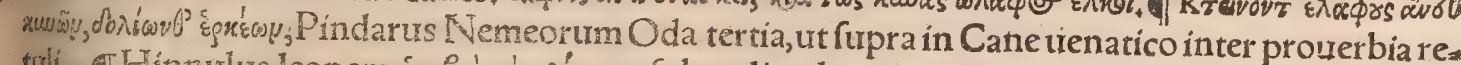

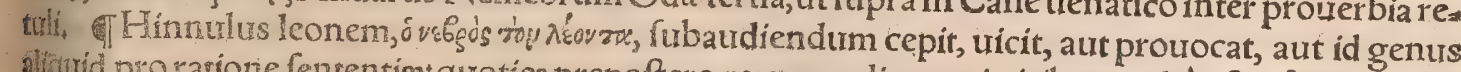
aliquid pro ratione fencentia: quoties prępoftero rerum ordine, qui uiribus multò eff inferior, furpetat potentiorem. Lucianus de captatore teftamenti, qui iuuenis à fene, captator à captato captus eft

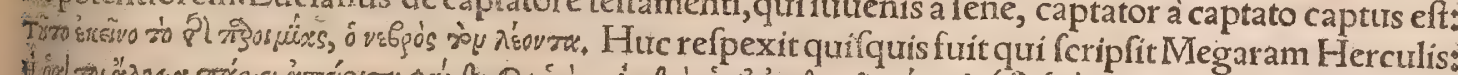

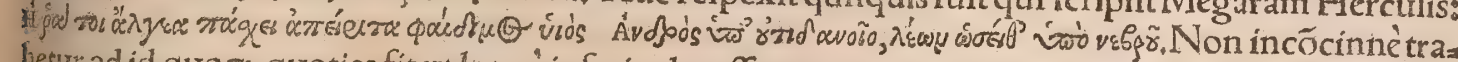
hetur ad id quoq, quoties fit ut longe inferior laceffat potentiorem, aut multis partibus indoctior cer

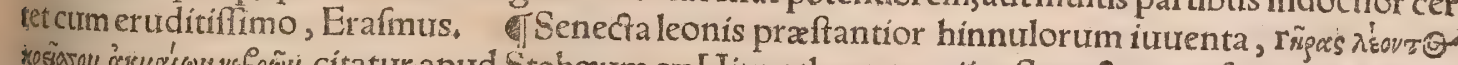

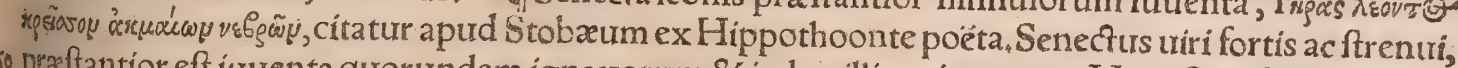
praftantior eft iuuenta quorundam ignauorum $8 \mathrm{imbecillium}$ iuuenum. Venuftius fiet fiad inge

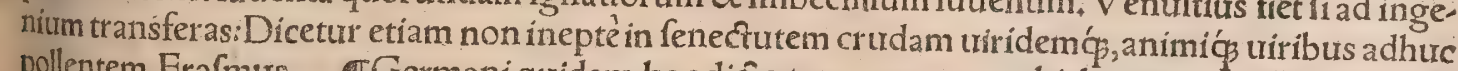
pollentem, Erafmus. TGermani quidam hoc dicro tanquam prouerbiali utuntur, 选 in füt fif if wol fo felyam ntlptit in binmel/als ein birts in cins armen mans tudbe+Princeps tam rara auis in coelo eft, quàm ceruus in culina pauperis.

$$
\text { DE COL O. }
$$

A P VD Scythas \& Sarmatas quadrupes fera eft, quam colon( cerium 8 arietem, albicante corpore, eximia fupra hos leuitatis ad curfurm. Naribus potans trahic ad caput, hinc poftmodum complures ad dies feruans, adeò ut per carentes aquís agros facile pabur lum carpat, Strabo lib.7. Sniatky apud Mofchobios uulgò nominatur animal fímile oui fylueftri can didx, fine lana:capitur ad pulfum tympanorum, dum faltando delaffatur, ut doctiffimus uir Sígif mundus Gelenius nobis retulit. Hoc idem colon effe, ex regione in qua capitur, 8 colore 8 magnis
tudine conício. Hircus etiam mutilus wóres uocatur apud Varinum, 


\section{4 \\ DeQuadrupedibus \\ DE CVNICVLO.}

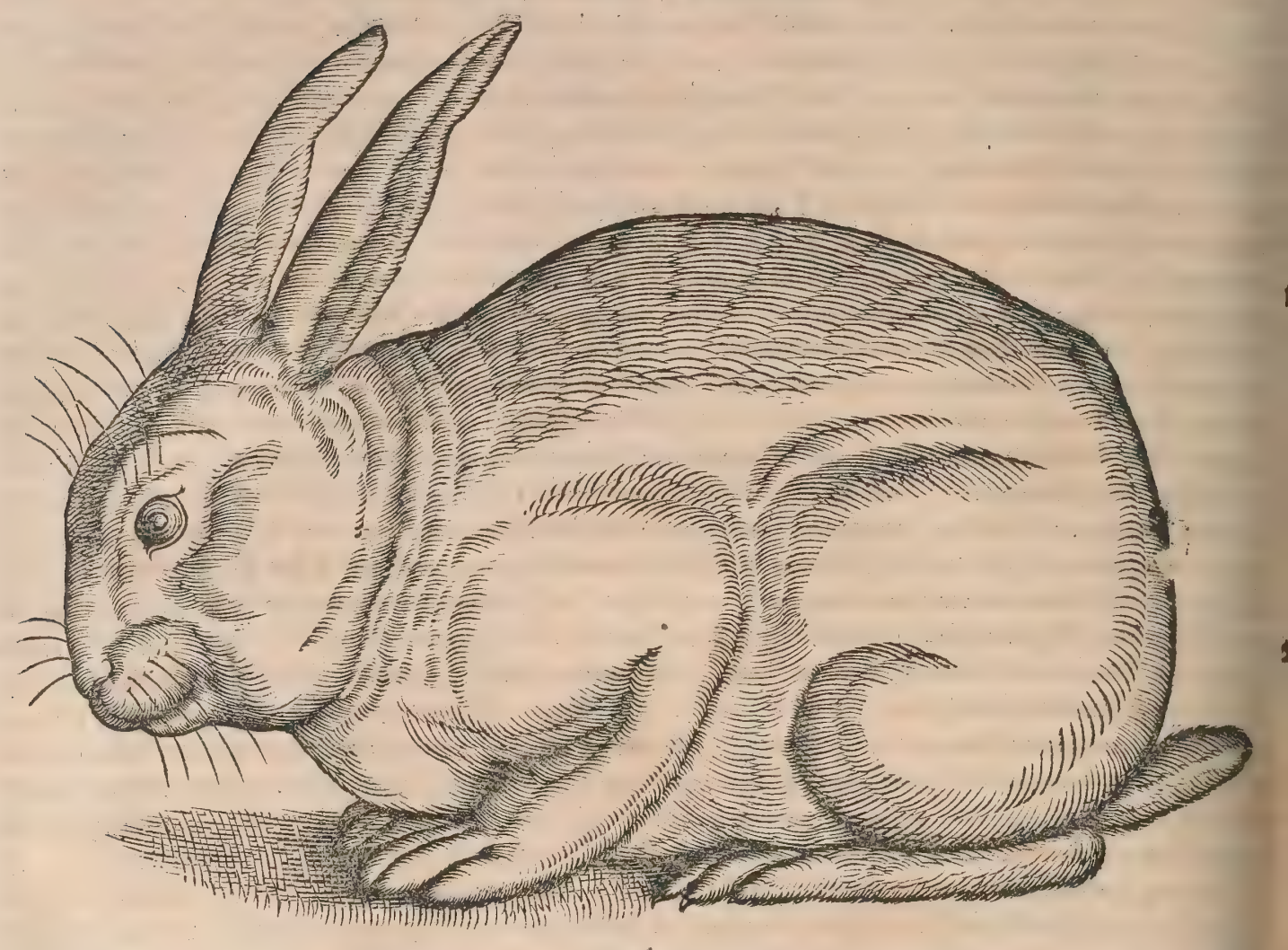

A.

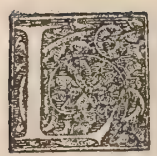

EP OR $\checkmark$ M triplex, Italicum, Gallicum fiue Alpinum qui toti funt candidi, (de quibus in Leporumbia foria dicam in $L_{\text {it lera: }) \text { ) }}$ tertium Hifpanum adapis nomine, quos (ut Polybius eftath thor,) appellamus cuniculos, Hermolaus in Diofcor, Leporũ genus minus eft,quod fub terra in cuniculis uitam magna ex parte ducit,Platina. Eft inter lepores genus quoddam, nonnullit lepufculos, Hifpania cuniculos nominat, quiòd fub terra cuniculos ipf faciant, ueluti mures, quas di

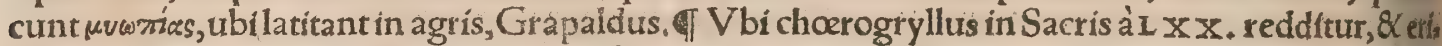

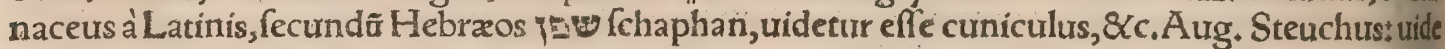
caput 11.in Leuiticum, De chœerogryllo plura uide mox in Echino. Pfalmo 104. pro fchephanim uul garis interpretatio herínaceos habet: Fed Hebrai communiter accipiunt pro cuniculo. Deuteronos 40

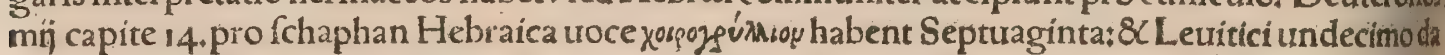
fypodem:Hieronymus utrobiç chœrogylium, \& Prouerb, cap،3o.lepufculum:Pfalmo 104, herinala ceum, idóg in commentarińs in feptimum cap. Matchæi, afferere uidetur, inquiens : Timidum aninal in petrarum cauernas fe recipit,cure afpera, \& 2 tota armata iaculis tali fe protectione tutatur, Atinlih bro ad Suniam \& Frerelam Pfal, 104 . fuper his uerbis, Petra refugium herinaceis; Omnes, inquith yospo zu irirs fimili uoce tranftulerunt: foli $\mathrm{L}$ X X. lepores interpretati funt. Sciendum autem eff animal effe non maius hericio, habens fimilitudinem muris $\&$ urfi, unde $\mathcal{Q}$ in Palæeftina a a magna eft in iftis regionibus hurius generis abundantia, femperćp in caueknis petrarum \& terra fos ueis habirare confueuerunt. Sed de hoc muris genere, quod ajpífouṽ appellat Hieronymus, alibi dis cam inter Mures:id enim effe exiftimo quod cricetum Albertus uocat, Illyrị Nkreczek \& Germani i

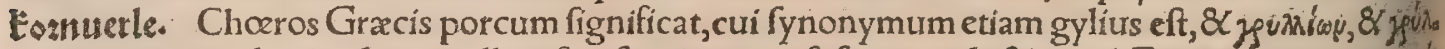
$\lambda \theta, \&$ uidetur id animal nonnullam firis fpeciem præ fe ferre, unde \& apud Germanos nomen, $r$ viv

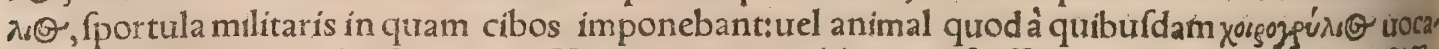
turr, Scholia in Pacem Ariftophanis. Hanc fportulam oblongam fuiffe aiunt, \& in acutum defiffe, (forte ab aliqua roftri uel corporis porcini fimilitudine:) alij ore angufto, Varinus:Idem júxisoy expos nit porcum, aut leonem. Gyraldus in Opere de dijs,gylion à quiburdam choerogryllon exponi fris bit:choerogryllum autem ipfe porcum fpinum interpretatur, ut Syluaticus etram, qui corruptecily rogrillium frribit. Eft autem porcus f pinus qui apud ueteres hyftrix dicebatur, de quo in $\mathrm{H}$, literà dis cam. Chortogryllium ab Hefychio, Varino, Alberto Mag. \& lfidoro, echinus exponitur. Erinact chirogrilli nuncupantur, propè magnitudine mediocrium cuniculorum, de cauernís petrarum pros cedentes gregatim $:$ in eremo, qux eft contra mare mortuum, depafcuntur, Eucherius. Cyrogrillits (inquit Albertus, quamuis alibi herinaceum inter pretatur) animal parturm $\&$ debile, in terre fouels 


\section{DeCuniculo.A. Lib. I.}

habitat, animalculis paruulis terrenis infeftum. Cirogrillus animal infirmum, fed rapax 8 mor. tiferum effe dicunt. Gloffa fuper Leuiticum, ex D. Hieronymo ni fallor : hoc ad arfomyn con irenire uidetur, ad leporem cuniculum $\&$ herinaceum minime. Ego ut meam tandem fententiam aperiam, chorogryllum, uel choerogylium, uel chorogryllium (omnibus enim his tribus modis reciè fcribi uideo : reliqui inepti funt:) herinaceum effe crediderim. Obijcienti aliud apud Gra cos herinacei nomen $\mathrm{ef}$, nempe echinum $\div$ refpondebo, unum animal etiam in eadem lingua, pro dialecis $\&$ regionibus diuerfis, duo aut plura habere nomina, ufitatum effe, $\&$ apud Gracos pracipue. Verifimile eft etiam cum echini nomen ambiguum fit ad terreftrem marinumós echi

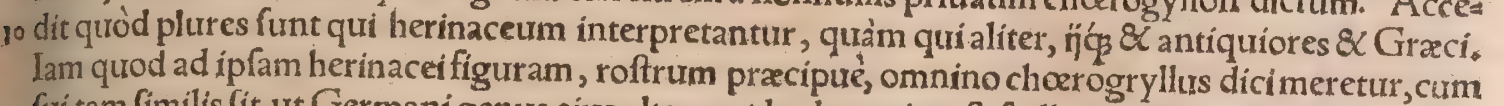
fui tam fimilis fit, ut Germani genus eius alterum(duplex enim eft)fuillum nominent: Angli herinaceurn omnem porcum fapium, quod inter frepes latitent. Hac fuis circa roftrû praccipure fimilitudo, neculli iam dictorũ animalium, nec hyftrici cötuenit:neq̧ criceto, quem arçomyn effe purto, nec ulliz denị̧ notorũ mihi uifu auditúue, aut ex hiftorís animaliư. Choerogryllus igitur herinaceus terre: fris efto, donec aliquis certius quidpiam attulerit. An uero faphan Hebraorum herinaceus potius urel cuniculus fit, fi quis ex me quarat, cuniculü effe dicam: Primum Deuter,cap, 14 . cum lepore no=
minatur, utpote congener animal, quod ruminet quidem, fed ungulã non bipartitam habeat: deinde quia certus fum aliud herinacei nomẽ in facris literis reperíri, nempe 7 p kipod, quod licet alí aliter 2o exponant, ego tamen herinaceum effe in hiftoria eius demonftrabo. Et quamuis apud ueteres non meminerim legife, nec ipfe obferuatrerim leporem ruminare, inde tamen hoc eum facere colligo, quod coagulum habet, utruminantía omniatlicet unus tantum ei uenter fit, cum cæteris ruminana tium omnibus plures habeantur+fed inter pifces fcarus quog, ruminat, etfi unũ duntaxat $8 x$ fimpli cem uentrem habeat, ut pifces omnes, \& utrinģ dentatus fit, Ruminant $\&$ Pontici mures, utrinque dentati, Ariftotele tefte. Lepore aütruminare conceffo, ut in facris traditur, cuniculos quogs urpote generís eiufdem animalia ruminare non negabimus. Porró quòd herinaceus ruminet, nec authores ullimeminerunt, nec ulla opinor ratione confirmari poteft : quamobrem idem non furerit Hebrao: rum faphan. Cuniculus \& lepus ruminant, ut Hebraice legitur Leuirici $\because$, ubi in translatione Gracorum ruminare negantur:fed apparet expungendam effe neyationem : nam Deuter, cap. 14. so eorundem translatio Hebraicam ueritatem fecura ruminare cos afferit. Qui apud nos cuniculos in cunicularïs (utitur hac uoce Budæus)alunt, de ruminatione ipforû certi nihil docere me potuerunt: hoc tantum quidam affirmabat, frepius fe poft cibum eis ante hora dimidiû exhibitum, mandentes adhuc deprehendiffe. GHieronymus etiam cum Prouerbiorum cap.30. lepufculum urtit, lepori
rimile animal intellexiffe uidetur, minus tamen:tale cuniculus fimile animal intellexiffe uidetur, minus tamen:tale cuniculus eft. Grapaldus fanécuniculos à nonnullis lepurfulos uocari fribit, qued ego ab alio authore factum quâm Strabone non memini : quí

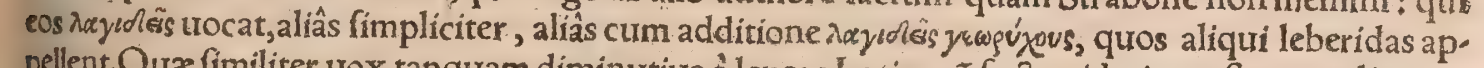
pellent.Qux fimiliter uox tanquam diminutiua à lepore Latinor ũ facta urideri poteft, cum alio pros prio uocabulo Graci carerent; quanquã Varro A coles Boeotios Graco uocabulo antiquo hoc animal leporem diffum author eft, \& ab ins ad Latinos derituatum arbitratur. Quare fi faphan, ut pros 4 baffe mihi uideor, cuniculus eft, chorogryllus autẽ herinaceus, Septuaginta interpretes \&C fecutum illos D. Hieronymum Hebraicæ uocis fignificationem non affecutos dicemus. Deuteron, cap.14, pro Hebraica uoce faphan, Chaldxus reddit Ny, thaefa: (legendum apparet thapfa $:$ nam $P$ falmo quoģ 104.per pe, non per ain pro fephanim Hebræorū Chaldæut reddit thapfia : dapficus autem 86

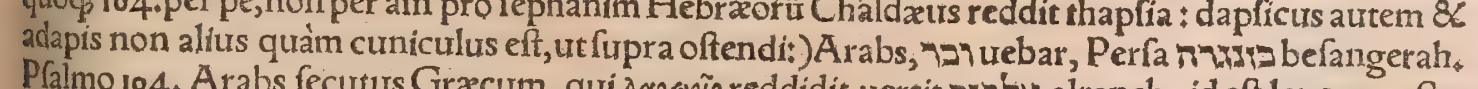

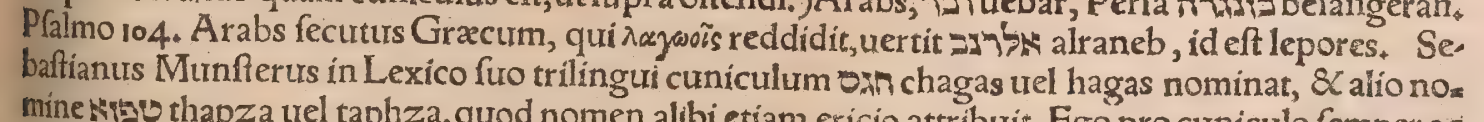
mine sto thapza uel taphza, quod nomen alibi etiam ericio attribuit, Ego procuniculo femper ac ceperim:nam Symeon Sethi, ut mox capite fexto referam, dapticon uocat, Hermolaus Barbarus a. dapis, ubi a litera forte abundat, uel articuli Hebraici loco eft. Gracus Leuitici undecimo dafypo. 80 dẽ uertit, de qua toce paulò poft plura dicemus,. Vincentius Belluacenfis in cuniculi hiftoria, tures eius in remedica defcribēs, If aaci uerba de Kericulo imperitifimé cirat.Pertinent enim ea omnia ad. herinaceum, quem barbarus Ifaaci interpres kericulư nominauit. Cunicull apud Ariftotelem per lepores intelliguntur, Aug. Niphus in commentarn’s in Ariftot. Eralibi, Cuniculos (inquit)àlepori. bus non difcernic. Strabo lib. z.leberidas (ut paulò ante dixi) a quiburdam appellari tradit ipfos cus niculos, qui ab effectu lepores georychie, hoc eft foffores, ab ipfo cognominatur, Hermolaus in Dio

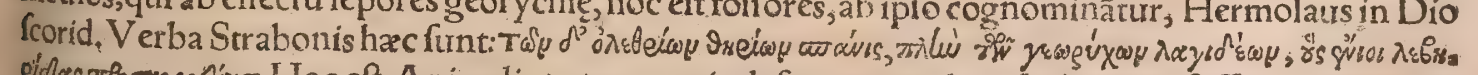

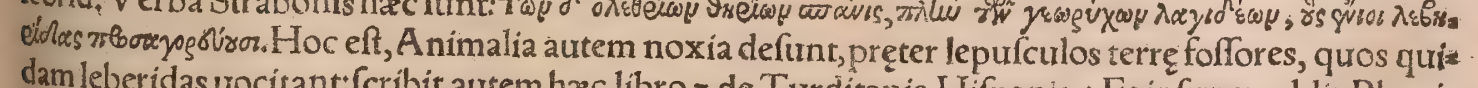
dam leberidas uocitant: ́cribit autem hac libro z.de Turditania Hifpania: Et infuper addit, Plantis 60 Maffiliam utitatem inferunt, 8 fatorum radices efitant: 8 hoc per totam ferme obueniens Hifpaniam, 60 Maffiliam ufog prorogatur: quin \& ipfas perturbat infulas. Nempe Gymnefiarum infularum incolac miffis aliquando Romam legatis terras peṭ̄ffe dicũtur:ab iffis enim eiectari beftís, quibus propter

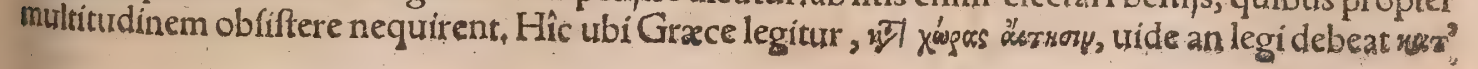




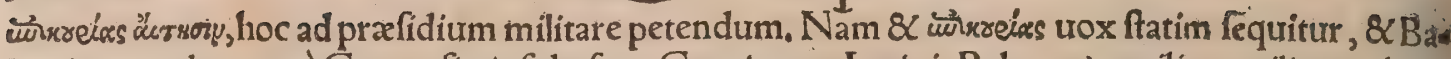
learicos(eædem uerò Gymnefiæ infulæ funt Græcis, qux Latinis Baleares)auxilium militare aduer.

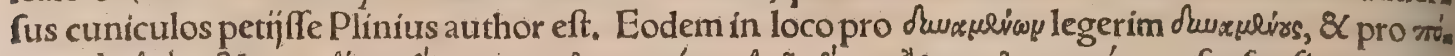

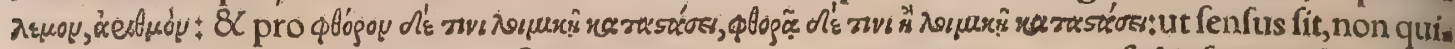
dem cuniculor um multitudine peftilentiam importari, ut uertit interpres, fed ipfam ex aliqua cor. ruptione aut aëris conftitutione peftilenti prouenire, ut ferpentium aliquando 82 murium agrefiü copia. Quanquam id ita accidere mihi non uidetur : nam quę in praua aut peftilenti aëris ftatu plü. rimum aliquando multiplicantur animalia, praui omnia temperamenti effe uidentur, nec in homi. num cibum uenire, ut ran $x$, mures, locufta, ferpentes, $\mathcal{Q}$ infecta diuerfa:cuniculi uerò \& bene tem. perati $\mathcal{Q}$ in cibo non infalubres uidentur, utalia fozcundiratis eor $\tilde{u}$ abundantis ratio quzerenda fit, Polybius lib, 12, hiftor, animal lepori fimile effe ait, cuniculum appellatum, his uerbis: Cunicultus( $x$ $v เ x \lambda s$ ) urerò dictus, eminus quidem uidetur paruus lepus: at fi quis in manus acceperit,multũ differt,

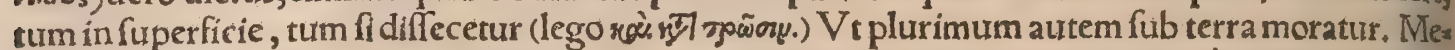
minit corum Pofidonius quoç philofophus in hiftoria: $8<$ nos inter nauigandum à Dicatarchia Nea polin permultos uidimus. Eft enim infula quadam non procul â terra, iuxta poftremam Dicaarchia partem, paucis quidem hominibus habitata, fed cuniculis abundans, Hac A thenæus lib,9. Dicæar: chia olim dicta eft ciuitas Campanix in Iralia, quoniam iuftiflimé regebatur, qux nũc Puteolialliqui Dicæam uocarunt. If Superfoetant dafypus, \& lepus tantum, Plinius. Oblatrant Budæo quidam (uerba funt Io, Brodxi, tractat aüt de lepore $\&$ dafypode Budaus in prioribus Annot, in Pandect, ) leporem idem animal cum dafypode effe fcribenti. Ego in ea fententia Plutarchum in commẽtario, 11 utrobi in terreftribus, an in aquatilibus brutis maior fit prudentia, fuiffe concerto, A thenaum lib, $\%$ Pollucem quinto. Ar Vegetius uolumine quarto, Aliud genus oppugnationis eft fubterraneĩ atç fecretum, quod cuniculû̃ uocant, à leporiburs qui cafulas fub terras fodiưt, ibićq códuntur, \& Strabo

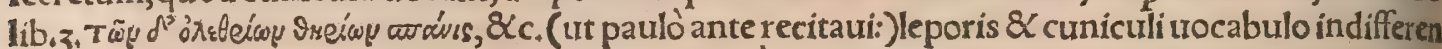
ter funt ufi, licenter me hercule nimis, Gnefion fané uerumóg leporem (funt enim adulterini \&degen res) fub terram cafulas fibinunquam fodere, aut cuniculos facere ubi lateant in agris, ex uenatorum omnium axiomatibus fumo pro certo. Ariftoteles aperté, femel opinor, dafypodẽ à lepore diftinxit

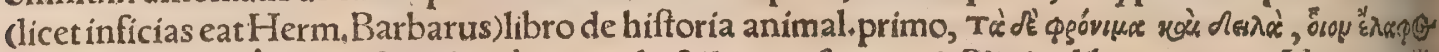

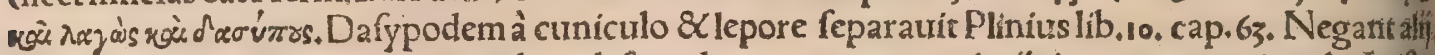
Leonicenus $\&$ Theodortis cuniculum dafypoda uocant:quos qui rej̣ciunt, quo nomine ab Arifto, 3 rele $\&$ ueteribus Gracis dictus fit patefaciant:eis fiquidẽ hominibus aut nufquam uifum, aut intan to otio ac diligentia non internotum, uerifimile non eft. Cótra fi cuniculus dafypus eft, quamobrem

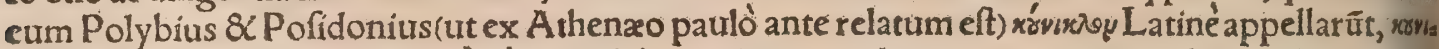

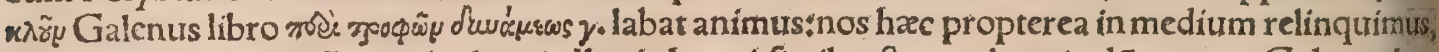
Hucufos Brodæus. Animalculum in lberia lepori fimile eft, quod cuniculũ uocant, Galenus loco iam citato, nec plura de eo. Plinius lib, 10, cap, 63. dafypodem cuniculis ita affociat, ut nullateruis pro eodem capi uideantur poffe:ni generis loco pofitum ibidafypoda coniectemus. Nam 82 Theon dorus lib. 6. de hiftorïs cap. 33. dafypodas, id eft lepores coire auerfos interpretatur, Caelius. Inge

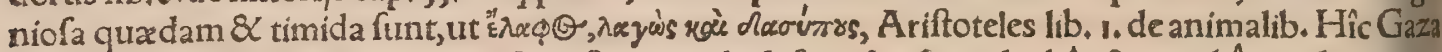
pro dafypode cuniculum uertit. Quaftionem de dafypode, ficut de thôe 2 panthêre aclynce, ne 4 gligentia quadam antiquis authoribus ita pratermiffam putat Theodorus Gaza, ut excufari hatd facile poffint, $C$ alius. Leonicenus repreheridic Pliniũ, qui tanquam diuerfa animalia diuerfis in lo. cis memoret leporem $\&$ dafypodem, ut capream $\&$ dorcadem, uefpertilionem $\&$ nycteridem, \& $\alpha$. Dafypodi nomen factum à pedibus hirfutis manifeftum eft, quod plantas etiam pedum pilis munis tas habeat, quod ut leporibus \& cuniculis commune eft, fic prater eos nulli animaliũ conuenit, Hins \&lagopodi herba nomẽ, \& aui de quafuo loco, Prouerbia quidem à dafypodis celeritate \& pulpi fumpta, ad leporem magis quàm cuniculum fpectare mihi uxidentur. In Lexico fymphono Sig, Get leníp pro cuniculo Græce $\sigma x u ́ w a \xi$ redditur, uox apud authores mihi nondum reperta:fuerit autem for fitan recentionis Gracia. Cuniculus Italicè nominatur conigli, Gallicè connin, Hípanicé co

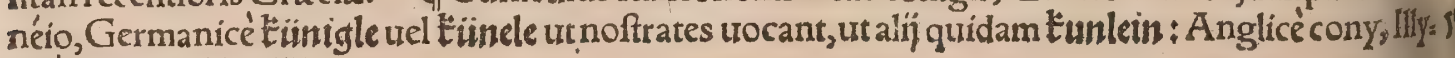
ricé kralikuel krolj̈k.

Ebufo cuniculinon funt, fcatent in Hifpania Balearibus $q_{\zeta}$, Plínius. Baleares cuniculis animallı bus quondã copiorxe, Solinus. Quibus in locis ita abundauerint, ut urel fuffodiendo uel meffibus po pulatis noxíf fuerint, dicam cap.5. Tertị leporum generis eff quod in Hifpania nafcitur, fimile no frolepori ex quadam parte, fed humile, quem cuniculum appellant, Varro. In Hifpania annisita fuiftimultis, ut inde te cuniculos perfecutos credam, A ppius apud Varronem, Cuniculus leporemi nor, fed fortior eft:colore $\&$ figura feré ut lepus, Albertus, Credideram leporẽ fic forma fimillima fallit, Ambo fuperfoetant, dente uel aure pares: Ambotiment, \&c. Bapt. Fiera. Allud eft etiam genus leporum, natura perparuum, nec tamen augetur unquam, ei cuniculus nomen eft; quod quist dem ipfum nouatum à me non eft, at etiam in confcribenda hiftoria Graci quidam ufi funt, quodà principio Hifpani impofuiffent, Caudam cateris breuiorem habet, catera reliquis leporibus confi 


\section{DeCuniculo.B.C.D.E. Lib.I. 397}

is eft, praterquam quiód magnitudo capitis quippiă differt, quia exilius fit, 8 minima carne prä. dium, eius uniuerfum corpus candidius quàm reliquorum leporum, Aelianus. Plurima in eis co= lorum diuerfitas, funt candidi, funt atri, fuifi, fubflaui, ruffi, $\&$ alips coloribus; $B \times$ rurfus uel toti colio ris unius, trel uarị. Cuniculis (inquit Ge. Agricola)non unus eft color:uel enim in cinereo fufcus, uel lepori nonnihil fimilis, urel maculofus : quo modo candidi nigris uel rutilis maculis ftellantur. Cara nem habêt albam, Albertus. Cuniculorũ exta in Bxtica gemina fape reperiuntur, Plínius : uidetur autem ícur potifimum intelligere nam de leporibus quoç fertur, quòd nonnnullis in regionibus bina iecinora habeant.

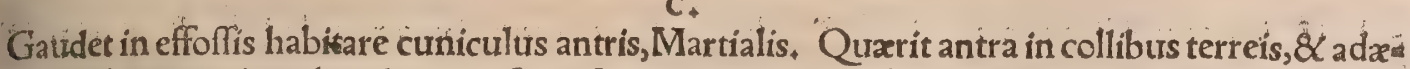
quat ea puluere ne deprehendatur, uefpere $\&$ mane ante antra fedet, Albertus. Emergunt ali fit $f$ : inde, alip redeunt in cuniculos. Prouerbiorum cap. $3 \circ$. fchephannim, id elt, cuniculi, callidis \& pro. uidis animalibus(formicís, locuftis; araneis)adnumerantur, Cuniculi (inquit fapiês) genus non for a te, in fala, id eft petra collocant habitationem furam. EtPfalmo 104. felaim, id eft petras, latibulü effe lafchephannim, id eft cuniculis legitur:Schaphan Hebrai cómuniter pro cuniculo accipiunt, Mun. ferts in fcholijs in eundem Pfalmum. Hinc forfitan dubitet aliquis an fchephannim cuniculi fint, cum non in faxis aut faxofis locis uerfari foleant, quód fciam, quod fodere illic impediantur: reno potius folo, \& collibus terrenis, iut ex Alberto retuli: Herinacei ueró circa parietes latent, aut ín cauis arboribus. Sed quoniam inter faxa quadam in collibus fpecus uel meatus oblongi reperiưtur; \&cuniculorum receptaculis apti, quxrendũ eft an in leant. Hac iam fcripferam,cum amicus quidam Hifpanus hac de re per literas noftras interrogatus in hac urerba refcripfit:Cunicull apud nos copiofiffimi funt in montanis locis atç in praruptis mon tibus, Neq dubiũ mihi eft eos habere fubterraneos meatus in locis afperioribus \& petricofís:quanquam id nunquam: accurratè obferuaui. Fư ego in uenatione cuniculorũ in loco montofó $\&$ faxis oppleto, inter quax uidebam cauernulas perfoffastutrum autem in locis interioribus fuerint faxaj; an

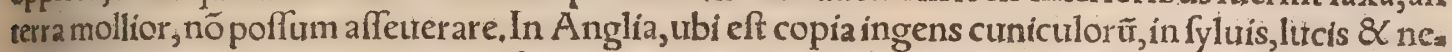
moribus, locis uidelicet planis delitefcunt, quoniā regio nó eft montofa, Hac illè. Cuniculus mula tos fodit fpecus, $\&$ in colles terrenos agit cuniculos. Mane $\&$ uefperi egreditur, reliquo tempore fere latet.Aliquos autem fpecus operit puluere ne deprehendantur. II Coitus aurerfis, elephantis, ti. gtibus, lyncibus, leoni, dafypodi, cuniculis, quibus auerfa genitalia, Plínius, Quæ retrourinam init= tunt, auerfa coéit, ut leones, lepores, lynces, Ariftot.de hift.animal, 5.2. Auerfurm eft cuniculis mem brum genitale, \&C femen paucum habent, quamobrem auerfis pofterioribus coëunt, Albertus، $\mathrm{Da}$ fypodes omni menfe pariunt \& fuperfcetant, fícut lepores, A partu ftatim implentur, concipiunt quamuis ubera ficcante foetu: pariunt nó cxros, Plinius lib, 10, Habent fanè hac omnia cưniculi cumin leporibus communia. Generare incipiunt; ut audio, cum fex menfes atatis lunares habent : trel ut Anglus quidarn mihi retulit, annicula: nam cum pro matricibus Martio menfe tantum natas alerec, quod per fequentem aftatem commodius nutrirentur, prolem ex eifdem non ante fequentis anini Martium fe habuifre. Superfoetant dafypus \&lepus tantum, Plinius. In cuniculis manifeftiffima effuperfoctatio, Aug. Niphus. Narrauir mihi quidam cuniculorum nutritor, forminas quafdam hú ius generis quas domi alebat, binos aut ternos foetus enixas, $\&$ poft dies circitér quatuordecim ite. rum totldem:hoc ipfum fuperfotare elt. Pariunt ferè circiter quinos, nouenos ad fummum, aliquan. dófingulos:eosó̧ cæacos ad nonum circiter diem. Facit hac corum foecunditas ut numerus corim breui multiplicetur. Statim à partu requirunt mares: $8 \times$ nifi admittantur, indignantur aliquando ita ut coitum poftea ad dies aliquot, plus minus quatuordecim recufent. Hyeme apud nos non pariunt, nifi rarò cum fatís calida elt aêris conftitutio. Lac prabent catulis per dies unum \& uiginti feré.Ma res catulis infefti funt, $\&$ morfu perimunt ut feles. If Progrediuntur noçu $\&$ uineas frugesá pafcuntur, Albertus $\&$ author libri de naturis rerum, Gramine, trifolio pratenfi, alípśs herbis $\&$ frú cibus uefcuntur, ut dicam capite quinto.

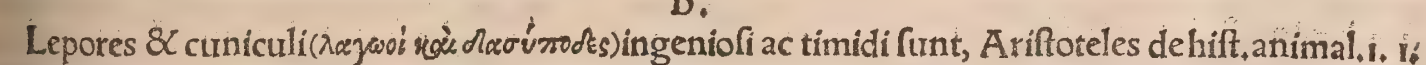
interprete $\mathrm{Gaza}$ Cuniculi inter femifera animalia connumerantur, que nec placida, nec fera funt; fed medix naturæ; non enim manfuefcunt, nec feritatem tamen habent, Grapaldus, ex Plinii, it ap: paret lib, 9.cap. 6.ubi legitur, Himanfuefcunt raro: proximé autem de leporibus dixerat, \& ante eos de cuniculis. Timidum eft animal, $\&$ locum ubi aliquid periculi aut iniuria fenferit, mox déerit: quòd fi unus aut alter migret, reliqui etiam tanquam communem ducentes fociorum iniuriam, gre gatim abeunt, Albertus. Iracundi funt, hominem tamen non mordent:fed inter fe, æmulationis fiu dio, morfibus adeò infefti funt, ut auriculis aut pedibus quandoģ alter alterum mancirm aut mutid lumreddat.

E,

Foecunditatis innumeræ cuniculi funt,famemǫ̣́ Balearibưs infulis populatis meffibus affereñ tes, Certum eft Balearicos aduerfus prouentum corum auxilium militare à D. Aurgufto petïffe, Plia

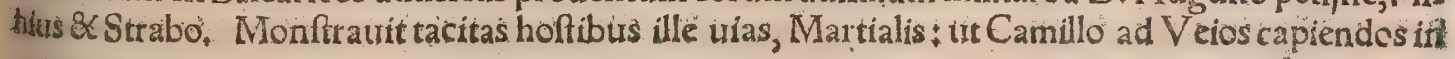


Hetruria. M. Varro author eft à cuniculis fuffoffum in Hifpania oppidum, Plinius, बI Magna pro pter uenatum eorum tiuerris gratia eft: immittunt eas in fpecus qux funt multifores in terra, unde \& nomen animali:atog, ita eiectos fupernè rapiunt, Plinius, In Turditania \&c. cuniculi aliquandón abundant, ut meffes uaftent, \& militari præfidio aduerfus cos opus fit: Vbi uero mediocritas adfit (inquit Strabo) plures reperta funt trenationes, Itaç de induftria muftelas fylueftres afferunt, qivas

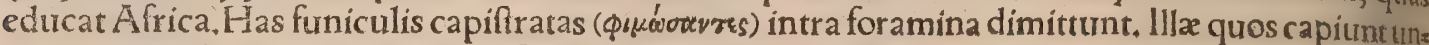
guibus extrahunt; aut in apertum fugere'compellunt:egreffos uenantur qui id agunt \& aftant, $\mathrm{Et}_{t}$ alsbi libro 3. In Balearibus infulis (inquit) nullum animal noxium facile reperias. Nam cuniculos nequaquam indigenas effe afferunt: Quinimo cum ex propinqua infula quidam marem ac foemi, nam attuliffet, tanta ab initio facia eorum eft procreatio, ut ex fubterraneis cuniculis domicilia futb, uerterentur, \& arbores, \& (ut fuperius commemoraui) homines ad implorandam populi Romani opem, confugere coacti fint. Nune autem cum ad traçandam corũ uenationem aptiffimi facti fint, nulla inualeicere fibi damna permittunt, uerum poffeffores magnam ex terra fructibus utilitatem affequuntur, Hæc Strabo. Cuniculũ uiuerra atఢ̧ parui quidã canes, quibus eft ad inureftigandium fagacitas narium, in fpecus \& cuniculos immiff, aut liquor feruens in ecfdem infufus, fugatum \& excurbatum pellunt in retia, quibus capitur, Ge,Agricola. Audio in Germania inferiore quibus hoc ftudij eft, perforatis uiucrrarum labïs $\&$ annulo argenteo inieço, fuperius labrum inferiori conne. êcre, ne cauis immiffi cuniculos morfu perimant: In Narbonenfi Gallia, fi rectè memíni, fporttilas quafdam aut capiftra capitibus uiuerrarum adponunt eandem ob caufam, $8 \mathrm{~K}$ tintinabula alligant. Oportet autem trenatorem cum prope cuniculorum foureas eft, magno ftrepitu $\&$ clamore excitato cos perterrefacere ut in latibula fua omnes confugiant, atç ita retibus circumpofitis uiucrras capi, fratas immittere. Accipitres quos aftures uocant, atxilio canum urenantur lepores $\&$ cuniculos, Ridicula eft apud Ifidorum Etymologia:Cuniculi, inquit, dicti funt quafi caniculi, eo quod canum in dagatione capiantur, uel à fpeluncis excludantur. T Sunt in Anglia qui folis feré cuniculis alenı dis uitam fuftinent. Deftinatur eis cella in domo: aut cafa extra domum extruitur, in qua locaturcar pra oblong a foraminibus diftincta, qua aliquot cuniculos føminas fubeuntes recipiunt, ut illic par riant. Maribus, ne ingrediantur, $\&$ catulos ut folent morfu conficiant, lignei paxilli collo appendin. tur.Sunt qui cancellis ex palis ligneis fupra partem horti ad parietes includãt \& ne qua elabi fodien do poffint, folum ad duos aut tres à fuperficie pedes pauimento ex lapidibus $\&$ intrita fternant, lateri bus etiam erectis pro magnitudine cafula. Leportum tria genera, ex quibus unum cuniculorĩeft, in lepor ario habere oportet, Varro.Gramine \& alĭs herbis aluntur, trifolio maximé: gratæ eis braffi cx, tum alia, tum capitata:item panis, \& poma eorumós putamina, ut raporum quó̧. Hyemefors no, auena, furfure, \& ïfdem putaminibus ter die nutriuntur. Si quis pullos adhuc ieneros traciet,ma tres pullis ipfis indignantur, $8 \times$ uel defer unt, uel mordendo lædunt, aut etiam interimunt. $\mid$ Pelles in ufu ueftimentorum funt, fuff $\&$ uariæ minoris pretip, maioris albx \& emaculati candoris : maxim qua nigredine fplendent, apud Anglos pralertim: ubi quaterna huiufmodi pelles tribus plarunç denarijs, id eft drachmis argenteis, ut audio, uæneunt. Ex nigris etiam praferuntur, qua pauciflimis albis hinc inde pilis tanquam afperf $x$ funt. Ex dor fis cunículorum confutæe pelles, durant quidem diutius, fed grauiores funt $\ddagger$ ex uentribus uerólicet minus durent, quia tamen leuiores mollioreş́ funt, in maiori habentur pretio.

\section{F。}

Catuli cuniculorum, uxt đixi, circiter dies unum \& uigintilactent: pingues \& in cibo fuatiores exiftimantur cum menfem ætatis exegerunt. Multi ftatimà quartodecimo die edunt. Cicures in Hil: fpania contemnunt, nec eos perinde falubres aut aptos efui putant, ac fylueftres. Nam cum animal natura fit graueolens, augetur hoc uitium fi aére inclufo alatur, \& motus liber tate prituetur, Duilcis corum caroeft, \& fapore (ut quidam feribit) felium carni proxima. Eadem cum iunipero (iuniperi

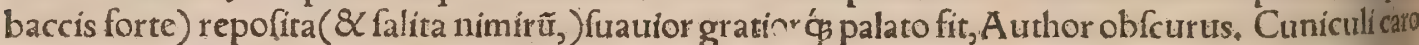
melius ac facilius alit quàm leporina, Platina. V da c...ticultus affert Fercula, uifcofum femiimitata gluten. Hunc torre igne tamen,Bapt. Fiera. Cuniculi \& leporis cerebella contra trenena commen dantur, Platina. Decuniculis ificia proximum locum habent, poft ificia de phafianis quar praferun tur, A picius 2.2. De cunículi coctura uide infra in Lepore ex Platina. Cuniculorum foetus uen tre execros gratiffimo cibo laurices appellant, Plinius: Noftri inhumanas iftas 8 inimicas naturade licias non agnofcunt. Laurices unde dícantur non facile coniecerim : nifi quis laurtices tanquam à lautitips malit,

\section{G.}

Ad fynanchen remedium fic, Cuniculum uiuum in olla rudi combures, \& puluerem de ipfocira cofto \& folio æquis ponderibus mifcebis, \& fic in potione plenum cochlerare de hoc puluerecum uino dabis, atcs etiam fauces inde perfricabis, Marcellus. Reponitur etiam adeps cuniculi, Is attê, ut Syluius feribit, inter taurinum \& fuillum fuerit, ut uulpinus etiam, melinus, felinus, \& c. Pingue dine neruos Mulceo, Vrfinus Velius,Stomachum pulpa torata iuuat, Idem: Appareteum dects ptum ab Ifaci interprete, qui pro herinaceo cuniculum uertit, $\&$ alia etiam qua partim ad marinum partim ad terreftrem echinum pertinent, uni cuniculo falfó attribuit, quem recentiores multi fecuri 


\section{0 \\ DeQuadrupedibus}

rinum ubiģ nó aliter quàmech num interpretatur, Plinit̃ forte imitatus, at eum qui terreftris efi crinaceum conuertit, Maffarius, Ego aquatilem echinum à Lati, nis erinaceũ appellari authorem non habeo: (licet Itali uulgo bo die riciü tum terreftrem tum $\mathrm{ma}$ rinum appellêt pro ericio per as pharefin.)Quramobrem \& Maf: farium miror \& Hermolaü, qui cchinũ pifcem (fic enim impro, prié uocat cutm branchias nổ ha. beat ${ }_{30}$ melius quidam oftreis ad, numerant)erinaceum Latinéuo cari fcribic. Herinaceus qui $\&$ herix, $\&$ hericius, quod fpinis horreant dici, , ut quidam uolüt, Perottus. Herices, quòd fpinis horreãt, Grapaldus. Hericiĭ, qqui 8 echini dicuntur, Eucherius, Varro inueniffe fe ericium cum probofcide fcribit, ut Nonius cis tatex Varronis Sexagef, his uer bis: Inueniffe fe cum dormireco piffet, tam glaber quàmSocrates, caluum effe factum ericiumèpla lis albis cum probofcide. Sylua. ticus barbare iriccium proculit. Implicitumą̧ finu fpinofi corpo 5 ris erem, Nemefianus, of kipod Hebraice herinaceumfor nat : quam uocem licet alij aliter interpretentur, herinaceũ tamen effe conftat: quoniam medici ut Serapion, Syluaticus, $8 \mathrm{C}$ alif qul Arabice fcripferunt ceufud ap pellant (apud Aurcênamcaufed (cribitur) 8 Grxcorum de echis. no terreftri uerba eius mentioni is adfcribunt. R. Daưid Kimhias uem folitudine gaudentem in, terpretatur, quam Lofeph Kinhil pater Dauidis Arabice uocatil

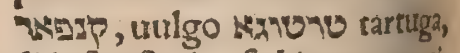
(id eft teftudo, fed inepie ut ul decur cum pro aue ponaturffor. te turtur legendum, qua uulgo ubíg ferè nomen Latinum retis ner, \& folitaria auis eft.) Idë Kimy hi Sophonia a.lingua If́maëlitica

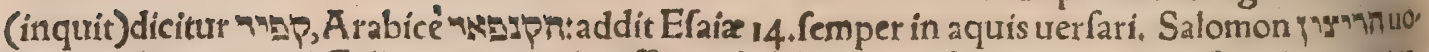
cat, (alludens puto ad Gallicam uocem heriffon,)id eft hericium, fecutus nimirü noliros interpretes, Nam Septuaginta Éaiæ 14.8X Sophonię 2. exyivoy uertunt, Hieronymus hericium. Ita etiam Efaix 34. ubi Salomon auem dicit Nowny ziuetta uel ciuetta,id eft noduam. Redigam Babylonem in poffefa

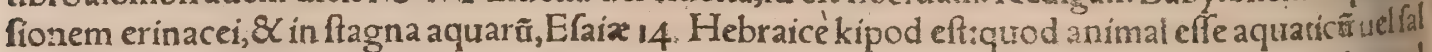
tem quod iuxta aquas habiter, ex his concludi poffe aliqui putant: \& quoniam uerbũ pracidere uel

fuccidere Hebrais fignificat, eruditus quidam apurd nos lutram, feu potius caftore, qui arbores fuc, cidit, effe colligit, A b hac uoce ultima tantum litera differt $r$ pipoz, quam R. Kimhi eiufdem cum kipod fignificationis exıftimat, quoniã zain \& daleth crebrò inter fe permutanuur:fimiliter $S a$ lomon.Septuaginta etiam echinum, \& Hieronymus hericium exponit. Abraham Efra non fine ra tione refellit, auem effe contendens. Nam Efaix 34. auem effs apparer ex eo quòd alïs tribus auium 
Echinus terreftre animal eft, cuniculi magnitudine, fed fpecie porcina, aculeis uallatus quemadi modum hyftrix eft, Maffarius. Vallatus elt aculeis extra quàm ore pedibusćs ac parte inferiore, quam rara tantũ $\&$ innocua lanugo operit, Hermolaus. Porcelli formam habet, fpinofus ubiģ pra, terquam in uentre,Ilidorus. Pinguis eft $\&$ porcelli modum exprimit cum excoriatur, Albertus, Mirabile in Creta apros, herinaceos, \&c.non effe, Plinius. Hericí ita fpinofo defenduntur tegmie ne, ut ne contingi quidem poffint, Eucherius . Aculeos qui à nonnullis trice pilorum gerun tur, genus effe pilorum exiffimandum eft, ur herinaceorum aculeos, Ariftoteles. Herinaceortun pili paulatim adeò duritate degenerant, ut non pil is præterea, fed fpinis fimiles effeuideantur, Idem, Aegyptĭs muribus durus pilus ficur herinaceis, Plinius. Herinacei teftes intus funt, cutis enim $\mathrm{CO}_{2}$, rum efficiendo fcroto inepra eft, Axiftot, Et alibi teftes eis intus lumbis adharere fcribit. Omnibus quæ animal generant, teftes antẻhabentur, uel intus, uel extra, praterquam herinaceo: hic enim unus lumbisadhrerentes continet; ob eandem qua aues caufam: coitum enim herinaceorũ celeriter fieri neceffe eft, cum non more quadrupedum fuperueniant tergis, fed erecti coniungantur propter aculeos. Duos anos ad ftercus emittendum folus ericius dicitur habere, Albertus,

C.

Herinacei in fapibus dumofis \& uineis per autumnum pracipué ditrerfantur. Conduntur in ar: bores cauas hyeme, \& cibis (pomis pracipuè) per æftatem congeftis uefcuntur. Echinum aiunt ad annum ufg fine cibo durare poffe, Arifoteles in Mirabilibus, Praparant hyemi $\&$ heri= nacei (ut mures Alpini) cibos, ac uolutati fupra poma (mala $\&$ pira, ut alifi: $u$ uel etiam ifchadas, ut Phi les) affixa fpinis, unum non amplius tenentes ore, portant in cauas arbores, Plinius, 8 Aeliantis.

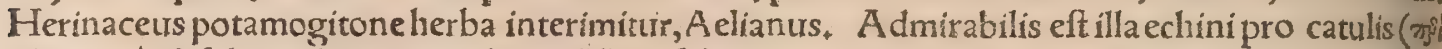

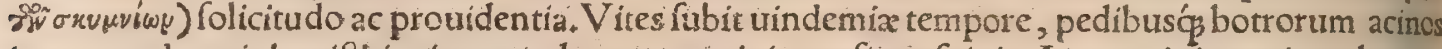
in terram decutit:hos ifthic circumuolutatus, excipit confixos fpinis. Ac memini cum iam olim nos bis quitum aderamus omnibus fpeciantíbus botri reptantis ingredientisóǵ fpeciem praberet, adeò fe cumulauerat at $̧$ s oppleuer at uừis. Mox ut fubiuit latibulum, ex fe decerpenda qux collegit cattu lis prabet, ut partim fruantur, partim recondant, Plutarchus in libro V tra animalium, \&c. Ko Keratu

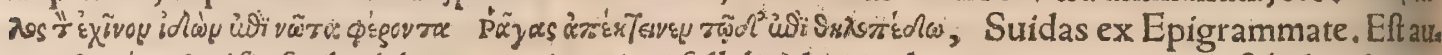

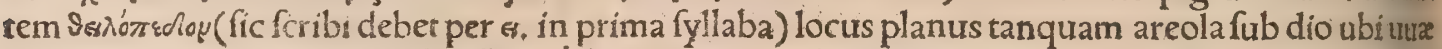

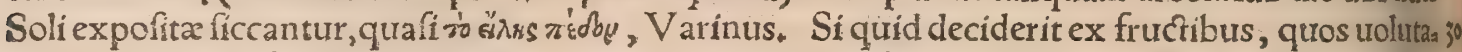
tus aculeis fuis infixerit, reliquos ctiam omnes excutit, reditḉs ut aculeos omnes repleat, lorach. Lac etiam $\&$ uinum bibunt cum in domibus aluntur. Herinaceis coitus erechis, partibus fupinis hęren tibus fibi aduerfis, Ariffoteles. Herinacei ftantés ambo inter fe complexi coéunt, Plinius.Cur cois tus eis celeriter peragatur pracedenti cap. dixi, Echinus parturiens cunctatur, uide capite ociau intex Prouerbia

\section{D.}

- Echinus animal eft uafricia infigne, quo nomine Nauplium ex ingenio nimis callido Echinum appellauit Lycophron,Cælius. Herinacei mutationem aquilonis in auftum condentes fe in cubi le præíagiunt, Flinitus. De herinaceorum fenfulocis multis perpenfum eft, ut qui in cauernis funt, commutent fua cubilia, aquilonum $\&$ auftrorum mutatione:qui autem intra teça altuntur, ad parie tes dirceduns: quod ita fieri cum Byzantif quidam animaduerriffet, confecutus exiftimationem elt, tanquam tempus futurum pofiec præfagire, Ariftoteles. Dto ucro foramina eius cubile ( rotruêu, q $\omega \lambda e^{\circ}$ s) habet:altcrum ad auftum, alterum ad boream pertinet:ac pro temporis ratione, ficut uelum gubernatores nauis uicibus transfertnr, fic id qued ad ucntum fpectat, obftruit:alterum autem ape rir. At to hoc Cyzicenus quidam crmm animaduertifet, nomen fibi ea ex re peperit, tanquam fuopte ingenio uentos prædiceret, Plutarchus in libro V Vtra animalium, \&c. ET Serpens $\&$ herinaceus (ut $O p$ pianus refertlibro de Pifcatione fecundo) mutur inter fe odio flagrant. Quamobrem fi in latibulis occurrant, echinurs mox in orbem fe contrahit, ut prater fpinas nihil emineat. Irruens uero in eum ferpens, \& fpiris implicans, fruftra mordet: $\delta \mathrm{C}$ quo arçius illum circumuroluta premit , eò magisipfa feaculeis infigit $\$$ uulnerat:quibus utctnç afthicia, non remittit tamen, donec emoriatur:aliâs quis dem fimul ambo pari cafu intereunt : aliâs echinus euadens, ferpentis inmmortui corpus aut carnes adhuc aculeis infixas geftat. Herinaceum lupus timer ac fugit,Iorach. Memini aliquando audis re leporem deprehenfi herinacei aculeos fingillatim dentibus extrahere, $\&$ nudatum poftremò cor pus uorare, quod mihi parum uerifimile fit.

E.

Herinacei ubi fenfere uenantem, contraço ore pedibus'ś, ac parte omni inferiore, qua raram \& innocuam habent lanuginem, conuoluuntur in formam pilæ, ne quid comprehendipoffit prater as culcos, In defperatione uero, urinam ex fe reddunt tabificam tergori fuo fpinisós noxiam, propter hoc fe capi gnari. Quamobrem exinanita prius urina uenari, ars eft. Et tum præcipua dos tergori, aliàs corrupto, fragili, putribus Spinis atç deciduris, etiam fi uiuat fubtraçus fuga, Ob id non nifino uiffima fpe maleficio illo perfunditur. Quippe $\mathcal{Q}$ ipfi odere infitum ueneficium ita parcentes fibi, terminumǵs fupremum opperientes, ut ferméante captiuitas occupet, Calidæ poftea aquæa afperfur 

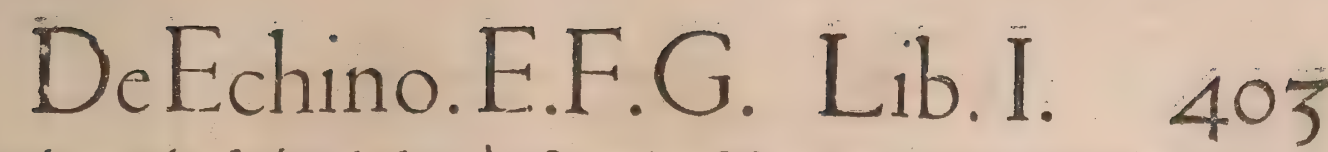

fefoluitur pila:apprehenfuśş́ pede altero é pofterioribus, fufpendio ac fame necatur. Alicer nen eft occidere 8 tergori parcere, Plinius. Terreftris herinaceus inter animalia inuida cenfetur, fatim ut capitur, urina fua reddita tergus futum cófpergit, cuius uí perfufum corrumpitur, \& quod futurum erat ad multa utile, reddit inutile, Aelianus, Mihi quidem non inuidia aduerfus homine (quam fuls téetiam alịs quibuídam animalibus tribuit antiquitas, plebeiam filicet $8 C$ anilem perfuafionem $f e=$ cura) fed metu potius, cum capiendus eft herinaceus urinam reddere uidetur. Cum infidias fentit, undiģ fe fpinis claudit, \& difficulter fe uidendum præbet at $q$ palpandum $*$ fed quando in aquam ca lidam mittitur, ftatim ea delectatus in planam membrorum deiectionem oftenfionemó̧̧ refoluitur, \& fic inoffenfe uidetur atç palpatur, Ifídorus. Vide etiam infra in prouerbio, Scit multa uulpes, fed to echinus unum magnum. Terreni herinacei nunc ueteratoriam explicabo: Cum enim is uicinus eft utcapiatur, contortifime feipfum concludit, 8 tantopere contrahit, ut comprehendi non queat, fimul $\mathcal{X}$ animam continet, fpiritumó́ comprimit, $\mathcal{X}$ ab omni mocu cóquiefcens, mortui fpeciem pra fefert, A clianus \& 2 Philes, TIpfum animal non uerentur pleriç dicere uitæ hòminum fuperua cuum effe, fi non fint illi aculei, fruftra uellerum mollicie in pecude mortalibus data. Hac cute expo= liuntur ueftes, Magnum fraus 2 ibi lucrum monopolio inuenit, de nulla re crebrioribus fenaturicon fulcis, nulloǵs non principe adito querimon’̣s prouincialibus, Plinius. Huius monopolij (inquit Hermolaus) mentio fit in luftiniani codice, quem locĩ recentiorés Leguleiridiculèfunt inter pretati.
Pecten echini(nempe terreftris) uocatur iureconfultis echini pellis ueftium deterfui accommodècon cinnata, cuius author reiPlinius eft, Calius. Erinacei cute expoliuntur lina, \& uulgò ericium appel 6 lät, Maftarius, Pellis herinaceicum fuis fpinis haftili prafigitur, ut co fugentur canes.

F.

Veteres herinacei cute expoliebant ueftes, cibum uerò ex co non fumebant ut nos facimus, Sis pontinus. Audio apud noftrates fuarium tantum, non item caninum echinum mẽfis admitti.Cute detracta inferuefaciunt paululü uino cum aceto:inde lardo $\&$ caryophyllis confixũ in ueru affant. Herinacei carnem iucundam effe aiunt, fi ca pite percuffo uno ictu interficiatur, priufquam in fe uri nam reddat, \&c. Plinitus. Caro eitus in cibo fumpra aduerfus quos morbos ualeat fequenti capite di. cam. Hyftricis caro, ut herinacea, licet non admodum inter efculenta comedatur, ftomachum tanjen adiuuat, aluum folurit, \&c. Platina à barbaris authoribus deceptus : marinis enim tantum Graci ifta attriburunt.

Colicim remedium per experientiam receptum, Baccas lauri decem, piperis grana feptem, opos panaca magnitudine ciceris, conijce in aqua cyathos tres, totumó fimul feruefactum bibendü præa fculi; ad forminas muliebris fexus herinacei internã membranã accipere; exiccarȩ̣́ ac contundere, eiusćs partes tres prædiçis amnifcere, Aếrius Itb.9. cap.31. interprete Cornario. Gracum exemplar non uidit (ed conício Grace echinum legi, cum aliud herinacei nomen ufitatü non habeant Græci. Significat autem echínus, ut capite octauo oftendam, membranã quó̧ interiorem urentriculi in gal linaceis aut gallinis, quam aliqui ftomachicis commendãt; Et de hac forte intelligenda funt Ẫêtị uer ba. Herinacei utriuf ${ }^{\circ}$ tum marini rum terreftris corpus uftum cinerem efficit facultatis tum exter fo gentis tum digerentis, tum detrahentis. Itaç eo quidam \& ad excrefcentia, \& ad fordida uff funt ula cera, Galenus de fimplicib.11, 28. Diofcorides tamen cam facultatem marino priuatim attribuít. Ter= reftris fimul \& marini echini cinis, abftergit, refoluit, \& exiccat, Auicenna. Cinis de pelle herinace (terreftris, fiue marini)confert ulceribus fordidis, $\&$ carnem fuperfluam compelcit, Idem, Rafis, Al. bertus. Pellis herin, terreft, unà cum iplius capite tofta, 8 in puluerem tufa ex melle inungitur ad alopeciam, Galenus lib.ı. Parabilium cap.14. Cinis ufti echini cum fpinis fi pici mifceatur, cicatrici bus pilos reddit, Albertus, \& Philes bufum cum pice liquida, alopecias emendat. Caput quidem eius uffum per fe, etiam cicatricibus pi los reddit. A lopecias autem in ea curatione praparari oportet nouacula \& finapi. Quidam ex aceto utu maluerunt. Qua urerò de herinaceís dicuntur, eò magis ualebüt in hyftrice, Plinius, Terreftris o tierinacei corium combuftum, alopecís cum piceliquida aptiffimè illinitur, Diofcorides, Aelianus, Auicenna, $R$ afis, Albertus. Erinacei caput 8 pelicula cốbufta, ciniśḉ ei adiecto melle inlítus alo. pecijs cito prodeft. Caput autem eius per fe combuftum, $\&$ adiecta iplius adipe, cinis ille alopecijs inlitus, etiam cicatricofis facit pulos renafci: quod fi torum ip furm quís exurat, \& pultuerem eius bene tritum cum adipe urfina caluo ad integrum capiti imponat, decorem priftinum reftituet capillorum, Marcel,Er alibi, cinis(inquit) exufti erinacei recêtis, uel fimus erinacei recẽs, $\&$ fandaracha, cũ aceto $\&$ pice liquida mixta $\&$ impofita fuẽeres capillos côtinent. Author eft Achriton alopeciæ mederi ci nerem ericiorum marinorum cum gallis rubeis $\&$ amygdalis amaris, aquali omnium portione (ut fint tres partes aquales, quibus addatur fimi nurium pars dimidia, Albertus:) permixta hac cim aceto diu teres, 8 impones, (Medicamentum hoc apud Galenum, ftatim poft Critonis pharmaca ad

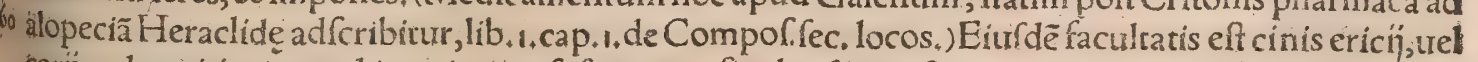
corin, uel capitis eius, uel interiorum, fi fepum urfi admifceas : \& iam currit a qua abfg fepo in iutua thento, (uel ut Albertus habet; iam enim incipiet humor recurrere abfoglabore:) poftquam fricatur 
locus affectus donec rubefcat, Rafis \& Albertus. Herinaceorum marinorũ teftas exuftas \& aqu rubactas locis prafrictis impone. In quiburdam exemplaribus non aqua, fed adipe urfino excipi de bere herinaceorum cinerem reperi, quod mihi magis placuit:hoc enim modo efficacius redditur, $G$ a lenus lib.r. de compor,med. fec.locos, inter Critonis medicamenta ad alopeciam, Herinaceorũ ma. rinorum teftas uftas, ex melle $\&$ aceto prarafis illine, Soranus ibidem. Ericius uftus tritus fi impo= natur fifulax, iuuat, Rafis $\&$ Albertus. Lichenas in facie cinere herinacei ex oleo illinunt: In hac curatione pritus nitro ex aceto faciem foueri præcipiunt, Plinius, Attritis medetur cinis muris fyl uaticicum melle, uel herinacei,Plinius. Herinacei ter,cinis in uini potione fumptus, remediumad dolores renum adhibetur, \& ad aquam intercutem, A elianus: Vetuftiores carni ficcæ in cibo fum,

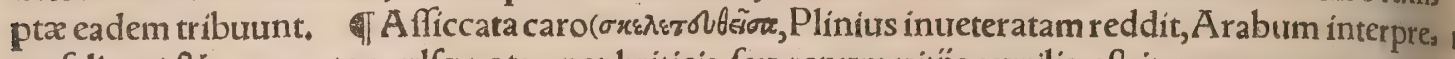
tes falitam) \& cum aceto mulfo pota, nephriticis feu renum uitijs auxilio eft:item aquæ qua cutem fubít, conuulfioníbus, elephantix, 8 male habitis, quos Graci cachectas uocãt, (Araburm interpre= tes initium hydropis uertunt:) uifcerum fluxiones exiccat, Diofcorides, Eadem ex Diofcoride repe tit Galenus de fimplícib. $11+3$. his uerbis, Scripferunt quidam herinacei terreftris carnem deficcatam prodeffe elephanto obnoxijs, cachectis, conuulfionem fapenumero patientibus, nephriticis, labo= rantibus aqua inter cutem quam anafarca uocant:Quòd fie efficere poteft, facultatê habuerituàlenter fimul digerentem deficcantemó́, ficut $\&$ caro muftel $x$ arefaça. Eadem quoo apudRafin \& Albertum legimus. Ifaaci interpretes magna imperitia cuniculo, uel ut Belluacentis habet keri, culo, attribuunt trim diffoluendi, ftomachum roborandi, aluum molliendi, urinam prouocandi 1 le pra deniç \& elephantiafi medendi: Alĭ herinaceo eadem omnia:fed ï quo $\$$ peccarunt : nam cum 2 Diofcorides alĭç $\beta$ Græci feorfím de marino echino fcripferint, eum in cibo fumptum ftomacho gra=

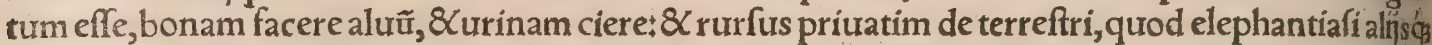
paulò ante enumeratis morbis fubueniat, illi in unum omnia confuderunt. Ericius montanus me. lior eft domeftico, $\mathcal{Q}$ habet fpinas in modum acuum (fagittales Auicenna) $\mathcal{Q}$ eft confimilis in cusa ra, melioris comeftionis, magisḉ̧ iuuat ftomachũ, \& uentrem magis mollit, urinamós ciet efficacius, Rafis \& Albertus, Mihi quidem herinaceus montanus ille hyftrix effe uidetur, adulbus ab Auicen. na dictus:nam Syluaticus quo ${ }_{3}$ adualdul primum, deinde adubul ericium montanum interpreta tur, qui uulgò dicatur iftrice. Quòd autem is in cibo fumptus ea præftet, quæR Rafis, Albertus, \& cos imitatus Platina ei tribuit, ex ueteribus authorem habeo neminem: Echinis enim marinis tantũ om, nes has facultates attribuunt:herinaceo uerò terreftri \& hyftrici, neç fimpliciter, neq̧ magis aut mi: 30 nus quàm marinis. Quanquam enim in remedñs ex ufto corpore corióue aut fpinis, eandem uim terreftri 8 marino echinis effe Galenus tradit:Plinius uerò, Qux de herinaceis, inquit, dicuntur,eò magis ualebunt in hyftrice:longé tamen alia ratio eft, fi in cibo fumantur:quod illinon animaduerte runt. Ericius terreftris falitus aduerfus elephantiafin prodeft:item paralyfi \& fpafmo, \& uitijs ner, uorum omnibus, Auicenna. Cocius aut affus erícius in lepra remedium eft, $R$ afis. In contraction ne neruorum caro palumbina in cibis prodeft $\&$ inueterata, herinaceifpafticis, Plinius: Diftingtien, dum forte poft prodeft, non polt inueterata, ut cum Diofcoride ei conueniat. Carnes inureteratęhe rinacei fumptæutiles funt hydropicis, Plinius. Salfa ericin caro cum oxymelite iuuat hydropicos, Auic nna \& Rafis: Albertus addit, ad omnes hydropis differentias prodeffe, nempe carnofam, (ut ip(e loquitur, ) tumidam, \& citrinam. Eadem caroffalfa, cum oxymelite pota, falubris eft in dolore 4 renum, Rafis, Auicenna, \& Diofcorídes, \& alï:Solus Philes herinacei ufti cinere cum uino albo po: tum dolentibus renes mederi fcribit. Caro erich̆ falutaris eft in phthifi, Auicenna. Ericius cocius aut affus phthificos iuuat, Rafis, Emplaftrum ex ericio ualet contra neruũ contractum, $\&$ dolorem in uentre natum ex craffis flatibus, \& difficultatem digeftionis, $R$ afis:quẽ autem bonum authorem har fribendo fecutus fit, non inurenio. Herinaceorum cinis cum oleo perunctorum cuftodit pars tus contra abortus, Plinius. Inueteratas (inquit Plinius) herinacei carnes quís poffit dare potuifu renti, etiamfi certa fit medicina? Herinacei carnem iucundam effe aiunt, fi capite percuffo uno ictu interficiatur, priufquam in fe urinam reddat : Eos qui carnem ederint, ftranguria morbum contras here minimé poffe. Hac caro ad hunc modum occifi, ftillicidia ueficæe emendat: Item fuffitus ex e0, dem. Quòd fiurinam ex fe reddiderit, eos qui carnem ederint, ftranguria morbum contrahere trà s" ditur, Plinius. Caro ericíj terreni efficit ne pueri lectos permingant: urinam enim tantopere reti= net in cibo fumpta, ut fi affidure quis ederit, urinæ difficultatem incidere periclitetur, Auricenna, \& Rafis fimiliter, fed obfcurius. Si abfcindatur caro herinacei $a b f_{q} ;$ decollatione, deinde fufpendatur fuper beftiam aut hominem, qui agre reddit urinam, mox \& facile eam emittet, Rafis. Herinacel caro optimè decocta atç̧ in cibo fumpta, ftranguriofis mirè fubuenit, \& citò naturalẽ urinæ curium. relaxat,Marcellus. Idem alibi echinos cum aculeis fuis teri iubet, $\&$ ex mulfa aqua frequenter accipi aduerfus dyfuriam: Plinius uero echinos cum fpinis fuis tưfos \& è uino potos, calculos pellere fris bit, de marinis intelligens, qui $\&$ aliâs(inquit)in cibis ad hoc proficiunt. Caro ericü terreni confert febribus diuturnis, Auicenna \& Habix apud Serapionem. Eadem fuccurit-morfis à ferpentibus (uermibus) uenenofis, Auricenna, Medicinalis eft herinacei pellis, nifi ab eo permingatur, Philes. 6 बHerinacei adeps (caro afficcata potius, fecundum Diofcoridem)prohibet uifcerũ fluxiones, Auris cenna. Ericỉ falfi, 8 in aqua feruentis innatans collecta pinguedo, fi illinatur baculo, 8 is in donio 
nentes (teftimonia, uel teftium dicta) conịciebantur, aliâs coniecta fignabantur : ciưs mêtio fit apurd Demofthencm, Ariftotelem, \& Ariftophanem, Suidas, Maffarius, Caelius, Pollux. In hanc capfam fiue fcrínium, reftium dicta, aça litis, omniaḉ à partibus prolata conỉciebãtur, notisḉ̧ additis ligna bantur, ne quis dolus malus in $\ddot{j}$ s fubeffet. Vnde ea quæ in acta prolaturi crant, apud fequeftrem de

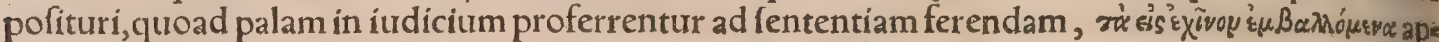

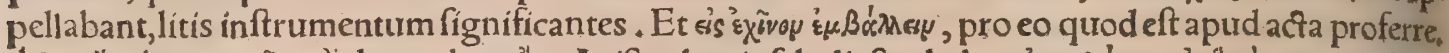

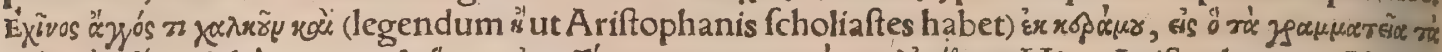

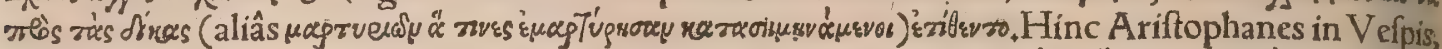

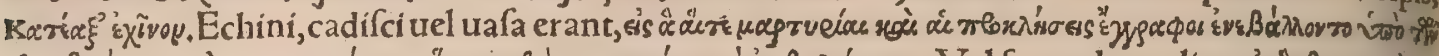

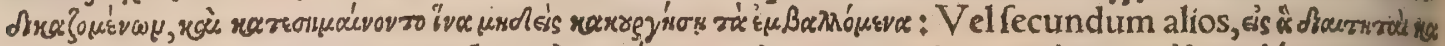

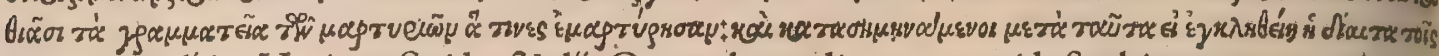

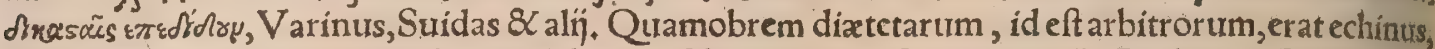
$\&$ ab ijs cum opus erat iudicibus tradebatur. Plura uide in Commentarịs Budxi. ब1 Poctla cum cyatho dum fuftinet, aftat echinus Vilis, cum patera guttus, Campana fupellex; Horatius Serm. 1. Sat. 6. Híc, ut Acron docet, echinus genus eft uafis ænei in quo calices lauantur, quam alĭ am, pullam dicunt effe uitream:Scoppa Italice defrefcatoro exponit. Echinus genus eft chytra, ideft

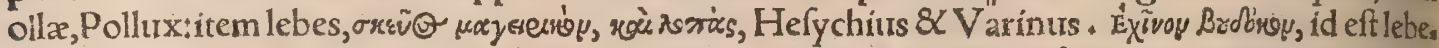
tem, Etymologus. Sunt item echini circa manus carpum ornamenta: ficut pericarpia, \& item pfel. lia ac bubalia, Calius. Echinus muliebris ornamenti genus eft, non difimile omnino brachialibus 84 armillis, Hermolaus ex Polluce, đIEchînus, placenta fecundæ menfæa apud A thenæum libro i4.ti. detur autem in Rhodo fieri folita ex uerbis Lyncei illic citatis: "ckus uerò, cui comparatur, Athenis.

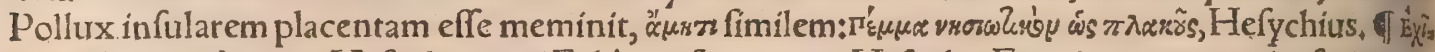

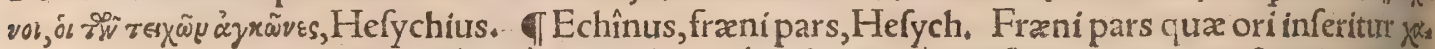

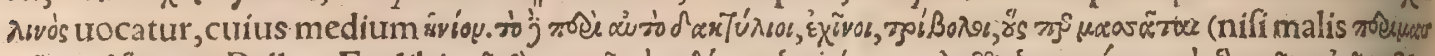

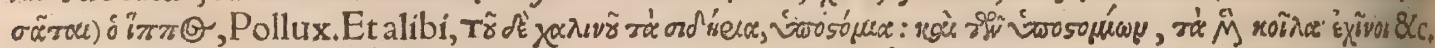

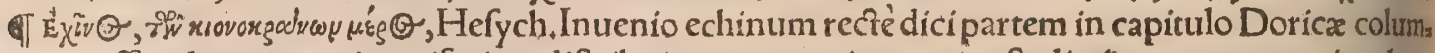
næ: craffitudo quippe eius trifariam diftribuitur : una enim portio eft plinthus cum cymatio: alcera echinus cum a nnulis; tertia hypotrachelio contrahitur columnæ, Cælius. Echinocephalum Cratis nus Periclem appellauit, Pollux libro 2. melius legetur fchinocephalum, ut fupra docui in Cane, $\mathrm{Ca}_{\mathrm{a}}$ pitis octaui parte 2. Scilla genus unum, aut bulbum eius omnem ab Hippocrate fchinum uocarial thor eft Galenus in gloffis. Edulia quædam, ex amygdalis pracipue, $\&$ alia ex uruis paffis ad hetia naceorum fpeciem à coquis parantur, \& corundem nomine apud noftrates uocantur, ut legimus in Balthafar is Dillingenfis coqui libro Germanico. Eft $\&$ militare in lingua noftra herinacei uocabir lum, quum acies ita inftruitur ut haftis undiquaç rigẽtibus hoftes excipiat, Ruftici denigg noftri her rinaceum nomínant abfceffum, qui medias pecoris, uaccarum præfertim ungulas obfidet. Non alienum eft ab hoc loco quod Caffiodorus Variarum libro quinto fcribit, ubi diuerfas amphitheatra Ics pugnas hominum aduerfus belluas defcribens, Alter (inquit) fegeftabili muro cannarum, con tra fauifimum animal, ericï exemplo receptatus, includit: qui fubito in tergus fuum refugiens, int tra fe collectus abfonditur, \& cum nufquam difcefferit, eius corpufculum non uidetur. Nam ficutil le ueniente contrario reuolutus in fpharam, naturalibus defenfatur aculeis, fic iffe confutili crate pre cinctus, munitior redditur fragilitate cannarum, $\mathrm{Hac}$ ille.

बEchînus Ariftoreli eft pars uentris ruminantiũ (ut \& Hefychitrs fcribit, ) Gaza omafurm tranfs

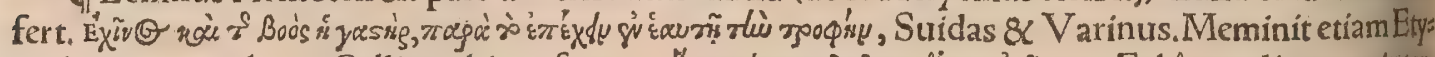

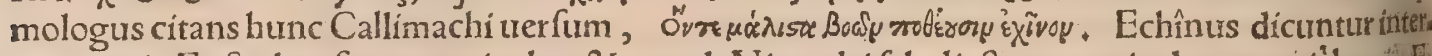
na uentris Euftathio, fure uentriculus: $\mathcal{Q}$ ut uult Nicandri fcholiaftes, uentriculus propriébouis, Ex

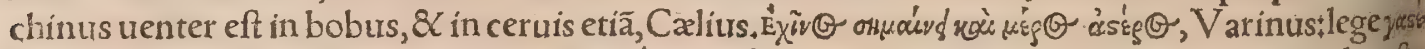
$\rho \bullet$ ex Etymologo. Lac coagulatur etiam à domeftic gallinæ pellicula, quæ intra uentriculumfter cori deftinata eft, echinus ab afpritudine Gracis appellata, ceu cortex quidam, Berytius in Geoponi

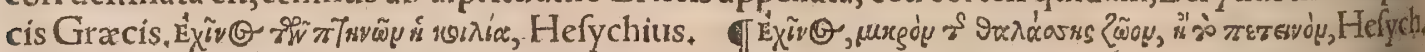

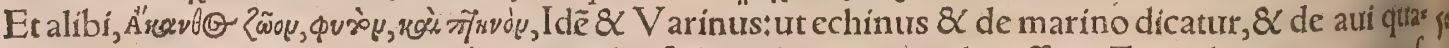

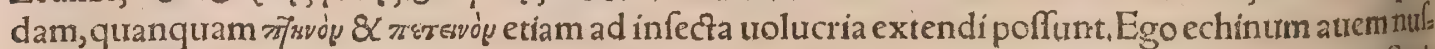

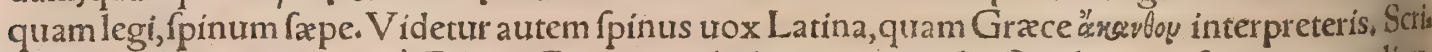
bitur autem $\sigma \pi \tilde{i}$ G etiam à Gracis, Gaza acanthidem aurem ex Arilfotele nunc fpinum nuncligus rinum uertit:urictitat enim ex fpinis et carduis. Imperitus aliquis profpino echinum facile foripferit, $\&$ facilius Gracis literis!nec rari huiufmodi errores in Gracorum Lexicis funt. In his uerbis A'tuy ₹woy, intelligo echinum animal fiue terreftre fiue marinum, nam $\&$ alins nominibus ab acantha des

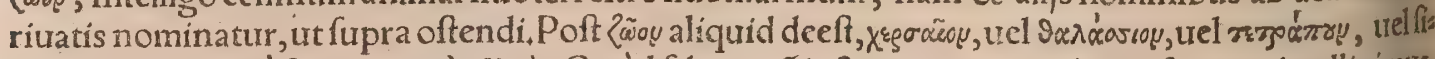

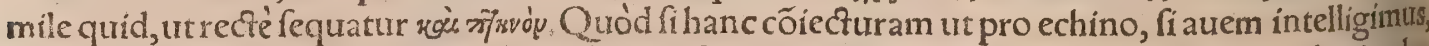
fpinus legatur, quæ mihi quidem probabilior eft, aliquis non receperit: aliam habeo, ut echini uel as canthif pinitue nomine, infectum uolucre, nempe maximum fcarabeum cornutũ accipiamus, quem aliqui uulgo ceruum uolantem uocirat $:$ is enim compreffis cornuum ramis tanquam fpinis colu

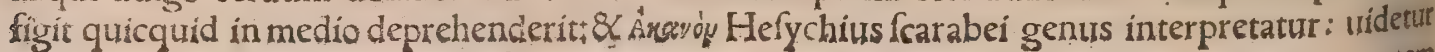


attem acanos idem quod acanthos, uttacanion quogg nổ aliud quàm acanthion eft. Sutnt fanè ctiam cruribus fpinofi fcarabei quidam, ut in Hiftoria infectorum uidebimus, TEchinifcus Pollucilib.

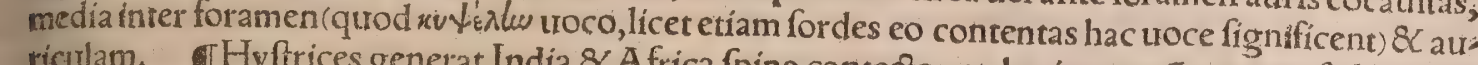
riculam. THyftrices generat India \& A frica fpina contectas, ex herinaceorü genere, fed hyftrici longiores aculei, \& cum intendit cutem miffiles, TPlura murium genera in Cyrenaica regione; alih lata fronte, alin acuta, alij herinaceorum genere pungentibus pilis, Plinius. In Cyrene aiunt plura

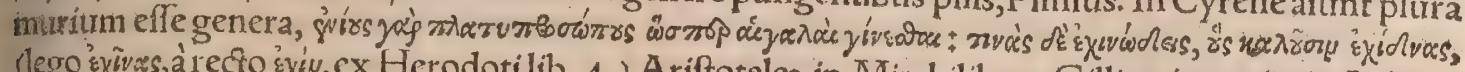
(lego exyives, à recro sycu, ex Herodotilib. 4.) Ariftoteles in Mirabilibus. Gillius imperite in Aeliano 1. 8. \%. Extrío'ss uertit, uipera fpeciem \& fimilitudinem gerentes, quos indigenæ echinatos uocent Aegyptijs muribus durus pilus ficut herinaceis, Plinitus, \& Ariftoteles in finelibri 6 , hift, animal,

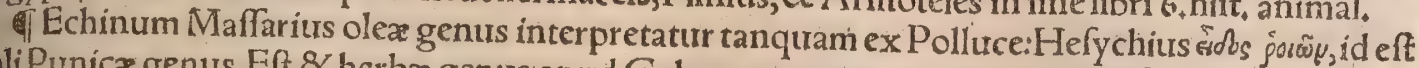
mali Punica genus. Eft $\&$ herba genus apud Galenum, quam etiam erinon Diofcorides uidetur ap
pellaffe:quanquam in uetuftis codicibus non erinos, fed echinos legitur $:$ eft $\&$ apud Hippocratem echini herba mentio, Maffarius. Apud Plinium lib.23. cap.7, erineos legitur:ubi de fícis \& caprifi= cis agens, Herba quoç(inquit)quam Graci erineon uocant, reddenda in hoc loco propter gentili= tatem. Palmum alta eft, cauliculis quinis ferè, ocimi fimilitudine, flos candidus, femen nigrum, par tum: tritum cum melle Attico, oculorum epiphoris mederur : utcunç autem decerpta manatlacte multo $\&$ dulci herba, perquam utilis aurium dolori, nitri exiguo addito : folia refiftunt uenenis. $\mathrm{Ni}_{3}$

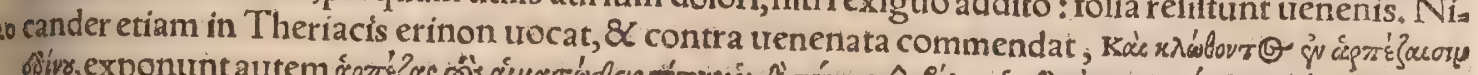

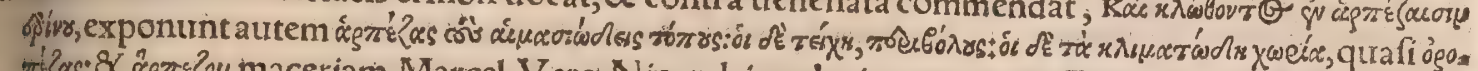

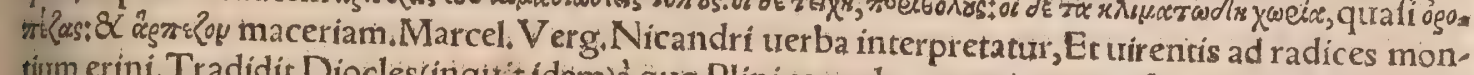
tium erini. Tradidit Diocles(inquttit idem)à quo Plinius multa accepit, ocimo fímile effe: nafci prope flumina $\&$ fontes: 8 prxter id apricis locis $\&$ ad radices montiũ, Hæc ille ex fcholijs in Nicandrum,

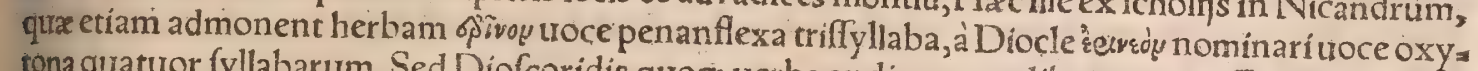
tona quatuor fyllabarum. Sed Diofcoridis quoç uerba audiamus ex lib.4.cap+30. Erinos (inquit) funt qui ocimoides, qui hydreron, Romani ocimum aquaticum dicunt(ut Marcellus uertit)nafcitur fecus fiuuios \& fontes: folia haber ocimi, minora tamê, $\&$ in fuperiore parte incifuris diuifa. Ramuli

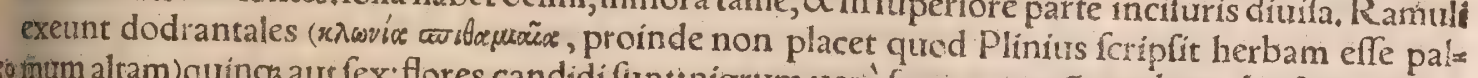

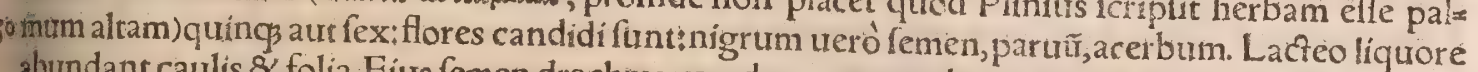
abundant caulis \& folia. Eius femen drachmarum duarum ponder e quatuor cyathis (drachmis, Ae. gineta)mellis temperatum, contra oculorum deftillationes inungitur, fiftíćç eas. Aurium dolores fi. nit addito fulphure ignem non experto \& nitro inftillatus fuccus, Haec Diofcorides. Galenus lib. 6 . fimplic.medic.echinon uocans, eaflem eius uires refert. A egineta, per ígnorantiam forte, bis cômé morat, primum in Erino ex Diofcoride, deinde in Echino ex Galeno. Hac herba quòd fciam medi= corum hodie nulli cognita eft, quorum fcripta in lucem edita uíderim:ego non hanc ipfam, fed con generem aliam demonftrabo, quam Plinius militarẽ appellaffe uidetur 24.18. Lacforis; inquit, nota uulgòeft, plena lacis, quod deguftatum uomitiones concitat. Eandem hanc aliqui effe dicunt, alif fimilem illi, quam militarem uocant, quoniam uulnus ferro factum nullum non intra dies quinque ofanat, ex oleo impofita:Nec alibi plura apurd ullum authorem de duobus his nominibus fiue unius fiue duarum ftrpium reperio. Ego diuerfas effe puto urel hoc argumëto, quód quæ uulnera tam cito glutinant, infignem aftringendi uim poffidere probabile eft, qux quidem contraria eft uemitoria fa cultati. Habet autem erinus fiue echinus uim illam reprimendi, ficcandiḉs $\&$ conftringendi, uel Ga leno 2 Aegineta teftibus in cenfu fimplicium. Quanquam etiam lib.9. cap.7. de compofitione fecun dum locos Galenus, Succus echini, inquit, facit ad inflammationes $\&$ prolapfam fedem. Eafáem pla néuires habet herba quam Hieronymus Tragus lib. $1_{3} c a p_{+} 100$.efulam dulcẽ nominauit:manat enin lacte, ut efula $\&$ títhymallorum genera, unde forfan $\&$ erini, id eft caprifici nomen impofitur ob fimi lem liquorem. Verum lac eius dulce; non acre ut tithymallorût eft, quamuis tihymallos afpectu, flo ribus, pericarpís \& femine ita referat, ut prorfus eiufdem generis uideatur. Pericarpia tamen non - lauia habet, fed hirta \&quodammodo echinata, ut illorum gratia echini nomen merito ei contreniat. Aftringit omnibus fui partibus, maximé tamen radice, quam albam habet, digiti ferécraffitudine, ge riculatam, tranfuerfam, duos aut tres palmos longam, eminentibus nodis totidem, quot caules prax cedentibus annis ædiderat. Locis aquofis prouenit, \& iuxra fapes, fyluefribus tantữ aut montanis

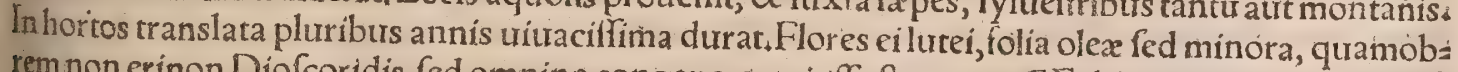
rem non erinon Diolcoridis, fed omnino congenerem ei effe fratuo. Echini uocantur etrã quer cuum cyttari, id eft panicula quædam ceu nucamenta qua ex ramis earum dependent, Hefychius Echinus, fructus platani, Idem, Ricinus quog ut foliph platanư imitatur, fic echinata habet feminum trafa. Eft \& echinatum pomum in folani cuiufdam peregrinigenere, quod Fuchfius framoniam \& nucem methel appellat. Dicuntir item in caftaneis echini, quia eo modo quo echini marini aculeis armati funt. Graci enim echinon hirtum uocãt (hoc teftimonio aliquo fulcire debebat:ego cchinon adiectiué fumptum nufquam legere memini)inde echinatum dicimus, quod ad finúlitudinem caftas nearum calycis aculeis hirtum eft, Maffarius, Armatũ caftaneis echinato cortice uallũ eft, Plin, $15+2 z_{3}$ 
Dipfaco in cacumine capitula funt echinata fpinis, Plinius. Chamxleon candidus ferpit in terrià echini modo fpinas erigens, Idem. Glycyrrhiza \& ipfa line dubio inter aculeatas eft, folijs echina tis, Plinitus: ego nihil tale in glycyrrhiza noftra hactenus deprehendi. Echinopus A thenzo lib, 9.

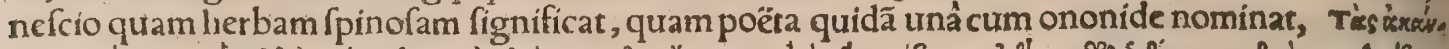

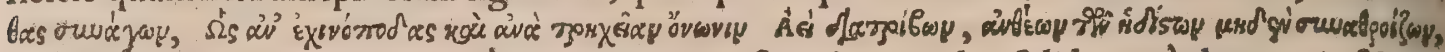
in grammaticum quéndam anxiè diligentem circa fingulas uoculas, folidæ uerò eloquentix \& erụ ditionis negligentem. Ceras ex omnium arborum fatorumó floribus apes confingunt, excepta ru mice \& chenopode: Herbarum hae genera, Plinius 11, 8, malim echinopode: quoniam chenopodis nomen nufquam inuenio: conuenit autem herbx fpinof $x$ ab echino factum nomen.

- Infula Echinades dicf $x$ funt ab Echione quodam, uel à multitudine echinorum, fitue terreftres is illi, fitie marini fuerint: Vel quod folum earum afperum $\&$ fpinofum fit echinorum inftar, Euftathius in Dionyfitm. Oxix infula, quas Homerus Thoas uocauit, Echinadibus propinqua funt, aded ut inter eas à Strabone collocentur, Hermolaus. Echinę infula funt circa Aetoliam, quibus Achelous

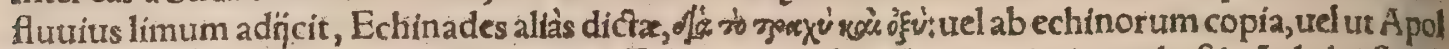
locoro placet ab Echino uate, Strphanus, Echinades, infula A carnanix iuxta hoftia Acheloi flui, in quibus Epei dicti habitãt, Scholia in lliad.2, Plura quxre in Onomaftico noftro. Echînus nomen eft cituitatis; cuitus(ud uíri a qquo dicfa eft, ut Etymologus habet)meminir Demofthenes Philip. quin

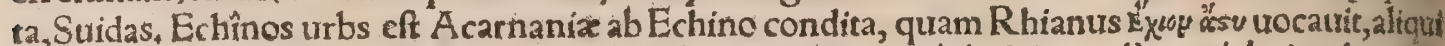

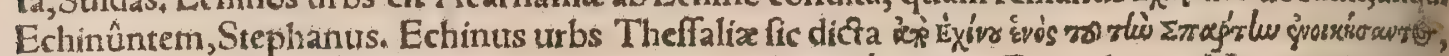

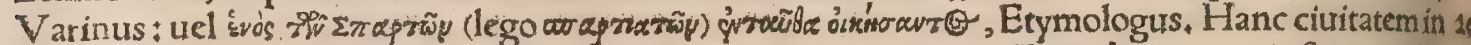
Phthiotide collocat Ptolemaus, in farcibus Sperchï amnis , Plinius. Echinúntis mentio fit apud C. ceronem in A rato, Dicitur excellis errans in collibus amens, Quos tenet Alegeo defixa in gurgite Echinus. Echinos Thracia urbs ad Pagafeum finum, Pomponius lib, 2, Sperchium tamen in Mar liacum finum definere P tolemaus f́ribit.

C. Mures alpini totam hyemem in latibulis ûfg ad uer crínaceorü inftar conuoluti delitefeunt \& dormiunt, Ge.Agricola,

4. Sanguine herinacei cum decollatur, xquali oleo mixto, fi inungatur corpus uiri ignoratt: tis quid fit, ligatur ab omnibus mulieribus ufç ad menfem, Rafis \& Albertus. Oculus herinacel dexter frixus ad pondus uncix ( $R$ afis nefcio quas ponderũ notas hîc habet) cum oleo alinulx (aliầs alnula) uel feminis lini, fi ponatur in uafe arris rubri, \& collyrï modo inde illinantur oculi hominis 3 qui noctu uidere defyderat, in tenebris condita qualibet tam uifu difcernet quàm interditr, lidemt

बा h. Magos qui Zoroaftren fectantur, imprimis colere aiunt herinaceum terreftrem, maximi uerò odiffe mures aquaticos, Plutarchus in Sympofiacis lib, 4. quaftione ultima. Idem ín librode Ifide, terreftres echinos ab his magis bono deo attribui fcribit, aquaticos autem malo. De herinaceo facrificato fupra dixi capite primo.

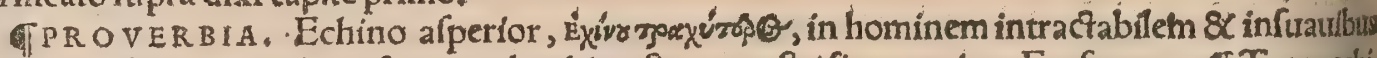
moribus dictum, metaphora fumpta ab echino fiue terreftrifiue marino, Erafmus. बT Totus echi-

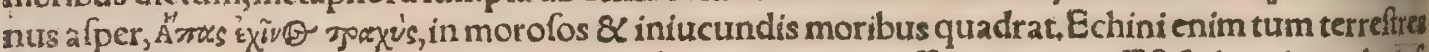
tum marini undió foinis ob́fepti funt, ut nufquam impune poffis attingere. Eft \& hominum huiul modigenus cum quibus nulla ratione poffis agere citra litem. A riftoteles in Pace, óv f's

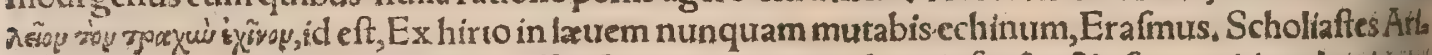
Rtophanis aptum huius dicti ufum effe oftendit, cum quis alicui infenfus $\&$ afper, mitis ac benigntur

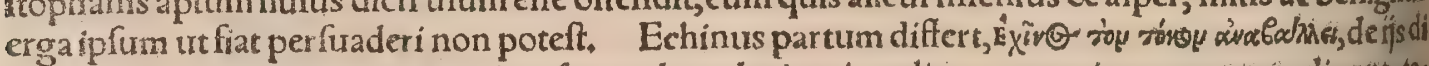
ci fuetum qui prorogarent quippiam fuo malo: ueluti qui creditam pecuniam comperendinant, tar men aliquando redidendam uel maiore cum fonore. Aiunt echinum terreftrem fímulata aluo remo rari partum, deinde iam áperiore ac duriore facfo foetu mora temporis, maiore cruciatu parere, ath thor Surdas, Erafmus. Echinus parturiens curnctatur; uel Echinus partum procraftinat, prouerbium in eos qui in perniciem fuam morarum caufas innectunt:cuiufmodifunt illi urerfuram faciẽtes, \& c

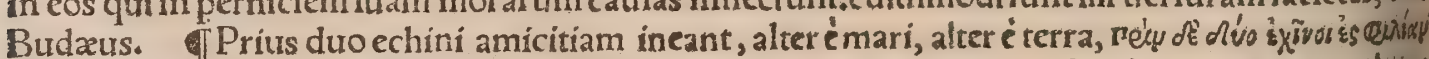

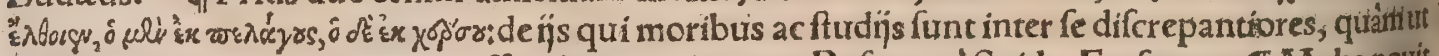
fpes fit aliquando inter cos necelfiturdinem coituram, Refertur à Suida, Erafmus. बI Multa nouit

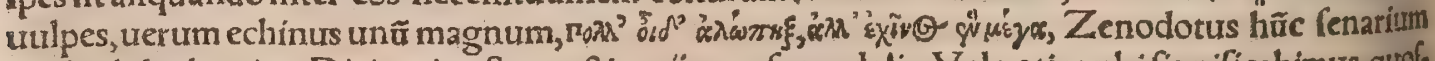
ex Archilocho citat. Dicitur in aftutos, 86 uarijs confutos dolis. Vel potius ubi fignificabimus quof dam unica aftutia plus efficere, quàm alios direrfis technis. Nam uulpes multijugis dolis fe turetrir aduerfus uenatores, \&C tamen haud rarò capitur: Herinaceus unica duntaxat arte tutus eft aduerfurs canum morfus. Siquidem fpinis fuis femet introluit in pila fpeciem, ut nulla ex parte morfu prehen

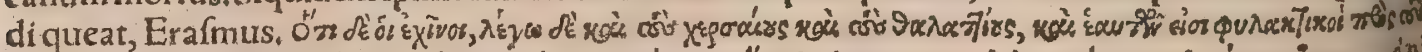

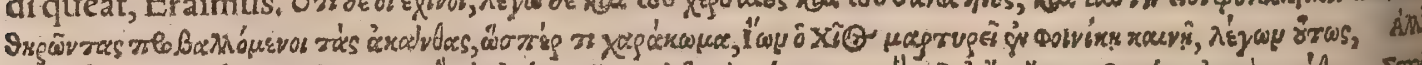

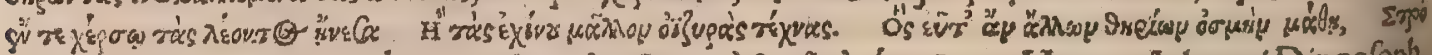

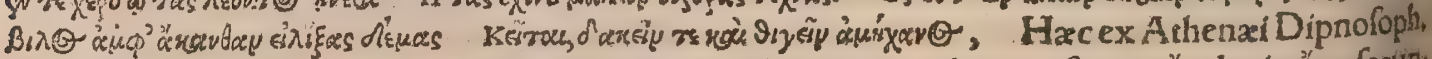

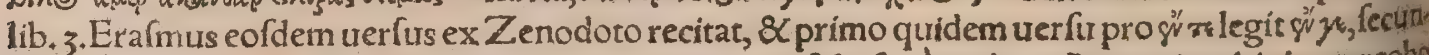
do autem pro "ैlegit wòे, \& ita rransfert:Leonis artes in folo fané probo, At magis echini comprobo 


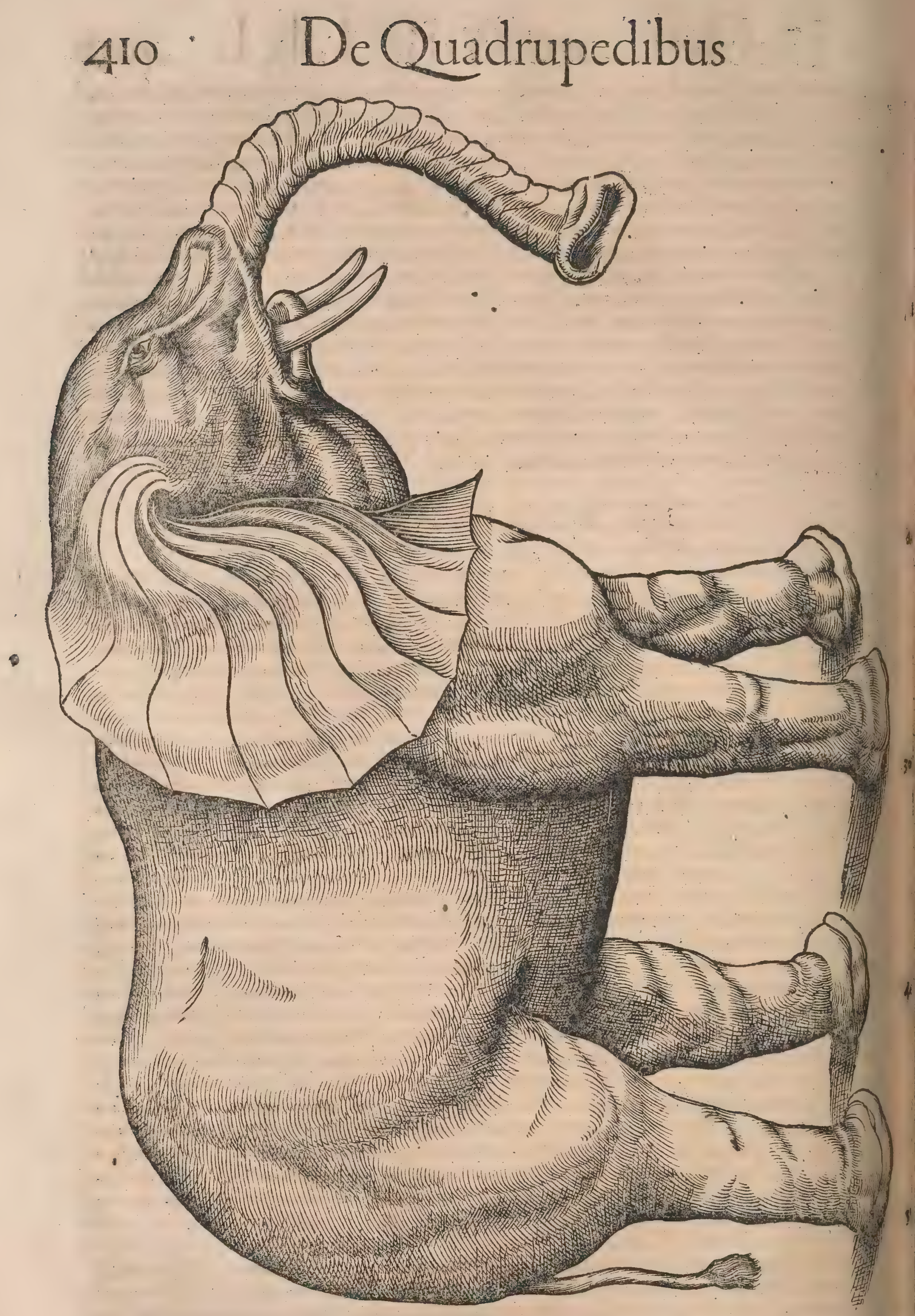

leones cafi, elephantes deinde, horrendum quippe dirumós fpectaculum, Plutarchus in urita eitus, Mirum eft libro feptimo Plinium fcribere, L. Metellum elephantos primum bello Punico prinodiv xiffe in triumpho:quum tamen libro idem oftatro tradat, elephantes Italiam uidiffe primum Pyrth bello, \&c.Sed in feptimo forfan de r̈s fenfit, qui modò in Carthaginenfes depugnarunt, ficuti coms meminit libro decimonono ab Vrbe condita Liuitus. Certe author Seneca eft in libro de breuitate ui, tx, principem omnium Curium Dentatum elephantes duxiffe in triumpho. Sed $8<$ mox paulo, Idem: (inquit) enarrabat, Metellum, uictis in Sicilia Ponis, triumphantem unum omnium Romanortin ante currum centum $\&$ uiginti captiuos elephantes duxiffe, Cælius; Victo Pyrrho Manius Curit!s 


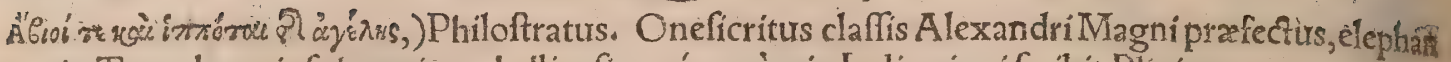
tos in Taprobane infứa maiores bellicofiores q́s quàm in India gigní fcribit, Plinius.

(1) Elephanti magnitudo $\&$ tota fpecies fupenda eft. Terreftrium(inquit Plinius)maximü ani mal eft clephas, Elephantis opitulata eft natura magnitudine corporis:fufficit enim hac ad necerh arccndam, Arifoteles. Mares forminis maiores excelfiores $\not_{\beta}$ funt, Auicenna. Vartomannus, $\&$ Gillus; Eorum uaria eft proceritas;nam alï ad dưodecimum, alij ad decimumtertium dodranten excelfitate procedunt, alij ad decimumquartum, Gillius:aut etiam decimumquintum, Vartomana nur. Indici elephanti nouem cubitorum altitudine funt, ut Aelianus refert. Elephas'unus maior eft tribus bubalis, Vartomannus. Oppiani de huius beftix magnitudine uerfus hi funt,

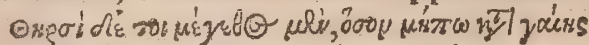

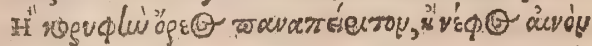

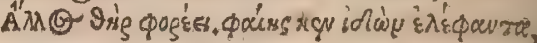

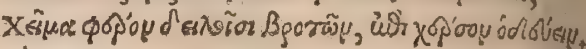
IIndicis color eft niger uel murinus ; in Aethiopix uero regione quadam nuper inuenta albus. Quid tibi uis mulier nigris dignifima barris \% Horatius. Pellem habet nigram quafi puniceam \& fcabiofam, Albertus. Colore elt bubalorum, Vartomannus. Totus niger eft; \& glabra cuti, fine pis lis, Obfcurus. Durifimum dorfo tergus, uentres molles, fetarum nullum tegumentum;ne in cauda quidem prafidím abigendo trdio mufcarum(nanq̧ id $\mathcal{Q}$ tanta uaftitas fentit)fed cancellata cutis; ¿ inuitans id genus animaliũ odore. Ergo cum extenti recepere examina, arctatis in rugas repente cancellis, comprehenfas enecant. Hoc ịjs procauda, pro iuba, pro uilloeft, Plinius, Duriffimũ do"* fo tergus eft, uentri mollius, fetarum hirfutia nulla, Solinus. Plinius curm reprehendiffet illos qui fubrilitatem animi conftare non tenuitate fanguinis putant, fed ea magis bruta effe quibus craffior cutis eft, fubdit: Elephantorum quoç tergora impenetrabiles fecas. (aliấs cetras) habent, cum tamen omnium quadrupedum fubtilitas animi præcipua perhibeatur illis. Hîc ubi fetas legitur, uetur le. cío erat fcafetias:qua uox cum fit deprauata, \& 2 Plinius lib. 8. neget fetas elephantis ullas effe, fieri poteft ut fcribendum fit, quafi fctas : non enim fetæibi funt, fed quafi fetæ, Hermolaus. Sutumpili crafliores funt quàm bubus $\&$ elephantis, quamuis tenuiorem quàm boues $\&$ elephanti cutem has beant, Ariftoteles. Pilos eorum ex nouo orbe terræ deportatos uidi, qui ad duorum palmorumlon gitudinem procederent, Gillius. Pelle quidem robufta, fed turpi $\&$ afpera teguntur † cam ferrum peracutum non incidere poteft, Gillius ex Oppiano, Fòs री фưं

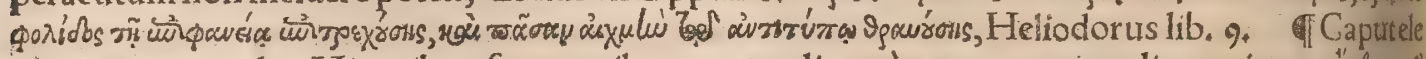

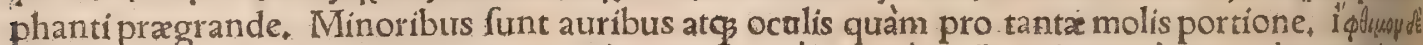

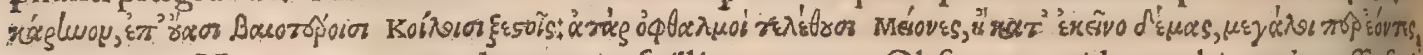
Oppianus. Vartomannus oculos eorum fuillis comparat; Obfcurus quidam rubicundos effe frit bit. Auriculæe erum duos dodrantes longæ funt, quoquo uerfus bene lat $x$, Vartomanntrs. Auria culas habent, quales draconum pinguntur, aut uefpertilionum alís fimiles, Obfcururs. A pud Samn bros (in Africa, uel Sambros Aethiopes ut Solinus habet) quadrupedes omnes fine auribus, etiam elephanti,Plinius,

Elephanto dentes utrineq quatuor, quibus conficit ciburm, ates in farina fpeciem molit, Dito præterea prominent grandes, quuos mares grandiores refimatosḉs habent: fominæ minores, \& cons tra quàm mares:uerguntením dcorfum, proníq deuiant, A riftot. Elephanto dentes intus ad nant dendum quattror:praterḉ eos qui prominent, mafculis reflexi, foeminis recti atçs proni, Plin, Scas tim cum natus eft elephantus, dentes habet:quanquam grandes illico perfpicuos obtinet, Ariffotel, Dentes exerti fint apro, hippopotamo, elephanto, Plinius, Duos ei dicũt prominere exertos, quos aln dentes, alij cornua uocant, A elianus. Sunt autem illi in fuperiore mandibula, Vartomanuls, Quemadmodum duobus dentibus apri, fic elephanti armantur, fed fitu contrario:ilis en im in fublit me feruntur, his deorfum retorquentur, Gillius. Eorum quífunt confirmata atate, ea magnitudine dentes exiftunt, uícem ut poftum praftent in domicilngs (quod capite quinto etiam ex Plinio confin mabimus, $\&$ pro palis Nigritæ ad fepimenta utantur : fæpe enim ad longitudinem decem pedum augefcunt, Gillius. Grandia taurorũ portant qui corpora, quaris An Libycas poffint fuftintifî trabes? Martialis de dentibus eboreis. Innominatus quidam cuius liber de terra Sancta Italicusex= tat, frribit fe uidiffe dentem elephãti à Veneto quodam mercatore durcatis, id eft denarïs aureis, fex \& triginta emptum, longitudine dodrantum ipfius quaturordecím, craffiturdine dodrãtum quatuor: tanto pondere ut humo tollere non potuerit. Vartomannus fcribit uifos fibín Sumatra infula diọs elephanti dentes qui ambo appenderint libras trecentas $\&$ triginta fex: libram autem quantamacs cipiat non exprimit. Paluftrium elephantorum dentes liuidi funt, rari, traçúćp (forte rractatu)difl's

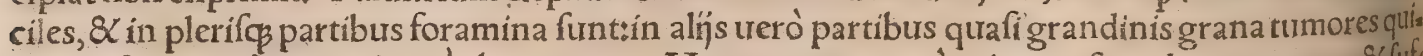
dam infurgunt, \& artí minimé obtemperant. Montanorum uerò minores funt dentes, uerum \& fuft ficienter albi funt, \& nihil in eis difficile inuenitur. Optimi autem omnium funt campeftriú clephar torum dentes:maximi enim albiffimióg funt, \& incidi faciles, ut nullo labore in quancunos mattus uoluerit partem deducantur, Philoftratus Alemano Rhinuccino interprete. Ex elephantino gea nere cornua foemina maius pretiü quàm maris habere fertur, Aelianus. A bïciunt ea decimo quoog ąnno $\&$ defodiunt, ut inferius dicam, Prædam ipfi in fe expetendam feiunt folam effe in armis fuis, qux Iuba cornua appellat; Herodotus tantò antiquior \& confuetudo melius dentes, Plinius libro 8 


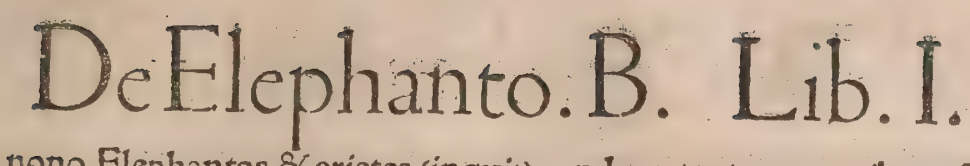

Libro quidem nono, Elephantos $\&$ arietes (inquit) candore tantum cornibus affinulatis, in Santo num littore reciprocans deftituit Oceanus. Quoniam autẽ de ambabus belluis (ut feribit Mafrarius) fcilicet elephantis $\&$ arietibus fimul loquitur, dentes elephâti marini Plinius hî́c cornua uidetur ap pellaffe, ne fi dentes dixiffe, arietes, de quorum cornibus non dentibus fermo eft, ab appellatione cornuum exclufiffe uideretur. Nam fi dentes elephantorum dixiffet, opus fuiffer, arietim quoç cor nua expreffiffer: fed tolerabilius Plinio uifum utrif $\phi_{\beta}$ animalibus feruiendo cornua appellare : quod a libietiam hac de caufa feciffe uidetur, dentes elephanti cornua impropriénuncupando, ut libro dé cimooctatio quando ait, n̂t ţ̧ cum in arbores exacuant limentó́c cornua elephanti, \& duro faxo rhi. nocerotes: ne fi dentes elephanti dixiffet, rhinocerotes quod cornua non dentes exacuunt, fimiliter jo exclufiffet. Sed quando de folis elephantis loquitur, dentes proprié appellat, ut libro octauo, (undé eius uerba pauló anteretuli, ) Dentes quog; Ariftoteles fecundo de hiftoria appellauit: 8 terrio dé ad necem arcendam fufficeret, Hacienus Maffarius. Iuba dentes elephantorum cornua effe arbié tratur, è quod à temporibus nafcantur. A cuere autem ipfa elephantes dicũtur, quod nulli alî́ ineft́ animalium, permanere eadem etiam qux primitus nafcuntur, nec decidere ficur dentes ac rurfus nafci. Ego autem his rationibus nequaquam affentior. Cornua enim etfi non omnium animalium, ceruorum faltem decidunt ac renafcuntur. Dentes autem, in hominibus quidem decidunt actenas fcuntur omnes, aliorum uerò animalium nulli contingit ut dentes cateris eminentiores, quas fan= 10. non renafcuntur : armorum inftar natura maxillis eos inferuit. Infuper cornua lineam quandan ueluti torno impreflam fingulis annís circa radices obducunt, quod oures etiam, capræ, bouesćp te=

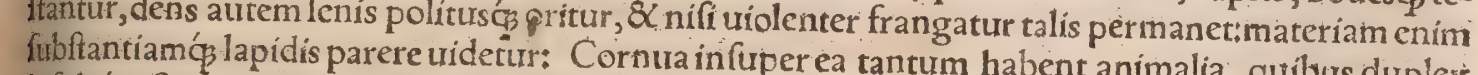
bifidáć. ét ungula:Elephas ueròr: Cornua infuperea tantum habent animalia, quibus duplex pedes imprimat, fi quando in hïmido folo forte conftiter $\&$ plantam multipliciter fciffam, ne altius pedes imprimat, fi quardo in himido folo forte conftiterit. Praterea natura cornutis omnibus anim malibus perforata, \& in medio uacua offa fupponens, fupra qux cxrinfecus cornut producitur:ele. pliantorum autem plena \& per omnes partes fimilia of faint: quod fi illud extrinfecus quis ada pertum infíciar, in medio tenue foramen ( óverye intrenict, ficut in dentibus effe videmus, Hace Philoftratus libro fecundo de uita Apolloni, ex interpretatione Alemani Rhinuccini, quam licet non probem, ea tamen quod Græcum exemplar ad manim non effet neceffariö ufur fum. In ele= phante nô potius dentes quàm cornua, tefte Aphrodifienfi, appellari debent, Grapaldurs, Quos den tes multidicunt, cornua funt, Varrolibro tertio de lingura Latina, item Aelianus: qui $8<$ cornuñ me. dullam in elephantis edendo effe fribit. Quicimque (inquit Pafanias) elephantum of a quodex ore promineant dentes potius quàm cornura effe purant, confiderare debent alces mares (fremina enim îs carent)fua habere cornua in fupereilís ; Aethiopicos uero tauros in nafo fita : ut non ualde mirum fit eadem elephanto ab ore prominere. Accedunt $\&$ hac argumenta affertioni noftra + Cor: nua annorum circuitu animalibus nonnullis decidunt 82 renafcuntur, in quo genere ut ceruos 8 dorcades effe conftat, fic nos etiam elephanios ponimus. Dentes certe animalium adultorum nulli folentrenafci. Quomodo igitur renafcerentur hac elephantioffa, fi dentes, non cornua effent? Sed ut boum fic elephantorum non concedit (quod fi cogas dilatari, franguntur, Oppianus:) at cornua ut boum fic elephantorum, ex rotundis fferiplana, $\&$ in alias uerti figuras uri ignis poffunt. Hippo= potamis $\mathcal{Q}$ apris dentes exertos inferior maxilla profert, at cornua non uidemus ex maxillis nafei (In Gręco non legitur negatio, fed uidetur mili deefre, quamuís Calius fine negatione uerterit, Gil litus difimulanter praternt:)Sciendum eft a utem cornua elephanti à temporibus fuperné defcende:

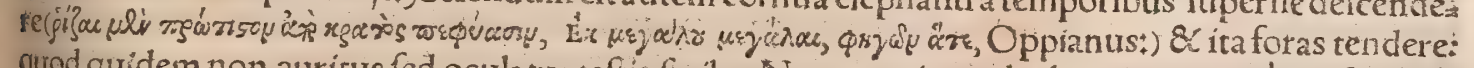
quod quidem non auritus fed oculatus teffís foribo: Nam cranium elephantis accuraté confideraui in Campania in templo Dianæ, quod triginta plurimú fadings diftat à Capua metropoli Campania: Elephas itą̧ ut magnitudine \& f pecie corporis à caeteris a nimalibus permultã differt, fic diuterfurm eliam 8 peculiarem fibi cornuum haber exortum, Hucufgs Paufanias lib. . Eliacorum: Eundern los cum Calius tranfulit lib.13+cap.18. Eifdem argumentis Oppianus utitur lib.2, de uenatione, ubi ele. phantum inter cornuta animalia defcribit.

Linguam perquam exiguam elephantus habet, atozinterius pofitam quàm in cater is fit, itá ituix eam uidere poffis, Ariftot. Lingua ei bene exigua eft, A elianus. Lingua lata elephanto pré. cipué,Plin. बा Proborcis, arb6orxis, in elephanto tocatur à Gracis \&' Latinis nafus elcphäti, uel po tius pars à nafo porrecta demiffaćs terram uerfus : fic autem uocatur quod ea ante fe extenfa paf́ca. turt, hoc eft cibum potumó́ ori admoueat. Plinius nunc probofciden, nunc manum uocat ut libro 8. cap. 7.Probofcidem(recentiores quidan codices promufcide habent, Probofcidem, inquit Cęlitus 3. 3o.nos etiam promufcidem dicimus, ratione qua b.tranfit quandog in $\mathrm{m}$, undexúbudu illi, nos cy mindin pronuntiamus: Hæc ille fine authore, Ego cybindin apud Gracos legere non memini, fed cymindin tātum: quanquam Hermolaus cybindin apud Ariforelem frribi ait, depratiato for fan co: dice ufus. Promufcidis quidem uocabulum apud Vitruuium etiam, \& in Gaze translatione ex Ar: fotele reperitur) eorum, inquit, facile amputari, Pyrrhi praliorum experimentis pacuit. Et alibi 
Mandunt ore:fpirant, \& bibunt, odoranturó̧ haud impropriè appellata manu. Ita promufcide tario quam manu utitur, Gillius ex A eliano. Eadem ratione pronomęam Graci hanc partem uocant,qui

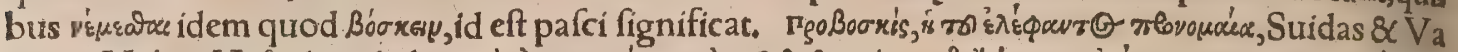

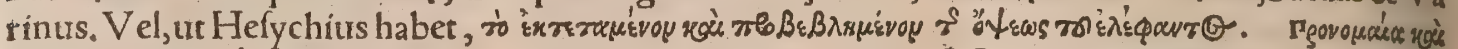

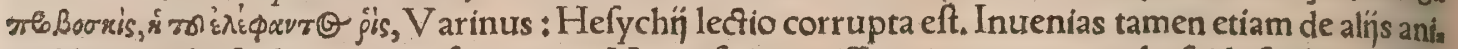
malibus probofcidis nomen ufurpatum. Varro fe inueniffe erícium cum probofcide fcribit, ut No. nitus citat. Probofcis, ut apud A thenæum legimus, qux \& pronomaa, elephantum eft, proprié uerò etiam de mufca \& lolligine profertur: $\&$ ut idem alibi habet, de fepia quocs:De mufca quidem Lucia nus ufurpauit. Habet elephas talem tantamç̧ narem, ut ea manus uice utatur:quippe qui non nifi $\mathrm{ad}$ os illam admouens, \& bibar, \& edat: fuo etiam rectori eam erigit, atç̧ offert: $\&$ arbores quoqge $a_{3}$ dem profternit: $\&$ quoties immerfus per aquam ingreditur, ea ipfa edita in fublime, reflat,atç refpio rat, Adtunciufcula parte fui poftrema, naris hac eft, fed flecti non poteft:cartilaginea enim, \& proin, de rigidiưufcula eft, Ariftot. Et alibi, Elephantis prolixa ualidaḉ naris augetur, eiusḉ̧ ufus ídem quí manus: ea nan $\$$ cibos tam ficcos quàm humidos colligunt, capiunt, \& ad os admouent foli animan. tium omnítrm. Et rurfus, Elephas prioribus pedibus non utitur loco manuum, fed nare fua. Pro, mufcis corum intus concaua fuilli labri fpeciem fimilitudinemó̧ quandam gerir: mobilis eft, utmo

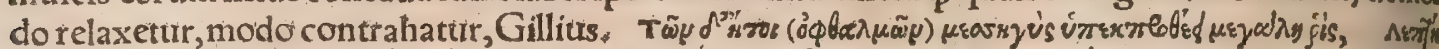

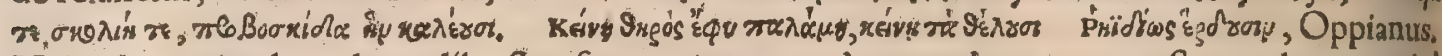
Habet hoc animal quo loco aln̄s eft nafus, partem quandam pendentem, anguftam ac longan adco ut ad terram pertingat. Hac pro manu utitur, \& extrema eius parte fic omnia tractat, ato ita rebus apprehendendis applicat, ut ne minima quidem numifmata ipfum effugiant, qux etiam fublata pro: bofcide (fic partem eam trocant) rectori infidenti tradit. In fine perforata eft, \& animal ipfum per fo ramina illa uelut per nares refpirat. Poftquam autem mortuo elephãte $u f \sigma_{\text {, }}$ ad radicem partis ipfius diffecans, meatus, quía foraminibư furfum feruntur, reperi non aliter quàm in nobis exitum habe re duplicem: unum quidem quí ad ipfum cerebrum perueniebat, alterum autem in os perforatum, impêfius adhuc naturæ artem fưm admiratus. V bi autem etiam didici,ipfum animal, cum flutium, aut lacum profundum trañcit, ut totum ipfus corpus demergatur, per fublatam in altum hanc pros bofcidem refpirare, naturæ protidentiam intellexi, non in eo duntaxat quod partes omnes ipfius animalis pulchrè conftruxerit, fed quiod ipfum étiam eis uti docuerit , Galenus ab initio libri feptini decimi de ufu partium. Probofcis ei ad terram demiffa, $\mathcal{L}$ anterius carnofa eft hac cibum potumí $3^{0}$ affumit in os, quod ei fub ceruice eft ficut fturioni. Eadem aliquoties numum è terra tollẽtem uidi: 8 aliquando detrahentem ramum arboris, quem triri uigintiquatior fune trahentes ad humum lies ctere non potueramus:eum folus elephas tribus ticibus notum detrahebar, Vartomannuis. Prou mufcis eius longa eft decem cubitos, qua pro manu utitur ín bello, cibo, $\&$ alijis operibus, Albertus: Hanc alibi calceum uocat, \& plura de ea fcribic libro 2. tracfatu 1. cap. 1. de animalibus. Aquam,in quit, ea haurit, $8 \times$ afpergit uénatores aut circumftantes, $\& \mathrm{c}$. T Duplici turm corde, tum fenfu animi, elcphantus effe diciur, \& $\mathrm{C}$ altero quidem ira incendi,altero mitigari \& leniri Maurorum fermonibus peruagatum eft, A clianus. Galenus libro feptimo A natomicarum adminift. fcribit fe ex elephand diffecti corde magnum os exemiffe, \& quòd duos tantum uentriculos cor eius habeat, contra Arifto telem qui magnis animalibus tres attribuit. TElephanto etiam iecur fine felle:incifa tamẽ partę qữa 4 fel adhærere folet, humor felleus effluit plus minus, Ariftoteles, Fel nö ad iecur, fed ad pecius firum

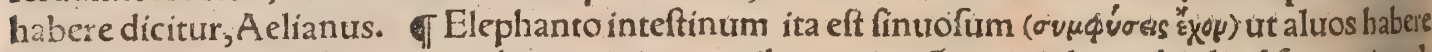
quatuor uideatur:in hoc etiam cibus recipitur : nullum enim cóceptacultim cibi aliud feparatim ada eft. Exta quocs eidem fuillis proxima, fed maiora. Iecur enim quadruplo maius bubulo eft: $\&$ reli qua pariratione, excepto liene:hic enim minor ex proportione eft, Ariftoteles. Plinius non iecur fed pulmonem cius quadruplo maiorem bubulo facit. Ventres elephanto quaturor, cætera fuibers fimb lia, Plinius. TMammas duras habet paulò citra pectus, Ariftoreles. Sub armis ei papilla exiftunt, $A e_{t}$ lianus. Elephas tantum mammas fub armis duas habet:nec in pectore, fed citra in alis occtiltas: Nul la in foeminibus (aliâs femoribus) digitos habentium, Plinius. Elephanto mammá funt fub armis

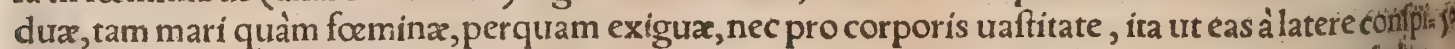
cere propemodum nequeas, Ariftoreles. Et de partib.anim, 4.10. Elephas, inquit, duas tantum habet, easćs fub armis: caufa cur duas habeat, quod uniprolis eft: cur non inter femora, quod mûltifidú eft: nullum enim inter femora habet, cui pedes difcreti in digitos funt. Cur fupra fub armis, quodin ifs qux plures obtinent mammas $\&$ primæ funt, \& plurimum lacis hauriunt qux ea parte côtinentur. Elephantus genitale equo fimile habet, fed paruum: nec pro corporis magnitudine. Teftesidem non for is confpictros, fed intus circa renes conditos habet; quocirca initum celerius agit, Ariftoteles, Teftes intus habet propter pondus fui corporis, ut fit uelocioris coitus:tamen tempore coitus emit tit eos, Albertus. Teftes ei intus ad altum necturntur, Ariftot. Et alibi, Teftes intus habet ob fua cus tis duritiem, cum ex ea fcrotum non poffet fieri. Teftes elephanto occulti,Plinius. Ctefias Cridius plané mentitur ea quax de femine elephanti fcribit : ait enim uf́p̧ adeò dirrari ficcefcens, ut electroid́ 6 eft fuccino fimile efficiatur, quod nunquam fit, A riftot. de generat animal.2.2. Fomina etiam ele phantorũ genitale, ut cæteræ, inter fernora habet, Ariftot. $\mathbb{T}$ Malleolos pofterioribus imis cruribus 
reft. Sed tantum dare periculofum eft: fex aut feptem dediffe modios, in ufu frequenti fatis eft:fed fä rinæ non plus quàm quinq:uini etiã quinģ mares, quę menfura heminas continct fex; $A_{\text {riffoteles, }}$

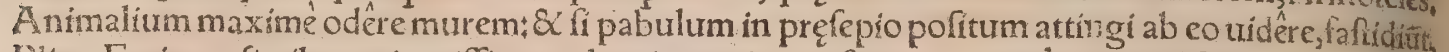
Plin. Farinam fimilem minutiffimo pulueri permixtan feparat optime, ita quod farinam in paftum colligens nihil admittit de puluere, Obfcurus, Elephanti poftquam cicures euraferunt, panibus ma* ximis, hordco, caricis, uuis, capis, allińs, iunco, palma, hederaceis folins uefcuntur, $A$ elian. A pud In dos tractus eft, cuinomẽ eft Phalacrus, quafi Latine caluus: eóg ita appellatur, quòd quui herbam in co nafcentem guftauerit, \& pilos \& cornua amittit. Itaç clephanti, nifi cogantur, non acceduntad locum illum, imò uerò prope cum accefferint, perinde atọ homines prudêtifími, ab omnilliurs löci germine refugientes, pedem referũt, A elian. - I Iam quidam amphoras (metrctas, Aeliants) menfura Macedonica quatuordecim eodem haufit potu, $\&$ rurfus à merídie eírdem dici of?o, $A$ it ftoteles. Claræ \& nitidæa aux potio elephanto inimicifima eft, nec prius bibic quâm conturbarit turbida enim \& fordida, ei fuauifima eft:proinde cum ad fumen aut lacum accefferit, contum per dibus perturbat, A elian. Huius rei caufam Simocatus adfert, quòd in aqua pura fuam ipfe umbram extimécat;ideoós folere Indos cum tran̈cienda elt aqua,obfcuram \& illunem obferuare rocié. Sine potione ocfo dies fert, Aelian. Elephantus quidem gregarius affuefactus, aquæutitur potione: $\mathrm{El}$ verò qui ad bellum certat, non modò ex uitibus confecti, fed etiam ex oryza facítīi uini urfus inúul, getur, Aclian. Et alibi, Potionem, inquit, qua ipfi pro uino utuntur, ideò ipfis largiuntur, ut ad pras, lium audaciores efficiantur. Elephantes $\&$ fimix uini potu inebriantur, ut A thenæus citat ex $\tilde{R} \mathrm{H}^{\prime}$ fotelis de ebrietate libro. Recens captos $z$ ythi potione cicurari, capite quinto dicam. TOnnia bene olentia amant, unguentorum 8 florum odore permulcentur, Aelian. Et rurfus, Flores eis dan: tur, atc; in prata ad legendos flores, quia fuauitatem odorum amplexentur, aguntur:ipfo enim odo= ratt fores internofcentes colligunt, atç etiam hos lectos in calathum inferunt, quem eorum rector fuftinet. Foftquam hunc floribus compleuerint, tanquam uindemia facta , lauatione fimiliter atque homines lauti delectantur: V t uero ea ufi reuerterint, eò ubi quafillum floribus plenũ reliquerint, expetunt. Quod fi reçor afferre tardauerit; barritum edunt, neø̧ prius cibum fumũtt, quàm eis quilis piam quos collegerint flores attulerit, eos allatos de quafillo tollêtes fui præfepis labra ornant, Hane nimirum cibofuauitatem ex hís bene olentibus comparantes, ftabulum ubi diuerfantur, floribus permultis fternunt, Hæc A elian. Sagaciffime odorantur(quod forfitan propter nafi longitudinem eis contingit, ut auritis acurius audire) \& uenatorum infidias hoc beneficio fugiunt, herba quam fen 3 ? ferint humanis calcatam ueftigị́s euulfa, \& per manus deinceps tradita, ut capite quarto ex codem authore dicemus, of Velocitate non quifquam tanta eft, quem non uel fuo tardo gradu affequan, tur, Gillius, Agminatim oberrant, Solin. TNare propter magnitudinem corporis non poffunt, Plin. Digiti pedum eis indiuifi leuterọ́ difcreti, ex quo fit ut ad natandum minimé fint habiles, Aelian. Incedit etiam per aquã, \& eatenus mergitur, quatenus eius promufcis fuperat: reflatenim per eam, \& fpiritum accipit \& reddit, fed natare fatis pondere furi corporis non poteft, Ariftoteles, In naureis autê immittuntur, ponte utrin $̧ \bar{\beta}$ ramis frondefcentibus adumbrato, ad fallêda huiufcemodh animalia: hoc enim ipfum cum uident, fe per terram, quia eis hæc mare uidendi facultatem adimatt; etiam nunc iter facere arbitrâtur, Â elian. I Somnum erecio corpore capiunt: quia operofumeis effet decumbere, fimul \& deinde à cubitu exurgere graue, A elian. TDormituri non recumbunt, defeffi uerò arboribus magnis fe applicant, quibus fuccifis cum cadũt furgere nequeũt, Obfcurtus,

gi Nec adulteria nouére, nec ulla propter foeminas inter fe præalia, cæeteris animalibus pernicialiat non quia defit illis amoris uis (nam $\&$ homines ab eis amatos conftat, ut cap.4.indicabimus,)Plinius \& Solin. Ab omni immoderata libidine caftiffimi funt. Nunquam enim, neqg ut conftupratores, the que ut itẽ ualde laf́ciui focietatē ueneris cum foemina faciunt, fed tanquã generis fucceffione carth tes, liberis procreandis dant operam:fic hi, fua ftirps ut ne deficiat, complexu uenereo iunguntur: Neç id fanè plufquam femel in uita, \&eo duntaxat tempore, cum fe iniri foeminæ patiưtur, A elian, Mas quam impleuerit coitu, eam rurfus non tangit, Ariftor. Vt quif̧́ uxorem impleuit, nô eamam plius attingit, Aelian. Idem alibi, Cum libidinis furore ardent, incurfu parietes euertunt, \& fimili= ter atक̧ aries frontis tri atç impreffione palmas profternunt. Ad coitum, inquit Ariftoteles, efferari folent:quamobrem apud Indos îs haudquaquam permitti initum aiũt:libidinis ením rabie agitati, cafas profternunt male conditas, plura ós alia incommoda faciunt + mitígari pabuli copia narrantur: plagis etiam temperant, adductis alins quibus ferire pracipiant, A riftot. Elephantum quamtis rato

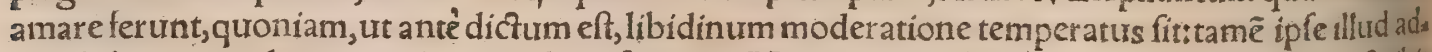
mirabile, amore plenum audiui, quod confequitur: Vir uenandi elephantos haud imperitus, fribit $f_{e}$, cum ab Imperatore Romano cum poteftate in Mauritaniam ad uenandos elephantos alliegatus effet, ex elephantino genere, adolefcentem formofam uidiffe, coeuntem cum elephãto $\&$ adolelcens te 8 pulchro:alterum uerofeniorem, quia huiuis fiue amator fiue maritus effer, ut fe fpretum, igrios minia loco hoc tuliffe:quare acriter animo incitatum impetum feciffe, ut nihil proprius facium fices rit, quàm nos, inquit, omnes perderet, fiḉ̧ incurriffe in illum formofum riualem futum, pugnanị̧ edidire tanquam eum qui de amica fibi er epta doloribus acerrimis premitur: adeoćg infeftis animis utrun ç cum altero pugnam commififfe, ut ex impetu cornibus ambo mutilarentur. Neurrum ideo 


\section{DeElephantô. C. Lib. I.}

non iviciffe, quòd multa uerberatione cos uenatores diftraxerint. Poftea autem quàm amifís armis in pofterum inutiles ad conferendam quafi manum inter fe facti effent, riualitatem amantium conquieuiffe. Domantur rabidi fame $\&$ uerberibus, elephantis alhis admotis, qui tumultuantem care nis (quarendũ an recté hic legatur, catenis, malim plagis, ex Ariftotele, id eft uerberibus, quam ur. cem Plinius etiam proximéante pofuit) coerceant: $\&$ aliâs circa coitus maximé efrerãtur $\vdots$ \& Rabula Indorum dentibus fernüt, Quapropter arcẽt cos coitu, foeminarumós pecuaria feparant, qua haud álio modo quàm armệntorũ habent, Plin. Pudore nunquã nifi in abdito coểunt, Plin. A perte porrờ acpalàm in aliorum oculis non coéunt, fed fecedentes; aut fefe in arbores denfas, \& frequentes oc cultant, aut in concauum locum, \& profundum, ad occultandos cos facultatem habente, $\mathrm{fe}_{\mathrm{abdunt}}$ Aclian. Solitudines petunt coituri?fed pracipuefecus flumina, \& qua pafciconfueuerunt, Ariftot Coéunt locis occultis \& paluftribus, $V$ artoman. Elephas foemina in coitu fedet (fe fubmittit) $\&$ e. quitat fuper eam mas:quam ob caufam foemina dércendit in fouream aliquam, ut mas cômodius fir = perueniat. Pracipué uerò in aqua iniri defiderat, unde cum foeminæ turm mari maximè commoditas accedit : nam is 81 coiturus per aquam facilius tollitur, $\&$ poft coitum facilius defcendit, Albertus

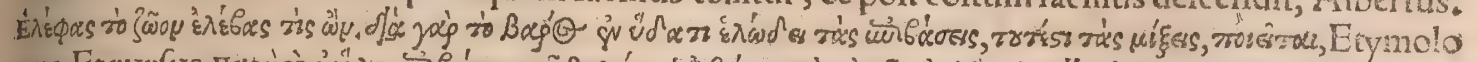

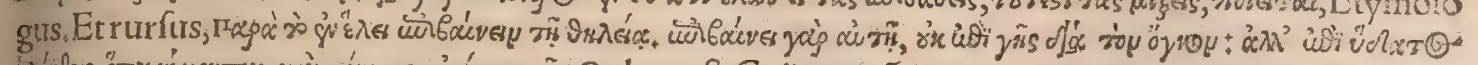

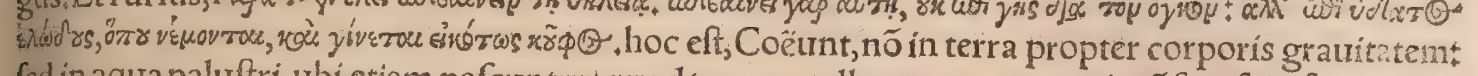
fed in aqua paluftri, ubi etiam pafcuntur + quod (aqua attollente corpus maris cõfcenfuri foeminam) leuiores nimirum fiant. Cótigit aliquando(uerbis utor Alberti ex Auicenna)marem coirccum fer - mina in regione qua dicitur Virgea de Caureryuryz: qưod quidem mirum uidebatur, cum aliàs ex= tra terram natalem fuam, hoc eft Indlam, coire non foleant. Tum temperis uero extralndiam in res gionem Corafcenorum, \& fínitimam educti coibant: Mas focmina falíns culmo (probofidem puto intelligit, cum in fingulari numero proferat: nam alibi dentes eius fiure coinua barbari culmos appels fant) caudam eius remouit, Hac Albert. Proli operam daturi Orientem uerfus perguntad proxí mum Paradío locum, ubi inuentã mandragoram formina prior guftat, deince perfuarurs ab ea mas, fic mifcentur $\&$ foemina concipit, ut nurgatur Author obfcurus libri de natura rerum. Elephantus tam mas quàm foemina incipit coire anno atatis uigefimo, Ariftot, Et alibi, Elephantus foemina incia pircoire anno, aut duodecimo, cum celerrimé aut quintodecimo, cum lêtifime. Mas quinç aut fex. annos natus fuperurenit ineunte uere. Mas coir quínquennis, foemina decẽnis; Plin. Venerẽ ante rannos decem foemina, ante quiln $\varphi_{3}$ mares nefciunt, Solin. Mas coitum triennio interpofito repctit: Quam grauidam reddidit, eandem praterea tangere nunquani patitur, Ariftot. Maritempus cois tus eft cum domidetentus furerit, \& farierit + tunc etiam pingue quiddam emittit per fpiramentum quod ei fecundum tempora eft: Fominę uerò cum hic idem meatus apertus fuerit, Strabo, Bx'uyetait

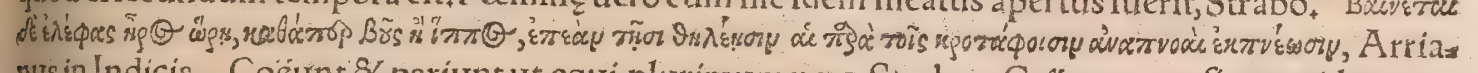
nus in Indicis. Coéunt \& pariunt ut equi, plurimum uere, Strabo. Coêunt, non ficut quidam pur tant promifcue, fed uelut equi, \& reliquar quadrupedes, Diodorus Siculus interpretePogio. Grac exemplar defyderabam. Subfidis foemina, clunibusç̧ fubmiffis infiftit pedibus, ac innititur: Mas fur pertueniens côprimit, atç ita munere urenereo fungitur, Ariftot. Elephanti, cameli, tigrides, lynces, thinocerotes, auerfi coéunt, Solinus ex Plinio: qui auerfa eis genitalia effe adł́cit. Fomina initur biennio quinis, ut ferunt, cuiufç anni dicbus, nec amplius: fexto perfunduntur amne, non ante re duces ad agmen, Plin. Biennio ccêunt, qưinis, nec amplius, in anno, diebus, nố prius a ḋ gregarium numerum reuerfuri, quàm uiuis aquis abluantur, Solin. "Ferendi uteri tempus alíj annum 8 fex menfes, alï triennium ftatuunt; caufa quamobrem incertum hoc fit, quod non pateat coitus, A riftot. Etalibi, V terumbiennio gerit:parit fingulos*uiuiparum nanç eft. Vterum gerunt menfes, ut mia nimum, fedecimtut plurimum, octodecim, Strabo, Diodorus Siculus, \& Arrianus in Indicis, Decem annis geftare in utero urulgus exiftimat A Ariftoteles biennio, nec amplius quàm femel gignere, plu=

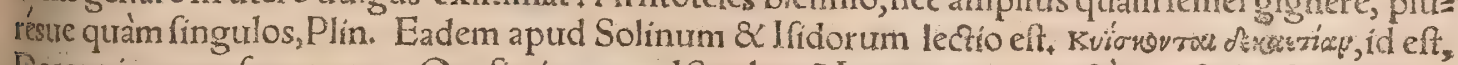
Decennio grauefcunt utero, Oneficritus apud Strabonê,; Interpres non recté tranftulit, Concipiun decimo anno. Hinc natum prouerbium, Elephanti celerius pariunt, de quo infra. Audiui fepe hoc utigo dicier, folere elephantum grauida perpetuos decem effe annos, Plautus in Sticho. Biennium gerere uterum audio:alif féquiannum tantum grauidas effe aiunt, Aelian, Paritenitens pofterio ribus cruribus; \& fubfidens ctrm dolore, Ariftot, Partus in caput procedit ad lucem, Aelian. Ani malia quo maiore corpore, eò minus foecunda funt; fingulos gignunt elephanti, cameli, equi, Plin Vnicum ueluti eque pariunt, quem nutriunt matres annis fex, Diodorus Siculus interprete Pogio: Ad annum uff̧ octaurum lactant, Arrianus in Indicis. A pud Strabonem legitur, fenis mêfibus foe. tum à matre nutriri. Partus magnitudo ef infar integræ ætatis $\$$ iuftæ magnitudinis porci, Aelia hus:uel, ut Ariftoteles, magnitudine uituli:Idem alibi clarius, bimeftris aut trimeftris itituli magni. tudine effe foribit. Elephanti, ut diximus, pariunt fingulos, magnitudine uituli trimeftris, Pliniust anniculi, Aelian. Statim ut natus eft,cernit $\&$ ambulat, A riftor. Orefugit, non promufcide, Idem \& Aelian. Elephantus in quadrupedum genere ex minimo maximus euraditu tex aquatlibus, cro codilustex uolucribus, magna fruthio, A elian. Cum funt in catulorum (uitulorum potius $\$$ nam adulti etiam boures Luca dicuntur)metu, infeftifimi funt, Idem, Et alibi, Nec uerò fi quis foetum à 
partur recentem contigerit, matres indignantur, Plane enim nof cunt non animo quidem lędendi cort treçari,fed ad ludicram delectationem, \& blanditias fufcipi, effeç̧ hominis naturam ea excelfitase animi, fuo ut partui adhuc tantillo incómodare nollet,Aclia. Foemina parturiês ingreditur aquam uf́, ad ubera, \& illic parit metu draconis:qui extra aquam parienti foetum deuorarer . Mas etiam à pariente non recedit, propter ferpentem, qui inimicus eft eius ficut draco, Author obfcurus libri de nat.rerum, Elephantorum foeminæ proximè uias, quò carniuroras beftias minimè accedere fciunt, foetus comprimis ędunt, \&c. Interpres libri Plutarchi Vtra animalium prudentiora, \&c. fed falfus eft cum hac é $\lambda$ al $\phi \omega \mu$ (ut in noftro etiam codice Graco Bafilex excufolegitur) id eft ceruorum, non ele, phantum tiatura fit. In Mauritania quemadmodum quotannis ceruis, fic decimo quoģ anno cors

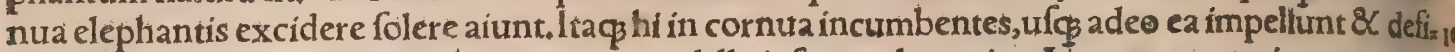
gunt in terram expofitam in planiciem, quoad lla 2 pfa occultauerint. Nam præ cæteris camporum patentium æquiora \& paluftria amant, A elianus, Et alibi, Locum (inquit) in quem abftruferunt \& repofuerunt cornitum thefaurum pedibus exaquant 8 complanant. Terra autem quod fit feracifi. ma, poft paulum herbam proferens, abditorum cornuum afpectum uiatoribus adumbrat. Eorum perueftigatores, qui fane ad illorum infidias $\&$ aftus prudentes funt, in eum locum in quem cornua defoffa furpicantur, utribus a quam deportant, \& uero aliumaliò ex utribus difpertiunt \& difponût, atcs il i commorantur: Alius quidam dormiens, alius potans, alius cantiunculam canens fuos amo res meditatur. Quod fi cornua fint alicubi prope defoff 2 , quadam mirabili illecebra ex utribus fic an quan eliciunt, ut uafa exíccent $\mathcal{Q}$ exinaniant, li autem qui cornua exquirunt, ftatim fine canibus far gacifime pradatm odorati, locum illum perfodiunt, \& optat:um confequuntur ; fi uero utres per. manferint pleni, eos inde transferentes, alió fe conferunt, Hae A elianus.

ब Focmina elephas mare multò robuftior, alacrior ; 8 magis magnanima eft quàm mas. Et foemi næe quadam in hớc genere planè uiriles funt, Vartomannus. Nó modo foeminę maribus ferociores, fed ad onerum ureciones etiam fortiores exiftimantur; Gillius. Mas tamen praelĭs aptior eft, utpore altior, Obfcurus. Euertít adificia elephantus, dentes admouens magnosipalmas uerò fua fróte im pellit, donec declinet, tum pedibus inculcans profternit in terram, A riftoteles. A elianus hacc eũ pra cipue facere fcribit, cũ̃ libidinis furore ardet. Palmas excelfiores fronte profternũt, ac ita iacentium âfumunt fructum, Plin. In bello etiam roboris $\&$ fortitudinis facinora defignat egregia, \& 2 aliâs ad imperium. Probofcide quantum poffit, fupra retuli. Vnus fanc animalium omnium, ut maximus, fic robuftiffimus effe uidetur. Vidi (inquit Vartomannus ) nauem palangis impofitam (fi rectèueto) tribus elephantis in genua demiffis, frontibus annixis, è marim littus protrudi. Oppianus fylueftes

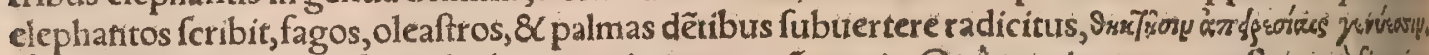
jévures dentes ưocat per fynecdochen, continens pro cótento. Quó magis oneratus eft, tantó firmius incedit: in dorfo geftat turrim ligneam, quę homines triginta \& uiçum quantum fatis eft contineat, cum armis inftrumentisćs bellicis, Author obfcurus ‘ Tã ualidi funt, ut in cruce (lego turre) lignea fuper fe ferant homines duodecim \& ampliuss, ita quod aliqui magni quadraginta homines poffepor tare dicuntur, Albertus. Indorum regem hoftibus bellum inferentem, bellatorum triginta milla ele phantorum antecedunt:tum uero maximorum $\&$ fortiffimorum tria milia fubfequuntur, ad hotis

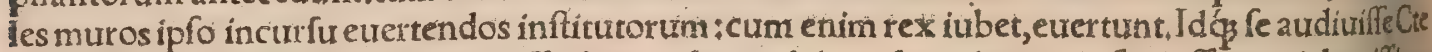
fias fcribit:idemó̧ Babylone fe uidiffe dicit, palmas ab his ad moderatoris fui iuffum uiolentifimo impetu extirpatas, Aelianus. De ui $\&$ robore ipforum ad belli ufum, plura adferam capite quinto. qf Elephantem alị annos ducentos uiuere aiunt, alị trecentos, Ariftoteles \& A Aelianus. Vt longifi mum, annos circiter ducentos uiuit: $\left(e d\right.$ multi ante hoc tempus morbo pereunt ${ }_{3}$ Arrianus in Indicis, Viuere elephantos mares alí annos ducentos, alï centum $\&$ uiginti aiunt ; foeminas etiam feré tolis

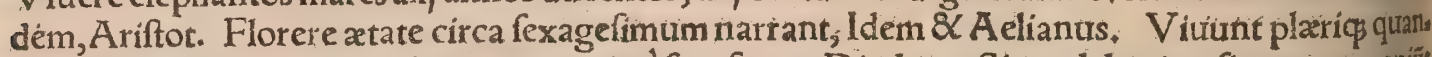
tum longaui homines:quidam (qui maximé fenefcunt, Diodorus Sic.) ad ducentefimum perureniilt annum. Ariftoteles uiuere ducentis annis, 8 quofdam trecentis exiftimat : Iuxuenta corum à fexas gefimo incipit,Plin. Viuunt in annos trecentos, Solin. Oneficritus dicit cos ad trecentefimumi an num uiuere, raros ad quingentefimumtcirciter ducentefimum robuftiflimos effe, Strabo. Iuba rex Elephantum fcribit patri fuo fuiffe, qui multa fecula uixiffer, nempe qui emanaffet, \& per maitus s traditus fuiffet, uf $c_{3}$ ab huius alta ftirpe. Et Ptolemæo Philadelpho Aethiopem elephanturin fuiffe, qui uel multas ætates uixiffet, uel ex hominum confuetudine, uel inftitutione manfuetiffimum: ate idem ipfe ait, fe uidiffe el ephantum Seleuci, cognomine Nicanoris, quí ufक̧ ad Āntiochorum polie mam expugnationem uixiffet, A elianus. De elephantorũ atate, qutod longiffimx uitæx fưnt, ab aln s pluribus fcriptum eft:ueruntamen qui habitant apud urbem Taxilam, omnium India urbium maxl mam, elephantum inueniffe perhibent, quem uittis ac myrteis coronis indigenæe ornabant, afferen. tes unum ex his effe, qui pro rege Poro aduerfus Alexandrum pugnauerat: quem propterea quod in pugna promptiffime uerfatus effet, A lexander Soli dedicauir. Effe autem illi torques aureos circa dentes, feu potius cornua libeat appellare, 8 in torquibus literas Græcas infculptas, hæc uerba refes rentes:Alexander louis filius Aiacẽ Soli. Hoc enim Aiacis nomen ipfe elephâto impofuit, magntin magno nomine exornans. Coníciunt autem indigen $x$ annos quinquaginta fupra trecentos, abiea quara diximus pugna ad ea tempora interceffifle, cum tamen fcir e nó pollint quot fuerít natus an 
ficut homines, uim medicinæa agnofcût, Ảelian. Elephantos cæteris malis immunthès aiunt, inflation ne autem alui acrius infeftari, ${ }_{3}$ Ariftot. Frigoris impatientes funt : maximum hoc inalum, inflatio nemç \& proflutuium alui, nec alia morborum genera fentiunt, Plin. Morbis inflatione contractis $\downarrow_{2}$ borant:quo fit, ne poffint excrementũ trel uefica tiel alui reddert, Äriftot. Niphus hunc in eis affe, ćtum çolicum effé conícit. Fluore infuper tentantur:qưo cum uires languerint,curantur potione aqua calidx, \& cibo forni melle ímbuti:utrunģ enim id fiftit proflutrium alui, Ariftoteles.

D.

Elephanti yregatim femper ingrediuntur. Ducit agmen maximus natu, cogit atate proximus, Plin. Et alibi, Gregatim femper ambulant, minime ex omnibus foliuagi. Oberrant agminatim $\mathrm{S}_{\mathrm{g}}$. linus. Nunquam uerò elephantus ab reliquorum agmine fecernitur, nifi aut filiorum fuorum, aut xgrotantíum caufa:pro his nimirum nihil nó moliens inexpugnabilis manet, Aclían. बPradam ipli in fe expetendam friunt folam effe in armis furis, qux Iuba cornur, alij melius dentes appellant; Quamobrem deciduos cafu aliquo, uel fenecta, defodiunt, Plínius: tanquam inuidia quadam aduer fus hominem ducti id faciant. Quód áutem abiecta cornua defodiant, pracedenti etiam capite ex A cliano dixi,nec non qua arte defoffa inueniantur. Noctu fuam fertiendicondítionem deplorare

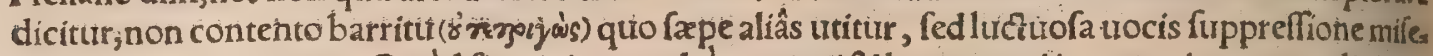
rabiliter immurmurans. Quód fi quis ita occulté gementi $\&$ lamentanti intertienit, uerecundia quas dam motus, querelis fuis moderatur, 8 gemirus facere defifit, Gillius ex Philoftrato, $\mid$ Gaudent phaleris argenteis, बMulieris forma hoc animal capitur, at $\not$ h hebefcens ad eius pulchritudinem, remirtit furorem animi fui, A elian, Traditur unus amaffe quandäm in A egypto corollas uenden, 1 tem:Ac ne quis uulgariter electam puttet, mirètur gratam Ariftophani (Byzantino in urbe Alexan dria,A elian, ) celeberrimo in arte grammatica, Plin. Sunt ferartim ämores etiam, idç̧ plurimaruin: feri alí \& rabidi, quemadmodum $\&$ hominưm:álị nec ambitione barbara, nec inurenufto cógrefiv: qualis Alexandrix grammatici Ariftophanis tiùalis elephas fuít. Coronatiam eandẽ utterç deperí bant, cum clephas quidem grammatico haud fégnius amorem ftudiumós declararet:poma forữ tran

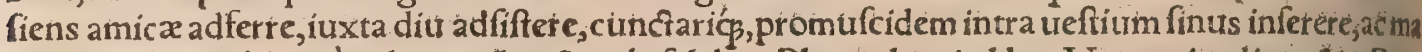

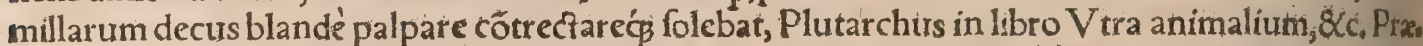
ter hanc aliam quicos mulierem corollas fimiliter uendentem in Antiochia Syriz urbe cicurem de phantum amaffe aiunt: de quto A eliani hec uerba funt, Hunc audio dum ad paftiones iret, mulierem corollas uendentẻ cum quâm fuauiffime adfpexiffe, tum uérò etiam quàm libentiffime in illius conk "? fpectu acquieuiffe, atque huius faciem promufcide terfiffe, fuauiterós contrectando illi blanditum fuiffe:Muliercm uiciffim ex fuo artificlo illecebras amatorias, cotollas uidelicet ad tempirs ita conte xuiffe, ut cotidie illi quidem fumere cpera pretium, huic uero etiam opus largirl effet. Poffea autem quàm mulier exceffit e uita, eléphantus nec priftína confuretudinis cópos, nec quam amaret amplius mulierem uidens, tanquam amatis qưui amafiám amiferit, fic eam defiderabat, anímọ́́ incitabatur, ac qui antèmarifuetus fuiftet, humanirate expulfa, feritatem induebat; tanquamós homines ex thi

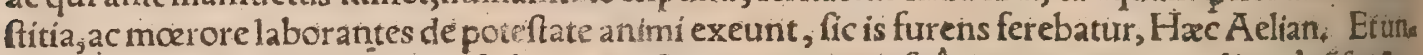
guentariam quandam dileçam Iuba tia dit:Omníttm ámoris fuêre argumenta gaudium à cớfpectur,

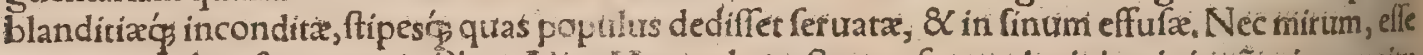
amorem, quibus fitmemoria, Plin. Alius L henandrum Syracufanum incipientis iưuêtre in exercitu to Ptolemai, defiderium eitrs quoties nô urideretinedia têtatus, Plin. Nunc quàm memoria fintbona quam ç̧ diligenter praceptũ̃ officin a duérus pracipientes teneant, quàm fimul eorum qui quippiam eis committunt, uel expecłationem uei fidem non fallant, explicandum eft. Cum Antigonus Megas renfem urbem obfideret, mulier fimul cum uno de elephantis bellatoribus uerfabatur : hac enim it lius qui elephantũ aleret uxor, infantë puerum pepererat, quem huic elephanto, lingira urens Indi ca, quam elephanti intelligúnt, credidit. Vruero is primum fibi credítus eft, illum diligebat, \& cufion diebat, ex eóśp proxime adiacente magnam uoluptatem capiebat:cum ploraret, oculos tum aurertis bat, tum urero ab eo dormiente mufcas abigebat: Artundines ei pro pabulo obr̈ciebantur, quas, \& nem cibutm, nifi puer adeffet, reípciebat. Nutrix igitur neceffe habebat poftea quàm eum laciecomi pleuiffet, elephanto curatori apponere, uel omnino elephantus non parum iracundia incitabattfi; io ac nonnunquam in uerbera erumpebat. Interdum eviam cum uagiret infans, cunas ubi iaceret mo. uebat:fić́s eidem ipfi ex hoc motu oblectamenta $\&$ folatia, ficut nucrix, afferre futudebat, Aelianus, Eandem hiftoriam, quoniam perelegans eft, \& patrló aliter refertur ab A thenæo lib. 13 . ut ex tem. pore inde tranffuli recitabo. Phylarchus (inquit)libro uticefimo mirificũ elephanti in puellum amo rem his trerbis defcribit. Mas erat elephas, \& cum eo foemina, quam Niczam uocabant: cuímoriens Indí uxor infantem fuum dies natum trigintá appofitum commirerat. Mortua igitur muliere, mira a bilem quendam bellua infantis amorem concepit. Nam feiungi à fe infantem non fuftinebat, \& nifi confpiceret indignabatur. $Q$ uamobren quoties eum lactaffet nutrix, mox inter pedes bellux collo. cabat in cunis:quod nifi facetet, elephas cibum recufabat. Tota autem deinceps die, dormiente puté ro, calamos urel aliud quippiam de pabulo teriens mufcas ei dejellebat. Quód fi ploraret, cunias pto bofcide mouebat; $\&$ fopiebat ipfum. Idem \& mas elephantus fapenumero factitabat. fI Lafi di: cuntur offenfam meminiffe, longóǵp tempore polt iniuria uindictam reddere, Quiad boures accen 
modo. Vulgare erat per auras arma iacere non auferentibus uentis, atcs inter fe gladiatorios cor. grelfus ædere, aut lafciuiente pernicitate colludere . Poftea \& $\alpha$ per funes inceffêre. lecicis etiam fe, rentes quaterni fingulos, puerperas imitantes : plenisç̧ hominum triclinís accubitu, iêre per lectos, ita libratis ueftigijs, ne quis potantium attingeretur, Plin. Ad numerum faltare, inquit Aelianus, tibia auditione denulceri, curfum tardare ad foni tarditatem, fećp remittere ad remiffionem tibia: rurfurs cum acute fonans impellit, feftinare, difcendo affequi perfecte elephantus folitus eft. Neces ure ro natura modò illum fumma ex omnibus animalibus magnitudine ornauit, fed $\&$ difciplina mans fuetum, \& tractabilem edidit. Elephanto ad morum manfuetudinem \& facilitatem erudito, nibil mi rius, nibil ad id quod uolumus obremperantius eft. Cum Tiberï Cæfaris nepos Germanicus gladia, torum fpectaculum edidit, plures iam grandes utriufģ fexus elephanti Romæe crant, è quibus alĭ ple riç generati extiterunt, quorum artus interea dum committebantur, \& confirmabantur, $\& / \mathrm{mem}_{s}$ bra infirma conglutinabantur, peritus uir ad pertraçandos eorum fenfus, animosćs, nunc eos difés plina manfuetioni, nunc terroris 8 mirifica uerberationis plena excipiens, erudiebat, Primum enim cos maxima lenitudine $\&$ mollitudine, cibos nimirum illecebris $\&$ uarietate fuauium inuitamento, rum refertos indulgens, ad difciplinam informabat, ut fi quid effet agrefte, expelleret, ex feritatead manfuetudinem, \& quafi ad humanitatem quandam tranfformaret: fiḉ̧ eis moderabatur, ut feritaa te expulfa, difciplínis \& mufica ftudio operam darent, tympanorum fono nihil exterrerentur, pes dum ingredientium ftrepitum, cantumć mifcellaneum ferrent : cos præterea exercebat ad non fors midandam hominum multitudinem. Illa uero uirilis difciplina, non ad grauem plagarum ictum ex: candefcere, coactos membrum aliquod ad faltandum flectere, non rabiofe (cum effent maximoiobo re præditi) incitari. Cum magifter elephantorum fpectaculum edidit, ij tempore furo fpecimen dede runt, fe recte inftitutos effe, illum क́s in feipfis erudiendis non operam perdidiffe oftenderunt: nã duo decim numero theatrum ingreffi, compofito gradu incedebant, ac toto corpore diffluebant, tanto or natu, nimirum ftolis faltatorins induti, folaćs magiftri fignificatione uocis ordinatim inftructi, utfen runt, gradiebantur. Ac uero rurfus, fi illis hoc imperaretur, in orbem faltabant, eundemóp orbemad imperantis uocem repetebant, atģ̧, nunc flores pauimentum ornabant fpargentes, nunc modefépe dibus terram pulfantes mufica moderatam faltationem una confenfione obibant, Hactenus Aelian. Certum eft unum tardioris ingenĭ in accipiendis qua tradebantur, fapius caftigatum uerberibus eadem illa meditantem noctu repertum, Plin. Elephantum cxteri quidem hoc potifimum miran tur, quod difcendo $\&$ doctoribus fe prabendo, in hominum coetibus eas in geftu figuras $\&$ uarietia tes effingat, quarum elegãtiam ac copiam uix ipfa hominum induftria exprimere aut memoria com, plecti facile poffit:ego uero hif́ce magis ex affectibus motibusć̨ , quos fuapte fponte citraćp doctirnam tenet, uelut fimplicibus $\&$ impermixtis ac fynceris, aftimandam beftix intelligentiam putârim. Nam Romæcertum eft cum haud ita pridem ad geftus quoldam miros indipifcẽdos, \& motus etro lutu difficillimos ingeminandos antea quidem inftituti fuiffent, unum tardioris ingenï, quia agrius hrec affequebatur, ubilibet peffime audientem, \& urerberibus fxpe caftigatum, deprehenfum nodu eadem illa ex fefe ad lunam meditâtem molientemós, Hæc Plutarchus in libro Vtra anímalium \& Vidi ego elephantum cymbalo ludẽtem, aliosćs faltantes. Cymbala autem fingula utrị̧ cruriantes rioriappenfa erant, $\&$ aliud appellatæ probof cidi. Ille alternis utrunç in cruribus cymbalum probo. fcide feriebat numerof $e_{\ddagger}^{\prime}$ alĭ circumcirca faltantes tripudiabant $\$ \&$ alternis anteriora crura toilentes fleĉenteś́ numerofe ingrediebantur, ita fcilicet ut cymbalorum fono admonebantur, Arrianusin Indicis. Elephantum mimus Aethiops iubet fubfidere in genua, 8 ambulare per funem, Anneus Seneca in epiftolis. Mirum maxime $\&$ aduerfis quidem funibus fubire, fed regredi magis utiç pio nis, Plin. Illa uero uel ad ridicule infaniendum fpectatorem inducere poffint, in theatri harena hu, miles lectos fpectare, uario ftragulo textili $\&$ magnificis operibus picfo ornatos:lauta item potula \& argenteas crateras, aureasḉs, permulta aqua repletas, menfasí̧ magnificas, tanto pane $\&$ carnibus extructas, ut uel edaciffimorum animalium uentrem implere poturiffent : omnibus ita recte apparat tis, conuiur intromiffi funt elephanti, mares fex, uirili uefte induti, totidemọ̧́ foeminæ, ftolà mulic。 briornata, decorè epulis accubuere, ac in menfam promufcides tanquam manus porrexerunt, furm

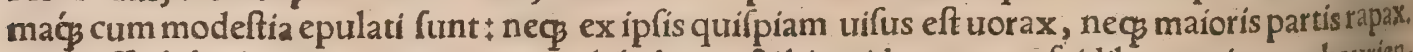
Cum effer bibẽ dum, unicuíç cratera exhibebatur, $\mathcal{Q}$ hi quidem promufcidibus potionem haurien. tes, moderate bibebant:deinde circunftantes leuiter $\&$ feftiue, fine contumelia a fpergebant, $A$ elian. Elephãtus omnium ferarum mitifimus $\&$ placídiffimus eft:quippe qui permulta officia $\&$ erudiat, Q intelligat:quando etiam regem adorare condifcit, Ariftot, Nam quod ad docilitatem attinet, tha gem adorant, genua fubmittunt, coronas porrigunt, Plinius. De fupplice elephante Martialis tetia ftichon, Quod pius \& fupplex elephas te Cærar adorat, Hic modo qui tauro tam metuendis erat: Non facit hoc iuffus, nulloóg docente magiftro, Crede mihi, numen fentit $\&$ ille tuum, Elephantus Indorum regem ad forum euntem, primus adorat. Huic præeft recfor, quillum huits infituti commonefacit, ipfiós memoriam difciplinæ inftrumenti quo illum moderatur pulfu, atç in ce Indorum propria renourat, cuius natura quadam admirabili recondita elephanti intelligẽtes fun, Aelianus. Viginti quatuor elephanti Indorum regi permanent cultodes alternis uigilijs, alĭ alijsin fationem fuccedentes tanquam cateri cuftodes homines. Sapientia item quadam Indica ad uigilia 
(aliâs Ànulo) nitefcente Luna noura greges corum defcendere, ibiç̧̧ fe purificantes folenniter acưon circumfpergi, atç ita falutato fydere in fyluas reuerti, uitulorum fatigatos præ fe ferentes, $\mathrm{Plin}, \mathrm{Hi}$

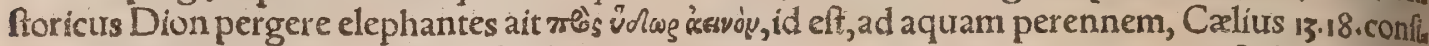
derandum relínquens an Plinius ásiviy ex authore aliquo ceu proprium nomen tranftulerit, qua tro ce deprauata Anulum librarï fcripferint. $\mathrm{Ab}$ interlunio recrefcente luna, elephåntos intelligo quadam natura recondita notione, ex fylua primum, ubi pafcuntur, ramos decerpere, coş́́ deinde fublimes ferre, tum uero iplos ad lunam fưficere, ac leuiter ramos mouere, tanquã fupplicationem quandam lunæ prætendentes, eis ipfa ut propitia exiftere uelit, Aelian. Vifi funt feffi æoritudine, quando $\&$ illas moles infeftant morbi, herbas fupini in coelum iacientes, ueluti tellure precibus allis gata, (aliàs allegata, ) Plinius : A elianus (ut mox fubn̆ciam) hoc eos moribundos facere fcribit. Luba fupplices dijs immortalibus effe tradit: quippe qui fuopte ingenio \& mariluftrentur, \& furgentem Solem adorent proni, promufcide uelut manu in coelum fublata:unde chariffimum dijs animal effe conftat(ex Ptolemai Philopatoris facto, qui elephantos quatuor immolauit, ut cap.8. dicam)Plitar, chus in libro Vtra animalitm, $8 c$. Exorientem folem elephanti urenerantur, promufcidem, tan. quam manũ aduerfus folis radios alleuantes, Itaç hos ei charos effe \& egregie diligi Philopator $\mathrm{Pto}$ lemæus teftis eft nobis locuples. Is fanè poft partam uictoriam eius belli quod cum Ântiocho geffif fet,cum quàm gratiffimus aduerfus folem, quem deum exiftimabat, effe uellet, próq́ uiçoria eigna tias perfolueret, tum alia magnifica facrificia fecit, tum uero quatuor elephantos, bene magnitudine grandes, exiftimãs fe fic deum religiofe colere, primum immolauit: deinde cum in fomnins minis dei perculfus fuiftet, ob inuifam numini talem hoftiam, religionis metu permotus, pro immolatis, ex are quatuor elephantes in honorem Solis excitauit: hoc ut fupplici facto hunc fibi placatum efficere, A elianus, \& Plutarchus loco proxime citato. Elephanti cadauera fui generis fepeliunt, Tzetzes, Eadem de religione ipforum tum in alijs fepeliendis, tum fub fuam cuiufç mortem, Aelianiuerba hac funt: Vt Aethiopum(inquit) rermonibus peruagatum eft, elephantus, cum alterum perfpexe rit morturum, non praterit, quin humum promurcide hauftam, uelut fanctam $\&$ myfticam inijicia, communem naturam miferatus mortuo parentans, ut ne aliquid impie committat:nam hoc quidem ipfum non agere, execrabile ducit. Quare ad hoc nefarium fcelus uitandum, fatis eft ei uel ramum in jucere, quo facto, abit, communem omnium finem non afpernatus. Tum etiam ad nos is fermo per manauit, elephantos cum ex uulnere, fiue id in bello, fitre in uenatione acceperint, uicini funtadmio riendum, aut obuiam herbam, aut for tuito obieçum puluerem alleuãtes, in coelum fufpicere, eumb̧̧ puluerem, herbámuciacere, \& fimul uoce fua propria lamentari, \& miferabiliter fupplicare, tanquí? deum ob ea qua iniufte, $\&$ indigne fuftinent, obteftantes, Aelian. Patres fuos ætategrandes nua triunt, Tzetzes. Aetate affectis iuniores delegitimo cibo cedunt(quod etiam Tzetzes teftatur)eofs demó fumma \& obferuantia colunt, \& à periculis feruant. In forfam delapfos, iniectis fruticú fafcia bus fubtrahunt, quibus tanquam fcalis fenectute graues afcendentes, liberantur, A elian. Etrur fus, Iuniores, uel labores, uel pericula fufcipiunt, \& antecedentibus ætate, de cibo \& potione conte dunt, propter obferuantiam per quam cultu quodã, $\&$ honore natu maiores dignandos exiftimant, Nunquam enim negs ex fenectute infirmum, necs eum qui morbo teneatur, fui gregales deferunt, fed $\&$ tidiflimi ei permanent, eiusç̧ cum cateris in rebus ftudent incolumitati, tum uero etiamfliph infectatione urgeantur, pro co propugnant, \& faucios, \& feffos curant: ac integri, à uulneribus hat 4 ftas, \& iacula è corpore fauciorum, tanquam chirurgi periti extrahunt, ut ne homines quidem fcients tius, Hac A elian. Natugrandiores $\&$ minores, infirmos etiam, \& feffos ac faucios quantopere clls rent, fequenti capite dicam in uenatione ipforum. Cxterum quanto erga foetum furum ducantur amore, fuperius explicaui. Ābftracti à fuis elephanti fedibus patrïs, quamuis uinculis primum \& fame, deinde uarijs cibariorum blandimentis manfuefacti fint, tanta tamen naturalis foll illecebra tenentur, ut patrix memoria eis obfcurari \& cuanefcere nequeat.Quare cum horum plerigg grauifh mo mor ore fufcepto conficiuntur:tum uero quidam ex his, uberrime flentes(ut Tzetzes etiamfcri bit)tantam lachrymarum uim profundinnt, ut oculorum fenfibus capiantur, Aelian. Antipater dis uinationem quandam iuftitix elephantis ineffe tradit. Nam cum Bochus rex triginta elephantis, to, tidem in quos freuire inftiturerat, ftipitibus alligatos obieciffet, procurfantibus inter cos quilaceffs, rent, nó potuiffe effici, ut crudelitatis alienæ minifterio fungerentur, Plin. Elephãtus quantoperea uerfetur \& oderit adulteria, hiftorijs aliquor ab Aeliano relatis probabimus: Elephas quidã (inquiti) cum uxorem fui domitoris $\&$ altoris ftuprari manifeftò deprehen diffet, ambos, \& eum qui fuprum inferebat, $\&$ eam qua cum id faciebat cornibus transfigens, interfecit, ac in ftragulis conftupratis, $\&$ lecto adulterato iacentes reliquit. Vtuerò prímum elephanti rector ueniffet, \& manifeftó nefarium facinus, $\&$ huius uindicem cognourit. Hoc quidem factum, ab India huc ad nos manauit. At Roma aliud fimile euenifle audio:praterquam quòd addunt, ibi elephantum non utrung modo occidif́, fed \& ftragula uefte eos texiffe, \& 2 nutritio aduenienti ftragulam reieciffe, \& retexiffe, \& proxime inter fe iacentes demonftraffe, I ta ille tum facile iniuriam illatam fibi fuiffe intellexit, tum etiamma xime facinus ei liquebat, ubi cornu quo ipfos confixiffet, cruentum perfpexit. Et rurfus, Cum quis dam cicuris elephanti moderator, coniugem non illam quidem amabilem, fed fanè diuitem haberet, amoris oculos primum ad aliam adiecit:deinde eam uxorem ducere ftudens, alteram priorem fram 
tympanorum fupplicio afficiebant, uidetur indicare ligna quibus imponerētur trel alligarentur fon tes. Pollux libro octauo carnificis inftrumenta numerat, gladium, laqueum, tympanum, $\&$ uene,

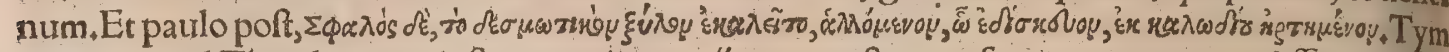
panum apud Theodoriturm inftrumenti tortorí genus eft, quo fontes torquentur differunturé,

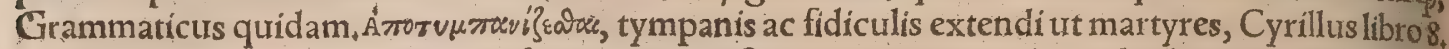
Fidicula numero plurali tantum, fumitur pro inftrumento torquendi, ex duobus, ut putatur, oblis quatis lignis compacto, ab extorquenda ueritate ac fíde: Vel à nerueis funibus, uinculisć́s, quibtrs ad illum modum homines torquendi alligantur, V alla libro I. Sed alin potius effe putât tormentum quo fontes à tor tore funibus alligatí, uulgo torquentur, (appenfis feilicet ad pedes lapidum ponderia bus.) Cum igitur tam uaria fit tympani, cum profupplicî́ tormentiue genere accipitur, fignificatio,

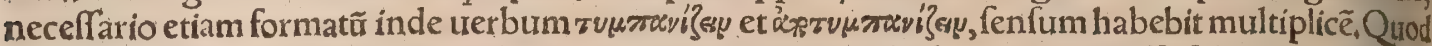
ad Plutarchi uerba, quibus dicit elephantum ita puerum probofcide fua rapriffe fublimê, ut uideree tur illâ '̊x

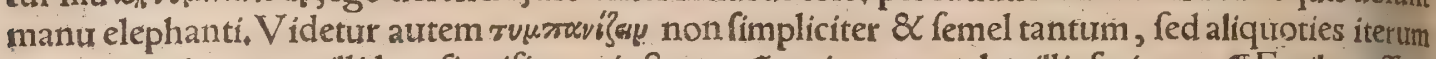
atø̧ iterum in terram illidere fignificare, inftar eorũ qui tympana bacillis feriunt. đFacile poffunt manfuefcere elephanti, Ariftot.Et alibi, Mites \& manfuetudini addiçi funt. Quomodo manfuefiât,

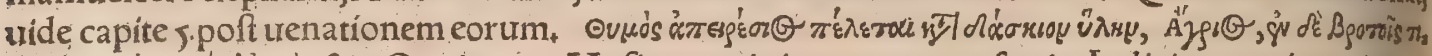

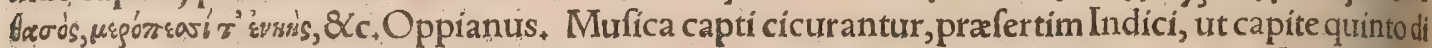
cam. Ex Strabonis doctrina didicimus elephantes cantu mulceri, \& tympanorum fono, Calius,

T Elephanti etiam pugnant inter fe uehementer, \& dentibus alter alterũ ferit : quí autem uxictus fuerít,adeò animum amittit, ut ne uocem quidem uictoris toleret, Ariftot. Elephantum quomo: do expugnaurerit canis Indicus, retuli fupra in hiftoria Canum robuftorum. Magnus Indorumrex quotannis diem unum proponit, tum hominum, tum beftiarum certaminibus: committũtur autem pugnatura inter fe \& alia beftix, \& elephanti. Elephanti ad certamen ut incendantur, promufeide fponte fua fefe uerberant, A elian. Clara eft unius éRomanis dímicatio aduerfus Elephantum, cum Annibal captiuos noftros dimicare inter fe coëgiffet, $\mathrm{Nam}$ ç unum qui furpererat obiecit elephanto: \& ille, dimitti pactus, fi interemiffet, folus in harena congreffus, magno Poenorum dolore confecit. Annibal cum famam eius dimicationis contemptum allaturum beluis intelligeret, equites mifitqul abeuntem interficerent. Probofcidem eorũ facilime amputari Pyrrhi praliorum experimẽtis patuit Romę puggnaffe Feneftella tradit primũ omniũ in Circo Claudí pulchri ædilitate curuli M. Antonio A.Pofthumo Coss, anno urbis fexcentefimo quinquagefimo quinto, It $\tilde{e}$ poft annos 20 . Lucullorllim xdilitate curuli aduerfus tauros. Pompei quoç altero confulatur, dedicatione templi Veneris uicti cis pugnauere in circo 10, aut ut quidam tradunt 17. Getulis ex aduerfo iaculantibus, mirabili unius dimicatione, qui pedibus confoffis repfit genibus in cateruas, arrepta fcuta laciẽs in fublime, quade cidentia uoluptati fpectantibus erant in orbem circumacta, uelut arte non furore belux iacerentur. Magnum \& in altero miraculum fuit uno ictu occifo. Pilum fub oculo adactum, in uitalia capitisue nerat. Vniuerfi eruptionem tentauere non fine uexatione populi, circundati clauftris ferreis, Qua de caufa $C æ$ far dictator, poftea fimile fpectaculum editurus, Euripis harenam circundedit, quos $\mathrm{N}$ ro princeps fuftulit equitíloca addens, Sed Pompeiani amiffa fugæ fpe, mifericordiam uulgi inenars rabili habitu quęrentes fupplicatrere, quadam fefe lamentatione complorantes, tanto populi dolore, ut oblitus imperatoris, ac munificentia honori fuo exquifitæ, flens uniuerfus confurgeret, diraśc Pompeio, quas ille mox luit, ponas imprecaretur. Pugnauere $\&$ Cafari dictatori tertio confulati eius, 20, contra pedites quingentos: iterum totidem turriti cum fexagenis propugnatoribus, eodem quo priores numero peditum, \& pari equitut ex adưerfo dimicante. Poftea finguli, principibus Clats dio 8 Neroni in confummatione gladiatorum, Plinius. Pugnam illorum primus omnium in Cir dedit $\mathrm{Cn}_{+}$Pompeius ludis, quibus à fe factum theatrum dedicauit, ut fcribit Afconius Padianus, $\mathrm{VI}$ de fupra initio capitis fecundi. Declinas ut lucas boues Olim refumpto præferoces pralio Fugil iutuentus Romula, Aufonius. Edita munera in quibus elephantos $\&$ crocutas, \& tigrides, \&rhis nocerotes, \& cr, exhibuit, Iulius Capitolinus in Antonino Pio, Qui modo per totam flammis fimullatus arenam Suftuleratraptas taurus inaftra pilas, Occubuit tandem cornuto ardore perints Dum facilem tolli fic elephanta putat,Martialis. Hac omnia Plinius lib, 8.cap.7. Elephantoitrin pleríg ignẽ fugiunt, ut ex hiftorīs confirmabimus fequẽti capite, ubi de ufu ipfor ũ in bellis dicetur.

IT Si elephantus feritate effertur, ftatim ad arietis confpectum manfucfcit, Gillius, Elephas fu rens ariete uifo quiefcit, ac conflaccefcit ímpetus, Carlius ex Sympofiacis Plutarchi: \& Zoroaftes in Geoponicis, Arietis cormua horrefcit elephas, Aelianus, Et alibi, Romanos (quoniam non cora nua modo arietis, fed etiam fuilli pecoris grunnitum oderunt) Pyrrhi Epirotarum regis elephantos in furgam uertiffe homines dicunt, uictoriamç amplam ex eo bello retuliffe. Elephanti cx animalis bus maximé exhorrent hircum, ceraften, porcum‡ quibus fané machinamentis Romani elephantos Pyrrhi regis primum urertentes, uictoria funt potiti, Volaterranus:qui perperam forte pro ariete cor" nuto, hircum ceraften reddidit. Regem infipientiam fugientem fignificaturi Aegyptĭ, eleplan nut (uretus interpres ineptèceruum red didit) \& arietem pingunt: fugit enim ille cũ arietem uridet, Oras, CumElephanti in uenatione fugantur, fieos fic frequentes coactos leones perficiant, alin alio in fu 
Chiliade octaura. Sanguinem draconis Serapio defcribens, quem hemalocoen uocat, non aliter de. fcribit quàm Diofcorides quartam fideritidis fpeciem, nec alías ei facultates attribuit, \& Galeni de fideritide uerba citat. Quarta fanéfpécies fideritidis apud Diofcoridem (apud quem primam quoè fpeciem fanguinem Titani cognominatam legimus)uulnera fanat $\&$ aftringit, quam multi mille $f_{0}$ lium putant: $\&$ reuera é genere millefolij eft qua ruftici noftri ad boues $\&$ equos uulneratos fanan. dos utuntur. Serapionem fecuti recẽtiores etiam, ut Genuenfis, Pandectarius $\&$ alī, per fanguínem draconis, fideritidis herbæ fuccum intelligunt: non tamen inde paratus in pharmacopolịs reperi, tur, fed alia tria generałunum in rotulas conuolutum, quod ex rubrica, qua boli Armeniz loco ple. riģ̧ hactenus uțebantur, $\&$ terra fit:Alterum, curiufdam arboris lachryma: Tertium, gummi arboris: in quo cortices etiam apparent, in lachryma non item+utrunģ guftu aftringit. V trunç è Libya ad, ferrifcimus, \& ex Aegypto Venetias, Antonius Brafauola. Et rurfus in minij examine, Non por, fum (inquit) aliter fufpicari quàm cinnabarin effe guttam illam uel lachrymam (arboris ex Libya) quam in officinis fanguinem draconis appellant, nec in uili pretio eft. In quo certe color profundus uifitur, ut de cínnabaris fuæ colore Diofcorides feripfit, Is non ita dudum Venetias adferri coepit, $\&$. paucus quidem; utuntur eo pictores ad fingendum fanguinem. Apud hos fimul $\&$ medicos in ma gno ufu eft. Idem fentit Matthrolus quoos in commentarÿs fuis Italicis in Dicfcoridem. Sanguinis draconis(inquit)color ad fanguinem omnium maximè accedit, translucidus \& friabilis eft:pharma copola hodie fanguinem draconis in lachrymis uocant, ad differentiam adulterati qui in paftillos re dactus habetur, Verus enim, ut Aluigus Cadamoftus fcribit, libro quarto fux nauigationis in Afri, cam, lachryma gummofa \& líquida eft, ex arbore deftillans:cuius ut maiorem copiam habeant $A$ fri, ferramentis quibufdam corticem urulner ant, $\&$ collectum liquxorem $\&$ ad ignem decoctum, fanguie nem draconis uocant. Hinc uerifimile fit (inquit Matthæolus) hanc effe Diofcoridis cinnabarin, ut quæ ex Africa, \& perpauca quidem afferatur, unde magno in pretio eft. Vires etiam hæmatitælapis dis habet, \& à recentioribus medicis fatis feliciter ad fanguinis fputum, eius óp fluores, tưm alios, tum dyfentericos tum muliebres ufurpatur propter uim aftringentem. Accedit quod etiam Diofcoridis tempore cinnabarin fanguinem draconis uocabant: fic enim ille fcribit, infinuans non uerédraco: nis hunc effe fanguinem, fed à colore ita appellatum. Sed apparet illi non fatis conftitiffe de hoc pí gmento, undenam fumeretur: $\&$ multo minus Plinio, qui putaffe uidetur cinnabarin uerum draco. nis fanguinem effe: nec fubijt ei dubitare, quo pacto fieri poffet ut fanguis extra trenas ficcus, acter. ræe permixtus, tam uituum fanguinis colorem redderet, quale ipfe cinnabarin reddere fcribit, \& nos $3^{0}$ in noftro fanguine draconis Africano manifefté uidemus, Hæc ferè Matthæolus, De fanguinedra" conis (uerba funt Monachorum qui nuper in Mefuen feripferunt) optinè tractauit A nt. Brafaultis, Habentur autem uenalia hodie duo genera hoc nomine, quorum alterum fictitium eft, ex bolo non Armenia, forbis contufis, \& caprino hircinóue fanguine, alịśćs diuerfis rebus, in placentarunfor. mam redigi folitum, \& furno aut fole deficcari, Hoc ut plurimum in equorum $\&$ fimilium (anima: lium)remedijs utuntur:multi etiam hominum. Alterum uerò fuccus eft $\&$ lachryma quarundam $m a$ gnarum arborum, in infulis Lufitanorum nuper inuentis copiof ${ }^{\prime}$ nafcentium: Cuius generis arbo: res Vlyffippone maximas uidimus. Sunt enim tanquam columna, unicæ cimaturæe (fic illi loquun tur)more palmarum, abf pramis folia funt eis fimillima fpatulæ foetidx, craffiora tamen:cortex at: boris fubcinericeus, \& unà cum tota arbore rubri fucci plenus. Arbor tempeftiuè fcarificata emitit lachrymas fanguineas, quas gummi inftar côdenfatas abradunt è cortice incolę, nec uilius uendunt, Multi etiam lignum eius fruftatim incifum ebullire faciunt, $\alpha$ decoctum igne aut fole condenfant, 8c. Vtrumó enim fanguinem draconis appellant. Sed longè melior eft lachryma feu fuccurs cols lectus ligni decoctione. Caterum an hic fanguís draconis eafdem uires habeat quas Achillea fiden ritis(Serapio, ut ex Brafauola fupra citauimus, non Achilleã aut Achilleam fideritin, fed fimplicter dicta fideritidis fpeciem tertiam fanguinem draconis uocat: Galenus fimiles utriufọ facultates fa cit, fed Achilleæ efficaciores magiśḉ aftringentes)nefcimus. Sed præftare putamus uti furco fideri, tidis uel lactucæ authoritate Auicennx, quàm alia re abfó̧ ullo authorũ teftimonio, Hactenus Mos" nachi in Mefuen. Ego has arbores Libycas $\&$ in nouis repertas infulis palmarum generis effe conily cio. Nam palmis folia gladioli herbæ folins comparantur, unde fpathen Græci nominant. Truncie:s tiam ramorumós natura eadem. Natales ịdem, loci feruidi $\&$ arenofi. Colorem praterea palmarum germina phoniceum fiue puniceum habent, unde arbores ipfę phonices Gracis diczx.Sunt autem illarum tam multa genera, eaḉ longé diuerfa, ut uix ullius arborum puto plura reperiantur:quòmi nus mirum fuerit hanc etiam adnumerari. Poftremo uires conueniunt. Nam fructus palmarum as fringunt, uulnera glutinant: fanguinem excreantibus in cibo commendantur, hamorrhoidas $\&$ dy

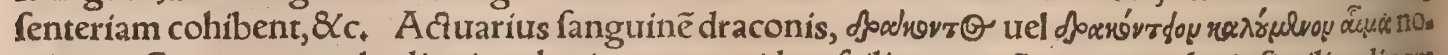
minat. Cæterum quæ hodie cinnabaris uocatur, idem fcilicet nomẽ propter coloris fimilitudinem fortita, alia foffilis, a lia factitia eft, utraç, metallica \& uenenofa, nec ullo modo in corpus admitcéda Illa in fodinis argenti uiui reperitur, ut Matthrolus feribit, rubicunda, non admodum dura, fed frias bilis, magni ponderis, $\&$ argenti uiui tam plena aliquando, ut fponte defluat. Factitia ex argento ui: 6 uo \& fulphure fit, fublimatis ut uulgò loqurntur. At minium uulgare hodie ut plurimũ fit ex plumbo \& ceruffa ufta, unde id ipfum Galeni ac Diofcoridis fandycem elle apparet, Serapionis uero mis 
incidunt, 8 in ipfa fectura fune alligant, ut ob doloris fenfum uinculis concedant, \& ex feritate con quiefcant, Nam collum circumacturis unlnus fune atteritur. Proinde agnofcentes infirmitate fuam

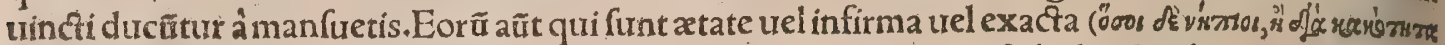

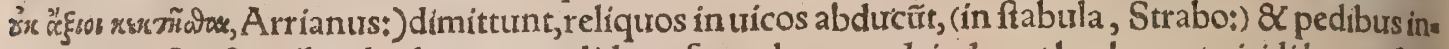
uicem uinctis, \& collo ad columnam ualidam, fame domant, deinde aut her ba, aut uiridi harundine pafcunt, Hi moleftia afflicti, pabula recufant fumere : illi uerò cantibus eos \& tympanis \& cymbalis demitrlcent ac deliniunt, Hæc Arrianus $\&$ Srabo.

TInc alias etiam uenationis el ephantum rationes, ex Ā eliano præcipué, adfcribam: \& primum quomodo ne in foucas incidere coganur aduerfus uenatores tum armis turm ignibus refiftentes pu gnent. Infidix (inquit) quas elephantis uenatores inftruxerint, non eos facile latent. Nam cum ad foueam, quam contra ip os fuffodere uenatores folent, proximi accefferunt, feu naturali quadam in telligentia, feu retrufa \& abdita prafenfione, \& fcientia rerum futurarum, à progrediendo ulterius fe fuffinent:ac quàm mox itinere conuerfo, in uenatores inuadunt, uíç $\&$ impreffione fefe in men dios infidiatores incitant, fimul \& cos euertere conantur, fuga ut falutem contra infidias fuperiores facti adipifcantur. Id igitur temporis cum atrox pugna, tum uero uel hominum, uel elephantorum cæades, \& occifio fit multiplex. Huius pugnæ ratio talis eft: Homines quidem eminus haftas \& iacin Ia intorquentes, ac collimantes, ictu directo cos feriunt. Contrà elephanti, ex hominibus fi quem ces cidiffe animaduerterint, ftatim uiolenter illum $\&$ corripiunt, $\&$ ad terram à fe abiectum, proterunt, $\&$ conculcant; fimul $\&$ cornibus ( fic enim eorum dentes appellantur) tandiu profligant, quoadmis ferabili \& referta accerrimis doloribus morte, hunc proiectum affecerint. Cum autem huiufcemodi a animalia inuadunt, tanquam uela ex animi incitatione quàm contentifime aures, quas habent pattr las, intendunt, \& pandunt more magnarum ftruthionum, qux trel dum fugiunt, uel dum inuadunt explicatis alis feruntur. Itemǵs promufcidibus, fub cornua redactis, \& contractis, quemadmodim roftra naurium pleniffimis uelis propulfa, fic elephãti uehementi impreffione irruentes, multos mor, tales funditus euertunt. Tumć $\beta$ perinde ut tuba belli clafficum fonans, clamores uaftiffimos edunt, Humi porrò proftratorum, $\&$ genibus con tritorum, et offium obtritorum, tantus eft frepitus, utuel illinc longiffimé exaudiatur:nec non fape elifis oculis, naribus diftractis, fronte difrupta, facieiç for ma amifla non uel ầ proximis cognatione fibi nofcuntur. Iam ex ịs nonnulli ad hunc modıminopi natò feruantur. Quamuís enim fané uenatorem beluxa curfus celeritate comprehenderit: pra tamen tehementi impetu, hunc tranfcurrens, genibus in terram præcipitibus actis, cornua aut in radicem, $;$ aut in quippiam aliud tale compingit+ ex quo retinetur, ac uix dum fe retraxir, cum urenator elapilus iam falutem fuga eft confecutus. In hac igitur pugna, elephanti frepe uincunt, frepe item uarís terro ribus iniectis uincuntur, Tubarum enim clangor uaftum clamorem efficit, ipfiçąhomines armis con crepantes, clypeos uidelicet hafís contundentes, \& ululatum tollentes, ftrcpitur undics omnia cire cumfonare faciunt: tum uero partim in terra ignem incendentes, partim in fublime tollentes, actan quam funda eum contorquentes, partím ignitos torres iaculantes, atog etiã longas faces in ferarum oculos magna ui inferentes, $\mathbb{Q}$ intrudentes, eis hæc omnia agre intuentibus, timorem afferunt. Vna de adeo impelluntur, exterrẽturǵ 3 , ut interdum in foueam, quam ante declinabant, detrudantur, \& compingantur, Hæc Aelianus. Er rurfus, quomodoà uenatoribus in fugam acti, incenfis tandem fyl uis ab ea cohibeantur, defcribens, Qui uenandi (inquit) elephantos fcientiam tenent, nobis tefans tur, hos infectatione uenatorum preffos, cum robore inmenfo, tum impetu effrenato atç pracipiti, 8 quem fuftinere poffit nemo, fic quidem per maximas arbores, tanquam per fegetes excurrese, casćs tanquam fpicarum calamos, ubi curfum ramorü proceritate retardari uident, perfringeretul uero ipfi ex arboribus emínent, \& proceriores exiftunt, turm omni neruor um contentione currere, tum uiam infequentibus præcidere:nec mir $\tilde{\pi}$, locorum enim confuetudinem tenent, Cum autemfe exinfectatorum fuorũ confpectu eripuerint, cosḉ maximis proceffibus itineris lógè \& retro politos fenferint, tum ex fuga recipiunt animü fimul, \& tanquã periculo liberati, infiftũt: ibiós tum metusfo licitudine expulfa, ex immenfo labore requiefcũt: his interea ad cibi cogitationẽ memoria excitatu; iuncos $\&$ hederas per arbores erraticis ímplicationibus ferpẽtes depafcứtur, atç palmarũ teneraca

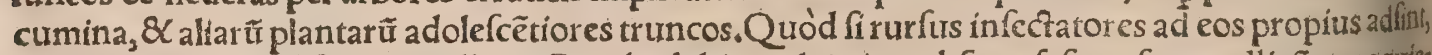
hi etiã iter um fefe in fugã impellunt:Cumḉ ab his muliã uiam abfunt, fée ex fuga colligêtes, reqự tem curarũ ex itineris labore habent. Infequentes autem præcipitante fole debilitati,fylưã incendứt, $8 x$ uiã ipfis obftruunt:quod ipfum fentientes elephãti,fe fuftinent à progrediendo. Ignem non mints quàm leones extimefcunt, Hæc omnia Aelianus. Gabinius Romanus fcriptor de elephantis tradi fabulofa quadam, dicit enim cateras feras ignem fugere, elephantes ei refiftere ac repugnare, proper rea quod fyluam confumat: cos cum hominibus certare, \& fpeculatores pramittere, \& cum illos uide rint fugere:cumó bo. Troglodytx contermini Aethiopix, quil hoc folo uenatu aluntur, arbores propinquas irine: ri eorü conf cendunt. Inde totius agminis nouiffimum fpeculati, extremas in clunes defiliunt, Latra apprehenditur cauda, pedes ftipantur in finiftro femine. Ita pendens alterum poplitem dextra cias dir:ac pracucuta bipenni hoc crure tardato profugiens, alterius poplitis neruos ferit, cuncta pracele ri pernicitate peragens, Plinius, Elephantũ usenatio ad putcũ dicta,ab Elephantophagis habitatur 


\section{DeElephanto.E. Lib.I.}

qui dum has feras uenantur, gregem earum per fyluam ex arboribus cernentes, eum miniméa do riuntur, fed eos quí à grege aberrârint ad pofteriora furtím accedentes, neruos incidunt, Strabo. Gillius copiofius profequitur his uerbis $¥$ Aethiopes ex proceriffimis arboribus elephantorũ introi tus atç exítus obferuant, non in multos uno eodemós tempore inuadunt, fed in fingulos tantũ ma 'gno robore animi infiliunt: nimirum fpeculator caudam belux appropinquantis ad arborem, in quan abditus is latet, defiliens, manibus comprehendit, pedes'̧́ ad dextrum femur obícíens, fecuri, guæ ex humero pendet, expedita $\&$ acuta, dextri poplitis neruos fuccidit:in quo certamine utriufice falus periclitatur. Interdum elephantus incifis neruis in fauciam partem procumbens, Aethiopem fectm in terram abricit, atq̧ interficit $\$$ Interdum fuo pondere hominem ad arborem aut faxum alli - dens, occidit:ac nimirum nonnulli elephanti dolore preffi, quando infidias facienti nocere nó que unt, fefe tandiu in fugam impellunt, dum crebro fecuris icfu decumbunt : tum ad rerram fratorum pofteriores partes incolæu uicini comedunt. Alin (ex Troglodytis Aethiopiæ conterminis) tutiore genere, fed magis fallaci, intentos ingentes arcus defigunt humilongius. Hos pracipui uiribus iurue nes continent, alý connixi pari conatu tendunt, ac pratereuntibus fagittarum uenabula infigunt, mox fanguinis ueftigịs fequuntur, Plin. Nönulli(ex Elephantophagis)fagittis cos interficiunt fer. pentium felle tinctis. Sagittatio per homines tres perficitur, quorum duo arcum tenent, \& ultra pro giediuntur, tertíus ueró neruum trahit. Nonnulli arbores obferuant, ad quas elephanti reclinari $\&^{\prime}$. quiefcere folent. Harum ex altera parte truncum fuccidunt. Ita $q$ beftia fe inclinans, pariter cum ar= bore ruit: 8 cum furgere nequeat, eò quod crura continuo $8 \alpha$ fine flexu offe conftent, illi ex arbori- bus defilientes eam obtruncant,Strabo. Iam apud Ariftotelem uenatio elephantorum huiufmodi legitur: Confcendunt(inquit)mites aliquos animofosép elephantos, qui uenantur, curfú ós infequin tur feros:quos cum occuparint, feríre præcipiunt fuis, dum fatigent, uiresćs diffoluạnt. Tum rector

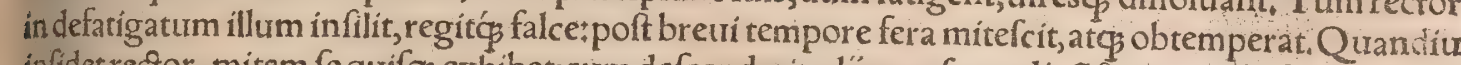
infidet recior, mitem fe quifọ exhibet:cum defcenderit, alî̉ manfuetudinê feruant, alĭ fuã repetunt feritatem:itaçs immitefcentiứ crura priora prẹpediunt uínculis, ut quiefcant:capiuntur 8 nattr íam grandes, \& pulli, Ariftoteles, Capiuntur in India, unum ex domitis agente rectore: qui deprehen fum folitarium abactumue à grege, ucrberat ferût: quo fatigato tranícendir in eum, nec fecus ac pric=rem regit, Plin. Vetulus elephas efferatior eft, $\&$ non facile capitur, Sed minores quogs natu cape: re operofum eft, quoniam à maioribus, qui eos tuentur, nó facile relinquuntur. In Caf pio lacur oxy 30 rynchi pifces capiuntur:horum exempta uifcera excoquunt. Vinde ad permultos ufus accommoda tun fit glutinum: nam non modo ad quxcunq̧ applicatum fuerit, adhærefcit: fed \& firmifimè retí net, ut $\&$ decem diebus madefactum nunquam poftea diffoluatur: $\&<0$ ad elephantos comprehen dendos trenatores utantur, \& pulchra facinora adant, Gillius ex A eliano.

THactenus de hominum aduerfus capiendos elephantos technis dixerim:nunc fubbijciam quid ipfi contra has elephanti faciant, 8 quibus modis euadere conentur. Quomodo uenatorum infie dias herba euulfa per manus tradita fibi inuícem prodant, capite quarto explicauimus, Circum. uenti à uenantibus primos conftituunt quibus (dentes illi exerri) funt minimi, ne tanti pralium pu. tetur. Poftea felfi impactos arbori frangunt, pradaç̧ fe redimunt, Plin. Cum uenatu premuntur, pariter cófringunt utrof $\xi_{3}$, ut ebore damnato non requirantur. Hanc enim fibi caufam periculi pre folentiunt, Solin. Elephanti caufam cur petantur prænofcentes, ex fefe qui dente inutili funt, ante ca teros in prima acie conftiturunt, ad primum hoftum impetum fine rhagna iactura excipiendum:re: liqui qui in fubfidijs manent, dentium robore integri, auxilium feflis ferunt, Aelian. Equitatu cir; cumuenti, infirmos aut feffos in mediũ agmen recipiunt: ac uelut imperio ac ratione, per uices fubeunt, Plin. Conflictu fortuito fi quando pugnatur, non mediocrem habent curam faciorum : nam feffos uulneratos ́q in medium receptant, Solin. Amor eis mutuus intercedit:\& cum fugiunt uena tores, robuffi ac florentes atate extrema tenent, in medium ueró uretulos $\&$ matres cum pullis recipiunt, Tzetzes. In uenationibus fibi mutuò ferunt auxilium, ita ut fi quis eorum labore deficiat; alter pro illo fefe opponat, Philoftratus, Cumà uenatoribus elephanti, tanquam milites in bello, funduntur \& fugantur, non alị ab alips feparatim, fed omnes fimul \& communiter in fugam fe dant, ac fimul interfe prementes ad gregales fuos adhęrefcunt. Horum autem qui iam funt firmata $\&$ in tegra æate, reliquos fic circuncludunt, tanquam pugnacifimi propugnatores totũ agmen circum= muniunt:quiuero longius funt ætate prouecti, atç matres fub fe quxós fuos pullos ita occultantes, perraro hi partuli ut uideantur, fubtermedium obtinent locum, Aelian, Cum elephantifolam tranfilire non queunt, de his unus aliquis in hanc fefe demittit, 8 tranfurerfus folfa fans, partinua cuitatem occupat, partim pontis fe uicarium praetat. Cateri fupra hunc gradientes tranimitunt, \& euadınt, fimul \& eum, qui pontis loco erat, hoc modo ex foffa cofferuant. Superiore enim ex loco guifpiam porrigit pedem, quem is qui infra eft promufcide circumplicat, reliqui aute urirgultorum fafces deijciunt, ad quos ille, cum fortifime, tum cautiffime pedibus adnitens, celeriafcenfu fubtra hitur, A elian. Cum foffas tranfeunt profundas, \& difficiles fuperatu, ducerb\&ros : qui inter cæeteros o robuftior $\&$ maior fuerit, ftans medius, tanquam pons, tranfmittit omnes $\$$ alij autem ingerentes de. inde farmenta multa folfa, feruant eum per quem traiecti funt, Tzetzes. Societatis $\&$ comercij uim non abfo intellectus fenfu elephantos oftendere, Iuba author eft:folfa ducta, eaćs fruticibus paruig 
\& humoleui obteça, uenatores his ftrunt infidias. Huc igitur quoties decidit aliquis, cæteri qui= cunç comitantur congeftam undiq̧̧ fyluam faxáq̧ inịciunt, dum cauo foffę expleto egreffus capti: wo detur, Plutarchus in libro V tra animalium, \& c. Poftea quàm in foueam inciderunt, \& fe iam teneri fentiunt, animaduertentes exitus locum nullum eis relictum effe, cum eos priftini animi, tum libertatis capir obliuio:tum uero facile cibos ex largientibus fumunt; tum fi quis prabeat, libenter bt bunt, atक̧ uinum fi in promufcides effundas, fine recufatione admittunt, Āelianus, Quomodo tra nent fluuios cum urgent uenatores, pradictum eft capite quarto.

TElephantos natura manfuetos effe $\&$ facile cicurari codẽ fupra capite docui:nunc quomodo $\&$ quibus artibus cicurentur expediendum. Manfuefcunt igitur uel neceffitate, ut uinculis \& fame, uel blandimentis tum Muficis tum alijs, ut ex Aeliano deinceps docebimus. Quid elephantis (in: quit A elianus) poftquam captifunt faciant, ut manfuefcant, dicendum eft. Primo in fyluam non ita longo interuallo $\mathrm{ab}$ ea foffa, ubi comprehenfi fuerint, diftantem, fic eos ftriçé conftrictos funibus tra hunt, ut ne permittant quidem, néue hi pracurrant, néue rurfurs retrahãtur: deinde certo $\&$ dimenfo fpatio horum queng ad maximam arborem illigantes, ut neui in anteriorem partem infilire, neu rur fus admodum in potteriorem refilire queant, neue ipfis ex funis laxitate facultas fit ad inferendum iniuriam, uiçus tenuitate $\&$ fame, horum robur frangunt. Poftea uerò quàm eorum domitores dua ritiam animi tandiu paulatim molliuerunt, quoad priftinæ inexpugnabilis feritatis eos ceperit oblik uio, de manu cibum fumendum dant. Hi neceffitate preffi, cum non malitiofe iam, tum uerchilario ribus oculis, \& manfuetioribus, quàm effent foliti, inturentur. Horum autem, qui funt atate robuft, uinculis ruptis, cum dentium robore, tum uerò promufcide arbores reuellunt, \& frangunt: uixón fero admodum, partim fame, partim ciborum illecebris, partim uerberiburs manfucfunt, Hęc Aelia, nus. Et rurfus, Indi homines, licet permulti \& magna machinati, non elephantos iam atate proce dente confirmatos facile comprehendere queunt.Quare ad loca fluminibus proxima (rofcida enim \& paluftria pafcua frequentãt) urenatores profecti, corum catulos tantum capiunt. Hos cum adhuc xtate infirmos $\&$ teneros ceperunt, ciborum blanditịs $\&$ affentationibus ad parendum informant, ac inftituunt, blandỉoquentiá́ manfuefaciunt: Hominum enim indigenarum línguram elephanij intelligunt. Breuiter perindeillos quafi infantes puieros alunt, partim cibaria eis largientes, partin difciplinas tradentes:qux res efficit, ipfi ut ad obediendi facilitatem transferantur, \& exuta feritate, humanitatem induant, Aelian. Et alibi,Si Indicus elephantus robore atatis confirmatus capiatur, ex feritate agre traducitur ad manfuetudinem; \& quod defiderio libertatis teneatur, ideo cædes far cit:ac fi uinculis deuinciatur $\&$ conftringatur, magís incitatur animo, neq ullam feruitutem perpa " titur. At enim Indi uarijs $\&$ multiplicibus cibariorum illecebris eum delinire ftudent: ille tamẽ nithil

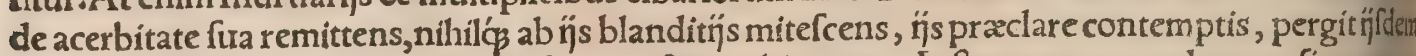
infeftus effe.Quid igitur ï comminifcuntur $\$ \mathrm{~K}$ machinantur?' Inftrumento quodam mufico uerna culam cantiunculam ei canunt, is animum attendit, auremós ad audiendum erigit ${ }_{5} \& \alpha$ fuauiratellilus demulcetur:animi incitatio comprimitur. Tum paulatim in obiecfum cibum répicit, $\&$ tamerifom nibus uinculis exoluitur, tamen cantu deuinctus, non amplius ad priftinos mores àmanfutetuditie deficit, Hæc omnia Äelianus, Ex Strabonis doctrina didicimus elephantes cantu mulceri, \& rym panorum fono, Calius. Capti celerrimè mitificantur hordei fucco, Plinitus \& Solinus. Zythus po tionis genus eft quod ex hordeo fit, quo madefactum ebur in omne opus tractabile redditur, Diolco

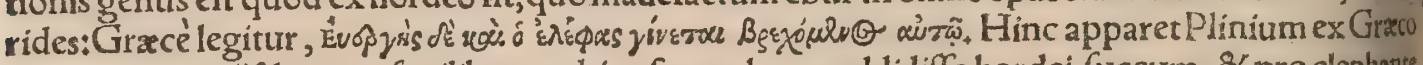
aliquo authore îfdem aut fimilibus uerbis ufo, zythum reddidiffe hordei fuccum, \& pro clephante homonyma uoce non ebur, ut debuerat, fed ipfum animal.H"

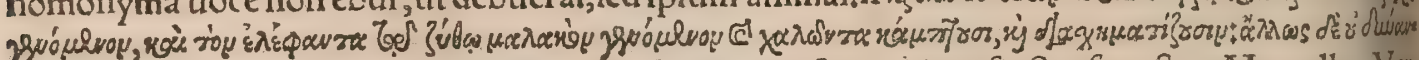
2800 plutarchus in commentariolo, An ad infelicitatem fatis uitium fit. Senfus eft, utMarcellus Vers gilius transfert, Cinere $\&$ aceto madens os licio(fiue acia malis dicere) fecatur, \& ebur $z$ ytho molli,

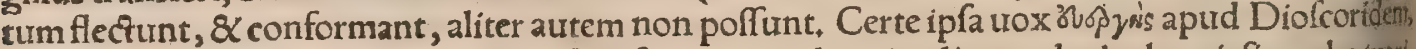
operi facilem $\&$ tractabilem materiam fignificans, neq, de animali, neç; de elephantiafi morbo(utris diculè dubitat Marcellus) uerba cius accipi poffe cóuincit. Accedit ratio, ebur fcilicet macerarimals liriós zytho, quoniam is acorem $\&$ uim aceto fimilem, qux folidiffima quxes penetret, in fe cótineati, $/ 6$ facile enim acefcit aqua in qua hordeum aut aliqux fruges aliquandiur macerantur. A cetum etiam ex zytho \& fimilibus, ut cereuifía, potionibus fieri conftat. Aceti fertidi tris tanta eff ut faxapenes iret, cum cinere offa emollit, Plutarcho tefte: non mirum igitur fi zythus etiam acorem in fe contia nens, \& facile acefcens, eadem facultate eboris foliditatem remittat, Zythum Symeon Sethi фrxixu appellat. Elephantina olla, inquit, in zytho aliquandiu macerata, ceræ inftar emolliuncur : addit \& reliqua qux Diofcorides de zytho. Democritum intreniffe aiunt quemadmodum ebur molliretri', Seneca lib.14.epiftola 91. Quód fi quis Plinio patrocinari uoluerit, dixerit forte fieri poffe ut pariter utrum ${ }^{3}$ uerum fit, \& ebur zy tho molliatur, \& eiufdem potu mitigetur elephas animal:nam cum ul no delectetur uel ad ebrietatem, utfupra diximus, zythum quoqis libenter ab eo admitti uerifimile efle, prafertim cum hordeogaudeat ex quo conficitur. Elephanto qui ad bellum certat, non modo ex uitibus confecti, fed etiam ex ory za factitn̈ uiniufus indulgetur, A elianus.

In quibufdam regionibus pretiũ elephanti eft, ducati (denarï fiue drachma ponderenummi 


\section{DeElephanto. E. Lib.I. 433}

aurei)quinquaginta, in alpis mille, \& alibi ad fummum bis mille interdum, Vartomannurs. Infueti infidendi in eis, non aliter quáth ị̆ quí in mari naugant in naufeolã incidunt, neç̧ infiftere poffunt. Nonirem in adolefcentium elephantorum feffione fit negotium, imó ex illorum molli gradu feffor tantopere oblectatur, ut fi mula treheretur, Gilliưs $\&$ V artoinan. Curm in elephantưm afcènditur; is in terram abrijcit genura, \& confcenfionis gradum fcandenti facit: neqs porro frenum eorum cui quam inífictur, neq̧ funis ad ceruicem ullus adftringitur, fed foluti ad infulam Zanzibaram gra diuntur, Gillius. Seffore confcenfuro elephas alterü ex pofterioribus crus inflectit, ut per id afcen-

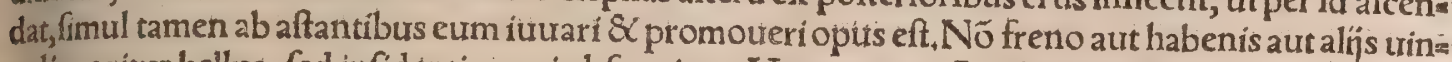
culis regitur bellua, fed infidentis uoci obfequitur, Vartoman. A pollonius iuxta Indum flutuium purero occurrit, qui annos natus tredecim, elephanto infidens, acriter ftimulis belluam urgebat, $\mathrm{Phim}$ loftratus. Elephantiften Ariftoteles uocat elephantorữ moderatorem, elephantarchen Plutarchus; Calius, Sed forfan elephantiftes is tantum ef qui infidet elephanto, etiam pritiatus: clephantarches autem qui imperat in bello(ut inferius dicam)non ipfis belluis ${ }_{j}$ fed milítibus qui elephantis inuehun tur, ut Calius non reciè fynonyma fecerit. Puer infidens elephantum rentéugomi regit apud Philo

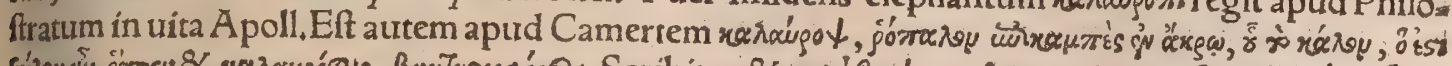

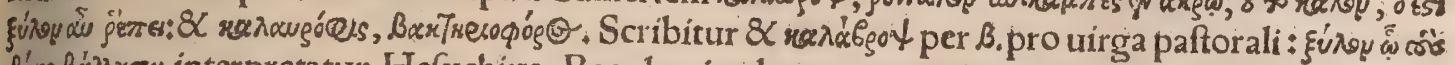

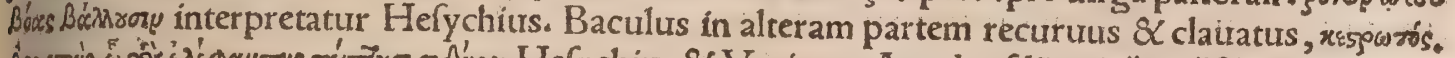

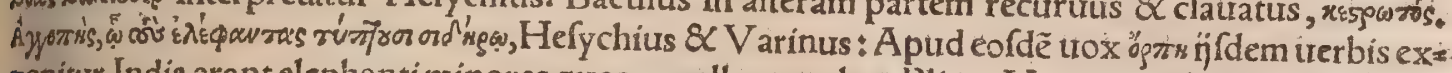
ponitur. Indis arant elephanti minores quos appellant nothos, Plin. Vita mitioributs populis Indorum multipartita degitur: Genus unum eff femiferum, ac plenum laboris immenfir uenandi elephan

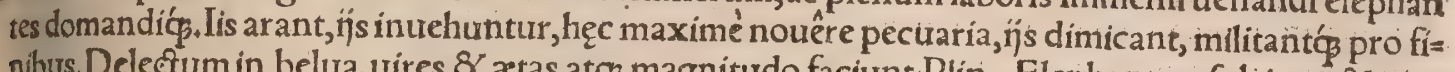
nibus. Delectum in belua, uires $\&$ atas atç̧ magnitudo faciunt; Plin. Elephantem fubiugữ \& uin

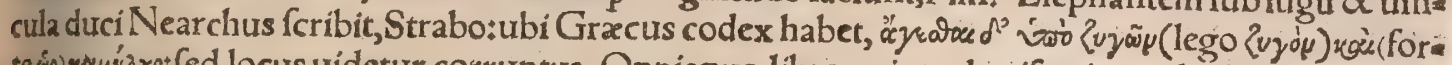

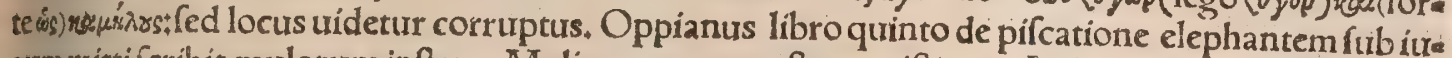
gum mittifcribit, mulorum inftar. Mulierem eam praftare exiftimant Indi, qux munus ab amanté dephantem acceperit, ut Nearchus refert:fed hic fermo contrarius eft illi qui equum 8 , elephantum regibus duntaxat poffideri afferit apud Indos, Strabo. Mulieres apud Indos, qua quide pudicitix famã appetunt, nulla alia mercede eam amiferint:pro elephanti uerò munere ei qui dederít mífcerí, turpenon exiftimant:quinetiam gloriofum mulieribus uidetur, fi cuius forma elephanti pretio di gna fit iudicata, Arrianus in Indicis. Quadriga elephantorum Gordiano decreta funt, utpote qui Perfas uiciffet, ut triumpho Perfico triumpharet:Mifitheo autem quadriga equorum $\&$ triumphalis currus, Iulius Capitolinus. Anthologï Gracilib.1. fectione 69, in bellum, Philippi epigramma ex

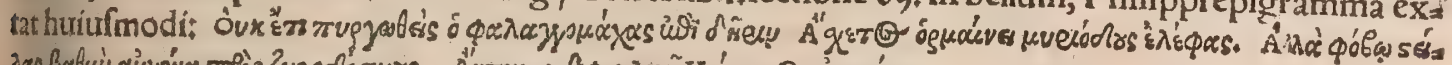

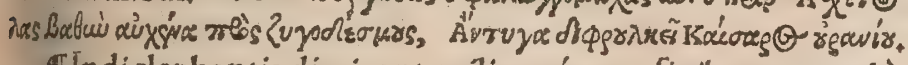

IIndielephantis dimicant, milizantćs pro finibus, tut paulờ ante ex Plinio retuli. Nouiffima İn. dizgente Gangaridum Calingarum regio Partalis uocatur ; regi elephanti feptingenti in procinctu bellorum excubant, Plinius 8 Solinus. Rex Palybotrx omnibus diebus elephantorum octo millia

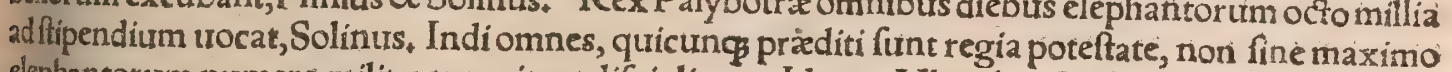
elephantorum numero militarem agitant difciplinam, Idem. VItra hos fiti funt Modubx, iNolin. d: Qc.rex horum elephantos quadringentos in armis habet, Plin. Antipater author eft, duos ele. phantos Antiocho regi in bellícis uribus celebres etiã cognominibus fuiffe:etenim nourere ea. Certe Cato, cum imperatorum nomina annalibus defcriberet, eum qui fortiffimè præliatus effet in Punica acie, Sutrum tradidit uocatũ, altero dente mutilato, Plin. Quidã feffores furos excuffos contra uim hoftiũ tutati funt, \& fele pro illis in mortem obiecerût: aliquifublatos è pralio extulerunt ad fepultui ram, Arrian. Elephanti quidã aurigas fưos, qui in côfliçibus fanguine exhaufti cadunt, fublatos épugna eripiunt ac feruant. Sunt qui defenderint $\&$ fertrarint eos qui fpatium inter anteriores ip forum pedes fubiuerant, Strabo. Cum Porus Indorum rex, in pralio, quood cum Alexandro com. miferat, multis telis confixus effet; elephantus quo uehebatur, etfi fane multis etiam ipfe fagittis uu! neratus erat, defixa tamen in corpore Pori tela, leniter $\dot{\alpha}$ caute promufcide extrahere non prius de. fitit, quàm dominum intellexiffet, ex redundanti fanguinis profufione, debilitari, \&, euanefcere. Itaç leniter \& fenfim fe inflexit, ut ne ex alto decidens, Pori corpus graui cafu affligeretur magis; Cum autem Pyrrhus Epirotarum rexad Argos occubuiifet, in eo conflictu elephantus fuir, qui fefforem fuum tantopere amaret, ut nó prius, quamuis auriga iam cecidiffet, currere omiferit, quàm furm nutritium ex hoftibus $\&$ feruaffet, $\&$ intra fines amicos reportaffet. Turrigeres elephanto. rum miramur humeros, Plin. Domiti militant, $\&$ turres armatorum in hoftes ferunt, magnaćs ex parte Orientis bella cóficiunt. Profternunt acies, proterunt armatos. Iidem minimo fuis ftridore ter rentur, uulneratióg $\&$ territi retro femper cedunt, haud minore partium fuarum pernicie, Plinius. Equorum $\&$ elephantorum infignis ufus eft ad pugnas: ductor elephanti, elephantagogus tocatur. \& qui eis praficitur elephantarches, Pollux. Elephantarchas quidam fedecim elephantis praeffe cribunt: \& munus ipfum elephantarchian tocant. Quantum fit robur corporis elephantitum ad alios tum bellicos ufus capite tertio expofưi. Militaris elephãtus dorfo furo uel nudo tres bellatores fert,alterum dextra, alterum finiftra pugnantem, tertiũ retro uerfus bellantem, ac fimul quar tơ, $m a$ 


\section{4 \\ DeQuadrupedibus}

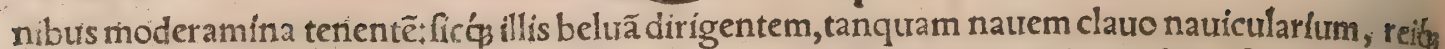
nautricæ peritũ, A elian. Purgnant onufti turribus, quibus decem aut etiã quindecim Indici homines fuperfãt, qui ex turribus tanquã proptrgnaculis in hoftes iaculantur, aut arcu fagittas torquent, Phi loftratus. Cum eos ad bellũ Indi armãt, in clitellas, geminis ex ferro catenis infra aluũ cinctas, utrin tanquã caueam ligneã imponunt, atç̧ ad collũ alligant, fingulas caueas terni milites ingrediũtur in utriufas medio auriga fedet, quibeluam patrio fermone alloquitur, \& cum progrediendum autre. - grediendum eft, oftendit:Ferias, inquit, hunc:ab illo abftine manum. Item'q̧̧: In hos inuade, ab ïjs te contine. A tog ea magnitudine tanquam caftellum aliquando dor fo conftituunt, ut uel quindecimex co armati homines pugnẽt, quod cum pugnã cómittere moliuntur, afferibus fuperintegunt: ad pro, mufcidem loríca circummunitam diftrictus gladius longitudine duorũ cubitorum, craffitudine hu= manx palmæailigatur. Neģ modo forminę maribus ferociores, fed ad onerũ uectiones etiá fortiores exiftimantur, Gillius \& V artomannus. Sed uter fexus fortior aut robuftior fit inquífiuimus fupra cap.7. Fœmina aptior eft geftãdis oneribus bellicis, mas uerò ipfis pralị̂s, utpote animofior \& pro cerior, Obfurus. De elephantis, quibus rex Porus in pralio aduerfus A lexandrum ufus eft, menz tionẽ facit Plutarchus in uita Alexandri. Elephanti in pralins homines alios conculcant, alios pros bofcide eleuatos rurfus in terrã allidunt. Heliodorus libro nono Aethiopicorũ , in prælij cuíurdam

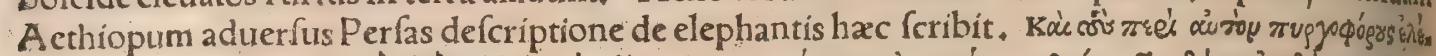

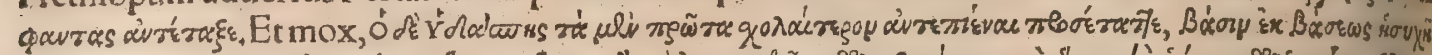

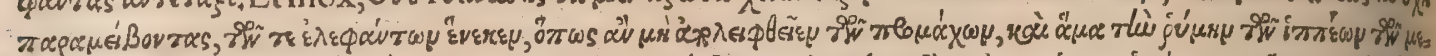

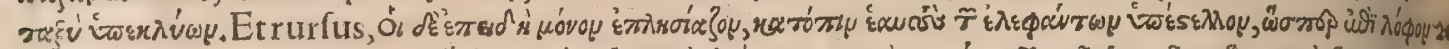

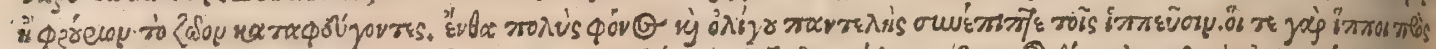

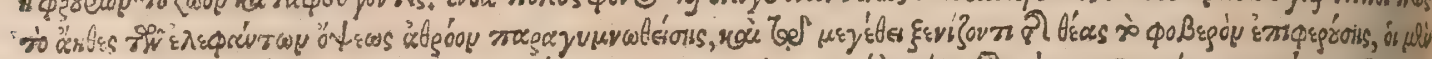

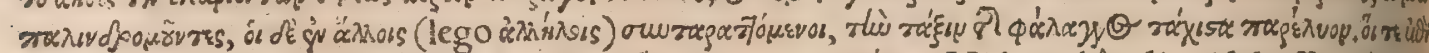

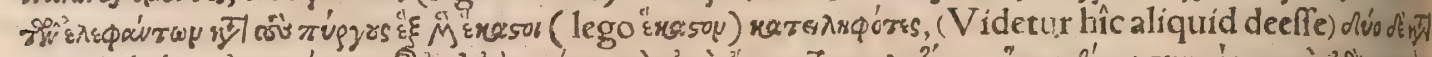

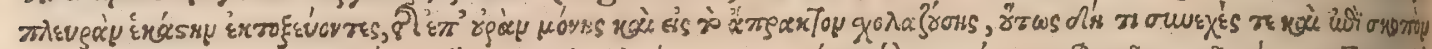

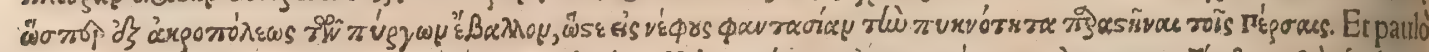

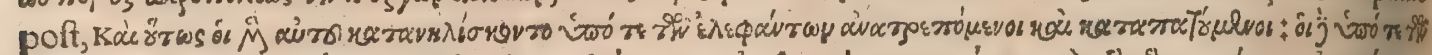

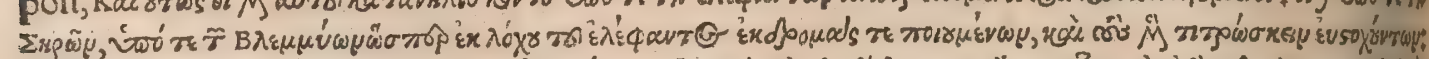

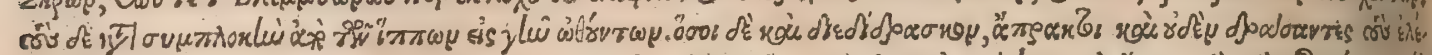

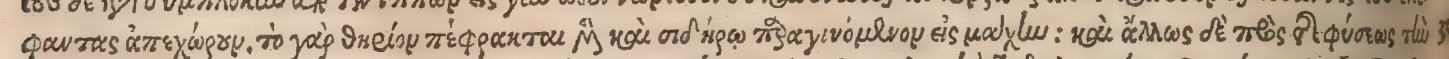

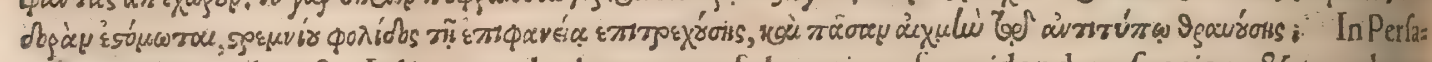
rum exercitu aduerfus Iulianum, elcphantorum fulgentium formidandam fpeciem $\&$ truculentor hiatus uix mentes pauidx perferebant : ad quorum ftridorem odoremó́ $\&$ infuetum afpectum man gis equi terrebantur: quibus infidentes magiftri, manubriatos culcros dexteris manibus illigatosge itabant, acreptx apud Nifibin memores cladis $\&$ f fi ferocius animal uires exuperaffet regentis, nere uerfum per fuos, ut tunc acciderat, collifam fterneret plebem, uertebram, qux caput à certrice differ. minat, ictu maximo terebrabant. Exploratum eft enim aliquando ab Hafdrubale Annibalis fratte, ita citius uitam huíúmodi adimi beluarum, Ammianus Marcellinus paulo peft inítiü libri 25. Idem libro 19. Lux (inquit) nobis aduenit moetifsima, Perfarum manipulos formidatos oftentans, adie chis elephantorum agminibus, quorum fridore immanitateós corporum, nihil humana mentes cerri th bilius cernunt. Elephantis pugnaturis non modo ex uitibus confecti, fed etiam ex oryza factitij ui ni ufus indulgetur, A elianus. Potionem qua pro uino utuntur ideo ipfis largiuntur, ur ad pralium audaciores efficiantur, Gillius, of Elephantis ui magna propulfis, quos Alammis coniectis undiģ cir cumnexos, iam corporibus tactis, gradienteśǵ retrorfus, retinere magiftrí non poterant, Marcellic nus libro 19. Quomodo Megarenfes in prælio aduerfus Antipatrum, fuibus pice oblitis incenfiseg, in elephantos ipfius immiffis, eos perturbarint, iam capite quarto retuli : Romanos (quoniam non cornua modo arietis, fed etiam fuilli pecorís grunnitum oderunt) Pyrrhi Epirotarum regis elephan tos in fugam uertiffe ferunt, A elianus. Elephanti in pralijs magnitudine corporum, barrhitus hors rore, formæ ipfius nouitate, homines equos ç conturbant. Hos contra Romanum exercitum primus in Lucania rex Pyrrhus eduxit. Poftea Hannibal in A frica, rex Antiochus in Oriente, Iugurtha in Numidia copiofos habuerunt. Aduerfus quos diuerfa refiftendi excogitarunt genera armorum. Nam \& centurio in Lucania gladio manum ( quam promufcidem uocant) uniabfcidit: \& bini cata: phracii equi iungebantur ad currum : quibus infidentes clibanarij fariffas, hoc eft longiffimos cons tos in elephantos dirigebant. Nam muniti ferro, nec à fagittarís, quos uehebant belux, ląebantur; \& earum impetum equorum celeritate uitabant. Alij contra elephantos, cataphractos milites immis ferunt, ita ut in brachịs eor $\tilde{u}_{3} \&$ in caffidibus uel humeris aculei ingentes ponerentur é ferro, nema nu fua elephas bellatorem contra fe uenientem poffet apprehendere. Pracipué tamen uelites antia qui aduerfum elephantos ordinarunt. Velites autem erant ituenes, leui armatura, corpore alacri, quí ex equis optimémiffilia dirigebant. Hi cquis pratercurrentibus ad latiores lanceas uel maiora fpicula beluas occidebant, Sed crefcente audacia, poftea collecti plures milites pariter pila, hoceft mifilia, in elephantos congerebant, eosćs uulneribus elidebant. Illud tamen ad ditum eft, ut fundito res cum fuftibalis $\&$ fundis rotundis lapidibus deftinatis, Indos (per quos regebãrur elephant) cum 


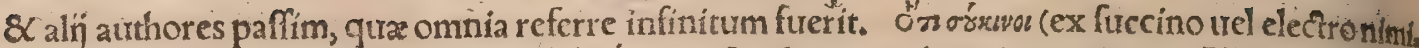

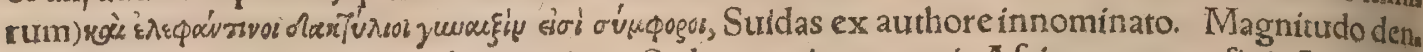
tium uidetur quidem in templis pracipua, Sed tamen in extremis Africæ, qua confinis Acthiopix eft, poftium uicem in domicilins prabere : fxpesćg in îjs $\&$ pecorum ftabulis pro palis elephantorum dentibus fieri, Polybius tradit, authore Guluffa Regulo, Plin. Eorum qui funt confirmata atate, ea magnitudine dentes exiftunt, uicem ut poftum praftent, $\mathcal{Q}$ pro palis Nigritæad fepimenta utan, cur: \{æpe enim ad longitudinem decem pedum augefcunt, Gillius. Atramentum A pelles commena tus eff ex ebore combufto facere, quod elephantinum uocant, Plin. 35. 6. Pinxit ebore ceftro (aliâs cefto)id eft uíriculo, Plinius 35. 10. Et firperius paulò, Et penicillo pinxit $8<$ ceftro, Sophocles ceftrâ dixit pro ftimulo fiue ftylo, ut aic Pollux. Hoc genus miffilis, quod Graciceitram uocant, noftriut rículum

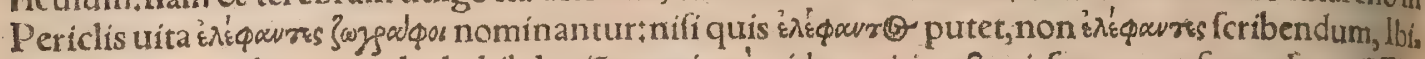
dem. Plura de ebore quod ad philologíã præcipué, uíde capitis oçaui fegmento fecundo. đI Ele phanti offa \& pellis, ubicunç̧ incendantur, ferpentes fugất, nec ullum animal uenenofum accedit, Author obfcurus libri de naturis rerum. Quæendum an hæc potius ad elaphon, id eft ceruum per, tineant: Vt\& illud quod apud A elianum legimus. Contra omnium ferarum uenena remedio efle clephanti adipem:quo inunctum, Hicet nudus contra efferatiffimas beftias procedat, illafum difce dere.Sed uidetureadem uis utriufog animalis partibus iam diotis contra ferpentes ineffe. Namul uum etiam utrunģ ferpentibus infeftum eft. Ea quidem quax uruntur omnia ferè, fi fumi mordacis tati odoris grauitas accedit, ut maxime fic in offibus, pilis $\&$ corijs, ferpentes fugant. Vide plura caz pite feptimo.

Elephantophagi à belluis quaras uenantur eduntḉ dicti,à Nomadibus immundi uocantur, Strabo lib,16. Er proxime ante hæc uerba, $\mathrm{Sabx}$ (inquit)ciutas maxima eft, quam Eumenis lucus fequitur: Vlierius eft urbs Daraba $\&$ elephantum uenatio, qux ad puteum nominatur, eam Elephantophagi habirant. Troylodytæ contermini A ethiopia, folo elephantorum uenatu aluntur, Plin. Afacharin Africa)montes habitant, uitunt elephantorum uenatu,Plin. A fachæi ex A ethiopum numero cat ptos uenatibus elephantes deuorant, Solinus, Contra Meroën funt Megabari, uel A diabarz dichi, pars eorum Nomades, quí clephantís uef́cuntur, Plinius. Aethiopes qui Nomades appellantur, ci uitates in curribus pofitas habent: Proximi autem illis funt qui elephantos uenantur, illos đ̆g in fru: 3 fra diuifos uendunt, unde cognomen adeptiElephantopliaginuncupantur, Philofiratus, Intue, nit luxuria commendationem $\&$ aliam(prater eam qua circa opera ex dentibus facta eft:)expetíin callo manus uim faporis, haud alia de caufa credo quàm quia ipfum ebur fibi mandere uidetur, Plin, Ex tanta clephanti mole nihil efculentum eft nifi pronufcis, \& labra, \& cornurum medulla, Aelian, Aethiopes elephantum in uenatione caprorum pofteriores partes comedunt, Gillius. Vidinquls buf́dam regionibus ferculũ omnium pretiofiffimũ æftimari \& regi apponi folitum, renes eleplanti, Vartoman. Carnem elephanti cum alïs quibufdam decoctam ueteri tuffi mederi $R$ afis \& Allbers

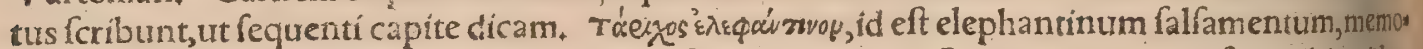
ratur apud Athenæum lib.z.nec explicatur. Nam quos recitat $C$ ratetis comici uerfus, mihi quidem obfurifunt: nec ab Hermolao \& Calio A thenai locum citantibus explicantur. Quod autem(inity quit)percelebre fuerít Cratetis illud elephantinum falfamentum, Ariftophanes in Theímophoran

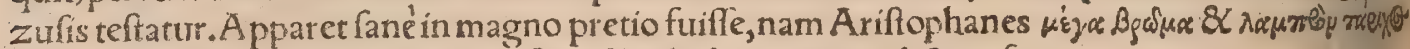
cognominat:Elephantinum autem fortaflis ab eboris colore dictum fuerit.

G.

Muftelx exuftre cinis, \& elephantis fanguis, immixtus $\&$ illitus elephãticis corporibus medetur Marcellus Vergilius. Elephanti fanguis pracipuèmarís, fluxiones omnes, quas rheumatifmos uo

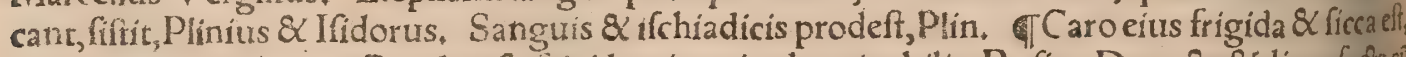
abominabilis, All ertus:Ponderofa, frigida, pinguis, abominabilis, $R$ afis, Decocta \& liquefactacü aceto \& femine ferulæ, fi prægnans hanc guftauerit decoctionem, projicit quicquid hat er in utero, ldem. Qui guftat de carne elephanti cum a qua \& fale cocta, cum feminiburs afquefim (ferulę Alber ') tuss) fanat tuliim antiquam, $R$ alis : \& mox fubricitur, Quando coquitur \& liquefit cum aceto \& $\&=$ mine feni, (Albertus, ut iam citaui, legit fer ulx: $\&$ addit, hunc potum abortiuum effe pręgnanti) Glephanti adeps contra uenenata ualet. Nam fi quís eo inungatur, eiúsure fuffimêto expietur, hiac ab illo aufugiunt longiffmè, A clianus: Vide fupra circa finẽ capitis quinti, Illitus fugat uenenola, Auicenna. Adipe ceruino elephantinó́ perunctos, lerpentes furgiunt, Diofcorides 2, 86. Sepum elephantis illitum capiti do'enti prodeft, Albertus $\&$ Rafis citans Ariftotelem, Fumo quog quilit ex ungula \& pilis elephantis, animalium quxlibet uenenata fugantur, Ifidorus.

Gibur tota fubíantía cor roborare, \& conceptum iuuare, practicis frribitur, frigidum ficcum primogradu, Syluius, Cauendum efl ne fit adulteratum offibus pifcium, aut aliorum quorundamas ninalium. Elephas (inquit Pla tearius) habet offa quadam folida ut dentes, (dentes etiam elephantos i rum medullam habent, $\&$ fallitur Platearius, Monachi in Mefuen) quæ non cremantur, fed ad diucr fos ufus feruantur. Quadam ueró medullam habent; qua combufta dicuntur fpodium, Eft aurem 


\section{DeElephanto.G.H. Lib. I. 437}

fpodium frigidum in tertio gradu, ficcum in fecundo. (Hęc graduum affignatio falfa apparet, \& ne. que urero fpodio, neçantífpodio ex offibus elephanti crematis conuenire.) Adulteratur quandoque offibus canis combuftis, quandoç etiam marmore combufto, fed id eft minus (lego nimis)pondero. fum. Eligi deber fubalbidum, ualde leue $\&$ continuum, Hac Platearius, Pharmacopola ubigg ho= die pro l podio offibus combuftis utuntur, fitre elephantis, ut ipfi afferunt, fiue potius bouis, uel arie. tis, uel canis, aut alterius animantis:quis enim ufta difcernat?Monachi in Mefuen. Huius fpodij(ex offibus elephantorum uftis) ufus eft in fyrupis ad refrigerãdum. Puluis eius cum fucco plantaginis ad dyfenteriam $\&$ fanguinis fputum datur,Platearius, Ebur uim adftringendi obtinet, Diof corides $\&$ Serapio. Ego nullam in guftu aftrictionem percipio, fed emplafticam uim potius $\&$ abf ficcantem. Diofcoridi forte impofuit ficcandi natura: at nô fi quíd fluxiones ficcat, ftatim altringit. Spodij ex cbore apud recentiores medicos præparatio huiufmodi prafcribitur $¥$ Eboris in partes fecti libram fictili crudo impone, $\&$ operculum luto circunquaq̧ obline $\&$ agglutina:fic cremari fi. nito donec fictilia percocta fint: deinde exemptum ebur in tenuiffimũ puluerem terito $\&$ cribrato: mox in patina uitrea liquor is ftillatiti rofarum libras duas fuperinfunde, \&exiccari finito: deinde fe: cundo terito, $Q$ tantundem liquoris rofacei affundens ficcato. Vbi ueró iam tertio contriueris, admifcebis liquori rofarum camphora fubtiliffimè trita drachmas quatuor: \& pariter conteres in tae bula marmorea duriffima, fingesḉs paftillos, $\&$ in denfo aliquo uafe, ne expirent, repones, Quòd fi ebur defuerit, cornu ceruinum fimiliter praparabis : eft enim hoc quogs efficax medicamentum ad multa, prafertim contra uenena. Alij monent ebur aper to fictili cremandum effe: fic candidum fieri, fecus nigrefcere, Ad elephantiafin, Eboris \& cornu ceruini ramenta cochlearn̈ menfura fape ad pradictam menfuram (pharmaci ex cedria, quod fic fit:acetum optimum, cedria, 8 fuccus braffice, fingula cyami menfura mifcentur, $\&$ ieiunis mane prabentur) ammifcentur. Nam $\&$ per feipfum unumquod q̧ corum potatum utilifímum exiftit, Aétius 13.122, Ebur $\&$ caftoreum ex lacte rabido equoinfunduntur, Nemefianus. Qui poft ægritudines aliquas, ut lethargum aut peftilentiam, in oblitionem deciderint, eos maximè iưuat hiera Ruffi: \& caftoreum cum oleooccipiti illitũ. Poft pur: gationem hieræ, fcobem dentis elephantis circiter drachmam unam é mulfa potam non parum iu= uare creditur : \& caftoreum fimiliter poft purgationem drachmæ pondere cum melicrato, Aétius. Eboris fcobe illito paronychia fanantur, Diofcorides, Serapio \& Pliniurs. Ramentis eboris cũ melle Attico, ut aiunt, nubeculix in facie tolluntur, Plin. Ebur cum melle contritum $\&$ impofitum, ma culas miréranat, Sextus. Mulier fi quotidie de puluere eboris faciem fuam fricaurerit, plagas mun. dabit, Id $\tilde{e}_{;}$Per plagas(inquit Humelbergius) intelligit, quas priore curatione maculas, Plinius 28.8. nubeculas, urocat. Drachmam (unciam, Albertus)de alkal, id eft offe elephãti, cum decem drachmis (uncins, Albertus) mentaftri montani aqua potam ab eo quem primum infecerit lepra, plurimum prodeffe dicunt, Rafis. Capitis doloribus prodeft limacis inter duas orbitas inuentæ officulum per aurem cum ebore traiectum, Plinius, Naufeantibus fuibus falurtaris habetur eburnea fcobis fale fricto, Columella lib، 7. Cornu ceruinum \& ebur aliqui mifcent aduerfus lumbricos. Ioan, Agri. cola frribir medicum quendam fcobem eboris uino, aut liquore alicuius herbæobftructione liberan tis chymittarum fornace extracto, maceratum, ieiunis ictericis propinaffe non abfog fucceffu: (Ego idem remedium in manufcripto ludxi cuiufdam libro legere memini.) Conducit (inquit Agricola) hoc medicamen obftructionibus diuturnis egregié, \& remouet infuper ftomachi dolores fupra alia pharmaca, qux in hunc ufum comparantur. Exhibetur etiam cum mulfa ualde infigni facultate in comitialibus. Eboris uftifarina cum fanguine hirci pota, calculos in renibus $\&$ uefica frangit abfós cmni periculo, Obfcurus. Eburnei pectines capiti præ cæeteris falubres exiftimantur: forte quód re liqui ex cornibus facti plerí̧s graui odore fint, ex ebore non item. I Proboficidis tactu capitis do lor leuatur, efficacius fi \& fternuar. Dextra pars probofcidis cum Lemnia rubrica adalligata, impe. tus libidinum ftimulat, Plinius. đlecur comitialibus morbis prodeft, Pliníus, Extremitas (aliâs additamentum) hepatis comefta cum aqua(furmac) $\&$ folyjs citranguli, hepati dolenti medeur, Rafis \&Albertus, Elephanti fel aliqui commendant tanquam auxiliare morfibus ferpentium, Diócori des 6.39. Fel eius ad pondus aurei(aliâs alkifat, lego alcirat, id eft ceratium, tertia pars oboli) per na. res immifum, iuruare aiunt contra morbum caducum, Albertus : $R$ afis æequale morchi pondus adin $=$ cit, Fimo elephantis fillinaturpellis (cutis) pedieulofa, 8 in ea reficcari permittatur, pediculis liberabitur, Albertus $\&$ Rafis. Eodem fi fuffiatur domus aut alius locus, ciniphes (aliâs culices) fugiunt $\&$ moriuntur, lidem. Si fuffiatur eo uenter febricitantis, prodef, $\mathrm{Hali}$. Si fupponatur (cum lana fubmittatur)mulieri, conceptionem prohibet, Auicenna 8 C Hali.

H.

a. Elephas apud Græcos inflectitur per antis, anti, \&c. quo modo Latinorum quidam, præfertim

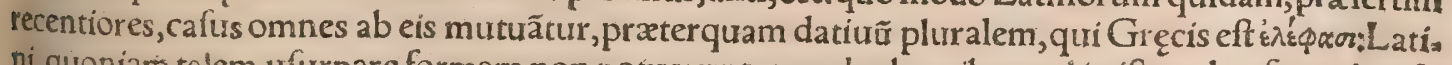
ni, quoniam talem ufurpare formam non potuerunt, nec elephantibus uel in ifto uel auferendi cafu dicere placuit, elephantis dixerunt: 8 huius terminationis occafione alios quogs cafus omnes in fecunda declinatione ufurpant. Quanquam in Plinio nominatiuum Elephantus (quo Gaza utitur) nondum inueni, (ed cafus ab co factos in utroç numero omnes: $\mathbb{K}$ nónullos ex eis apud Vergílium $\&$ Ciceronem $G$ racorum elephas in recto fingulari, $\&$ elephantes tum in recto tum accufandi cafi 
pluralibưs, apud Pliniũ inueniưtur ( quanquã frequentius in plurali elephãti \& elephantos) nec all. præter hos ter tiæ declinationis caftis. Plautus in Sticho, elephantũ grauidã dixit. Sed ifta curiofitasad grãmaticos relegetur. E' $\lambda^{\prime} \notin \emptyset a s$ Gręcis aliâs femper mafculinum eft, fed cũ de fơmina peculiaris fermo

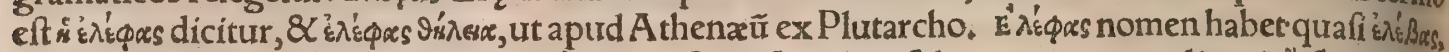

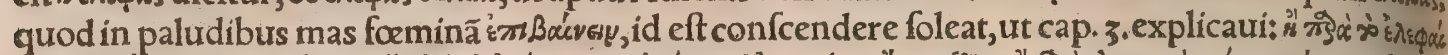

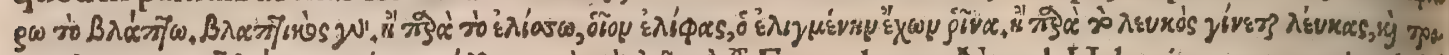

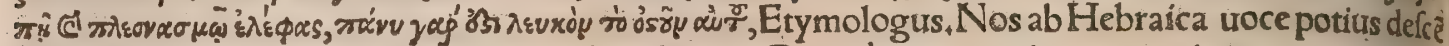
diffe oftendimus fupra capite primo. Elephantem Graci à magnitudine corporis urocatum putant,

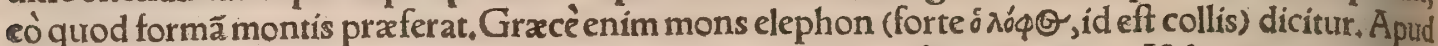
Indos autem à uoce barre uocatur, unde $\&$ uox cius barritus, $\&$ dentes ebur, Ifidorus apud Vincen

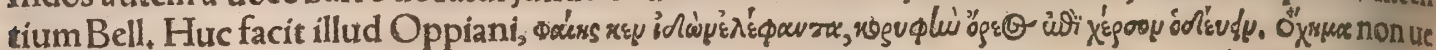
hiculum tantum fignificat, fed quoduis etiam animal, cui inuehuntur $\&$ inequitanthomines, ut funt

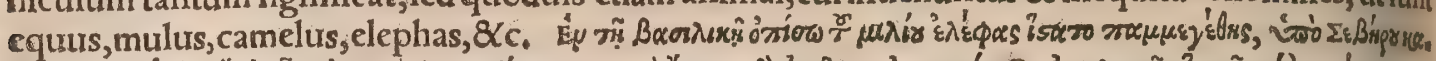

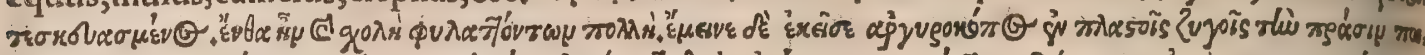

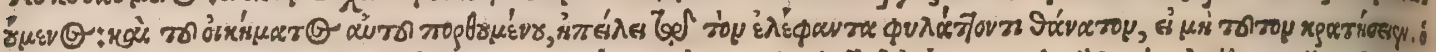

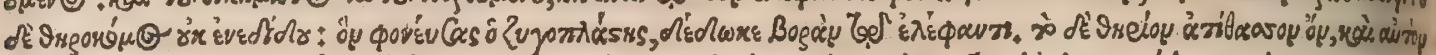

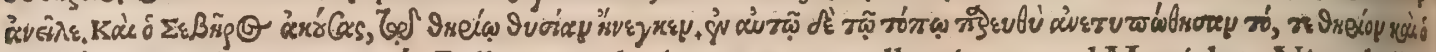

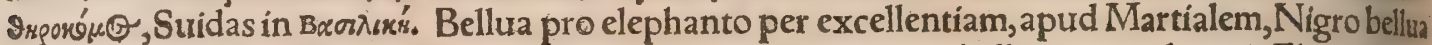
nil negat magiftro: 8 apud Plinium, Nondum pretio excogitato belluarum cadaueri. Elephantima ximi effigies in Hypnerotomachia Italica Polyphili defcribitur. If Elephanto, qui in Punica aciefor tiffimè furerat praliatus, Cato Sutrum nomen impofuit. De Aiace elephanto Pori, quem Alexấder captum dimifit torque ornatũ, fupra dixi; Item de Äiace \& Patroclo Antiochi: \& de Nica elephara: to foemina, qua mulieris fibi commiffum infantem matris inftar curauit.

AEpitheta, Anguimani elephanti, Lucretius libro 2. fic dicti, quod manum fitse probofidem flectunt ac contorquent ut angues propria corpora. Clemens. Ferox. Getulis. Immanis. In dicus, Infrenis, Libycus, Lucano lib,6, Libyffus, Marmaricus, Nigrans, Niger, Quid uibi uis

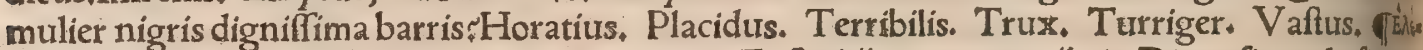

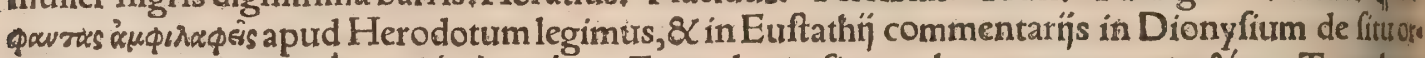

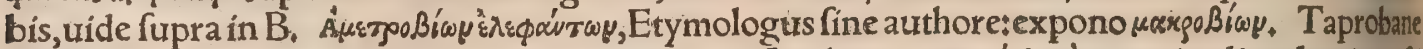

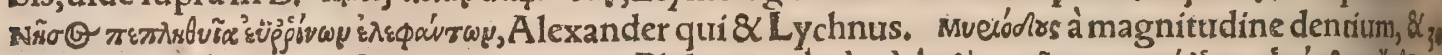

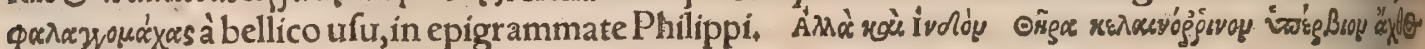

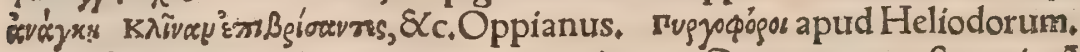

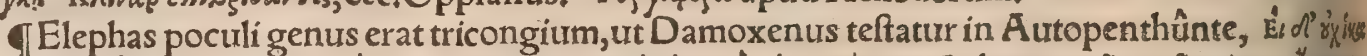

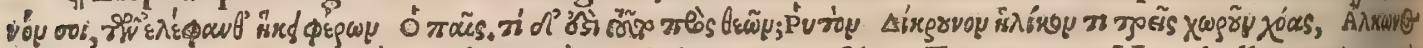

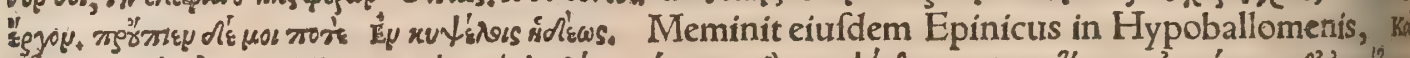

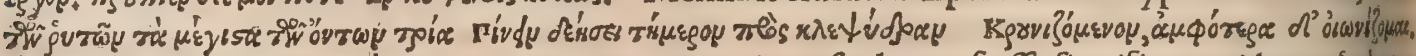

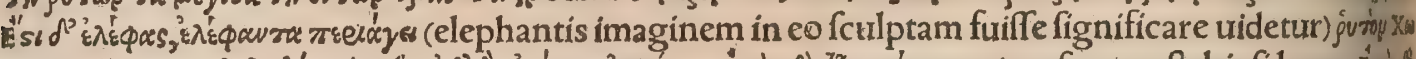

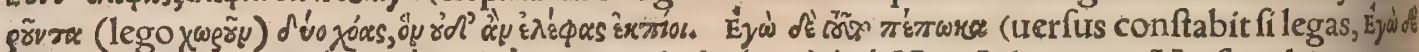

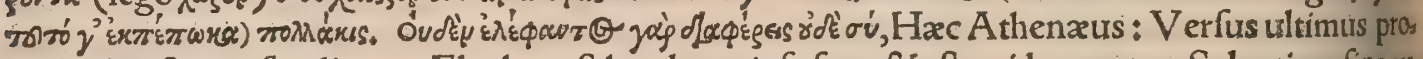
trerbialis eft, ut infra dicam. Elephas eft hordeum infufum, \& eft quidam potus, Syluaticus fine atl thore: fortelegendum phucas, фrxãs:qui potus eft ex hordeo, non alius quàm Diofcoridis zythus, ut fupra docui:cui cum elephante nihil commune eft, núfi quòd eo nimium utentes elephanticifieri di cuntur: $\&$ ebur (quod Gracielephantem uocant) in co maceratum molliri aiunt. Eburnea facies, id eft eboris inftar alba, Perottus. De eburneoPelopis humero, uide Leonicenum in Varijs, \&c, Ele phantinus nomen poffeffiuum, ut pellis elephantina. Elephantinum emplaftrum defcribit Celfus li bro quinto:fic autem dicitur, eodem tefte, quod fit percandidum. De elephantino falfamento fuper ritus dixi. Libros ueteribus elephantinos effe nuncupatos ex amplitudinis ratione, funt quiopinen tur +ips uerò triginta quínç numero $\&$ tribuum $\&$ tribulium contínebantur nomina . Scribit tamen in Tacito Fl. Vopifcus, in libris hoc genus folita perfcribi fenatusconfulta, quæ ad principem perti. nerent, In Vlpia ueró bibliotheca feruabantur hi, Calius. Elephantia, fiuc quod idem ef Aegine tæ Paulo, elephantiafis 8 elephas: ut in Plinio quogs poffis defendere, ficubi elephantis (ut libro 20, cap.18.) proelephantịs fcriptum eft. Eft autem id ceu lepræ quoddam gents, elephantorum critilis mile, crebris fumma corporis parte maculis ac tumoribus, rubore paulatim fe in atrum uertentetips non ora modo atç manus, fed fura ac pedes inflantur, ut hinc recentiorum plariç non alios effe pir tent elephãtiacos, quàm quibus crura fic intumefcunt, ut pedes elephantorum habere uideantur. Ori go morbi ex atra bile, non quidem omni, fed retorrida:morbus inexpugnabilis, atç ut cancer unius partis, fic elephas totius corporis quafi cancer exiftimatur. Caffiodorus, Cutis (inquit) animalis ele: phanti ulcerofis uallibus exaratur, à qua tranfportaneorum nephanda paffio nomen accepit, Har Hermolaus in gloffematis Plinianis. Idem in caftigationibus Plin.libro 20.cap.18.reprehendit mea dicos recentiores, qui elephantiam uocant morbum quo pedes \& crura uehementer intumefetul, 6 Diximus elephantiafin (uerba funt Pliní 26.1, ) ante Pompci Magni atatem non accidiffe in Italia, \& ipfan à facie fa pius incipientem, in nare prima uelutilenticula:mox inualefcente per totum cor 


\section{DeElephanto.H. Lib. I.}

pus, maculofa, uarn̈s coloribus, \& inx quali cute, alibi craffa, alibi tenui, dura, ceu fcabie afpera: ad poftremum uerò nigrefcente, $\mathcal{Q}$ ad offa carnes apprimente, intumefcentibus digitis in pedibus ma= nibusć. Aegypti peculiare hoc malum: \& cum in reges incidiffet, populis funebre. Quippe in bali neis folia temperabantur humano fanguine ad medicinam eam. Et hic quidem morbus celeriter in Italia reftinctus eft, Hucuf̧̧́ Plinius. Elephantiafis (inquit Aëtiùs 13. 120.) à quibufdam leontiafis, $2 b$ alijs fatyriafis appellatur. Elephantia fis quidem à magnitudine $8<$ diuturnitate affectionis nomen accepit, imo $\&$ propter cutis afperitatẽ qua in nonnullis apparet, Leontiafis autem appellatur, cum frons ægrorum cum quodam tumore laxior redditur, ad finilitudinem pellis flexilis fuperciliorum leonis, Satyriafis ueró, propterea quod malæ faciei ß̈f fem cum rubore attolluntur, \& mufculis ma= - xillaribus ueluti conuulfionem patientibus, mentum ipfum dilatatur, quemadmodum etiam riden. tibus euenire folet, fimilitudine quadam ad picturas fatyrorum : quin 8 alacritas uehemens ad coi. tum ipfis adeft, quemadmodum $\&$ de fatyris fertur. Ef autem grauis morbus, \& propé ex eorum nư mero qui incurabiles exiftunt, \&c. Elephas affectus cutẽ craffam atç inæquabilê reddit, liuor adeft tum cuti tum oculorum albis, exeduntur partes manuum ac pedum fummę, ex quibus fanies liuida ac foxtida emanat:apparent etiã in huiufmodi partibus affectis uenæ craffo nigró̧̧́ fanguine plenæx; Galenus in definitionibus \& Therapeuticis ad Glauconem. Plura de hoc malo uide apud Celfum 3. 35. \& Manardum in epiftolis, \& alios recentiores, quoru diuerf $x$ quidem opiniones funt : $f e d$ plures $\&$ doctiores feré in hoc conueniunt, morbũ qư in facris literis lepra uocatur (alia enim eft quam Gręci medici lepram nomínant, non adeò difficilis curatu) 8 Címiliter hodie ưulgò, non alium quàm - elephantem effe. Elephantiafis genus eft lepræ, Hefychius $\&$ Varinus, Elephantiafin certe alicubi in lepram mutatam apud Galenum legimus. Phoenicius morbus, фoเvıxis vóos, qui in Phoenice $\mathbb{X}$ alips regionibus ad Orientem fitis abundat: uidetur autem elephantiafis effe, Galenus in Gloffis in Hippocratem. Et rurfus, Phoenicinum affectum(inquit) coniecerit aliquis à colore dictum elephan. tiafin effe. Galli morbum quendam in equis appellant farcin, in quo(ut audio)tumida $\&$ uaricora funt crura: eruditus quidam elephantiafin exponit:fed hæc Arabum non Gracorum elephantiafis eft,ego uarices potius dixerim, uocabuli etiã fimilitudine fretus. I! Hefychius $\&$ V arinus. Archigenes apud Aëtium lib, 13. lepram à leuce, alpho, pfora, $\&$ imperigine fera certis notis diftinguit. Scitu dignum (inquit Calius) ex uictus ratione ac coeli aftu hoc malum apud Alexandriam uigere plurímum : In Germania uero ac Myfia rarenter admodum quenquam ita infici:atç codem modo apud Scythas galactopotas nunquã uifum ferê. At in Alexandria dixtæ modus plurimum id genus concinnare ualet:athara fiquidẽ uefcuntur, fiue pulte, id elt farina frixa, nec lentem abnuunt, urel falfamenta, aut limaces:quidam nec afininas carnes, aut eiufmodi alia quí bus chymi uis comparatur craffior \& melancholica. Quod quư alibi, tum in fecundo ad Glauconem comprobat Galenus. Elephanticos nuncupat Firmicus elephantiafi laborantes, Elephantia fer. pentes fic dicti, quod is quem momorderint hoc genere lepra afficiatur, ut quidam ex Solino citat. đAnacardus fructus ab imperitis uocatur pediculus elephantis, Syluaticus, đElephantum ce. tacei generis ad Aquatilia differo. Vrimagnitudine paulo elephantis inferiores funt, Cafar, Bel lux marina, cui A ndromede expofita fuit, coftarum excelfitas elephantis Indicis eminentior fuiffe traditur, Solinus. Equifluuialis reliquum corpus (præter ungulas, aures \& caudam)elephanto nó 10 difimile eft, Gillius, Monoceros fera pedibus elephanto fimilis eft, Plin. Eale fera apud Aethí. pes caudam elephanti habet, Plínius,

1Q. Fabius propter candorem Eburnus cognominatus eft. Elephantis, qux \& interdư à Græa cis Elephantine uocatur, lafciuiffima mulier uaria concubituũ genera defcripfit. Hurius meminit $T a$ tianus Affyrius in libro aduerfus gentes, \& Suridas, Martialis quo $\$$ \& Plinitus, Latini quidã, alioquí literati, falfó marem putarunt, Gyraldus. Elephantine Thebaídis oppidũ, ubi nulli arbori decídunt folia, Plinius $16+21$. Elephantina elt infula fpatio femiftadif, cum ciuitate qua Cnuphidis templum habet, \&Nilometrio, Strabo lib.17. Elephantis Nili infula eft infra nouiffimum cataracten, nauriga tionis Aegyptix finis, ibi Aethiopicæ conueniunt naues, Plinius. Elephantina urbs diftat à Thebis Aegyptijs uriginti et octingentis ftadīs. De hac fribitA ppion quod Onychina dici debuiffet:quems admodum enim ony $x$, id eft unguis refecfus, iterum crefcit, $\&$ quod demptum eft refarcit:fic Nilus proconfumptis inundatione per agros aquis, quotannis rurfus paulatim colligitur, $\mathcal{Q}$ rurfus inun. dat,Etymol, Nilus Aegyptum \& folus, \& totam, \& in rectũ permeat, à minore cataracte fupra Sye. nen \& Elephantinã incipiẽs, qui funt \& $\angle$ A egypti \&A Aethiopięfines, uf̧̧́ ad Nilioftia in mare, Strabo lib. 17. De Elephantophagis dixi fupra capite fexto. Elephas, mons Arabix in mare expofitus, Strabo libro decimofexto. Eleutĭ, Ėᄉớror, gens A pulix, Hecatæus in Europa: (forteaddendum Elephantiam uel Elephantinã uocat, propter gentile quod fequitur.) Parthenius Elephantidẽ eam nocat, Gentileà priori Elephantinus, à pofteriori Elephantites Ptolemais à Philadelpho condita eft ad uenatts elephantorum, ob id Epitheras cognominata iuxta lacum Monoleum, Plinius 6. 29* Philothera eft ab Heroum urbe nauiganti iuxta Troglodyticam, à forore fecundi Ptolemai appel 60 lata, Satyri opus, quiad Troglodyticam \& Elephantum uenationem perforutandam miffurs eft, Stra bolibro decimofexto. Et rurfus, Arabỉ finus pars qux Troglodyticam fpectat ad dexteram eft, ubi natugantibus ab Heroum urbe ufque ad Elephãtum uenationem $\alpha$ Ptolemaidem, fradiorum funt 
nourem millia ad meridiem \& paululum ad Orientem, Et alibi codem libro, Poft Stratonis infulam

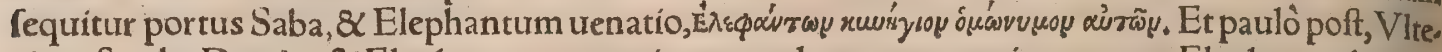
rius eft urbs Daraba, \& Elephantum uenatio, quæ ad puteum nominatur, eam Elephantophagiha bitant, (à quibus elephanti quomodo capiantur fupra recitaui capite quinto.)Sunt $\&$ alia quædam

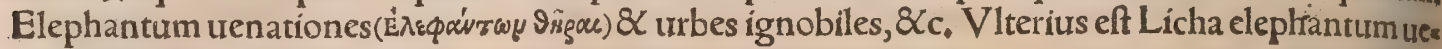
natio, Straboeodem lib, 16 .

b. Ebur uel ebor neutri generis, elephanti dens, quafi ébarro,id eft elephanto producturm, tefte

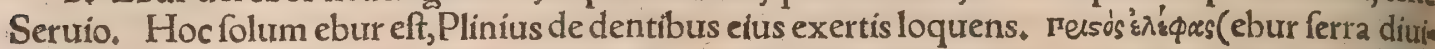
fum)os elephantinum, fic ebur Græci per excellentiam trocant : additur autem wersós ad ipfius bel. lux differentiam, V arinus. Ė $\lambda \in \Phi x^{\prime}$ Orientalibus canens, Latini etiam elephantum quandocs pro ebore fiue dente elephanti ponunt: ut, In foribus pugnam ex auro folidóǵ elephanto, Vergilius Georg.3. Altera candenti perfecta ni rens elephanto,A eneid. 6 . Eft 8 nitreum epitheton eboris, 8 nitidum. Ab ebore deriuantur adie, ctiua quadam; Eburneum, quod ex ebore eft. Plinius lib, 36. Iouem fecit eburneum in Metelliade qua campus petitur. Liuius lib, 5. ab Vrbe, Eburneis fellis federe. Eburneum fignum, Cicero 6. Ver rina, Eburneolus diminutiuum, Cícero3. de Orat. Quem feruum fibi habuit ille ad manum, quum eburneola folitus eft habere fiftula, Eburneumi apud poétas reperitur. Hanc primum ueniẽs plectro modulatus eburno, Tibullus. Legitimę́́ collo fufpendit eburnum, Vergilius:pro uaginam eburneam,Seruius, Eboreum quno fit ab ebor, Quum in triumpho Cafaris eborea oppida effent translata, Quintilianus lib, 6. Ante Apollinem eboreum qui eft in foro Augufti, Plinius lib.7. Eburatum, ebore tectum. Lectos eburatos, auratos, Plautus in Sticho. Eburata uehicula, pallas, 8cc. Idem in A ulularia. Homerus ebur eléphanta vo. cat acuta antepenultima:per fynecdochen, ut caput pro homine:funt qui ultimã acuant, \& elephan

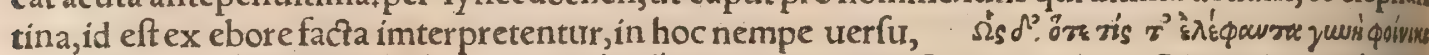

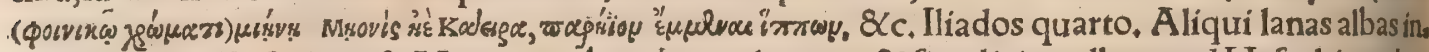

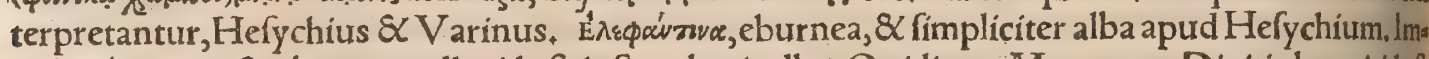
pubeś́́s genas, \& eburnea colla, id eft inftar eboris alba, Ouidius $3_{+}$. Metamor. Digiti eburni, ideft candidi, àpud Propertium. Ebur item ponitur pro uafis $\&$ alịs rebus ex ebore dolatis. Non ebur, neç aureum Mea renidet in domo lacunar, Horatius 2.Carm. Vt omne ebur ex ædibus facris aus ferret, Cicero 4. Verrina. Dum Tyburtinis albefcere collibus audit Antiqui dentes fufca Lycoris ebur, Martialis lib،13. Merulis anniculis roftrum in ebur transfiguratur, duntaxat maribus, Plinius, Non enim eft è faxo fcalptus, aut ebore dolatus, Cicero 4. Academic. Ebur ex inanimo corporeex tractum, haud fatis caftum donum deo, Cicero 1. de Legibus, mutuatus eum locũ ex Platonis dele

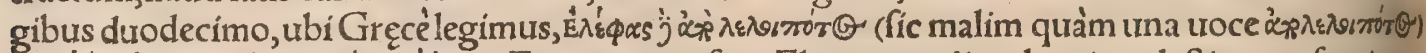

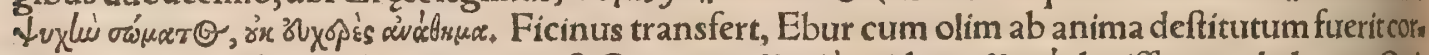

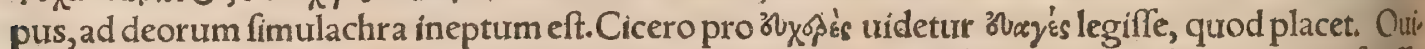
dius libro decimo Metamorphofeos Pygmalionem fabulatur ex ebore uírginis fimulachrum feciffe, eiusós amore captum à Venere impetraffe ut in ueran uiuamá̧ uírginem uerteretur: \& ex eius con

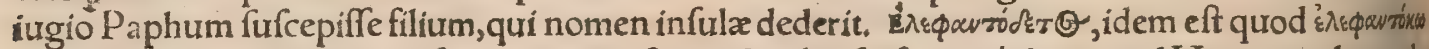

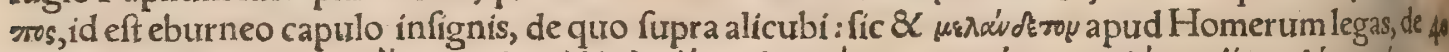

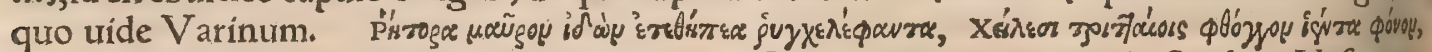
Epigrãma authoris incerti lib, 2. Anthologị. $\quad$ IElephantos Mauritania alit,Strabo. Nafcuntur elephantes apud Hefperios Aethiopes: \& qui rhizes uocantur, qui magnitudine $\&$ pugnandi uiris bus elephantos referunt, Idem ex I phicrate. Marcello inter alia prodigia, infantem elephãtis capite natum a dhuc effe fuperftitem nunciatum eft, Plutarchus in Marcello. Alcippe elephâtum peperit, quod inter oftenta eft, Plinius.

e. Liberales fanè mihi ac magnifici, miniméç parci in pecunj̄s circa diưinurn culturm Gręci ex. titiffe uidentur, quibus ab India ufges \& Aethiopia ebur ad concinnanda fimulachra aduehebatur,

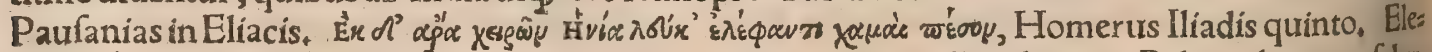
phantotomiOppiano dicuntur, qui ex ebore aliquid faciunt. De eburneo Pelopis humero fabtrs lam lege apud Ouidium Metamorphofeos libro fexto, \& reconditam de codem hiftoriam in Leoni ceni Varijs 2, 61.

Sunt geminæ Somni portę, quarũ altera fertur Cornea, qua ueris facilis datur exitus umbris,

Altera candenti perfecta nitens elephanto, Sed falfa ad colum mittunt infomnia manes,

His ubi tum natum Anchifes, unaćs Sibyllam Profequitur dictis, portá̧́ emittit eburna,

Vergilius circa finem libri fexti Aeneidos, Somni,id eft fomniorum, inquit Seruius. Eft autẽ in hos

loco Homerum fecutus.

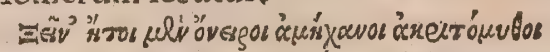

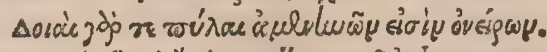

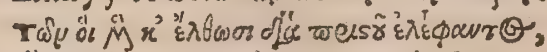

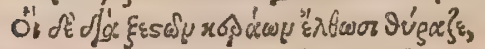

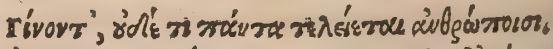

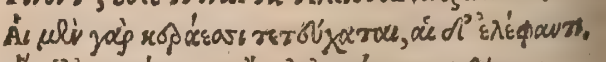

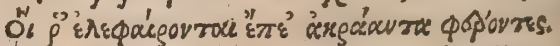

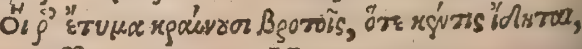

(Hęc Penelope ad Vlyffem Odyffeę lib.19, In hoc tamẽ differt, quod ille(Homerus)per utranģ por 


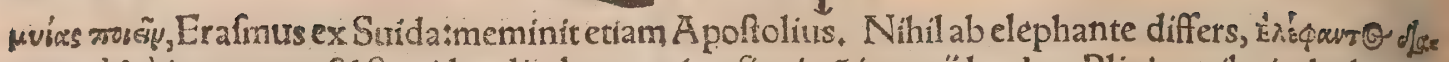

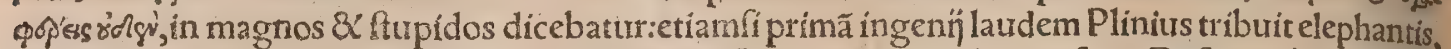
fed inter bruta. Verum corporis moles $\&$ formæ foeditas, adagio locum fecit, Refertur à Diogenia no. Videtur huc allude:e $\mathrm{P}$ alaftrio Plaútinus, qui herum fuum non fuo, fed elephanti corio circuna rectum ait; nec plus habere fapientix quàm lapidem, Erafmus. Legitur etiam aptrd Suidam \& $\mathrm{Apo}_{\mathrm{z}}$

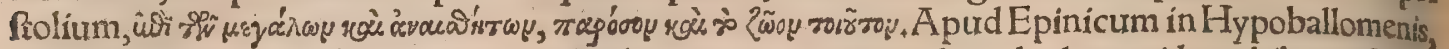
cuni iacfarct quidam fe elephantum poculum tricongium, quod ne elephas quidem ebiberet, fẹpitus

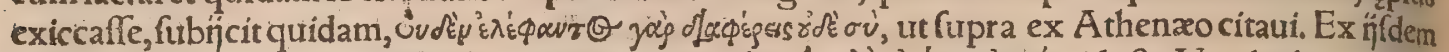

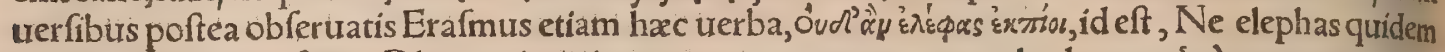
ebiberet, adágịs inferuit.R hytus (inquititerrat autem, nam pro poculo rhytum, furò, genere neutro femper profertur) poculi genưs eff, fpecie cornu, quod uidetur (hoc ex fua cốiectura dicit, mihi quis dem non tridetur) eburneum fuifle, impofitum imagini elephanti; ita ut quadruplex in iftis uerfibus elephanti mentio fiat (poculi, imaginis belux; eiufdem uiux, $\&$ hominis ebibentis, omnium elephan

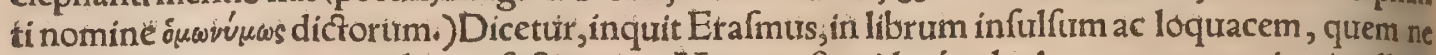
patientiffimus quidem perlegere fuftineat. Magnos ftupidosćs elephantorum nomine intellige, bant, uel Græco fuffragante prouerbio; Calius. Celerius elephanti pariũt: Sunt quibus hoc quiog (inquit Erafmus) inter adagia uidetur adnumerădum, qưod friptum eft apud Plinitum Secundum in prafatione hiftoriæ mundi $+N a m$ de Grammaticis, inquít, femper expectaui parturiri aduerfus lia bellos meos, quos de grammatica adidi: \& fubinde abortus fecêre iam decem annis, cum celeriuse tiam elephanti pariant, Hactenus Plinius. Itaģ cunctationem immodicam, 8 quorundam nimis len ta molimina, his uerbis licebit fignificare. Porrò de elephantorum partu Plautus in Sticho:Audiuife pe hoc uulgò dicier, folere elephantum grauidam perpetuos decem effe annos. Licebit adagiũ etiam in hãc uertere formam:Quando tádem paries obfecro, quod tot iam annos partiris, ut nec elephana ti diutius? De elephantorum pariendi tempore fententias authorum diuerfas, capite tertio pofui. In

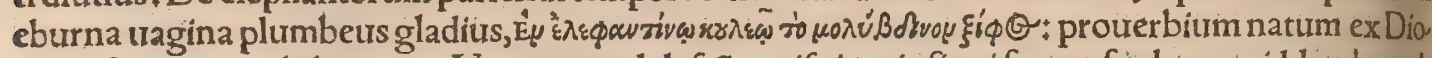
genis Cynici apophthegmate. Nam cum adolefrẽs quifpiam infigni forma, foedum quiddam jaţ̧ ob focnum dixiffet:Ex eburna,inquit, uagina plumbeum gladium educis. Ebur atramento candes facere, eft genurinę formæ, cultum at 3 ornatum externum inducere, quo decus illưd natiutum obfır retur magis quàm illuftretur.Proinde læna Plautina puellę naturali forma præditæ, tamen ceruffam ad oblinendas malas poftulanti: Vna, inquit, opera ebur atramento candefacere poftules.

\section{DE E Q V O.}

\section{A.}

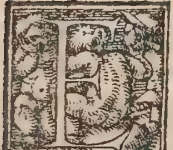

ov v s nobiliffimum inter quadrupedes animal, $\&$ uitæ humanx multis omnino mo: dis utiliffimum,è iumentorum numero cenfetur:cui equidem nullum anteferri poffeint ter bruta exiftimo, cum ingenï fimul $\&$ corporis eius dotes perpendo. Habent \& alix quadrupedum furas laudes, \& nonnullas quibus equum fortaffis excellunt: nam quiod bcue pluribus modis uictum iuuet humanum animal nullum eft. Sed fi cóferas inter fe ufus omnes, $4^{\circ}$ licet uno aut altero equus uincatur, pluribus femper trincet. Accedit quod ubiog terrarum equus ali \& nafci poteft. Quamobrem merito prima ei quadrupedurm, imó animalium ómnium, dignitas, præ cipuè in planis regionibus, ut bouri in montanis.Sed equilaudes $\&$ utilitates plurimas palfim uniurt fa hrec eius hilforia oftendet, eò cæeteris prolixior; quó plura de hoc animante, utpote omnium nobillif fimo, apud authores inurenimus, बEquum Latini etiam caballum uocant, de qua troce plura dicam initio capitis octaui. Hebręi olo fus, ut equam fufah, quam uocem Canticorum primo aliquiequi rattm urel multitudinem equorum exponüt. Appellant autem Graci quocs, tum equam, tum equita tum, hippon in foeminino genere:ero quidem Hebraice equum aliqui dictum putant quafi ve à gaudio. Hieremix octauo fus uel fis auem quandain fignificat; quam R. Salomon aliter corcaia dis

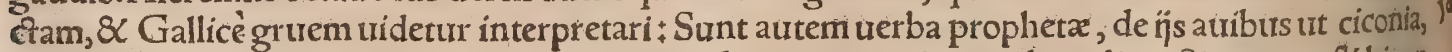
turture, hirundine $\&$ grue, qua norunt tempus futum migrandi ac redeundi. Sicut grus $\&$ hirun do fic garriebam, meditabar ficut columba, \&cc. Efaix 38. progrue Hebraice 51o fus legitur, Kimhi equum exponit, ut etiam Ionathan, qui in iam citato Hieremix loco equum expofuit: A quila quow equum reddit. Hieronymus alibi miluum, alibi hirundinis pullum, Septuaginta \& Symmachus yeris Mìn, id eft hirundo. Eroías, equus Syris, V arinus, waר rekeich, Dauid Kimhi docet R. Ionam putas re equum præftantem $\&<$ non annis confectum fic appeilari: ipfe Kimhi aliud genus animaliumnic fcio quod (iumenti, Munfterus) efle fufpicatur: $\&$ tertio Regum capite quarto fcribir quofdam pera dim, id eft, mulos interpretari. Leuri ben Gerfon equos urelociffimos intelligit, quorum ufus in beilo fit: \& fimiliter author Concordant, genus equorum. Hieronymus Efther octauo, ueredarios, Idem Genefeos 14.equitatum intelligit per wa7rekefch, poffeffionem uerò per way rekufch. Danielis un 60 decimo rekufch apparatum bellicum notat, alibi poffeffionem pecorum $\&$ rerum inanimatarum. ńchaftranim Efther oçato Hieronymus ueredarios transfert, Dauid Kimhi \& Abraham Eldre. 


\section{DeEquo. A. Lib. I. 443}

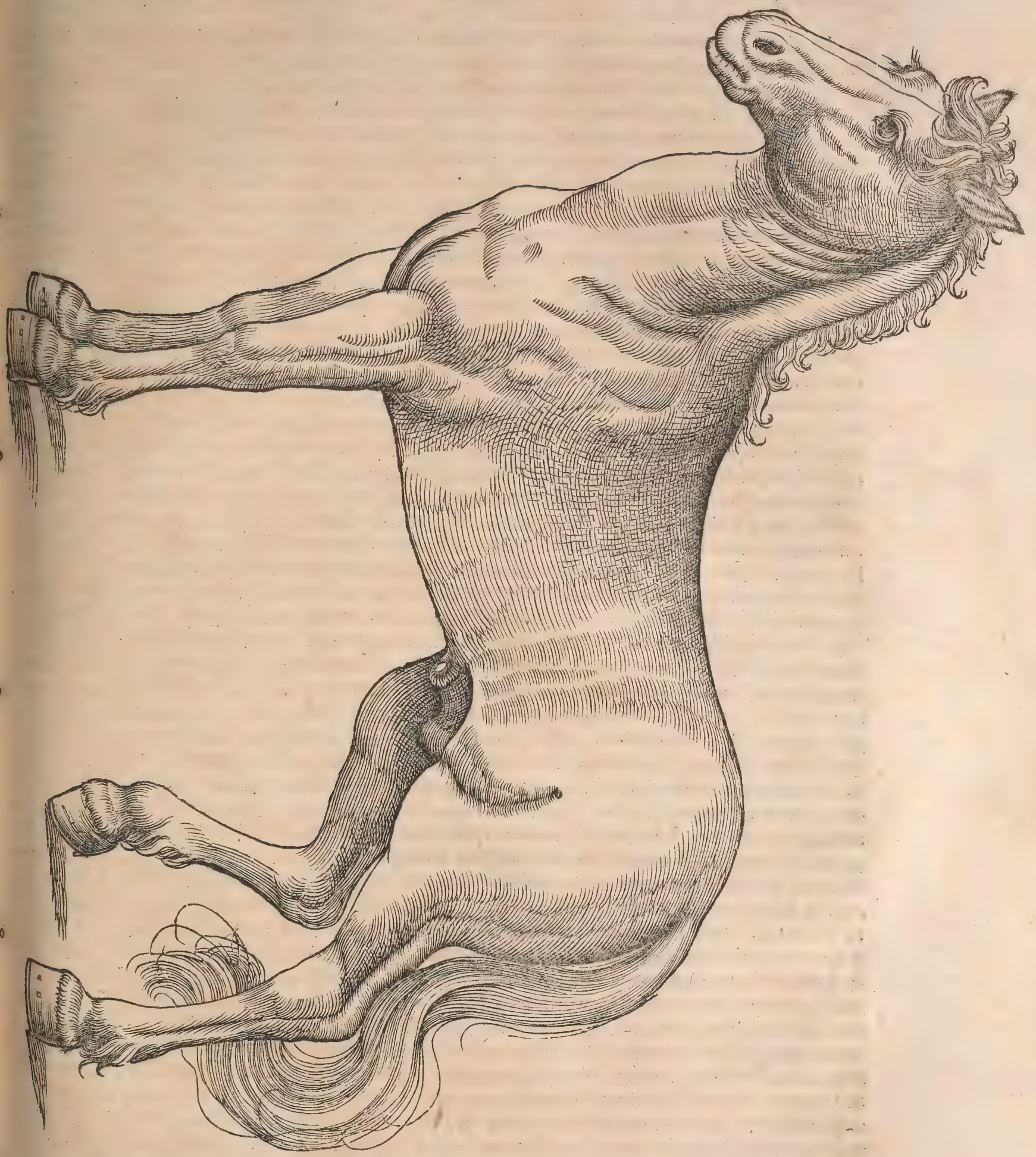

mulos, R. Salomon camelos celeriter currentes. Nominantur autẽ eodem capite achaftranim, bene, id eft pulli haramakim: ubi Dauid Kimhi ex traditione patris fui equam ait Arabica lingua uocari nמăramaka: R. A braham quogs notat Ifmaélitica lingtra equos ita trocari. Videtur fane iumenro. rumgenus celerrimum fignificari. Chaldaica translatio habet ramakim, id eft equi, Græcus snier: pres omittit:Hieronymus, Vt nouis epiftolis ueteres corrigantur. ๑n lentiam tauri $Q$ caballi dicuntur. $\quad$ Profus, id eft equo Exodi nono, Chaldaicé legitur furfathas. Arabice' $>$ ' baiel, Perfice kñok asbecha. Syluaticus uocem faras equx̃ exponit, $8<$ hara faras fer. cus caballinum, $\&$ anfefcalferas coagulum caballinum : $\&$ dheneb bachil , caudã equinam her bam: dunab quidẽ \& fanab pro cauda poni reperio, ut hachil equus fit. Si calcaueric zofach, id ef ecuus, o ueftigium dorim, id eft urfi(Hebræis \& Chaldxis dob urfus eft, zeeb uerò $\&$ deba lupus:pertinecau. tem ad lupi ueftigium quod hic feribitur, ut capite quarto confirmabimus) accidit ftupor eius ped! Aefculapius, Equus Gracis nominatur innQ , Italis cauallo, \& fimilicer Hifpanis : Gallis cheual, 


\section{4

Germanis to/f3, Anglis horfe:Bohemiskun, Polonis konï. Reliqua uide initio capitis octauí. B.

In admiffario quatuor fpectanda funt, forma, color, meritum, pulchriturdo. De cæateris aliâs, $\mathrm{CO}_{3}$ lores hi pracipui, badius, aureus, albineus, (abineus apud Cẹlium, ruffeus, murteus(mureus Cęlio,) ceruinus, gilbus (giluus Calio,) fcutulatus, aibus, guttatus, cãdidiffimus, niger, preffus (preffè niger Calio.)Sequentis meriti, uarius cum pulchritudine nigro, uel albineo, uel badio miftus, canus cum quouris colore, fpumeus, maculofus, murinus, obfcurior. Sed in admiffarijs præcipué legamus clari $\&$ unius coloris, cxteri trerò defpiciendi, nifi magnitudo meritorum culpam coloris excufet, $\mathrm{P}_{2} \mathrm{ll}_{\mathrm{a}}$ dius in Martio tit. 15. Murinus color uulgaris eft in afinis, Columella lib. 6. Myrteus eft preffus in purpura, Ifidorus. Canus \& colore candido \& nigro eft. Scutulatus fic dicitur propter orbes quos habet candidos inter purpuras, Idem. Scuttulata ueftis dicta eft à fcutula uafis genere, qux habet quofdam orbes uel circulos, quafi fcutulis diftincta. Galli fcutulis ueftes diuidere, qua fcutulata di xerunt, inftituêre. Guttatus eft qui ueluti guttas habet,šxī» Gręcis eundem puto, Et píta perdix, Numidícxós gurtratæ, Martialis. Ruffeum equum ueteres ruftici nominabant, qui non planèrube xet, fed proximè ad eum colorem accederet:fafinatum hodie quafi fanguinatum uulgó equifones ap pellant,Nic,Erythraus. Secundum Iordanum color baydus(nimirum badius) \& femialbus obfir rus fupra omnes eft laurdandus, Laur.Rufius. Sępe etiam improbati coloris equi, perquàm egregï funt, Idem, Oppianus per uenationum genera equorum colores diftinxit. Nam qui colore cęruleo

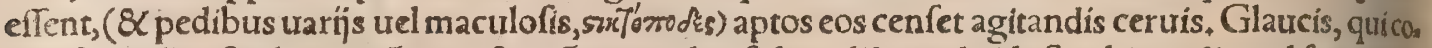
lor eft nitidior \& clarior, cótra urfos:cōtra pardos, fuluis, (daxфouvoös, id eft rubicundis, uel fanguineo 2

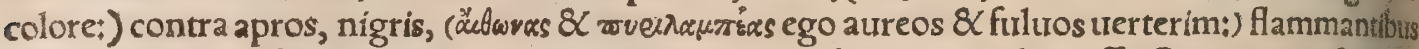
oculis ac renidentibus, qui uitrei nunc uocantur, contra leones utendum effe, Camerarius, Sed yaso ż่́s, ut Græce legitur, melius forte ad totius corporis, non oculorum duntaxat colorem retuleriss. quamuis glaucos etiã equos recentiores quidam oculorũ tantum ratione intelligunt. Venanti me lius pugnat color, \&c. Gratius:quæ fequũtur mutila funt: Multos certí colores iuuant. Nónulihiti aus aut illius coloris equos felicius à fe agitari putant: qua de re $\&$ aftrologi nô dubitant monere atch pracipere, infpecto cuiufgs themate genitali, Camerarius. Color naturalis equi, qui in fylueftribus deprehenditur, eft, cinereus, per dorfum linea fufca, à capite $u f \$$ ad caudam porrecta. In domeficis tamen boni inueniuntur nigri, ruffi, \& $\&$ albi aliquando: \& fimiliter grifei, qui quafi circulis partis ine terpolitis nigros albis immixto habent pilos, Albertus. Noftri obferuarunt nullos equos nafci pills albis, fed canis, qui tandem progreffu temporis dealbefcant. Putant etiam huitus coloris equos maa gis durabiles $\&$ uiuaces haberi, minusć morbis obnoxios. Sylla equum album, animofum, \&ue

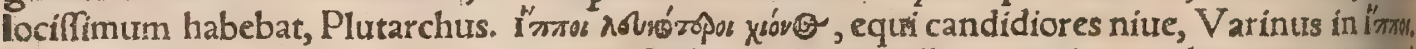

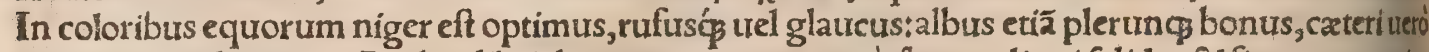
deteriores iudicantur, A uthor libri de natura rerum. Iryós innss, aliqui folidos $\$$ firmos equos in

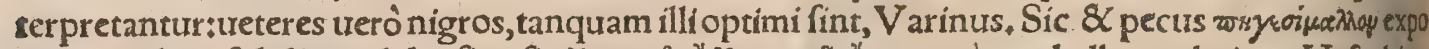
nunt, cuilana folidior uel denfior fit, ơ Venanti melius pugnat color, optima nigri, \&cc. Gratius:quę fequuntur mutila funt. iex'ś, ,qutus coloris illius quem Graci œnopòn quafi uneum appellãt(qualis in uino nigro apparet,) Hefychits

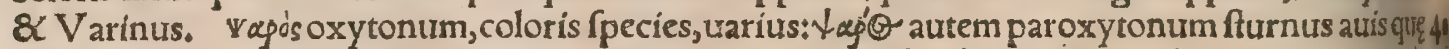
\& ipfa uaria eft:unde pifces etiam pfari dicti uidentur. Hine tagoi equi huius coloris uocantur, Y(x)

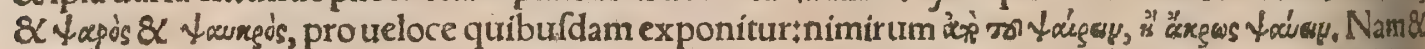

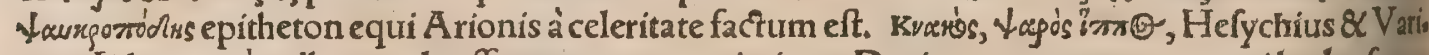
nus, Iidem xyeroy album uel ruffum exponunt, nimirum Dorice pro cneco:nam creci herba femen

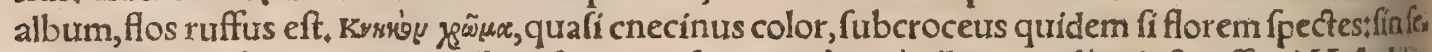

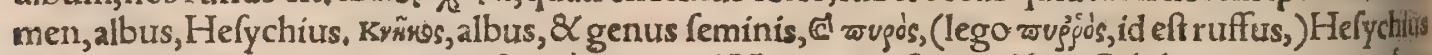

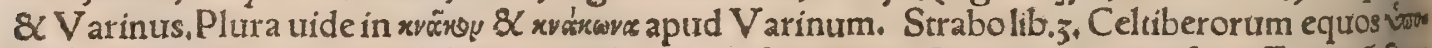
$\checkmark$ Leǵrs effe fcribit, interpres fubalbos reddit. Bonafus colore eft inter cinereum \& ruffum, nó ficur wajēas (paroí, Gaza uel parí, licet Codices impreffi corrupté partos habeant) dicti equi, fed fupra fqualidiore pilo, fubter lanario: nigri aut admodum ruffi nulli funt, Ariftoteles hift, animal, $9 \cdot 45 \cdot 9$ pagwöi (oxytonum) equi dicuntur quidam colore ruffi, Hefychius \& Varinus. Eft \& waṕ 0 o propa. roxytonum apud Hefychium de ruffo colore equi. Reperio $\&$ parium $\&$ balium colores equis attri butos, Hermolaus in Corollario, nec plura de pario. Ego meam fuper hac toce fententiam in $B 0$.

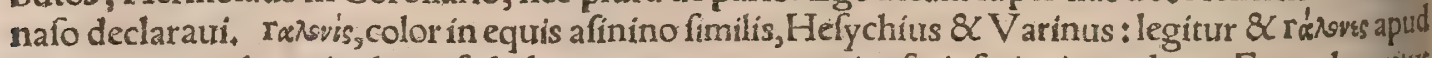
Varinum, quod magis placet; fed id qurogs per omega potius fcripferim in medio, ut Etymologusitut gániwy equus dicatur, tali colore infignis, nempe muftelino:nam galen Gręci muftelam uocant,crits color quoniam afinino fimillímus eft, afellum quogs infectum à colore dicium, alio nomine yeñay appellant. Honeft Spadices, glaucióp, color deterrimus albis Et giluo, Vergilius lib. 3. Georgiu corum: quem locum enarrans Vuilliclius, Germani (inquit) fpadiceum equum uocant ein bauss lingt: glaucum cin graulingt uel founlingt (fbimmelfarw, quem nofrates etiam pracipuè lat dant)forfan àcolore mucidi panis:giluum, ein pfacls pferot: (noftri falw fcribunt, tanquam àflato deducta uoce, fubflaum enim fignificat: Graci eum colorem wépoly dicunt, ) Audio huius coloris 

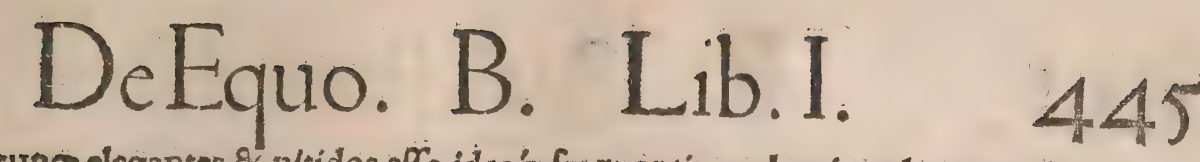

equos afpectu plerung elegantes \& nltidos elfe, ideóģ frequentius palpari, unde natum fit prourer bium in lingua noftra uulgare, ben falben bengft fry ben, de ïs qui affentantur 8 palpum obtrus dunt, Nifaus equus, id eft flauus, Exulós. Nifa enim equos omnes flauros habet, $V$ arinus. Grammaz cici noftri (Seruius) glaucos dici equos interpretantur felineis oculis, id eft quodam fplendore perfu fis, Cælius. Glaucus eft uelut oculos pictos habens, \& quodam colore perfufos, Vincentius Bell. ex lfidoro. Glauci equi felineis oculis, qui uxilgò glaurcioli dicuntur, Perottus, A tquí glaucus tam de reliqui corporis colore quàm oculorum ufurpatur, $8 \times$ de inanimatis quoqg rebus. Vergilius glau cas falices dixit \& oliuas $\&$ uluam, quod admiftum habeant uiridi colorialborem quendam. Sed ne uíridis quidem color(inquir Gellius lib, 2,)pluribus quàm à nobis urocabulis dicitur. Negs non potuit Vergilius colorem equi fignificare uiridem urolẽs, coeruleum magis dicere equum, quàm glaucum: red maluit uetbo uti notiore Graco quàm inufitato Latino. In animaliũ pilis puniceus, purpureus, \& porraceus ( coloribus, Iam cum porraceus color uiridis fit, qualis in porri folf́s nofcitur, repugnant hac Arifto relis tterba Gellio, qui glaucum in equis colorem uiridem exponit. Non placet etiam quod eundem colorem coruleum appellari poffe feripfit Gellius : mihi enim omnes tres diuerfi colores uidentur. Varium in equo colorem noftri uocant fobegget. Acolopoli Homero celeres potius equi quàm uarif funt, ex Porphyrị fententia, 8cc. Calius lib. 21. circa finem capitis 24. Inter colores equo. rum(ínquit Camerarius) elt rarior ille quidẽ, ideóq́, mea quidem fententia praclarior, urarius:quem lingua Teutonica appellat uerbo deriuzato à ftrabis oculis, quia refplendeát diuerfi colores, \& uifum quafi diftorqueant:quemadmodum $\&$ ueftes binis coloribus intextis ftraba uocantur. Sed hos, ma ximé equites certarum gentiữ non probant, quam tamen ob caufam nihilo funt deteriores habendi. Cur enim bis uarï equi non placent? Quia infidijs, latebris, ignorationi funt contrarī. Hic quidem color argumento uidecurr effe natura bonæ, \& conftitutę temper ata quadam miftione htumorum, de quibus \& albi \& nigri \& fului pili extiterint. Itaq \& elegãs feré eft horum corpus:fi qui autem inter hos excellunt, eos uideas tanta uenuftate $\&$ pulchritudine praditos, ut equeftre nullum Calamidis fignum fpectabilitus effe potuiffe uideatur: Et in equis certe diuerfi coloris, macula alba in fronte lau datur:qualis ille Vergilianus, quem etiam uariú toto corpore introduci fentio:tales cnim fuiffe con fિt Thracios, qui patrio urocabulo Marones dicerēturr, \& de colore $\lambda$ olsó $\psi$ axpor, admiffioni quidē non expetiti, quod deteriore colore pulli ab his gigni crederêtur. Qư ipfo nomine admirabiles etiam iu. - dico uarios, quippe hunc decorem forma qui quafi diuinitus confequi, non à parentibus accípere uideanur. Hos Marones à ueteribus dicos cum comperiffem, admodưm fuimus delectati, plurisć etiam quàm antea facere copimus, propter cognomen praclariffimi poëta, cuius de his uerfurs funt: Thraciusalbis Portat equus bicolor maculis, ueftigia primi Alba pedis, frontemóg oftentansar dutus albam, Hac Camerarius huius coloris equis pra cateris delectatus, Abfyrtus cap.14+(unde Camerarius mutuatus eft)tractans de coloribus, non equorum, fed afin/admiffarij, ita fcribit inter prete Ruellio:Speciofiores funt afini, quorum color in purpuram fpectat, idós fi nigram, nec urilate-

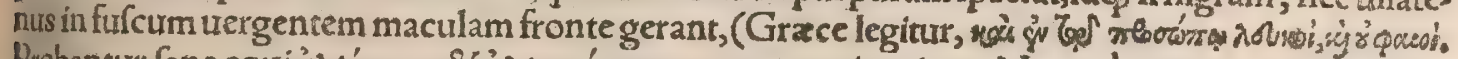

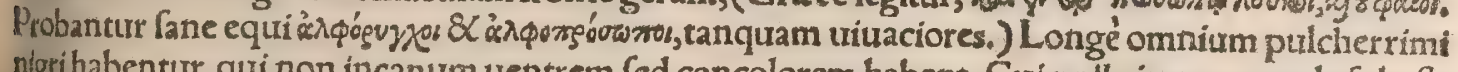
nigrihabentur, qui non incanum uentrem, fed concolorem habent. Cui pulla in ore macula fubeft,

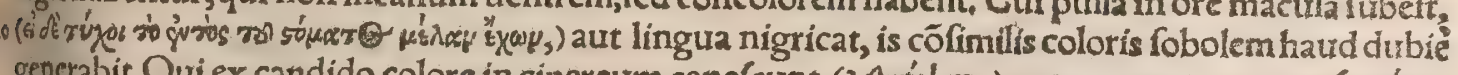
generabit. Qui ex candido colore in cinereum canelcunt, ( habetcodex impreffus) ij ad admiffuram non accerfantur: fiquidem colores nullo in pretio habiti, magna ex partereddentur foboli, Hac ille de afiniadmiffarĭ coloribus, Defpadicibus quaritum multis, qui nam effe uideantur:ac certut eft punicei coloris hos aliquid habere, ut $\&$ furfi illi, $\&$ fului, $\&$ in quibus rubentes macula albo infperf $x$ funt, ut purpurei appareant, fpadices habendi int, $\mathrm{Ca}$ merarius, Caffius medicus in problematis equos balios laudat, quos Gręcé Baciss, balos urulgo appel lant:Vergilius fpadices, id eft palmeo colore, Volaterranus, Spadiceus color eft palmeus:palmarũ. enim termites cum fructu furo fpadices \& baia Gracia nuncupat. Vnde 8 nunc baius equus (lo ca: uallo baio, Scoppa) qui badius Varroni, ut eft apud'Feftum, 8 balius Caffio medico nominari uide. our. Nam is in problematis generofos ait equos effe balios. Color hic uulgò aliâs Lionato dicitur, $\mathbb{N}$ i col.Erythraus Italus. A di Gellium lib. 2. capite quo de coloribus tractat, Bx́іoy, ramus palma, Vari. nus. Balius color (apud Plinium libro ultimo cap.7.) uidetur accipi pro uario ab Euripide: quidam pro fpadice, hoc eft palmeo, qualis eft equorum quoģ (quos \& phalios aliqui frribunt) apud Maro. nem. In Vopifco diximus baltias fiue balias à colore uefes appellari; fed blatteas fcribendum ibicen lco, Rura hodie fubrubrum colorem panni blattum Roma appellant fiue bladum $\div$ ut hinc uideri poffit ortum, quamobrem frumentum quoqs ipfum ica barbaré nominetur unlgònnam robit tritici Co

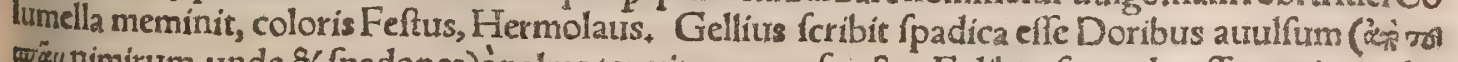
wäy nimirum, unde \& fpadones)é palma termitem cum fructu: Et libro fecundo, effe punicei calo. ris fpecie. Spadices(inquit Seruius)phoniciatos urocant, id eft profeffos myrteos. Tincrores $8<$ fpa dicarï apud Firmicum nominantur. Spadix, phonix \& lyrophonicium, inftrumenta mufica funt Polluci. Balios uentos accipiunt uiolentos:nam $8<$ balias equos, celeres intelligunt poéta, Cælius. Scoppa Grammaticus fpadicem equm, palmatum quog uocat. Palmatum parietem Quintilianus 
dixit. Mihi quidem fpadix color uidetur proximus illi quem nos àcaftaneis denominamu êt ef nenbran, \& huius coloris equos, imprimis laudamus, Puniceum ueró, licet is etiam nomen à phot: nice, id eft palma mutuatus uidetur, laetius rubere puto, non fine fua nigredine tamen, qualis in rofa. rum quodam genere apparet, tanquam purpura faturata \& nigricante, qualis forfitan apud Phoenj ces populos, à quibus $\&$ oftrum Tyrium dictum, tingebatur: ut ind e potius ei nomen fit quàm ab ar. bore. Badium antiqui uadium dicebant, quia inter catera animalia fortius uadat, Idem fpadix eft quem phonicatum uocant,à colore palmx quam Siculi fpadica appellant, Vincentius Bell, ex Ifido ro. Equi badrin nominantur etiam à Gratio poëta, Bxגíxs, paroxytonum, nomen equi A chillis, fignifí cat etiam uarium, in qua fignificatione Bario quogs cum omicro fcribitur in ultima. Balium aliqui

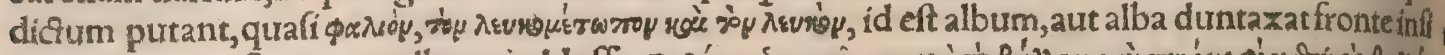

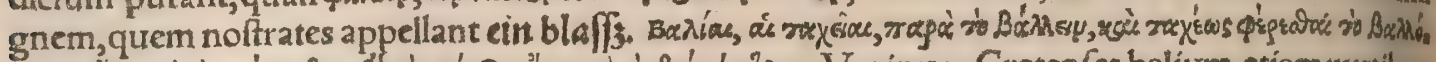

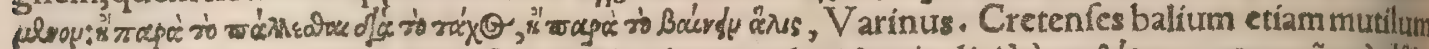

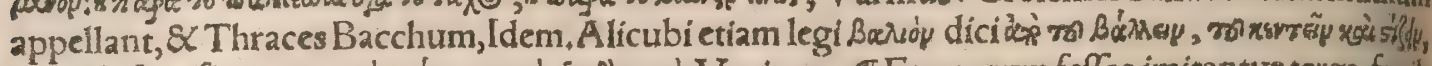

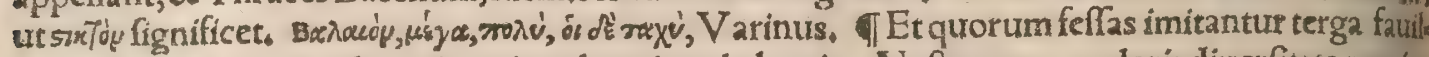
las, Gratius de equis colore cinereis, uel canis, uel glaucis. Noftrates pro coloris diuerfitate nomina quogs diuerfa equis imponunt, qualia funt rapp/ / bimmel/ blaff5. Iubam effe concolorem cotpori cenfuere ueteres effe optimum:nunc tamen in fuluis laudatur albicantis comx quafi canicies, 81 iो

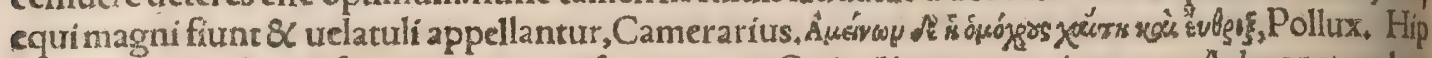
pocomi fape colorem fuco, robur inani fagina, ut ait Quintilianus, mentiuntur. Admonet me hrec de coloribus equorum tractatio, utiftos etiam quos Gracioryngas uocant, wgyyes, hoc potifimitn loco commemorem, Horum genus amabile, uarium ( $5 \times x^{\circ} \psi$ ) ac perpulchrum uocat Oppianus libro primo de uenatione. Nomen autem eis inditum putat, uel à montibus, uel à libidine, hifce uerfibus:

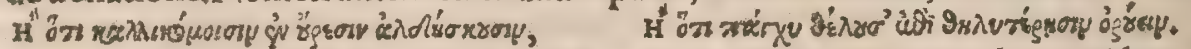

Addit, alios eorum maculis fiue tanţ̇s oblongis frequentibus ornari, quales tigridum fpecantur; alios rotundis ut panthere:atog has maculas cauterio adhuc pullis adhibito fieri. Sunt \& alię(inquit) mangonum artes, quibus pullos etiam quocung, placuerit colore concipl $\& \mathrm{Kafci}$ efficiunt. Nam cun equa libidini obnoxia eft, equire dicunt, admiflarium bellè ornatum $\&$ pulchris pictum colori

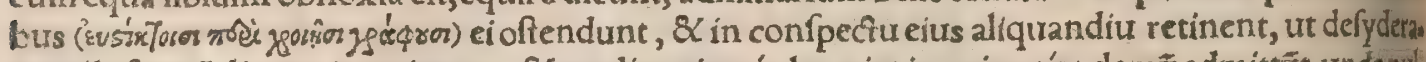
cam illa fpeciẽ diưtius imaginetur, $\mathcal{Q}$ oculis animoç hauriat imprimatóg: demũ admittứt, unde pul Ius fimilis patri concipitur. Columbas etiam pulchris \& uarijs coloribus, quales in confpectu eis per libidinis tempus fuerint, nafci, fuoloco dicemus. In hippoconicis libris Germanica linguazditis, nigrum colorẽ pilis equorum albis induci reperio fi abluantur filicis radicũ $\&$ faluix in lixiuia deco. cto. Dealbari uero pilos illos qui illiti fint pinguedine collecía ex decocto talpre in olla noua: fuptu natat enim pinguredo, fi talpa diutifimè decoquatur. Vel fic, Pilís euulfis locus illinatur mele crudo cum adipe melis. Alij aliter idem moliuntur. Sxpius quidem fimiles foetus parenti zedere confurut runt equæ, ut Pharfalica femper, quam ideo probam nominarunt, Camerarius. Prater hominempl los equo tantum canefere Plinius foribit, Equis pili in fenecta aperté canefcunt, Ariftoteles, Ek:al bi , Equis maximé omnium quæ nouerimus animaliữ canicies innotécit:quodos in quo cerebrum, tenuius quàm cæetera pro magnitudine habeant:argumentum eft, quod ictus in co loco periculofir eft:unde illud Homeri, Et qưa fetæ hærent capiti, letaléós uulnus Præcipuè fit equis.

a De pilorũ coloribus equi tum alijs, tum canicie, iam proxime diximus: Reftat ut ipfas corporis equini partes enumeremus. Equo $\&$ boui plum quotannis deciduum effe quidam fcripferunt, $C x$ lius. Quia pilis equi in gena feu palpebra inferiore carent, propterea Apeli Ephefio quil equuin quempiam pinxiffet, reprchenfionem attuliffe ferunt. Alij non A pelli hoc accidiffe, red Niconialitit, cum tamen fcientifime cateras equi partes pinxiffet:hanc partenilli uitio uerfam fuiffe, $\bar{A}$ elia, lu

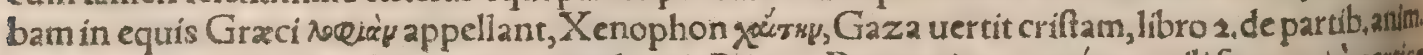

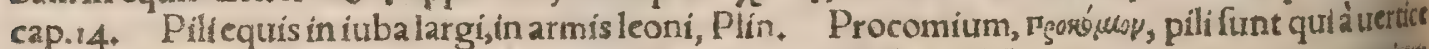
equi iuxta oculos \& tempora propendent. A pud Vegetiư libro 1. Veterinarię cap.11.protocomiun legitur, quod non adeò placet. Xenophontis interpres iubam uerticalem tranftulit, Latinius capro nas dichurus. Sunt enim capronx, comx ante frontem, quafi à capite pronx, telte Nonio: uel uifes $\beta$ Rus ait, equorum iubęin frontem detrexæ. De his Lucilius in Satyris apud Nonium, A ptari capui,

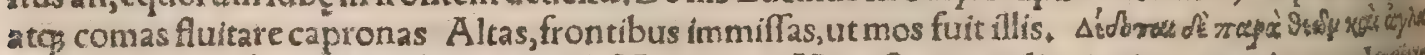

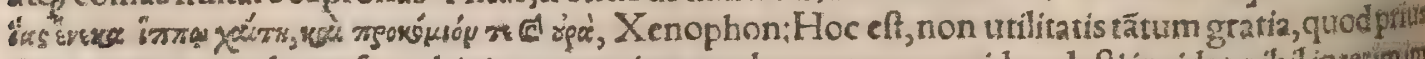
dixerar(nam cauda mufeas abigit: procomium oculos tuetur ne quid moleftincidat, nihil inter im in pedito pilorum prolixitate ứfu:afinis quidem \& mulis procomí loco ad oculos defencendos aures cata func longiores. Iuba confcenfori adminiculum praftat, cǫ́ magis quo fuerit prolixior) iuba caprone \& cauda equis contigerũt, fed etia decoris ornamentiğ loco.Quod uel equi ipfi intelligute

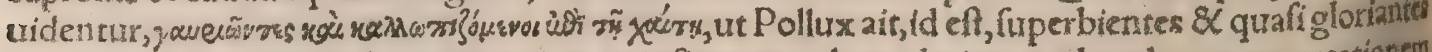
cbiubam furam, Quamobrem perorigre qui afinos equabus admittunt ad mulorum procreationem

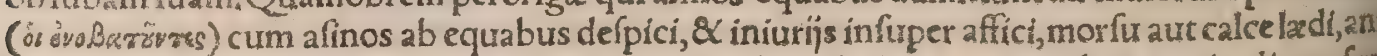
ucrtunt, iubis detonfis equas ad fontes tanquam fpecula ducunt, in quibus turpitudinem fuam \& ademptum coma decus contêplata, ignobiles illos admiffarios non amplius dedignantux, of \& tom 


\section{DeEquo. B. Lib. I.}

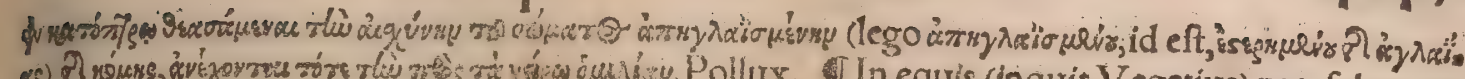

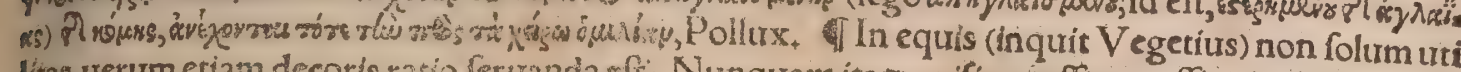
litas, uerum etian decoris ratio feruanda ef: Nunquam ita $\beta$; nifi neceffitas paffionis exegerit, de articulis refecandi funt cirri. Nasmale enimornamentum pedumnatura ín illis cōtituic. Ceruicem ctiam ipfam diligens deber ornare tonfura. Multi enim ficut currulibus, ita \& fellaribus iumentis preffirs colla radunt. Qua res licet praftare creditur augmentum, tamen fub honefto feffore defor mis el. Alï ita tondent, us arcum uideantur mitari. Nonnulk Armeniorum more crines aliquos in tonfura ipfa per ordinem der elinquunt. Sed gratiora funt qua translata de Perfis pofterior ufus in uexic, Nam media iuba ad omnem accurationem ex finifta parte tondetur, â dextra ueróomnino - infecta feruatur. Et nefcio quo pacto plurimum deceat, quia illud quod naturalicer laudatur Ver glius imitatur; Denfa iuba, \& dextro iactata recumbit in armo, Quod fí bicomis fuerit, ut urulgus appellat, medię ceruịcis fetas eqqualiter oportet attonderi,ita ue tam dextri quàm finiftri limitis conti-

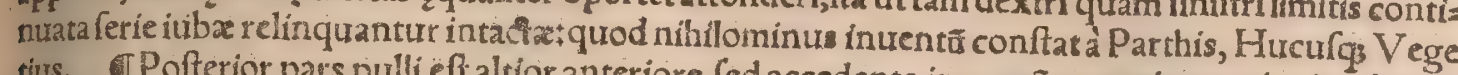
tius, GPofterior pas's pulli êfi altior anteriore, fed accedente increméto $x$ tatis anterior in plerifos fublimior fit. Pulli equini, inquit Ariftoteles, pauló fuis parentibus fummiffiores funt, atç adulti crure pofteriore caput attingere nequeunt, quod nouelli facilèattingunt. Mulomedici quorum barbara dictio eft, ut Laur. Ruffius, paftoralia in equo uocant iunciuras fiue articulos pedum ni fallor: quod ea parte numella (uinculigenus, Itali paftoram uocant: \& ita uincire,paftorare)adhis berifoleant. Tlumentum habet in capite offa duro, $\mathbf{a}$ fronte ufg ad nares alia duo, maxillaria in. - feriora duo: dentes quadraginta, id eft molares uigintiquatuor, caninos quatuor, rapaces duode. cim. In ceruice autê funt fpondyli feptem, fpatulx (lego fpondyli) renum funt octo, à renibus úfog ad anum feptem. Mufcarium (id eft cauda) habet commiffuras duodecim. In armis prioribus funt ragula dux: ab armis uffę ad brachiola duo:à brachiolis ufig ad genua duo. In genibus paraftatica

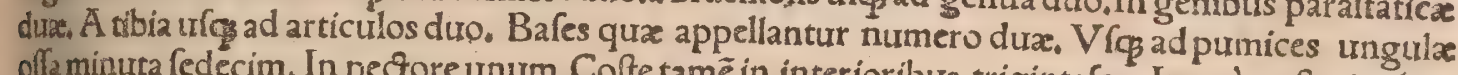
offa minuta fedecim. In pectore unum. Coftę tamẽ in interioribus trigintalex. Item à pofterior ibus à cumulari (aliâs colưmellari, fed paulò poft commiffuram renum cumulare uocat) uíq ad molaria duo:àmolaribus ufopad uertebras duo : coftales duo. Ab acrocolephio (acrocolion incelligo, id eft coxam uel fuperiorem femoris partem, nam inferior hypocolion uocatur) ufggad gambam (id elt tibłam:ut Itali \& Galli hodiéǵ uocãt) duo: à gamba ứç̧ ad cirros tibiales (pilos longiores incelligit,

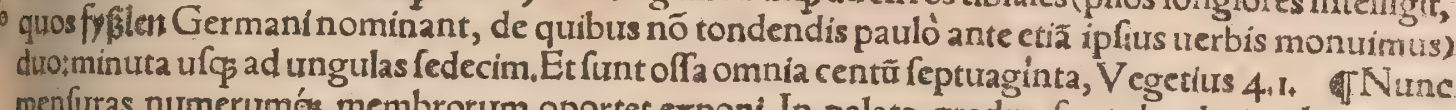
menfuras numerumǵs membrorum oportec exponi, In palato gradus funt duodecim: Iongitudo lingux habet pedem lemis:labrum fuperius habet uncias fex, inferius uncias quin Ix uncias denas:à cirro frontis (procomium fic appellare uidetur) ad nares haber pedern, auxicula fin gula continent uncias ferias. In oculis autẽ fingulis uncix quaterna. A cirro ubi definit ceruix ufga ad mercurium continentur calculi octo. Spina continet fubterfpatulas trigintaduas. A commifura renum, quod cumulare dicitur, uf ad imum mufcariun commiffura funt duodecim. Sagula lon. gicia uncias duodecim. Áb armis ufq ad brachiolum uncias fex. A brachiolis ufg ad genua loas gitudo continet pedem. Ab articulis uff ad ungulas uncias quatuor. In longitudinem uel prolixita.

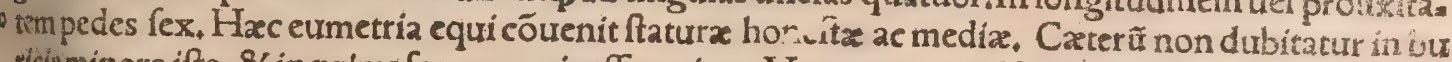
ricisminora ifta, 8 in primę formę equis effe maiora, Vege. 4.2. GNeruorü quo co numerus, qua

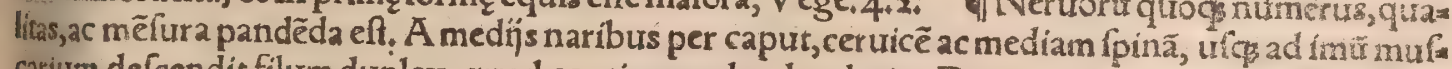
carium defcendit filum duplex, quod continet pedes durodecim. Duro nerui in ceruice palmarĭ con tinertpedes quatuor. Ab armis uf́p ad geniculü nerui duo. A geniculo ufकs ad bafim nerui quatuor. In prioribus funt nerui decê, in pofterioribus decê. A renibus uf̧̧́ ad teftes nerui quatuor. Fiunt in

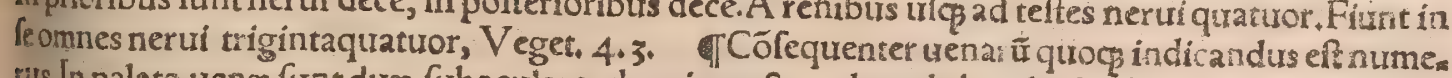
rus. In pala to uena funt dux, fuboculares dure, in pecfore dux, de brachiolis dua, de fubcirris quaz itur, de talis dua, de coronis quatuor, de feminibus quatuor, de femoribus uero dua, de futh gambis dux, de muf́cario una, uenæ matricis in ceruicibus dux. Fiunt pariter uenę uigintinouem, Vegetius 4. 4. ब1 Veneq quadam fupra oculos fecantur equis, minutis in eum ufum factis phlebotomis. De. trahitur etiam fanguis ex palati uenis. In ferto diui Stephani mos erat olim apurd noftrates uenã in certuice equor ũ aperire, propter plures eius temporis ferias:nunc propemodđ̃ exoleuít. Sanguinem detrahes de ceruice, id eft de matricali uena, V egetius 1. 13. Spadonibus equis inter authores conftitit fangtrinem de matrice nunquam, nifi forte ex nimia \& extrema necefitate, tollendum: propterea quod caloris maximam partem cum teftibus amiferunt. De palato tamen, fi non impediar negligen. tia , omnibus propè menfibus tam fpadonibus quàm tefticulatis minuendus ef fanguis. Admiflari uerò fi cohibeantur à uenere, ubi dematricati fuerint(id eft fanguis ex matrice urena eis detrac?us, ut ego interpretor)cacari fape dicuntur. Quamuis eo anno quo admiffum faciunt, non fis eís tuena la. xanda, ne generationi intentum corpus cura gemina neceffitatis exhauriat, Vegetius 4.7 . Recen tiores uenam magnam, aliâs nigram, \& fontanellam eandem faciunt. Vocant autem Itali fontanel. $\mathrm{lam}$, locum qui in equis forinfecus cauus apparet circa coxendicem, quin \&'iugulum feu thymum in honine eodem nomine appellant, Si equus fuerit morfunditus, fcinde pellem fupra fonsanellam 
hanchx, QC. Lau.Ruffius cap. 93. Spauanus morbus circa garectü ex latere interioti fubtu garen cium parum inferius, quandogs tumorem inducens circa uenam magiftram quę dicitur fontanella Iden cap.103. Extremitates gulae cum parua rofneta in tantum cauentur funditus, donec uena man giftra pedis qua tendit ibidem, rumpatur, 8 fanguis fluat, Idem cap. 129, In dolore corporis equie $x$ fuperfluo fangưine, de uena quę tigrarica dicitur, uidelicet prope ungulam ab urra $\$$ parte corporis minuatur, Idem. Vena confueta inter iunciuram \& pedem ex latere interiori aperienda eft in attras ctione dicto affectu, Petrus Crefcent. Hanc uenam effe puto qux uulgo à noftris uocatur biefy.

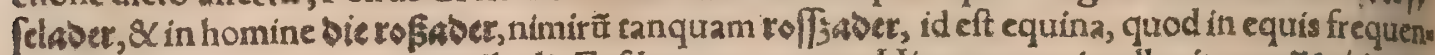
ter incidatur:eft autem uena malleoli. Eafdem puto uenas Hippocrates intellexit moorijop violes uo.

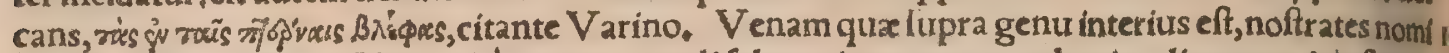
nant vie fbrancta ber:Illam uerò qua pertundi folet ea in parte, qua calcaria adiguntur, die fpost ser:quam Petrus Crefcent, 9.18, cingulariam, ut conäcio, appellauit:Si equus(inquit)doleat ex abun dantia fanguinis uel humorum intra trenas, \&<c. ftatim à uena cingularia, qux eft prope cingula ab

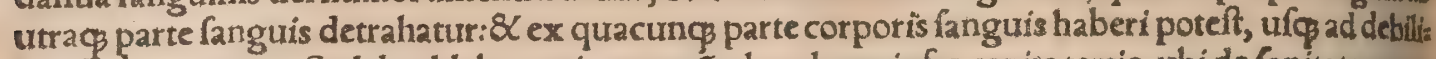
tatê feréminuatur, Sed de phlebotomia equorü plura leges infra capiec tertio, ubi de fanitate equor

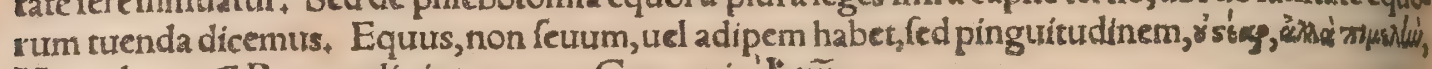
Herocles, Pars media inter aures, Germanicétam.

TOculi equorum quibuídam glauci,Plinius. D. Augufto equrorum modo glaud fuére, fuprấ hominem albicantis magnitudinis, Idem. Cur alibi tam homines quàm equi oculis magna ex parte cxfüs (glaucis in Graco)funt? A n cum oculi uriplici coloris genere diftinguantur, nigro, capring, \& cxfí, cor poris totius colorem oculi quocs color confequitur:ità ha had immeritò cafius eft, Arifto, teles Sect, 10.problem, 13. Grammatici noftri glaucos dici equos interpretantur felineis oculis, id ef quodam fplendore perfufis, Calius: Fed de hos colere circa reliquum corpus fupra diximus, Noftrl

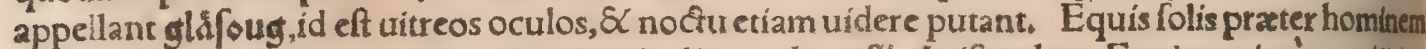
uariat oculorum color:proueniunt enim eis aliquando caffĭ, Áriftoteles. Equi maximé omniêta terorum animalium oculis uariant: aliqui enim cxfin altero oculo nafcuntur, quod nulli ex cxteth

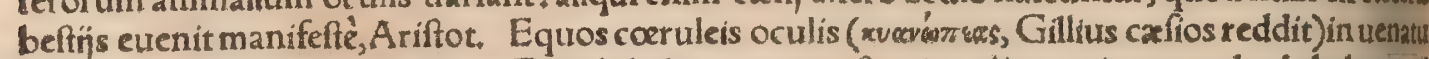
contra ceruos Oppianus probat. Exophthalmos equus eft cui oculi prominent, ccelophthalmos cul in receffu cauo cöduntur, Cælius. Equi heterophthalmi habentur quibufdam pulcherrimínérinsw praftantiflimi)cuiufmodi fuit AlexandriBucephalus, Pelagonius in Geoponicis 16.2.ut Calius ues 30 cit. And. à Lacuna heterophthalmos reddit monoculos. Inter optimos, inquit, monoculos à quibuldă cenferi Pelagonius ait, fi a natura talem orbitatem contraxerint : nam fi à cafu, abfurdum efletid dis cere. Idem Cornarium reprehendit, quod heterophthalmos interpretetur ab alterius oculi uarictet fic diços. Videtur autem deceptus uerbis Ammonä, qui in libro de uocabulorum differentäshet,

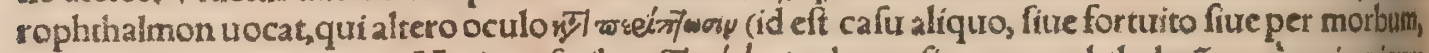

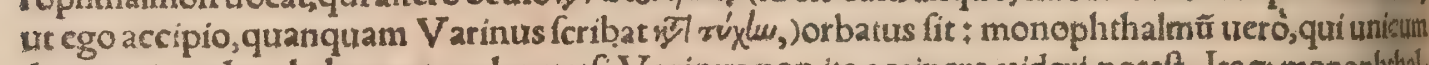
duntaxat oculum habeat, ut cyclops:etfi Varinus non ita accipere uidert potelt. Itaq monophthals mus, nifi monftrum aliquod fortaffis, nemo fuerit: heterophtbalmi uero Ammonio dicii quicunģ al tero oculo caci, altero tantum uident, fiue ita nati fint, fiue cafu poftea fuperueniẽte. Sed huiufmodi equi qua ratione laudari poffint non uideo. Abfyrtus certe lib. i. Cap. 13. longe alios uidetur hetero 4 phrhal mos dicere, his uerbis ut Ruellius tranftulit: Heterophthalmi, id eff qui uarietate oculorü nou

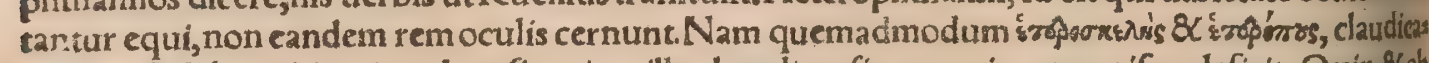
re folet, \& labori itineris cedere:fic etiam illos hac diuerfitate uariegatos uifus deficit. Quin \& ob hanc oculorum uarietatem, \& improbi, \& rerum eis occurrentium uerentes, nee non ad fpeciente rum oculis cbiectarum confternabiles funt. Hos tamen Parthi magno in pretio habent, \& pro gene rofiffimis adfumunt: apud quos primû procreatos fuiffe côftat. Qui ueró difcolores notas in cęgo. re referunt, eos Parthos ueteres appellarunt, apud quos primum in lucẽ æditi produntur, $\mathrm{Hac}_{\mathrm{B}} \mathrm{b}$,

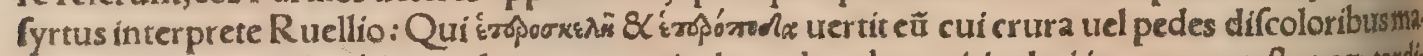
culis euariant, quod mihi non placet:neos enim hoc admodum uitio dari in equo poteft, neg tardis

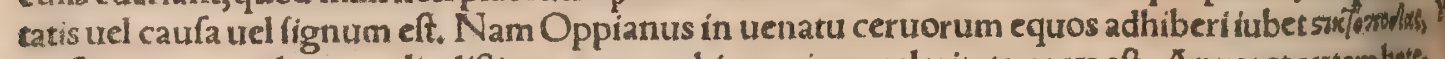
id eft quorum pedes maculis diftinguantur, ubi pracipua celeritate opus eft. Apparet autemhiet? rophthalmon quoç Ruellium intellexiffe eodem modo, cui uarn̈s punctis aut maculis coloratifint

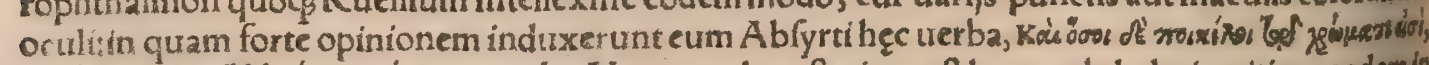

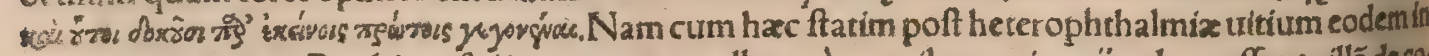
capite fubriciantur, Parthicos fculicet equos appellatos à ueteribus qui uarn̄ colore effent, illá deco loris oculorum uarietate intellexí, cum author nihil circa colorem eis commune, fed nomẽ tantum à gente apud quam utriq̧ nati primum celebrentur, infinuer. Proinde non probo quod Ruelliusure cit, Qui uerò difcolores notas in tergore referunt, \&c.quafi uero etiam beterophthalmi fimiles, ideft difcolores notas in oculis referrent. Alia igitur quadam uarieras $8 \times$ ditrerfitas unius frilicet oculliad alterum collati intelligenda eft, fiue ea in colore fit (nam ex Arifotele fupra citauimus equos nónuls " los altero oculo cafios nat́ci, quod nulli ex cateris beftïs manifefré eueniat; )fiuc alio quodá affectur, Huc facit quod heterognathos equus appellatur, non ulla coloris ratione fed qui caput in alterum 


\section{0 \\ DeQuadrupedibus}

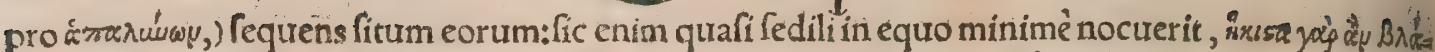

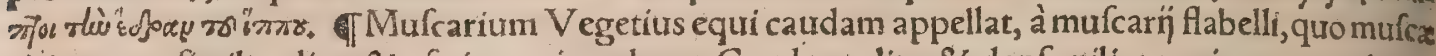
abiguntur, fimil tudine, $\&$ ufu in equis eodem. Cauda prolixa $\& \mathcal{L}$ denfa pilis pracipuum equi oma mentum eft, de qua fupra ctiam ex Xenophonte nonnihil dixi in procomí mentione. Equorum caudxe tenor breuis, pili prolix: bubus contra, Ariftoteles. Cauda animalibus pralongis fetof $x_{5}$ ur equis, Plinius. TSuffrago id eft in pofterioribus pedibus quadrupedum, quod in prioribus gentu. Vel eft nodus aut ar ticulus fub crure, quo pedis uerfura conftat, tibiaćl ita anneçitur pes, utuerti poffit:id quod Spectamus in bobus, equis, \& cateris armentis. Dicf fuffragines quod fuffringan= tur, hoc eft in altum frangantur:uel quod ad greffum fuffragẽtur. Conftat fanè genua animalium, qux animal generant, ante fe flecti:fuffraginum úerò artus in aduerfum:Quemadmodum igitur po plites dici funt, quod polt plicentur : ita fuffragines quod fubter frangantur. Aues $\&$ quadrupedes in priora curuant, fuffragines in pofteriora, Plinius libro 8. Barbari fuffraginem garreçum nomio

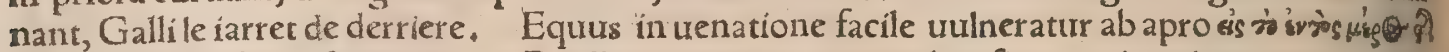

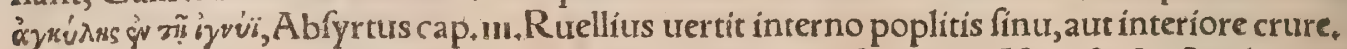

If Vegetius crura ipfa in iumentis gambas uocat, quafi campas. Nam \& Âriftoteles campen no: minat in pedibus, qua fuffragínes poplitesç̧ habentur, Hermolaus. Legimus etiam fuper gambam apud Vegetium 3.20. \& fubgambam 3. 22. Si laccx in gambis fuerint, aut aliquis dolor coxa uel gamba, fanguis detrahatur gambis:funt enim uenæà uifceribus defcendentes per gambas interius, Vegerius 1.27. Idem lib.3, cap.19, de laccis gambarum feribit, \& mox cap.20.de iumento ganbofo,

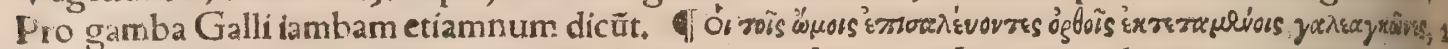

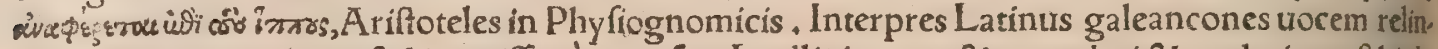
quít, catera ad uerbum, fed ineptiffime, transfert. Intelligi autem $\&$ emendari $\&$ expleri poteft hiclo

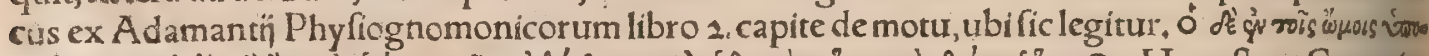

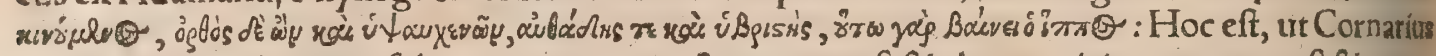
uertit, Qui uero humeris fubcommouretur, rectus autem eft $\&<$ alta ceruicis, contumax eft \& contur meliofus, ita enim graditur equus, $r a \lambda b x$ x nus (uel breurius) habear : grammaticus quidam recentior cundem Latinè ancum uocari ait, Fefus ancum illum effe docet, qưi aduncum brachium habet, ut exporrigi non polfit, nimirum ab ancône, id eft cubito incururo, Sed hoc quid faciat ad iam citatum Ariftoteliş locum, non uideo. Adamantils

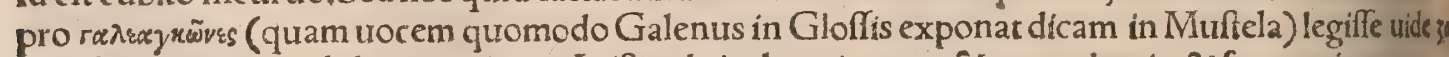

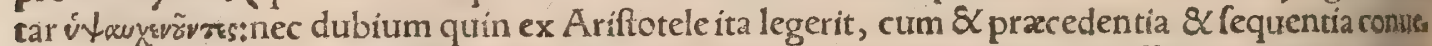

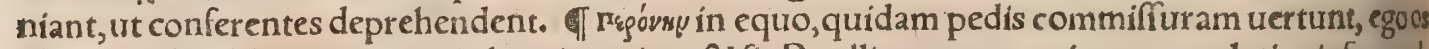
tibia quod radium uocant, ut in homine etiam, \& fic Ruellius quog; capice 13. translationis fua red

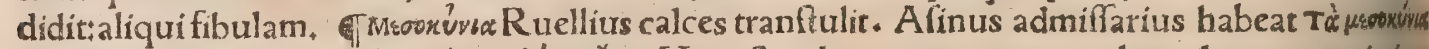

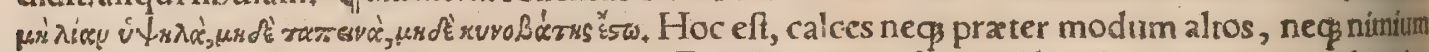
depreffos: fed neģ nixus talis ingrediatur, ut Ruellius uertic. Idem alibi talos, ut capite 7.uel uteius

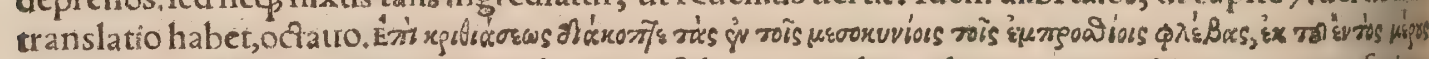

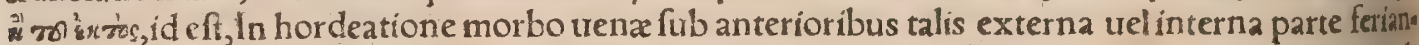
tur. Rurfus capite viz.de domitura pulli, $P$ ullo (inquit) qui commițitur exercitationi, folum nonal ta profunditate fubînciatur: quippe cũ facile tibię radiũ hinc contingat abfredere, id quod pedis arti 4

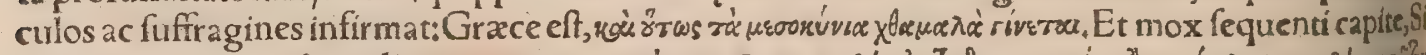

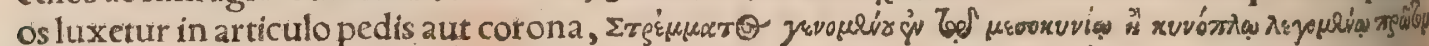

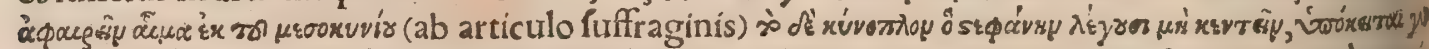

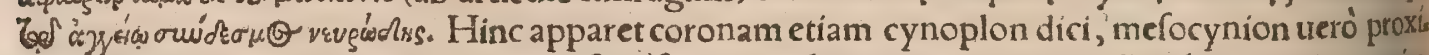
mam (fuperius nimirũ paulo) partem, \& ipfam quandoç propter uicinitatẽ codem nomine uenire

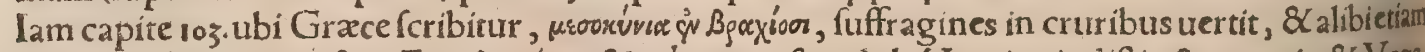

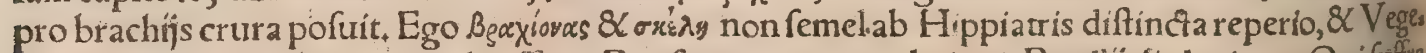
tium etiam brachiola in equis dixifle. Rurfus cap.112, translationis Ruelli, fic legimus: Quif ififin

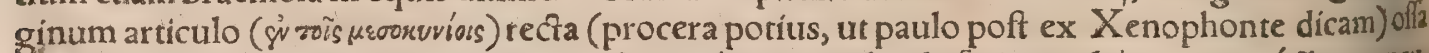

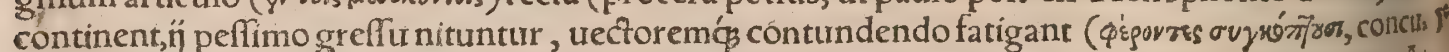
tiunt nimirum ut equi fuccuffatores) n̈ quod ceruino pede conftant, elaphopodes nominantur + $\bar{A}$ t qui eifdem in locis breuia condunt offa $\&$ humilia, ob id ç $_{\text {cyno }}$ hobatæ uocantur, î ungulas ad inters

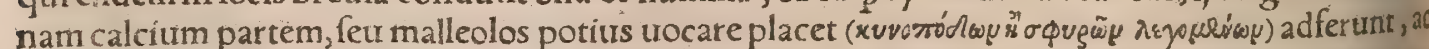
pedes tractim agunt ( $\dot{\varepsilon} \lambda \varkappa \tilde{\gamma} \sigma$ lego ex Xenophonte, cuius uerba paulo poft citabo, id eft, uulnerantpes

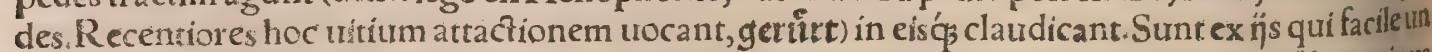
gulis aberrent. Kuvo Bulusey uocatur equrus quidam, Hefychius \& V Varinus. Equos quofdam mints probandos cynepodas fuiffe nûcupatos inuenimus, Calius: Ego nufquam ipfos equos, fed tibiarum in eis partem fic appellari inuenio:Pollux tantum in Canum hiftoria xuvímodas inors fimpliciternos

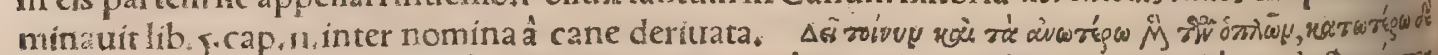

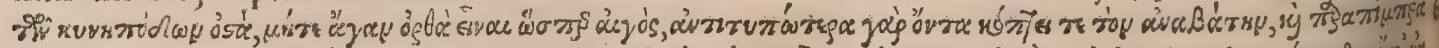

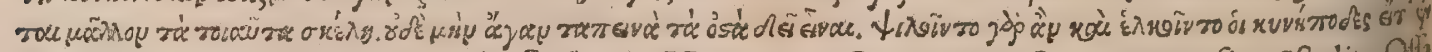

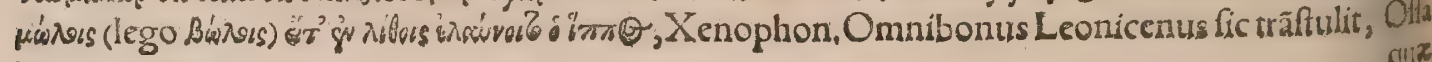


gulx, quam nutrit etiam, eiusćg radices in fe cötinet. Hac fape clauis folearum malè adaçis laditur,

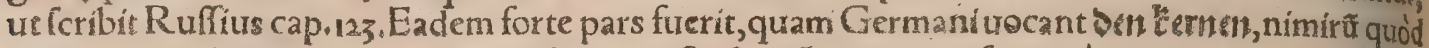
mollior intra duriorem tanquam nucleus in tefta fua cótineatur?nifl quis à carne nomen deductum malit, quòd carnis fubftantia conftet, Eandem aut proximam partem à Gracis batrachon díci conif. cio. Nam A bfyrtus in Hippiatricis cap.8. de hordeatione fribẽs, Frictio (inquít)fecundum pilos ad imas partes fpeciet: fiquidem per pedes huiufce morbi impetus erumpere creditur : quapropter pe, cus ungulas abijcit; in quibus partes illæ quas batrachos, id cft ranas uocant, tener fiunt, \& fanguti, nem emittunt, quas inferius f carificare \& circuncidere oportet, Ruellitus hoc in loco aliter uertit, \& ranas incrementa lingux (ut in homine accipi folent)interpretatur, abfurdo(ut mihi uidetur) fenfur, Nam quod ungulæ pars fit, manifeftifimũ eft ex Geoponicis Gracis, ubilib, 16, cap. I. pulli eligendi figna ex A bfyrto traduntur, \& inter cærera laudantur, oz

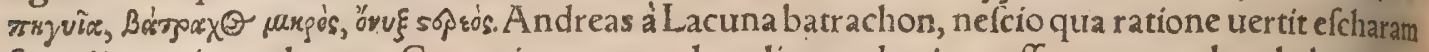
fingulis crurium adnatam; Cornarius ranunculum, licet codex impreffus renunculum habeat, Evise

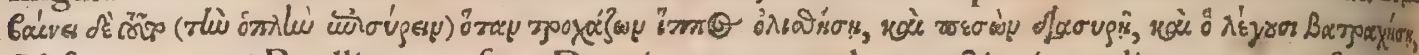
A bfyrtus cap. 26. Ruellius transfert. Deterit autem ungulam tractim ingrediens, cum curfitansla

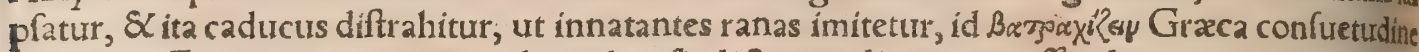
nominant, Ego potius uerterim, ad ranulam fic dictam pedis partem offendere:quam trocem Ruel. lius alibi tanquam ignotam fibi praterit. Oportet ferramento conciforio foleas ramulas ǵg(lego ranix las) purgari, Vegetius 1. 56.

TEupodia, uirtus pedum in equis: unde equi ipfi eupodes dicuntur, pedibus \& ungulis bene' conftituti, præcipué cum duras $\&$ folidas ungulas habent: qui fecus, nerónod

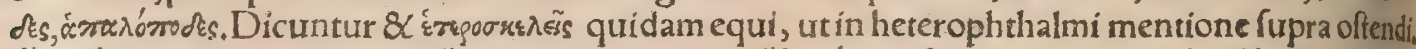

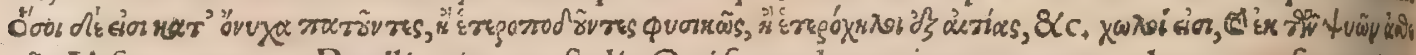
vế, A bfyrtus cap.110. Ruellius ita tranftulit, Qui fecundum unguem cornu caleant, aut furopte inge nio uario pede, uel ex certa caufa diuerfis ungulis conftant, \& c.claudicant, \& lumbos habentinfir mos. TSunt $\&$ alia quxdam nomina partium equi, ut qux in Hippiarricis circa finem capitis 114 .

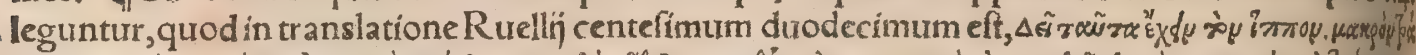

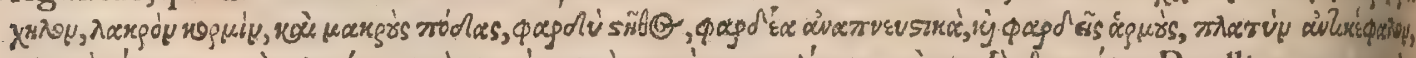

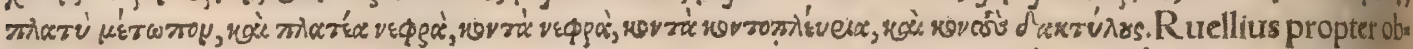

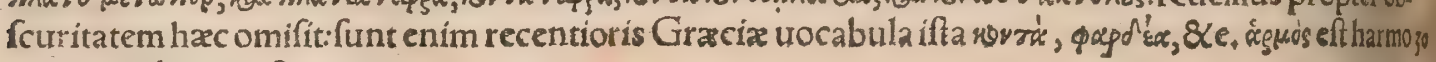
nia, articulus, iunctura.

DE ELECTIONE EQVOR V M.

Palladius in equo admiffario quatuor fpecfari iubet, formam, colorem, meritum, pulchritudine? Sed eadem quatuor in alïs etiam equís, feu pullis educandis, feu emendis adultis, pracipue mihifpe cranda uidentur. De coloribus equorum iam fupra copiofé dixi, dicentur tamen híc etiam nonnul la obiter in obferuatione forma. Forma equorum quales maximé legi oporteat, pulcherriméquils dem Virgilio uate abfoluta eft:fed $\&$ nos diximus in libro de iaculatione equeftri condito, \& fereins ter omnes conftare uideo, Plinius. Sed primo loco de pullo eligendo pracipiemus, initio à Vergilia nis urerfibus facto quilib. 3. Georg. leguntur huiufmodi: Nec non \& pecori eft idẽ delectus equino. Tu modo, quios infpem ftatuis fubmittere gentis, Præcipuum iam inde à teneris impendelaboré, Continuo pecoris generofi pullus in aruis Altius ingreditur, 8 molliacrura reponit. Primus 8 ire uiam, \& flurios tentareminaces Auder, 8 ignoto fefe committere ponti: Nec uanoshor

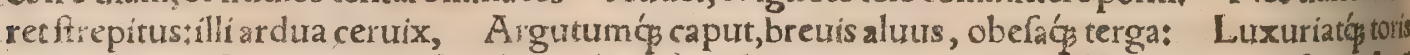
animofum pecius, honefti Spadices, glauciós:color deterrimus albis, Et giluo:tum, fi qua fonï procul arma dedere, Stare loconefcit:micat auribus, \& tremitartus: Collectumóp premẽs (alitis fremens) uoluit fub naribus ignem. Denfa iuba, \& dextro iactata recumbit in armo. Atduplex agitur per lumbos fpina:cauatés Tellurem: \& folido grauiter fonat ungula cornu, Seruiusar, gutum caput, brete exponit ; pectus toris luxurians, torofum \& eminens pulpis. Deterrimus albis, A tqui alibi ait, Qui candore niues anteirent. Sed aliud eft candidum effe, id eft quadam nitentilite perfufum:aliud album, quod pallori confrat effe uricinum. Giluus autẽ eft melinus color, quem untl to gó fuluum uocant. Multi ita legunt, albis $\&$ giluo (forte, E gilluo) ut non album $\&$ giluum, fed albos giluum uituperet:quod fi finguli colores uituperandi funt, quanto magis mixtus utrog, id eft albo: giluus? Spina duplex, aut reuera durplex: aut lata, ut alibi, Duplicem gemmis auró́g coronam, Hạ omnia Seruius. Equi boni futuri figna funt, fi cum gregalibus in pabulo contendit, in currendo, aliáue qua re,quo potior fit:ficum flumen tran̈ciendum eft, gregi in primis pragreditur, nec refper tatalios, Varro. C.um natus eft pullus, confeftim licet indolẽ aftimare (qualis futurus fit equur é pullorôiectari poteft, Varro:) fi hilaris, fi intrepidus: fi neç confpectu, nouxćs rei audítu terretur, fi ante gregem procurrit, fi la fciuia, \& alacritate interdư $\&$ curfur certans aequales exuperat: fi folfam fine contracione tranfilit, pontem flumenós tranfcendit. Hac erunt honeftianimi documenta, Mos res autem laudantur, qui funt ex placido (uidetur addendum, concitati:) $8 x$ ex concitato miriffimi 64 Nam hi $\&$ ad obfequia reperiuntur habiles, $\&$ ad certamina laborum patientifimi, Columella, Mo* res, ut uel ex fumma quiete facile concitentur, uel ex incitata feftinatione non difficile teneantut 


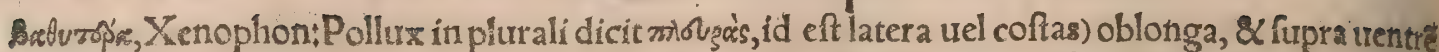
turgidiúf́cula, tum aptiorem ad refidendum, tưm robuftiorem meliorisḉs de paltu fucci equum in.

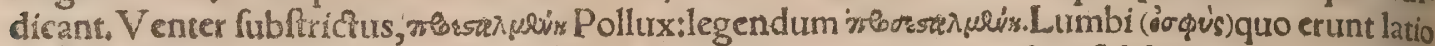
re $\&$ breuiores, hoc facilius attollet priores pedes equis, \& polterioribus fubfequetur:ita etiamilia

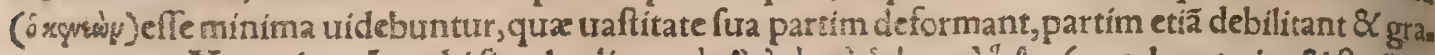
uantequos, Xenophon, Lumbi fint duplices : to of auro roù jalyss rà 'sjox (quod uerterim, \& fimiliter reliqua fpina, \& quare inter clunes eft:)maximé uerò illa fpina pars cui infidetur, Pollux. Coxas effe latas \& carnofas oportet, ut confentanex fint cum pectore 8 lateribus, Clunes folidxa aclatx, Caus, da longa non ornamento folum fed etiam utilis eft, ut infeftantes fcilicet mufca abigantur. Femora

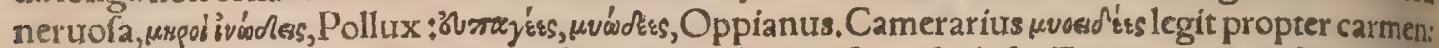
ego irwotzs malim cum Polluce:neruofum enim folidius eft mufculofo. Femina quidem fub cauda fi

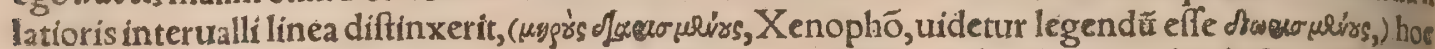
pacto quia crura pofteriora fpatiofius (maiorl interuallo diftantia)attrahentur, ideo \& fucceffio(visó.

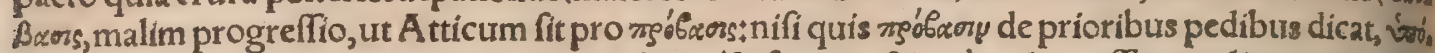
Exoy de pofterioribus)ac equitatio erit terribilior'\& firmior, \& quàm aliter effent meliora omnia. $F_{*}$ mur fub armis fi craffum fit, habet, ut in uirili cerpore, nô folum robur, fed etiam uenuftatem, Tibix excarnes. Tibiarum offa fint fpiffa, utpote corporis totius ftabilimenta:fed fpiffitudo non erituena: rum neq carnitum: nam hoc pacto cum per afpera agitur equus, impleri hæe fangurine neceffe eft, $\&$

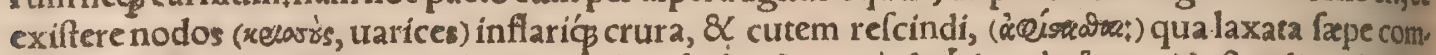

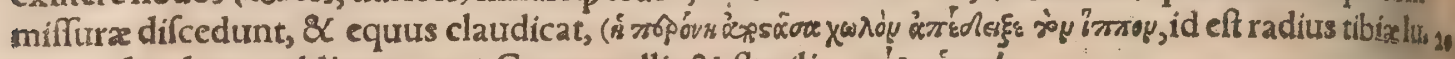
xatus claudum reddit equum.) Crura mollia \& flexilia, oris $\lambda s$ ígool.

-1. Pullus cuius à primo ftatim ortu altiores tibia fuerint, is maximus futurrus eft. Onnium enim quadrupedum tibix proceffu temporis parũ crefcunt altitudine, fecundũ has uero (id eft, fi illęuero in pullo altę fint) confentiente magnitudine corpus reliquum augetur. Genua fi pullus lubrico fiexu moueat ingrediens, cólec $t u r a m$ ex hoc facere poffîs, in equitatione crura fímiliter lubricum motum habitura effe:quanquam enim mollities illa flectendi procedente tempore maior fit, meritò tamenin

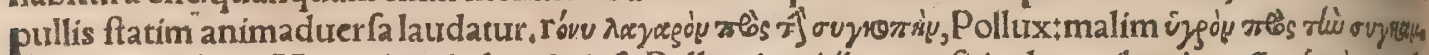
rwì uel

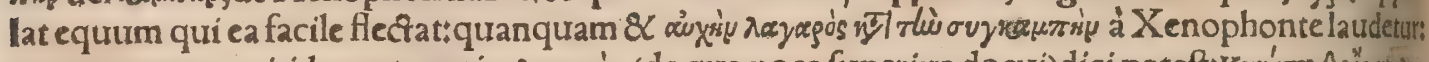

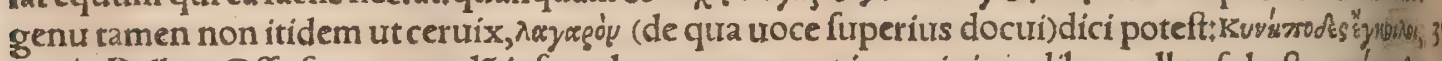
segrobi, Pollux. Offa fupra ungulã infra talos, qua parte ut in caninis pedibus callus fubeft, xuvirixoduss dixere, neçerunt procera, neç uero depreffa, ut fuperius expofui in partium equí enumeratione Sed omnium prima erit pedum, utpote fundamenti totius corporis, confideratio, Et in his primum ungula confideranda. Spiffa enim ad pedum bonitatem longé praftat tenui, Deinde cognofrendum urium ungula fint ardu $x$, an tam priore parte quẩm pofteriore depreffx fiuc humiles, Nam arduæ altius à folo teftudinem (chelidóna) quam uocant, ela tam habent: at depreffae fic gradiuntur, pedíut molliores $\&$ duriores partes aquabiliter fulciant inceffum: ut fít in hominibus quops quorumcrtw ra diftorta funt, qui ualgi uocantur. Recté etiam Simon fcripfit fonitu deprehendi pedum bonitatế. Non fecus enim ardua ( (bí $_{y}$, id eft, caua) ungula, quàm cymbalum refonat. De pofteriorum pedum ralis feu tibijs, deć́s ïs quos nuvisrodas uocari diximus, $\&$ de ungulis, eadem qux de prioribus pedia 4 bus tradita funt, perhibemus, At $q$ haec in pullis eligendis qui obferuare uoluerint, eos adepturospu to optimis pedibus $\&$ robuftos $\&$ fatis corpulentos, tum uero pulchritudine $\&$ magnicudine pradil tos equios, Hactenus Xenophion \& Pollux. Apparet autem ex poftremis hifce Xenophontis uerbis, hæc ab eo tradita electionis figna, non ad bellatorem duntaxar equum, de quo præciptré differit, fed ad alios etiam pertinere. Ilam contraria qua uitio dantur, etiamfi ex pracedentibus per fe pofint intelligi, adfcribam tamen ex Polluce translata, ut huic inftituto pleniffimè fatísfaciam. Improbanturi

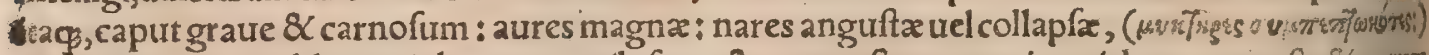
oculi caui, ceruix oblonga, iuba parum pilofa, pectus anguftum, armi caui: latera angufta \& parum carnofa:lumbi acuti,coxæ afperę, crura duriora, id eltstarda ad motưm:genua æogré flexiliatnam quę mollia funt \& facile flectuntur, greffum equi faciliorem tuttoremós prę̧tant, ut \& minus delaffetur,

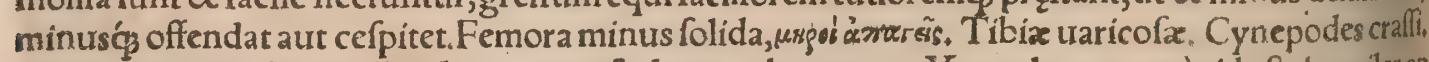

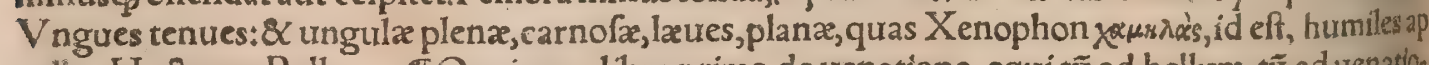
pellat,Hactenus Pollux. OT Oppianus libro primo de uenatione, equi tũ ad bellum tũ ad uenation rẽ apti notas laudabiles in plerrifģ fimiliter defcribit, nos ea tantũ recitabimus, ubi uel amplius uel di

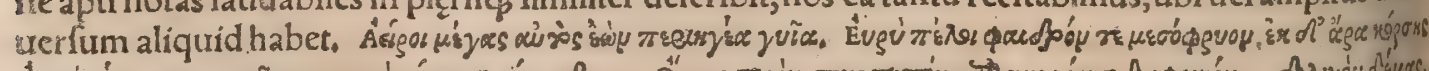

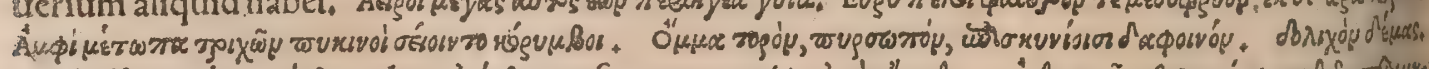

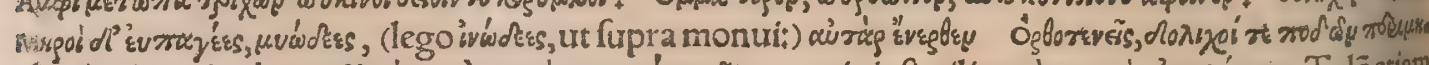

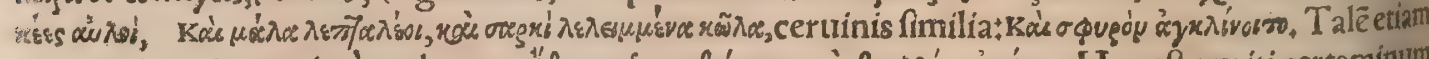

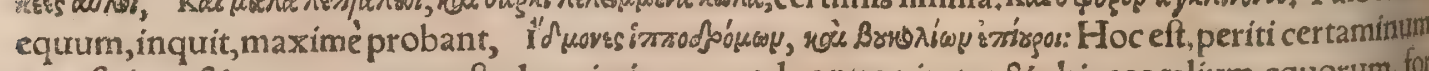
equefrium, \& armentorum cuftodes: nimirum quod contra piratas $\&$ abigeos talium equorum, for ritucine $\&$ celeritate prêfantium, ufus in fua aut alijs regionibus fuerit. đI In adulto etiã equro emen do eadem feré qua in pullo obferuanda funs. Qua autem pracipuè circa ingenium $\&$ mores eius 


\section{DeEquo. B. Lib.I. 455}

perpendl debeant, inferius dicetur. 1 Emptio equina fimilis feré ac boum \& afinorum, quod rifdem: rebus dominium in emptione mutatur, ut in Manilĭ actionibus funt perfcripta, Varro,

In admiffario etiam \& matrice eligendis, pleraç fimilieer examinari debent, ur in equo fimplici ter emendo uel educando pullo: quanquam mulio plus refert admiffarium effe egregium, ut tota ab co prognata foboles laudabilis habeatur. Equos ad admiffuram quos uelis habere, legere oportet amplo corpore, formofos, nulla parte corporis inter fe non congruente, Varro. Forma effe oporter magnitudine media, quod nec uaftos nec minutos decet effe. Equas clunibus ac uentribus latis, Id $\tilde{e}_{*}$ Inadmiffarijs quaturor fpecianda funt, forma, color, meritum, pulchritudo. In forma hoc fequemur, Vaftum corpus $\&$ folidum, robori conueniens altitudo, latus longifimum, maximi \& rotundi cluz nes, peçus late patens, $\&$ corpus omne mufculorum denfitate nodofum, pes ficcus $\&$ folidus, $8<$ cor nu concauo altius calciatus. Pulchritudinis partes $h \nsim$ funt: ut fít exiguum caput $\&$ ficcum, pelle pro pemodum folis offibus adharente: A ures breues $\&$ arguta, oculi magni, nares patula, coma $\&$ cau da profufior, ungularum folida \& fixa rotunditas, Palladius : Ea qux de coloribus mox adịcir, iam lupra enumieraui. Etmox, Eadem (inquit) in equabus confyderanda funt, maximeut fint longi $\& x$ magniuentris $\&$ corpolis: fed hoc in generofis feruetur armentis ${ }^{C}$ - 2 ter $x$ paffim to to anno inter $p a$ f́ua, dimifis fecum maribus impleãtur. Eadem feré de pulchritudine equi Albe tus frribit, \& inter alli, Oculi (inquit) magni fint, \& quafi ante caput fiti: aures breues $\&$ acutx (argurix Palladius, ex quo transfcriplit: quamuis \& Ruffius acutas haber, \& quafi afpideas, nefcio quo lenfu) $\&$ quafían. rorfun porrecta:cauda magna $\&$ longa:nares aperta, quas cum bibit profundè in aquam mergat Ruffirs ad equi pulchritudinem prater catera, maxillas graciles \& ficcas commendat: os magnum

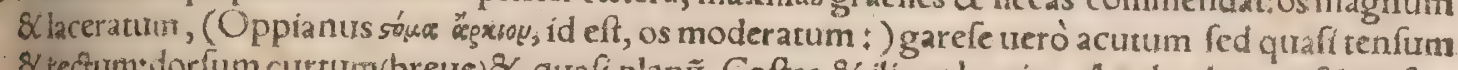
\&rectum:dorfum curtum(breue) $\&$ quafi planũ. Coftas $\&$ ilia urt bouina. Anchas longas $\&$ tenfas: coxas intus foriś́ latas $\&$ carnofas:garetta ampla $\&$ ficca $\&$ tenfa : filces curuas $\&$ amplas, ceruinis fimiles:crura ampla, pilofa $\&$ ficca. Iunciuras crurium groflas, \& non carnofas, propinuluas uns gulis, ad fimilitudinem boum. Pofterior pars corporis altior fit anteriore, ut in ceruo, $H x c k$ uffius. Pukhtitudo equi melius apparet in macilento corpore quàm obefo. Nam pinguitudo fape uitia
quadam occulit, Idem.

Regibus hic mos eft ubi equos mercantur, opertos Infpiciunt, ne fi fácies utt fape decora

Molli fulta pede ef, emptorẽ inducat hiantẽ Quód pulchrzclunes, breue q caput, ardua ceruix. Horatius lib. I.Serm. Sat.2. Equi pulchritudo maxime exeellit, fi ceruicen natura erectam \& fubli= mem gerat, \& uerticem magnum, \& aures minor es quàm procapitis modo, Pollux. Alia etram non. nulia qua ad pulchritudinem equi feorfim i ferri porerant, inter alias electionis notas iam recitaui mus. Eligendi funt parentes boni \& pulchri, ut pulli etiam fimiles generentur, tum corpore, ium moribus, quod ut plurimum fit:nam ut cótrarium accidat, alia quadam caufa fupertueniat oportet, Rufius. Si equus leurcoma, id eft albuginem uel candicantem notä in oculis oftendat, non içu con

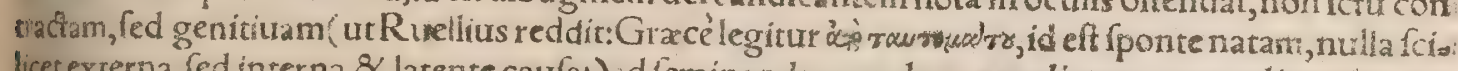
ficet externa, fed interna \& latente caufa:) d feminandam prolem repudiatur: nançedítum hoc pa. xente pecus cum ad eandem deuenerit xtarem, fimili modo cxcitate afficietur ₹ Equam uero tali ge nitore procreatam, propter anniuerfariam purgationem, id malım non manet; fed mas quen ea pes peritmatrix, auitum referet uitiư. Iam qui infiliendis equabus uel pigni uel inhabiles fpectantur, ữ pote cum opericedant, funt fegregandi. Qui etiam unico tefte conftant,a d admifuram afcifcere nó oportet:cum ex maxima parte infoecundi reputentur, aut pullos fux fírpi mutila fimiles progene: rent. Quibus uarices in teficulis prominent, feminandx fobolinon habentur idonei, hos uaricofos (*oasóáb wores) uocant. Admiffarium enim corpore effe integro 8 omni uacare culpa oportet, $\mathrm{Ab}=$ lyrtus, Sed plura de admiffarís equis dicam capite tertio:hic enim ea folum propofui, qux circa cor $\Rightarrow$ pus eorum fpeciantur.

TDe notis equi ad uenationem apti Oppiani fententiam retuli iam ante: fed Nemefiani quoque perelegantis poëtac eadem de re uerfus audiamus.

Cornipedes igitur lećos der Gracia nobis, Cappadocumá notas referat generofa propago A rmata, 8 paimas nuper grex omnis auorü. Illis ampla ratis latri funt aquora dorfo,

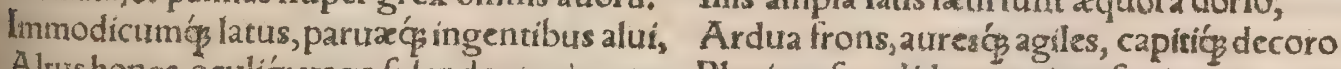
Altus honos, oculiḉs uago fplendore micantes, Plurima fe ualidos ceruix refupinat in armos; Fumant humentes calida de nare uapores: Nec pes officium fandi tenet;ungula terram Crebra ferit, ứrtus'̧̧́ artus animofa farigat. Belifarius Aquiuiuus in libro de urenatione Oppianü

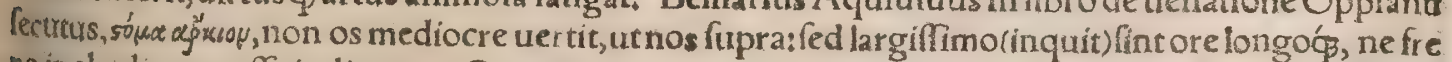
no inobedientes effe iurdicentur. Capica etiam alta idcirco effe wult, ut fi quandogs equum cefpitare contigerit, fubleuari facilius quo minus corruat freno poffit. Alia quadam de equo uenatorio infe. tius hoc in capite afferam. Non illi uenator equus, non fpicula cura, Claudianus. Equi alí funt idoneiad rem militarem, alin ad uecturam, alij ad pradam. Itaqp peritus belli alios eligit, atç alir; ac docet:neog eodem modo parantur ad ephippium, ut ad pradam:quòd ut ad rem militarem, quód ibi

De equis infitutigs $\mathcal{X}$ bigeneris qui debent ad iugü deftinari, $A b$ fyrtus capite centefimo transla* 


\section{De Quadrupedibus}

tionis Ruellị fe feribit:Equos qui diuerfo parenturm feminio procreantur, à corporum notis noffe commodum eft qui ad iuga capeffenda fint habiles $\&$ idonei. Tali autem habitu conftare debent:pe ciorelato, ampla fimiliter ceruice, naribus apertls, prominentibus armis, cruribus (Bpexúron) rectis,

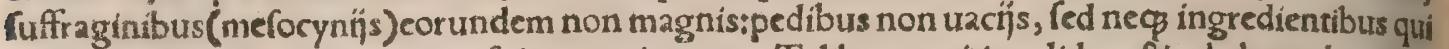
difplodantur, uentre non paruo, fpina non incurua. Talibus meritis ualidos, $\&$ ad obeunda munia robuftos ribi comparabis. THis pauca quadam addemus de nonnullis corporis equini partibus, circa electionem cbferuandis, tanquam appendicem omifforum fuperius. Equorum animindices aures, ficut \& leonum cauda, Plin. Et alibi, In equis (inquit) $\&$ omnium iumêtorum genere indicia animi aures praferunt, feffis marcidx, micantes pauidis, fubrectx furentibus, refolutx æogris,Qux, cunc fic nafcuntur in ueterino genere, ut notam cam habeant, quam leporinum dentem uocant,

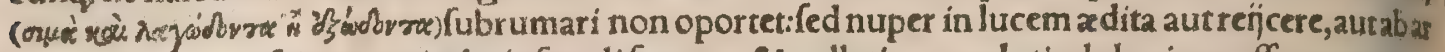
mento fegregare: fcientes utigg huiufmodi foeturas \& pullationes ueluti adulterinas effe natura no. cas $\&$ portentofas:maxime autem yignuntur in hinnis $\&$ bigeneris animantibus, $A$ bfyrtus. Pollux

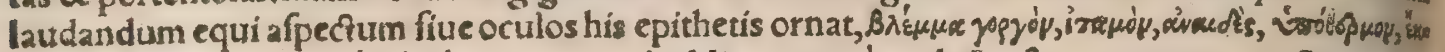

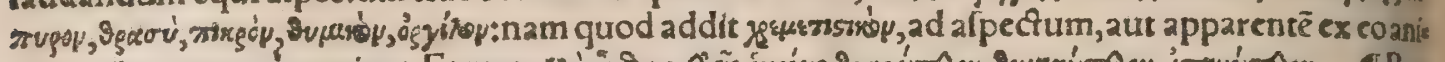

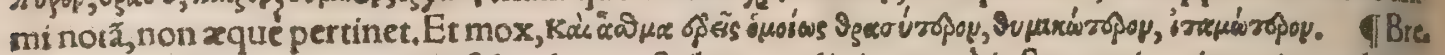
uitas colli femper commendari folet ab equeftribus, prolixitas uerò inftar gruis mir um in modumul

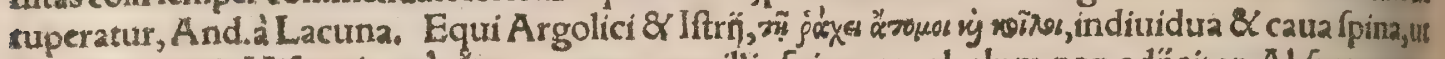
Ruellius uertit, Hifpani ueró givorot, quanquam illic fpina uocabulum non adj̄citur, $A$ blyrtus cap.

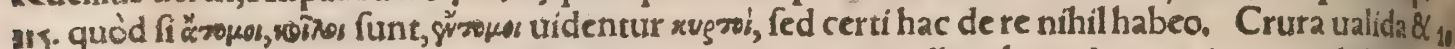
ficca fint, \& a qualiter à genu uf̧̧ ad pedem porrecta, ita ut nulla tubercula promineant, nithil etiom ad tacium cedat, Albertus. Pes æqualis $\&$ planæ fuperficiei, id eft non afperæ, rotundus, undigiter. ramtangens, Idem. Pedum laudatam conftitutionem Pollux 2 rrodiay uocat. Ab eodem probatur

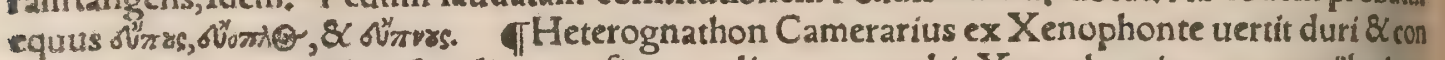
cumaris oris equum. Huiufmodi autem fiunt, ut liquet ex uerbis Xenophontis, cum maxilla altera durior uel afperior, altera mollior uel tenerior eft. Praciplatur curatori(inquit idem)ne unquarm ha benis attrahat equum:hoc enim heterognathos facit, (os durum, Camerarius.) Et alibi, Heterogna thus equos prodit, non folũ equitatio illa quam wódilu uocãt: fed euidentius etiã mutata fubito eqư tatio. Nam pleriç nolumt excurrere, nifi ita fiexus eueniat ut improbior maxilla domủ \&ad reditum conuertatur. Et rurfus, A gitationem autem in primis probamus eam qua w' dix appellatur, qutoniam, ambas buccas ad conuerfionem affuefacit. Eft $\&$ hoc bonum agitationẽ ipfam mutare, ut equi buc

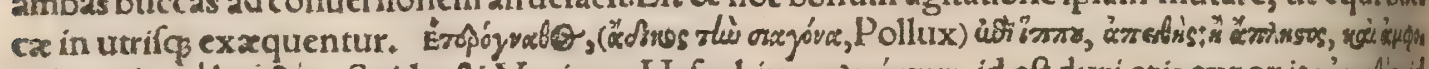

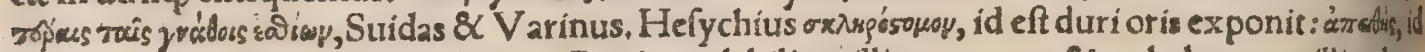
eft contumax $\&$ effrenis, latius patet: Pro inexplebili, ut illi exponunt, $\&$ ambabus maxillis cibum uorante, apud authores legiffe non miemini. Heterognatho contrarius $\&$ Jaudandus eff, o rt*ohtorin

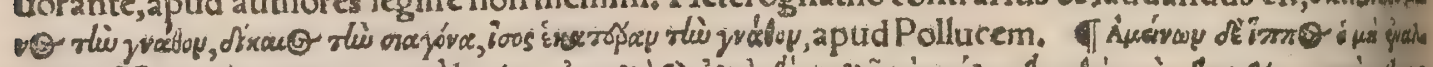

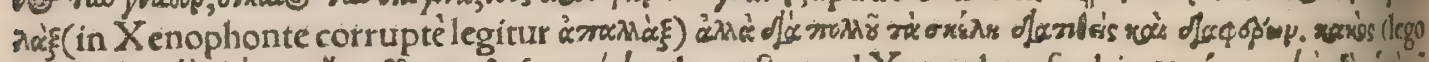

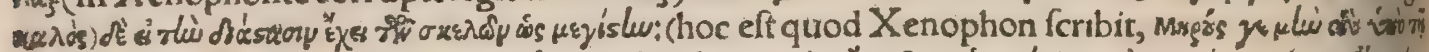

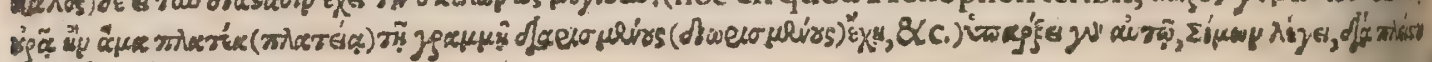

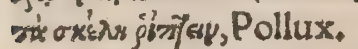

T Teutones(inquit Camerarius) cum bonum \& generofum equum depingunt, diuer forum anti mantum concinnatis uirturibus, ut Homerus fingit de däs Agamemnonem fuum, à lupo cria, \&à

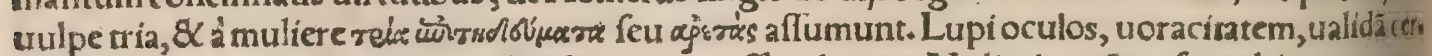
uicem. Vulpis aures breues, caudam longam, greffum lenem. Mulieris pecfus, fuper biam, comam, Alfi magis pudendo intelleĉu inter muliebres in equo virrutes pofuére, confcenfionis patientiam, Itemós alí hxec ita expofuêre, generofo equo uírtutes ut attribuerent duas leporis, uelocitate $\$ c$ aglo litatem, Duas uulpis, bonorum oculorim $\&$ pilofa caud $x$. Lupi duas, lenitatem greffus $\&$ uoracis taten. Duas afini, coxas ualentes $\&$ firmitatem pilorum : uel ut quibufdam placet, bonas ungulas, Mulieris duas, fuperbiam \& fubiectionem. A tọ̧ etiã alin aliter hoc modo:(declarant enim haec ciam Teutonum maiorum noftrorum fapientiam:) De lupo (hucio potius) pifce adeffe debere equio tuora fi citarem \& exiliendi facultatem. De anguilla agilitatem, \& (ut meminiffe uideor)celeritatem. De fets pente, oculorum aciem $\&$ gyros, De leone, amplum pecfus $\&$ denfam iubam. De foemina, quze dixia mus. De fele, nitorem 8 lenitatem gradus, Hac omnia Camerarius. TNunc de indole etiam, ina genio $\&$ moribus $\&$ actionibus nonnullis, qua circa equum eligendum confiderantur, dicamuls, In equo igirur adulto $\&$ iam uectore parando, primum æras ignoranda non eft, (de cuius dignotion ne capire tertio dicã:) atate perfpecta, inquit Xenophon, uidebimus \& lupos quo pacto ore, \& uer" ticale lor um quo pacto ad a ures admittat. Hac minimé erunt obfcura, fi coram empture $\&$ applis catum frenum: $\&$ detractum fuerit. Mox animaduerten dữ quo pacto fufcipiat dor fo confcenforem? multi enim equi refutant ea, qua laborem fibi allatura effe intelligunt. Obferuabitur \& hoc, utrum cum equite non recufet ab alīs equis digredisaut, fi forte prope afint, an ad hos fele efferre foleat, Re periuncur etiam qui de mala educatione ex equitationibus recurrunt ad domefticos feceffus, (De heterognathis iam paulò ante dixi.) Neç fugere nos par fuerit, an ctiam inftigatus ad celeritaten 
teriores, diu $\&$ xqualiter coniunctos infiftat, ita ut unum pedem ante alterum noti exteridat; autele uet, aut uno quàm altero leuius ac debilius terręinnitatur, membra inferiora fe habere fana $8 \mathrm{c}$ firma declarat. Equus naribus magnis $\&$ inflatis, oculis groffis, non concauis, natura ut plurimum au. dax eft. Equus ore magno, fciffo feu ualde diducto, maxillis gracilibus \& macris, collo longo \& gra cili uerfus caput, facilem freno fe prabet. Equus truncum caudx ftrictum ad fe tenens, \& fortiter. iuxta coftas ftrictum, magna ex parte fortis \& $\alpha$ patiens eft, fed nó celer. Equus habens crura \& iun ĉtrras crurium fatis pilofas, pilos longos, eafdem partes ad laborem ualidas habet, fed idem plerung celer non elt. Equirs culmine longo \& amplo praditus, hanchis longis \& extenfis, altior pofterius quàm anterius, uelox in curfur effe folet. (Quę de claudicatione fequuntur capite ter tio inter morbos. pedum addentur.) Equus cui interiora corporis male habent, auriculis \& naribus ut plurimumfri, gidis, \& oculis concauis, pro femiuiuo habetur. Anthrace laborans fi flatus narium emittat frigi. dos, \& oculi lachrymentur affiduè, morti uicinus iudicatur. Equus afflictus enorra uel uerme uo, latico in capite, \& continuè naribus humorem reddens aqua pinguis \& frigídæ inftar, trix etrader, Equus patiens morbum arragiati, $\&$ foriolus, id eft liquidum fubinde ftercus emittens, ita ut uenter cius prorfus inaniatur, in infufionem cadet, $\&$ ut plurimum breui morietur. Equus habẽs uiuulas fi fubito in furdorem toto corpore refoluatur, $\&$ membris omnibus contremifcat, $\&$ animo fubinde deficiat, nó uidetur poffe euadere. Sínares equi alíquantíper comprimantur, 8 mox redditusex cis fpiritus foenum aut ftramen iuxta pofitum fortiter pröjciat, à ftranguria(ftranguillione) $8 \%$ eno: ra liberum habet caput. Equus habens pares balfas(falces, forte)natura, $\&$ non impares, non facile bene habitus euradet.

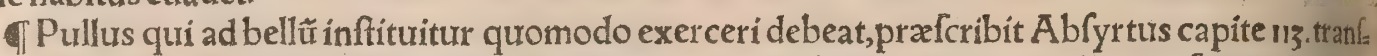
Iationis Ruelli. Bucephalus Alexandri Magni equus bellator optimus qualisnam fuerit, dicemus infra capitis ochaui parte ultima. De equorû ad militiam delectu fcribit Valturius 6.9. Xenophotin tis,Pollucis 8 Oppiani fententias de eligendo militari equo in pracedentibus iam retuli. Alia quiz dam de equo bellatore inferius adferam.

- Equus quia ad oftentationem $\&$ forma merito alitur, ab alta \& erecta ceruice commendatur:

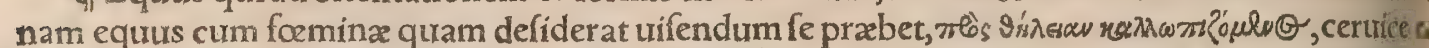
recta fuperbit, \& curfu fertur procace. In primis uero elegans furerit, fi ceruicem natura tollat $\& e_{*}$ tendat:uertice magno, auribus quàm pro capitis modo minoribus, Pollux ex Xenophonte, Catera qua ad pulchritudinem equi faciunt, cum alî́s fuperius explicauí.

De regionibus qua infignes equos producunt.

Deftirpe magni intereft qua fínt, quod genera fint multa : Itags ad hoc nobiles à regionibusdit cuntur, $V$ arro. In permutandis equís uel detrahendis(lego diftrahendis, id eft uendendis)maximã fraudem patrix folet afferre mendacium. Volentes enim charius uendere, generofiffimos fingunt, Quæ res compulit nos, qui per tam diuerfas $\&$ longinquas peregrinationes equorũ genera uniul': Ia cognofcimus, 8 in noftris ftabulis fape nutriumus, uniufcurufio nationis explicare figna uelitus rita, Vegetius, Equorum tot funt genera, quot hominum nationes difcretx:ego (in quit Oppianus) praftantiffima tantum dicam, Öasos $\vartheta^{2}$ inna renti ædere confureuerunt equa, multum etiam coli habitus $\&$ regio refert, ut de patria inquifiti non inutilis fit aftimanda.

4 Acarnanum \& Aetolorum folitudo, pafcendis equis eft accommoda non minus quàm Thet falia, Strabo, Achiui, Áxoub, Armenị, \& Tyrrheni, ad bellum apti funt, Oppianus. Vide Epei,De Græcis inferius dicam. Aegyptï, Nec fruos miratur equos terrena Syene, Gratius. Alexandira equorum ftudijs $\&$ equeftribus certaminibus, olim maximé dedita fuit, ut feribit A pollonius libro yr Aethiopia pennatos, ut fertur, equos generat, 8 cornibus armatos. Aetnai, uide Siculi. Aetoli, uide Acarnanes. Afri, uidelibyci. Algoici, uide Heluetï. Apulos Varrolaudat. Eofdẽ $2 R_{0}$ reanos Volaterranus bellis aptiffimos fcribit. In Arcadia fertilia pecori fuêre pafcua, præfertimes quis atç afinis admiffarn̈'s ad mulos procreandis: Equorum fanè genus excellit Arcadicum, Strablo, Idem alibi Theffalicos Arcadicis prafert. Idem mox Argolicos celebrat.Argolici probis funtpedi

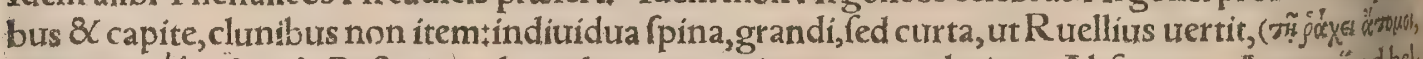
* lum apti, Oppianus. Armenị \& Cappadoces à Parthis genus ducunt, capite tantum grauiores. Vi de infra in Nifais. De Afture uel Afturcone equo dicam inferius in tractatione de differêria equo rum ab inceflu.

T Barbari, uide Libyci, Vegetius poft Hunufcos, Toringos \& Burgundiones celebrat, inituris tolerantes. Britannia mannos equos $\&$ tolutares hodie mittit, Volaterranus.

TDe equís à Calpe monte celebratis, uide in Hifpanis. Cappadoces $\&$ Armenị à Parthisgge nus ducunt, fed capite grauiores funt, Abfyrtus.Cappadocum glcriofa nobilitas, Vegetius, Cappa docia ante alias terras altrix equorum, \& prouentui equino accommodatiffima eft, Solinus. Cap: padocum'́c notas referat generofa propago Armata, \& palmas nuper grex omnis auorum, Nemle fianus. Cum Cappadoces Perfis quotannis pendant, prater argentum mille \& quingentos equios \&c.duplum ferè horum Medi pendebant, Strabo, Oppianus Cappadoces inclytos $\&$ celeres ${ }_{2}$ 
ca parte ftatura (ö nccrefpondente:pernices $\&$ animofi. Verum in tota Gracia Theffalici praferuntur, Abfyt. Corni pedes igitur lectos det Græcia nobis, Nemefianus. De Achæis fuperius dixi.

6) Heluerĭ́ bellis idonei funt, \& pracipuè Algoici, qui durare diutiffimé putantur, Camerarius. Hifpani magno funt corporis habitu, concinno \& erecto, eleganti capite, compage corporis lucus

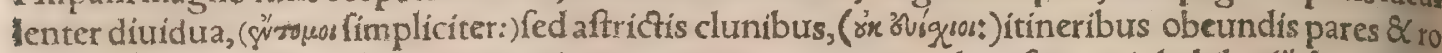
bufti, corpore nec gracili, nec ad maciem opportuno:creterum ad curfuram inhabiles ("edjophor, forte ovjoouob, ur ex fequentibus authorum uerbis apparebit) in equitatione calcaribus non incitantur (è

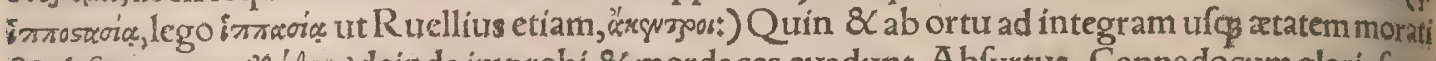
So obfequentes, (ớndes, ) deinde improbi \& mordaces euadunt, Abfyrtus. Cappadocum gloriofa nio bilitas : Hifpanorum par uel proxima in circo creditur palma. Nec inferiores propé Sicilia exhibet circo:quãuis A phrica Hifpani fangtrinis uelociffimos præftare confueuit ad ufum fellz, Veget.Par this (inquit Oppianus)præftantiores funt Iberi;celeritate enim tantum praftant inter equos, quan: tum aquila aut circus accipiter in aere, $\&$ in mari delphinust + ed exígui funt, \& uiribus partuis $\&$ ani

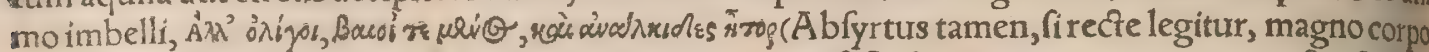
ris habitu effe fcribit*) \& curfus celeritatem pauca emenfi ftadia amittunt: corpore uenufto, fed uns gulam habent parum folidam, चा gnatibus expetunt, Camerar. Ex Hifpania leuitate elegantiaç confpicui funt, Volater. Equir ma. iores corpore à tertio climate ufoß̧ ad finem fexti procreantur, \& præcipuè in Hifpania:Fortiores au tem \& fatis magnos etiam in feptimo climate procreari uidimus, \& eordẽ patientiores laboris quaihi

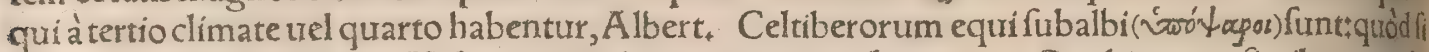
in exteriorem traducantur Hifpaniani, colorem permutãt; funt autem Parthicorum fimiles: nam \&

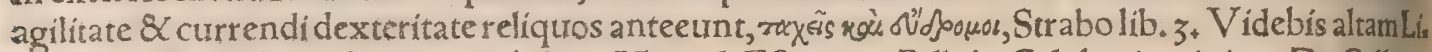
ciane Bilbilim Equis $\&$ armis nobilem, Marrial, Eft autem Bilbilis Celtiberix ciuitas. De Callacis \& A furconibus uel Afturiburs dictis, item à Calpe monte celebratis, omnibus Hifpanis, pauló poft dicam in differentips equorum fecundum gradum. Hunufcorum longé primo(prima) docetur utuli tas patientix laborís, frigoris, famis, Veget. Et paulò mox, Hunufcis grande $\&$ aduncum caput,ex tantes oculi, angufta nares, latx maxill r, robufta ceruix \& rigida, iubx ultra genua pendertes, naa iores coft $x$, incurua fpina, cauda fyluofa, ualidifimx tibix, parux bafes, plenx ac diffufa ungula, ilia caurata, totum q́ corpus angulorum, nulla in clunibus aruina, nulli in mufculis tori, in lógitudine j" magis quàm in altitudie ftatura, propenfior uenter exhauftus, ofla grandia, macies grata, \& quis bus pulchritudinem praftet ipfa deformitas, animus moderatus \& prudens $\&$ uulnerum patiens, Hac Vegetius. Hunufos equidem (aliàs Hunnufros per n. duplex, alibi etiam Hunnicos uocateof dem olim Hunnos, \& hodie Vngaros díctos puto. Hunnorũ examina pernicibus equis hucillucóp uolitantia, cadis pariter ac terror is cuncta compleuerunt, Hiercnymus ad Oceanum. Equimorda. ces $\&$ calcitrones, ut Pannonici pleriģ (Pannoniam hodie V.ngariam uocant) de quibus \& proters bium malignitatis ortum, non ferè nifi irritati, aut opinione aut metu offenfa ferociunt, Camerar. Pannonï ad bellum idonei funt, Idem,

G Iberi, uide in Hifpanis. Indicum equum exultantem, \& immoderatius excurrentem conti nere $\&$ coercere, habenas adducere, uel remittere non eft cuiufuis, fed hominum qui à primis tem poribus atatis ad rerum equeftrium fcientiam inftituti fint: hi freno ipfos fuftinere affueuerût, fimul 8 refractarium lupatis refringere, quos quidem equinæ tractationis bene periti, ex indomita effre natione in exigurum gyrum conpellunt: Veruntamen ad hunc gyrum agendum, atç ad conficien. dum orbem manuum robore opus eft, \& fumma rei equeftris fcientia. Qui huius difciplina funtex. perientiffimi, \& callidiffimi agitatores, currum uer fare in orbem plane norunt cuius certamennon eft contemnendum, præfertim cum duos milites pugnantes ferre queat, Aelian. A pud Indos Ply. los(nam funt etiam alteri Africi) arietibus non maiores equigignuntur, Idem. Terram Indiames quos uno cornu praditos procreare ferunt, quorum è cornibus pocula conficiuntur, in quax ues nenum mortiferum coniectum, fi quis biberit, nihil graue, quòd cornu repellat malum ipfum, pers petietur, Aelian. De hoc uide plura in Monocerotis hiftoria : Ipfe quidem A elianus alibi, $\&$ fecutuss eum Philes, idem fcribunt de poculo ex afini Indici monocerotis cornu facto. Iones, Oppiant. Iftrin

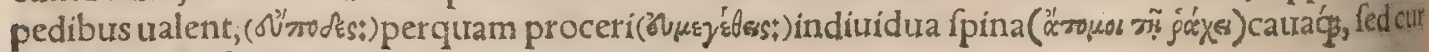
fu pernici, Abfyrtus,

Libyes, Oppianus. Mauri(inquit) praftantiffimi funt tum in longis curfiburs, tum duris labo" ribus ferendis. His proximi Libyes durabiliceleritate. Forma fimilis utrifọ:nifi quòd robufti Libyes maiores funt, corpore oblongo, coftis \& lateribus craffioribus, $\&$ ampliore ad rectum impetumpe,

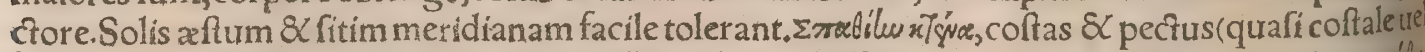
e coftis contextum) interpretor ligna \& ferramenta oblonga, anfa anguftiore, reliqua parte latiufcula ad feriendum, radendum, \& eximendum aliquid apta. Hinc \& I patha Apuleio \& V Vegetio, longior ac latior enfis, quod nomen fermo Italicus adhuc retinet. Vulgus fpathulas uocat, fpecilla latiuffcula, quorum ufus eft frequetis pharmacopolis \& unguentarịs:Spathula lignea mentio eft apud Celfum lib.8. Greci etiam fpathen 


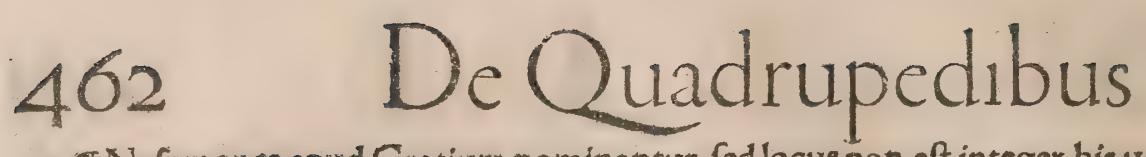

बा Nafamones apud Gratium nominantur, fed locus non eft integer, his uerbis: Mureibif ulx ore tenacia ferro Concedunt, aut(forte at) tota leui Nafamon*. Sunt autem Nafamônes populi Libyz nauium Syrtibus inuolutarum fpoliatores. Pulcherrimus omnium equus Niffaus eft, eo reges use huntur; que demiflis fubflauis, $\mu$ risgévoos, Oppianus : qui Nıasãop fribit, per iôta \& figma duplex:Hierodles in proazmio Hippiatricorum Nvoxioy (cum ypfilo \& figma fimplici) à Perfarum regibus in pretio ha beri. Regio fub Cafpinjs portis in humili \& cöcauo folo, \& Armenia, eximié pafcendis equis apta eff, unde pratum quoddam Hippobotum uocatur, per quod iter faciunt quil ex Perfia \& Babylone in

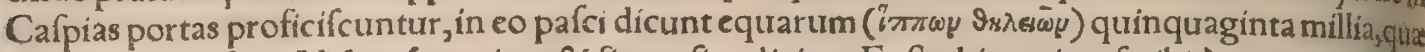
armenta regia funt. Nifxos (cum iota \& figma fimplici, ut Euftathius etiam fcribit) equos, quibuste ges utebantur,oprimos ac maximos, alï hinc genus habere dicunr: alÿ ex Armenia, habent autem propriam quandam formam, quemadmodum Parthici nunc dicti pra Gracis $\&$ alings qui apud nos funt. Et herbam qux præcipue equos nutrit, cò quod ibi abundet, propriè Medicam uocamus, Strag

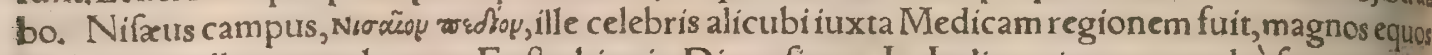
Nifros appellatos producens, Euftathius in Dionyfium. In India animantes multó funtgrandio res quảm cæteris in locis, præterquam equi:nam Indici equi uincuntur à Mecicis qui Nifæi uocan rur, Herodocus lib. 3. Et libro feptimo in defcriptione exercitus Perfarum, Poft haftatos (inquitince debantequi decem quàm pulcherrimé ornati, qui Nifai dicuntur, ideo fic dicti, quod eft ingens Meo dic regionis campus nomine Nifaus, qui grandes fert equos. Hos fequebarur louis currus quem cro equi albi trahebant. Poft quem ipfe Xerxes uehebatur curru equorum Nifxorum. Quantum equo Ny fro maior eft Libycus elephas, tanto Libycis elephantis maiures funt Indici, Philoftratus,

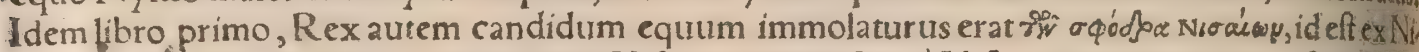
fxis de meliore nota, ut quidam exponit. Nifæi equi dichi funt à Nifęa(nimirum regione)fiute Arme nix fue Medix. Sunt qui Nifaum locum Perfidis faciant, ubi Nific equi celerrimi nafcantur. Ali

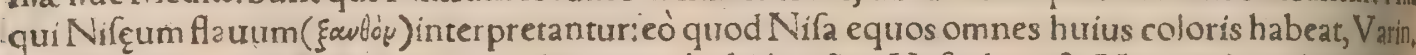

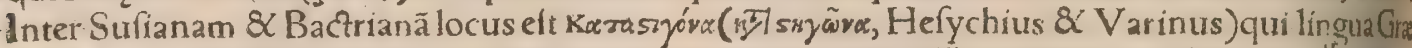

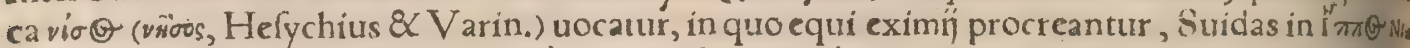

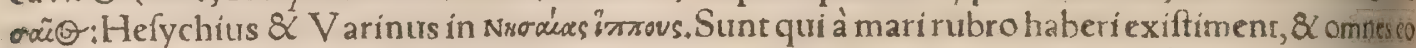
lore flauos effe. Herodotus Nifaum Mediæ locum facit. Orpheus in Dicfye Nifam locum inmari

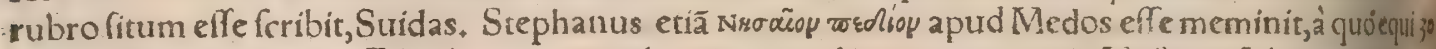
Nefæi dicantur. Calius Rhediginus reprehendir quendam qui pro equis Nefęis infulares uerterti, Aucfor Plutarchus eft Pyrrho fpeciem oblatam, uelur Nefæo equo infenf́, ducem fe illi prataret Alexander Magnus:id quod nô percipiens interpres trãfiluit. Sed et in Gracos codices irrepfitmen

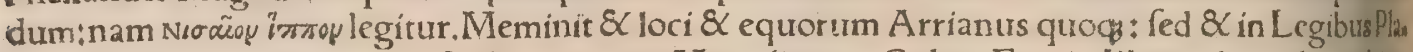
to, ut Strabonem præteream, \& A mmianum Marcellinum, Cxlius. Ego in Plutarchi codice, ubiN: -ačop per iota frribitur, mendum effe non puto, cum apud alios etiam authores cquos citauimus, $\mathrm{Op}_{\mathrm{p}}$ pianum, Strabonem, Philoftratum, Herodotum, Suidam, Euftathium, omnes endê modo fribatur: Solus Stephanus \& Hefychius Grammatici per $\approx \pi$ fcripferunt, Varinus urroque modo. Quaremiror 8 Hermolaum, qui a pud Plínium lib, 6. cap. 25. ubi fcribebatur regio Nıæa, Nefæa legendum purar. Sunt apud Mẹdos foerus equor um nobilium, quibus (ut fcriptores antiqui docent, nośg tis dimus)incuntes pralia uiri fumma ui uehi exultantes folent, quos Nefeos appellant, Marcelinus lib. 13. Numidici, uide in Libycis.

बi De Paphlagonum in alendis equis fudio, uide infra in Venetis. Parthi magno \& amplofint corpore, animoli, fpecie uenerofa, ac pedibus eximiè ualẽt, A bfyrtus. De heterophthalmis apud Para thos commendatis equis, \& n̈s qui uario colore diftinguuntur ab iifdem primum profecis, ex Ablyr

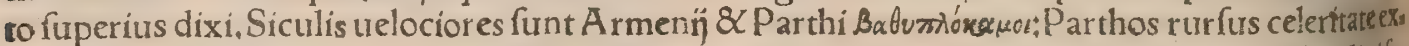
cellunt Iberi,Oppianus, Scilicet \& Parthis inter fua mollia rura Manfit honor:treniat Caudinifat xa Taburni, Garganúmue trucem, aut Ligurinas defuper alpes, Ante cpus excuffis eadetun guibus, $\&$ tamen illi Eft animus, fingetós meas fe iuffus in artes. Sed iuxtà uitiũ pofuit deus, Grar tius. Celtiberorum equi fubalbi, fi in exteriorem traducantur Hifpaniam, colorem permutant, Sunt autem Parthicorum fimiles; nam $\&$ agilitate $\&$ currendi dexteritate reliquos antecunt, Strabo: $P_{2 t_{1}}$ thi quomodo in tottonarïs uel fuccuffarĭs equis greffus molliant ad Aiturconum fimilitudine, ins ferius dicam ex Vegetio. Pellæi, uide mox poft Theffalicos. Perfis prouincijs omnibus praftates quos patrimoniorum cenfibus $x$ ftimatos, tam ad uehendú molles $\&$ pios inceffibus, nobilitate pres tiofos, Vegetius, Ex pauló poft, Perfis $\&$ ftatura $\&$ pofitione à cateris equorum generibus non plitu rimum differt, fed folius ambulatura quadam gratia difcernuntur à carteris : gradus eft minutus $\&$ creber, \& qui fedentem delecter \& erigat, nec arte doceatur, fed naturæ ueluri iure præftetur. Ineti colatorios(malim tolutares)enim, \& eos quos totonarios uulgus appellat, ambulatura cortmme dia eft, \& cum neutri fine fímiles, habere aliquid creduntur ab utrifọ, commune, ficut probatumett, In breui amplius gratix, in prolixo itinere faxuior patientia, animus fuperbus, \& nifilaborefubitu h gatus, affidue aduerfum equitem contumax mens, tumens, prudens: $\&$ quod mirum eft, in tantofer uore cautiflime decoris eft obferuantior : incuruata in arcum ceruix, ut recumbere uideatur in pe 


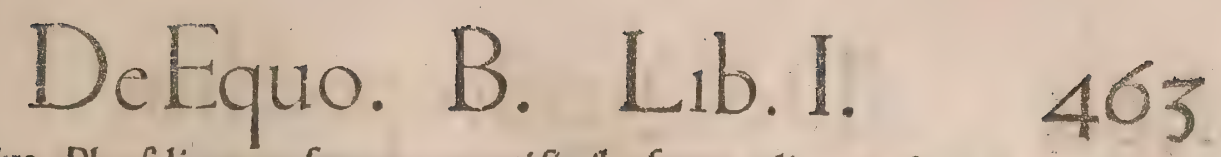

chore, Hac Vegetius. Pharfalica equa femper parenti fimiles foctus adit, eam ob caufam proba no minata, Camerar. Phafianos equos inuenimus ab eius auis inufto infigni, ucl quoniam ad Phafin equi habeantur pulchritudine praftantes, Calius.

TRofeani apud Varronem à R ofea diciticofdem Volaterranus bellis aptiffimos effe feribit. ER autem Rofea apud Feftum (alidas Rofcea) campus in agro Reatino, dicius quia in co arua rore fem. per humida feruntur. Rugi, uide fupra in Menapīs.

- Sacarum equi, fi qui fefforem excufferint, fubito confifunt, ut rurfum afcendere poffit, $A$ elia. nus in Varị́s. Vegetius 4.6.cum Perfas equos laudaffet, fequũtur (inquit) Armeni atçs Saphareni. Sapphirine quidem infula eft in A rabico finu $8<$ Sapiri populi iuxta Pontum : de Sapharenis cert - nithil habeo. Epirotas, Samaricos ac Dalmatas, licet contumaces ad frena acuiles, armis ac bellis af feuerant cruribus, Vegetius:ego polt armis diftinguo, 8 proac lego at: Cuius uerò regionis Sama ricifint non inuenio. Sarmaticum genus non inelegans $\&$ in fuo genere cócinnum elf, ad curfum

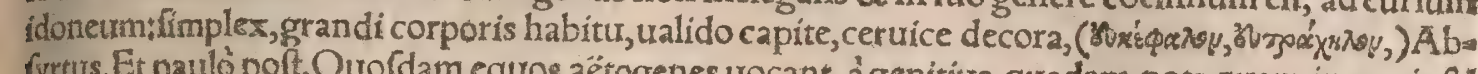
fyrtus. Et paulò poft, Quofdam equos aëtogenes uocant, à genitiua quadam nota quam in armis $\&$ coccoreferunc quos Sarmata fibi ut probos adfcifcunt, apud quos cum reliquis de pernicitate cer

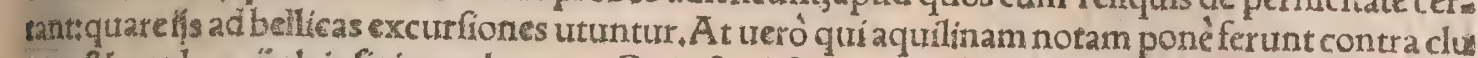
nem \& caudam, î ab ipfis improbantur. Quin $\&$ obferuatum efle apud fe tradunt, ne ex eis præa lientur:Qtrippe aut equitem facile h̆s infidentem perire, aut in guippiam moleftiz incurrere. Sar matalonginqua itinera acturi, inedia pridic praparant eos, exiguum tantum potum impartientes: 20 atop ita per centena milia \& quinquaginta continuo curfu euntibus infident, Plin. Sarmaticibellis apti funt: 2 mulci corum reperiuntur caftrati in tenera atate, atç ijs dentes cadere negantur, Came. rarius, Scythica gentis $\&$ Sarmatic mos proprius elt, equos caftrare, ut mälretiores ad parendum fiànt:parui enimfunt ac celeres, et acres, atç rebelles, Strabo lib, 7+ Scythici, Oppiamus. Videqua proxime ante de Sarmaticis fimul \& Scythicis ex Strabone diximus. Nee inferiores Hifpanis equos propéSicilia exhibet Circo, Veget. Et rurfus, Nec Epirotas Siculosís delpexeriś, fl mores ae

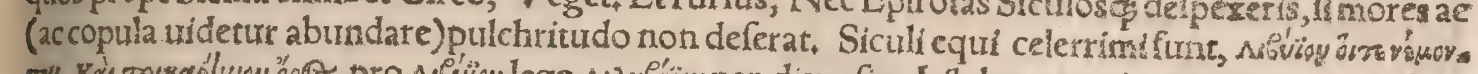

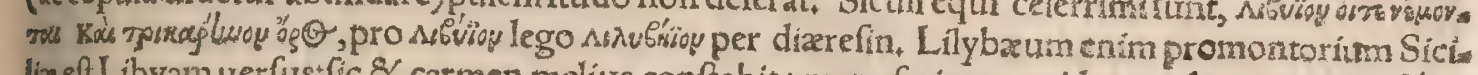

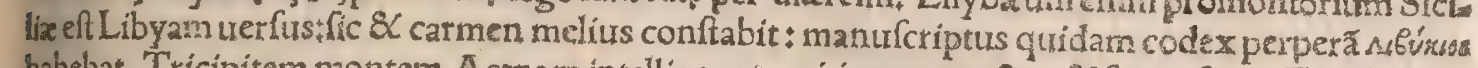
habebat, Tricipitem montem Aetnam intelligo, ut qui ignem cructer, \& furppofitum Enceladigim - gantis cadauer tegat:quod hic de hoc monte Oppianus, ali de Aetna nominatin fcribunt, Cecterum Siculis(inquit)uelociores funt Armenî \& Parthítuide etiam fupra in Mauris. Sed Gratia ctiam de equis Siculis audiamus: Sic (ut Libycis) 8 Strymonio facilis tutela Bifila; Pofient Aemazs utinam fe ferre per artes, Quiludus Siculis:quid tum fi turpia colla, Autrenuis norfochna= tur fpinapper illos Cantanus Granjs Agragas, uictaç fragofum Nebroden liquere ferz.O quantus in armis Illemeis, cuius dociles pecuaria foetus Sufficient, queis Chaonias contendere contra Aufic uix merita quas fignat Achaia palma, Hac Gratius: Mihi quidem locus tanquam parum integer fufpectus eft. Agragas mons eft Siciliz, cum oppido eiufdem nominis in fum. mitate, apud quem optimos equos alere confureuerunt ueteres, Ef $\&$ Nebrodes Sicilię mons, quem aliqui à damarum copia dícum putant, fine authore. Imprefus Gratï codex non rectéhabet Hes to broden, Magnanimum quon dam generator equorum Agragas, Vergilius Aeneid.z. V bi Seruius, - Seeundum Pindarum, inquit, quondam Agrigentini equos ad agones Gracize mittebant, quí inde vifores reurertebaniur. Legimus etiam illud, quim in Cappadocia greges equorum periffent, Dela phici A pollinis refponfo reparauerunt greges de Agrigento, eosćp mellores. Aetnxum cantharum Ariftophanes in Pace uocat magnum, fiuc ẩ montis Aetnę magnitudine, fiue quod magni canthari, in eo nafcerentur:uel ab equis Aetnais uelocitate \& curfu celebratis, Excellunt equíin Syria $8{ }^{\circ}$
Cappadocia nati, Albertus.

fin Graecia nobiles funt Theffalici equi, Varro: Excellunt in tota Gracia,Abryrtus, Gratij poéz tauerba de Theffalo equo lege fupra in Mycenæo, id ef, Mycenis nato equo. A camanum folitudo pafcendis equis eft accommoda, nó minus quàm Theffalia, Strabo. Cerrum eft Theffaliam equorum to ualere praftantia: Vnde etiam Xerxes certamen curule ibidem loci fecifle dicitur, ut fuos illic expe. riretur equos, ubi Grecorum optimos effe audiueratDecernetur equa Theffalica, Ėmets orasch bxis,prouerbialc dictum de fummo pramio, propterea quod antiquitus prima laus fuerit equa rum Theflalix: Id quod fatis indicat oraculum Aeginenfibus reddirum. Citar Eultathius in fecun= dum Iliados librum. Suidas refert, haud dum feio ex quonam authore:

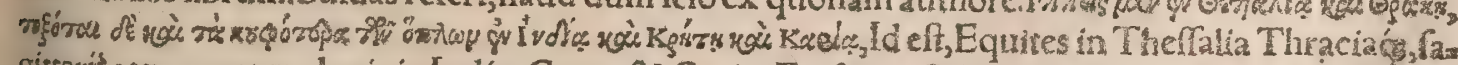
gittarif atç armatirra leuis in India, Creta, \& Caria, Erafmus. Scholia unigata in fecundum Iliado

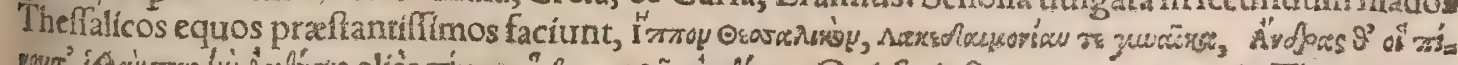

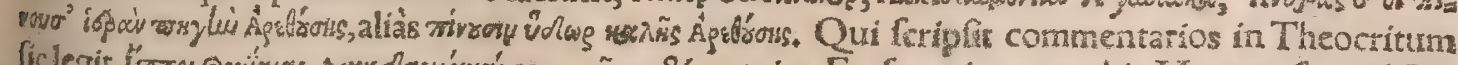

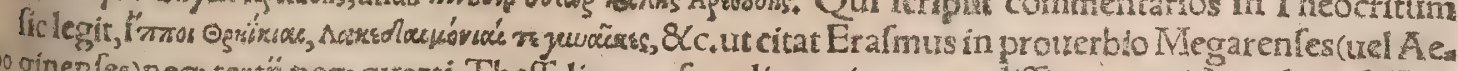

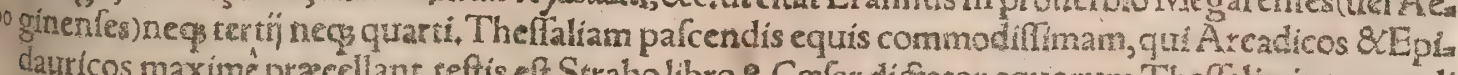
dauricos maximé pracellant, teftis ef Strabolibro 8. Cafar difator equorum Thefalia in cauros di micantium eośç necantium primus fpectaculum Romanis fertur dediffe, Textor. Theffalicus Oa $_{2}$ 


\section{4 \\ De Quadrupedibus}

nipes bellis feralibus omen, Lucanus libro s. Pella etiam Theffaliz urbs eft,å qua Pelleos equos a pud Gratium dicfos puto, quanquã \& alix fint Pell xutMacedonix \& Achaix. Spadices urix Pellaj ualuêre Cerauni, Et tibi deuotz magnum pecuaria Cyrra Phobe decus, noftras agere in accran $_{n}$ ria tenfas, Gratius de uenatione. Sunt Ceraunï montes Epiri,\& Cyrrha Phocidis oppidum in radia cibus Parnaffi montis, ubi colebatur Apollo Cyrrhaus. Tyrrheni tanquam bello aptiab Oppian no laudantur. Ex Tyrrheni maris infulis, prafertim Corfica \& Sardinia, breues admodum, fed anji

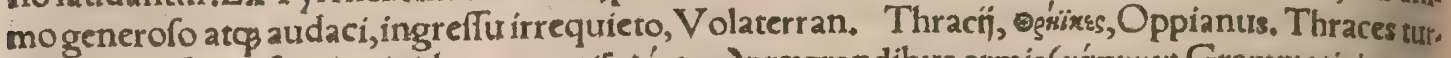

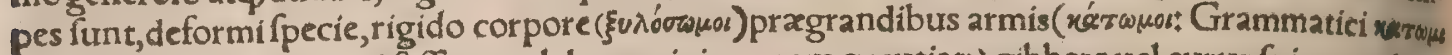
sry exponunt equurm qui feffor em ab humeris in rerram excutiat:) gibbere uel curua fpina:uari, atc idec ingreffu uacillante curfứç, A blyrtus interprete Ruellio. Oraculum Delphicum, quod paulo 10 ante recitauimus, Theffalicos, uel ut Scholiaftes Theocriti fcribit, Thracios equos prę omnibus ex: collit. Strymonio facilis tutela Bifalta, etc. ut mox fupra in Siculis ex Gratio dictum eft. Toringos $\$$ Burgundiones tanquam iniurix tolerantes Vegetius commendat, ita ut proximum poft Humisa fros, quos omnium primos facit, locum obtineant. Burgundiones olim loca ultra Viftulam tenue runt: Thuringi Heffis uicini funt, qui Plinio, ut Volaterran.conjúcit, Cimbri mediterrañnei uocent,

- Venetos aliqui putant defendere $a$ Venetis Paphlagonix populis, qui poft bellum Troianum ad hac loca peruenerint: $Q$ huitus conicciura argumentum faciunt induftriam ipforum in alendis equis:qux hoc omnino tempore defecit: antea tamen in fumma apud illos cura fuit, ueteris feilicet ftu

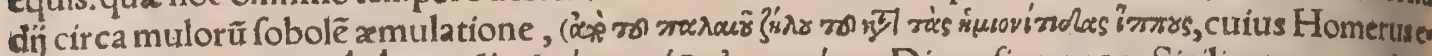

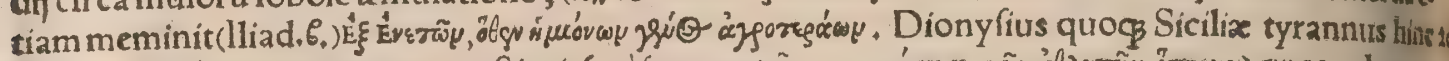

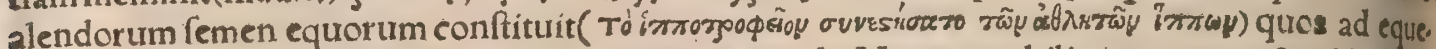
ftrecertamen tollebat:adeo ut per Grxcos equina prolis Venerze nobilitas maneret, \& ad longum tempus propago ipfa famam uẽdicaret, Strabolib. Y. I'znob Évırio'ss nominantur apud Stephanumin Enetis, uicinis, ut ait, Paphlagonia populis, Évézr as (proparoxytonum, malim paroxytonum)rátiss

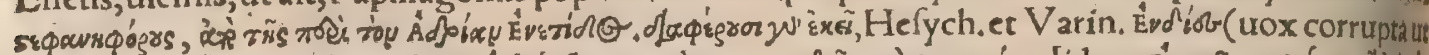

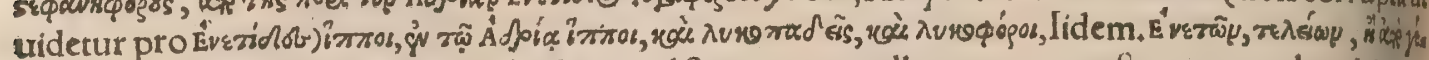

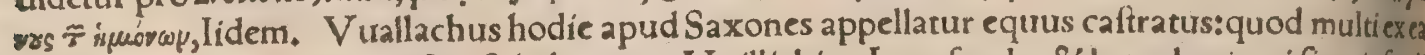
regione, qua olim Dacia dicta eft, habeantur, Vuillichius. Lycolpades SK lycophori qui fint, infradi cam in celerum mentione.

De equrorum differentīs à gradu $\&$ inceffu.

Equorum gradus, uel qualitate differunt, uel quantitate. Qualitatem troco, cum equum mollith Culé, durré, aut mediocriter ingredi dicimus:quantitatẽ uero celeritatis \& tarditatis dif́crimë. Quaths quam $\&$ hx qualitates quędam $\&$ potentix naturales funt in animantibus, non fine temporis tamê, quod quantitatis generi adfcribitur,animaduerfione:propriè autem tardum $\&$ celere dicimus ratio ne motus, qui cum fut omnis continuus, ea quidem ratione quantitati fubijcitur. Sẹd priore locode differentins in qualitate dicam. Motus igitur equorum(ut tradit Alhertus) quatuor funt: Curfua quil ex faltibus equi conftat: \& fit cum fimul eletrãtur anteriores pedes, fimul etiam pofteriores, etequis fe impingit anterius. Trotratio, quando uelocius quàm in ordinato greffu, oppofitorum latertim ans teriorem fimul \& pofteriorem pedem tollit: quo quidem modo fit etiam peditatio, fed prater equil concitationem. A mbulatio(Germanis, Dreffapf)deniq, cum fimul in eodem latere anteriorem d pofteriorem leuat pedem:qua quidem mollius agitur, fi propius terram non alté fublatis, fed quali ractis pedibus fiat, \& pauló citius anterior quàm pofterior pes figatur: quro magis autem ab hoc mon do recefferit gradus, eo durior erit: $V$ nde neceffe eft optime ambulantes equos frequentius cefpita re, pracipué in uia afpera, Haçenus Albert. I Succuffores equi ( quos alin fuccuffatores uocant, fuccuffonésue) frequenter fefforem inquietant, inde nomen fortiti: nam Marcello authore lucculfas re eft furfum frequenter excutere, Grapaldus. Ex Germania(inquit Camerarius) grauiores et fic cuffarí habentur, qui fubfultim molefté ingrediuntur. His fimiles appellat Nonius tortores equos: Aufonius uerò cruciantes, ut cruciante(inquit)canterio: fuccuffarios Feftus. Succuffatores tardi, raríç̧(aliâs tetri tardíç) caballi, Lucilius, Et alibi, Campanus fonipes fuccuffor nullus fequatur, Ag te, ac uulnus ne fuccuffet greffus, cautè ingredimini, A ctius. Pedetentim ite, et fedato nifur, ne fucculf fu arripiat maior dolor, Cicero 1. Tufcul. Greffum ipfum huiufmodi fuccuffaturam aliqui uocant, Albertus(ut fupra pofui) trottationẽ, troce Iralis, Gallis, Hifpanis et Anglis ufitata: ( Tortores ex No nio ferè intelligo, qui et cruciantes à poétis dicuntur:uulgo quoģ paucis immutatis appellantur hou die tortores, forte trotones, equi, Hermol.) Germani trab. Pomponius Decuma fullonis, Et ubi infis lui in cochleatum equuleum, ubi tollutím tortor, id eft torqueor, Nonius. Parthis confuetudo ef equorum greffus ad delicias dominorum hac arte mollire: non enim circulis at $\beta_{\beta}$ ponderibus prat grauant, ut foluti ambulare condifcant:fed ipfos equos, quos uulgò trepidarios, militari uerbo totio narios trocant( prius uerbum ad Germanicam fuccuffatorum nomenclaturam traber alludit, ure

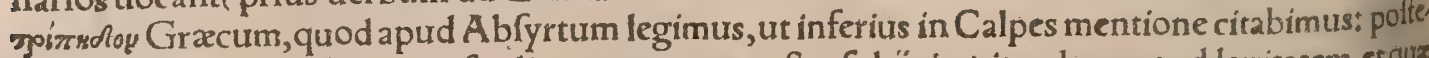
rius ad Gallicum uel Italicum, fi $\boldsymbol{r}$ literam tantum poft $t$ fubjicias) ita edomant ad leuritatem, etqua dam blandimenta uectura, ut A furconibus fimiles uideantur. In ficco itaq̧ xqualióp folo qumqqua ginta paftus in longum; \& quing in latum plenis cophinis digeritur per ordines creta, ad fimilitus 


\section{DeEquo. B. Lib. I. 465}

dinem ftadĭ, quod aulicibus(uide an filicibur legendum) afperius fit, tum difficultate coronam ue locitatis optantibus ingerit, in quo fpacio cum equus frequentifime exerceri coeperit, in illos aulices neceffariò offendit, \& priores \& polterlores ungulas impingit, $\&$ aliquando uel cadit, trel fic of fendit ut cadere uideatur:polt quod admonitus iniuria, tollitaltius crura, \& inflexione geniculorum atç gambarum molliter uehic. Praterea minutos greffus imitatur, ut inter aulices ungulas ponat: nam fi extendere uoluerit, offendit in cumulum. Minutim autem equus ambulans commodius ut, hit, \& pulchrius tidetur incedere, Hæc Vegetius 1. 56. Quxerendum an hic aut fimilis, ut puto, fit greffus ille quem Germani uocant \$yy folag. THabentur et in pretio cuiufdam mollioris gradu. equi,ad quem magna cura, uti ne nímis alte tollant crura, affuefieri folent:fed ï delicatiffimi, quor - hic non inftitutionis, fed natura gradus eft, Camerarius. Huiufmodi equus a pud Simonem ( quem

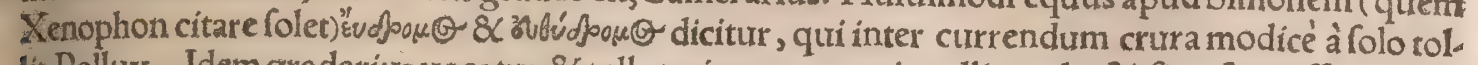
lit,Pollux. Idem gradarius uocatur \& tollutaris equus, qui molli gradu \& fine furccuffatura ge ftat. Varro, Qui re gradu(inquit) tollutim (aliâs tollutilí) melius quâm turte molliter uectus, citô relinquat, Afturconibus \& tollutaribus mannis, Seneca in epiffolis, Demam Hercule iam de ordeo, tollutim nibadizas, Plauturs Afin. V t equus quíad uehendum eft natus, tamen traditur magiftro, ut equifo doceat tollutim, Varro. (Tolutim per 1 fimplex, quafi uolutim uel uolubilitex, Nonius:qui - multa etiam fuper hac uoce ex ueteribus teftimonia affert.) A dequitatio hæc, ut arbitror, "ॄvofoo $\mu(0)$ Iulio Polluce dicit, quia carpatin curfur terrã, $\&$ tollat uolubiliter ac modice uefrigia tetem toll urtim, quafí uolutim interpretâtur, Hermol. In Hípania Gallaica gens \& Afturica equini generis, quos o thieldones uocamus, minori forma appellatos Afturcones gignunt: quibur non uulgaris in curfur gradus, fed mollis, alterno crurum explicatu glomeratio: unde equis tolutim carpere incurfus trad ur arte, (Hermolaus legit, tollutim carpere in curfer traditum arte, \& tieldones, fine afpiratione:) Plin. Tieldonum uocabulum accedit ad Germanicum geltnet: fic enim uulgò nominant equum gra darium: Angli an amlyng nag:hunc enim ab Anglis audio paruum, caftratum \& perö molli greflu effeillum ueró quem uocitant a hobye horfe, paruum quidem, fed minus molli greffu, \& caftratum: etalium à hackeney horfe, hedozporicum mercede conduci folitum, mediocri magnitudine, frue is ca fratus fiuenon caftratus fit. Galli 8 Cermania inferior, hacquené:quod alternatim pedibus eleua tis fonitum citet fimilem illi qui auditur cum olera aut aliud quippiam geminis cultris minutatim fur per abacoligneo inciditurłquod Galli dicũt hacquer, noftri bacten. Franc. Arlunnus equum man o num, thieldonem uel Afturconem, Italicis uocibus ubino 8 chinea exponit: Scoppa mannum pala. freno:mannulum palafrenetto: fiturconem uero, lo cauallo portante, che ua ferrato, acchinea et che tra a lambro, uel adafotet alibi Tollurarium fimiliter. Voces quidem chinea $8 \times$ achinea à Gallica hac quenéfacta uidentur. Aftureo, lacquence ouguilhedin, Robert, Stephan. Sunt quigradarium 8 tolutim factum equi inceffum, Iralicéambiaduram uocent: Albertus, ut fupra dixi, pedicationem. Palefridorum ufus eft uectio, qua equitatio dicitur, \& horum etiam eft non caftrari, ne effominent, Albert. Gualoppouel galoppo Italice, equigreflus inter fuccuffationem et curfum medius eft thũe etiam Arlunnus Latiné gradarium interpretatur, quod non probarim: De hoc paulo poft plura in Calpe, Hermolaus prouoce ticldones apud Plinium, aliquando fcribenduri putauit Tyddones, a Tydda oppido citerioris Hifpania, Grzecorum originis iuxta Gallecos. Nec decerno id magnopere (inquit) nec refello. Ipfe equus non formofus, gradarius optimus uictor, Lucilius, Seneca epifto= la 40.per metaphoram Ciceronem gradarium uocauit, cuius oratiolenté incedebat * quoniam gra= darij equi fine fuccuffatione molliter incedunt. Tolutarius uel tolutaris equers, à pedum uolubilita. te quali uolutarius. Tolutim, quafi uolutim, hoc eft uolubiliter, Nonius, O peftifera, trux, acerba to= lutiloquentia, Næuius citante Nonio. Tolutarium ab Afturcone 8 manno diftinguere uidecur Se= neca epiftola 88. his uerbis, Ita non omnibus obefis mannis $\&$ Afturconibus et tolutarijs praferres: unicumillum equum ab ipro Catone defrictum? Mannulus, equus pufillus, Martial.lib.12. Nurf qiuam eft mulio, mannuli tacebunt. Habebat puer mannulos multos, et iunctos, \& folutos, Plin, in epif, Manni apud Horatium Carm.z.dicfi funt, ut ibi inquit Acron, quòd manfuretudine manum fe quantur, Et Appiam mannis terit, Horat, in Epodis, Detonfi manni, Propertius lib. 4. Elegia 8. Currit agens mannos ad uillam, Lucret, lib. 3. Manni equi non admodum magni ueftigia glome, rant+nunc fané id genus ex Britannia uenit, Volaterran. De his nonnihil adferam etiam in ginnis uel nanis equis, Equifones \& arulatores, fiue mauis cociones, arte $\&$ induftria talem (qualis Aftur conum eft) gradus glomerationem equis dederunt, Grapald. Hic breuis ad numerum rapidos qui colligit ungures, Venit ab auriferis gentibus Aftur equus, Martialis libro ultimo. Hic (aliâs His) paruus fonipes, nec Marti notus:at idem Aut inconcuffo glomerat ureftigia dorfo, Aut molli pa. cata celer trahit effeda collo, Silius de Afturibus populis loquens. Callacis luftratur equis ferupo. fa Pyrene. Non tamen Hifpano Martem tentare minacem Aufim, Gratius. Pifis in antiquiffimo marmore infcriptio qua dam A fyrum mentionem facit, ut refert Fran. Robortellus lib. 2. Variarum amnotationum cap. 21. Âftyras uerò ego puto (inquit) intelligi equites, qui equis Hifpanis, ab Aftu. ria regione uterentur: nifif fortafle malis ab Aftura oppido Latij uocatos Afturas. Vergilius opinor ad hos equites alludens nomen illud ita protulit cum ait, Aftur equo fidens; etfille Latinus non erat, Hacille. Sed cum infcriptio illa fic habeat, Prafecius cohortis fecundę Aftyrum, Aftures uero, ut ex 


\section{DeQuadrupedibus}

orreclenthur elares, bells idonei non fne, non aftentior Robortello: \& nec illi coniectrix,

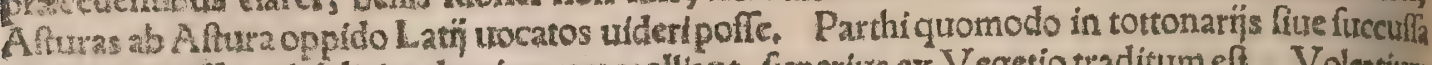
rif cau:s, gielfus a delicias dominorum molliant, furperius ex Vegetio traditum eff. Voleatium nobilen Afturcone ́l fuburbano redeuntem, canis à graffatore defendit, Plin, Aus Afturconi lo

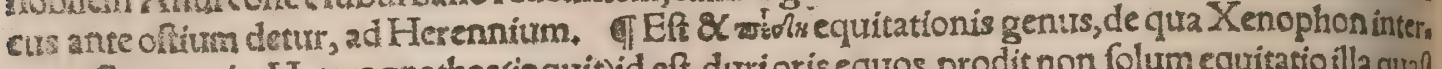
prece Canerario: Heterognathos(inquit)id eft, durioris equos, prodit non folum equitatio illa qualf

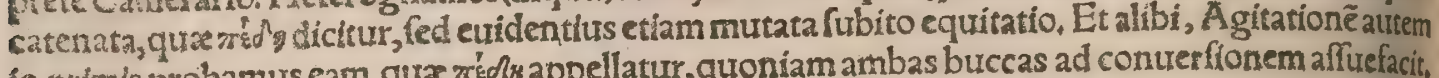
in primis probamus cam, qux més appellatur, quoniam ambas buccas ad conuerfionem affuefaci, Ent \& hoc bonum, agitationem ipfam mutare, ut equi bucce in utrifg exequentur, Nos etian exa

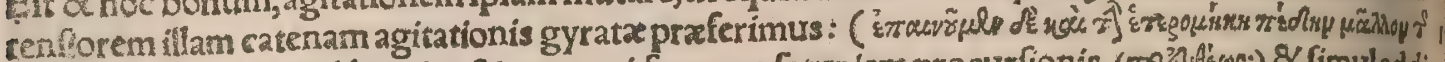

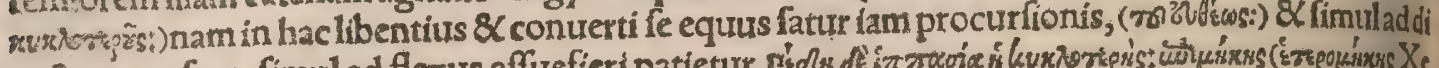

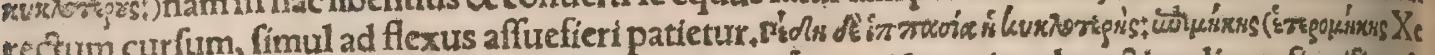

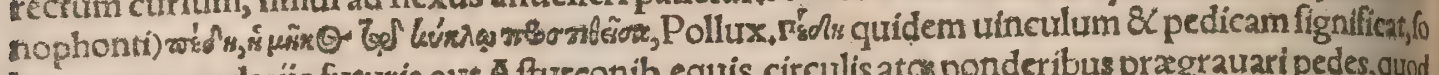
lent auten gradarijs futuris aut $\mathbb{A}$ fturconib.equis, circulis at $\$$ ponderibus pragrauari pedes, quod patet ex V egetio 1. 56.ut idem fortaffis greffus fit $\pi \delta^{\prime \prime} x$ Gracorum, \& Latinorum gradarius uel tolir

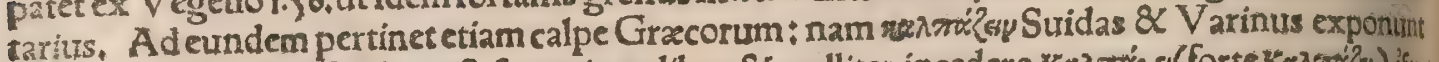

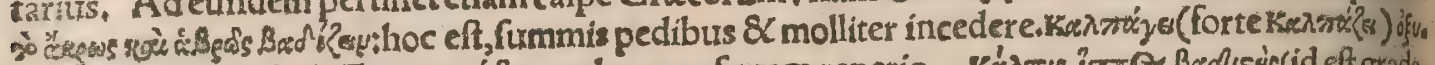

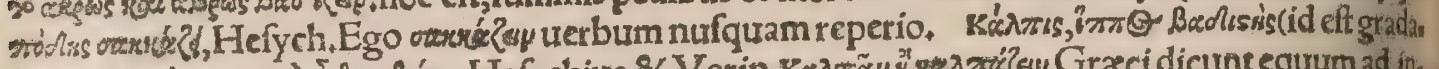

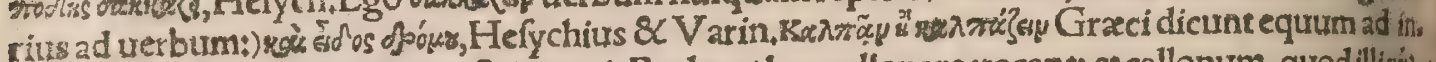

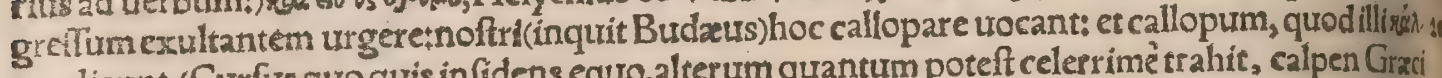
arw dicunt. (Curfus quo quis infidens equo, alterum quantưm poteft celerrimè trahic, calpen Graci

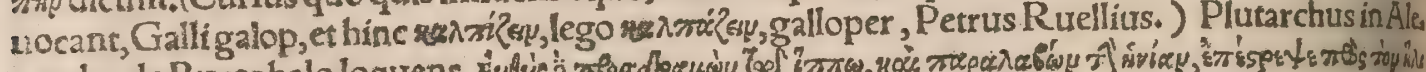

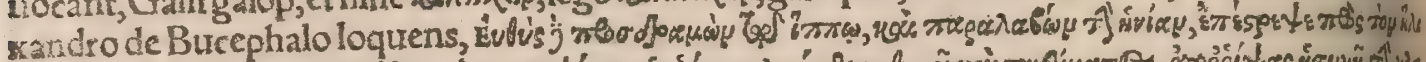

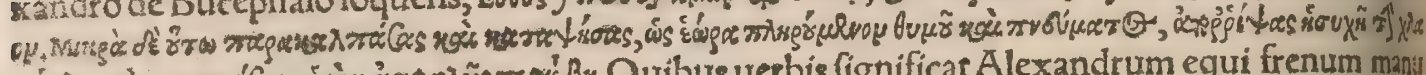

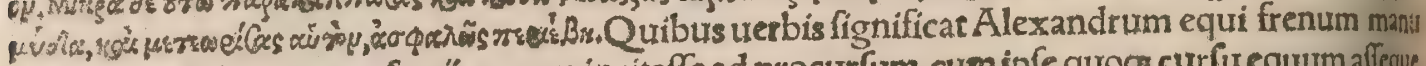
cenentem ad aliquantum fpatī equum incitaffe ad procurfum, cum ipfe quoç curfu equum affeque retur atcs aquaret $₹\{X$ deinde, manu plaufúćs permulfiffe, ut folent equifones equos ferociores des mitigare $\&$ deinde in Bucephalum infiliuiffe $\&$ confcendiffe. Legimus et in Hippiatricis hac ure

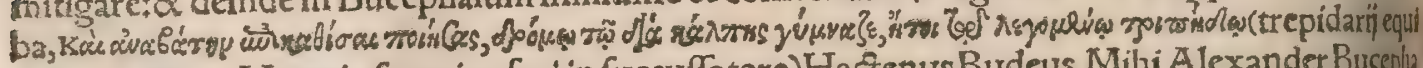
mentionem ex Vegetio fuperius feci in fuccuffa tore) Hactenus Budęus, Mihi Alexander Bucepla 3

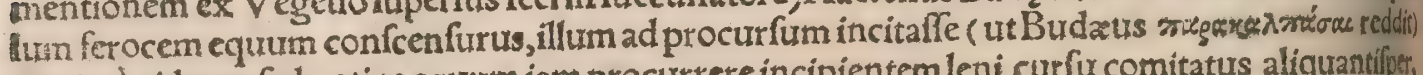
miniméuidetur, fed potius equum iam procurrere incipientem leni curfur comitatus aliquantifotut, ita ut potuit confcendife: ut urerbum illud non actiax, fed neutrę fignificationis fit, ut fimplex etiam

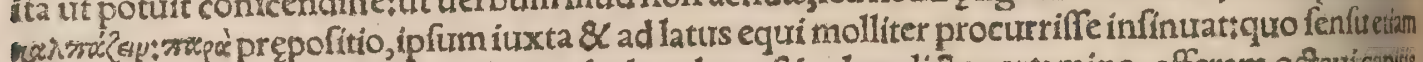

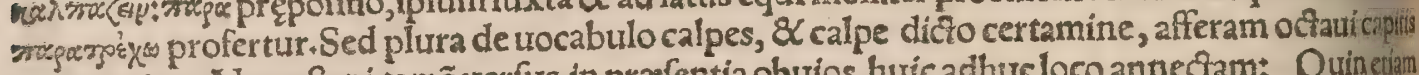
parte quinta: Nemefiani tamẽ uerfus, in prafentia obuios, huic adhuc loco annecfam: Quin eciam cens ampla iacet trans ardua Calpes Culmina cornipedum latê foecunda proborum. Nanģ̧ass lent longos pratis intendere curfus: Nec minor eft illis, Graio quãm in corpore forma, Nec non rerribiles f pirabile numen anhele Prouoluunt flatus, \& lumina uxiuida torquent, Hinnírusíçiêt tremuli, frenisós repugnant. Nec fegnes mulcent aures, nec crure quiefcune. Calpemons efthi Ipanix, oppofitus A bylx monti A fricx, qux dux dicuntur columna Herculis, Ex Tyrrbenimaris infulis equi habentur greffu irrequieto, Volaterran.

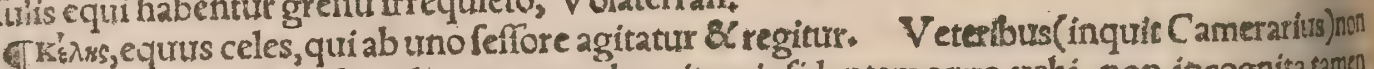
fuit in frequenti ufu agi fingulos equos, uel equitem infidentem equo urehi, non incognita tamen res, Itacs ef Homerus defcribens Vlyflis refidentis diuaricatis cruribus fuper una fracta nauls trabs in mari iachationem, ufus eft fimilitudine equitis agitantis equum folum, quem líns rat udcat, Hine

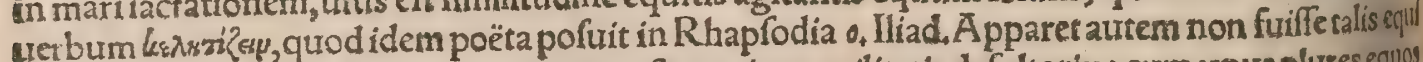

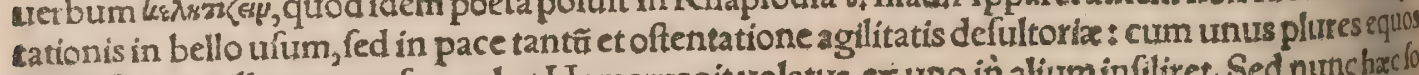
aleret, \& inter illorum curfus, uel ut Homerus ait uolatus, ex uno in alium infiliret, Sed nunchacto la agitatio nota \& confueta eft, illa autem curulis defita et ignota. Vocatur hac agitatio pómmo mo nippos uocant uno depugnantes equo, Calius) inuentum Bellerophontis: Cui pater Neptumushuls us enim fuiffe filium tradunt, cum putaretur patrem habere Glaucum Sifyphidem: ) illigitur $\mathrm{N}_{6}$ ptunus uelociffimum equum Pegafum dedit alis praditum, Aliqui hoc inuentum ad regem prifu cuendam Acgypti referunt, Sefonchofin nomine, quifit apud Herodosum Sefoftris, Aliqui etian ad Orum, quibellum gefturus cum fratre Typhone, potius equum quàmleonem ad pralia ferturin Iruxiff: quia ad perfequendum quogg hoftem equus, leo in ip fo tantum conflictu elfe utilis uidere cur. Virgilius huius agitationis authores $\&$ inuentores frenorum, facit Lapithas gentem Theffalica in Georgicis ita canens; Frena Pelechronỉ Lapithae gyrosés dedere Impofiti dorfo, arę equiren docuere fub armis Infultare folo 8 greffus glomerare furperbos. Sed alit Centauros hane primos ufurpaffe perhibent, faltem ut ex equis pugnarent, Sed de Centauris plura dicam in H. a. Non eo dem modo parantur equi a ephippium(hos celetes dixeris ) ut ad pradam, Varro, immínganon Iimpliciter rei equeftri wacare fignificat, led unico equ uo uehi, quem nunc celetem appellant, Ariftopha 


\section{De Quadrupedibus}

neç idem, qui uectorios facere uolet, Varro de re ruft. Numidis defultorum in modü binos trahent tibus equos, inter acerrimam fape pugnam in recentem equum ex feffo armatis tranfultare mos e* rat, tanta uelocitas ipfis, tam $\dot{\zeta}_{\beta}$ docile equorum genus eft, Liu. lib. 23. ab Vrbe. Quin \& eum quicer, tat, rectè defultorem dixeris'quod comprobat Vlpian. Digelt, de prafcriptis uerbis, Túç̧ defultor in his cucurreris 8 uiceris. Cicero pro Murena ait, Qui nefcio quo pacto mihi uidetur pratorius candidatus in confularem, quafidefultorius in quadrigarum curriculum incurrere. Defultorem porrò défignat Elegiacum illud fcientifimé concinnatum, Eft etiam auriga fpecies uertumnus,

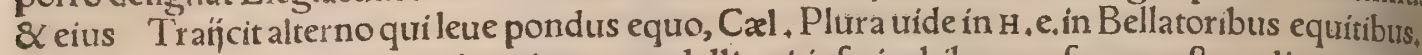

- Dentes luporum maximi equis quo $\$$ a alligati, infatigabilem curfum præftare dicuntur, Pli nius. Sarmaræ longinqua itinera acturi, ine dia pridie praparant equos, exiguum tantum potum 10 impartientes:atç ita per centena milia \& quinquaginta continuo curfu euntibus infident, ldem.

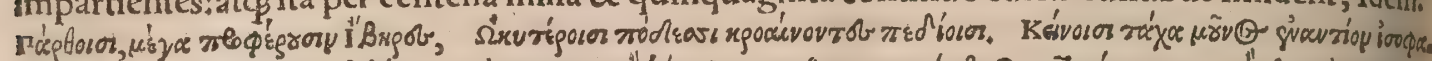

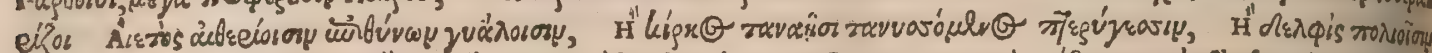

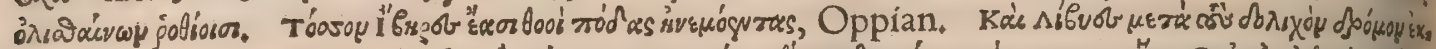
rє ró

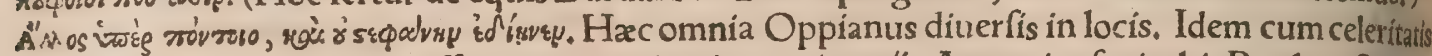
palmam Iberis equis attribuiffet, ut iam recitaui : proximos n̈s Armenios facit : his Parthos, Siculos, Mlauros, 8 poftremos Libyas. Seneca in epift.12.86.de uelocitate per fe xftimata, non qux tardifit morum collatione laudatur, hac carmina effe fcribit, Illa uel intacta fegetis per fumma uolate? Gramina, nec curfu teneras lafiffet ariftas: Vel mare per medium Huctu fufpenfa tumenti, Fer, retiter, celeres nec tingeret æquore plantas, ex quo pcéca autem defumplerit, tacet. Nos quidem eadem Gracé a pud Homerum Iliados uicefimo legimus. Nam de Dardano rege fcribens, Huius (inquit) roq qíl

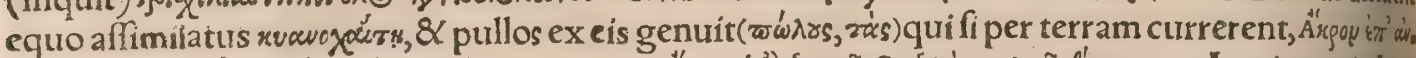

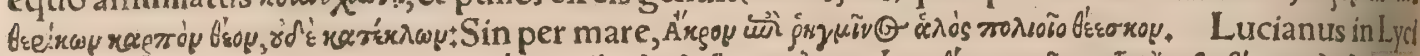

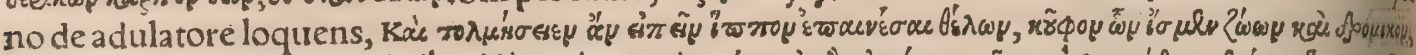

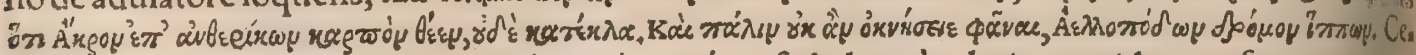

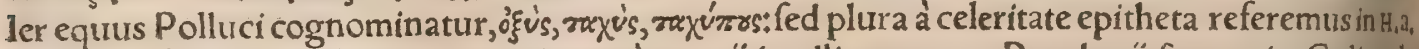

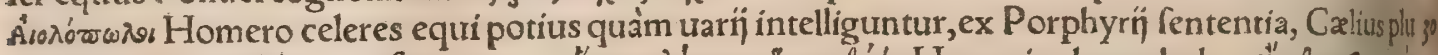

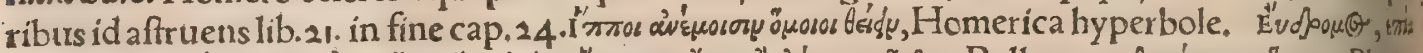

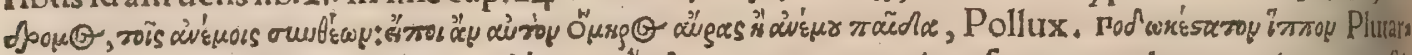
chus dixit in Sylla, Xenophon rod'wrs. Éxdoopoy uocant equi curfum, cum ultra terminum confit

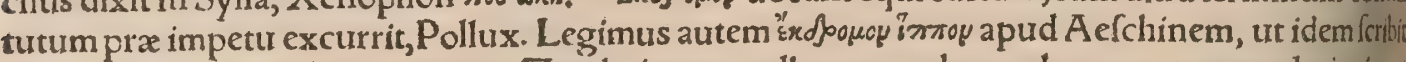
3.30. Arabes, quorum principem Zambeium appellant, equabus uehuntur, tantæ celeritatis, ut per diem noctemćs circiter centena milia itineris conficiant. Volare p̈ potius quàm equitare uiden. tur: ephippijs uulgus non utitur, fed proceres tantum : qui etiam foli ueftiuntur, reliqui induffis $c_{0}$ tentifunt, Vartomannus. Equa mater optíma, fumma charitate \& fide pullum fuum amat, cuitus fané modi amoris Darius ætate inferior non imperitus, equas à partu recentes relictis domi pull ad pugnas ducebat. Pulli fic alieno lacie à matribus orbi, quemadmodum homines parentib, amif fis aluntur. Darius cum inclinata iam acie in eo pralio quod ad Iaffum (lego Iffum) commiferat pera farum res premi cœpiffent, cumćs uiçus fuga falutem adipifci neceffe haberet, in equam afcendil: qux quòd reliçi memoriam pulli recordaretur, quanto maximo potuit ftudio \& celeritate eun ipu fum prædicat ex periculis eripuiffe, Aelian, Cîrca extremũ Septentrionê(ut fcribít Paul. Venet, 49.) regio quadã eft in qua multo per annũ tempore Sol non apparet, ita ut non folum noću tenes bræ fint, fed etiam interdiu aër in modum crepufculicaliginofus, Hanc regionem confines Tartari prædæ gratia ingreffuri, ne propter fubitò ingruituram noctem periclitentur, hoc modo catient, E. quas cum pullis accipiunt: 8 pullos in primo regionis ingreffu cuftodibus committunt, ut fellicre dituros expectent. Sic equa nocturno itinere diligentius obferuato, rectà ad pullos fuos in reditu contendunt, idés celerrimé. Laxant enim eis feffores habenas, \& liberé quo fuo inftinciu feruntur

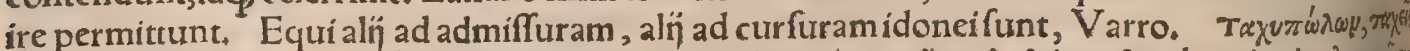

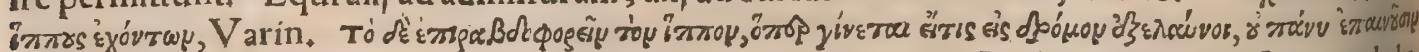

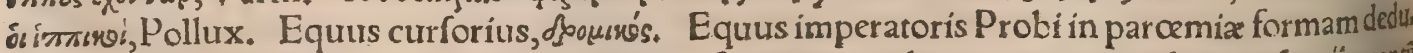
ci poteft. Is erat nec decorus quidem, nec ftatur ofus, trerum celeritate tanta, ut diurnis ipatîs centî obiret miliaria, uel in decimum diem labore haud interpellato. Eum tamen fugaci magis quàm forth ac ftrenuo cógruere militi pronunciautit Probus idem, Cæl. Fuit autem hic equus Alanicus, in bello Probicontra Alanos captus. Equos generofiores 8 ad curfum præfertim paratos, quos barbaris cos dicimus, paleis $\&$ zeatico hor deaceoue cibario, ${ }_{2}$ qui funt principum equifones alere confuetue runt,Grapaldus. Albertus equos celeres inepta uoce curriles dixit:Horum, inquit, ufus eftadtu gas $\&$ infecutiones præcipué: $\&$ ne indurefcant eis nerui ex calore curfus, caftrantur. Voluptatem equis ineffe, Circifpectacula prodiderunt. Quidam enim equorum cantibus tibiarum, quidam fali tionibus, quidam colorum uarietate, nonnulli etiam accenfis facibus ad curfus prouocantur, Solin, 
raret, foeminam nullam alienare confueffe. Equinam hinc pracipux celeritatis progeniem extí viffe. Hac uero tempeftate, ut diximus, omnis huiưfmodi rei defecit exercitatio, Hucufog Strabo, Plura qua ad Philologiam de celeribus equis fpectant, referemus in $\mathrm{H}, \mathrm{b}$.

बEx uelocibus equis funt etiam uenatici, de quibus partim diximus, partim dicemus . Surt 8 ueredi curfu pernices. Veredos antiqui dixerunt, quòd ueherent rhedas, id eft ducerent, Feftus, Veredarịs ad celeritatem comparatis equis nomen olim fuit, fuxta hoc Martialis, Parcius utaris mo neo rapiête ueredo Prífce, nec in lepores tam uiolentus eas. Et alibi, Stragula fuccincti uenator fur me ueredi, Nam foletà nudo furgere ficus equo, Veredos (inquit Calius) fi modò non abertret interpres, aliâs arris non multi, a pud Procopium Perfíci belli fecundo libro, equos accipimus publis cos. Veredarium metaphora decenti legimus apud Hieronymum: Quia fíngulę, inquit, metuunt ure redarium urbis offendere. At Procopius idem ueredarios intelligere uridetur, eos qui celeriter equis inuecti regum literas prouehunt. Equorum publicorum in hec ufu, commeminiffe Ammianus uide tur Marcellinus: Tranfeo (inquit) qưod quidam per ampla urbis fpatia fubuerfośç̧ filices fine peri. culi metu properanter equos uelut publicos, fignatis ( quod dicitur) calceis agitant, familiariuma gmina tanquam prædatorios globos trahentes à tergo: ne Sannione quidem, ut ait Comicus, domi relicro. Procopn̈, uel interpretis fententiam adiuuat Firmicus Mathefeos tertio:Regum, inquit, nun cios ueredariosóg reddent, Curfus publicus dicebatur aut fifcalis, quum ab imperatoribus certis los cis equi ad genus praceleres deftinabantur:quibus non utebantur alifi, nifi facultate impetrata, quant uocant tractatoriam, Hucufó, Calius. Verba hac apud Liurum lib, , ita leguntur : Repéte quibus renfus equefter erat, (equi publici non erant affignati) confilio prius inter fefe habito, fenatũ adeût, factaćg dicendi poteftate, equis fe fuis ftipendia facturos promittût, quibus ampliffimis uerbis ablea natug gratix acta funt.Puto (inquit Fr.Robortellus) Liuium per equos publice affignatos intellige re, equos qui uectigales à Cícerone uocantur in Philippica or. 2. cum ait, tum exiftimauit fe fur iure cum Hippia uiuere, \& equos urectigales Sergio mimo tradere. Antonius redemptas habebat abata rio uectigales quadrigas, A fconius + Sed redeo ad ueredos. Scythx forminis (ut nunc noftrifint curfores caballarị) ùti maluêre: (ed in praling, quod urinam curfu non impedito reddant, Grapaldus.

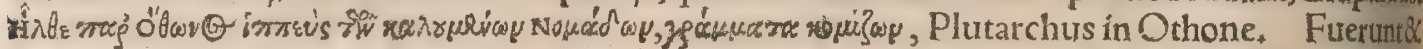

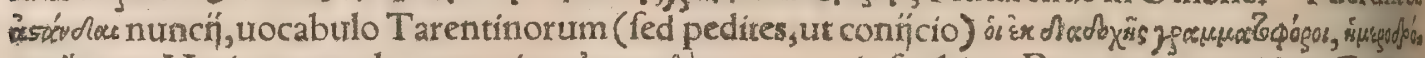

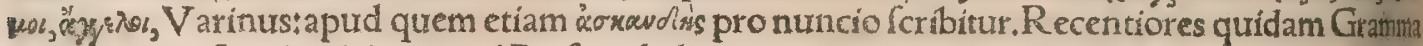
rici fcribunt aftandas dictos apud Perfas tabellarios, qui certis interuallis itinerum permutabatutur, 3

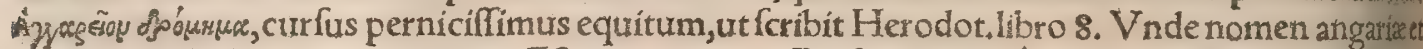
parangariæ in libris iuris manaúit. Eft autem nomen Perficum, uulgò poftas appellant, Bud, in Ån,

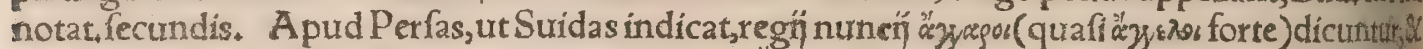

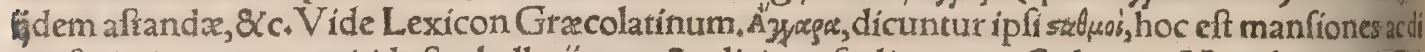

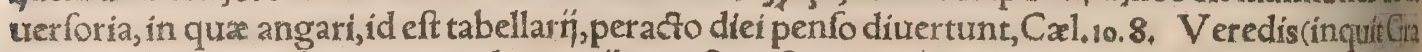
pald.) noftra tempeftate utuntur lancearí equeftres ftratioticos quos dicunt, lances manibus teds procantes. Commendantur ad hoc Turcorum caballi tefticulis ut plurimum ademptis, cantherios uocant, perniciffimi. A ueredis curfores, feu mauis tabellarios equeftres celeri celeritate perferens tes, ueredarios, ut à caballis alín caballarios appellant:qui tefte lulio Firmico fub equi coeleftis fydere nafcuntur. Veredarios hodie uulgo poftas appellant, forte quod equis per interualla difpofitis, ,tite centes fubinde habeant, utantur. Equos Pegafidas ad defultoriam uiciffitudinem é feffo in recenta tem affiliendi ín uenationib, thabere oportet, Bud. Pegafarĭ curfores à Gallia Lugdunenfi quinto aut fexto demum die Romam aduolant, fubinde per ftationes mutatis equis, Bayfius de re Vef.

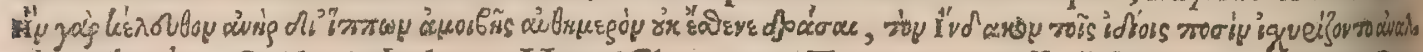

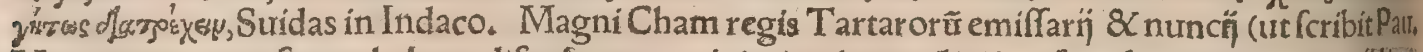
Venet, 2,23.) manfiones habent difpolitas per uiginti quings miliaria, ufç ad extremos imperịlimi, tes, ita urt in locis etiam uaftis alioquin $\&$ defertis hurufmodi diuerforia triginta aut quadragintani liaribus diftantia reperiantur, Conficiunt autem fic difpofiti equites uno die ducenta aut trecêtamia liaria, relictis fubinde equís feflis, 8 recentibus fubftitutis.

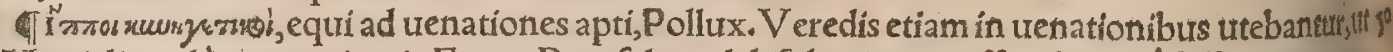
ex Martiali paulò ante recitaui. Equos Pegafidas ad defultoriam uiciffitudinem è feffo in recentem affiliendi in uenationibus habere oportet, Bud. Mares ad uenationis ufum praftant + nam foemint minus celeres funt ad longos per nemora curfus: fed abigendx funt procul foeminx, ne equi hinti tu feras difturbent, Oppian. Reftat equos fínire notis, quos arma Dianx. Admittant, non omne meas genus audet in artes. Eft uitium ex animo. funt quos imbellia fallant Corpora: pratueniens

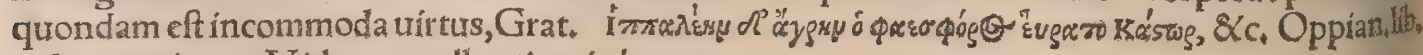
1. de uenatione, Vide nonnulla etiam in b.

Tा Equi licet pleriç animofi fint, \& infigni animorum pra cateris animantibus praditi magnittle dine $q$ quidam ramen hac ipfa excellunt, \& corporis infuper uiribus pollent, atç hi foli bellis idonei funt. Lanigera pecudes \& equorum bellica(aliàs duellica)proles, Lucret, Bellatoris equi forma qux probetur per totum corpus \& fingulas eius partes, Xenophon \&O Opian, docent, quorum uet ba fuperius pofur in electione equín genere. \$Quoniam ureró propofuimus (inquit Xenophól 
feram ad capitis 8. fegmentum quintum. ) Sed qualecuncs, contigerit frenum, cum hoc, cuncia ea qua fubịcientur, praftabít is qui uoluerit formam equi efficere eam, quam fupra diximus, Os igitur

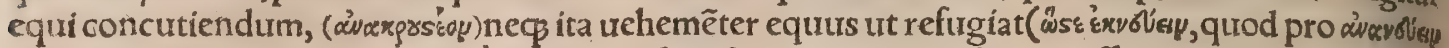
pofitum uidetur:) neç ita placidè ur non perfentif́cat. A tç iam polt concuffionem ubi equus cerui, cem atrollet, ftatim freno indulgendum:item fcitè obfecundârit, uicifím illi gratificari. Cumø̧ animaduerfum fuerit deleçari equm elatione cer uicis, \& habenarum laxitate, tum caurebitur ne quid illo tempore huic moleftix objiciatur, quafi ad laborem equum adigere uelimus, fed blandimentis tum equum demerebimur, ut fperet requierę: ita enim magis prompto animo ad celeritatẽ agitationis deureniet. Iam uerò celeritate etiam gaude re equos, ratis argumenti eft, quod liberatus pedetentim nullus abit, fed aufugit: hæc enim certe eft toluptas equorum, nifi forte ad curfuram importunius fuerint incitati. Sed cum inter agitandume quus exultabit, fcilicet edocłus iam priore agitatione fuit de flexibus ad celeritatem incitari+quod cii facere fciucrit, fi quis tum illum adductis habenis retineat, 8 fignum aliquod det concitationum, coércitus hic frenis, imperio concitationis commouetur, \& pectus effert, $\&$ iratus protollit crura ala tius, non mollia tamen bac: quippe in offenfis iam non magis mollibus cruribus utuntur equí, Sic igitur exardefcente equo, fi frenis indulgeas, ibi pra gaudio, quod in laxitate fe freno liberatum plis tet, exultabundo habitu, mollibusćs cruribus elaté fefe inferet, plané repręfentans pulchritudinem qua componere fe equi folent feftinantes ad alios equos. Quiç hoc cernunt, talem equum appellàt liberalem, \& uoluntarium, \& equitatorem, \& ferocem, \& fuperbum, fimulí̧ \& $\&$ iucundum \& rerris bilem afpectu, Hac omnia Xenophon.

बIMinuti in deliç̄s fxpe habentur, \& pueris potentum atç diuitum parantur, Camerarius, Ex equa $\&$ mulo generatur innus, Ariftoteles $\& V$ arin, i yvó gramatici mannum $\&$ equum pumilum exponunt. Sed de manno \& mannulo dixi fupra in mentione equi gradarï. ivvoi, os noro Boi rิ innap:

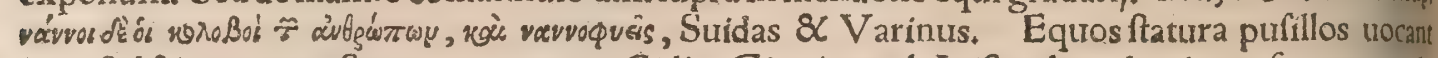
inos, fed $\&$ ginnos pofterinuncuparunt, Cæli. Ginni apud Ariftotelem deminuta forma equidis cuntur, quos $\&$ gygenios ab Strabone nuncupari, putant nonnullitquanquam $\&$ mulorum genus fic in Liguria uocet. Plura de ginno, hinno $\&$ inno, $\&$ uario harum uocum tum fribendi tumfignt ficandi ufu, diximus in Hinno poft Affini hifforiam, \& in Ceruo capitis 8. parte 1.

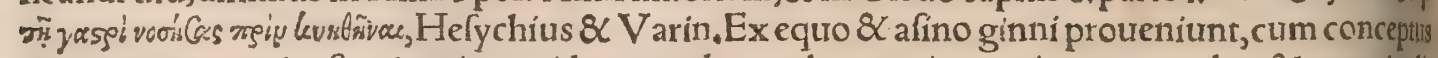
in utero agrotauit; eft enim ginnus idem quod metachœrum in porcis, cum membra $Q \times$ magnitudi

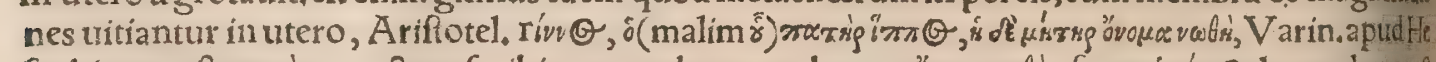

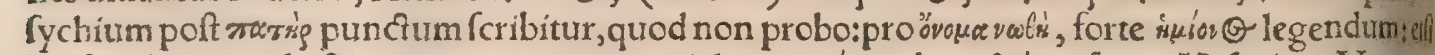

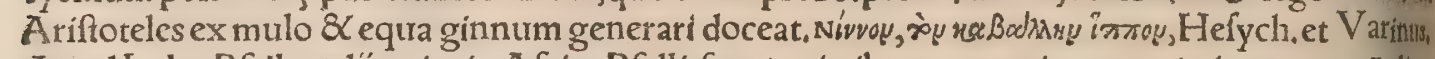
Apud Indos P fyllos(alï enim in A frica Pfylli funt) arietibus non majores equi gignuntur, $A$ elian, Mannos fiue mannulos equos pufillos, buricos etiam nominant, ut eft apud Acronem \& Porphyio nem, Grapaldus: Calius burdos uulgò uocitari, non buricos, ex Por phyrione citat. (De burdonein ginno dixipoft A fini hiftoriam.) Buricos quidem equos minores uocari legimus apud Vegetiuit quoç libro quarto capite fecundo, Runcina Plinio funt maiores ferra, quibus fabri materiatiffe cant arborum moles, fubiectis canterịs . Canterị uerò funt, qui à rufícicis ferè nominanturr cabalili: quia ipfos equos, ut notum eft, canterios urocamus. Sed 8 runcinos agrefteuulgus dicit minorese quos, ex hac for taffe runcinarum, quas diximus origine, Hermolaus. Runcini equi habentur ad has bores onerum ucl tractus quadrigarum $\&$ rhedarum:licet etiam alí aliquando his laboribus depus tentur, Albert. Minores quofdam equos, quibus carpenta 8 petorita traherentur, manos, $\& /$ uce diminuta manulos appellarunt:horum, ut nune quoog fit, iubæ tondebantur: quod $\&$ Propertins lis gnificat lib +4 . Huc mea detonfis auecta eft Cynthía manis, Camerarius, Mufimon, afinus, nuw aut equus breuis, Nonius. Pretium emit qui uendit equum mufimonem, Lucilius lib, 6. A finum, alls mufimonẽ aut arietem, Cato Deletorio, Nonius. De mufmone in Sardinia, fera ouri uel arietifimili, dicam ftatim poft Ouis Hiftoriam.

6I Canterius (aliqui cantherium fribunt t afpirato)equus, cui adempti funt tefticuli, Catocap, 149. Vegetius fpadones dixit, Cantherium Germani monachum uocant, cin mind, : $\&$ aliubi Viral lachum, Vuillichio tefte: quod eorum copia ex ea regione, quę olim Dacia dicta eft, habeatur Angli a geldyng. Scoppa canterium iannettum I talicé uulgo dictum interpretatur, de quo fuperius inter ce leres dixi.Galli cheual ongre, cantier, cheuron. M. Cato Cenforius cantherio uehebatur, Senecat Cruciante canterio, Plautus citante Fefto:Cruciantem interpretantur fuccuffatorem: Locus Plant eft in Cap. Tum pifcatores qui prabent populo pífces foetidos, Qui aduehuntur quadrupedant, crucianti cantherio. Vtitur cantherij uocabulo etiam Cicero ad Patum libro 9. \& lib, 3, de Nat, Ve redi uelociffimi in curfu funt, \&c, commendantur ad hoc Turcorum caball, tefticulis ut plurimum ademptis, cantherios trocant, Grapaldus. In uijs habere malunt placidos: propter quod difrimen maximè inftitutum, ut caftrentur equi. Demptis enim tefticulis fiunt quietiores: \& ideo quod femine carent, î cãtherĭ appellati, in fuibus maiales, in gallis gallinaceis capi, Varro. Multos ego fcio non modo afinos inertes, uerumetiam ferocilfimos equos nimio libidinis calore laborãtes, atç ob id trun ces uefanośç̧, adhibita tali deteftatione, manfuetos ac manfues exinde factos, A puleius libro\% 
8 infecutionem aptos, curriles uocat. A curru fellam curulem nominarilegimus, $r$ fimplicl et prims breui. Celerius uroluntate Hortenfij ex equili educeres rhedarios, ut tibi haberes, mulos, quàm i pifcina barbatum mullû, Varro. Videtur fanè rheda de mulis proprie dici,cuiad itinera conficienda ungebantur, ut apud Græcos émrísw: nam rhedarium equum (quanquam Grapald.fic uocet) apud ueteres non memini legere ut mulum rhedarium. De uarijs uehiculorum generibus, dicam in $\mathrm{H}, \mathrm{C}$ Vefarí (inquit Cameraríus)ad plauftra, effeda, rhedas, carros adiunguntur . Veteres tamen Gra, ciæ \& Italix populi, non equos ad plauftra \& uehicula, fed boues aut mulos adiunxere, \& uiatorib, mulis magis quàm equis ufi fuere. Noftri autem homines, nifi ubi montana funt, non ferè boues,ne que aratores neç trectarios alunt. Videas etiam alicubi fyluarum ingentium accolas, $8 \mathrm{carbonari}$ os, ante boures equos agitare. Veciuræ optimi canterï, equi uidelicet caftrati, Volater. Vectarn̈ robur effe oportet: hi ruri educuntur, fui cuiufdam generis, quamuis $\&$ bonos equos interdum rura mittant, fed in oppidis ad uecturas plarung dantur effocti annis, aut læefi, qui illis operis reliquas ui, rés confíciant. Neç eft tanta noftri temporis humanitas, ut ociofus alatur equus, poftquam confe nurerit \& uires amiferit, ut abdito domi, Camerar, Runcini equi habentur ad labores onerum uel tractus quadrigarum \& rhe darum: licet etiam alin aliquando his laboribus deputentur, Albert. Dignum eft notatu dextratio uerbum apud Solinum, (de curfur equorum quadrinugum, ) unde modo equos maximé bigarios, $H_{\text {e }}$ truria dextrarios appellat, Hermol, Ego equum infignem potiffimum, quibufdam Italiz locis uulgo deftriero nominari audio. Equi farcinarí aut iugales, Bud.libros. de Affe, Clitellarius equus id eft farcinarius, à ferendis clitellis, Textor. De clitellis plura attuli in Afino in $\mathrm{H} \cdot \mathrm{e}$. Equi $\&$ canes fi ruri alantur, fumptus $\&$ curas qux in ipfos conferuntur, facile compenfant. Nam equo fiue mane fiue ferò dominus ad negotia feftinet, expedite uehitur, Xenophon, De equis bigeneris $\alpha_{\text {adiroú }}$

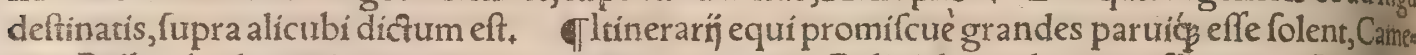
rar. Pollux hodoeporicos nominat nos itinerarios, ur Calio placet, dicere poffumus . In ǘpllas bere malunt placidos, propter quod difcrimen (placidorum ab acribus, qui ad rem militarem cotute niunt ) maximè inftitutum, ut caftrentur equi, Varro,

9 De equis autem ad pompam idoneis (pompicis)quióp fefe erigere 8 præclari uideri foleant,, 1 quis tales requirit, is fciat non cuiufuis equi hæc effe opera:fed corum qui fint animis ingentib, \& ualidis corporibus præditi.Quòd autem nonnulli arbitrantur, cum mollitudine crurum conitucia effe erigendi facultatem, id uerum non eft:fed lumbi (lumbos, ${ }^{\circ} \sigma \phi v$, nunc appello, non qua caudam

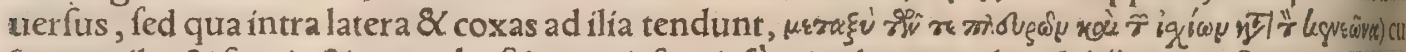
funt molles $\&$ furccincti atç̧ robufti, poterit fpaciofé prioribus cruribus fubä́cere pofteriora, Hocdü

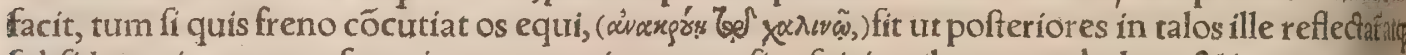
fubfidat, erigat autem fuperiores corporis partes, fíc afpicientibus contrà aluus 8 inguen utappas reat. Ibi igitur frenis indulgendum, uti equus, quod pulcherrimum eft in hoc genere, facias libens, $\&$ ita fpcéatorib. hoc facere uideatur. Sunt qui ad hoc etiam erudiant equos:quorum hi uirgatalos

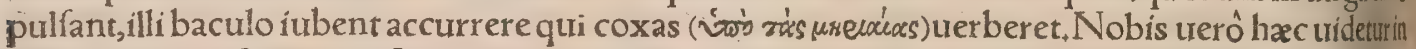
ftitutio optima, fi, id quod femper dicimus, non omittatur un $\not \tilde{B}$, equo ut quies contingat, poftquam

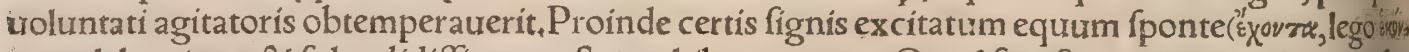
zxo) pulcherrimos \& fplendidiffimos geftus exhibereoportet. Quod fi poft equitationem et copiofun

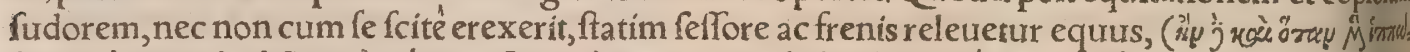

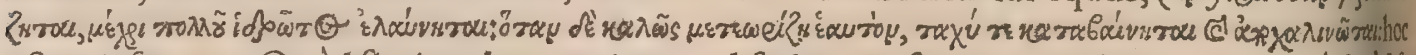
eft, ut ipfe uerto, Quòd fie etiam dum equitatur, ad fudorem uf̧́ agitetur:ubi primum ueró fciréfele erexerit, ftatim feffore ac frenis leuetur ) non dubitandum quin fua uoluntate poftea ad erectione peruenturus fit. Super huiufmodi iam quidem agitationi idoneis equis refidentes, 8 dij pinguntur, \& heroës: hominesós in ufu horum decente, magnifici uidentur. V fqueadeo ueró equus qui fefe eris git, uel pulchra uel admirabilis, uel etiam expetenda res eft, ut omnium oculos fpectantium inferó uerfos teneat, tam iuurenum quàm feniorum, \& reliqua. Maximé fanè laudatur talis equus, quicols pus $\&$ altiffimè \& frequentiffimè erigat, \& lentè interim procedat, $\mathrm{Hac}$ omnia Xenophon. Tranferi pfit \& Pollux ex eo nonnulla, fed breuíus ac obfcurius: \& quadam à Xenophonte relata ad equum f militarem cum ad oftentationem equitatur, ipfe non recté ad pompicum refert.

đOppianus fylueftrem equũ compofita uoce hippagrum uocat, equiferum Plinius. Equi feritr periuntur, Ariftotel. Idem in Mirabilibus equos feros in Syria reperiri feribit, eosḉ̨ famam effelli! nioribus qui ad foeminas accefferint, tefticulos mordicus abfcindere, curfu perfequentes $\&$ capilt per pofteriora crura immiffo. Alpes habent equos agreftes, Strabo, Et alibi, Hifpania producites quos fylueftres affatim. Equi feri in Hifpaniec citerioris regionibus aliquot funt, Varro, Fuernt fub Gordiano Roma equi feri quadraginta, Iulius Capitolinus, Et alibi in Gordiano primo, Extat (inquit)Gordiani fylua memorabilis, picta in domo roftrata $\mathrm{Cn}$. Pompeí, in qua pictura prater alias feras equi feri trecenti continentur. In Aethiopum locis preruptis, multi funt equi feri, duroburs dell tibus exertis $\&$ uenenatis præditi:quibus non folida pedum ungula, fed fimiliter ut ceruorum brida eft,iuba per mediam fpinam ad extremam ufç caudam pertinet. Ac fi quando eos pofitis laqueorí infidís Indi comprehenfos in feruitutem redigere uelint, abfinent fe proprerea cibo $\&$ potionie, 


\section{DeQuadrupedibus}

mum equis:eadem quog trifolium uocatur, Varinus \$ Sed fatis iam multis in Boue de Medica dixi eap. 3. Ad maciem equorum, ut Columella prodidit, nulla res tantum, quantum Medica poteft. Plura de lac herba in Boue capite tertio differui: \& inter catera uocari eam hodie uulgò ab Hifpanis diflifes, apud Arabes alaffeft, \&c, Bellunenfis alaffeft \& faffafa eandem effe feribithic paucaceu paralipomena adjiciam. Faffafa, trifolium eft quod datur equis faginandis, fimile fulx, Vetus Glofs fographus Auicennx. Sulla, id eft arthritica: uel fecundum quordam herba dulciffima \& grata equis, qua Calabri equos faginant,Syluaticus. Et alibi:Sual, id eff fulla. Cytifum in Italia uulgo ple ricg uocant trifolium caballinum, quod paftu eius equi delectentur, Matthęol. Sed cum trifoliunca ballinum, ut ex defcriptione eius apparet, nô alia fit herba, quàm quę Germanis fibengetygt appella tur; \&c.eadem cytifus effe non poteft, ut facile intelliget qui cytifi hiftoriam fupra in Boue legerit caz pite tertio, Tribulo herba uiridi Thraces Strymonis fluuij accola equos faginant, Diofcorid, Verno tempore equis, iumioribus in primis, per continuros dies plurculos farrago exhibetur, qua \&s purgantur $\&$ obefiores euadunt. Farrago eft commiftura multarum frugum in equorum pabus fum, Germanicé cin gemengbe, Vullich. A trimatu farrago dari folet. Hac enim purgatio maxis mé neceffaria equino pecori, quod diebus decẽ facere oportet, nec pati alium ullum cibum gufiare, $\mathrm{Ab}$ undecimo die uf $\$$ ad quartumdecimum dandum ordeum, quotidie ad"̆ciẽdo minutatim. Quod quar to die feceris, in eo decem diebus proximis manendum:ab eo tempore mediocriter exercendü, \& cum fudauerit, oleo perungendum. Si frigus erit, in equili faciêdus ignís, Varro. Eadem omnia in Hippiatricis, qua Ruellius tranftulit, tan ơ Eumeli recitantur $+(n a m$ Gracus codex impreffus sö habet: Et infuper hæc uerba, Farrago etiam bubus caterisćs pecudibus optime diffecta prabeturi, Et fi depafcere fxpius uoles, ufgs in menfem Maium fufficit. Noftri equorum mangones (inquit Rirell.)dragetam, quafi uario pabulorum genere conflatam nominãt, Graecigraftin. Farragop!li expolit, cum frugibus grauida eft : fed duris iam horrens ariftis inutilis eft, Ariftot. Graci mixim farraginem ad equos purgandos graftin uocant, Ruel. De farragine $\&$ ocymo, quantum adbo, wes atrinet $\mathcal{Q}$ in genere permulta attuli in bouis hiftoria cap. 3. Memineris ftatim cum in affection nem inciderit, hordeum ei fubtrahendum penitus et potus, herbas uirides uel farragines ad fuften candum dandas, Vegetius de uefica morbis loquens. Pafce igitur fub uere nouo farragine mollit Cornipedes, Nemefian, Vbi equum priuatim locauerimus, uere circa idus A prilis, farraginem da bimus:maximé probatur triticea:fin defit, hordeacea:dabitur autem per dies quin क̧, inde iam dite, decem alís objicietur. Longe melius cedet fi iuxta mare fata farrago fuerit . (uentrem enim facilius foluit, humoremós deducit, Veget, 1.25.) ea fi defit, prafente utemur $\$$ indies fextarium unum hordé príori modo a dieciffe fatis eft. (Ego uerterim, prafente utemur cum hordeo:ut legatur, non rat, fed

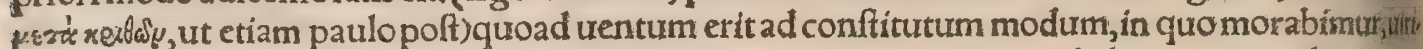
de foenum quandiu fuppetit fine intermiffione dantes. $A$ primis quinq diebus equum ad aquaspro ducemus, totumóg fic undis proluemus, ut natandi detur poteftas : dein omni deffricta cutis illuute oleum \& uinum oportet infpirare, \& manibus preffis terga fecundo pilo fubigere, dum infidens hu mor prorfus abftergeatur, reliquis diebus, ut paulò ante fripfimus, hordeũ unà cum farragine dann. dum erit. ( Sí tamen farraginis penuria fuerit, alia ineunda erit ratio, ut initio à calendis facto aduth cefimum ufos diem perueniamus.) Sed neceffarium eft dum(Ruell, non rectè tranftulit anteç) fart: raginem prabemus, fanguinem mitti, feçtis in pectore uenis, fauciatisç̧ palati toris, ut qui praftu rat fanguis unà cum fanie à folidis fuffundatur, nourus ́́ inanitas impleat uenas, $\&$ in palatumfera rur. Hac ratione uiuendi firmatus equus, non facile aduerfis ualetudinib, patebit, \& obeundispar erit laboribus, Caterum equo qui ita uiridi pafcitur herba, falem(fuper tabella aliqua uel difco, uffa cile fumant quantum uroluerit) praberi per ${ }^{*}$ utile fuerit, ne os manantibus ulcufculis, qua ueterina rij figriafes, (ovyggías in excufo)nonnulli aphthas uocant, obfideaturr. (Eodem os totum mantu mula ceatur, aduerfus idem malum aphtharum ne fuperueniat, Theomnef, ) Non eft committendum, 24 equus qui malide implicatur, in hac per farraginem curatione, fub dio pafcat. Nam facilelues hac tergus fubtercurrit $\&$ fcabiem creat, ex qua flagrante folis aftu furor uel infania concipitur. Opor ret ergo claufum intra tecta continere, \& ita cibum obịcl. Porró longéoptimum ante fuerit aluridèie ctionem moliri, dato cucumere(nimirum fylueftri) 8 nitro, $\not$ buiridi fegete genus equinum exhilare tur, $\mathrm{A} b$ fyrtus, Hierocles, Theomneftus, Eadem hac ratio circa fartaginem, mulis quoç conduditur Theomneftus fcribit. Cum uiridis pabuli tempus adpetit(inquit Hierocles) dabis operam ut uno die fylueftri foeno (gramine) uefcantur: Poftridie in nares medicamentum infpirabis, quod coect

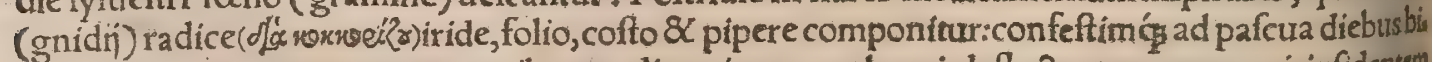
nis aut ternis emittas, ut rapto naribus medicamine caput humi deflectentes omnem ei infidenten humorem excutiant, Hierocles. Theomneftus eundem puluerem aliter defcribit his uerbis: Radib cis cocci (gnidî) piperis, pulegî̀, origani, fingulorum uncia:folip, cofti, iridis, radicis cucumeris erra tici $\vec{c}$ leuiffime triti, fingulorum femuncia:omnia tufa \& cribro tenuí farinario creta, per arundinem in nares infpirantur. Caput femiffem hor fufpenfum extolliturinfequentí̧̧ triduo(tuel biduo) par ftioni ueterinum indulgere finit, ut omnis pituitofus humor, qui frigoribus hyemis in cerebro coie rat, capitis depreffu cum incumbit paftui, defillans ruat. Ea res omnem pituitam per nares elicit, \&

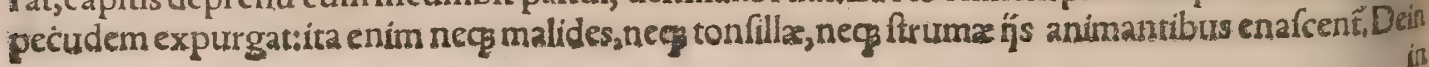




\section{DeEquo. C. Lib. I. 477}

in equilia reducas, \& fylueftre foenum quattror aut quinq diebus repræfentes . Quinetiā farragine (poftridie incipe dare farraginê)in primis triticeã,fi defideret̂, hordeaceã, quinq̧ diebus miniftrabis, Deinde fanguinẽ detrahes, \& $\&$ cữ eo qui profluxit, nitrũ $\&$ acetũ additis ouis (Theomneftus oua nỗ addit) \& oleo mifcebis, ac totư animal oblines(à capronis ad calcệ fecundũ pilos illines) \& tấtifper in fole continebis, dum omnis illitio reficcetur. Poftea remittes in ftabulũ, $\&$ rurfum alĭs quinq̧ diebus farraginem obijcies, in quibus ftrigiles non adhibebis, Sexto, ftabulo educens equum lauabis, $8 \mathrm{C}$ a. fperisftragulis dererges, ut omnis exhauriatur humor, $\mathcal{E}$ fordes radantur; dein ubi in equile fe rece. perit, farraginem objicies complurimum diebus quatuordecim, uel faltem non paucioribus quàm fe ptem uxel nourem, quò praepinguis $\&$ obefus eniteat. Similem huic curam uide infra inter ry yesvà de purgatione per aluum, ubi ex Vegetio recitabitur qua obferuatione cyclo curentur animalia. Cas meraritus cum ad noftras regiones hanc curandi equos $\&$ à morbis præfertuandi rationem retocare trellet, in Hippocomico furo lic fcribit: Vere cibi proderunt, nequaquam aridi, fed molles atç teneri. Hanc ob caufam uidetur ad ualetudinem turendam optimum effe, equus ut in prata boni \& fuccidi graminis deducatur atç̧ ibi pafcatur pro uoluntate fua. Nam fatiari uel etiam repleri illum non obe rit,Sialiquid impedimento forte fit, quo minus in prata deduci equus rectè poffit, afferrigramina de fecta,qualia diximus, curabuntur, $\&$ ante illtum humi in corbe ampliufcula apponentur, 8 hic cie bus prabebitur, fi ita unideat (nam tempus non aufim præfinire) à Calendis Maí ufọ in Nonas, at ${ }^{\circ}$ prabebitur folus interdiu. Vefperi autem auenæ uel ordei non multum dabitur, ut uerbi caufa con fueti pabuli pars quinta, atģ huic fal infpergetur, uel proponetur hoc equo ut lingat. Interea frepius ofernuttationum fremitus excitabimus indito naribus puluifculo quem ueteres præferipferunt, ut fint pondera aqualia piperis, pulegti, origani, amaraci, cofti, ireos, malabathri, radicis (cocci)gnidin. Per calamũ aût inflari iufferữt. Nos illa exotica, fi utri puluifculo uelimus, uel omittere, urel mutare, ut: opinor, rore marino, nardo, faluria, rectè poterimus, de quo cuiufgs fuum efto iudicium. Poftea alios dies fex pafcetur gramine defecto, neq̧ uiridi, neq̧ arido adhuc, léd foeno quodam urirefcente: \& fuû́ pabulum integrum apponetur. His peractis fanguis minuetur, \& 8 quídem largius, atq̧ ita refume* tur ufitata cura atç traçatio. Hoc, ut ratio mea fert, \& uigorem equi augebit, \& corpus reddet pleni us aţ̧ nitidius, non quadam exuberantia, fed robore carnis: idemćp fanitatem praftabit tutam atç defenfam, neqs patietur leui momento affigi. Sed quandiu in gramine detinebitur equus, accura tèoportebit à frigore defendi:ideoǵg nifi fereno coelo in prata non educetur, \& nociu ftragulis atç otegetibus operietur, Hac Camerarius, Secale elixum \& cum pabulo datũ equís uendendis, falfam corpulentiæ fpeciem repræfentat. Ocymum Venerem ftimulat, ideo etiam equis afiniśćs admiffue sa tempore ingeritur,Plin. Plura de ocymo in Botre cap, tertio dixi, ubi etiam de farragine. De ma cerata fruge quam ftrigofis equis Cappadoces exhibent, Ccribitur in Hippiatricis 129, \& nos forte re

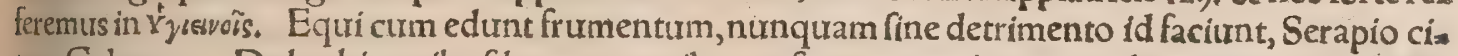
tans Galenum. De herbis quibufdam, tum quibus uefcuntur equi, turm quę denominantur ab eis, in Philologia docebo. Quibus iumenta in genere nutriuntur aut faginantur, ut gramen, eruum, ui fum, ad librum de animalibus communem pertinent, I Horotas $\&$ Gedrufios fama eft tanquă fconum pifces equis edendos obijcere: Celtas audio boures \& equos pifcibus alere: Et nonnulli quo= queteftantur, Macedones $\&$ Lydos pifcibus equos furos pafcere, A elianus. Apud Prones qui Pra oliadem palıdem habitant(unde breuris admodum in Macedoniam uia eft)iuxta montem Orbelum, equis \& fubiugalibus pifces pro pabulo prabent, Herodot. libro s. De pabulo equorum plura dis cancapite quinto in tractatione equi:De pullorum autem alimentis priuatim quadam, hoc ipfo cae pite inferius. Qui citò obefos efficere equos defiderant, tortucas (id eft teftudines cum pabulo mol lidecoquunt, 8 inde equigrandem fed falfam corpulentiam acquirunt, Albert. f Helleboro ni groequi,boures, fues necantur:itaç caurent id, cum candido uefcantur, Plin. Prourenit apud nos egolethros, noxia herba, orobanchæe fimilis, de qua in Boue dixi:hac non ipfa folum boures abftinẽ ${ }_{3}$ fed etiam gramine circumcirca nafcente, licet eodem equi uefcantur. Quranam in cibo abortume. quabus moureant, dicam inferius.

TEqui forbendo bibunt, ut $\&$ reliqua animalia, quorum dentes continui funt, Ariftot. Equi, uut cameli, aquam turbulentam $\&$ craffam fuauius bibunt, quippe qui ne ex fluuio quidem prius hauriant, quàm pede inturbent ; poffunt uel ad quatuor dies tolerare fine potu, mox bibunt quàm multum, Ariftotel. Et alibi, Bibunt equi aquas libentius turbidas: quod ficiara eft, inturbant eam ungulis fuis, $\&$ cum biberint, lauant fe totos, lymphisó́ potiuntur : balneum enim omnino hoc ani= mal adamat, \& aqua deditum eft:quamobrem natura etiam equi flutiatilis ita conftat, ut uiuere niff in humore non poffit. Bos contrà quàm equus, nifi aqua fit clara, frígida atç lympida, bibere nolit Obferuandum eft (ut fcribit author quidam obfcurus)ut aqua bibenda equis, non fit nimium lenta aut mollis, fed durriufcula, turbida, et leniter fluens. Hęc enim craffiore fua fubftantia melius nutrit. Caterum quo frigidior aquta eft, \& urelocius fluit, eò minus alit. Conceditur tamẽ per xftatem cum nimium calorem temperari res poftulat. Non parum etiam confuetudini dandurm eft, qua licet mala fuerit, fubitò tamen mutari non debet, fed paulatim. Et quoniam equus nifi affatim bibat, non fa= tis proficit, os ei interdũ fale (qui uino nonnunö̈recenti confperfus fit)perfricandũ eft:fic enim bi= bendi fimul edendiça auiditas acuetur: Adferentur $\&$ capite quinto in traçatione equi nonnulla 
qua ad potum eius pertinent. Quroacrior equus eft, cò altius in bibendo nares mergit, Plin. Qui fiat quód equi bibentes capurt in aquam ad oculos ufọ demergãr, muli uerò \& afini fummis tantum labris forbeant, Hieronymus Garimbertus inquirit quantione 45. Illud mirum utiog uel Homero aucfore, uinum iumentis folitum dari:fic enim Hector Iliados octauo equos alloquitur fuos. Repen

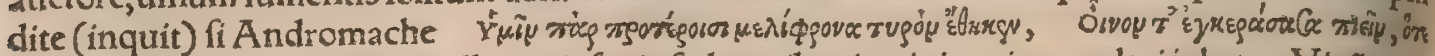

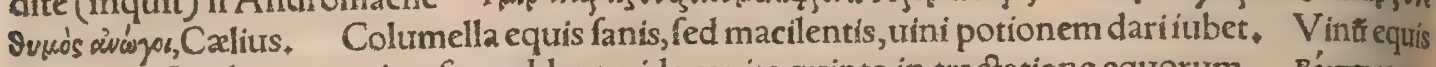
quidam infundunt, ut animofos reddant, uide capite quinto in tractatione equorum, Bógrages,, $2=$ na, auena; uel fecundum aliquos frumentacea equorum potio, Varinus: Hefychius diftinguir, utalin equorum potionem exponant, alij uerò frumentaceam. Eft autem frumentacea potio, ut curmi, \& zythus ex hordeo.

T Somnus \& uigilia,incrementum \& corruptio, \& uita \& mors, cæterać: accidentia ex fenfis bus, funt in canibus, ficut in equis $\&$ hominibus, Author obfcurus.

If Equos etiã fomniare palàm eft, Arifteteles, Plinius. Equos ftãtes dormire \& fomniare fuppe rius dixi in Canterij mentione.

đI Equi cur plus excrementi ficci egerant quàm humidi, A riftoteles fectionis 10, problemate g\&, V tequa ita $\&$ uacc $x$ crebrius mingunt, Ariftotel. Scythx per bella forminis uti malunt, quoniam urinam curfu non impedito reddant, Plinius. Cur mas in equino $\&$ afinino genere, urinam fomi næodoratus, caput erigit, $\&$ dentes nudat? Hieron. Garimbertus quaftione 46 . Spumantemógag tabat equum, Virgilius Aene. II. Vectus equo fpumâte Sages, Aene.12. Seu fpumantis equifode retcalcaribus armos, Aene, 6. Inquirit alicubi Galenus cur equi currentes fpumam emittant, 20 Equx lac fecundum locum tenuitatis habet poft lac cameli, Ariftoteles. Plura de lacte equino cas pite fexto leges. TEqux purgãtur menftruis, modo quidem ampliore quàm oues $8<$ capra, fed mul tó minus proportione, Ariftoteles. Equabus menfes fiunt, 8 uaccis, fed his minus, Idem. Et alibi, E: qua menftrunfa non eft, imò minimum inter qutadrupedes emittere folet. Etrurfus, Equa uacatad. modum purgamentis in partu, minimumós emittic profluuium fanguinis uidelicet pro corporisma gnitudine. Item alibi, Conceptus indicium maximè in uaccis, equabusq́z, cum menfes ceffarunt,papa cio temporis bimeftri, trimeftri, quadrimeftri, femeftri:fed id percipere difficile eft, nifi quís iandudi fecutus, affuetusćç admodum fit:quamobrem non defunt, qui menfes in his animalibus negent,

d Cum equa peperit ftatim fecundas deuorat, atç etiam quod pulli nafcentis fronti adharet, tif pomanes dictum, magnitudine minus carica parua, f pecie latiufculum, orbiculatum, nigrum, fuluo colore, Solinus: legendum forte fufco:) hoc fi quis prarepto odorem moueat, equa excitatur, furtit anito eo odore: quapropter id à ueneficis petitur \& percipitur mulierculis, Âriftotel. Et alibi, Quod hippomanes uocant, haret quidem fronti nafcentis pulli, ut narratur : Sed equa perlambenice abx fergentesćp, id abrodunt, qua autem de hoc fabulantur, figmenta muliercularum, \& profeflorum carminis incantamentorum effe credendum potius eft. Proditur equis (inquit Plinius) amoris ins nafci ueneficium, hippomanes appellatum, in fronte, caricx magnitudine, colore nigro: quod fatim xdito partu deuorat forta, aut partum ad ubera non admittit:olfacfu (nempe huíus caruncula) inata biem id genus agitur. A elianus etiam hippomanes huíufmodi in fronte pulli nafcentem caruncus lam efle fribit. Hi autem (inquit) qui per præftigias 8 captiones mulieributilludere folent, uim aîi quandam alliciendi ad libidinem, at $\$$ amatoriam flammam excitandi habere:eamç ob rem equati rens inuidia, non homini has præftigias permittit affequi. In VariniLexico de hippomane Ariffo

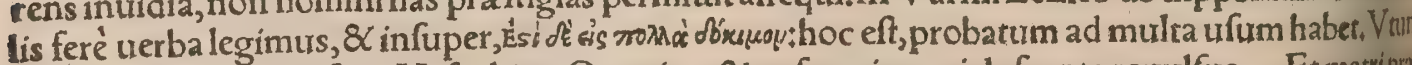
tur eoad philtra uenefica, Hefychius. Quaritur $\&$ nafcentis equi de fronte reuulfus, Et matripriz reptus amor, Vergilius lib 4. Aeneidos. Atqui Georgicorum tertio aliud hippomanes facit, his fibus: Hinc demum (cum libidine agitantur equæ) hippomanes, uero quod nomine dicunt $p$ res:lêturn diftillat $\mathrm{ab}$ inguine uirus, Hippomanes, quod æape mala legêre nouerca, Mifcueruil herbas, \& non innoxia uerba. Sic \& Tibullus, Hippomanes cupidę ftillat ab inguine equę, Sed hion Ariftoteles quo $\$$ agnofcit, uide infra ubi de libidine equarum hoc in capite agetur. Coitus fimu lat uirus à coittr equi V ergilio quoç defcriptum, Plinitus. Hinc perorigæ coitum admiffarijs exc. tant, ut inferius dicetur. Id pracipué armentum fi prohibeas, libidinis extimulatur furn̈s: Vnaie cs tiam ueneno inditum eft nomen hippomanes, quod equinęcupidini fimilem mortalibus amorem ac

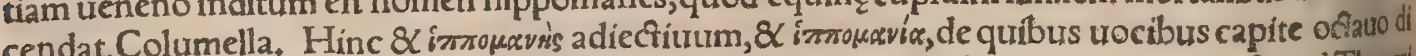
$\mathrm{cam} ; \&$ im

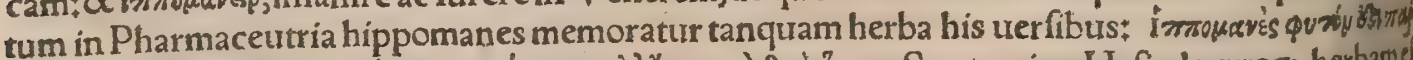

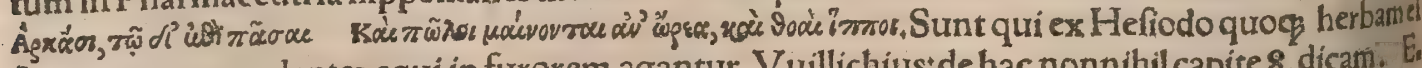
re putent, quam edentes equi in furorem agantur, Vuillichiust de hac nonnihil capite 8, dicam. E. quarum uirus à coitu in lychnis accenfum, Anaxilaus prodidit equinorum capitum uifus reprafen qure monftrifice: Similiter ex afinis, Nam hippomanes tãtas in ueneficio uires habet, ut affufum art mixturæ in effigiem equx Olympix, admotos mares equos ad rabiem coitus agat, Plinius. Olyn pix Phormis Arcas (ut Gillius ex Paufania uertit) ex are equum pofuit, In eundem dum in fermonem Elienfium uenit, hippomanes ínclufitín hunc et fi abfiffa cauda turpior eft, eq tamen ruptis uinculis libidinis furore feruntur, ac fi de manibus ducforum effugerint, in eum ipfum 


\section{DeEquo. C. Lib.I.}

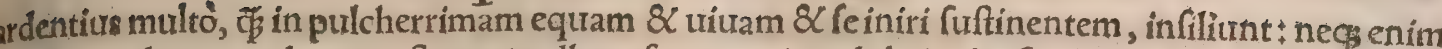
quodungula cum ad aream ftatuan adharefcere cupiunt, lubrico lapfu eludantur, idcirco coitum defperant, imò uero magis magisç̧ ore hiante atç imminente adhinniunt, \& urolentius inuadunt: neq, pritufक्, flagris \& magno robore equifonis abftrahuntur, ab rereo fimulacro depelli poffunt. Eadem A clianus fcribens, Abftrufa quadam(inquit) artificis machinatione hippomanes recondít intra aream ftatuam equos alliciebat:necs enim erat tam accurata fabrica, ut ex ea equi catenus falle rentur $\&$ inducerentur, ut tantopere ad illius confpectum in uenerem ftimulari deberent. Liche

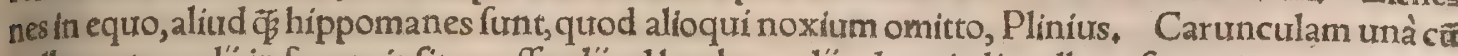
prillo enatam, alí in fronte infitam effe, alij ad lumbos, alí ad genitalia adharefcere aiunt, cam fane nuncupatam hippomanes, primum ut ex féfe equa peperit, continuo deuorat, 8 dei benignitate mis fericordin equinam ftirpem occultat, ne fi, ut ferunt, idipfum ufç ad extremum uxitx diem pullus femper infitum in fe perfeueraret habere, ad effrenationem impotentis ueneris, tam mas of formina rueret, \& libidinis rabie equinum genus funditus periret. Quod gdem ipfum penitus cognitum pa ftores habent, ac fi quando ad moliendas alicui amatorias infidias egeant, ut ipfum ad cupidineri ue neris inflamment, diligenter obferuant quando equa uentrem ferens pariat, atç̧ ftatim à partu pulli um à pullo abfcindunt, $S$ in equa ungulam iníciunt : ( $n$ am in hanc abditum $S C$ conditum optime feruatur)fimul \& 2 pullum qu ipfum poftea non lactaret mater illa, infigni \& propria beneurolentix no ta carentem, exorienti foli immolant: nam ideo pullum uehementer amare ingreditur, glllam deuro rấtitcarunculam. Iam quicunç̧ per infidias carnem illam guftauerit, proiecła 3 præcipite amato rialibidine conftricfus tenctur, furit $\&$ perbacchatur $\&$ uociferatur, at $q$; effrenatus ad omnem mulie bris fexus atatem, cupiditatis adijcit oculos, ac morbum teftans obuñs omnibus quemadmodum conflagret amoris flamma, exponit. Tum ex eo llius corpus diffuit $8 \alpha$ extabefcit, $q$ queneris infania animus exagitetur, Hac A elianus. Videtur autem pullium (Ariftoteles rwan wop uocat, in Gaza tranf latiote pulium per 1 fimplex legimus) cü hippomane confundere. Ariftoteles manifeftẻ diftinguês, Enittietiam (inquit)ab equa prifus क्; pullum, quod pulium dicitur, certum eft. Pliníus eandem rem (Hermolao tefte) duobus locis non pollon, fed poleam uocat: quod nomen tamen alibi attribuit afis ninipulli fimo, quod primum edidit.

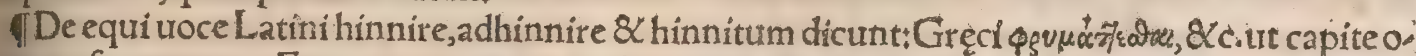
chatro profequemur. Equorum etiam uoces(inquit A riftoteles)differre palàm eft: foeminze enim fis mul acnatæ funt, uocem exiguam mittunt, ac tenuem:mares exiguram quidem $\&$ ipfi, fed pleniorẽ ta men, \& grauiorem, quàm foemina, \& indies maiorem reddunt, Bimus cum eft, atç̧ inire incipit, uocể magnam grauemọ́ mas mittit:formina maiorem, quàm ante, 8 Clariorem ufģ ad uigefimum ætatis atinum magna ex parte: fed ab hoc tempore imbecilliorem tam mares, quàm foemina reddunt.

IVita equorum (inquit Ariftoteles)plurimis ad decimumoctaum, atg etiam uicefimum annü: led nonnulli etiam quinç $\&$ uiginti, atç triginta egerunt, \& fi cura diligenter adhibeatur, uel ad quinquaginta protrahitur ætas: Iongiffima tamen uita in pluribus ad tricefimum annum, quod mas gha ex parte fieri norimus. Fomina magna quidem parte quincs $\&$ uiginti annos uritere poteft: fed iam nonnulla etiam quadraginta trixer . Minus temporis mares uiuunt quàm foemin $x$, propter col tum: Et quí domi alunurur, minus đ̧ gregarï, Hzec Ariftot. Et alibi, Coéunt mares ad annos tricenos tenostfoeminz ad quadragenostita ut per totam ferè tritam coitum equís feruari eueniat. Viuit eñ magna exparte mas annos circiter quin $\%$ \& triginta, foemina plus $\ddot{\beta}$ quadraginta.Iam \& quinç et fexaginta(feptuaginta, A thenxus \& Plinius) annos uixiffe equum proditum eft. Eadem urerba leg mus apud A thenaum libro octauo, citata ex epiftola Epicuri. Albertus narrat fe audiuiffe à quoda mitite, equum eius annum fexagefimum exceffiffe, \& femper ad pralia utilem fuife. Nos etiam (in. quit Aug. Niphus)accepimus ab equifonibus Ferdinandi primi, fuiffe equum in regio ftabulo fep. thagenarium. Viuunt annis quidem quinquagenis; fomina minore fpatio, Plinius contra ç Ars ftoteles, qui maribus propter coitum(ut paulo ante dixi) uitam breuiorem attribuit. In Lufitania quadam ex uento certo tempore concipiunt equat fed ex his equis qui nati pulli, non plus triennitis uilunt, Varro, Cur equus cum tardius maximè infra in equæ partu . Aetatem iưmentorum ex dentibus alỉs lamentis imperitix fubeamus incommodum, uel curantes agrotantis ignoremus ztatem. Quia fi cut hominibus, ita $\&$ equis, aliud conuenit cum iumenta funt feruida, aliud cum fenexfute iam fris gida. Manifeftum eft autem notas corporis cumatate mutari, Vegetius. Etalibi, A etas longetra Per fis, Hunnicis, Epirotis ac Siculistbreuior Hifpanis ac Numidis . Equus fi diligenter curetur, \& me= diocriter equitetur, ita ut non nimio labore exhauriatur, ut plurimum ad uigefimum annum in ui gore fuo perueniet, Ruffirs. Foeminx quinquennio finem crefendi capiunt, mares annoaddito, Plinius. Fomina(inquit Ariftoteles) quinquennio finem, tum longitudinis, tum etiam proceritatis fui corporis recipit, fed mas fexennio: pôft, annis fequentibus totidem crefcitin corpulentiam, \& $\mathrm{kad}$ uiginti ufque annos pergit proficiensłuerum celerius fominæ quàm mares perficiuntur: quanç in - utero mares, quàm foemina citius, quemadmodum etiam homines: ̊d idem, urel in cæteris atumali

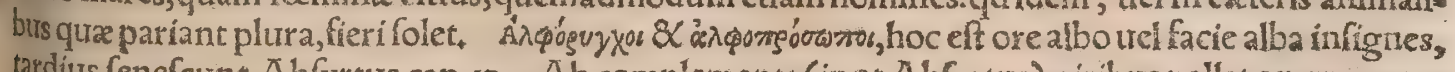
tardius fenefcunt, $\mathrm{Ab}$ fyrtus cap, 13 , Ab complemento(ingt $\mathrm{Ab}$ fyrtus) uiribus pollet equus anios 


\section{DeQuadrupedibus}

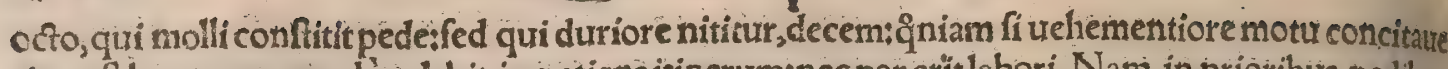
ris, pof hoc tempus malé tualebit,impatiens itinerum:nec par erit labori. Nani in prioribus pedibus coronx $Q$ fuffragines, quas mefocynia nominant, à malleolis dimittũturł nec ingredi poftea, nec pe. dibus infifere ualet, féç ipfe proijcit. A primolucis rudimento ad fenium folido pede fultus, octo $\&$ uigintiannos, uel undetriginta uiuit, nec facile trigefimum implet:porrò molli pede praditus, quatuor \& uiginti annos degit, Hæc ille. Plures funt dentes maribus $\ddot{\not}$ fominis: Vitæ funt breuio ris quibus pauciores, uiuaciores quibus plures. Equo dentes quadraginta numero funt, Arifotes. les $\&$ Plinius. Habet autem(inquit Abfyrtus) in anteriori parte fuperiores octo, \& totidem inferio $x$ res, cum caninis $\&$ molares in maxilla fuperiore fenos, ac inferiores totidem: $\mathcal{X}$ in altero laterefimi

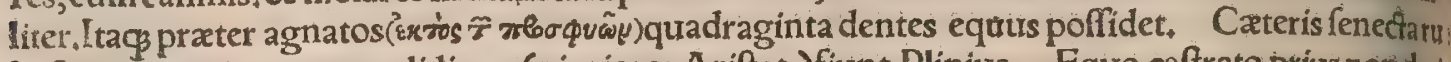
befcunt, equo tantum candidiores(nigriores Ariftot.) fiunt, Plinius, Equo caftrato prius non deci dunt dentes, Plinitus, Aetas ueterinorum(equorum, $\&$ aliorum qua folidas ungulas habent; $A b_{*}$ fyrtus: \& $\&$ feré omnium qua ungulas indiuifas habent, \& etiam cornutorum, $V$ arro $\$ \&$ ferẹc cornutio, rum, alius qdam) dentibus indicatur. Horum (ut fcribit Arifot.) primores quatuor, menfe tricefimo mutantur, bini utring, fuprà dico, \& fubter : tum ubi praterea annum compleuerit, quatuoritem modo eodem mittuntur, duo fuperius, totidemós inferiusłrurfuś́s anno altero peracto, fimili modo quatuor alï mutantur:quibus iam prateritis annis quatuor, 8 menfibus fex, nullus praterea mitti, tur, quan 范 eueniffe in aliquo certum eft, ut cum primis omnes amitterentur:atq̧̧ etiam in alio, utcế ultimis omnes, fed hac raro, Hac Ariftoteles. Amittit equus tricefimo menfe primores utring duos: fequenti anno todidem proximos, cum fubeunt dicti cólumellares، Quinto anno incipientetis nos amittit, qui fexto anno renafcuntui:feptimo omnes habet, $\&$ renatos 8 immutabiles, Plthius. Equus (ingt Varro)triginta menfium, primum dentes medios dicitur amittere, duos fuperiores, \& totidem inferiores. Incipientes quartum agere annum, itidem eifciunt $\&$ totidem, proximos eorum quos zmiferunt, 8 incipiunt nafci quos uocant columellares, Quínto anno incipienti item eodem modo amittere binos, quios caninos habent, tum renafcentes eis, fexto anno impleri. Septimo omnes habere folcnt renatos; \& completos, His maiores qui funt, intelligi negant poffe, prater कृ cum den res funt facti brochi(plicati, Crefcentius) \& fupercilia cana, \& fub ealacunæ ( $p$ artes fubiecta fup cilins caux, $\&$ oculi f cilicet caui, $\mathrm{A}$ bfyrtus) ex obferuatu dicunt eum equum habere annos fexdecim Dum bimus \& fex menfium eft equus (ut Columella \& Palladius fcribunt)medĭ dentes fuperio 8 inferiores cadunt (quos lacientes uocant, Vegetius) cum quartum agit annum, pellantur, deiectis, alios affert, intra fextum deinde annum, molares fuperiores (molares cadunt, getius)cadunt. Sexto anno, quos primos mutatit exæquat. Septimo omnes explentur aqualiter, ex eo cautatos gerit. Nec poftea quot annorum fit, manifefto comprehendi poteft. Decimo tamen no tempcra catrari incipiunt, \& fupercilia nonnun $\not ̈ \not B$ canefcere, $\&$ dentes prominere, Eadem Vi tius, \& infuper, Duodecimo anno (inquit)nigredo in medietate dentium apparet. De brocbis den bus, dixi fupra in canis hiftoria, hic illud monere fat fuerit, quos Latini brochos \& prominente cant, $\pi$ wew Jwror A A byrto dici. Abfumpta hac obferuatione(ex dentibus) fenecius in equis, 8 teris ueterinis intelligitur dentium brochitate, fupercillorum canicie, \& circa ea lacunis, cum fer decim annorum exiftimantur, Plinius ex Varrone ut apparet. Dentes anteriores qui primum

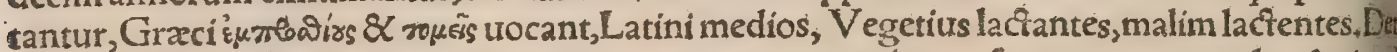
pullinos iacere, Plinius de mula lib، 8. Dentes anteriores quibus palcuntur, numero diodecim, getius rapaces nuncupat. Cum pullus triginta menfium eff (author Abfyrtus: Ruellius perper anniculus $\&$ fex menfium, tranftulit)primum dentes medios, quos fectores appellant, amittit; fuperiores $\&$ totidem inferiores, qui facile principes $\&$ maiores habentur. Vbi quartum agereani caperit, femeftri fpatio proximos abíncit: nec multo poft in eodem quadrimatu fuperiorem u

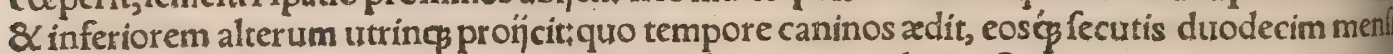
complet;intra fextum deinde annum molares fuperiores cadunt. Sexto anno quos primum m uit, exæquat $+\grave{a}$ feptimo ad ocfauum omnes explet æqualiter, Hæc Abfyrtus imitatus(ut appa Varronem. Et $\mathrm{P}$ auló poft, Sunt qui aditis primis dentibus interlecto octimeftrifpacio fecund ferant, \& emittentes ultimos parimora dentitionem interpellant, Caterum tempora prima(tr meníes intelligo, quo dentes primi mutantur)nullus eorum qui primores amittit dentes, pertr neģ linquitur. In reliquis uerò non omnes fors eadem manet, nec fimile tempus obfertratur:

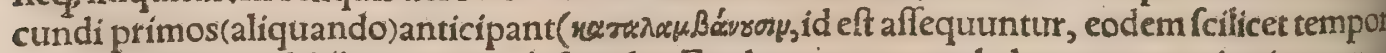
tantur, ut \& mox fubịcitur)ultimiḉ̧ fecũdos. Exploratưm autem habemus eos qui primorưm ia

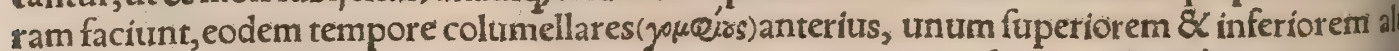
emíttere, ( $\left.\beta \alpha_{\alpha}^{\prime} \lambda \lambda \in y_{\text {. }}\right) \&$ ab utroog latere primos ex eis cum agnatis ip forum ( A complemento cum reliquum trimatum agunt, dens rumpitur ac rotundatur, $\alpha$ in triangula figuram exit:quo tempore præcipuè defluxio in ora equorum decumbit, Hactenus Abfyrtus, uerba de eadem re paulò aliter leguntur in Geoponicis libro 16. cap. 1. qui urolet, conferat, Dentes

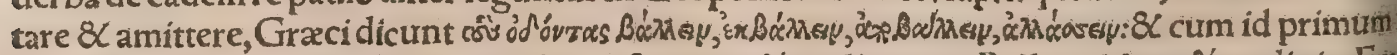

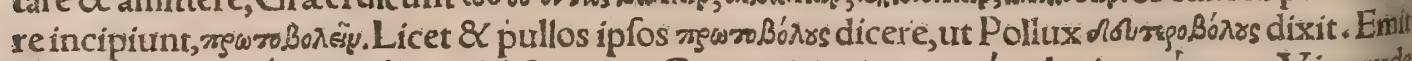
re uero dentes, фí 
8c, commune eft, imro Bćrss proprium afino quilequam falit. Forminę ipfa fubmitti dicumtur. Pers origa appellatur quifquis admittit;eo enim adiutante equa alligata celerius admittitur, negg equi fru ftra cupiditate impulfi femen en̈ciunt, Varro.Quo fit, inquit Calius, ut apud Plinium libro 8. capite de equis, rectius forfan peroriga legatur quàm auriga (ut modo agnofcitur) quem ab æqua lacera tum fcribit:quanquam apud Varronem hiftoriæ eiufdem relatione auriga item circumfertur. Pero,

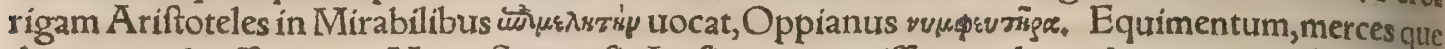
darur proadmiffura equi.Varro Sexagefi. An fi equam emiffes quadrupedem, ut meo afino Reati. no admitteres, quantum popof ciffem, dediffes equimenticut citat Nonius, qui per $x$. diphthongum fcribit inter dictiones ab a,incipientes, non per $e_{\text {, }}$ ut in dictionarijs fuis recentiores, ab equo deritias ri exiftimantes, cum potius ab æquitate deriuetur, proinde parem uicem exponit Nonius, frilicet mercedem pro eo quod admiffum eft. Idem reprehendit cos qui aquamentum fcribunt.

| De admiftarij electione fuperius fcripfi poft electionem equi fimpliciter. Equinum pecus tri partito diuiditur: eft enim generofa materies, qux circo facriśç certaminibus equos praber:eft mu* laris, qua pretio foutus furi comparatur generolo: eft \& uulgaris, qux mediocres foeminas, maresí progenerat:ur quxç eft praftantior, ita ubere campo pafcitur, Columella. IEquas ex quibus pro. pagare ftudemus, oportet effe bene compactas, magnitudinéç decenti : uifu præterea fplendidas of fpectabiles, uentre $\&$ ilibus magnisłætate non minores quầm trium, nec maior es quàm decem anno rum, Abfyrtus. St utilem admifrarium $\&$ ad creandam prolem idoneum libeat experiri, digitis dio

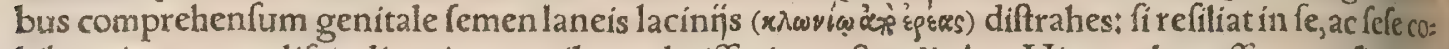
hibeat, ita ut non difcindi patiatur, utilem admiffarium oftendit: hoc Hipparchus affeuerat:fin proti nus tactu diftractum diffindatur, nec uifci more glutinatum len tefrat, feminandis filijs ut inutilere, pudiatur:talis equurs ad ineundas matrices non eft adfrifcendus, Pelagonius capite 14. Equos ataa re affectos aiunt, pullos cum cater is in rebus debiles, tum pedibus infirmos procreare folere, Aelias nus. Hunc quocg, ubl aut morbo grauis, aut iam fegnior annis Deficit, abdedomo:nec turpi igno fce fenectx. (id elt, $\&$ fenectx non turpi ignofce) Frigidus in Venerem fenior, fruftráć laborem In. gratum trahit: \&, fi quando ad pralia uentum eft: Vt quondã in ftipulis magnus fine uiribusignts, Incaffum furit, Vergilius . Illud in admiffarịs feruandum eft, ut medr̆s aliquibus fparn̈s feparent tur, propter noxam furoris alterni, Palladius. Equos pretiofos reliquo tempore anni (præterquam admiffura) remoticre oportet à fominis, ne aut cum uolent ineant, aut fi id facere prohibeantur cls pidine folicitati noxam contrahant:itaç uel in longinqua pafcua marem placet ablegari, uel ad pra repia contineri, Columella. Et rurfus, Eo tempore quo uocatur à fominis admiffarius, roboralts dus eft largo cibo, 8 appropinquante uere, ordeo eruo $q_{\beta}$ faginandus, ut ueneri fuperfit: quantóp fortior inierit, firmiora lemina prabeat futuræ ftirpi. Sed eadem de re Vergilium audiamus,

His animaduerfis, inftant fub tempus, 8 omnes Impendunt curas denfo diftendere pingu

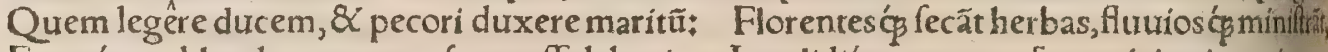
Farráq́:ne blando nequeant fupereffe labori: Inualidiós patrum referant ieiunia nati Ipfa autem macie tenuant armenta uolentes. Atọ ubi concubitus primos iã nota uoluptas Sollicitat, frondes ́́s negant, \& fontibus arcent. Sape etiam cüfu quatiunt, \& Sole fatigani:

Cum grauiter tũfis gemít area frugibus: $\mathbb{Z}$ cum Surgentẽad Zephyrũ paleç iactãtur inant Hocfaciunt, nimio neluxu obtufior uftis Sit genitali aruo, \& fulcos oblimet inertes. Sed rapiat fitiens Venerem, interius ḉprecondat. Equi ad generandum admittendicopi pafci debent, \& fine labore, non prorfus tamen otio relinquendi, ne iners \& pituitofus humo: au tur, fed moderatis exercitijs recreandi magis quàm fatigandi funt, Ruffius, Admiffarium equum laxare conuenit ab operibus, Ābfyrtus 、 बI Marem putant minorem trimo non effe idoneum admil furæ,poffe uerò uf $\not \beta$ ad uigefimum annum progenerare, Columella. Aetas incipiẽtis admiffarïquin ti anni initio effe debebit:foemina recté \& bima concipiet:quia poft decennium iners ex ea fobo tarda nafcetur, $\mathrm{Palladius.} \mathrm{Fominam} \mathrm{bimam} \mathrm{putant} \mathrm{recté} \mathrm{concipere,} \mathrm{ut} \mathrm{poft} \mathrm{tertium} \mathrm{annum} \mathrm{enixafu}$ tưm educet:eamós poft decimum non effe utilem, quod ex annofa matre tarda fit atç̧ iners pro Columella. Generat mas ad annos triginta tres, utpote cum à circo poft uicefimum annum mit rur ad fobolem reparandam. Et ad quadraginta duraffe tradunt, adiutum modo in attollendap parte corporis (hoc Arriftoteles de equo Opuntio fcribit:) Sed ad generandum paucis animaliur nor fertilitas; qua de caufa per interualla admiffuræ dántur, nec tamen quindecim ínitus eiufdent an ni ualet tolerare, Plinius. Qux ætas in equis coitus initium $\&$ finem adferat, dicetur etiam infra, I Coeundi initium equis in uere, Ariftot. Et alibi, Admiffarios (inquit) non ut equx, fic afinęeqgul noctio admourent:fed æeftuo folftitio, ut tempore calido pulli nafcantur. Coitus (inquit Plinius) ule no æquinoctio bimo utrin $\varphi_{p}$ uulgaris, fed à trimatu firmior partus. Foturæ initium admiffionist cere oportet, ab aquinoctio uerno ad folfitium, ut partus idoneo tempore fiat, $V$ arro. Admiffur in uulgaribus equís certa tempora non feruantur:generofis circa uernum xquinocitum maresiut gentur, ut eodem tempore, quo conceperint, iam latis $\&$ herbidis cãpis poft anni meffem partroc(III) labore foctum educent. Nam menfe duodecimo partum æedunt:maxime itaç curandum eft pręc tempore anni, ut tam foeminis, quàm admiffarïs defyderantibus coeundi fía t poreftas. quon

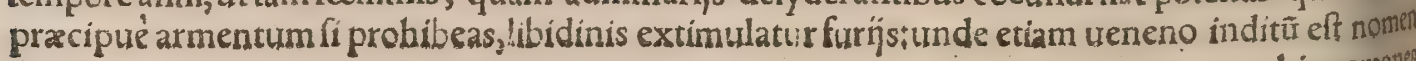




\section{DeEquo. C. Lib. I. 483}

hippomanes, quód equinat cupidini fimilem mortalibus amorem accendat, Columella, Menfe Martio faginati ac pafti ante admiffarn̆ generofis equabus admittendi funt, 8 repletis foeminis item ad ftabula colligendi, Palladius, Tempus congreffui aptifimum exiftit ab æquinoctio uerno, hoc eft à trigefima fecunda Martí, ufç 3 ad uigefimam fecundam I unị, ut partus uidelicet fiat circa tempe ratiffimam herbefcentemós anni conftitutionem. Equa fiquidem utero gerit undecim menfium de. cemćs dierum curriculo. Etenim quæ concípiuntur poft æftuum folftitium, ea fanẻ infoelíciter edur cantur, prorfusḉ̧ inurilia funt, Abfyrt. Commodum uidetur ut equi locis calidis menfe A prili, fri gidioribus autem Maio admittantur. Nam circumuoluto anno pulli eodem tempore nati, \& aërem temperatũ \& copiofurm inurenient nutrimentũ̃ : autũuus etiã eafdẽ ob caufas non incōmodus eft na 10 fcentibus in eo pullis, Ruffius. Admittere oportet cum tempus anni urenerit, bis die, mane $\mathcal{Q}$ uefpe re, Varro \& Abfyrt. Si equa femel fubacta marem poftea refpuerit, poft dies denos rurfus funt con ciliandi. Quód fi ne tunc quidem equum exceperit, fecernenda eft, ceu iam grauida. V.bí autem e= qua ipfr conceperint, obferuandum eft ne mifceantur plus iufto, néue in locis frigidis diuerfen. tur, Ablyrtus + Quoad fatis fit admitti ipfa fignificant, quód fe defendunt, Varro.

Quidam pracipiunt eodem ritu, quo mulos, admiffarium faginare, ut hac fagina hilaris pluri: mis forminis fufficiat; ureruntamen nec minus $\widetilde{\beta}$ quindecim, nec rurfus plures $\widetilde{q}$ uriginti unus debet implere, Columella, Lucienus apud Varronem, Ego quoos adueniens aperiam carceres (ínquit) et equos emittere incipiá, nec folum mares, quos admifTarios habeo, ut Atricus fingulos in foeminas denas, è queis foeminas Cómodius Equículưs uir fortiffimus etiã patre militari iuxxta ac mares habe to rolebat. Neç tamen xqualẽ numerũ (inquit Pallad.) omnibus debemus adhibere, fed xftimatis uribus uniufcuiufos a dmiffarĭ, fubmittenda funt pauca urel numerofa coniugia, quæ res efficiet ad

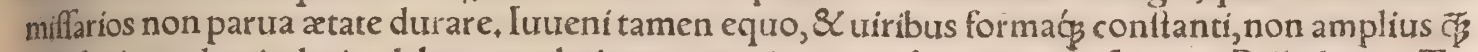
duodecim, uel quindecim debemus admittere, cæteris pro qualitate uirium furarum, Palladius. Tri cenæ forminæ, aut pauló plures, maribus fingulis dantur, Ariftoteles . Regi Babylonis erant pecu. liares equi, præter bello deftinatos, admiffarị octingenti, cum equarum quibus admittebantur fede cim millibus:nam finguliad uicenas admittebantur, Herodotus libro primo. Hippotrophium Stra boni libro 16. locus eft equis alendis accommodus, qualis ad Syrix A pamiam uifebatur, equarum uel fupra triginta millia capiens, admifrarios uerò trecentos, Calius; fic uni admiffario equa centum affignarentur, qui fané nimius eft numerus. Non defunt qui dent operam, quo magis equar um a= o moreflagrent admiffarï, ut iuba fuor urmós capillorum uenuftate, nec non cæateris elegantibus ho=

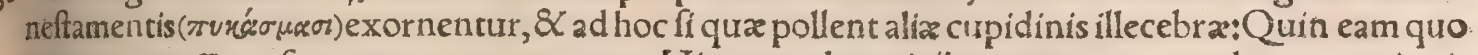
que equo tan ${ }_{3}$ curfu certantem proponunt. His autem lenocinijs putant equum ad amorem inuia tari. Mares quinqs menfibus antea ${ }_{\not ̈}$ trocentur, à forminis funt fegregandi, frumento etiam roboran di, torrido paulatim eruo $\&$ fimilagine aqua macerata largius faginandi, ut ueneri fuperfint, et hoc fulti cibo fortius ineant, Hac Anatolius. Vt admiffarius equus in uenerem proruat, uftam cerui caudam cum uino terito, teftes $\&$ genitale linito:fic hebes equus, uoluptate folicitatur ad uener em: fed cum furentis in libidinem impetum compefcere uoles, oleo perungito, Abfyrtus, Ocymum ue nerem ftimulat: ideo etiam equis afinisḉ admiffur $x$ tempore ingeritur,Plinius. Satyrï genus ery thraicon arietibus quog $\&$ hircis ad uenerem fegnioribus in potu datur : $\&$ à Sarmatis, equis ob af ofidurm laborem pigrioribus in coitu, quod uitium profedanũ uocant, Plinius. In foeminis iumen torum coitum incitat urtica, fi folij seius perfricetur uulua, Macer. Coitum in equo iuuat puluis te fticulorum equi in potione datus, Aggregator citans Pliní librum 28. Sunt qui rerum perpulchr 2 num ftudiofiores, afinum, equum, aut alium quemuis admiffarium, huius color is ueftimento conte. gunt, quem futuram pullationem referre uelint. Siquidem qualem ueftitu colorem ï mentientur, in talem enata progenies degenerabit, Abfyrtus. Admiffarium eo colore pictum, quo pullum nafal defiderant, (uel uno uel uario) aliquandiu ante equam libidine ardentem detinent, demum dimit= tunt, fic pullus fuo tempore nafitur eo quem optarunt colore, Oppianus, G) Proles ut uel foemina,uel ut mafculus concipiatur, noftri arbitrỉ fore Democritus affirmat, qui pracipit, ut cum proge. nerari marem uelimus, finiftrum tefticulum admiffarn̈ líneo funiculo, alióure quolibet obligenus, cư. - forminam, dextrum:idemćs in omnibus penè pecudibus faciendum cenfet, Columella. Si quípia am marem nafci trelit, cum Aquilonius infpiratuentus, infiliendam equam ob̆jcier: fi forminam fingi fit in animo, cum Aufter perflat, A fricanus. Vbi admilfarius equãfuperuenerit (inquit idẽ) certis fignis comprehenderelicet quem fexum generauerit ; quoniam fi parte dextra defiliuit, mare feminafle manifeftum eft:fi læua, foeminam, A fricanus in translatione Ruellin cap.15. His fimilia, uel eadem potius, de tauris etiam fcribunt authores, quantum attinet inquam ad curandum, ut hic uel ille fexus concipiatur, uel uter conceptus fit dignofcatur, ut in Tauro docuimus circa finem ca! tis tertij. Marem pariet equa fi fubmitratur (hoc Germani uocant beroffen) tertio ante pleniluniū die; fominam, fi tertio poft plenilunium, Obfurus. Mares (uerba funt Ariftotelis) hoc genei e foeminas fibi focietate coniunctas dignofcunt olfactu, effi paucis antè diebus unà furerint:quod fi foe - mina diuer fa pernifceantur, mares alienas mordendo expellunt, fuasç̧ finguli feorfum habentrs pafcuntur. Tricenæ, aut paulò plures fingulis dantur: quoties mas accefferitaliquis, confeftim in eum maritus conuertitur, \& currens gyro aggreditur pugna: $3 \times$ focminam $_{2}$ fi quà fe moueric, mor iu 
reurocat. Etalibi,Equi temporelibidinis equos mordent,fternunt equitem atgs infequuntur.

Nónne uides, ut tota tremor pertentet equorum Corpora, fi tantum notas odor attulit auras?

Ac neq̧ cos iam frena uírûm, nec uerbera fęua, Non fcopuli, rupeş́́́ cauę, atọ̧ obiecta retardất

Flumina, correptos unda torquentia montes, Vergilius de ui amoris fribens, Coitus(inqu

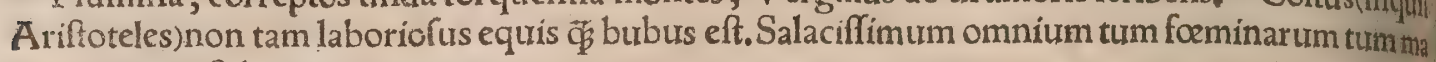
rium equus eft, homine excepto.

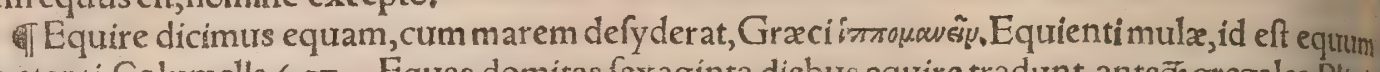
appetenti, Columella 6.37. Equas domitas fexaginta diebus equire tradunt, ante $\bar{\not}$ gregales, Plini, us, Incenduntur libidine (inquit Ariftoteles) ex forminis equæ potifimum, mox uacca. Equa itaç cquiunt: unde rocabulum id ab hoc uno animali trahitur, maledicto in mulieres libidinofas(tit

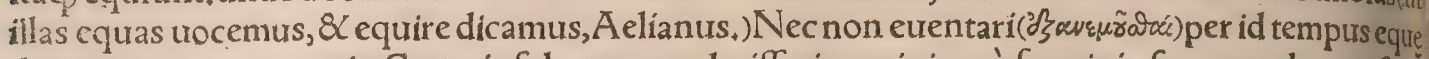
dicuntur : quapropter in Creta infula equos admiffarios minimeà foeminis femourendos cenfent. Cum ucro ita affecta fuerint, currunt relicta focietate:fimile hoc uitium eft, ut quod fubare infui, bus dicitur. Currunt non orientem, aut occidentem uerfus, fed ex aduerfo aquilonis, aut auftri: nec appropinquare quenquam patiuntur, donec uel defatigatæ defiftant, uel ad marem deueniant, (Vis de infra in mentione conceptus earum ex urento.) Tum aliquid emittunt, quod hippomanes appella tur, eodem, quo illud quod nafcitur, nomine. Tale hoc fane eft, quale fuis illud, quod apriam uocâ: fed hoc pracipue ad amoris ueneficia petitur. Equa tempore coitus colligunt fefe, \& focietate ma: gis quàm antea gau dent:iactant caudam crebrius, uocem immutant, humorem emittunt fuís genilat libus fimilem genitura, fed multo tenuiorem, quàm mares, quem hippomanes nonnulli appellant, non quod pullis nafcentibus adharet; accipi eum humorem difficile effe aiunt, quod paulatimal modum labitur. Mingunt etiam pluries, atç inter feludunt cum equiunt, Hactenus Ariftoreles, Mirum ef, quadrupedum prægnantes uenerem arcent, prater equam \& fuem, Plinitus, Sola ani malium (inquit A riftoteles de generatione animalium 4.5.) mulier \& equa, grauida coitum patiun tur. Equa quidem foliditare fux natur $x, \&$ quod aliquid fpatĭ in utero fuperfit, ut dictum eft,an us quidem, quàm ut $a b$ uno occupetur:fed archius quàm ut alterum perfectè poffit fuperfotari. bidinofa natura eft equa ob eundem effectum, quo folida omnia ueneris funt appetentiora: illa ita fe habent, quia carent purgatione, qua perinde eft foeminis, ut coitus maribus : equa enim men Itrua minime emittit. Albertus caufam facit abundantiam cibi, 8 temperamentum calidumac midū. Scilicet ante omnes furor eft infigis equar: Et mentẽ Venus ipfa dedit, quo tēpore Glau

Potniades malis mêbra abfumpfere quadrige. Illas ducit amor trans Gargara, trans ós fon

Afcanium: fuperant montes, \& Aumina tranant, Vergil. Tum equa tum uacca indicitm libidinis præftant, genitalis fpecie prominentiore, Ariftotel. Equarum libido extinguitur iuba fa,Plinius, Albertus \& Rafis. Equarum libido extinguitur magis iuba tonfa, \& frons triftior re tur, Ariftoteles, Tondentur etiam equarum iuba, ut afinorum in coitur patiantur humilitatem. All ccnna feribit equarum libidinem minui cum praciduntur eis pili:quafi motus pilorum in canda of iuba, libidinis caufa fit, Albertus,

Tivuas poft tertium annum, aurt poft unum ab enixur utiliter admitti putant, coguntés in Plinius, Iuniorum coitus prater ætatem contingit pabuli bonitate \& copia, Ariftot. Equuscoi incipit bimus, tam mas quàm foemina:fed hoc in paucis fit, pullíg corum ipforum minores imbech lioresćs funt.Quod autem plurímum trimatu, tam mares quàm forminæ incipiunt, \& proficiunt inde ad prolis praftantiam, in uicefimum ufg a nnum, A rift, qui $\&$ alibi eadem repetit. Et alibi, $C$ re itaqs incipit equus uel tricefimo menfe: led quoad digne procreare poffit, tunc tempus eft, cum dentibus mittendis ceffauit:uer um iam nonnullos etiam cum mutãt, implere potuiffe aiứt: iḍ́̂́ ita confirmant, nifi natura feriles fint. Et rurfus, Fit ita $\$$ ut equo fere tenpus idoneum maxin fit ad procreandum, cum annum quartum, \& fex menfes complếrit: feniores equi profectó foect ores funt,tam foeminæ, quàm mares. Coëunt mares ad annos tricenos ternos, foeminæad quad genos:ita ut per totamferè uitam coitum equis feruari eueniat, Arift. Mares coire ad annumti fimum tertium, nonnullos ad quadragefimum, fed adiutos, fuperius ex Plinio recitaui , paulò pol initium mentionis de admiffario(fribit autem eadem ferè etiam Solinus cap.47.) ubi $\&$ alia qu attuli qua ætate equi in utroģ fexu coire $\&$ incipiant $\&$ definant. Gignunt equæ annis omnibs ad quadragefimum, Plinius, Mas (inquit Ariftoteles) omnibus temporibus init, nec ceffat qu diu uitrit. Foemina etiam quandiu uiuit initur, nec tempus ullum certum libidinem aufert: fed i! nium hominis arcet, aut uinculo, aut aliquo huiufcemodi impedimento: non tamen quouis tem refacto initu, facultas enutriendi quod pepererint, datur. Equxum apud Opûnta gregarium fuift cepimus, quiannos quadraginta natus poffet coire:fed adiumentum quoad fui pedes priores at rentur(quod fupra etiam ex Plinio recitaui)defiderabat. Idem alibi, Ferunt regi Scytharumfu equam egregiam, ex qua mares generofi omnes gignerentur:quorum unum, qui praftantio ha retur, cum ut ex matre procrearet, placeret, admiffum omnino recufaffe: opertam deinde la matrem, ut imprudens fuperueniret:uerum ubi à concubitu faciem matris detectam agnouerat, gam properaffe, atç feipfum actum præcipitem interemiffe, Alij addunt, regem Scytharum hocf riuoluiffe, cum reliquus praftantium equorum grex pefte abfumptus effet: $Q$ ne fe ex odoreno 


\section{DeEquo. C. Lib.I. 485}

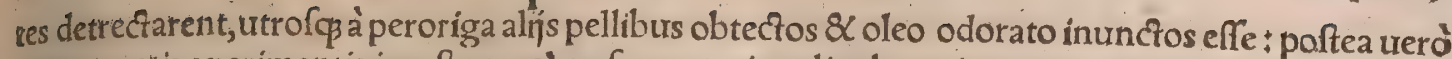
cum remotis operimentis inceftum cognofcerent, uinculis abruptis magno cum hinnitu procurrif, fe, \& capita tandem petris illifa confregiffe, Oppianus $\&$ Aelianus thic tamen ut Ariftoteles, fefe pra cipites egiffe fcribit. Plinius Ariftotelem fequitur, his uerbis, Alium(equum ferunt) detracto oculo rum operimento, \& cognito cum matre coitu, petïffe prarupta atç exanimatum, Equam eadem ex caufa in Reatino agro, laceratumó̧ pariter aurigam inuenimus. Nanq̧ \& cognationum intellectus in n̈s eft; itaq̧in grege prioris anni forore, libentius etiam quàm matre, equa comitatur incredibile(inquit Varro)quod ufur uenit, memorix mandandum:Cum equus matrem ut faliretad duci non poffet, \& eum capite oburoluto peroriga adduxiffet, \& coégiffet matrem inire, curm defcen - denti uelum dempfiffet ab oculis, ille impetum fecit ín eum, ac mordicus interfecic, Camelos in Ad mirabilium relatione tradtit Ariftoteles nunquam coiffe cum matre. Hoc idem $\&$ in equís ex Plinio aftruere conantur aliqui, quod tamen falfum conuincimus ex A riftotele libro fexto frribente, Equi uel fuas matres \& filias fuperueniunt, atç tunc perfecfum effe armentum uidetur, quum parentes fuam ineunt prolem. Suppetit Ouidij authoritas ex decimo Metamorphofeos, Coéunt animalia nullo Catera delectu, nec habetur turpe iuuencæ Ferre patrem tergo, fit equo fua filia coniux, Calius. Falfum igitur fuerit quod Oppianus fcribit ftatim ante hiftoriam equa 8 pulli regis Scy=

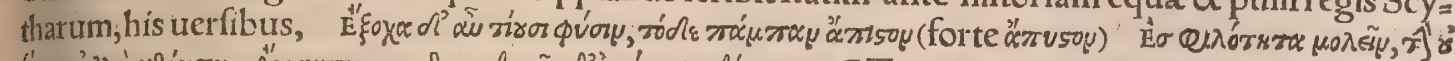

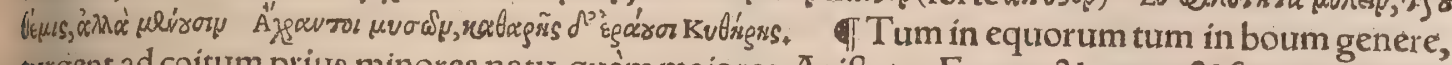
turgent ad coitum prius minores natu, quàm maiores, Ariftot. Equos, \& canes, \& fues initum ma 10 tutinum appettere, foeminas autem poft meridiem blandiri, diligentiores tradunt, Plinius . Equis non cer to dierum numero implet, fed aliquando uno, aut duobus tribúsure, aliquando pluribus: feriis certe quàm afinus, equam fuperueniens implet, Ariftot. A pud Myfos cum equinum genus co it, quidam uelut Hymenæum quendam nuptijs præcinunt, \& 2 cantus fuauitate permulf equx gras . uidæ fiunt, \& forma pulchritudine, eximios pullos ex fefe pariunt, A elianus. Et alibi, Euripides di, cit, paftores hymenzos ad fiftulam cantantes, ad Venerẽ equas incitare, atç etiam equos ad ineun

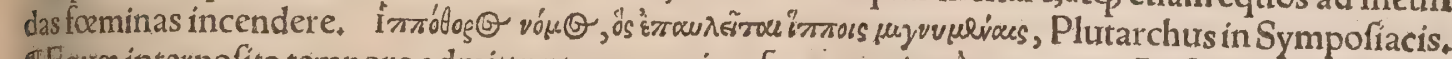
- Equa interpofito tempore admittuntur, quoniam ferre continuó nequeant, Ariftoteles, Alternis quiadmittunt, diuturniores equos, \& meliores pullos fieri dicunt. Itaģ ut reftibiles fegetes effent ex= uctiores, fic quotannis qux prægnans fiat, $V$ arro. Non ftatim à partu equa implętur, fed intermif 30 \{o tempore: 8 melius quarto aut quinto anno interpofito procreat. Omnino, fi nihil plus detur, unư tamen interponere annum, \& quafí nouale facere neceffe eft, Arifroteles. Vulgari formina folen neeft omnib.annis parere, generofam conuenit alternis contínere, quo firmior pullus lacte materno laboribus certaminum præparetur, Columella . Generofas equas, \& quæ mafculos nutriunt, alter nis annis fubmittere debebimus, ut pullis puri $\&$ copiofi lachis robur infundant, cæteræ paffím re= plendx, Palladius. Quòd fi aut foemina recufat, aut non appetit taurus, eadem ratione, qua faftidí. entibus equis mox pręcipiemus, elicitur cupiditas, odore genitalium admoto naribus, Columella. Etin equis, Quòd fi admiffarius (inquit)iners in Venerem eft, odore perfricatur deterfis fpongia forminæ locis, \& admota naribus equi. Idem feribit Abfyrtus, ut in Geoponicis legimus. Si equa marem non patitur, detrita fcilla (fquilla $P$ alladius) naturalia eitus linuntur, qua res accendit libidi $40 \mathrm{nem}$, Columella. Si faftidium faliendi eft, inquit Varro, fcillæ modicum conterunt cum aqua ad mellis craffitudinem, tum ea re naturam equa, cum menfes ferunt, tangunt:contrâ, ab locis equę na res equi tangunt. Si equa marem non patitur, gallinaceo fimo cum refina terebinthina trito, natus ralia eius linuntur: ea res accendit libidinem:longéç magis, fi faliendi faftidium eft, oblitus fcilla co ëundi cupidinem elicit, Anatolius. Non eft committendum, inquít idem, ut ftrigofa equa \& obfita forde faliatur + quíp pe cum talium cupiditate celerius equum folicitari conftet, perinde quafi ftimula tus hac colluuione gaudeat. Nonnunquam ignobilis quroģ uulgaris (equus)elicit cupidinem $\mathrm{CO}_{2}$ ëundi. Nam ubi admotus ferè tentauit obfequium, formina abducitur, \& iam patientiori generofior equus imponitur, Columella. Sape accidit ut equa patiatur equum fuper fe, coitum tamen detre ctet, quod ex defectu caloris ipfius circa naturalia contingit: quamobrem urtica uel fquilla perfricaYo ri debent, Ruffius. Admiffarius quomodo alacrior ad Venerem fiat, fupra feorfím diximus. Exci tatur $\&$ tibiæ cantur libido in utroqs fexu, híppothoron uocant, ur ex Aeliano retuli. Vide etiam fut pra in Capra hiftoria,capite s. Sed non ulla magis uires induftria firmat, Q Q Venerem, \& cæcifti mulos auertere amoris. Siue boum, fiue eft cui gratior ufus equorum, Vergil. De equorum in Syria fylueftrium amulatione, qua impulfi mares in furo genere primum natos caftrant, fuperius di= xicapite fecundo. đConceptus indicium, maximè in uaccís equabusćs, cum menfes ceffarunt, fpatio temporis bimeftri, trimeftri, quadrimeftri, femeftritfed id percipere difficile eft, nifi quis iandu dum fecutus, affuetuş́́s admodum fit, Arift. Colorem(equæ cum concepere)illico mutant rubriore pilo, tel quicunqs fit pleniore thoc argumento definunt admittere etiam uolentes, Plinius. Aliquiot regionibus(inquir Columella) tanto flagrant ardore coëundi foeminæ, ut etiam fimarem non habe 6 ant, affidua 8 nimia cupiditate figurantes fibi ipf $\underset{x}{ }$ Venerem(cohortalium more auium) urento con ripiant. Quæ poëta licentius dicit,

Continuog̣ auidis ubifubdita flãma medullis, Vere magis (quia uere calor redit offib,) illa 


\section{DeQuadrupedibus}

Oreomnes uerfa in Zephyrĩ,ftant rupibus altis, Exceptantópleureis auras:\& fxpe fine ullis

Coniugịjs uento grauidx (mirabile dictu)

Diffugiunt, non Eure zuos, neqs Solis ad ortus: In Boreã, Caurứćp, aut unde nigerrim, Aufter

Nafcitur, \& pluuio contriftat frigore coelum. Cum fit notiffimum etiam in facro monte: Hifpanix, qui procurrit ín occidentem iuxta Oceanum, frequenter equas fine coittr uentrem pertu liffe, foetumćs educaffe, qui tamen inutilis eft, quod triennio prius quàm adolefcat, morte abfumitur: quare, ut dixi, dabimus operam, ne circa æquinoctium uernum equæ defyderīs naturalibus angan tur, Hac Columella. In foetura (inquit Varro) res incredibilis eft in Hífpania, fed eft urera, quod in Lufitania ad Oceanum in ea regione, ubi eft oppidum Olyffippo monte Tagro, quadam eurinto concipiunt equa, uthîc gallinæ quoo $\$$ folent, quarum oua hypenemia appellant; fed ex his equis qui nati pulli non plus triennium uiuunt. Conftat in Lufitania circa Olyffipponem oppidum \& $T_{2 x}$ gum amuem, equas Fauonio flante obuerfas animalem concipere fpiritum, idć partum fieri, \& gi gni pernicifimum ita, fed triennium uitæ non excedere, Plinius \& Solinus. Proprium equa eft Albertus fcribit ex Auicenna) pede aut coxa aliquantulum recalcitrare cum defyderat coitum: 8 hoc modo aperit uterum, haurití co meridionalem aut feptentrionalem uentum, quo plurimumde lectatur. Scribit etiam Auicenna fenem quendam fide dignum, natum in infula cui Arabicum no men Dealturfa, fibi narraffe, quod equa Arabica illic concepto uento non ceffầrit cưrere per defyde

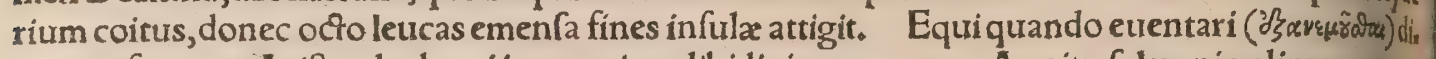
cantur, fupra ex Ariftotele docui in mentione libidinis equorum. A coitu folx animalium currunt ex aduerfo Aquilonum Auftrorúmue, prout marem aut forminam concepere, Plinius. In Lufitanis iuxra flumen Tagum equas Fauonio fpirante concipere falfò prodidiffe complures ait luftinur, fis gmentumć ex equarum focunditate ac gregum multitudine, qui in ea prouincia multi \& pernice vifuntur, Huxiffe autumat. Eorum qui aliter opinantur turba eliditur Iuftinus, quibus diuus Aug ftinus afcribi poteft. Nonnullifi uentus à mafculis flauerit, equas obuerfas odore fieri pragn tanturn, asç ex pis natos pullos triennium uitæ non excedere produnt. Silio Italico, Septimaogh bulis long!ffima ducitur ætas, Hac Io. Brodæus. Fit in equorum genere, inquit A riftoteles, utalia omnino fteriles fint, (quod $\&$ alibi affirmat:) alix concipiant quidem, fed æedere nequeant:cuibi indiciuns aiunt, quòd fectus circum renes alia quædam, fpecie propemodum renum, ita continet, refciffus quatuor renes habere uideatur. \$Quomodo efficiatur ut armentitix concipiant, legin in Hippiatricis Gracis capite quintodecimo:Si gregalem, inquit Hippocrates, equam concipere lis, urticam in os equi pellito: $Q$ r reliqua. Porrò fterilis equa concipiet, fi fafcem porrorum in pila fum uini cyatho perfundes, $\&$ cantharides uerficolores numero duodecim, ex aqua biduum ori rio clyftêre in uuluam ingeres, pofiero die equum ad ineundam forminam emittes : poftquam de urit, bis genitales locos elues. Aliud, Nitrum, pafferis fimum, refina terebinthina fimul deteruntur, in unum coacta naturalibus inferuntur. I Vbi equx conceperint, obferuandum eft ne mifceail plus iufto, néue in locis frigidis diuerfentur:frigus enim grauidis aduerfatur, $A$ blyrtus in Geo cis. Gratida non urgeantur, nec famem uel frigus tolerent: nec inter fe loci comprimantur an ftrĭs, Palladius. Cum conceperint equa, uidendum ne aut laborent plufculum, aut ne frigidis fint, quòd algor maxime pragnãtibus obeft. Itaq̧ in ftabulis ab humore prohibere oportet hun claufa habere oftia, ac feneftras, \& inter fingulas à prafepibus interïcere longurios, qui eas diff nant, ne inter fe pugnare poffint, Pragnantem necs implere cibo, neq efurixe oporter, Varro. conceptionem (inquit Columella) maior pragnantibus adhibenda cura eft, largóç pafcuo firm? dx. Quód fi frigor hyemis herbx defecerint, tecto contineantur; ac neqs opere ne 3 curfu exercent tur, necg frigori committantur:nec in angufto claufoure, ne allax aliarum conceptus elidant: namba omnia incommoda foetum abigune. Cauendum ne grauidx pabuli mutatione tententur, neç in ftentur aquarum infuetarum nouitate, fiquidem huiufcemodi per egrinarum rerum obiectu fa abortus contrahitur, Anatolius.

Non illas grauibus quifquam iuga ducere plautis

Non faltu fuperare uiam fit paffus: $\&$ acri Carpere prata fuga:fluulosés innarerapaces.

Saltibus in uacuis pafcant: 8 plena fecundũ Flumina:mufcus ubi, et uiridifrima gramineri

Speluncx́ć tegant: \& faxea procubet umbra, Vergilius, Grauida mox feparenturà maribi 8 it curentur ut necs macilentæ nimis, nec obefa euadant, fed inter utrunç habitum mediocte Vrerç, enim immodicus, ut uel abortus fiat, uel infirmior aut minor foetus, in caufa ef, $R$ uffuss, $A$ impedit partus quafdam ab opere, falluniç grauidx. Viciffe Olympia pragnantem equam Echec tidis Theffali inuenimus, Plinius. Qux cura prægnantibus adhibenda, Vt facile partus a datur, $A$ fecundas hærentes, Mulomedici Græci docent capite quintodecimo: item de perferendo uentre \& enecando partu, partim eodem, partim antecedente capite. Vide etiam nonnihil infra, in tractation de morbis equorum in ịs qua utero accidunt, qCertum eft equas, fi fint grauida, tastas (à mulit proflurrio menfium laborante) abortum pati:quin \& afpecqu omnino, quamuis procul uifas, fi pul gatio illa poft uirginitatern prima fit,aut in uirginea atate fpontanea, Plinius. Abortum facit ec odorem fentiens fungi fumigantis lucernæ extin cta, quod $\&$ mulierum nonnullis accidit, Arif les, Aelianus, Rafis \& Albertus, Ex his Ariftotelis uerbis corrupta iudico ea qua Vincentius $B$ citat ex Zenonis de animalibus libro, Equa fota (inquit) cum odoratur quod eft in fepo uacc $x, 8$ 
ditur partur eius. Abortiunt ferérumenta, glandibus cerri dettoratis, Ruffius, Ex fene quodam noftrate audiui, gentianam quo $\beta$ aborturs caufam effe equabus, Si poftea quàm trachuri caudam abfeideris,ipfum q̧ in mare liberum emiferis, eam equx uentrem ferenti appendas, non multò certe poftabortum pariet, A elianus, Aegyptỉ mulierem qua aborriuum fecerit fignificaturi, equam feri bunt qua lupum prefferit, Equa enim abortit, non modo filupum calcauerit, fed etiam fi ipfius ueftigia attigerit, Orus. Vide infra capite quarto. Si cum equa ex equo pragnante coierit afinus, foe tus iam conceptus corrumpitur, n̂niftotel, Etrurfus, Quum equus cum afina, uel afinus cum equa inierit,multo magis abortus cofequitur, quàm cum unigenæe inter fe iungantur:uerbi gratia, equa cum equo, aut afina cum afino. Conceptum ex equo fecutus afini coitus abortu perimit: non item 10 ex afino equi, Plinius \& Ariftoteles, qui caufam reijcit in afinini feminis frigiditarê. Ecrurfus, Equi gSi aut partu aut abortu equa plit afinus: fed equtus afini minime, cũ equa iã afini initu cóceperit: đSi aut partu aut abortu equa laboraưit, remedio erit, filicula trita \& aqua tepida permifta, dataćs per cornu, Columella. Scy thæ equabus graubus equirant, cum primum fe mourerit foetus, \& nimi rum eas proficere ad partus facilitatem arbitrantur, Ariftoteles, Equi \& ĭjs cognata animalia, quan. quam minus temporis uiuunt, tamen diutius uterum ferunt:alia enim annum, alia quod plurimum menfes denos grauida exigunt, Ariftoteles. Idem problematum fectione 10. Equus (inquit) ut tardius maxime quam homo parit, fic uiuere minus poteft:cuius rei caufam, uuluæ fiue uteri durities ha=

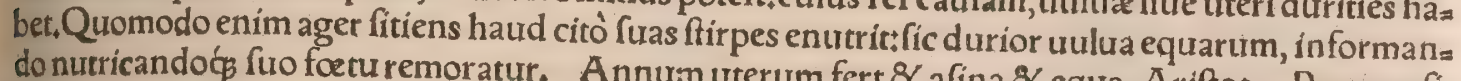
do nutricandó̧ fuo foetu remoratur. Annum uterum fert $\&$ afina $\&$ equa, Ariftot. Partus afi\& fimili modo, Plinius. Partum in eo genere undenisus: totidem quot equę, 8 cifdem menfibus,

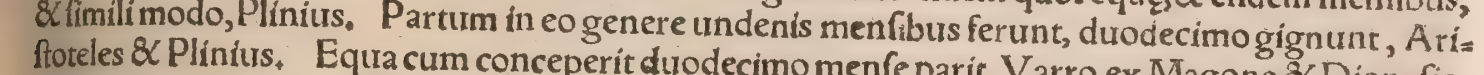
Columella. Ventrem fert duodecim menfes, Varro Et alibir, Varro ex Magone \& Dionyfio, nafcitqux poft(id)tempus nafcuntur, feré uritiofa ato. Et alibi, Duodecimo menfe die decimo aiunc foatio duodecimi menfis abfoluere, Palladius. Equs inutilia exiffunt. Equarum natura eft partû́ rumicurriculo,A bryrtus. Mares citius perficiuntur in um geritundecím menfium decenćp diea um quadrupedum parit, Ariftot, Et rurfus, Cxter quadrupedes iacentes parere fua facllime omni. cưm tempus iam ædendi appropinquârit, et igit $f e$, ftansóg emittit partum ftans parit, Plinius. Equa fingulos parit, A riftoreles . In hor genere grauida gulos: fed gemellos quoc: aliquando parit, Ariftoteles . Etrurfus, Pariunt magna ex parte equa fin= uacat admodum purgamentis in partu, Gracium procreant, Singulos gignunt equi, Plinius. Equa uacat admodum purgamentis in partu, (Graci lochia uocant:) minimumģ́ emíttit profluuium fan guinis, uidelicet pro corporis magnitudine, Ariftoteles. Cum peperit, ftatim fecundas deurarar, atc etiam quod pulli nafcentis fronti adharethippomanes dictum, Ariftot. De polio feu pullio dicto, quod ante partum emittit equa, dixi fupra in hippomane. बMatrices equas quidam uocat eas qua foctum alunt. Pullatio \& pullities apud Columellam foetura pullorum eft, urel ipfi pulli: fed de alijs quoogs animalibus non equís tantum in ufut funt. Afinis à fortu mamma dolêt, ideo fexto men fearcent partus, cum equæ anno propé toto prabeant, Plinius, Lactare mulum femeftre temporís fatium referunt, equo autem plus temporis tribuunt, Ariftot. Equi $\&$ afini ad biennium lacten. tur, Anatolius, Pullus commodiffime ablactatur hoc modo, Separetur à matre triduo ante plenifis 40 nium, \& per horas uigintiquatuor ab ea exclufus, rurfus mane admittat́, \& ubilac copiofe fuxerit adeo ut uenter turgeat, remoueatur nec admittatur amplius:fic deinceps habitior manebit, \& elegã. tior fiet, Author obfcurus. Quinquemeftriburs pullis factis, cum redacti funt in ftabulum, obijciendum farinam ordeaceam molitam cum furfuribus, $8 x$ fi quid aliud terra natum libenter edent. Anni culis iam factis dandum ordeum, 8 furfures, ufọ quoad erunt lactentes. Neç prius biennio confe. cto àlacte remouendum, Varro. Dethippothelis afinis quilacte equarum aluntur, pauló poft dicam. Terram attingere ore pullum triduo proximo quàm fit genitus, negãt pofie, Plinius : ut fupra etiam in B.dictum elt. Pulli equarum nati manu tangendi non funt, quia eos tactus ladit affiduus: quan tum ratio patitur, defendantur à frigore. In pullis pro xtatis merito ea funt confideranda, quæ fignti bonx indolis monftrant, qux in patribus, uel matribus fpectanda pracepi;dabit $\&$ hilaritas $\&$ alacr - tas, agilitasć́ documentum, Palladius. De p̈s qua circa pullum eligendim confideranda funt, fatis lam dixi capite fecundo. Si partus profpere ceffit, minimémanu contingendus pullus erit. Nam la ditur etlam leuiffimo contactu. Tantum cura adhibebitur, ut $\&$ amplo $\&$ calido loco cum matre uer feur, ne aut frigus adhuc infirmo noceat, aut mater in anguftijs eum obterat. Paulatim deinde pro= ducendus erit, prouidêdumó̧́, ne ftercore ungulas adurat:mox cum firmior fuerit, in eadem pafcua in quibus mater eft, dimittendus, ne defyderio partus fui laboret equa. Nam id pracipue genus pe: cudis amore natorum, nifi fiat poteftas, noxam trahit, Columella, In decem diebus fecundum par: tum cum matribus in pabulis prodigendum, Varro. Etrurfus, Pullos, cum fent cum matribus, in: terdum tractandum, ne cum fint difiuncti, exterreancur, 8 reliqua, ut in domitura ipforum dicam 5 . capite. Prafepia altiora effe oportet, ad qux iumenta capiftentur, ut furfum uerfus fpectantia ci. 60 bum capiant. Id maxime in pullis obferuandum eft:fic enim erecta ceruice níticonfuefcent:qua res equino pecori maximam uenuftatem adfert, Anatolius, Etrurfus, Equa poft alterum aut tertium menfem( (dito iampartu) longè magis exercitationibus credi debet, quó lac in ea praftantius gigna 
tur: fequens equuleus curfibus committat̂. Si pulli molles gerant ungulas, afperis locis eos citatius a gemus, calculos pedibus fubfternentesł fic enim ungulæ durantur: qua fi ìs parum adhuc folidatæ mollefcant, hanc curationem oportet adhibere: Adeps fuilla uetus, \& hircina, fulphur ignem non ex pertum, \& alliorum fpicæ mifcentur:ịs sungulæ \& eartum caua perunguntur, Hæc Anatolius. $\mathrm{P}_{2}$ f́cua prouidere oportet nó adeò mollibus locis nata, ut ungularum firmitas de afperitate nil fentiat, Palladius. Ad firmitatem ungulis comparandam, utile uidetur ut pulli faxofis $8 \mathrm{Z}$ montanis locis na fcantur, ut duris $\&$ afperis locis $\&$ aëre frigido durefcant, Conducunt autem montana loca duplici nomine:primum quia pedes in eis ualidiores, aptiores, craffiores ac duriores reddunt:deinde quon am fubinde per inaqualia loca afcenfu defcenfứç exercitati, laboribus fuftínendis præparantur 10= boranturós, Ruffius. Ex afino $\&$ equa(inquit Plinius)mulus gignitur menfe duodecimo: $\overline{A d}_{10}$ tales partus equas neq̧ quadrimis winores, neq̧ decennibus maiores legunt : arceríq úprumq ge= nus ab altero narrant, nifi in infantia eius generis quod ineant lacte haufto. Quapropter fubreptos pullos in tenebris equarum uberi, afinarúmure equuleos admourent. Gignitur autem mula ex equo $\&$ afina, fed effrenis $\&$ tarditatis indomitx. Equo $\&$ afina genitos mares hinulos antiqui uocabant; contraćp mulos, đ̊s afini \& equæ generarent. In plurium Græcorum eft monumentis cum equa mu li coitu natum, quem uocauerint hinum, id eft paruum mulum, Generãtur ex equa $\&$ onagris man, fuefactis mula ueloces in curfu, \&c. Hurcufç Plinius, Equuleos q̊rum hoc in loco Plinius(lib, \&, ca, 44.) meminit, Ariftoteles hippothelas quafi equimulgos uocat. Arcebit (inquit) ab initu \& afinum equa, \& equum afina: nifi contigerit ut afinus equæ lac hauferit : ob id de induftria pullos afinorum fupponunt, qui uocantur hippothela, Hermolaus. Pullum afininum (ingt Varro) à partu recen=: tem fubriciunt equa, cuius lacte ampliores.fiunt, $q$ id lac व̧ $_{3}$ afininum ac alia omnia dicunt effe melia us. Praterea educant eum paleis, \&c.ut in Mulo perfequemur. De equi $\&$ afinę, uel afini \& eque coitu, geftatione, partu, \& alia quadam uide fupra in hiftoria Afini. Si quem mulorum genus (in: quir $\mathrm{P}$ alladius) creare delectat, equam magni corporis, folidis offibus, \& forma egregia debet eliges re, \&c.ut in Mulo explicabitur, ubi etiam de afino admiffario ad mulos procreandos eligendo copio rétractabimus, Anna focer Efat primus equis afinas copulauit, ut ludæi afferunt, lfidorus, Es quarum iubas tendere pracipiunt, ut afinorum in coitu patiantur humilitatem + comantes enim $\mathrm{g} \mathrm{o}_{0}$ ria fuperbire, Plinitus, \& Á elianus, cuius uerba in Mulo recitabo. Quin \& alioqui equarum libido extinguitur magis iuba tonfa, Ariftotele tefte, \& frons triftior redditur. Cur Eleiequas finibusedr clas iniri faciant, Plutarchus inquirit problemate 52, inter Gręcanica: \& Leonicenus in Varïs 1, 64 Cur equa in Elide ex afinis concipere non potuerint. Muli afiniá̧ (inquit:Herodotus libro 4) uin hyemis ferre non queunt:quò magis miror cur in omni Eleo agro muli nequeunt gígni, cum neglo cus fit frigidus: neç ulla alia caufa appareat. Aiunt Elienfes ipfi ex imprecatione quadam id fibicon tigiffe: Cumós tempus aduentat conceptus equarum, fe in loca finitima illas educere: Ibi poft miferint afinos dum equa conceperint, tunc rurfus eas reducere.

Defanitate equorum tuenda, $\&$ pracauendis morbis.

Mulomedici \& ueterinarị dicuntur communi uocabulo, qui ueterina curant, equos, mulos,all nos. Dicuntur autem ueterina animalia ad uecturam idonea, quę aliquíd uehere poffunt, quafiun terina, $q$ ad uentrem onus religatum gerant. Vngula ueterino tantum generi renafcuntur, $\mathrm{Pli}$ us. Ergenus omne qd eft ueterino genere partum, Lucretius lib,5. Veterinarium pro medicou terinorum dixit Columella, 8 medicinam ueterinariam.Vegetius artis ueterinariæ fiue mulomed cinælibros quatuor reliquit, $\&$ eadem uocabula in præfatione ufurpat; quan $\tilde{\beta}^{3}$ ars ueterina in excu fis codicibus legitur, perperam ut uidetur. Equarius, equorum curator, apud Solinum capiter, $\mathrm{He}$ rophilus equarius medicus, Valerius Max. Equorum medici, equinarï, treterinarín, manucald, mulomedici appellantur, Textor. De medicinis uel plurima funt in equis, \& figna morborum, \& genera curationum, qua paftorem fcripta habere oportet. Itage ob hoc in Gręcia potiffimum medici

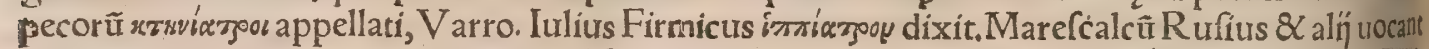

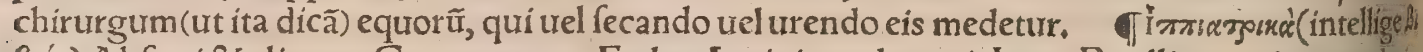
Cría) A bfyrti $\&$ aliorum Græce extant. Eadem Latinitate donauit Ioan. Ruellius, cuius translatio pura ğdem \& elegans in Latino fermone eft: $q$ ad rem ueró, multis in locis \& manca \& corrupta, ipfe cum Græcis conferendo animaduerti. Sunt autem præter Abfyrtum authores ifti, Hierode Theomneftus, Pelagonius, Anatolius, Tiberius, Eumelus Thebanus uel Chiron, Archedemus, Hip pocrates, Aemilius Hifpanus, Litorius Beneuentanus, Himerius, A fricanus, Didymus, Diophianes, Pamphilus, 8 Magen Carthaginienfis. Citantur etiam obiter in eodem opere, Agathotyches, $\mathrm{Ne}$ phon, Hieron, Caffius, Hemerius. Geoponicorum etiam, qua Conftantino adf cribuntur, liber fes

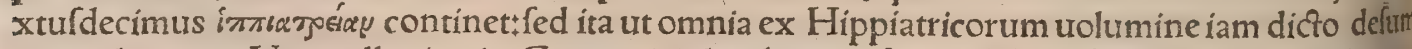
pta uideantur . Nonnulla qux in Geoponicis legebantur, \& in Abfyrti, \&r. Hippiatricis deerant, Ruellius translationi fux adiecit. Scripfit $\&$ Laurentius Rufius librum eiufdem artis:in quo prate alios authores, copiofé de frenis corumó̧ differentīs tractat, expreffis pariter piçuris eorum. $\mathrm{Pr}$ mus omnium puto hippicum, id eft de equis $\&$ equeftri arte librum Simon quidam Athenienfis tel quit, ex quo omnia qua placebant in fuum tranfcripfit Xenophon, nos pleraç ex Xenophonte in hunc noftrum. De equis praterea(ut Camerarius obferuauit) quadã fripfit Clleodamas A chnartsi: 


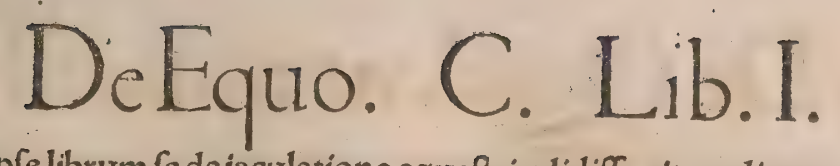

Plinius etiani, qui ipfe librum fe de iaculatione equeftri edidiffe ait, tradit equitem quendam Sarme: nem primurm de equitatu fcripfiffe, effictum à ftatuario Demetrio: Et Mecon quidam, \& alï. . Magía fer Maurus Hippiater citatur à Laur, Rufio cap $+44,8{ }_{151}$. Petri Crefcentienfis de agricultura lia ber nonus capita 57. de equis continet. Multa de ijfdem docet ABbertus Magnus quoç libro 12, hi= foriæ animalium: Multa etiam rei rufticæ prifci fcriptores, Varro, Columella, Palladius, Extant des . niģ in omnibus fere uulgaribus linguis de equis curandis côfcripti libri, Germanicè, Italicè, Gallicé: Italicèquídem excufurm uridi Auguftini Columbinilibrum.

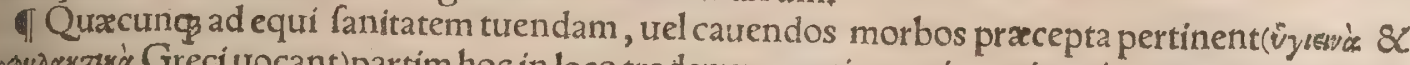
noфuraxzmkè Gręci uocant)partim hoc in loco trademus, partim capite quinto, in ea parte qua eft de tractandis equis, TDe dentibus equi, q̊s uulgo fcalliones uocant, \& corum exemptione, fupra di. cum eft. Ad hos autem eximendos (inquit $R$ ufius) tempus uindemiarum aptiflinum eft + nam fi racemi uuarum in cibo eis tum dentur, uulnera oris melius curantur $\&$ confolidantur, nec uer= mes aut prauæ carnes innafci poffunt:itaç ex hoc cibo os equi melius efficitur, ac ipfe etiam pingue fcit. Ad eandem curam (fcallionare uocant) obferuandum ef ut Luna decrefcat. đA Animalium dorfa ut laboris plurimum fentiunt, ita diligetrius funt curanda. Exceptis enim his qui deputatifunt circo,reliquum mulorum, equorum, a finorum q́s genus fub fellis aut fagmis folo tergo praftat offici um. Vnde laudabilior induftria eft, qua incolumitatem tuetur, क्ष qua cupit lafa curari. Nam dili. gentia defendic à uitio:fi centones uel faga primum fufficientia, deinde mollia imponantir, \& lota, atç ad tempus diligenter excuffa, ne aligd fordium aut a fperitatis inhareat $q$ d fub pondere inulce, ret pellem:tunc fagmarum urel fellarum menfura conueniens $\&$ apta qualitas debet adhiberi. Si ễ ifta minora fuerint uel maiora, anguftiora, urel ultra modum lata, uel qux non congruunt, grautiter nocent. Hinc enim collifiones, fuppurationes, apoftematá̧ nafcuntur, cum nimis locis inęqualibus premitur pondere, uel difcentes tracturam mercurius aut ipina deteritur. Ipforum quoç pondere, etiamfi in ftratis nulla fit culpa, enormitas nocet, $\mathcal{X}$ ideo temperanda eft menfura ne inferat uulnus, $\mathrm{H}_{2 \mathrm{c}}$ Vegetius, TMultum autem refert(inquit Columella)robur corporis ac pedum feruare, $q \mathrm{~d}$ utrǘp cuitodiemus, fi idoneis temporibus ad prafepia, ad aquam, ad exercitationem pecus duxerimus, curáç furerit, ut ftabulentur ficco loco: fed de ftabulis inftituendis capite, , dicetur. Auena aliáue annona equo exhibenda, bene purgentur prius, ne quid pulueris aut aliud inutile infít: pul= uis enim facile tuffim inducit, \& interiora deficcat, quod malum ferè incurabile eft, Rufius. Iưmen

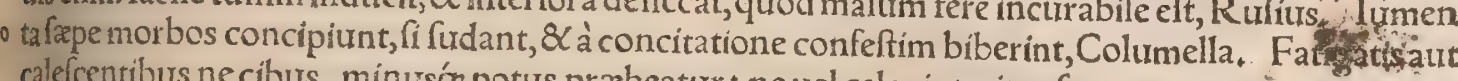
calefcentibus ne cibus, minuśśs potus præbeatur : ne uel celer interitus fequatur, aut uenenum in crura decumbat, $8 \mathrm{c}$, Camerarius. Et rurfus, Crithiafis omnia membra debilitat, ut nec ingrediure lit equus, \& pafcatur humi iacens : idem'śs accidit de potu íntempeftiuo, fed cum minore of 1 cufo. Sed de hoc \& eo đ̊d ex retenta urina in longiore itinere fit periculo, amplius dicam capite s. Tem= pore ueris equum frenatum Soli matutino aliquantifper exponere, ad fanitatem tuendam facit. (1) Pltrimum iuuat(inquit V egetius) fi frepius 8 cum moderatione animalia fedeantur (forte exer ceantur, nempe equitando.) Nam imperitia reçoris, $\mathcal{Q}$ inceffus eorum debilitat, $\&$ mores, pracipué flagellis, fed etiam calcaribus cæedunt, dum aut inter furos uelocitatem cupiunt experiri, aut cum alie onis uehementi obftinatione contendunt, nec reuocant aliquando currentes, nec temperant: nec $e_{=}$ Ilim de damno domini cogitant, quod cidem contingere gratulantur. Quam rem diligens paterfami liầs fumma feueritate prohibebit, \& iumenta fura idoneis $\&$ moderatis hominibus, fcientibusć́ tra= chare committet, Poft fudorem quoqs fi xeftus fit, pufca os ablui conuenit: fí hyems, muria. Vinum quoos $\&$ oleum faucibus infundi oportebit ad cornu, $x$ ftate frigidum, hyeme tepefactum, ita ut hye memeri fextario, olei uncia tres, æftate autem dua tantummodo mifceantur, Hæc Vegetius. Acci dithis equis qui parum exercentur, ferè ut anhelitus difficultate laborent, Camerarius, TVicinû. frabulum conuenit effe loco arido, fiercore uel paleis mollibus adoperto, in que ante potum anima lia uolutentur: Quod exercitium \& fanitati proficit, $\&$ ægritudinis uitium commonftrat:nam quo= ties animal, aut non folito more fe tranfuroluit, aut omnino detrectat accumbere, fcias illud ex tædio laborare, \& ideo feparari debere atç curari, Vegetius, Si ueterinis in itinere defeffis fellæ uel fag. ma auferantur ut loco aliquo commodo liberé uolutari poffint, ita recreantur ut laffitudine pofita,

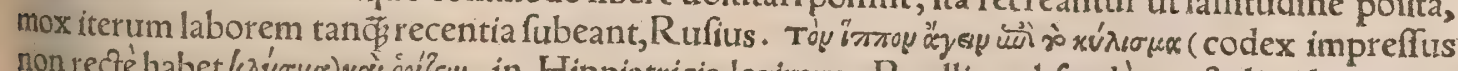

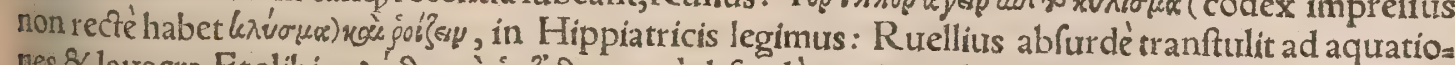

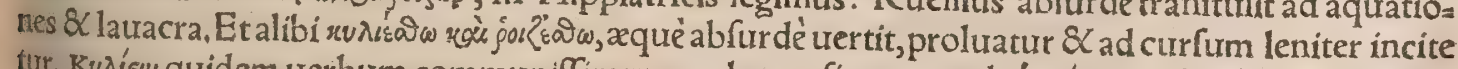

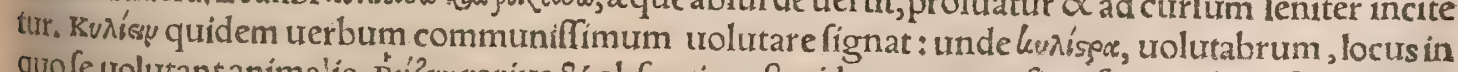
quo fe uolutant animalia, Poík « rarius $\&$ obfcurius eft:uidetur autem fignificare ad curfum incita.

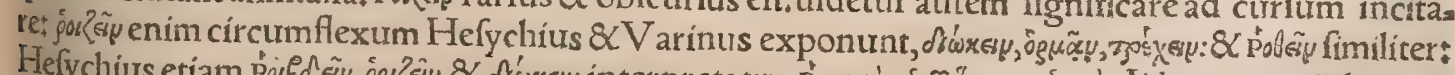

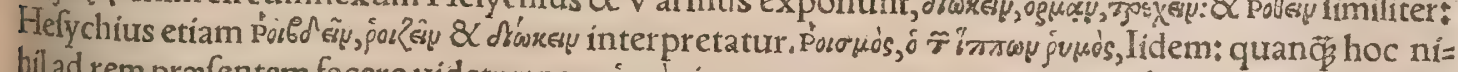
hil ad rem prafentem facere uidetur:nam jusju interpretantur temonem inter binos equos, Caterû o cum confydero $\$$ apud coldem joíc exponitur locus iuxta fluuium $\&$ arenam in quo equi uoluten

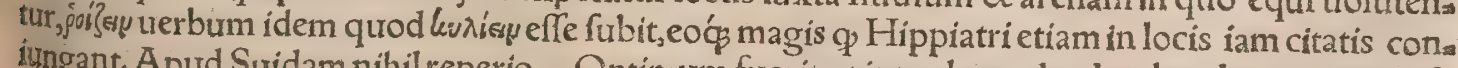
iungant. A pud Suidam nihil reperio. Optimum fuerit ut interdum ad uolutabra ducantur qua fo 
lidas gerunt ungulas:locus ad id eligendus folidus, terrenus, æquabilis, non lapidofurs nec falebro fus, quo fefe pollint citra noxam faburrare. Improbantur la ti tractus, Baetuysob, graminofi, ftercoraz ti, quod expeditum non reddant equum, nec corporis agilitate praftantem, (

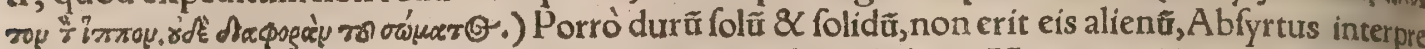
te Ruellio. \Equã aiunt lautatione \& unguêtis delectari, Aelian. Monent quidã ne macilenti equl fupra uentrem in aquam adigantur:quod uentre eis refrigerato alimentum non fentiant: pinguios res ucrò fapius $\mathcal{Q}$ altius in aquam agendos, fic effici ne nimium pinguefcant, \& corpus fanum ac in tegrum conferuent. Equus ad aquam potaturus ducatur partio paffu: $8 \mathrm{X}$ tam mane quàm uefíperi retineatur ufo̧ ad genua uel pauló fupra fpatio trium horarû̃ in aqua dulci frigida uel marina: nam aqux naturaliter equis conueniunt, duk is quidem frigiditate, marina uerò ficcitate fua conftringent do humores quiad crura defcendunt $\&$ morborum caufa funt. Inde rediens equus frabulum non ingredietur, donec crura eius deterfa $\&$ ficcata fint. Nam ftabuli uapores in cruribus humidis facile excitant gallas $\&$ prauos humores, Hac Petrus Crefcent. If Sunt qui hircos in ftabulis alant: tan, quam hircinus odor falubriorem equis aêrem reddat, $\&$ nefcio quos morbos amoliatur. Omnisex tremi frigoris rolerantion equino armento uacca eft, ideó́s facile fub dio hybernat, Columella. Sias nimal (inquit Vegetius) domi foris ç perfrixerit, calidioribus unguentis, qux multa funt, lumbieis dem confricentur $\&$ cerebrum, potionibusćs $\&$ pigmentis, $\&$ herbis quarum feruentior eft uis, per os continuò oportet infundi, ut perfrictionis incommodum euincatur atç pellatur. Nam fín tif(cet ribus permanferit algoris iniuria, diuerfos periculofosç̧ procreat morbos. In locis circa Tanaim \& Caucafum borealem tantum elt frigus hybernum, ut præ illo equi, muli, \& pecora moriantur, ut fcribit Dionyfius A fer. In Scythia ingentem $\&$ diuturnam uim hyemis equi perferunt, muli aliniq ne incipientem quidem ferunt, cum tamen alibi ftantes in gelido equilabefiãt, afini uerò ac mulidur rent, Herodotus. Equus hyeme gerat operimentum lancum propter frigus:aftate lineum, nelada tur à mufcis $\&$ fimilibus infectis, Rufius. Si dierum canicularium tempore ęftu animal fatigabirur, uel aquis frigidis eft perfundendum, uel in mare fluménure mittendum; frigidis etiam potionibus:h creandum, ut neceffitati laborũ aut temporũ aptior medicina fuccurrat, Vegetius. đSi fanis eftma cies, celerius torrefacfo tritico quàm ordeo reficitur: fed $\&$ uini potio danda eft, ac paulatim eiufmo di fubtrahenda immiftis or deo furfuribus, dum confuefeat faba, $\&$ puro ordeo ali. Nec minus quori die corpora pecudum quàm hominum defricanda funt, ac fape plus prodeft preffa manu fubeginte terga, quàm fi largiffime cibos prabeas, Columella. Animalia macie tenuata(inquit Vegetir abiog ftudio diligentí reuocantur ad corporum firmitatem. . Nam oleo ueteri uinó́ permixis \& ic pefacis in Sole, per totum corpus unguntur, $\&$ contra pilum multorum manibus perfricancur,ur $\&$ nerui mollefcant, \& cutis laxetur, \& fudor erumpat: Quo facto cooperta in pontili frato collocen tur. Et fi hyems fuerit, condira cum femiuncia ap ipfius oportet infundi. Si æftas fuerit, abfinthium uel rofatum cum quatuor fertupulis croci, \& duan bus uncijs olei frigidum per os fimiliter debet accipere. Quorum fi non fuppetit copia, uinum imp citer conuenit praberi cum cæteris. Præterea eiufmodi fpecies tempore hyemis cum hordei mi quatuor mifces, faba fextarios octo, tritici fextarios quatuor, ciceris fextarios octo, fornigracilicxa rios quatuor, erui fextarium unum+\& fi meritum equi uel facultas domini fuppetit, uuę paffa \& clei fextarios fingulos:qua omnia folerter commifta cum fuerint, unum modium in aq̨ua munt ma pridie debes infundere, $\&$ paululum mane ficcare, ex quo equo femimodium ante prandititi, remimodium ad uefperam dabis per plurimos dies in loco optimo. Vigintiuno die ita frabuletut, intrinfecus bibat. Quòd fiultra modum fagina prouenerit, ne plethora noceat, auferenduseftín guis à matrice. Præterea graminum radices, quas aratrum frequẽter eurellit, ftudiofé collige, \& q potueris longas minutatim concide, hor deoç commifce, $\&$ quotidie prabere non dubites. Ac uerò, excepto eruo, fpecies illæ quas diximus, pro xftimatione menfuræ farraginis adinuicemprä beantur, hoc eft, hordei uiridis plures maiores $q$, fafciculos, tritici uel ciceris, uel fœnigraci mi \& pauci:Quæ omnia contufa oportet apponi, Hucufó Vegerius. Aegrotanti pecori aut fame fecto (ut in Hippiatricis Græcis legimus cap.119. in translatione Ruellin) curatione huiufmodi op eft:Seminis apij fextarius unus, feminis lini drachma tres, foenigræci fextarij duo, erui trepond dicis panacis, irídís Illyricæ, herbæ Sabinx, fingulorum felibra, axungix libra fex, uino excip uetere, \& coguntur in paftillos, qui ficcantur in umbra. dantur iuglandis magnitudine: cum

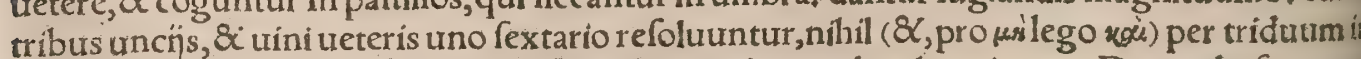
tur. Canis etiam caput efficaciter fuffitur, fic ut nidor naribus hauriatur. De morbofa corporism cie dicam plura inferius, ubi de morbis toti corpori communibus agam. Nec conuenientiun tionum (inquit V egetitrs) cura debet ceffare:nam languor, macies, \& tuffis, \& internorum dol cile fubmouetur, fi fulphuris uiui femunciā, id eft fcrupulos duodecim, myrrha fcrupulos qu redactos in puluerem, ouoóg crudo immixtos cum hemina (fextario, ut habetur libro 4. cap. 8 optimi per os dederis. Eft alia fumptuofior, fed accommodatior potio ad omnes morbos, qux $\&$ rirer reficit, \& cum intrinfecus purgauerit, curat omnes morbos, tuffim ueterem, phthificos, th \& quæcuncs uexata funt in opertis. Ptifanæe fextarium, feminis lini heminam, foenigræci hemi croci unciam, acronem faifum porci pinguis, uel longanonem; uel fi porcina defuerint, caput $b$ 


\section{DeEquo. C. Lib.I.}

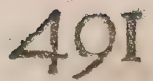

num depllatum, cum pedibus fuis, \& cordulis inteftinorum mundis, hyffopi fafces duros, cochleas germanas quindecim, bulbos quindecim, ficos duplices uíginti, ruta fafciculum unum, baccarũ lat vi cum uirent fextarium, dactylos uiginti, allij capita tria, feui caprini uncias fex, pulegỉ ficri fafcicu lum harc omnia purgata leniterós contufa decoques in aqua cifternina, uel coeléti, donec acron ille. uel certe caput hod di liquefcat $8 \mathrm{C}$ diffoluatur ab offibus:propter quod affidue aquam refundis (adij= cies) ne comburatur, fed feruendo pinguefcat, uel fuccus ipfe pinguior (Ipiffior) efficiatur. Poft hace diligentiffime colabis ad colum, (excrementa $\&$ offa abïcies)tum tragacanthre unciam in tres diuia des partes, ita quod exinde in unam potionem miffurus es, pridie infundas in calidam, utinturge fcat. Tunc addis paffi fextarios tres, \& 2 tribus diebus fingulos fextarios dabis, oua numero fex (in die fecundo olei rofati oua plena numero duro)butyri uncias tres. (In die tertio) anagallici uncias tres: amyli uncias tres:pulueris quadrigarị (quem defcribit lib. 4 , ca.13.) felibram, lomenti fabę felibram. Quro omnia mifces, ut dictum eft, aquis ponderibus per triduum diuides (ita temperabis ut per cor nu defluant) \& ieiunum animal potionabis, \& horis aliquot deambulare facies, uf $q$ ad feptimam, cibo abftineatur \& potu, Hæc V eget.1.56.8 rurfus 4.8, ubi pauca quædam urariant, \& medicamen tum adChironem refertur. Et fi uolueris(inquit) feptem diebus interpofitis repetis $\&$ das à capite po tionem. Aliud ibidem, ̊̊d iumenta à morbis uindicat $\&$ cuftodit: Gentianæ, ariftolochia rotunde, myrrhæ troglodytidis, rafurę eboris, \& baccarum lauri azuis ponderib. puluis immixtus, (fi ebur de mas, erit theriaca diateffaron dicta: defcribitur etiam in Hippiatricis cap.113, in Ruellin urerfione, hoc titulo, Potio neceffaria omni tempore pralibanda.) ex quo grande cochleare plenum fumis: Addes hyflopi triti fcrupulos quaturor, mellis uel paffi uncias tres, uini fextarium, gifni refoluti paftillum $\mathrm{u=}=$ num,poft curfum fiue polt laborem conditi bene(piperati)heminam adícies, xftate roris(forte ror if marini) uel abfinthï tantü dem, $\&$ per os dabis ad cornu. Idem Vegetius 3.75.pctionem contra om. nes morbos defcribit. Eryngî radices aduerfus morburm tam equorum क्ष boum plurimũ profunt, utin Boure ex Vegetio docui. Nec equi nec boures morbo prementur aliquro, fi illis cornu ceruinü appenderis, Abfyrt, in Geopon. Si aeftu animal fatigatur, purfam cum pulegio trito mifces, nares \& faciem confouebis, oua quogs trita cum hemina uini ueteris optimi faucib.infundis, ut per oui re frigerium uini uirtu's accrefcat. Infuffio uires equi recreans defcribitur in Hippiatricis Gracis ca= pite 128.item potio qua uires mirificéreficit, $\&$ ad omnem eorum curationem, pracipué tufîs, con= ducit: \& cum aliae diuerf infufiones potiones $q$, tum qux ab anni partibus $æ f t i u x$ aut hybernæ $c_{*}$ oghominant: $\&$ alia quxdam medicamenta communia, quan $\ddot{\beta} \&$ morbis quibufdam peculiaria ne glecta ordinis ratione inferant. Si cum inceffit hyems (ut in Hippiatricis Græcis legimus, ca, 129.) animal oleribus uef ci placet, pridie diligenter olus excoques, 8 in offas agglomerabis, addito oleo, \& trito fale, petrofelino \& cumino illo die.Poftridie ficcius offerri condiment am adĭcies $\mathcal{Q}$ exhibebis. Et mox, De danda adipis offa: Optimû aduerfus inteftinas ualetudines au xilium, cũ hyem's adeft, offas axungi $x$ cũ pice liquida $\&$ oleo præbere; fed cum æftas acceffit, axungiam ex melle, butyro, porris, 8C rofaceo dediffe fatis eft. Verũ hoc medicamen fubinde repetens $a=$

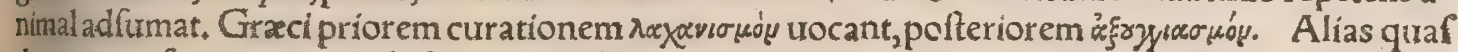
dam compofitiones prophylacticas, hoc eft ad pracaurendos huius armenti morbos, inferius recenfe. bo:ubi locus erit de morbis eius in genere tractandi.Apophlegmatifmü pręferuantem à malide, ton ofilis \& frumis, defcripfi fupra in mentione farraginis inter cibos, TCurandum ut equi ftabulen tur ficco loco, ne humore madefcant ungullę:fed ftabula qualiter inftrui oporteat capite s. dicemus,

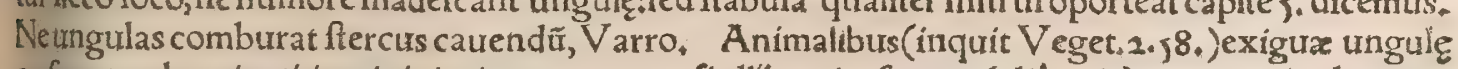
crefcunt, usel attritæ(íciner is iniuria)reparantur, fi allí capita feptem (aliâs tria)rutæ manipulos tres,

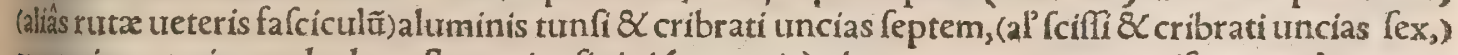
axungix ueteris pondo duo, ftercoris afinini (recentis) plenam manum commíreas ac decoquas (domi) 8 utaris (in itinere ad uefperam: Hoc idem medicamentũ defcribit $1 \cdot 56$.$) Prudentius confili=$ um eft pedum tueri fanitatem, $\overrightarrow{C_{B}}$ paffionem curare. Corroborantur autem ungula, fi iumenta mun= diffime fine ftercore uel humore ftabulentur, $\&$ roboreis pontibus confternantur: articuli quoç uel fuffragines poft iter calido foureãtur uino. Naturaliter autem molles ungulæ folidantur, fi hederæ fe 0 minis duas partes, $\&$ aluminis rotundi unam partem pariter contundas, \& calciatis pedibus per mul tos dies inducas, Item fubtritis pedibus prodeft, picis liquidx felibram, aceti heminam, falis libram, hedera folips quanturm fufficit pariter contundis, $\&$ laboranti quotidie pedes perunges. Mollifima ungula hoc uno medicamine, quo potentius nihil eft, affolent in durari: Lacertum uiuum uiridem, (pedibus iumentorum attritis prodeft fanguis lacertæ uiridis, Plinius ut citar Aggregator) in ollam nouam mittís, adijcies olei ueteris libram, aluminis Iudaici felibram, cera libram, abfinthí tunfi feli= bram, \& decoques cum lacer to: Cum fuerit refolutum, calentia uniuerfa colabis, abiecriṣ́́ offibus \& purgamentis, liquatum medicamen in ollam remittes $\$$ \& cum ungues indurare uolveris, ungulā fubradis, \& factum ungtrentum in cannam uiridem mittes, adhibitis carbonibus, propé feruens, per cannam inftillas ungulis: prouifurus ne coronam tangas autranulas, fi his exceptis, in folo \& in cir- critu folidaturus ungulam confricabis. Memineris autem ungulas excrefcendo renouari, \& ideo interpofitis diebus uel fingulis menfibus talis cura non deerit, per quam natura emendatur infirmitas, Hæe omnia Vegetius. Et alibi, Pedes equorum poft uiam eruendifunt diligenter, ne quid luti uel fordiumin articulis bafíģ permaneat. Vnguento etiam confricabis, quod ungulas nutric \& tir 
mat:Picis liquida libras tres, abfinthy̆ libram unam, allý capita nourem, axungix libram, olei ueteris libram femis, aceti acriorís fextarium unum, uniuerfa contundes 82 mifces, \& decoques, \& ex eo co ronas uel ungues animalium confricabis, Etrurfus 2.55. Animalium (inquit) ungula afperitate ac longitudine itinerum deteruntur $\&$ impediunt inceffum, \&c. Et mox poft curam apoftematis intra ungulam orti, Subtritos pedes fomentabis aqua calida, axungiáç ueteri perunges; deinde tefta can denti decoquis, oleo poft $\&$ fulphure pariter contrito lana candenteleuiter ures per triduum. Siue. ro contuderit, fanguinem de corona emittes, $\&$ calida fomentabis, axungia ueteri perúges : ouinum quocs ftercus cum aceto permifcebis $\&$ imponis : quamuris alin caprinum efficacius credant. $V_{n_{2}}$. gulas his temporibus (inquit Camerarius) fímo bubulo maximé folidari conferuaríg credunt; cuius rationem funt qui apparere negent:fed adiuuari fimo bubulo ungulas compertum putatur, Parans, tur etiam ad has uel conferuandas, uel etiam reparandas, medicamenta quadam unctionum, Huilf modi medicamenta adhibere noftri uocant ynfblaben:Vide infra capite quinto, \& hoc ipfo capite infra ubi de ungularũ cura $\&$ morbis tractabiț. T Vngulã fubradere Veget, dixit, cauare trel fqua

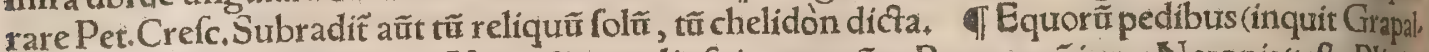
dus)foleas è ferro addimus, at Nero olim mulis fuis ex argêto:Poppea cóiunx Neronis(tefte Plinio) delicatioribus iumentis fuis foleas ex auro quoq induere folebat. A prill quotidie mane in camp per quofuis gurgites equitato, item IMaio + fic ungula \& cornu firmantur. V tile aute fuerit foleasex ferro inducere cum noua eft Luna, \& cum in Virgine uerfatur, Obfcurus, Contingit aliquandour nix inter foleas $\&<$ ungulas equorum recepta congeletur, nof tri uocant ymfollen, id ne fiat quidam hoc pa€to cauẽt:fafcias ex marginibus pannorum pracipuè fectas, nouem ferè digitos longas, aqua ardente madidas ferreo inftrumento inter foleas $\&$ ungulas mane equitaturi infarciunt, \&f quid forte promineat, abfcindunt:ita ab hoc malo fecuri totum diem iter faciunt, uefperi rurfus auferît, Cofmetica quadam, id eft qua ad ornatum \& pulchritudinem in cor= pore equi ab equifonibus fiunt.

Caput equi macrefcit(inquit Albertus) \& ficcatur, fi ante da abluatur $\&$ fricetur. Collum autem eius craffefcit, $\&$ crines melius crefcunt, fi aqua calida ape ac diligenter iuxta fcapulas humectetur, $\&$ crines digitis fcalpantur $\&$ prope caput: fed frigida, 80 calida aqua:quía caput debet effe gracile. Si menfe Maio teneras fagi frondes equis in cibumder deris, pilus elegantior cum aliâs tum colore nafcetur, $\mathrm{Ob}$ fcurus, đEquís é cicatrice cur pilini tur, nós candidi, A riftoteles quarit fectione 10, problamate 29, \&31. Cur equis pili per cicatricesoli s ri queant, hominibus non item, A phrodifienfis libro primo problemate 46 . Pilorum in colore us rietas, itemó oculorum (ut fi unus albi coloris fuerit, alter nigri, uel unus albus $\&$ alter uarius, $\&$, mutari non poffunt, quia contingunt in ipfa generatione, Ruffius. Vt pili renafcantur in cicartion bus, uel qui aliter effluxerunt, Rufius 163. V egetius 1.63. Cur cicatriciburs equorum infperfustorn dei puluis faciat ut pili non albi, fed cxteris unicolores oriantur, A phrodifienfís inquirit lib mate 45. Pili concolores nudis cicatricum areis reddentur hoc modo, ut fribir Tiberius : Hord pinfiti fextarios duos fubigito, 8 adiecta nitri fpuma, exiguróg fale, panes formato, dein in funnum dimittito, donec in carbones redígantur:poftremo tufos tritosǿs permifto oleo ulcerum cicatricbus oblinito:hoc diebus uiginti facito . Aliud ad idem medicamentum, \& alia ut pili nafcantur, ctel

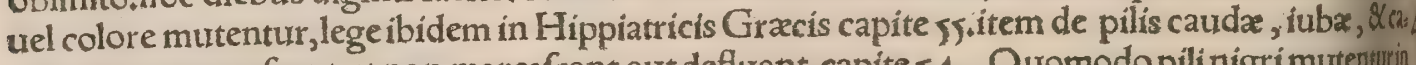
pronarum, ut crefcant, et non marcefcant aut defluant, capite 54. Quomodo pilinigri mutenturi) albos Rufius docet capite 164 . Talpam in aqua difcoquito, 8 ius illud, poftquam triduo feruatun fuerit, rafis prius locis ubi pilos albos enafci uoles, illinito, eoćc abluito. Vide nonnihil fupra capiti fecundo, ubi de coloribus equorum egi. Sicubi pilos in equo albos defideras, loco rafo fel caprini inunge, Author obfcurus. Feces feui in lucernis ufti,illita partibus glabris pilos eliciunt, utqui dam fcribit. Si album pilum nigrefcere cupias, Atramentl futorĭ fcrupulos feptem, rhododapints fucci frupulos quatuor, fepi caprini quod fufficit, pariter temperabis $\&$ uteris, Vegetius 2,64 nos locum planè corruptum emendauimus ex Gracis Hippiatricis cap. \$5. Si ediuerfo albos pilos fazer uolueris, cucumeris fylueftris radicum libram unam, nitri fcrupulos duodecim, in pulueres cogis heminam mellis adịcies, quibus permixtis uteris, Eadem in Gracis Hippiat, loco iam citatopallo y aliter leguntur, Ve equis hirfutis pilli nafcantur molliores, Hippiatrica 94. Si in tibjis uel co exulcer ati pili forte implicentur, pfilothra adhibentur, qualia defcribit Camerarius in Hipuocu mico furo. Haud fcio quali pilorum affectione uitiatos equos Germanicè lego uocari ftr wufth suigi De feabie $\&$ pruritu, uide in fra inter morbos unionis folute. Si pili marcef cunt tel corrumpunturiin extrema parte cauda, remedia, Hippiatrica ss. De fluxu pilorum cauda, Rufius 161. De lan! caudx, qui morbus eft inftar cancri, Idem 162. De pilorum in cauda rigore, hyftrichidem uocant, fetis fuillis fimiles pili enafcantur, Hippiat. 59 . Cauda prolixa 8 denfa pilis præcipurum equi orna" mentum eft. Huius igitur incrementum ftudiof ẻ procurabitur:quod fiet, fi crebrò humectetur fin gida, uel etiam fero liquidiore: hoc enim pręfentem habere efficaciam quidam affexunt, Camerarius De purgationealui.

De purgatione qua per farraginem fit, fupra docuimus in ciborum mentione. Abfyrtus capp

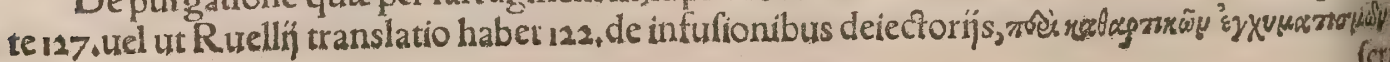




\section{DeEquo. C. Lib. I. 493}

fribit:Catulum lactentem iugulatum deglubunt, uifceribus $\dot{\alpha}$ extis exenteratum eluunt, dein olla mandant, ut aqua tantifper incoquatur, duin corpus offa relinquat:cuius iuris, adiecto melle, per tri duum heminas binas quotidie fatis êf infudífe, Decocto fuilla itidem praftant, aut candidi gallina cei iure: ea maioribus noftris memoria tradíta funt. Nos îs ufi fuimus infưfionibus, tenuem tithy mallum incoquentes in aqua, aut peucedanum, aut abfinthium, aut minus centaurium, aut arifolo. chix radicem codem modo decoctam, aut fylueftris cucumeris radicem ex nitro, ut prius fcriptum eft:aut colocynthidis Aegyptia femen cum pulpa cruda reficcatum:fit aquix modus fextarius, quo, tidié́s feptem dierum fpatio per os infundatur. Optimum fuerit fylùeftrem cutcumerem ex nitro de fudiffe, Hac ille. Et capite un, in translatione Ruellị, Tufam (inquit) in tenues particitlas fylueftris cucumeris radicem infolathus, dum flaccefcens inarefcat:rurfumç ut in tenuiffima leuigetur, con tundimus, adiecto túnfi nitri pari modo; falićp permifcentes uorandam obícimus Porrò grauidis

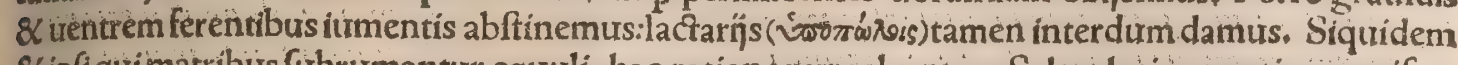
\&ipfiqui matribus fubrumantur equuli, hac ratione purgabuntur. Salem huitus gratia permifce mus, üt animal hoc illectum condimento, deiectorium medicamen non afpernetur. Melius cedet ff

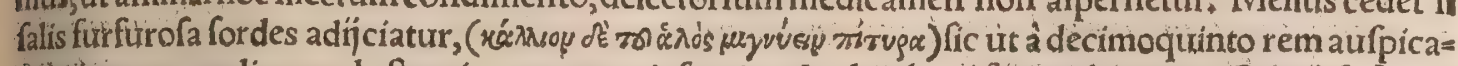
ti, quitinto quoģ die, quod eft ter in eo temporis fpatio, ad calendas ufos prabeamus. Qurod fi fuerit ita factum, nec pfora nec fcabies inuadent, cxteræós ualetưdines arcebuntur. Audio gentiana etl. am exhibita purgari equos, IV tile eft equum(inquit $R$ ufius) femel in anno purgari, ut $8<$ firmior ualetudo \& ipfe uiuacior fit:quamobrem aliquos hic purgandi modos aperiam. Purgatur ergo e quus farragine, ut Romæ $\&$ locis uicinis fieri folet. $\mathrm{Pafcuntur}$ cnim equi herbis, quas farraginis no= mineuocant diebus quindecim, quo tempore abunde purgantur:dènde uéró eodem pabulo etiam pinguefcunt. Herba genus in Apulia trifolium uocant, (trifolium uulgare, fiue lotum pratenfeni interpretor) quod femel fatum trieninio durat. Qurotannis autem uiridem $\&$ teneram herban pioducit, qux per totam xftatem uefca manet. Huius paftur non minus quàm farraginis purgantur fi= mul $\&$ habitiores fiunt. Porro in locis frigidioribus, quales funt Gallia, Germania, Anglia, \& fimi= les,quroniam pafcua humidiora, magisć cuiridia $\&$ tenèra funt, equi pratenfibus herbis inirifice $\&$ purgantur \& pinguefcunt. In quibus ueró regionib, melones uel pepones abundant, hos fructus minutatim concifos equis exhibent:purgant enim mirabiliter, præcipué per urinam; \& pinguiores deinde reddunt equos. Eft \& alia ratio, eaç melior, huiufmodi: Annona per dies quindecim præbetur, ita purgati habitiores mox fiunt. Huic etiam praferunt eam qua truis fiue racemis abinde ex. hibitis purgatio fit:qux uulfos etiam(morbum pulfiuum)iuuat; $\mathcal{Q}$ unice præomnibus remedijs cu rat, Similis huic modus elt, quod ad purgationem equorum, ficus affatim edendos obieciffe. Sunt $\&$ alia quadam purgandirationes, qux tamen corpus non augent, minusćs tutó adhibentur, utpoté magismedicinales:ex quibus unum \& alterum folum proponam, reliquos induftria peritorum hus ius artis relinquo. Tincx uel barbi pifcium interanea omnia, fiue de uno, frue etiam fio pus fit de plux ribus pifcib.minutatim incifa cum optimo uino albo mifce, $\alpha$ per cornu in gulam equi infunde, pur gabit mirum in modum. Aliqui filiginem(fecale intelligo: fic enim flíginem accipiebant fuperioris feculi homines indocti) in aqua fluuiali diti coquunt: fed praftat non diu coquitita ut non rumpatur cortex, \& minus faftidiatur ab equo:deinde ficcatam equio annona loco in cibo prabent: mirabili= ter purgat, \& lumbricos etiam expellit. Hoc rènedium utile quidem eft, modo equi admittant: fape enim diebus aliquot afpernantur $\&$ abftinent. Curandum eft autem ut equius qui herbis purgatur; contineatur fub tecto, \& operimento aliquo laneo tegatur, Hæc Rufius. Cannabis aqua firmpta aluo itumentorum prodef, Plin. बQua ratione cyclocurentur animalia Veget, defcribit 2, 6. his uretbis: Memineris autē omnes ualetudines capitis, pracipué ưeterès $(\&)$ periculólos, cyclo oporteré curari:Cti haec obferuantia $\&$ ordo eft adhibendus, Tridtio ab hordeo abftinebitur animal, tempe rabitur etiam mollibus cibis, poft diem tertiam de dextra ac finiftrajprout atas aut uries uel ualetr. do permiferint, de matrice(fic dicta uena) fanguis auferetur, Quo facto per tridutum uiridi cauliculo rumac lactucarum fuftentabirtur cibo. Primo uno die à cibo cum fuftinebis $\&$ aqua; nono autem die offas caulium cum liquamine 8 oleo optimo temperatas non minus ưiginti digeras, cui nihilomi nuis lactucam dabís in cibo ter in die. Poftpotionem bibere femper incipiat; Si urero uenter uehe: menter folui incoeperit, caulium offas dare defiftes: fed dabis paleas $\&$ furfurés, ita it fequenti die pe nitus nihil manducer, fed folam aquam percipiat ad bibendum, ac poftero die inducatur in cellam balneicalidam $8 x$ fudet. Opus eft autem diligentia ut reducatur celeriter de calore; ne interclúfo fpi. ritu pereat:tunc extergetur diligenter, uínóç \& oléolargiter perfricatus, accipiet cum nítri pulưe. re folia raphani confperfa, quantum comnodum eft, Poftmodum cum radicibus cucumeris afinini uiridis minutatim concifis oleum optimum mifces, 8 in uafe nouo ita decoques ut tertiam perdat: ex quo fingulas heminas per capita animalium per triduum dabis; ut potio uentrem refoluat. Sed fi ultra modum fluere coperit, lenticulam $\&$ hordeum pari menfura friges, $\&$ de his fingulas bilibres per díes fingulos cum furfure ec paleis dabis. Quinç itaç diebus operam refectionís eius impendes; \&leuiter exercebis, ut intelligas quantum uires corporis fanitaş̧́ profecerit. Poft hàc eum pro ar bitrio defpumabis. Sequente die caput eius purgabis exorica (uox corrupta uídetur) uel radíce Dià haria quam Artemifiam dicimus; fi hac non fuerint, ex liquiamine optimo cum oleo mifto cuius cea 
pur pedesq́g connecris, cum bene purgatum agnoureris, foluito : butyrum ex oleo roleo folưturum fundes in nares, ut illo purgationis mitigetur afperitas, ita ut fingulæc cotylæ fingulis naribus infun dantur, Si fupradichx potiones non foluerint uentrem, mellis, hellebori albi pondus unius denarĭ hemina dulcis uíni bene tritum in potione recipiat, uel certe fcammonix pödus duorũ denariơtur diligenter tritæc cum dulcis uini hemina fimili ratione diffundes in fauces. Quòd fi uenter ultra mo dum diffolutus difcrimen importat, anagallicum fucco ptifanæ ad reftrictionem ipfius dabis, lentic lamćs $\&$ hordeum frixum, fingulas bilibres cum paleis $\&$ furfure prabebis in cibo. Ad ultimum, tes quæ in caufa funt, finapizabis diligenter, finapizatum cautêre ferreo, tuel quod utilius credit cuprino combures, ufta curaturus ex more, Potionem quogs ex antidoto polychrefto per dies plo mos dabis, \& exercebis leuriter, \& ad cibaria ipfius aliquid per partes femper adiunges, donec adp finam confuetudinem reuocetur. Infanabiles ualetudines cyclo affirmantur poffe curari, id eft, in ni corroborari:Caduci cyclo curati uruntur in capitełmorbidi urerò, dyfenterici, coriaginofi, ortho, pnoici,ftrophofi, cyclo curentur in renibus, Hucufge Vegetius.

De fanguinis miffione.

Phlebotomum hoc eft ferreum inftrumentum quo uena inciditur, Vegetius alicubi fagittam to

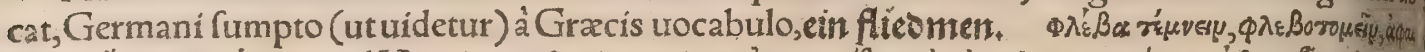

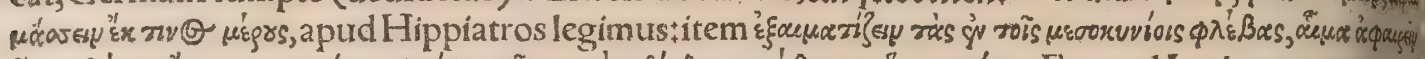

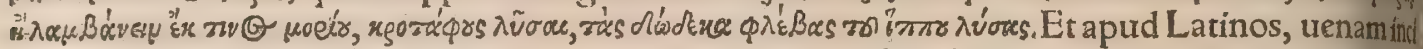
dere uel fecare, ferire; apud Vegetium etiam percutere, pulfare: fanguínem detrahere, uel mittere, mittere, auferre, laxare, minuere, fubtrahere, tollere;deplere etiam Vegetius dixit $\&$ phlebotomate Et alibi, Vena icta fanguis acontizet, poft decurfionem fafciola ligabis uenam. De uenæ fectio \&. uenarum à quibus fanguis detrahi folet nominibus qua dam docui fupra capite fecundo. Plo bus membris ac morbis (inquit Vegetius) generale remedium diligenter oportet exponi,quoodi cipuè in fanguinis detractione confiftit, fir rationabiliter pro tempore $\mathcal{Q}$ uriribus animalium, \& æquitate perfecti mulomedici adhibeatur induftria. Qui fi ignarus fuerit huius rationis, non fo per detractionem fanguinis non curabit, uerum etiam periculum iumentis frequentiffimè gen bit, cum uita uirtus'́ç animantium confiftat in fanguine. Rurfus tempefítue detraçus fanguis, pori præftare adfolet fanitatem, Et rurfus 2, 40. Conuenit de ceruicis curatione díçuro, obff tionem indicare phlebotomi, (phlebotomix:) quia circa ea loca frequenter operatur. Detraci Fanguinem animal à cibo abftinebis $\&$ potu, aquali loco conftitues, tunc locum fupra ceruicê teneat $\&$ adfrtingat ad normam, ut uena facilius appareat, Deinde furpra laqueum de finiftrę m pollice uenam deprimas, ne ludat, tum fagitta tangas. Duxæ autem uenæà capite fummo defcen

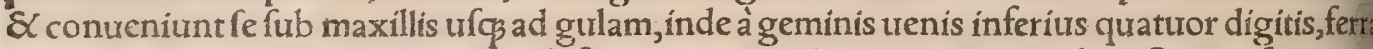
tum deprimis, ne in gulam mittas, \& bifurcum tangas, \& iumentum occidas. Statim fagittam bus digitis tenebis, nec plus ferri imprimas, quàm extra digitos eminebat. Nihilominus etiamm no digito manum tuam moderando furpende, ut fit leuior, ne uehemêtius imprimas quàm opo quia non plus debet quàmm mucro defcendere. Si parum aptè proftuat fanguis, itumêto foenum autt aliquid quod manducet. Agitatione maxillarü plus fanguinis (de) uena profluet, $\mathrm{Harc} \mathrm{V}$ Quæ de phlebotomia equorum in genere fcripferunt $A$ bfyrtus $\&$ Hierodes, $\&$ de uenis quibu priuatim, leges in Hippiatricis Græcis capite nono:In inffem capitis decimi inferiptiones ha $\checkmark$ trum optima equis fit uenæ fectio, Quód interiores femorum uenas fecare non conducat: \&

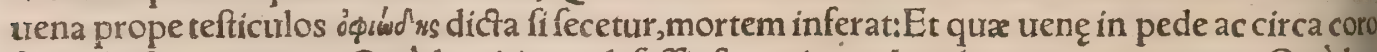
fecandæ fint, quæ non:Q uoò ex itinere defeffis fanguinem detrahere non conueniat: Quoòd po cifionem uenæ non oporteat diua â potu arcerę $R$ urfus quod equo ex itinere feffo non fít feca na, \& quomodo tractandus fit. Caftratorum fanguinem non detrahendum. Hippocrates dep romia equi tum in genere, tum circa ceruicem $\&$ temporał De inflammatione ex phlebotomias na fecta immodicèjlanguínem fundat. Rurfus ad inflammationes ex phlebotomo, \&' contra on inflammationem. Vt fanitas equi feruetur (inquit Petrus Crefc. \& ex eo repetit Rufius) uen confueta quater eft incidenda anno, fcilicet uere, æxftate, autumno \& hyeme. Equis nunquan bet minuide ftontris, feu de peciore, nec de coftato feu de flancis, quia tales minutiones requiruit fuetudinem $¥$ nificaufa aliqua $\&$ neceffitas poftulet, $R$ ufius. Ad morbos particulares in equis,a \& mulis fanguinis detractione utendum eft, Hippocrates in Geoponicis. Pafce igitur fub uere uofarraginemolli Cornipedes, uenamós feri, ueteresós labores Effure afpecta nigri cum cruoris, Nemefianus. Equus ut praferuetur à diuerfis affectibus, ut minimum ter anno fangu mittendus eft, authore Mauro, primò circa finem A prilis, fecundo circa principium Septembr tio circa medium Decembris.Mutari tamen hæc debent pro equorum qualitate $\&$ locorum in bus degunt. His autem fignis cognof citur an equus uenæ fectione indigeat, fir rubeant oculi, fit plus folito turgeant, $f_{i}$ cutis $\&$ crines pruriant, fi pili cadant, fi in dorfo equi tumores aliqui rub di appareant, fi equis non bene concoquat, Hac cum apparent, principís obfta, \& fanguinem te de uena organica equi qux eft in collo ( Dic bal $5 a b e r$ ) idós fatis abunde fi uires equi patia Quòd fi à phlebotomo uena infletur, impone folia uitis alba cocta, fic tumor demittetur, Hæx fius:A lia fanguinis abundantis figna lege apud eundem cap. 41 , Pleriq̧ ueris tempore (inqu 


\section{6 \\ De Quadrupedibus}

Cephalalgicis autem, arpiofis(appiofis forte, ut $2,10^{\circ}$ ) infanis, cardiacis, caducis, phreneticis, bifturi cỉs, ficardicís, rabiofis quoquo modo pracipitur de auriculis fanguinem demere. Veruntamen me lius eft de temporibus, qux in dextra ac finiftra funt parte, detrahatur, id eft fub cauatura temporí tribus digitis ab oculo interpofitis inferius uena perquiritur, \& ex utraq emittitur fanguis, Eis ur, rò quibus fuffufio cótingit oculorum, uel catera uitia quæ oculis nocent, inferiores uenæ fub oculis pofita, qua defcendunt fub angulis oculorum inferioribus, quatuor digitis inferius quàm ocul funt, inciduntur. Quibus quidem faftidium inhæret, uel arteriarum uel faucium tumor, uel pragra uatio capitis, de palato auferendus ef fanguis. Quibus autem pulmo eft in caufa uel iecur', trel catera qua his uicina funt membris, de pectore minuendus eft, ex uenis qua pofitæ funt in dextra ac finiftra, ubibrachiola coniunguntur, \& flexura fit cum armus plicatur. Quibus quidem armus eff in caufa, de brachiolis fanguis minuatur: quæ uenæ pofitæ funt interius, ubi centuriæ, id eft mu. feulibrachiolares funt, fex digitis fuperius quàm genu, tribus uel durobus digitis inferius đo centur, riæ. Hæu venæ fagitta percutiãtur, fed cauté modeftẹ́ tangantur, propter debilitatem animalisłquia hæ commix ta funt neruis. Quibus autem articuli in caufa erunt, uel fi articulus infertus uel intor, tus furerit, uel aut aquatilia habuerit, uel quiduis fimile in articulis cótigerit, de fubcirro fanguis fub, trahi debet:quæ uenæ pofitæ funt inferius quàm articuli tribus digitis fub coronam:qux uenæ cum furmma cautela tangendę funt, quia articulorũ coniunctx funt neruis. Creciaco uel fi bafim molierit, de coronis rectis tollitur fanguis, Hac Veget,1.2 s. Quibus autem iumentis uel fuffufionis uitio, vel per uoluntatem excruciata ungula fuerit, uel quibus remorata bafis longi temporis claudiginem fe cerit, his quomodo incidenda tena et reliqua cura adhibenda docet capite 26 . Et mox capite 27 . quil bus ín morbis 8 quomodo incidenda fit uena fub cauda, quatuor digitis ab ano, ubi pilos non ha bet, in media caudæ diuifura, loco prius cæélo tabula aliqua non ponderofa, quoufó fe uena demion ftret:erigenda eft autem $\&$ refupinanda cauda ad lumbos. Equus podagricus curatur inter dia remedia fi fanguinem tollas é palato non multum, \& rurfus poft f́eptem dies ex pofterioribus pedir

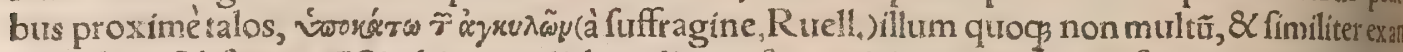
terioribus, A blyrt. बI Si, ubi antea diebus aliquot fponte ieiunarint, mox in furorem uertantur, fan

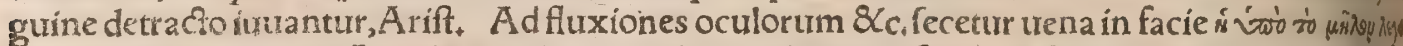
whrs, A bfyrtus capite u. In palato audio duas aliquando uenas feriri, ut fanguris per gulam defiuat,

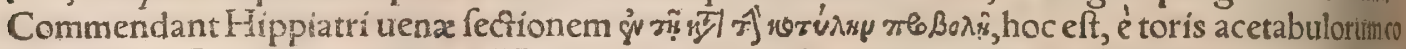
xendicis, ut Ruellius uertit. $\quad$ IVenæ in equo interdum(inquit Albert.) fcinduntur per tranfuer, fum, ira ut lignum ferra fecatur: ex quo ne fanguis uel fuxus ad partes debiliores, ut oculos, pedes aut alias decumbat, incifio hunc in modum adminiftranda eft. Pellis equi, ubi incifio fieri debetprih mum calida foureri, \& à pilis radi, deinde manibus diu fricari debet; ita ut aperiat̃ (eleuetur)aliquants tulum: \& fic altior pauló circumiacente pelle, findatur fecundum longitudinem urenę qua findenda eft:tum uena à carne feparet et findatur: quod fi craffa et plena fuerit, detrahat ab ea fanguris quanú fatis eft: Mox eleuretur cum bacillo ex ligno molli ad fpatium duorũ digitorum: \& fic filo molli tarint que ligetur. Facta pracifione capita uenarum ex utraф\$ parte aliquãtulum adurantur: \& 2 tam filut quàm capita uenarum extra uulnus dependeant, ut à urena qux inter ligaturas eft putrefacta leuitur abftrahi poffint tum fila tum partes abfciffæ uenæ.Quód fi fanguis in aliqua parte, \& pręcip de collectus furerit, anteós educatur, debet uena ex inferiore parte ligari, \& non ex ea qux ad rigitur: \& ita detrahendus eft fanguís, Hæc Albert. Vide etiam Rufium ca, 45. de ferratione fell lat queatione uenarum. Venarum laqueatio feu incifio(inquit $R$ ufíus) omnino uitanda eft: quia

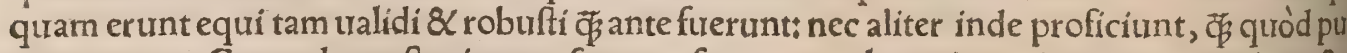
res apparent. Caurendum eft etiam ne fecones(fetones)aut laquei unquam ponantur in pectore, caufa omnino neceffaria poftulet:nam grauis inde fit equus, \& pectoris grauitati obnoxius, De cauterins

Coquere \& decoquere, pro adurere: \& cocturam pro aduftione, apud ueterinarios Vegetium \&

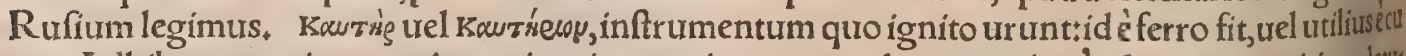
pro. Adhibetur equis cauterium etiam in curatione per cyclum, pracipue ad ueteres capitis ualettru dines, ut fuperius dixi ubi de purgationibus alui fermo fuit. \ Chirurgia appellatur quodcuncey fecatur ferro, uel cauterị’s uritur:quæ cum fit omnibus membris animalium, præcipué tamen capis tis neceffaria eft medicina, Veget, In animalium curis ac medicinis(inquit idem 1, 28.) duplex re. medium authores effe uoluerunt;minutionem fanguinis, per quam conftricta laxantur: \& uftion? cauterï, per quod laxata firmantur. Sed cum phlebotomi ratio euidenter uideatur expofita, cau quocs, licet nouiffima cura fit, aperienda uidetur utilitas. Nam aduftio laxata conftringit, inflatal

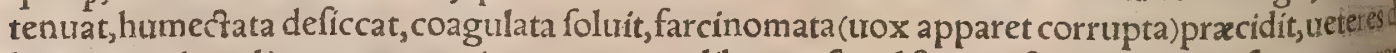
lores emendat, alienatas corporis partes ex qualibet caufa ad fatum fuum reuocat ; fuper naturam excrefcentia, fublata $\& C$ adufta crefcere non patitur. Nam cum candente ferro ruperis curtim, uit omne concoquirur atç maturatur, $\&$ beneficio ignis diffolutum, per foramina qux facta funt ef: fluit cum bumore: atç ita fanatur paffio $\&$ tollitur.dolor. Poft qux cicatricibus claufis , conftriciof \& robuftior redditur locus, ac prope infolubilis cutis, Sciendum uerò cuprina cauteria plus effecti ad curandum habere quàm ferrea. Præterea fi in capite morbus eft, inuritur ceruix: fi fubretnali 


\section{DeEquo. C. Lib. I. 497}

eft, lumbis ignis adhibetur. Interdũ aưt puncta infiguntur, interdư ad fimilitudinem lineæ candens deducitur ferrum, aliquando urelut palmula fiunt. In hoc enim laudatur mulomedici ingenium, fi ita animal cauterio curauerit, ne deformet, Pro locis autem in quibus eft paffio, \& pro pellis æeftimatio. ne, cauteria uehementius imprimuntur aut leurius. Memoria autem retinendum eft, quaffaturas $\left(a_{z}\right.$ liâs fracturas, )emota uel extorta, aut eiecta de locis fuis, uri peniturs non debere: nam perpetua debi litas confequitur:fed melius eft cum locis fuis repofita fuerint, \& ligaturis diligentius communita, at que ita naturæ induftrix'̧́ beneficio corroborata, chalafticis unctionibus $8 \mathrm{r}$ malagmis , poftremum caufticis eadem percurare ad fpem perpetura fanitatis, Quod fpecialiter admonendum eft, ne mulo medici feftinantes, dum foco curare cupiunt, animalia debilitent aut detorment, cum phlebotomis, potionibus, unguentis, fyringis, medicaminibusḉp diuerfis ante fit tentanda curatio \& 2 fi nihil profe, cerint, ad extremum ignis adhibetur, Hac Veget . De cauterïs adhibendis in febri, opifthotono, nephritide, \& ijs qux paraprifmata uocant iuxta poplites: \& $c$. \& de cauteriorum uftionibus fanan= dis,qui legere uolet adeat Hippiatricorum caput 97 . in quo etiam particulares aliquot compofitio nes medicaminum caufticorum ex calce, chalcitide, \& $\&$. prafcribuntur: $\&$ apud Vegetium libro 4. ca.14. Si diuturnam equi fanitatem defideras(inquit Rufius) ita $q$ gall $x$, furperoffa, fpinella, ierdx,

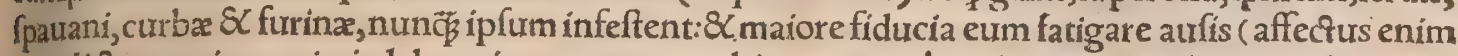
iam dicros equí præ nimio labore incurrunt) curabis ut equus à perito eius artis homine decoqua tur in locis ubi uitia ifta oriri folent. Si equi coquantur cum funt bimi uel trimi, urel ante $\not$ f feparen tur de armentis, ftatím cum iumentis per pafcua liberê dimitti debent, non adhibitis alijs medicamen tis: fic melius curabuntur, $\&$ pulchriores apparebunt coctura:ros enim ignem, aduftionem, $\&$ pru ritum mirabiliter remourere, \& cocturas curare poteft. Sciendum eft etiam quód cauterium eodem in fatu, in quo inurenerit equum conferuat:quamobrem fi equus alicui ex prædictis urithis obnoxius lit,non debet ignis remedium adhiberi quoufós dolor ceffaurerit, Hæc Rufius. Cauteria felicius ad hibentur uere uel aftate, Abfyrt.item decrefcente Luna potius quàm crefcente, Rufius. Equum tis midum $\&$ pigrum ure in flanco in modum rota, $\&$ fac cruces $\&$ punctos in els: fimiliter $\&$ in renib. \& quatuorp ulfibus: \& panicum edendum obijcito, \& in loco calido diligenter cuftodito, Rufius Medicamentum caufticum ad neruorum dolores Vegetius defcribit capite ulttimo, Cauteria con. fulunthippiatri in diuerfis morbis, comitiali,ftropho, dy fenteria, orthopncea, hydrope, abfceffibus motbifarciminofi, malandríns, id eft uulneribus ceruicis, coriagine, $\&$ radio fracto. Cauterium ad hibetur tumentibus tefticulis, fi alia remedia $\&$ fanguinis miffio non itruant; fed curandum ne teftes attingantur cauterio, Hierocles

De morbis equorum $8<$ curandi ratione quadam in geftere.

Nonnullos equrorum morbos cognofcere difficile eft, cum eadem fape figna diuerfis in morbis appareant: Verbigratia, non folum febriens capite in terram demiffo anhelitum ducit frequentio. reni, fed cum alí etiam dolores urgent, Rurfus opifthotonicorum nota traduntur, qux etiam proue niunt î̉s animantibus, quæ longior infolatio aut diuturnus labor ad imbecillitatem perduxit. Ea nó poffunt infiftere, fed commiffis in unum pedibus concidunt. Non ergo putabis ipfe dolorem effe ventris, aut tormina:neç ab ijs medendi rationem trahes, fed conueniens morbo remedium adhibe: bis, Multa igitur germanarum agrotationum figna fimilitudine confunduntur : multa quocs pror $=$ fus diffidentium indicia facile deprehendes, fi diligentius animaduertas, Pelagonius. A Aures etiã fri gidxindicant morbum. Signa diuerfa equí uirtutes aut uitia aut morbos nofcendi Rufius per $a_{\star}$ phorímos prafcribit ca +7 .unde nos quadã recitauimus fupra in $B_{+}$in electione equi. Equro ferè qui homini morbi, præterq̧́ ueficæ conuerfio, ficut omnibus in genere ueterino, Plin. Homines ufu pe rititotidem fere morbis equum, atç etiam ourem infeftari, quot hominem referunt, Ariftot. Tres acuriffimi morbi equis $\mathcal{S}$ alip's querum folidæ funt ungulæ accidunt, uefica, conuerfio inteftinorum qua ileos uocatur, $\mathcal{Q}$ cardiacus:creteri urerò morbi ad dies aliquot differunt. Solet tamen etiam crithiafis, \& fuffocatio, \& uentris dolor illico perimere, nifi prafens remedium auxilietur, Hierocles ca, 33. Frenes morbum urocant recentiores, qui uel infra duas horas aliquando occidit. Sunt $\mathcal{Q}$ parifth mia periculofa. Hernia equi ex calcitratu alterius ad inguen orta, tertio feré die occidit. Strangu lina intra duodecim dies uel occidit, uel tranfit in moruellam. Malis nifi citò fuccurras in afthma tranfit. Afthma, ut aliqui putant, incurabile eft. Malis etiam qua ficca appellatur \& rupto pulmone fit, incurabilis eft + articularis uerò difficilis curæ : at fubtercutanea $\&$ humida facilius curantur. Morbialí afcititÿ funt, alí naturales quos foetus in utero experiri incipit. Frequens opinio elt (in. quit Veget.)Barbaricis equis nulla adhilbenda medicamina, $q$ uf $q$ p adeo natura beneficio agroti conualefcant, ut eis nocitura fit cura . Sed falfa erat ifta perfuafio. Nam quanto fortiora membra funt, tanto diutius uiuunt, fi ex aëre urenientibus medela non defit. IIn equis $\&$ omnium iumen. torum genere, indicia animi aures praferunt, feffis marcida, micantes pauidis, fubrecta furentibus, refoluta æaris, Plin. Continuò animal quod ualetudo tentauerit (inquit Vegetius) triftius inueni tur, aut pigrius, nec confureto utitur fomno, nec folito fe more tranfuroluit, nec requiem ut affu= mat accumbit, nec deputatum cibum affumit ex integro $\&$ potum aut intemperantius accipit, aut omnino faftidit, ftupentibus oculis, auribus flaccidis, erecto uifu, turpi pilo, exhaufta funt ilia, fit fpi= na rigidior, anhelitus crebrior aut grauior:inceffus ipfe, quo maximé notatur, fegnis ac nutans, Cur. 


\section{De Quadrupedibus}

hurufmodi figna in iumento unưm uel pltura confpexeris, ftatim illud feparabis à cateris, ut cốtágie nem non inferat proximis; \& facilius in folo iam caufa morbi polfit agnofci. Si diligenter habitum polt unam, fecundam, uel tertiam diem ab illa moeftitia fuerit abfolutum, nihilç̧̧ refederit in corpore ipfius quod putetur ambigurum, fcito ex leuioribus caufis illam ureniffe triftitiam, 8 animal confue, tudini priftina effe reddendum. Nec explorandi omittatur intentio: nam frequentius infpici debet \& cautius, quod femel c œpit effe furfpectum, Hucufç Vegetius. Cadunt in morbis nonnullis equi ut caduco inde dicto, \& eo quem frenes uocant: \& malide humida, \& morbo acuto ex pabulo con. tracto, quo laborantem equum noftri uocant $\boldsymbol{x}$ \&d bom füter, uidetur autem crithiafis elfe : nam in hac quoos cadunt, \& erigi recufant. In podagra etiam fere ftare $\&$ ambulare nefciunt: fi coguntur, claudicant: fxpe fe prö́ciunt, ut in digéfta ex hordeo animalia, qua propter dolorẽ non coquuntci:

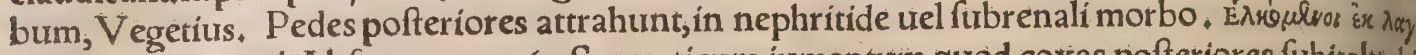
vou, legunutur apud Abfyrtum cap.62. Syrmaticum iumentum quod coxas pofteriores fubitoftrahit, $V$ egetius 3.22.Sed figna $\&$ fymptomata unde ad certiorem morborum cognitionem ueniamus ac curarè $\&$ ordine tradere non inftitui, fat fuerit occafionem aliquam praftitiffe alĭjs, qui hæe forte ma* gis defyderant. Venetæ factionis homines \& Prafinæ, equorum fubinde retrimenta olfactare con fueffe leginus: ut hinc pernofcerêt, $\tilde{\phi}$ facile cibos conficerent, bonã eorund $\tilde{e}$ habitudinem fic depre

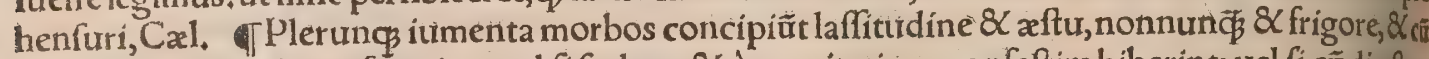
fuo tempore urinä non fecerint: uel fi fudant, $\&$ à concitatione confeftim biberint: uel fí cũ diuffete rint, fubito ad curfum extimulata funt. Frigus quantopere noceat equis, dictum eft fupra in rys: voís. Prohibet Rufius ne ferro tangatur pars ulla equi, qux alicui figno zodiaci refpondeat,ini guto tum temporis Luna fit. Si equus doleat ex retentione urinæ ueficam inflantis, equus cum aligua equa per ftabulum liberè permittatur abire,fićḉ̧ neceffario proưocabitur ad urinam: Et notaquod hoc remedium ad omnes dolores utile reperitur:quia uoluntas coitus ualde naturam corrobotat\& confortat, Crefcentienfis. Suffumigantur equii in diuerfis morbis, ut dyfuria uel ifchuria, tetano, malide, ftrangulina ex frigiditate capitis, $\&$ morbo infeftati apud Crefcentium qui accidit equiscin ftatim à calore refrigerantur. Sudoris remedium adhibetur non paucis : farciminofi ad fudorem ufcs ambulare coguntur: hydropici bene operti mediocriter exercentur ad fudorem. Multum equir tantur etiam tetanici, ni fallor: \& quí ifchuria laborant, \& qui r rో屯 à noftris trocantur. Podagriciam bulando minutatim exercentur loco ficco donec fudêt: In Gracis Hippiatricis opertos ad fudorem ufós paulatim agitari lego. Inambulatio $\&$ lenis curfus conuenit equo ex urinæ difficultate laborant ti, Vegetius. Perfrigeratus equus, $\&$ qui inteftini peruerfionem patitur, deambulatione et equitario

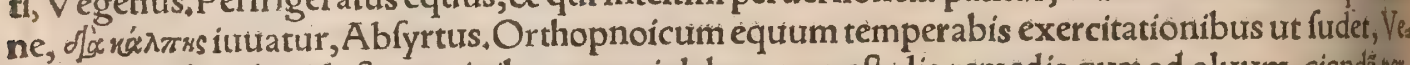
get.Equus ftropho, id eft, torminibus uentris laborans, poft alia remedia qux ad aluum ciendă pers tinent, ad curfum agitur, fed nec diuturnum nec citatum: dein de uacuato uentre rurfus ad fudorem uf $q_{3}$ agitatur, Abfyrtus. बHippiatri radice hibifci frequenter utuntur, Tragus, Sanguinedtato nis fictitio ex bolo non Armenia, forbis contufis, \& caprino fanguine, alịs ş́ diuerfis rebus, ad equo rum \& iumentorum morbos utuntur, Monachi in Mefuen. Sulphuris genus nigricans pharmacus pola noftri uendunt, quod caballinum uocant, non aliam puto ob caufam, quàm quod in equorum remedís locum habet. Aliqui non folum grauior anhelitus fi fit, fed ad omnes uifcerum \& interas neorum morbos prodeffe uolunt, fulfuris uiui pulueres infufos cum paffo: Qui etiam acrius reddut hoc medicamentum liquefacto fulfuread ignem, 8 ita poftea trito $\&$ admifto pabulo, ponderedena riûm trium aut quatuor. Sed hoc ut egregie curari omnia equorum latentia mala affirmant infuccel fu, ita contrariam fortunam equo effe ftatim letalem aiunt. Quare, nifi neceffitate urgente, ab liocici licet abftinebimus, Camerarius. Hedera terreftris ad omnes morbos $\&$ languores equorim pro fens remedium habetur, quæ non folum ab illis mandatur, fed etiam trita inferatur naribus ut fernu tatio prouocetur, Camerarius. Sunt qui radicem uulgo carlinam dictam equo in itinere alligatilit xta os iubent in freno uel lupatis, fic $\&$ uires fuas confertuaturum, \& nullo fubito morbo (in in ures cant noftri) correptum iri. Serpentis caro $\&$ decoctio equo uulfo datur, ítem fcalmato ut trocani. $8<$ ad tuffim ficcam ac lumbricos uentris. Confiliginis herbx (de qua plura diximus alibi) radix, ulel fi ea defit, ueratri nigri, multiplicem apud hippiatros ufum habet:diapyron Græce uocant, In orthos pnoa (inquit Pelagonius) fi cætera remedia non fuccedant, curabitur equus inferta pectoriradicu

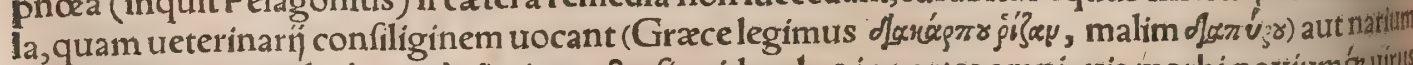

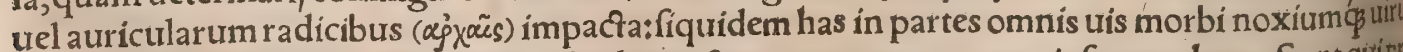
elicitur. V tuntur etiam confiligine in hydrope, \& contra omnes contagiofos morbos. Sunt quitipla fentiffimum aduerfus oculorum albugines remedium putent, aurem fubula tranffuere, facfọóg for

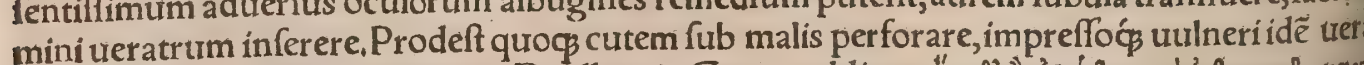

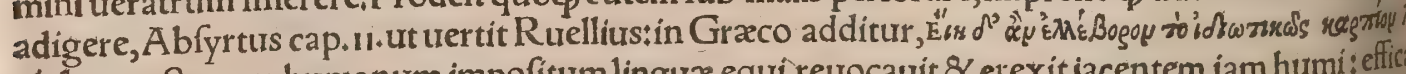
qómevop. Stercus humanum impofitum linguæ equi,reucauit $\&$ ex exit iacentem iam humi: eff cius autem, fi etiam naribus inferes. Iacobus Dondus ad morbos quadrupedum (in genere) ex nio commendat, capram folidam cum corio $\&$ ranam rubram diffectas: Cytifum $+R$ utam per nar cum uino: Semina perfura amurca olei: Sideritin, præcipuè ad anginam quadrupedum libro 26.

Saliuandum pecus, hoc eft, quafi faliua potionandum, ut Petrus Ruellius exponit: \& faliuatif 

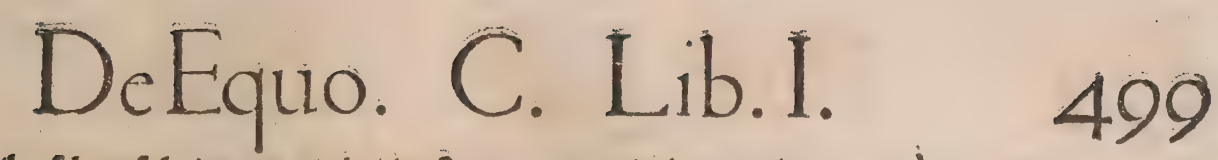

(inquit idem )å quiburdam faluiatum, potionis eft genus quo in iưmentis maximé utuinturr ureterina

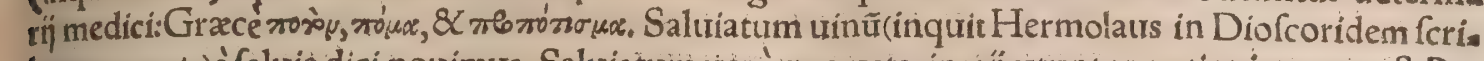
bens ca.9०4.) à faluia dici nouimus, Saluiatumi ureró quo ueterinarí utuntur, potionis genus eft.Po, tòn Graci uocant, ex hordeacea aut triticea farina \& fale, à quo fortaffe faluiaturm. Quidam in Colu. mellam faluiatũ atut falinatũ legere malunt: ab eo falinare uerbum deducitur. Itẽ in Piliniữ 27.11. Pro falinati uoce(inquit)codices antiqui 8 Columella habent, falitiati:eft autẽ ubi et faluiatum fribatur: omninọ́́ potionis genus eft, quo ueterinarị utuntur:à faliua, ut purto, quã ueteres pro fúcco accipe re confueurerunt: nifi quis \& faluiatum, aut falinatum quoç legi probet, à fale. Ego trerò faluriatum non potionem, fed offam uel ut uulgus loquitur magdaleonem effe, qux nó bibatur nec infundatur 10 in os animalis, fed manibus inferatur demittaturó̧ in fauces, collatis authorum locis deprehendiffe mihi urideor. Opus eft autem arida tritá́g in farinam, ut eruum, hordeum, milium; lentem, aut her bam aliquam, liquore aliquo excipi, ut lacte, aqua, uino, fapa, ouo, $\mathbb{X}$ in offam fiue globum formari: fed authorum loca fubijciam. Veterem tưfim fanant duæ libræ hyffopi macerati fextarïs aqux tri. bus:id medicamentum teritur, $\&$ cum lentis minutè molitæ fextaríns quatuor more faluiati datur: ac poftea aqua hyffopi per cornu infunditur, Columella 6,10 . Vocat autem aquam hyffopi, in qua ma= ceratus eft hyffopus. Nam proxime antè, remedium ad recentem tuffim his urerbis ei defcribitur, Len tes ualıulis exemptæ, \& minute molitæ mifcentur aquæ calidæ fextarị duo, factaćs forbitio per cor nu infunditur. Hinc facile apparet forbitiones, ut potiones quogg (forbitionem ueluti craffiufculam potionem dixerím cum farina aliqua decoctam, ita ut cremorem habeat) liquidiores effe $\&$ per cor. o nu infundi, faluiata non item. Tenero olere commifto torrido molitó́ $\$$ milio, $\&$ per unam nociem lacte macerato faluiatur, Columella. Eft enim faluiare, faluiatum inferere, uel faluiati more faucibus immittere. Vitulis (pro alimonia) toftum molitum'́s milium cum laçe mifcetur, faluriati more pra: bendum, Palladius: Noftri huiufmodi turundos faginandis anferibus parant. Ad lumbricos uitur. lortum, lupini femicrudi conteruntur, $\&$ off $æ$ faluiati more faucibus ingeruntur? Poteft etiam cum a. rida fico $\&$ eruo conteri herba fantonica, \& formata in offam, ficut faluiatum demitti, Columella. Limeum herba appellatur à Gallis, qua fagittas in uenatú tingunt medicamento, quod uenenũ cer uarium uocant: Ex hac in tres modios faliuati additur, quantum in una fagitta addi folet, ita offa de: mittitur in bourm faucibus in morbis, Plin. Recens tuffis optimé faluiato farinæ hordeaceæ difcu= titur, Columella. ficcum hoc medicamentũ uidetur, fed Vegetius ouum crudũ 8 heminam paffi ad - lextarium farinæ hordeaceæ addi iubet. Eruum cum hordeo molitum faluiati more in fauces demic titur tuffientium boum, Columella. Hoc etiam aridum uidetur, fed Graci remedium idem ferè cum hordeo madefacto fieri iubent. Errant igitur quifaluiatum potionem exponunt grammatici recen= tiores: $\mathbf{\alpha}$ ij etiam, ut mihi uidetur, qui à faluia fucco dedưcunt:mihi quidem faliuatum fcribi pracis pué probatur, quod unà cũ faliua in pecoris fauces immífum deglutiatur. Erraurit $\&$ Ioannes Ruel lius in Hippiatricis Gracis propotifma quod infunditur faluiatum reddens, cap. i28. in Gracis : Et

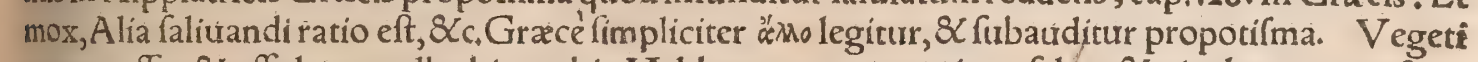
us $\xi, 60.0 f f a s \&$ offulas appellat his uerbis, [Mel, butyrum, axungiam, falem $\&$ piculam commifces, offas facies $8<$ in paffo intinctas digeras. Et rurfus alio medicamento décripto, foenograco, apio, ru ta, caricis, tragacantho, anagallico \& allio commixtis, fubdit : Omnia conterantur, offuliş̧́́ ad nư= 40 cis magnitudinem factis, tern $x_{\text {; }}$ quin $x$, feptenæ per triduum digertintur, (hoc eft, primo die tern $x$, al terno quinæ, tertio feptenæ.) Faciunt autem utraç hęc remedia ad equos tuffientes, uulfos, ruptos. Abfyrtus in Hippiatricis 62 $\mu x y d \alpha \lambda i \alpha s$ nominat. Equum (inquit) itinere aut curfut defeffum reficics hoc modo: Polentam urino odorato mixtam rediges in magdalias, \& apprehenfa língua inferes, Et ưurfus cap. 89. Si equus gallinaceum fimum deuorârit, fimum album gallinaceum cum denario adi pis $\&$ duobus polentæ choenicibus, uino permifcens $\&$ magdalias effingens edendum datc. Hiero. cles ibidem mazas tuocat. Sed fatis de faliuato. बMedicamentorum genera diurerfa defcribuntur áVegetio 4.27.Potio aftiua 1.57.8 4.27. Hyemalis 1.58.8 4+27. Autumno \& uere $1+59.0$ omni tem pore, 60. Potio diapente 1.6.4. Aduerfum omnia genera morborum confectio 4.11 . Confectio fuffi= mentorum falutaris 4,12, Puluis quadrigarius, 4.13. Eiufdem apud Hippiatros Græcos capite penul so timo diuerfis in locis uariæ traduntur compofitiones: Malagmata plurima \& hippacopa quadam prä́fcribuntur in Hippiatricis Gracis capite ultimo. Sunt $8 \alpha$ apưd Vegetium malagmata quardam libro 4. capitibus $17+20.21 . \& 23$. Synchrifma apud Vegetium 4, 18. Anacollema \& fynchrifma 4. 21. Infufionum, id eft potionum qux per os infunduntur, Græci enchymatímc's uocant, uarix cô. pofitiones in Hippiatricis Græcis tapite penultimo, Sed non eft inftitutum de compofitionibus fiue medicamentis ad equiorum morbos fecundum genera agerełalṕs hanc curam relinquimus, qui tum hæc tum alia ex Vegetio \& Græcis Hippiatricis $\&$ aliarum linguarum diligentius $\&$ curiofius per. fequantur, mihi fumma capita digeffiffe fat operofum fuerit. बPotiones medicamentofre equis per os infundi(digeri, ut Vegetius loquitur)folent, per uas ligneum, ut Columella meminit alicubi:

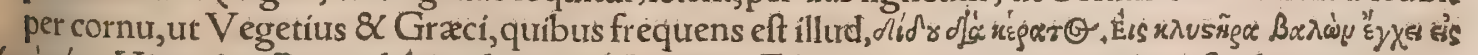
60 zo sóux, Hierocles, Per os dabis ad cornu, Vegetitis. Filicula trita \& aqua tepida mitta datur per cor

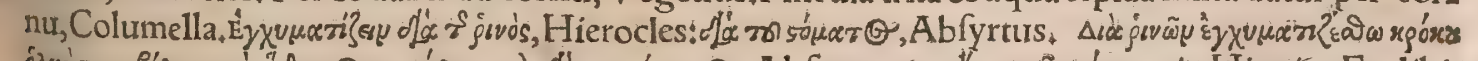

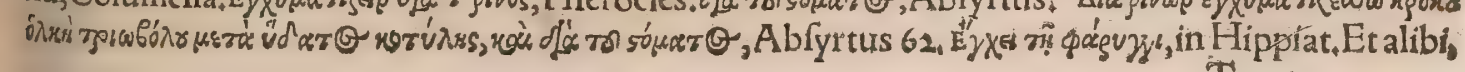




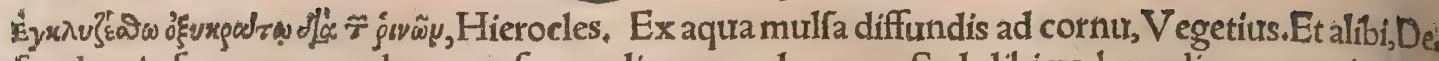
fundere in fauces, per os dare, per fauces digerere ad cornu. Sed alibi urerbum digerere accipit pro eo quod eft in'os manu inferere, ut $3 * 60$. Offula ad nucis magnitudinem facta per triduum digerun tur. Et, Offas in paffo intinctas digeras. IInferitur $8 \mathrm{r}$ manus uncta in anum in diuerfis morbis, ut ftropho uel torfionibus uentris, inflatione $\&$ alins, ubialuus obftructa eft. I Clyfter proprie di. citur inftrumentum quo aluus colluitur hoc adhibereV egetius clyferiare dixit, Quoties autem dy fteriabis(inquit)capur animalis in ualle ftatıes, $\&$ clunes ad altiora conuertes, ut quod per clyfterem diffundis ad interiora perueniat. Diutiffimè autem polt potionem in talibus locis animal retinetur,

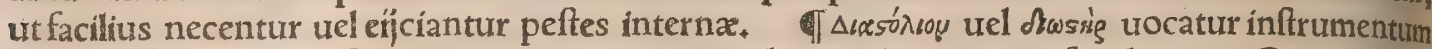
quoddam, cuius ufus efi ut equis per nares commodius medicamenta infundantur * Camillus(uox " barbara)inftrumentum quro aliquid inflatur;uide ne cannula potius legendum. Cum lignea bro: cha humor qui intra cutem eft moureatur, Rufius, Exeronabis in Hipplatricis cap. 128.inftrumentum quo aliquid apprehenditur \& extrabitur, forpex, Rofnettam uocant barbari ferramentum, quofo lex equi raduntur \& fcinduntur : fed de huriufmodi inftrumentis plura alicubi in Philologia dicen tur. Aphorifmos aliquot de fignis \& iudicís circa morbos equorum, lege apud Petrum Crefcenti. enfem libro 9,cap.57+\& Rufium cap.7. TMorbi naturales (inquit Rufius) dicuntur, qui contin. gunt in utero, quibus cum animal nafcitur. Fiunt autem uel augmento, uel dimínutione, uel errore natura, uel ex parentibus hæreditarí, Rurfus morborum ex augmento, alí funt ex fimplici abun. dantia, aut materia corrupta, \& c.ex hac gignuntur fcrophulæ, teftudines, glandula \& fimilia, Exdi

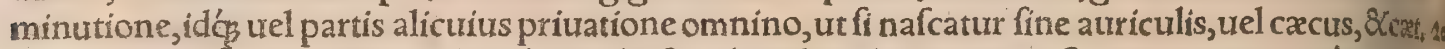
uel prauitate, urt cum naris, uel oculus, uel teftículus, alter altero minor eft, aut coxa una quàm altera breuior $\div e f$ quando crus totum minuitur, qualem equurm uulgo fculmatum (fcalamatum ) dicint, Eft quando natura errat in formatione foetus, ut fi nafcatur equus cruribus obliquis, uel ungulis,an terius, aut pofterius, aut utrobiqs:uel cum pars aliqua non furo fita eft loco. Parentum deniq̧ uitiaet morbi fæpe in focturam deriuãturt hinc gerdæ $\&$ guttæ(zardæ $\&$ gallæ, Petrus Crefcent, oriuntur, \&c. Nafcitur quandoç equus uitiofus ita ut maxilla inferior fuperiore longior fit, Et aliquando nafitur cum aliqua fuperfiuitate in pedibus uel alia corporis parte qua murus uel callumutulg (uerbis utor PetriCrefcent, ) dicitur, qui murus fine corio fit. Eft quando errore natura nafciture quus obliquis cruribus, uel cum zardis in gareciis, \& gallis in cruribus, \&c. Plura de his urithiseo: rumós cura \& emendatione, lege apud Crefcentienfem loco iam citato. đILiceret hoc in loco eli am ingenī $\&$ animi uitia ceu morbos quofdam annotare, qualis eft equus refragator uel refractaris us $\&$ conturmax quem noftri uocant fettig, Itali reftio \& a dombrato, cum fepius ita reftitat \& fuble fit, ut nec uerbis nec uiadigi ad pergendum in uia uel opere poffit. Frequenter pullus (inquitRufi us) propter malam eruditionem \& inftitutionem dum domatur, uitiofus \& reftiuus fir, quod vititum non facile relinquit. Tradit autem(capite 160, ) $\alpha$ alia quædam remedia, \& optimum effe $q$ caftre: caftratos enim $8 \mathrm{C}$ manfuetos $\&$ non reftiuos fieri, $8 \mathrm{c}$. Equo refractario radicem urtica inter cartit 8 cutem infere qua parte calcaria adiguntur, Innominatus, Contrario Iaborant uitio quros Xeno phon anagogos uocat, ita contumaces, ut ubi conftitueris, confiftere abnuant, Calius, Equa mordax aut calcitro, uitiofus, non morbofus, Gell, 4.2. Potio ad fruitiam mordentium, in Hippiat

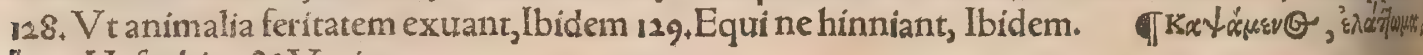
imr.,Hefychius \& Varinus.

De îjs morbis qui toti corpori communes funt, fiue quod omnes partes fimul occun pent, ut febris, peftis, \&c. fiue quòd nulli parti fint proprï, fed uel quamuis partem, uel cutem duntaxat inuadere foleant.

Xenophon A pomnemoneumatum libroz. atrophos equos intelligit imbecilles, quiq̧́ conlequil

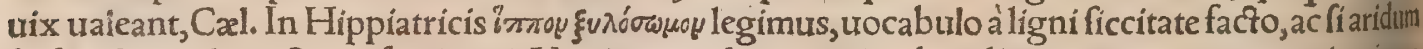
$\&$ fine fucco dicas. Strigofus, inquit Nonius, apud ueteres morbus dicitur iumentorum qui corpora ftringat, aut fame, aut alia uitij caufa, quafi ftringofus. De equis ftrigofis \& macie laborantibus; in pra dixi in $\mathrm{B}$. inter uitia equi:hic plưra adīciam, de ea præcipué macie quæ fanitatis limites excefii $\&$ morbis annumerari debet. Plenitudo 82 obefitas quamuis morbus non dicatur, equum tamen Iredit, \& medicationem requírit, Camerar. De equis emaciatis, Hippiat, cap. 62, De extenuatis \& frigofis incertam ob caufam, Ibidem capite 68. Si extenuatus fit equus, Geoponica 16.3. ex Abfyrto, De equo qui cũ abunde edat non proficit ${ }_{2} R u T_{1} 156$. Ad cutis fíccitatem \& maciem, Pelagonius cap, 128. De macerata fruge quam frigofis equis Cappadoces exhibent, Hippiat, 129. Totius corpotis macies fequiẗ etiam illum morbum, quem malidem ficcam appellant. Recentiores quidam fcalant tum uel fcalmatũ trocant equũ emaciati exhauftiç corporis, cuius etiam excrementa foetent, \& inte riora omnia ficca funt:fiuce à malide, fiue à fceleto potius corrupta uoce. Hunc morbü Rufitus fcalma turam ưocat cap. 4 11. Equum cum fic afficitit, fcalmari dicunt:quod eis accidit cum aliâs, tư quâdoper nimiữ calorem laborant . Vide Pet. Crefcent, 912. Vocatur \& coxa luxatio apud eundem cap, 32. fcalamati:aliâs fculamati. Er forte Germani hinc fuũ detorfére uocabulum ein f̧ beftix fignificat, $8<$ equum uiurum quidem fed præ macie cadauerofum: hincetiam ad animi $8<\mathrm{mos}$ rum in homine malignitatem transfertur, tantam prafertim qux publicé plecti mereatur, \& carnifi 
noris formęfunt:nam fi maioris, etiam congios. Ea res ómnem pituitam per nares elicit, \& pecuden expurgat, IVuula apud recentiores nominantur glandulx quxdam inter colium \& caput equi (legendum uiuula) quæ auctæ deglutitionẽ $\&$ refpirationem impediunt, Aliqui morbillos uocant, Ex his laborantes equi, aures fubinde concutiunt, fitiunt, lambunt quod apponitur, \&c. Rufius 62. (Videtur aũt tonfillas intelligere, non uiuulas noftrorum.) Glandula funt circa maxillas, $\alpha_{c}, \mathrm{Pe}_{\mathrm{a}}$ trus Cref,9.17. Itali, ut audio, uulgo uiuas appellät:Germanify fel/fifel/fetbel/forte quoniã aliqui uer miculos effe putant: wybel aute uulgo eft uermiculus uel gurgulio, qui exeft legumina. Plerio̧ tamẽ non uermiculos, fed grana effe afferunt milip ferè inftar, Equus habens iunulas (lego uiuulas) fífubie tò uniuer fus in fudorem foluitur, \& membra ipfius fingula contremifcunt, ac ipfe continuo frordi. tiones patitur, nó uidetur poffe euadere, $R$ ufius. Audio equís fic affectis uenas fub lingura aliqualn do aperiri, uel poft auriculas, uel in medio utriufo auris. Sunt apud nos equarï, qui equi aurem de: xtram deorfum ad maxillam iuxta collum extendunt, $\&$ qux poftrema parte auricula cutis atting tur illam refcindunt, \& uermiculos, uel grana, uel glandulas peftifer as eximunt. Símiliter ni fállor extenfa auricula retro ad locum inter iubam $8 \times$ maxillam, ubi mucro auricula definit, uenam pera

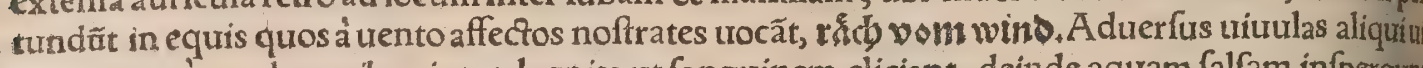
gas teneras écorylo naribus intrudunt ita ut fanguinem eliciant, deinde aquam falfam infpergu Alif in medñs naribus intrinfecus utrinç urenas liuidas apparere aiunt, eas aperiẽdas effe ut fang nem emitrant, $\&$ digitis intra nares quàm penitiffimé adactis pertractata cute fanguinem detrude dum effe: $\&$ fi fanguis in os equi influat,permittendum ut lingat, ipfum uero equum non conceden dum loco frare, fed fubinde circunducendum. Viuulis quidam hodie, 'ut audio, medentur, pro nio menfrui muliebris per potionem infufo, atç aiunt deinceps perpetuó liberum fore equum ciufmodi pefte. I Strangulina uel ftrangulio apud recentiores eft catarrhus $\&$ pituita narium refrigeratione, cum anhelitus difficultate, multo per nares humore effluête: qui nifi fponte fluat, fil fimentis aut erthinis prourocatur. Germani uocãt frenge urel ftrengel: $\&$ equum fic affectum firt

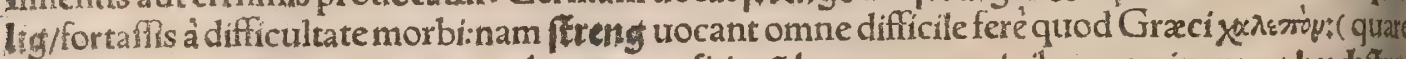
tiam in alịs partibus equorum morbos compolitis cũ hac uoce nominibus nominant, ut bud btufigeftreng) uel potius à ftrangulando, quod equi fic affecti naribus obftructis propter refpi tionem impeditam quafi ftrangulari uideantur. Stranguillio, inquit Rufius cap. 63 . glandula funi ca gulam equorum qua uidentur effe carnes, quas aliqui trocant branchos caballi, alij ftrang nes. Hæ branchant gulam, \& mandibulas, ita quod cum gurgulatione quadam fpirant equi, \& uix transglutiunt, \& c.Sed hic forte alius morbus eft quàm noftrorum ftrangulio, qui $R$ uf scen, cymorra uidetur, cum \& morbi deferiptio \& remedia conueniãt. Cymorra (inquit Rufust) defcendit à capite equi diu refrigerati, proueniens ex curfut rheumatis, quod per nares contini qua inftar emanat, 8 humores frigidos $\&$ quandog craffos educit. Accidit autem propter anti frigiditatem, 8 aliquando propter uermem diçum uolatilem, unde ferè omnis humiditas capitls vares fuit. Et inter omnes morbos qui propter in temperiem qualitatum accidunt equis, nullust pcriculofus \& fufpectus eft quàm paffio rheumatica qua ex frigiditate contingit, \&c. Profunt wariæfuffumigationes, errhina, fternuramẽta, \&c, Apud eundem Rufium circa finem capitis $7 . \pi 0$ cymorra fed enorra hutius morbi nomen fcribitur, Equus (inquit) an helitum fortiter à fe proğeiri ftranguria (lego ftrangulione) liberum habet caput.Petrus Crefc.9, 24, cimonam uocat, guo

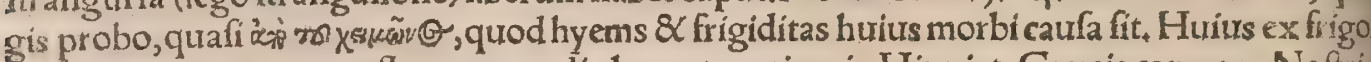
wadi humoris per nates fluxus remedia leguntur etiam in Hippiat, Gracis cap. 129. Noftri equ ficlaborantes tocantffteng/ritzig/uel potius rïbig 8 robig;quanquam hoc ad fimplicë pir five coryzam \& grauedinem magis pertinet, In ftrangulione uerò proprièà noftris appellaio, prar alia remedia audio cauterium fub mento (ut ita uocem) adhiberi, \& caput ita ligari ut deorfum ip ctet, quo liberius effluant humores. Idem fortaffis eft morbus Anglice dictus glanders, quem aith catarthum effe per nares cum tuffi. IAd fafcinum, Vegetius 3.74 . Deincerto equortm mori Theomneftus in Geoponicis 16,12,

- Crithiafis, resticcors, id eft hordeatio, ut Gaza apud Ariftotelem tranftulit, morbus eft equorm

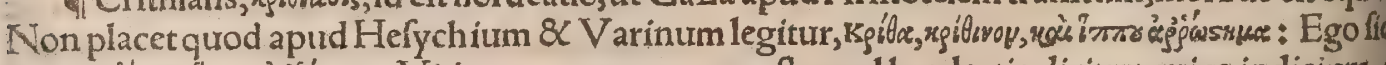

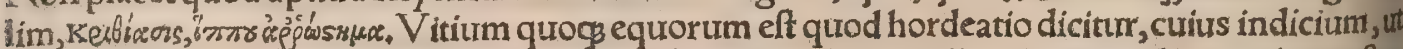
Iatum moleftet, \& feruentius fpiret equus quàm ex confureto:nullum huius mali remedium eft,

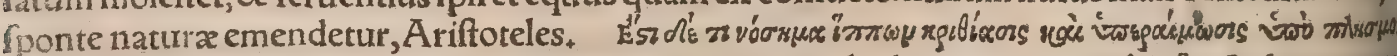
Pollux \& V arinus, Sed ne quis decipiatur, ac unius morbi duo nomina crithiafin \& hyperatmo efre putet, apponam uerba Xenophontis, qui de equili fcribens id claufum effe oportere, nốfo ne furto pabulum equi diminuatur: fed etiam ut appareat fi forte effundatur ab equo: quod ubif

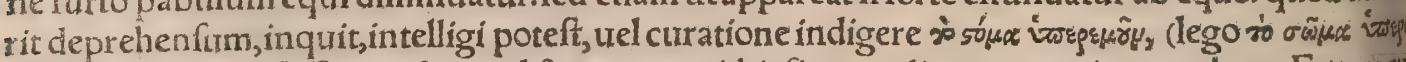
$\left.\mu \delta y_{0}\right)$ aut quiete defeffa membra, uel furrepere crithiafin, aut alium quempiam morbum. Equus crithiafin patitur, kediçy uel kebbex'sy dicitur. Si equus doleat ex fuperflutitate fanguinis urel hu rum prauorum in uenis, torquentur $\&$ mouentur ilia, $\&$ frequenter cadit in terram, $\&$ uen $æ$ plus livo tumefiunt, Crefcentienfis 9.18. Quum ex itínere aut curfu(inquit Hierocles in Hippiatr \& Abfyrtus fimiliter) adhue anhelabundum pecus hordeum deuorarit, cruditate uexabitur, $q$ 


\section{DeEquo. C. Lib.I. 503}

fubter tergu's irrepens, per totum corpus euagatur:itą̧ conuellitur equrus, ut nẻe pedibus infiftere ( erumpit, Cibus inter fufpiria datus, raptim cum halitu trahitur. Caducus recufat exurgere, fed decû. bens pabulo uefcitur. Deinde remedia fubiungit, qux alia funt ab hordei, alia à tritici largiore ciba. un affectis equis, Quòd fi equus in itinere non diffimile uítium potu raptim haufto contraxerit, eif

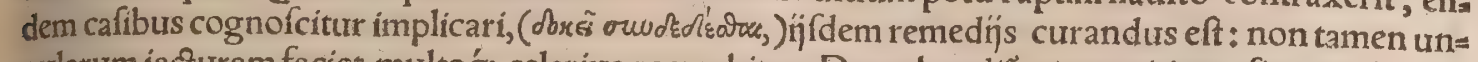
gularum iacturam faciet, multó̧̧́ celerius recreabitur. Deprehendiť autem uítium, fi equus horro= re concutitur, 8 in palato cutis intumefcit. Qui huiufcemodimorbo fupereft equis, fefe nun $\tilde{C}_{\bar{b}}$ ita recolligit, ur deinceps fuum obire minifterium \& folitos ufus praftare queat, Hæc Hierocles . No

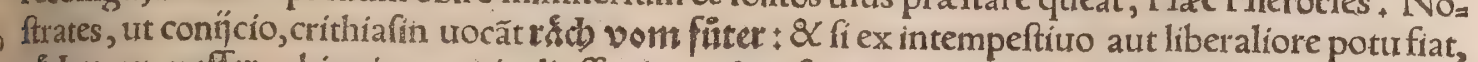
tho vom waffer, ubi minus periculi effe aiunt: $\&$ nifi pituita à naribus deftillet, uena colli incifa curant, Poft Hieroclis uerba alix hordeationis notę ex innominato quodam authore fribütur huiuf modi: In crithiafi oculi male habent, os foedis ulceribus (aphthas uocant) obfidetur. Crenæ palati uer fusćs fublimes attolluntur, \& fertrorem quendam expirant:fanguine turgent uenæ: uifuićs caligo furcedens offunditur. Albertus Magnus Ariftotelis crithiafin interpretatur forcin, \& Germanice fouf uel fbule. Ego in Hippiatricis quiburdam Germanicis foul nominatum lego morbum, in qưo palatum \& gingiux præe nimio fanguine intumefcãt. Iubent autem urere fi magnus fit tumor: fin paruus, aperire cultello. Sed hunc morbum oris recentiores lampafcum uocant, qui ab hordea=

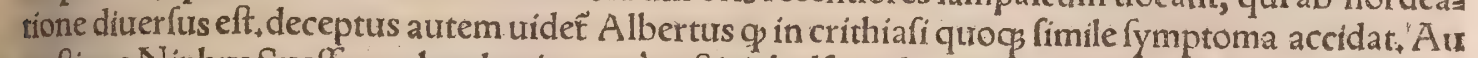
guftinus Niphus Sueffanus hordeationem à rufticis bulfum dici interpretatur, quod itidem non pro bo:uulfi enim pulmonarỉ funt. Sihordeo malo aut nimio ladatur animal, Vegetius 3.73+ ' Equo hordeatione laboranti caduco cubitoriḉs, qui nec progredi nec exurgere poteft, Hippiatrica 129. Equus podagricus humi iacet non aliter $\widetilde{\phi}$ qui hordeatione laborat, $A$ bfyr. De dolore ex nimia inge ftione hor dei uel fimilis indigefti, Rufius iso. fribit autem præter cætera fymptomata etiam uentris torfiones ingruere, Plethora ex hordeo fir, fi equi dum fudant hordeum comederint:uel ipfum hor deum nouum fuerit, quia urehementius calet:uel copiofius quàm oportet otiofa pafcuntur. Sudant, ligati funt armi, ambulant incertum, Vegetius 3.44 . Alibi etiam apud Vegetium indigefta ex hor: deo animalia legimus. Si equus (inquit Albertus lib.21.) hordei uel alterius frumenti aut leguminis grana, nihil aut parum dentibus contrita deglutiat, idós nimium abunde, morbus fit unde concoque go te non poteft, neç caput fatis erigere: fed id ualde à fe extendit, $\&$ fiti affligitur: debet autem abfine= riâ potu, \&c.hoc etiam Hierocles, Nonnulli, inquit, praceperunt equum à potu abftínendum efre, Et mox, Sunt qui manu oleo inuncta fimum eximant. Et Albertus loco iam citato, Sunt qui manus (inquit)per inteftinum equi immiffa, grana attrahunt $\&$ uiam aperiunt, $8 c$. Equi interdum ( $C a$ merarij uerbis utor) peftilente humorum corruptione laborant, uel cum agitantur ita ut in labore $8<$ fatigatione deficiantur uiribus, imprimis fi contra uentum incitentur $:$ uel de aftu $\&$ fidere : etiam nonnun $\vec{\beta}$ de frigore $8<$ diuturniore inedia: Nec non fi poft longiorem quietem repente fatigentur. Aut nifi fuo tempore urinam eiecerint:potiffimum autem, fi uel in fudore, uel de uehementiore agi= tatione aquentur. Sæpenumero etiam aquæ ip $\mathfrak{x}$ uitiof $æ$, interdum $\&$ contagia quædam illos infici $=$ unt. Hoc malum, quo equus fuerit generofior, è citius eum extinguere folet, nific celeriter fuccurra * tur. Vix aũt un ơ priftina ftrenuritas in talibus recuperatur. Fit etiam ut expulfo ureneno, uel naturę robore, uel medicamentis ad extímas corporís partes, ungula delabatur de pedibus morbo correpto rum. Contra hoc malum nota multa funt remedia, quadam etiam obfcona, (ut excrementum hom nis cum allio in uino dilutum infufurmós.) Sed fangtrinem mitti, fi uires ferant, omnino optimưm $\&$ prafentiffimum, Veteres pulueres duos ualde probarunt, quorũ cochleare unum laboranti equo infunderetur. Horum unus teritur de radice gentianæ $\&$ ariftolochiæ longæ, baccis lauri, myrrha, eboris fcobe, his omnibus aquali pondere inter fe miftis ac comminutis. Alter de pullo ciconiæ, plux mato quidem illo, fed nondum uolucri. Hic indetur in ollam uiuus, 8 hac diligenter contecia, in fur no toftus cinefiet, $\&$ puluifculiafferuabuntur in uitreo uafculo, unde ad fuprafcriptum ufum proz mantur, Hæc Camerarius ex Vegetí libro I, cap +17 . Vegetius quidem inter cateras huius mali (maI so leum ipfe urocat)caufas, illam quoç numerat, fi hordeum fudantes acceperint, $\&$ fi polt curfum cali dibiberint, \&c. quas fupra hordeationis quoọ caufas fecimus: ut dubitem an malleus porius Vege. tijfit ille morbus à quo nos equum ri̊d dicimus, nam totidem ferè eius ex caufis differentias capite iam citato Vegetius, facit:an quam fupra defcripfimus crithiafis. Videtur $8 C$ infundatura, ut Alber tus urocat, non aliud quàm crithiafis: \& equus infunditus, qui crithiafin patitur. Infunditus fit(inquite Petrus Crefcentienfis $9+19$.) ex nimio alimento uel fanguine per crura diffufo. Infundatura (inquit Albertus)accidit equo ingefta multa annona, quando nimis feftinanter ducitur (forte manducat) \&mox nimio potu repletur, ante đ̧ cibus fatis fit concocfus. Item fi à magno labore puram et bonam annonam aliúmue cibum ualde efuriens $8 \times$ uentre uacuo, nec haufto potu, multa grana parũ denti= bus fracta unà cum cortice uel palea tranfglutit:hinc aliquando infufio ad pedes defcendít. Quód fo inter pellem $\&$ carnem fluxerit, pruritum ciet. Equus ita affectus incedit titubans, ac fi furper car. bones ardentes ambularet:cum ftat, pedibus tremit:nec extenfis, fed quafi contractis membris fat: quin fubinde iacere cupit, \& propter gratitatem polteriora à terra erigere nequit, ac fi freno anteri: 


\section{4

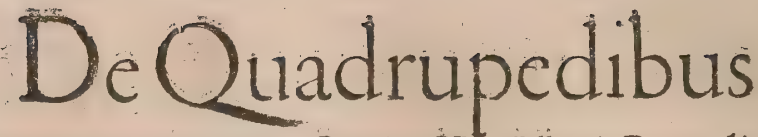

ess retrahatur, \& fuper genua quafi cadit pofteriora, Hęc Albert.Curandi rationem omitto. Equìis noftris $\tau$ \&b dictus, rigida habet membra \& conuulfa, \& fanguine ei detracto calido perfricatur; hoc remedium in malleo etiam peftilente $V$ egetius adhibet, $\&$ alin in ali ss morbis, ut cap. feptimo dicam,

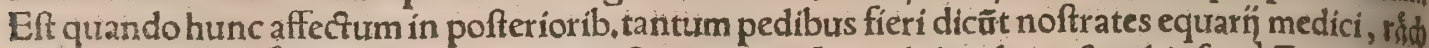

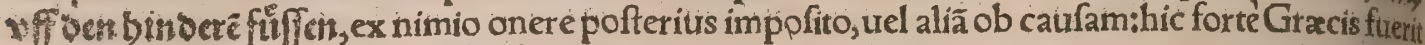
Ex $\lambda_{\text {ce }}$ óต fefius, ut conñcio, circa ungulam. Sed hi duo particulares affectus funt: cateri uero, irtít grtitten,

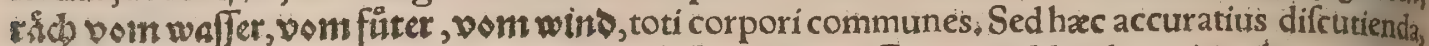
8 Germanica aliá̧ barbara nomina proprïs Latinis aut Gracis reddenda peritioribus rei eque. fris relinquo, Sunt qui flores, qui in agris frumento aut fecali confitis proueniunt, quibus à cyanteo colore nomen, falutares in cibo affirment equis laffitudine ita affectis ob curfus uel faltus uiolenter

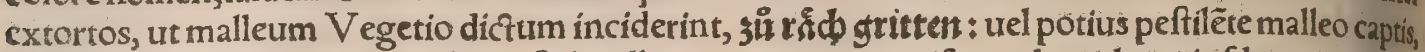
quibus etiam modicum de pellemuftelæ alba minutatim concifx, uel caudam eiufdem, in pabulo prabent. A uento fic affecits, uena inter oculos $\&$ aures aperiturtà pabulo uerò, ubi uenter inflatur (ego crithiafin appellârim) faponem inteftino inferunt. ISyderatitia iumenta dicuntur, cum ure nas uacuas percufferit frigus aut aftus, aut impleuerit cruditas, aut ieiunia bulimum fécerint, Red dirur enim fttupidum animal, \& titubans ambulat, Veget.3.35. THyperamofin, id eft fanguinis abundantiam à crithiafi différrefupra ex Xenophonte docui. Sanguinis exuberantia fpiritus ladi tur: hanc curarunt quoondam pabuli mutatione $\&$ exercitijs: nunc fanguinis miffione crebriore ma lum plenitudnis emendãt, Cametar. De dolore ex fuperfluo fangiuine intra uenas, unde dolores \& torfiones in corpore oriuntur, Ruf, 148,Crefcent.9.18. De fanguine fuperabundante, Idem 4: De infeltatione fanguinis, Veget.1. ss.

De unionis folutione, abfceffibus \& tumoribus.

Defluxu fanguinis é uulnere, \& fi fequatur hamorrhagia, Rufius 43.\& Albert, lib، 12, demor bis cquorum. De reftringentibus fluxum fanguinis, Idem 44. Si percuffa uena claudi non poffi, Veget, z.14. Fuxui fanguinis iumentorũ utilis eft fimus fuis infufus in aceto, Plin. Si fanguis flua perdorfum \& fecundum pilos, Hippiat. 44. Sanguinis profluuio exhaufi, Ibid. 42. TAd ofla fracta, Hippiat. 7 4. Ruf. 168. Ad caput fractum uel nudatum aliquo cafu, Veget,2, 13. Ad omniae

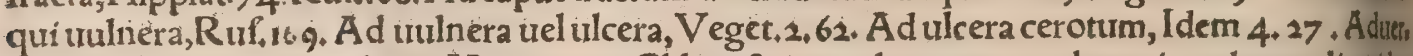
fus uetufta \& recentia ulcera, Hippiat,129. Chlora \& tetrapharmacum ad omnia uulnera elimpidan da uel fine difficultate claudenda, Veget.4.27.8 rurfus aliud, \&c. Vulnerarị mixtura, Hippiat, 129. Traumaticum, Veget. 4.16. Traumatica medicamenta duo, Veget.4.19. Vulnerarium emplas ftrum, Hippiatr.129. Aliud ad cruenta uulnera, Ibidem, Erigeron mixtura ad recenter tulneraton Ibid. De ungento ad reparandam carnem, $R u f_{+} 177$. Genus eft millefolï quo ruftici noftri ad bous $\&$ equos uulneratos utuntur, Brafauola. Ad ulcera iumentorum $\&$ animalium, facit afphodeliza dix cocta illita, Plin. Cinis excrementi menftrui cum camini pultere \& cera, Idem. Pix humida, $S_{e}$ rapio. Rubi foliorum puluis, Plin. Herba quam Germani confolidam auream uocant, guibitg guh

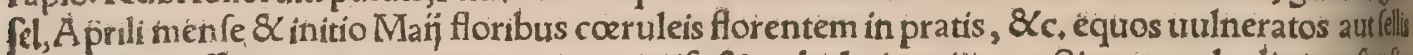
compreffos efficaciter iuuat, minutatim concifa \& pabulo immixta, Si equus ab alio morfis fit, Hippiatr. 73 . Si quem alter equus calcitro icerit, lbid. Si iumentum aut rota aut axis iciu fueritu. lifum, Veget. $3+21$. Surculis hærentibus $\&$ clauis refigendis, Hippiat, 129. Si truncus aut fpina int tret in aliquam parten corporis equí, $R$ ir, 170 . Si equus fagitta uulneratus fit, cancros duros cum adipe leporis contufos uulneri fuperilligato, \& extrahetur fagitta, Innominatus, Pracipitatiautin foueam deuoluti,Hippiat, 72 . Emplaftrum ad ruptos, Hippiat , 129. De ïs quibus aliquid interné conuulfum eft, Ibídem 66. Si quid intus conurulfum aut ruptũ eft, Ibidem. De dorfo læfo à fell, Rufius 76 . Si compreffo equi dorfo in itinere tamen pergendum eft, pannum fell $x$ quo pili conti nentur aperies, \& pilos exemptos diduces dígitis ut molliores fiant, iterumó̧ claudes, ita ne ulla du rities aut afperitas inde equum ladat, \& fimul medicamenta appones. Sunt qui tritum piper loce Ia fo infpergant, \& interim in itinere pergant. Eft quando dorfum lafum inflatur $\&$ carnes puttef? ctas producit, ex compreffione fellæ uel oneris. Inflatio hæc inueterata putrefcit, \& putrilago iuxit: offa efficitur aliquando coagulatio praux carnis, unde fanies aquofa affidue deftillat, \&Chic morbus dicitur lafio pulmonis uulgo, Crefcent.9.28. Vocant autem pulmonem, non uifcus, fed genus abr fceffus à forma. De pulmone feu pulmoncello, Rufius 81. Pulmunculum in dorfo animalis natum difficile eft medicamentorum appofitione ficcari, Vegetius 2, 61. Idem pulmunculi in pede meminit 2. 56. Noftri ulcus ex attrione in dorfo factum, rupturam uocant, bauds vinos bem fattel. Id aliqui hoc modo curant: Ollam nouam dimidia parte implent afinino fimo, $\&$ dimidia ouis formicarum: $\&$ fic urunt: $\&$ ubi locum oleo unxerunt, cinerem inde infpet" gunt bis quotidie. De læfione dorfi, Rufius 75. De profinda plaga dorfifuprafpatulas, Idem 78, De dorfo 8 armis lafis, dolentibus, attritis, ulceratis, fuppuratis, tulneratis, diuerfas ob caufas, Hip piatr.26. Vlceratio fpinæ, Theomneftus in Geopon.16.15. Decurra dorfilafi, Veget, 1,63, 82,60i Pet.Crefcent.9.30. Intertriginem uel attricionem dorfi, noftri uocant fratt: Vide etiam infra qua dam ubi de fcabie dicet: $\alpha$ rurfus inferius de coriagine $\alpha$ cornu dorfi. De inflatione dorfi ration 


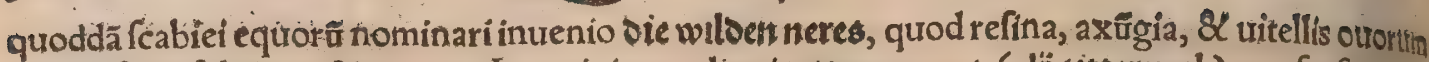
mixtis 8 in fole inunctis curant. Impetiginem aliqui tetter uocant (alif sittermal) qua forfitan uo, ce corrupta itcres fcriptum eft, ut impetigo fera intelligatur. Defcabie \& pruritu colli \& caud equi, $R$ ufius 72 . Et de fcabie in genere, quam rungiam uocat Gallica uoce, ibidem, In collo equi (in. quit) iuxta garefe quadã fcabies fít, $8 x$. De lafione garrafí feu guida, Idem 86 . Cum garrefe(inquit) fuerit nimis inflatum $\&$ plenum putredine, uratur pluribus punctis foci, aut ferro idoneo fcindatur, 8 c. De quibufdam pulueribus ad fanandum dorfum uel garrefum equi, ldem 88 . Hoc malum no, frates puto uocant Er\&ttigteit, \& equum fic laborantem trettig, uel potius Eróttig, à rana rubeta quód locus affectus fimiliter infletur, Idem aut fimilis affectus eft, unde equum nuncupant trant. rinvig. Depuziolis (puftulis) qua nafcuntur in dorfo equi, Rufius 87 . funt autem, inquit, puffil lax excoriationes, \&c. Papula erumpentes, Hippiatr.69. Intertrigo bis in die fubluitur aqua cali da:Mox decocto ac trito fale cum adipe defricatur, dum faniei uis emanat, Columella. Albre vitili, gini citra fcalpellum méderi, Hippiatr.129. Contra morpheam, ferpiginem 8 impetiginem equo, rum, $R$ ufius i 80 , accidunt autem hac uitia ut plurimum circa oculos feu palpebras, $\&$ circa nareset os equi. De impetigine fuperius etiã dixi ex Colum. De impetigine crurum, alins ś́ uith̄ feorfim dice rut infra. TDe elephãtia, Hippi.z. Elephãtiafis figna, Vegerius 1,9,cura, 1.16. Numeratur autẽabeo inter fpecics malidis. Leprac curatio, 1 8. TDe fpallatijs, Rufius 84 . Sic autem uocant barbari th morem $\&$ duritiem carnis fuper fpatulas fiue armos, qua dorfi fuperficiem fuperat. Vegetiusi bro 2,cap. $3^{\circ}$, entomata nominat tubera $\&$ tumores diuerfos, ut funt fteatoma, meliceris, aneuryli ma, atharoma, ganglion. A dif cit $\&$ curam omnibus unam $\&$ communem. In malide articular bercula quadam nafcuntur per totum corpus, Hippiat +97 . T Dracunculus uermis eft tinea lis, non in uentre, fed in lacertis, formore, tibijśç, parte A egypti fuperiore copiofus: qui latera quoç paruulorum infeftat, mouetur'̧́ hic fine dubio, Petrus Ruellius. A duerfus dracunculum, Hippian, 12.9. hoc infeftante, toto corpore puftula erumpunt, $\$$ animal clamitans obftrepit. Farciminof morbifigna, Vegetius 1.7.cura, 1.14. Cenfetur $8 \mathrm{x}$ hic inter malidis genera, 8 huiulmodi argumento deprelienditur: In lateribus (inquit Vegetius ) $\&$ in coxis, \& in uerendis quo $\$$ partibus, \& praci: pué in iuncturis membrorum, uel in toto cor pore collectiones inflantur: rurfumḉ his uelut fedatis, alia renafcuntur: cibum potum $\not \dot{\beta}$ ex more recipiunt, macrefcunt ramen:quia digeftio eis plenation prouenir, hilares afpectu, fanis ́́s fimiles creduntur. Haud frio an huius generis fint qua in Hip tricis cap. 97. $\$$ exגinsy dicuntur, farcimina forte legendum: qua tumores funt (inquit Abfy: lis quos Graci dothiênas uocant fimiles, maioresćs, ac fuppurantur, \& fonte erumpunt, fiuntio fufa malide articulari. Farcina (inquit Albertus)nafcit ex nimia carnis humectatione, \& immodera ta repletione; aliqui uermem uocauerunt, eó quod fuperfluus humor in carne \& cute for amina fací tanqu $m$ uermium, contingit autem ex fangurinis fluxione extra uenas: \& interdum ex mag ga, ueticiu \& liuore fi non curentur intra duos menfes, 8 in locis fuerint cauis, ac inter armos lateribus:interdum ex morfu alterius equi farcinam patientis, \&c. Hæc ille. De uerme diciof no, Rufius 146. De uerme dicto anticor, Idem i 47. Fit autem cum prauus humor colligitur $\& p$ feit in cafula cordis', unde pars ad pectus propellitur, \&, fi collum occupauerit, tumorem facit, hoc corrupta cordis fubftantia mortem fequi neceffe eft: quamobrem anticor, id eft, cordis tio uocatur. Auticax (aliâs antiquor uel anticar, qui tres modicorrupti uidentur, ut anticor t reciè frrbatur, quod morbus ante $\&$ circa cor $\&$ in pericardio fit) glandula funt, uel tumot, - uel apeftema circa cor,Petrus Crefc.9. is. De uerme uolatili, Rufius 145. In hoc ulcera, praci cap tte oboriuntur, humores é naribus fluunt: Vocatur autem uolatilis, quoniam humores fup petunt:aliqui talpinum appellant, $\&$ tranfit aliquando in cimorram fupra dictam. De uerm Rufius 144 . Is incipit in pectore, uel intra coxas iuxta tefticulos: deinde ad crura defcendens t cit ea, \& crebris ulceribus perforat:aliqui guttam uocant. Vermem dicunt glandulas in pector coxis inflammatas, \&c. Petrus Crefc,9.14. Realgar fitex fulfure, calce uiua, \& auripigmento idiomate noftro uocatur foricoria:occidit forices puluis eius, et omnia animalia: abolet fifulasetur mes equorum, $8<$ omnem malam carnem corrodit, Syluaticus. Ad eadem omnia ualet aconitum cipué autem eo aconiti genere ad uermes equorum apud nos utuntur, qued pallidum florem radice ad retis fpeciem incifa. Hinc natus uidetur error, ut res longé diffimiles, aconitum $8<$ rea propter uirium fimilitudinem à recentioribus quiburdam confunderentur. Equus uermemp nunquam ad priftina ualetudinis robur aut priftinam alacritatem redibit. Vermem Germanil ben wurm uel burtsel alị piurbel, à farcina uel farcimine forfan detorto nomine. Diftinguunt loco tripliciter, ut alius nafcatur in nafo, alius inter genu 8 coxam, alius in pudendis uel uirg maris. Rurfus uermes alios apertos effe legimus, ubi tubercula aliquot apertis foraminibus a aufswerfende wüm:alios uerò tectos. Sed remedia quo in libris quibufdam noftra lingua feriptis reperta adịciam. Cicutæ fuccus cum melle illinitur, quo guftato uer $\mathrm{mcm}$ illico mori Radice petafitis herbx (quam noftri radicem peftilentix uocãt) ueterinarị quidam utuntur, mes equorum, alia ós uiria tum intra tum extra corpus, Tragus. Pecudi ex uerme laboranti, $\mathrm{p}$ tim equo, folia carduorum edenda prębe: Aut commanfam herbæ phu radicein fuperilliga: $q$ mini quoç prodeft. Sı uacca uel bos uermem patiatur, ouis rubetarum in palude aligua ue 


\section{DeEquo. C. Lib. I. 507}

reperti locum affectum diligenter perfricabis $\$$ indeftercus humanum calidum impones, \& linteo obligabis: 8 nigri folani fuperficiem edendam ob̆́cies, radicent collo appendes ne aquam adeat $a_{2}$ nimal cauebis, fanabitur. Sunt qui locum fcindunt $8<$ extracto uerme fucco perficarix herba, quam pleriøg hydropiper faciunt, abluunt: Alị herbam cum lapide fuperponunt, mox defodiunt, morbo ita paulatim decrefcente, ut ipfi fuperftitiofiflimè credũt, quemadmodũ berba defoffa flacce fit ac putrefcit. Älíh radicem polygonati, carbones quernos, thus, hordeum non decorticatum \& $\mathrm{fa}_{2}$ lem,omnia minutatim contufa concifátre mifcent, \& in de quantum manus capit pabulo equi infper gunt, idóq bis aut ter repetunt. Si equo uermis inter carnem $\&$ cutem nafcatur, tumorem urito, $\&$ medullam ceruinam infundito. In libris Hippiatricis noftra lingua excufis, uermes ubiuis nati cauterio uruntur, deinde arugo infpergitur, fi inter coxam $\&$ genu fuerit:fi in nafo, arugo cum offe equino ufto:fi in pudendis, ærugo, fulfur, \& hyof cyami femen ueteri axungia excepta illinuntur. बDe cancro, Pet. Crefcent, 9.46. De cancro cum alibi, tum in labijs, Albert, Cancer (inquit Rufius 171.) fit circa iunciuras cruriữ iuxta pedes aut inter iuncturas $\&$ pedes, uidelicet in paftora, et quan: doçalibi in corpore, $8 C_{*}$. De carcinomate, Hippiatr ${ }_{+} 76$. De fiftula ex cancro, Pet, Créfent, $47+$ De fiftulis, Hippiat, 128. Rufius 17 2. fit autem(inquit)ex antiquo urulnere non curato, uel ex cancro. ' Defiftula ubiuis corporis, Veget, 2,27.Collyrium fiftulare, quod fiftulis immittitur uulnerum; qua ab initio curata fuerint negligenter, Veget.4.16. Enilaftrü contra omnia cacoêthe ulcera, phage= dænas ulcerum diuturnas, 8 abfceffus ano prafertim erumpentes, Hippiat.129, Muri, caro in pelle fuperflua,Pet,Cref, 11 . De tuberculo in morifpeciem, Hippiatr,127. Malagma ad uligines, Ve= get, 4,24, hæc alibi puto tulcera glycea uocari, Agglutinans medicamen ad fauos, Hippiatrica 129. De glandulis et frophulis inter pellem \& carnem, Pet.Crefc.12. De glandulis, teftudinibus \& fcro phulis, $R$ uf, 139. Omnes hi tumores fiunt ex materia corrupta in uno loco fe condenfante inter cori um $\&$ carnem. Pendigo ad fcirrhos pertinere uidetur. Si iumento fcapula ulcerentur, duligenter infice, ne quas inter neruos $\&$ commiffuras pendigines faciat, Veget, 2. 44. Pendiginem circumci. des ad uiuum, Idem 2.55. Glycium ad fordida \& cancrofa uulnera, Veget, 4. 27. Malagma ad uli= gines, Idem 4:24. Linimentum ad phazalam (abfceffum puto) morbum peculiarem equis mare rubrum ingredientibus, TEmplaftrum quod dolores fopit, \& incandéfcentes inflammationes di icutit,Hippiat.129.item aliud, Ibid. Traumatica duo ad phlegmonas tollendas, Veget, 4.27. Radinculus (forte carbunculus) eft phlegmone occurpans cutem \& carnem uf $\beta$ ad profundum, cum fanguinolenti humores fuperabundant: funt autem eius differentix pro diuerfitate humorũ , \& cat Albert. Ad inflammationem omnem, $8 \mathrm{cmalagma}$ ad Ppinx uertebram, Theomneftus in Geoponi cis 16,16. Debarbulis $\&$ carbunculis, $R$ ufius 85 . Barbula forte à carbinculo corruptum eif nome: fiunt autem ex fuperfluro fanguine, $\&$ aliquando mifcentur étiam alỉ humores: cura éorum docetur in capite de lafione dorfi. Squillares dicti furunculi; Hippiat,8o, Ficus eft collectio rubicunda uel liuida prominens ex nimio intercutaneo fanguine, Scc. Albert. De ficu qui nafcitur alibi quàm in pedis folea equi, Rufius 140 . Ignís fácer uel pufula, Hippiat. 25 . Si equus aut bos fícolos tumo res(fey g wart

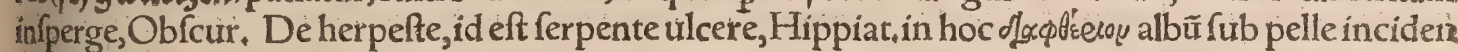
dum, $\&$ aftringentibus inde curandum eft, $\& c_{*}$. Turtx (inquit Albert.) a poftemata funt in fuperfi* cie carnis intra cutem exorta, in modum panis qui turta uocaț fiunt ex abundantia fanguinis maxi=

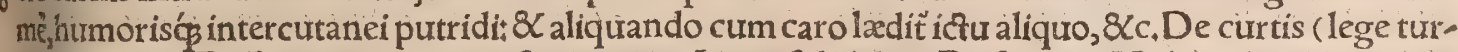
tis) equorum; Rufius 8. . De equo fuper quem Lina fplenduit; Rufius 83. Videtur autem de apo= femate uel ulcere intelligere, quod Lunæ radïs tactum putrefcere uel corrumpi alibi etiam legere memini. Verruca ubiuis, Veget,3+17. Traumaticum ad uerrucas tollendas, Idem 4+ 27. Verrurcas in equis quidam pilis ipforum uinciunt; $8 x$ teftas concharum qux in aqua dulci reperiunt uftas

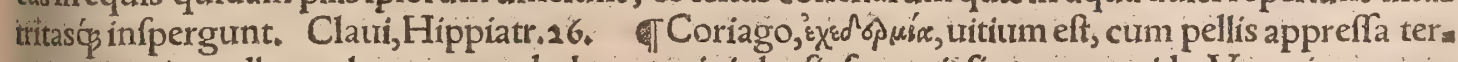
go pertinaciter adhæret:hoc cum ambobus armis inhefit fynomiafin urocant, uide Vegetium 3.54. \& Hippiatrica 26. Cornu uocatur cum corium in carne dorfi, uel fola caro antea lafa, uidetur fi= cut cornu induratałquod ex nimio pondere fella urel alterius oneris accidit; ita ut rumpatur aliquan dopellis dorfi, $\&$ ulcus aliquando etiam ad offa pertineat, Fit etiam radunculus interdum in cornur; \&c. Albertus, \& Petrus Crefc.9,27. Compreflum in hec malo(inquit Rufius 80 .) corium cum car= ne conglutinatur: 8 cornur uocatur, quía inftar cornu formam rotundã habețuel à diffúfione lati= tưdinis qua protendit̂ in acutum: uel à corio cum cute inuifcato, \&c. De coriagine diximus etiam

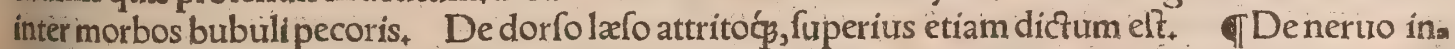
cifo \& eius cura, Rufius 173. Neruorum unulnera,Hippiatrica 84. Ad ictus \& dolorem neruor $\tilde{4}$ cataplafma, Hippiatr, 129, Cateros neruorum affectus, quære infra ubi de articulis $\&$ partib.extre mis dicetur. TVarices, Hippiatr.77.Crurum offa (inquit:Xenophon in electione equí)fint fpiffa, fed fpiffitudo non erit utenarum nę carnium:nam hoc paco cum per afpera agitưr equis , impler

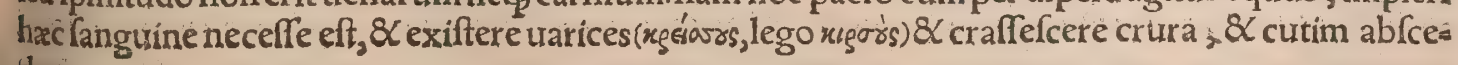
dere.

Àlexipharmaca $\&$ Theriaca.

Sxpe imprudens animal uenenum in pafcuis uel prafepibus uorat, contra quitatm noxam alexio 
pharmaca remedia ubi ab authoribus petenda fint monftrabimus: fape etiamá treneñofis animalib ictu morfúce lęditur; quibus theriaca dicta medicamenta fuccurrunt. De braffica fylueftri cum fo no depafta,Hippiatr.90. Deaconito,91. De cicuta, 92. De ueratro \& orobanche in cibo furm ptis fuperius dixi. Interit ueneno fandaracha \& equus, \& quoduris iumentum fiue ueterinum: da tur in aqua percolatum, Ariftoteles. Eft quando equus fordidos $\&$ abfterfioni deftinatos pannos uorat, contra quod malum in Germanicis libris remedium inuenio oua aceto calido macerata do nec teft a abfecdant, \& $c$. Si equus terram uorârit, pro remedio fauinam in pabulo dant minutatim incifam, Obfcur. De equo qui comedit pennam, $R$ uf. 133 . Contra fimum gallina deuoratum, Hip. piatrica 89. Veget.3.85.843.15. Stercus fuillum iumentis propinat̃ contra uenenofos morfus, Ve get. 3.77. Si araneum comederit equus, Veget.3.80. Bupreftes beftiola(uulpeftres, corrupte) arar nex fimiles, cũ deuoratæ fuerint animal prafocất, Vege.3.15.ubi de caufis impeditæ urina loquitur, Si bupreftin comederit in feeno, Idem 3,78. Contra bupreftin, Hippiatrica 86. Qui remedia Germa nicè fcribunt, hoc malum uocant Effern im magen. De erucis, Hippiatrica 93. Contra hirudines hauftas, Abfyrt, in Geoponicis 16,18. Hippiat. 88.

बDe morfu canis rabidi, Hippiatrica 87. Veget.3.84. Hippiatrica in fine capitis 87. De aque metu, Vegetius 3+31. Muris aranei morfus(inquit Ariftoteles) equis alị̆śç iumentis moleftifimus eft:puftula hoc excitant: \& periculofior quem defixerit grauida: puftula enim rumpuntur, ex qur interitus fequitur: fed fi non grauida eft, non interimit. De morfu muris aranei, Hippiatrica $87 . \mathrm{Ve}$ getius 3.77. uocat autem murem cacum: 8 3.82, ubi murem araneum trocat. Fit aliquando ut mu, ftela iumentum morfu fauciet, cuius dentes inficiunt animal, $8 \mathrm{moritur,} \mathrm{nifi} \mathrm{fubueniatur.} \mathrm{Remedio}$ eft fi uulnus oleo perungat, in quo muftela fuffocata computruerit, expreffo ualidiufculè per li lum. Fricatur \& locus faucius arida pelle muftela, ut incalefcat, \& datur iumento antidotus theria: ca,Camerar. Quinetiam ea(inquit A riftoteles) quam alij chalcidam, alij dygnidam uocant, fuomo: fu aut interimit, aut uehementem dolorem mouet:fimilis hæe paruis lacertis eft: fed colore ferpentiquam cæciliam nominant. De uulnere ex fagitta intoxicata, Rufius 178. Ad morfus ferpentium Hippiatrica 85.\& 86. Rufius 179. Quadrupedibus à ferpente lafis hæc profunt, ut Aggregato feruauit:Cancri in cibo fumpti, Plin. Daucus, idem. Filix impofita capiti iumentorum defendit àfer pentibus, Idem.Muftela catulus nudus recens cum fale appofitus, Plin, Ruta per nares cumuino, Idem. Vefpertilionis fel cum aceto, Idem. Si uipera animal percufferit, Vegetius 3.79. Hipp 85. \& 86.Aduerfus colubros, Veget.3.77. Ad ictos à fcorpione, Hippiat, 86.à fcorpione uelal ptili beftia læfos, Hippocrates in Geoponicis 16.19 . Veget.3.77.8 3.83. Si animal mordeattrià pla langịs, Veget.3.77.8 3.81, Hippiatrica 85. \& 86. Si paftinacam (ftaphylînon, infectum) deuơa rint, cuius magnitudo qua uerticilli beftiolæ eft, irremediabile malum eft, Ariftoteles. De eodenin: fecto, Hippiatrica 119. De paftinacæ marinæ ictu, Hippiatr.87. Eft in exemplis equos ab apiurs occifos, Plin.11.18. Apes aliquando equurm non modo fortiffime inuafiffe, fed etiam interemiffe, Ali ftoteles affirmat, A elian. Ne mufcis infeftentur ueterina, Hippiatrica 85.8 ne ulcera ab îs uermibus fcateant, Ibidem, Mufcas quog 3 uulnera infeftantes (inquit Columella)fummouebim $\mathrm{ce}, \&$ oleo uel unguine miftis, $\mathcal{Q}$ infufís, cæetera erui farina reçè curantur. Sunt quí uulneribus iubent unguen illud quo axes rotarum perungunt:aut ferum aquámue cafei infpergi, Culicespro pellendi, Hippiatr. 85. Contra tabanos uel oeftra, Ibidem. Contra cimices $8 \times$ pulices, Ibidem, Contra pediculos, Veget. 1.44. Hippiat.95. Contra ricinos, Ibidem. Quidam argentumuitun axungia uetere extinctum, fa ciæ ex cannabi illinere iubent, eamćç collo appendi. Alín aqua,inqua refina decocta fit, abluunt.

De particularibus morbis à capite ad pedes.

Omnes ualetudines capitis, præcipuè ueteres \& periculofos, cyclo curare oportet, Veget.Cydl autem rationem ex eo defcripfi fupra, ubi de equo purgando egi. Ad paffiones capitis iumentiby onia $\&$ uitis nigra profunt, Plin. 23. ut citat Aggrcgator. Ad caput fractum uel nudatum aliquoca fu, Vegetius 2. 13. Si capurt equí ex icqu morbóue languet, raphani(feminis nimirum) \& zedoariz partes æquales tritas cum uino mifce, $\&$ faucibus infunde; id'́; toties, donec fanies à capite fluxeril, Obfcurus. Ad capitis dolorem, Vegetius 1.8.capitis \& caluaria, Hippiatri.104. Capitis dolorem, inquirit Columella, indicant lachrymæ quæ profluunt, aures ćp flaccidx, \& ceruix cum capite aggran uata, $\&$ in terram fummiffa. Tum refcinditur uena, qua fub oculo eft, \& os calda foutur, cibó ftinetur primo die. In poftero autem potio ieiuno tepida aquæ prabetur, ac uiride gramen, thin ue tus foenum, uel molle ftramentum fubfternitur, crepufculó̧́ aqua iterum datur, parũós ordei cum uiciz libris duabus $\&$ femis:ut perexigua portione cibi ad iufta perducatur. Appiofus, id eft hemis

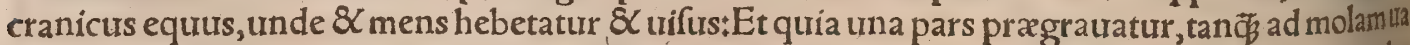
dit in gyrum, Veget, 2.2.Et rurfum 2.10.A ppiofum iumentum (inquit) prafepio incumbit, oculos tenfos habet, micat auriculis, \& c. Vide etiam paulo poft in Rabiofo. Sol canicularis ardentior atit malia percutit in cerebro, unde caput deiectum habent, Vegetius 3.36 . Ad firiafin, id eft capitis ars dorem, Hippiatrica 129. Capitis ualetudines, Vegetius 1.1. Cum ex aftu(inquít)uel frigore debulis tata funt membra, \& in capite frixus fanguis uertitur in uirus, tüc repletis uenis cerebri membranta diftenditur, \& fomni falubritatem frequenter excludit; ex quo neceffario dolor capitis, moeftitia \& 


\section{DeEquio. C. Lib. I.}

Imbecillitas fubic. Diftentionis quoç ualetudo(Vegetius 1,9.) ad capitis pracipué caufam refer tur. Obfcuratur in ea uifus, capitis membrana diftenditur, adeft tremor $\&$ furdor totius corporis. Co tingit autem diuerfas ob caufas, fi fudans biberit, exindigeftione cibi, fi non dormiar, fi fubftrictus manferit, Capitis refrigeratio, ut cum equus ex calido ftabulo fubito ad frigus perducitur: unde equirs aliquando tuffit, \& appetitum amittit, \&c.Pet, Cref, 9,25. De frigiditate capitis equi, quę tuffim proutrat, oculos inflat, aliquando lachrymas eurocat, Rufius 70. De uiuulis, Petrus Crefe. 9. 17. Deftratigutillione, Rufius 63. De ftrangulione 81 cymorrha, ut quidam foribunt, item de uriuulis, fu pra inter morbos communes docuisetfi potius ad capitis morbos referri debeant, Pro chimorra aut fimili tuoce, apud Petrum Crefc.9.14. hęmoagra ineptè legitur. Deftrangulina etiam inter thoracis \& pulmonis morbos nonnihil dicetur infra. Ad defluxiones uel deftillationes à capite, Hippiatri. 104. Pituitx, id eft fluxui humorum, uel rheumati iumentorum uel pecorum, ut Aggregator obfer vauit, prodeft cretani(id efficethmus) Plinius lib.16,item hellebori nigrifurculus per aurem traie. fus, \& portero die eadem hora exemptus, Idem lib. 25. Equo cui catarrhus per nares fluit (rütsig) oleilibram, in qua argenti uiui quadrans decoctus fit, refrigeratam ab ignis calore per nares infundes:fic enim uel intra octo dies, uel fex menfes faltem conualefcet: atut morietur, Obfcurtus, De ge= nere et qualitate mucorum qui per nares fluunt, Vegetius 2,36. Medicamentum ad faniem liquidam énaribus, Hippiatrica 129. IT Vegetius libro 1.maniam quo og inter malidis fpecies numerat. De phrenitide, Vegetius 2.3. Si, ubiantea diebus aliquot ponte ieiunarint, mox in furorem uertantur, fanguine detracto iutuantur, Ariftoteles. Equis furentibus auricula funt fubreçæx, Pliníus. De infania, Vegetius 2.12. Oculi, inquit, ardent fanguine 8 humore fuffunduntur, auricula ftant uel micantindomitorum inftar capi non poffunt, capti parietibus fe illidentes conantur effugere. De furore \&rabie, Hippiat. 102. In ribus micant, \&cc. Vege.3.43. Contra maniá feu furiã in equís, Ruf.158. De chirurgia adhibẻda in equo furiofo, propinato ei opiato pharmaco, 8cc, Idem 159. Rabies(inquit Vegetius) eadem omnia \& maiora oftendit $\$$ infania. De equo furiofo uel leprofo(lego rabiofo)R uf 154. Rabiofus, Vege. tius $2,5.82,11$. Cum appiofo(inquit)accedit thoracis paffio, ftatim fit rabiofus, fupercalefacto ieco ire \& fanguine, \&c. Dolor eft loci, adeò ut mordendo fe comedat(prafepia aut ilia mordicet:) uel alia um impetat, Subito hinnit tan $\tilde{\beta}_{\tilde{\beta}}$ fanus. In parte capitis ubi uitium remanfit, poft curationem, diffici. le fe gyrabit, \& parietibus fe iunget, \&c. Rabiofi esui (inquit Camerarius)fiunt uarís de caufis, tit 0 ab reftu, à pabulo non idoneo, à cerebri inflammatione, à bilis in uenas exudatione. Flagrant $\&$ rigêt oculis, fpumam eijciunt. His uenas ftatim incidere oportet, qui ficaftrentur, refipifcere fubitó perhibentur. Noftri equos infanos lunaticos uocant, \& cerebrum cum luna eis minui aitunt. Circa Abderam $\&$ limitem qui Diomedis uocatur, equi pafti(nafentibus illic herbis)inflammantur rabie, circa Potnias uerò afini, Plin.non exprimit autem quibus herbis. Equos efferari \&crabie inflamma riferunt, bibentes ex Coffinito flumine Thracix; qui defluit in Biftonicum ftagnum, ubi Diomedis Thracis, qui immanes equos habebat, quiros Hercules expurgnauit, regía olim fuit. Ex eodem morbo laborare dicunt equos bibentes de fonte. Potnix, qui non longe aburbe Thebis abeft, Aelian. Equi dicunturvvн@ä̌s, quí lymphatico morbolaborant:in quo ad tibix fonum quies contingit, fronte de= miffa quod uocatur ratwrixury, Crlius. Quod autem lymphari dicitur, tale eft, ut equus ad tibiæ fo= to num quiefcat, \& demittat frontem: cum uerò confcenderis, citetur contentius donec retineas: demif fus etiam femper triftiśç̧ eft, fi rabie tenet̃icuius indicium, ut auriculas demittat ad iubam , rurfusćs protendat, id ç uiciffim factitet, Ariftoteles. Rara quidem (inquit Columella) red 82 hrec eft equa= tum nota rabies, ut cum in a qua imaginem furam uiderint, a more inani capiantur. Et per hunc oblite pabuli, tabe cupidinis intereant. Eius uefaniæe figna funt, cum per pafcua ueluti extimulata concur. fant,fubinde ut circumfpicientes requirere, ac defyderare aliquid uideãtur. Mentis error difcutitur, fideducas ad aquam. Tum demum fpeculatæ deformitatem fuam priftinæ imaginis abolent memo riam. Eadem hæc uerba Ruellius in Hippiat.15.tanđ̆ Theomnefti repetit, cum in Gracis nihil tale hoc loco legatur, nulla Columellæ mentione facta. Hydrophoba, id eft aquam timentia iumenta, ex qua paffione in rabiem conuerti folent, Vegetius 3.31. Syderatio, Veget,2.39. In hac(inquit) la. yo bia $\&$ maxilla $\&$ nares etiam deprauantur in parte, ita ut uix cibaria dentibus inlidat, qua etiam hu moribus plena reperies $\$ \mathcal{Q}$ bibiturus os ad nares demerget in aquam, quia infirma funt labia quibus hauftus attrahitur, Defyderatione $\delta$ comitiali morbo, Hippiatrica 109. De epilepfia, Veget.3.35. Si equurs morbo incognito collabatur, filicis foeminæ radicis partem lingue fubŕcito, mox alui ac ue fica excrementum reddet $\&$ exurget, Hieronymus Tragus hocipfum fe expertum faribens. Ad tertiginem, Hippiatrica 128. Paralyticum iumentum ambulat primum in latere ad fimilitudinem cancri, ceruicem incuruat ac fi fracta effet, reetos pedes non ponit (parietibus fe illidit) cibum $\&$ po. tum non recufat, hordeum ipfius udum femper apparet, Vegetius $3.4 r$. Indicia refolutionis neruo rum, Hippiat, 129 . Ex impetigine inureterata iuxta oculum uermis fit, qui ad cerebrum penetrat, un de animal ftatim moritur, Incertus. Cerebrum commotum facit ut male ambulent equi, frequenter fo offendant, \& toto fe corpore cömoureant, \&c. Veget.2.7. Ad lethargicos, Hippiatrica 128, quod pe nultimum eft caput de diurerfis morbis. De lethargico equo, ibidem ror, in uerbis $A$ bfyrti de thlafma te. Animal lethargicum femper iacet ac dormit, Vegetius 3.48. Lethargicl, Hippiatr.10 4, Aśbag gos 2 


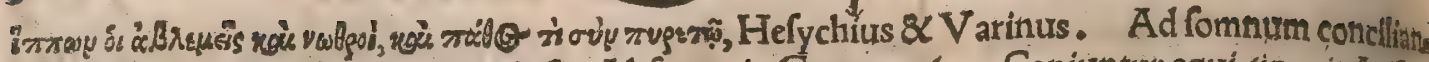
dum, Hippiat.128. đNeruorum lafio, Abfyrtus in Geopon, 16.7. Capiuntur equi (inquit Arifto.) etiatm rigore neruorum: cuius indicium, uena ut omnes neruíq intendantur, \& caput ceruiceś immobiliter rigeant, rectiś̨́ crumibus gradiantur, Roborofa paffio (Vegetius 3,24, dicitur, qua animal rigídû facit ad fimilitudinê ligni. Totum corpus aftringitur, extêf $æ x$ funt nares, $\mathscr{Q}$ aures frigl dx, immobllis ceruxix, os conftrictum, caput extenfum, pedes conftrict, ut nulla commiffura flecta tur, \&c, Tetanus uidetur hic affectus: $\mathcal{X}$ idem forte eft quem Germani uocant, erfdhrecten off aller fietet, hoc eft noxam per omnia crura:in quo allium cum aceto tundunt, $\&$ crura bis aut ter illinutip; \&. donec incalefcant inequitant, \& calefactum operiunt. Spafmus, oer trampff/ oder vertütht àert. Vide infra in affectibus ceruicis \& colli, \& rurfus in affectibus neruorum inferius. Tetar nus, Fippiatr. 34. Tetanum uel rigor em neruorum, uulgò in Italia incordatum uocant. Tetanus vel robur, opifthotonus, emprof thotonus, Veget. 3,24. Opifthotonus, Hippiat.34. Vegetius 3,47, Ad opifihotonicos unguentum, Hippiat.129. Spafmus in caufa eft ut fubito concidant, articulien rum extenduntur, toto corpore palpitant, aliquando etiam de ore fpumam emittunt, \&c. Vegetits $\xi_{3}$ 3.. In opirhorono non debet incidi uena, Abfyrtus cap.9.

of De morbis oculorum, Hippiat. 11,Rufius 52 , Vegetius 2.21. Heterophthalmos equus, vide füpra in B. fed hic affectus naturalis fiue connatus eft. Oculis iumentorum \& quadrupedum (utob feruauit Aggregator) prodeft anagallis, Plinius lib,25. Chamelæa, Idem 24. Sal, fi infpuatur oculis, Idem 31* Oculus lunaticus uitium eft, quod interdum oculo album inducit, interdum lympidat, undelunaticum ueteres nominauêre, Vegetius 2,18. Noftri aiunt oculum (malim, maculam aut fuf fufionem oculi) cum Luna crefcere 82 decrefcere, \&Cinterdum prorfus obcæcari. A duerfus hoc itik tium aliquílapillos in capitibus cancrorum repertos terunt, melle excipiunt, $\&$ oculis illinunt (hos aliqui eriam ad cicatrices $\&$ ungues adhibent.) Alip uitellum oui cum fale fubigunt, \& uftum inde puruerem oculis infpergunt, quod cicatrices etiam abolere aiunt. $P_{i l i}$ in oculis, Vegetius 1, 15. De Ianguine qui apparet in oculis equorum, Rufius 57 . Oculi cruore fuffufi, Hippiatrica 11. Ocula rum wulnera \& ictus, Ibid. Ad oculum percuffum, Vegetius 4,27. Rufius 59. Ad album uel glati coma ex percuffura natum, Vegetius 2, 21. ICfus uulneris $\&$ inde carcinoma, Ibidem, Adruptu ras, \& $X$ de tuniculis feruandis, Vegetius $4+27$. Noftrates uulnus oculi ab acuto aliquo ligno infixo uocant vern $A u g\}$ tal $\mathcal{Q}$ uenam ftatim ante ocilos incidunt:Alij uero eam qua mox fub uinculon fi (ut uocant) reperitur, $\&$ caput humilius alligant, ut fanguis effluat. Exulcerati oculi, Hippiat. y. Vlceribus in oculis animalium medetur papauer, Auicenna, $P$ apaueris cornuti folia \& flo

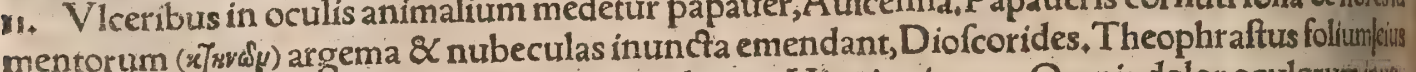
argema in ouibus tollere feribit. Dolor es oculorum, Hippiatrica II. Omnis dolor oculoruminum Ctone fucci plantaginis cum melle Attico, uel fi id non eft, utigs thymino celeriter leuatur, Columin la. Oculorum inflammationes, procidentia, defluxiones, Hippiatr.12. De lachrymis oculorim, Rufius 13. Contra ruborem $\&$ dolorem oculorum, Rufius 61. Lippitudo, Hippiatrica n1. Ab 1. Ceoponicis 16.5. De epiphoris oculorum, Vegetius 2.22. Hippiatrica 11. Auticax eft theurs ad oculos, epiphora uel ophthalmia uifum impediens, Petrus Crefc, 9, 26. Apud eundem 9.15 .

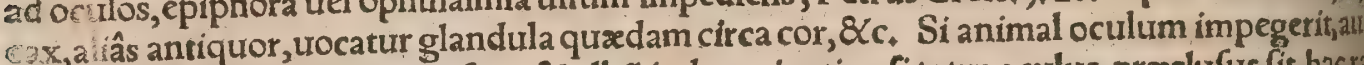
fi. icauerit, uel ex percuffura laferit, $\&$ albũ induxerit, etiamfi totus oculus praclufus fit, hac $r$ cut abis, Sxc.Vegetius 1,20. Ad confricationem oculorum, Rufius 20. Fluxionem oculorum qui curant infperfo puluere, ex uitello nui ufto, 8 careo, hedera terreftri ac ruta uftis mixtisq̧ or hus, De tumore callofo oculorum, Vegetius 2, 12. Oculorum carcinomata,Hippiatricall, Di caligine oculorum, Rufius 54 . De caligine \& panno fiue panniculo albo, qui pupillamoculiocu pat, \&uifum obumbrat, Rufius 55. Oculi (inquit Camerarius) caligine $\&$ nebulis frequenter ia duntur, claritatem reftituere putant medullam de cruribus caprinis exemptam recentibus $\&$ in ctis, cum rrochifcis rofeolis (cư rhodoftagmate, ut habet Abfyrtus in Hippiat, ca, I1, unde harc tratil lit Camerarius, \& ut rhodoftagma non recté paltillos rofeos uertit, fic compofitionem eorum frufira de fuo adfert:de rhodoftacto, uide A eginetam 7.15 , de rofeis paftillis, $7,12$. ) $\&$ illinetur octuis ginofus (equi uel muli bis aut ter penna illinetur, \& fanabitur, Abfyrtus, ) Quòd fi etiam purtulasp pareant, aut rubedo oculorum, proderit idem medicamentum, uel medulla cerui cum croco po

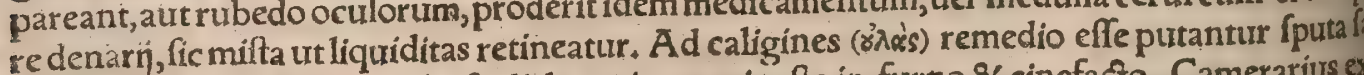
ore iejuni liquefacti: aut puluifculi de corio ueteri tofto in furno 8 cinefacto, Camerarius ext platricis. In quibus nos cap. II, fic legimus, Medulla ceruina purgata, ne quod officulumrem \& in pila marmorea trita cum drachma croci triti mícetur $\&$ reponitur in uafe lígneo (uitreo, $R$ Eivis) vel corneo ad ulcera oculorum. Oculos equi claros reddet hoc medicamentư, Ad unciam is puri,zinziberis drachmas duas admifce, \& ftillatiti liquoris ruta unciam femis : hoc octuisin un 8 iumentis \& homini prodeft. Contra maculam equorum, Rufits s8. Cicatrices oculorts Hiopiatrica 14 . Vegetius 2.22. Cicatrices oculorum (inquit Columella) ieiuna faliua $\&$ fale de ta: exrenuantur: uel cum fufili fale trita fepia tefta $¥$ uel femine agreftis paftinacæe pinfito, \& per tecum firper oculos expreffo. Pterygia, id eft ungues oculorum, Hippiatr. 11. De ungula octlo (cingel)Rufius 56 . Ef autem (inquit) cartilago, qux frequenter medium oculorum occupat 


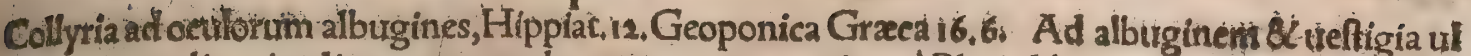
cerum in oculis animalium commendatur centaurium minus à Plinio lib; 1 s. cinis de offe repia lib. 3a. fideritis libro 15. \& flos papaureris campeftris ab Auicenna . Cicatricem effe puto quod nofiri in oculo uocant $\$ a$ s ffil, quafi pellem dicas, niff quis pannum potius barbaris dictum interpretecur : ea aliqui curant uitello our cum fale fubacto \& ufto, ut \& lunaticum ocultum, ficut fupra dixi, Alíp tum ad cicatricem tum ungutem oculi duodecim lapillos è capitibus cancrorum urunt, \& inflant in octs. los equi, donec rubefcant: deinde mel illinunt. Hoc etiam fupra ad oculum lunaticum retulinus, Alij unum autr alterüim oưum coquunt donec durefcant, $\mathcal{Q}$ qurod album eft fuper ferro urunt dum in cinerem uertitur, cui admifcent pipèris $\&$ zingiberis albi farinam cribro excretam, hoc arido re,

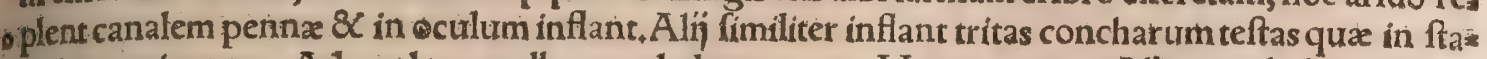
gnis reperiuntur. Ad oculorum album uel glaucomata, Veget. 4.27. Album urel glaucoma ex humore uel percuffura natum, Vegetius 2.12. Si animal oculum impegerit, aut confricauerit, uel expercuffura laeferit, \& album induxerit, Vegetius 2,20. Oculus lunaticus uititum eft quod inter dum oculoalbum inducit,interdum lympidat, Veget,2,18. Collyria diuerfa, ad albutm in oculis, ad glaucoma, Vegetius 4.27. Suffufio urel album quomodo per nares curentur, Veget. 2.21. Suffurs fio oculorum, Vegetitus 2.16. Hippiatrica II,Paracentefis in cicatrice oculi, \& qux fit incurabilis, Ve get, 2.17. Apud Gracos medicos non in cicatrice fed fuffurfione oculorum, paracentefin adhiberi fo: litam legimus. Eft fuffufio, Gracis hypochyfis, barbaris cataracta, Germanis cin ftatr uel ifarn, undecompofitum ftartblint, id eft ex fuffufione crects, Staphyloma oculi, Hippiatrica u. Vege. tius 2.19 .

(Deextrahendis equo dentibus, qui dicuntur fcalliones, $R$ ufius $4^{\circ}$. Sunt autem (inquit ) qua. tuor in maxilla inferiori, extrahendicum equus fuerit annorum trium $\&$ dimidif : duo ex eis fcaillio: nes, \& duo plani uulgo nuncupantur. Plura de his dentiburs feripfi fupra in B. Si gingitix urel den* tes doluerint, Vegetius 2,32. Ad Parulides, id eft gingiuartum rollectiones, Hippiatr.12\%. Pulliaria, tumor inter gingiuas $8 \mathrm{C}$ maxillas, tanta tenfurra ut manducare uix poffint; funt autem glandulę quę dam, Veget, 2.25. Os ulceratum, Hippiat,6e. Aphthx oris, [bidem 61. Vlcus putridumuel mañ cidum in ore, Hippiat, 18 . De malo oris equi, ubi glandula in uturf(os maxillis intrinfecus turmefae Ax apparent, inftar amygdalarum, Rufius 64 . Hoc malum Germanicus quidam liber exponit, Cie phwollen balis/ober fo ca nit fdlinden mag. Si tumores in ore fint, quos noftrigallas uocant, é ué o nis fublingua fanguinis bonam partem extrahunt, $\&$ os perfricant uino uel accto, cti fal $\&$ arida fax uini æquali inter fe portione mifcentur: Ali gallas ferro curuo excifas ita perfricant:quod fi pa. latum tumeat, gallas fecundum longitudinem excindunt, \& uulneribus diligenter affricatit falem non tritum. Si equus ex uulnere oris aut faucium febriat, Vegetius 1.36. Ad fiftulam in maxilia tuel ore, Vegetius 2.26. Equorum communia mala funt, immundicies oris, aut dentium afperitas \& inzqualitas, \&c. Camerarius. De lafione linguaz, ubi multa ulcera fiurnt, ut ex morfu dentitur, trel freni, uel malo pinzanefe dięo, R ufius 68 . Malum (inquit Albertus) in lingua equi aliquiandó fit, cum ex putrida efca fanguis putridus $\propto$ phlegmaticus generatur lingtiam putrefaciens : undé lingua excoriatur, \& urene fub ea nigrefcunt. Hoc malum aliquando ad pedes defẽ̃dit, ita ut equus trix ftare poffit, \& cc. Lingua incifa, fibulis confuenda, \&c. Veget. 2, 31. Ad linguram intererfam, 10.Hippiat. .29. Ad ligulam, Hippiatr.129. Ad palati dolorem cataplafmata, Hippiatr.129. Si uena in palato incifa claudi non poteft, Vegetius 2.35. De palatina, Rufius 65. Sunt autem fulci quidam in palato equi,caui uel profundi,ex pabulo acuto $\&$ ariftís pleno pungente palatum, aut ex phlcge mate orti. De lampafco, Rufius 66. Eft aittem lampafcus in equis palati tumor, \& forte per metae thefin literarum fic nominatur uoce à palato detorta. Anglice etiam lampas uocatur, Germanice fकul uel ftül, in quo affectu quidam gingiuis fuperne tumidis cauterium adhibent, Lampiftus (inquit Albertus) ex abundantia fanguinis in fuperiori parte oris iuxta dentes eft protenfa inflatio, ita tit fulei quis inter dentes funt emineant, \& equo efca(fluratura \& moruellata, Rufius)de ore cadat, Qc.Columella in butbus tumorem palati trocat. Palati tumor accidit etian morbo quem crithiafin trocấ, unde Albertus apud A riftotelem deceptus non fymptoma tantum palati tumorem (ipfe molo ro litiem uocat) fed eundem omnino morbum cum crithiafi facit. De barbulis fub linguz, Rufius 69. Barbulz quadam (inquit Albertus) fiunt in palato equi, ficcæe, in modum ronorum mamillarium al cuitus beftiol $x$, qua cum crefcendo longiores partro grano furerint; equum ab edendo impediunt. Germani, ut conício, v\&fen uel befent nominant, quax fint eminentia quadam fub lingua, fimiles granis frumenti quod fêfer appellant, \& equum ita impediant ut ex cibo nihil proficiat: nifi fofcels lis potius, de quibus ftatim dicam, hoc nomen contueniat, quod magis placet. Ioan, Ruellius in Hip piatricis quodam loco ubi de ranis pedum parte mentio fit, ineptiffime uritiofa incrementa lingura in terpretatur, \& Petrus Ruellius errorem eilus fecutus à Gallis uulgò les barbes nüncupari fcribit Fofcella(uel floncellx, Rufio 67.) inflationes(molles $\&$ parux, Rufius)intra os equi in labijis natz terfus extremos dentes, in medio nigricant:fiunt autem cum equi ingerunt frigidas $8 x$ afperas her. Co bas, qua fuper labiîs $\&$ maxillis diu manent, $\&$ impediunt quo minus pabulum equi fuo commode loco mandi poffit, ut in lampafco etiam côtingit, \& cr. Albertus. Videtur autem hoc êffe illưd malưm qquod fuperius dixi à Germanis pefern appellari, quod aliqui definiunt urmorem effe fub labijis ad 
dentes laterales; \& eadem Germanicé de co fcribunt, qua de folcellis Albertur Latinè : ut fefett â fo fcellis detorrum fit nomen:barbulx uerò fupra dicła Germanica lingua trocentur, werglin ober j\$ p fin im raben. Glandula inter maxillas \& fauces inferiores nafcuntur, \& ad fimilitudinem pilu larum maiores, aliz ueró minores connexa ex carne obdurefunt, \& tumorem fine doloribus faci unt, \&c. Vegetius 2.14. Si ex plethora fanguinis fauces tument, Vege.2.19. Tumor faucium \& capitis interius adeỏ ut bibere aut manducare non poffint, Vegetius 2, 28. Tonfillæ, Hippiat, 18,2 20. TMaxill interdum dolent $\&$ tument, interdum etiam lapides in eis concrefcunt, Hippiatr, 18. Si equo maxill $x$ dolent, calido aceto fouend $x, \&$ axungia uetere confricandxe funt, eadem medicina tumentibus a dhibenda eft, Columella. Maxillarum ulcera putrida, Hippiatr.18. Os fra fum iuxta collum, uel molares, uel alio oris lcco, ut morfum equus claudere non poffit, Vegetius., 33. De fanguine per nares fluente, Hippiatr. 42. Vegetius 1. 54. Nonnun ff $_{\text {etiam }}$ per nares proftu uium fanguinis periculum attulit, id'̧́ repreffum eft infufo naribus uiridis coriandri fucco, Coltra mella. De cuferino uel cuferio, id eft cum poft curfum fanguis denaribus fluit, Vegetius 2.37. De cartilagine nariũ corrupta $\&$ fanguine fluente, Vege.2.34. Si nariũ feptum refciflum eft, Hipplat, 129. De polypo, Hippia, 21. In polypo nariũ praclufo fpiritu ftrangulari uidente, ftertũ̃t, muci humidi profluunt, V eget, 2,38. Chanan eft fonitus accidẽs in nafo, quo fit faplus ifta uox chaha:uel fecun dum alios eft exitus uaporis foetidi ex naribus, ficut accidit equis, Andreas Bellunenfis. Ozænæ ili tia pedum funt Vegetio, item Abfyrto cap+ 12\%, ut errauerit Ruellius qui foeda narium ulceraillic interpretatur. Podagræ indicium, ut alter teftium dexter palpitet, uel ut pauló citra nares cauum quiddam rugofumós gignatur, Ariftoteles.Sternutatorium, Hippiatr +129. đAurium dolores, at Hippiat. 17. De aurbus contufis, \& collectione aurium uel fuppuratione, Veget.1.14. Detumo. re iuxta aur em, lbidem, Si aqua ingrefla fit, Ibidem, \& Hippiatr. 17. Strumæ $\&$ parotides, ideff duri tumores iuxta aurem, Hippiatr.16. Vegetius 2.23. Vlcera auricularum, Hippiat.17.

I St equo collum ita tumeat, urt deglutire non poffit, bacillũ anterius fiffum \& ftupa inuolutum, inferito in fauces equi ut ulcera rumpantur, deinde tria oua cum aceto mixta infundes, Scriptor int nominatus. A pud eundem morbus quidam nominatur E̊lfudt), id eft gutturis morbus, cuihocier medium adhibet: Album liquorem(inquit)de ouis uigintiquatuor thuri mifcebis (quod remedium ufurpatur etiam in lampafco dicto, quem f hillfudbt interpretamur ) $\&$ in collum defundes; deinde colio circulum circumpones (quidam $\&$ alterum peciori addunt) $\&$ equitari facies donec bene fuda uerit: alij aliter medentur, ut in libris Germanicis prafcribitur. Ceruicis tumor $\&$ attritus, Hipp 23. Stiua (inquit Albertus)in collo equi dicitur, cum collum fine dolore huc illuc flecti non potel nec equus efcam nifi per interualla capere poteft, accipit autem à terra raptim $\&$ feftinanter. Carfía eft extenfio neruorum colli $\&$ repletio, Curatur fubulis candentibus transfixis, \&c. Defcima(fih ua lege) (eu lucerdo, $R$ ufius 73 . fit (inquit) ex nimio onere fcapularum, 82 deficcatione nimia netio rum colli, \&c. Noftrates hoc uitium in quo tendines ceruicis rigent, uocant balffartig. Defpafnio $\&$ tetano fupra dixi in morbis capitis. Eft et aliud colli uitium, quod uulgo uocamus ben fpectible er equum it affectum [pectb hllig: quem in Germanicis libris reperio fimiliter cur ari, ut fcabiem od li, de qua furpra diximus. Audio tumorem effe mollem laxumós, qui in caufa fit ut collum \&iubain alterum latus inclinentur: $\&$ aliquando excindi. Collum equi inflatur, inquit $R$ ufius, fi intra quar diem poft extractionem fanguinis, plagam fuper lignum $\&$ lapidem fortiter, aut alius equusillam 4 corroferit, a ut fi cito poft reftrictionem plaga duram efcam comederit, \&c. Si iumentum certicel uel uertebras eiecerit aut luxauerit, Vegetius 2.41. Hippiatr.26. Peruerfio ceruicis, Hippiatt, 1 , Ceruix deftiliationem patiens tumidior uidebitur, foetorem habebit canceraticum, cum humorenis gro \& liquido: diligenter fcrutaberis foramina eius, \&c. Vegetius 2.43. Si iuxta collum ex punf rafpatulæ aut lateris inflatus fuerit equus, \& c. Albertus Malandria, id eft uulnera ceruicis, Vegr tius 1.42. TStruma rumpend $x$, Hippiatr. 20. Strumæ uel parotides uel frophul $x$, iumentơtun guttur $\&$ fauces infeftantes, Vegetius 2,23. Strum $\&$ parotides, Hippiatr,16.

T) Arteria ulcerata aut rupta, Hippiatr.63. Ad fcabrítiem gutturis, Hippiatr. 129. Cynanche, id eft angina, Hippiatr.19, बAd pectoris uulnus ferro uel aliter factum, Hippiatr. 47. Pectoris aggrauatio, Petrus Cref. 9. 34. De grauedine pectoris qua fit ex plethora feré, \& impeditgrefum equ:,Rufius 91 . Equi aperti ante pedes anteriores paftorentur, \& pecius uino calido lauetur, Ru: fius 92 . Si animal lædatur cum accipit potionem, ut $f$ in arterias pulmonis refilierit, Vegetius $3,7 t^{5}$ De uritñs pulmonis, Hierocles in Geopon.16.10. In dolore pulmonis fter tit equus, tuffit, excreatpl rulentum, \&c, Vegetius. De eodem Hippiatr. 5. Pulmonís uitio contingit ut equi propter tufim difficilem offa deuoraffe putenturthic morbus cum nouus eft, equus inde peumorrox uocatur, à th mone rupto ( de quo Hippiatr. 6.) \& facile curatur : inueteratus iam pure collecto in pulmonibis pneumonia dicitur, \& equi pncumonici, hoc eft pulmonarí uel uulfi, \& agré curatur, Hipplatr, Pulmonis exulceratio,Hippiatr.17. Pulmonarí \& uulfi, Hippiatr.7. Ad tuffim equorum, Hier, in Geopon.16.11. Hippiatr.22. Vegetius 3.61.82 69. Tuffis ex humoris acerbitate, Vegetius 3,67 hid ruflim ficcam, Idem 3.68. Rufius 165 . Ad tuffim fi quid faucibus inhaferit, Vegetius 3. 62. Ex faucibus, Idem 3.66. Exafperato gutture, Ibidem. Si ex uulneribus faucium tuflis urgebit, Vegetiu 3.70, Si a b internis tuffierit, Ibidem, Ad tuffim ex perfrictione, Vegetius 3.63 . In hac caput deoffum 


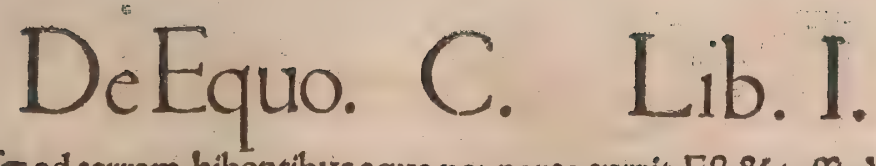

mittunt tuffiendo uf $\$$ ad terram, bibentibus aqua per nares currit, Eft 84 tuffis à colibus, cum coles iniuriæ pleni funt, tument'ś, dum bibunt fic affecti continuò ruminant, Veget. 3.64. Eft deniç (ixiquit idem 3.65.)ab interioribus, grauior \& pene infanabilis; hæe nares iumenti pracludit ut fpiritum reddere non poffit. Si ilia fpiffis pulfibus ducit, fignum eft prouenire à iecore uel pulmone, uel pr cordijs: Sin lentis pulfibus ilia duxerit $\&$ uentrem, indicat tuffim de his locis, in quibus inteftina li= gantur, quorum tenfione $\&$ iniuria compelluntur tuffire. Nam fi curfu nimio uel latiore falu conue xata ilia fuerint, hæe nafcitur caufa. Ex nimio quo $\$$ xeftu uel intolerabili frigore interiora uitiantur se faciunt tufficos. Vnde uulfi appellantur, Hæc Vegetius, Ad tuffim \& uulfos, Vege.3.69, 8 >0. et 4.9. Capitis refrigeratio interdũ facit ut equus tuffiat, Petrus Cref. Recens tuffis celeriter fana - tur, pinfita lente, \& à ualuulis feparata, minuteç molita. Quæcum ita faça funt, feftarius aquæ cal dæ in eandem menfuram lentis mifcetur, \& faucibus infunditur, fimiliş́́ medicina triduo adhibe. tur, ac uiridibus herbis, cacuminibusćp arborum recreatur agrotum pecus. Vetus autem tuffis di. futitur porrifucco trium cyathorum cum olei hemina faucibus infứ: ĭfdemç, ut fupra monui= mus, cibis prabítis, Columella. Ad tuffim recentem dari putant utiliter piforum lentíumue, aut eti am fabarum lomentum, Camerarius ex Hippiatr. Grac. Ex eodem remedium ad anhelitum grauio rem ex fulfure fupra retuli, ubi tractatum eft de morbis equi in genere. Tuffi $\&$ afthmati iumento rum, ut Aggregator obferuauit, conducit gentiana, Plin. 26. Verbafci cuius flos eft aureus, tanta uis eff, utiumentis etiam non tuffientibus modo, fed ilia quogs trahentibus, auxilietur potu, Plinius 16. De uulfis etiam in pracedentibus quædam citaui:uidentur enim uulfos(in Græcis etiam Hip

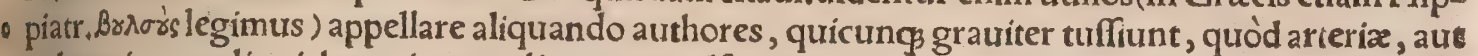
pulmonis aut reliqui thoracis pars aliqua conurulfa in eis uídeatur, uel rupta, unde $\&$ pneumorrhô ges dicuntur. Vegetius 3. 42. uulfare pofuit pro ualde tuffire. Vulfa quidem, Gracis fpafmata, in quocunq̧ corporis loco dicuntur, quoties non ruptum modo aliquid, fed nerui quoqs ì, quos ives, hoc eft fibras dicunt, laceffiti funt atq uulfi. Barbari quidam recentiores, pro uullis uulfiuos $\&$ pulk fitros equos dicunt:à quibus etiam Germani mutuati uidentur fuum bïljen, quod eft cum difficulta re $\&$ maiore fono tuffire. Quinetiam pulfiuum equum noftri uidentur tan $\bar{\beta}$ à cordis pulfu nominaf fe en betsfdulegig roffs: cum tuffientem, ut puto, folum, aut etiam anhelofum intelligãt, quod uel ex remediorum natura cốncio: nam inter cętera gentianam cum quarta falis parte in uino coqui $8 \times$ ine fundi iubent. De pulcina(aliâs pulcini fiue mulfiuri, deprauatis codicibus,)Pet, Cref,9, 20. Morbus - hic(inquit)fit ex calore liquefaciente pinguedinem, qua obftruit pulmonis arterias, ita ut equus uix refpirare poffit:Signa funt, narium magna fpiratio, \& ilium (circa coxas)crebra pulfatio, (hinc for te aliquis pulfiuum equum dici conïciet, non tanक्ष uulfum : fed cum res una fit, de uocabulis nemini contendimus, ) Incurabilis feré eft:tentantur tamen remedia quradam, \& $c_{*}$ A Autumní tempore cibe. urr uuis maturis, uel duki mufto potetur. Mangones quidam ad uiridia pabula ducunt, ut fallant emptores. De uulfis, Vegetius 3. 66. De equo pulfiuo, Rufius 142. In hoc morbo(inquit) narium có tinua \& magna fuffocatio contingit. Dantur pro remedio carnes $\&$ decoctio ferpentum; $8 \mathrm{c}$. Ad uulfos $\&$ ruptos (grauiter tuffientes) Veget, 3.70 . Chamaleuce (inquit Calius Calcagninus epifto licarum quaftionum libro 3 .) ea eft, quam olitores 8 agreftium uulgus ungulam equinam uocat: $x^{\circ}$ antiquis nonnulli tuffilaginem uocauerunt, $q$ arcenda tuffi fit accommodata. Ex eo factum puto ut to uete inari", ad difcutiendam equorum peripneumoniam, illa utantur. Ea eft uehemens pulmonis in flammatio, ex deftillatione plerungs proficifcens, quam grauis anhelitus fublequitur: hinc equos pneumonicos appellant medici, quos Latiné pulmonarios rectż nuncupaueris à grautitate refpiratio nis, $8 \mathrm{ab}$ ilibus qua difficulter admodum trahunt. Mulomedicorum imperitia hoc tempore uulfos uocitauit, Hac ille. Sed alius mihi uidetur peripneumonia peracutus in homine affectus, quam quî in uulfis feu pneumonicis \& pulmonarïs equis intelligitur, inureterata fcilicet tuffi laborantibus, ue Calcagninus in hoc errârit. Iumenta nimio faltu, uel curfu, aut ruina, cum aliquid intrinfecus rupe rint, uulfant: ftranguriam patiuntur, excreant purulentum aut fanguinem ab initio, \&c. Vege.3.42. Deepiftomicis(forte pneumonicis) uulfis, colicis, \&c.unde fanguis tollatur, Veget.1.27. Quorum pulmo uerfus cartilaginem enfiformem (fic reddo Das betsblatt) contrahitur, his fifymbrium car. daminen dabis in cibo, Hippiatr. liber German. Equus pulfiuus fi utuas uel racemos abunde ede. rit,liberatur:nec fímile huíc remedium reperitur, $R$ ufius, \& Pet, Cref.cuius uerba pauló ante citaul。 Spiritu diftenti equi, Hippiat. 62. Ex anhelitu inflationes, Vege.3.39. Aduerfus ftrangulatum prorenientem cum equus fatur cibo ad curfum agitur, Hippiat. III. In Germanicis etiam libris inuenio

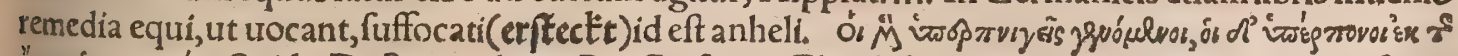

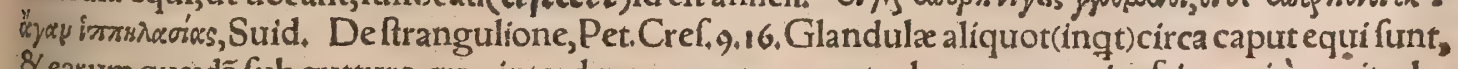
\&earum quadã fub gutture, qux interdum augentur propter humores equil refrigerati à capite de. fcendentes, unde totum guttur inflatur, 8 meatus refpirandi comprimuntur, 8 c. Haud fcio an hae glandula, tonfilla fint, de quibus Hippiatri Graci agunt $18 . \& 20$. conij̄cio autem eafdem effe, quron am non reperio alium morbum à recentioribus defcriptum qui magis accedat: Quanç \& uriuula aे - quibufdam dicłæeodem in loco glandulæ quadam fint, fimiliter ab influxu capitis auctæ, \& arteri am fimiliter ita conftringentes ut animalia fuffocentur, nifi in tempore fuccurratur, per cauterium vel incifionem, Exciduntur autem etiam ftangulionis glandula: : 8 apud Gracos Hippiatros ton 
fillis cauteritm adhibetur. Strangulinam trocant (inquitAlbertus) cum omnes meatư gutturis qui, per quos anhelitus ad nares meat cum tuffis grauedine conftringuntur; Fit ex putrida efca $\alpha_{a}=$ qua nimis craffa, \& ex phlegmate collectio propter otium equit uel ficca efca cum puluere comefa uel potu nimis frigido, uel cum tempore frigido nimis biberít equus, $\&$ poltea fine coopertorio in fri gido loco fteterit, prazcipué fi antea laffus furerit $\&$ ieiunus.Si per ocfo dies equus laborauerit, defpe. ratur. Frequenter infra duodecim dies euraditjuel in moruellam tranfit, \& $\propto$ periclitatur. Per contagio: nem etiam inuadit hic morbus, \&c. Eft quando ftrangulina ex frigiditate capitis uel tuffis ficca pe

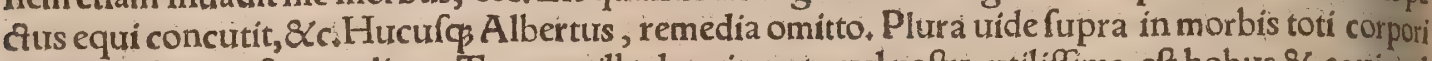
communibus de ftrangulina, Tormentilla data in potu uel paftu, utiliffima eft bobus $\&$ equis pul monarńs ob defluxionem à capite cum afthmate, auribus flaccidis $\&$ faftidio cibij, Albertus in Arifo telis hift, anim, 8,23. Malidis ficca caufa refertur ad pulmonem in dextrolatere ruptum, \& pleuritis dem inde factam; nihil per nares fluit, emaciantur, gratuiter anhelant $\&$ cum foetore, Vide Hippiat, 2. De nalide in uniuerfum fupra dictum eft inter morbos communes. "Hippacare, celeriter anis mam ducere, ab equi halitu qui eft fupra modum acutus, Feftus. De afthmate, id eft furpirio, Vege tius 3.68. De afthmate \& orthopnoca, Hippiatr.27. Noftri nefcio quem in equis morbum uocant burf gefreng, quem curari aiunt fi pectus inungatur fimo canis ex oleo de feminibus cannabistuel tanaceto cum fale ex aqua infufo, \& tanaceti herba naribus inferta, Prafcribunt etiam remedia ad

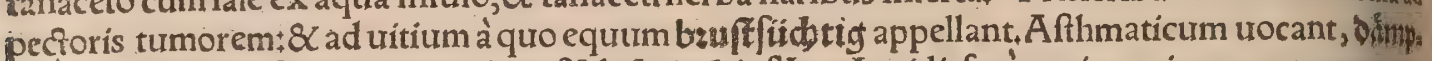

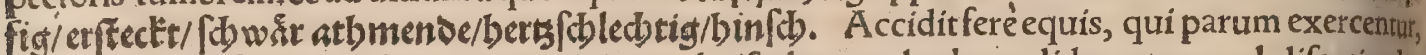
ut anhelitus difficultate laborent, tum igitur admifcebuntur herba calidæ naturæ ad difcutiendos humores lentos $\&$ tenaces, ut artemifia \& origanum. Hedera autem terreftris ad omnes morbos $\&$ languores equorum præfens remedium habetur, quęc non folum ab illis mandatur, fed etiam trita in feratur naribus ut fternutatio prouocetur. Sed ad difficultatem fpirandi laudatur $\&$ cichorexradix, \& gentiana. Laadatur $\&$ fulfurr (aliqui fulfuris unciam dimidiam pro una dofi terunt; \& $\propto$ pabulo ins fpergunt) curius ufus tamen periculo non uidetur carere. Quidam erinacei uiui cum fpinis exuffi, pulueres datos in ftabulo ftatim corrigere hoc,uitium affirmant, Hac Cameraritus, Sunt quiafth maticum fanandum promittant, fi triduo furfures aridos ederit. Aliqui helleborum nigruin inie runt inter cutem $\&$ carnem foramine transfixo fubula, Eft $\&$ alterû̃ hellebori nigri genus ad่ Hier Tragó defcriptum, abrotono uel efulx uulgo diçæ non diffimile, quod ab efficacia adirerfis aft Germanicébinfdtetut nominatur. DeOrthopncea, Hippiatr,27. In orthopncea fitve plagiorj equius etiamfi trahatur, ambulare detrectat, anhelat grauiter, frequieriter fufpirat, ronchos ducit, fufpendit:dum manducat, tuffit: difficile liberabitur licet diu uiuat; $\& \mathrm{c}$. Veget. 3.46 . Empyiequii cuntur, quos fuppuratio infeftat, Cell. Ad uomicam, Veget.3.69, \& 3.53.ubi \& empyema trocath hoc morbo(inquit)tuffiet equus, purulentum excreabit, os grauiter olebit, cum accubuerit difficle furget. Iumenta nimio faltu uel curfur, aut ruina, cum aliquid intrinfecus ruperint, ftranguriā ps untur, excreant purulentum, aut fanguinem ab initio, $8 \mathrm{c}$. Veget. 3.42. TCordis dolor, Hippint, 29. Irremediable malum eft, inquit Ariftoteles, fi cordis dolore uexatur equus:cuius indicium, latera fubfidant, 8 ilia præftringantur.

Ttomachicus uel potius fyntecticus, Vegetius 3.55. Vide fupra in morbis communibus, De fyncopatis 8 confixis, Vegetius 1. 53. Cardiaca, id eft cordis (oris uentriculi potius) dolor, uel quium animi \& fưdor, Vegetius 2.4. Cardiacus morbus, Hippiatr, 29. De bulimo, id eft inter me, Hippiatt, 67. Vegetius 3. 35. De bulimo ex fame uel laffitudine, Vegetius 3,38. Eft quandoic iunia bulimum faciunt, unde fideratitia iumenta dicuntur, \&c. Vegetius 3.35. Sanguinis tromilly Hippiatr, 42.Vegetius $3+13$. Deaqualiculo, id eft ftomacho ( uentre potius $\&$ inteftinis) $\&$ quir uitio contingant morbi. Ad faftidia cibi 8 naufeam, Hippiatr.129. Dé inedia laborantib ftidiofis iumentis, Hippiatr. 120. Noftri hoc uitium dicunt verftoffert: os \& linguam in eo aref aiunt. Huc pertinet quiod fupra ex Xenophonte $\&$ qui ab co mituatus eft Polluce retulimuts

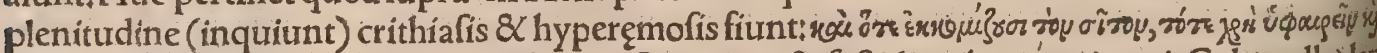

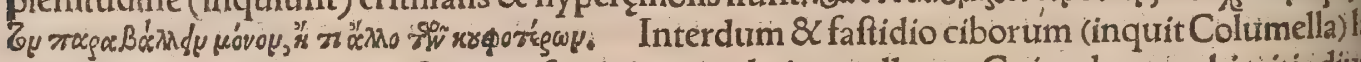
fir pecus. Eius remedium eft genus feminis, quod git appellatur. Cuius duo cyathi triti adit tur olei cyathis tribus, \& uini fextario, atç 3 ita faucibus infunduntur. Et naufea difcutitur, eti caput allị trítum cum urini hemina frepius potandum probeas. Si abunde non 'edat equus, $\bar{A}$ tus in Geoponicis 16.13. Capitis refrigeratio aliquando tuffim indircit, \& appetitum omnem abnlet, Petrus Crefc. Ad cruditatem, Hippiatr,128. Oppletio 8 cruditas, morbus acutus, Hippiatt.994 ut crithiafis quocs, \& ipfa cruditas. Cruditas agritudinem facit, ob quam modo in unam partem, modo in aliam ambulates inclinant, Vegetius 3. 37. Si equus ab indigeftione febriat, Vegetius 1.35!? Sideratitia iumenta dicuntur, cum uenas uacuas percufferit frigus, aut aftus, aut impleuerit crital tas, \&c. Vegetius 3.3). Noxa ex putrí foeno, Hippiatr.31. Si animal forno malo laxdatur, Vegerilus 3.72. Si hordeo malo aut aut nimio lędatur, Veget, 3.73. De alins in cibo uenenofis furpra diximus, Si equus doleat ex nimia ingeftione hordei uel alterius fimilis tumefacti in uentre aut ftomacho, quod nof citur fi aenter fit durus $\&$ ilia tumeant, Petrus Crefc. 9.18. Si equits ualde calefactis nis mium aqua frigida bibat, dolet aliquando $Q$ inflatur, fed rarò, Idem, Affectus quidam crithiafi fimt 
aluo nafcuntur, at $\$$ his liberari equos diffícile alif albidi in anu adharefcere uidentur:fios eximn 8 infperges cinerem de foco, Sed ad uermes generalis medicina, infundere chalcanthiboni non rit bicundi cochleare unum in decocto abfinthî, aliqui abfinthite utuntur, Prodef \& caparũ aut luth: bricorum terreftrium pondus denarí unius tritorum in aceti hemina, quę infundatur naribus eqừi. Aliqui gentianam minorem radice alba et femper perforata (mobelg氏tr urocamus) aduerfus equòrî lumbricos utuntur, alï bryonia. Sunt qui hoc medicamentum celebrent ori infundendum; Exite fis ouorum, pipere ufto, \& rubigine ferri, pultuis aridus fit,mifcendus aceto tempore ufus : aliqui \& ralem addunt, Huius potionts ui lumbricos omnes ex uentre $\&$ inteftinis exigi pollicentur. Alin uri. num infundunt, in quo anagallis concifa ebullierit. TI lecoris dolor, Hippiatr, 32, Vegetits 3.58 . Sequitur hanc noxam cibi faftidium, potus appetentia, uentris inflatio, macies, IEterus, Vegetius is 3.j6. Hũ c oculi uirides comitantur, lippitudo \&c. Morbus regius, Idem 3.49*. Hydrops, Hippiatt. 38. Vegetius 3.25. Hypofarca, (pro qua farcoftis ineptéfcribitur) Idem 3, 26. Tympanites, Hippiatr, 38. Vegetius 3.27. TSplen, Hippiatr +40 . De lienofis, Vegetius 3.28. Implecticus fimilem lieno 10. paffionem fuftinet, fimili unctione perfricandus, Veget.3.29. TS Subrenalem morbum Veget, libro I.inter fpecies malidis numerat.Signa eius, Veget, 1.8. Cura 1,15. Vnde fanguis tollendus fir in fubrenali morbo, Veget, 1.27. Dolor renum, Veget,3.7.\&3.4. parte fecunda eius libri, Nephriti. cus equus pofteriore parte tractim progreditur, $\mathscr{\mathcal { L }}$ uacillans inter incedendum parietes ambit, Hip, piatr, 30 . Frenes apud Albertum uocatur morbus, in quo maxima influxio renes equi mordicet 38 immobiles faciat+unde animal tan ${ }_{\beta}$ epilepticum ad terram cadit, 8 humores ad cor difcurrunt $: \&$ equus aliquando intra duas horas moritur.Rufius ca,89. guttam renalem feit morfuram renum no 1 minat:Et fanè frenes uox apud Albertum à renibus deprauata uidetur, Equi fic affecti , qưod fitdio

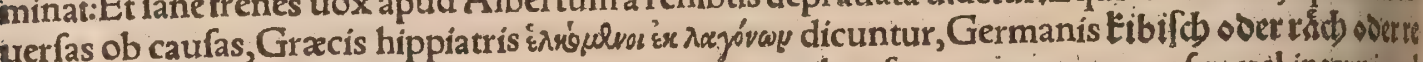
bifh mirt ben binberen beineth. Si mufculi qui in renibus funt; uexantur ex cafu; uel interni, ue externi tantum, Veget.3.5. De calculofis iumentis, Veget, 1.46.

बDolor ueficx, Vegetius 1. 5\%. Indignatio uefica in genere, \& fpeciatim, Veget.3, is. Vrina difficultas, Idem 1.61. Dyfuria, Hippiatr. 33. Ablyrt, in Geopon, 16.3.Theomnelt, ibídem 13. Vers tius 3.15. Dyfuria etiam in tetano accidit. Non malis equis frequenter morbus dyfurria infeftuseffe confueuít. Succurritur his, fi aut ea,in loca deducantur, qua madent adhuc aliorum equorum recen ci urina: aut in conum demittantur:aut etiam penis molliter fricetur, aut uiua mufca in illius candili culum immittatur:nam inuitariad mictum hos fibilis $\propto$ fonis quibufdam oris, notum eft. Sed fil non profuerint, fuadent $(V$ eget. 3.1 ..$)$ ungula ramenta teri $\&$ in uino infundi equo: aut intectum 6 fuum à ceruice uf $\$$ a d coxam fuffire ímiper i baccis, aut croco, aut caftorio, Contra hoc malum, ni accidat, prouidendum, ne, hyeme prafertim, in frigidam demittatur equus, maximé de itinerefefils, priulä̧urinam fecerit. Hoc quidem paulò nugacius à Gracis traditur, fi difficulter méperé, urinà ue quafi guttatim exprimere foleat equus, tum cimicem imponendum, in aurem, dextram quideri foeminx, lauam autem maris, futurumç ut malum ceffet, Camerar. Aliqui cimices tritos (inein

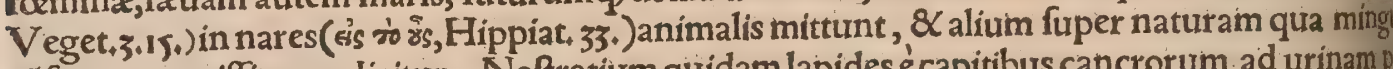
cófricant:certiffimum dicitur, Noltratiưm quidam lapides è capitibus cancrorum ad urinam pri mouendam equis tritos in potu mícent: Vel pifcis quiem urulgo harengam dicunt, inteftinum qur uefica inftar inflatum in recentibus reperitur, in pabulo dant: Sunt qui pediculos uiuos in ainum imponendos feribant. De conuerfione ueficæ̇, Hippiatr, 121. Equo feré qui homini morbi,pr ueficæ conuerfio, ficut omnibus in genere ueterino, Plin. Irremediabile malum eft, fi uefica dim ueatur de fuo fitu:cuius indicium ne urinam reddere poffit, $\&$ ut ungulas clunesćs trahat, Arifto les. De ifchuria Albert.Hippiatr.33. Veget.5.15. Si equus doleat ex retentione urin $x$ ureficamin flantis:quod ex aliquo loci tumore cognofcitur, \& iacfatione frequenti in terram, Petrus Cref. De dolore ex retentione urinæ, uel de ueficæ inflatione $\&$ torfionibus, ftrãguria \& ifchưria, Rufiu 151. Si urinam non facit (ínquít Columella) eadem feré remedia funt, (quæ proximè ante adlafitu dinem præf cripferat:) nam oleum immiftum uino fuper ilia $\&$ renés infunditur : $\&$ fi hoc partum profuit, melle decocto $\&$ fale collyrium tentre inditur foramini, quo meat urina:uel mufca uiua, utel thuris mica, uel de bitumine collyrium inferitur naturalibus. Hæc eadem remedia adhibentur, flurit na genitalia deufferit. Vegetíus quidem in ftranguria compunctiones 8 morfus in urinali fiftu. fieri ait ut non alius morbus ftranguria uideatur, quàm quià medicis recentioribus ardor urinax citur. Nonnulli uinum in quo auen a bullierit, refrigeratum equo infundunt, urinam ita ftatim ci endam fperantes, De ftranguria uel ftillicidio urina, Hippiatr.33. Veget.3.15. Rufius ij!. Iument ta nimio faltu, uel curfur, aut ruina, cum aliquid intrinfecus ruperint, uulfant, ftrangtriam pati tur, 8c. Veget. 3.42. Tormina urinæ iumentorum releurat, (ut Aggregator notatiit,)allium tritum naturæ inunctum, Plin.20.Cretani(crethmus)Plin, 26. Vefpertilio alligatus, Idem 30. Si equus las boret torminibus urinæ (noftri uocant Die barnwintoe) femunciam de baccis lauri tritis ex uino lit cereuifia tepidis infunde, Innominatus, Ad fanguinis mictum, Veg,9, 10, Theomneft in Geopol 16.14. Vrina fi fanguinem trahit, Hippiat.42. Ad fanguinis mictum tum ex plethora in otio, furi aliâs in labore nimio, onere, uel afcenfu, Veget, 3.12 . Sunt qui ad auertendum fanguinis mictur uenas qua calcaria adiguntur femel aut ter per duos aut tres dies fecant. Morbum quem Germ 
propofuimus allterum ungulam in altum fuftollit : tertium cum eadem offringitur, ut in pròteet

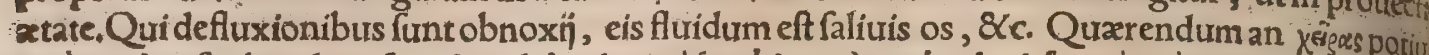

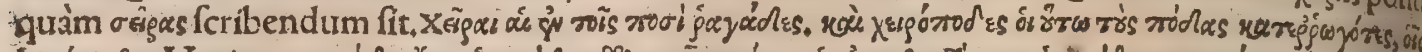

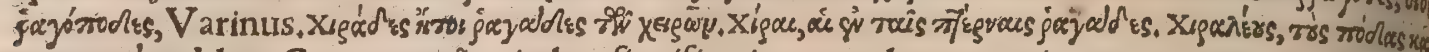

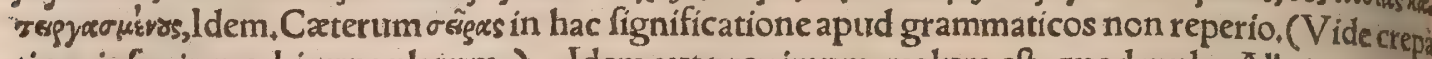
tium infra in morbis ungularum.) Idem aut proximum malum eft, quod mulas Albertus trocat Rufius etiam feracias, nomine quidem ad oejgess alludente. Hx (inquit Rufius 115.) ex frigiditate ei humiditateà uia excitantur, crura ultra genua inflantur hyeme $\&$ uere: $x$ ftate $\&$ auttumno fine infli tione latent:nof cũtur tamen ex pilis rigentibus đ̧uis madidis. Mula(inquit Alber.) dicta funtla fiones pofteriorũ crurũ $\&$ pedum, quę fiunt têpore frigido, cum equus in uia difficili $\&$ cœnulenta imultũ laborat, $\&$ poftea etiã neglectus refrigeratur. Vnde humores ftatim, prafertim in eqưo mino re natur, ad pedes pofteriores defcendũt, $\&$ deinde $\mathrm{p}$ frigus ibi coagulant, $\&$ aliquando pariuntinfta tiones à pede ufq̧ ad genu:aliquãdo fciffurę fiũut, aliquẫdo inflatio nulla eft, fed pili crur is horrêti etrl

x. gễt,Hęc Albert. De omnibus coronę duritrijs qux tofacei calli nominãtur, Hipp.113. In pedis corona nafcentes ficus feu marif́ca, \& uerrucæ formicẩtes, Hipp. 82. De marmore, id eft tuberculo iuxtac

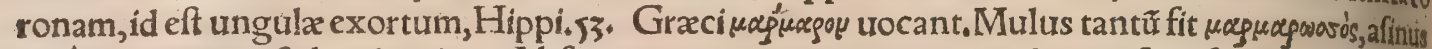
raró: equus non, fed podagricus, $\mathrm{A}$ b fyrtus cap. 53 , in quo tamen paulo ante foripferat marmora du?i ros effe tumores, claudicationis caufam in equis, Si thlafma fuerit in ungula, uenã in corona fcalpe lo foluere non oportet, quod ob hoc erratum uaguexgens contingat, Abfyrtus cap, 101. Hierodis de marmore uerba ex Hipplatricorum cap.82, referuntur à Syluatico in dictione Marmoro: ineptealu tem pro Hierocle Herodium fcribit. Marmoris duri tumoris in articulis meminit etiam Vegeturs 2.48. Thlafmata in doffuarïs pracipué iumentis nafcuntur, $\&$ in tubercula palmularum imagi nem exhibentia, phœnicas nominant, facile degenerant, Abfyrtus in Hippiatr, 101, De morofiue celfo, Rufius 138. Eft autem (inquit) fuperfluitas carnis granulof $x$ in cruribus, \&xc. Furina (inquiti Rufius 106.) uulgò uocatur uitium equi inter iuncturam pedis \& ungularum fupra coronam pedis in ipfa paftora, quod ab initio inflationem quandam uel callofitatem carnium fupra pedem excita Furma uel furmclli fit ex percuffione mala, \& c inter iuncturam pedis $8 \times$ pedem fupra coronam in ipfa paftora, impediens greffus equi : cum ueterafcit, efficitur fuperos duriffimum, Petrus Crefcet, 9.4\%. Curua morbus dicitur, eò quod curuet crusteft autem inflatio in tibia iuxta iuncturam polt uel ante fupra genu facta, ex concuffione uel impactione alicuius duri; Albertus. Curba(it Rufius 105.) fit fubtus caput garecti in magno neruo pofteriori tumorem faciens aliquem per long tudinem nerui, unde equus claudicat. Si talus exeat animali, quod ex perfrictione nönunquami Veget. 3.6. Adnafcũtur etiã cirfi, id eft uarices, equorum tibíns: Hoc uitiư apưd Gallos audio farcin appellari, Robert, Stephanus in Diçionario Gallicolatino elephãtiafin exponit:in quo forfanerraț eft cò quod tibias inflatas \& uaricofas Auicêna \& aln̈ quidã recentiores elephãtiam appellarint, $D e$ uaricofis, Hippi.77. De uaricibus plura uide proximé inferius in meliceridũ mentione. बDeozz nis, Hippiatr. 19. Sunt autem uitia pedurm, fiuc ulcera foetida, ut apud Vegetium quog;: uteriatil Ruellius qui in Hippiatr. loco iam citato foeda narium ulcera interpretatur. Ozænæ cilicipsum

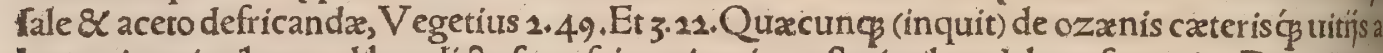
lorum in prioribus pedibus dicta funt, fcias etiam in pofterioribus debere feruari. De paënna, uardo feu aquarola $\mathrm{R}$ ufius 118 . Hoc malum fit ex allifione ferri, lapidis, uel ligni retro pedem in ungulam fine inflatione crurum, unde locus crepando finditur, $\&$ humor foetidus emanat, $R$ $8 x$ Albertus. Artus inflammationibus ac meliceride laxati $\&$ uliginofi, Hippiat, 52. Vbi Gracele

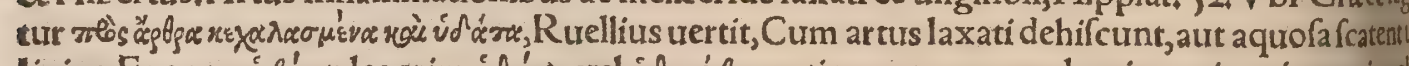

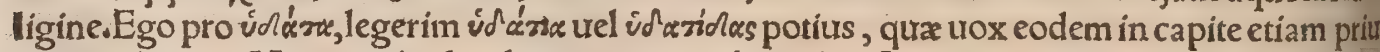
quoties legitur. Vegetius hydatidas uertit aquatilia uel puftulas aqua plenas, Cæterum ulig cera funt Vegetio, qux Graci glycea uocant, quafi dulcia dicas, forteà fuauitate illa quã pruxienti rabendo iumenta percipiunt. Melicerides, Hippiatr.77. Sunt $\&$ ulcera quadam (inquit ibiden Hierocles) crebris tumoribus exafperata, paraprifmata inde urocant : aut quod in faui fpeciemco creta fint, meliceridas appellant. Alif quod per foramina fertur humor, hydatides uocare malueru in talis $\&$ calcibus nafcuntur, (non ut propriẻ dictx melicerides $\&$ pompholyges, id eft bullätespufula paffim in cute; ) nec urens medicamentum poftulant, cum plané uarices iudicentur \$ qua 8 alterum fit genus uaricum, quod cacum fallit : Qux res ita deprehenditur, cum pecus in ifabu decumbit, \& folito diutius inibi iacet:nam exurgere non poteft, nifi quis ei ferat opem, \& c. Caltic trum adhibetur in genere ulceris quod paraprifmata uocant, iuxta poplitem. Nam paraprifmataque hydatides uel melicerides dicuntur circa malleolos non debent uri, Hippiatr، 97. Aquatilia in art culis uel gambis, Vegexius 2.49. Puftulæ aqua plenæ, Hippiat.77. Impetigines in articulis uelgeni bus, Vegetius 2. 51. Impetigines Græcilichenes uocant, genus fcabiei \& erofionis in cute, quodim petit ac ueluti lambendo ( unde nomen à Gracis impofitum) proximas partes infeftat atç depacio tur. Sed alterius generis funt calli illi fimiliter in articulis aut genibus nati; quos lichenas Diofcorides appellauit,improprie ut uidetur. Prius et propriẻ fic diçũ genus Germani rappent appellất in equi

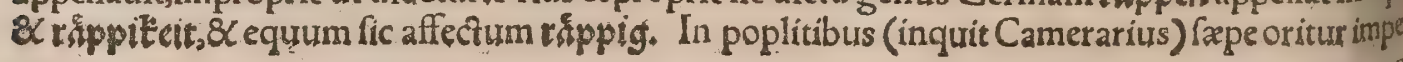


go, qtzam percurarinon putant bonum effe, quod humor defidere foleat in pedis corollam : Teuto nes erucas nominant. Ego fcribendirationem diuerfam animaduerto:erucas enim uocant taupen: impetiginem uerò rappent. Hanc in artubus ante $\&$ retro fieri aiunt. Garpx, rimx funt $\&$ fifura in pedib. \& cruribus, Scc.Pet. Cref.9.44. De grappis in iuncturis crurum cir ca pedes, qua rum= punt carnẽ per longû uel tranfuerfum, R uf. III. V nguentũ ad grappas ex tranfuerfo \& teftas lógas, Ruf. 114. Aduerfurs hanc noxã aliquii ungentũ parant albo liquore oui, excremento alui hominis, fulfure \& axungia mixtis, loco calido aut in Sole illinendũ. Alỉ fel porci cẩ tribus ouorũ uitellis mí fcent, et illigant, malũ fic una nocte depellendũ promittentes. Alij deuftis candela pilis loci affecti ut glaber fiat, fulphur axungia exceptũ inungũt, 8 ecdem modo curari promittunt uitium à quo equễ muchig uulgo appellant. Aliqui fcribunt móbig, 8 interpretantur fcabiofum in pedibus. Sunt qui axungiam de porco ruffo liquefactam igne in aquam defundunt, 8 rurfus collectam agia tatam ̧́ cum fulphure mifcent, $\&$ inungũt;tertio poft die cruftulas fiue efcharas minores diligenter remouent, \& quotidie ungere pergunt. Idem hybernę fcabiei mederi aiunt. Si equus impetigine labo rat, aut uitium patitur quod Germani uocant gagtenbüf,hoc modo curabis: Vitrum læuifimé tritữ mifebis refinæ liquefacta, \& expreffx de carne fuilla duos digitos craffa pinguedini:hoc bene cali: dum circa pedem partilxfę circumligabis:refrigeratum demes: \& locum cultro abrades donec fan. guinem emittat:tum infperges chalcanthum $\& 6$ uitrum lęuiffimè trita, $8<$ relinqures donec fpōte ex= cidant. Alif idem remedium his uerbis defcribunt:Stupam puram duorum digitorum craffamento (hoc potius placet $\bar{\phi}$ quod de carne fuilla paulò ante dicfũ eft) pici feruid $¥$ inferes, $8<$ loco affecto ca ididum impones:triduó poft religabis, \& infricabis acetum furfuribus $\&$ fale mixtum. Alius quidam hoc remedium præf cribit pro equo quem uocatbolbiffig. Eft $\&$ praua quadam fcabies in crure inferius ftatim fupra fubcirros, in qua pilos fitu contra naturam prouenire aiunt : noftri fruppent tocitant, \& equum fic laborantem ftrippig: Ad hoc etiam malum, \& illud quod iam gagenbif apa pellauimus, commune remedium adhibent, corticibus tiliarum (fuperioribus reiectis) per quatuor. decim dies in aqua maceratis, \& eo quod falis inftar concrefcit inuncto. Idem prodefle aiunt ambu= ftis, ita ut ne ueftigía quidem aut cicatrices relinquantur. De grifaria, qux fit in coronis equorum fupra ungures, \& curatur fimiliter grappis: fxpe tamen incurabilis eft pręfertim inueterata, Rufius i1. Idem forte uitium eft qurod Germanice uocant gurfee/gurfey/ourfüle;fit enim id circa fubcir ros, cutím $\&$ pilos corrumpit, $\&$ cornu etiam quandoø infeltat, nonnunquam incurabilis. Aliqui allia cum melle trita equis fic affectis in cibo dant, \& lupato alligant. Scracies(nomen barbarum, nec memini iam ubi legerim)impetigo elt in pedibus, in locis excarnibus prafertim infra furam: um untur aduerfus eam finapi:nafcitur enim ex frigore. Aduerfus fcabiem in pedibus, axungiam ue terem liquefactam $\&$ aqux infufam rurfus collige mifcéç cum polline gentianx, \& inunge. Sunt qui ferpentis adipe equi ungularum oras inungant aduerfus fcabiem, Galenus de parabilibus cap. 104. Vligines etiam in pedibus, cruribus, unguibusćs, uel fub armis aliquando generantur (quid ̃̃ dulcedines uocant) habentćs fimilitudinem fcabiei: Diffundunt \& pedes ulcerant, Veget,2.52. Can cer cum in reliquo corpore, tum circa iuncturas crurum iuxta pedes, aut inter iuncturas \& pedes, uidelicet in paftora fit, Ruf, 171, Paracercís uocat̂ collectio quædã circa radiũ in tibia equi, Hippiatr.

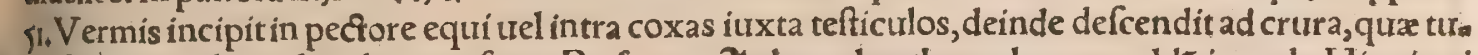
to mefacit, 8 crebris ulceribus perforat, Ruf.144. 2lgley uel eygley uulnus quoddã in pede Hippiatri

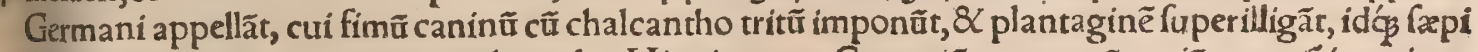
us repetût, De rimis quas uocãt rhagades, Hippiat, 122. Crepatiũ uocant cũ coriũ rumpit inter iun= ciuram cruris et ungulam, Pet.Cref.9.45. \& Ruf,112. Rumpunt(inquit $R$ uf.) corium \& carnes inftar fabiei cum ardore. Crepatia magis longa $\&$ tranfuerfa(inquit idem $113_{+}$) inter carnem uiuam $\&$ ungulam, uidelicet in bulletis, magis impedit greffum. Vide firas, chîras, \& chiramata, fuperius in pe dum malis:exponunt enim calces rimis fciffas. Spattent, ut audio, Germani uocant duriufculos quofdam nodos iuxta ungulam tuel coronam, unde pes incuruetur:quidam excindere folent. Equ $\bar{u}$ fic affectum fphettig nominant:noftri puto etiam le!ftig. Sumt qui tuberculis illis fcarificatis menta= frtum illigant: Alif aliter medentur. Vide ne fit furma uel curua fuperius dieta. Excinditur etiam jo tuber illud quod Germanis dicitur elntbogett. Equi quorum ungulas rhagades $Q$ rimæ diffindunt, fattfiffig uel lactbutffig à nonnullis noftratium uocantur: \& ungulx fic affeçę, gefbusunden ober gefpalten over ryffenbe fús: uitium ipfum uocant fattbîf uel bornkiufft, \& aliud quoddã in ungu lis Den biffitraud. TCalcibus $\&$ talis utile emplaftrum, Hippia.129. De ambuftis glacie, Theo mneftus in Hippiat, 125. Hybernis itineribus(inquit) glacies equos reliquaḉ iumenta torquer:quod uitium pagoplexiam appellant. Iis intument calces $\&$ cum ungulis feruore laborant, \&c. Si equus haberetmalurm in pede ut fubularet feu elanciaret in corona: primo remoue pilos, \&c. Rufius i34. Noftri, ut conịcio, uocant buifłwang, cum ungula crefcit uerfus calcem introrfum, \& pungit. Si equus doluerit in pede propter laborem, $R$ uf, 135). De podagra iumentorum, Hippiatr, 54 . Vege, 2 , 33. Equus podagricus humi decumbit non aliter quàm hordeatione affectus, Abfyrtus. Equorum 6o gregales morbo immunes funt, excepta podagra:hoc ễ uno laborãt, \& plerũç̧ ob id ungues amit tunt, Sed amiffis aln̈ ftatim enafcuntur:fit enim ut altero fubnafcente ungue, alter amittatur. Indici= um morbi, ut alter teftium dexter palpitet, uel ut paulò citra nares cauum quiddam rugofumḉs gige 
natur,Arriftoteles. Eft quando cornu feparatur $\&$ difcedit à carne ( prafertim in cauro pedis circa chelidona dicham)quod malum noftri uocant erbelle uel verbellt, \& remedia quradam prafcribunt, Qurecunģ de ungulis priorum pedum dicta funt, fcias etiam in pofterioribus debere feruari, Vege, 3.22. Graci malacopodes equos nominant, quorum molliores funt ungula:eas noftri murbe fin uocant, \& medicamentis indurant:Vide Hippiatr. 105. Subtriti pedes, Hippiatr.105. De nins quic cor nua calcando proterunt, Hippiatr.100. ut Ruellius tranftulit, perperam ut milhí uidetur : Græecelecria

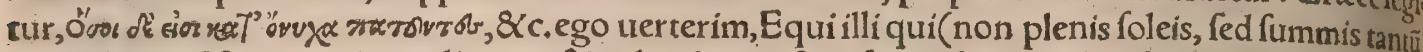
unguibus infiftunt aut ingrediuntur, \&c. claudicant, $\mathbb{Q}$ infirmis funt lumbis, \& curfurinferiores. $R_{e}$ medium atitem nullum prafcribit,cum pro ungulis attritis multa tradantur, qua fatis explicata funt

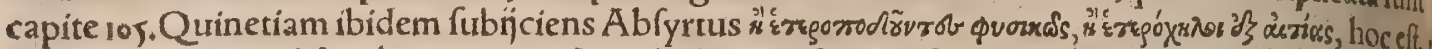
(ut ego interpretor) fiue à primo ortu, fiue ob aliam poftea caufam, pes alter $a b$ altero diuerfus (lonz

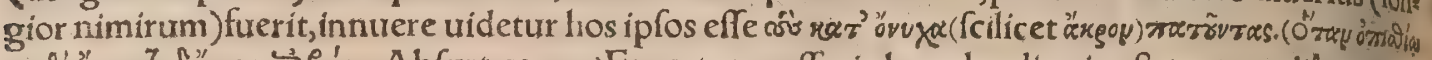

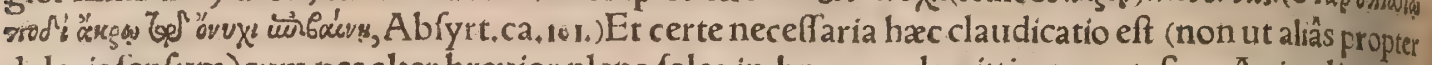
doloris fenfum) cum pes alter bretrior plena folea in humum demitti non poteft. Animalitim un, gulze(inquit Vegetius 2.55.) a a peritate ac longitudine itiner um deteruntur, $8 \mathrm{C}$ impediunt inceffum, Ex tortura quop;, fi in afpero uel lapidofo itinere iumenta coguntur ad curfum, indignationes oris untur.Poftremo eciam otiofa in ftabulis ex collectione humorum incipiunt claudicare. De pedis: bus fiue ungulis attritis aut mollibus, Veget. 2. 58. I umenta, quandoós ungulas mutant $\&$ abicicuit,

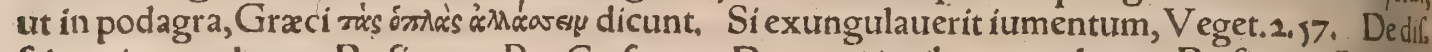

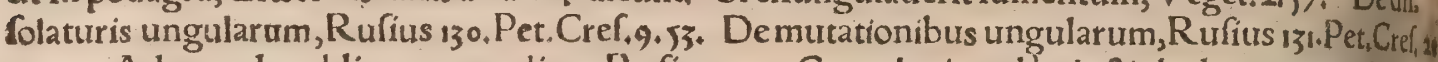
9.54. Ad ungulas oblig̨uas semedium, Rufius, 121. Cum clauis male adactis laduntur ungulas,

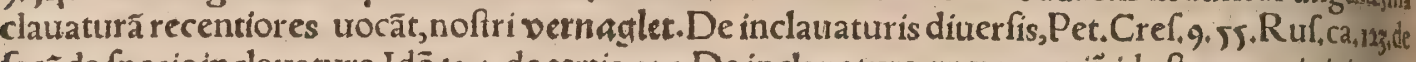
fecûda fpecie inclauaturę̧, Idê 124, de tertia, 125 . De inclauatura qua rumpit, id eft pus emittit in coro na pedis, $R$ uf, 126. Verbafci folia recens contufa inter duos lapides, \& inclauraturis equorũ inferta, Itatim fanant, Petrus Mat hax olus. In hoc malo foleas ex ferro refigunt, \& $\mathrm{X}$ thus ex aqua imponunt uulneri.Alih milium bene cocium cum axungia calidum imponunt:A lị clauum tantũ extrahunt,er

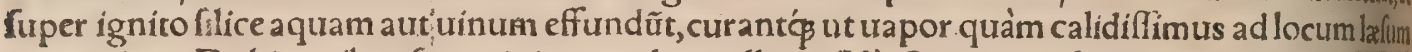
perueniat. De his quibus fanguis in ungulam tollitur: Al', Quomodo fanguis tollatur his, quin, gulam cogunt uel eiecerint, Veget.1.26. of úcrata, morbus equi circa pedes, Hefychius \& Varm,

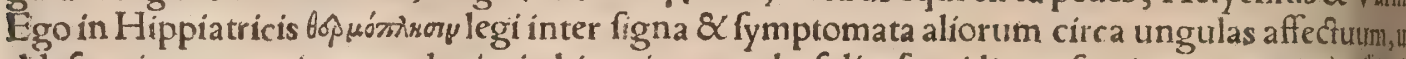

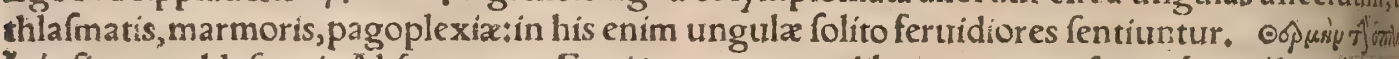

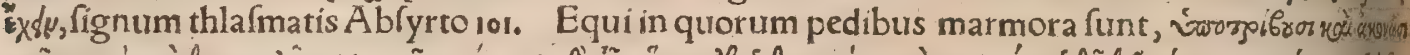

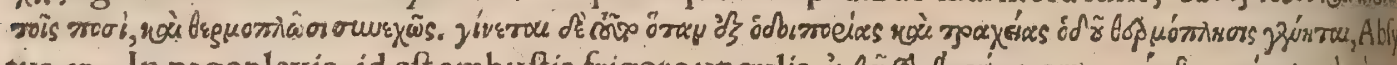

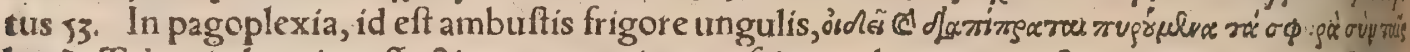
izsriaus: Talem in homine affectionem unguium ex frigore obortam, prafert im cum nimis refrigen

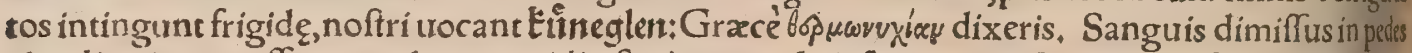
claudicationem affert, quod cum accidit, ftatim ungula infpicitur : tactus autem fert.orem demon, Itrat, Columella de bobus. Si equus fuerit tutellatus (al' cudellatus) fiue multum fperatus in pell, aut fihabuerit multum frigus in pede, Ruf.122. Defpumaturis ungularum, fiue infufione quaxd pedes defcendit, Ruf.129. Malpitium (Rufius pinfanefe uocat capit, 120.) fit in bulletis ungula rum, ubi carnes uiux iunguntur ungulis, ex prauis humoribus qui illuc defluxerunt, \& imped

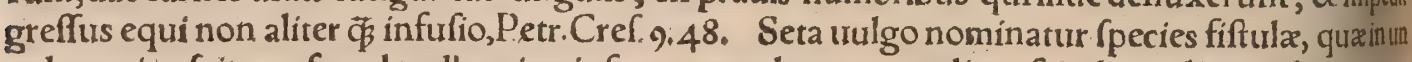
gula equi nafcitur, ufog ad toellum intrinfecus ungulam per medium fcindens:aliquando autremex latere, $\&$ tunc dicitur fetula; fciffur a eius à corona pedis incipit, $\&$ protenditur per longum inferius

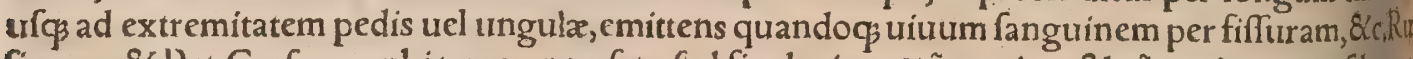

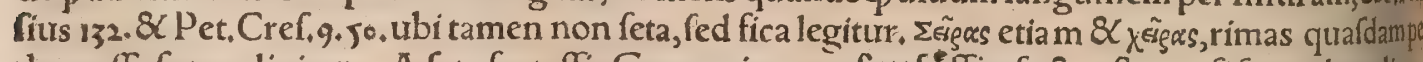
durm effe fupra diximus. A feta fortaffis Germanica uox fattfúffig, facta eft, quafi fetipedem dicas, fignuficatio quidem conurenit. De maledicio in pede, $R$ uf. 133 . Hæa noxa qualis fit non explicarad hiber autem remedium, falurix partes duas, lardi unam, trita imponi iubens. Si iumentum ad apert turam pulmunctulum fecerir, fctas totum folum hoc eft affem hac ratione tollendum: Vngulam fibs, radis, \& c. Vegetius 2.56 Idem 1.61.meminit pulmunculi in dorfo nati. De fubiaçura, Rufius 128. Cum equus (inquit)fine ferreis foleis per loca afpera diu ducitur, ungula ita atteritur, ut tuellus trinfecus defendi non polfit: itaç inter tuellum $\&$ foleam fit congregatio fanguinis cum dolore, \& humores confluunt. Accidit quandoos $q$ pes laditur fubtus ungulam in medio folex ex ferro (ull offe, uel lapide lignóue) uel alia re dura uffe ad tuellum intrante, unde tuellus la ditur:ex qualafior ne cum ungula non inciditur circunquaq, ut debet, nafcitur fuper tuello quadam carnis fuperfluis ras, qua fuperat foleæ fuperficiem, \& $<$ uulgo ficus nominatur, \&c. Petr.Cref, 9. Y6.\& Rufus 127. Ad incrementum ungula promouendum, Hippiat, 10\%. De incremento cornus, Ibidem 117. Vngule productionem moliri, Hippiat. 123. Si ungulæ $\mathcal{Q}$ in ungulis caro minuãutur, nof ri medicamentis occurrunt, qux in Hippiatricis libris noftro fermone defcribuntur, $\boldsymbol{G}_{0}$ oer Eern fdw wynet. Plurat uide fupra, in hociplo, capite, inter íyıtrvod. 
que gcniburs falutabat, moxx́g confurgês uolucri faltu in aèra fefe efferebat; Text. Homertis equitis non tantũ intelligentiã, fed diuinã intelligentiam, atఢ̧̣ etiã orationẽ attribưit, Nã apưdhunc poêtam 8 ad prå fepia otio contra naturã fuam languẽtes moerent, \& Patroclo occifo perturbant̃aninís, $\&$ ipfiA A hilli futtura pradicunt, Camera. Hac de re uerfus Homeri citat Io, T zetzes s. 118. Affectum cquinum lachrymæ probant;Solin. Equi prafagiunt pugnam, 8 amiffos lugent dominos, lachry masćs interdum defiderio fundunt, Plin, Poft bellator equus, pofitis infignibus Aethon It lachrya mans, guttisćs humectat grandibus ora, Vergilius libro n.de Pallantis equo. Sunt \& Oppiani uerø fus lib, de uenatione I. fuper equorz intellectu et erga homines amore qui cómemorentur digniffimi, i"mous jo's wopicass o фú

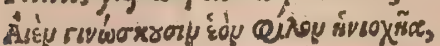

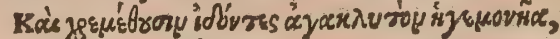

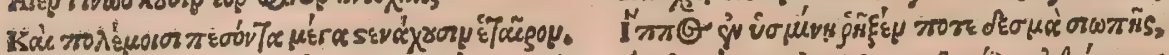

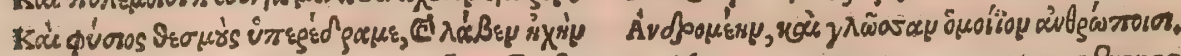

Accurfits legum interpres, refert Cæarem triduo antequam moreretur, afturconem furum flentem inueniffe, futura quidem mortis indicium:quod fidem non caperet, nifi Tranquillus in eiufdem us. ta fimile quid teftaretur. Proximis diebus, (inquit) equorum greges, quos in traịciendo Rubicone Marti confecrauerat, ac fine cuftodibus uagos dimiferat, comperit pabulo pertinaciffimé abfinere, ubertimćs flere, Hxc Textor. Ab equis generofis dominos miré diligi certiffimum eft: argumento fuerit equus Rodati, quià morte Caroli magni monachus apurd Meld. factus, aliquantò polt irruenti bus paganis, equum quem in monafterio depofuerat infilĭt: quem equus licet iam declinantis atatis alacriter fufcepit, $\&$ donec de hoftibus fuis triumpharet, portauit: Erat autem hic equus ex illorum \& numero, qui nullum fefforem prater dominum proprium admittere dignantur, Vincentius Bellua ex Alexandro quodam. Plures huiufmodihiftorias capitis octaui parte ultima referam. Fidelif mi ante omnia homini canes atç equi,Plinius. Siaccuraté \& liberaliter tractetur equus,cumbene uolentia erga eum quífibi benefecit, cumć amicitia accepturm beneficium compenfat,Aelia, $H_{0 c}$ quidem compertum elt, nifi forte uel morbo ( nam $\&$ rabie equi corripiuntur ut canes) uel ira infa niat equus, non facile hominem læderé, maximé xtatis aut fexus imbecillioris. Itaq̧ mordaces iffi calcitrones, ut $P$ annonici pleriq̧, de quibus 8 prourerbium malignitatis ortum, non feré nifi irritat aut opinione aut metu offenf $æ$ ferociunt. Quamuis ut inter homines, ita inter equos quoç, malitio fi $\&$ nocentes aliqui præ cæeteris inueniantur, Camerarius. Amiffa parente in giege armentireli: qua forta educant orbum, Plinius \& Tzetzes. Equa focietate coniuncta, fi altera forte perierit,al tera pullum parente orbatum enutrit, A riftoteles. Equarum genus miro quodam amore proliste neri putatur: cuíus reí indicium eft, quod fapius fteriles auferunt pullos ầ matribus, quos ipfa amore profequentes tueantur:fed quoniam lacte car eant, deprauant eos quos diligunt, A riftoteles, "Hip' pomanes de fronte ftatim ædito partu deuorat foeta, aut partum ad ubera non admittit, fi quis praie ptum habeat, Plin. Equæ plerungs macrefcunt defiderio pullorum abféntium:propterea dimitten di funt in eadem pafcua quibus mater, Columella. Qui equas ad reditum faltem, aut fi opus fit,iti gami, treloces defiderant, à partu recentes accipiunt; qua quoniam relictos pullos recordantur, quis plurimum amant, quanta poffunt celeritate qua uenerunt repetere folēt iter, Qui metaphrenoin, id eft partem inter f capulas fupinam (Uँ huiufmodi in equis eft, Ariftoteles in Phyfiog.

TEqui ab elephantis in pralio terrentur, ut in Elephanto dixi cap. 5. ex Heliodoro \& Marcelli: no. Equis odio naturali camelus adurerfatur, Ariftot.\& Plinius. Quantum camelum equusteflis midet, Cyrum \& Crofum cognouiffe aiunt, Aelianus. Simonides in Iambis dicit, Perfas poff Cyri pugnam in Lydia camelos fimul cum equis alere, equorum metum ex camelis conurictu conâtesexa pellere, Aelian. Cyrus in pralio aduerfus Croefum, camelos contra equitatum inftruit hac ratione, quod cameltrm equus reformidat adeò quidem, ut nec fpeciem eius intueri, nec odorem fentire futil neat, Id ideo commentus eft, ut equitatum Crofi, quo ille fe praualiturum cōfiderabat, inutilem red deret.Simulatç in pugnam itum eft, equiolfactis protinus confpectisćs camelis retro fe auertunf, un de fpes Crœfi interít, Herodotus libro I. TRumpi equos traditur, qui ueftigia luporum fub equitit fequantur, Plinius. Veftigia lupi calcata, equis afferunt torporem, Idem. Si cafu equrus lupi ueftiti giumi conculcet, torpore comprehenditur:fi ítem lupi calcaneum equi quadrigam trahentes concu cent, fiftentur tanquam î cum quadriga conglaciati effent, Aelian. Equiluporum ueftigî́s calcatis obtorpefcunt cruribus, Pamphilus in libro rerum natural. Geoponica, Si calcaucrit zofacts, id efte quus ueftigiumi dorim, id eft urfi (lupi potius, ut cæteri omnes fcribunt) accidit ftupor eius pedi, $A$ ece fculapius. Mulierem quæabortierit fignificaturi Alegyptï, equam fcribunt, quęlupum prefferil Equa enim abortit, non modo filupum calcauerit, fed etiam fí ipfius ueftigia attigerit, Orus, Prat gnans equa incedens fuper ueftigia lupi, irafcetur, $R$ afis \& Albertus, Et alibi, Si calcet equus uelti gia lupi uel leonis, pedibus obtorpefcet, ut moueri nequeant, Iidem. Dextrarî non caftrati et fortes, ex audacia appetunt adire \& impugnare leonem (hoc Oppianus de charopis equis fcribit, cateros uerò omnes leonum afpectum non fuftinere:) caftrati autem adeò timent, 'ut nec calcaribus nec fia gris adigi poffint ut propius ad leonem accedant, A uicenna . Inimica omnia fuilla equino getier ri, grunnitus, foctor, halitus, Camerarius, Equum ferunt ftruthiocamelum refugere, nec intueria 


\section{DeEquo. E. Lib. I. $\quad 523$}

dere, Cardanus, Equi amantur abotidibus, Arriftoteles, Otis ex omnibus auls equorum ftudiofiftima cenfetur: nam cum catera animalia in pafcuis oberiantia afpernetur:equum ut afpexerit,ma gno ftatim cum gaudio ad ipfum aduolans, apppropinquarè pergit, Â elian. Si quis equinam pellem induerit, quotquot uolet otides uenabitur: nam equiorum ftudio captę accedunt, Gillius. Hominē uiribus infirmum qui fortiorem fugiat fignificantes Aegyptï, otidem auem $8 \mathrm{C}$ equum pingunt:etio. lat(injorou)enim illa uifo equo, Orus 2.20, Sed hoc aliorum friptis aduerfatur, ut de antho potius ç ctide aue id uerum fit. TEquum odio habet florus auistpellitur enim ab equo pabulo herbae qua uefcitur:nubeculans hic, nec ualens acie oculorum eft:quippe qui uocem quidem equi imitet, atc aduolans equum fitget:fed interdum excipiatur occídatuŕç ab equio, Ariftoteles. Barbari, ire Allbertus $\&$ alij, ubi in Graco anthon, id eft florum àem legimus, ibis uel yboshabent. Philes Grae cus ineptè non anthum auem, ut debebat, fed anthiam pifcem ab equo odio haberi fcribit. Ent auis quxe equorum hinnitus, anthus nomine, herba pabulo aduentu corum pulfa; imitatur, ad hinc mo; dumfe ulcifcens, Plinius.

Eporedicas Galli uocant bonos equrorum domitores, Plinitus 3. 17. Raurifius Textor r. literam in medio afpirat. Eporadia Plinio Italiæ tranfpadanæ oppidum eft, Ptolemęo Salafiorum, hodie Hiauł rea. Equifo dicitur equorum domitor ${ }$ Nam ut equus (inquit Varro) qui ad uehendum eft natus, tamen traditur magiftro, ut equifo doceat tolutim incedere. Hippocomưs Græcis utocatur equorü.

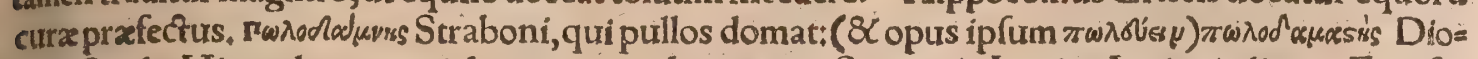
doro Siculo, Hippodamus, qui domat equos, lo cozone, Scoppa in Lexico Latinoitalico. Equifo nes $\&$ arulatores, fiue mauis cociones, arte \& induftria equis gradus glomerationem dant, Grapald. Depulli domitura, Hippiatrica 116. Abfyrtus in Geoponicis 16. 1. Manfuefaciendi (inquit) funt pulli,inftituendiós, ubi decimumoctauum menfem compleuerint: Tunc enim eos deligantes capi. fro, prafepi frenum fufpendere conuenit, utillud contrectantes affuefcant, nec trepident ob fonu âfielifterins (poftomides uertit Cornarius) profectum. Cxterum dum fuerit trimulus domandus eft, prius व̈ uentricofus euadat, De domitura \& inftitutione equi, Crefcentienfis copiofé agit libro per totum caput fextum. De nutritione paruorum pullorum, Rư, 18, De educatione adultorü, Idem 19. Quomodo \& quo tempore illaquireari debeant equí qui ducuntür ad armenta, Rur,20. Quomodo $\&$ qua cautione equi domẽtur, Idem $22 . \alpha$ de cuftodia equorum poft donationem, $\mathrm{Ca}_{1}, 3 \%$ De equo difciplina inftituendo, Rurfca.24. In pullo inftituendo(inquit Xenophon) non decet ip fum equitem occupari, fed potius domitori trader, \& quomodo inftitui ab eo uelit præf́cribet, Prouis debitur autem ut accipiat domitor pullum manfuetum \& manưum patientem, atç amantem homis num, qux plexaç domi à curatoribus(hippocomis)illorum efficiuntur, qui norint, cum famem at=

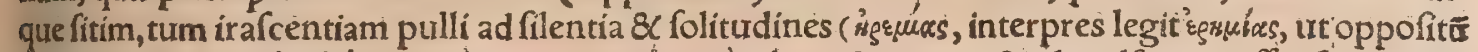

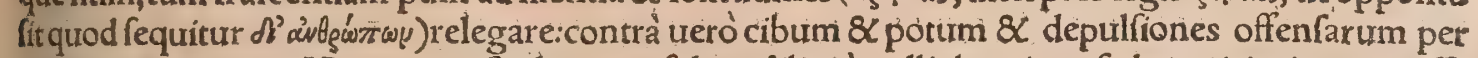
homines procurare. His enim cuftoditis non folum diligia à pullis homines, fed requiri etiam neceffe eft, Contrectandæ etiam ex partes corporis, quas maxime tangi equus gaudet: hæ funt denfiffima pilis, \&àquibus molefta depellere ipfe nequit. Iubeatur $\&$ curator pullum cum traducere per tur bam,tum uarias ad fpecies $\&$ uoces admouere. Ex his, fi quid forte illumi perculerit, oftendere opor= o tebit placando, non fruiendo, terribile non effè, Hæec Xenophon. Quando \& quo tempore edo. mari debeant pulli, Rufius 21. Pulli domantur Martio, ubi tempus bimæ ætatis excefferint, Pallad. Sunt qui dicant poft annum $\&$ fex menfes equulum domari poffe, fed melius poft trimum, à quio tem pore farrago dari folet, Varro, Equus bimus ad ufum domefticum recté domatưr, cerrtaminibus au , tem expleto triennio, fic tamen ut poft quartưm demum annum labori committatur, Columella. Di' urerfa autem circo ratio quęritur:itaq̧ cum: bimi in alio fubigantur imperio, non ante quinquiennes ibicertamen accipit, Plin. Domitores equorum non uerbera folum adhibent ad domandum, fed $\mathrm{c}$ bum etiam fxpe fubtrahữt, ut fame debilitetur equuleorum nimis effrenata uis, Cicero in Hortenfio ut Nonius citat. Pullos, cum ftent cum matribus, interdum tractandum, nè cum fint difiuncti, exter reantur. Eadem q́ caufa ibi frenos fưfpendendum, ut oculis confuefcant $\&$ uidere eorum faciem, \& êmotu audire crepitus. Cum iam ad manus accedere conftreuerint, interdum imponere his puerư bis, aut ter pronum in uentrem, poftea iam fedentem : hac facere cum fit trimus, tum enim maxime crefcere, ac lacertofum fieri, Varro. Pullus paffum fuauem uel durum cui affuefcit iuuenis, uix iam prouectús atate relinquere poteft; 8 c. Ifidorus libro 8. Ducendum effe equum per loca ubi fint fonitus $\&$ ftrepitus, Rufitus 36 . Hippocomus equium uiix lapidof $x$, fed non nimium afperæ af

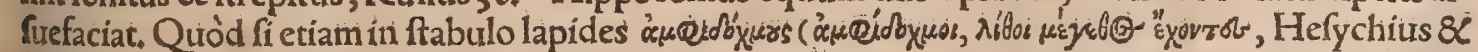

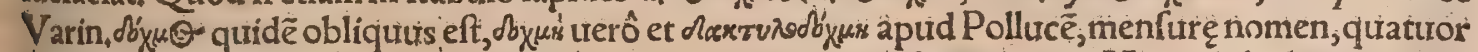

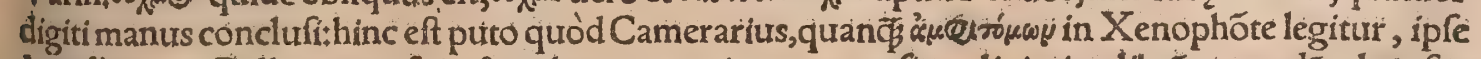

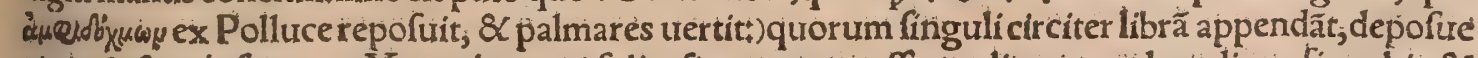
tis, incluferiśḉ ferro, ut Xenophon confulit : fic qượ ex affuetudine eos calcandi confirmabit \&

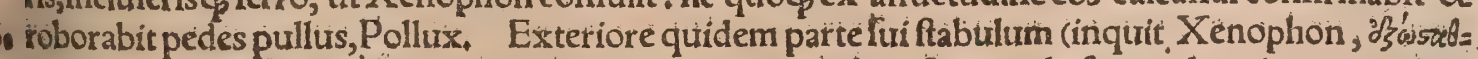
$\mu$ i uocans)ita rectifimé fe habebir, $\&$ pedes equi ampliabit, fi rotunda faxa palmari magnitudine

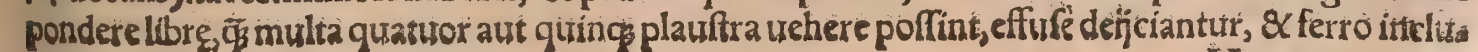



cifper gradiatur. Nam fiue deftringatur, feu à mufcis pungatur, uti ungulis illum non fecus ac fir dat necelfe eft. Etiam teftudinem(chelidona)pedis hoc modo effufi lapides folidant. Equitantifire quenter defcendendum de equo $\&$ afcendendum effe, Rufius 37. Ad infenfionem tam inftratu

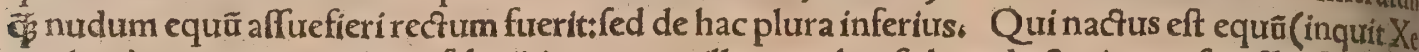
nophon)omnino imperitum falturi, is uacuum illum prehenfo loro ductorio tranfgreffus foffam or attrahito ad faltû. Quòd ille fi renítaț, à tergo aliquis flagrũ aut uirgã fummis uiribus incutia tranfiliet non folum illud Tpatium, fed longius etiam $\widetilde{\beta}$ debuiffet, $\alpha$ in pofterum non expectabit bera, fed ubi fenferit modò poné accedere aliquem, ftatim faliet. Cum uacuũ affurefeceris, ita etia gitabis confcenfum, primũ quidem trans minores folfas, mox etiam latiores, In conatu autem di fubdes calcaria, itidemóç cum fubfilire equũ $8 \mathrm{Cum}$ defilire uolueris, calcaria fubdito: toto enir corpore in omnib, his annitens equus, faciet illa ita, magis ut cum ipfe, tum eques in tuto fint, quàn fi pofteriore parte fui quafi deficeret, uel in tranfiliendo, uel in erumpendo furfum, uel in defiliendo Caterum ad decliuia primum leuiori in folo equos affuefieri conuenit. Ita tandem affuefacii lib tius per decliuia, quàm recto curfu ferentur. Nam $q$ quidam uerentur, ne fi per decliuia incite equi, armos rumpant, neminem debet terrere, qui cognouerit \& Perfas $\&$ uniuerfos Odryffas cul: fu per decliuia certantes, nihiló minus habere fanos equos, quàm Gręccs. Porrò feffor ad hac om accommodum prabere debet. Itaç ad primum ille equi impetum proclinator, ita miniméequi giuerfabitur, aut eques fuccutieturłftatimćs reprimens equum, refupinator, ita minimé ipfe iaçabì cur. In traiectu foff 2 , \& cliuiafcenfu, non fuerit incongruum iubam tenere, ne fimul $\&$ loco \& frem grauetur equus. Sin per decliure agetur, 8 refupinator eques, 8 equũ fuftineto freno, ne prace uterç deorfum feratur, Hac Xenophon. IAd circumactiones autem utrunç in latus, \& ing ros,item ç conuerfionem celerẽ directi curfus, eft id quidem non uulgaris induftrix equũ infittuete? fed nifi fit ualde nihili pecus, affiduitas $\&$ diligentia etiam hæc celeriter affequit. Loquor auten equo integro, \& curus uires nulla iniuria morbi debilitauerit. Nam talium labant crura, neqs th detentim per plana etiam loca ingredientibus his uehâre, nedum illos ad curfum concites $\&$ in ros torqueas aut agas per falebras, Camerar. De gyris equi infra etiam dicemus inter equitat precepta.

IDe caftratione dictum eft furpra capite fecundo in Canterio.

ब1 Equorum \& equarũ greges qui habere uoluerint, ut habent aliqui in Peloponnefo \& in App lia,primum oportet fpectare ætatem, quam pracipiunt. Videndũ ne fint minores trimæ, maior cem annorum, Varro. Aetatem quomodo difcernas capite tertio docuimus. Ad equarũ gi quinquagenarium bini paftores fufficient, utiç uter $\$$ horum ut fecum habeat equas domitas las in ỉs regionibus, in quibus ftabularï folent equas abigere, ut in Apulia 8 in Lucanis accid pe, Varro.

đEquile ftabulưm equorũ eft, Varroni \& Catoni.De hoc fupra etiam in domiturę mentiont nihil diximus. Plancę roborex fupponant ftationibus equorum cum ftramine, ut iacentibus ni fit, ftantibus durum, Vetus quidam nefcio an Vegetius. Curandum eft ut ftabulent ficco loc humore madefcant ungula: quod facile euitabimus, fi aut ftabula roboreis axibus conftrata, al ligenter fubinde emundata fuerit humus, $\&$ palex fuperiecte, Columella. In ftabulo reprob. plerifos pauimentum ligneum afferum, feu trabiũ atos axium, Camerar. Stabula equorũ uel meridianas quidem plagas refpiciant, non tamen egeant feptentrionis luminiburs, qux per hyent claufa nihil noceant, per aftatem patefacta refrigerent, Pallad. Diligens dominus(inquit Ve 1.56.) ftabulum frequenter intrabit, $\&$ primum dabit operam ut ftratus pontilis ( hunc etiam infe in hoc capite fimiliter nominat: \& libro 1, ca. 58 . Iumenta, inquit, mundiffimé ftabulent, \& rob pontibus confternant̂̉)emineat:ipfumó̧̧ fit, non ex mollibus lignis, ficut frequenter per imperitiant uel negligentiam eurenit, fed roboris uiuacis duricia \& foliditate compactum. Nam hoc genus equorum ungulas ad faxorũ inftar obdurat, Foffa pręterea qua lotium recipiat, deductorium de habere cuniculĩ̃, ne pedes iumentorum redundans urina contingat. Patena qux appellat̃ (uox uidetur â $\varphi^{\prime}$ rvs Gracorum) hoc eft alueus, ad hordeum miniftrandum fit munda femper, ne fordes?

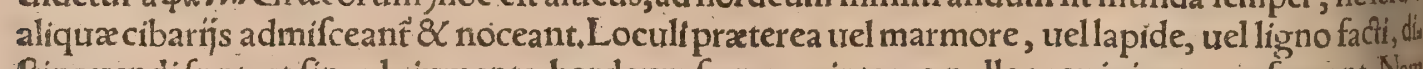
ftinguendi funt, ut fingula iumenta hordeum fuum ex integro nullo praripiente confumant, Nam funt animalia ad edendum auidiffima, quæ cum celeriter propria deuorauerũt, partem confortis in uadũt. Alia uerò naturali faftidio tardius comed đut, $\&$ nifi feparatím acceperint, uicinis rapientibus macrefcunt. Cratis, qux iacca uocatur à uulgo, pro equorum ftatura nec nimis alta fit, ne cumm initi ria guttur extendat̃:nec nimis humilis, ne oculos contingat aut caput. Luminis plurimum fabulo infundi oportet, ne tenebris affueta, cum productũtur ad Solem uel caligent, uel aciem uífus imrni nuãt. Aeftate in apertís locis tam noctibus quàm diebus iumentis libera aura praftanda eft. Hy ueró tepere debêt ftabula potius quàm calere:nam nimius calor licet cuftodiat pinguredinem \& cere uideatur, tamen indigeftionem facit, 8 uehementius nocet natura. Propter quod diuerfa ra morborum ex uapore ip fo animalibus generãtur: \& fi producuntur ad frigus infolitum, ftati gritudinem ex frigoris nouitate percipiunt, Hucufos. Vegetius. In quo quidem loco fues ftab 
quod magis laudatur confectis culmis frugum, Hac Camer. Qui equrum \& fanitate \& robore tia lidior 3 baberecupic, palear $\&$ hordeum to to anno ei prabebit, \& ne herbas aut farraginem tempore uerno det cauebit, Cxterum autumno herbas rofcidas dabit épratis, \& nihilominus adğciet anno nam hordei pro nocfe: Sic equus \& fanior \& laborum tolerantior, \& à morbis tutior ac uítacior ent nec timium pinguis.Si tamen mercatoris fuerit equus, pinguem reddere licebic ut pulchrior appa, reat.Pullis enim tempore ureris expedit farragines feu alias herbas exhiberi, maximè quuí fatigãdition funt, Hac R ufius capite ultimo. Audio in quibußdam Anglia locis panes ex leguminibus, ur fablis et pifis, confectos equis in cibum dari. Cum iter facies equo ne dederis multum annonæ in meridie, fed còamplius boni foeni, \& fi libet panem maceratum ébono uino. Conam maturè dabis, utmatlla rius quiefcere incipiat, Obfcurus. Pabulum madefacere quamuis pleriq̧ improbent, ratione tamê, ut interdum hoc fi $t$, carere non uidetur. Sicut neqg hoc, ut fruftum panis nonnunquam prabeatur equo cum fale. Nã eft pabuli magna ariditas, de qua ut equus ficcitate laboret, facile acciderit. Sed fa ftídiolos hrc equos reddere putant, Id quod, fi uero modo $\&$ hæc $\&$ alia omnia adminiftrêtur, non ui detur pertimefcendum, Camera. Feffum $\&$ fudantem equum potu abftinebimus : nec grana,fed fonum santum obríciemus: \& ftragulo opertum paulatim circunducemus, donec calor fatis euapo rârit, Obfcurus. Eqưus fi labor auerit aut fudầrit $\&$ incaluerit, cibum potúmue nó fumat, nifi pritis coopertus aliquo panno, paulifper ambulãdo duçus fuerit, $\&$ fudor $\&$ calor abierint, $R$ uffius. $(\mathrm{Que}$ intempeftiuum huiufmodi ciburm \& potum incommoda fequãtur, plura diximus fupra in c.) Nhii

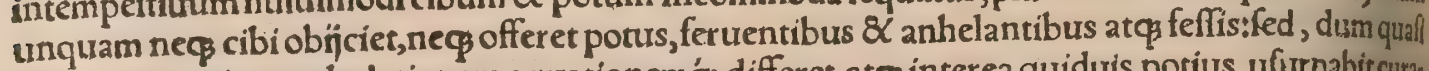
Spiritum recipiant, pabulationem aquationem q́ $_{\text {differet, at }}$ interea quiduis potius ufurpabitcuta: tionis. Nam quifedulus $\&$ fidelis erit, femper inueniet, quod equo benefacere quoquo tempore re ciè poffit, Camerarius. Aliqui polt abfumptum pabulum ftramenta carpunt, ne fordida quidem ré fpuentes, quod putatur anhelitum ladere : quamuis quibufdam hoc non nocere, quiburdam etiam prodeffe uidearur: Quod mihi quidem nemo facile perfuaferit, quo minus temere hoc referentibus affentiemur. Ergo qui ftramenta carpent, îs capiftrum inducetur poft pabuli comeftionem, hoe animam non impediet, $\&$ ftramenti paftum prohibebit. Id quidem facile, qui cogitabit, uerum reperiet, quò uel pabulum uel potus purior atque fyncerior fuerit, eò meliorem habendum, Quar propter de auena \& pulueres excutiendi, $\&$ fordes etiam eximendx funt, præfepéç diligenter exter

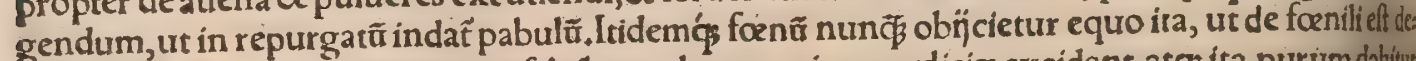
traçum, fed prius intra manus uerfabit, ut puluer es et immundicia excidant, atos ita purum dabitur equis, Camerar. Capiftrum é corio ualido inÿciatur in caput equi, \& binis retinis alligetur pralepi $\&$ pedes anteriores pedica lanea uinciantur, \& pofteriorum pes alter alligetur; ne huc illuc mouer poffit:hoc ad crurium conferuandam fanitatem facit, Petrus Crefcentienfis 9.5. Ex mox, Eftetian perutile ut equus affidué in terra iuxta pedes anterlores ciburm capiat, ita ut collum cogatur longh us extendere, quod inde gracilius \& pulchrius euadet.

Te potu adminiftrandononnulla iam proximé diximus in cibimentione. Aq qua propotili qui aliquantulum falita fit,leniter currens, uel parum turbata (aliquantulum falfa $\&$ turbida, fualu ter currens uel quafi nihil, Rufius) tales enim aquæ calidę funt, \& craffiufculæ, unde magis nuriâl frigidæu uero \& ueloces in motu perparum, Petrus Crefc.9. 5. \& Rufius 27. Temporibus tamentil mium calidis, dulces aqua conuenire uidentur, Sed habenda eft confuetudinis ratio. Et quia equis ni copiofe bibat, corpulêtus non fic, abluatur os eius interius $\&$ fricetur cum fale madefacto intini fic enim auidius eder bibet'́c, Rufius. TA Aqua in potu equis limpida ac frigida, etiam perennisar profluens miniftranda eft. Nam quicquid importunius fluit, uirus non admittit, Vegetius, Equis feffus equitatione aliótre labore, non eft potandus, nifi prius urinam emiferit, utcunq diutiusexpo ctandum fit, nein periculofum aliquem morbum incidat. Difentio morbus periculofus, cumaling ex caufis contingit equro, tum fi fudans biberit, Vegetius 2.9.Videas äliquando fegnes iffos \& nthi li curatores, plerungs importatam aquam, fi propefit unde petant, offerre equis, neq $\$$ illos foras edts cere ad aquationes, quod ualde culpandum eft, Camerarius, Et rurfus, A qua autem nunquamoft retur eque, qua in uafe aliquantifper retenta fitum duxerit, aut in quam illo aperto aliquid decidific incubuiffére pulueris feu quifquiliarum poffit, fempeŕ́g in ftabulum importabitur, quandocung hoc fieri oportebit, 8 offeretur equo recens. Etfi non defunt, quai ftagna turbidiora optimas ac falus berrimas aquationes fuppeditare exiftiment, cuius rationem ipfi reddiderint:hoc certe uidemusple rof $\beta$ equos faftidire tales aquas, neq ${ }^{2}$ uelle bibere quamuis fitientes. Etfi uir peritiffimus Ariftor les frribit camelos \& equos craffiore \& turbidiore potu gaudere, neq de flumine nifi prius pedibur turbato bibere.Ipfe quidem potus largior reddit obefiora iumenta, Camer. Domefticam (in dem) $\&$ intra ftabulum curam fidelem $\&$ affiduam effe oporter. Xenophon non patere, neck acceff illa uult loca effe, in quibus equorũ ftabula furerint, duabus maxime de caufis, ne pabula fub tur néue ignorari poffit utrum equus illa diffiper. Ac funt certe duo pracipua figna fanitatis equic rum:unum intra ftabulum, fi auidè $\&$ libenter pafcatur:alterum foris, fi os abundat fpumis \& $h$ re. Omni imbecillo pecori alté fubfternendum eft, quó mollius cubet, Columella. Locus ubim ratur equús, mundus fit interdiu, noću ueró paretur ei cubile è palea uel craffiore foenoúg ad nua,Petrus Crefc, Stramenta ad noçurnam quietem, itidem ̧́ hyeme quàm aftate plenioralug 


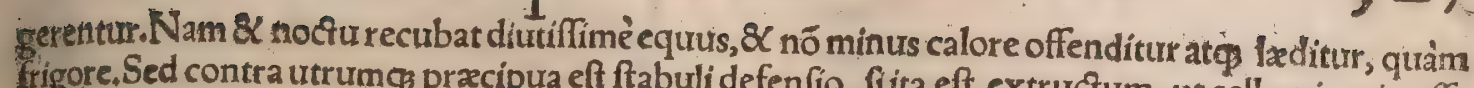
frigore, Sed contra utrum $\$$ præcipua eft ftabuli defenfio, fiita eft extructum, ut cellæx uinarix effe debent, hyeme ut tepidum, xftate gelidum ut fit. Sin aliter, arte $\&$ ratione tam calor quàm frigus re. \& aluro equorum mé \& aluo equorum, Camer. Et rurfus, Nonnulli equi ftramenta prioribus pedibus diffipant, his f́licet feppiufculè componentur:quid'enim aliud fieri contra hoc poffit non trideo. Oportet equum habere continue tegmẽtum lineum tempore calido, propter mufcas, \& laneum tempore frigido proz pter frigus, Petr.Crefc. Vefperi etiam maximè,fed $\&$ alijs temporibur, ungulæ emundabütur, ad quem ufum diligentiores ferreũ uncinum habent, quo fub folea abditas arenas $\&$ lutum prorưư Tum deinde timus bubulus maxime, aut, fi hic defit, equi, in cauam ungulam inculcabitur, applica* coftramento, quo minus citò excidac.Placet hoc quibufdam fieri maximé alternis diebus, quidam non dubitant fingulis iubere. Quidam malũt pluribus intermitti. Neç defunt qui hanc curam, ut fu peruacaneam, aut etiam inutilem planè negligant: qui tamen confenfu pené omniữ redarguứtur. Contrà aliqui non folũ probant $\&$ obferuant, fed infuper etiam feuo aut aruina illas crebro perun. gi uolưt, Camerar. Sunt quii ungulis uefperi purgatis in cauitatem inferciant fimum bubulư aut e quinum, unà cum ouo recenti agitato $\&$ cinere calido commixtis. Abfyrtus fi fractû (thlafma) in pe defuerit,fimum bubulũ recentem cũ origano in aceto 8 oleo feruefactũ pedi frequenter fubijcere confulit. Sed de ungularũ cura plura diximus capite tertio inter úyısv'́. Prifci foleas ungulis affige re non confureuere. Catullus tamen ferrex folex meminit,cum de mula loquitur, 8 quendam optat in luto ueternû, \& fupinum animum relinquere, Ferream ut foleam tenaci in uoragine mula, Camerar. Si induća noux folex fuerint, aut ueteres nouis clauiculis firmatæ, aliquantifper equâ, quiefcere patiemur, ne poft recentem moleftiam alia mox illi obijciatur, Idem. Equi ungulx con. gruis muniantur ferramentis, rotundis inftar ungula, lenibus(lego leuibus) frictis ita ut ungulis in circuitu bene adhæreant. Nam leuitas ferri reddit equum agilem ad leurandũ pedes, \& fríciura eius ungulas maiores ac fortiores facit, $\mathrm{Pet}$.Crefc. Vngulæ quomodolædantur clauris malè adactis, ui. dein c inter uitia pedum. Hippocomus curabit ut fatis mollia fint equi labra, quo facilius frenum fentiat.Molliuntur autem fricatione manuũ (leui) $\&$ a qux tepidx fotu, et oleo interdum inunc?a. Fre num etiam admittent facilius quorum molliufcula erunt labra, Pollux: $\&$ Xenophon, ut Cameraria us citat. TDe magno calore $\&$ labore graui ut paulatim refrigere te equus, optimum. Nam celeriter outrumgs fieri, equo non folum perniciofum, fed fape etiam exitiale, Camerar. IS quís equum (inquit Xenophen)detergere uelit talifitu, ut oculos habeat uerfos in eam partem, in quam fpectat equus, in periculo tierfabitur ne in faciem fibi equi tum genu tum ungula incutiat. Sin contra equx propter crus exterius iuxta fcapulam procumbens defricauerit, neç ipfe affligi, \& fic cautum pedís ungula explicata repurgare poterit. A t $\phi_{3}$ fimiliter $\&$ pofteriora crura repurgantur. Hoc memineric equi curator, \& harc $\&$ alia quibus opus factis, nequaquam ita fieri debere, ucuel contra faciem, uel contra caudam equiaccedatur, ideo oq equits, fi uim facere conetur, utraç illarum partium fui homi nis uires uincit. Ad latera uerò a diens maximè \& fibi cauterit, \& equũ prolixè traçare poterit. An. teriores pedes, inquit Pollux, capite uerfo eodem quo equus fuum uertir, abftergere oportet, ne læd poffit. Pofteriores uerò, in contrariam equi partem refpiciendo. Eadem de re Camerarius, Contra o equum à latere aftare(inquit) quicquid agas, 8 ad operis dexteritatem, 8 ad uitandum pericuftum profuerit; Omninoḉç cauebit curator, ne aut caput aut caudam uerfus ad equum accedat. Quare $\&$ frenati educentur fic, agitator prope armos ut habenam tenens ingrediatur. Habenam nunc uoco

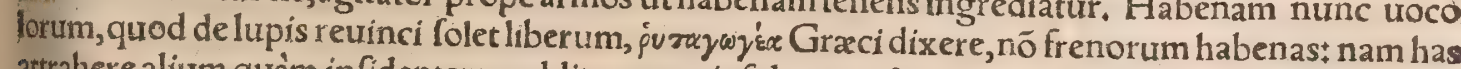
attrahere alium quàm infidentem, reddit equum infolentem, 82 qui in alteram partem plerun 6 con= uertinolit. Cum produci equum oportebit ( Xenophontis utor uerbis) fic duci illum ut fequatur (ego potius fic intelligo Graca, ut is qui ducit fequatur equum) hac de caufa improbatur nobis, $q$ hoc pacto ductor fibi minimé profpicere, equus autem omnia patrare poffit qux uoluerit. Neqs ita placet duci, ut longo loro alligatum fibi illum fuccedere ductor affuefaciat, propterea quòd in uttru. cung latus obuertere queat improbitatem fuam, et conuertere fe aduerfus ductorem fuum. Iam plu - res fiunà ducantur hoc modo equi, quomodo abftineant mutuis iniurïs? A latere ueró duci affuefa ctus equas, nees homines, neq $\beta$ alios equos facilelaferit, $\alpha$ rectiffimé praparatus fuerit ad confcen. dendum, fi quando hoc celeriter fieri oportuerit. Caballi minus fedulo cum cirrantur, non modò quod ad pabulum attinet, fed in tota tractatione reliqua, fiunt frigofi \& deformes, Græci igrós uo. cant: nam attenuantur \& macrefcunt, \& coxæ eminent, \& depyges fiunt, non aliter, quàm uel mani fefto in morbo, uel occulto interdum languore. Id non accidit ins equis, qui bene $\&$ diligenter curan: tur, prafertim cum ftrigile, atop etiam manu fola. Incredibile enim eft quantum $\&$ ualetudini $\&$ renuftati equorum conferat hac cura. Itaque cum in langurore extenuarentur equi, impri mis fricatione ureteres ufos legimus, Camerar. Sxpe plus prodeft preffa manu fubegiffe terga, quàm fi largiffime cibum præbeas, Columella. Vngulis purgatis curatisćs, tum manipulo ftra menti puri \& aridi detergebitur equus, ita ut manus fequatur pilorum fitum : hoc enim nitidos illos reddere folet, Camerarius, Et alibi, Quotiefcuncs (inquít) de agitatione reductus in Ras bulum $\&$ inductus in fuam cellulan fuerit equus, tum curator detergeat totum quidem cor 
pus framento arido, diligentiffimè uerò pedes $\&$ aluum: trum rectè atç commodè praferratze fint confyderabit. Detergebit autem füdores ato̧ humiditatem omnem cum magna cura. Strata fudantibus $\&$ defatigatis non ftatim auferet, fed fub illis patietur refrigerari $\&$ recipere uires equos. Fuit $\&$ ueteribus in ufu(inquit Camerarius) irt ligneo gladiolo perpurgarent cutem equorum, $\&$ de pilis fordes atç pultuerem excuterent. Item q́ texta quędam de corticibus palma ut inducerent manibus curatores equorum; quibus pili deterfi complanarenturet fplendefcerent, owgexíd $x$ hanc Graci uocarunt. In deftringendo(inquit Xenophon)ordiemur àcar pite \& iuba. Nam fruftra inferiora nitemur perpurgare, fi fuperiora immunda fưerint. At $\phi^{3}$ ita dein ceps per tótum corpus, cunctis îs; qux ad repurgandos equos comparata funt, utemur, ad pilos eri. gendos, 8 expellendum pultuerem fecùndum pilorum fitum:(uidetur addenda négatio, non fecins

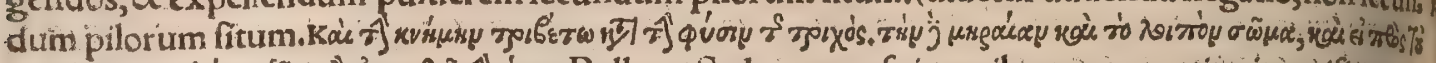

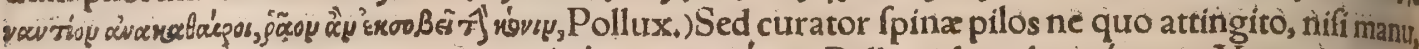

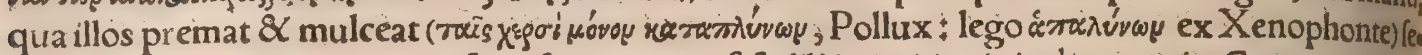
quens fitum eorum, quod enati funt:fic enim quafi fedili in equio minimé nocuerit, Caput aqua eluio to. Nam cum offeum fit, fi ferrơ aut ligno perftringat, moleftiam equto obiecerit. Iubam ưerticalem (procomion) \& ipfam hum:ectare debet. Prolixitas enim hơrum pilorum nō prohibet afpicere equî,, ac repellit ea ab oculis, qux moleftiam equis afferrent. Deinde incrementa caudx $\&$ colli pilis procu rabuntur; quo longius pertingere cauda, \& molefta fibi repellere, qưọ́ plenius adminiculum con fcenfor habere poffit. Crura lauari nobis non placet; nam cum nullam habeat utilitatem; damnof incerim eft ưngulis quiotidiana humectatio. Minus etiam fape inferiùs aluum repurgari oportet, $q$ ? \& in primis hoc fit moleftum equo: \& quò fuerit illa pars mundior, eò plitra qua moleftiam cxhibe: anr equoipfa colligat. Prxterea quamuis in hoc elabores, uix eduxeris equum, $\&$ mox fimilis eftip futurus, quos repurgauerit nemo: quapropter hæc omittêtur, Crura autem manibus deftringifatis fuerit, Hactenus Xenophon. Cum deftringetur equus $\&$ detergebitur (inquit Camerar.) optinuth fuerit extra ftabilum educi, $\&$ alligari laxiore habena, ut quafi folutus $\&$ liber aftet: infiftere autem faxis ter eribus, at ita placidé \& fricari \& fordes repurgari atç etiam flabello excúti conueniet T⿱艹 iubam \& pilos uerticis at $\bar{\beta}$ caudx humectari \& pectine difponi. Ipfum curatorem tum iubereftern cora \& madida ftramenta efferre. Quòd fi cotidie factum fuerit, \& equo prodeft, \& $\mathrm{miniftrorum}$ dil pertitum laborem minuit. Veteres non frenatos, fed capiftro circundato ori produxere equios adfin gilem \& pectinem \& uolutabra. Nunc in omnibus rebus laboris \& opera minimum fubire i ii, quibus iminifteria incumbunt, Camerar. Ante aquationes femper deftringi equum \& pectilitr bam oportebit. Id debebat fieri extra equi cellam in loco patente, ut funt atria et ueftibula:ita enimet excuti puiveres, \& fordes eximi:\& omnia, qux affolent, ritégèri poffent. Sed famulorũ ignauiaple runç laborem fugit, \& fupra ftramenta equum aftantem ad prafépe deftringit, deterget, fricat, plas ciit: fi tamen etiam hoc ab illis fit, ac nó potius magna ex parte, fiue etiam totum negligitur, quo ab modum equi uitiantiur, Camerar, Et alibi,Xenophon(inquit) aluũ et tenuioris pili aut glabralora fape emundari non putat bonum effe:cuius quidem rationi $\&$ nos affentimur : fic tamen, ne penis

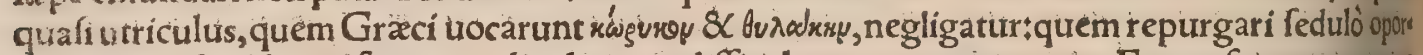
tet:nam illo fordibus referto, accidit plerunç difficulter ut mingat equus. Equus fummo manepai lea uel cralliore fono é cubili eius fublato; abftergere oportet per dorfum 8 crura; 8 omniament bra, Pet.Crefc. Sciendum eft(inquit Xenophon)nunquam effelori eius, quo ad prafepe all equus, aftringendum nodum, ea parte capitis, in quam uerticale(coryphra)freni applicatur, Cum nim crebro ad prafepe caput equus moueat, nifi fuerit circa aưres uerticale innoxium, fapen ro iilceris caufa exiftit: his igitur exulceratis, et deftrictioni $\&$ frenationi equus refragabitur. Vitle tiam imperari curatori, ut quotidie ftercus equinum \& ftramenta in unum locim exporter: facto \& ipfe minus laborabit, \& equo confulet. Sciet etiam curator accommodare equio capiftum quoties uel ad deftrictionem, uel uolutabrum edicere uolet. Deniqg quocungs fine freno ducendus erit,capiftrum induetur. Nam hoc refpirationem non impedit, 8 morfibus tamen obftat, at $f^{\prime} f(u)$ inuafiones equicrum cohercet. Alligari equumà capite fuperne rectum eft : quicquid ènim os offeridit, declinare folet elato capite equius. Id cum facit ita alligatus, magis laxantur quàm rump tur uincula. Aquare \& mergere equos pro lauare uel abluere per aftatem in praterfluente dix ris. Nunc coridie bis aquatum equi folent agi, ut ipfis crura \& uenter humectetur; quorum Xeno phon neutrum probat, madefactionem etiam crurum nocere dicit ungulis. Sed hóc contra tam recen ptam confuetudinem \& ufurpationem omnium afferere nimix airdaciæ fuerit, prafertim cum \& ur teres eluiffe fordes tam crurum, quàm uentris folitos fuiffe, $\&$ hoc aliquioties praccepiffe reperiatuCamerar. Etrurfus, Ego (inquit)in ea furm opinione, in hyeme crebro equos mergi non oportere omnino autem nunquarm adhuc aftuantes $\&$ fudantes, Aquari quidem non debent prorfus infulpi cione uití morbi ue, neç cum medicari illos uoltterimus, fiue pharmacis, feu manu, Quidam wino calido aut fece poft interualla certa temporis colluunt crura equorum, nam neruis hoc prodeffeco ftat: etfi nonnullis difpliceat, Camerar. Articuli uiel fuffragines poft iter calido foueantur uino, utco roborentur ungula, Vege.2. 58. Nonnulli uéperí crura equor ã perluũt aqua calida écoquina,qư abluta funt uafa efcaria(mit Earfpiltë:)aut uino collectitio, quod obiter dum uina depromimus;ait 


\section{De Quadrupedibus}

patrifimi, cum hoc fit, non admittunt frenum, Praclpiatur $8<$ hoc curatori, primum, ne unicurain hatbenis attrahat equum, ita enim durum os (heterognathurs)redditur. Deinde ut à buccis conuenien ce fpatio diftet frenum. Nam cum illas premit, callum folet obducere, ita fenfus retunditur, Cum aili: tcra longitus dependet ufiç ad fummum os, poteftas tamen fit equo, fi frenum momorderit, minus parendi domino. In his acrem effe curratorem non minus quàm ulla alia in re elaborare conurenit, Tantum enim momenti in hoc eft fitum, libenter ut equus frenum admittat, ut fi quis omnino retici as, is nulli ufur effe cenfendus fit, Quod R curator non folum cum ad laborem equurs, fed etiam cum ad pabulum ducetur, $8 \mathrm{C}$ de agitatione domum reducetur, frenum illi induerit, nimirum iam uftro appetet fratim ubi hoc offerri fibi uiderit. Cum frenandus(inquit Camerarius) 8 infternendus exit equus, tum deterfus efto, \& nitidus atç pexus: frenetur autem fic ut minimè offendatur:ita libentitis frenos admittet, quos, uidi qui initio fale confpergerent, quòd cum lingeret equus et fimul manderet frena illa pati affuefieret. Quidam comprimentibus equis dentes, neç|recipere frena intra os uolen tibus, ferro labra $\&$ gingiuas urgent: quod etfi in pręfentia, nifi fint ferociores, facit, ut admittant fre num, odium tamen illius perpetuum excitat, Quare melior eft ratio Xenophontis, digitis prèmere labrum;non enim in hoc tantus fenfus doloris, uel dolor potius nullus omnino ineft. Frenanturair eem hoc modo. Habenæ, quibus equus regitux, obducuntob equi uerticem $\&$ deponuntur ad imath utubam f cu f capulas, urel(fi quis hoc mauulc)armos aut fpinam. Tum finiftra teneat ferrum freni fine urpos, \& c extra fubter collum equi fenfím circumacta uerticale lorum unà cum reliquo frenofun loreo quafi reticulo applicet atç circundet capith, \& qua nectenda fuerint connectito, \& satenus lam qua nunc maxilla reuinciuntur, infibulato:atg ita inftructus equus ductorio loro, fi confiftere ad prafepe diutius debeat, religator fuperne de furcillis feu clatris, in quas equis foenum noftrismo ribus obñ citur, ut foeniles dicere poffe uideamur, Sed melius fuerit extra fuam cellam productume quum in loco aperto $\&$ libero, ubi atterere latera nequeat, neç eriam attingere, quod ore inpetat, vincire, ut ibi confiftat tantifper dum confcendatur. Atw hac erit frenationis ferératio, $\&$ adminis fratio. Dentes fcalliones $\&$ plani uulgơ dicti, equis extrahi folent ut frenum commodius admits

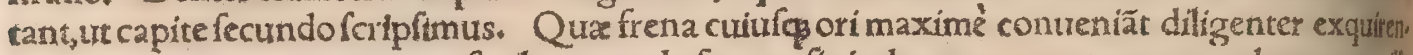
dum, conuenientia autem non facile mutanda funtea fic indentur, ne aut angantur buccæ, altilli in dentibus uoluantur. Qutorum alterum callos in malis creat, alterum obftat moderationitnantic facile morfu freni arripiuntur ab equis, quo facto illiferegi non patiuntur, Camerar. बiBenequt dem(inquitidem) cingula ftrati adduci cum ad alia prodeft, tum minus reddít moleftū \& gratu pon dus fefforis, cum frrata non quafiurolutuantur fuper equi tergo. Strata autē placidé apponenturita,

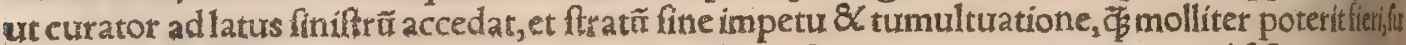
per dorfo equi deponat, ut illius ueluti capulus fupra fpinã, qua parte ceruix exorit, fiftatur: onnia aũt, qux expedita effe debent, cauebit, ne fuper ftratum dorfo equi impingantur, ut funt cingula, ,t tlia feffionis adminicula, \&C lorum pectoris fiue armorum, nec non reticula illa lumborum, fi annexn fortefibi ftratum habear. Tum deinde printut omnium annectetur lorum pectoris, \& per illa reticula I affint, cauda exeret, ut fieri confueuit, atog ita ftrati diligenter compofiti urinculum adducemts infibulabimus caute. Nam bene equitant, gqui bene cingunt, Id'q́, us ante dixi, equo prodeft: ne ctum uerò eques ur leui impulfu delabatur, in caufa effe poterit. Hoc cingulum debet crati pecto fubligari, non aluro rees ilibus. Inftrati uel inditis uel nondum inditis frenis, minus laxè reuincien. tur, ne fortè procumbant, id quod neq, equo bonum, 8 ftratis nocet. Educi autem optimum decel la tum equos in aperta $\&$ libera loca, \& alligare loro prolixiore; ibi ut quafi ar bitrio fuo aliquanth lum uer fentur, quo generolos admodum oblectari putant. Etiam ad eas partes, quas cingulumnobí, fapius refpiciendum, ne forte illo perufta cute uulnerata fint: quod malum cito curari debet, \& fach le poterit intertriginum communibus $\&$ notis omnib,remedinjs, Camerar.

TConfenfurus equum (inquit Xenophon)primum de freni parteinferiore, feu etiam deatill

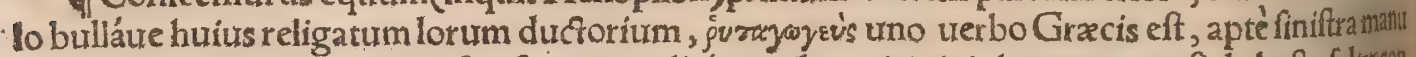
prehendet, ea laxitate, ut neog fi infưrgens, pilis's auribus uicinis inharens, neç fi de hafra faltur cenfurus eft, conuellat equum, Dextra capiet habenas depofitas in fummis armis unà cumiuba, ne rilicet ullo paco conuellat habenis os equi. Polţ̧ fe alleuârit ad confcenfionem, tum ígitur fin quidem librato corpus, dextra uerò intenfa fubleuet ipfe fefe. Huiufmodi confcenfio etiama omnem deformitatis afpectum excluferit. Confcendet autem crure incuruato, necs genu dorfo impinget, fed in latus dextrum tibiam traíjciet. Vbi uerò iam circumaçum pedem applicuerit, tuin. deinde \& natibus refideat fuper equo. Quòd fi forte eques finiftra manu ducet equum cum ge dextra haftam, equidem cenfeo utile effe ufum ille fibi ut paret etiam $\grave{a}$ dextro latere confende

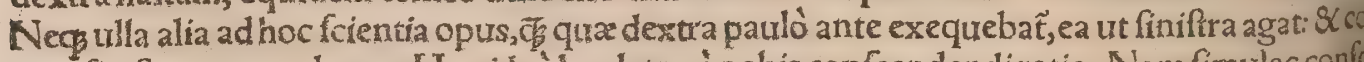
qua finiftra, ur tum dextra. Hæc ideo laudatur à nobis confendendi ratio, Nam fimulac confinde rit eques, paratus mox eft ad omnia, fi quod forte ingruat fubitum certamen hoftibus irruenti Hac Xenophon. Qui equũ afcendir, primũ ab altiore loco id faciat, ut neç feipfum inter confon dendũ offendat, neģ ponder is ful impertr equo molefus fit, Pollux. Ad infcenfionem tam inti

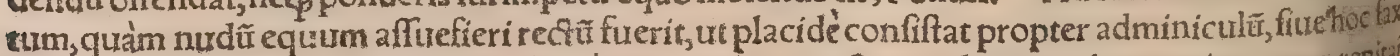
feu trüci, fiuce etiam foli editionis fit. Quód fi accedere autfare nolit,aut uehementius qugog ren 


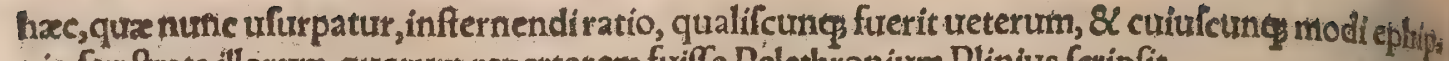
pia feu frrata illorum, quorum repertorem fuiffe Pelethronium Plinius feripfit،

- $V$ bi iam refederit eques (uerba funt Xenophontis)fiure fuper nudo equo, feu etiă in ephippio, non laudarur quafi curulis quędam feffio, fed ut cruribus diuraricatis maximè rectitudo cuffodiatur: fic enim $\&$ feminibus firmius adhaeferit equo, ac erectus ualidius $\&$ coniecerit iaculum, $\&$ icium, $\hat{A}$ res poféat, intulerit ab equor. Hoc etiam ftudendum, tibize unà cum pedibus ut remiffa fub genibra dependeant. In rigiditate enim fi crus aliquopiam impegerit, periculum fuerit ne frangatur: fluxatie rò tibia facile cefferit offendentibus, neq̧ femur tamen demutaurerit. Currabit $\&$ hoc eques, ut trǘüs quoos, id eft ea corporis pars quax eff fupra coxas, quafi ad fluxum quendam agilitatis compofitaffit hoc enim modo $\&$ efficacior fuerit, $\mathscr{Q}$ minus, fi quis detrahere aut impellere conetur, fubfultârit( 中 quuus, infiturtus effe debet, durm attrahat eques, fi quid forte oportet, \& habenas coxquet, \& haftam adaptet. Tum deinde brachium lauum laterí adponito, qui habitus equitis eft elegantiffimus, \& $\mathrm{PO}_{0}$ bur manui addit. Habenæ laudantur æquales, non fragiles, neq̧ lubricx, neq craffx: etiam hafalls la matnu, fi opus fit, comprehendi ut queat. Infidens equo (inquit Pollux) femina noti admodum premes, fed pedes molliufculè fufpendes, ita ut fanti fimilis appareas. Validior enim qui fatquàm qui fedet. Curabis quoog ne quam corporis equi partem laborantem attingas, ut pedes aut latera, Has enim praccipue partes in perpetuo motu effe oportet. (

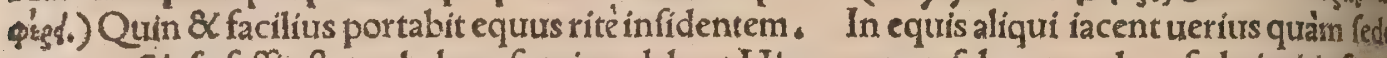

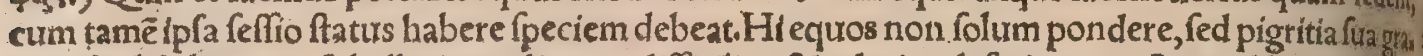
uant $\&$ debilitant, ut fub illis ingrediantur difficilitus, $\&$ celerius defatigentur. A t $\epsilon_{2}$ talibus equith tamen, niff ftrata funt penè plumis, ut nunc fit, efferta, femina facile aduruntur, itemćs nates:Qunơ ff accidiffet, ueteres remedio effe prodidêre, ut illinatur fpuma equi colleça de ore $\mathcal{Q}$ inguinibus, $C_{2}$ merarius. Et alibi, Curm eques fe collocấrit in ftrato, tum adductis habenis quafi erigat caputequi, ita pergendum effe equus intelliget, turm feffor paululü remittet habenas, fic tamen femper ut tereal arduiores, neç has unà curm manu defluere patiatur. Reddit enim hoc equos fegniores in defatigat tione: contra diligens $\&$ attenta habenarum prehenfio, uegetos efficit. Aliquibus ora funt neggit

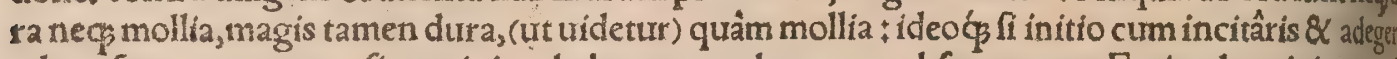
ad curfum aut gyrum, fi tum igitur habenas attrahas, non obfequtruntur. Faciendum igitur urtaly bus laxifî̉méremittantur primum, ita poftea regere $\&$ pro uoluntate quifog fua moderari facilepor terit. Equus natura generofis, etiam laxato ei freno, erecta cervice pergit ignobilem frenocogu ut decorum feruet. Cauendi uero funt afperiores freni, quos equi eodem effe loco non finunt, lid hus illuc fubinde mourent, commodiorem fibi tandem locum inuenien di fpe. Quamobrem ferotori bus equis duriores freni inígciendi non funt (mordicus enim illos tanquam obelifcos arripintit,

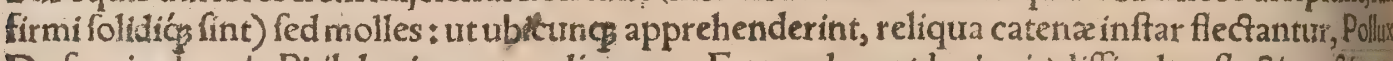
De frenis plura in Philologize parte 5 . dicemus. Equus durus(duri oris) difficulter flectitur:\&(cum

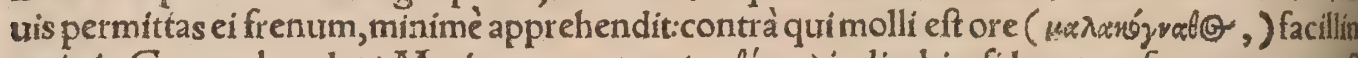
gatio in Graco abundat.) Morigerum autem (ซøetivivou) itidicabis, fi laxatum frenum contracturou

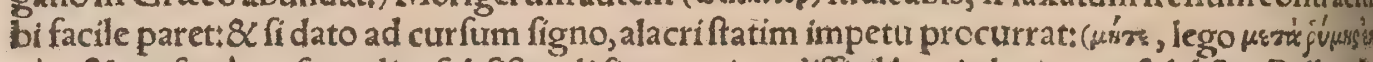
$\left.\mu \omega_{y}\right) \& 2$ rurfus à curfu audito fubfiftendi figno, etiam difficilbus in locis mox fubfiftat, Pollux, Locu

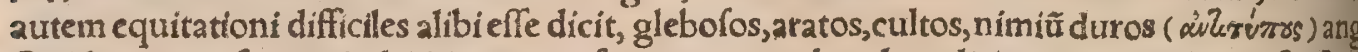
Quidam tanta funt cris duritia, ut cum frenos, quemadmodum dicitur, momorderint, fruffraincou tinendo feffor laboret: Hos omnino repudiat Xenophon, Camerarius. Equi fi mor fúfenuman prehenderint, inclinato capite extra iter inftitutum uiolenter feruntur: \& ceruice obliqua crebiot concuffa, uim facere 8 excutere conanttr: 8 in dorfum (elatis fcilicet cruribus prioribus) tergiut

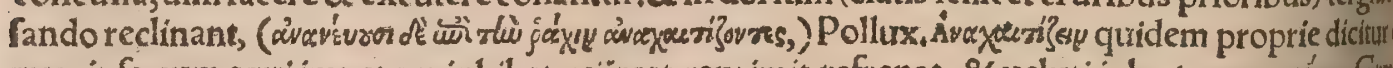

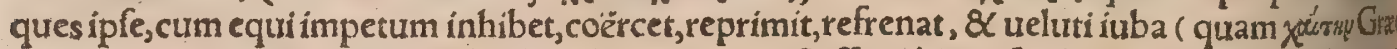
uocant) correptum retinet: ut pluribus dicam in H.e. Seffor ubiconfcẽdit, non ftatim agitabitequin,

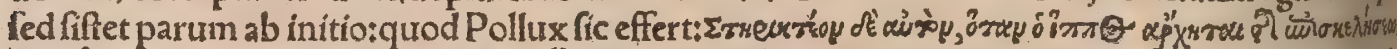

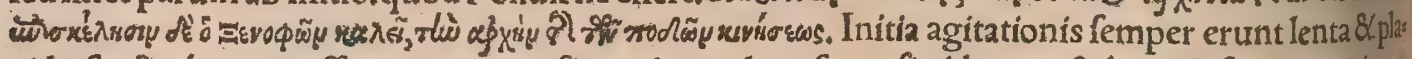
cida, fenfimćs progrefliones maiores fient, dum ad curfum, fi uideatur, \& 2 hunc ipfum intentioent

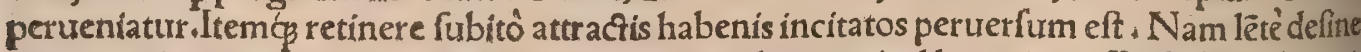
tationem, ita ut coperat, æequum. Sunt autem quidam equi ad hoc etiam affuefacti ut de inci mo curfu repête confiftere, \& fubito omni ui excurrere fciant. Sed hoc fingulare fcilicet fuerit, ne in pracepta referrí queat, Camerarius. Signo dato ut equus progrediatur (inqurit Xenophon) fait

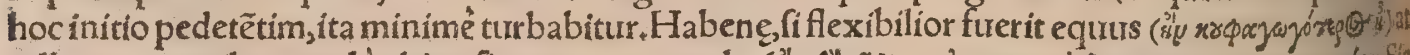

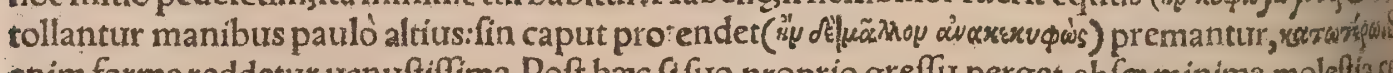
enim forma reddetur uenuftiffima. Poft harc fif fuo proprio greffu perget, abfos minima molefti colv

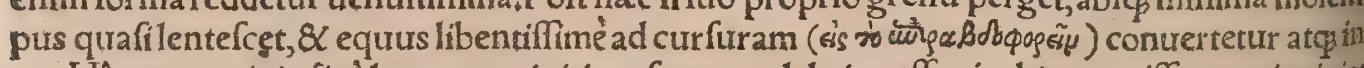
tur. Hîc cum opinio fit à læua parte initium facere pulchrius effe, ita hinc potiffimum incipietur, greffum poft confcenfionem dextrum mourente equo, tunc fignum detur ad curfuram: ita cnimilit

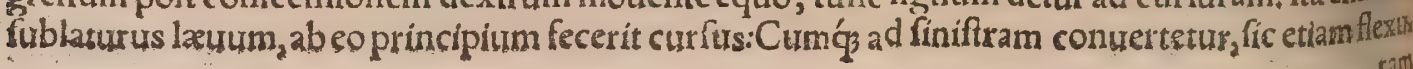



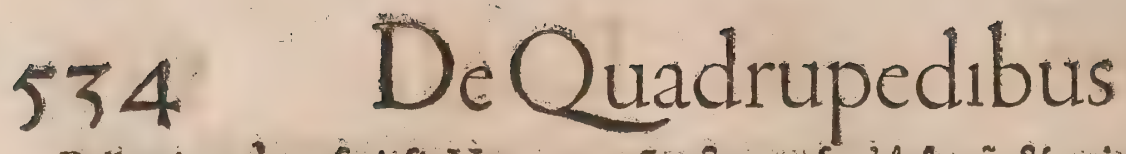

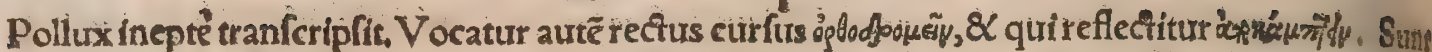
quadam (inquit Camerarius) in equitatu horum temporuma à ueterum more diuer $\{a$, ac pleraøs on: nia barbara \& immania, delectaturć $\beta$ audacia \& temeritas noftrortum hominum fimilibus befthis Quippe quit maiora pericula ludere in equis foleant, quàm unquam in ullo circo adira comperlan, tur. Nam incitatis uideas equis in medio quordam \& contentifimo curfư fic infidere, ut remiflis ha beris a mbäs manus furfum $\&$ in latera iaçitent: quod tamen factum fcio cui mortem $\&$ exitium at rulerit, cum ita, ut diximus, inftigatus equusus ad faxum offendiffet, $\&$ obruiffet impetu illatus fefforê.

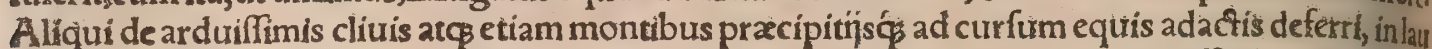
de\& oftentatione ponunt, Quid ille? quí per fcalartim plurimos gradus uíx \& difficili molitionè ar tractum equum confcendit $\&$ de editiore eo loco defilire fecum, uerberibus, calcäribus atç uocecon egit, Quid uero alter?qui in roboreum lacum, cuiufmodi in oppidis feré adductx aqua excipiùntur 8 continentur, cum inftigato equo infilijt, Taceo totam illam in uenationibus agitãdi temeritatem, ubi omnia infequentibus confpecfas feras effe plana oportet, qua \& Teutonico prouterbio notatur, quo dici folet, De manibus $8<$ pedibus tum actum urideri, fellicet quod inter hanc uita fi conferuetur, felix eques fuiffe uideatur. Verum fi ratio \& dífciplina accederet, nunc quidem, ut ego iudico, tese queftris ad quandam admirabilem perfectionem perducifacile poffet:Ita eft inftructio equiorü prat clara $\&$ commoda $\&$ omni à parte tam equis quàm uiris apta atø̧ opportuna, Hurcurç Camerabitus. Et alibi, Ea qua contraria funt equis \& ingrata, temoueriab illis omni tempore oporter, ut diximus' imprimis aurem cauendum ne quid tale de improuifo \& inopinato illis obticiatur, praferteimfiani mofiores fuerint:nam fic perturbantur, $\&$ ad infaniam quodammodo adiguntur. Hoc nonfertiantit his temporibus quibus furrof $x$ ift $x$ exul tationes equorum expetũtur. Itaq $\&$ ftatim cum fein eghi collocarunt, habenas attrahunt, \& equum extimulatum circumagunt; fape etiam ad faltumimpel, lunt, Atç audiui ego de quodam, qui cum delectaretur ferociffimis \& acerrimis equis, quoties uh let etiam illorum augere animos, tum foleret adductis loro altitus capitibus, $\&$ difclufo ore imbrice, infunderć illis trini, quantum quidem uifurm effet, quo haufo cum incaluiffent fub à gitatore lillouter fano,ipti plané furerent. Ergo pleriç equitatus ftudiofi, nibiluolunt effe placidi neque domin in equis fuis, Sed uinum apud Homerum quoque potus eft equorum, quod fuis mifcere folitamils Andromacham Hector diligentius quidem $\&$ accuratius, quam fibi, qui ipfius effer maritus.

Ne autem iracundé tractetur equus, utiliffima eft doctrina atç inftitutio in re equeftri \& Nam ira nihil proutidet. Itaç ea defignat plerun $\varphi_{\text {, }}$, uorum poenitentia neceffariỏ eft comes, Xenophon, Nunc demonftrabimus (inquit idem) fi cui forte oblatus fit ferocior, aut ignauior iufto equus, quio pacfo utro qg recté uti queat. Primum igitur fciendum, ferociam in equo fimilem effe iracundix tion minum. Vt igitur non irritantur facile, quibus nihil neq dicitur ne $\phi$ fit, quo offendanturitta \& rociorem equum minime commouerit is, quil hon laferit.Quapropter ftatim in confcendendoproul dendum, né confeenfor moleftus fit equo. Cum autèm in equó confeffum fuerí, acquiviefcẽdum pir

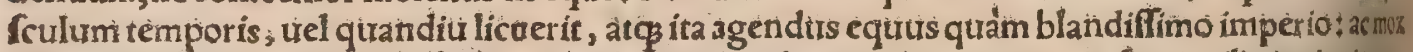
lentifininis à gradibus initio facto, ad celeritatem adigetur: inter qua uix fentiet ille incitationtm, Imperio autem repentino equus ferocior!', litidem ut bomo perturbatur animo, fiue quid tumas fpexit fubito, feu audiuit, feu etiam patitur, Quare hoc non ignorabimus, repentina omnia itrequil perturbationes efficere. Verum fi incitatum ad celeritatem contineri ferociorem in curfur uolueris, non attrahes derepente, fed placidé adduces frenum, ut inuites; non cogas ad confiftenditit Placantur etiam equi longioribus fpatís magis, quàm fi crebrò conuertantur:atç lenta diti equitio

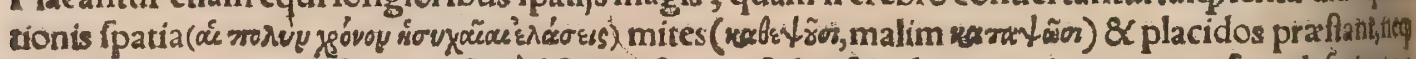
ferociam equorum fufcitant. Quód fi quis Yperat, fi diu $\&$ celeriter agitet equum, fore defarigatum deinde manfuetiorem, diuer fum fentit atg accidere confueuit. Nam hxc inter, ferocês magis uilen tìam ufurpare, inç̧̧ ira, quemadmodum homines iracundi, fape \& fe \& fefforem indignis mơdista ctare folent. Proinde ad celeritatem fummam equos feroces non facile incitabimus. Nequaquaman

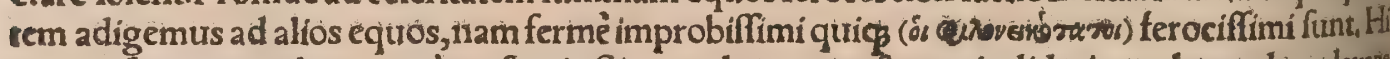
ptiores freni quoop læures quàm afperi. Si quando tamen alperos indiderimus, laxando ut laurs deantur efficiemus. Prodeft etiam ut feffor affuefaciat fefe ad talem in equó potifimum ferocto cationèn, qua $\&$ ipfe minimè commouéatur, $\&$ nulla feré alia parte equum contingat, quám tib fionis firma caufa contingi illum neceffe fuerit. Nec hoc ignorădum, pracipi poppy fmo (id ell, tur

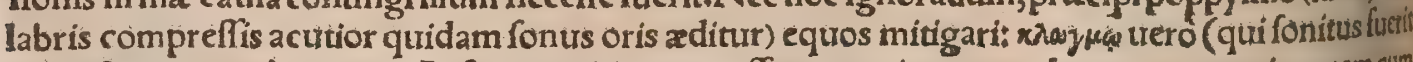
palati \& guttitris, ) incitari. At fi quís initio equo offerat gratiora cum clogmo, contraria autem cum poppyímo, citò ille didicerit, poppy fmo ia incitari,mitigari ueró clogmo, A ro fimiliter inter clamores ac tubas cauendum, ne equo formido aliqua noltra appareat, néue illi hoc tempore turbulentumath quid obijciatur:fed quantum fieri poterit, quietem tum conciliare equo ftudebimus, $\&$ (fi fieri po teft) màt ưtina aut uefpertina pabula prabebimus. Hoc autem confilium optimum fuerit, ne quis bi equum ferocem ad bellum parare utelit. Verum de ignauis tantum fcripfiffe fatis fuerit, in his om

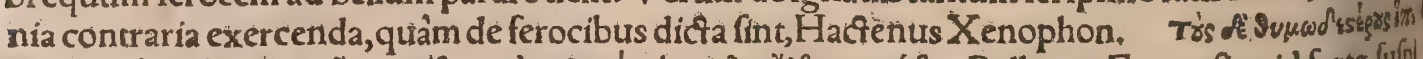

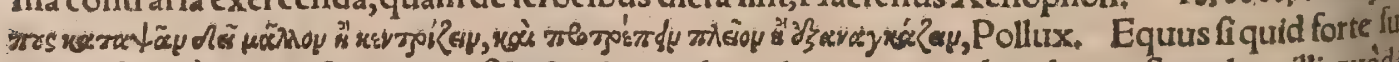
catus ( 
A thenęus libro quarto foribit, apud Perfas diebus natalitijs fuifte morem, ut diuites bourem, afinum, equum \& camelum apponerent, totos in clibano aut camino coctos, Erafmus in prouerbio Solides clibano boues. Equinam \& camelinam in Damafco edi, apud Vartomannum legi. Strabolibro feptimo de Myfis loquens, quorum Homerus Iliados $\mathrm{N}$, meminit his uerfibus, Aurios de' rér

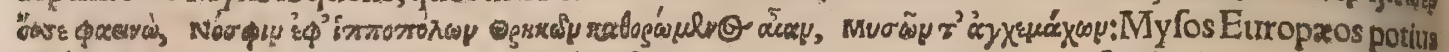
quàm A fiaticos intelligendos fcribit. Cui fententix(inquit)etiam poêtze teftimonium accedit, quioni Hippemolgos, Galactophagos \& Abios eis adiungit, qui gdem in plauftris uiuêtes Scy thę \& Sarma

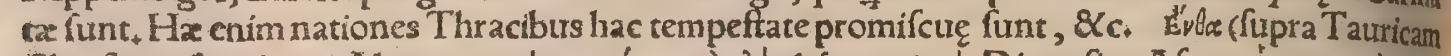

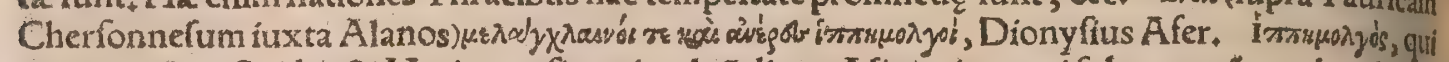
equas mulget(Suidas $8 \times$ Varin, )ac fit equimulgư dicas, Alini etiam qui fubrumant equabus, hippo thela Gracis dicti, equimulgi Latinè nominari queunt. Hippomolgos uocant paftores equorî, $q$ lacte equino uruant: iufmodigentem in Scythia efle, quam \& A bios uocant, utpote ỏn

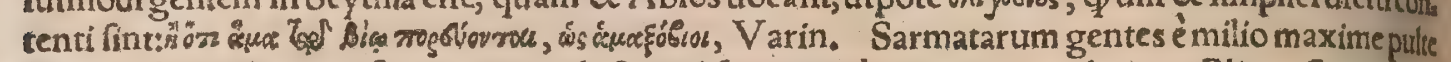
aluntur, $\$$ cruda etiam farina equino lacte uel fanguine è cruris uenis admixto, Plin. Sauromate (inquic Panfanias in Atticis)plurimos aluntequos, utpote Nomades, quibus non tantư ad bellum utuntur, fed dịs etiam fuis immolant, $\&$ cibo adhibent. Tartari incidût $\&$ uulnerant equos, cruo remíg \& per fe, \& cum milio uorant: Carnes pecudurm, pecorü, \& equorum comedũt, etiam femicus das. Caballos pridic tum fponte tum morbo mortuos, excifo loco apoftemate infecto, perlibenterco medunt, Matth!as à Michnu. Tartari equos $\&$ canes comedứ,, Paulus Venetus. Vergilius tertio 2 Georgicôn de febri ourum fcribens fic canit: Profuit incenfos ęftus auertere, \& inter ima ferire pedis falientem fanguine uenam: Bifaltz quo more folent, acerç Gelonus, Cच̃ fugit in $R$ hodopẽ, atç in deferta Getarû́: Et lac concretum cum fanguine potat equino: Pelias Neptuni \&" Tyrûs filius ab equa educatus fertur, Calius \& A elian, in Varñis libro 12. imatia twy Kigsvor

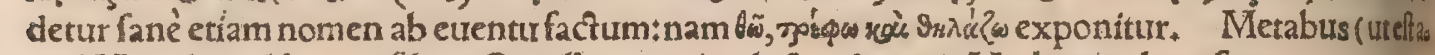
pud Vergilium libro ${ }_{1}$ ) filiam Camillam equino lacte educauts, Verba cius hac funt,

Hic natam in dumis, inter ́́́ horrẽtia luftra Armentalis equx mammis \&lacie ferino

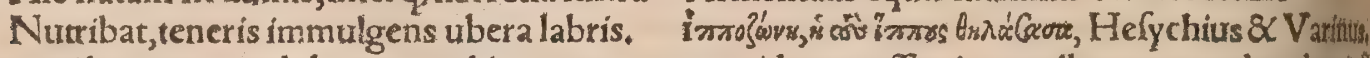
Tartari lac equarum bibunt, quod ita prap parant, utuideatur effe uinum album, non admoduminfi

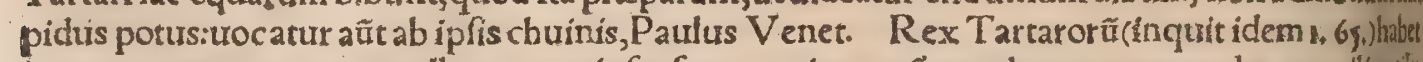
armenta magna equorum alborum utriuf $q$ f fexus, qui putan fexceder numerum decem miliumith feftiuitate aû́t qua ce!cbratur uigefimo octauo Augufti, prap paraț lac equinum in uafis decentbis, $\&$ rexipfe manibus fuls diffundir hinc inde lac illud pro honore deorum furorum, ar bitrans $\& \alpha^{\prime} \mathrm{m}$ a $\mathrm{g}$ is fuis fic edocfus, $\varphi$ dĭ lac bibant effufum, \& foliciti fint conferuatores omnium corum qua pollu det. Poft facrificium illud nefandum, bibit rex de lacfe equarũ albarum, nec ulli alteri licet illa diebl bere de lacte illo, nifi fuerit de progenie regis, prater populum quendam regionis illius Horlachuou catum : qui hoc etiam fruitur priuilegio, propter uicroriam quandam magnam, quam promagi Cham Chinchis obtinuit. Barbari quidam(inquit Albertus) emulfum equarû lac Soli expontnit nec pars craffior fubfidat, poftea in uafe feruefaciunt ut ficeram, (cereuifiam:) $\&$ quod cliquatum ef bibunt: $\&$ hoc poru utunt Tartari, Comani, Pruteni, \& finitimi eis barbari. Plurimum autemil pinguefunt,illi maximé qui non funt in affiduo motu \& exercitio. Bubulum afininum \& equinin lac, uentri magis ( $(\dot{\phi}$ orillum, quod crafinus eft)idonea funt, fed ipfum turbant, Diofcorides. mé perpurgar lac equinü,tum afininum, deinde bubulum, tum caprinũ, Varro. Lachis equinipon tus aluum foluit, Plin. Lac equarum, ficut $\&$ camelorum partui uricinarum, tenue elt, aquofim, of uentrem mollit, Auicenna. Vel cum lacte capra falfum mulfumćs capeftes. Crede tamen pothin meliorem lactis equini: Dicitur hic ualidos afinx peruincere fuccos, Serenus de uentremoll Tenuiffimũ lac camelis, mox equabus, craffiffimum afina ut coaguli uice utantur, Plin. Equin lac ocyus defcendit, fimilićç modo afininum, quod \& pauciftumæ pinguedinis particeps eft, pro rea rarò in alicuius urentriculo tranfit in cafeum, Galen. Serum delacte equinc potui datum, \& fine periculo uentrem molliter purgat, Marcellus. V tile eft etiam lactis fero urentrem fubdur re:ueruntamen id non fit quod ex cafeo fuerit expreffum:melius enim eft id, quod per decoctionem ex lacte feparatur, prafertim equino uel bubulo, Aëtüus. Equinũ ac afininum lac mifrent ad Phry gium cafeum conficiendum, Ariftoteles. Quod hippacen uocant, cafeus eff equinus : ea uirusper gium cafeum conficiendum, Ariftoteles, Quodo lum appellarint, Diofcorides, Glycyrrhiza, id eft dulcis radix, fitim reftinguít, fi teneat in ore. Qua de caufa Scy tha hac contenti, decem duodecimás dies degunt, $\&$ uitam non aliter quàm hippacéclu prorogant.Quod Plinius undecimi uoluminis calce confirmat. Quradam enim exiguo viifu famî ac fitim fedant, confertrantȩ́ uires, utbutyrum, hippace, glycyrrhizon. Hippacen apud Theophra Itum Theodorus equeftrem uertit, quafi radix effet dulci radici par ingenio ad abigendam fitim fan memóģ:fed cafeum equinum, non radicem aut herbam effe, Diofcoridis Plinḯक teftimonio confat, Hermolaus una litera difcernic, fic ut hippice herbam, hippace cafeum defignet. Scycha Nom 

tur, in Tauro dixl ex Diofcoride:quanquam eius interpretes horum animalium nomina omittut, Equi axungia fuffumigata, éj cit mortuum partum foras, \& fecunda fequitur, Sextus, ol Medullari equinam recentiores quidam ungentis ad fpafmum mifcent . If Si equus labor et abfceflus illoge nere quod uulgò uermem uocant, cưm alibi, tum in nafo, cutem cauterio aperiunt, \& ęrugininem cum offe equino ufto infpergunt, adiecto interdum hyofcyami femine. TDentes equi mafculi (non car ftrati, $R_{2}$ fis ) pofiti fub capite (uel fuper caput ftertentis in fomno, prohibent ne ftertat; Albertus;') allius qui in fomnis opera gerit, prohibent, $R$ afis. Dentium equi farina perniones rimasós pedurn fanat, Plinius. Dentes caballini tunfi ulcera pernionum, fi fint tumidi, utlliter curant, 'Marcellus, I Dentis caballini contufi farina priuatim fublutuem fanat, Plinius, Eadem (inquit alibi) infperfa,ue rendorưm cateris uitrís (de formicationibus uerruciş̧̧́ prius dixerat) medetur. Et rurfus alibi dya fentericis ac coeliacis falutarem effe foribit. Dens caballinus contufus, $\mathcal{Q}$ in puluerem tenuifimum redactus; ueretro infperfus efficaciter prodeft, Marcellus, Equi dentes qui primum natifuerint, dentem qui dolet tetigerint, remedio erunt, $N$ am $\&$ fí infans equi roftrum bafiauerit, dentium dolo, rem non fentit, \& nec equus mordebit infantem, Sextus. Dentes qui equis primum cadunt, facts lem dentitionem praftant, infantibus adalligati:efficacius, fi terram non attigêre, Plinius, Colloigi cur molli dentes nectentur equini, Qui primi fuerint pullocrefcente caduci, Serenus ad infantes dentientes, Dentes pulli annículi, adalligati celeriorem \& fine dolore dentitionem praftant, Ralis \& Albertus, I Pilo equino circumligato uerrucas tolli audiołratio eft, quoniam propter aftrifto nem alimento priuata ar efcunt, Pilus equinus ad hoftum domus alligatus, prohibet ne culices aut ciniphes per hoftium inuolét, Rafis (apud quem pullus pro pilo fcribitur) \& Albertus. Inqui na \& ex ulcerum caufa intumefcunt:remedio funt equi fetæ tres, totidem nodis alligat intraulcus, Plinius, Sanguinem fiftit pilorum afini cinis illitusłefficacior uis ẻmaribus aceto admixio, \&inla na ad omne profluurum impofito:fimiliter ex equino capite (f́ilicet pilorum cinis) \& femine, Plit nius, đCorium equi aduftũ illitumó̧ ex aqua puftulis, quas bothor uocant, refrigerat eas, Auicen,

A A lienem fedandum datur equi lingua inueterata ex uino, prafentaneo medicamento diciffe fe ex barbaris Cacilius Bion tradidit,Plinius, Equilingua arefacta, \& ad leuitatem tritaxig ex uino potui data, protinus utilitatem fuam fedatolienis dolore manifeftat, Marcellus. Equ agulum aliqui hippacen uocant, Diofcorides \& Plinius. Hoc ex uino potum aduerfus ferpe morfis falutare creditur, Matthæolus, Cum uino propinatum omnes dolores fedat, Áeful Priuatim coliacis dyfentericiş̧́ conuenit, Diofcorides, Dyfentericis $\&$ coeliacis quidam pr prodeffe feripferunt, Galenus de fimplicibus 10, 11. Equi coagulum, inter auxilia coeliacorum\& dyfentericorum tradunt, etiamfi fanguinem detrahant, $P$ linius. Idem apud Auicennam $\&$ Helye gimus, quorum interpretes pro affectione colliaca diuturnum uenuris fluxum uerterunt. fum equi, \& fanguis caprinus, uel medulla, uel iecur aluum foluit, Plinius: Sed hac omnia potius ficcantóg aluum, ut in Capra docuimus, đIn corde equorum inuenitur os, dentibus caninis maximé fimilẹ hoc farificari dolorem : aut exempto dẽnte emortui equi maxillis ad numerum qui doleat demonftrant, Plinius. I Equi iecur theca cedrina reponito, deinde Chio usino $\&$ a lutum exhibeto:quibus enim iecur ulceratum eft, ne amplius exedatur, efficitur, Galenus depa facilibus 2,38. - Ti mortuus partus fentiatur, lien ex aqua dulci potus ëricit, Plinius, $\mathrm{C}$ mulant tefticuli equini aridi ut potioni interi poffint, Plinius, $\int \mathrm{P}$ anos $8<$ apoftemata in quarme parte dífcutit ungulæ equinæ cinis cum oleo $\&$ aqua illitus, Plinius. Strumas difcutit ungula afin uel equi cinis ex oleo aqua illitus, \& 2 urina calefacta,Plínius. Vngularum equinarum exufarum cinis cum oleo impofitus vel illitus, ftrumis medetur, Marcellus. Rubori cum prurigineill equi fpuma, aut ungtula cinis, Plinius, In Hippiatricis Græcis equo ileofo remedium commendar cur huiufmodi:Ramenta ex ungulis anteriorum pedum, trita cum uini cotylis tribus per naresina funduntur. In ïfdem Hippocrates equo frophofo infundi iubet ramenta ungularum anterionum trita in quatuor cotylis aqua. $R$ amenta ex ungulis equi ex uino per nares equo infufa, trinam promouent, Hierocles, Vegetius 3.15. Aduerfus calculos prodeft ungula equi cinis in uino 2 qua, Plinius. Vngulæe equinæ fcobem, uel exufta cinerem, fi calculofis in potionem acceperi, tô fanabitur, Marcellus, Vngula fuffiur partus mortuus eịcitur,Plinius.

Fel equi tantum inter uenena damnatur, ideo flamini facro equum tangere non lice,, $\mathrm{P}$ TLac?e equino uenena leporis marini \& toxica expugnantur, Plinius, Lackis equi potus foluit, Idem, Diofcorides \& Auicenna : uide fupra capite fexto, Comitialibus datur lactis potus, Plin. In comitiali morbo teftes aprinos bibiffe ex lacte equino aut ex aqua prodeft, $\mathrm{P}$ Ad comitiales coagulum uituli marini bibunt cum lacte equino, afininóue, Plin. Aétius de fuppul ratis renibus tractans, Lac (inquir) cum melle poft puris eruptionem eis prabendurm: \& primum quidem afininum aut equinum : ad ulcera enim repurganda conducit:poftea uero cum repur

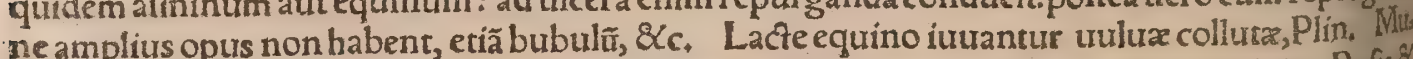
lier qua non concipit fi lac equinum ignorans biberit, 8 mox cum uiro coierit, concipiet, Rafis of Alber tus, Equa lac potum, matricís laboremfedat, \&, educum (aliâs caducos, abortưn for 


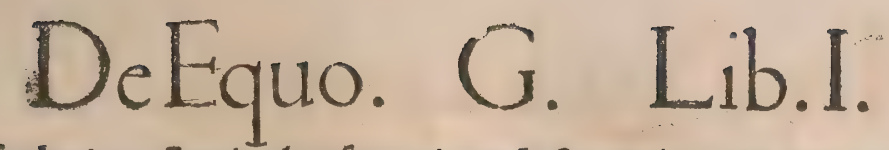

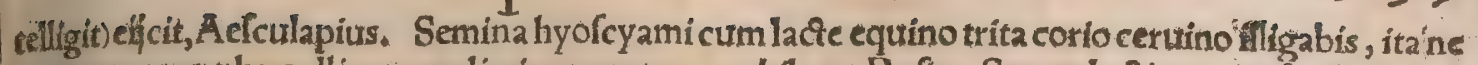
kerran tangant; hac alligata mulieri conceptum prohibent, Rafis، Sertum lactís equini facile \& fine periculo uentrem molliter purgat, Marcellus. Cafeus equinus uentrem reprimit, $\&$ torfones tols lit, A efculap. đEquifpuma (eam intelligo qux in corpore equi cum incaluit $\&$ fudat, apparet, quanç etiam de fudore feorfim inferius dicã) illita per dies quadraginta, priufö́̈ nafcanț primum pí. lireftinguntur, Plin. Equi fpuma fi puero inuefti pectine linieris, pili eiurs non crefcunt, nee gene. rantur, Sext, In dolore uel grauitate aurium commendatur equil fuma, uel equini fimi recentis ci nis cum rofaceo, Plin, uidetur autē rofaceũ utrig̨addendum: Nã $\&$ Marcel, fic feribit, Spuma equi recens detracta, \& cum oleo rofeo infufa, auricularum quamuis uehementes dolores refolutit. Si abọ equitando uexata fuerint inguina, aut intertrigines dolebunt, fpuma equì fricentur, ftatinn remedia. buntur, Marcel.Plinius ad hoc remedium non fimpliciter fpumam, fed fpumam ab ore (id eft faliua, qua alterius facultatis, quàm reliqui corporis fpuma fudorl permifta uidetur) ingưinibus ớcollectâ Ulini probat, his uerbis: Femina atteriaduriç, equitatu notum eft: $V$ tiliffimum eft ad omnes inde cau fos, fpumam equi ex ore inguínibus ğ illinire. Rubori cum prurigine equí fpuma, aut ungula cis nisillinitur, Plin. Ego ad hoc uitium oris faliuam potius, quàm aliunde collectam fpumam \& falfed nefua mordicantem adhiburerim. In feruido faucium malo, quod aftate nonnunquam graffatur pefilentilue in milites prafertim, noftri à liuido lingux 8 faucium colore uocant bie brïhi,hoc re medium commendari inuenio: Salitra equi auenam aut hordeum pafti, os agroti diligenter colluis tur:deinde ex cancris uruis contufis humorem exprimes eodemó rurfus lauabis, Quod fí uxiuos ha= berenon potes, pollinen de cancris aridis in clibano toftis infperge, poftquam equi faliua ablueris. Tuffim fanat faliua equi triduo pota, equum mori tradunt, Plin, codices excuffaliam \& obfcuram le cionem habent; Ego hanc noftram confirmo ex uerbis Sexti $\$$ Marcelli qua híc fubieci. Equi fali. uam fi biberint phthifici \& qui malẻ tuffiunt, fani efficiuntur. Expertifimum fané, equus morietur, Sextus, Ad phthificos remedium \& prafens \& maximum:nam etiam uitæ dubios fanat, \& quibus fes fupereffe nulla uídeatur:equi faliuam uel fpumam cum aqua calida bibendam per triduum da bisstiam quem tuffi intoleranda $\alpha$ diutina laborare uideris, hoc remedio liberabis: $x g r u m$ quiden fine cunctatione fanabis, fed equum mors fubita confequitur, Marcellus, बा Sudor equí miftus c î uino, abortum facit potus à grauida, $R$ afis $\&$ Albertus. Sudor beftia (equi, Albertus) in Hat faciem,

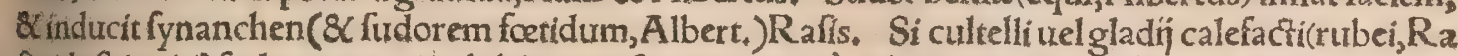
fis, id eft igniti)fudorem equi imbiberint, inficiuntur adeo ut locus ab eis uulneratus fanguine ante mortem animantis manare non definat, Alibertus. Idem apud Rafis interpretem, fed ineptiffimélegit tur. Slequum fagitta uenenata urulnerâric,fudorem alterius equi 8 panem combufum cưn urina hominis in potu dabis, deinde in uulnus quogs immittes admixta etiam pinguredine, Rufius 178. Sunt quitineas \& ferpentes è uentre hominis exigi promittant, fi equi fudorem cum urina in bals neobiberit, Innominatus. बf Fimi afinini idem qui equini effectus eft, Auicenna. Fimi equini inueterati fautilla adrodit carnes, Plinius. Armentarí(equi uel afini) qui herba pafcitur, ficcum fi= mum liquatum in uino, mox potum, contra fcorpionum ictus magnopere auxiliatur, Diofcorides. Ad ferpentes uturntur carne $\&$ fimo equi in agro pafti, coagulo leporis ex aceto, contra \& murem araneum, Plin. Tanta uis eff in ureneno rabiofi canis, ut urina quogs calcata noceat, mas ximé ulcurs babentibus: Remedium eft fímum caballinum afperfum aceto, $\&$ calfaciom in fico ap ofitum, Plinitus. Marcellus empiricus capite 8 , collyrium quoddam fieri docet in olla operculo te= ca cum foramine cui inferta fir canna ut expiratio pateat:ollam uerò cooperiri iubet fímo caballino recenti. Hoc putrefaciendi modo(fic enim urocant)etiamnum $\&$ medici $\&$ maximé chymiftæ utun'tur. Tam afinorum quàm equorum fimum, fiue crudum, fiue crematum, addito aceto fanguinis eruptiones cohibet, Diofcorides, Rafis 8 Albertus, Aridum infperfum fanguinem fiftit, Aefculap. Stercora afinina uel equina, fi, dum calida funt, apponantur, fanguinem ex uulnere fluentem fi: ftunt, Rufius inter equorum remedia. Et alibi, Sanguinem(inquit) cohibet ftercus equinum recẽs, cum creta $\&$ aceto acerrimo mixtunn agitatumćc. Et rurfus, Sanguis aperta urena ad contrariam par tem reuellatur:deinde fimum equi cum filtro (lana feltria)uftum uulneriaut uenæimpone. Neuea nx equi fecta plus iufto exinaniantur, ftercus ipfius iumenti fluentibus uenis admotum fafcips obli getur, Columella \&Vegetius $2.45+\&$ rurfus $3+14$. Secta uena equi fanguinem nimis fluentem fi ftes, fi fimum ipfius equi imponas, Pelagonius. Siure fimus manni cum teftis uritur oud, Et repri= mit fluidos míro medicamine curfus, Serenus ad fangurinem é uulnere nimis fluentem. Stercus e quir recens, olfactum etiam fanguinem reprimit, Albertus $\& R$ afis, apud quem tamen corruptus eft: locus. Si fanguis ex uulnere immodice fluat, fimi caballini cum putaminibus ourorum cremati ci. nis impofitus mirèfiftit, Plin. Si exuulnere immodicus fluat fanguis per nares, fimus caballinus. quo modo egeritur adpofitus, ftatim fubuenit, Marcellus. Et alibi, Stercus caballinum exprimitur dum recens eft, eiusḉ fuecus naribus trahitur ab eo cui importunlus fluunt, Si thlafma (fractum,

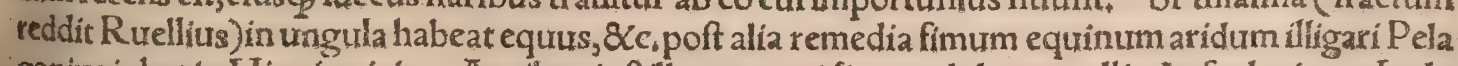
gonius iubet in Hippiatricis. Auribus inftillatum equifimum dolorem tollit, Aefculapius. In do lore aut graultate aurium equini fimi recentis cinis cum rofaceo prodeft, Plinius. Stercus caballinum recens colliges, 8 in furno calefacies, tunc oleum medio sapiti infundes contra uuam, \& fic 
ftercus pradictum in panno uel in linteo fpiffo capitifuperligabis in noctem, Marcel. Regio morti fimum afinini pulli, quod primum xdidit a partu,datum faba magnitudine cuino intra diem terti

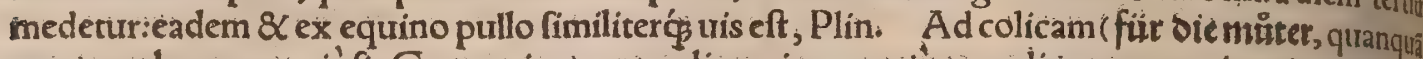
uteri morbum proprie fic Germani uocant, colicam improprie)remedium certum, ita etiam ut mor bus nof repetat: Fimi de equio qui aùena aut hor deo pafcatưr, non gramine, manipulum in dimidia menfura trini(uncias circiter ocfodecim intelligo) decoques donec par's dimidia confumatur: hoc pau Iatim bibendum eft, donec exhaurietur:erit autem eó utilius quo exhaurietur cititis, Empiricus in. nominatus. Equini fimi cinis in aqua potus altum fiftit, Plin. Ad uentrem fluentem, Equiftercus ä qua liquefactum \& percolatum, fi bibatur, facit regireffum, Sextus ${ }_{6}$ Fimum caballinum combi res, \& cinerem fimi ipfum cum ưino uetere mifcebis $\&$ conteres : $\&$ fic dabis dyfenterico bibendum fine aqua, fi non febricitabit, Marcellus. Equini fimi cinis coliacis \& dyfentericis falutaris dicitur, Plinius: paulo ante etiam afinini fimi cinerem ex uino, utriç uitio efficacem effe fcripferat. Si par tus mortuus fentiatur, lien equi ex aqua dulci potus, éjcit:item ungula fuffitù, aut fimum aridum, Plin. Mihi uerborum conftrucio parum cohærere uidetur?quamobrem legerim potius, Item ungti, Ia fuffità, aut fimum aridum, fcilicet fuffitü. (A pud Vincentium Bellixacen, legituri, aut ungularum fuffumigatio, uel fimus aridus.) $\mathrm{Nam} \&$ apud Haly mędicum fic legitur, Suffitus ex fimo equifer cundas foetumćs morturum educit. Fauilla fimi equini inueterati partum mortuum enjcit, ut quida ex Plinio citat, TQuidam trinam equi aqua ferrarix ex officinis mifcent contra comitialem

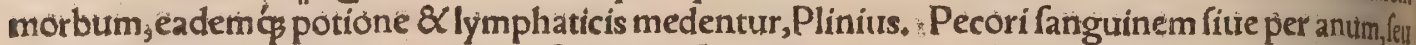
uuluam, feù nares emittertiti, pujtem facito ex farina tritici $\&$ ouo $\&$ butyro tritis in lotio ex equili haufto:deinde pultem uel maffam illam coctam in cinere pecori dabis, Empiricus innominatus. Lis tum ex cuiuf cungz equi lotio factum ưino permifces, colatumq́; per nares ínfundes, \& confefin prourocat urinam, Veget.1.61. \& Hippiatrica: in quibus $\&$ hoc additur, lutum huitufmodi etiamarh dum eafdem uires obtinere. Vulgare $\&$ uerum eft remedium, lutum de uia ex lotio cuiufcuing qui factum, ưinoćs permixtum \& colatum naribus infundas, Vege.3.15. TLichènes funtin equo rum genibus, \& fuper ungalas in flexu harum partium indurati calli:qui triti $\&$ in acero poti, comt tialibus mederi traduntur, Diofcorides $\&$ Galenus de fimplicib. medic.11.17. Aliqui $\&$ ad criula uis fera mor fum adhiberi confulunt, Galenus ibidem, Comitialibus datur ex equo lichèn inareto mulfo bibendus, Plin. Zeidę funt augmentationes in crưribus \& iunciuris equiortum \& animalium maiorum, Serapion 444. Dentes labantes confirmari aiưnt lichéne equi cum oleó infufoper alts remteft autern hoc in equorum genibus, ac fuper ungulas, Plin. Ferunt additiones illas, quafuns in genư equiti, tritas \& potas cũ aceto, fanare fodam \& epilepfiă,Äuicenna intèriprès. Calculos $\chi_{x}$ pellunt lichênes equini ex uino aut mulfo poti diebus quadraginta,Plin. T Véftígium equiexc fum ungula (ut folet plerun $\phi$ ) fi quis collectum reponat, fingultus remedium effe traditur, recordan aibus quonam loco id repofuerint, Plinius.

ì. ลे.

a. Equi dicuntur ab æqualitate fiue paritate, eò quiod pares antiquitus cruribus (bigis quaditi gis (́) iungebantur, Albertus \& Sipontinus. Equa, mula, $\&$ c datiuum $\&$ ablatiuum pluralemin abus faciunt:Prifcianus inter har nomina pro equa afinam pofuit. TCaballum pro equoLani dicunt, Græeci ra Bádssy, Itali catrallo, Galli cheual, Illyrï kobyla, \& forte Germani etram inde uocem 4 gaul mutuati funt. Caballos antiqui equos dixerè, fortaffe (licèat enim fufpicari nobis) uocelifin de fonitu qừm edunt, pulfu ungularüm, undè \& fonipedès dicti, Camerar. Caballus, quòdcaret terram unguila impreffa, Obfcurus. Caballos tuidesur intelligere Hieronymus maiores equor, cuti mañiós accipimtis ininores, Cálius. Sunt autem Hieronymi uerba hæc, Vt ftatimcernami tiaras galeis, caballos equis cedere. Ego contra conịcio:nempe utgalea militare capitis uelament ualidius eft quàm tiara in pace apud Perfas \& Medos geftari folita;fic equus quafi per excellentian de animofo \& bellatore equo dictus, caballo prafertur qui pacis tempore ad diuerfos labores feruith Nam operarium $\&$ uiliorem equium proprié caballum dictum effe, ex aliquot author um tefinashits qua fubíciam, apparet: etfi nonnulla eiufmodi fint, ut caballi nomen pro equo fimpliciter ufurp uidearitur. M.Cato Cenforius cantherio urehebatur, $\alpha$ hippoperis quidem impofitis, ut fecum tith lia portäret. O quantum erat feculi decus imperatorem triumphalem Cenforium, uno caballoefie contentum: 8 ne toto quidem. Partem enim farcin $x$ ab utrog latere dependentés occupabanit; $\rho_{\text {st }}$ neca. Succuffatoris tetri tardićs caballi, Lucilius. Alius caballum arboris ramo in humilli alligas tum relinquit, $V$ arro $P$ armenone. In caftris permanfi, inde caballum reduxi ad cenforem, $k$ abe

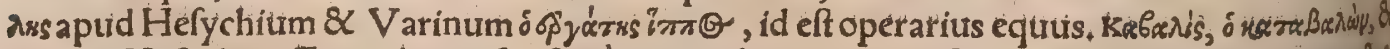
Suidas, Hefychitis, Etymologus:fed forrè in omnibus erratum eft:nam ifta interpretatio o

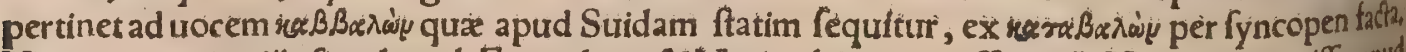
Hoc erratum in alịs fimplex, ab Etymologo \& Varino bis commiffuth eft. Hoc igitur omifo apud

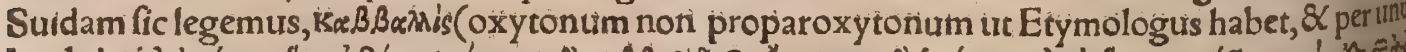

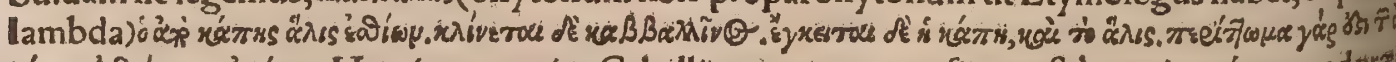

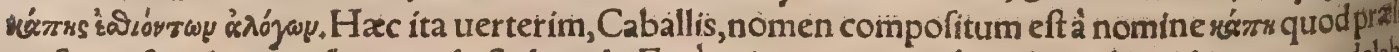
pe fonat, \& aduerbio äriss quod eft abunde, Feré enim tanquam abundans aliquid in terram dela 


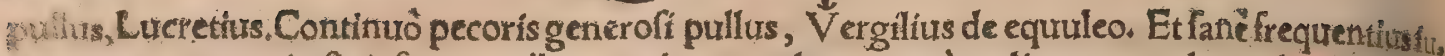
mentorum, ut equi, afini, foetus pullos nominant authores, quàm aliarum quadrupedum: urt etiam

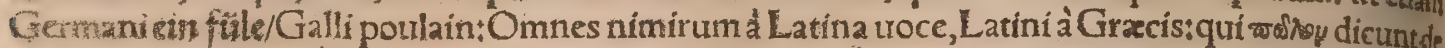

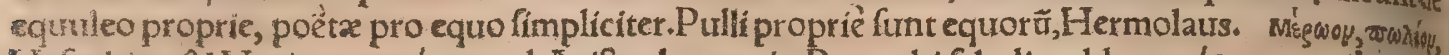
Hefychius $\&$ Varinus, rasió apud Ariftophanem in Pace, ubi fcholia addunt wéturs proprlé dici foe

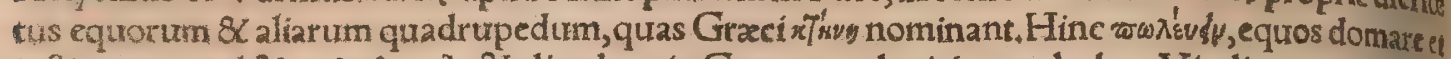

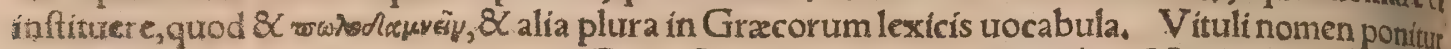
etiam de equis apud Vergilium tertio Georg. Iam uritulos hortare, uiamós infifte domandi, ut Gram maticus quidam exponit:Seruius quidem eo in loco generaliter tum de equis tum de bobus accipi ait, Vergilio de utrif $̧$ pariter docente. TEquum omnium primumà Neptuno productum ferû́, ur parre ultima huius capiris dicam. qMorem literas inurendi in equis,agnofere uidetur Arifton phanes, qui in Nebulis coppatiam inde equum nominat, cul inuftum effet cappa:ficuti famphorasfi

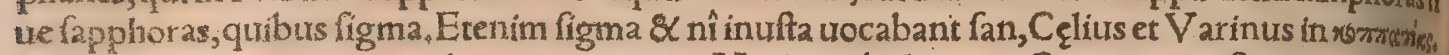
Seruantur autem etiamnum hæ notę in equis, Varinus ibidem. Coppa urero eft numeri figura, compacta ex cappa \& fígma, hoe modo, s, fignat autem nonaginta:etiamfi coppatiam quidam infer prezati funt quafi wó patum, qux tatio etiam bucephalos fecit. Et Corinthiorum rex Sifyphus, animalium ungulis mono gramnaton nomen fuxum inferibebat, ut furto intercepta co repeteret argumento. Trifippion quis dem fuxit ueluti rotula quardam publica nota, qux candens malis equorum imprimebatur, qui iam confenuiffent: dicebatur $\&$ i bit figma literam Doricé fan appellari, \& equos propter impreffam eis huius literæ notam apud Arit foph, in Nebulis famphoras. Calius fua ex Scholịs in Nebulas Ariftophanis (uel Suida, apurd quem eadem leguntur, fed loco uno manco) tranftulit, fed omifit obfcura quadam, qux etfineciple

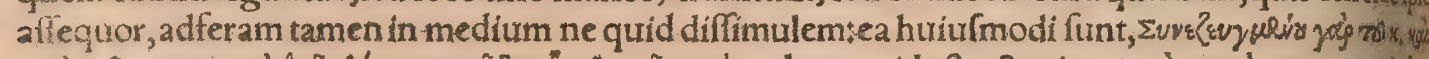

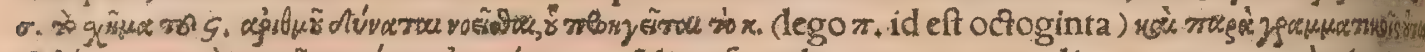

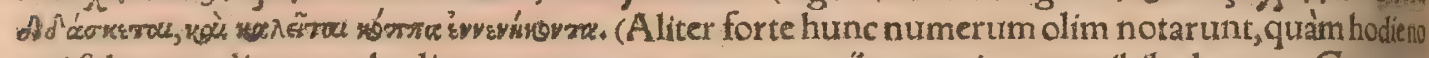

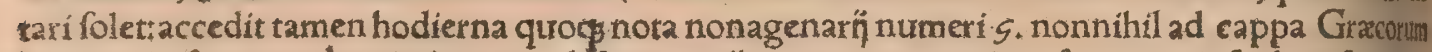
hoc modo fcriptum le.tt inde coppa dictum conijcias:ueteres quidem figma maiufculum figura lus

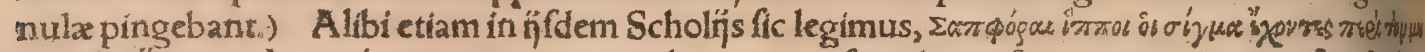

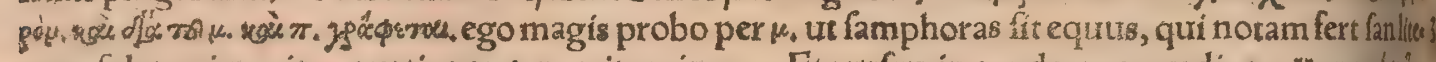

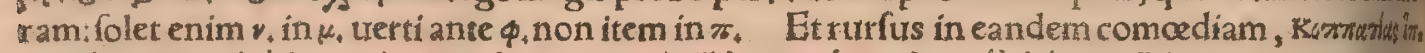

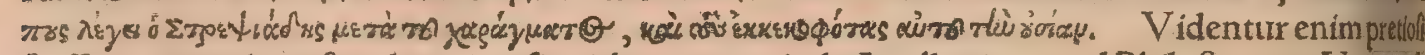
fuife equi, qui hurufmodi notis infigniebantur: proinde Apollonius apud Philoftratum, Necacenti ui quenquam (inquit) pifcium caufa, quos maiore pretio emunt pleriqs, quàm coppatias quiondam

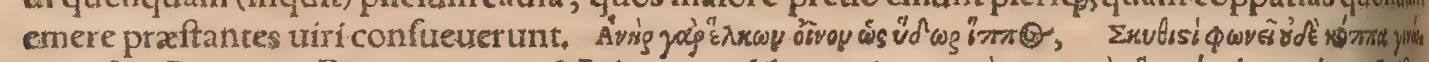

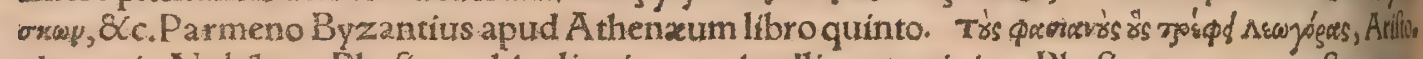
phanes in Nubibus. Phafianos hic aliqui equos intelligunt qui circa Phafin amnem praftante" na fcuntur:ain phafiani auis nota infignestali ipfas aues.

TRuftici \& aurigre noftri equis à colore, figura, allas ob caufas diuerfa nomina impotint, 2tapp/colore nigro:toll/qui tintinnabulum geftat:tmperle/à figura bouris breui \& corpulentatitem,

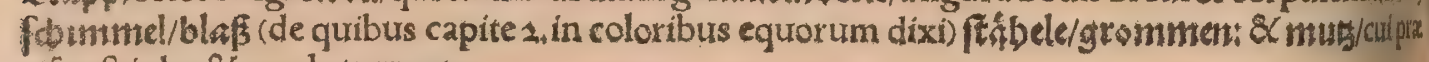
cifa eft iuba \& cauda truncata.

ब1 Equorum nomina propria quę apud̉ ueteres pracipué poétas reperi, ordine literarum hicfub ieci. Alaftor, Aethon, Nyctaus, \& Orneus, equi Plutonis apud Claudianum libro it de raptu

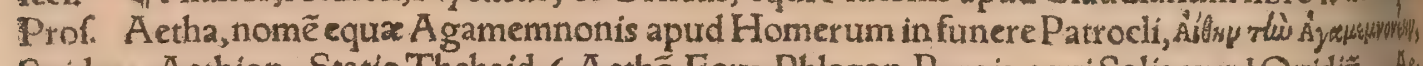
Suidas. Aethion, Statio Thebaid.6.Aethô, Eous, Phlegon, Pyrois, equi Solis apud Ouidiü, At chon,Plutonis equus, uide Alaftor. Aethon, Lampus, Podagrus, \& Xãthus, Hectoris equil apurdito merum liadis ocfauo, Aethon Pallantis equus Vergilio. Arion equis filius Neptuni $\&$ unius ex Furijs, Varinus: Thelpufí quidem, Paufania tefte, Cererem Exinnyn uocant. Lactantius maricus in Theffalia terram tridente percuffama Neptuno fcribit, unde profiluerint equi dro phios 8 Arion. Cererem arun mutatam in equam, ex Neptuno in equum mutato filiam peper. fe, cuius nomen non initlatis cralandum fit, \& equum A rionem: $\&$ hanc ob caufam (dicunt Thelpts fi, Neptunum apud fe primum inter Arcades Hippium effe dictum. Et hoc probãt carminibuses

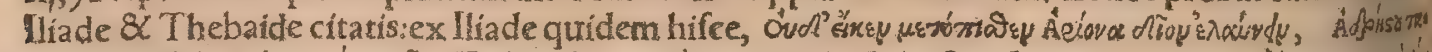

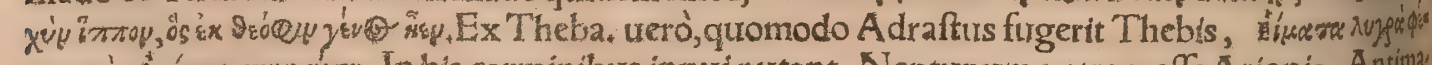

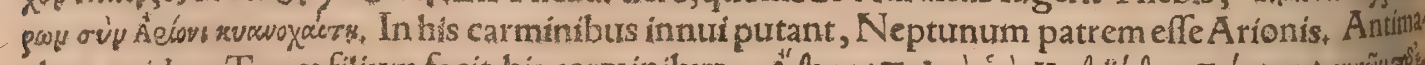

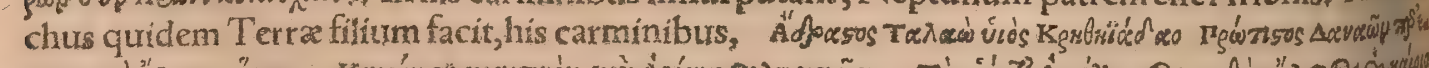

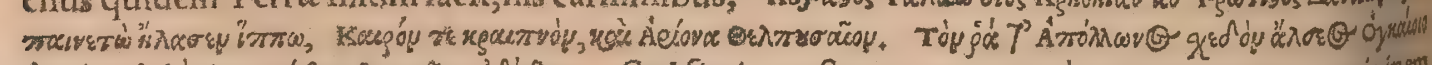

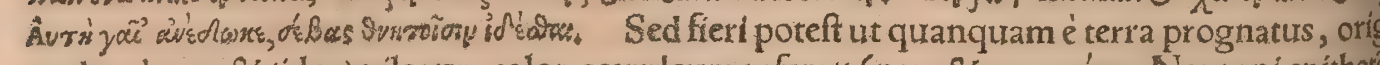
ex deo ducat, $\&$ (ideo) pilorum color cceruleum referat: (nam $\&$ xvavoxárss, Neptuni epitheró eft) Sunt qui $\&$ hanc hiftoriam referant, Herculem cum bellum aduerfus Eleos gereret, ab Oncoper ăfffe equum, \& Arione in praliģs inuectum Elin obtinuiffe +Poftea uerò Adrafto equum donafie 


\section{4

gines illic fieri curauic, adfcriptis etiam equorum nominibus, qux funt Phoenix \& Corax: \& utrito

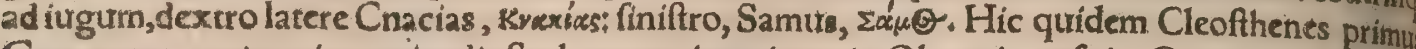
Graecorum, qui equís nutriendis ftuduerunt, imaginem in Olympia pofuit. Quan $\not$ \& Miltiades A thenienfis \& Euragoras Lacon pofuerunt:fed Euagoras currum folum abfo fua imagine; de Mil, tiade alibi dicam, Hæe Paufanias. Pholoë, lib.6.Theb.Statī. Podarces, Ibldem+dictus nimirum ualeat pedibus. Podarge à celeritate pedum, uide in Balio. Podarges fimiliter, uide in Cyllaro, Podargus inter equos Hectoris erat, ut in Aechone dixi; \& alius eodẽ nomine Hippamonis equits,

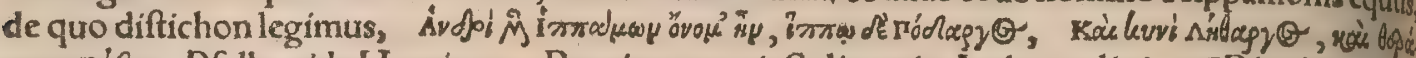

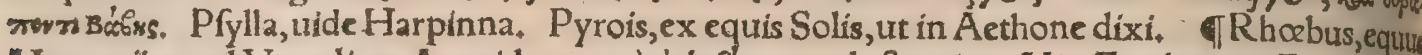

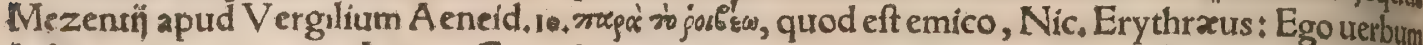
poubsy in uulgari tantum Lexico Gracolatino(quod multis modis corruptum eft)pofitum reperio fir

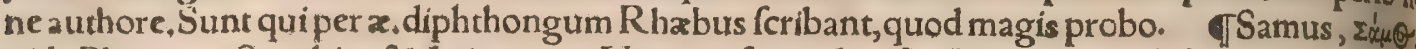
uide Phoenix. Scyphios \& A rion, equi Neptuni fecundum Lactantium, Kaejo's \& Arion Adraftife cundum Antimachum, ut in Arione dixi. Sicoris, penultima breui,lib.16.Silip. Sthenon, uidefir pra in Encelado. Strymon,Statio Theb.6. T Tagus,apud Silium lib.s.equi nomen eft, utferbibit Textor: locus iam non occurrit, fed deceptum puto Textorem, ut in Ilerda. Theron equus, Silitusil bro 16. Thoés, Statius 6. Theb. I Volucris, equi nomen, Cælius. Verus imperator (inquit Iul. $C_{2}$ pitolinus) Prafinis contra Venetianos turpiffime fauebat. Nam $\&$ Volucri equo Prafino aureumfin mulacrum fecerat, quod fecum portabat. Cui quidem paffas uuas $\&$ nucleos in uicem hordei in pra fepe ponebat, quern fagis fuco tinctis coopertum, in Tiberianam ad fe adduci iubebat. Cuimortuo is fepulchrum in Vaticano fecit. In huíus equigratiam primum coeperunt equi aurel uel brauia pos ftulari, In ranto autem equus ille honore fuit, ut ei à populo Prafinianorum fape modius aureormm poftularecur, Hax ille. In hec quidem Silin carmine libro 16. Primus equum uolucrem Maffylimu nera regis Haud fpernenda tulit, uolucris pro epitheto accipi poteft, cum nullum aliud equinomi co in libro, licet complura fint, Latina originis habeatur. Ouidius etiam trolucres equos epithetixes fecundo Meram, dixit, \& Pegafum priuatim fexto. \Xanthus, equus Herforis, ut in Aechonedi xi: \& alius Achillis, uide in Balio. đHactenus uetera equorum nomina ordine literarum recentue rim. Nunc adíciam recentiorum quædam, ubi prius Statĭ aliquot uerfus è fex to Thebaidos renlan uero, ut certius confter de nominibus quibufdam fupra pofitis. Nominibusćç cient, Pholoën Adr metus $\&$ Irin, Funalemáç Thoên:rapidum Danaëius augur Afcheton increpitat, meritumég̣t to: cabula Cygnum. Audic \& Herculeum Strymon Chromin, Euneon audit Igneus A ethion, tardi Calydona laceffit Hippodamus, uariumó Thoas rogatire Podarcen. GNic, Erythræus de Xant tho A chillis equo dominum fuũ allecuto fribens in Indice fưo Vergiliano, Commentũ hoc (inguli uocalium equorû̃ ac immortalium, uernacula poëtarû Mufa audacius xmulata eft : quippe quăliu roum fuorum generofiffimos equos proprijs nominibus fabulofius etiam decantauit, ut $R$ holand Brigliadorum \& Vegiantinũ, Baiardũ Rainaldi, Rubicanũ ârgalifæ, Hippogryfum Rugerï, Fion tinũ \& Fratalatum Sacripantis, Rondellum Oliuerï, $\&$ aliorum aln̄s nominibus alios.

TE Eithetorum equi teftimonia reperies apud Textorem uno in loco omnia: nos ea pro argutith ti ratrone diftriburimus, cum a lia bellatori alia celeri equo conueniant, de quibus partim fupra capi fecundo dixi, partim paulo poft fecunda huius capitis parte dicam: Alia ad animi aut corpo tutes a ut uitia fpecfent, de quibus fímiliter infra dicetur. In prafentia ea ferè tantum adferam, quix quo fimpliciter congruunt. TAeripes, uide inferius inter Græc2, Afridui. Cornipedes, Fo na cornipedifemper adhinnit equo, Ouid. Ponitur \& abfolure pro equis, Quem ceperat ipfe Cot nipedem, Silius: ut eriam Sonipes. Acre, $\&$ cornipedum curfu fimulấrat equerum, Vergititis. mans, Sufpenfus cura fumantum totus equor $\tilde{\pi}, M$ Marullus, Frenigerum equurm Textor dicit, ealt forma qua alam frenigeram Statius lib.3. hoc uerfu, Quis nam frenigerx figntี dare dignior ala Hinniens equus, Politiano. Humentes Noctis equos Claudianus dixit, forte à Noctis natura, batus, apud recentiorem quendam. Puluerei, Valerius Argon.4. Quadrupes, Deniç ui magna quadrupes equus, atç elephanti Prö̈ciunt féfe, Ennius apud Gellium. Quadrupedante inut çus equo, Silius. Quadrupedante putrem fonitu quatit ungula campü, Verg. Spumantemọ́ as bat equü, Vergil.Et alíbi, Veçus equo fpumante Sages. Et rurfus, Seu fpuman tis equi foderetcal caribus armos. Spumifero portatur equo, Codrus Vrceus. Squamigeris inuectus equis, Richalt: dus quidam. Sudans. Ceruog fugacior ibat Sudantitremebundus equo, Claudian. $\int$ Carera ut dixi, epicheta, paffim proargumento digeffi. I His Graca fubnectamus, qua cuituis equio:

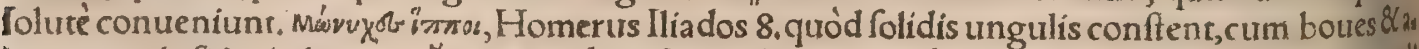
Lia pecora bifidas habeant. I" tur, non folum qui firmis ualidisḉ funt ungulis dicuntur, quafi æripedes:fed etiam qui pediburs tra

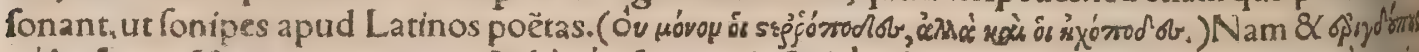

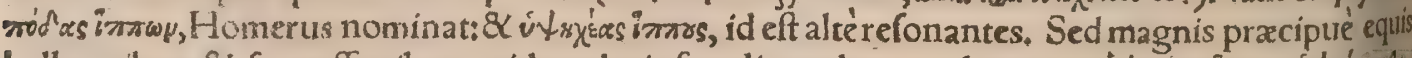

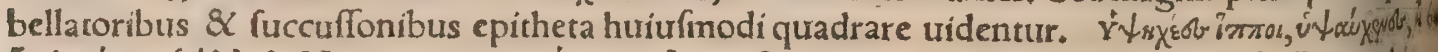

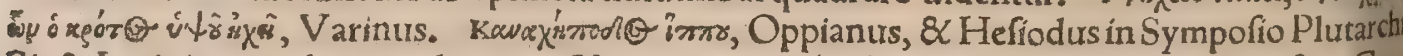
Sic \& Latinis zeripedes equi dicuntur.Narrat \& aripedes Martis araffe boures, Ouid, epift, 6. Gram 


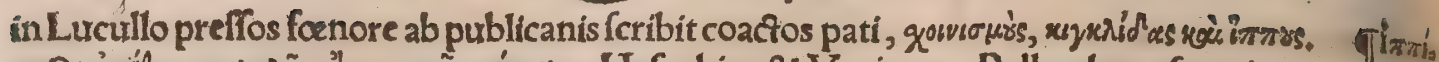

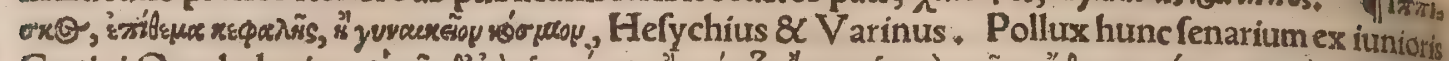

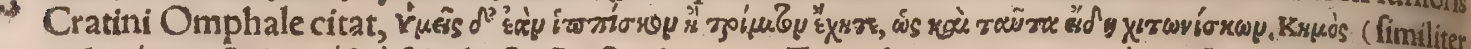

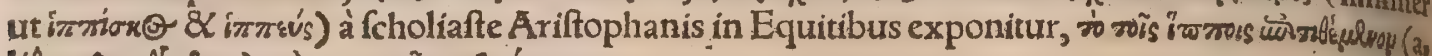

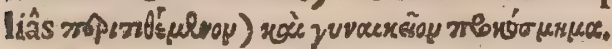

ब1 Hippobinum Scholiaftes in $R$ anis Ariftophanis à lafciưia \& coitu dictum feribit: quoniamiln

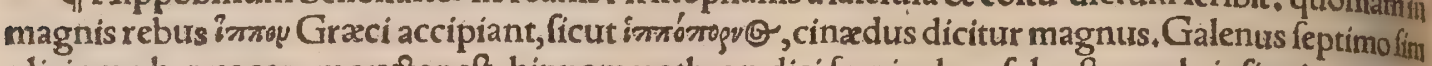
plicium pharmacorum aucfor eft, hippomarathron dici foniculum fylueftrem ab infigni magnitus dine. Diofcorides fylueftrem foeniculum hoc nomíne grandiorem effe ait. Sed \& hippofelinû (quod olus atrum Romana urocatur lingua) eodem modo à magnitudine nuncupari uidetur aftipulante

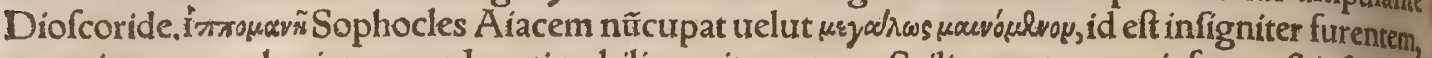
ex ratione metaphorica, quando, uti nobilis canit poeta, Scilicet ante omneis furor eft infignis $\ell_{n}$ - quarum: Vel, ut præftruximus, quia ï nimum, Hac omnia Calius. Vide Varinum in uoce i Pratum iлmuctès, apud Sophoclem, herbofum, floridum, equis expetitum, uel herbis ualdeluxus

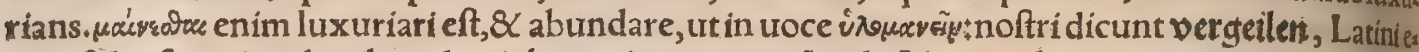
tiam fyluefcere in arboribus: de uitibus prituatim rooxōy, id eft hircire dicunt, cum nimia alimentico

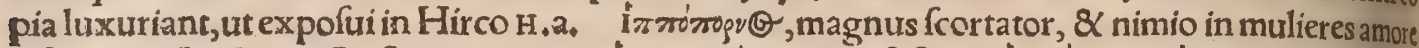

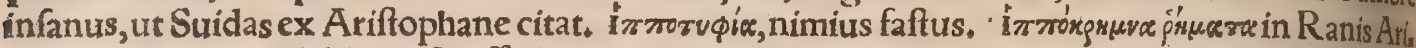
ftophanis legimus, fublimia \& affectata uocabula intelligo, Horatius ampullas \& fefquipedalia uer

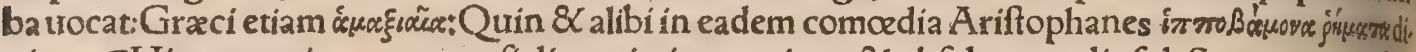
xit. THippocronia, nugx, quafi dicas nimium antiqua $8 \mathrm{cob}$ foleta, qualia fub Saturni regno fue: runt, Vide Cronippum in proprịs uirorum infra. Eft \& Neptuni cognomen Hippocronius, de quo infra dicam. Hippalectryon apud Ariftophanem nonnullis dici uidetur de ingenti gallo: alifs de

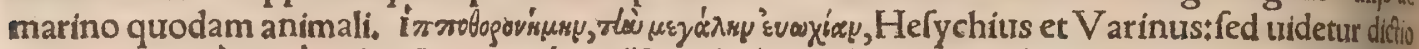

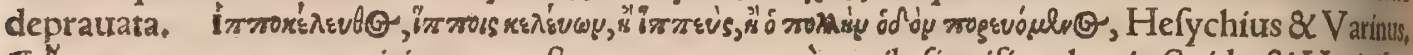
TI Tresw paroxytonum uiri nomen eft, oxytonum uerò equile fignificat:hoc in Suid $\&$ Varinili,

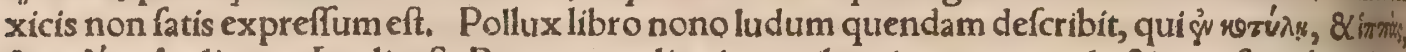

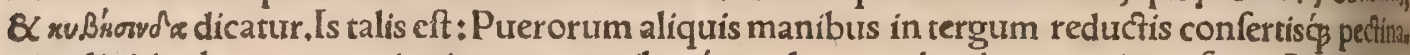
rịm digitis, alterum genu innitentem manibusḉ oculos eius obnubentem circunfert. Accipiturfa né cotyla pro cauitate, ut hîc uolam, id eft cauum manus, urel qux coniunctis mutuò digitis inter ur tramqs manum interius fit cauitatem fignificet. İ moxio uerò huncludum dici apparet, quodquicit

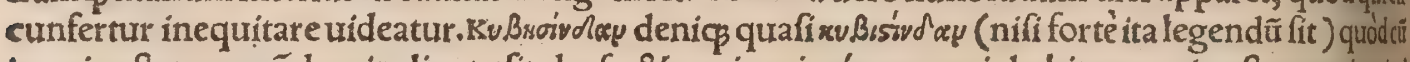
is qui geftat pra pódere inclinato fit dorfo \& capite, eius'́ç corporis habitum qui geftatur etiamin

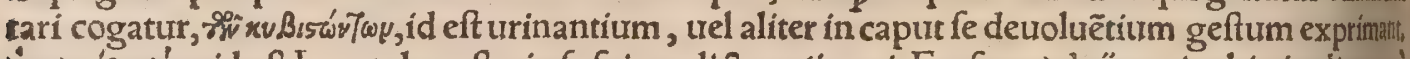
부 libitum effet, huc ate\$ illuc ducerentur, aut ubi quis indulgentius fouerit. Tractum adagiumà luo puerili, \&c.non aliud enim quàm recitata iam Pollucis uerba fubiungit. Hippadas legimus lactilı cia dicta Athenis qux mitterent equites uocatl, Calius. Cæterum hippiades, ftatux mulierum

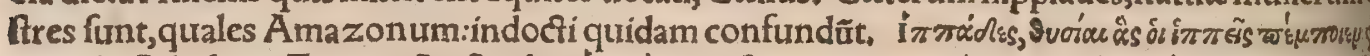

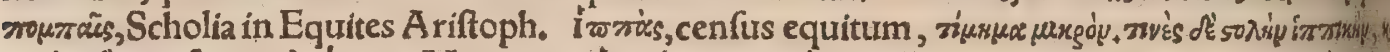

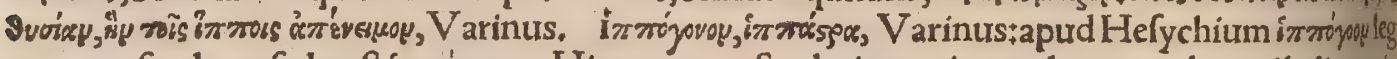
tur, non fuo loco, fed poft im romosts. Hippacare, eft celeriter animam ducere, ab equi halitu quiel

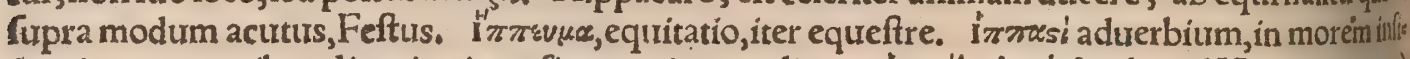

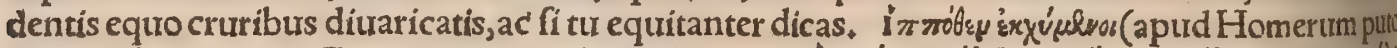

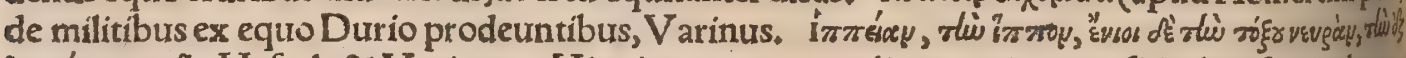

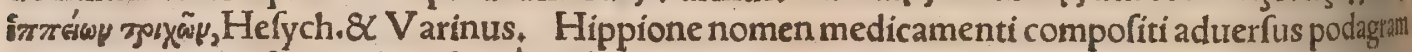

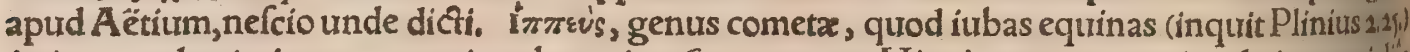
imitatur, celerrimi motus, atç in orbem circa fe cuntes. đHippios pes in carmine dicitur, quia epitritus. Hippia entea in Pindaro uafa intelligunt Phidonia, feu menfuras, quas Corinthi print comperiffe Phidonem tradunt : hippia autem dici, quoniam Argos unde fuit Phidon, nuncrpeti

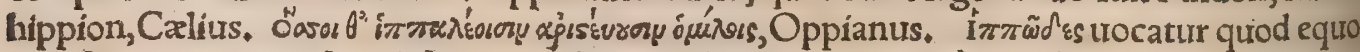

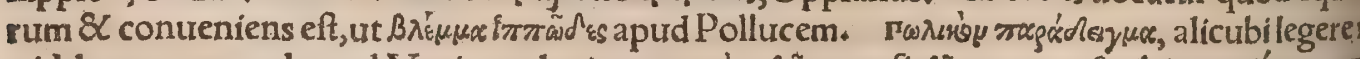

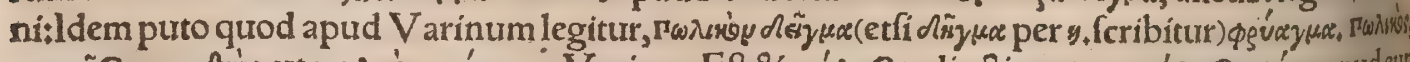

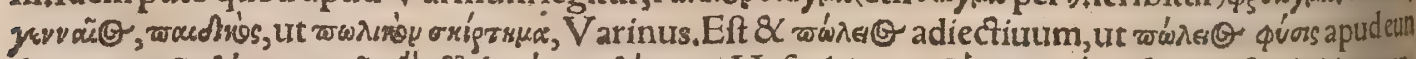
dem. $\Gamma^{\prime}$,

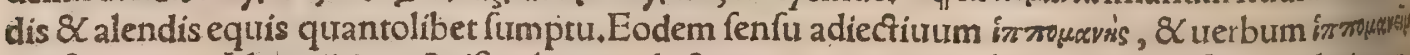

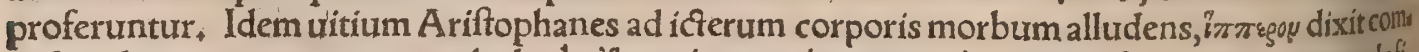

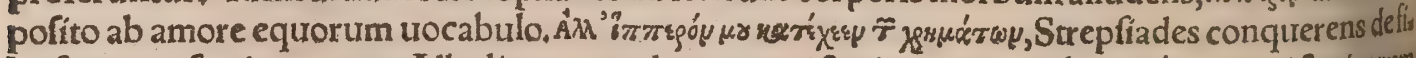
lio fumptuofo circa equos. Alludit autem ad naturam icteri etiam in uerbo karífer, nam icfericorum

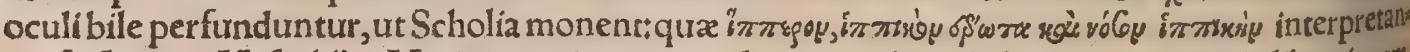
tur. In Lexicis Hefychị et Varini (quęinnumeris deprauata locis habentur, non modolibrario 
intubum, aphacam, andryalam, hypochorin (Gaza porcelliam uertit) renecionem, \& alia quatintu

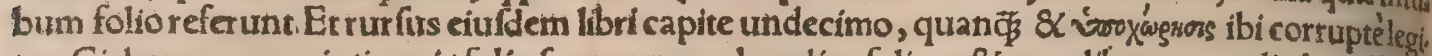
tur. Cichoracea omnia (inquit) folio funt annuo, ab radice foliata, \& $<$, caulibus atg radicib, differût, Deinde cum cichoream defcripfiffet, fubiungit, Hypochoeris lauior, \& afpectu mitior, \& dulcior eft:(forte fonchus lauis, aut cögener faltem)nec ut candralia, qux omnino inguftabilis ef, \& in radi ce fuccum lacieum, acrem, eundem q́, copiofum habet: Hac Theophraftus, nec alibi apurd eum ulla andryala aut candralia mentio fit:proinde facile fúf picor, librariorum inf citiam utrumq prauafle, \& chondrillam legendum: (Andryala in Theophrafto, condryala in Plinio, pro condrilla deprauate legitur, Hermol.)nam \& Plinius ut fupra citaui chondrillam cum hypochoride coniun git: \& alibi fimiliter ut Theophraftus laçeũ radicis fuccum (Theoph.uno uerbo ơroy dixit) eumíg col piofum $\&$ acrem ei attribuit. Hoc etiam ex Diofcoride \& Galeno conftat inter fylueftres intubos chondrillam effe, quam duorum generum Diolcorides facit. In ramulis prioris gummi maftichesfin millimum inueniri folet, tuberculo faba: Graci tuberculum fiure grumum chondron appellant, inde chondrilla nomen, ut ego quidem conị cio: nam Galenus per ch. fcribit, Diofcorides per k. Plinitls chondrilla fabæ radicẽ tribuit, $q$ non intellexerit, ut puto, gummi tantum fabr femini comparati, Galenus chondrillam amariorem ficciorem ç paulò facit quàm intubus fit. Lemonium(inquit Pli nius 25.9. ) fuccum lacteum mittit, cócrefcentem gummi modo, humidis locis:datur denarï pondis in uino cötra ferpentes. Hor equidem cum Diofcoridis chondrilla idem effe cọ̈̈ciołnam \& illa lacteî furccum gerit gummi modo consrefcentem, $\&$ in uino contra uiperas datur. In pratis (à quibus limo, nio nomen) apud nos naf citur intubi fylueftris genus, cubitale, aut longius, ftrigcfum, floribus flat uis, quod \& hieracị generib, adnumerari poteft. EA $\&$ aliud genus, longiffimum in intubaceo gent $r e$, trium aut quatuor cubitorũ feré proceritate, quod locis humidis,opacis, $8 \mathrm{cmontanis}$ fapenalici, sur, flore (ni fallor)purpureo in pappos abeunte. Sunt $\&$ alia quadam limonia. Eft $\&$ aphaca Theo. phrafti inrubaceigeneris, amara, nec apta cibo:multũ diuerfa à recentiorum Gracorũ aphaca qua leguminũ gener is cenfetur. A d hane digreffionem nos inuitauit Hermolaus, qui apud Pliniū 21,15, nô hypochœrin tantû (nifi quis hypochœrida malit, quoniã rectus oxy tonus eft) quod nos pbamu, $\&$ in Gracis codicibus Theophrafti fic fcriptum inuenimus: fed hippochœrin uel hypochoerinlegit, tanquam indifferenter utrun $\$$ probans, aut certe dubitans. Similis in (cribendo diuerfitas inalij tiam aliquot plantarum nominibus accidit, ut hypogloffo, 8 hypophæito: multi enim hippog \& hippophafton fribunt, cum neq̧ magnitudo, neq̧ aliud ad equũ pertinens eis attribuaturi, us Galenus libro 8. de fimplicibus vó y rymbis fubnafcantur quadam lingulis fimilia. In hippophaito $\&$ hippophäe, utro potius modof bendum fit, certi nibil habeo. Apud Diofcoridem quidem hippophaës alïs nominubus hippophy hippophanes \& hippion uocitari legimus, qux omnia ab equo ducta fint urocabula. Hippoptis quoqg(inquit)alij hippophaës uocant, Ex Plinius de utroq loquens, Debent (inquit) accommodar effe equorum naturx, neq̧ ex alijs caufis nomen accepifte:quippe quadam a nimalium remedhisn fcuntur, \&c.Sed Marcellus Vergilius, Nibil nos mouet authoritas Plinij , inquit:nibil enim co tuit dicens, Debent accommodata effe equorum naturx, \&C.nos nihil aliud hippon in his uo

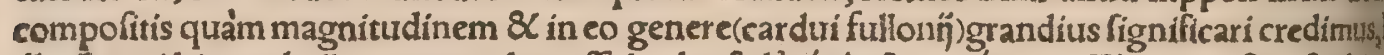

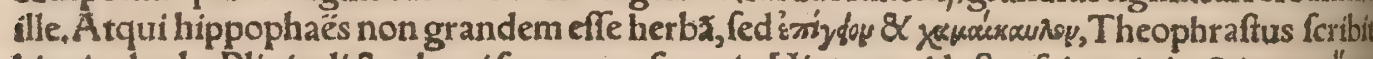
hippice herba Plinio dicta, docui fupra cap. fexto in Hippaces, id eft cafei equini mêtione. Âjom

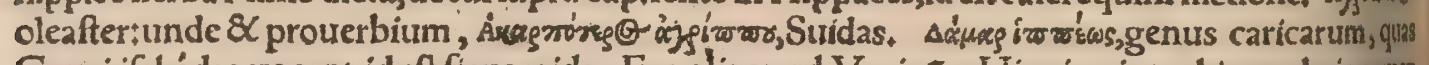
Græci ifchádas uocant, id eft ficus aridas, Eupolis apud Varinū. Hippion inter hippophais nomen claturas eft apud Diofcoridem, बHippogloffon, idem quod antirrhinon Diofcoridi. Depropis dicto hippogloffo uel hypogloffo potius, fuperius dictum eft:Eft \& laurus A lexandrinx cogncmei apud Diofcoridem. Hippolapathưm maius fatiuo eft, candidiusíg ac fpiffius, Plin. Hippomantis idem quod a pocynũ apud Diofcoridem, quod et Hermolaus obferuauit:eft $\&$ inter capparis nomer claturas apud eundem. Hippomanes herba genus elt Hefiodo, quod \& Seruius teftatur, Hierm Hippomanes, fecundum Crạteiam, planta eft fructu cucumeris fylueftris, folio nigriore, tanquamp paueris fpinofo, Hac Theocriti interpres: Plura uride fupra in $\mathrm{c}$.in mentione excrementort equ ter fignificationes hippomanis. TFoniculum fylueftre aliquihippomarathrü uocant, Plin, bi, Neruofi cauliculi quibufdam, ut marathro, hippornarathro, Nomen huic à magnitudine contig fe fuperius indicaui, Strabo in Mauritania hippomarathrifcapum duodecim cubitos longü, \&quar tuor palmos craffum nafci fcribit. Et quanquam tum hippofelino tū hippomarathro ad equotí dya furlam Hierocles hippiater utatur, utrü tamen à magnitudine potius in fuo genere, hoc foenic illud apî, nominatũ dixerim. Theophraftus(inquir Nicandri interpres) hippofelinon in petrofis pro uenire locis dicit, à magnitudine fic nuncupatŭ, uel propter equorum ftranguriam : Gaza equapi tranfulit. Hipporizon in Hippiatricis Gracis nominatur ca, 15. mifcetur aût alịs quiburdamad clyfferem uteri equa, promourendx conceptionis caufa. Hipparifon, nifi mendum eft, apud Did ridem inter uerbenaca alterius nomenclaturas legitur. Ego uerbenacam alteram effe conịcio, qu uulgo Germani confolidam auream uocant: eam in cibo falubrem effe equis quibus ulceratume dorium fupra dixi. बHippuris herba à cauda uel feta equina fimilitudinenomen tulit apud Gra 
quoniam diftillatur ad fuffumigia \& alia uaria odoramenta, nec aliter adhuc in ufum medicumitis, nic. Hac illi, quo au emà ueteribus nomine dicta fit, ignorare fatentur. đGermani mentaftrum uocant $\boldsymbol{x}$ ffismün 5 , id eft mentam equinam:tuffilaginem, ut \& Latiné quídam recentiores, ungulan caballinam, rofj引büb / (Marcellus empiricus herbam quæ Gallicé calliomarcus, Latiné equi ungula uocatur, commendat ad tuffim:) oxyn Plinĭ, quod trifolium acidum dici poteft, roff3ampffer/ideff oxalidem equinam: maluam fylueftrem maiorem, roffspappelen/id eft maluam equinam: Phu, quam uulgo Valerianam uocitant, Germani senmmate, haud fcio an ab equo compofito nomine; equum enim marcam appellabant, noftri nunc equam tantum.

बf Fera qux ab equo hippardium nominata eft, capronas (xáeræy) gerit in fummis armis: differt ab hippelapho, quod barbam ut ille non habet. Hac fimiliter ut hippelaphus, tenuiffimo iuba ordis

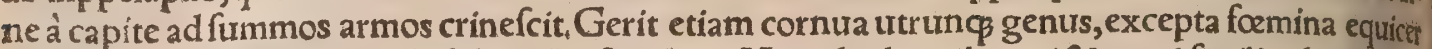
uini generis: $\&$ pedes habet bifulcos, Ariftoteles. Hippelaphus ab equi $\&$ cerui fimilitudine diĉus eft, nec alius Volaterrano quàm tragelaphus uidetur:de quo plưra dixi in Cerui \& HirciPhilologia, Hippotigrin animal celebratum inuenias in Antonino Caracalla ex Díonis Niczi hiftoria, Calius, Hippocameli nihil quàm nomen apud Aufonium reperitur. Sciurus, uocatur $\&<$ campfiurus, \& hippurus, Varinus \& Hefychius. Hippocyon (fi rectélegitur,)nomen Satyræ Varronis, *i inmia eov, auis quardam uulpanferi fimilis, Hefychius $\&$ Varinus. Hippalectryon dici uidetur ftaturoitus (magnus) gallus, Putant aliqui effe marinum animal, etiamfi in rerum id natura compertum quan, doç abnuant philofophia imbuti pleriø̧, Calius. A efchylus in fuis tragoedijs hippalectryonemfin xit, non animal naturale, fed infigne nauis, ut ipfe exponit in $R$ anis Ariftophanis, ubi cum Euripi:

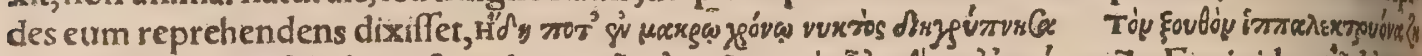

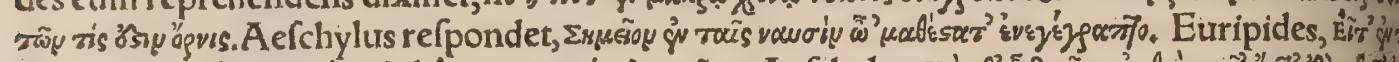

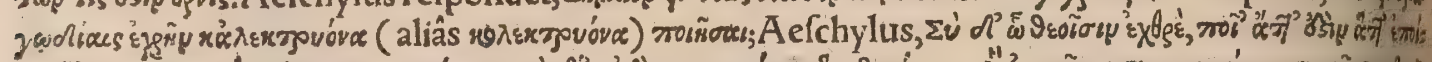

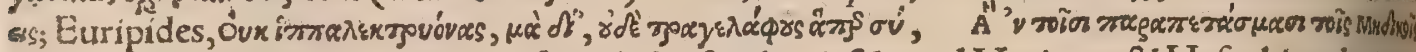
2f $\phi$ ror. Hippalectryonem, ut in fcholips Ariftophanis 8 apud Varinum \& Hefychium legimus, aliqui magnum gallinaceum interpretãtur, ut gallinaceo fimile genus Perficum fir : alï gallinaceun in uelis fiue tapetibus Perficis pingi folitum : alij deniog marinum animal: \& licet philofophihippo lectryonem in rerum natura effe negarint, meo tamen tempore (inquit fcholiaftes) quidam in tale ant mal forturió è mari prodiens incidit, $\&$ à fe occifum cum paffim oftentaffet, in figillo fuo $\&$ clyper pingi curauit, " $\pi$ (n), pipo auis, ut Gaza transfert ex Ariftotele libro 9, de animalibus: alibitame

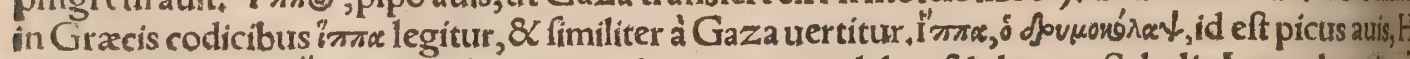

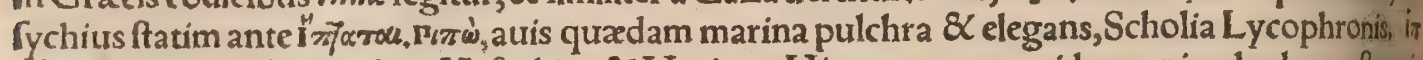

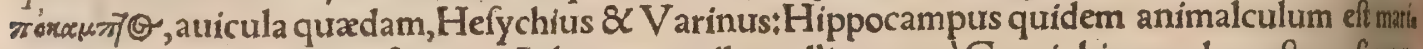
num, ut inter aquatilia referam. A thenaus pullos gallinaceos a Gracis hippos, hoc eft quafiequlut los uorari fribit;credo, quia pulli proprie funt equorum, Hermolaus. बi $1 \pi n \Theta$ magnus pifcisma 1 inus, Hefych. \& V arinus. A thenæus libro feptimo dubitat an hippi pifces ïdem fint, quos Eple

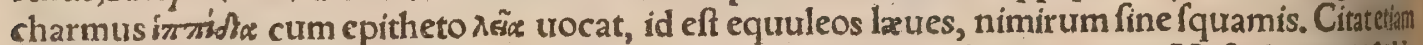

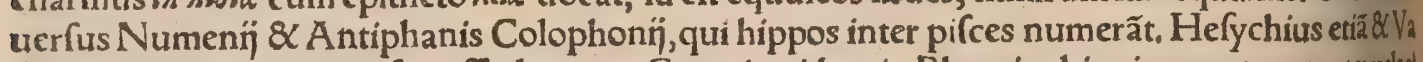
rinus hippidion genus pifcis effe docent. Cancri quidam in Phænice hippi uocantur, tantæulod taris, ut confequi non fit, Plinius, Hippurus pifcis apud Ariftotelem, Gaza equifelim urerit nomine Plinius hippurin herbam uocat?. uocatur. Eft autem cius naturæ, uti Numenius docet, frequenter ut exiliat, \& eam ob caufam uyin $\tau$ żs, id eft urinator uoratur. Hinc fortaffis $\&$ nomen fortitur quod equi inftar fubinde exiliat,

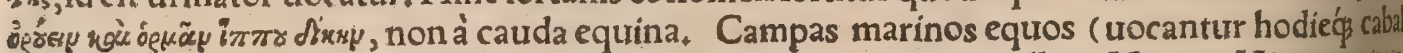
marini Italis) Gracià flexu pofteriorum partium hippocampos appellant, Varro. Hippopo id eft flutiatilis equus, caput \& uocem equi habet. In fluuio nomine Aftræo, qui inter Bercam Theffalonicam fluit, peculiare genus mufcarum eft, apibus fimile tum magnitudine, tum bomb pitu, uefparum colore,equifeles (hippuros Græcé legi conijcio) appellant indigenæ⿱ eæad fumm aquam uerfantes à pifcibus corripiuntur, \&c. Gillius ex A eliano, i za ex Ariftotele, à magnitudine puto dicta. In Sicilia formicx qux equites appellantur, non funi

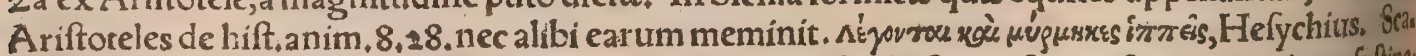
rabei genus uiride, dorfum habet nota quadam aureola fic illuftre, ut Luna fpeciem exiguar futine re uideatur, quare non inuenuftè à Cofentinis equus Lunæ nuncupatur, Thylefius. Mufcxqua dam circa equorum capita obuolare folent, ex fimo (ni fallor) equino nata : ut $\&$ fcarabei gen

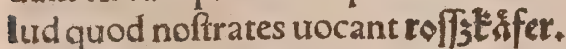

- Cenrauros(inquit Camerarius) equitationem primos ufurpaffe perhibent, faltem ut ex equis pngna:ent:adós hanc accommodant fabulam monftrofx formx, qua illià poétis introducuntur,

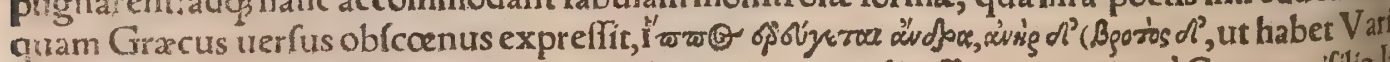
in Centauris) 'é nis fufcepto ex nube \& è re nominato, qui commifcuiffet fefe cum equabus Magnefís fub montse

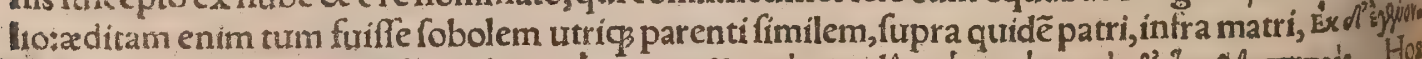

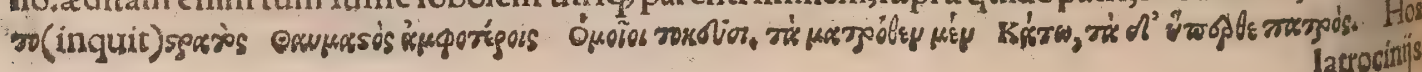




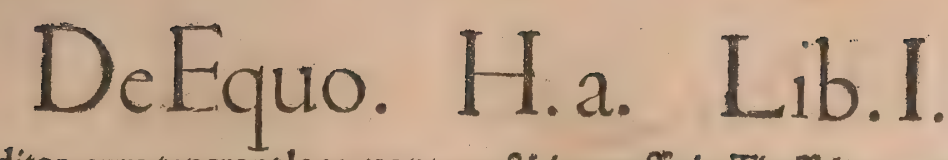

latrocinhis aitunt deditos, cum tenerent loca montana $\&$ inaccefla in Theffalia, excurriffe in equis, \& prædas egiffe,cumóg ante fe abigerent armenta \& greges, extimulantes foilicet quo celerius per* gerent, exclamantes in agris \& uricinorum opem implorantes, quibus fua eripiebantur, hippocẽtau. rosíg nominantes, troeiferabantur. Hanc autem fpeciem prabebant alli raptores intuentibus à tergo, qux poftea pingi $\&$ effingi coepta, dimidiati ad umbilicum hominis $\&$ parte pofteriore equi. Eodem referunt \& procreationis horum fabulam, \& Ixionis parentis rotam, quibus in ačre, hoc eft fub dio

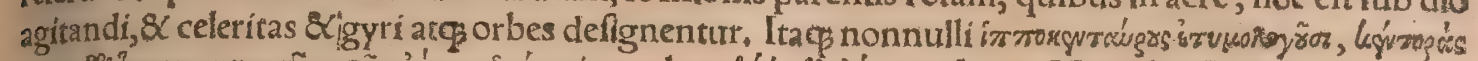

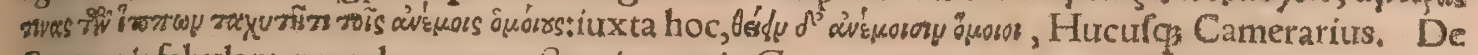
Centauris fabulam quandam narrat Seruius tertio Georgicorum, qux ueluti nurgæ répuenda uide turr, Diodorus in quinto, Centauros nonulli uolunt in Peleo a Nymphis nutritos, poftea equos fubm

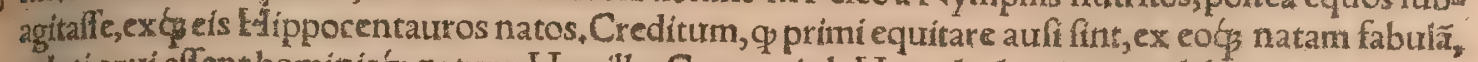
ueluti equi effent bominisq̧́ natura, Hac ille. Centauri ab Hercule domiri, inter labores eíus nume, rantur. Vide Palrephatum ca, 2. Hippocentaurus, canis nomen apud Pollucem. Plutarchus in conuiuio apientum, in domum Periandri allatum foribit à paftore infantem ex equa natum, cuius caput, collum 8 manus hominis effent, cætera equiteiulatus infantium. Hoc infpeco Thales Peri andro dixit, fibi quidem non uideri rem prodigiofam $\&$ ceu portentum à dís immiffam, quo feditio. nes 82 diffidia fignificarentur, ut Diocles iudicabat: fed rem effe naturalem, ideóng confulere fe utuel equifones non habeat, uel uxores eis tradat. Claudius Cafar fribit hippocentaurum in Theffalia. natum eodem die interńffe, Et nos principatu eius allaturm illi ex Aegypto in melle uidimus, Phr. , DeCentauro fydere uide Higinum. Lapitharum \& Centaurorum pratium Oridius defcribir libro 12.1Metam, Pugnare ex equo Theffalos inueniffe tradunt, qui Centauri appellati funt, habitantes fecundum Pelium montem, Plin. De Centauris 8 Ixione multa legimus apud Euftathium in pri mum liadis, $x$ ditionis Romanx folio 102, \& alia Homeri fcholia in eundem locum:\& Etymologicon in Hippocentauro:item Varinum in eadem uroce Chironis fabulam anagogicé exponentem: item in Onomaftico noftro in Centauris, Hippocentauris, Chirone, Ixione, Caneo \& Lapithis: \& Fry, Flo = ridi Sabini Lectionum fuccifiurarum lib,2, ca,6. Homerus Centauros фinges uocat, quar uox Latini. etiam in ufu eft, \& feras fignificat: $q$ femiferi, $\&$ femihomines effent. Pirithous cum Hippodamian Adraftifiliam uxorem duceret, Lapithas \& Centauros tanquam affines uocauit. Centauri uero ine? ebriat mulieribus quotquot aderant uim facere conabantur, ita ç à Lapithis iratis interempti funt, ${ }_{30}$ Scholia in Odyffex phî, in mentione Eurytlonis Centauritalin aliter de Eurytione fribunt, ut ibidë ex Bacchylide citatur. Humano capiti ceruicem pictor equinam Itrngere fi uelic, Horatius de $\bar{A}$. te. Hoc monftrum puto centaurus foret. inmów tarchum hippocentaurus dici uidecur pro equitatore praftantiffimo \& inexfuperabili. Ipfe, inquit,

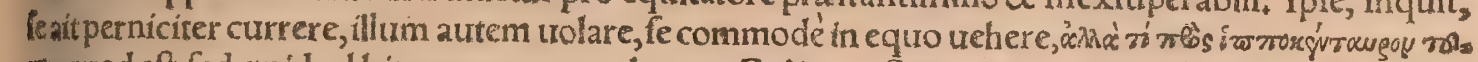
wyquod eft, fed quid ad hippocentaurum hunc ? Calius. Sociates apud Ariftophanem, Nubes

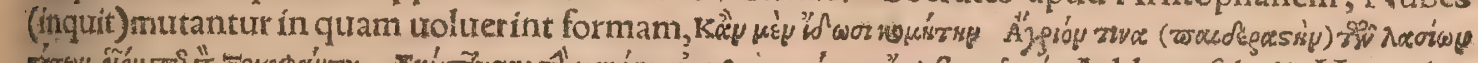

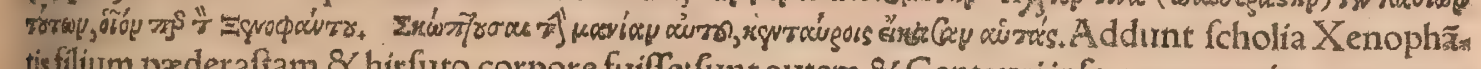
tis filium paderaftam 8 hirfuto corpore fuiffe:funt aurem $\&$ Centauri inferna corporis parte, utpo. te equina, hirfuti: \& ipfi quo $\$$ propter amoris infaniam aduerfus Lapithas pugnarunt. Taurus par 40 tem hominis pudendam fignificat, 8 inde fortaffis centaurus ut laftaurus, pro molli $\&$ libidinofo as

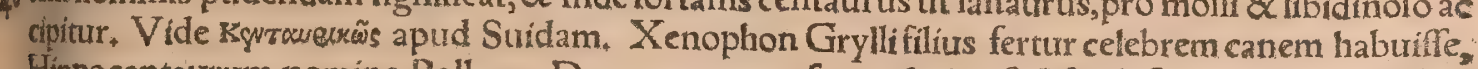
Hippocentaurum nomine, Pollux. De onocentauro fupra dixi poft Afini hiftoriam. De Ocyrhoé Chironis filia in equam mutata, Ouidius lib.3, Metamor. Italiam onnium principes inhabitaffe fe runtur Aufones indigenx, feu autochthones. At uetuffimum fuife Marin quendam nomine, cuius antica corporis humana prorfurn uiderentur: poftica uerò, equina omnino. Nam $\&$ nomen ipfum propemodưn idem pollere, quod apud Græcos imroxy wis, id eft equo immixtus, Videri autem poteft equum infendiffe primus, 8 freno inhibuiffe, atç argumento eiufmodi fichysis creditus: eundem quínetiam uixiffe fabulantur annos centum ac tres $\$$ uiginti:ter item morturum, recrixiffe ter. Sed enim fimile ueri mibi haud fit, in Varia hiftoria inquit Aelianus libro g. Nec defunt qui equitandi so artem, id eft of im win'y, in Libya compertam primo tradant: Qua ex caufa nuncupârit Pindarus in

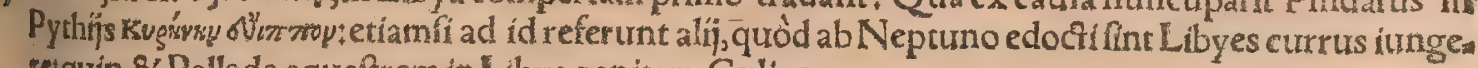
requin 8. Pallada equeftrem in Libyagenitam, Calius.

In mari rerum, non folum anímalium fimulacra infunt, ut utra, glad"̈, \& $c$, quo minus miremur equorum capita in tam paruís eminere cochleis, Plinius. Exeunt è mari belluæ quadam equorum capicibus, Plinius, Orfei Indi a fperrimam uenantur feram monocerotem, reliquo corpore equo fimilem, capite ceruo, \&c.Plinius, Nabim Aethiopes uocant collo fimilem equo, pedíbus \& crurib. boui, Plinius:hac camelopardalis eft, cuius hiftoriam fupra dedimus. Rhinocephalus ceruicem ha betequinam cum uniuerfo corpore: flammis quas ore explrat, homines pereũt, Phyfiologus author obfcurus. Ego nullum hurifmodi animal in natura extare arbitror. Paufanias in Corinthiacis, in 6. templo quodã Gabalis, effigiem effe fcribit equi qui partes poft pectus cetaceas habeat. Catoblepon bellua, de qua fupra fcripfinter boues fylueftes, iubam gerit equinam. Xenophon Lampfacenus author ef in Oceano Scythico infulas effe, quarum Hippopodes indigena, humana uf ç ad ureftigiti 
forma in equinos pedes definunt, Solinus ca.21. Ab Iftrofeptentrionem urerfus habitant Germate ni,Sarmatz, Geta, \& c itê Neuri, \& Hippopodes, qui ab alị̧s Zagari dicuntur, Euftathius in Diony fium. Coruda circa Indiam locus eft, ubi beftia uifuntur Saryris fimiles, equina cauda, \&c. A elian, Satyris iuxta coxas enaf́cuntur caudar non multó minores equinis, Paufanias, Lamia pedes habet equinos, cętera capris conformí, Glofla in Efaiam. Anthus auis equorum hinnitus imitatur, Plin, $_{\text {, }}$ \&c, ut fupra dixiad finem capitis quarti.

đA Auilam Romanis legionibus C.Marius in fecundo confulatu furo propriè dicauit. Erat \& an.

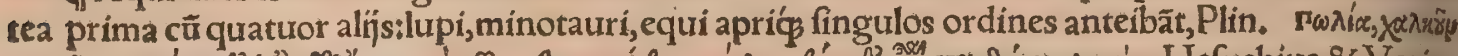

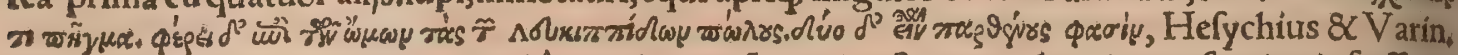
Plutarchus in Nicia ait equi charactêrem alicuius fronti inuftum apud antiquos feruitutis fuiffe ar. gumentum, Textor. DeCleofthenis Epidamnij \& aurigæe eius, \& currus \& equorum imaginibus ab Agelada fabricatis, primis omnium, ut uidetur, in Olympia collocatis, fuperius dixi inter nomie na equorum propria. Elephanti $\&$ equi maximorum imagines Poliphilus in Hypnerotomachia fua ltalicadepingit, C,Iul. Cafar equifui quem habebat pedibus propriè humanis, inftar (id eft fig, num)proade Veneris genitricis dedicauit, Suetonius, Ânthologî libro 4. rectione 7+PhilippiMa

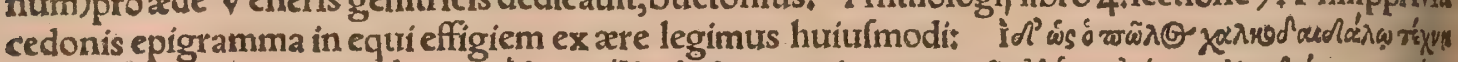

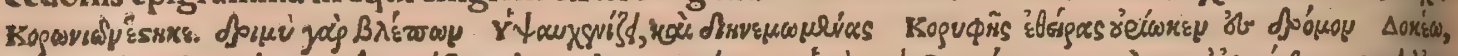

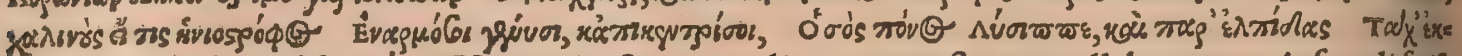
do fe uidentur Amażonum, quas mortalium primas equum fcandere aufas Lyfię oratori creditur, Her 2 molaus. Sunt qui hippades hurufmodi ftaturas per imperitiam prohippiades nominẽt, Talis Cles lix ftatua inter obfides Porfenæ pofita dicitur, Grapaldus. Pollio Afinius ut fuit acris uehementie, fic quoç pectari monumenta fua uoluit, in ̈̈js funt Hippiades Stephani, \&c, Plinius 36.5. Et rurfus 34.6. Equeftrium ftatuarum (inquit) origo perquam uetus eft, cum forminis etiam honore commu, suicato. Cloelia enim ftatua eft equeftris, et qua fequuntur. Statux equeftres etiam Cloelia, Q. Mar, cio Tremulo, Domitiano, \& alins multis erecta funt, Textor. Equeftres utiç̧ ftatur Romanamce, lebrationem habent, orto fíne dubio à Gracis exemplo. Sed illi celetas tantum dicabant in facris uia clores. Poftea uerò $\&$ qui bigis uel quadrigís uiciffent. Vnde $\&$ noftris currus in his qui triũ phauifo fent. Serum hor, $\&$ in his non nifi à diuo Augufto feiuges, ficut et Elephanti, Non uetus $\&$ bigatum celebratio in his qui prætura functi curru uecti effent per circum, Plin.34.5. A riftodemus bigas cî̉ 3 auriga fecit,Plinius,. Pificrates biga Pithò mulierem impofuit, Idem. Menogenes ftaturarius qua drigis fpectatus eft, Idem. Pralium equeftre ad Trophoný oraculum Euthycrates Lyfippi filius op: time expreffit:item quadrigas M̂̀edex complures, equum cum fifcinis, Plin. Fictiles quadrigæ Ro. ma erant in faftigio Iouis templi, quas faciendas locauerant Romani Veienti cuidam artis figlina prudenti, $8 c$, ut in H.b, dicam inter Celeres equos. Conftantinus cum urbem luftrans ad Traiani forum ueniffet, fingularem fub omni coelo ftructuram, hærebat attonitus per giganteos contextus circunferens mentem. Omni itaç fpe huiufmodi quicquã conandi(æedificandi) depulla, Tralani e quum folũ locatũ in atrī medio, qui ipfum principem uehit, imitari fe uelle dicebat, \& polfe. Cui pro. pé aftans regalis Hormifda è Perfide, refpondit geftu gentili: Anté (inquit) imperator ftabulum tale condi iubetc, fi uales; equus, quem fabricare difponis, ita late fuccedat, ut ifte quem uidemus, Ammi $4^{\circ}$ anus Marcellinus libro 16. Metellus Macedonicus fecit porticus quæ fuêre circundatæ duabusa dibus fine infcriptione pofitis, qua nunc OCtauix porticibus ambiuntur : $\&$ hanc turmam ftatuarổ equeftrium, quæ frontem ædium fpeçant, hodieḉ maximum ornamentum eius loci, ex Macedonia detulit, huius turmæ hanc caufam referunt : Magnum Alexandrum impetraffe à Lyfippo fingulari talium authore operum, ut eorum equitum qui ex ipfius turma apud Granicum flumen ceciderant, expreffa fimilitudine figurarum, faceret ftatuas, \& ipfius quock his interponeret, Velleius $P_{\text {atercus }}$ Ius, Equulos argenteos nobiles, qui Q.Maximi fuerunt, aufert, Cicero 6. Verr. De equis aureis ui de in Volucri equo fuperius inter propria equorum nomina. Exquilia gemini funt in urbe mon tes. In altero corum funt Diocletiani thermx, $\&$ duo equi marmorei ingentes, cum uiris feminudis lora tenentibus, miro artificio infignes, quorum unus inferiptum Latinis literis habet, opus Praxi. $\varphi^{\circ}$ telistalter, opus Phidix. Conftat hos à Tyridate Armeniorum rege Romam delatos, quem Nero ut laute exciperet, theatrum Pompeip unius diei opera totum inaurauit, Sipontinus. De equoligneo, quo capta eft Troia infra dicam inter prouerbia. Athenis in Acropoli Durius equus ftabat, cum

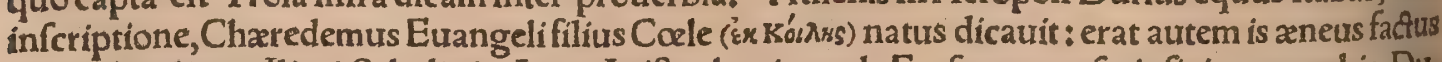
ad fimilitudinem Iliaci, Scholia in Aures Ariftophanis, unde Erafmus tranfcripfit in prouerbio Du, reus equus. Quum apud Ephefum Macedo Alexander fuam ipfus effet intuitus imaginem, pro uiriliab Apelle expreffam, non fatis pro picfura dignitate laudauic. Forte uerò interim equo indua ćo, 8 ad picfum equum mire adhinniente, tanquam urerum plané ac fpirantem: O rex(inquit Apel.

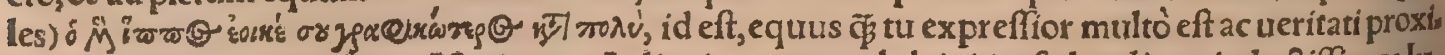
mior, Calius 13.38. ex libro 2. Variorum A eliani,non procul ab initio: fed melius uir doctiffimus lu. 60 ftus Vulteius nofter yga@icuregop tranftulit, meliore in difcernendis picturis iudicio præditum: quæ \& argutior fententia eft, \& uocabuli yerexís uim recté exprimit:fímili enim terminatione ad aliarum 
res inquirent, qui urel hominum gefta \& hiftorias, uel Geographicos libros adiderunt. Nos etiam in Onomaftico permulta ab hippos deriuata aut compofita nomina propria uno in loco dedimus ho. minumlocorumás : 8 in Bibliotheca feriptorum. Graeciquidem compofitis deductisḉ ab equo nomintous propria hominum nomina formare plurimum delectati funt, $8<$ plurimum hac in parte Iuxuriati, ut fingulis mox enumerandis apparebit. Exiftimabant enim nefcio quid dignitatis eque. Aris nobilitatis equi uocabulo conferri Hinc eft quod in Äriftophanis Nebulis legimus, Strepfia dem cum uxore de nomine filio imponendo contendiffe: \& cum illa Xanthippum aut Charippiden uocari urellet:Strepilades uerò auf fui nomine Pheidoniden, conueniffe tandem ut ueluti conitncis nominibus Pheidippides nominaretur. Apud Latinos uix unum aut alterum fimíle reperio: qualia funt apurd Varronem de re ruft. Equitius \& Equiculus. A pud Vergilium Aene, q. penultima per o. " frribitur. Continuò Quercens \& pulcher Equicolus armis. Commodius Equiculus uir fortifimus \& patremilitari natus Varroni memoratur. Ex proprịs uocabulis Gracis proponam primum hominum propria, \& uirorum prius quim mulierum; deinde locorum \& populorum, feruato fere iterarum ordine in fingulis, ब Tippalcus, Hippodamiz 82 Pelopis filius, Hippalmus apudd $Q$

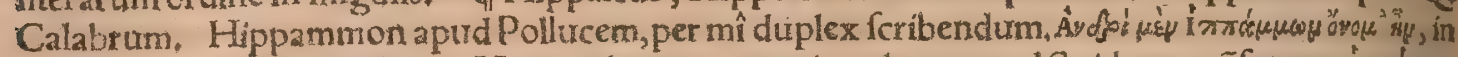
uerfu heroico. Hippagoras. Hipparchus:quo nomine plures apud Suidam recẽfentur, imúpextos

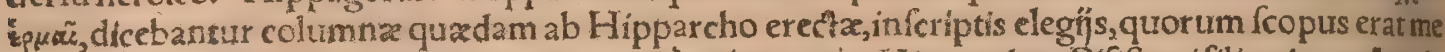
lores reddere lectores. Hipparchí murus, Tó I mmésye rexis: Hipparchus Pififtratifilius iuxta Acade miam murum adificauit, maximo A theniêfum fumptu,quem illos facere coegit:unde prouerbium iftuc de rebus fumptuofis in ufum uenit, Suid. Hipparchus Colargeus primus oftraco damnatis, 11 Plutarchus in uita Nicia. Ima certare deberet aduerfus Rufnum citharcedum, obmutuit. Hipparchides, apud Ariftophanem, Hipparinus nobilis Syracufantus Dionis pater, Dionyfif focer \& collega, apud Plutarchum in uita Dicnis. Dí́ Hipparini, Syracufanus, philofophus Platonicus, Dionyfy uxoris Arifomaches frater 8c.Suidas. Hippafus Metaponsinus. Hippafus in Corinthiacis Paufanix. Sôcus Hippafihippo dami, ic eft rei equeftris periti filius, Homerus Iliad. $\lambda$. De Leucippe \& filio eius Hippafo, quê ipfa $\propto$ forores per infaniam laniatum ederunt, fcribit Plutarchus in Gracanicis quaftionibus 37. Hip. pafides apud Q. Calabrum. Hippias, plures huitus nominis uide.apud Suldam, \&c. In Hippiam, mi nuptijs Antonius, ut in eius uita refert Plutarchus, per totam noctem bibic. Hippiothon, imára

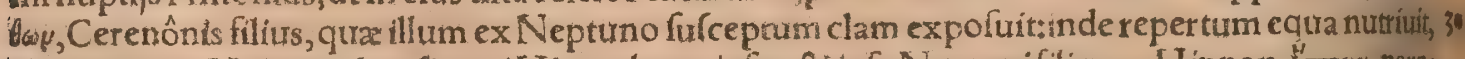

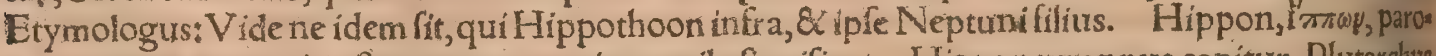
xytonum, nomen uiri eft: oxytonum enim equile fignificat. Hippon tyrannus capitur, Plutarchts in uita Timoleontis. Hermogenis Lycrí nobiliffimi curforis Hippos cognominati mentio fit fecun do Eliacorum Parfanix: uicit autem octies in tribus Olympiadibus. Hippobotx ariftocratiam in Chalcide Eubore cluitate, Ariftotele tefte, aliquando tenuerunt, Strabolib. 16. Hos ex Chalcidenfli bus exactos Plutarchus memorat in uita Periclis. Hippobotus philofophus quidam, Suridas, Hip

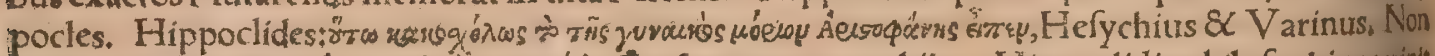

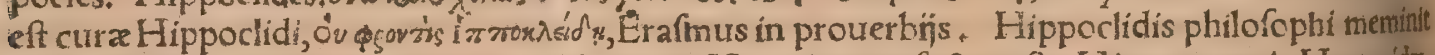
Valerius Max. 1.6. Hippocoon cum liberis ab Hercule interfeeturs eft. Hippocoontis Hyrtacida,

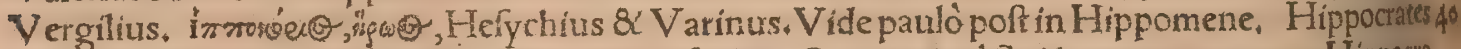
muli fuerunt:medici quidem huius nominis feptem, Coi omnes, à Surda enumerantur. Hippocta ces Syracufanorum dux foedera uiolat, \& Syracufas capit, aptrd Plutarchum in uita Marcell. Hip pocrates Mathematicus mercaturam exercuit, Plutarchus in uita Solonis. Hippodami cuiufdam mentio fit in Equitibus Arifophanis. Hunc aiunt Milefium fuife Euryboontis filium: habitaffeatu tem Pir zum, \& illum(trel domum quam in Prao habebat) A thenienfibus difribuiffe, $\&$ in honore

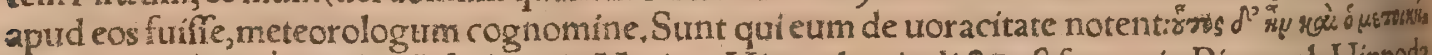

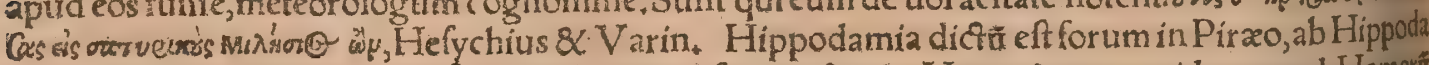
mo Milefio architecto, qui Piraum Adhenis adificauit, Suid. Hippodamus quidam apud Homerü

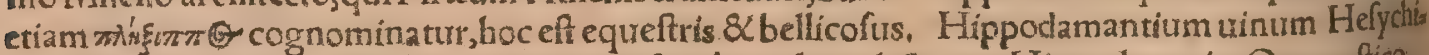
us \&. Plinius inter tranfimarina celebrat, nefcio à quo loco dicfum. Hippoderus in Onomaftico, Hippodotes apud Gyraldum de dijs. Hippodromus fophifta apud Calium. Hippolochus, Belles rophontis filius $\&$ Glauci pater, Homero: $\&$ alius Antimachi Troiani filius, Eidem. Hippoloctus Macedo, Athenaus, Hippolytus filius fuic Therei \& Hippolytes Amazonum reginæ(Antiopx cundum allos, Plutarchus in Thefeo) quam Hercules uictam Thefeo uxorem tradidit. Hic cum cur rum iuxta mare agitaret, apparentibus phocis equi territi currum ruperunt, 8 . Hippolytum difcer. pferunt: qui exitus eius nomini tanquam omini inforlici refpondit. Vide Onomafticon, \& Plutars chum in $\mathrm{P}$ arallelis minoriburs, $\&$ prouerbium Hippolytum imitabor, cuius etiam Suidas meminit Idem nominis omen in Hippolyto nof tra religionis exentũ habuit, Is enim in Oftijs Tyberinis mat tyr (fub Decio Cærare \& V aleriano prafecto) ab equis dilaceratus eft: \& membra inde collecta Ro mam translata. Huíus mortem defcribens Prudentius, de iudice Romano hos uerfus reliquit: Ille fupinata refidens ceruice, Quis, inquit, Dicitureaffirmant dicier Hippolytum, Ergo fit Hippolys rus, quatiat turbetćn iugales z Intereatç feris dilaceratus equis. Sed de Hippoiyzo Therellegis 
fecl. Daniafippus, apud Iutuenalem \&CMacrobium. Dioxippus apud Plinium \& A elianum in $\mathrm{V}_{2}$ Iịs libro 12. Drafippidas nomen fictum in Vefpis Arriftophanis. Ephippus, uiri proprium, Suid, 8 poétre apud Macrobium. Euippus filíus Megareiregis Megarenfium, Paufanias in Atticis. Eu - ripides cũ per $p$.fimplex fcribat, non uidetur ab equo compofitũ effe nomen, etfi antepenultima pro

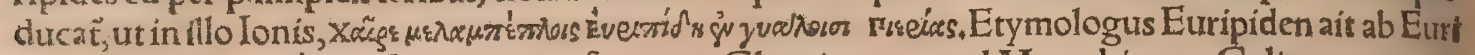
po dictum effe, quồ in Euripo natus feratur. Glaucippus, apud Macrobium. Gylippus, nomen Lacedamonium, Varin. Hermippus philofophus, uide Suidam. Lahippus, ftatuarius apud Plini um. Leucippus Oenomai filius, Pauraniz in Arcadicis:8 philofophi nomen Axiftoteli li., de hift, animal, 8 canis apud recentiorem quendàm: apud Pindarum Proferpinæe epitheton, ut infra dicã. Lyfippus, Plinio nobilis feulptor:item poéta comicus:uide Onomafticon. Melanippus, uir Thebas nus in bello fortifimus, quir Tydeum occidir, \&c. Paufan, in Boroticis. Melanippi \& Charitonis hi foriam defcribit A elianus libro 2. Variorum. Menippus, Suid. Nicippus. Nothippus poéta op: fophagus a pud A thenæum. Phænippus quidam turpis $8 x$ libidinof $x$ uitæ homo fuiffe fertur, Tifa menus ureró peregrinus \&. maftigías, unde Tifamenophanippos huiufmodi homines Ariftophane in A charnenfibus dixit. Pheidippides Strepfiadis apud Ariftophanem filius, ut fupra dixi. Phei. dippidis Athenienfis tabellarị meminir Herod, $i_{*} 6$. Philippus. Hefychius philippos etiam moechos interpretatur. Philippides \& Philippion, Suid. Philippicus, qui \& Bardónes, Iuftinianum regem

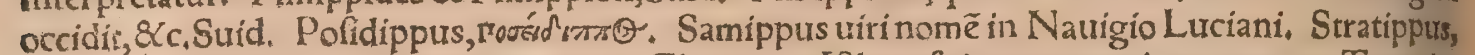
- in Equitibus Ariftophanis. Taraxippus Glaucus in Ifthmo fuit, quen equi peremerunt. Taraxip" pum eriam nuncupari inuenio herôum Myrtilo ả Pelope fructum, in quo 82 rem diuinam illiobie rit, ut perpetrata cadis iram l nniret. Nominis ratio ef, quòd in eo loco Myrtili arte iniectus fit Oes nomai equis terror. Sunt qui ab Oenomao id folitum peragi, fabulentur. Quidam inibi in foffa ali. qua à Pelope, fiblab Amphione tradita Thebano: quibus non Oenomai modo exterriti fint, uerum exterreantur omnes illac tranferntes equi. Fuife uerò A egyptī putantMagicx peritum Amphio natpropterea petras illi in Thebarum moenibus fuftruendis uifas obtemperare, ficuti Orpheo ration ne cadem ferzo obediuerunt, Cali:Vide plura apud Paufaniam Eliacorum fecundo. Epigrammatum

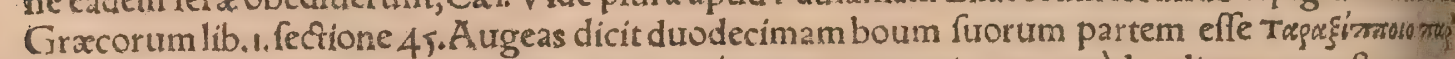

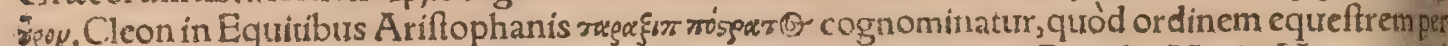
rurbaret. Telefippus filius Hippocratis, Varin. Xanthippus pater Periclis, Varin. Hoc nomena Patro ecui colore inditum apparef, ut cirrhippus à giluo, Leucippus ab albo, Melanippusân nigro، "3" Zeuxippus, dux Lacedamonius, Xenophon de rebus Gracorum.

- Mulierum nomina. Hipparchia uxor Cratetis Cynici, \&c, wide Suidam. Hippe merettix A thenaro libro 13. Theodotum quendan foeno pratectum regis P tolemai amatorem habuit, \& cum in comeffatione aliquando apud regem uinum copiofius infundi pcteret, uchementer enim fitiefer Meritò, inquit rex:plurimum enim foni deuorafi. Argüé quidem, cum \& ipfa Hippe, id eft equa uocaretur, \& Theodoti cui commiffum erat foenum opes confumpfiffet. Hippe Chironis Centatui filia in equam mutata, ut fupra in equo fydere dixi:uide Onomafticó. Hippe 8 . Aegle uxores Thie rei, Hefiodo tefte, Athenæus libro iz. Hippe filia Danai, à qua hippion A rgos dictum, Hefychitso Varin. Hippia, irzía, Arfinoëuxor Philadelphi, Hefych. Spartana uirtus apud Leuctra atrti corruit, infefto numine, fi credimus, ob fcelus admiffum in Scedafi puellas, Molpian \& Hippo, utià 4 Paufania(in Arcadicis)relatum fcio, etiamfi ex Plutarcho alibi Miletiam feripfímus, Calius. Plura nide apud eundem libro 5. ca.8. Ex Fuluio quodam \& cqua Hippo puella nata fertur, Caliusex Plutarcho, Celebratur Athenis quoç foemina Hippo, ut eft apud V alerium Maximum. Hippo

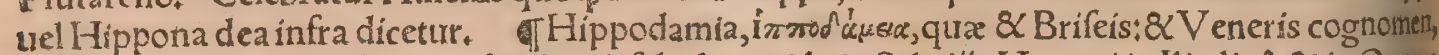
Hefych. Hippodamix Pelopis \&Myrtili fabulam, uide in Scholins Homeri in Iliadis B. \& in Onoma fico. Hippodamia Pelopi peperit fex filios, ut Pindarus frribit, Atreum, Thyeften, Pittheum, Alar thûn, Phlifthenem (pro quo alij Hippalcum numerant) \& Dian aut Chrylippum, Varín. Hippoly te A mazonum regina, Hippolyti ex The eo mater, ut fupra dixi: Vide Onomafticon, ubietiam Hip polytes Acafti uxoris mentio fít. Aenippe, Eudori filia, ex Aeneo marito Cyzicum regem Dolo pum peperit, Orpheus in Argonauticis. AlcippeMartis filia, Paufanias in Atticis, Alcippeelea phantum peperit, quod inter oftenta eft, Plin. Aftrxus Neptuni filius Alcippen fororem imprudës compreflit, \&c. Plutarchus de fluuñs in hiftoria Caici, Anippe filia Nili Bufiridem ex Neptutiopt perit, Plutarchus in Parallelis minoribus. Archippa uxor Themiftoclis ex tribu Alopecia, Plutar, chus. Archippen meretricem å Sophocle iam fene amatam apud Athenęum legimus libro iz. Aris ftippe, uide Leurcippe. Chryfippes qux Hydafpen patrem amauit, hiftoria legitur apud Plutarchỉ initio libri de fluuijs. Cydippen fecit Protogenes Rhodius, Plin.Cydippe Ochimi filia ex Cercapho Solis filio peperit Camirum, Lindum \& Ialy fum, Scholiaftes in. Olympia Pindari Carmine 7. Fuitel alia Cydippe Cleobis \& Bitonis mater, apud Stobaum in Sermone de morte. Euexippe, filia Sceda fiBocori, Calius, Eurippe, mulieris nomen in epiftolis Theophylacti, Heurippa, Diana co

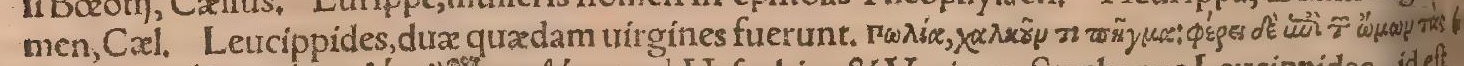

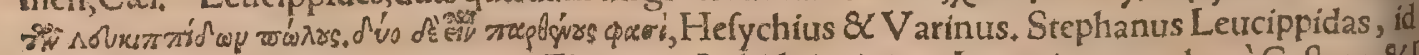
Leucippi Gilias nominatPhoben $\&$ Elaira, ex Aphidnis ciuitate Laconica ortas; has à Caftore $\&$ Pol 


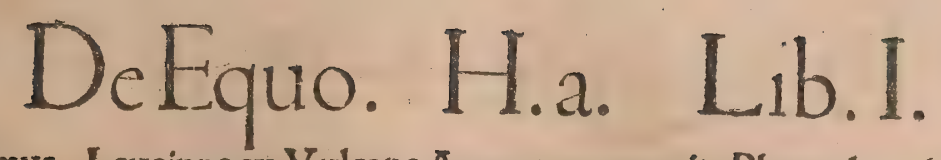

luce raptas legimus. Leucippe ex Vulcano Aegyptum peperit, Plutarchus de flurñs in Nilo. Leucippe, Ariftippe \& Alcithoëforores, Minyades cognominatx, cum Bacchi choream contemnes rent, in furorem conuerfa, Leucippa filium tenerum adhuc difcerpferunt, hinnulum effe putantes, 8 poftea in aures mutata funt, una cornicis, altera uefpertilionis, tertia noctura forma affumpta, $\mathrm{Ae}_{2}$ lianus libro 3. Variorum, Plutarchus in Gracanicis quaftione 37 . laceratum iftum Leucippes filiư, Hippafum nominatum meminit. Lyfippe mater Teuthrantis Myforum regis, Plutarchus de flu= üips in Caico. Lyfippe, filia Proti,cum cæeteris fororibus à Iunone in uaccam mutata. Menalíppe apud Homerum. Xanthippe Socratis uxor. Zeuxippe, mater Priami, Varin.

TLocorum 8 populorum nomina. A Nare amne úf̧ ad Equiculos tenent Sabini,Cato Orig. ${ }_{10}$ Equeftris \& Rauriaca Colonia Plinio 4. 17. inter Galliz populos numerantur, Ptolemaus Eque. frem Sequanorum in Gallia Belgica ciuitatem facit. Equeftres, ut Antoninus in Itinerario aperre fcribit, funt citra Iuram iuxta lacum Lemannum, à quo diftant 20.M. p. Quare conijcitur effe Neut dunum, ficut 8 liber puinciarum meminit Neuiduni Equeftrium, qua ciutitas hodie uocatur $N e$ e. uils, uulgo Neau. Sed cum Antoninus Equeftres pritus commemorat ac deindelacum Laufunũ (qui idem eft Lemanno) uidetur hac urbs citra lacum fuiffe, ut forte fit illa qua hodie Dunoy uocatur, qua urox nomini Neuiduni non malé refpondet, \&c. Hac Sebaft. Munfterus in caftigationibus cir ca finem operis de Rhatia Alpina. Videri fane poteft Neuridunum duplex fuiffe, ut alterum diffe,

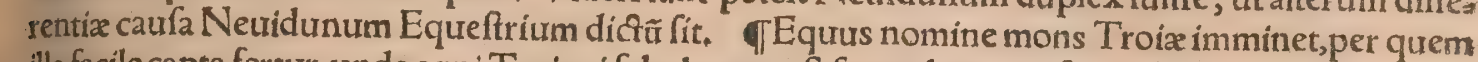
illa facile capta fertur, unde equi Troiani fabula nata eft fecundum qưofdam, Nic. Erythraus. $\mathrm{Da}_{a}=$ 20 phidas cum eius ftudij effet, cuius profeffores fophifta uocantur, inepte $\&$ mordacis opinationis, $A=$ pollinem Delphis irridendi caufa confuluit, an equum intrenire poffet, cum omnino nullü haburif fet; cuius ex oraculo reddita uox eft, inurenturum equum, fed ut eo perturbatus periret. Inde cum io cabundus, quafi delufa facrarum fortium fide, reuerteretur, incidit in regem Attalum frepenumero àle contumeliofis dictís abfentem laceffitum, eiuśç iuffu faxo, cui nomen erat Equi, pracipitatus, ad deos ufo cauillandos dementis animi iufta fupplicia pependit, Valer. Maximus, Roboam Sae lomonis filius inter alias urbes condidit Hippam \& Mariffam, Iofephus Originum Iudaic, 8, 10. Ea.

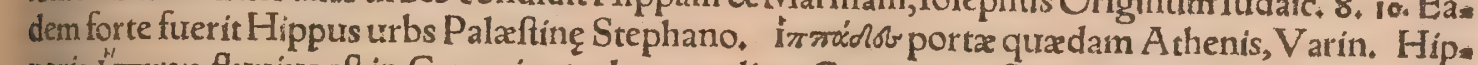
paris, I' 'magus, fluuius eft in Camarina(uel, per mediam Camarinam fluens)cuius a qux pars una dul cis eft, altera falfa: hunc noum fubinde lutum afferre 8 ripis apponere aiunt, unde ædificandima so teriam incolx fumant:alij uerò quoniam per mediam fyluam quandam fluit, unde arbores mult $x$, $\mathrm{p}=$ cerxós nafcantur, hoc modo xdificantiburs Camarinæis prodeffe. Fertur autem $\&$ natrigabile $\& x^{2}$ i fcofum effe flumen: fontes habet in monte quodam Siciliæ. Ligna qua in fyluis fecuerint ei iniecta in urbem uehuntur, Hac ex Scholijs in quinturm Carmen Olympiorum Pindari. Hipparenum Me. fopotamix oppidum: Muros Hipparenorum Perfæ diruêre, Plin. Hippia (i aliâs Phalanna dicta, Stephanus, Phalanna eft urbs Perrhabis quondam fubdita, Strabo. Oppidû in Gracia "mmıoy Ägyos ab equis cognominatũ eft, Varro. Argos hoc A chaicum dicebatur, Peloponnefi urbs, hippobotum etiam alio ab equis cognomine dictum, utpote equorum pafcuis aptum. Hip pion Argos ab Hippe filia Danai appellatum apud Hefychium \& Varinum legimus, Plura uide in. ferius H.b.in patrins equorum. Dauniorum oppidum Harpi, aliquando Argos hippium Diomede $10^{\circ}$ condente, mox Argirippa dictum, Plin. Ptolenzus Scyracenos ultra montem Hippicum in A fia col locat, Hermol. Fuit \& Hierololymis Hippicus dicta turris, curus meminit Iofephus de bello Iudaico 6.6. Longinquiores eodem difceptant foro Halydienfes feu Hippini, A polloniatx, Trápezopolitę, Aphrodifienfes, Plín. Hippus fluuiur eft Mofcorum. Phafis amnis maximé inclaruit Aea X V. IM. p. a mari, ubi Hippos \& Cyanos uafti amnes è diuerfo in eum confluunt:accipit etiam Glaucum, $\& c_{*}$. Plin. Phafis Glaucum in fe recipit \&.Hippum ẻ uicinis montibus cadentes, Strabo:idem ex co in Dio nyfum fcribens Euftathius repetit. Hippocoum uinum ex infula $C_{\hat{A}}$, dicqum ab agro generofo cui niomen Hippo, Feitus. Hippu acra, id eft equi pmontorium, urbs Libyæ, Steph. Hippucome, uicus Lycia, dicius ab equo uiatorum quorundam illic mortuo, Stephan. Hippomenes filiam fuam uiti-

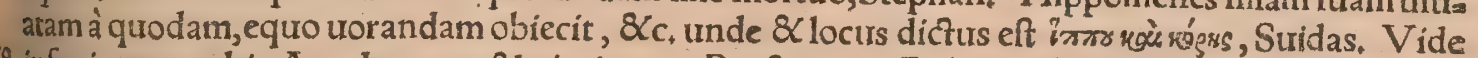
- infra in prouerbio A pud equum \& uirginem. Prufa ciuitas Bithynia fub Hippo monte fita, Plini. us paulo ante finem libri quinti. Coloni,Korwoul(fic dicti fcilicet colles in Attica: nam 86 fimpliciter whavoy locum altum interpretantur) duo fuerunt, unus imt: (malim ims!G, ut Paufanias habet, uel inse per $\epsilon_{4}$ ut author argumenti in Sophoclis Oedipum in Colono) appellatustcuitus Sophocles meminit, tanquam Oedipus ad illum confugerițalter in foro erat iuxta Euryfacis herôis templum, ubi contreniebant mercenarị homines, ob hoc ipfum Kon wvizue dichi, Pollux. Oftenditur 8 locus ap

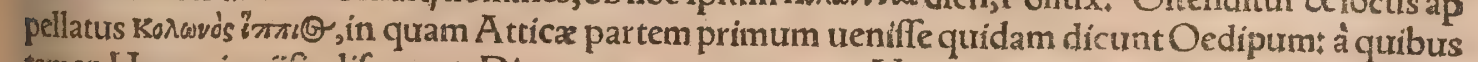
tamen Homeri poëfis difcrepat. Dicunt autem aram quoģ Neptuni hippĭ, \& Mineruæ hippiæ ( in hoc colle effe, ) Paufanias in Atticis. Templum Furiarum quas oukvess uocitant, in hippio Colono eftcuri nomen, quoniá templum in eo fit Neptuni hippï, \& Promethei:et oreocomi, id eft qui mulo trum curam habent, in eo habitant, Author argumenti in Sophoclis Oedipum in Colono. Et paulo

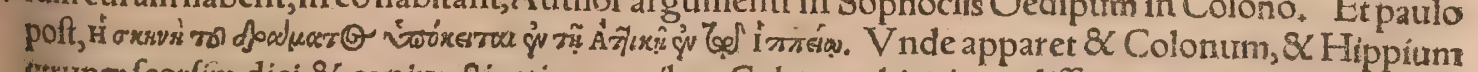
corung feorfim dici, \& coniunctis etiam uocibus Colonum hippium, differentiz caula nimirum ab. 
558.

\section{De Quadrupedibus}

altero Colono, Colonus hippius in Attica prope Ȧcademiameft, Paufanias. Adraftum aiunt cum Thebis fugeret, equos in Colono prímum cohibuilfe, \& Neptunum ac Mineruam hippios ap:

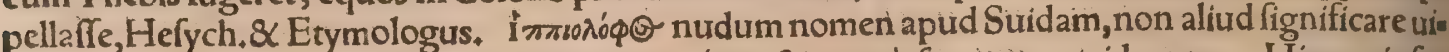

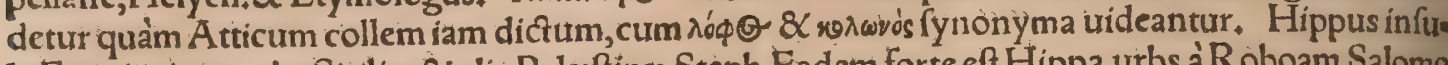
Ia Eretrix, item urbs Sicilia, \& alia Palaftinæ,Steph. Eadem forte eft Hippa urbs à Roboam Salomo nís filio condita, ut fuperius retuli, Lacus in quem Iordanis fe fundit, amoenis circumfeptus oppidis eft; luliade \& Hippo, Plinius 5+15. Inter Decapolitanæ regionis, qua Iudza iungitur, oppida, Plin, 5.18. numerat iam díctum Hippon Dion. Sic enim etiam Hermolaus legit, idćs facit (́nquit) autho, ritas Dionis, qui fribit, Dion olim Hippo nominabatur. Erythræciuitas eft Ionica, qua portum habet, \& quatuor ex aduerfo ei fitas (mexentúcs) paruas infulas, qua Hippi dicuntur, Strabolibro in 14. quare corruptum Stephani locum conịcio, ut legamus Hippum non Eretria, fed Erythrarum in fulam effe. Mentionem de his infulis facit etiam Plin. 5. 29. Hippuris maris mediterranei infula Pom ponio:Hippurifcus infula Carię Stephano. Meminit etiam Plin.4.12.ubi pro hippurufa, hippurifcus legendum uidetur. Annï Plocami libertus circa Arabiam nauigans, Aquilonibus raptus prater Carmaniam X v, die Hippuros portum eius inuectus eft, Plinius. Portus quidam in Taprobane Hippuros nominatur,Solin. Hippo uel Hippon ( $\mathrm{i} \pi \omega_{\mathrm{\omega}} \mathrm{y}$ ) duplex elt in Africa:unus (profertur \& fomino genere) regius cognominatus : alter diarrhytus ; quod paluftri folo madeat, unde $\&$ terra motibus frequentius infeftatur, quare uagam Silius dixit, utran $\varphi_{\beta}$ uno uerfu complexus, Tum uaga, $\& 2$ antiquis dilectus regibus Hippon. V tranq $H_{\text {Hipponem }}$ Græcos equites condidiffe author eft So. linus.Cirta in A frica Mafaniffa \& fuccefforum regia eft, in mediterranea, urbs optimé ftructa, cum a à cæeteris, tum à Micipfa, qui \& Græcos in eam habitatum deduxit:\& tantam effecit, ut decem equí

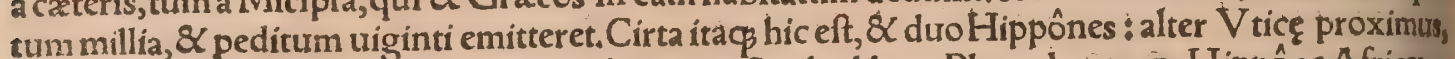
alter remotior, $\&$ Trito propinquior, jambo regiæ, Strabo lib.17.Plura de utraç Hippône Africa å pud Plinium ex Indice requires. Eft $\&$ Hippo oppidum Locrorum in Brutís, Hipponium

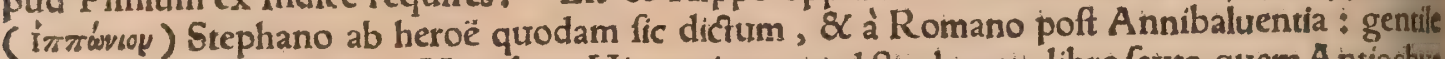
Hipponiates,Stephanus, Hinc finus Hipponiates apud Strabonem libro fexto, quem Antiochus Napininum dixit, Plinius Terinæum. HippoLucania ciuitas, Plutarchus in uita Ciceronis, De hoc Plinius 3.5. Hippo (inquit) quod nunc Vibonem Valentiam appellamus: Idem apud Straboe nem legimus libro 6.A b eodem Plinio 2.1, in Hifpanix defcriptione Hippo Catırafiarû memoratur Regio qua fub Cafpịs portis in humili \& concauo folo iacer, \& Armenia, eximiè hippoboti,ideft 30 equis pafcendis apta funt:urocatur autem $8<$ pratum quoddam Hippoboton, per quod iter faciunt quì ex Perfía \& Babylône in Cafpias portas profícífcuntur,Strabo. Argos Âchaicum etiam hippo boton cognominatum, fupra monui. Hippocephalum fuburbanum Antiochix dictum alicubile giffe memini. Hippocorona eft in Ä dramyttena regione, \& Hippocronium in Creta,Strabolib.10 Fontes in Bcootia ä Plinio numerantur, Hippocrene, Aganippe, Gargaphie, \&c. Hippocrene, iंगतो kṕnvy, fons in Helicone à Pegafo equo diçus, qui fitiens ungula terram perculfit, unde fons emicuit, ut Hefiodus in Theogonïs canit (item Âratus, \& Higinius:uide in Pegafo infra in h.) Hefych,Cum Bellerophon Argis fímifret, terra iça pede Pegafi fontem emifit, qui inde fons equi, uel Pegafeus (Tw groóxe lepury) dictus eft, Varinus. Iuxta Hippocrenen in Bcootia alter etiam fons Äganippe eft, non procul ab Helicone móte, Perfius Hippocrenen fontem caballinữ dixit, ex quo qui hautfiffent proti 4 nus furvre afflati poétæe fieri credebantur. Hinc Hippocienides Mufx. Vide Onomafticon. Ore. ftes à cæde materna expiatus fertur, tum alịs modis, tum aqua ex fonte Hippocrene:qui etiam apur

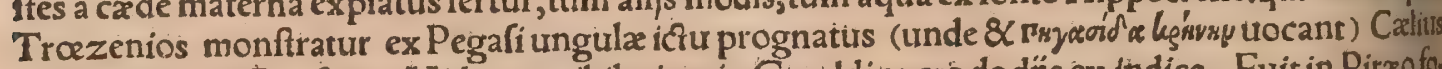
ex Corinthiacis Paufania. Vide nonnihil etiam in Gyraldi opere de dïs ex indice. Fuit in Pirzo fon rum nomine Hippodamia, à Milefio Hippodamo qui Piraim ftruxit meminit Demofthenes. inav:

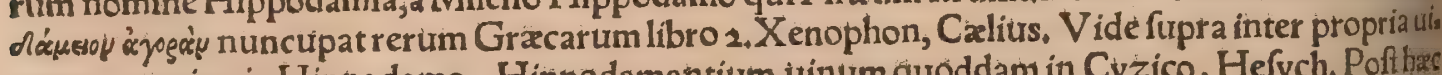
rorum nomina in Hippodamo. Hippodamantium uinum quoddam in $\mathrm{Cyzico}, \mathrm{Hefych}$. Poft bor authoritas Hippodamantio, Myftico, Cantharitæ, Pliníus de uínis tranfmarinis. Sternęa, uia Hippo

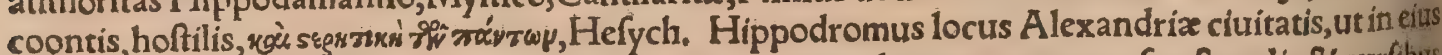
defcriptione refert Strabo lib. 17. fignificat autem quemuis locum, equorum fpectaculis \& curfibus \{ aptum. Hippola, ${ }^{\prime \prime}$ modec, urbs uetus Laconica:gentile Hippolaites, Stephanus. Herodotus adBos

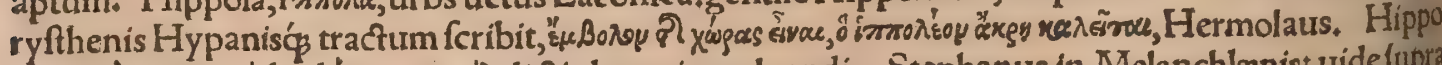

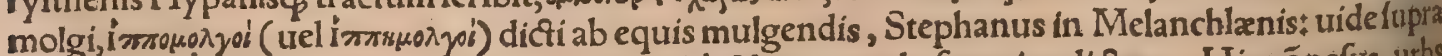
capite fexto. Hipponium urbs Brutiorum, aliâs Hippo, paulo fuperius dictum. Hippónefus, urbs Caria, \& alia Libyæ, Stephanus. In Ceramico finu infula, Hipponnefos, Mya, Sepitffa, Plin, 5,3 ii Hippophagi populi Scythia in Afia, (ut cap.6. docui) $\&$ alï Hippopodes, de quibus fuperius etiam hoc ipfo capite dixi, fupra Tauricam Cherfonnefum iuxta Alanos. Solinus in Oceano Scythico ha* bitare fcribit, $\&$ humanam ufog ad ueftigium formã tenere, fed in equinos pedes definere: Et Plintits 4.13.in quibufdam maris illius infulis. Hipporex, gens Aethiopie, atri coloris, tota corpora rubrica illinit, Plinius. Hippotamadx, uicus in tribu Oeneide, Stephanus,

बI A ganippe, Bootia fons, ut fuperius in Hippocrene dixi. Argippai Scy tha ab ipfo natalical ui, mares paricer \& fomina, \&c, facri dicunt effe, arma non poffìdent:uocantur aüt Ärgippxi, He 


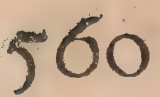

\section{De Quadrupedibus}

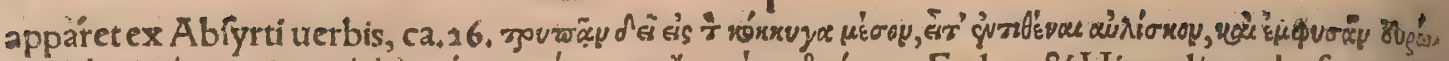

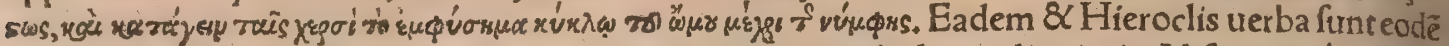
capite. Ruellius in Hreroclis uerbis Grxcum nymphx uocabulum reliquit : in Abfyrti uerò uerbis,

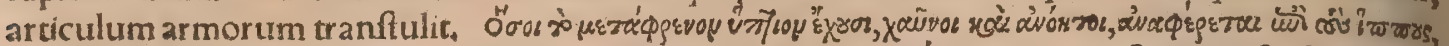
Ariftoteles in Phyfiognom. Si fagma uel fella maiores minorésue aut anguftiores iufto furerint, $\mathrm{col}$ lifiones \& fuppurationes nafcuntur, uel difcentes tracturam (locus non integer uidetur:forte legen

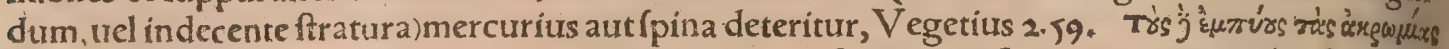

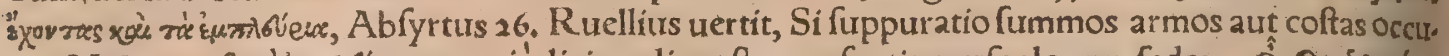

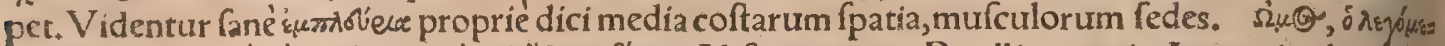

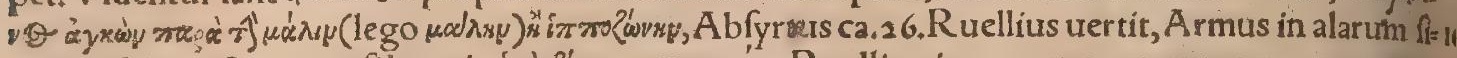

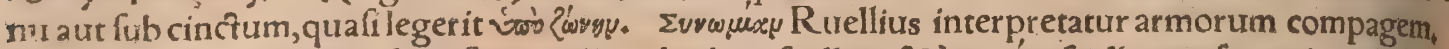

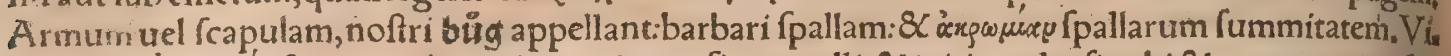
dctur fane isxpewuxa fuprema thoracis pars iuxta finem colli, \& initium dorfi, ubi 8 coccygem pofui

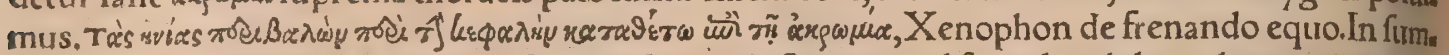
mis armis, Camerario interprete. Si omoplatas (id eft armos uel frapulas)dolor uehementius excru

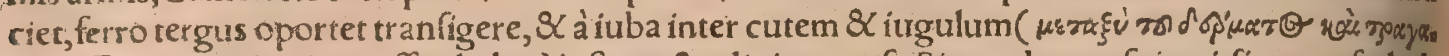
və̈, ut Graecus codex impreffus haber)inftar octo digitorum rectiunculam aufpicari,fic ut ne fcalpels lo iugulus ipfe contingatur,Pelagonius in Hippiatr.ca.26. interprete Ruellio. VItimo quidem Hipn piatricorum capite, traganum pars quædam narium appellatur. Luxatio accidit, cum nerutus qui fcapulas comprehendit, aut articulus quem gumphum uocant, acetabulo propulfus excidit, $\bar{A}$ bfyr=

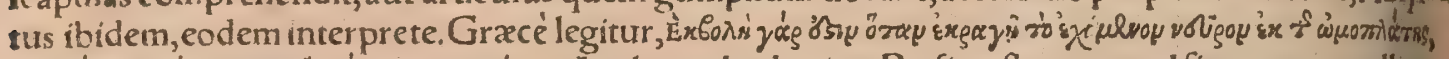

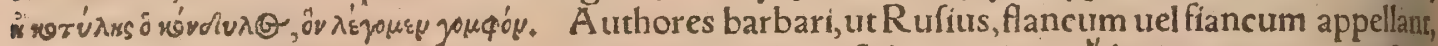
locum ut puto inter coftas \& coxendicem medium, hoc eft ilia, usvedvo. E'dso in equo pars dorficui

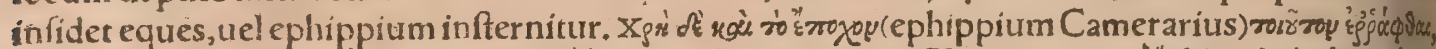

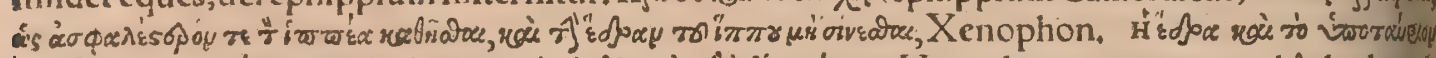

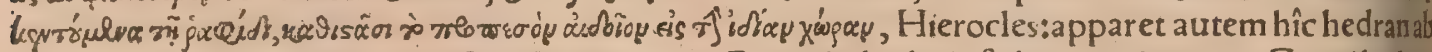
eo pro ano pofitam. Plinius in fedem recipere de Bucephalo dixit, fedem nimirum, ut Græci hedran de dorfi parte intelligens, nifi quis fellam potius accipiat. Penis quafi utriculus, quem Græci toca

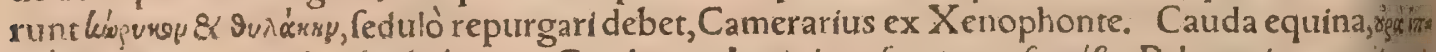

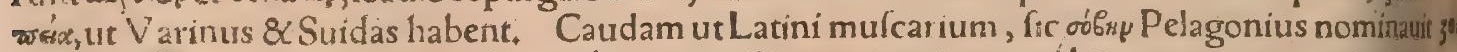

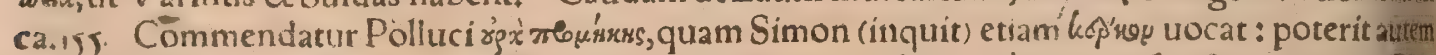
Q '̈w wres deci, pprïfitimo nomine. Caulis cauda longior afinis quàm equis, fetcfus ueterinis, Plin. Caudec $x$ cificllæ ex iunco, à fimilitudine equinæ caudæe dicta, Fefus. Supragambam pro femore

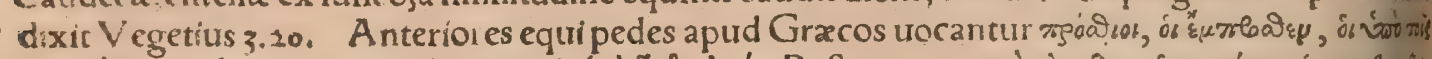

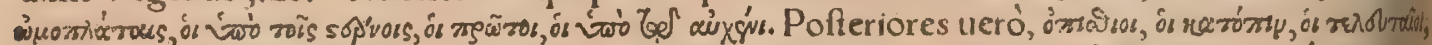

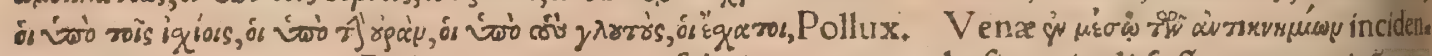
dx. Pelagonius ca. 26. Pedis in equo partes, fubcirrus, corona, ba fis, articuli, fuffrago, nominầrur a

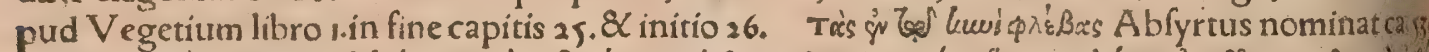

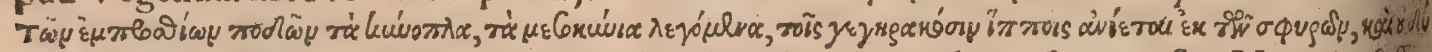

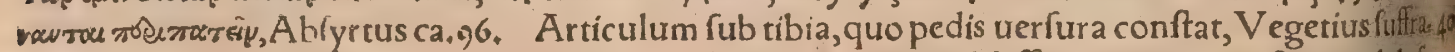
ginem, \& per excellentiam articulum uocare uidetur. Articuli uel fuffragines equi poft iter calidofo

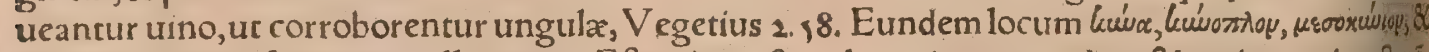
recentioribus paftoram a ppellari puto. Eft enim paffora locus inter ungulam $\&$, pximam iuncturá, Ruíius ॥5. Pedes poft uiam eruendi funt diligenter, ne quid luti uel fordium in articulis bafíqper

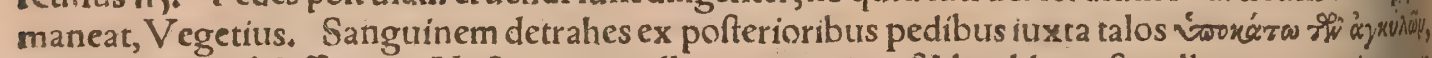
Ruellius uertit à fuffragine. Noftri partem illam, uocant ben [ dblegel, hoc eft malleum, qux inter un gulam \& tibix iuncturam media eft: huic à pofteriore parte infurnt caua illa quæ nominant dic fy] lóduer. Probant autem eos potius quibus breuior ea pars eft, tanquam robore crurum ualidiorestin quibus ea oblongior elt, infirmiores funt cruribus, 8 ferédum ingrediũtur nefcio quomodo pedem inæqualiter anterius primum deinde pofterius fubmittunt, urforum inftar, unde eciam bstrmb) nonnullis appellantur, quafi degreob'cuovor. Aliud ab hoc uitium eft, cum heteropodes funt, nec ungulis ex aquo innituntur, fed in alterutrum latus magis uergunt, curiufmodi equos audio quo

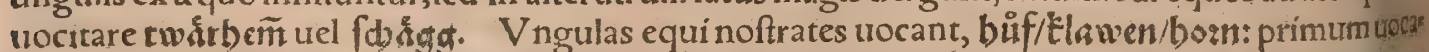
hulum pprium eft, alterum ad bifulcos etiam $\&$ multifidos ungues pertinet, tertium à fubftantiasor nea fumitur. Vnde \& Latini poétæx cornipedes cognominant equos, ut Vergilius A eneid. 7. Er silit us libro feptimo, Fului iuga celfa trahebant Cornipedes. Cornipedi Fauno cara de more capella,

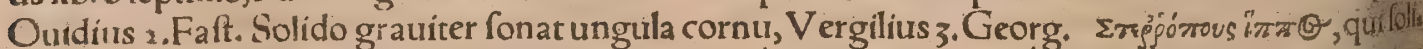

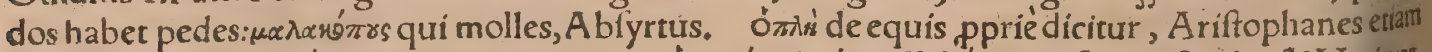

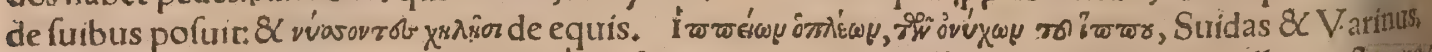
Stygis aqua cum uafa omnia, lapidea, é cryftallo $\&$ murrhina, offea, \& ex quouis metallo conflatape o netret $\&$ perrumpat,fola equi angula illæfa continetur. An uero etiam Alexander Magnus huits aqua ueneno uitam finierít, dicere certò non poffum, famam uerò effe fcio, Paufanias in Arcadicis 
562

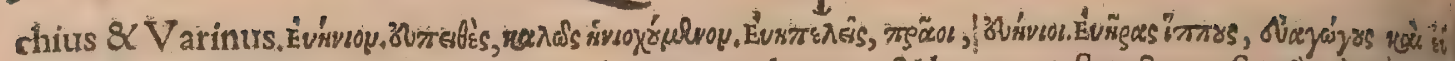

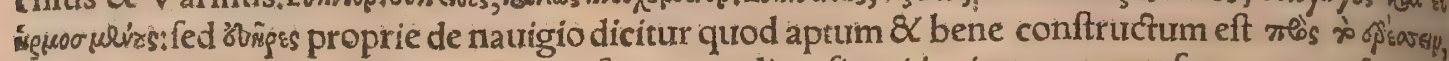
id eft, ad remígandum, V arin. Animofus equus diuerfis epithetis ornatur, ut funt : generofurs, mai guanimus, fortis, ardens, acer, cupidus, ferox, audax, minans, terribilis, fremens, Hæc præcipue in es Gư bellatore (de quo plura inferius) laudatur uirtùs. Emicatộ̧ ut equi potẽtis animofitas, Sidonitus,

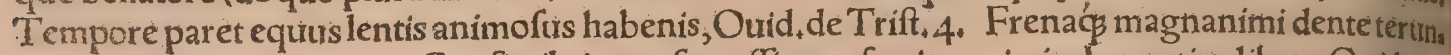
aur equi, Ouid. de Arte i. Confimile in curfu poffint, ac fortis equi uís, Lucretiuts lib. 3. Quid tam egregium fi fomina forti Fidis equo? Verg. Aene, 11 . Quippe uidebis equos fortes cum membra acebunt. In fomnis, fudare tamen, Lucret, lib.4. Nec te fortis equi ducet ad arma fonus, Etad li ttros hilarem,intrepiditúç.tubarum Profpíciebat equum, Statius lib. iI. Equum alacrem latus afpexit, Cicero lib.1, de diuinatione, Filius ardentes haud fecitis aquore campi Exercebat equios, Verg.Aene.7. Ardentes 8 equos ad mollia ducere frena,Manilius lib. 4. Effodere loco fignum quod regia Iuno Monftrârat, caput acris equi, Verg. Aen, I. At purer Afcanius medís in ualitibus acri Gaudet eqư, Aen.4. V tóş acres concuffit equos, utọ́g impulit arma,Aen.8. Dení̧̧ ubime dio nobis equus acer adhafit Flumine, Lucretius lib,4. Acer equus quondam, magnæx́ć in pulue re famæ, Ouid,Metam.7. Milite non illo quifquam foelicius acri Infultaret equo, Silius lib,10. Vt cupidicurfus frena retentat equi, Ouid.libro 3. de Ponto. Non fonipes in bella ferox, non iret in aquor, Lucan, lib, 4. Siue ferocis equi luctantia colla retorques, Ouid, in epift, Phadræad Hippo, lytum. A udacifrenua fertur equo, Pontanus. Troilus haud aliter gyro leuiore minantes Eludes bat equos, Stat.lib. 5.Sylu. Vtqui terribiles pro gramen habentibus herbis Impius humanos ui: Icere pauit equos, Ouid, in Ibin de Diomedis equis, quibus haec non animofitas, fed crudelitasamiti buritur: Decet ueró etiam animofum equum hoftibus terribilem effe. Subitisć̣́ frementes Vortici bus contorfit equos, Lucan, lib +4 . Vexare turmas, \& frement $\tilde{e}$ Mittere equum medios per ignes, Horat,lib. ${ }_{4}$ Carminum. Ad hunc frementes uertere bis mille equos, Idem in Epodo. Et media

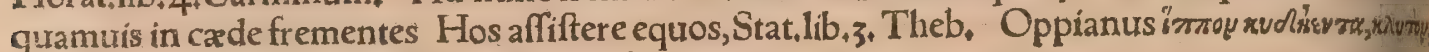

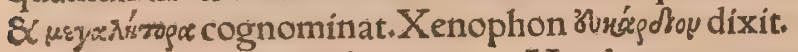

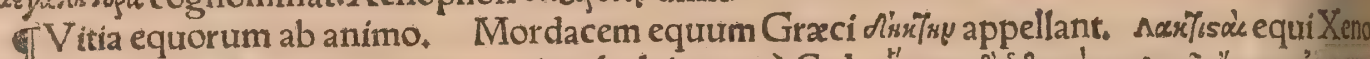

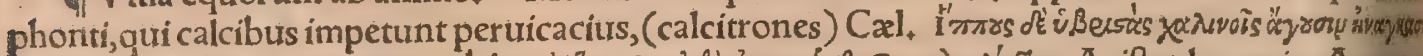

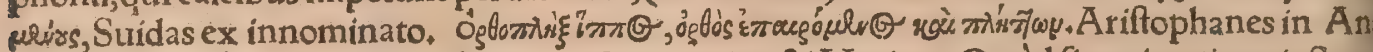

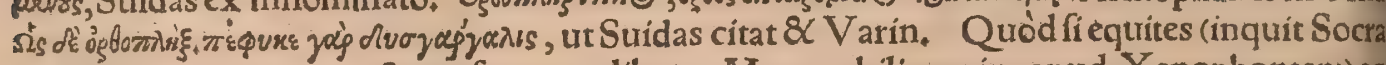
quendam equitum magiftrum futurum, libro 3 . Memorabilium eius apud Xenophontem) equ bi adduxerint tam uitiatis pedibus ac tibís : quofdam uerò ita debiles ac ftrigofos ut fequi non fint: $\mathcal{Q}$ quordam ita malé educatos, ut non maneant quocunq $\$$ tu loco ordinatreris : quordam tam calcitrofos, ut non fit poffibile de uno in alium aciei locum tranfferre, qua tibi utilitas erit e

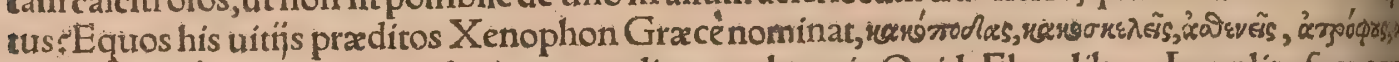

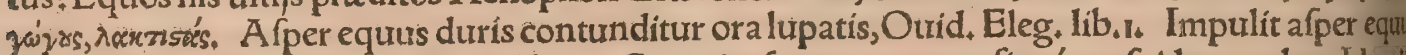
feftusćs fub quora merfit, Silius lib, 4. Corruit afper equus, confixạ́́cúpide membra, Idem 17. Seu frena fonantia flectes, Seruiet afper equuss, Statius lib.4.Sylu. Immitẽ quatiebat equt fpumantia fxio Frena cruentantem morfu, Silius lib:12. Ipfe humero exertus gentili more par tum Difficili gaudebat equo,Silius lib.8. Moriẽtumó̧ ora furenti Hippomedon proculcet equ Stat lib, 8. Theb. Vtrapit in praceps dominum fpumantia fruftra Ora retentantem durior oris

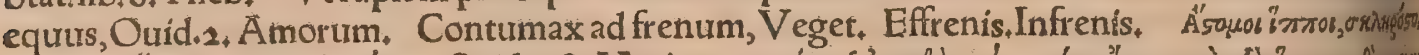

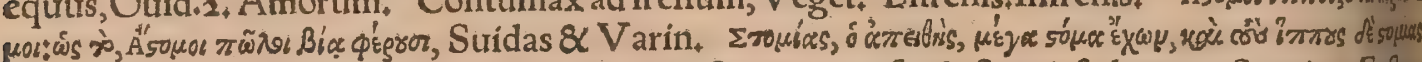

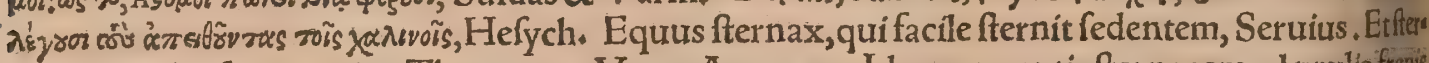
nacis equilapfum ceruíce Thymoten, Verg. Aene, 12. Idem correptis fternacem ad praliafenti

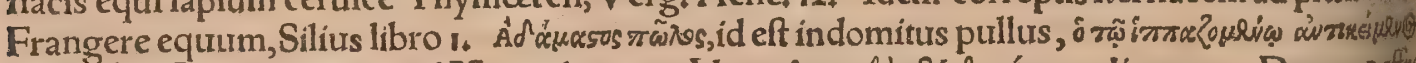

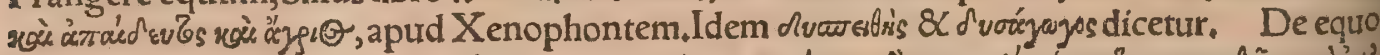

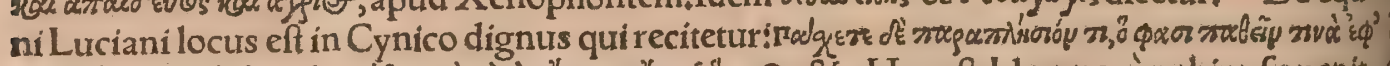

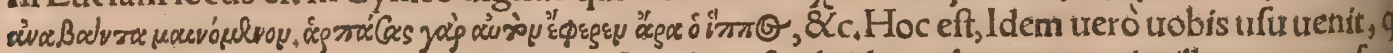
contigiffe cuidam ferunt qui equum confcenderat furibüdum: abreptum enim illum equus feré nec ulla defcendẽdi equo currente facultas erat. Cum ațt obuius quidam interrogaret quónam per geret:refpondit, quò illi uidetur, demonftrans equum. Sic à uobis fi quís quarat quò pergatis,

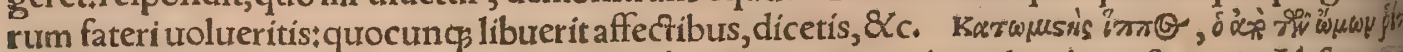

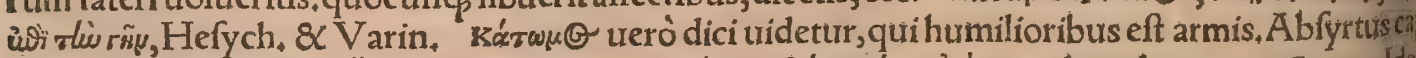

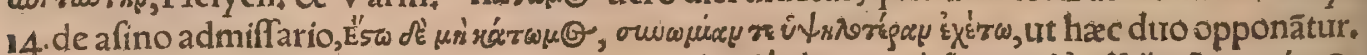

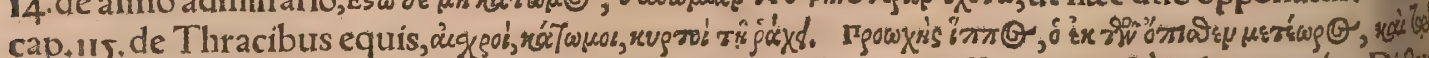

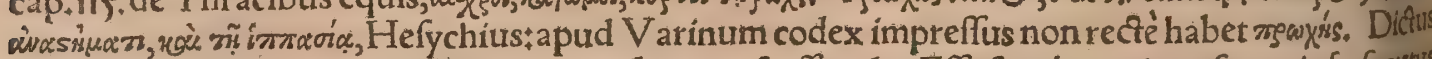

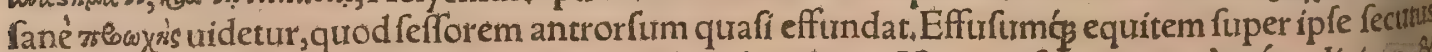

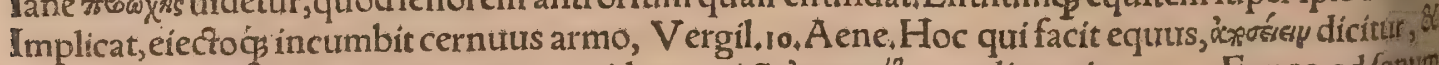

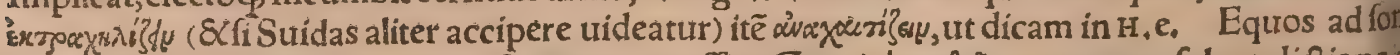

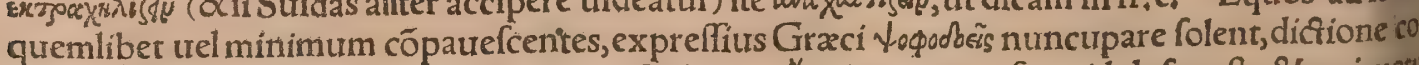

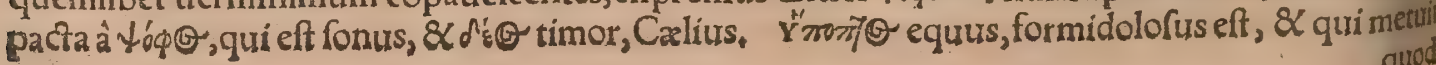


564 De Quadrupedibus

cogis equum, Claudian. Et celer hinnit equus,Author Philomela. Aut quis equum celeremute archo compefcere freno Poffit Tibullus libro 4 ubi (inquit Textor) ure diminuit, aut debet expunn gi m.litera non clifa, Ora citatorum dextra detorfit equorum, Aen, 12. Tum ueró incubuit Libyes fuper ipfe citato Ductor equo, Sillibro 10. Volat ille citatis Vectus equis, nullág latus ftipantecan terua, Claudiã. Ante citos quantum Pegafus ibat equos, Ouid.4. de Ponto. Vt cupidi curfus fre na retentat equi, Ouid,lib.z, de Ponto. Lam fulgor armorum fugaces Terret equos, Horat,li, $2_{\text {, }}$ ar. Torquentem frenis ora fugacis equi, Ouid.in epift.Phędræ ad Hippolytum. Flectitis aut frenocol, Ia fugacis equi, Idem in epift. Herûs ad Leandrum. Tela fugacis equi, Propert, libro 3.' Ceruoósfu gacior ibat Sudanti tremebundus equo, Claudian.Stat, I. Theb. Clarabit pugilem non equers im piger, Horat. lib 4 . Carm. At non Sarmaticos attollens Sufana muros Tam leuibus perfultate quis, Silius libro3. Anfractus leuioris equi, Valer+6.Argonaut. Pernix. Sic ubi profiluit piceo de carcere præceps Ante furos it uictor equus, Sil. lib.15. Impulit aduerfo præceps equus Ochea conto, Valerius Flac, 6.Argon. Sitḉ focer, rapidis qui tonat altus equis, Ouid.in epift. Deianiræad Herculem. Hippolytum rapidi diripuiftis equi, Idem $\mathbf{1}_{+}$de Arte, Rapido certamina linquit In $l_{a}$ tebras euectus equo, Silius libro 16. Nec fortibus illic Profuit armentis, nec equís uelociburs effe, Ouid,Metam,8. Vt noua uelocem cingula ladat equum, Ouid.lib.s, de Remedio. Seneca in Agas memnone, Vos Græcia nunc tefte ueloces equi. Volucres portis auriga fub ipfis Comit equos, Statius libro 4. Theb. Vertice fic Pholoës uolucrum nutritor equorum, Idem libro 10. Volucris non prapere curfu Vectus equi, non Pegafeis adiutus habenis, Claudian, libro r.in Rufinum, Dü uolucri quatit afper equro, fyluasç̧ fatigat, Valerius Flac, 3.Argon. Fuit $\&$ proprium equi nomen z Volucris, ut fupra diximus. Iuruenal,Sat, 8,equum tum celerem tưm ignauñu, his uerfibus defcribir

Nempe uolucrem

Sic laudamus equum, facili cui plurima palma

Feruet, \& exultat rauco uicforia circo, Nobilis hic, quocunç uenit de gramine, cuius

Clara fuga ante alios, et primg in ęq̊re puluis. Sed uenale pecus Corithæ,pofteritas $\&$

Hirpini, fi rara iugo uictoria fedit, Nil ibi maiorum refpectus, gratia nulla

Vmbrarum, dominos pretrís mutare iubent̃ Exiguis, tritoọ́ trahunt epirhedia collo

Segnipedes, digniç molam uerfare Nepotis \De celeribus equis in certaminibus, nonnifild cam in $H, e$. Vergilius in Georgicis de equo iam triennium fuperante, \& ad publica certaminainiti

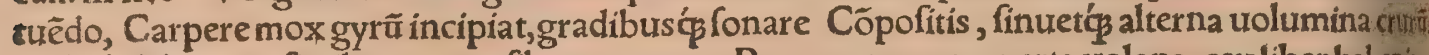

Sirćs laboranti fimilis:turm curfibus auras Prouocet,ac per aperta uolans, ceu liber habenis, 30 A equora, uix fumma ueftigia ponat arena. Qualis Hyperboreis Aquilo cum denfus ab oris

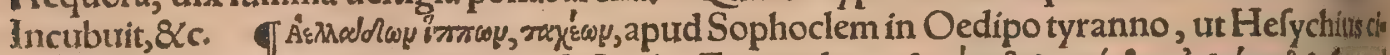

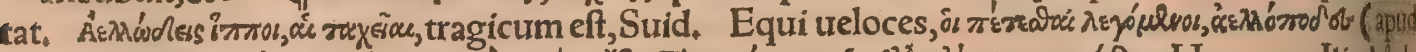

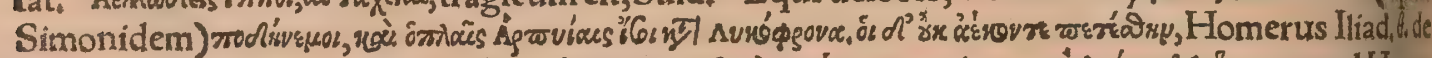

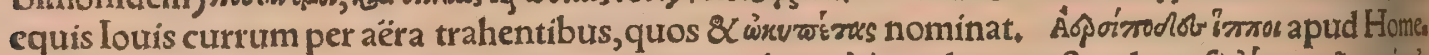

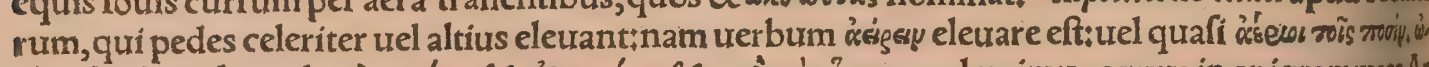

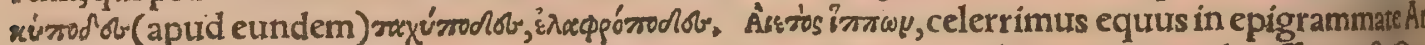
chix, Anthologí 1 .33.pro equo omnium pernicifimo, quando a quila inter aues uelocifima eft. Op:

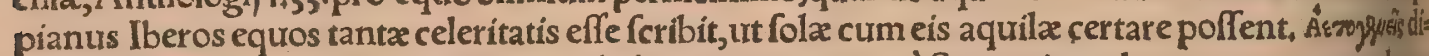
cti equi à genitiua quadam nota, quam habent circa armos, à Sarmatis probantur tanquam ad curt 4 fus aptiffimi:improbantur qui eandem circa caudam $\&$ clunes habuerint, $A$ bfyrt. 11 . Conuenit fax néà perniciffima auium aquila equos etiam uelociffimos fic appellari, etfi nulla huiúmodi corporis

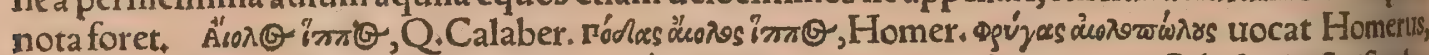
fiue quòd celeres equos poffideant, fiue quood uarịjs equitandi modis utantur, Scholia iri Ariftophat

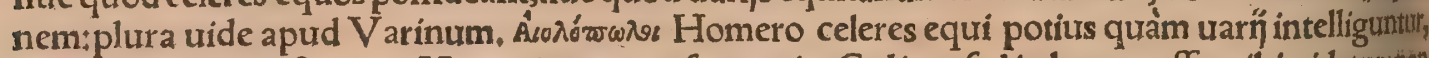
ex Porphyrï(Quętionum Homericarum 3, fententia, Calius : fed in hoc erraffe mihi uideturtion

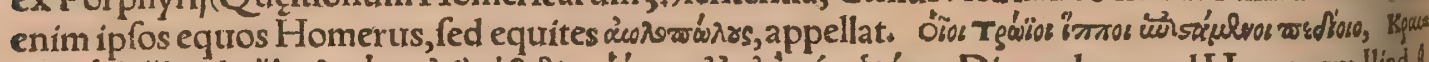

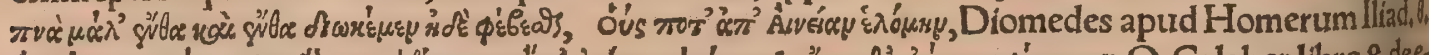

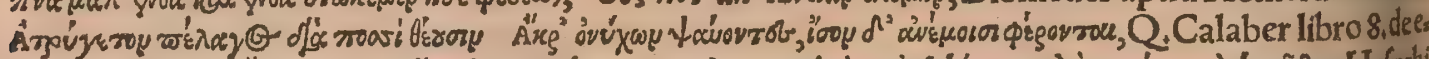

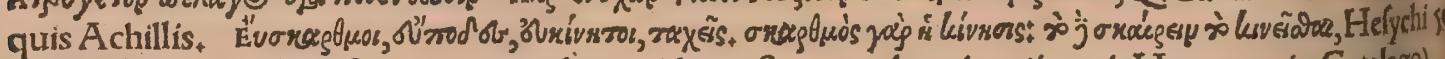
us \& Varin. In Ilienfi campo tumulus quidam eft, quem homines(inquit Homerus in Catalogo)

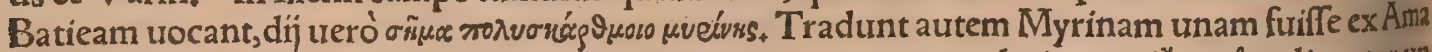

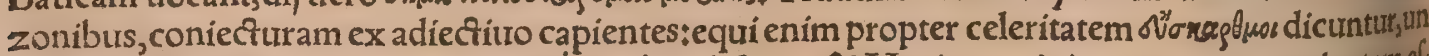

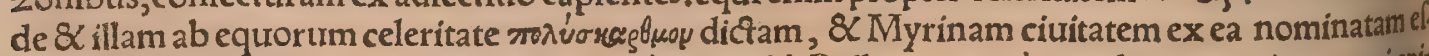

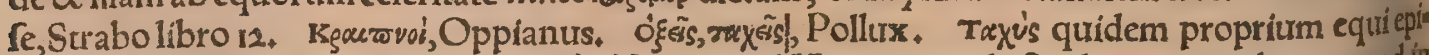

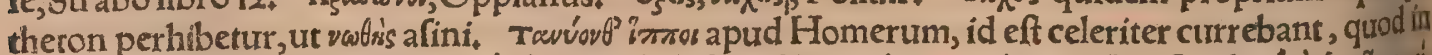

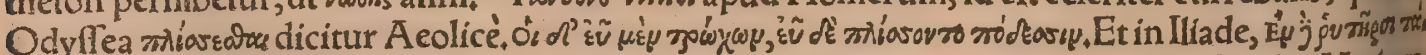

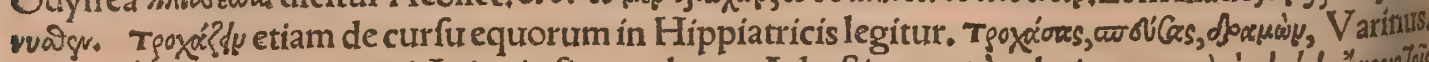

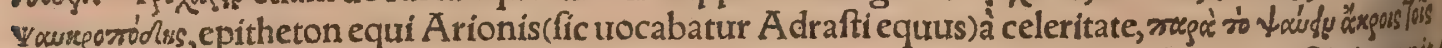

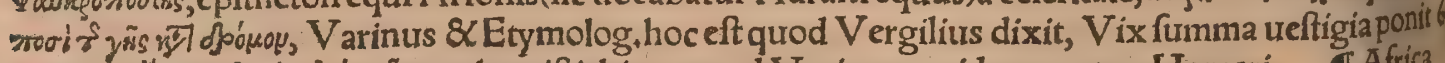
arena. Y" equos uelociffimos praftat ad ufum fella, Veget. Ratumena(inquit Feftus Pompeius) porta àno 
H. $c$.

inmo'Bonj uocant locum equorum pafcuis idoneum, ut Argos hippoboton, \& pratum hippobo

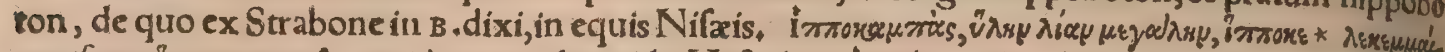

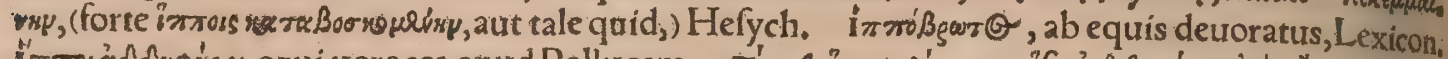

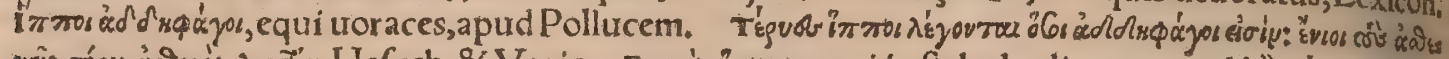

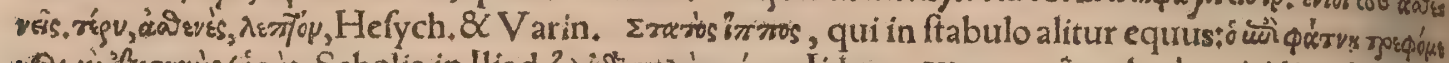

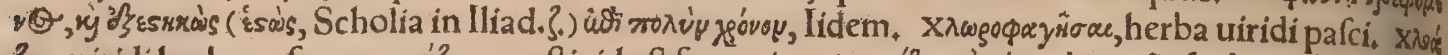

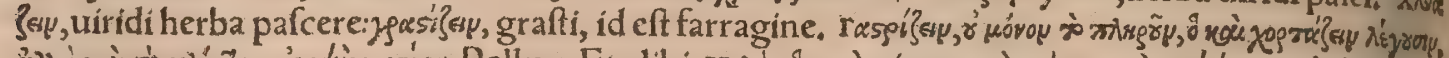

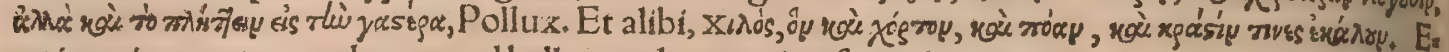
quis qui anno quarto demum ad bellum uel certamina facra domantur, Tum demum craffamas gnum farragine corpus Crefcere iam domitis finito.nanç ante domandum Ingentes tollent ania mos,prenfió̧ negabunt Verbera lenta pati, \& 2 duris parêre lupatis, Verg.in Georg. Foenumalibi bis tantum, alibi ter aut quater etiam anno fecatur. Armentorum id cura, iumentorumó progenera tio fuum cti $\$$ confilium dabit optimum, maximéquadrigarum quęeftus, Plin. Thraces qui ad Stry

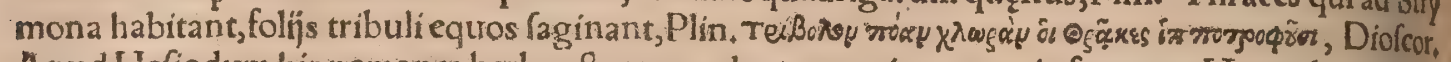
A pud Hefiodum hippomanes herba eft, quam edentes equi aguntur in furorem, Hermolaus. Qux, nam herbæ hippomanes dicfæ fint, uide fupra parte prima huius capitis inter plantas. Circa Scy, tharum \& Medorum dictam Thraciæ regionem, locus eft uiginti feré ftadiorû fpatio, qui hordeum producit quo homines uefcuntur, equi uerò \& boues abftinent, \& C. Ariftoteles in Mirabil. Ávosí,

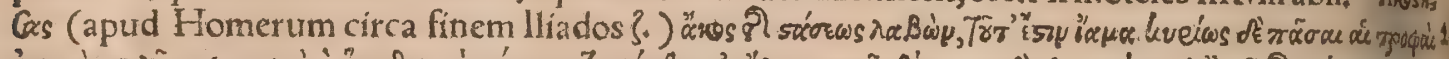

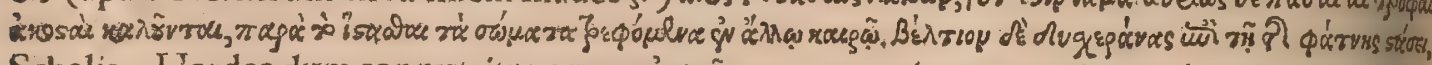

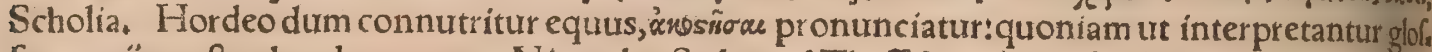
fematarị, a coften hordeum uocat Nicander.Sed apud Theffalos cibaria 8 alimenta omnia nuncu pari acoltas, traditum ueteribus eft (noftrates forfan ab hac origine Eoft appellant.) Sunt quiaptid

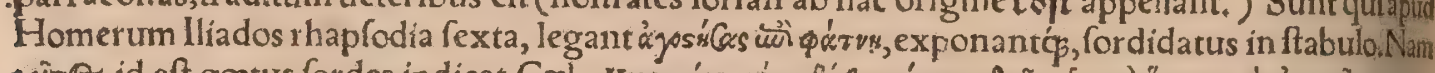

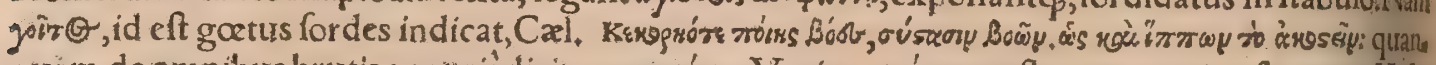

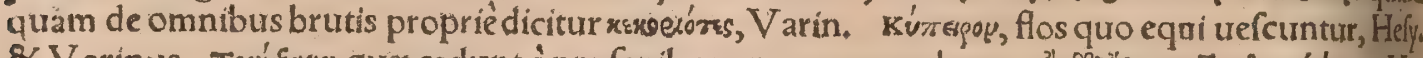

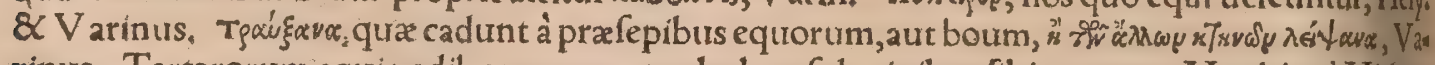
rinus. Tartarorum equi pedibus aquam ex pabulum fub niuibus fibi quarunt, Matthias à Michou, In prouincia Aden equi, boures, cameli \& oues uefcuntur pifcibus, quorum ingens illic copia, $8 \mathrm{Cl}_{\mathrm{i}}, 30$ bentius quidem ficcis quàm recentibus : nam propter immenfum calorem herbis $\&$ frugibus car rent, Paulus Venetus. Tondentes campum laté, Vergilius de equis pafcentibus. V tante lucem urri equiḉ pranfi effent, Liuius, Egregia funt illa Perfa cuiufdam \& Libyos dicta; Nam alter inters rogatts, qux res potiffimum fagínaret equum, refpondit, Oculus domini. Alter, çuod ftercus effer optimum, Domini ueftigia,inquit, A riftot, r. Oeconom. Huc pertinet illud quod refertur à Gellio, quod cum quidam corpulen tus ac nitidus, equum haberet macilentum, rogatus quid effer in caula: refpondit mirum non debere uideri fi equio effet habitior, quadoquidem iple fe pafceret, equumeth raret feruus. Eleganter dixit equifo quidam, nihil perinde faginare equum, ut regis oculum,

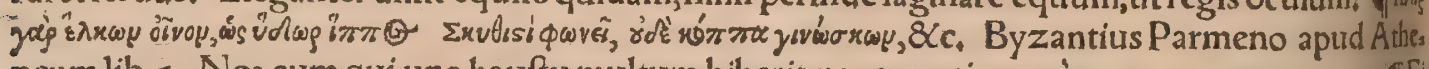
nęum lib.5. Nos eum qui uno hauftu multum biberit, uaccæ potius quàm eque comparamus. (fFi

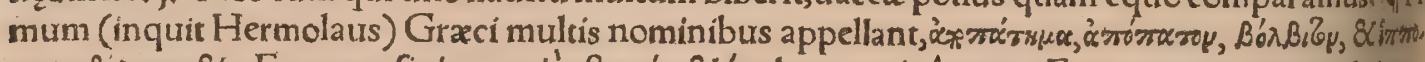

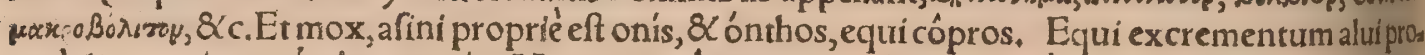

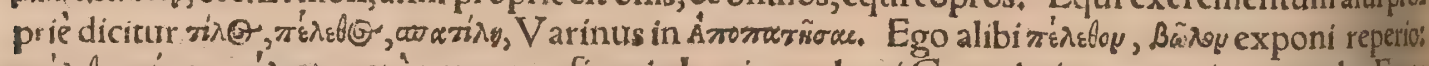

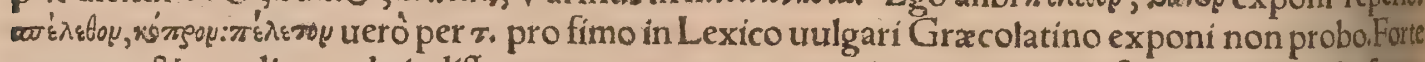
autem $\pi . \& \approx$, aliquando indifferenter ponuntur : nam etiam pro caprino fimo pyrathon \& fpyra thon legimus. In A charnẽfibus Äriftophanis $\pi \varepsilon \lambda \varepsilon \delta \dot{y}$ oxytonum (quod minus placet) legi in his uerf

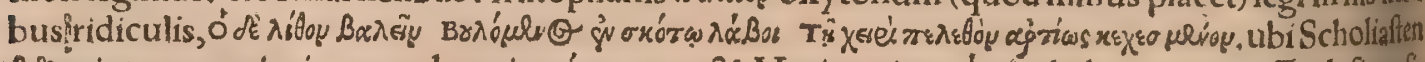

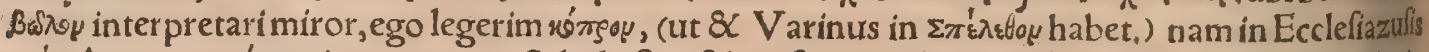

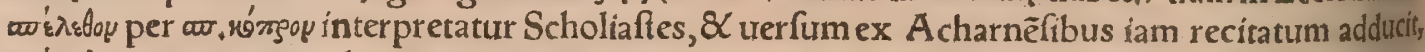
$\varpi{ }^{\prime} \lambda \varepsilon \theta_{0}$ per $\omega$. non $\pi$, legens, cum acuto in prima, non ut illic habetur in ultima. Bài $\theta$ quidem pro so

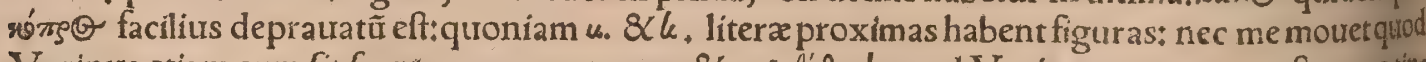
Varinus etiam eum fit fecutus errorem:quare $\& \pi \varepsilon \lambda_{\varepsilon} \theta_{0} \beta_{\alpha} \psi$ apud $V$ arinum exponetur, ftercore tirs

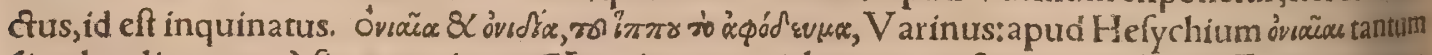
(in plurali numero) fic exponitur. If Immitem quatiebat equum fpumantia fruo Frena crtientan tem morfu, Silius. Et fpumas aget ore cruentas, Vergilius de equo curfu certante in Eleo campo, "1

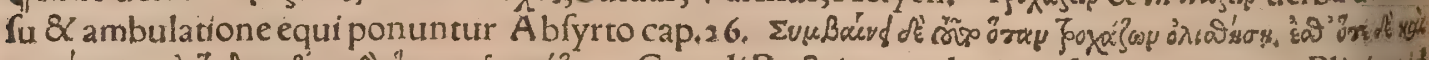

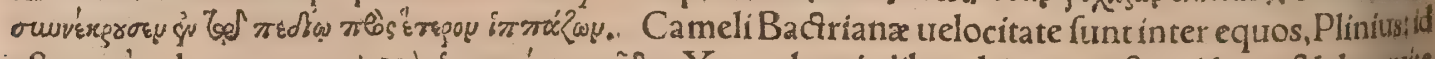

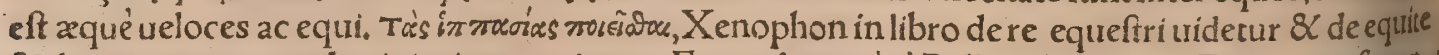
$\&$ de equo ponere, ut Latini etiam equitare. Equus irwrissis à Polluce laudatur. De equorefonath

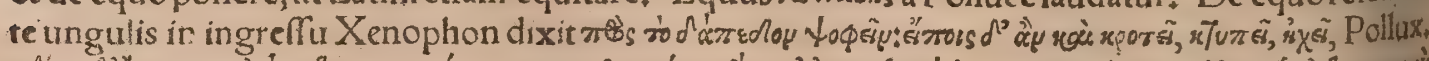
xdova j" kx 


\section{8

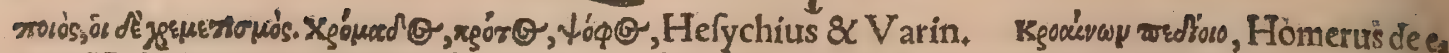

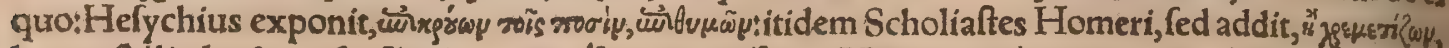

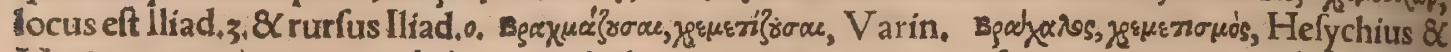

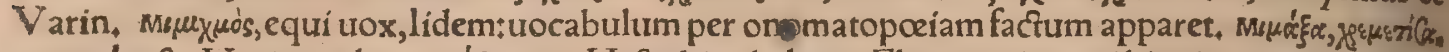

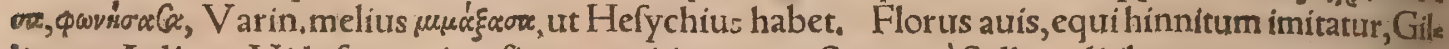
lius ex Aeliano: Vide fupra circa finem capitis quarti. Satyrus à Sylla mílitibus captus, uocem afpe ram equi prafertim hinnitu \&C hirci balatu permiftam adidit,Plutarch,in Sylla. Homines quidam uocem adunt fimilem afini, equi, aut alteriurs beftix uoci; conj̈ciendum eft autem eiufdem animan tis ingenium quoç referre qurenq, cuius uocem exprefferit, Adamantius.

(1) Effe uerò equum animal philolutron ac philydron, id eft balneorum $\&$ aquaexpetens, aucfor 1 probat Ariftot. Cal. Equus animal eft lauationis cupidum,gaudetć paludib. \& turbulentis aquis,

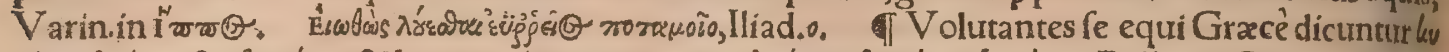

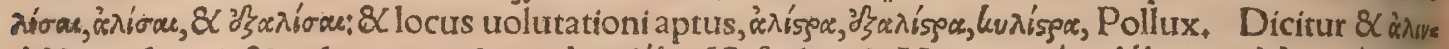

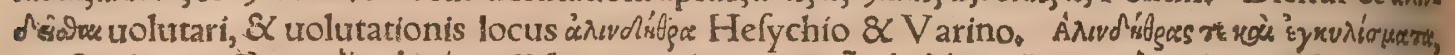

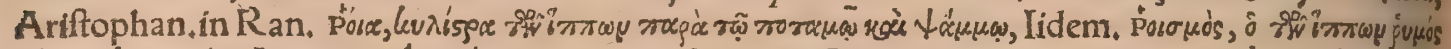

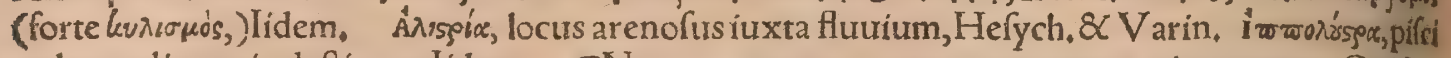
na lauandis equis deftinata, Iidem. TNec uaccam uacca, nec equas amor urit equarum, Ouid, Metam. Quum tibi flagrans amor, \& libido Qua folet matres furiare equorum, Sauit, Horat.

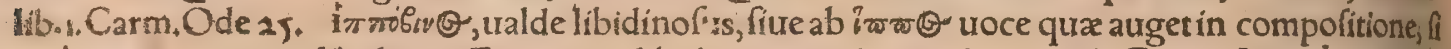
ueà nimia equarum libidine. Equa cum libidine accenduntur, i w wopavê̄ Gracis, Latinè equire di

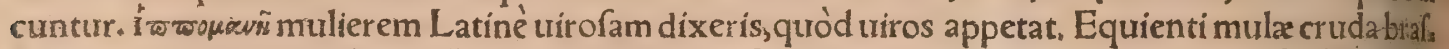
fica datur, Columella lib. 7. Equum admiftarium ltali hodie ftallonē uocãt, Germani fobstlbengfl,

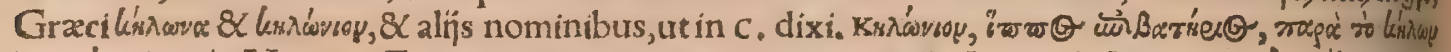

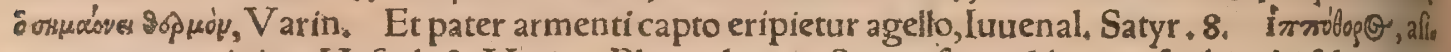
nus equarum initor, Hefych,\& Varin. Plutarchus in Sympofiacis (libro 7.) fcribit ubi faliantur e. qua nómon incini folitum, quem wocent hippothoron, Cal. Erat autem cantus equis in Venerem

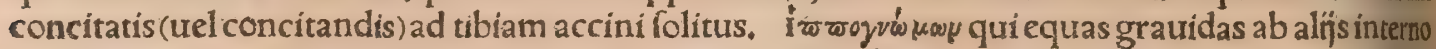
rcit, Hefychius \& V arin. Eadem uox magnanimum fignificat. Quum Xerxescum exercituHel lefpontum tranfiffet,ingens prodigium oblatum eft. Siquidem equa leporem peperit: quod facile erac interpretari, fore ut Xerxes qui exercitum aduerfus Graciam maximo frepitu \& ambitiofiff: $3^{\circ}$ mè ducebat, rurfus pro feipfo folicitus ad eundem locum fuga recurreret, Herodot, Jibro 7. Idem prodigium fimiliter Valerius Maximus defcribit 1. 6. Audio in Rhętia alpibus monte Speluca, ut uocant, equum ex tauro noftro feculo natum effe. Retulit etiam nobis amicus fide dignus, uifuma $f e$ in Gallia in aula regis equum pofteriore parte ceruum. De infante centauro, \& Hippo puellae equa nata, fupra dixi, huius capitis parte prima. Phocylides apud Stobaum in fermone ubinti lieres uituperantur, pro diuerfís earum ingenijs alias ex alins animantibus natas fcribit, ut cane, apti cula,fue, equo. Et eodem ín loco Simonides idem argumentum latius profequutus, ex equo natam mulierem fcribit ab omni labore alieno effe animo, \& feipfa folum ornanda tempus infumere, inutis lem marito, nifí is perquam diues aut princeps fuerit, Equam Eudemus ait adolefcentem,ac armens i praftantiffimam, tanquam omnium formofiffimam puellam ab equifone adamatam fuiffe, prit 4 mumǵs fú amoris hunc flagrantia moderatum fuiffe. Deindelibidine inflammatum, ufós co pron ceffiffe cum equa, ut uenereo complexu iungeretur, remǵg tandem perficeret turpem. Vbi ueros qux pullus incefto ftupro matrem contaminari perfpexiffet, eam fic à domino tyrannicé tractarias cerrime tuliffe. Itaç impetu facto, uirum interemiffe, at $\beta_{3}$ cum obferuaffet, ubi humaretur, eó pro fectum refodiffe, omnibusíg fupplicịs cadauer iam nullum fen fum ex mœrore percipiens uexans tis, afflixiffe, Aelianus. Equum adamatum à Semiramide ụ̧̧́ ad coitum, Iuba author eft, Plinits, Regi Babylonis erant peculiares equi, prater bello deftinatos, admiffarí octingenti, cum equarum quibus admittebantur fedecim millibus, Herodotus libro primo, Quód fi equarum numerumcoll feras admiffariorum numero, deprehendes fingulis admiffarïs uicenas fominas deftinatas fuif

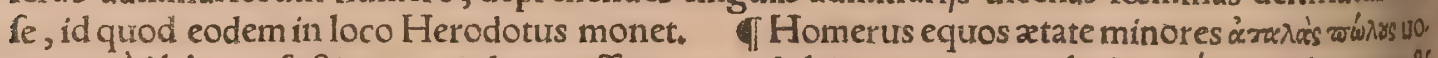

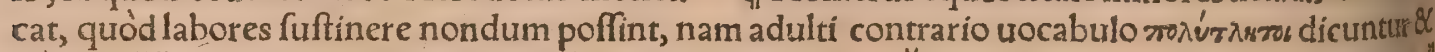

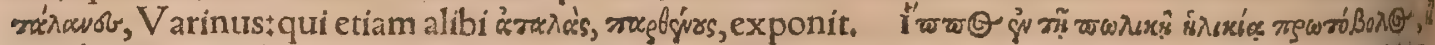

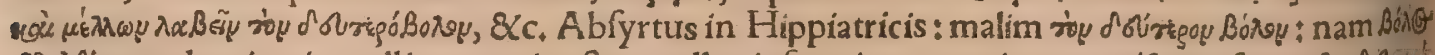

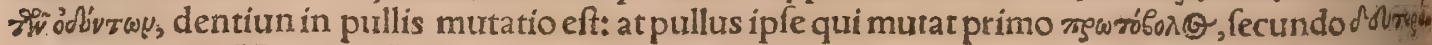

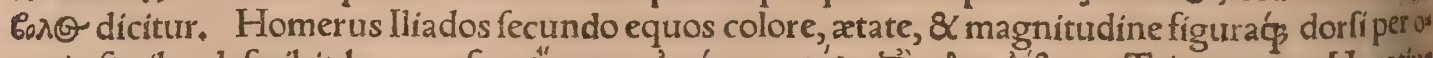

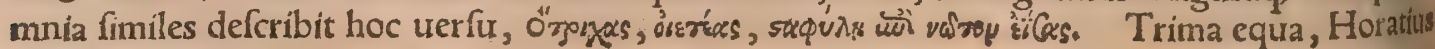
tertio Carmin.

đ Hippiatrum uulgoItalice $\&$ in finitimis linguis marefcalcum appellant, aliqui perperam mene fcalcưm $\&$ manefcalcữ. Origo uocis Germanica eft:nã Germani,olim equos (nũc equas tantum)ina ras uel marcas nominabant. flam equus laudatus ocio interdum \& quiete perit: Vnde dicitur, in th

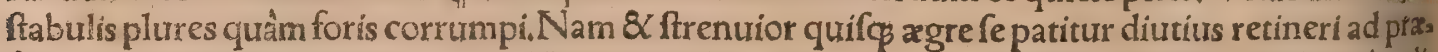
fepe, \& in campum excurrere auet. Tum igitur $\&$ recto curlu, $\&$ ambagibus, \& falur $_{2}$ colliumóq adis 


\section{DeEquo. H.c.d.e. Lib.I. 569}

tu \& cliurorum defcenfu exercebuntur, modo quidem \& fcite, non infano quodam \& ebriofo impe tu, Ita $\varphi_{\text {s }}$ traditur hoc de Eumone ingeniofo rege $\&$ forti, cum quodam in caftello ab Antigono obfer fis non haberet patentia \& fpatiof loca, in quibus equi exercerentur: ne ftando perpetuo languo rem $\&$ focordiam atģ etiam uitia, ut fit, contraherent, funibus tranfurerfas fubter præcordia illorum trabes curaffe fufpendi, \& adduci poltea has ita, ut priore parte corporis paululum fupra terrã equi attollerentur, cui cum infiftere laborarent, negs impediti fubiecta trabe attingere poffent, ita etiam commoti,omnes uires intendebant, \& nitendo toto corpore defatigabantur, ut etiam fudor elicere.

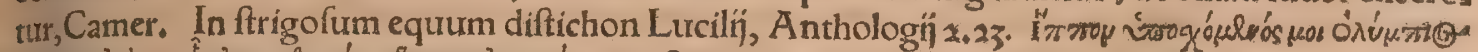

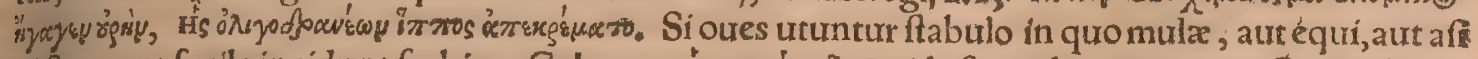

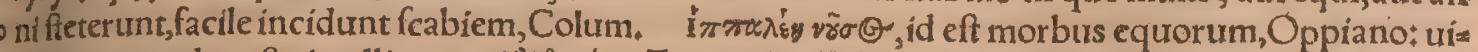

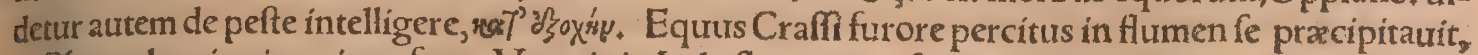
ut Plutarchus in eius uita refert. Vermis in Indo fl.reperitur feptem cubitorum longitudine: is tam robuftus eft, ut in quodcunq̧inciderit animal noctu egrediens conficiat, equum, bouem, \& c. Aelia. Silurus graffatur ubicun $\phi_{\beta}$ eft omne animal appetens, equos innatantes fape demergens, pracipue in Mono Germanix amne prope Liboum, Plin. Creditum quondam ex equo, occifo hafta bafili: $\{\mathrm{fo}$, \& per eam fubeunte ui, non equitem modo, fed equum quogs abfumptum, Plinilus,

$\mathrm{H}+\mathrm{d}$.

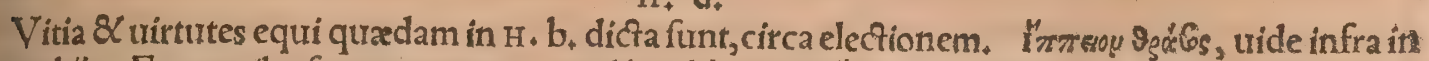
prourerbijs. Equus cibo farur procurrit. Kudiowu: v' 1) inb. tractauimus. Mithridates Ponticus fomnum capiens, corporis fui cuftodiam non modo fatel litibus, fed \& tauro \& equo \& ceruo manfuefactis committebat, ut pluribus in Tauro retuli ex Ae. liano. Philarchus refert Centar etrium è Galatis (A elianus interprete Gillio eandem hiftoriam nar. rans, hominem hunc natione Gallum, nomine Centoaratum furife ait) in pralio occifo Antiocho po titum equo eius confcendiffe ouantem: At illum indignatione accenfum domitis frenis, ne regi pof

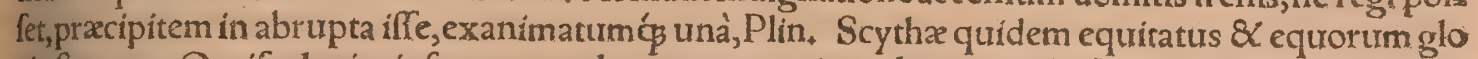
ria ftrepunt. Occifo deniçs ipforum regulo ex prouocatione dimicante, hoftem cư uiçor ad fpolian.

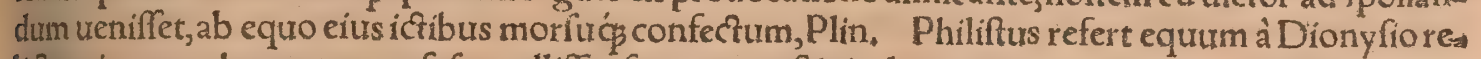
lictum in coeno harentem, ut fefe cuelliffet, fecutum ueftigia domini, examine apum iubę inharente: coǵ̣p oftento tyrannidemà Dionyfio occupatam, Plin. Interfecto Nicomede rege, equus citus ine. dia uitam finiuit, Plin. Socles forma pulchritudine egregius A thenienfis, quê mihi permulti igno rareuidentur, equum emit pulchrum, \& tam uehementi in fe amore incenfum, ut cum adeffe fenti: ret dominum, exultaret $\mathcal{Q}$ geftiret; $c u m$ afcendere pararet, le ad confcenfum praftaret obedientem: cum ante oculos confifteret, ille fuauiter $\&$ amatoriè in eum in tueretur. Qux omnia catcnus amato ria $\&$ iucunda uifa funt, quoad petulantiam in adolefcentem attentare conatus eft, fimul \& fama tur pitudinis de ambobus difipata extitit:tum eam infamiam Socles fibiconflari non paffus, ut in ama= torem flagitiofum, \& petulantem, odio incenfus equum urendidit. Is non ferens ab adamato fuo fe di fractum abeffe, acerrima inedia uoluntariam fibi confciuit mortem, Aelianus, of Nerua Traianus fimulac $P$ arthorum $\&$ Armeniorum fines ingreftus eft, regionis fatrapx, ipfiç; mox reges cum mu ' neribus ei occurrerunt, equumós duxêre ita cdoctum ut regem adoraret. Nam pedes anteriores in modum fupplicantis flexit, caputós pedibus eius qui proximus effer fubiecit, Dion Caffius in Ner.

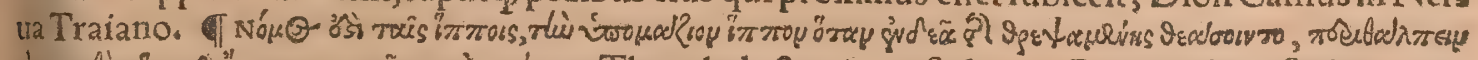

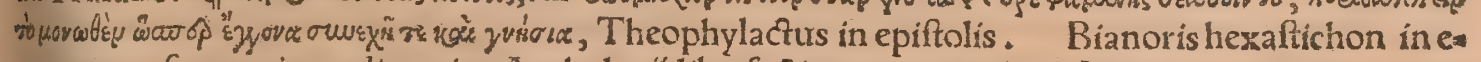
quum recufantem ingredi nauim, Anthologï lib. I. fectione 33, extat huiufnodi.

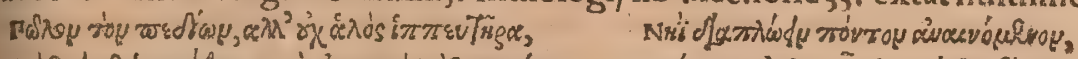

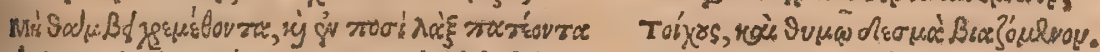

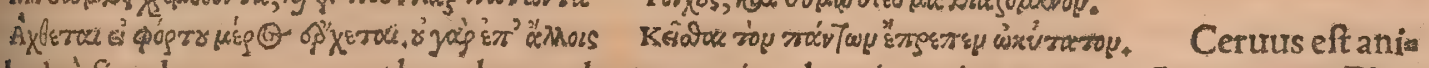
mal adeó fimplex, ur equo aut bucula accedente propius, hominem iuxta uenantẽ non cernat, Plin. H. $e_{*}$

Equres, communis generis, qui infidet equotitem qui equeftrem habet ordinem. Nos primo loco de Romanis equítibus loquemur, deinde A thenienfibur, poftea de reliquis, \& in genere quadam de ins qua ad equitis uocabulum pertinent, Sequentur ludi $\&$ certamina equeftria, equeftris res bel lica, equitatio ipfa, traçatio, ftabulum, inftumenta, currus, pretium \& fumptus in emendis alendiść equis:poftremo quędam de laudibus $\&$ ufibus equorñ, tum in uniuerfum tum ex fingulis partibus,

TEqueftrem ordinem (ut fcribit Sipontinus) medium fuifle conftat inter patricios 8 plebem. Principio equites iudicesç p̧ confulatu fuo equeftre nomen ftabiliuit, Senatum ei conciliâs, celebrans fe ex eo ordine prourecium effe, (ut Plinius refert 33.2.) Ab illo tempore plané hoc tertium corpus in repub, factum eft, coepitç adijci fenatui populoós Romano equefter ordo:ob quam caufam poft populum feribebatur, quia no - uiffimé coeperat adíci. Imprudenter quidam hoc tempore huius dignitatis uiros, qui gefiandi auri ius habent, milites uocant, cum fint equites iure optimo appellandi. Hi olim fub Romulo regibusćs Celeres dicebantur à Celere Remi interfectore, qui initio à Romulo prapofitus fuit:qui primo elect? 


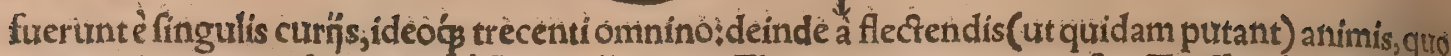
hiam iưdices erant, fiue potius à flectendis équis, Flexumines uocitatiłpoftea Troffuli, â Troffulo op pido Thufcia circa Vulfinios nouem millia paffuum, quod fine ullo peditum adiumento equites ce pifient, (ut Feftus teftatur, \& Plinius 33.2.) Varro, Nunc emunt Troffuli nardo nitidi uulgó Atth, co talento equirm. Iunius, Quòd ad equeftrem ordinem pertinet, ante Troffulos uocabant, nunc equites uocant:ideóg quia non intelligunt Troffulus nomen quid ualeat, multos pudet eo nomine appellari,inuiti tamen Troffuli fre uocantur, Hactenus Sipontinus. Horatius 2, Serm, Tu quũ proiectis infignibus, annulo equeftri. Equeftris ordinis princeps, Cicero ad Brutum libro II. Eque Itris difciplina, Verr, 6. Equitibus purpura, ut patricịs \& fenatorịs, uti non licebat, Ius ueró annu lorum aureorum non equitibus modo, tanquam bellicæ uírtutis infigne, fed $\&$ fenatoribus $\&$ milis tia primoribus datum fuit. Cautum fuit olim, ne quis huic ordini adfcifceretur, néue ius annulorum aureorum daretur, nifi ipfe ingenưus, pater \& auus ingenui forent, cuiḉ̧ feftertia quadringenta( $S e$ Tertia quadringenta, ut Robertus Cenalis computat, ualent uiginti millia librarum Turonicarum, folatorum uero bilibrium decem millia, fcribit Budxus cenfum equeftrem ad hane fummam tempen ratun fub Tiberio:cum prius quingenta feftertia requirerentur:) quod peculium equeftre habitum ef, cenfus fuiffet, (ut Plin. fcribit 23.2.)Principes equeftris ordinis olim publicani fuêre, flosín equitü Romanorum publicanorum nomine continebatur : poftea deprauatis moribus paulatim mancipes $8 x$ fcriba pro concione ab imperatoribus, uelut pracipuro munere, aureis annulis donari coppere, $A_{1}$ lexancier ab Àlexan qui copiofé \& eruditè multa de equitibus pracipué Romanis fripfit libro 2 cap, 29. Genialium dierum. Iw torem d: rnitatis, Suidas. Equites etian iudices uocabantur, quia iudicum decuriæ ex equeftuiot: dine ciel: gebantur, Budaus ex Suetonio in Cafare. Quem tu fi ex cenfu fpectas, eques Romatus eft, Cice: o pro Rof $c_{+}$Com. Equites ordini fenatorio dignitate proximi,Cicero pro Cluentio. Mar cius primus dicfator magifirum equitum fibi affumpfit $S$ purium, qui fecundus ab ipfo effet. Nam dictatura: tempore, cum munus illud magiftri equitum primum inuentum eft, proximum ab illa ho nore dignitatég erat, Suidas in Hipparchos . De equeftri ordine quadam \& origine anulorumath reorum, tradit Pliníus libro 33. cap. $1.82_{2}$.qua hic breuitatis caufa omitto, paucis tantum inde recitas tis:Quod antea(inquít)militares equi nomen dederant, hoc nunc pecunix iudices triburnt. Necpri dem id factum D. Augufto decurias ordinante, maior pars iudicum in ferreo anulo fuit: "íç none quites, fed iudices uocabantur. Equitum nomen fubfiftebat in turmis equorum publicorum, \&cs, Equites Romani quomodo iudices facti fint, Apppianus libro I. de bellis ciuil. Et libro 2, Equitess (int quit)ad omnia potentiores ob facultates, urectigaliumí̧̧ $\&$ onerum cæterorum mercedem, quxàpo pulis penduntur capientes, multitudine infurper feruorum abundantes, tertiam tributorum partem fiti remitti à Cæa fare impetrarunt. Impolitias Cenfores facere dicebảtur, inquit Feftus, quume equit as abnegabant, ob equum malè curatum. Nimis pingui hominí $\&$ corpulento(inquit Gellius infit ne libri 7.) cen fores equum adimere folitos, filicet minus idoneum ratos effe cum tanti corporis pon dere ad faciendum equitis munus + non enim poena id fuit, ut quidam exiftimant: fed munus finein nominia remittebatur. Tamen Cato in oratione, quam de facrificio commiffo fcripfit, obrícitbantic criminofius, uti magis uideri poffit cum ignominia fuiffe. Equitare antiqui dicebant equum pub cum mereri, Feft. Equeftre as, quod equiti dabatur, Feft . Pararium aes appellabatur id quod equio, tibus duplex pro binis equis dabatur, Feft. Equeftria, quatuordecim ordines in quibus equitesin theatro fedebant. Equeftria omnium equitum Romanorum funt, Seneca lib. 7. de Benef, Et iterm, Sed cum in theatrum ueni,fi plena funt equeftria, $\mathcal{X}_{c}$. Item, Habeo in equeftribus locum, non ui uendam, non ut locem, non ut habitem, fed ut fpectem. Suetonius in Domitiano, Et quia pars mas ior intra popularia deciderat, quinquagenas tefferas in fingulos cuneos equeftris ac fenatorij ordi nis pronunciauit. De fubfellís in quibus equites fpectabant, plura leges apud A lexandrum de Alle xandro 5.16. Equitatus (inquit Hermolaus in Gloffematis in Plinium) non modo equitum mantiu fignificat, $\&$ actum ipfum equitandi (ut illud Plinï: Femina equitatu atteri $\&$ adurí folent;item illud, $\mathrm{Ab}$ armorum $\&$ equitatus laffitudine $\left.{ }_{+}\right)$fed et ordinem equeftrem, uolumine 35 . capite 1. Quinetiam, inquit,ipfum equitum nomen fape uariatum eft in īs quo $\$$, qui ad equitatum trahebantur: fed ure $q$ tufti codices æequitatem habent, non equitatum, quam lectionem. Hermolaus approbare uidetur, G Athenienfium primus \& ditiffimus ordo(ut legimus in Scholijs Ariftophanis in Equites, \& aptd Calium 25.18.) erat illorum qui pentacofiomedimni â quingentis medímnis dicebantur, qu tantum fpatij ararent. Hi neceffitate urgente talentum pendebant. Secundi ordinis erant irsisis, id eft equtla

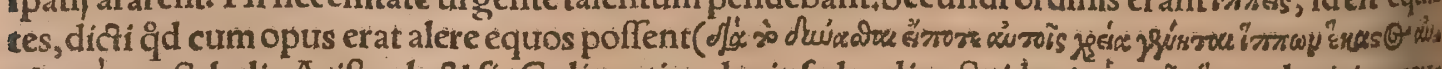

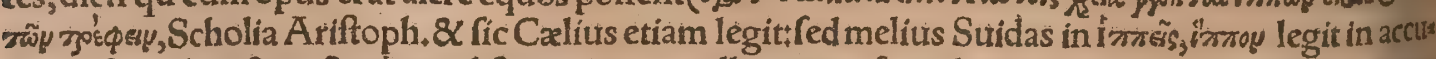
fatiuo fingulari, $\&$ poft 3 gum rou diftinguit:ut intelligamus, fingulos equites ciurtatis nomine equos fingulos alere oportuiffe:nam fi in plurali legas, de numero non conftabit.) Hi ad medimnos trecen tos poffidebant, femitalentum pendebant : $8 \mathrm{C}$ antiquitus numero fexcenti erant ? deinde aucius eft cortum numerus in tantum ut mille ducenti fierent; facrificia quar ipfin in pompis mittebant, hippades 60

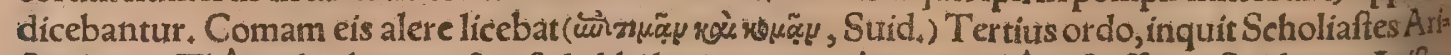
Itophanis, Thêtes dicebantur, \& $c_{4}$ fed alibi legimus zengitas ante thêtas fuiffé, ut Suidas ex Arifo 


\section{DeEquo. H.e. Lib.I.}

telis de Athenienfium rep, libro citat in dictione irmàs, $\& \mathrm{~V}$ arinus fimiliter, Sed hoc intereft, quód Varinus eo in loco fcribit in quatuor ordines diuifum fuiffe populum Athenienfem, pentacoliome dimnos, equites, zeugitas, \& thêtes $\$$ Suidas quintum addit, hippảda uocans:quod minus placet, quw Hefychius etiam quatuor tanturm ordines faciat, Zeugitx dicebantur, fecundi cenfus ciues, qui zeûgos, id eft iugum mulortum alebant, Budæurs: Vide etiam infra in re curuli hac ipfa parte huius capitis, Sacrificia ab equitibus celebrata hippádes dicebantur $\div 8$ bos ad facrificium adhibitus, $B \tilde{s} s$ innexs: cenfus etiam quem conferebant inziós uocabatur, Hefych. Diximus autem fuperius ex Calio dimidium talentum equites pendere folitos fuiffe, hoc eft coronatos aureos trecentos: quamobrem miror hippáda ríunux uungóy, id eft paruum cenfum à Varino exponi. Hippada aliqui penfionem ea

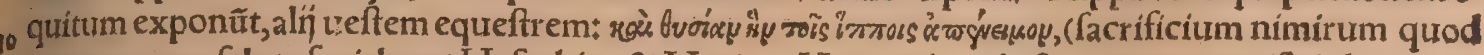
pro equorum falute faciebant) Hefychius $\&$ V arin. Hipparchi, id eft equitum magiftri duo tantur (quod \&. Suidas fcribit)ex omni A thenienfium numero creabantur, qui curam bellorum gererent: plylarchi urerò decem, unus falicet ex quaq, tribu, equitibus praficiebantur, Pollux, De hippars chi officioXenophontis librum habemus: 8 Socrates apud eundem libro tertio A pomnemoneuma.

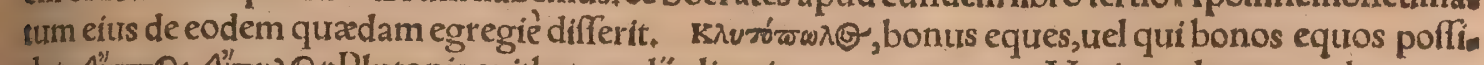

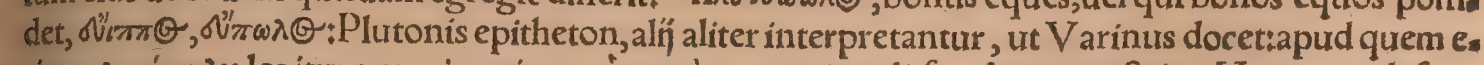

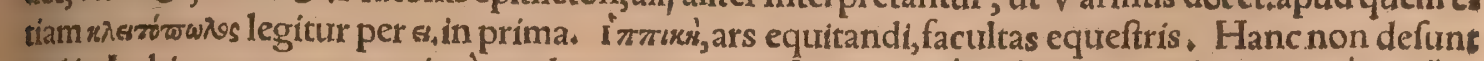

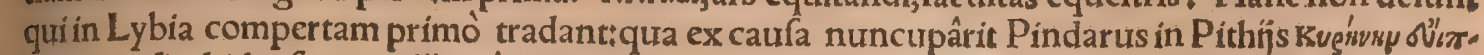
mop:etiamfi ad id referunt alin quòd ab Neptuno edocti fint Libyes currus iungere $\ddagger$ quin $\&$ Pallada - equeftrem in Libya genítam, Cal. Vide infra in Neptuno hippio. IEques etiam pro ipfo equo accipitur à Vergilio, ut fupra dixi. Omnes antíqui fcriptores (inquít Seruius apud Macrobíum circa finem libri 6.) ut hominem equo infidentem, ita $\&$ equum ctim portaret hominem, equitem trocaue. runt ( 8 equitare de utrog; ut infra probabimus:) Ennius, Deníg ui magna quadrupes eques atç elephanti Proijciunt fefe. Hominem qui equo infidet, Veget. fefforem uocat. Equifeffor uox com pofita apud Calepinum legitur, fed fine authore. Equeftris, qui equo urehitur, ut circulator equeAtris apud A puleium, Scoppa. De equitibus 8 eorum officio, in diuerfis epiftolis quadam fcripfit Antonius Gueuara Hípanus: Extant autem epiftola illa Hifpanicè, ut ab eo fcriptæ funt, 8 in Itali cam linguam translata: Qui qualesç̣ fuerint equites Achri, Chalcidenfes, Cretenfes, Capuenfes, Gaditani, Germani, Patauienfes, Perfae, Alexander ab Alexandro docet in diebus genial, 2. 29. - Hippobotas Chalcidenfium ex hiftoria dici nouimus prædiuites, gloria quog pracellentes, Calius, intês apud Lacones uocabantur adolefcentes (veaviou, iutrenes transfert Caliús 19,22.) qui iuftos $a=$

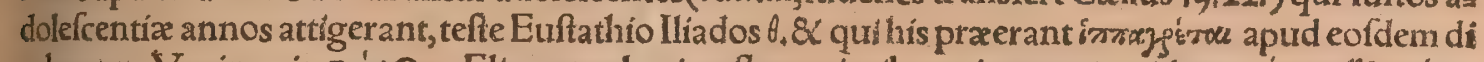

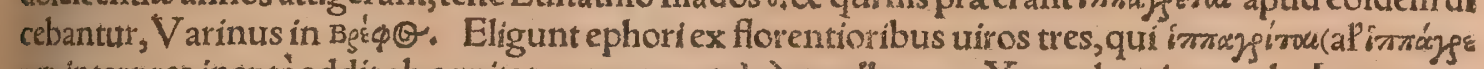
rou, interpres inepte addit ab equitatu congregando) appellantur, Xenophon in repub \&aconum. In Lacedamoniorum repub, monarchia ad reges, arifocratla ad fenes, oligarchia ad ephoros, demo. cratia deniç ad hippagretas 8 iuuenes pertinet, Archytas Pythagoreus apud Stobaum in Sermo:

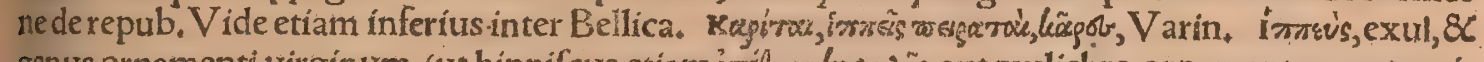

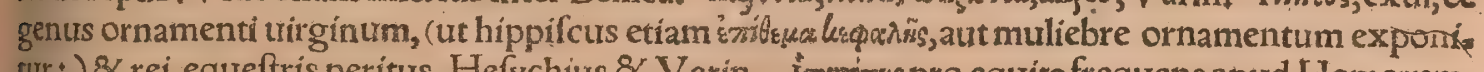
tur: ) \& rei equeftris peritus, Hefychius \& V V arin. i iroross pro equite frequens apud Homerum, o prafertim pro epitheto Neftoris:recentiores aliqui exulem exponunt, fed melius eft equitem inter

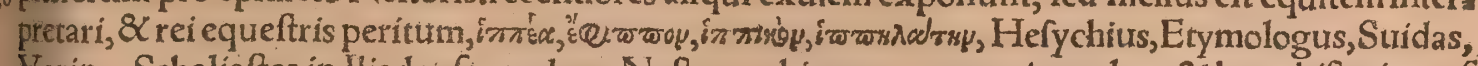
Varin. Scholiaftes in lliados fecundum, Neftorem hippoten exponit exulem, $\&$ hanc hiftoriam af fert, Hercules cum occifo Iphito expiari à Neleo non impetraffet, $P$ ylum obfedit: $\&$ propter Nelei fi. lioum imprudentiam magnis fubinde malis urbem afficiebat. Qua quidem quandiu nueret Peri clymenus Nelei filius, difficilís expugnatu erat:quòd is amphibius (uitæ mutabilis, uide Onomafticon in Periclymeno)effet. Sed tandem in apiculam mutatus, cum Herculis currui infideret, proden. teMinerua, ab Hercule interemptus eft. Tunc igitur Pylouaftata, \& undecim eius fratribus occi fis, Neftor qui in Gerenis alebatur, folus remanfit, Gerenius inde cognominatus, ut Hefiodus in $\mathrm{Ca}$ talogis refert. E"rox $\chi($, qui uehitur equo izel curru: hinc orationem metro $8 \mathrm{~L}$ numeris aftrictam "zros oxy appellant à fublimitate : profa enim ueluti pedeftris \& humilior eft, ut refert etiam Calius 7.1 . "Toxov inter equi inftrumenta legiffe uideor alicubi, Calius: Vide infra in ephippip mentione i i

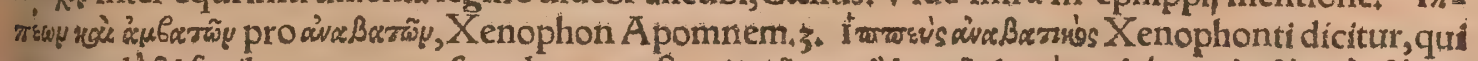

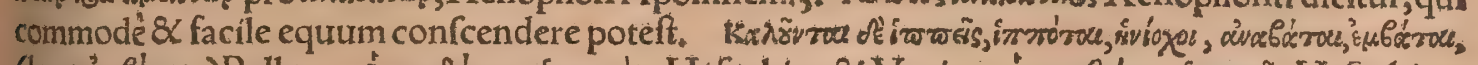

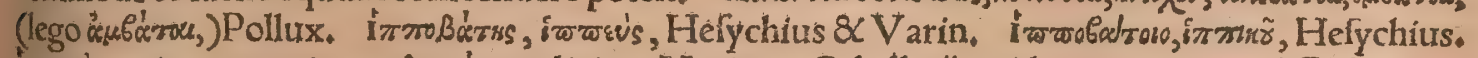

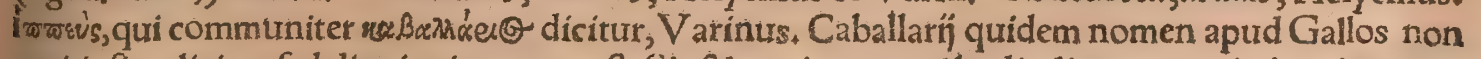
equitis fimpliciter, fed dignitatis nomen eft. Sic $\&$ equites aurati hodie dicuntur qui uirtutis merito âregibus uel cæararibus, torque aurea, ni fallor, donantur, Equites etiam fiunt (fi modo per cenfum li ceat)hoc dignitatís nomen adepti, qui religionis caufa fepulchrum DominiHierofolymis adeunt,

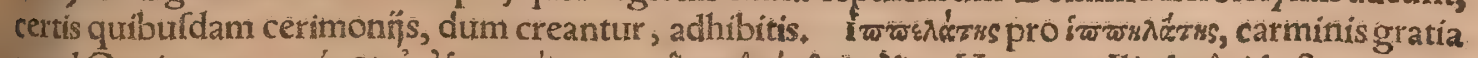
o apud Oppianum, Nóroly \& $\varphi^{\prime}$ in ftris peritorum. Apud $V$ arinum $6 \pi$ mo

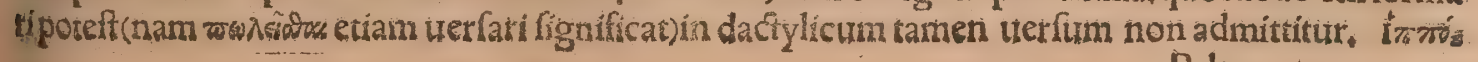




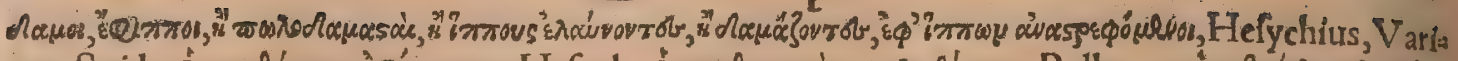

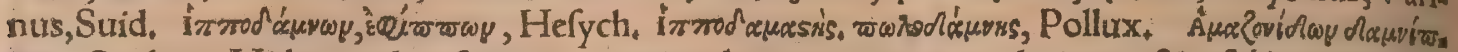
woy, Orpheus. Vide quadam fupra parte prima huius capitis inter deriuata : \& infrà hac ipfa parte

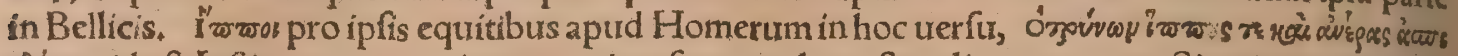
fívers, id eft, Inftigans tum equires tum uiros fcutatos, hoc eft pedites ar matos. Sic etiam communi.

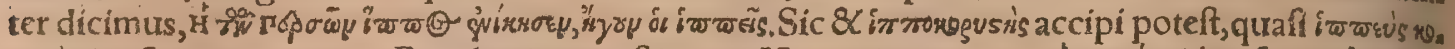

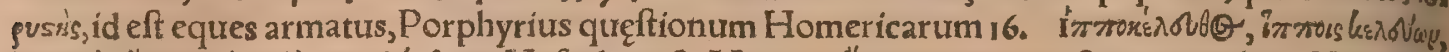

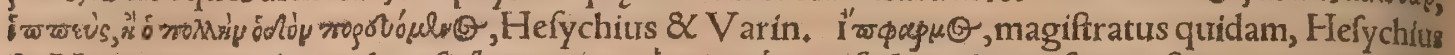

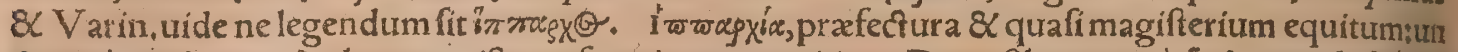
de uerbum i๘

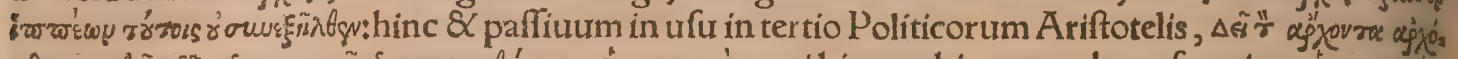

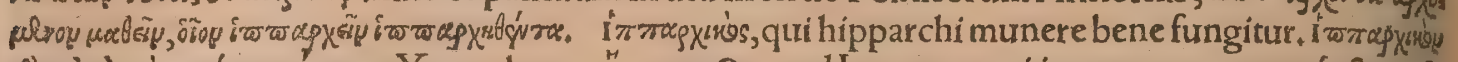

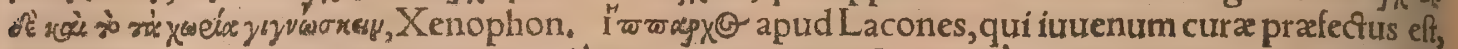
Hefychius \& Varin.nos eundem paulò ante hippagretam Laconice dicimonuimus. Hipparchi ta bula:quoniam apud Syracufanos hipparchi feripta in tabulis nomina illorum qui aliquid deliquifo tent notabant, Suidas:ex quo etiam mancus Hefychỉ locus reftitui poteft. Videtur autem prouer. bị uim habere, ut uulgó etiam ca talogum pro reprehenfione dicimus, $\mathcal{Q}$ catalogum alicui legendr̂, pro eo quod eft increpationem expectandam:nimirum à ludimagiftrorum more qui puerorum no mina in tabulis feripta (ut in matricula, fic uocant, academiarum rectores) cum uel abfuerint, uel pec carint aliquid, ne per obliuionem impune abeant, puncto notant in fulco cera expleto. Erafmus in Chiliadibus it wapyes in pluralí numero fribit, et Hipparchorum tabulam uertit, cum Suidas et He

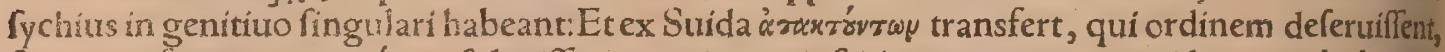

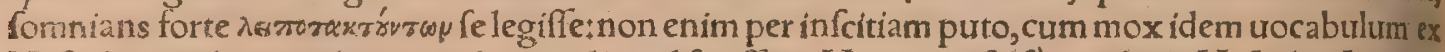
Hefychio meíus reddat, qui indecore aliquid feciffent, Hoc etiam falfó attribuit Hefychío Laceda: moniorum hipparchum delinquentium nomina in tabula fcribere folitum; nihil aliud enim de Laco num hipparcho Hefychius feribit, quàm quod iuuenibus prafectus fuerit . Deinde nouo initio fas

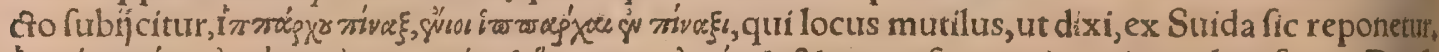
17r rá prourerbij recté Erafmus, quoties haud impune futurum, fi quid peccetur, fignificabimus. In eundem

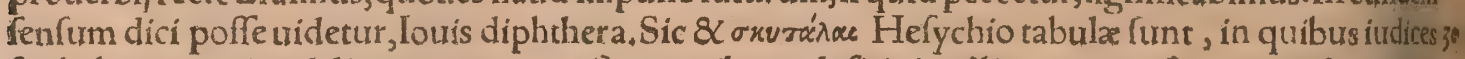
fcribebant nomina delinquentium. TSunt quibus calafiris intelligatur equeftris tunica latior, quã

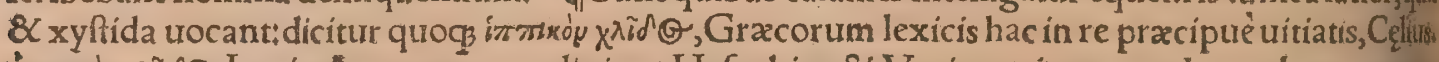

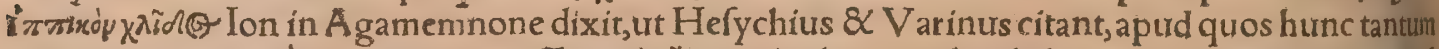

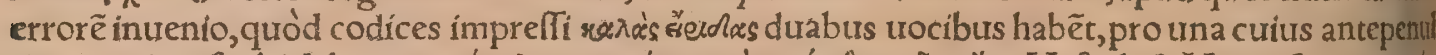

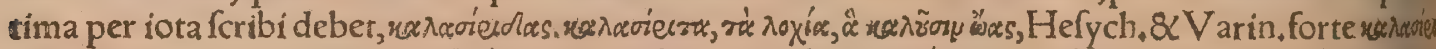

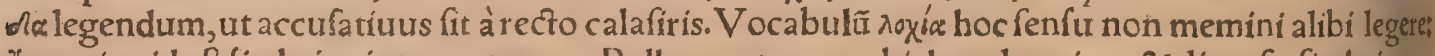
was enim, id eft fimbrias inter pretantur. Pollux certe 7.13 . ubi de oa loquitur, $8 x$ diuerfa fimbriartim uocabula recenfet, nuilum habet huriufmodi. Idem 7.16. calafirin tunicam Aegyptiam thy fanotam, id eft fimbriatam effe docet: ubi tamen utrunç tocabulum, calafiris dico $\alpha$ thy fanotós, nonrecie

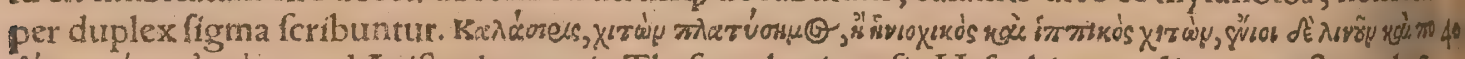

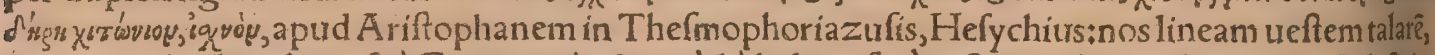
uocamus ein dbitrel, quafi à Græco yørìn*\& quód à balneo feré geftetur, cin basbembo. Calafiris,

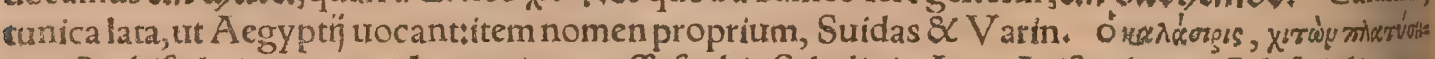
No: Cephifodemus uocem A egyptiacam effe fcribit, Scholia in Aues Ariftophanis: Calafiris linea tre fis facra, Varinus in I'es. A egyptịs in more fuit ut Calafiries, qui precipui habentur milites, ànuls lo doçore, fed à patrefolum, militia pracceptis erudirentur, Alexander ab Alexandro.Kéaras inths xós nominat Xenophon in Cyri inftitutione: funt autem غ̇ã

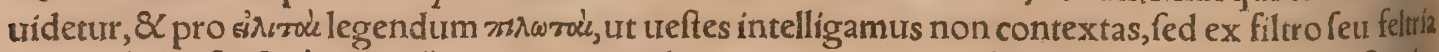
lana in fe confercta à pilotarijs concinnatas, de quo panni genere pluribus in Tauro docui : eft enim hor genus foliditate denfitatéćs fua equitibus præcipué aptum aduerfus pluuias. Germani uocant 1

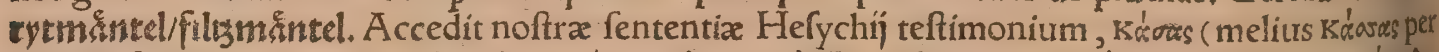

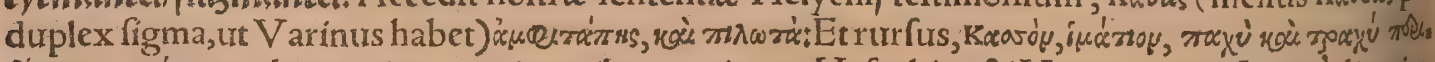

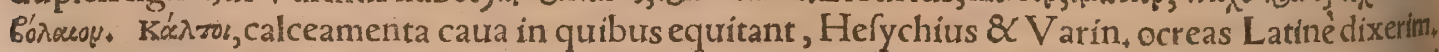

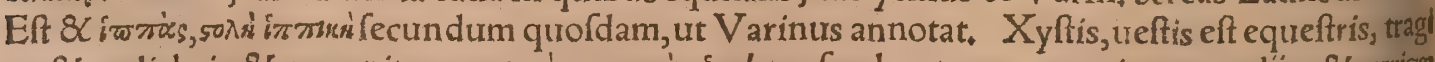

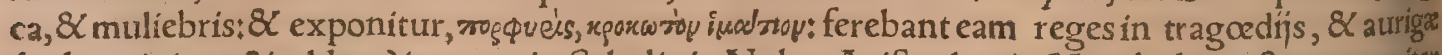
(uel equis inurecti athletæ)in pompis, Scholia in Nubes Ariftophanis: Vocabulum eft communiter oxytonum, Atticé paroxy tonum, Mantelli nomine pro uefte equeftri, \& Germani ưtuntur, ut iam dixi,\& Galli alizéç gentes:uidetur autem originis Perficæ uox, Maudíxus, genus Perficæ ueftis qua utebantur in bellis, Varinurs \& Hefychius. Reperitur \& xávd vs eiufdem fignificationis, ut alterutrú

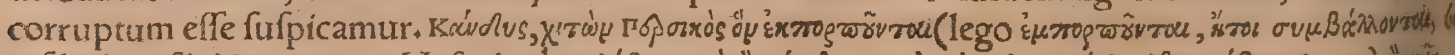

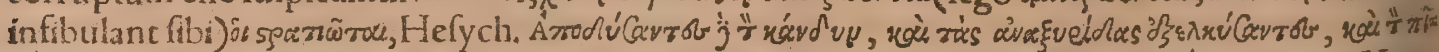

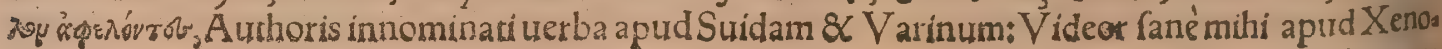


ubi plura de curribus dicentur.) Quod,inquit, uel ad mea feruatum tèmpora eft. A péne autem mis las equorum loco iungebat. Celeta inftituiffe Bellerophon traditur primus; fynorida uerò $C$ aftor, currum Erichthonius Athenicnfis, aftraben Oxylus Aetolus, Hucufq̧̧ Calius, Quantum clamore iutuatur Elaus fonipes, quamuis iam carcere claufo Immineat foribus, Lucanus libro I. Vergilius in Georgicis cưm alia quadam pertinentia ad equos curfu certantes in circo uel agône Olympico fcribit (qux fupra alicubi recitaui, in celeris equi, ni fallor, mentione) tum qua fequuntur carmina,

Ergo animos aưứć notabis, Et quis cuiç3 dolor uicto, quæ gloria palmæ;

Nónne uides?cum præcipiti certamine campum Corripuere, rưntóg effufi carcere currus:

Cum fpes arreçx iuuenum:exultantiaç haurit Corda pauor pulfans, illi inftất uerbere torto,

Ex proni dantlora:uolat ui feruidus axis. Iamós humiles, iamó́s elati fublime uidentur Aér a per uacuum ferri, atç affurgere in auras, Nec mora, nec requies: ut fultuæ nimbus arenę Tolliturthumefcunt fpumis, flatứ̧̧ fequentum. Tantus amor laudũ, tantæeft uictoria curr. Et rurfus, Sin ad bella magis ftudium, turmasćs feroces : Aut Alphea rotis pralabi flumina Pifa:

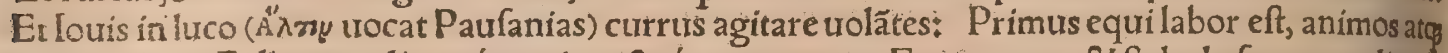
arma uidere Bellantum, lituosós pati:trąqúç gementem Ferre rotam, \& ftabulo frenos audire fo nantes, Hrcille. Quis Eleas potior luftrauit arenas? Gratius de equo Theffalico uel Mycenis nan to. Suntquos curriculo puluerem Olympicum Collegiffe iuùat, metaç feruidis Euitata rotis, palmáćs nobilis Terrarum dominos euehit ad deos, Horatiưs Carm, Ode 1. Etrurfur Carm, li.4. Ode 3. Illum non labor Iftmius Clarabit pugilem:non equus impiger Curru ducet Achaico Vis ctorem. De certaminibus facris, Celius 21.31. De quatuor facris Gracię cèrtaminibus, Leonicentus 1.68. Quis primus inftiturerit apud Gracos Olympicum certamen, \& alios id genus ludos, Polydow rus 2.13. Deprimis Olympici certaminis fundatoribus, \& reftauratoribus poltmodum, Leonicenits 2.57. Nulieres ab Olympijs excludi folitas, Calius 14.14. Hellanodicæ qui, \& quomodo in fola Ariftopatera legem Olympiorû tranfgreffi fint, Tzetzes 12.407 .81 1.23. \& Leonicenus in Varijs 56. ubi hanc mulierem Olympris fpectandis contra leges admiffam, Callipateriam irocat, \& filium

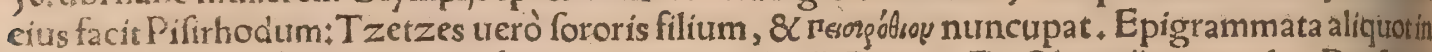
quatuor facros agônes habemus à principio Anthologî Graci. De Olympijs permulta Paufanias in Eliacis libro 1. ex quibus translata quadam per Calium Rhodiginum fupra recitaui . Entunerat

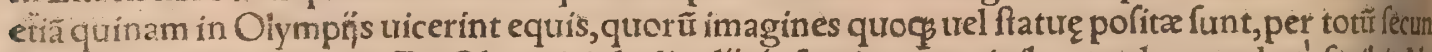
dum Eliacorum librum. De Olympicis ludis, alijsḉ facris certaminíbus multa praclaré feribitAle

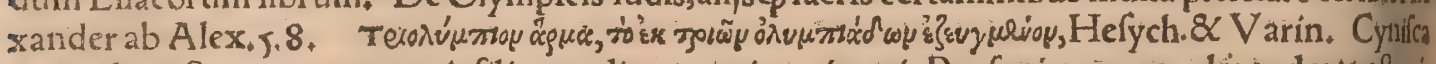
Archidami Spartanorum regis filia, mulierum prima, inquit Paufanias, equos alére adorta eftiprí má́s curru adepta uiçoriam elt in Olympicis. Eius herôum uifebatur in regione, quam de platano rum copia plataniftam uocant, Calius. Equi eius ænei, magnitudine equis minores, uifunturinuti

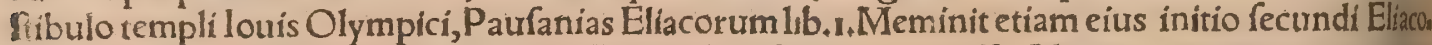
rum, Equo in Olympia uiciffe aiunt Iafium, Paufanias. Viciffe Olympia prægnantem equam Echecratidis Theffali inurenimus, Plinitus. Miltiades unus ex decem ducibus Athenienfium in.48 rathône, patrem habuit Cimonẽ Stefagoræ, qui Pifftratum Hippocratis ex Athenis fugit: $\$$ dum fugit obtinere Olympiadem quadrịugo certamine, quam uictoriam muneris gratia trãftulit in Mi tiadem ex natre germanum : proximáç̧ Olympiade eifdẽ equabus aliam Olympiadem cū uíiffet, â filịs $P_{1}$ ififtrati interfectus eft, mortưo iam Piffifrato:fepulturs $\not \beta$ ante urbem trans uriam quęuocatur Diaccle: Et ér egione fepulta funt equa illæ, qux treis Olympiacas urictorias reportarãt. Idem quod ifta iam aliæ equæ fecerunt, quæ fuerunt Euagor Lagonis (quę etiam in ludis Eleis uictricesfựe) alix præterea nulla, Herodotus libro fexto interprete $V$ alla. Huius Cimonis meminit etiã Tzetzes 1.12, uitam eius Plutarchitss confcripfit. De Olympia, id eft Iouris Olympö templo in agro Pifano, \& iuxta eam luco campọ́, \& Olympici certaminis origine progreffuḉ, lege Strabonem libro octati, - Hippodromus, locus ad cur fus equorum deftinatus, qui ftatim intrantium oculis totus fimul offer turr, hinc atç hinc platanos, aut buxos, aut cupreffos, aut alias arbores perpetuó uirentes habens. In eo de pernicitate equorum certatur; citra fimulachrum pugna, \& à curfu equorum a ppellatur, Bus,

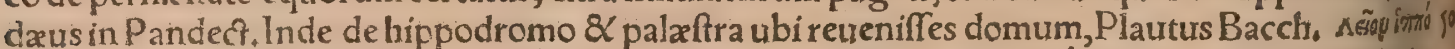

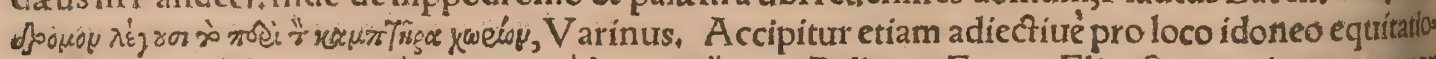

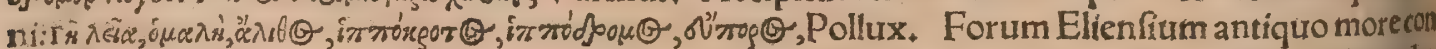
ftructum, porticus inter fe diftantes habet, \& uias per eas: Vocatur autem noftro tempore Hippodro mus, $\mathcal{L}$ inftiturunt in eo equos íncol $x$, Paufanias Eliacorum 2. Cum omnis Alexandria equorum Itudijs uehementer incumberet, atç in hippodromo ad hoc fpectaculum ciuitas uniuerfa conuenis ret: tantaćs plerunç or iretur contentio decertantium, ut fefe mutiò etiam perimerent, hunc morem graniter redarguit A pollonius, Philoftratus. Hippodromus certamen Athenis in honorem Thelei celebratum, Hefychius $\&$ Varinus. Hippodromia, id eft certamen currentium equorum, poftreli cua certamina celebrari folebant, Scholia in Pacem Ariftophanis. Azanen Arcadis fuiffe filium, Paufanias fcribit, quo moriente, certamina fint propofita primimm, pracipue uero hippodromiam, 60 id efi cquorum curfum, Cal. Philoftratus in Hippodromo fophift, Olympiodoro eitus patri gloriz

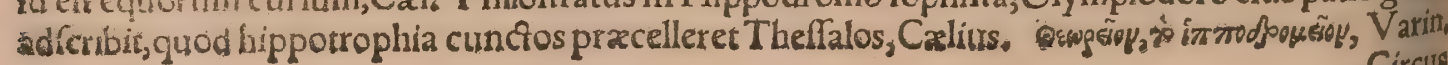


mus effet hizeticorum, Siquidem adhuc erat in uiuis, quum ea fcriberet Tertullianus, Hæec Erafm. Quintilianus libro undecimo ita fcribit, Tranfire in diuerfa fubfellia, parum uerecundum eft : nam \&Caffius Seuerus urbanè aduerfus hoc facientes lineam popofcit. Hic ego lineam(inquit Calius s. 14.) longurium accipio:fic enim longiores perticas, aut robuftiora ligna, qua in ftabulo equis inter: ponumtur, ne confurgant in pugnam, aut fe mutuó feriant, appellari obferuauimus. Seruius Aen. quinto, ubi in ludorum celebratione Virgilius ait: Signóç repente Corrípiunt fpatia audito, lie

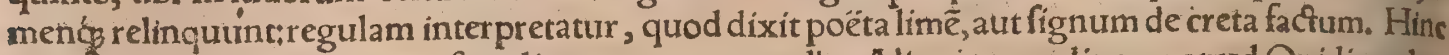
eft cur in ludis ab eruditis perfape linea nuncupetur alba. Aliqui tamen lineam apud Ouidium lon gum in Circo fedendi fpectatorum ordinem interpretantur. Porrò ut in carceribus uifebatur linea, fic $\&$ in meta, ubi uincentibus proponebantur pręmia, ut $P$ indaricus tradit interpres. Longis porró lineis quid fieri, eleganter dicitur, quod è longinquro fit:uelut, extrema linea amare apud Terentiú, Hac Calius: Ego lineam uideo pro filo etiam \& fune accipi, tut in linea pifcatoria ¥ trebantur autem

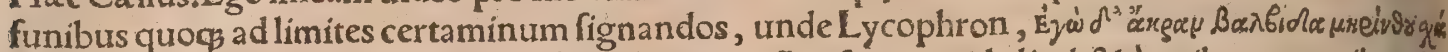
Cos:quanquam \& lignis tranfuerfis ufos reperimus. Ars fit, an quid aliud, \& à quibus carceribus der currat ad metas, Varro de re Ruft.1.3. Curriculum, locus in quo certamen currendi exercetur, Sunt quos curriculo puluerem Olympicum Collegiffe iuuat, Horat,nifi quis curriculum à currı diminutiuum accipiat, ut Curtius lib. 8. Aliorum turbati equi non in uoragines modò, lacunasć, red etiam in amnem pracipitauêre curricula. Tu cum de curriculo petitionis deflexiffes, Cic, pro Mur. Accipitur etiam pro curfu, Quod fine curriculo \& fine certatione corporum fiat, Cicero 2, de Legib. Karridjoopor eft ftadium, in quo equites decurrere folebant imaginario prælio (hippodro mus uero citra pugna fimulacrum) Latinè decurforium dixeris, Budaus in Annotationib, Ekykghts oliv, locus equeftrium certaminun, \& templum lli,Hefych.\& Varin. Enechelidon, locus Athenis fladiorum octo, in quo hippodromix fiebant, ab Echelo quodam dictus, Varin. Fuit autêEchelus

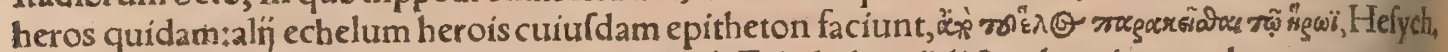
Echelidx (authore Stephano) uicus eft Atticx, ab Echelo heroé dictus: heroi autem hoc nomen cona tigit à loco qui dicitur Helos, inter Pirzeum \& Tetracomum Herculeum fito, ubi in Panathenxis a

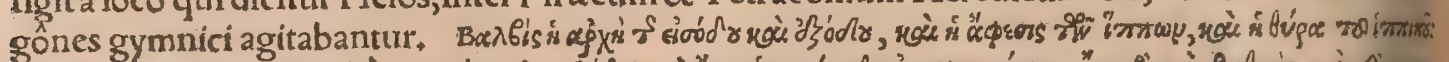

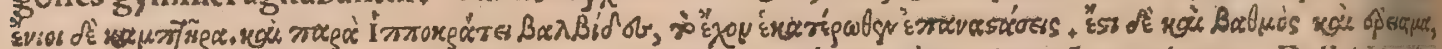

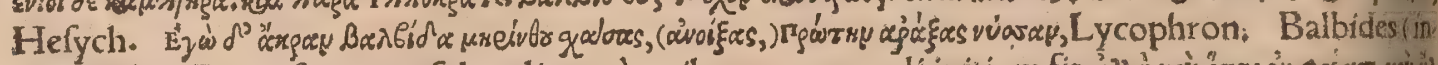

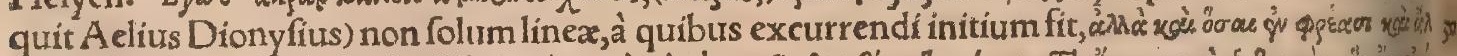

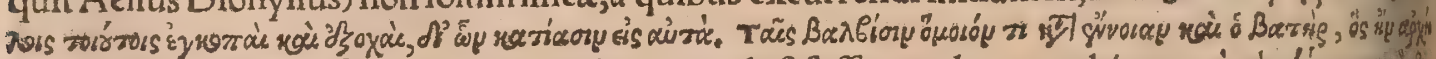

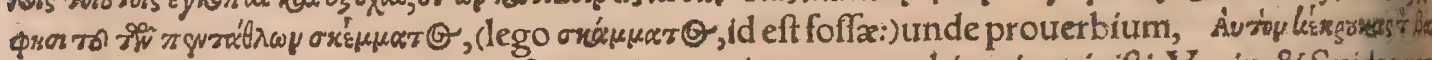

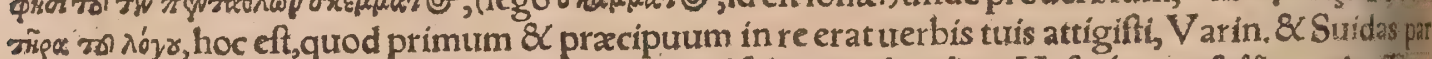

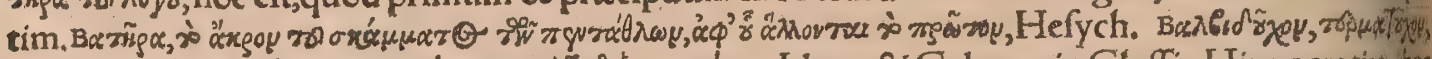

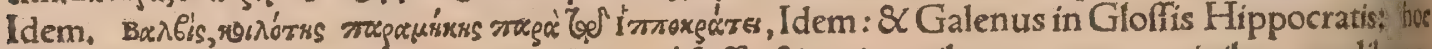
eft cauitas oblonga: per metaphoram fcilicet à foffis, 8 eminentibus earum marginibus, qualibus as

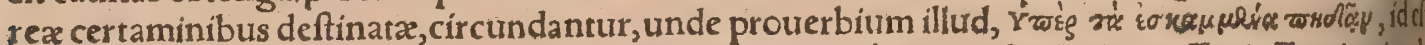
ultra foffas faltare, cuius meminit Suidas, $8 \mathrm{~K}$ metaphoram à pentathlis duclam effe ait. Ferri enim it Phayllo Crotoniata uel Opuntio pentathlo, $Q$ foffas qua pedum quinquaginta latitudinem habs bant, primus tranfilierit: quod teftimonïs ex epigrammate $8 X$ Cratylo Platonis probat. Simile ef 4 prouerbium, Extra oleas, quod Erafmus locum habere ait, ubi quis terminos prafcriptos tranfgre

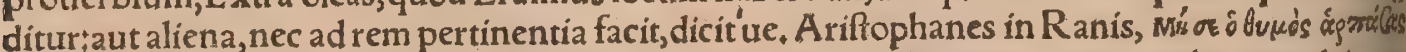

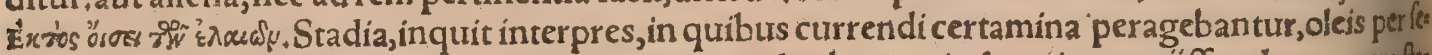
riem pofitis utrin ${ }_{\beta}$ fepiebantur, quas præterire non licebat:proinde qui praterịffet oleas, extrafar

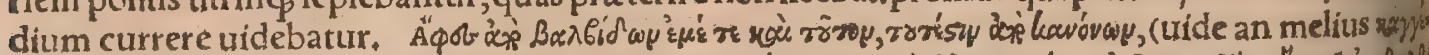

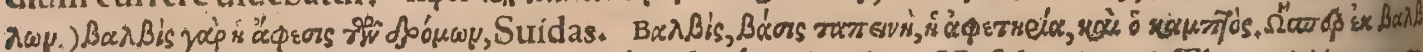

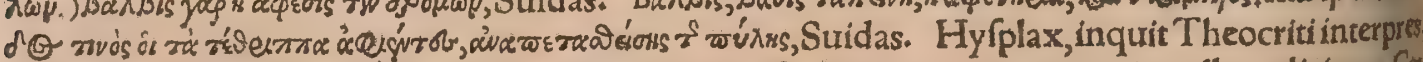
laquei fpecies eft, proprie autem curforum carceres fíc uocantur, quem nos cancellum dicimus, $\mathrm{C}$ (a)

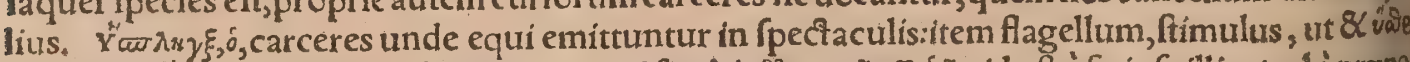

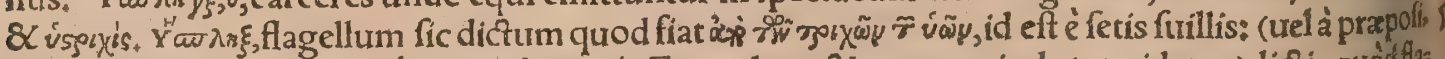

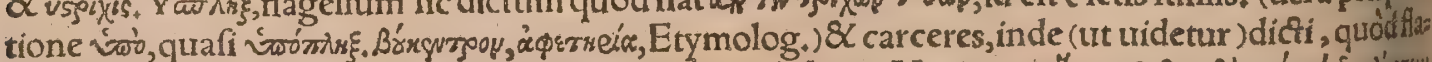

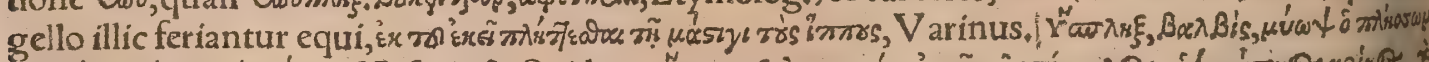

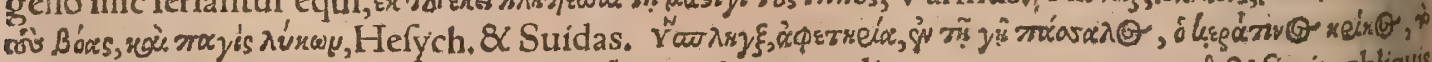

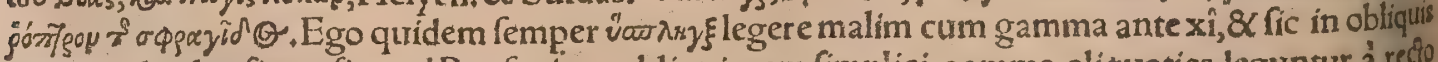
gamma duplex fiet:etfia a ud Paufaniam obliqui cum fimplici gamma aliquoties leguntur à recto

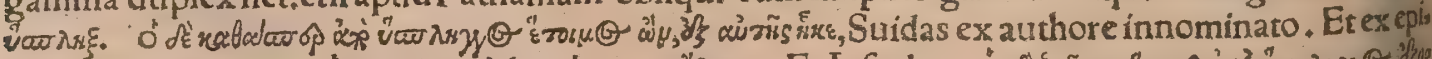

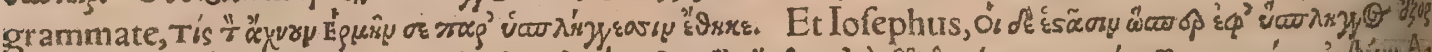

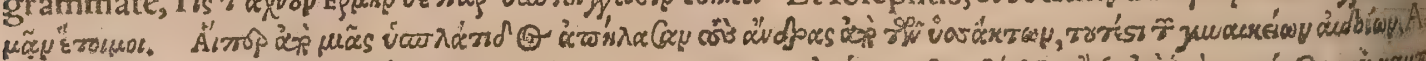

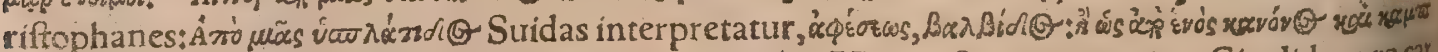
axip (0). Circumfribere cancellis, Erafmus in prouerbio Minore finire pomcrio. Cinclides pro car

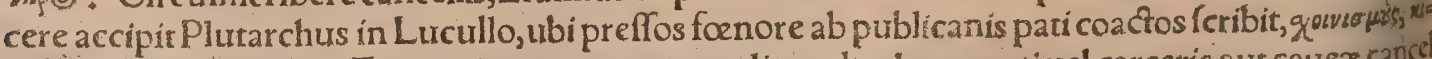
jaídas, ky imars, Calius: Ego potius certun genus aliquod uel tormenti uel carceris aut cauea cancel 


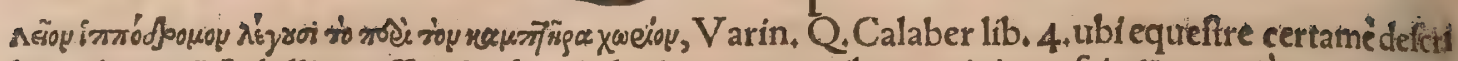
bit in honcrẽ Achillis, nyffan duobus in locis pro carceribus accipit, nefcio đ̆ proprié:eodẽ certe in

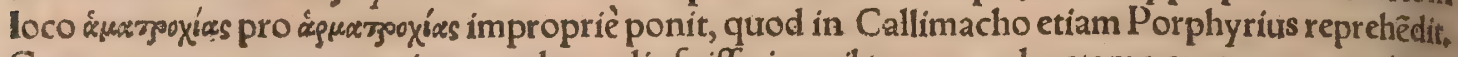
Caterum non nego certamina quadam talia fuiffe, in quibus cum ad metam peruenerant equi, cirs ca illam reflectebantur, $\&$ ad carceres redibant, fiue femel fiue quotiefcunç uifum fuiffet:in his qui dem metam \& nyffam fiue camptêrem pro eodem termino accipere nihil uetat; in fimplici aũt curfur,

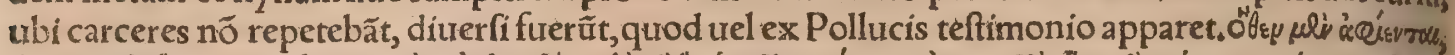

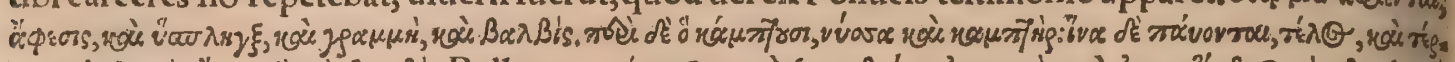

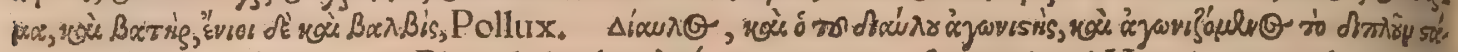

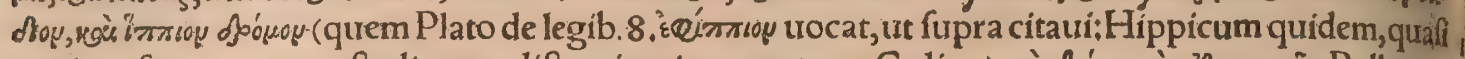

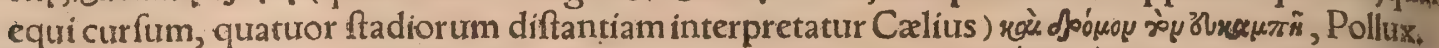
Meta, congeries feu ftrues in acutum tendens, ceu turbo inuerfus, cônos à Gracis appellata, quia ef fet pofita in dimenfo fpatio, trel quia eam metiantur quadrigæ circùm currentes; moris enim erat fe. pties metam luftrare, Propertius libro 2. Eleg. 16. Aut prius infecto depofcit pramia curfu, Septio ma quam metam triuerat ante rota. Quum enim iam carceribus emifix ad metam ueniffent qua. driga, erat opus ut circum ipfam fiecterẽtur. Vergilius quinto Aeneidos, Hic uiridem Aeneas fron denti ex ilice metam Conftituit, fignum nautis pater, unde reuerti Scirent, \& longos ubi circùm flectere curfus. Seu feptem fpatịs circo meruêre coronam, Ouidius de equis in Halieuticis. Hic ucl ad Elei metas ${ }_{3} \&$ maxima campi Sudabit fpatia, Vergil. Metæ quàm mollis flexus, Perfits Sat, 3. Indici equi apti funt certaminibus currutum, quos qui urehũtur in orbem agunt, ut fupra in $B_{\text {d }}$ di $=8$ xi. Hamatrochia, affociatus curfus, quafi opoodo opax harmatrochia uerò, rotarum orbita. Hanc interfi tionem Callimacho in Homeri enarratione (lliad. ф.) fuiffe incognitam miratur Porphyrius (in qua ftionibus Homericis,) Calius. De curfus certamine per calpen $\&$ apenen, nonnihil etiam fuperius dixi, ex Paufania interprete Cęlio. Tranftulit eundem locum Leonicenus etiam 2. j8. fedinepté,nec integrum, ut Calius quoọ. Nos hî́c quę illi omiferunt ex eodem authore conuerfa addemus. Calpès igitur certamen, ut Plutarchus etiam in Sympofiacis meminit, Olympix introductum, non multó

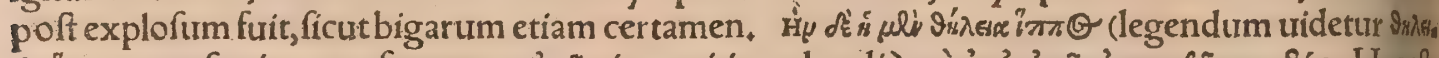

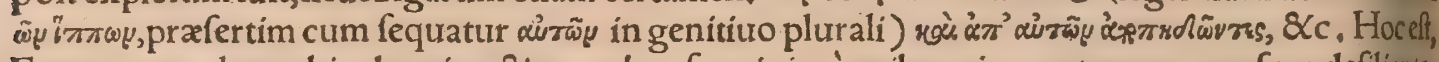
Erat autem calpe uchiculum iunctis equabus foeminis, à quibus circa extremum curfum defilientes

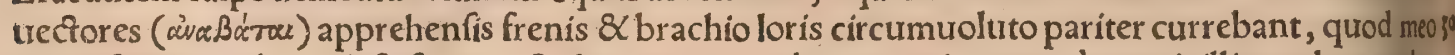
etiam feculo anabatæ dicti faciunt. Sed qui nunc anabatæ nominantur, à ueteris illius calpes anabar. tis differunt:nam \& currendi figna uariant, \& equis utuntur mafculis, Cęterum apene neq̧ uetusiu mentum elt, neç fanè decora erat. Similis enim erat bigis, fed mulos prọ equís habebat. Tó 7fivvartuy

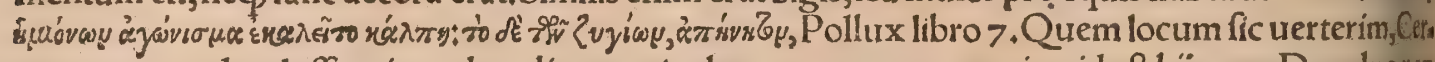
tamen per mulos doffuarios calpe olim nominabatur, apene per zygios, id eft bịuges, De calpetion

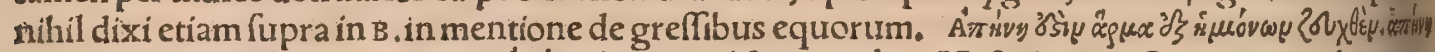

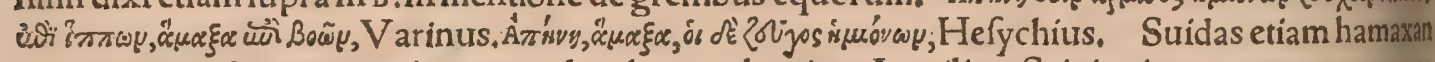
inter pretatur: \& ex innominato quodam hæc uerba citat, Aemiliam Scipionis uxorem præter onna

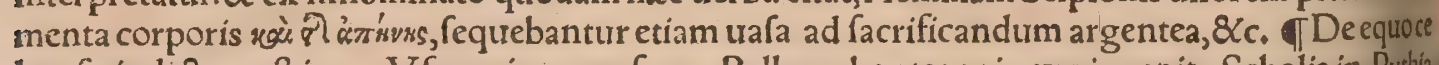
lete fatis dictum eft in B. V fum eius cum freno Bellerophontes primum inuenit, Scholia in Pychia

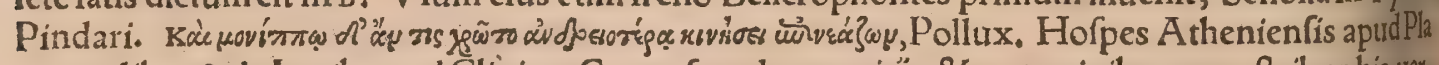
tonem libro 8.de Legibus, ad Cliniam Cretenfem de exercitịs \& certaminibus equeftribus his uer, bis utitur : Equorum ufus in Creta magnus non eft : Quare neceffe eft ftudium in nutriendis equis,

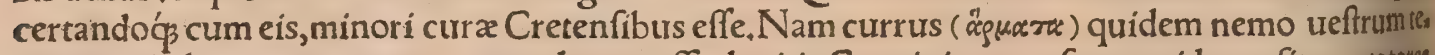
net:neç in hoc operam ponere præclarum effe ducitis. Cum igitur confuetum id non fit, certatopes

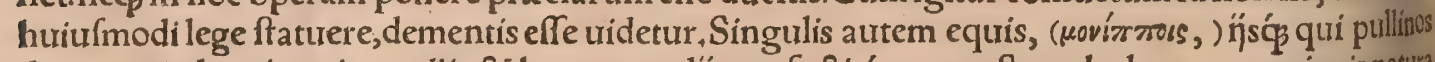
dentes nondum iecerint, pullis, \& horum medij's perfectis ǵs, equeftrem ludum pro regionis natura tribuere licet, Hurufmodi ergo certamen fecundum legem fit: in eoóp iudicium magiftris equitunet tribunis, tam de omni curfu equorum, quàm de his qui cum armis defcendunt, communiter tribuas tur. Non armatis uerò neģ in gymnafticis ludis, neq̧ hic, certamen præmiumó̧ imponimus, Hade nus Plato. Synoris, इuvweis, (inquit interpres Ariftotelis in Nebulis) ef currus non plenus, fedex duobus iunctus equis, quem nunc diphron uocamus: quanquam eo proprié dicitur nomine incurs ru pars, ubi cum parabate urerfatur auriga:unde etiam inclinatur quafi fooфóg $\Theta$, id eft duos ferens, aucfor Euftathius, Cæl. Synoridem Caftor inuenit, Scholiaftes in Pythia Pindari. Synoris cratbiga

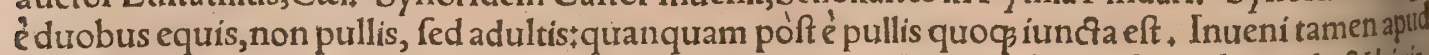
Ariftotelem in libro de mundo, etiam in bello ufos fynoride, Calius, Plura fuper fynoride \& bi quære in Dictionarị̂s Græcorum Latinorum'̧́, 8 in Commentarñs linguæ Græcæ Budxi. drigas bigasćs $\&$ equos defultorios agitauerunt nobiliffimi iuuenes, Tranquillus in uitaCấri Dict. Iam brijuges $\&$ quadrïuges, $\&$ tota curruum uectura atç aurigatio, quæ circi quondamfuit

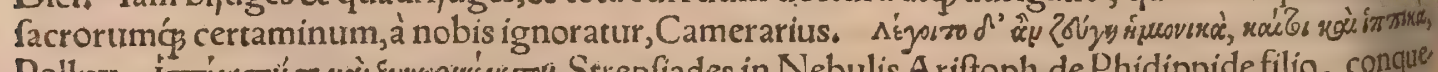

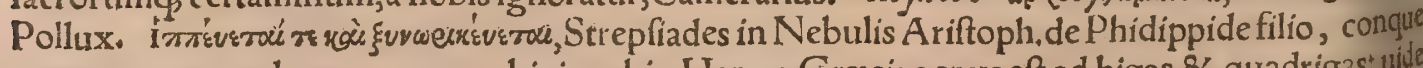
rens eum nunc celete equo, nunc bigis uehi, Harma Gracis genus eft ad bigas $\&$ quadrigas; 


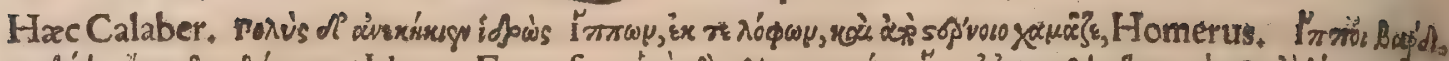

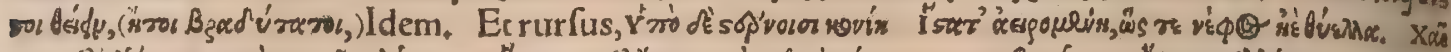

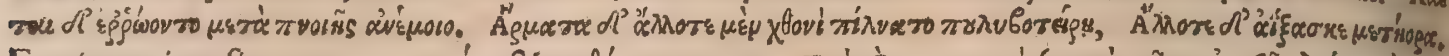

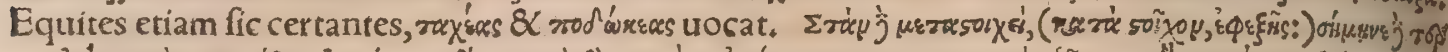

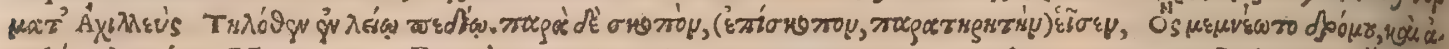

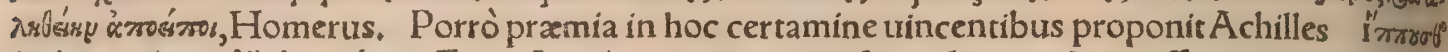

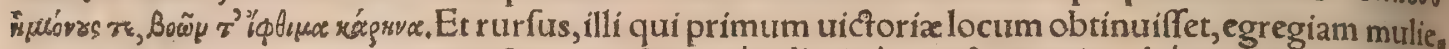

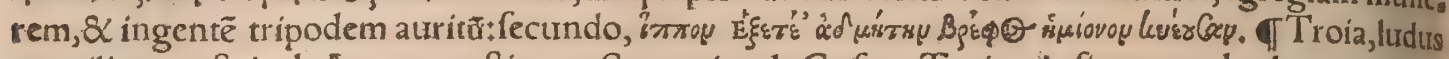
puerilis equeftris ab Aenea conftitutus. Stretonius de Cafare, Troiam lufit turma duplex maiorum minorumó puerorum. Ludus ipfe quem uulgo Pyrrhicham(ego Pyrrhicham aliud non effe quàm faltationis genus in armis hactenus femper legi) appellant, Troia uocatur, cuius expreffit originem in libro de pueror um lufibus, Seruius.

Frenatis lurentin equis.

Pars laxues humero pharetras.

Ducfores:pueri biffeni quen क̧ fecuti. Incedunt pueri, pariteró́ ante ora parentum Cornea bina ferunt prafixa haftilia ferro:

Aepyides longè dedit, infonuitó̧ Hageilo, (id eft uirga.)

Tres equitum numero turma, ternićs uagantur

Olli difcuriête pares, atç agmina terni

Conuertêre vias, infeftáç tela tulêre.

Aduerlis fpatijs, alternosø̧ orbibus orbes

Diductis foluêrechoris, rurfuśg urocati ( fể)

Inde alios ineunt curfurs, aliosćp̧ recurfus

Et nunc terga fug̉e nudãt: nûc fpicula uertũt Infenfi:facta pariter nunc pace feruntur.

Hũc morẽ curfurs, atq̧̧ hxc certamina primus Afcanius, longam muris cum cingeret Albam

Rettulit, \& prifcos docuit celebrare Latinos. Hinc maxima porrò

Accepit Roma, \& patrium fertuauit honorẽ: Troiáç̧ nunc pueri, Troianưm dicitur agmen, Hucufģ, Vergilius. Notiffimum apud noftros ludi \& exercití puerilis genus eft, quod uulgó apa pellant oen braten iagen, id eft uenationis feu feræ perfecutionem:improprié quidem, cum uelian tionis bellicæ, non uenationis imaginem referat. Sed pueri pedites $\&$ inermes hunc ludurm ludunt, utra ${ }_{3}$ pars tanquam hoftes caftra e regione metati. Progreditur ab alterutra parte unus ad hoftum cafira, tanquam prouocans ad pugnam, occurrit illi propius accesenti quifpiam ex hoftibus, \& fugia entem perfequitur: affecutus enim fi manu attigerit, captiuum ducit:fed cauendum eft ei ne dum cu pidé nimis perfequitur, ab hoftium aliquo occurrente deprehendatur. Captiui alicer liberarition 3 poffunt, nifi quis fuorum íntactus ad ipfos in hoftiũ caftris detentos peruenerit, Exercitatio ifta tion celeritatis tantum in curfu eft, fed ingenium etiã euitandi aut deprehêdendi per flexus $\&$ ambages hoftem requirit, \& f pectatores oblectat. Hanc Troiam pedeftrem appellabimus, ne pueri literarum ftudiofi nomine tam pulchri ludi deftituantur. Catadromus, ut fupra dixi,ftadium eft in quoequl res decurrere folebant imaginario pralio. Theffalorum gentis inuentum eft equo iuxta quadrupe dante cornu intorta ceruice tauros necare:primus id fpectaculum dedit Romæ Cæ far dictator, $\mathrm{Plis}$ nius. Sulegian(fus q̧uidem equus efl Hebraicæ $\&$ finitimis linguís)eft ludus, in quo equitãtes fpha ram ligneam baculis feriunt, apud orientales populos in ufu, Andreas Bellunen. TDe ludorum militarium celebrationibus lege Valturium 12,12. Et de equeftri exercitatione, eundé $4 \cdot \xi$. Aladar, eft profequi equum currentem cum baculis ipfum percutiendo, quum gradum feu curfum fiftere uoluerit, \& eft exercitium forte, Andreas Bellunen. De equitum armarorum exercitñs fententiam Platonis ex octauo de Legib. paulo fuperius recenfui. De exercitio uenationis, aut fi duoequites ex compolito, hic fugiat, ille fequatur cum armis : item de conflictu equitum eorundem eminus \& cominus, ac derjciendi modo, Xenophon in libro dere equeftri.

TDe equis bellatoribus fupra dicfum eft in $\mathrm{B} .8 \mathrm{H}$.b.reftat ut de equítibus etiam qui îs uehuni 8 militant uerba faciamus, Habebat Salomon 40,millia præf́epia equorım curulium, \& duoder cim millia equeftrium, ut legimus 3. Regum 4. Curules equos Robertus Cenalis interpretatur, quion neribus uehendis, quadrigiś̨̧ uoluendis: equeftres uero qui uehendis militibus inferuirent, Liby: es ex curribus pugnabant, ficuti apud Homerum heroës; hic enim nouiffe monippos non uidetur: fic enim trocitant uno depugnantes equo, Cæl. Et alibi, Duobus modo equis ad currum adhibitis heroés depugnaffe, in Iconibus Philoftratus fcribit, eriãfi Hecfor audacia pręlẩs quaturor utetetur.

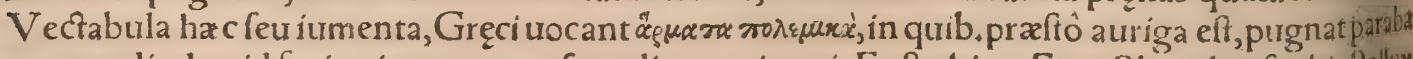
tes, aut aliud quid facit etiam propter fynodiam, ut inquit Euftathius. Eum Plato (ut f́ribit Pollix

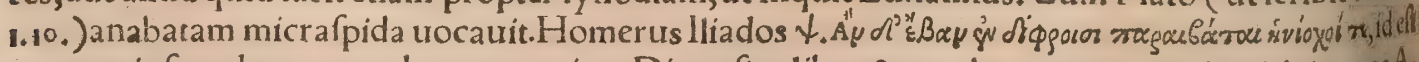
currum infcenderunt parębatæac aurigx. Dionyfius libro 8. parabatas pro aurigis accipi, quos $A_{3}$ thenien fes a pobatas (forte epibatas)uocabant. A riftophanis interpres currum inicendere folitos forl bit, hoplitem \& parabatem, ac id genus currus à Thefeo excogitatos primum, Hac Calius. Pugnas

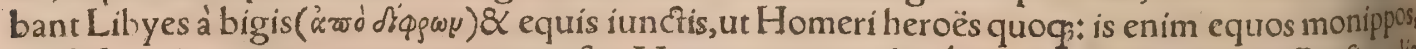
id eft fingulari equo utentes non agnof cit. Vocatur autem diф jéś quadam Libyca, alia Perfica, alia Laconica,Pollux 1.10 Olim non equo celete, fed curribus tantum utebantur:aut fi Gracè mautis, $T$

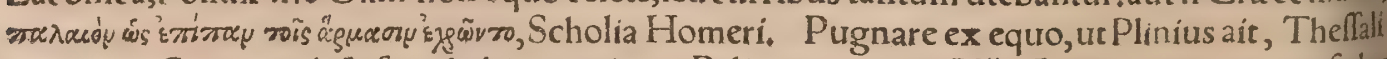
cuere, qui Centauri dicti funt, habitantes iuxıa Pelium montem, Alij nó ex equo pugnare, fed equir 


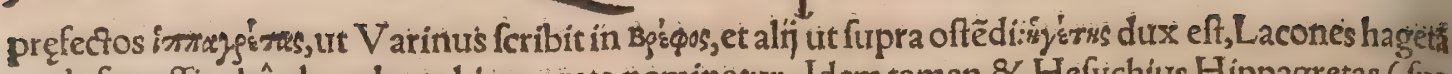
unde fortaftis thô abundante hippagreta nominatur. Idem tamen \& Hefychius Hippagretas (fuo

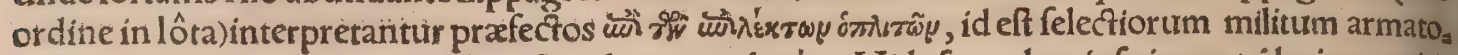

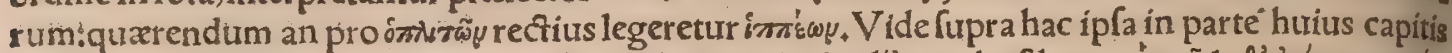

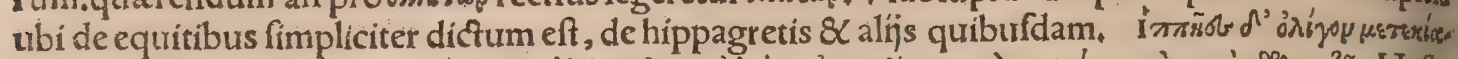

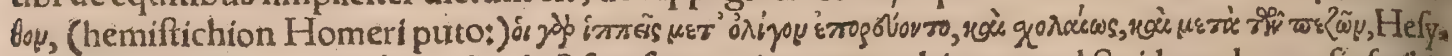
chius $\& \mathrm{~V}$ arinus, Xwe's inmeis, id eft feorfim equites, prouerbium apud Suidam, de quo fic fribit: Cirm Datis Athenicnfium agrum inuafiffet, Iones aiunt quum feceffiffet ipfe confcenfis arboribus Athenienfibus fignificaffe, equites feparatim effe. Vnde Miltiadem feparatione ipforum intellecta, inito mox conflictu uicroriam obtinuiffe: $\mathcal{X}$ locum habere prouerbium de njs qui ordinem diffol= uunt. Plutarchus alicubi dicit Batalos effe Germanorum equites praftantiffimos, qui infulam co, lant quam circunfluat $R$ henus, Calius.Idem docet batales à Græcis ap pellatos molles $\&$ cínædos, Caterum Plutarchi locus eft in uita Othonis:ubi Gracus codex impreffus Barzínzs habet, fed inter pres rectéBatauos tranftulit: \& fic etiam Alexander ab Alexandro legit in defcriptione Germania, Taciti de Batauis uerba funt hæc: Omnium harum gentium uirtute pracipuéBataui, non multum à ripa infulam Rheni colunt. Vangiones Batauiç, truces, quos ære recuruo Stridentes acuêre tux

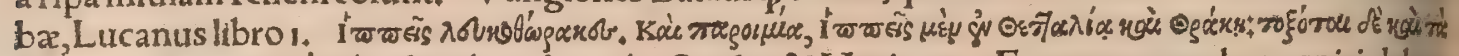

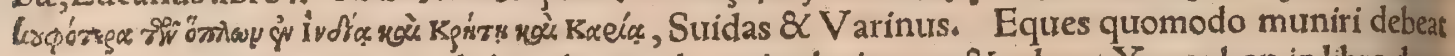
armis, thorace, galea, manu uel chirotheca, et lacerti ueluti ocrea, \&c, docet Xenophon in libro de re equeftri circa finem. Equitatus(inquit Caliurs) ex armatura genere diuerfa fortitur nomina, figuie a dem aln̈ funt equites cataphracti, alin acataphracti. Cataphractos intelligi cos uolo, qui non folum fua corpora, fed etiam equos lorica undiq̧ muniunt. Hos fcribit Vegetius $\left(3,23_{+}\right)$effe quidem à uulneri bus tutos, fed propter armorum impedimenta $\&$ pondus capífumma facilitate. Et $Q$. Curtius equiti bus tradit equisćs Perfarum tegumenta fuiffe ex ferreis laminis ferie inter fe connexis. Cataphracios equites fcribit A mmianus Marcellinus, etiam clibanarios nuncupari. Idem inter equeftres copias cataphractarios recenfet fagittarios, formidabile genus armorum. Lampridius in Alexandri Cęfaris oratione de Perfis perdomitis innuere uidetur planè, cataphractarios ab illis clibanarios uocari.Lori catos equites dici cataphracfos Liuius tradit. Equites antiquitus non habuiffe thoracas, fcribitin co: mentatione de Romanorum militia Polybits: Verum, inquit, in fubligaculis periclitabantur, ad in fcenfum defcenfumóg praceleres. Eorum clypei ex bubulo concinnati corio, placentis erant umbli caris perfimiles, quibus in re diuina uti moris fuerat. Scribit in Adriano grauis aucfor Dion, equites qui uocantur Baftai; Danubium armatos enataffe. Cataphracias naures $\&$ aphractas recenfet hiftoria arum quinto Polybius. Cataphractorum equitum apud Perfas panopliam defcribit Heliodoruslia

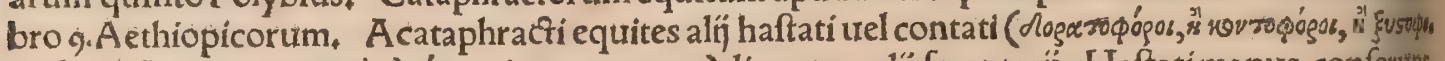

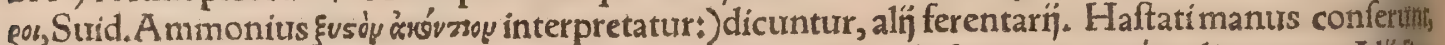

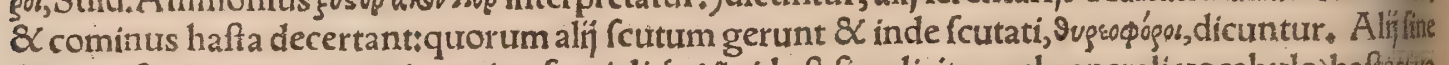

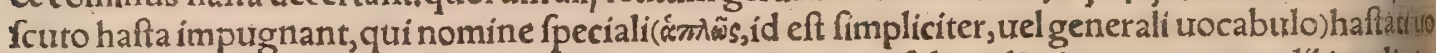
cantur $\&$ contati. Ferentarí equites í dicuntur, qui eminus folent dimicare: quorum alị iaculis (an contrís) alif arcu utuntur. Iaculantur, quos Tarentinos uocamus: Arcu utuntur, qui equites fagittae rï (i

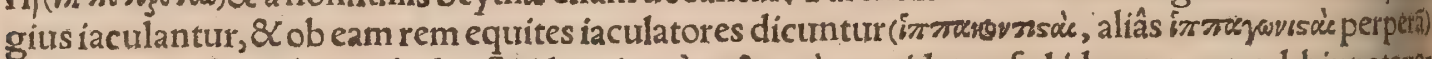
\& Tarentini fpeciali urocabulo, (Suida etiam 'expoßorssá, ut uidetur: fed idem nomen ad hippotoxon tas quoçs pertínerc iudico: utriqs enim inter equítes ita funt, ut in peditum numero uelites, Gaza fen rentarios tranftulit, imitatus Saluftium, qui in Catilinæ coniuratione ferentarị militis meminit: Ve

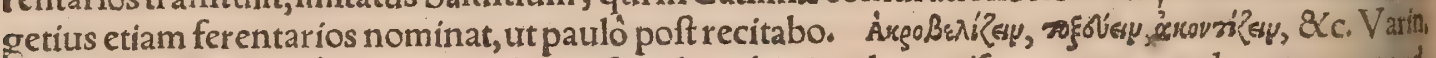

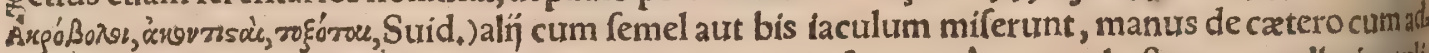
uerfario conferunt, \& cominus pugnare incipiunt, non fecus quàm quos haftatos appellari retuli: mus. Leues hos nominari folitum eft, (hi iaculis emiffis cominus'etiam pugnant, fpathis aut fecuri, bus utentes, Suidas:)Hæc A elianus in libro de inftruendis aciebus interprete Gaza \$ \& Calitis 21, 31. $\mathrm{fed}$ obfcurius quadam: 8 in hoc errat, quód Tarantinos arcu uti fcribit, Suidas quoç in uocabu i lo Im mix' eadem fere habet, $\mathrm{fed}$ obfcurius, uocabulis quibufdam deprauatis, ut etiam libellus Gros cus de vocabulis rei militaris innominati authoris inter appendices Lexici Gracolatini iam fapeex cufus, $\&$ in fine dictionarn̈ Suida. Bonos iaculatores antea ferentarios nominabant, Veget;:14 A pud ueteres inter pedites erant qui dicebantur leuis armaturæ, funditores $\&$ ferentarï, qui pra»

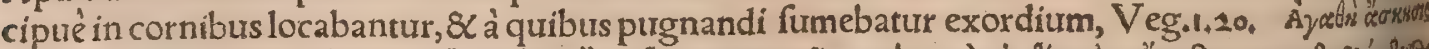

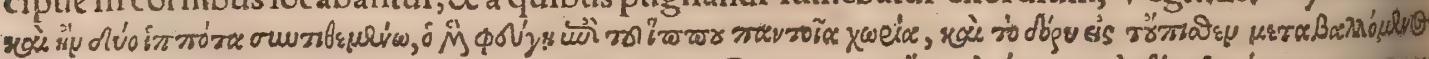

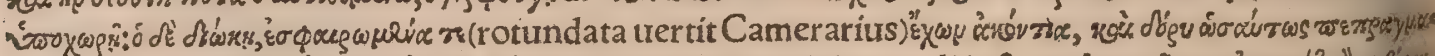

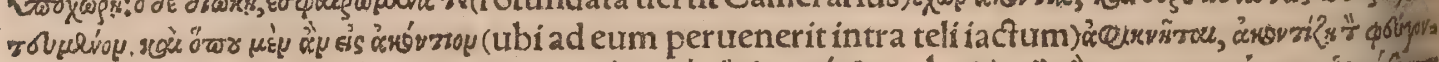

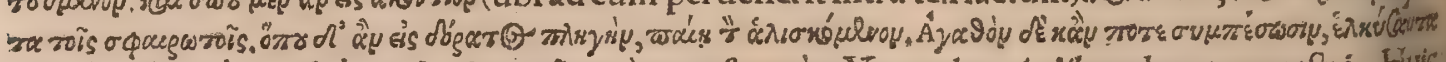

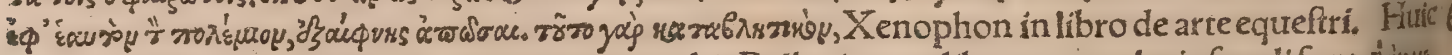

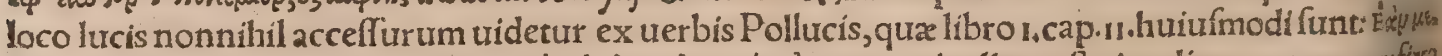

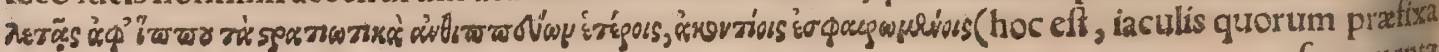


breuior:Iongiffima, qưę eatenus fumi poteft, quatenus tenere miles $\&$ uti facile ualeat, Aelian. Sunt 8 qui dicanț chryfophalari equites, aut etiã argyrophalari: cuiufmodi in ludis produxit Antiochus Epiphanes, Cẹl. Quemadmodũ inter pedites centuria uel manipulus appellat, ita inter equites tur ma dicit́t, \& habet una turma equites 32. qui à decurione fub uno uexillo reguntur. Eligendus elt aũt decurio habili corpore, ut loricatus et armis circundatus omnibus cum fumma admiratione equum pofit afcendere, equitare fortiffimè, conto fcienter uti, fagittas dociffimé mittere, turmales fuos, id eft fub cura fua equites pofitos, erudire ad omnia qua equeftris pugna depofcit: eofdem cogere lori cas fuas uel cataphractas, contos furos \& caffides frequenter tergere \& curare. Plurimum enim ter. roris hoftibus armorum fplendor importat, Vegetius 2.14. A tqui Ammianus Marcellinus libro 26, equitum peditum q́s turmas dixit, Dicuntur $\&$ drumi, equitum globi:Scire debet dux contra quos drumos, id eft globos hoftium, quos equites oporteat ponere, V egetius. Grumis quidem uocatur terra in aceruũ collecta, minor tumulo:item de alṕs rebus grumus uel grumulus falis, pro globulo, ubi Graci chondrum dicunt, noftri cin tlogen. Turmæ uocis etymologiam dixi fupra. Tormarches tormæ prafectus apud Cretenfes, Calius. Prima legionis cohors præter pedites, equites loricatos 152, habet: fecunda fexaginta fex, \&c. Vegetius 1: 6. Equitum alæ dicuntur, ab eo quòd ad fimilitur dinem alarum ab utra ${ }_{3}$ parte protegant acies, quæ nunc uexillationes uocantur à uelo: quia uelis, hoc eft flammulis, utuntur, Eft aliud genus equitum, qui legionarỉ uocantur, propterea quòd con。 nexi funt legioni:Ad quorum exemplum, ocreati funt inftituti, Veget, 2.1. Ala, equitum ordines vocant(ut ait Gellius lib.16.) quòd circum legiones dextra finiftrá̧̧ tanquam alæ in auium corporis bus locabantur. Dum trepidant alax, (id eft equites, Seruius) faltusćs indagine cingunt, Vergilius 4. Aen, Pluś́s aliquanto damni hæc ala equitum amifla Annibaliquàm Salabia fuit, Liuius, Sic az la legionum, Cic.Att.lib.11. Alam príuatim dici inuenio duplicem phalangem apud Græcum au chorem innominatum de militaribus uocabulis, qui Gracis etiam literis uocem Latinam imitatur, ut paulò mox dicam. Äzusex, ala equitum, quanquam $\&$ de peditibus dicatur, Calius ex Arrianio, Ä swute, agmen elephantorum, peditum, atçequitum quod regem præibat, Varinus; $\&$ in Lexico Græcolatino quidam ex Arriano. Sunt qui agema dicant effe potiorem $\&$ ualidiorem partem exer citus Macedonici,uiribuśq̧ $\&$ corporum habitudine fuperiorem, Varinus, Hefychius, \& Suid,Age

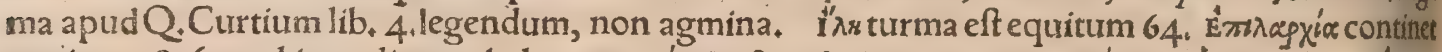

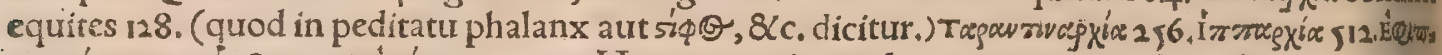

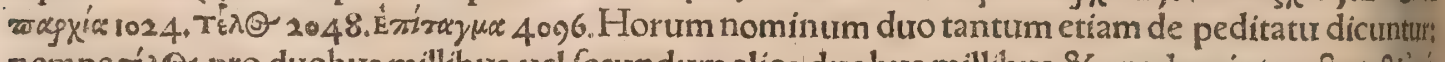

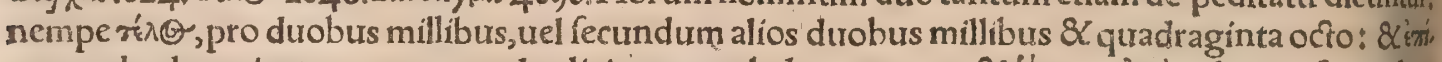

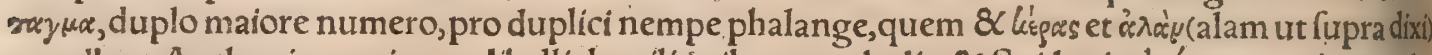
appellant. Author innominatus libelli de militaribus uocabulis, \& Sứdas in Ėérsmwy, qui tamenlo. cus omnino mutilus eft, \& ex libello (quem dixi) reftitui poteft. De uroce ${ }^{\prime} \lambda s$, uide plura in Lexicis,

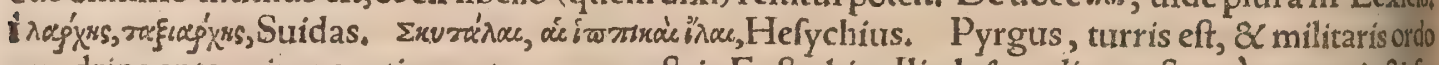

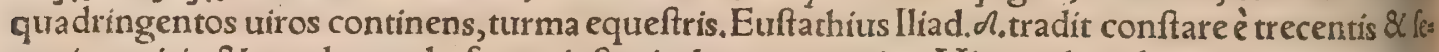
xaginta uiris, \& quadrangula forma inftrui ad typum turris. Hipparchia, ala equitum, quæ quina gentis infuperós duodecím conftabat equitibus, Cælius ex Arriano: In Taciicis Aeliani interprete

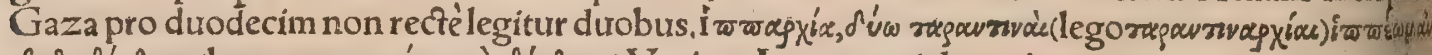

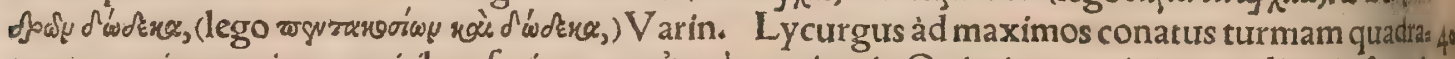
tam ex quinquaginta equitibus fecit, quam rina $\mu \dot{o}^{\mu}$ uocitauit: Qui etiam equites ac pedites in fex tris bus diuifit, quarum quęlibet tribunum militum, $\&$ quatuor præfectos manipulares habuit, \&c. Et tametfi centurix, decuria, turmæ, cohortes, equitatus, pro uoluntate proç̧ arbitrio fæpe auctæ \& im minuta, nonnunquam duplicatæ fuerint; idem tamen nominis, quamuis mutato militum numero,

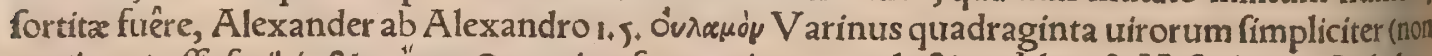

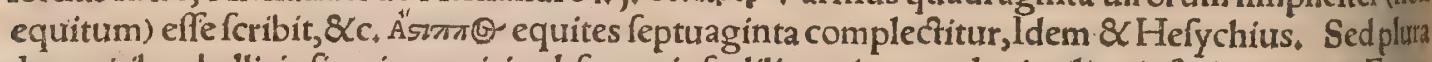
de equitibus bellicis fi quis requirit, obferuet ipfe diligentius apud rei militaris feriptores. đEquos armis pramuniri(inquit Calius 21.31.) fciunt omnes, fed eorum nomina (ni fallor) nota patrciffimis, Igitur qua à fronte propendent, prometopidia:qua ab auribus, parotia:pareia, quæ maxillas pras fulciunt, appellari debent: profternidia ueró, quę pecfus: parapleuridia, quæ lateribus obiacent: para $\varphi$ meridia, qua femoribus, folet ea uulgus coxalia nuncupare:paracnemidia, tibijs apponi confurertit

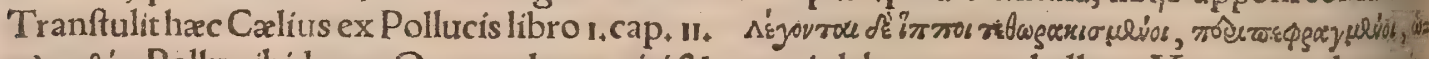

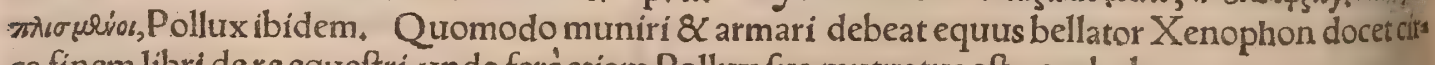
ca finem libri de re equeftri, unde feréetiam Pollux fua mutuatus eft uocabula.

TNunc de ipfa equitatione, fiue equitatu $\&$ actu equitandi agendum, $L$ atinis primum, deinde Gracis uocabulis, 8c. Equitandi ac fagittandi fudium à Medis ad Perfas 8 . Armeníos profectum eft,Strabo, Quia equitandi artem primus excogitauit Neptunus:inde facfum opinatur Paufanias, ut dicatur hippios, potius quàm caufa alia . Alị à Centauris equitandi artem, alij non hanc, fed ex es quo pugnandi intrentam prodidere. Vide fupra parte 1. huius capitis poft Centauros ftatim in men tione Maris . Amazones mortalium primas equum fcãdere aufas Lyfías orator credit, Hermolaus, 60 Alï Bellerophontem, alij Neptunum, primum domuiffe equos, \& equitandi artis authorem effettas dunt, uc Polydorus profequitur 1,12, de inuentoribus rerum, Ctefilaus ftatuarius fecit equitem Sat 


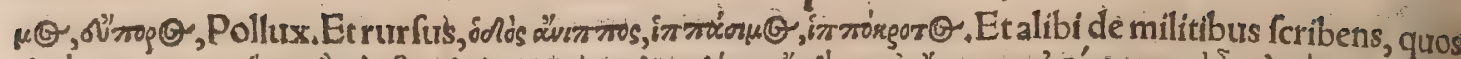

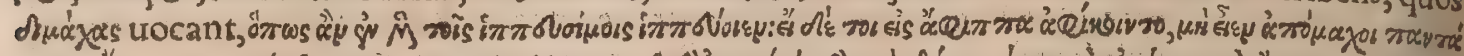

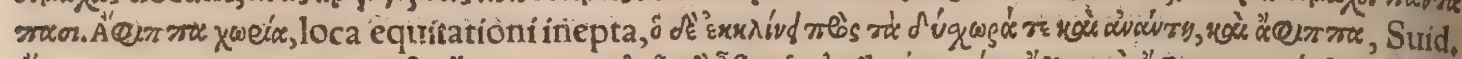

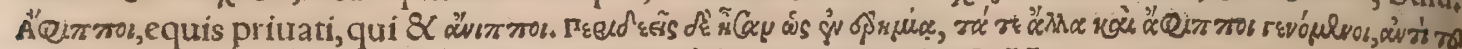

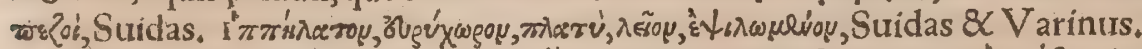

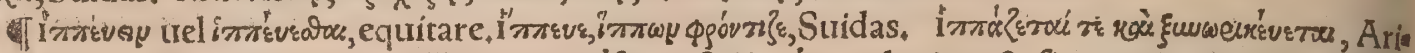

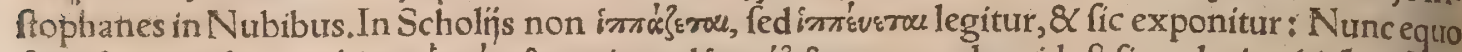

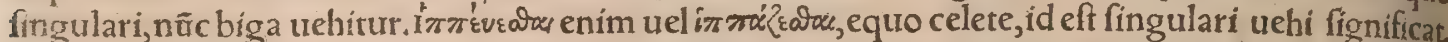

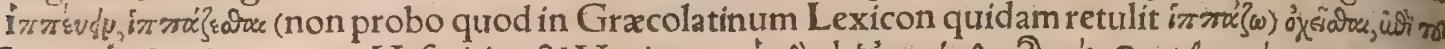
:ं

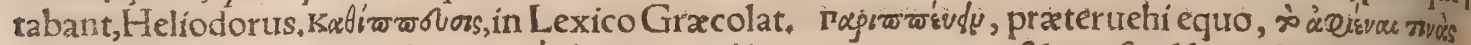

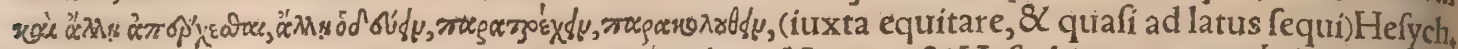

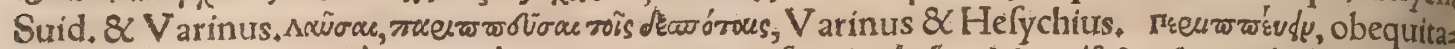

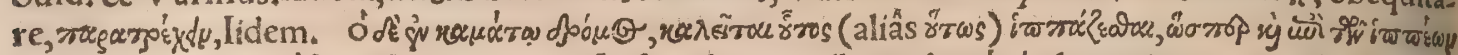
خ่

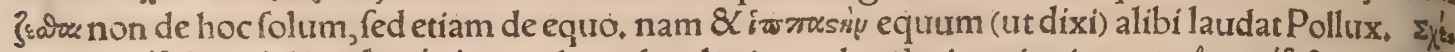

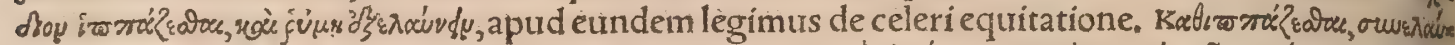

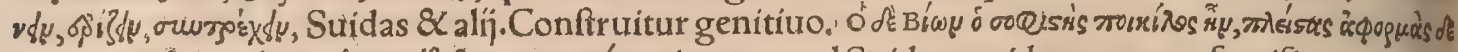

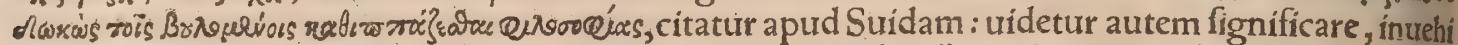

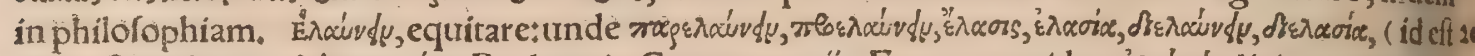

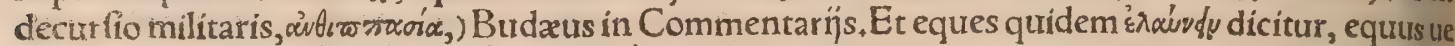

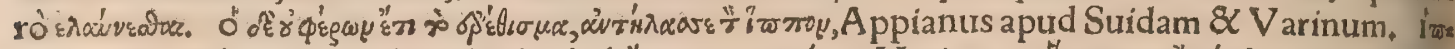

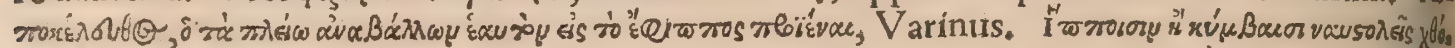

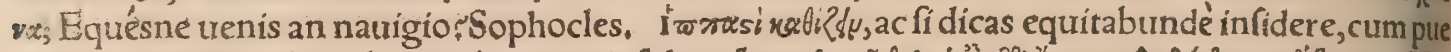

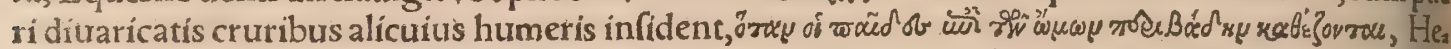

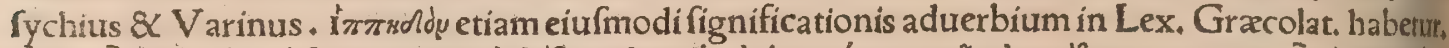

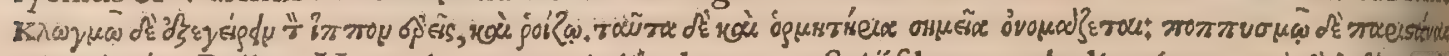

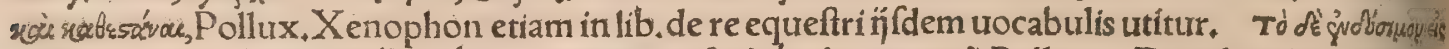

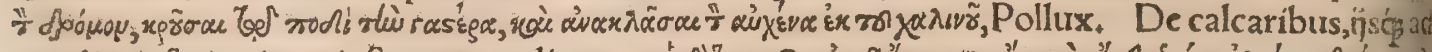
gendis, inferius inter inftrumenta dicam, ó dह'

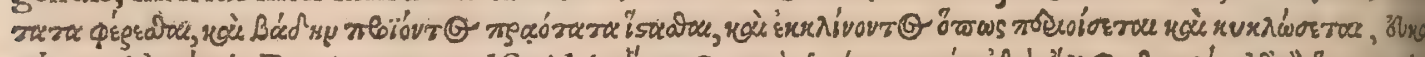

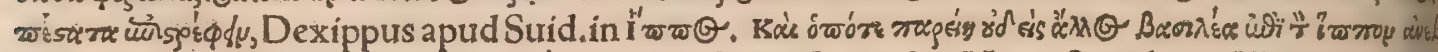

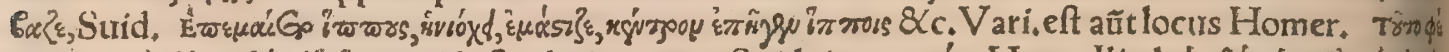
$\rho$ we i

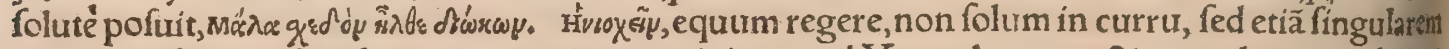
cui quis infídet, ut fimpliciter pro equitare accipias, apud Xenophontem: \& etymologia quidem ni

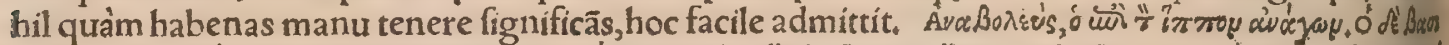

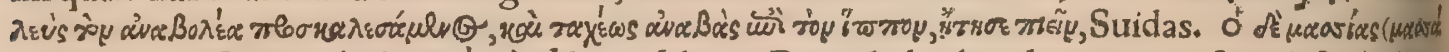

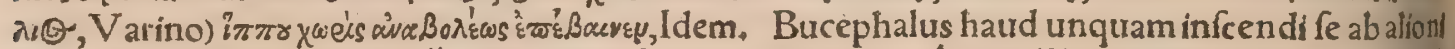
fià rege paffus eft, Gellius, "Iw

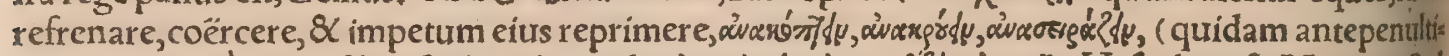

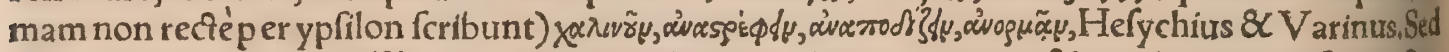
iple etiam equrus áva youri?\{y dicitur, cum erectus anteriore parte caput $\&$ ceruicem retrorfum iactat, excutiendi præcipué fefforis caufa. At qui pofteriore parte altius fublata equitem excutit \& tâquam

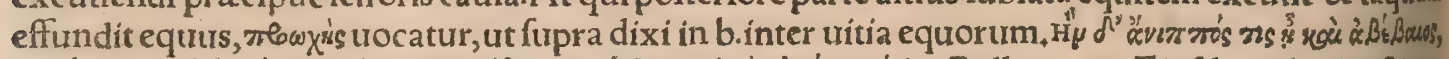

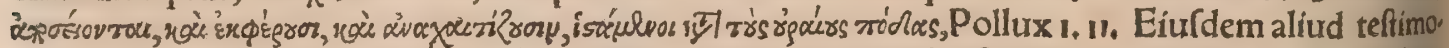
nium in E. recitauifuper hoc uerbo. Plutarchus in Sympofio fapientum proco quod eft iubam $\&$ ceruicem erigere accepit: Multus, inquit, cum imaginem fuam in fluuio confpexiffet, formam \&

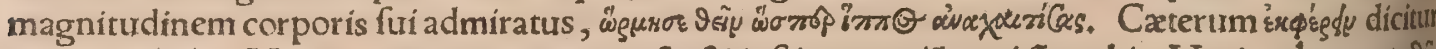

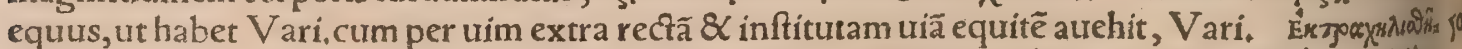

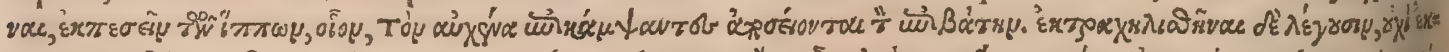

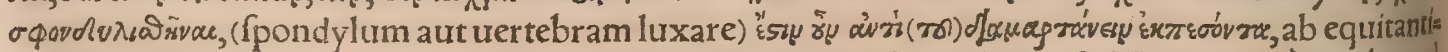

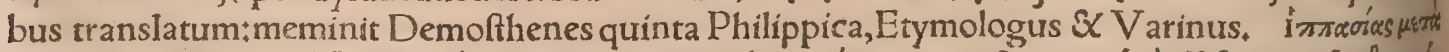

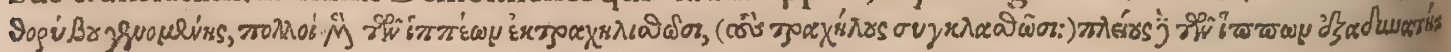

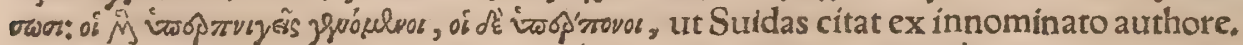

qCur qui equo uehuntur, quo longius equus decurrerit, eó magis emittere lachrymas folent, A riftoteles fectione 5 problemate 13.8234 . Equitatio ftomacho 8 cexis utiliffima, Plin.lib, 18 , Mo tuum qui exercití caufa affumuntur, alih per nos fiunt, ut ambulatio: alip extrinfecus, ut nauigatio \& geftatio qualibet. Nonnulli mifti planéfunt, ueluti equitatio. Non enim ut in uehiculis, prafer. rim in quibus ftratus qưief́cas, ica etiam cum equo infideas accidit, ut à geftante tantum agitêt is, ip 6 fe nihil agas: quin fpinam erectam fuftinere, tum utrifos feminibus equi coftis firmiter harere, et cru

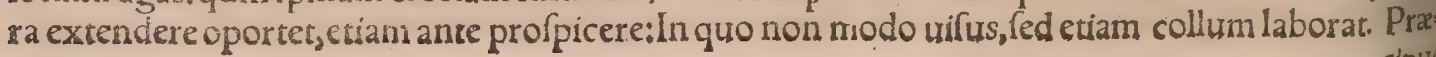


ciptue tamen uifcerà hoc genere agitantur; Galenus de fanitate tuènda 2.31. Equitationes concita. ta fape aliquam circa renes partem ruperunt, aut circa pectus læeferunt, quandogs etiam feminarios meatus:ut ne dicam de ipfis equorum delictis, per qua fxpe equites fella excuff, ftatim perierunt, Galenus in libro de parux pilæ exercitio. V fus equitationis uniuerfus $x$ gris non multum coniert: fi tamen fuauiter gradiatur equus, hihil ultra facit quàm femorum laffitudinem, eiuś́ partis ubi crura plicantur $\&$ unde pendent:at fi impellatur, perturbat uniuerfum corpus $\&$ defatigat: habet ta men etiam modus ifte quidpiam utilitatis in ualentioribusiroborat enim prax cunctis alījs exercitins fpiritum, reliquumó corpus, fed ftomachum maxime:purgat etiam fenfus, acutiores q́ 3 reddit; thora citamen peffimus eft hic exercendi modus, Aëtius 3.7. Scythre corpora habent nimium fluxa \& la ta:neç enim fafcijs(infantes)colligantur, quemadmodum fieri folet in Aegypto. Deinde quòd non

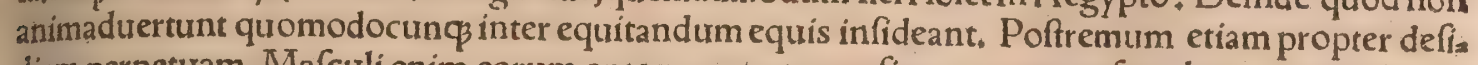
diam perpetuam. Mafculi enim eorum antequam potentes fiant equos confcendere, atos in illis ue: hi, plurimütemporis defident in curribus, \&c. Hippócrates in libro de aëre, aquis, \& locis. Et mox cur Scythx parum appetant Venerem, fieri ait ex continua equitatione, qux eos ad commiftionem reddat impotentiores. Ab equitatione (inquit)diuturni cos corripiunt articulorum dolores. Nimis rum propendentibus femper ex equis eorum cruribus, deinde claudi fiunt, contrahunturọ́ coxen= dices quum inualuerit morbus. Medicantur autem fibi ipfis à principio morbi utraq̧3 uena retro au. res incifa, unde cum fanguis effluxerit, hæc ipfa etiam fterilitatis caufa eft. Afficiuntur autem hoc ma lo illi pracipué inter Scythas, qui genere \& potentia praualent, ex nulla alia quàm continux equita tionis caufa:pauperes minus, cum non multum equitent. Vbi enim frequenter 8 continure homi. nes equirant:ibi plurimi à diuturnis doloribus arciculorum, coxendicumá̧ maximé \& pedirm corri= piuntur, ad coitum'̧́ fiunt impotentes. Accedit quòd anaxyrides (braccarum fiue feminalium ge nus) femper habent, \& plurimum temporis in equis defides agunt, ut neq manu tractare pudenda liceat, $8 c$.Hæc Hippocrates. If In Scandinauía $\&$ uicinis locis, equorum 8 homínum pedibus ro und clypeorum forma tabulæ fubligantur, ne peffum eant in niuen, ut Olaus Magnus annotauit.

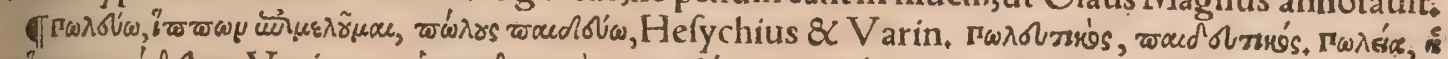

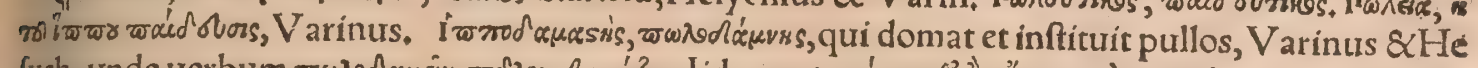

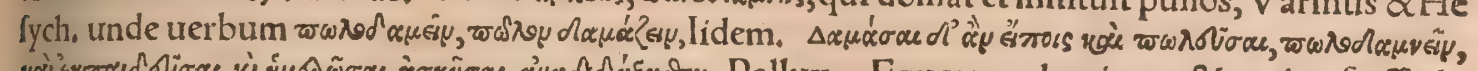

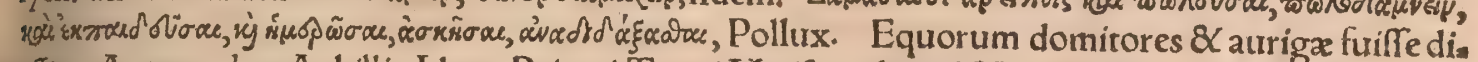
cîtur, Automedon Achillis, Idæus Priami, Turni Metifcus (apud Vergilium,) Myrtilus Oenomai, Cebares Darï, Anniceris item Cyrenaus, \& apud Vergilium Picus, Mefapus, Laufus: apud Silium Cyrnus, Durius, A tlas, Iberus memorantur, Textor in Epirhetis equi. Cillas, Pelopis auriga.Patro dits auriga erat Achillis, PatrocliA utomedon, Auromedontis Alcimedon, Varin, in Hiviox@. Tel = chius \& Amphitus, uel Rhecas \& Amphiftratus, Caftoris \& Pollucis aurigx. Corax aurigx nome

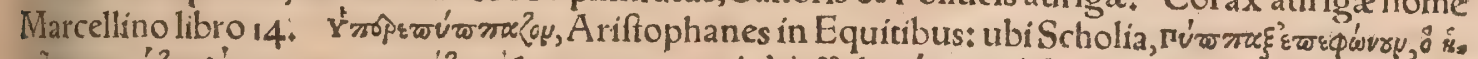

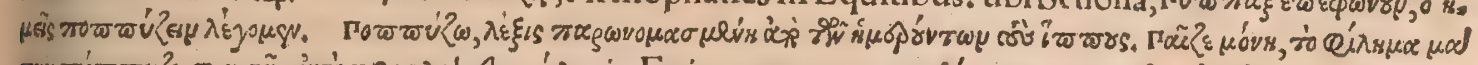

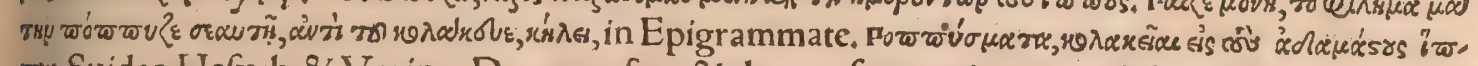
wrs, Suidas, Hefych. \& Varin. De poppyfmo \& clogmo fupra etiam nonnihil ex Polluce \& Xeno phonte docui. De poppyfmo uel poppy fmate $\alpha$ diuerfa ad has uoces ueterum teftimonia, uide in - Mifellaneis Politiani cap. 32. THippocomi, mangones qui equos componunt, Grapaldus * i

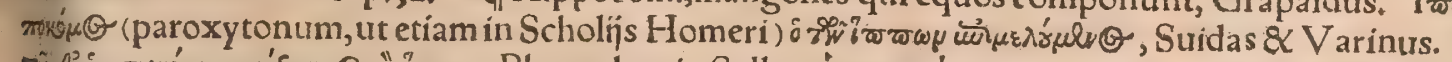

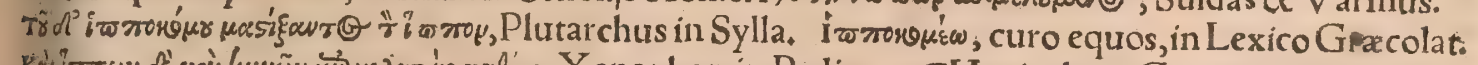

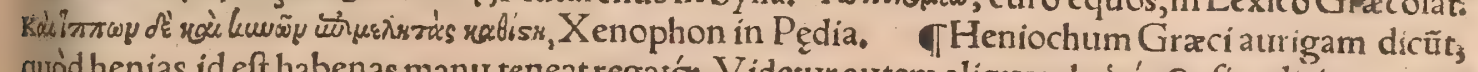
quòd henias, id eft habenas manu teneat regatóg. Viderur autem aliquando iviox(S) fimpliciter pro $e_{*}$

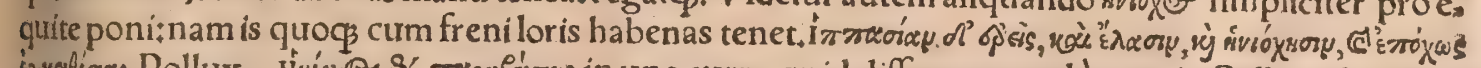

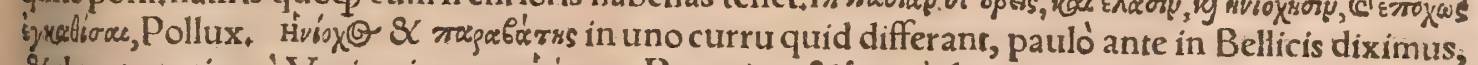
$\&$ docetur etiamà $V$ arino in uoce Hivioger. Reperitur \& ivioxivs (apud poëtas puto) nimirum ab svid

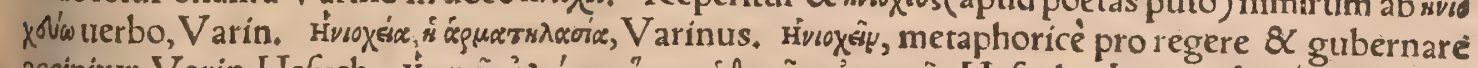

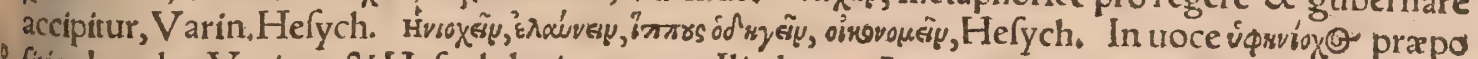
fitio abundat, Varinus \& Hefych, legitur autem Iliados 3. Auriga communis generis, propriédici tur, ut ait Seruius, qui currum regit. Hic fitus eft Phaêthon currus auriga paterni, Ouid. Aurigarí us,idem quod auriga. Aureax, auriga, ab aureis, id eft freno equorum circa aures alligato, Feftus Circumftant propere aurigæ (id eft agafones, Seruius) manibusćs slaceffunt Peçora plaufa cauis, Aurigam uideo uela dediffe rati, id eft nautam, Ouid. 1. Trift. Hinc aurigare uel aurigari uerbum,

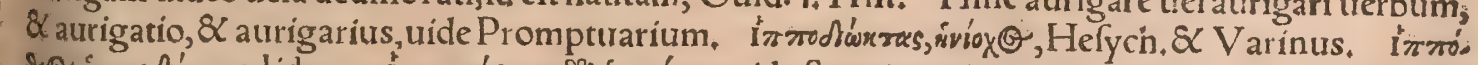

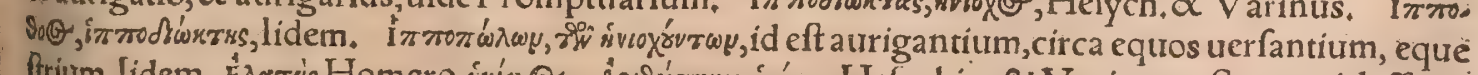

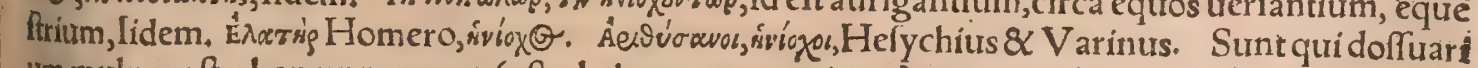
um mulum aftraben nuncupent:(aftrabelaten uero aurigam) aut notophorũ , id eft dorfo ferens ac gerulum iumentum, Calius, V arinus Onocindynon, onelaten $\&$ aftrabelaten interpretatur, hoc eft - agafonem uel mulionem, non aurigam ut Cxlius. Kgwzó́runos, ó svíox@, Varinus:quòd feriat ftimu lis, (nimirum quales boum ftimuli funt, non calcaribus.) Hefychius kgyzotúros (paroxytonum) exi

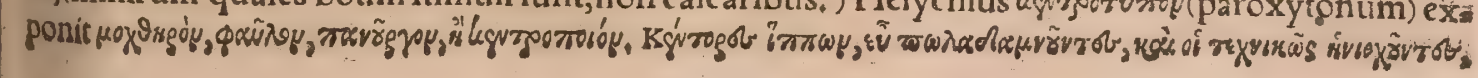


Varinus, Kçvoug, siviox $\odot$, Hefych, Heniochus comicus Àthenienfis apud Suidam. Heniochiare gio eft apud Caucafum, cuius incolæ Heniochi, Stephan. Heniochi Ptolemazo 9.5. populi Sarma. tix iuxta Pontum non longè ab Achais. Plinius 6. T.à Télchio \& A mphito Caftoris \& Pollucis auri gis Hentochorum gentem feram ortam dicit. Idem fcribit Ammianus Marcellinus libro 22. Diofcu. riadis (inquit)in Colchica authores funt Amphitus \& Telchius, \& 8 . Strabo uerólibro I1. Tradunt (inquit)Laconas habitaffe Heniochiam, quorum duces R hecas $\&$ Amphiftratus fuerunt, Caftoris \& Pollucis aurigæ, unde Heniochi (ut par eft)ex ñs quidam funt nominati, \&c. In ora ante Trape zunta flumen Pyxites, ultra uero gens Sãnorum Heniochorum, Plinius 6.4. Et rurfus, Deinde mul tis nominibus Heniochorum gentes. Et cap. .. Cyrus oritur in Heniochijs montibus, quos alí Cora xicos uocauere. Traianus Heniochorũ regê profecutus honore eft, Dion Caffius. Dextra atţ̧ in= tima Ponti incolunt Colchi, Heniochi $\&$ A chæi, Velleius $P_{a}$ terculus. Erichthonius omnium prin. ceps, ut Arati uetus teftatur interpres, currus equis iunctis docuit quadrigis folaribus perfimiles $c_{n}$ pingere. Qua fane admiratione eft inter cœlitum tralatus imagines, quod non tacuit Manilius aftro nomicôn prımo, heniochi nomenclatura infignis: Heniochus fudio mundum.̧́ \& nomen adepı tus, Quem primum curru uolitantem Iupiter al to Quadrïugis confpexit equis, coeloós facrauit, Scribit uerò Theon coeleftem Heniochum, uel effe Bellerophontis idolum : uel Trochili, Callithea qui eft natus, facerdote apud Argos prima, quićç currum iunxit primus. Alị̆ effe Myrtili dicunt, Sunt qui Cillantis Pelopis aurigæ, aut Oenomai quog, Calius. De Erichthonio, \& quòd primus o, mnium curru uel quadrigis ufus fit,Polydor, 2.12. Auriga, fignum coelefte fuper Tauri cornua: re tinet autem ftellas duas in manu qua hoedi uocant. Quarto nonas Octobris auriga occidit, Colits, mella. Auriga Sublæua Geminorum abductus parte feretur, Cic.2.de Nat. Vide Higinium \& alios. $1 \pi$ rov'wexy Ariftophanes Solem tocat, quòd aurigx inftar agat $\&$ regat currum $\&$ equos, $V_{2}$

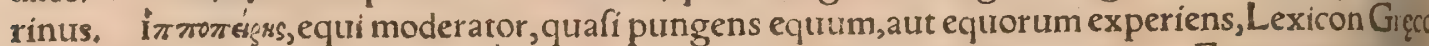
lat. Agitator apud authores feré ponitur pro recfore equorum aut curruum. Et equorum agitaı tor A chillis; Armiger A utomedon, id eft auriga,Verg.1.Aen. O quicuncs fatres foelix agitatore quorum, Ouid. z. Amorum. Nec eft melius quicquam, quàm ut Lucullus fuftíneat currū, equosiģ, ut bonus fape agitator, Cic. ad Att, lib.13. Idem 4. Acad. Ego enim ut agitator callidus, prius quàm ad finem ueniam, equos fuftinebo. Gubernator (metaphoricé pro agitatore)magna contorfit equ⿰̂́ ui, ut Quintilianus citat. Sxpe oleo tardi coftas agitator afelli, \&c. Verg.ı.Georg. hoc eft uerbera, tor, Seru. Agafo, equos agens, id eft minãs, Feft. fed menare pro agere uel ducer e Gallica trox eft, Pinxit $\mathcal{S}$ in una tabula agafonem cum equo,Plin.lib. 35 . Et duo equi phalerati cum aga fombus, $L_{i n}$ uius. Sumitur etiam pro hippocomo feu equifone, $\&$ equorum curatore. Si patinam pedelaplus frangat agafo, Horat. 2. Serm. Sat. 8. ubi Acron, Agafo proprié dicitur feruus qui iumenta curachîc autem Saryricè efcarum miniftrum agafonem appellauit, quem uulgò dicunt inferiorem. Equifo proequite(fed locus uidetur corruptus.) Varro Triodite, Nam ut equus qui ad uehendum eft natus, tamen hic traditur magiftro, ut equifo doceat tolutim, Nonius, Et alibi, Equifones non equorum ta. tum moderatores aut magiftros, fed omnes quibus regimen conceditur cuiuslibet rei, dicipofferer teres probatierunt. Varro Marcipore, Hic in ambiuio nauem confcendimus paluftrem, quam naul tici equifones per uiam conducerent, loco. Equorum paftor, equifio(hoc non placer) feu equifo \&

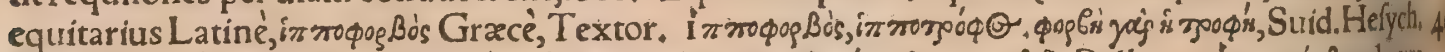

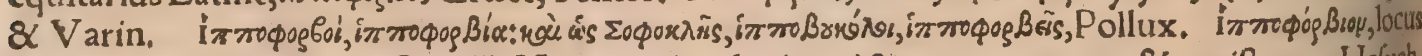
in quo aluntur equi (ut in Scholijs Homeri etiam legimus) \& grex equorum, \& capiftrum, Helych, Varin. Polia iureconfultis effe uidetur equinư armentũ:nam quod Gręcé in roфog Bion dixit hifforia

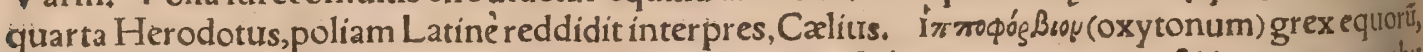
Scholia Homeri. Hippophorbon dictam tibiam Scenitæ Libyes excogitartint, \& in equorum pabu lis utuntur:fit ex lauro, Calius ex Polluce. Fit ex lauro(in quit Pollux)detracto curtice: exempta

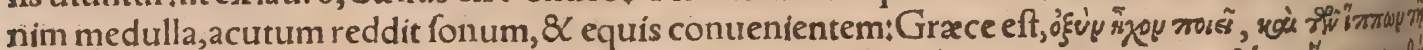

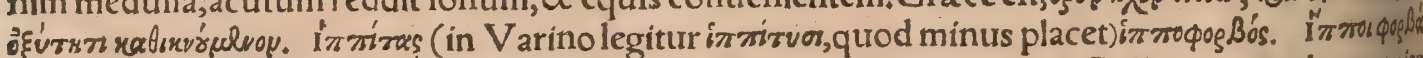

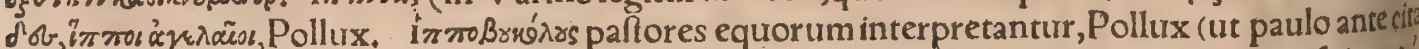
ui) Hefych. \& V Varin quare non probo illum qui in Lexico Græcolatino bubulcum expofuit, Tohiv. \{

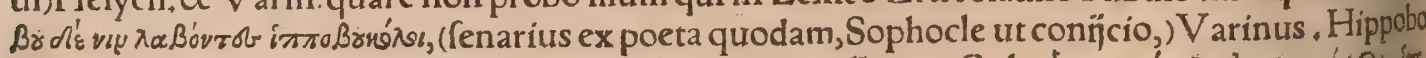

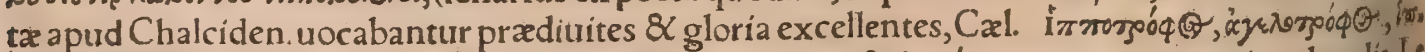

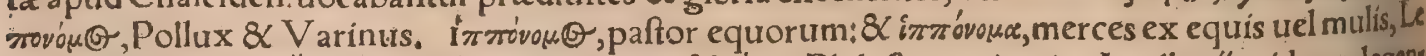

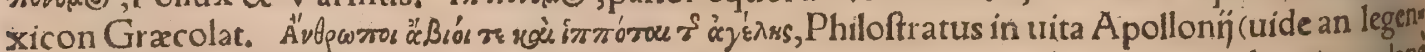

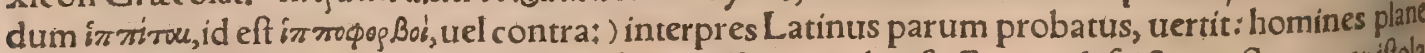
inculti $\&$ armentorum equites curatoresćs. TEquum ab ipfo Catone defriçum, Seneca epiffola 88. Diftringere apud Plinium 34v 8. prodefricare in balneis, 8 uti ftrigilibus. De equotribis \&

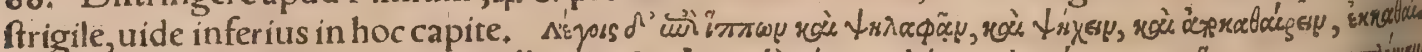

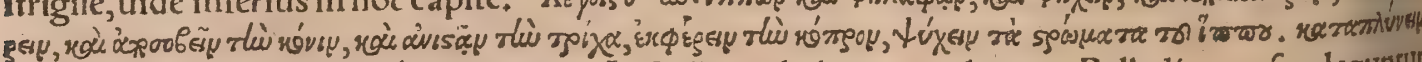

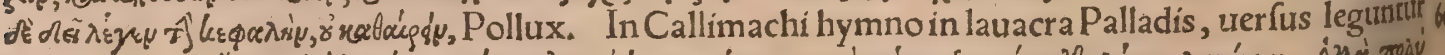

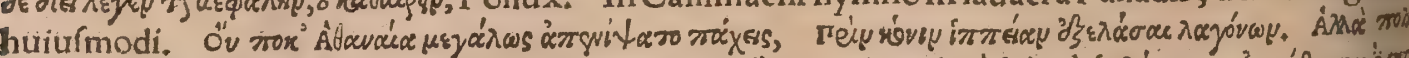

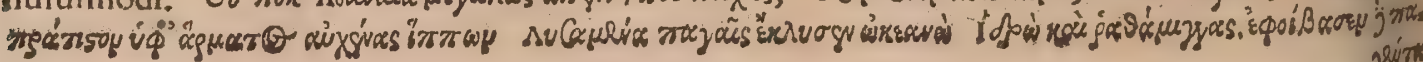


tere, ut Gracô userho utamur, fi quando minus occurret Latinum:ne hoc ephippịs 82 acratophoris potius quàm prö̈gmenis $\mathbb{Z}$ apoproégmenis concedatur , Cícero 3.de Finib. Ephippium de equo dicitur, non fella, inquit Budæus, Sella à fedendo dicitur, Ifidorus inter inftrumenta equi. Vulgus quidem Iralorum $\&$ Gallorum ephippium fellam nuncupat. A frica equos uelociflimos praftat ad tium fella, Veget. Equorum mulorumọ́ genus fub fellis aut fagmis folo tergo praftat officium, Idem 2, 59. In ledem recipere, Plinius de Bucephalo: ubi uel dorfi equini partem, cul infidet eques, quam 8 Graci hedram uocant:uel ephippium intelligas licet. Ephippiati,qui ephippia habentin equis. Cæfar lib.4. belli Gallici, Non eorum moribus turpius aut inertius habetur, quàm ephippins unistaģ ad quemuis numerum ephippiatorum, quamuis pauri, adire aưdent: loquitur autẽ de Sules uis. Ephippiarij equi dicebantur, qui inter meritorios ephippia gerebant, Sipontin. Scoppa ephips, piarium, ephippiortm artificem interpretatur. Parephippius in codice de curfu publico (licetpats phiphum legatur) qui equo currit (ine ratione artis equeftris, Scoppa. Numidar equo nudo, ideft Ine ephippiss, in bello urebantur, A ppianus de rebus Libycis. Nec legimus, neç fané ex ueterum monumentis aut marmoribus af picimus, equos eorum ephippia more noftro, necs penitus ftaffias (ftapedes)uulgo dictas haburiffe; fed tantum in dorfo ephippia eius gener is, quibus hodie domitores equorum utuntur, Volaterran. Equis inftructi \& ephippijs ac frenis decentibus prorfus, Ael, Lam

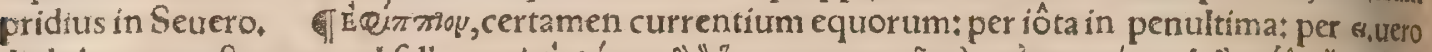

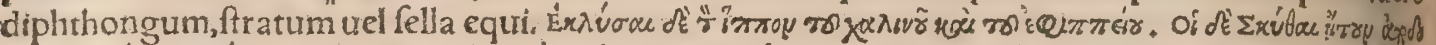

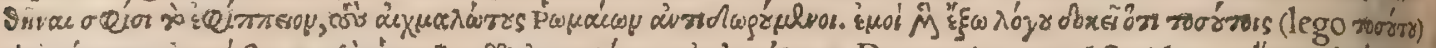

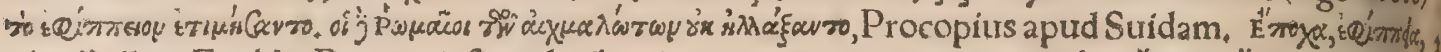

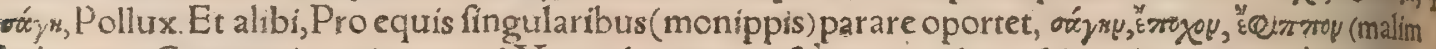

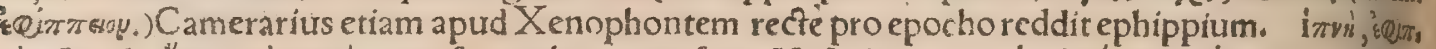

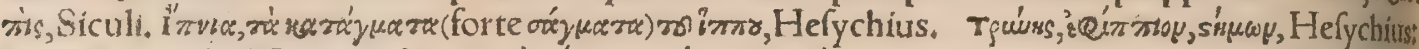

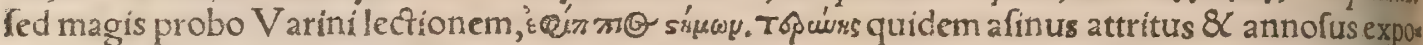
nitur. Sic $\mathcal{X}$ aftraben interpretantur afinum, mulam, quoduis iumentum, doffuarium mulum: $\mathbb{Q}$ in ephippás lignum quod manu tenent fedentes, Calius. De clirellis \& fagmis dixi in Afino H,e, fed hîc etiam nonnulla addemus, prafertim quod ad equos. Vide etiam infra in mulis. Clitellarintul clitellati muli $\$$ equi dicuntur, qui onera uel farcinas in clitellis ferunt. A clitella fimilitudinelocus Romæ Clitella uocabatur:item in uia Flaminia loca quædam deuexa \& accliua. Eft etiam torment genus codem nomine, Sipontín. Clitellarṇ uel dorfuarn̆ uel dofl uarï (nam doffum pro dorfo uete rer es dicebant) î̉dem funt:quin $\&$ farcinarii, quood farcinas clitellis alligatas dorfo geftent, Equifel la,uel barda, fifalmam portatuerit, Hæc uerba apud Vegetium, ni failor, leguntur. Sagmarituses quus, orzu'cee

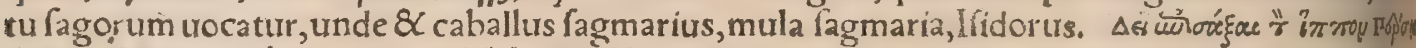

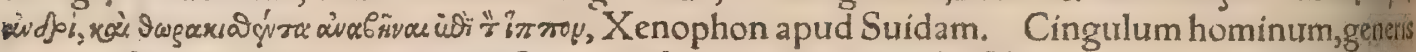
neutri eft:nam animalium, genere formininoldicimus has cingulas, Ifidor. Vt noua uelocem cingu Ia ladat equum, Ouid,libro I. de Remedio. Ephippium loris canniabinis ( quæ cingulas uocitant) uentrem cingentibus, ne diffuat, continetur, Grapald. Poftilena incuruum lignum fiue craffiuslo rum dicetur, quod fub iumentorum cauda pofuêre, eò quod à pofteriore parte habeatur. Plautusi in Cafina, Ira te aggerunda curuum aqua faciam, probè, Vt ex te poftilena poffiet fieri. Hincpercon 4 trarium antilena, qua peçus cingitur, ut pecforali, Grapald. \& Sipontinus. Antilena, ১as vostots

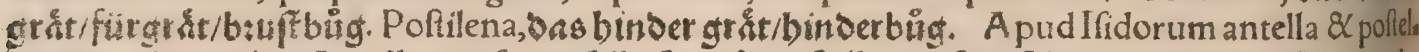
la legitur, his uerbis: A neella, quafi antefella:ficut \& pofiella, quafi pofteella. Aliqui poftilenamden

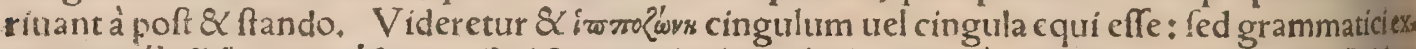

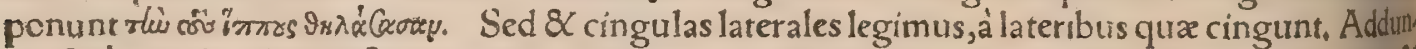

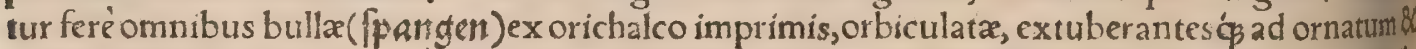

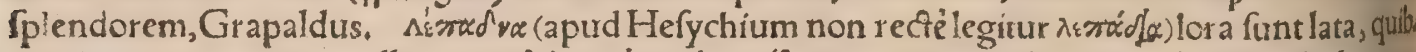

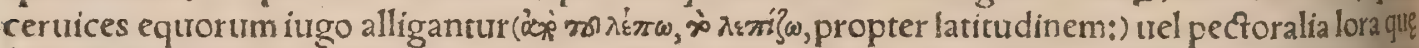

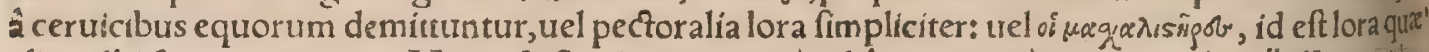

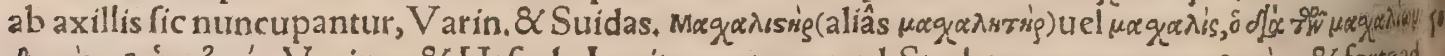

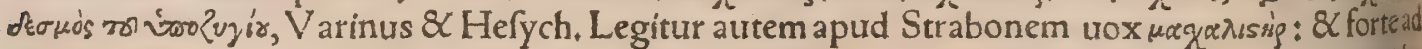

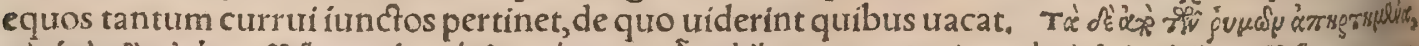

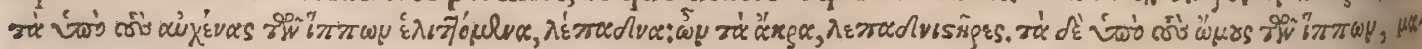

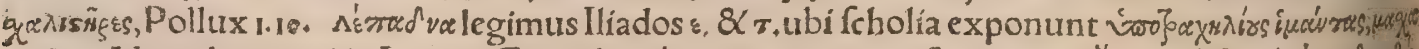

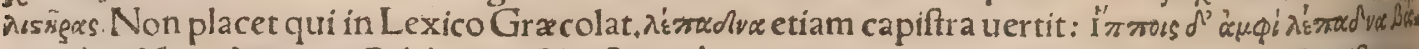

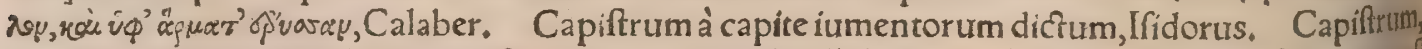
capits uincultım, quod iumentis $\&$ cuicunq̧ animali adhibetur, nefugiant. Primać ferratis prafi gunt cra ca piftris, Vergil.z. Georg.id eft duris, Seruius. Hinc uerbum capiftrare, Vide Promptuar

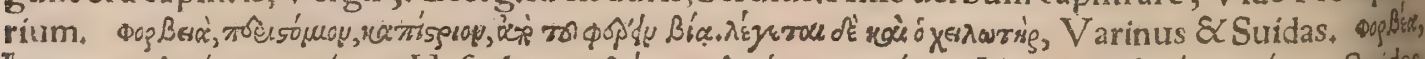

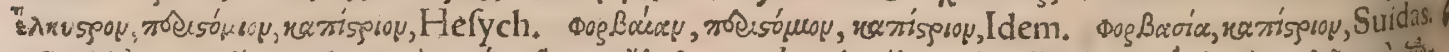

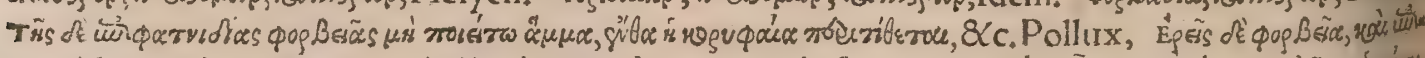

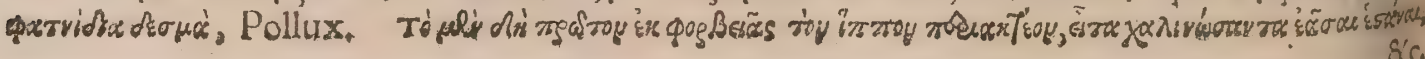


quod ad aures equorum religabatur:oreas que ora coércebantur, Feft. Et alibl, Orex freni quód a: ri inferuntur dicti. Titmnius in Setina: Etfi tacebir, tantum gaudebit fibl permitti orex. Cacilius in Ariolo:Deprandiautem Leonis obdas oreas. Cato Originum libro 3. Equos refpondit oreas milhi, inde tibi cape flagellum. Trebelius pro fe apud populum; Equus qui mihi fub feminibus occifus en rat, oreas detraho. Lupati funt freni afperrimi, dicti à lupinis dentibus, qui inæquales funt, ( quod \& Seruius feribit:) unde \& corum morfus uehementer obeft, Ifidorus. Lupi, fręni afperrimi, à lupis: nis dentibus, quia inzquales funt:fiue quia duritiam habent lupinorum dentium fimilem, 8 propte rea morfus eorum a perrimus. His frenis utebãtur Galli. Vuillichius Germanicé reddit brecbjeunt. Camerarius apud Xenophontem pro fromiolupos uertere folet. Tempore paret equus lentis anis mofus habenis, Et placido duros accipit ore lupos, Ouid.4. Trift. Non afpera prabet ora lupis, Papinius in Achil.Quadrupedern flectit non cedens uirga lupatis, Silius. Prenfićn negabunt Ver bera lenta pati, $\mathcal{X}$ duris parêre lupatis, Verg.3. Georg. Afper equus duris contunditur ora lupatis, Ibid. Solinus genere mafculino dixit, Isḉs adeò fpreuit lưpatos, ut de induftria incuruatus, ruina $\&$ re $\&$ equirem pariter affligeret. Lupatis temperat ora frenis, Horatius 1. 8. Carm, Paftomis(aliats poftomis, quod minus placet) dicitur fertum (inftrumentum ferreum fiue ligneum ) quod ad cohis bendam equorum tenaciam naribus uel morfui imponitur, Gracé à món gore. Paftomides huic ingentes de naribus pendent, Lucilius, citante Nonio. De formis frenorum utilibus, tam pullis, ö equis fcallionatis \& non frallionatis, Rufius capite 3 r. Idem docet nonnihil de freno \& frenationeca pice 40. quod infrribitur, De extrahendís equo dentibur qui dicuntur falliones. Varias etiam fres norum differentias eleganter pictas, in $k$ ufí tolumine reperier qui defiderabit. Vt iniecfoequillin freno repente exagitantur nouo, Cicero 3 . Tufcul. Immitem quatiebat equum fpumantia fruo Frena cruentanten morfu, Silius, Frenatis lucent in equis, Vergil. Vt armatus eques frenatos fratos'́g teneret equos, Liuius. Equites infrenati, id eft quorum equi non habent frenos, Idem, $\mathrm{N}_{\mathrm{i}}$ midz frenis rö utebar $\tilde{t}$, Oppius de bello A frico. Maffyli equos uirga non freno gubernãtundet Vergilius infrenes uocae Numidas. Murcibij uix ora tenacia ferro Concedunt, Gratius, Defie nis \& reliqua inftructione equorum Libycorum dixi in $\mathrm{B}_{+}$in Mauris \& Libycis. Confrderari deber (inquit Petrus Crelcent.) durities $\&$ mollities oris equi, ut pro illius ratione frenum commodum ad. hibeatur. Sunt enim frena quadam ualde leuia, quadam minus: alia afperrima $\&$ duriffima, aliamin nus:quadam media inter praedicta. Formas corum fribere omitto, quia nota apud frenorum artifi, ces:nec poffunt tam apté défcribi, quemadmodum poffunt oculata fide uideri, Hac ille. Arrianus 3 libro octauo de rebus geftis Alexandri Indorum frenandi morem his feré uer bis defrribit. Equieo,

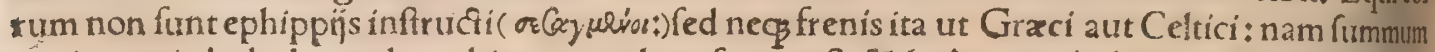

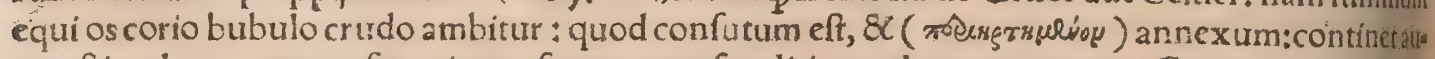
tem ftimulos ex are aut ferro introrfum conuerfos: ditiores eburneos parant, Caterum ori ferreum

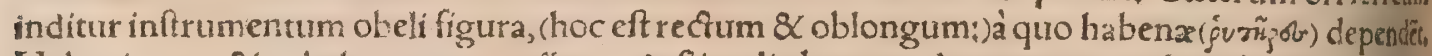
Habenis attractis, obelus equum coérçet, \& ftimuli ab eo pendentes pungendo habenis parereco

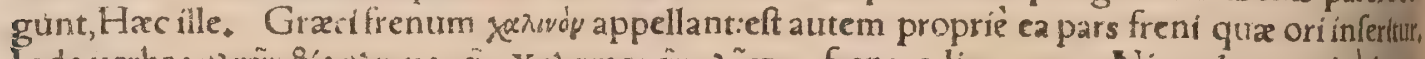

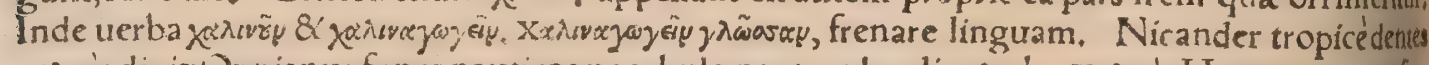

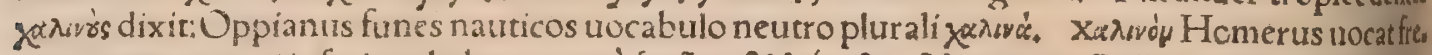

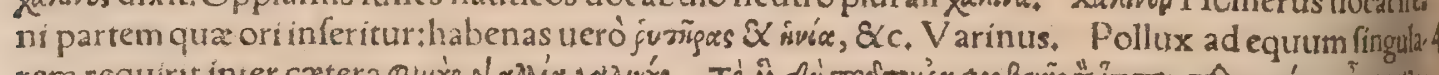

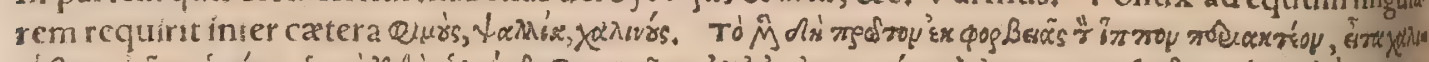

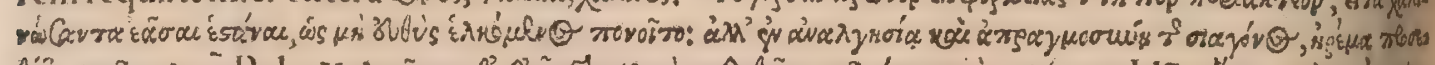
biß

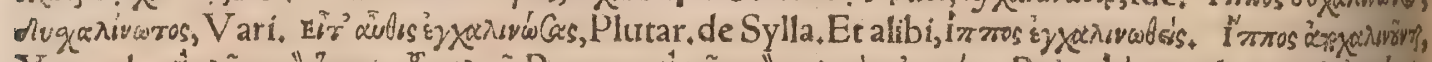

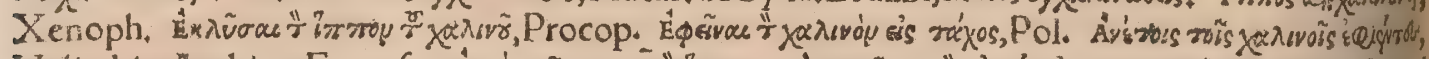

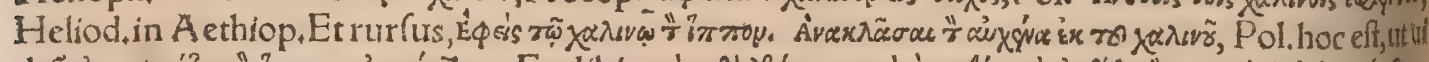

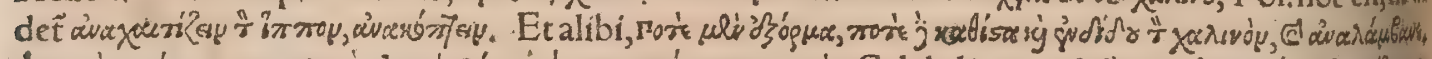

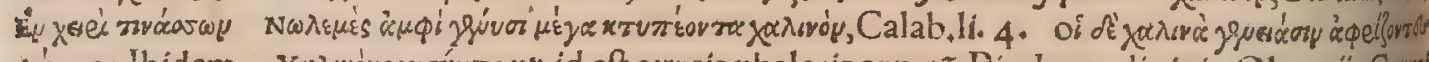

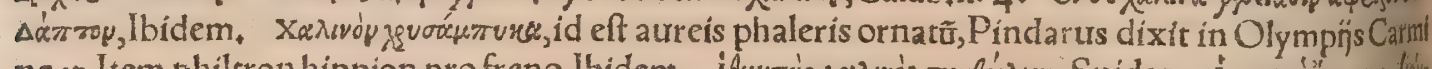

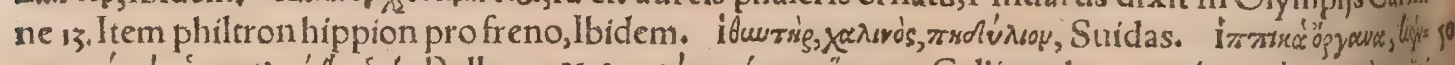

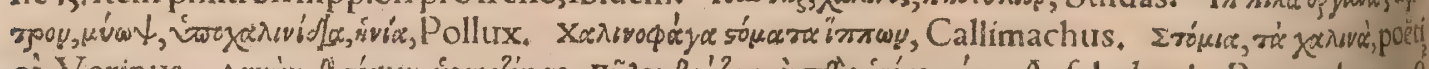

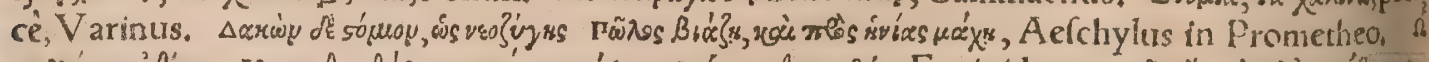

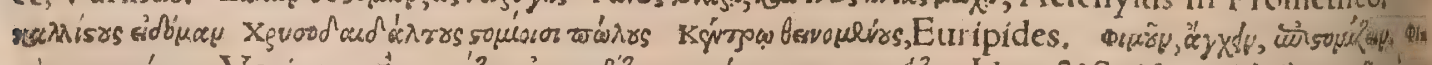

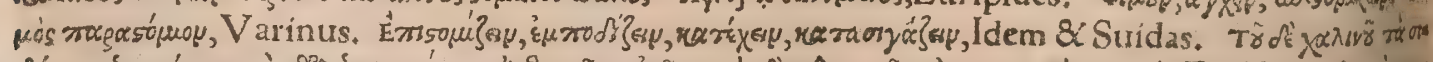

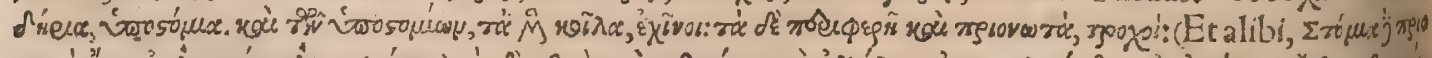
v

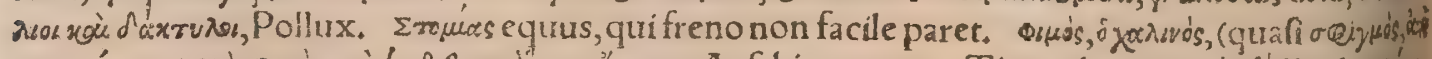

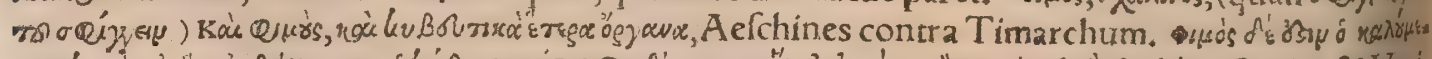

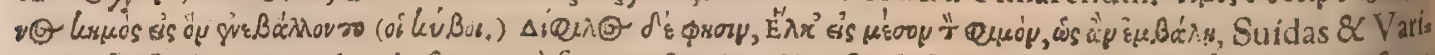

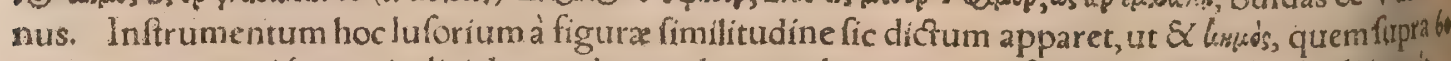
quogs inter pretati fumus iudicialem cadum, uel operculum eius coniforme, per quod calculi immit

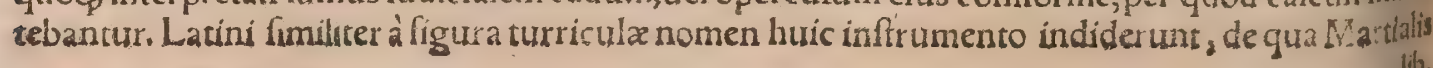




\section{4

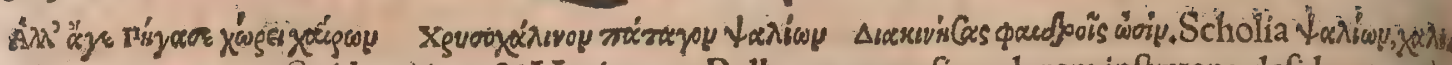
vw̃y exponunt, ut Suidas etiam \& V arinus, Pollux equum fingularem inftruens defiderat $x$ sus

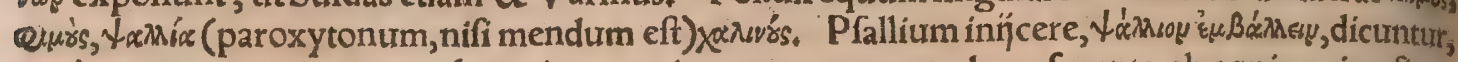
qui ferocientem animum moderamine quopiam premunt, metaphora fumpta ab equis animofiori,

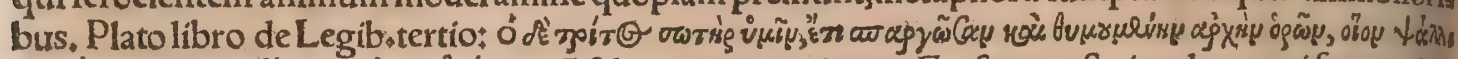
op ş่ tur, unde \& pro freno ponitur interdum. Nifi forte allufit ad bubalos, qui circulo ferreo naribus in: iecto circumaguntur, unde prouerbium, Naribus trahere. Rufius quidem inter picturas frenorum, nonnullos cum circulis pingit media parti anteriori annexis, ut pro equis Turcicis, \& genetis $\mathrm{Hi}$,

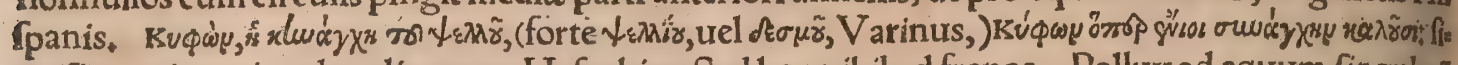
gnificat etiam uinculum ligneum, Hefychius,Sed hoc nihil ad frenos. Pollux ad equum fingularę

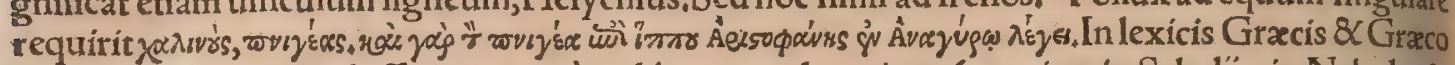
latino wuvyzu's non aliud effe dicitur quàm clibanus, uel caminus (ut etiam in Scholins in Nebulas \& Aues Ariftophanis:) \& propriê ubi extinguuntur ac fuffocantur prunz: mihi fane in uerbis Pollua cis freni uel lupati âfperioris genus effe uidetur, quơd ferociores equos ita aliquando coérceri opor

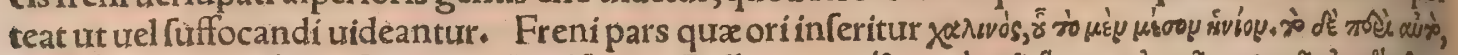

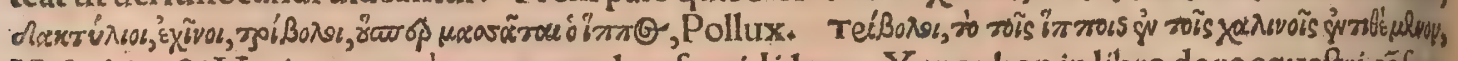
Hefychius $\&$ V arinus, $\Phi x$ s, pars quxdam freni,lidem. Xenophon in libro de re equeftri cófcen

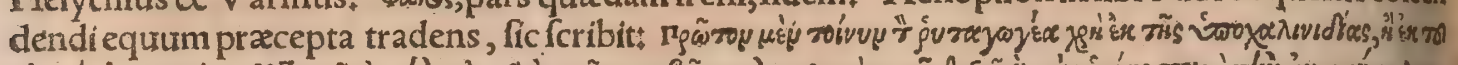

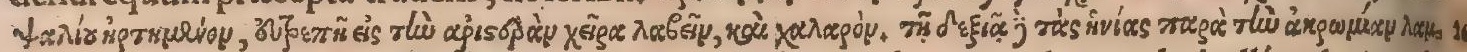
Bavez $\omega$. . Camerarius uertit: Primum de freni parte inferiore, feu etiam de annulo bulláue huius reli gatum lorum ducforium, aptéfiniftra manu prehendet, \& fatis laxé. Dextra capiet habenas depofis tas in fummis armis. Et rurfus in eodem libro, ex eiufdem uerfione : Primum non pauciora frena duobirs parabimus:qưorum unum leuius orbes (7̧oxís) habeat grandiores:alterum eoldem cum gra ues tum depreffos. Echini autem, id eft claufura, erunt acutiores, ut cum iftud prehenderit offenifus equus afperitate mox dimittat: Cum autem lenius illi inditum furerit, tum gaudens huius quidemle nitate, alia nithilominus ad qua af periore freno inftructus fuer at, fub leni quoqs exequatur. Sinlents tate contempta in hoc penitus incumbere urolet, cogent frilicet illum hanc ob caufam fubiecti gran diores orbes, os pandere, atc ita admittere lupos. (Sed Graca mihi aliud fonare uidentur, proinde

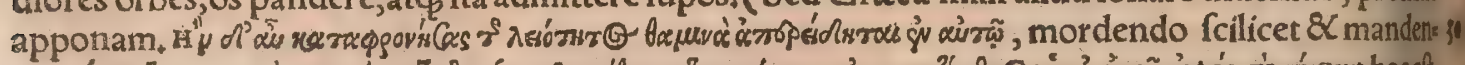

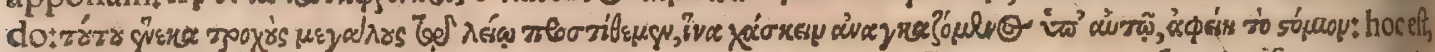
ut os pandere coactus, frenum mordere $8 \times$ mandere definat.) Poterit autem afperius frenum tarias

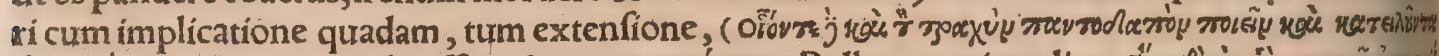

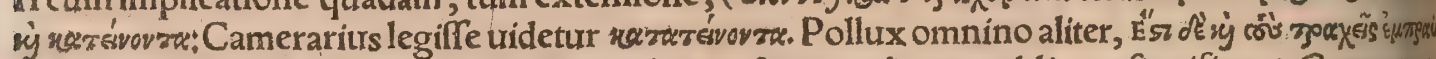

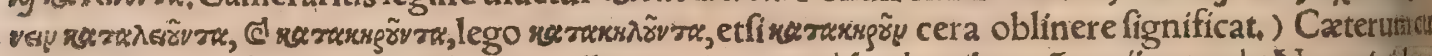

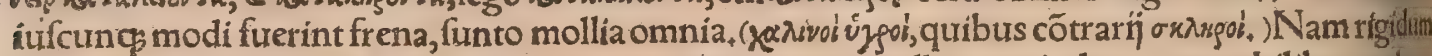
quauis parte fui prehenfum retinet equus totum inter maxillas, perinde ac ueru ubilibet prehen das totum fuftuleris. Alterum uerò non aliter quàm eatena, ea parte tantummodo qua tenetur, non

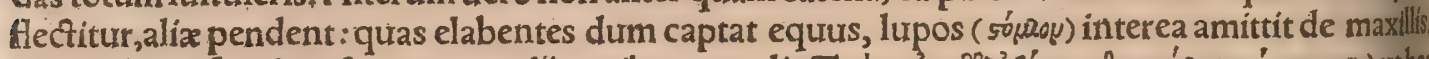

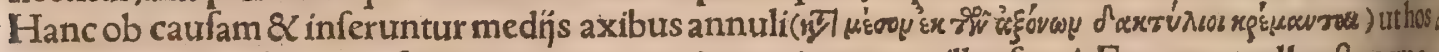
lingua at $\$$ dentibus prenfans, omittat correptionem inter maxillas freni. Frenum molle eft, cum an

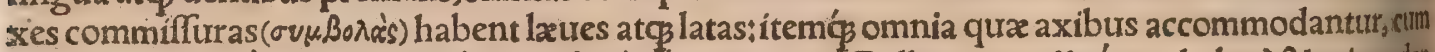

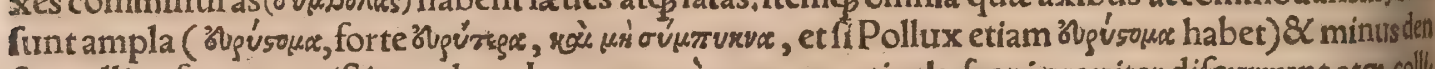
fa,mollius frenum exiftimandum. In quo uerò omnes particula freni grauiter difcurrunt at $q$ colll,

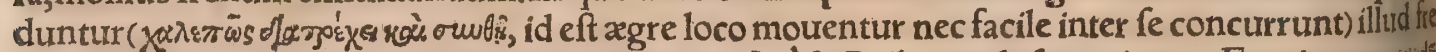
num rigidum erit, Hackenus Xenophon, Eadem feré \&Pollux:uide fupra in E. Freni pars quàth nuncupatur echinus; ficut quod circa mentum eft, pfellium: quod ori inferitur, chalinus:cuius meil

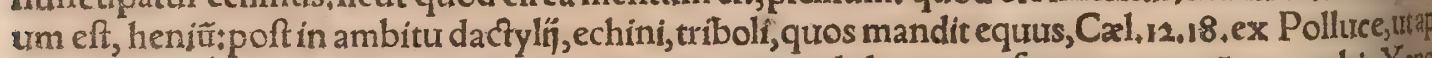

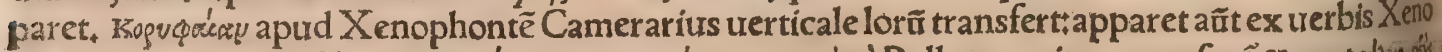

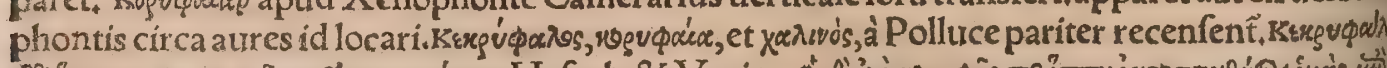

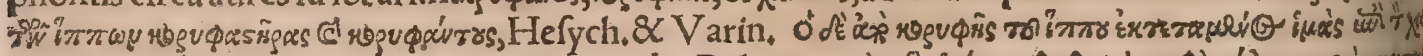

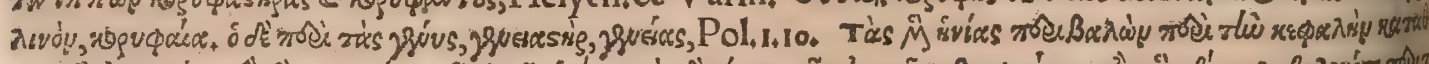

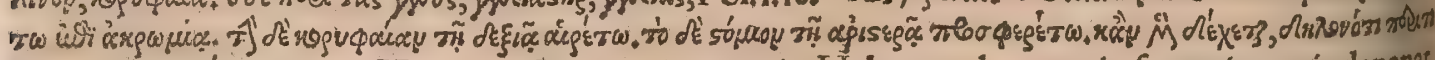

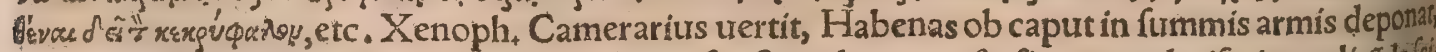
ưrticale aût attolless in dextra teneat, ac lupos finiftra admoueat: q̊s fi equus admiferit,applicẩda î̀ licet erût freni lora. Coryphęã fortaftis Latinè frontale lorũ uel frontale fimpliciter nố ineptè dixertis. Nam freni ipfi (ut fcribit Grapaldus)à frontalibus pendent, quæ caput equi hinc inde uinciunt, 8 addicis bullis interdum auratis, gemmisq́p uenuftant. Plinius 37.12, de cochlite gemma, Quondani tanta magnitudinis(inquit)fecere, ut equis regum in Oriente frontalia, atç prophaleris penfiliafas cerent.Sed ampyx, potius quàm coryphaa, frontale uidetur, de quo infra. Aliqui frontale expontut ornamentum, quod fronti equorum fiue elephantorum imponi folebat. Ingentes ipfi erant, a bant feciem frontalia \& crifta, \& tergo impofita turres, Liuius, Pollux quidem rbustwridge, in 
comam è renuifimis fllis fericis fiue bombycinis, diuerfis coloribus alternatim diftinctam : trulgus appellat cin bervel. Á nam ampyx in equo fuerit, multis docet $V$ arinus. Ampyx, inquit, mafculini generis fecundum ueter res, diadema quoddam effe fertur capillis religandis deftinatum, quos collectos ueteres huic uinculo fubijciebant:qua quidem defcriptio kr̃ ф̧a uulgo dictam non aliud effe quàm ampycem demonftrat,

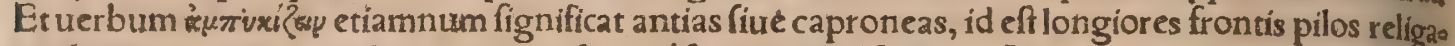

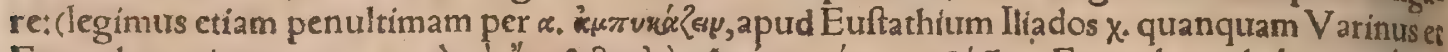

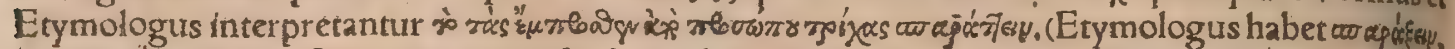

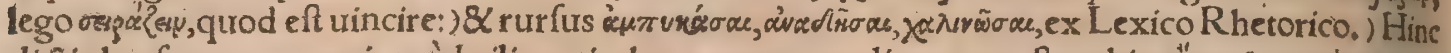

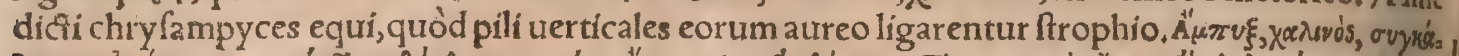

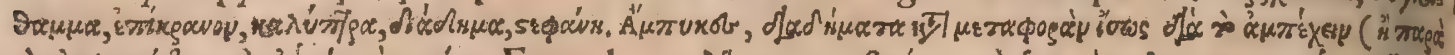

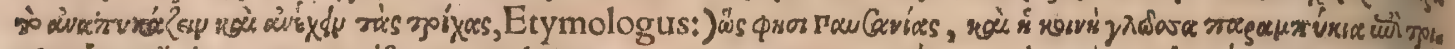

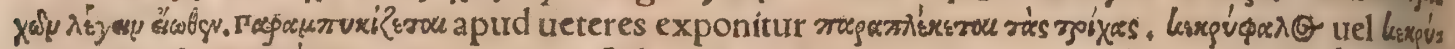

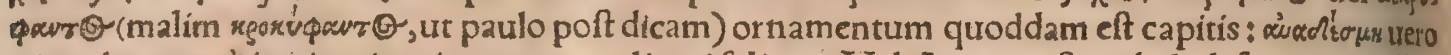

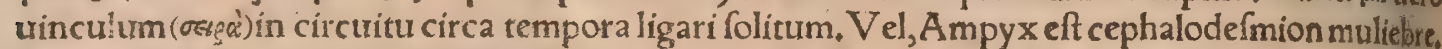
Ampyx apud Sophoclem in Philociete pro rota accipitur propter rotunditatem, $V$ arinus. Xevoritu

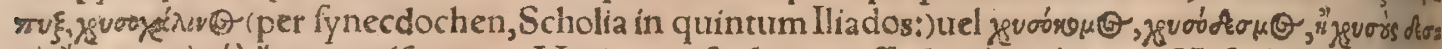

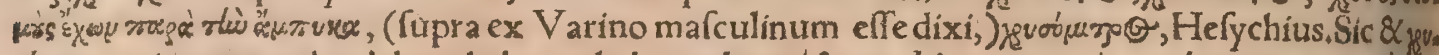

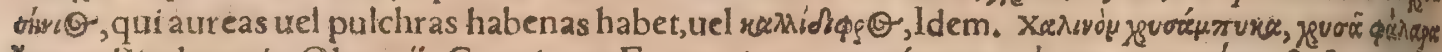

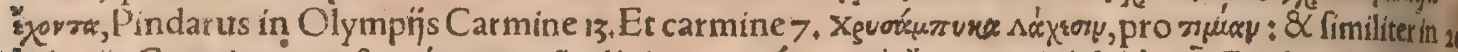

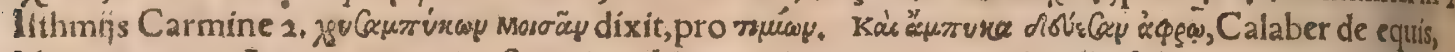
libro quarto. Ampyx proprie eft capitis obligamentum, ac auro \& lapillis fplendicans lorum, capi ticircumiectum formineo:terum metaphorice aurolitum fic nominant frenum, Calius ex Varino

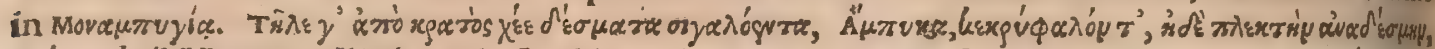

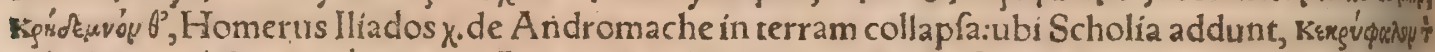

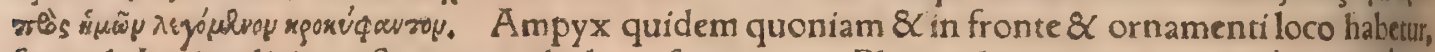

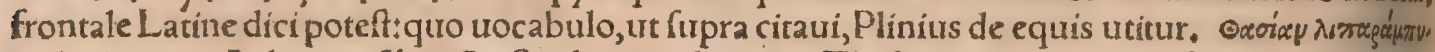
ro, legimus in A charnenfibus A rifiophanis: ad uocem, Thafiam, aliqui muriam fubaudiunt:alippltha

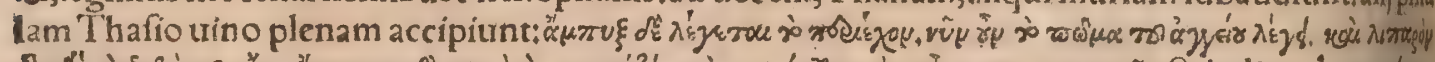

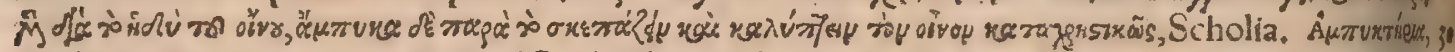
phalera, equina ornamenta, apud Sophoclem in Oedipo in Colono, V'arinus. Mova $\mu \pi v$ yiav equum

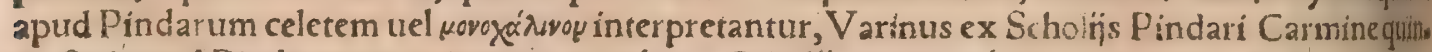

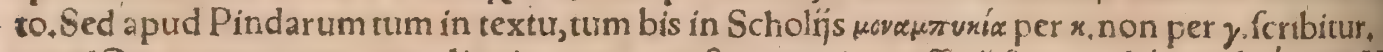

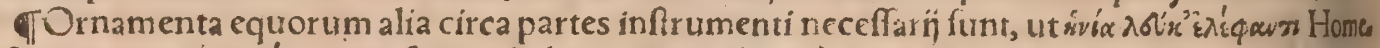
ro, \& aurum gemmá ue circa frenos, habenas: de quiburs hî́ nibil aut pauca dicemus : alia folius or natirs gratia adduntur, ut frontalia, monilia, phalera. Phalera equrorum ornamenta dicuntur, âter bo Graco quuod illuftrare fignificat, Grapaldus; $\phi \alpha \lambda$ ò Graci illufire dicunt. Reperitur autem in piu

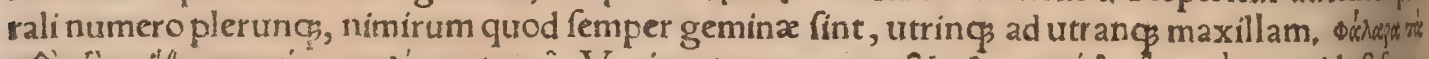

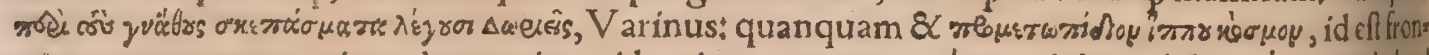

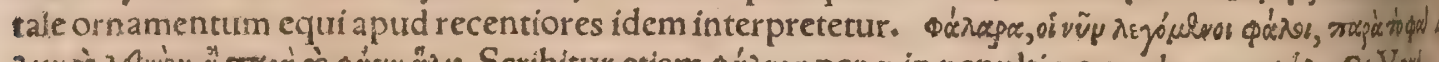

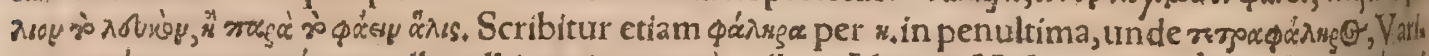

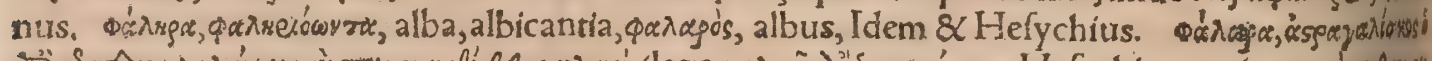

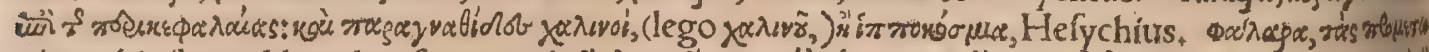

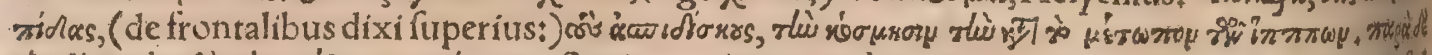

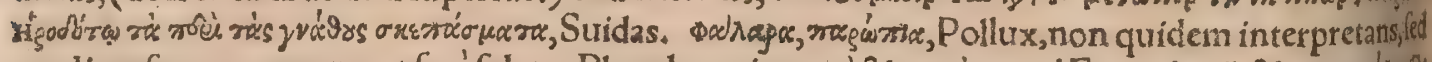

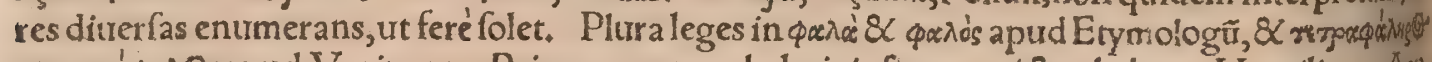

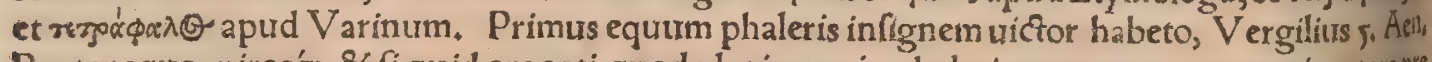
Prxter equos uiros'́s, \& fi quid argenti, quod plurimum in phaleris equorum erat, omnis cęterapię da diripienda data cir, Liurus. Frangebat pocula miles, Vt phaleris gauderet equus, Iuuenalis $s a$ ryr.11. Plinius etiam in fingulari protulit libro 23. his uerbis: Eftenim adiecium hoc quoç; : fed $\&$ phalera pofita, propter qua nomen equitum adiectum eft. Phaleratus, phaleris ornacus. Stretonius in Claudio, Craffus frugi equo phalerato, 8 in uefte palmata. Munera qquz legati ferrentregi, den creuerunt, equos duos phaleratos, \&c. Vt phaleratis dictis ducas me, Terentius in Phormionetubi Donatus phalerata interpretatur honefta at $\$$ ornata. Primo die phalerato equo infignis, Suetouly us in Caligula. Equitatum frenis, ephippijs, monilibus, phaleris prafulgentern, Gellius libro s, Pha

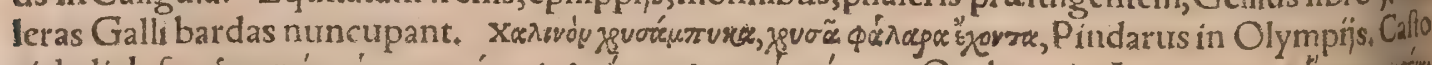

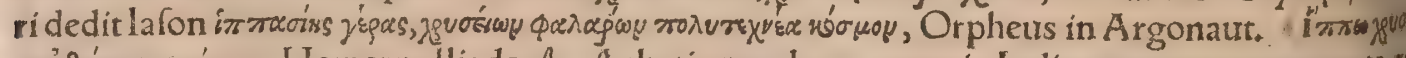

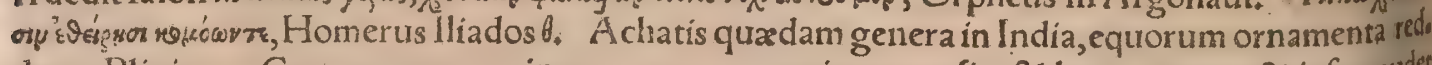
dunt, Plinius. Certe equus non iners, neç corpore incompofito $\&$ bene curatus, $8 \mathrm{~L}$ ipfe gauder quodam comptu, \& equitem exhilarat. Neq3 hoc fugit, quem nihil fugit etiam minimarum rerum, h Homerum, qui ornamenta equorum, \& ipfos reddere confpicuos dicit, \& equitibus dignitatemac

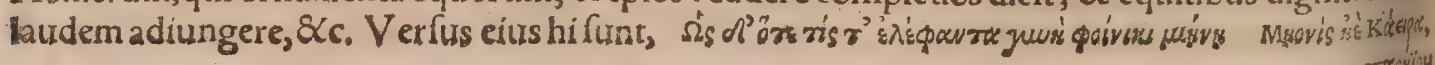


patinfcium uulgus) ab Auricenna interprete, primo Canonis dicuntur fubfellares, quia fub fella propendeant, ut docti interpretantur. Monct autem inibi Princeps, non oportere fubfellares, aut pe dum integumenta effe iufó àchiora, quoniam eius membri motus lôge facilius arcere ualeat frigus, Cxilus, Equos ueterum neq legimus, neç ex monumentis eorum afpicimus, pedum fuftentacula, qua uulgò ftaffas appellant, habuiffe, Volaterrantus، Ephippio dextra ac finiftra loris quiburdam ferrex machinulz: adduntur, quas ftapedes elegãter $\&$ Latialiter appellabimus: quia in his feffores, dum terga premunt equorum, pedes habere confureuerunt: apud maiores, ut in ftatuis equeltribus apparet, non fuêre, Grapaldus. Germani trocant ftß̊greiff. I Calcaria diça quia in calce hominis ligantur ad ftimulandos equos ( $\&$ iumenta) qùibus aut pügnandum eft, aut currendum, propter pla gririam animalium aut timorem, nam ex timore ftimuli nuncupati, Ifidorus. Calcari quadrupedem agitabo, Plautus Afinaria. Seu fpumantís equi foderet calcaribus armos, Vergil.6. Aene. Ferrato calce, atcos effura largus habena Cunctantem impellebat equum, Silius 7.Punic. Calcaria addere per metaphoram eft cupiditatem ac ftudium alicuius augere atçacuere. Vide Erafmum in Chiliad, Et narbus adderè calcar, Horatius 2. Epift. Ifocrates dicebat fe calcaribus in Ephoro egêre, contra atitern in Theopompo frenis uti folere, Cicero z.de Orat. Laudatá̧̧ uirtus Crefcit, \& immenfum gloria calcar haber, Ouid. 4. de Ponto. Ventus fuo cafu uehementius fufflare, \& calcar id eftim. petum) admouere, Varro apud Nonium. Generoffim $x$ creduntur gallinæ, qux quinos habent dia gitos, fedita ne cruribus emineant tranfuerfa calcaria ( $\left.\pi \lambda \hat{n}_{n}\right\}_{0} \alpha_{\text {, }}$ ) Columella. Inter equeftria inftu

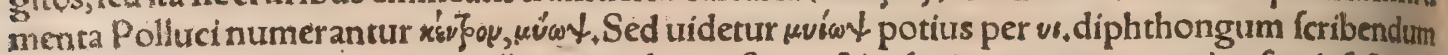
kum infectum fignificat, quod alins nominibus oftrum \& tabarium uocane, aculeo fuo infeftum, cuius fimilitudine ftimulus etiam fiue calcar, quo equi urgentur, dicfum tuiderur: eft enim illudinfen" Aum ex genere $\mu v i \tilde{\omega}$, , id eft mufcarum, cuius uocis fimiliter primam fyllabam per diphthongumferi bunt. Cum uerò lufciofum, fiue illum qui proxima tantum uidet, remotiora nô uidet, fignificat, per

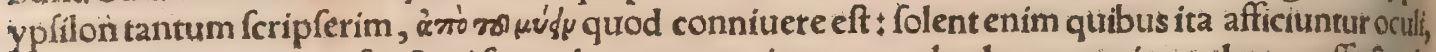
cum quid accuratius infpecturi funt, plerunģ conniuere, quod uel ex proprio ocullorum affectur cla rius intelligo. Sed uideo in multis dictionibus ypfilon merum provt, diphthongo frribr, quod apud

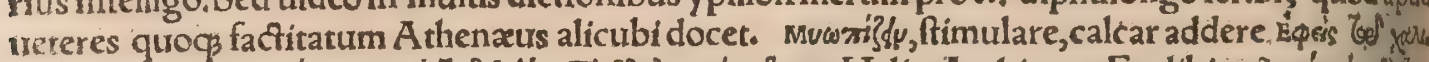

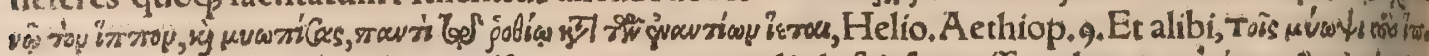

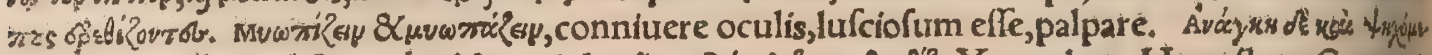

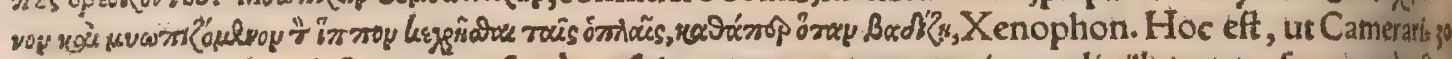
us uertic: Nam fiue deftringatur, feu à mufcis pungatur equus, uti ungulis illum non fecus quàm fi

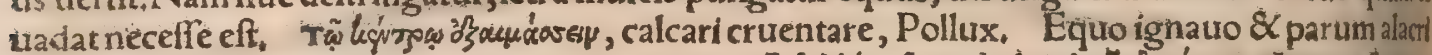

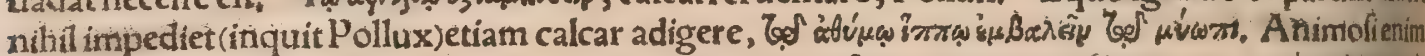
indignantur, \& icfu lafi tanquam accepta iniuria in curfum præiracundia aguntur, ('ix doóciov:) \& impetu qui periculofus eft domino propter iram feruntur. Quód fi quis equitandi artis in fcius fuerit, parumç̧ firmè infederit, illum etiam excutiunt, $\&$ ab inftituta uia auferunt, $\mathcal{Q}$ in pofteri

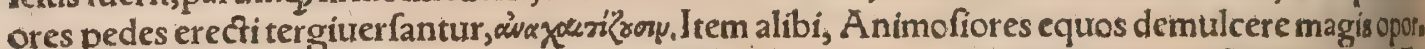

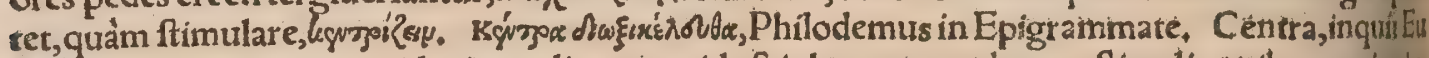
tathius, funt quæ encentrides item dicuntur, id eft inhærentes calcanco ftimuli, quibus excitarie quós nouimus. Erant $\&$ fux furibus encentrides, quibus per parieres obrepebant, uelut facitafle Corøbus dicitur apud Paufaniam, Calius. Encentridas pedibus circa calces alligabant equitan

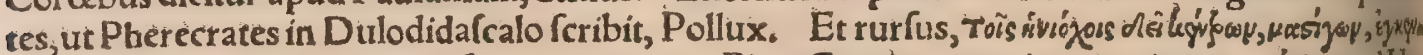

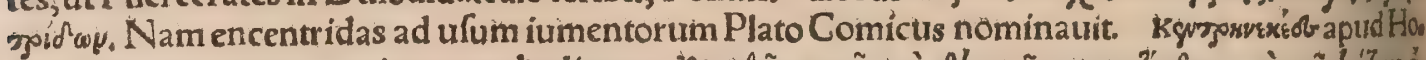

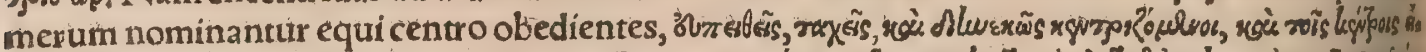

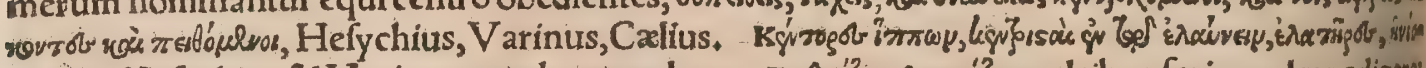

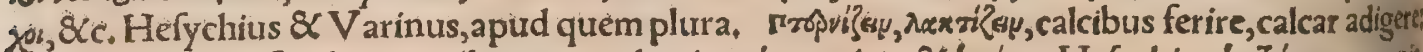

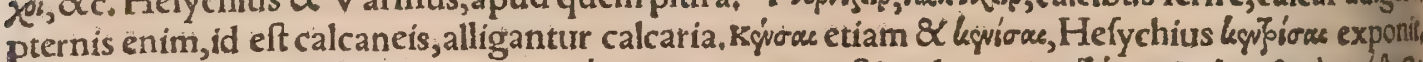

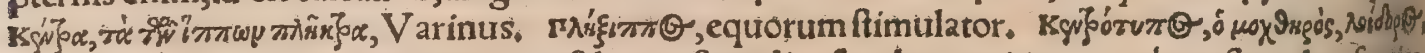
"ó siviox $\theta_{\text {, }}$ Varinus. De butcentris, id eft boum ftimulis, fuo loco egimus, sánzzs, ftimulus, fcuria,

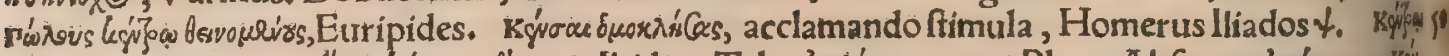

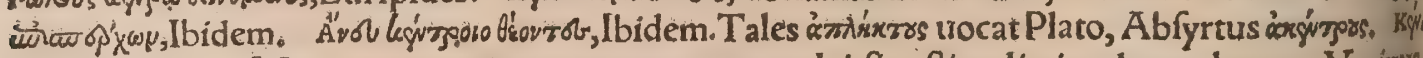

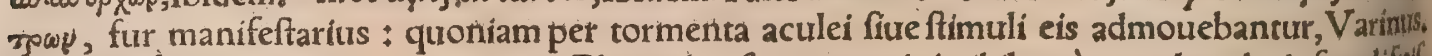
Irors fane tormentigenus, cuius ex Plutarcho fupra menini:nihil quàm aculeos huiufmodifutio fe crediderim: ut una litera mutata eculeos aliqui dixerint, alh̀ equuleos, ut cocum \& coquum dício mus:quod non animaduertentes Graci imrs potius quàm kévorox tranftulerint : nifi quis inde pou tius hippos $\$$ equuleos dictos arbitretur, quòd homines eis ita ftimularentur, aut etiam crudelius, ut itimulis $\&$ calcaribus equi. đCalcaribus equos concítamus, non aliter quàm flagellis éfummis arborum partibus, (id eft uirgis lentis $\&$ flexilibus, )è loris, è neruo taurino, Grapaldus. Eloris flagris

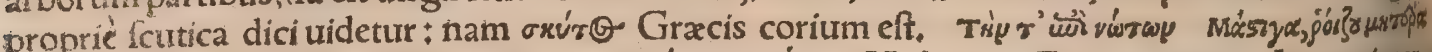

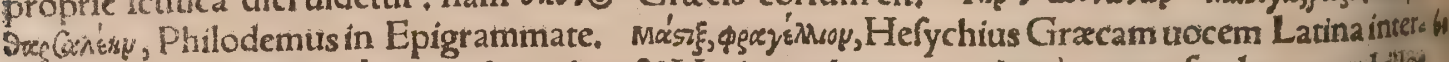

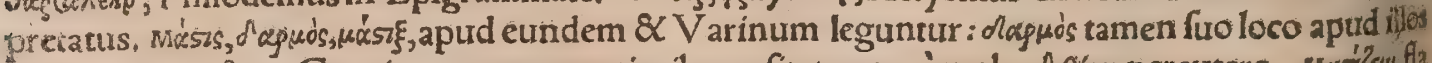

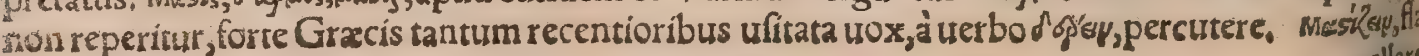




\section{0 \\ DeQuadrupedibus}

lorumćs affectis corporibus, Plinius de fpongịjs loquens. Hinc ftrigilecula diminutiurum. Strigis lare, idem quod fringere, Grammaticus quidam finè teftimonio. Strigiles à ftringendo, id eft exie,

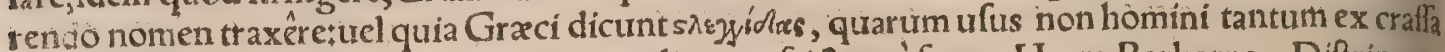
\&ruida lacinia, fed eciam iumentis in quotidianum frictum è ferro, Herm. Barbarus. Diftringere apudPlinium 34, 8. prodefricare in balneis, \& utiftrigilibus. Vide fupra in E.nonnihil de defrican,

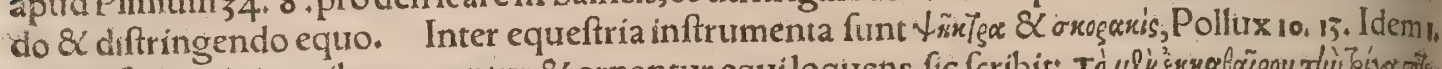

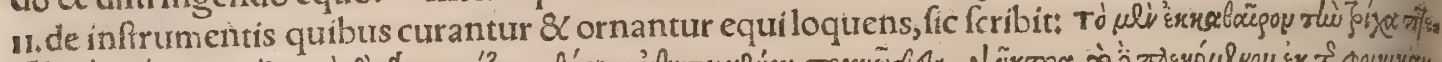

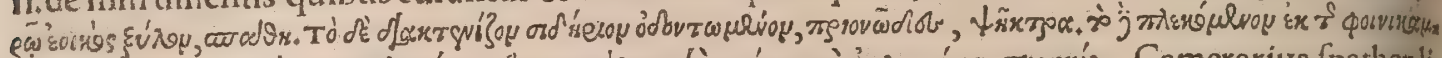

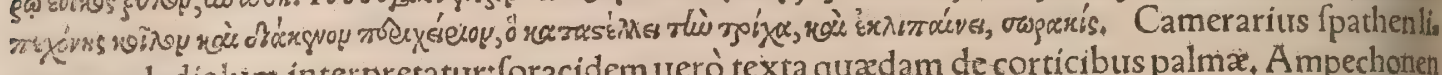
gneun gladiolum interpretatur:foracidem uerò texta quadam de corticibus palmæx. Ampechonen 1cio ueftem fignificare, 8 arborem fuo cortice tanquam ueftiri : de palma tamen ampechonendi= Cam nuf́quam legitmafchale quidem palmæ ramum fignificat. fed legi alicubi ex palmæ, ni fallor, fo

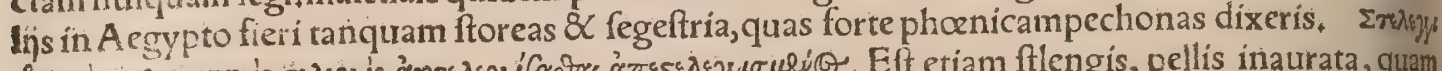

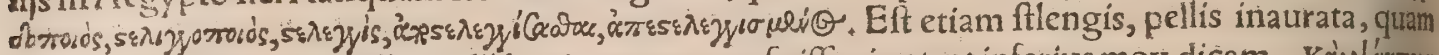
capiticircumponunt, Pollux: alij laminam auream fuife aiunt, ut inferius mox dicam. Kà ฟ'

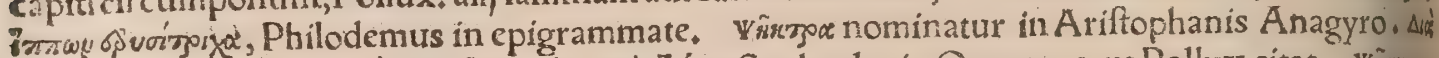

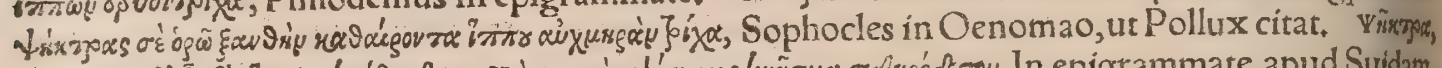

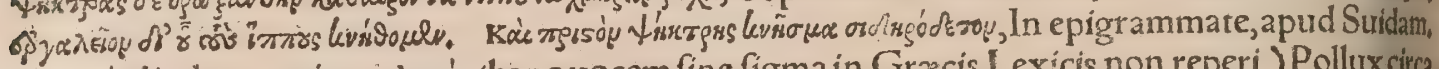

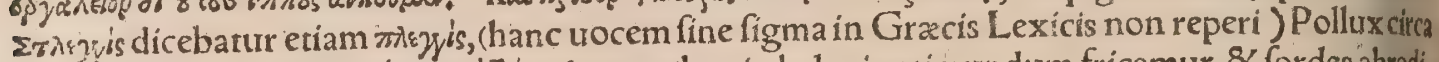

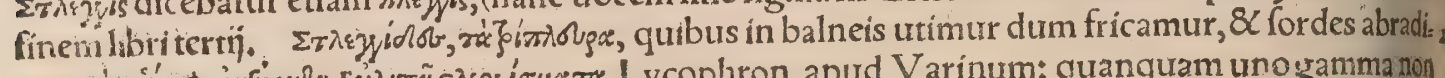

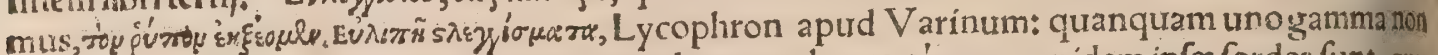

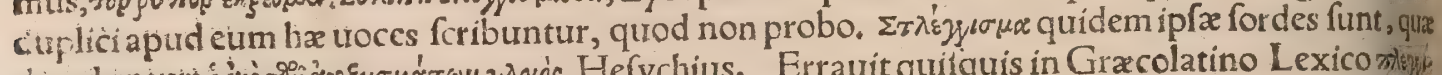

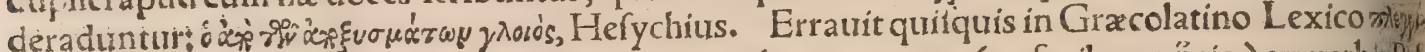
- Ie uas olearium interpretatus eft : incidit autem in hunc errorem ( ut facile conñcio) ex uerbis Pol

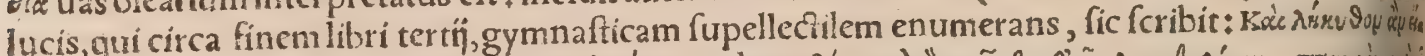

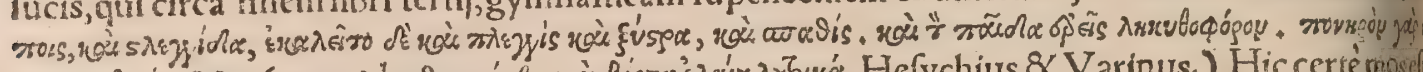

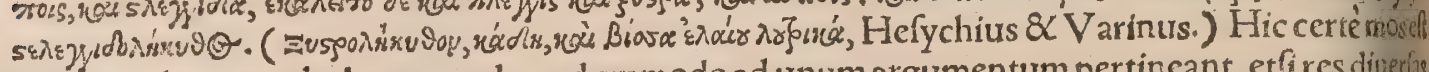
Pollucis plura uocabula accumulare, dummodo ad unum argumentum pertincant, etfi res diveríns fignificent. Quòd uerò non fit uas olearium, etfi ufus cius ad hauriendum élecytho, id ef ócari uafe oleum elfe polfit ( alia forte quædam ftrigilis figura olim fuit), fed obiter $\&$ per acciden 8 , e

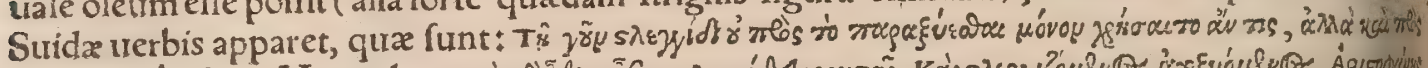

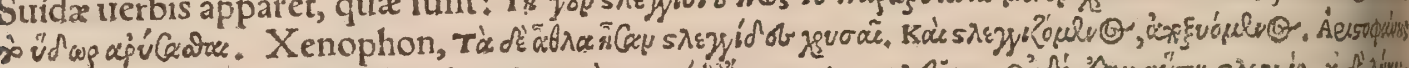

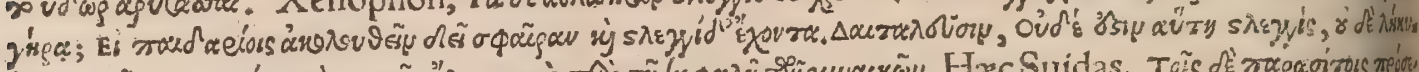

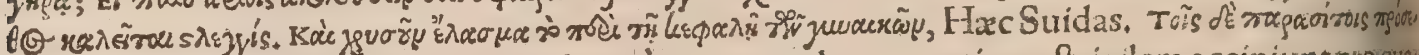

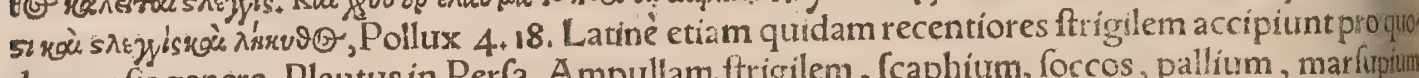
dam uafis genere, Plautus in Perfa, Ampullam, ftrigilem, fcaphium, foccos, pallium, marfurtum habeat. Et in Sticho, Rubiginofam ftrigilem, ampullam q́a rubidam. Cum nitil prohibeat his \&litis quos citant locis frígilim balneatoriam accipere, qux cum ampulla olearia ferebatur, ut poff fititi onem, \& fudoris abfterfionem, quæ frigilifiebat, ungerentur. Gliris nardo decoquitur ufe adier

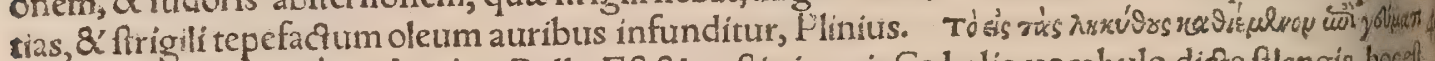

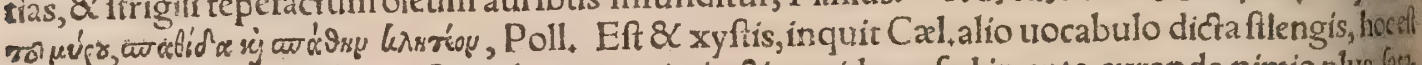
frigil: unde xufticos feu xyfticos legas pro indoctis quidem, fed in cute curanda nimio plus fats gentes. Legitur id nomen apud Epicharmum 8 Diphilum. Ego xyftidem in Lexicis Gracorum Polluce, Ariftophanis fcholijs, \& fecundoIdyllio Theocriti, pro ueftis aut etiam iaculigenere exi poni reperio, pro ftrigile nufquam : xyftra uero pro ftrigile, receptum omnibus eft uocabulum Stlengis fignificat etiam ductam ex auro bracieam fiue laminulam, qua coronabantur, non mulie res rantum, ucrum $\&$ uiri, quod indicat per initia quartilibri Ashenæus, Cælius. Phidias fecitdi ftringentem fe, Plinius 34.8. Et paulo poft, Lyfippus fecit diftringentem fe: Etmox de edem

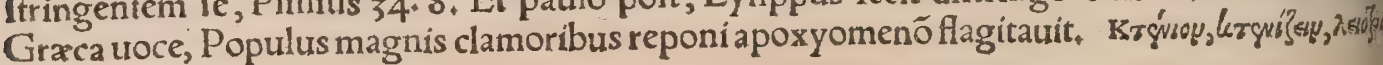
in Hippiatricis.

ब1 Venio ad rem curulem, in qua cum copiofiffimus effe poffim, temperabo mihi tamen, utadle quentia feftinem. Plura conquirendi materiam ftudiofi habent ex Gręcis Latinisćg dictionarns. pfit $\&$ Calius Calcagninus, ni fallor, de appellationibus rei curulis. Ego ea tantum afferam qua in prafentia fe offerunt qualiacunq, nemini caufam dicturus etiamfi praftantioribus quibufdamonil is leuiora commemorauero, Curules equi,id eft quadrigales, Feftus, Textor etiam currilem dixt cqurm ex recentiore quodam, dubitans an currulis potius dicendum fic. Curules equos (per lim plexr. ut \& Feftus) Robertus Cenalis epifcopus interpretatur qui currus uehunt. De curribus quat dam, bigis $\&$ quadrigis præfertim, uide fupra in Certaminum equeftrium mentione. of zounps, idel iugum uocari poteft quicquid iunctum eft, etiamfi ex tribus aut quatuor iumentis (hypozygij) fur rit Pollux. Subiuges carpento equas, Plinius, Iungere dicimurs non equos tantum, fed ipfos etiam

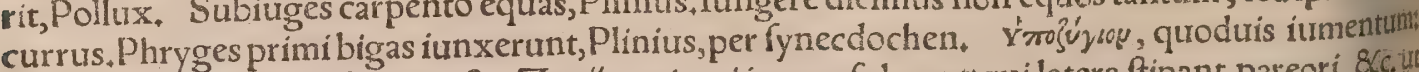
hypozygios uero adiectiumm elt. Zygï equi, qui iugum fubeunt:qui latera ftipant, pareori, \&ci. un 


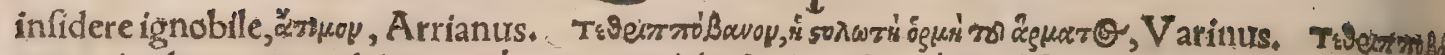

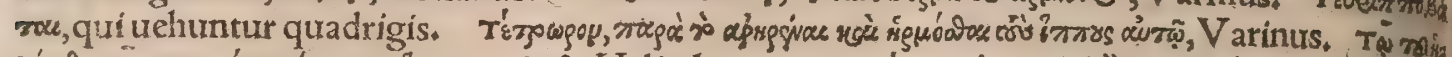

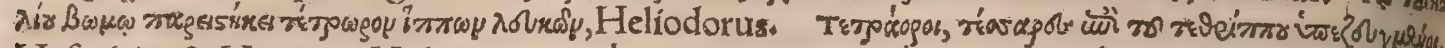

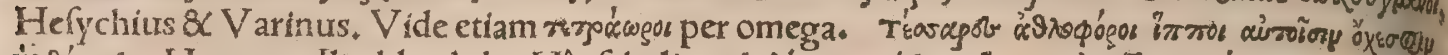

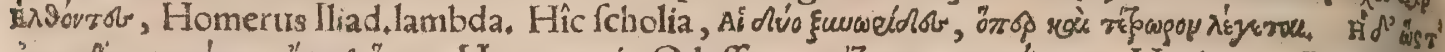

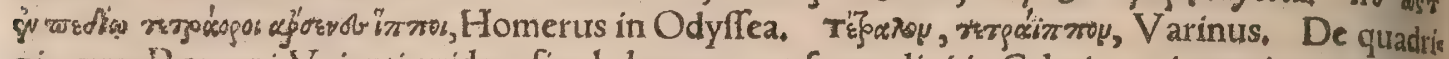
gis, quas Romani Veienti cuidam figulo locauerunt, fupra dixi in Celeris equi mentione in $H_{0}, b_{*}$ OBgas primum iunxit Phrygum natio, Plinius. Bigati, Lituitus. Bijuges equi $\&$ böugi Verglio dt? yyes, Homero. Eutychides pinxit bigam, regit Victoria, Plinius, Et rurfus, Pificrates bigæ $\mathrm{Pia}$ tho mulierê impofuit. Bigarij equi: tales maxime Hetruria dextrarios uocat, Hermolaus, Synori

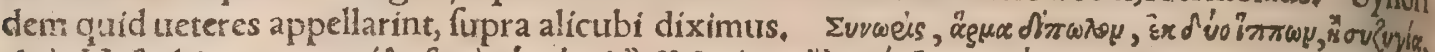

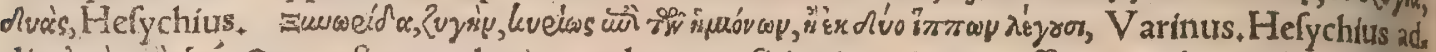

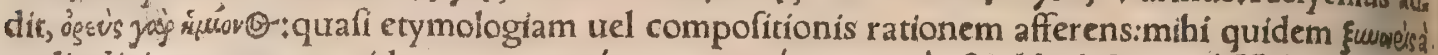

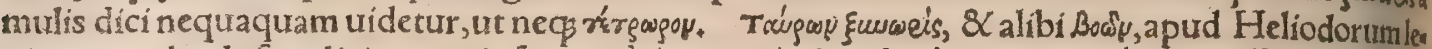

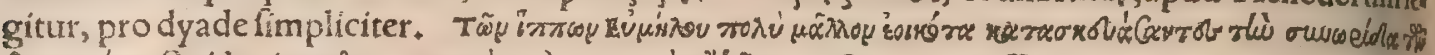

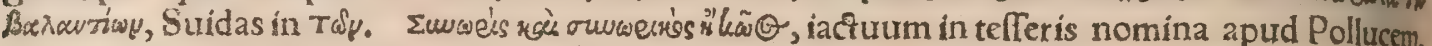

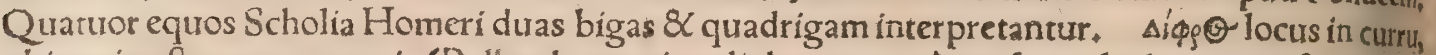
ubi auriga fans equos regit, (Pollux harmation diphron uocar) per fynecdochen pro ipfo curruto

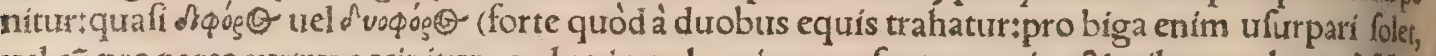
vel cư pro parte currus accipitur, $q$ duo in ea homines uerfentur,auriga 8 miles parabates, ) Vide

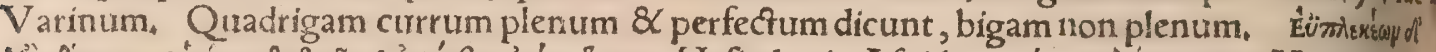

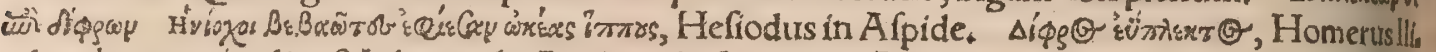

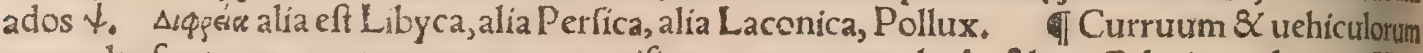
permulta funt genera, ut carrus, carruca, cifium, carpentum, rheda, $\& c_{*}$ Celerius uoluntate Hor. tenfí ex equili educeres rhedarios, ut tibi haberes mulos, quàm è pifcina barbatum mullum, Varto. Rheda uocabulum Gallicum,genus leuriculi currus, quo geftabantur nobiliores in uillas furas, cuiluf modi funt hodie quos Itali cochios uocant. Plurima Gallica ualuerunt, ut rheda 8 petoritum quo que, Quincilian. ad Atticum. Omnemćç aciem fuam rhedis \& carris circundederunt, Cæfar 1, bel.Gal, Quem tol lere rheda Vellet iter faciens, Horat, 2, Serm. Rhedarius auriga rectorós ipfius rhedx, apud $\mathrm{Ci}_{3}$ ceronem proMil. Rhedam mihi uideri, feré ufurpari pro uehiculo cui mulı ad ítinera conficienda aunguntur, dixi fupra in E. ubi \& diuerfa equorum à uchiculis formata nomina protuli, qualia funt;

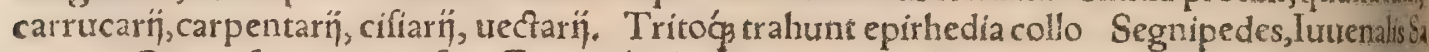
tyr. 8. Quum fítepi præpofitio Græca,rheda Gallicum:nec Gracus tamen, nec Gallus utitur com pofito: Romani furm ex utrog, fecerunt, Quintilianus libror. Eporhediccetiam, tefte Plinioj, Galt lica tox eft, bonos equorum domitores fignificans. Petoritum, Gallicum uocabulum, genus retil culi, apud Belgas Gallize ciutatem repertum, ut Varro fcribit: quamuls fint qui ex Græco uocabli lo \& Latino compofitum uelint, dicrumó à uoluendis rotis, ut Gellius teftatur 15. 30 . Legiturhardl ctio apud Horat.ı. Serm. \& Sccũda epiftola, Effeda feftinant, pilenta,petorita, naues. Et apudPlin, 34. 17. Benna lingua Gallica genus uehiculi appellatur; unde urocantur combentiones (focios unl, gò hodie compaignons nominant) in eadem benna fedentes, Feftus. Bennæ emantur, Cato sap, 23. Nos bennas hodie urocamus inftrumenta monotrocha, quibus ruftici lętamen in agros inuehunt, anfis utrinģ̧ prominentibus ante fe impellẽtes. Rob. Stephanus bennam hodie à Gallis tomberealu uocari docet, à Picardis bareu. Effedum, uehículi genus Gallorum Britannorumá̧, apud Belgas primo repertum. Et propriè effedum in equo. Hic Vedius uenit mihi obuiam cum duobus effedis \& rheda equis iuncta, Cicero 6, ad Att. Solitus in geftatorio ludere, ita effedo alueoćs adaptatls ne lufus confunderetur, Sureton, in Claud. Vtitur $\& \mathrm{C}$ Carar 4, bell. Gall. Gallica uel mollimelius feret effeda collo, Vergil.z. Georg. de equo. Britannica effeda,Propertius lib.2, Eleg.1. Multho nora effeda, Claudianus de mulabus Gallicis. Effeda etiam fominino genere legitur apud Sente cam in epiftolis. Pilentum, inquit Feftus, uehiculi genus, quo matronx ferebantur. Idem uidetur effe çuod petoritum, quod eft quatuor rotarum, ab Hifpanis introducfum. Varro delingua Latin. in confuetudinem fua atate primum ueniffe feribit, Eftó̧ eius forma, qua noftri temporis principü Italia mulieres uectantur:ita libratum, ut confidentes in puluinis in aére fufpendi agitatæ uideant tur. Caftx ducebant facra per urbem Pilentis mătres in molliburs, id efi penfilibus, Verg. 8. Aes neid. Honoremóç ob eam munificentiam ferunt matronis habitum, ur pilento(codices imprefí ha bent plauftro: ueus exemplar, pilento)ad facra ludosḉ , carpentis fefto profeftóć uterentur, Liuli us Y.ab Vibe. Ante fores iam pompa fonar, pilentá́ facra Praradiant ductura nurum, Claudia nus de nuptijs Honoriij. Carpentum, genus uehiculli, dictum quafi carmentum à Carmenta Euants dri matre. Nam prius Aufonias matres carpenta uehebant, Hæc quons ab Euandri dica parente reor, Ouidius I. Faft. Nulionem euitantem fuper ipfum corpus carpentum agere pracepir, Plint us de uiris illuftribus 7 . Nero ofrentabat hermaphroditas fubiuges carpento fuo equas, Plin, hift, Nat. Carpentis utebantur in bello, Liuius I, ab Vrbe, Serica carpenta, ferico panno ornata, Prot 


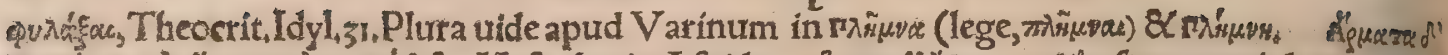

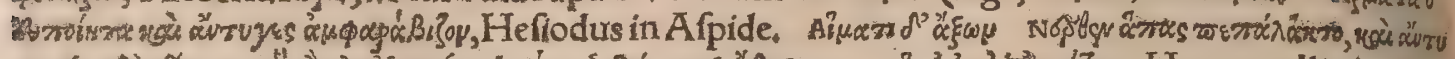

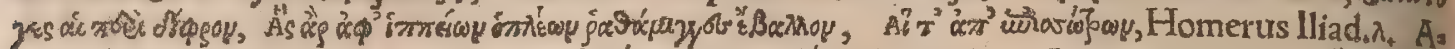

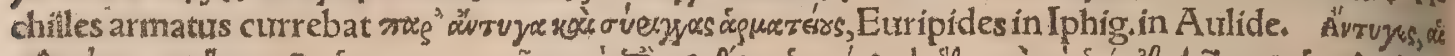

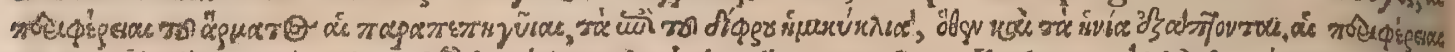

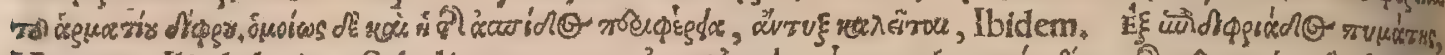

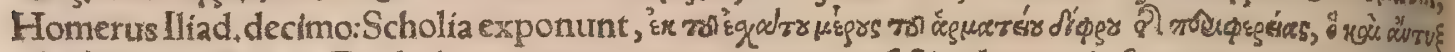
vè̀ uึ fo

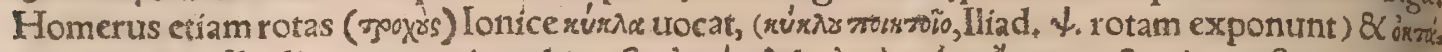

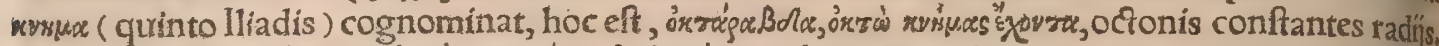

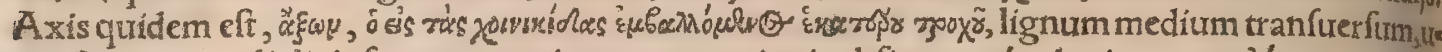

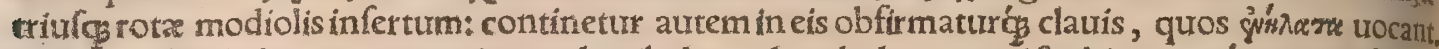

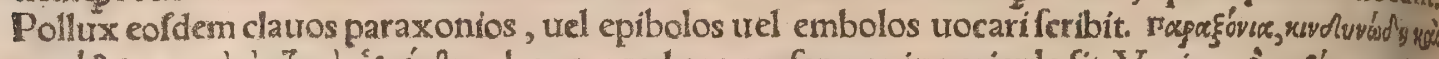

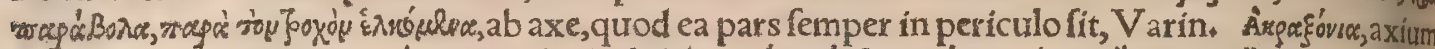

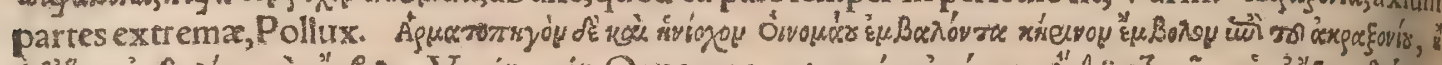

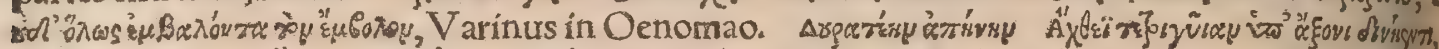

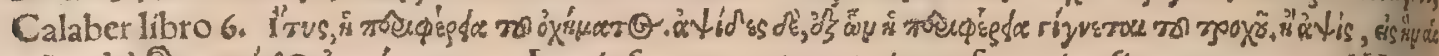

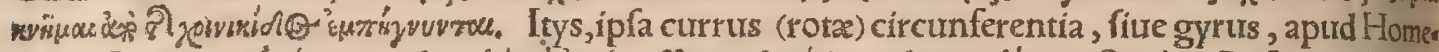

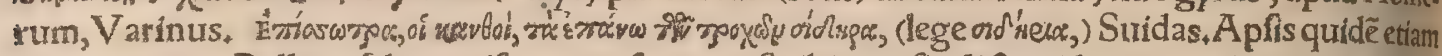
orisgow uocatur, Pollux. Idem epifotra per $f$, unum icribir, ut fic dicta uideantur tanquam epifoftra,

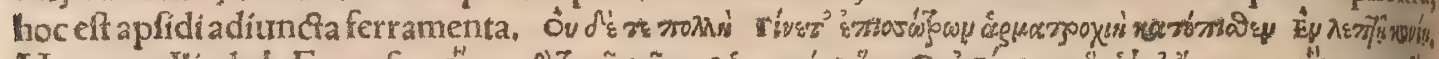

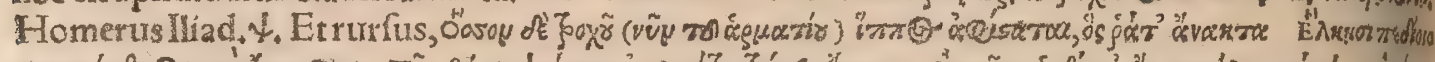

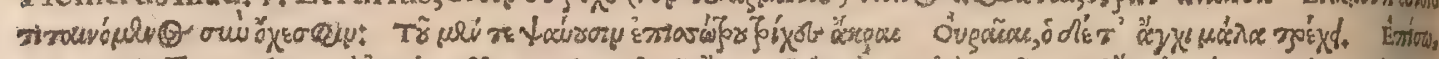

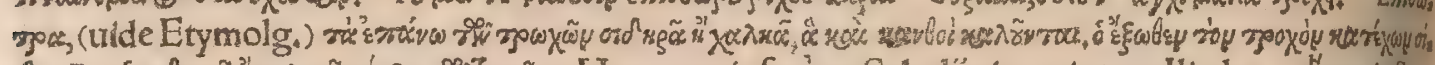

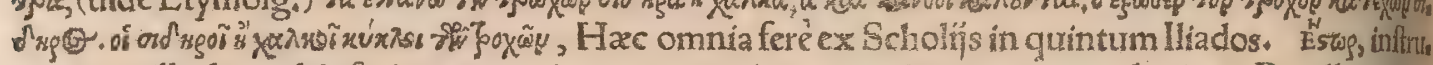

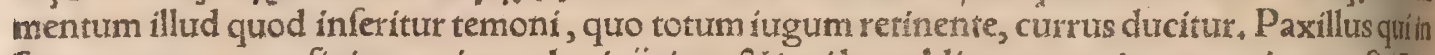
Jummo temone prafigitur, cui annulus inịcitur, \& iugi lora obligantur, ut iugum retineant, fic Arts fophan. Alij curuaturam, uel circinatum foramen iugi, quod iumentorum ceruicibus aptaturtitum

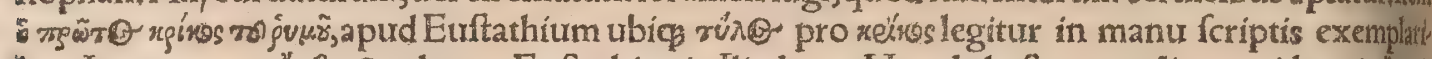

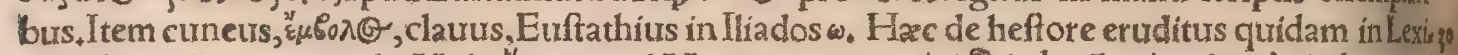

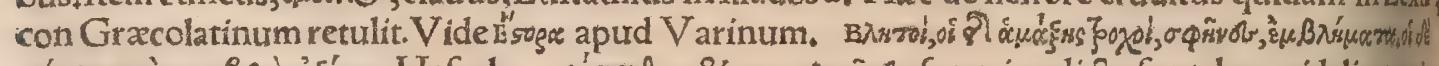

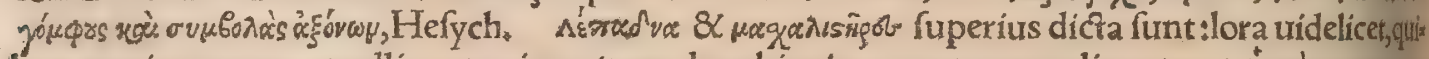

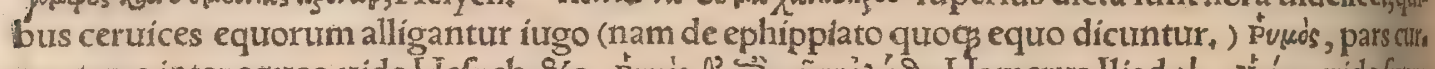

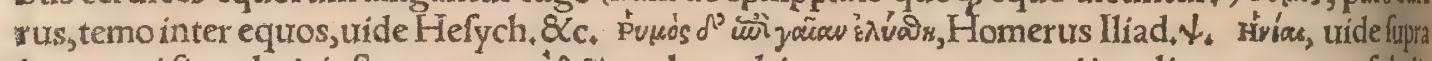
inter equi fingularis inftrumenta. ABop'rox, lora altiora, qux terga equi iugalis excurrunt, fubalis eius fuccincta, Budatus in Annot. fec.

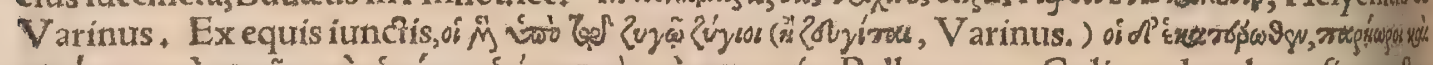

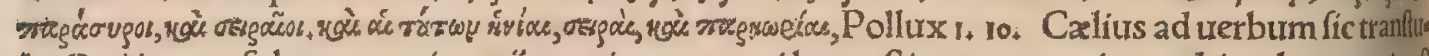
lit:Qui iugum fubeunt equi, zygh̆ nominantur $\$$ qui latera fipant, pareori, penultima longa (etianfl Dionyfius difcrepare quadantenus uidetur ) $\&$ parafyri, ac etiam fíraphori, item firæi: ficurí corum habenæ firz, ac pareorix dicuntur. Ego pareoros cumo, breư potius quầm producto fcripleti

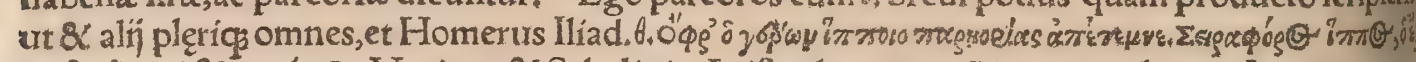

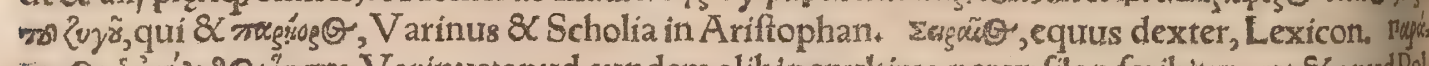

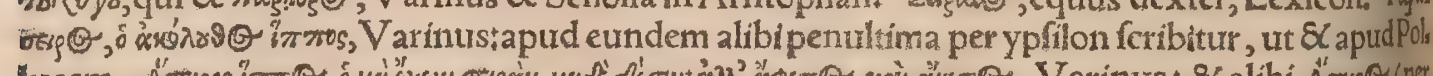

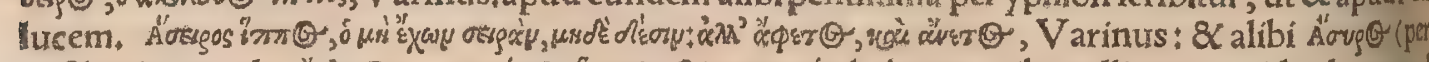

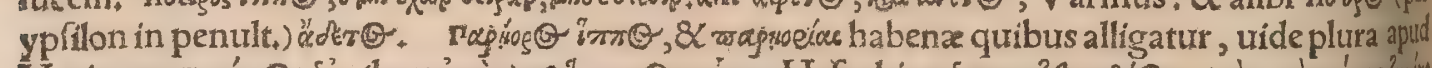

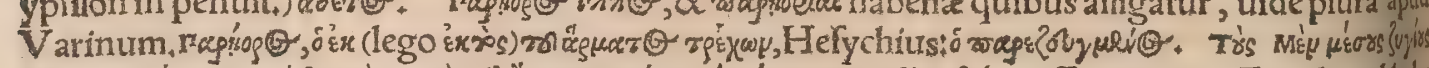

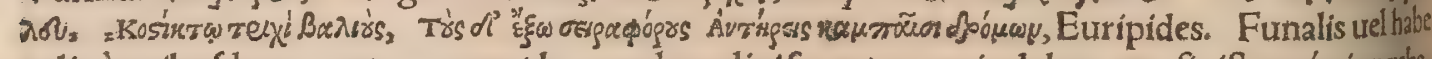
nalis à quiburdam uocatus equus (de quo plura dixifupra) currui ad dextram finiftramḉ iungebas tur, quare eundem oteqxфópoy effe conício.

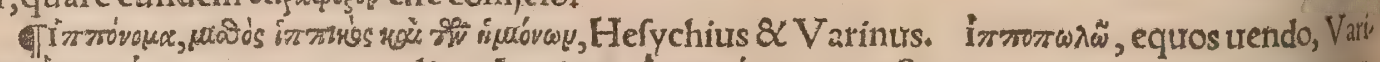

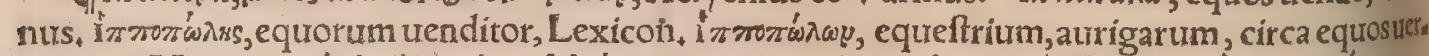

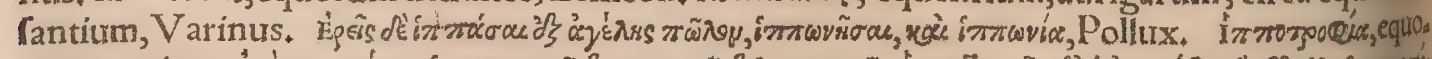

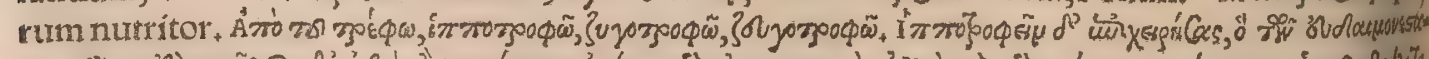

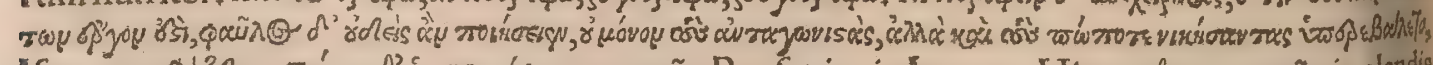

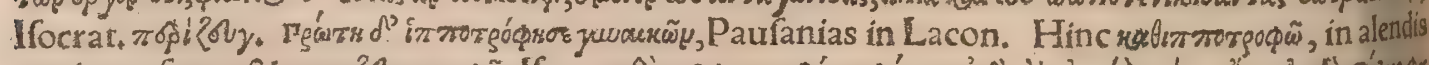

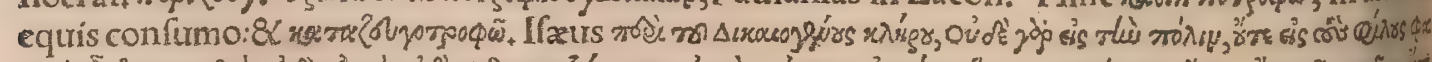

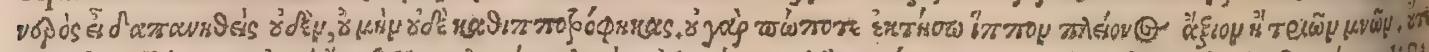

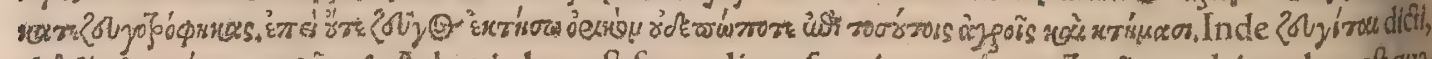

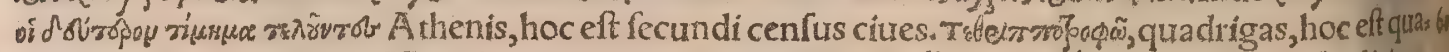
drïuges equos alo, apud Herodotum, Kalıtr

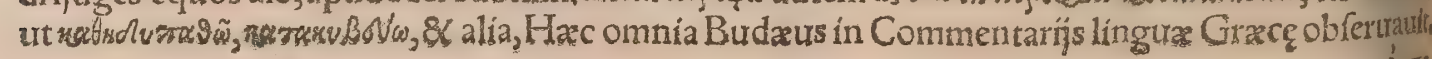


* pis quoqs genus galex, de quo uide Varinum. In hoc medio apparatu fulgèntem gla dium è lacuna ri feta equina aptum (appenfurm) demitti iuffít, ut impenderet illius beati ceruicibus, Cicero s. Tuf,

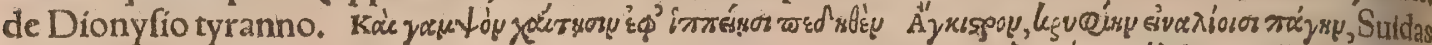

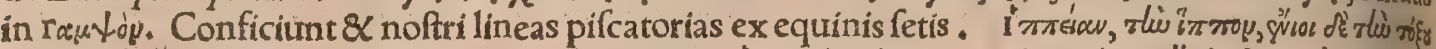

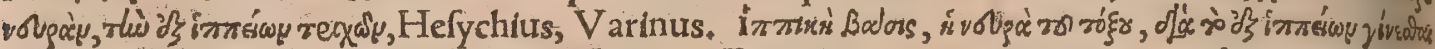

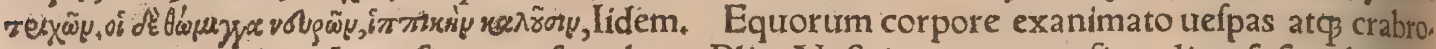
nes procreari putant, ficut afinorum fcarabeos, Plin. Noftri ex equor um fimo diuerfa farabeorum génera nafciaffirmant, ut inter Scarabeos dicemus . Preffus humo bellator equus crabronis orts

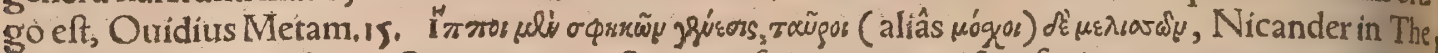
ríacis: Vide in Apibus. Super omnia eft compofitio, qua inuictos faciunt magorum mendacia, cauda draconis \& capite, pilis leonis è fronte, \& medulla eiufdem, equi uictoris fpuma, canis unguji bus adalligatis certuino corio, \&c.Plinius.

H. h,

Licinius imperator cum filiam Chriftianæe religionis cultricem ab equis difcerpi uellet, ipfeà fuo. rum uno morfu interfectus eft, Textor. Neocles Themiftoclis filius, equi morfu intern̈t, Plutarchuss Metius Suffetius ab equis difcerptus eft (iubente Tullo rege Romanorum) quod tefte Vergilioa Romanis ad Fidenates defeciffet, Textor:Vide Onomafticon noftrum, De Hippolyto Thefeifilio, 8 eiufdem nominis martyre, qui ab equís difcerpti funt:item de Hippomene qui filiam equo deuo: randam prabuit, nonnihil dixi fupra inter propria hominum nomina ab equo ducta. Plutarchurs in Parallelis (minoribur) ponit Conminium quendam, Comminñ ex Aegeria filium, quí à Gidiano uerca (culus uotis parêre noluerat) ftupri inftar Thefida accufatus fugiens, ab equis fit dilaniatus, Textor. Pyrechmum Euboia regem Bocotịs bellum inferentem, Hercules profigatrit, eumọpul lis equinis alligatum in diuerfas partes difcerpfit, Onomafticon. Hippomenes cum filiam depres hendiffet uitiatam, equo famelico uorandam obiecit:uide in H. a. 8 infra in proverbio Hippomene iniuftior. De Glauco Potnizo ab equis difcerpto, \& Diomede deuorato, dicam inferius inter hifiton rias fabulofas, Equorum lapfu perierunt apud Vergilium, Nipheus, Leucagus, Liger, Clonitus, Re mulus, Amycus: Apud hiftoricos Agenor, Fulco Hierololymorum, Philippus Ludouici Craffifitis Gallorum, Bela Pannonia, reges, Textor.

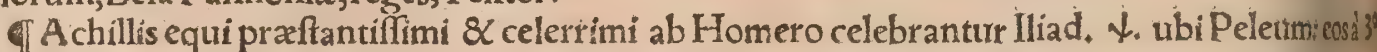
Neptuno accepiffe legitur. Nomina corum dixi in $\mathrm{H}_{+} \mathrm{a}$, Calaber libro 4 . A chillem equos praceleres à Telepho, quem uulnerârat, dono accepiffe fcribit. Admeti equos Homertus lib. 2.lliados pernichls rimos fuiffe fcribit, "ogvibou ws, id eft attum inftar. Noctemç̧ diemćs Affimilant maculis internigranti bus albæ, Statius de equabus Admeti, Admeti Theffaliæ regis cequas patuiféfabulätur A pollinem, ut infra dicam inter deos. De Adrafti equo, cui nomen fuit Arrion, fupra dixi in a. inter propria quorum nomina. Ab A genoris equo Argos hipporrophon dictum eft, Etymologus. Alcibiadio \& Cimonis (Simonis) equi inter generofos numerantur. Conftat Alcibiadem nutriendis equistania tam adhibuiffe operam, quantam fui faculi trel regum uel hominum priuatorum nemo, Textor. A, lexandro Magno \& equi magna raritas contigit:Bucephalan eum uocarunt, fiue ab afpeciutortic, fiue ab infigni taurini capitis armo impreffi, Plinius. Bucephalus uocatus eft equus Alexádílr gis , propter quandam bubuli capitis fimilitudinem, Feftus : uel âlatitudine frontis, Strabo libroly Bucephala fiure Bucephalia, India urbs eft iuxta $\mathrm{Hydafpen}$ fluuium, ab Alexandro condita, ficap pellata à Bucephalo equo, qui cecidit ibidem in pralio, quo tricit Porum: $\&$ eo ipfo in loco fepultus eft, Author Strabo li, is. et Plinius 6.20. Meminit etiam Stephanus duorum huius nominis locortm, Eft \& Articx (Achaiæ,Plin, 4.5.) portus Bucephalas Stephano dictus, Bucephala Paufaniz, Buck

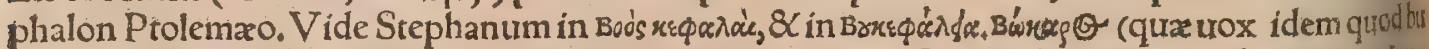
cephalos fignificat) fluuius in Salamine apud Lycophronem. Inter tribuli etiam herba nomendtath ras bucephalon reperio. Alexander mortuo Bucephalo Alexandriam (Bucephaliam potius) condir

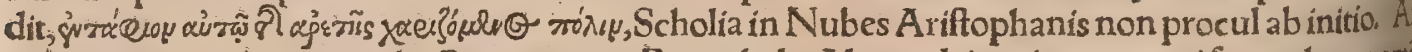
ni Indi trium urbium incolę: Caput eorum Bucephala, Alexandri regis equo (cui fuerat hoe nomé)

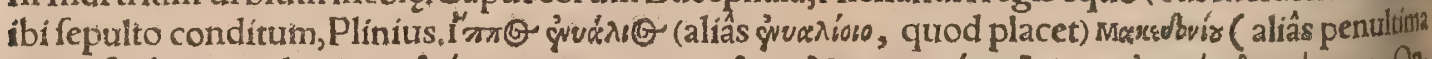

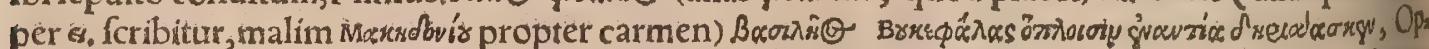

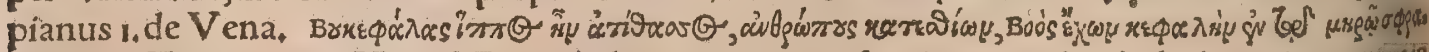
jif oct, Śc c T zetzes 1. 28. Hoc eft, Bucephalas equus erat indomitus, mordax, bubulo capite notarusin femore, non caput uel cornu bouis geftans. Bucephalus (inquit Etymologus') dictus eft Alexart dri equus, non quod bouis cornura haberet, quod falfum eft : aureis enim ab Alexandro ornattses rat. Non tamen à cornibus nomen tulit, fed quoniam fic urocabanturin Theffalia equi habentes intus ftum Bruǵ'vıo, id eft bubulum caput.Quod ita fe habere uel ex. Ariftophanis Anagyro conftat, boc

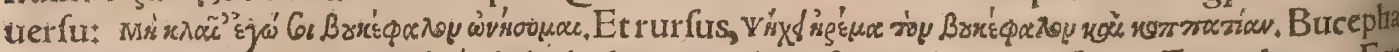
igitur uocatur qui in coxis (iqious) bubuli capitis characierem habet inuftum, Etymologus. Equ Alexandri regis 8 capite $\&$ nomine bucephalas fuit, Gellius. Sedecim talentís emptum ferunt ex Philonici Pharfalíg grege, etiã tum puero (Alexãdro) capto eius decore, Plin. Emptũ Cares (Chares 


\section{DeQuadrupedibus}

rum libro 1. Dardani illius diuitis Iouis filij trium millium equarum armentum, at $\not$ pracipué ex his duodecim pullos patre Borea genitos, Homerus fuo praconio nobilitauit. Item Eumeli equas, Erythraus, Oenomai equi Pfilla \& Harpinna, uide Varinum in Oenomao. Alius fuit Oenomas us qui Partheniã \& Eripham equas fuas quũ iugulaffet, iuffit fepelini, Cal, Pelops equos à Neptuno accepit, Varin. in Oenomao: Vide Palxphatư. Penthefilex equus ab Orithyia Boreæ uxoreac, ceptus, ut Q.Calaber fabulatur. Probi equus nec decorus nec ftaturofus erat, fed mira celeritate,

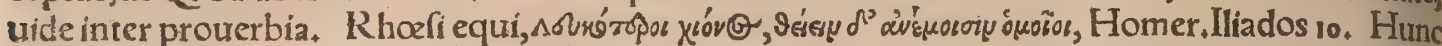
uerfum integrum ad Turni equos tranftulit Maro libro 12. Aeneid. Meminit \& R hœfi equorum lib, 1. Aeneid. Trois equi immortales ad fabulofos mox dicendos pertinent. Simonis equi, uide in $a_{\text {* }}$ inter imagines equi, Turni equi apud Vergilium ex Orithyia Borex uxore, uide inferius in fabu* 11 lofis. Vlylfis equi, uride infra in Neptuno Hippio.'

(Equi fabulofi. Bellerophon uel Bellerophontes, primò Hipponus, in róvrs, (aliâs Hipponours) dicturs eft, poft ab interfecto Corinthiorum primate Bellero, Bellerophontes. Hic fumpto à Neptu, no Pegafo equo ad Chimaram perimendam euolauit, eamó̧ occidit. Deinde ex rerum felici fuccefa fu fuperbiens, quum in colum cum Pegafo uolare tentaret, Iupiter indignans œftrum Pegafo immi fit, à quo agitatus Bellerophontem excuffit , cecidítós in campum, qui poltea Aleius appellatus eft, Pegafus autem à loue inter fidera relatus eft. Perniciffmus hic equus $\&$ alatus fuiffe perh hetur, ex Neptuno \& Pegafide natus, Gyrald. Sunt qui Diem àPegafo equo uehi fabulentur, Scholia in Ly coph. Vifus eram molli recubare Heliconis in umbra, Beilerophontai quà fluit humor equi, Propert. libro 3. Vide plura in Onomaftico noftro de Bellerophonte, \& de Pegafo in utriufes meta rione, item in Scholins in quintum Iliados Homeri: 8 in prouerbio Bellerophontis literæ apudEral= mum: \& fupra in $H$, a. ubi de equo fydere: Hefiodi Theogonia, Scholins in Lycophronem, \& in unoce

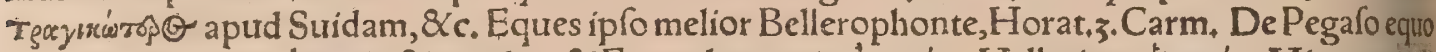
uide Varinum in rih

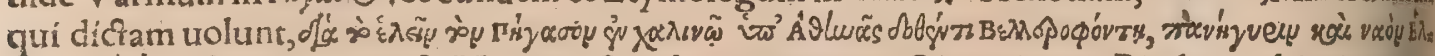

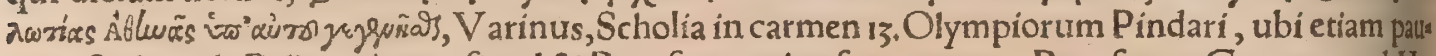
lo poft plura de Bellerophonte fimul \& Pegafo reperies: fertur autem Pegafus ex Gorgone vel Mes

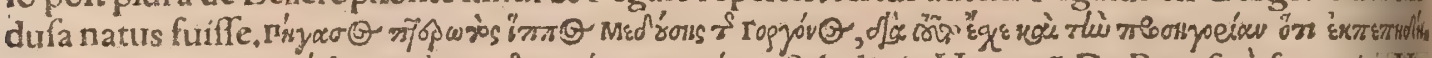

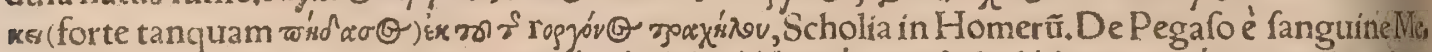

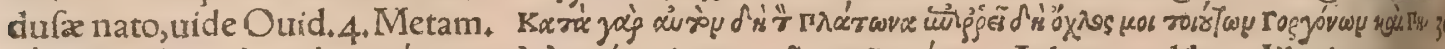

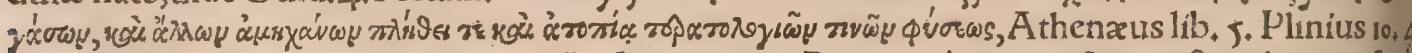
Pegafos fabulofos fuiffe exiftimat. Ariftophanes in Pace rnycoloroy adiectiuum facir, hoc uerfu, silty

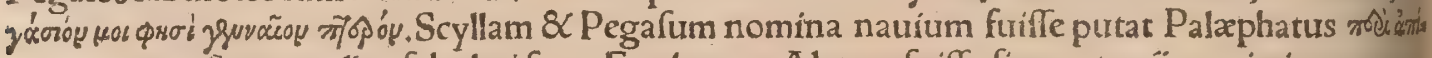
swy, non monftra ut poêtra fabulati funt, Erythręus. Alatum fuiffe fingunt poëtæx, nimirum propter celeritatem eximiam: nam \& quofuís equos celeres poëtæuolucres cognominant, ut fupra in $a, \& b$, diximus: \& Solinus tauris Indicis uolucrem pernicitatem tribuit. Inftratos oftro alipedes, Vergil, Pegafi equi effigies Gabalis in templo quodam uifebatur, Paufanias in Corinthiacis. Pegafus(iit quit Albert. Magnus)animal eft compofitum, quod in Aethiopia generatur, permagnum \& horten dum,equi formam praferens anterius: alas habet ut aquila, fed multò maiores:caput cornutû́ (quod \&:Plinius fcribit) \& adeo monftrofum, ut multa animalia folo afpectur terreantur. Alis non uolatin fublime clatus, fed aërem tantum ferit $\&$ curfus fui uelocitatem fic promouet, animantibus cuncis infeftus, maximé uero homini, Hæc ille fine authore: Alíf eiufdem commatis fcriptores, adíciunl; graui corpore effe, fuga mirabiliłalarum remigio adiutum currere potius quàm prouolare: $8 \mathrm{Collit}$ fo aére ur pennarum inftar turbinis impellere uentos, uroracem efle, $\&$ in quiete moueri. Pegafides Mufx dicta funt à fonte, quem Pegafus ictu ungula fingitur aperuiffe, ob quam caufam \& Grace appellatæ funt Hippocrena, Feftus. Vide fupra inter propria ab equo deducta nomina. Tarfus $\mathrm{Ci}$ liciæ ciuitas, fic dicta eft à tarfis, id eft calcibus Pegafi, qui è coelo cum Bellerophonte feffore in fentes Cta iam delirante, in Aleium campum deiectus eft, Euftathius in Dionyfum A frum . Dicius eftati tem campus Aleius àx? $r "$ " oberraret, qux etymologia uel Homero approbata uidetur, Euftathius, Pegafarium curforem Bay fius ueredarium appellat. Centhippe dictus eft locus Argis, quod Bellerophon illic primum ftimula

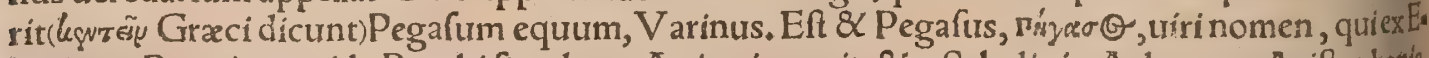
leutheris Bcotiæ oppido Bacchi fimulacra Atticæ inuexit, \&c. Scholia in Acharnen. Ariftophantis Pegafos equino capite uolucres, \& gryphas auritos aduncitate roftri fabulofos reor:illos in Scyth hos in A ethiopia, Plinius: Et alibi, A ethiopia lyncas 8 Cphingas generat, multáç alia monftro fimi lia : pennatos equos $\&$ cornibus armatos, quos Pegafos uocant. Aethiopici coeliales eft Pegaftrs, fed hæc ales equinum nihil præter aures haber,Solinus. Penthefilea Amazonum regina equum celers

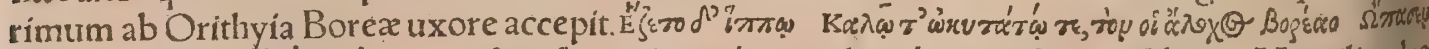

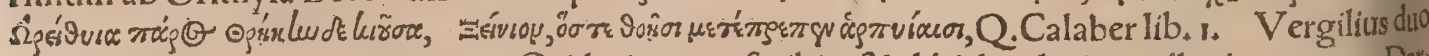
ćecimo Aeneidos Turniequos ex Oríchyia natos fcribit, $\&$ alibi duodecim pullos in armento Dati dani patre Borea genitos. Bufiris $\&$ Diomedes equos humana carne pauerunt, Textor. Abfenti

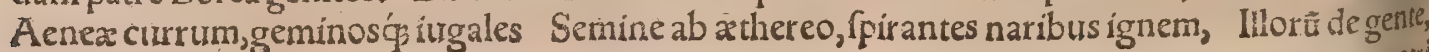


patri quos dædala Circe Suppofita de matre, nothos furata creauit: Landínus exponit, Ctrce Solis filla furtim $\&$ clam patre fupponẽs matrem, fcilicet equã, equos Solis creari fect: hos uocat nothos, quód eorü mater mortalis, pater uero diuinus effet: nam proprié nothi dicûttur, quos nobilior pater ex fgnobli matre creaurit. Tractû eft, ingt Seruius, de Homero, quir tales equos habuiffe inducit An

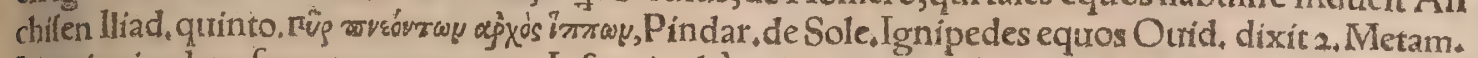
Licetignipedum frenator equorum Ipfe tuis altè radiantem crinibus arcum Imprimat, Stat. Dio medes rex Thracix, ab Hercule fuis equis in pabulum datus eft, eadrm talione qua ille in horpites fo

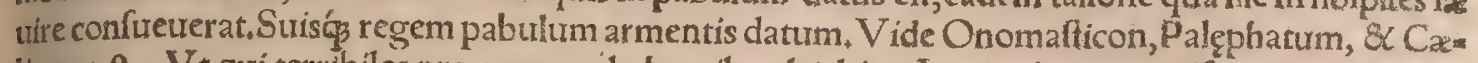
lium 13.8. Vt qui terribiles pro gramen habentibus herbis Impius humano uifeere pauit equios, - Orid. Vide prouerbium Diomedea neceffitas apudErafmum. Diomedes Thrax cum filias habe

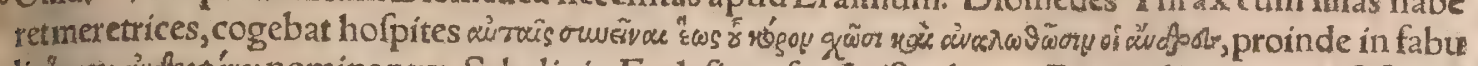

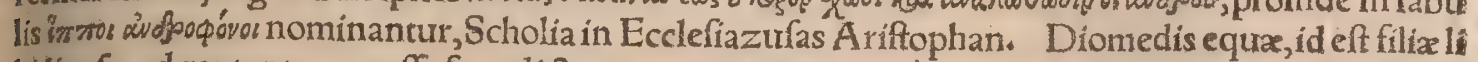
bidinofx, aduentantes uoraffe funt dicta: quanquam interimi a patre folitos intelligere maluit Eufta thitrs, Cæl. Ex Diomedeis equis prognatus fuiffe creditus eft equus $\mathrm{Cn}_{*}$ Seip, de quo dicầ in prourerbto Seianus equus. Equus albus Diomedi immolabatur apud Venetos, ut mox inter facrificia refe ram. Circa Abderam $\&$ limitẽ qui Diomedis uocatur, equi nafcêtibus illic herbis pafti, inflamman tur rabie, circa Potnias uero afíni, Plin. Aelianus nó afinos, fed equos etiam ex fonte Potnix biben tes, qui non procul Thebis abfit, in rabiem uertiait. Potnia urbs eft Bootia, non longe à Thebis, ubi Glaucus Sifyphi filius \& Meropes, habuit equas, quas confureuerat humana carne alere, quo cupidius in hoftem irruerent: quem ipfum tandem, cum alimenta deficerent(uel ut alih, cum facra Vene. ris prohiberet) deurorarunt. Hinc dicta equa Potniades apud Ouidium in Ibin. Vide Onomafticon in Glauco, et Palęphatũ, aut etiam Vergilin interpretes in tertium Georgicorum fuper his carminib, Ermentem Venus ipfa dedit, quxo tempore Glauci Potniades malis membra abfumpfere quadri.

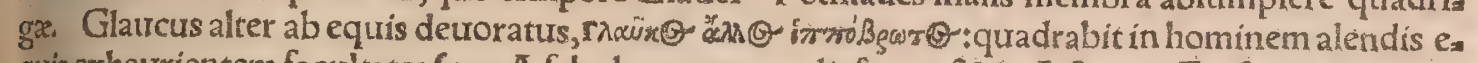
quis exhaurienten facultates fuas. A fabula natum, qualis fertur $\&$ de A cfrone, Exafm, in prourerb.

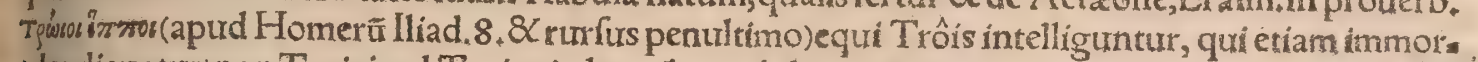
tales dicuntur $¥$ non Troici uel Troiani, de quibus nhil eximium prodiur, Varin, Propter Trôis equos regnante Laomedonte captum ab Hercule Ilium fertur. nam cum Laomedon equos praftan tiffimos Herculi, ut Hefionen eius filiam monftro marino expofitam liberaret promiffos, re peracia o negaret, Hercules indignatus Troiam euertit, Onomafticon. Fertur autem hos equos Laomedon a loue pro Ganymede accepiffe, Scholia in Lycophronem, Cai.

1) His attexemus qua ad religionem pertinent, circa deos, facrificia, fepulchra, omina. Et quon am plufcula de dị́s fe offerunt, ordinem literarum fequemur. TApollo, uide in Sole. đCaftoris equus nomine Cyllarus, ut inter propria dixi. TCeres in equam mutata, Oncip armento fe immi: fuiffe fertur,cum Neptunus amore eius Proferpinam quęrentis captus infequeretur: Neptunus au. tem decipi fe intelligens, etiam ipfe in equum mutatus, rem cum illa habuit:unde Ceres initio ualde indignata eft, \& Erinnys inde cognominatatpoftea ueró ira remiffa in Ladone flưuio fe abluit, et in. de Lufia dicta eft, Paufan in Arcadicis. Exhoc concubitu Arionem equum natum fabulantur, ur inter propria equorum nomina dixi.Prope Phigaliam Arcadię urbem in monte Elaino, Cereris Me lenx, id eft nigra pullatx ue facrum furt antrum. Dex cum Neptuno congreffum fub equina fpecie celebrant Arcades. Verum non inde natum Phígalenfes equurm uolunt, fed quam dicunt Arcades dilcwowvow. Deam urero indignatione in Neptunum concepta, prateró, Proferpina raptu confterna tam, fibi pullam induxiffe ueftem ac in fpeluncam fefe infinuantem, diu poftea non effe uifam, \& $\epsilon_{*}$ hinc antrum illud Phigalenfes Cereri facrum afferunt, ato fimulacrum inibi confecraffe, habitu qui dem in petra fedentis, ac cæetera mulieri perfimile, prater caput, quod cum coma erat equinum, adne xis draconum \& ferarum id genus item iconibus. Tunica ad calos demiffa. Deiphin manu fuftine. batur:columba uerô altera. Cereris 8 antrific quodam refponfo meminit A pollo, quum Phigaléfes

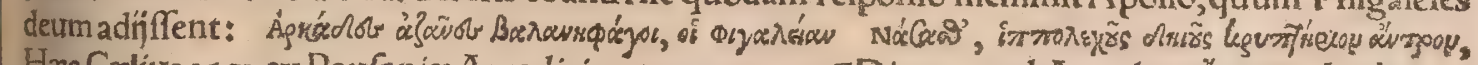

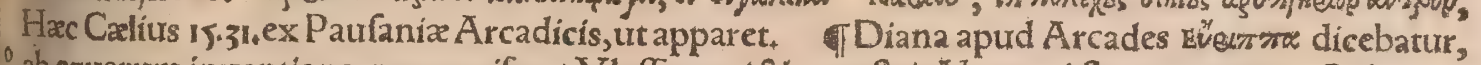
- ab equarum inuentione, quas amiferat Vlyffes, qui \& equeftris Neptuni ftatuam er exit, Calius ex Paufania Arcadicis, Fiunt autem Vlyffem(inquit ibidem Paufan.) cum equos illic (ubi nunc Phe: neatarum acropolis eft)reperiffet; troluiffe equos in Pheneatarum regione nutrire, utboues in Epiro quà èregione lthaca eft. Caterum equeftris Neptuni ftatuam ex are ab Vlyffe pofitam, parum mi: hi uerifimile fit, quo tamen temporis aris fundendi ars nondum extiterit, Hæc ille. Calius ex hoc lo coineptè uertic, Vlyffem ftatuam equeftris Neptuni erexiffe, fed non ex xre. Hippolytum ab equis difrafum reuocatum aiunt ad uitam herbis quiburdam (A efculapï) \& amore Dianæ. Iupiter uero talis medicinax, qua mortur uitæe redderentur, repertori indignatus, A efculapium fulmine ad inferos deiecit, At Triuia Hippolytum fecretis alma recondit Sedibus: 8 nymph Aegeria, nemoríg rele gat: Solus ubi in fyluis Italis, ignobilis zuum Exígeret, uerfọ́ ubi nomine Virbius effet. Vnde (ietiam Triuia templo, lucisćs facratis Cornipedes arcentur equíquoòd littore currum, Et iưuene, monftris pauidi effudêre marinis, Vergilius 7. Aeneid. Vide Calium 11.24. Poétæe equos Nochî nigros adfrcribunt, Dici candidos; Luna nigrum alterum, alterum album, Textor, Lunx Aechiopes: 


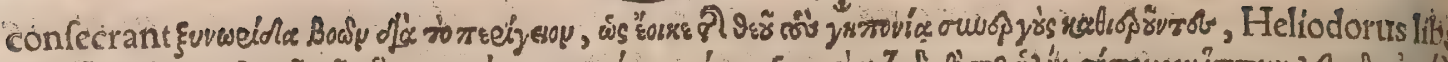

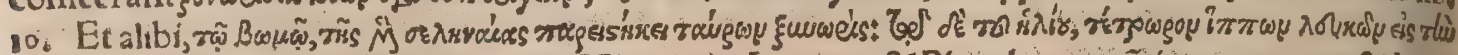

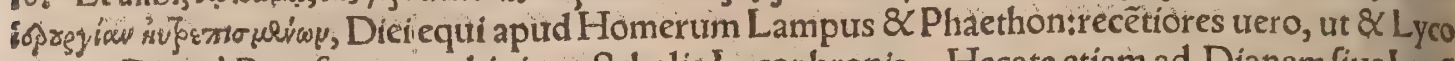
phron, Diem à Pegafo equo uehi aiunt, Scholia Lycophronis. Hecate etiam ad Dianam fitre Lunã

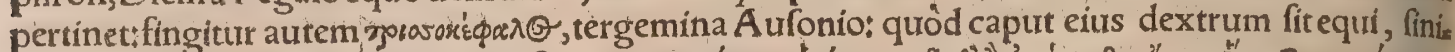

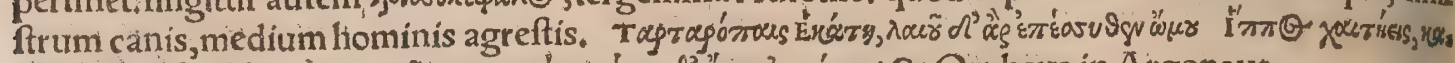

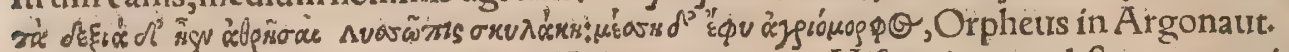

बFortunæ equeftris $æ$ dem uouit Fuluius prætor in Hifpania, quod ftrenua equitum opera in Celriberos ufus foret, Calius.Et alibi, Equeftris Fortunæ templum fuiffe, legimus in Taciti Annaliz bus, apud Antium, nec in urbe ad fua tempora uifitatum . THecate, uide in Diana. De Henio, chofyderefupra in e, diximus. Hercules imnodizns cognomine Onchefti colitur, uel (ut alii) The, bis, Hefychius $\&$ Varinus. Hippodotes (per o.in penultima, malim per epfilon) Hercules cognon minatus, ut fribit Paufanias: cui templum Boeotỉ conftruxêre, ea fcilicet ratione, quod cum Orchoz mení aliquando ufq ad eum locum ueniffent, Hercules nocqu equos, qui ad eorum currus erant

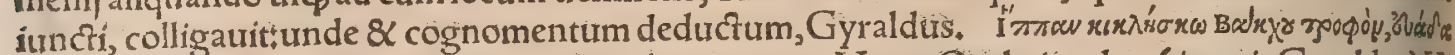
xช́์sy, Orpheus in hymno ad Hippam Bacchi nutricem, Vetus Orphei codex (inquit Gyraldus)Hi

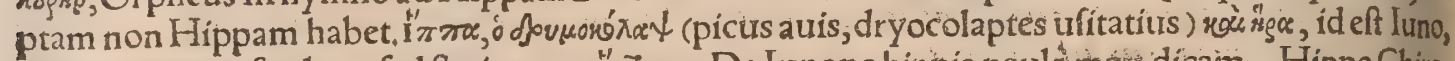

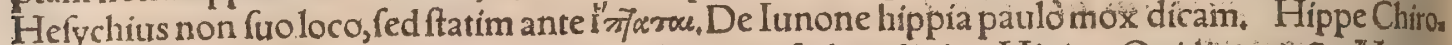
nis Centauri filia in equam mutata, ut fupra in equo fydere dixi ex Higino. Ouridius taime 2 , Metam, Ocyroên Chironis filiam in equam mutatam fabulatur. Hipponam deam equorum \& ftabulianti qui uenerati funt, ut Bubonain boum: de hac dea Plutarchus in Parällelis meminit, \& Apuleitus lib, 3. A fini aurei, \& Tertullianus in Apologetico, \& Fulgentius ad Chalcidium:eam enim inter deos Se mones, qui uocantur, (quos nec coelo dignos purabant; ob meriti uidelicet paupertatem, Fulgent,) commemorat. luuenalis quoç eandem intellexiffe â plèrif ç purtatur in illo: Iurat, Solam Hippo,\& facics olida ad præfépia piças:ut fcilicet Hippò \& Hippona dicatur, Gyraldus fic Dido \& Manto pro Didonem \& Mãtonem dicimus. De Hippona puella (aliqui, perperam pùt to, Eponàn ùocitant) quam Fuluius quidam ex equa genuit, fupra dixi inter propria hominum . Refpicio pila medio, quæ ftabuli trabes fuftinebat, In ipfo uero meditullio Hipponæe dex fimulacrum refidens ædicule, quod accuraté corollis rofeis quidem recentibus fuerat ornatum, Apuleius 2, Metam, II luno etiam hippia, id eft equeftris cognominata eft, Gyraldus. Hefychius Hippam interpretatur Iunonem, ut 30 paulo anteretuli. Iouis currum, qui in exercitu Xerxis Xerxen ipfum pracedebat, ocfo equial: bi trahebãt, Herodotus libro 7. Equo urehi flamini Diali non licebat, ne fi longius digrederetur, $f_{2}$ cra negligerentur, Feftus. Fel equinum tantum inter uenena damnatur, ideo flamini facro equm tangere non licet, cum Romæ publicis facris equus etiam immoletur, Plinius. Pirithous, Iseélbrs, no

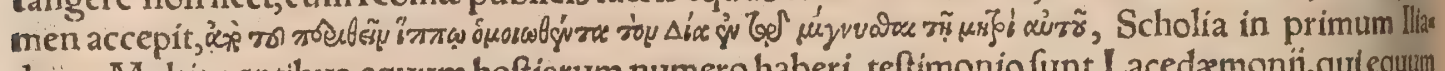
dos. Multis gentibus equum hoftiarum numero haberi, teftimonio funt Lacedæmonij, qui equum uentis iminolant, \& c \& \& Salentini, apud nos memranæ ( $*$ fic habent imprefli codices mutilati) Ioui dicatur, ưiuus conńcitur in ignem, Feftus, Calaber libro 14. Iouris currum \& equos defcribit hice

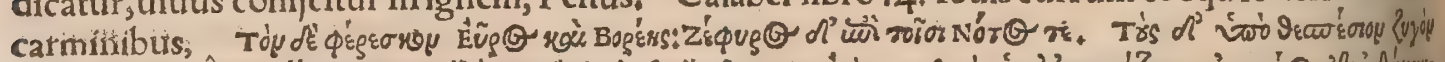

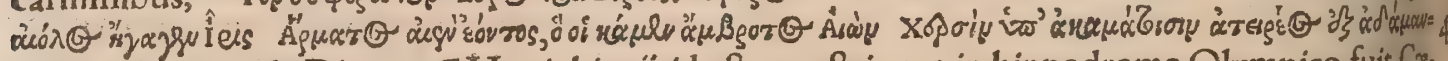
TO. Luna, uide Diana, TMartis hippin, id eft equeftris, ara in hippodromo Olympico fuit, $\mathrm{C}_{z}$ lius ex Paufania. Equiria, ludi quos Romulus Marti inftituit per equorum curfum, qui in campo Martio exercebantur, Feftus. Cur Idibus Decembris (uerba funt Plutarchi in Romanarum rerum qưreftionibu's capite 93 ; $\$ \rho$ ós, malim isnG, id eft equus) in curfu equorum uictor dexter facer, (Vider tur autem non Decembris fed Ocfobris legendum, ut mox ex duobus Fefti locis recitabimus: \& Gy raldus afferit in libro de annis \& menfibus: Eft fanè October uniuerfus Marti facer.)Marti immola tur, \& $<$ caudam ftatim decifam ad R heginam (regiam, Feftus) qui dicitur locus, deportat aliquis, $82 a$ ram cruore fpargit, de capite uero inter fe decertant, alij de facra uia defcendentes, allí de Suburra aduerfus eos impetum facientes? An quod Troiam equo captam putant, idcirco equum fupplicio afficiũt, $\phi$ é Troíanis oriundi, Mixtaḉ Troiugenûm fint pignora clara Latinis? An quod iracundủ, 50 ferox, \& bellicofum animal eft equus ๆ dị̉s autê grata \& |accómodata imprimis immolãt, Viçor aũi idcirco immolatur, quod uicrorix Mars auther elt: Vel potius, quoniam Marti conurenit ftare loco, et qưui locum fuum in acie tuentur, uincunt eos qui non manent fed fugiunt: ut celeritas (per equum

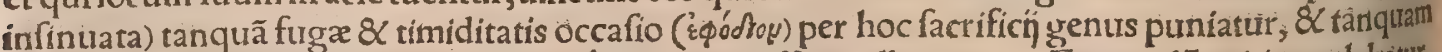
fub ànigmatis inuolucro fugam minimè falutarem effe intelligatur. Equus Marti immolabàtur, quod per eius effigiem Troiani capti fint, uel quod eo genere animalis Mars delectari putaretur, $\mathrm{Fe}$ ftus, Et alibi, Panibus redimibant caput equi immolati idibus octobribus in campo Martio: 8 id a crificium fiebat ob frugum eurentum: \& equus potius quàm bos immolabatur, qurod hic bello, bos frugibus pariêdis eft aptus, Feftus. Etrurfus, October equus appellatiri, quítin campo İMartió ment

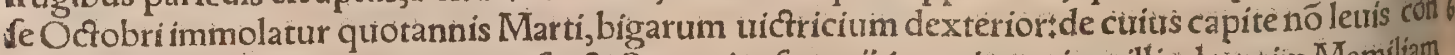
tentio folebat effe inter Suburranenfes \& Sacrauienfes tut hi in regia pariete, illi ad turrrim Mamiliam affigerent; eiufdemós cauda tanta celeritate perfertur in regiam, ut ex ea fanguis diftillet in focum, 
fint Libyes currtrs iungere, Cal. De Neptuni equeftris templo \& miraculis, uide Leonicenum in

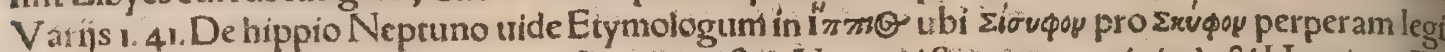
suir. Vlyffes inuentis equis quos anififerat,equeftris Neptuniftatuam er exit:inde \& Heurippa Dia

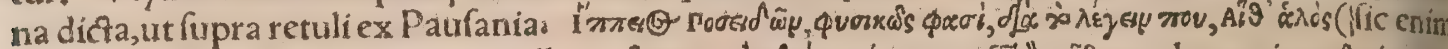
legendum puto, ut forte natres intelligat) in \&. Yegalum equos genuit Neptunus, Varin. Achillis equi praftantifimi $\&$ celerrimi erant: acce

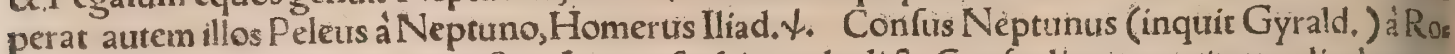
manis, qui er equeftris uocatus eft, ut Liuius fcribit, unde dicta Confualia, qux primum dicebantur, mox Circenfes \& ludi magni, \& Romani. Tum Iouis \& Confi germanus, Tartareus Dis, Aufoni. is Et albi, Canea mutauit proles Saturnia Confus. Plutarchus cum alibi, tưm maxime in Romulo Romulum ait cuiufdam dei aram conditam fub terram in Circo inueniffe, eí̧̧ deo indidiffe nomen Confo(tanquam abfronfo forte, extra Plutarchum)ficie à confilio, quod confiliarius foret: fiue Nep tinn equeftris:aramç ip fam reliquuin tempus larere, in equeftribus tero certaminibus aperiri. Sic uero $\&$ Dionyfius Halicar, in primo hiftoriarum, Dedicarunt, inquit, 8 Romani Neptuno equeftri templum, atç diem illum folennem, quem Arcades Hippocratia, Confualia Romani uocant : indem conftituête $q$ tu in die apud $R$ omanos ex confuerudine ceffant ab operibus equí, $\&$ muli redimiti foribus capica. Equos $\&$ afinos cur Confualibus ociari finant, ex Plưtarchi rerum Romanarũ pro blemaris in A lino lcripfi. Varro Confualia dicta ait à Confo, фisum ferix publica eideo, \& in Circo àciaram cius à facerdotib us fiunt ludi illi, quibus uirgines Sabinę rapta. Confuàles ludos ait Fefus celebrari mulis foiros effe in Circo maximo, q id genus quadrupedum primó curruti uehiculisøăad iunctum putetur Idem tamen alibi, mulos Lunae afcribit, Hactenus Gyraldus, apud quem filibet e tlam plura de Confo \& Confualibus lege, Syntagmate quinto Operis de dijs. i $\pi$ romordiny, Nepti nis Confus, Lexicon. Neptunus equo,ficerta priorum Fama pater, primus tener is laffffelupatis Ora, \& littoreo domitaffe in puluere fert, Papinius in Thebaide. Fuir \& Thebis hippodromị tem plun Neptuni, quod Chryfippus ex carmine fignificat Pindarico ex Itthmịs, Cælius: Gyraldus alia rer, Hippocronius inquit, Neptunus cognominatus futit, cutius $\&$ Thebis facrum celebrabatur, int Pindarıs in Ifthmijs, itemćs in Nemeis manifeftat:legi $\&$ hippocuritum Neptunum alicubi nun patum. Conniciat fanè aliquis hippocronium dictum Neptunum, quod Saturnus, Graci Cronondis cunt, hippon, id eft equum proeo dectorârit. Hippocronia quiden nugas interpretantur, quafld cas ninitum antiqua 8 obfoleta, qualia fub Saturni regno fuerunt. racisoxos (epitheron Neptini)

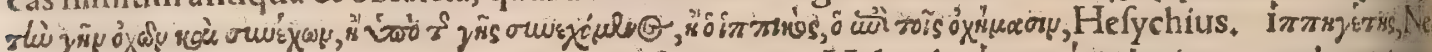

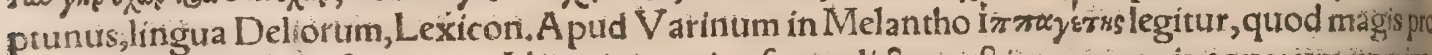
bo. De Arionè Adrafti equo ex Nepruno genito, fupra diçum eft inter propria equorim nomina Bellerophon à Neptuno fumpfit Pegafum equum. Ab eodein Pelops dono accepir equós, Varintis in Oenomao. Fabulantur aliqui de Methymnæis, oraculo iuffos uirginem Neptuno in mare demi fife: \& Enallum ducem quendam eius amore captum ut eam feruaret enataffe: $8 x$ tum quidem uiro que mari obteços effe:poft tempus uero aliquod Enallum redïfle, \& narraffe $q$ uirgo quídem inter Ner eides fit, ipfe ueró equos Neptuni cum aliquandiu pauiffer, magno fuperueniente fluctur natan. do fequentem fe euafiffe, A thenæus libro 11. Sillius libro 3. fingit Neptuni currum trahí equis mart. nis, Non aliter quotiens perlabitur æquora curru, Extremamóp petit Phœbæa cubilia Tethyn Fre natis Neptunus equis. Peliam Neptuni $\&$ Tyrûs filium equa nutriuit, Aeliani.12, Variorum. Ne ptuni in equum mutati fabulam Ouidius defcribit 6.Metam. Meminit \& Paufanias in Arcadicis, fupra dixi in Cerere. INochi equos nigros poétæa adfcribunt, Dié candidos: Lunæ nigrumatter rum, alterum album, Texror. Humentes iam Noctis equós, Lethraćp Somnus Frana regens,

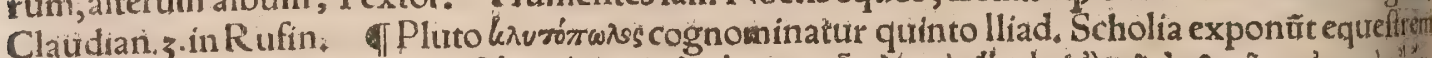

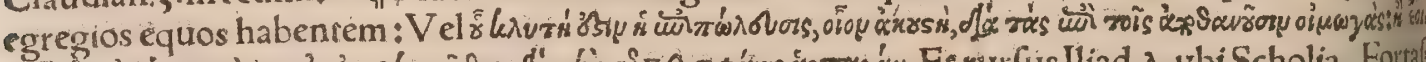

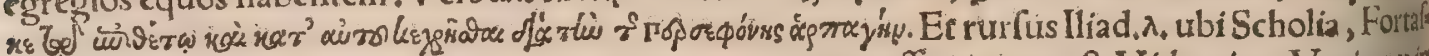
fis autem infignes equi ei attributuntur, quia mortem nemó effugere potelt.Vide etiam V arinum in

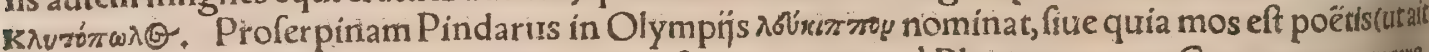
Scholiaftes) huiufmodi epithetis deos or nare:fiue ç cum eam à Plutone raptam Ceres mater quarte rec, albo currui infidentem inuenerit. TSaturni in equum mutati fabulam recenfet Ouid.6. Ne tam. Talis $\&$ ipfe iubam ceruice effudit equina, Coniugis aduentu pernix Saturnus: $8 \mathrm{~L}$ altum Pelion hinnitu fugiens impleuit acuto, Vergil. in Georg.cum equum bellatoren defcripfiffet, Rher Neptuntim enixa inter gregem agnorum iuxta Arnen fontem ab agnis appellatum occultatuit, turno autem equum $f e$ peperiffe dixit, $\&$ pullum equinum ei deuorandum dedit, $P$ aufanias in $A r$ cadicis. Sol rouróruntos, quod duobus equis albis uehatur, Lexicon. Solem Ariftophanes trocat ins

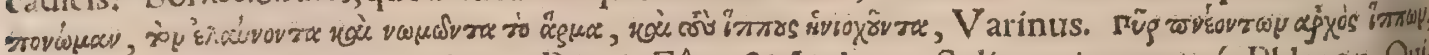
Pindarus de Sole. Interea uolucres Pyrois, Eôus, \& Aethon, Solís equir, quartus ó́ Phlegon, Ouls

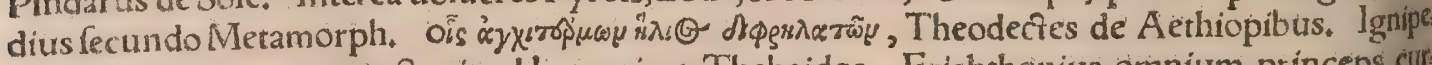
dum frenator equorum, Statius libro primo Thebaides. Erichchonius omnium princeps, curs rus equis iunctis docuit quadrigis folaribus perfimiles compingere, ut fupra dixi. Apollo romius, id ef paftoralis, quod pauerit equos Admeti, de quibus fupră etiam memini, Vide Ono: 


\section{DeEquo. H.h. Lib.I. 613}

mafticon in $A$ dmeto, Inpes, locus Theffalicus, qui forte paluftris erat $\&$ aptus alendis equis, $\mathrm{P}_{2}$ uit autem A pollo Eumeli equos, tanquam pantor $\&$ mercenarius ( $\$$ srob Cas) Admeti: aut à loue coa. curs, ut qui Cyclopes occiditfet, non illos Homericos, fed alios quofdam, Varin. Iofias rexaboleuit equos, quos dederant reges Iuda Soli, in introitu templi Domini, iuxta cameram Nethanmalech eu. nuchi, qui princeps erat in fuburbijs: \& quadrigas Solis combuffit igne, Regum I. 23. Hic Munfte= rus, Adoraturi Solem (inquit) infidebãt equis illis, equitabantó̧ ab ingireffu templi ufç̧ ad cameram Nethanmalech. A pollinem Perfę equo placabant. Placat equum Perfis radijs Hyperiona cinctum Ne detur celeri uictima tarda deo, Ouidius lib. 1. Faftorum.Maffageta etiam, ut Herodotus in fine li bri primi docet, equum ut pecorum perniciffimum, Soli ut deorum perniciffimo immolant. Idem de Perfis Varinus refert in troce Táugrs. Equum Soli immolari à Maffagetis fcribit Strabolibro in. He. rodotus etiam à Scythis idem fieri tradit, Gyraldus. Philoftratus in Heroicis refert Palamedem Grę cis práacepiffé, ut orienti Soli candidum equum mactarent. Quadrigæ de equis albis Soli ad facrifiz cium apud Aethiopes adornantur, Lunæ uero bigx boum fiue taurorüm, Heliodorus. R hodí quo. rannis quadrigas Soli confecratas in mare iaciunt, quod is tali curriculo fertur circumuehi mundũ Feftus. Pullum à que pullium, uel hippomanes, abftulerint paftores, Soli immolant, ut fupra in hip. pomanis mentione ex Aeliano resuli. Exercitu Perfarum progrediente, ignis quem ipfi facrũ ater uumćs urocabant, argenteis altaribus praferebatur. Hunc mox infequebantur magi, magos itutenes 165. puniceis uelati amiculis, quot in anno dies funt. Mox Iouis facer currus, quẽ alibi traherêt equi: Poft quos infigni magnitudine uifebatur equus Solis, fic enim dicebatur, Calius. I Ventis equum immolant Lacedæmonī in monte Taygeto, ibidem ḉ adolent, ut eorum flatu cinĩs eius per finitimos quàm latiffimè deferatur, Feftus:in caufa forte eft uentorum celeritas:qua ratione, ut diximus, etiam Soli immolabant equum. Venus hippodamia, i EL: neris filius Aeneas, cum occafum uerfus nauigaffet, equum mox confcendit, \& hac ftatua marrem.

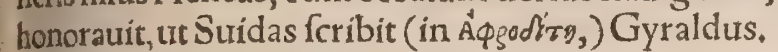

đRomæ publicis facris equus immolatur, Plinius: uidetur autem Octobrem 'equum intelligere qui Marti Romæ immolabatur, ut fupra diximus, loui etiam, \& Soli, Ventiş̧́́ facrificatos equros in fingulorum mentione retulimus. Apollonium adeuntem Babyloniorum rex Grxcofermone $\mathfrak{f}_{a}$. crificare unà fecum dịs iuffir: Erat autem candidum equum mactaturus ex Nifæis de meliore nota - ficinftructum tanquam in pompam profecturum, Philoftratus libro 1. Regem Indortum aiunt ad

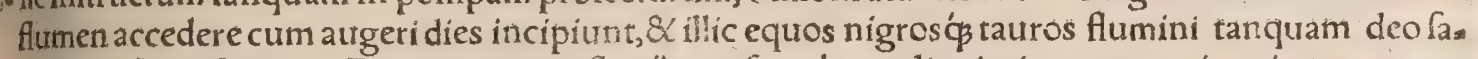
crificare, Philoftratus. Tauros, ueteres fluuijs confecrabant:aliqui eciam equos triuos in eortum tror.

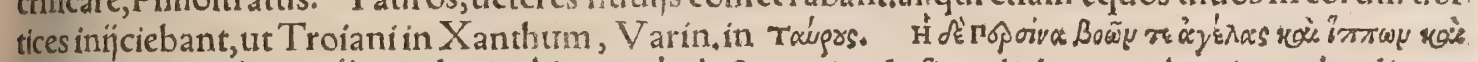

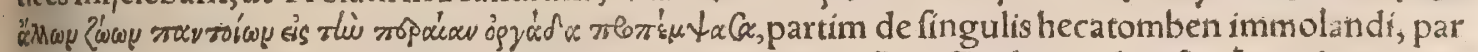
tim epuli populo parandi gratia, Heliodorus 10. Aethiop. Cum Thebani aduerfus Lacedæmonios bellum gererent, Pelopidx uni ex ducibus Thebanis Scedafum in fomnis uifum aiunt:aduencare $e$. nim Leucira Lacedæmonios, fibiac filiabus pcenam daturos; uno trerò pritus die quàn cum Laced

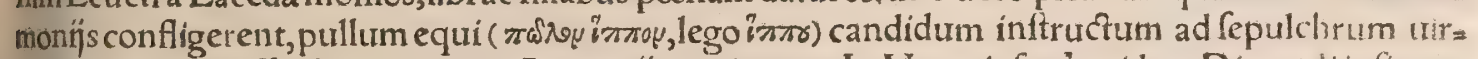
ginum mactari iuffit,Plutarchus in Amatorịs capitez. In Venetis fanẻ quídam Diomediinfignes exiftunt honores: nam candidus illi immolatur equers, Strabo libros. \& Euftathius in Dionyfiur. In Theffalia is qui uxorem ducturus eft, pronuptins facrificans, equum bellatorem inducit frenatur, 2 omnibus armis inftructum:Deinde facrificatione facta, equum uxori habenis ducendum tradit.

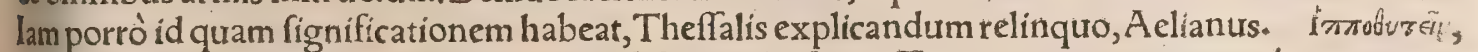
equumimmolare apud Strabonem. In feftis quibufdam Tartarorum praparatur lac equinum (equartrm albarum) in uafis decentibus: 8 rexipfe manibus fuis diffundit hinc inde lac illud pro honore deorum fuorum, arbitrans $\&$ à magis fuis fic edocqus, quod dij lac bibant effufum, \& follicis tifint conferuatores omnium eorum qux poffidet. Poft facrificium illud nefandum bibit rex de las cie equarum albarun, nec ulli alteri licet illa die bibere de lacie illo, nifi futerit de progenie regis, prae ter populum quendam regionis illius Horiach uocatum, qui hoc etiam gatudet priuilegio, propter ui o ctoriam quãdam magnã, quam pro magno Cham Chinchis obtinuit. Hinc fit ur equi albi atç equa in magno à populo illo habeantur honore. Rex quidem huius coloris equos $\&$ equas fupra decem millia poffidet, Paulus Venetus 1.65. Sauromatx plurimos alunt equos, utpote Nomades, quibus non tantum ad bellum utuntur, 8 in cibo: (ed dipjs etiam fuis immolant, Paufanías in Atticis*

In rogo Patrecli comburebantur etiam equi apud Homerum Iliad. $\psi$. ol Volucer equus Veri imperatoris fepulchri honore affectus eft, utinter propria equorum dixi in a. Cimonis equx poft tres uictorias Olympicas, Athenis fepulta funt, ut in Olympiorum mentione diximus. Magnum in equis alendis ftudium pofuerunt Megacles 8 Cimon Athenienfes, qui equos fuos etiam fepeliri curarunt, $T$ zetzes Chiliade quarta, in epiftolio. Scythæ cum rege defuncto aliquam eius pellicum frangulatam fepeliunt, \& eum qui uina mifcebat, 8 cocum, 8 hippocomum, $\&$ miniftrum, \& io qui eratà nuntijs, nec non equos, $\&$ alias res. Circumacto anno rurfus hoc agunt. E famulis regis, qui ingenui Scythæ funt, intimos fumunt. Horum quinquaginta cum frangulatierunt, ac totiden? praftantifimos equos, educis inteltinis expurgatis paleis implent ac confuun: Et ubi dimidium 
fornicis fuper duro ligna refupinatum ftatuerint, alterumç dimidium fuper altera duo ligna, \& ittom alia multa huiufcemodi detixerint, tum fuper ea equos imponunt,craffis tignis in longum ad certub $\mathrm{ccm} u$ fge traiecios, ita ut priores fornices fuftineant armos equorum, polteriores uero iuxta femor? fúcipiant urteros, utrifo̧ cruribus fuperné pendentibus. Equos infrenant, corumḉ habenas ad palos exrentas aligant. Dehinc fuper corû fingulos ftatuũt fingulos quinquaginta iuuenû ftrangulatorü, hunc in modũ: Vnicuiç corû reçum ftipitẽ per fpinam ad ceruicẽ uf̧̧́ transfigunt:quod inferitus fil pitis extat ultimum, infigũt trigno illi, quo equus tranfiectus eft. His equiribus fepulchro circumpof ris abeunt. Hunc in modum reges fepeliunt, Hac Herodorus libro 4+ Boryftheni equo uenationi, lus aptifimo, fepulchrum ab Adriano fubftructum fcribit Dion, Cal. De Bucephali fepulchrofur pra dixi inter hifforias. Oenomai(Marmacis, ab Oenomao occifas, Paufan. Eliac. 2.) equas tradunt uncaras Partheniam \& Eripham, quas quum iugulaffer iuffit fepeliri, Cal. Miltiades tres equas $\mathrm{O}_{\text {. }}$ lympix orcifas, fepulturæ honore in Ceramico affecit. Item Euagoras Lacon,idem ć Olympionices equos ad fepulturam magnificè dedit, A elianus. Fecit $\&$ diuus Auguftus equo tumulum, de quo Germanici $C_{a}$ faris carmen eft. Agrigenti complurium equor um tumuli pyramides habent, Plin,

êl Meramorpho? fiue transformationes in equos, uel equas, Saturni, louis, Neptuni, Cereris, \& Hippes ue Orythoês Chironis filix, in pracedentibus fparfim in fua fingulorum mẽtionerecenfui.

(1) Omina oftenta. Pedeftrium aufpicia nominabantur, quar dabantur à nulpe, lupo, ferpente, es

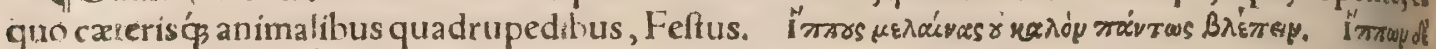

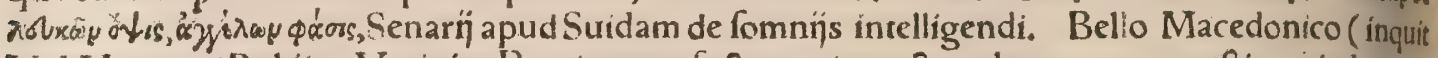

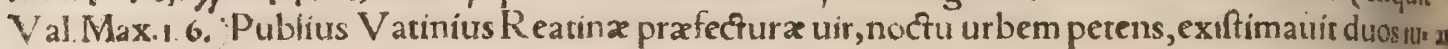
tenes, excellentis formæ, albis equis refidentes, obuios fibi factos nuntiare, die qui præter ierat, $\mathrm{Per}_{\mathrm{i}}$ fen regem à $P$ aulo captum : quod cum fenatui indicalfer, tanquam maieftatis eitus $\&$ amplitur dinis uano fermone coniemptor, in carcerem coniectus: poftquam Patliliteris illo die Perfen capt"̈ apparuit, \& cuftod a liberatus, et infuper agro ac uacatione donatus eft. Caftorem uer o \& Pollutin etram illo tempore pro imperio P. R. excubuilfe cognitum eft, quo a pud lacum luturnæ fuum equo rumóp fudorem abluiffe uifi funt:iũctaç̣ fonti ædes corum, nullıus hominum manu referata pauil, Hax Valerius. Quratuor hî́, primum omen,equos in gramine uidi Tondenıes campum lare, rân dore niuali. (Candore nitu, hoc, inquit Seruius, ad uictoria omen pertinet.) Et pater Anchifesitels lum ò terra hof pira portas: Bello armantur equi, bellum hac armenta minantur. Sed tamen ijdem clim curru fuccedere fueri Quadrupedes: \& frena iugoronco dia ferre. Spes eft pacis, ait, Verta funt Aenex a pud Vergilium Aeneid.z. Primus ab aquorea percuftis cufpide faxis Theffalicus fonipes, beliis feralibus omen, Exiluit, Lucan.libro 6. Germani ex hinnitu 8 fremitu equorum, monitus futurorum pradici putant, quos nullo opere contactos candidi color is plurimos educebá, Alexander ab Alexand. Darius quomodo hınnenre equo eius in aurora prin ò, rex inter feptem principes uiros Ferfas, inter quos ita contrenerat, fit declaratus, defcribit in Thalia Herodotus. Ues bares, inquit, Darị equifo, ubi nox aduenit, unam equarum quam equus Das ij maximé ad:malat, in fuburbana adducit, ibiós alligat. Tum equum Darñ endem ducit: eumḉs circumagens idenidem equa admouet, ac tandem admirtit. Poftero die fimulatgs illuxit, fex Perfa ex conuento affuerunt equis affidentes. Etcum in fuburbanis ultrò citró̧ uectarentur, ubi ad lorum peruenerunt, uhifu. periore nocie equa fuerat alligata, ibi Darij equus accurrens hinnitum adidit: $\mathcal{C}$ hinnitu $x$ dito pro 4 tmus fulgur fereno cæelo tonitruás extitit. Hac cum Dario tanquam ex compofito accidiffent, cum compotem ucri tecerunt. Nam cateri ex equis defilıentes Darium adorauerunt. Sunt qui hoc diąa Oebarem fuifte mas hinatum, funt qui aliud:nempe attrectatis huius equa genitalibus, ipfam manü inrra fubligaculum tenuiffe abditam: \& fub ipfum ftatim Solis ortum, cum equi digr effuri effent, ea

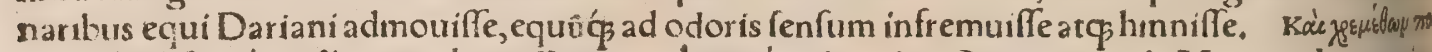

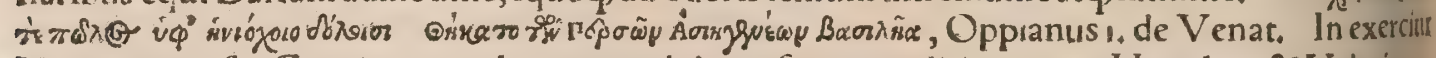
Xerxis aduerfus Græciam equa leporem ædidit, ut fupra reculi in $\mathrm{H}_{+} \mathrm{c}$. ex Herodoto \& Va'erio. De equa qua noftro feculo leporem peperit, uide in lepore $H_{+} c$. Ros equuleum peperit, Lituits 3, Delli Punici. Proximis diebus equorum greges, quos in traĭciendo Rubicone Marti (alıâs non Mar ti legirur, fed flumine) confecrauerat, ac fine cufiodibus uagos dimiferat, comperit pabulo pertinas $p$ ciflimé abfinere, ubertimés flere, Tranquillus in uita lulī Cæefaris. Niphus Sueffanus equos ante mortem Caligula pabulo abftinuiffe \& ubertim fleuiffe fcribit, nō citato authore. Nero of enrabat hermaphroditas fubinges carpento fuo equas, in Treuerico Galliz agro repertas, ceu plané úfenda res effet, principem terrarum infidere portentis, Plin. C. lulius Carar utebatur equo infigni pedi bus p:ope humanis, $\&$ in modũ digitorum ungulis fiffis: quem natũ apud $f e$, quũ arufpices imperiú orbis terra fignificare domino pronunciaffent, magna cura aluit:nec patientem fefforis alterus, pti mus afrenditicuius etiam inftar pro $a d e$ Veneris genitricis pofteadedicauit, Sueronius. Plinus cum de Bucephalo frripfiffet, fubdit:Nec $\mathrm{C}$ afaris diciatorís quenquam alium recepuffe dorfo equis traditur, idęmó homin is fimiles pedes priores habuife, (idem foribit Plutarchus in eitus uita) hac efs figie loratus ance Veneris genitricis adem. A uctor hiftoricus Dion, CaCari Lulitaniam gerenci

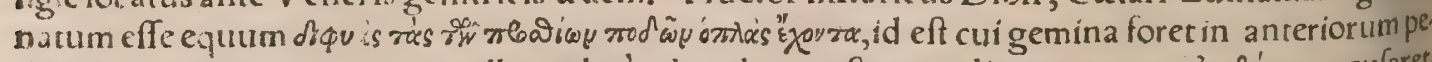
dum ungulis natura, qui mox illum elaté admodum geftarer, reliquos omnes àva $B$ úazs recularet, 


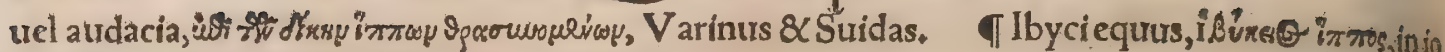
cum prourbialem abiffe uidetur, de ijs quí nolentes præter atatem ac uires ad periculofum (urel dif, ficile)negotium adigerentur. Dicti originem refert Plato in Parmenide, Ibyco poëtæe equus crat iam annofus athleta, multis certaminibus detritus. Is quum ad certamen currui iungeretur, extimuit,ui. delicet expertus eiufmodi ludorum aleam. Ridente populo lbycus furgens, Equus (inquit)domini fimilis eft:nam $\mathcal{X}$ ipfe iam fenex ad amandum compellor. Huc allufiffe uidetur Horatius in epiftos lis, Non eadem eft atas, non mens. \& , Solue fenefcentem maturé fanus equum, ne Peccet ad exa tremum ridendus, $\&$ ilia ducat, Erafmus, Eodem prouerbij fenfu Sophocleus etiam equus ufurpas tur, ut ínfra dicam. Incita equum iurxta nyffam, id eft lineam uel carceres, \& $c$. Vide fupra in H,e, in

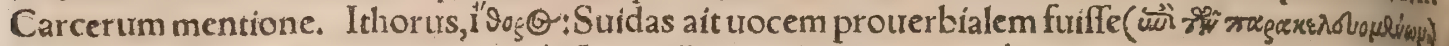
in eum qui üelut inftigator hortator $c_{\beta}$ foret alijs:translatum opinor à nautis, quos remigantes naule cleri uox animat ad gnauiter laborandum, fiue ab equorum curfu. Plutarchus fcribit im nó opoy (ui, Ie fupra in c.) appellatam cantionem ad incitandas equas: Qogęü Gręcis eft impetu infilire. A pparet Græcam uocem compofitam ex $\%$, uade: \& o osejy incitare, Erafm. Tl Lydius currus, uíde fuprain H.e.ubi decurribus, T Optat ephippia bos piger, optat arare caballus, prouer bialis uerfus apud Horatium, ut in Boue dixi. fln planiciem equum, quoties quis ad id prouocatur, in quo plurimin ualet, quoḉ trel maximè gaudet. Equus in campo tanquam in fua eft harena. A pud Lucianum in $\mathrm{C}_{2}$

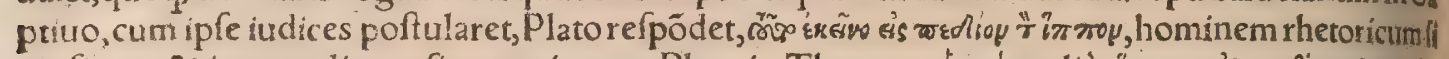

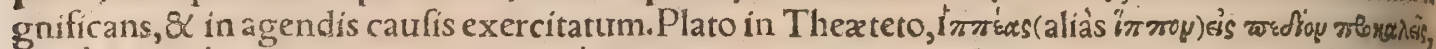

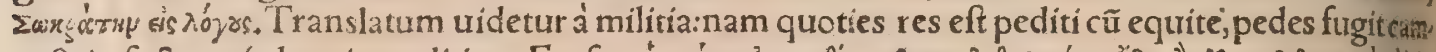

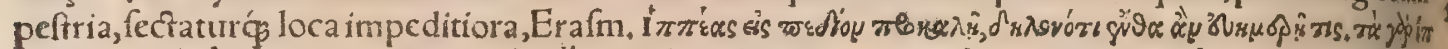

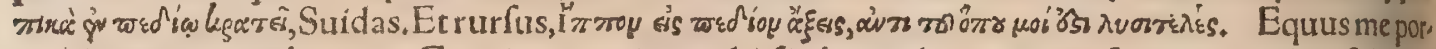
tat, alit rex:prouerbium, ut Graci parcmiographi fcribunt, hinc natum. Iuuenis quidam fub rege Philippo ftipendia faciebat. Is cum admoneretur ut miffionem peteret, feféçs à militia abdicaret, ne.

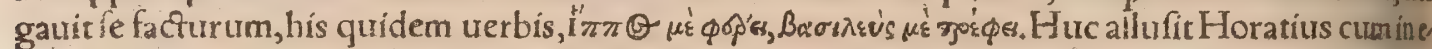
pifolis fub Ariftippi perfona fic ait: Rectius hoc, \& Splendidius multó eft, equus ut me portet, ar lat rex: Quo quidẽ in loco Acron huius admonet prouerbij, cuius etiam meminit Diogenian, Appa reté tragozdia quapiam a citum:eft enim carmen anapæefticum dimetrum, Erafmus. Probi impera toris equus in parcmix formam deduci poteft. Is erat nec decor us quidem, nec ftaturofus : uerum celeritate tanta, ut diurnis fpatịs centum obiret miliaria:uel in decimum diem labore haud interpel, lato. Eum tamen fugacimagis quàm forti ac ftrenuo congruere militi pronunciauit Probusidem,

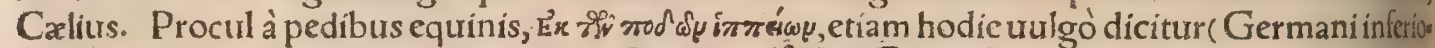

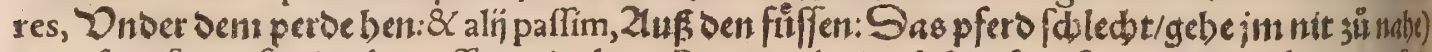
cum fignificant fugiendum effe periculum. Proprius huius dicai ufus eft in certaminibus equeffiris

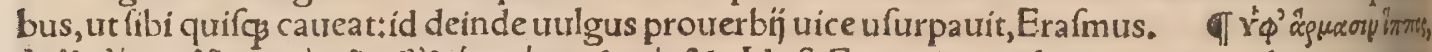

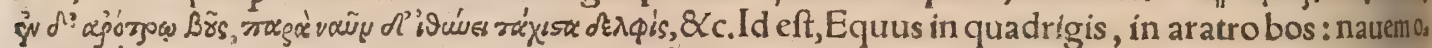
cyffimé præuertitur del phinus, Pindarus ut à Plutarcho citatur, Erafmus in prouerbio Quam quilas que nôrit artem in hac fe exerceat. Equis $8 \mathrm{Q}$ quadrigis, id eff omni conatu, Cicero ad Q, fratrem, lde 2. Offic.Cum his uelis equisḉ, ut dicitur, fi honeftarem tueri ac retinere fententia eft, decertandęm eft.Si huic occafioni tempus fe fubterduxerit, nunquam ædepol albis quadrigis indipifcet poffea, Plautus in Afinaria, ut citat Erafmus in prouerbio Equis albis pracedere, TSaluete equorumfif lix, uide in Mulo. Equum hahet Seianum, olim protierbio dicebatur in calamitofum, \& ad exrits mam inopiam redactum. Allegoria fumpta eft a b equo quodam fatali, cul à $\mathrm{Cn}$. Seio domino nomen inditum eft Seiano:is ex Diomedis equis prognatus fuiffe creditus eft. Fuit infigni quidem fpecie, ne rum erufmodi quodam fato, ut quifquis eius equi poffeffor effet, is cum omni domo ad internicionê ufç̧ deperiret. Id quod $\mathrm{Cn}$. Seius ipfe capitis damnatus, ac miferando affectus fupplicio : deinde\& Cor. Dolobella bello interfectus:poft hunc C. Caffius ab hofibus occifus: deinceps M. Antoniurs des teftabili exitio perditus, probauit. Hunc equum C. Baffus Argis fe uidiffe refert, haud credibili puls chritudine, uigoré $\alpha_{\beta} \& \alpha$ colore exuperantifimo, nempe puniceo. Hoc ada gium $\&$ refert, \& copiofis us explicat A. Gellius 3.9. Hæc Erafmus, Equus Cn. Seij (inquit Ioan.Rauilius)à Cor. Dolobella cens tum milibus feftertīs emptus, inufitata quidem magnitudine, fed eo fato, \&c. ut fupra. Vide etiam Cælium 12.13. de codem equo:cuius hiftoriam Antonius de Gueurara quoę narrat epilt. 25. Scytha

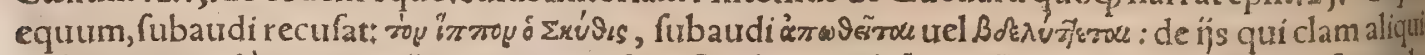
defiderant, palàm uero reṇciunt \& reculant, Suidas in Tó̀ in mo. Prouerbí ratio clarior fit exalten

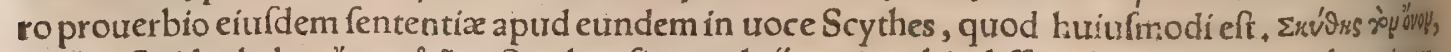

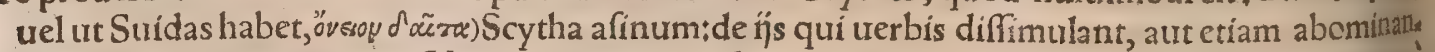
tur, re ipfa autem appetunt. Nam cum quidam afinum mortuum uidifiet, dixit $\leftleftarrows$ En tibi coenamo Scytha+1lle uero primum deteftatus, paulo poff curiofius de eo perquifiuit, \& circa eum parandumer

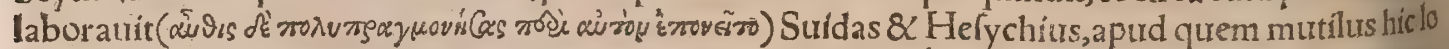

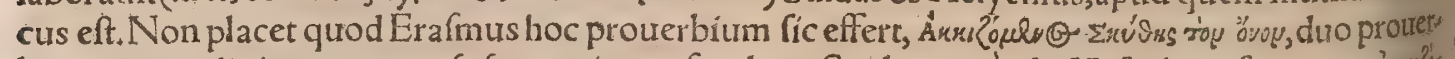

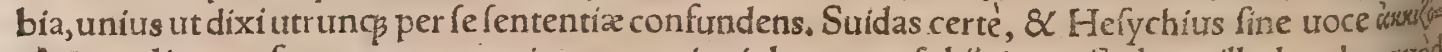
who melius proferunt;mox uero inter pretationis loco eam fubijciunt: Sed nec illud probo, quto 


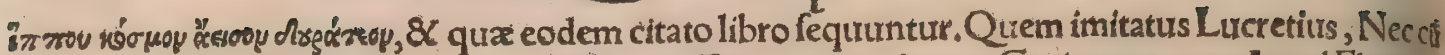
durateus Troianis Pergama partu Inflammaffet equus nocturno Graiugenarum. A pud Flaccum Argonauticôn 2. Manet immotis nox Duria caftrisłalị codices habent Duricà eodem fenfư: quidã fimplicius legunt Dorica pro Graca, ut, Et Dorica caftra, Equo autem ligneo inclufis Danais expur gnatum fuiffe llium fabulofe poetæ commenti funt: fed rei ueritas ita habet. Equum ligneum, fimula to pro reditu Minerux uoto, Graci ea magnitudine conftruxerunt, ut intra mœnia Troiana reci, pi non poffet, nifi portæ muriós urbis deponerentur. Eum Sinon, transfugam fimulans, perfuafit Troianis, fi in urbem inducerent, futurum, ut nunquam Graci aduerfum eos amplius arma motrete poffent. $Q$ iramobrem deiectis portis $\&$ murorum parte, equum introducunt. Capientibus mox ip fis cibum fecurè, ac nihil tale uerentibus Troianis, Danaûm ductores ex loco, ubi in infidijs fubfia derant, unde adhuc illi Argiuorum infidiz nomen eft, prodeuntes apertam urbem inuadunt, atque hoc pacto capiunt, Hac ex Palæphatiapiftís. Alĭ fentiunt poếtas equi commentum de monte quo. dam arripuiffe, cui Equo nomen effet, qui Troix immineret, per quem etiam facile capta fit:ad qurod $\&$ Vergilius his alluferit, Inftar montis equum diurina Palladis arte Aedificant, Hactenus Erythrę, us. Equum, qui nunc aries appellatur in muralibus machinis, Epeum ad Troiam inueniffe traditur, Plinius, Equum durium Epei opus, fuiffe Paufanias(in Atticis)interpretatur machinam muris difs foluendis, cuius aneum fimulacrum in Acropoli fuerit, Calius. De equo Durio \& 2 . Troia per eum capta, multa Calaber lib.12. Arietem à Carthaginenfibus excogitatum, Vitruuius \& Tertulliants in libello de $\mathrm{P}$ allio memorant. Higinius etiam Troianum equum, machinam oppugnatoriam fuifie frribit Et hic quidem, Plinius \& Paufanias, plus fidei merentur quàm Dictys \& Palxphatus. Eftpre terea equus Troianus Liuñ poetæ tragoedia,Brodæus. Equus Troianus (inquit Calius) prouerbio ufurpari poteft profocietare non in perniciem modo cuiufpiam inita, uerum \& ad bonam frugem aliquam. Cicero alicubi fcribit ex Ifocratis ludo, ueluti ex equo Troiano, innumeros principesexia uiffe. Huc delecta uirùm fortiti corpora furtim Includunt cæco lateri, Vergilius. M. Varro, quod ad equum ligneum attinet, Epeum eius concinnatorem fuiffe coquum fcribit, \& Argiuis cibum chn raffe:ídeó́s a Plauto fumicum coquinatorio epitheto nominat 25. \& Politianum in Mifcellaneis, capite quinto, \& fupra in $\mathrm{H}$, a.inter imagines equorum. Propertis us libro 4. Elegiarum abiegnum equum dixit. Troiam fertur ob Laomedontis equos primumab Hercule, deinde per ligneum equum ab Agamemnone, tertió propter equum qui in por ta confiftês Ilienfibus claudere uolentibus impedimento fuit, à Charidemo duce captam fuiffe, Plutarchus abini jo

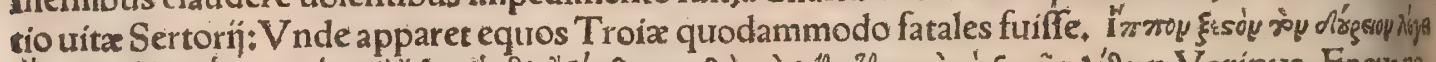

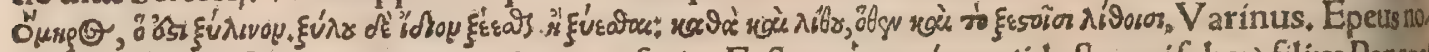

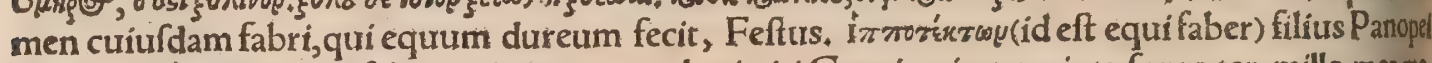
durium ( '́réop) equum fabricauit, in quo ocultati uiri Graci quinquaginta fupra ter mille mea me

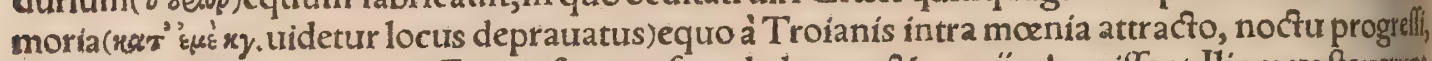
cateris qui in Tenedo erant Græcis fignum face dederunt: 8 cum n̈ adueniffent, Ilium uaftauerint,

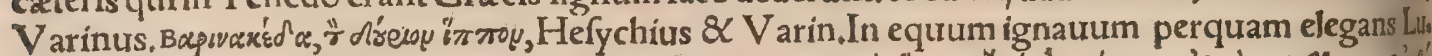

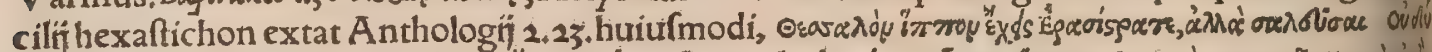

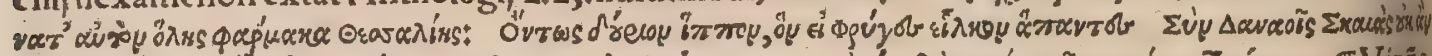

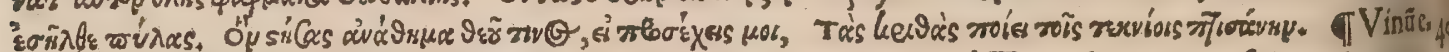
quus poëræx. Demetrï Halicarnaffei diftichon huiufmodi citatur à Zenodoto, etiamfi in epigtramma

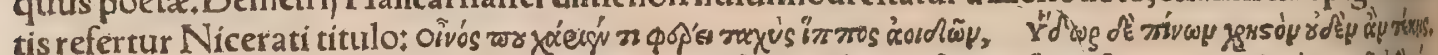

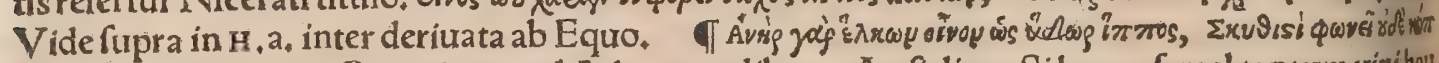

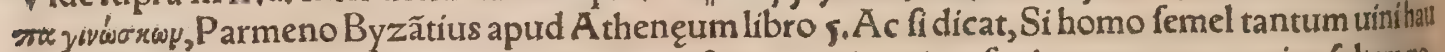
ferit, quantum aqux folet equus uno potu confumere, minus iam fapit equo:equsus enim faltem no, men fuum femper agnofcit, ut coppatias dictus à coppa numero, de quo dixi in $\mathrm{H}$, a, inter nomilla quorum. Nos potioni nimium indulgentem, uaccæ inftar bibere dicimus, Cum peditibus cucuriu fti, \& illi fatigarunt te:quomodo ad certamen prouocabis equos? Hieremix 12.

ब Germanis ufitata prouerbia ab equis ducta, quiburs eiufdem feré fententix Latina abfogegull mentione enuntiata adiungemus. Sas p feror ift feins füters weed / E quus meretur pabulum, Canis digna pabulo. Sieroff binder ben wagen fpannen, Equos currui poftponere: Currus boué

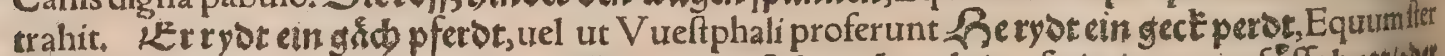

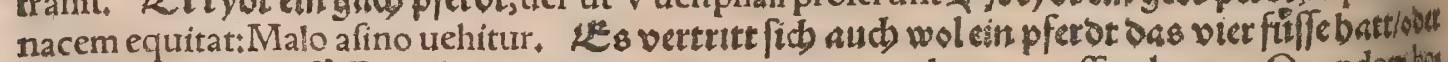
cin p ferst mit vier firffen: Eft quando equus quanquam quadrupes greffur aberrat: Quandog bon nus dormitat Homerus. (5aul alogurr, Equus equa dignus:Mali thrîpes, maliipes. Rieform

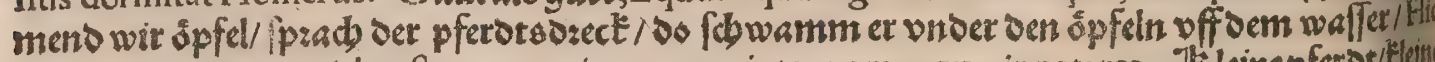
nos poma natamus, aiebat ftercus equinum, cum inter poma aqua innataret. Tkleine pferot/tet

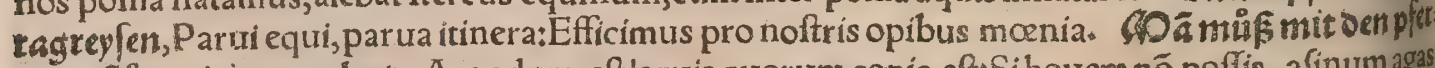
Den pflügen die man bat, Arandum eft equis quorum copia eft: Si bouem nó poffis, afinum agas.

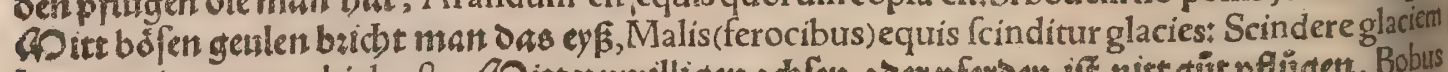
Latinis etiam prouerbiale eft. SD itt vnwilligen odb fen oser p ferben if nitt gur p flugen, Bobus aut equis inuitis non bene aratur; Inuitos boues plauftro inducere. 2i 
Et alibi, Pritus tamen quàm exilem terram iteremus, ftercorare cóuenit: nam eo quiafi pabulo glifcii, Hinc, ut uidetur, gliferum quoq̧ conuiuium, ut Cęlius meminit, dici poteft, quod aditiale ar ganea tum dubiumḉ̧ fuerit. Glis animal, glis terra tenax, glis lappa uocatur, carmen apud Syluaticum. Es à recêtioribus quibufdã grammatícis parum clafficis, glis foeminini generis, unde genitiuus fit glifis, terra cretofa uel argilla exponit: Scoppa exiftimat uocem non Latinam effe. Cum prolappa(uel cara duo, ut Calepinus haber, foemininum quoç faciens)accipitur, genitiuum faciunt glitis: (ed hoc quo que Latinum non uidetur. Syluaticus glirem interpretatur anımal quod in radice napelli moretur, deceptus(ut apparet:) quoniam utrun q $_{3}$ muris genus uidetur, utrun $\beta$ fylueftre. Sed de mure qui de git circa napelli fitre aconiti radicem, inter mures dicemus. Glis tuero in arboribus $\&$ latibulis fyltan rum habitat. Albertus Magnus murem uarium nominat, propter colorem, ut infra dicemus quan $_{\sqrt{5}}$ quã \& murẽ Ponticũ recentiores uariû abfolutè appellant. רy akbar uocem Hebraicam murem . interpretantur, fed glis potius uidetur. Hieronymus Leuit, 11. muftelam uertit: Efaiæ 66. murem, quem nos glirem uocamus, uel iuxta Orientis prouincias $\mu$ voǵzs. Septuginta $\mu \tilde{u} y$. Chaldaus, akbera,

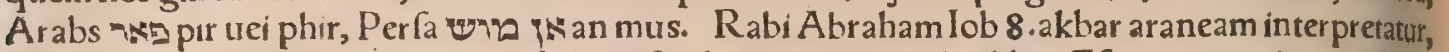
Munfterus. Comedentes carnem fullam, \& abominationem, \& akbar, Efaix 66 . murẽ reddit Mün fterus:etiam Leuitici 11, ubi fic legitur ex translatione ipfius: Hoc quoqs uobis inmmundum fitin re. ptili, quiod reptat fuper terram:muftela $\&$ mus atç̧ bufo, ericius, chamęleon, lacerta, limax, \& talpa Graciglirem $\mu v o \xi o y$ appellant. Myox us animal morıtur femeftre tempus, \& rurfus poft tempora lua reuiuifcit, Epiphanius in A ncorato inter argumenta de refurrectione credenda. Item in fine primil tomi fecundi libri contra harefes, Tradunt (inquit) naturæ rerum experti, myoxum latitare, \& $\alpha$ f 18 tus fuos fimul in eodem loco mulros parere, quings 8 amplius: Viperas autem hos uenari. Et fi inue nerit corum latibulum ipfa uipera, quum non poffit omnes deuorare, pro una uice ad fatietatem edit unum aut duos, reliquorum ueró oculos expungit, \& cibos affert, excæecatosá̧ enutrit, donec uolue rit unumquenq̧ cortum deuorare. Si ueró contigerit, ut aliqui inexperti in hos incidant, ipfoś́s inci bum fumant, uenenum fibi ip fis fum unt, eos quià uiperæueneno funt enutriti. Sic etiam ô ruOrige nes à Graca docfrina mente excacatus, uenenum his qui tibicrediderunt, euomuifti, \& factuses ipfis in edulium uenenatum, ita ut per qux ipfe iniuria affectus es, per ea plus iniuria affeceris, Ad, derem \& Oppiani uerfus circa finem libri 2. de Venatione, nifi nimium indulgere poetarum elegan tiæ uideri meruerem:quamobrem fat fuerit fenfum exprimes e. Prater infiturum eft (inquit) mino

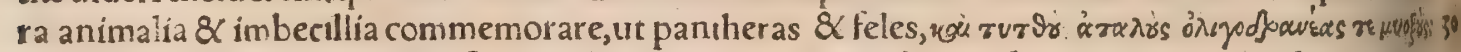
hoc eft paruos $\&$ teneros $\&$ infirmos glires, qui tota hyeme fomno fepulti mortuis fimiles iarent, at uere demum nouo reuituifcunt, expergifcuntur, $\&$ ad cibum redeunt capiundum. Non dicam etiam hirfutum \& imbecillem friurum, \& c. Hinc quidem conftat myoxum non effe bufonem, ut quidam interprerantur,(Gyllius ex Oppiano:) fed nihil aliud quàm glirem: A pud Syluaticum quogs moles (promyoxos)'glis exponitur:quanquam mox idem, mifoxum, ranam terreftrem uenenofam rubes am incerpretatur. Ipfum certe myoxi nomen animal ex myôn, id eft murium genere, effe oftendit,

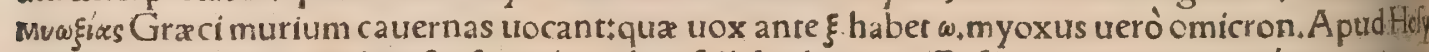
chium \& Varinum codem fenfu $\mu$ gixas tribus fyllabis leg:mus. Eafdem cauernas $\mu v \omega$ rixas nominant, fimiliter per omega:etfi örix, id eft foramen per omicron fcribitur. Myxus quoç animalis nomen el, de quo incantationem leg mus apud Suidam $\&$ Varinum, ad afini dyfuriam : Gallus bibit $\&$ non 40

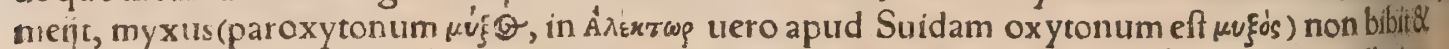

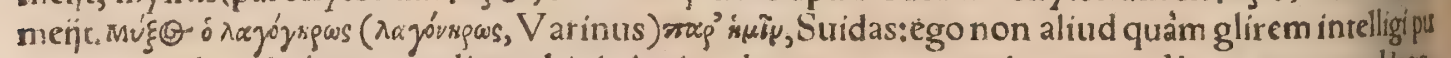
to, quem uulyus I talorum hodie mulcis in locis galerum urocat, quod nomen ad lagogerum, uel lagos nerum fatis arcedit, literis tranfpofiris. An uero glires non bibant, affirmare non poffum : uerifinile tamen eft longo tempore fine potu uiuere poffe, \& meijere tamẽ, ut mures etiam. Ego cuniculosàte neris aliquot iam menfes potum afpernantes $\&$ recentibus tantum herbis contenros enutriui, culm interim in meiendo plurimi fint. Myxum etiam prouerbialicer dicimus de homine arrogante $\&$ ia ćabundo, à Myxo quodam Diane facerdote, qui homo nimis urbanus $\&$ iactator erat, Suidas \& V/

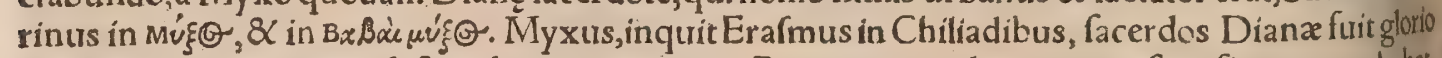
fus $\&$ magniloquus, qui fe fingebat omnia mirari: $P$ apx autem admirationis $f$ :gnificationem habet, $f$ Referrur à Suida \& Zenodoto. Ego apud Suidam de Myxo non reperio quòdomnia mirarífe fint xerit,id quod parafiti \& Gnathonis, potius quàm Thrafonis ac Myxi eft: Quamobrem illud Papa

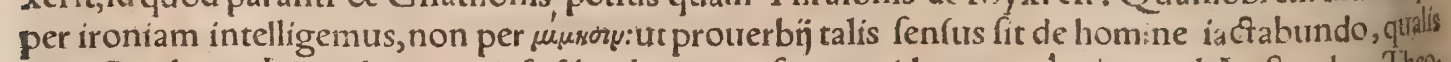
illius Cerebrum louis, de eo qui ipfe fibi plurimum fapere uideatur. Ė $\lambda$ eis apud Ariftorelem Theo. doro interprete glis eft, \& uox ipfa fatis alludit. Varinus eodem modo feribens genus accipitrisina terpretatur. È $\lambda$ eirs Ariftarchus inquit nafci inter frutices fimiles lacertis, Calliftratus uero animaleh

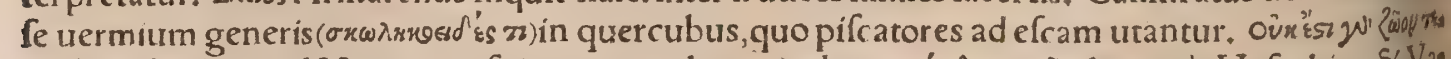

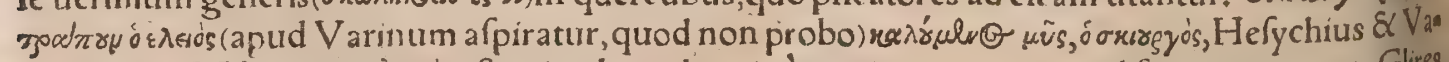
rinus: hoc eft, Neç enim छ̇ $\lambda$ esios eft animal quadrupes è murium genere quod fcuurum uocant. Glires quos Gracia u̇iris uocant (legendum i $\lambda$ erss) in ipfis arboribus hyeme pinguefcunt, Volaterranus.

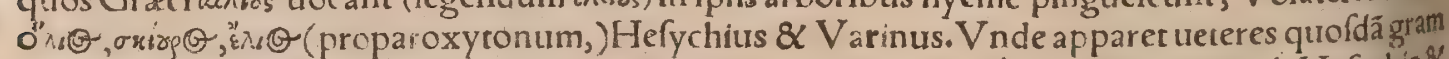

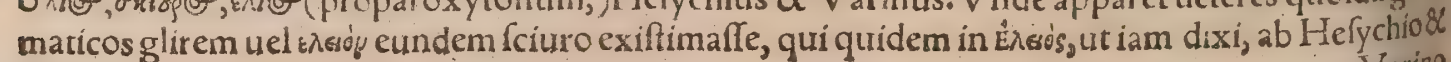




\section{DeGlire. A.B. Lib. I.}

Varino reprehêdunturr. Nuper etiam Ge. Agricola in libro de animantibus fubrerranneis, eiufdem animalis hæe nomina effe afferuit, nullo tamen uel tefte uel argưmento adhibito, pręterquam etymo logíx à fe confictax. Glirem, inquit, Ariftoteles ènesiy à uertendo nominat. Vertic enim \& fur fum uer: fus inflectit caudam:qua de caufa alị̂ Graci rau tirgou uocarunt:aliquil uerò $\sigma$ xirgop: quòd cauda fua uillis ueftita $\mathcal{Q}$ conferta, quafi flabello corpus foleat inumbrare:aliqui $\mu \tilde{v} y$ oxirzoov, quôd praterea fimilitudinem quandam gerat fpeciemóp muris. Ego glirem à fciuro differre uideo, tum authoritate grammaticorum quos dixi:tum quoniam $\&$ Oppianus apud Gracos de myoxo (quem glirem effe oftendi) $Q \mathcal{Q}$ fciuro: $\&$ apud Latinos Plinius de glire $\&$ fciuro feorfim agunt. Accedit quod omnes qui Larina lingux teeftigia feruant, Itali inquan, Galli \& Hifpani, \& glrris \& friuri diuerfor um anima* lium diuer fa nonina retinent, utraq̧ antiquam originem teftantia. Glirem in delicñs ciborum habẽt

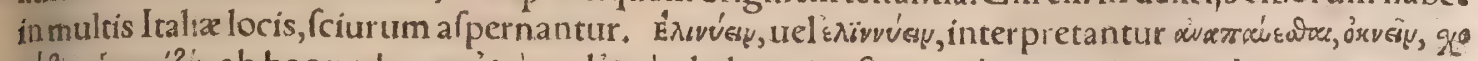

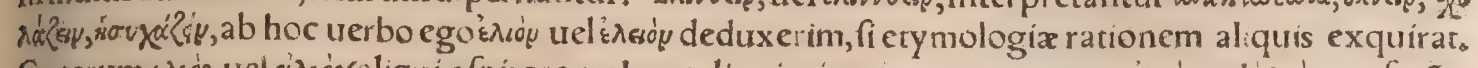

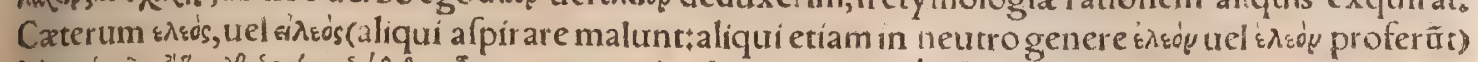

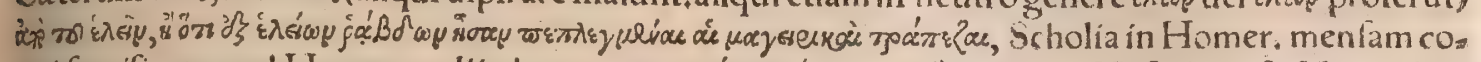

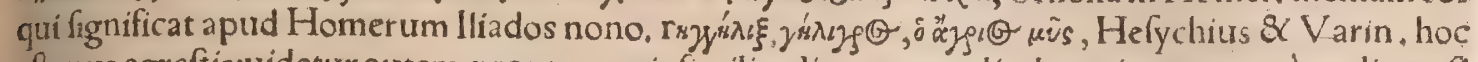
eft, mus agreftis:tidetur autem, propter uocis fimilitudinem, non aliud muris genus quàm glirem fi

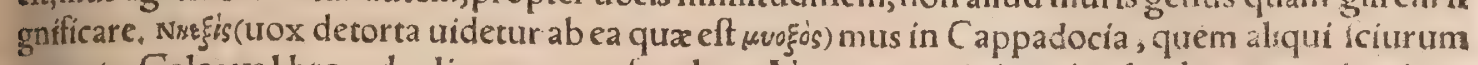
uocant. Galenus libro 3. de alimentorum facultate, Non opus erit, inquit, pluribus exequi anima* lia omnia quæ apud fingulas gentes propriènafcuntur, qualis eft apud lberos cuniculus: in Lucania âtem Italia regione quod incer urfum ac fuem quodammodo eft medium:ceu aliud quoddam inter

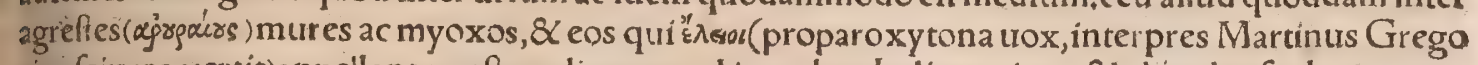
rius friuros uertit)appellantur, eft medium:quod in eadem Italix regione, \& alins pler: $f_{C B}$ locis man: ditur. Qux enim ex eiufmodi anımalibus bene habito corpore ac planè pingui funt, ea experientia explora, praparandorum ipforum rationem, quam incolx experientia didicerunt, ab ipfis audiens acdifcens. Ex his Galeni tuerbis exiftimabit aliquis, ên $\lambda$ Go \& $\&$ myoxòn animalia effe diuerfa : fed fieri poteft, ut myoxos fubiuncta per epexegefin copulatiua coniunctione elios interpretetur. Aut fí nó idem funt, proxima tamen inter fegenera effe apparet. I Glirem Itali uocant lo galero, lo gliero, uel ghiro, ut Scoppa, Arlunnus \& Niphus docent. Hifpani lirón Galli fimiliter liron, uel ractliron: fe cundum alios, ung loir, ung rat ueul. Germani circa A thefin etn greul: Heluerí, e uel groffeba|clmu. . Nam $\&$ aliud fyluatici muris genus eft, glire minus, cui a b auellanis quibus ue ficur nomen êft apted noftros:fed hoc in cibum nö urenit:fimuliter tora hyeme in fyluis dormit, unde apto uocabulo dormus, hoc eft dormẽes mus, ab Anglis appellatur ( prepr um quiden gliris nomen Anglicum non reperio)de quo plura in murium hiftoria diram. Hoc non pratercundum, animal cuitùs imaginem dedi, fub uentre albicare: \& mor dax effé adeò ut rarò ưuum capiatur. Hanc piç̃̃ cum oftendiffem amico cuidam, qui rellios mures nofiros, ur ita uocem, uidir editíg: nonnihil interef fe dixit, quòd noftri oblongicre roftro uideantur, $\&$ acutioribus auriculis, extrema cauda non aque uillofa, uentre medio mag s protuberante inter pectus $\&$ ilia contractiora, tergo $\&$ latere pro:fus ci nerei, in uentie (fi bene memini)fubruffi, non albi faltem. Capiuntur aliquando Claronæ (qui Helue. tix pagus celebris inter altiffimos montes fitus eft) in fyluis 8 arboribus. Vt un $\phi$ maius fciuro oft, itrung, animal murium generis eft, urtungs efculentum $\&$ pinguiffimum: ut dux fpecies unius ge neris uideantur. Lardironietium, quorum Cardanus meminit libro 10 de fubrilitate, nô alĭ quàm glires uidentur: $\&$ nomen hoc à Cardano conficfum propter lardum, hoc eft pinguitudinem qua glí Icunt:quanquam ipfe mufellarum generi adnumeret, his uerbis:Sunt(inquit)animalia pellibus no biltora, ut lynces: \& è muftelarum genere plurim $x_{2}$ martori, uarii, lardironi, viulerræx, ginetræx. (fed ua rï, \& lardironi, fi glires funt, muribus potius adnumerari debent.) Et mox, Pelles colli diuturntores plerunq, ut in uulpe, uiuturra, lardirolo. Ineptiffimè quidam in uernacula lingua rattum uxulgo dis

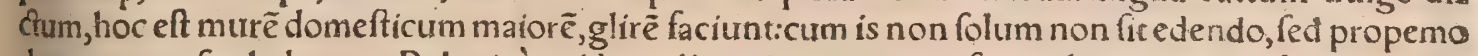
dum uenenofus habeatur. Polonicè quidam glirem interpretatur frzurek qux uox ad fciurum acce dere uidetur : fed fciurum uocant wijewijorka. Audio in Croatia $\&$ alibi illud ctiam muris genus edi, quod bild)uitis Germanicé uocant, de quo plura inter mures.

B.

In Mæefia fylua Italia, non nifi in partu reperiuntur glires, Plinius admirans rerum naturam non folum alia alijs dediffe terris animalia, fed in eodem quog fitu quxdam aliqubus locis negalie. Au dio glirem maiorem effe friuro, colore nigricante: uel, ut alij referunt, dorfo fufco, uentre albo, (qui color etiam ijs eft, quos iam mures ab auellanis uulgo dicfos nominaui) cauda breut, in extrems uil. lofa, facie quodammodo urfina. Albertus eriam glirem colore uarium elle fribic, in dorfo grifeum, in urentre album: breuioris pili, $\&$ tenerioris corn̈ quàm animal quod verè uarium (murem $P$ onticü, uulgò pundtmuß̧, intelligít)uocatur. Axungia \& laridum funt in animalibus non cornigeris, quó rum quatuor dentes ut plurimum prominẽt, ut funt glis, felis, canis, urius, \&'c. Monachi in Mefuren. - Veras glires $\&$ fciuros cæcum inteftinum tantum nactum fcimus, ut magnitudini corum uentricu lifácile refpondeant:atģs idem in fectione facibus turgidum reperitur, Vefalius. 
Fagiglans muribus gratiflima eft:glíres qưoळ̧, faginat, Plinius. Nucibus regīs uel iuglandibus delectantur glires. Arbores fcandunt, \& poma edunt:uel ut Alber tus fcribit, fucco pomorum alün, tur. Noftrates non ipfa poma uel mâla à muribus rellịjs ediaiunt, fed aperiri tantưm, ut nucleis pon tiantur:\& fxpe fub arboribus copiam pomorum nucleis exhauftam à gliribus, inureniri: atç inde no men impofitum ut rellen dicantur : nam idem trocabulum legumina fub mola decorticare fignificat, ita ut inter molendum medulla quafi nutcleus à cortice ambiente purgetur:hoc Graci rijiardy, Latinj pinfere uel pinfare uocant:quod olim pilis tundentes faciebãt, hodie molentes in molis, ut Budaurs etiam teftatur.Panicum pinfitum \& euolutum furfure, Columella $V t$ in piftrino pinfecur ac torrea tur, Varro. Solent autem glires noftri poma, quorum appetũt genera, diuaricatis alicubi ramorum । ceu furcis imponere, ut fic inferța obfirmataóg cómodius euacuent, Sed de cibis corum plura dicam capire quinto. Glires latent in ipfis arboribus, pinguefcuntó̧ per id tempus uehementer:ur $\& \mathrm{mu}$ res (albi, quod Gaza omiferat, Plinius addit) Pontici generis albi, A riftoteles. Sorices $\&$ ipfoshye, me condi autor eft Nigidius, ficut glires: quorum fenium finitur hyberna quiete: conditi enim $\&$ hi cubant;rurfus æftate iuuenefcunt, fimili \& muftelis quiete, Plin. Somniculofos ille porrigit glires, Martialis. Dic, ceffante cibo, fomno quis opimior eft ? glis, A ufonius. T/ Myoxi quomodo lateant, 8 quotuplicem foeturam 2 dant, capite primo ex Epiphanio recitaui. I Animalia tractilia dicûtur, qux cum mutant locum fe trahunt, ficuti mouentur lepores, qui faltando fe trahunt: $\&$ glires inala ti,quimutant locum quafi fe trahendo, \& alia multa huius generis, Niphus in Arifotelis hiftoriam animalium 1.2. Ego tractilia, quæ Ariftoteles sidrzirx' tocat, non alia effe puto, quàm qua in locimus

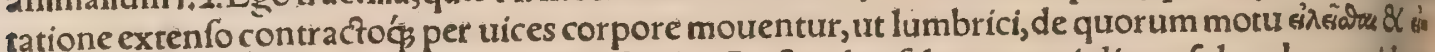

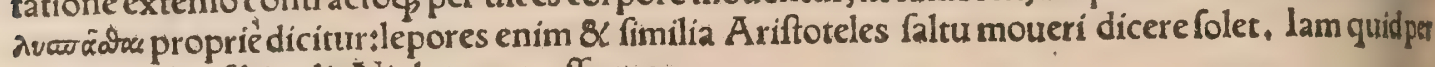
uocem inalati fibi uelit Niphus, non affequor,

D.

Glis animal eft femiferum,Plinius. Si in uiuarijs doliorum (de quibus mox in E, dicam)alere placear, notatum eft non congregari nifi populares eiufdem fylua: \& fi mifceantur alienigena, amb ne uel monte difcreti, interire dimicando. Genitores fuos feffos fenecta alunt infigni pietate, Plinius. Vipera quàm aftutè myoxos deuoret, in A. dixi ex Epiphanio. Serpentes quidem etiam muribus infidiari certum eft.

Glis hyeme dormit:quamobrem fi in fyluis fourex profundæ fiant, \& terra, palea \& lignis fuper, ne operiantur, plena his animalculis per hyemem inueniuntur, Alberturs. Et alibi, Circa Boëmiam\& Carinthiam ruftici autumno in fyluis cellaria parant, in quibus glires numerofi fe collocant, \& inde ad efum hominum colliguntur. Audiouagari in fyluis per arbores fciurorum more, \& ex unain alteram tranfilire: $\&$ fxpe à uenatoribus fagitris feriri, pracipue circa caua arborum, ubi latitatefí lent:hac enim reperta, obftruunt uenatores:reuerfi ad ea glires $\&$ in aditu patefaciendo occuparif riuntur: ₹xpe in ipfis deprehenfi cauis baculo immiffo cæduntur. Ex gliribus magnum emolumen tum effe non poteft, Appius apud Varronem. Leporarï genus uenaticum, duas habet feciestun, in qua eft aper, caprea, lepus:alteram extra trillam, qua funt, ut apes, coclex,glires, V arro. Gliriul craria in dolinjs, idẽ qui apris inftituit, (hoc eft Fuluius Hirpinus, Grapaldus) Plinius. In Gallia trant. alpina T.Pompeius in confepto ampliffimo præter animalia cætera, dolia habet, ubiglires côcludun tur, Varro de re ruft,3.12. Et rurfus 3.15. Glirarín (inquit) locus, non aqua, red maceria fepitur, Tot laxui lapide, aut tectorio intrinfecus incruftatur, ne ex ea erepere poffint. In eo arbufculos effe oporn tet, qux ferant glandem : quix cum fructum non ferunt, intra maceriam iacere oportet glandem, \& caftaneam, unde faturi fiant. Facere his caueas oportet laxiores, ubi pullos parere poflint. Aquam oportet effe tenuem:qutod ea non utuntur multum, \& aridum locum quarunt. Hi faginantur indo lịs, qux etiā in urillis habent multi, qux figuli faciunt multò aliter, at $\beta$ alia:quod in lateribus eorum femitas faciunt, $\&$ cauum, ubi cibũ conftituant. In hoc dolium addunt glandem, aut nuces iuglan des, aut caftaneam. Quibus in tenebris, cû cumulatim pofituี eft in dolịs, fiunt pingures, Hac Varro, F.

Glires cenforix leges, princepsḉ̧ M. Scaurus \& Marcus in confulatu, non alio modo cœnisader mêre, quàm conchylia, aut exalio orbe conuectas aues, Plinius, Et alibi, Extant cenforix leges, glan dia in cœnis glires $\phi_{\beta} \&$ alia dictu minora apponi uetantes. Sunt qui $\&$ taxos $\&$ glires cœnis addát qux animalia in qualitatibus hyftrici haud multữ diffimilia funt,Platina. Apud R haxtos qui ltalict locjuuntur, glirium carnem falfam reponi audio, quoniam dulcis $\&$ pinguis fir fuille inftar. Pofun tur in conuiuịs aliquoties trutin $x$, ut adpofiti pifces $8<$ uolucres ponderentur, \& glires: quorổ ma: gnitudo fæpius delicata non fine tædio præentium, ut antehac inufitata laudatur adfidue, $A \tilde{m}$. Mar cellinus lib.28. Glıres (inquit A picius 8.9.) ificio porcino: item pulpis ex omni membro glirium tritis cum pipere, nucleis, lafere, liquamine, farcies glires, \& futos in tegula pofitos mittes in furnum, aut farfos in clibano coques.

G.

Ambuftis medetur glirium cinis cum oleo, Plinius, Glirem integrum fuperligabis, uerrucas 


\section{DeGulone. Lib.I. 623}

mox tollit, Sextus, Glires $\&$ forices combufti, $\&$ cinis corum melli admixtus, fi inde quotidie mane guftent qui claritatem oculorum defyderant, fanabuntur, Sexturs . Mus gliris deglubtus, \& cum o, leo ac fale affatus, pleumoniticis uel empyicis cibo datur, miréfuccurrit: eos quó̧ qui purulenta ex creant celerrimè fanat, Marcel. Glirium, uel foricum, uel trermium terrenorum cinis, ex oleo impofi us pernionibus medetur,Marcel. Gliris pingue $\&$ gallinæa adeps, 8 medulla bubulina liquefacta tepensíg infufa auribus, plurimum prodeft, Marcel. Paralyfin caurentibus pinguia (Albertus non rectè urinam legit) glirium decoctorum \& foricum utilifima tradunt effe,Plin. Glirís adeps reme. dium adferet ad eos qui paralyfi tentantur,Sextus. Gliris detracta pelle inteftiníş́́ exemptis deco quitur melle in uafe nouo:fed medici malunt nardo decoqui uf́p ad tertias, atọs ita afferuari: deinde - cum opus fit ftrigili tepefacta infundere. Conftat deplorata aurium uitia co remedio fanari, Plinius. Gliri feu blatta pellis detrahitur, 8 inteftina eius decoquuntur in uafe æreo nouo cum mellis hemi. nis tribus, uf́ç ad tertias, atc ita feruatur, ut cum opus eft ftrigili medicamentum tepefactum aurribus infundatur, Marcellus. Ex blattis quidem ad aures remedia in libro de infectis ex Plinio \& Dio fcotide referentur $\uparrow$ ed $\&$ gryllus auribus prodeft, \& $\&, \&$ cogitandum an glirem pro gryllo Plinitus et Marcellus pofuerint:congenera enim feré hæc animalia auribus falutaria creduntur, ut $\$$ millepe. $\mathrm{dx}$, fitre afelli, quos aliqui in lingtra noftra porcellos uocitant:fignificat autem gryllus etiam porcum Gracis. Gliris urinã cótra paraly̨in ualere Albertus ex Plinio citat, fed falfó ut paulo ante monui. H.

Epitheta. Somniculofi glires apud Martialem. Apud alios, ut Textor refert, breues, foporati, hy

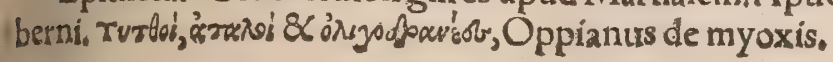

\section{DE GVLONE.}

\section{阅}

LONIS nomen de Septentrionali quradi urora. ciffima fera etfi noữ eft, et ab OlaoMagno, urt puto, ad imitationẽ Germanice uocis primũ côfi ctum, placuit tamen retinere, \& boc in loco collo care,cum ueteribus ignota indictaḉs uideatur. Plurima ta: o men concurrunt ut aut ipfam hyænam, feu crocutam (quã aliquí eandem hyxn putant, alij ex hyęna $\&$ cane, alin ex hyęna \& lcęna natarn:omnia dentibus frangit , protinuśq deuorata conficit uentre, Plin,) aut omnino congenerem beftiam exiftimem, ur facile iudicabunt qui utriufos hifto. riam conferent: $\&$ commodè quidem accidit, ut hyenæ hi foria proximé fubücienda literarum ordine fic pofcente fe quatur. In Lithuania \&Mofcouia(uerba funt Matthix à Michour ex libro 2, defcriptionis Sarmatix Europęx, cap. 3. animal troraciffimum \& inutile, quod alibi non compa= oret,roffomaka nominatum, magnitudine canis, facie catti, corpore $\&$ cauda uulpinis, (lyyæna uidetur quafi ex lupo \&uulpe compofita) colore nigro: cadaueribus uef citur. Inuento cadauere tantum uorat, ut extendatur \& infletur tympani infta: $\mathrm{ita}$ s anguftiam aliquam inter arbores in= greditur, \& per uim fe ipfum intrudit, ac uentrem premens Rringensćs exonerat, ut uiolenter ingelta urolentius ege
rat:fic extenuatum rurfus ad cadauer properat 8 rurfus impletur, ita ut uicifím de cadaure quan. tum poteft deuoret $\&$ excernat, donec toturm abfumpferit. Et forfan natura tam infatiabile animal in illis regionibus producit, ut homines fimili uoracitate laborantes redarguat. Quoniam potentes quum conuiuari cozperint, fedent à meridie in medium noctis, continuc cibo $\&$ potu fe opplendo, et cum natura exigit furgendo à menfa ut egerant, $\&$ rurfus fe ingurgitent, idó̧ ad uomitum uf̧́ $\&$ ra tionis ac fenfus amiffionem, ut inguinis et capitis quæe fint difcrimina tandem nefciant. Eft'̧́ illa con fuetudo perniciofa in Lithuania \& Mofcouria, magis uero \& abfas pudore in Tartaria,Hac ille. Atç utinam intra illas tantumgentes piufquam belluina illa ingurgitatio circumfcriberetur, nec Germa niam noftram inuaffret in tantum, ut quo nobiliore quifóp fere natus eft loco, eo bibacior $\& 4$ uoraci:

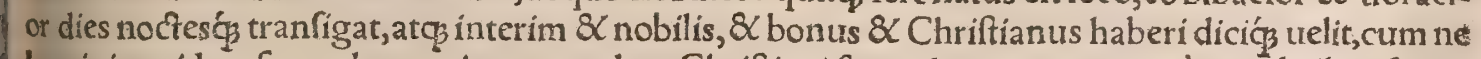
hominis quidem fecundum rationem, nedum Chriftiani fecundum pietatem, imò neq bellux fecun dum naturam uiuentis uitam tureatur. Nam ut hyęna aut crocuta, $\&$ alía quædã pauca naturæ mon. ftra huic tam immani uitio obnoxia fint, pleraç tamen omnia bruta in cibo potúḉ naturæ modum is nunquam excedunt, ne uerberibus quidem aut ullis illecebris ut id faciant adigenda. Sed redeo ad roffomacan: de qua eadem fcribit Olaus Magnus in libello quem adiunxit Septentrionalium regio num defcriptionizunde nos etiam picfuram hic appofitam mutuati fumus: quam quidem ad uiuun 


\section{4

factam non affero, fed dedi qualem inureni, Animalià, inquit, qua Germani vilfraf, , id eft multiuo ra, Suredi ièrff appellant, immodicæ ườ acitätis:nimium repleta uentrem inter duas arbores ftringû̉ ut excrementa protrudant. Petuntur à urenatoribus(fagittis, aut bombardis)pellis gratia folum; qua apud nobiles $\&$ ditifimos ad ueftimenta in pretio eft, utpote fplendidis $\&$ florum inftar diftinctac loribus, quales in Damafcena uefte fpectantur, Sed illi cum geftant huius beftię pelles, in eiufdemfe té naturam mutantur.

\section{E H Y AE N A.}

Hanc imaginem qualemcung; in ueteri Greco codice manu fripto poematum Oppiani repes rimus : mibi quidem non placet.

A.

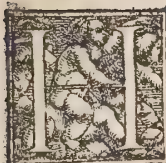

YAENAE quadrupedis no men, utpote peregrinæ $\&$ is gnotæ plerifos Græcis Lati= niśá̧ fcriptoribus, non folü cum crocuta \& leucrocuta quadrupedi bus rape confundi uideo: Fed etiam mul ta eadem aliâs quadrupedi hyęnæ aliâs eiufdem nominis ferpenti, aliâs pif́ci attri bui. Ego hoc in loco de hyęna quadrupe de primum agam:deinde de illis animali bus qua fiuce eadem liyęnæ; fiue diuerfa fint, congenera tamē, nomine faltem dif. ferunt: eoćs uel Græcis Latinis'śs ufurpa to, ut crocuta \& leucrocuta: uel barbaris tantum friptoribus, ut papio, zilio. Y'ouv, quadrupedis \& pifcis nomen, $\mathrm{He}=$ fychius \& V arinus. Dehyęna ferpen. refuo locỏ ex Â eliano \& alịs dicam. Hyęnam alî̉ glanum appellant, Arifteteles interprete Gaza

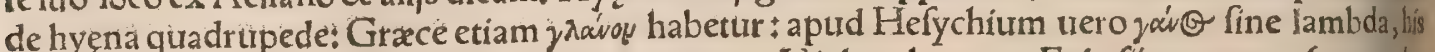
uerbis:Phryges 8 Bithyni hyęnam, ganon uocitant. Niphurs hyęnam Ephefís gannum (pern, dira plex) urocari, ex Philopono annotauit ، Ego ctum lambda glanum potius quàm ganum dixerim, bạc coniectura motus:quoniam hyęna etiam pifcis nomen eft, ut libro feptimo apud Áthena umlegi mus, qui \& vauvíd a ex Epicharmo nominat, quale uerò pif́cis hoc genus fit tanquam ignorans nion defcribit. Mihi quídem pifcis idem uidetur qui $\mathcal{Q}$ us illic ab eo nominatur, de quo Archeftrati uertis

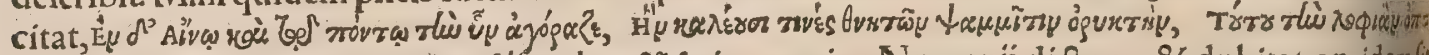

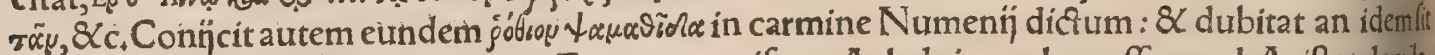
pifcis qưi capros, id eft aper tocatur. Ego aprum pifcem Acheloi trocalem effe apud Ariftotelemle, gi, ut illum à uoce $\&$ quafi grunnitu fic diçum appareat. At pfammîn orycien, hoc eft arenarium fofforem, hyn, id eft fuem dici, quòd arenam roftro, ut fus terreftris conum fodiat, facile eft cöricere: nifi quis malit ab aliqua corporis fimilitudine appellatum, quoniam Archeftratus noevèy ( quax 10x proprièad fuilli dorfi fetas pertinet, fed fimpliciter etiam pro fumma dorfi parte accipitur) eius affanı dam frribit. Sed de pifcibus, quibus à fue nomen contigit, propter pinguitudinem, uocem, autcorpo ris figuruam, alibi fcribam. Quoniam igitur hyęna quadrupes, etiam glanos uocatur : \& pifcis quọ ciufdem nominis effe traditur, inuenimus autem glanyn uel glanidem pifcem uocari quendam, que aliqui eundem filuro putant, omnino hyęnam eundem effe putauerim. Silurus certe pifcis uroracif fimus eft, nec pifces tantum inuadit, fed etiam equos: ut uel co nomine ab hyęna nomen fortitus uide ri poffit. Illyrica lingua, ut ex Sigifmundo Gelenio didici, hyęnam quadrupedem uocat fan, quod no s

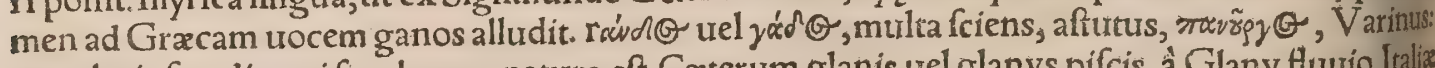
certe huiufmodi gani fiue hyęnæ natura eft. Caterum glanis uel glanys pifcis, à Glany flutuio Italia uel Cumæ nomen habet, V arino tefte.Quidam hyenam fcribunt fine diphthögo, quod non probo: Graci enim per $\alpha$. fribunt:nomen autem à fue indiderunt propter fetas, ut capite fecundo dicam, Porphyrius in eo opere quod infcripfit de abftinentia ab ufu carnium, hyenam dicit ab Indis appella ricrocutam, Gillius: fed de crocuta, quæcunq apud authores reperi, feorfim poft hyęnæ hiftoria confribam. Belbi,id eft hyęnx, decem, fuerunt fub Gordiano Romæ, Iul. Capitolinus. Piniciantus grammaticus noftri feculi, hyęnæ nomen Germanicum finxit, geabrbier, quod circa fepulchratierfetur:ego vilfeaf interpretarer:quoniam uel gulo eft, uel omnino congener ei fera, ut iam fuptain Gulonis hiftoria dixi. Albertus ut pleraqs corrupté, fic ionam pro hyẹna fcribit. Syluaticus ye exponit bellulam (Galli muftelam belette uocant) \& rurfus yentam beftiolam quandam. Hyana portentofum'ne magis an fabulofum animal fit nefcio, alieini cerrè orbis animal credendum eft, Mart 


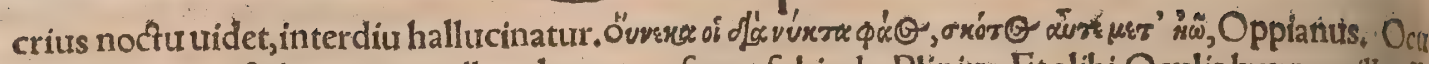
li uituli marini $8<$ hyænæ in mille colores tranfeunt fubinde, Plinius. Et alibi, Oculis hyænę mille effe uarietates, oculorumó (melius, colorumós, ex Solino) mutationes traditur, Aiunt hyanam colorem mutare ad libitum, Aibertus: Fed hoc de oculis apud ueteres legitur. In oculorum hyanæ pupillis la pis inuenitur, hyænium dicunt, præditum illa poteftate, ut cuius hominis fuerit linguæ fubditus, pradicat futura, Solinus. Germanorum artifices narrant hanc beftiam in oculis uel uerius in fronte geftare lapídem pretiofum, Albertus. Lapis hyæna, inquit Syluaticus Albertum citans, ab hyæna be ftia nomen habet, cò quod oculi eius in lapidem uertantur. Aiunt autem Euax $\&$ A Aaien (Solinus, ) fuppofitum lingux diuinationem conferre. Hyæna gemmam in oculis geftat, uel ut aliqui dicunt in fronte, Author libri de naturis rerum. Collum $\&$ iuba continuitate fpinæ porrigitur, flectiq́ nificir cumactu totius corporis nequit, Plinius. Hyæna cum fpina riget, collum continua unitate flesti ne: quit, nifi to to corpore circumacto, Solinus. Ceruix leoni tantũ $\&$ lupo $\&$ hyænæ ex fingulis rectiśs offibus riget, catero fpina adnectitur, Plinius. Hyæn cor magnum, A riftoteles, Hyænæ cor ma ximum eft pro portione, ut $\&$ reliquis timidis (muribus, lepori, afino, ceruo, panthera, muftelis) aut propter metum maleficis, Idem \& Plinius،Quòd de hyæna fertur, genitale fimul \& maris \& foemi

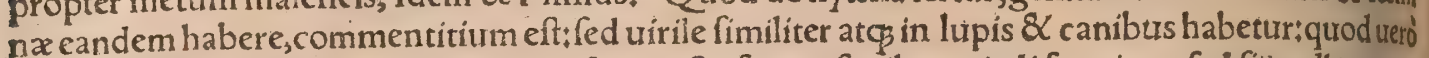
formineum effe uidetur, fub cauda pofitum eft, figura fimile genitali foeminæ, fed fine ullo meatur, fub hoc meatus excrementorum eft. Quinetiam fomina hyæna, prater fuum illud, etiam fimileut mas habet fub cauda fine ullo meatu, à quo excrementorum meatus eft, atç fub eo genitale uerum continetur:uuluam etiam hyæna fomina, ut cæeteræ huiufcemodi (lupi $\&$ canes) formin $x$ animants tes, habet, Ariftoteles. Idem alibi promptius effe fcribit marem capere, quàm foeminam, utpote calli, diorem, fexum \& ingenij fecundum eum difcrimen manifeftò ponens. Hyænis utranqgeffe nattis ram, \& alternis annis effe mares, alternis foeminas fieri: parere fine mare, uulgus credit, Ariftoteles negat. Sic $\&$ Oppianus, Audiui (inquit) uno anno hyænam patris uice fungi, altero matris, Sic\& Philes poétra recentior: 8 Iorach apud Albertum, qui etiam uenenum in cauda hyęnæ colligi fcribir, fed lorach ifte (inquit Albertus) freqtienter mentitur. Si tamen eft aliquid miræ nouitatis in iftis, Alternare uices, 8 qua modo foemina tergo $\mathrm{Paff}$ marem eft, nunc effe marem miremur hyænam, Ouidius 15.Metamorph. Aelianus 8 Orus in Hieroglyphicis, hyæanam, non quadrupedem, fedfer pentem per uices marem $\&$ forminam effe prodiderunt.

Hyænæ noctu uident, cum interdiu nihil ferè uideant ut feles, A phrodifiēfis in problematis 1,66 De hoc etiam pracedenti capite dixi in oculorum eius mentione. Cadauera hominum, \&ipfos homines $\&$ canes à fe interfectos, ut fequenti capite dicam, deurat. A $\mathrm{A}$ uno animali fepulchra erul inquifitione corporum tradunt, Plinius $\&$ Solinus, Sepulchra effodit humanæa auida carnis, Arifioti ब Vox ei qux propria fit non legi : humanum uerò fermonem (ut crocutam quoç \& mantichoram) $\delta$ uomitionem hominis eam imitari fequenti capite referam, बHyænam per uices annorum nunc marem effe $\&$ generare, nunc foeminam $\&$ concipere, pracedenti capite refutatum eft. Videctiam inferius in Trochi mentione. Hyænæ coitu leana A ethiopica parit crocutam, Plinius $\&$ Solinus,

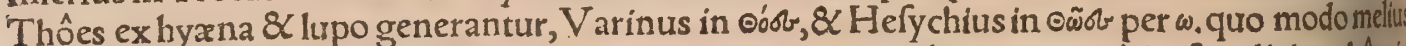
fcribitur. Ex his grammaticis $V$ alla etiam Herodoti interpres libro quarto, ubi is fimpliciter thôes in A frica generari dixerat, de fuo addidit ex hyæna $\&$ lupo genitos, quod quidem parum fidieftinter pretis, Sed thôes quales fint, et unde generentur, ex ipforum hiftoria petẽdum eft ftatim poft lupum, De trocho $\&$ hyæna (inquit Ariftot. de generat. 3.6 .) Aultè magnoóg errore narratur:hyænam enim complures aiunt, trochum Herodorus Heracleota fcribit duplex genitale habere, maris ac foeminar $\&$ trochum feipfum inire: hyanam inire $\mathcal{Q}$ iniriannis alternis $;$ fed uifa eft byæna mas, \& alterafie mina fui difcrimine genitalis: locis enim nonnullis penuria huius confpectus non eft. Verum hyza næ tam mares quàm foeminæhabent fub cauda lineam quandam fimilem genitali fominino:quix quidem nota quamuis communis fit, tamen in maribus potius cernitur, quia mares quàm formina

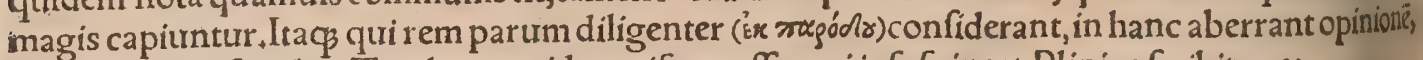
Hactenus Ariftoteles. Trochum quidem pifcem effe, qui ipfe fe ineat, Plinius fcribit 9.52.

D.

Maximum cor eft pro portione murribus, lepori, pantheræ, muftelis, hyænis, \& omnibus timidis, aut propter metum maleficis, Plinius \& A riftoteles. ER in eis pietas crocodili, àftutia hyęna, Man tuanus. Promptius eft marem capere:forminis enim ingenita eft callidior aftutia, Solinus, Raro'lyę na fcemina capitur, (quod etiam Plinius fcribit:)nam inter undecim numero unam tantum cepiffe uenator quidam retulit, Ariftoteles.Qưodcung animal ter luftrauerit hyçna, in ueftigio hęrere mouere fe nó poffe traditur: quapropter magicã f́ientiam ineffe ei pronunciaurerunt, Plinius \& $\$$ linus. Hyęnæ umbræ contactu canes obmutefcere tradunt, Plinius \& A elian. Si canes uenantes umbram eius dum fequuntur contigerint, latrare nequeunt, uoce perdita, Solinus, Cum Luna ora bis plenus eft,retro pofito Luna fulgore fuam canibus umbram inícit, quos ftatim mutos reddit, $\alpha$ tanquam ueneficio quodam, corum fenfus perftringit: deinde elingues abducit $\&$ optatis fruitur, Aelianus \& Philes. Canes uomitionem hominis imitando capit, Ariftot. Vomitionem hominis 
potum expauelcentibus faciem perungunt adipe uituli marini: efficacius fi medulla hiy çthà \& dể Elentifco \& cera mifceatur. II Medullas opitulari doloribus fpinæ \& neruorum, laffitadini renú, Medullade fpina hyęnxe, admix to felle eius \& oleo uetere, ad temperiem \& lenitudinem acopi de,

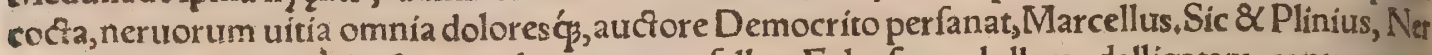
uis mederi medullas è dorfo cum oleo uetere ac felle. E dorfo medullam adalligatam, contra uanas fpecies opitulari. A Adipe accenfo ferpentes fugari dicunt: Eundem illitum à cane morfis auxiliari.

- Siniftra parte cerebri naribus illita, morbos perniciofos mitigari, fiue hominum, fiue quadrus pedum. I Sterilitatem mulierum emendari, oculo cum glycyrrhiza $\&$ anetho fumpto in cibo, promiffo intra triduum conceptu. TDentes eius dentium doloribus tactu prodeffe, uel alligatos ordine. Dentes fi de finiftra parte roftri eruti fint, illigatos pecoris aut capri pelle ftomachi cruciati l" bus. Contra nocturnos pauores umbrarumós terrorem, unus é magnis dentibus lino alligatus fure, currere narratur: Furentes fuffiri eodem, \& circumligari pectus cum adipe renum, aut iocinere, aut pelle pracipiunt. Dens alzabo fufpenfus fixper brachium dextrum ab humero uf $q_{\$}$ ad cubitum, obliuioni refiftit, $R_{a}$ fis $\&$ Albertus. बMaxilla parte comminuta in anifo, \& in cibo fumpta, hor. rores fedari:Eodem fuffitu mulierum menfes euocari. \Palato arefacto, $8 \mathrm{cum}$ alumíne Alegy: ptio calefacto, ac ter in ore permutato, fortores $\&$ ulcera oris emẽdari. T Ceruicis carnes, fiue man dantur, fiue bibantur, ar efactæ, lumborum doloribus mederi. đHumeros humerorum \&lacerto rum doloribus tactu prodeffe. T Pulmones in cibo fumptos coeliacis (uetus lectio, iliacis) auxilias ri: Ventriculis, cinerem cum oleo illitum. T Cor in cibo fumptum omnibus doloribus corporum auxiliari. Tremulis, [pafticis, exilientibus, \& quibus cor palpitét, aliquid ex corde mandendum, ta ut reliqux partis cinis cum cerebro hyęna illinatur:Pilos etiam auferri hac compofitione illita, aut perfe felle, euulfis prius quos renafci non libeat:Sic \& palpebris inutiles tolli. . IMulieri candida a pećfore hyęnæ caro, \& pili feptem, $\&$ genitale cerui, fi illigentur dorcadis pelle, collo fufpenfa conti nere partus promittunt. Carnes uel offa hominis, fi quæ in uentriculo occifæ inueniantur, fuffi tu podagricis auxiliari. TOmentum, ulcerum inflammationibus cum oleo. TMedulla exdor fo, uide fuperius in Medulla. Podagris, fpinx cinerem cum lingua $\&$ dextro pede uituli marini,ad dito felle raurino, omnia pariter cocta at s illita hyęnx pelle. Offa ex fpina parturientibus prodef fe. TCoftarum primam $\&$ octauam fuffitur ruptis falutarem effe. q Carnes fi cdantur, contraca nis rabidi morfus efficaces effe:etiamnum iecur efficacius. Febribus quartanis iecur deguftatum ante acceffiones. Glaucomata iociner is recentis inaffati fanie,cum defpumato melle inunctis fana 3 ri dicunt. Iecur potum torminibus $\&$ calculis mederi, $q$ Fel efficaciffimum creditur forpionils marini, \& callionymi pífcis, marinæé́ tefudinis \& hyęna, Diofcorides. Cum pharmacum aliquod paras, cui fel mifcetur, colorem fellis fpectato, qui alius in alịs animalibus eft. Paftillis enim dictistau rinum admifcent: ocularibus trero medicamentis hyen $x$, galli, perdicis, $\&$ aliorum quorundam ani malium, Galenus de fimplicib.10,12, Et rurfus, Taurinum fel efficacius eft fuilo, ouillo, caprino, \& bubulo:ignauits tamen auàm hyęnę: ut huius quàm callionymi aut fcorpï marini aut teftudinis tia rina. Fel hyęna per fe illitum pilos auferre, euulfis prius quos renafci non libeat : fic $\&$ palpebris inutiles tolli. Si felle hyęnæ loca quibus molefti funt pili in palpebris nati adfidué tangantur, conte ftim tabefcent:certe fi pritus uulfis fuperducatur, non renafcentur, Marcellus. Idem remediumas pud Galenum legimus Euporifton 1.42, his uerbis, Euulfis prius radicitus pilis, fel aut hyęn aut hir ci confeftim inunge. Animalium quorundam fel (inquit Galenus de fimplicib, 10. 11.) pra ceterts laudatur, $\$$ \& uifum acuat, \& fuffufionum initia difcutiat, ut callionymi pifcis, hyęna, \& $\mathbf{c}$. Hyęnx fel cum melle uifum acurit, \& illitum fuffufiones difcutit, Galenus ad Pifonem. Suffufionem oculo rum canino felle malebat quàm hyęnę curari A pollonius Pitanęus cum melle:item albugines oculo rum, Plinius. Fel urfinum atç hyęnæ cum melle optimo mixtum \& diu coagitatum, caligines ext mit, fi adfidưe inde oculi fuffundantur aut fuperlinantur, Marcellus, Lippirudini mederi fell illitum fronibus:aut ne omnino lippiatur, decoctum cum mellis Attici cyathis tribus $\&$ croci uncia intrin fium: Sic $\&$ caligines difcuti \& fuffufiones: Claritatem excitari melius intreterato medicamento, $A$, feruari aurem in Cypria pyxide. Eodem fanari argema, fcabritias, excrefrentia in oculis, item cica: trices, Plinius. Democritus adfirmat felle hyęnæ fi frons perfricetur, epiphoras incipientes, 8 oms nem oculorum dolorem poffe fedari, Marcell. Medulla de fpina hyęna, admix to felle eius $\&$ oleo uetere, ad temperiem acopi decocta, neruorum uitia omnia doloresḉs aucfore Democrito perfanat, Marcellus, Fel alzabo maris ligatum fuper femur alicuius finiftrum, promourer coitum cum mulie requandiu retinetur, $R$ a fis $\&$ A Abertus. Fel alzabo pondere drachmx potum cum decoctionefpis cæ nardi, remedio eft aduerfus tympanitem, Iidem. Membranam qua fel contineat, cardiacis potam in uino, uel in cibo fumptam, fuccurrere. Podagris fel prodeffe cum lapide Afio. ILienemlienl bus mederi. TLumborum doloribus carnes élumbis edendasillinendasḉ cum oleo. Adipee Iumbis fuffiri difficulter parientes, \& ftatim parere. IVeficam in uino potam contra urinaxincon tinentiam fuccurrere: Qua autem in urefica inuenta fit urina, additis oleo ex fefamo $\&$ melle, halls ftam prodelfe arimonię ueteri. $\mathrm{V}$ Vuluam cum mali $\mathrm{P} u n i c i$ dulcis cortice in potur datam prodel fe mulierum uulux. Af Spafticis, genitale é maribus fuffitu opitulari. Venerem ftimulari genitali ad fexus fuos in melle fumpto, etiam fi uiri mulierum coitus oderint. TLiprientibus, ruptis, $\alpha$ 


\section{DeHyæna. G.H. Lib.I. 629}

contra inflationes, feruatos pedes opitulati tactu; lęuros dextris partibùs, dextros lęuis. Sintiftrüm pe. dem fuperlatum parturienti, letalem effe! dextro illato, facile eniti. T/ Fimum quod in inteftinis in uentum fit, arefactum, ad dy fentericos ualere potum:illitum $\not$ cum adipe anferino opitulari to to cor pore lafis malo medicamento. Aëtitus 13,6, emplaftro cuidam imponendo aduerfus crocodili mor fum ftercus hyçnæa adiungit:hoc, inquit, fi defit, porcino utitor. Hyęnæ ftercus putrida curat uul. nera, Hieronymus contra louinianum ut Vincentius Belluac,citat,

H.

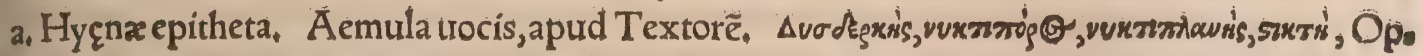
piano.

d. Qui uoluerit tranfire per loctrm animalium alzabo, non infeftabitur ab eis, fi manu geftet ra* dicem colocynthidis, Rafis 8 Albertus.

e. Grandini creditur obuiare, fi quís crocodili pellem, uel hyęnæ, uel marini uituli per fpatia poffeffionis circunferat, $\mathcal{Q}$ in uillæa aut cortis fufpendat ingreffu, cum malum uiderit imminere, $\mathrm{Pal}$ s ladits. Callius Rhodiginus poft claui ænei mentionem 29, 6. Confimile(inquit)huic ferè adagiü ua furpari poffe, uideo:ut qui fuopte prafidio aduerfus potentiorum trim præmunitus eft, dicatur hyds na geftare, id eft tuberra, nẹc non hyęnx phocarumọ̧́ pelles, quôd hac minimè tangantur de coelo: Quo nomine uelorum fumma hifce communire nautici moris eft. Amplius fcribit Horus, fi quis hyęnaxa pellem fibi circumponat, intrepidè per medios hoftes tranfiturum, nocumento nullo: proinde Aegyptijs ratione bieroglyphica intrepiditatis ac conftantia in calamitatibus indicium haberi hyx= nix pellem expictam. Quod ficus de coelo nón tangitur, id utíg; amaritudini eitus acceptum referri oportet: (tota enim arboris dulcedo in fructurm fecernitur.) Id genus quippe non attingunt fulmina, quod uitulus comprobat marinus atç hyæna, $C x 1$. Nonnulli pelle hyænæe fatoriam trimodiam uea fítunt, atç ita ex ea, cum paulum immorata funt femina iaciunt, non dubitantes protrentura qua fic fata fint, Columel.2.9. Gentiana diebus feptem cum hyæn $x$ pelle amuleti loco geftatur aduer fus ra bidorum canum morfus, Açuarius. Frontis corium fafcinationibus refiftere magi pollicẽtur. Plin, (Sanguine tactis pofftbus, ubicun ${ }^{2}$ magortum infeftari attes:non elici deos, nec colloqui, fiue licer nis,fiue pelui, fiue aqua, fiue pila, fiue quo alio genere tententur, Idem. of Hyæn $x$ linguam fi quis manu tenear, contra canum impetum maximam cautionem habebit, Zoroaftres in Geoponic. Eos quil linguam in calciamento fub pede habeant, non latrari à canibus, Plin. Oppianus lib +3 . de uena= tione uidetur idem de pelle byænæ fcribere, uel quauis eius parte, in calcen geftata. of Pilos roftrí admotos mulierum labris amatorium effe, Plin, of Tantumós eft uanitatis ${ }_{j}$ ut fi ad brachium adallis getur fuperior is roftri dextræ partis dens, iaculantitum ictus deerraturos negent, Idem. T'Magi aiñt rocits domus concordiam, hyænæ genitali \& articulo fpinæ cum adharente corio adferuatis, confta requem fpinæarticulum fiue nodum atlantion uocant: eft autem primus. In comitialiñ quoģz remedins habent eum, Super omnia eft, quòd extremam fiftulam inteffinic contra ducum ac poteftatũ

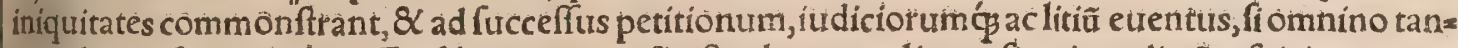
tun aliquis fecum habeat. Eiufdem cauerna finiftro lacer to religata, fi quis muliere refpiciat, amato, rirrm effe tam prafens, ut illicò fequatur. Eiufdem loci pilorum cinèrem ex oleo illitum uiris, qui fint probrofx mollicici, non modo pudicos, fed \& feureros mores induere, Plin. Si pili de collo (culo ui, detur legendum ex Pliní uerbis iam recitatis ) mafculi zabo combufti tritićs cum pice inungantur ano fodomitæ patientis, liberabitur illo uitio, Rafisłapud Allbertum uiro legitur prouitio. Si pes fit niffer $\mathcal{Q}$ ungues alzabo in linteo alligentur dextro alicuius brachio, non obliuifcetur quacunq; aus diuerit aut cognouerit, $R$ afis $\&$ Albert. Manus dextra al zabo unà cum corio abfciffa anímalli uía uenti, adalligata ingredientibus ad reges att alios, negotij alicuius obtinendicaufa, gratiam $\&$ faur rem eis conciliat, ut quod petunt obtineant facile, $R$ afis $\&<$ Albertus, Si manus dextra alzabo, quă hominis finiftra abfciderit, ab aliquo geftetur, illım diliget quifquis triderit prater alzabo, lidem, Medulla pedis finiftri trita utilis eft mulieri quiz maritum non diligit:nam fi ing̈ciatur in nates(nare $\tilde{e}_{\mathbf{z}}$ Albertus)eius, diliget eum pra cæateris. Tali finiftri cinere decocio cum fanguine muftela, perun cios omnibus odio urenire:idem fieri oculo decocto, Plin. Excrementa fiue ofla reddita cum in terimitur, contra magicas infidias pollere, Plin. Si ungues inueniantur in tentriculo occifa, mortem alicuius capientium fignificari, Idem。 of Democritus fcribit therionarca in Cappadocia $8 \mathrm{My}$ fianafcente, omnes feras torpefcere, nec nifi hyænæ urinæa afperfu recreari, Idem.

\section{DE BARBRIS NOMINIBVS VEL}

Hyanæ, uel congenerum ei animalium.

A KA B O pro alzabo perperam feribitur apud $R$ afim, ea occafione quita 1.82 z. literas fi cöiungas, referunt ferék. literam depratrata. Vide fupra in Hyæna capite primo.

AN A animal dicunt effe Orientis, ualidifimis dentibus, acutis, \& longis \& tunguibus acutis, per quam fruum, gregarium $\&$ ualde amans quæ fui generis funt animalium:alienis infertum . Si quod enim alterius generis accefferit animal, gregatim refiftunt: \& uel fugant, uel perimunt. Dentibus \& unguibus fe defendit ita, ut folitariũ etiã ab aliquo robuftiori deprehenfum plerunģ euadat, Albert, 
B EL B $\vee S$, hyxana, apud Iulium Capitolinum.

CHA VS etiam 8 L Y C A ON congeneres hyana uidentur, de quibus infra dicemis, ftatimpo! lupum.DEGVLONE ante hyanam ftatim docui.

L A C T A in fepulchris habitat, $\&$ uefcitur cadaueribus, Albertus. Hoc ueteres de hyena friburt

LV P V S uefpertinus, uide fupra in Hyæna capite primo circa finem.

PA P1O animal circa Cxfaream abundat, pauló maius urulpibus, luporũ ingenio. Collecta enim hxe animalia ululant, uno pracunte (pracinente) $\&$ alïs poftea fimul refpondentibus, Pilo uulpem referr. Vno ex eis occifo catera circa ipfum ululant, tanquam plangant morturum. Voces eoruma deò fonora funt, ut quamuis remota ex propinquo audiri uideantur. V rgente fame fepulchra homi num aliquando ingredi $\&$ cadaueribus uef́ci dicuntur. Videntur fanẻ ex lupo \& uulpe compofita, Albertus, Abenauin,id eft baburin,animal eft fimile cani, quod noctu latrat, \& uorat cadaura:te periuntur autem permulta in Syria inter Damafcum \& Berutum, Andreas Bellunenfis. Etalibi, Dabha uel dahab, animal eft medium inter lupum $\&$ canem, comedens cadauera: $\&$ comeditur ca ro cius ab hominibus, $\&$ reperitur in Syria in magna copia. Et rurfus, Aldabha eft animal notumin Syria, medium inter lupum $\&$ canem, pilis color qui urfo, $\&$ comedit cadatrera. Munfterus in Lexi co trilingui lupum Hebraice zeeb nominat: Chaldaicè autem, ut reor, (zain in daleth mutato) dee ba. Dhoboha (dabha potius, ut Bellunenfis corrigit) animal ef, de cuius uiribus in podagra $\&$ a thritide iam libro 3 . diximus, Auicenna libri 2, tractatu 2, in fineliteras D. Satis itaç conftat dabia 8 fimiles uoces, nihil aliud quàm hyanam fignificare.

ZIL ro animal apud Albertum in fine libri 22, non aliud quàm ipfa hyæna eft, omnibus quari attribuit confideratis: quamuis ipfe compofitam effe fcribat ex hyæna \& fimia qua maricommotion uocetur. Maricomorion quidem eodem libro in $M$. litera, corruptifima uroce pro ueterum manti chora utitur.

CROC VT A, apud Gracos per $\tau$. duplex feribitur: \& per omicron tam in fecunda quàm prima fyllaba. K९oríżos animal eft quadrupes A ethiopicü, Hefych.\& Vari. Mantichora et crocuta é fimla rum genere, hominum geltus $\&$ fermones imitantur, Volaterranus teftem citans Plinium, fedfallo Etfi enim apud Plinium legimus has befias uocem imitari humanam:imitari tamẽ etiam geftus hu. manos \& fimiarum generis efle nufquam legimus: nec fi quid imitatur, protinus fimia eft:fimiaqul dem gefus imitatur hominis, uocem non item: \& fi maxime illam imitaretur, non tamen hoc farsfo ret ad probandum eiufdem gener is animal effe quod eam fimiliter exprimeret, cum aues etiammul. ta imitentur. Hyænæ coituleana Aethiopica parit crocutam, fimiliter (ut ipfa hyæana) uoces imis tantem hominum pecorumć. A A cies ei perpetua in utraç parte oris, nullis gingiuis, dente continu qui ne contrario occurfu hebetetur, capfarum modo includitur. Hominum fermones imitarierman tichoram in Aethiopia auctor eft Iuba, Plinius. De mantichora ftatim in Leucrocuta dicam, Solinus eadem de crocuta qua Pliniust hoc tantum intereft, quod Plinị uerba hac, Acies ei perpetua, $S$ nus à fequentibus diftinxit $\&$ ad oculorum aciem retulit, cum Pliníus de dentibus tantum accepi uideatur, nulla oculorum mentione:nam $\&$ dentium aciem dicere quid prohibet? Solini uerba fun

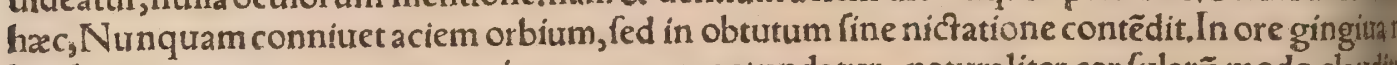
la: dens unus at $\beta_{3}$ perpeturus, qui ut nunquam retundatur, naturaliter capfularũ modo claud Crocutas (inquit alibi Plinius) uelut ex cane lupọ́ conceptos, omnia dentibus frangentes, pris nusćs deuorata conficientes uentre, Aethiopia generat. Vide fupra in Gulone. Beluarum, Gillius, quas Aethiopes crocutas appellant, natura ex cane \& lupo temperata, utrif́, robore fuperior eft: omnia enim of a confringit: Porphyrius in eo opere, quod inferipfit de abftinentia ab fu carnium, hyænam dicit ab Indis appellari crocutam. T Callidum animal (inquit A eliants)e crocuta:primum enim fefe in denfas fyluas occultans, materiarios fabros nominatim inter feap lantes aufcultat, illorumć cuiufpiam nomen addifcit. Deinde fumma humani fermonis affimu ne comparans infidias, quod audiuit nomen humana uoce appellat, ad eam accedit appellatus, ueró illa cedens rurfurm appellat, idem iterum frepiusćc ad humanam urocem accedit; ubi autem eumir â focís feduxit, $\&$ iam ab auxiliatoribus nudum conftituit, correptum interimit:ex eóǵg quem uoc pellexit, fibi inftruit $\&$ conficit cibum. Edita munera, in quibus elephantos, \& crocutas, \& ti des exhibuit, Iul, Capitolinus in AntoninoPio, Io. Rauifius Textor multa etiam qua Pliníus deo nagris feribit, crocutis attribuit, fua an librariorum of citantia nefcio. A pud Albertum procrocuti ineptiffimé círocrothes, apud alios cirotrochea feribitur, citatis Solini qua de crocuta funt nerbis Poft Barygazam continens ad Auftum pertingens Dachinabades uocatur:qua fupra hanc eft me diterranea regio ad Orientem, montes magnos continet, $\&$ omnigena ferarum genera, ac inter ali

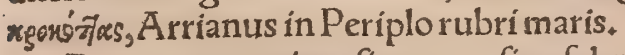

De LA I I A etiam fitue uera fiue fabulofa beftia, quædam hyan congruentia legimustnemp animal effe crudele, nociu fyluas exire, hominem aggredi. Sed de hac mox plura in $L$. litera.

IE V CR O C V T A M (A ethiopia generat:uel potius India, poteft enim ad utrumqs quodam referri, Plinius 8 , 21.) perniciffinam (uetus Icctio, perniciofiffimam ) feram, afini fere (feri, uetus ctio) magnitudine, cruribus ceruinis: collo, cauda, pecfore lconis, capite melium, bifulca ungula, ad aures ufog refcillo, dentium locis offe perpetuo: hanc feram humanas uoces tradunt imirari, 


\section{De Quadrupedibus}

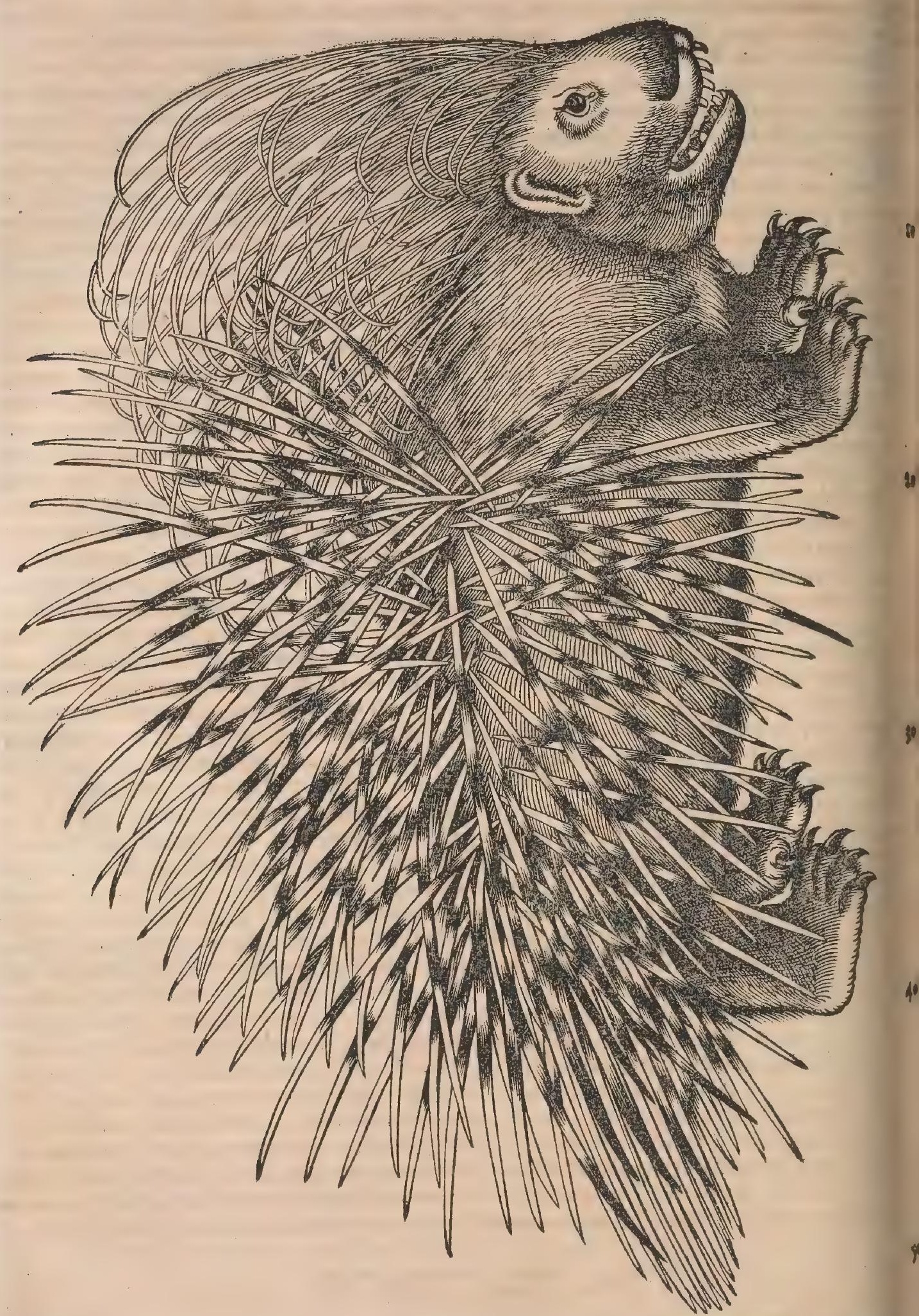

ftico, \& habet fpinas in modum acuum: confimilis in medendo facultatis, praftantior in cibo, utilior ftomacho, \& uentrem magis mollit, urinamó ciet efficacius, Hac rafis \& Albertus. Sed apud Gra cos facultates ift echino marino attribuuntur. Verus gloffographus Aurcenn $x$, wocem adulbus, en ricium montanư interpretatur:Syluaticus adualdul $\&$ adubul, fimiliter: $\&$ in lingua noftra (inquit) uocatur iftrice. Alierha fecundum aliquos eft ericius magnus fpinofus, fecundum alios uerò ericin us minor, Andreas Bellunenfis. Albertus hyftricem etiam fucca nominare uidetur, nefcio qua lin. gua, ut in B .r eferam. T Syluaticus $\&$ alị recentiores hyftricem animal quod uulgò porcus fpino fus dicitur, interpretantur.Sic $\&$ Graci quidam, ut Suidas, acanthochceron, quod idem fonat ad uer bum:fed \& uulgarem echinum terreftrem eodem nomine uocitant, Etymologus \& V arinus. Quód uero hyftricem quocs echinum terreftrem Suidas interpretatur, falfum eff. Syluatico etiam acan. 


\section{DeHyftrice. A.B. Lib.I. 633}

thochderos porcus f pinofus uel hyftrix eft. Gyraldus in opere de difs, gylium à quibufdam choro gryllum exponi fcribit:choerogryllum autem ipfe porcũ fpinum interpretatur, ut Syluaticus etiam, qui corrupte cirrogrillium faribit:fed chorogryllum nos potius herinaceum effe in Cuniculi hifto: ria capite primo docuimus. Varinus quidem gylion exponit porcum, aut leonem, Ä us $\&$ Varinus outm interpretantur, uel hyfrichem fecundum Cretenfes. Domitius Calderinus a: pud Martialem orygem pro hyftrice ridiculiexponit. I Hyftrix Italicéporcofpinofo, uel hifurice, uel iftrice fine afpiratione. Hifpanicè puérco efpin. Gallicé porc efpic. Anglicé porkepyne. Illy rice porcofpino. Polonus quidam interpretatur morska f zwijnña,imitatus puto Germanos, qui por cum marinum nominant, cin meer [d wyn. Ea nimirum ratione qua uxulgus in mediterraneis, à mari remotum, incognita $\&$ peregrina pleraq marina $\&$ tranfmarina uocat, Quanquam parum idoneus author Libri de natura rerum, hyftricem circa mare degere foribit, $8 \times$ cum maritimis locis deftituitur in cauernas montium diuertere. Iuxta marina (maritima potius) habitat, $\&$ aliquando in montibus, Albertus, Certum eft quidem hoc animal amphibium non effe, fed in fyluis agere, quod $\&$ Oppia. nus teftatur. Quamobrem ridiculus eft illius error, qui nuper quadrupedum hiforia Germanice e. dita, porcum fpinofum(hyfticis enim nomen non agnofcit) pifcem marinum facit, Germanica ap. pellatione deceptus. Aliqui hyftricem Germanicé taran uocitant, nefcio qua origine : aliqui Oorn: I6weyn, hoc eft porcum fpinofum, ficta ab eis uoce ad imitationem cæaterarum aliquotgentium. Na ea uoce, ut fupra oftendi, Itali, Hifpani, Galli, Angli, \& Illyrï quoq̧ utuntur. Quinetiam Germano. rum aliqui peregrinitatis fudiofi uocem potcopict receperunt:alin ifacbelf b weyn appellant, hoc eft fuem pungentem, ut Ge, Agricola docet. Hyftrix animal eft marinum, teftaceum(oftracodermon) cibo aptum, Hefychius $\&$ V Varinus: Apparet autem eos echinum marinum intelligere: nam Suidas

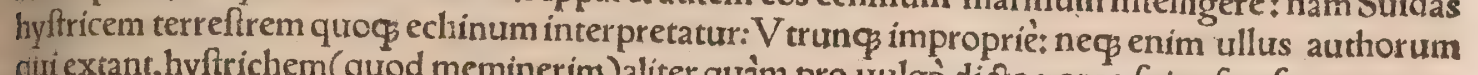
givi extant, hyftrichem(quod meminerim) aliter quàm pro uulgò dicto porco fpinofo ufurpat

Hyftrices generat India \& A Arica (unde ad nos nuper allatæ funt, Ge. A gricola) rpina contectas, ac erinaceorum genere (genus forte:) fed hyltrici longiores aculei, 8 cum intendit cutem miffiles. Ora urgentium figit canum, \& paulo longius iaculatur, (tanto etiam impetu, ut in ligno figat inter:
dum, Ge, Agricola,) Plin. Hyftrix in Aethiopia(hocetiam in Hieronymi libro contra louinianu legitur)frequentiflima, erinacins fimilis, fpinis tergum hifpida, quas plerung laxatas iaculatione e. o mittit uroluntaria, ut affiduis aculeorum nimbis canes uulneret ingruentes, Solinus. Herodotus li. bro quarto hyftriches apud A fros paftorales nafci tradit. Circa Scaffem urbem Tartarię multi funt fures fpinofi:qui cum capiuntur, fpinis fuis fape homines \& canes ladunt:nam canes in eos prouroca ti, adeo irritant feras illas, ut fimul concurrentes terga fua, quibus fpinæ innituntur, trehementer com thoueant, atţ in uiciniores homines et canes uibrent, Paul. Venet, 1. 34. Homines 84 quafctigg feras infequentes, fugiendo pugnans, emiffis à tergo fpiculis, uulnerat. Canes ictos quandog perimit: quamobrem urenatores retinent canes, $\&$ alio ad capiendum dolo utuntur, Oppianus. Cer to deftina toćs ictu(ut audio) ferit quem uolueric, uulnere interdum incurabili propemodum, utpote angufo

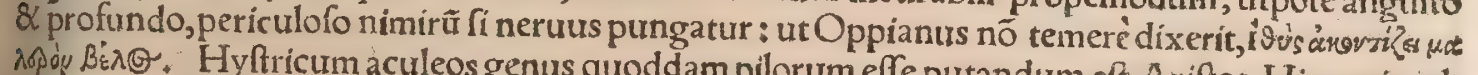

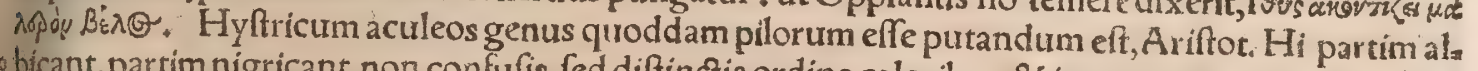
bicant, partim nigricant, non confufis, fed diftinctis ordine coloribus: $\&$ in mucronem exeunt. Eos in pileis fape adferunt peregrini a S. Tacobo Compoftellano reuertentes. Spinis uritur hyftrix pilo rum $\&$ armorum loco, non etiam pedum ut quidam dixerunt, Albertus. Echinos quiden marinos actricis fuis pedum loco uti tradît. Nö in opacis fyluis(inquit Oppianus)tam horribilem ac rigidü quicquam præ fe fert confpectum ac hyftrix:cui magnitudo paulo minor quàm lupo, corpus tali= dum, \& fpinis, ut herinaceorum, undiģ rigens. Axungla 8 laridum funt in animalibus non corni geris, quorum quaturor dentes ut plurimum prominent, ut funt porcus, porcus fpinofus, glis, felis, ca nis, \&c. Monachi in Mefuen. Albertus libri 1, tractatus 1. capite 8.de animalibus, cum hericium alls um caninum, alium porcinum effe dixiffet, fubdit; Et fimiliter animal quod uocatur fucca: quod etiam hos duros modos habet, quòd alius in eo genere habet pedes porci, \& alius pedes canis : eft autem - idem qui porcus fpinofus. Hoc quidem de hyftrice nullus authorum prodidit: echinorum autem, ut in ipfortm hiftoria dixi, differentia hac hodie uulgo affertur. Hyftrix quem ipfe uidi, tres circis. ter pedes longurs erat. Agyrta qui circunducebat, os eius leporino conferebat, aures humanis: pedes anteriores melis, pofteriores urfi pedibus. Hyftricem Grxci(inquit Ge. A gricola) ércentótespoy uo. cant, quòd $\&$ fimilitudinem gerat fpeciemós porci bimeftris, $\&$ fpinis erinacei inftar hirfutus fit: arta men caput habet leporino fimilius:aures humanis, pedes urfinis, Iuba ei eff fuperiori parte erefta, et priori caua:tubercula cutis, qux ex utraç oris parte funt fetas longas $\&$ nigras continent ex eis nat tas:quin reliqux etiam fetæ funt nigræ. Primæ fpinæà medio oriuntur dorfo $\&$ à lateribus, fed lon giffimæ à fuperiore corum parte. Qux fingulæ partim nigra, partim candidx funt: longæ duos uel tres uel quatuor palmos:quas, fi quando libitum fuerit, ut pauo caubam erigit:ingreffurus in cauea demittit. Dentes, ut lepus, quatuor habet longos, duos fuperiori parte, \& duos inferiori, Hac Agric

9) Hyftrici potius quàm cuiuis alteri fiue animal fiue monftrum illud, quod Hieronymus Carda nus libro 10, de fubtilitate defcribit, adiungendum exiftimaui. Varígeneris, inquir, incertáǵ natura 
fuit animal, quod prafenti anno (1550.uel uno prius) decimo nono Iantrarī Papię uidimus, Vulbis magniturdo, aliquanto longius, ore \& riçu leporino, cum pilis longis, duobusś́ł dentibus pralongis fiquidem digiti humani longitudinè prominentibus ad modum fciuri (dentium:) oculis ferpentinis, quippe qui angulis carerent $\&$ nigri effent, Pileus inerat capiti, hircina barba fimillimus, fed non a liter quàm crifta pauoni, Pilus muftellinus ac pulcher, nifi quod fuper collum uelut lana candida uia debatur:anteriores pedes utr taxitaures $\&$ pofteriores (pedes) nihílo differêtes ab hurmanis, niff quod pedibus ungula urfi pro humana erat. In dorfo poftremáç parte, fpinæ circiter centum, hyftricisina ftar, quarum quadam in apice curuabantur, prominebant, alioquin imm obiles, nec ut de hyftrice $f_{2}$ runt emiffariæ*cum moueretur, ftrepitum dum fe colliderent, ędebant. Cauda anferina, fed in fpinas pluma finiebantur. Si reliqua non uideas, anferem dices:candidis ac cinereis plumarum fedibur, la in tó́s lumine anferem æmulantibus. Vox fubobfcura, rauca quafil latrantis canis, Iracundum animal, fed tamen quod facile à circulatore tractaretur. Canes odio profequebatur maximo, fexus foeminei, etatis iuuenilis. Potus nullustcibus, panis aqua madefactus. Animal hoc fui generis uix effe credam, fed ex byftrice alió, s, uelut urfo, natum. Hyftricem enim conftat effe fuem fpinas illas habentemin dorfo, quas poffit eiaculari.A fricam mittere proditum eft + fed nunc \& Gallia habet \& Italia . Sping palmi (dodrantis) longitudine, præacuta, leures, albo nigroḉ, diftinct $x_{+}$Sunt erinaceo fpinæ fimiles, fed longè minores, \& quxemitti nequeant, Hactenus Cardanus,

$C_{i}$

Hyftrici ingreffurs grauis, (difficilis,) Albertus. Annimal generat:Quraturor hybernis fe mêflbus condit, ut urfa, utrum propter frígus an alia de caufa, ambígitur: $\mathcal{Q}$ totidem diebus fert uterum grot irra (nempe triginta) \& rèliqua facit perinde uturfa, Ariftoteles \& Plinius. Latet æeftate, \& déa uernis prodit hyeme ${ }_{\text {; }}$ cótra quàm multa animalia; Albertus nec authorem nec fuam obfertuationem adhibës, nec contrariam ueterum affertionem redargurens:quamobrem miror idem à Ge. Agricola uiro alioqui doctiffimo diligentiffimǫ́́ proditum effe. Audio hyftricem animal foetidum effe, \&in fyluis cauernas fodere melis inftar, cui et pedes anteriores in eundem nimirum ufum, fimiles habere

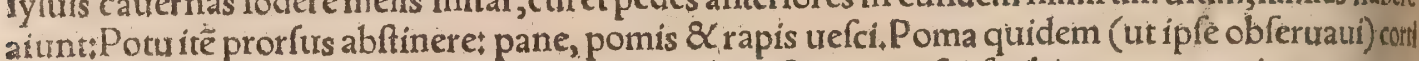
ce dentibus feparato, uotat. Atqui Ge. A gricola hyftricem uefci fcribit pane comminuto, pomis, piris, 1 a pis, paftinacis; bibere aquam, fed cupidè uinum dilutum: noctu uigilare, interdiu dormire

T. Quomodo aduerfus homines $\&$ canes fe defendat emiffis aculeis, in B, iam dictum cho

बा E. Hyfricis pinna fifcalpantur dentes, ad firmitatem pertinet,Plinius. Mulieres alicublfiji nis hyfricum uti audio ut uerticis capillos difcriminent.

$$
\text { F. } G_{\text {. }}
$$

Hyftricis caro, ut herinacei, licet non admodum inter elculenta comedatur, ftomachum tamen adiuuat, aluum foluit, lepram ac fcabiem diminuit; falita hydropem mitigat : mingentes in lecto, quo minus id faciant, adiuuat,Platina. Gracinihil tale hyftrici tributunt.fed ftomachum iuuare, alum foluere echino marino: uim aduerfus lepram \& f cabiem, \& urinæin pueris profluurum, terrefiti Quæ de herinaceis dicuntur, inquit Plinius, omnia tantò magis ualebunt in hyftrice. Hoc ut uereutit fit quod ad remedia, ex cinere prafertim uftorum aculeorum: ad carnis tamen facultatem in cibofu menda (herinacei enim afficcata uel inueterata in morbis quibufdam edenda commendatur) nons nihil intereffe uidetur. Partus conceptos, hyftricum cinis potus continet, ( 8 amolitur abortus) ith fte Plinio:Idem tribuunt herinaceorum cineri fi cum oleo perungatur. Ericius montanus eft aduls dul, habens fpinas fagittales, propinquis natura fylueftris uel terreni, Auicenna,

H.

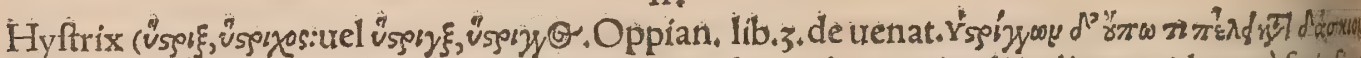

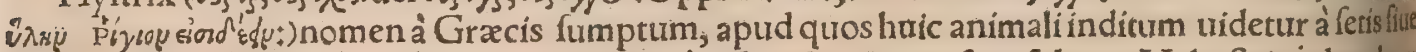
aculeis potius, quibus multó magis horret, quàm fetis fuis rigere fues foleant: Vt hyftrix ad uerbun fuem fetofum fonet. Aculeos enim eius, generi pilorum adfcribendos Ariftoteles iudicat. Hos diure fis nominibus, pilos, fetas, uillos, pinnas, aculeos, aut fpinas, diuerfi authores nomínant. Hyftrixia cipit flatilem in ultima etymi ratione in obliquis, Calius. Plinius 8.3 , hyptrices fpina contectas in

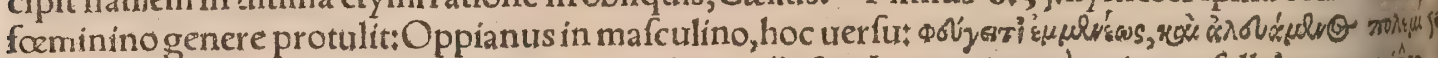
2\$. Recentiores quidam Grammatici in dictionarn̈s fuis Latinis ineptè primam fyllabam periốa fcribunt. Iugyou, caprafylueftres, hyftrichides, Hefychius \& Varinus, Hyftrichis (usposyss, apud Varinum non recté vsobxi legitur) fera fetis inftar fuis ueftita, quas aduerfus infequẽtés eíaculattrr, Suidas \& Scholiaftes Ariftophanis, Significat etiã flagellũ: \& hyltrix fimiliter. V trunç quide toca bulum utroç fenfu, apurd grammaticos faltem ufurpatur: apud authores tamen proprie magis hy ftrix pro animali, hyltrichis pro flagro in ufu eft. Hyftrichis, flagellum è fetis fuillis, (inde 8 nomern

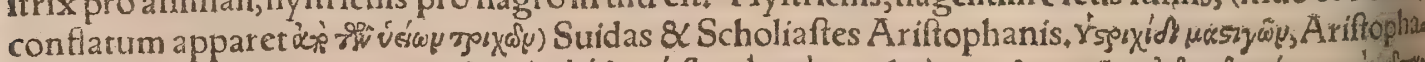

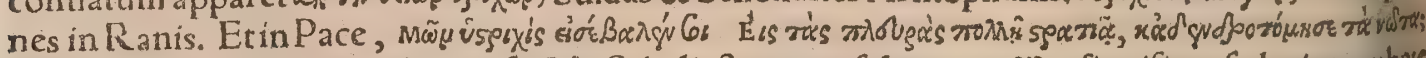
"ैw rian, id eft carceres: $\&$ infuper hyftrichidem, non animal, fed feriendi inftrumentum, quod ex feris 6 fuillis ad uerbera aptum conficitur : corio nempe fuillo oblongo $\&$ angufto unà cum feris parum re:

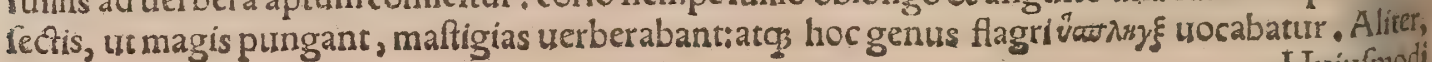




\section{Delchneumone. A. Lib.I. 635}

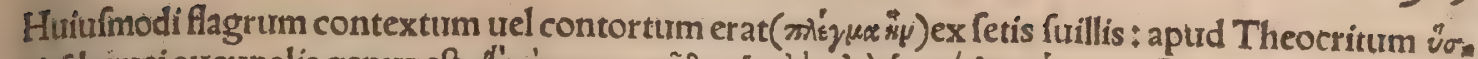

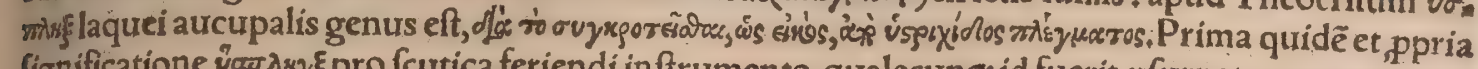
fignificatione $v^{2} \leq \lambda_{x} y \xi$ pro fcutica ferien di inftrumento, qualecunq id fuerit, ufurpatum apparet: po

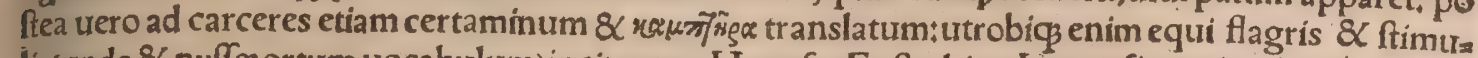
lis(unde 8 nyffx ortum uocabulum) incitantur, Hucuf ${ }_{3}$ Euftathius. Hæec etfi magis ad philologiam defue pertinebant, uocis tamen affinitate illectus cum hyftrice pofui, De woce vow $\lambda$ sy $\xi$ plura dixi

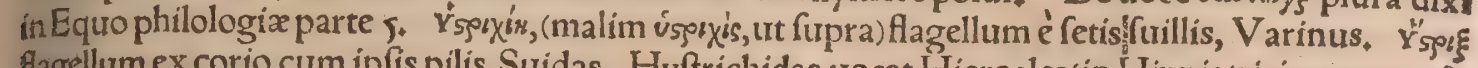
flagellum ex corio cum ipfis pilis, Suidas. Hyltrichidas uocat Hierocles (in Hippiatricis cap. 59.) fi. ue equos ipfos, fiue equorum caudas, in quibus fetæ fuillis fimiles nafcuntur: Ruellio hoc uith pilare

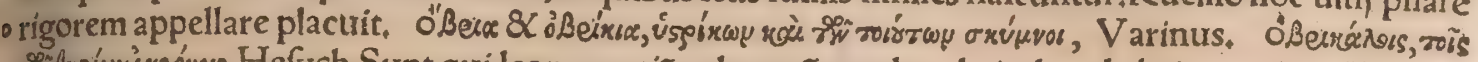

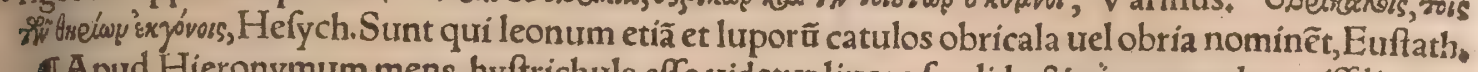
If A pud Hieronymum mens hyftrichula effe uidetur liuore fordida, \& uirus mordax miffilium $2=$ culeorum inftar eiaculari confueta, $\mathrm{C} \mathrm{l}$. Penultimam hyftricis Oppianus, ut fupra citaui, per duplex gamma protulit, ut neceffariò producta effet:aliter enim corripitur, ut apud Calphurnium: Ve nit $\&$ hirfuta fpinofior hyftrice barba. Videtur autem etiam prouerbỉ fpecie, agreftis aliquis $\&$ ina

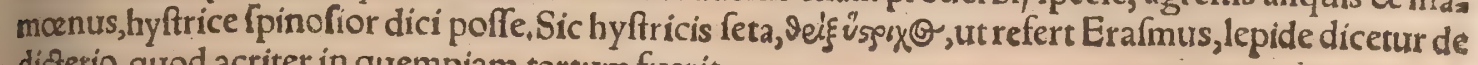
dicterio, quod acriter in quempiam tortum fuerit.

\section{DE ICHNEVMONE.}

ichneumonis hanc imaginem, cui parum tribui, ex uetufo manuf cripto codice Oppiani Venetijs nactus fum. .

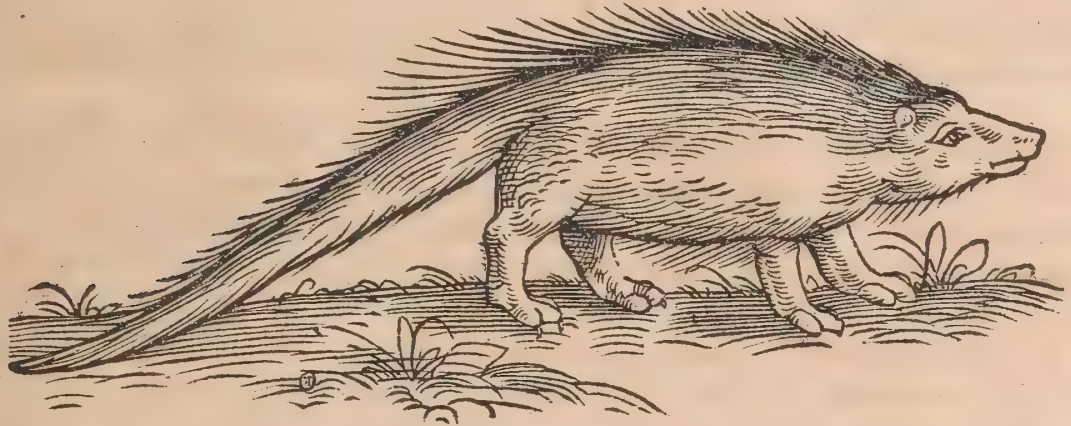

A.

CHNE V M ON, ixusukw, Nicandro etiam ixuouris, hydri fiuc enydri, id eft lutræ fpecies eft in Aegypto:quanquam Marcellinus \& Solinus non ichneumonem hydri, fed hydruี ichneumonis fpeciem facit, quafi hydrus latius pateat, quod non placet:hydrus enim, id eft lutra (de qua in L. litera feorfim agam) plerifos in regionibus reperitur, ichneumon terolutra eft Aegypto peculiaris iuxta Nilum. Enhydrus, alterun ichneumonum genus, Solinus ca pite 3). Enydros, inquit Ifidorus, eft beftiola ex eo nuncupata, quod in aquis uerfatur, \& maxime in Nilo. Hac Grace ichneumon uocatur, \& c.quafi uerò enhydrus quoģ non fit Gracum uocabu lum. Et alibi,Hydrus eft animal uolatile(lego fluriatile)in Nilo fl,inimicum crocodilo. İyourode, os

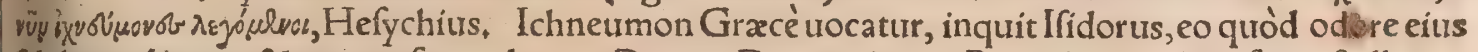
falubria ciborum \& uenenofa prodantur:De quo Dracontius air, Præcidit (prædicit, forte)fuillus $\left(a_{z}\right.$ liâs fuillis)uim cuiufcunç ueneni. Diçus eft autem fuillus à fetis. A pud Albertum neomon pre ich neumon legitur. Latinè, inquit idem, fuilius uocatur, quoniam fetas habet pro pilis:odore cibum con uenientem à uenenofo diftinguit. Ego ichneumonem dictum coniecerim ab inueftigando: Quòd ficut canicula(quam forma etiam corporis refert)feras indagat:fic ille inueftigat $\&$ obferuat crocodi. lum $\&$ afpidem, eorumǵs our, ut capite quarto dicetur. Aduerfus omnia lumbricorum genera mis rum in modum medentur pili animalis nominati alcafim, A uicenna libri 3, tractatu 5. fen 16, cap. 6. Andras Bellunenfis in caftigatis codicibus non alcafim fed harimun legimonet, quodnam ueroid animal fit ignorare fe fatetur. Sed Io. Manardus in epiftolis 3.1 . alcafim interpretatur ichneumonem: quoniam A egineta etiam(quem Auicenna ferè (equi folet)fic fribit: In uniuerfum omnes à lumbri cis agrotantes ichneumonos pili iuuant fuffiti. Ichneumonem funt qui murem Indicum uocari modó fentiant, Hermolaus in Plinium. Hac ætate quòd murinam fpeciem fímilitudinemós gerit, uulgó murem Indicum uocant, Gillius, Ichneumo in Aegypto folum nafcitur, magnitudine felis, fpecie muris: uulgò nunc murem Indicum uocant:alif uocant damulam. Albertus deceptus uerbis Árabicis uocat ibim, id eft ciconiam qux tota nigra dorfo eft, \& inuenitur gilua (grifea)etiam, $N_{i p h}$ 'Eft autem locus Alberti in Ariftotelem de hift.anim, 9.6.ubi pro ichneumone anfchycomon fcribit cetr Gracã uocẽ, \& ab Auicenna thyamon uocari ait. Scriptor quidã(nomen iam non occurrit) ich nétumonem interpretatur murẽ Indicum uel murẽ Pharaonis. Caterũ damulam pro muftela(quuan 


\section{6

donolam ưulgo Itali uòcitant)A Albertus, Vincentius Bell, \& alij accipiưnt:qua etfichneumoni quir dam communia habet(corporis formam fortaffis, $3 X$ quòd ferpentes impugnat) ab ea tamen differre neminem ex eruditis dubitare puto.

\section{B.}

Ân nimalia fua habet Ȧegỳptus, ichneumonem \& A egyptiam afpidem, Strabo, Ichneumonem aliī canicula dicunt fimilem effe, alij muftella, Gillius. Nicander formam eius confert ictidi áuvdpon, id eft tiuerræ uel muftellæ ruftic paruæ, uel(ut alí exponunt) iracund $x_{+}$Catertum ictidis magnitu, do, tefte Ariftotele, ea eft qua catuli Melitęi. Pilos eius fuillis fimiles Ifidorus parum grauis author

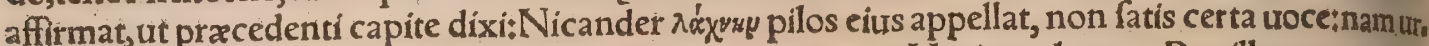
fi,uul pis, fuís, \& hominis etiam pilis eam attribuunt poétæ, ut $V$ arinus docet. Pupillæ parua a

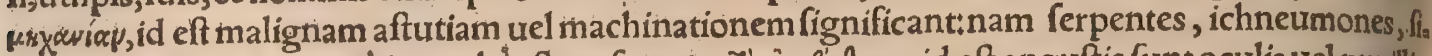

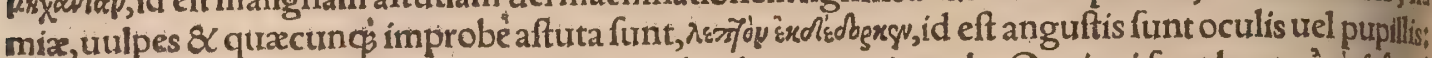

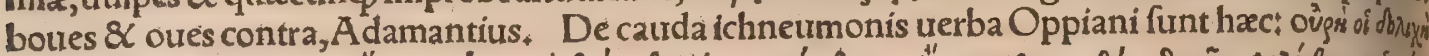

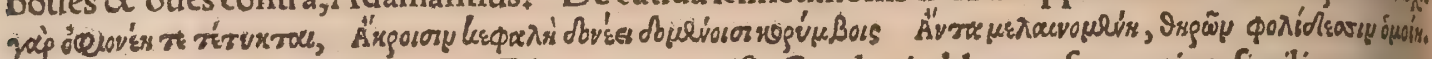
Hoc eft (ut ego interpretor:nam Gillius pratermifit)Cauda ei oblonga, ferpentinæ fimilis, extrema fui parte è regione capitis conuoluta, nigricans, $8 \alpha$ ut ferpentibus fquamora. Verfum medium cor,

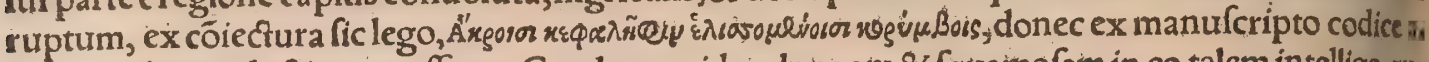
liquis meliorem lectionem afferat, Caudam quidem longam \& fquamofam in co talem intelligo, qu! lis propemodum muribus eft. TIchneumoni(inquit A elianus)utriufọ̧ fexus participi à naturatri butum eft, ut \& fuo fernine grauiditatem \& partum alipjs afferat, \& ipfe quoç uentrem ferat, \& ex fet fe pariat, (idem ferè de hyęna quidam fcripferunt: ) qui in pugna quam inter fe pưgnant uiçi fue. rint, ea bellicæ offenfionis nota inuruntur, ut $\&$ in uiliorem fexum cenfeantur, $\&$ muliebria patian. cur, (Ariftoteles idem perdices factitare feribit,)Contra, í qui ex bello fuperiores euaferunt, vicios fubigunt, \& fimul fuo femine implent:at uicti ex ea malè à fe pugnata pugna, hoc pramio afficiun. tur, ut \& partus dolores fufferant, \&\& ex patribus qui iam ante fuiffent, matres reddantur.

c。

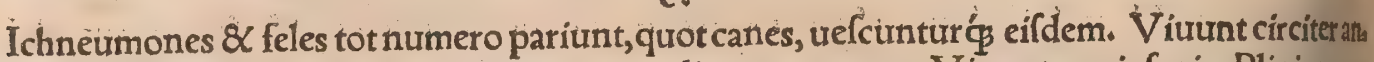
nos fex, A riftoteles. Felium $\mathbb{Q}$ ichneumonum reliqua ut canum. Viuunt annis fenis, Plinius cum prius de canum coitu \& partu dixiffet. Circa fluuios degit, Nilum peculiariter: unde Nemefianu, Et placidis ichneumona quęrere ripis Inter arundineas fegetes. Mihi quidem amphibium uidetrr hoc animal, non folum quiòd circa aquas moretur, fed etiam quòd in ijs lutra inftar fe mergat, Nam Nicander in Theriacis deferibens quomodo contra afpidem pirgnaturus luto fe muniat, fic caniti

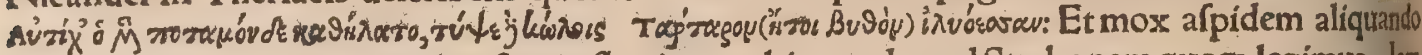
mordicus ab eo cauda apprehenfam in fluuium trahi, quod apud Strabonem quoç legimus, lam cum crocodili uentrem $\&$ uifcera per fauces illapfus exedat, neceffe efl eum diutius abfog; refpiration ne, quàm qux amphibix non funt quadrupedes, uitam agere poffe.

D.

Poffum de ichneumonum utilitate, decrecodilorum, de feliutum dicere, fed nolo effe longior, Citi ro de natura libro 1. \& 5. Tufculan. Beluas etiam in eos ipfos, å quibus beneficium acceperint, trehte menter gratas effe,teftimonio funt uel Aegypti admodum fera animalia, feles, ichneumones, croco 4 dili, A elianus. Et alibi, Cum homini infeftiffimis beftijs afpide $\&$ crocodilo inimicitias gerunt. TTrochilos(inquit Solinus)auis paruula eft: ea dum reduuias(reliquias)efcarum affeciat, os bellua huiufce paulatim fcalpit, \& fenfim fcalpurigine blandiente aditum fibi in uf́ $\beta$ fauces facit: Qutodeth hydrus confpicatus, alterum ichneumonum genus, penetrat belluam, populatis ç uitalibus, erolis exit aluo. Eadem omnino fcribit Ammianus Marcellinus libro 22. De trochilo aue Aegyptia, alia à uulgari trochilo, id eft regulo (etfiPlinius eandem faciat) in Auium hiftoria dicetur. Crocodilun (inquitPlinius) faturum cibo pifcium, \& femper efculento ore in littore fomno datum, parua awlis, quæ trochilos ibi uocatur, rex auium in Italia, inuitat ad hiandum pabuli fui gratia, os primum eius adfultim repurgans, mox dentes, 8 intus fauces quo $\$$, ad hanc fcabendi dulcedinem quàm maxi, mé hiantes:in qua uoluptate fomno preffum confpicatus ichneumon, per eafdam fauces ut telumali quod immiffum, erodit aluum, Hac Plinius. Alin nullam trochili mentionem faciunt, fed fimplici ter in apricantis eius uel dormientis fauces hiantes infilire feribunt. Ichneumones crocodilis apsis càntibus infidiantes, in oris hiatum intrant, $\mathcal{Q}$ exefis uifceribus è uentre morturorum egrediuntur, Strabo lib, 17. Cum crocodilus humi iacet ftratus, (uerba funt Gillij ex Oppiano)\& rictu immento os gerit patulum; tum ichneumon dolofa confilia de illius pernicie iniens, limis oculis tandiu eum obferiat, quioad arc9o oppreffum fomno intuetur:tum confeftim (in arena \& luto urolutatus, aglis procurrit) \& fingulari animi fiducia mortis portam ingreffus per latum guttur in aluum delabitur, Crocodilus uerò inexpectatum malum in uentre fentiens, fomno foluitur: $\&$ incitato curfu furibun dus 8 confilin inops, longè laté $\not$ uagatur, modò in imam flưứ fedem fe demergens, modò magnumm acerbitatis uirus anhelans fefe ad terram abijcit;fed nihil hæc curans ichneumon, \& uifcerum(iecos ri pracipué incumbens) fuaui cibo expletur:ac tandem fatur, iam exinanito crocodili urentre profi lit foras, Hac ille ex Oppiano, Plutarchus etiam de ichneumone fcribit, infidiantẽ crocodilo corpus 
Quid autem per uirus ichneumonum hic intelligat, dubitet aliquis: neç enim urenenati a liquid illon habere legimus: fieri tamen poteft ut habeant, ficut $\&$ muftela, quibus quodammodo fimiles funt, ut fupra oftendi. Bafilifco multelarum uirus exitio eft, Plinius; id eft, necant eos odore, Budaus, Sed $\$$ morfus ichneumonum nonnihil ueneni habere apparet , cum remedia aduerfus ipfos fcribantur, Eft $\&$ alia iris ceræ fimilis $\&$ pradura : quam Horus crematam tufamç ad ichneumonum morfü remedio effe tradit,Plinius de gemmis fcribens 37.9. Ge.A gricola hanc iridis fue cryftalli fpeciem, a gemmarïs citrinam nominari fcribit, \& in Mifenæ \& Boëmiæ metallis reperiri, fed ferè mollem \& fragilem, quum Plinio in.Perfide nafcens prædura fit. Perniciofum ichneumonem Martialis dixit, Quod fi non totus ichneumon uirofus eft, genitalia certe eius talia effe credendum eft, ut qui de en. hydrifiue lutra genere fit, ( animalis certe to to corpore fortidi) cuius teftes proxime ad caftoreum accedere indicabimus, caftorea autem uirofa dixit Vergilius:hoc eft grauiter odorata potius quàm uenenata. Fugiunt au cm ferpentes omnia feré quę huiufmodi fuerint ${ }_{*}$ Virus quidem de genitalitum odore peculiariter dicitur.Lentum diftillat ab inguine uirus, Ver.z.Georg. Virus uerrinum è fcro

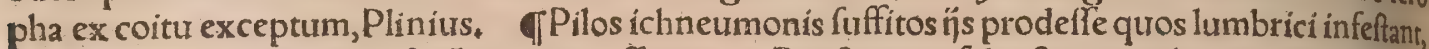
capite primo ex Aegineta \& Auicenna afferui. बProftercore felis, ftercus ichneumonis in medi, cina furpponi poteft, ut inter A ntiballomena Galeno adf cripta legitur. \&Lotium ichneumonis cum lakte uacca nigræ dabis in impetu coli potandum, continuò fubuenies, Marcellus,

$\mathrm{H}$.

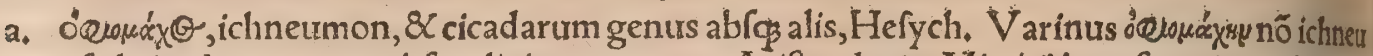
monem, fed cicadam tantum abfos alis interpretatur. A riftoteles in Mirabilibus fcorpiomachi cican dx meminit, fed de his inter infecta. Ichneumon quidem quadrupes merito ophiomachus nuncts patur:fiue is contra afpides tantum pugnat, fiue etiam, ut conïcio, contra cxteros ferpentes. Huni enim (inquit Cícero) Á egyptij confecrarunt, quod non fínat ferpenteis, maximam eius regionis pe, ftem, augeri. Ichneumon quadrupedis \& pifcis nomen, Varinus. Eft \& inter uefpas ichneumon, qure cum phalange uel phalägio diffidet, A riftoteli \& Plinio memorata. If Epitheta. Solers apud Textorem, Deleçat Marium fi perniciofus ichneumo, Martialis. Srrabo afpidi \& crocodilo óneleleh Jxoy, id eft maximé perniciofum effe dicit, ut fupra dictum: fi quis pro uirofo aut uenenofo interpre

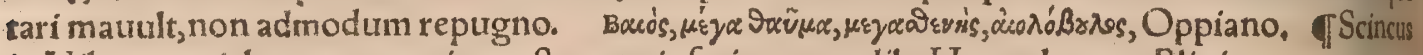
in: Nilo natus ichneumone minor eft, tanto inferior crocodilo, Hermolaus exPlinio.

ब h. Latonx \& Lucinæ facri effe exiftimãtur. Apud Aegyptios Heracleopolitas uenerationem $8 \mathrm{religionem}$ poffidere feruntur, A lianus. Idem capite 4 . ex Strabone afferui. Ichneumonem Ae gyptij colunt, quod non finat (erpenteis, maximam eius regionis peftem, augeri, Cicero. Ichnetrmo nes Aegyptị lugent \& fepeliunt,eodem quo canes modo, Herodotus libro 2.ubi V alla indagatorg tranftulit, quod non probo.

\section{DE L A M IA.}

A.

A M I A nomen homonymum eft: nam \& terreftrem beftiam Libycam (fitre ueram illam, , ue fabulofam, \& fpectrum quoddam, \& pifcem fignificat. Omnibus quidem illis uoractio tis notam ueteres impingunt. Genua, gulofi, Lucilius libro zo.Illo quid fiat lamia, \& pit to ixio dentes. Quòd ueniunt genuæ illa, uetula, improbæ, inepta, Nonius: Verfus duo heroici fint, fed (ut apparet) corrupti. sćsuse apud Gracos feré cum acuto in prima fcribi reperio, ta

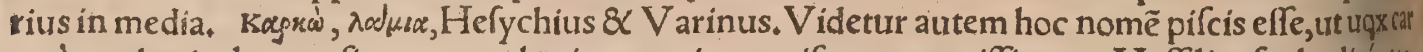
co à carcharia detorta fit:nam carchariam marinum pifcem uoraciffimum, Maffilienfes hodiég (te

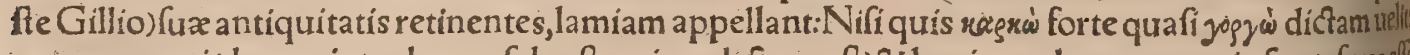
nam gorgoni(de qua inter boues fylueftres iam dicfum eft) $8 \times$ lamix multa communia funt, feras effic

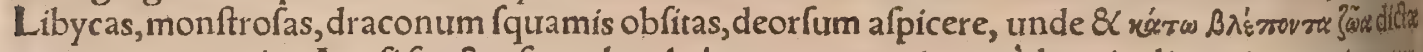
gorgones priuatim, Aut fi fpectra funt, hac habent communia: quòd terriculi gratia nominantur, tanquam forminæ quadam, uoraces, oculis exemptilibus. Sed rurfus quædam gorgoni attribul tur, ut alæ, \& c , qux lamijs negantur, \& uicifim. Multa etiam de onocentauris feribuntur \& lam militer, ut fpecics humana, mammæ muliebres, fumma uelocitas. Recentiores quidam dum lamize tiam equinos pedes tribuunt, ut ueteres onocentauro afininos (pofteriores tantum) idem prorfus ab nimal facere uidentur. Sed onocentauri hiftoriam fupra poft afinum $\&$ onagrum abunde retuli. Phocarum odorem habebat, lamia uero tefticulos illotos, cameli autem podicem, Ariftophantesín

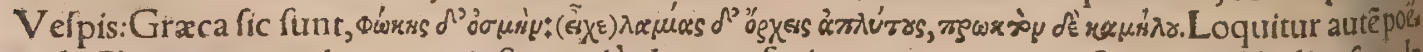
ta de Cleone: quem phocarum inftar malè olentem facit, ut qui coriarius fucrie, \& libídinofum, 1 n

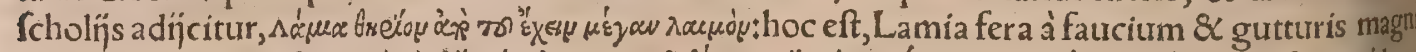

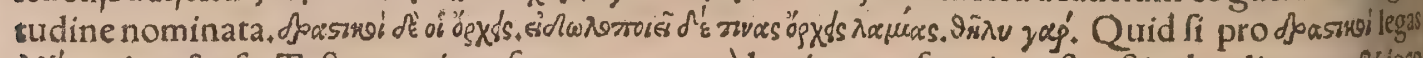
ápjevwu, hoc fenfu. Teftes marium funt: poeta uerò lamia qux foemina eft, tefticulos (licenter \& 100 (e) affingit:fed doasinoi apud Suidam etiam et $V$ arinum legimus, ut fufpicemur forte aliquid deel 


\section{0

primum agnolcens, grauribus ćp ac contumeliolis uerbis illud increpans, focios ut idem facerenthol tabatur id ením contra huiufmodi inuafiones optimum fciebat effe medicamentum, Eius dictis cî focí partuifent, ftridens phantafma celeriter tanquam idolurm aufugit, Apud Ariftophanem in $R_{a}$ nis quidam fe uidere ait magnam feram, qua in uarias formas tranfeat, bouris, muli, muliexis formo, fa: Et cum alter dicerer, A tqui non amplius mulier eft, fed iam canis, fubricit ille, Empufa igitur eff, Chryfoftomus. Dion fic in Libyca fcribit fabula, Effe in locis illis feras muliebri facie, etiam formofa? uberibus quo qu cum pectore fpeciofiffimis adeo, uti nullo pictoris ingenio effingi queant, Color fpe chatur prafloridus, ex oculis pracellens promicat gratia, manfuetudini adnexa. Corporis reliqua fquammis pradura, ut frangere non fit; alis carent, ficut uoce, fed fibilum elidunt modo , draconum imagine quadam. Terreftrium cenfentur omnium uelociffima, utceleritatem euadere nemo uale, 2t. Viribus cætera peruincuntur, fraude tantum homo:fiquidẽ reteguntur pectora, quorû illectinis tore confabulandi defiderio adeuntes rapiuntur protinus, Cælius, Dion quil Libycam feripfit hiffo riam(inquit Gyraldus) de lamị sin hunc propè modü prodidit: Haudlongè âlittore maris curtum effe locü, arenofum, mari perfimilem, in quo littora magna exiftunt, $\&$ arenofi aggeres in mari, cik cumuicina uero omnia deferta fere manêt. At fi ibi fortenaufragi electi fuerint, feræ apparentes eos omnes qui uel peragrant, uel aberrant, rapiunt:quarum natura \& corporis figura talis habetur, $F_{a}$ cies eft mulieris, \&cc. (utiam ex Calio retuli)inferiora funt ferpentis, ut ima pars in caput definat fer" pentis, \& quídem ualde horrentis : hæ feræ alas non habent quemadmodũ fphinges $¥$ neq enim los quuntur ut illæe, neç aliam uocem emittunt, fed folë fibila acutiffima quemadmodü dracones, Catte ra quidem animalia uiribus expugnant homines: ha folum fraude ac deceptione: pectora aperiunt, \& ubera oftentant: eum utero qui af pexerit, ueneficinjs quibufdã cogunt ad confabulationis defyderi, um. Et hi quidê ueluti a di mulieres accedũt, illæ intrepida manent, deorfum in humũ fape refpicien tes (nimirũ ut gorgones, uel catoblepontes, ut fupra dixi) ornatũ ac pudorẽ mulieris imitantes, atque ita eum qui propius accefferit, rapiunt:nanq manus funt ferarum, quas aliquantifper occultant, $C_{2}$

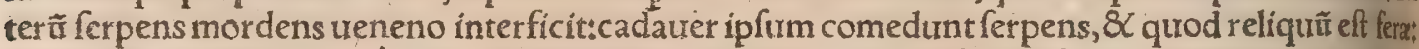
at $\phi$ hactenus Dion fermè de lamijs feris, quibus uidemus eos $\&$ falli $\$$ fallere, qui equinos lamilspe des attribuunt. Has $\&$ propheta Hieremias uidetur agnofcere, cũ ait:Sed $8 C$ lamize nudauer û́t mams mas, \&̌c, quanquã locưs hic ab Hebræis aliter effertur. D. Hieronymus quadã ibi fubinnuit. Pon' Q. Efaias lamiz cubile dixit. Hebracorũ nonnulli lamias, furias interpretantur. Scribit Picus quodä damonas incubos effe interpretatos, exiftimafféć fuperiores partes habere humana fpecie, inferio , res belluinas. Lamias ineptè à laniando dictas purtauit Ifidorus. Hebrailamiá lilith uocant, degua monftra confingunt.Lamia præterea pifcis genus, cuius Nicander in Gloffis meminit, qui etia cart charias appelleturr:pifcis huius Ariftoteles, Plinius \& A thenęus meminêre, Audio \& hodie uocaria Maffiliêfibus lamiã, \& ingentis interdũ magnitudinis inueniri, integros ḉ homines ab ea uoratosa liquando repertos, Lamias puerorũ effe terriculamenta, uel ex A puleio latis conftat. Sunt quiftri ges putent, qua infantium in cunis fanguinem fugunt. (Nos de ftrige inter aues dicemus.) Quin \& Horatius in Poetica ideo dixit, Neu pranfac lamix uiuum puerum extrahat aluo, Delamijs \& Plato meminit in Politicis, Hac omnia Gyraldus.

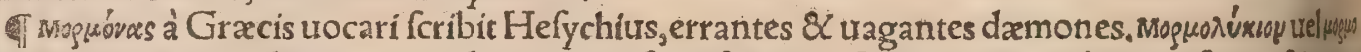

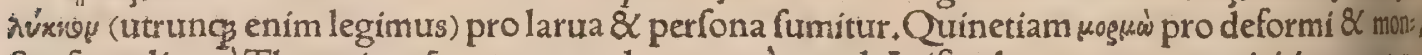
frofa muliere a Theocrito ufurpatur:pro larua uerò, apud Ariftophanem grammatici interpretath tur; Gyraldus de dịs Syntagmate 15, Et rurfus ibidem, Lamix etiam ftriges â noftris tocantur,Duris Libycorum libro 2. \& Suidas \& Phaurorinus ( $\&$ Ariftophanis Scholiaftes) Lamiam mulierem formo fam fuiffe tradunt, Beli $\&$ L Libyes filiam, quam Iupiter adamauit, et ex ea filium fufcepit:fed Iunopie

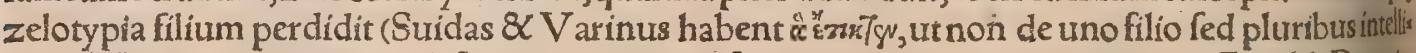
gas ) \& Lamia præ moerore deformata, alienos infantes rapere ac perdere dicitur, Gyrald. Reperizs nonnulla etiam in Alciati Parergis libro 8. Iupiter cum Beli filiam amaret, ex L_ibya eam tranffilit in Italiam, unde \& nomen urbi ltalica. Ibi cum filios ex ea fufcepiffet, Iunonem non latuit, qua lites ros natos perdidit. Itaç Lamia agrè ferens, alienos quop̧ liberos per inuidiam fuffurata interemil Hinc $\&$ nutrices aiunt pro infantium terriculamento, Lamiam (ut apud Germanos mulierem ine s) cturnam , dienad)tfrouw) uocare. Fabulantur enim infomnem eam effe uoluntate lunonis, trt dies noctesćs in luRu exigat:mifertum uerò eius Iouem oculos exēptiles effeciffe, ita ut eximí reponith poffent: \& facultatem addidiffe, ut in quam libuiffet formam fe uerteret, $V$ arinus \& Ariftophatiis Scholiaftes, Lamia, mulier quadam antiqua Libyffa, fic dicta, Hefychius. Nec quodcung uoletpo fcat fibi fabula credi, Neu pranfa lamix ưuum puerum extrahat aluo, Horat, de Arte. Sic etiant per Accó \& Alphítò tanquã̃ monftrofas foeminas/deterrebant pureros à peccando, Erafmus in piou uerbio Acciffare. Noftræe etiam muliercula pueris fape minantur mulierem nofurnam. Lamix, mulieres qua frigum inftar infantium fanguine fugunt, urelipfe ftriges, Perot, A tille colorefpura cifími humoris percufirs, quo me lamia ille infecerant, afpernatur, A puleius lib. ${ }_{\text {, de }}$ Afino, Ter ricolas lamias, Fauni quas Pompiln̈'ś Inftituêre Numa, tremit has, \& 2 c. Lucilius apud Lactantium, Lamia fecundũ̃ quofdã, mater fuit Scylla, unde Vergilius in Ciri, Ip fi feu Lamia mater fit, fiure Cra teis: qux ex puella in monftrum uerfa infantes necare dicitur, quoniam omini fobole quam ex Iove 


\section{DeLamia. Lib. I. $\quad 64 \mathrm{t}$}

peperterat, à Iunone orbata eft. Gyraldus de Empufa fcribens, Noftro, inquit, hoc tempore quibus hoc phantafma muliebre apparuerit audiuimus. Legi qui putarent illud regis Dauidis meridianum dæmoniū, huiufcemodi terriculamentâ fignificare. Reperias etiã in plurali numero empufas dici, ut lamias. Nos de Empufa \&C onofcelis dẹmonibus in A fino diximus:tribuunt aurêe etiã lamịs recentio

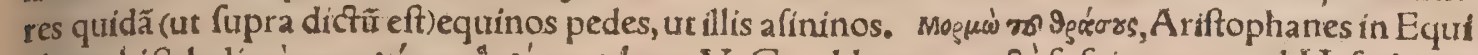

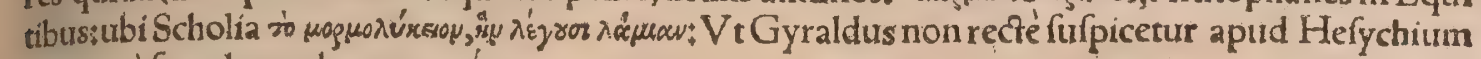
pro

- Lamia uirinomen, quo uor acem fignificari dicunt, Cęlius. Acli uetufto nobilis ab Lamo, \& ç Horat. Carm, 3.17. Eratenim Roma quaedam familia nobilis Aeliorîr(Heliorum Perottus, ) à Lanu Antiphatis patre \& Lxiftrygonum rege, qui Formị s regnauit, ortữ habens, Calepin. Hoc nocuit La. miarum cęde madenti, Iuucnal. Hutius familize etiã M. Cicero meminit. L. Lamia, nomen uiri prąe

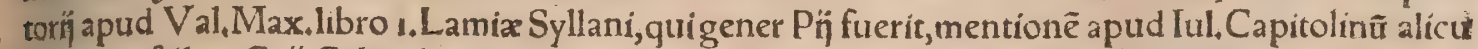
bilegi,ni fallor, Cań Caligulę cadauer clam in hortos Lamianos afportatũ elt, \&c. Sueton. Lucanis imperauit Lamifcus, cuius pedis digitus tertius à magno, fimilis lupinę ungula fuit $t_{i} H_{\text {Heraclides in }} \mathrm{Po}_{\mathrm{o}}$

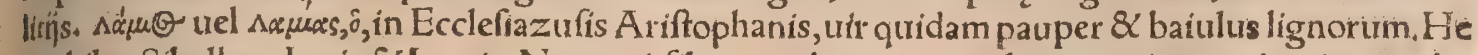
rophilen Sibyllam louis \& Lamix Neptuni filiam tradunt, quæ mulierum prima cecinerit oracula,

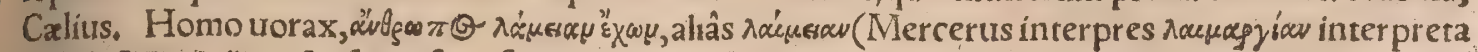
tur)ab A egyptís picio fcaro fignificatur: is enim folus pifcium ruminat, et pifciculos quotquot acré

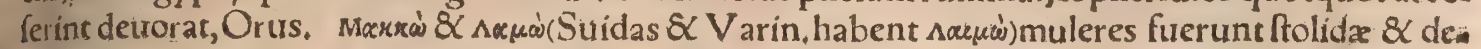

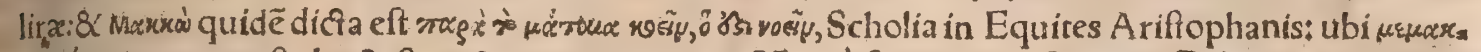
* prefationem in priora Ariftotelss Analytica Lamiętitulo, in cưus initio, Mihi, inquir, eciã puerulo auia narrabat, effe aliquas in folicudinibus lamias, qux plorantes glutirẽ pueros. Vicinus quoç ad. huc Fefulano rufrulomeo, licens fonticulus eft(ita enim nomen habet) fecreta in umbra delitefrês, ubi fedem efie nunc quoç̧ lamiarũ narrant muliercula, quxcun $\xi_{3}$ a quatũ uentitant. Lamiam igitur Plutarchus habere ait oculos exemptiles. Hxc quoties domo egreditur, oculos fibi fuos affigit ; ua. gaturó̧ per fora, plateas, quadriuia, \&́c.per conciliabula omnia, circumfpectatćp fingula, f́rutatur, indagat:nhil tã bene obtexeris ut eam lateat.Miluinos effe credas oculos eínulla eos pręerit quãlibetindiuidua minuties, nulla cos euadit quamlibet remotiffima latebra. Domum uero ut revenit; in in ipfo ftatim limine demit illos fibi oculos, abricitç̧ in loculos. Ita femper domi cęca, femper for is ocu lata. Quęras forfitan domi quid agitet. Seffitat lană faciens, atç̧ interim cantıllat. Vidiftis" ne obferro unquam lamias iftas uiri Florentini, qua fe \& fua nefciunt, alios \& aliena fpeculātur ب Negatis ‘ A qui tamen funt in urbibus frequẽtes: Verũ perfonatæ incedunt, homines credas, lam ę funr, Hucur

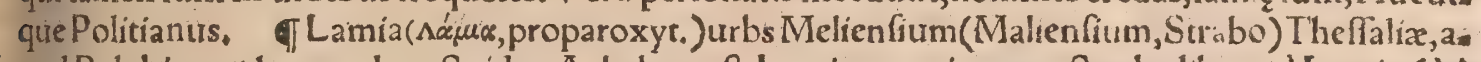
pud Polybium, (de qua plura Suidas: A chelous eft Lamix propinquus, Strabolib. 9. )à Lamio (ica

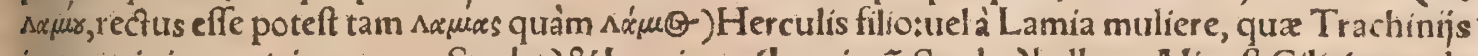
imperauit:in qua (circa quam, Srrabo) \& Lamicum(Lamiacũ,Strabo)bellum. Alia eft Ciliciæ, unde gentilia Lamienfes, Lamiotx, Stephan Idem Lamon, $\Lambda \propto \alpha \mu o \psi$, Cilicix fluuiũ elfeferibit, \& adiacentem eiregionẽ Lamufiam. Eft \& $\wedge \alpha \mu \in s \alpha$, per ediphthongũ in penultima, mons Arcadię, Srephanus. Sunt

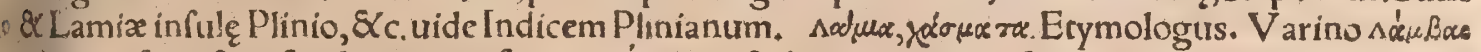

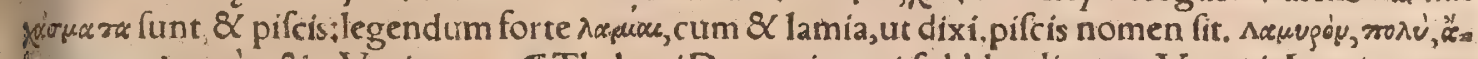

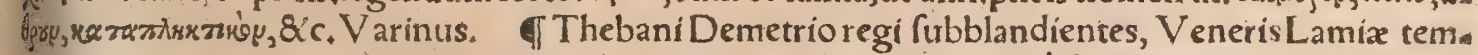
plum excitarunt:erat autem eo nomine illius amica, ciuitatis pernicies à Comicis poëris drêa, Cali. us 8 Gyraldus. Lamia tibicina à Demetrio Poliorcete amata, \&r. A thenaus libro 13. Meretrici qui dem Lamix nomen pulchré conuenir:cum lamix, fiue fere, fiue muliebria fpectra, tum libidinis tum troracitatis uitijs infames exiftimatre fint. Videntur enim meretrices, amantes fuos quafi deurorare exhauftis eorum opibus, qua de re iocum in Capra fcorto retuli, \&ic.Sic \& Charybdin Horatius me retricem trocar:fic Diomedis filix equa hofpites deuorarunt, fic lupam pro meretrice dixerunt ue: teres. Damiam \& Auxefiam deas Epidaurn̈ coluerunt, ut terram eis fructiferam redderent, ut 10 Gyraldus ex Herodotilibro quinto refert, apud Paufaniam uero non Damiam, fed Lamiam legof

fribit. Sufpicetur forte aliquis lamiam feram aut fpectrum nomen ab Hebrais rulif. liffe $n$, litera in 1.mutata, illis enim nemiot tis (rectus fingularis eft nemia) uc frribit Munfterus in Diktionario fuo in uoce nny iziah. 


\section{DeQuadrupedibus}

DE LEONE.

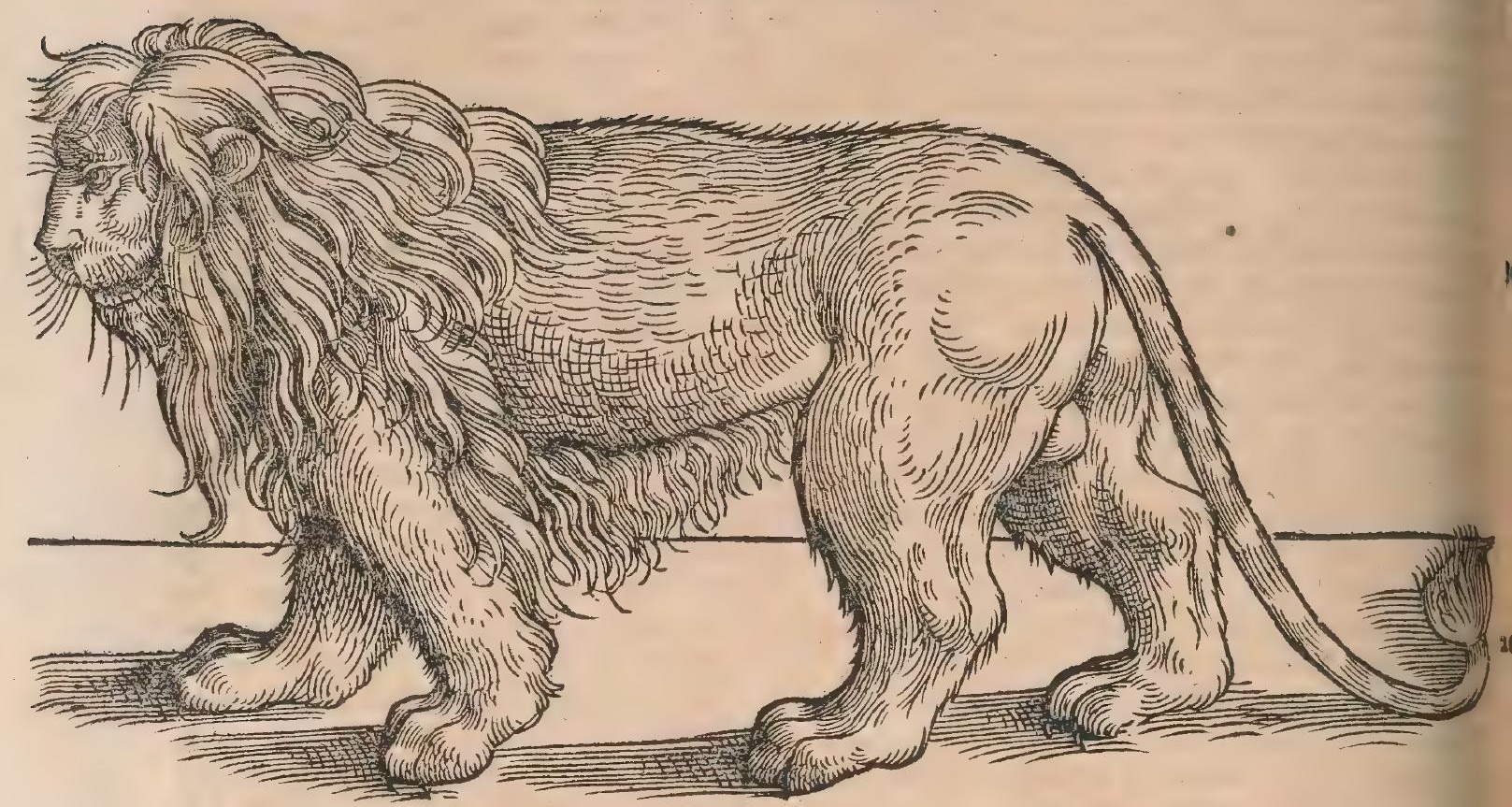

A.

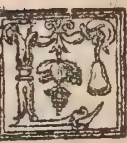

o rex quadrupedum, nomen Gracum, $\Lambda$ śu, curius etymon in Philologia dicam, nonfo, lum apud Latinos, fed plerafog etiam barbaras trodie in Europa gentes, ut infra patebit,fer,

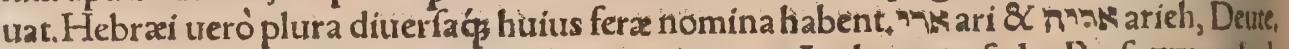

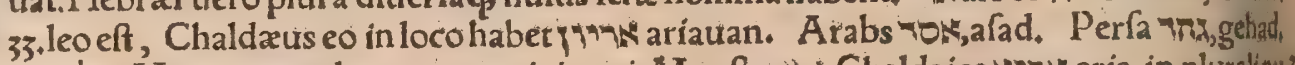

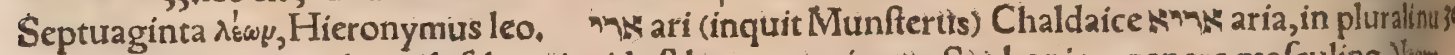
meroaranim et araiot:(araoth fchoagim, id eft leones rugientès, So phoniç 1. genere mafculino, )iemt figura leonum 3. Reg.7. Hinc ariel idem quod fortis i.Paralip. 11. $82 . \mathrm{Reg} .23$. uolunt a utem incellis giprincipem quendam. Ifaix uerố 29. \& Ezech. 43. accipitur pro altari holocauftorum fectindum Hebrzos, in quo ignis è coelo delapfus cubauit, tanquam leo in fpelunca: uel quod remplum habure

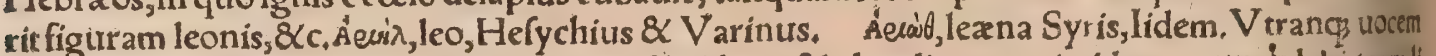
Hebraicam effe apparet:pofterior quidem Chaldaica $\&$ pluralis numeri uidectr. $\$$

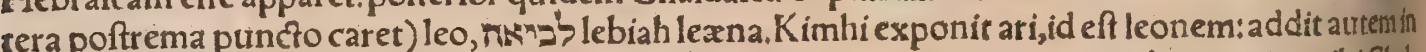
commentarn's ari minorem effe, labi maicrem. Numerorum 23.iunguntur ambo nomina : ibiChals

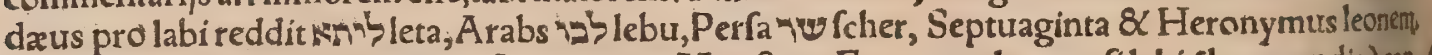
Locus ex Numeris citatus talis eft, interprete Munftero: Ecce populus quafi labi (leo grandis ) con 40 furget: \& quafi ari (leo) eleuabitur, Labi, leo prouecta atate, Iob 38. Lebaim,leones, P falm. 57 , Le baot, leanæ, Naum 2. W', laifch, Dauid Kimhileonem magnum exponit. Chaldaica uerfio Elaix 30. catulum leonis interprețatur, Septuaginta oxúnvop, Hieronymus leonê. Rurfus Iob quarto Chalı dxus pro laifch uertit laitha, quod uocabulum factum uidetur ex laifch:A braham Prizoleñ. leonem

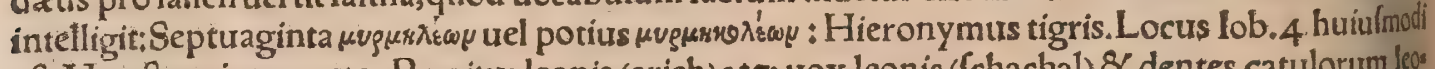
eft, Munftero interprete: $R$ ugitus leonis (arieh) at ${ }^{2}$ uox leonis (Ichachal) $\&$ dentes catulorum leo nis (kephirim) eutulfi funt. Leo (laifch) perït propter defectum uictus, 8 catulileonis (benelabi) dilis fperfi funt, Eruditus quidam noftræ atatis hoc in loco per bru fchachal nonleonem, quumaliudes ius nomen adiunctum fit, fed cognatum leoni animal, nempe leopardum intelligit: fed fi hoc arghts mẽtum admittas, ne labi quidem aut laifch leonem fignificabit, cum arieh ufitatius leonis nomen in " eadem fententia legatur. Leopardi quidem nomen Hebraicum effe nemer, in panthera (quam recen tiores leopardum dixerunt) docebimus. Verum \& Septuaginta Ofee quinto pro fchachal mavblist contuertũt.Proleana, inquit Hieronymus, Septuaginta interpretati funt pantherem: 8 tam nomen beftix quàm omnis beftia poteft accipi. Atqui $D$ auid Kimhi fchachal interpretatur arieb, id efteon nern: \& Commentarius kabuenaki nomen leonis, fiquidẽ multa funt ei nomina. Confentit Leur bên Gerfon. Iob 4.Chaldxus pro fchachal uertit fchachala, Septuaginta \& Hieronymus leęnam. Iidem

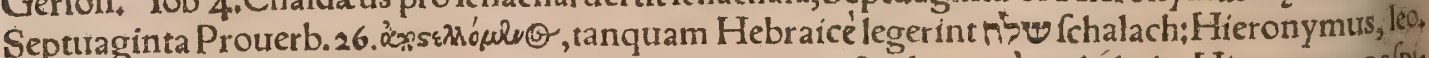
palmo 91. Chaldaus f́chachal catulü leonis interpretatur, A rabs dem. Verba Oree quinto funt hac:Ego fum uelutileo (fchachal) Ephratais, \& ueluti catulus leonis (kephir) domui lehuda. Etrurfus Ofee 15 . Factus fum eis ficut leo' (fchachal) ficut pardus (namer, id eff pardalis uel panthera) direćtus ad uiam: deuroraboón cos quafileo, (iabi,) Munfterus: nam Hie ronymus profchachal leanam reddit, uc folet. Septuaginka hîc etian profchachal panther vertun 


\section{DeLeone. A.B. Lib.I. 643}

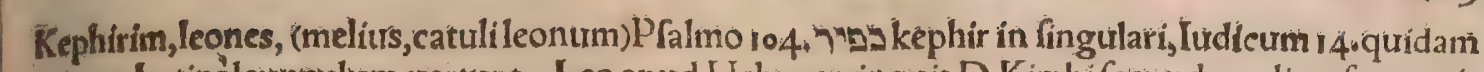
parum Latinéleunculum uertunt. Leo apud Hebræos, inquit D. Kimhi fecundum dituerfos ætatis gradus diuterfa fortitur nomina, in primo gradur uocat 74 gur, in fecundo kephir, in tertio arieh, in quarto labi, Q in fupremo laifch,Munfterus. Gur D. Kimhi cuiufuis animantis catulum aut pullǘ nominari ait: ferè tamen per excellêriam de leonis catulo ponitur (ut $\sigma x \dot{u} \mu \nu \mathbb{G}$ apud Gręcos) hinc plu ralia gurim mafculinum, 8 guroth foemininum. Gur arieh, Deur, 32. Hieronymus uertit catulum

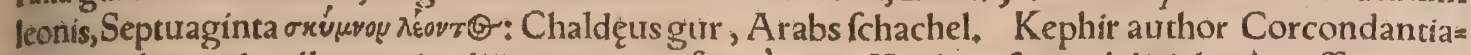
rum catulum uel pullum animaliũ exponitita fermè etiam Kimhi,nifi quod dicit kephir effe adultio

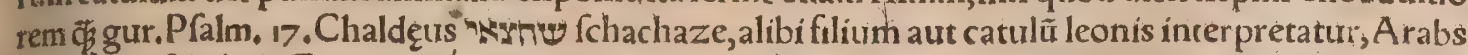

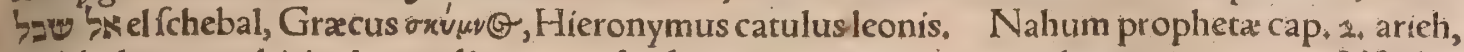
leo:labi,leęna:cephirim,leunculígur, catulus leonis, omnia in una periodo continentur. Allebha, inquitBellunenfis, eft nomen commune ad omnes quadrupedes qux dentibus $\mathcal{Q}$ unguibus homin $\tilde{\mathscr{e}}$ mordendolaniandoós aggrediuntur, \& aliquando interimunt, ut leo, lupus, tigris, Hæc ille. Vetus interpres Auicenna libro 2, capite de carne, lupos uertere folet. Si fuper cortices quercus (ilicis)cal cauerit zarim (aliâs farim) id eft leo, formidabit continuò, A efculapius. Hac de re alios authores cita bo capite quarto: hic de nomine quęritur. Videtur fanè zarim uox Perfica:nam Numerorum 23, pro labi,Perfa fcher (uel fer )pofuit. Leonem Saracenis hodie febey appellari, apud recentiorem quen= dam legi. đLeoltalicé leone, Hifpanicéleón, Gallicè \& Anglicé lyon, Germanicè \& Illyricé lew. IVncia à recentioribus barbaris dicta fera, lonza ab Italicis quiburdam feriptoribus, leęna exiffima tur, uel pardus, uel panthera, uel lupus ceruarius, ut Fr. Arlunnus fcribit: Ego pantheram effe furo locodemonftrabo.

Leonum duro funt genera:quorum alterũ breuius, crif́pioréć pilo, quod ignauius eft:alterũ lon's gius,piloǵp probiore, quod generofius eft, Ariftoteles interprete Gaza. Plinius eundem locum fic reddit, Leonum duogenera Ariftoteles tradit, compactile $\&$ breue crifpioribus iubis: hos pauidiores

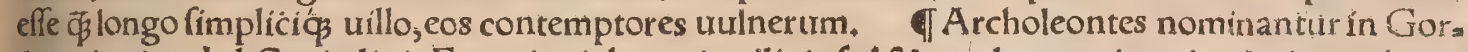
diano itniore lul.Capitolini, Egnatius íubatos intelligit:fed $\&$ acroleontes, inquit, plerigz probant. Atqui ego leones mares omnes iubatos effe puto(quanquã Oppianus de Libyco leone fcribit, $x^{\prime} x \underline{t} z z$ $\lambda$ axyéres) qui modo legitimi fint:nann leopardos, hoc eft ex adulterio leęnx cum pardo natos in's carere. - fcio. Quid fi archoleontes genus aliquod leonum prægrande intelligas ut qui magnitudinis ratione

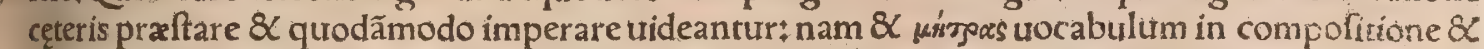
magnitudinem $\&$ imperium fignificare uidetur inter eiufdem generis animalia, ut or tygometra (ita,

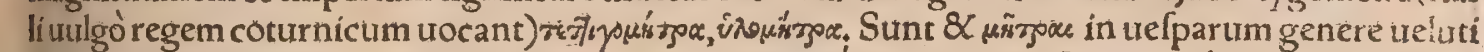

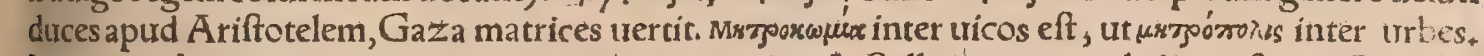
Leonum iubatorum centum pugnam primus omnium L. Sylla in pratura dedit: poft eum Pompei: us Magnüs in Circo fexcentorum, ac in ins iubatorum C C C X V. Plinius. Vbi per iubatos lèones for taffis mares fimpliciter intelligemus. Quod fi quis apud Capitolinum archoleontas, leones nondum cicuratos intelligat, quafi agrioleontas, quoniam in eodem fpectaculo leones manfuetos exhibitos di zerat, non contradicam.

1Leunes in Europa potius funt, \& ea Europæ parte, quęinter Acheloum amnem \& Neffum eft, Ariftoteles, Er rurfus alibi, Leo animal rarum eft, nec multis nafcitur locis:fed Europx totius ea par: te folum, qux inter A cheloum amnem $\&$ Neffum eft. In Europa inter Acheloum tantum $\&$ Neftũ amnes leones effe Ariftoteles tradit, longé uiribus praftantiores ḥ̂s quos A frica autr Syriagignãt, Plinius. Circa Pęonium agrum atq̧ Creftonicum fuper amnem Chidorum Xerxe cum exercitu tran feunte leones impetum dederunt in camelos, 8c. Herodotus libro 4. Et mox, Sunt autem per ea loca leones multi:terminus eorum eft Abderorum flumen Neftus, \& Achelous qui per Acarnaniâ fluit. Nam nemo aut ad auroram trans Neftum ufquam gentium uiferit leonē in Europa, aut trans Ache loum ad Hefperum in reliqua continenteł fed in horum flutiorum medio leones gignuntur. Mon tana Thraciæ regio(inquit Paufanias Eliacorttm *.) intra Neftum flutium qui per Abderitarum re= sionem fluit. prater alias feras producit etiam leones, qui camelos quondam in Xérxis exercitur cố meatum geftantes intuaferunt:hi frepe in règionem circa Olympum euagantur montem, cuius latus unum Macedoniam, alterum Theffalos \& Peneum flumen ípectat. De Nefto amne feribit Plinius 4.11, ubi Hermolaus, Neftus fl.inquit, à P tolemæo Ammianoóg Neffus appellatur, 8cc. Leones nó gignit Peloponnefus, quod doctiffimus Homerus nõ ignoraffe uidetur, cũ aiebat, Dianam in Tayge 10, \& Erymantho Peloponnefi montibus delectatum fuife in uenandis apris, \& ceruis: leonum aure

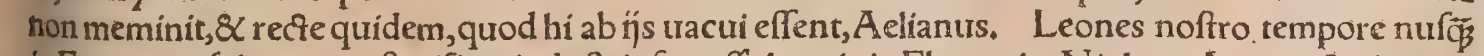
in Europa nafci certum eft:nifi ex induftria fortaffe hominis, Florentix, Niphus. Leones \& rigrides in regionibus ad Orientem $\&$ A Afrum nafcuntur, quòd maiorem caloris copiam hæc animalia defi.

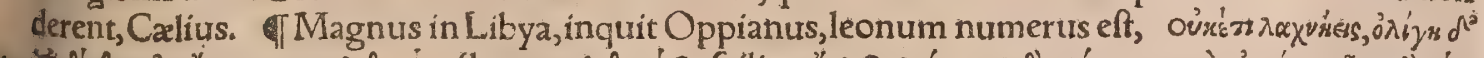

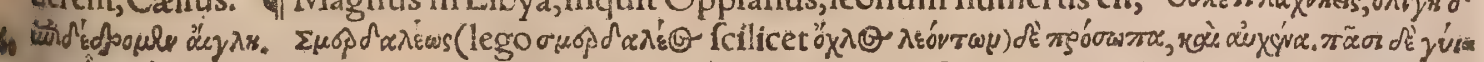

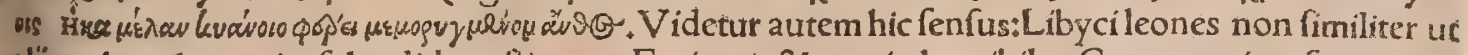

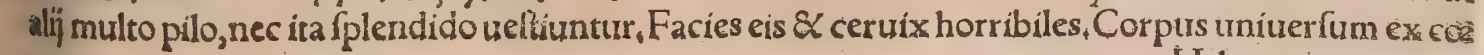


ruleo colore ad nigrum inclinat. Addit præterea, robur eis immenfum effe, $\&$ leones omnes fẩ fuperare. Gillius hunc locum ineptè tranftulit. Si à Libya dictx effent Lucx boues, fortaffe panthe requog, \& leones, non Africana beftix dicerentur, fed Lucx, Varro. Mauritania leones alit,Stra bo. VItra Catadupa Níli procedens A pollonius $\&$ comites, uiderunt leones $\&$ pantheras, Philo. ftratus. Circa Meroén Aftaboras \& A ftapas influunt: Hæc loca leones alunt, qui fub canis exortĩ a maximis culiciburs hinc expelluntur, Strabo libro 16. Vide infra in D. A pollonio, cum ad maredes fcenderet, dextra quidem Gangen, finiftra tuerò Hyphafin fl, habenti, multi leones occurrerunt, Phis loftratus. In parte Syriz contermina leones $\&$ pardales plures maioresḉs reperiưtur quàm in Libya, Diodorus. Aethiopicum quandoģ leonum genus in Libyam migrat, mirandum afpectu, colore nigro, bene comatum, capite amplo, pedibus hirfutis, oculis igneis, folo ore ex fuluo rubicundurn,

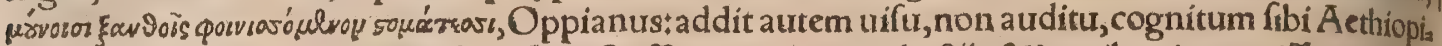
cum leone. ब Cilicia qưd fylueftre eft efferatur plurimis beftins \&Cleonibus immaniffimis, Leo num alij ad Iftri oftia, alij roborelftrianis inferiores in Armenia \& Parthia nafcuntur, craffo colloet capite magno, oculis lucidis, fupercilífs denfis $8 \mathrm{C}$ ad nafum dependêtib. (fic uerto ex Oppiano) collo \& maxililis comantibus, Gillius apud Aelianum, Locus omnino ex Oppianofumptus eft. Is ifrita,

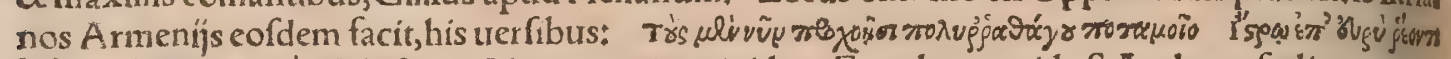

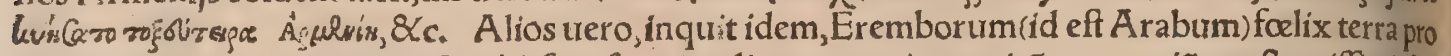
ducir:his quoq3 ceruix \& peçus hirfutta funt,oculi ta nquam igne micãtes, omniũ praftantiffimi, fed pauci. Circa A den Arabix urbem montes uifuntur excelfi:ubi magna leonum copia eft, quihomie nibus, ubicunģ̧ poffunt, plurimũ nocent. Itą̧ nifi multi homines coniuncti, ut minimũ circiter cen a tum, pariter incedant, non funt tuti per iftos montes, Vartomanus. Leones qui generantur in ter ra Coratenorum(inquit Albertus, ex Auicenna ut fufpicor)\& pracipue a pud Hyconiã (Hyrcaniam forte)ferociores $\&$ audaciores funt ị́s qui auftrum $\&$ meridiem uerfus gignuntur. Cecrerû in quarto climate uel prope illud nati, timidio es funt $\&$ infirmiores, quòd coeli illius conftitutio cum tempera mento ipfor ú non conueniar. Circa Hyconium quidem adeo feroces funt, ut pauci uenatoribuscas pi queant, cum tamen non fape noceant hominibus, Hac Alberus. Leonum color in Syria tanir niger eft, Plinius:nos iam ex Oppiano A ethiopicos etiam nigros effe diximus. De leonibus Mefor potamix, qui à culicibus infeftatioculis, uel in flumina fe dantes pereunt, uel oculos unguibus lancia nando effodiũt excęcanturç̧, capite quarto dicã. Terra India animalium marer optima, leones euñ fert maximos, qui immanifimi dicuntur:pelles eorum a fpeciu nigr $x$ funt, \& horrid $\&$ \& formidolo, fa. Capti mirû in modum manfuefcunt(ut capite quarto dicam, Aelianus. Leones in regno Nâts finga plurimi, periculofa faciunt itinera, Vartomanus. Rex Tartaror um habet leones maximos at que pulcherrimos, maiores illis qui funt in Babylonia : in quorum pilis radioli quidam uarí coloris apparent, fcilicet albi, nigri arç rubei, \& illi quo $\$$ docfi funt artem uenatoriam. Nam plurimum pros funt uenatoribus, ad capiendum apros, urfos, ceruos, capreas, onagros, atog, boues fylueftres. Dueizal tem folent duo leones in uehiculo quodam dum uenatum itur, fequente utrung cor ũ caniculo pars ıo, Paulus Venetus. In Tartaria leones alín nigrialin rubei coloris inueniuntur, Idem. Etalibi, $n$ prouincia $A$ bafix nafcuntur leones, leopardi, \& c, Et rurfus, In prouincia Gingui funt plurimi leo, nes, ut etiam præ timore eorum nullus audeat nocfu extra domos dormire: nam quofcunq inuenis unt lacerant atç decuorant. Naues qua afcendunt $\&$ defcendunt per flumen, propter leonum metú 49 ad ripam non ligantur, fed in medio fluminis anchor is eiectis retinentur, alioquin leones noctur nas ues ingrederentur, \& quicquid uiuum in eis reperirent deurorarent : ( quomodo capiantur int, dicam.)

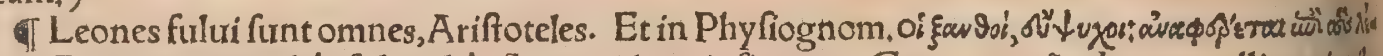

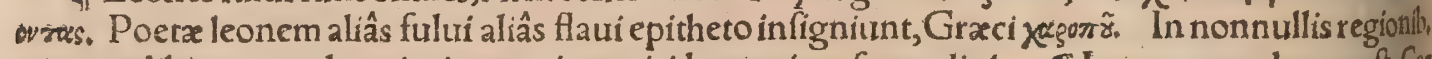
nigy:os, alibi ex cocruleo nigricantes inueniri leones iam fupra dixi. $\quad$ Leo corpore longo eft, $\mathrm{Car}$

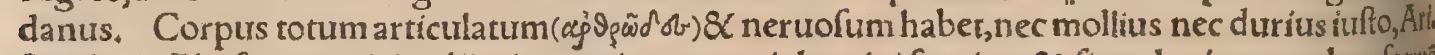
ftoreles in Phyfiognomicis, ubietiam totius corporis leonini fpeciem $\&$ fingula eius membra, formä uirilem(ideam uiri)præc cuncis animantibus maximé referre ait:ut pardaliñ, formineam。 Lco uali: dus eft pectore $\&$ priore corporis parte, ac degenerat pofterioribus membris, Macrobius . Interios so ra omnia canibus fimilia continentur, Ariftoteles. Interiora eius funt canis, $\&$ dentes eriam, nifi maiores funt:exteriora ueroficut cati, Albertus, Leonem fer arum regem effe argumento funt, pe cीus, genua, inceffus, faltus \& celeritas curfus, uifus, iuba, os caraphractum(nimirum dentibus)late ra firma, nerui folidi, ungues magni, nà $\beta \varepsilon \beta$ siós iqiou, Philes, TLeonum genus alterum bretius, crifpioréçs pilo eft, (crifpioribus iubis, Plin.)alterum longius piló́s probiore ( pilo reço \& fimplić, A elianus:longo fimplicíç uillo, Plinius:)idemóģ generolius eft, et uulnera contemnir:illud ignaurus \& pauidius, Ariftoreles. Pilus leoni non recius anterius, fed mollis ac flexus, breuior parte poftres ma, Cardanus. Quoniam pili tum plani rectiós $(\phi e \xi \xi a i)$ tum ualde crifpi timiditatem fignificantiquit

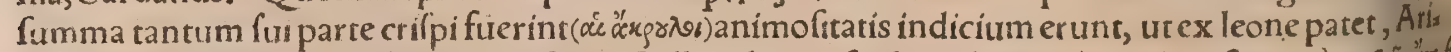

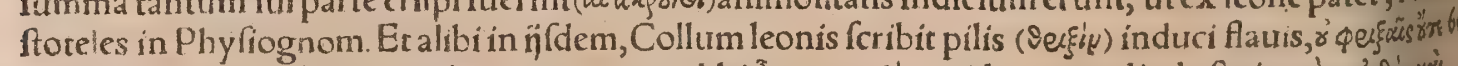
"̌́

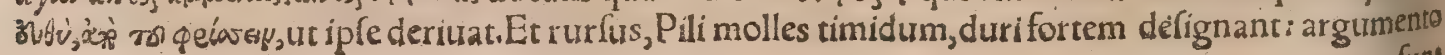


dit, Leo fupra frontem iuxta nafum (melius forte, èregione nafi) pilos habet inclinatos:poltrema uer

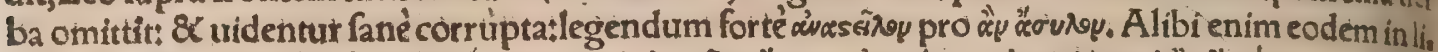

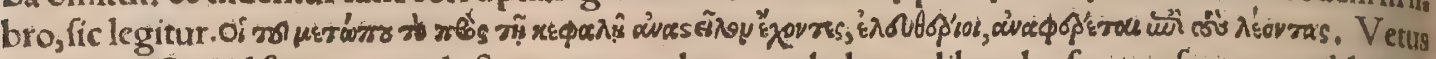
interpres, Qui id frontis quod eft ante caput eleuatum habent, liberales funt: referuntur ad leones;

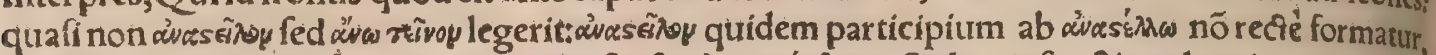

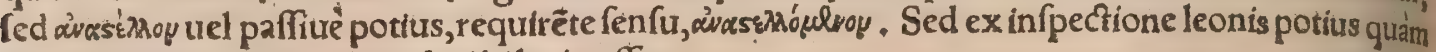
Grac lingux peritia emendari hi loci poffunt.

- Oculos habetcharopos, concauos, non admodum rotundos, nec nimium oblongos, magnitus dinemediocri.Calius tamen oculum ei permagnum effe fcribit. Charopi \& caui mediocriter oculi, leonis te admonebunt:ualde caui uerò maligni funt, 8 fimiam referunt, A damantius, Oculi partum cauí, animi magniturdinem innuunt, argumento funt leones, Ariftoteles. Frento canes paftorales

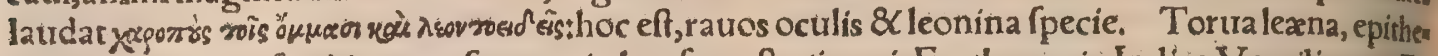
ton ex cculorum fauitia, qua fumma in hac fera eft, (inquit Erythraus in Indice Vergiliano:) Ex quo \& Ariftoteles leonem charopón trocat, quem Catullus cafium appellauit, id eft glaucum:quia glaucis oculis praditum hoc animal afpectu horribili apparet, Hac ille.Sed oculos glaucos \& charo, pos confundit, ut $\&$ alí quidam recentiores: A riftoteles manifeftè diftinguit, ut cum fcribit in Phyfio

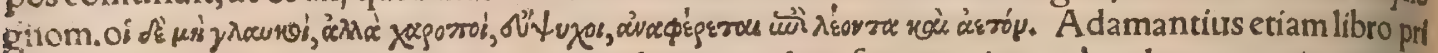
mo Phyfiognom. Oculi uarí, inquit, cum charopo colore frequentius quàm glatico contingunt, $E_{t}$ rurfus, Charopi bculia nigris trarietate differunt: fiunt autem pluribus modis:nam fi quis fimpliciter infpiciat, nigros putabit: fin accuratius, grana quæ dam uidebit, quorum qua dami ruffa funt, non ad, modum tamen, alia magis minúsue albałalia pallida,uel fimpliciter, uel ruffo fimul nigróué admix, ro:alia deníg cruenta, \&c. Qui plura fuper hoc colore defyderat, legat $\mathrm{C}$ alium 13.8. Leonum pus pillx prafulgent, \& dilucidiffimum continent humorê, ita ut uideantur ignita, Plutarchus $\&$ A phro difienfis: Plura uide capite fequenti de uifu ipforum. Acri funt intuitu leones, Cardanus, Leoocu lis patentibus atç igneis cernitur femper, Macrobius, A pertis eum oculis dormire ( propter gena fuperioris breuitatem) capite tertio dicetur. TSupercilium ei pragrande, Ariftot. IN Nafus craf:

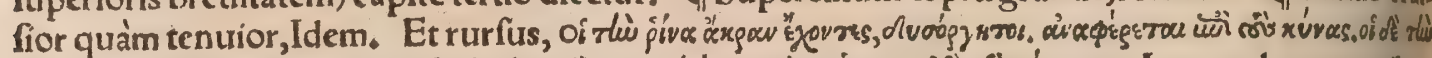

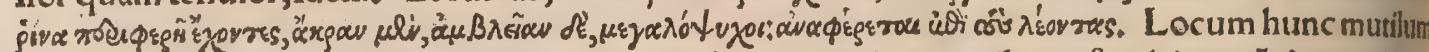
efle apparet:nec poteft ex ueteri translatione, ubi magis etiam mutilatur, farciri: ex. Adamantio po,

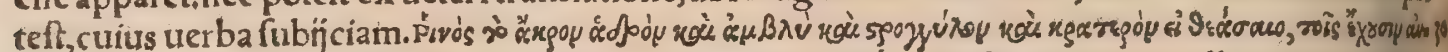

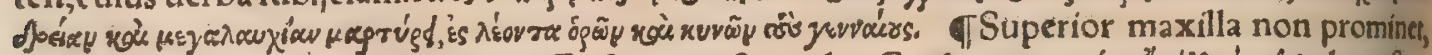

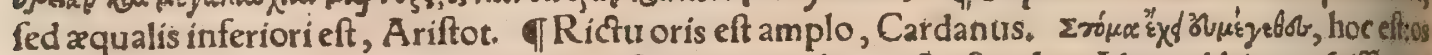
amplum habet (non, tit quidam uertit, iuft $x$ magnitudinis, ) A riftotel. Idem alıbi os refciftum ei tribuit. Labra tenuia in ore magno, ita ut partes fuperiores inferioribus fuperiniecta fint, eademí

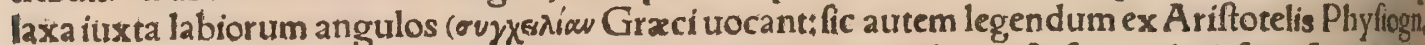

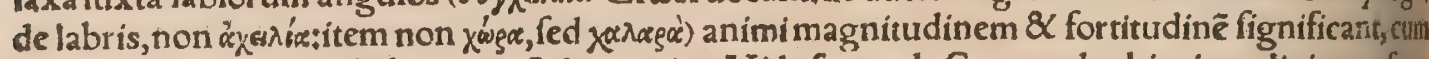
in leonibus huiufmodi habeantur, A damantius. Vide fupra de Cane H:d, ubi etiam diximus, fum mum leonis nafum rotundum, craffum $\&$ folidum effe. Tleo dentes habet ferratos, Ariftoreles, Dentibus ferratis prædita dicuntur, qux dentes teretes $\&$ acutos habent, ut lupus, canis, leo, Aelian, Eorum qua dentes habent ferratos nonnulla non amittunt caninos, ut leones, A riftoteles. Et alibi, 49 Dentes eos tantummodo mutat leo, qui canini uocantur (quod \& Plinius feribit) quatuor, duos fin

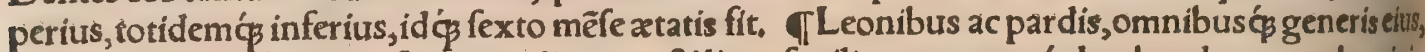
etiam felibus, imbricatæafperitatis lingua, $\&$ limæ fimilis, attenuansó́ lambendo cutem hominis, Qux caufa etiam manfuefacta, ubi ad uicinum fanguinem peruenit faliua, inuitat ad rabiem, Plin, Leoni ceruix offe uno rigida conftat, nec uertebris ullis iungitur, Ariftoteles $\&$ A elianus. Leoni \& lupo collum offe perpetuo riget, Ariftot.lib, 4 . departib. Ceruix leoni tantum \& lupo \& hyat na, ex fingulis rectisćs offibus riget, Plinius. Non conftat articulatis offibus, nec flectitur, fed feguil

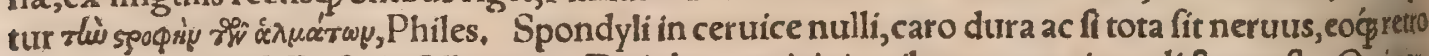
fpicerenon poteft,Rafis \& Albertus, De iuba ceruicis in pilorum mentione dictum eft, Quicers

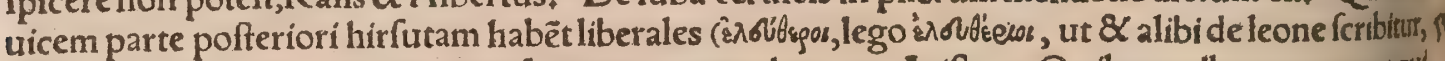
8 fic uetus interpres quoo uertit) funt, argumento leonum, Ariftot, Quibus collum magnum quil

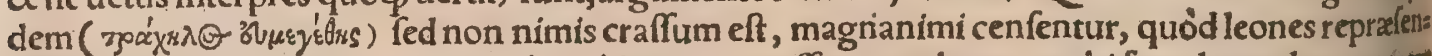
tent, Ariftot, Et alibi, Leo collum habet oblongum, craffum, moderatum: ubi forte legendum, non an

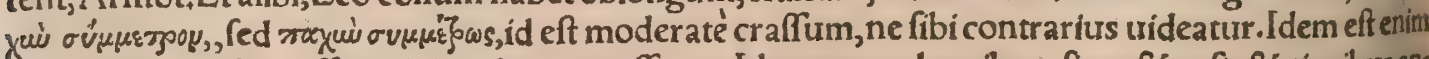
dicere, non ualde craffum, $\&$ moderate craffum. Ideo natura leonibus, ficut $\&$ urfis $\&$ tigribus an guftiora (breuiora intelligo) creauit colla: quia in terra ceruicem $\&$ ora non deijciunt pafcendi gra

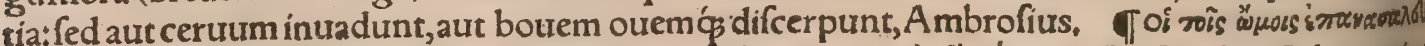

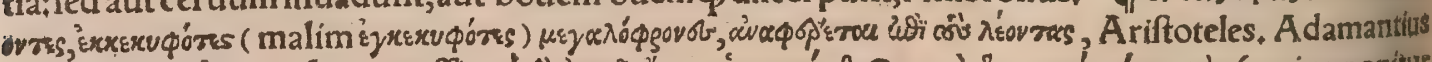

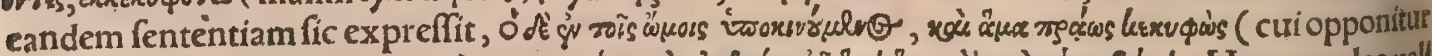

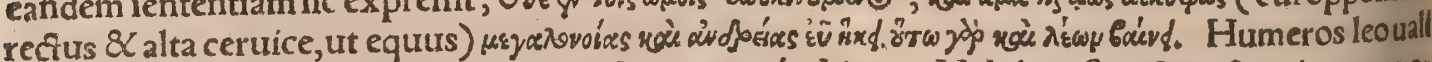
dos habet, Ariftot. बPectus quogs robuftum, veaviró, Idem. Validus eft pectore $\alpha$ priore corpo* ris parte, ac degenerat poftericribus membris, Macrob. Leoni uis fumma in pectore, Plinius, Pars 
dixit, At quondam Libycis leo dum mugiret arenis, forte quòd primàm uerbi rugire productere no, lebat. Rugitus leoni afper. Canes Albani ultra leones rugitibus infonant, Solinus, Fremereidê quod rugire: unde illtud aptid ueterem quendam poëtä, paufam fecêre fremendi, Varro àleonibis

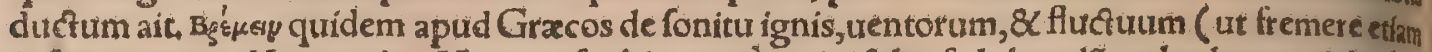

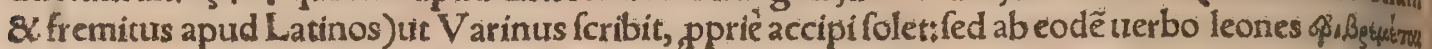
\& ojißß̨opuos à poêtis cognominantur. Fremere quidẽ \& fremitus apud Latinos, de equi etiam hínitu uftrpantur. Fremit leo ore cruento, Vergilius g.Aen. Vafto 8 graure murmur hiatu lnfremutit, Lucanus de leone. Leo in uriros pritus quàm in foeminas fremit, Plinius. A uditur quantum Malfy la per auia murmur, Innumero quoties fylua leone furrit, Martialis. Non fremit in infantes leo nifi magna fame, Plin,libro 8. Leo frendens, Silius libro 10. Ouidius in Arte antandi aprum fren

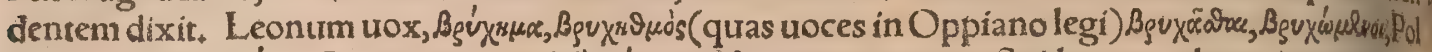

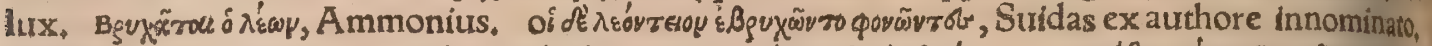

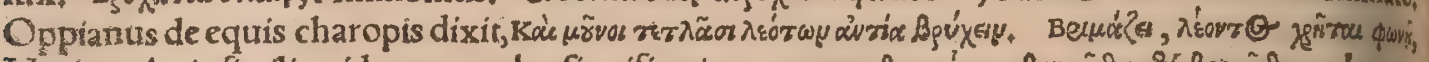

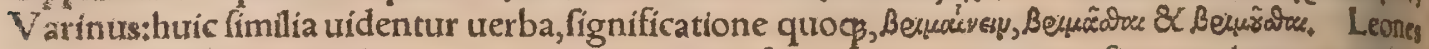
iuuenes pradam naci, clamore in uitulini mugitus formam contemperato, fignum dant, uocantẹffe niores, Plutarchus in libro Vtra animalium, \&c. Animalia fortia uocem ædunt grauem, ut leo \& taurus, Ariftot, in Phyfiog.

of Leo quamtuis in edendo ferociffimus fit,tamen paftus, 8 fame iam uacans, facilis mitisónma iorem in modum eft, A riftot, \& Philes, Satiati, innoxĭfunt, Plinius, In fame, fummo periculoeios curritur:poftea uerò quàm cibo completus eft, manfuef cit, \& fimul lufionibus delectari fertur, Aeli, anus. Non pafcitur mas cum foemina, fed uterq, feparatim: Vide capite quar to in fortitudinis iplor rum mentione. Vefritur leo carnibus crudis, unde cussis Oppiano dicitur, quarto de pifcatione;

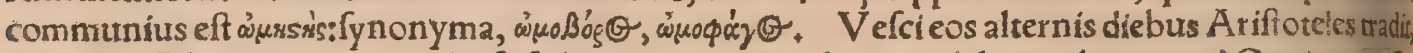
Plinius. Cibus einunqram deeft:fed per uices nuncedit, nunc laborat, (uenatur,) Oppianus. $C_{i}$ bo nunquam caret, quod ad illius inquifitionem haudquaquam fegnis fit, Aelianus. Non ueletut nifi ex uenatione, nec uenatur nifi femel in die, Auicenna, Leo animal eft ualde calidum $\&$ ficcum,

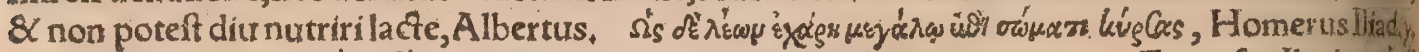

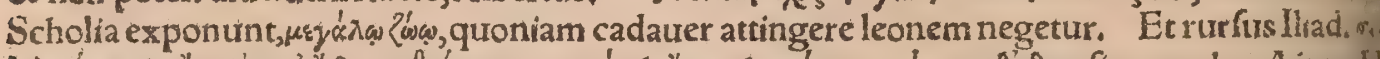

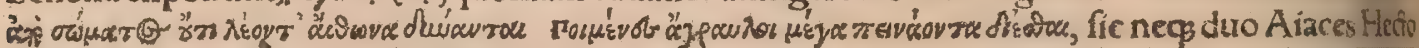

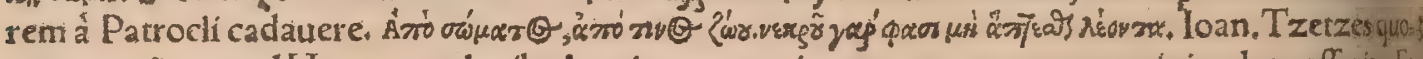
que 5.9. $\sigma \tilde{\omega} \mu \alpha$ apud Homerum de ciboleonis, corpus uiuum non morturum accipiendum afferit. Et praterea ibidem, Leones, inquit, $\&$ aquila cadaurera non deguftant: $(e d$ quod uiuum comprehetiligh rint edunt nec poftea ad idem, fi quid réliçum fit, redeunt. Cuius rel aliqui caufam afferunt fororê; mihi ueró per fuperbiam quandam id facere uidentur, cum in furo uterç genere regiam dignitatem

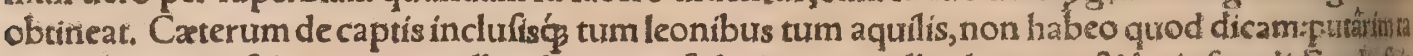
men nó mortua folum corpora illos deuorare, fed etiam ex melle placentas $\&$ huiufmodí. Et talis fuit leo quidam A pollonï temporibus (de quo dicemus in $H_{\text {, }}$.) quem ille A mafidis animam habereale bat, Hactenus Tzetzes, Leo uefcitur quidem carne ritu carerorum fylueftrium ferratorum, feddi bo incontinenter admodum utitur, multáç deurorat folida, fine ullo diffectu, mox nihil triduo, alt certe biduo edit: ferre enim inediam poteft, ut qui iam ad multam fatietatem repletus eft, Aviftoteles, 4 A faturitate leones interim triduo cibis carere Ariftoteles tradit: $2 \alpha$ qua poffint in mandendo folid deuorare(quod \& A elianus fcribit:)nec capiente aluo, conicctis in fauces unguibus extrahere, tth

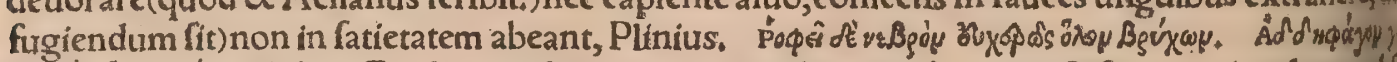

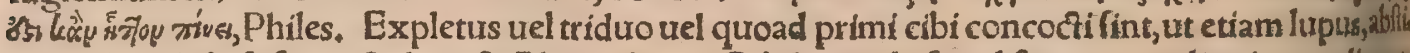
net, cubandó̧́ fe fouet, A elian. \& Plutarchus. Calida prada femel faturatus, reliquias amplus at tingere dedignatur, confidens nimirum nouam rurfus pradam fe poffe uenari, Philoftratus, $P_{21 i}$ ter omnes parcuntà fagina:primum quơd alternis diebus potum, alternis cibum caplunt;a frequen ter fi concoctio non eft infecuta, folitx cibationi fuperponunt diem: turm quỏd c'arnes iufto amplius deuoratas, cum grauantur, infertis in ora unguibus, fponte protrahunt. Sané \& e crm fugiendum of in fatietate, idem faciunt, Solinus. Saturatus leo carnibus alicuius fer $x$, rellquias aperto gutture luo halitu infpirat:unde ita foetent, ut à nullo animalium attingantur:poftridie ad uenationem rediens, fi quid recens affequatur, hefternas reliquias contemnit:fin minus, ad eafdem redic, Philes 8 Adlia nus. Contacta halitu eius nulla fera attingit, \&c. Plinius: Vid epaulò inferius in mẽtione excremen torum eius. Saturitatem dierum inedia, uel fimia deuorata uomitionibus purgat, Volaterrantus, Sed de remedio eius ex fimia, infra dicam in morborum eius mentione, Quañã animalia inuradar, fiue cibi tantum gratia, fiue etiam naturali quodam odio, capite quarto dicetur. A deunt urbes, \% iniuriam hominibus inferunt, potiffimum tempore fure fenectutis:tunc enim per corporis imberilis tatem, $\&$ dentium defectionem uenari nequeunt, Ariftoteles. Leones $\&$ lupicum per ætatem uena ri non poffunt, uillas accedunt, ubi homines inuadunt, 8 rapiunt pueros, Albertus, Leofenex c ztate proceffit et animus(uis) uenandi deeft, ad frabula $\&$ paftorum cafas proficifcitur, quôd iam ad montanas pradas perfequendas infirmus fit, Aelianus 8 Philes, Stabula paftorum armenta ith uadit fame compulfus, ut Homero placet, Nomen authoris excidit: Intelligit autem forte de loco 


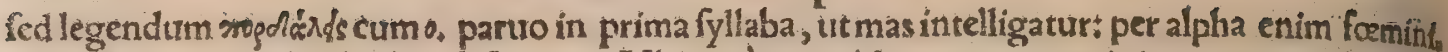
num eit) in leonum cubilibus fufcipere. Vbi uerò pariendi tempus appetit,ín montes confugiunt, (\& lora pardalibus confueta) pariunt autem maculofos catulos : propterea in denfifinzis fyluis oc cultatos nutriunt, fimulantes uenationis caufa fe à maribus abeffe. Leones enim fi catulos deprehen

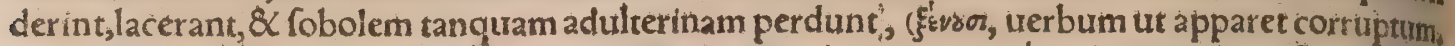
Interpres inepiè uer tit, matremç̧ tanquam adulteram abigunt:ego ģécuren legerim, hoc eft unguibus uulnerant $\&$ lancinant.) Hyanæ coitu lexna Aethiopica parit crocutam, Plinius \& Solinus. At: cadiccs canes $a b$ initio ex canibus $\&$ leonibus prognatos dicunt, $\&$ uocatos effe $\lambda \varepsilon 0 v r o \mu \gamma \varepsilon \hat{s}$, Polltix \&. Cxlius, Calius Rhodig. 7.34. fcribit felegiffe apud authorem fidei integra, ouem fuiffe in $C_{0}$ infula de grege Nicippitqua non ritu naturę agnum, fed monftrifico partu leonẽ pepererit:quodipfî Nicippo tyrannidem portencebat, 'quam mox affecutus eft, quum ædito monftro hominem pritua turn adhuc ageret.

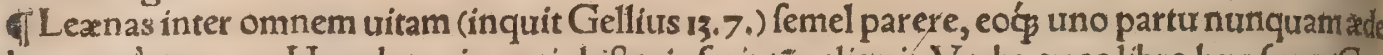
re plutes quà̀m unum, Herodotus in tertia hiftoria fcriptuี reliquit. Verba ex eolibro hac funt: (Gra ca à Gellio pofita omirtam, Latínis propter breuitatem contentus.) Animalium acerrimum leanąt audaciffimum, femel omnino in uita $\&$ unum parit. Enitendo enim cum foetu pariter matricem pros rijcit, Rei uerò huiufce caufa eft:quod cum in matrice manens motitari incipit catulus : motus illeun guiculis præmunitus ferarum longéomnium acutiffimis matricem difcerpitttum in maius continuó augefcens, multó magis ungues imprimendo exulcerat, ita ut ad poftremum dum partus adeft, nihil de utero relinquatur incolume. Homerus autem leones (fic enim forminas quog epicano getere

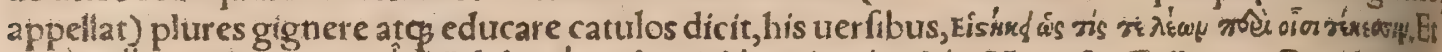

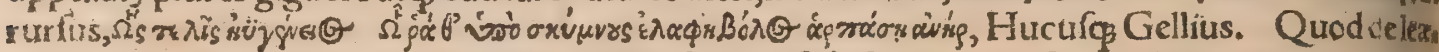
na fertur, unluam cum partu emittere, delira fabula ef, facta ex ea caufa, quod rarum genus hoc an malis ef: $n$ ec rationem cur ita eflet, comperire author ille fabulæ poterat; rarû bec enim eft, necmul tis nafcitur locis, A riftoteles. Semel $x$ di partum, lacerato ungurium acie utero in enixu, tulgum ers didiffe uideo:Ariftoteles diuerfa tradit, Plinius. Quod in fermonem hominum uenit, fabula eft, ca: tulos uuluam dilacerare, Aelian, \& Philoftrat.Idem tamen Aelianus uariæ hift, lib, 1o, hoc eos facere

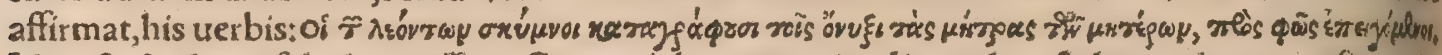
Idem $8 \times$ A efopus fabullator afferit: Contendebant (inquit) olim uulpes \& leana de generoficute: in ter alia quum uulpes ofífcer et, leanam unum femper parere, fuum treró multiplicem effe partum, inç̧ co fibi placeret plurimum:refpondit leæna, parere fé quidem unum, fed leonem. Quod 8 in ada gium uertitur (inquit Calius) quum uirturem ac animi excellentiam fpectari oportere, aftruimus, non uilem numerum $\&$ inutilem. Leanæ fatus intra duos menfes perficitur, Fhiles. Geftarefer tur in utero menfes fex, Philoftratus. Lexnæ paulatim fterilefcunt, cb nimiam foecunditatem prih mam:primum enim quinç aut fex pariunt catulos, tum annofecundo quatuor, mox tres; deindepa ri modo per annos fingulos minus uno, poftremo nullum,cum \& excrementum omne cófumptum iam fit, \& atate definente femen unà defecerit, A riftoteles. Leanam primo foetu parere quinq̨ tas tulos, ac per annos fingulos uno minus (deinde per fingulos partus numerum decoquere, pro minte re.Solinus) ab uno fterilefcere, Ariftoteles tradit, Plinius . Idem feribunt Solinus, Oppianus, Phis les, Aclianus. Hic infuper addit peftremo parte unum cmnium praftantiffimum leonum regema" di, Sed hor idem Ariftoteles alibi de Syriacis priuatim fribens, Leones, inquit, terra Syriæquin, quies urita pariunt:primum quinç, pòft uno fubinde pauciores, deinde fteriles degưt. Cur animan tium alia partu funt numerofo, ut fus, canis, lepus:alia non, ut homo, leo? An quod alia uuluas firet teros continent multos, totidemó formandi loculamenta, quibus impleri percupiunt, quibusíg les men genitale diuidendum, inferendumós eft : alia contra fe habent, Árifoteles problematum ie,16, A pollonio \& comitibus (inquit Philoftratus lib, 1.) ftadia uiginti Babylone progreflis, leana inith nere occurrit à uenatoribus interfeça : erat autem fera ing inti magnitudine, quanta antea uifa non fuerat. Círca hanc clamor erat magnus uenatorum, \& eorum qui ex proximis uicis ad uifendamfes ram concurrerant, qui magnitudinem infuetã $\&$ præterea maius aliud in illa admirabantur:cafo nim uentre catulos octo in utero habentem inuenere. Traduntur autem de lexnæ partu huiufmodit geftare leanam in utero fce rum menfibus fex, ter $\not$ s omnino in tota uita parer e:parit autem (ut aiüt) prima quidem uice tres, fecunda autem duos:quód fi tertiò forte parere illam contingat, unum dun taxat parere confueuit, quafi natura uolente rariora producere qua magnam in fe feritatem habêt";

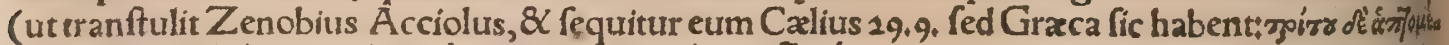

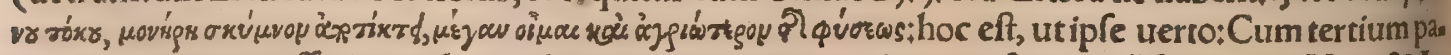
riendi tempus accefferit, catulum ædit unicum, magnum nimirum \& ingenï ferocioris. $N a m \& A c$ lianus fimiliter fcribit, ut paulo fuperius retuli.) Cötemplatus igitur feram A pollonius, cum aliquâ diu tacitus perftitiffet: $O$ Damis, inquit, noftra ad Indorum regem peregrinatio annua futura eft, $\&$ praterea menfium ocfo. Hoc autem ex catulorum numero conijcere licet, quorum finguli fingulos denotant menfes:ipfa autem lexna integrum annum nobis defignat : perfecta enim perfectis confe to renda funt, Hre Philoftratus. Minus autem mirum eft tot catulos leanam illam concepiffe, cum omnium admiratione fpectantium maxima furerit. Leana (inquit Auicenna) rarò generat, \& ad 
652 DeQuadrúpedibus

femper quartana laborar, \& tunc maximé carnes fimia appetit ut fanetur. Idem haufto fanguinec nis morbo fuo medetur, Phyfiologus. Sic. $\&$ Albertus, Potatus aliquando fanguine canis fanatur, Sed neuter ulla ueteris alicuius fcriptoris atthoritate nititur. Plinius non in febri fed faftidio, fan. guine fimiæ non canis ipfum fibi mederi ait, his uerbis: A egritudinem faftidn tantum fentit, in qua medetur ei contumelia, in rabiem agente annexarum la ciuia fimiarum: Guftatus deinde fanguis in remedio eft. Continue febrim quartanam pati fertur: fed hoc pro cer to falfum eft; quia natura nul, Ium animal facit, nífi xqualitatem habeat temperamento fux fpeciei debitam, in qua quidem fanum degir, Albertus. Aeyrotanti leoni nulla poteft alia medicina adhiberi: fed fi comedat fimiam, id ei morbi remedium exiftir, A elianus in Varijs 1.9 . Et rurfus in hiftoria anim. Leoni, inquit, \& delphino multa funt communia. V terq; imperat, ille terrenis, hic aquatilibus beftijs: fenećtute ambo tabefcît, \&i cum funt in agritudine, illi terreftris fimia medetur, huic marina quogs fimia remedio eft. Et alibi, Supra quàm ferre queat cibo expletus, aut quíete $\&$ inedia fe exhaurit, aut fimiam nactus uorat, illi, usís adefis carnibus urentrem mollitum extenutat. Leo faturitatem dierum inedia, uel fimia detroia ta uomitionibus purgat, Volaterranus fine authore:prioris tamen remedip, per inediam dico, autios res habemus. Sed tromitionem pro faftidio uertiffe uidetur ex Graco vau zic, nec uerborum ordinem reçè percepiffe. Simias maximi faciunt Indi, quoniam piper is (ut fic dicam) uindemiattices funt; quapropter $\&$ armis $\&$ canibus leones, $\&$ cateras feras ab ipfis arcent. Infidiatur autem fimia leo, agrotus quidem medicinæ gratiałaiunt nangs fimiarum carnes leonum morbis mederi: fenefens autem, paftus cibíģ caufa. Nam ubi propter fenium ceruos aut apros uenari leones nequeunt, fimis as capiunt, in ipfas quodfupereft uirium exercentes, Philoftratus, Lupus 8 leo pro remedinse. dunt gramen, \& herbam frumenti, \& rapefta, (rapiftrum).qua uomitum prourocant, Niphus,

iT Viuere annos multos putantur, \& quidam qui captus eft claudus, dentes complures fracios habebat:quo argumento quidam longam effe leonum atatem exiftimarunt : haud enim hoc accide re, nifilongo tempore potuiffe, Arifoteles. Et Plinius, Ariftoteles (inquit) uitam leonibus longam efre docet, argumento, quòd pleriç, dentibus defecil reperiantưr. Viunt \&leones \& lupi permul tos annos, ita quòd aliquando ob fenectutem fiant edentuli, Albert. Leo fenecturte tabefcit, utetam delphinus, Aclianus,

Animos leonum frons \& cattda indicant, Solinus, Ex cauda quomodo de animo cius iudicants dum, uide infra ex Plinio, ubi de fortitudine eius dicemus. Sunt quadam corporis partes, capitefe; cundo à nobis explicatæ (ut pili,frons, oculi, nafus, labia, collum, humerorĩ in inceffu motus) quibus qui leonem referunt, fimiliter ut ille magnanimi, fortes, \& liberales effe iudicantur. A rifotelesin Phyfiognomicis cum corpus leonis defrcipfiffet, idç's uiri ideam maximè repręfentare demonftraflet, ut pantheram forminx, corpore fimul $\&$ animo:qui in uiris, inquit, fortior eft \& iuftior, in fominis

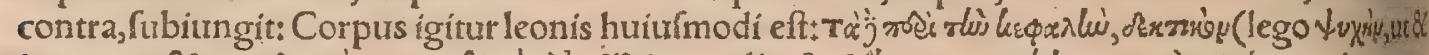

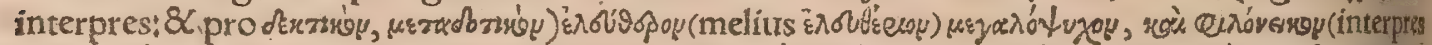

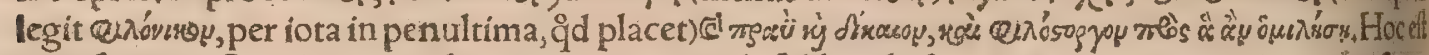
ut ipfe uerto, Quod animum leonis attinet, animal eft liberale $\&$ ingenuum, magnanimum, uicori: fudiofum,mite, iuftum, \& pio quodam amore in eos quibus cum uerfatur afficitur. Leonumge nus breuius crifpioré́s pilo, ignauius eft:alterum longius pilọ́ probiore, generofius, Ariftot. Vit fupra capite fecuindo, ubi etiam fecundum regiones diuerfa eorum ingenia effe, ex Alberto it cenfuiv

ब1: Paftor fape in paftionibus(uenator in montibus)leonem afpicit pro catulis acerrimé propugr nantem, \& præclarè contemnentem factam faxorum lapidationen, \& crebram miffionem telorumi neç uel infinitis uulneribus confectus, inuicto robore animi prius omittit cos tueri, quàm omino moriatur:neç enim fané tantopere fua morte mouretur, quàm ut ne $a b$ antro fui catuli abripiantu Gillius: tranftulit autem ex Oppiani de pifcatione libro :. Aiaxcirca Patrocli cadauer ftabat, is

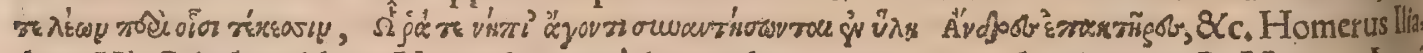
dos e.H Hîc Scholia addunt, Notandum quòd etiam leones mares, catulos ducunt, At Varinus, Leonê ( $\lambda$ sev $\sigma x)$ inquit, ueteres obferuarunt Iliadis $\rho$. de foemina dici, tanquam lexnam foeminino generepro

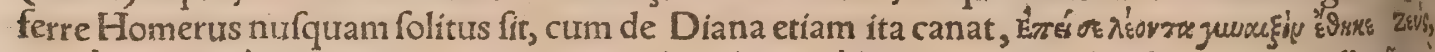

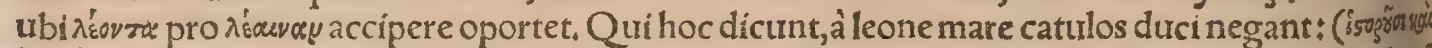

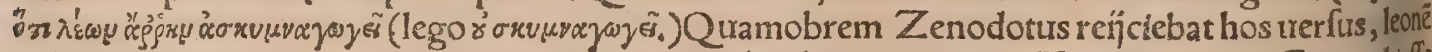
iple de mare tantum intelligens, marem urero catulos ducere negans. (Negationem in Graco deeffe apparet.) Atqui Antimachus \& alij à leone mare catulos duci affirmant, Hac ille. Gellius quidem 13.7. (ut pracedenti capite recitaui) leonis uocabulum epiconum effe, 8 de foemina quoq accipt ait,id quod nos pluribus in Philologia probabimus. Mihi certe leonem marem, tam forte $\&$ generos furm animal, ut maris ideam maxime omnitum repręfentet, quod foeminæe etiam urenando fe adiunges re non folet, fcemineum catulos circunducendi officium fubire, uerifimile non fit. Philoftratur qul dem in urita Apollonï, ețfi lexna nomen aliâs ufurpet, tamen libro fecundo iam dictum Homerilót

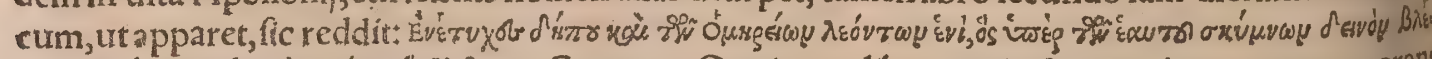

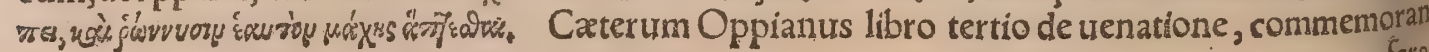




\section{4

dant, uocantós fenes:illi fatim ut fenfere accurrunt, ac in commune prada frưntur.

TLeones liberales, fortes $\&$ nobiles funt, Ariftoteles. Nihil fúpicatur leo, nullizs furpiciofus eft:feftiuus, ludibundus, beneuolus admodum fuis cum fecrïs $\&$ familiaribus, Idem. Leo amathor mines cum quibus confureuit, pracipuè nutritores fuos, Albertus. Dolis carent \& fufpicione: nec limis inturentur oculis, afpició̧ fimili modo nolunt, Plinius. Nunquam limò uident, miniméģ fe uro: lunt afpici, Solínus. Creditum ef à moriente humum morderi, Iachrymamć́ leto dari,Plin. Leo. ni tantum ex feris clementia in fupplices:proftratis parcit: \& ubi faxit, in uiros prius quàm in foemts nas fremit, in infantes non nifi magna fame, Plinius. Scribit Auicenna(inquit Albertus)fi quis lapi dem aut telum leoni immiferit, $\&$ aberrauerit, ita ut uel nihilladat, uel parum, leonem irruere in it. lum folere $\&$ minari (terrere)non tamen interficere: (ed forte tantundem incommodi relaturü quan tum ipfe accepit; addit etiam hiftoriam militis à quo ipfe audiuerit, hominis fide digni . Exiueratille cum focn̈s in dextrarïjs (equis) ad contemplandum leonem. Dextrarï enim non caftrati \& fortes ea funt audacia ut ultro in leones pugnandi gratia ferantur (hoc de charopis equis, id eft quorum f́j funt oculi uel raui, Oppianus feribit) caftrati uerò adeò timent ut nec calcaribus nec flagris adigi poffint ut propius accedant. Equitantes igitur illi inuenerunt tres leones pariter, quorũ uni quidam ex eis fagittam immiffurus aberrauit, fagitta prope caput illius traiec?a. Quod animaduertensleo, fubftitit aliquantifper, cateri duo praterierunt non uelociter fugientes: quos ille paulò poft fecutus eft. Tum miles idem, qui fagitram prius emiferat, in equo ad eũ feftinauit antequam alís duobus leor nibus coniungeretur, \& lancea confodere conatus elt:fed iterum uano ictu percuffit terram,tangè aliquantulum fine uulnere caput leonis, \& fimul de equo ad terram delapfus eft. Leo autem accur is rens, militis caput in galea compreffit lafitó, , ed non uulnerauit negs occidic eum, 8 mox alios leax nes fecutur eft. Hic igitur eft mos leonis, ut tantundem ferè ladat quantum lafus eft ipfe, \& unguih bus quafi minetur caftigetós hominem, ato ita dimittartid quod de lupo etiam fertur, Hacienus Al: bertus ex Auicenna. De hac leonis ceu iuftitia quadam in ulcifcendo iniurias, plura dicemusinfra ubi de fortitudine eius priuatim agetur: \& quàm diligenter percufforem obferuet, ibidem. Recen tior quidam parum idoneus author libri de naturis rerum, nefcio quam feram melofum appellar, qux ualde magna fit $\&$ truculentos hoftes (uerbis eius utor) perfequatur, tanquam ad hac creata, Rictus (inquit) habetingentes, dentes quog fortes 8 prominentes, quibus cum audacter aduerla ros aggreditur, Et cum hominibus fortibus terribilis fit, puerorum tamen innocentiam \& eorú par,

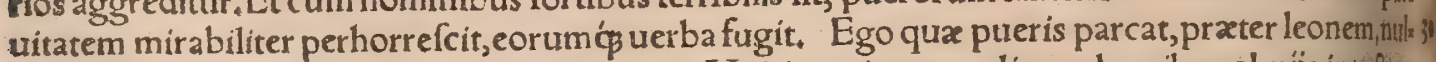
lam apud clafficos feriptores beftiam inuenio. Multi captiuorum aliquorleonibus obujps intacitit patriauerunt, Solinus, Credit Libya intellectum prouenire ad eos precum. Captiuam certe Geru lix reducem audiui, multorum in fyluis impetum à fe mitigatum alloquio, auf $x$ dicere fe foeminam, profugam, infirmam, fupplicem animalis omnium generoliffimi, cæteris ç imperantis, indigname ius gloria prædam. Varia circa hac cpinio ex ingenio cuiufos uel cafu, mulceri alloquins feras: quip. pe \& iam ferpentes extrahi cantu, cogíg in poenam, uerum fallüumue fit, uita non decreucrit, lilin, Getulæ mulieris nomen Iuba libris comprehenfum eft, qua obteftata occurfantes feras, impuniste dijt, Solinus. Leo in uulnera aut morfus non affurgit, fi qui proftratus ab eo eft, quibufdam indicis uictum fe fateatur, Eam ob rem ferunt hoc diftichon pro foribus Romani palatĭ inferiptum fuifer Iratus recolas quàm nobilis ira leonis, In fibi proftratos fe negat effe feram, Textor. Deleonibus \&lupis fertur, fi inter hominem 8 aliud animal optio detur, parcere eos homini, Albertus. Strntur ro $\&$ fortuita eorum clementix exempla.Mentor Syracufanus in Syria leone obuio fuppliciter tio lutante, attonitus pauore, cum refugienti undiç fera opponerer fefe, \& ueftigia lamberet:adulant fimilis, animaduertit in pede eius tumorem uulnus $\varphi_{\beta}, 8$ extracto furculo liberauit cruciatu. Pictura cafum hunc teftatur Syracufis, Plinius. Et mox, Similimodo Elpis Samius natione in Africamder latus naue, iuxta littus confpecto leone hiatu minaci arbor ẽ fuga petit, Libero patre inuocato: (quo niam tum pracipuus uotorum locus eft, cum fpei nullus effi) neç profugienti, cum poturffec, feraint ftiterat: \& procumbens ad arborem, hiatu quo terruerat miferationem quarebat. Os morfu auidios re inhæferat dentibus, cruciabatćs inedia, tum pené in ipfis eius telis fufpectantem, ac uelut murio precibus orantem : dum fortuitu fidens non eft contra feram, multo diutius miraculo, quàm 8 metu ceffatum eft. Digreffus tandem euellit prabenti, \& quàm maxime opus effet accomodant Traduntós quàm diu nauis ea in littore ftetit retuliffe gratiam uenatus aggerando.Qua de caufa $L$ ir bero patri templum in Samo Elpis facrauit,quod ab eo facto Gracilszuóror scovur appellateré, Miremur poftea ueftigia hominum intelligi à feris, cum etiam atxxilia ab uno animalium fperêt. Cur enim non ad alia iêre? aut unde medicas manus hominis fciunt? nifi forte uis malorum, etiam feras omnia experiri cogit, Hucufog Plinius. His adiungam Androclis ferui hiftoriam, quem leo fugiti uum in A frica triennio nutriuiffe, \& poftea feris obiectum(inter quas fortuito idem leo tum captus erat) 2duerfus pantheram defendiffe fertur, ex A eliano \& Gellio 5. 14. Cum à fenatore Romano, in quit A elianus, feruus, cui nomen Āndrocles erat, aufugiffer, quia facinus quodpiam nefarium (id vero quale fuerit ignoro) admififfet, \& uerò in Africam ueniffer : relictis urbibus in déertiffimam proceffit regionem, (Quum prouinciá A fricã proconfulari imperio Androclis ferui Daci dominus obtineret, Androcles iniquis 8 quotidianis uerber ibus ad fugam coactus, ut à domino terræ illits 


\section{6 \\ De Quadrupedibus}

urfa inter fe colluderent, \& ludicris morfiunculis conflictarentur, urfam repente ad feros mores re uertiffe, $\&$ canem fimul inuafiffe, $\mathcal{Q}$ uentre mifero unguibus indigniffimè diftraxiffe tem facti leonẽ indignatum, perfidix urfinæ odio, quod $\&$ fordus frègiffet, $\&$ amicitia inftitutam uio laffet, inflammatum, iufta $\&$ merita iracundia contra urfam $\&$ exarfiffe, $\&$ ab ea pares poenas, quia bus illa prius canem affeciffet, repetîffe, Aelianus.

बIoan. Rauifius Textor in Epithetorum libro leonis hiftoriam feribens, quales ba feræerga fail ctos aliquos $\&$ martyres ad ponam eis obiectos, fe præburerint, recenfet:cuius nos hic uerba recita. bimus, or dine quodam literarum, de uiris primum fanctis, poftea de mulieribus $\&$ uirginibus, Scien dum eft autem hanc in martyres leonum clementiã, non ex ipforum natura, fed maiore ui profectã,

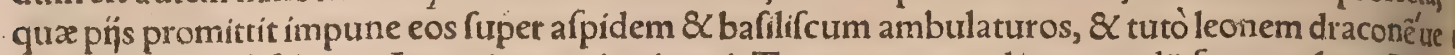
conculcaturos, $P$ fal.91. A ntonio eremitx, inquit Textor, quum ad excauandã foueam ( $q u a P_{\text {auli }}$ primi anachoretæ humaretur cadauer) farculum deeffet, duo leones terrã unguibus effoderunt, $a c$ foffarñ feu(fi mauis) libitinarï fubier unt munia. Daniel propheta à Babylonijs in carcerem conic çus, famelicisḉ leonibus (quibus dietim ad efcã duo damnatorum corpora, ac totidem dabantur ou ues)deuotus, eifdem tamen manfuefactis, periculum euafit: Vide in hiftoria Danielis, cap , 6.\& 14 * de Daniele bis obiecfoleonibus, bis feruato, $\&$ mox iniectis illis qui eum falfó accufauerant, detrota tisćs. Eleutherius \& Prifca uirgo leones(quibus hæc Claudị Cæfaris, ille Adriani mandato fuerắt deuroti)manfuefecerunt, cicures ́q́ reddiderunt. Macarius cum leænæ (cuius cauernæa cellam habe bat uicinã) catulos cæcos uifu donaffet:belua præftiti obfequin gratiã referens, pelles ouiũ eidem plu rimas memoratur attuliffe. Primo \& Foeliciano martyribus adducti ad tormentũ leones, nihil tamể nocuerunt. Tharaco martyri blanditus eft leo, cui maximi prafidis iuffu datus fuerat in pabulum, Vitum, Modeftum, \& Crefcentiam martyres quum Diocletianus leoni obieciffet deuorandos, fama eft beftiam columba mitiorem ad eorum pedes fupinam decubuiffe, neç ulla in refanctis incommo daffe. TFerunt itidem leonem pedibus terram effodiffe, ubi conderetur Mariæ A egyptiacx cadau trer, id ạs Zozima abbatis mandato. Irruentibus in Teclam uirginem urfa \& leone, acerrimocon, fliciu lexna reluctata eft, folo feruandx puella defyderio. Martinam uiri confularis filiam quum nullæ terrerent catenæ, nulla à fide uerbera dimouerent, nulla ad A pollinis cultum pollicitationes inducerent; leo Alexandri imperatoris iuffu cauerna eductus, fefe ad uirginis pedes blandiente cau da, armis \& $_{\text {Q }}$ iuba demiffis inclinauit, qui tamen ad inferendam mortem fueratfolutus. Daria uir ginis fub imperatore Numeriano beftís adiudicatæ leana cellam ingrediens, puellam ab omni init:30 ria non ferarum modo, fed fatellitum quo os tutata eft, $\mathrm{Hac}$ omnia Textor. Ignatius epifcopus An tiochenus, itẽ Satyrus \& Perpetua martyres leonibus obiecti, ab eis deuorati funt, ut referamin h,

बLeo ideã maris maximè omnium refert, ut pardalis foeminæ, Ariftoteles \& Adamantius, Leo ut animofus $\&$ fortis eft ingenio, ita corporis forma id præ $f$ fert, Adamantius. Iracundumgenuit natura, utpote fortiffimum, Cardanus. Leonum animi, inquit Plinius, index cauda, ficut \& equorï aures. Nan 8 has notas generofiffimo cuiç natura triburit. Immota ergo placidus, clemens, blants dientiós fimilis, quod rarum eft:crebrior enim iracundia eius. In principio terra uerberatur: inctia mento rerga, ceu quodã incitamento flagellantur. Cum blanditur caudã habet immobilê:iratusu? ro quatit, primo terrã, poftea dorfum, \& fic infilit, Albertus, Vide etiam fupra capite fecundo incalts damentione. Alexander A phrodifienfis problematum 1.144. ad quaftionem cur plurima ex anil malibus fuas peruibrare caudas foleant, cum notos fibi agnofcunt: \& cur leo iratus coftas per cardă

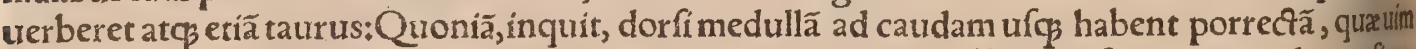
continet animale, $\&$ motionis authorễigitur cum animal notum fibi agnof cat, per caudã quafiper manum ritu hominum excipit, \& partê fui corporis mouet qua agilior \& promptior eft. Leonumule ro $\&$ taurorum anima, ut per iram affici poteft cum natura, fic eandem naturã propterea motreriute hementius cogit, ut etiã homines fxpe manus, aut aliquã fư corporis partẽ per iram percuterenoulis mus. Cum enim ilico ulcíci animus nequeat, alio quodã modo feruorê fuum extinguit, id efticul, aut frepitu, aut alio quolibet generis eiurdẽ remedio, Hæc ille . Leo ne quid ignaué faciat, flagela âs femetipfum cauda excitat, A elianus. Hoc $\&$ Lucanus innuit libro 1.Pharfalia, Cæfarẽ ante tranfi: cum Rubiconis de inuadenda patria cogitantẽ , leoni comparans, ubi ait:

Inde moras foluit belli, tumidumó̧ per amnẽ Signa tulit properełficut fquallentibus armis Aeftifer Libyes, uifo leo cominus hofte Subfedit dubius, totam dum colligit iram.

Mox ubi fe fæuæ ftimulauit uerbere cauda, Erexitós iubas, uafto \& graure murmur hiatu

Infremuit:tum tortaleuis filancea Mauri Hæreát, aut latum fubeant uenabula pecius,

Per ferrum tanti fecurus uulneris exit. Non poflum praterire eadem de re elegantifintiog etiam Homeri uerfus Iliados ypfilon, qui funt huiufmodi:

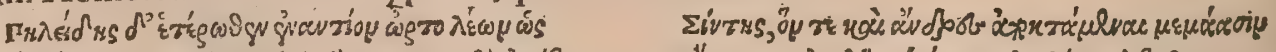

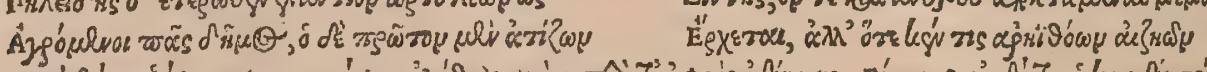

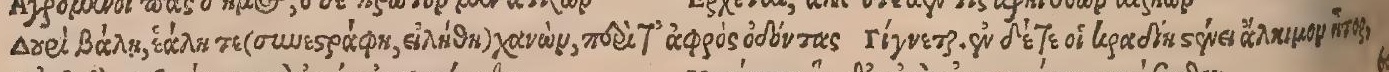

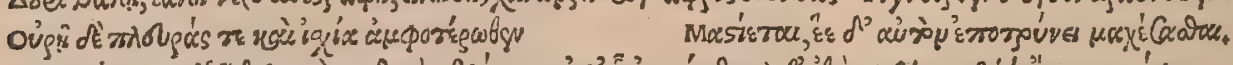

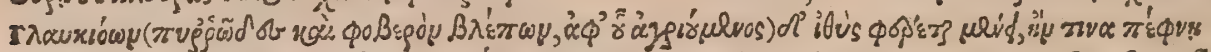

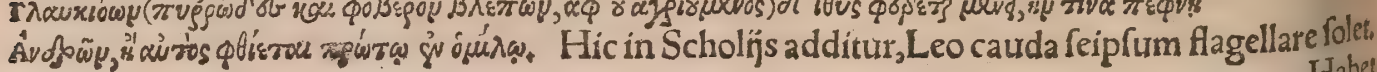


fur 8 fame iam uacans, facilis mitisćs maiorem in modum eft, Áriftotels، A prima atate cicul factus, cum manfuretiffimus eft, tum uero eius occurfatio facillima et iucunda: lưfionibus delectatur: quiduis, modò id futo altori gratum effe fentiat, libenter fuftinet, Aelianus; Et rurfus, Cibo comple turs manfuelcit, \& fimul lufionibus delectari fertur. Leo perfacilis eft ad ludendum : fed ludi eius frequenter malè exeunt, nec ante multum temporis ludum defèrit, Albertus. Leonibus manus mas gifter inferit, of culatur tigrim fuus cuftos, Seneca in epiftolis, Er rurfus, Tigres leonesćs nunquant feritatem exuunt, aliquando fubmittunt, \& cum minime expectaueris , exafperatur toruitas mitiga ta, Leones iugum fubcunt, Plinius: Vide capite quinto de leonibus ad fpectacula adhibitis:ubi $M_{4}$ Antoním primum eos lugo fubdidiffe dicetur. Plutarchus in Politicis praceptis, Annonèm coan ctum fribituertere folum exilñ caufa, quod in expedítionibus leonem haberet $\sigma x$ sloфógoy, id eft far,

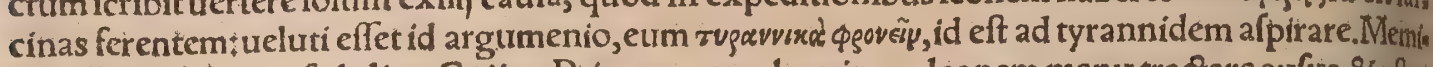
nit hiftorix Plinius, fed aliter, Cxlius, Primus autem hominum leonem manu tractare aufus, 8 offen dere manfuefactum, Hanno éclariffimis Pœnorum traditur:damnatuś́ illo argumento, quoniam nihil non perfuafurus uir tam artificis ingenij uidebatur : $\&$ male credi libertas ei, cui in tantumcefr fiffet etiam feritas, Plinius. Hanno Carthaginenfis leonem, quo ad uectiones farcinarum utebattri, habuit, uná̧̧ cum Berenice manfuefaçus leo uiuebat, lingua ó ceitus faciei blandiebatur, leniter ab. ftergës, ac complanans rugas, demulcebat, cum eaćs in menfa conuiuebat, humaniter $\&$ apte come dens. Onomarchus Catanæe tyrannus etiamleones habuít conuictores, Aelianus, Et alibi, In Ely, imaa regione templum eft $A$ donidis, ubi leones tantopere cicures funt, ut eos, qui intra templũ ingre diuntur, amplexentur, $\&$ adulentur. A tक̧ etiam fi quis edens appellet, $і$ i tanquam inuitati conuiu, accedunt, \& acceptis qua eis prabuerit, moderate difcedunt. Leones in India, fi capiantur, mantiue fcunt quidem, modó ne maximi fint § tum uerò adeó affuefiunt loro, ut facile fimiliter atọ canesad uenandos ceruos, apros, tauros, \& afinos fylueftres duci queant:fagaciffimé enim (ficurt audio) odo rantur; A elianus. De Amafide A egyptiorum rege in leonem mutato, qui manfuefactus ex loro ure luti canis ducebatur, \&c.ut Philoftratus fcribit, dicemus in Philologia. Leones (inquit A pollonius apud Philoftratum libro 7.) quos manfuefcere tolunt homines, iubebat Phraotes uerberibus non cadi: nam recrudefcere uerberibus illos aiebat. Nec rurfus blanditijs nimium leniendos putabar, quia fic nimium fuperbieuaderent. Opinabatur itaç blanditias minis permixtas facilius admorts optatos illos poffe deducere. Id autem nos non pro ferarum duntaxat manfuefactione dixerimusied tyrannis quafi frenum quoddam inijcimus, quo fi uténturr,à mediocritate nunquam aberrabunt, Leo domandus, caniculam íuxta uerberandam uidens, difciplina imbuitur, Albertus. Hybernano

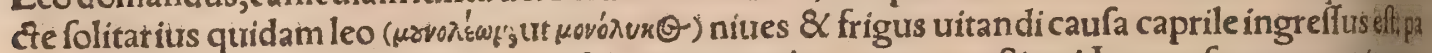
Ptores eo uifo de fe magis quàm capris foliciti magnógs in metu conftituti lourem feruatorem inuora bant. At leo nocte illic peracta, nec capris, nee uiris lafis, mane difceffit. Vnde laxtati capratîj fimular crum (leonis f cilicet) Ioui dedicatum à quercu fufpenderunt, Author incertus in Epigrammatis i,ji. Leones in delicipjs atçs item leopardos habuiffe narratur Heliogabalus, exarmatos cicures'́p: quos ita inftituerant manfuetarï, ut ad menfas fecundas iuffiaccumberent ex inopinato, nemine conficio exarmatas effe feras, Calius, Heliogabalus ebrios amicos pleruncs claudebat, \& fubito noćélen nes \& leopardos \& urfos exarmatos immittebat, ita ut expergefacti in cubiculo eodem, leones, ur' fos, pardos cum luce, uel quod eft grauius noct e inuenirent, ex quo pleriç exanimati funt, Lampiri dius. Et alibi, Iunxit fibi $8<$ leones, matrem magnam fe appellans,

Gradientes, mucrones unguium uaginis corporum claudunt, ne acumina attrita retundan tur. Hoc adeò cuftodiunt, ut non nifi auerfis falculis currant, Solinus: ut ex alijs etiam in c, dixi, $\checkmark$ eftigia leo quã callidẻ obliteret $\&$ diffimulet, ut fallat uenatores, ne catulos in cubili deprehẽdantu, fupra hoc in capite dixi in mentione amoris eius in catulos. Veftigia fua terram cauda fpargens, operit ufag ad latibulum furum, Lorach. Leones in Mauritania muliebribus uerbis repelli, eiusẹgen tis linguam intelligere, Aelianus his uerbis afferit:Cum homine Mauro \& aliarum rerum communi tatem quandam habet, \& a quam de codem fonte bibit. Hunc audio, cum trenandi ratione fallus, me premitur, Matrorum domos adire, ıbi fi uir adfit,illum ab ingreffu prohibere:uiḉs procul arcu fin domo is abfuerit, $\&$ fola mulier ad domum turendam relicta fuerit, hanc obiurgatorio fermone, 1 lum ut ne ulterius pergat, inhibere:illiḉ̧ ira moderari, ut is contineat fefe à progredien ${ }^{\circ}, \&$ minim famis immanitate efferuefrat Intelligit fanè leo uocem Mauryfiam. Verborum quibus mulier leon nem increpat, huiufmodi fenfus perhibetur : Non te pudet, cum fis leo omnium animalium rex, ad meum tuguriolúm, uti pabulum tibi concilies, mulieri fupplicatum urenire, uicéḉ̧ horninis corporê male affecti in muliebres manus refpicere, ut muliebri mifericordia digniatus, quę tibi opus funt,affí quaris:quem potius in montibus ad captandos ceruos, aliaćç animalia, quxadleonis paftum perti nent, exerceri:non autem more caniculi infelicis uictum quaritare oporteret. His quafi cantionibus mulieris leo excantatus, afflicfo animo \& uerecundię pleno, fenfim oculos in terram deíciens, infils rationibus uictus, difcedit. Neq uero, cum equos $\&$ canes ob conuictus communitatem minacesho minum fermones intelligere, \& timere uideamus, mirum uideri debet, fileones Mauros hominesin telligant, \& uereantur. Cui rei teftimonio funt pueri eorum infantes, quos fimili atç catulos leonum 


\section{DeLeone. D. Lib. I. 659}

nqualitģ uictus ratione uno eodemq́a tedo alunt. Quamobrem leones Mauryfias uoces intelligere poffe, nec incredibile, nec prater opinfonem exiftimandum eft, Hac A elianus,

qLeo cuiufuis fera carnibus gauder, maximé uerò cameli, Philes. Camelicarnes à leonib, comed Colere, teftimonio eft Herodotus, cũ in Xerxis camelos, qui commeatũ portarunt, dicit leones inuă fiffe, \&ex alìs animalibus nulla, neqgiumenta, neque homines attigiffe, Aelian. Herodoti hac de re uerba in camelo recitaui capite quar to. Leo onagrum odit $\&$ irenatur, Albertus :nimirum ex Eccle fraftici capite 13. ubilegimus, Venatio leonum onager. Bubalides caprearum generis inuadit, $\mathrm{O}$. piantus. Leo, iam fenex prafertim, fimias caprat, ipartim cibi, partim remedi caufa, ut in $c_{\text {s }}$ dixi. Leo 8c lupus ceruarius (thos) inimici funt: cum enim curne alantur, uictum ex eifdem petant necelfe eft, Ariftoteles 9. 1. Albertus proleone hic lupum inepte ponit: thoém uero, id eft lupưm ceruariunt toboz nominat. Diffident thôes \& leones, Plinius. Thôes commiffos (clariffima fama) leones Et fubiere aftu, \& paruis domuêre lacertis, Gratius. Cum leo infidias bubus molitur, fưo robore pru: denter utitur:nam nociu proficifcens ad fabula, fort tudiné fua omnes quidem exterret, unum ut arripiat, Aelianus. Iphicrates fcribit leones elephantorum pullos aggredi, quos cum uulnerarint; iam matribus furccurrentibus fugiant.lllas uerò cum filios fanguine maculatos uiderint, eos interfi, rere, leones poftmodum reuerfos cadauersbus uefci, Strabo. Si elephantos, dum in uenatione furiunt, frequentes coactos leones forte perfpiciant, alif alió tanquam hinnuli ab elephantis fibi incre dibiliter timentes, fefe in fugam conj̈ciunt, Aelianus, ब Canes Indici robore 8 animo tantum tia ent,ut alijs ferè beftís neglectis leones tantum fibi pares ad pugnam $\&$ fe dignos antagoniftas exia timent, ut pluribus in Canis robufti híftoria commemoraui. Lauzani feram apud folum autho. em libri de naturis rerum inuenio, ut Vincentius Bell, citat inter quadrupedes his uerbis : Lauzan It animal à cuius crudelitate nulla beftia effe tuta potelt:nam \& ipfum leonèm omnibus formidabi= em deterit, furo tamé generi parcit, in cæetera graffatur atç reliquas beftias deprędat̃. Et cü hęc fcelus nalihs perfequatur, propríx tamen iniquitatis non meminit; \&c. Ego lauzani, fi qua eft ita dicta fe a, non aliam quàm tigrin effe coniecerim, ut unam omnium fæu Irimam fimul \& robuftifimam, cữ fel elephanti ueftigia fpernat, \& nonnullis in locis dưplo maíor leone reperiatur. ${ }_{*}$ Martialis quidem feonem etiam ferum à tígride cicure difcerptum frribit. Leo non folum rugitu fuo careras te: ret fe ras: fed \& pradx femper inhians, cauda fira defcriptione per fummitm puluerem aưt niuem protra fir, circulum defcribit, cuilus circunferentiam tranfire non prafümunt beftix inclufae, Liber de na= Uuris rerum:ridiculé quidem, ac fi leo magiam calleat, Etrutrfus, A d leon is rugitum anímälia omnia figunt gradum, etiam qux eum nunquam uiderunt uel experta funt. Irem Ambrofius, Voci eius (inquit) tantus ineft terror naturaliter, ur etram animantia qua per celerita tem imperum eius eua. iere poffunt, rugiente eius fonitu uelut quadam uiattonita atgs icia deficiant. Et Gloffographus nuerba propheta Amos, Nunquid rugier leo in faltu nifi habuerit pratdam? Leo, inquit, cum tame patitur, fi uidet pradam, datrugitum, quo audito fera ftant fixo gradu Itupefacta. Corium leonis fum corio lupi pofitum, depilat ipfum(hocetiam de hyænæa ac pardalis corio fribitur) \& fimiliser as Hiacoria, $R$ afis \& Albertus, Leo ueneno fexpentis occidirur. Eximia leonis pulchritudo per coman

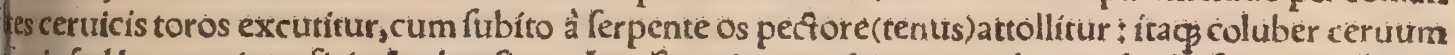
ugit, fed leonem interficit, A mbrofius. Leo fcorpionem ubicunģ úiderit, uelut holtem tút: fux fut fit, \& a bhorret, Albertus \& Phyfiologus. Exiguo frorpionis aculeo exagitatur, Ambrofus, in A'

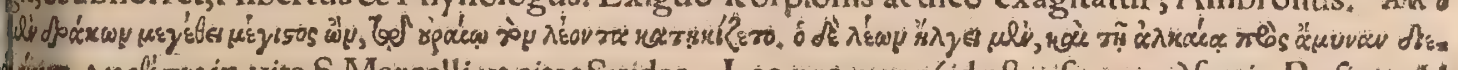
dés dnanfore + Ariftoteles de leone fribit quòd aliquando v๊ id eft fuem(non $\mu \tilde{y} y$, id eft murem)timuerit, Autúpră cítatii.

TGalliterrori funt etiam leonibus generofifimis ferartum, Plinitus, Tale \& tam faum ani nal gallinaceorum criftæ cantusḉ́ etiam magis terrent, Idem, Leonem fimul \&bafilifum gallina. eus magno terrore afficit, A elianus, Er rurfus, Gallorum cantus leones $\&$ miluos exterret; metu (afilifcos exanimat. Timet leo gallum eiusćc cantum, \& eo uifo fügit, Zoroaftres in Geoponicis ist (fallum, \& maximéalbum ueretur, Ambrofius, Album gallum leo timere dicitur, forte propter peciei contrarietatem:uel quia bafilifco fimilis effe dicitur, Alhert, li.s3. Animalia funt folaria mul da, trelut leonès $\&$ galli,cuitifdam folaris (uirtutis) pro futa natura participes. Vnde nimirũ eft quan, um inferiora in eodem ordine cedant füperioribus, quamuris magnitudine potèntia ç̧ non cedant. linc ferunt gallum à leone timeri quàm pluríntum \& quafi colí cuíus rei caufam à materia fenfúue fifignare non poffumus:fed folum ab ordinis fuperni contemplatione:quoniam uidelicet folaris prę ientia urirtutis conuenit gallo magis quàm leoni; Proclus in libro de facrificio $8 \mathrm{magia}$. Gallum qui. dem maxime Solare animal effe, in hiftoría eius pluributs docebo:leonem uerò cum Solis natura cō. finuicare, in Philologia ex Macrobio. Huc pertinent etiam haec ex quarto Lucretí carmina, Quin ứtiam gallum nocie explaudentibus alis Auroram clara confuretum uoce uocare, Quem nequeấ dapidi contra conftareleones, Inç̧̧ tuerítita continutomeminere fugaí: Nimirum quia funt gal dorț in corpore quadam Seminatqua quum fint oculis immiffa leonum, Pupillas interfodiunt cremćp dolorem Prabent, ut nequeãt cótra durare feroces. Gallinaceo iure perunctos, pracipud 2) \& allium fuerit incocfum, panthera leonesḉs non attingunt, Plinius, 
9 De leontophono, qui urinam leoni exitialem fpargit: \& efcis admixtus eundem interimit, dio ctum eft capite praxcedenti. Circa Carras oppidum campis \& frumentis incenfis, exufte funt ferm plurimx, maximéćs leones per ea loca fxuientes, immaniter confumi uel cacari fueti hoc modo , ln ter harundineta Mefopotamix fluminum \& frutecta leones uagantur innumeri, clementia hyemis, ibi molliffima femper, innocui. At ubi Solis radijs exarferit tempus, in regionibus aftu ambufts, in pore fideris \& magnitudine culicum agitantur, quorum examinibus per eas terras referta funt om nia. Et quoniam oculos, quafi humida \& lucentia membra, eadem appetunt uolucres, palpebration libramentis mordicus infidentes, ijdem leones cruciati diutius, aut fluminibus merfi forbentur, at qua remedị caufa confugiunt:aut amiffis oculis, quos unguibus crebro lacerantes effodiunt, imm nius (Cxlius legit, in amnibus) efferefcunt: Quod ni fieret, uniuerfus Oriens huiufmodi beftijs abun daret, Ammianus Marcellinurs libro 18. Strabolibro 16. circa Meroën fimiliter leones fub Canisor. tumà maximis culicibus expelli fcribit.

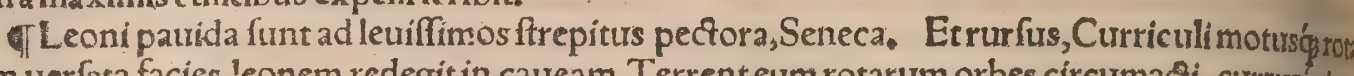
rum uerfata facies, leonem redegit in caueam. Terrent eum rotarum orbes circumacii, currusctinia nes, Plinius. Extat elegantiffimum Alcxi decaftichon in facerdotem Cybeles, qui obuium in mon te leonem tympani fonitu perterrefactum euafit, Anthologï 1. 33. \& rurfus aliud Antipatri 7 . il fed hic ab Alcxo uariat, quod facerdotem Cybeles frigus \& niwes uitandi caufa interdiu leonis fpecum ingreffum ait, \& leonem fub uefperam reuerfum tympano (ex bubalo corio) terruffe. Similiter lu

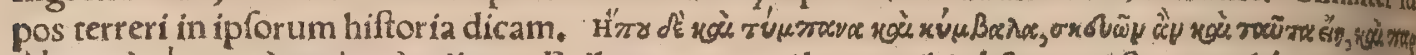

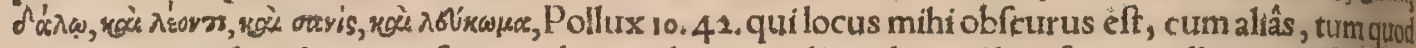
neq ex pracedentibus neģ fequentibus uerbis certi aliquid, quod huc faciat, colligere poffun. $V_{s}$ rum elt quod de leone narratur, ignẽ pracipuè formidare, ut Homer.quo ģ teftatur, cũ dicat:Arden tesćp faces, quas, quamuis fauiat, horret, A riftoteles \& A elianus: Gracos Homeri uerfus recitaboin fra in H.c.Leones cum fint natura uehementer ignita (anteriore ful parte) unde \& Vulcanoab Aer gypurijs facri cenfentur, ob copiam interioris ignis, eggerrimé intuentur exteriorem, \& fugiunt, Aelia, Lupus etiam ignem filicibus excufum fugit, Recentior quidam. Ignem metuic lco, utpote naturafer uidum animal, $\mathrm{Phlles}$. Terrent leonem rorarum orbes circumadti, $\&$ gallinaceorum crifta cantuso etiam magis, fed maximé ignes, Plinius. Igne etiam in retia adiguntur, ut capite quinto dicaminues natione ipforum. Leones per Solem ingredi acriorem non patiuntur:funt enim acie oculorum acu tuffula, \& ignem interdiu îjdem ob eandem fugiunt, $A$ phrodifienfis. Vrfos leonesḉ̧ mappa pro, ritat, Seneca. Leo calcatis folijs ilicis ftupefcit, (torpore tenetur, )A elianus, Zoroaftres in Geopon, Sifuper cortices quercus calcauerit leo, formidabit continuo, Aefculapius. Leo timet lignum qued

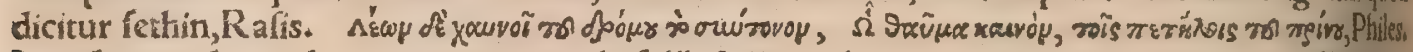
Item fi conculcat uxel appropinquat modo folịs fcillx herbx, torpere capitur, Aelianus, Elleborts \& fquilla canes \& leones plurimos beluasćp interficiunt, $R$ afis. Democritưs adamantida herbam nominat, Armenia Cappadocixọ́ alumnam:hac admota leones refupinari cum hiatu laxo:nominis caufam effe quod conteri nequeat, Plinius. Nauis in qua leo dormit, mergitur plus folito: eodentex

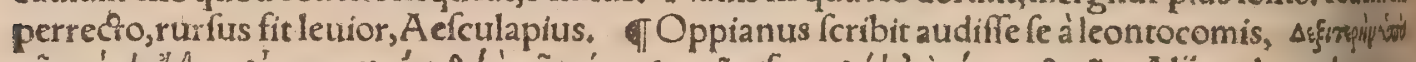

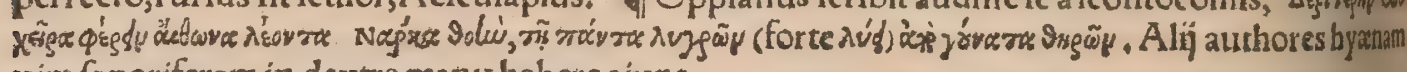
uim foporiferam in dextra manu habere aiunt.

\section{E.}

Tartarileones habent uenationis cum canibus focios, ut fupra in B, dixi. Magnus Cham imper rator Tartarorum, leones maximos atç pulcherrimos habet, ad uenãdum induftrios, Paultis Ventes tus. Leones Indici, immaniffimi quidem funt, fed capti adeò manfuefcunt (modo nc maximifintut loro affuefacti, facile fimiliter at $\$$ canes ad uenandos ceruos, apros, tauros, \& afinos fylueftes dud queant:fagaciftuné enimeos odcrari aiunt, Aelianus,

IIndici canes $\&$ alị quidam uenatores robufti, tauros, apros $\&$ leones aggrediuntur, utin $C$ a num hiftoria docuimusł maximé uerò id faciüt, è tigribus conceptæe canes apud Indos $\&$ Hyrcanos, Et truculentus Helor certare leonibus audens, Fr. Mantuanus de cane. In prouincia Ginguimat

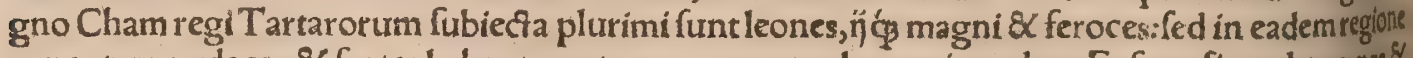
canes tam audaces $\&$ fortes habentur, ut non uereantur leones inuadere. Et fxpe fit ut duo canes $\&$ uir fagittarius equo infidens leonem fternant:na m quum canes leonem adeffe fentiunt, magnolitta tu eum inuadunt : prafertim uerò quando fciunt fe hominis auxilio fultos, thon definunt mordere leonem in partibus pofterioribus atç̧ cauda: Et licet leo fape rictum illis minetur, huc illucẹ́ fe uter tens, ut illos dilaceret, tamen canibus magna cautela fibi prouidentiburs, non facile ab eoladuntur, præfertim cum infequens eques tunc leoni iaculum infigere ftudeat, quando canes trucidare cona

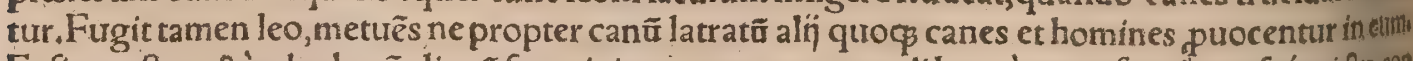

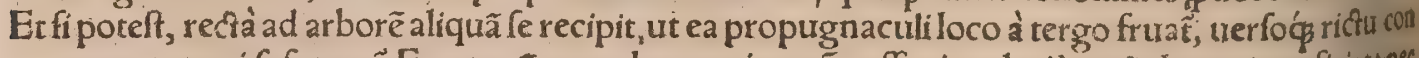

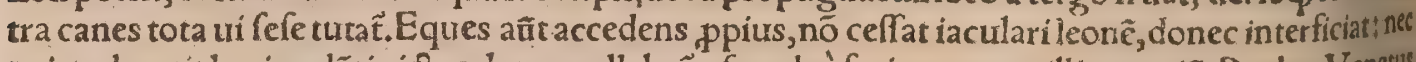

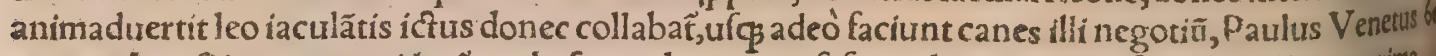
2.49. -Teo fi in uenatu uideat, erubefcens dare terga, fefe paulatim recipit, fi mulcitudine oppima

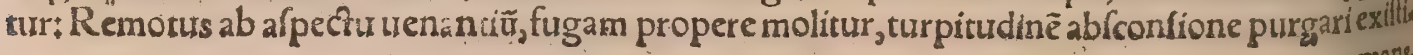


bore fractus, $\&$ fpuman in ore agens, decumbit, ac nimirum humi ftratum, 8 iam ualde qitletum

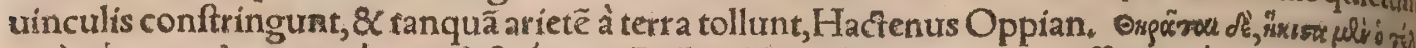

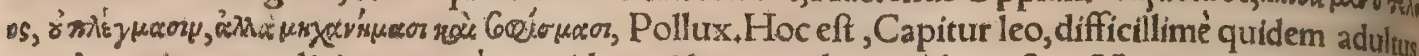

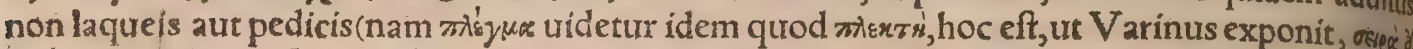
ikés row: quidam in Lexico Gręcolatino rete exponit:)fed machinamentis quibufdã $8<$ dolis, Leones etiã laqueis intricari inuenio, ad palũ alligatis iuxta locũ aliquẽ anguftũ per quẽ tranfire folêt, $\AA_{c} c_{1}$

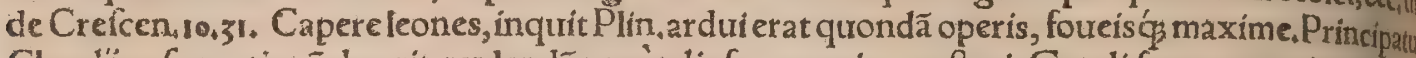
Claudị cafus rationê docuit, pudendã penè talis ferę nomine, paftoris Getuli fago contra ingruentí impetum obieç̃o: quod fpectaculü in harenã protinus trâslatum eft, uix credibili modo torpefrente tanta illa feritate, quamuis leur inicctu operto capite, ita ut deurinciaturr non repugnans:uideliceto. mnis uis conftat in oculis. Quò minus mirum fit, à Lyfimacho Alexandri iufír fimul inclúo firan gulatum leonem. Item alibi, Nuper inuentum, urforum in harena \& leonum ora afpergere chal cantbo, tantaçs eft uis in aftringendo, ut non queantmordere. Caffiodorus libros. Variaum, quomodo contra belluas decertaretur, feribens, fic habet: Alij tribus, ut ita dixerim, difpofitis hoftio lis, paratam in fe rabiem prouocare prę̧umunt, in patenti area cancellofis fe poftibus occulentes,tito do facies, modo terga mốfirantes, ut mirum fit euadere, quos ita refpicis per leonũ ungues denteśg uolitare. Quibus cibis uel ceis leones occidantur, capite z. dicfum eft.

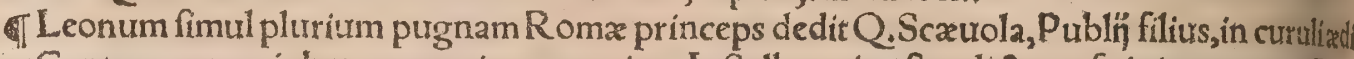
litate; Centum autem iubatorum primus omnium $L$. Sylla, qui poftea dictator fuit, in pratura, Plin, Primus L. Sylla in Circoleones folutos dedit, cum alioquin alligati tune darentur, ad conficiendo cos miffis à rege Bocho iaculatoribus, Seneca de breuitate urita. Pofl. Syllam (inquit Plinitrs)Pom peius Magnus pugnam leonum in circo dedit fexcentorum, ac in n̈s iubatorum $\mathrm{C} \mathrm{C} \mathrm{CXV}$. Cafar dictator quadringentorum. Pompeitus Romæuenationes exhiburit, quibus quingenti leones cẹli, Plutarchus in uita eius. Itrgo fubdidit eos, primusós R omæ ad currum iunxit M. A ntonius, \& quith dem ciuli bello, cum dimicatum effet in Pharfalicis campis, non fine oftento quodam temportum, generofos fpiritus iugũ fubire illo prodigio fignificante:nam quod ita uecius eft cum mima Cyher ride(citharceda, Crininus, ) fupra monfra etiam illarum calamitatum fuit, Plinitus. Ant. Heliogab lus quaternos canes ad currû̉ iunxir: eoǵp modo ueçatus eft: Idem leones iunxit, Cybelen fe appeh Ians, Lamprid. Leones nô manfuefacios exarmare cófueuerant, ut olim Heliogabalus: quíden et ungubus exeçis, triclinị̂s etiã, c pulantib, cóuiuis, eos immittebat. Sed exarmare p manfuefacté quidã dixerût, Grapald. Antoninus Pius cẽtũ leones una miffione æcídit, lul. Capitolin. Fuerut fub Gordiano Romæ, leones manfueti lexaginta, archoleontes decem, lul, Ca pitolin. Archoleontes quos fuiffe conï ciamus, in B diçum eft. Aciliũ Glabrionẽ confulẽ in Albanũ Domitianus etora vit per Iutrenalium feftos dies, quos inibi celebrabat, iufit ćç cum ferocifimo leone ac urifendx ma gnitudinis congredi.Sed prudenter in pugná prodiens Acilius feram confecit ; (İd quod Satyitus poéta doctius exfequitur, ) Callius ex Dionis hiftoria. Extat Martialis carmen libro ocfauode cxi mio quodam leone per Domitianum exhibito in fpectaculo, hurufmodi:

Auditur quantữ Mafryla per auia murmur, Innumero quoties fylua leone furit:

Pallidus attonitos ad plena ma palia paftor Cum reuocat tauros, \& fine mente pecus:

Tãtus in Aufonia fremuit modo terror arena, Quis non effe gregem crederet ? unus erat,

Sed cuius tremerent ipfi quoeg itura leones, Cui diadema daret marmore picta Nomas.

O quanrũ per colla decurs, quễ fparfit honorẽ, Aurea lunatæa cum ftetit unda iubx?

Grandia quàm decuit latûu tienabula pectus? Quantạ̧́ de magna gaudia morte tulit:

Vnde tuis Libye tam felix gloria fyluis? A Cybeles nunquid uenerat ille iugis?

An magis Herculeo Germanice mifit ab aftro Hane tibi uel frater, uel pater iple feram?

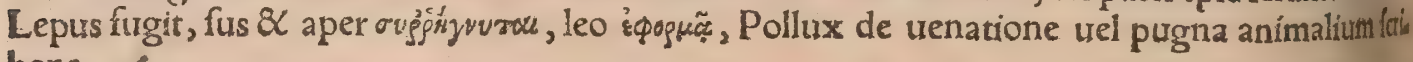
bens.

T Sanguis hircinus adamantem emollititem leoninus, Eft enim inter cateros horum fanguis as lidilímus. Adamas autem cũ frigidus ficcusć́ fit, ab eo quod fibi maximé contrariũ eft praci uincitur,Simocatus, T De pelle leonina, qua fe quidam ueftierunt, dicam in $H_{*}, e_{*}$

F.

Rapacium omnium carnes declinant ad ficcitatem, quę facile in corporibus bilem atram geterat: maxime urero præ cateris improbantur lupinæ $\&$ caninæ, $\$$ corruptos gignant humores, $R$ af Leo

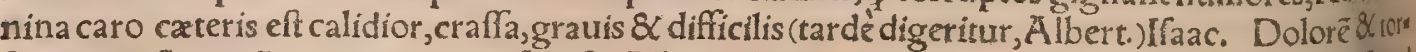
fionê(et inflationẽ)trentris generat, Idẽ SC Alber. Calidior eft quã canina, fimulós ficca:prodeffind bo paralyticis(uide in G.)Albert. Agriophagi populi in Aethiopia, pantherarũ \& leonum carnibus uefcuntur, Plin. \& Solin. dicti(ut apparet) quod animalia edant agria,id eff, fera. Barbari inter Call

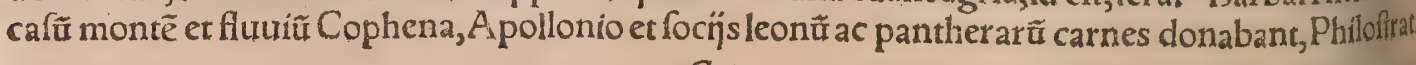

G.

Sanguis leonis confricatus fuper cancrũ, curat eum, $R_{2}$ fis \& Albert. Leonis fanguine fiquriscot to pus fuum linierit, ab om nibus beftijs erit tutus, Sext. fed Plinius hoc adipi leonis adfcribit, ut paulo poitreferemus Q Quicarnes leonis decoctasmanducãt, phantafrnata non patient, Sext, Leonis'ca 


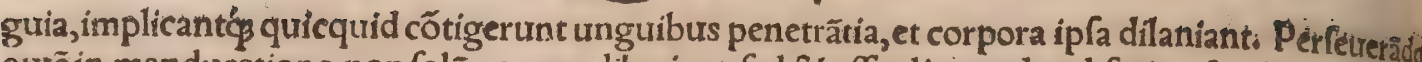
autê in manducatione, non folũ corpus dilaniant, fed $\&$ offa aliquando ad farina fimilitudinẽ con fringunt: unde $\mathcal{\alpha}$ uicini pungũ tur nerti. Satis uerò manifeftü eft, $q$ corpora qux in eiufmodiac tas calamitates inciderưt, nö effugiunt periculum abalienationis:nã etfi maneant, putrefaçionê $\mathrm{fu}$ piunt, et ulcera ferpentia inducunt. Huiufmodi igitur uulnera cũ aceto elota $\&$ circumrafa, folutio irem corporibus ac offibus extractis, emplaftris integere oportet, \& poft fuppurationē partiû̃ dilania tarum, repurgantibus linamentis curare: $\&$ cicatrice ê inducere, quemadmodum in cömunibus ulce ribus folemus. Emplaftra autem his conuenientia funt, id quod ex falibus conftat, \& fimilia, quorĩ defcriptionem qui defiderat, adeat Aétílocum iam citatum.

a. Leo Gracérex interpretatur Latinè, eó $q$ fit princeps omnium beftiarû, Ifidor. Ego nec leonis nec fimile uocabulum pro rege apud Gracos accipi inuenio, ut mirer hoc Ifidori fomnium. Leones

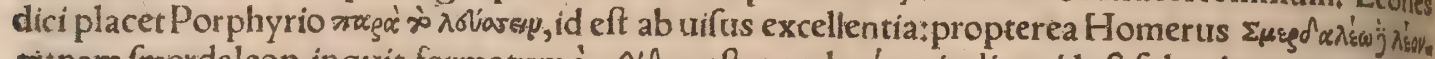

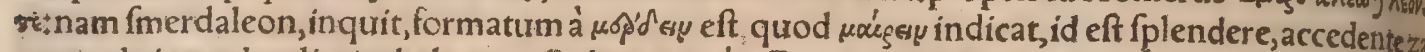
particula intendendi uim habente, Calius. ndw Gracis eft urideo, inde àraxós crecus:hinc $\&$ leoni nomèn, quoniam acie oculorum præ cæreris animalibus ualet, ut fcribit Manethô in lib.ad Herodo. tum, Etymologus $\&$ V arin. Panthera, leo, à Gracis funt:à quo etiam rete quoddam panther, \& lex na, \& muliercula Pantheris, Varro. Lexna, $\lambda$ 'acux, uocabulum Gracis \& Latinis in ufu, leonis fou mina eft:fed apud Latinos poêtas lea etiam pro leana reperitur, Irritata lex iaciebant corpora faltu, Lucret.lib. y. quod carmen etiam Nonius citat. Saxua lea, Ouid.4.Metam. sis (oxytonum, ut pletio

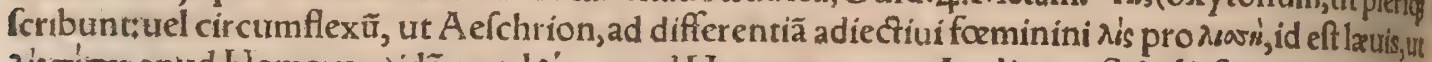
$\lambda$ is $\pi$ izgos apud Homerum)idẽ quod $\lambda \dot{\varepsilon}$ (wy apud Homerum, uox Acolica, ut Scholiaftes monet, $A$ injace

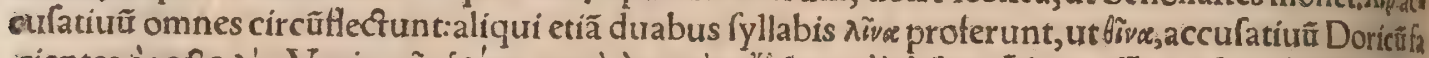

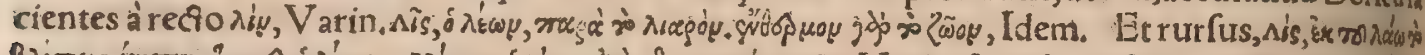

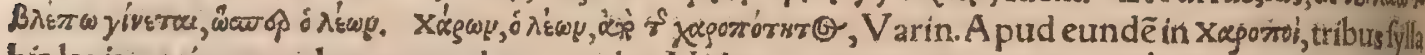

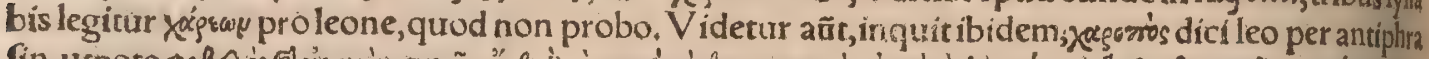

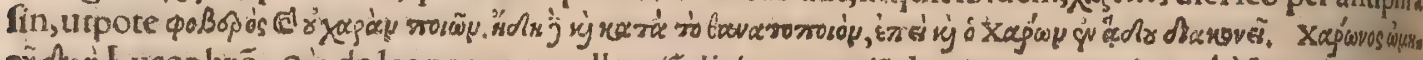

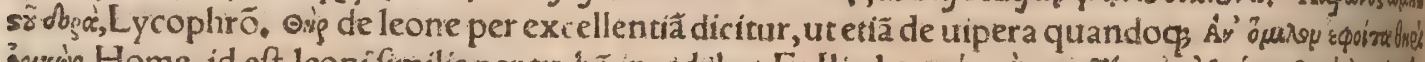

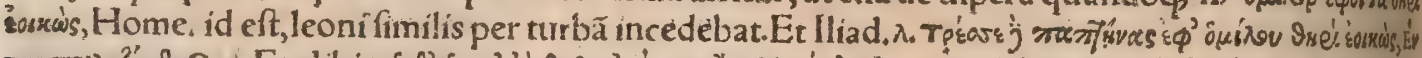
gुo rre

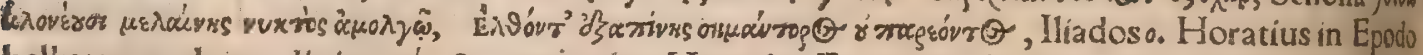
belluam proleone dixit. rúrıe, porcus, leo, Hercules, Etymolog. \& Varin.plura de hac uoce vide in Cuniculo A, Leonem Homertus epicone genere etiam de foemina protulit, Gell. Hac dere enf multa dixerim capite quarto, paulo poft initium, hic tamen pluribus confirmabo. Vocabulum diuy more Attico de focmina etiã úurpari, ex Ariftotelis uerbis de partib. 4.10. deprebédimus, quá fuit:

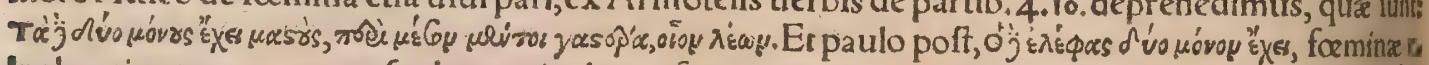
lephantis nomen cum mafculino articulo proferens, utpote epicoźnũt: fic et leonis uocabulĩ Atticé

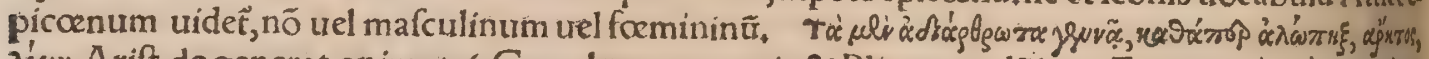

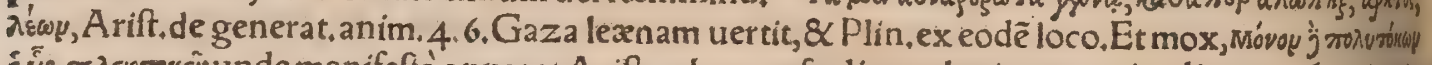

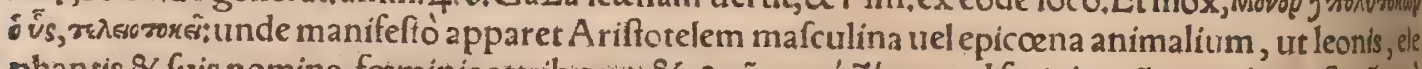

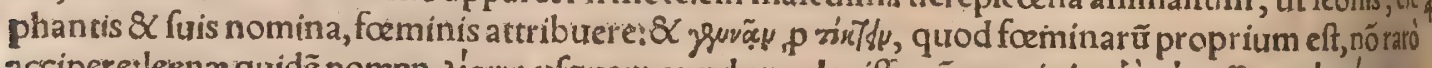

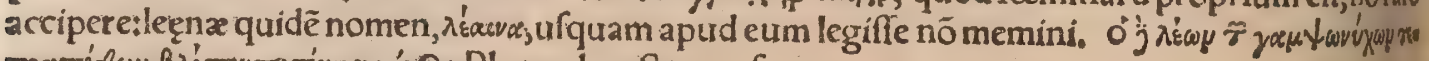

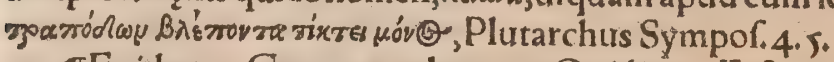

बEpitheta. Genus acre leonum, Ouidius 4.Faftorum. Animofi,Claudianus، Alper, Horat 3. Carm. Ode 1. Sponfus lacelfat regius af perum Tactu leonem. A udax. Emicat extemplo cuncis trepidantibus audax Craffa moleleo, Claudianus lib.2, in Eutropium. Auridus, Ouid.epif, o, Vill de poteft auidus capta leo parcere pręda, Martialis. Si quis per fummas auidus produrxerit undas Ora leo, Manilius lib. 4. Aftron. Cæafius.Solus in Libya Indiáç tofta Cæfio ueniam oburius leoni, Catullus de Acme. Carniuorans, Vrfi ctrm uitulis fimul cmnibusć $\beta$ animalibus carniuorans leo comeder paleas ad prafepia, Laciantius de diuino pramio 7.24 . Calpius. Cade redit: fic Hyrcanta 90 leo Cafpius umbra, Statius lib. 8. Theb, Celer. Veluti celeres cum fepta leones Plena bouminua dunt, Cantalycius. Cleonæus: Aufonius in laboriburs Herculis, à Cleone oppido Arcadia prope Nemeam fyluam. Dominumós ferarum Crefcere miratur genitrix Maftyla leonem, Clatıdiantus lib. I. in Eutrop. Dominus \& rex nemorum, Martialis. Ferox Acremḉ dolorem Prabent, ut nequeant contra conftare feroces, Lucretitus lib.4. Ferus. Narciffíç comas, 8 hiantis frua leonis Ora feri, Collumella. Leo nunc ferus alta Surgentes ceruice toros, 8c. Sillius 5 . Villofa leonis Terga feri, Idem lib.16. Flautus, Credula nec flauos timeant armenta leones, Horatius in Epodo. Fortis, Crinitus 17.2. Fremens, Car pitó̧ fremens, auidusḉ̧ cruoris, Sabellicus. Frendens, Es ftetit ante oculos frendens leo, Sillius lib. 10. Dentibus horrendum frendens, Pamphilus Saxus. Fulmineus. Te fenfir Nemeęus arcto Preflus lacerto fulmineus leo, Seneca in Agamemnone, Ful 6 uus. Fuluiḉs infternor pelle leonis, Vergil.2. Aeneid. Optat aprum, aut fuluum defcendere mon te leonem, Idem 4. Aeneidos. Furens, lam fine patre furens luitrat leo tecta ferarum, Cimbriacus, 
lconum catuli. Leontiafis morbus, qui uulgò hodie lepra, unde dictus fit, in Elephante $\mathrm{H}_{+} \mathrm{a}_{+}$ex $\overline{\mathrm{A}}_{\mathrm{e}}$,

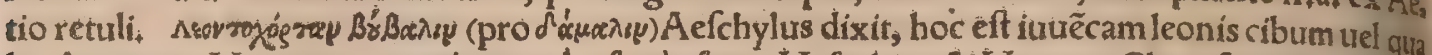

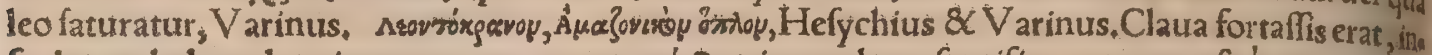

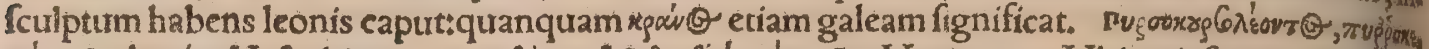

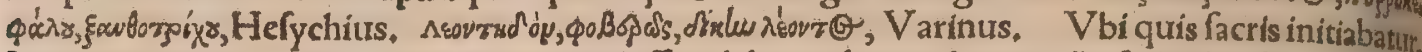
Leontica uocant, aquæ loco in manus mel affundebant, ab omnibus noxijs fceleribusós ac triftitian, inferentibus fic expurgariarbitrantes. Linguam item melle detergebant $a b$ omni peccatilabe, $C a t$ tranftulit autem ex Porphyrï interpretatione in antrum Nympharum apud Homerum, ex quolo comelius ita trertiffet: Melle manibus illorum, qui facris initiantur Leonticis, pro aqua infufo,man zus ab omnire molefta, noxia \& abominabili abftinendas fignificatur ; itaç lotionem igni familian rèm adhibêt, tanquã ifti purgationi eius quí initiatur conueniat, reieça qua ignis extinguitur aqua, Quà uerò $8 x$ qualia \& cur Leontica dicta facra hac fuerint, legiffe non memini. Hoc obiter admo nendum, uocabula apudd Græcos quęà leone uel deriurantur uel componuntur, tres de obliquis caft bus hurius ferę fyllabas retinere, $\&$ in fecunda per omicr on femper fcribi:alia urerò multa à $\lambda$ sùs quod Attice populum fignificat fiunt, qua per omega fribuntur, nec onto uel onti fyllabas obliquorim

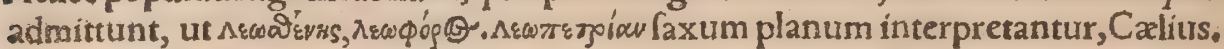

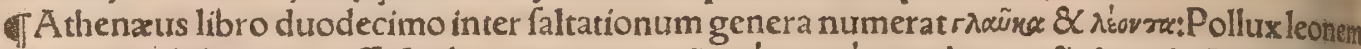

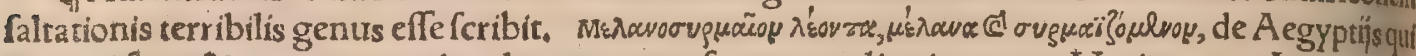
\& nigri funt, \& potu utuntur hordeaceo, quem fyrmæam aliqui urocant, Varinus, ex Lycophrone

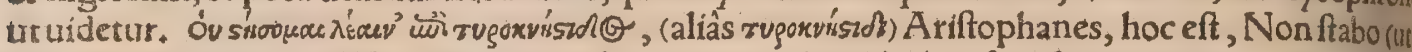

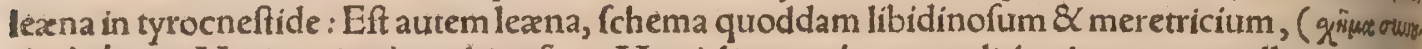
ต่a's ผ่ mus in prouerbio Leonem radis.) Tyrocneftis genus eft cultri: folebant autem in manubrijs cultro

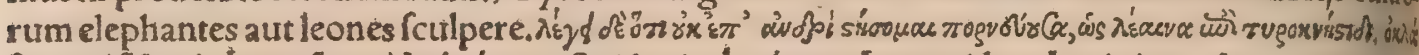
¿̧

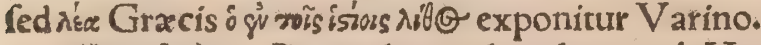

- Leo fydus. Poeræ dicunt duos leones ab Hercule interfectos, unum apud Teumeffunt Beor cix montem feu oppidum, \& hunc effe uolunt quem Iupiter in coelum tranftulerit: ut f́ilicet Hercu lis, qui feram inermis occiderat, gloria confulcret. Higinus tamen alium fuiffe tradit, quem fribità Luna iuffu lunonis in Arcadia nutritü (apud Lunam in Nemea regione Arcadia, Nigıd.) \& deinde in exitiư Herculis dimiffum, quem quũ Hercules interfeciffet (iuffu Euryfthei cữ Molorcho holpite, Nigid.) ab indignata Iunone in fydera relatũ fert̂t. Sed ut breuitati ftudeamus, fequemur Germani. cĩ in Arati Phęnomenis fcribentẽ , Leonem beneficio Iunonis inter aftra collocatũ, eò qquirtuteferag omnes pracellat. Periander (Pindarus R hodius, ut habet Varinus:qui tamê haec uer ba illi nonatti buic) R hodius refert eum ob primos labores Herculis memoria caufa honorificé aftris illatum, $\mathrm{Hic}$ notabilis \& maximus inter figna eft:habet ftellas tres in capite, in pectore claram unam, \&c. Qunim Solad eius fignum peruenit, menfe fcilicet Itulio, tunc $x$ ftatis calor uehemẽtiffimus terras adurit,ext ficcat flumina, \& fruges concoquit, Hac Rauifius Textor. Leo quoniam inter quadrupedes prin cipe loco elt, eam ob caufam à loue fyderea fededignatus uridetur, Varinus. Aegyptí(inquit Mario bius Saturn.1.20.) animal in Zodiaco confecratrere ea coeli parte, qua maxime annuo curfu Sol uali, do efferuet calore:leonisçs inibi fignum domicilium Solis appellant, quia id animal uidetur ex nath ra Solis fubftantiam deducere:primumós impetu $\&$ calore præftat animalia, uti præeftat Sol fydera: ualidusćceft leo pectore, \& priore corporis parte, ac degenerat pofterioribus membris, xquéSolis uis prima parte diei ad meridiem increfcit, uel prima parte anni à uere in aftatem:mox elanguefens deducitur, uel ad occafum, qui diei, uel ad hyemem, qua anni pars uidetur effe inferior: Idemóp orth lis patentibus atç igneis cernitur femper, ut Sol patenti igneóq oculo, terramq̧́ confpecfu perper tuo atç infatigabili cernit, Hac Macrobitus. Et rurfus in Somnio Scipionis 1, 12.Cumanima (in quit) ì cancro ad Leonem labendo peruenerint, illic conditionis futura aufpicantur exordium, Bt quia in Leone funt rudimenta nafcendi, $\&$ quædam humanæ naturæ tyrocinia aquarius autem ad uerfus leoni eft, 8 illo oriente mox occidit, id eo cum Sol aquarium tenet manibus parentatur, urpo te in figno quod humanx uita contrarium uel aduerfurm feratur. Scribit Nicephorus in Aftrolabin fruciur a cor cceleft is Leonis dicibafilifcum, Calius, Leo Solis fymbolum habet habet ignitos, faciem (ut placet nonnullis) rotundam, $\&$ in ambitu radiorum quadã imagine etiam pilos, ut fit planè Solis fimulacrum. Quo argumento Hori thronoleones fubijciunt. Eft autem cono

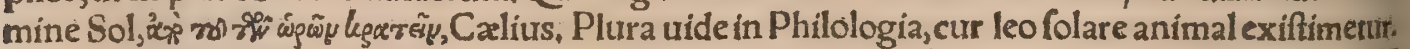
Leonis fyderis epitheta:A eftifer, æftiuus, ardens, arens, calens, feruidus, flammifer, flammiger, Hers culeus, horrendus, horridus, horrificus, rabidurs, fruus, terribilis. Horum ex poéris teftimonia Tex tor affert, fed commifeet ea epithetis leonis terreftris. Stella uefanileonis, Horatius\%. Carm, Alis qui apud Homerum Iliadis quinto yó $\lambda x$ s. fuife, leonis fydus interpretantur: Vide Scholia Homeri.

Icones, In templo quodam Paufanias fribit, in Agamemnonis fcuto formidinem fuiffe expi ctam capite leonino (quoniam leo minimum dormit, ac dormienti etiam oculi fublucent) cum epia 
inunctis faciem extenfam \& fine rugis feruari, Plinius etiam ïfdem quibus Diofcorides uerbis de calia refert 26.16. quod itidem Ruellius non animaduertit. Cacalia quidem dicta uideri poteft, quât coccalia, quod coccis, id eft granis peculiaribus infigniatur: Leontice uerò, uel quod fimiliter ut litho fpermon (quod \& ipfum, ut paulo ante monui, leontion uocatur) grana margaritis fimilia proferat" Vel quod radicis commanducata fuccus arteriam fimiliter iuuet ut glycyrrhiza, Galeno tefte, Voca tur autem glycyrrhiza quoc leontica inter nomenclaturas Diofcoridis. Caterum Galenus proca:

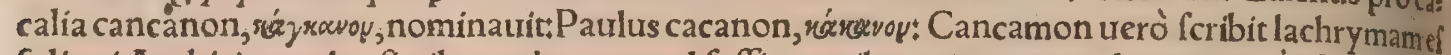
religni Arabici, myrrhx fimilem, odoratam, ad fuffitus utilem, ui extenuandi corpora obefa, item ab. ftergendi $\&$ aperiendi obftuctiones, ut $\&$ Diofcorides pluribus. Hanc Serapion $\&$ alï A rabes fac appellant:laccam uertunt interpretes. Sed qux hodie in officinis lacca uocatur, nec odorata eft, nec fimiles habere uires uidetur: Ego eius loco medicamentis myrrham potius iniecerim, quàm ur $\mathrm{M}_{0}$ nachis qui in Mefuen foripferunt placet, draconis uulgò dictum fanguinem, cui uís aftrictoria. Non, probo eos qui canchamum apud Diofcoridem per c. afpiratum fcribunt: Mirum autem nullam her ius lachrymæ mentionem à Galeno fieri. Ex confinio cafiæ cinnamiós \& cancamum ac taruminuei hitur, Plinius, nec alibi plura. Caccaliam Paulus per cappa duplex fcribit, $\mathcal{Q}$ eandem cacano facul tatem habere tradit: Cacanon autem, ut iam dixi, Galeni cancamon, \& Diofcoridis cacaliam uock ut non folum eandem uim habeat, fed eadem omnino fit. Sed huiufmodi errores Pauli etiam alibi ie perias, res eafdem propter nominum diuerfitatem diuerfas exiftimãtis. Redeo ad cacaliam herbam, quam leonticen quroq̧ uocatam dixiłeam quę hodie fit nullus adhuc demonftrauit, nam qurod decar tri agrefti Ruellius foribit, certi niht eft, \& ex auditu tantum (ut apparet) ab eo fcriptum: ego conies ciuram faltem meam afferam, ut excitem diligentiores. In Gallix \& Italix hortis uidi lachrymamul gò dictam herbam, folip̧s magnis harundini fimilibus, candicantibus, inter quę caulis rectus affurg \& inter folia caulemós nafcuntur grana candida, lapillorum duritie, unde recentiores etiam aliquili thofpermon nominant. Ea filis inferunt muliercula, 8 quadam ita preculas fuas numerant. Hacti fi cacalia eft, aliam doceri cupio. Eft fané perquam dulcis, ut arteriæ quod de cacalia fcribitur, nonmi nus quàm tragacantha aut dulcis radix utilis uideatur. Herba huius mentionem facit Hier. Trag 1.140.lithofpermum maius uocitans, gr of ffeinfamen. Leontopetalum herba dicta uidetur, acfial quam in folijs ( tamen authores non exprimunt. Leontium etiam $8 \mathcal{C}$ leoninum femen, eiufdem herbæ nomina funt inter Diofcoridis nomenclaturas. Habet hac planta, ut Plinius \& Diofcorides fcribunt, caulemfer mipedalem aut maiorem, alis numerofum, quarum cacumine in filiquis femina ciceris modobina ternaćs continentur, florem puniceum, a nemones fimilem, folium brafficx, diuifum papatterisfờ ma:radicem nigram, fimilem rapx, ftrumofam, tuberculis quibufdam ceu nodis articulorumemin nentibus: nafcirur in artris frumentario agro. Hanc ego me ignorare fateor: 8 fanè melius etiam Ru ellius idem de fe confeffus effet, quàm patam leonis uulgò dictam, eandem afferendo, reprehenden, di nobis occafionem reliquiffer. Nam pata leonis apud Gallos non alia quuàm confiligo urel pulmo. naria ueterinariorum eft, de qua abunde docuí in Boue capite tertio. Ea quantum differat à leontou petalo, \& defcriptionem partium fingularum conferenti fatis patebit $+\& \mathcal{Q}$ infuper uires confideranili; radicis enim leontopetali ufus intra corpus eft, confiliginis non item.Leontopetalon tertio graduca lida \&C ficca eft:confiligo, ut mihi uidetur, in quarto \& cauftica : eadem aut maiore potius effica qua helleborus niger, ideoós illi antiballomenon. Leon topetali radix aduerfatur omnium ferpêtum generibus ex uino pota, nec alia res celerius proficit, Plin. Alia elt leontopodium ( quamúis iden nomen leontopetalo etiam tribuitur:A puleius capite feptimo leontopodion defcribens, eademeino mina triburit, quze Diofcorides leontopetalo) de qua Diócorides: Digitalis, inquit, herbula ef: follila habet angufta, longitudine trium quatuórue digitorum, hirfurta, ab radice lanofa et albicantia,flort nigros, \&c. Hanc quoç, hodie ignotam puto:nec eft quod magnopere eam nouriffe affectemus, ctit ad ama toria tantum in ufu furfife Diofcorides fcribat (licet in extremo capite Graco addatur, phymata quop̧ difcutere:) ut Plinius quogs cemon uel camon, qua eadem eft. Et Diofcoridis ctian de leontopodio caput in uetuftifimis codicibus de cemo infcriptum erat, ut Marcellus Vergilisis cet, qui \& alia nonnulla affert de herba hac cognofcẽda laborantibus utilia. Atqui Plinius alibileons topodion aluum fiftere $\&$ bilem purgare fcribit, femine lymphatica fieri fomnia, campeftri: $\&$ gr li folo nafci. Item alibi, femen leontopodij tritum in aqua cum polenta, tela omnia infixa corpori (fop cula fagittarum, alibi) extrahere. Sed hæc de leontopetalo intelligi debent: quod inde facile colligo, quoniam à Plinio cognominatur liceron, (litheoron, ut Hermol, legit, \& corypetron) dorypetronet toriuentoron:quæ nomina apud Diofcoridem inter leontopetali nomenclaturas leguntur, paulum

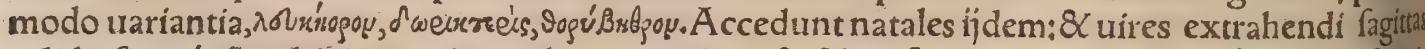
calida ficcæćç facultati in tertio gradu conueniunt: 8 fi hac facultas quibus ineft, à tota fubftantia ineffe uideatur. Sed fi aluum fiftit, quomodo bilem purgat ego ciere potius quàm fiftere dixerimi eá̧̧ caufa à Diofcoride etiã tradi, leontopetalon mifcericlyfteribus ad coxendicis dolores, nimirum ea tacultate qua centaurium minus \& colocynthis, \&c. Leontopodion, inquit Hermolatus, in ues tuftiffimo Diofcoride appictam uidimus, fimillimam herba quam ưulgus ex noftra confuetudine lendulam appellat, ut eadem omnino effe uideatur, Hac ille. A pud me uerò nulla huius piçura 8 


\section{DeLeone. H.a. Lib. I. 669}

fimiltum authoritas eft, ubi defcriptio longè diffentit: Pata leonis, fi bene memini, in quíbufdam Italie Gallix'ue locis, non folum confiligo, ut iam dixi, fed etiam geranĭ montani quoddam genus uoca tur, radicibus oblongis, rubris, $\mathcal{Q}$ maxime aftringentibus, flore purpureo anemones, folins multifidis fpecie quadam digitati pedis, noftri blitwurt, id eft radicem fanguinis, quòd illum fiftar, api pellant. In hortos translatam, uiuaciffimam effe obferuaui, Branca leonis, herba flaura, Syluaticuss. Et alibi, Herba flauta (aliâs Maura ) planta leonis, id eft trifolium maius. Iligas, id eit pes uel brancha leonis, herba, Idem. Eruditi haec nomina de trifolio afphaltite inteligunt, Oro banchen herbam in Bouis hiftoria capite tertio copiofé demonftraui, Eam Itali quidam, authore Petro Matthxolo, lupam urocant, quòd deuroret plantas quæ prope ipfam nafcuntur: alï caudam leo nis:Inter Diofcoridis certe nomenclatur as leonem quoç appellari legimus: Item in Geopon. $2.4^{\circ}$ ubi Sotion is uerba hac funt. Leguminum leo, ofprioleon Gracis $\&$ orobanche appellatus, nó proue niet in artuis, fi in quatuor angulis et in medio aruo rhododaphnes ramulos infixeris.Quod fi welis hăc herbã in totũ nó apparere, quinç teftas accipito, \& in ipfis cum creta aut alio colore aibo, Hercu lem leonem ftrangulantem pingito, easq̧́ teftas ad quatuor angulos $\&$ in medium arui deponito. Alij teftam ita depicram in inedia tantum area defodiunt. Eft $\&$ alia quædam naturalis cura, (nos hic ex Gręco mutulam Cornarị translationem reftituimus)à Democrito etiam prodita, hưiufmodi. Quro niamleo animal gallo uifo expauefcit \& contrahitur: fi quis gallum manibus frenué cóprehenfum

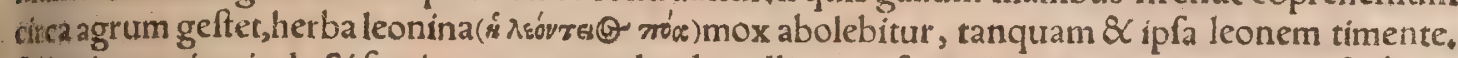
Aliqui experientia doci femina terræ mandanda gallinaceo fanguine irrigant, tan $\bar{\not}$ tuta fic à leo

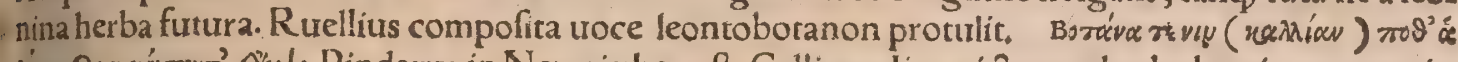

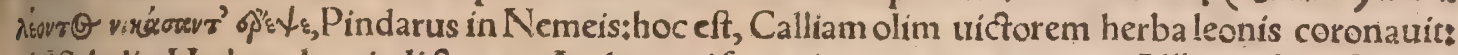
ubi Scholia, Herbam leonis difam ex Archemori fanguine prognatam aiunt. Aií, quod praftat, ip.

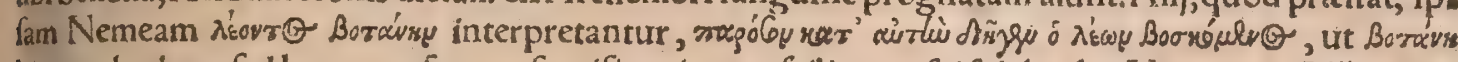
hic non herbam fed locum pafcurum fignificet, in quo fcilicet pafci folebat leo Nemeçus. Allỷ apium herbam: $q$ Hercules uicto leone, apio coronari in Nemeis uictores initituerit: fed imperite, cum $\&$ certaminis inftitutio, \& ex a pio coronæe pręmium, Archemoro authori tribuantur, Hxc Scholia, Leonis cuiufdam herbze meminit etiam Columella in Horto fuo, his uerbis, Et hiantis fęua leo= nis Ora feri. Et rurfus, Ofcicat er leo. Numerat autẽ inter herbas ueinas $\&$ florum gratia feri folitas, utnarciffum, hyacinthum, uriolas, rofas. Apparet fanénomen ei à floris figura indirum, qua leonis inftar hiantis ofcitet, ut ipie loquitur. Libro qu dem undecimo, ubi profa rem hortenfern eodem or dine defcribit,quo prius carmine, nulla eius mencio:fatetur \& Hermolaus in Corollario fibi ignotã Os leonis herba flore purpureo, Perottus fine authore: Videtur autem exiftimaffe eandē leon tope talon Diofcoridis effe, cư flos puniceus anemonę fimilis attribuitur. Cyclaminû Theffalus herbã leonis(fyderis:nam \& alias herbas à fignis zodiaci denominat) appellat, Aggregator. Leontocha= ron, polium, ut habent nomendaturæ cum Diofcoride. Cichorif fylueftris genus follo latiore, quod hedypnoida cognominant, flore luteo in pappos abeunte, leonis dens utigari uoce dictus creditur; Ruellius, Eandem, aut omnino $\&$ genere $\&$ uribus fimillimam, Diofcoridis hieracium alterum effe dixerim. Herbarij quidam in Gallia thymelaam, leonem terræ nuncupant, Ruel!.

Animalia. De leopardo in Panthera dicetur. Leontophonus capite tertio explicatus - eft, Chimaram monftrum ex leone, capra, 8 dracone compolitum fabulantur: fabula allegori. am, \& fingulorum in ea animalium fignificationes interpretatur Calius 13.9. Prima leo, poftrema draco, media ipfa chimara, Lucretius. Vide fupra in Capra H. a. Chamæieon quadrupes ouipa ta, fuoloco tractabitur. Leo, feram fignificat, $\&$ uirginem, $8 \mathrm{c}$ pifcem, Hefychius $\& \mathrm{~V}$ arinus. Pro uirgine ufquam legiffe non memini: Homerus quidem de Diana, qua femper uirgo fingitur;

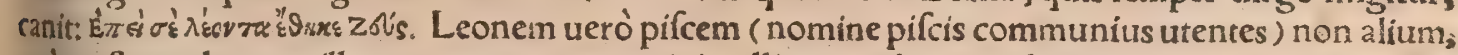
quàm oftracadermon illum cancrorum gुeneris intelligere uidentur, de quo in libro de pifcibus die cemus. In mari magno circa Taprobanen infulam infinitos pifces procreari ferunt, habentes ca: pita leonum, pantherarum, \& arietum, aliorumó̧ animalium, Aelianus. Eft 8 inter ferpentes leo apud Nicandium, alio nomine cenchrines dictus, oblongus, maculofus : quem Scholiaftes leonem dici purat, uel ex uariantibus f́qumis, aut ex generofitate, aut quia rectam geftat caudam, \& fe ea difflagellando excitat in pugnam: uel quia mordet, ac hominis fanguinem exforbet, quxipfa $\&$ leo facit, Calius. Laifch, wh, uox Hebraica lob capite quarto ab Hieronymo tigris transfer

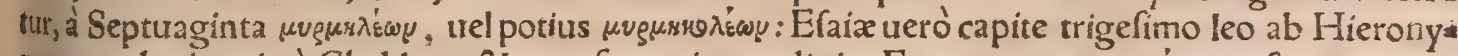

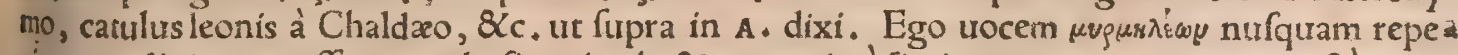
rio, nec diuinare poffum quale fit animal: $\&$ ut maximé fit in rerum natura, non rectétamen pro Hebraica uoce laifch poni uidetur, qua leonem doctiffimi plerique fignificari teftantur: prouecta quidem ætatis Dauid Kimhi, catulum uerò Chaldaicu sinterpres $\&$ ipfi Septuagín. ta Efaia capite trigefimo. Ahraham Prizol leonis genus intelligit. Haciam feripleram cum repe ri apud Strabonem libro fexto hæc uerba: Extremæ Arabia ultimum promontorium fert parda

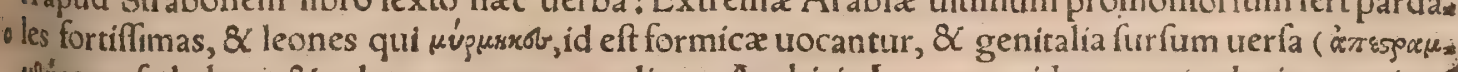
Mük a $u$ erfa)habent, \& coloremaureum, nudiores Arabicis Leones quidem aurei coloris reperiun 
ctiam in fritima A frica: uide in b. TTigris ef irtleo, Varro. Tigris lean nomnino fimlis uidet prater folam pellem inaculis exornatam; Gillius.Megafthenes friptis mandauit, in Prafijs tigres gi gni leonibus duplo ferèmaiores, $1 \mathrm{dem}$. Catus leoni uel potius lexna quodammodo fimilis eft: fed cati auriculæ acutiores, leęnæ rotundiores funt. Gryphem Indicum aitunt quadrupedem ut leone effe, $e_{\text {, }}$ nuibus ctiam robuftifimis leonum fimilibus, A elian. Sphingem fabulantur ex co pore vir ginis \& leonis compofitam effe, Aelian. Camelopardali pofteriores cor poris partes leonina funt, Mantichorx Indicx ferx corpus leonis effe Ctefias fcribit, caudam fcorplonis modo fpicula infigen, tem, Plin. Leucrocurz etiam fer Indic , collum, cauda, \& pectus leonis apud euridem contributh tur. Dxmonium leoninum, eft permixtio rationis cum actis malis ladentibus $\&$ iracundis, An dreas Bellunenfis.

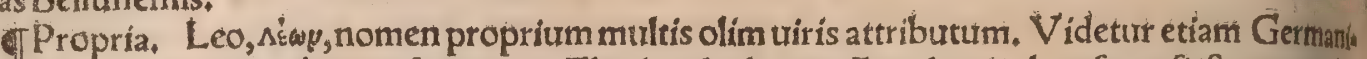
cum Leonhardi nomen à leone fachum, ut Eberhardi ab apro, Bernhardi ab urfo, ac fi iftorum infar animalium fortes dicas، Leones dictos Romanos imperatores $\&$ pontifices aliquot in hiftori|jlegl

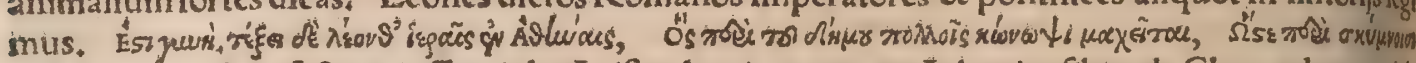

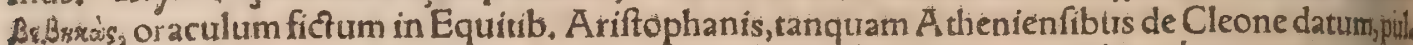

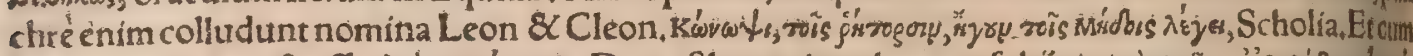

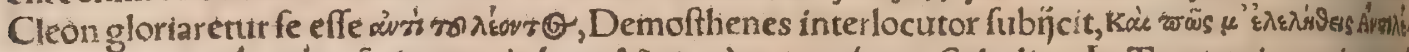

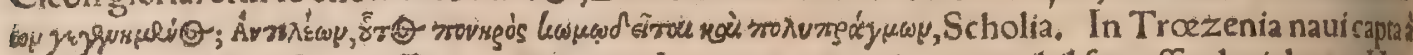
clafte Xerxis, uiro ftrenuiffimo nomen erat Leoni, quo nomine nonnihil fortaffe gloriabatur, Hero cot, Wb. 7. Leon nomen ducis A thenienfis apud Xenophontem rerum Gracarum libro 1. Theo 1 dofius iunior imperator Eudociam Leonis A thenienfis philofophi(Leontĭ fophifta A thenienfis fill am, (sytald.) uxorem duxit, Egnat. De Leone imperatore Romano, uide Suidam: item de eifude nominis Alabandenfi rhetore \& Byzantio philofopho, cuius hiftoriam in Onomaftico quog; repe ries. Platonis Alcyon à quiburdam Leonis Academicieffe creditur, A thenæus libro 11 . Leo Tor nicius dux defeciionis contra Conftantinum monomachum, poft aliquot pralia ab eo captus, octlili

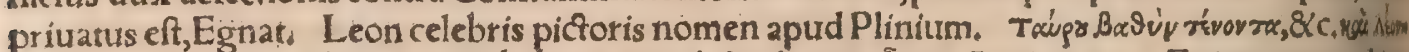

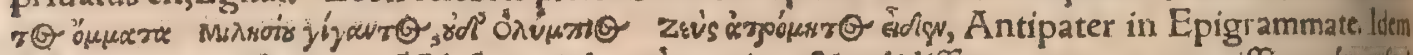

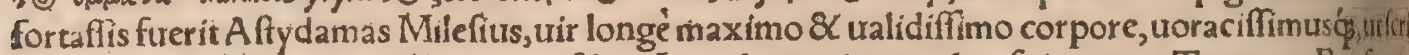
bit Aithenaus lib. 10. Leo Eurycratis filius, Lacedamoniorum dux fuit contra Tegeatas, $P$ aufan,in Laconicis. Leo A thenienfis, unus ex eponymis triburm Athenis, filias fuas publica falutis calla 3 ex otaculo traditur deuouiffe, Idem in Atticis. Pantaleontemè Pifis criundum tyrannum, Pilatio Icm appellat Nęuius, cum aliquil inde profecti nunc Pifani dicantur, Fefr. Legitur hoc nomen ettain Statibus Hermogen. Leones aliquot fcriptores, ueteres $\&$ recentiores, in primo Tomo Bibliodica commemoraui. Leontcus ( 1 rovtrvis) Argiuus Tragoedus inter opfophagos numeratur ab Athentico libro 8. Leontios aliquot uide in Bibliotheca noftra, ( 8 aliquos apud Suidam. Leontitrs fratuatius, \& Leontion pictor, apud Plinium nominantur:)Vbi etiam Leonellts, Leobinus \& Leodrifitisichit prorum recentiorum nomina, à Leone formata uridentur. Asoyrioliss nudurm nomen apud Suridani curi fimile eft Leonides, non tamen à leone façum, cum fecunda per o. magnum fribatur. Vuetiam Leonicus, Leophron, Leonâs, à quo etiam alterum nomen uiri Leenatus façum apparet ; apưd Sul, dam per n, fimplex (aliqui non rectè $n$.duplicant) 8 omicron in fecunda, quod non placét, Leonti ades tyrannus apud Xenophontem rerum Gracarum libro 5. Leontichus uir in méretricip dialo gis Luciani. Samï $R$ hadinx et Leontichimonimentü habent, ad quod qui amore torquenturi, uora facerefolent, Paufan, in Achaicis: Leontychida etiam uir nomen apud Calium Rhodig. legi, Leon tífcus, à Leontio diminutiuurm. Hoc nomine pictor Plinio celebratur ‘ De Leontifco Meffenio arto cherfite lege Suidam:Eiufdem Eliacorum fecundo Paufan,meminit, Leontifcus pancratiaftes (lia niam meretricem amauit, $A$ then. TLeontius turile, Leontium muliebre nomen eft.Sed uitosde flexum à leone nomen ornat, \& fortitudinis fignum uel omen eft; in mulieribus libidinis notat Lon tĭ enim $\&$ Leęna nomina meretricibus tantum pofita legimus: for te quod leo etiam pro mulietrip pł dendo accipiatur, ut fupra dictum eft, \& leana pro fchemate libidinofo. Leontíj meretricis Epicus ri, qux philofophix etiam Epicurex operam dedit,meminit Athenaus libro 13. Leontium Epicuri cogitantem pinxit Theodorus, Plin. Cum meretrictula etiam Leontium contra Theophraftum icti bere aufa fic,Cicero I, de nat, Leæna meretrix apud Lucianum. Patientia corpor is innumerado rumenta peperit:clariffimum in foeminis Leænæ meretricis, quæ torta non indicauit Harmodirm \& Ariftogitonem tyłannicid as, Plin.lib.7.Et rurfus lib.34.Iphicratis(ftatuarij) leana laudatur, Sen tum hac lyrx cantu familiare Harmodio \& Ariftogitoni, confilia corum de tyrãnicidio, uf̧́ ad mor" tem excruciata,tyrannis non prodidit. Quamobrem $A$ thenienfes $\&$ honorem hảbere el uolentes, nec tamen fcortum celebraffe, animal nominis eius fecere:atç ut intelligeretur caufa honoris, in ope relinguam addi ab artifice uetterunt. Propter Hipparchimortem (inquir Paufanias in Atticis) Hippias iracundiam fuam tum aliâs declarauit, tum in mulierem nomine Leanam. Hancenim in tormentis donec periret afflixit, fciens illam amicam A riftogitonis fuiffe, $\&$ confilij eius minime int fciam exiftimans. Propter hanc foemina uirtutem, delectis tyrannide Pififtratidis, aream leęnamA, thenienfes in rei memoriam conflarunt. Demetrius Poliorceta tum alias tum Leanammeretricem 
cla recufantum, \& fera fub nocte rudentum, Vergilius de Circe 7 . A ene. बfMinimum dormfint fus lucentós dormientium oculi:propterea in Agamemnonis fcuto formidinem leonino pictam capite

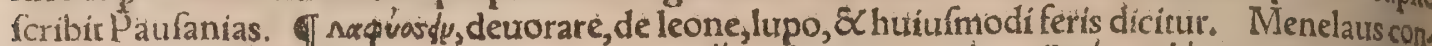

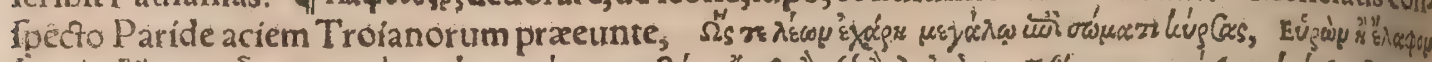

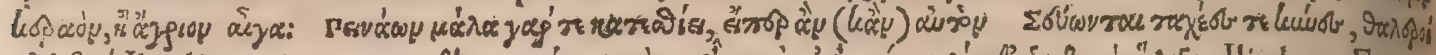

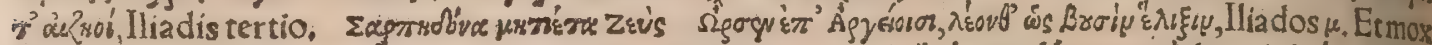

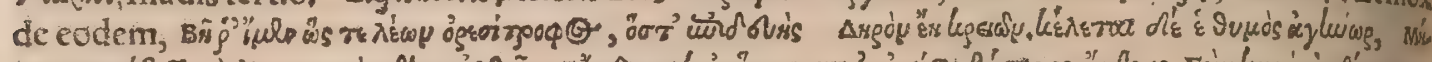

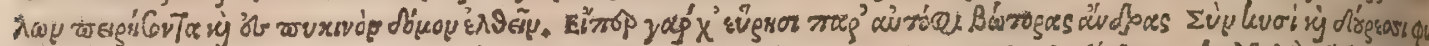

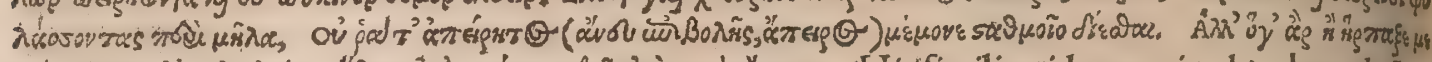

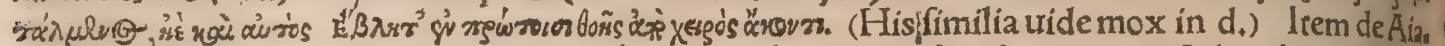

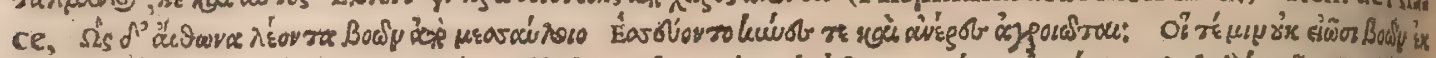

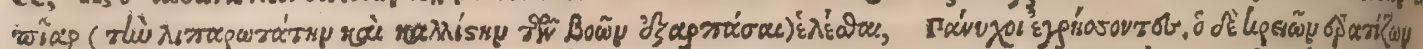

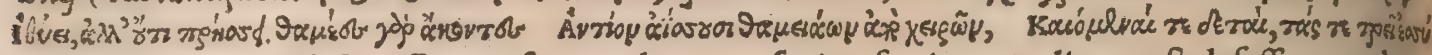
uhlves mop, lliados lambda. Ceruus forte uulneratus fagitta, fugit quamdiu potef, defeffum ueròtan.

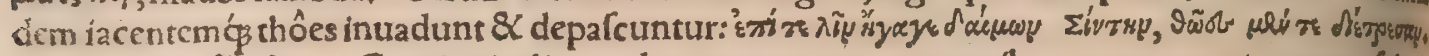

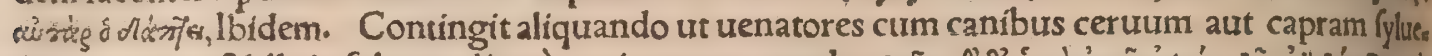

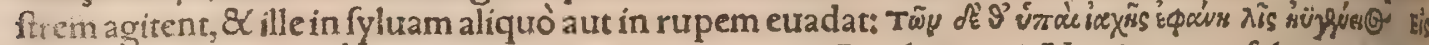

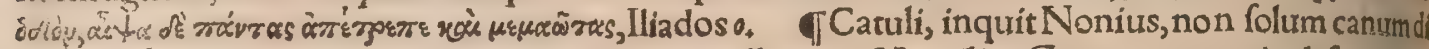
minutiué, uerum etiam omnium animalium appellantur. Vergilius Georg. quarto in deferiptione peftis, Tempore non alio catulorum oblita leana Sxuior errauit campis. Lucretius lib. Y. Atcan al Ii patzherarum, fcymnićg leonum. Exúsuos peculiariter leonum catuli dicuntur,Pollux $\&$ Varinus:

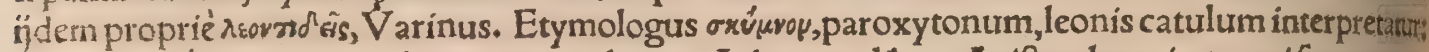
oxveyóy ueró, oxy tonum, aliorum anímalium. Athenzus lib. 7. A riftotelem citat, qui fcymnonpi fcem muftelarum generis faciat. Scymnus Tarentinus, 9xupcromoros erat excellens, A thenaus,

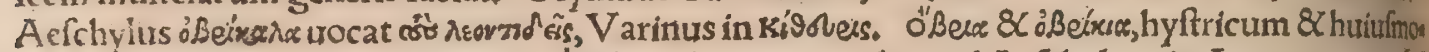

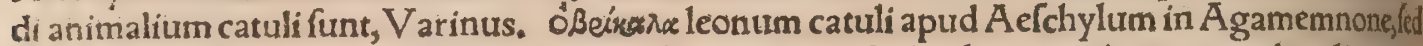
ualidi 8 fpeciofi:dicuntur $\&$ oैBexos? funt qui luporum catulos eodem nomine comprehendiputant, Eufrathius, ut quidam in Lexicon Gracolatinum tranfcripfit. In Co infula, apud ueterem auctore fidei integra (A elianum in Varijs lib,1.)legimus, de grege ouiarico Nicippi, ouem non ritu natura agnum, fed leonem peperiffe. Prodigiale id(ut erat)uifum multis?fiquidem Nicippo tyrannidem por iendit, quam mox is eft confecutus, quum ædito monftro priuaturm adhuc ageret, Cælius, qFrar

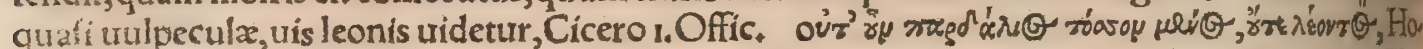
merus Iliadis thô. Meles primus Sardius rex ex pellice fua leonem genuít:quílco quacunque parte murorun circundatus effet, ex ea parte Sardes inexpugnabiles fore Telmiffes iudicauerant. Eum Meles per cæteram partem murorum circunduxit, quacunc $\beta$ poterat ar $x$ oppugnari, per unam un ró partem, tanquam inoppugnabilem $\&$ præcifam, circunducere pratermifit qua ad Tmolum fur uirm uergit:atç illic regnante Crofo à Darjo capta ef, Herodotus lib, I.

6) d. Extant Martialis epigrammata quin $\$$ li.1.nempe, feptimum;16.19.28.79, \& 148, de lepore per lufum tranfeunte per os manfueti leonis, ex quibus uel unum recitaffe fat fuerit: eft autem 16,

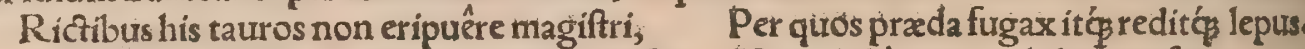

Quod's magis mirum:uelocior exit ab hofte, Nec nihilà tanta nobilitate refert.

Tutior in fola non eft cum currit arena, Nec cauex tanta conditur ille fide.

Si ùitare canum morfus lepuš improbe quęris, Ad qux confurgias ora leonis habes, Aliud eiufdem poétæa 9.73, de leonis $\&$ arietis concordia legitur huiulmodit

Maffyli leo fama iugi, pecorisćs marítus Lanigeri,mirum qua poluểré fide.

Ipfe licet uideas, cauea ftabulànturin una, Et pariter focias carpit titèrq̧ dapes,

Nèc fótu nemorũ gaudẽt, nec mitibus herbis, Concordem fatiat fed rudis agna famem, In magnis feftis Tartarorum adducitur regi corumleo cicur, qui ad pedes eius inftar catulimanfuer ti iacens dominum furm agnofcit; Paulus Venetus; Titl Vefpafiani Stroza egregium carmen les gimus libro quarto Eroticôn, in leonem Borfí ducis Ferraria: qui obieços ei in cauea tauros, urfos $\&$ apros dilaniare folebat, lepori \& catulo circa fe uaganti parcens:tandem uerò depofita manfutetu dine, puellam Suftulit ingratus, cui quondam plurima debens, Pecłendaś́́s iubas \& fera collada

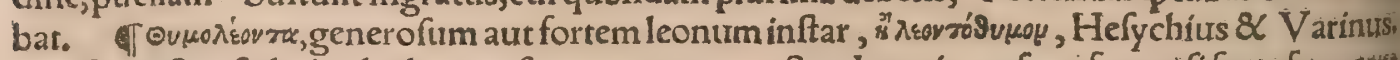
(Impaftus ftabula alta leo ceu frepe peragrans (Suadet enim uelana fames)fi forte fugacerti

Cófpexit capreã, aut furgentẽ in cornua ceruũ: Gaudet hians immane, comasḉ̧ arrexițethèret

Vifceribus fuper accûbens, lauit improba teter Ora cruor, Vergilius Âeneid.10.Similis eft com

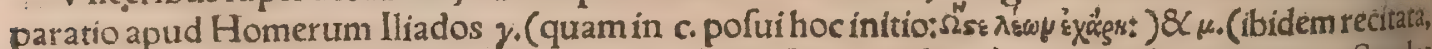

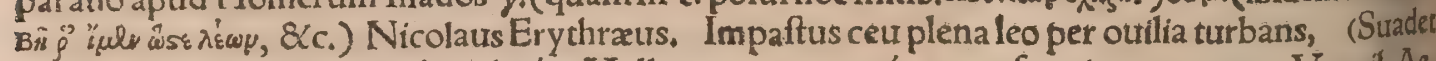
enim urefana fames)manditós trahitós Molle pecus, mutum'́s metư fremit ore cruento, Vergíl, Ảs

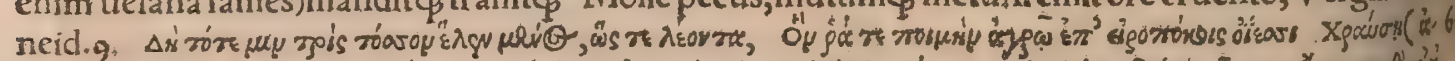

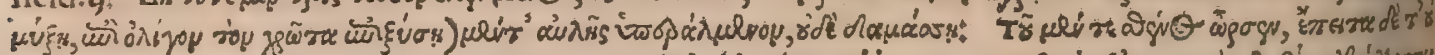

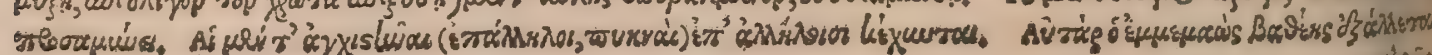




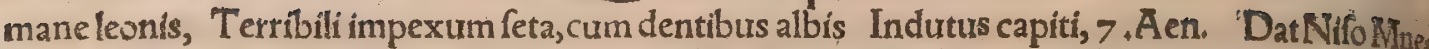
ftheus pellem, horrentisćs iconis Exuruias, 9.Aen. Fuluiós infternor pelleleonis, Aeneas 2.Âene, Præcipuumós toro, \& uillofi pelle leonis Accipit Aeneam, 8 .Aen. Aurifero perfufa Tago uillof leonis Terga feri, Statius libro 6. Thebaidos inter pramia certaminum. Herodorus uir uoracill

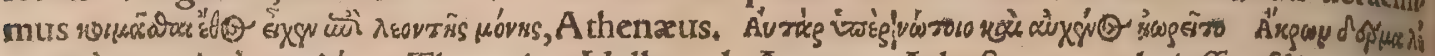

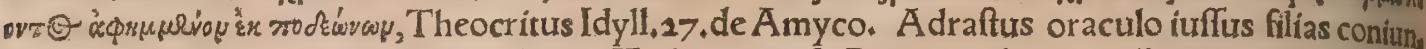
gere apro \& leoni, cum uenirent ad eum, Tydeus apri, \& Polynices leonis pelle induti, illis elocauti,

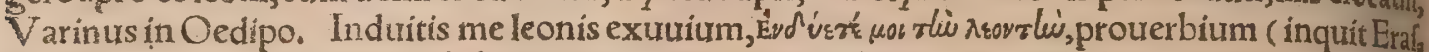
mus) in cos dici folitum, qui furfipiunt negotium maius facultate, quíç fe magnificentius germ! quàm pro fura conditione. Quidam ab Hercule fumptum putãt, cuius hic ornatus erat, ut leonis exu xio tegeretur, deinde altera manu clauam, altera geftaret arcum, at $̧$ hoc ornatu defcẽdit ad inferos, Cerberum extraciurus. Huc alludens Ariftophanes in Ranis, Bacchum fingit, Herculis inftar, leo, nis exuuio claua ̧́́ inftructum, ad inferos defendere parantem, ut Euripidem cum Aefchylo certan tem audiret. Ridetur autem ab Hercule', quod id geftaminis neutiquam illum deceret, utpote mol, lem \& efforminatum. Eodem pertinet quod Menippus ille Lucianicus eodem ornatu fe ab inferis te diffe adfimulat. Nihil autem prohibet quò minus prouerbium ad apologum illum refer atur, euius meminit Lucianus in Pifcatore: Apud Cumanos afinus quífpiam pertæefus feruitutem, abruptolo, ro in fyluam aufugerat:Illic forte repertum leonis exuuium corpori applicabat fuo, atç ita proleone fegerebat, homines pariter ac feras uoce caudaḉ territans. Nam Cumani leonem ignorât. Ad hunc igitur modum regnabat aliquãdíu perfonatus híc afinus:donec hofpes quifpiam Cumas profectus, qui fapenumero uiderat $\&$ leonem $\&$ afinum, at $\$$ ob id non erat difficile dignofcere, aurium pro, minentium indicio, neç̧ non alijs quiburdam coniecturis afinum effe deprehendit, ac probé furiga tum reduxit, dominóg agnofcenti reddidit. Cumanos autem hîc appellat, non qui funt in Italia, fed quifunt in Acolide fupra Lefbum. Nam \& Lefbij \& Cumani notati funt ftoliditatis, ut indicat ftes phanus. (De afino Cumano frribit etiam Tzetzes $4+10.8 \mathrm{~K}$ 11, \& 10.521.) V furpat hoc adagium Sorm tes Platonicus in Cratylo, negans oportere deterreri fefe magnitudine difputationis inftituta, pon

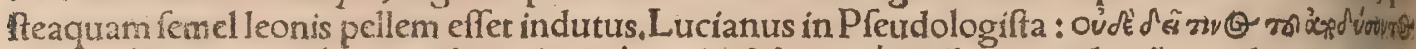

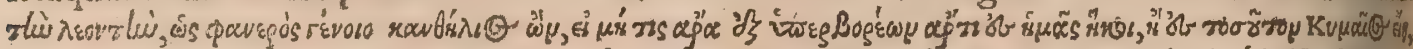

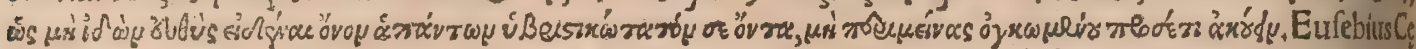

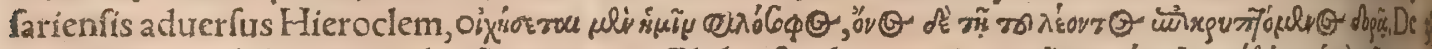

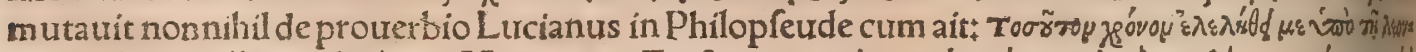

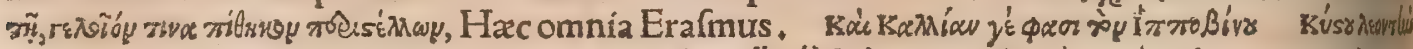

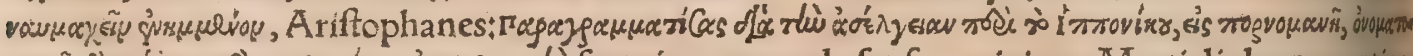

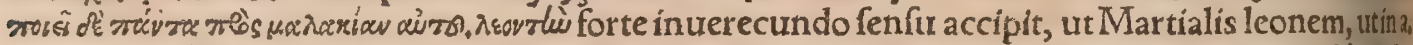
dictum eft.Leonis tergus geftare, ceu prourerbio dici poffet in uirum fortê, quod id olim geffấrit Her

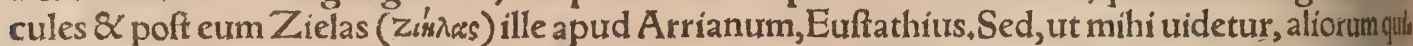
dem animalium, ut uulpis, hinnuli, pantherę, pelles geftare illos, quorum fimilia funt ingenia, elegan

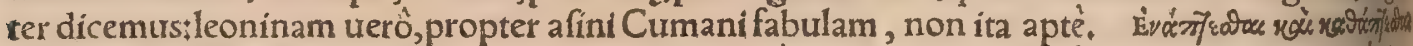

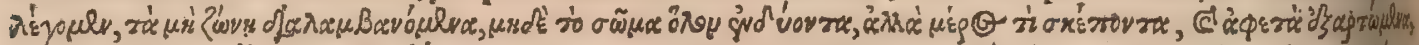

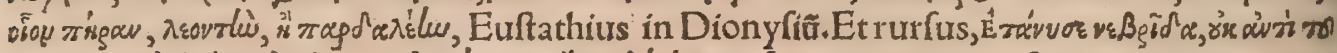
vов тఢึ, parcemia, quæ locum habet, cum duro quxpiam copulantur, qưorum alterum cum altero nequa quam congruit. Sumptum à Baccho qui hoc ornatu defcendit ad inferos, apud Ariftophanemit Ranis; (ur dicitum eft in præcedente ftatim prouerbio:) quo uidelicet Hercules creditus, formidablis

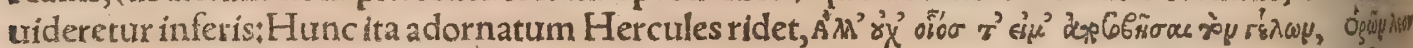

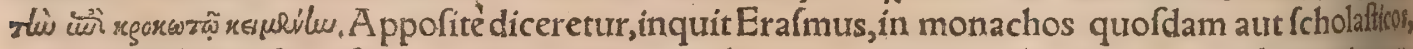
qui foris infignia fui inftituti portant, interius militarem imitantes cultum: aut qui uultu tetrico, thion

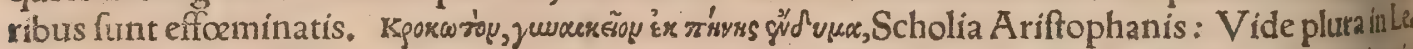

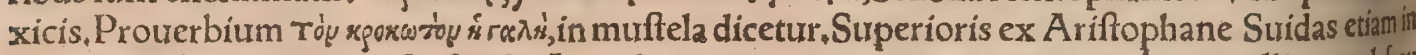
uoce Korw zò meminit. Lyfander Lacedæmonius cum ei uitio uerterctur a nonnullis, quod frat i de fubinde agere uideretur:Quó (inquit) leonis peruenire pellis non poteft, uulpinam affuiffe haud

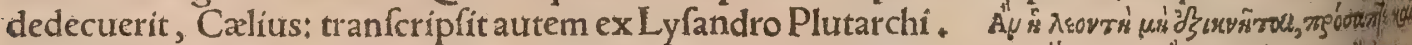

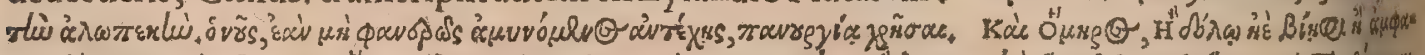

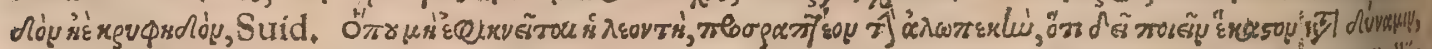
Apoftol. बा Veftes in corioleonis deuolutę, tuta funt à tinėis, $R$ afis \& Alber. Si fepo leonis cüallin

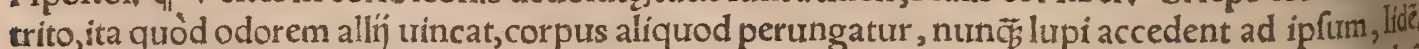
Si cum fepo leonis liquefacto circuitus ouium inungatur(aliàs, diftilletur)niunquam accedent ad eú lupi,nec alia rapacia, $R$ afis $\&$ Albertus. Si quis linat corpus furum fepo renum leonis, terrentur ab colupi, Aefculap. Si fepo eius liquefacro inungatur animal, non accedent a dipfum mufcæ (uelu alij habent, lupi, aut beftix, aut ferpentes)Rafís. Si fuffitus ex fepo leonis circa aquam fiat, uel ex eo aliquid in aquam ueniat, prohibet lupos ne bibant eam(ne accedant $\&$ ne bibant eã, $R$ a fist)

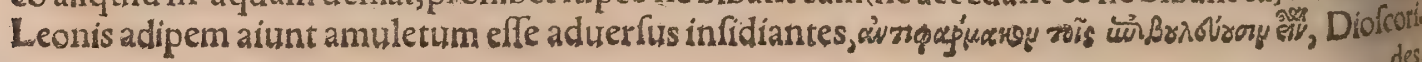



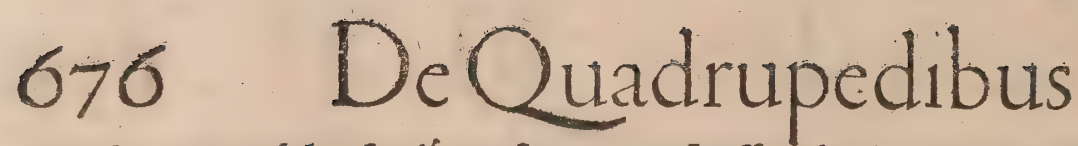

cepiffet, aut pardalim fimilemue feram interfeciffet: fed fi lean am effet nacta, animum extuliffe, fit biga in eo placuiffe, A elianus in $V$ arịs lib.12. A b Acropoli defcendentibus (inquit Paufanias in $A$ ricis) Septentrionem uerfus, monumertum eft Alcmenx, $8 \times$ c. 8 prope illud Hyli filì Herculis: à quo non mu: rum abeft A pollinis \& Dianæ fanum, quod extructum aiunt ab Alcatho cum leonem Cithe ronitum occidiffet. Ab hoc enim leone interemptos aiunt tum alios tum Megarei regis filium Eurin pum:Itaqg regem illi qui leonem iftum occidiffet filiam promififfe uxorem, \& fimul regni fucceffio

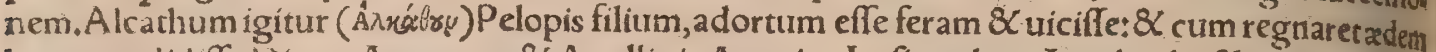
hanc condidiffe Dianx Agroteræ, \& Apollinis Agræi. Lyfimachus Agathoclis filius, dum Callie ftheni philofopho(quem lapius de uirtute differentem audierat)ab Alexandro in fouea cum cane inciufo, ad remedum miferia, uenenum propinaffet, ac propterea eiufdem Alexandri factum æare ferentis iuffu, leoni fuiftet obiectus, rem toti memorabilem pofteritati egit.Manum fiquidem amicu lo inuolutam in os leonis intulit, arreptáç lingua feram exanimauit, Textor. Hoc facto, ut quidam Icribunt, uchementius poftea Alexandro dilectus, \& apud eum in honore maximo fuit, \& candem poft mortem cius Peigamo prafuit, ubi thefauri regis fuerunt: Vide Trogum libro 15. Alexander Magnus Lyfimachum familiarem fibi leoni obiecir. Nunquid ergo hic Lyfimachus, felicitate quadã dentibus leonis elapfus, ob hoc cum ipfe regnaret, mitior fuit? Nam Telefphorum Rhodium amicü fuum undiq̧; decurtatum, cum aures illi nafumćs ablcidiffet, in cauea uelut nouum aliquod $\&$ inufi tatum diu pauit, \& c.Seneca de ira. Polydamas (Scotufaus)leonem magnítudine uifenda \& robo, reconfecit, \& quidem inermis prorfus inobfeptus ó, Herculis fimilem audaciam amulatus, Caliuss: Trâftult autem ex $\mathrm{P}$ aufania, qui Eliacorum fecundo, Montana, inquit, Thracię regio intra Nefưm fluuium leones alit, qui fape in loca Olympo finitima euagantur. Huius montis latus unum ad $\mathrm{M}_{21}{ }^{4}$ cedoniam uergit, alterum ad Theffaliam $\&$ flumen Peneum. Hoc in loco Polydamas leonem in $\mathrm{O}_{\mathrm{B}}$ lympo confecit, $Q c_{\text {, uc }}$ ex Cæalio recitaui. A b eodem Polydamante ferociffimi tauri pedem manu de tenrum, donec ungulam dimitteret, in Tauro dixi. In leonem à bubalco occifum Anthologï 6 ,llh hexaftichon extat huiulmodi:

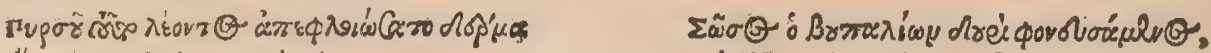

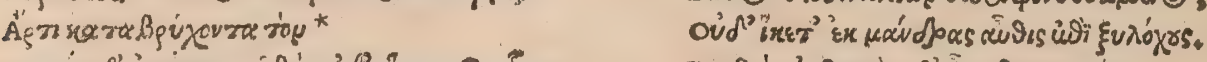

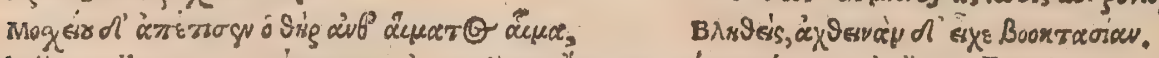

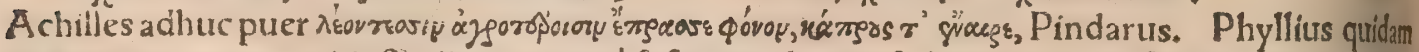
propter amoreni pueri, iuflu illius capras à fe feras, uolucres, \& leonem quoç, ferum, ei tradidit domi tas:taurum uerò poftremo uiçum cum illinegaret, indignatus puer faxo defiliens in cygnum auem mutatus eft, Ouidus 7. Metam. IT Teumeffus mons eft Bocoriæ feu ciuitas, \&c.ut in Onomafico docetur: unde dicfus leo Teumeffius inauditæ magnitudinis, qu omnibus terrori erat, quem Heru les adhuc pené puer occidit, eićç pellem detraxit, qua poftea pro pallio femper ufus eft. Hic leoàlo ue in colum translatus dicitur, ut gloria Herculis confuleret, qui eum inerm is occiderat. Alintramen non hunc, fed Nemex um leonem, itidem ab Hercule interfecoum, inter fydera relatum dicunt, Sid

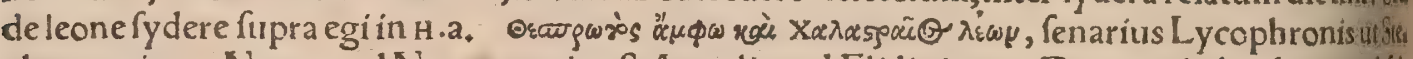
phanus citat. Nemea urel Nemee, regio eft Arcadix uel Elidis, in qua Dryopes habitabant: uel yyı ua, inter Cleonas $\&$ Phliuntem. In hac Argiui ob Herculis memoriam Nemexa facra celebratecun fueuerunt, eò quod immane leonem in ea inter feciffer, Molorchi horpitis fui fưa fu cuius fillumleoin teremerat. Vnde \&Molorchaum leonem quidam cognominãt. Si fauum premeres Nemeatum Phœbeleonem, Lucanus libro 1. Eft \& Nemea fons, item mons. Vergilius Aen.8. de Hercrle, Til Crellia mactas, Prodigia, \& uaftum Nemex fub rupe leonem. Aufonius pro Nemexo leone Cleone um dixit, àCleonis oppido Arcadix prope Nemeamfyluam, Cognominatur \& Bembinetas apur

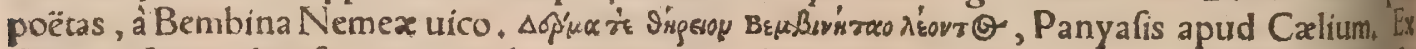
Cleonis Argos dux funt uix, una breuior qua pedibus tantum itur:altera quamuis $\&$ ipfa angula circumieftis montibus, curribus tamen aptior eft. In his montibus adhuc oftenditur fpectrs leonis, \& regio Nemea quindecim circiter ftadia abeft, in qua templum uifitur Iouis Nquér, Paufaniasin Ai golicis. Nemeorum ludus funebris eft ob Archemori mortem inftitutus, \& $c$. Hunc Hercules de uicto Nemearo leone inftaurauit, \& Ioui confecrauit. Celebratur autem tertio quoç anno, Paneml menfis duoderimo die, certaminibus equorum 8 gymnicis, Scholia in Pindarum. De Nemeorum certamine reperies nonnihil apud A elia num libro 4. capite de ïs qui memores beneficior um furêli Leo, inquit Varinus, in Nemea regione A rgiua erat, nec ferro urulnerabilis, nec ullo genere telithunc Hercules fuis manibus compreffum occidit, \& exuuium pro uefte geftaurit. Contigit autem aliquan do ut eum tranfeuntem Telamon ei amicus, qui filips carebat, loui facrificans inuitaret rogartí, ut fic amicfus leonis pelle Ioui patri fuo facrum faceret, $\&$ ut filius ei nafceretur oraret. Herculeigi tur phiala aurea accepta facrificante, \& pro filio Telamo ni impetrando Iouem orante, aétòs, id eft? quila præteruolauit. Itaç iuffit ut filium nafciturum Aẽtòn nominarer. Quare filius Telamonis nå tus, primum Aëtòs, poftea Aiax diçus eft. Adultum Hercules pelle fua obtexit, eamḉ ci donauit' qua tecius, ut nugantur, inuulnerabilis erat: (ut \& Hercules) eo tantum, ut quidam uolunt, locoes: cepto, qui pharetra prius tegebatur, cum pellem adhuc geftaret Hercules: (in Aiace uero eam geftan te, excepto eo loco quo fcutum tenebat, Il $a c$, Tzetzes,) Sed hac nuga funt; Veritas aute fic fe habeh 
peftilentia laborarent, \& à multis imperatoribus id celebratum conftat.

TSub A tergatis fimulacro fpecies leonum funt, eadem ratione terrã effe monftrantes, qqua Phr ges finxếre matrem deûm, Id eft Terram, leonibus uehi,Macrob. Phafiana dea, nó alia quàm Rhę uidetur: cymbalum enim manbus tenet: $\&$ leones throno fubijciuntur, Arrian, in Periplo. Cureter louem in Creta clam nutriuerunt, à R hea eis commiffum : quod cum Saturnus refciuiffet, iratus in leones cos mutauit; Iupiter uerò lam regnans effecit, ut inter feras omnes principatum tenerent, \& fub iugo Rhex matrís currum traherent, Oppian, Rhea Cybele uocatur à Cybelis montibust efte, nim dea montana, eamḉ̧ ob caufam fuper leonum iugo inuehitur, Varin. Sophoclis gloffularius

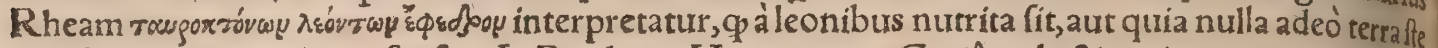
rilis fit qua culta nó manfuefcat, Io.Brodxus, Hanc ueteres Graiûm docti cecinere poetæa Sedibtro in curru bijugos agitare leones, Lucret, lib, 2. Et iuncta currum domina (Cybeles)fubiereleones, Verg. 3. Aen. Cui Dindyma cordi, Turrigeracós urbes, bijugíḉ ad frena leones, Idem 10. Aeneid, de Cybele. Nicomachus pinxit deûm matrem in leone fedentem, Plinius. Leonem fimul \& galli naceum folaria effe animalia, fed hunc gradu fuperiore, ideoćç ab illo metui, diçum eft capite quar, to. Aegyptij (inquit Macrobius Saturnalium 1,21.)animal in zodiaco confecrauere, ea coll parte, qua maxime annuro curfu Sol ualido efferuet calore, $\& c_{\text {. }}$ ut fupra recitaui in a, de leone fydere: tubj plura etiam a ttuli cur leo folarefit animal. Leonem à fomno inuictum effe, nempe qui femper ujgi let, Acgyptī fe obferuaffe gloriantur: idcirco hunc Soli cos comparare exiftimo, quód Sol laborio. fifTimus ad nullum temporis punctum uerfari intermittens circum orbem cerræ, ab inftitutocurfu nunquam conquiécit : curi rei Homerum teftem afferunt, cum Solem inquit operum $\&$ laborum requietem nullam habere, Gillius ex A eliano. Mitras (uel, ut alï fcribunt, Mithras) apud Perfas Sol eft, 8 primus corum deus. Huius fimulacrum fingebatur leonis uultu, ambabus manibus reluctart, tis bouris cornua recentans: quo fignificabatur Lunam ab eolumen accipere, cum incipitab eitustan dîjs fegregari:ipfa enim indignata fequi fratrem, occurrit illi, \& lumen fubtexit obfcuratóc. Solau tem, id eft Mithras, ideoleonis uultu effe dicitur, quia Sol leonem fignum principale habet:uelo ur leo inter animalia, ita Sol inter fidera excellit, Gyraldus. Plutarchus fcribit leonem propteread ci Solare animal, quod inter quadrupedia unguibus aduncis , catulos fola uidentes parit leathat mi nimum porrò dormir, fublucentćs quiefcentis oculi, Cælius, Leo in anteriori parte calidær natus r $\mathrm{eft}$, in pofteriore frigid $:$ fic $\&$ Sol cum eft in leone, Author obfcurus, đDicitur quibufdam quocs leo inter uigilandum pracipué oculos occludere, quos a periat dormiens. Hinc templorum clauftrís leonem fymbolicè appingebant priores, $\mathrm{C} \approx \mathrm{l}$. TOnofceli damones, maresfíe ut plurmum exhibent, interdum quoqueleonem $\&$ canem induere uidentur, Calius. Canis Serapidiconiuns crus eft triceps, capite medio leonis, finiftrolupi, dextro canis : uide fupra capite primó de canibus diuerfis, ubi de Cerbero agitur. I Ampraciotæ leænam furmma religione colunt(adorant), gutod tyrannum fuum lacerârit $\&$ diftraxerit, tanquam fur libertatis uindicem, Aelianus. Leonibusina quit idem)in Aegypto religiofus cultus non modò tribuitur, fedetiam ex ïs urbs nomentaxit quorum fanè ưim ac naturam exponere non alienum uidetur. Templa habent fibi confecrata, \& des ad commorandum amplas, $\&$ ad exercendum fpatia $\&$ curricula laxa : tum eis bubular. nes qurotidie prabentur, quas diftractas atque ab olfibus nudas cum interea exedunt, $\&$ confici unt, ab Aegyptijs incantantur Aegyptia uoce. Cantionis argumentum huiufmodi eft, ne ex afpis cientibus quenquam fafcinent, Neque uero eorum modó permulti diuinitatem \& relígionemapul ipfos habent: uerum etiam fedes eis dedicatæ, èregione contrarios auerfos q̧́ afpectus habentiqua rum feneftra, tam qua ad folis exortum pertinent, tam etiam qux ad occafum fpectant, aperta fuauiorem uiuendi rationem eis \& iucundius habitandi domicilium efficiunt, tum eis etiam lunt exercitationum loca ad tuendam ualetudinem, tum propinqua palaftra, Eos ideo Vulcano Aegy ptí confecrarunt, quód fint natura uehementer ignita, atque adeo exteriorem ignem ob coplaminu terioris agerrime inturentur, \& fugiunt: tum ipfos idcirco folis domicilia conftiturunt, quodignt fint: fimul $\&$ folem, cum eft xftuo tempore calidiffimus, accedere ad leonem coeleftem dicunti \& î quidem qui magnam Heliopolim incolunt, in templi ueftibulis cos díuinæ cuiurdam fortin ut A egypin dicunt, participes alunt. Nam ịs, quibus propitius eft deus fomniorum fignif bus fecundum quietem, futura non folum oftendunt, fed etiam à periuriffimis, quod iufurant dum non conferuent, \& fidem uiolent, non longo interuallo, atque adeo eueftigio, deo eis ith fum imperum affante, poenas illorum fraudidebitas, repetunt, Hactenus Aelianus, ILyou

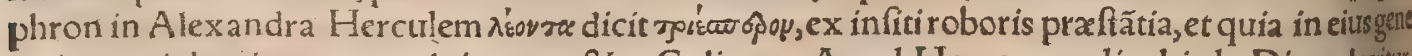
ratione tiplex in unam coiuit nox, 8 c. Calius. Apud Homerum alicubi de Diana 1

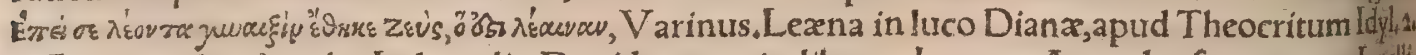
- Ecce uicit leo de tribu Iuda, radix Dauid, ut aperiat librum, Ioannes A pocalyp feos quarto. Intelis git autem dominum noftrum Iefum Chriftum, quem $\&$ agnum paulò polt uocat, ab innocen leonem à forritudine, quòd folus potuerit aperire librum, quem nullus alius fpiritus aperire poterati Sed etram princeps tenebrarum ab apoftolo Petro leoniconfertur, non fimpliciter, fed rugientiof fa meirco: ferociam enim \& iracundiam leonis in fame fummam effe diximus.

4L Leonis ad frugifera \& fructuofa loca profectio ficcitatem pranuntiat, Aelianus, Periclis mater 


\section{DeLeone. H.h. Lib. I. 679}

Agarifta per qutierem fibi uifa elt leonẽ partu ædere, \& polt paucis diebus Periclem peperit, Plutar.

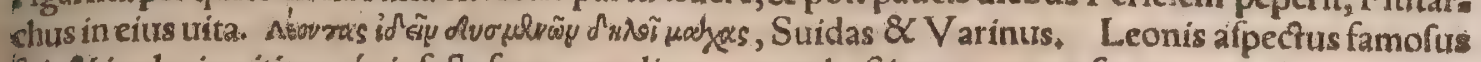
fuit 8 inglorius, ítinerá̧̧ infelta facere creditus : nan $\not ̧$ hoftium pugnam fxpe portenderunt, Ale: xander ab Alex. fed deceptus uidetur, non intellecto nimirum quem recitaui fenario, cum is ad fom nium pertineat, non ad leonem obuium uel in itinere uifum. Erafmus eundem fenarium inter pros uerbia ntrmerat, (quod parum probo,) translatum ut inquit, uel à fomniorum conicêturis, uel ab obfertzantibus auguria. Sed ad fomnia duntaxat pertinere, uel inde clarum eft, quod paffim apud Stidam 8 Hefychium plurimi fimiles fenarij monoftichi onirocritici recitantur. Alexãdrum Mas gnum in Babylone multa prodigia perturbabant. Ex his enim quos educabat, leonem quendam ext mix magnitudinis ac formæ manfuetus afellus calcibus exanimârat, Plutarchus in eius ưita. Leo in Co infula ex oute natus quid portenderit, capite tertio diximus. Apollonius ille magus cum non procul Babylone receffiffet, leanam inuenit, in cuitus utero cafo catuli octo cótinebantur: unde con iecit peregrinationem fuam ad Indorum regem anni unius $8 \mathrm{C}$ menfium octo futuram, ut capite ter tio recitaui ex Philoftrato. Cypfelus Corinthi tyrannus fuit, patre natus Eetione, é Petra tribu, ma: tre uero Labda, \&c.ut pluribus perfequiturr Herodotus libro quinto. De hoc adhuc priurato Pythia huiufmodioraculum Bacchiadis cecinit: Concipit in Perris aquila enixura leonem Robuftum, fa ium, genua \& quimulta refoluet. Hæc bene nunc animis uerfate Corinchia proles, Quícolitis pulchram Pallenem, altamq̧́ Corinthum. Aquila Gracis ás.ros eft, quo nomine ad Eecionem Cyple. lipatrem alluditur.

qLeonis catulum ne alas. Aefchylifententia prourerbialis refertur apurd Ariftophanem in Ra=

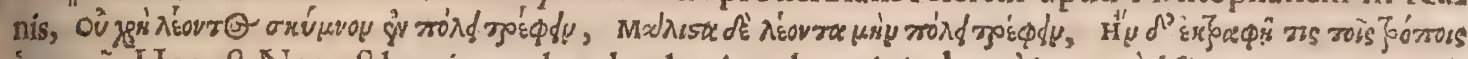
trongerses. Hoc eft, Non eft leonis catulus alendus in urbe, minimè ueròleotquòd fi tamen nutritus all quis fuerit, moribus eius obrequi oportet. Refert hunc locum Valerius Maximus libro 7. capice de fa pienter dictis. Admoner ænigma (inquit Erafmus) non effe fouendam potentiam, qua Nges pollet opprimere: quod fi forte talis quifpiam extiterit, non effe è repub.decertare cum illo, quem nequeas nifi magno reipub. malo deuincere. Tyrannus aut ferendus eft, aut non recipiendus, Meminit eiur.

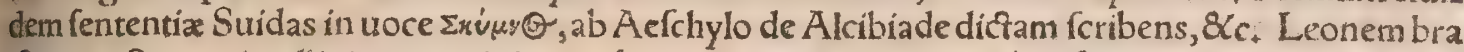
cteatum Seneca intelligit, peregrinis excultum ornamentis, et naturali deftitutum generofitate: quo niam gloriari nemo nifi fuo debet, Cxlius. Et ftatim, Apud eundem (inquit) adagium fubnotauis - mus alterum, Magnis telis magna portenta feriuntur,fubula leonem non excipit. Caprea contra ieo

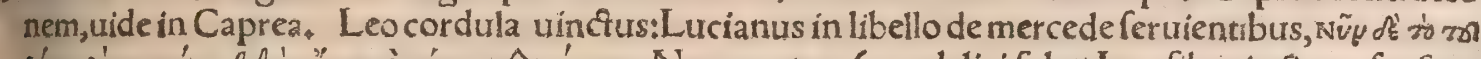

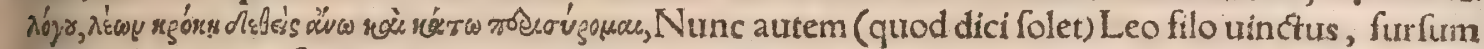
as deorfum circunferoricum quís exiguro commodo captus, apud aulicos oftentatur paffim, quod princeps tantum alat uirum. Hoc enim principes fibi gloriofum ducunt, fiepifcopes aut doctos ui= ros cogant fua relinquere negocia, \& aulica feruire pompæ, Erafmus. Domi leones, in pugna uul=

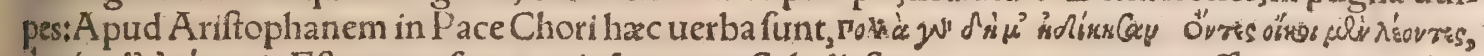

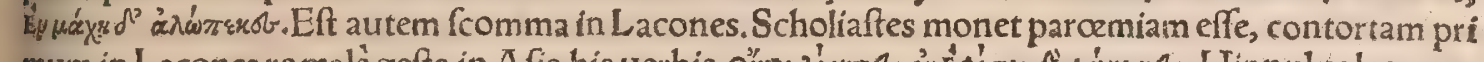

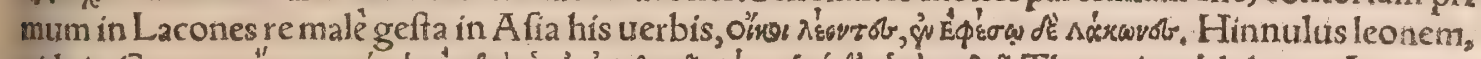

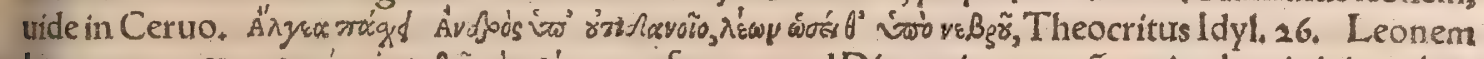

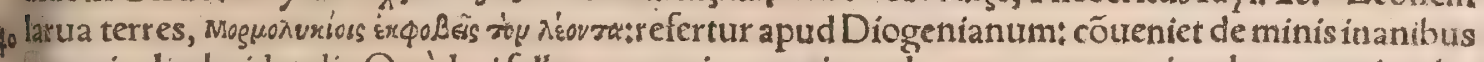
acterriculis deridendis. Quòd, ni fallor memoria, reperi apud autorem quempiam, leonem etiam lar uis 8 appofititijs uultibus offendi.A dagium ufurpat Seneca libro 2.Erafmus. Mortuo leoni etiam lepores infultant, tride in lepore $h$. Murem oftendit proleone, prourerbiall fchemate dictum, pro eo quod eft, ingentia pollicitus \& fortia, longe diurerfa exhibuit. Synefius in epiftola quadam ad Ana.

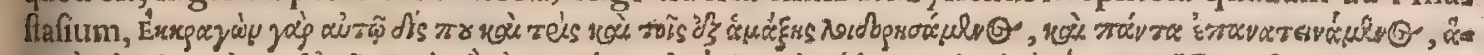

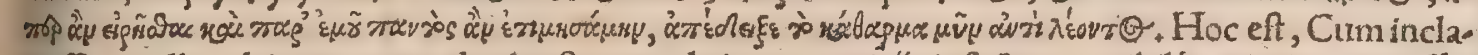
maffet in illum bis aut ter, ac de plauftro quod aiunt conuricís infectatus, nihilǵg non in eum effec trociferatus, cum eiufmodi uel à meiplo dicta fuiffe maximi fecerim, deinde murem proleone exhi= buit fcelus. Sumptum apparet à beftiarĭs, quui ridiculigratia multa polliciti, quafi leonem immanem - Scinfolitz magnitudinis emiffuri, mox murememittunt in caueam, Erafmus. A leonis pelle facta qua dam prouerbia, memorauimus iam in $H_{.} \cdot e_{.}$nempe ifta, Leonis exuuium induere, Leonis exu.

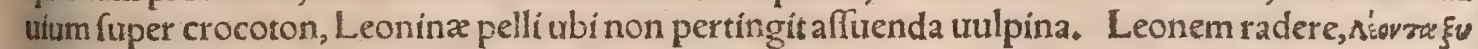

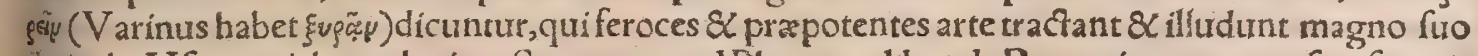
periculo. V furpauit hoc adagium Socrates apud Platonem libro de Rep.primo, negans fe ufque a.

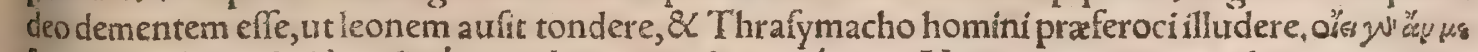

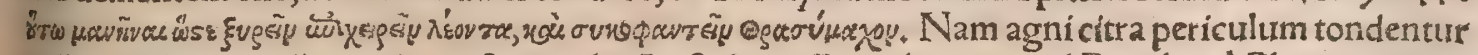
tellunturć, leo nullo modo tractari uulc. Ariftides in Panathenaicis ad Periclem à Platone taxatũ

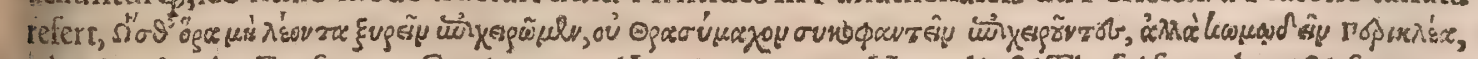

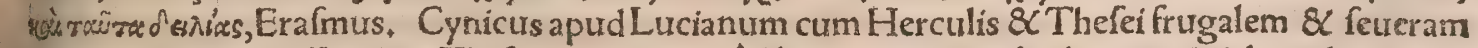
60 uitam commemoraffer: $\$$ de Thefeo priuatim quòd barbam comam

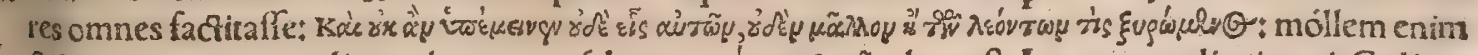

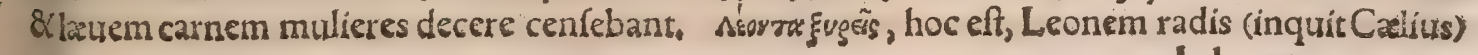


adagium de ifs qui factu impoffibilia tentant, (codem modo à Surida explicaturt) aut not citra peris culum. Propterea Plato, ficuti commeminit etiam Philoftratus, idem effe dixit leonem radere, \& Thrafymachum ouroфavresin, hoc eft calumnijs circumuenire, Ad qued alluferit Epigrammatum i $0_{i}$ Martialis (ut Erafmus etiam annotauit) illis uerficulis in Ligellam qux partem pudendam fibi urelle bat, Quare,fi pudor elt, Ligella noli Barbam uellere morturo leoni. Caterum cur poêta leonem membrum muliebre nominauerit, interpretes aut non tradunt, aut inepta quadam afferunt. Sunt enim qui ideò dici opinêtur, quod mirum in modum leoni foetet anima:uel (inquit Domitius) quod placet, prouerbium eft, quum uolumus aliquem excitare, qui moueri non poteff. Sed boni confulant eruditi, (inquir Calius) fi meam quogs coniecturam attulero. Legimus in Nicâdri Theriacis de cen chrine ferpente, qui alio nomine leo uocetur. Interpres autem lconem uocari conn̈cit, uel alias ob caufas (ut inter Serpentes referetur) uel quia morder, ac hominis fanguinem exforbet, qua ipfa \& leo facit, Ex ijs animaduerto Martialem muliebre pudendum leonis nomine feftiuiter appellaffe, quoniam fubinde mafculorum fanguinem (urinam genitalem, qui fanguis concoctus eft) exurgat; Mortưum uerò dixit, quoniam æatate iam uideretur emeritum, $\&$ adV enereos ufus hebes ac frigidü, Hæc Calius: Ego in Martialis uerfu Domitñ interpretationem magis probârim. Vide fupra in a.ubi

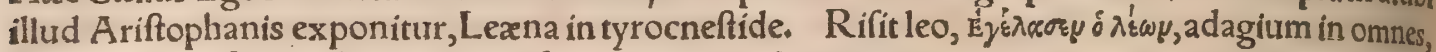
qui rugatioris frontis $\&$ Catoniana feureritate, quando $\$$ samen matutinam exporrigunt grautitatem ac comes fe praftant, folito hilarius agentes.Pronunciatum id in Thucydidem, qui Cylonium fcelus explicaturus, confuetò a pertius, \& intelleçu nemini non obuio narrationem contexuit : quro nomis ne miratus eam technographus (Hermogenes puto)edifcendam fumma cura iunioribus pracipit, ut a orequ'siaw \& facilitatem eandem ftylo ualeant exprimere, Calius 13.19. Et mox, Facilem huic adayic uerba Plinỉ praftiterint intellectum:Cauda, inquit, immota leoni placido, clemens, blandientíg fir

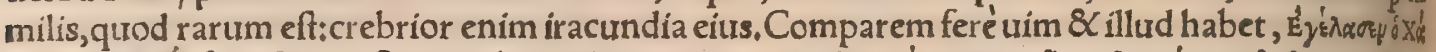

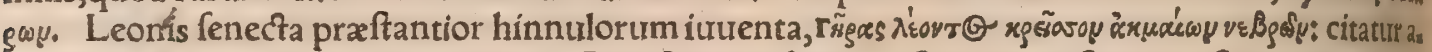
pud Stobęum ex Hippothoonte poéta. Senectus uiri fortis ac ftrenui praftantior eft iuuenta quorü, dam ignauorum \& imbecillium iuuenum. Venuftius fiet fi longulè transferatur: Velutifi quisin. genium docti fenis $\&$ exercitati præferat ingenio parum eruditi iuuenis, Dicetur non inepte $\&$ in fenecfutem crudam uiridemós, animićp uiribus adhuc pollentem, Erafmus. Leonina focietas eft, inquit idem, cum omne commodum ad unum aliquem redit, reliquis ui fraudatis: qualis fermé foler effe cum regibus, aut præpotentibus plebeiæ fortis hominibus, Extat in Pandectis, in quibus ex Vlo piano refert Arifto, Caffium refpondiffe, focietatem talem coiri non poffe, ut alter lucrum tantum, alter damnum fentiret, 8 hanc focietatem leoninam folitum appellare. Caterum Caffianam appel lationem, haud dubium prouerbialem, ex Aefopi Graci apologo natam apparet, qui talis circunfer, tur. Leo, afinus $\&$ utulpes focietatem inierant, ut quod uenatu cepiffent, id in commune partirentur. Prædam ubi erant nacii, leo iubet ut afinus partiat, Ille, ut eft ftolidus, in treis zequas portiones diftris buit.Qua gratia mox indignatus leo, quod cateris æquaretur, afinum adortus dilaniat, Reftabatuul pes, eam deintegro partiri iubet, illa totam fermè prædam leoni attribuit, fibi uix paucula quadani feruans. Leocomprobata diftributione rogat, quifnam illam artem partiendi docuiffet : Calamitas,

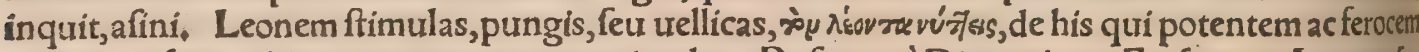
in fuum ipfius exitium protrocant atç extimulant. Refertur à Diogeniano, Eralmus, Leonemlitu bula excipere, prouerbium fuperius dictum, ftatim à Leone bracteato, Leonis ueftigia quaris, tì

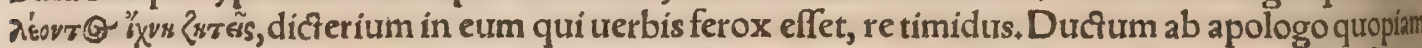
A efopico, quo narrat uenatorem quendam paftorem obuium rogaffe, nuncubi leonem uidiffet, ut eum libi commonftraret. Atç eum refpondiffe: Equidem tibileonis ueftigia mox oftendero: neque enim procul abfunt. Tum ille, Satis eft, inquit, neç enim ultra quicquam requiro. Conuenit cum co quod alio pofitum eft loco, Cum urfus adfit, ueftigia quaris, Erafmus, Leonem ex unguibus a

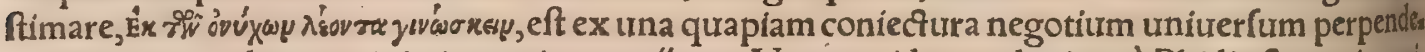
re, ex paucis multa, ex minimis maxima conícere. Natum uidetur adagiumà Phidia ftatuario, qui, ficut narrat Lucianus in Hærefibus, infpecto leonis duntaxat ungui, quantus effet totus leo perpen dit, totumó̧ ex indicio unguis effinxit. Plutarhus in commentario de defectis oraculis, uridetur ad

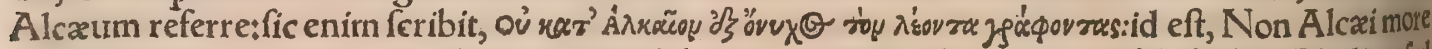
(melius,iuxta Alcæum, ut Cælius trertit:ut Alcæus, non origo huius prouerbï fit ficut Phidias, led co tantum ufus in fcriptis fuis) leonem ex unguibus depingentes: hoc eft, ex re minima maxima cols

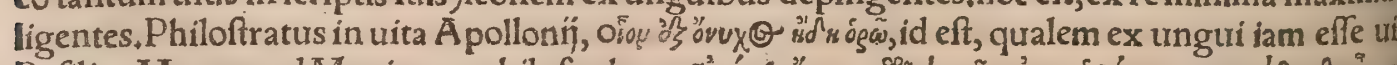

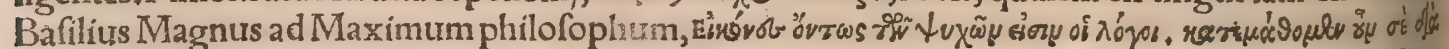

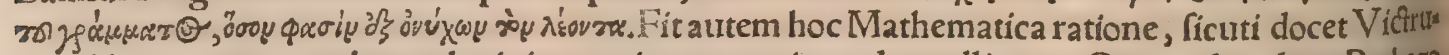
uius libro 3. ut ex membro uel minimo, totius corporis modus colligatur:Quemadmodum Pythago ras Fierculani corporis menfuram, ex Pifano ftadio, quod Hercules fuis pedibus fuerat metatus, tar tiocinatus eft, Erafm. Ex ungue leonem deferibere per adayium dicimus, quum certioribus arghts mentis quippiam demonftrari fignificamus, aut à proprietate apertiffima. Plutarchus in libro deora 6 culis qua defecerant, Admirantibus uerò qui aderant, Demetrio autem ridiculum ftatuente, à tam minutis rebus adeò magna uenari, neciuxta Alcaum, ex ungue leonem defcribere, Cleombrotus 


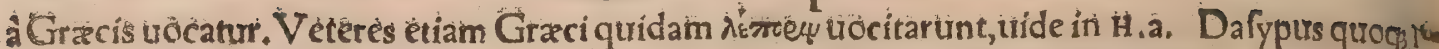

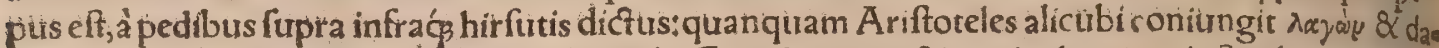
fypoda (urPlinius lepórem \& dafypodem) ubi Gaza leporem \& cuniculum irertit 5 Strabo cuniculos

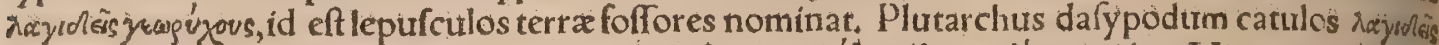

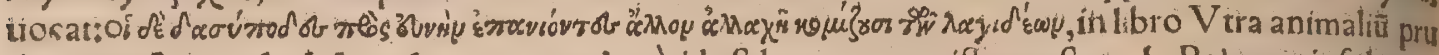
dentiora, \&c.unde dafypodem eum prolago, id eft lepore accepiffe conftat. In Baleares infulàs (ut fribit Euftathius in Dionyfium Afrum) inuectos aliquando ferunt duos $\lambda \alpha$ jı $\delta^{-1 s}$ (cuniculos) marem \& fóminam, qui mox ita aucti funt numero, ut domos etiam $\&$ arbores fuffoffas euerterint

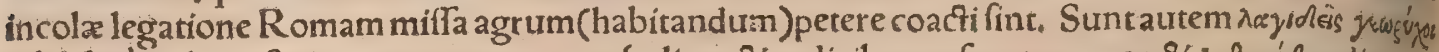

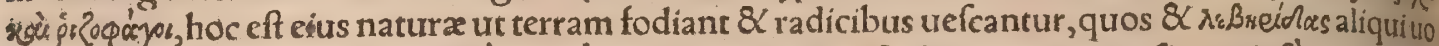

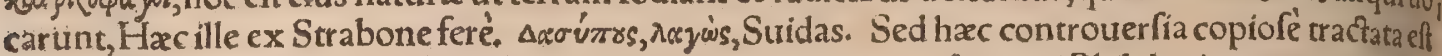

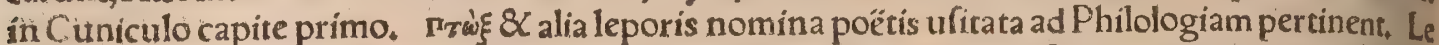

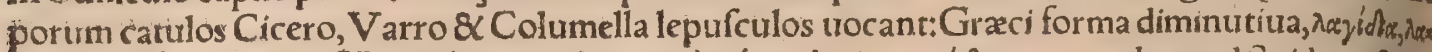

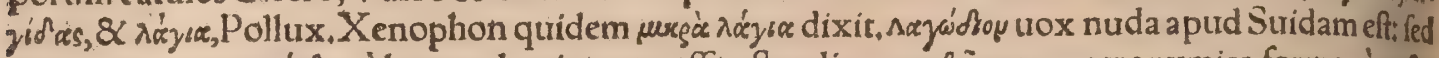

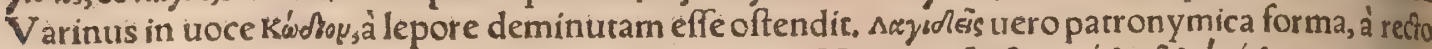

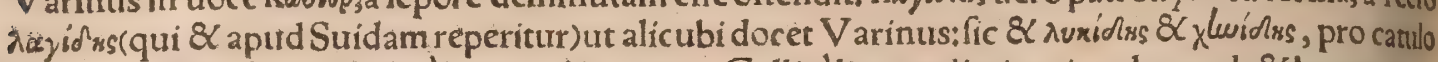
lưpi \& pullo anferis. Italicèlepre uel lieuoræ. Gallicélieure (diminutiua, leurault \&leureteau,) Hifpanicè liébre. Germanicébaß̧ uel baas. Anglicè an hare. Illyricèzagicz.

Lepores in Ả egypto minores quàm in Græcia fiunt, Ariftoteles. Velociffimi funt montani, rama peftres minus, tardiffimi paluftres: fed qui loca omnia pererrant, in curfu molefti funt: etenimi fciunt compendiofa tiarum, \& currunt per aduerfa uel plana maximé, per dituerfa uariè, per declitria mini

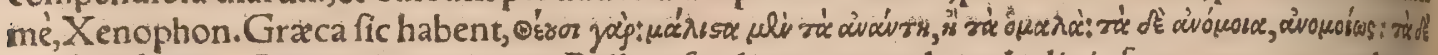

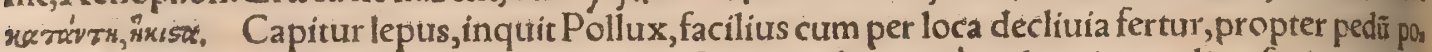
fteriorum altitudinem, præceps actus in caput. In accliuibus uerò pedum inequalitas facit, ut corpus quabiliter feratur, cum quantum locus humilior fubfidit; tantum ipfe alticudine crurum erigatur: ut quafi in plano currere uideatur, aut quod ad ipfum faltem locus uideri planus poffit. Sed decur fu $\&$ uelocitate leporum, dicetirr etiam in $\mathrm{E}$. A pud nos lepores montani differ unt à campeftribus, in Tridentinis \& Vicentinis alpibus frequentes, nigritia, magnitudine, ferocia, denfiore pilo à cates ris diftincti, Hermolaus، Iul.Pollux lepores quofdam Elymaros uocar, uulpibus non feréminores, \& nigricantes, corpore oblongo, albicante macula, prope fummam caudam longiore. Sunc \& quid cuntur mofchix, quorum in ueftigïs fpiritim tanta ui fentire canes memorant, ut furce plane creu dantur. Chelidonios etiam quofdam dicit Athenæus, Calius, Elymæi à regione dicti uidentur, vi \& canes Elymæi, de quibus dixi in capire de canibus uenaticis in genere. Mofchiæ ueró ab odoris uehementia fortaffis, ut $\&$ mofchus odoramentum quod Arabes mefch appellant, \& urerifimileefl Gracos ab Arabibus mutuatos. Pifis lepores funt magni, in noftra regione parui: quia cibus lepo, rum illic maior quàm apud nos $\mathrm{ef}, \mathrm{Niphus}$. In Pannonia inferiore multó Iralicis pinguiores \& lapt diores uidi,Manardus. Leporum tria genera feré funt: Vnum lealicum hoc noftrum pedibus pria mis humilibus, pofterioribus altis, fuperiore partè pulla, urentre albo, auribus longis : qui lepus dici tur cum prägnans fit, tamen concipere. In Gallia tranfalpina, 8 Macedonia fiunt permagni, In Hi. 4 fpania $\&$ in Italia mediocres. Alterius generis eft, quod in Gallia nafcitur ad alpes, qui hoc fere mus tant, quòd toti candidi funt. Hiraro perferuntur Romam. Terín generis eft, quod \& in Hifpaniana fcitur, fimilis noftrolepori ex quadam parte, fed humile, quem cuniculum appellant, Varro, Lepon rum genera duo funt, pars magni, fubnigri (

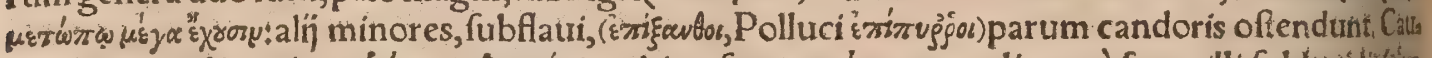

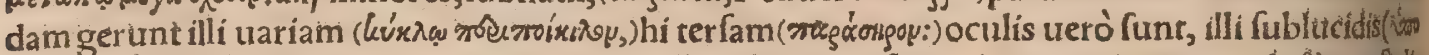
xásorros) hi fubglaucis.Circa fummam aurem illi ualde nigrefcunt, hi perexigurum. ( of weli tranffulis mus illi, ut referatur ad maiores leporesi of dè, hi, ad minores. Pollux fimpliciter, leporum aliós charo pis, alios glaucis oculis effe fcribit.) Sed ex his minores, plerungs incolunt infulas deferrâs, uelcele bres, (habitatas:) 8 in his turba maior quàm in continente ueriatur, quòd ibi ut plưrimum nec uuls pes funt, à quibus ipfi cum catilis occiduntur: nec aquila, qux montes magnios faptus quàm partos frequentant:nam parui plerungs in infulis funt. Venatores etiam rarò defertàs infulas adeuntinhtis. quiæ habitantur paucifunt, \& if ferè negligentes uenationis: in facras autě̉n nè tranfirè quidem can nibuts licet. Itaç innumeri proưeniunt, Xenophon. Platina magnos \& paruos lepores non aliter difingutit, quàm quod illos lepores uulgò dictos effe ait, hos uerò cuniculos, quod parum placet. Goifum leporinum proprie eft pullum, Thylefius, ut pluribus dicam mox in pilorim mentionte Leporis colorem lego dici epipercnon:quòd fit percne, oliuæ fpeciès, non acerba quidem, fed nes nigrefcentis omnino. Sunt qui percnon punctis maculisḉg nigrioributs interftincturm accipiantinam de animalibus lib. q. Ariftot. quoç quartum aquilarum gentus percnopteron dicit appellatum abala rum notis. Eius a quila meminit liad, ultimo Homerus. In Plinianis codicibus fcriptum modo oble

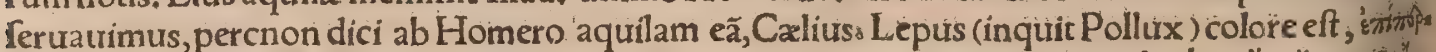

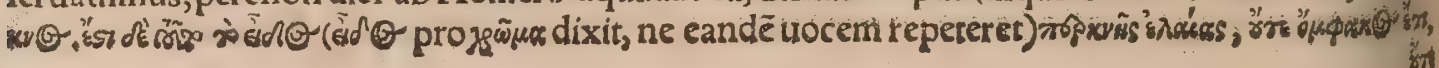




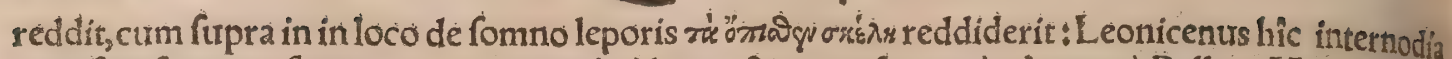

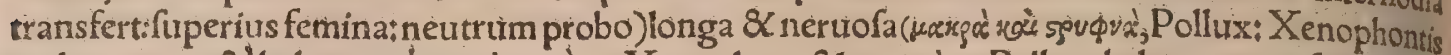

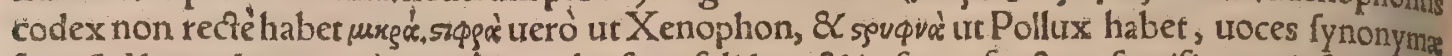

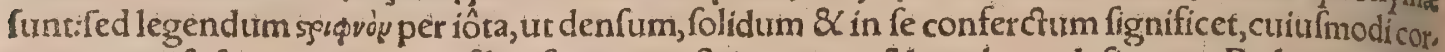
pora neruofa funt;nam per ypfilon faporem aftringentem $\&$ acerbum defignat, ) Pedes anteriores

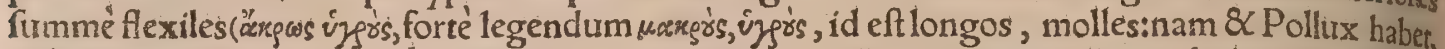

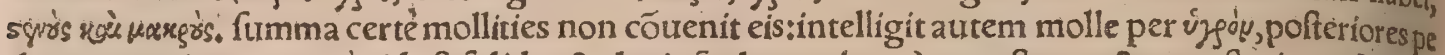
des contraria uoce sopers, id eft folidos $\&$ duriufculos probans) anguftos, rectos: pofteriores folidos, latos, nullius utrof $\mathrm{qB}$ non contemptores afperitatis. Pofteriora crura prioribus multum longiora, $\mathrm{pa}$

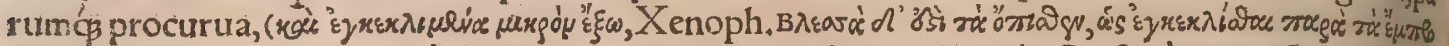
aेgi, $\mathrm{Pollux}$, ut pluribus paulò fuperius recitaui.) Villos breures leuesćp. Sic fanè compofitum corpus fieri non poteft quin \& ualidum, \& molle (aut flexile) \& fumma agilitatis fit, Hactenus Xenophion, Caudam tantum, inquit idem, ad currendum incommodam habet, proinde in curfu auribus le gu,

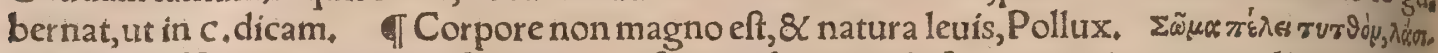
ou, Oppian. Nunquam pinguefcit, ut in F. referam:ubi etiam de fanguinis eius natura dicam. $\mathrm{D}_{a}$ fy podi pili $\&$ in buccis intus, \& in pedibus funt: $Q u x$ utraç Trogus $\&$ in lepore tradit, hoc exemplo libidinofiores hominum quogs hirtos colligens. Villofiffimus animalium lepus, Plin. Lepori unipi

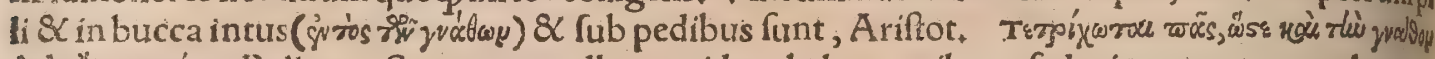

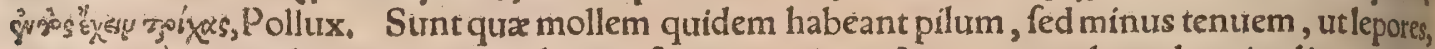
contra quàm oures:leporum enim pilus per fumma cutis enafcitur, quamobrem longitudíne caret, $\&$, fimile accidit, ut in ijs qua lino decerpuntur:quæ quamuis mollia fint, tamen nullam longitudinem habent, nec implexum ullum recipiunt, Ariftot. Et in Phyfíog. Lepus cum timidiflimum animalet molli pilo fit, ut oures etiam ac ceruus:homines quog mollioris pili, timidi exiftimantur. Villos has

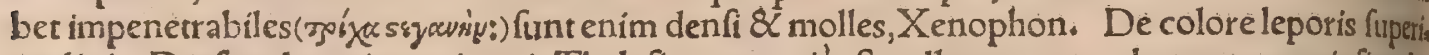
us dixi. Dorfum leporinum, inquit Thylefius, proprié eft pullum ₹ quamobrem naturæipfius do ctus magifterio, terram recentem ab aratro metu pauidus quarit ille, ibiḉp nonnunquam ftratus, nul laḉ̧ re abditus, uenatores canesḉ̧ iplos prætereuntes, ac fagaciter propé omnia perquírentes, colos ris tantum beneficio fapiffimé latet: \& , ut in quodam epigrammate de lepore diximus, Quem fun ga non rapit ore canum, non occulit umbra: Concolor immotum fub loue terra tegit. TLepus

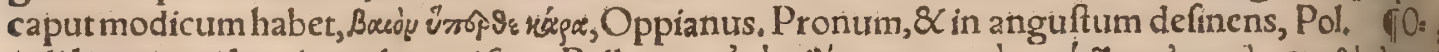
culi leporim glauci aut charopi funt, Pollux. Aủrde op"i

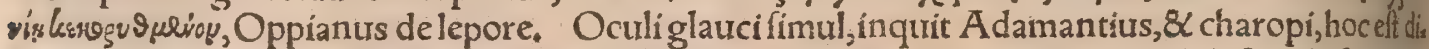
uer forum colorum punctis milị magnitudine circa pupillas notati, ingenium dolofum \& furriutu gnificant, fatis quidem folers, fed nec forte nec audax, cuiufmodi lepores funt. Acie oculos rum funt, inquit Xenophon, multis de caufis minimé acuta. Oculos enim habent exporrectos, 7t

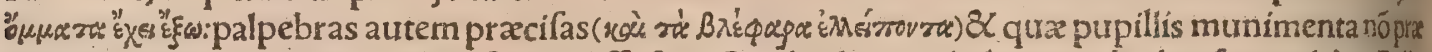
beant:quapropter hebes uifus eft atçs diffufus. (Oculi cilia non habent, eoćç obtufius uident, Poll.) Ad hac fomno etiam multum dedirur animal, qua res nihil ad uidendum prodeft, (unde oculition parum læduntur, Poll.) Et trelocitas ad obtundendam aciem plurimum facit: citius enim ferè tem is namquan ós pertranfeunt, quàm quid fit accurate perfpiciunt: Canum quioģ urgentium terrotes prouidentiam auferunt: unde fape in retia incauti feruntur. Palpebris claufis (rezrauvivy, id eff con niuens) urigilat, a pertis dormit $\&$ immotis, Xenophon lentes Aegyptij, leporem pingunt; habet enim oculos hoc animal femper apertos, Orus, Lucentin charopis eorum oculis uigilia muniti hircquitnunquam enim grauatis (demiffis) fomnum capiunt palpebris, ut qui tum feras tum homines metuant; nocte etiam uigilant, Oppian. Superior in homi

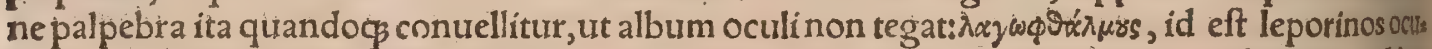
los habentes, qui hoc patiuntur, uocant Graci.Auicenna afcera, \& palpebra inuerfationem, Idem inferiori contingit, \& eciropion Gracis eft,Manard. Lagophthalmus, inquit Cxlius, uitium eft thi oculus in fopore non occludditur:fit autẽ, ut Celfus lib.7. fignificat, ubi curatione adhibita plus equo cutis exciditur, ita ưt oculus contegi nequeat, uel aliam ob caufam quando ģ. Nam fi palpebra inferi or minus furrigitur; fed pendens hiat, nec cum fuperiore coit, uitium facit, quod (codem aucfore) 'es= tropium uocant. Glaucophthalmus pro lagophthalmos apud Celfum non rectè fcriptum Hermolas us thonet. Kopußauzzãu, inquit idem, uerbum apud Græcos factum eft à pupillis oculorum quas kat gos appellant: ficut \& Corybantes \& Curetes:Qui cum cuftodes Iouris effent, non modo excubart, fed etiam apertis oculis dormire cogebantur: hine natum uitio ex fabula uocabulum, ut quileporü modo fomnum caperent oculis patentibus, ita nominarentur. Proinde qui Corybantes à choreis dia cfos arbitrantur, errant: etiamfi Lucretius ita cecinerit : Cum pueri circa puerum pernice chorea Armati in numerum pulfarentaribus ara. In eundem fenfurm \& Ariftophanes poêta ufurpat uêtu

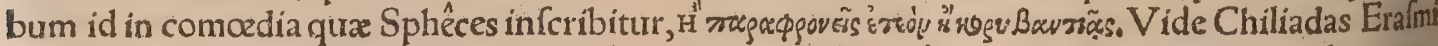
duobus in locis, ut index monebit, fuper hoc uerbo corybantiân. Dormiunt lepores oculis patens tibus, multiç hominum, quos ropußawriąy Graci dixêre, Plinius. Plura hac de re afferemus in c.

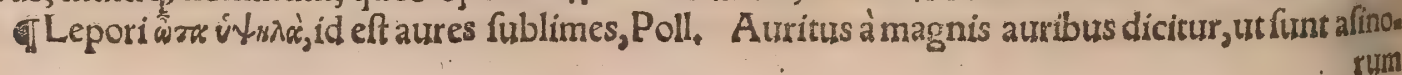




\section{DeLepore. B. Lib.I. . 685}

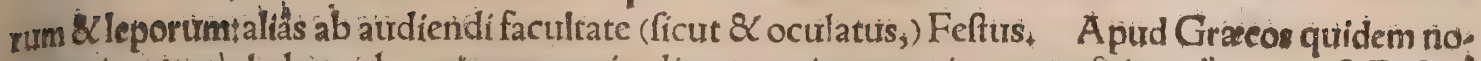
men etiam $\lambda \alpha$ jòs habet, $\mathrm{ab}$ aurium magnitudine, $\lambda$ e enim auget in compofitione, $\omega^{\prime \prime}$ auris eft, Et fane decebat ut timidum \& inerme animal bene auritũ effet, quó longius pericula $\&$ infidias perciperet \& maturé fibi confuleret: fed h̆fdem in curfu quog fe gubernar, ut in c, referani. Aures ei longa \& pilofa, Gillius, II Labia perpetuò moute, Obf́curus, Bucca pilos etiam interius habet, ut fu* pra diximus in pilortum mentione. Rimam illam in medīs labris rectà fub naribus, noftri uocant bafen/barten: $8<$ audio etiam homines quofdam ore fic deformato nafci, id'ç feré accidere ubi gra uida fubito leporis afpectu territa fuerint. Vtrinç dentatus cum fit, coagulum tamen habet, Aria ftotel. Quxcunģ fic naícuntur in ueterino genere, ut notam eam habeant, quam leporinum den.

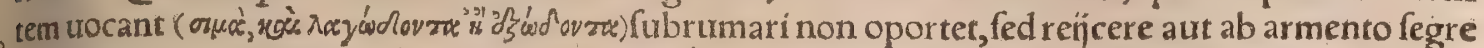
gare tanquam adulterinas foeturas \& portentofas, Abfyrtus capite 1 \%. interprete Ruellio, TLepus habet collum anguftum, teres, molle, oblongum, Pollux. of Cor maximum eft proportionemuribiss, lepori, afino, ceruo, pantheræ, muftellis, hyænis, \& omnibus timidis, aut propter metũ maleficis, Plinius \& Ariftoteles. Tlepus folus ex ijs quibus pedes multifidi coagulum habet, Poll. Cum utrinç dentatus fit, coagulum tamen habet, Ariftoteles. Et alibi, Lepori foli ex iṕs qua unum uen. trem habent, coagulum eft. Fit autem ei coagulum, quoniam herbam fucci lactei pafcitur $:$ talis enim

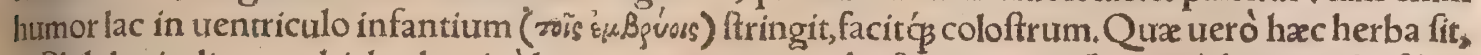
in Philologia dicam, ubi de plantis à lepore nominatis uerba faciam. GLepores locis quibufdam bina iecora habere uidentur, Ariftoteles . Et alibi, Leporum generi cuidam.(quod tum alibi, tum e* tiam in Sycino agro circiter Bolbam lacum gignitur) iecoris partes fepofitæ funt, nec eadem certa origine continentur : quippe quos bina habere iecinora credideris, quoniam meatus procul admo= dum coéant. Bina iocineraleporibus circa Briletum \& Tharnen, (in Thracia Therne eft, non Thar ne,Hermolaus) $\mathcal{Q}$ in Cherronnefo ad Propontidem:mirumó́, translatis aliò interit alterum, Pliní. Idem alibi, cuniculor um in Batica exta gemina fape reperiri fribit. Theopompus in Bifaltia lepo res bina iecora habere prodidit, Gellius 16.15, \& A Alianus, Quod Plinius dixit in Cherronnefo ad Propontidem, uidetur id effe quod Ariftoteles, in Sycino agro circa Bolbam lacum: etenim Syce, ut libro quarto diximus, uidetur in Cherronnefo Thraciae oppidum fuife: de lacu autem Bolba, Ste: phanus quidem meminit ịs uexbis:Bolba \& urbis \& ftagni nomen eft: fed qua in terra fit non expli cat, Hermolaus in undecimum Plín̈̆. बf Archelaus de leporibus feribit, utranģ uim (utrunģ fe: xum) fingulis ineffe, ac fine mare æquè gignere:Benigna circa hoc natura,innocua \& efculenta ani malia foecunda generauit, Plinius. Quod idem lepus aliquando mas, aliquando foemina fit, \& natü ras tranfmutet, \& quandoç uelưt mafculus generet, quando $\not \zeta$ ut foemina pariat, manifeftum effe Democritus tradit Geoponicorum 19+4. Lepus a Phyficis dicitur incertifexus, ac effe modo mas, modo foemina, Donatus. Mares lepores, uel potius androgynos, uno eodemóp tempore tum alios' implere, tum ex fefe parere, pluribus dicam in c. ex Aeliano. Arnebet, id eft lepus apud Hebraos, terminationem foemininam habet:quod unum indiuiduum habeat utrunç fexum, Munfterus. Quí dam è uulgo alternis annis mares $8 \mathrm{C}$ forminas fieri putant. An fine mare gignat lepus, adhurc dubiü eft,Blondus. Albertus frribens in Ariftotelis de generat. anim, libri z.caput fextum, \& alia multa ineptiffimé traditconfunditćs $c_{3} \&$ lepori quadam attribuit, qux Ariftoteles ad muftelam refert: nan his $\&$ hyr zus eo in capite uoces Arabicæ, ut conịcio, non leporem fignificät, ut ipfe exponit, fed mur Relam. Et paulo poft adhab quoģ leporem interpretatur, eadem de co fcribẽs quae eo in loco Arifto teles de hyæna (nos adapem cuniculum effe docuimus, adhab hyænäłarnab uerò Arabicé lepus eft) fed ipfum Albertum audiamus.Quod (inquit) putant delepore, quem adhab Arabes uocant, quod habeat utrung; membrum per uices menfium, non elt uerum; fed fub cauda habet quafdam lineas fiffuris uuluarum fimiles, qua linex femper inueniuntur in maribus $\&$ forminis * (Et dicir Auicen na quod fecundum numerum annorum atatis fur imultiplicantur illæ fiffuræ : ita quod aliquis ca= ptus eft de quo uenatores putabant quod octo uuluas haberet: ) falfum tamen eft quia illa linea in= treniuntur in maribus $\&$ foeminis: fed quia plures capiuntur mares, magis obtinuitopinio eos her maphroditos efle quâm foeminas, Hac omnia, îjs exceptis qua parenthefi includuntur, Ariftoteles o dehyæna foribit. Fit enim frpe cum habent catulos recentes, alios ut in uentre habere reperiantur. Itaq de his Archelaus fcribit, annorum quot fint fi quis uelit fcire, infpicere oportet foramina natu= rę, quod fine dubio alius habet alio plura, Varro. V V mafculum leporem à foemina dífcernas, ut Ar chadius fcribit, naturæ foramina infpícito: nã fine dubio mafculus unü, foemina duo inuenitur habe re,fi cauté et fubtiliter infpiciantur, Créfen, fed apparet eum pximè recitata Varronis uerba, codice nimirum deprauato, perperã legiffe, \& pro Archelao Archadiũ fcripfifle, \&c. Vide etiẫ infra cap z $_{\text {. }}$ Delepore fortaffe (inquit Niphus) fillilud eft uerư, quơd lepus fit mas \& formina, eft ad alterum incư bus, ad alterum autem fuccubus ; unde tradunt uenatores, in genere leporum inureniri eum qui eft formina tantum, fed nullum effe marem qui non fit formina, quod fenfibus fubiacet + nani inuentus eft lepus teftibus atç mentula praditus, qui lepufculos ferebat in utero: nec non sc lepus ferẽs lepur f fulos, teftibus carens $\&$ mentula:per qua dilutio obiectionum perfpicua eft. Nos ueró teftamur ui diffe leporem folum marem, \&leporem tantum fominam, 8c leporem utriuffę fexus, Hæc Niphus, Etrurfus alibi, lllud quod Albertus de leporibus dixit, mihi femper fuit dubium nam in uenationib, 
obferuaurimus lepor $m$ habuiffe penem $\&$ teftes, et deferre in utero lepufculosiobferuauimus ètiam leporem habuiffe uuluam, $\&$ in ca lepúfculos, carere uerô teftibus $\&$ peni. Et rurfus, Ariftoteles hấ de fexu leporis q̨uaftionem non attingit. Ego uero leporem mentulatum \& tefticulatum ferre in utter ro legufculos obferuaui fape in uenationibus, $\&$ apud noftros trenatores hoc probatiffimum tabes tur. - Leporum urulux dum partum gerunt acetabula habent, Ariftoteles, Sus, canis, lepus, pare ru funt numer of o: nimirum quod uruluas fure uteros continent multos, totidem ́́ formandi locula menta, Idem Problematum 10.16. बILepori tibix negg magnæ nec acquales funt, Gillius ex Oppia

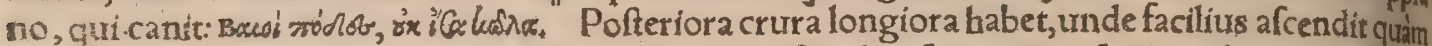
defcendit, ut fupra dictum eft. Solus animalium, Äriftotele tefte, pronam fupinamí̧ pedum partem hirhutam habet, unde dafypodis nomen, quod apud Cratinum $\&$ alios legitur, factum uidetur, Poll, Cum procumbit lepus hypocolia, uel potius, ut Pollux habet, pofteriora crura, ilibus fubincit, Xeno, phon, of Caudam nimis breuem, $\&$ ad currendum incommodã habet, proinde in curfu auribre fegubernat;utin C, dicam.

Lepores alh montani, ali campeltres, aln̈ paluftres funt, alĭ per diuerfa loca uagantur, Xenoph, Cubant ferè in arbuftis obductioribus, \& denfis fruticetis, aut fciffuris terræ profundis, Aut $1 \mathrm{Gr}$

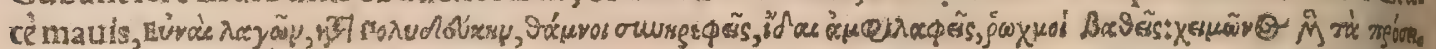

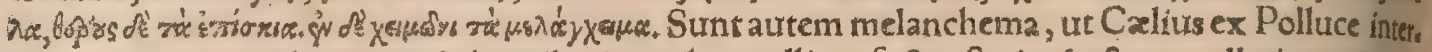
pretatur, cauitates (loca caua 8 humilia)in quibus colliquefacta eft nix, ducta appellatione nigredi nis argumento:quoniam operimento niưum agris albicantibus, ea portio plane nigrefcat. Obieu, al ri quidam authores leporem fuper petris cubaref cribunt, fectuti opinor locum quempiam ex utere reftamento, ubicuniculü potius interpres Latinus reddere debebat: Vide in Cuniculo c. Rationẽ tนี uentor đ̃ tẽ temporü lepus plané ́rit. Hyeme apricis locis cubilia idcirco informat, atos imprimit, q apricationem uehementer appetit:frigus hoftilẽ in modum declinat: aftate uero, altioris fedisfur dio captus ad aquilonem cubitar. Temporum commutationes nares ei indicant, A elianus. TXe nophon fcribit leporem acie uidendi effe minimè acuta multis de caufis (ut fupra in B , retulit)Plutal chus urrò in Sympofiacis fenforiorum excellentia hoc animal praftare annotauit, Cali. AtquiPlit, tarchus non ab acri fed indefeffo uifu leporem pradicat:hac enim eius uerba funt in Sympofiacisli bro 4. quaftione ulima:Senfutum acrimonia lepus excellit, Siquidem oculi leporum indefefiume itacs dormiunt apertis. Audicu quoç acerrimo pręditi creduntur:quem admir ati Aegyptn̈ in lacris 3 picturis auditurn defignaturi leporem pingunt. Animalia fortia, rocem ardunt grauem, titali rus, canis:timiỏ? acutam, ut ceruus, lepus, Ariffoteles in Phyfiognomicis. Glaucitat $\&$ catulus,at lepores uagiun, Author Philomela. Nos uagire apud bonos authores prima producra, \& deinfan

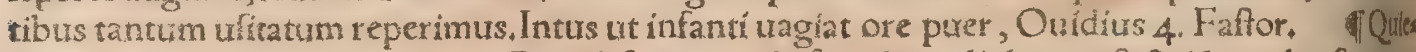
feunt interdiu, nocturugantur. Frigidi fanguinis \& frigidi cordis lepus eft, \& ídeo ad paftumion nifi nocie progreditur, Alber tus. In pattion!bus tum noçurnis tum longinquis pabulum inquirit, fiue quiò forte peregrini cibi defiderio tenetur, fiure etam quantum equidem intelligo, ut fe exu" ceat, \& pedum celeritatem firmet, A elianus. Vnum animai digitos habentium herba aliturlepus, plinius, Lepori coagulum fit, quoniam herban fuccilaciei paŕcitur, Ariftoteles. De hac $\&$ alip, it quibus uefitur lepus, tum aliâs ab eo dencminatis herbis, in Philologia dicam. Vefcuntur etam

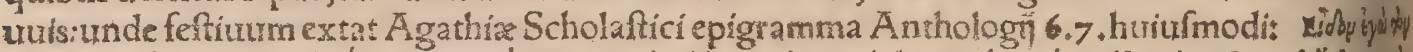
m

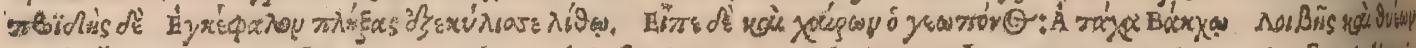

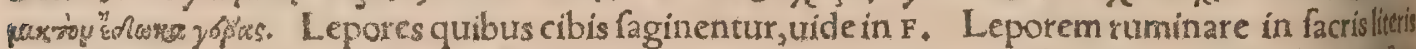
legimus, uide in Cuniculo A. Lepores urinam retro mittunt, Ariftot, Et alib, Lepus in alerfunt (alibi, ex auerfo) mingit:mas inquam, nam foemina quadrupedum omnes ita mingunt, Leportis ar cranfirimum eft, Ariftot, Soli animalium lac habent etiam ante partum, Pollux \& A riftot, Lac fullo fimile fua craftitudine efi, Ariftot. TS Somno multum deditur hoc animal, Xenoph. sayày gram

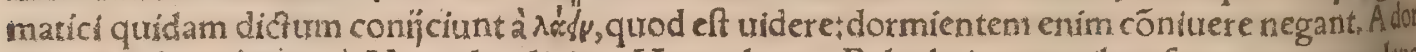
miendi habitu ofoprouvis Nicandro dicitur, Hermolaus. Palpebris patentibus fommum capere, lepo f ri naturale ef, A elianus, Etrurfus, Non oculos claudit cuni fomnun capit, imó uero cum reliqua membra fomnum accipiunt, interea tamen oculi uident. Vide etiam fupta in $\mathrm{B}$. de oculis leporis, 8 interpretatione wocis lagophthalmus $\&$ infra in puerbio, Lepus dormiens. Dorcas, id eit caprea

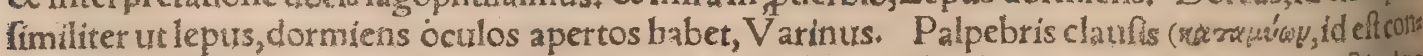
niuentibus)uigilat, a pertis dormit $\&$ immotis: (Locus hic apud Polbucem corruptess, hinc refituipo teft:)oculos etiam tenet immotos. Nares dormiens frequenter mouet, uigilans uero minus, Xenophi Parafitus quidam a pud thenaum, multorum animalium quibus aliqua in re compar atur, nomina accipit, ut $\pi$ s ब Lepores auerfi coêunt:retro enim urinam reddunt, Ariftot, Foemina etiam frpenumero marem prior fuperuenit, Idem. Et rurfus, Coëunt $\&$ pariunt quoo tempore. Dafypodes omni menfépas riunt, \& fuperfoetant ficut lepores, Plinius, Foecundiffima funt natura:unde prafinitum coneps tionis terminum non babent, Simocatus, Lepus coitum quxrit cum aliâs femper, tum uernoteme 
defcendat, Albertits, ut furpra etian dictum eft in B, ex Polluce : habet enim polferiora membra lon giơra, anteriora ueró bteuiorałita §̧ deorfưm ùerfus agrè decurrit, furfum facile, Aelianus, Pofte. riora crura in curfu (inquit Polluxx) ultra anteriora extendit, falit ç pofterioribus obnitens, nec ullio modo interim anteriores impedit, quod illi interiưs magis uergant. Salit autem magis quâm, curtit

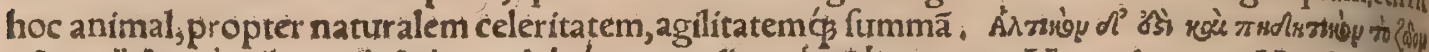

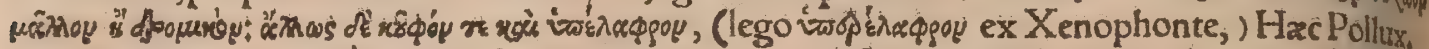

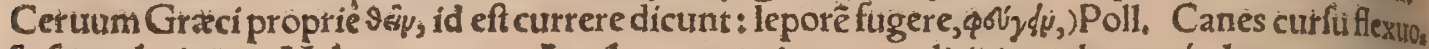
fo fape decipiunt, Volaterranus. Auribus corporis motumi dírigit moderaturó $\$$ lepus, tanquam remis, quod in alịs animantibus plerunç efficit cauda, (Cxlius ex Poll.) fed hxe leporibreuior, \& huric uffui idonea non eft:ita

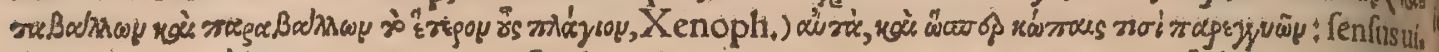
detur, inoueri à lepore aures in curfu alternis nưnc ante nunc retro, ut nauium fcilicetremi agûtur; ut tragsyva tant:cum círcumagitur, altera aure ab ea parte demiffiore pro gubernaculo utitur, Volaterranusex Xenoph. TArchelaus autor eft, quot fint corporis cauerna ad excrementa lepori, totidem antios efle atatis:uatius certe numerus reperitur, Plinius. Eius annos indicant foramina quædam; nam

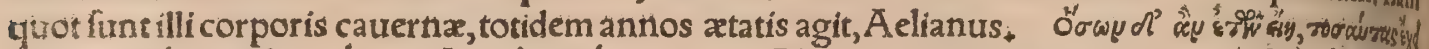

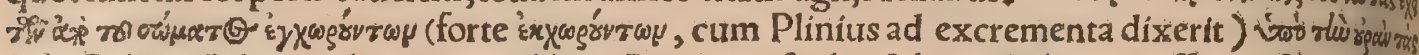
órres, Pollux. Albertus (ut in B , retuli) ex Auicenna fcribit, fub cauda leporis effe quiafdam fifuras uel lineas uuluarum fimiles, in maribus fimul $\&$ foeminis, easós fecundum numerum annorum $a$ cis mulciplicari: 8 captum effe aliquando leporem quem uenatores putarint octo uuluas habere

$$
\text { D. }
$$

Lepores manfurefcuntrarò, cum fera dici iure non poffint: complura nanģ funt, nec placid, ziec fera, fed medix inter utrun $\$$ naturx, Plinius. Audio quidem à teneris nutritum, fatis cicur \& ${ }^{\prime}$ pidum, mirlśç corporis geftibus ac faltibus, iucuindum hoc animal fieri, Quadam timorenonciu rantur, ut mures $\&$ lepores quomodo enim amabis, quem infidiari uitæ tuæ fit pèrfuafum! at hoc $\hat{f}$ bi perfuadent qui timent, Cardanus, Lepores, cuniculi, \& fimilia animalià femifera, ita quidemé curantur, fi tenera educes, ut hominem non metuant nec refừgiant, fed fponte etiam accedant, cibi pracipur gratia:nullitus uerò difciplinz capacia funt, nec uocis agnofcunt imperia : tocanti adefle, increpata difcederè non affuefcunt, nec aliud quidquamiufta facere. A nimal eft fimplex \& fol ga fe defendens, Albertus, Lepus plané timidus, pautidus \& fugitiuus eft, naturæç debilis \&imbs cillis, Blondus. Ingeniofi ac timidi funt, Ariftoteles. Et in Phyfiognomicis, Pili molles hominemnis midum fignificant:nam ceruus, lepus, \& oues, pilis funt mollifimis. Formidine pracellir animal

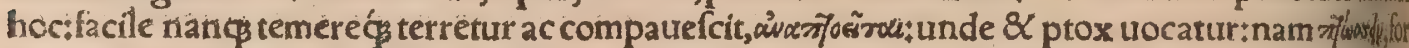
midare eft, Catlius ex Polluce. TLeporem pro uentorum temporưnć ratione cubilia mutrerin c. dixi. Cubile non prius fubire $\&$ fuccedere folet, quàm modò ingrediês, modò egrediens fua con turbârit ueftigia:ut ne ea ftruentibus fibi infidias appareant, naturali quadam fagacitate homines aftutédecipiens, Aelianus. Lepus omnium præd nafcitur, Plinius:nempe aurum rapacium, etre ftrium ferarum $\&$ hominum. His uel hyrzus, uox barbara (Arabica uel Perfica) muftelamfinith cat: Albertus ineptiffimè leporem exponit: deceptus, ut conïcio, quoniam utrumg animal caulos ore de loco ad locum frequenter trãsfert; quod eo in loco, ubi ipfe leporem red dit, A riftoreles demu ftela fcribit. Lepores (inquit Plutarchus) in cubile fe recepturi, fapiculè iugeri etiam intertuallora tulos alium aliò diffitos transferunt:ut fi uel homo uel canis fubeat, idem omnes in periculum neuo

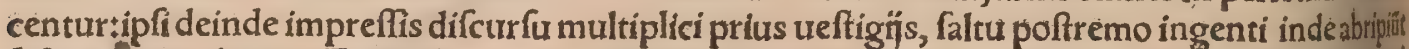
fefe, atç ita cubant. Foetus fuos (inquit A elianus) in plures locos difpergit, hoc pacto arbittans?

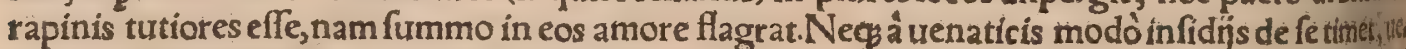
rum etiam uulpium incurfiones perhorrefcit, nec minus auium impetus extimefcit, fed $\&$ corturu $\&$ aquilarum ưocem multò maximé metuit, atọ horret \$ \& fané quídem cưn his auibus nutlla pare coniungitur, fed fefe abftrudit in dumeta, in aliâue fruteta, aut cefpites, aut cum neceffitate urgetur, in quroduis aliud latibulum fe occultat. Et alibi, Aquila lepores rápit, Lepores non canes folum meturunt; uerum \& $\&$ a quilas: ab his enim quoties adita \& aperta loca fuperant ( $\left.\left.\psi_{t} \lambda_{0}\right)^{\prime}\right)$ rapiuntur, quantifper anmiculi funt \$ nam maiores incurfu canum auferintur, Xenophoon $V$ ide etiam in E. Lepus uocem accipitris exhorret latitans, Volaterrantis. Accipitres dicia afut res auxilio canum uenantur etiam lepores $\&$ cuniculos, ut alicubi legímus. Vulpes $\&$ aquila lepo ribus infidiantur, ut in B.retuli ex Xenophonte, Lepores (inquit A elianus) interdum à uulpibut non tantum curfut, fed etiam magis arte comprehenduntur. Captiofé enim circumutenire, inducere uulpes probe notit: Cum enim noctu in leporis ueftigium inciderit; \& fenfum ex eo perceperit, anl

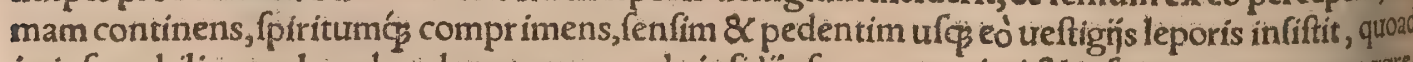
in ipfo cubili eum deprehendens, tanquam de infidịjs fecurum animi $\&$ infperantem càpere aggres ditur. A t enim non hic diffoluto \& ignauiter remiffo animo, fed fufpenfo $\&$ follicito fomnum sapily fimul ac primum uulpem aduentantem fenfu comprehenderit, de cubili exfilit, properans fugam capere, \& curfun ad fummam celeritatem facit; uulpes item ueftigís eum infequens ingrediur 


\section{DeLepore, D.E. Lib. I. 689}

furrere?tuerum longam uiam ubi hic confecerit, ut qui iam longinquio abfceffucontra urulpem fupe tior facius fit, fub dumeta, aliá ue fruteta denfiora fubiens, ex longo curfu, libenti animo \& prolixo fequieti dat; at uulpes eureftigio infequens, ei non concedit ex fuga ut confiftat, \& laboris requietem habeat, fed ad alterum curfum ex quiete eum excitat, \& agitat; poltea uero quàm incitato curfu is permultum uia procedens, tinera non minor a quàm prius fugerit, rurfus uehementer quietem cupit capere: Illa ueró frutetum quò fe is coniecerit urger, ac radicitus excutiens, ab affiduo curfu non finit conquiefce: e:taq̧ is iterum excurrit, illa quroqs non fe ad infequendum tardans, currere infi. fit. Cum autem continenter ex alio alius curfus hunc uigilins diu multumç fatigatum exceperit, currendo feffus, \& laboribus fuccumbit, \& longius procedere defiftitípfa uerò confecuta, eum ip. - fum non fanè curfu, fed longinquitate tempor is, \& captiofa inueftigatione comprehendit, $\mathrm{Hxc} \mathrm{Ae}_{\star}$ lianus. Quintum lupi genus, minus cateris, pilis rigidis, leporibus maxime infidiatur, Oppianus. Muftela dicitur dolofe colludere lepori:quem cum ludendo fatigârit, gutture apprehendit, ualideç adharens comprimit, ne currentem quidem relinquens: laffum tandem interficit $\&$ urorat, $A$ lber. Leporcm aliquando audiui ericí fpinas fingulatim mordicus euellere, \& ita nudatum uorare:quod mihi quidem uerifimile non fit:cum lepus non fit carniuorus; de uulpe potius probabilis hic dolus eflet.

E.

Venatio. Lepori uifus cur obtufus fit, in B diximus. Caterum præter alia canum quoce terro, res prouidentiam auferunt cum inftantes pfequuntur. Quo fit ut irruens ad multa improuidus, in - retia ctiam incautus feratur. Quòd fi rectà fugeret, rarò hoc pateretur. Nunc uerò quia locos com: plectitur $\&$ amat, ubi natus $\&$ enutiritus eff, capitur:fed pleriog omnes prater corporis naturam forte quadam capiuntur : nihil enim quod pportione conureniat, ab huius (corporis partium, ut in $B_{\text {. dia }}$ ximus)compofitione diffenti, Xenophon. Lepus uiam retrouerfus pertinentem cupide amplexa. tur,confuetam fedem omniburs locis antefert, có̧̧́ non parum fape capitur, quờd affiretum cubile relinquere non poffit, A elianus. De curfu leporum $\&$ uelocitate, uide quadam in B. \& plura in $c$. Hic quadam illic relicta adjiciemus, ut qux propius ad uenationem pertineant. Lepores ftatim ue canes $Q$ uenatores fenferint, ad cliuos confugiunt: hos uenaror à curfu accliut quantum poteft auer fos in decliucm agattnam cum pedes priores eis breuiores fint, facilius per colles fcandunt, ubi canes $\&$ urenatores non paruo negotio fequuntur, Oppianus. In femitis etiam \& aruis celerius currunt, to quamobrem inde quo ģ auertentur, Idem. Et mox, Aeftate pedes eis grauãtur: \& hyeme (terra ni: mirum adharefcente, aut aftringente gelu ex pruinis $\&$ niubus) ureluti calciatiad malleolos uf q̧̧ $_{3}$ im. pediunt. Noftri niues pfundas obferuant, ut minore negotio capiant. Montium incolæa, inquit Aelianus, non tam ueloces, quàm qui in planicie uerfantur, nifi quando fub montem fubiectos ha= bent tractus in planiciem explicatos, quó ex montibus decurrant: unde fit, ut tameti montes inco= lant, tamen in campis exerceantur, unde fxpe campani homines eos excitant, atos infequuntur. Cu autem proximi funt ut capiantur, campeftris uia breuitatem declinantes, in altiores locos 8 monto. fos fe conuertunt, in fuas nimirum fedes feftinantes, idcircoćs euadunt, $\mathcal{X}$ inf́peratam falutem affe. quuntur, quòd canibus $\&$ equis montium itinera infefta at $\$$ inimica, pedes obterunt $\&$ debilitant, fed eo acerbius canes uexan tur , quòd carncos pedes, \& minimè ad perpetienda faxa refiftentes, \& quemadmodum equi ungulas, habent. Contrà, lepus conuefitos pilis pedes habet, \& duritatis \& $2=$ feritatis patientes. Iam ex leporibus qui in crebris dumetorum frequentialocis commorantur, labo ris inertia fegnes, non ad curfum uelocitate ualent, ex pedum tarditate ad fugiendum laborantes. Nam huiufcemodi opimo habitu, \& ceflatione torpentes, currendi infueti funt, \& ad pficifcendum Iongiffimè perimbecilles. I forum ratio uenandorum talis eft. Primum per frutices perparuulos $8 C$ minime continenti crebritate denfos permeant: denfiores uerò, quit tranfiri non poffunt, tranfiliunt: ueruntamen ubifruticetum aliud ex alio nexım latifimé continuatur, ibi hoc ipfum facere coaci cum fint, corporis graticate ad faltum parum ualentes, fanè quàm ciro laborant \& fuccumbunt. Ca. nes uero $a b$ cis ip fis primum aberrant, quòd non eos ppter minutarum arbufcularum frequentiam uident, \& uerò per frutices faliunt odoris fenfu illecti, deinde tandem aliquando uifos, infequuntur, 90 de contentione currendi nil remittentes gam longiorem remollefcunt, \& uiribus defecti comprehenduntur, Hacfenus helianus، Et rur. fus, Lepus, inquit, quen canes $\&<$ equi infectantur, fi campeftris fit, celeriore $\&$ concitatiore curfur quàm montanus uiam conficit, ppter corporis exiguiratem, \& tenuitatem. Cum enim gracili habitu fitipfun celeritate praftare urero pximum eft. Primum igitur ex terra exfiliens faltu fertur, $\alpha^{\prime}$ per dumeta aliátue denfiora uirgulta expeditus perlabitur. Tum uero ficubiherbx fint alra $\&$ frequen. res, ex eis facile fefe explicat, atç elabitur: ac quemadmodum leonibus caudx ad excitandas uires magno adiumento effe dicuntur, fic huic aures roboris numina, $8 \times$ uexilla, $8 \mathrm{C}$ curfur incitamẽta exi. ftunt: fugiens eas ad tergum retorquet, ficós ipfis tanquam fimulis torporem $\&$ ignauiam, neà curr rendo retardetur, concitat. Iam porro curfum nec unum, nec recià tenet, fed $\&$ hurc illuc fe uerfat, $8 \&$ 6o uero de recto curfur deffectit, ut exterreat canes, $\&$ circumueniat ad id quidem diuerticulum, quio uult irer conuertere: de auribus alterutram intorquet, atç inflectit, eáç quafi moderatrice curfum di rigit, Neq̧̧ uero improuidè uno eodemóş tempore omnes fuarum uirium neruulos contendit, fed $\mathbb{C}$ 


\section{0

impetừm infequentis obfềruat, \& fi ad infequendum tardus $\alpha$ fegnis fit, non omnem fuam celeri tem profundit:Sed duntaxat canes antegredi maturans, fefe integrum feruat; $\&$ uiribus fuis modee ratur, ne omnem fuam currendi facultatem urgens, ex incitato curfur uiribus deficiat, Penitus enim cognofcit fe ad curfum longè multumćs antecellere, \& uidet impenfius laborare non effe neceffe. Quod fi pedum celeritate canis ad conficiendum interpollet, tum omnibus reuocatis uiribus leptris quanto maximo poteft curfu fertur. Cum autem longè multum $\not ̧ \zeta$ canibus anteuerterit ; $\&$ longof nè interuallo uenatores atq̧ equos reliquerit, tum fane in aliquem timulimi afcendit, \& in pofferio, res pedes fefé erigens, tanquam ex aliqua fpecula, \& infectantiums certamen profpicit, \& quantum equidem exiftimo, eos ut debiliores ridet. Poft ex eo loco intuens, fe omnia fuperiora habere, is nimi rum quietem $\&$ tranquillitatem adeptus, ex laffitudine grate $\&$ libenter dormit, Hæc ominia Aelia nus, Catuli magis fubolent quàm adulti:quoniam eorum membra adhuc mollia per terram unin uerfa traliuntur. Sed tenellos ftudiofi uenatores dimittunt, gratificantes dex: qui uerò iam iutuenes ("zrsio, id eft anniculi, ut paulò poft etiam uertit) funt, primo curfu uelociffimè feruntur, deincens non ita:agiles enim funt, fed imbecilles, Xenophon. Syluofa loca (inquit Xenophon) magis redon lent quàm nuda.Síquidem lepus, modò percurrens, modo procumbens, multa contingit, Procum bit aute: ad ea qux terra gignit, uel ipfius fuperficies habet, fub omnibus, fuper ipfis, in ipfis, pro, pius, longius, nunc diu, nunc parum, sunc mediocriter : $\&$ in mari nonnunquam ad id quod poreft

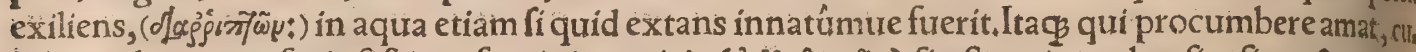

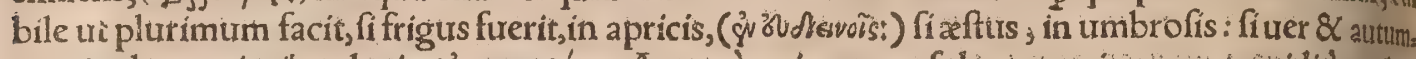

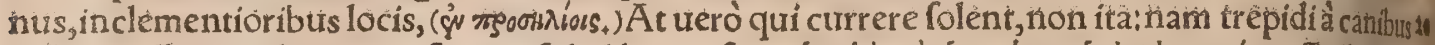

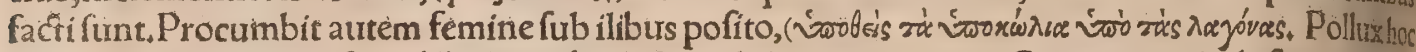

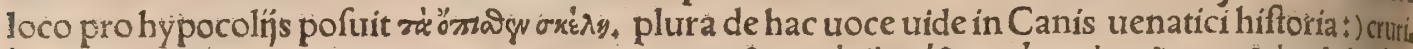

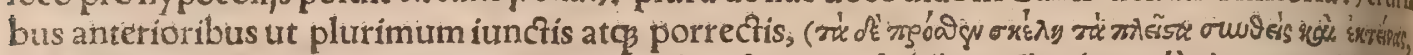

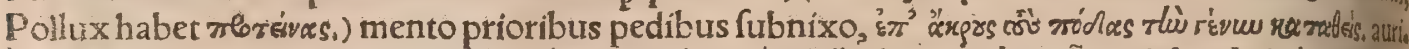

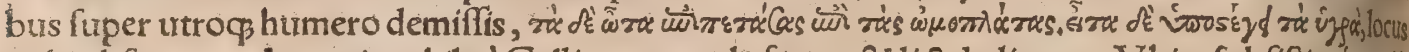

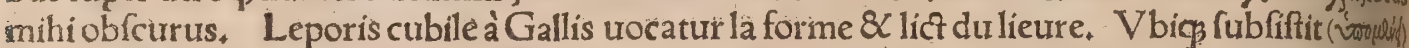

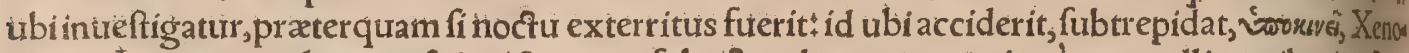
phon. Inter agitandum perfpicui funt, per fubactam humurm pracipure nonnulli, quibusisineffrte bor:per arû́dines etiam, quia ex aduerfo refulgent, Perfpicui funt quo $\xi_{3}$ in tramitibus $\&$ uñs, fiphas

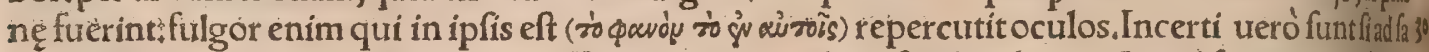
$\mathrm{xa}_{\mathrm{a}}$ ad montes, ad rupes, ad opaca fecefferint, propter coloris fimilitudinem. Qund fi canes prafenfer rint, fiftunt pedem, \& refidentes feipfos erigunt: \& canum, ficubi prope eft, clamorem ftrepitumgẹta ptant, $\mathcal{Q}$ unde audierint auertuntur. Eft etiam cum nihil aurdierint, fed audiffe opinătes, velfitip prt fuadentes, huc illuc trepidantes, ueftign̄s infilientes, in ueftigia fecedunt. Porrò longiffimè currunt, qui nudis ex locis excutiuntur, quia in aperto funt:breuiflimé uerò, qui ex opacis: nam tenebra $(\vec{x}$ oxbrevòy) impediunt, Xenophon. Ea quidem ueftigía, quræ refidens feipfum erigendolepus impri

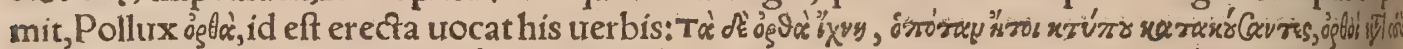

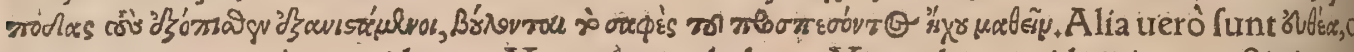

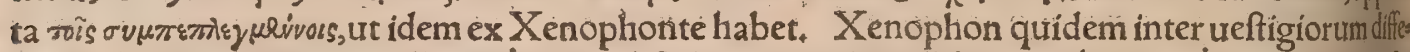

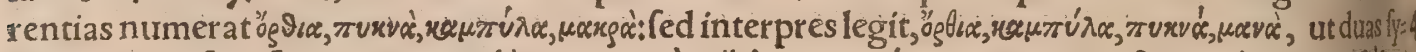

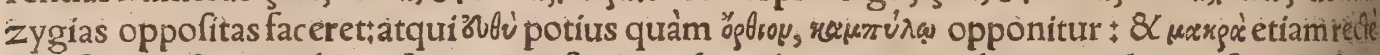
poteft, ut in fequentibus. Leporis ureftigia multurm hyeme procedunt, quia longæ funt noctes: par rum aưtem xiftatè, quia è contrario funt breues. Nec uerò fubolent hyeme dilucullo,cum prutinalitie rit aut gelu, \& c cut in Cane fagace $\&$ inueftigatore ex Xenophonte recitatui, In plenilunio pracip leporum ueftigia incertiffima funt:nam exultantes ad Lunamlepores inter fe colludunt; \& cealoi diffipantes dirimunt, Xenophon. ¿Et rurfus, Verno etiam magis quàm alio anni temporê confuluta funt:nam lepus coitum quarit cum aliâs femper, tưm hoc tempore:quamobrem fimul tragai

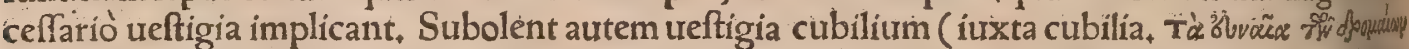

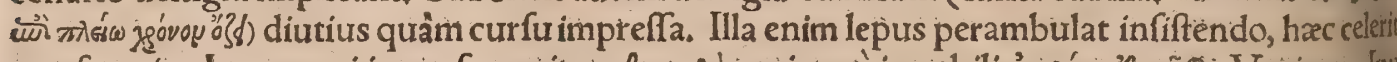

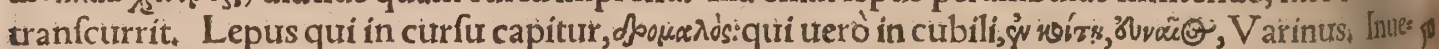

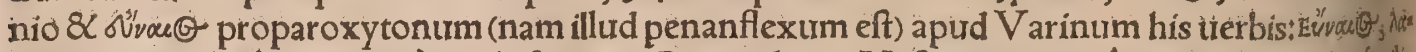

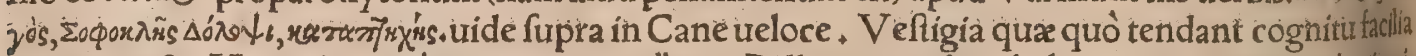

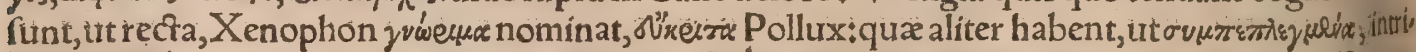

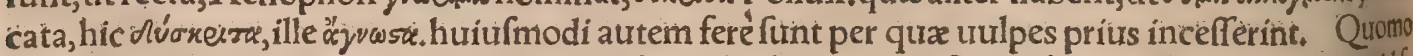

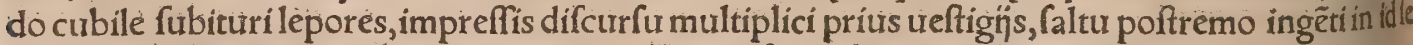
resipiant, fupra dictum eft capite quarto. Flexuofo curfu canes plexung decipiunt, Textor.

- Exeundum eft autem ad uenationem, inquit Xènophon, diluculo, ne uéftigatione priuếturññ fi mora fiat, nec leporem canes inueniunt, nec fruchum uenatores faciunt: neç enim manet natura ueftigin, qux fingulis horis euranefcit. Stolam cuftos retium leurem indutus uenatum exeat:retiburs di

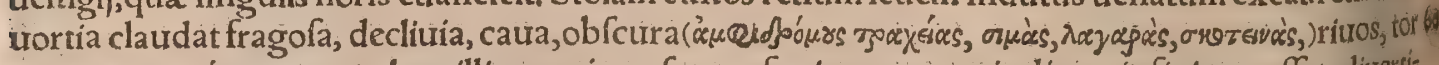
rentes, aquas ćs perennes. hæc illis præcipua funt refugia:nam omnnia dicere infinitum effet, diturtlis cula, biuia (oroo' rs: qux trox etiam fimpliciter uias uel femitas fignificat) lata urel angufta. Id ortoiam solé 
ferecidunt, dum infultant, $\&$ clangentes infurgunt, dum profiliunt, dum uenatorem fpectant, $\&$ hasc lam uera effe demonftrant, leporem ultto excitabunt, \& latrantes inuadent: fed fiue in retia pra cipiret, fíc exterius, fiue interius prætereat, ad unumquod ptt:s fierit, alium inquirat: fin minus, hifdem ut antè hortationibus tranfcurrat. Sed cum iam ferum diei fuerit, canibus propemodum currendo defatigatis, tunc leporem uenator feffum exquirat, nihil relingurens corum qux rerra gignit, uel ipfius fuperficies habet: fed crebrò eadem relegat, ne prateri rus fallat. Procumbic enim in angufto, nec refurgit pra labore $\&$ metu. Superinducat $\&$ canes ho" tando: hiandiendo, fi qua ef humana, multum:fiaudax, parum:fi mediocris, mediocriter : donecipa

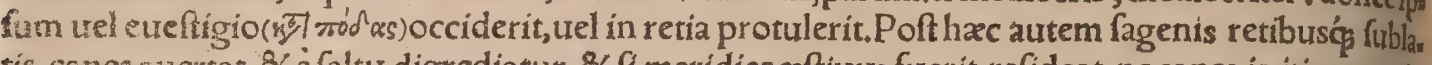
tis, canes anertat, \& $\dot{e}$ faltu digrediatur, \& fi meridies $x$ ftiuus fuerit, refideat, ne canes in itinerepedia bus urantur, Hactenus Xenophon Omnibono Leoniceno feré interprete. Et rurfus, Veftigent au

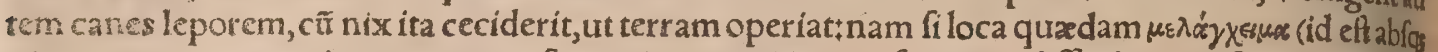
niue, cum ea qua circunquaque funt niue operiantur) fuerint, difficilis inueftigatur erit. At

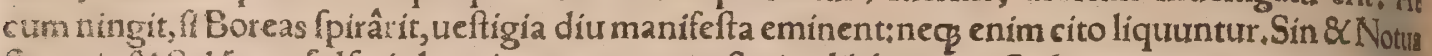
fiauerit, \& Sol fuperfulferit, breui apparent: nam ftatim dilabuntur . Sed neģ cum nix iugiter cadit, ueftigia enim obducit:neç cum uentus acriter incumbit, niuem enim conuoluens incerta facit, $A d$ huiumodi uenationem cum canibus exeundum non eft: fiquidem nix canum nares adurit, \& pedes ac leporis odorem gelu nimio tollit. Sumptis igitur retibus $\&$ comite fibi adiuncro, ab agris ad mon

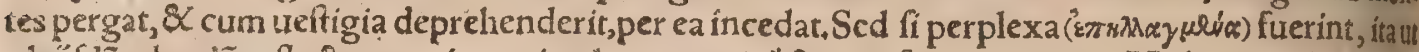

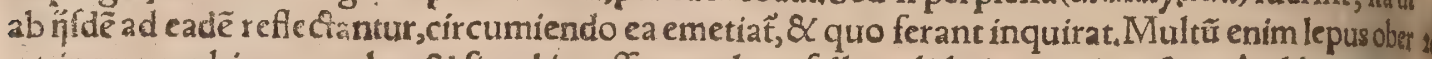
rat, incertus ubi procumbat, \& fimul inceffư perplexo fallere didicit, ut qui perfæpe â talibus(canib, \& uenatoribus) agitetur. Vbi iam ueftigium apparuerit, procedat ulterius : perueniet autem uel ad locum aliquem umbrofum, uel abruptum, quod per huiufmodiloca uenti niuem tranfmittất;quofit ut opportuna cubiltbus multa in eis relinquantur, $\&$ talia quarit lepus, Huc igitur cum ueftigia dir xerint, non accedat propius, ne promouearur lepus, fed undigs circundet: nam ibi effe fperatur, ath gumento erit, fi nufquam inde ueftigia deduxerint. Sed cum ibi effe certum fuerit, illum relinquat,

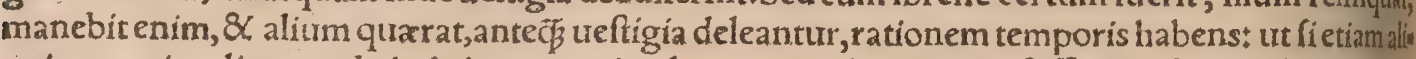
os inuencrit, reliquum diei ad circumueniendum(circundanda retia)fufficiat. Quod ubi acciderit, retia unicuicg corum circumtendat, non aliter quàm cum melanchima(id eft loca quxedam abfghnis ue, cum cæetera circumcirca omnia niue operiantur) fuerint, locum uniuerfum cingendo, ubicunt tandem in eo lateat lepus. Retibus erectis, accedens commoueat. At fi elapfus fuerit è retibus, perue ftigía fequatur: conferet en im fe rurfus ad fimilia loca, nifi in ipfa niue opprimatur. Obferuãs igtur ubicung, fuerit, circumuenire debet, quòd fi non expectet, curfu infiftere. Nam \& fine retibus capit ture, quia profunda nitue laffatur, \& in extremis pedibus (ut Pollux etiam repetit, \& Oppianus)ubitil lofus eft, moles niuis haud modica fuccrefcit, Hacienus Xenophon. De canibus celeribus, iepora rio, Gallico, Vertago, in canum hiftoria fatis dictum eft. Galli grandiores etiam canes, quos cetuan rios appellant, ut \& fuarios luparios ç fub nomine leporariorum comprehendunt, Budaxus. Venas ror leporis ueftígia captat, ex agris fupernè fubducendo canes, fed qui culta non adeunt, prata, falt cus (vcras) Huenta, lapidofa fyluofáç petunt. Et cum mouretur lepus, clamorem minimé tollat,nepa

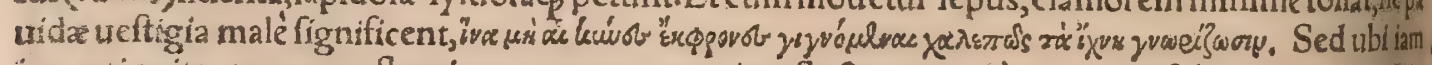
inuenti agitantur, nunc flumina tranant, nunc uiam flectunt, modò cauernas fubeunt, ac penteriât neg tum canes folum metuunt, uerum $\&$ aquilas, ut in $D$. dixi. Venatici canes leporem, fi necarint ipfi, difcerpunt, $\&$ fanguinem auidélambunt; confeçum autem curfu $\&$ exanimem confecuti, non attingunt, Plurarcinus, Lepores $\&$ uulpes per aftatem noctu progrediuntur, Tardiutus. Nos alla tem uidimus, inquit Blondus, uenantes in capiendisleporibus hunc modum feruare infidiandi. Din uifi ac fparfi uenatores per inculta frequentius quàm per culta, arte quadã incedunt laqueis cantem Ieporarium detinentes: fpineta $\&$ fentes, fiue dumeta, faltúsue potius celebrãtes quàm nemora ، Nön. nunquam etiam pramittunt odorum canem qui èlatebris pellat timidum leporem, poft quemé ${ }^{2}=$ queis mittunt canem fugacem, altis clamoribus perfequentes, qui funt exhortationes fugacium cas mum. Comprehenfi denum lepores frequentius fcinduntur à canibus, quàm crurenti ab ore cantum cuellantur à uenatoribus. Quidam etiam fedentes poft fruticem fiue carecta feu dumum leporbus infidiando, optimorum uena torum confequuntur nomen , hoc fit autem cum uenantium maxima par è longis circuitibus expellit lepores infequendo uf̧́ ad infidiantes, quos improuifo aggrediun tur canes. Venantur autem lepores $\&$ poft uindemiam in uineis, \& in campis aratorís confeftim poft menfem. Verum turgidi ac pingues maximé decipiuntur rigente bruma $\&$ fuper niurm, Sed in diluculo leporum praftantiffima uenatio eft, Hæc Blondus. Nec uerò canum cuiufģ generis fas miliz fagaciores ueftigia tantum ferarum odorantur, fed feras, $\&$ perdices, $\&$ lepores: eorumé centia cubilia perfentícunt è longinquo, utpote aduerfo uento eorum odorem captantes erectisn ribus $\&$ exorbentes, Budxus. Lepufculi timentes, hoe quadrangulum dedit Diana rete, nexile, aut uífcum, fuge, lineamós compedam, Varro in Prometheo ut à Nonio citatur. Eft autem uifcum hoc 60 locogenus retis. Cerui, lepores $\&$ uulpes retibus capiuntur $\neq$ præcipué eo genere retis quod arolum uocant, (quod ab eo défribitur 10.22, Pet, Crefc, Etrunfus 10,:9. Lepores pracipué capiuntur ca. 
dunt, Varro. Et Appius apud eundem, Sequítur, inquit, actus fecundi generis, affictitius ad utllan qui folet effe, ac nomine antiquo à parte quadam leporarium appellatum. Nam neç folum lepores in eo includuntur fylua, ut olim in iugero agelli, aut duobus:fed etiam cerui aut capræ (lego, caprean) in iugeribus multis, Quintus Fuluius leporarium dicitur habere in Tarquinienfi feptum, ingerum quadraginta, in quo funt inclufa, non folum ea quæ dixi, fed etiam oues feræ : Etiam hoc maius hic in Statonenfi, \& quidam in locis alijs. In Gallia uero tranfalpina T.Pompeius tantum feptum uena tionis, ut circiter triginta millia paffuum locum inclufum habeat. Prxterea in eodem confepto habe re folec, de animalibus coclearia, at $\$$ aluearia, atç etiam dolia, ubi habeat glires conclufos. Sed ho, rum omnium cuftodia incrementum, \& paftio aperta, praterquam de apibus. Quis enim ignorat $f_{l_{3}}$ pta è macerïs, ita effe oportere in leporario, ut tectorio'tecta fint, $\&$ fint alta? Alterum ne feles, meles, alia' ue qua beftia intrare poflit, alterum ne lupus tranfilire: Ibió̧ effe latebras, ubi interdiu le, pores delitefcant in uirgultis atç, herbis : $\&$ arbore's patulis ramis, quæ aquilæ impediant conattus, Quis item nefcit,paucos fi lepores mares in forminas intromiferit, breui tempore fore ut impleatur! tanta focunditas huius quadrupedis. Quatuor enim modò fi in tromiferis in leporarium, breuifole repleri, Leporum omnia tria genera(qua capite fecundo defcripfimus)fi poffis, in leporario habe re oportet: duo enim utíg te habere puto, \& quod in Hifpania annis ita fuifti multis, ut inde te cuni culos perfecutos credam, Varro. Etrurfus, Lepores quoge nuper inftitutum ut faginarent plerac, cum exceptos è leporario concludant in caueis, \& loco claufo faciant pingues. De uiuarïs facien, dis, 8 includendis pecudibus fer is multa fcribit Columella libri noni ca.1. qux differo ad librum de animalibus communem. De minoris aurem incrementi animalibus (inquir ibidem) qualis eft lepus, hac pracipimus, ut in ijs uiuarịs, qua materı (maceria:fic enim fupra dixerat, \& muro)mutita funt, farraginis, \& olerum, feré intubi lacfucæ ós, femina paruulis areolis per diuerfa fpatia factis in ijciantur:item horreo promantur, \& aqua coelefti macerata obṕpciantur : nam ficca non nimis ab lepufculis appen tuntur. Hac porrò animalia uel fimilia his(eriam filente me)facile intelligitur, quàm non expediat conferre in id uituarium, quod uacerris circundatum eft:fiquidem ,ppter exiguitatem corporis fach, le clatris fubrepunt, \& liberos nacta eg: effus fugam moliuntur, Hacc Columeila. Epigrammainle porarï ingreffum Ferraria, T. VefpalianiStrozæ, libro 1. Aeoloftichon. Adeò nihil omiftum effi, ut leporem furdum celerius pinguefcere reperiamus, Plinius. Hoc fi uerum eft, in caufa fuerit ford fis, quod cum auditu fruitur, ad quemuis fubinde fonum $\&$ ftrepitum trepidus expauefcit, undead corpus augendum continuo metu pauoréç impediri uídetur. Quod fi etiam furdus natura non lit, auribus cera uel aliter obftructis auditus eis obrundi poffer.

TScribit A el. Lampridius, Heliogabalum non facile cubuiffe in culcitris feu accubitis, nifiqua leporinum pilum haberent, aut perdicum plumas fubalares. Veftes etiam leporino pilo facere,cen tatum eft, taciu non perin de molli ut in cute, proprer breuitatem pili dilabidas, Plini. Eleporinis pets libus cum pilis fuis manicx $\&$ caligx parantur ad ufum eorum quir efrigeratis aut articularijsmeri bris laborant; affuũtur etiam tegumentis pro uentre interioribus:multum enim calefaciunt, \&leutes fímul ac molles funt, triplici nomine grata. Indumentum ex pellibus leporum, corrobor at corpora

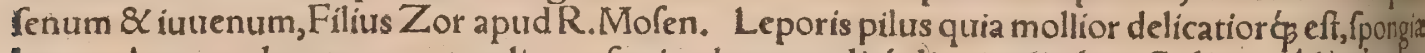

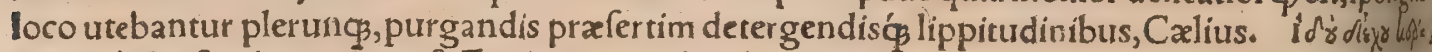

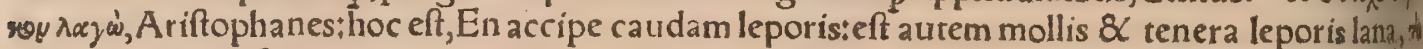
op" Graci uocant, abftergendas, Suidas \& V. arinus in uoce Kopines. Pedum etiam pro fcopis ufus,adpul uerem detergendum $\&$ uerrendas quifquilias, \&c,

- Leporina femper in delichỉs fuit, $Q$ in fplendidis epulis appofita. Inter autes turrdus, fi qquis meiu dice certet, Inter quadrupedes gloria prima lepus, Martialis. In pentametro quidam pro gloria le. gunt mattya:quod nomen à maza fit, uocanturós fic pretiofa omnia edulia, ut fcribit $A$ then aus, $C$ lius. Antiphanés poëta in Cyclope, dafypodem, id eft leporem, in conuiuio inter alia appofiturt ce lebrat, Athenzus. Leporem guftare fas non purant Britanni, Cælius. Lepus quanquam rumis nat, ludxis in ciboà Mofe interdictus eft, quoniam pedes non bifulcos fed digita tos habet, Leuitilb \& Deuter.14. Plutarchus in Sympofiacis libro 4. quęftione ul tima, ubi quęrit de Iudais, utrum ill colentes fuem aut deteftantes, carnibus eius abftıneant:Quin $\&$ leppre, ait, quidam ludxos abfine: re ferunt, a nimal tanquam immundum $\&$ abominabile deteftantes. Tum Lamprias, (hic locus mu tilus eft, ego ex coniectura uertam:) A tqui fortaffis lepore non odio, fed cultu aliquo profequentes abftinent, ppter corporis cum afino fimilitudinem. (Paulò ante enim afinum quog ab ipfis coli Callit ftratus affirmatrerat.)Quamuis enim \& corporis mole multum inferior fit afíno lepus, \& celeritate longè fuperior: mirè tamen cum co conuenit colore, auribus, \& oculorum tum pinguedine tum fat: fedine, ut uix aliud animal paruum tam fimile alicui magno reperias. Nifi fortafis A egyptios circa fimilitudines fecuti, animantis celeritatem diuinum quiddam exiftimant: \& fenfuum eius acrimonis 6 am, (de qua in C. dixi,) Hæc Plutarch. TCaro leporum fanguinem quidem gignit craffiorem, fed melioris fucci đ̧̧ bubula \& ouilla, Galen, s, de aliment, facul,Paulus A egineta tamen non meliorem, 


\section{DeLepore. F. Lib. I. 695}

fed minus craffurn ex leporina quàm bubula \& ouilla carne furceum generar f feribit. Et furfus in li. bro de attenuante uictu, Caroleporum ad uictus rationem ficcantem eft accommoda : ad propofi: tam uerò non admodum confert:fangutnem enim urehementer craftum gignit, Eadem ex Galeno Arabici quidam fcriptores repetunt, $R$ afis, I $f_{2} a c \&$ alij. Celfus leporem in media materia numeraridebere dicit, \& boni fucci effe, aluum adfringere, \& urinam mouere. Caro leporis gignit fangui nem craffum \& melanchollcum ; deficcat, \& non attenuat, ideoç medetur uifcerum dolori; Huxu\& irentris, (\&c.ut in G.referam) Rafis \& Albertus, Quanquam ficca \& craffa, hírcorum tamen \& $\mathrm{ca}$ prart carnbus antefertur, Ifac. Calida eft 8 ficca $\& \alpha$ aflata prodeft ulceribus inteftinorum, ut qu damex Auicenna cităt, a pud quem ego nihil tale reperlo. In Tacuinis uerò Elluchafem fị legimus: - Caroleporina utilis eft fenibus, 8 frigidi temperamenti hominibus, in fenecta pracipue: iuniori. bus ueró non conurenit:qui tamen fi eam in cibo fumpturifint, per noctem prius in fucco $\mathrm{Pualco}$ pum \& aceco macerent, Hrec ille, authorem citans $R$ a fin. Idem ex Haly afferit, calidam \& ficcam elle leporinam in fecundo abfceflu, uentrem fiftere, \& urinam prourocare: praferendam effe fi lepus in urenatione captus fít à canibus, \& magis hyeme, \& regionibus frigidis, prodeffe nimium corpulẽtis, trigilias facere:cum condimentis uel aromatibus qua attenuent praparari debere. Auicenna, ur in: terpretes reddunt, leporem fylueftrem nominat pro terreftri, ut conijcio, ad differentiam marini. Lea pus frigidus eft \&xficcus, falubrior futurus cum melle, Auicenna:fed hac eius urerba, ut Bellunenfis monet, in emendatis codicibus nulla funt * ut negs ifta, De eo qui in domibus nutritur adufto fus. mitur in potu medietas drachmx. Mihi legendum uiderur, Eligendum effe leporem qui liberè pafca o tur in campis, non qui domi alatur: qua ferè eriam Elluchafem in Tactzinis fcribit. Carerum drach: ma dimidia delepore ufto in potu fumendo, for tè ad remedium aduerfus calculum pertinet, quod ex lepore ufto fieri fequenti capire docebimus. Praterea quod ftomachum mundificet, fic loquũtur, id quogs meliores codices non agnofcunt: Lepus fit carnofum, fed non pingue animalthuius carni. bus utantur qui macréfere atç exienurari cupiunt, Blondus, Aetius fcribit carnes tulpinas, Icpor nas $\&$ erici, naturz humanzelfe difimiles, 8 alimenta efficere peffima, cuius argunentum fir odor focdus, 10. Agricola Ammon. Talis quidem odor excoriantibus circa inteftina pracipuẻ apparor. Cuniculi caro melius \& facilius alit quàm leporina, qux frigidx $\&$ ficca natura eft, \& bilem atram gignit, Platina. V da cuniculus affert Fercula, uifcofum femiimitata gluten, Bapc. Fiera, hoc eum à le pore differre fcribens. Catify.ureftres temperamento ad lepores accedunt:caro eorum calida \& mol lis eft, Rafis. M. Cato Cenforius ægrotos ali iubebatholeribus, 8 carnibus anatis, palumbis, aut leporis:hanc enim leuem effe aiebat \& agrotantibus commodam: nifi quod multa parit infomnia, Plutarchus in uita cius, Somniolos fieri lepore fumpto in cibis Cato arbiratur, Plinius. Ioãnes Ma" nardus in epiffolis 13.4 . de leporina carne, quòd frigida ficcá̧́ fit, \& bilem atram gignat, ad Iaco bum Pharufum medicum R hegienfem id negãtem, copiole fribit:nos inde quædam excerpemus: Applauferunt mihi, inquit, rationes tura, quibus leporinam carnem \& bonifucci effe, \& cocturnon difficilem probas: Verum quó minus confentirem deterruit me ueneräda antiquitas, \& ad hae uIç fecula quafi per manus nobis tradita fententia. Scribitur enim in libro de Dięra fecundo, qui quidem Galeni tempore à multís, nunc ab omnibus Hippocrati adferibitur, in hunc modum: Leporina caro' ficca \& adftringens, lotium aliquantifper mouet. (Deinde enumeratis Galeni uerbis, qux nos etiam - paulò a nte pofuimus, addit:) Et apertiffimé libro z, de locis afiectis, magnam eam habere uim dicit in melancholici fanguínis generatione. P fellus quoģ et Paulus eifdem ferè uerbis Galenofubferibunt: EtSimeon in libro de Elcis, quafi quxeun qe dicta à uetưfioribus erant colligens, inqutir: Carnes le. portum his qui exiccare corpus uolunt, ualde conducuntiminimé uerò his qui temperatura funt ficciore: [anguinem quippe gignunt craffarum partium et melancholicum. Deinde expofitis quibuf dam preceptis de omni alimento dïudicando, fubíncit:Durities leporinx carnis facit, ut ferò \& par latim nutriat:quod dura alimenta omnia faciứt, Galeno tefre. Quemadmodum autem, eodern refte, id quod facile concoquitur 86 celeriter nutrit; eft quo ad nos calidum : ita è contrario quod tardè $\$<$ paulatim, quo ad nos frigidum. Eadem duríies euidens ficcitatis indicium eft:quod etiam reftatur diffimilitudo quam haber cum carne porcina, quxe prae cunctis carribus, Galeno \& ipfo fenfu tefte; eft noftrx magis fimilis. A b hacleporinam per frigus $\&$ ficcitatem recedere, nemo ( $n$ i fallor) ambia get; qui utranç bene nôrițexanguis enim arida 8 ueluti ufta leporina uidetur, fuiliz comparata ua poreç omni at ţ humore ac tenacitate fere priuata:fragilis uerò $8<$ ceu fibris abundans : quaz ornnia $\&$ difficilem concoctu \& feram ad diducendum oftendunt. Agilitas quocg \& in currendo uelocita: eam ualde à fue differre of endunt; fed $8 \mathrm{C}$ timiditas frigus indicat, Si enim ficcitati coniungeretur ca liditas, audaciam, quam fummam in leone calido \& ficco animali uidemus, in lepore quog efficeret. Quỏd ais tale tenperamẽum effe carnis quale fanguinis fí, non ef neceffe: mirtarienim nutrimen tum à nutriendo debet, nun è contrario: \& alize etiam corporis partes à fanguine nutriluntur, quas ta men ciufdem effe temperamenti nemo dixerit, Sanguis certè longè calidior eft quàm caro, \&cc. Sed quanquam tenus ef leporinus fanguis, aqueus fere, \& fine fibris, non fequitur non effe melancholl 40 cim. Tenuitas enim 8 (ut tu uocas) aqueitas, frigus oftendunt, non calorem: (anguis erim dilutior, Arifotele tefte, frigidior efteaćg animalía, quibus dilutior eft, timidiora. Tauri quidem animalis ual de calidi fanguis craffus eft, \& fibris refertus, Praterea licet, Galeno tefte, dulcis fit fanguis leporis 
8 fapidus, ita ut dulcedine $\&$ concoctionis facilitate fanguinem autium fuperet: didicimus tamene codem Galeno, non omnia dulcia effe calida, fed ea tantum qua dulcedinem magnam habent; qua uero modice dulcia funt, effe frigida ad tantam autem dulcedinem leporinus fanguis non attollitur, (Deinde tractata quęftion e affar ne carnes an elixx humidiores fint: 8 utrum affa aliquid caliditatis acquirant, Leporinę quidem carni, ínquít, modice atç̧ ut coquina requirit aff $x$, nullam arbitror $c_{2}$ lidiratem fuperaddi, Hucufक̧ Manardus.

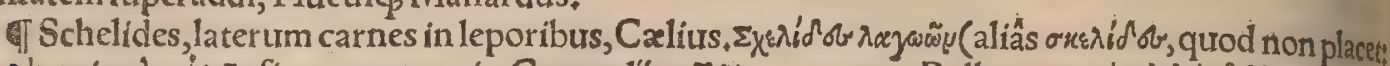

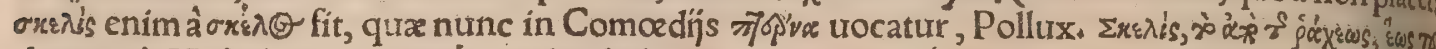

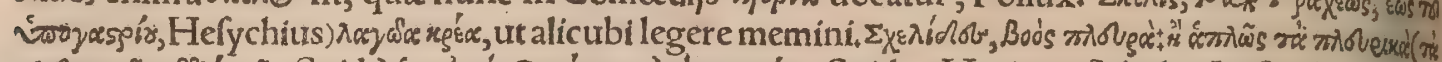

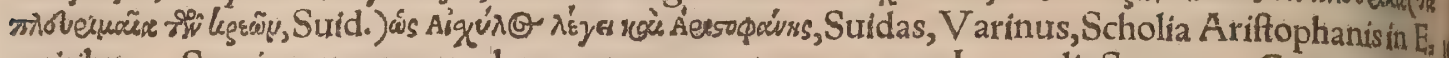
quitibus, Sumine cum magno lepus, atç, aper, atos pygargus, Iuxuenalis Satyra I. Canes pro ama toriburs (inquit Crinitus 19.8.)paffim accipiuntur, ut quilepores magno ftudio confecientur, affes rente Donato: Hinc illud uulgatum, Foecundi leporis fapiens fectabitur armos, (ex Horatif is Ser, monum:) Etillud etiam Terentianum ex Liuio Andronico, fi Lulio Capitolino (Flauio Vopíco in Numeriano, Erafmus)credimus, pro militaridicto, Tute lepus es $\&$ pulpamentum quaris, Lepus à pofteriore parte, hoc eft à lumbis $\&$ clunibus pulpamentum de fe prabet, eaćg corporis parte lauth tiffimus eft. Terentius Eun.Lepus ture es $\&$ pulpamentum quxris: Id eft ea requiris ab alins, quaip re affatim habes domi, (Quod in te habes, hoc queris in altero: 8 eft tropus allegoria, Donatusi) Donatus in hunc locum, Lepus, inquit, pro infamia multa ponitur:uel quód magis à pofteriori par, $r_{\text {, }}$ hoc eft armis, pulpamentum de fe prabeat, quum in conuiuio carpitur appofitus:uel quồd tertan rur illum \& perfectantur canes, quos pro amatoribus allegorice intelligimus, ut ipfe Terentius ait, Ceruam uidere,fugere, fectari canes: Vel quod illum fic fugiant omnes, conftituat ut hunc libidoff forminata: (Obfcuriora funthæc, \& ab Erafmo etiam in huius prouerbij mentione omiffa ;) Vel a à phyficis dicatur incerti fexus, ac effe modò mas, modò foemína. Obfcurus quidam Terentininter pres fic interpretatur:Quoniam nunc fominæ nunc maris libidinem exerces, non eft quod palpes mulierem. Lepus tute es \& pulpamentũ quaris: Id eft ab alio quæris quod in te habes:hoceft,blan diris fcorto, cum ipfe fis fcortum. Quod fi Donatus $\&$ cæteri Terentij interpretes intellexiffent, non fuiffent tot ambagibus ufi in re fimplici at $\$$ aperta, Sipontinus. De lepore prouerbium dictum, 4 an

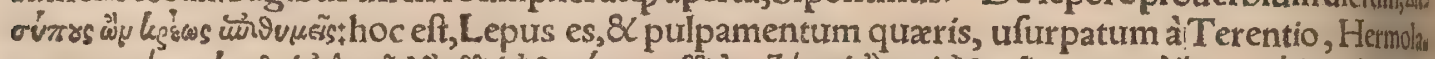

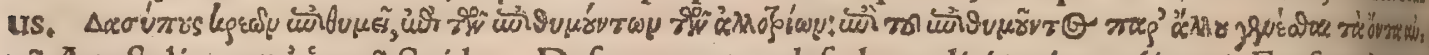
चॅ. requirunt $a b$ alins, qux ipfis affatim funt domi. Etmox, Sunt qui exiftiment prouerbium, Tutels pus es, \& pulpamentum quxris, curm, pximo idem effe, Dictum eft autem à milite gloriofo apud $T_{e}$ rentium in adolefcentem $R$ hodium, qui fcorto fuo alludebat, ipfe ea atate qua fcorti uicibus fungi poffet, Donati commenta frigidiora mihi uidentur, ac ut fimplicius, ita uerius effe puto, ad Gracem

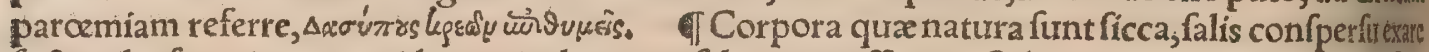

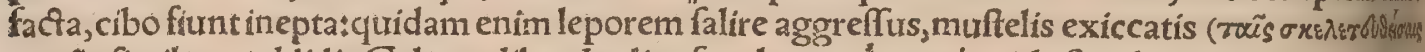

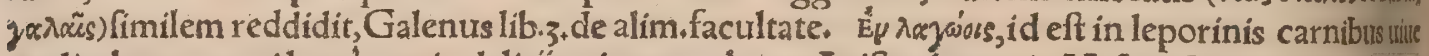
re dicebantur, qui lauté atçs in delicís uitam agebant. Ariftophanes in Vefpis, Sunt,inquit, mille uitates, quænurnc nobis tributum foluunt. Harum unicuios fi quis imperet ut uiginti alat uiros, duv

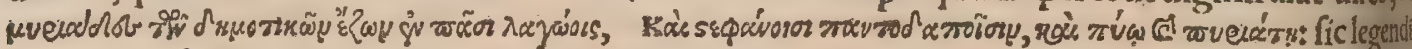
non ut Erafmus habet wucegirit. Verfus quem ibidem citat tanquam Homeri Erafmussầ Scho non ita citatur:nec hercle Homeri effe uideri poteft. Ariftophanis quidem de leporinis uerba Suid etiam adducit. Hoc ef, Viginti milia de populo hominum uiuerent in omniburs leporinis, oming nisć́ coronis, \& coloftris, Rurfus in Equitibus, quum Cleon $\&$ aduerfarius certatim promittul lautiffimas epulas populo, multis deliciarum generibus nominatis, promittuntur \& leporinecann

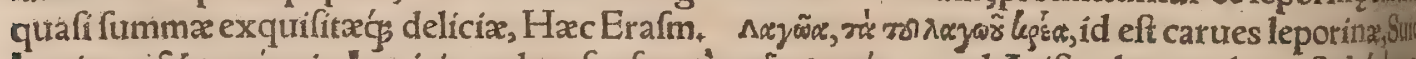

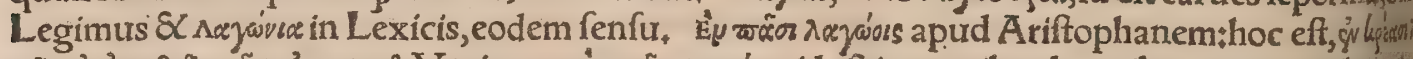

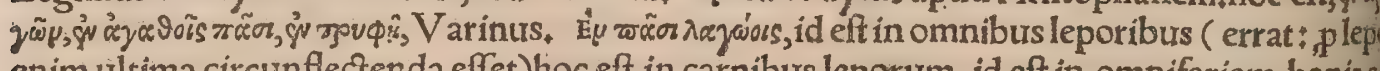
enim ultima circunflectenda effet) hoc eft in carnibus leporum, id eft in omnifariam bonis a

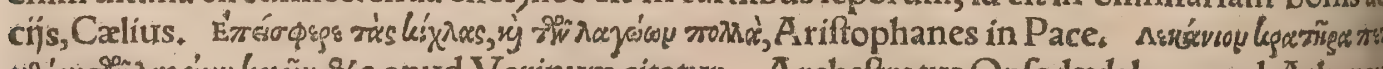

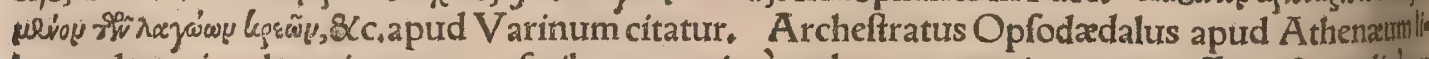
bro 9 , de optimo leporis apparatu fcribens, maximè probat carnem eius parum affam, \& modicerul dam adhuc, needum fanguineo humore prorfus priuatam, fine alins condimentis fale tantum afpers fam, calidam flatim à ueru conuiuis apponi. Sed praftat uer fus ipfius (quamuis duo poftremiob́cin rifint)recitare, fi quis forte etiam plura inde colligat.

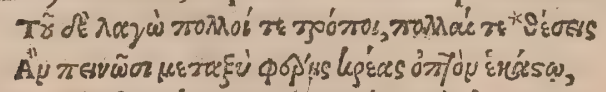

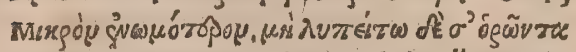

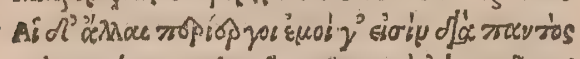

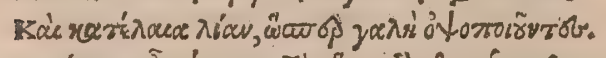

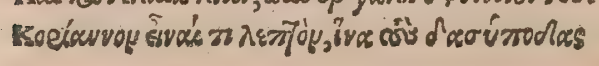

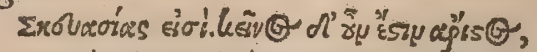

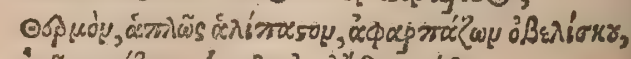

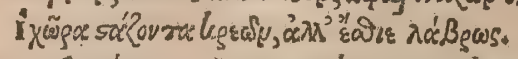

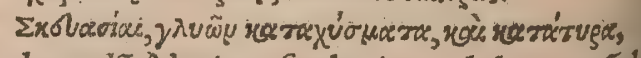

Apud eundê Alcęi uerfus legimus de lepore códiento,

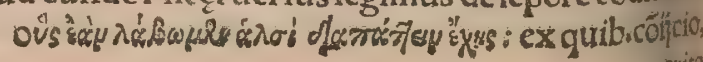




\section{DeQuadrupedibus}

idem aut fimile cibarium quod noftri ex fanguine $\&$ extis aut uifceribus leporis parant, \& piperat

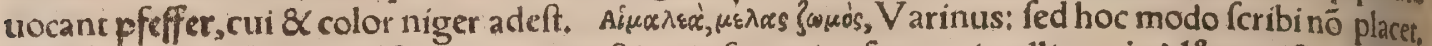

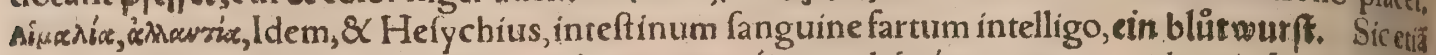
éfanguine \& inteftinis thynni, iuris uel gari genus fit, quod ácuézzoy uocari quidam in Lexico Gra colarino annotauit. Ex fanguine $\&$ iocinore \& pulmonib. leporinis minutal, ut A picius praferis bir 8.8. A dícies in cacabum liquamen $\&$ oleum, cocturam: porrum $\&$ coriandrum minutatim con cides. Iocinora \& pulmones in cacabum mittes, cum cocta fuerint, teres piper, cuminum, corianditi, laferis radicem, mentham, rutam, pulegium:fuffundes acetum, adincies iocinora leporum \& fanguia nem, teies, adijcies mel, ius de fuo fibi, aceto temperabis, Exinanies in cacabum, pulmones leporum minutatím concifos in eundem cacabum mitres, facies ut ferueat, cum ferbuerit, amylo obligas, pis , per afperges 8 inferes. 1 Hoc quoç nuper infitutum eft, ut lepores faginarentur, cum exceptosé leporario quondam in caueis $\&$ loco claufo fatiant(faciant)pingues, $V$ arro, \& cx eo repetens Mas crobius in Saturnalibus 3.13. Nunquam multum pinguefcit lepus, fed quando fub tectis nutritur 8 non mouetur, aliquando ren eius dexter Sepo operitur, 8 tunc moritur, Albert. \Erafrus in prouerbio, Leporem non edit: Antiquitus, inquit, fuperftitiof creditum eft, efu leporinx pulpa con ciliari formam. Vnde extat iocus Martialis in Gelliam libro s qua miffo lepore addebat ex utilgata opinione ad muneris commendationem, Formofus feptem Marce diebus eris. IdPoéta in ipfam tor quens, qua deformis effer: Si me non fallis, in quit, fi uerum lux mea dicis, Edifti nunquam Gellia ru leporem. Plinius fribitleporem in cibis fumprum gratiam corporis in feptem dies confertare, Lampridius fcribic poétam quendam in Allexandrum Seuerum quod quotidie uefceretur leporina, jia lufife: Pulchrum quod uides effe noftrum regem, (Calcagninus fic citat, ut carminis rationicó fulerer:Pulchrum quiod uideo ducem cffe nofrum, Quem Syrum fua protulit propago, ) Queth Syrum fua detulit propago, Venatus facit \& lepus comefus, Ex quo continuum capit lepốremi, Hos uerfus cum quidam ex amicis ad A lexandrum detuliffet, refpödiffe fertur in hanc fententian: Pulchrum quod putas effe ueftrum tegem Vulgari miferande de fabella, Si uerum putas effe,nó irafcor, Tantum tu comedas uelim lcpufculos, Vtfias animimalis repulfis Pulcher, neinideag livore mentis. Si uideris lector, inquit Erafmus, parum obferuatas merri leges, memineris imperator rem fcripfiffe, cuius eft prafcribere leges, non parêre, Sed non animaduerrit Erafmus quod Lampri dius refert imperatorem Gracis uerfibus refpondiffe, unde fuperiores ab ipfo Lampridio uel alio quopiam translatos apparet. Somniofos fieri lepore fum pro in cibis Cato arbirratur, urulgus \& gra tram corpori nouem (feptem potius, Martiale refte)dies fruolo ioco, cuiramen aliqua debear fubcts fe caufa in tanta perfuafione, Plinius 28.19. ubi Hermolaus, Somniofos quidem ex leporina fieri ada huc uulgò creditur: uretus tamen lectio erat fomnos, non fomniofos. Cur uulgó rerepta fit opinion pud uerer es (inquit Calius Calcagninus epiftolicarum quafionum libro ı.) eos formclos diebusalia quot fore qui lepore uef erentur? nonnulli rastionem afferre conati funt, quòd id pulpamentum ul polieat extergēedi bilem atram atçs ira animos exhılarandi. Ar ego hoc quicquid cft uulgó affertum, ex ui uocabuli tractum puto. In uocibus enim antiquiras religionem \& aufpiciorum ohferuationem magna parte conftare dixit. Hinc in delecfucenfúó faciundo primi Valerıus, Saluius, Stateriusno, minabantur. Non fecus igitur cos le pidos fieri, le fồ eníg mutuari crediderunt, quilepore uteren zur. Leporem(inquir $\mathrm{C}$ al lus R hodiginus) Graci amoribus lacrum fabulantur, ducto argume

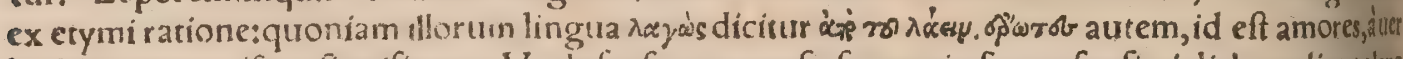
bo opäst utroç uifum fignificante. Vnde forfan prorepfit fententia, formofos fieri diebus aliquotlepo rina uefcentes carne.

\section{G。}

Leporinus cinis cum olco myrteo capitis dolores fedat, Plinitus. Enterocela lepus illiniturtiut cum melle, Idem. Lep, integri combufti cinis confert contra calculum, Raf. \& Alberc. Leporisan guinem $\&$ pellem totam in olla cruda combures, ur in cinerem conuertatur, \& in aqua calida poul dabis cochlearium unum íeiuno, mox deliquefcet lapis \& en̈cietur foras. Hoc experimentim nol ipfi fecimus. Ne dubites. Hoc facies expcrimentum, mitres in aquam cochlearium pulueris, illucpo nes lapidem qualem uoluer is, ftatim deliquefcer, ut mireris uirturem, Sextus. Pellem leporisrecen, tem(ut Marcellus docet)in olla munda, uel tegula, ita cum lana fua combures, ut in tenuiffimü puls uerem redigere poffis, quem cribratum in uafe nitido feruabis: in de cum opus fuerit tria coclearin in potione dabis bibenda:quæ res fiue calculos, fiue ueffic dolores continuo compefrit:fed mulio pos tentius erit remedium, fileporem uiuum in olla noua claudas, \& gypfo omnia feiramenta uafis obs

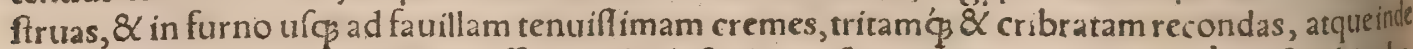
certas menfuras in potione uini offeras calculof:s, \& qui fanguinem mingunr, miréeos fanabis, Le poris integri combufti cinis, confert aduerfus calculum renum, Rafis \& Albertus. Leporis catulus utero excifus in olla uritur aduerfus calculum, Hieron. Tragus non citato authore. Pharmacum fimplex ad calculofos, cui Marcianus teftimonium praber, medicus A pher: Leporis pellen in ollula conijce, $\&$ in furnum demitte, at q̧ ubi uffa fuerit ut probé conteri polfit, acceptam tere, \& ex iplaco chlearium unum cum uino, ieiun is in folị calidxa aqua infcenfu prabe. Si uerò uelis ex perimentum pharmaci ipfius accipere, ex eo in uinum conjice, \& contectum per paucas horas fine, \& in grumos 
lapis diffoluetur, Retius u. 9, de calculo ueficx fcribens, Antidotus ad calculolos úalde bonà apud Nicolaum Alexandrinum interprete Fuchfio: Recípe leporem uiuum, ipfumḉs iugulato, ac fanguinem eius olla noura excipito: dein detraça quoģ eius pelle integram una cum langurine in ua. frulum immitte luto oblitum, \& operculo contectum:crematóg, donec pellis unà cum fanguine in cinerem redigatur. Amoto fubinde operculo, pellis fanguiniśç cinere accepto $\&$ latrigato, ce. chlearium unum ex merotepido dato, eft praclara. Bartolemaus Montagnana in Ancidotario firo, ubimedicamenta ufu à fe cognita recenfet, electuarium de lepore combufto defribit, ad. mifeet tamen etiam ludaicum lapidem, $\&$ in fpongị̂s repertos 8 lithontribon electuarium Nicolao defcriptum, \&c. Et rurfus in electuario ad frangendum ueficx calculum, inter alia leporem crematum adjicit. In Germanico quodam libello empirico manufcripto medicamen tum reperio huiufmodi: Si uenter tormina fentiat, $\&$ contrahatur, $\&$ calculi renum infeftent: $b a l_{-}$ neum parabis in folio aqua, in qua decoxeris maluam, chamamalum, fium alterum \& cepas: Sumes etiam per interualla cum pane tofto puluerem ex cremato lepore, capite $\&$ inteftinis abie, ets. Indumentum ex pellibus leporum, corpora fenum \& iutenum corroborat, Filius Zor apud R. Mofen. Auis cuculus leporina pelle adalligatus, fomnos allicit, Plinius . Si equers pofterioribus pedibus anteriores forte feriat ac ladat, attactionem uocant (anreidene) uenam fta. tim fupra fuffraginem circa malleolos (Dic fy/elaber) incidunt, \& leporinam pellem in trino cale factam imponunt aliqui. Theporinus fanguis ficalidus illinatur, ephelidas (id eft afperam $\&$ difcolorem ceu ab aftiuo Sole cutem, Marcellus Vergil,Ruellius fimpliciter uitia cutis in facie uer: , tit ) uitiligines \& lentigines fanat, Diofcorides 2.18. \& rurfus 2. 70, calidus illitus ephelidas \& lenti: gines emendat. Sed ut Celfus docet, interpofitis pluribus horis mane eluendi funt loci illiti, oleoćj leniter ungendi. Leporis fanguis lentigines de facie pellit peruncqus, Sext. Et Serenus ad lentigines Cygnzos adipes hilari mifceto Lyao, Omne malum properemaculofo ex ore fugabis, Sanguine uel leporis morbus delabitur omnis. Sang.lep.calidus fuperponitur morphex 8 panno, Auicenna in capite de fanguine:nam in capite de lepore, panno tantum legitur:reddunt autēe Arabes feré pan. num p ephelide Gracorum, interdum p fugillatis:aliqui etiam inepté pannum in panariciá conuer tunt, quęuox à paronychia barbaris detorta eft. Ineptiffimè Blondus, Sang. lep.inquit urelamê oculơ tum(pannữ barbaram uocéfic interpretatus)abftergit. Sí maculę nigra, umbrofe cum fang lep. un gantur, remouen ur, Rafis et Albert. Orno cutim, pduco pilos, 8 fedo podagram, Sanguine fi fue rint membra peruncia meo, Io. Vrfinus in leporc exKyranide. Sed alñ cinerem capitis, uel uentre cum inteftinis uftũ, pilorum in capite defluuiú emendare aiunt; Fanguini eandè uim nemo attribưit Marcellus quidẽ contrariam:Pilos, inquit, oculis moleftos diligentifíme uelle, atఢ̧, corü loca hircino fanguine recenti, aut leporis, aut uefpertilionis inlines.Sanguinê lepor is magi illinunt, ubi euulfos pilos renafcino'unt, Plinius, fi bene memini. Hirci, capræ, leporis \& cerui fanguis, dyfenterias \& coliacorum profluuia fiftit, fi frixus (inaffatus) in fartagine ftatim fumatur: in uino potus contra toxica efficax eft, Diofcorides, Sanguis leporis frixus confert dyfentcrix $\&$ apofremati inteftino rum, \& folutioni antiqua: $\&$ uenenum fagittæ aufert,Auicenna. Sanguine leporis apofternata ca lida citò maturantur, Idem in capite de fanguine. Et rurfus ibidem, Calidus linitur fuper apofte. mata calida \& lenia: qux uires etiam hircino adfcribuntur ab eo. Leporis fanguis recens defufus ${ }_{j}$ $\&$ cum polenta coctus, $\&$ datus dyfenterico, illico uentris proflutium fiftet, Marcellus. Aluum fiftit coagulum lepor is, \& cat. alī per fe leporis fanguine contenti funt lacte cocto, Plinius. San guis leporis quomodo ad conceptum faciat, uide infra in medicinis ex uulua leporis. TDe carne le porina etiam quod ad uires in medendo dictum eft nonnihil pracedenticapite. Leporina caro cali da eft et ficca:affa utilis eft ulceribus inteftinorum, Auicen. Deficcat $8 \mathrm{C}$ non attenuat, $\& \mathrm{~L}$ ideo prodeft inteftinis dolentibus, $\&$ urentrẽ fiftit fluentem, \& ulcera inteftinorũ fanat, Rafís \& Albert. Calculum frangir, Filius Zor apud R.Molen. Si cum oleo frigatur, \& inde fiat clyfter, trentris profluuium $\&$ ulcera inteftinorum curantur, $A$ lbert. Si affa in furno uel fartagine edatur, idem efficit, $R$ afis $\&$ Als bertus, Carnis eius ius fiue decoctum podagricos 8 arthriticos iuuat, eadem feré efficacia, qua de. coctum uulpis, Auicenna. बPingueleporinum empirici, quorum libellos widi Germanicos, adhe bere folent, ubiquid infixum corpori extrahendum eft. Aliqui flores fabarum et leporis pingue tun

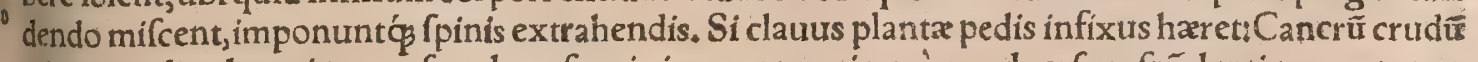
cư pinguedine lepor is contufum, loco faucio impone: parti uerò ex aduerfo refpódenti, tres aut qua= tuor fabaceos flores fuperilligato:per diem $\&$ noctem finito, fanabitur. Telữ equo infixũ extrahes, illigato uulneri medicamento ex duobus cancris cum pingur leporino tufis. बLeporis pilor $\tilde{n}$ cinis fanguinem fiftit, Plinius: $\quad$ Pilos fub uentre uiuo lepori candidos uelles, 8 feruabis, $\&$ cum ufus exegerit intortos naribus fluentibus fulcies, Marcellus. Leporina lana exufa cinis cum oleo myrtino $\&$ felle taurino $\&$ alumine trito mifcetur, tepefactumép medicamen inlitum ad flu entes capilios admodum prodeft, Marcellus, Leporis pilorum cinis cum melle decocius, in = teftinorum uitîs magnopere prodeft, Pliniurs. Pilos leporinos adiecro melle comprehendes, at de globulos paruulos facies thi finguli fapius glutiti, inteftina quamuis perniciofe rupta?, certa con iunctione connectũt, Marcel. Etrurfus, Ad inteftina rupta, leporinum ftercus, atç etiä pili uel lana eiss de fubuentrili cũ melle decoça ad magnitudinẽ fabęglutiẽ da frequiẽter data, quãuis perniciofe 
ruptis inteftinis celeriter medetur, ita ut etiam tenuiora qua fuerint difrupta glutinet: fed adfidu hoc medicamine utendum eft, donec periculum omne tollatur, Marcellus, Pili leporis fuffitie trahunt pulmonibus difficiles excreationes, Plinius, Stercoris caprini pilulas $\&$ leporis pilos, pin, gtredine phoca fubacfa fuffito, Hippocrates de natura muliebrí inter remedia ad menfes ciendos \& fecundas eurocandas . Et rurfus ibidem inter fubdititia medicamenta ad cofdem, ut appare?, ufus: Cucumeris fylueftris femen, \& teftam combuftam, uino fubactam, cum pilis leporinis in lana fubdito. Si ex partu os uterorum fuerit exulceratum, florem rofarum tritum \& uino im butum, in pilis leporinis apponito: $\&$ acerbis colluito, Hippocrates de natura muliebri. Et rutr. fus ibidem, Si ulceratum fuerit os uterorum aut inflammatum, myrrham $\&$ adipem anferinum $\&$ ceram albam, $\&$ thus, in leporis pilis, qui fub uentre funt, mifceto ac terito; $\&$ in lana mols lifima apponito. Si ex partu crus ab uteris claudum factum fuerit, \& exurgere non pote, rit: Semen hyofcyami chemæ menfura in uino nigro ad triduum bibat: fi uerò mente percellar tur ipra bibens, lactis afinini poculum bibendum dato, deinde pharmacum à quo pituita purgatur, ex fandaracha autem \& cerato $\&$ pilis leporis, per tridurum fuffitus fiat, Ibidem. Suffitui cuidam ad conceptum promourendum Aérius 16.34. pilos leporinos admifcet. Si pedes adufí fint frigo, re, leporinipili cinis remedio eft, Plinius.

f Lep,caput exuftum, $\mathcal{X}$ cum adipe urfino aut aceto illitum, alopeciarum inanitatibus medettri, Diof Leporis totum caput quidam comburens, utebatur eo ad alopecias cum adipe urfino, Galen, de fimpl.11,6. Combuftum cum feuro urfino, $\&$ ut cataplafma adhibitum, alopecias emendat, Auli cenna, Vftum tritumq́ cum aceto, alopeciam illitum curat, Rafis \& Albert. Vfto eo(cinere eirs) quidam curant alopeciam, Serapion ex Diofcoride, \& Auicenna. Cinis de capite leporis pprile marini, ualet ad alopeciam, A uicenna: fed hoc echinis magis conuenit. Dentes à dolore prafertan tia: Lanam fuccidam linteolo illigatam terito, adiecta deinde tertia falis portione, terito omnia finul, \& perfricato hoc puluere dentes. Idem praftat puluis ufti contritiçs capitis leporis, Galen. Eupp.,6y, Dafypodis caput uftum cum foeniculo quàm albiffimo $\&<$ fepix tritis offibus admifcens, utereadde albandos dentes aliał́p̧ eorum uitía fananda, Galenus Euporift 2,12. Capiris leporis cinis dentifit cium elt, adiectó́s nardo mulcet graueolentiam orisł aliqui murinorum capitum cinerem mifcuif fe malunt, Plinius. Capitis leporis exufti cinis cum nardo uel cum melle impofitus lenit gra ureolentia oris ulcera, Marcellus. I Cerebella leporis \& cuniculi contra uenena plutimum poffe aiunt, Platina, Terreftris leporis inaffatum cerebrum manditur, iutuandis tremorbus qui ualetudine contracti funt, Diofcorides interprete Ruellio, Marcellus Vergilius şó ma $\$ G$ y Hermolaum Barbarum qui uertit tremores qui in morborum acceffionibus contingunt. Videtur nim, inquit, de his tremoribus intellexiffe, qui in febris acceffione cum frigore nos torquent:atquifes brium cum algore tremores Graci ppria uoce $\rho^{\prime} h s$ appellant. Habet fané omnis tremor uniterfalem ex infirmitate neruorum caufam, quod feneçus apertè oftendit: priuratim ueró plures $\&$ diuerasa lias, frigidius natura temperamentum, frigid $x$ aqua nimium $\&$ importunum potum, frigidi \& gitu nofi humoris abundantiam, \& fi quę alia huriufcemodi funt. Omnibus his tremoribus, aut illis falem quibus natura poteftatéq fua cõueniat, tôftũ lepor is cerebrũ.iudicio noftro mederi Diofcoridesalit, Perfua fitḉ id facile Paul.A Agineta, quilib.3.capite quo de tremoribus in uniurerfum agit, cummuls ta de febrium tremoribus docuiffet, ftatim fubiecit:Simpliciter autem trementibus profunt, in $\mathrm{p}$ caftoreum, \& leporis in cibo cerebrum, $\&$ c manifefta inter febrium $\&$ aliarum affectionurith mores diuifione, Hæc Marcellus Vergilius, in quibus nos quoque fententiam eius approbantlst.

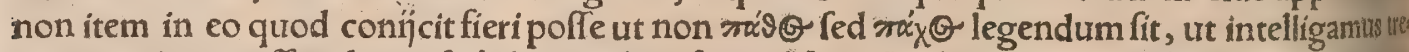
mores qui ex craffis glutinofisćg humoribus fiunt. Nam Arabes quoque rágo legerunt, utex fubiectis eorum uerbis apparet, Cerebrum leporis affatum confert tremori accidenti in fuccellit one agritudinis, Auicenna. Si affo capite cerebrum edatur, aduerfus tremorem ex infirmitalis tibus protienientem opitulatur, $R$ afis \& Albertus. Confert tremori qui accidít polt ægritudines, Serapio ex Diofcoride, Leporis cerebrum ex uino potum, tremores membrorum fanat, Sextis, Affum in cibo trementibus membris atrxiliari,Blondus experimento fe deprehendilfe fcribit Aptud

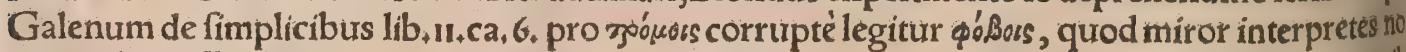
animaduertiffe. Aliqui, inquit, etiam aduerfus timores (lege, tremores) cerebrum leporis in cibo auxiliari prodiderunt. Si edatur de capite leporis, quantum eius edendo eft, medetur adurerus tremorem: ego quidem experientia didici utilem effe hunc cibum dormitationi ( torporí) \& para lyfi, Filius Zor apudR. Mofen. Cerebrum inaffatum, manditur (ut dictum eft) iuuandis tremo ribus: idem affrictu aut cibo facilem infantibus dentitionem præftat, Diofcorides: uidetur autem in hunc quoç ufum affari uel torreri debere. Ex cerebro leporis cocto fi gingiuas infantibus defri ces, dentes fine dolore crefcent, Sextus. Mundantur(fricantur) cerebro leporis gingíux, fic dent tes citò $\&$ facile ac fine dolore prodeunt, Auicenna. Cerebrum leporis attritum $\&$ efum urile efle didicimus pueris dentientibus, capite uidelicet toto elixo, ut ego facerefoleo. Non tamen eximia uis eius eft, fed fimilis melli $\&$ butyro, \& alís qua ad dentientes pueros conueniunt, Galenus. $P_{a}$ lus Aegineta libro primo docet inflammatis infantium ex dentitione gingiuis, nihil effe dand! 


\section{DeLepore. G. Lib.I. 7 or}

qutod multo \&difficiliconatu commanducandum fit:tum digitis palpandas gingiuas, gallinaceo rumǵ adipe aut leporis cerebro molliêdas effe. Lacte caprinu uel cer ebro leporum perunctx gingi ua, faciles dentitiones faciunr, Plin. Serenus Samonicus legit lacte caprino cum cerebro leporino Slc,fic enim fcribit, Aut teneris cerebrũ gingiuis illine porci, Aurleporis niueum bibitur cum la cie caprino. Leporis cerebrum in uino utiliter bıbitur, eiusós tefticuli tofti falubricer manducan. tur ab eo quí uefficæ moleftijs laborat,Marcellus. Vrinæ incontinentiam cohibet cer ebrum lepo. rinum in trino, uel eiufdem tefticuli tofti, Plin, Leporinum cerebellum ex uino potum, urina ine continentiam refrenat:eiufdem refticuli torrefacti \& ex uino poti, par remedium fubmeiulis praftãt, Marcellus, Si urina prater uol untatem uel nimia fluat, Tum leporis cerebrum ex uino potar e dece 0 bit, Serenus. Ad mingentes in ftragulis, Leporinum cerebrum ex uino propinato, Galenus Eupo rifon 3.276. TDens lepor inus appofitus parti ubi dentes alicuidolent, fedat dolorem, Rafis $8<$ Albertus. Tleporis uentriculum coctum in fartagine admix to oleo myrtino impone capiti, cas pillos fluentes continet $\&$ cogit crefcere, sextus. . Lepor is uentriculum cum fimo fuo, uno uetee relauabis, ita ut fordes ipfa ibi fint $\&$ mifceantur:aut fi in trentriculo non inueneris, pululas de timo ipfitus impares numero tritas cum uino uetere dy fenterico dabis bibendas, Marcellus. TCoagula Germani uocantmigle/ teum uel lip. Leporino coagulo pares unres habent coagulum hoedi, agni, hinnuli, dorcadis, caprex plarycerotis, dorci, cerui, uituli $\&$ bubali, Diofcorides. Vide in Ceruo G. Coagulum hinnuli(quidam inepte pro hinnuli legunt inutile, leporis, hoedi laudatum : præcipuum tamen dafypodis, unius ucrin ${ }^{\circ}$ dentatorum, Plin. fed dafypudem \& leporem idem fignificare ut plus , rimum, dafypodern ramen aliquando priuatim pro fpecie quadam leporis quæ cuniculus uidecur(ut Gaza uertit apud Ariftotelem femel aut iterum, ubi datypodis \& lagi coniuncta erant nomna) accipi,quod Plinius non animaduertit, fupra in A.dosuimus. Laudauit $\&$ Nicander in Theriac is fuis contra uenenata leporis coagulum:quo loco interpres eius, authore Nicoonte antiquiffimo me* dicina aurhore, primum in coagulis honorem hinnulo tributit, fecund un lepori, tertium uerò agno, contra quàm Diofcorides, qui leporino primum ordinem dedit, Marcel. Ve gil. Coagulum omne acris ac digerentis potentix eft, ac nim rum etiam exiccatorix, quod fuperiora neceffar iò fequitur. Lac in uentre co gulatum diffoluit, quod \& nos, inquit Galenus, non folum in leporino, fed eriam in aliorum animalium omnium coagulo experti fumus. Artamen leporinum omnium eft praftan. tiffimum: fed $B$ fanguinem in uentre concretum fimili modo epotun diffoluit, ac efficacius quidem - cateris, uerum non folum quod qubufdam feriptum legitur:fed $\$ 2$ hoc commune eft omn: coagu:

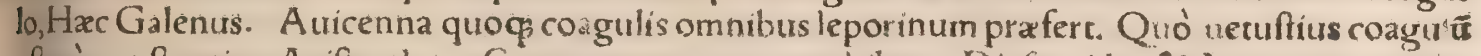
eft,eo præftantius, A riftoteles. Contra uenena ex aceto brbitur, Diofrorides: $\$$ A Aureuna, qui the riacâ $\&$ bezahar ía fumpturm contra uenena effe fribitinon aurem, ut quidam ineprè cirant, theria cam infuper milceri iubet. Contra uenena additur antidotis, Plin. Coagulo leporino, incuuit ide, ad ferpentes utuntur ex aceto, contráğ frorpionem $\&$ murem araneum utuntul :aiunt autem non feriri leporis coagulo perunctos. Ad irorpionum \& ferpentum morfus, Leporinum coagulum cư tino potui datum, aduerfus uenena reffit $\&$ difcutit, Sextus. Tribus obclis ex uno bihtur con:

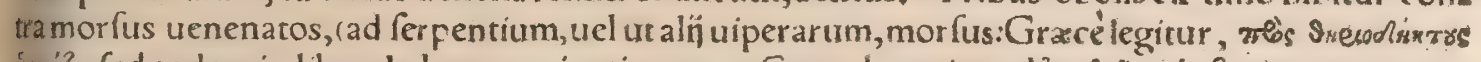

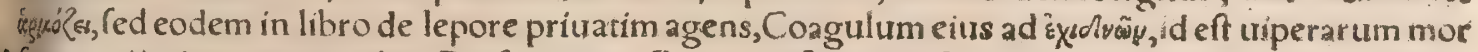
- fus peculiariter commendar:) Diofcorides. Contra paftinacam 8 omniưm marinorũ ictus uel nor. fus coagulum leporis, uel hodi, uel agnidrachma pondere ex uino fumitur, Plinius. Sanguinem in grumos concre um difutit tribus obolis ex uino potum, Diofcorides. Leporinũ coagulû fi cum aceto ebibatur, fang uninem in uentre concretum diffoluit, ac efficacius quidem cateris, uerum non folum, quod quibuídam friptum legitur, fed 8 aliud quoduis coagulum, Galen. Videtur autem, cum inquit, Quod quihufdam fcriptum legitur, Diofcoridem notare, immeritò camen. Etfienim Dio

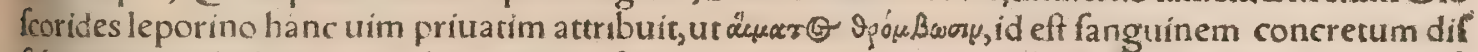
foluat, trium obolorum pondere ex uino fumprum:mox tamen diuerforum animalium, qua paulo ance nominatim recenfui, roagula parem leporino faruliatem habere frribir, \& omnia auxiliari con tra aconitum potu in uino fumpta, $\&$ in aceto contra concretum fanguinem. Intelligendum eft aute thoc denfati concreciue fanguinis malum in uentriculo factum, quod maximè $\&$ periculofiffimè fanguinis caurini calidi adhuc haufu contingit, Coagulum hoedi contra uifcum (rhamaleonta ixia an) $\&$ chamæleontem album, \& fanguinem taurinum remedio eft:contra quem $\&$ leporis roagulum exaceto, Plinius. Eadem fanè ui aconito refiftere uidetur:nam id quoģ ftrangulando, ut fanguis et lac concreta, uenenum eft. Coagulum leporinum uel hinnulicontra aconitum datur ex uino, Nis cander. Contra uenena ex aceto bibitur, pręfertim aduerfus concretum (in uentriculo) lac, Diofcor, Er alibi, Contra lactis coagulati pericula auxiliatur coagulum omne, maximè ueroleporinum, quod ex aceto bibere fxpius cogimus. Lac in uêtre coagulatum diffoluit( (frilicet cum aceto potum) quod certe $\mathcal{Q}$ nos experti fumus, non folum in leporino, fed etiam in alior men leporinum omnium eff praftantifimum, Galen. Idem fortaffis Aurcenna fripfit, qurod ab ins io terprete (ut quidam citant:in meo enim exemplari non reperio) hunc in modum deprauatum uidet: Coagulum leporin um cum acero lac in mulierum mammis coagulatum diffoluit, quanquam fortaf. fis ea quxipota coagulatum in uentriculo lac diffoluunt, lactis etiam in mamillis grumos diffoluer 
poffe uidentur, extrinfecus applicata. Arundines $\&$ tela, quæćł alia exrrahenda furtit cơppori, elro cant cochlex ex his qux gregatim folia fectantur contufx impofitæć cum teftis \$ \& ex qux man duntur exemptæ teftis, fed cum leporis coagulo efficaciffimè, Plinius. Etrurfus fpinæ ac fimilia cor pori extrahuntur, coagulo quocungs, fed maximéleporis, cum thuris polline $\&$ oleo, aut cum uifer pari pondere, aut cum propoli. Et fimiliter Marcellus, Cuiufcunç animalis coagulum, maximéle poris, cum pari pondere thuris urel uifci impofitum, permanere in corpore quxa calcata funt, nonfit, nit. Et alibi, Ad ea qux calcata erunt, \& ea qux corpori inheferint, extrahenda, leporis coagulum cum malua tritum impofitum $q_{\beta}$, potenter opitulabitur. Sanguinem fítit coagulum ceruinumex aceto, item leporis, Plinius, Sic \& Marcellus, Coagulum ceruinum deglutitum fanguinem exintio mis profuentem facile ftringit:idem facit $\&$ coagulum leporis. Sanguinem é pectcre educentes quomodo iuuet paulò poft dícemus. Vlcus etiam annofum coalefcet, fi inducas leporis afperfa $\operatorname{cog}^{10}$ gula uino,Serenus. Strumis exulceratis duntaxat coag. lep, èuino in linteolo imponitur, Plinits. Carcinomata curat coagulum leporinũ curm pari pódere capparis afperfum ưino, Plinius: (utrung̣ uino afperfum unà teritur, \& fic adponitur, Marcellus.) A duerfus quartanam, magi fimi bubullici nere confperfo puerorum urina illinunt digitos pedum, manibus ć́ leporis cor adalligant,coagulum ante acceffionem propinant,Plinius. Aut leporis tepidi (aliâs, timidi) diluta coagula trade, Serea nus ad quartanam. Coagulum leporinum comitiales iuxuat, Diofcorides. In comitiali morbo dana tur coagula lepor is, Plinius: (item pulmo uel cor eiufdem, eo quem mox declarabimus modo. Lep, ccagulum comitialem morbum, fi cum aceto ebibatur, fanare proditum eft, Galenus $\&$ Ā uicenna, Parum olei leporis coagulo infundito, \& pilulas facito, ex quibus modò unam, modò duas prabeto, is Galerius Euporifton 2. 3. Coag. lep.mifcetur etiam antidoto luliani, medicamento ad calculum \& comitiales \&c. deftinato, A pud Acrium. Si grauitas fit audiendi, laudant coag, lep. tertia denarif parte, dimidiá̧̧ fagapeni in Aminæo uino, Plinitus . Ad aurium dolorem, Lep. coag auriculęinfun dicur, Sextus: Sed legendum uidetur, dentium, non aurium, ex Plinio, ut fequitur: Leporina coagut la per aurem infura contra dolores dentium, efficacia funt, Plinius, Idem 24. 10, de Erafiftrato, Edera acinos quin $q 3$ tritos in rofaceo oleo, calefactos in cortice Punici, inftillauit dentium dolorià contra ria aure. Lep.coag, relectioniburs à pectore auxiliatur trioboli pondere ex uino, Diofcorides; Intelli

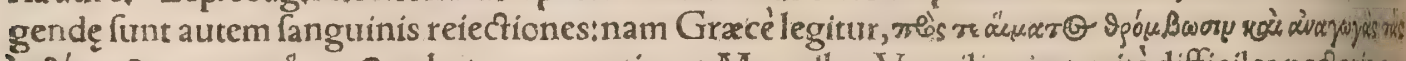

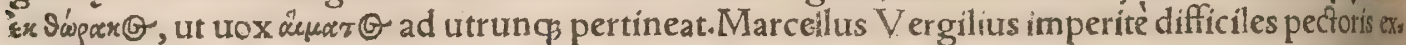
creationes reddidit, Quoduis coagulum refoluit fanguinem coagulatum in pulmone, Auicentai, eadem fcilicet ui qua in uentriculo. Quidam fangurinis ex thorace reiectiones lep, coag, epotum fupprimere prodiderunt: Caterum nec alium quempiam eo ufum noul, nec ipfe fum aufus acriutire medio ad affectum aftrictione egentem, Galenus. Apparet fanè notari ab ipfo Diofcoridempraci, puè, quí tamen non fifti hoc remedio fanguinis eductionem, fed fimpliciter iuuari fcripfit: id quod uerifimile eft. Duplex equidem, cum fanguis è thorace fluit in pulmones $\&$ arterias a fperas,pericu lum eft, alterum commune, ne nimio fluxu uires exhauriantur, itacg opus eft fiftere; alterum, ne $x_{\text {, }}$ tra uafa fua profufurs fanguis in arctis illis meatibus condenfatus hareat, ita ut nec ipfe educi polit, $\&$ fanguinis deinceps fluentis uiam impediat, unde fuffocationis periculum thic grumos diffoluen tibus remedịs opus eft, quale pracipuum eft coagulum+aliqui utraq̧ mifcent, ut Plinius his uetbis: Sanguinem expuentes coagulum leporinum tertia parte denarï cum terra Samia \& uino myiteo potum fanat.Medici certe eruditi, fi fanguis è pulmonibus reñciatur (quod colligitur ex eo, fiater \&ै in grumum concretus cum tuffi etiam $\&$ dolore partis affectæ reṇcitur) primum pofcam dilutam \& tepidam exhibendam pracipiunt, ut fi quis fanguinis grumus in uifcere hæreat, inde diffolutuseft ciatur: neç quicquam obftat (inquiunt) bis $\&$ ter in tribus horis hanc potionem iterare, Pofthode mum medicamenta adfltringentia \& emplaftica adhibent, Caterum cum coeliacis quoç \& dyente ricis \& foeminis fuxione uuluæ laborantibus utile pradicetur à Diofcoride $\&$ alïs coagulum, pra cipuè leporinum:apparet illos credidiffe fiftendi omnino aliquam ei facultatem ineffe: \& uerifimile eft ficut extrinfecus liquores quidam, ut lac, coaguli ui denfefcunt, ita etiam fanguinem $\&$ alioshur mores in corporibus noftris, liquidos quidem denfari, denfos autem concretosćs diffolui, Namoms ne coagulum (ut inquit Auicenna) fanguinem $\&$ lac dẽfata, \& humores craffos diffoluit:quarcung y uerò liquida funt,coagulat, \&c. Coagulum hinnuli,leporis, hoedilaudatum: pracipurum tamenda fypodis, quod \& profluuio alui medetur, unius utrinq̧ dentatorum, Plinius. Habent coagulum om: nia ruminantia, 8 inter dentata utrinģ̧ lepus. Quò uetuftius coagulưm eft, eó præftantius:tale (uide

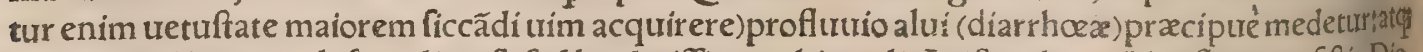
etiam quod leporis (dafypodis) eft:fed laudatiffimum hinnuli, Ariftoteles. Alui fluorem fiftit, Dios fcorides. Aluum fiftit coag. lep. in uino ciceris magnitudine : aut fi febris fit, ex aqua: aliqui \& gal lam adĭciunt, Plin. Leporum coagulo illito ubere, fiftitur infantiū aluus, Idem. A d infantiũ uentris fluxũ, Leporinû coagulũ illinitur in fumine mulieris:fed \& puero dabiêt bibere:fi fine febricula fues rit, cum uino:febricitanti uerò cũ aqua calida:Idem facit $\&$ maioribus cũ puluere galla, Sexturs, Coas gulum omne potum, fiftit aluum $\$ \&$ debet dari in fluxu. agit enim ui quadam occulta, quam expes rientia oftendit, (uidetur notare Galenum, qui coagulum tanquam acre ubi quid fiftendum eft dari prohiber, ) quod fi etiam uentri puerorum calidum imponas, fanat, facultate nimirum coagulante \& 


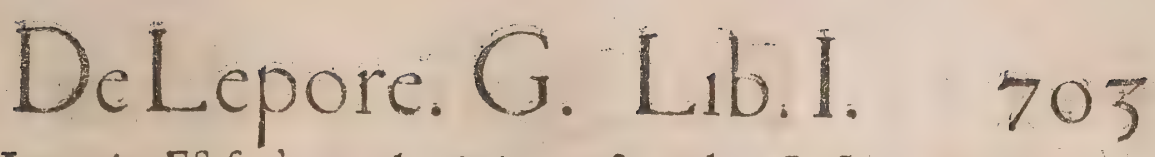

indurante humores, Autrois, Eft fanè coagulo uis ignea, fecundum Ariftotelem : non quod fummum caliditatis gradum ut ignis obtincat, fed quoniam fimiliter ut ignis heterogenea di. fernit, ut in lacte partem craffam, aquofam $\&$ pinguem. Mihi nuper coagulum uitulinum ali quot iam menfes repofitum guftanti, odor, fapor $\&$ fubftantia, per omnia cafeum inueteratum \& putref́centem referebant : $\&$ fanè uídetur idem in cafeis efficere coagulum, quod fermentum in maffa farinx fubacta, cuius exigua pars iniecta mafiam uniuerfam fapore $\&$ qualitate fua imbuit. Sed cum uetus maximè cafeus, coaguli uim repræéntet, nil mirum fi facultates etiam aliquot eafdem habeant, Quamobrem uenter utroque fiftitur: utrique uis ineff diffoluendi prater: naturam concreta:ut de coagulo iam fupra diximus: cafeo autem uetere concretos induratosćs ar: thritici curiufdã tumores fe diffoluiffe fcribit, fubacto eo in mortario exquifite, cũ príts madefeciffec decocto faliti cruris porciniac peruetufti, Lep,coag. tribus obolis ex uíno potum, coeliacis $\mathcal{X}$ dy= fentericis fuccurrit, Diofcor. Coeliacos \& dy fentericos iuuat potum leporis, turm hinnuli, tum etiam caprex coagulũ ex uino, nec non immiffum cum oryzæ cremore, Galenus Euporifton 1,11\%. Coelia cis coagulum leporinum fubactum in pane datur+fiuerò fanguinem detrahût, id eft dệciunt, in po: lenta, Plin, Coay, lep, ex uino dilutum tepidum dyfenterico dabis bibendum, de quo coagulo fi fin gulos frripulos in fingulis ouris forbilibus ieiuno per triduum dederis, miré fubuenies, Marcellus. Lac caprinum ad dimidias decoctum dyfenter. 8 coeliacis datur : fi fint $\&$ tormina, additur protro pum, Torminibus fatis effe remedin in leporís coagulo poto è uino tepido uel femel, arbitrantur ali. qui: Cautiores \& fanguine caprino cum farina hordeacea $\&$ refina uentrem illinurnt, Plinius, Colo , fedando, pauidi leporis madefacra coagula pota, Serenus. Vrinæincontinentiam cohibet coagua lum leporinum cum anferino adipe in polenta, Plinius. Vulux fuorem fiftit, Diofrorides, Et yurfus, Tribus obolis ex uino potum forminis fluxione uulur laborantibus auxiliatur. (Eandem uim Sextus cordi leporis, Plinius pulmoni ac iecori adfcribit.)Menfes retinet, ut quidam citatex $A$ ui cenna : apud quẽ nos ita legimus, Quoduis coagulum phibet quemuis fluxũ fangưinis, et muliebre quog, Coag, lep. pfluuium muliebre fanare proditũ eft, Galen. uxidetur aũt addendum quod pximẻ fcriplerat, fi cũ aceto bibaturr. Cum calidũ fit uitandum ubi fanguis fluit aut fluxurus eft, non uideo quomodo poffit coagulum, quod acre eft, menfes immodicos cum practicis $\&$ medicorũ uulgo fifte. re,Syluius, Secundas adiuuat coag.lep.cauentur pridiana balnea.Illitum quoge cum croco \& porrifucco, uellere appofitum abortus mortuos expellit, Plinius. Leporinum coagulum poft triduum

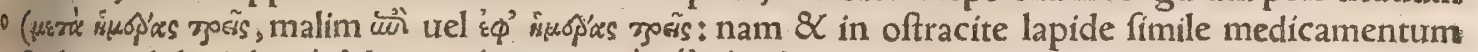

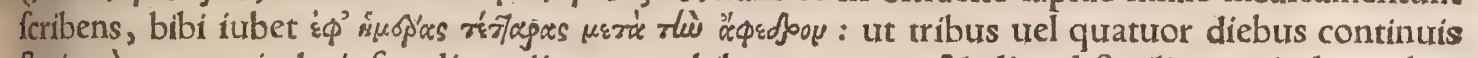
ftatim à puerperio hurufmodi medicamenta bibantur: nam $\&$ alla ad fterilitatem inducendam

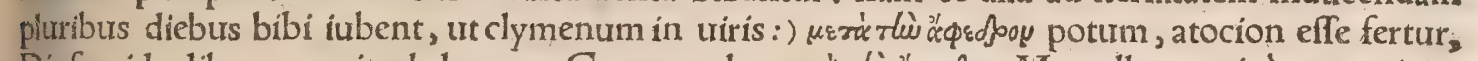

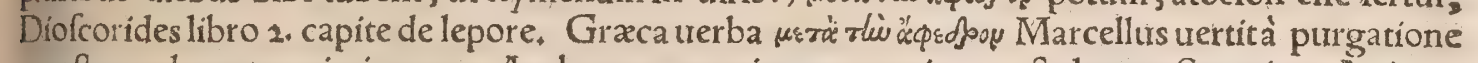
menftrua, deceptus nimirum per Arabes, quorum interpretes ita tranftulerunt, Serapion, Auicen. na $\alpha$ Rafis:quòd autem non fignificet menftruam purgationem, conuincitur ex càpite de lepo:

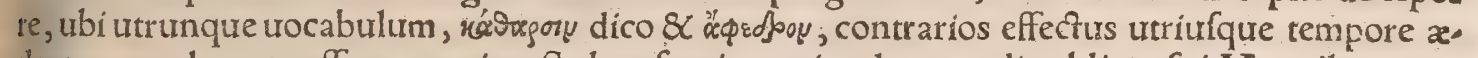
dente coagulo, expreffum reperies. Sed rurfus in capite de coagulis oblitus fui Marceilus, ean. dem uocem, \& recie quidem, puerperium transfert. Sic \& Ruellius in eodem capite de coagulis re. to cè puexperium urertit, in capite uerò de lepore concubitum. Hermolaum utrobiç puerperium uer $z$ tiffe puto. A phedrum pro puerperio accipiunt quandoģ Græci, Calius. Eandem uocem reperío apud Galenum libro 2, de antidotís, ca. 133. Sunt autem Nicoftrati uerba:Símorfus à cane rabido,

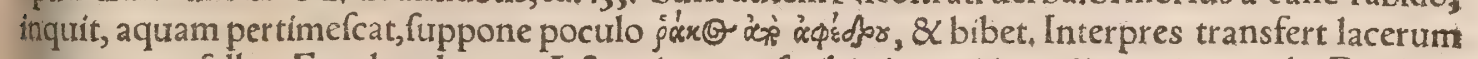
pannum ex fella. Eundem locum Actuarius tranfcribit in antidoto diacarcinon, ubi Ruellius fibirurfus non conftans, lacerum pannum fub fedem uertit, cum intelligatur puerperæ pannus uterino fanguíne pollutus. Hæc pluribus, quoniam in dictionarijs, Græcorũ etiã, nihil huiufmodi re

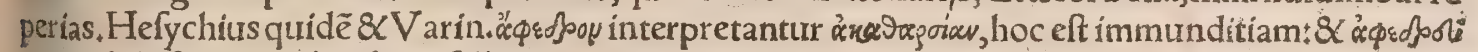

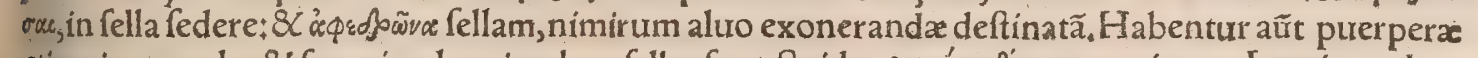
etiam immundx, \& fux eis ad pariendum fell funt, Suidas roxúrs dí pgrs nominat, Iam in eodem - Diofcoridis loco uocem atocion, alíj aliter interpretantur. Hermolaum Marcellus reprehendit; Marcellum Maffarius + Ruellius ambigué transfert, ut in utranç fententiam accipi poffit, atocion reddens, quod pariendi uel partus fpem intercipit. Ego certeMarcelli fententix accedo, cuius hæc

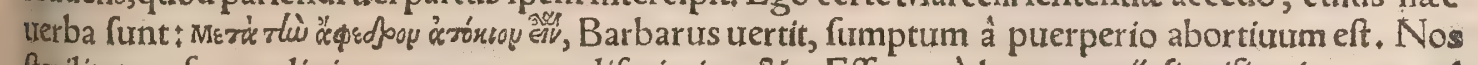
fterilitatem facere diximus, non paruo difcrimine, $8 \mathrm{c}$. Effe uerò hanc atocí fignificationem, uel ex Plinio conftat, qui 29, 4, de phalangịjs agens, In tertio(inquit) phalangï genere inureniri dicun. tur uermiculi, adalligatiós mulieribus ceruina pelle ante Solis ortum, praftare ne concipiant, Vis ea annua eft, quam folam ex omni atocio dixiffe fas fit, quoniam aliquarum forcinditas plena lie beris tali uenia indiget. Ne concipiant, atocia homini præftare Plinius dicit: demirorćs hoc maxíme loco Barbarum, qui in Plínianis caftigationibus a tocium expofuerit effe, quodcunq $\beta$ conceptus adi. 60 mit \& partus fpem intercipit;hoc lcco autem abortiuum idem dixerit. Et in hoc ipfocapite trariata interpretatione, prohibere partus atocion uerterit : nec animaduertit, non poffe aliter quàm de fte: rilitate in Diofcoride intelligi, cum dicat à puerperio potum coagulum atocion effe, quo tempore 
fine nouro conceptu abortus fieri nön poteft, Hucufo $\$$ L Marcellus. Sed audiamus etiam Malfariuthi, qui Hermolaum defendit: Coagulum leporis, inquit, magnum habet in medicinis ufum, pracipue ad concipiendum mares, fi cibo ante conceptionem præfumatur, (quiod Plinius feribit:) ut tlermolä um nof́rtim iam liberatum pateat à falfa calumnia Marcelli, qui eum falfó accufauit, quod in Diofco ride, leporinü coagulum non abortiuum effe, fed fterilitatem facere interpretari debuerit, quod ef totum oppofitü:non animaduertens Plínjum lib.28. teftatum reliquille, coagulũ leporis in cibo fum ptum mares concipi facere. Et, quod magis ridiculum eft, Hermolai uerba in caftigationibus.s Plinia nis exponit:nec ip fa quidem intelligic. Ait enim 28.libro(Hermolaus; ) Eft autê atocion quarungue medicina conceptum adimit,hoc eft partus fpem intercipit. Non enim dixit conceptionem, fed con, ceptum, id eft foetum, qui iam conceptus eft, adimit hoc eft ut ipfemet exponit, partis fpem, interci: pit,ceu foetum,qui conceptus eft, peruenire ad partum impediat, $\&$, phibeat:quod quidem non feri litatem, fed abortum facere dicimus:quafi conijcere liceat ex horum antiquorû́ fcriptorunı uerbis, coagulum leporis, ante conceptionem fumptum mares concipi facere, poft conceptionem uero fum ptum abortiuum effe, Hac Maffarius nimio, ut meum eft iudiciũ, Hermolai ciuis fui defendendi a fectu commotus, Etfi enim nonnihil dicere uidetur, quamuis id quoç refutari facile poffit, ualidion camen Marcelli rationes non attingit. Pro Marcello quidem ftat etiam Budaus in prioribus Anno in Pandecias, his uerbis: Ecbolia medicamenta funt quibus medici utuntur abigendis infantibus in ureto enectis, qua \& phthoria dicuntur: Verba funt crebra apud Diofcoride, Latiné eiectoria \& elé ćrices medicinæ dici polfunt. Aegyptus ưuam ecbolimã (aliâs ecboláda, utrunç̧̧ reçé)habet, aborti uos facientem, Plinius. Idem de fcammonite uino, Hoc uinum (in quit) phthorium uocant, quoniam abortus facit. Sic enim in antiquis exemplaribus legitur, manufcriptis, licet in impreffis ectromat

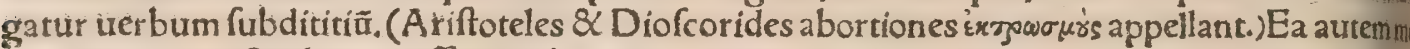
dicamenta qua fterilitatem afferunt $\&$ conceptũ adimunt, hoc eft uim concipiendi, atocia dicunt Diofcorides de cedria loquens, Circũlita (inquit)genitali ante coitû, atocị uim habet, Hæc Buda

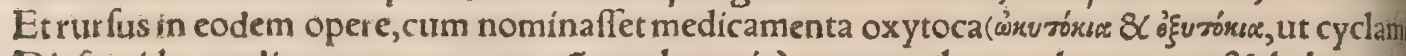
Diofcorides medicamenta uoeat part $\tilde{u}$ accelerantia) arregona (lego arrhenogona) \& thelygona, dit: Phthoria funt $\&$ ecbolia ad partus abigendos:atocia ad focunditatem inhibendã \& fupprimen dam exrogitata fuerunt, Conftat igitur hac medicamenta ut funt diuerfa, fic nominibus etian uen rediuerfis:quod quidem tam manifeftum mihi uidetur, ut pluribas demonftrari nemo defideratu rus fit, puto. Certe etiam $A$ rabes, Serapio, Auscenna, $R$ afis, atocion uerterunt quod impragnat pbibeat.Caterum Plinius cum paffim plura quæ abortum faciant memoret, unum duntaxat an on fupra dicfum ex phalanghís, fe prafcripturum pfeffus, alibi tamen oblitus fui alia qucos affert le eft illud lib. 20,ca.11. A pium fexu diftinguitur:caula fceminx uermiculos gigni aiunt: ideóg

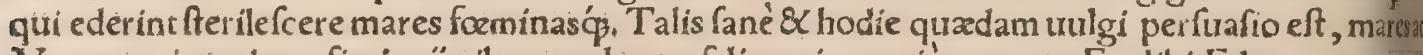
Venerem ineptiores ficri apị cibo, quod petrofelinon impprié uocant. Er alibi, Ederæe nigrac diores corymbi poti, fteriles etiam uiros faciunt, (Hedera alba fructu femen fterile fieri aiun, 1 ) phraft. 9.19. de hift. Hederæ nigræ fuccus \& corymbi poti inducunt éroviow, \& la rgius fumpti me turbant, Diof.lego ả yoviav.Sic \& in Heraclea Arcadix uinum nafci Theophraftus frribit, quod tum uiros mente moueat, mulieres autem freriles reddat, àrexv'óxs. Hederæ quidem nigræ coryn etiam nigri aut crocei funt, Diolcor, tefte, non candidi, ut Plinius ait, \& c.) quafi dicat fterilitatisn dicamenta non folis mulieribus dari; ut de clymeno alibi, fterilitatem ea pota etiam in uiris fieri fplenon quoç forminis dari phibet, quoniam ferilitatem facit. Item de filice 27. 9. Neutra (inqu eft, nec mas nec focmina) danda forminis; quoniam grauidis abortum, creteris fferilitatem facit E in capite epimedion quoç'́(effi corrupté epimenidion legitur) foeminis cauendam ait, nec additcall fam, quam Diofcorides exprimens, A tocios (inquit) eius radix eft, 8 folia trita cum uino drachm;

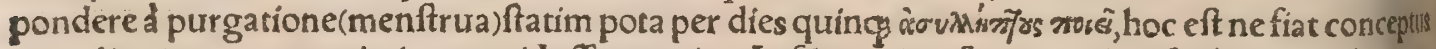
impediunt, exponens nimirum quid effet atocion. In filice etiam formina, idem fcribir quod de utrach

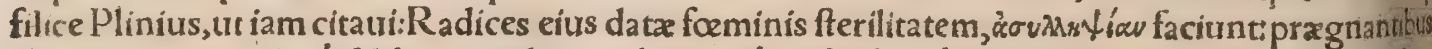

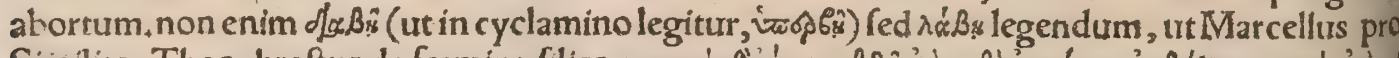

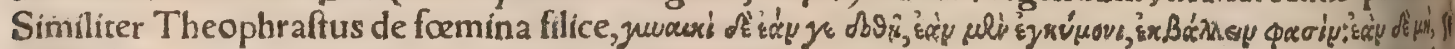

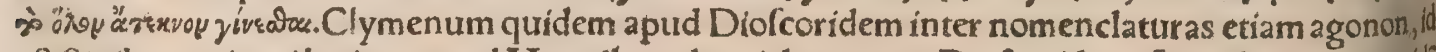
eff fterile nominari legitur:quod Marcellus ad periclymenum Diofcoridis referendum ait, atç idê

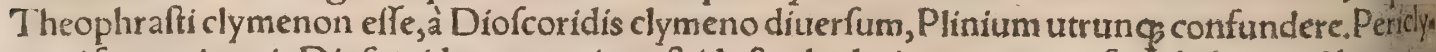
meni femen(inquit Diofcorides)ocytocion eftid eft, ad celeritatem parturs facit:habent eafdem uires \& folia:feruntur hac triginta fex(aliâs feptem, Theophraftus triginta tantum habet) diebus pota, ágórs robsin, fterilitatem in uiris facere, ut Marcellus uertit: nam Theophraftus quoç de uiris id lcris bit. Hoc obiter monuerim cyclaminum alteram Diofcoridis eandem periclymeno tum defcription ne tum uiribus mihi uideri:nec impedire quod periclymeno radix craffa tribuitur, cyclamino alteri inurilis: qualiscuncs enim fit, ad remedia inutilis fuerit, cum nulla ex radice Diofcorides tradat, $\mathrm{Cy}$ claminum autem uocatam dixerim, non quod aliquid, quod ad formam, cum prima \& propriédicta cyclamino commune habeat, fed quoniam, ut Diofcorides ait, in orbem fuis flagellis $\&$ cauliculi uoluicur, Xiphï fuperiorem radicem ferunt Venerem in uino potam excitare : inferiorem uerò 
fenfu. Eft $\&$ aliud genus medicamentorum, qux uel poft concubitum ftatim adhibentur, ut ne fiat conceptus, in peffis aut fuffitu, qux aperiendiuterum attrahendiç femen|facultate funt pradita, ut piper:de quo Diofcorides, Foeturs, inquit, ex utero trahit,creditur $\&$ atocion effe poft coitum muliee bri uulua fubdium $\&$ appofitum. Hedera fuffumigata poft menftrua conceptum impedit, Serapio fecundum Diofcoridem, ut Aggregator citat; fed in Diofcoridis codicibus excufis fic legitur, Hede re corymbi à purgatione foeminis poti fterilitatem faciunt. Iam relicturus eram hanc digreffionem cum forte fe obtulit Calĭ Antíquarum lectionum codex, cuius index, fcripta eius de atocijs, hęc que fubício, demonftrabat. A tocia, inquit, in Diofcoride, ubi de cedria mentio eft, intelliguntur abHer molao qux $x$ abortum concinnant:quod approbat $\&$ Ruellius, Id reprehendunt quidam, quod Gro cis atocia fint qua fterilitatem inducunt. Crterum ex Plinio comprobari prior translatio uideturfic enim apud eum legitur 24.1. de eadem cedria, Portentum eff, quod tradunt, abortiuum fieri in Vene re, ante perfufa uirilitate. (Ego non magnam Plinỉ in ïs qux ex Græcis transfert authoritatem effe dixerim: fed quantacun q̧ fit, plures eiufdem locos habemus iam recitatos, quos ex Gręcis contiertit, qui nobifcum faciunt, quàm contra.)Idem Calius 4.13. Budxi de phthorn̈s \& atocīs uerba fuperiu enumerata recenfet, tanquam fua $\&$ fux prorfus fententix. Et alibi, Prolifici feminis priuationem 2 goni nomine intelligit Diofcorides, ficut in forminis fterilitatem atocion idem appellat frequenter:

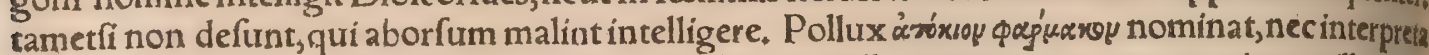

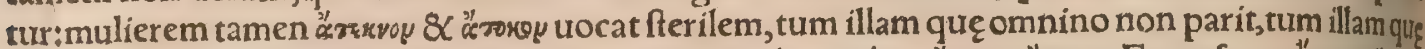

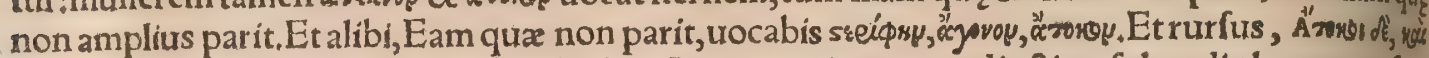

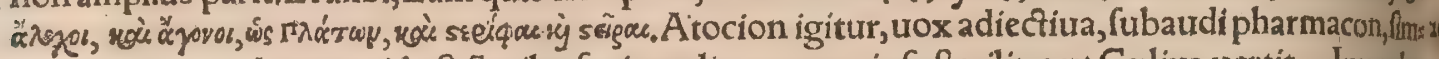
pliciter erit quod atocos, id eft fteriles facit mulieres, non ipfa fterilitas ut Calius uertit. Imptoba quadam mulieres, ne concipiant, uenas quafdam(malleolorum puto)fxpius incidunt, ut fanguinẽ uteri canquam foetus materiam detrahant. In uiris quidem uena poft aures fecta, frerilitatem \& ima porentiam adferunt, Hippocrates ín libro de aere, aquis \& locis. Coagulum leporis poft menfrizas purgationes appofitum uuluæ(peffi inftar)cum butyro, præftat mulieribus ut concipiant:potumu ro partus enecat, $\&$ à puer perio fterilitatem facit, Diofcorides in capite de coagulo, Arabes, utSerå pio \& Auicenna, locum hunc mutrilatum recitant, purerperĭ enim mentionem omittunt, \&c, Sibl berit mulier poft purgationem furam(triduo poft puerperium, Diofcor, )tribus diebus continuécoat gulum leporis, dicunt quidam quòd prohibet conceptionem : $\&$ aliquando(poft purgationem men fium peffi modo adhibitum, Diofcorid.) iutrat, ut dicit Auicenna : Si autem impofuerit uuluxpols fuam purgationem, femper iurrat ad (contra, $R$ afis) conceptum, Albertus: fed ineptre ifta transiatio nes prorfus relinquenda erant. Hoc obiter monendum, medicamenta qux ad uterum fire uuluant perrinent, ut aut foecunditas aut fterilitas ei concilietur, aut moureatur aborfus, ut ex pracedendbus aliquot citatis authorum (præcipué Diofcoridis) locis, colligere eft, ferè eo tempore exhiberi qro menfes fluunt aut recens potius fluxerunt, tum aliâs tum poft puerperium: tunc enim apertismeat bus, \& dehifcentibus acetabulis, medicaminum uis facilius penetrat \& recipitur, Quamobremcon: ceptionem quoc; Galenus in libro de uteri diffectione, incipientibus fluere menftruis purgationi bus aut definentibus fieri ait:tunc enim uaforum uteri of cula, qux ipfum ingrediũtur $\&$ fanguinem effundunt, aperta funt, Quanquam autem, inquit, aperiuntur etiam reliquo toto purgationis tempo rehac uafa, non concipit tamen intra fe tum mulier : neç, enim poteft in utero femen manere, cum 4 nimio influente fanguine eluatur. Hoc etiam ceu corollarium addam, Budxum rectè quidê ectolia medicamenta interpretari qua alio nomine phthoria dicuntur:medicis tamen accuratius hac difin guenda. Videtur enim medicamentü aliquod phthorion \& ecbolió pariter effe poffe, \& aliux phitio rion tãtum, aliud ecbolion tãtum, utra ç feorfím Aggregator recenfet, Phthoria quidem, hoc eftură

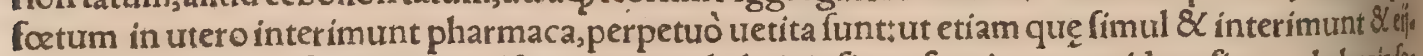
ciunt, qux tamen fi facultas expulfiua uteri muliebris infirma fuerit, per accidens fit ut phthoriafoe lum fint, non etiam ecbolia. Ecbolia uerò iufta $\&$ licita effe poffunt, quę f cilicet uel intro fumpta ut foris impofita, foetum iam prius mortuum quacungg ex caúla, ne grauida co computref(cente inlocil periclitetur, expellunt. Similiter quodammodo res fe habet circa lumbricos: funt enim medicament quæ illos in inteftinis interimunt, funt qux interimunt fimul $\&$ eịciunt. Diofcorides cum in cycla

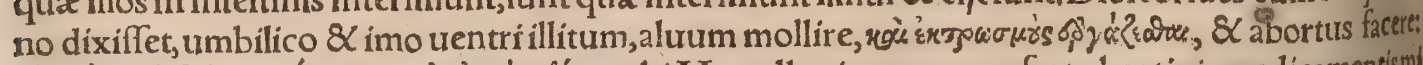

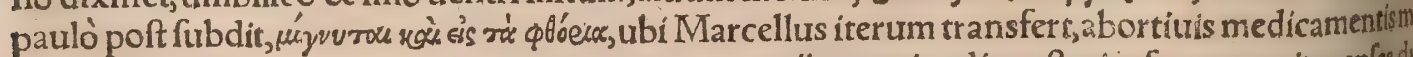
fcetur, quod non probo. Acrimonia qua in centaurn̈ magni radice eff, ium fuam exerit menles cendo, \&C foctus tum mortuos detrahẽdo, tum uiuos corrumpendo eijciendóğ, Galenus, Aetus, As gineta, Diofcorides ut hac efficiat, in collyrín formã deradifubdị́, fribit, Lep. coag. ad drachmas quatuor in potione datur unini, foemina de foemineo, \& mafculo de mafculino, \& mox faciant coithi, $\&$ poft abftineãr fe, ftatim concipit. Etiam pro cibo omnibus utatur, (uvilua, telîtculis, coagulo, ) 2 balneo unçionibusḉ utatur, mire concipit, Sextus. Dorcadis, hordi, leporis, coagrulum \& fel, cum agnino fanguine $\&$ adipe, medullaćs ceruina, nardino $\&$ rofaceo olen commilce, \& poft purga nem fubdito, (utero prius purgato, ) Aetius 16.34. ut conceptus fiat. Er rurfus ibidem, Peffulus cor ceptioni inducendx idoneus, Coaguli lep, partes duas, alum inis fciffilis partem unam, cum melled! luito, $\&$ peffum conficito, Lep, coag. Aterili mulieri impofitum (pelfi inftar) fatim foecundam reddi 
ab ip fa animantis foecunditate orta tridetur, ut in coagưlo dixi. Matricem leporis ficca $\&$ tere, $\& d_{2}$ bibere quando furerit à menftruis purgata, concipiet, Galenus Euporift.2,135. Vt fterilis concipiat, Leporis confumit foemina uuliam, Serenus. Vt mulier concipiat, Leporis uterum frige, trituma, affidué propina:habeat autem 8 Cleporis fanguinem, Galenus Eupor, 3.234. Si uuluæ leporum in cibis fumantur, mares concipi putant. Et mox, Conceptum leporis utero exemptum, his qua parere defierint reftibilem foecunditatem afferre putant:fed pro conceptu, leporis faniem \& uiro magi ppi nant,Plinius. Vtmulier concipiat foeminam, Lepus incidatur, $\&$ de fanguine qui à uulua fluxerit,il liniat fibi naturam, \& de coagulo eitus, Sextus. Vt mulier mafculum concipiat et pariat, Leporis utul uam ficcam derafam in potione uini bibant utric $\&$ \&ulier $\&$ mafculus. Nam fi mulier fola biberit, androgyne(androgynus)nafcitur, hoc eft nec mafculus nec formina, Sextus. I Ventris quidem dolore tentarinegant talum leporis habentes, Plinius. Talum leporis tolle \& ligato ad uentrem,mi rè fanat, Sextus. Si quis talum leporis fecum haburerit,immunis ả dolore uentris $\&$ periculo huiuf, modi perpetuò permanebit, Marcellus. Frequentiffimè eurenit ut ex qualibet caufa fubitò dolor uentris exiftar:fed qui talum leporis fecum habuerit, huíufmodi cafum, id eft fubitum dolorem uena tris nunquam incurret, Idem. Et alibi, Leporís talus uẽtriculo fubligatus dolorem eius ( $\&$ uentris) excludit. Irem inter remedia ad coli dolorem, Lepori uiưo, inquit, talum abftrahes, piloş́́ eiusde fubuentre(fubuentrili)tolles, atç ipfurm uiuum dimittes: de illis pilis uel lana filum ualidum facies, \&. ex eo talum leporis conligabis, corpuş̣́́ laborantis præcinges, miro remedio fuburenies:efficacius tamè erit remedium, ita ut incredibile fit, fi cafu os ipfum, id eft talum leporis in ftercorelupi inur

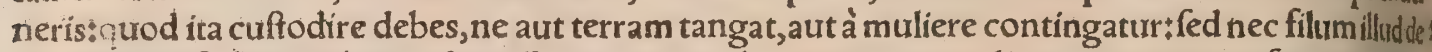
lana leporis facturm debet mulier ulla contingere, hoc autem remedium cum uni profuerit,ad alios translatimm cum uolueris, \& quotiens uolueris proderit: filum quoo quod ex lana uel pilis quos de uentre leporis tuleris, folus purus $\&$ nitidus facies: quod fi ita uentri laborantis fubligaueris, pluri mum proderit, ut fublata lana leporem uiuum dimittas, $\&$ dicas ei dum dimittis eum, Fuge fugelepu fcule, \& tecum aufer coli dolorem, Hæc nugator Marcellus, Leporis talum Humelbergitsititith pretatur officulũ in articulo pedis in pofteriori fuffragine duntaxat, quo feilicet modo in alins quoug animãtibus talus reperitur, qux modo habeant, ut bifulca ferè: nam folipeda $8 \times$ digitata Ariftotelete fte, non habent: quare lepus etiam carebit, quod Humelbergius non animaduertit: fed exculatur, quoniã Plinius quoq $\&$ Marcellus talum leporis nominarunt: uidêtur autem illi impprié fic uocare officulum in genu pofteriori, uel fuffragine potius, quod geniculi parella effe uidetur, noftri uul uocant sen bafenfprung, hoc eft faltum leporisłnimirum quod ea parte ceu bafi inter faliendum nis tatur. Hanc aridam tritam ex uino frequenter bibi contra calculos aliqui commendant inter praci, pura remedia. Eadem officula cum pari pondere macis dicti aromatis cötrita in uino Creticouel uatico (aut fi mauis Monembafico) ad dimidias coqui, $\&$ calidum bibi aliquoties, aduerfus colicam feu uentris dolorem quidam cófulunt. Leporum uel capreolorum talos ex uino aut ftillatitioligur repulegin, parturientibus muliercula pro ocytocio propinant, Tragus, Ad comitialem, Vifiqi cini,corallí, margaritarum, feminum pxonix, officulorum de fuftragine leporis, lapillorume cal cris partes æquales mifcentur, Obfcurus. TReperitur in latere leporis acui os fimile, hec fearfiti ri dentes in dolore fuadent, Plinius. đArticulorum uitńs leporis pedes adalligatos, utiles effet dunt, Plinius, Podagras quidam mitigari(credunt)pede leporis uiuentis abfciffo fi quis affiduith beat,Idem. TFimum leporis ambuftis medetur, Plinius. Vt ftent perpetuò mamma, uirginino uem grana fimi leporis magi ppinant, Idem. Liquatum cum aceto $\&$ illitum, impetiginem cur Rafis. Leporis fimi cinis in uino uefperi potus, nocturnas tuffes fanat,Plinius * Contritum ex uno calido fumptum, arteriæ \& columella uitīs \& fpiritus difficultati fummopere opitulatur, Galenu Eupor +3.37 . Coeliacis $\&$ dyfentericis prodeft leporini fimi cinis infperfus potioni tepid $x$ uini, Pin, Leporis uentriculum cum fimo fuo uino uetere lauabis, ita ut fordes ipfa ibi fint \& mifceanturtalli Ii in uentriculo non intreneris, pilulas de fimo ipfius impares numero tritas cũ uino uetere dyfentert co dabis bibendas, Marcell. Lep.ftercoris pilulas feptem tere, 8 cum dulci uino colico per riduum da bibendum, Marcellus. Fimum leporis cum melle decoctum, \& quotidie faba magnitudinefin ptum, rupta inteftina farcire míré traditur, ita ut deploratos fanaurerit, Plinius: Vide exiam fuprat ter remedia ex pilis. Peffus quo Afclepiades in nobilibus foeminis utebatur ut conciperent, $N$ rhæ drachmas quatuor, iridis, fimileporis, fingulorum drachmas duras, cum aqua collyria cóficito \& fupponito, ubi menfes defiuerint, poftea cum uiro concumbant, Aëtius 16.34. Stercus leporisp tum fuper mulierem qua nunquam peperit, nunquam pariet quandiu tenuerit : (fi ligetur per mulierem, non concipiet quandiu tenuerit, $R$ afisł) Et fi modicum eius uulua impofuerit, defl cat(remouet ab ea, Rafis) menftruum fanguinem, \& matricem uehementer exiccat, Albertus of Rafís.

$$
\text { H. }
$$

2. L. A elius putabat ab eo dictum leporem à celeritudine, quòd leuipes effet. Ego arbitror àGrẹ co uocabulo antiquo, quod eum Aeoles Boeotíl leporem appellant, Varro 3. de re ruft. In opereturo de lingua Latina:Lepus, inquit, quòd à Sículis quidam Graci dicunt $\lambda$ 'swexy:à Roma quod orti Sicu li, ut Annales noftri ueteres dicunt, fortaffe hinc illud tulerunt, \& hîc reliquer uns id nomen. Le 


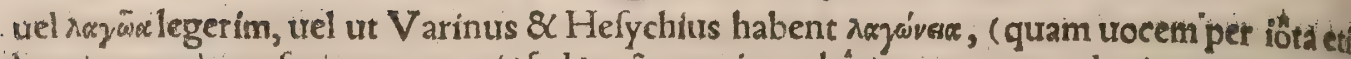

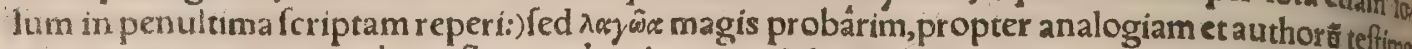

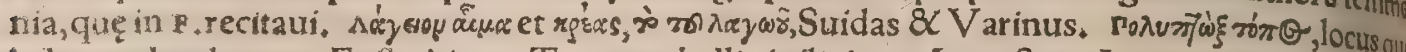
habet multos lepores, Eultathius. Tempore belli ciuilis inter Auguftum Antoniumó Cornificiu poeta à militibus deffitutus interịt, quos fxpe fugientes galeatos lepores appellârat, $\mathrm{C}$ ll. Rheginen fé uulgò lepores dici funt, urpote pauridi \& formidolofi, Eraf, in prouer. Lepus pro carnibus, TLe pus inter fydera nominat́ in fphęra Procli. Nofcitat etiã in cololeporis fydus, fub quo qui natifi, rint, tanca erũt corporis leuita te, ut qữ currere coperint, uelocitate fua agitati aues fuperare uide? tur, inquit Firm. Hunc locum fi Mars refpexerit, Ptadiodromos facit: fi uero Luna cũ Marte, pyctoma charios, id eft pugiles, Cal. De hoc fydere Higinus, Lepus (in quit) dicitur Orionis canem fugeter ue nantis:nam cum, ut opor tebat, eum uenatorê finxiffent, uoluerunt etiã hoc fignificare aliqua de calu,

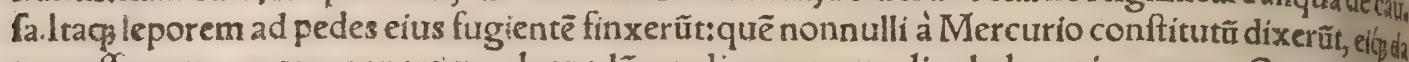
tum ciffe pręter cxtera genera quadrupedũ, ut alios pareret, alios haberet in uentre. Quí aûtabhac caufa diffentiunt, negant Orionem tam nobile \& tam magnũ uenatorê(de quo $\&$ ante in Scorpions figno diximus) oporter fingi leporem urenari: Callimach ̃̃ qưo des, eam leporum fanguine gaudere, \& cos uenari dixiffet. Itaqg Oriona cum tauro decertantemfe, cerunt:leporis autem hanchiftoriā memoriæ prodiderunt, A pud antiquos in infula Lero (Lerusud Leria Straboni, infula eft Icarí maris ) nullum leporem fưiffe : fed ex eorum ciuirate adolefcentivm quendam fudio generis inductum, ab exier is finibus leporem foeminam prægnantem attulife, \& ad eius partum diligentifimè miniftraffe. Itaç cum peperiffet, compluribus cius ciuitatis ftudiâninc diffe, et partim pretio, partim beneficio mercatos, omnes lepores alere copiffe. Itaç non longo inter. uallo tantam mulcitudinem lepor ũ procreatã, ut tota infula ab his occupata diceretur: quibus cumab hominibus nihil daretur, in femina cortrm impetu facto omnia comeder uni. Quo facto incolar calat mita te affecti, cû fame forent oppreffi, cómuni confilio totius ciuricatis uix deniç eos ex infula abengif fe dicuntur. I taç (deos)poftea leporis figuram in aftris conftituiffe, ut homines meminiffent nil flite tam exoptandum in uita, quin ex eo plus doloris quàm latitiz capere pofterius cogerentur, Hade nus Higinus. Similes leporum in Carpatho \& Aftypalaa infulis multiplicatorum hiftorias fuprain c.retuli. - I Anaxilas Rheginus, ut feribit Ariftoteles, cum lepores in Siciliam inuexiffet, quxillis

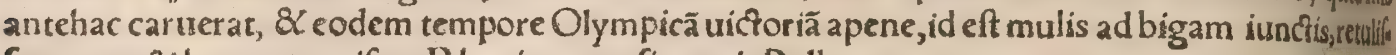
ret, apene 8 lepore numifma R heginorum fignauit, Pollux.

q Herba leporina, id eft fatyrion, Syluaticus. Lepori coagulum fit, quoniam herbam fuccilatei

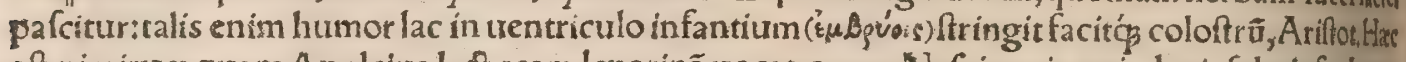
eft nimirum quam A puleius laçucam leporinã uocat, ca. 112. Nafcirur, inquit, locis fabulofis, Lepus

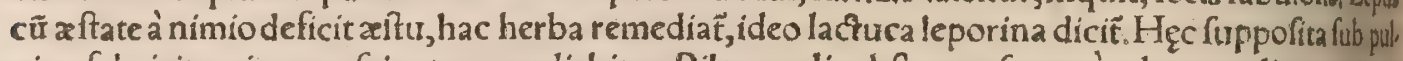

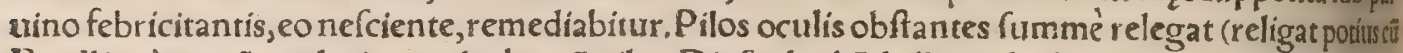

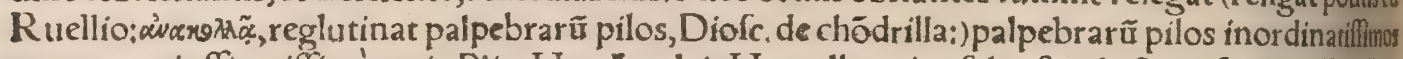
pro gummi efficaciffimè regit, Plin. Hęc A pulei. Humelbergius fylueftris lactucę fpecié effecöindtô, cam nimirũ quâ Itali cafam, id eft domũ, leporis uocant. Sonchũ (inquit Ruel.) Diofrorides cicethilẫ à Romanis dici prodidit, q̊d nomen adhuc hodie in Hetruria feruat Veneti lace ucinos, Galliladero nes appellant herbarij nönulli leporis palatiñ, $q$ hoc animal ut ab aftu uindicet, $\&$ caloris propulfet incõmoda, foleac fub ramis eíus decübere $\&$ fapenumero ftabulari. Hęc eadẽ forfitã eft quę ab Ap̣ur leio laçuca leporina nomina $\tilde{t}$, etc. quãuis pilos qui obftant oculis, hac inquiat religariqquęà Diofut Plinio de chōdrilla tradunt, Hac Ruel. Ex rurfus alibi, Arthritice, inquit, apud recentiores duo funt genera: Vnü flore luteolo, odorato, uerno, uulgus primulā ueris appellat:alterum, palatiû leporisuto cant, $q$ fubinde lepores fub eius umbra lateant, cubitali altitudine, foling foeniculi, baccis punicels, rat

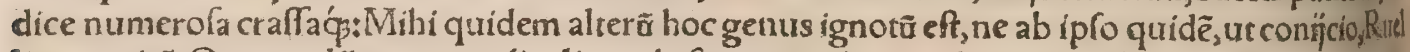
lio cognitũ. Quarendũ autem an fic aliquod afparagi uel corrudx genus. Tragus Tomo I. ca.88. herbam Germanicé diçam bafenlatridb uel bafenfiraub, fimilem effe docet hieracio minori(quod 8 dentem leonis aliqui uocant, noltri f affenrörle) (ed per omnia minorem, cauliculis tenuibus, (xa übus, floribus luteis, locis cultis \& inter fruges feré prouenientem: \& eandẽ laçucã leporinamA Apuy leị effe conïcit. Diofcorides quidem nullum lactuca fylueftris genus, ut funt fonchi, hieracia, chons

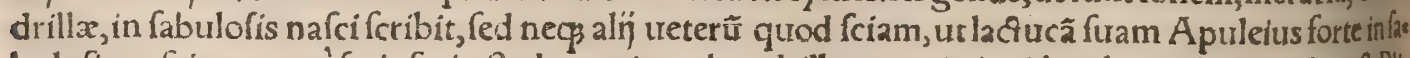
bulofis naf́i non ueré fcripferir. Sed quoniam chondrilla mentio incidit, obiter detegendus ef? Plip nï error: is libro 26.ca.8. aluum, inquit, fiftit 8 chondris, fiue pfeudodictamnum. Hoc Diofcorides chondrillx attribuit, non chondridi aut pfeudodictamno:quãuis enim Plinius 25. 8. fic fcribat, Pîu dodictamnum multis in terris nafcitur, à quiburdam chondris uocatum:tamen certum eft pleudodi ctamnum uires habere dicramni, eamó̧ pulegī, cui mouendi potius quàm fiftendialuum medici fas cultatem tribuunt:dorcis quidẽ uel dorcidiư inter diçamni nomenclaturas eft, non chondris. q $L_{a}$ geos uua, quę Latinéleporaria diciț.Verg.2.Georg. Ex paffo Pfythia utilior, tenuisćǵ lageos. Sertuits apud Macrobium quoog lageam inter uuarum genera numerat. Hac plurímum delectari lepores pu tant. A mãr quidẽ uuas in cibo lepores, $\&$ genus quoddã ex uuis albis prędulce $\&$ maculis quiburdãa cum maturuit ex fufco ruffis infigne, leporum urina afperfum uinitorum apud nos uulgus dic 
corrupte in Theophrafto legiẗafine, ubi Theodorus uolucrũ interpretatur, arbores amplexu hede

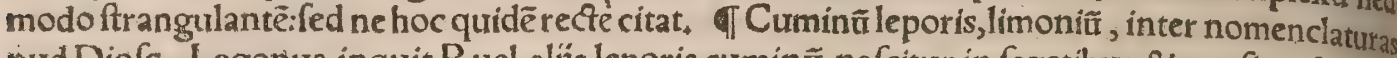
pud Diofc. Lagopus, inquit Ruel, alijs leporis cuminü, nafcitur in fegetibus, \& quafi pes lepor citur:Sanè \& fimilis ef ei afpecใu: proinde nõ probauerim eorũ fententiă, qui caryophyilatã uul ctam rentur, in opacis montanis nafci folită, nó in fegetibus ut lagopus. Genus potius eft humi folit, in fegetibus $\&$ aruis enati, đqd uulgus trinitate uocat, Hippocrates lagopyron nominat, quafile poris triticũ intelligas, furfuribus cũ inaruit fimillimã, folio paruo quafi oleagineo, longiore tanturn (hoc noftro humili trifolio:nó cóuenit)cruentis uulneribus imponẽs. Hanc Galenus leporinã in

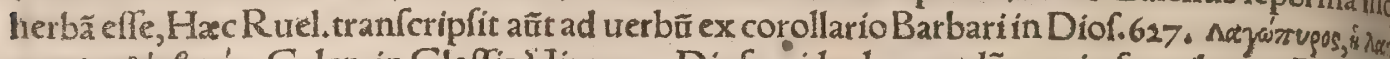

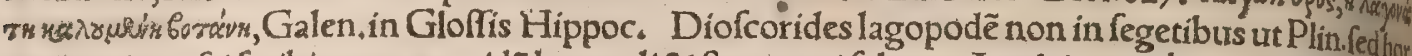
torũ areis nafci fcribit: utraq̧ quidẽ loca coli \& ftercorari folent. A puleius ueró ca,61,Pedẽlepo inquit, Graci lagopũ, Romaniuocant herbã benedictã, leporinum pedẽ. Nomen ei à fimilitudine dis leporini. Nalcitur in pratis:aftringit uentrẽ, \&c. Videtur autẽ ex Gręcis prafiàs, id eft hortorit reas, ineptẻ pro pratis in terpretatus, alliciente uocabulorũ affinitate, Et quia à Romanis benedictâu cari meminit, inde nimirũ decepti funt quidã, ut eandẽ effe putarẽt, quẹhodie uulgo eo nomine,era lio caryophyllata uocatur:qua leporínũ pedẽ nó panicula uillofa ut genus trifolíp proximè diçi, fed folio in tres ceu digitos diuifo repręfentat. Caryophyllata, pes leporis, fanamunda, Sylurat.Sed hacin re periculü non eft:quando $\&$ ueterũ lagopus fere nô aliunde cõmendatur $\bar{\phi}$ quod uentrêfiftatiad quod prę̧ tandũ benedicta etiā noftra non fuerit ignaua. Lagopodẽ humilis trifolỉ genus defert

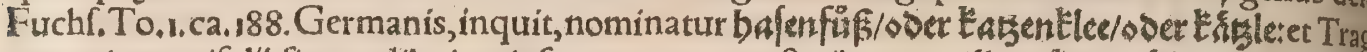
2.ca.3, inter trifoln fiue meliloti, ut ipfe uocat, genera, fimiliter appellans

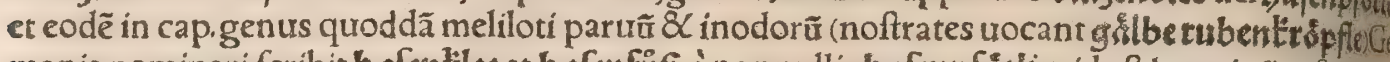
manis nominari fcribit bafentlecet bafenfüf, à nonnullis bafenp fớtin, id eft leporinũ trifoliü,erpe dem leporis. Idẽ Tragus fcribit hieraciũ minus (dentê leonis uocant, noftri pfaffentózle) recentiori, quibufdã lagopoda uideri, q equidẽ non probo. Et rurfus To.1. ca. 10\%, herbã gnaphalio uel fitchn citrinæ diçx fimilem, candidã in ficcis \& apricis collibus nafcente, florum corymbis mollibus, candi dis, uel purpureis, aut utrogs colore mixtis, uiuaciffimis, etiã in fufpenfa herba, \& $c_{\text {, fimiliter Germas }}$

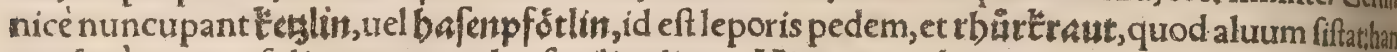
ego fanè propter foliorum cum olea fimilítudinem Hippocratis lagopyron puto:non autem la dem Diofcoridis, quę inter fegetes \& cultis tantum locis nafcitur, illa minimét quod ad uim aluumfir ftendi, \& fimpliciter ficcandi, utra utaris non refert. Diptamum, id eft leporis auricula, Syluati, cus. Circa montem Peffulanum aurículam leporis uocant herbam quandam annuam (aliquiela phabofcon putant) caule ramofo, floribus luteis per umbellas, folịs omnino cum recens proderin auriculas imitantibus, trientalibus, $\&$ inftar mínoris plantaginis (fi bene memini) neruofis, radice candida, fimplici, ut apiorum genus. Huius folia pota ad calculos commendãt. Fungorum qưt dam genus quercubus innafcens, Germanicé quidam à figura bafendzle, id eft auriculas leporun nominant, Tragus tertí Tomi de plantis cap, 1. Malua fylueftris duplex eft:maiorem in quiburdan Germanix locis equinam, minorem leporinam cognominant, bafenpapel, Tragus. Idem $T_{0,1,1}$ 35.inter foeni trel graminis genera unü recenfet, quod ba a enb sot, id eft leporinum panẽ appellat, alio nomine 3 yetn, à tremore ut cöócio:nam flores eius fpecie finguli rotunda(undelep.panis fort nomen) per fpicas digefti, pediculis harent exiliffimis, unde fit ut femper moueantur ac tremant:ali qui bafenólin, id eft auriculam leporis uocitant.

Ф Alpibus peculiaris eft pręcipuo fapore lagopus auis:pedes leporino uillo ei nomẽ hoc dedere, č tero candida, columbarû magnitudine. Eft \& alia nomine eodê à coturnicibus magnitudine tantum differens, croceo tinĉu cibis gratiffima, Plin. Nos lagopodẽ alpinã atễ à colore perdicê candidá uoca

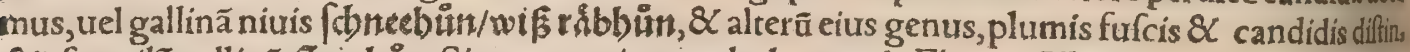

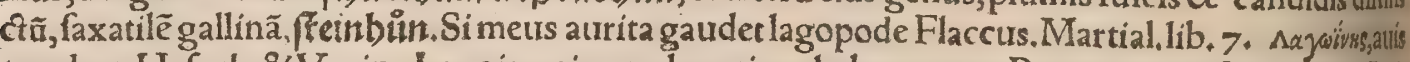
quędam. Hefych. $\&$ Varin. Lagois, auis qux leporinas habet carnes, Promptuariũ fine autore.Auli quam Galli \& Itali francolinã uocitant, delicatiffima omniũ, Germanis eft cît bafelbün, quafigal

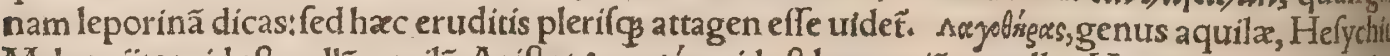
Melænaëton, id eft pullã aquilã, A riftot $\lambda a y \omega \phi_{o v}$ ov, id eft leporariã appellat, Hermol. Vulturễ aliqui

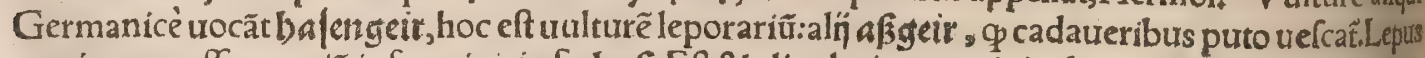
marinus, maffa quadã informis, cin feeba $\beta$. Eft $\&$ alius huius nominis, de quo A elian, Magni maris lepus ex omni parte ad terreni fimilitudine accedit,pręter pilos, quos fpinofos $\&$ erectos habet, $\& c_{c}$ Nec fcarus aut poterit peregrina iuuare lagois, Hor,Ser,2.2.ubi A cron, Lagois aut (nó aut, led aui legendũ uidet) carnê leporis habere perhibetur, aut eft genus pifcis quod in mari Italo non intrenit.

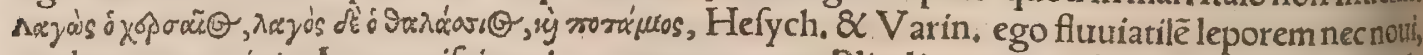
nec legere memini. Lepus pifcis ex lacertorum genere, Plin, $1 i_{3} 32_{*}$ (prope finê) ut quidam in fuis dils CHonarĭs citant, fed omnino falluntur: decepit cos uerbũ fubftantiuũ funt, đ̣̊d expungendũ Hernor laurs monet: omnino fané lepus marinus nihil cômune lacertis habet, ut et alĭ ibidem nominatí.

Lepos, faltatoris nomen Horatio 2.6. Serm. ut Acron fribit. Lagus, sáyos, paroxyt, pat Ptolemai fuccefforis Alexandri, Nobilitas Pharï proles clariffima Lagi, Lucanus 10 . 


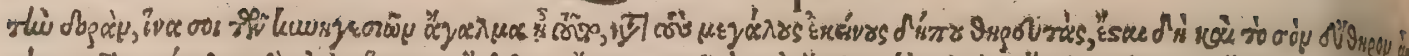

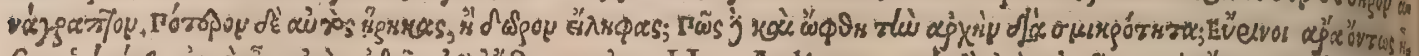

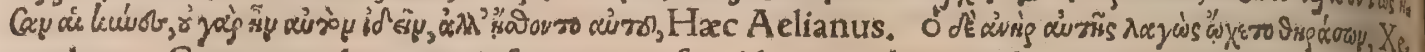
nophon. Canes cum leporem infequuntur, fiquidem occiderint ipfi, gaudent dilacerare, ate;

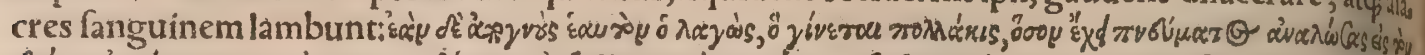

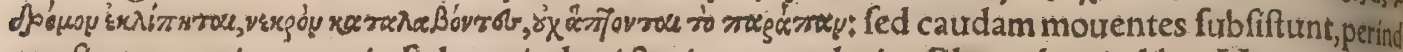
quafi non carnium gratia, ed magis de uictoria contenderint, Plutarchus in libro Vtra anim. \& $c$, Veftigía leporum(inquit Theophraft, hiftorix plant, 6,29, ) leutiter irrorato folo certius redolen us enim impreffa firmiter adharent, nec fublimiter uagantia delitefcunt:quemadmodum cum humus eft: neos demerfa in profundum abolentur, ut cum terra limofa ob imbrem uel auftum eff, Flatus enim $8<$ aqua aduerfantur perimuntó uelut abftergmenta rerineat. Quum euafffe retium anfas leporem fignare uolunt Graci, eleg

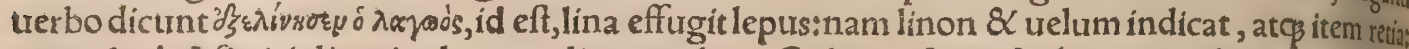
proinde ab A fiaticis linaria pleruncs dicuntur hæc, Calius, Lepufculi timentes hoc quadrang dedit Diana rete, bis legitur apud Feftum:Perottus legit, quadranyulum dedunt fefe in rete, Imo do, uenare leporem, nunc itym tenes, Plautus in Capt. Vide infra inter prouerbia. Vocabulaleportîn uenationi accommodata apud Germanos huiufmodi reperio: Ser bajo fosteyet/ faart: $\sigma_{\text {atr tho }}$

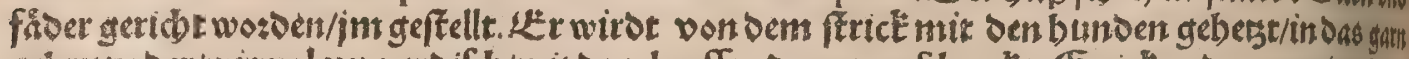
geberst:- Der/wiewol vnwey

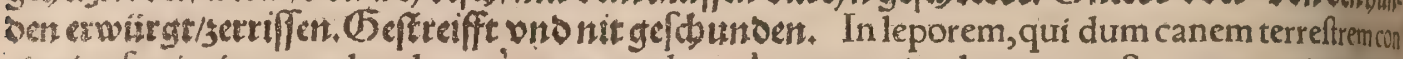
cisatius fugit, in mare deuolutus è rupe quadam, à cane marino laceratus eft, extant epigrammata duo Germanici Caefaris, \& unum Tiberī, Anthologij Graci r.33. Eft \& Aufonï fuper eodem th maftichon huiufmodi: Trinacrí quondam currentem in littoris ora Ante canes, leporem coruler us rapuit. At lepus: In me omnis terræ pelagíç rapina eft: Forfitan $\&$ coeli, fi canis aftra tellet, Aquila genus quoddam in Europæremotifimis ad Septentrionem locis circa Noruegiam, detratin leporis aut uulpis pelle, in ea parit \& incubat, Olaus Magnus. In Scythis auis magnitudineotidls, binos parit, in leporina pelle femper in cacuminibus ramorum fufpenfa, Plinius. Leporumpe pro fcopis quidam utuีtur. A duerfus talpas: Locum prius mulfo eluito, deinde bubulum felinitici \& leporis ftercus, Galenus Eupor. $3+163$. Non latrari à cane(magi nugantur)'leporis fimumulelp los tenentem, Plinius: fed uerifimilius hoc amuletum hyænæ quàm lepori adfcriberetur, $\&$ lingua \& pellis, \& alix partes geftatæ hac ui pollere dicuntur, ut quæ naturalem quandamadiels fus canes antipathiam habeat: adhab hyæna eft Arabice, arnab lepus: qux fortè nomina interpresall quis peruertit, ut a pud recentior es etiam Albertus confurdit. Ad Indos fapientes, ut frribitPhilo fratus, adducia eft mulier, quæ iam fepties magna cum difficultate \& periculo pepererat, (

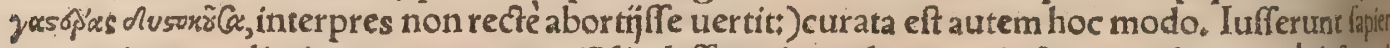
tes maritum mulieris, cum tempus pariêdi adeffet, uiuum leporem in fnu occultatum eó defere

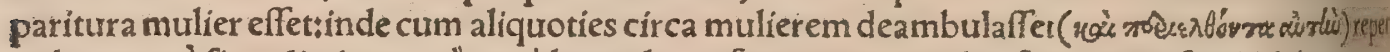
te leporemè finu dimittere, ( fileporem illico foras enjceret, Hac ille in uita Apollonï. Videtur autern fiulca hac perfuafio init fumpta, quoniam lepus facillimè parit.

बf $\mathbf{f}$ Lepores dipnofophiftis apud A thenxum appofiti: \& Roma in coena Lentuli, cumprofta mine Martiali inaưguraretur, tefte Macrobio.

Th. Titus Vefpafianus Stroza à principio fecundi Eroticôn delepore albo, quem amicádona uerat, fuga elapfo conqueritur: Sed aliquot eius uerfus recitabo,

Hũ c ego per uirideis umbras cũ matre uagantẽ Ad ripam excepi Sandale amcene tuam,

Paruus erat, totọ̧́́ nitens in corpore candor Mzandri niueas exuperabat aureis.

Paulatim pofitóg metu mitefcere coepít, 8 c. Meleagri epigramma uel epitaphium in leporem, qui catulus adhue captus, $\mathcal{X}$ herbis enutritus, pra nimia pinguitudine morturus erat, habetur Anth logị Graci 3. 24. Teporem Graci amoribus facrum fabulantnr, ducto argumento ex s

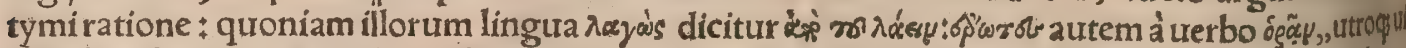
fum fignificante, Calius. Tranfulit autem, ut apparet ex Varini uerbis, qua in dictione Fobxulegun

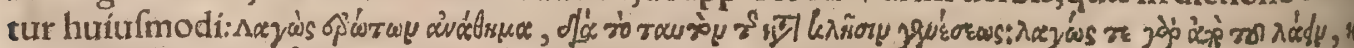

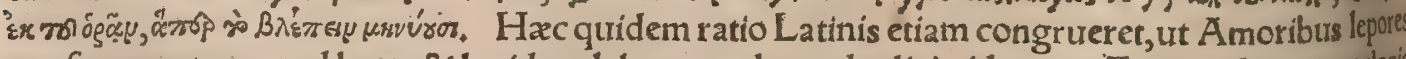
confecrarentur, quod lepos $\&$ lepidus ab hac quadrupede dici uideantur, Et ex eadem etymologia nata forte perfuafio en cibo eius formofos fieri, ut in $F$. diximus. Sed fuapte etiam natura, ut Xenou phon fcribit, lepus animal adeò gratiofum eft, ut nemo fit, qui fi eum uideat dum ueftigatur, dum in urenitur, dum fugit, dum capitur, quicquíd amârit non obliuifcatur: quare uel hac ratione extra ery,

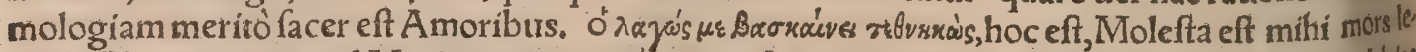
poris, Pherecrates apud Varinum in Broxauve. Tlaginia dicta fuit Carum dea, Gyraldus, urbs Caria Hecatefia prius uocabatur, Câres enim templo conftrucio deam Laginitín uocarunt, quod lepus illuc confugiffet: \& cum etefia, id eft annua facra illic facerent, inde nomen impofuê co,Stephanus، Lepus auerfus auerfionem fignificat, Orus in hieroglyphicis, Boeas Laconia 


\section{6

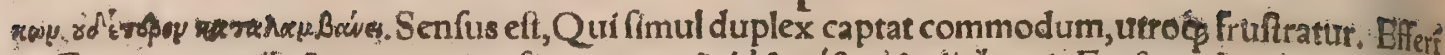

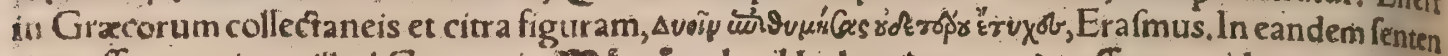

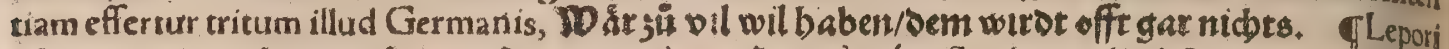

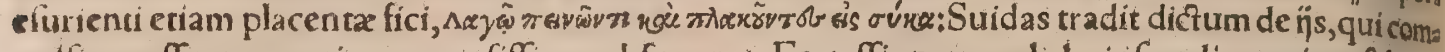
pulfi neceffitate, res etiam pretiofiffimas abfumunt. Fortaffis natum ab huiufmodiquapiam fabula, qualem de fe narrat $A$ puleius, quòd adactus fame, placentas primum lambere, deinde etiam comef,

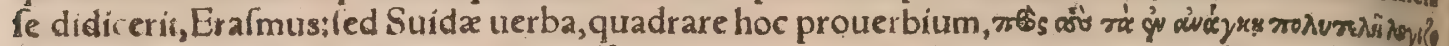
whirs, melius reddidiffet:in eos qui neceflitatis tempore res qualescung pro pretiofiffimis habent, Tlter infortunatum lepus appar ens facit: Vide paulò fuperius inter omina. I Mortuo leoni \&lee pores infultant. Extat epigramma Gracum(inquit Erafmus) cuius argumentum fumptum eft ex Homerica Iliados x. ubi Herculem ab Achille iam interfectum circumfiftunt Graci mortuo infulo tantes, nec quifquam erat qui extincto non aliquod uulnus infligeret. Epigramma fic habet, Bathe

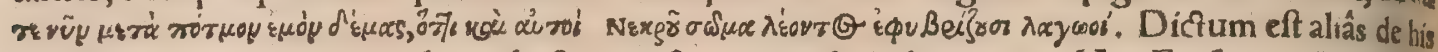
qui mordent mortuos, cum laruis luctantur, \& cum umbris depugnan,, Hxc Erafmus. Alciatiems blema de leonibus qui leporis mortuibarbam uellunt,recitaui in Leone. TLepores ad illorum mee nia dormire dicemus, quos prorfus simidos effe fignificabimus. Vide fupra inter omina, hac ipfa in parce huius capitis. $\quad$ ILepus tute es $\&$ pulpamentum quaris: Vide fupra capite fexto, IPriug

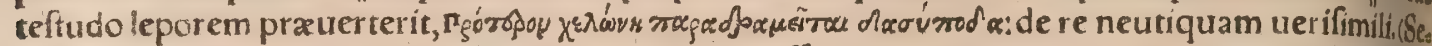
narius p, ouerbialis, de re impolfibili, Suidas; factu difficili, Sipontinus. )Meminit Diogenianus, Eraf mus. Fabularum conditor A efopus leporem curfu à reftudine fuperatum frihens, rardi ingenin homi a nes ad affiduum laborem incitat, ingeniofos uerò à pigritia deterrer, Tzerzes 7.105 . II modou, nare leporem, nunc itym tenes, uerfus à Plauto in Captiui duo prouerbiali figura dichus. Id eft,hầc interim conam qualemcun $\beta_{3}$ certam habens: quare alter am, fi potes, potiorem: Itys enim auis, quë à hafide Scythia flumine phafianum uocant. Proinde cum iubebımus, ut qui nactus fit commodl quippiam, ad aliud fefe accingat, nó intempeftiuiter hoc uremur adagio, Erafmus. Mox autemfubif cit exiftimare fe deprauatum effe lor um, nec itym legendũ ut codic es habent, nec ichthyn, id eff pirê, ut cuidam uiderur: fed ictin, id eft uiuerram: uiuerris enim refie Plino pracipuã effe gratiam ppter uenatum leporum \& cuniculorum: fed dictionem, leporum, de fuo adulit Plinio: negg enim in ullisco dicibus legitur. Etres ip fa monet longè aliam cuniculos uenandi rationem effe qui in fuos mulfifos res fpecus ftatim fe abdunt, quòichicies \& muftela fppter rorporis paruitatem facile eas fequuntury) aliam ue ò lepores, quí quàm longiffimé poffunt cöcitar fimo rut fu ferunur, ubi uix canes nedurn muftela aut uiuerra fequi poffunt. I modo uena e leporem, nune itym senes, Vide fupra in e.Plua ra forlitan adferemus in phafiano: in hanc enim auem lrys mutatus fertur. Leporis uitam uiuere,

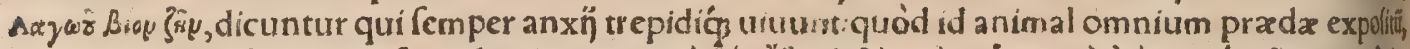

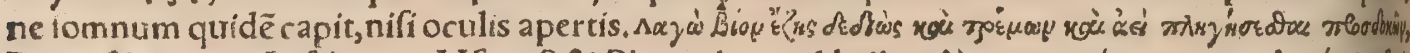

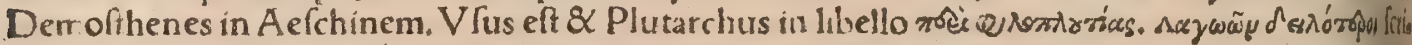
pfit A thanafius in Apologia prima: $\&$ apud Strabonen, Phrygị leporibus timidior, Erafmus, le por is uiram agere apud Lucianum is dicitur, qui prapotentes ac facundia claros infans ipfereform dat affidué, Calius.

1 Sunt $\&$ peculiaria Germanis ex lepore puerhia. Su mift fuds vnd baf fepn : eodemlen 4

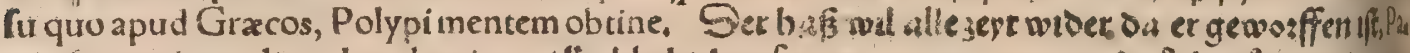

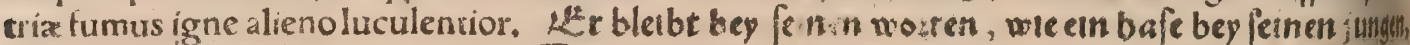
Aliudftans, aliud fedens loquirur. Sas baafen banner annemnen, Volam pedis oftendere, fuge

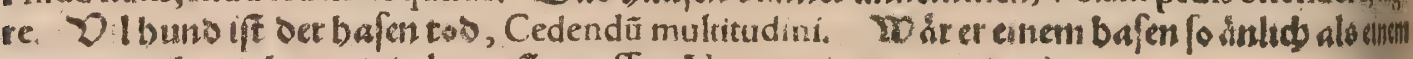
narren/ore bund betrens in langeft 3 erriffen, Non tam ourum ouo limile.

TSimile. Lepores aiunt parere fimul \& educare alios factus, \& iterum fuperfoctare:at impion rum iftor um $\&$ barbarorum hominum mutua, priufquam conceperint pariunr. Petunt enim ufurí ut primum dederunt, $\&$ quam pro ufura accepere pecuniam mex rurfis mutuant, ut ea queg no. uam pariat ufuram, Plutarchus in libro de non accipiendo mutuo.Sed hac Gracé elegantius piofe runtur, ubi $\&$ ufura tocos à pariendo nominatur.

\section{DE L V P O.}

\section{A.}

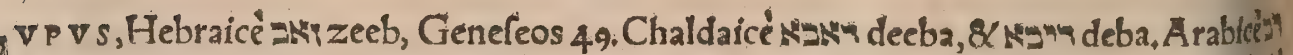
dib Foemininum, zeebah, lupa: 8 plurale mafculinum zeebim, Ezechielis 22. Zebeth, id eft lupus, Aefculapius. Alfebha(inquit And.Bellunenfis)nomen eft commune ad omnes quadrupedes qua hominem dentibus $\&$ unguibus inuadunt, mordent, lacerant, \&alist quando interimunt, ficutleo, lupus, tigris, \& fimiles. Inde mores alfebhaie dicuntur, ferini frilice, immanes, cr udeles, belluini, quales turius generis animalium funt, Hac ille, Hinc forte facfurm eft, II 


\section{DeLupo. A.B. Lib. I.}

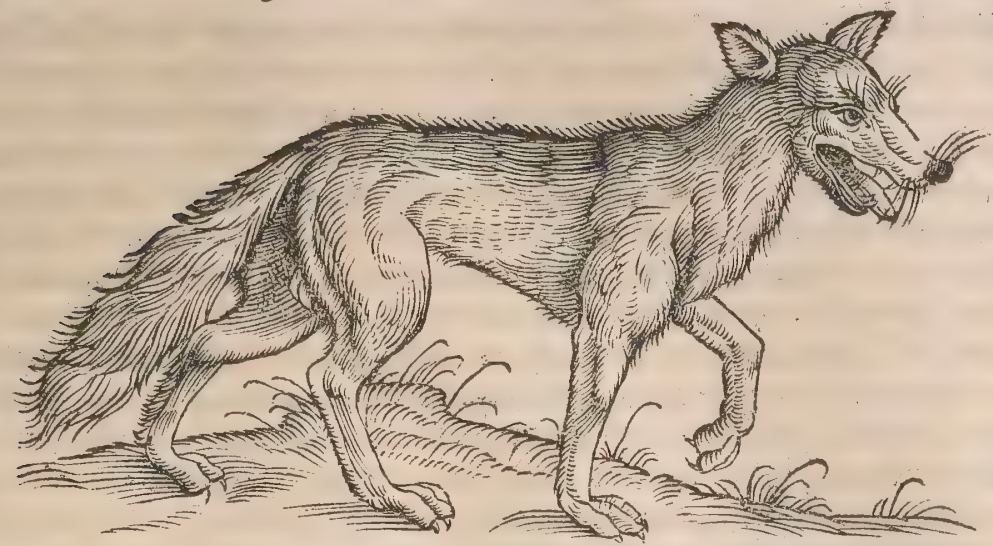

Albertus $\&$ alh̆ quidam obfcuri fcriptores, multa qua de leone Ariftoteles pdidit, in lupum confers rent. Oppianus inter catera luporum genera, unum in Cilicia, \& Tauro Amanó́: montibus chrỳ feon, hoc eft aureum uocari fcribit(ut in B .referam:) conincio autem Hebraicam fiue Syriacam illis in locislinguram fuiffe, qua fahab uel fehab aurum uocant, feeb lupum; aut dahab uel dehab, aurum: deeb uel deeba, lupum. Dib(aliâs dṇb) A rabícum fiue Saracenicum nomen, in medicorum libris exhac lingura translatis, diuerfe feribitur, adib, adip, adhip, aldib:ego poftremam feriptionem præutu lerim,qua \& Bellunenfis utitur. Aldib alambat, id eft lupus furiofus, Idem. Hyanam quoque lupo congenerem Syriacé dabha uel aldabha, uel dahab, uocari docui fupra : videtur autem lupus quem aureum, ut iam dixi, Oppianus uocat, ad hoc genus accedere, tum nomine aurum fignificante:tum natura, quỏd fub cane terram fubeatuítandi aftus gratia, quod Oppianus fcribit, ut hyana uel dab= ha fepulchra, ut cibum ex cadaueribus quarat. Eft etiam cateris hirfutior lurpus aureus, ' mó tix iubata + fed differt regione, $\&$ coloribus, quorum nullus ei abeffe dicitur. Adeps adib fubtilis eft, Auicenna. Vetus gloffographus lupum intelligit. Bellunenfis legit aldub, quam urocem in gloffis urfum interpretatur. Anoftris, id eft lupus, Syluaticus. Aulma, id eft lupi, Idem. Quar quidem duo uocabula ad quam linguam referam, non uideo. T $\Lambda u ́ x(-)$ Græcis lupus eft, \& hodie uulgò

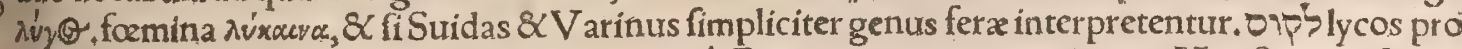
lupo, eriam apud Arabicos quiofdam fcriptores à Gracis mutuatos reperitur, ut Munfterus in Lexi. cotrilingui annotauit. Italicè,lupo. Gallicè,loup. Hifpanicè,lóbo. Germanicè, wolff. Anglicè, Vuolfe. Illyricé, wlk, quafi per metathefin literarum Gracx uocis,

B.

In Sardinia infula neog ferpentes ulli, neg lupi nafcuntur, Paufanias in Phocicis. In Creta lü pos, urfos, uiperas, \& fimiles feras noxias nafci negant, eó quod Iupiter in ea natus fit, A riftoteles in Mirabilibus. In Olympo Macedoniz monte non funt lupi, nec in Creta infula, ut nec uilum alud maleficum animal præter phalangium, Plinius $\&$ Solinus. Theophraftum audio dicentem, Cre tam luxpis \& ferpentibus infeftiffimam effe. Macedonicum uerò Olympumà lupis non adiri, Gilli us ex Äeliano, ineptè \& ambigué:nam fi quis regionem lupis infeftam dicat, intelligi poteft, abunda rein ea lupos homini infeftum animal. Sic Liuius, Vias latrocinijs, pafcuaćs publica infefta habue. rant. Vel, ipfam regionem infefram effe lupis, eisḉs aduerfari:fic Cicero, Quis bunc audet dicere a = ratoribus infeftum aut inimicum fuiffe? Nullos etiam fouret Britannia, Textor ex Plinio, ni fallor. TSunt quxdam genera urforum alborum, \& canum, ac luporum, \& fimilium quorundam, qux ue nantur 8 habitant tam in aqua quàm in terra, propter fimilitudinem temperamenti corum a dutrit. que elementum, Albertus. Lupi in Aegypto minores quàm in Gracia fiunt. Ariftoteles, Inertes hos paruoş́́ Africa \& Aegyptus gignunt, afperos truceśç frigidior plaga, Plinitus. Herodotus Aegyptios lupos non multo uulpibus grandiores effe ait. De lupis uefpertinis; uel ( ut alip vertunt) Arabix, in Sacris literis, uide fupra in Hyana capite primo.

In Heluetia 8 alpibus perpauci reperiuntur: raró enim ex Gallia cifalpina (Lombardia) \& uicir nis regionibus adueniunt: $\&$ fi quis deprehendatur, mox tanquam communis hoftis, datis uicatim campanarum, ut uocant, fignis, uenatione publica capitur. Pellium apud nos artifices, lupos Suedi cos imprmis commendant, quod egregï, magni, \& cinereo fiue cano colcre fint. Magni etiam funt circa al pinas regiones, $\mathrm{R}$ hatiam, A thefin, $\&$ Tirolenfem, ut uocant, comitaturm. In R hartia quidem confoederata Heluetị $s$, magni lupi nigricantes reperiuntur, robuftiores, $8 \mathrm{C}$ maioris precin men cum illis fape etiam alios minores $\&$ communes lupos reperirl. Caterum in regionibus planis ut Galliæ multis, minores magiş́́ rufi habentur. Mof couia qua iungitur Lithuanię, paffim in Her cynia fylua pragrandes ac atros lupos eosćs ferociffimos gignir, Antonius 10 ted in tabula Morco=

6o riax, Lupi in Scanzia fi ulterius per congelatum mare procefferint, luminibus feruntur orbariob nimium frigus, Iornandes. In Septentrione Europa (circa Norucgiam puro) capiuntur tria lupo, rum genera, in fylua Landfexucca, qux per ofoginta milharia extenditur; Olaus Magnus ; Lifem 
in locis alces à lupis montanis inuaduntur, ut in Alcis hiftoria dixi. Galli fura lingua lupos garou appellant illos, quífemel carnem humanam guftarint, encharnes dicunt:fiue inde facto nomine, $f_{i}$ ue à guftato cadauere quod charongne nominant; Tales quidem hominibus poftea femper infeft funt, $\&$ metuendi, quod carnem hominis appetant: ideó̧́ cauendi, unde nominatos quidam coni ciunt:cauere enim Gallis eft garder: Vide plura in D + Italia lupos habet, qui cum cateris fimiles non fint,homo quem prius uiderint conticefcit, \&C. Solinus : Plura in D. ubi idem quibufuis lupis, non Italicis tãtum, apud alios authores attribui docebimus، Sed prius Āppulis Iungentur caprea lupis, Horatius, Apud Crotoniatas maximè abundant, Paufanias 2.Eliacorum, De lupis Mrotidis, qui parte pradxà pifcatoribus donantur, ne noceant aut retia lacerent, A eliani uerba recitabo capite quarto. Audax eft magis eorum genus quod breue, quàm quod longum eft, Liber de natus ris rerum: Sed corruptus eft locus ex Ariftotele, qui non in luporum, fed leonum genere, generofio rem effe fribit,qui longior piló́s planiore eft:ignauiorem uerò, qui breuior $\&$ crifpiore pilo. Oppia nus libro tertio de uenatione, quinģ luporum genera paftoribus cbferuata defcribit, rofouripen, circum uel harpagem, aureum, \& acmonas duos, quorum alterum ictinum, alterum nullo peculiari

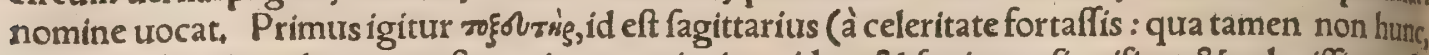
fed fecundum inter lupos præftare ait poeta:tigris quidem $\&$ fagittam fignificat, $8<$ uelociffimam fe

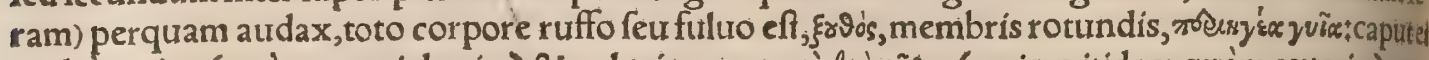

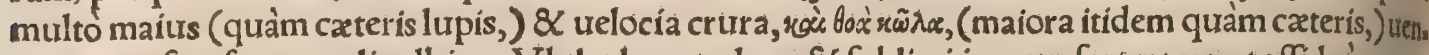
ter canis afperfus maculis albicat. Vlulat horrendum, \& fublimi impetu fertur:caput affidué concule tit, igneis oculis. Alter quem circum (nimirum à fimili ingenio circi auis in accipitrum genere) 2 harpagem, id eft raptorem appellant, corpore maior $\&$ longior eft, omnium uelociffimus. Hicmar gno cum impetu fummo mane uenatum exit, ut qui fubinde efuriat : argenteo per latera $\&$ caudam colore:montes habitat: quibus per hyemem niue oppletis, interdum ad urbes per famem impudentif fimus accedit, furtim omnino 8 placidè, donec in propinquo alicubi capram corripiat. Tertiumge nus nitrofos Tauri fcopulos, Ciliciæ rupes, \& Amani iuga incolit, hic pracipua pulchritudine fpecta bilis, non merito aureus nominatur, multis comatus pilis refplendens: non lupus, fed lupopraftanti

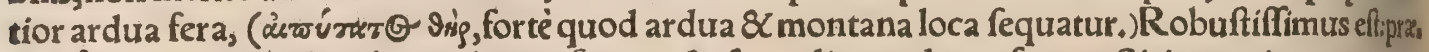
cipué autem ore $\&$ dentibus ualet, as, ferrum $\&$ faxa aliquando perforans, Sirium orientem metuit, $8 \mathrm{mox}$ in aliquem terra hiatum aut obfcuram fpeluncam fe abdit, donec Solis aftus imminuatur; (Simile quid de oryge fertur: hoc quidem lupi genus præcæteris ad hyænam accedere mihi uideri, in $A$. dixi.) Quartus $\&$ quintus communi nomine acmones nuncupantur, (acmon genus aquila eft, $V$ arinus: \& forfan $a b$ hac aue rapace nomen eis inditum, ut circo etiam iam dicto, \& proximedi: cendo ictino:nifi quis malit à corporis figura, capitis nimirum \& colli aliqua cum incude, quam Grę ci acmona uocant, fimilitudine, fic appellatos, Et forfitan acmones alio uocabulo fed idem fignifican te alterius lingua fic nominantur, unde Oppianus ad uerbum tranftulit, ut chryfeon quoog: Vitig

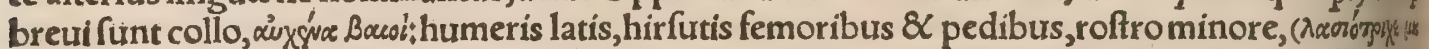

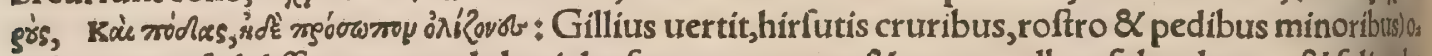
culis paruis: fed differunt, quod alteri dorfum argenteum $\propto$ uenter albus fplendeant, \& folipedss infimi nigricent:hunc aliqui iĉinum (id eft, miluum) canum nominarunt. Alter colore niger, ${ }_{2} 01$ re minor, non tamen infirmus, in lepores pracipuè inuadit, \& rectis undiq̧ pilis riget, $\mathrm{H}_{a}$ ctenu pianus. Albertus de animalibus $8.5,1$, bonafum, qui generis boum fylueftrium eft, defcribens, taurolupo \& equo compofitum effe nugatur.

T Lupi forma fimiles funt canibus magnis paftoralibur, Oppianus:maftinis, Albertus. Lupum nonnulli canem fylueftrem effe dixerunt:quia forma ei canis, ululatusḉ̧ confimilis, fed latratu caret, Author de nat. rerum: atqui Albertus carere eos latratu falfum effe ait. Color in lupis pro generum $\&$ regionum difcrimine uariat, ut iam ante docui : funt enim ruffi, candidi, cani, nigri, uarî., Cantu quidem color magis proprius eis $\&$ communior exiftimatur : unde Oppianus licet de diuerfisetiam

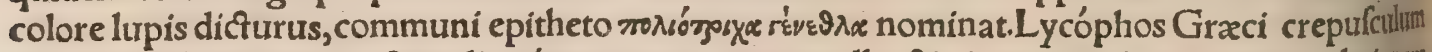
dicunt, medium in ter noctem diemć tempus, tanquam albo $\&$ nigro participans:per translatiotiem à pilis lupinis, quorum ima ad cutim pars albicat, fuperior nigricat, Etymologus: Vide in a, inter dert uata. TVillus lupi in carne uerminofus eft, Obfcurus, TAnimalium cerebra crefcunt decres

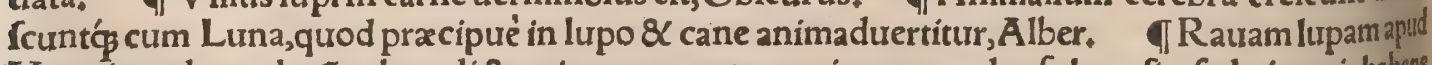
Horatium de oculor ü colore dic\{am interpretantur, quia rautus color fuluus fit, fed nigroris habens aliquid. Theodorus oculos charopos in Ariftotele fuluos interpretatur: proinde rauros oculos chas ropos recté dixeris, Calius، Oculi capra lupọ̧́́ fplendent,lucemọ̧́ iaculantur, Plinius, Ignitífunt oculi primo luporum generi, quos fagittarios uocant, Oppian. parui poftremis duobus, acmonas no minant, Idem. Oculi iracundis fimiles \& palpebris apertis patuli, quales in lupis \& apris apparenth omnium peffimi, Adamantius. Raui luporum oculi,uide paulo ante in colore pilorum. Vifume is acerrimum effe, $8<$ in tenebris etiam, capite tertio dicam. TCarcharodontes, hoc eft dentibus fert ratis, nempe teretibus $\&$ acutis praditi funt lupi, $A$ elianus:inæqualibus, quare morfus eorum uehte menter obeft, Ifidorus: hinc $\&$ lupata frena afperrima, nomen tuler unt. Lupus aureus Oppiatio, dentibus tantum ualet, ut lapides etiam $\&$ metalla uincant, I Animalia dentibus acutis carn 


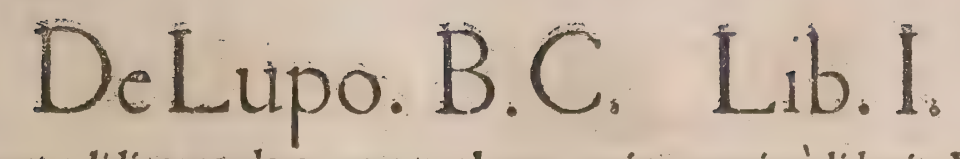

richu funt ampliore; ut ualidius mordere queant: ut lupus , qui os maximé diducit, Vicent. Bell: 1Lupo \& leoni collum offe pepetuo riget, A riftoteles de partib.libro 4. Certix leoni tantum, lit, po, \& hyzenx fingulis rectis ćp offibus riget, Plinius. Lupus natura corporis rigidus facile $\int_{e}$ infle dere non poteft, impetu furo fertur, \& ideo frequenter illuditur, Gloffa in Lucam. Ceruix folida \&

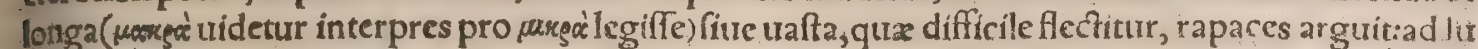
pos enim refertur, Albertus ex Platone. Quibus ualde breue collum eft ut lupis, infidiofi feré funt, Arifoteles in Phyfiogn. Lupi collum in eas breuitatis anguftias compulfum arque uehementex compreffum eft, ut contorqueri retrọ́ trunfum retorqueat neceffe eft, A elianus: Idem Plinius $8 \times$ Solinus de hyana fcribunt. Bpryvin de rov

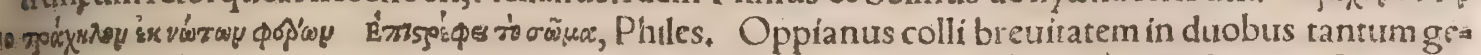

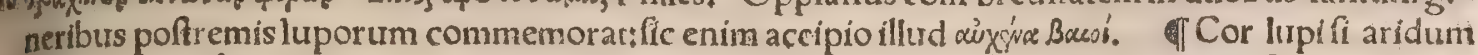
feruetur, ualdè odoratum fieri dicitur, Albertus, fl lecur luporum equinæungula fimile efle trar ditur, Plinitus ब In uefica lupilapillus reperitur, qui fyrites appellatur, Plinius. Syrtitx gemma imelleo colore croco refulgentes, intus frellas languidas continent: inueniuntur in littore Syrtiuni \& Lucania, Ge, Agricola ex Pliní 37,10 . Alius eft Syriacus la pis, qui \& Iudaicus, ad uefic $x$ calcu= losexperitus. Tlupo genitale offeum eft, Ariftoteles, Plinius \& Albertus. II Vulpibus \& lur pis uillofus eft caulis caudx, Plinius. đLupi pedes priores quinis diftinfos digitis habent, pow fteriores quaternis: nam priores pedes in digitatis aliquiot, manibus fermérefpondent: $\mathcal{X}$ quintus in eis digitus pollici:ut in lcone, cane, lupo, panthera, Áriftoteles de partibus 4.12. Hic locus apud Plis nium il, 43. corruptus, ex Ariftotele reftitui poteft.

Oculi caprx lupoóg fplendent, \& lưcem( nociu frilicet)iaculantur, Pliniurs. Equi \& lupi noçè melius uident quàm homines:homini ratiolumina monftrat, Cardanus. Lupus interdiu obtufiuss, nocieclarius uidet, Phyfiologus, Vrgente fame noctur uagantur, (graffantur, Oppianus, Lupurs acerrimis atque acutifimis praditus eft oculis. Enimuero intempefta nocte, uel Luna ipfa flente, lucis ufura perfruitur: hinc lycóphos id temporis appellatur, cum lucem is folus natur $x$ munere o culis perceptam habet: (lycóphos crepufculum dicitur, uide infra in a,) $8 \times$ uerò Homerus mili uoca

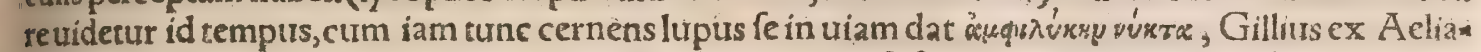
no. Et rurfus in Cicindela, Nocfu etiam, inquit, luce tum ipfa fruitur, tum circunftantibus illucefcit: 30 qua in re mihi lupo praftantior uidetur:qui etiamfi id temporis quod appellat Homerus lycophos lucem natura munere oculis perceptam habet, tamen fibi foli, non uicinis, lucet. Amphilycen exor

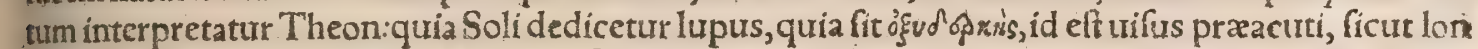
ginqua fpectat Sol,Calius, Lupus famelicus per noctem uento aduerfo, efra odorem uel per medif miliaris interuallum (hoc eft quantum à pedite horæ fpatio conficitur) aut longitus percipit, Stumpfius.

of Vlulando unus præcinit, $\&$ alï condamant, Obfcurus. Vlulant autem in fame præcipuè. Vlulaturs luporum horrendus, Obfcurus. Lupum nonnulli canem fylueftrem effe dixerunt : quia forma ei canis, ululatuś́ confimilis: fed latratu caret, Author de naturis rerum. Quod lipos latràa ut carere dicitur, falfum eft, Albertus. Vlulare proprium luporum eft, fed ad homines quoque 4 transfertur, Varro, Claudianus ulul atum etiam pro uagitu infantis dixit. Af lupus ipfe ululat, fren det agreftis aper, Author Philomela. A pparet fané uox ad imitationem foni facta,onomatopcciam tocant. Et alré Per noctem refonarelupis ululantiburs urbes, Vergil, I. Georg. Vlulare canum eft \& furiarum, inquit Seruius. Vide in Cane H.c. Hinc 8 Germani habent furm bülen uel beuler,

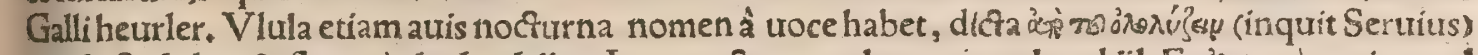
quod eft ululare 8 flere, cin bubu/büru. Item noctua apud nos, ein eule uel ïl. Et óroruyouy auis apud Gracos, ut Varinus fcribic. ódon'́\} retunde dicta etiam ỏntrvyày Ariftoteli uox, quam ranæ mares emittunt, cum forminas ad coitum

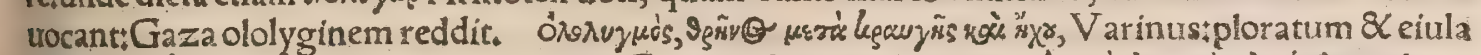

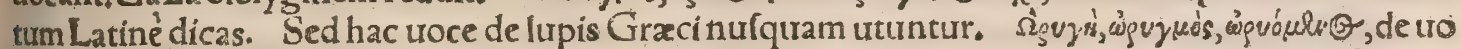

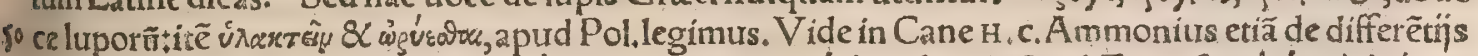

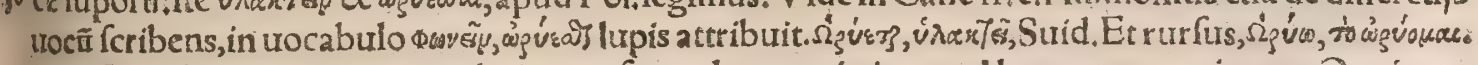

Inter lupos pracipuam celeritatem fecundo generi, circos uel harpages nominans, Oppianus

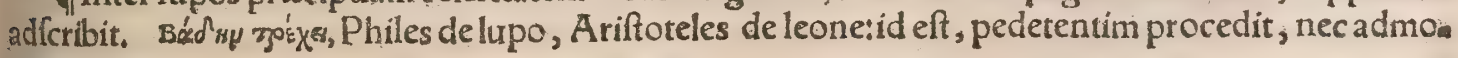
dum currit.

\$Voracifimi \& propemodum infariabiles funt : pilos 8 offa deuorant, \& integra rurfus altu reddunt, Stumpfius. Carniuorus eff (ut cæetera etiam quorum dentes ferrati) $8 \mathrm{~m}$ milta folida deuo. rat:quamobrem non pinguefcit, alimento non concocto, ( $\&$ frequenter hanc cb caufam agrocat:) femel faturatus abftinere uel triduo poteft. Vorat potius quàm comedit carnes : \& pauco utitur po. tu, Aurthor de nat, rerum, \&Albertus ex Arifotele, qui hac omnia non de lupo, fed de leone feribit: 6o videntur tamen pleraq̧, etiam lupo congruere. Leones $\&$ lupi carnibus farti nimium, abfinent; cubandớg tantíper fe fourent, dữ percoquãt, Plưtarch. In fame pracipuè fauiunt (ut leones etiã) \& quamuris domi nutriti, dum edunt nemine amant, quinetiă afpici interim indignantur, Exaturatus 
lupus (inquit Ȧ elianus) longum temporis interuallum inediam fert, atç ei quidem uenter late pro citur, lingua tume fcit, os obftruitur, et fimul ut famem multo cibo depulit, fimiliter orcurrentiburs at que agnurs manfuetus exiftit. Neç uero unquam tum, nec homini, nec beftís ullis, ne fi quidem per medium agmen ingreditur, infidias molitur. Poftea uero ei paulatim lingua extenuatur, ac in anth quam figuram redit,iterumás lupus exiftit, Eadem ex Aeliano Philes . Leoetiam, Ariftot, tefte, ia ftus \& fame uacans, facilis micisḉp maiorem in modum eft. Lupi fæuiores funt uicina nocte citât ad rabiem diurna fame:unde fcriptum eft, Velociores erunt lupis uefpertinis, (Efaix 20.) \& , Iudices cius lupi uefpere, (Sophon.3.) Obfcuri.Sed delupo uefpertino fententiam meam expofui in Hyena capite primo, Quæ animalia cibicaufa impugnent ac deurent, dicam in D. Lupis peculiateeft terram quandam in fame edere, A riftot.Plinius \& Solinus, Albertus hoc lupos facere fcribit, non nutrimenti caufa, fed ut ita pondere auchi facilius maiora quaxdam animalia quę inuaferint molefua deprimant; uocatur autem hoc terra genus $a b$ eo glis, ab alijs Latinius argilla. Cum equum (inquit) uel bouem, ceruum, equiceruum (alcen) uel aliud robuftum animal inuadere parat, hoc tenacis ters ræ genere fe ingurgitat, mox oppletus in facies eorum infiliens adharet $\& \alpha$ pondere fatigata tandem profternit, \& guttur arteriam ḉ morfu infixis dentibus dilaniat; tum terra uomitu reddita, animantis proftratæ carnibus faturatur:quod fi leuis effet, facilius excuteretur, Hac ille. Lupus herbas nion edit nifi agrotus: tunc enim guftat aliquid herbæ pro remedio $\&$ uomitat ficut faciunt canes, Allber turs: Vide infra in mentione morborum eitus. Cum pradam habent $\&$ alia fe obtulerit, fecundam inuadunt, quafi präentis obliti, Albert,fed uidetur deceptus, quoniam Plin. \& Solin. non lupo,fer lupo ceruario hoc adferibütt. Qurod fupereft cibi defodientes abfcondunt:diuidũt autẽ ex azqutohis qui in uenatione fucrint: \& fi quid fupereft alios ululatu a duocãt, Albertus: Apparet autẽ Ariftotelis uer ba, quibus eadem leonibus attribuit (ut in $\mathrm{D}$. de leone recitaui)deprauatis etiam nonnullisadlu pum tranftuliffe. Sed lupos pradam communicare etiam ipfe alibi negat, uide in D. TExcremens tum alurificcum reddunt, \& cum flatu, (id ç̧ frequenter fuper fpinam albam:) urina eis odora, Alber tiss. Videtur autem haec etiam deprauata, non recté de lupo fcribere, Nam Ariftoteles deleone, Exa crementum alüi (inquit) durum $\&$ arídum emittit; flatum etiam alui acerrimum $æ$ dit, $\&$ urinam gra uiter olentem. Cöuenire tamen etiam lupis non nego. Vrinam odoratam effe, id eft bene olere,mini mè mibi uerifimile fit:experiantur curiofí.

Ad promontorium Bubonicum innumeri thynni uerfantur, quorum maximi fimiliterufiues foli $\&$ feparatim natant:alih more luporum bini proficifcuntur, \&c. Aelianus, Quartumgenus lus' porum, aureum uocat Oppianus, fub Sirio loca fubterranea fubit.

- Lupi codem coeunt modo quo canes, A riftot. Auertuntur dum coeunt canes, lupi, phoca, in médióśs coitur,inuitió̧ etiam coharent, Ariftot. Cocunt lupi toto anno non amplius diesdios decim, (ut Ariftoteles fcribit,) Plinius, Solinus, Ifidorus, Coit lupus (inquit Ariftot.) uno tempore

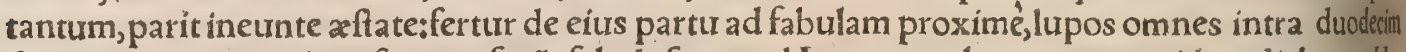
dies parere:cuius rei caufam proferũt fabulofe, quod Latonam oberrantem totidem diebusex Hy perboreis Delum deduxerint fub fpecie lupe, propter metum Iunonis. Sed an tempus hoc parientid fit, nondum exploratum habemus. Fertur quidem fic uulgò, fed uerum minime effe uidetur: quale uel illud ferunt, lupos femel in uita parere, Hæc Ariftoteles. Lupos noftri per duodecim dies ques à natali Chrifti fupputant, coire tradunt, ideo tum maximè furibundos lupos timent, Vuillichius, Cur lupa certo anni tempore omnes intra duodecim dies pariant, caufam inquirens Plutarchusis bro de naturalibus problemate 38 . Antipater, inquit, in libro de animalibus, partum lupas projicere adferit, cum glandiferæ arbores florem abijciunt, quo guftato, uteri illarum referantur:cum eils $\mathrm{c}_{1}$ pia non eft, partum in ipfo corpore emori, nec in lucem uenire poffe:praterea regiones illas à lupi

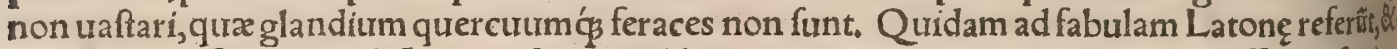
ut iam ex Ariftotele retuli. Lupi, urfi, leones libidinis tempore acrius in eos qui accefferint, fatuith inter fe tamen minus dimicant, quia nullum eorum gregale eft, A riftoteles. Lupus fert $\&$ paritu canis, tum tempore, tum etiam foctus numero, Idem. Multifida, ut canis $\&$ lupus, \& parua eiufd generis, ut mures, multa pariunt, Idem.Cacos pariunt catulos canes, lupi, panthera, thôes, Ariffor Et alibi, Quadrupedum multifida, omnia cacos generant, poft palpebra dehifcunt, ur lupus, uulpts, lupus ceruarius, \&c. Multifidæ qux pariunt imperfecta, omnes multiparæ funt, earum quędamca tulos inarticulatos propemodum pariunt:fed omnia feré cae cos, ut canis, lupus, lupus ceruarius, Ariftot, ut in Cane recitaui. Vulgaris quidam apud nos fermo eft, lupum nourem catulos gener: re + ex his poftremum $\&$ in fenecta genitum, canem effe, Aiunt autem ad aquam ab eo duci carulos, ut bibentes obferuet: \& canis inftar lambentem reịci. Nuper à Rhato quodam audiui, catuloslix porum ex latibulis auferri in Rhętia circa calendas Maij, feptem uel nouem aliquãdo ex una partl te. Idem aiebat uulgo ferri, lupam primo partu unicum eniti catulum, fecundo geminos, \& fic dein ceps fingulatim catulo femper uno auctiorem fieri partum ufģ ad decem,inde fterilefcere. unt animalia $\&$ quorum genus diuerfum quidem, fed natura non multum diftat, fi modo par ma tudo fit, $\&$ tempora æquent grauidtatistraro id fit, fed tamen fieri $\mathcal{\&}$ in canibus, $\mathcal{Q}$ in uulpibus, $\&$ in lupis certum eft, Ariftor. Lupicum canibus coéunt in Cyrenenfi agro,Idem. Crocutas uelut exc ne lupoóç concepas, omnia dentibus frangentes, ptinuśç deuorata conficientes uentre, Aethiopia 


\section{DeLupo: C.D. Lib. I. 721}

genetât, Plin, fed decrôcituta furperius dixi mox poft Hyęnam: de lupo canario, et ceruario,id eft thồ, infra ftatim poft Lupurn agam. Supra etiam in Canibus mixtis nonnulla attuli. Thoes feræex hya na \& lupo nafcuntur, Hefychitus \& Varinus, Ex lupo pardali(panthera)thôes gignuntur, Oppià nus. Hyana uideturir compólita ex lupo \& unlpe, Albertirs

T Vitunt $\&$ leonès $\&$ lupi permultos annos, $\&$ dentibus in fenecta malé afficiuntür, íta ut alie ando per atatem edentuli fiant, Albertus. Senes lupi facile capiuntur : accedunt ením ad domos, ( $Q$ in periculum fe pracipitant, quafí uitæ faftidientes.) funt enim longæuitæ, \& dentès tandem amic ant, Idem.Ariftotèles eadem ferènon de lupo, fed deleone prituatim fribit. THerbas lupus nifi xgrotus non edittunc enim remedị caufa aliquid herbxe edit uomitọ́ ficut canes, Albertus. Lupus \&ileo pro remedọs edunt gramen, \& herbam frumenti, 8 rapefta(rapiftrum, beserich) quae uomitu prouocant, Niphus. Vifcera habent infirma: $\mathcal{X}$ cum laborant ex eis, herbas comedunt, dracontium pracipué ad acuendos dentes, Albertus: ineptiffimè quidem, quorfum enim dentes acuuntur ubi ui frera dolent? Ariftoteles nihil tale de lupo, de ưrfo autem, Aiunt(inquit) latebram egreffum, primü herbam arum dictam(dracontium aliquando reddunt Arabes:cui quidem proximum eft tum aliâs, (num uirib,) guftare, utinteftinû laxetur $\&$ hiet. Etrurfus, Solent urfi herbă arum comedere cum è lari bulo egrediuntur, lignum etiam manducant, quafi dèntiant:Locus eft dè hift. anim.9.6.in quo red. dendo Albertus $\&$ hunc errorem $\&$ alios committit, Auicennx puto ridiculos interpretes fecutus. Canibus $\&$ luppis fimiliter accidunt quidam morbi, rabies fcillcst; fynanche, \& podagra, Albertus ex Ariftot.de hift. anim, 8, 22. fed Ariftoteles eo in loco de canibus tantum, nihil de lupis feribit,fieri ta. men poteft, utïfdem morbis et lupus, tanquã fylueftris canis, tentetur. Aldib alambat, lupus furio. fus, Vetus gloffographus in Auicennam. Cætera animalia(præter canem)ut lupl, uitlpes, \&c. incur runtrabiem potius aftate quàm hyeme, Ponzettus. Cerebrum lupi $\&$ canis, euidentius quàm alio. rum animalium, crefcentem ac decrefcentem Lunã fequitur,Albertus. Hac fortaffis caufa etiam fuerit cur hæc animalia pracipuè rabiant, De remedijs ad lupi rabidi morfum capite feptimo fcribam,

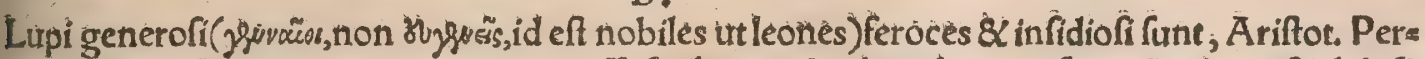
petuo feri, Idem:Albertus tamen cicurrari poffe feribit, ut pluribus dicam infra. Audaces $\&$ dolofi, Albertus, Luporum rapax eft natura $\&$ ignobilis:nam ubi caulas intrauerunt, non folum interfi" ciunt quod fatis eft ad uentrem, fed totum gregem paffim ittgulant, Plinius fi bene memini. Vide in. fra quomodo graffenturi in oues. In fame eos pracipuè fruire, faturatos ferè innoxios effe, ur leo= nes etiam, pracedenti capite dixi. Lupus cibo fatur, non lupus fed agnus tideri poteft, uel inter me dios greges:nec enim amplius deglutire poteft:fed uenter ei \& ligula iuxta tonfillas tument: mox ci. bo concocto ingenium lupinum redit, Philes. Lupam fominam aliqui mare fortiorem $\&$ audacio= rem effe aiunt, quod falfum eft, Albertus. Breures lupi inter cæteros magis audaces funt, $[\mathrm{dcm}$, Leo nes aliquando debilitati timent $\&$ fugiunt demiffis auriculis ficut canis: $\&$ hoc faciunt etiam lupi; Albert, Ariftoteles idem de leonibus tantum feribit.

TLupos cum uel in foueam deciderunt, uel aliter fe inclufos fentiunt contrario quàm feles inge nio)omnino pauidos quafićs attonitos, \& 4 pra ftupore innoxios effe audio. Et in Italia ante paucos annos non pcul Medrolano contigiffe, ut lupus fame coactus ad uillam quandam uenerit, \& ingrefí foconaculum ubi uillica cum pueris erat, exterritam illam pueris relictis foras fe proripuiffe, attra= co poft fe hoftio coenaculi. Mox uillicum reurerfum, uxore demonftrante, lupum in conaculo liberis illafis placidum $\&$ obftupefactum ftantem deprehendiffe. Huic loco non polfum non adf́cribere mirabilem hiftoriam, quam ex clariffimo uiro luftino Goblèro nuper didici,cuius ex literis ad me da sis uerba funt hxc: Exemplo Gefnere oftendam tibi, lupum terreftrem captum non fruire in homi. nes. Fuit mihi propatruus, Michael dictus, uenationi $\&$ autcupio mire deditus, qui cum folfas ali quas in agris fuis ex patrio more haberet pro capiendis feris, altas ita ut nulla beftia quamlibet uio. lenta erumpere capta poffet:accidit ut una nocte, eaćs Dominica, tria animalia longè diuerfá natura unam eandemq́ in foffam caderent:mulier uicina prior, qư⿱ ut poftea ipfamet retulit; fola decurrẽs in agrum fub uefperum betas rapasćs in obfonium fequentis diei iftinc exportatura erat: deinçe uul pesttertio ac ultimò lupus capitur, Singuli fibi in foffa locum occupaturm primo tota nocie quícti ob tinent, $\&$ ut uerifimile eft, fefe inter fe muturo metuunt, Lupus, quanquam animal ferocius, neç uula pem tamen neg mulierem attingit inuaditure, fed fura quafi in ftatione timidus perfiftit. Trepidanti interea mirum in modum mulieri nihil ab utra $\varphi_{\beta}$ beftia mali contigit, nifi quod ob metum ab illis us na nocie ferè tota canefceret, \& tantum non ad amentiam redigeretur. Mane uenator propatruus it more furo folfas perluftrans, prædam triplicem infperato confpicit, $\&$ ad confpectum mulier is uricinę lux obftupefcit, quam alloquens uoce fua quafi ex morte reurocat, ac opem mox falutemós praftat. Itaç foffam infiliens, ur erat cordatus, ac robuftus, fiatim telo lupum interficit, deinde ưulpem, taridem fcalã nactus, mulierem femimortuam humeris fuis extrahit $\$$ in planiciem fifit, domumó de: o fert.Quo facto fuat illa familix domuiós reddita, deinde per omnem uitam triftior femper quàm ante comparebat. Tantum confternata erat illa node inter befias lapfa muliercula . Caterum ad uenatứ pradamq́ fuam propatruus rediens, míratur lupum, fauam beluam $\&$ uoracem; muliercula meth 
culofifima tamen \& uulpe capta,nocie tota abftinutre, Hacienus Goblerư. Ego nuper eandem hiftorlam peregritum quendam eodem ferè modo narrantem audiui:fed addebat prater mulierem, lupum ac utupem, monachum etiam eadem nodie incidife.

(7) Leonis hic mos eft, ut tantundem ferélæadat, quantum lafus eft ipfe, \& unguibus quafi minetur caftiger lupus percufforem cognofcit, atç, ex obferuato inuadit, Cum iuxta Romam uenarer in fyluis, cat ne meo inuadente lupum, ab equo defendens gladio lupum uulnera uítqui ín me conuer fus conar batur mordere, nec alium prater me: quòd nififuifem adiutus, non fine periculo euafifem, $\mathrm{N}$ phus. Dicuntur inter fe rapinam æqua diufifone diuidere, Liber de naturis rerum. Plutarchus hoc de leonibus fcribit, non de lupis, atate exhauftos à minoribus natu ad prædæ communionem uoca, ri. Lupus non communicat pradam ficut leo: fed potius reliquias pradx fur fodit in terram, do, nec rurfus efuriat, Albertus. Hiftoriam de lupo, qui equarum armentum ad fideiufforis pro fe capto dimiffóç ftabulum agitautit, ut gratiam referret, ex Strabone recitaui in Equo B.

(- Lupi, utcunque rapax animal, foetus fuos amant: foemina partus cuftodit, mas pro catula rum falute cibos ad ipfam defert, Philoftratus in uita A pollonĭ. Cum fugiunt catulos fecumfer runt, \& $c_{*}$, hoc A riftoreles urfis tribuit, non lupis, ut obfcuri quidam ex eo citant.

IA defertis locis ad habitata refugientes lupi, tempeftatis acerbitatem fe horrere oftendunh Aelianus.

6erunt lupos in magna armenta certaturos, uentrem explere terra: ut hoc onere gratlat, non tam facile excutiantur, Textor: Vide fupra ubide cibo eorum egimus. Animalia cornutaility uadunt à tergo: Vide paulò poft quomodo boues inuadant. Infidiantur gregi pracipuécolo nubilo $\&$ nebulis obfcuro, ut magis lateant. Cum fraudulenter incedit lupus, lambit \& lubricas facit pedes, ne incelfus audiatur, Albertus. Cum inter folia incedit, ne percipiatur ex fonitu, lingua pedes fuos lambit, \& fic eos lubricos ac humidos facit, Author de natur, rerum. Per fapem tranfiens, occulte infidiaturus ouibus, fi forte pede ftrepitum fecerit, mox pedem quafi reum mordet, Idem. Lupi( inquit in Hipparchico Xenophon) qux cuftode carent prædantur, 8 a qua funt in occultis locis rapiunt: ac fi quis accurrat canis, fi inferior uideatur, lupus cumintai dit: ff fuperior, pecude, quamcunque tandem tulerit, interfecta recedit. Quod fi etiam prafl dium cuftodiamós contemplerint, ita fe ipfi inftruunt, ut alj̈ cuftodes depellant, alifipecudes raph

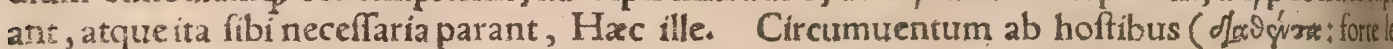

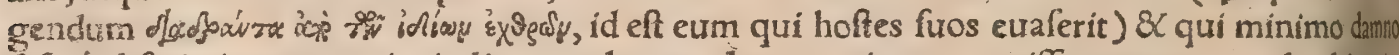
lefe à difcrimine exemerit, indicare urolentes, lupum pingunt amiffa extrema cauda: hic enim cum periclitatur capi à uenatoribus, pilos şextremamós caudam abícit, Orus interprete Mercer Lupi furtios tranfmittentes, ne ui fluctuum atque impreffione funditus euertantur, ftabilitati ac firmitudinem fibi è natura fua conftituentes, ex undarum tempeftatibus fe feruant, shtis miru qua tranfiri non poffunt, ad tran̈ciendum facilia, hac machinatione efficiunt: Caudas nh mirum inter fe mordicus tenentes, refiftunt ad perferendos fluctus, nulloós negotio turilinin tranfnant, Aelianus. Ne impetu undarum abripi poffint, mordicus alter alterius (quitit pracedentis ) caudam prehendit, \& feriatim traijcit, Philes, Tzetzes, Volaterranus, Ab hos

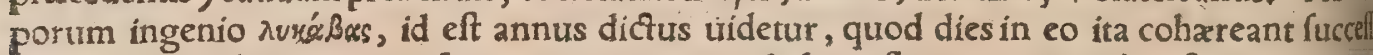
mutur, alter alterum nexu fequens continuo, ut de lupis fluuios tranantibus fertur: nempe finguli apprehenfis morfur pranantium caudis, una ferie tranfmittant : aliqui tamen annum! fum urolunt, quòd $\lambda$ uyácus hoc eft obfcurè \& latenter prætereat, (uel celeriter, Suidas, cuitustanten

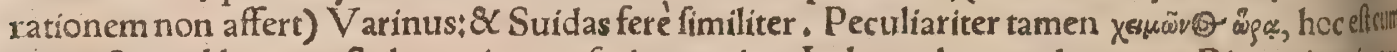
tempeftas uel hyems eft, lupos ita tranfmittere ait. In lupos hoc modo nantes Bianoris epigta ma Anthologi 133 .

Eis Batovi

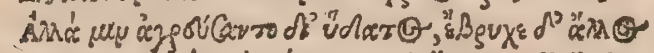

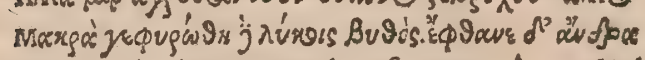

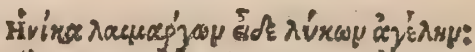

Ä

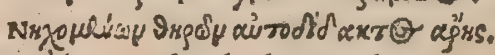

Quomodo lupiapprehenfis mutuô caudís bouem é lacu uel palude extrahant, inferius hoc inca pite dic...in,

- Lupiamantur à pfittacis.

Apud Venetos duo luci monftrantur, alter Iunoni Argitra, alter Dianx Aetoliz dicatushilit ce in lucis feras ita manfuefcere fabulantur, ut cerui lupis aggregentur, aduentantiumóg hominum eas manus demulcentes pati,Strabo libro quinto. Secundum Mrotidis paludis Conopium nun patum, lupi quos nóà domefticis canibus differre dicas, cum pifcatoribus ftudiofe uerfantur: Qu'd fi maríim $x$ præd $x$ partem fuerint affecuti, cum his uiris rem maritimam tractantibus, \& pacem

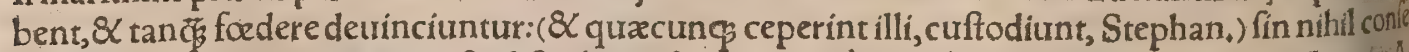
quuntur, eorum retia lacerant, $\&$ diftrahunt, \& pro eo quòd nihil dederunt, damnum retriburn, $A$ lianus \& Stephanus. Volaterranus inepre uertit in Canopo Mareotidis hoc fieri: unde Texto etiam deceptus eft. Ariftoteles lupum perpetuò ferum effe ait : Albertus (catulum adhuc) cin rari poffe, \& canis inftar ludere: non tamen deponere odium ad uenatorem $\&$ agnos, \& ail 


\section{DeLupo. D. Lib. I. 723}

animalia minora quxa à lupis urorant. Lupi catulus ab homine cictrari, dutci, demulceri $\&$ canis mo do tractari fe patitur, omnino hominum conuerfationi affuefcens : quod fi tamen folutus éf a aut prad aliquid inuenerit, ingenitum lupinum pdic $\&$ difciplinam omnem obliuifcitur. Dum cibum capit, nemini amicus eft: \& uel intuentibus interim fuccenfet, Stumpfius. Vtcunque catulus nian: frefcat, fenefcens tamen facile írritatur, ut urfus ctiam: \& minora animalia cum poteft inuadit, canes; anferes, anates, gallinas, Obfcur.

T Tam leones quàm lupi, ut fertur, fi homo pariter $\&$ aliud animal fe offerant, ut penes ipfos electio fit, femper parcunt homini, Albertus. Lupi fenefcentes facile capiuntur ; ad uillas enim accedunt, $\&$ in periculum fe præcipitant quafi faftidio quodam uitæ: diu enim uiuunt, $\&$ in fene= cta dentes amittunt, Albertus:A Atqui A riftoteles hrc leoni non lupo tribuit. Oppianus fecundum genus luporum (circos $\&$ harpages uocat) hyemead oppida accedere fcribit. Tam leo quàm lus= pus(inquit Auguftin. Niphus) in fenectute rura(uillas) petit, $\mathcal{X}$ homines inuadit, potifimum pue. ros, (tefte etiam Alberto)quód illa xtate iam imbecilles \& dentibus fractis (cxtera animalia aut ro= bufta aggredi aut uelocia perfequi non poffint.) Me quidem exiftente in Auiano, lupus quidam ualde fenex uenit in rus, \& puellam inuafit, quam celeri prafidio liberauimus: $\&$ lupum interfe=. cimus, qui ętate $\&$ dentibus mirũ in modum laborabat, Hæc Niphus. Lupi hominem illi potius pe tunt, qui inertes \& unipetz quidam funt, quàm qui uenatores, Ariftoteles $\&$ Albertus. Venato res lupos (zic xursýenx uocat A riftoteles: nifi mendum eft)in telligo, qui alacriores urelocioresćs funt, utanimalia aggredi aut perfequi $\& C$ cupiant $\&$ poffint. Vnipetas trerò qui non gregatim, fed fo- litarï incedunt, atque ideo ferè inertes $\&$ tardí funt, cum nullo amulationis ftudio excitentur.

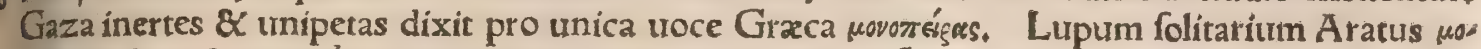

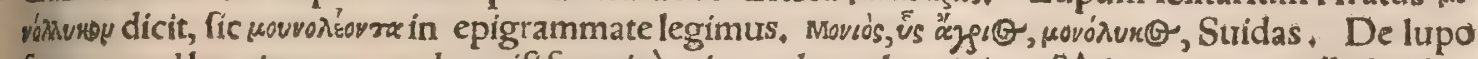
fertur quod hominem non edat, nifi fortuitò prius cadauer hominis guftârit ; tunc enim illectus hu= manx carnis dulcedine, non dubitat hominem inuadendo periclitari, Liber de naturis rerum. Lupi aliquando homines uorant, fed raró : ubi uero femel guftauerint, impetu deinceps in eos feruntur propter carnis dulcedinem, Alberturs. Hos lupos Galli appellant garoulx, ut in B.retuli. A lupis periculum eft in noftris etiam regionibus, per hyemem prafertim in multa niue iter facien tibus. Quomodo fibi quíqueà lupis cauere, $\&$ obuios arcere poffit, docebimus infra hoc ipfo in capite.

TCanes foliuagos fi deprehendant, interimunt \& defodiunt, Albert. Nonnunquam canis $\&$ lupus aliqua focietate amica confoederantur, adeò urt \& ipfi fures nocte pariter caulas ingrediantur, Liber de natur.rerum. TAlces inuadunt lupi montani circa Nortregiam, ut in earum his ftoria dictum eft. $T$ Lupus afino, tauro, \& uulpi ef hoftis:cum enim carne ipfe alatur, boures in= inadit, \& afinos, \& uulpes, Ariftoteles. Lupi circumureniunt afinos, Plutarchus : nullo negotio comprehendunt \& iaterimunt, Aelianus. Capras lupus captare folet, cui opponimus canes defenfores. In fuillo pecore tamen funt qua fe uindicent, fues, uerres, maiales, fcrofa ‘ propé enim hac apris, qui in fyluis fape dentibus canes orciderunt. Quid dicam de pecore maiore? cum fciam mulorum gregem cum pafceretur, eoćs ueniffet lupus, ultro mulos circunfluxiffe; $\&$ ungulis crdendo eum occidiffe $\div \&$ tauros folere diuerfos affiftere clunibus continuaros, $\&$ cornibus facile propulfarelupos, Varro. Lupo etiam fus obfiftere repugnaréç poteft, Arifo= teles. Surs pugnat cum lupo, (inquit Albertus, ) 8 lupus ingeniole pugnat cum fuibus, ac= cedens fubito recedenṣ́́ \& attentans morfum gutturis eius. Narrauit fanè mihi quidam lus pum fe uidente, morfu comprehendiffe lignum triginta uel quadraginta librarum in fylua: \&cum eo fe affuefeciffe tranfilire grandem eo in loco arboris abfciffa truncum: tandem cum fa. tis peritus tranfiliendi fibi uideretur, fe abfcondiffe: $\&$ adueniente propter fatam illic atienani porca fylueftricum pluribus atate differentibus porcis, anniculis, bimis + prorupiffe, apprehen. fó́s porco, qui aqualis pondere uidebatur ligno quo cum tranfilire truncum didicerat, (faltu. retro truncum fe recepiffe) \& interemptum ibi porcum deuoraffe: \& paulo poft cum receffiffent apri, ipfum etiam abiffe, Hæc Albertus. Vifum eft aliquando quód lupus frondes $\&$ ramulos falicis ore porrexit, ut capras his frondibus gaudentes inefcaret ac deciperet, Idem. Lupus fi in minorem aliquam pecudem, ut furem aut capram inciderit, auricula comprehenfa fecum ab. ducit currendo : renitenti clunes cauda ferit, ita ut mifera pecus ipfo etiam lupo interdum cele. vius currat ; donec ad alios lupos prædam expectantes pertienerit: ibi ftatim dilaniatur momen. to, ut fape nihil prater inteftina reliqui fiat: recipit autem fe quifque cum parte prada feor . fum aliquò, ubi cam foltus auidè uix ex dimidio commanfam utorat, Michaél Herus. Lupos (de lupis) aiunt cum fint nacti fues (in accufandi cafu) trahere ufque ad aquam, quod dentes fera uorem carnis ferre nequeant, Varro. TCerui amiffis cornibus latent, \& pafcuntur de no. cte, quia lupos fugiunt, Vincentius Bell. बा Quintum lupigenurs, minus cateris, pilis rigi dis, leporibus maximé infidiatur, Oppianus. - I Lupum grauiore pedis fonitu ouis ftulta uo. 60 cat, Plutarchus. De lipo fertur quod cum ourem rapueris infequente paftore, dentibus eam non ladat, ne motu fugam eius retardet, Author de natur, rertum. Raptam ourem, cum audit perfequentes, illafam portat, ne morfa \& lafa fibi faciat curfus impedimentum, Albertus, 
Oubus infidians ouffe circuit, canis fomnũ et paftoris defidiam urel abfentiam explorans, Gloffa in Lucam. Vbi caulas intrauerunt, tuel aliàs inciderunt in greges ouium, non folum interficiunt, qurod fatis eft ad uentrem, fed torum gregem, fi polfunt, palfim iugulant, Text. Albert. Omnesocci dunt antequam aliquam ad comedendum attingant, Author de natur,rerum ; nifi clamore pafio, rum, aut aliter impediantur. Sunt $8 \mathrm{C}$ naturales quadam in lupi ouisç̧ mortuorum partibus (ut pelle, lana, chordis) contrarietates feu antipathix, de quibus inferius dicam. T Contra taurum lupus ire, \& fimul eum à fronte ideo adoriri non audet, quod \& cornua extimefrat, \& eorum ro: bur mucronatum declinare ftudeat. Quamobrem primum uelut recta uia contra eum pugnas turus effet, pra fe gerit minas, \& illius oculis fefe crebro inculcat: deinde fe retorquens in dorfum infiltit, \& uerò acerrime ad eius perniciem incumbit, atque cum naturæ aftutia fuam infirmitatem

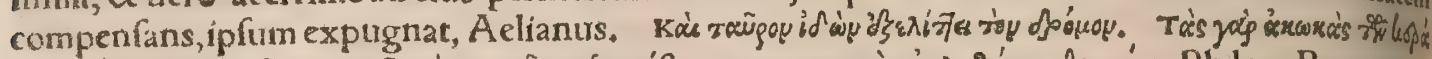

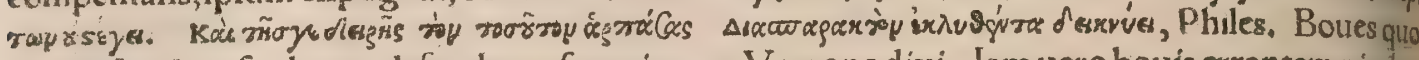
nodo fe aduerfus lupos defendant, fuperius ex Varrone dixi. Iam uero bouis errantem uitulum per infidias inuadunt, $\&$ arreptis naribus trahunt. Is contra fefe retrahit: $\&$ permulta interim pu gna editur dum illi hunc ui expugnare, hic refife ere conatur. Cum autem hunc tam pugnaciter cồn ie repugnare perfpiciunt, eum obnitentem remittunt. Is ex ui retrahendi fe, \& contra eos tergitur, fand:, retro uerfus in dorfum fuum recidit. Lupi facto imperu, eius uentrem lacerant, \& diftractum exedunt, \& conficiunt, A elianus. Etrurfus, Si boui qui in profundam inciderit paludem, lupi interuenerint, extrinfecus terrorem ei faciunt, eundemó̧ periculi denunciatione agitant, non ex tra paludem eum permittentes egredi. Quem diu multum pulfum, $\&$ in luto uolıtatum fuffocari coégerunt, maxime omnium illorum ftrennuus in aquani infliens, \& mordicus bubulam caudam tenens, extra paludem in terram ipfum trahere aggredi tur: Simul $\&$ huius alter caudam apprehendens, ipfum trahir, \& fecundum tertius, $\&$ hunc ipfum quar tus: hoc idem ufque ad poftremum qui extra aquam confiftic, faciunt. Arque ad hune modum extracto in aridum boue, lupi explentur $\&$ fatiantur, Hactenus Aelianus. A pollinis Lycï tema plum Argis à Danao conditum eft, deląo ei imperio proprer omen lupi qui taurum armenti ducem ante moenia proftratuerat. Lupi natura immanes 8 crudeles ideo exiftimandi funt, quòd inter le uorant, ad hunc modum mutuas fibi molientes infidias . cos enim ferunt primò in orbem cirum agi, deinde excurrere, cum ex uertigine currendi \& caligine corum aliquis lapfus fit, in eum bus mi fratum cateri omnes facto imperu ipfum laniant. Hoc quidem facere folent, cum uenationis la $\left._{3}\right\}$ cultate deficiuntur:Ita enim pra fame omnia nugas putant, quemadmodum fcelerati homines nitil non præ pecunia præclare contemnunt, A elianus. IIn Tartaria aquilæ quadam cicurata adét funt audaces, ut non dubitent magno impetu in lupos infilire, eosḉ in tantum diuexare, ut ablio, minibus fine labore \& periculo capi poffint, Paulus Venetus. Prouerbium, Lupus aquilam fugit, referam in $h$.

In ltalia creditur luporum uifus effe noxius:vocệ́ homini, quem priores contemplentur,ads mere ad prafens, Plinius. Italia lupos habet, qui cum cateris fimiles non fint, hono que prius widt rint, conticefcit: $\mathcal{Q}$ anticipatus obtutu nocentis, licet clamandi wotum habeat, non habet trocis mhin ferium, Solinus, A tqui cateri authores lupis fimpliciter non Italicis tantum hoc adfribunt, ut Solinus uideri poffit non reciè accipere Plinij uerba, tanquam peculiares fint per Italiam lupiloc maleficio praditi: ego potius poft uerbum creditur apud Plinium diftinxerim, hoc fenfu: Int talia quoque (quæ fuperftitiofis alioqui aut falfis perfuafionıbus minus obnoxia fit ) credi, uilum luporum effe noxium: non autem, luporum in Italia uifum effe noxium. Homo quem lupis prior uiderit, ut Plato refert, obmutefcit, \& grauem uirium iacfuram facit, Ruellius : fin lupus ab homine prius fuerit uifus, ipfe debilior redditur, ut alius quidam addit tanquam fimiliter ex $\mathrm{PO}_{0}$ liria Plaronis. Ruftici dicunt hominem uocem perdere, fi lupus cum prior uiderit; unde fubit tacenti dicitur, Lupus in fabula eft, Vincentius Bell. Vide infra in h. inter prouerbia. Lupush primo hominem uiderit, uocem ei cripit, \& eum tanquam trictor uocis ablata defpicit : fi autem fe praxuifum fenferit, ferociam deponit, \& currere nequit, A mbrofius. Lupus fi te prior iridensth bi uocem abftulerit, folue amicfum tuum, ut fermonem refoluas, Phyfiologus: fi homo foluerit a micium, audaciam recuperat, ut fertur, Albertus. Lupus cuius prior ueftigia profpexeris, tibl nocerenon porerit: fed fi ille te ante notauerit, caudæ fummam partem fi habueris tecum, fine metu iter conficies, Sextus. TOculum lupi erutum cum uident quadrupedes domeftica, the ment $\&$ fugiunt. Et fi quod animal (mulier, Rafis) minxerit fupra urinam lupi calidam, non concipietunquam, Pythagoras. बCauda lupi furpenfa ad prafepe boum, prohibet boures co medere, Albertus $\&$ Rafis. GR umpi traditur equos qui ueftigia luporum fub equite fequantur, Plinius, Si cafu equus lupi ueftigitum conculcet, torpore comprehenditur: fi item lupi calcaneunts equi quadrigam trahentes conculcent, fiftentur tanquam ì cum quadriga conglaciaffent, Gillius

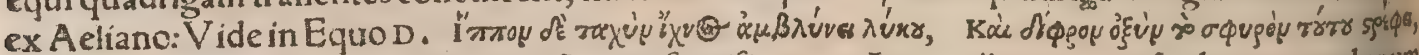
Philes + Mulierem quæ abortum fecerit fignificantes Aegyptï, equam foribunt quæ lupum prefferit: equa enim abortit, non modo fi lupum calcauerit, fed etiam fi ipfius ueftigia att. gerit, Orus. Si calcauerit zofach, id eft equus, ueftigium dorim, id eft urfi (lege deeb, is 
inflixerit, ibi fuccrefcere folêt pullularéğ uermes, Orus, Lupus ignem metuit fimiliter ut leo:quan obrem qui per hyemem 8 inter niues iter facientes à liupis fibi metuunt, duos filices intra ueftes (uf calidi permaneant) fecum geftant: \& ficubilupus fe obtulexit, collifis illis ignem excutiunt: Lupus uerò frintillis emic antibus ita terretur, ut accedere utcun aufit, Michael Herus. Audio etiam fonitu è ferrogladĭ percuffi, lupos furgari. Si quem lupus infi, diofus paulatim fequitur, fubfiftens fignum aliquod medium ponat inter fe et lupum uidente illo:lic enim illagueationis metu fubfifter, Albertus \& Phyfologus, Sunt qui mihi affirmarint, lupum in uia ad hominem non acceflurum, fi uirgam, aut quiduis aliud poft fe traxerit: nam uiatorem quen, dam apparente lupo, cum nihil aliud a manum effet, peram fafcins cruralibus alligatam poft fe tha xiffe, \& abïffe illifum. Si quis corpus fuum illinat feuro de renibus leonis, uel eiufdem fimo, abfters rebit lupos, Aefculap. Lupus cuitus prior ueftigia profpexeris, tibi nocere non poterit: fed fille te ante notauerit, caudx fummam partem fi habueris tecum, fine metu iter conficies, Sextus.

E.

Draconis legem fuiffe reperio, ut qui lupun occiderit, talentum accipiat: qui lupum uetulum, duo. Lycoctonos Apollo appellatus, hoc eft lupicida (inquit Gyraldus) ex lege A thenis Iata, qua catrebatur, ut qui in Atrica lupi catulum occideret, talento donaretur: quilupum ipfum, duobus: quod Ariftophanis interpres fribit, ( \& exeo Varinus in surw. ) Meminit Sophocles in Electra\&

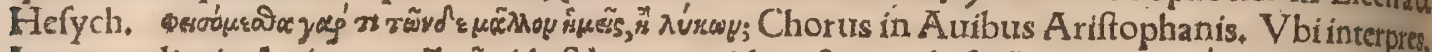

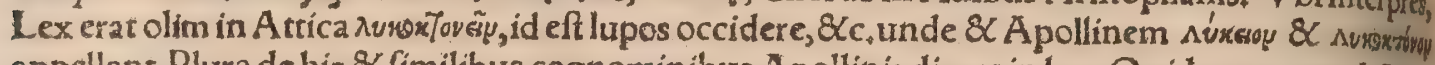
appellant. Plura de his $\&$ fimilibus cognominibus Apollinis dicam in $h$, Qui lupum apud Athes

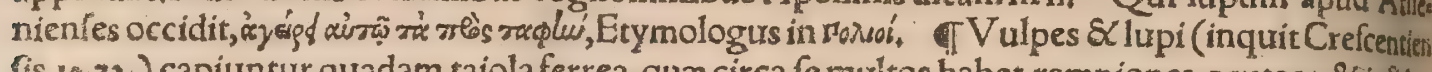
(is 10.32.) capiuntur quadam taiola ferrea, qua circa fe multos habet rampiones acutos: $\&$ ipf ha bent circa fe annulum prope fe ubi annexi uoluuntur, ad quem annectitur fruftum carnis, omniag occultata pręter carnem, in terra firmata iacent, Cum autem lupus carnem dentibus captam eleuar, annulus eleuat rampiones circa capur $\&$ collum lupi, qui cum fortius trahit $\&$ recedere nititur, fori tius ftringitur $\&$ tenetur. Fiunt $\&$ alix taiolx, quibus in pedibus fiue cruribus, qualibet omninobes fir capi poffunt, qux occultantur in itineribus quibus utuntur, quarum figura aut forma nonifi oculata fide intelligi potef: quamobrem lectorem ad harum rerum artifices remittimus, HacCre fcentienfis; Scoppa caffidem genus retis interpretatur, Italice tagliolam. Harpago, lo rampino, lind

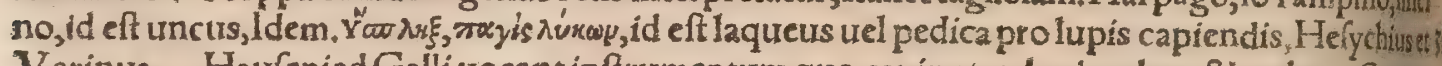
Varinus. Haurepied Galli uocant inftrumentum quo capiuntur luppi, uulpes 8 meles. Capitar inrerdum lupus laqueo facto arte paftoris, cui ut primum caput impofuerit uel pedem, detine tur, Blondus. Fera, \& pracipuélupi, foueis hoc modo capiuntur. Effoditur lata fouea inftar ampl" putei, \& profunda ne pateat exitus:operitur autem crate (cratis, eint but\$) rotunda, quxe non totam foucam fed feré totam operiat. Sub crate in medio alligatur ftanga (pertica) longior crate \& rotun da. In medio ponitur uinctus anfer uel agnus: \& paleis operítur uniuerfus locus. Tum lupusanfi rem aut agnum arrepturus, in foueam cadit cum crate fubito reuoluta, Pet, Crefcen, 10. 33 . Et mox in codem capite aliud fouex genus defcribit, pro lupis, rulpibus, leporibus \&c. Crates qua tegiturfo uea non debet effe tam ualida, ut hominem uellupum fuftinere poffit: fed anferem tanturn uelagnif alligatum, fite uiuum, fiue mortuum, cum gramine quo infternitur. Siclupus ad pradam ueniens, una cum crate in fouream eadit. Sunt qui ea arte eratem componant', ux lupo delapfo ipfa rur fus und cum efca erigatur, ut plures etiam lupi aut alia fera quando q\$ capiantur. Oporter aurem foteas biu iufmodifieri in terra folida firmaćsł aut fi talis non fit, fourez latera ligneis tabulis muniantur, nef́s ra pedibus fodiendo exitum fibi faciant, Innominatus. TConftat luparios ( id eft trenatores lupo rum) carnibus tinctis ueneno lupos necare, Seruius in Georg. Sed de ueneno lupario, aconitoin quam $\&$ fimilibus, dicam in aditem de uenenatis medicamentis compofitis. Rhati in montibus lue pos capiunt machina cuiufdam dolo, trabibus aut ftipitibus arborum quodam modo inter fe confer tis annexa ́q́ funi efca, quam cum attingit lupus obruitur, fimiliter ut mures in domibus maiores opa primi folent. Lupus transglutit carnes feré fine commanfu:quamobrem complures bamos inbo: lis carnium concifis abfcondunt:hos lupis exponunt, quibus illi deuoratis moriuntur, Albertus, बidimus quofdam rufticos (inquit Blondus) per urbem (Romam) deferentes pelles luporum, quos aiebant fe occidiffe puluere quodam folo ex herba quam cardu uarium appellabant: \& eodent mures necari affirmabãc, Eft autẽ idem hic carduus quo canes necari diximus. Vide in Cane cap̣tte tertio. Apocynon lupos, uulpes, \& pantheras interimit, Diofcorides:quadrupedes omnes, Plinits? de hoc quogs multis egi in Cane C. Sicyone A pollinis Lycxi templum eft, inquit Paufaniasin Co rinthiacis:nam cum lupi in greges ouium ita fubinde grafiarentur, urt nullum ciues ex eis fructum capere poffent: deus, quocungs tandem modo elocutus, oraculo monuit, ut ubi aridum lignum iaces ret, corticem eius detractum unà cum carnibus feris proponerent: quo cortice lupi guftato,ftatimpe rierunt. Ac id quidem lignum in Lycxi templo fitum fuit, fed quod arboris genus effet, id neq Sicyo niorum facerdores, quorum talia explicare munus ef, nouerunt, Hæc ille. Perpaucæ çuidem arbo res uenenofa reperiuntur:herba uerò complures: \& fanè in pręfentia prater taxum inter arbotes (quanquam fraxini etiam ramenta $\mathcal{X}$ iuniperi in potu quidam ueneni uim habere fcribunt:)ac inter 


\section{DeLupo. E.F. Lib.I.}

arbufta euonymum et rhododaphnen, nulla noftri orbis uenenofa mibí in mentem uenit. Huilus rể caufam, fi quis inquirat, in fuccum quo plan ta aluntur reiecerim; nam ille fi bonus ac bene temperan us fit; altas magnasç ftirpes alere poteft; fin praua qualitate aut uenenofa imbutus, non poteft; ar bores prafertim qux \& copiofo \& folido alimento egent; fed hoc mopspjyws. Blemmi(inquit Diopha ries in Geoponicis 18:14, ) funt marini quidam pífciculi, quos nonnulli lycos, id eft lupos appellant. His lupos terreftres hunc in modum uenantur. V bi uiuos huiufmodi pifces plurimos expificatus fue risieos in pila mortariótre probe contundito. Poftea uero, in monte, in quo diuerfantur lupi, ma. gham prunam extruens, flante frilicet uento, portionem aliquam de dictis pifciculis ígni injucito cruorem praterea atç ouillas carnes minutim fciffas, cum pífcibus comminutís confundens, relin-

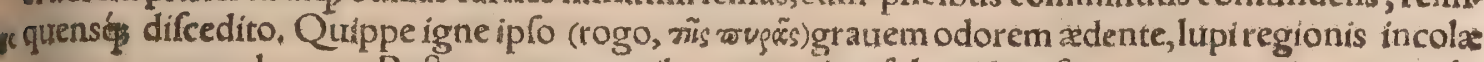
omnes congregabuntur. Poftea autem carnibus, aut etiam folo nidore fruentes, uertigine capti oba dormient:quo tempore tu ceu ftupidos ac torpentes eos reperiens, iugulato. Pifces quidam nigri uenenati in Armenia reperiuntur: horum farinam in ouium aut caprarum difciffum latus abdunt, eamó efcam ad feras alliciendas obịciunt: ac cum eiufmodi quippiam pardalis, leo, lupus guftarint, continuo moriuntur, Aelianus. Quomodo lupi $\&$ uulpes alliciantur à uenatore catum mortuum poft fe trahente (noltri uocant ein betrse) dixi in Cato E. Sed $\&$ alium hic modum adfribam ex li, broquodam Germanico manufcripto; Felem detracta pelle exenteratam in furno torrebis, 8 modi

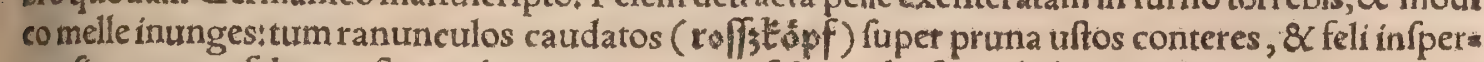
gestfic paratam felem poft te trahes inter contiguta fyluís arbufta, uel ubicunç lupos aut uulpes uet , farifciueris, Sic allectas $\&$ apparentes iam propius feras, alter uenationis comes, fagitta aut bom. barda feriet.

T Teucri \& Myfi Thraces qui Âfiam incolunt, ueruta ad lupos conficiendos apta geftabant, Hé rodotus. Lupi uxulnerati,gregi luporum fe non immifcent; quia occiderentur ab eis timentibus de prehendi fanguine ipforum: quamobrem foli euntes uulnerati, fanguinera fuum lambunt, ne depre bendantur:quod ipfe expertus fum, Albertus. Canibus capiuntur apri ac lupi, fed a uxilio uenato: rum:nam rarò foli ad eos præfumunt accedere, nififint maftini fortiflimi $\&$ audaces, Petrus Crefcen tienfis. A canibus uerò comprehenduntur, quia lupus ucrfutior $\$$ fagacior cane eft, Blondus. Canes quidam grandiores Gallis ceruarí dicuntur, quod ceruos tantum uenentur : hos etiam fub nomine leporariorum comprehendunt, ut $\&$ fuarios luparios 6 , qui etiam apripetæ \& lupipera dici - poffent, Budarus. In Anglia pręfantiflimos canes luparios haberi audio. Lupus non admodum procul à canibus fugit, nifi Molofli $\&$ maftini urgeant. IMllus, collare canum uenaticorum, fä cum ex corio, confixumę̧ clauis ferreis eminentibus adurerfum impetum luporum, Feftus. Lư. pi, in quit Blondus, funeis retibus funt decipiendi:quoniam omnis alia uenatio, præter eam qux re. tibus fit, uana eft in lupo. Parentur itaque retia ualida ac difenfa, ut uidebitur: nam quo tenfa mas gis fuerint, eo utiliora erunt : debent autem extenfa alligari arboribus, uel alijs retinaculis arre facis, dummodo forti nexu contineantur. Plerifque ctiam partibus diligenter prategentur ramofis frondibus, ne lupiadeuntes ftatim intelligant infidias. Præterea utrinqure iuxia retia fient quxdant attegix ex ramis fyluarum, fimiles tectis autlatibulis ferarum, in quibus latitent infidiatores cum a: cutis haftilibus, ut lupos retibus intricatos fratim conficiant: quod nifillico fecerint, ut incidête o jrimum, liberabunt fe à retibus lupi ac diffugient. Quamobrem illi curabunt ut $\&$ celeriter $\&$ forti. ter uentrem \& tergora luporum uerutis \& iaculis perfodiant. Porro maxima pars uenantium, cumt canibus circundabit loca in quibus lupi latitant: $\&$ operam dabit ut canes fíc latrando tantum lo ris detenti, fiue ind uftria agitatione, lupos ita cohibeant ne retrorfum euadant. Hoc ctiam obferuan dum, ut cum longé diftant à retibus lurpi, lentius agitentur: propinquiores urerò magno cum impetút $\&$ clamore uenantium \& canum, qui omnes tum dimittendi funt, impellantur: fic enim plerique lupi dicipiuntur, $\mathrm{H}_{x c}$ Blondus . Lupi \& uulpes retia đentibus difcerpunt, urfi nó item, Plutarchus in caufis natural. 28.

TPellibus lupinis potentes $\&$ nobiles induntur: parantur autem fic ut pars hirfuta foras fpet ctetnuda introrfum, nec ullo quidem panno illa induci folet. Corio lupino, inquit Blondus, ueft o untur nonnulli ad itinera $\&$ uenationes: hac enim fe intectos non imbribus, non gelu aut uentis les

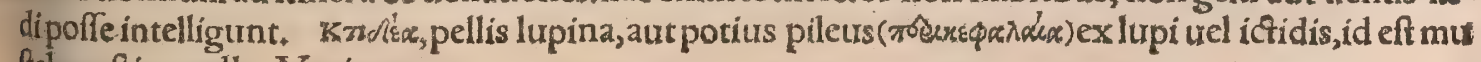
ftela ruftica pelle, V arinus.

\A defertis locis ad habitata refugientes lupi, tempeftatis acerbitatem fe horrere oftendunt, $A$ c* lianus, Xøuctver, id eft tempeftatem fignificar lupus, cum folitarius uadit $\&$. diutius ululat: aut cum parum curans aratores $\&$ frigore coactus ad rura accedit ut propius homines calidiore loco uerfe.

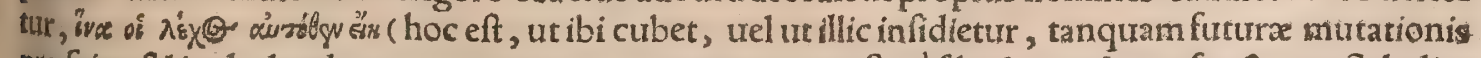
præcius, $\&$ includendorum propter eum pecorum, tempeftitué fibi de prada prófecturus, Scholia. fes, ) hoc cum fit, tertio poft die tempeftatem expecta, Aratus,

$\mathbf{F}$.

Lupi caro, ut fylueftrium omnium ferarum qua rapaces $\&$ carniuora funt, apud honeftos ho: mines in cibum non admittitur. Audio tamen in Italia ab Infubribus lupos quandoģ edi. Caro lupi eft frigida, foetida, ficca, craffa, Rafis \& Albertus: frigidior carne canis, Albertus. Caroluporum 
(uel, ut Bellunenfis transfert, quorumuis animalium rapacium)mala eft, Auicenna. Et rurfur, Car nes luporum $\&$ habentium roftra $\&$ ungues(Bellunenfis legit, Carnes animalium rapacium, \& $2 u$; um rapacium habentium roftra $\&$ ungues rapaces; aduncas) conferunt oculis $\&$ confirmant $\cos$, Laudant aliqui carnes luporum(animalium rapacium, Bellunenfis) tanquam utiles ftomacho frigi do, humido, $\&$ debili, A uicenna. Er mox, Carnem luporum $\&$ habentium (Bellunen, legit, animaliti rapacium, \& auium habentium, \& $c_{\text {. }}$ ) roftra $\&$ ungues(aduncos)abhorret ftomachus. Et paulo poft cafdem carnes laudat ad hamorrhoides, Rapacium omnium carnes declinant ad ficcitatem, qutre bilim atram in corporibus generat: peffim $x$ autem funt lupina $\&$ canin $x$, corrumpuntí humore? 8 animum, Rafis:fortaffis autê animũ (nifi deprauata fit translatio)ab eis corrumpi fcribit, quia met lancholiam \& prauas imaginationes generant, ut de bouina etiam \& fimilibus Arabes fcribunt, $C_{2}$ ro lupi trita, cum modico piperis $\&$ curm melle defpumato confecta, affectui colico medetur, $R$ afis et Albertus. Alia quędam de remedijs lupina carnis, uide in G. đDe Romulo \& Remo,item Lycafó \&. Parrhafio, quios lacte lupino nutritos ferunt, dicam in $\mathrm{H}, \mathrm{d}$.

G.

Ad podagras magnificant uulpem decoctam uiuam, donec offa tantum reftent:lupứmue uiutun oleo cerati modo incocum, Plinius. TDe lupi prada, id eft de reliquinjs ueruecis, aut capra, aur cuiuslibet animantis, quam comederit, carnem uel pellem, uel os, collige \& ferua : \& quando aliquii iccur doluerí, inde cum tange, continuò fanabitur, Marcellus. đPellis lupi(lupiculi, aliâs luputicu li) fi geftetur ab co quem canis rabidus momordit, non incidet in metum aquae, Hali. Si coriolupl conftringatur uenter laborantis colica: $\&$ fi xger fxpius ipfi corio infideat, prodeft, $R$ afis $\&$ Alberi, Si corium (ftercus, $R$ afis)lupiad coxam colici fufpendatur, alligatum filo lanæ quam lupus momor: dit,opitulatur, Albertus:ego de excremento potius acceperim: Vide infra. Lupi aut uulpis corium fi quis elaboret, \& calceos geftet, pedes non dolebit, Galenus Euporift-3.248. T Sanguis lupipers mixtus cum oleo(nucum, Rafis) medetur furditati, Albertus. Sanguris $\&$ fimus lupi, iuuant incolia co affectu, Obfcurus, बI Lupi carnem conditam \& decoctam quir ederit,à dæmonibus uel umbis qua per phantafmata apparent, non tantum inquietabitur, Sextus, Lupl caro cocia in cibolum, pta, phantaficos fanat, A efculapius. Carnes lupi ediffe parituris prodeft:aut fi incipientibus partu rire fit iux ta qui ederit, adeó, ut etiam cótra illatas noxias ualeat, Eundem fuperueníre, perniciofrin eft, Plinius. Plura de remedïs ex carne lupi in cibis fumpta, uide in pracedenti capite. ॠAdeps lupi non minorem efficaciam habet quàm caninus, Sext. \& A Afcul. A deps è lupis illitus, in hisqua $)^{4}$ rumpere opus eft, plurimum profícit, Plinius. Lupinum adipem recentiores quidam cum cateris medicamentis articularịs ad unguenta mifcent. Illitus uuluas mollit, Plinius, Eodem fricariocu" los contra lippitudines pracipiunt, Idem. Adeps adib (id eft lupi, fed Bellunenfis legit aldub, idet? urfi) fubtilis eft, Auicenna. T Caput lupi fupponito fub puluino, 8 dormiet ager, Sextus, Ad dentes mobiles magnum remedium eft in luporum capitis cinere, Plinius. Febres quacerto dierü numero redeunt, oculus lupi dexter falfurs adalligatus óp, fi credimus magis, arcet, Plinius. Ocuius dexter lupi alligatus, febres difcutit,Sextus C Confricatus(infricatus)\& illitus lupi oculus, glaucos mata extenuat, \& tollit ftigma, $\&$ linitur fi ante puncfum(forte, pund $\checkmark$ teris autem dextrolupioculo, fi hominis dexter laborat:finiftro, fi finifter, Sextus. đI Lupi des" cer caninus dens, in magnis habetur operibus, Plinius. Hominem qui Lunam fenferit (Lunaticum) is canini dentes adib, id eft lupi, curant, $\mathrm{P}$ ythagoras. Dens lupi gingiuas infantum extenuat, quio den tes leuius proueniant, Blondus, Et alibi, Infantum gingiux canis dente conteruntur, (leniter perfib cantur:)fed citius eis euocantur dentes (infricto) dente lupino. TQui per lupi guttur (arteriam uocalem) biberit in (ynanche, certiffima falute euadit, Ioan, A gricola: qui fe hoc experimentumabes gregio Auguftano medico Ädolpho Occone accepiffe feribit. êulmo lupi coctus \& ficcatus, \& tritus cum pipere, ex lacte bubulo potus, utilis eft anhelofis, $R$ afis $\&$ Albertus citantes Galentum; apud quem ego nihil huiufmodi legere memini:pulmoniautem uulpis tum ipfe tum alin hanc facule tatem adfcribunt, \$Lupi cor fi aridum reponatur, perquam odoratum fieri dicitur, Albertus \& Scriptor de nat.rerum. Si crematum tritumó̧ bibatur, epilepticum iutuat:dummodo à libidine pus rum deinceps fe conferuet, Scriptor de nat, rerum. In libro quodam manufcripto Germanice, medié camentum aduerfus comitialem huiufmodi reperio: Vif ci quercini unciam unam, uifci de piro unc, femis:mucronum de cornu cerui fcobis drachmas duas, cordis lupini drachmam, permifce, ut fiat medicamentum aridum, quo in diluculo femper utatur: praftantius erit fi addas f́cobem de occipi vio craneihumani. THepar lupi ad remediorum ufum non aliter quàm pulmo uulpis praparari $8 \mathrm{C}$ reponi deber, co modo quem in Vulpe explicabo. Hepar lupi in medicamẽtum ex eupatorio he paticum fape indidi, nec tamen effectum praftantiorem, qui mentione quidem dignus fit, quàmin eodem medicamento finelupi hepate parato, deprehendi, Galenus libro $\mathrm{II}_{+}$de fimpl. Idem tamenlio bro 8. de compof. pharm. fec.locos, hepar lupi hepaticos tota fubftantia iuuare (non fecundum unam aut alteram qualitatem)abunde fe expertum fcribit. Et fieri fane poteft, ut cum diuerfis temporibus haè à Galeno feripta fint, aliquid ei uno tempore innotuerit quod non alio, ut annotauit Aloifits Mundella epiftola 7. Dicat etiam aliquis hepaticum ex eupatorio medicamentum per fe tam inflis gniter opitulari, ut etiam egregio alsero medicamento adiecto, nihil aut parum eius uir bus acceffiffe 
uideatur:nec obftat tamen id per fe efficaciter agere. His \& límilibus rationibut excufarí concilia. rí̧ poffunt loci quos citauimus Galeni:ego interim remedips tum alips tam longé petitis parum fido, rumad iecoris caufas lupino iecinore nunquam equidem uti uelim, nifi forte cateris plurimis, in quif bus et rationis \& experientię plus eft, fruftra tentatis. Antidotus hepatica e nourem fpeciebus apud Nicolaum Myrepfum, numero 16,4 recipit iecur lupi: 8 mox alia 166, ex eupatorio infcribitur, curi ta men iecur lupi non addicur. Archigenes apud Galenum libro fexto de compof, fec. loc, hepar lu: piad oris cruffas rommendat:ubi Galenus hoc medicamëtum probare fe poffe negat, quoniam com pertum non habeat. Lupinum iecur (inquit Galenus de comp. fec. loc. 8.8.) abữde experti furmus ad hepatis affectus utile; ufus autem ipfius eft (ut cochlearum etiam quas A folepiades ad eordem af io fectus laudat) fieius exacté triti drachma una detur cum uino aliquo dulci, ut Theræo, Cretico. Ben gna enim liac funt uifceri, ipfum nutrire potentia, \& media iuxta calidi \& frigidioppofitionem : $\&$ ob id ralia pharmaca omnibus intemperaturis conuenire uídentur, ut qua ex fubftantix proprieta te commoditatem de fe exhibent. Cærerum non obfcure febricitantibus, praftat ex aqua calida, aut feridis fimiliue fucco pharmacum prabere. Hac Galenus, \& ex eo Rafis, Albertus, \& alif. Eadem ex Galeno defcripfit Actius 10.3. Iecur lupi (inquit Marcellus empiricus capite 22. quod infcribitur ad iecoris uitia)fublatum Luna decref́cente in fumo ponitur, $\&$ cum ficcatum eft teritur:inde par ticula trita mífetur pulueri equis porrionibus facto de foenograco, lupino $\&$ abfinthio $\&$ cofto, ita utex eo quod in fe rotum permixturm fuerit, menfura coclearis cumulati detur ad diem non febrici. tanti ex uino mixto, fi febricitabit ex aqua, ita ut per triduum hoc medicamen ieiunus accipiat, $\&$ - porrecto brachio in dextro latere uel femilora iaceat:inde diutiffimé deambulet $\&$ tardiffimécibum imat: $\&$ obferuct ut illo triduo puriffimus $\&$ digeftiffimus fit, 8 frigidam non bibat, neg falfum ali quid aut dulce manducet. Et paulò poft, Potio faluberrima ad hepaticos, à Procliano medico often. fa:Ficatum (fic Itali hodic uulgó iecur nominant) lupi integrum folís lauri inuolues, \& ita ad Solem uel ad ignem ficcabis, \& ficcatum diligenter fublatis folihs in puluerem rediges:quem puluerem in ua fulo nitido feruabis, atos ex co coclearia duo, cum piperis granis decem tricis, adiecto melle optimo defpumato quantum fufficiat, cum carceni cyatho, in porsone ieiuno dabis, quam prius ferrocan denti calefacies, $\&$ diligenter in mortario permifcebis, fedentich in leço dabis, ita ut accepta potione contractis genibus hora integra in dextro latere iaceat, $\$ 2$ poftea uel una hora deambulet, Hac Mar. cellus. Auicenna libro 5. fumma 2.tractatu Y. defcribit medicamentum ad hepatis duritiem, quod ré - cipitopium, byof fyamum, caftoreum, myrrham, crocum, ípicam, cordumeni, eupatorium, hepar luw pi, 8 cornu dextrum de cornibus capra aduftum, omnium partes æequales, excipiuntur melle, \& $e_{\text {. }}$ Alia prorfus eft compofitio paftilli de eupatorio a pud Actuarium de compofitione medicamentort. lécur lupi mifcetur fpeciebus electuarị quod dicitur oxifemea, \& prodett ad morbos heparis, Rafis Galenum citans:quamobrem pro oxifemea, lego de eupatorio. Gugir (Gyrgyr, Albertus) philo. fophus afferit omnium animalium hepata ad hepatis dolorem prodeffe, Rafis. Iocineris dolores re ficit lupi iecur aridum ex mulfo, Plinius. Lupi iceur denarñ pondere ex urini dulcis fextario exhibi tum, ad iocineris uitia bene facit, Galenus Euporift,2.58. Tuffim iecur lupi ex uino tepido fanat, Plinius. Si quem tuffis intolerabilis uexat, de lupi iecore arido uel exufto, quantum uoluerit conte rat,adijciatç uinum, $m e l, \&$ aquam tepidam, atq̧ inde ad diem cyathum iciunus bibat, intra paucos o dies mire fanabitur, Marcellus. Ad acutum morbum lateris, iecoris quxratur fibra lupini : adde co fum, folium, piper, propina ex uino diluto, Serenus. Pthíficis medetur iecur lupi ex uino, Plinius. Dolorem \& inflationem ftomachi fanatiecur lupi, pritus aqua coctum, mox arefactum $\&$ tritum, po. tionić infperfum, Marcellus. Lupi hepar bydropem curat, Platina. Puluerem ex eo in bydrope cur uino albo in dies aliquor mane potum, inter fecreta quadam remedia reponunt nonnulli, Syluius. Vuluarum dolores iecur lupi (in cibo uel potu) mitigar, Plinius. If Fel lupinum candem efficaciam habe t, quam caninum, Sexus $\&$ Aefculap. Fel lupi (pondere dauic, $R a f_{0}$ ) cum grano mofchi mix tum, \& femel in principio menfis, femel in medio, naribus adhibitum caduci,iultat, (confert ei loco electuarï quod dicitur effe hylece, ) Albert. Fellupi cum elaterio umbilico illigarum, aluum foluit Plinius. Fel caprinum per fe condylomatis fedis medetur, lupinum ex unino, Plinius fi bene memijo ni. Si edatur pars de uirga lupi in furno affa $\&$ incifa, ftatim excitat appetiturm coitus, $R$ afis $\&$ Albert. De lupi genitali uide nonnihil etiã in uulpe. बI Si quis tefticulü dextrum lupi ( 8 cruen= tum, Raf, cum olcomíceat, \& mulieri cum lana ad imponendum uuluæ dederit, remouebit abea coeundi defyderium, etiamli fcortum fuerit, $R$ afis \&Albertus. बLupi excrementis circumlini(ocut lorum) fuffufiones prodeft:cinere eorum cum Atrico melle inungi obfcuritates, Solinus. Lupi fi mus diu perfrictus ad fummam lęuitatem, cum melle mixtus etiam inunctione adhibitus oculorum hypochyfin difcutit, \& ad fummam claritudinem eos perducit fuffufione ficcata, Marcellus . Den: tes mobiles confirmat luporum capitis cinistcertum q̧ eft in excrementis eorum plerunģ inuenír offa: hæc adalligata eundem effectum habent, Plinius. Lupinum fercus (inquit Galenus de fim: plicibus 10.18 .) quidam colicis potandum dabat non tantum in iplis paroxyfmis, fed etiam in inter bo uallis, fiquidem phlegmone uacarent. Quorum ego quofdam uidi non amplius inuadi : \& qui erane inuafi, non amplius id grauiter paffos, fed nec poft parcum temporis. A ccipiebat aũt ille albidius po tius ftercus, quale ubiofla ederint, folent excernere. Verumillud eciam in eo mirabar, quod uel ap: 
penfum euidenter aliquoties iuuriffet. Itag hic ftercus capiebat qued non decidiffet in terram: quod non erat initentu difficile. Ea enim eft luporum natura, qua canum, ut fufpenfo altero pofte riórum crurum \& meiant \& cacent in eminêti quopiam ex terra. Itaq̧ in fpinis fape æeftate fercus

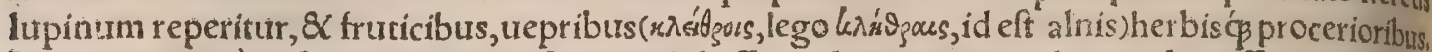
Inuenitur porrò in ftercore illorum \& nonnihil offium deutorati animalis:quod ut effugit comman: fionem, ita \& concoctionẽ: quod $\&$ ipfum cötundens ac conterens, bibendã prabuit colicis:acli ho mo effet puritatis amans, mifcebat $\&$ falis quippiã aut piperis, aut quippiã eiufmodi: ut plurimû̃ aut ex uino albocốfiftentiæ tenuis bibendũ prabebat:interim uerò etiá ex aqua. Hoc aû́t ftercoris quo patientis inguinibus, lagónas Græci uocant, applicandum effet, præcepit fúfpendi ex uinculo cont cro ex lana, fed non qualibet : tuerum multò praftabat eam effe ouis à lupo laniatæ. Quod fiea no adeffer, lorum tum quod cingeret inguina, tum alterum quo ftercus contineretur, parari pracipiet bat. At nos in ollulam fercoris maximé faba magnitudinem (uel in ollulam cuius magnitudoerat qux maximæ fabæ, aliquantulum ftercoris)iniecimus, eamćs experiundi gratia quibufdam appendi mus, nec potuimus non miräri, cum plurímos ipforum uideremus adiutos: caterum ad ollu!ă duas ceu aures affiximus, per quas lorum tranfmitti poffet, Sed hoc quidem obiter dictum efto, fi quisint uenietur quific fufpenfis fidem habere dignabitur. Dico autem fic, ut fubftantia fit quę fufpenditur, non tioces barbara, ut quidam facere praftigia torum affolent: quando $\&$ alias exper tus fum fill, ftantias, quxe in alins affectibus fimiliter operarentur, Hucufq̧ Galenus, Meminit ex Galeno etiam Conflantinus in libro de incantatione \& fufpenfione, fed locus eft deprauatus: item Aëtius 9, 31, in. rer pharmaca ad colicos: \& Auicenna decimafexta tertí,tract.4,ca,14. Stercus lupi cũ uinoalbo\&

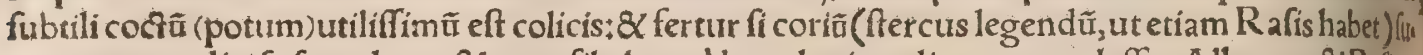
per coxam colicifufpendatur $\&$ cum filo lanz à lupo laniatæ, ligetur, prodeffe, Albertus \&Rafis, Lupiftercus, dummodo non in terra inuentum, fed fupra fuftem, aut fupra aftulas, aut fupra iunố, colliges \& feruabis: \& cum opus fuerit laboranti colico alligabis ad brachium, uel ad collum in ofle, aut in cupro, aut in auro clufum, lició́s fufpenfum: fed prius ex ipfo ftercore pufillum ignoranties aqua calida bibendum dabis, mirè celeriterọ̧́ fubuenies, Marcellus. Et rurfus, Ad coli dolorem ter quires fimum lupi, \& offa quæ ibidem inueneris contundes, 8 puluerem ex his facies, 8 in aquafil gida ieiuno bibendum dabis. Qua in excrementis lupi inueniuntur offa, fi terram non attigetint, colo medentur, adallígata brachio, Plinius. Talus leporis in fimo lupi repertus quantum profit ad coli dolorem alligatus, in lepore dixi ex Marcello:fed mera funt nuga: Fimus albi(albus)lupicolică ; curat, Hali. Inteftinum magnum lupi uincit cruciatus colicos, ut \& fimus eiufdem, Blond,

61 Lupi dentes inæquales funt, quamobrem morfus eorum uehementer obeft, Ifidorus, Lupus rabidus fuo morfu idem periculum adfert quod canis rabidus, Albertus \& Bertrutius. Eiufdem fententia fuir Aggregator, qui uno titulo remedia tum ad canis tum adlupi morfus complecitur, Nos ea copiofé recenfuimus in Cane. Vulnera ex morfu lupi $\&$ unguibus, periculofa funt: effint ab eís fanies per ligamenta etiam \& fpongias: curantur autem non aliter quàm canini morfus, lby $_{\mathrm{s}}$ fiologus: fed Ariftoteles hac de leone fribit, non de lupo. Trito allio defricio curatur in bourat biofæcanis uel lupi morfus: qui tamen $\&$ ipfe impofito uulneri uretere falfamento, \&québene fanatur, Columella, Gentianæ drachmæ dux é uino potæ remedio funt contra morfus canis rabiofi \&oms nium luportım (rapacium, uel morfu \& unguibus laniantium beftiarum, A uicenna.

H.

a. Lupurs, quiod nomen uenit ex Græco lycos, apud maiores communis erat generis, Feft, Lut pos quidam uocatos dicunt quafi leopos: eò quod quafileoni in pedibus fit illis uírtus:unde \& quic

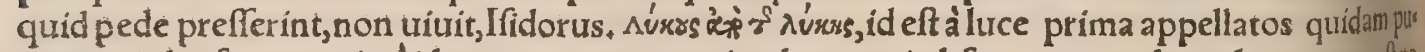
tant:quia hæ feræ maximé id tempus aptum rapiendo pecori obferuant, quod antelucanum poftno

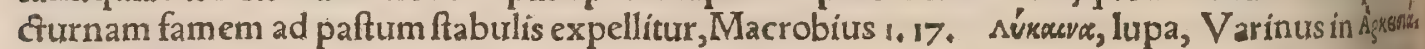
oxs. Irpini appellati nominc lupi, quem irpum dicunt Samnites:eum enim ducem fecuti agros ou

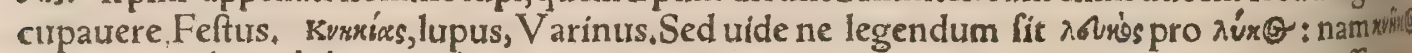

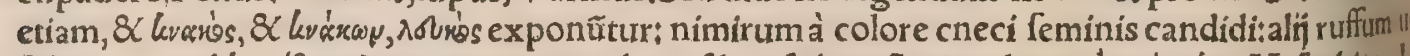

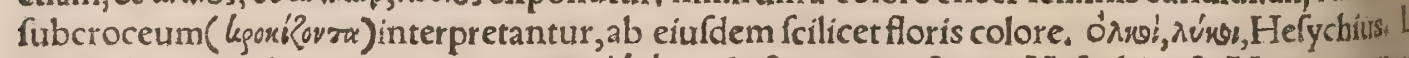
pi apud ueteres dicuntur etiam vuxropivoi kúus, tu eft canes nocturni, Hefychius $\&$ Varinus, aper fylueftris, lupus folitarius, Suid. Cyrillus apud Oree prophetam interpretatur afinum,

- Epirheta. His ubicungs authoris nomen non addetur, inter Textoris Epitheta reperinifictn dumeft. Acres, Horatius Epod. Agreftis, Appuli, Horatio, Afper, Ouid, I,Metam. Arro\%. Audaces, Gratius. Auidus, Ouidius I.Trift. Auidus, Verg,Iı,Aen, đCanus, Ouid.7. Metalth Carniuorus, Cautus, Celer, Cruentus,Statius 5. Theb. Cupidus cruoris, I Degener, Du rus. Edax. Efuriens. Expugnator pecoris. TFamefcens. Ferus, Fuluus, Ouid, 11, Ne tam. Il leiunus, Immitis, Improbus. Indomitus, Infeftãs. Infeftus pecori, Hora. Epod.Osidi, Faft. Infrendẽs, Infatiabilis, Ouid.in lbin. Infidiator. Martiales, Horat. 1, Car. Martius, quodur teres eum in tutela Martis effe finxerunt. Moftus. Montani, Ondius epiftola $1 \%$ ब Nociurn đPrædo. Proceri, Horat, 2. Serm, TRabidi, Rabiofus. Rapaces, Horat, Epod, Rapidus, Raptor, Rauus, d Sauts. Sarcinofus, Sanguineus. Sanguinolentus, Spumiger, Superth, 


\section{DeLupo. H.a. Lib. I. 731}

Vallerius 3, Argonaut. TTrepidans. Trifis. Triftelupus ftabulis, Vergil.z.Aeg. Trux, GVeo hemens, Horat.2.epift. Vlulans. Vorax, ILupa epitheta. Foeda. Immanis. Inhumana, Pro pert.4.Eleg, Martia. Obfcona, Olida. Rapida,Ouid.z.de Arte, Raua, Horat,z. Carm. Ro mulea, Spurca. Trux. Volfca.

đGraca, Ainw

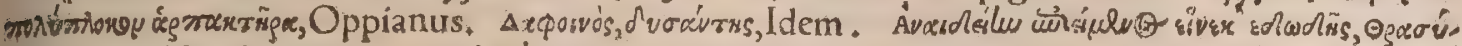

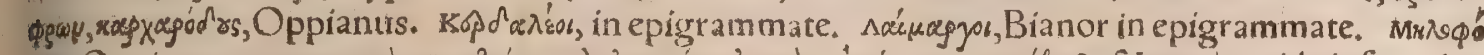

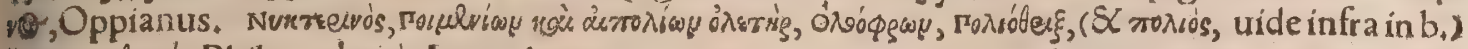

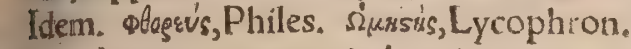

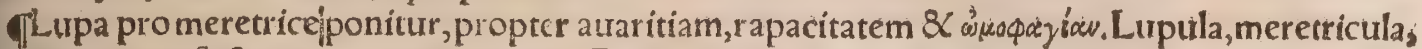
Apuleio. A lupo facta meretricum nomina Graca (Lyce, Lycoris, \& Lycanis) infra ponả.inter pro pria. Deuorrunt mores uirgini longé ac lupx,id eft meretrici, Plautus Epid. Romulum \& Remum aliqui non à lupa fera, fed à meretrice nutritos aiunt:qua de re Plutarchus in Romuli uita. Sunt qui dicant nutricis nomen ambiguitate fabula locum dediffe; nam $\&$ feras $\&$ meretrices communi uoca bulo lupas uocamus:ita Fauftuli uxori, proftrato paftoribus corpore, lupæ cognomẽ effe additum, cum Laurentia antè nuncupata effet. Hinc lupari (Nonius ex Turpilio) profcortari: \& lupanar uel lupanarium pro habitatione meretricum: \& lupanaris adiectium, $\left(\mathrm{C}_{\text {alepino }}\right)$ deriuantur. TCa uete uobis à preudoprophetis, qui ueniât ad uos in ueftitu ourum, fed intrinfecus funt lupi rapaces;

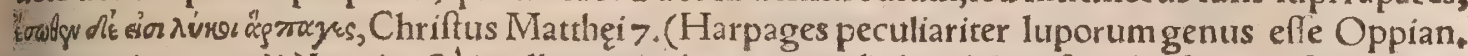
- docet, ut in B , retuli.) Lupi recté intelliguntur haretici, callidi uidelicet fraude, fortes difputatione, crudeles occifione: Vnde apoftolus ad Ephefios, Intrabunt lupi rapaces ad uos, Ghoffa in A cta . No ur quod ingrefiuri fint poft difceffum meum lupi graures (Baęeis) in uos, non parcentes gregi, $\mathrm{P}_{\mathrm{at}}$ lus Actorum 20. Lupos ferrulas uocamus manubriatas, agreftium ufibus accommodas, Cælius * Vtitur hac fignificatione alicubi Palladius : ban $\$$ agen : dicta nimirum propter dentes inaquales quales lupini funt, quibus exafperanturtut \& lupi in frenis. A Ad dolorem capitis lupinum: Suil= lum fimum comburito, 8 cinerem melli admifceto, capurćs rafum inungíto : ac fuper braffica folia dato, Galenus de parabilib, 3.285 . GLupurm appellant ulrus non ualde diffimile illi, quod fornicem tel noli me tangere nominant : nifi quod non faciem, frcuti illud, fed inferiores parres, pr æcipue au. tem crura infeliat:celerrimè depafcens, \& quafi lupus famelícus, proximas fibi carnes exedẽs:quod 30 $\&$ dubio procul de genere elt phaged $x$ na à magis exufta tantum materia factum, $8<$ propterea tielo cius cbambulans, Manardus, Lupus quomodo differat à cancro $\&$ malo quod uocant noli me tan. gere, docer $C$ alius $3^{0}, 14$. Germani lupum uocant, interrriginem in fede ex attricione ortam, ut eque tantibus folet. Huius remedium ex felle bubulo, \& carlinx chelidonix $c^{\prime}$ fuccis permixtis $\&$ pro em plaftro impofitis, in Boue fcripfi, IEft \& lupus inter fidera, cuiftella affignantur nouendecim 2 ta

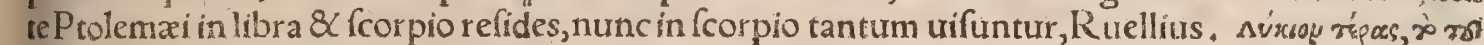

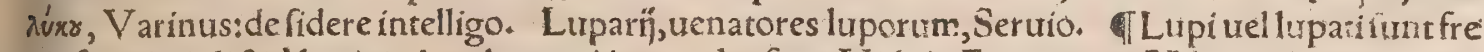
ni afper rimi, dicti à lupinis dentibus qui inæquales funt. Vide in Equo H.e. Mibi quidem non ram integrum aliquod freni genus afperioris uidetur, quàm cuiufuis freni ferrum quod ori inferitur, lum pus aut lupatum recté dici, (aut certe utroç modo accipi, ) hoc Graci sópesy uocant, pro quo Camera to rius apud Xenophontem lupos uertere folet. Nicandri Scholiaftes lycon effe ait ferrum habena:

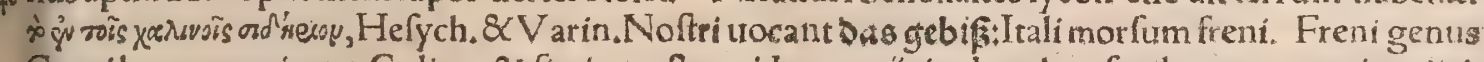
Gracilycon nominant, Calius : $\&$ fieri potef, ut idem conícit, ab eolycofpadas equos porius dici, alacres f́ilicet $\&$ ferociores, quàm qui à lupo demorfí fint: folentenim animofi equil lupos \& frenum morfu quandog corripere $\&$ attrahere. TLupus, inftrumentumaduncum quo uafa quar in pus

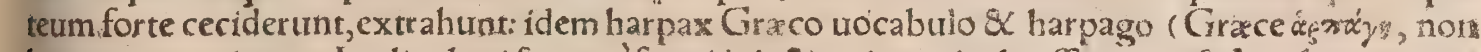
harpago) nominatur. In alios lupi fupernè ferrei iniecti, ut in periculo effent, ne fufoenfi in murum extraherentur, Liuius 8 belli Punici. Hac infrumenta uocantur etiam on gri, corui, $8 \mathrm{C}$ manus ter. rex, ut in Onagro docui. Lupus, qui \& canicula, ferreus harpax, quo fi quid in puteum decidit rapitur \& extrahicur, Ifidorus, Lycos ctiam, id eft, lupus uocatur fufcina, qua caro ollis eximia

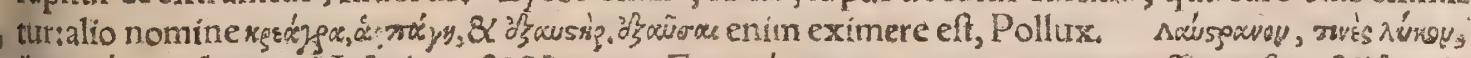

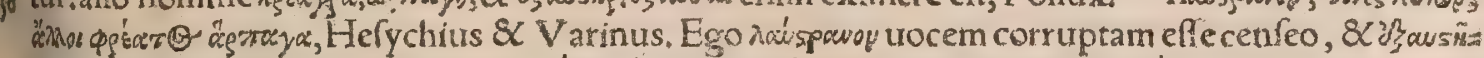

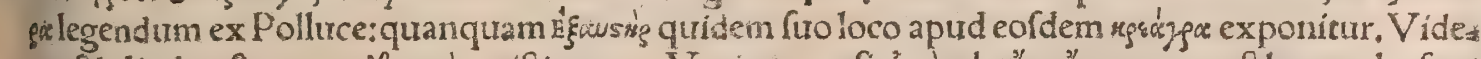

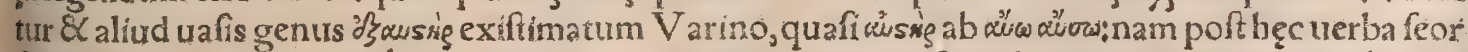

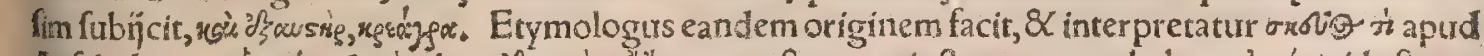

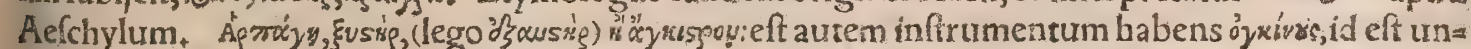
cinos fiue uncos, quo cadi in puteos delapf extrahuntur: Euripides lycon nominat, Hefychius \& Varinus, Creagran 8 harpagem $\&$ lycon appellari feribit Paufanias, Calius. Et alibi,Sunt \&' in belli ufibus harpagæ, ab Agrippa excogitatæ, capiendis oblaqueandiş́́ nauibus. Ea uerò funt cubi torum quinç ligna, ferro circumplexa, fibulasḉs ab capite utroģ prafixas continentia, uni falx fer= 6o ro curuata inheret, alteri funes deftinantur plurimi, falces machinis attrahentes, ubi in tendiculam incidit hoftica nauis: cui intercipienda machinulę præfto $\&$ altera eft:coraca uocant, id eft roruum, Harpagones (inquit Plinius) Anacharfis excogitauit primus, et manus Pericles Athenienfistauclor 
nobis eft in Viris illuftribus Nepos Cornelitis, hifce ufum ex Romanis primum imperatorem Duth lium, Hęc Calius, Lupinus, adiectiuum.Quem inauratum in Capitölo paruum atq̧ lactentem hu beribus lupinis inhiantem fuiffe meminiftis, Cicero in Catil. Galea lupina, Propertius.

A.riftophanes in Vefpis fycophantas appellat lupos. Theomneftus in Hippiatricis cap. 14

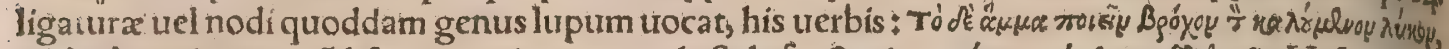

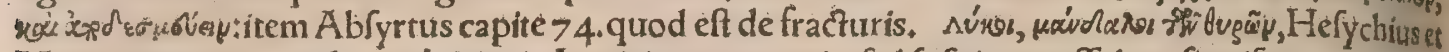
Varinus:urocem quidem $\mu w^{\prime} d \alpha \lambda \theta$ in Lexicis non reperio:fed fufpicor peffulum fignificare, quo obfe ratur \& offirmatur ianua promoto, \& retracto aperitur:(cin rigel) uel ferrum in fera mobile, quod claui retrahitur ut aperiamus, cin vfsug : quod Latiné etiam peffulum uocant. Claue peffulis fubie, cia pandit fores, A puleius. Subdita claue peffulos reduco, Idem. Itali uulgó cadenatium uocant, $\mathrm{C}_{2}$ lepinus. Idem peffulum dici putat quafi paruum pedem:uel quòd ne peffundetur hoftium affigi io,

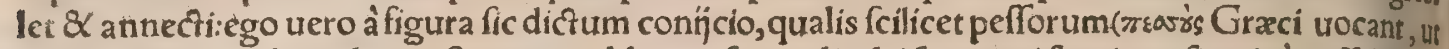
Diofcorides)medicinalium eft, nempe oblonga, fiue cylindri fiue coni fpecie: nifi quis à paffalo $\mathrm{G}$ ra

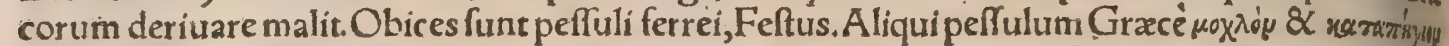

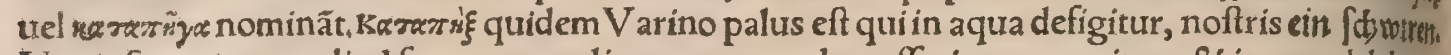
Nos inftrumentum aliud ferreum aut ligneum, quo depreffo ianua aperitur, \& iterum delabente clauditur, à lapfu uocamus èn fallen, hoc etiam Latinè quidam peffulum interpretatur. A mandalo

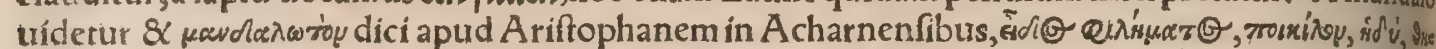

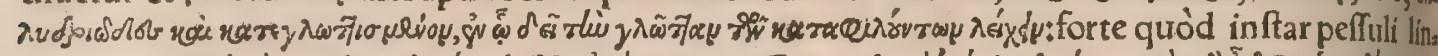

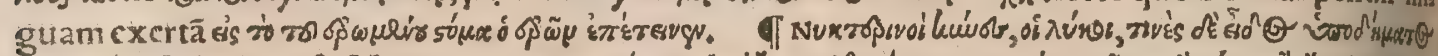

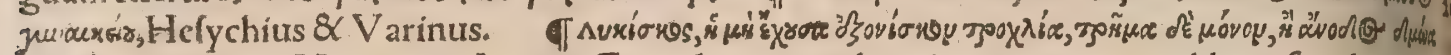
$\tau$ Go, Hefychius $\&$ Varinus: in Lexico Gracolatino quidam interpretatur trochleam fuculis cartent

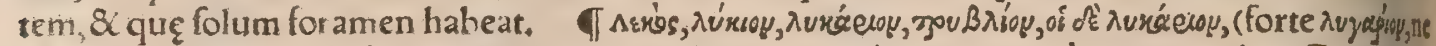
idem bis (cribatur, ) Hefychius $\&$ V arinus:uidētur autem hæc nomina à recentioribus Gracis facta à ligula Latinorum, qux paruum cochleare eft, à lingendo forte dicta:nam aliqui lingulam dicunt,

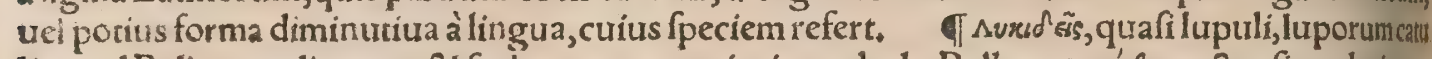
li, apud Pollurem:dicuntur \& f cylaces communiori uocabulo, Pollux, suxidiss rectus fingularis non diminuriux, fed patronymica forma eft, Varinus in sayoós, Galli louveteaux nominant. (Avis

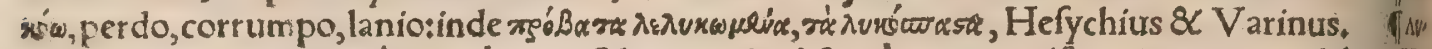

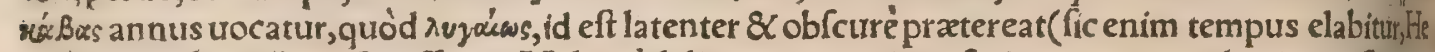
fychius ex Scholijs in Odyffex $\xi_{\text {. }}$ ) Vel quòd dies anni continua ferie pergunt, ut lupi cum flumina traíciunt: fertur enim illos, cum rapidus aliquis fluuius trap̣ciendus eft, caudis murtuo mordicusap

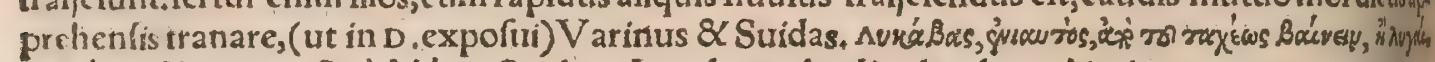

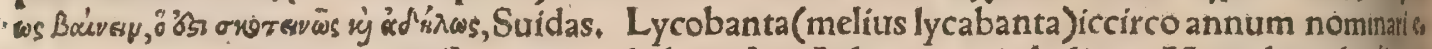
xifimmant, quod erga lupum Sol amorem habeat, \&c. A elianus, ut in h. dicam.Macrobius lycábanta

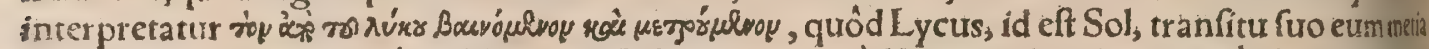

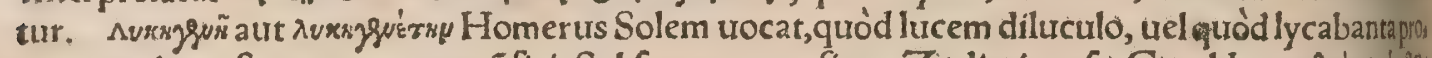

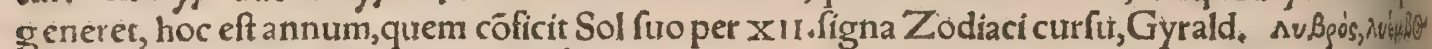

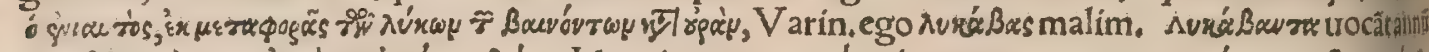

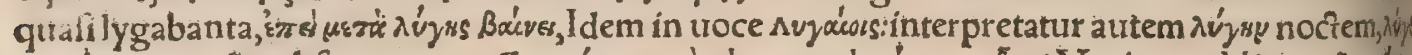

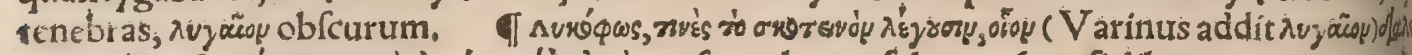

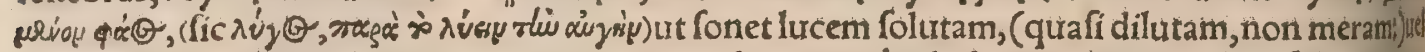
tempus ex luce \& tenebris permixtum, per translationem à pilis lupinis; qui interiore fui parte quä cuti contigua eft, albicant: exteriore nigricant, Etymologus, Varinus \& Euftathius apud Calium,

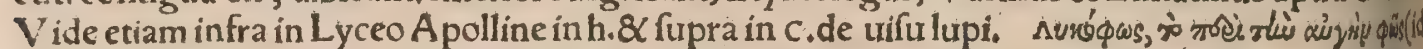
eft marutina lux,crepufculum; )Suidas, Euftathius quidem in lliad, $x$. $\lambda \dot{v} x$ y lucem matutinẩ interprę

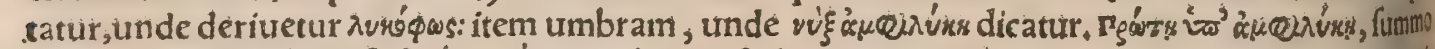

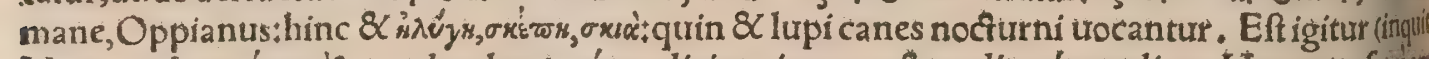

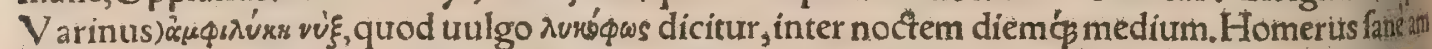
philycen nociem uocat, qux diei propinqua fit, \& auroram feu diluculum pracedat. Vel tempus quo Sol oriri $\&$ tenebras foluere incipit, nondum tamen ortus eft, necdum plena aurora apparet, $n 0$ minis ratio eft, tuel q̊d uox $\lambda u_{\text {ź }}$ tenebras fignat; ut amphilycó exponamus tenebrofam, quafi amphily gen: \& lycóphos, quafi lygóphos:uel à lycea, id eft pelle lupina : cui color cinereus, non totus niger,

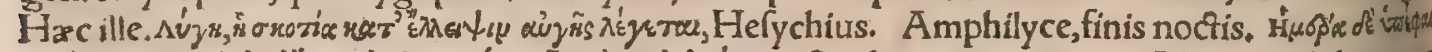

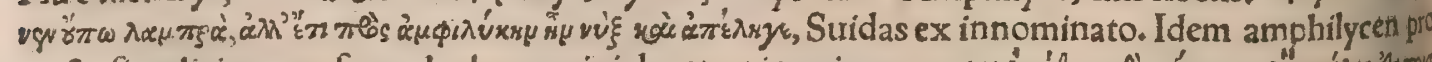

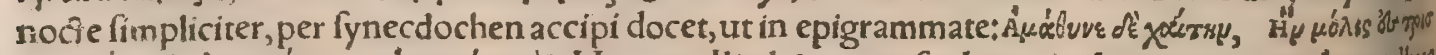

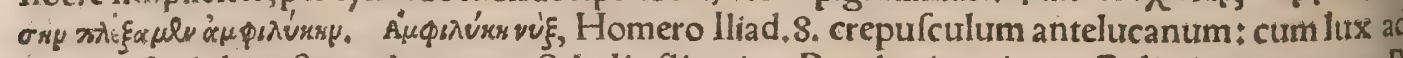
crepera $\&$ dubia eft, necdum pura,Scholia:Sic etiam Porphyrius, citante Cælio, interpretatur. Prifd Gracorum(inquit Gyraldus)primam lucem, qua pracedit Solis exortum, $\lambda \dot{u} u x y$ appellauere,

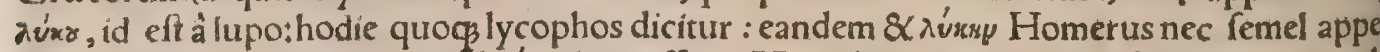
quin $8<$ Latini uidentur lucem à $\lambda u ́ x s$ deriuaffe (ex Macrobio.) Quin idem ipfe Homerus eam lucem

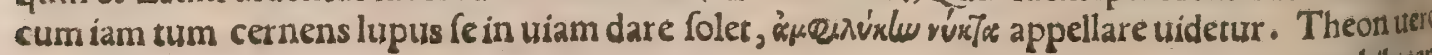




\section{4

(1) Lycophthalmos gemma quatuor eft colorum, ex rutilo \& fanguineo in medio nigrum dido cingirut, ur luporum oculi, illis per omnia fimilis, Plinfus lib.;7.

Ti Stirpes. Lupum falictarium Plinius lib, 21, numerat inter herbas Italix quæ in cibum ure

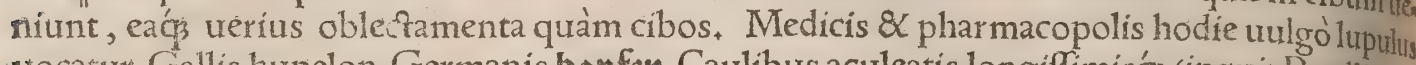
uocarur, Gallis hupelon, Germanis bopfen. Caulibus aculeatis longiflimiśḉ (inquit Ruellius) in uepribus $\&$ falictis reptat, folijs uitis alba, hifprdis, \& nigrioribus + Hore cinereo, ac multis exili. bus folliculis fquamatim compaćtili. Hoc frugibus admifto, Germani fuam condiunt ceruifiam, Subit fandités falices, \& arbanta omnia circumuoluendo fe complectitur, nonnufquam qu reptitius lupus utocatur hodie. Graci uulgo bryon uocant, à bryonix ut puto fimilitudine ( bryoniam quoç, ut audio, in Burgundia uitem lupi uocant) brufcandulum Irali, quafibry fcanfile, Hac Ruellius, Lupulos ego aut à colore lupino aut ab afperitate fic appellatos p

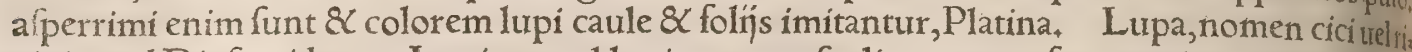
cini apud Diofcoridem. Lupinus uel lupinum (mafculino genere frequentius) genus legumi nis, quid cum lupo commune habeat, haud fio:circumagitur quidem cum Sole, \& Sol quogd uerfa à lupo cognomina fortitur. Thermos Graci uocant, noftri feigbonen/ whll siferm. Lycos flores herbx iridis dici inuenio, quòd labiorum lupi fpeciem reddant, Calius ex Scholijs in Nicandrum, fi bene memini. Apud Hefychium $\&$ Varinum non reciè legítur xom

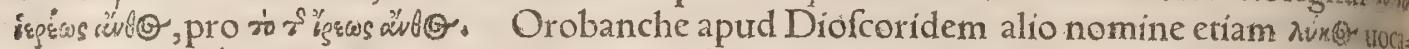
tur, \& hodie à quiburdam lupa Matthæolo tefte Vide fupra in Boue capite tertio. Chamaly: cos, uerbenaca altera, inter nomenciaturas Diofcoridis i Lycium eft fpina pyxacantha, uel

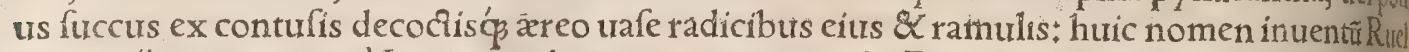
lius conn̈cit, quoniam à Lycia inueheretur, pręcipuũ urbe Patara + Lycanthemon, fmilax afpet a,Diofcor. Lycophryx (aliấs leurcophryx)artemifia, apưd eundem. Per hyemis tempora Spar

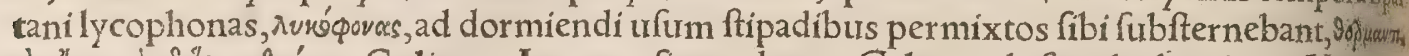

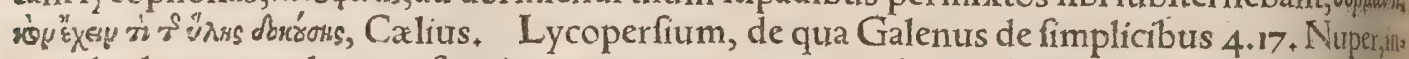
quit, herbam quandam confpeximus, quam centurio quidam ex barbarica circa Aegyptumira gione comportauerat, odore adeò graui, adeoćs inamceno, ut ne guftare quidem auderem, edtls talem effe conícerem:urebatur autem ad urgentes articulorum doloresłatos ipfis etiam laborala tibus refrigerandi pollere facultate eft uifa, Eft autem colore fubflauro, odore tam grauxi quamm cuta:nifi quòd leuem quandam inftar aromatum odoris adferat gratiam. Nomen herbxe ex qua furccus hic exprimitur, lycoperfum effe dicebat, Hxc Galenus, Lycofcytalion, fefamoides in: gnum, Diofcorides, Lycopfis anchufa congener, miror quomodo ab afpectu lupino nomen il lerit, Ruellius lingure canis hodie uulgò dictæ hoc nomen adiudicat ₹ folia ei (inquit Plinitslib, 27.) longiora quàm lactucæ craffioraćps, \& $c_{*}$. Pro thermuntiade lycopfolon fubftitui, in Succida neis legimus, Meffení echinopodem, lycophanon( $\lambda$ uróфwow) uocitant, Hefychius $\&$ Varinus, de echinopode herba uide in Echino fupra in $\mathrm{H}, \mathrm{a}_{4}$ Lupi cor, capparis 82 limonium, apid Dion fcoridem. Lupi pes, (ut feribit Ruellius, ) Græcilycopoda nominant; herba eft marrubio fylue ftri fimilis, folio lupini pedis effigie, diffecto, grauis odoris, caule angulofo geniculató́p, fungo intus medulla, radice frequenti capillamento fibrata : folia trita prafentaneo remedio impor zur difioluto ftomacho. Galli nunc patam lupinam, nunc herbam pectoralem, nunc manum

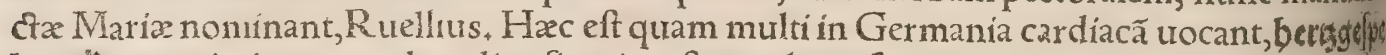
berblerunt:nimirum quod car diae (fic etiam ftomachum fiue os uentriculi ueteres nominabant) impofita medeatur.Quod uerò Ruellius ait Græce lycopodem nominari, nufquã reperio apuld Gracos, fed neq̧ apud Plinium:quare confictam ab eo ad imitationem Gallicæ uocis Gractim conijcio. Tragus meliffam fylueftrem facit, Fortaffis hoc Galenilycoperfium fuerit, cuitus proxl

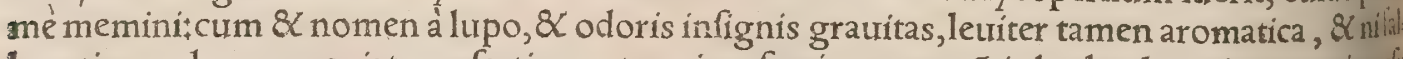
lor etiam color conueniat, præfertim maturo iam femine pragnãtis herbæ: leuari autem cius ufi articulorum dolores facile crediderim, cum egregie difcutiat, \& mediocriter calefaciat enocetch in uaporem refolutos craffos humores, $8 \mathrm{c}_{\text {, }}$ nam quod Galenus refrigerare putat, non procerto afferit, fed uulgi refert opinionem, qui forfitan actu frigidam herbam aut eius fuccum ad huills in modi dolores admourebant. Vix hercle grauius odoratam inuenias herbam, ut nó mirum fit Ga lenum noluiffe guftare + ego uero certius cognofcendi gratia, ea etiã quę uenenofa effe fciebă,ple raq̧ omnia guftu iudicare uolui, fed ne quid deglutire diligêter caui, et apotherapia mox aliqua ufus fum. Magna quidẽ inter plantas ualde refrigerantiũ pars, odoris grauitate notatur, qurodfin gulatim oftendere poffem+non continuó tamen omne grauiter olens refrigerat. Fungi quidam (inquit Ruellius) terra cohærent, nullo fulti pede, in globum circinati, nec ulla fui parte patentes dehifcunt:qui cum rumpuntur, atram fuliginem eructant, toto callo in fumum abeunte: hos cres pitus lupi noftrum uulgus appellas, ij nullo pacto manduntur. Germani nominant p fawentif? id eft crepitum pauonis $\div$ Matthæolus ueficas lupi, Tragus tertij Tomi cap.1.bibenfif , \& ourats à figura ${ }_{+}$Crefcunt, inquit, in campis gramine ueftitis, albo colore, 8 cum aruerunt, crepant, if puluerem feré flaum eructant. Hunc aliqui uetuftis $\&$ humidis ulceribus infpergunt, ut ficcer tur \& facilius curationem admittant. Fungus quem crepitum lupi uocant, cum itercore port 


\section{DeLupo. H.a. Lib. I. 735}

gramina pafcentis tritus $\&$ calidus appofitus plagx, fanguinem fiftit debet autem intra triduum non remoueri,Rufius, Comarus Gracé, Arabice catilabinch, uel haruanchieth (apud Serapio= nem)Latiné ficus lupi, uel fuborbito(lege, arbutus) noftro idiomate armoni uocant, Syluaticus Idem alibi iufoph, ficum lupi interpretatur, Arnoldus fcribit arbutum in Hifpania ficum lupi uo cari. Caret eo Germaniatin fyluris Gallix Narbonenfis frequentem uidi, T Dipfacum é genere carduorum, noftri uocant wolffifral, hoc eft fulmen lupinum $\$ \&$ efulam, hoc eft pityuam, uel quemuis etiam tithymallum, wolffomikb, id eft lac lupinum ; aliqui non recté wolffwurb, id eft radicem lupitquod nomen aconito conuenit, ut iam docebo, In Hippiatricis Gracis cap+26, hel leborum album auroiúncoy uocari legimus, aut certé eiufdem facultatis plantam.

đ Aconitum quoniam lupos alias śs feras plerafq̧ omnes occidit, homini etiam intus forisć uenenum, fed \& remedium aduerfus morbos \& uitia quxdam, \& lupariæ nomẽ, tum apud Ger manos tum Gallos $\&$ Italos habet, hoc pracipué loco, quxe fuper eo mihi obferuata funt, ftúdio= fis communicare uolui. Pluribus autem de eo mihi agendum eft, propter ueterum pariter ac re= centiorum circa huius ueneni genera, partim ignorantiam, partim errores, \& codices quoç uete rum uitiatos. Antiquorum curam(inquit Plinius) diligentiam $q_{\beta}$ quis poffit fatis uenerari, cum conftet onnium uenenorum ocyffimum effe aconitum+ +2 tactis quo $\$$ genitalibus foeminini $f e=$ xus animalium, eodem die inferre mortem? Hoc fuit uenenum, quo interemptas dormientes a Calfurnio Beftia uxores M. Cxcilius accufator obiecit. Hinc illa atrox peroratio eius, in digito eas mortuas, Hac Plinius, Et alibi, Nafcitur in nudis cautibus quas aconas (ćrívas) nominant $¥ \&$ - ideo aconitum aliqui dixêre, nullo iuxta, ne pulurere quidem nutriente. (Hinc forte Ouidius uia uacia dixerit,) Et dira aconica creat $\cos$, A ứonius. Hanc aliqui rationem nominis attulêre. Alḯ, quoniam uis eadem in morte eflet, qua cotibus ad ferri aciem deterendam, ftatimós admota uelo citas fentiretur. In Ponto eft portus Acone, ureneno aconito dirus, Plinius. Theopompus Chi= us, uir fide dignus, de Clearcho Heracleota Ponti tyranno fcribit, quod multos uiolenter fuftule rit, \& kívesoy plerif́p bibendum dederit; quod cum cognouiffent homines, nulli domo prodibant nifi guftata prius rutathac enim prafumpta nihil obelie aconitum afferunt + eft autem hoc uene num, quod fic nominatum ait inde quód nafcatur Aconis loco circa Heracleam, A thenæus libro

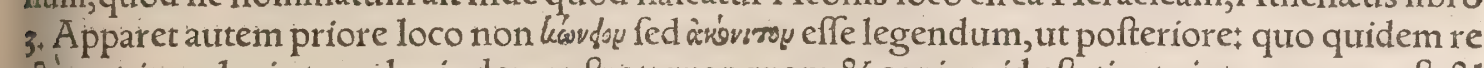
cí aconitum legi etymología demonftrat: quanquam \& conion, id eft cicuta inter uenena eft, \& 30 ruta inter utriulifs antipharmaca nominatur, Aconitum præterea ex Ponto, de cuíus hic loquia tur rege, commendabatur. Quæ quia nafuntur dura uiuacia caute Agreftes aconita uocant; Ouidius lib, $7+$ Metam. Euftathius quidem in Dionyfium Afrum fcribens aconitum fonare pu

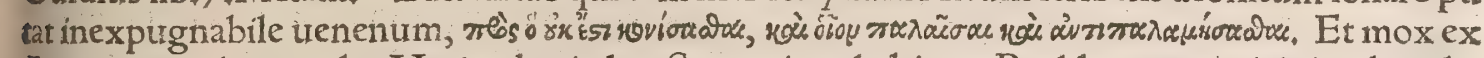
Arriano citat hæc uerba, Mariandyni ultra Sangarium habitant, Paphlagonum uicini, ubi urbs eft Heracleatquo in loco Cimmerî́ fumpto in cibis aconito malé habuerunt nam pro patrio mo-

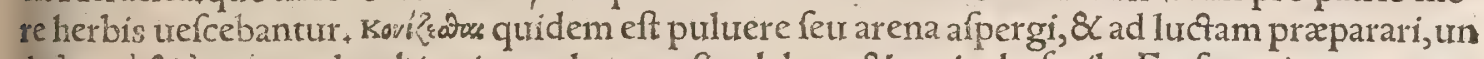

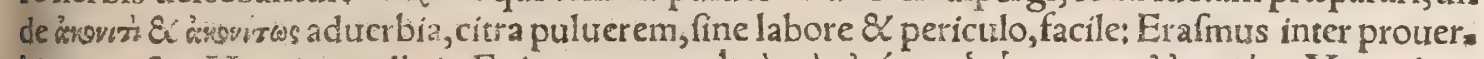

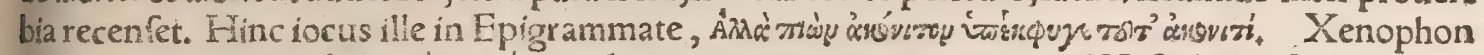

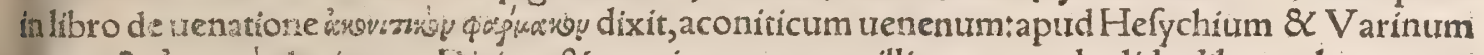

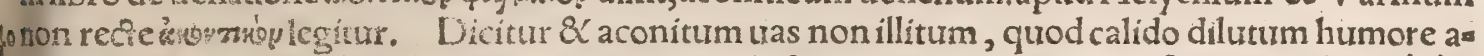

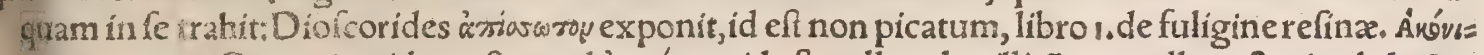

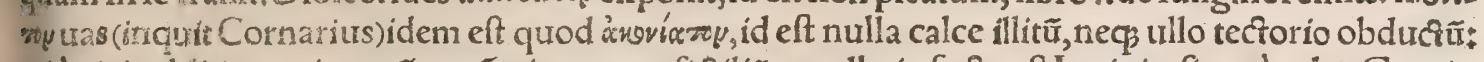
ná à picis oblitione picatorũ et nó picatorum fiçiliũ appellatio facta eft Latinis, ficut à calce Gracis;

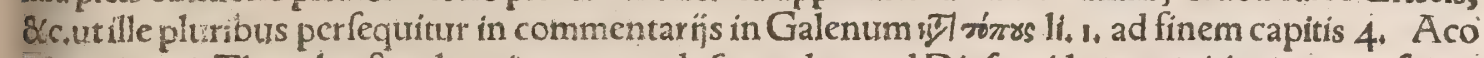
nitum(inquit Theophraftus: loquitur autem de fecundo apud Diofcoridem aconiti genere) nafcitur in Creta atģ Zacyntho, red plurinum optimumós in Heraclea Pontica+Et paulò poft, Nafcitur ubi que, \& non in A conis folum, à quibus habet appellationêtis autem uicus eft Periandynorum : amat autem loca potiffimum faxofa, Hoc in loco(de hift, plant, 9. 16. non Periandynorum ut Gracè La= tinéç legitur, \& à Marcello alïsḉs citatur, fed Máriandynorum legendum eft. Sunt enim Mariandy ni(ut Diony fius Afer fcribic $\&$ interpres eius Euftathius)populi uicini Paphlagonix, ubi extracius Cerberus ab Hercule fpumam rabiens euomuit, unde uel natum eft aconitum, ut Nicander $\&$ Oui dius lib +7 . Metam, fribunt:uel cum prius innoxium effet, Cerberi uomitu contactum uenenofum enafit. Cerberum aiunt in lucen eductum, cimm eam ferre non poffet, euomuife, atcg inde ortum a= conitum. Eft autem Acheron fluxius Heracleæ Ponticæ, \& iuxta Aconitus collis, ubi canis in lucẽ extractus fertur. Ibidem fubuerfum eft oppidum Priolai, qui Lyci regis Mariandynorum filius fuit; $\&$ in Heraclea Pontica morturus eft, cum Hercules bellum gereret in finitimos : unde urbem Hera= clex uicinam Lycus fic appellauit à fili nomine Priolai, Scholia Nicandri, Mariandynia regionis Stephanus quoq meminis. Alij tamen Cerberum non in Ponto, fed in Laconica iuxta Tænarum eductum ab Hercule fabulantur, ubi fpelunca quadam oftenditur, ut refert Strabo libro 8. Fabu io la narrauêre è fpumis Cerberi canis, extrahente ab inferis Hercule, ideo'́s a pud Heracleam Ponti cam, ubi monftratur eius ad inferos aditus, gigni, Plinius de aconito. Nicander aconitum fentire uí detur non ab Aconis Ponti uico dicium, fed a cautibus in quibus nafcirur: Aconitum, inquit, aliquí 
thelyphonon \& cammoron uocant: producit autem foemineum (foeminarum perniciem) hoc acom

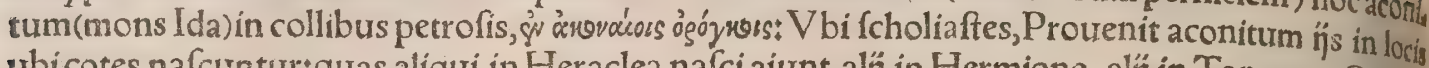
ubi cotes nafcuntur:quas aliqui in Heraclea nafci aiunt, alíp in Hermione, alï in Tanagra: Quibis uerbis cotes eum non pro petris aut faxis fimpliciter accipere apparet, fed procotibus illis tantum quibus ferrum acuitur:quod equidem non probo, quanquã Theophrafti aconitum, quod fecundĩ eius genus apud Diofcoridem eft, fimpliciter petrofis in locis nafci ab eo proditur: Nicander de mo loquitur, quod pardalianches, 8 c. urocant. Ipfe quidem fapiffime aconiti Diofcoridis fecund duo genera, luteum inquam $\&$ coruleum, ratione floris, iuxta petras montium emicare uiditluteum etiam in ipfis petris \& rupibus, fed terra intectis, non ut Plinius feribit nudis, nullo iuxta ne pulturer quidem harente ac nutriente hanc plantam; hoc enim Grammatici commenti uidentur, ut nomin

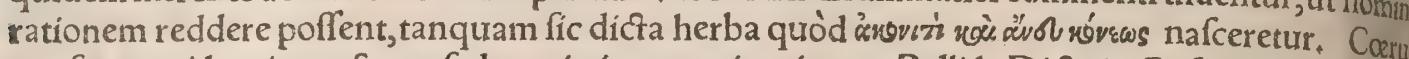
um fape quidem iuxta faxa, fed magis in terrenis oritur. Pallida Dictxis Cæfar nafcentia faxis Infundas aconita palàm, Lucanus lib; 4. Syluaticus 8 alin quidam hurius farinæ omnem hexbantis uenenofam aconitum dici poffe fultè perfuafi funt. Nunc ipfa aconiti genera défribemus ex $\mathrm{Dio}_{\mathrm{i}}$ fcoride, Theophrafto,Plinio. Aconitum(inquit Diofcorides) aliqui pardalianches, alij cammorom alï thelyphonon, alin myoctonon, alï therophonon appellant: folia habet tria quatuórue cyclamin aut fycin, id eft cucumeris(Marcellus interpres addit fylueftris)minora tamen \& fubhirfuta( $\chi^{\prime} \varepsilon$, quadantenus afpera, Marcell, ) Caulis illi eft dodrantalistradix fcorpionis caudx fimilis, alabaffit modo nitet. Nomina eius eadem omnia Nicander $\&$ Plinius recenfent, prater therophonon, Rivell us theriophonon legit, Idem \& Marcellus thelyphonon apud Diofcoridem \&Theophraftum dep uatam effe uocem pro theriophono temere fufpicantur, cum $\&$ Nicander fic habeat, qui etiam

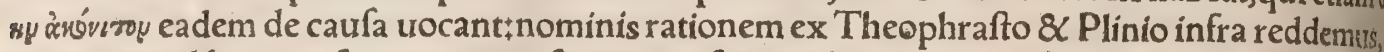
niam genitalibus cuiufuis animantis formina inferta radix, mortem inferat. Pardalianches quidem uocatur, quoniam pantheras ueluti ftrangulando occidat, ut legimus in Scholij̧s Nicãdri, undehær translata fubijcimus . Pardalis deuorato aconito moritur $¥$ quamobrem non prius id guftat, quadm prope fe uiderit excrementum humanum, quo fcilicet antipharmaco utitur. Itaç paftores exces: mentum ab arbore fufpendunt, in eam altitudinem quam faliendo pardalin affequi non poffecon íciunt. Hoc uifo pardalis, fecura propter antipharmaci prafentiam, aconitum edit; deinde antiphat macum appetens affiliens ćs, cum propter altitudinem attingere nequeat, crebris tandem faltbus

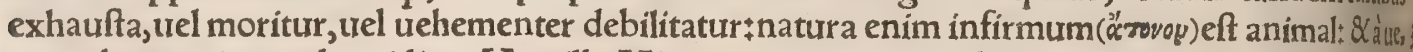
natoribus capitur uel occiditur, Hæc illa.Minus autem miretur aliquis curari excremento honinis hanc ueluti anginam feu ftrangulationem, quam pantheræ feu pardales ex aconito patiuntur (tiu neno fcilicet guttur, fauces $\&$ gulam inflammante, $\&$ humores illuc attrahente, ut helleborus eriä.) fi legerit apud Galenum libro decimo de fimplicibus experimentum memorabile de faucium ina flammatione pueri excremento fananda. Panthera guftato aconito liberantur morte excremen: torum hominis guftu, Plinius. Quod ad cammari nomen, Galenus in Gloffis Hippocraticis camla moron interpretatur marinum animal(malacoftracum, generis cancror $\tilde{\mathbf{u}}$ ) paruæ caridi, id eff fquit! la(cancello)fimile: $\&$ aconitum, propter radicum eius cum fquilla fimilitudinem + fed apud Hippo: cratem(inquit)in libro de Locis in homine de neutro iftorum accipi poteft, ubi in ardoribus camt moron affumitur. Vnde Erotianus (Herophilus, Cornarius) non folum ipfum animal cammoron, fed etiam circumfitum ipfi mufcum ita appellari ait. Zeno autem Herophilius cicutam, Zeuxistil dicamentum refrigeratorium, Hæc Galenus. Ego apud Diofcoridem inter nomenclaturas cammat ron nomen etiam mandragoræ \& delphinio attribui obferuaui, in quarum hiftoria utrobiç pentls tima per alpha fcribitur (quanquam in delphinio per m. fimplex camaros, quod non probamus) id quod placet, \& fi cammoros pro aconito apud Diofcoridem, Nicandrum, \& Galenum in Giolilis per 0 . paruum friptum fit: $\&$ infuper Nicandri fcholiaftes, cuius non magna apud me authoritas,

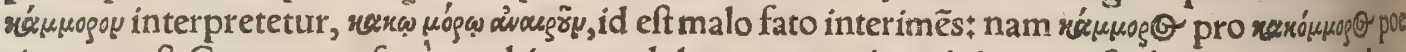
tica uox eft. Cammaron fané utrobigs per alpha pro cancri marini genere fcribi, nouerunt uel tmes diocriter eruditi omnes thuius autem figuræ(Galeno etiam tefte, \& Plinio)radices aconiti conferun tur, ficut etiam fcorpü caudææ quamobrem fcorpium aliqui uocauerüt: (arida radix incurtratur pal lum forpionum modo, Ruellius.) fic $\&$ alterius aconiti radix fquillæ cancelli marini cirris confer tur. Sed \& cammaros aliqui caridas ( non revídos ut apud Hefychium habetur falfó) id eft fquillas rubentes uocitant. Kó́pogo quidem per omicron $\& \mathrm{~m}$, fimplex, alnus eft Hefychio $\&$ Varino. Aco nitum folia habet cyclamini(inquit Plinius) aut cucumeris, non plura quàm quatuor ab radice lenta ter hirfuta:radicem modicam cammaro fimilem marino:quare quidam cammaron adpellauête, alih thelyphonon. Radix incuruatur paulum fcorpionum modo, quare \& f corpion aliqui appellauere, nec defuêre qui myoctonon appellare mallent. A conitum(ut legimus in libro de fimplicibursadPa ternianum, qui Galeno attribuitur herbula eft qua folia habet à radice duo uel tria, fimilia cucumen ri: \& thyrfulum non altum:radicem oblongam, $\&$ ad imum magis tenuiorem $\&$ minutiorem, fpecis em $\&$ colores ad fimilitudinem fcorpionis pufilli fine pedibus. Thelyphonum (inquit Theophr ftus 9.19 , de hilt. plant.)alí fcorpionem appellant, habet folium cyclamini, radicem fimilem fcorpio ni; nafcitur graminis modo, \& geniculis conftat; loca amat umbrofa, Hac Theophraftus, Nicandri 


\section{DeLupo. H.a. Lib. I. 737}

interpres gramini fimile effe aconitum dixit, in quo reprehendendus eft. Theophraftus enim non hoc dixit, led nafci ut gramen, nimirum propter genicula, ut hoc ipfum ceur epexegefin fubiecerit:fic etiam illud quod priuatim aconitum trocat, frumento fimile effe ait, caulibus nimirum geniculatis e nodofis, non alia parte. Forma quadam peculiari fpectatur, nepa(forpii) uocata radix, reprafen. tat enim fpeciem fcorpionis, Theoph.9.14. Strangulator alnemer nafcitur in rerris edeilla, (areno. (is, Bellunenfis:) \& eft amari faporis 8 horridi odoris, Auicenna lib. 4. fen.6. IT Tranfeo ad aconitumalterum, quod Diofcorides $\&$ Theopliraftus defcripferunt:à Plinio præteritum admiror ، Aco nitum alterum (inquit Diofcorides) funt qui cynoctonon, qui lycoctonon, qui cyamon leucôn, Ro. mani colomeftrum(colomeftin, Syluaticus)appellant, Huius tria genera funt:unum quo uenatores, duo quibus medici utuntur. Ex his tertium quod Ponticum urocant, ( or erit fyntaxis, ut Ruellius fecit:fed ita uidebitur medicinale aconitum, non uenatorium defcribe= re:cum hoc à fe defcripto uenatores uti in fine capitis doceat. Theophraftus quidem aconiti genus unum tantum, quo medici fimul $\&$ uenatores utantur, defcribit) plurimum in Italia Iuftinis montie bus nafcitur, antedicto(altero quo medici utuntur, quod non defcripfit, ut neç uenatorium, ) effica.

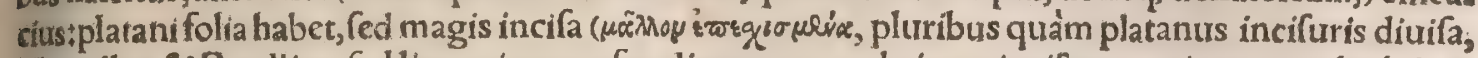
Marcellus \& Ruellius: fed licet etiam profundiores non crebriores incifuras accipere*) multó́g lon:

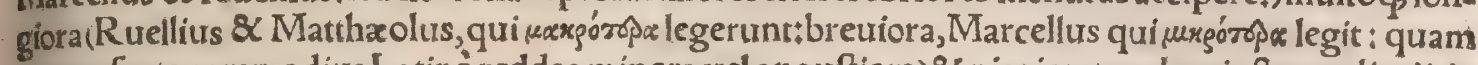
uocem forte commodius Latine reddas minora uel anguftiora) 8 nigriora:caulem inftar pediculi in

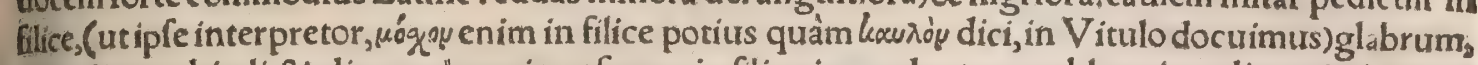
altitudine cubitali, $\&$ aliquando maiore: .emen in filiquis quadantenus oblongis, radices cirris mari narum fquillarum fimiles $\&$ nigras : quibus ad uenationem luporum utuntur, crudis eas carnibus imponentes:qux in cibo ab illis fumptxe es enecant, Hac Diofrorides. A conitum(inquit Theophra

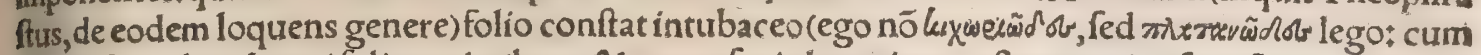
\&. Diofcorides platani folium ei tribuat, \& nos ea facie lupariam noftram, cuius funt flores, noueri mus:radice tum (pecie tum colore nuci proxima, (ut Gaza uertit:Fed legendum reeid, id eft fquilla;

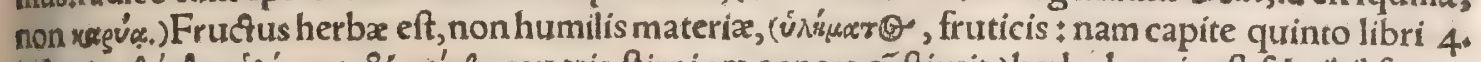

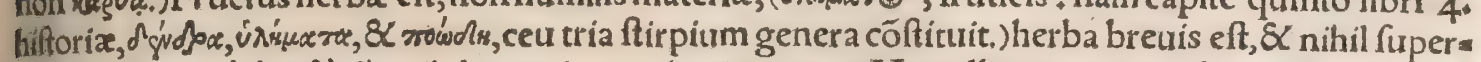

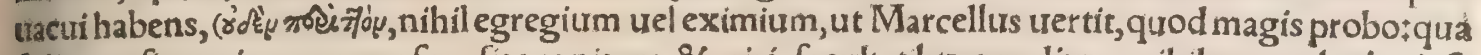
fidicat, etfi maxime uenenofurm fic aconitum, $\&$ miris facultatibus praditum, nihil tamen herba ipfa o infigne habet aut admiratione dignum, nifi radicem fortaffis ut $\&$ thelyphonum : fed hic de herba, hoc eff fuperficie priuatim loquitur:) fed frumento fimilis, femen tamen in fpica non haber. Matihao lus nefcio quomodo negationem nó uidit, \& femen in fpica, uelut frumentum, habere falfó foripfit, TA Aconitum Diofcoridis primum, hodie à quibufdam tora uocatur:de qua feorfim agam inferius, Hicillud tantum monebo, errare Leonardum Fuchfium, qui herbam par is appellatam uulgo ab Ita lis, utMatthæolus fcribit, aconitum primum effe afferit, cum ea omnino fit folani generibus adnume

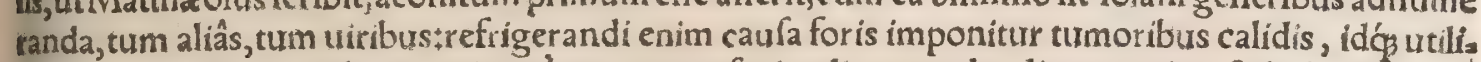
ter ut experientia nos docuit:minimé uero putrefaciendi aut erodendi ut aconita: fed non eff quod pluribus refutem, ne fim prolixior:mecum quidem $\&$ Mathxoolus $\&$ Tragus fentiunt rum numero hic non uincitur. Fuchfius fanèrum aliâs tum inde mihi deceptus uidetur, quod herbả - paris (quam aliqui non recté afterem Átticum putant)nonnulli uuam uulpinam, lupinam, aut cani. nam uocant: unde $\&$ Germanicum nomen factum, aut fictum potius ab imperitis puto medicis wolffsbeer (noftri uulgo uocant crüglekrut, id eft cruciatam, propter folia femper feré quaterna, cru cis inftar difpofita:alin fproffenErut/augentrut,Fuchfius etiam polwurts, quo nomine aliud folani genus in Boure in C.defcriprum nos appellamus.) Sed uua lupina apud Arabes folanum eft:tefte $\bar{A}=$ uerroi, ut Syluaticus fcribit:quamuis aliqui, eodem tradente, ftaphifagriam interpretentur. Alì fola num non lupi, fed uulpis uuam uocant. Gerunt autem uuas omnia folani genera. Cuculus uel uua lupina a pud authorem de fimplicibus medicamentis ad Paternianum,cap.83. ipfum folanum fimpli citer dictum eft. Syluaticus non cuculus fed caucalis legir, \& uuam lupinam exponit. Plinius certe folanum cucubalum uocat. T Secundi Diofcoridis aconiti genera duo agnofcimus, luteum (ut die o xi) \& coruleum, quorumillud multó uenenofius \& uehementius eft, à Theophrafto \& Diofcoride defcriptum : folījs enim ad platanum accedit, \& extremæe radices in cirros ceu fquillarum abeunt; \&lc.hoc uero n̂rabum napellus uidetur, radice figuram napi prafentante, de quo infra feorfm. No. fri utrunç lupariam uocant, molff wurn ( Rhæri qui Iralicéloquuntur ris de lup, id eft radicem lu= pi) fed luteum praccipuéper excellentiam $\div \&$ quoniam coerulei radix nigrior eft, lutei minus nigra, fufca fcilicet $\&$ interdum albicans, lupariam albam $\&$ nigram aliquando nominamus, sic weifs wolf wurts/siefcb warts wolfwurts. Lupacia, inquit Syluaticus, eft herba interficiens lupos, 8 potiffis mum puluis ex ea quidam falfó dicunt radiculam effe fiue helleborum nigrum, cum reuera fit ftran gulator adib fure aconitum. Coerulei quidem aconiti radicibus qui pro helleboro nigro uterentur, pharmacopolas in Sabaudia uidi; \& lac. Syluius alicubi reprehendit idem à nonnullis in Gallia fie it ritcuius erroris occafio eis fuit niger radicis color, \& quòd uentris proflutuium fimiliter moureat, ut in napello dicam, 8 quód helleborus ipíc eis deeffet. Aconitum inueniffe prima dicitur Hecare; uenenorum infigni crudelitate fomina, qua Perfam patrem Solis fitium perinde crudeliffimumi 


\section{8

ueneno fuftulit, author Diodorus, Proinde Ouidius in Metamorphofi, cum herban nominat Hen teida, creditur aconitum intellexiffe. Habẽt \& rufticilupariam uulgo nominatam, ad eundē ufurn, folio uitis, multas habente diuifuras, et maculas candidas, flore oblongo, luteo:quare recentiores her barij lycoctonon arbitrantur effe, Ruellius. Aliquihanc plantam Gallice madriettes uocant: a tam lupinam, ut etiam cardiacam, de qua fuperius. Ponticum aconitum, inquit Matthaolus, quind Diofcorides defcripfit, in omnibus ferè Italiz montibus nafcitur, folńs magis quàm platani incifis, caule filicis, floribus luteis, figura fimilibus ranunculi floribus, fed muliò maioribus (nofirx luparin tum Jurea tum coerulea, cucullatos, ut ita dicam, flores habent, uel quodammodo galeatos, ranuncu lifloribus longè diffimiles, quare deceptum hic Matthæolum puto:) \& uulgòluparia uocatur, quah, quam in Tridentino (montem effe puto ituxta Tridentum) herba uulpis nominetur, eò quod radices eius tritæ \& carnibus mixtæu ulpes interimunt. Lupariam luteam deferibit Fuch hus hiftorix ph tarum capite tricefimo: Luteam fimul $8<$ cortuleam Tragus Tomo primocap. 82 . Folia, inquit, lui tex diuifa funt in quinç partes, ut fanicula uulgò diçx, uel ranunculi hortenfis, ex uiridi nigrican, tia, (coerulea potius, fi bene memini, huius coloris folia habet, quęetiam alabaftri inftar réplendent, id eft uafis ex alabaftro factis, quod de primi aconiti radice Diócorides foribit: eft autem is folendo

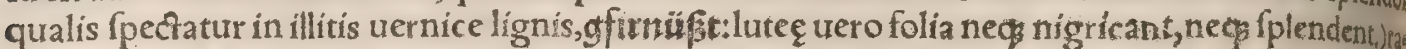
dix eft nigra, multis capillamentis ur a fparagus aut ueratrum nigrum, odoris non ingraticaules fer bicubitales, quaterni aut quini ab una radice uetula procedunt: $\alpha$ fores menfe Maio proferunt pis leoli acuti fpecie, fímiles feré floribus linariæ uulgò dicta: folliculi fubnafcunfur quales in açuicen quam uulgò uocant, quibus femen includitur nigrum, angưlofurm, nigellx aut cepæ femini no fimile, hoc fi quis mandat, fputum efficaciter mouetur, \& acrimonia ferè pyrethri fentitur. (Acont ti coerulei radicem pyrethri \& ftaphifagria guftu urente linguam afficere, ipfe certò deprchendi, $O_{2}$ dorem cum tunditur ingratum f pirat, foris nigra eft, intus alba, fubftantia tenaci $\&<$ fine neruis, Lite etiam A mmonium A gricolam in libro de Simplicibus, $) \mathrm{Nafcitur}$ locis afperis, montanis, fyluofis, in uallibus profundis, ut in fylua Martia, \&c. Coruleam Argentorati in hortis colunt: ea fpecie \&la pore luteam refert:procerior tamen \& per omnia maior eft, flores fimiliter per caulem déncepsann

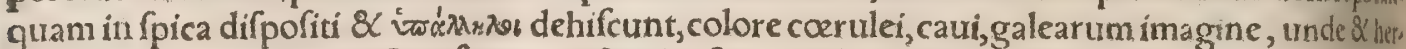
bæ nomen apud aliquos $y$ [enbutitlin, id eft galea ferrea. Norimberga plantatur etiam siterumgenus flore fimiliter coeruleo, \& tertium rofeo, Hac Tragus. Coruleum commune genus, radices quedain modobulbolas \& napo figura fimiles habet, qux in iunioribus fingula, in vetulis tern $x$ autplures à capite cohzrentes pollicis ferè craffitudine, paulatim in mucronem attenuantur, ut hoc eriamnow mine fcorpï caudx conferri poffint, aut potius integro cum cauda fcorpio fine pedibus, ut primum aconiti genus ab authore de fimplicibus ad Paternianum. Viderat ille fortaffis aridas radicesiexno ftris quidem recentibus pedati etiam fcorpij effigiem facile eft imitari, paucis fibris refectis, utretipt pedum loco fint. Noftri hanc plantam uocant Eappen blumen, ac fi pileatam aut cucullatam potius dicas, propter florum fpeciem:aliqui nartenk appen, id eft cucullum ftultorum : alí tüf déswing, id eft radicem diaboli, in Heluetia $R$ hatis contermina. Licebit uero diftinguendi gratia à generelute, cui eadem florum figura eft, hanc pileatam luteam, illam coeruleam dicere (blaw uno gelb tapplith blimm ut fic generum quogs cognatio intelligatur. Coruleam herbarĭ quidam inferioris Germa nia fuperbia:n uxocất, nimirum à thyrfo qui $\&$ procerus $\&$ rectiffimus uf̧̣ ad finem eft. Luceaprid nos in uallibus $\&$ lateribus minorum etiã montium crefcit, coerulea non nifi in altifimorum month Irm lateribus; non enim in imis, ut lutea fxpe, neqg in fummis; tum alibi, tum iuxta faxa, locis terenis, 8 circa lactariorum tug uria, intactum à ua ccis:ita ç fxpe cius fylux circa cafas lactarias fpectantur, nulla ferè alia internafcente planta:eft autem uiuaciffima, \& in hortos translata facillimè compreten dit, 8 omnium diutiffimè dur at, luteam in hortis nunquam uidi:ego fxpe fruftra plantaui enim refugere homines, repetere folitudinem:ter quater mihi plantatx mox emortux funt, cortulea uteunç neglecta, 8 ' malè etiam tracłata, pertinaciffimé uiuit: plantatur autem propter coloris gratis am, qua uel ipfum corruleum metallum prourocat. Jutex nulla gratia pallidus enim $\&$ triftis ei color, qualis illi quam digitalem Fuchfius nominauit, ex luteo albicans $\&$ dilutus, Nodi quidem geniculo, rum protuberantes gemmarum inftar, coerulea peculiares funt+ut lutea mirifica radicis textura, re f tiformis quodammodo, maculis fiue foraminibus paffim debifcens, præfertim fi maior \& annofafite rit radix. Luparia pediculos occidit, item mufcas in lacte. Confiliginem, de qua in Boure dixi, aliqui

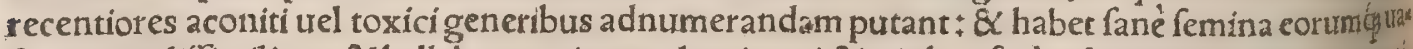
rcula non diffimilia, ut $\&$ helleborus niger uulgaris: cui $\&$ uiribus ferẻ refponder: $8<$ illius ego portu us quàm aconiti generibus adfcripferim. Galli pomeleam, id eft pulmonariam uocant, aliqui ductury,

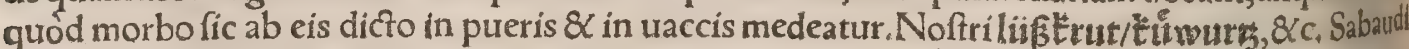
marfieure, alobre, quafi elleborum+aliqui patam leonis. Stulte quidam aconitum realgar interpre tatur, quod uenenum metallicum eft, quamuris potentia aconito non diffimile, de quro Syluaticusca pite 602. THis adiungam qua animalia aconito fumpto intereant. Aconitum uim mortiferm in radice tantum habet, folium $\&$ fructum nihil nocere affirmant, Theophraftus. Idem tamen, trtmox recitabo, folium quoq $\beta$ genitalibus fominarum inditum, mortem afferre ait. Lurida terribiles mu. Icent aconita nouercæ, Ouidius. A conito fugitiuos in uinculo uti folitos defponfo animo fertur? 
codices habent, uel potius $\mu$ sqóvou, per s diphthongum impropriam) quoties herba ferulacea, neruis caulis \& umbellam gerens fignificatur, femper fcripferim, cum aliâs, tum lomonymix declinanda

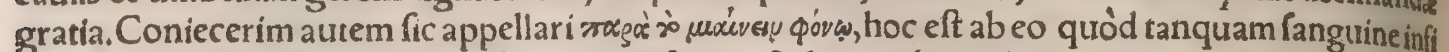
ciat: $\varphi^{\prime}(\mho-$ enim fanguinem fignificat, quare $\&$ atractylidem aliqui phonon nuncupant: $\&$ Theophra

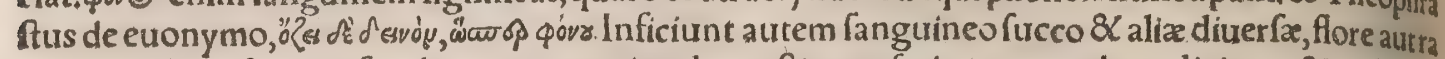
dice aut aliter: $\mathcal{Q}$ inter ferulaceas ac neruicaules, paftinac $x$ fatiux quas rubras dicimus: $\mathcal{Q}$ paftinaca fylueftris : quam Diofcorides fciadion, id eft umbellam habere fribit ex floribus albis, \& in medis am eius partem exiguam purpureocolore fpef́ari. Hæe planta uulgò cognita eft: \& $\mathcal{L}^{\prime}$ meminialiı quando audire partem illam umbella purpuream à quiburdam colligi ad eundem colorem tingen dum, quamuis ea exigua eft, 8 longo tempore parum colligitur : cuti quidem infricta colorem reds dit purpureum. Hanc ipfam, aut proximam ei genere ac forma ftirpem Theophrafti \& Plininmic, phonon effe dixerim. Nicander in remedips contra ixia uenenum polium quogs myoctonon uo, cat, quod(inquit Scholiaftes)nullus alius fecit: neç enim mures occidit polium. Thelyphonumad

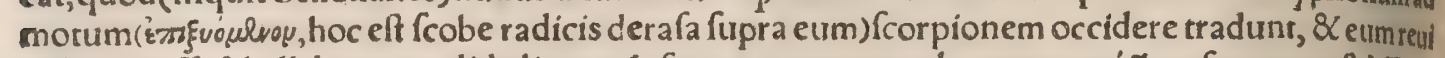

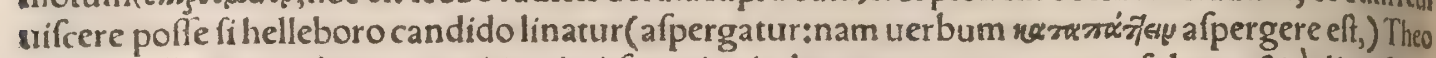
phraftus. Ferunt radicem aconiti(primi)fcorpioni admotam, tor pore eum refoluere: $\&$ é dituerfoad, moto ueratro excitari, Diofcorides. Thelyphonum Theophraftus narrat, fi ad fcorpỉ dorfumade moueas, hüc ftatim perire: $\&$ fi candido helleboro oblınas, integritati ualetudinis mox reftitui, Gil, lius ex Aeliano. Torpefcunt fcorpiones aconiti tactu, ftupentóg pallentes \& uincife confitentur; auxiliatur eis elleborum album, tactu refoluente : ceditćp aconitum duobus malis, fuo \& omnium, औ Plinius. Quinetiam intra corpus aduerfus fcorpionum ictus aconitum datur, ut inferius dicam, Therionarca in Cappadocia \& Myfia nafcente, omnes feras torpefcere Democritus fcribit, necrifi hyænæ urinæ afperfu recreari,Plinius. Ego hanc therionarcam eandem aconito primo crediderim?

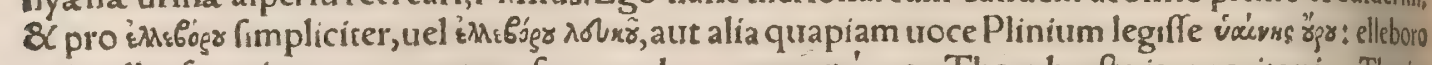
enim albof corpium ut recreetur al pergendum, rarkros'soy, ex Theophraftc iam recitaui. Therio, narca (inquir iterum Plinius 25.9.) alia quàm magica (Democrito prodita, ut nunc recitaui) $\$$ in no, fro orbe nafcitur, fruticofa, folijs fubuiridibus, flore rofeo:fer pentes necat, cuicungs admotaferact hæc torporem adfert. Hac forte delphinium Diofcoridis fuerit(cuius aliâs non meminit Plinius) cü facultas florısḉ color cöureniant. (Eft $\&$ infula Therionarca, Plinio 5. $3 \%$.) nam fruticofa cumfit,aco nitum primum effe non poteft, cui coliculus dodrantalis tantum. Scribit autem de delphinio Dio 30 fcorides, Ferunt admota herba contactos fcorpiones languefcere, ( cendum inefficaces fieri: amotáq̧ ftatim in antiquam redire naturam: quare non immerito inter no: mina crus paralyfis eft, quod uim uigoremó̧̧ fro pionư refoluat, quo fenfu in homine eriã paralyin

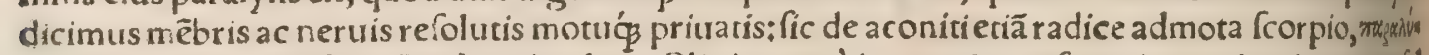
eu, id eft refoluere ipfum, D ofcorides dixit. Plinius uerò in aconito, ut fuperius recita ui, uocemrelol uere contraria fignificatione ufurpauir, pro eo quod eft maleficio foluere, liberare, mederi. (Aporys non quoçs paraly lis cognominatur, quod folia cius cum adipe feris obiecta, ftatim ecrum coxend ces refoluant.) Vocatur $\alpha^{\prime}$ cammarus idem del phinium, ut aconitum, nó quod parte aliqua canmma rum animal exprumat, fed quod cammari aconiti inftar forpipis refiftat: nam $\&$ foris admotum, lid is xi, eis exirio eft: \& aduerfus ictus eorum in uino bibendum datur, nec alia eius remedia tradunturi ut de aconito fimiliter, à quo tamẽ partium furarum difcriptione differt. Diachyfis quidem $\&$ diachy ton, eadem ratione uocari puin qua paralyfin : hyacinthum,à colore foris aut etiã figura: buccintî, à filiquis fortaffis: del phinium uero uel delphiniadẽ, ut Diofcorides ipfe docet, à folior um figuratha"

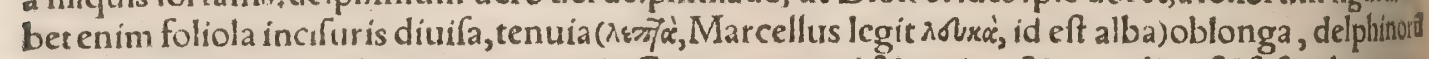

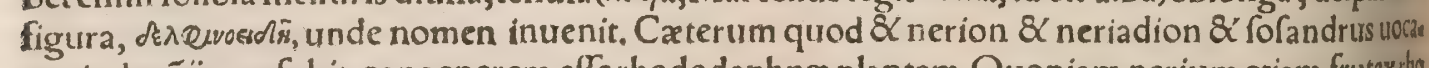
tur, inde cóijcere fubit, congenerem effe rhododaphna plantam. Quoniam nerium etiam frutextio dodaphne eft: 8 multa cum delphinino communia habet:flores rofeos, filiquas, folia oblonga: temi dium, quo delphinium (femen eius)é uino cótra fcorpionum ićus bibitur, unde fofandros uocatur"

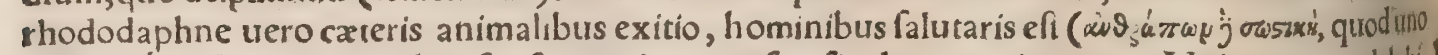
uerbo oẃsaudpoy dixeris)aduerfus ferpentium morfus, fimiliter ex uino pota. Videtur ceite delphis nium quogs non fine ueneno effe, cum \& fcorpios torpore afficiat, $\&$ homini non nifi aduerfus fors pionis merium detur, ut $\&$ alia multa uenenofa aduerfus uenena dantur. Quamobrem fiquis dele phinium, rhododaphnen minoren uel humilem dixerit, meo quidem iudicio non falletur. Nafitur apud nos herba fruticofa, folijs amygdala, floribus rofeis \& leucoin forma, \&́c, tora, ni fallor, Specie rhododaphnæ fimilis, quam in Canis philologia defcripfi in zinziberis canini ex Auicenna mention ne: uidetur autem uel delphinium effe, uel fane eiufdem generis herba.Semen an milio fimile fit,iam non memini: continetur $\&$ lana in fili uis, cuius nulla apud Diofcoridem mentio: Sed rhododapho nes etiam filiqux lana infarctæ funt:ut huius faltem genus effe concedarur, fi cui delphinï nomen adinittere non placeat. Nam quod fena uulgo diça, del phinium non fit, ut fibi pei fuaferar Marcel lus, tam clarum mihi uidetur, ut uel paucis refutare tadio forec. Leones pardalianches uenenum," ficuti pantheras occidit, Ariftoteles. Thactenus qure animalia priuatim aconiti primi tueneno ins tereant, dictum eft. Venio ad fecundum, quod triplex facit Diofcorides, nos (ut dixi)duo tantumeius 


\section{DeLupo. H.a. Lib.I. $74 \mathrm{t}$}

genera cognof cimus, luteum $\&$ coruleum, eadem utrunģ facultate: $\int e d$ luteum efficacius, lupis pr $\varepsilon$ cipué occidendis unlgò creditur:quare illud tantum per excellentiam pleriç lupariam uocant:pau= ciutrunç, coloris tantum differentiam addentes. Proximè Nilum herba nafcitur, quę non fine caun fa lycocfonus appellatur, quòd eam lupus calcans conuulfionibus moritur : propterea Aegyptí in terras fuas eiufmodi herbam importari prohibent, quòd hoc animal uenerentur, Gillius ex Aeliano: fed deceptus uidetur in uerbo calcans: quod Grace quomodo habeatur nefcio, coninjcio autem alí

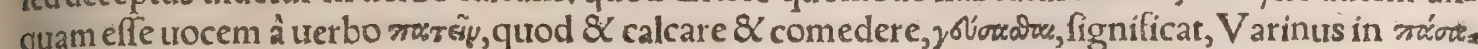

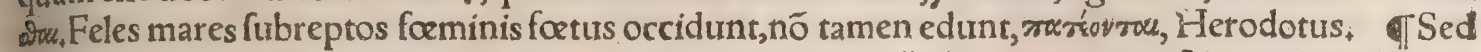
quoniam uenatores apud nos aconita luparia certis modis alï aliter præparant \& componunt, ut lut - pos ac uulpes interimant, compofitiones huiufmodi aliquot, ut partim in Germanicis libris manu= fcriptis reperi, partim à pharmacopolis noftrís cognoui, huxc adfcribam. Primum igitur an feræ, quas capturifunt, eum ad locum ubi efcam uenenatam proponere ftatuunt, urentitare folcant, carne aut aligs efcis fine ueneno obiectis explorare folent, tanquam inuritantes :atç hoc uenatorio uocabulo uocant lis erent quafí laben, hoc eft inuitare folent enim illuc redire ubi efcam femel repererunt, \& alias etiam forte fecum allicere, fiue fpōte, fiue quòd ad efcã profecta latêre alias nó poffint. Quod fi efram abfumptam deprehenderit uenator: certus adeffe feram, globulos fuos uenenofos exponit, qui quidem fabis paulò maiores, $\mathrm{ab}$ alís magnitudine iuglandis, hunc ad modum ficri folent. Aconi ticraffiufcule triti, uitri Veneti, utriufog cochlearia duo:corticis fagi, foliorum taxi, utriufģ cochleas

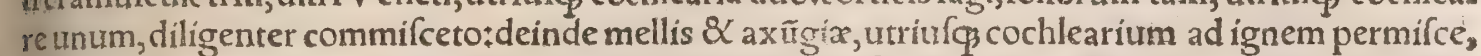
\& bullientibus puluerem pradictum immitte+hine pilulas formabis, quas prolupis capiendis axun= gia illines, pro uulpibus non item. Agyrta qui aronitum apud nos uendunt, taxi folia non aliam ob caufam ei mifceri aiunt, quàm ut ne uomitu redsi poflic; cum tamen taxum fimpliciter uenenatam effeconftet:fed docet Diofcorides ftrangulationem ab ea fieri, unde conïcimus non guttur tantum fed fauces etiam \& gulam ueneno eius comprimi \& arfari, unde uomitus impediatur: ut duplici nomine noxia fit, furo inquã ueneno, $8 \times$ ne aconitum retromatur prohibendo. Catiuulcus rex Ebur ronum taxo fe exanimaut, Cafar 6.belli Gallici. Alị hoc modo mifcent, lupariæu uncias duas, fo, liorum fraxini uel taxi potius unciam unam: corticis fagi, uitri Veneti,calcis uriuz; arfenici citrini, fingulorum fefquunciam:amygdalarum dulcium uncias tres, mellis quantum fufficit : fiant globi magnitudine nucis, lardo inungendi. Aliquí pira ficca admif́cent, uel potius eis inuoluunt:pro uul pibus puto. Sunt qui Luparix radici effoff $x$ Luna decrefcente, folia betula, fraxini corticem, \& $\mathrm{Va}=$ lerianam, pari omnium menfurra mífceant, $\&$ globos cum melle factos anferino adipe illinant. Alip lurpariam, arfenicum citrinum $\&$ taxi folia xqualiter. Aliter, Lupariæ unciam, cum femuncia uitri \& melle quantum fufficit fubigito, piris ficcis contufis intoluito, \& feuum fuperinducito. Alij lú team $\&$ coeruleam lupariam, helleborum album, uitrum Venetum, lardum uel axungiam, adipem felis fyluefris,taxi folia, mel, farinam auenæ, arfenicum album $\&$ citrinum, fungos mufcarios pallis dos aut rubentes, $\&$ oleum, omnia in unam maffam redigunt, certis ponderibus $\&$ menfuris permia xta, plurimum autem de fungis addunt, \&c. Aconito pafcitur neç pecus, (ouis, neç ullum anis mal, Theophraftus. Luparia, ut R hati narrant, necat omne animal quod cęcum nafcitur, ut lupos, milpes, urfos, canes, Ego fimpliciter quoduis animal eo deuorato interire crediderim. Ruftici a= 40 gyrtæ ut mures tollantur in Sabaudia $\&$ apud nos uendunt:iubent autem noftri farinam ex auena aut tritico mifcere, $\&$ in pultis formam redigere. Ego quidem nuper aconiti lutei puluerem cum bir tyro, lardo \& farina copiofurm ratto (id eft muri domeftico maiori) in mufcipula capto per triduum appofuifine ullo potu, nec tamen inde mortuus eft. Pofiea cum minores mures cepiffem, auripig= mento in lardum infricato eis appofito, intra horam morientes uidi. Auripigmentum enim prafer. tim luridum, quod rofagallum uocant(ut frribit Cardanus)tum mures, tum lupi fi guftaterint, non folum moriuntur, fed in rabiem adeó efferantur, ut fuigeneris animalia inuadant, \& quactunç mo= morderint in eandem rabiem incidant, ut totum genus breui pereat:cuius rei quando $\xi_{3}$ feci experi mentum. Sed tamen periculofum eff, ne etiam cicurata perdas $\&$ innoxia animalia, \& ne aqua in. uenta fruftreris. Verum parua re, fi bene cedat, domum muribus plenam expurgabis. In lupis diffi. so cilius eft, cum aquam celerius inueniant, Hæc ille. Pediculos etiam occidit, ex oleo inuncta radix: urel fi caput lauet lixiuio in quo decocta fit, ut Tragus fcribit:ego quidem ita laurari nemini confulo, inunctio forte tutior fuerit. Sed nec mufcæeuadunt, deguftato lacte in quo macerata fit. Canes codem interire iam prius dixi: \& Diofcorides inter catera fecundi generis nomina cynoctonon ponit, Codices quidam manuferipti aconiti cynoctoni peculiarem titulum habent, librariorum (ut rectéconịcit Hermolaus)culpa, duo capita diftrahentium in tria:nam cynoctoni Diofcorides neçs formam neq medicinas exequitur. A pocynon quidem herba alia uenenofa, cynoctonó etiam 8 par dalianches cognominatur. $\llbracket$ Non omittemus $\&$ antipharmaca quxdam qua medeantur ijs qui aconitum fumplerint. Pantheræ quidem excrementis hominum fibi medentur, ut fupra retuli : Ho mines mulfo, ut Theophraftus docet. Ex uino aut mulfo potum, nihil poffe officere putant, Idem, 60 Sed planécontrarium Euftathius apud Macrobium 6.7. afferit his uerbis:Si quis aconitum nefciês hauferit, non nego hauftu eum meri plurimi folere curari. Infufum enim uifceribus trahit ad fe calo rem, \& ueneno frigido quafí calidâ iam repugnat, Si ueró aconitum ipfum cum uino tritum potuí 
datum fit, haurientem nulla curatio à morte defendit. Tunc enim uinum natura frigidũ admiftion fui frigus auxitueneni, (mihi certum eft aconitum uenenum minimè frigidum effe) nec in interior bus iam calef́cit, quia non liberum fed admiftum aly,j, imò in aliud uèrfum defcendit in uifcera, $H_{a c}$ ille, Mihi rationes iftre non placent. Puluerem mufconum(id eft paruarum mufcarum) napellun depafcentium aduerfus napellü darem, uel puluerem coturnicis feu turdi, Ant. Gainerius:deceptus nimirum ab Arabibus, aut eorum interpretibus, qui coturnices aconito pafci fcripferunt: cum ftur, nos(non turdos)cicuta pafci fcribendum fuiffet, ut pluribus pauló polt dicetur. Acetum calidum potum, ( $\&$ mox uomitionibus redditum, ) contra cícutã $\&$ aconitum prodeft, Aggregator ex Sera pione fecundum Diofcoridem, ego apud Diofcoridem nullam aconiti mentionem in aceto reperio, Lac bubali \& afinx contra aconitum bibitur, ouillum uerò contra cicutam, Aggregator ex Plinio Coagula hoodi, uituli, capreoli Haliabbas contra cicutam propinat, alí côtra aconitum, Allium de, bellat aconitum quod alio nomine pardalianches uocatur,Plinius, Rutam aduerfari aconito, fun perius ex Athenæo recitaui, Galenus libro 2, de antidotis, rutæ manipulum tritum, è uino puro bibi confulit; aut ius gallinaceum pingue. Reliqua remedia et figna fumpti huius ueneni, leges apud Dio fcoridem 6.7, item Aétium, Nicandrum in Alexipharmacis. IS Sunt aconito etiam in medendo utiles homini uires:quamuis Syluaticus nec intra nec extra corpus adhibendum feripferit: ex Auls cenna nimirum, qui idem de utroģ aconito tradidit. A conitum fiue pardalianches (inquitGales nus)feptica, id eft putrefactorix et urenenofx facultatis eft, in cibo potứç cautendum:idoneumuero ubi quid foris in corpore, aut circa fedem, exedendo tollendum uidetur, ad quos ufus radix éiusfus menda eft.Sed $\&$ alterum quod lycocionon uocant, eiufdem eft facultatis. Aconitum(primum) uires habet thapfix, A urhor de fimplicibus ad Paternianum. Mifcetur oculorum remedins leuandi doloris gratia (ophthalmicis medicamentis anodynis,) Diofcorides. feptica quídem idem feréfinedo lore præit ant, quod cum dolore cauftica. Proinde ego fic uerterem:Mifcetur oculorum remedĭs que fine dolore exedunt, quamuis Diofcorides non fatis expreffit:fed res ipfa loquitur. Nam fimpliciter ad dolorem tollendum aconícum applicare, infaniam dixerim. Maiores oculorum quoog medicat mẽtis aconitum mifceri faluberrime promulgauere, aperta profeffione, malum quidem nullumeffie

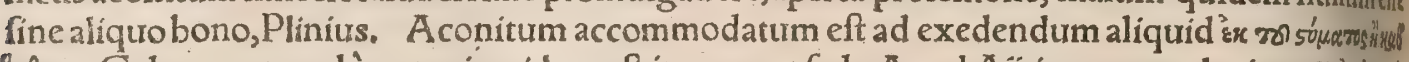

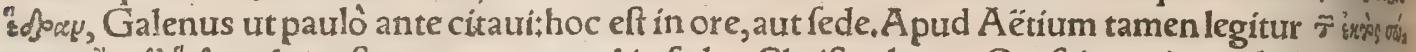

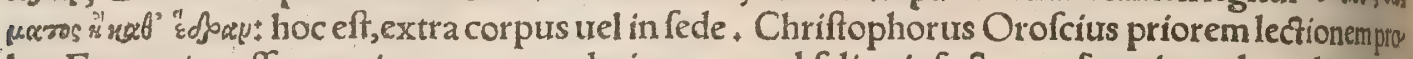
bat. Ego tutius effe puto intra os non admittere, ne uel faliua infecta, aut fortuito uel modicumeirs deglutitum, periculi cauffa fit Foret etiam periculum fi forte ulcufcula aut ưenæa aliâs a pertæ \&fanta guinem fundẽtes in ore effent.Āegineta etiam 'zxzos ow'jurvs, \& fimiliter uetus interpres Latinusuler tit. Sed ftaphifagria quoq 3 aphthas cum melle fanat, tefte Diofcoride:qua tamen propemodum finis lem aconito uim habet $\& \&$ fandarach a apud eundem oris ulceribus commendatur, quam tamenlis bro 6.inter uenena cum calce $\&$ aurripigmento numerat; quamobrẽ nihil affero, nifí tutius abflinerf cum minus periculora ad cordem affectus remedia abunde reperiantur, Aconiti radix emplafir modo impofita, putrefacit (exedit) efficaciter hæmorrhoides \& pudenda, Arnoldus citans Gale num, cum tamen apud Galeñ̃ non fic legatur. A coniti herbæ fucco pilor ũ ortum prohiberiferant; A.étius, atqui lıæc facultas non aconiti fed lkwv'ri, id eft cicutae eft, frepius aũt hæc ab imperitis confun duntur. Vtuntur thelyphono medici pro putrefactorio:fed $\&$ alips quiburdam de cauffis epotum 4 nihil penitus poffe officere aiunt, neç ex uino necs ex mulfo, Theophraftus. Et rurfus, Nepar catee( f corpif, thelyphoni)radix fpeciem fcorpionis reprafentat, \& utilis ad eius ictum \& adaliaglua

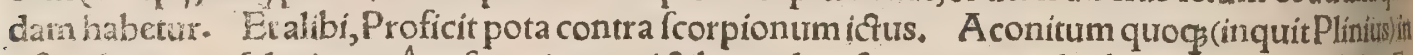
ufum humanæéalutis uertêre, fcorpionum ictibus aduerfari experiendo datum in uino calido, Ela eft natura ur hominem occidat, nifi inuenerit quod in homine perimat, cum eo folo colluctatur, lies lur pari intus inuêto. Sola hac pugna eft cum uenenum in uifceribus reperit:Mirumós, exitialiaper fe ambo cum fint, duo uenena in homine commoriuntur, ut homo fuperfit, Hac Plinius. Videri autem poteft non de fcorpí tantum ueneno loqui, quod aconitum id folum in hominerepertumim pugnet, fed quouis etiam alio, ut Hermolaus etiam \& Ruellius acceperunt : \& fi à nemine alio uetes rum id fcriptum inueniam, ego quidem credere quàm experiri malo, poffet tamẽ aliquis periculum facere in cane, fi modo noftrum aconitum, quod fecundi generis eft, idem præftare poteft quod pria mum, de quo ipfí loquuntur. Extra corpus quidem ubi quid erodere, aut urehemẽter ficcare opor teat, eundem ufum præbebunt, aconitum, ftaphifagria, iris fylueftris, helleborus niger, thapfia, chan mæleo niger. Staphífagria quidem non facultate tantum, fed tota fpecie, radice excepta, xmularimi

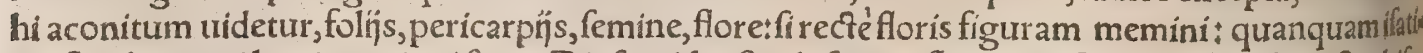
dis floribus, qui lutei et exigui funt, Diofcorides flaphifagrix flores confert: quod noftræ ftaphilas grix non conurenire Fuch fius etiam teftatur : nifi quis ita excufare uelit, ut non ifatidis floribus, led coloriqui huius herba fucco expreffo decocióg ( ut R urellius meminit) coeruleus fieri folet, uulgo Indicum uocant, entoidb, ftaphifagria flores qui fubcoerulei funt, comparentur. Author medicanis num fuccidaneorum pro aconito irin fylueftrem reçè ufurpari poffe docet. Sed iris fylueftris qua ab ipfo intelligatur, non facile dixerim. Aétius quidem ipfum aconitum alio nomine irin fylueftrem uocari fcribit:apud Diofcoridem uero xyris \& ephemerum nonletale ita cognominãtur. Ego uero 


\section{DeLupo. H.a. Lib. I. 743}

letale potits ephemerum, hoc eft colchicum, aconiti uires habere dixerim. Xyris etiam intra corpus turo fumitur. Quamobrem aliud iridis fylueftris genus quarendum uidetur quod aconito fubftitua mus:ego commodius non inuento quàn quod fpatulam foetidam uocant, quo \& pediculi oscidun. tur, ut etia colchico, \&c. Caterum ut aconitum alterum platani folia habet, fic etiam cici, ne ipfunt quídem fine ueneno, Graci cici alkerua uocãt, de qua Auricenna, Dicitur quòd perfcrutatio ultima in expreffione kesb alkerua \& fefami, admodum uenenofa $\&$ mortifera fit, Cornua de fumbel Ara bice, id eft fpica, pro qua translatum eft in Almanfore, cornua cerul montani, ladit fimiliter napello quen odore etiam refert, A rnoldus. De cornu fpica calidiffimo $\&$ erodente ueneno mihi ignoto; Auticenna ftatim poft napellum traçat. Et fubinde de ueneno quod muikion appellat, (Bcllurnefis le - git farfiun)cui eodem modo refiftatur quo napello: \& herbam ipfam napello fimilem effe putar, fate $\Rightarrow$ tur enim fe ignorare, Ego apud Græcos nihil quod cum eo conferri poffit reperio. Gloffa A rabica; inquit Bellunenfis, cicutam exponit, Atqui Auicenna inter calida uenena de co rractat. Myofôta

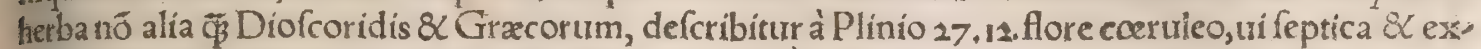
wlceratrice, qux $8 \times$ xgilopas fanet, \&cc. Eft autem plané eaden quę altera muris auricula Diofcoridi i quam tamen fepticam effe uel exulcerare alius nemo feripfit, Galenus in fecundo ordine eam ficcas refcribit,caliditatem uerò manifeftam nullam obtincre, tanturm abeft ut exulceret. Sed neç neceffe eft exulcerare aut exedere quicquid ad egilopas recté admouetur, cum et refrigerantia quzadam, fed ficcantia admoueãtur. Quòd fi has quas Plinius ci falfo tribuit facultates haberet, aconito uriribus coniungenda effet, qua quidem occafione eam bîc memoraui. Luparix puluerem cum butyro fubs oaftĩ omne genus impetiginü fanare promittũt, in iumentís $\&$ hominibus. Mulomed -1 apud nos

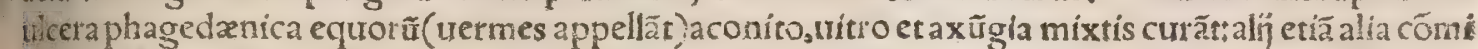
fcent. बN Napellĩ aliquí recentiores aconiti genus faciunt, Mathęolus negat:quamobrem priuatim deillo agere uolui, aliorum primum fcripta propofitums, inde meam fententiam, aconiti genus effe, confirmaturus. Syluaticus Arabicas uoces bix, bifmus uel biffum, morgnapelli (mus napelli, po= cius) \& alfarfas, diuerfis in locis rapellum interpretatur; bix is uero toram, quam aconitum prinum effe infra docebositem alchlehil, gumm i napelli, cum aliorum nullus quod friam ullum napelli gum mi commemoret, fed ixize chamalcontís ucnenofi, quem thelifie trel taffia nnminat Auicenna. Hine natus error ut aliqui thap fiam frribant, $\mathcal{Q}$ gummi eius uenenofum faciant, ut Arnoldus:cum thap. fia longè alia apud Græcos herba fic. Albis, id eft napellus, Bellunenfis, Et rurfus, Albifi eft medica g men in quo recipitur albis, id eft napellus. Bifmus, mus napelli, Idem; Inde forfan corruptè bis, id eft napellus mofi uocatur:mos quidem Perficè murem fignificat. Bifmus buha, id eft napellus Moy fi,Bellunenfis. Befalbi, id eft napelli, Vetus gloflographus Auicerna. Farfas, (forte farfím, de quo paulo fuperius diximus) dicitur quiòdfit uapellus, alin uenenum letale, Idem. A pud Auicennax

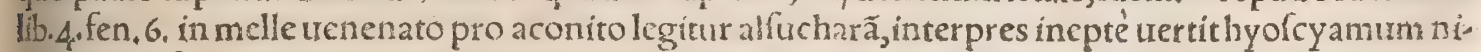
grum:fignificat enim cicutam, ur Bellunenfi quroc; placet. Arnoldus aconitum uncat ufcat, $\&$ ly. cotoroix, pro lycoctonon: $\&$ alterum genus folijs cyclanini ediforion, pro thelyphonon. Bis, ideft bapcllus (inquit Auicenna) ef ucnenum perniciofum, immodicè calidum 8 ficcum:illitum delet als baras(id ef uritigines:) \& potum ctiam cum sx cins geguerifet in potufumitur (Bellunenfis fic le git, Confectio dicta alberzachald in potu himpra delet aibaras: Syluaticus fimplicius legit, delet alba

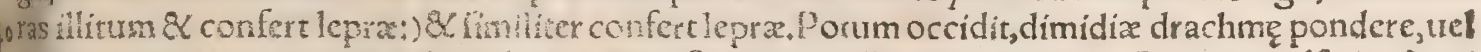
etiam minore, ut euoiudico. Ansidotum cius eft mis napelli, qui co nutritur. Coturnices (feman) qui dem co pafta non morintur, (apparct hac uerba ineptex Galeno translata qui fturnos cicuta ci. tra noxam pafcitum alibi fcribit, tum in 11 , ad Pitonemtcoturnices autem elleboro, ut $\&$ Arifor. Iib. 1. de plantis.) \& præ omnibus diamofchu compofitio eirefiltit maximè, Auicenna lib, 2, ca, yoo. Et mox fequenti capite, Bifmurs buha(inquic)id eff rapellus Moyfi, tefte loanne, herba eft qux nafitur cum napelio: \& quicunos napelius ei uicinus elt, non crefit, aut functum non producit: \& cf praci: puum antidotum napelli, utilis ad omnia fimlicer, ut contra albaras \& lepram. Bifmus ueró feu na pellus mus, eft animal quod moratur in radice napelli ficut mus, urilis ad albaras $\&$ lepram, (datur etiam contra omne uenenum $\&$ morfis a uipera, ) Hac Auicenna jo mus non habentur in quibufdam codicibus. Napellus, inquit Syluaticus, herba elt fimilis hellebo to nigro, cuius radix digeritur inftar retis, $\&$ antonomaftice eft her ba (qualibet)uenenofa $\&$ eft pri $=$ ma pars aconiti. Napellus (inquit Crefcentienfis)eft napus marinus, in littore maris crefcens, illitus delet maculas cutis: 8 cum bibitur medicamentis qux uenenum elus remittant admixtis, ualet con. tra lepram. Et quod miraculi inftar eft, mus paruulus pafcitur $\mathcal{X}$ inuenitur iuxta ipfum, antidotum ipfius. Glis animal, glis terra tenax, glis lappa uocatur : \& illud animal moratur in radice napelli, Syluaticus, Arabice quidem mus ille bix uel bifmus uocatur $\&$ forte aliquis pro bis legit glis. De ue ro quidem ylire, nos fupra abunde fripfimus. Sunt qui nurem illum napelli, fi reciè memini, colos re uarium effe fcribant: talis autem $\&$ glis eft, fufcus reliquo corpore, uentre candidus: $\&$ muris illurd genus quod $a b$ auellanis apud nos nomen fortitur, de quo plura in Muribus. Vtrunģ per fyluas $\&$ So môtes reperitur, ubi nimirum aconita quoog crefcunt, \& fieri poteft, ut inter fres præcipué, ubi frư cius aliquos colligunt uel exedunt, fapius iuxta aconira reperiatur:quanquam $\&$ alios quofdam mi nores mures in montibus uidi jịfem, qui $\&$ aconita producunt, 
hominibus, cum diligenter interrogarem, nufquam refciui, Napellus (inquit Ponzettus Carding. lis) fiue aconiti fpecies, fiue non fit, adeò certe perniciofus ef, ut eius fuccus rumpat uafa, in quibus reponitur, Quod autem dicitur animal paruum reperiri in eius radice, antidotum aduerfus ipfum, non puto uerum, nec hactenus fuit expertum. Lapidis aut cornur genus, quod linguam ferpentis uocant, fudore arguit fel leopardi, uiperam, napellum, fi quod horum adfit, non item alia uenena, Matchaolus ex Aponenfi. Idem A ponenfis in lib, de uenen is capite 30 . de fucco napelli tractans, bezoar(inquit)eft mufcus natus in radice eius:cuius aridi drachmæ duæ in potu dantur. Napellus (inquit Auicenna libro 4.fen.6.tract.1.fumma 2, cap, 1.) uenenum eft deterrimum, quiod fi qquis bibe rit,inflammatur labp̈s \& lingua oculi prominent, uertiginem \& fyncopen fubinde patitur, \& crurn mouere uel exercere nequit. Quòd fi qui euadunt, ut plurimum hectici aut phthifici fiunt: eft quãdo epilepfiam mouet uel odor ipfius. Inficiuntur eius fucco fagitta", quibus uulnerati ftatim intereunt, Quod ad curam, tomitus ftatim prouocandus eft cum decocfo feminis rapa: dandumós in potư uia num $\&$ butyrum bubulum coctum, multis fubinde potionibus: prodeft $\&$ corticurn glandium cum uino decoctum. Deinde præcipua eius cura eft bezahar, \& medicamen de mofcho, \& algedtrar, \& ture (buha, feu bif́mus buha, ut Bellunen. legit*) \& theriaca magna quãdoģ uf̧̧́ ad terminum, (fin, tra certum tempus detur, nee nimium differatur.) Praftantiffimum omnium, fi detur mofchus in fii catione albezahard:aut quantitas drachmæ de medicamento molchi cum filiqua una molchi. Sunt qui radices capparis bezahar napelli putent. Conueniunt quidem omnia albezaharad, fed maxime quod fimile elt alumini, \& fila ut lithargyrus habet. Item animal quod uocatur furinus (mus napelli, Bellunen.)in cibo fumptum aduerfatur napello, Hactenus Auicenna. Et mox capite terrio,Murki: on etiam uenenum fimile napello effe putat, ac fimiliter curari. A ponenfis figna quxdam adiji quæ Auicenna non habet:ut funt, illum qui fumpferit napellum fite fructum eius (lego fuccum) if ue fubftantiam, intra unum uel tres dies moritdenigrari ac defufcari omnia membra eius, \& deinde tumere totum corpus, lingtram in ore continere non poffe. Curam addit, ut curm butyro $\&$ aquami fceatur terra figillata ad uomitum prouocandum, \& mox exhibeantur fmaragdi contritiffimidiaci ma duæ cum uino, $\&$ cordi imponatur fericum cocco tinctum madefactum liquoribus ftillatitiph bus glofix \& rofarum, id'́, aliquoties iteretur: $\&$ à feruis ore fugantur extremitates corporis, quiprixs aliquid fmaragdi biberint, ne $\&$ ipfi de uita periclitentur. Ego maioris fecerim, fi mofchiautambiti aliquid cum terra figillata ex uino bibatur, quod \& Mathæoolo placet tanquam præftantiffimumna pelli antidotum. Napellum album Arabes nominant, \& alibi cinereum ob talem radicis colorem, Bellunenfis, Napellus dicitur quòd fit bryonia, Vetus gloffematarius Auicennæ † fed hacopini ftolidior eft, quåm ur refelli debeat. Ego omnino aconiti aliquod genus napellum effe puto: \& fors taflis id fuerit luparia noftra corulea, cui radix partro napo fimilis eft, pollicis aut amplitus crafition ne, in mucrenem ceu fcorpí definens, ita ut fibris aliquot refectis, \& cateris pedum loco relictis, nino forpium referat, ut fupra dixi:nam \& ultima pars mucronis fape recurua eft. De uenenoqli dem eius conftat: 8 Hier. Tragus fcribit perịffe aliquor A ntuerpia, radicibus eis coct is ( nimirum quod genus aliquod napi aut fifari aut fimilis radicis exiftimaffent)in cibo fumptis . Scio Auic $\&$ lib. 2, ubi plantas defcribir, napellum $\&$ aconitum diuerfis locis tanquam cmnino differente bas defcripfiffe: 8 rurfus lib, 4 . ubi de uenenis agit, alibi de napello, alibi de aconito fcribere, \&rem dijs $\&$ accidentibus feu fignis quibufdam diuerfis. Sed hoc non fatis eft ad afferendum aliud ab aconito genus effe: neç enim tãta apud eruditos Auicenna auhoritas eft. Ip fe quidem and hoc afferuerim, napellum aut aconiti genus effe: (fcio tamen quibußdam in locis Auicenna in tes napellum pro cicuta ponere, ut $4 \cdot 6 \cdot 1.2$.) aut fi de nomine contendere non placeat, $i$ fdem quibu aconitum remedins curari:utrung 3 ifldem uiribus præditum, calidum $\&$ ficcum ac fepticumue num effe: eó́ş nomine utrunģs toxicum, hoc eft fagittis inficiendis idoneum: (neç̧ enim ullumirit dum uenenum toxicum effe poffe crediderim :) quod de napello Auicenna teftatur, aconito autem primo hodié́ fagittas tingi, mox in tora dicam. Ponzettus quidem Cardinalis toxicum pol quando effe frigidum feribit, ut f pumam uel fanguinem botracis(ranæ rubetæ) fupercalefacia, hoc uenenum frigidum effe alius nemo fribit:neqs ratione defendi potelt. Nicander membra cendi prodit.Similium etiam animalium uenena feptica, ut falamandra, lingux inflammatione crelegimus. Certe cum feptica \& calida uenena, in exigua etiam portione uenena fint, frigid item, fed certa quantitate, illa potius utpote toto genere uenena $\&$ ab exiguo fomento per totu pus inficiendo progredientia, fagittis tingendis delecta exiftimo:neç enim multum eis inharerep tcf: \& exiguum illud quod inharet ferri candentis ui fuam refrigerandi noxam amitteret. Frig enim uenena tofta uel ufta infirmantur: calida uel feptica non item, cum etiam deteriora aliquant euadant. Certum eft autem quòd fagittarum cuípides prius ignitæ fucco aliquo uenenato ti tur:recipit enim ferrum candens medicas uires $\&$ imbibit fuccum:quare ad parandum sómulu,

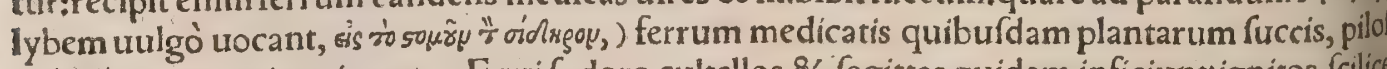
uel alrjs, ignitum immittunt. Equi fudore cultellos \& fagittas quidam inficiunt:ignitos feilicer intingentes: unde ita uenenati fiût, ut parti quam uulnerauerint, nimium fanguinis profluurumint ferant, Arnoldus ex Rafi \& Alberto. Scio Hermolaum Barbarum, dorycnion, quod frigidum en uenenum,fic dictum conícere, quòd cufpides telor um inficere mos eflet illo, ex Plinio 21,31. Dor 


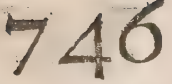

\section{DeQuadrupedibus.}

quoç A Auicenna, ut iple fatetur, non mirum fi parum perfectam tum eius tum quxa prourentutit ah co fymptomatum defcriptionem reliquerint. Hoc potius mirum effer, toxicum tam celebre uenten \& tantopere cauendum, omnibus adhuc medicis ignotum effe, ut fe quidem ignorare Matthatu

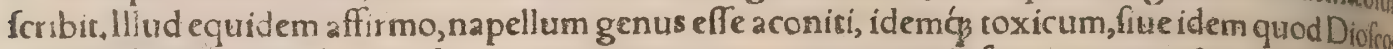
rides defcribit(durerfa enim funt toxica)aut præcipuam eius unde fieı ct materiã: fiue alıt quidem toxicum, fed quod ïfdem poffit remedijs iuuari, utpote calidum ficcum ac fepticum uenenum, $\mathrm{N}_{2}$ pellus Moifi( inquit Matrbax olus), mus eft napelli,quem fxpe uidi 8 cepi in altiffimis uallis $A$ nanis montibus: fed non cuiufuis eft eum inuenire, cum magna ad id ( tredĭ) patientia $\&$ uigilantia renuli rantur. Itaq non miror quod philofophus quidam $\&$ medicus infignis ( ut apud recentiorem quen, dam legimus) cum mures huiufmodi nullos inueniret, cepiffe tādem paruas quafdam mufcas foling $\&$ floribus napelli infidentes $\&$ exugentes inde fibi alimentum, \& ex eis fuam antidotum compo, fuilfe, ad mufcas uigintiquatuor, terr $x$ figillatæ, bacearum lauri \& Mithridatif, fingulorum duabur uncij s adiectis, cum oleo \& melle quantum fatis erat excipiendis illis. Et hac quidem antidotomiri fucceffibus, ut ferunt, ufus eft, non folum aduerfus napellum, quem dicierfis animalibus faciundi cauffa periculi exhibuit, fed multa etiam alia crudeliffima uenena, Hacille. Autcenna quidem (fiue ip fe, fiue interpretes, fiue librarij:quod addo propter Matthæolü qui ualde reprenenditLeonii cenum, tanquam iniurium in Auicennam, quod interpretum forte aut fcriptorum uitia, tanquam certus ab ipfo commiffa authore, fimpliciter tanquam Auicenna notet: ego breuitatis fudio, Aulis cenna nomine complecti foleo illam qux extat aditionem qualemcunq, quoniam in ea qua fertipit lingua, quamuis extat, nondum tamen publicus nobis eft factus:) Āuicenna igitur, inquam, circan pelli murem parum fibi conftare uidetur, $\&$ ipfe etiam dubitaffe, effet ne aliqua huius nominis hitrs ba, an potius a nimal fiue mus huius nominis:utrumes enim bifmus appellat libr. 2, cap.yi, quamuis ad bifmus herbam, etiam uox buha additur à Bellunenfitutrum $q$ aduerfus napellum, \& albaras \& lepram utile facit. Buha(inquir Bellunenfis)fecundum Gloffam Arabicam, eft planta quędiciut gieduar, de qua Auicenna ca pite de zedoaria feu gieduar dixit, quod eius uicinitas infirmal plan tam napell, iadfertur autem hoc nomine radix ex India, nigra, craffa, ficut radix doronici, Gaporisa cuti: \& uidi ipfam exhiberi cuidam principi Syrix, Hxc ille. Ego apud A uicennam libro quatoin curatione napelli, buha $\&$ alguedar pro diuerfis napelli antidoris accipi obferuaui, Sed has denulu re napelli nugas, propemodum dixerim, Arabum et qui eos fectãtur medicorum, ta ndem relinquio fiue herba quxdam, fiue mus quadrupes, fiue mufcus ad radicem nafcens, fiue mu fea iniectum, fite mofchus odoramentum, aut diamofchi antidotus, (quod plus rationis haber)praftar tiffimumadurt fus napellum antipharmacon fit. Tam diuer(æ quidem opiniones ex ipfa nominum uicinitate uderl poffunt exortx. In Aethiopia radix quadam letifera eft, qua fagitras illinunt: \& in Srychiaum hrec, tum alix quadam, Theophraftus 9. 15. Rhododendron Diofcorides ait maritimis loris 8 les, cus amnes nafci, (uerba funt Marcelli Vergilï, ) q̊d res ipfa etiã nunc indicat: Er nos fcimus aliguot locis rhodanem corrupta uoce appellari plantam, qux quoniam paftu animalia enecet, pro toxicolia beatur, \& toxicum pariter uocerur, Hac ille. Vulgus Gallorum \& Italorum feré quouris uenenoin fectos, intoxicatos urocant. Non indignum hoc loco etiam Aufonï epigramma eft, fuper toxid uiribus huiufmodi:

Toxica zelorypo dedit uxor mocha marito, Mifcuit argentiletalia pondera uiui,

Diuidat hac fr quis, faciunt difcreta uenenum, Ergo inter fefedum noxia porula certant, Protinus \& uacuos alui petiêre receffus,

Nec fatis ad mortem credidit effe datum, Cogeret ut celerem uis geminata necem, Anridotum fumet qui fociata bibet. Ceffit letalis noxa falutiferx:

Lubrica deiectis qua uia nora cibis.

Quod fi hoc etiam toxicum de aconiti genere fuit, ut nobis uerifimile eft (Gallus enim Aufonius fuit, \& aconiti genere Gallos pro toxico ufos, 8 etiamnum uti, conftabit ex fequentibus, ) cum Hor molao \& Ruellio faciet, qui ( ut dixi) ab aconito primo non ex fcorpï iciu folum, fed aliud quodus in homine repertum uenenum impugnari putant, $8<$ illis inter fe collucfantibus hominem feruari, Quin \& alui fuxum aconito moueri in homine non dubitamus, cum idem in feris fiat, $P_{2}$ rdalinor cidunt tum alịs modis, tum aconito efcx admixto, unde fera per diarrhoeam inanitur, Pollux. Eiali bi, Elateria dicuntur pharmaca, qux nimium euacuando etiam necant, ut aconitum $\&$ elleborum, Quanquam etiam argentum uiuum per fe, tum pondere fuo tum mobilitate per inteftina deuolutel exitum quarere folet. Sed plura de toxico, $\&$ quòd ex aconitigenere conficiatur, in Ceruodocuica pite quinto: (hic nonnulla illic omiffa adincimus ) $\&$ inter cxtera ex Ariftotelis Mirabilibus, pardan lion (id eft pardalianches aconitum ) uenenum in Armenia nafci, \&c.atqui Arabes pro toxico, Ar menæ fagittæ uenenum plerif $\not$ in locis reddere folent. đI Acuftum(aliâs aucafton) fecundú Glola fam Arabicam eft interfector lupi, Andreas Bellunen. Videtur quidem ab aconito interpolata rex: quod $\&$ aconiftomon ( unde forfan colomeftrum nomen corruptum apud Diof coridem) uocari, $x$ Aëtio citat Hermolaus:item irin fylueftrem, \& pharmaciadem:nos prater iridis fylueftris nomen excufis Aétrï codicibus nullum reperimus aconito tributum. Faba lupina feu marcillium, datu in adipe, necat canes, lupos, uulpes $\&$ urfos, A rnoldus. Videtur autê apocynon Diofcoridis, quo filiquas habet ceu fabarum; et folia cum adipe in panes coasfa, canes, lupos, uulpes, \& pĩcheras ene 


\section{DeLupo. H.a. Lib. I. $\quad 747$}

cant: dicitur \& cynomoron. Cieria, id eft faba lupi, Syluaticus. Cenarafab, fabalupi, Idem. Apud Diofcoridem quidem kíx $\mu$ G $\lambda$ olu's, id eft faba alba inter aconiti alterius nomenclaturas ef, \&'forté cyamos lycu, id eft fabalupilegendum foerit;ut eadem caufa fic nominetur qua apocyrion, quòd lupos utrunģ occidat. Catilabket, id eft ftrãgulator canis, aconitum, Syluaticus. Cat lałich, id eft ftrangulator patris fui, Idem. Interfector patris fui, non eft aliud quàm fatyrion, ut docent $\mathrm{M}_{0=}$ nachi in Mefuen. bulbus enim nouellus tanquam filius uidetur, quirures ueteris \& rugofi, ceu pa= tris fui, in fe tranffumpfit, mox ipfe idem ab aliofubnafcente paffurus. Marcillin quidem uox ad confiliginis nomenclaturam Sabaudicam accedit,qua eft marfieure, quafi Marficam aut à Marfis in uentam dicas herbam, quod de confiligine Plinius teftatur : fiue fabam lupinam pro confiligine $\mathrm{Ar}$. noldus accepit,fiue eodem fimiliue nomine confiligo \& apocynon propter limilem in fer is necãdis, ut quidem exiftimo, facultatem, a ppellata funt. Chanach aldib, id elt ftrangulator lupi, fuffocat lus= pos, porcos $\&$ canes, Auicenna. Chanach alnemer, id eft ftrangulator pardalis, fuffocat alfhed $\&$ all nemer, (uetus interpres leopardos $\&$ lynces reddit, quod Bellunen, non probare uidetur:) Idem. All us eft interfector canis, de quo apud eundem libro 2, in fine I. litera legimus, canes eo fumpto confe fim interimi: \& in homine fanguinem per fputum \& nares moueri, (Arnoldus in libro de uenenis, idem de aconito fcribit, tanquam ex Galeno.) Ego hoc uenenum quod lic, non facile dixerim ₹ neqs enim uilli iliorum, quibus canes necari in ipforum hiftoria dixi, conuenire inuenio: fed neçalteri curipiam qua Diofrorides defcripfit uenenorum. Theophraftus fanememinir ele plantas quardam, qux fanguinem ad fe trahant; alias quæ repellant: $8 \alpha$ Galenus alicubi hiforiam narrat herbæ inuen= to ta, quam quifquis fibi appl.caffet, fanguinem excerneret atç boc pacto interiret, \&c. Dagabaorh, id eft aconitum, Syluaticus. Debacul, aconitum, Idem. Amanaram, id eft aconitum, Syluaticus. Baccemafculi Hifpanix. funt uenenum kacilkebi, id eft interficiens patrem fuum, A rnoldus. Elis forion, aliâs elifon, id eft aconitum, Syluaticus \&A rnoldus:eft autem nomen deprauratum pro aconi to thelyphono. Diaferiticum \&' er ufitium uoces corrupta leguntur apud Arnoldum in libro de ue nenis, proeriphia herba(de qua pluribus dixi in Hodo)qua aconito aut thapfia uires habet fimiles: mili quidem etiam genus aconiti uidetur uel propter radicis figuram, qua inftar bulbi oblongi eft, ad imum extenuati:(lic enim legerim in libro de fimplícib. ad Paternianum, non ad unum extuati, qux uerba nullum fenfum continent)accedit $\&$ uiolaceus flos, thyrfus oblongus, radicum appendi $=$ ces, natales in montibus, quę omnia nimirum in luparia noftra coerulea uidentur; folia quoģ non 0 mnino diffimilia apio funt; quare \& artemifix à Matthæolo comparantur:nifi quis non a pij, fed pla tanilegat, ut illihomines omnia corruperunt. Plinius quidem de eriphia fuperfitiofa quadam tra dit, quix fi luparix noftræ non conuenunt, erifichi tamen (fic feribitur) apud aurhorem de fimplicib. ad Paternianum defcriptio, \& cum eriphia Plinit, \& cum noftra facic luparia corulea, ut certe congener exiftimari debeat: 8cli theriphonum potius quàm eriphium dici mereatur, fi quis de etymo la= boret. In libro de mirahilibus mundi, legitur planta Aegyptia nomine adiporis(à lupo, ut uidetur, dicta)qux collecta immatura guftata mitigat fitim, odore cydoní pomi:matura uero fenfum interci pit, greffum impedit, linguam retardat, lædićç actiones mentis $\&$ corporis tanquam inebriando, A no:dus in libro de uenenis, बI Bixis, id eft tora, Syluaticus:quibix eriam napellum interpretatur.

Dahag, id eft tora,Idem. Brths(forte bix; aut bixis legendum) id elt napellus feu tora, habet folia lon go giora, uicifiora petrocillo(lego, incifiora platano:) radicem duram afperamćs, fummitatemćs grof fam, \& frondes (caules potius) quafi trium palmarum, flores purpureos, pulcherrimos: nafcitur in montanis, ut in montibus pineis, puta prope Podium Seritanum, (Hifpania locum effe puto, ) Ar noldus:a pparet autem plantam effe de altero aconitigenere. Et mox, Orobus coturnicum eft calidie tatis \& ficcitatis fummę, infert fyncopen, urertiginem, epilepfiam, \& linguam inflammat:necatós cele ritertnifi fuperedatur confeftim planta ad pedem eius nafcens, radnar uel radores uocant, alij napellum Moyfi, alij anthoram: \& eft fimilis ariftolochix, fed folia minora habet, nec floret, nec fronder, Hac ille authorem citans quendam Algafik. Eft fanéhic orobus coturnicum non alius quàm Auia cenna napellus, quo is etiam fcribit coturnices abfq̣, noxa nutririterrore, ut tridetur, nato ex Galeni

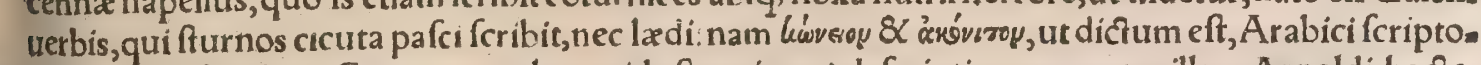
res fxpe confundunt. Cæterum anthoræ (id eft antitoræ) defcriptionem præter illam Arnoldi hacfe. nus nullam legi. Er mox, Filipendula (inquit idem)eft fpecies anchoræ(anthoræ) nigra exterius rits uero alba,radices funt obrotund $x$, minores glandibus: \& folia pimpinella, dicta lodomo, eft the tiaca uenenortım omnium, proprié napelli. Sagitta eciam illita fucco napelli, omne animal uulneratum necar. Corona ex eo geftata in capice, infert fyncopen, \& epilepfram. Gummi item ipfius, uene. num eft,Hxc omnia Arnoldus. Videtur autem filipendula eam ob caufam antitoræuel antinapelli genus exiftimari, quòd cœruleo napello noftro fimilem fermè radicem habeat, tum colore, tum figu ra \& magnitudine: fibris tamen \& cirris caret, ut fcorpï fine pedibus effigiem referat. lam quod in capite geftatum napellum, noxium effe frribit Arnoldus: admonet me illius quod nuper ex anicula quadam audiui, fi iuuenis inter tripudiandum cum uirgine, quæ lupariæ cœruleæ flores in corona 6o habeat, forte uulneretur, uulnus incurabile effe. Anchora eft herba in ortis(in montibus potius) na fcens, rara inuentu, nifi cum floret. Botanicus fibi ignotam fatetur, Simon lanuenfis. Et rurfus, An= cora herba eft theriaca contra toram, habens duas radices, ficut fatyrion, unam pinguem, alteram 
extenuatam:meminit earum Botanicus. Quæ uerò Gallis ancholia hodie urocatur ; angelica qul bufdam, non alia eft quàm aquileia noftra. Vt leucomata $\&$ albuginem quamuis denfam ex oculo detergeas, turam \& anturam herbas uirentes nitidiffimè collectas contundes, \& per linteum tenue fuccum earum exprime, cóç oculos inunge, Marcellus Empiricus: Vnde apparet toræ, uel tura, uel taurænomen, non ita recens effe. Ex Plinio quidem aconitiufum ad oculorum medicamenta fuiffe, iam fupra dixi. Herba qua taura uulgò nominatur, fiuc rora, flore eft coeruleo, folio rotın, do, radice polypodị hirfuta, \& uermis nigri effigie: Venenofa herba, cui per antipathiá natura alia occurrit herba, antitaura $\&$ antitora cognomine, folio rotundo, Hermolaus in Diofcoridem Corolla rio 54 1. in Lychnidis mentione: qua 81 ipfa taurion cognominatur, ut aconitum taura uel tora : eaç admora fcorpiones fimiliter torpefcunt: $\&$ quanquam aliud commune, quod friam, nibil habeant, hac tamen obfertatu digna nobis uifa funt. Apud A uicennam libro quarto inter pracipua napel, li antidota ture(tura, uel pótius antura legendum puto) numeratur, ut uetus interpres habet; ubi $A_{\text {, }}$ rabicébuha, uel bifmus buha legitur. Valdenfium populus in montibus habitat Gallix, non prow cul Auenione, Italiam uerfus, harefeos ab ecclefia Romana damnatus: apud hos toram herbã abun de nafci audio, cuius fuccum expreffumin bubulis afferuant cornibus, ad fagittas tingendas uenen no præfentaneo:ipfi toram $\&$ toxicum uocant, homo aut quoduis animal telo inde imbuto ictum in tra femihoram moritur:homini tamen pracipué letale hoc malum eft. Vim eius experturi, acumeo fucco inficiunt, quo ranam pungant: qua fi illico moriatur, ita præfentaneum iudicant. Mortiferum negant fi deuoretur bibaturue, etfi ne id quidem fine noxa fit. Præefentiffimum uerò effe coniuna cum fangurini, quod per fagittas contingit: fi tamen locus ictus frigida mox abluatur, remedium pol licêtur. Sanguis qui è uulnere defluxit etiam ad imum pedem, hoc ueneno contactus recurrit, $\mathcal{L}_{i n}$ uulnus iterum fubit: Tanta in eo fanguinis uitxó mine fide digno, qui cum $V$ aldenfibus ipfe uerfatus fuerat. Radicis certe $\&<$ foliorum forma, $\&$ uis ipfa ueneni, non aliud hanc toram, quàm primum Diofcoridis aconitum effe euincunt: quod \& ther lyphonon uocatur, quòd uerendis foeminarum inditum mortis caufa fit:nimirum quòd illic etiă uis

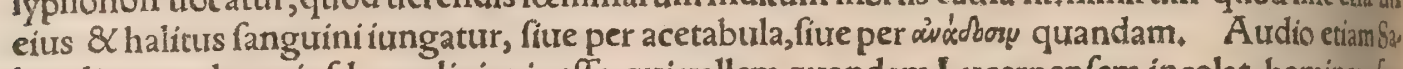
baudia populum eiufdem religionis eीe, qui uallem quandam Lucernenfem incolat, homines afue ros, nec admodum fuo principi obedientes : quòd metuendi fint propter fagittas herbæ tora fucco uenenatas. Singulos domi uafculum huius fucci plenum feruare audio : \& tali fagitta icros pallo poft mori, uulnere incurabili. A b hac ualle exïffe quidam aiunt $V$ aldenfes, qui ab huius herbe ufu Torelupini nominentur: nam lupos alias ç feras in uenatione, fimiliter huiufmodi fagittis feriunt Audiui etiam, fi bene memini, folis in Gallia Valdenfibus, priuilegio quodam hoc toxico uri liceret, forte quod $\&$ ad uenationem indigere uideantur, cum montes habitent: \& tanquam uiri boni cirz hominum noxam id poffeffuri exiftimentur: Sic $\& \mathcal{Q}$ de aconito in Ponto feribit Theophraftus, ,ifstane tum qui præparare nouerint poffidere conceffum, cæeteris interdicum capitis poena. Anthora, itts quit Syluaticus, dicitur quafi antitora:quod aduerfetur thoræ. funt autem dux herba, qua fimulna fci folent:folijs uiolarum, rotundioribus tamen, 8 parum incifis: floribus cyclamini, nifi quiain thes ra bene uiolacei funt, in anthora fubrubei: hac fanat, illa occidit, Hæc illetremittit autem ad Thora mentionem, tanquam plura illic dicturus in $T$, literał ubi tamen nihil prorfus fuper his herbis fripa tum inuenimus. Ant, Gainerius in libro de pefte, antoræ radicem tanquam egregium antidoum commendat, cuius experientiam ipfe uiderit, fi in potu detur fcrupuli pondere cum aceto \& aqqaro farum. Eft autem, inquit, herba qua nafcitur iuxta toram, ex qua uenenum conficitur, quo cumin alpibus Saluciarum \& $<$ Pinarolị capras fylueftres uenantur. Radix eius (antoræ ) fimilis eft nuclis oliuarum, cuius mentionem in Synonymis Simon Ianuenfis facit: $\&$ eft bezear tore, qua nullam tí animal fuo ueneno interimit. Admonet me antora herbx cuiufdam rarx, quam femel tantum in monte quodam alto Sabaudia reperi, ultra Lemannum lacum èr egione ferè Laufanna: foliunnelio tundum, planè circinatum, ea fere magnitudine ut diameter duos pollices æquet, in circuitu ferratü, folidum, albicans: \& fi bene memini, fing!llis plantis unicum, florem non uidi, radices funt albe, glan dibus aut oliuis quodammodo fimiles utffilipendula, guftu feruido. Árabes quidam A fcirapplet lantur, quoniam bubulos utres binos fternentes ponte, piraticam exercent fagittis uenenatis, Plini us. Portulacæ fylueftris quam peplion uocant, memorabiles ufus traduntur: fagittarum uenena,es ferpentilim hamorrhoidum $\&$ prefterum reftringi, pro cibo fumpta, \& 2 plagis impofita extrahi, Pli nius. Scincus prodeft contra fagittarum uenena, ut A pelles tradit, anté pofteáç fumptus, Idem, Silphium uenena telorum \& ferpentium extinguit potum, ex aqua uulneribus circumlitum, Plin, Venenum ferpentis, ut quxdam etiam uenatoria uenena, quibus Galli pracipué utuntur, nongith fur, fed in uulnere nocent, (hoc etiam hodie de tora fertur, ut fupra dixi:) ideóḉ colubraiṕa turo eftur, icius eius occidit, \&c. Celfus. Primum aconiti genus(folio cyclamini) f̧̣pe in Tridentino man te, ubi abunde nafcatur, collectum Matthæolus fcribit: nomen uero eius nullum adfert, nec ullamde friptionem. Toram enim alibi Diofcoridis orobanchen nominat, fic diçam (ut ait) quòd ea guffata uaccr mox tauros defiderent: ean dem ait lupam uocari : quód deuoret plantas iuxta nafcentes, led de orobanch $x$ multis differui in Boue C. De primo aconiti genere fuerit, in quit Matthrolus, tar dix illa qua quidam circa Romam \& Neapolin utuntur, qui unam hanc lupos necandi artem pros 
Ixftinam translacum, fine periculo mandi coppit, Hermolaus Corollario 38 . quem Ruellius efian, rolet, fequitur. Ego utrunģ, deceptum uideo, neç enim de helenio hac uerba Arifotelis (aut nuil, quis eius libri author eft) neqz de ulla alia herba intelligi debent: fed de perfea arbore: de qua Diofo rides, Retulerunt quidam letalem in Perfide hãc arborem effe, translatam uero in Aegyptum mus taffe naturam $\&$ cibo idoneam effe. Idem Columella et Theophraftus teftantur. Nihil aurem mirum fi pro perfea beienion legatur:cum paffim eo in libro $\&$ barbara $\&$ corrupta nomina multa legath tur, ut artemifia etiam pro arbore, \&c. Galli fagittas in uenatu elleboro tíngunt, circuncifoćtint nere teneriorem fentiri carnem affirmant, Plinius libro 2 5. ad finem capitis 5 . Vnde apparet elleboro quogs uim ad fagittas eãdem ut aconito effe: $\mathcal{X}$ alias infuper, ut mures, mufcas $\&$ pedes necare, qua ibidem commenorat Plinius, Sed hoc etiam fufpicari licer, fieri poffe ut Galli ellebori nome aconito dederint olim quoç, ut hodie adhuc multis in locis, pharmacopola etiam, quod Syluius teftatur \&" ipfe uidi, errore quidem capitali: fed hodie illi aconiti coerulei radices pro elleboro nigro ufturpant: Plinius de albo loqui uidetur, quo fagittx tingantur. De toxicis $\&$ fagittarĩ uenen is annotauit qure dam Calius 23.10, Eúryyes, radix qua fues (apri)capiuntur, Hefychius \& V arinus. Hanc quioeo aconito fi quis adnumeret, non aberrabit. fcribit enim de primo aconiti genere Diofcorides, quod? alias feras, \& fues occidat, nimirum angendo et quafi ftrangulando, unde \& $<$ pardalianches dicium, Hactenus de aconito, toxico, napello, tora, $\&$ fimilibus feu facultate feu forma plantis, quibus $\& l_{u}$ pi $\&$ aliæ feræ, fed $\&$ homines necantur, cauendi gratia, $\&$ antidota cognofcendi, dixerim; prolixills quidem quàm argumento de animalibus conueniat:non tamen ingrata, ut fpero, hominibusiliera tis, pracipue nedicis futura:quod plerags omnia primus noftro faculo longa $\&$ diligenti obferu ne ifta partim ipfe protulerim, partim collegerim.

A Animalia. Hyænalupo fimilis eft, ut Philoponus inquit, Niphus. Colore lupi prope eff, fed hirfutior, 8 iuba per totum dorfum pradita, Ariftotel. Dabha (hyæna) animal mediun inte Iupum \& canèm, Bellunen. Avronóvbrso, animal mixtum ex pardo \& lupo, ut quidam in Lexico Græcolatino annotauit: Vide infra inter congeneres lupo feras. De chao \& lycaone, lupo cantario, $\&$ thôe, id eft lupo ceruario, infra poft lupum ftatim dicam. Lyncem aliqui eandem thôi cxiftumantí, Itali uulgo hodiég lupum ceruarium, aliqui lupum cattum nominant: Germani ludo uel lue, Vala lenfes Heluetri tbierwolf.De Lycifco id eft, cane ex lupo \& cane nato, uíde infra in c. Nominibus non longiffimis appellandi funt canes, ut Lupa, Cerua, Tigris, Columella. aurád os Thefialicaca nis epitaphium in Cane fcripfi ex Polluce. Avxirt's, unus ex canibus Actronis apud Aefchylum, Pollux. TLupus, $\lambda u^{\prime}$ I $_{\text {, }}$ ex graculorum fiue monedularum genere auis, Ariftoreli; quamuis apud

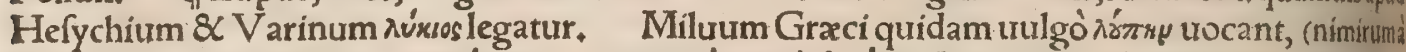

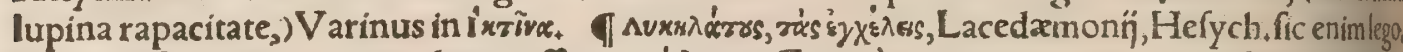

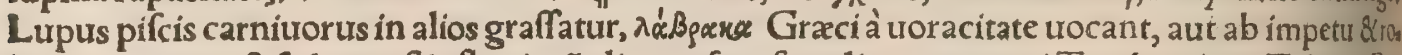

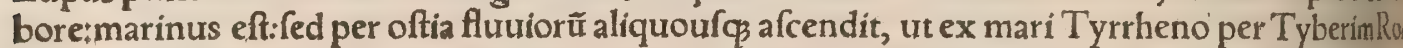
mam ufo. Recentiores quidam imperiti maris, lucium pifcem robuftifimum uoracifimumó, ialis dis dentibus acuris armatum, lupum effe putauerunt, lucij etiam nomine, tanquam à lyco Gracoí alludente, fed lupum pifcem Graci labracem, non lycon uocant; \& marinus eft, ut dixi, \& 6 , Lycos quidem etiam Gracis, ut Hefy. $8 \mathrm{~V}$ arinus teftantur, pifcis nomen eft; qualis uero is fueritnon fatis conftat. Hicefius pifcem anthiam, ab aliquibus lycon, ab alins callionymon uocari fcribit, Äthentus libro 7. Vide in Lupo inter pifces، Engrauli, engraficholi, uel craficholi pifciculi, alio nomine lyos: ftomi dicuntur, Aelianus + Suidas apux pifciculi epitheta effe fribit. I Lupos phalangiorum fitre araneorum generis, in libro de infectis quares, Nicandri Scholia lycon etiam muffar genus elie docent.

IIcones. Aquilam Romanis legionibus C. Marius propriè dicauit: erat $\&$ antea prima cum quatuor alịs:lupi, minotauri, equi a prí̧̧ fingulos ordines anteibant,Plinius. Lupo Apollinem de lectari aiunt, quia hic ex Latona in lup $x$ fpeciem conuerfa, editus in lucem \& fufceptus fuiffefera tur : eamćs ob remlupi fimulacrum in Delphico templo ex ære excitatum effe arbitror, \&c. (plura uide in h.in Lycæi A pollinis mentione.) Quem inauratum in Capitolio paruum atç lactentem hu beribus lupinis inhiantem fuiffe meminiftis, Cicero in Catilinam. Denarij etiamnum uetufifinim reperiuntur argentei, cum imagine lupæ qux Romulo \& Remo infantibus ubera præbet. Lycus

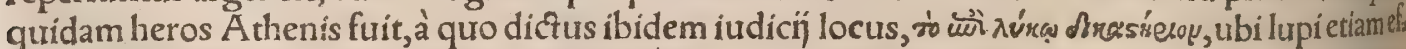
figies pofita erat ad defignandum loci \& herôis nomen, Pollux. Vide mox inter propria uirorınt, Lycópodes, fatellites tyrannorum*qui pellibus lupinis pedes induebant, uel in fcutis lupi infigne ha bebant,Suidas $\&$ V arinus,

đI Virorum propria. A Lupo nomina uirorum habent Germani, Dolf/ Wolfbart/ Wolfs gang. TLupercus Berytius grammaticus, uide Suidam. Lupus Seruatus presbyter, \& Lupls de Oliueto Hifpanus monachus, in Bibliotheca noftra, Lupum uirum Romæclarum fuis carmini bus carpfitLucillius, tefte Horatio. Plinius 8. 52. Fulun̈ Hirpini meminit: hunc M. Varro(inquil Hermolaus) Fuluium Lupínum uocat. Vide pauló poft ab initio de proprïs loc, \& popul. Lycambes filiam habuit Neobolen, quam Archilocho in matrimonium promiffam cum non daret: irratus Archilochus in eum maledicum carmen fcripfit, quo Lycambes tanto eft dolore compulfus, ur ctum 
for, Paufanias in Eliacis:alibi etiam Lycini equitis infignis, \& $\alpha$ alibi pugilis meminit. Rectus uti ures Lycini, neça âltum Semper urgendo, Horatius Carm.2.10. Lycis(urel Lycus) poéta comicus $\mathrm{ab}$ Ariftophane tanquam frigidus notatur, Suidas. Lycifcus ftatuarius fecit Lagonem purerum fubdola ac fucata uernilitatis, Plinius 34.8. Lycifci cuiufdam Paufanias in Meffenicis meminit, ey Aepytidarum genere. Lycomedes rex Scyri (cuius in Thefeo Plutarchus meminit) filiam habul Deidamiam,ex qua Achilles Pyrrhum genuit, Vide Onomafticon. Lycomedes Creontis filius pud Homerum lliad, g. hurius cum uulnere in uola picti, Paufanias in Phocicis meminit, Lycomea des Mantinenfis, uir nobilis \& diues, Xenophonti rerum Græcarum lib. 7. Lycomedes natus ex Parthenope Ancari filia \& Apolline, Paufanias in Achaicis. Megalopolis conditores ab Arcadi, bus electi, Lycomedes \& Poleas Mantinenfes, \& alï, Paufanias in Arcadicis. Aurouńd EQ,

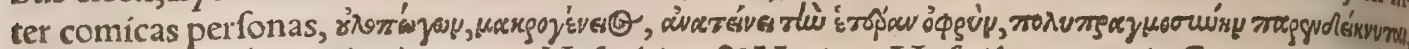

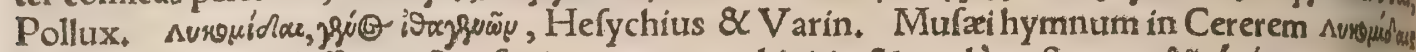

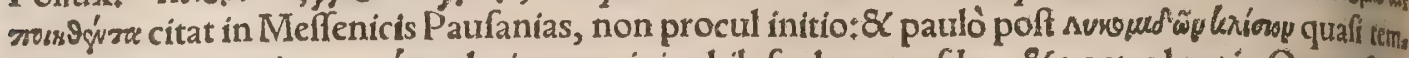
plum eorum nominat, $\Lambda u ́ r w y_{+}$huius nominis philofophos quofdam \& poetas lege in Onomafico, Lycon Comodus in nuptins Alexandri Magni fuit, A thenæus lib, 12. Eodem in libro Lyconis Perie patetici meminit. Lycon Scarphei filius Comœedus, ab Alexandro Magno decem talenta accepit, Plutarchus in Alexandro. Lycon Achæus, apud Xenophontem Anabafeos lib. 5. Lyconislafen fis librum de Pythagora citat Athenęus. Lycos uel Lycon quidam pentathlus fuit, Scholia in Ver fpas Ariftoph. Lycophron, uiri proprium $+\mathcal{Q}$ adiectium, crudelis, fuperbus, Hefych.et Varit, Ly cophron Chalcidenfis, Ariftoclis filius, adoptatus autem à Lyco Rhegino, grammaticus \& poerat Tragicus, \&c.Suidas. Vide Bibliothecam noftram \&Onomafticon, \& quadam Calin loca exindis ce. Nicias A thenienfis Lycophronem Corinthiorum imperatorem occidit, Plutarchus in Nicia, Lycophron Perinthi Corinthiorum regis filius, matrem occidit uiluente adhuc patre, Onomaft, Ly cophron Pheræus uniurerfa imperare Theffalix quarebat, Xenophon rerum Grac,lib.2, Lyco

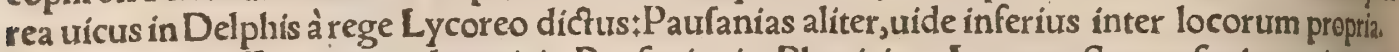
Lycormas Lariffęus equo celete uicit, Paufanias in Phocicis. Lycortæ Syracufani mentionem in Eliacis facit Paufanias, \& alins in locis, ut index in translatum demonftrabit. De LycortaMegalon politanorum imperatore nonnulla fcribit Plutarchus circa finem Philopoemenis uritz. Lycurgl cuiufdam Itrennui uiri Homerus meminit, quem filium facit Dryantis: fit autem Lycûrgus contra

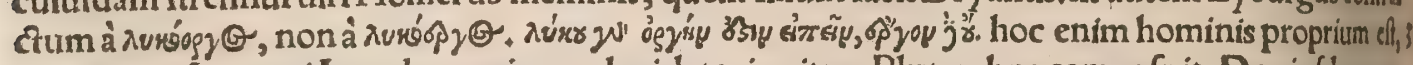
$\checkmark$ arinus. Lycurgi Lacedamoniorum legislatoris uitam Plutarchus compofuit, De eiufdem cons Ititutionibus, 8 morte multa legimus apud Suidam. Vide Onomafticon, 84 indicem in Calium \& in Herodotum. Lycurgus unus ex decem rhetoribus A thenis, Lycophronis filius (nepos Lycurg legislatoris, Varinusł)plura leges apud Suidam. Lycurgides, filius Lycurgi, nepos Dryantis, An: caus nomine+uide Onomafticon. Hoc obiter addam, inter phialas fuiffe qux dicerẽtur lyciurges

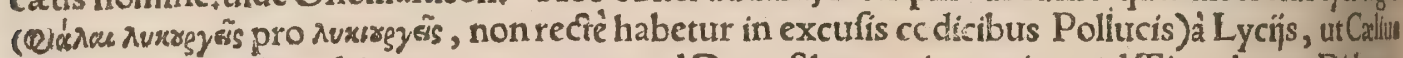
ait, Aururegyis, (malim ultimam per $x_{0}$ ) trox apud Demofthenem in oratione ad Timotheum.Didymis interpretatur phialas â Lycio Myronis filio (à Lycone quodam alï, A thenazus libro undecimo)far

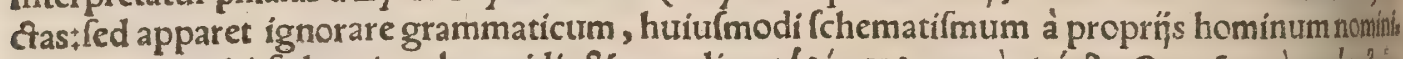

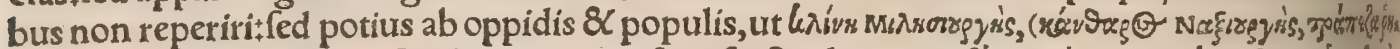

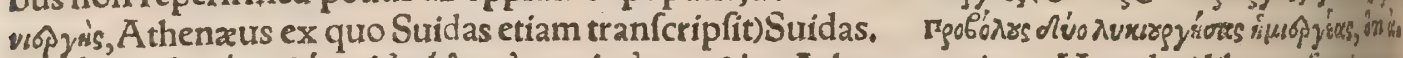

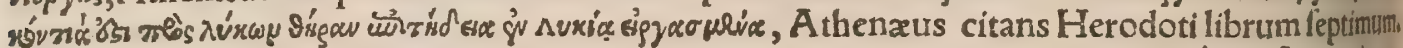

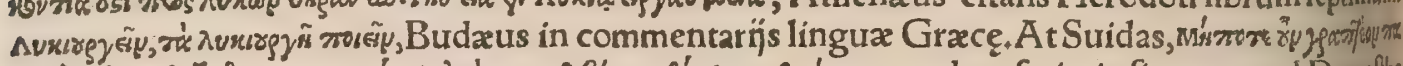

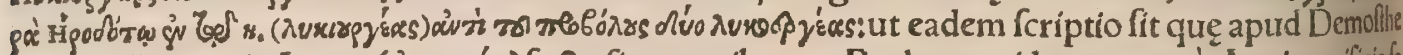

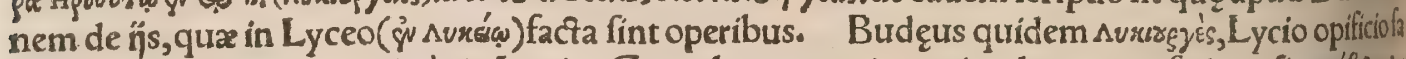

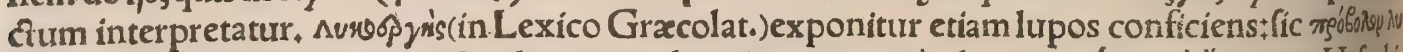

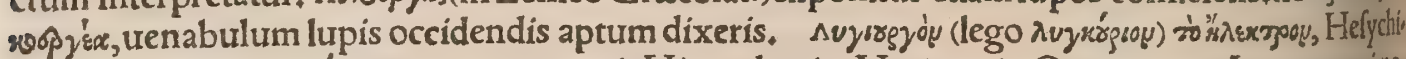
us \& Varinus. $\wedge u x r e \theta$, untus ex procis Hippodamix, Varinus in Oenomao, Lycus purino, men, Horatio in Odis 2.32. Lycus (Apollonio in Argonauticis)DafcyliBithyniz regis filits, fare lum Caftori \& Polluci dedicauit, magna cura liberatus, interfecto ab ipfis Amyco Bebrycum rege, Hermolaus in Plinium. Celænûs \& Promethei filin memorantur Lycus \& Chimareús, Varinus in

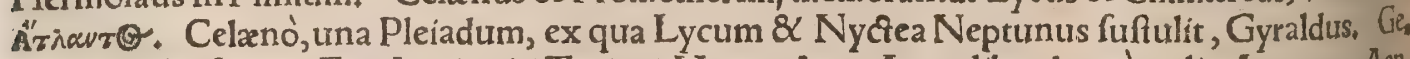
mit crudelia fecum Fata Lyci, (uiri Troiani) Verg.ı.Aen. At pedibus longé melior Lycus, q. Aen, Lycus ftatuarius puerum fuffitorem fecit, Plinius 34.8 . súx@e uel súxwe quidam pentathlus fuil, Scholia in Vefp. Ariftoph. Athenis in templo Minerux pugnans Cycnus confpicitur. Is Cycnus, ut aiunt, cum alios tum Lycum Thracem propofitis ad fingulare certamen præmijs occidit, Ad Alur uium uerò Peneum ab Hercule eft interfectus, Paufanias in Atticis. Hercules Lycum Thebarum regem quòd Megaræ coniugi uim uoluiffet inferre interemir. Nycteus (cuius filia Antiopecele bratur)ex uulnere moriens, Lyco fratri imperium Thebanorum committit, Paufanias in Corinthia cis:de eodem plura in Bocoticis fcribit, \& quomodo ab Antiopæ filins ( Amphione \& Zetho) pugna fuperatus fit, Vide Onomafticon. In itinere ex agro Corinthio Lyci Meffenï monumentum cerni tur, quifquis tandem Lycus ille fit. Nec enim illum inuenio Lycum Meffenium qui pentathum 
ferua Lycimnia(forte Licymnia fribendum, ut uiri quoç nomen) furtim fuftulerat, Verg. 9. Aen, Vel qualis equos Threiffa fatigat Harpalyce, Verg. I. A eneid. Eft \& uiri nomen. Harpalycus,

बPropria locorum \& populorum. Irpini appellati nomine lupi,quem irpum dicunt Samnite eum enim ducem fecuti agros occupauêre, Feftus. Fuluium Hirpinum diçum à Plinio 8. 52.Marcus Varro 2.de re ruft, Fuluium Lupinum uocat. Ab Hydrûnte Soletum defertum, dein Fratuertiü, Portus Tarentinus, ftatio militũ Lupia,Plinius 3.11. aliâs Lufpia.Antonius Lupiam XXV.M,pab̆

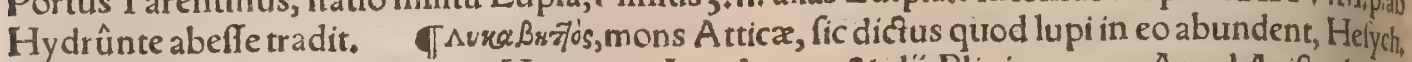
\& Varinus. In Attica montes, Hymettus, Lycabettus, \& alï, Plinius 4.7. A pud Arifophanem in Ranis per t.fímplex legitur, ut Suidas etiam $\&$ Varinus ex eo citant, fed loco corrupto, fic enim

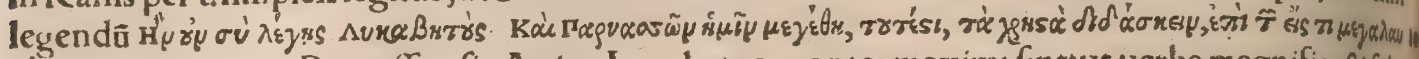

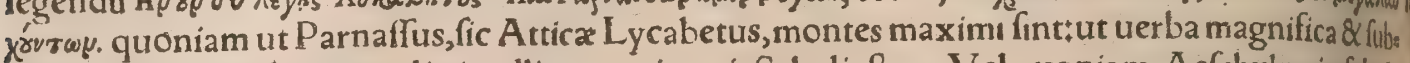
limia, quafi montibus æqualia intelligamus, inquit Scholiaftes. Vel quoniam Aefchylus in fabula

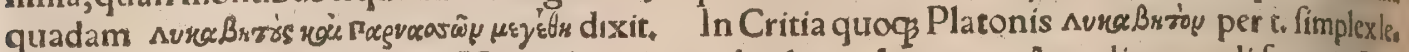
gimus, in Oeconomico autem Xenophontis per duplex. Lycæatæ, Arcadix populi fuerunt, $P_{\text {att: }}$

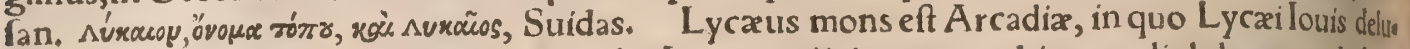
brum, Plinius. Quum promonte Arcadix Lycæum dicimus; penultima æ. diphthongum habere

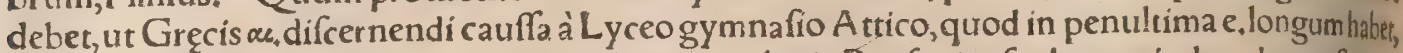

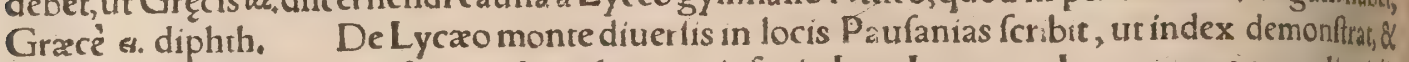
ex Paufania Calius 24.17.8 nos plura dicemus inira in loue Lycæo. Lycæum montem aliquidia çum fribunt à lycis, id eft lupis, quibus propter frequentiam pecudum abundabat; Er gelidifeula runt faxá Lycæi, Vergil.Aegl. 10. Confitá ćs arboribus Lycea reliquerat arua, Ouid. 2.Metampiót. aliqui Lyrcea legunt, quod magis probo uel profodix ratione, Lycæa uel Lycætha, urbs Arcadia; gentile Lycæus, Stephanus. Hypermneftra cum patris imperium contempfiffer, à patre fuit ad Ly, cei for um citata,Paufanias in Corinthiacis. Lycaones, populi A fix Pbrygibus \& Galatis feuGal logracis uicini, Pomp. Mela. Lycaones in A fia funt, Pifidarum \& Cilicum tinibus, Hermolausiter

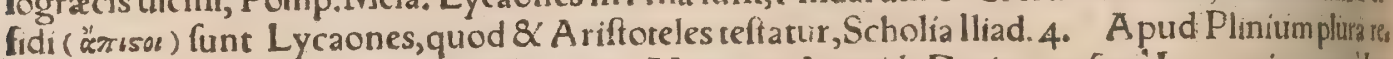
quires ex Indice. Lycaoniumḉ Ericaren, Verg. 10. A eneid. Deriuatur fané Lycaonius utumály, caone rege, Foda Lycaonix referens conuiuia menfx, Ouidius: tum à regione, à qua etiam Lycan eł Lycaon gentilia funt, Stephanus. Lycaonı, serovía, A fir regio, \&c. uide Onomafticon, Dicha eft autem hacregio à Lycaone rege, de quo iam fupra dif̂m, Varınus. Arcadia dim Lycaomiadi

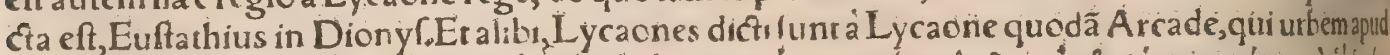

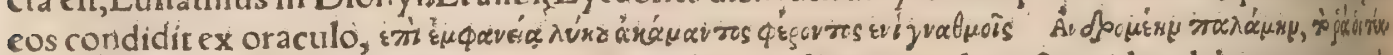
usegu Ả obcuntis:ut inter pretemur oraculum, illic condendum efie oppidum, ubi lupus ore geftans mantum hominis occurriffet. Lycaonía \& Lycarnia, regienum nomina, Varinus. Stephano quidem Lia caria uel Luceria, urbs eft Italiæ, incola Lucrini, Lycapfus, núra tos, uicus prope Lydiam, Stepha nus. Lycafpus, urbis nomen, Hefychius \& Varinus, ego Lyca fius legerim. Sic enim Stephanous cacur urbs Cretæ, à luporum multitudine diça, qua ibi effe creditur. (Atqui Ariftot, in Mirabiltb, Lupos, inquit, 8c limiles feras noxias in Creta elle negant.) Memirerunt eius, Mela libi 01.8Stras

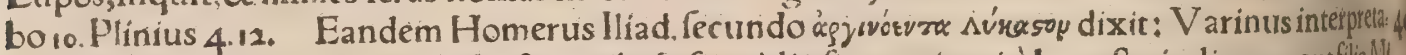

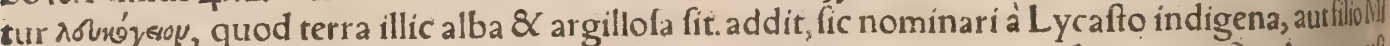
nois. Eft SCPontica Lycaftus, inquitidem, ut refertfriptor erhnicorum: fic uocant Stephanum, eti in impreffis Stephani codicibus nihil tale reperiam. fed conftat eos multis in locis mutilos effe. Lyca fum etiam Plinio ciuitas eft Cappadocia. surésiou, regio Leucofyria ( Cappadoces quicndamLells

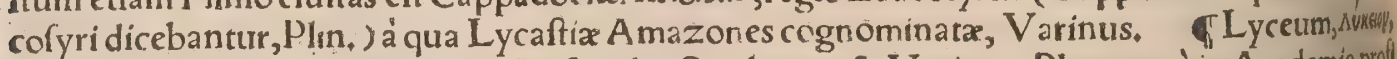
cor tebatur hincilliCiceronis uerfus, Inós Academia umbrifera nitidcós Lyceo, Fuderunctaras forcundi pecforis artes. Aliqui Latiné etiã Lycium fcribunt. Qui erant cum Ariftotele, Peripatetid dicti funt,quia difputabant inambulantes in Lycio. Lyceum, ut habet Suidas, Theopompus Pilis ftratum conftruxiffe ait:Philochorus uerò, pratide $\&$ dicfante Pericle factum effe. Erat autemlocis if ( gymnafium ) iuxta urbem, in quo exercebantur ante bella : $\&$ antequam milites educerentur ad

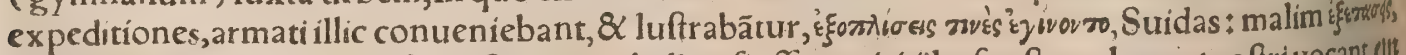
fecundum Hefychium: $\&$ fi qui ftrenui ac bellic ofi effent uiri, illic fe oftentabant, ( noftri uocant tlik mufterplas campum uel aream faciendi delecfus militum aut exercitus luftrandi.) Eadem ferefort bit Scholiaftes Ariftophanis in Pacem. Lyciades ( $\&$ alibi, Lycaides)uil gines numero triginta, qliz aquam ferunt in Lyceum, Hefychius \& V Varinus. Lyceum fuit etiam gymnafum Ciceronisin Tufrulano, à nomine fcholæ Ariftotelicx, de quo libro I. de Diuinatione fic refert: Nuper quum ela fem cum Qu. fratre in Tufculano difputatum eft. Nam quum ambulandi caufa in Lyceum uenifit

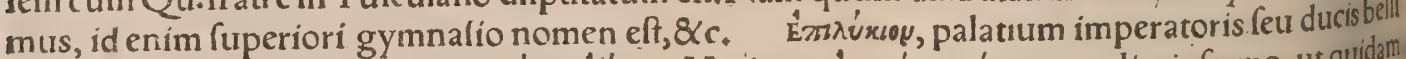

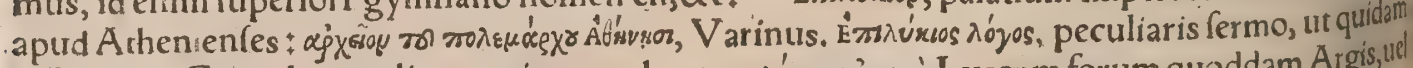
in Lexicon Gracolat retulit, non citato authore. $\Delta u ́ x \operatorname{sos}$ àyogá. Lyceum forum quoddam Argis, ull in terra Argiua, ubi conueniebant, Apollini facer, Hefychius \& Varinus, súxesov, locus thel urla 


\section{DeLupo. H.a. Lib. I. 755}

Theffa lix, à lupo denominatus, qui illic in faxum conuerfus fuit, Varinustapud quem perperam le

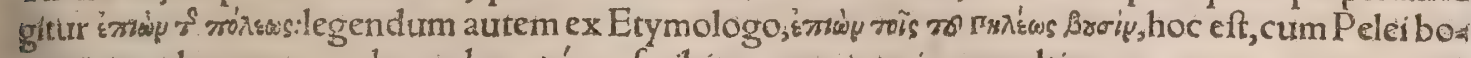
ules aggrederecur ; apud eundem Aúrsoy fcribitur, per iota in penultima.

T Teuthranex fupra Aeolidem fitæ, oppida funt, Haliferne, Lycide, 8cc.Plin. Lycirna, paguis prope Calydonem, Strabo libro 10. Lycinopolis, ciuitas quaedam in Originum libro Catonis. Lycï dicti funt fecundum quofdam à Lyco Pandionis filio, qui in A fiam traiecit, Euftathius in Dionyfurm ex primo Herodoti. Lycius gentíle, \& cognomen Apollinis, I núnox, urbs Ar* radix, Stephanus ex Paufanix oftauo, id eft Arcadicis, ubi fic fcribit In Manali montis extremis partibus figna (rudera) ciuitatis Lycox apparent, templum item Diana Lycoatid dis. Super Pfyllos in Africa lacus Lycomedis eft, defertís circumdatus, Plínius. Aunóns, urbs Thracia, Stephan. ^úxwve, nudum nomen apud Suidam. Lycopolis, urbs Aegyprific a lupis cognominata, eò quod Aethiopes agros Aegyptios incurfantes, lupi facta acie uíç ad ciui tatem Elephantinam repulerint, Ibidem igitur ciuitatem conftuctam A egyptij à beftijs illis Ly copolin cognominarunt, ac pro dijs lupos ipfos uenerantur, Diodorus Siculus libro 2. Lycan polis, id eft Luporum citritas, una eft in Lycopolitide prafectura Aegypti + altera in Sybennitica iuxta mare, Stephan. Luporum ciuitatis meminit Strabolibro 17. \& Plin. 5.9. Eidem alibi, Lyco politis una eft ex prefecturis Thebaidis A egypti. Lycopolitana Thebaidos ciuitas, pari religio ne Apollinem \& lupum colit, (ut in h, dicetur, Macrobius. Lycorea, suríugsax, nícus in Delphis,

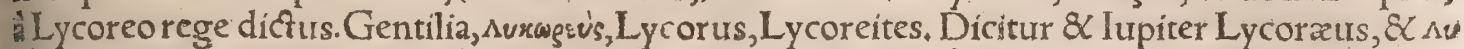

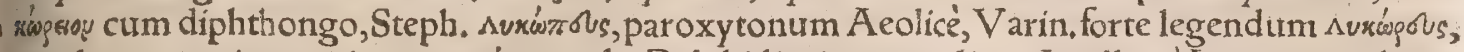
quod communiter acuitur, suríges, urbs Delphidis, in qua colitur A pollo, à Lycoro conditore

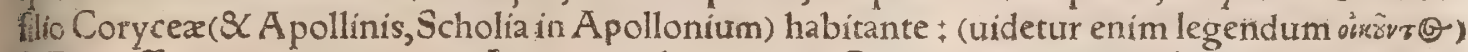
in Parnafo: qui montem quoç (Lycoriæ urbi)uicinum Coryceumappellauit à nomine matris, $\mathrm{E}=$ tynolog. Corycium antrum à nympha Corycia dicium uolunt, â cuius filio Lycoro cíuitati fa cum Lycoriæ nomen fit. Ex Lycoro Hyamus nafcitur, cuius filia Celænò Delphum ex Apolli: ne concepir, à quo nuncupatı Delphi, Calius ex Paufanix Phocicis. Oppidum(inquit Paufani= as ibidem) ibi antiquifimum aíunt effe condirum à Yarnafro, \& $c_{+}$à quo \& monti nomen índitum: oppidum id quogs diluuio Deucalionis tempore fuiffe fubmerfumaiunt. Quicunq̧ autem homis

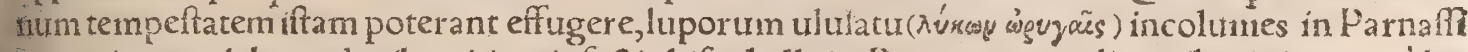
cacumina euadebant, ducibus itineris factis hifce beliuis, Propterea conditam íbi ciutatem, à lu. pis Lycoream appellarunt $u$ unde \& A pollo Lycoreús dictus, aliâs Lycoræus, Hac Paufanias \& ex co Gyraldus. Aurwoó, nudum nomen apud suidam. oübs svragoi, Orpheus in hymno ad A pols

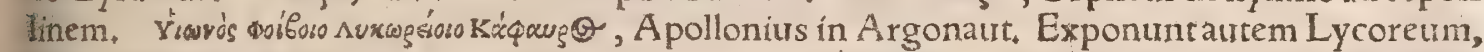
Delphicum + nam Delphi primum suxeseses dicebantur, à Lycorea uico, Varin. Deucalion \& Pyra tha cum terra diluuio obrueretur, arcam ingreffi, fupra Parnafium, uel fecundum alios Lycoreum montẽ clati funt, Scholia in Olympiorü Pindari Carmen 9. Lycoithene uel Lycofthenıa, Auraa ǵvs;

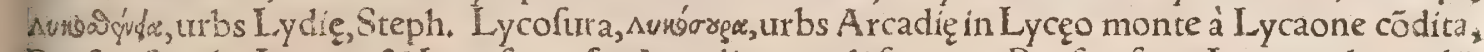
Paufan,Steph. Lycotz \& Lycofurenfes Arcadix populi fuerunt, Paufan, forte Lycoata legendü: fic enim à Lycoa ciuitate dicuntur. Prope Lycoluram effe dicuntur montes Nomī, in quibus $\&$

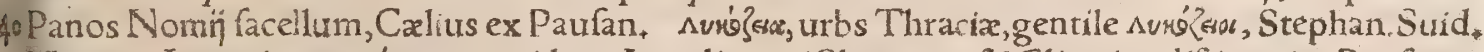
Varin, Lycuria, sureeix, ager quidam Arcadix, quiPheneatas 8 Clitorios difinguit, Paufan. Lyctos oppidum Creta, à Lycto Lycaonis filio conditum, Stcphan.

Euenus furuius in Aetolia oritur, Lycormas olim dicus, Strabo lib, 10, \& Stephanus in Ly corma, ubi pro Eueno perperam Eycnos legitur+uide Onomaft Meminit \& Srobęus fermone 98. de morbis, \&c. Lycus fl. Ponti, uiginti ftadijs ab Heraclea diftat, A rrianus in Periplo Ponti. He raclea opp.Ponti, Lyco fl.appofitum, Plin. Et rurfus, Præteifluit \& Neocafariam. Multis etiama lïs in locis, ut Index oftendit, Lyci fl, memin it. Lyci amnis in Heracleenfiagromeminit 8 A pol lonius in Argonauticis, qui \& regem tractus eius Lycum fuiffe refert $\$$ \& Orpheus in n̈fdem, iuxta Euxinum effe canens hunc fluuium, ubi Argonautza Lyco rege fufrepti fint. Fluti per regionem -Mariandynorum, Varin. Minorem Armeniam Lycus amnis diferminat, Plin, 6.3.Et mox, Iris fir men deferens Lycum. Iris in Ce recipit Lycum ex A rmenia fluentem, Euftath. Caper f.Laodia ceam Caria urbem cum Lyco \& A fopo amnibus alluit, Srrabolib.12, Landicea urbs A fia impof ta eft Lyco flumini, Plin. Lycus fluuius Heracleenfis agrı duorum iuger um latitudine, Euftath. ex Xenophonte:A A ud quem hunc locum reperias libro 5 , de expeditione CyriłubiRomulus Ama

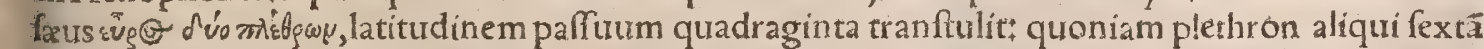
ftadij partem interpretantur. Lycus in A fia cerr $x$ hiatu abforptus, \& alio loco renafcens, tandem in Pontum cadit, ut tefatur Ouidius li, 4 . de Ponto Eleg.10. Et Metam. Iib.11. Iuxta Cnloffas Phrya gia urbem Lycus amnis hiatum terra fubiens occulitur:deinde feré quinç poft fradia emergens, $e$ labitur 8 ipfe in Maandrum, Herodot. Lycus A.Cilicix, Plin. 5. 27. A Thyflagetis quaturor in bo gentes amnes per Mrooteos fluunt, in Mrotin paludem fe infinuant, Lycus, Toaris, Tanais, Syrges, Herodotus, Lycus flutuius Telchinum, Herychius $\&$ Varinus, Lycos fi.in ora Phonices, Plini us; meminit eius $\&$ Strabo, Eft \& LycusAfiyriorum fludus, qui Tigrimmifretur, Onomaficon: 

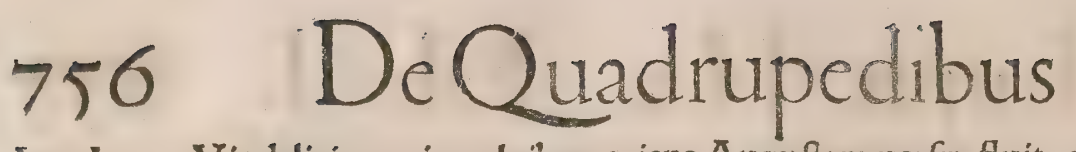

Item Lycus Vindelicix, qui ex alpibus oriens Augufam uerfus fluit, ac tandem Danubio mífee tur, accolx uocant Den $\mathbf{Z}$ ed : hic Vindelicos à R hæris diferminat. ^ux moro, Lyceus potus, à fontequem A pollo inuenit, ex quo lupi bibunt, uino \& meile manantem, Suid. Hefych. Var. Sed diftinctius Erafmus in prouerbijs:Lupinum potum(inquit)dicebant, ubi quis uoluptatem fui periculo capitis emeret. Narrant duos erupiffe fontes facros A pollini, quiorü alter uino fcateret, alter melle, ad quos cum aues aduolarent feriebantur. Porrò A pollo Lucius di. cीus eft, fitue à lurce quam aperit, fiue â lupis interfectis, Authores Zenodotus 8 Suidas.

बI $b$. Ferè onnia quæ diximus de leone, habet etiam lupus, fed pleraç hic minus, ille magis: moribus tamen lupus improbior eft, $\&$ magis infidiofus, Albertus. Formicis Indicis magnitudi Aegypti luporum. đLupi à colore epicheta quadam inter catera retuli fuperius, súr@ mìté

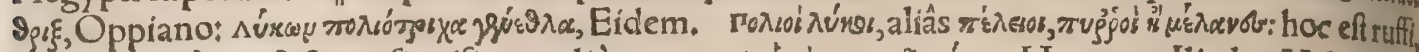

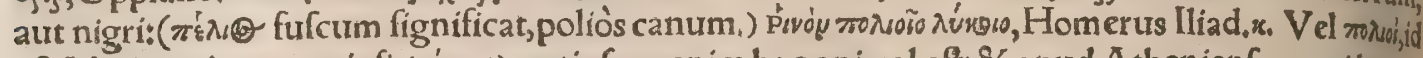

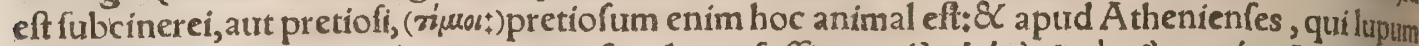

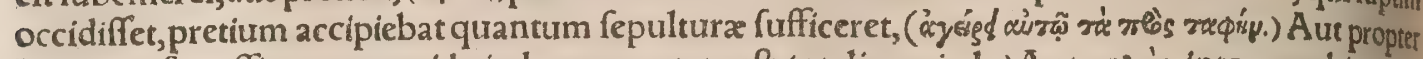
Latonam fortaflis qux grauida in lupam mutata eft, (ut dicam in h.) Aut moגirs interpretabimural, bos $\neq$ nam pilis corum, parte proxima cuti, color eft albus $\neq$ media, niger:fuprema ruffus, ut per fynec, dochen $\mathrm{ab}$ albicante parte lupi toti monvoi dicantur, Etymologus $\&$ Scholiaftes in 2. Argonaut, Anol lonï. Vide fupra $\lambda$ uró terius nigricant, Varinustinde $\lambda u r o ́ p \omega s$ tempus matutínum nocti $\&$ diei confine. Lupina pellio $c_{i}$ nerca eft, $\&$ nigredinem non puram haber, Varinus in Ácenúxs, Lycophthalmos gemma lupini in oculi effigiem refert, Plinius. Lupati uel lupi, freni afperrimi à fimilitudine dentium lupinorun,

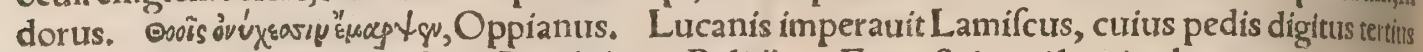
à magno fimilis lupi digito fuit, Heraclides in Politijs، Ex noftris qui lautius loquuntur, peculia

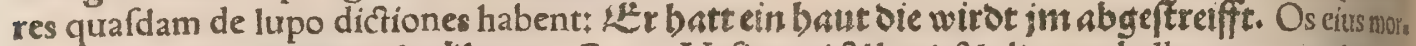
fum uocant, cin gebif̈tpedes Hlawent. Caput Vrfi, apri \& lupi, \& aliarum belluarum mordentium Galli peculiariter hure uocitant. IIn equo bono \& generofo Germani requirunt lupioculoset ualidam ceruicem, \& eiufdem uoracitatem, \& greffus lenitatem, Camerar.

I c. Lupus ex longinquo $\&$ acute uidet: noctu etiam, inftar noctux, Philes. Terram eduntlu

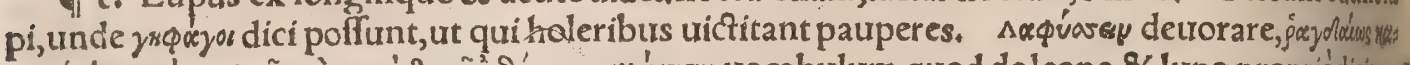

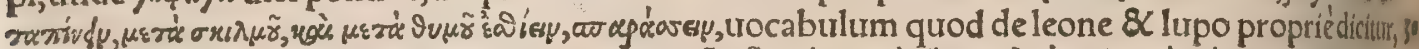

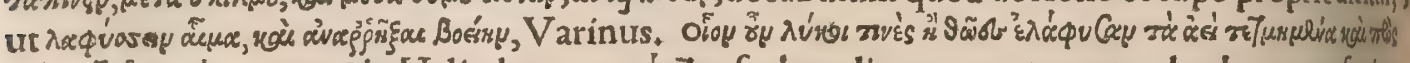

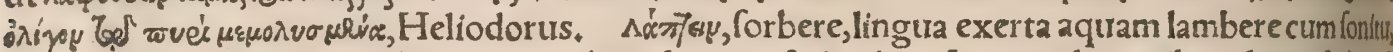
per onomatopœiam(ut nobis etiam uerbum lappert, \& lambere Latinis) de canibus, lupis, \& huluff modi animalibus proprié dicitur, Varinus \& Scholiaftes in Iliad. $\pi_{*}$ đ Vlulare, deluporum \&ैu num horribili \& uulgo ominofa uoce:per onomatopoziam, qua eadem Germanís eft bülen, \& Gal lis uller. Exululat, Ouidius de Lycaone. Vifæćç canes(id eft Furiæ, Seruius) ululare per umbră,

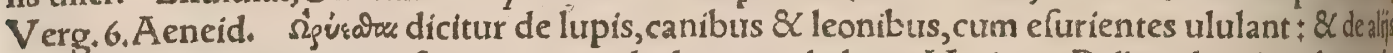
animalibus qux proprium fux uocis uocabulum non habent, Varinus. Pollux de minoribus, ut lu

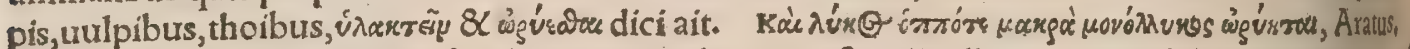
ふं

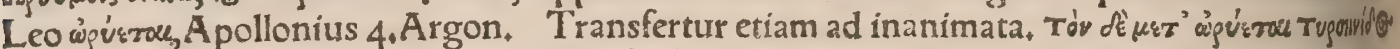

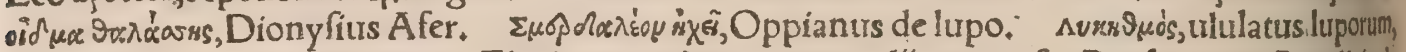
\& barritus (de qua uoce dixi in Elephanto c.) in primo pralij concurfu, Paufanias in A rgoliciscla

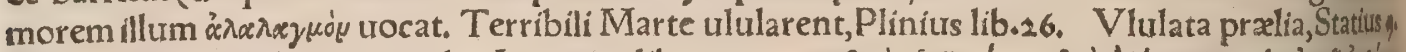

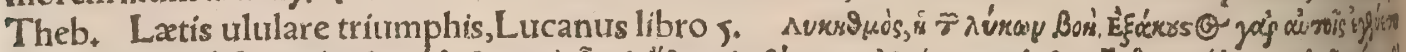

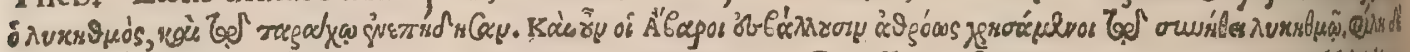

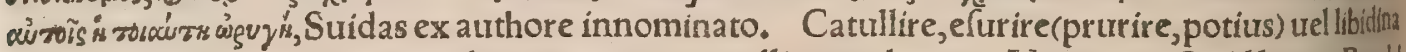
ri, Laberius, Scinde unam exoleto impatienti catullientem lupam, Nonius. Quidlynces Bachl uarix? \& genus acre luporum A tọ canum? Vergilius in Georg.de ui amoris foribens. Lupata cit f́ iniri à lupo, exponit fe ineundã Galli fic proferunt, $L_{a}$ louve fe fait aligner aur loup, Robertus

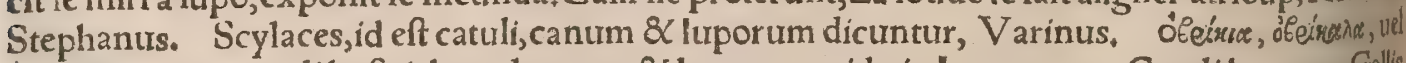
óbria, dicuntur catuli hyftrichum, leonum, \& luporum+uide in Leone $H, c$. Catuli luporum, Gallis louveteaux+cheaux uerò communiter dicunt de lupo, uulpe, mele \& lutra, Robertus Stephantust Ex lupis \& canibus nafci genus quoddam canum, in Hiftoria de canibus mixtis docui a liqui fictia tum lycífcum uocant. Latiné lupum canarium, aut canem luparium dixeris ₹ quanquam Gaza 2 Niphus pantherem lupum canarium transferunt, (ut à panthera diltinguant,) de quo mox inter con generes lupo feras dicemus. Galli canem foeminam cum ad libidinem incitatur lifie uel lyce nomi nant, quafi lycifcam, noftri leut fdh. बDente lupus, cornut taurus petit:unde nifi intus Monftra tum? Horat, Serm, 2, +Et mox, Mirum, Vt neq; calce lupus quenquam, neç dente perit bos,

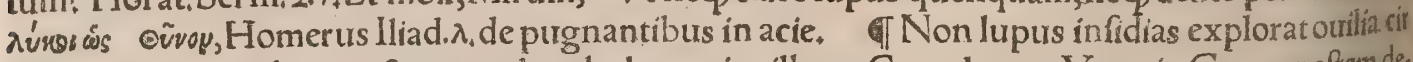
cum, Nec gregibus nocturnus obambulat+acrior illum Cura domat, Verg. in Georg.peftem der fcribês, Quafilupus ab armis ualeo, clunes infractos fero, (aliâs defertos gero,) Plautus Ámbroico, 


\section{DeLupo. H.d. Lib. I. 757}

utt Nonitus \& Feftus citant

If $d$. Quem tu ceruus uti uallis in altera Vifum partelupum,graminis immemor Sublimí firgies mollis anhelitu, Horat.Carm,1+15. Vt pauet acreis Agnalupos, caprexóg leones, Idem E. podo 12. Lupis $\&$ agnis quanta fortitó obtigit Tecum mihi difcordia eft, Idem Epodo 4. Rapinã

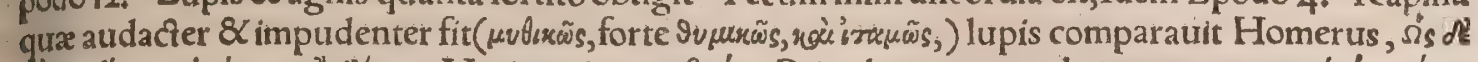

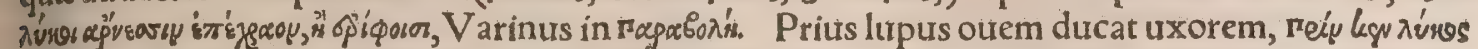
oiv vimerecoi, Ante lupus fibi itunget ouem, Ariftophanes in Pace, de his inter quos infanabile diffidiũ. Confimilifigura dixit Horatius, Sed prius A pulis Iungentur caprea lupis . Plautus in Pfeudolo, Vtmauelis lupos apud oues linquere, quàm hos domi cuftodes. Hoc prouerbium(inquit Erafmus) , ad rem relatum, erit lepidius; quod genus, fi dicas, pecunia ftudium non coharere cum ftudio litera rio. Scholia Ariftophanis fimpliciter de re impoffibili prouerbium accipiunt: $\&$ poetæ cuiufdam

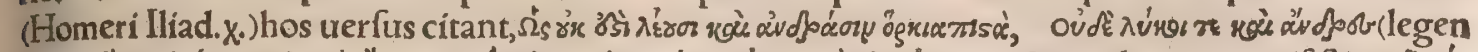

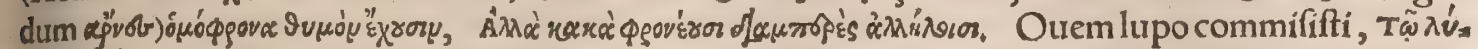
rut riv oifu. Terentius in Eunucho,Scelefta ourem lupo commifinti; de Chærea ephebo, cuí uelut eunu cho uirgo foli credita eft. Donatus admonet prouerbium effe quod contineat foemineam reurerentiam,meretricium fenfum . Concinnè utemur, inquit Erafmus, quoties ei feruandum aliquid coma mittitur, cuitus gratia cuftodem magis oporteat adhiberi. Cicero tertia Philippica, Etenim in concio. ne dixerat fe cuftodem futurum urbis. O præclarum cuftodem, ouium (ut aiunt) lupum. Cuftos'ne urbis, an direptor $\&$ uexator effet Antonius? Vnde quadrare uidetur, quoties inimico negotium , committitur, quićs nobis peffimé uelit, propterea quòd lupus $\&$ agnus genuino quodam odio diffi.

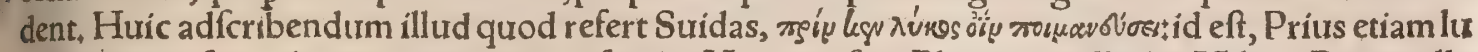
pus ouem pafeet, de re neutiquam uerifimili. Huic confine Plautinum illud in Milite, Bone cella fuppromo credita. Sed propius accedit quod eft in Truculento: Nam oues illius haud longe abfunt

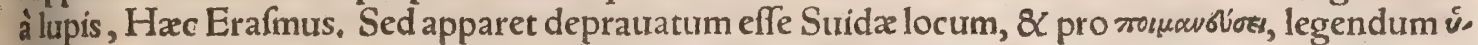
plecuô, ut ex Ariftophanis V efpis pauló fuperius recitaui, \& ipfé etiam Erafmus inter prouerbia re

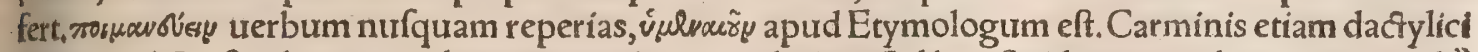
ratio apud Ariftophanem uerbum moinavolios non admittit. Ad hæc Suidas prouerbium exponit uึ

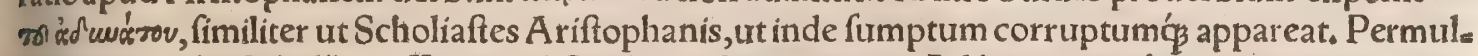
ta enim ex illis Scholịs paffim apud Stridam adducuntur. Ad hoc prouerbium pertinet nomen - o'́ónuros, de quo inter propria urirorum dixi. Euryfthenem \& Proclem audio(inquít Aelianus)cum in matrimonium foeminas ducere conftitutum haberent, profectos ad Delphicum oraculum, deum confuluiffe, quo cum Gracorum Barbarorúmue affinitate deuincti pulchre $\&$ prudenter nuptijs alligati uiderentur + ins deum refpondiffe, quà ueniffent, in Lacedamoniam reuerterentur. Vbicunque porrò terrarum fumme ferum animal ferens mitifimum eis occurreret, inde ducendas uxores effe:fic enim feliciter ipfis \& profpere proceffurum effe. Cui oraculo obtemperantes, cum in Cleo naorum regionem ureniffent,ipfis occurrit luptrs, agnum quem alicunde diripuerat portans: Ex eo illi coniecerunt Apollinem de îs animalibus oraculo fignificationem dediffe:proinde ipfos The an

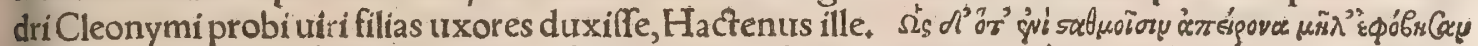

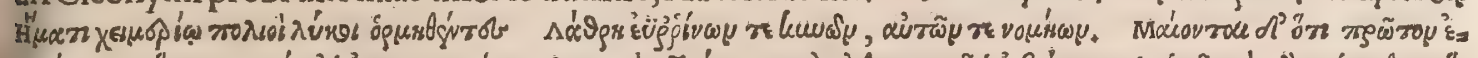

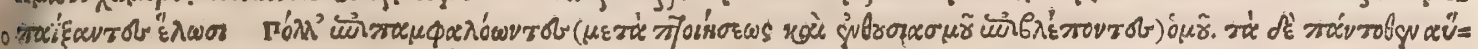

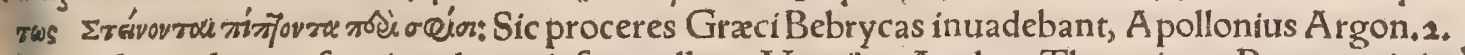
Torua leæna lupum fequitur, lupus ipfe capellam, Vergil.2. Alegl,ex Theocrito, Pecora minime inuadet lupus, fi ducfori dicto fquillam appenderis, Anatolius * Lupo etiam fus obfiftere repugna. ré́, poteft, Ariftoteles. Ephefíts interpretatur, A riftotelem hic fuis nomine intelligere gregem fuum, uel aliquot fimul fues. Vnum enim \& folum obfiftere lupo non poffe, nifi rarò, \& cum fuerit ma gnus, $\&$ bene exertis dentibus. Alphec (melius alfhed, id eft leopardus, panthera minor) lupos li= benter occidit,Albertus 、 TQuicquid lupus pede prefferit, non uiuit, Ifidorus. बब Si fepoleonis liquido animal inungatur, non accedent ad ipfum mufcae, (fecundum alios interpretes lupi, uel be. ftia, uel ferpentes,)Rafis $\&$ Albertus:tide etiam mox in e. $\quad$ Romum \& Romylum(Remum)ut - Dion fcribit, lupa nutriuit:eleganter autem translatum eft lupæe nomen ad meretrices, quòd lupor $\tilde{u}$

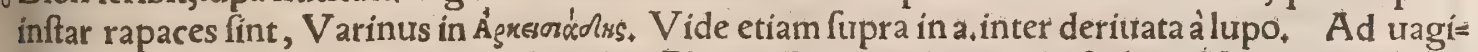
tum lupa accurrit, eosós huberibus fuís aluit, Plinius Cacilius de uiris illuftribus. Nam quę de in fan tibus ferarum lacte nutritis, qurum effent expofiti, traduntur, ficut de conditoribus noftrís à lupa, ma gnitudini fatorum accepta ferri æequius, quàm ferarum natura arbitror, Plinius Nat, hif. lib. 8. Sunt qui Laurentiã et Larentiã diftinguant, ut altera Ảcca Fauftuli fuerit, altera etiã meretrix: amı bas tamē Firmianus fub una recitat Lupa, Romuli \& Remi nutrice, \& c. Gyrald. Syntagmate primo de dijs. Lycaftus \& Parrhafitus Phylonomes ex Marte filin, in Erymanthum abiecti, cum ad cauam quercû̉ depulfi hæfiffent, à lupa nutriti funt, \&c.Plutarchus in Parallelis minoribus ca. 36 , ubi mox Romuli eriam \& Remià lupa nutritorum hiftoriam profequitur. Colitur ficus arbor in foro ipfo a ac comitio Romæ nata, ob memoriam eitus quæ nutrix $R$ omuli ac Remi conditoris appellata:quoni am fub ea inuenta eft lupa infantibus prabês rumen(ita ưcabant mànmam)miraculo ex xre iùta

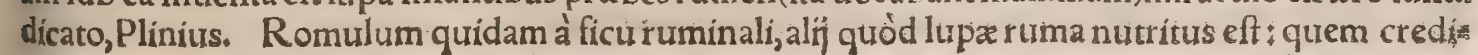


bile ef à uirium magnitudine, item fratrem eius appellatos, Alij dicunt à virtute id eft robore, Gre jóssy uocant,) Feftus. Vide etiam Plutarchum in uita Romuli,non procul initio. GDe his nouere uoci parcere, adagium eft, $\lambda$ ưr citatem $\&$ diffiruitatem loquendi faciat prior infpiciens. Hoc eft quod deum uides lupino nelami obfeptum. Nam \& hor genus animal dum prædam agit, ne hifeit quidem, quum foicant carer more latitian indicare, Cxlius Calcag.

đe. Nunquam cuftodibus illis, (Laconico autMoloffo cane,) Noçurnư ftabulis furem fusćs luporum Horrebis, Very.in Georg. Quid immerentes hofpites uexas canis Ignatus uer um lupos Horatius Epodon ode 6. in maledicum poétam. बQuorum apud noftros elegan tior fermo eft, de lupis eorumós uenatu, hunc ferè in modum loquuntur, LEr frifst/ setrelfit:t

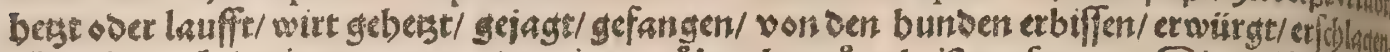

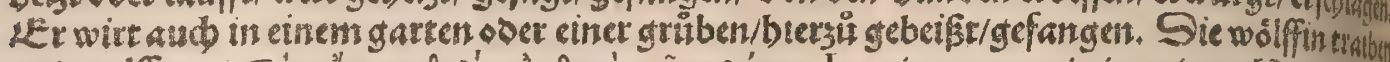

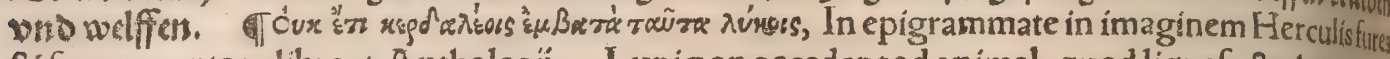
$\&$ feras arcentem, libro 4. Anthologï. Lupi non accedent a d animal, quod liquefacto leonis fepo inunctum fuerit, $\mathrm{R}$ afis \& Albertus. Eodem cum allís trito, ita quod odorem (odor) allij uincar, quod corpus perungatur, lupi non accedent, lidem. Sepoleonis liquefacto fi circuitus oúuminth gatur (diftilletur, )nunquam accedent lupi, nec alia rapaces feræ, lidem. Si f́pum leonis fuifias tur circa aquam, uel inde aliquid a quæ immittatur, prohibet lupos ne uel accedãt, uel bibant, Kidem, Septa è macerījs in leporario alta efre oportet, ne lupus tranfilire poffit, Varro. Magi dicuritu in agrum non accedere, fi capti unius pedibus infractis, cultroćç adacto, paulatim fanguis circ agri fpargatur: atc $\$$ ipfe defodiatur in eo loco, ex quo coeperit trahi: A ut fi uomerem, quo primu cus eo anno in agro ductus fit, excuffum aratro, focus larium, quo familia conuenit, abfumat taclit pum nulli animalium nociturum in eo agro quandiu id fiat, Plinius, Maffurius palmam lupino adipi dediffe antiquos tradit:ideo nouas nuptas illo perungere poftes folitas, ne quid mali medica menti inferretur, Plinius. Si capur lupi columbario fufpendatur, feles, murfelax, \&c fiqua alia $c_{s}$ lumbis nocent, non adibunt, $R$ afis $\&$ Albertus : Huius rei cauffam inquirit $C a r d a n u s$ in opere de fubtilitate, Oculum lupi erutum fi uiderint quadrupedes domeftic $x$, timent $\&$ fugiunt, $P$ ythign ras. Oculus dexter lupi ( ficcus, $\mathrm{R}$ afis ) puero adalligatus amolitur timorestitem ós dentes eius,ilu pellis, Albertus; dens eius caninus, $\&$ nerui, $\&$ pellis, Rafis. Et rurfus, Si quis dentem lup impauidus erit. Dentes, corium uel oculos lupi quifquis fecum habuerit, in caufis fuis obindeit per aduocatos furos, eritó̧ diues apud quofuris homines, lidem. Dens lupi adalligatus, infantium pauores prohibet, dentientiśǵ morbos : quod \& pellis lupina praftat, Dentes quidem eorum maxi mi equis quoç adalligati infatigabilem curfum praftare dicuntur, Plinius : hinc forte animolosac

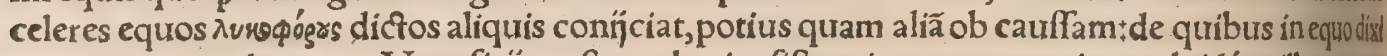
capite 2.inter celeres. Veneficñs roftrum lupi refiftere inueteratum aiunt, ob idç̧ uillarum por" tis prafigunt, hoc idem præftare 8 pellis è ceruice folida exiftimatur : quippe tanta tris eft animalis, prater ea qua retulimus, ut ueftigia eius calcata equis afferant torporem, Plinius. Vt'́p lupitars bam uariæ cum dente colubræ Abdiderint furtim terris, Horatius Serm. 1. 8, de mulieribisulia neficis. Felle lupi cum oleo rofaceo fi quis in fupercilijs inungatur, diligetur à mulieribus cunde ambulauerit cum eis(fi confpiciatur ab eis, $R$ afis, )Albertus. Sil uirga lupi in alicuius nomitre uiti uel mulieris ligetur, impetens erit ad Venerem, donec nodus ille folutus fuerit, Albertus: Hacligat tione nulla eft uehementior, $R$ alis. Lupus cuius prior ueftigia profpexeris, tibi nocere non pois rit: ed fi ille te ante notaurerit, caudx fummam partem fi habueris tecum, fine metu iter côficies, fex, tus * Silupi cauda in uilla fepeliatur, prohibet ab introitureius lupos $\&$ mufcas. Albertus: Cand? fepulta in domo, non inuolabunt mufca, Rafis, Quin 8 cauda hurus animalis creditur uulgoin effe amatorium uirus exiguo (extremo atos exiguo, Blondus) in uillo, eumíg cum capiatur abjicré, (al. abj̈ci,) necidem pollere, nifi uiuenti direptum, Plinius \& Solinus, Lupum aiunt in furmo perfequentium periculo extrenuũ caudx floccum elidere, confcius eum maximé ad amatorios calts rus appeti folere, Calius Calcag. fed hoc tam falfum mihi uidetur, quàm feipfum caftrare caforem, Bos offa non deuorabit, fi lupi caudam ad prafepe fufpenderis, $P$ axamus, Cauda lupi fúpenfla fupra præfepe, non poterit cibo frui (bos, Albertus ) quandiu illic relicta fuerit, Rafis. Si quisin lancea geftet calcaneum lup formin $x$, ( furpendat in capite lancex, Rafis:) $\&$ hoftes cum lanceisel occurrant, non lædent eum, (non accedent ad ipfum, $R$ afis:) quandiu in lancea calcaneus remaniles rit, Albertus. Si mulier minxerit fuper urinam lupi, non concipiet unquam, Rafis. Si quodalip mal minxerit fuper urinam lupi calidam, non concipiet unquam, Pythagoras. Lapis utilgarisiths xta flumina fert mufcum ficcum, canum, hic fricatur altero lapide addita hominis faliua, illo lapide

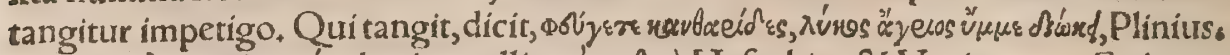

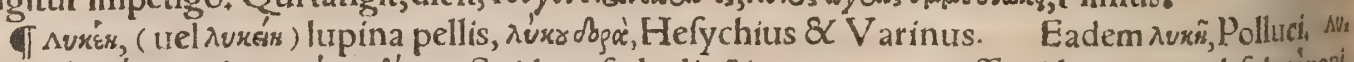
$x$ soy, aliâs $\lambda$ úx

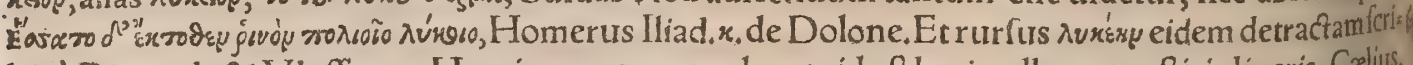
bit à Diomede \& Vlyffe. Hominem rapacem lycea, id eft lupi pelle contreftiri dixeris, Calitis,

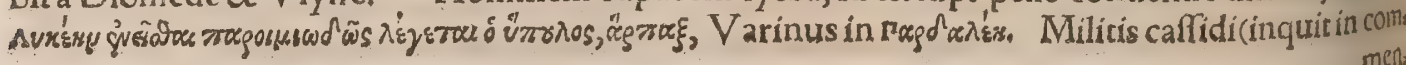




\section{DeLupo. H.e.f.h: Lib.I.}

mêtratione de Romanorum militia Polybius)lupi imponebatur pellis, aut eiufmodi quippiam, qưod integumentum pariter atęs infigne foret, ut ftrenuè ignaueóg fe gerentes latere haud poírent, Cẹlius: Galealupina, Propertius $4+11$.

fo De Romulo \& Remo, item Lycafio \& Parrhafio, quos liupa lactarunt iam dicium eft in d. (1) h. Diræ feu Lupus, poémation fiue Aegloga Camerarĭ. Scripfit $\&$ lo. Lorichius nuper elea ti carmine Lupi querelã. De lupis qui Sicyoniorũ greges infeftarû́t, dixi in E。 Infêtarũt \& Trœe zenios olim, Paufan. Lupus boures \& oues, quos Peleus A cafto mittebat, laniaurit, Vari,in Mrdolis, Lyciü locus Theffalię, fic diçus à lupo, qui illic dum Pelei boures infeftat, in faxũ mutaturs eft, Etymo logus. Milonem Crotoniaten Paufanias fcribit àlupis concerptum, quod genus feræa apud Croto niatas fcateat uel maximè, Cælius \& Ariftophanis Scholiaftes in Ranis ex Paufania, Milo cim nimia neruorum fiducia arborem in parte media hiantem diducere uellet, brachijs hinc inde conftri= Ciis, \& deficiente conatu retentus, lupis fuit praeda, Onomafticon. Lupus maxima magnitudine (inquit A elianus)cum in ludum inurafiffet, $\&$ de manibus Gelonis Syracufani pueri tabellas rapuifa fet, Gelon de fella furrexit, $\&$ fané quidem feram non timore perterrens, fed tamen acerrime tabella rum fuarum retinens, eum infequebatur. Poftea autem quàm hic extra tabernam ludi literarij fuif: (et, hre quidem labem fecit, \& repentina ruina concidens, pueros (fupra centum, Tzetzes $3.131_{4}$ ) una cum praceptore confecit, \& oppreffit + folus Gelon diuina prouidentia munere fodalibus fuis fur. perfurt.Quod ipfum non eum àlupo occifurm, fed potius feruatum fuiffe, magnam profeço admira tionem habet. Non igitur rationis expertia Deus negligit, imò utero chara habet, cum diuino inftin ctu partim ex his regnum prafignificarit, partim ex impendente periculo feruauit, $\mathrm{H}$ æc ille.

A Auguria. Pedeftria aufpicia nominabantur, qua dabantur à uulpe, lupo, \& $\mathcal{c}_{\text {, }} \&$ alijs quadrü pedibus, Feftus. Inter auguria ad dexteram commeantium pracifo itinere, fi pleno id ore fecerit, nullum omnium praftantius, Plinius. Vifo quondam lupo(lupis uifis, Alexander ab Alex,)in Ca pitolio, ut dirum putatum, urbsćs propterea lußtrata, Volaterranus ex Liuio، Lupum quoç caftra introiffe, \& laceratis obuị̂s intactum abijffe(ut annotat Alexander ab Alex.) exitizm \& cladem por tendiffe eurentus docuit, to to poftea exercitu ingenti clade affecto.Rurfus cum cerua à lupo fugata, inter duas acies euafiffet illafa, infignem uictoriam Romanis dedit. Lupos quo $\$$ in foro uifos, inco fumes euafiffe, armis opprimi patriam, \& magna rerum momenta defignauit. Cum in Libyam colo. nia duceretur, lupos metas, quibus agger defignabatur, mordicus diffipaffe, uelut diri euentus, effe= citquòninus deduceretur: (Lupos Carthaginis terminos detuliffe, Plutarchus in Parallelis alicubi (cribit.) Non fic Samnitibus deducentibus coloniam, qui lupo duce(quem irpum dicunt Samnites, unde $\&$ illi Irpini diçi) aufpicatam deduxêre. Fuitớs animaduerfum lupum fubnigrum obuiam fa cum, grande difcrimen afferre, Hactenus Alexander. Impios parrærecinentis omen Ducat, $8<$ pragnans canis, aut ab agro Raua decurrens lupa Lanuruino, Horat. Carm.3.27. Sil lupus uoret nobis beftiam, quid fignificetur, per 12.figna, Luna in fingulis exiftente, exponit Niphus libro $\%$ de atgurińs tabula quarta. Antonius Baucius in epiftola quadam ex D. Marcellini dicto Gallize oppia do ad Petrum Toletum fcripta anno falutis i537, tale prodigium defcribit:Reducebat oures pafras in caulam opilio: \& forte accidit, ut pecus quadam macilentiflima, ac pené fcabie confecta, longo in. teruallo reliquas fequeretur:eam lupus pragrandis, \& cui cilia iam canefcebant, confpicatus, uelo= ciffimè infequi copit. Ego illac tranfiens ouiculam miferatus, quàm maximo poteram clamore $\&$ curfur, lupi uim ab innoxia arcere conabar. Sed antequam appropinquarem pecudi, ouis macie ipfa macilentior holtili $\&$ rabido animo lupum aggreffa, ftrangulauit. Pecus in forum adducta \& lupus interemptus, delectabile fpectaculum prætereuntibus dedêre. Cærterum Doletus ad eum refribers, prodigium his uerbis interpretatur: Occidetur certe, occidetur lupus $\&$ hoftis humani generis, pròh dolor iam diu in ourem Chrifti $\&$ terra $\&$ mari graffans, nihil nifi ferociam, iram $\&$ perfequxtionem dans, Quare deprehendetur, pœenaśç celeriter dabit mífer ille quifquis elt, cuíus ego nomini parco: nam beltia eft multorum capitum:moreḉ foricis peribit, qui dum rofitat, feipfum prodit, Etfi ouis plagis onerata fit, uictura tamen eft illum, qui delictum haud inultum feret, maleớs illum multabit per Chriftum, Hæc illi, Lupus taurum confecit, eoćs aufpicio Danaus regnum obrinuit, ut inferi:

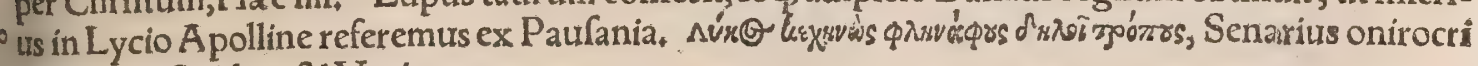
ticus apud Suidam \& Varinum.

TMetamorphofes, Lycium Theffalia locus(oppidum)eft, ubi olim lupus dum Pelei boures in. feftat, in faxum conuerfus eft, ut fcribit Etymolog. Lupus in faxum conuerfus, Ouidius alicubi in Metam, DeLycaonis in lupum migratione, $\&$ alterius cuiufdam innominati, fupra dixi inter pros pria uirorum. Homines (inquit Plinius) in lupos uerti, rurfumós reftitưi fibi, falfum effe confiden. ter exiftimare debemus, aut credere omnia qua fabulofa tot feculis comperimus. Vnde tamen ifta uulgo infixa fit fama intantum, ut in maledictis uerfipelles habeat, indicabitur. Euanthes inter auto res Gracix non fpretus, tradit Arcadas fcribere, ex gente Antri curiufdam forte electum ad ftagn wै quoddam regionis eius duci, ueftitúç̧ in quercu fufpenfo tranare, atç̧ abire in deferta, transfigura. orićs in lupum, \& cum cateris eiufdem generis congregari per annos $\%$. Quo in tempore fi homine $f e$ ablinuerit, reuerti ad idem ftagnum: $\&$ cum tranauerit effigiem recipere ad prifinum habitum ad dito nouem annorum fenio, Id quoģ Fabius, eandem recipere ueftem. Mirum eft, quò procedats 
Graca credulitas. Nullum tam impudens mendacium eft, ut tefte careat, Itaç Copas A griópas, Olympionicas feripfit, narrat Demanetum Parrhafium in facrificio, quod Arcades Iour Lyceo hu mana etiam tum hoftia faciebant, immolati pueri exta deguftaffe, \& in lupurm fe conuertiffe: elunde decimo anno reftitutum athleticx, certaffe in pugilatu, uicforemćs uictoria Olympla reuerfum, $H$ ufç̧⿻三丨 Plinius, Paufanias(inquit Hermolatis in hunc locum fcribens) hune qui Olympionica fue $\&$ in lupum conuerfus decimo polt anno reftitutus fir homini, \& catera; qux hic dicuntur, fecerin non Denaenetum, fed Demarchum Dinyttx filium ait uocatum, de qưo epigramma quocz haber

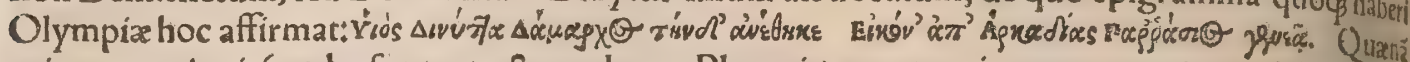
origo mutationis (uerba funt ex octauto de rep. Platonis) ex tutore in tyrannum $\div$ an uidelicet poftä copit qui praeft id agere, quod circa templum Lycai loutis in Arcadia fabula refert? Quidman?

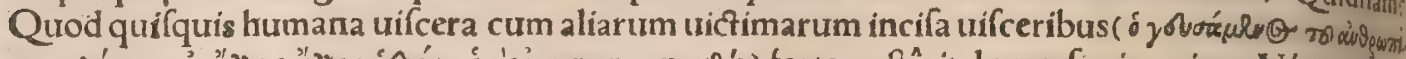

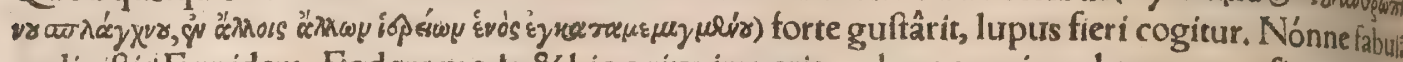
audiuifti Equidem. Eodem modo $\&$ hic cuius imperio uulgus omnino obtemperat, fi cognato nö abftineat fanguine: fed falfis, ut folent, confictis criminibus, in iudicium trahat eos à quibus timet (isg

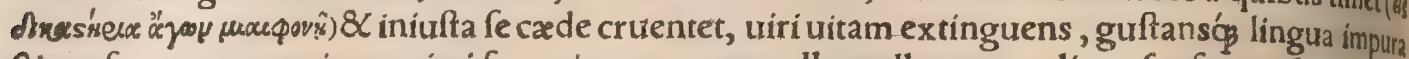
$\&$ profano ore generis proximi fanguinem: ac nonnullos pellat, necet alios, fuaforem fearis alient decidendi ( micis interficietur, trel tyrannidem exercebir, lupusćs ex homine fiet, $\mathrm{H} x \mathrm{Pl}$ Plot. Neuri, Noveoi (in quit Herodotus $l_{i}, 4$.) Scythicis utuntur moribust bi relicto fuo folo propter ferpentium multitudine cum Budinis habitauerunt. uidentur autem (levolwolizm, non ut $V$ alla transfert, periculum faciunn) homines effe malefici, jórt \& : quòd dicuntur à Scythis, \& ab ïs qui in Srythia incolunt Gracis, feme! quotannis finguli ad aliquot dies effici lupi, \& rurfus in prifinum habitum redire $+q u o d$ tamen dicen tes mihi non perfuadent : nilhilominus ipfi tamen aiunt ita effe, ac deierant. Meminit Neurorum Dionyfius etiam, cuius inter pres Euftathius Neuritas quoģ nominari fcribit, \& Herodotide eis ba citat.Apud Neuros Boryfthenes oritur. Plinius $\&$ Solinus. Neuri, ut accepimus, aftatis tempo ribus in lupos transfigurantur, deinde exacto f patio, quod huic forti attributum eft, in priftinam fat ciem reuertuntur, Solinuss. Latona in lupam mutata, uide paulò poft, in mentione A pollinis sumy ขrss, \& ipfius Latona.

TVrfos qui facri funt, \& lupos non multò uulpibus grandiores, A egyprī cò loci fepeliunt, tbl iacentes inueniunt, Herodotus lib. 2. Lycopolitani in Aegypto lupum colunt, Strabolibro 17. Vi, de fupra inter propria locorum. Lycoctonon herbã, qua guftara lupi conuulfionibus moruntur, (aconiti genus effe docui in a.) A egyprị in terras fuas importari prohibent, quòd hoc animal uen, rentur, Aelianus.

TA pollini diuerfa à lupo facia funt nomina, de quibus fingulatim dicendum: $\&$ primumexAle liano cur $\wedge u x$ rguris dictus fit. Lycabanta, inquit, iccirco annum nominari exiftimant, quòd ergalits purm fol amorem habeat:tum eo A pollinem delectari aiunt, quia hic ex Latona ín lupx fpeciem lint litudinemó conuerfa, editus in lucem, \& fufceptus fuiffe feratur: Cuius fanè rei Homerus meminití,

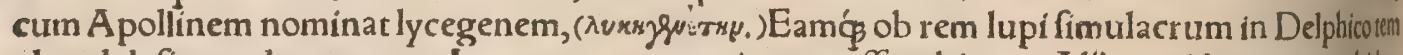
plo, ad defignandum partum Latonæ, ex xi e excitatum effe arbittor. Alin non id propterea hidem pofitum effe dicunt, fed donaria ex templo cum expilata direptáć fuiffent, eademćs à facrilegis dr foffa, lupus indicauit, cum intra templum ingreffus, prophetarum quempiam (facram illius uefem mordicus comprehendens)traxit ad locum uiq $\beta$ in quem donaria occultata fuiffent ; Deindeanterio ribus pedibus eum ipfum locum effodit, (aurum Delphis furto direptum, $\&$ in Parnaffo defofium,, cut dicit $P$ alamon, lupus inueftigauit: quamobrem Delphi lupum colunt, Ip fe A elianus alibis) Hars Aelianus. Meminit etiam in Phocicis $P$ aufanias: 8 addit facrilegum illum in Parnaffo dormientem à lupo occifum effe, deinde quotidie urbem adñffe ululaffeçs, donec tandem fequentibus iplumats

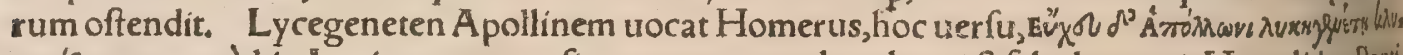
rorós $\omega_{\ddagger}+$ non quòd in Lycia generatus fit, (nam recens admodum eft fabula, ut ait Heraclides Pontia

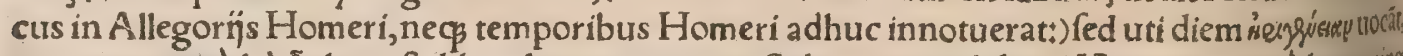

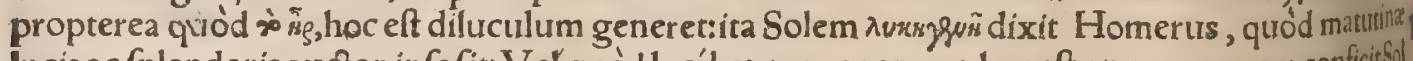
lucis ac fplendoris aucfor ipfe fit: Vel quod lycábanta progeneret, hoc eft annum, quem conficitfol fuo per 12. figna Zodiaci curfu, Hæe Gyraldus. Ego citatum ab eo carmen Iliados quarto reperio,

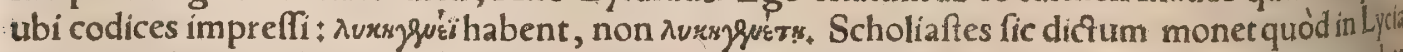
colatur, uel etiam illic natus fit. Latonam enim dum fugeret zelotypiam lunonis, in Lyciam utlate ret abïffe, atç illic peperiffe A pollinem. Varinus tamen Latonam poft partum fugiffe fcribit in Lye ciam fiue maiorem fecundum aliquos, fiue minorem qua $\&$ Troia uocatur. Aliter, suksyguis dithus eft A pollo eó quod lupus Latonx parienti apparuerit, unde \& r r

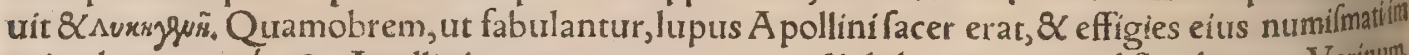

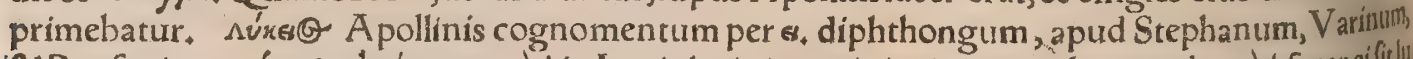

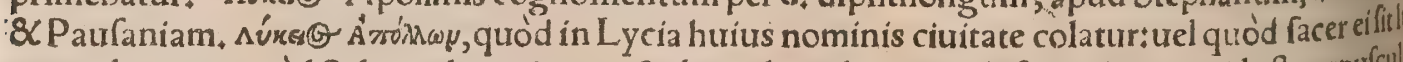
pus:uel potius, quod Sol recedente iam nocie lycophos (de quo uride fupra in $\mathrm{H}_{\text {. }}$ a.) id eft crepufuli efficiat, Varinus, Item in roúxx, A nimalia quadam inquit, dís fola uocis fimilitudine confecrantru; 


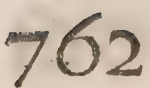

\section{De Quadrupedibus}

errantem fpecie lupe fingunt duodecim diebus ex. Hyperboreis Delum deductam à lupis ideó pos uno tempore tantum anni totidem diebus parere aitunt, Ariftot, Meminit etiam Etymologus in rons oó. At in Homeri Scholijs lupũ Latonæ parienti apparuiffe legitur, ut fupra recitaui. FR ham pfinitum regem Aegyptiorum uiuum aúunt ad inferos defcendiffe, \& cum Cerere alea lufiffe, \&uite rum rediffle thoc tempus ab cius defcenfu ad reditum, dicebant feriatum effe apud Aegyptios, quo facerdotes unum ex fuis palliatum, oculis mitra obductis in uiam deducerent qua fert ad Cere, ris templum,ipfos redire illo relicto. Hunc autem facerdotem oculos uelatos habentem aiumt,à gemi nis lupis agi ad Cereris templum, quod ab urbe uiginti ftadia abeft : 8 rurfus à templo in eundem locum à lupis reduci, Herodotus libro fecundo.

Tl Lycex Dianæ templum apud Trczenios fuiffe ab Hippolyto excitatư, auctor Paufanias cf, qui tamen eius rationem cognomenti ignorare fe fatetur: fed ex Macrobio aucupari (opinor) lices ubi differitur, cur Apollo dicatur Lycigenetes ac Lycos, Cxlius, Paufanix quidem in Corinthiacis uerba funt hxc: Trœzene iuxta theatrum Dianæ Lycex fanum Hippolytus fecit, De cognomend ratione nihil ab interpretibus potui percipere. Sed quia lupos fortaffis Trozeniorum agi um infer ftantes, expulerit Hippolytus, aut genus furum materna ftirpe ab Amazonibus deduxerit (⿻丷木 Áugen

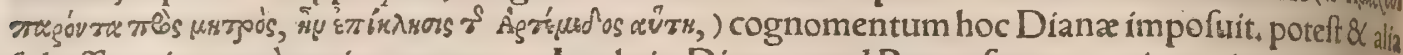
fubeffe ratio qua à me ignoratur. Laphria Dianæapud Patrenfes magno in ara igne excitato,a pros, ceruos, aliqui luporum aut urforum catulos uiuentes inñciunt, $\mathrm{Paufanias} \mathrm{in} \mathrm{Achaicis,} \mathrm{fLy}$ carus Iupiter (inquit Gyraldus)à Lycaone dicturs, ut Paufan,in Arcad.tradit,cui deo \& Lycra certat men inftituit. diçus etiam Lycaon in lupum à loue conuerfus, quod infantem immolaffet.alia tamen apud Ouidium legitur fabula in Metamorphofi, alia item apud Suidam, Lycaon(inquit Suidas)Pes lafgi filius, A rcadum rex, patris inftituta fumma aquitate feruabat * fed ut fubditos ad iuftitian fers uandam quoç pelliceret, Iouem boni malićs infpectorem in hofpitis forma ad fe fæpe uenirefimula bat:quare cum aliquãdo fe facra facere uelle, ut deum accepturus, dixiffet, eius diuerfís ex uxoribıs procreati liberi noffe uolentes, an deus nec ne uenturus effet, pueri clam cafi carnes carnibus facria

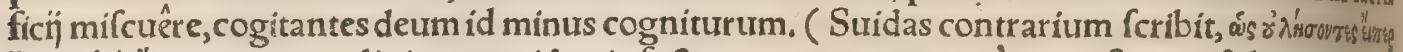

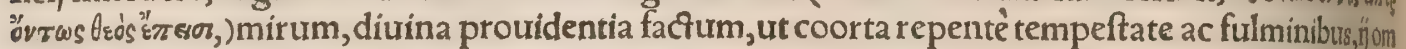
nes interirent qui puerum interfecerant, (Hactenus Suidas.) unde mox Lycrea inftituta, quoutum cum alibi Pindarus meminit, tum in Olymp, ad Diägoram R hodium. In Arcadia, inquit, Lycaalus di in honorem Iouis Lycxi agebãtur, in quibus pramia arma area fuêre, (tripos ęreus, Varinus.ed Scholiaft $x$ Pindarici uerba hac funt, Ė

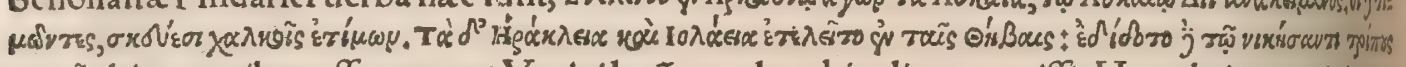

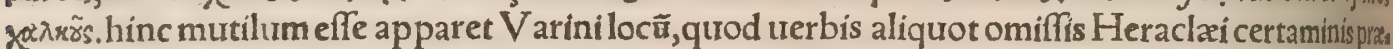
mium ad Lycæum referatur. Aut fi mutilus non eft, ab altero Pindarico Scholiafte nó intelleçode ceptum dixerim Varinum.) Sunt qui Lycæum montem Olympum in Arcadia tradant, quem \& ple

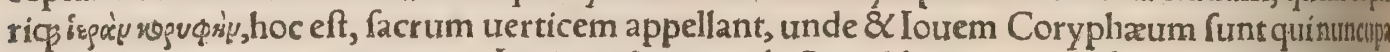
tum putant, in co autem uertice Iupiter educatus ab Arcadibus traditus eft. Fuit $\&$ fons mirabilis prope louis Lycæi templum, \&c. (aliaó ibidem, in Lycæo monte, miracula, quæ Paufanias in Arrad, \& Colius 24.17. referunt.) Sed de Lycro Ioue \& Strabo, item Callimachus \& in eum Scholia, \& Hy ginus in Vrfa defcriptione, In louis (inquit) Lycæi templum(lucum, Cælius) qui acceffiffet,morspe na erat, Arcadum lege meminit idem alibi, nec femel, Hæc Gyraldus. Lycæa (

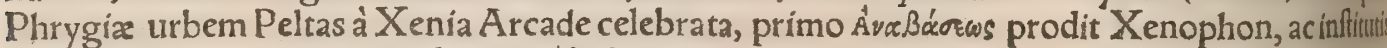

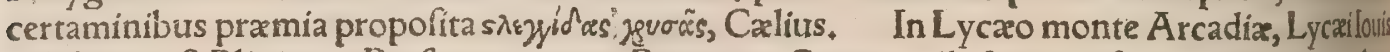
delubrum eft, Plínius. Perfa expugnata Barce, per Cyrenen illafam tranfierunt : inde cumadru pem Lycai louris fubfediffent, panitentia eos fubijt quod Cyrenen non occupaffent, Herodotiscir ca finem libri quarti。. De Lycoreo A polline fupra dic?um + legimus $8<\mathrm{Lycoreum}$ Iouem apud fie

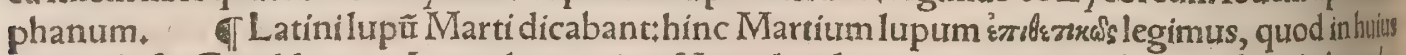

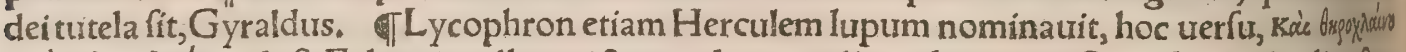

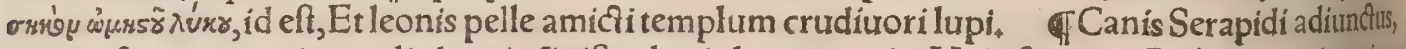
triceps fingitur, capite medio leonis, finiftro lupi, dextro canis: Vide fupra in Cerbero, capiteprimo s de canibus diuerfis, In Palatini montis radicibus (ut ex Trogo fcribit Iuftínus libro 43.) temts plim Lycæo, quem Graci Pana, Romani Lupercum appellant, conftituit : ipfum dei fimulachruin nudum, caprina pelle amictum eft, quo habiru nunc Romæ Lupercalibus decurritur. Februalis feu februa Iuno nuncupabatur, tefte Fefto, quod ipfi eo menfe facra fiebant : eiusćç ferix erant Lut percalia, qua die mulieres februabantur à lupercis amiculo Iunonis, id eft pelle caprina, Gyraldus, Panos de more Lycæi, Vergil, In Lycæo, inquit Placidus Calius grammaticus, templum fuit Panos, in quo natus afferitur. Paufanias uerò in A rcad, in monte Lycæo \& templum 81 lucum, \& hippodro mum ac ftadium fuiffe eius numini dicatum, unde illi nomen. Lupercalia, inquit Gysaldus, $R 0$ manorum celebritas is, calend.Mart, (licet aliter alin fcribant) celebrabantur. (Lupercalia feria ftalit uæ funt, hoc eft certis ac conftituris diebus ac menfibus annotatæ, Macrobius.) in his capræ candida immolabantur, uel ut alin tradũt, canes. Februatus is dies tefte $V$ arrone \& Cenforino dicebatur, $F_{3}$ brualia facra ad expiandos manes fiebant, Grace $u$ uroüx dicta à Pane Lycæo, deo Arcadico, hac àlus 


\section{DeLupo. H.a. Lib.I. 763}

bercis celebrabantur, quoorum uaria fertur inftitutio, ut â Plutarcho in Romulo pluribus traditur. Magis illa recepta eft, qura de Euandro Arcade rege proditur, qui ex Arcadia profugus, in Latio pas latium tenuerit, nudosćs ibi iuuenes hoc facrum per ludum \& lafciuiam primum agere inftituerit, quam \& Iuftinus commemorat ex Trogo, \&c. V aria quoģ de nomine traduntur. Plexíģ enimà lus pis, qui lyci Gracè dicuntur, nomẽ deductrt, q̊d fcilicet lupi arceantur à ftabulis, alīj à lupa non miti, qua abiectis infantibus pepercerit:ante $\&$ Luperca dea eft aucfore appellata $V$ arrone, ut fribit $A r$ nobius. Aliqui ludicrum ipfum feu templum in fpecu fub monte Palatino, Lupercal dictum fuiffe aiunt:quod \& poéta innuit, cum ait: Et gelida monftrat fubrupe Lupercal, Et Ouidius de Romuli lupa nutrice, Illa loco nomen fecit, locus ille Lupercal, Magna dati nutrix præmia lactis habet. Lu - percal, ait Liurius, ludicrum in môte Palatino. Nec defunt qui auctore Fabio, Lupercal dícant uoca tum effe, quafi luere id eft purgare per capram + nam de capra in primis facrum fiebat. Sedenim ea Lupercis fuit præcipua ueneratio, ut quæ minus foccundæ mulieres haberentur, mínusḉs fortus æde rent, ad lupercos cófugere folerent, qui capris direptis tergoribus, eisḉ̧ fuccincti, circum antiquum oppidum, hoc eft $\mathrm{Pal}$ atium difcurfabant, loris corijs ue occurrentes, uerbera incurientes. His foemi. na ultro obuiam prodibant, facilem eo uerbere partum fibifperantes. Hinc Ouidius in Faftis, Exci pe foccundę patienter uerbera dextræ, Iam focer optatû́ nomen habebit aui. Et Propertius, Ver= bera pellitus fetofa mouebat arator, Vnde licens Fabius facra Lupercus habet. Plura Plutarchus in Caufis Rom. Nec prodeft agili palmas praberc luperco, Iuuenalis in molles, \& pathicos, \&c. Plura de his facris leges apud Gyraldum (unde $8 \mathrm{C}$ hac omnia defumplimus) Syntagmate 17, de dịs, , Et alibi,PaniLycro in Lupercalibus canis immolabatur, ut ait Plutarchus : quoniam gregis amicus \& cuftos eft canis. Alï capram albam dicunt; nonnulli hircum, ex cuius corio luperci facerdotes fla,

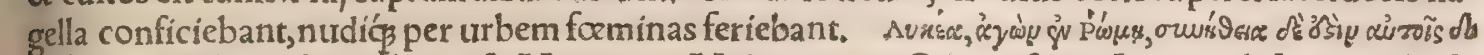
gas'stra Luperci.

(I) Magi Arimanio, quem dæmonem malum effe dicunt, facrificant res quafdam triftes, ut mala deprecentur. Nam herbam quandam omomi dicfam, in pila contundũr, \& Plutonem $\& C$ Tenebras inuocant: deinde admixto fanguine lupi iugulati , in locum aliquem Solis luce carentem efferunt \& eftundunt, Plutarchus in libro de lfíde.

P R O V E R B I A.

Lupo agnum eripere poftulant, nugas agunt; Leno quifpiam in Pcnulo Plautina, Vbi quis fru fra conatur prædam recipere, cui fernel manus iniecit rapax aliquis, Erafmus. Confine, quod mox

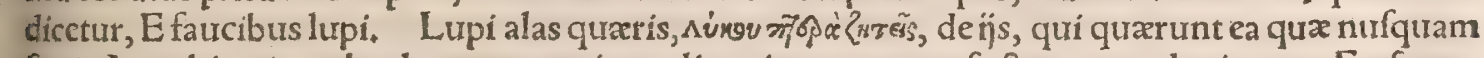
funt, Aut ubi quis uerbo duntaxat territat, alioqui re nunquam facturus quod minatur, Erafmus.

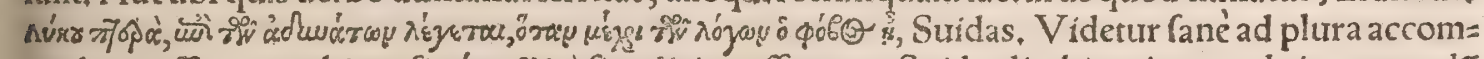

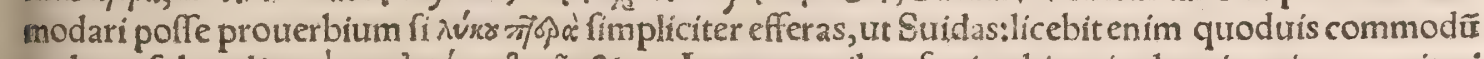

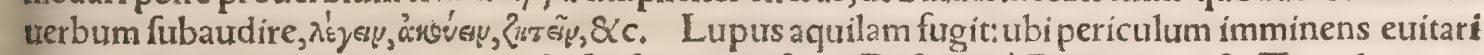
non poteft. Aquilä enim alata cum fit, fruftra lupus fugit. Refertur à Diogeniano $\&$ Zenodoto: nec indicant originem prouerbüłnunquam enim audiui aquilas moleftas effelupis, Erafmus. Nos fupra capire quinto aquilas in Tartaria cicures, tam audaces effe diximus (ex Paulo Veneto) ut non dubia te tent magno impetu in lupos infilire, eosćp in tantum diuexare, ut ab hominibus fine labore \& pericur

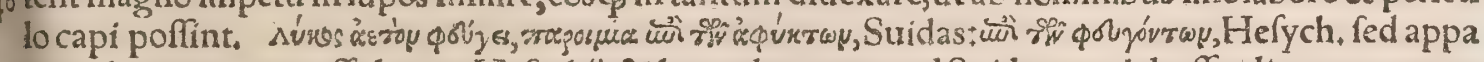
ret uel deprauatum effe locum Hefychî, \& legendum ut apud Suidam : tel deeffe aliquam uocem;

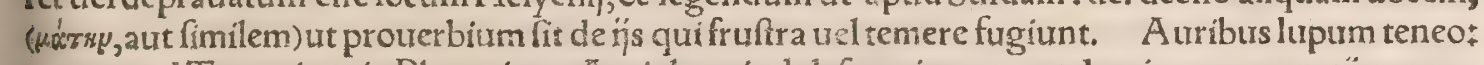
extat apud Terentium in Phormione, Antiphonti adoléfenti uxor erat domi, quam nec enjcere poterat aut libebat, neç rurfum retínere. A uribus, inquit, lupum teneo: nam neç que modo amittam

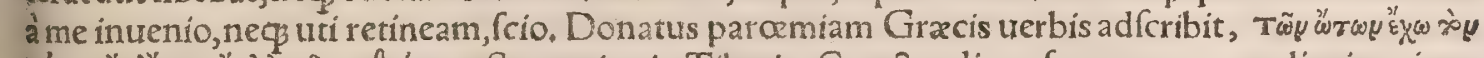

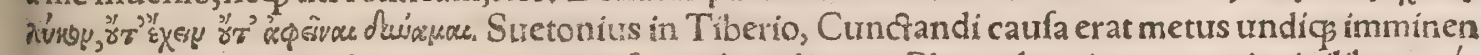
tium difcriminum, ut fape lupum tenere $f_{e}$ auribus diceret. Plutarchus in præceptis ciuilibus, $\Lambda v^{\prime}=$

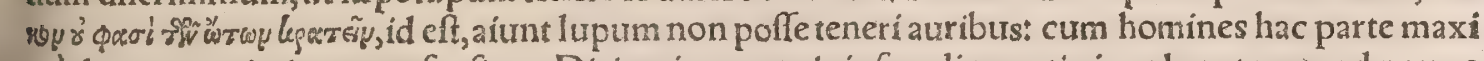
o me ducantur, nimirum perfuafione. Dicitur in eos, qui eitufmodi negotio inuoluuntur, quod negg re linquere fit integrum, ness tolerari poffit, Cacilius apud Gellium if. .. citra metaphoram extulit: Nã hi funt, inquit, amici peffimi, fronte hilaro, corde trifti, quos neqs ut apprehendas, neqs ut amittas fcias Refertur \& à Varrone pro exemplo adagionis, Auribus lupum teneo, Erafmus. Finitimum

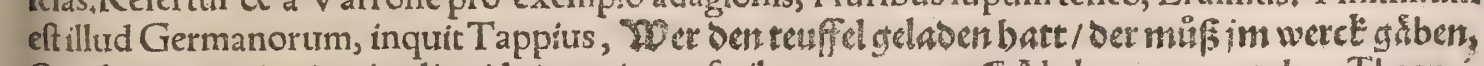
Qui dæmonem inuitauit, aliquid ei operis prafcribat oportet. If Ale luporum catulos. Theocri-

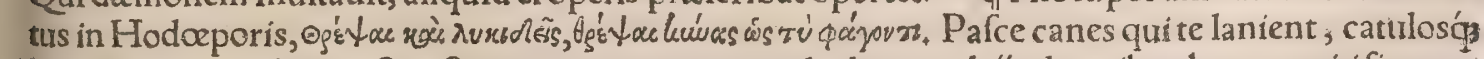
huporum. Prourerbium eft, tefte interprete, in eos quiladuntur ab j̈s de quibus bene meritifine, aut

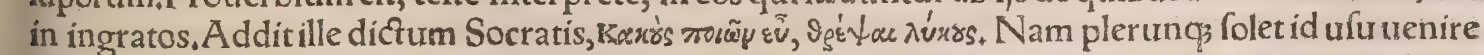
illis, qui catulos luporum enutriunt. Extat fuper hac re non inelegans epigramma, quanquam incer

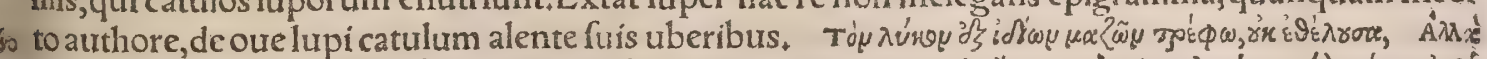

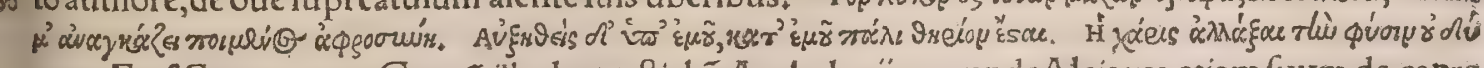
varue, Eraf,Extat autem Græcũ illud tetraftichố Anthologị 1.30, undeAlciatus etiam futum de capra 


\section{4 \\ De Quadrupedibus}

lupum lactante emblema effinxit, quod in Capra recitaui + in Gracis quidem uerfibus nec capra nec ouis nomen exprimitur, néc refert utrum accipias $¥$ fed roukiy ouium proprié paftor elt. Lupus

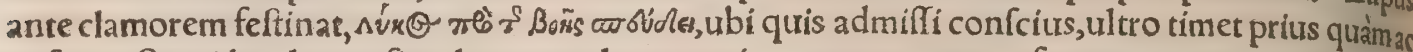
cufetur. Siquidem lupus fimul atç pradam rapuit, mox properat aufugere, ne coorto rufticorum clamore ueniat in periculum, Autor Diogenianus, Erafmus * Lupi decàs, Vide fupra inter pro pria uirorum. Tlupus in fabula cum forte forturna in medio fermone interuenit cuius mentio

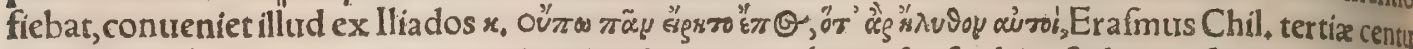
ria 8. Et rurfus Chil. 4. centuria quinta in idem prouerbium fic fcribit: Solitum eft dici 2 quoties is, de quo confabulatio eft, de improuifo interuenit:quod inde fumptum putat Donatus interpres $T_{e}$ rentī, quòd lupus ei quem prior uiderit, uocem adimere dicitur, ut cum cogitatione in qua prius in fuerat, fimul $\&$ uocem amittat $\&$ uerba. (Poft hac huius rei caufam ex quorundam fententia depro mit:fed fruftra quaritur ratio cur fit res, priufquam de quaftione an fit conftet,) Donatus huc pert

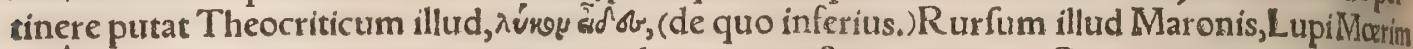
uidêre priores, quum uocem per atatem ademptam paftor quereretur. Sunt qui ex nutricum fabus lis natum exiftimant, qux narrant ludificato puero terrore lupi, uerum lupum à caurea paulatim ues niffe ad limen cubiculi. Nam eft $\&$ in apologis, matrem, ut puerum uagientem compefceret, lupin frequenter inclamaffe, ut nifi defineret plorare, deuorandum auferret. Tandem lupum fpe prędxue niffe næ pollicenti. Nam hoc, opinor, fenfit Donatus, Locus enim in libris euulgatis non uidetur carete mendo. Tertiam opinionem reịcit Donatus, quæ putat hinc natum \$ quum in Næuiana fabuha re: præfentaretur, quomodo Romulus $\&$ Remus aliti fintà lupa, repente uerum lupum actioni inter ueniffe:quo factum ut fubitum effet totius fabulæ filentiư. Sic ufus eft Terentianars Syrus in Adel, phis, filentium innuens Ctefiphoni, quòd Demea pater adolefcentis, quem ruri effe credebat, pras ter expectationem adeffet, Feftiuius etiã ufus eft Plautus in Sticho. A tq eccum, inquit, tibi lupus, in fermonem præfens efuriens adeft. Loquitur enim de parafito Gelafino, qui fratribus de ipfocone fabulantibus derepente interuenit. Addit enim prourerbio gratiam, allufio ad hominis edacitatem:

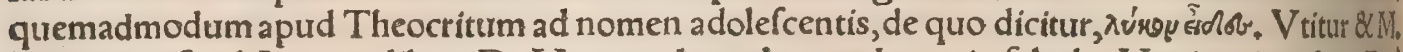
Tullius epift.ad Atticum lib.13. De Varrone loquebamur, lupus in fabula. Venit enim ad me,Fere fit autem ut quoties interueniat, de quo colloquimur, obmutefcamus: propterea quód fiue laudaba tur, pudet in os dicere quod rectè narratur de abfente:fiue uituperabatur, timemus offendexe, Hacto omnia Erafinus. Ruftici dicunt hominem uocem perdere, fi lupus eum prior uiderit : undé fubió

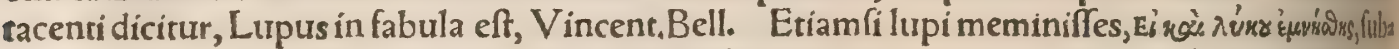
audiendum interueniffet: Quoties prater expectationem interuenit is, de quo furerat mentio: con gnatum ei, (quod iam recenfuimus,) Lupus in fabula. Id frequenter accidir (inquit Erafmus) incon modịjs ac tragoedīs, arte curạ́́ fcriptoris, ut de quo fiunt uerba mox interueniat. Accommodart poterit ad rem, ueluti fi apud autorem protinus uel cafir occurrat, id de quo uertebatur fermo:adar

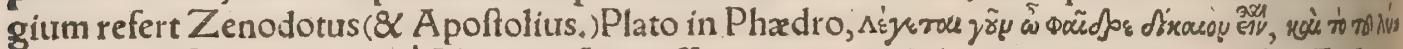
xr eirseip:id eft, A iunt igitur ò Phędre iuftum effe, etiam quod de lupo dicitur narrare, $\mathrm{H}$ xc Erafmust, Tappius huic prouerbio Germanicum illud accommodat, Do man ses teuffels gedencti/Qn will

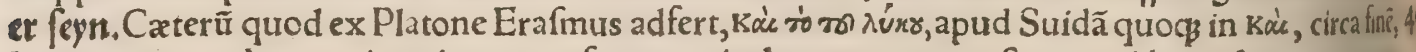
legimus:ex a pologo, ut inquit, ortum: ferunt enim lupum, cum paftorem uideret de oure ex grege ipfius mactata uefcentem, dixiffe, Ego fi hoc facerem, quantus excitaretur clamor? Eundẻ apologí legimus apud Plutarchum in fympofio feptem fapientum. Lupi illum priores uiderunt, in raucum dicitur, \& cui uox repente fit adempta. Feftiuius dicetur in eos, qui metu alicuius obticefcunt,alios qui feroces. Vergilius in Aegl.cui titulus Mœris Vox quoç Morim Iam fugit ipfa, lupi Moxim tuidêre priores. Seruius admonet phyficos authores effe, inelle tam uim lupis, ut fi quem hominem priores uiderint, ei uocem adimant. Socrates apud Platonem libro de rep.1. rem ad allegoriam uert tit, dicens Thrafymachum fibi tocem adempturum fuiffe, ni forte for tuna prior illum confpexiffet

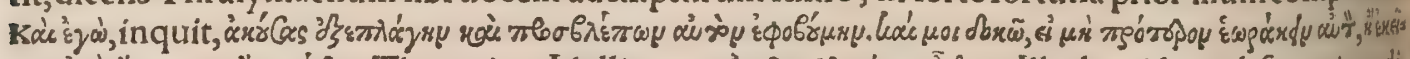

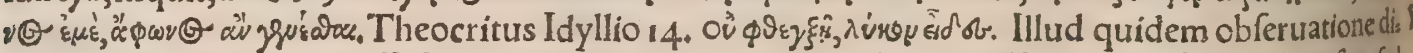
gnum, Theocritum uertiffe fententiam, cum negat eum proloqui poffe, non qui à lupo fit uifus, fed qui lupum uiderit. Sed allufit duntaxat ad prouerbium Theocritus, cum fignificaret riualem cóper

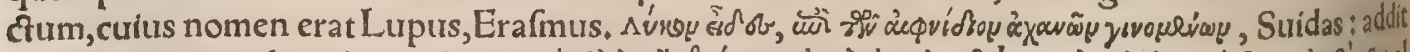

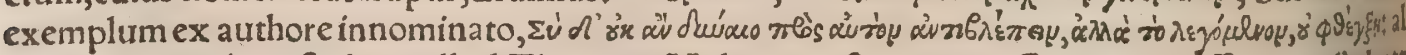
ludit autem ad hemiftichium illud Theocriti. Vide etiam fupra in D. Germani fic efferunt, Lerbatt

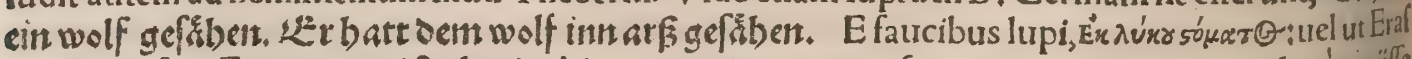
mus transfert, Ex ore aut rictu lupi: ubi res quæpiam præter fpem recipitur, quæiam plané perinfle uidebatur, \& cr. Sic Flaccus in Odis, Vel hoedus ereptus lupo. Adagium refertur à Diogeniano.Nas turm uidetur ab A efopica fabella, quar narrat gruem, cum ftipulata mercedem, os quod lupigu inharferat, immiffo capite eduxiffet, pramiũ exigentem irrifam à lupo fuiffe, cuin is diceret, abunde magnum effe præmium perfolutum, quòd ex ore lupi caput incolume retuliffet, Erafmus. Ex hưr

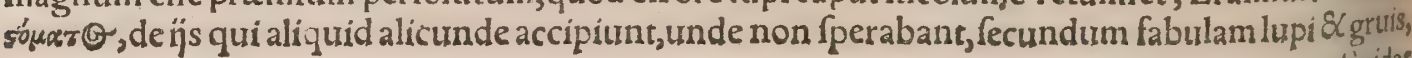




\section{DeLupo. H.h. Lib. I. 765}

Suridas \& A poftolitrs, Kàe nós

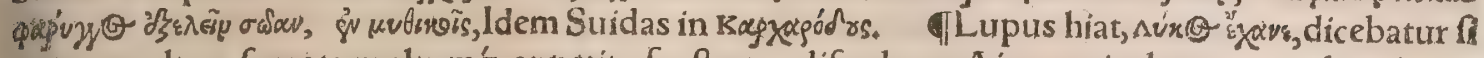
quis re multum fperata multumćç appetita, fruftratus difcederet. Aiunt enim lupum pradæ inhian= tem riçu late diducfo, accurrere; qua fi fruftretur, obambulare hiantem. (Vidêtur haec parum bene.

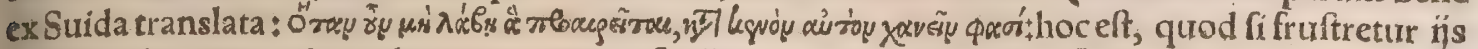

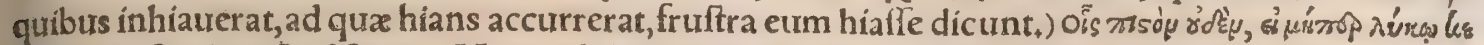
javort, Ariftoph. in Lyfittrata. (Vertendum uidetur, Quibus nihil fidum ac tutum eft, nifi quid lupo

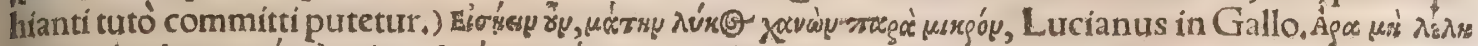

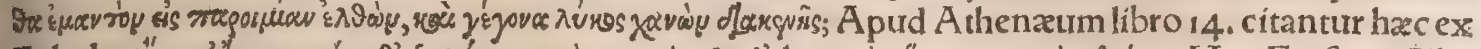

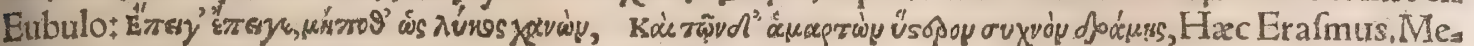

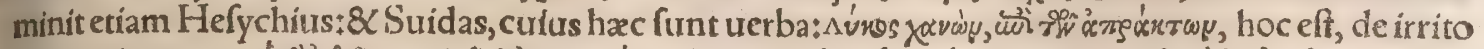

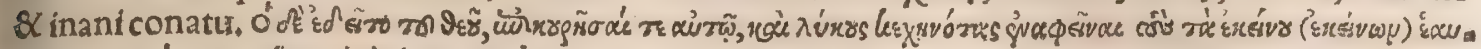

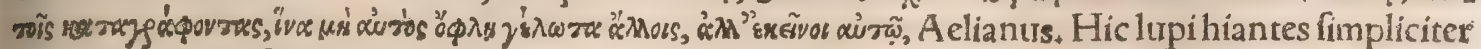
homines rapaces $\&$ prad $x$ auidi nominantur, non qui fruftra appetant, fed potius qui confequan= sur : hoc enim illeà deo petebat. Nonnihil huc facit etiam fenarius ille onirocriticus, ut apparet,

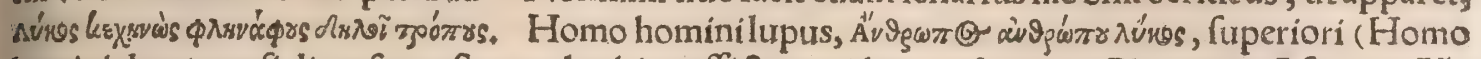
homini deus)quafi diuerfum eft, ac uelut hinc effictum uideturł ufurpautit Plautus in A finaria. Nio nemur eo, ne quid fídamus homini ignoto, fed perinde atçà lupo caucamus, Lupus eft, inquit, ho= mo homini, non homo, qui qualis fit non nouit, Erafmus, Eiufdem fententix funt Germanica illa;

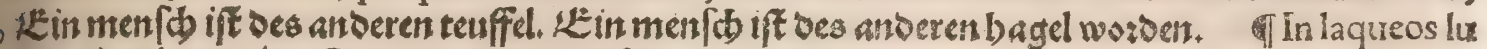
pus, Eis $\pi x$ yos ó $\lambda u ́ r o s+$ Cum improbus quifpiam tandem in extremum adducitur difcrimen. Etenim cum lupus animal fit infidiofifimum, applauditur ab omnibus, fi quando contingat illum irretiri, $a c$ protinus acclamant omnes, e's wáy ys o $\lambda$ unos. Refertur à Zenodoto, Erafmus. Apoftolius interpreta

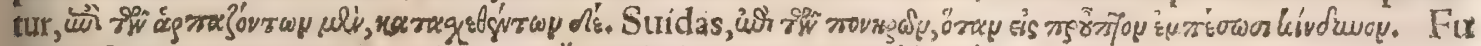

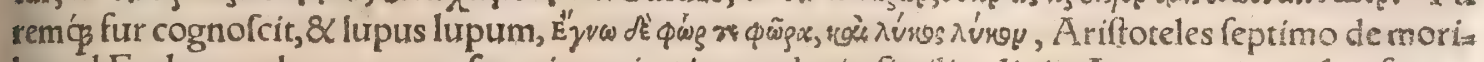
bus ad Eudemum hunc quoos fenarium citat inter adag!a fimilitudinis. Amant enim uuligo fe mus:

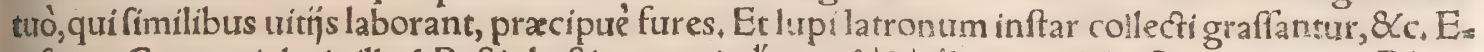
rafmus, Conuenit huic illud, Beftia beftiam nourt, Éy

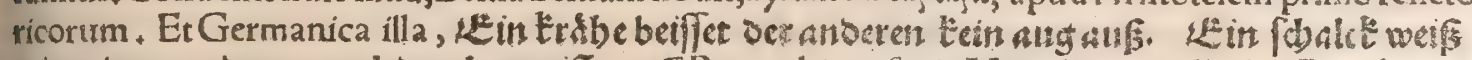

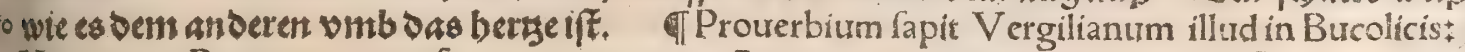
Hic tantum Borea curamus frigora, quantum Aut numerum lupus, aut torrentia flumina ripas. Rectédicetur, in hominem impudenter furacem. Extathodiḉ̧ uulgò iactatum adagium, Lupus non ueretur etiam numeratas oues deuorare, (Ser wolf if auch wol ein gesele fbah.) Porrô fu= res paulò timidiores, confureuerunt à rebus abftinere manum metu, uidelicet ne hoc indicio deprehendantur, Erafmus, बProuerbia, Prius lupus ouem ducat uxorem, 82 Ouem lupo commirtere

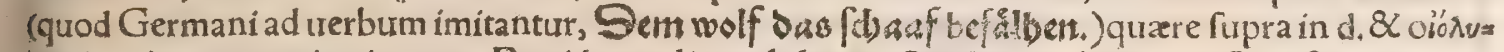
$x(0$ in a.inter propria uirorum, Rapida tradis ouile lupa, Ouidius 34 de Arte. Incuftoditum ca*

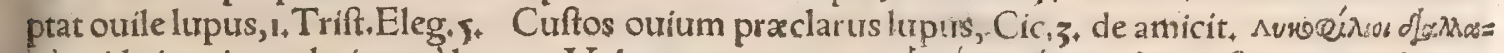

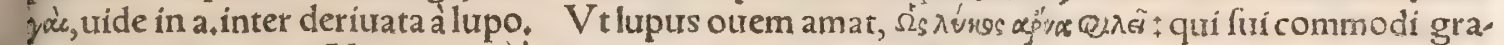
to tia fimulat amorem. Nam is uulgó dicitur amor, quum reuera fito dítum. Iuruenís enim cum pucllam uenatur ut illi pudicitiam eripiat, \&c, quafo quid deterius hofis faciat hoft : Socrates citat carmen

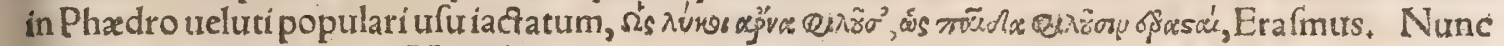
et oues ultro fugiat lupus, Vergilius in pharmaceutriatcitat Erafmus in prouerbio Ceruus canes tia hit, propter confimilem fenfum, cum adynaton feu præpofterum quippiam fignificamus. INon

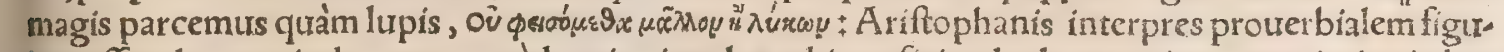
ram effe admonet, inde natam, quód antiquitus lex ad interficiendos lupos etiam pramio intitiabat apud Atticos, (ut in E. retuli, prope initium:)unde \& A pollinem Lyceum \& Lycoctonon cognomi

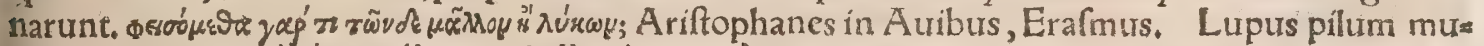

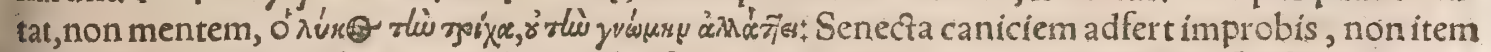
aufert malitiam. Canefcunt enim lupi, uelut $\&$ equi, more hominum per ætatem, Erafmus. Nos ex Hieroglyphicis fupra in D. fcripfimus, lupum cum à uenatoribus periculum fibi inftare uidet, extre

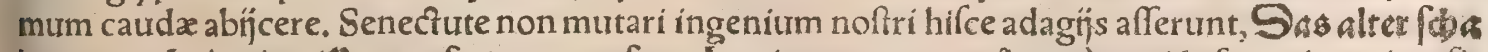

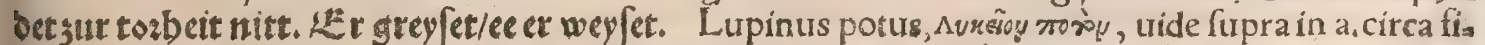

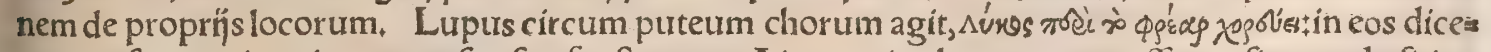
tur, qui fumpta inaniter opera fpe fua fruftrantur. Aiunt enim lupo morem effe, ut fi quande fitiar, nec tutò fe poffit demittere, circum puteum oberret, fruftra inhians aqua, quam non poffit contin= gere. Sunt qui paroemiam inde ductam exiftiment, quòd aliquando ueniat ufu, ut lupus pecudem aliquam, aut hominem infectetur + qui poftea quàm fe in puteurm quempiam altiorem metu demife=

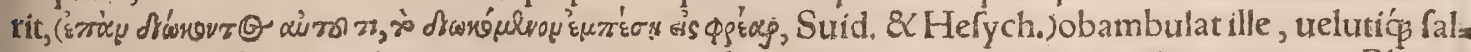
60 tantium in modum in orbem circumagitur pradx cupiditate, qua tamen potiri non queat. Plutar=

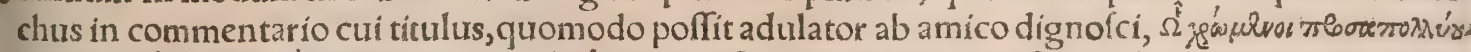

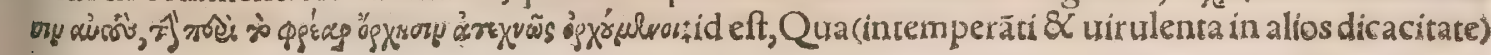


qui utuntur, feiplos quog, in perniciem adducunt, reuera faltationem illam circum puteum faltane

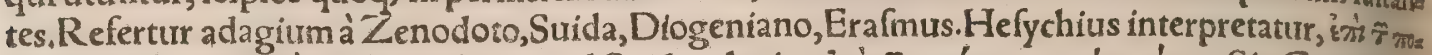

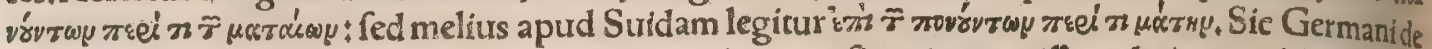
fele fruftra circumeunte edulium feruidum quod non aufit attingere, $\mathcal{E}^{2} \mathrm{r}$ gebt $\mathrm{tarumbber} \mathrm{wicein}$

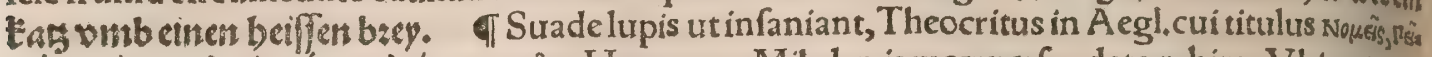

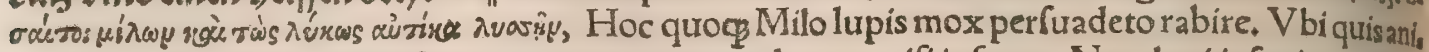
mum inducit ad rem ftultiffimam, quam non aggrederetur nifi infanus. Nam lupí infaniunt uel lua fponte, ucluti fi quis tyrãnum inftiget ad crudelitatem, cum plus fatis fruiat fuopte ingenio. Rabies propria canum eft, unde Scholiaftes Theocriti putat hoc uelut abfurdũ proponi. Sed canes aliquanı

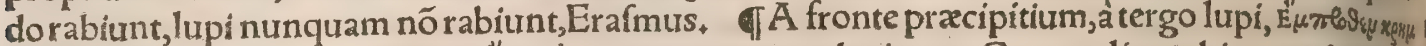

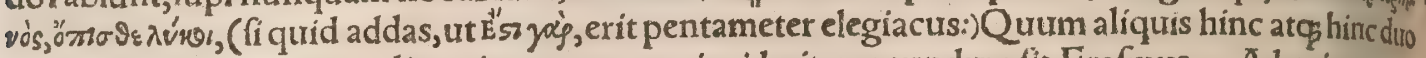
bus maximis premitur malis, ut in utruncung inciderit, pereundum fit, Erafmus. A lupi uenatu,

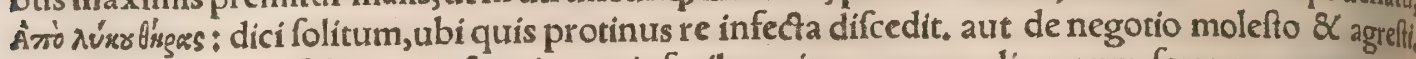
Neg enim tutum eft lupum infequi, neç is facile capitur, quum reliquarum ferarum uenatus non

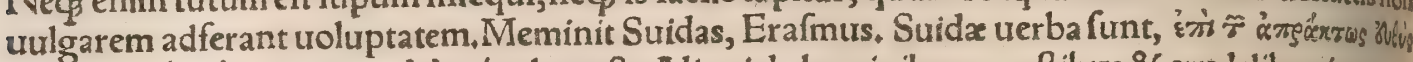

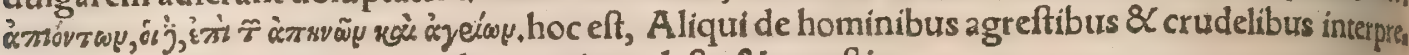
cantur, non ut Erafmus uertit, de negotio molefto \& agrefti.

TPeculiaria Germanis à lupo prouerbia . Ser bunger treibt bett wolf auf Dem bu[dbe Ouo

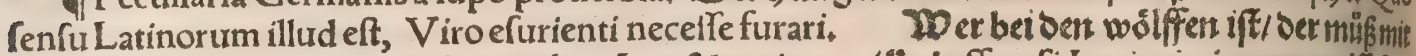

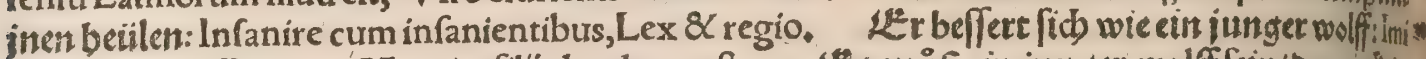

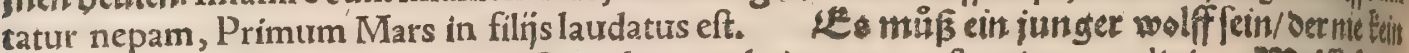

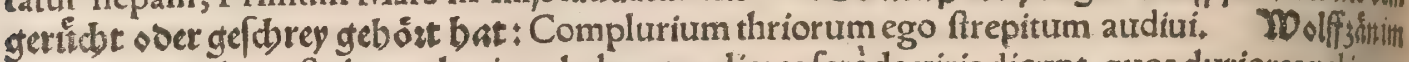
muno baben, hoc eft, dentes lupinos habere:mulieres ferè de uir is dicunt, quos duriores uel iracun dos elfe infinaant.

Gunt $\&$ in Sacris literis noftris à lupis tanquam prourerbia. Pfeudoprophetæu uftitu ouitum, intrinfecus lupi rapaces, Matthxi 7. Intrabunt poft difceffum meum lupi, Áctorum 10. Emitto uos ficut oues in medio luporum, Matthxi 10. Mitto uos ficut agnos inter lupos, Lucæ 10, Videt lupum uenientem, \& relictis ouibus fugit $\$ \&$ lupus rapitac difpergitoues, Ioan.10. Principes in medio eius quafi lupi captantes prædam, Ezechiel 226 Si communicabit lupus agno aliquando, fic peccator iufto, Ecclefiaftici 13. Habitabit lupus cum agno, \& pardus cum hardo accubabit, 31 Efaiæ 11. Lupus $\&$ agnus pafcentur fimul, \& leo $\&$ bos comedent paleas, Efaix 6 \%. Huiufmodiet?

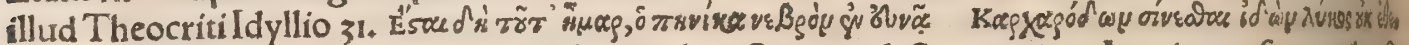
$\lambda^{\prime}{ }^{\prime} \sigma$ \&. T Stobzus in fermone de adulatione hoc Socratis dictum recitat, Lupi cum fint canibusfis miles, affentatores amicis, dituerfa tamen ftudia fequuntur. Et aliud Epicieti in fermone de tempe rantia, huiufmodi: Velutilupus animal eft cani fimile : ita $\&$ adulator, $8 \times$ adulter, $\&$ paraficus antico fimilis eft. A nimum igitur aduerte, ne canum cuftodum uice perniciofos lupos nefcitus admittas,

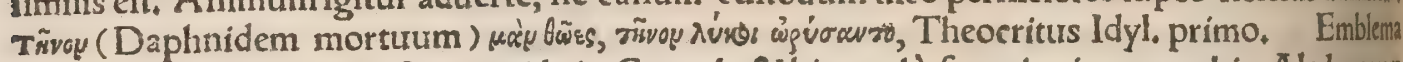
Alciati de capra lupum lactante, uide in Capra h. \& hic paulo fuperius in prouerbio, Ale lupotum catulos, Gracé pofitum.

\section{DE FERIS ILLIS QVAE LVPO CONGENERES \\ $S$ VNT. ET PRIM V M DE THOE, PANTHERE, Lupo canario, Lycaone, \&C.}

\section{A.}

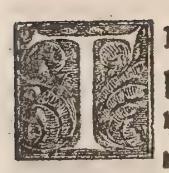

H O E $s$ duorum funt generum, ficut etiam pantheres (Eft \& pardalis fiue panthera ditr plex Oppiano, maior \& minor, fed quia minores uiribus $\&$ animo maiorenihil inferios res effe fcribit, apparet illos alios effe quàm mxivtwęas ab eo alibi dictos ) magnitudine diffep rentes. Videtur autem thos minor, panther minor, lycopãtheros, \& lupus canarius, iden omnino animal effe. Thôes luporum generis funt, Plinius. Oús, twòs, Suidas, Reperitur etiarn prima per omicron in plurali numero, in Lexicis, quod non probo:quamuis etiam apud Arrianum in libro de rebus Indicis ita fcribitur. Thos, beftia lupo fimilis, Hefychius. Et rurfus, o'way, ferault lupus: non quod $\theta^{\prime} \omega \omega$ nominandi cafu proferat. folent enim illi Lexicorum fcriptores uocabula ${ }^{0 \prime}$ dem cafu quo apud authores, prafer tim poëtas reperiunt, in Lexica referre.legitur autem f'cuup apuld Homerum lliados v. Hebraicum uel Arabicum thôis nomen nullum habeo, Quanquam apud Albertum legitur, Eft quoddam genus lupi, quod chabez uocat Ariftoteles, Auricenna autẽ bertuch (Perfica nimirum lingua ) uocari fcribit, Qua uerba Alberti funt in hiftoriam animalium Arito: telis 9. 44. eodem loco, ubi de thôe Ariftoteles agit, \& ïfdem uerbis. Etrurfus alibi, ubi Arifototes leonem $\&$ thôem inimicos effe fribit:Albertus reddit, Lupus pugnat cum animali quod toboz (it) hos forte, corrupto nomineà thos: \& rurfus à tohoz uel toboz, chabez fcripfiffe uidentur libraril 


\section{De Quadrupedibus}

guendi gratia à pardali, qua fera maior, \& Latinis fơminino genere panthera eft. Thôes,fera par, ux in montibus, Hefych.Oppianus etiam inter uiles $\&$ imbecilles feras pantheres numerat, cumfe libus, glíribus \& f́ciuris, lib, 2, de uenatione non procul à fine. Quamobrem cón̈ciat aliquis genetta quog dictas, de quibus fupra poft equû feorfim fripfimus, aliquod minimi pantheris genus effe: Cardanus muftelis adnumerat; fed muftelarũ maximas dicere, pantherum minimos, nihil forfitan prohibebit.Quinetiã zibetti catum, ut uulgo nominant, de quo ftatim poft pardalim fribam, ad hoc

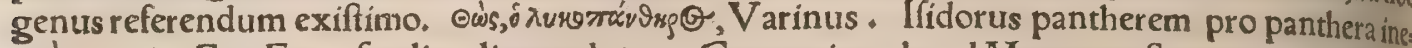
pté accipit. Ego Francfordiæ aliquando(qux Germaniæ urbs ad Moenum eft,emporium celeberti mum, )uenales uidi pelles quas leopardor ̃̃ dicebant, maculofas quidẽ $\&$ elegantes, fed multómino, res $\&$ diuerfas ab illis quas in Gallia uideram leopardorĩ pellibus, ex A frica aduectis:quę candidio

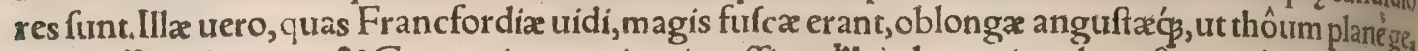
neris effe uideantur, \& Germanice nominari poffint, Elein leppar Den, hoc eft paruileopardi, $X_{b_{2}}$ nophon lib.de uenat.ca.penult. Leones, inquit, pardales, lynces, mávirgob, urfi \& alię huiufmodi fere in locis externis capiuntur circa Pangæum montẽ, \& Cittum fupra Macedoniã:alię in Olympo My fio \& Pindo fx, partim foueis. A pud paftorales A fros, præter alias feras, nafcuntur arietes agreftes, dictyes, thô,

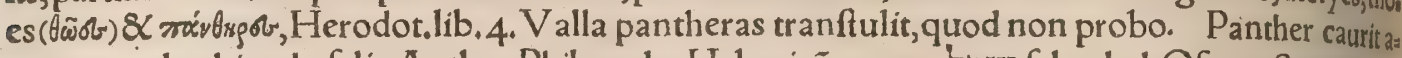
mans, pardus hiando felit, Author Philomelx. Hebraicã uocem bnש fchachal, Oree iz.Septuagintą gráw Lupus canarius(panther) cacos parit luporũ ritu, numero complurimũ quatuor, Arif, hift, animin,

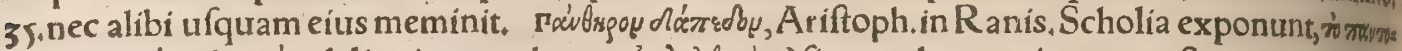

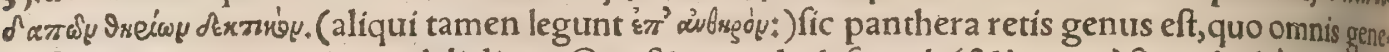
ris feræ capiuntur, ut in pardali dicã. Quaftionem de dafypode ( 8 lepore.) ficut de thôe, panthere ac lynce, negligentia quadam antiquis authoribus ita pratermiffam putat Theodor. Gaza, utexul farihaud facile poffint. Plinius certe, Oppian. \& A Ariftotel. lynces, thoës, \& pantheres, diturfis locis $\tan \tilde{\beta}$ animalia diuerfa memorant; It $\tilde{e}$ Xenoph. (ut modó recitaui)lynces $\&$ pantheres, Pollux ac $\mathrm{H}_{\ell}$ rodotus, thôes \& pantheres apertè diftinguunt, ut quan $\not \mathbf{z}$ congeneres feræx, magnitudine tamen, \{ non etiam aliter,omnino differre uideri debeant:quod accuratius difcutiendũ relinquimus illis qui peregrinas terras adierint adituríue funt: nos hæc in angulo patriæ noftræ fcribimus. PA THION (aP pathyo, inquit Alber.) animal eft, quod naturæ decore e mirabilem habet;colore enim purpureon! tens adeò refplendet, ut uifus in ipfo quafi f́ntillare uideatur. Mortuo, pellis quidem rubor manet, fed interit fplendor:magnitudo ei canis, admodum manfuefcit, $\&$ delicaris cibis gaudet.Quidãanti quorum putauerunt hoc animal habere aliquid diuinitatis. Offa eius duriffima \& fortiffrma funt, nerui tam ualidi, ut non nifi magna uiolentia poffint dirumpi, Hæc Albert. fine authore.Quódficu bi tale animal reperitur, thoum pantherumós generis effe uidetur: \& à panthêre forfan corrupta ulu rituox pathio. Tt Thôem non fuigeneris effe animal, fed ex lupi coitu cum pardali nafci Oppias nus recinit. Thóes, @óbr, G'ouv, fer $x$ ex hyæna $\&$ lupo natæ, Hefychius $\&$ Varinus, Thos animal eft fimile hyænæ, Scholia in Iliad,v.

B.

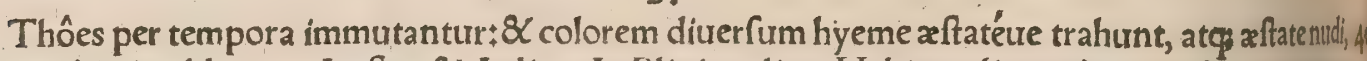
hyeme hirri redduntur, Ariftor $\&$ Aelian. At Plinius aliter, Habitum(inquit) non colorem mutanti, per hyemes hirti(comati, Solin,)æftate nudi. Thos interna omnialupi fimilia habet, Arift, Lupo longitudine procerior eft, breuitate crurum diffimilis, Plin. Veloces funt quanquã brenia habent crura, Var. Thoés cómiffos leones Et fubiêre aftu, \& paruis domuêre lacertis, Grat. Afpectulno

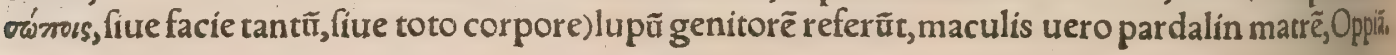
C.

Thos uelox eft faltur,uenatu uiuit, Plin. Proprium eorum $q$ in faliendo ita nifus alitis habent, ut non magis proficiantcurfu quàm meatu, Solin. Vincent. Bell. non meatu legit, fed in faltu, Animal eft robuftum \& agile, \& uelox, quanquã breuibus cruribus, Scholia in Iliad.v.\& Varin. Quadiu pedum multifida, omnia cxcos generant, ut canis, lupus, thos, \& $c_{\text {, }}$ ut in Cane ca.z. ex Ariftoteledos $p$ cui. Caccs gignunt canes, lupi, pantheræ, thôes, Plin. Coitu ut canes impletur, \& cacos generat, numero duos aut tres autr quatuor. Lupus etiã canarius(panther) cæcos parit luporum ritu, numero

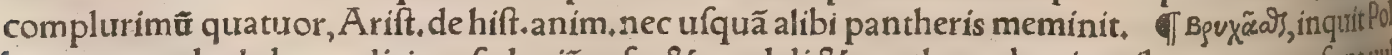
lux, non modo de leone dicitur: fed etiã urfo, $\propto$ pardali $\&$ panthereł de minoribus uero, ut funt uul

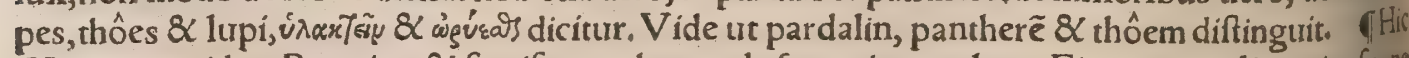
(Hagnon quidam Bocotius) \& femiferam thoum de fanguine prolem Finxit.non alio maior fuape ctore urirtus, Gratius:canes ex thoibus natos, fortes $\&$ aptos uenationi effe afferens: proinde femlte ros dixit, quòd altero parente cane manfueto, altero thoé animante fera nafcantur.

D.

Thôes hominem diligunt, 8 neq̧ offendunt, neq̧ metuũt ualde, Ariftot. Innocui homini,Plin, " Homines nunquã impetunt, Solin. Thôa legimus effe animal humaniffimum, præcipuéǵ homini 


\section{Ferælupocongen. H. Lib. I. 769}

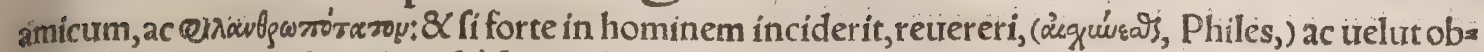
feruanter fufpicere. Amplius, fi à feris alijis circumuentum fenferit, tum uero accurrere protinus, opi

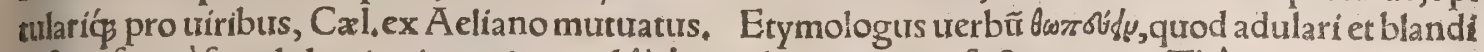
ri fignificat, à fraudulenti animantis, quod fà่ $\downarrow$ appelletur, natura factũ putat. Thôes pugnant cum canibus \& leonibus:quo fit ne eodem in loco fint thôes \& leones, Arift, Et rưfus, Leo \& thos inimila ci funt:cưm enim carne alantur, uictũ ex eifdẽ petant neceffe eft. Diffídent thôes \&leones, Plin. (Aliqui non recié ex Plinio citant lupum cerurariũ cum leone pugnare.) Thôes, cómiflos (clariffima fama)leones Et fubiêreaftu, et paruis domuêre lacertis, Grat. Vide fupra in Cap.de canib. mixtis et bigeneris. Thôes collecti(inquit Oppian, lib.2.de pifcib.)ceruum inuadunt, \& morfibus quantum poflunt carnis laniando rapiunt, ac fanguinem lambunt; fugit ille cruẽetus aliâs ad alia montiũ iuga: non deferunt tamẽ eum thôes, fed fobinde infeltant, \& per interualla tandẽ cófumunt. A ppares aũ mutuatum hac Oppianum ex Homerilliad, I1, quem locum recitaui in Ceruo $\mathrm{H}_{,} \mathrm{c}_{\mathrm{i}}$

H.

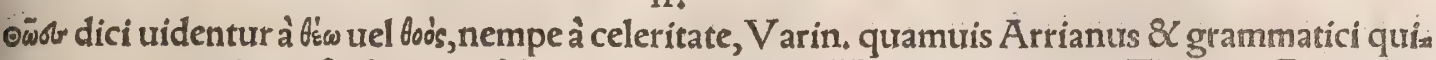
dam primã per omicron fcribant in obliquis, poeta tamen (Homerus, Oppian. Theocrit. Grat.) fem

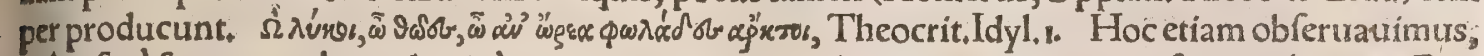
thôas ferè femper unà cum lupis à poetis nominari, ita nimirum congeneres infinuantibưs. TEpi=

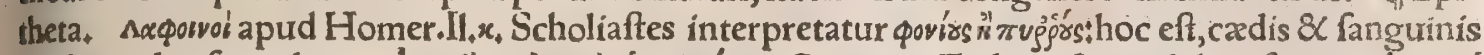

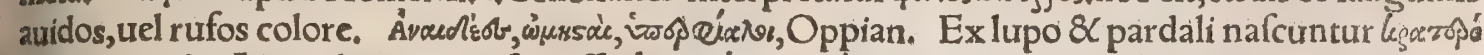

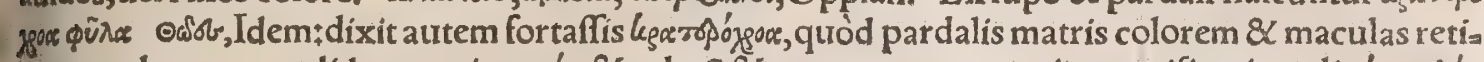

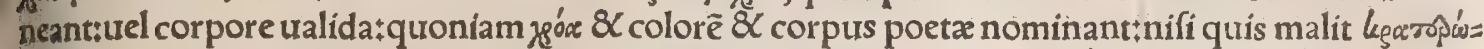
rvya. quod epitheton etfi eis conueniat, nihil tamen temere mutandũ.

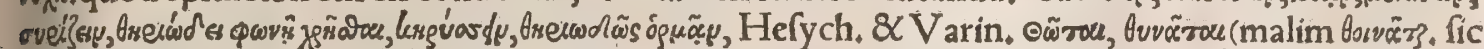

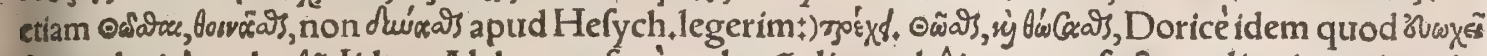
âru epulari, â uerbo $\theta \tilde{\omega}$, Iidem. Ab horum fané urerbor ũ aliquo thôis nomen factum aliquis coniecerit,

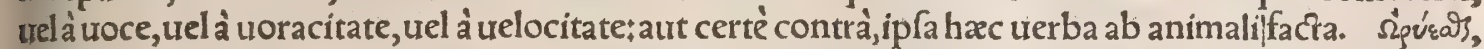
ululare, de thoibus dicitur, ut de alijs quoq̧ minoribus feris, lupis, uulpibus, Pollux. Varinus quide

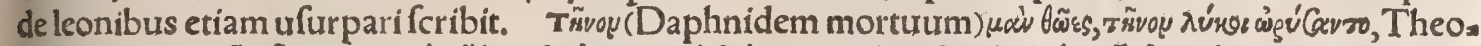

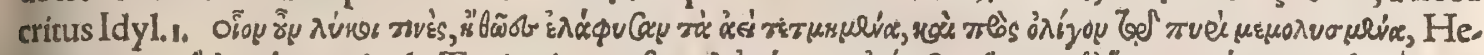

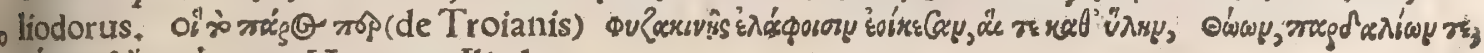

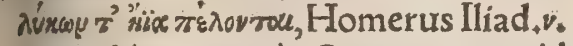

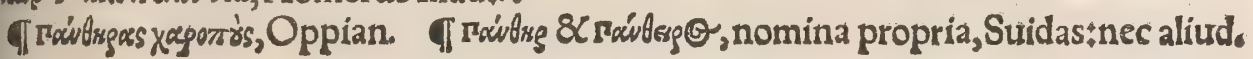

\section{DE L V P O C E R V A R IO,}

\section{YNCE \& CHAO.}

Figura bec lyncis est fuce lupi ceruarij, ut Itali wocant, qualem habere potuimus.

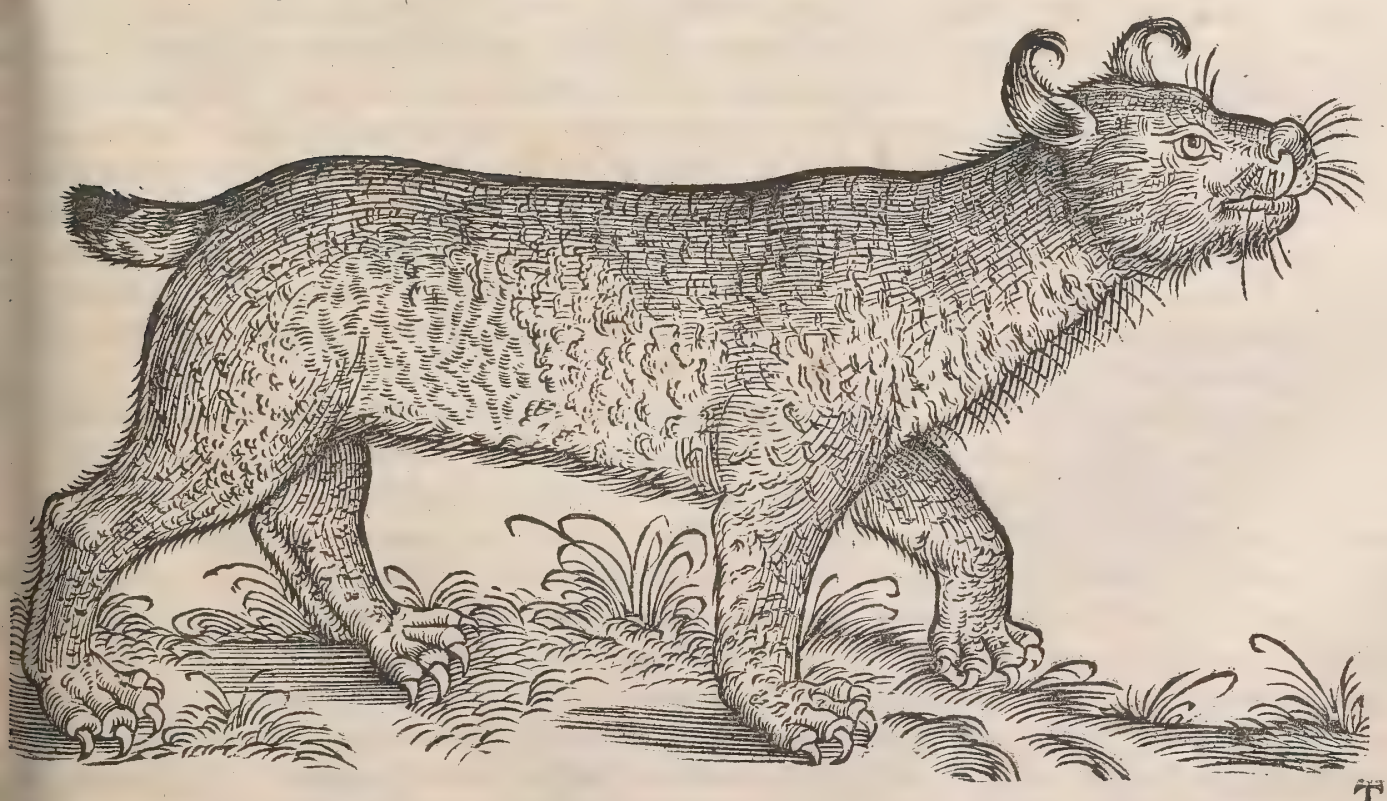



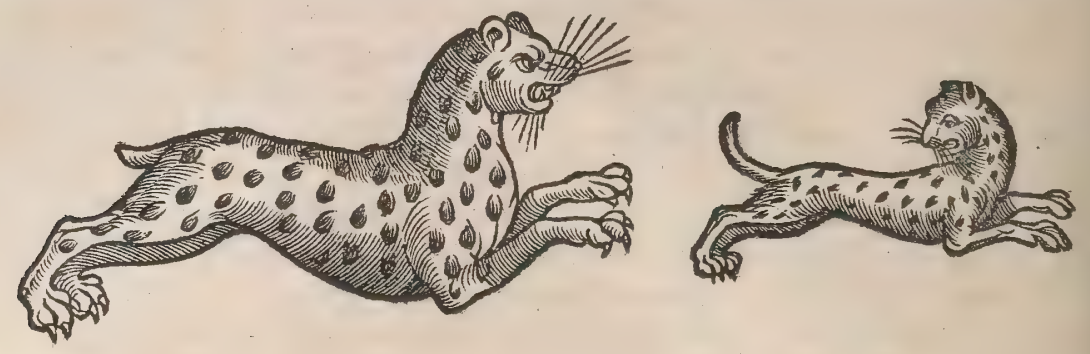

A.

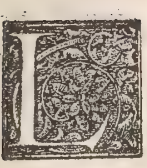

v p v $S$ Ceruarius quanquam hodie apud Italos $\&$ uicinos quofdam populos, de illafern dicitur, quam noftri uocant cin ludbs, facto nimirum à lynce uocabulo: tamen apud uele res duo aut plura genera hoc nomine comprehenfa funt. Sunt in hoc animaliữgenerere (de lupo \& lupo ceruario proximé dixerat) \& lynces,Solinus. Ceruarium lupumals. thor quidam obfcurus (nomen iam non fuccurrit) fcripfit animal effe mixtum natumó ex cerva $Q$ lupo, aut ceruo \& lupja, fed hęc tam ditrerfænaturę \& hoftilis inter fe animi animalia, fimulcolien wix credibile eft.ego potuus ceruarium appellari putârim, uel quod ceruos infeftet, tuel quod certuotinm hinnulos maculis fuis imitetur, Pompeî̉ Magni primum ludi oftenderunt chatrm, quem Gallita phium uocabant, effigie lupi, pardorum maculis, Plinius. Et alibi, Sunt in luporum genere quicete uarĭ uocantur, qualem è Gallia in Pompeij Magni harena fpećatum diximus. Huic quamuisinfas me mandenti, fi refpexit, obliuionem cibi furrepere aiunt,digreffum'ś quarere aliurd. Vnde apparel chaum, raphium, \& lupum ceruarium, unius feræ diuerfa nomina effe. Chaum à Pompeio primum in fpectaculis oftenfum, Seneca quooş alicubi meminit, ut quidam citat. Chaonides canes dichasen quã ex chao \& cane natas Hermolaus fufpicatur, fed chaus nomẽ apud Gręcos nō reperitur, neeral bi puto quàm femel apud Plinium, ut iă citaui. Vide in capite de canibus uenaticis in genere, $\mathrm{Al}_{3}$ bertus pro chao chamam dixit:pro raphio, rufinum, quem non Gallia, fed Aethiopia mittat, addih animal effe ludis aptum, \& difciplin $x$ capax $\div \&$ in hoc conuenire cum natura canis. Thoem, ut pracedenti capite diçum eft, Gaza ex Ariftotele lupum ceruariû́ uertere folet, quod meis illicallin

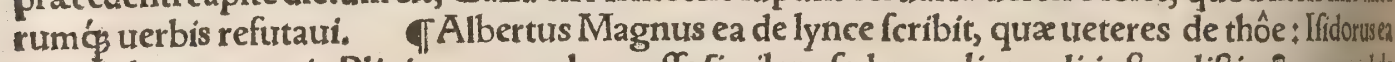
qua de lupo ceruario Plinius, nempe lupo effe fimilem, fed maculis pardí inftar diftinctam,quodde thố e etiam Oppianus canit. Gaza exiftimare uidetur thoem, lyncem, \& pantherem unius antimen tis diuerfa effe nomina, cum tamen pro thôe lupum ceruarium reddat,pro panthere lupum canarifí, fed qua pracedenti capite explicata funt, hic repeti fuperuacaneum. Lynx habet formam ut lis pus, Iorath. Plinius lynces peregrinas effe tradit:Et alibi, in Aethiopia uulgo frequentes, Solinus capite ocfauo lupos ceruarios in Italia reperiri fcribit : mox eiufdem generis etiam lynces effetethat tus, ex qua regione habeantur omittit. Lynces beftias è quibus lyncurion, Zenothemis hangss appellat, $\&$ circa Padum ips uitam affirmat, Plinius. Et alibi,Beftias langurias in Italia effe quilian dicunt, è quibus (quarum urina) fiat langurium, quod ali lyncurium uocant. Scribitur antem

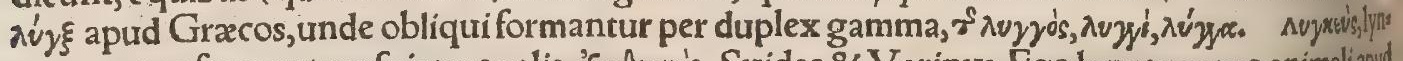
ceus, genus fer $x$, aut perfpicax oculis, ogsudepgris, Suidas \& Varinus. Egolynceum pro animali ippld nullum ueterem fcriptorem legi, proprium autem uiri fapius, ut dicam in $a_{*}$ Solus Oppianuslit bro 3, de uenatione, lyncis duo genera facit, maius $\&$ minus. Lynces paruę, inquit, lepores uenantur: maiores trerô in ceruos atф̧ oryges facile infiliunt. Ambx corporis figura fimiles: \& fimiliteroull utrifog fuauiter fulgent, \&c, ut in B, dicam, Hunc locum Gillius transferens, ineptiffimélynces parta lium generis facit, tanquam id adferente poëta.

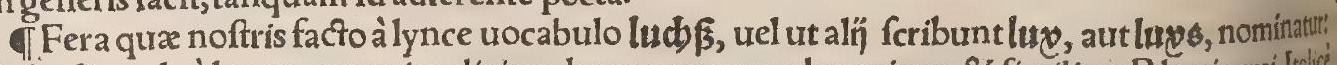
Italis hodie uulgò lupus ceruarius dicitur, lupo ceruero uel ceruiero: $\mathcal{Q}$ fimiliter $R$ hatis qui Italiè loquû́tur, \& Sabaudis: \& Dalmatis uel lllyrị́s ceruiro. Nuper fanè Bohemus quidam coniecturam fuam mihi narrabat, lyncem Illyricé rys uocari, (et eam effe luchfam Germanorum: ) certuiro antili eft ceruarium Illyricè dictum minorem effe, fimilem alioqui. Hifpani adhuc Latino nomine trocitia lince, ut et Italici quidam fcriptores in lingua uulgari,Arlunno tefte. Ego luchfam noftrâ Trideñi ante annos octo in arce epifcopi uidi, ubi à nonnullis Italicé uocabatur loup chatt, id eft lupus cattsts catum enim feu felem quodāmodo facie refert, $\&$ unguibus fimiliter acutis $\&$ maleficis pradita nifi quis malithoc nomen deriuatum à chao ut Plinius uocat, In quiburfdam Heluetix locis, \& cirra Sedunum, appellant tbierwólf. Vncia quadam fera apud barbaros fcriptores nominatur:quam ego pantheram effe puto: hanc Fr. Arlunnus ab Italis quibufdam in uulgari lingua feríptoribuslon zam uocari ait, nonnullis leæenam, alís pardum, aut pantherã, aut lupum ceruariü inter pretantibus 
morbo regio occirrri fiex uino bibatur, aut fi portetur, Hucufque Plinitus. Vrinam furam/ynce illico arenartum cumulis contegunt, ut Theophraftus perhibet; tranfit ea in duritiem pretioficalcu li. Is colore furccini eft, pariter fpiritu attrahit appropinquantia, dolores renum fedat, medetur egerio morbo, Solinus. Victa racemifero lyncas dedit India Baccho, E quibus (ut memorant)quicquíd uefica remifit, Vertitur in lapides, \& congelat aêre tacto, Ouidius 15, Metamorph. Lyncis urim quam lyncurium ( $\lambda v$ ys ŕecou) appellant, creditur eiecta ffatim lapidefcere, fed fallo : eamós ob caufam inanem $8 X$ inutilem habet hiftoriam. Eft enim lyncurion quod à quibufdam electrum pterygopio: ron dicitur, quơd plumas ad fe alliciat:id potum ex aqua ftomacho, aluoó́p fluxione laboranticicont urenit, Diofcorides. Lyncurrium an fit, aut unde fit, authoribus non conftat, Hermolaus. Lyncuri, um, quod fuccinum, itemós electrum appellant, Aétius in antidoto Philagrị ex damafonio adcal, culofos. Miraturr Calius quòd Diuus Hieronymus de lyncurio nil fibi compertum apud auctores

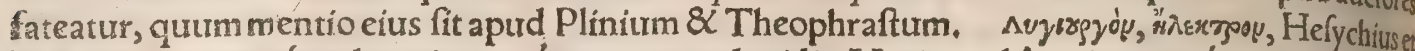

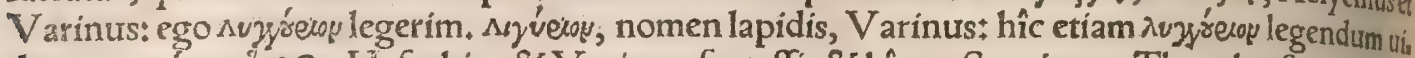
detur. svyretop, va $\lambda$, Hiefychius $\&$ Varinus: fortaffis $\&$ hîc. Succinum Theophraftus in Ligut ria effodi dixit, Sudines $\&$ Metrodorus afferunt arborem effe in Liguria, quax electrum gignat, Plit nius. Mihi quidem uerifimile fit electrum, ex aliquo Liguriæ emporio in Graciam olim aduettum, atç inde uulgò primum â regione dicfum Ligurium, per imperitiam poftea inuritante trocabuli affí nitate lyngurium quafi lyncis urinam nominari copiffe. Fertur utriufque populi (旅

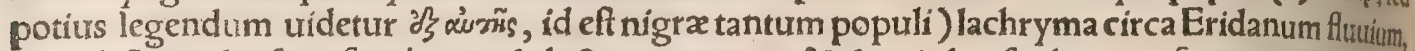
cum defluxit denfari, fierióp quod electrum uocant, $\&$ aliqui chryfophoron ( forte quod aurume, tiam ad ferapiat, ut aris ac ferri laminas, quod fupra ex Plinio recitauimus) colore auri, in attritu

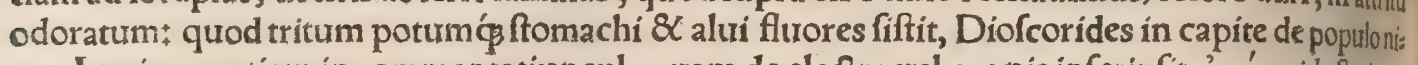

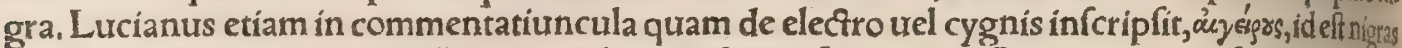
populos nuncupat arbores illas, ex quibus electrum fundi circa Padum ueteres fabularifine; fed quoniam leucx, id eft alba populi, eiufdem generis arbores funt, fieri poteft ut fuccum concretum quem leucx circa Padum fundant, ftatim lapidefcentem, aliqui circa idem flumen lyncas quafdam animantes fundere dixerint: Sed ha coniectura funt noftra. Oritur \& è faxo (inquit Hermolaus corollario 698 .) id eft lapide lyncurio, fiue lyncæo uulgarl uoce dicto, fungus, admirabilinatura, Praciditur hic in efum, \& alius fubnafcitur anno toto: pediculi pars relicfa duratur in filicem, alç ita femper crefcit lapis, reftibili foecunditate murs, Noưum $\&$ hoc uita fibi comperit, inuicemóg multa perdit: quanquã eft ubi Plinius hocinnată ut in Caftigatione Pliniana XXIr.librí diximus. Ego nihil tale in Caftigationibus fitue prioribusfs ue pofterioribus eum in librum reperio. Sunt $\&$ ex utraç populo fungi, corticibus earumdiffer

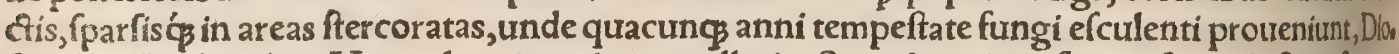
fcorides. De his aliter Hermolaus in eodem corollario, Sunt $\&$ xgiritæ fungi, fed induftria, fermen to in ipfis populi nigrax truncis diluto aqua, protinus coalefcentes. Elecorum, lego electrum, idet lapis lyncis, Syluaticus. Lapis lyncis fit de urina lupi certrarî in montibus coagulata, qui domifer uatus generat optimos fungos fupra fe quotannis:creditur prodeffe dolenti fomacho, morboregio,

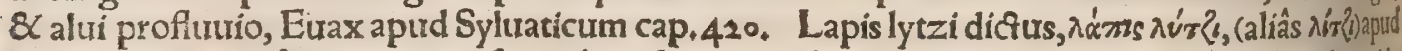
Nicolaum Wyrepitrm, in compofitionibus aliqurot medícis nominatur: $Q$ primum in librode anidio tis compofitione 30. Vbi Leonhartus Fuchfius interpres uerba haec adiecit + Lapis lytzi uarie apdid Nicolaum fumitur. Hîc certè haud fecus atç in antidoto fequenti $37 \cdot$ accipitur pro lapide prafio, (ut ipfe Nicolaus illic exponit, Lapis prafius, in quit, ab Italis lapis lytzi uocatur.) Eft autem prafius, uel prafitis Theophrafto, fic dięus lapis, quòd uiridi colore porri fuccum repręenset. (qua etiamñ apud Germanos nomen feruat, ut Ge.A gricola frribit.) Plinius 37.8. tria eius genera effetradit Ea dem quas iafpis ( $\&$ fmaragdus) facultates habet, quare in hanc compofitionem inferitur ut uenticu lum robcret, Hac Fuchfius: fed forte tanquam nephriticum pharmacum huic compofitioni tricelt mæ, quæ $\&$ alia plura diuretica accipit, lapis litzi adijcitur. Cærterum in alís quibufdam compoliti onibus lapidem litzi pro coeruleo fiue Armeniaco accipit, inquit Fuchfius : ut in antidoto 46 \% dias fenæ inferipta. Porró in antidoto $\xi 9$. diacomerôn, pro lapide lyncis fiue lyncurio, quod nihil alind quàm fuccinum eft. Antidoto etiam é cicadis apud Nic. Myrepfum, lyncurium mifcetur: Qchodie ufitatis compofitionibus Philanthropo \& Benedictx purganti,lapis lyncis. Phrygius lapis (inquit $\mathrm{Ge}$. Agricola lib.y. de natura foffilium) ex Phrygia, curius infectores eo ueftes tingunt, nomen inue nit:fed nafcitur in Cappadocia. is gleba eft pumicofa, mifti faporis: nonnihil enim \& adfringit to mordet:optimus autem eft colore pallidus, uenas uero tanquam cadmia, habens candidas. non robtur ftus compage corporis, mediocriter grauis, tino refperfus $\&$ uftus, magis fit fuluus: hunc aliquilitu die pro lyncurio urendunt:ficut alĭ pro eodem, ut dixi, belemniten. In medicina exiccat: Fed prattes rea miftis uiribus praditus eft:nam repellit $\&<$ digerit, utilis ad ulcera putrida, $\&$ ad oculor $u m$ media

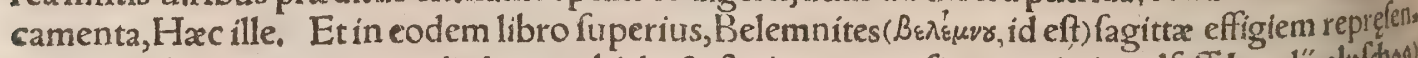

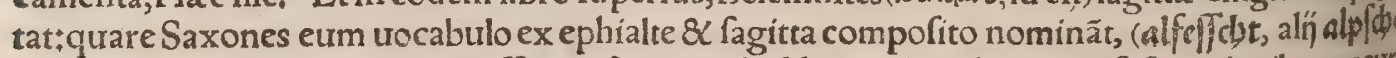
potumós contra eiufmodi fuppreffiones $8 x$ noctis ludibria ualere dicunt, ac fafcinationibus occursere, Hunc lapidem hodie quidam medici pro lyncurio habent $\mathcal{Q}$ utuntur, qui ex urina lyncis noth 


\section{Ferælupocógen.D.E.G.H.Lib.I. 773}

concreuit:nec enim ullum tale fuit lyncurium, fed ueteres fcriptotes fuccinum, ut dixi, fic appellia runt. Plura de belemnite cognitur digna, qua eo in loco A gricola docet, omitto ne fim prolixior * hoe tantum addam, ut medicos ad eius cognitionem inuitem*Qunoniam uero, inquit, belemnite exiccãt; Prufficis \& Pomeranicis chirurgi curant uul nera:ijfdem medici, \& Saxones fuis, non alirer ac lapi de ludaico frangunt calculos. Antonius Mufa Brafauolus terram lyncum urina madidam fapi us collectam fibi $\&$ repofitam fcribit, fed nibil unquam in ea concreuiffe mirè autem foetidam fuife. Ge.A griccla lib.6.de nat, foffilium, oftracian alteram achatæe fimilem effe fcribit, translucida uiridita te mifta nigrore: $\mathcal{Q}$ eius fragmentis quofdam noftris etiam temporibus alias gemmas fealpere thanc Germanice interpretatur lue fapbir, quafi faphirum lyncis, nefcio quam ob caufam+nifi quòd ipfius - etiam uiridis lapis à Nicolao Myrepfolapis lytzi, quafilyncis, nominatur. De urina onagri,cum interficitur, in terra fpiffante fe, ut fertur, dictum eft fupra. Ego in officinis pharmacopolarum apud nos lyncurium illud, ut uocant, cófideraui, quod ceu pumicofa quadam (leuitate fere pumicis, non raritate)gleba eft quæ pugnum impleat, aut maior, porius quàm lapisł alterum fufci uel nigricantis alterum lutei coloris, quod \& folidius, arenofius, \& pinguius eft; commanfum lutef cit, utrungs pelli. culis feu membranis quiburdam albis intercipitur, luteum quidem manifeftus, fungof $x$ cuiufdam tenaciś́s fubftantia, ut hoc forte genus fit, è quo fungos nafci Hermolaus teftatur:apparet fanè tumn ex membranis illis, tum calculis in eo repertis, corpus effe heterogenès in terra coalefcens, In Sabau dia alium lapidem lyncis mihi demonftrarunt, fubftantia cryftalli, 8 pellucidum, ea duritie ut ignem excutias, triangulum ferè+colore partím candido, partim paffeo diluto, Lyncurius lapis effula lyno cis urina feptem dierum fpatiogeneratur, lorath.

\section{D.}

Lynces, pardales, leones $\&$ tigrides, foetus furos mirifice amant: Vide in Leone D .ex Oppiano. Lynx rapax eft animal inftar lupi, fed callidius. In arboribus latet, ut in prætereuntes pecudes defí

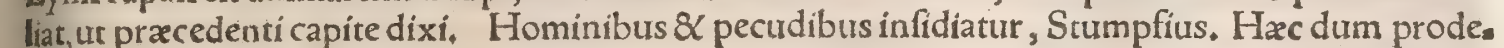
rem, à uiro quodam fide digno audiui, lynces in regione Germaniæ qua duci Vuirtenbergenfi pa. ret, non rarò capi $\$<$ contigiffe aliquando ut lynx in querculatitans, in rufticum pratereuntem de filiret:quam ille præuifam in ipfo faltu, fecuri quam forte geftabat, exceperit, $\&$ in terram proitrauc= rit, ubi mox aliquot ab eo ictibus enecata fit. Lupi quos ceruarios dicimus, quamuis poft longa ie ftnia repertas agrè carnes mandere coperint, ubi quid cafu refpiciunt, obliuifcuntur: $8 \times$ immemos so mores præfentis copix, eunt quæfitum quam reliquerunt fatietatem, Solinus: \& Plinius ut in A retui li. Rex Tartarorum habet leopardos cicures, qui mirum in modum uenationi inferuiunt: item lynces non minus ad uenandum induftrias, $\mathrm{Paulus}$ Venetus.

E.

Lynces, pantheres, urfi, \&c.in montibus capiuntur, partim aconito, partim equis \& armis intro. clufi, non fine uenatorum difcrimine. Sunt quibus $\&$ foureas latas in orbem durcunt, \&c, ut in Leo. ne recitau ex Xenophonte. Iifdem foueis lynces capiuntur, quibus \& lupi, Olaus Mag. † Pel. les lyncum noftrarum, unx omnium ferè pretiofiffima funt, $\mathcal{Q}$ à nobilibus tantum in ueftimentis oftentantur.

Vngues lyncum omnes cum corio exuri efficaciffimè in Carpatho infula tradunt. Hoc cinere po to, propudia uirorum:eiurdem afperfu, foeminarum libidines inhiberititem pruritus corporum: Vri na, ftillicidia ueficx. Itaç eam protinus terra pedibus aggefta obruere traditur. Eadem autem \& iu= gulorum dolori monftratur in remedio, Plinius, Sed de lyncurio, \& remedijs ex eo, capite tertio di= cium eft. Vngues lyncum albicant; fingulos apud nos argento includunt, \& ad fpafmutum commen dant,figeftentur:fortaffis quoniam incurui funt $¥$ quo argumento radices etiam nonnullas, curuas

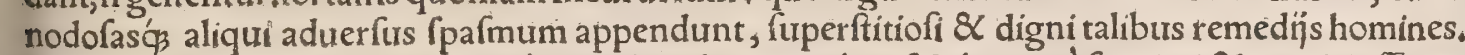
Sunt qui uiuulas in equis (ut uulgò appellant) his unguibus faluberrimè fauciari $\&$ aperiri afferunt: \& eam ob caufam ả multis equitantibus circunferuntur. Lynx feu lupa ceruaria, feles, muftela, $\& \varangle_{6}$ plus uulnere quàm ueneno ladunt, Arnoldus.

\section{$\mathrm{H}_{*}$}

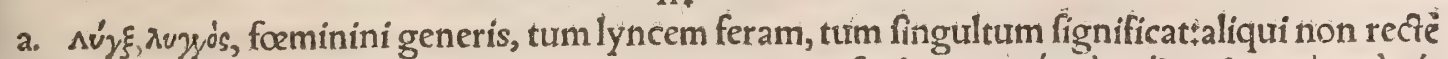

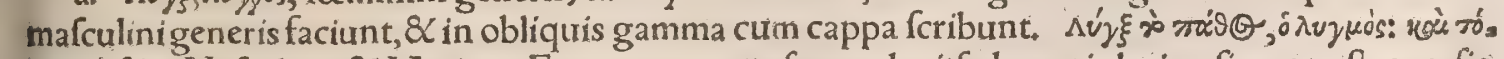

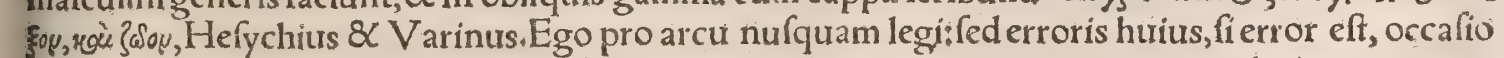

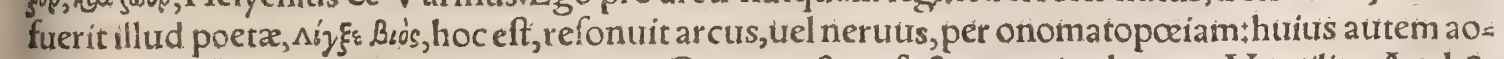
rifti, inquir $V$ arinus, thema nullum extat. Quorum fupefactx carmine lynces, Vergilius Aegl.8،

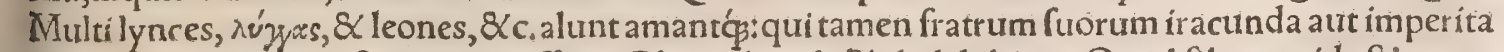
aut ambitiofa ingenia ferre non poffunt, Plutarchus de Philadelphia. Quod filycon, id eft lupum

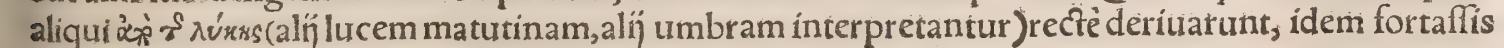
etymon lynci etiam perf́picaciffumo animali congruet.

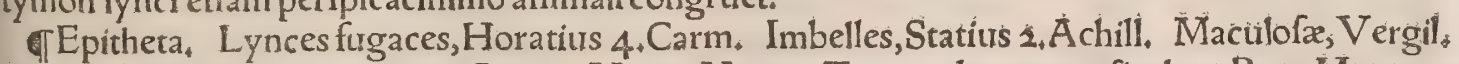
Timidas agitarelyncas, Horat.2.Carm. Varix, Verg. Tergore lynces uerficolore, Bapt, LMantua=

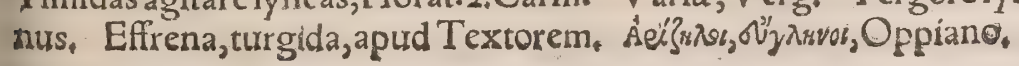




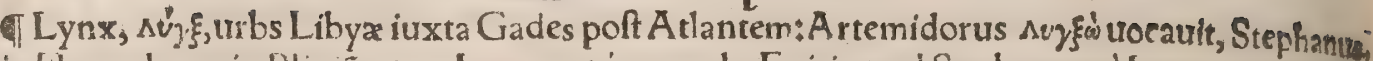
Vide Hermolaum in Pliniũ y.l. Lyncus, $\Delta$ yjus, urbs Epiri, apud Strabonem,à Lynreo dicta. Gen tilia, Lyncius, Lynceus, Lyncift $x$,Stephanus, A Lynceo (Hypermneftræ marito) dic a ef Lyn. cea regio, quam mox Lyrro incolente Abantis filio notho, Lyrceam quoque nominarunt, $C$ alits, Lynceftij amnis potu inebriantis meminit Ouidius is.Metam. Lynceoperfpicacior:Lynceiper. fpicacitas (inquit Erafmus) in proue bium ab̆̈r. Plinius nat. hift. 2. 17. Nourfimam, inquit, Lunam, p: imaniģ eadem die uel nocte, nullo alio in figno, quàm in ariete confpici: id quod paucis mortalıü contigit. Lt inde fabula cernendi Lynceo. Sunc qui tradunt Lynceum primum reperiffe fodinas me tallorum, æris, argenti, aurı. Er hinc uulgó natam fabulam, quod ea quogg uideret, quæ fub serra fo, rent.teftis Lycophronis interpres. Meminit huius \& Plato in epiftola quadã. A riftophanes in Pluto, 11

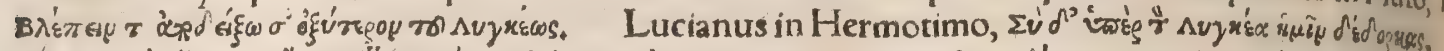

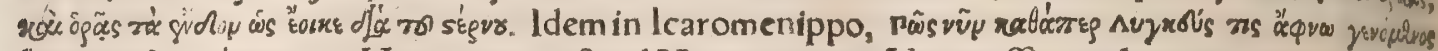
äray drayıvíwoxss; Horatius 1, epift. adMecoenatem, Non poffis oculo quantum conendere Lynceus, Nontamen idcirco contemnas lippus inungi. M. Tullius M. Varroni, Qurs efi tam Lynceus qui in tantis tenebris nihil offendat, nufquam incurrat? A pollonius in Argonaut. (memi. nic etiam Orpheus) (cribit hunc Lyceum uf $\$$ a adeò fuiffe perfpicacem, ut etiam terram iplam oculo. rum acie penetrarer, quax q́s a pud inferos fierent, peruideret. Plutarchus in commentar:o adueriu Stoicos teftatur famam fuiffe de Lynceo, quod faxa quog 86 arbores oculorum acie perietrare, (hoc recentiores quidam de lynce quadrupede ferunt. ) Paufanias in Corinthiacis tradıt Lynceũ Dillao urta defuncto, regni fuccelfionem fuicepiffe. Pindarus in Nemeis hymno decimo meninit Lynceis quex Taygeto monte uiderit Caftorem \& Pollucem fub quercus truncolatitantem, \& horumala terum iaculo uulneraffe. Pindari interpres citat hiftoriam rerum Cypriarum, Ariftarchum \& Didy mum, Hace Erafmus. Quód fi quis lynceum, ut Suidas 8 Varinus, pro animali nempelynce accis piat, fic etiam quadrabıt prouer bium in hominem acutiffimi uifus, aut etiam ingenï per metapliorä, hac enim quadrupes, Plinio tefte, clariffime omnium animalium cernit. Sed \& lynceus adieciuum, àlynce fera fieri uidetur, non à Lynceo uiri nomine. Omnes ( inquit Galenus citante $C_{2 l i o)}$ une. becilliore fumus cernendi poteftate, fi aquilarum $\&$ lyncis acuminibus conferamur. Ne corperis optima lynceis Contemplêre oculis, Hypfea cacior illa Qux mala funt fpectes, Horatius ı. Serm,

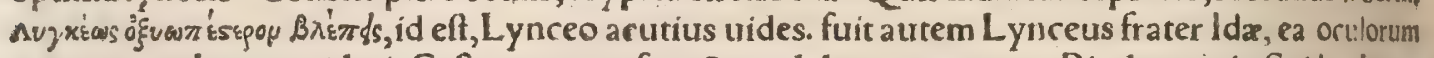
acie, ut per abietem uiderit Caftorem cum fratrê per dolum necaret, ut Pindarus ait, Suidas Locus 30 Pindari eft in Nemeis Carmine decimo, de Lynceo \& eius fratre lda, qui Caftorem lancea uulnerás rit, \&c. unde corruptus Suid $x$ locus reftitui poteft. Plura ab interpretibus $P_{\text {indari petet qui uolec, }}$

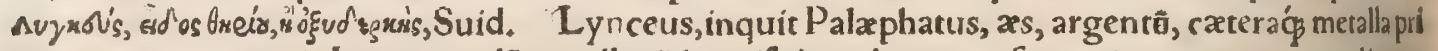
mus inquirere cœpit, In qua quidẽ metallorũ inquifitione, lucernas fecum intra terrę penetralia cirr cunferens, ibidem eas forte relinquebat, ac furfum ipfe aes ferrumç reportabat. Quod facium uiden tes homines, dicere confueuerunt, quod Lynceus fubterranea etiam profpiceret, ob id́ćs argentum inde furfum afferret. Lynceus, cullyrium quoddam a pud Galenum de Compof, fec, locos, \& Paul,

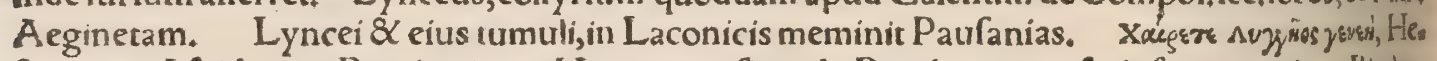
fiodus in Afpide. Porphyrus in Homerum, fi modo Porphyrius ea fcripfit, in tertium lliados, Idam \& Lynceum frribir A pharei filios, Leucippidum amatores, ad nuptias 'T yndaridas aduocaffe 4 Caftorem \& Pollucem, qui fponfas Phoehen \& Ilairam rapere conati funt. hinc orto certamine Ida (Idas) Caftorem occidit. fed hac re iratus lupiter, Idam fulminauit, \&c. Gyralders. Eadem leguntur in Scholihs Pindari: \& infuper, Perfei familiam à Lynceo ortam effe. De Lyncei contra Cafform pugna, Theocrirus Idyllio 27. Hypermneftra inter filias Danai, qux omnes ex pairis prafcripto maritos noc?u iugularunt, fola marito nomine Lynceo pepercit: Vide Calium 11*13, \& 25. Lynseus Samius grammaticus', \&c. Suidas.

बe. Succinctam pharetra, 8 maculof tegminelyncis, Verg i. Aen.

ith. DeLynco rege Scytharum in lyncem feram mutato, fcribit Ouidius 5. Metam, GMa culofa quadam animalia ueteres Baccho confecrarunt; ut lynces, pardales, axin. Victa racemife rolyncas dedit India Baccho, Ouid.is.Metam. Quid lynces Bacchi uariar.Verg. 3 Georg. In India Crefias nafci fcribit feram nomıne axin, hinnuli pelle, pluribus candidioribus $\phi_{\beta}$ marulis, fa. cram Liberi patris, Plinius. Bacchus aliquando ffictus eft in curru pampineo $\&$ triumphans, qui pantheris modo, modo tigribus aclyncibus trahebatur, Gyraldus. Nebridem quogg, id eft ma culofam hinnuli pellem, Bacchum, \& Orgia celebrantes geftaffe legimus.

Hxc fcripleram cum accerfitam à pellifice lyncis pellem infpicere ipfe wolui. Longitudo extenfx â fummo nafo ad caudam ufos dodrantes quatuor, digiti quin $\$$. \& caudx poltea digiti feptem Latis tudo círca collum, ( non ambitus dico, fed dorfi tantum, ) palmi duo, in imo dorfo, dodrans $\&$ digiti fex. Crurum anteriorum longitudo, dodrans cum digitis quinç, pofteriorum, dodrans cum digtis tribus. Pilus undiquaç molliffimus eft, $\&$ denfa lanugine conferefus. Extrem $\underset{x}{ }$ pilorum partes in dorfo albicant, interius ruffx. albicant autem magis partes utring à dorfo medio recedentes. mediü magis fufcum $\&$ ruffum eft. Venter medius candidus, \& maximé imus. partes utrir $q$ parsim didx partim ruffx. Paffim etiam in uentre puncta quadam nigricãt, pauca, crebra uero iux ì imum 

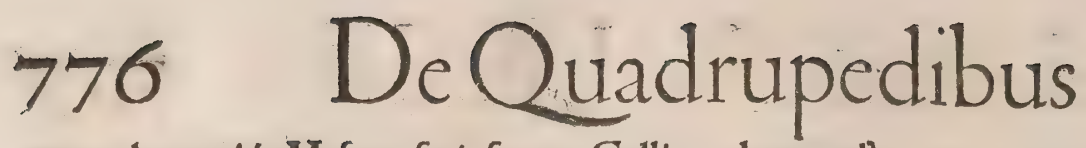

monachos qui in Mefuen fcripferunt. Galli une loutre, al' ung loutre: Sabaudi quidam une leure. Hifpani nútria. Germani \& Angli ottex. Illyrị wydra.

B。

Lutras alunt pleręç regiones, quibus amnes, lacus aut Itagna pifcora non delunt. Habet eas Italia, Gallia, Ger: mania, Heluetia, Anglia,Scandinauia, \&c. In Boryfthe, nis ripa \& Sarmatia tota plurima funt, Hermolaus. $R e=$ periuntur in Iralia ubi Padus mari iungitur:fed in Neapo litano agro frequentiores funt, Brafauolus. Fibris cauda pifcium, cæetera fpecies lutræ, Plinius. Feli non admodũ diffimilis eft(aliqui trulpi comparant, corporis longitudi. ne prafertim:) fed longior \& latior, ( $\&$ capitis fpecie diz uerfa, magnitudine pari)Albertusł caftoreminor, Pelle pilis bene denfam habet:hinitidi $\&$ molles funt, ut etiam caftoris,à quibus tamen differunt: nam lurræ pilus fufcus nonnihil ad caftaneæ colorem deflectit, $\alpha$ breuis ac æqua

- lis eft + caftori in cinereo candidus $\&$ inaqualis, Ge. Agri. cola. Caftor pilo fuperné canino eft, alibilutra, Syluius, Dentes habet acutos, \& ualde mordax eft, Albertus: crus ra breuia, pedes omnes caninis fimiles, caudam longam, Ge. A gricola \& Albertus . Caniculæ flumiatili cauda eft pilofa,Aelianus.

Lutrasè genere fibrorum nufquam mari accepimus mergi,Plinius, Reperiuntur apud nos, tum iuxra fluui. os tum lacus, caftores uero iuxta fluuos tantum. Lutris greffilis eft, 8 degit quidẻ in fluido, urctumá̧̧ inde emoli: tur, fed aërem non humorem recipit, \& foris (in furis cauer nis)parere folet, Ariftot. Lutra (lutius corruptélegitur) 8 caftor, uenantur tam in aqua quàm in terra, Albertus. In antris habitatiuxta aquas, Idem. Referunt quidam côs Itrui ab eo uelutí tabulatum ex ramis aut uirgis aprè difs pofitis, cui incumbat, ne madefiat. Pifces uenatur: $\&$ quamuis refpiratione indiget, diu tamen fub aqua fe con cinet:eft quando gurguftia(íd eft naffas)ingreffus, fuffoca tur, cum necs redire poffit qua ingreffus eit $\div$ neqs naffam fatis maturè difcerpere. Qưin \& aliâs fæe dum prædam auidius fequitur, aberratis impeditur \& fuffocatur:omni= no enim per interualla ore $\&$ naribus exertis aërem hau. rire ei neceffe eft. In uenando quidem mira ei agilitas ac uelocitas. Latibula fua tot pífibus replet, ut etiam aêr inficiatur: quod quidam non fine periculo expertifunt, qui hoc animal capere uoluerunt, Albertus $\&$ alij. Hinc \& ipfa tam foetida redditur, ut uulgo noftri in hominem graue olentem dicant, fotere eum lutræe inftar: ut Latini, hircũ olere. Pifces uenatur mira frequẽtia,Belluacenfis. Pifcibus maximé delectatur + prater illos tamen etiam ali. os cibos edit, (fructus \& cortices arborum, Ge. Agricola,) Albertus, Ecauernis ad paftum capeffendum egrediun tur, etiam hyberno tempore, Ge.Agricola. TLutris eti am hominem mordet, (ut fiber, )nec defiftit, ut ferunt, nifi fracti oflis crepitum fenferit, A riftot.

D.

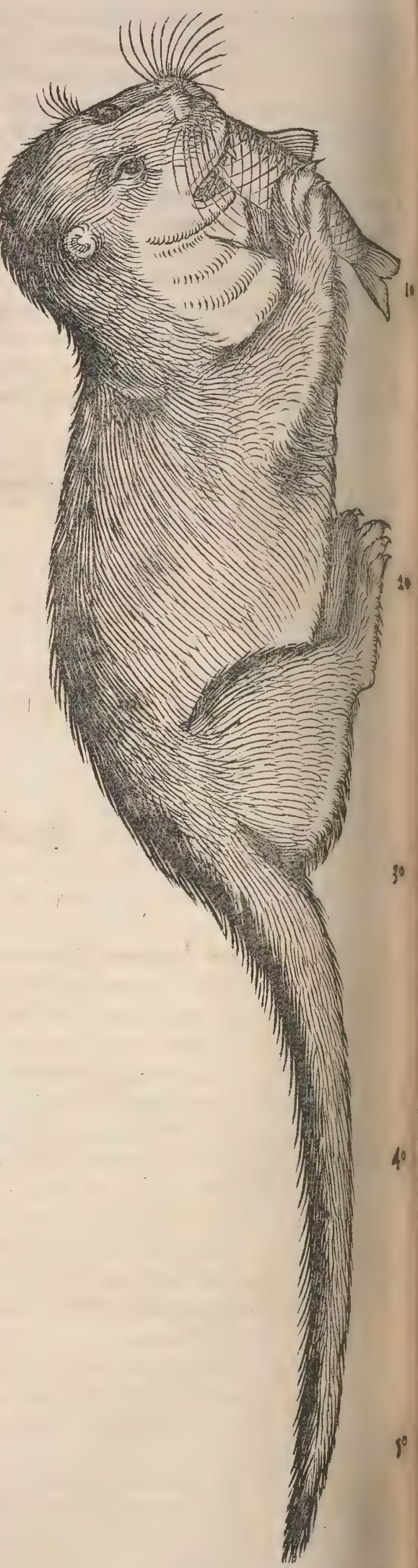

Lutra animal eft aftutum $\&$ malignum, Obfcurus, Cicuratur aliquando, ita ut pifces circuiftu fuo in retia compellat, magno pifcatoris emolumento. Olaus Magnus lutras in Scandinauia alicubi manfuefieri fcribit, ita ut pifces eriam cocis ex aquis adferant in culinam. Sed quoniam auidiores præd $x$, inquit, plures quàm fit opus occidunt, rarius ad hoc opus ufurpantur. Cicur facilis $\&$ alacris ad ludos eft, Albert. $\&$ ali $\not$. Falfum eft quod aiunt lutram à fibro cogi, ut aquam hyeme circa caus dam eius moueat, ne congeletur: fed fiber fortior lutra eft, $\&$ acutiffimis dentibus:quare uel expellit eam, uel occidit, Albertus. 
latagem uocat non ipfum proiectum liquorem, fed phialam æream, in quam potus inïciebatur, \& plura enim ibidem fcribit fuper hoc ludi genere. Redamarife à fuis amoribus conïciebant rậ, қrú,

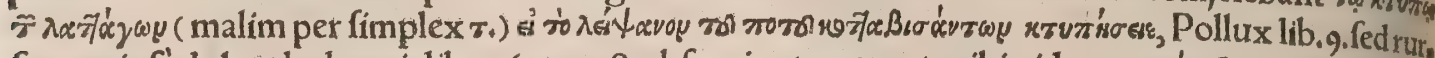

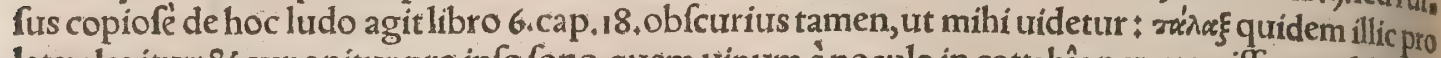
latax legitur: $\&$ exponitur pro ipfo fono, quem utinum é poculo in cottabîon uas emiffum reddit, Vi

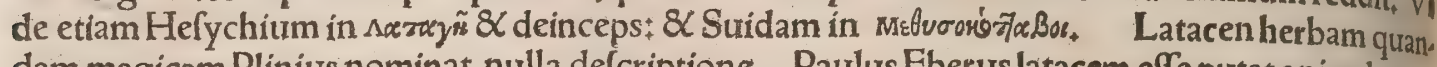
dam magicam Plinius nominat, nulla delcriptione. Paulus Eberus latacem effe putat animal quod uulgo noértza dicitur, quod inter Muftelas defcribam.

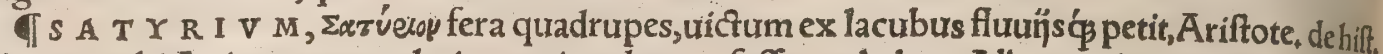
anim. 8. 5. ubi A uicennx translatio nomine detor to faffuron habet. Albertus interpretatur chebar lum Latiné dictum, cuius hirfuta \& nigra fit pellis, ualde pretiofa, affui folita ante pallia uaria, (intel) ligit forte confuta ex muribus uarijs, id eft Ponticis.) Sed chebalus uox Latina non eft:zobelum ho, die uulgò urocant, cuíus pretiofiflima omnium pellis, de qua inter muftelas dicam, neç enim amphis bion eft animal.

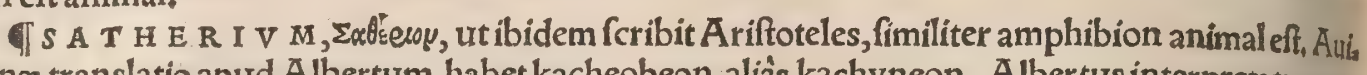
cennæ translatio apud Albertum, habet kacheobeon, aliảs kachyneon. Alber tus interpretatur mats tarum, animal fuluum, gutture albo, magnitudine cati. Niphus Alberti uerbis negligentius aftimar tis, fatherium ex eo cebalum (chebalum)facit, fatyrium uerò martarum. (Alï), inquit idem Niphuss,fa tyrium putant uulgè appellari foinam, qux magis aquas petit.) Sed martem quoọ (uulgus martarũ dicit) $\&$ foinam, id eft icfidem, muftelarum generis effe, nec amphibia, in ipforum hiftoria dicemus.

P O R C O s, rópros, animal quadrupes, fluuiatile, amphibium, Varinus, rogroy, oxytonum, He fychius cyrtum, id eft naffam pifcatoriam interpretatur.

D E M AES O I O.

M AE S O I V $S$, Máüros animal quadrupes in India, uitulo fimile, Hefychius \& V arinus,

\section{DE MELE.}

picturam melis reperies in fine libri

A.

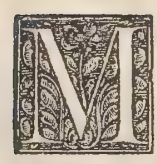
E L E S uel melis, utroģ enim modo fcribi reperio, ut feles $\&$ felis, focminini generis apud grammaticos, Lucifugæ melis, Gratius, Albertus \& recẽtiores quidam mafculino genere protulerunt, ut felem quoq;:ego utrun q̧ foemininum potius fecerim. Beftia melis, sta monicus cap.48. Septa leporarĭ è macerińs tectorio tecta fint oportet, ne feles autmet les aliátue qua beftia intrare poffit, Varro; alị legunt, felis aut melis. Melis autem ingreffum ideópro hibendum ab eo confuli apparet, quoniam aluearia in eodem confepto aliqui habeant, quiburs meles infidiatur: Vndeetiam nominata uidetur, quod mellis auidiffima fit, A pud indoctos quofdamnó meles, fed melo $8<$ melotus nominatur. Melo diçus eft, inquit Ifidorus, quod fit iucundiffimo(rotun 4 diffimo, ut apud Vincentium Bell.leyitur) membro, uel quod fauos petat, $\&$ affiduè mella captet, Mèlo uel melotus, animal quod $Q$ taxus dicitur, curius pellis hifpida ualde melota uocatur, Gloffain epiftolam ad Hebræos, fed melotam Græci pellem ourillam aut caprinam urocant, non melis(curiusne nomen quidẽ Gracũ reperias)ut fưo loco dicetur, In medico quodã diuz Hildegardis libro Hellus pro mele fcribitur, librarij forfan uitio. Eft fanè meles non alia quadrupes, quàm quax à recentiou ribus taxus uel taffus nominatur, alịs taxo, Alberto daxus. Scribit Sipontinus ignoraffe quid mer lis effet longiffimis temporibus Latinos omnes Græcos'̧́, alh̆s aliter hoc uocabulum exponentibus; tanquam ipfe primưs taxũ effe docuerițcum idem Aggregator 8 alĭ ante ipfum prodiderint,Graz cum uerò eius nomen nec ipfe nec alius adhuc quifquam oftendit, nam $\mu$ sisis quod fciolus quidam in Calepini dictionarium inferuit, falfum $\&$ fictitium eft. Georgius Alexandrinus melem, animal p auribus inimicum putat effe, id nempe quod uulgus fouinum(foinum, Volaterranus) \& marturelliñ appellat, fed erraffe conuincitur, quroniam in loco Varronis quem citat 3,1, non meles, fed feles lege tur. Feles apud Columellam \& Varronem accipi uidetur pro fouino, fic enim uulgus appellat beftiolam gallinis maximè infeftam, Phil, Beroaldus. Sed felem, catum effe, fupra affertum nobis eft, fouinus $\&$ marturellus muffelarum gener is funt, multum diuerfà mele feut taxo natura. Albos zao(uocem corruptam pro alzabo, $Q \mathrm{C}_{\text {. }}$ ) R Rafis interpres non recté taxonem interpretatur, omnino enim hyęna eft.

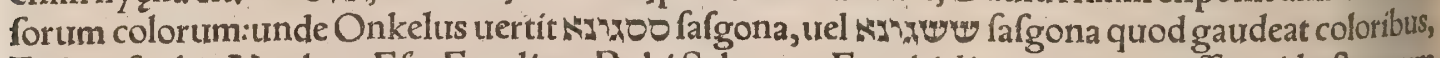
Eadem fcribit A braham Efra Exodi 25. Rabi Salomon Ezechielis 16, yeירת teffon, id eft taxum interpretatur, quod Nic. Lyranus probat, $\&$ uir quidam huius linguæe eruditus apud nos. Numeri 6 (ut Aug. Steuchus teftatur ) 14. Ebræi quidam bouem, quidam taxum duriffimæ pellis exponunt, Aquila \& Symmachus ianthinon,item Ezechielis 16 . Aquila \& Theodotion ianthina, Septraginta 


\section{DeMele. A.B.C. Lib. I. 779}

byacinthum: fed animalis, non coloris aut ueftis nomen effe patet ex fcriptura locis, qui funt:Pellès arietum rubentes, \& pelles taxorum(techafchim) Exodi 2 , interprete Munftero:Hieronymus uer tit,pelles arietum rubricatas, pellesç̧ hyacinthinas, \& Septuaginta fimiliter. Et rurfus eadem uerba capire mox fequenti. Ex rurfus, operient arcam pelle taxorum (tachafch) $\&$ expandent pannum fu per ipfam qui totus fit hyacinthinus, Numeri 4. Et paulò poft, Extendentó̧ fuper ifta pannum coca cineum, quem operient alio operimêto de pelle taxorum facto, Munftero interprete. Septuaginta \& Hieronymus hîc etiã pellem hyacinthinam uertunt. Calciaui te tachafch(corio taxi) Ezechielis ı6. hyacintho, Hierony mus $\& \mathbf{L x X}$. Numerorum quarto Chaldaicus interpres, ut dixi, fafgona red. dit:Arabs wank, darafch:Perfa Thos afthak.Sed quoniam taxi pellis nec elegans nec pretiofa eft, - quarendum an thos forte aut lynx aut fimile animal, cuius $\&$ pretiofa fit pellis $\&$ colore puncrisćp uaria fignificetur. Vox quidem ipfa tahas uel tabafch fatis ad thos accedit, quanquam ad taxum for te magis: fed ex uocum fimilitudine, nifi res ipfa conueniant, nihil probatur, of Meles Italicè taffo trocatur.R hatis qui Italicéloquuntur, tafch. Gallicè taffon: uel ut alị feribunt, taiffon, taixon, teffon: \& à colore pilorum, grifart‘aliqui blaireau(aP̉ blaureau)appellant, Carolus Bouillus: aliqui Lutetix, ut audio, bedour. Hifpanicè, tafúgo uel texón. Germanicètadbs uel Days. Anglorum nomina diuerfa funt, a brocke, a bagert, ( aliâs badger) a baufon, a deer, a gray. Illyrice gezwecz.

fi Sefquítolos \& taxones animalia quædam appellat author libri de mirabilibus facræ Scripturæ qui uxulgo A uguftino attribuitur. Brafauolus taxum fere murium alpinorum generis effe con. ijcit, forte quod fimiliter in cauernis latitet, \& fomniculofus efre putetur, Sed muris alpini forman - naturamág longé diuerfam effe, facile ex eius hiftoría apparebit. A pud Lucanos in Italia animal re-

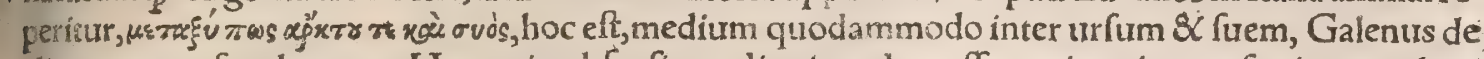
alimentorum facultare 3.1 . Hoc animal forfitan aliquis melem effe coniecerit, prafertim cum hac proprio nomine Graco deftituatur? aut fi pro ovós legas $\mu v$ ós, murem alpinum intelligere poteris, aut

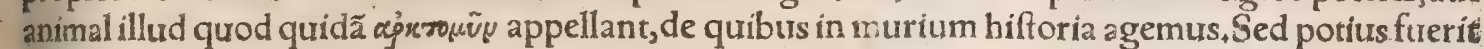
gihil mutare \& meĩe intelligere. Nã, ut doctiffimus uir Cælíus Secundus Curio nos docuit, mele (urul gó taffo nominant)abundant non Lucani modo, uerum etiam Siculi, \& reliqua regni Neopolitani orx: $\&$ ea uefcuntur autumnali prafertim tempore, quòd tum maturis uuis $\&$ reliquis fructibus maximè pinguefcit.

Meles in alpinis 8 Helueticis regionibus plurimx capiuntur. Dur funt genera, unum canis inftar digitatum, quod caninum uocant:alterum ungulas, ur fues, habet bifuleas, quod iccirco fuiliư appellant; Ge. Agricola ex Alberto. Diftinguuntur \& erinacei genera fimiliter. Quidam non ungui bus tantum, fed ore etiam fiue nafo \& roftro, fuillum fui, caninum cani fimilem faciunt: ut crinaceos quog;. Differtnt hæc taxi genera, tof trifigura, \& infuper uifur : nam caninus uef citur cadaueribus, $\&$ ijs cibis quibus canes : fullus ue: radicibus, \& ins quibus fues, ut retulit milhi Normannus quidam qui utrunç genus aliquando fe ceprfe aiebat. Thaxts eft magnitudine uulpis, Alberi. fed craffio e breuioi éç corpore. Magnitudine fer é uulpis, fed humilioris ftatura, proptèr crurum breuitatem, Magnitudine eft uulpis aut canis mediocris, cuius quodammodo fpeciem præfe fert, maximè caninus, Ge. Agricola. Fiber meli feré fimi is elt, fed paulólongior, pilo fubtiliore. Craffi o meles non funt, pingures tamen, Ge.Ägricela. Taxi fagina (adeps) Luna crefcente augetur, decrea fcente minuitur, interlunio nulla, Liber de naturis rerum. Cutis ei dura $\&$ fordidifima, Ifidor, fpif $f_{2}$, Albert, uillofa \& fatis rigida, Obfcur. Pilum haber gríiei coloris, Ifidor, fimiliter ut feles coloris incani. Vnde quidam Gallorum à colore grifart uocitant. Duris ueftitur uillis, qui funt uel albi uiel ntgri: 8 dorfum quidem abundat nigris, reliquum corpus albis:excepto capite quod alternis quibur dam quafi lineis nigris $\&$ candidis à fuxprema capiris parte ad rictum ductis decoratur, Ge, Agrico la. Pilo tegitur magis albo quàm nigrołfed in dorfo plures funt nigri, in lateribus plures albi. Capitis pilus in medio niger, utrings (ad latera) albus, Albert. Dentes habet acutos:quamobrem mordax eft animal. Dorfum latum. Crura breuia: $\&$ ut quidam feribunt inaqualia, nempefiniftri lateris bre uiora + unde fiat ut celerrimè currat, fi pedes dextros rotarum or bitis inferat, $8 \mathrm{C}$ hoc modo uenatores - effugiat. Hoc ego, inquit Albertus, non deprehendi, cum tamen fapius hoc animal confiderauerim. Ipfeetiam inf́pecta aliquando mele, nihil tale reperi. Cauda ei uaria, uillofa, non longa. $\mid$ Zibe. thus, animal ore oblongo ut taxus, Cardanus,

c.

Meles fubit cauernas, fed egreditur ad paftum capeffendum, etiam hyberno tempore, $\mathscr{\&}$ uraga. tur in fyluis, Ge, Agricola. Quamobrem Gratius melem lucifugam dixit. Taxus fomniculofurs eft gliris inftar, Arlunnus: fed glis tota hyeme dormit, meles non item. Mel auidè appetit, ex quio no: men inuenit, Ifidor. $\&$ Ge. Agricola. A pibus $\&$ melli infidiatur. Crabronibus 8 alijs uermibus ta xum uictitare ferunt: quia non eft uelox ad uenandum, Albert. Amat loca feracía pomorum \& fru. citum arboreorum, quorum efu autumno præcipuè pinguefcit, Stumpfius. Animal eft ualde pin. o gue, Albert, hinc uulgó hominem ualde corpulentum, taxi inftar obefum effe dicimus, Lupi, melis; uulpis \& huiufmodi animalium catulos, Galli cheaux appellant. 
Cauternas fubterraneas dum fibi parant, ut audio, effoffam terram in unum refupinum conĭci. unt, quem mox fatis oneratum pedibus apprehenfum mordicus uecforem extrahunt, totiesḉ re: petunt, donec ampla fatis fit habitatio. Similis quædam fibrorum $\&$ alpinorum murium indus Itria fertur. Propriam libi foueam uulpes non parat; fed melis foue $a$, ablente ea, introitum excre mento inquinat:rediens illa uirus olentem deferit, $\&$ uulpi habitandam relinquit, Ifidorus $\& A$ : bert. Cicurata, facilis eft \& ludis indulget, Albert,

E.

Canes quoldam exiguros, qui melium uulpiumós caua ingreffi, mordendo eas expellunt, noftri uocant lodb bünole. Meles quidem fí quando cum canibus pugnat, ualde mordet, Ifidortus infefta tam à canibus aut alijs animalıbus, fupinam fe dentibus pedibusó̧ defendere fcribit. Meles in me tu folertes, fufflata cute diftincté(al'diftentu)ictus hominum $\&$ morfus canum arcent, Plin. Hoc au dio hodiȩ́́ à taxo fieri compertum. Galli pedíca genus uocant haufepied, illaqueandis lupis, uul pibus $\&$ taxis idoneum. TI Melium pellibus pharetras muniunt, \& helcía equortm, (Eonmet.) Ne uulnerentur canes à beftís, imponuntur collaria, quæ uocantur melium, id eft cingulun circa collum ex corio firmo cum clauis capitatis, Varro. (Ex taxi pellibus in Italia etiamnum collaria ca num conficiunt; $8<$ pharetras uillofas: $8<$ facculos quibus tum paftores tum alij utuntur $;$ his enim inclufa præclaré ab aquæ iniuria defenduntur,) Collaria canum aliqui millos uocant, quafi melia nos, ab hoc animali, ut grammatici quidam uolunt, quos potius fequor, quàmillos qui à mulatudi ne clauorum, quafi à mille clauis dictos aiunt. Plinius Frontinuś́ tegi fcuta melium pellibus (cri bunt, (eaśq̧́ effe denfas $\&$ ualidas $)$ Hæc apud Plinium $\&$. Frontinum iam non reperio, nec memia ni authoris nomen qui hac tanquam ex illis citat. Ge. Agricola Germanis fuis melium interpres tatur ein balf̧band Darunder Dayo gefitteret/fo man Den bunden anlegt. Collaribus ergo Sunt qui lucifugæ criftas inducere melis Iufsêre, auc facris conferta monilia conchis, \& cc. Grat, ne canes fafcinentur aut ne rabiem incidant. I Pilos in equis albos fubnafci reperio, fi prioribus euulfis locus illinatur melle crudo cum adipe melis.

F.

Taxos in Germania Italiać menfis apponi fcio, \& à multis laudari. Quidam apud nos pira lis mul coquere folent. Sunt qui $\&$ taxos $\&$ glires conis addant, qux animalia in qualitatihus hygtri ci haud multum diffimilia funt, Platina.

G.

Ad fanguinis relectionem é pectore prodelfe putatur, Ourorữ cinis, aut cochlearum, autdeniq, melis, Seren. Melis $\&$ cuculi $\&$ hirundinis decoctum $\&$ potum, ad morfum canis rabidilaudàt, Plin. Sanguis taxonis cum fale cornibus animalium inftillatus, à pelte $\&$ mortalitate fertal: notum eft omnibus, Brunfelfius nefcio ex quo authore. Recentiores quidam liquorem fillatiti um (deftillatum uulgò uocant'è fanguine taxi, aduerfus peftilentiam commendant. Suntquiaduer fus eandem luem hoc medicamentum præfcribant, ut in manufcripto quodam libroreperi, Bans guis taxi recens, terra A rmena, crocus, tormentilla, ficca teruntur reponuntuŕç mitur inde ad magnitudinem fabæc cum quarta parte denarij aurei in tenuiffimam fcobem limares dacti. Præcipitur autem etiam flammulam (herbam fic dictam à facultate urendi) iuxta uel fub bus 4 . bonem illigari oportere. Taxonis fanguis ficcus $\&$ in puluerem redactus, mirum in modum les pra morbo medetur, Carolus Bouillus, TTaxi pinguedinem Graci pratereunt; conftat autem plurimum emollire,Brafauolus. Iacobus Syluius adipem melinum, caninum, felinum, \&cc, inter taurinum $\&$ fuillum conftituit:nimirum quod fuillo craffiores, taurino tenuiores fint:mihiquidem omnes hi adipes fuillo $\&$ taurino magis calfacere, $\&$ digerere uidentur. Nec fpernendus adeps dederit quem beftia melis, Serenus contra febres $\&$ calores nimios corporis. A dipe taxi intnil febrientes fanantur, Aefculap. Axungia eius ualet ad renum dolores, Albert. Quidam nephriti cís \& calculofis inungunt $\$ \&$ al lips etiam membris dolentibus, Obfur. Inuncta melium pinguitu do uel cum alips infufa(per clyfterem nimirum, )renum dolores fedat, $\mathrm{Ge}_{+}$Agricola. Adipes raxi,

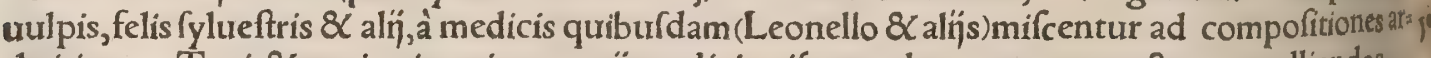
thriticas. Taxi $\&$ canis pinguia equarï medici mifcent ad neruos contractos remolliendos, ब Cerebrum cum oleo coctum omnes dolores curat, Aefculap. I lecur melis ex aqua oris gralth tatem emendat, Plin. T Tefticuli taxi cum melle cocti libidinem accendunt, Aefculap. TMor fus taxi aliquando uenenofus eft, fed non remper, Albert. Morfus eius plerunç grauiffimus eft, $\&<$ exitialis + nimirum quia uefcitur crabronibus $\&$ animalibus uenenatis qux in terra repunt, unde dentes eius inficiuntur, Liber de nat,rerũ. Taxus, lynx, catus, \&c, uulnere magis morfur fuiquàm uenenoladunt, Arnoldus.

Meles lucifuga, Grat. Licebit etiam obefam, opimam, uel pinguem cognominare. hafta é ligno mali dicta, Feft، ut Græcæ originis fit, qui melean malum arborem uocant, prima lona gałmêlon, fructum eius, \& per excellentiam cotoneum toneis paratum, ut oleum melinum+à mele autem quadrupede melinum, penultima longa formari 


\section{DeMonocerote. A. Lib. I. 781}

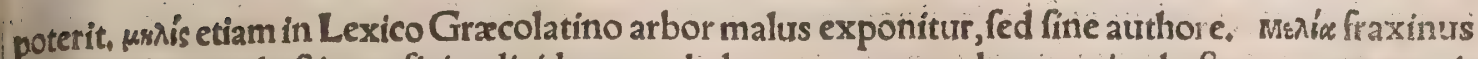
eft, culus lignum haftis conficiendis idoneum habetur \$ quare eodem nomine haftam quog nomis nant Graci. Mali certe arboris lignum haftis ineptum elt. TLeucrocuta fera caput ef nelium; Plin, camelinum,Solin, TA taxu Ferrarix nobiliffima Taxonorum familia nomen fortita eft, Bra faurolus, $\quad$ Fiente, id eft fimus Gallica lingua, non de quibufuis feris, fed propriè foetentibus dici turr, ut uulpe,mele.

\section{DE MONOCEROTE.}

Figura hace talis est, qualis à pictoribus feré hodie pingitur, de qua certi nihil habeo.

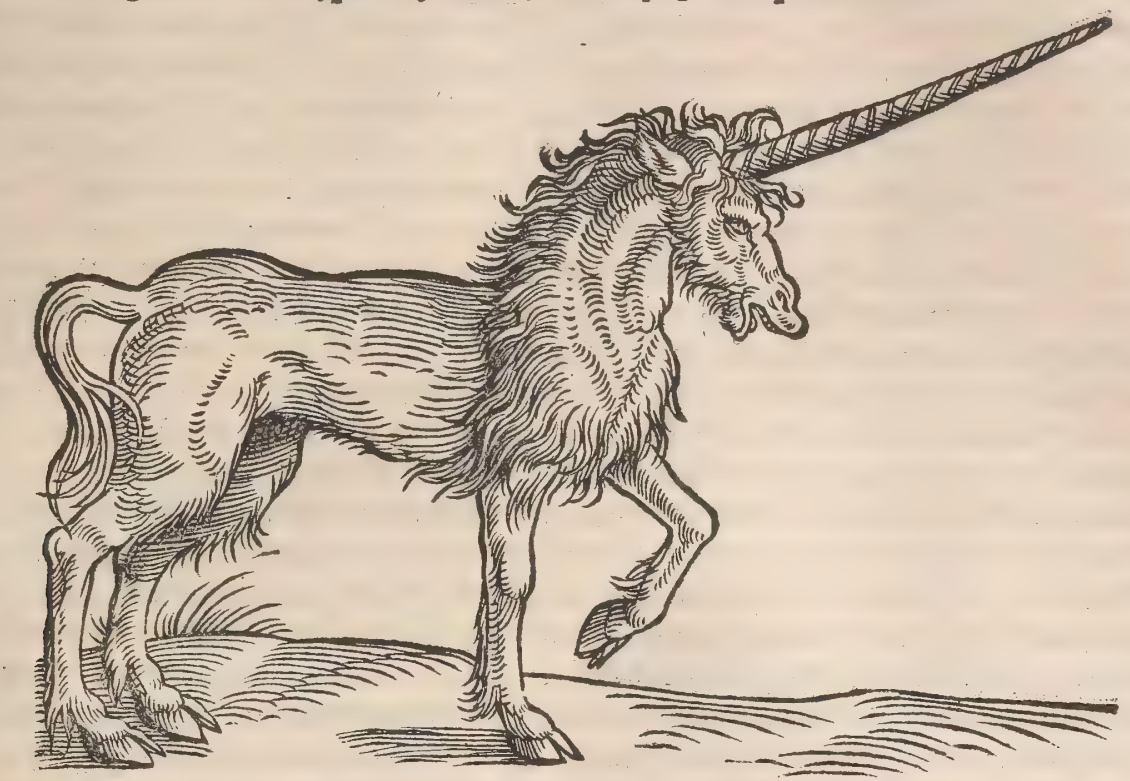

A.

O N O C E R O s, hoc eft unicornis fera, ab alijs aliter deferibitur fiue quoniam diurerf $x$ funt unicornes animantes, ut conftat: fiue quòd aliqui notas diuerfarum tanquam uni= us confuderunt. Minus autem mirum de fera tam peregrina \& toto à nobis orbe diaifa, nec unquam in Europam adducta, diuerfa ab Europxis fcriptoribus auritis ferè omni= bus non oculatis, memorix prodita effe. Hoc magis mirum, recentiores etiam, ut Ludouicum Roma num $\&$ Paulum Venetum, qui regiones illas in quibus reperiuntur luftrarunt, diuerfas tamen mo nocerotes defcribere. Ego fingulorum uerba adnumerabo, ut doctioribus diligentioribusćp̧ olim cer otius aliquid his de feris ftatuendi occafionem prabeam. TOrfei Indi uenantur afperrimam feram monocerotem, reliquo corpore equo fimilem, capite ceruro, pedibus elephanto, cauda apro, mugitu graui, uno cornu nigro media fronte cubitorum duum eminente. hanc feram triuam negant capi, Plinius. Phyfiologus quidam author obfcurus, $\&$ alip eum fecuti, monocerotem animal paruum effe fribunt, hoedo fimile, acerrimum, uno in capite cornu, Sed illi ex Plinio acerrimum pro afper. rimum legerunt: $\&$ hodo pro equo, unde neceffarius ferè alter error fecutus eft ut animal paruum effe putarent. $\quad$ Montes(inquit Aelianus)effe dicuntur in intimis regionibus India; ad quos dif= ficulter eatur, ubi prater alias beftias feras reperiatur monoceros, quem (Indi) uocant cartazonon;

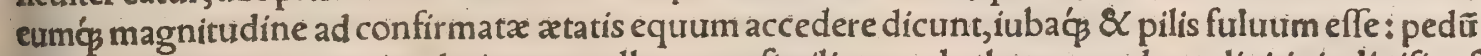
bonitate $\&$ totius corporis celeritate excellere:at $\varphi_{\beta}$ fimiliter ut elephantos pedum digitis indiuifis ef - fe:apri caudam habere, inter fupercilia cornu uno, eodem ́́s nigro, non læu quidem, fed uerfuras quafdam naturales habente, atç in a cutiffimum mucronem definente ornatum exiftere, Hęc Aelia. nus. Mihi omnino Plinius $\&$ A elianus unam eandem ćs beftiam defripfiffe uidenturł fed nec aliam Philes fimia Aeliani, cuius uerba fingulatim in fequentibus per partes recitabo, Quinetiam afinum fiue onagrum Indicum, fi non idem, inter unicornia tamen animalia iam defcripto omnium proxi= mum effé dixerim, Conueniunt fané pręter cornu utrí̧̧ unicum émèdia fronte, locus natalis India, equi magnitudo, ungulæ folidæ, celeritas, uita folitaria, robur inexpugnabile, \& quód confirmata atate nulli capiuntur. Colore tantum differre uidenturł cum afinus Indicus albus fit reliquo corpo re, fed capite purpureo:monoceros fuluus, qui color etiam rhinoceroti à quibufdam tribuitur : fic $\&$ cornu color non idem:monoceroti enim fimpliciter nigrum Plinius tribuit : afino Indico Aelianus o medium tantum nigrum, inferius album, fuperius puniceum; fed forfitan omnes ifti colores in cor pore potius quàm in cornibus fpectantur, caput purpureum, media pars corporis nigra, poftrema al ba.Philes quidem cornu totum nigrum effe fribit, excepto mucrone, Sed de afino Indico unicorne 
fupra docui abunde ftatim pof A fini hiftoriam, ex A eliano, Phile, Ariftotele, Plinio, Hic de codem Philoftrati uerba adijciam ex lib.3.de uita A pollonij. Afinos fylueftres (inquit) in uicinis $\mathrm{H}_{y p h a f i d}$ India fl. paludibus multos capi dicunt:effe autem huiumodi feris in fronte cornu, quo raurorâmo re generofé pugnant: \& Indos ex illis cornibus pocula conficere: afferuntóg nullis mor bis illo die af fici, qui ex huiulmodi pcculo potarint: neq fi uulnerati fuerint dolere, et per ignem etiam incolume tranfire, neq̧ ullis uenenis ladi quxcunç̧ nocendi gratia in potu dãtur. Iccirco regum effeeadem pocula, nec alï quàm regi eiufmodi fer $x$ uenationem permitti. A pollonium itaç, feram afpexiffeei, uş́́ naturam cum admiratione confideraffe ferunt. Interroganti autem Damidi, an fermoni quide poculo iam dicro ferebatur fidem adhiberet: Adhibeo, in quit, fi huius regionis immortalem regem el

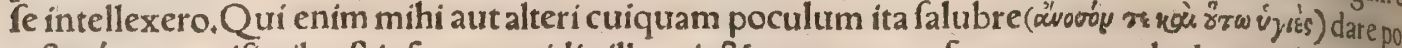
teft, nónne uerifimile eft ipfum quotidie illo uti, \& ex eo cornu frequenter uel ad crapulam ulgh hi: bere? nemo enim ut puto calumniabitur eum, qui tali poculo etiam inebrietur, Hæc ille. Suncerä (inquit A rift. de partib, anim. 3.2.) qua cornu fingulari armentur, ut oryx $\&$ afinus Indicus; oryx bi fulcum, afinus ille folipes eft:gerunt fanè medio fui capitis cornu fixum ea qua unum habent: fice, nim maximè pars utrą̧ cornu obtinebit, cum medium cómune pariter utriq̧ extremo fit, Solipes potius quàm bifulcum effe unicorne recté uideri poteft:ungula enim tam folida quàm bifulca, eandê? naturam habet quam cornu, itaç eifdem fimul $\&$ ungulam findi \& cornu congrưum eft. Fiffioer ungula $\&$ cornu ex defechu naturæ euenit:ita $\phi_{\beta}$ cum exuperantiam ungulæ folipedum natura de: diffet, rectè demplit fupernè, fecitḉs unicorne, Hac Ariftotel. Illa fanè cornua qua hodie in prinncia pum quorundam, uel cituitatum uel ecclefiarum thefauris oftendûtur, ut Venerins, Argentorati,, tis, audio anfractuofa effe, \& Spiris conuoluta, tanquam duobus filis aut funiculis in fe contorns, quale quidem cornu duplex iudicari debet, etiamfi unicum $\&$ fimplex appareat. Huiufmodi etiam

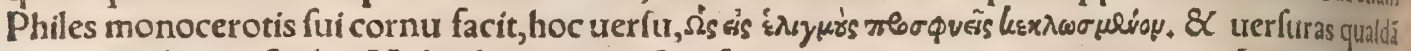
habere Aelianus feribit. Vide plura in B. Oneficritus inquit, equos unicornes in India effecerulis nis capitibus, Strabo. Terram Indiam equos uno cornu præditos procreare ferunt, quorum e cur, nibus pocula conficiuntur, in quę uenenum mortiferum coniectum fí quis biberit, nihilgraut, quòd cornu repellat malum ipfum, perpetietur, Aelian. Ceruinum caput etiam Plinị monocerns geri, qui tamen(ut fupra dixi) ab Aeliani monocerote non differt: ut etiam equus Indicus unjcornis non alius uideri debear: nam $8<$ monoceroti feu cartazono forma $8 \mathrm{~m}$ magnitudo equi eft. Quod autem Aelianus poculum ex eius cornu factum uenenis aduerfari fcribit, quod tum ipfe alibi tum Phlo. Itratus \& Philes afino fiue onagro Indico unicorni attribuunt, rurfus argumento eft eandẽ effe ferä qua diuerfis dũtaxat nominibus appeller̆: aut fi differat, colore tantũ differre, ut paulo ante afferui,

IMecha qua urbs eft Arabix Mahometis fepulchro \& delubro infignis:iuxta quod (inquicLu douicus Romanus patritius ) fepta feu clauftra uifuncur, in quibus unicornes gemini affertiancur, quos loco miraculi populo oftentãt, nec ab re.res eft miratu digniffima. Sunt autem eiufmodi. Alter rum eorum, quem conftat longè proceriorem effe, pullo equino triginta menfes nato haud abfinis lem crediderim. Prominet in fronte cornu unicum, longitudine trium cubitorum. Longénatumir nor eft alter, utpote anniculus, ac equino pullo fimillimus : eius cornu quaterni palmi (quatuor palt morum, dodrantes intelligo) longitudinem haud excedit. Coloris eft id animal equi muftellini, as put cerui inftar : collo non oblongo, rariffimxć $\mathbf{i}$ iubx, ab altera parte folum dependentis. Tibias $1 \mathrm{a} a$ ber tenues, eafdemós graciles admodum hinnuli modo. Vngulas anteriorum pedum bifidashabth, caprinos pedes ferme referentes. Tibiarum pofteriorum pars exterior uillofa êt, pilió̧ plurimi, Sañ id animal ferum uidecur: uerum ferociam nefcio qua comitate condiuir. Eos unicornes quípiam Sultano Mechæ dono dedit, ceu rem inuentu rariffimam $8<$ maximé pretiofam. A duecti funtex Âs rhiopia ab A ethiopum rege, ut eo munere neceffirudinem coniunctiffimè cum Sultano Mechã prat fecto iniret, Hactenus Lud, Romanus, ex quo Cardanus etiam in opus fuum de fubtilitate tranfictis pfit: fed errat quòd pro monocerote rhinocerotem nominat. Apparec autem diuerfum hoc mono, ceros a nimal effe ab afino Indico, qui folipes eft:nec non à Plinï \& A Aeliani monocerote, quem limlis liter folipedem effe dixerim, quoniam pedes eius elephantinis comparantur.quamuis enim elephan $t \mathrm{t} m$ non fimpliciter folipedem ueteres dixerunt, ur qui digitos quin $q_{s}$ leuiter formatos $\&$ informes habeat, tamen equinis pedes eius conferuntur. Vnicorne quidem bifulcum animal prater orygem Ariftoteles \& Plinius nullum agnofcunt. Eft autem orygis etiam cornu nigrum, altum, \& ferrei,id eft duriffimi mucronis, in Libya, ex caprarum fylueftrium genere: ut mirer Oppianum, quir rhinocen rotem non multó maiorem oryge effe frribit, cum Plinius eundem elephanto longicudine parem far ciat, alị paulò minorem tum longitudine tumaltitudine. Sed de oryge aliàs in hiftoria ipfius. diutras fum enim illum effe à fimpliciter diço unicorni, omnino cum Nipho contra Albertum fentio. Re gnium Bafman (inquit Paulus Venetus) magnum Cham pro domino agnofcit. Inureniuntur ineo elephanti $\&$ unicornes permulti, Sunt autem unicornes paulo minores elephantis, pilis bubali, per dibus elephanti. Caput habêt ut aper, $\&$ more porcorum in coeno morarigaudent, $\&$ alijs immunt dis locis. In medio frontis geftant cornu unum, craffum \& nigrum. Linguam habêtt fpinofam, eą̧ ladunt homines $\&$ animalia. Hoc etiam animal, fi uera defcriptio eft, à fuperioribus omnibus di uerfum fuerit: in nonnullis fané ad rhinocerotem accedit, magnitudine, capite, pedibus, fedrhino: 
Fawiós, Philes \& Plin. Os leonis, Idem. đCornu è media eius fronte protenditur, fplendore mirif co, ad longitudinem pedum quaturor, ita acutum, ut quicquid impetat facile ictur eius perforet, Soli nus. Sxpe monoceros concuffa tuerticis iuba longum \& exitiale cornu propellit:quod è fupercilï natum, non caurum, nec leue (liz $\phi$ y) aliorum modo cornuum eft, nec planum $8 \mathrm{C}$ æcquabile, fed uel fer rea lima afperius, in multas fubinde fpiras reuolutum: $\&$ telo acutius, utpote non recuruum, fed pha né reçum+undíģ nigrum, mucrone excepto, Philes, Plura uide in pracedenti capite, \& feptimo in fra. Duo integra eá̧ maxima $\&$ pulcherrima cornua Venetî́s in ærario D. Marci recondi $A$ n, conius Brafauolus fcribit: Argentorati etiam unum affertraríaudio, recium et fpiris contortumitem bina in thefauro regis Poloniæ, fingula ad hominis feré proceritatem. Monocerotis cornu Brafautin lus fubnigrum uel fubcinericeum effe tradit: Nos illud (inquit Mundella) non comperimus, terum nigrum effe iuxta Pliní fententiam. Afinus Indicus unicum cornu habet; 8 animal illud quod ue terum quibufdam archos quafi princeps uocatur, unicornis Latinè, rhinoceros Gracé (uide in R'hi. nocerote $A$. )habet unum cornu maximum, $\&$ folidum ut ceruinum, longius denis pedibus, utipfe menfurauitdiameter circa radicem cornu fefquipalmum (fefquidodrantem) excedebat, Albertusin Ariftot. de partib.3.2. Monocerotis (ut putatur) cornu circa annum Salutis i520. (annis antectram hac feriberem circiter triginta) repertum eft in Heluetia flutio Arula iuxta Brugam oppidum, al bum, fed in fuperficie fubflauum, duos cubitos longum, nullis tamen fpirarum uerfuris : odoratum cum aliâs, tum accenfum inftar mofchi ferẻ: id mox ad proximum monafteriưm uirginum delatum Campum regium uocant, à prafecto Badenfi, tanquam in iurifdictione ad octo Heluetix pagos per tinente repertum, repetitũ eft. Hęc mihi narrauit amicus quidã qui eiufdem cornu fragmenta qued habuit. TCaudam habet apri uel fuis, Solinus, Philes, Plinius, A elian. TPedes elephanti,soli nus \& alï: Veloces, fed inarticulatos, Philes, Crura ei proportione breura, Ifidorus : fed hocrhino, ceroti magis conuenit.

c.

Defertiffimas regiones perfequitur monoceros, $\&$ folitarius errat, Â elianus $\&$ Philes, Inexcel fis montibus uaftisç̧ folitudinibus commoratur, Ifidor, đMonftrum eft mugitu.horrendo, Solin, Omnium maximé animalium abfonam uocem $\&$ contentam mittere fertur, Aelian. TMaximo robore præditus $\&$ inexpugnabili cornu armatus eft, Aelian, Morfu eft graui, $\&$ calcibus crudells ter pugnat, $P$ hiles.

Vitus non uenit in hominum poteftatem: $\&$ interimi quidem potef, capi non potelt, Solinus \& Plin. Monoceros robore fuo inexpugnabilis \& indomita homini fera eft: V nde illud(Icb. 39.1 ) Non uincies eum loro, neç cubabit in præfepi, Varin. Ferrum non timet,Ifidor, IAd alias quidem beftias ad fe accedentes manfuefcere fertur, cum uerò gregalibus fuis pugnare:neq̧ modo cum marl bus naturali quadam consentione diffidere, fed contra etiam forminas certare, purgnamóqu ufọ ad mortem ingrauefcere. Coitus uero tempore ad forminam manfueté affurefcit, $\&$ gregalis fit: $C u m$ hoc tempus tranfierit, \& uentrem fomina ferre coperit, rurfus efferatur $\&$ folus uagatur, A elian. Cum alienis animalibus placidum $\mathrm{f}$, ceu catulus gregi affuetus exhibeat, fuo tamen generi infenfifimus hoftis eft. Manfuefcit uero erga forminam, feritatem eius ui amoris deprimente, folo temporelibidi nis, Philes. Hoftis eft leonis, quare leo confpecta hac fera ad arborem aliquam fe recipit, \& irruen: 40 tem in fe declinat:illa cornu arbori infixo haret, \& à leone occiditur : aliquando tamen contra accir dit, Aethiopia rex in epiftola Hebraica ad pontificem Romanum.

E.

Vnicornem aiunt adeò urirgínes puellas urenerari, ut ipfis uifis manfurefcat, \& aliquando itrti eas in fomnum delapfus capiatur ligeturós, Albert. Amore uirginum $\&$ odore allici feruntmonor cerotem, Arlunnustrhinocerotem lfidorus, cum monocerote, ut $\&$ alï quidam, ineptè confundenss Iutuenem aliquem robuftum uenatores puellæ inftar ueftitum $\&$ aromatibus afperfum ftaturntere gione loci in quo monoceros fuerit, ita ut odoris fuauitas auræ flatu ad belluam derituari poffit. Ipi interea occultantur. Mox fera odore illecta ad iuuenem accedit, ille amplis muliebribus manicisto: tis refertis aromatibus eam obuelat. Tum uenatores accurrunt, \& cornu, quod uenenis refifti, refe' cto, feram aufugere patiuntur, Tzetzes 5.7 . Propofita in feræ confpectum uirgo (inquíunt recen, tiores)aduenienti finum aperit, in quem illa omni ferocitate depofita caput inclinat, ubi fomnocapta uelut inermis comprehenditur. Sed fufpicetur aliquis hanc de monocerotis uenatione perfuafionê (qua admodum recens eft, neq3 enim uetuftiorem eius authorem habemus quàm Tzetzen quitils xit anno Salutis 1176 . )inde natam effe quòd(ut fupra diximus) fui generis feras hoftiliter perfequat

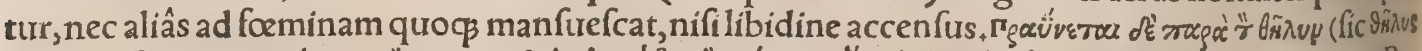

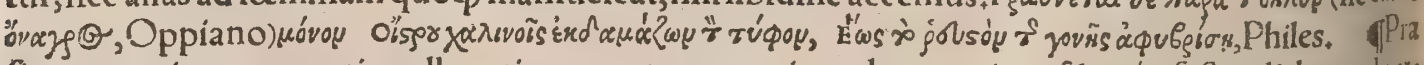
forum regi monocerotis pullos etiamnum teneros aiunt deportari, coldem $\phi^{\prime} \beta$ feftis diebus ad plt= gnam committi, ad robur oftendendum:nam integræ æatatis $\&$ perfectæ nullum unquam quifquam meminit captum furffe, A elianus. Et alibi, Domari poffunt dum biennium non excefferint: uretulie. 6 nim ab immaniffimis \& carniuoris feris nihil differunt. Capitur etiam $\&$ domatur, cum adhuc pulo lus eft, Albertus. 


\section{DeMonocerotè. F.G Lib.I. 785}

F.

Carnes afini Indici amaras $\&$ cibo non idoneas effe; A clianus meminit. His fimiles tnonoceroti carnes crediderim,cum ut fupra dixi, uel nihil, uel minimum, colore forfitan folo, differant,

G.

De cornu monocerotis fupra fcripfi, capite primo $\&$ fecundo $\&$ in primo etiam qua ueteres de remedins ex eo prodiderunt:hoc in loco recentiorum præcipuè fcripta de eodem eiusć remedijs, \& noftras obferuationes adijciam. Meminialiquando dodrantale huius cornu fegmentum apud mer catorem quendam uidere, foris nigrum \& planum, non in fpiras contortum, fed tum temporis non admodum obferuabam. Nunc apud pharmacopolas noftros exigua tantum fragmenta reperio, ex quibus medullam effe dicunt qua rotundiora, albiora, mollioraḉ funt; exteriorem uero partem ceu corticem, qux durior af perior color ifte, tum fubftantia nimium, fi mandas, friabilis, non lenta ut cornuum, adulteratum quippiam indicare, alterius fortaffis animantis cornu igne uftum, $\&$ odoribus quibufdam adiunctis adfrititia quadan aromatica fuauitate imbutum, fortaffis etiam ignitum in liquoribus odoratis extinctum. Curandum eft ut recens habeatur, 8 odoratum(fi modo natiuus odor ille fit,) non uel atate exoletü uel frequentibus poculis exhauftum. Diuites enim fruftula huius cornu poculis fuis frepe inijciunt uel praueniendi quofdam morbos uel curandigratia funt qui auro argentóue includant, \& fic quo que poculis inijciant, quafi uero multis annis quantumcunq̧ in uino macerati uis eadem perdurare poffit.Sed quod uinum imbiberit fufcum colorem trahit, candore amiffo. Plerigs ad remedia ex co promiffa cornu fimpliciter uti iubent:alị medullam præferunt. Vino iniectum ebullit, quood quida fiue imperitia fiue dolo genuini fignum effe putant, cum quauis cornua ufta, in aqua aut uino am= pullas moueant. Nebulones quidam nefcio quam mifcellam, quam Venetífs uidi(calcis \& faponis ut audio: aut fortaffis terræ uel lapidis alicuius:qux itidem ebullire folent) pro cornu monocerotis uen dunt, Quamobrem tutius fuerit, uel de integro cornu, fi fieri polfet, uel maioribus fruftis $\&$ qux cor nu fpeciem probé referant, emere, quàm fragmenta minora ubi dolum minus deprehendas. Anton us Brafauolus omnes ferèlapidem pro cornu monocerotis uendere fcribit, quod quidem fieri non nego, qui certi nihil habeam: fieri tamen etiam poteft, ut prædurum $\&$ folidiffimum cornu, circa mu cronem prafertim(qux pars etiam inferioribus prafertur, ut in ceruinis quoçcornibus) cui uel fa. xa \& ferrum concedant, qualia \& rhinoceroti \& unicornibus cæteris authores triburunt, lapidis fpe ciem præ fe ferat. Nam fi Orpheus de ceruinis cornibus propter foliditatem inter cornuáne aut lapi des potius cenferi deberent, reçè dubitauit: magis opinor in unicornium genere dubitandum fuea rit. Non enim folis ceruis, utA riftoteles putauit, folida funt cornua:fed unicornibus etiã qualia dixi. Monocerotis cornu hodie ufurpatur longinquitate temporis in admodum fanè à cornea diuerfam naturam conuerfum, Mundella. Iac. Syluius, Aggregator $\&$ alin, qui rhinocerotem cum monoce rote confundunt, quod hodie in ufu medico eft rhinocerotis cornu nominant \$ de quo tamen autho. res nullas huiufmodi uires tradiderunt. Monocerotis cornu aliqui fuperueniente ueneno fudare aiunt, quod falfum eft, Ferdinandus Ponzettus. Sudat fortaffis aliquando, utpote folidum durum et laue corpus, ut faxa etiam $\&$ uitra, uapore externo circa ea concreto, fed hoc nihil ad uenenum . Sic $\&$ lapidis genus, quem linguam ferpentis uocant, fudare fabulantur ueneni fuperuentu. Audiui 8 legi etiam in libro quodam manuf́cripto, monocerotis cornugenuinum à quibufdam hoc modo probaritueneno (arfenico uel auripigmento) duabus columbis dato, altera qua fuperbiberit aliquan tulum de uero monocerotis cornu, fanatur : qua non fuperbiberit, moritur. Ego hunc experiendi modum diuitibus relinquo. Nam pretium eius quod uerum effe afferunt, non minus hodie quàm auri eft. Drachma pondus aliqui floreno uendunt, fiue denarijs octo+alị coronato, fiue denarijs duro decim.Medullæ quidem pretium maius eft quàm durioris fubftantix. Aliqui drachmam quinq̧ obo lis indicant:tanta eft diuerfitas. Cornu unicornis, præcipuè ex nouis infulis allatum, tritum $\&$ in aqua potum, miré facit contra uenena: ut nuper experientia oftendit in homine qui à fumpto uene= no, cum iam tumere inciperer, hoc remedio reftitutus eft, $\mathrm{Obfcur}$. Audiui $\&$ ipfeà uiro fíde digno, quód cum à cerafi efu(uenenatum fu(picabatur)uenter ci tumeret, medulla huius cornu é uino haus= fta, illico fanatus fit. Ad comitialem laudatur à nonnullis hodie:ut ab A eliano quog, qui hunc mor bum facrum appellat. Sed ueteres uim medendi attribuebant poculis ex hoc cornu factis, uino ex eis poto:nos quoniam pocula habere non foffumus, fubftantiam cornu propinamus, uel per $\mathrm{fe}$, uel cum alïs medicamentis. Ego feliciter aliquando trageam, ut uocant, ex hoc cornu, cum fuccino, fcobe eboris, folịs auri, corallio, $\&$ alijs quiburdam exhibui, \& craffuffule contufum cornu ferico ine clufum, in decoctum uux paff $\&$ cinnamomi, \& $\&$, in aqua, conieci, non neglecta interim reliqua medendi ratione. Commendatur præterea à medicis noftri feculi aduerfus peftilentem febrem: 86 (ut Aloifius Mundella fcribit)aduerfus canis rabidi morfus $\&$ aliorum animalium ictus aut mor. fus uirulentos:priuatim uero contra lumbricos $\&$ praua inde fymptomata pueris in ditiorum fami= lips datur:deniqģ contra uenena quæuis $\$$ multos grauffimos morbos. Indorum rex è poculo con

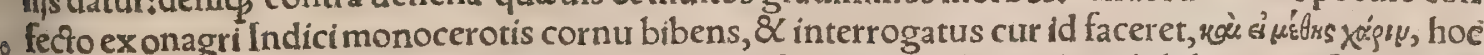
eft, $\&$ an ebrietaris caufa, hoc eft fimpliciter bibendi $\&$ uino fe oblectandi inde biberet, refpondit ö $\pi$

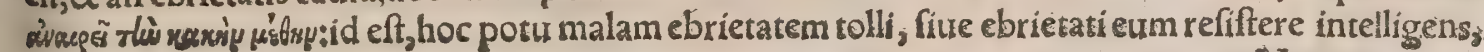




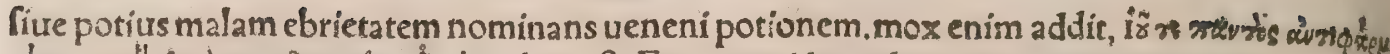

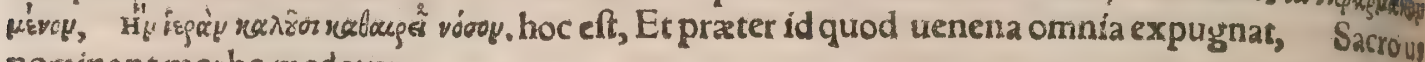
nominant morbo medetur.

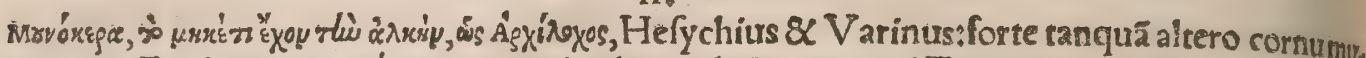

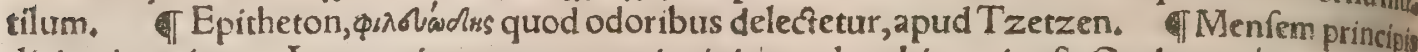

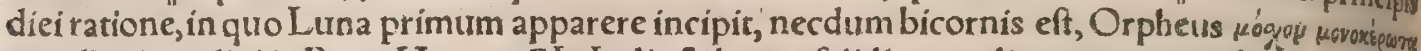
appellauit, ut dixi in Boue. H.a. In India $\&$ boues folidis ungulis unicornes nafri, Ctefias forl bit, Plinius. Boures unicornes, 8 tricornes, folidis ungulis, nec bifidis, in India reperiuntur, Soli, nus. Aonijs tauris uarijs coloribus diftinctis, perpetuæ indiuifáğ ungulæ funt: ïfdem unicum cornu ex media fronte exiftit, Aelianus \& Oppianus. In Zeila urbe Acthiopia uaccas uidicorntr unicũ in fronte media habentes inftar monocerotis, longitudine fupra palmi (dodrantis) magnitudi nem, refupinatum in tergum : ipfa coloris funt phœnicei, Ludouicus Romanus 2. 15. Eft bos in Hercynia fylua cerui figura, cuius à media fronte inter aures unum cornu exiftit, excelfius magisich directum, quàm ea qua nobis nota funt cornua : ab eius fummo ficut palma ramićs laté diffundun tur, Cafar lib. 6.ubi Pet. Gillius non recié pro boue bifonem legit. Dicitur Periclialiquandoarie, tis caput uno cornu ex agro effe delatum, \&c. uide infra in Ariete h. Symeon Sethi capreolum il, lum ex quo mofchus colligitur, unicum habere cornu fcribit, quod pręter ipfum à nemine prodirum memini, ut ex proximé hîc fequente eius hiftoria patebit. Vnicornes aues in Aethiopia reperunn tur, Aelianus, Monoceros Alberto pifcis eft marinus cornu fingulari in fronte armatus, $\mathrm{Q}_{\mathrm{C}} \mathrm{c}$.

Th. Monoceroti comparantur homines pïj,qui Deum unum adorant, ut monocerus cornu fe une defendit. Et erigetur cornu meum tanquam monocerotis, Dauid (Pfalmo g2.) Suidasin Movóregess.

\section{DE MOSCHI CAPREOLO.}

A. B.

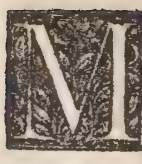

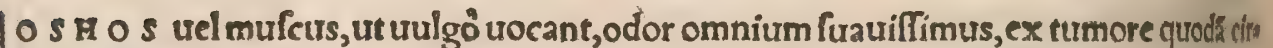
ca umbilicum animantis cuiufdam peregrinæemanat, hanc ueteres Græci Latiniós igno, i" rarunt: defcripferunt autem Arabicx lingux medici primum, nam recentiores Graxi, us Aëtius \& Paulus Aegineta, quamuis meminerint, uidẽtur tamen ex A rabum libris trals feripfiffe. In eius defcriptione uariant foriptores: fed plures uetuftioresóq $\&$ fide digniores funt,quí dorcadis, id eft caprex fiue capreoli genus faciunt hoc animal; ut ex uer bis fingulorum iam recian dis apparebir. TCaprea peregrinæ, figura,colore, cornibus, (magnitudine, lfidorus \& Albertu, ) ab alijs non diffident:fed dentibus tantum caninis difcrepant, quos binos $\&$ uerrium more exertos palmi longitudine gerunt, Serapio. Duos dentes albos habent, intrò reflexos tanquam duo cornua, Auicenna, Serapionis tamen interpres albos ualde 8 rectos effe ait, Platearium erraffe puto, quil albos non dentes, fed pilos eis tribuit, de quorum colore inferius dicetur. Eft hoc animal caprea fimile, unico armatum cornu, pragrandi corpore, Symeon Scthi, cuius plura de hoc animali $\alpha$ iplo 4 mofrho uerba inferius recirabo:Qux tamen Ruellius in uolumine de plantis Aétio artributi, \&limi liter Matthęolus in commentarn̈s in Diofcoridem. Hermolaus etiam mofchum ab Aétio defrribiath apud quem ego nihil tale ínuenio. Brafauolus etiã \& Monachi Mefuen interpretati, nominariqule dem aliquando ab Aêtio \& Aegineta mofchũ aiunt, defcribi uerò nufquam. Quamobrem autmer moria lapfi funt illi, qui ab Aëtio defcriptum aiunt:aut potius Symeonis Sethilibrum Aërï autho ris elfe crediderunt. Ego prorfus Symeonis non Aétī elfe contenderim. Sed quifquis fuerit, erraflét in eo mihi uidetur, quod unicornem hanc animantem facit, ut $\&$ Gracé legitur, \& Gyraldus, Ruel lius ac Matthaolus tranftulerunt. Quod fi error eft, ut puto, cum aliorum nemo id fcripferit, the oculati quidem authores:inde forfitan natus fuerit, quod Auicenna, ut retuli, dentes huic caprex in" trò reflexos tanquã duo cornua effe fcribit, qua uerba uel ab interprete uel à librario pertuertipotues" runt. Gazelus mofchi habet duo cornua erecta uerfus altum, Elluchafem. Sed necs maximum hoc

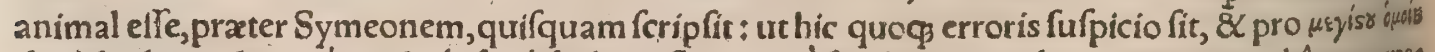

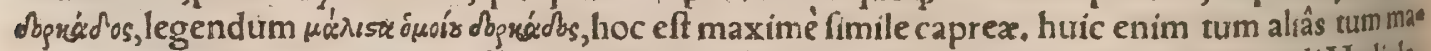
gnitudine par aut proximum effe alij authores teftantur. Mofchi animal mortuum uridi Mediolas ni, magnitudine, forma ac pilo, nifi quod coloris eft magis glauci, capreolo fimile. pilus tamen etiam craffior eft pilo capreoli. Supra binos, \& totidem infra dentes habet, hoć̣́́ folo diflert \& odore àcas preolo, nam pili uarietas à regione or tû̃ habere poffer, Cardanus. Gazellæ (ideft caprex) mofchi, capreolis fimiles, graciliores, minores, elegantiores, ex Á egypto aduehuntur, Authoris nomen excia dit: Dorcas peregrina colore ceruo fimilis eft, dorcade aut capreolo paulò maior, \& nonnunquamm

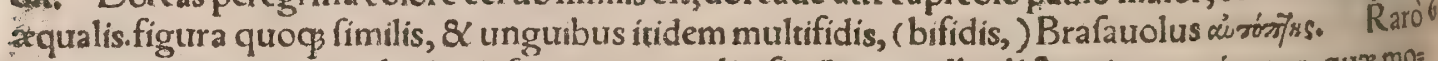
uiux capiuntur, tantæ uelocitatis funt : uerum aliæ fimiles gazellæ dictæ uiuæ capiuntur, qux mo= ¿chum nullum adfexunt, Alex.Benedictus. Voluerunt nönulli animal mofchi diuerfum à gazella 


\section{Demofchicapreolo. A.B.C.Lib.I. 787}

efe: fed nos fllis credimis qui ex peregrinis regionibus profecti gazellam appellari dicunt,Bralauø lur. Animal ex quo mofchus colligitur, catti(librarị forte error eft, \& legendum capreoli) magnitu dinem haber, pilis groffis ut ceruus, pedibus quogs ungulatis:dentes ei quatuor, bini fupra $\&$ rotide infra, longitudine trium digitorum;reperitur circa prouriciam Cathai, \& regnum Cerguth, quod ma gno Cham Tartarorum regi fubijcitur:mofchus quidem illinc adueçus omnium prafiaztifínus eft, Pa. Vener. Odoratiffimum mofchum Venetijs uidi,fubnigrum:quem mercator quidam habebat, ex prouincia Cathai fe attuliffe afferens, iter non ineptum fibi fingens per mare Euxinum, Colchí, dem, lberiam, \& Albaniam, ufç ad ingreffurm Scythix:eft enim regio Cathai, Scythix extra Imaum pars. Nec mirum uideatur; quoniam eo in loco regio eft à Ptolemao undecima $A$ fiæx tabula $R_{a}$ anda - marcoftra nuncupata, in qua nardus abundat, 8 quam Sotus fluuius alluit. Incola regionem, ubi da ptimus mofchus nafcitur, Ergimul uocitant:particularem uero urbem, Singui, Brafaubl. Idẽ in $A_{e}$ gypto \& pluribus Africx locis hoc animantis genus reperiri fcribit, In Thebeth funt multre ciuita= tes: Sed mofchus omnis qui circa ea loca colligitur, auehitur à ciuitate quæ priuatim totius regionis nomine Thebeth nominatur, Serapio. In regione Tebeth inueniuntur multa animantia qux mus fchum producunt, quax gadderi uocantur. Venantur ea canibus, abundantćs mufcho, $\mathrm{Paul}$. Vener, A bundant etiam haec animalia in prouincia Caniclu, Idê, In Syria quãdoq̧à noftris uifuntur, Alex, Benedict. Vide etiam in G.infra, quibus ex locis aduehatur mofchus. Morchus odoramentum fant es galefæ (gazellæ) inter inguina concreta, quam potius algaliam(de qua plura uide infra in fele $z i$ bethi poft pantheram: $8 \mathrm{~L}$ mox in prafentis animalis hiftoria cap. . .) dicimus quàm mof hĩ. Mofchus , uero compofitio ex multis potius quàm naturalis res $\mathrm{eft}_{\text {, }}$ cui bafis animalis cuiufdam dapfico, id eft cuniculo fimilis, fanguis eft, qui ex India pracipuè Pegu prouincia ad nos tanquam pretiofiffimus odor affercur, Rodericus Lufitanus fine authore. Mufcum, qui et nunc in delicatiorem ufum uenit, ab Hieronymo dici quandoģ peregrinum murem funt quí opinentur, $\mathrm{C}$ l. Mufcus $\&$ ananthe et peregrini muris pellicula, Hieronymus ad Demetriadem:quis autem fit peregrinus mus odoratace lebratus pellicula, non uideo, nifi quis animal hoc intelligat, ex quozibettum excipitur, ( $\&$ c. Vide mox poft panthera hiftoriam.) Mufcus quidem Hieronymo al iud nō eft quàm bryon, id ef mufcus arborum odoratus, (cuius Diofcorides $\&$ Plin.meminêre.) Nám \& Plinius eadem féé mentione de bryo SC cenanthe difputar, Hermolaus. Sed Hieronymus forre per muris peregrini peliculan, folli. culum animal is mofchi intellexit:nã in eo adhuc pilofo mofchus includi afferriç folec, ut forte muris - genus elfe putârit nominis uicinitate deceptus. Mus mufcus ex Acthiopia Arabiaḉ̧ ucnic, Volater.

T) Principes $\&$ alij quidam pradiuites uirihoc genus capreolos ex peregrino orbe aduectos in de litịs habent, aluntó̧, in Italia præefertim. Venetị́s mercatores uidimus, qui Alphonfo duci Ferras rix gezellam uendere cupiebant, norchum in folliculo habentem, Brafauolus. Audio ibidem Cas tharinum Zenum patritium Venetum huius generis dorcadem habuiffe, \& reliquiffe ante paucos annos haredibus fuis,

बi Hanc feram, dorcadem capreámue aut gazellam Indicam, peregrinam uel Orientalem appel. les, aut durcadem mofchi, uel fimpliciter animal mofchi, parum intereft. lfidorus \& Albertus nefcio qua ratione mufquelibet nominant. Mofchon Gracifcribunt, $\mu$ ogou: Arabes mefch tuel mifch, uel almif́ch. Germani bifent, 8 animal ipfum periphraftice bifemtbier; cæteræ gentes, Italica, Gallica, - Hifpanica, múfci uel mufchi nomen à recentioribus Latinis ulurpatum retinuerune. Syluaticus et alius quidam mofchum Græcè abonafa uel aboanifa dici,ftuliffimè fcripferunt : cum hoc authoris nomen fit cuius de mofcho uer ba Serapio recitat. Itali mufcum $\&$ múfcatum dicunt, uulgó mu fchio. Angli mufke: $\&$ animal mufke carce, id eft mofchi felem, quod nomen ziberhi animali potius conueniret. Illyrij pizmo, ut Germani bifentquę uox origine Hebraica mihi uiderur.nam Regum 3, 10. ¿us bofem exponitur aroma, fuauis odor, In trilingui dictionario Munfteri, pro Aromate fori bitur etiam टura bofem, \& oosbefam.

\section{c.}

Capræ peregrinæe agiles ualde funt, $\&$ urelociffimé currunt, Brafauolus. Tantæu uelocitatis ut raro thix capiantur, Alex. Benedictus. THerbis odoratis pafcuntur, unde etiam mofcho, id eft fangui nis circa umbilicum collectioni odor conciliatur, ex nardo pracipué, ut dicam in $G$. GMofchus omnis funditur ab umbilico dorcadis peregrin $¥$ qux cum ruit in Venerem quafi furnth fímulata

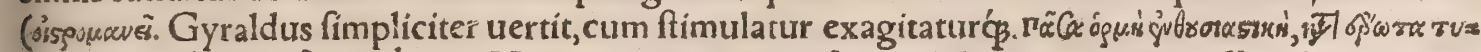
Х่ tum confluit:tumćs animal ipfum pabulo \& potu abftiner, humíg uolutaturtum demum (hac vier (atione umbilicum feculento fanguine turgentem exprimit, Ruellius) prö̈cit umbilicum fanguine plenum turbulento, qui certo quodam tempore cuagulatur, bonumọ́ odorem obtinet, $\mathrm{Sym}$ con $\mathrm{Se}$ thi, ut Gyraldus fere \& Ruellius transferunt. Folliculus quo continetur mufcus, eft umbilicus an malis, fiue circa umbilicum uefica, plena fanguinis, qux aliquandiu ferurata in mufcum tranfit, Ellut chafem. Cardanus hanc ueficam infra umbilicum effe fcribit: Paulus Venetus iuxta umbilicum - inter cutem \& carnem:Ifidorus in inguine abfceffum. Dorcadi peregrinæ quidam ueluti abfcelfus innafcitur folliculí modo, cum pilis ceruinis fimilibus pendens, putri ueluti fanguine, uectigali ceut onere, exonerante fefe natura, Alex, Benedictus. Hunc uel per uim aufexunt uenatores capreis quion 
uis modo captis aut interemptis, plerung immaturum, ideog̣ minus laudabilem, ut plutribus in a. referam:uel fponte ab ipfis emiffum maturumç in locis defertis colligunt, ut iam ex Serapione reci, tabo, In fylueftribus (inquit) capreis, quæ in montibus oberrant, \& liberé uagantur, concepta fanies, antequam uomica rumpatur, fuapte natura ad maturationem fpectat:ad quam cum uentum fuerit, fera titillantis humoxis lancinatu noxio (ualde pruriente)laceffica, cotibus \& faxis(arboribus, Ifido rus) fefe longo infolatu candentibus affricat magno oblectamento, donec facto uromicx emiffario, cota faniel uis à uentriculo(folliculo)fupra lapides effundatur:non aliter quàm abfceffus pure cocto fractus diffilit, ita utriculus maturo humore per naturam exaniat (emittit faniem, ) ulcuśg poftmoa dum ducit cicatricem, rurfumóç ruens fanguinis impetus eò fe recipit,impletọ́̂ umbilicum, dưnab: (cedens in confimilem uomicam extuberet. (Quotannis hoc fieri Ruellius fcribit, fed fine authore.) In Cxterum indigen $x$, qui loca ubl uerfantur huiufcemodi feræ ad unguem norunt, faxa facile deprea hendunt, quibus fufa colluuies $\&$ candenti Sole reficcata cohxfit. (Solis enim calor ac repercuffus non modo denfat effufum cruorem, fed odorem etiam commendat, ) Hunc igitur mofchum incola metunt, \& utriculis ferarum earum afferuant, quas uenatu captaurerant. Ille mofchus multituanit, ac inter magnifica \& regia munera cenfetur, Hucufqs Serapio paraphrafte Ruellio. Sifolliculus ab animali dematur, ad mofchum progignendum deinceps aptum non eft. At fi fponte fua exeat,in maturitate confricando, tunc iterum atф̧ frepius mofchum facit, Eiufmodi animalia mofchũ quidem maturant apud nos, fi habuerint quando conuehuntur $\div$ illa enim fanies ad cocturam uenit ; tamen iterum non emittunt pus, aut inepté emittunt: quod ratione coeli, àëris $8 C$ earum rerum quibus uja uit, euenire arbitror. Videtur fane excrementitio ifto humore hoc animal fecundum naturam purt gari, ficut multa fanguinis menftrui fluxu:neqg diu uiuere poffe, nifi ita expurgetur. Propterea in noftro coelo breui expirat, Brafauolus. Omnis caro huius animalis $\&$ excrementum dicitur mit. lcus, fed multó praftantior eft qui ab apoftemate fluit, Ifidorus \& Albertus : totum quidem animal, utin $\mathrm{E}$, dicam, ueficx illius beneficio odoratum eft.

$$
\text { Exemptis dentibus longioribus manfuefcunt, Alex. Benedictus, }
$$

Venantur eas canibus in prouincia Tebeth, $P_{a u l}, V$ enet. Morfu in perfequentes fauiumt, $A_{l}$ xander Benedict. Laqueo aut fagittis eas barbari uenantur, tanta uelocitatis ut raró uiuxa capian tur, Idem. Venatores hanc feram caffibus aut laqueis captãt;aut fagittis uel miffilibus uomicafol 30 liculum decutiunt, Ruellius ex Serapione, fed ineptè:neq̧ enim folliculos miffilibus ampurarifentil" Serapio:fed fer $æ$ quouis modo iam captæ folliculum quamuis immaturum ab eis abfcind?. $q \mathrm{M}_{0}$ fchus omnê rem ad hanc uf̧́ diem cognitam magnitudine $\&$ fuauitate odoris uincit \& exuperab, Cardanus. Propter ueficam qua mofchum infra umbilicum continet, totum animal quantummitit car iucundi odoris, uix dicere queam:tametfiid quod uidi iampridem mortuum erat; fed \& folliculo illo per multos annos arcis indito, omnes qua intus ueftes feruantur, miro odore fragrant, Cardaht In maximo hodieluxu eft mofchi ufus, circa ueftes eius odore imbuendas, \& fuffitus, \& orbiculos ad preculas numerandas:ad pilas, quas argento auróue includunt pauló ditiores, qui uel amant,ul aliter molles ac delicati funt, uel fuas oftentare opes uolunt, uel ut ä́rem infalubrem aut foetidum caueant, uel fuos deniç animæ aut aliunde graues halitus emendent, uel deniç aduerfus motbos quofdam prafertim cerebri frigidi $\&$ humidi. Hoc matronæe pertranfeuntes procos ad Venerem inuitant: exotici unguenti uicem reginis reddit. Animalis uitium feculo noftro placet, \& in uitum vertitur. Venetis matronis non placer, quibus nec zibethi fordes, Alex.Benedictus, Qui geftatip re non fentit, Idem. Succinum orientale (ambra)confuetudine odoris fuigratiam acquirit, cumzis bethum 8 murcus faftídium pariant, Idem. Aétius 16.133 . fuffumigio molchato fcrupulos quatiot mofchi admifcet:eundem fequentibus etiam aliquot fuffumigïs, \& alips, $\&$ regïs, \& in ecelefiaten ceptis admifcet:ut Nicolaus Myrepfus qurog, quem Leon. Fuchfius nuper nobis Latinum deditin capite de fuffimentis. Sed ex Aétio unum ad́cribam, é capite 134. Suffumigí regí confectio: Styraa

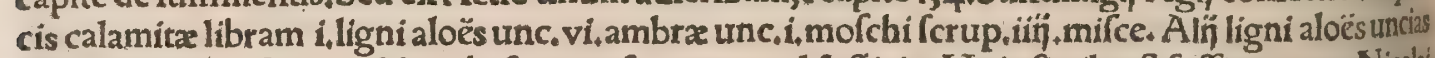
iiip. careris admifcent, adduntó̧ fucci rofarum quod fufticit. Huic fimile eft fuffimentum Nicolaj Myrepfi, numero tertium, quod ad fyncopem \& imbecillitatem cordis infcribitur: \& alipta mofcha tx compofitio hodiéç in ufu:item gallia mufcata apud Mefuen inter trochifcos:ubi \& galliaales phanginx, \& febellix, \& magnæ fiue regali, mof chum admifcet. Nonnulligaliam I, fimplici fcribunt, alij algaliam (uide plura in felezibethi de algalia.) Harum compofitiones aliquot Serapio etiam pia fcribit, \& Auicenna. Cyphi (urox eft Hebraicæoriginis ab urendo, id eft fuffiendo uel adolendo di cta)compofitionem, ueteres fine mofcho pararunt, recentiores (ut Nicol. Myrepfus) addiderunt: hine uoce corrupta Cyprias auriculas aliqui dixerunt, uulgarem ad fuffimenta compofitionem, quâ aliqui pharmacopolæ auicularum forma, alī aliter effingunt. If Aquis odoriferis, qux in chymia farum fornacibus, aut balneo Marix, ut uocant, parari folent, ut $\&$ aquæ rofacex fimplici,pro ditio ribus nonnihil mofchi \& camphoræ quidam adjịciunt, \&c. Huiufmodi fanè aliquot egregios liquos res defcribit Andreas Furnerius libri Gallice æe diti de humanæ natura decoratione, parte fecunda,
qua eft de ornatu muliebri:ubi \& fmegmatis fiue faponis mofchati compofitionem docet, $\&$ oleorî̉ 


\section{Demofchicapreolo. E.G. Lib. I. 789}

quorundam mofchatorum. Aëtius 16.116 .8 deinceps unguenta quadam fiue olea mofchata, id eft mofchum odoramentum recipientia defcribit, Eodem capite 116 . orbiculos rotundos odoratos quil $\&$ alia quadam odorata $\&$ mofchum accipiunt,parare docet $\$$ ac éfdem acı perforatos traiecto fus

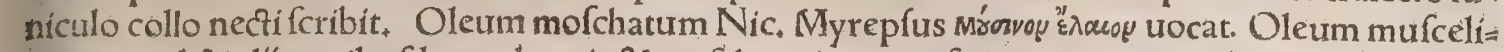
num, quod $\&$ alijs quibufdam odoratis $\&$ mofcho mixtis conficitur, in ueteri æeditione Nicolai re perio, \& in translatione quam Nic. Alexandrini nomine Nicolaus Regienfis edidit. TMofchus, galia, \& fimilia, non debent decoqui cum alp̈s medicamentis $\div$ fed cum exigura parte decocti mi iceri, \& fic reliquis affundi. Aliqui mofchum in lana xylina ponunt in aliquo uare, \& coloinfufam decoctionem paulatim fic per lanam träfmittunt, Monachi in Mefuen. Sed neģ conteri debet mo: - fchus, uerum in liquore rofaceo alióue diffolutus cateris medicamentis mifceri, uel alia quadam ar tificiofa ratione, Iidem. TSeruari potet mofchus in uafe uitreo, denfo, ac diligenter oblito cerat uel potius in uale plumbeo(quod \& Alexan. Benedictus fcribit)ut frigida \& humida huius nuetal: İ qualitate melius feruetur. Quòd fi in alio uafe fuerit, apponẫtur duo uel tria plumbi frufta, ut me: lius conferuetur. Caurendum eft autem ne quid aromaticum addatur, fic enim furum odorem amitte ret.Quem fi amiferit, in olla(uafe uitreo aperto, Syluius) ore aperto fufpendatur in cloaca, \& recus perabit eum, Platearius. Odoris amiffi uim in foetoribus \& latrinis (lacunis \& Rercoribus, Alber. tus,) recuperat; contra fotorem eluctatur, \& fic quafi luctando reuiuifcit, Ifidor

๑Pilæ molchi odore, quarum fupra mentionem feci, qux tenıpore peltilenti pręcipué parantur, quo pacfo componi debeant, pleriç medici recentiores, quorum de pefte fripta extant, prafcribe. re folent. Eft \& compofitio una apud Alexandrum Benedictum pro confirmandis h́s qưi animi dè liquium patiuntur, fi bene memini.

Tlecore hoedino arefacto mofchus adulteratur, Alex. Benedictus $\div$ Radice dicta makir $\&$ herba falich trita, Elluchafem. Facillimé adulteraturłunde fape ftercus murium, $\&$ alia diuterfa pro mix fco uenduntur. Folliculis quidem integris non ftatim adhibenda fides $\neq$ quoniam non defunt impo $\Rightarrow$ fores, qui eos effingunt fimillimos, \& uarịs rebus impletos, wero mufco interponunt, donec eius odorem recipiant:atç fic mulierculis \& utris etiam imperitis uendunt, Monachi in Mefuen. Adul teratur etiam cuiufdam auis fimo, Alex. Benedicius. Adulteratur mofchus \& pracipuéniger, \& niger ad fubrufurm colorem accedens, admixto pauco fanguine hircino modicè affo, uel pane affo: ita ut tres uel quatuor partes ex iftis contritis ad unam mofchi admifceantur $\$ \&$ uix dignofcitur. o fed panis affus, nimium friabilem reddit mofchum. Sanguis ureró hircinus curm frangitur lucidius eft, \& clarus interius. Quandoq̧ uenditur cum ipfis pelliculis, 8 adulteratur fimiliter, utiam dis cum eft. Incifis enim pelliculis Saraceni uerum mofchum auferunt, $\&$ infarctas? adulterato rurfus ita conglutinant, ut non deprehendatur ${ }_{*}$ Sed morchus adulteratus cum pelle, duplus eft pondere fi fyncero conferas, Plateariurs, Morchus fictitius à quibufdam hoc modo fit: Nucis morchat $x$, macís, cínnamomi, caryophyllorum, fpicæ nardi,fingulorum pugillus unus : trita omnia diligentifi= mé $\&$ cribro excreta, cum fanguine columbx recenti fubiguntur, $\&$ ad Solem ficcantur : mox trita aqua rofacea mofchata irrigantur, feptiestita ut femper irrigata denuo ficces ac teras. Tandem ter tiam uel quartam partem ueri mofchi contriti admifcent, 8 rurfus aquam rofaceam mofchatam infpergunt, $\mathcal{X}$ in aliquot partes diuifam maffam (fi recte lego) pilis minutis albis capreoli uel hoed - fub cauda inuoluunt, $\&$ in uafe uitreo reponunt, Authoris nomen excidit $\$$ uideor autem mihi in manufripto cuiufdam empirici libello reperiffe, \& fequentem quo compoficionem, qua huiuf modi eft. Benzuinum, cera candida nouri examinis, caries fraxini arboris, $\&$ mofchus mifcentur autem a mbra factitia, mofchum uel zibettum redolens. Aliter,Styracem, ladanum $8<$ fcobem lign aloês mifcent ¿debet autem ad utranq, compofitionem mofchus uel zibettum addi, atç omnia cum aqua rofacea commifceri $\div$ fed facile fraus deprehenditur $¥$ nam natiua non ita celeriter ut factitia $a=$ quis mollefcit, 8 ab eadem odore coloréóp differt. Cætera figna mofchum dignofcendi fyncerum eligendićs præftantiorem, fequenti capite referam. Audio à quibufdam augeri mofchum admi= xto femine herbx, quam noftri aquilegiam, Galli angelicam uocant; quod etiam fe deprehendiffe $a=$ micus quidam mihi retulit, cum mofcho in aqua(rofacea) refoluto, uerum fupernatare anímadtuer teret, \& quod ex feminibus accefferat fubfidere. Sed impoftor ille rem forte non intellexit. Síqui. dem herba quam Galli angelicam uocant, undiquaq̧inodora eft. Germanis uerò dicta angelica (eru diti quidam lafer Gallicum interpretantur)radice præfertum, mofchi odorem præfentare fxpenus mero mihi uifa eft, tưm aliâs, tũ paưca eius quantitate medicamentiscópofitis adiecta. đ Mớchưs odore in humido crafto perennante, uruaciftimus eft, Syluius, Vncia fènis aureis emitur, Alexana der Benedictus.

Mofchus in Perfas primum, inde in Ämanum inuehitur, \& in Ảegyptum exinde lis fuis etiamnum à Venetis in calicibus urenundatur, qui etiam in pretio funt, Alex. Benedicius. Indicus eft melior $A$ fro:fubflauus etiam nigricanti prafertur; quanquam ex Catay praftantiffimus hodie habetur, idemós niger,Syluítus. Vide fupra in A. Morchus(inquit Platearius)omnino niger non probaturtprafertur illifubniger. Alius eft fubruffus; omnino accedens ad colorem fpicx nar di, qui maximèlaudatur. Huiufcemodi quidam haberi aiunt ex capreis qua fpicam nardi depafcun 
tur. Quare eligendus eft fubruffus, qui quidem uix adulterari poteft: \& Caporis amari, qui guftatus Itatim odore fuo cerebrum feriat; qui ne gु ftatim foluitur, nec admodum refiftit; 8 qui non omnino clarus ( fplendidus ) fit intrinfecus. grana latiufcula, 8 per totum æqualia, xyloceratị inftar, optima iudicantur, Quod ad regionem mofchum praferunt A ntebium, uel Afciltion, (Beliunenfis legit Scinium, à Sceni regione fortaffis) deinde lurgium, poftremo Indum marinum, Auicenna, Fol liculi continentes mofchum Cubit funt fubtili ex ueficula $8 \times$ mofcho. Gergeri folliculi funt his con trarij:qui mofchus minus fubtilis, minus q̧ aromaticus eft. Sed mofchus Charam medio inter prædj, ctos loco eft: quo cum fcobs argenti \& plumbi mifcetur, ut augeatur pondus, Morchus Salmindide, terior eft, quia folliculo fuo exemptus in uafe uitreo fertuatur, Elluchafem in Tacuinis, Sunt quit Tumbafcinum anteponant (inquit Serapio) odorisćs praftantiam caprearum pabulo ferantacce

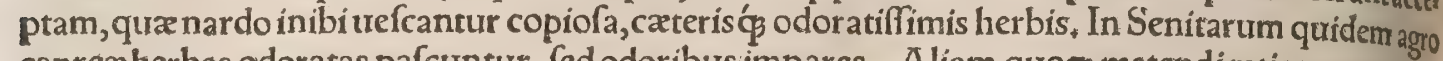
caprea herbas odoratas pafcuntur, fed odoribusimpares. Aliam quo metendi rationem caulan tur Tumbafcini, hanc faniem uomicæ folliculo non eruunt, 8 blandiente coli ferenitate merumle, gunt. Senici uerò uomica uentriculum exprimũ $\mathrm{r}, \&$ exclufa fanie adulterina permifcent, nubilopa rumó $\beta$ arridente coelo, $\mathcal{Q}$ uafis uitreis recondunt, obturant'́s: deinde mittunt in regiones Saracenoa rum \& in Hamen (Amanum, Alex. Benedicłus, ) \& Perfida, \& Haharac, aliaṣ́́g regiones Babylo nix, ( $\&$ in Aegyptum, Alex. Benedictus:)ac fi Tumbafcinus effet, Hac Serapio, Præfertur mo, fchus dorcadis, qux depafcitur utrunç been $\&$ fpicam, \& almaru, Auicenna. Quum hac anima lia proculà mari uerfus deferturn pafcuntur fpica, mofchus ipforum erit fuauior : cum ueró prope mare funt, pafcuntur myrrha, Elluchafem. Melior mofchus fit in urbe quadam qua multó magrs orientalis eft quàm Chorafe, qua dicta eft Tupata ( Trwíra, Ruellius prima fyllaba omiffa Pattrant: ftulit. candem Serapio Tumbafci nominat. ) Colore quidem hic morchus fubflauidus eft:huic bonis: tate cedit qui ab India defertur, colore in nigritiã uergente. hoc etiam imbecillior feu deterior ef quil ex Sinis ( aliâs Dinis, dè̉ sivcoy, ex Senitarum agro, Ruellius, hanc regionem Seni uocat Serapio ha betur,Symeon Serhi. Quod ad colorem 8 odorem, pomalis(pomi odore forfan) citrinus laudatur, Auicenna. Citrinum Auicenna præfert, qualem nos nunquam uidimus.nam nofter ferruginetrs eft, Brafauolus $\&$ Syluius, Mufcus ferrugineus feré eft nofter, non, quem Auícenna probat, cirry nus, Alexandrinum uocans, eft odore in opum Cyrenaicum inclinante, fed ualentiore, prater fumis mam aliam in eo fragrantiam. glebulis exiguis conftat, Syluius. Syncerus niger eft. conglobatus melior.folitudinis odorem habet, aut anguium quorundam ftato tempore, aut cuiufdam auis fimi quo adulteratur.ex quo plus eft, acrius nares ferit, $A$ lex. Benedictus, lego, \& quo propius eft,actius (id eft minus grato odore)nares ferit, nam de zibetho quoc $\beta$ fic fcribit, Ex proximo nares acriusfes rix, \& ex quo plus eft, (lego, \& quo propius eft.) mufco tamen charius comparatur: quoniam odorem quigerit ipfe non fentit. Sed hoc idem de mufco quog fripferat, odorem eius ab eo quigerit non fentiri. Venatores in regionibus Beteth ( Tebeth) \& Seni, plerunç capreis quas uel fagittisinte, remerint, uel aliter ceperint, folliculum adhuc immaturum abfcindunt: qui mof chus pręcox tetro \& infuaui odore difplicet. Verum tantifper libero aëre fufpendunt: dum abacto prorfus fœrorematlu ruerit. is hac concoctione perfecta miram fibi conciliat fuauitatem. Simile quippiam in arborum fructibus fieri confureuit, qui præcoces decerpti, tandem exuta acerbitate, $\&$ dulces $\&$ fuaueolentes euadunt. Sed praferri debet mofchus ille, qui in folliculo fuo maturefcit, antequam refcindaturab 40 animali,Serapio. Folliculus mofchi antequam maturuerit, graue olet. Venetịs odorari uoluiada hærentem adhuc animali:is omnino grauem odorem habebat, quia nondum ad maturitatem pertit nerat. Quod fi accidat ab animali auferri antequam abfceffus cốcoctus fit, concoquitur quidem, fed ineptius olet, Brafauolus, Perfectus mofchus non multus ad nos adfertur, fed folliculi folum ul ab animali abrepti, ex regionibus orientem $\&$ occidentem uerfus ad nos comportantur. perfectior eft ex oriente allatus, ifjs pracipuélocis ubi nardus $\&$ odoratæ herbæ nafcuntut, Brafauolis . An mofchus legitimus $\&$ non adulteratus fit, quidam hoc modo probant; Ponderatum in peluim aut malluuium madens humenş́́ deponunt, tum poft aliquantulum iterum ponderant: fi fuperat, tum non adulteratum putant:fi uerò non, fuppofititium illegitimumó iúxdicant, Symeon Sethi Gyraldo

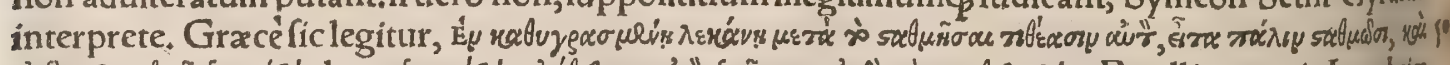

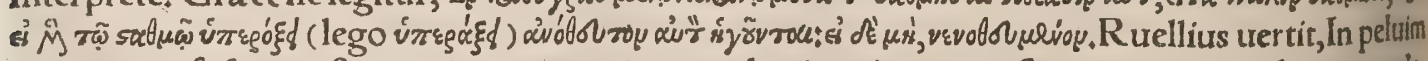
humore perfuram poft examinatum trutina pondus immittunt, poftea iterum aqua lance ponde. rant. Quod fi protinus ad ftateram reductum fuperferatur, fynceri experimentum putant ; fin repểs cedat \& pondere degrauetur, fpurn̈ indicium exiftimant. Hanc opinionem Syluius quog fequitur.

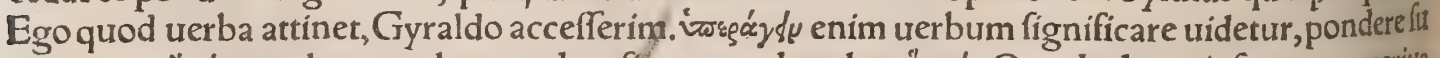

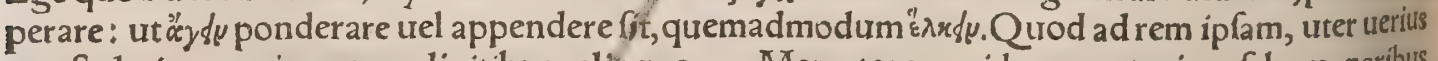
tranftulerit experimentum diuitibus relinquo. Mercatores quidam empturi mofchum, naribus obturatis 8 refpiratione cohibita ad medium iactum lapidis currunt, 8 inde attrahentes aérem

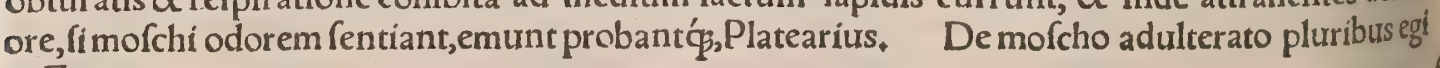
in $\mathrm{E}$.

TMufcus eft calidus \& ficcus, fed ficcior quàm calidior fecundum quofdam, \& fubtilis, A uicen na $\&$ alï. Cal, \& fic in fecundo gradu, Mefarugie, Cal, \& fic in fine fecundigradus, Auerrois. 
quenquam grammaticorum. Morchũ aliqui dictũ putant, quia Gręci animal hoc ex qưo mofhurs colligitur, uitulorum colorẽ habere iudicarũt, quos $\mu$ ogrs appellant. Alij inquiunt ita appellarí quil Graci primos ftolones mofchos uocant: mofchus autem odoraturs, eft tanquã in co a nimante folo: red uerifimilius eft ab Arabica uoce mich Gracos deflexiffe, Brafauolus, cui $\&$ iple facile accedo, - Et celebris fuaui eft unguine mufcus Arabs,Alciar. TSunt ex plantis qua mofchũ olent,Dean gelica noftra in E. fuperius dixi: de dorcadiade uerò uel mufcio, itẽ mufcilio uel dorcide herbis, \&uiua mofchata, in hiftoria Caprex. Alfengemifch, eft ocymũ caryophyllatum, uel mufcatũ, ut aliqui pur tant: nam milch Arabice molchus eft, Monachi in Mefuen. Solanum, tum cómune, tum ureficarîn quog, ni fallor, fæpe mihi folỷs fuis mofchum prorfus redolere uifa funt. Eft \& herbula quradăras ra, nec ulli adhuc defcripta, quam circa Bafileã \& Laufannam reperi, locis opacis \& pinguribus, Vix ultra fefquipalmũ affurgit, apị ferè folins, tenera, flofculi parui $\&$ pallidi quaternis finguli foliolis, $f$ rectè memini, fummos coliculos coronant, mira proefus $\&$ peculiari rationeł furnt enim quaterni in circuitu laterũ, in uertice unus, omnes contíguitradix fubeft, parua, alba, denticulata, fimilis illi quă in Heffia faniculam albam uocant: fed hanc quoça à nónnullis fic appellari audio. Superficies eitus ipfiffimum mofchum olet, breui quidem $\&$ fugitiuo fed fuauifimo odore. In fummis etiã circaSedu num Helueticis al pibu s, herbulã quâdam breuiffimam rofeis uel purpureis floribus inueni, mofchi uel ftactes porius aut fyracis calamitæ odore $+u t \&$ fatyrí genus digitatum, florũ capitulo coloris rux bri adufti \& nigricantis (quamobrem incolx brendi uocitant, hoc eft aduftam)quo nihil unquã fita. uius mihi odoratus uideor, \& ea quidem gratia qux caput minime repleret. Rofa Damafcenafeut mufcatella uulgò diça inter fylueftres annumerari poteft; quam Auicẽna Canone 2.ca. 514. Nefrin uel nefrin, uel neferin nominat, ut Bellunenfis incerpretatur, cuius hacc funt uerba ${ }_{\ddagger} \mathrm{Nefrin}_{\text {eftrofa. }}$ doris acuti, quęuulgò in Hifpania \& Barbaria rofa mufcata dicitur. Damafci rofa nefrin uel neferin, $\&$ eft fpecies rof $x$ fylueftris. Simon Ianuenfis etiä, \& 2 Pandeciarius, neferin uel nefrim, autoritate Al haui dicunt effe rofam fylueftre $\&$ albam, qux in frutice fpinofo ut fatiua nafcatur. Serapio neffin uocar, \& ab aliquibus rofam fylueftrẽ et rofam Seni nominari fcribit, Monachi in Me؟. Alibi etäné rin rofam paruã, fylueftrẽ , albam interpretanturł cui A uicễna \& Serapio eandem facultatêattribuâ? qua pręditum eft zambacum uel iefemínum, fed infirmius:ut in penuria olei zambacini, oleo de ne frin, id eft rofis Damafcenis uti liceat. Nerfin, inquit A uricen. calidus $\& \alpha$ ficcus eft ordine tertio. Om nis fpecies (pars)eius uim habet abftergendi $\&$ attenuandi,fed flos pręcipué. Neruis frigidis prodelf. Vermes aurium occidit $\$ \&$ tinnitum earum tollit. Dentium dolore mitigat. Sylueftris in hoc genere fronti in capitis dolore illinitur. Prodeft gutturis $\&$ tonfillarum abfceffibus. Drachno quatuorinde potæ, de fylueftri præcipué, uomitum $\&<$ fingultũ fiftunt, Hæc Auicen.de nefrin. Sed cum planta fit calida $\&$ ficca in tertio, \& eadem feré quæ zambacum efficiat, rofis eam adnumerare non poffunits: neq; enim ulla nobis rofarum fpecies fiue fatiua fiue fylueftris cognita eft, qua tertio gradur calfaria \& illa præftet qux plantã nerfin præftare ex Auicenna nunc recitaui. Quamobrẽaliam effe oporie rofam Damafrenam fiue mufcatã uulgò in Italia dictam:cuius Matthæolus etiã meminit,peç̣̂, dợ: riferam effe fcribens, colore albo, \& uentri mourendo cæereris efficaciorem, Ego loco nerfin iefemini uulgò dichum, aut leucoia potius quàm ullum rofarum genus ufurpare malim, Nefrim, id eftam bacum fylueftre, calidum eft et ficcũ: \& calidi temperamenti capurt læedit, (\& uel fanguinê ènarbus aliquãdo odore fuo elicit)Rafis. Idẽ a pud Serapionẽ, Vidi, inquit, in Corafceni qui dabantfoliorio 4 eius duas aut tres ad fummum drachmas, unde uenter admodum mourebatur. Nerfin eft ficut nars ciffus, Auicenna \& A ben Mefuai: ego narciffun hîc falfò legi uideo, fiue authorum, fiue inteppretü aut librariorum hæc culpa fit:nam neథ̧ forma, cum fit frutex rofæ fimilis, aut faltë magnitudinepar: neq̧ uires cum narciffo cốueniunt. Fieri quidẽ potelt ut ea uøx corrupta fit pro iefemino, Quanqulấ rurfus in Narciffo etiã apud Serapionẽ fcribitur, narciffum ea efficere qua iefeminum. Sed legendũ eft nerfin nö narces (fic enim narciffum uocant) ea præftare qư icfeminum, ut Auicenna \& Melas rugie docent.Serapio quidẽ uel citatus ab eo author, uocum affinitate facile falli potuit, Ef aûtzam bacum fiue iefeminum frutex floribus odoratis, quẽ Galli $\&$ Italietiãnum iefeminum appellant, do. ĉt quídã iafminum, $\&$ ungentum eiufdẽ nominis Diofcoridi defcriptum ex floribus eius conficiars bitrantur. Ego eundẽ fruticẽ Vergilí cafiam efle puto, apibus gratam, ut pluribus in A pum hiforia docebo.Quod fi nefrim iefeminum fylueftre eft, ut $R$ afis fcribit, non recte Auicenna huius plantęge nus fylueftre priuatim nominaret, fatiuum etiã genus eius alterum effe intelligendum relinquelis, cum de fambaco, id eft iafmin (fic enim Bellunenfis hæc uocabula fcribit) feorfim agat, Scribit autem fambacum calidum $\&$ ficcum effe ordine tertio, $\&$ oleum eius prodeffe neruis frigidis, in fenibus pre fertim, fed odore fuo caput lædere, quod Diofcorides etiã de iafmino tradidit unguento. Sed fiurefant bacum fylueftre hæc planta eft, fiue fimilis ei, fat fuerit intelligere eandẽ utriuf $\bar{\beta}_{\beta}$ facultatẽ effe, fam baci tamen efficaciorẽ paulo: $\&$ nullum pro eo rofarum genus fubftiturendum. Rof quídẽ nomen (úocant enim nerfin aliqui rofam agreftẽ , \& rofam Seni, ur apud Serapionẽ legimus) nô fariseftad probandum proprie dictæ rof $x$ han f fecié effe turr leucoia Diof coridis, \& leucoion Theophrafti. Oleum de nerfin utile eft aduerfus pleurefin ex as 6 tra bile, \& uteri dolores, A ben Mefuai. of Vinum quod uulgò mufcatum uocant (noftri mufcatels

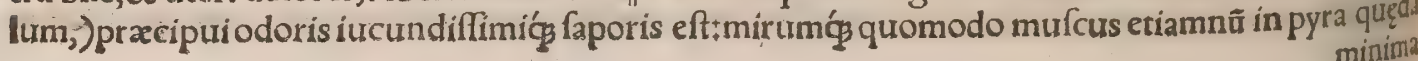




\section{DeMulo. A. Lib.I.}

minima tranflerit, fuperba(ut dicđt)cognominata parua hæe $\&$ ocyffima, fed ætate noftra $\&$ in ma. iora etiam ferotina idem odor tranfiuit. Vuam albam ac nigram quogs iam occupauir: in alios frut cius non tranfiuit is odortin pruna ac ficus à nobis fruftra tentatum eft; Alexander Benedictus lib. 10. cap. 10. operis fui practíci, ut uocant.

TReddunt interdum $\&$ feles fylueftres (martes potius, $8<$ mures, mofchi odore recrementum, ut fxpe in dirutis agrorum adificijs uidimus : fed id acceptum ferendum eft odoratis fruticum cibis, quibus aluntur, Ruel, ego hxe animalia frutices minime depafci puto. Sed de marte, \& mure mo rchardino, ut quidam appellant, fuo loco dicetur. Mofchix dicti lepores quidam funt, quorum in ueftigijs f piritum ranta ui fentire canes memorant, ut furere plané credantur, ut dixi in Lepore $\mathrm{B}$. 10 gMorchus in Calechut affertur ex regione Pego dicta, à qua diftat quingentis millibus paffuum, Ludovicus Romanus.

\section{E M V L O.}

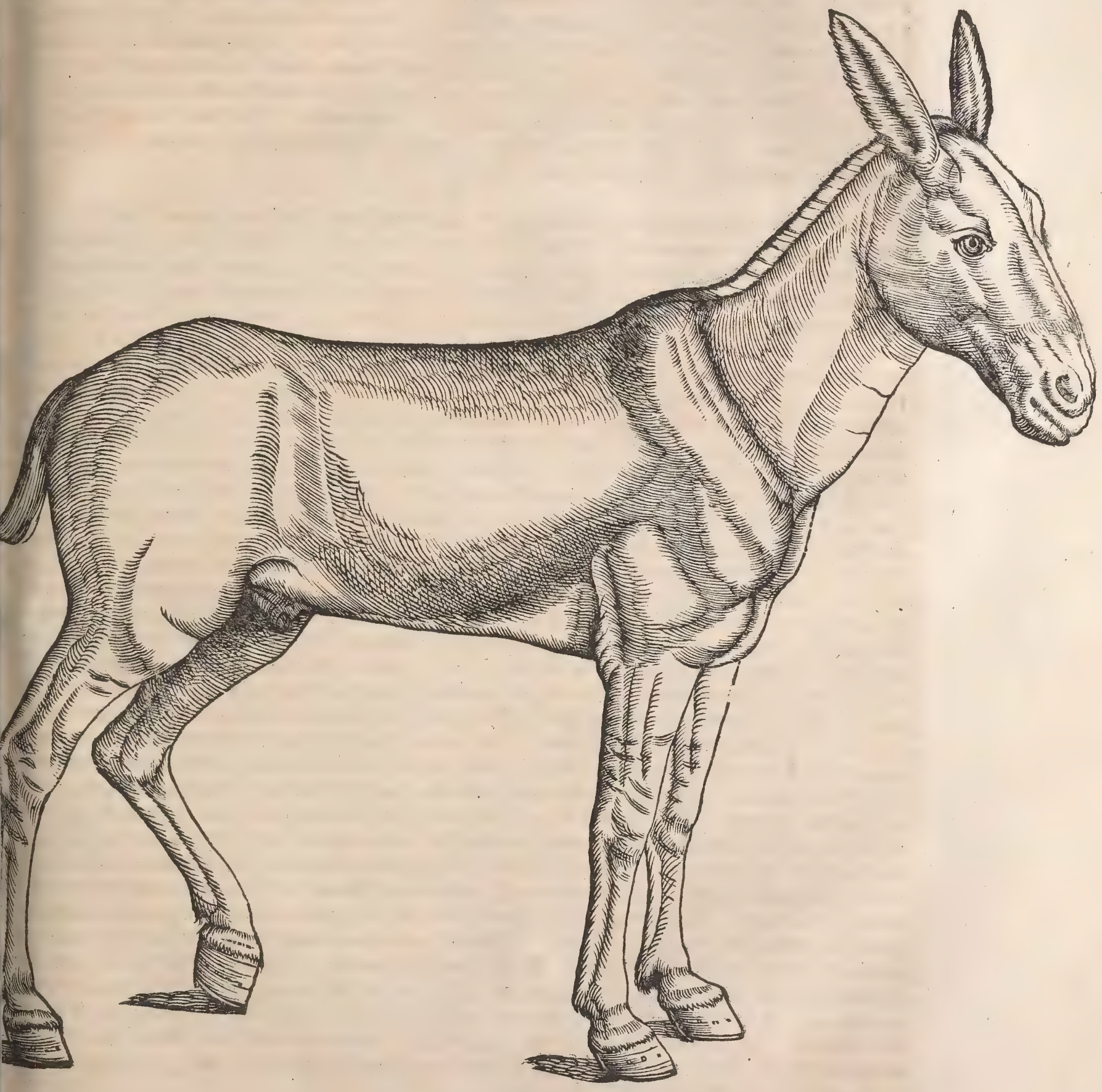


A.

V I V s iumentum eft, quod Hebraica lingua 79 pered nominatưnde fominind Mh pirdah, Regum 3.1. Dauid Kimlí foribit ex fententia R. Hai, pered animalà feparatione fic dici, quod non pariat. Pfalmo 32.pro Hebraica uoce pered, Chaldaus haber cudana, Arabs ' ל בע, beal,at Genefeos 36.pro iemim Hebraica uoce, (mulos pleriogintey.

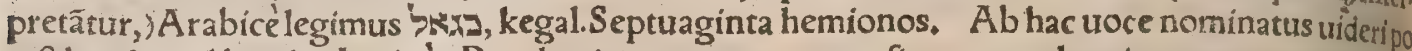
teft burdo uel burdus Latinè: Porphyrio equum mannum fiue mannulum interpretatur. Albertis Magnus uidetur muli genus intelligere ex equo natum $\&$ afina, hinnum uel hinnulum ueteres uo, cant, ut in hinni hiftoria ftatim pof afinum dixi $; \&$ nonnulla dicam mox in $\mathrm{B}$. T"an iemim, $\mathrm{Ge}_{3}$ nefeos 36. Saadias \& Salomon interpretantur peradim, id eft mulos, fimiliter Steuchus \& Sanctes; Hieronymus aquas calidas, alị onagros, \&c. Vide fupra in A fino H. h. Docriffimi quidem pleries mulos effe confentiunt, ut $\&$ D. Kimhi in libro radicum. dum annofos, aut uelociffimos, alij mulos effe putant:uide in Equo A. A chaftranim Efther 8. Dar uid Kimhi $\&$ alij mulos interpretantur.R. Salomon camelos uéloces, Hieronymus ueredarios, Ses ptuaginta omittunt, Sed diuerfa apud Hebraos muli nomina effe minus mirum, cum prater com, n une genus muli aliud quoddam peculiare in Syria habeatur, ut dicam in B. Ápud Munfterum

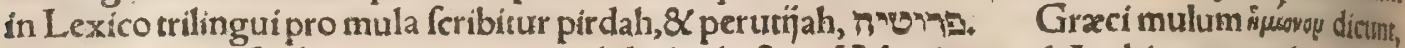
$\&$ alio no mine aftraben, qux uox nonnihil ad achaftran Hebraicam uel Arabicam accedit. He. mionos quidem femiafinum fonat, quod mulus altero tantum parente afinus fit, altero equis, in plu ribus tamen afini quàm equi naturam fequi uidetur. Italis, mulo. Hifpanis, fimiliter: foeninina, 10 mula, ut Latinis, Gallis mulet, formina mule, Anglià Gallis mutuantur a mule, Germanis, multbiet uel mulefel. Illyrijs mezeck.

B.

Sunt in Syria, quos mulos appellant, genus diuerfum ab co, quod coitu' equx \& a fini prectea. eur, fed fimile facie. quomodo afini fylueftres, fimilitudine quadam nomen urbanorum accepere, \& quidem ut afini illi feri, fic muli praftant celeritate. Procreant eiufmodi mulæ fuo in genere.citus rel argumento illæe funt, qux tempore Pharnacx patris Pharnabazi in terram Phrygiam uenerunt,qule adhuc extant, tres tamen ex nouem, quot numero olim fuiffe aiunt, fer uantur hoc tempore, Arifito teles. Et alibi, In terra Syria fuper Phœnicem mula \& coëunt, $8<$ pariunt omnes : fed id genus di uerfum eft, quanquam fimile. Theophraftus uulgò parere in Cappadocia tradit, (quod in Arifo 30 telis quoog Mirabilibus legitur) fed effe id animal ibi fui generis, Plinius. In India equarum \&afi norum greges funt, \& afinos equæ facillimé admittunt, \& rubros mulos pariunt, ad currendumpriz Ptantiffimos, Aelianus. Apud Indos Pfyllos (nam funt etiam alteri A frici ) arietibus non maiores equi gignuntur:afini quoc $\beta$, muli, \& boures minimi, A elianus. II In terra Scythica neçafinusne. que mulus gignitur, ac ne ullus quidem uifitur propter frigora, Herodotus libr.4. Et paulo ftrperiss cum idem feripfiffet, fubdit:Quo magis miror cur in omni Eleo agro muli nequeant gigni,cumnes que locus fit frigidus, necs ulla alia caufa appareat. Aiunt Elienfes ipfi ex imprecatione quadam id fibi contigiffe, (idem ex Herodoto Euftahius reperit:)cum f̧ tempus aduentat conceptus equarum, fe in loca finitima illas educere: Ibi poftquam admiferint afinos dum equx conceperint, tunc rufus eas reducere. Plura uide fupra ín Equo c . T Mulus natura fua afinum magís quàm equunre in fert, burdo autem contra, quamobrem mulus afini uocem reddit, burdo equi, urerç ex diffimilis nar tura femine generatur, ideoç fterilis eft, Albertus. Videtur autem innuere burdonem ex afina $\alpha$ equo gigni, (ueteres hinnum uel hinnulum uocabant:) )ur mulus ex equa $8 \mathrm{x}$ afino, quanquam Alun nus, Burdo(inquit) uel hinnulus, Italis mulo baftardo(id eft mulus fpurius) dicitur, ex equa 86 afino nafcers. Burdonem è genere mulorum elfe Sextus Empiricus etiam manifefté innuit, eodem ia capite ex mưto pariter $\&$ burdone remedia numerans:ubi $\&$ Humelbergius burdonem hinno eula dem facit in fuis enarrationibus. Adde quod remedia quadã ex burdone fcripta à Sexto, alij demu lo fimiliter fcribunt. Ginni apud Ariftotelem deminuta forma equi dicuntur $;$ quos \& gygenios ab Strabone nưncupari putant nonnulli, quanquã $\&$ mulorü genus fic in Liguria uocet, Cẹlius. Mu fimon, afinus, mulus, aut equus breuis, Nonius, Mulus habet qua dã afini propria, auriculas logas, \{1 uocem, crucem in humeris, pedes exiguos, $\&$ corpus macilentum : reliqua uerò ut habet equus, Li: ber de nat.rerum. TMuli nigricant colore: cardinales in Italia cinericei feré coloris ut audio, com parant, cofdem ́́ magnos \& caudatos. Afinis $8 \mathrm{r}$ mulis procomị loco ad oculos defendendosatī res datæ funt longiores, Xenophon. Mulo dentes mutantur, Arifoteles, A finus 2 mulus den

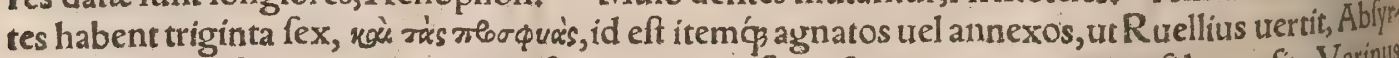
tus cap. 95 . Ceruix mulorum $\&$ afinorum non eft erecta ut equorum, etiamfi longa fit, Varints

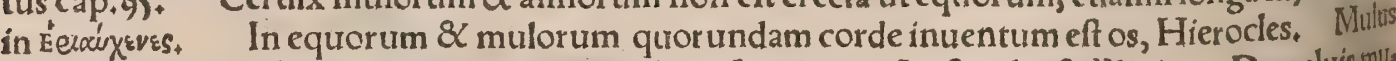
$\&$ omnia folipeda felle carent, $\&$ uentrem habent fimplicem, Ariftoteles \&Plinius. De unlusis mis larum, uide in $\mathrm{C}$, in caufa fterilitatis earum,

Equi,muli, \& afini fruge herbá̧̧ uefcuntur, fed maximè potu pinunuefcunt, A riftoteles. dam pracipiunt equum admiflarium codem ritu quo mulos faginandum effe, Columella, 


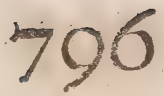

\section{DeQuadrupedibus}

ftoteles efellit, opinionem profert, Problematum fuorum libro primo, his fe:2 uerbis:Mula Rentes uidcntur, quoniam ex anımalibus confant fpecie chuerfis; miftio enim feminum, qux tam habitı, quàm natura inter fe dif́crepant, aliud quippiam prater uires furorum fimplicium conficit, \& natua ram cor um penicus abolet:quemadmodum albi $\mathcal{Q}$ nigri miftio, abolitis extremis coloribus alitm rit colorem fufcum nominatum, qui neuter extremorum eft:igitur habitus genitalis aboletur, $\$$ f fo cierum habilitas onnis deftruitur, qua creatrix certi indiuidui eft, $\mathrm{H}_{2} \mathrm{c}$ ille, Mihi quidem hac ratio etiam contra $A$ s:iftotelem defendi polfe uidetur:nam cxtera animalia, qux ex diuerfis fpecie parens tibus nafcuntur, ut canes è cane $\&$ lupo aut uulpe: $\&$ accipitres ex accipitribus fpecie diuerfi $\&, \&$ gal lina ac perdices, ideo non fterilia forte fuerint, quòd parentes eorum quamuís fpecie diuerfi, natura tamen non adeò differant çuantum equur $\&$ afinus, corumó femina : de quibus etiam Arifotzles ipfe teftatur, hoc frigidum, illud calidum effe. Alcmzon(ut refert Plutarchus de placitis philofo. phorum ร.14.) mulos mares fteriles effe fcribit, propter tenuitatem, hoc eft frigiditatem feminis, Fo, minas vero, quòd uteri earum occlufi fint, neģ dehifcant (acetabulis fcilicet unde fanguis menfrut us funditur in alịs animalibus non apertis.) Empedocles uero(cuius aliam opinionem ex Arifoter le paulò ante retuli ) propter uterum nimis paruum, eundemćç humilem $\&$ anguftum, \& obliquofiz

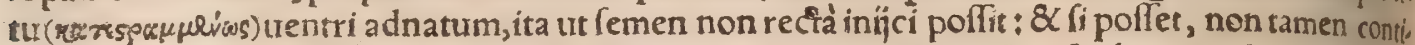
neatur. Huic affentitur Diocles, fxpe in diffectionibus talem fibi uifum fcribens mulorum urerum, ac uerifimile effe eandem fterilitatis caufam in mulieres quoç cadere. Mula quogs iam facta graulia da cf, red non quoad perficeret at ${ }_{3}$ xderet prolem, Ariftoteles. Et alibi, Mula aliquando gemelles peperit, çuod oftenti loco habendum eft. Mula fi gemellos peperit, oftentum dirum peftemíg des nũciat, Alexander ab Alexan. Eft in Annalibus noftris peperiffe fxpe,tuerum prodigñ loco habiñ, Plin. Cum Darius Babylonem obfideret, Babylonị nihili pendere obfidionem; nam confcenflspra pugnaculis tripudiare, probraç ingerere Dario atç exercitui : quorum quidam ira inquit:Quid if ic defidetis $\mathrm{Perfa}$, quin potius abfreditis, runc expugnaturi nos, curm pepererint mula. Hoc quidă Babyloniorum dicebat, credens nunquam parere mulam. A nno ac feptem menfibus obfidione con fumptis, \&c.Zopyro Megabyzi filio hoc contigit portentum, ut quadam mularum eius, qualrts mentum fubuectabant, pareret: quo oftento cómotus ille curm recordaretur eorum qux Babylonits ille dixer at, ut ipfe tanti facinoris author fieret, tanquã omnino fatalis, nafo \& auriculis feipfum muld lans, Dariũ cófilịs inftiturit de capiểda Babylone:ipfe trãsfugã fe fimulās, 8 à Dario mutulatũ quờ fuafffet ei à Babylone tanquam inexpugnabili recedere, cum poft aliquot praclara eius aduertus Perfas facinora, dux exercitus \& murorum cuftos creatus effet, urbem Dario prodidit, ut plurbus recenfet Herodotus libro 4. Etrurfur libro feptimo, Cum Xerxes, inquit, aduerfus Graciampron ficifcens cum exercitu Hellefpontum traieciffet, mula mulum edidit, ancipitia genitalia habentem, mar is $\&$ foemina, fed maris fuperiora. Pariunt aliquando mulx in terris ualde calidis, in qubus exterior calor frigiditatem afini temperat interiorem, Albertus; quam cius opinionem ipfe nomproe bo, nec quo nitatur authorem habet, nifi for te $V$ arronem, cuius iam uerba recitabo, quood fi ithiah ḩ̨ caufa eft, cur aliqux tantum \& raró,non omnes qux eodem calore ex $x$ quo fruuntur his in terrispa riunt? Romæaliquoties dicitur peperiffe mulam. Mago fané \& Dionyfius frribunt mulam \&'es quam cum conceperint, durodecimo menfe parere. Quare non, fi hic in Italia cum peperit mula fit portentum, adfentiri omnes terras. Neq enim hirundines $\&$ ciconix, qux in Italia pariunt, in omnit 4 bus terris pariunt. Non fcitis palrnas, cariotas in Syria parere, inuectas in Italiam non pofte? $\mathrm{H} x \mathrm{c}$ Varro. Quidam nó diffimulandi auchores, utM. Varro, \& ante eum Dionyfius ac Mago prodide runt, mularum foctus regionibus Africa adcò non prodigiofos haberi, ut tam familiares fincincolis partus earum, quàm fint nobis equarum, Cclumella. In terra Syria fuper Phœnicem, 8 in Cappar

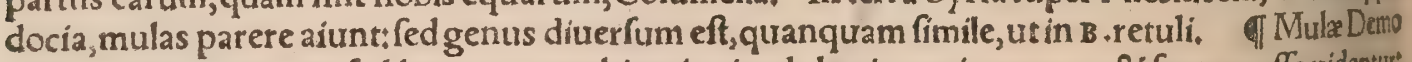
crito non naturæ opus, fed humanæe machinationis adulterinum inuentum \&' furtum effe uridentur; nam cum Medus quidam afinus uim equx inferens, fortuiro grauidam reddidiffet, homines poftea huius uiolentix difcipuli facti,in confuetudinem procreandi adduxerunt, Aeliants. A pud Vener tos Paphlagonia urbem mulorum genus primum excogitatum $\&$ inuentum eft, Scholia in Homer lliadis fecundum, Genefeos 36 . legimus, quodd A na focer Efau dum pafcit afinos patris fui in des ferto, inuenerit on iemim, id eft mulos, ut plericg interpretantur (alï uero aliter, ut in Afino friph in $h$.) Sunt qui arbitrentur onagros ab hoc primum admiffos effe ad afinas, ut uelociffimi ex his affe ni nafcerentur, qui uocantur iamim. Pleriç putant quod equarum greges ab afinis in deferto iṕe curauerit primus infcendi, ut mulorum inde noua contra naturam animalia nafcerentur.

T Afini opera fine dubio geruli mirifica, arando quoo, fed mularum maximé progeneratione, Plinius, Ex equa $\&$ afino fit mulus:contra ex equo $\&$ afina hinnus:utric enim bigeneriatq inlis titï, non fuopte genere ab radicibus, Varro $\&$ allin, ut pluribus dicam inferius, Ex afino \& equam!s lus gignitur menfe duodecimo, Plinius $\&$ Abfyrtus. If Si quem mulorum genus creare delectar, equam magni corporis, folidis offiburs, \&. forma egregia debet eligere : in qua non uelocitatem, fed robur exquirat. Aetas à quadrima ufós ad decennem huic admiffura iufta conueniet, Palladius. Ad tales partus equas neç quadrimis (trimis, Palladius, $8 \mathrm{~A}$ bfyrturs apud Conftantinum) minores, nes que decennibus maiores legunt, Plinius, In educando genere mularũ antiquiffimum eft diligenter 
gerant.) Longè omnium pulcherrimi nigri habentur; qui non incanum uentrem, fed concolorem bent. Cui pulla in ore macula fubeft, (Cui os intrinfecus nigrum fuerit $t_{j}$ ) \& lingua nigricans, is confi. milis (nigri)coloris fobolem haud dubie generabit. Qui ex candido colore in cinereum canelcune (nouró lo in pretio habiti magna ex parte reddentur foboli, Hactenus Abfyrtus in Hippiatricis capite it, Ruellio feré interprete: nos quidem nonnulla mutauimus Gręcum codicé excuf́um fecuti. Af fino admiffarios(inquír idē Abryrt.)eligemus, qui cum equis educati fint. Nōnulli pulchrè facientes agre - ftes afinos manfuefaciunt: eft ex illis propagatio prolis optima, quòd liberé pafti illi et non inclufifue rint. Mitefcir fanè maximé hoc animal, admodumós oblequitur fecundum omnia, non aliter quàm manfueti afini. nec unquam ficuti animalia cætera, ubi femel cicuratum eft, efferatur, lam uei o too. tus ab hoc animali aditi, ipfi quàm fimillimi euadunt. Porrò ad mulos procreandos admiffio fieridea bet paucis dicbus ante folftitium xftuum . Curandum eft autem ut afini infcenfuri eleganti forma fint præditi:talis fiquidem \& proles erit. Itaq̧ uenuftatis quidam ftudiofi, afinum aut equum autals terius generis admiffarium, tali amiciunt frragulo, quali fortum uolunt nafci colore tinctum, Abfyt tus: Vide in Equo C. Multiadmiffarn̈ (inquit Columella) fpecie tenus mirabiliffimam fobolem forma, uel fexu progenerăt. Nam fiue parui corporis forminas fingant, fiuc etiam fpeciofi plures ma res quàm forminas, reditum patrisfamilix minuunt. At quidam contempti ab afpectu, pretiofifimo rum feminum feraces funt, nonninquam aliqui gener ofitatem fuam natis exhibent, fed hebetesuo, luptate, rariffimè folicitantur ad uenerem: huiufcemodi mari fenfim magiftri fubadmouere debent generis eiuldem foeminam, quoniam fimilia fimilibus familiariora fecit natura. Ita enim efficitur, una eius obiectu, cum mas etiam fuperiectu eblanditus eft, uelut incenfus \& obcæcatus cupidine, fut

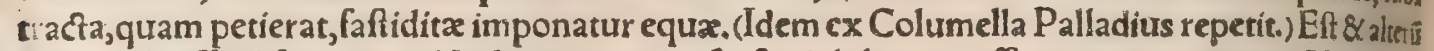
genus admiffarī furentis in libidinem, quod nifi aftu inhibeatur, affert gregi perniciem. Nam \& las pe uinculis abruptis grauidas inquietat, $\&$ cum admitritur ceruicibus dorlis mit morfus; quod ne faciat, paulifper ad molam uincius amoris feuitiam labore temperat, \& fic ue, neri modeftior admittitur. Nec tamen aliter admittendus eft etiam clementioris libidinis, quoniam multum refert naturaliter fopitum pecudis ingenium modica exercitatione concuti, at $q$ excitali,

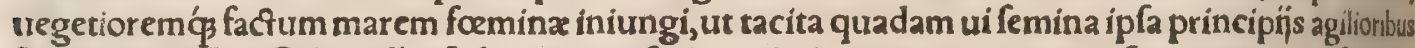
figurentur, Hac Columella. Libycorum afini maximi non equas comatas fuperueniunt, fed dunt raxat tonfas:nec enim has cum ornamento fuperbientes harum rerum periti aiunt eiufmodi mati is cos pati, Aelianus. Igitur qualem defcripfi afellum, cum eft à partu ftatim genitus, oportet marriftas tim fubtrahi, \& ignoranti equa fubïci, ea optime tenebris fallitur. Nã obf́curo loco partu eits amon to, pradictus quafi ex ea natus alitur. Cuideinde cum decem diebus infueuit equa, femper poftea deftinanti prabet ubera. Sic nutritus admiffarius equas diligere condifcit. Interdum etiam, quamm uis materno lacfe fit educatus, poteft à senero conuerfatus equis familiariter earum confuecudinem apperere, Columella. Pullum afininum à partu recentem fubriciunt equa, cuius lacte ampliores fiunt, quod id lac quàm afininum ac aliz omnia dicunt effe melius. Praterea educant eum paleis, fro no, ordeo, Varro, Afinum ab equa, 8 equum ab afina arceri aiunt, nifi in infantia eius generis quod ineantlacte haufto. Quapropter fubreptos pullos in tenebris equarť̃ uberi, afinarúmue equit leos admouent, Plinius, Afinos qui equas fuxerint, Ariftoteles hippothelas uocat. Equa cum 4" ex afino conceptum edidit, partum fequenti anno uacua nutrit.id enim utilius eft, quàm quod quile dam faciũt, ut \& foetam nihilominus admiffo equo impleant, Columella. Matrifuppofititiz quon que inferuiunt, quo equa ad minifterium lactis cibum pullo prabere poffit. Hic ita educatus abinit. cio poteft admitti.negg enim eum afpernantur propter conluetudinem equinam, Varro. Annio cula mula rectè à matre repellitur, \& amota montibus aut feris (afperis) locis pafcitur, ut ungulas duret, fitḉ poftea longis itineribus habilis, Columella $\&$ Palladius, A finarum pullos equabus iub rumare oportet. fic enim $\&$ lacte fruentur meliore, $\&$ equino generi affuefcent, diligêté. lactabun tur autem ad biennium, $A$ bfyrtus. Afinum minorem fi admiferis, $\&$ iple citius fenefcit, \& quzex coconcipiubiatur fiunt deteriora. Qui non habent eum afinum quem fuppofuerunt equa, \& afinum admiffarium habere uolunt, de afinis quen $\phi_{3}$ ampliffimum $\&$ formofiffimum quem habere poffunt, eligunt:quiç̧ Seminio natus fit bono Arcadico, ut antiqui dicebant ; ut nos experti fumus, Reatino, ubi tricenis ac quadragenis millibus H.S.admiffarij aliquot uænierunt. Quos emimus itêut equos fipulamur in emendo, ac facimus in accipiendo, ut dictum eft in equis. Hos (admiffarios) palcinus præcipué foeno atç ordeo, 8 id ante admiffuram largius facimus, ut cibo fuffundamus uires ad fora tûram: eodem tempore quo equos adducentes, ïdemç ut ineant ( per) perorigas curamus, Varto, A finum non oporter(inquit Columella)minorem quàm trimum admitti. Arçsipfum fi concedatur, uere fieri conueniet, cum $\&$ defecto uiridi pabulo, \& largo ordeo firmandus, nonnunquam eriam faliuandus erit. Nec tamen tenera ( temere, fortaffis ) foeminx committetur : nam nifi prius eama' rem cognouit, adfilientem admiffarium calcibus proturbat, 8 iniuria depulfum etiam cateris equils reddit inimicũ. Id ne fiat, degener $\&$ uulgaris afellus admouetur, qui folicitet obfequia foeminx: 111: que is tamen inire finitur. Sed, fi iam eft equa ueneris patiens, confeftim abacfo uiliore, pretiofo mari iungitur, Locus eft ad hos ufus extrucius(machinä uocant ruftici) qui duos parietes aduerfo clitulo 
fito in ftabulo uel uia loco commodo,pro arbitrio fe uolutare permittatur, fcripfi in Equo E, ex Ru

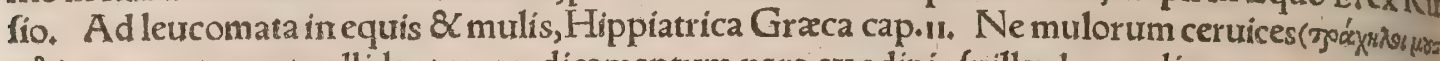
$\lambda \omega(u)$ rumpantur aut collidantur, medicamentum para ex adipis fuilla dupondio cum aceti duobus fextarịs + hoc ad tertias decoctum colatumąg illine,Pelagonius in Hippiatr.26. Ventris \& inteltino rum dolor in bubus fedatur uifu nantium (anferum natantium, Vegetius 3. 3.) \& maxime anatis, quam fi confpexerit cui inteftinum dolet, celeriter tormento liberatur, Eadem anas maiore prof, ctu mulos $\&$ equinum genus confpectu fuo fanat, Columella. Dixerunt quidam mulos quofdam rabie correptos, momordiffe dominos fuos, quiinde in maniam inciderint, Auicenna Muliarthi tis uehementior eft quàm equi๋de qua curanda lege Abfyrtum \& Hieroclem in Hippiatr,ca.2, Mu

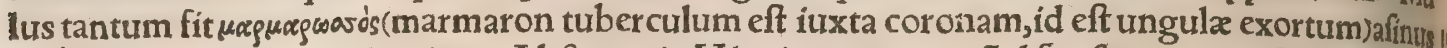
raró: equus non, fed podagricus, Abfyrtus in Hippiat, cap. 53 . Ad ficofos tumores 8 myrmecias equorum $\&$ mulorũ in quauis corporís parte, maxímé uero in cruribus $\&$ pedibus, Abfyrtus ibid, 81. Cætera exequemur in mulis, ficut in bobus $\&$ equis, ut in ipforum remedijs tradidimus, Colus lumella. IA Animalia qura frequenter coêunt, breuroris funt uita:inde fit ut muli equos exupe, rent uitrendi diuturnitate, Cælius.

D.

Mulus femper eft cicur, Arriftoteles. Equi cum fufpicantur uel metuunt aliquid, manifefum eft, fic utinfidens cauere fibi queat:afininum uerò pecus $\&$ bigenerum (ut muli) rerum confpectu confternabile nouitatiś́ ćserens in dífcrimen adfert, Abfyrtus. Muli ingenium multò illiberaliuss, minuś́p benignum homini uidetur quàm equi. đ Mula calcitratus inhibetur uini crebriore po, tu, Plinius, Et rurfus, Mulas non calcitrare cum uinum biberint, quidam fcripferunt. Vt fimis quadrupedeş́́ affuetæ uinum bibere unguibus careant, accidere quidam putant(inquit $\mathrm{C}_{2}$ lius $_{\mathrm{C}}$ cagninus lib.2.epiftolicarum quxftionum) quoniam in uino fit uis difcufforia, 8 ad emolliendum efficax. Hinc euenit ut qui plus nimio fe uino ingurgitauerint, refolutis neruis in paralyfinfacilede. labantur. Sint igitur ungues uel neruorum claufula, ut dixit Plinius : uel caro concreta, \& quafin

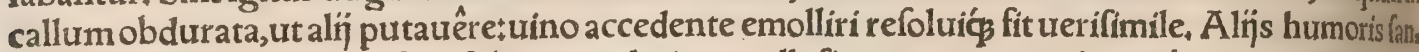
guinis, qui plurimus uino fieri folet, exundatione callofiorem contumacioremć ac retorridamillam partem quafi macerari uidetur \& emollefcere, ut aqua fruges \& legumina incoctilia percoquunturt ace to plumbum in ceruffam refoluitur $\$ \&$ ourum ita tenerefcit, ut uel per annulum toto calice inter gro pertranfeat. Ex hoc item facile colligi poteft, cur ueteres exiftimauerint uini potu effici, utmula calcitrof $x$ effe definant. Mitefcente enim ungula, \& pede quodammodo exarmato, feritas illa tollitur extunditur ćsłprafertim fi quando euenerit, ut calcibus impetentes folido illidant, plusís inde dam, ni accipiant quàm afferant: quare confcia imbecillitatis fuæ ferocire defiftunt, Hac Calcagninus, Columella in boum domitura ferocientium taurorum adhuc tergora mero refpergi iubet, quofamis liariores bubulco fiant * TS Scio mulorum gregem cum pafceretur, eóģ ueniffet lupus, ultro mith los circunfluxiffe, $\&$ ungulis credendo eum occidiffe, Varro,

E.

Mulus iumentum eft, Āriftoteles: animal uiribus in labores eximium,Plinius, Mulis fuperiori atate uehi cœperunt opulentiores: fed nunc tamen etiam non nifi importatis Germania noftra(utt Anglia)utitur,Camerarius. Et rurfus, Veteres Graciæ \& Italiæ populi non equos ad plaufia \&

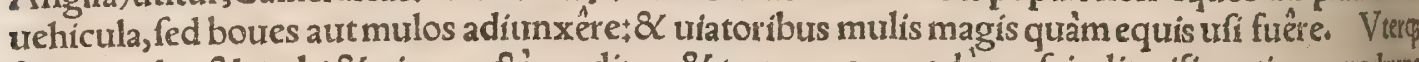
fexus(mulus $8 \mathrm{~L}$ mula) $8 \mathrm{C}$ uiam rectè graditur, \& terr am commodè pró́cindit:nifi pretium quadrupe dis rationem ruftici oneret, aut campus graui gleba robora boum depofcat, Columella. Succofolio rum cucurbitæ fi quis mularum aut equorum pilos intin xerit aftate media, non paruorei miractio mufcarum moleftia carent+ita mihi hoc perfape utile fuit, Cardanus,' Annicula mula à matre amo: ta, montibus aut feris locis pafcitur, ut ungulas duret, fitć poftea longis itineribus habilisłnam ditel lis aptior mulus, mula uero agilior, Idem. TSi muli ungula (finiftra, Belberus in libro de fenfibus) domus fuffiatur, fugantur mures, Rafis \& Albertus.

G.

Puluere, in quo fe mula uolutaurerit, corpori infperfum mitigare ardores amoris quidam fcriple, runt, Plinius. Veneno infectus in neceffitate debet poni in uentre mulx uel cameli ftatim occifi: quoniam calor iftorum refoluit uenenum, \& roborat fpiritus ac omnia membra, Ponzettus: memis nit $\&$ Cardanus in opere de fubtilitate. Mulorum pellis ac fimilium cinis locis igne aduftis apponi tur:Et ulcera calefacit, quum non funt apoftemata:utilis eft etiam attritis iniuria calceorum pedibus, $\&$ coxis, itemćs fiftulis, Auicenna, ut quidam citant. Plura de pelle mulæe, uide infra inter remedia ex tefticulis, \& ex fordibus aurium inter excrementa. Si quis de medulla mula ad pondus trium aureorum fumplerit, ftupidus efficietur, $R$ afis $\&$ Albertus. T Auriculæ muli (aurium fordes potius, ut infra diceturr) \& burdonis tefticuli fi ferantur à muliere, non concipiet, A efculapius. De for: dibus aurium $\&$ oris fpuma, dicemus inter excrementa. II Mulæc cor ficcum $\&$ uino afperfum, datur bibere poft purgationem tricefimariam, ut ne concipiat mulier, Sextus $:$ A ggregator non cor legit, fed iecur: Vide in tefticulis. Mula quoniam natura fterilis eft, curiofis \& fuperftitiofis hominis bus occafionem dedit, ut diuerfa ex diuer fis eius partibus me dicamenta tum intra corpus fumenda, 


\section{DeMulo. G.H. Lib. I. 801}

tum applicanda for is, ad inducendam fferilitatem impediendumó conceptum excogitarent : De quorum nonnullis in Lepore etiam dixi. Eadem perfuaffone herbam quoqg hemionó dictam, quiòd ferilis fit, nec flores nec femen gerens, inter atocia numerant. बा Muli iecur, uide in tefticulis in. fra, 8 in ungulis, Topuli alba cortex cum muli renibus potus, fterilitatem facere creditur, Dio forides, ur in Lepore inter remedia ex coagulo eius recitaui. Scolopendria (afplenos Diolcoridis, hamionos Theophraftí)ut quidam tradiderunt,adalligata mulieri, uel fola, uel cum fplene mulç idćg in die qui nocfen illunem habeat, ne concipiat efficit, Serapio \& Auicenna, ut Aggregator citat, - Si duo refticuli muli (duo tefticuli gatti conftricti in parte cor n̈ muli, $R$ afis) in pelle eiufdem corif conftringantur, \& fuper mulierẽ fufpendantur, non concipiet quandiu ei adalligatí fuerint, Alber. - tus. Muftela tefticulus finifter in pelle mula ligatus, \& potus, atocion eft, Vel tefticulos cius abfcin de decrefcente Luna, 8 tiuam dimitte, $\&$ da mulieri in corio mula, Kiranides, Burdonis teftict lum fuprafterilem arborem combuftum $\&$ extinctum de lotio fpadonis, illigato pellimula, \& pof menftrua brachio fufpendas, conceptum impedies, Sextus \$Sed aliter hunc locum citat Aggregator, his uerbis: Tamarifcí(quæarbor fterilis eff)carbones extincti in urina cameli, in pellicula mula bra dhio alligentur mulieris ne concipiat. Sed priori lectioni aftipulantur barbari quidam recentiores, Aefculapí (hunc enim ferè pro Sexto citant) uerba hæc adferentes, Auricula mula \& burdonis tefti culi fi geftentur à muliere, non concipiet. Tefticulus muli combuftus brachio mulieris pro atocio alligetur:Quòd fi uirgo ex eo biberit poft primam purgationem, nunquam cócipiet: Vel iecur eitrs fimiliter cum uino biberit, Sextus apud Aggregatorem. Thatrix mula fi decoquatur cum car. , he afinina aut alia, 8 inde comederit mulier ignorans, non concipiet unquam, Rafis. Si dentur oc= cultè mulieri edendx carnes quibus cum coctum fuerit aliquid de matrice mulx, uel de ipfa matrice cocta, non concipier, Kiranides. Lampyris uermiculus in matrice mulæ alligatus mulieri, frerilita tem facit, ldem. ब Vngularum muli uel mula cinis ex oleo myrtino alopecias replet, Plinitus Vngularum muli uel mula exuffarum cinis \& oleum myrtinum, cum aceto $\& \mathrm{cum}$ pice liquida mi= xta $\&$ imporita, etiam fluentes capillos continenr, Marcellus. Sextus pro ungulis muli ad idem re. medium burdonis iecur ponit, his uerbis: Burdonis iecur combuftum cum oleo myrtino mixtum, $\&$ illinitum capiti, capillos fuentes continet $\&$ facit crefcere. Mula ungularum cinis medetur ca teris uerendorum uritis, (prater formicationes $\&$ uerrucas, arietis pulmonis inaffati fanie curandas) Plinitus. Vngulx mulinx exuftxcinis falubriter infpergitur uitḩs ueretrorum, Marcellus. Vn. o guis mula geitatus à rnulier e prohibet conceptum, $R$ alis,

De mula auricula fordes alligatze in pellicula ceruina, \& brachio fufpenfa poft purgationem mulieris, efficit ut non có ipiat. Quxdam lana alba illigant: quxdam ex aqua bibunt, Sextus. Si co romula fordes aurium(cerumen uocant barbari)incluferis, \& appenderis mulieri (uel ocrulie dede ris, Kiranidestin cibo nimirum uel potu)nunquam concipiet, $R$ a fis, Caftoreum cum fordibus auri um mula fterilitatem facit, Kiranides, Paoniæ femine aperto(forte, operto) $\mathrm{cum}$ fordibus aurium mulat circumligetur ne concipiat mulier, Idem. If Stercus mulinum cum oxymelle lienofis potui datum, dolores efficaciter tollit, Marcellus. Si mulieri fuxus oboriatur(ex utero, )ftercus muli com bufum, tufumós ac cribratum, uino dilutum bibat, Hippocrates lib. 2. de nat. muliebri. TClatros ped m ranat urina muli mulaúe cum luto fuo illita, Plinius. Mulier fi bibat affam foetidam ma= o gnirudine fabx infufam in urina mula, non concipiet, Rafis. Medicamentum ex urina muli poda gricis utile, deferibitur apud A eginetam libro 7. his uerbis: Vrinæe muli fextarï quatuor, argêti fptra ma libra dux, olei ueteris myftrum, trita diu omnia ut frigmenti fiffitudo fiat, incoquito donec di gitos non inquinent. TSi mulier fudorem mula exceptum lana xylina propeffo fubdat, plané fte rilefcet, $R$ afis, If Lichenem mula potũ in oxymelite cyathis tribus, comitialibus morbis utilem tradunt, Plinius. Muli impetigines in utroç crure fuper genua nafcuntur, \& ueluti cutis aridx modo inharent: has incende, \& ftranguriofum diuaricatum defuper pone, ita ut fuffumigationem illam expanfis ueftibus tegat, ne qua odor aut fumas emanet, efficaciffimé incommodi eius uritio ca. rebit, Marcellus. बA A fufpiriofos remedium falutare: Spumam de cre mula collige, $8 x$ in calim cem mitte, atç ex aqua calida fiue uiro feu focminx qua hanc moleftiam patitur, continuo da biben dam, homo fratim fa nabitur, fed mula morietur, Marcellus.

TIn parte quam mula momordit (inquit Ponzettus) nafcuntur aliquando puffula plenx hut: more rubente uel pallido. Hunc morfum al qui uenenatum effe purarunt: $\&$ fané fequütur eum ac* cidentia fape noxia,eaćs deteriora ex morfu fominx, qua faliuam habet obnoxiam putredini, qua amplius etiam per iram animalis inflammata, non mirum fi hominis morfihumores $\&$ fanguris alte tentur. Mulus uerô etfi maiori impetu mordere poffit, minore tamẽ periculo morfum infligit, quod non 2 que putredini aptum in fe humorem habeat, Accidit autem aliquando ut morfi urina retinea tur, cum a quofus humor uidelicet omnis feré in fudorem agitur. Aliquando $\&$ uiferum contortio (Ponzetti funt urerba) fequitur, Curandi funt fimiliter ut à cato mor fi, \& ulcus decocto nepetx cir. cunquaç fourendum.

a. Video authores quofdam mulam pro utroç fexu mulari, $\&$ fimiliter mulum aliquando ufur pare: ut fi dicas mulum ex afino $\&$ equua procreari, urel mulā fimiliter, Plinius in remedins aliquioties 
diftinguit, ut cum fcribit, ungularum muli uel mulx cinerem ex oleo myrtino alopecias replete.

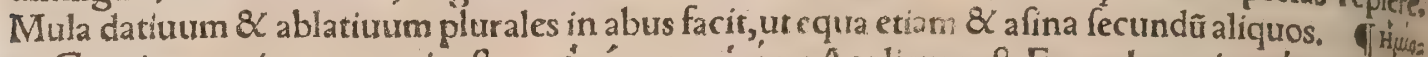

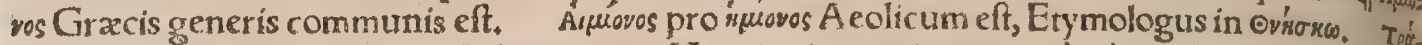

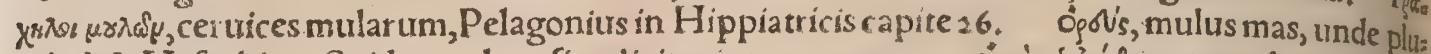
rale öjess, Hefychius. Suidas mulum fimpliciter interpretarur. ogrès, óčsid cesos ( quod nomen nuf,

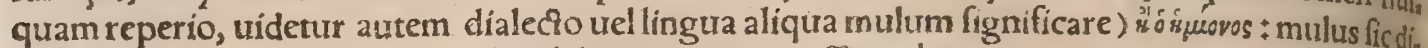
cfus, quod ży ôsery, id eft in montibus laborare magis poltit quàm catcra iumenta, ( ut dicetur etiam

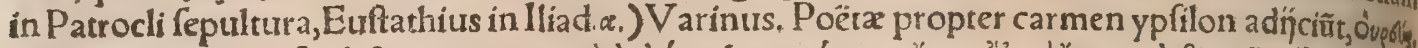

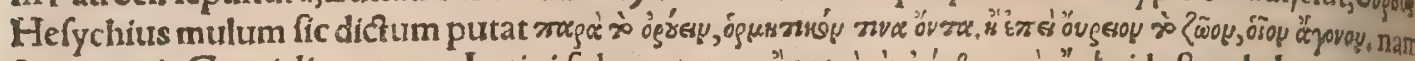

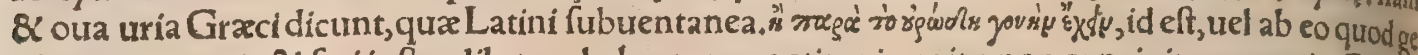
nituram aqueam \& feri inftar dilutam habeat, quare etiam in coitu non concipit neç parit, Etymo, logus. Oua generationi inepta řere dicilegimus, quafi flatuofa. nam uron dicunt uentum quo as

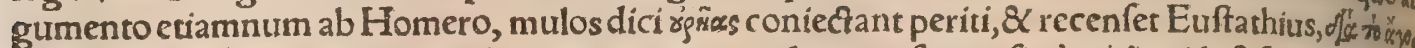
vov, id eft ob infitam non gignendi proprietatem, quod eorum femen fit a'vęuxiẽo, id eft fpiritofum, $\alpha$

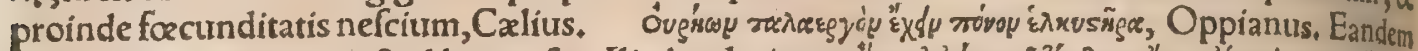

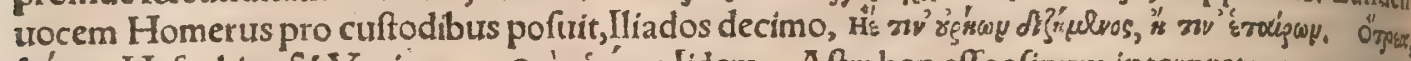

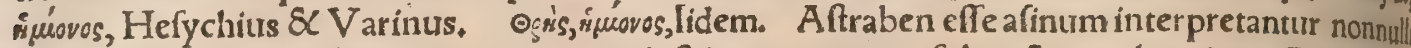
aut mulam. Quidam hypozygion omne, id eft iumentum quo fubuectentur homines. Dicitur $\alpha_{2}$ ftrabe in ephippös lignum, quod manu continent fedentes. Sunt qui doffuaríum mulum aftraben nuncupent, (aftrabelaten uerò aurigam:)aut ipfum notophorum, id eft dorfo ferens acgerulum ills 8

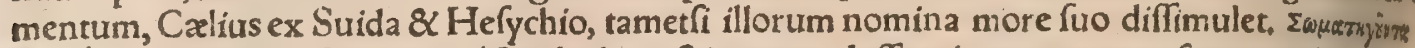
¿́so?'uy ego quidem alibi nufquam legere memini. fic autem uocantur, quod corpore fuo uebant impofitum

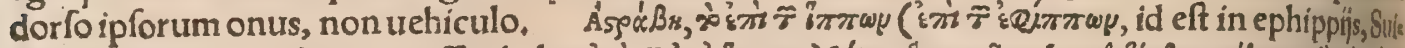

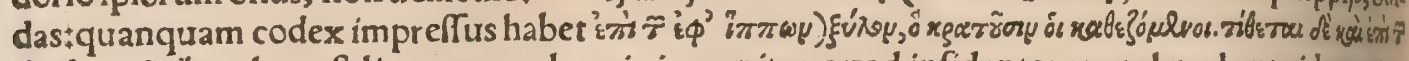

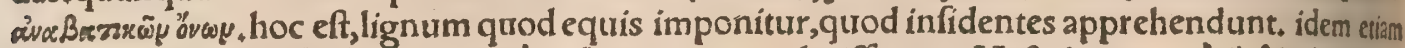

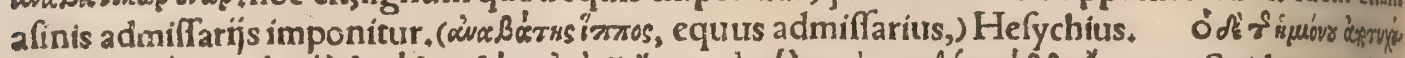

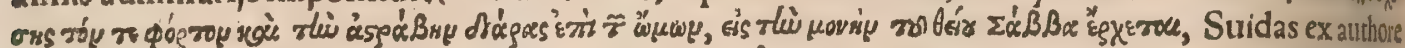
innominato:in quibus uerbis ảşó Bry clitellas rectè trerter is, uide in Afino H.e. Demofthenes in

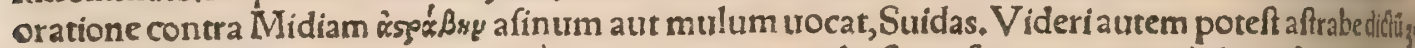

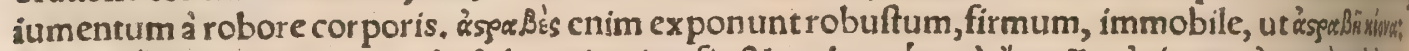

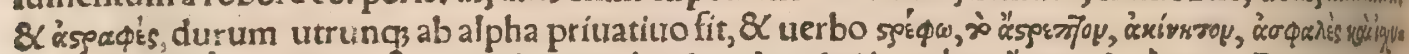

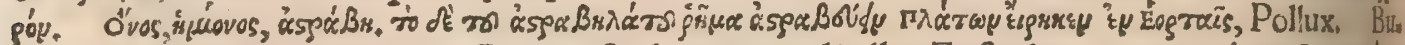

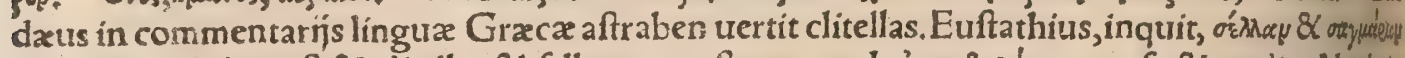

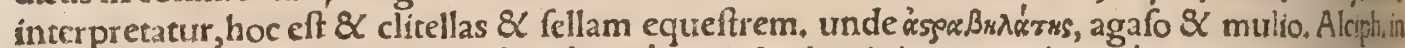

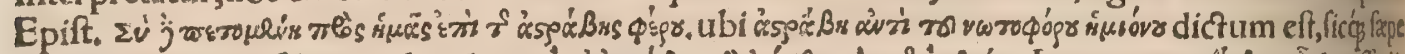

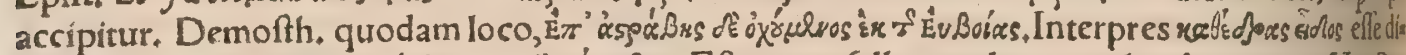

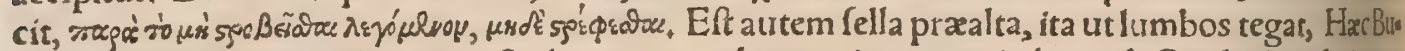
dxus, Eft \& uehiculigenus aftrabe, (quo utebantur in certaminibus) ab Oxylo A etclo inuens fum, ut harma, id eft quadrigæ ab Erichthonio Athenienfi, fynoris (id elt bigx equorum) à Caflore,

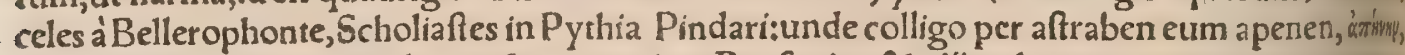
accipere, hoc eft, bigas mulis íunctas. quoniam Paufanias \& al" in horum certaminum enumera

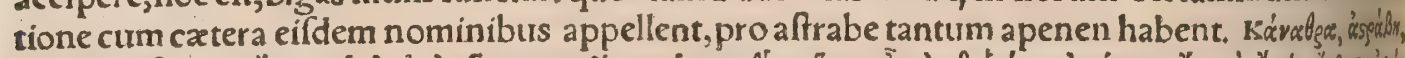

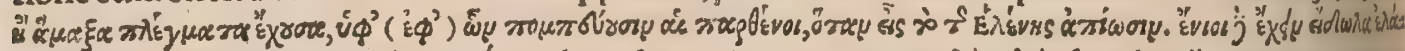

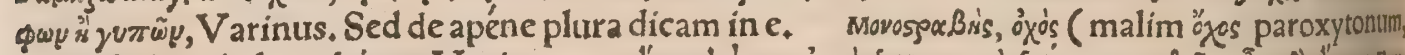

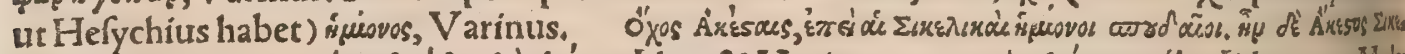

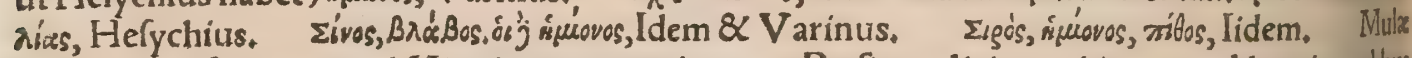
quídem fiue feracix, apud Hippiatros recentiores, ut Rufium, dicitur uitium quoddam in pedibus cquorum:qui cum fordidi humectióp non curantur, frigore accedente, intumefcunt, \&c. Videin

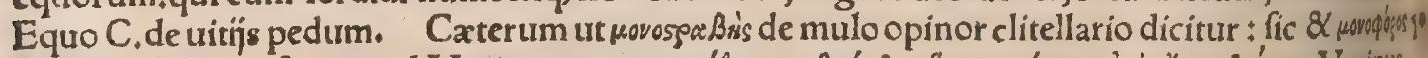

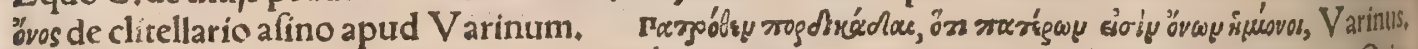

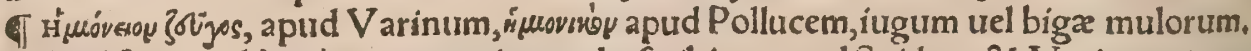

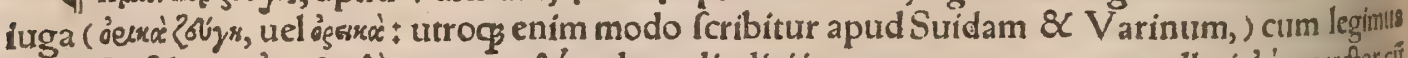

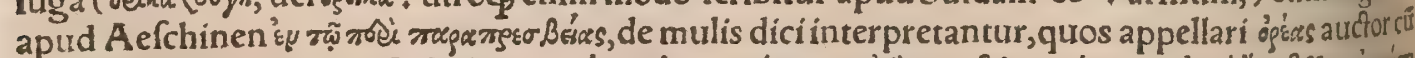

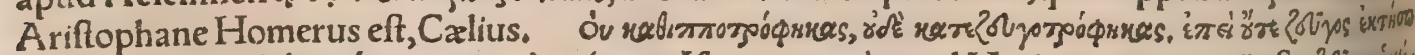

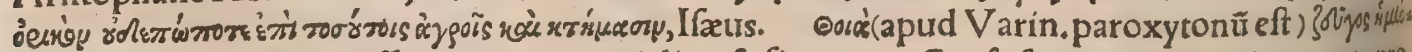
vov, Hefychius. TDiffimilis patri,matri diuerfa figura, Confufi generis, generi non apta pro pago, Ex alijs nafcor, nec quifquam nafcitur ex me, Aenigma de mulo in Rhetoricis Cas merarï.

Epitheta. Mulus clitellarius, clitellis aptus, apud Textorem. @Mula, Iutulenta, biformis,

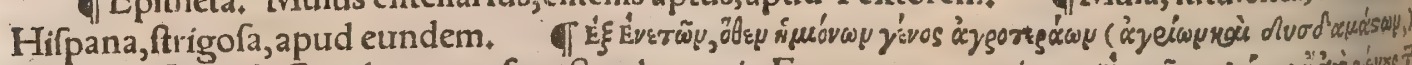

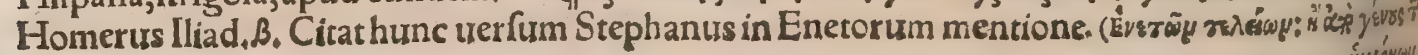




\section{DeMulo. C. Lib. I. 803}

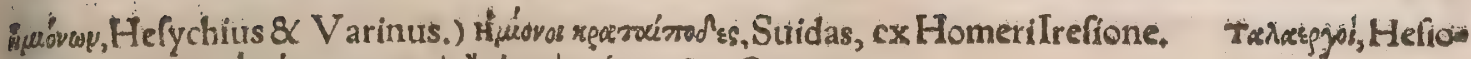

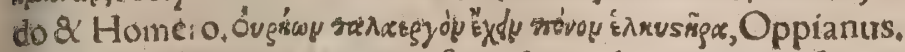

Thuli Marian druntur furculæ quibus religatas farcinas uiatores geftant, (cin trff:) à Maric Intrentore dicix, qua de re Frontini uerba pofui in Afino H. e. \& Gracas nomenclaturas adieci. Muli Mariani dici folent à C.Marị inftituto, cuitus milites in furca interpofita tabella traricofius one rafua portare adfueuerant, Feltus: Erafmus fic legit, Muli Mariani dicti funt uaricofi milites, qui in furca fua onera po tare confueucrunt. Et alibi, Aerumnulas Plautus refert furcillas, quibus reli. gatas farcinas uiatores gerebant; quarum ufum quia C.Marius retulit, muli Mariani poltea appella bantur : Itaç3 arumna labores onerofos fignificant: fiue à Graxcolermone deducuntur, nam äe 10 Gracè, tollere Latinè dicirur. Nouo genere prouerbin in ufir uenit, ut quit tam ad imperandum quàm parendum iuxtà paratus foret, quiç̧ non fegniter mandata exequitur, mulus Marianus dice. retur. nang, Marius quxcunqs milir bus mandaut onera, ipfe inter infimos obiuit imprimis: quam* uis furculas, qubus farcinas uiatores gerunt, quas Marius primus commentus fuit, mulos Maria nos aliqui dictos uelint, Alexander ab Alex. Plutarchus in uita Marił originem adagij bifariam refert: Cum Marius imperator milites curfu uarn̆ṣ́́ ac longis itineribus geftandisḉ̧ oneribus exer.

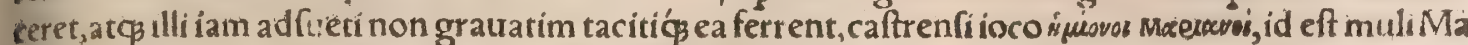
riani dicti funt. Hinc translatum eft in quofuis qui facile parerent imperatis. Sunt qui dituerfam ada gî originem referant: Quum enim Scipio Numantiam obfidens, ftatuiffet infpicer e non arma modo militum, uerum etiam equos, mulos, \& currus, Marium produ xiffe equum pulcherrimé ab ipfo nus - tritum, praterea mulum habitud ne corporis, nanfuerudine ac robore longè cateris ancecellentem. Itaç quum imperator Marï iumentis delectaretur, acfubinde horum faceret mentionem, tandem factum eft, ut ioc ofa laude, qui in officio fe praftaret affiduum, patientem ac induftriū, mulus $\mathrm{Ma}=$ rianusdicererur. Hominem fpurium $\&$ non legitimo matrimonio natum Itali uulgo mulum no minanr, Alunnus. Seneca in ludicro libello in Claudium Cararem, mulos (ego nô mulos, fed mu liones reperic, ut in e dicam ) perpetuarios nominat. Feftiuius erit, inquir Eralmus, fi detorquearur

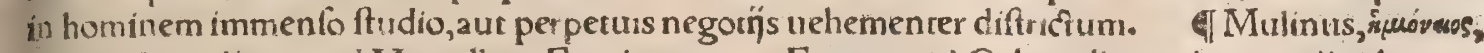
ut ungula mulina apud Marcellum Empirıcum. Equa aptid Columellam tripartito diuiduntur, eft enim(inquit)generofa materies, qua circo facriş̧́ certaminibus equos prabet: eft mularis, qua pret o fcerus fui rom paratur generofo eft $\&$ uulgaris, qua mediocres fominas maresćs progenerat. - Materiem mularem uocar,iplam equam matrem fiue matricem, ex qua muligenerantui:. Strabo fis bro, de Venetis ficribens, simevind as innos uocat equas illas ex quibus afini admiffarín mulos pros creant, quafi dicas mulares equas. Mulio, qui mulos agit:uide infra in e. Mulomedicina, ars eft teterinaria, quæ non mulis tantum fed alïs quoq̨ iumentis medetur, ut equis, unde Græci hippia trtcam uocanc, huius artis profeffores mulomedici, ueterinarï, \& hippiatri nominantur, uulgo mare

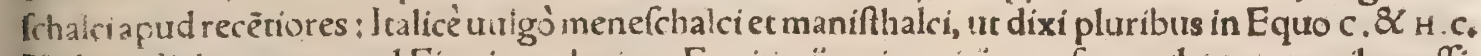
Mulomedici nomen apud Firmicum legitur. Equitiarĭ qui equitins prafunt uel curant,quibus affi. nes uel mulomedici habentur, Catius.

Protogenes $R$ hodius pinxit A thenis nobilem Paralum $8 \times$ Hemionida, quam quidam Naufica

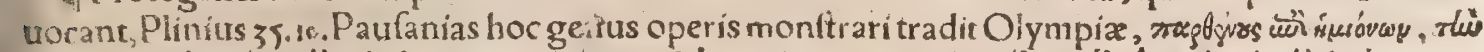
o w'v" है

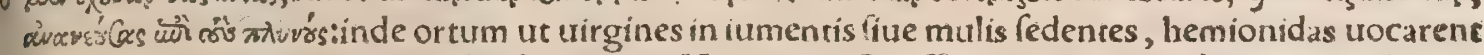
artifices, Hermolaus. A tqui Nauficaa apud Homerum Odyffex 3 . non mulis, fed apenæuehiculo quodà binis mulis trahitur, infidet.

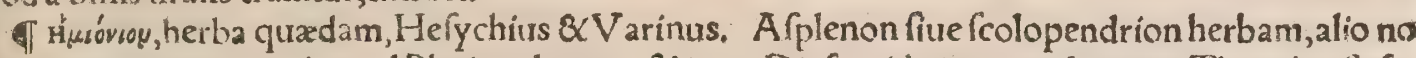
mine hemionion nocari, apud Plinium legitur, 8 inter Diofcoridis nomenclaturas. Theophralti fanè hemionos, non a lia quàm afplenos Diofcoridis eft : diuerfa uero ab hemioniti D ofcoridis, quam Plinius etiam teuerion' diuerfum à Diofioridis teucrio) 82 hemionion appellauir. De utraq̧a copiofé dixi in Boue capire 3.ubi de morbis boum traçaui. Viriç nomen factum uidetur à mulis propter fte rilitatem:cum fimiliter caule, flore $\&$ femine careant: 8 afplenos infuper fterilitarem mulieribus fa - cere cum muli liene adalligata à Diofcoride feribatur suide in Lepore capite feptimo, ubi de atocïs egi. Theophraftus tamen 9.19, hemionon fic uocari fcribit, quòd mulilibenter ea uefcantur. Nos dia herba coriariorum officinis nora, ea mular is dıcitur, alijsós nominibus mamćs aduerfus fcorpiones effe potam in trino aur pofca reperio, Plinius: Nec alibi ufquam uel iṕe uel alus quifquam hoc nomine ullius herbx meminit:ego tametfi nihil habeo certi, coniecturam ta. men meam non cęlabo ftudiofos. Nodia igitur mihi uidecur quax centinodia hodie à multis uocatur, Gracis polygonon; cum \& nomen à nodis, quibus referta eft, impofitum, \& remedia conueniant:nã polygonon, Diofcoride tefte, ad ulcera maligna facit, nempe geniralium, \& herpetes ac eryfipelata, ut nodia ad nomas, id eft ulcera depafcentia.Bibitur etiam polygonon ad uenenatorum morfus cum uino, Diofcoridi:\& Plınıo proferpinaca (quam polygonocandem effe eruditi confentiunt)eximì ad - terfus fcorpiones remedij eft. Nec refert quòd Plinius eodem capite proferpinacam $\&$ polygonum quafi diuerfas herbas demöftrat, $\&$ nodiã quoç priuatin cömemor at: multa enim huruf́modi a pud Plinium, qux nominibus tantum,differunt, ceu re ipfa diuerfa recenfentur, Ceterum cur no: 
dia mularis cognominetur, non facile dixerim, nifi eius paftu forte muli delectantur. Coriarịs quí. dem in ufu fuiffe etiam polygonon poteft propter uim aftringendicoria, ut $\&$ rhus byrfodepficos, 8 noftris cortex abietis aut picea, alibi è quercu, ut audio. Omphacitis galla, eft cauum illude quo glans querna enafcitur, quo coriarij utuntur, Aegineta lib. 3 . cap. de dyfenteria. Mandragoramma gi hemionon cognominarunt, ut in nomenclaturis eius apud Diofcoridem reperitur.

TH Huóvsoy, auis quadam, Hefychius $\&$ Varin. Muliones é culicum genere non amplius quàm uno die uiuunt,Plinius.

Tb. Quid ad rem pertinent mulx faginatæ unius omnes coloris? Seneca epiftola 88. nowir, iuba equorum \& mulorum. Nanq hic mundæ nitet ungula mulæ, Iutuenalis Satyra 7: Vngu, las tantum mularum repertas, neç aliam ullam materia $m$ qua non perroderetur à ueneno ftygis $2=$ qux, cum id dandum Alexandro Magno Antipater nitteret, memoria dignum eft, magna Arifote lis infamia excogitatum, Plinius, Idem legimus apud Arrianum libro octauo. Alíj non muli fed afi ni, alí equi ungulam fuiffe fcribunt, qua Stygis aqua ad occidendum Alexandrum allata fit: Vide in A fino $\mathrm{B} .8 \mathrm{in}$ Equo $\mathrm{H}_{\text {. b. }}$

Tc. Odorandi fenfu mulos pracellere aiunt, atç eius beneficio derelicqos alicubi uel odore foloredire in femitam: hinc etiam fieri ut facilius tabidam uím aêris concipiant $\&$ pefte infician. tur; ut canes quo eodem fenfu præftantes:quamobrem Homerus hæc animalıa primum peftem fenfiffe ingruentem in lliade fribit, Calius. Scholiaftes Homeri canes quidem primum periffle f́cri bit,quòd caprtibus fubinde ad terram inclinatis odorem trahant $\&$ inueftigent; halitum autem cor ruptum, qui peftis caufa fit, ex terra oriri.Mulos uero, quòd ex diuerfis fpecie parentibus prognatis fint + bigenera enim omnia facilius interire. Quæ ratio mihi non admodum probatur + nam uiuaciffi

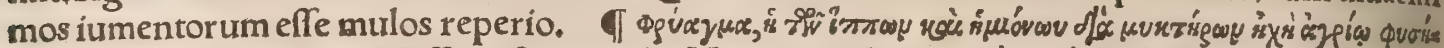

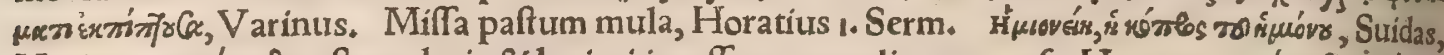

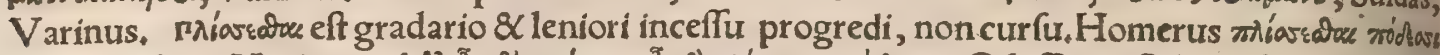

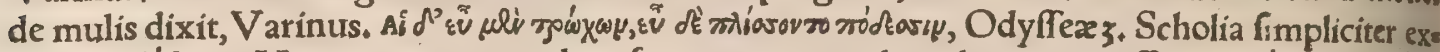

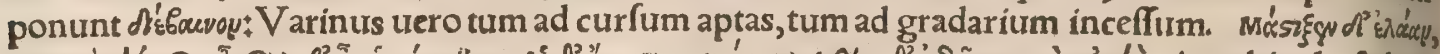

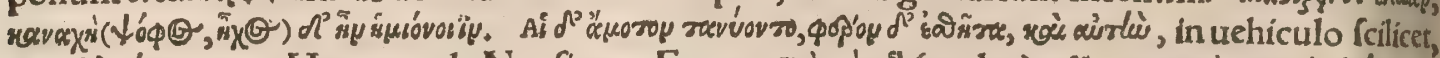

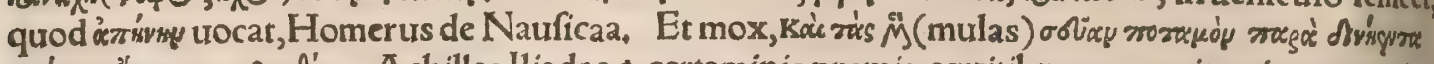

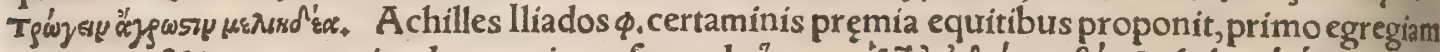

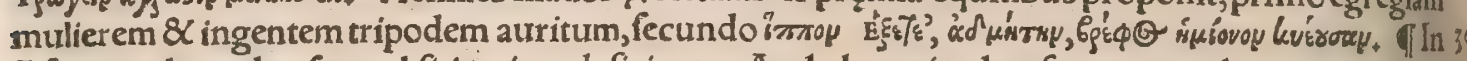
Africa mulos uel caros, uel fitl animo deficientes, Archelaus ait, plerofóp mortuos humi iacere proz iectos, fapéćs magnam ferpentium uim influere ad eorum cadauera depafcenda, Aelianus.

ศd. Mulus quidam(inquir Plutarchus in libro Vtra animantium, \&c.) eorum de numero, qui bus aduehendi falis negotium dabatur, traíciens flumen lapfus eft non fponte: fale uero liquefacto exhauftóç furgens expeditior iam, fenfit notauitó̧ caufam:poftea quoties flumen tranfiret, ex in. duftria fubmifit merfitóg uafa, defidens leniter ac utrunq in latus quantum id fieri poffet nutans. Hac ubi Thales accepit,pro fale, lana fpongịsç̧ compleri uafa, clitellas imponi $\&$ agi mulum rư fus iuffit;ille cum de more fe mergens, onus aqua fubeunte uehementer grauaffet, par um common dum fibi hunc dolum ratus, ita deinceps caute fcienter contingerent onus aqua. Eandem hiftoriam A elianus recenfet, Ad ociogefimum annum uixit 4 mulus quidam Athenis, qui cum templưm (Minerux à Pericle in Acropoli) ædificaretur quamuis dimiffus iam munere per fenectam, commeans tamen ac obiens iumenta exhortabatur ad opus: quamobrem decreto à nemine eum arceri à frumentorum aceruís fancitum eft, Ariftoteles. Mulum 80.annis uixiffe, Athenienfium monumentis apparet:eo gauifi cum templum in arce facerêt, quod dereliçus fenecta, cadentia iumenta comitatu nifứç exhortaretur, decretum fecếre, quo caureretur

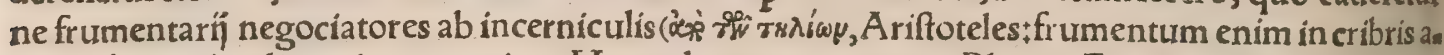
ceruisćs uendendi gratia proponitur, Hermolaus)eum arcerent,Plinius. Eandem ab Ariftotele mu

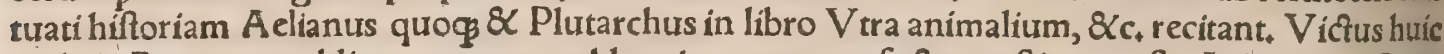
mulo in Prytaneo publicus, tanquam athletæ iam ætate confecto conftitucus eft, Aelianus, Cæte:

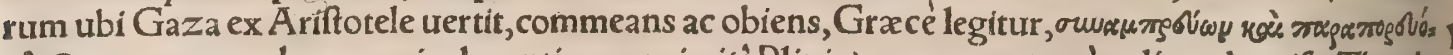
$\mu 2 u$, , quorum uerborum uis elegantius exprimi(à Plinio)non poterat quàm dicendo, nifi. Theodo rus A riftotelis interpres hoc affequi inon potuit. Vide in Equo H.e.ubi de partibus currus . Plutar.

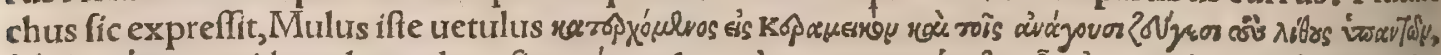

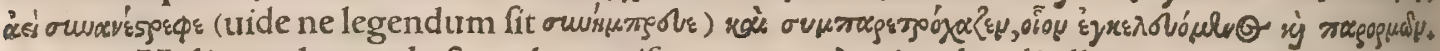

बe. Mulio, mulorum ductor, (ut equifo equorum,)qui mulos clitellarios, uel ad uehículum iunctos ducit. Mulius apud Calepinum legitur pro mulione, ex Horatï libro 2.Serm, Audit,cum magno blater as clamore, fur iş̧́, Mulıus. Miluius hic legit Acron, qui parafitus fuit. Mulionemes uitantem fuper ipfum cor pus carpentum agere pracepit, Plinius de uiris ill.7. Cocco mulio fulget Incitatus, Martialis 10.76. A pud Suetonium Incitatus equi nomen eft. Nec pigri rota caffa mulio, nis, Martialis lib.9. Nam mihi commota iamdudum mulio uirga Innuit, I luenalis Sat,3. Voces 6 Amphionem tragoedum:iubeas Amphionis agere partes infantiorem quàm meus eft mulio, Varro in Afino ad lyram apud Nonium. Quartarios(inquit Feftus) appellabant antiqui muliones mer. 


\section{DeQuadrupedibus.}

rum, hámaxa boum eft, Varinus, Sed uideo hac uocabula confundi, Homerus Odyfex fexto bigam

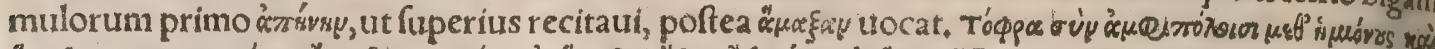

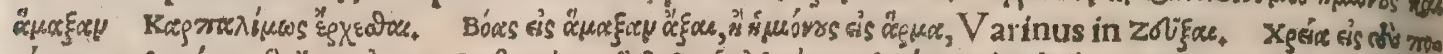

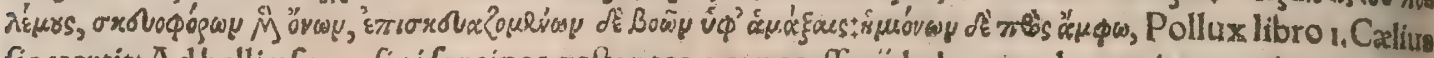
fic uertit: A d belli ufum afini farcinas geftantes, perneceffarij habentur, boues item qui currus tran hant,muli utrung praftant. इuvweidlo ?vyriv, propriè de mulis dicitur, uel equis bijugis, Varinus: ogrvis enim mulus eft, Hefychius. fed alia uridetur hurius compofitionis ratio. Paufanias quidem apen

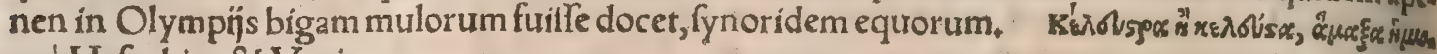
vuxs, Hefychius $\&$ Varinus.

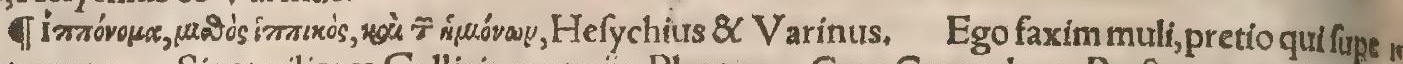
rant equos, Sient uiliores Gallicis canterins, Plautus. Cum Cappadoces Perfis quotannis pen. dant, practer argentum, mille $\&$ quingentos equos, mulorum duo millia, ouium quinquaginta mils lia, duplum fere horum Medi pendebant,Strabo. Pramia uincentibus in funere Patrocl A Achils

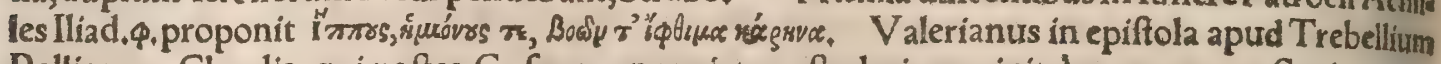
Pollionem Claudio, qui poltea Cæfar pronunciatus eft, dari pracipit à procuratore Syriæ mula annuas nourem, $\&$ mulionem, quem refundat, unum.

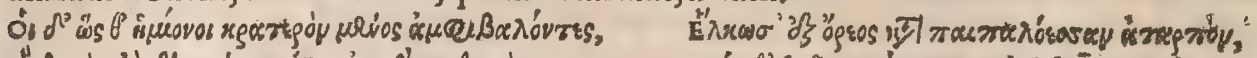

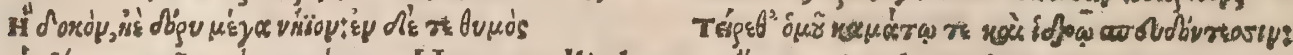

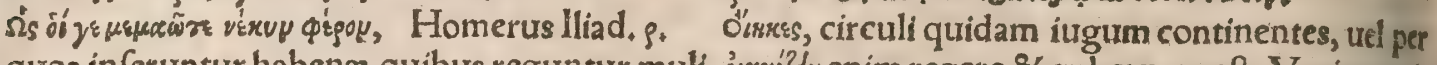

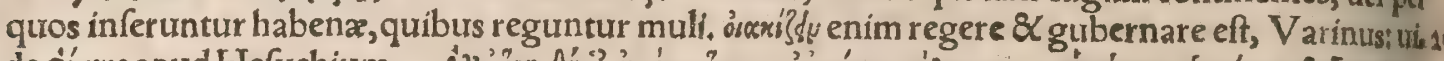

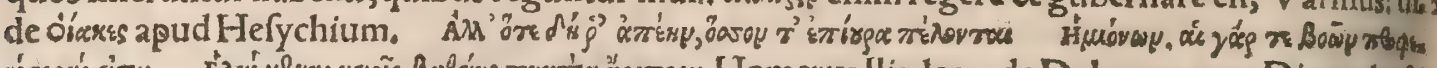

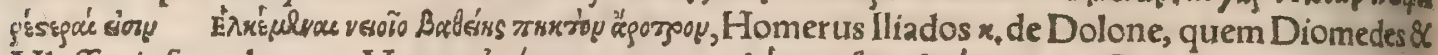

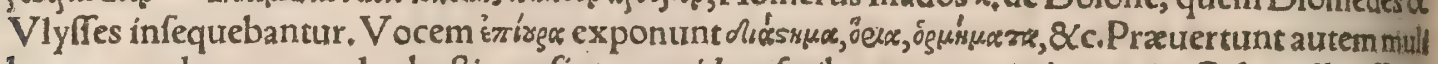
boues arando, non quod robuftiores fint, ut quidam fcribunt, (contrarium enim Columella afferit, ut fupra in E, recitaui:) (ed quod celeriores, fi pariter emittantur. $\mid$ Cogunt concipere inuitas fera ex cauda mulæ, fi iunctis euellantur inter fe colligatx in coitu, Plinius. TSi oues utantur fabulo in quo mulx aut equi aut afini fteterunt, facile incidunt fcabiem, Columella,

Th. Pifcibus inuentis $\&$ forta compare mula, Iuuenalis Sat, 13. Non aliter ridetur A tlas tum compare gibbo, Martialis Epigr. lib. 6. Politianus in Mifcellaneis 23, non gibbo fed mulo legit, quod in plerifg uetuftis codicibus lic inuenerit. Atlantem autem(inquit) de Iutuenal is uerbis, nanũ queth dã pumilúmue fưffe, temporibus illis haud ignoratum, colligimus, per antiphrafin fcilicet, fic enim inquit, Nanum cuiufdam Atlanta uocamus. Sed 82 muli pumili tum in pretio funt inç deliç̄s habi. ti. Erat autem proculdubio ridiculum hominem nanum, mulo confimiliter nano \& compare fibi uehi. Scytharum equi in pralio aduerfus Darium,cum afinos prius rudentes nunquam audiuif fent $\&$ mulorum fpeciem tum primum uiderent, in fugam conuerfi funt, Herodotus lib.4. Croelo Delphis quarenti nunquid diuturnum foret imperium fibi, Pythia in hac uerba refpondit: Regis apud Medos mulo iam fede potito, Tunc ad fcrupofum fugere Hermum ftrenue Lyde, Nec perftare:nec ignau um tunc re effe pudendum. His ex uerfibus, cum allati effent, multó magis quä ex cateris uoluptatem Crœfus accepit, fperans fore ut nunquã apud Medos mulus pro uiro regnas. ret, Herodotus libro I. Pififtratus Hippocratis filius tyrannidem Athenis affectans, feipfum ac mu

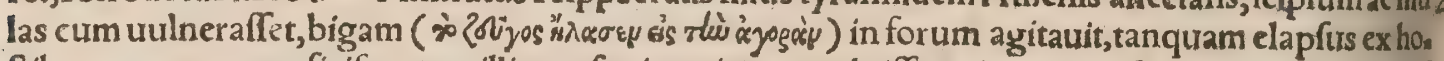
ftibus, quem rus proficifcentem illi prorfus interimere uoluiffent, ita $\varnothing \beta$ populum orauit, ut aliquid cuftodia circa fe habere permitteret, \&c. Herodotus ibidem. TMulus (pro) uehiculo luna ha. betur, quod tam ea fterilis fit quàm mulus:uel quod ut mulus non fuo genere, fed equis creetur: fic ea Solis non furo fulgore luceat, Feftus. In bafi throni Iouis Olympij tum alia deor um imagines expreff $x$ funt, tum Luna equo, ut mihi uidetur, inuecta: alí tamen mulo eam uehi aiunt, non equo: \& ridiculam ( $3 u \dot{s} b$ ) ) quandam fabulam de mulo addunt, Paufanias Eliacorum I. Mulis, equis,afis nis feria nullæ, nifi fi ín familia funt, Cato. In Confualibus ceffant ab operibus equi 8 muli, redi: mitifloribus capita, Dionyfius Halicarn. Mulis celebrantur ludi in Circo maximo Confuales, quiz id genus quadrupedum primum putatur coeptum curru uehiculoógadiungi,Feftus، In Confuar jo libus mulus immolabatur, equi \& afini feriabantur, Alexander ab Alex, fine authore.

đ Mulus quidam Lydus cum imaginem fuam in fluuio confpexiffet, formam 8 magnitudinem corporis fui admiratus, ceruice erecta equi inftar in curfum fe dedit: deinde afini filium fe recorda tus, mox curfum fiftit, $\&$ hinnitum animośç deponit, Aefopus in conuiuio feptem fapientum Plutarchi.

\section{P ROVER BIA.}

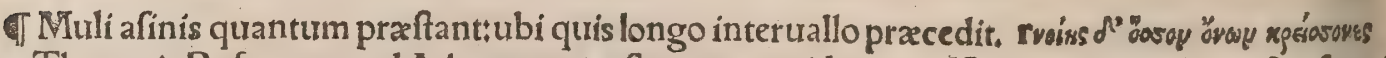
infurvol, Theognis. Refertur apud A thenæum 7. Sumptum uidetur ex Homero, cuius hi uerfus funt 60

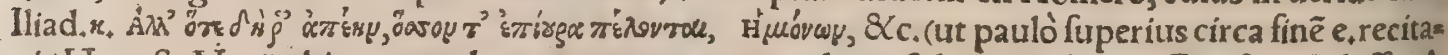
ui.)Hoc eft, Verũ ubi tantum aberant, quantum pars ultima fulci Mularum, Rurfum Odyffeç 


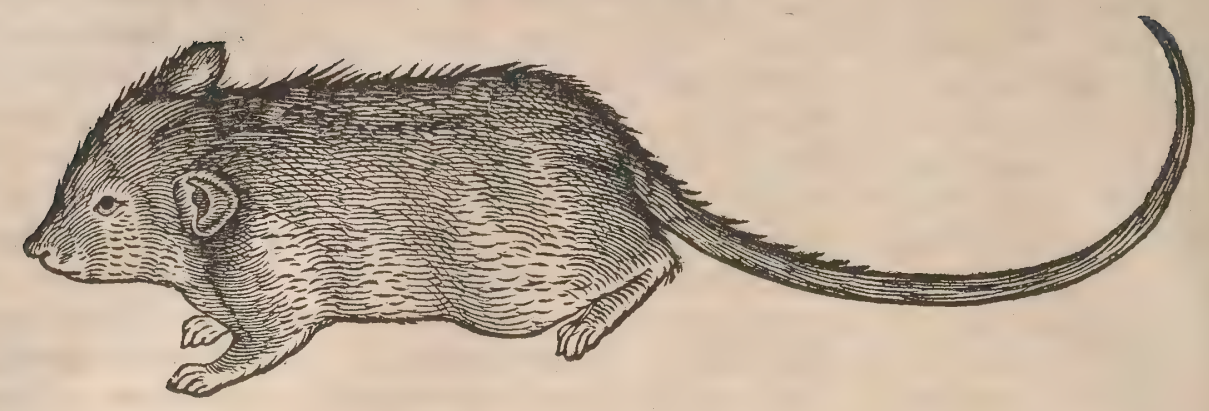

A.

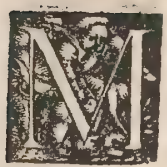

v $s$ exigutum eft animal, incola domus noftræ(ut Plinius loquitur) rofor omnium serti: undeà fono, quem rodendo facit, Latinè etiam forex urocatur, quamuis aliqui ita diftin guant, ut mus domefticus fit, forex fylueftris, Sipontinus。 Plinius certè foricem à mure manifeftè diftinguit, foricem fylueftrem faciens, 82 maiorem, auriculis etiam caudáć pis lofis $: \mathbb{Q}$ ubi Ariftoteles murem aruenfem nominat, foricem Theodorus reddit. Quamobrem infra 10 inter diuerfos mures de forice priuatím confcribam, quantum de eo apud ueteres reperio: nam res centiores uariè foricem interpretanturłalin, , ut dixi, murem fimpliciter, communem nempe $\mathcal{Q}$ urba: num, quem Galli adhuc uernacula lingua foricem uocant : alij illum quem hodie rattum uocamus: alij quem myzerum Germani appellant (qui certe mus araneus eft) foricem effe putant. Rattum hodie dictum, id eft murem maiorem, de quo infra feparatim agam,obfcurrus quidam author femper intelligendum putat, quoties muris nomen apud medicos occurrit:foricem uero murem commun nem minorem effe. Ego quoties mus nominatur, nec fylueftrem, neq̧ rattũ, id eft domefticum malo

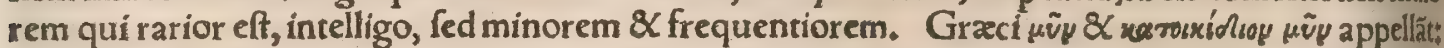

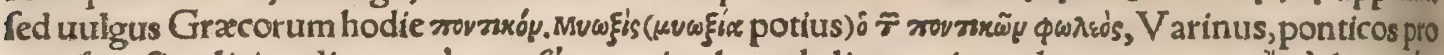

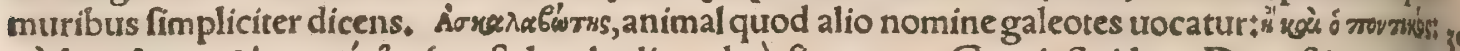

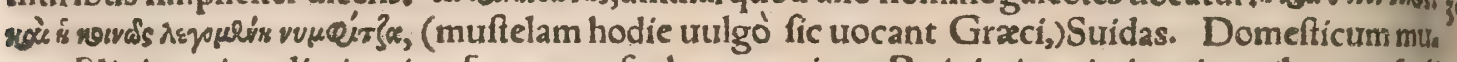
$\mathrm{rem}$ Plinius etiam diminuciua forma mufculum nominat : Ruinis (inquit) imminentibus mufculi

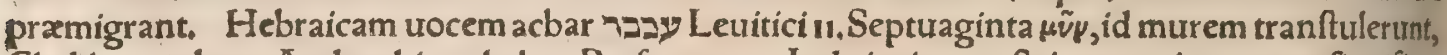
Chaldaus acbera, Arabs phir uel phar, Perfa an mus.Iudxi etiam noftri temporis murem fignificas re aiunt, ac ita Munfterus uertit. A rabicé eciam Auricennæ mus far nominatur, $\propto$ Saracenis hodie fa $\checkmark 2$, ut alicubi legi, qux uoces exdem aut fimillim $x$ Arabic $x$ in Biblins uoci phir funt, $\&$ fortelegend phar, in medio quidem aleph feribisur:fimilis $\&$ Hebraica eft, fi primam fyllabam auferas, Proinde non accedu Hieronymo, qui Efaix 66. myox um, id eft glirem effe putat, cum Leuitici undecimo mu rem fimpliciter tranftulerit. Sed praftacmurem interpretari, quo tanquam communiori tocabulo glis etiam continetur. GMus Iralicé ropo nominatur, uel forice aP forgio o rato di cafa. (Sed ratti 49 uocabulum, Germanis, Gallis, \& Italis commune ad murem domefticum maiorẽ , ut dixi, pertinet.) Hifpani Latinius talpam non murem tópo uocitant. lifdem mus appellatur rat, maior ueroratón, Gallis minor eft fouris, trox facta à forice:maior rat:Germanis hic, rab, Anglis rat uel ratte:ille, ,nut Germanis, Anglis mows uel moufe, Illyrijs, Polonis, minor myls:maior fczurcz, quafi forex. Vened maiorem panteganam appellant, quafi ponticum, à uulgari nomine Graco, alif circa Romam fourco.

B.

Mures domeftici non uno omnes colore funt, fed alip nigricant, alij ex fufco colore ad ruffirm aut giluum, alin ad cinereum tendunt. Eft quando candidifimi reperiuntur, qualem ipfe uidi, nonmino rem tamen, fed maiorem quem rattũ uocamus. Mus albus prouerbialis fuoloco dicetur, In murium go genere albi inueniuntur, \& in eorundem excrementis lapilli albi, \& funt ualde multæ generationis, (falaciffimi,) Albertus. De murino colore, uide in a. Murium alĭ funt magni, alị mediccres, alif parui,Matthæolus. . Muri cor magnum, Arifoteles. Cor maximum eft proportione muribus, lepori, panthera, muftelis, \& omnibus timidis aut propter metum maleficis, Ariftoteles \& Plinitus: T Mufculorum iecufcula bruma dicuntur augeri, Cicero 2, de Diuin. Murium iecufculis fibra ad numerum Lunæ in menfe congruere dicuntur, totidemḉs inueniri quotum lumen eius fit:praterea bruma increfcere, Plinius. Et tibro 2, Soricum fibras, inquit, refpondere numero Luna exquifiuere diligentiores, Luna alit oftrea, $Q$ implet echinos, muribus fibras, Lucilius ex Gellio. A coitu recre fcente Luna murris iecufculum mirum in modum fibi fibram quotidie quandam progignit ufgh ad plenam Lunam; deinde Luna decrefcente fibræ pariter decrefcunt, ac in unum corpus extenuatz to paulatim euranefcunt, Aeliantss. Cum Luna panfelenos eft, iecur eius crefcit $\alpha$ diminuitur in utro que interlunio, Alber tus, Ego femel \& iter um diffectimuris iecore infpecio numer um qui cum Lu- 


\section{DeMure. B.C. Lib. I. 809}

na conueniret nullum inueni, $\&$ omnino falfam hanc perfuafionem exiftimo, Plutarchus in Symi

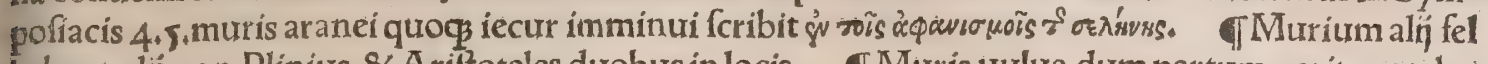
habent, alif non, Plinius, \& Ariftoteles duobus in locis. TMuris uulua dum partum gerit, acetabu la habet, Ariftoteles.

ब De muribus Aegyptịs, A fricanis, $\&$ alịs quià regionibus denominantur, dicam inferius ínter mures diuerfos.

Mures in domibus noftris habitant, ubicunç apta fuis refurgḧs loca caura inuenerint:aut fi minus fint apta, dentibus ipfi arrodunt $\&$ excauant+in medîs præcipué, quęcaua relinqui folent, inter duo coenacula locis:item intra parietum caua, \& circa teça. Mũs ógoQínes, ut Varinus refert ex Scholijs in Vefpas A riftophanis, funt mures qui uerfantur circa orophàs, id eft domuum tecta, \& ea abrodunt. Mus domefticus in horreis $\&$ domibus habitat, niger $8<$ paruulus, Âlbertus. Noctu ferè difcurrũt, latitant interdiu quood hominem aut alia animalia eis infefta uideant audiántue. đNullum aliud animal acrius afino audire ferunt, excepto mure, Suidas in Mida. T Mus panis cupidus eft, $\&$ eO= rum qua ex frugibus ad cibum hominis fiunt. Eft autem in perquirendis cibis folertiffimus, eorr̃ ć gratia fape periclitari non dubitat:et ut eis potiri queat, duras folidaśq̧́ materias, quibus aditu prohí betur, multum diućç erodendo fe fatigat, Obfcurus. Omne murium genus grano (frumento) $\& \mathrm{pa}=$ ne uef citur:præfert autem durum molli. Si multos fimul cafeos inuenerit, guftatis omnibus, de me= liore poftea comedit, Albertus, Aegyptn̈ in fuis notis mure depicto iudicium accipiunt:mus enim - pane multo ac diuerfi generis fímul pofito, cptimum quen $q$ feligens comedit(quod \& Aelianus fori bit, ) unde $\&$ optimi panis iudicium in muribus effe putatur, Orus. Fagi glans muribus gratiflima eft, $8 \mathrm{r}$ ideo animalis eius unà prouentus, Plinius. In Arcadia fcio effe fpectatam fuem, qua pra pinguitudine carnis non modo furgere non poffet, fed etiam ut in eius corpore for ex exefa carne nidu feciffet, \& peperiffet mures, Varro. Sues fpir antes à muribus tradunt arrofas, Plinius. Mures in Paro infula ferrum exedere $\&$ conficere dicuntur $\div$ A myntas in Teredone Babylonica fribit eodem cibo uti, A elianus, Gyaros infula una Sporadum eft, ubi mures ferrum erodunt, Suidas \& Stepha nus, In Cypro infula aiunt mures ferrum exedere, Ariftot.in Mirabilib. Mures fabulantur Chalci denfium ferrum erofiffe, Heraclides. In quadam prope Chalybes infula, fuperiore loco fita, aurum à muribus uorari aiunt, ideoç in metallis eos diffecari, Ariftoteles in Mirabilib, fic enim lego, locus eft deprauatus. Theophraftus atthor eft in Gyaro infula cum(mures)incolas fugaffent, ferrum quo

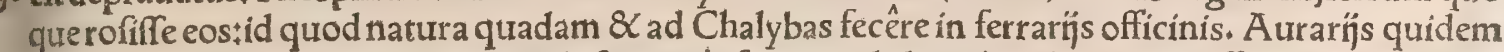
in metallis ob hoc aluos eorum excidi, femperó̧ furturm id deprehendi: tantam effe dulcedinem fu andi,Plinius. Marcellum multa figna perturbabant, $8 x$ mures in cella louis aurum corroferant, Plutarchus in uita eius, Bellum fociale, cuius author fuit Marius, diuerfa figna præceffere: Mures fufpenfum in templo aurum corroferant, è quibus æditui quandam caffe (rxys) forminam ceperût: ea ibidem quinç enixa mufculos, tres abfumpfit, Plutarchus in uita Sylla, A Antiphili hexaftichon in murem qui propter fcobem auri deuroratam incifus eft, extat Anthologị 1.33. T Mures etiam uulgares ruminant, non folum Pontici, Plinius \& Albertus, ब Mures lambendo bibunt, etfi den= tibus ferratis non fint, Ariftoteles. Mures in Africa(Obfcurus quidam ineptèlegit, in aqua)cum bi berint, moriuntur, Idem. In Africa maior pars ferarum aftate non bibunt inopia imbrium + quam ob caufam, capti mures Libyci, fi biberint, moriuntur, Plinius, An noxius muribus fit potus, uide in E+ubi de uenenis corum. Cuniculos etiam à potu menfibus aliquot abftinere fupra dixi, In Lufis Arcadiæ quodam fonte mures terreftres bibere $\&$ conuerfari, Theophraftus fcribit, Plin. đMus eft temperamenti admodum humidi, Obfcurus.

TFlagranti libidine dicunt mures effe, teftemç Cratinum afferunt, dicentem in Fugitiuis, po:̈. mate fic infcripto: Agenunc tibi ex æthere murinam lafciuiam Xenophontis fulmine percutiam:

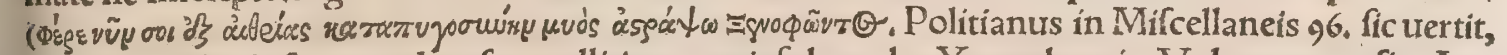
Agenunc tibi de fereno aduerfus mollitiem muris fulgurabo Xenophontis. Volaterranus fic, Age

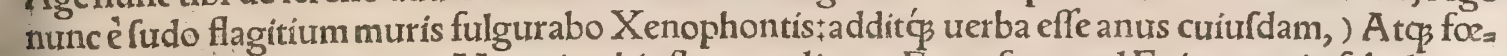
minam quog murem maiore Veneris rabie flagrare dicunt. Et rurfus apud Epicratem in fabula quę infcribitur Chorus: Poftremó fubüt me deteftabilis lana(leno, Volaterr.) deierans per Dianam (per puellam, per Dianam, per Perfephattam, Politianus) efte uitulam, effe uirginem, effe pullam indomi

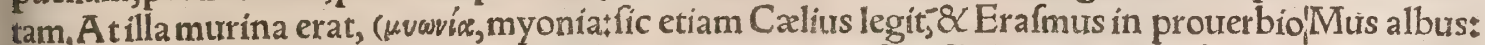
\& V olaterranus ut uidetur, nam fimiliter murinam transfert. Politianum $\mu v \omega r i x$ uel $\mu \nu \omega \xi i c$ legiffe uideo, \& magis probo:uertit enim, At illa cauus erat murinus ${ }_{+}^{+}$nimirum quod uirginitate non am, plius integra fed perfracta effet, \& quofuis amatores admitteret ut caurerna murium fubeuntes fibi mufculos:myoniæ quidem urocabulum nufquam legere memini, ) Superiectione falaciffimam eam dicere uoluit, cum prorfus murinam (cauum murinum, Politianus) uocauit, Aelianus interprete Gil lio. SedPolitianus hac etiam tanquam ex Aeliano addit * Et Philemon, Mus albus, cum quis eam, o fed pudet fari.Clamaurit adeóftatim deteftanda læna, ut fape latere non eft. In feptimo Epigramma ton Martialís in uulgatis codicibus legitur, $\mathrm{Nam}$ cum me uitam, cum me tua lumina dicís : fedenim uetuftifimi quíg fic habent, Nam cum me murem, tu cum mea lumina dicis, Videtur autem puella 
blandiens amatori murem eum uocare codem intellectu quo etiam pafferculum folet, quila mures quogs perhibentur falacifimi, Politianus:cui accedit etiam Erafmus in prouerbio Mus albus. Dow meftici mures falaciffimi habentur, prafertim a!bituide infra in prouerbio Mus albus. Mures alb! multæ ualde generationis (\{alaciffimi) funt, Albertus. Mus in coitu complecitur cauda, Albertus, Supra cuncta eft murium foetus, haud finc cunciatione dicendus $\neq$ quanquam fub authore Arifote, le $\&$ AlexandriMagni militibus:generatio eorũ lambendo conftare non coitu dicitur, Plinius, Sa lis guftatu feri prægnantes opinantur, Idem. Accedente falis ufu longè focûdiores tiunt, Aclianus, Sunt qui uehenienter confirment mures, fi falem lambant, impleri fine coitu, Ariftoteles. Terræ Perficæ parte quadam mure formina refciffa, foetus foeminini pragnantes comperiuntur, Idem \& ex eo repetens Plinius. Murium generatio mirabilis præter catera animalia maiorem in modum 1 eft, tum numero, tum celeritate, Iam enim foemina præxnante in uafe miliario aliquando occupata, paulò póft referato uafe, mufculi numero uiginti $\&$ centum reperti funt, Ariftoteles. Ex una genitos centum ưiginti tradiderunt, Plinius. De mirabili uno tempore agreftium murium redundantia, infra dicemus ubi de muribus agreftibus priuatim agetur. Multifida, ut canis $\&$ lupus, \& parua ciufdem generis, ut mures, multa pariunt, Ariftoteles. Mures etiam ex terra, uel terra $\&$ imbre nafci infradicam in agreftium hiftoria. Ibidem quogs narrabimus qua loca muribus infeftata fint, \& quæ propter murium copiam reliquerint incolx. TMures qui non ex infidins, fed fua fponte moriuntur, defluentibus membris è uita paulatim excedunt:unde profectum id quod eft in prouer: bio, Iuxta muris interitum, curius Menander meminit in Thaide, Aelianus interprete Gillio: Volater ranus ex eodem fic tranffert, Vita his longiffima, membris paulatim deficientibus, 8cc, Deagre. 20 ftium morte infra dicam.

\section{D.}

E uolucribus hirundines funt indociles, è terreftribus mutres, Plinius, Quædam timorenond curantur, ut mures $\&$ lepores, quomodo enim amabis quem infidiari uitå tư fit perfuafum? fibi perfuadent qui timent, Cardanus, đR Ruinis imminentibus mufculi pramigrant, Plinius. Vbl domus aliqua confenuit $\mathcal{X}$ ruinam minatur, mures primi fentiunt, $\&$ celerrimé fugóientes aliud do, micilium quarrunt, A elianus in Varïs \& in animalium hiftoria, Et rurfus in eadem, Quod uicinam (inquir)domum ad edendas ruinas mures $\&$ muftellę præfentiunt, idcirco eius cafum $\&$ prolapfios nem prauertentes, ex ipfa emigrant, quod quidẽ ipfum in Helice oppido ufu eueniffe dicitur. Cum enim Helicenfes impium facinus in fe aduerfus Iones admififfent, eos nimirum in altaribus macian tes, tum fanè his propinqua ruina ex oftentis portenta fuit. Nam quinç antè diebus quàm Helice funditus euerteretur, qui in ea effent mures, muftellar, ferpentes, \& uerticilla, cæateráç eiufmodi ex eo loco exierunt: quod quidem facinus Helicenfibus id ipfum intuentibus, fummam quidem ada mirationem mourebat : ueruntamen quam ob rem difcederent, caufam conícere non poterant. po. ftea uerò quàm ex urbe hæc animalia exceffêre, ex terræ motu tantæ labes domorum noĉu facta funt, ut non modò ex hoc cafu defederit urbs, \& conciderit, atç ex permultæe tempeftatis alluuione funditus deleta fuerit:uerum etiam cum forte decem naues Lacedamoniorum in urbis portuftatio: nećs effent, ex marinorum xeftuum tempeftate perierunt, Hæc Aelianus. TMus domicilium fibi parat, Ariftoteles. Sed tamen cogitato, mus Pufillus quàm fit fapiens beftia, xtatem qui unicu bili Nunquam committic fuam:quod fi unum obfideatur, aliunde perfugium Gerit, Plautus 40 Trucul. Si quis ex muribus in aquam cadat, porrigens caudam alter hunc extrahit, acferuaté pe riculo, Tzetzes . Cum mures in aquatile uas delapfi afcendere non queunt, mutuas inter fe call das mordicus tenentes, fefe fubtrahunt, fecundum quidem primus, tertium fecundus : fic enim eos mutuas inier fe operas fapientifsima natura ponere docuit, Aelianus. Siclupi caudis inter fe mora

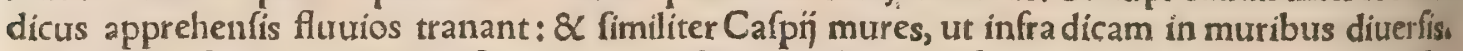

बPeruer forum morum muftelæ \& mures funt, eamç ob caufam Iudxis tum cibo tum contaçu corum interdicqum eft, A rifteas. fed per hac animalia eiufdem ingenï homines reprehendũtur, qui frilicet timidi $\&$ ad quemuis pauidi ftrepitũ funt, interim uerò furaces $\& \mathcal{C}$ clam infidiofi, Procopius,

6) Muribus maximé infidiantur feles, unde $\&$ murilegos recentiores quídam trocarunt. muriles guli uerò apud iureconfultos muricis \& purpurarum inquifitores nuncupantur. Muftelis eadem $y^{\circ}$ quæ felibus natura in murium tuenatu. perniciofffimæ eis qua muftelarum minimæ funt, \& fimpli citer nomine generis appellantur: quoniam ha caurernas etiam fubire poffunt mufculorû, nec egreffos folum ut maiores muftelæ catí̧́ uenantur. Videntur $\$$ mortuas muftelas horrere mures: nam cafeos, fi cerebrum muftela coagulo addatur, negant à muribus attingi,Plinius. Et alibi, A biguntur cinere muftelæ fparfo. Muftela ruta in murium uenatu cum îs dimicatione cóferta uires refouet, Plinius. Eâdem fe præmunit contra ferpentes. Vulpes callidèadmodum mures captat. Eofdem in pratis anguís niger, (carbonarium Itali quídam uocant, Nicander eundem puto myagron à mu. rium uenatu) comprehenfos deuorat. Murem animalium maximé odit elephas, \& fí pabulum in prefepio pofitum attingi ab eo uidêre, faftidiunt, Plinius. Odorem muris uel maxime fugiunt elephanti:pabula etiam qua àmufculis contacta funt,recufant, Solinus. Leo murem fugit, Rafis: 60 for taffis autem corruptus eft locus, nam A riftoreles de leone fcribit, quod aliquãdo hyn, id eft fuem, non myn, id eft murem timuerit. Muribușaccipitres uefcuntur:item aues nocturnx, ut noctux, 
chinam uafi fictili aut ligneo impones, unde muribus exeundi facultas non fit. Praftiterit autem ob, rui maffam frumenti uel alterius grani, Sic una opera quotquot mures intrauerint $\&$ ad efcamac. cefferint, delapfi capientur, charta femper in priftinum reuoluta locum. Alius modus: Orbis men, farius aut fimile lignum rotundũ infixis utrinģ̧ a cubus uel exiguis ligellis, duobus in fedili aliquo erectis breuibus ligellis bifurcatis (uel ramulũ tranfuerfum habentibus) imponitur, Curandum aute ut pars orbis pofterior, hoc eft fedile uerfus paulò grauior fit, \& fedile attingat, anterior ueró circiter pollicis lati alcitudinem eleuetur. Tum farina alia ue efca fedili prope orbem infpergitur, ut inuiten tur mures, efca etiã orbi alligaturr anterius. Mus à fedili in orbem progreffus, eo reuoluto in lebetem, qui aqua femiplenus fubỉci debet, delabitur, orbe mox in priorem ftatũ redeunte, ut fape plurimi mures una nocte una eademós opera capiantur, omnes in lebetem delapfi. Alip pro orbeligneo ma: chinã quandam uerfatilem fa ciunt, quales funt puerorũ apud nos rotulæarundinibus aut uirgis allia gatæ, in curfu ad uentum uerfatiles, II Sunt \& uaria mufcipularti genera, ubi mures pondereol ruuntur. Mufcipulæ quadã fiunt, inquit Crefcentienfis, ex paruo ligno cauato, in quod delabitur liud lignum paruum, fed graue $\&$ opprimens ingreffos ad efcã muresłanneciitur enim furilla cutis ad lignum quoddã exile, quo attaço ruit moles + fed hic modus notior eft quàm ut pluribus explicari mereatur. Huic affine eft genus illud, quod noftri hoc modo parant + Tabula duæ coniunguntur pedem latæ unũ, longæ duos. Hæ pofterius ligneo clauo iunguntur, qui tabulę inferiori infigitur fu perior enim eidé clauo non affigi, fed inferi tantũ debet foramine fuo (ampliore quàm ut motum ei us impediat, ita ut facile anterior eius pars furfum deorfumós moureatur. Præterea inferiori tabula anterius forma patibuli(duobus lignis erecis tranfuerfo uno impofito)fiue Græcæ literæ $n_{0}$ infigi= tur, altitudíne dodrantis, latitudine quanta permittitur. Oportet autem de fuperiore tabula anteritus nonnihil utrin $q$ refcindi, ut patibulum fubiens æqualiter curm inferiore extendi poffit, Deinde infe riori tabula lignum reçum $\&$ tenue fecundû latitudinem(quæ pollicem ferẻ aut unciam æqutrat)in ponitur in medio, \& poftrema parte alligatur ad clautm ligneum, quo tabula coniunguntur. In hu ius medio laridum uel quæuis efca alligatur. Debet autem anterius ad finem uf $\phi$ tabula pertinge. re, \& illic etiã crenatũ effe fecundum latitudine, crena ad dimidiati cunei formam duça. In hanc es nim ligno eleuato aliud fuperné per exigữ lignữ inditur, dưos ferè digitos longum, latũ uno:hoc in. quam parte inferiore in crenã ligni efcarỉ (id eft continentis efcam)inditur+ fupernè uero ad orã fữ pericris tabulæ leuiter offirmatur, ut efcæc contactu facilius ruat moles. Idem hoc ligellum(quod obs firmatorium, ad efcarí differentiã nominari poteft)filo annecti folet ad furperiore tabulam fub medio patibuli, atç̧ inde cum mufcipulã erigere placet ultra patibulũ traj̣citur. Sunt qui inferiori tabula circa ef́ã clauos infigant ferreos, quorum mucronibus cadentis ui ponderis mures illidantur, Potef etiã lapide fuperior tabula onerari, ut grauius feriat. Porrò uiuos obruendi machina maximé extem poranea hoc modo fit: Ex tenui ligno pars palmũ alta $\&$ digitû ferè lata fcinditur, $\&$ ab altera parte ín cunei formã fecta attenuatur thoc lignũ columellæ inftar erigitur, \& cuneus eius inditur crenæal terius ligni, quod huic ferè aquale uel paulò breuius fit, fimile alioqui nifi quod altera crenata non cuneata eft. Poteft aũt obfirmatoriũ appellari:hoc enim columella \& lignum efcariũ continentur obfirmantur'ç ne ruant priufquã mus efcam attigerit. Lignum efcariũ dodrantale uel pauló longitus effe oportet, ef́ca circa mediũ alligatał pars eius anterior fciffurã habebit, quæ paulo poft caput incle piat, 8 ad duos ferè cum dimidio digitos retrorfum extendatur: debet autê fieri ad angulos rectos et ${ }_{4} 0$ dimidiam ligni latitudinem auferre. His tribus lignis ita paratis, columellã eriges, ita ut cuneus furr= fum fpectet, cui obfirmatorị crenã inferes, ita ut obfirmatoriũ ipfum retrorfum fpectet, quò efcarîi quoos f pectare debet:efcariũ anteriore angulo columellæ admouetur, ad pofteriorẽ uero eius angulü in fine fcifur $¥$ obfirmatorí cauda, hoc eft pars non crenata detrahitur, obfirmaturó́ trahas \& obfirmes tabulam columella iam fuftinenti obfirmatoriư impones. Sic dolo inftructo mus fi efcã tetigerit, ruente tabula opprimetur. Eundem hunc dolũ defcribere uidetur Crefcentienfis, fed obfcurius, his uerbis: Capiuntur mures affere quodã eleurato cadente, qui ex quadã columella es leuatus fuftinetur, quadã fpatula cutem fuillam habente fic præparata quòd columella diuifa non aperitur, nifi cum mus cutem tangit in fpatula eleuatam. Eft $\&$ alius ufitatus apud nos modus, In tabella pedali quínq̧ aut fex digitos lata, circinatũ foramen fit, cuius diameter digitorũ fit quaturo: huic foramini fubiectũ inditur uas ligneũ orbiculatum cauũ palmi longitudine; in huius uafis latere altero, quod appellemus $\bar{A}$, foramen paruũ fit in medio, ubi filum efcariư é ferro inferitur, id circun uoluitur paruo filo quod tranfuerfurm foramini infixũ eft, ita ut in mufcipula primo defcripta diximus:pars enim fili in fine hamata qux longior eft, introrfum pertinet, ut infigatur ei efca, pars altera breuior $\&$ in fummo modicé ad angulũ reçum inflexa foras fpectat, ut ligello obfirmatorio impona tur:qurod quidem ligellü filo percutienti èregione efcarỉ annexũ pendet. Filũ percutiens appello, quo mus inferto in uas capite $\&$ efcã tangens percutitur, illiditur ć acui ferrea, quæ illic prope fum mitatem uafis in aduerfum latus, quod $B$. appellabimus infigitur, ita ut mucro recta ad $A$. fpectet. Hoc filü percutiens bene craffum eft, $\&$ per totũ $B$, latus tabellx à principio ad finem rectà defcen, dit:mox extra tabellam in femicirculũ incuruatur, cuilus uertex à tabella palmo ferè recedit: 8 in $1 a=60$ tus A. reflexũ, illic annectitur $\mathcal{X}$ infigitur. Sic paratam machinam cum inftuere 8 intendere uo= les, ligellum obfirmatorium in latus A, detrahes $\&$ altera parte obfirmabis in marginem eiufdem la. 


\section{DeMure. E. Lib. İ. 813}

teris inferiorem, (quod ut firmius fiat, crenam illic uel fciffuram aliquam in ligno facere poffis) alte: ri uero nempe inferiori parti, fummitatem fili $\mathrm{efcarj}$ inflexam impones, $\&$ inftrumentum totum in lactus $B$, inclinabis. Eandem aut frmillimam machinam Crefcentienfis defcribit, fed obfcurè, trerbis torte per librarios deprauatis $\$$ funt autem hæc, Mures etiam aliter capiuntur cum in aliquo nodo cannæ amplx in capite fit arculus cum chordula, in qua acus magna confiftit in media cannia fora minis foramen habet in medio, \& cutim fuillam interius cuidam uirgula alligatam, \& fic praparas tam, quòd cum mus per for amen cutím mordet ac mouret, arculus defcendit, \& a cus magna perfo. rat caput eius, eumog retinet ne fugere poffit. Sed pra cateris ingeniofum eft machinx genus, quod fubíciam. Trunculus ligni duos palmos longus, unum latus, duos digitos craffus, in medio o duobus circiter digitis excinditur paulò ultra dimidium latitudinis fua, Latus illud ubi fciffura fit decliurus $\&$ humilius effe debet,id appellemus $A$. huic lateri femicirculus oblongus è ligno inflexo inditur, in foramina terebrata parte media $A$. lateris, ab utrąs parte fciffura, ita ut femicirculus ille recto $\&$ plano ad truncibafim fitu fit, $8 \times$ inftructa mufcipula eidem femicirculo incumbat: Supra func femicirculum eiurdem figurę tabella adaptatur ferreis mucronibus in circuitu denticulata ita ut mucrones femicirculum collabente machina ingredi poffint, propemodum attingentes ipfum. Hax tabella trunculum uerfus ita refcindetur, ut fiffuram eius ingredi poffit; ubi tranfuerfa chorda equinis fetis contexta alligetur. Chorda autẽ per latera trunculi perforata tranfmitritur, anfulis utrin que ligneis annexa, ut ịs remitti intendiós poffit:îjs enim intenfis tabella mucronata uehementius fe rit murem. Supra trunculum ftatim retró fciffuram lignum erigitur quinç circiter digitos altum re - êumó, \& mox eadem longitudine recuruum(buris inftar)anterius pertingens \& furfum inclinãs: huic in fine filum annectitur cum ligno obfirmatorio paruo, inefcatorium urero lignum ima fcifua r $x$ alligatur. Mús efcam attingens inter tabellæcorruentis mucrones $\&$ femicirculurm conflgitur có friçusćg tenetur. Vidi $\&$ aliud hưic fimile genusł fed defino effe longior. Eft præterea alius mo dus, cum usas aliquod ex quo euadere nö poffint, ad dimidium aqua impletur, cuius furperficies zea feu fpelta innatante operitur, quam uidens mus $\&$ non aquam, in uas defcendit $\&$ fuffocatur, Cre fcentienfis, Audio noftros aliquando paleas aqua inịcere, quòd fácile fưpernatènt, \& fic mures ali= quando nthil fufpicantes de aqua infilire:facilius autem puro ad infiliendum allicerentur, fi paleis fa rina auenæalia' ue tofta infpergeretur. Hoc circa mufcipulas omnes quibus uiur mures capiuntur obferuandum, ut eximantur ftatim: nam fi perminxerint, mures alios dolum fufpicantes difficilius - allici putant: quamobrem pollutas urina, abluere folent, aliqui etiam fumo imbuere, tanquam uri. nzodor ita aboleaturi.

T. Mures fiamurcam fpiftam patina infurderis, 8 in domo nocte pofueris, adharebunt, $P$ alladia uss t. Si amurcam, inquit A natolius, in æneam peluim infuderis, eamćs in media domus parte reli= queris nocqu, mures congregaueris omnes, Paxamus in Geopon.Græcis 13.4. TMus ficaftretur uíuus \& dimittatur, fugat cæeteros, Plinius libro 30, ut Aggregator citat. Ego de foricibus tantum apud Plinium hoc fribi reperio. Si deprehenfum murem unum excoriato capite abire permíferis, cae teri in fugam uertentur omnes, Paxamus. Mus mafculus cum excoriaturt $\&$ dimittitur in domo, aut caftratur, aut abfcinditur cauda eius, fugat reliquos:maximè uero fi excoriatus fuerit. Fertur eti= am fi mus pedeligatus ad paxillum in domo retineatur, cxteros in fugam uerti, Auicenna. Memini - aliquando audire, fi muri capto tintinnabulum alligetur, ac ita dimitratur, fugaturum cateros. Fu mus foliorum taxi occidit mures, Plinius. If Aconitum (primum, quod 8 pardalianches) procul \&èlonginquoodore mures necat, unde aliqui myoctonon appellarunt, Plinius. Myoctonon quide cognominari, Diofcorides etiam \& N Nicander meminerunt. Recentior quidam obfcurus author, hæc Pliní uerba de fumo aconiti interpretari uidetur: quanquam luparia uulgo dicta fumum id fa= cere fribit, quę ad fecundum aconitigenus pertinet. Ego cum nuper radicem coerulei primum, de= inde etiam pallidi aconiti ratto capto per triduum edendum obíncerem, butyro \& farina, aliâs cafeo mixtis, atc is multum abfumeret, nec periret tamen, fed neladi quidem uideretire, occidi iuff. In caufa forte erat parum recens pollen flaui aconiti: pharmacopolx enim non integras luparix radi ces, fed contritas ferè feruare folent. In Sabaudia quidem uidia â rufticis has radices uendi, 8 muria

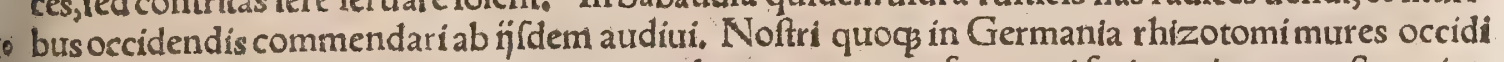
promittunt, filuparix radicem tritam cum pulte ex auen $x$ aut frumenti farina mixtam guffauerint: Eafdem feréaconito urires ftaphifagria obtinet: $\&$ huius quoç (è radice, uel femine potius) pollinen cum farina in butyro frixum mures occidere Tragus fcribit. Fugantur mures \& calacantho, origa=

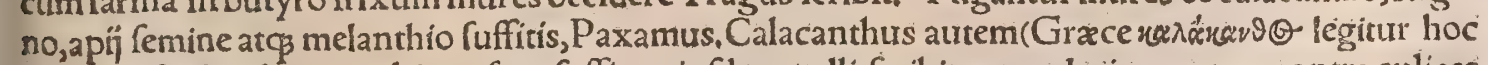
in capite, \& duodecino ubi mufcas fuffitu eiufdem pelli feribitur : undecimo autem contra culices

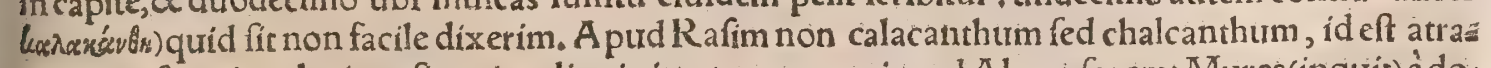
mentum futorium legiturł fic enim aliqui citant ex opere eius ad Almanforem: Mures (inquit) è do. mo chalcantho fumigata fugiunt. Calycanthemon quidem apud Diofcoridem inter clymeni $\&$ peri clymeni nomenclaturas eft. Fugiunt 8 Lamatite lapide fuffito, nec non myrica uiridi fumigante, of Paxamus. Si domum fuffumigaueris ungula muli finiftra, non remanebit in ea forex, Rafis, Alber tus, Belberus. ( foricem improprie dicit pro mure domeftico.) Si muli ungula domus fuffiatur, fugit unt ab ea mures, Rafis \& Albertus, Vnguibus mula uelafini (adufis) mutres figantur, Vrfitutis 
Mures abiguntur cinere muftela uel felis diluto, 8 femine fparfo, uel decocrarum aqua: fed redole (frilicet frumentum) uirus a nimaliun eorum etiam in pane ${ }^{\circ}$ b id felle bubulo femina attingl utilit's putant, Plinius: fed hac ad mures agreftes magis pertinere uidentur, qui quomodo fugentur fuolow co infra priuatim dicemus. Afphodeli radice mures fugantur, cauerna praclufa moriuntur, Plinis us. Cucumim ex quo elaterium fit, \&c, multi hunc effe apud nos, qui anguinus uocatur, ab alijs sers raticus, arbitrantur:quo decocto fparfa mures de eius medicina non attingune, Plin. Agreftis cucu meris \& colocynthidis fuffufio mures necat, Palladius i. Si cerebrum muftelx coagulo addatur, di cunt cafeos à muribus non attingi, Plinius. Frumento ne gurgulio noceat, neu mures tangant, Jưs tum de amurca facito, palearum parum addito, finito marceicant bene, $\& \mathbb{X}$ fubigito, eo granarium io tum oblinito craffo luto, poffea confpergito amurca bene omne quod lutaueris. Vbi arcuerit, è fruz mentum refrigeratum condito, Cato, Abfinthium defendit pannos 8 pelles à muribus, Circain: frans. Atramentum librarium ex diluto abfinthí temperatum, literas à mufculis tuetur, Plinius \& Auicenna. Mulieres quadam apud nos abfinthium decoquunt cum linimento illo farinaceo qrio lecforum culcitras illinunt, utrà muribus tutx fint, Tragus. TSi uis excacare mures, tithymallum in tenues partes incifum miftumóg cum polline $\&$ cenomelite apponito:fiquidem ubi ex eo comede. rint,occacabuntur. Anatolius quidem $\&$ Tarentinus dum de horreo mentionem faciunt, eifdem medicamentis funt ufi,Paxamus. TV eratrum album mures polenta admixtum necat, Plinius, Ex polenta ueratrum, aut agreftium cucumerum femen cum ueratro nigro, colocynthide \& farina permíftum, mures perimir, Paxamus. Necabuntur fi helleboro nigro cafeum uel panem, ucladi. pes, uel polentam permifceas \& offeras: \& agreftis cucumeris \& coloquintidis fuffufio fic nocebit, 10 palladius. Nonnulli elleborum alburm \& corticẽ cynocrambes renuiffinè comminuta cribrataç, cum farina, ouis $\&$ lacte mifcentes $\&$ laxigantes, paftam faciunt, quam murium foraminibus inle runt, Paxamus. Auicenna etiam elleboro mures occidi fcribit, \& merdafengi, id eft lithargytio, utro $\not \beta$ nimirum per fetut $\& R$ afts, qui tamen utriç farinam addit. Albertus omnia permifcer, elle, borum inquam, lithargyrium $\&$ farinam. Elleborus cum melle $\&$ farina fubacius, frixusás, prafer: tim niger, mures $\&$ rattos necat, Tragus, Tortella ex elleboro cum farina $\&$ aqua fact $x$, Circa ins ftans. Elleborus cum polenta, uel cum fauich (fauich Arabicè polenta eft)\& melle, Serapio fecundä Diofcoridem, \& Auicenna fed Diofcorides de chamaleonte albo hec fcribit, non de elleboro. Chat maleon albus cum polenta fubactus, $\&$ aqua oleoç̧ dilutus, mures, fues $\&$ canes occidir, Diofcori. des:uide in Cane. Idem apud Auicennam de mezereon legitur, facili lapfu:quoniam mezereon cha 3 melæa non chamxleon eft. Succus decoctę radicis chamęleontis herbx additis aqua $8<$ oleo, mures in fe contrahit ac necat, ni protinus aquam forbeant, Plinius lib, 13. Rufticos uidimus cardum ua rium (id eft chamaleontem) uendentes, cuius puluere tum luspos tum mures necari affirmabant, Mures perimit $\&$ hyof cyami albi femen, $\$$ radix caulis, (aliâs lauri,)A uicenna. Si rubi radicembr tyro pani $\&$ cafeo permiftam guftarint mures, exanimantur $\&$ pereunt, Paxamus. Helenï radix mures contrita dicitur necare,Plinius. Baffal alfar(id eft cepa muris, qux $\&$ cepa canina dicitur; eft autem eadem qux fquilla)mures occidit, Auicenna, fecundum Bellunenfem $\& \alpha$ ueterem gloffo, graphum. Ixim niam \& f cillam diuerfas plantas. non negauerim tamen fcammoniam quoog muribas uenenatam effe poffe:ut Auicenna mezereon, id eft chamelax uim mures necandi attribuit, quam Diofcorides 4 $\&$ alin chamaleonti, non infeliciter lapfus, ut uidetur:nam chamelæam quogs idem praftare credide rim. Sylueftrem a paragum Graci orminum aut myacanthum uocant,Plinius : dubitauerit autem aliquis cur myacanthus, id eft murina fpina nominetur, aliam ne ob caufam, an quód mures force in terimat:nam canes quog afparagi decocto perire, autore Chryfippo, Plinius fcribit. Theophrafus 6.4. de hift. plant. Quxdam(inquit)folium iuxta aculeum gerunt, ut tribuluss, phleum, ononis, myan canthus, \& alia. Gaza pro myacantho fpinam murilem reddit. Videtur autem Theophraftus de run fco intelligere:nam is quoges myacantha cognominatur apud Diofcoridem:quanquam non iuxtafo lia fpinas habet rufcus, fed ipfa eius folia in aculeos definunt. Sylueftrem quidem afparagum horten fi fimilem uidiffe memini, aculeatum autem propriè dictis aculeis, hoc eft duris \& pungêtibus, nun quam. Sed afparagum fylueftrẽ Theophraftus af paragian forte nominat lib.6, cap. 3 . de hift. plant, 8 ubi \& f forpium defcribit, \& ipfum ut fufpicor de genere fylueftris afparagi; quoniam pro folís fimi liter fpinas habeat, \& eodẽ tempore floreat.Marcel. Vergilius conịncit rufcũ myacanthã dici, quôd ruftici in Italia hanc fpinã in carnario fufpendãt, ut tueatur à muriữ iniurrỉs pernas, \& cafeorũ fifcel las:neq̧ enim acuminata in cufpidem foliorum eius acumina penetrare animalia illa audent:quã ob caufam, inquit, murinã fpinam diçã fuiffe credimus. Hetruria certe modò non aliunde fa fô nomi ne appellat, (pongi topi, à pungendis muribus, Matthaolus.) Theophraftus libro tertio de plant.hi" ftor.centromyrrhinon id eft cufpidatam myrtum uocauit, (ur Diofcorides oxymyrfinen \& myrtha canthan,)Hæc Marcellus. Noftri iunipero fimiliter ad fuccidiam â muribus defendendam utuntur. An ueró rufcus Theophrafto myacanthus aut centromyrrhinon dicatur, aut etiam utrif s $_{\text {his }}$ nomi. nibus, aut myacanthus illi non alius fit quàm afparagus fylueftris, aut alia fui generis planta, cum to neç rufcus neq̧ afparagus fpinas iuxta folia habeat, aut murtilatus forte fit codex Theophrafti, cura iufģ iudicio liberum relinquio. Aconitum myocionon, aliqui etiam myophonon appellant; $\mu$ vóçovgy 


\section{DeMure. E. Lib. I. 815}

herba qua $\&$ aconitum, Hefychius $\&$ Varinus:fic enim lego: fed aliud etiam myophonon uel potia

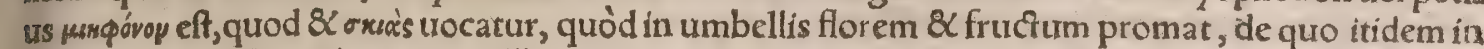
aconito dixi. Nicander in remedijs contra ixiæuenenum polium quoç myoctonun cognominat: quod(inquit Scholiaftes) nullus alius fecit, neç enim mures occidit polium, Hæc ille. Subftratum qquidem uel fuffitum polium ferpentes abigit, graui enim odore eft, \& amarum. Hoc fané fufpicamur quoniam mufce fuffitis quibufdam, ut abfinthio, galbano, melanthio, \&c. abiguntur, Græci autem

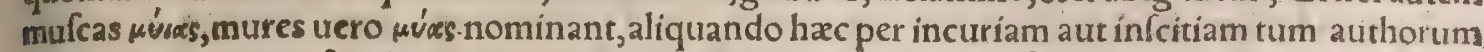
tum librariorum confundi: polium quidem aptum uidetur quod fuffitum mufcas $\&$ culices depel lat. Si querno cinere infarferis aditus (caua)murium, eum contingentes adfiduè, fcabie inficiuntur \& pereunt, Paxamus. TSi arfenicum citrinum cum farina fubactum mus ederi, morietur, Alber cus. Noftri arfenicum per excellentiam miisg Ifft, id eft uenenum murium appellant, quod inter as lia murium uenena efficaciffimum ocyffimum ós fit:accipiendum eft autem non pallidum quo libroz rum compacfores libros illinunt, ut aureo colore niteant:fed rubicundum, cuius etiam minima por tio ftatim necat:cuius periculum ipfe nuper feci in duobus muribus mufcipula inclufis, utercz enim minima lardi portione uorata, inuoluta in hoc ueneno contrito, modica farina fuperinfperfa, intra horæ fpatium perít, magna cum admiratione mea:uix enim tria grana ueneni fingulis deuorata pu to. Sic ab alijs etiam interemptos hoc ueneno mures audiui. Optimum fané fuerit uenenum lardo in tenuffimas laminas fecto illinere. fic enim facilitus 斿 alio quouis modo edent. Plura de auripigmento $\&$ mirifica cius in muribus lupisćs necandis facultate recitaui in Lupo a. in Aconito. Famuliss me , us farinam frumenti mixtam pauco arfenico læuigato muribus necandis in domo propofuit; fed id forte guftatum catellus unus é duobus domefticis cum paulò poft uomitu redderet, euafit: alter uea ro de uomitu illo guffans, perịt, Ponzettus. Egofané cum uulpi quam domi alebam confiliginis fe mina aliquando dediffem, experiundi gratia num uenenofa effent ut fufpicabar, ea quoç cum ré uomuiffet nibl paffa eft. Qui uenenum apud nos muribus proponunt,pleriģ aquam etiam in uta fe apponi iubent, tanquã ïs fibiberint citius morituris:fic enim uenenum in uenas dirigi, 8 inflatos mori aiunt. Ego quidẽ duobus illis muribus, quorũ iam memini, nullü appoftii potum, \& intra hor utriç perierunt, ut neç fimpliciter, neq ut citius moriantur neceffarius uideatur potus. Imo uerif mile eft aliquos fibiberint facilius uomere, at $\not$ ita euadere:aut alia quadam ratione aquxe port ue. neni uim retundi. Nã $\&$ chamalcontis herba fuccus additis aqua $\&$ oleo, mures in fecontrahit ac - necat, ni protinus aquam for beant, authore Plinio. Crefcentienfis etiam ueneno muribus propofito aquam remoucri iubet, ut paulò poft recitabo. Nec me fugit quòd Ariftoteles fcribit de hift , anim.8. 28, mures Africæ fi biberintmori:quoniã animalibns A fricanis etiã cxteris infolens potus eft, pro pter inopiam aquarû, quód aftate illic nulli fint imbres : itaque contra quàm cæaterarum regionum animalia tempore hyberno magis quàm xftiuo potum quarunt. Sed forte hoc uniuerfale eft omnib. muribus, ut legit(Michäèl) Ephefius, Niphus. Homerus certe in Batrachomyomachia murê bibente facir. Hac ueterû inter fe $\&$ recentiorũ diffidia ut componantur, experientia magis quàm uerbis $\&$ rationibus uti oportet, Carnem infumatam $\&$ minutatim concifam cü butyro friges in fartagine: refrigeratis addes dimidiã partem calcis uiux ad læuorẽ tritæ. hoc pharmacum in tabellas aliquot di ftribues, \& propones ea in loca ubi mufculos aut rattos uerfari fcieris tabellis etiam fingulis uafa fin gula cũ aqua appones utbibant $\&$ citius moriantur, Ex libro quodam manufcripto Germanico. Aliquı calcem cum farina fubactã, alị aliter, rattis proponunt. Mures necat alfceh, (aPalfech, Aů cenna:Bellunenfis interpreratur realgar(aPrefegal)feu toxicũ muris, Realgar, inquit Syluaticus, fit ex fulfure, calce uiua, $\&$ auripigmento, $\&$ idiomate noftro ucatur foricoria:inter ficit forices $\& \mathrm{O}$; mnia animalia:puluis eius extinguit uermes equor $\tilde{u}, \&$ fiftulis medetur, $\&$ omnem malã carnē cor rodit. Occiduntur mures refalgario trito $\&$ cafeo aut farina mix to, quibus in cibo delectãtur. Sed

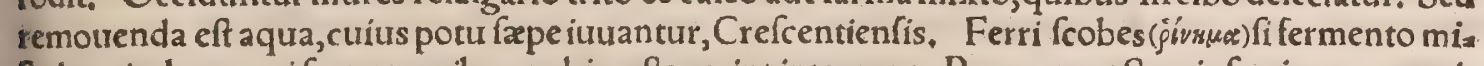
fta loco indatur qui fcatet muribus, ubi guftauerint intereunt, Paxamus. Scoria ferri mures peri= mit, $\&$ crocus eius, A uricenna. Rafis fcoriam ferri cũ farina fubigi iubet. Lithargyrium : uide fupra in ellebori mentione. Crocus ferri à Bulcafi defcribitur, ex quoetiã Syluaticus mutuatur cap. 191. Argentum uiutum mures interimit, Auicenna : argentum uiuum fublimatum, Serapiofecundum Ralim.

TDe muribus qui regiones aliquas magna multitudine inuaferuut, $\&$ aut fegetes populati funt, aut etiam incolas expulerunt, dicam infra in hiftoria muriư agreftium.

I Scythize magna pars tergore uulpiư \& murium operti incedunt, Alexander ab Alexandro. Scy tha pellibus tantum murinis ac ferinis utuntur, luftinus libro3. Sed mures quorum pelles in ufu ues ftim habentur, omnes fylueftres funt $\&$ diuerforum generum, ut infra in fingulorum hiftorịs dice

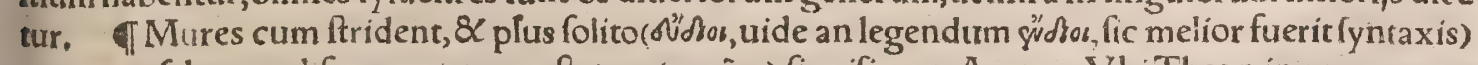
tanquam faltantes difcurrunt, tempeftatem $(\chi \Theta \mu \omega \hat{v} v \alpha)$ fignificant, Aratus, V bi Theon in commenta rijs, Strident autem, inquit, faltantó̧ mures, fiue quòd aërem aftringi percipiunt : fiue quòd cum te= nuem $\&$ infirmam habeant cutem, cum terram refrigeratam calcant, non ferentes frigus exiliunt. Etrurfus, Mures interdiu(inquit Ararus)pedibus uerfantes fuum cubile, dormire appetunt cum im minet imber, Hic Scholiaftes nihil adiecir, cum fententia tamẽ aduerfa uideatur fuperiori:quomodo 
816 DeQuadrupedibus

enim dormiturfunt imminente pluuia; ff plus folito difcurrunt $\&$ faliunt? Muftela $\&$ mures ftrt. dentes uehementem prafagiunt tempeftatem, Aelianus;

F.

Peruerforum morum mures $\$$ muftela funt, timidi,furaces, infidofi, ut in $D$. dictum eft, quami obrem lex dituina tum efu tum tactu corum Iudxis interdixit, mures quidem cuncta fodant, maló, afficiunt:homini non modo perniciofi in cibo, fed neculli prorfus ufui utiles, Arifteas, Comeden tes carnem fuillam, \& abominationem atç murem, fimul confumentur, dicit Dominus, Efaias 66 . Caro muris in cibo fumpta magnam obliuionem infert $\&$ abominationê, corrumpitós fronachum, Arnoldus de Villa noua. Dentibus muris, id eft macula qua fiunt in facie, pracipué infantium, propter efurm panis à mure corrofi, Vetus gloffematarius Auicenna: Vide in G, circa firiem. In, colar regni Calechut mure ac pifcibus Sole exuftis uefcuntur, Ludouicus Romanus 5,6 . का Muris caro calida eft, mollis $\&$ pinguis aliquantulum : \& in ea uirtus eft expulfiua melancholiz, $R$ afis \& Albertus. Si comedatur mus affus, deficcat faliuam fluentem ab ore puerorum, lidem: Vide in $\mathrm{G}$. Sunt inter magos qui murem bis in menfe iubeant mandi in dentium doloribus, doloresés ita ca, ueri,Plinius. Sed qua remedia ex mure fumpto in cibo promittantur in G, dicam. Veniffe mits rem ducentis nummis Cafilinum obfidente Hannibale, eumq́q qui uendiderat fame interifie, empto: rem uixiffe, annales tradunt, Idem.

Muris caro calida eft \& mollis, \& pinguis nonnihil, \& bilim atram ( cuíus cgo nullam rationemi uideo)expellit, $R$ afis \& Albertus. TArundines $\&$ tela, quaććp alia extrahenda funt coroori, erro, 80 catmus diffectus impolitus, Plinius. Mus degluptus $\&$ per medium exfecius appofitus qua inharerint corpori facile producit, Marcellus. Adurerfus ferpentium icfus efficaces habentur mures diffecti $\&$ impofiti, quorum natura non eft fpernenda, pracipuè in afcenfu fyderum (ut dixia mus ) cum lumine Lunx fibrarum numero crefcente ac decrefcente, Plinius fi bene memiri: Mus res, quí in domibus oberrant, concifos fcorpionum plagis utilifimé imponi in confeffo eft, Diofco. rides,Idem ex eo repetunt, Galenus de fimplic,11.46. Auicenna, Rafis, Albertus, Mus diuulfirs fcorpionis ictui imponitur, Plinius, Mus araneus fi iumenta momorderit, mus recens cum faleim ponitur, Plinius, Et mox, Et ipfe mus araneus cōtra feremedio eft diuulfus $\&$ impofitus: Quodads do, ne quis priore etiam loco de mure araneo potius quàm domeftico fenfiffe putet. बा Verru. cas omnium generum fanat $\&$ abolet(eradicat, $R$ afis \& Albertus)mus diuulfus, Plinius: diuiftus ata que appofitus, Marcellus. Empiricum quendam apud nos nuper ad firrhofi cuiurdam tumoris curationem ufum audio pinguritudine qua deftillauerat à muribus aliquot anferi inclufis fimulóg af fatis. Murini catuli triti in uno uetere ad craffitudinem acopi,fi illinantur, palpebras gignere di. cuntur, Plinius, Si inaffatos infantes ederint, oris faliuam exiccari promittũt, Dió corides: $\&$ poff eum Auicenna, Rafis, Albertus. Sunt inter magos qui murem bis in menfe iubeant mandi, utea ueantur dolores dentium, Plinius, Aqua in qua mus cocfus fuerit, aduerfum anginas falubrio ter inf́cio propinatur, Marcellus. Tradunt $\&$ murem cum uerbenaca excoctũ, fi bibatur is liquor, remedio effe aduerfưm anginam, Plinius. Pulmonũ uritris medentur 8 mures, maximé Africaní, detracia cute in oleo $\&$ fale decocti, at $\$$ in cibo fumpti. Eadem res $\&$ purulentis uel cruentis excrea tionibus medetur, Plinius. Vrina infantium cohibetur muribus elixis in cibo datis, Plinius: Sere 4 nus quidem cinerem muris ex uino aut lacfe caprino prabet, ubi urina pręter uoluntatem aut nimiü fluit. Podagras leniunt mures diffecti impofiti, Idem.

T Ambuftis medetur murium cinis, (aut glirium cum oleo,)Plinius, Cupreffi pilularum exu ftarum puluis tritus, ungularum muli uel mulx exuftarum cinis, \& oleum myrtinum, cinis quoque uel fimüs murium tritus, $\&$ cinis exufti erinacei recentis, uel fimus eiufdem recens, \& fandaracha: hæc omnia cum aceto, $\&$ cum pice liquida mixta \& impofita, etiam fluentes capillos continent, Mar cellus. Loco quem mentagra obfederit muris exufti cinerem cum oleo apponi falubre eft, Marn cellus. Alopecias emendat cinis èmurrium capitibus caudisç, $\&$ totius muris, pracipuèfi urene: ficio acciderit hac iniuria, Plinius. Mures domefticos in olla exuftos, tritosí̧̧ axungia (olcolauri,

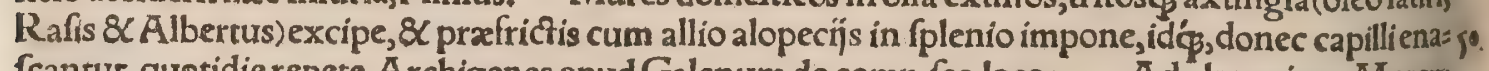
fcantur, quotidie repete, Archigenes apud Galenum de comp. fec.locos. Ad alopeciam, Murem combure $\&$ tere, $\&$ puluerem permifce cum melle, adipe urfino, $\&$ unge, Galenus $P$ arabil, 2, 86. Ea qua fequitur compofitio(inquit Cleopatra apud Galenum lib.I, de compofitione fec, loc, inter re media ad alopeciam)omnes ui fua præcellit, faciens item ad profluuium capillorum cum oleo aut un guento diffoluta:facit $\&$ ad rarefentes in principio capillos, $\&$ in caluiciem prolabentes, eft́ć om. nino admirabilis: Murium domefticorum uftorum, pãniculi ampelini (Cornarius à regione uel loco aliquo fic dictum conịcit. Heraclides quidem inter fua ad alopeciam medicamenta Cilicï panniculi meminit ) ufti, dentium equinorum uftorum, adipis urfini, medulla ceruina, corticis calami, fingtu, lorum partem unam, Hec omnia arida lecuigentur, \& fufficienti melle admixto, ad craffitudinem mel lis redigantur, indećs adeps $\&$ medulla liquefacta addantur, $\&$ pharmacum ipfum in aream pyxi= 60 dem reponatur, ex eoósalopecia donec capillos producat defricetur. Similiter autem \& proflui cas pilli quotidic ex eo illinantur. Murium cinis cum melle inftillatus, aut cum rofaceo decoçus aurriú. 
dolores fedat, Plinius, Murinus cinis, id eft puluis exufti muris, cum melle dentibus infrictus, oris faporem commendat, (halitum foxtidi oris emendat,) Plinius \& Marcellus thri radices, Plin. Vide infra in remedịs ex capite muris ufto. Si urina prater uoluntatem uel nimi um fluat, cinis prodeft (haufto nepetr quoç fucco)ex uino muris tritus uel lacte capella; Serenus; Plinius aliter, Vrina infantium cohibetur muribus elixis in cibo datis, De cinere ex capitibus murk um, paulò mox dicam.

T Graui difficilí̧̧ chemofi oculorum (fic uocant rubentem carnofamḉ inflammationem cors nex)medentur prafentiffimèaccuratius detritæ muriú carnes cum crudo oui luteo, ad cerati confia ftentiam, \& ex panno lineo impofitæ, Galenus Parabil,1,31. TSanguis recens murinus illitus, uel $10 \mathrm{p} f$ e mus diuulfus uerrucas omnium generum abolet, Plinius, Marcellus, \& A uricenna. Galenus de fimplic.10. 6.an murium fanguis acrochordonas deijceret ne experiri quidem fe uoluiffe ait, cum alia multa ad hoc uitium ufu probata iam cognofceret. Ad fuffufionem admirabile, quod illico uifum reftituit:Muris fanguinem, \& galli fel, \& muliebre lac æequis ponderibus mifce, $\&$ bene fubactis ute re:probatum eft enim, $8 \mathrm{~L}$ magnificé profuit, Galenus $\mathrm{Parab} \cdot 3 \cdot 16$. TMurina pellis cremata, exace to illito cinere, capitis doloribus remedio eft, Plinius. Caput muris in linteo geftatum capitis dolo. rem fedat, Idem caput muris(foemina, Albertus)appenfum epileptico curat, Rafis $\&$ Albert. Mü. rium capita ufta cum melle inuncta alopecias curare poffunt, Galenus ad Pifonem. Alopecias cí nis é murium capitibus caudisḉ \& totius muris emendat, præcipué fi ueneficio acciderit hæc iniù ria,Plinius, Alopecijs mufcarum capita contrita affrica, Cleopatra apud Galenum fec,locos: Gra cum exemplar $\mu$ ũ̃u habet, id eft murium : fed quoniam murium capita ad hunc affectũ alibi femper ufta tantum adhiberi confulunț authores, mufcarũ uerò fimpliciter infricari, præftiterit $\mu v \iota \tilde{\nu}$, id eft mufcarum legere cum ueteri interprete.Quanquam Marcellus etiam mufcarũ capita ufta ad alope cias commendet, Graci nimirum codicis alicuius uitium fecutus, Sed rurfum apud Galenum fec.lo

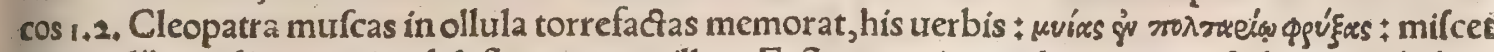
autem alips medicamentis ad defluentes capillos, Et Soranus in medicamento ad alopecias habet,

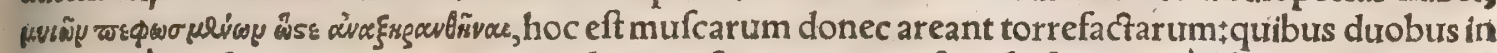
locis recié mufcas non mures accipi iudico. mufcas enim torrefieri fat fuerit, quód facile mifceri pof fint, nec opus eft prorfus adurere, ita uires etiam amiffurasłmures uerò ut teri mifcerićs poffint, pror fus aduri oportet + nec tamen uires amittunt, propter fubftantiã offeam, qua \& facultatis fuæ tenaci-

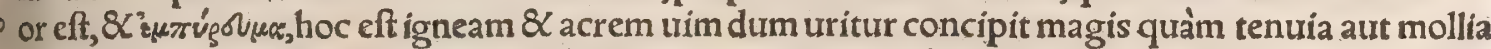
corpora, ut mihi quidem uidetur. Aliqui alopecias cantharide trita illinunt cum piceliquida, nitro præparata cute. fed cautendum ne alte exulcerent:poltea ad ulcera ita facta capita murium, \& fel mu rium, \& fimũ cum elleboro et pipere illini iubẽt, Plin. Mvเoxódlay, ,uv́bas i'Gas, hoc eft, pro mufcerdis to tidem mufcas fubftiture, Author Succidaneorũ qua Galeno adfcribuntur. Atqui Galenus de comp.

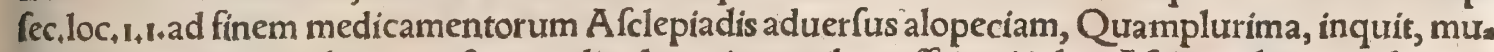
fcarum capita mox ubi captæ funt nudis alopeciæ partibus affricari iubet Afclepiades, atç id maxi méubi alopecia furerit exulcerata. Etenim confert, inquit, mufcarũ fanguis (tañ̋̈ mitigans \& empla ficus, ut uridetur)partibus tunc per pharmaca ex nitro ac alịs compofita exacerbatis, nimirü quum non mordeant hæc ipfas tantum, fed bullas etiã in eis excitent. Et quamuis Plinius non hac gratia me - dicamentum ex capitibus murium addat, cum $\&$ alia ualde acria admifceat, tamen non placet quód ipfa murium capita fimpliciter illini iubeat, quo modo mufcarum illinuntur, cum alip authores adus ftis tantum utantur, $\&$ rectè quidem ut fuperius monui. Murrium capitum cinis in melle mixtus et đlinitus per decem dics, facit oculorum claritatem, Sextus. Murium capitum caudarumós cinere ex melle inuncis claritatem uifus reftitui dicunt, multó̧ magis glir is aut muris fylueftris cinere, Plini us, Capitis leporini cinis dentifricium eft, adieçoọ́ nardo mulcet graueolentiam oris: aliqui muri norum capitum cinerem mifcuiffe malunt, Plinius: Ex eodem fupra fcripfi, totius muris cinerem cum melle infrictum dentibus, oris faporem commendare, $\&$ c .

TMuris cerebrum tolles $\&$ in uinum mittes, ac maceratum $\&$ tritum fronti illines, ad capitis $\mathrm{do}=$ lorem,Marcellus, Muris cerebrum dare potui ex aqua (quod magi præcipiunt)quis poffit phrene: go tico aut furenti, etiam fi certa fit medicina?'Plinius. đGrauedo emendatur, fi quis muris nares (ut tradunt) of culo attingat, Plinius, Et alibi, Gratredinem inuenio finiri, fi quis nares murinas ofcule tur. TIn quartana adalligari iubent magi muris roftellım, auriculaśç fummas rofeo panno, ip= fumćs dimittunt,Plin, बMuri uiuenti cor exemptum \& brachio mulieris fufpenfum, efficit ut non concipiat, Sextus, TSerenus aduerfus quartanam bibi iubet fibram murini iecoris cũ qua tuor fcrupulis uini aufteri. Murem diffecans per Lunæ filentium, iecur ipfius extrahito, \& affum epileptico ut comedat exhibeto, Galenus Parabil.2.3. TFel murium alopecīs prodeffe, \&c. ex Pli nio retuli fupra inter remedia ex capitibus muriurm. Si aliquod animal in aurem intrauerit, praci= puum remedium eft murium fel aceto dilutum inftillari, Plinius, Marcellus, \& Serenns, ICauda murium, uide in Capitibus eorum furpra.

6. TMurinum fimum Varro etiam mufcerdas appellat, Plinius. Marcellus quidem fingulas hưius fimi pilulas (nam fic quo $\$$ nominat)mufcerdas appellat, ut infra patebitin remedio ad coxendices . -

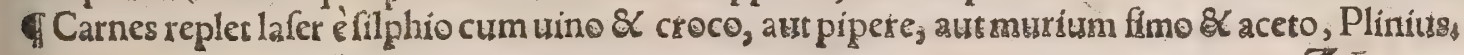


Excrefcẽtia omnia fpodij trice erodit ac perfanat canini capitis cinisłerodunt \& murino fimo, Plin Idcm fimus apud Aêtium mifcetur medicamentis ad impetigines, Lichenas in facie \& murinofi mo ex aceto illinunt: fed in hac curatione prius nitro cxaceto faciem foueri pracipiunt, Plinius. Loco quem mentagra obfederit, fimum murinum trifum ex aceto oportet imponi, uel muris uft cinerem cum olco, Marcellus. Murinum fimum admixto thuris polline $\&$ fandaracha panos di= fcutit, Plinius, De muris fimo pilulas feptem teres, $8 \mathrm{cum}$ aceto fronti uel temporibus dolentibus inlines, Marcellus, Inteftina terr $x$, mufcerdam, piper album \& myrrham, fingulorum unch am femis, teres, \& aceto fubacta hemicranico illines, miréfubuenies, Nicolaus IVyrepfus. Piperis grana 21.murini fimi pilulas 21. finapis quantum tribus digitis poffis tollere, teres, 8C aceto acri ad ceroti modum permifcebis, \& ita fronti impones, \& aluta defuper teges, Marcellus. Herba fru. mus $\&$ fercus murinum contrita, $\&$ ex aceto fronti inlita, celeriter dolores etiam heterocraní a. bolent, Idem. Furfures capitis extenuabuntur fiftercore murino liquefacto in aceto caput in bal: neo perfricueris, Marcellus, Fimum murinum alif alips medicamentis ad capillorum defiuuia admifcent, tumaliâs, turm ad alopecias \& palpebras glabras. Cleopatra apud Galenum de coms pof, fec, loc, medicamentis quibufdam ad alopeciam mufcerdas addit, Alopecias replec murinum fimum, Plinius ex Varrone. Mufcerdas tritas alopecrís illine, loco prius per linteoli affricuum fubcruento reddito, Cleopatra apud Galenum. Murinum ftercus detritum cum aceto $\&$ illitum, alopecins medetur, Diofcorides, Afclepiades apurd Galenum fecund, locos, \& Galenus ipfe in lis bro ad Pifonem, 8CParabilium I, 14. Stercus murinum cum aceto tritum ad alopecias unchas for. ma priore mirabiliter crines commodat, Marcellus. Fimus murinus tritus, cum aceto \& pice liqui 10 da tritus 8 impolitus: etiam fluentes capillos continet, Idem. Murium alui excrementa alopecias curare aliqui prodiderunt: $8 \times$ erat(noftro tempore)medicus quidã, quimedicamẽto cópolito uieban tur ex murium fimo parans, Galen, de fimplic, 10,29, Galenus fcribitfercus muris alopeciā fanare, fi trito admifceat fuccus eruc $\propto, \&$ nafurtí, \& ceparum uel alliorû,, ut cataplafma inde concinnatum imponatur, $R$ afis \& Alber. Fimum muris alopecix confert, prafertim illitũ cum cepe(melle, Bellu: nen.)idó magis fiadufum fuerit, Auicen. Stercus murris 8 thus permilce cum aceto, \& fac melis confiftentiam, \& ungue prafricando locum,(loco prius rubificato) Galen, Parabil, 1.86. ad alopeci. am, \& Archigenes a pud Galenum fec,locos. A ut ueratrum albũ, piper, mufcerdas prafrictis \& cona fcalptis exaceto illine. Aut mufrerdas \& ueratrum album illinito, Idem ibid. Ordeum tofum \& murinum fimum aquali pondere ex aceto illinuntur ad alopeciam, Galen,Parab, 1.14. Aliquialo, 3" pecias cantharide trita illinunt cum piceliquida, nitro praparata cute; $\{e d$ cauendum ne alre exulce rent.Poftea ad ulcera ita facta,capita muriô, $\&$ fel murium, $\&$ fimuี cum elleboro $\&$ pipere illini iu bent,Plin. Fimum muris $\&$ hirci torrentur $\&$ illinuntur ex melle palpebris glabris: Vide infrain. ter remedia ex fimi murini cinere. Fimum murinum aqua pluula dilutum, mammas mulieruma partur tumefcentes reficit, Plinius $\&$ Serenus, Stercus murinum ex quocun $\phi_{\text {g liquore ignorantico }}$ lico, ne horrefcat, bibendum dabis, mirum eft, Marcellus, Fimus muris uehementer laxat: unde $\&$ trutanni ( fic legitur apurd Vincentium Belluac, ) medicinas inde acuunt, Liber de natur, rerum, Audio mulierculas quafdam ut aluum morantem infantium $\&$ puerorum promoureant, nonnibi de tritis mufcerdis in pultem eis addere:apud ueteres nullus mufcerdæ intra corpus ufus fuit, (prat terquam colicis, ut ex Marcello retuli, quibus \& alla diuerfa excrementa à multis dantur: \& caleus $4^{\circ}$ lofis, ut mox ex Diofcoride fubriciam:) nec ipfe equidem utendum confuluerim, cum alia honeftion ra medicamenta non defint. Aliqui non recté ex Auicenna citant, fumptum fimum muris foluere puerorum uentres: non enim fumptum fed fuppofitum, collyrĭ forma,legitur. Mufcerda infantia bus fubditæ alui deiectionem promourent, Diofcorides. Albertus cum fale \& oleo(melle potius;nam fic $\&$ hodie quidam mufcerdas, tritas puto, glandibus mifcent, prafertim mulierculæ) fubigi, fubs diçs fcribit. Cum puero cuidam mourenda effec aluus, glandem medicus quidam cum mufcerdis parari iufit: ridebant autem qui audierant omnes, quód cum tam multa effent qua fedi appofita cx cretionem cierent, ille neglectis omnibus mufcerdas adhiberet, Profecto enim ne experiri quidem ta le quid fine pudore licet, nifi quis hac dicens aut faciens pro curiofo homine \& pręfigiatore habert uelit, Galenus de fimp, 10,28, Quanto magis igitur ridiculus fuerit ille qui etiam intra corpus mut go fcerdas fumi confulere non erubefcet? Remedium coxendicis mirü de experimento fic, Mufcerdx nouẽ tritæe exuini quartario, fuper fcabellư uel fellam laboranti potui dantur, ita ut pede uno, quem dolet, ftans ad Orientẽ uerfus potionem bibat, \& cum biberit faltu defiliat, \& ter uno pede faliat,aţ hoc per triduu faciat, confeftim remedio gratulabitur, Marcell. Muris fimum cum thure $\&$ mulfo (porum)calculos expellit, Diofcorides ${ }_{+}$Cum thure $\&$ aqua mellis potum frangit lapidem, Auicenna, Muris ftercus epotum calculos ueficx frangit, Galen, adPifnn. Murino fimo contra calculos illin re urentrem prodeft,Plin. Qui difficultate urinæ laborat, utiliter infidebit decocto fimi murinl in a* qua,Auicenna. Muris fimo illito pubi cohibetur uirorum uenus, Plinius. Vt fotus in utero mor. tuus uel etiam putrefachus egrediatur $\div$ Salem Aegyptium 8 murium ftercus \& cucurbitam fylue frem fumito, \& mellis femicocti quadrantem affundito, $\&$ refinę drachmam unam in mel inijciro, et 60 cucurbitam ac murium ftercus, omnia probẻ conterito, $\&$ in glandes'efformato, eaś́g ad uterũ fuba dito, quandiu opportunum effe uifum fuerit, Hippocrates de morbis mulieb. 
ब1 Cautis uel cauum uel cauerna dicitur locus excauatus, in quem fe recipiunt mures. Mures, cai uerna radice afphodeli præclufa, moriuntur, Plin. Me fylua, cauusća Totus ab infidifj tenui fola

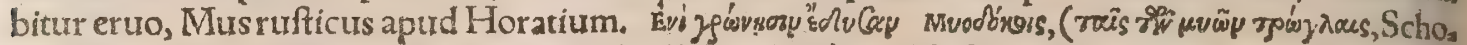

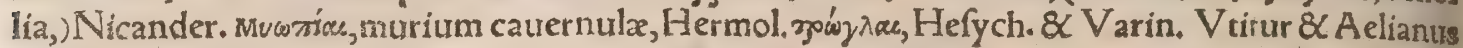
hac uoce: quamuis aliqui mycnia non myopiålegunt apud Aelianum pro muliere libidinofa, ut in c.retuli. Myopes dicuntur, $\mu u^{\prime} \omega r \delta$, qui non nifi admota oculis, contueri queunt, \& cum paulolon

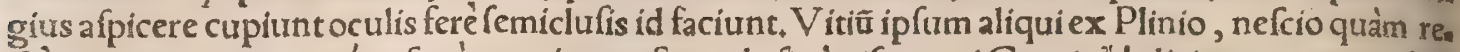

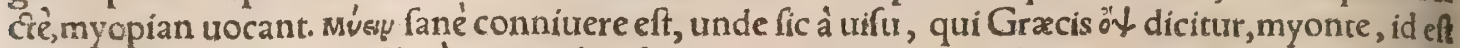
conniuente nominantur. Feré autem ab ipfo ortu hoc uitium contrahitur:neqg habetur remedium, Confpicilia tantum quædã parantur, quorum ufullongius extenditur uifus:ea funt hurufmodi, ut 1 minora reddantur, quxcunq̧ per ipfa afpiciuntur:nã qux fenes ufurpant, maiora qux uidentur red dere debent, quanç $\&$ fenes myopes vidi, qui itidem ut iuuenes hoc uitio laborantes ad lecrionem $\&$ res alias domi agendas confpicilijs uti non folent, fed tantum fi quid eminus cernendum eft. Sunt autem confpicilia myopũ (min (mer $g$ fidbt) oculis fanis aut hoc uitio non laborantibus, inutilia.Myoa pum uero uifum colligunt \& acuunt: \& altera quidem non multum,altera uerò multò minora redł dunt qux uidentur, duplicia uocant, quibus ipfé uti neceffe habeo, cum quid èlonginquo profpectur rus fum:nam ad lectionẽ non adhibeo, quòd quamuis multò clariores reddant charactêres, uifum ta men nimium colligendo offendunt,pauciffimi autem ita prorfus myopes reperiuntur : permultiex dimidio, qui fimplicibus $\&$ communibus myopum confpicilịs utuntur: qua minus, ut ica dicam, as cria funt, $\&$ minus fi quis ad legendum adhibeat, offendunt. Inter hac \& fenum confpicilia media funt quædam, quæ ad uifum in fuo ftatu conferuandum facere dicuntur, cum qua uidentur nec ma iora nec minora, fed eadem qua funt magnitudine repręfentent. Hoc mirum, cũ in hoc uitio tam bre uis fit uifus, qualem in me experior, ut charaçêres communis magnitudinis ff ultra quínç̧ digitos diftent, non difcernã, non facile ramen defatigari legendo, ne ad lucernã quidem, nec uilis ferè affed bus corripi, quod ego fciam. Hoc tantum memini, me adhuc puerũ, hippo laboraffe: is eft oculorû aft fectus, quo palpebræ propter uifus infirmitatem fubinde, tanquam trementes nictatione fua clau dunt aperiuntós oculos. Hoc etiam obferuaffe mihi uideor, cæfrjs oculis uel glaucis hoc uitium fres quentius quàm nigris accidere. Iam cum à puero ferè hoc uitium incipiat, \& oculi nihilò hurmidio. res inde reddantur, imò paulò ficciores potius, non recté nidentur recentiores quidã hoc uititĩ, ut alis os plerofģ oculorũ affectus, defluxione humorum è cerebro gigni afferere : hoc enim ficontinge ret, exiccantibus $\&$ attenuantib.curari poffet, nec perpetur̃ $\&$ incurabile effet; quamobrẽ alia quz, renda eft caúa, quam ego in fpiritus uifiui tenuitatẽ reñciã interim donec alius meliora adferat, Hoc non omitcendum, mirũ effe quod uulgo creditur, oculos fic affectos perpetuò ferè in eodê ftatu dura, re,neç timen dum ut paulatim deficiente uifu cxcitas inuadat. Latinum nomen myopü non inues nio:neq enim lufciofos aut lufcitiofos uertere placet, quũ nyçalopes etiã fic interpretentur, uitiun longè diuerfum:quod ipfưm etiã alị aliter accipiunt:ego quidem nyçalopem uidi fenem quendam, qui ad lucernã nocfu legere non poterat. Angli fic affectos, ut audio, uocant borblind, id eft caets tientes \& palpantes; boren enim uocant inquirere. Lufcioli, lufcitiof, (uel nufcitiofi Fefto)qui pro pter uitium oculorû́ parum uident, Arteus Philologus. Nufcitiofi, inquit Aelius Stilo, plus uident uefperi quàm meridie: nec cognó́cunt nifi quod ufó̧ ad oculos admouerint. Aln̈ eoldem ny ctalopas 4

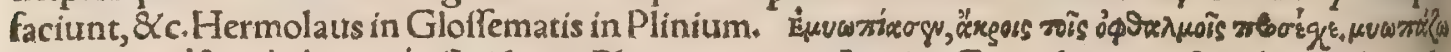

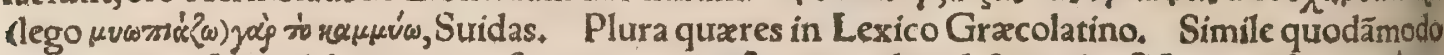
huic uitium eft, quo laborantes noftri uocant überfinnig, melius dicturiüberfichtig, ac fi hyperôpas dicamus:qui non folum propius admourent oculis quod dligentius infpecfurifunt, uerum etiá alts us $\&$ ferè fupra oculos eleuant. Accidere autem audio hoc incommodũ adhuc infantibus, quibus furfum ac retro refpectare in cunis nimiũ permittitur +fortaffis $\&$ fuffuffo inferiore oculorum parte, hoc eft infra pupillam exoriens eiufdem uittị caufa fuerit, Sed ifis myopũ confpicilia nihil profunt. Hęc per digreffionem pluribus quidem dixi, fed Lectori fpero non ingrata, rei medicę prafertim ftus diofo, quòd de hoc affeçu medici tanquam incurabili parü diligenter traçauerint. Cæterum $\mu v i w_{\psi} \psi$ cum per diphthongum vı, fcribitur, a filum fignificat, de quo inter infeça dicã: quidam diphthógum

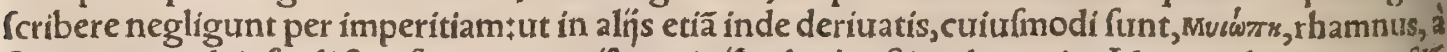

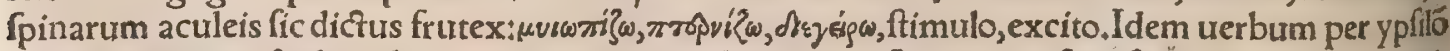
fine diphthongo fcribi debet cum conniuere uel myopũ infiar intueri fignificat, Varinus exponit

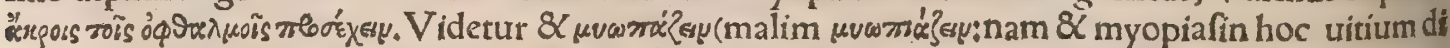

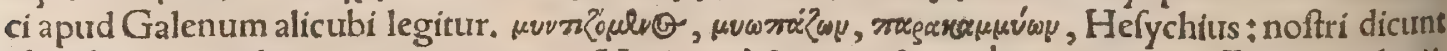

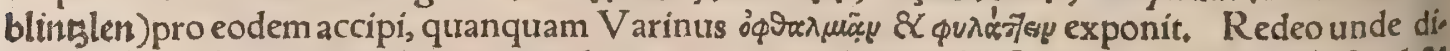
greffus fum. Non igitur myopia tantũ de muriũ cauerna legitur: fed frequentius etiã $\mu v \omega \xi \xi^{\prime} \alpha$, Suid, \&

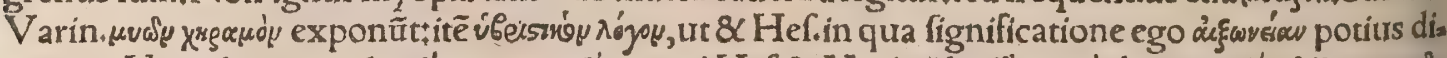

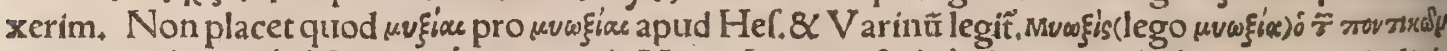

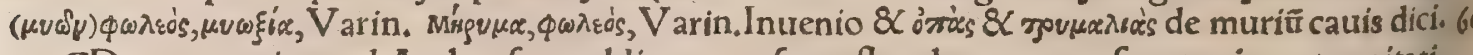

बDentes muris apud Arabes funt additamenta fuperflua dura, qux nafcuntur in extremitatis bus unguium iuxta carnem fecundum latitudinem, 8 uulgò à Venetis dicuntur fpelli, And. Bellu. 


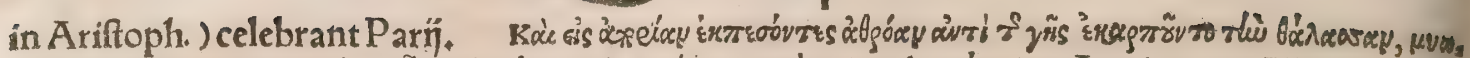
тxं citat Bayfius. Cicero actione quinta in Verrem myoparonem piraticum nominat; ex cuius uerbis Bayfius coniphcit myoparonem habuifle fex remorum ordines, \& inter longas naues adfcribendum effe. Idem Tullius paruos myoparones nominat feptima in Verr, paruor û enim minifterio prafect triremium \& maiorũ utebantur, Plutarchus in Antonio myoparonas uxocare uide $\vec{t}$, quos phafelos di xit Appian, quorũ forma mixta erat ex naure oneraria \& lôga triremi, quales hodie galeones uocãt, Quód firectè Ariftophanis interpres naues aliquot ab infulis dictas putat, ut corcurum à Corcyra, paronem à Paro, aufim \& ego(inquit Bayfius) conïcere, myoparonem effe nauigí genus compofi. tum ab utraģ forma earum nauium, quæ fieri folebant in Myunte \& Paro infula, Hæc ille. Sed forte dicta fuerit myoparo partra nauis, paroni aliæue maiori adiuncta, tanquam prodroma $\alpha$ anteambu latoria, ut holcadibus epholcia \& epholcides, triremibus cattæ $\&$ pontones, ftrategidi fpeculatoriæ \& catafcopiæ : à mure fiue mufculo pifce duce balænæ, ut paulò ante in mufculi machinæ oppugna toria mẽtione dixi. Deinde à parui myroparonis forma, maiores etiam fimiles naues fic dici potue

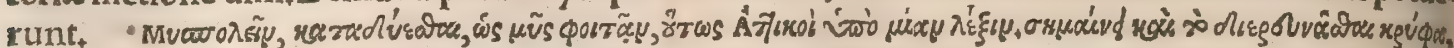

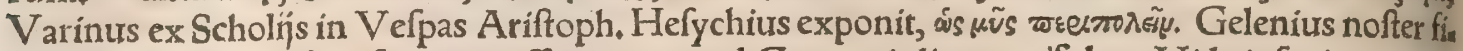
nitimum $\&$ uoce $\&$ fignificatione effe putat quod Germani dicunt wifplen. Vide infra in prourer

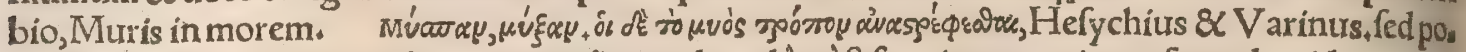

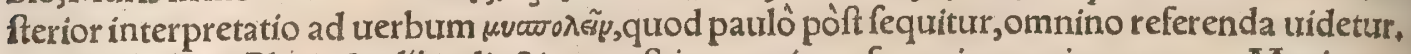

- Murinus Plinio \& alijs adiectiuum eft, ut murinus fanguis, murina caro, Murinus color 10 qui uulgaris eft in afinis, Columella libro 6. Phaum colorem ex albo \& nigro concinnatum uo, lunt pleríg, myinon item nuncupatum, quod in libro de morali uirtute confirmat Plutarchus, tefta tur 8 primo deideis tomo Hermogenes, Calits. Equi colore difparestitem nati, Hic badits, ille giluus, ille murinus, Varro in Afino ad lyram ut Nonius citat, Equorum colores pracipuos hofce comperi, badium, mureum, certuinum, \&c. Calius. A mure non murineus fed murinus des flectiturłut carmen illud Martialis, Campis diues Apollo Murineis, minimè ad Smintheum illü Hon mericum $\&$ mures populatores frugum referendum fit + quod dubio procul ad Gryneum referri os portet. Eft enim authore Stephano Gryni oppidulum Myrinæorum, ubi \& templum \& oraculum ure tuftum Apollinis eft, Calius Calcagninus in Epiftolicis quaftionibus. Murrhinum quidem pes nultima correpta, uel murrheam dicitur, quod ex murrha gemma factum elt, ut murrhinus calix, 3 Scoppa murrham agatham uulgo dictam uel porcellanam interpretatur $¥ \mathrm{Ge}$. Agricola murrhinam non murrham uocat, $\&$ interpretatur Chalcedonium, ut $\&$ onychem $;$ his enim duobus nominibus rem eandem Plinio defignari, onyx quidem etiamnum nomen apud multos retinet, onydjel. Ef \& murrina, aliâs murinưla uel murrinulum, potionis genus, non à myrrha fed à myro, id eft ungurento uel odoramento dictum, myratum aliqui uocant, \&c. Hermolaus Corollario $825_{6}$ ¿v́vouos (inquit

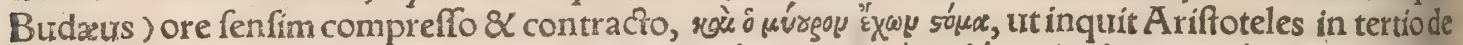

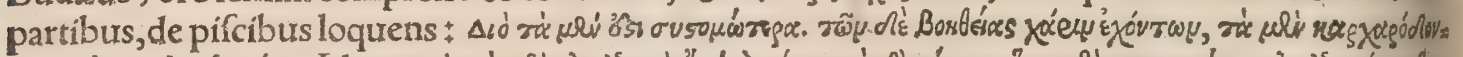

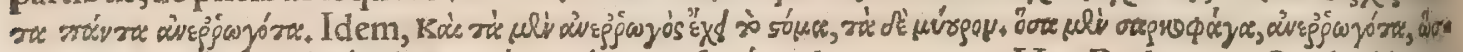

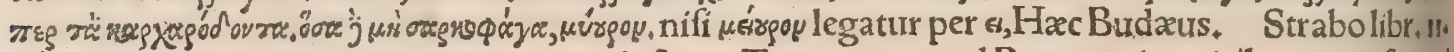

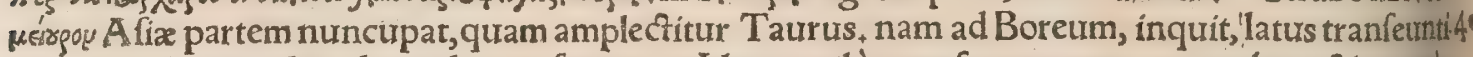

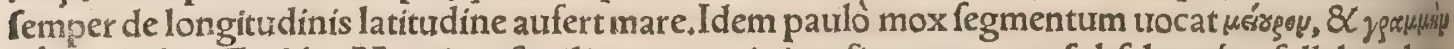

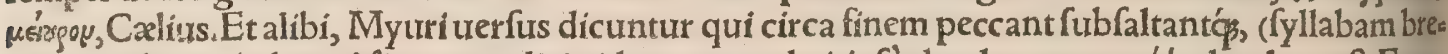

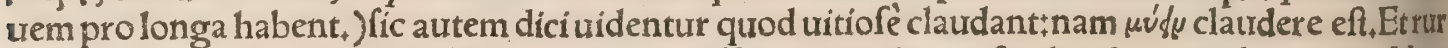
fus, Ärbitrantur nonnulli arteriarum pulfus poffe myuros dici ex fimilitudine cauda muris, Nam

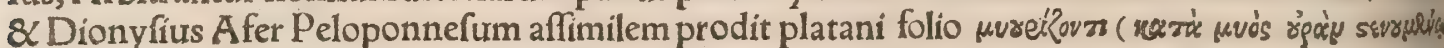

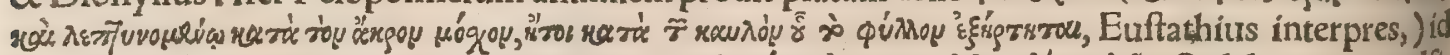

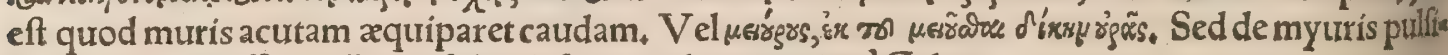
bus, eorumćs differentís confulendi funt medici,pracipuè Galenus.

ब Muodor $\pi \times v o u$, genus lapidis cuiufdam uilis, Hefychíus.

đHerba phoenicea appellata à Gracis, à noftris hordeum murinum, Plinius, Phoenix haec Dio 1 fcoridi eft, ubi inter nomenclaturas eius etiam lolium murinum legitur, Plinius hordeum murinum appellari ait, quod hordeaceo fit folio, $\&$ feminibus eius inter tegulas mures urefcantur, Marcellus Vergilius. De myacantha, id eft corruda, qua $\&$ myon uocatur, in $\mathrm{E}_{+}$dixi, quoniam decoctum cius mures occidere fertur + Er ibidem de myacantha, id eft rufco, cuius uirgis fpinofis fuccidiam \& cafeorum fifcellas ruftici contra mures muniunt. Inter nomenclaturas Diofcoridiadfcriptas, my itis caucalis eft:myites \& myopteron, thlafpi:myuros Armenins, fampfurchum* myortochon, auricu* la muris uel alfine. Mvéowroy, herba fimilis auribus muris, Hefychius ; Galeno $\mu$ voown ns uocatur.

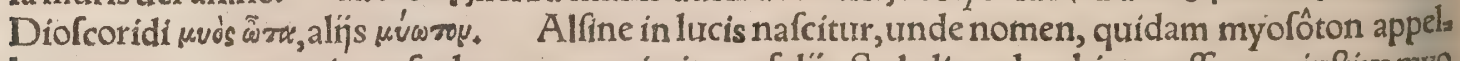
lant. nam cum prorepit mufculorum aures imitatur folīs. Sed aliam docebimus effe quax iuftius myo fôtis uocetur. Hæc eadem erat qux hel xine, nifíminor mínusḉ̧ hirfuta effet, nafcitur in hor tis $81 \mathrm{ma} 60$ ximé in parietibus:cum teritur odorem cucumeris reddit, Plinius. Demyolora Pliní cui uím fepti. cam \& exulceratricem tribuit, dixi quadam in Lupo a, in aconito, Diofcorides primum alfinem de: 


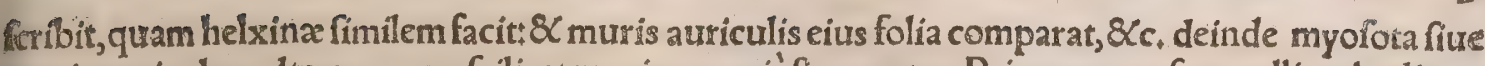
muris auriculam alteram, quæ fcilicet magis proprié fic uocetur. Priorem, morfum gallina hodi̊s uo cant: pofteriorem uerò aliqui effe conijciunt pulmonarix genus fyluaticum, non maculofum (macu lofum enim pulmonaria Pliní eft, buglofti folio, de quo pluribus egí in Boure c .) floribus caruleis, uernis, 8cc Suntqui $8 x$ helxinen fui generis herbam myòs otida, id eft muris auriculam trocẽt, Dinfcorides, Noftri auriculam muris, mufortle, aliam uocant herbam, ex lactucarum fylueftrium genere, cui folia feré olex peculiari modo raris \& oblongis pilis hirfuta funt, unde pilofella nomen apud aliquos; flos luteus, qui in pappos refoluitur, caly $x$ nigricat:caule recfo, fed aliquot circa eum flagellis (ut ita dicam)humi reptantibus. de hac multa fribunt recentiores; de antiquo nomine dubi - tatur. Multi etiam aliam eodem nomine uocant, gnaphalio uel fticadi citrin $x$ uulgò dictæ fimilem, floribus albis, aliâs purpureis, aliâs uarïs, mollibus inftar tomenti, \&c, mufö:lin / bafenpfờtlin, uide in Lepore a. Myagros herba ferulacea( $\$$ gryowínolss, Diofc.)eft, folips fimilis rubex, Plin. Pluribus de fcribitur à Diolcoride:qui herbam bicubitalem facit, femine foenograco fimili, pingui \& oleofo quio uufo toftós uirgas circunlinant, fic prolucerna utentes. Hanc Ruellius in Gallia uulgó notam effe fcribit,camelinæ aut camaminæ nomine, Seritur, inquit, quamuis $\&$ fux fpontis inter fegetes inue = niatur: femine minuto foenograci figura, in utriculis orbicularibus concepto. Hoc in ar eis pauitis rura flagris decutiunt, 8 uannis uentilant, dum filiquarum recrementa uanefcant, tum trufatilibus molis fubijciunt, uerfandó̧ fubinde oleum exprimunt : qưo non ad lumina tantum lucernarum, fed \& ciborum quo $\$$ condimentis pauperes utantur, magno huius olei prouentu. Matthaolus in Italia nec feri nec aliter nafci putat. Fateor $\&$ ipfe ignotam mihi. Marcel.Vergilius de nominis etiam origine nihil certi,inquit, afferri poffe $\ddagger$ nam quòd mures uenetur $\&$ perimat, ut nomen indicare uidetur, non conftat, Forte mures agreftes (quos myagros dixeris, ut apros fyagros) cum pingue \& oleofum proferat femen, ea delectantur. Vidi ego herbam paruis radiatam folins, fimiliter ut galion, (quod hodie fic uocant eruditi, luteis $\&$ odoratis florum corymbis infigne) fapore ferè nitrofo uel be. tæ, fputum ciente in quibus femina nigra papaueris magnitudine, fed quæ nihil cum foenogræco conueniant: qua fí myagros non eft, nomen aliud ignoro. Sicurion, aliâs fucturion, id eft tefticulus muris, Syluaticus. De myophono uel miephono, dixi in Lupo a.in aconiti mentione. Prope $A_{=}$ cheloum Aetolix fluuium mons eft Calydon, in quo $\mu^{\prime} \omega \downarrow$ herba nafcitur $¥$ quod fi quis oculos ablue rit aqua, in quam illa iniecta fuerit, uifum amittit; placata urerò Diana, recuperat, ut fcribit Dercyllus Aetolicorum tertio, Plutarchus in libro de flưứs

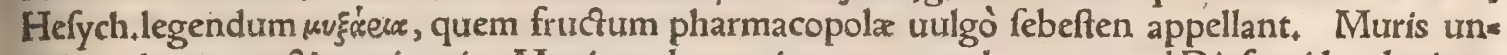
guris, polygonon: \& muris urina Magis, malua, ut inter nomenclaturas apud Diof coridem legitur.

- Ilchneumonem recentiores quidam uulgò murem Indicum appellari docent. Vefpertilionem noftri uocitant fixpermit $;$, quafi dicas uolucrem murem, Galli chauuefouris, id eft caluum murem, \&c. Eft $\&$ inter pifces mufculus, Graci myftocetum uocant, balænæ dux. Caprifcus pifcis uroca. tur etiam $\mu \tilde{u}$, Diphilus Siphnius apud A thenaum libro 8.(nifi quis non $\mu \tilde{u} y$, id eft murem, fed $\tilde{v} u$, id furem legendum potius exiftimet,) Hermol. Mus aquatilis, hoc eft teftudo, Gręcé $\mu \tilde{s}$, \&̇uv's $\&$ wiuv's no minatur, \& c uride in Teftudine. Sunt alíp prxterea oftreorum generis, hoc eft tefta filicea intecto=

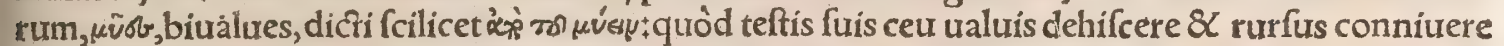
40 feu claudi foleanic. Gaza apud Ariftotelem alicubi mitilos transfert. Horum genus unum mufco obs ductum hirfutumć, ${ }_{3}$, murem quodammodo fua hirfutie refert, muffolum Venetí uocant, fiue à mus. fco, fiue quafi mufculum, Germani quidem mufdelen uocant omne genus teftaceum biualue. Myaces pifces intelliguntur murices + fed \& pro conchula accipitur myax, qua humores excipiun tur, Calius, At qui proprie loquuntur oftracodermorum genus à pifcibus excludunt. Tellinas, nó myacas, mitulos à Romanis dici, teftatus A thenæus eft: nos tamen aliorum in ea re obferuationem fe cuti, myacas non tellinas mitulos uocauimus, Marcel. Vergil, in Diofcorid,2+5. Murices quidem ego purpuras potius quàm myaces fecerim, aut certe fimilia purpuris oftrea, non biualuia, fed fim plicia, in orbem fe contrahentia , \& quibufdam aculeis mucronata $\ddagger$ uide in Purpurarum hiftoria Mya genus margarita circa Bofphorum Thracium, uniones rufos ac paruos gignens, ut ait Plin, lia

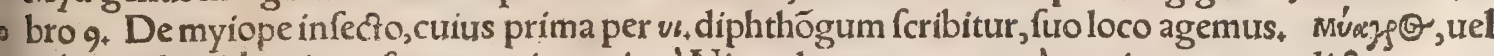

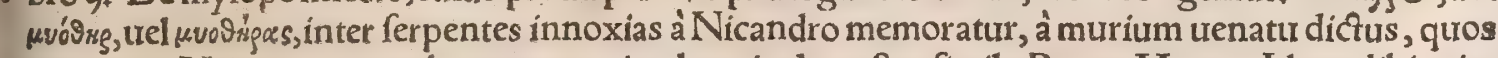
deuorat. V tias in nouo orbe uocant animal cuniculo noftro fimile, Petrus Martyr. Idem alibi utias muribus non maiores fcribit. Audio hodie exiguam quadrupedem ex nouo orbe afferri, candidam, cuniculo æqualem aut minorem, fpecie porcelli,fingulis menfibus ut cuniculi foecundam, \& àmer catoribus porcellum Indicum uocari, haud fcio an ab utia.diuerfam.

TEpicuri feruus nomine Mys, (Mus, Gellius 2.18.) philofophus non incelebris fuit, Macrobius I. 11. ǘs pugilis nomen apud Suridam \&V Varinum. Item uiri, qui claruit argento cęlando,Quis labor in phiala? docti Myos? an' ne Myronis? Martial. In futo Minerux Athenis Lapitharum pugnam aduerfus Centauros $\&$ alia quadam Mũy quendam artificem feciffe (ropoliou, tornaffe) aiunt, Paufan to nias in Atticis. Non procul ab Acraphnio oppido regionis olim Thebanorum, templum Apolli: nis Ptoi eft terrogaffe aiunt lingua uernacula, $\mathrm{Paufan}$. in Bocoticis(ex Herodotioctatio.) Parua mihidomus 
eft, fed ianua femper aperta, Exiguo fumptu furtiua uitro fagina, Quod mihi nomen ineft, Röme quoç conful habebat, Camerarỉ anigma de mure. Myagrus nomen calatoris feu ftatuarï, apud Plinium 34.8.item mufcarum deus, led in ea fignificatione primam fyllabam per $v$, diphthongum

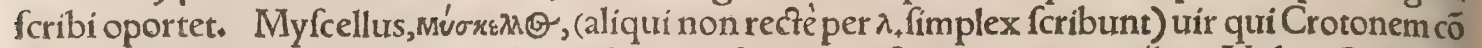
didit. Suidas bis eius meminit, pofterior locus defumptus eft ex commentarís in Nubes Ariftoph, Item Erafmus in prouterbio, Donum quodcun 9 dat aliquis proba. Oraculi huic dati ex Strabonis

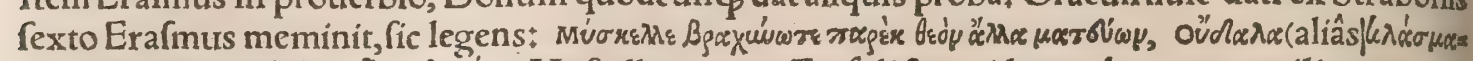
$\tau x)$ Ө habebat murinis fimilia, (fed ita per $\lambda$, fimplex fcribi deberet, $\&$ fieri poteft ut carminis gratia dupli. catum fit) brachynotus ob dorfurm contracium.

TArgilum Thraces murem uocant, quo uifo conditam à fe urbem Argilum appellarunt, ut fux: perius retuli, circa initium huius capitis, TMya $\&$ Sepiuffa infula, funt in Ceramico finu, Plin. 5.31. Myanda,oppidum in continenti Cilicia, Plin. 5.27. Myes, Múws, urbs Ionica, gentile Myefis us,Stephan. Herodotus non procul initio libri fexti Myefios, Musoris nominat, ubi in Valla tranf latione non recté Myufios legimus. Myon, urbs Locrorum in Epiro, cuius ciues Myones uel Mvo= vส̃s, Stephan. Paufanias etiam Eliacorum 2.Myones effe fcribit Phocidí uicinos, qui in Locridis con tinente incolunt. Myonia, urbs Phocidis, cuius ciues fimiliter Myones uel Myonếs dicuntur, Idẽ. Myonia urbs Phocidis fupra Amphiffam in continente, triginta ftadijs Amphiffa diftat. Myonen= fes hi \& Ioui Olympio fcutum dedicarunt, Paufan, in Phocicis. Myonnefus, urbs uel parua regio inter Teon \& Lebedon, Stephan,infula non procul Ephefo,Plin. 5.31. Muós öge $\mu$, primus portus Aegypti ad rubrum mare, Arrian. Memínit etiam Plinius 6. 28. Ad Myòs hormon, inquit, infula eft deferta, \&c. Myûs, urbs Ionia.Strabo libro 12, ciuis Myufius, Steph. Myûnta oppidum primo condidiffe Iones narrantur, Athenis profecti,Plin. Cydrelus Athenienfis Codri filius oppidum Myûnta,Strabo. Memínit huius urbis Herodotus etiam libro I. Myûntem \& alia quadam oppi= da Xerxes Themiftocli donauit, ut in eius uita Plutarchus tradit. Myuntiorum belli cum Milefijs meminit Calius 23. 1. Mũs, nomen gentis, unde Myfia urbs dic\{a, Etymologus ₹ fed locus uidea tur corruptus.

b. Vrforum foetus candida informisç caro eft, paulò muribus maior,Plin. Murris ódbrurobu a

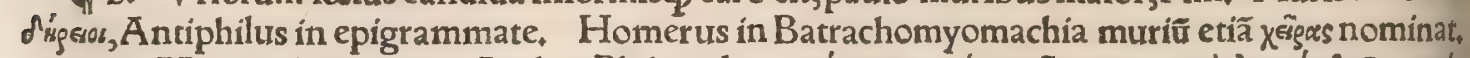

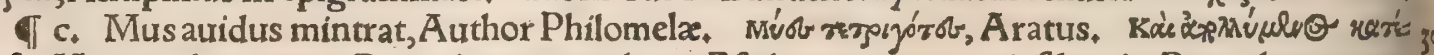

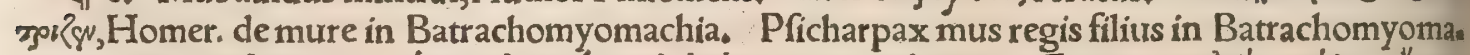

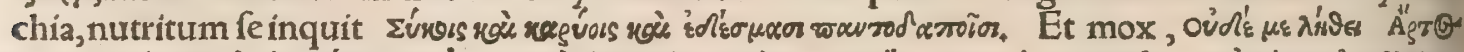

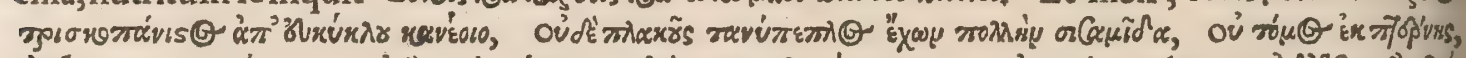
ớ X

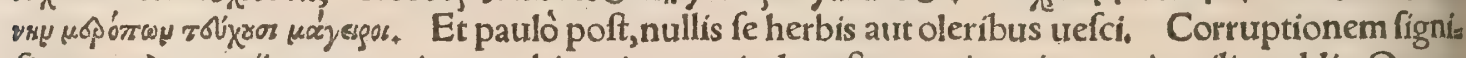
ficantes A egyptī murem pingunt: hic enim omnia deguftans coinquinat ac inutilia reddit, Orus. Plaurus in Captiui duo, Quafi mures femper edimus alienum cibum:nos tales parafitos uocamus fbmozotser \& tellerlecter. đMufcerdas prima fyllaba producta dicebantantiqui ftercus muri. um, Feft, fic \& fuccerda (fucerda Hermolao) uocatur ftercus fuillum, Murinum fimum Varro

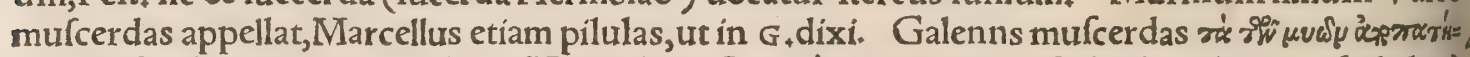

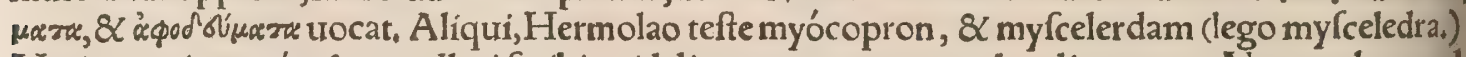
Varinus etiam uvóyodle appellari fcribit, uidelicet neutro genere, plurali numero. Non probo qund Calius legit myódocha, (uíde fupra in a.) cum myochoda uox recté componatur à mure $\&$ uerbo

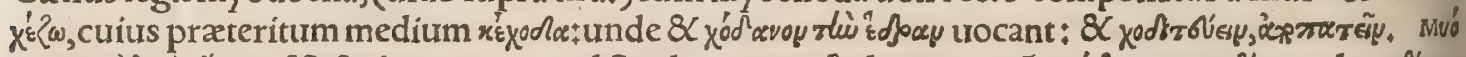

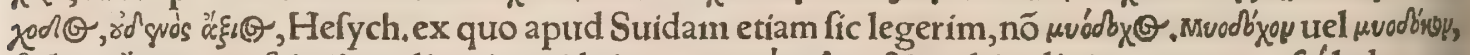

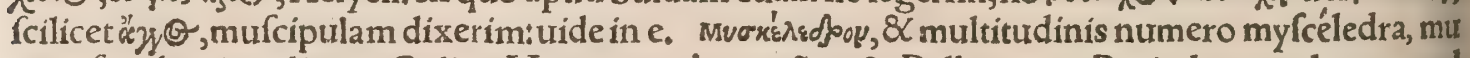
rium feculentiam dicunt, Calius, Varinus in Axrowerïrac, \& Pollux $5 \cdot 14$. Proinde non placet quod alibi apud Varinum legitur $\mu \nu \sigma x \in \lambda$ evoser, proparoxytonum $\$ \&$ eadem uox apud Hefychium oxyto: na. In Lexico Græcolatino $\mu \nu \sigma x \dot{\varepsilon} \varepsilon b_{\rho} \circ$ etiam fine authore fcribitur. Litemus, id eft fercus muris, Syluat. Murinos catulos de murium foctu Plinius protulit.

(1). Nos in partibus fuperioris Germaniæ murem uidimus, qui tenendo candelam miniftra= bat lumen comedentibus ad praceptum magiftri fui, Albert, de animalib.8. 5.1. 9 Itaç non folum inquilini, fed mures migrauerant, Cicero ad Attic, lib.14. \Brafidas à mure morfus, uide in pros

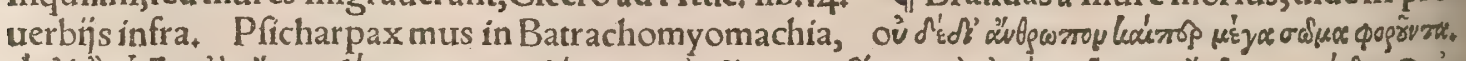

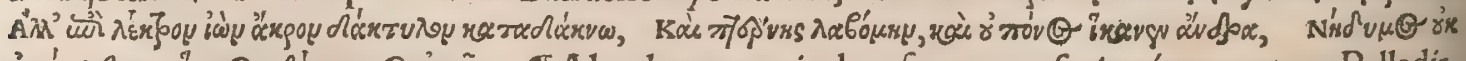

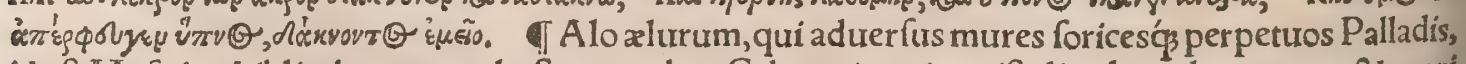
id eft Mufxi ac bibliothecx mex hoftes excubet, Calcagninus in epiftolis:plura de catorum \& muri úm difcordia uride in Cato. In Batrachomyomachia Pficharpax mus circum, id eft accipitrem, \& $\&$ yanı̇y, id eft muftelam maximè fe metuere dicit+\$X hanc pręcipuè, quòd in ipfa etiam caua mures perfequatur. Vncia animal eft fæuum in $A$ frica interiore +à quo uulneratum mures infeftunt ac permingunt, Obfcurus:De uncia quadrupede uide in Panthera A. Antiphili epigramma Antho logí 1.33 . legitur in murem, qui cum domi hiantem oftrei concham uidiffet, immiffo roftro carnem 


\section{DeMure. H.e.h: Lib. I. 825}

oftrei rodere copit:quo pra dolore teftam contrahente 8 occludente, mus cum euadere nequiret, fic interceptus perijt. Hinc Alciatus etiam in fua Emblemata tranftulit, fub ticulo, Captiuus ob gulam.

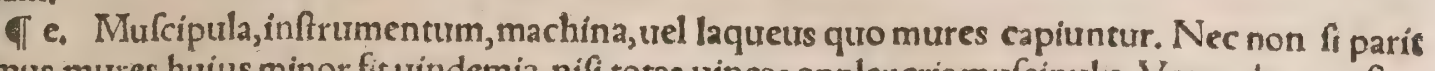
hurmus mures, huius minor fit uindemia, nifi totas uineas oppleueris mufcipulss, $V$ ar: o de re ruft. múuraxa, mufcipula, Hefychio \& Varino. Gelenitus tres iftas uoces, Latinam, Gracam, \& Germa.

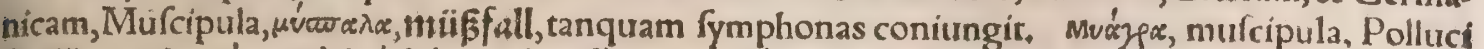

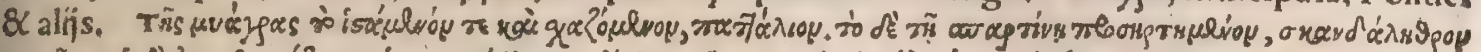

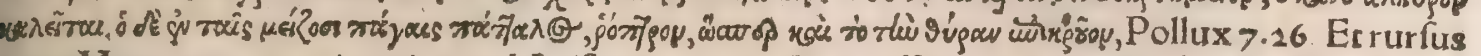

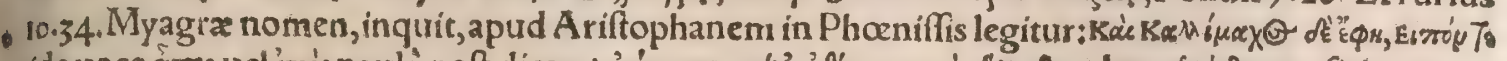

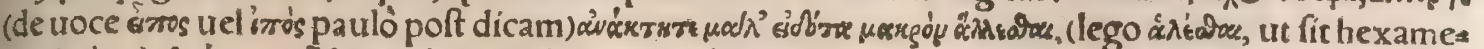

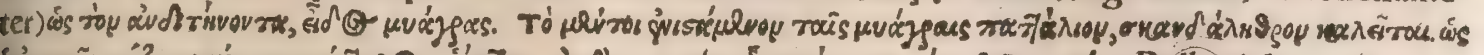

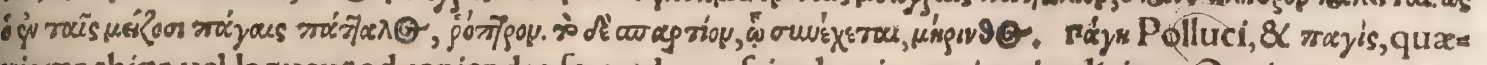
uis machina uel laqueus ad capiendas feras:de mufcipula etiam priuation dicitur Oppiano, ut in E.

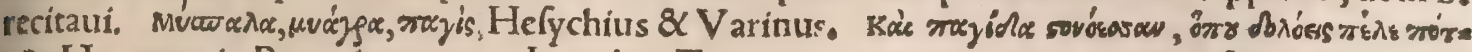
$\mu \theta$, Homerus in Batrachomyom. In eadem Troxartes rex murium conqueritur filium fibi mufci

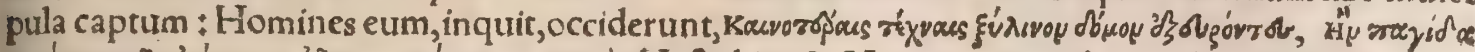

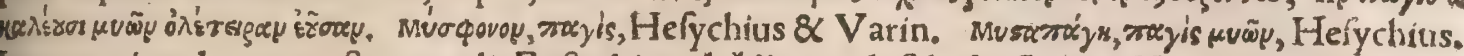

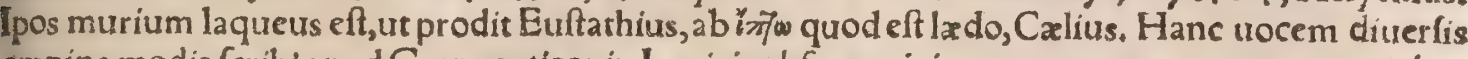
omnino modis feribi apud Grammaticos in Lexicis obferuaui; interpretantur autem omnes mazke

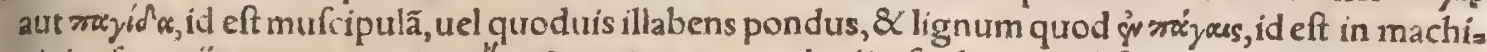

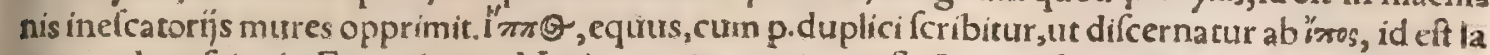

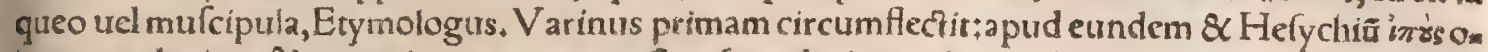
xytonum legitur, \& exponitur tanquam reçus fingularis quod non placet : uidetur enim accufatia uus pluralis à recio inos. Pollux siryos oxytonum habet ex Callimacho, ut pauló fuperius recitaui : fed

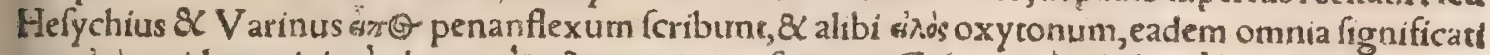

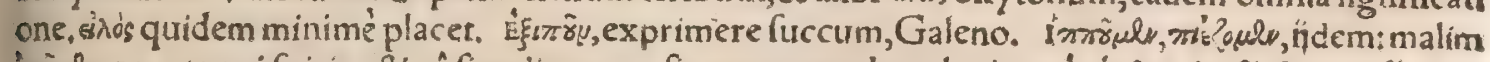

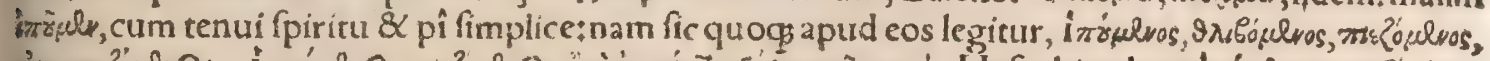

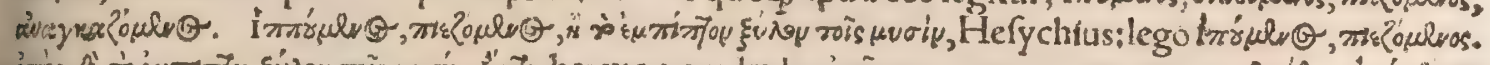

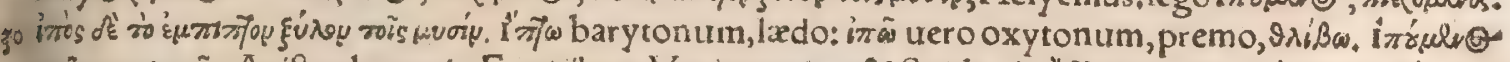
- тxüs cvequogäs, Ariftophanes in Equirib. ut Varinus cirat, \& Suidas in "inj $\omega$, quamuis idem pauló ante

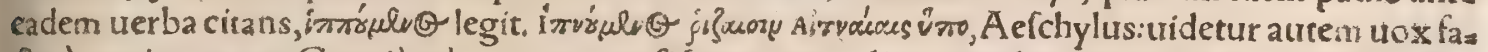
ça à camino quem Græci irnò̀y uocant, quafi fumisatum dicas, qurod contuenit Aetnæ monti arden ti. Dionyfius Siculus murium conceptacula recié dici poffe putabat,à feruandıs muribus, Ca! iuss.

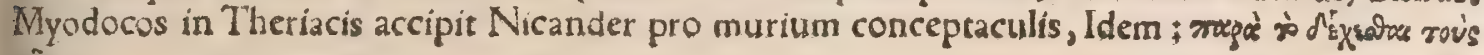
piviss.

Ti Si quod animal in muftum ceciderit, \& interierit uti ferpens, aut mus, forex'ue, ne maliodoris uinum faciat, ita ut repertum corpus fuerit, id rgne aduratur:cinisq́ ̧́ eius in uas, quò deciderat, friggi dus infundatur, atge rutabulo ligneo permíceatur:ea res erit remedio, Columella 12. 31. Tradunt 40 magici iocinere muris dato porcis in firo, fequi dantem id animal: in homine quogz fimiliter valere, fed réolui cyatho olei poto, Plin. Morchus facillimè adultrratur:unde fxpe ftercus murium $\&$ hus iufmodi ridicula pro mofcho uxneunt, Monachi in Mefuen, I Aedificare cafas, plofelllo adiun. gere mures; Ludere par impar, Horat.Serm.2.3.

- Th. Glaucus filius Minois $\$ 2$ afiphaés, cum murem perfequeretur, in dolium melle plenum ila lapfus eft, \& polea à Poiyide uate herba quadam ei impofita in uiram reuocatus, ut pluribus defcri bit Ifacius Tzetzes in Scholihs in Lycophronem. II In mures incolas ædium pauperum, ut fe reci. piant ad ditiores, Leonidæe epigramma, \& alterum Ariftonis, Anthologï Græci 1.33. đHeliogaba

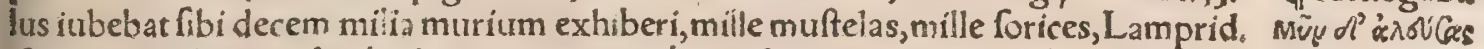

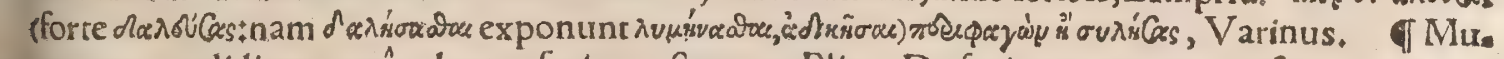
so res cum candidi prouenêre, latum faciunt oftentum, Plin. De foricum occentu, in forice mox pri. uatim dicam. Mures incolæ domus, haud fpernendum in oftentis etiam publicis animal, arrofis $\mathrm{La}$ uinni clypeis argenteis, Marficum portendêre bellum: Carboni imperatori apud Clufium fafcỉs, qui bus in calciatu utebatur, exitium, Plin. Mus corrodens aurum uel quiduis nobis iucundum, quid fignificet per duodecim figna, Luna in fingulis exiftente, Niphus explicat libro primo de augurin's,

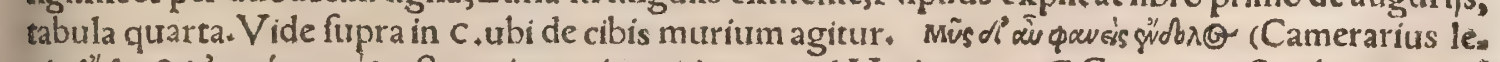

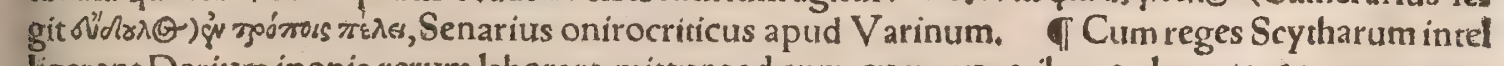
ligerent Darium inopia rerum laborare, mittunt ad eum cum muneribus caduceatorem, aue, mure, rana, \& quinç fagittis.Perfxeum qui munera ferebat, percontabantur quid illa fignificarent. Ifte ne gare fibi aliud effe mandatum, nifi cum illa tradidiffet, celerrimè rediret lubere tamen ipfos Perfas, ff so folertes forent interpretari quid fibi dona uellent. Hoc cum audiffent Perfa, confultabant. EtDarî quidem fententia erat, Scythas feipfos ei donare, \& terram atq̧ aquam, hac ratione coniectans, quòd mus quidem in terra gignatur, $\mathcal{Q}$ eodem quo homines uictiter; rana autem in aquis nafcatur ; auis 
uerò fit equo affimilisł fagittis dảdis, quod feipfos tradere uideantur. Āt Gobryas unus è feptem qui Magos fuftulerunt, hoc dicere dona coniecrabat: $O$ Perfae, nifi effecti ut aues fubuoletis in coelum, aut mures fubeatis terram, aut rana infiliatis in paludes, non remeabitis unde ueniltis, his fagittis confecti: ( $\&$ recte quidem ille, ) Herodotus.

-f Cum Philifai A zotîj arcam Dei a pud Se retinerent, nati funt mures $\&$ facta eft confufio mo: tis magnæ in ciuitate, Regum 1 . . ( ( fed hac uerba in Hebraicis exemplaribus non leguntur.) Percufa fitćs eos Dominus in inferioribus uentris, Et mox capite fexto: Sacerdotes eis confulunt, ut arcam Ifraellitis remittant, \& fimul dona, videlicet quing anos aureos $\$ \mathcal{Q}$ quinç mures (acbere) aureos, ad effigiem anorum hominis, ' 82 murium qui rerram perdebant. Smintheus Apollo nominatur Ouidio in Faftis, Homero, Orpheo, \& alins.fic cognominatus à muriburs, Caufa(inquit Gyraldưsituz to rié proditur.Crinis A poilinis fuit facerdos, is cum Dei facra neglexiffet, à rerreftribus muribus agro rum fructibus eft priuatus, cuius detrimento damnóg commotus Ápollo, bubulco cuidam Horda nuncupato iuffit, ut Crinin facerdotem moneret, illum debere confureta facra peragere, quod facer. dos cum feciffet, A pollo mures fagittis cófecitthinc A pollo Smintheus cognominatus eft. fminthas enim Cretenfes mures uocant, $\bar{A}$ elianus de animalibus, $t d$ tradit, mures adorari ab his qui Troadis Hamaxitum incolunt $;$ unde Apollinem qui apud eos maxima religione fuit, Sminthium appellas bant:mures enim Acoles \& Trciani fminthes nuncupant: ficut Aefchylus in Sifypho teftatur, cum ait: Sed agreftis quis eft Sminthius. Tum uerò apud eos fminthes cicures alunt, eisç̧ uictus publicé prabetur, atc infra altare, ubi degunt, latebras habent, Aelianus ut recitat Gyraldus, nam Gillius pauló aliter qurędam transfert, ego Gyraldo accefferim. A pud etiam tripodem Â pollinis mus manet, 10 de cuius religione (inquit A elianus ) hanc accepi fabellam + Permulta murium millia cum Aeolum \&. Troianorum fegetes inuafiffent, atç immaturas fuccidiffent, \& fimul eis qui earum fementê, \&c (reliqua enim mihi interciderunt,) Strabo ueró libro 13. aliam hiftoriam, feur fabulam, ut ipfeait, recenfer: In urbe, inquit, Chryfa eft A pollinis Sminthei delubrum \& fimulachrum, quod nominis ue ritatem feruat, nam mus quidem pedi fratuæ fubiacet, hãc ftatuam Scopas Parius fecit. Hiftoria fiue fabula, qua de muribus narratur, huic loco congruit. Nam Teucris è Creta profectis datum erato: raculum, ibi eos fedem pofituros, ubi terrigenæe es adorirentur. Id circa Hamaxítum dicunt conti= giffe, maximam ç agreftium multitudinem murium noĉu exortam, quicquid armorum \& utenfi. lium ex corio inueniffet, corrofiffe, \& Teucros ibi manfife, atç Idam ab Ida quæ in Creta eft, appel, laffe. Heraclides Ponticus aucfor eft mures ibi circa templum abundare, \& facros exiftimari; fimu: lachrum autem ita inftrucium effe, ut murem pedibus premat. Quidam tamen Smintheum quafi

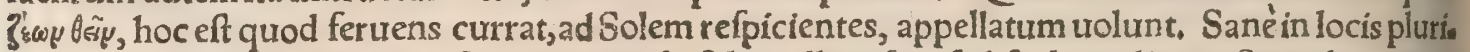
bus Smintheus A pollo cultus fuit, nec templa folum illi pofita, fed \& loca aliquot Sminthia aitapa pellata ille idem Strabo, Hxc Gyraldus. Murem Cretenfes fminthion fiue fminthea appellant, un

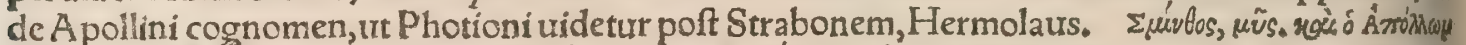

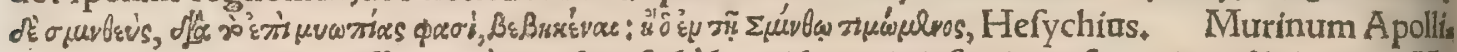
nem eundem Grynzo effe, non à muribus fed à loco id nominis fortitum, fupra in a. diximus, Mu foritæ quidam hæretici mures colunt, ut fcribit Philaftrius in catalogo harefeon I, 12. ApudEun febium legimus peplum Proferpina muribus contexiconfueuiffe, Calcagninus, Quantum eft cunos murium (inquit Aelianus ) in Heraclea, qux in Ponto infula eft, deum $S C$ religiofe colit, \& quod deo cunq dedicatum eft, non attingit. Itaque cum uitis, qua ibi deo frondefcit, \& foli eidem ad religionem confecrata eft, cuitusćs racemos dei adminiftri ad facra feruant, uux affecutæe fuerin maturitatem, tum de infula mures decedunt, ut ne firemanerent, per imprudentiam eas contingant, quas tangi fas non fit:poft uero ubi id anni tempus preterierit,ad domeficam fedem reurertuntur.

P R O V E R B I A.

Mus albus, Müs $\lambda$ suriss, apud Suidam : Mũs revis, id eft mus malus ( quod non placet) apud Dion genianum* In hominem laf ciurum \& libidinis immodica dicebatur. Nam mures domeftici falacifie mi funt, præértim albi, Erafmus. Vide plura fuperius in $c$, ubi de libidine murium. Mures dos

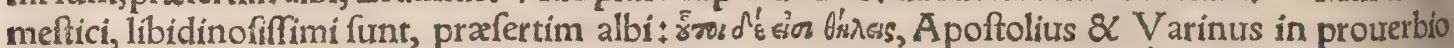
Mus picem guftans, debent autẽ hac referri ad prouerbiũ Mus albus, ut reçé habet Suidas, Oxines รe pro Briv doiac accipio, hoc eft mures albos effominatos effe, non focminașinterpretantur enim pro:

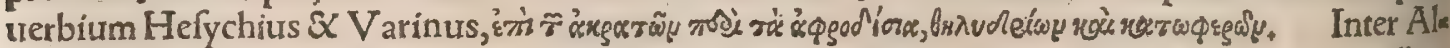
ciati Emblemata legimus hexaftichon iftud problema: Delicias \& molliciem mus creditur albus Arguere: atrationon fat aperta mihi eft. An quod ei natura falax, \& multa libido eft? Ornat Ronianas an quia pelle nurus? Sarmaticum murem uocitant plerique zibellum, Etcelebris fuaui eft unguine muf́cus Arabs. Hæc ille, fed ad prourerbï rationem prima tantum eius ex quatuor coniec?ura uera uidetur. Zibellum quidem $\&$ mufcum (quem à capreolo peregrino non mure has beri diximus ) ignorarunt ueteres qui murem album prouerbialem fecerunt. Exiftimantur fane etiam inter homines magis molles \& effominati quialbi fuerint, quamobrem imbelles homines \&

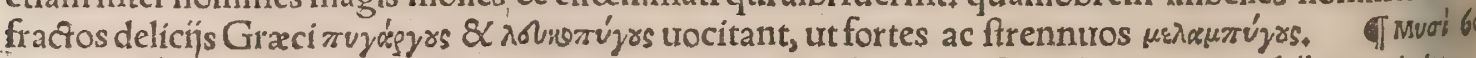

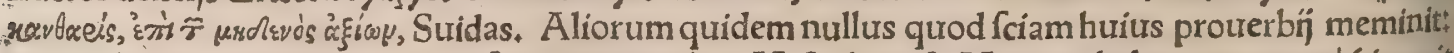

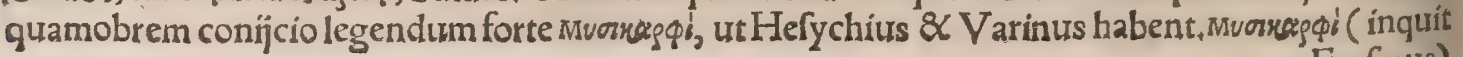


atç agreftes homines uiderent in monte terram intumefcere moueriḉ, concurrứt undiø ad tafn horrendum fpectaculum, expectantes ut terra noưum aliquod ac magnũ fpecfaculum æderet, mon te nimir um par turiente, forḉ ut titanes rurfum erumperent, bellum cum dijs redintegraturi. Tan. dem ubi multum diứç fufpenfis attonitisós animis expectaffent, mus prorepfit è terra, mox̧̣́́ rifus omnium ingens exortus, Eralm. Quanta Mus apud Pifam, öot $\mu \tilde{v}$ s şu riors, fubaudi tulit, aut fimile quippiam. De ins qui uincunt, 8 optatis potiuntur: $\int e d$ non fine fummo negotio, neç citra magnum incommodum fuum. Suidas natum ait ab athleta quodam, feu pugile Tarentino, qui in Olympiacis certaminibus apud Pifam, femel duntaxat uictor difcelfit, idéc plurimis acceptis plagis, Erafm. $\mathrm{Me}$

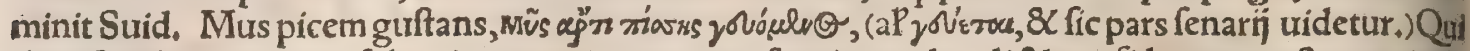
dam(Suidas)aiunt dici folere in eos qui cum antea fuerint audaculi $8 X$ confidentes, poftea periculo deguftato, planè(àdgóows)timidi uidentur. Nondum fatis liquet, utrum à mure in pice deprehenfo fit translata allegoria, ficuti placet Diogeniano:an ab illo de quo meminit Herodotus primo libro in pl ce deprehenfo, atç ita poenas dante:an à pugile illo Tarentino, de quo modo dictum eft, ut in zrias:

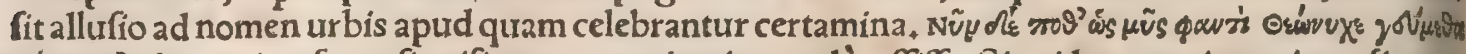
miarss. Sed quouis referas, fignificatur experientiam malèceffiffe. Siquidem mus imperitus, fi quan, do in picem inciderit, aut perit, aut uix eluctatur, ac deinde periculi memor timet contingere. Et pü gil ante ferox $\&$ iaćabundus, fimulatç certamen Olympiacum expertus eft, fenfitḉ quanti confil terit ea uictoria, deinceps abftinuit. Quare non intempeftiue dicetur in eum, quem poenitet experi,

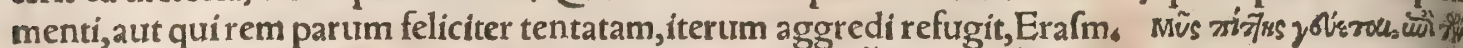

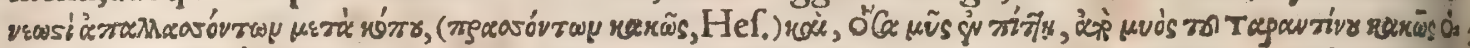

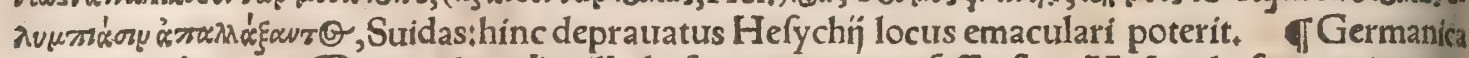
prouerbia à mure. Ser müjpzect will alwšg vnder bem pfeffer fyn, Mulcerdx femper intermi: fceri uolunt piperi: Huic refpondet quo Graci Latiniç utuntur, Corchorus inter olera. 10 crmis Easen jagt ber fadt gern müs: Qui cum felibus uenatur, ut plurimum mures capit: Corrumpunt

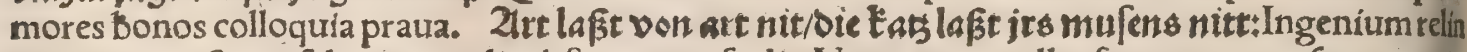
qui non poteft, nec feles captandis abftiner e mufculis:Naturam expellas furca, tamen uf $\$$ recurrit,

I A pologi. Fabula ruftici $\&$ urbani muris, quam defcribit Horat, 2. Serm. Sat. fexta, notiorell

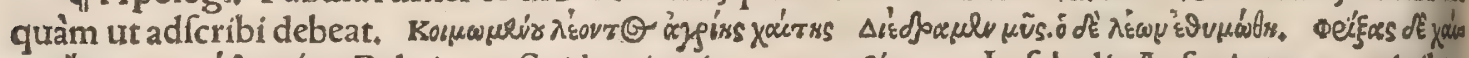
тжy है Babrï leo dormiens fingitur, cuius mus percurrens ceruicem, ex fomno hunc excitauit perterrefar

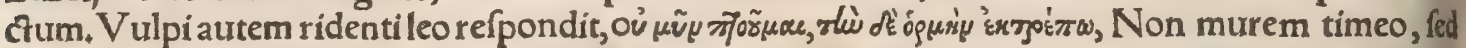
motum exhorreo, Tzetzes 13.490. De monte parturiente $\&$ emergente mure apologum recitaul fu perius inter prourerbia. Fabula de fele in mulierem mutata, \& fponfa cum effet murem perfequen

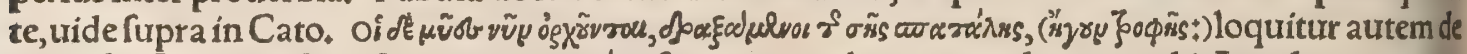
catto feu fele domeftica, Suidas in $\Sigma \pi x k r x^{\prime} \lambda s \div$ fumptum uidetur ex apologo quodã. Ā pud nos protrer: biale dictum eft, Fele abfente mures faltant, aut diem feftum agunt. एव

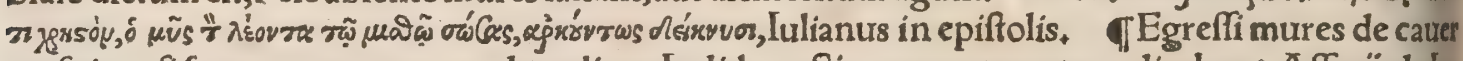
nis fuis aufi funt prouocare nos ad pralium, Iudith 14 . Sic per contemptum dicebant Affyrï delus. dxis Bethulia egrelfis aduerfus ipfos.

\section{DE MVRIBVS DIVERSIS.}

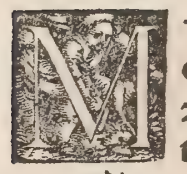

V R I V M permulta funtgenera, Älbertus. dam murium eft, Hefych. \& Varin. In A frica tria murium genera funt, quorum aliqul zegeries uocantur Punica lingua, quod in noftra pollet idem quod Bryoi, (Valla colles transfert,) Herodotus libro 4.

đṔiror,genus murium, Hefychius \& Varin.

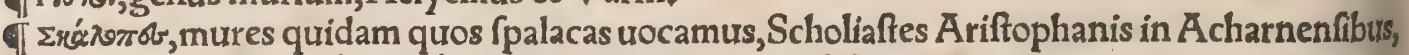
fed fpalax non alius eft quàm af pálax, id eft talpa, de qua poft Suem dicetưr.

$\uparrow$ Aegyptï mures pares funt Alpinis, fimiliteró́ refidunt in clunes, $\mathcal{Q}$ binis pedibus gradiuntur, prioribusç ut manibus utuntur,Plin. TNorduegia peftem peculiarem habet, quã leem uel leme mer uocant patrio fermone. Hæc eft beftiola quadrupes magnitudine foricis, pelle uariat hx per tem peftates $\&$ repentinos imbres decidunt, incompertum adhuc unde, an ex remotioribus infulis $\&$ huc uento delatæ, an ex nubibus feculentis temere natæ deferantur. Id compertum eft, ftatim ato 3 de ciderunt, reperiuntur in uifceribus herbx crudx nondum concocta: hx more locuftarum depalcun tur omnia uirentia $\&$ quæ morfu tantum attigerint, emoriuntur uirulentia : uiuit hac peftis donec non guftauerit herbam renatam. Conueniunt quoç gregatim quafi hirundines auolaturæ, fed fato tempore aut moriuntur aceruatim cum lue terra, ex quarum corruptione aër fit peftilens $\&$ adficit Norduegos uertigine \& ictero:uel ab alījs beftïs dictis lefrat (quafileopardis, quibus congeneres effe puto)confumuntur, unde pinguefcunt $\&$ reddunt pelles aliquanto laxiores humana menfura, Iacobus Zieglerus in Schondia fiue Scandinauia defcriptione. 


\title{
DeMurib.diuerfis. Lib. I. 829
}

\section{DE MAIORE DOMESTICO MVRE, QVEM}

\author{
VVLGO RATTVM VOCANT.
}

A.

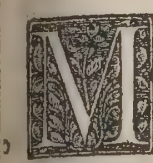

V R I S genus magnum, rattum uò: camus, Albertus \& Liber de naturis rerum. Ratti quidem uox non Gera manis tantum, fed Gallis etiam, Hi. fpanis, Italis \& Anglis in ufu eft. Plura de diuer fis nomenclaturis huius animantis uide fupra in Mure A. Soricem non effe rattum uulgò dictũ, id eff maiorem murem domefticum, fed omnino fylueftrem, ex Plinio demonftrabimus infra, ubi deSorice feparatim agetur.Sed murem araneumi quogż à ratto differre, ex eius hiftoria patebit:quă quam Ge.Agricola eundem effe iudicat, Colo. tes, ' num impugnare coloten fcribit, rattum imperite interpretatur. Sorex, rats, jossiss: haxc tria uoca. bula, Latinum, Germanicum, \& Græcum, '̌k mo' paxisísov ponuntur in Lexico fymphono Gelenin: Græcum forte apud recentiores ufurpatur:nam apud uteteres nufquam mihi occurrit, neç in Le xicis, Hyrax quidem, $\tilde{v}_{\xi} \times \xi_{\xi}$, quo pro mure Nican der utitutur, prima fyllaba omiffa, fatis cum Ger:

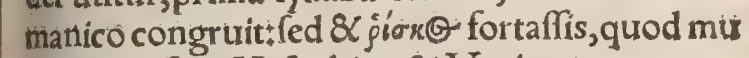
ris genus facit Hefychius $\&$ Varinus.

B.

Rattưs quadrựplo ferémaior eft mure: colos re fübniger uel fuffus, qui uentrem uerfus dilus tior eft. Capite longiiufculo, cauda procera, te= nui, nurda pilis: molecorporis muffela magnitus dinem affequitutur, Gè,Agricola. Ego rattum un diqua क albiffimutm uidi nuper apud nos captû Aprilis medio, ocullis rubičundis prominentibus; barba multis $\&$ oblonğis pilis hirfutà. Aungưfę Vindelicorum circa templum diui Huldrici rat: io tos nullos inueniri audio. Nó latet in terra uelu ti reliqui mures domeftici, tametfi in ualle loa chimica ex proximis domícilif́s in cutniculos (fo:

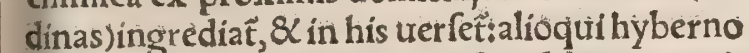
etiam tempore in domibus noffris folent tragari, Ge.Ägricolá. Affirmant quidam intueniri alía quando rattum cæter is maiorem, proceriore $\mathcal{Q}$ latiore corpore, qui à caterís otiofus alaturr. Rat. torum regem, taben tiuninig appellant. Fieri aute poteft ut aliqui in fenecta fic à minoribus natu at so lantur: nam \& glires legimus feffos fenecta pa rentes fúos nutrire. Ge. Agricolà rattưm, ut dis xi,murem araneum effe putans, fic de eo fcribits Mus araneus diçus uidetur, quòd muri fimilis fit, \& ut araneus parietes fcâdat, fed hoc de mure
araneo ueterum nemo fcripfit:trattum quidem facile per parietem alcenderēe auudiò,

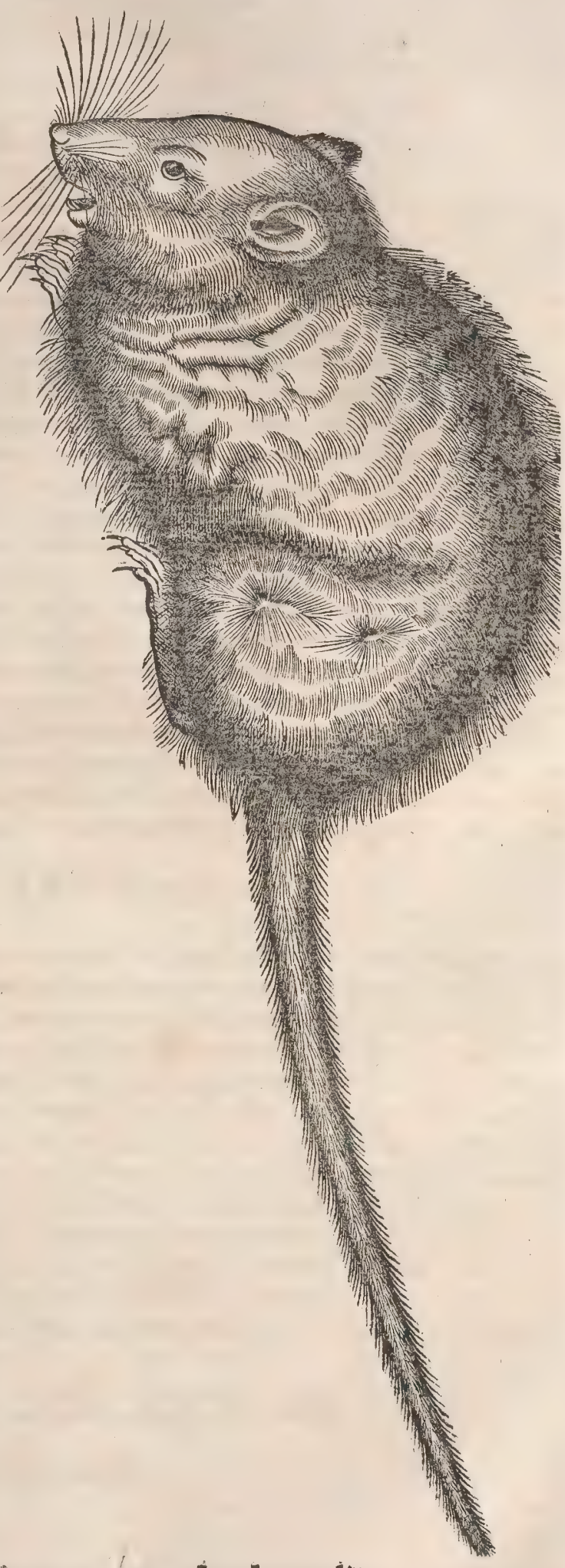

$\tau \mathrm{c}$. Cum lumen noçu ratto obtenditur, non fugit, acie oculorum quodammodo prątriça: mures autem fugiunt.

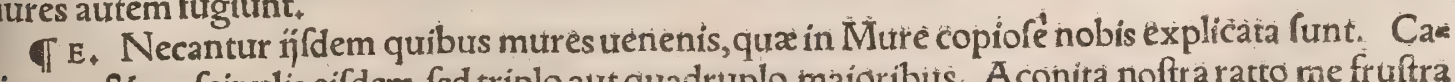
piuntur $\&$ mufcipulis eifdem, fed triplo aut quadruplo maioribus. A conita noftra ratto me fruitra dediffe, dixi in Lupo a.

I G. Rattorum tota caro calidior $\&$ acrior eft quàm muritum minorum, ut ex diffectorum odo

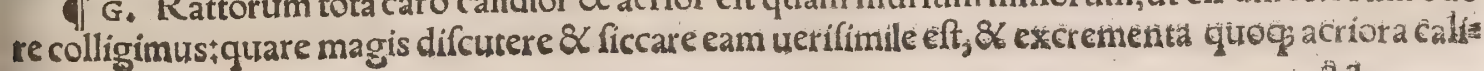




\section{0 DeQuadrupedibus.}

dioraç effe. Mcdici fimo ratti, id eft muris maloris, ad alopecias utuntur: Venenti in cauda geftare dicitur, Obfcurus. Nos mufcerdarum muris fimpliciter, i, minor is domeftici ad alopecias ufum effe, copiofe docuimus fupra in Mure G. Ratti cum libidine accenduntur, adeó perniciofi funt, ut fi cor um urina partem aliquam hominis nudam attigerit, carnes eius ufg ad offa putrefcere faciar, ne, que cicatrix ulceri poffit induci, Liber de naturis rerum. Alï, ut Arnoldus $\&$ Albertus, fimpliciter hoc de muris urina fcribunt.

\section{DE MVRE A Q VATICO.}

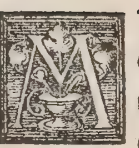

V R Is quoddam genus aquatile effe audio, magnitudine ferè rattl terreftris, colore quo. ${ }^{\prime}$ dãmodo fubruffo. Germani uocant waffermuks, Angli waterratte: Itali forgo morgange, id eft murem mergum. Gallirat d'eau. Pifces uenantur, ut aiunt: $\&$ a qua fubmerfiper caura quadam aliunde in terram redire creduntur, quoniam aliqui fx pe cum obferuaffent fubmerfos, diu expectantes nufquam rurfus emergere uiderunt. Rattus alius terreffris eft, alius flu uiatilis, Obfcurus. Ego non in fluuijs, nec alịjs aquis magnis, fed partuis tantum, riuis \& aligs uerfari audio. Quidam nuper in nonnullis Gallix locis etiam in cibum admitti rattum aquaticum mihi narrault:quod tamen uerum effe affirmare non aufim. In Colufis Arcadia fontem effe aiunt, in quo mures nafcuntur terreftres, \& natant in eo uitam agentes:idem in Lampfaco fieri aiunt, Ariffo, reles in Mirabilibus: Ego Lufis non Colufis legerim. Lufi enim(quanquam uulgati codices duplex S. habent ) urbs eft Arcadia, tefte Stephano, ubi Melampus Proeti filias lauit $\$$ infania liberauit. In " Lufis Arcadiz quodam fonte mures terreftres uivere $\&$ conuerfari Theophraftus fcribit, Plinius, Paufanias quoç Lufos urbem in ea terra collocat, qua Polybius Lufas in montanis agri Clitorif, Hermolaus. Magos qui Zoroaftren fectantur, imprimis colere aiuns herinaceum rerreftrem, ma

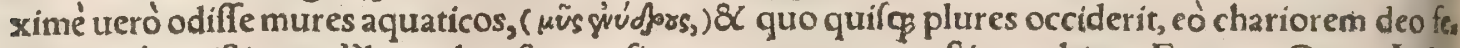
licioremć exiftimare, Plutarchus Sympofiacorum quarto quæftione ultima. Et mox, Quareludal etiam fi execrarentur fuem,occidere deberent, ut magi mures, Cæterum in Commentario de lfide, magos fcribir animalia quxdã boni dxmonis effe putare, ut canes $\&$ gallinas, $\&$ terreftres echinos:

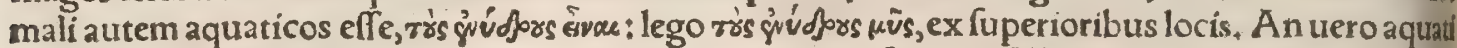
cos mures intelligat illos de quibus hîc frribumus, incertũ eft: ego teftudines aquaticas potius, ( nam has quogg mures appellant, intellexerim.

\section{MVS PEREGRIN VS.}

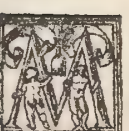

v S C V M, qui \& nunc in delicatiorem ufum uenit,ab Hieronymodicl quandoģ peregtio num murem funt qui opinentur, Cælius. Mufcus, $\&$ \&enanthe, $\&$ peregrini muris pel licula, Hieronymus ad Demetriadem.Quis autem fit peregrinus mus, inquit Hermolats, odorata celebratus pellicula, nô uideo:nifi quis animal hoc intelligat $\mathbf{e x}$ quo zibetum ex cipitur. Arqui nos zibetri animal longe diuerfum à mure effe poft $\mathrm{P}$ antheræ hifforiam deemonftrabl mus. Mihi quidem uerifimile fit hoc ipfum animal ex quo mofchus odoramentum funditur, Hie, ronymum genus muris elfe putaffe, hiftoria eius tanquam rei noux $\&$ ex alieno orbe aduecix non, dum cognita, ad quam opinionem nominis etiam uicinitas allicere potuit. Accedit qued in pellicus lis animantis fux adferri foleat. Quin \& Raphaël Volaterranus, uir alioqui docius \& noftri ferifiz culi, Murem illum, inquit, qui odoratus uulgò habetur, murem mufcû Hieronymus in epiftolis uon cat: \& in alia epiftola murem peregrinum. A pud Italos quidem hodie odoratum quendam murem M O S C H A R D I N V M appellari audio: ied illum in Italia reperiri, nec per egrinum effe. Rueh lius in hiftoria ftirpium mures fimpliciter mofchi odore recrementum aliquando excernere fcribit,

\section{DE MVRIBVS A GRESTIBVS.}

Figuram in fine huius Tomi requires.

A.

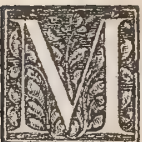

V R E $S$ agreftes in terra habitant, duorum generum, rubeus $\&$ niger, Albertus, Effigies quam damus ( in fine libri)muris agreftis maioris eft, qui terram fodiendo hortos 8 agros populatur. Eiufdem generis alij minores funt, domefticis fimiles, magis ruffi, quales me in alpibus etiam uidiffe puto. Caterum fylueftres aut fyluaticos mures, quorum generis $\&$ forex eft, eos uoco, qui non in aruis $8<$ locis cultis aratisue, fed in fyluis habitant, de quibus infra fe: paratim agam. Mus fubterraneus, quem alij agreftem uocant:Seruius à Cicerone nitedulam pu= 6 tat nominari, Ge.A gricola. V tilla ex uepreculis extracta nitedula remp.conaretur arrodere, Cicero pro S,Seltio.Nitedula quidem eft etiam cicindela dicta, ex infectis, qua noctu lucet. Sxpe exi. 


\section{DeMurib.diuerf. Lib. I. $83 \mathrm{I}$}

outus muss Subterra pofuitćs domos, atç̧ horrea fecit, Vergilius in Georgicis. Murem agreftem Marcellus empiricus nominat : Item Plinius, Mures agreftes (inquit) à ferpentibus lafi chondril=

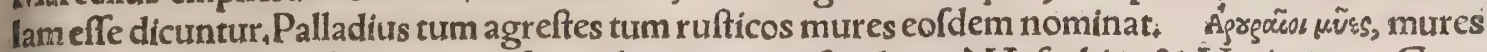
qui agros aut arua habitant, (quafi aruales aut aruenfes dicas, )Hefychius $\&$ Varinus. Gaza

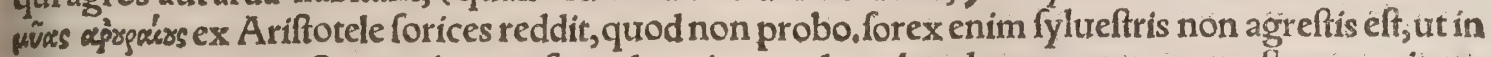
eius hiftoria dicam, Sorices hyeme fape dormientes deprehenduntur, mures agreftes non item,

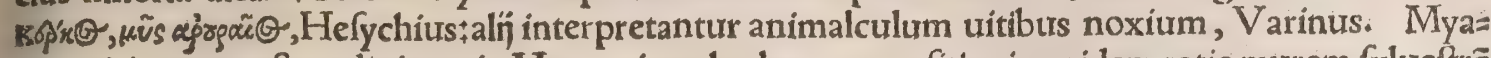
gros uiri nomen eft, ut diximus in Mure a,item herbx: compofitionis quidem ratio murem fylueftre infinuat, ut fyagros aprum fylueftrem. Graci agreftis fylueftrisç differentiam non ita obferuare ut

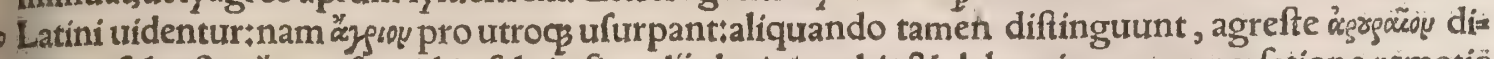
centes: fylueftre "ceprov, fiuc id in fyluis, fiue alijs locis incultis $\& \mathrm{ab}$ hominum conuerfatione remotis

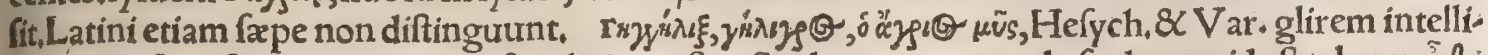
go, qui $\&$ fylueftris mus, non agreftis, dici poteft. Spalacem quoqs uel afpalacem, id eft talpam, స̇ids agregues uvós interpretantur Grammatici. Germani murem illum agreftem, cuius figuram pro hoc loco in fine libriadịciemus, uarïs nominibus appellant: :ut funt, felomuß (quo nomine etiam An. gli utuntur) id eft mus campeftris: (habent $\&$ Itali quem murem campaignolo nominant, haud fcio an eundem; ed differre puro:audio enim fic dictum, campaignolum murem, paruum $\&$ elegantem effe,cauda non glabra, fed pilofa: 8 aliquando cicurari. Mus agreftis,id eft quii in campis inuenitur, Marcellus;)eromuf, id eft mus fubterraneus.Lülmu

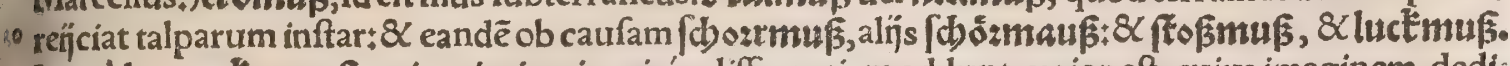

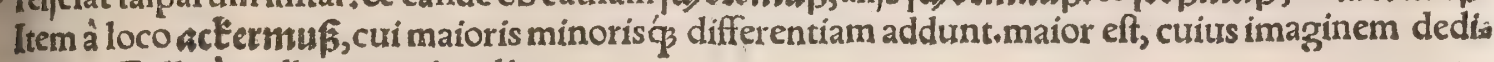
mus. Gallicè mullot uocari audio.

Non multo minor eft ratto, quin caudam ut ille longam habet ac craffam, Ge. Agricola, Auri: culis rotundis, capite magno rotundo nec eminente roftro, colore fufco ad latera ruffo, barba medio inter os $\&$ oculos loco rigente. Minoribus agreftium breuis eft cauda.

c.

Nafcitur omne genus muris de terra, licet etiam ex coitu fuigeneris generentur. Vnde in terris Aegyptís quando pluit plurimi generantur, Albert. Iuxta Thebaidem Aegypti quum Nili ceffa. uit inundatio, calefaciente Sole limum ab aqua relictum, multis in locis ex terræ hiatu multitudo murium oritur, Diodorus Sic. Et mox, In Thebaidis agro certis temporibus multi ac magni gene= rantur mures:qua ex re plurimum ftupent homines, cum uideant quorundam anteriorem, uf $\$$ ad pectus $\&$ priores pèdes, murium partê animatam moueri, polteriori nondum inchoata, fed informi. In Thebaide cum grandine pluit, mures in terra apparere audio, qui partim etiam nunc conum li= mofum, partim iam caro exiftunt, A elian. De muribus qui cum pluit in Aegypto naf́cuntur, \& in= colarum fupplicationibus Deo factis ab agris ad montem auertuntur, A eliani uerba recitabo infra in Aegyptiorum mentioné, tubi agam de muribus diuerfis fecundum regiones. In Aegypto mures de terra $\&$ imbre nafcuntur ${ }_{3}$ Macrob. Deturgente Nilo mufculi reperiuntur inchoato opere geni: talis aqux terræćç, iam parte corporis ùitrentes, nouiflima effigie etiamnum terrena, Plin. Alicubi é terra mures progigni, qui mox per coitum mirè excrefcant, Auicenna fcribit, Calius, Sunt qui affe rant omne animal idem fpecie ex femine \& ex putri materia fieri poffe, turm perfectum tum imperfe çum.Quo pofiro, concedendum effet ex putrimateria or ta animalia, alia eiufdem fpeciei per coitü generare, \& illa item alia, \& fic in infinitum. Huiùs fententix Euripides $\&$ Auicenna fuerunt, proz oter uniuerfalem hominum interitum éx diluuio. Alí dicunt perfecta animalia nequaqua fieri pol= fe ex putri materiatimperfecta autem eadèn fpeciè ex putri $\&$ ex femine, ut mures qui ex putri ma-

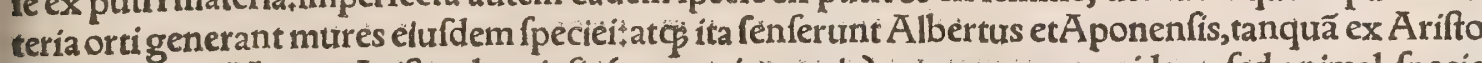
telis opinione. Verum Ariftoteles ait fic(ex putri materia)nata generare quidem, fed animal fpecie diurerfum,à quo nihil amplius gigni poffit, (ne procedatur ad infinitum.) Quamobrem concedo quị dem(inquit Niphus)mưres produci poffe ex materia putri qux in nauibus reperitur, 8 copiofiflime quidem, eosç̧ coëundo rurfus alios generare, non tamen eiufdem fpeciei, fed alterius, et qui ultra ge nerarenequeant. De muribus Cafpips qui fegetes fuccidunt, \& fructus in arboribus populantur, dicam infra inter Mures diuerfos fecundum regiones, Mus agreftis non femper in terra latet, fed nonnunquam egreditur, etfi rarius, Ge.Agricola. Tumuulos terræ inftar talpæ excitat. Corrodit, imó exeft, planȩ́ interdum confumit radices lupuli, paftinacx; rapa, \& reliquorum leguminum, Ge.Agricola. Radicibus tantum urefcuntur, nec prófundos agunt cuniculos; (fed ftatim fub ce= fpite ac fuperficie fodere pergunt, ưt inambulantes laxam fufpenfamiós terram $\&$ ueftigins cedentem percipiant)quorum introitus fi quis fofforio aperiat, mox reparant ac retegunt: quod $\&$ talpà faci: unt, fed tardius, fecundo interdum uel tertio demum die $e_{i}$ Cognito igitur mures fubeffe, inde quòd foramina breuiretexerint, iterum tribus aut quatưor locis aperiutitur, expećaturós ut cum ad rete= gendum urenerint, ligone aut fofforio in proximum poft eos locum ithflicto unà cum terra aut cefpi te enjciantur, eiecti conculcantur aut aliter occiduntur. Aliqui grameti in introitum inferunt, quod dum retrahere mus conatur, malleus ligneus in terrẩ proximo poft eưn locỏ àdigitur, ut foraming 


\section{2

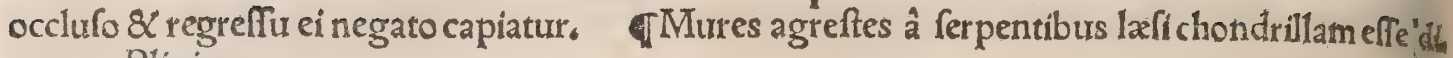
cuntur, Plínius.

बMirum percipimus ortum(inquit Arriftoteles)redundâtis agreftis murium generistlocis enim compluribus agri tam inaudito modo oriri folent, ut parum ex uniuerfo frumenti relinquatur:tam citò abfumitur, ut nonnulli mediocres agricola, cum pridie metendum ftatuerint, poftridie mane cum mefforibus accedentes ad fegetem, abfumptam inueniant totam; interitus autem minime etre nit ratione: paucis enim diebus omnino abolentur, quanquam fuperiore tempore homines ufncere uel fuffiendo, uel fues, ut latibula effoderent, admittendo, nó poffent. Quinetiam ưlpes eos uenå tur, \& catifylueftres in primis + fed tamen fuperare copiam, \& celeritatem prourentus nequeunt?nec aliud quicquam omnium uincit, nifi imbres: ịs enim quamprimum intereunt. Audio muftelas ualde perfequi mures fylueftres, ita ut meatus etiam hypogeos corum fubeant, ut uiuerra cunicu. lorum. Myagros uel myotheras anguis mures in pratis uenatur. Plinius de numerofa murium domefticorum foccunditate locutus, \& quód uel fale guftato fieri pragnantes aliqui opinêtur, fubı dit:Itaç definit mirũ effe, unde uis tanta meffes populetur murium agreftiü + in quibus illud quoq, adhuc latet quonam modo illa multitudo repente occidat. Nam nec exanimes reperiuntur, necs ex. tat qui murem hyeme in a gro effoderit. Plurimi ita ad Troadem perueniunt, \& iam inde fugauerü: accolas. Prouentus corum ficcitatibus tradunt: 8 iam obituris uermiculum in capiete gigni, Plin. Patrïs fedibus quofdam Italix populos incurfio murium agreftium expulit, (quod \& Diodorus Sia culus fcribit lib. 4 , de antiquorû geftis)atç in fugam compulit, Quód fané fic fegetes 8 plantas, tan quam fumma ficcitas, aut teterrimum frigus, alia ue tempeftas uaftarent, radices fuccidentes, Adia 20 nus. Colas Hetrurix ciuitatẽ mures deftruxêre, Volaterran, Coffa oppidum eft Vmbrix, Plinio 5.3. Orbitellum hodie, Caleni uidimus quòd una nocie totum campũ fegetis plenuี mures abfuma prêre, Niphus, In Hifpania ingens eft murium multitudo, unde peftilêtes fapenumero fecurifunt morbi. Hoc aduerfus Romanos aduenit in Cantabria, ut effent qui accepta mercede mures uema rentur, \& quantitate defignata, falutem uix affequerentur, ( wàे $\mu$ vo Zov ro $\mu_{0}^{\prime} \lambda / s_{\text {, }}$ ) Strabo libro 3. Theophraftus author eft in Gyaro infula cum incolas fugaffent, ferruin quop rofiffe eos, Plin. Er alibi, M. Varro auctor eft ex Gyaro Cycladum infula incolas à muribusfix gatos. Cum Palaftini arcam Domini captam apud $f e$ decinerent in ciuitate $A z o t o$, incola crudell dyfenteria affecti funt, \& prouinciam confurgens multitudo murium deuaftabat, ut legimus Sa muelis feu Regum primo: \& apud lofephum ab initio libri fexti Antiquitatum. Acolij \& Troiani, muriũ abundantia infeftati,Smintheo Apollini facrificarunt, ut in Mure fupra retuli in $h$. Et de mun ribus ex Heraclea Ponti infulæ recedentibus cum uuæ funt maturæ, $\&$ poft autumnum reurertenti bus,ibidẽ. Cum Sanacharibus Arabum Aegyptiorumḉ rex A egyptum inuaderet, Vulcanus in exercitum eius noctu uim agreftium murium immifit, qui militum tum pharetras, tum arcus, tum fcutorum habenas abederunt, ita ut poftera die hoftes armis exuti fugam fecerint, multis amifis, Herodoc,libro.2. Chalcidenfes incoluerunt etiam Cleonas, Elymnio Athi montis ciuitate pulfi, ui fabulis proditum eft, à muribus, qui omnia illorum bona ita deuorabant, ut neç ferro parcerent; Heraclides.

\$Mures abiguntur cinere muftela uel felis diluto, $\&$ femine fparfo, uel decoctarum aqua redolet uirus animalium corum etiam in pane: ob id felle bubulo femina attingi utilius putant,, lis nius. Aduerfus mures agreftes A puleius afferit femina bubulo felle macerãda anteçॄ fpargas, $P_{21}$ 1ad. A puleius (ut in Geopon. Græc, legitur) commendat fel bubulum, quo fi tingantur femina, tit ait,non infeltabuntur à muribus. Satius tamen eft per dies caniculares cicuta femen cum ueratio, aut agrefti cucumere, aut hyof cyamo, aut amaris amygdalis $\&$ nigro elleboro contundentes, at ex æqu farinæ mifcentes, fubigentesḉ oleo, id ipfum cauernis agreftiư murium adponere:pereunt ubi primum guftauerint. Hyofcyami albi femine fimpliciter mures necari Auicenna fribit: neris fimile eft autẽ îfdẽ medicamentis agreftes interire, quibus $\&$ domeftici, quorum uenena copiofé in Mure E.prodidimus. Nonnulli rhododaphnes folits aditus corum claudunt, qui rofis his, dum in exitu nituntur, intereunt, Pallad. Quí ex Bithynis(inquit A puleius) rerum experientia ualent, fo= lịs rhododaphnes meatus murium obturant, ut dum exire contendunt, ea contrecient dentibus? jo qux quidẽ ubi contigerint, pereunt. Sed chartã naçus, quæ fequuntê infcribito. A diuro uos omnes mures qui hîc confiftitis, ne mihi inferatis iniuriã, aut per alium eam mihi inferri patiamini. Affigno enim uobis hunc agrum(quẽ tunc nominas)in quo fi uros pofthac deprehendero, Matrem deortum teftor, fingulos ueftrum in feptẽ frufta difcerpam. Hxc ubi fcripferis, alliga chartam ipfam loco, quẽ obfident mures, id'̧́ ante Solis exortum: fic tamen ut charactêres extrinfecus appareant confpicui, nimirum lapidi natiuo adhærefcente charta.Scripfi hæc(inquit author Geoponicorum)ne quicquã præterire uiderer: nec probo quidem ut fiant talia, fed potius confulo omnibus ne adịciât animum alicui horum qua digna funt rifu. Mures rufticos, fi querneo cinere aditus eorum fatures, attactis frequenti fcabie occupabit ac perimet, Palladius.

đG. Muris agreftis, id eft qui in campis inuenitur, combufti cinis côtritus, $8 \mathrm{cum}$ melle adfidure 60 inlitus, aciem oculorum caligine extenuata confirmat, Marcellus.

Th. Ariftophanes in A charnenfibus A thenienfium inopiam uel malitiam notans, ait eos, ubia 


\section{DeMurib.diuerf. Lib. I. 835}

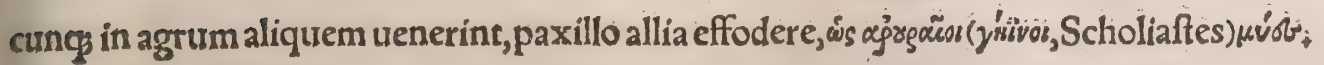

\section{DE MVRE S YLVATICO.}

I I V E S T R I S aut fyluatici muris Plinius aliquoties meminit, fed in remedís tantirni: Differre autem illum ab agrefti pracedenti capite diximus, quód non rura \& locos cultos ut agreftis habitet, fed fyluas $\&$ nemora. Sylueitrem murem Grace $\mu \tilde{u} y$ "ảgg

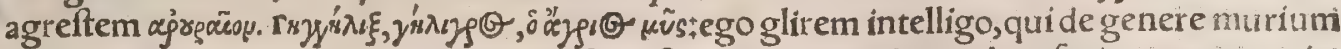
fylueftrium eft. Plinius quidem ex glire \& mure fylueftri, etiam remedium idem facit; tit mox recitá bo. Sed quoniam forex quoģ mus fylueftris eft, eundem effe crederem, nifi unus Plinílocus obfta ret, ubi cum muris fylueftris cinerem ad claritatem oculorum commendaffet; mox in eundẽ ufum foricis quoç cinerẽ prædicat, ut inferius inter remedia ex mure fylueftri recitabo, Ge. Agricola ma gnæ doctrinæ uir, murẽ fylueftrem interpretatur mure illum cui noftri ab airellanis nomen impo= nunt:foricem uerò illum facit, quem ego inferius murẽaraneĩ effe docebo. Ego muris fylueftris prò prie dictigenera duo effe uideo: Vnữ, de quo Albertus fcribit, Muris quoddam genus in arboribus habitat, fufcum, nigris in facie maculis:quod generali tantum nomine mus fylueftris appelletur. De codem Plinius intellexit, ni fallor, cum fcribit, Fagi glans muribus gratiffima eft, \& ideo animalis ei= us unà prouentus. Alterũ, quod priuratím forex nominetur, quxed Plinius per hyemem dor mire fori bit, $\&$ caudam habere uillofam:cuius figuram fubricimus. Sed ut diftinctius agã qua de mure fyluè. - ftri Plinius prodidit, feparatim bîc adfcribam, poftea de Mure auellanarũ etiam qua noftri tradunt; $\&$ ipfe obferuaui,ac de Sorice demum ex ueteribus priuatim fcripturus . Attritis medetur cinis mu ris fyluatici cum melle, Plin. Ofribus fractis, caninũ cerebrũ linteolo illito fuperpofitis lanis, qua fubinde fuffundantur, ferè quatuordecim diebus folidat: nec tardius cinis fylueftris muris cum mel le, aut cum uermium terrenorũ cinere, qui etiã offa extrahit, Plin. Pernionibus imponitur feutum pecudum, \&c, quód fi putrida fint ulcera, cera addita ad cicatricem perducunt, uel gryllorum(glirium uel foricũ cinis ex oleo, Marcell.)crematorũ fauilla ex oleo;item muris fyluatici cum melle, Idẽ. Murium capitum caudarumós cinere ex melle inunctis, claritatê uifus reftitui dicunt: multó̧̧ maz gis gliris aut muris fylueftris cinere, Plin,

\section{DE MVRE A VELLANAR VM.}

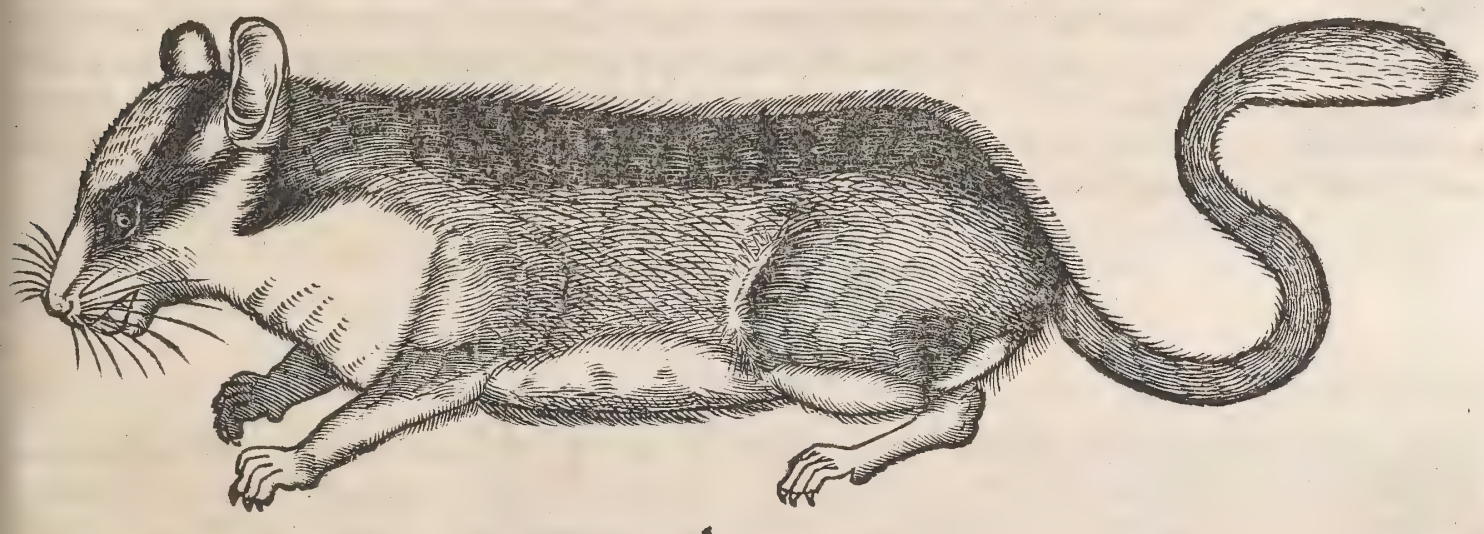

A.

v $S$ auellanarum, ut noftrates uocant, cin bafelmuf 3 , non alius quàm Plinï forex mihi uidêtur, ut præcedenti capite dixi: quoniã uero foricê alị a lium faciunt, feparatim de us trogs ağère uolui. Noftrorum äliquí glire quoqs,uel gliris genus, (hoc eft maiufculũ, fyl= ueftrem, pinguẽ $\&$ efculentùn murê)aùellanarum murem ưocât, fed maiorẽ, cin gro/fe Genus illud, cuius hic appofità eft fígutrà, corylinũ Albert, uocat, à corylo arbufto, cuius fructus feu nuces atuellanæ dicunt: his enim præcipué utefcitur. Flandri, utt audio, uocant cin flatep ratte, id eft rattum dormientem, ut Angli dormus, id eft dormientē murẽ. Galli lerot, cuíus fomni

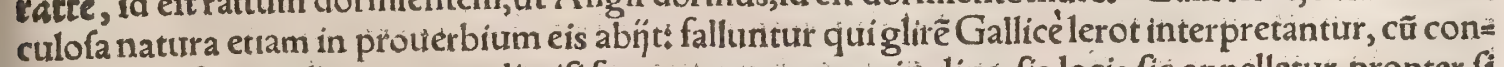
ftet murem fic appellatum non edi:nifi forte utrunge genus in diuerfis locis fic appelletur, propter fi milem dormiendi naturam.

\section{B.}

Muris genus corylinum rubeum eft, \& cauda pilofa, Albert. Magnitudine corporis non dif, fert à fciuro, uerum colore qui ei fufcus elt $\$ \&$ cauda, quam non habet uillis confertam $\&<$ plenẫ, fed ab eis nudam ut carterı mures, Ge. A gricola. At quẽ noftri murê atiellanarum uocanc, nȩ̧́ rubeus eft, ut Albertus ait:neq̧ cauda glabra ut Ágricola. Ego $\&$ uriưum aliquot dies nutriut, $\&$ occifum diligentius infpexi:hunc ipfum fcilicet cuius iconem adieci, Magnitudo \& forma ratti erat; color mit. 


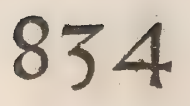

\section{De Quadrupedibus}

rinus per tergum \& latera, magis ruffus, præfertim in capite, auricula magnæ,glabræ, (Plinius qui dem forici pilofas tribuit.) uenter candidus : \& eodem colore crura, \& cauda parte inferiore extre. mitatem uerfus.nares $\&$ pedes rubicundi, cauda tota hirfuta, (quod Albertus etiam de hoc mure, de forice Plinius fcribit) \& qua definit albis denfisḉ uillis condita. Oculi maiufculi,eminentes, nigerriz mi, ita ut nihil ferè candidi in eis appareat. barba partim alba, partim nigra. Color niger infra furprá́ aures $\&$ circa oculos, $\&$ in polteriore parte caudæ fuperioris.Pedum anteriorum digiti quatuor, pol lex enim mutilus eft, pofteriorum quini. Pofteriorum crurum pars auerfa fiue fupina à fuffragine per totam tibiam ad extremos unguiculos glabra eft. Odor quidem in hoc genere, \& excremen ta, ita fe habent ut in domefticis muribus.

c.

Mus fylueftris non tam in arboribus latet, quas ur fciurus fcandit, quàm in terra, in cuius caurep. nas congerit fructus: in primis uerò nuces auellanas, $\&$ eas quidem optimas, quare apud Germanos ex corylo nomen inuenit, nam ei non pro cibo fomnus, fed prouifum pabulum, Ge. Agricola. $\mathrm{Mi}$. hi quidem rufticialiquot fide digni affirmarunt hunc murem à fine autumni ad ueris uf̧́ initium dormire: unde $\&$ nomen ei apud Flandros $\&$ Anglos à dormiendo pofitum, Plínius etiam foricihye mem dormiendo tranfigi fcribit.

Ruftici cauernas iftorum murium infixis defignât uirgis, ut his in dicibus hyemis initio effolfuri utãur.caueas enim feu cellas fubterraneas fatis amplas habêt, ubi auellanas congerunt, omnes quí. dem bonas $\&$ integras, relictis uitiofis.

In cibum non admitti certò fcio: quamobrem errant qui eundem glirem putant.

G.

Remedia eadem el attribuerim quax Plinius muri fyluatico, paulò ante nobis enumerata, quonin $\&$ animal ipfum uel idem eft, uel omnino cognatum.

\section{DE MVRE NAPELLI.}

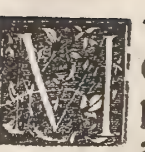

v s etiam napelli,fi quis eft, ad fylueftres referendus ưidetur, Surinus, aliâs fuccinus, ( ego uocem utranģ deprauatam puto pro bifmus ) mus eft paruus, antipharmacum na 3 pelli,Syluaticus \& Vetus gloffographus Auricennx. Napelli enim radicibus pafcitur, ut aiunt. Alip non animal, fed herbam iuxta adnafci fcribunt, qux uim illam napello contra: riam poffideat:cui fententix etiam ipfe accefferim, nam $\&$ apud Marcellum empiricum tor $x$ ans titor $¥$, hoc eft napelli $\&$ antinapelli herbarum nomina legimus : \& eadem hodié́ $\beta$ durant. Quana quam Matthxolus hunc murem fibi in altiffimis montibus iuxta napellum deprehenfum tradit, fed non defcribit,Plura lege in Lupo a, ubi de aconito \& napello copiofé differui.

\section{DE SORICE.}

A,

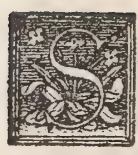

O R I C E M mihi uideri hoc genus muris effe, quod noftri ab auellanis nominãt, furperius dixi in capite de mure fyluatico:quoniam \& fylueftris eft, \& cauda pilofa, \& per hyemem dormit, qux omnia forici Plinius adfcribit, hoc tantum impedit, quod forici Plinius pilofas tribuit aures;ego noftrum auellanarium, ut ita dicam, murem, glabras habere puto, fedrell qua tres notæ maiores funt, quàm ut una tantilla impedire debeat. Mus exiguum eft animal, in: cola domus noftræ, qui à fono quem rodendo facit, Latiné etiam forex uocatur : quamuris aliqui ita diftinguant ut mus domefticus fit, forex fylueftris, Sipontinus, Itali quidem \& Galli foricis no, men pro mure domeftico etiamnum feruant: $\&$ forte etiam ueteres aliquãdo fic ufi funt. In Arcadia, go inquit $V$ arro, fus fuit adeo pinguis, ut in eits corpore forex exefa carne nidum fecerit, \& pepererit mures, Soricis iecinoris fibras cum Luna augeri ac minui, ita ut numerus refpōdeat Plinius fcribit, $\&$ alibi idem de mure. Irem fí caftratus emittatur fugari cateros, de forice Plinius, de mure Auicen: na fribit. Sorex fylueftris eft mus, maior domeftico, Fr. Alunnus. Plinianus quídem \& proprie dictus for ex, neç minor neq maior domefticus mus eft:utroç enim modo aliqui interpretãtur. Fed falfó, ut apparet, quum notæ foricis fupradictæ neutri conueniant. Muris quoddam genus rubeum eft, breui cauda, acutx uocis, quod proprié forex uocatur, \& eft uenenofum ; quam ob caufam non capitur à catis, Albertus : Sed hunc murem araneum effe, à noftris uulgó fpismußs uel muitzer dis çum, inferius demonftrabo. Quanquam \& Ge.Agricola noftrum fpitimuf murem araneum effe

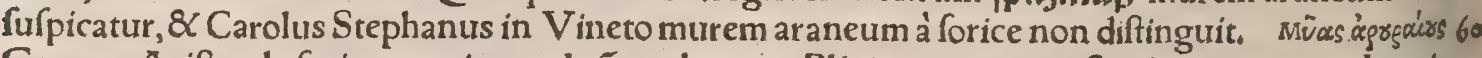
Gaza ex Ariftotele forices uertit:quod nó probo, cum Plinius mures agreftes interpretetur, de qui= bus fupra diximus. Hifpani foricem, ut amicus quidam ad nos fripfit, uocant force, uel raton 


\section{Demurib.diuerfis? Lib. I. 835}

pequénno:fed quẹrendum eft an id nomen muri araneo potius conueniat:ut Illyricũ etiam niemeg. ka myfs, quo foricem fignificari itidem ex amici cuiufdam literis accepi. Sorex Latinum eft uoca. bulum, eo quòd anim al huriufcemodi rodat, $\&$ in modum ferra pracidat, Ifidorus, Sed coniecerit ali. quis etymon effe Gracum, urà uoce ï $\rho \propto \xi$ (fic murem Nicander appellat)afpiratione in f.confonan. tem uerfa, ut ab iwį̀ fuper, ǔs fus, \&c. fiat fyrax $\&$ forex. Rattum Illyrica lingua fczurek uocac quafi foricem. Caulem pro cole, fauricem pro forice dicimus, Seruius,

B.

Aures foricibus pilofa funt,Plinius. Soricum fibras refpondere numero Lunæe exquifituêre dilt gentiores, Idem libro 2. Idem alibi de fibris in iecore murium fcribit: Vide in Mure B. Boum caty. 10 dis longiffimus caulis + idem fetofus eft ueterinis: leoni infima parte, ut bubus $\&$ forici,Plin.

C.

Sorices \& ipfos hyeme condiauthor eft Nigidius, ficut glires, Plinius. Sorex defticat, Author Philomela. Egomet meo indicio mifer quafi forex pern̈: Verba funt Parmenonis Terentiani in Eunucho, qui delufus à Pythia prodiderat fe feni. Donatus admonet effe prourerbium in eos qui fuapte uoce produntur. Atqg hinc exiftimat ductam effe metaphoram, quod foricum proprium fit uel ftridere clarius quàm mures, uel ftrepere magis cum obrodunt friuola, ad quam uocem multi fe extendentes, quamuis per tenebras noctis transfigunt eos. Vfurpat hoc adagium D. Arrelius $A u$. guftinus in primo de ordine lib, erga fuum Licentium, qui dum pulfata tabula, foricem ftrepitu ab. fterret, ipfe fefe prodebat Auguftino quòd uigilaret. Allufit eodem Origenes homilia in Genefim tertia:Sed uidebor, inquit,ipfe meis indicị́s captus, Erafm.

D.

Formicofam arborem forices cauent, Plinius 10.71. Sorices $\&$ ardeolx inuicem foetibus infidi. antur, Ibidem. Tranftulit autem hæe Plinius ex Ariftotelis libro g, de hiftor.anim. cap. I. ubi legitur,

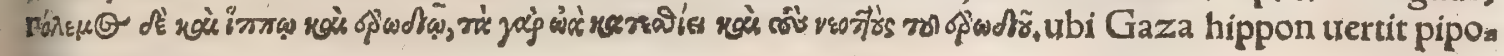
nem auem.

E.

Scripferunt quidam forices fugari, fi unus caftratus emittatur, Plinius, Hoc Aggregator ex Plis nio citans, non forices fed mures ita fugari fcribit, ut Auicenna quog;, ut recitaui in Mure E. Ne fo rices uel mures ladant uites, qua fecundum adificia funt, docet Columella libro de arborib, cap. Is. 10 cuius uerba recitabo infra in Mure araneo A.

G.

Si oculi nigri nafcentium placeant, foricem prægnanti edendưm exhibent, Plinius، Si prægnâs artus captiui foricis edit, Dicuntur foetus nigrantia lumina fingi, Serenus. Paralyfin cauentibus, pinguria glirium decoctorum $\&$ foricum utilifima tradunt effe, Flinius, Murium capitum cauda. rumó cinere ex melle inunctís claritatem uifus reftitui dicunt:multoós magis gliris autmuris fylue. fris cinere + Cum Attico melle cinis $\&$ adeps foricis combufti tritus lachrymofis oculis plurimû con fert,Plin. Glires \& forices combufti, \& cinis eorum melli admixtus, finde quotidie mane guftent, lanabunt qui claritatem oculorum defiderant,Sext. Glirium (gryllorum, Plinius: quod minus plas cet) uel foricum cinis ex oleo impofitus pernionibus medetur, ${ }_{2}$ Marcel

$\mathrm{H}$.

Sorex in mafculino genere prima producta effertur $¥$ Si prægnans artus captiui foricis edit, Sère nus. Licinius imperator fpadonum aulicorumós infolentiã mirè compefcuit, tineas foricesç̧ palati nos appellans, Egnatius ex Aurelio Victore. A forice fit foriceus $\&$ foricinus; unde foricinos den tes dixit Plautus, Sipontinus, Soriculata ureftis pretiofa,Plinio lib,8. Calcagninus legit furculata. Vide fupra in Mure H.a.in murinus adiectiuo. Mus foréxue fi in muftum inciderit, quomodo curandum fit muftum:uide fupra in Mure e THeliogabalus iubebat fibi decem milia murium exhiberi, mille muftelas, mille forices, Lampridius. Soricum occentu dirimi aufpicia, annales refer tos habemus, Plinius. Occentus foricis auditus Fabio Maximo dictaturam, \& C. Flaminio magi= fterium equitum, deponendicaufam dedit, Alexand,ab Alexandro, बProuerbium,Egomet meo ro indicio quafi forex perị, uride fupra in $\mathrm{C}$.

\section{DE MVRE NORICO VEL CITELLO.}

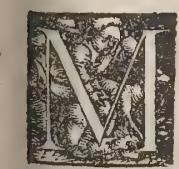

v s Noricus(inquit Ge.Ägricola)quem citellum appellant, in terra cauernis habitat, Ei corpus ut muftelæ domeftica, longum $\&$ tenuetcauda admodum breuris $¥$ color pilis, ut cuniculorum quorundam pilis, cinereus, fed dilutior. Sicut talpa caret auribus, fed nô caretforaminibus, quibus fonum ut auis recipit. Dentes habet muris dentium fimiles Ex huius etiam pellibus, quanquam non funt pretiofa, ueftes folent confici, Hęc Agricola Interpre ;o tatur autem Germanicépile. Mus quidam colore feré ficut cuniculi, magnitudine muftela, in terra habitat in Auftria, 8 uocatur apud nos $3 i 5 \mathrm{el}$ (lego $3 y$ fel.) aures non habet, fed tantum foramina aud tus, $A$ lbertus de animalibus $2+1.5$. Et alibi in nonum Ariftotelis librum capite 34 . Noc?ux , inquit, 


\section{6 \\ De Quadrupedibus}

uenantur mures, \& lacertulos, \& ceacoydolos; quod genus eft muris $3 y$ hd (lego $3 p[\mathrm{el})$ aptrd nos di

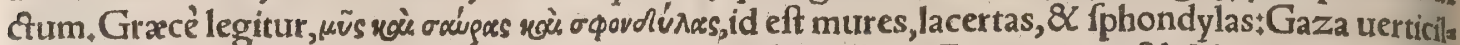
los interpretatur:funt autem infecta. Citellus uox ficfa eft ex Germanica $3 y$ fel. Aliqui dicunt gelfele genus effe muris apud Vngaros, fimile f́ciuro, in terra cauis fe condens. Hieronymus Tragus de pi

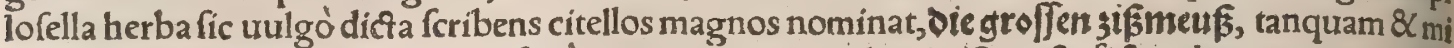
nores fint huius generis. Vocant fanè murem araneum aliqui sifîmu 5 , ficto ad uocem quam ædit nomine. Egoeundem murem noftros pellifices puto uocare bild Germanicé interpretatur pile. De etymo mihi nō cóftat. Aliqui eundem appellant groffebafelmußs, id eft maiorem murẽ auellanarium, quòd auellanas fimiliter congerat;differt autem à minore(quem fupra defcripfimus cum pictura)tum aliâs, tum magnitudine, tum quod in cibum uenit, minor né, quaquam. Bilchos mures, ut ita uocem, ex Croatia \& regionibus circa Venetiam mitti audio. Ego pelles tantum uidi in pileis inde confutis, colore fufco ex cinereo ferè, peculiari quodam odore, uns de capiti quidam nocere putant. Pileum inde confectum, drachma fere, aut infurper obolo, quiadure xerat uendebat, Complures in uno cauro reperiri aiunt, circiter quadraginta interdum, cum magna auellanarum caftanearumćs copia: $8<$ eam ob caufam à rufticis (per hyemem puto)inquiri, ut nuces

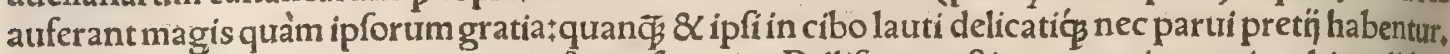
Eduntur autem tum recentes, tum in fumo ficcati. Pellifices ueftium margines etiam his pellibus ornant $\&$ muniunt, (quod ipfi dicunt verbz\&men.) conftant enim pilis in fe conferctis $\&$ firmis, Ab antris fuis infufo aliquo humore expelluntur cit elli, ut criceti etiam $\&$ cuniculi,Albertus. Animal quod nos(Bohemi) fy fel uocamus, criceto non omnino abfímile eft, nifi quòd pilo ueftitur leporinum 10 referente tam colore quàm mollitie. Præter morem murium cicuratur nonnunquam, Illud infigne habet, quod cum fit bucculis leuiter protuberantibus, duntaxat quoties inanes funt, tame in eas uix credibilem numerum trítici infarciat, ceu in folles quofpiam, atç ita in furos cuniculos commeatum in futuram hyemem congerat, $\mathrm{Hxc}$ ex Sigifmundo Gelenio Bohemo cognoui,

\section{E C R I C E T O.}
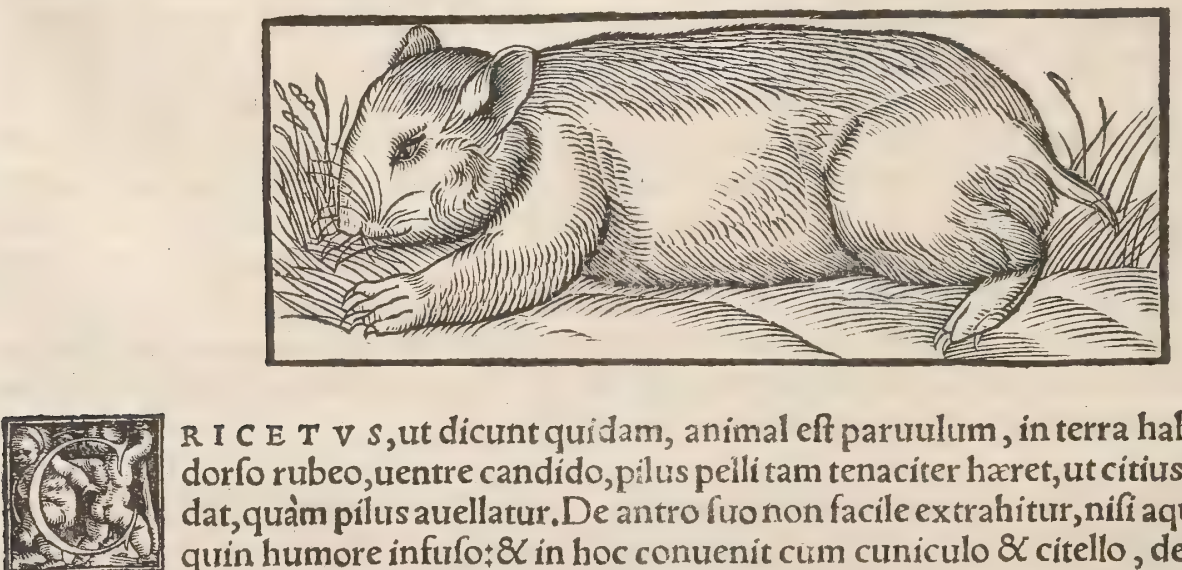

R I C E T V S, ut dicunt quidam, animal eft paruulum, in terra habitans, capite uatio, dorfo rubeo, uentre candido, pilus pelli tam tenaciter haret, ut citius pellis de carne rece 4 dat, quàm pilus auellatur. De antro fuo non facile extrahitur, nifi aqua fertrente, uel alio quin humore infufo $\$ \&$ in hoc conuenit cum cuniculo $\&$ citello, de quo alibi diximus, Germanice uocatur bameffer tanimal eft ualde mordax \& iracundum, Albertus libro 22. Haud fcio an idem fit animal quod eodem libro in litera T. defcribit, his uerbis: Traner(tridetur Germanica uox)animal eft paruum, fpatiofum (forte fpeciofum)rubei coloris, cuniculi magnitudine, mirum in modum pugnax $\&$ animofum:in cuius fignum ad protectionem capitis $\&$ cerebri à natura gales am offeam accepit. Ego cricetum uiữ non uidi, fed pelles olim Francfordiæ urenales, quas bainta fier appellabant. Effigies quam damus defumpta eft ex Germanico libro de quadrupedibus Mi: chaélis Heri:qui hoc animal ratto paulò maius effe fcribit, colore caftaneo aut fpadiceo (lifoerfarb o ber bzunlecht) agilitate mira, noxio morfu, ita ut homini etiam aliquãdo moleftum fit, perquàm iraz cundum $\&$ in uindictam præceps fi quis urgeat, aut à cauerna depellere conetur. Addit, aniculas quafdam adipem eius tanquam morbis quibufdam auxiliarem colligere. Audio etiam in agris cir= ca Argentoratum reperiri, \& uocari Ėnffirle, ac fi porcellos frumentarios dicas, quòd cauernas in aruis frumento confitis fodiant: pingurefcunt admodum, quam ob caufam porcellis forte comparan tur, (quanquam \& alị mures unde hyraces Oppiano dicti, fuibus roftro uel corporis forma confes runtur.) In Turingia abundant, 8 frepe frumentum populati in cauernas fuas congerunt: magnitt dine inter cuniculum $\&$ rattum:A udaces adeò ut in hominem aliquando infiliant, \& dentes cumin flixerunt uix remittant. In cibum non ueniunt, fed pelles confuuntur ad ueftimenta funt enim, ut Albertus inquit, pilorum tenaciflimæ. Ge. Agricola in libro de animantibus fubterraneis, cum uith uerram defcripfiffet, fubdit: Iftius generis eft etiam bamefter, quem quidam cricetum nominant, Ete nim exiftit iracũdus $\&$ mordax adeò, ut fi eưm eques incauté perfequatur, foleat profilire $\&$ os equi appetere: $\&$ fi prehenderit, mordicus tenere. In terræ cauernis habitat, non aliter atç cuniculus, fed 
ram fignificat: trerum muribus iftis nihil cum uipera commune effe, fed cum echino tantü fpinas acu tas, A riftotelis \& Plinï uerbis facile obtinetur. In A egyto audio bipedes mures maxima magnitu dine effe, $\&$ prioribus pedibus tanquam manibus uti, eofdemó ditcum autem infequentibus urgentur, falire, Aelianus ex Theophrafto, T Sunt $\&$ alin in A gypto mures, qui in agros $\&$ meffes graffantur:De quibus Aelianus, Primũ (inquit)ut in Aegypto pluit,perparuulis guttis mures nafci folent, qui longe latéç totis aruis uagantes, maxima calamitate ex fpicarum circumrofione $\mathcal{Q}$ fuccifione fegetes afficiunt, $\&$ manipulorum aceruos traftantes, $m a$ gnum Aegyptips negotium exhibent; $c$ o fit, ut ï infidias eis conentur mufcipulis tendere, et fepimen tis repellere, \& forsis ac incenfionibus arcere + fed mures ut minime ad mufcipulas accedunt,fic cum fint ad faliendum apti, \& fepes tranfcendunt, \& foffas tranfiliût. A egyptï uero de fpe $\&$ conatu dea pulfi,omni machinatione infidiarum, tanquam parum efficaci relicła, fe ad furppliciter deprecẩdam â Deo calamitatem uertunt.Mures diuina iræ metu, in montem quempiam aciei inftruetione ordis nem quadrangulum conferuantes difcedunt $;$ horum omnium natu minimi primo in ordine confi: funt, maximi uero extremum agmen ducunt, eos qui lafsitudine deficiunt, urgent, ac feipfos fequi cogunt. Quod fi ex itinere minimi natu laborantes fubfiftant, omnes quoç confequentes, ut eft in morebelli inftitutoćs pofitum, inftfunt, \& interquiefcunt: Simulḉ $\hat{\beta}$, ut primi mouere copperunt, cateri continuo omnes fubfequuntur. Hoc idem qui Pontum incolunt mures illic agere dicunt, $\mathrm{Ha}_{\mathrm{a}}$ ctenus A elianus. Caterum in Aegypto ex terra \& imbre mures nafci, pluribus authorũ teftimonijs comprobatum eft fupra in hiftoria murium agreftium.

ब) Afric $x$ mures cum biberint moriuntur, Ariftoteles: fed forte hoc uniuerfale eft omnibus muri i bus, ut legit Ephefius, Niphus. Vide furpra in Mure E, ubi de uenenis ipforum egimus . Pulmonü uitijs medentur \& mures, maximè Africani, detraça cute in oleo \& fale decocti, atç̧ in cibo fumpti. Eadem res $\&$ purulentis uel cruentis excreationibus medetur, Plinius. Africa murium diuerfa funt genera ali bipedes, alin duris erinaceorum pilis, alij lata facie ut muftela, Sed hos mures alij $C y$, renaicos uel Aegyptios uocant, ut fuperius retuli.

đAlpini muris hiftoriam infra feparatim dabimus.

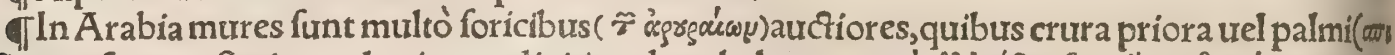

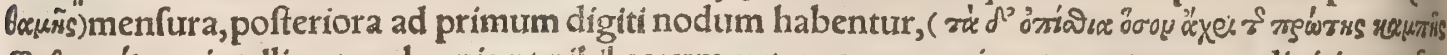

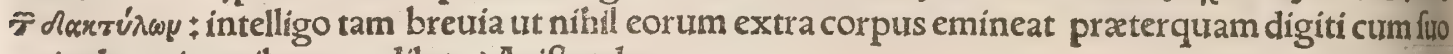
articulo, ut in auibus apodibus,) Ariftoteles.

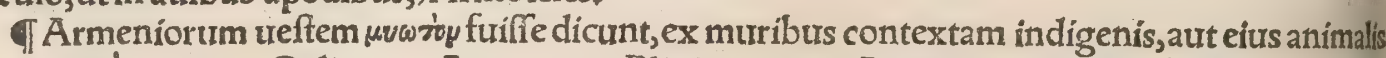
figura uarié ornatam,Cxlius * Aggregator Plinium muris Armeni mentionem facere fcribit lib, 29, mihi nihil tale apud Plinium occurrit;et forte murem Ärmenum alicubi pro mure araneo legit,

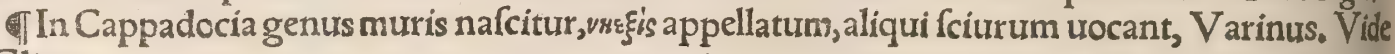
in Glire $A$.

-De Cafpips muribus A elianus fcribens: Amyntas(inquit)in Manfionibus',quas fíc infcripfit, in Caf piam dicit infinitam murium multitudinem accedere, eofdem $\not ́ s$ in perennibus fluurijs rapideprę cipitantibus intrepidè innatare, \& caudas inter fe mordicus tenentes (ut de lupis fimiliter fertur) firt mamentum habere, en $q$ sirmo ứnculo flưios tranfmittere. Cum autem in arationes tranfierint, fes getes furccidunt, $\&$ in arbores afcendentes fructus edunt, $\&$ ramos frangunt: Quibus Cafpï ubire, 4 fiftere non queunt, hoc modo infeftas corum incurfiones moliuntur ulcifci, ut nō habentibus uncis natos ungues auibus quippiam noceant, qux quidem ipf tantis gregibus ut nubes effe uideantut có aduolantés, mures fedibus pellunt, \& fưo proprio quodam natura munereà Cafpịs famẽ depels lunt, neqg magnitudine inferiores quàm Aegyptí ichneumones (intelligendum uidetur mures $C_{a}$ fpios ichneumonum magnitudine effe $\left.e_{+}\right)$Item $\phi_{\beta}$ agreftes funt $\&$ acerbi, $\&$ robore dentium non aliter diffecare ac deuorare poffunt, quàm mures ferrum in Teredone Babylonia, quorum pelles molles inftitores ad Perfas uehunt, quibus ueftes confuuntur, $\&$ corpus optime fouetur, $\mathrm{H} æ c$ A elianus,

बCyrenaici mures, uide fuperius in Aegyptijs.

IIndicus mus, uel mus Pharaonis, ut eruditi quidã recentiores fcribũt, non alius eft quàm ichneu mo. Hofpes quidam meus nuper Monaci in Bauaria fe uidiffe mihi narrabat murem peregrinü, $\rho^{0}$ quem Indicum appellarint qui demonftrabant, cauda oblonga $\&$ ore inftar muris acuminato.

ब De Norico mure id eft citello, iam fupra fcripfi.

बIMures quofdã fylueftres magnitudine muris \& fpecie muftellina, colore ceu uirides, per cam. pos uagantes, \& foramina fubeuntes in Pannonia confpeximus, Fr. Maffarius tà quo etiam Ge.Agri cola mutuatus uidetur.

IDePonticis \& Venetis muribus in fequentibus priuratim tractabo. 


\section{DeMurib.diuerlis. Lib. I. 839}

\section{DE PONTICOSEV VENETO MVRE,}

QVEM VVIGO VARIVMVOCANT.

Efigies buius muris à ciuromilgari colore tantum differt. Appofuimus autem fciurifiguram communnem, 6 hic infra in friuro, propter illos qui colores forte adijgient:aliter enim femel pofuiffe fatis cratt.

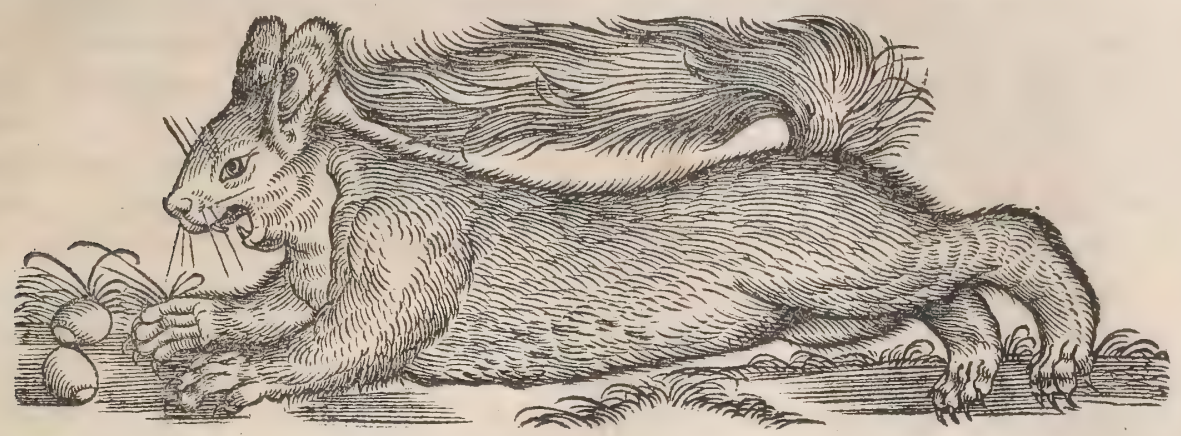

v s Ponticus Ariftoteli \& Plínio memorattus, nomen à Ponto habet, quòd à regionibus ad Septentrionem circa Pontum peteretur ad ufum ornatumó hodie uulgò etiam domefticum murem, ponticum inepté uocant. Pontici mures(inquit Hermolaus in Corollario)alị unius coloris funt, alin uarị. Ex hoc genere creduntur effe lies, quibus muniri ueftes contra frigora coppere ; candidos eorum armillinos, fordidum uulgus nominat+nam uarí parte tantum prona candicant. Venetis ín dorfo color, à quo doffuraria pelles uocantur $\ddagger$ quandogs ferrugineus deterior priore, Hac Hermolaus. Varios Ifidorus S Albert, hoc genus murium à colore uocant, ut pauló poft recitabo:Itali quidem etiamnum unlgò fic nominant, uare. Noftri fecb uel ved), quafi Fennicum aut Venetum, à regionibus unde adferuntur: aliqu Derct, quod nomẽà uario formatum urideri poteft, alijexpreffo etiam coloris nomine grauwerct. id eft uarios canos uel cinereos quoniam in fafciculos (quos noftri bïnts uocant) colligati uenduntur:in fingulos quinquaginta pretium ferédrachmæu uiginti. Hermolaus in uerbis iam recitatis Venetum murem à urario, colore faltem diftinguere uídetur:ego difcrimen nef́cio: fedi ica Venetus, aut (ut Ge. Agricola uocat) Fenni cus hodie dici uidetur, ut olim Ponticus, nempe à regione cuiufcuncs, colorís afferretur. Varius ta* men, fi totus fit albus, (uenter enim omnibus albicat) dici non poteft, Venetos olim ad Viftulam fe. diffe, \&Boruffix gentem fuiffelegimus : inde profecros Danubio traiecto occupafielliyriam, \&c. funt qui eos nunc Sclauos feu Vinthos $\&$ Vinthones, Densen diciuelint : ad finum Venedicum habitant. Fennos Ptolemaus 3. 5. Sarmatix gentes dicit, fub Venedis habitantes, Volaterranus hos effe putat qui hodie Prutheni aut Lítuani dicuntur. Nitres Pontici albi funt, 8 hyene conduntur: hos ego exiftimaurerim quos uulgò armellinos uocant, Volaterranus+Eiufdem fententia Ge, Agri= - cola eft. Diftinctius Hermolaus, non enim fimpliciter ut illi Ponticum murem armillinum interpre tatur, fed album duntaxat.armillini enim dici femper toti funt albi, extrema tantum cauda excepta quæ nigra eft. Sed hic etiam ad mur is Pontici genus referendus mihi non uidetur + quum non aliud fit quảm muftela alba, qua apud nos eriam hyeme albefcit, 8 bermelin appellatur. A tqui mus Pon ticus non muftelarum, fed murium generis eft: imo fciurorum, uel ipfe potius fciurus, nifi colore dif ferret, ut ex fequentibus apparebit, Nec refert quod hyeme condi 8 dormire dicuntur Pontici mu. res, quod hermelini etiam noltri faciunt. Verifimile eft enim non iftos tantum mures, fed alia etiam murium genera, \& fimilia parua animalia, ubi ingens frigus \& perpetux illo tempore profundá niues uagari impediunt, latere propemodum omnia. Aut igitur mus Ponticus albus colore tantu à cæteris differt, ut fit idem fciurus albus, etfi talem reperiri nondum audiuerim + aut fi hermelinus nofter eft(uel ut Itali proferunt armellinus)ueterum \& recentiorum ferè infcitia proditur, qui mufte lam murem Ponticum fecerunt. Quoniam ut lepores alpini albefcunt hyeme, aftate ad fuum colo: rem redeunt:fic $\&$ muftelæ in regionibus montanis aut frigidis. Armillini uocantur mures alpium \& Septentrionis, Hermolaus in Plinium, Plura uide in maftela $B$. Mus uarius, quem quidam glirem urocant, Albertus. Et alibi, Glis rolore uarius eft, in dorfo grifeus, in uentre albus; breurioris pili 8 tenerioris corï quàm animal quod uerè uarium wocatur. Sentit autem murrem Ponticum ueré ua rium uocari. Varius eft beftiola de genere piroli(id eft fciurí) pauló amplior quàm muftela: in ar bo ribus habitat, \& fortificat. A re nomen haber, in uentre nancs candidus eft, in dorfo colorem habet cinereum, elegantem at f $_{3}$ fpectabilem, Ifidorus 8 . Albertus. Sciurus Fennicus non cauda, non fi. gura 8 lineamentis totius corporis, non magnitudine, non moribus, fed folo colore differt à noftra* te fciuro:nam in candido cinereus eft, cum noftras aut rutilus fit aut niger:attamen in ea Sarmatia parte, quam hodie Poloniam uocamus, inuenitur cui rutilus color miftus cínereo. V triģ (hoc eft tam Fennico quàm noftrati) duo inferiores dentes funt lógi: uterç̧ cum graditur, demiftam caudam 
trahit; quirm urefcitur, cibum in priores pedes; quibus ut mures utiturr, pro manibus fumit:poferiorí bus clunibus infiftit. Vefcitur uero faginis glandibus, caftaneis, nucibus auellanis, pomis; $\&$ fimilie bus fructibus. Vtriq, cum hyberno tempore latent, pro cibo fomnus(ut gliri : quare fciurum $\& \mathrm{gli}$ -

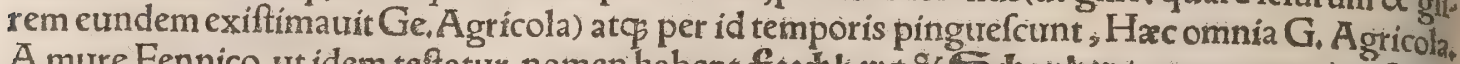
A mure Fennico, ut idem teitatur, nomen habent feebberg $\&$ S bonbetg; arces puto circa $S_{a x}$. niam fic dictx. Poloni murium fylueftrium, qui in pretio habentur ad ueftimenta, prafertim nobje lium, ut nuper ex indigena quodam didici, genera pracipua habent quatuor, qux \& nominibus di. fcernunt, Popieliza, grifei coloris eft. Gronofthañ, animal albiffimum in fine caudæi nigricat. Nouro. grodela (aboppido quodam puto eiufdem nominis) albicat quidem, fed ita ut fit intermixtum ali quid grifeum. Vuieuuorka caftaneo colore claro eft. Hac genera omnia parua funt: differunt colo: ribus, capitis forma: $\mathbb{Z}$ uictu, quòd alia in terra, alia in arboribus degant. Hæc Polono dictante exce pi.Secundum quidem genus, non aliud quàm hermelinum uulgòdiçum effe apparet. Primum \& tertium ad uariorum fiue Ponticorum genus retulerim; nifi tertium idem fit laflicio muri, de quoin. ferius, Quartum genus fciurum fignificat.

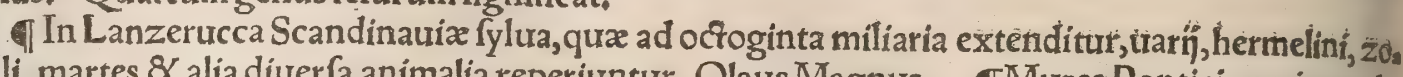
belli, martes $\&$ alia diuerfa animalia reperiuntur, Olaus Magnus. TMures Pontici ruminant, li. cet utring dentati fint, Ariftoteles. Pontici quoç mures fimili modo(ut pecora)remandunt, Plini us. Mures hiuulgares ruminant, quamuis ex alio(quàm Pontíci) genere fint, Plinius. Glires latent in ipfis arboribus, pingurefcunt'̣́ per id tempus uehementer +itidem mus Pontici generis, ( cuicolor

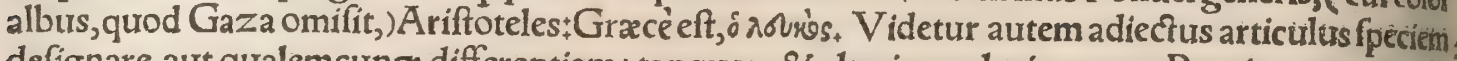
defignare, aut qualemcunqg differentiam : tanquam $\&$ alterius coloris mures Ponticos reperiti di. cat. Conduntur hyeme et Pontici mures, hi duntaxat albi quorum palatum in guftu fagacifimümi autores quonã modo intellexerint, miror, Plin. Varị nidũ \& $\&$ mores $\&$ cibû habent pirolí(id eft friu

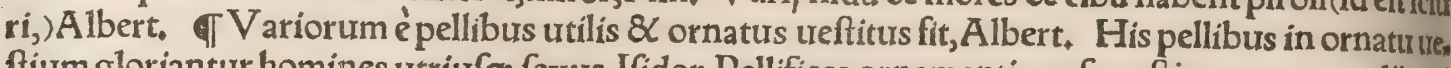
ftium gloriantur homines utriuf $f_{3}$ fexus, Ifidor, Pellifices ornamenti caufa ureftium, quas ex alijp pel libus confecerint, oras hifce pellibus muniunt. Habent $\&$ nefcio quas ueftes facerdotales, qui canoni ci dicuntur, multís in locis ex uarị́s una cumcaudis ad imurm dependentibus marginem confutas, Inftuxit \& ex muribus luxuriam fuam uita alios magnis frigoribus, alios medio anni temporeà Se ptentrionibus petendo. Armamus corpora, debellamus animos, Hermolaus.

\I Mures in Ponto incolarum fupplicationibus ad deum factis aurertunttur ab agris, ut A egypti ; quogs, Aelianus, Sed aliud hoc murium genus uidetur, agrefte, non fylueftre; ut illi etiam in Hera clea infula Ponti, de quorum religione dixi fupra in Mure $h$.

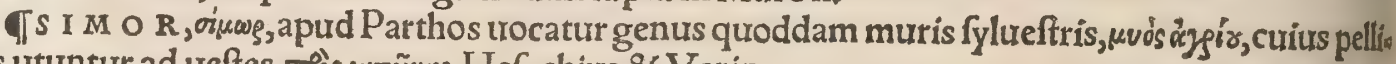
bus utuntur ad ueftes, mồs $\chi$ เrw̃ves, Hefychius $\&$ Varin.

I S C Y T H I C V M murem eruditus quidam con̄̉cit effe qui uulgò zobellus dicitur: quem nos muftelarum effe generis fuo loco docebimus, Scythici quidem muris ueterum quod fciam nee mo meminit.

\section{DE MVRE ALPINO.}

A.

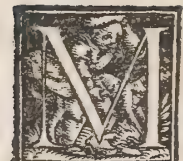

$\checkmark s$ alpinus cognomen traxit ex alpibus in quiburs nafcitur. Etfi enim alia quocg mutis um genera alpes gignant, hoc unum tamen genus, non nifi in altifimis alpium, \& circa ipfos uertices nafcitur, ut ipfe multis excelfiffimis montibus peragratis animaduerti, Itali uulgò murmôt uocant, uel (ut Hermol,feribit)marmotam; ut Matthæolus, marmon tanã, (Galli quidem cercopithecũ marmot uocant,)R hati qui Italicé loquưntur, montanellâ:Aliqưi etiam in Italia, ut audio, uarozam. Varios quidem mures Ponticos Italis nominarifupra dixi. Ger

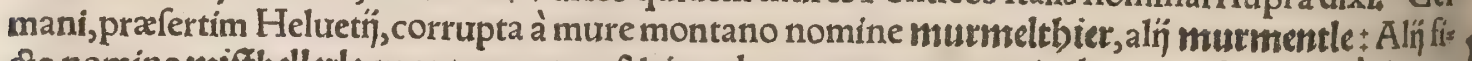
cto,nomine miftbellerle, propter acutam \& tinnulam uocem, qua caniculas etiam fic proprié dictas, fuperat. Emptra(Liber de naturis rerum habet Enitra) ut quidam dicunt animal eft paruulum in Germania ‡ quod quidam murem montanum uocant, nec inuenitur, nifi in montibus, maximuse murium genere quos noftra producit regio, Albert . \ Taxus animal eft ferẻ in murium alpino: rum genere, Brafauolus, Videtur autem hoc fufpicatus, quoniam $\&$ in caurernis agit, \& ualde pin gurefit:fed cum neç dormiat hyeme, ne $\$$ muris fpeciem referat, $\&$ ingenio $\&$ uictu multum diffe rat ab alpinis muribus, congenerem illis minimé dixerim. Grapaldus \& Alunnus Itali uiri non in docti, armelinos uulgó dictos, mures alpinos effe putant, inde fcilicet perfuafi, quòd fimiliter hyemê fomno fepulti exigant. Sed hi omnino muftelæ funt qux in locis aut regionibus frigidis per hyemem albefcunt, ut furpra in Muribus Ponticis afferui, $\mathcal{X}_{\text {pluribus dicam in Muftela } \mathrm{B} \text {. Saphan Hebraicá }}$

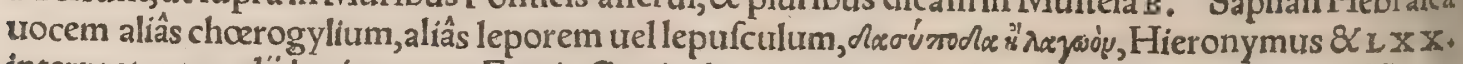
interpretantur, alij herinaceum. Ego in Cuniculo omnino cuniculum effe docui; quanquam Hiero= 


\section{Demurib.diuerf. Lib. I. 841}

nymus in annotationibus Pfalmorum ad Suniam \& Fretelam eandem uocem ag̉x: vuṽy interpretatur, animal in Palzftina abundãs, à fimilitudine muris ac urfi no minatum. Gelenius arctomyn murẽ uul= gò cricetum diçum, Hieronymi arcio. myn effe iudicat, cui $\&$ ipfe affentior, ut fupra in Criceti hiftoria dixi, Eruditus quidam apud nos, murem alpinum : qui effi ad hxc duo animalia quandam fimili tudinem habet, non uidetur tamen in Sy ría $\&$ locis calidis reperiri, quũ apud nos in fummis tantum montibus ịş́́ frigidiffimis \& niurofis degat. Galenus de a= limentorum facultate $3 \cdot 1+$ apud Lucanos

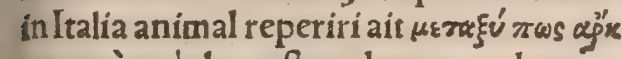
ir res ovós, hoc eft medium quodammo do inter urfum $\&$ fuem : quo modo fi re. célegitur, non aliud quàm meles aut ta: xus fuerit; at fi pro ovoos legas $\mu v o \dot{s}$, intelli. gi poterit uel mus alpinus, quem apud Lucanos etiá in Apennini iugis reperiri non dubito : uel Hieronymi arctomys. Vide quadam fupra in Mele A . circa finem.

\section{B.}

Murem alpinum ueterum nemo ne nominauit quidem, folus Plinius pauca de cofcripfit. Ego hiftoriam eius adfcrim bam, partim ut ipfe obferuaui cum domi alerem hoc animall,à quo etiam quam ad. ieci effigies ad uiuum expreffa eft : pars tim ut ab hominibus fide dignis, $8 x$ mon tium incolis cognoui: partim ex Chroni. cis Ioan.Stumpfï, unde etiam Gè. Agri= colam mutuatum uideo quar de hoc mus re in fuo defubterraneis animantibus lí. bello prodidit: $8 \mathrm{Cx}$ quadrupedum hifto ria Michaélis Heri, TAlpinos mures 4o in A egypto etiam reperiri ex recentiori= bus quidam fcripfit, Plinium teftem ad. uocấs, A tqui Plinîi uerba hæc funt: Sunt his(muribus Alpinis) pares $\&$ in Alegya pto:fimiliterćs refidunt in clunes, et binis pedibus gradiuntur, prioribusó̧ ut mani bus uruntur. Hinc intelligimus non eor. dem, fed fimiles eis, aut etiam magnitudi ne pares, in Aegypto nafci. TMuri al pino magnitudo fere leporis eft, aut ues rius inter cuniculum 8 leporem: fele cor pulentior eft, fed breuior cruribus. Speci es ac figura muris, ex qua mus dicitur.

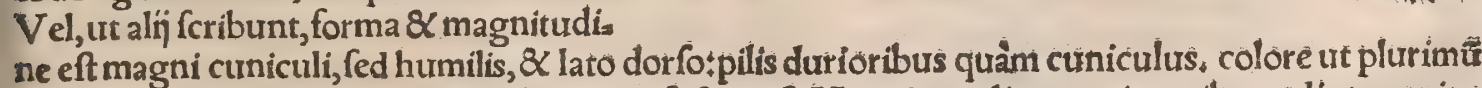

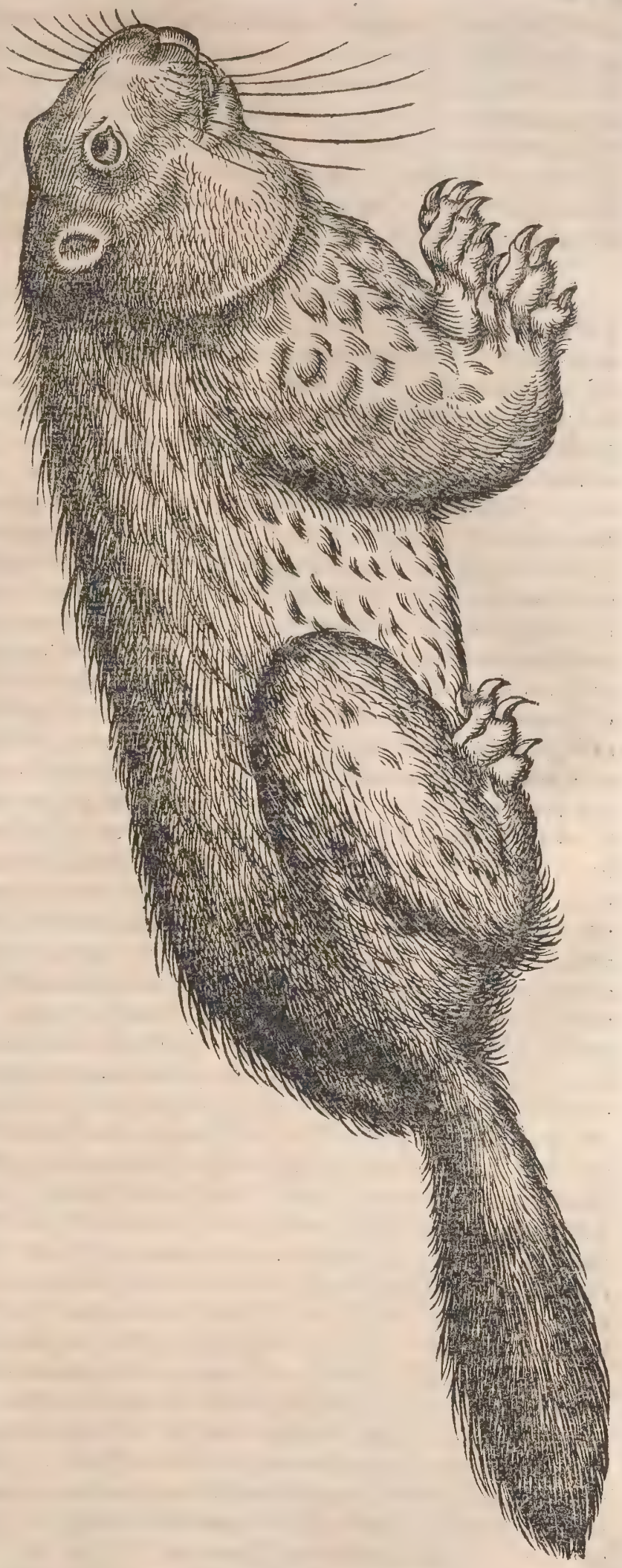
ruffo, qui in alins clarior, in alins obfcurior et fufcus eft.Magnis oculis, prominentib. media magnitu dine, Hermol. Apud Pliniũ fíclegimus, Condunt \& Alpini mures, quibus magnitudo media eft:ex quibus uerbis nihil affequor certi:Ponticos enim mures tantũ ante Alpinos nominauit; nec ullos ali os, inter quos et Ponticos Alpini media magniturdine effe dici poffint, quamobrếlegerim, Condưn: tur \& Alpini, quibus magnitudo media extat(id eft prominet) oculorum : fic $\&$ Hermolauts legiffe 6o uidetur:quanquam in caftigationibus nullam huius loci mentionem facit, ut neq̧ Gelenius, A uri culas mutilas $\&$ quafi decurtatas habet, (tam breues, ut uix eminere appareant, Matthæolus, Idem capur leporis ei tribuit, pilum taxi, ungues fatis acutos,) Priores dentes fupra infraç̧ binos ut féiț 
rus, \&x longos acutos क̧ habet, fibrinis feré fimiles, fubtlauos. Círca nafum \& labra fuperiora ni: græ ei $\&$ afperæ fetre rigent, tanquam feli. Longitudo caud $x$, dodrans dimidius, ut Stumpfitus: uel ut Agricola, duo palmi \& amplius. Crura breuia, craffa, \& uillis fuperits referta $¥$ quibus \& uenter imus denfis ac longiufculis munitur. Digiti pedum urfinis fimiles quibus altè effodit terrã. Pofterioribus pedibus non fecus ac urfus ire folet, ac interdũ ingredibi pes: quod \& Plinius feribit, ut paulò fuperius recitaui. Dorfum præpingue habent, quũ cateræ con poris partes fint macræ, quan đ̆ hac uerè nec pinguitudo nec caro dici poteft: fed ut mamillarü caro in bubus, inter eas eft medium quiddã. Crafitudine magis quàm longitudine crếcưt, Macthęolus C.

Si quando inter fe colludunt, urt catelli clamorem faciunc. Cxterum cum irafcuntur, uel tems is peftatis mutationem denunciant, argutiffimam uocem fiftulæ acutx $\&$ aures ladenti fimilem $x$ dũ: id́́, non in montibus tantum, fpeculator prafertim, de quo mox dicemus ‘fed etiam cum domi alun. tur apud homines. Ab hac roce adeò acuta $\&$ tinnula, aliqui Germanicè ficto nomine huncmu rem appellant mifbellerle, ut fupra dixi. đAmbulant aliquando bipedes, ut \& A egyprï mures, fubfiduntóg in clunes, $\mathcal{Q}$ prioribus ut manibus utuntur, Plinius. Cibum in priores pedes fumit ut fciurus: ut idem fciurus \& fimía erectus ufque eo in clunibus refidet, quoad ipfum comede. rit. Vefcitur autem non modo fructibus, fed $\&$ alins diuerfis cibis; prafertim fià teneris domea ficè educetur ₹ ut, pane, carne, pifcibus, iure, pulmento: cupidé ueró, lacie, butyro, cafco. In ala pibus cuniculis aliquando in cafas uaccariorum actis, ubi lac feruatur, in ipfo furto deprehenduri: cur. Dum lac edit, oris fuciu fonitum ficuti porcellus emittit, THi mures multum dormiunt: \& in cauernis fuis delitefcunt, quas miro artificio fodiunt. Nam, ut $R$ hatus quidam mini nuper narra

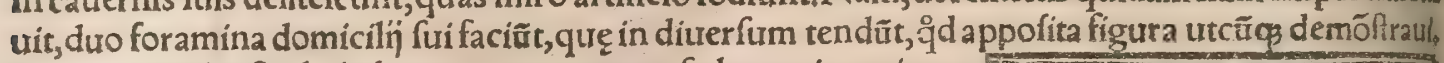
B . igitur iocus eft, ubi habitant, non apertus, fed monti continus. c. foramen, iuxta quod excernữt, nec unquã per illud uel ingredi uel egredifolent, fed tantũ per oppofitũ foramen A. Hoc idem ini= tio hyemis obturant iuxta principium aditus, deinde (polt aliquot dies ) excrementorum etiam foramen obturant, idćs non infra fed fupra excrementa, Eft autem $\AA$, fitum fuperiore montis loco, c.in. feriore. Cubilia exftrunt foeno, ftramentis, farmentis, Agri= cola. Cum niuibus iam montes teguntur, circa diuorum Michaelis aut Galli feftum, in domicilium fe abdunt, \& foramina, ut dixi, occludunt, terra tam folidè infarça fubaćaḉ̧, ut facilius fit fo diendo terram integram ad latera, quàm illam foraminibus infar: ctam penetrare. (Poftquam cubilia in fpecu ftrauerint, ipfum adi

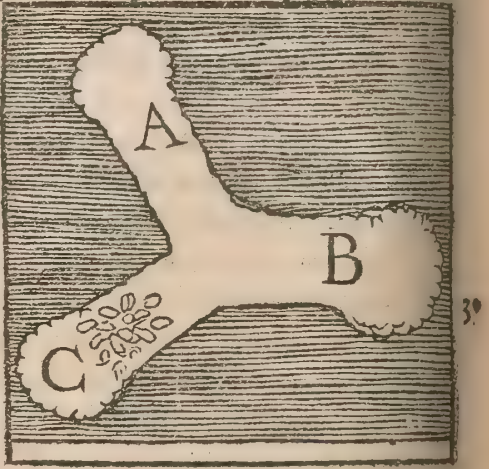
Cam penetrar. (Poltquam Sic tuti à entorum tum atgs os eius farmentis $\&$ terra obftruunt $\&$ obturant, A gricola.) Síc tuti à uentorum ui, ab imbrt bus, à frigore, degunt, \& dormiendo ad uer ufq̧ perdurant fine omni cibo \& potu, in globum erinas cei inftar conuroluti. Solent autem ferèquin ç, aut feptem, aut nouem, aut undecim, paulóre plures uno in meatu cubare. Hinc factum eft apud Alpinos populos prouerbium in hominem fomnis culofum, Ker muif fyn 3yt gefblaffen baben wicein mutmeltbier : hoc eft, Neceffe habet certum dormiendo tempus confumere inftar muris Alpini. Dormiunt autem hyeme etiamfi domi alan 4 cur, extra zetas uel hypocaufta emiffi : in aliquem fub fcalis aliumue recefium abditi. Ego cum dormiturientem aliquando hunc murem initio hyemis, in uas ligneum è fcandulis abiegnis concins natum $\&$ foeno femiplenum depofuiffem, addito etiam quo magis a frigore tuerer operculo, poft aliquot dies mortuum reperi. In caufa fuit refpiratio exclufa : quod fi foraminibus aliquot operculü cerebraffem, uiuus hyemem exigere potuiffet. Itą̧ miror cum aditus cauorum fuorum in mótibus tam folidèarctéç occludant, quî fiat quod refpiratio eis non intercipiatur. Conduntur hyeme Pontici mures, item Allpini. Sed hi pabulo ante in fpecus conuecto, cum quidam narrent alternos ma rem ac forminam fupra fe complexo fafce herbæ fupinos, cauda mordicus apprèhenfa, inuicem dea trahiad fpecum:ideóç illo tempore detrito effe dorfo, Pliníus. Mira uero eis machinatio \& foler tia, cum foenum iam congefferunt. Vnus enim humi ftratus erectis pedibus omnibus iacet in dorfo, in quem tanquam in plauftrum quoddam, cæteri ea quæ congefferunt coníciunt: \& fic onuftum, cauda mordicus apprehenfa in fpecum trahunt, \& quafi quodam modo inuehunt, Agricola, Eo: dem modo caftores ligna aduehere, 8 taxos effoffam terram pro domicilins, donec fatis ampla fint, euehere, apud recentiores legimus, Fides penes authores efto. Hoc quidem à faceto aliquo hos mine de induftria fictum apparet, folere hos mures fornum in dorfo geftare, cauda per dorfum ad os reducia $\&$ mordicus comprehenfa obfirmatum, pro fune fcilicet ut homines foenum baitlant,

Emptra, hoc eft mus montanus, animal eft paruulum in Germania, ut quidam dicunt: huius ges neris mas \& formina fimul foenum colligunt per æeftatem, unde hyeme uiuant, hoc per cumulos(for= te, cuniculos) in terram recondunt. Eft autem foemina aftuta $\&$ uoracior foni, mas contra parcus. quanobrem foemina de fpecu expulfa, aditum obturat, $\&$ ingreffu eam prohibet. Illa retro alicubi 6 aditum occultum fodit, \& foenum cófumit.Itą̧ uerno tempore foemina obela, mas autem perquàm macilentus egreditur, Albertus. Hoc fi uerum eft,emptram fominam potius quàm Ocni afellum, 


\section{4

tractis laudari foribit. Reliqua ex eo remedia uide in fine pracedentis capitis,

\section{DE MVRE LASSICIO.}

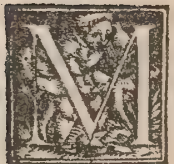

$V R$ i $S$ quem lafficium(laffits Germanice) nominant, pelles in pretiofarum numero hà bentur, is in cinereo candidus eft, nec dirobus digitis craffior, Ge. Agricola. Ego, fi re, ctè memini, muftelæ quoddam genus. Francfordix apud pellifices olim laxfet appellart audiui. Supra in Muribus Ponticis, nouogrodelam Polonis uocari dixi muris genus pretroli, cuius pellis albicet quidem, fed ita ut fit intermixtum aliquid grifeum, id eff cinereum;qua: rendum an idem lafficius fit.Polonus quidam cui pictur as animalium infpiciendas dederam, figute ra furronis adfcripfit Polonicum nomen nowogrodek, non rectè opinor. Alius Polonus muítelam albam Polonicèlafica uocari fcripfit. Sunt qui lafficium murem non aliter à muftela alba uei hermeli no differre putent, nifi quod duobus ferè digitis breuior eft, barnball uero Germanicè diçus eadê ferèmenfura hermelinolongior.

\section{DE MVRE ARANEO.}

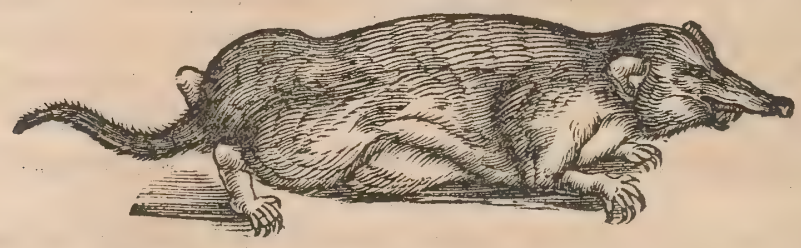

A.

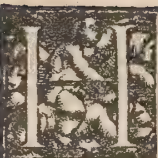

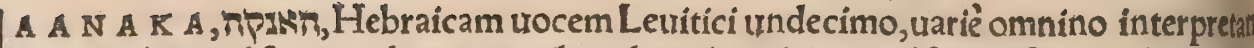
tur, reptile quod femper clamet, reptile uolans, hirudinem uel fanguifugam, hericium, 3" fibrum, ut fupra in Echino dixi:Septuaginta \& Hieronymus mygalen, id eft muremaz raneum. Mugali alcale eft, Auicenna 4.6.5.15. Apud Arnoldum Villanouanuminli bro de uenenis, legitur:Mugali, fehalhali. Sed uidentur hæe nomina Arabes à Graca uoce dedur cia corrupiffe, ut alia pleraq̧. Murem araneum mygalen \& myogalen Graeci appellant, Hermola us. Ego $\mu \nu \sigma \gamma \dot{\alpha} \lambda \kappa \mu$ uno tantum in loco apud folum Diofcoridem libro fecundo legi $i$ qui tamen alibi femper, ut $\&$ cateri authores omnes tribus tantum fyllabis mygalen nominat. Apud Suidam $\& V_{a}$ rinum $\mu v y a \lambda$ s oxy tonum fcribitur, (nec aliud addunt:) apud cæreros authores, nưnc oxytonũu,nine

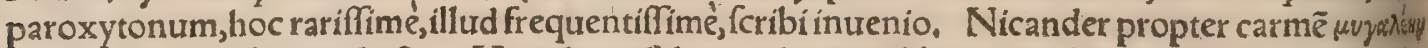
dixis, prima fyllaba producta. Herodotus(libro 2, de animalibus apud Aegyptios facris) mygalas

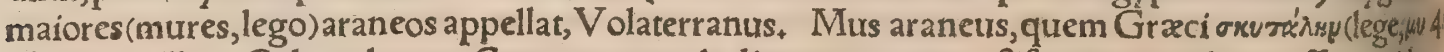
$\left.y_{\alpha} \lambda_{\lambda x}\right)$ appellant, Columel.7.15. Cur uero mygale dicatur, non una eff fententiał mihi ueriffima uide tur Aêtrĭ, qui mygalen magnitudine muris efle fcribit, (quamuis aliquanto minor fit ) colore autem

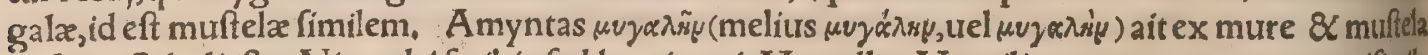
nafci, ut Scholiaftes Nicandri frribit:fed hoc, inquit Marcellus Vergilius, nec uerum nec uerifimile eft:quîenim ad generationem coibunt mus $\&$ muftela ? quibus non folum diffimilis penitus natura, fed natitræ \& exiriales inimicitia funt. Infulfé etiam Rodolphus quidam in Leuiticum, Mygale (ina quit)dicitur quafimus gulofus, Marcellus Vergilius Aêtrỉ fuper hoc etymo uerba non reçé trans fert’neqs enim eadem qua mus caudæa gracilitate eft mygale, fedmultò breuiori, ut Aérius fcribit: nec eadem riçus longitudine, fed multò longiore. Ge. Agricola rattum, ut uulgò dicimus, murem araneum effe fufpicatus, mygalen dici putat, quòd magnitudine ferè muftelina, muris autem fpecie fit, quamobrem Latinè etiam aranei cognomen huic murri adiunçum conị́cit, quod rattus ut arane us infectum parietes fcandat, Sed rattum à mygale differre, facile deprehendet qui eum diligenter cum ueterum defcriptione, quam mox capite fecundo recitabimus, contulerit. Muris genus rus beum, breui cauda, acutx uocis, propriè for ex uoçatur: eft autê uenenofum, 8 ideo non capiturà àfe libus, Albertus. Nos omnino hunc murem noftra lingua uocamus miỉ̧et, cuius hîc imaginem pra pofuimus, eundem uenenofum non edunt. Albertus fanè $\& \mathrm{Ge}$.Agricola, qui murem iftum foricem effe credicierunt, uocis maximè argumento adducti uidentur: quæ $\&$ huic murri quo de frribimus admodum acura eft, \& fimiliter acutã forici ueteres tribuiffe uidentur ex prouerblo quood apud Terentiurn legimus, Egomet meo indicio qua fi forex perii Sed meam de forice ueterum lententiam copiofe iam fupra ex 6 plicaui.Carolus Stephanus etiam in Vineto foricem \& murem araneum confundere uidetur:nifí fo ricis uocabulo tanquamgenerali utatur, quod ipfum quogeg non uidetur probandum, Mus aranea 


\section{DeMurib.diuerfis, Lib. I. 845}

us exiguim animal atģ leuiffimum eft, quod aranei modo tenuiffimum filum $\&$ gladí aciem coni. fcendit,Sipontinus: Egopotius araneum à ui ueneni dicfum coniecerim; utt uulgo etiam araneum pifcem cuius uenen of $x$ funt fpinx, fi pungant, Venetijs nominant: Et tale quid innuere uidecur Syl uaticus, cum fcribit; Mugali, id eft draco marinus, $\mathcal{X}$ animal uenenofum pufillum muri fimile $\div$ nam $\$$ araneum pifcem propter urenenum pungentibus fpinis infitum ueteres ophin, id eft ferpentem nominarunt, $\&$ hodie quidam uulgo draconem uel dracænam. Vegetius 3.77 . murem cacum no; minat, $\&$ fimiliter Samonicus 47 . Albertus murem cacum interpretatur talpam, ut $\&$ Hefychítis in

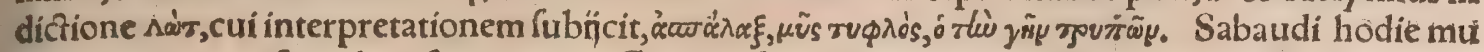
rem araneum mufet uel mufette uocant:Galli muferain, uel muzeraigne, qua uoce Rhæti etiam ú. tuntur, qui loquuntur Italicé, mífferaing. Burgundi,fery. Vites qua fecundum ædificia funt(inquít Carolus Stephanus)à foricibus $\&$ muribus infeftantur, interdum etiam ex qux in medís agrís. Eos autem forices uidimus roftrum acutum, exporrectum quidem admodum habentes; $\&$ pilis oblon: gis in morem felium onuftum, trenenatos quidem eos, tum ipfo morfu, tum etiam tactu: Vulgus no. frum uocat mefiraignes: quod uocabulưm quiddam commune cum mure araneo uidetur habere, Id uero ne in uitibus accidat (inquit Columella libro de arborib.cap.15.) cum Luna Leonis, aut Sagit tarï, autScorpionis uel Tauri tenet hof pitium, noctu putentur uites, Hac Carolus Stephanus, led uideri eum nobis foricem curm mure araneo confundere fupra diximus. Heluetij à uicinis forte Gallis mutuati nominant miiger, quafi murem araneum $¥$ reliqua Germania fpigmu $\beta$, ab acuta ro.

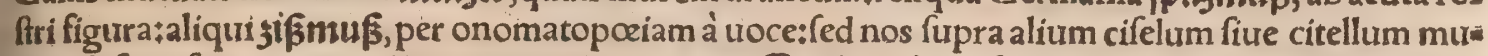
- rem defcripfimus, quem aliqui puto nominant gro/fesifmufs, id eft citellum maiorem. Hollandi, ut audio, mollmußs:nifi talpam potius hac troce fignificent, quam \& Flandrimol appellant. Matthro lus Senenfis ex Diofcoride topo ragno tranftulit: topo enim Italis hodie murem fignificat, ragno ara neum. Muribus araneis abundat infula Britannia, in hodiernumọ́ diem barbari illi uoce Roma= na utuntur, Hermolaus in Plinium. Fieri quidem poteft ut in nonnullis Anglia locis muris aranei nomen idem aut fimile Latino in ufu fit, tranfumptum feilicet $a$ Gallis, cum maxima Anglix pars $\mathrm{S}_{2}$ xonica \& Gallica linguis duabus in unam confufis utatur. Ego tamen ab Anglis nõ aliam huius mu ris nomenclatưam uernaculấ difcere potui, quàm fhrew:uel ut aln̈ fcribứt, fhrewe: aln̈ erdíchrew, id eft murem araneum terreftrem. De hoc mure Guilielmi Turneri Angli medici doctiffimi uerba ex epiftola ante biennium ad me data fubfcribam; Murem araneum (inquit) puto me in Anglia uidif o fe; is noltrate lingua uocatur a Throw aut a fhrew mus eft admodum niger (apud nos quide in Hel= uetia, ex fufco fubruffus) cauda ualde breui, $8 \mathrm{C}$ roftro admodum porrecto $8 x$ acuto. Caput quale ha. bet ad te mitto, (mifit àutể non myzeri noftri, quê hic depiçũ dedimus caput, fed alterius cuiufdam perexigui mưris, dentibus non differentis à reliquis muribus, cum araneus plurimum differat ut di= cam in $B_{*}$ ) ut melius poffis de eo iudicare. Si cui apud nos male imprecamur, dicimus, $i$ bef hrowe the, hoc eft imprecor tibi murem araneum, fiuc norfum eius, fitue aliud quodpiam ex eo malū, Hæc Turnertss. Hípänis huinc murem raton pequénno dici puto, Illyrice niemegka myfs, etfi amici Hi fpanus $\&$ Bohemus foricem ita interpretati fint per epiftolas. Polonis keret, $\Phi$ Aliqui animalcu. lum quod nos wifele appellamus, quod omnino muftela eft, \& à Gallis quibufdam prafertím cum al bo colore eft ermine nominatur, murem araneum effe putant: $\&$ Albertus mygalen marem muftela to interpretatur, qui aues in nido iacentes uenetur. fed horum error manifeftior eft, quàm ut uel paucis refutari debeat.

In İtalia murribus araneis urenenatus eft morfus s eofdem ulterrior À pennina regio non habet, Pli niưs. Mures araneos multos in Germania \& tota Italia uidi, præcipué uero in Valle Anania Tri. dentina ditionis, ubi tamen irenenofi non habentưr, fortaffis propter frigidam regionis temperiem: nam \& fcorpiones ibidem non funt uenenati, cum in cateris Italix locis plurimum fuo ueneno la. dant, IMatchaolus. TMygale chamæleonti fímilis effe dicitur, Obfcurus. Pracedenti capire mul ta diximus de huius muris corpore eiusćp̧ partibuts ‘ hî́c reliqua addemus, Mygalen aliquí dicunt

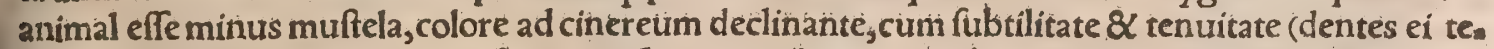

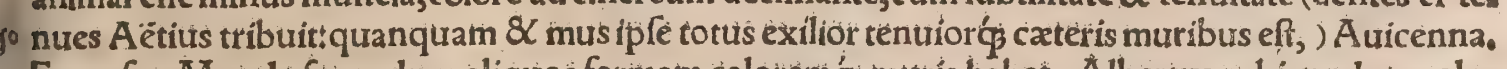
Et rurfus, Mygale fecundum aliquos formam coloremó̧ murís habet. Albertus rubicundum colo. rem muriuenenato tribuit. Oculis eft paruis, Idem:quanquam autem totus hic mus paruus fit, $0=$ culos tamen ei multò quàm pro portione minores êfe, ipfe étiam obferuaui, \& propter hanc oculo: rum paruitatem uifum ei admodum hebetem effe pinto, adeò ut ueterum quidam murem cæcum ap

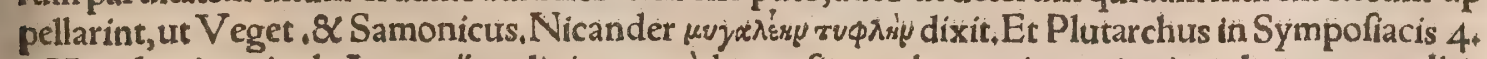
5.Mygalen, inquit, ab A egyptịs coli aitunt, quód cæca fit:tenebras enim antiquiores luce putant. Ibi= dem iecur eius in filentio Lunæ minui ab A egyptijs creditum fcribit:quiod alï de muris etiam $\&$ fori cis iecore prodiderũt. Roftrum habet oblongum \& acurum, Âêtius \& Auicenna ${ }_{+}$talpx inftar, Mat throolus. Ea quidem eft roftri eius figura, quæ apta ad fodiendum uideatur. Dentes habet tenues so atç cos duplici ordine fitos in utraqs maxilla, quo fit ut quatuor dentium ordines habeat $\&$ in mor. fis ab eo uulnera quadrifido ordine confpiciuntur, Aëtitis. Matthrolus ex Aëtio citat, duos ordinès dentium habere hunc murem, unum intra alium; quod mihi non placet, Græcẽ exemplar infpiciang 
quibus ad manum eft. Dentium, inquít A uicêna, tres funt ordines: quorum alỉ fuper alios torti funt retorfione parua ad fuperiora. Cateri quidem mures, ut \& f ciuri \& $<$ caftores, dentes binos anterius oblongos habent, in ore uerô interius molares in utraç maxilla quaternos feorfim, tum infra tum fupra:ut in fumma, dentes incifores quaturor fint, molares fedecim. Sunt autem molares, ut dix, non folum quaterni, in unaquaque maxilla, fed quatuor etiam ordinibus difcreti, ut recte tetrafichi,id eft in quatuor diuifi ordines, dicantur, fecundum Aétium + uidelicet ipfi molares tantum infra fü prá̧̧ confiderati. Quod fiab altera tantum parte, inferiore aut fuperiore duntaxat, tum molares tum inciforios dentes refpicias, tres ordines inuenies, fecundum Auricennam ; ex quibus incia

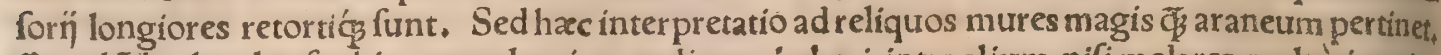
Quod Mathrolus fcribit unum dentium ordinem haberi intra alium, nifi molares multo interius it quàm inciforios effe intelligat, quid fibi uelit nó affequor. fcio pifces quofdam \& ferpentes, duros aut tres dentium uerfus habere, at $\$$ unum intra alium, fed in murium genere nibil tale inuenias. Murl araneo breuis $\&$ gracilis eft cauda, Albertus $\&$ Maffarius. qMus araneus exigurus eft ultra mo: dum, longo roftello, oculorum acie obtufa, Plinius Valerianus 3.55. Hxc iam feripferam,cumal. latum mihi hunc mufrulum accuratius infpicere, $\&$ defcribere uolui, Colore igitur partim furco par tim rufo eft, inter fe mixtis, uenter albicat,pedes pofteriores plané in poftrema corporis parte harêt, Totus grauiter olet, \& uel odore uenenum fuum prodit. Caudæ breuifimis pilis obfita longitudo, digiti duo, reliqui corporis tres, uel infuper dimidius. Ocelli nigri 82 minimi funt, pauló maiores quầm talparum, magnitudine capitis minimæ aciculæ, ut non mirum fit ferè cæcum effe hunc mư rem, cui poft talpam minimi omnium in quadrupedum genere oculi contigerint. Et fané uulgò ca: cum hoc animal creditur, atç ideò, ut anicula aiunt, oculis diuinitus captum, ut minus nocere furo morfu poffit, quod fi uerum effet, miraremur fexpentes omnes ( fola forte cacilia excepta) non uifu tantum, fed eoctiam in plerif $\beta_{3}$ acutiffimo preditos effe. Dentes ut minimi funt, ita fitu figurág $\mathrm{ab}$ aliorum tum quadrupedum tum murium dentibus differunt, componente quodammodo ferpen tium 8 murium dentes in unum animal natura. Anteriores bini oblongi, non ut al'̆p muribus fim plices funt, fed alijs, binis aut ternis denticulis enafcentibus exafperantur, tantillis ut nifi diligenter infpicias non appareant. Hoc etiam differunt à cateris muribus, quod bini illi oblongi non feparat fint à cateris interioribus, fpatio aliquo medio, fed unus omnium continuus ordo eft. Áfperi plant $\&$ acuti funt ferræ inftar, quidam binis alip ternis (ut tres pofteriores puto) cufpidibus, tam exiguis ut feré uifum lateant, laterentó̧ magis nifi extremæ partes cufpidum quarundam ruffo colore notás, rentur. Dentes circiter octo funt utrin $\phi_{S}$ ( reliquis muribus quaterni tantum) $\&$ infuper duo longio res fupra, infrać totidem, ipfi etiam ut dixi duabus uel tribus cufpidibus ferrati, quæ nifi quis accu raté obferuet dentes per fe uideri poffunt, 8 omnes ex uno offe enati.

Sed ut res clarior fieret, geminas icones hic adieci capitum muri= norum cum dentibus fuperioris maxillx. maior communem figu ram $\&$ fitum dentium in omni genere murium (excepto araneo) \& fimilium declarat, ad craniữ muris agreftis repręfentata.minor, aranei muris dentium fitum figuramó utcunģ refert.

c.

Mures aranei apud nos capiuntur fere circa hortos \& ftabula: hyeme quidem domos \& fabula fo magis quàm xftate ingrediuntur. Gaudent fané circa fimum bubulum urerfari. TVifum eishe: betiffimum effe, \& ideo à nonnullis cxcos credi in B dixi. đI Vox huic generi multò acutior quâ alijs muribus, unde aliqui foricem crediderunt propter prouerbium, ut in A, retuli. Per onomatos poeiam etiam à uoce aliqui Germanicé hunc murem jif̧mußs nominant, đPutauerunt aliquiaras neum murem ex mure $\&$ muftela gigni, ridiculé quidem ut in $A$, dixi, Plutarchus in Sympofiacis

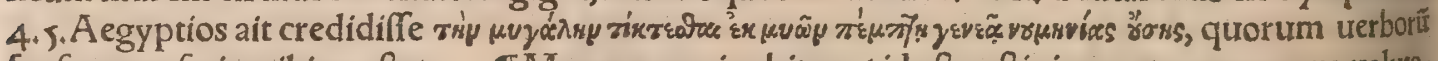
fenfus non fatis mihi conftat. बMures aranei orbitam (id eff ueftigium rotarum currus uolutas tione impreffum ) fi tranfiere, moriuntur, Plinius. Hoc quàm uerum fit, inquit Marcellus Vergi far. cile erit facto periculo cognofcere: atqui interim quodnam uulgó fit araneo muri nomen non docet Ferunt non tranfiri ab eo orbitam torpore quodam natura, Plinius. Negant tranfiri orbitam ats $\dot{e}$, natur $æ$ quodam torpore $\$ \&$ fi tranfierit, moritur, inde cótra morfum eius terram ex orbita fumen dam præcipiunt, Hermolaus. At aln̈ ueteres præter Plinium, non fi tranfierit, fed fí inciderítin orbis tam, hunc murem perire fcribunt. Noui $\&$ cæecam mygalen, inquit Nicander, in orbitis morientem: ubi Scholiaftes, Mygale cum cæca fit, in orbitas iuxta rotas incidens illic necatur : quafi non per ans tipathiam crbita, ut alij fcribunt, fed cum inde euadere non matures, aut forte non poffit, currualis quo fuperueniente, pondere rotarum opprimatur. Mus araneus fi in orbitam inciderit, naturalifas to illic detentus emoritur, Marcellus. Mygale ualde metuit orbitas, illapfa enim torpet ac tremic; ac fi immoretur (quafi etiam euadere poffit, fi uelit) fape etiam moritur, Philes * Si in orbitam ins ciderit, tanquam uinculis capitur ac moritur:quare et terra morfui quem inflixerit hic mus infperfa remedio eft, Aelianus. Oculorum acie obtufa eft, \& ideo quantum exiftimo, iners ei natura, utnó poffic tranfire orbitam, Plinius Valerianus. Tardiores multò funt quàm mures : hanc ob cauts fam pariter $\&$ propter hebetudinem uifus, fape in ftabulis deprehenfi occiduntur. Mygales cur 


\section{DeMurib.diuerf. Lib. I. 847}

fus urel inceffus ef in ultimo, Auicenna ut Bellunenfis legit, fenfu minime claro, uidetur atitem tar ditatem fignificare. Mygale animal paruum \& uenenolum, alicuius eft uigoris in iuuentute, fé continue per atatis incrementa torpefcit, Albertus:proinde non mirum fi iam ob atatem torpidi ali quando in orbitis reperiâtur, nec facile inde euadant. Mygale dicitur quafi mus gulofus, R odol phus in Leuiticum; fed ridiculam hanc etymologiam effe in $\mathrm{A}$, dixi. Fraudulenta eft, \& dolo rapic qux deuroret, Idem. Audio boum ungulas in ftabul is uituentium frepe ab eisperrodi,

D.

Mygale animal gulofum \& rapax, fingit fe manfuetum, fed cum quis ei appropinquat, mordens illico uenenum infundit, ut legitur in annotatis in Leuiticum, Arnoldus de Villanoua. Crudell eft animo, fed hưc diffimulans blanditur beftijs, \& fipoteft ueneno interficit, Albertus. TMygalen pardalis exhorrefcit, Philes, $\mid \bar{A}$ felibus capit quidẽ $\&$ occiditur, fed tanquã uenenofus nó editur. E. $F$.

Vites infefrant forices $\&$ mures, \&c.ut in A.retuli,ex Carolo Stephano, qui mures araneos effe furpicatur qui id factitant. T Neà felibus quidem in cibum admittuntur, ut mireris non defuiffe qui homini é uino bibendum pro remedio fui morfus exhiberent, ut in G.dicemus.

G。

Mus araneus, qui cum in orbitam inciderit moritur, uftus in cinerem redactus, \& cum adipe an. ferina permixtus, condylomatis infriçus, mirum remedium adfert, Marcellus, Mus araneus pen. dens enecatus fic ut terram nec poftea attingat, furunculum fanat, ter circundatus ei, toties expuren - tibus medente $\&$ eo cuimedebitur,Plin. Mus araneus fi in orbitam inciderit, naturali fato illic de tentus emoritur:hunc illic inuentum argilla, aut linteo, aut phoenicio inuolue, \& ex eo ter circunfcri be parotidas, qua in corpore fubitò turgebunt, mira celeritate fanabis, Marcell. Pro felle $\mu$ y yexisss, (malim y $\alpha \lambda \tilde{s}$, id eft muftela, cuius fel in ufu medico effe legimus, mygales nufquam: \& Galeno etia adferipra Antiballomena yaenis habent) fel cameli, Antiballomena apud Aeginetam. Muris aranei caudæ cinis(impofitus) prodeft mor fis à cane rabido, ita ut mus cui abfciffa fít cauda uiuus dimitta= tur,Plin. Equo ftrophofo Hippocrates ueterinarius per os infundi iubet ramẽta ungularum (equi)

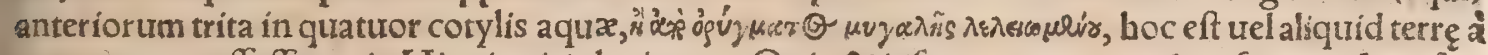
mure araneo effoffa, ut in Hippiatricis legimus, Quin \& ipfe mus araneus aduerfus morfum fut uarn̈s modis prodeffe dicitur, impolitus, potus, appofitus, ut in fequentibus dicemus. Prophylacti cum quidem remedium, ne mordeatur homo uel aliud animal, pręftantiffimum effet, fi fuperfitione amuleta carerentrecitabimus id tamen infra, ubi de morfu huius muris in iumêtis curando agetur.

\section{Muris aranei morfum uenenatum effe: deçá fignis eius, $\&$ medendi ratione in genere.}

In Italia muribus araneis uenenatus eft morfus, Plinius, Quibuldam in locis non haberi uenenas tum retuli fipra in B. Muris aranci morfus interimere quandoçs folet, Galenus ad Pifonem. Ipfi quaddem hi mures tam uenenati funt, ut ́upra dixi, ut capti etiam occifíç à felibus non comedantur. Cadaneribus eos uéci audio, ut non fir mirum uenenofam hoc alimento uin in corpus eurum diftri bui. Pracipuè urero noxius eft eius morfus fi pragnans momorderit, \& fi animal pragnans ab eo prafertim pragnanie mordeatur, ut infra dicam ubi de iumentis ab eo demorfis agetur. Affeuerãt

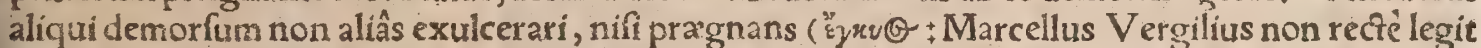
exrós) mus araneus fueritłtum enim auxilijs opus effe, Dicfcorides. Si pragnans momorderit, protirus diffilit, Plin. Puftula, fi pragnans percufferit, nec aliter, rumpuntur(erumpunt, \& ulcus ma= lignum faciunt, )ut Diofcorides \& Aêtius fcripfêre. Plinius non puftulas, fed ipfum murem araneũ, Ii pragnans ferịffet, diffilire protinus exiftimauit, Hermolaus. Ego Plinium Græeis non intellectis omnino erraffe dixerim. Vide etiam infra ubi de iumentis morfis agam, uerba Ariflotelis.

II Signa. Muris aranei morfum arguit, locum ambiens inflammatio, (dolor uehemens $\&$ pun= cura in corpore, \& apparens rubor in locis fecundum dentes eius, Auicenna:)nigrá̧́ puftula dilus ta fanie turgens exurgit. \& partes omnes uicinæliuent, (bafes feu radices fufcæ funt, \& partes proxi ma, Auic.) Rupta puftula, depalcens ulcus, non ei difímile quod ferpit ${ }_{3}$ occupat. (Cum puftula fin ditur, egreditur caro alba colore nerui, habens tunicas: $\&$ quando $\$$ apparet in eis aduftio quædam: $\&$ quando\& corroditur $\&$ cadit, imó fluít initio pus uir ulentum, deinde putrefit, $\&$ corroditur, \& $\mathrm{ca}$ ro cadit. Auic ) Inteftinorum quog tormina, difficultas urina, \& frigidxa afperginis offufio ( $\downarrow$ vygés vo rido mopíxvors) confequuntur, (fudor frigidus corruptus, Auicenna,) Diolcorides \& A çuarius. Sed uideo Auicennam fua feré exPaulo Aegineta tranftuliffe, quare Aeginetæe etiam uerba adfcribam. Vbi mus araneus lafit, fequuntur dolores pulfatiles, 8 in fingulis dentium eius animalis ictibus ru bores, ( $\& c_{4}$ ut Diofcor.) Cute pufula dirupta album ulcus apparet, nam ad membranas nertiofas deraditur.ad hæc, excidunt etiã partes depaftione oborta his qua ferpunt(ulceribus)fimili. præterea etiam inteftinorû̃ tormina comitantur, urina difficultas, \& frigidi fudoris undiç, eruptio, Hæc A egi neta. Manifefta funt nuris aranei uulnera, inquit Aétius : quadrifido enim ordine confpiciuntur. Et fanguis quidem primó purus promanat, paulo poft uero faniofus. Animal ením ipfum putrefa ctione occidit, Confueuerunt etiam bulla infurgere, quas fi quis dixumpat, carnem fubiacentem fe. 
culentam"uidebit, $8 x$ fiffuris difparatam.Inflatio autem fequitur demorfos, Caterum hoc animal fre quentius ad teftes infilire folet, (quod \& Auicenna fcribit))eosq̧́ percutere, non hominis folum,fed cuiufos etiam bruti animantis.

\Curandi ratio. Mus araneus pro fua magnitudine magna etiam ưulnera facit: quòd fi parua aliquando imbecillius imprimens fecerit, ea curatu faciliora erunt. Peffimus uero mor fus is eft quem prægnans (idç̧ magis etiam, fi prægnanti,ut fupra dixi) inflixerit. Morfus differentia ab inflamma tionis magnitudine apparet. Aêtius libro 13, cap. 14, iubet primum adhiberi communia remedia, qua fcilicet eiufdem libri capite decimo defcripferat, nempe urt morfus primum abluatur pofea call da, deinde ab aliquo exugatur, cucurbitula cum plurima flamma adhibeatur, loci uicini fcarificen: tur, \&c. Iubet etiam antidotos magnas exhibere. Strato apurd eundem,locum demorfum primó fca rificari iubet, deinde medicamenta imponi qua uirus extrahant, acria fcilicet, qualia inferius plura recitabimus, Si locus non fit exulceratus, nec puftula eruperint, imponuntur acria quzedam, itt pyrethrum, aut allia trita, aut finapis, aut etiam malua:(aut ablutus tantum negligitur) fi uero exe ulceratus fit(quod fit maximè (i pragnans mus fuerit)cortices granati dulcis decocti tritl imponun tur, \& ulcera eodem decocío, aut magis myrti, perfufa fourentur ; ut Äétius ferè \&Auicenna fcri bunt. Quacunç remedia ad fcolopendræ morfum faciunt, hî́c etiam falubriter applicantur, $\bar{A}$ êtu us $\&$ A egineta,

\section{Remedia topica, imponenda morfui muris aranei ordi.} ne literarum enumerata.

Abfinthium bibitur cum uino contra muris aranei morfus, \& draconem marinum, Diofcorid. meminit etiam Plinius lib.27. Medetur acetum fcorpionum ictibus, canis, fcolopendræ, 8 muris a ranei morfibus, \& contra omnia aculeatorum uenena \& pruritus, Plinius, Græci medici \&ali quorum fcripta uiderim aceto utuntur contra huius muris morfum, non per $\mathrm{fe}$, $\mathrm{fed}$ alïs remedijs $\mathrm{fo}$ exceptis, ut ipfo mure araneo ufto, galbano, hordei cinere, finapi trito, chryfogono. Alliurm neconi tra araneorum murium uenenatum morfum ualere miremur, aconitum pardalianches debellat, \& canum morfus, in qux uulnera cum melle imponitur, Plinius. Allia contrita illinuntur, Diofcoí, des, Actuarius, A egineta, Auicenna. Morfum cum cumino integito $\&$ allio, putamine extrinfeco non abiecto:eadem etiam cum oleo trita affidue $\&$ diligenter locis circunfitis illinito, Aétius. Alli um cum fículneis folin's cyminoç̧ emplaftri modo imponitur, Diofcorides, Althæa, uide in Malua zo inferius. Aqux calidx fotus conducit, Diofcorides \& Acquarius : ut Ruellius \& Marcellus uer*

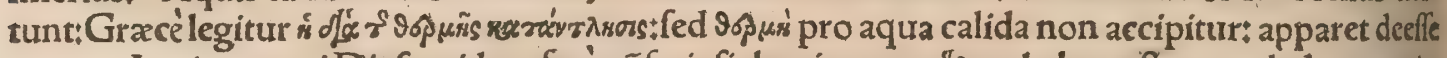

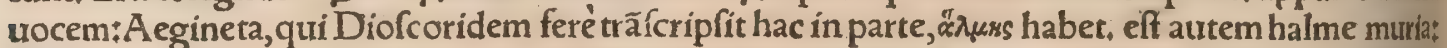
\& A eginetam fecutus Auicenna, Foureatur (inquit) aqua falfa calida, ut Bellunenfis legit. Aëtius

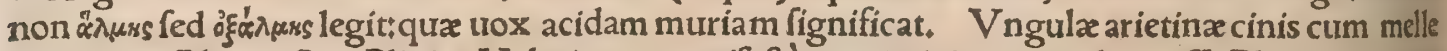
imponitur, Plinius Sec. Plinius Valerianus manifefté exprimit imponendum effe,Plinius tacuit,et medicamento bibendo mox fubiunxit. बBraffica femen aut folia, trita cum lafere $\&$ aceto morn fis à mygale, uel cane etiam rabiofo, utiliter imponuntur, Geoponica. đ Canis fimum illinito, quod 8 homini $\&$ equo medetur, Hierocles in Hippiatricis. Caprificus, uide in Fico infra, Chry fogoni folia contufa \& ex aceto impofita, Diofcor, Cuminum, uide in Allio fupra, IE nigrafis 40 cu candidi cauliculi illinuntur cum cera, Plinius. Caprifici cauliculi aut groffi quàm minutifime ad fcorpionum ictus è uino bibuntur: Lac quog infillatur plag $\&$ folio imponuntur: item aduer fus murem araneum, Plinius. Caprificorum grofficum eruo \& uino contra muris aranei morius \& f colopendras utiliter illinuntur, Diofcor. Allium cum ficulneis folips \& cy mino, Diofcorides. Tx Ealbano fplenium per fe, uel cum aceto tritum, Diofcorides, Auricenna, Actuarius. đH.or: deacea farina cum aceto mulfo illita, Diofcorides \& A ctuarius, Hordei cinis illitus, Plinius, Siru ptæ fint bullæ uel ulcera oborta, acida muria prolue, \& hordeum uftum tritum impone, Aëtius,

TLeporis coagulum cum aceto impofitum, ut Aggregator citat ex Plinij libro 18. Vide infra inre medins intra corpus fumendis. đMalua uel maluæ folia, Auicenna \& Aérius. Maluafyluefrís, A egineta. Althęa inter maluas (eft autem ex fylueftribus ) contra omnes aculeatos ictus efficaciot $\rho^{\circ}$ uis, præcipué fcorpionum, uefparum, fimiliumć, \& $\&$ muris aranei,Plinius. Mus araneus diffectus 8 impofitus, ipfe fui morfus ueneficia luit, Diofcorides, Actuarius, Galenus de fimplicibus 11.46 ، Tritus ipfe 8 impofitus ictum fuum fine dolore, curat, Galenus ad Pifonem. Ipfe mus araneus con tra fe remedio eft, diuulfus \& impofitus, nam fi pragnans momorderit, protinus diffilit, (non ipfe mus, ut Plinius malé ex Gracis uertit:fed ulcus tantum rumpitur, uel potius erumpit, ut fupra do: cui)optimum fi imponatur qui momorderit. Sed $\&$ alios ad hunc ufum feruant in oleo, aut luto cir cunlitos, Plinius. Murem ipfum araneum uftum cum aceto cataplafmatis trice imponito, Strato apưd Aétium.Mihi fanè multò magis probaretur aceturm addi ad ufti hurius muris cinerem, quàm ipfum per fe murem diffectum tritúmue imponi:quando $\&$ alin quidam cineres adhibentur, ut hor dei: $\&$ acetum per fe tum huic tum alịs uenenatis ictiburs refiftit, ut fupra dicfum eft. Myrti decocio 60 ulcera ex eius morfu uriliter fouentur: Vide infra in Punico malo, TTerra ex orbita, Plinius. Sin autem muris nocuit uiolentia caeci, Quafola fignauit woluendis orbita plauftris, Illine, mira 
बatur uili de puluere cura, Serenus, (Alị non illini uolunt, quod conuenit humidis fed arido pulue re tantum afpergi,) Musaraneus fi in orbitam inciderit, (uide fupra in $c_{*}$ ) tanquam uinculis cap. tus immoritur: \& morfis ab eoremedio eft terra ex orbitarum tranfitu fumpta, eáp fimul ut uulnus afperfum fit,ftatim fanatur, Aelianus $\&$ Philes. Matthæolus ex Nicandro citat terram curruum ro tis adharentem mederi morfui muris aranei, quod fibi inquit fabulofum uideri. Ego huius rei men. tionem apud Nicandrum non reperio. If Porri, Diofco: Refiftunt quoç acini(norsice, Marcellus Vergilius corium transferre maluit, non quidem ex Græcæ dictionis ui, fed quòd hoc rensediĩ ma= gis côtrenire uideretur, \& aliorum quo $\$$ authorũ confenfu niteretur) dulcis Punici decocti $\&$ illiti, Diofcorides interprete Ruell. Quod fi exortæab ictu ueficæ exulcerentur, malí Punici dulcis cori um cocium tritum impone, ulcerá̧́ ex eodem decocio, aut magis myrti decocto perfufa foute, Aêti= us, Siapoftema fit, cortices granati dulcis decocti imponentur,Auicenna. Pyrethrum,Aegineta \& Auicenna. Sinapi, Auicenna.Sinapi tritum cum aceto, Alegineta \& Stratว apud Aérium. बT Talpa difcerpta imponitur, Plinius Valerianus, Catera magorum placita de ralpa, fuis reddea mus locis: Nec quicquam probabilius inuenietur quàm muris aranei morfibus aduerfari eas, quoni am $\&$ rerra, ut diximus, or bitis deprefra aduerfatur, Plinius. Trifolium bituminofum coque, $\& \mathrm{de}_{*}$ rocto calido locum demorfum foue. Nullus autem fomento illo utatur qui non patitur. Tranfic enim affectus in eum, ut putet fe à uipera uel araneo mure commorfum, Galen. Euporif.2.143* of Ver benaca(Aétius addit rectam)tum propinata ex uino, tum pro cataplafmate impofita, iutrat, Aegine* ta \& Aétius.

Bibenda edenda'ue aduerfus muris aranei morfum.

Prodeft potum abrotoni decoctum, maximé fiin uino detur, Diofcorides, Actuarlus, Auicenta (qui \& paulò ante f́chea Arnienum pro abrotono nominauerat inter eadem remedia, ) Aeginera. Abfinthium ex uino potum, Plinius $\&$ Diofcorides. Agni hoediue coagulum, A egineta \& Aui. cenna. Coagulum agninum in uino potū, Plinius. Efficax eft remedium, fimifceantur, arifolochí corticis drachmæ quatuor, myrrhæ drachmæ ex, Aegineta. GBrafficæ foliorum aridorum farina muris aranei morfus alterutra parte exinanit, Plin.lib.20. Muris aranei $\&$ canis rabiofi morfus braf fica $\&$ femen $\&$ trita folia fanant, melius ficum lafere $\&$ acet trita imponantur +decoçũ quoģ folio run datur bibendum, Ruellius, elCapparis cortex, Aëtius, Cartamus, Auicenna.Cuprefli tea neræ pilula cum oxymelite, Á egineta:pro quo apud Auicennam non reçè legitur, Lac cum fyrupo

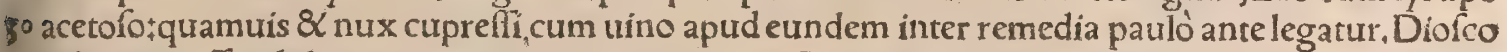
rides cupreffi pilulas recentes exaceto propinat. Cyclamen cum oxymelite, Diofcorides \& A Au: cenna. Chamæleontis radix ex uino, Diofcorides, A egineta. GElelifphacus, id eft faluia, Aegi= neta. Eruca ex uino, Idem, Diofcor, Áétius, Auicenna, Actuarius. Eruca femen, Plinius \& A Auicenna. Gentianæradix, Aëtius, Aegineta, Auicenna. Galbanum cum uino, Diofcor. Aegineta, Actuar. đHœdi agnítre coagulum, A eginera \& Auicẽna. đLauri foliorum tenerorum drach mam unam aut duas cum uino tritas bibendas præbe. Eadem pecoribus conueniunt, Aétius, Ali; qui præ cæteris commendant fuccum foliorum lauri, \& folia latri humida (recentia)cum uino deco Cta, Auicenna, Coaguloleporis ex aceto utuntur contra fcorpionem $\&$ murem araneum, Plinius: Aggregator hoc remedium foris applicari fcribic: Plinius non exprimit.ego in corpus fumendum - purấrim, ut et hoedi agníue coagulum. Lubleb cum uino decoctum, Auicenna. Nec defunt qu literarum monumentis tradiderunt, tritum (ipfum murem qui momorderít cum uino exactè detritư, A egineta) murem araneum contra fuos ictus commodè bibił quam hiftoriam apud alios inuentam, dignam duntaxat cenfuimus qua annotaretur, Diofcorides. Myrrha, uide fuperius in Ariftolo. chia. Muris aranei morfus fanatur muftela catulo, ut in ferpentibus dicqum eft, Plinírs, I $\mathrm{P}_{\mathbf{a}}$ nacis liquor, Auicenna: numerat autem hunc liquorem inter fortiora auxilia, ut \& cyclaminum, ra= dicem gentianæ, \& coagulum agni hoediue. Pyrethrum cum uino, Diofcor. Alegineta, Auicenna. I Serpyllum cum uino, Diofcorid, Aeginer, Actuar. Sifymbrium cum uino, Aegineta, Auicenna. Styrax cum uino, Aurcenna, Verbenaca (recta, Aétius) tum impolita tum ex uino propinata iư uat, Aegineta.

बMuris aranei morfus iumentis omnibus moleftifimus eft; puftula hoc excitantur, \& periculo fior quem defixerit grauridałpuftula enim rumpũtur, ex quo interitus fequitur. (His uerbis, ex quo interitus fequitur, quod refpondeat in Graco nihil inuenio.) led fi non grauida eft, non interimit. Mygale aliquando iumenta ueneno interficit, maximé equos $8 \mathrm{c}$ mulos, \& pracipuè equas pragnan tes, Albertus. Tradunt equos 8 iumenta, fi herbas in qquibus mus araneus uirus emiferit, depa. fcantur,ftatim exanimari, Sipontinus. Communem rarionem medendi iumento morfo à colubris, fcorph̆s, phalangịs 8 muribus cacis, defcribit Vegetius 3.77 . Idem 3.82, diuerfa remedia contra muris aranei mor fum priuatim recenfet, 1 fdem uerbis quibus Columelia 6.17. qua recitaui in Boue capite tertio, ubi de morbis boum egi.Eadem omnino etiam Pelagonius frribit : habet tamen hic $\&$ Vegetius quadam, quæ a pud Columellam non leguntur, inferhus recitanda.

đIigna. Mus araneus fi morfum infixit, locus tumore duro cingirur, gemitus animal expri= mit parum interpellans, A bfyrtus. Intumécit animal totum, oculió̧ collachrymant, $\&$ exfaniac 
tumor, ac uiro à uentre deftillat, pabulum refpuit, Hierocles. Equus in ftabulo iacens fi fubertis tem forte murem araneum premat, mordetur ab $\mathrm{eO}_{3}$ Hippocrates in Hippiatricis. Si afina pras gnans ab hoc mure mordeatur, periculư eft ne moriatur, Abfyrtus, Si pragnans mus fuerit qui per. culferit, his agnof eitur fignis:Puftula per totum corpus exeunt, fed fimili ut aliâs ratione curabitur, Vegetius, Normanni in Gallia hunc murem admodum uenenatum effe putant, ita ut fi equim uel bouem cubantem tranfilierit etiam, periculofi morbi eis caufa fit, ( ut circa lumbos claudum pe. cus, tiel quafi immobile uideatur; ) nec poffe curari nifi mus iterü per aduerfum latus uel fponte uel coactus tranfiliat, qua quidem ualde fuperftitiofa eft perfuafio.

TCura. Apij femen coctum in uino \& oleo demittes, ac tumentem locum fcalpello dífcitries, quo uirus euocetur, \& uellicatum punctim uulnus recrudefcat. Si per hęc inflammatio magis excan n defcat, in orbem teretibus ferramentis inni flagrantibus exulcerabis, fanæ partís aliquid deprelien= dens, rectis quogs ferramentis, quò fanies emanet, redulcerabis. Quod fi pars ea per exulcerationen intumefcat, hordeum crematum tritumćs confperges, fed antea uetưfam adipem inungere contre nit, Hippocrates hippiater. Aliqui, ut Tarantinus, tradunt allia tufa effe imponenda, firffienaitég cornu ceruinum. Abfyrtus melius effe putauit, fi lafa pars uratur fimul atç̧ dentium inituriam ien= fit. Stratonicus fcarificandum uulnus confulit, prafertim quod inflammatione cingitur \& \& fale $\&$

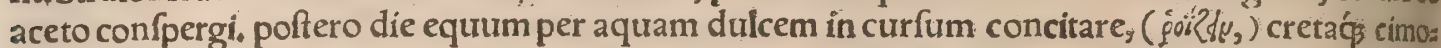
lia ace to fubacta lini, uulnus balnearum ftrigmentis nutriri, Hierocles, Aduerfus muris ar, mor= fum comprobatur allium tritum cum nitro: $\&$ fi nitrum defuerit, cum fale $\&$ cymino permifcere, ats que ex eo puluere loca, quæ morfu contacta funt, confricare. Quod fi eruperint urulnera uenenata 10 (fiphlegmone rupta in ulcus abeat, Pelagonius) hordeum combuftum in puluerem rediges, $\&$ di. luto aceto (abluto uulneri fimpliciter, Pelagon, )uulneri infpergis, \& hac ratione fola curabis, (xitâtip cæeterorum auxiliorum ufu magis atç magis glifcit uulneris iniuria.) Daturus potionem, polinem tritici, hordeum, (anethum, Pelagon.)cedriam \& uini fextarium per fauces digeres, Hæc Vegetius \& Pelagonius. Remedio eft locum lafum aculeo compungi, braffica trita cum aceto illini, allijs etiam ex aceto tritis, Abfyrtus. Tritas allihfpicas, falem $\&$ cuminum paribus fingulis menfuris uino miftis illines. Aut intritum murem araneum cum fextario uini faucibus infundes. Aut fi illum noir inueneris, creta figulari perlines, Hippocrates. Triti gith acetabulum in uino odorato per nares indidiffe proderit, (quod \& Hippocrates fcribitt+) playam $\not$ c canino ltercore lini, quod idem hominis bus falutare eft, Hierocles. Terra qua eruitur ex orbita aceto fubacta, illitu auxilio fore fertur. $L_{0=}, \beta_{0}$ cum lafum fubula compungas, pulueréć qui in orbitis fub ueftigio rotarum inuenitur, acri acto perfufolinas, Hierocles, Terram orbitæ urina fubactam impone, Hippocrates. Lauri foliorum tenerorum drachmam unam aut duas cum uino tritas homini morfo bibendas prabe eadem peco. ribus $\&$ iumentis conueniunt cum aqua trita $\&$ naribus infufa, eft enim præefens remedium, quare $Q$ hominibus commendatur, Äetius, Si iumenta momorderit (mus aran,) mus recens cum fale imponitur, aut fel uefpertilionis ex aceto, Plinius:Subiungit $\&$ alia remedia, qua pro iumentis com mendare uidetur, fed curm alị, authores inter hominis remedia eadẽ pofuerint, furperius à nobis enưr merata funt. Exiftimandũ fané eft plerą̧ eadem homini \& cæteris animantibus conuenire. đAu dio uaccarum ubera aliquando morfu huius beftiolæ lædi : quo facto ruftici axungiam maialis ruffi inungunt,

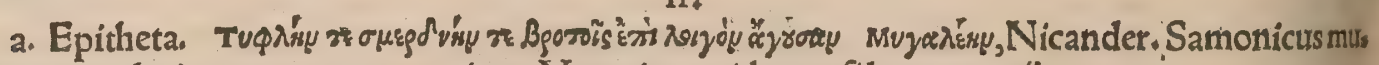
rem cacum dixit pro mure araneo, item Vegetius, epitheto ufi loco proprij.

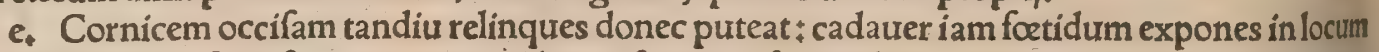
ubi mures aranei funt, $\&$ conuenient ad hanc efcam confumendam omnes totius domus mures arae nei. poterunt autem fic collecti uel fcopis opprimi, uel aliter occidi capiue: ut ex Gallo quodam ho: mine erudito, dum hac fcriberem, cognoui, qui fe quidem non expertum, fed à pluribus ita fe audi. uiffe aiebat.

h. Murem araneum colunt Āthribitæ, Strabo libro 17. IMygalas \& accipitres defuncios $\bar{A}^{\prime \prime}$ gyptĭ in urbem Butum afportant, Herodotus lib. 2. Murem araneû ab Aegyptīs coli $\&$ factum

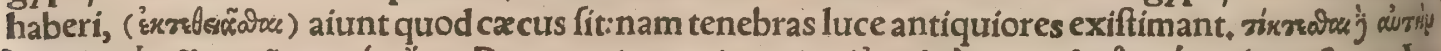

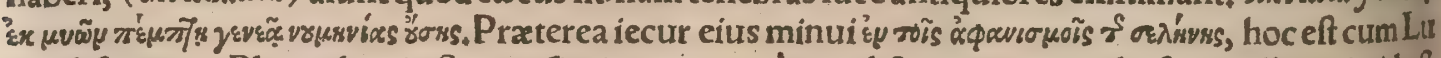
na obfcuratur, Plutarchus in Symporiacis 45, an ueró per obfcurationem, eclipfin intellexerit, id eft deliquium quod non aliter fit nificum per diametrum Soli oppofita eft Luna aut potius interluniî, id eft coitum cum Sole, (cum \& aliorum murium iecora pariter cum Luna crefcere $\&$ decrefcere aus thores tradant, in medio relinquo. 


\section{DeMurtela. A. Lib. I. 851}

\section{DE MVSTELA PROPRIE SIC DICTA:}

CVIVS HISTORIAE ETIAM ILLA ADDI. dimus, qux muftelis omnibus, ut uiuerra, marti,

\&c. ex æquo conueniunt.

Hace figura bis ponitur, quoniam mingela abba folo colore ab altera differt.

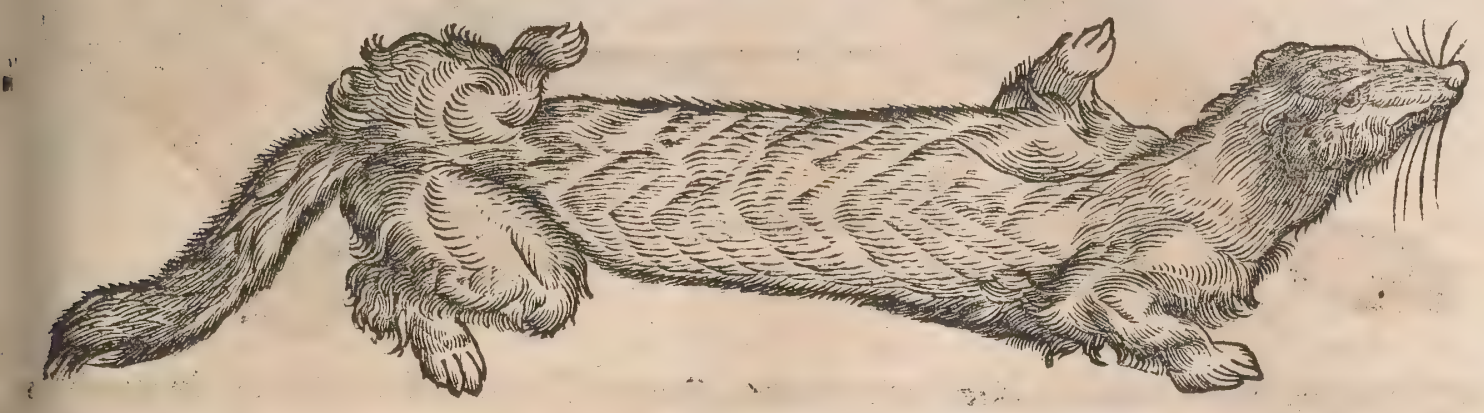

A.

(1)

V S T I A $\mathrm{N}$ V genera diuerfa funt, Nos defingulis feparatim dicemus: \& primuth

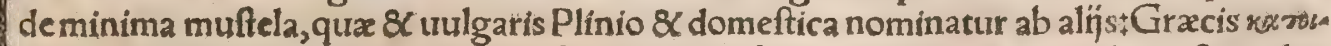
xidso, ut Hermolaus $\&$ alij eruditi(Ge.Agricola, \& Carolus Figulus qui de muftelis dia logum confcripfit)(entiunt. Muftelarum duo genera; alterum fylueftre, diftant magni. tudine, Graciuocant ictidas. Hæc autem qux in domibus noftris oberrat, \&.c. Plinitrs. Non probo quòd Niphus muftelam in urbanam $\&$ rufticam diuidit : nam domeftica muftela non in urbibus tantum, fed ruri etiam frequentius puto circa domos $\&$ uillas reperiuntur, Sed in hoc etiam errat, $\Phi$ muftelam urbanam, ut ipfe uocat,non aliã quàm catum feu felem effe uult, ut $\&$ Marcellus Vergil. Quanquam uero $\&$ alia quxdam maiores muftela fape circa domos reperiantur, ut domeftic dici - poffint, ut genus illud interdum quod noftri iltifum uocant, 8 martis genus unum, quia tamen ex dem fylueftres funt, nec femper domefticæ, non propriéfic nominabuntur. Iltiffus nofter uerfatur circa aquas, ubi pifces captat:in fyluis, ubi prehendit aues:in domibus, ubi gallinas, quare Plinius eã effe domefticam dicit, Ge. Agricola.Sed de alijs infra: hic de minima tantum agemus, cuius adiecta eft effigies, $\&$ abfolute etiam muftela nominatur Latinis, Gracis yern' fimiliter abfolute, Solemus e= nim fere qux uulgaria aut domeftica funt, fimpliciter nominare: rarioribus uero aut fylueftribus aliouid difcernendi caufa adijcere. ब 7 , choled, Leuitici undecimo muftela conuertitur ab omni=

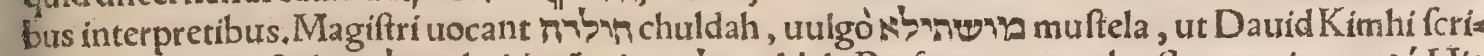

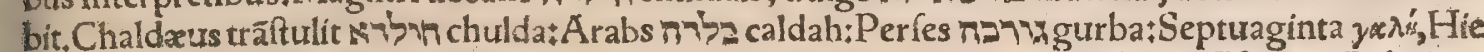
ronymus muftela. $M$ ks,oach, Hebraica uox, unde plurale ochim femel ponitur Efaię iz. (Babylon, inquit, fubuertecur, \& implebunt domos eorum ochim, Munfterus cercopithecos uertic.) Daurid Kim

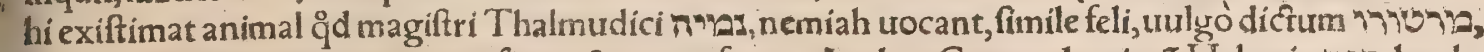

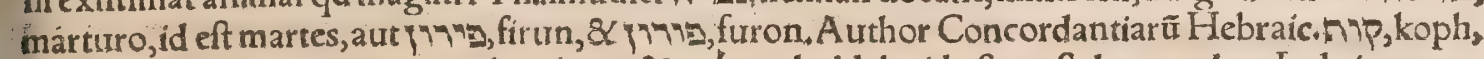
interpretatur cercopithecum uel cephum:8K mbn chuldah, id eft muftelam, uel, ut Iudæi putant,

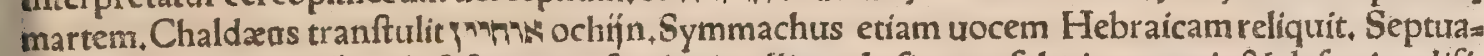
ginta $\&$ Theodotion " $" x$, id eft fonit (quafi echo intelligenda fit, quæ folet in magnis $\&$ defertis ædifis cijs refonare, ut in cauis $\&$ defertis circa montes locis.) Aquila typhones, Hieronymus dracones red dit. Koah quiden lacerti genus uel chamæleontem interpretantur Leuitici ı. Promuffela apud Albertũ barbara tocabula legimus his $\&$ hyrzus, qua nec ipfe intellexit; fed ex collatione cũ textu Ariftotelis hanc fignificationem ipfe deprehenditnam Albertus hyrzum ineptifimé leporem expo - nit, deceptus quoniam utrunģ animal ore furo catulos fape de loco ad locum transfert. Fethis eti= am apud Albertum in Ariftotelem 9.1.non alia quàm gale, id eft muftela effe uidetur, quanquam ad dit, \& gali, ceu de diuerfis animantibus agens. Nam 9.6. Feyton, inquit, ingenium habet ut uulpes, (f cilicet in inuadendis gallinis) \& eius altera fpecies eft katiz, id eft ictis. Ninifi,id eft muftela, Sylua ticus:forte nimfi legendum:nam nimfitza apud Gracos hodie uulgò uocatur. Ibanauge eft mufte la, Vetus gloffematarius in Auricennam. Ibinuers, id eft animal quod uocatur bellula, Syluaticus: Videtur autem bellula muftelam fignificare, troce ficta à Gallis uel Italis, qui belettam aut balottam pro muftela dicunt, Et alibi, Yena, id eft bellula. ra $\lambda_{\lambda i}$ Gracis ueteribus femper muftelam fignificar, recentiores quidam Graci pro fele, id eft cato abutuntur, ut fupra in Cati hiftoria dictum elt. Theo dorus Gaza apud Âriftotelem, interdum muftelam, interdum cattum interpretatur: nec quamobre 6o ita uerterit fatis conícere poffum, cum cattum Græci aluron, \& Latini felem appellent, ưti ipfe eriẩ

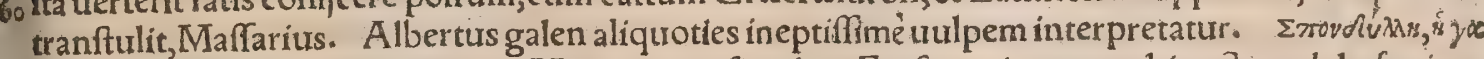
$\lambda \dot{\lambda}$, Atticè, Hefychius $\&$ Varinus, Malim per $\lambda$. fimplex, Erafmus in prouerbio, Spondyla fugiens 
peffime pedit, fpondylam felem interpretatur. Eft $\&$ fimile huic prouerbium rexis dopuinofoy, de aco cri uel acido, ut Erafmus uertit, uentris flatu. Ibidem fpondylen ferpentis(infecti dicere debuit) ge nus effe ait, quod emoriens grauiffimum odorem emittic. Eionno, animal quoddam, Hefychius \&

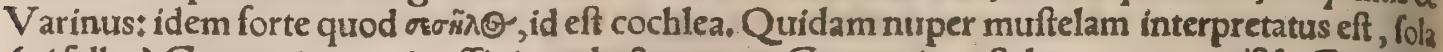
(ni fallor) Germanica uocis affinitate ductus, nam Germani muftelam uocant wifel. Graciho,

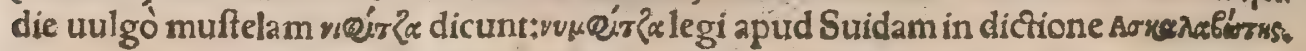

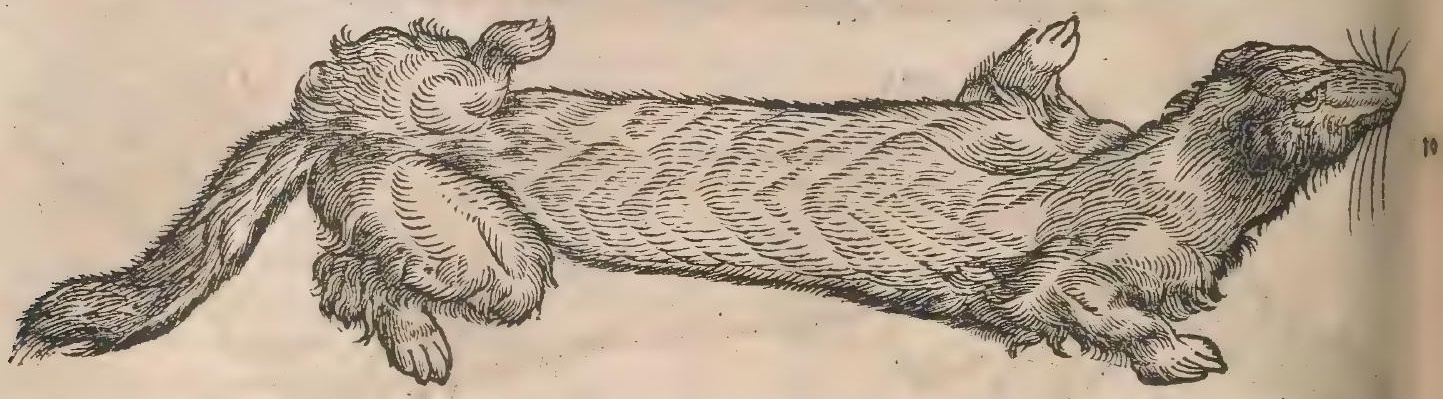

qMuftela Italicé nominatur donnola uel ballottula, Scoppa. Donnula $\&$ alibi dannula rocabulo Auicennæ interpres barbarus pro muftela utitur: Âlbertus \& Niphus damula feribunt: (quo uoca bulo aln̈ recentiores obfcuri damam intelligunt, qux de genere caprearum uel caprarum fylueftrta um eft. Damma fiue dammula, beftiola parua eft $\&$ debilis, ut fcribit lfidorus, fic dicta quód de ma nu fugiat. Cum parit, ftatim deuorat (ecundas antequam terram attingant: $\&$ prada eft alĭs animau libus, Albertus lib.22. Videtur autem damulam, fiue caprex gents fiue muffelam accipias, cum as lio quodam animali confundere quod fecundas deuoret:harum enim neutrã id facere legimus, $\mathrm{G}_{2}$ leotes quidem, id eft ftellio cum primum fuam exuit fenectutem, eam detrorare dicitur $\&<$ fieri poteff ut hune aliquis cum gale, id eft muftela cófuderit, \& fecundas profenectute, id eft leberide reddide rit. Domefticas muftelas foinos uocamus, Cardanus Iralus. Gallis muftela eft belette, aliâs belote te, aPbalotte.Aliqui, ut audio, circa Metas oppid ̃̃ baccal nominant, Carolus Figulus muftelã Galli cè fouinum uel marturellum interpretaturł qux duo genera diuerfa \& fylueftriũ muftelarumefle, infra oftendam. Hifpanis, comadreia. Khati qui ltalicé loquuntur, Latinum nomen retinent, Germanis wifel uel wifele. Ge. Agricola uifelam dici ait ex fono quem ædit. Aliqui in Heluetia bermelin uocant, alij corrupta uoce billemlin. fed illa duntaxat quę tota funt albx, quales apudnos hyeme frunt, fic nominari debent, ut in B, dicam. Anglis, wefell, alin feribunt wefyll uel weafyllat ba uerò muftela mineuer per tranfpolitionem licerarum Gallicæe uocis herminne. Illyrüs kolczar wa. Quidam hodie animal cuius figuram pro muftela dedimus non recté murem araneum eĺ fe putant:inde nimirum perfuafi quòd morfus eius fimiliter feré noceat.Albertus etiam muftelama rem, mygalen uocari fcribit, quòd falfum eft:mygale enim Gracis mus araneus eft, fiue mas fure foe mina. Ichneumonem uulgó nunc murem Indicum uocant, alij damulam, Niphus: fed damula fitue donula ltalis $\&$ recentioribus quibufdã barbaris, omnino muftela uulgaris eft, nọ ichneumon; quod peregrinum \& Alegypto peculiare animal $\mathrm{ef}_{2} \& \mathrm{C}_{\text {. }}$

B.

Muftela domeftica plerung eft in dorfo \& lateribus rutila, rarò fubfulua:in gutture femper can dida.quin nonnunquam tota candida reperitur, quanquam rarius, Ge.A gricola.In noftris qquidem regionibus, qux montanæ funt, muftelas omnes æftate fufcas uel fubrutilas effe audio, hyeme candi das:quod \& Stumpfius nofter in Chronicis fuis annotauit. Lepores etiam, non omnes, fed alpini tantum hyeme in Heluetia albefcunt. Vocantur autem armelini (bermeli uel bermletn)tum proprie cum toti candidi funt:aliqui apud nos per æeftatem quo og cum fufci aut fubrutili funt, ut dixi, fic now minant:quo tempore wifele potius dicuntur, non quidem à colore albo, quem noftri wif uroce fed per onomatopociamà fono uocis. Armelini in magno numero ex regionibus Europa ad Seps tentrionem fitis mittuntur, ubi maxima anni parte hyems \& frigus obtinet, xitates breuiffima funt: quos quidem à noftris nihil differre puto, nifi quodd pilus forte tenacius corum pellibus adharefcit, ut omnibus tempore frigido captis animalibus multo tenacior effe folet. Alba Ruffia fiue Mofco. uia, qua parte Cronio mari accedit, zebellinas armelinasós pelles nobilium ac matronarum delicias mittit,Erafmus Stella. Olaus Magnus in Lanzerucca Scandinauix fylua, cui longitudo ad ocion ginta miliaria, hoc genus muftela abundare fcribit. A pud Tartaros tentoria regia foris pellibus leo. num operiuntur:parietes uerò intus obducuntur pellibus nobiliffimis armelinorum \& zebellino. rum:etiamfi in regionibus illis hæ pelles pretiofiftimæ habeantur, ut quandogs uix pro duobus milibus Byzantiorum aureorum pelles pro una tunica fufficiant, Paulus Venetus. Grapaldus \& Alunnus, armelinum uulgò dictum, murem alpinum effe putant, quod falfum effe oftendi iam fus pra in hiftoria muris Alpini. Brachialis(id eft iunctura manus) ornamentum fimiliter ut pars ipfa brachiale dici poteft, ut ab armo armilla . A b armillis quidem armillini uocantur mures alpium \& feptentrionis, quorum eft candor eximius; quoniam ex ịs pelles ambire ueftium manicas armilla 


\section{DeMuftela. B. Lib. I. 853}

modo confueuiffent:nunc totis fubduntưr ureftibus, lectorum quogs ftragulis, Hermolaus in Giloffe matis. Ego Plinh̆ murem al pinum, alium effe oftenditquod fi quis armelinum etiam fic uocare uolet quoniam circa alpinas regiones maximé per hyemem alba habentur muftela, illi non admodum cố tendero, fed muftelam alpinam uel muftelam albam difcriminis caufa nominare commodius effe mo nebo.Idem illis dicam qui armillinum murem Ponticum faciunt, quòd 8 ex Ponto aduehatur, $8 \mathrm{C}$ al bus color ei (non omnibis tamen, fed uni duntaxat generi) ab Ariftotele \& Plinio tribuatur: quamuis enim forte propter duas has caufas fic nominari poffit, non tam confiderandum eft tamen quo res aliqua nomine dici poffit, quàm quo dicatur propriè. Sed de Ponticis muribus fententiam meam in hiftoria ipforum explicaui. Mus Ponticus, quem hodie uocant hermelam, hyeme folum in cauis ${ }_{10}$ latet arboributs. Eft urero totus niuis inftar candidus, excepta cauda digitum longa, eius enim dimi. dia pars, 8 quídem fuperior, (inferior, uel extremitarẽ uerfus, ut ipfe obferuaui:dorfum etiam mul: tó candidius effe, uentrem ex albo fubflauum)nigerrima. Magnitudo ei fciuritperfequitur mures et aués quitibus uefcitur. Eius pelles in pretiofarum numero habentur, Ge.Agricola, Eriminium(ali= âs, Ermineus, quod magis probo) quod quidam erinebinum (lego, ermelinum) uocant, animal eft paruulum, figuræ muftelarum, hyeme candens niusis inftar, æftate fuluum ut multela: candet tamen remper in urentre, $\&$ in extremitate caudx nigerrimum eft. Mures $\&$ aues infequitur, $\&$ carnibus urefcitur, Albertus. De genere muftelarum eft, fed forma minor, Liber de nat.rerum. Carolus Figu lus etiam herminnas, ut Galli uulgò uocant, tuel hermellas, ut Germani, muftelarum generis effe frri bit, colore tantum differentes. Pirolus, id eft fciurus, mutat colorem:ut $\&$ mas muftelæ qui mygale urocatur:(non recté:mygale enim mus araneus eft.) hoc autem eft animal quo aues adhuc implumes uenantur in nídis:fimile murri, \& quotannis albefcit magis magisḉ̧; donec tandem affimiletur color eius coloributyri, Albert. 3.2. Gronofthaij Polonis ưocari audio, muris uel muftelæ potius Septen. trionalis genus, undiç albifimum, fed in fine caudx nigitum:quare eundem hermelinum effe con, ifcio. Quanquam alius quidam Polonus demonftratam fibi muftelam albam, fua lingua lafica mihi nominauit.Sunt qui lafficium (fic enim G. Agricola nominat, et in muritum genere ponit. uide fupra inter Mures)ab hermelino non aliud differre putant, nifi quód duobus feré digitis breuior eft $\div$ ut ila lud genus quod barnball Germanicè uocant, eadem menifura longius ut pellifices noftri mihi nar, rarunt;quorum pleriç hoc etiam affirmant, muftèlx colorem album propter atatem, non propter frigus aut hyemem fieriłreperiri enim eas in noftris regionibus, primo atatis anno ruffas, altero mi xticoloris; tertio demum candidas. T Rofurella eft animal circa aquas habitans, ut frequenter miuftela maíús, \& pirolo(fciuro)minuss, In dorfo fubrufum, in uentre candidum. In terra facit habita cula: \& ègèrit ftercus perquàm odoriferum, mofctio fimile odore, fed diffimile facultate $\&$ uiolentia odoris. Vifus höminum fugit. Vno tantum in loco altui éxcrementa congerit, unde facile ab homini

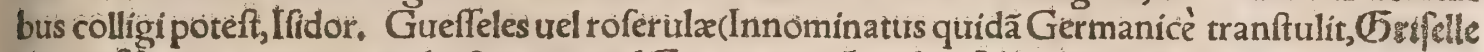

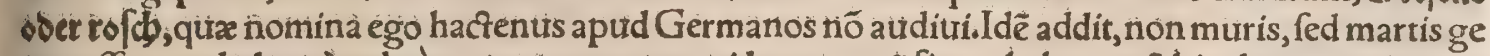
nus effe, quod placet) uuulgò uocantur mures quidam, quorû fimus habet morchi odorem:qui etiam in pelle hưius muris percipitur. In dorfo fuluus eft, in uentre albus. In pratis habitat $8 \mathrm{X}$ iuxta riuos aliquando in domibus quibus contigua funt prata herbofa, Albertus, Muftela quidem omnis, faltẽ finon capta fed libere alatur, fimum aliquo modo odoratum habet.

$\lceil$ Muftela alia maior eft, in uentre candida, \& in dorfo fültia, alia minor, Albertus, Mauritania muftelas alit felibus parès ac fimiles, nifi quiod ríctus eis emineritior \& oblongior eft, Strabo. $M u=$ ftela quàdam apud Afros nàfcùntưr in Silphio, fimiles Tarteffrís, Herodotus, Valla pro Tarteffins uertit murænis, quod non probo:quaramuis fcio apưd Ariftophanem quoç Tarteffiæ murænæ men tionem fieri, ut Varintis citat in Taprsoía, fed ibidem Tartefiam quo क̧ muftelam dici fcribit pro ma= gna. Eft autem, inquit; Tartefus urbs Iberiz iuxta Árnum palidem, Ariftophanis locus eft in $\mathrm{R} a=$

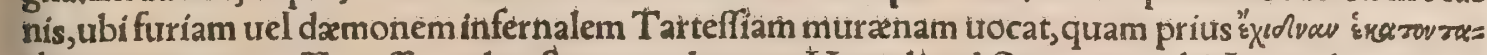
$x^{\prime}: \phi x \lambda$ u uocauerat. Tarteffus urbs eft extra columnas Herculis ad Oceanttm, ubi Arganthonius re. ghauit, habet autem muftelas maximas, Hefychitis, raxis Tagrworía, feles(muftela potius) Tarteffia, de magnis $\&$ ridiculis dicebatur. Tarteffị funt in Iberia, apud quós feles naximæ nafci dicuntur.

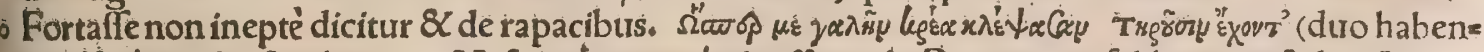

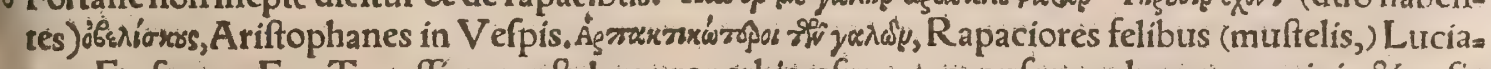
nus, Erafmus, EgoTarteffiam muftelam prouerbio ufurpatam nufquam legere memini $\$ \&$ ur fic ufurpetur, alio tamen fenfu quàm Erafmus accipienda uidetur, non de magno \& ridiculo homine: neç enim magnum \& ftupidum hominem ita mưftelæ magnæ conferas, ut afino magno, quo fenfur afinum Canthelium dicimus. In Pordofelena uia interiacet, cuitus ultra alterum latus gignitur ca. tus, ( $y \times \lambda s$, id eft muftela) citra alterum gigni non poteft, A riftotelés. In Pordofelene infula uiam mu* ftelæ non tranfeunt, Plinius:Albertus addit, $\&$ illatæe moriuntur, fimiliter in Bocotiam illatæ fugiunt.

TMuftela domeftica plerunç eft in dorfo \& lateribus rutila, raró fubfuluatin gutture femper cándida:quin nonnunquam tota candida reperitur, quanquam tarius, Gè. Agricola. De mutatio. go ne coloris eius per aftatem $\&$ hyemem, iam proxime dixi in Hermelini mentione. Figura corporis fimilior eft niartaro quàm muri, $\&$ habet anteriores dentes breues, quood nó habet mus, $\&$ infeîta cft muribus, unde patet, quòd non lit de genere murium, Albertus 
çum, Agricola tenue 8 gracile inftar fciuri, Stumpfius. Primores dentes breues habet, non ficut

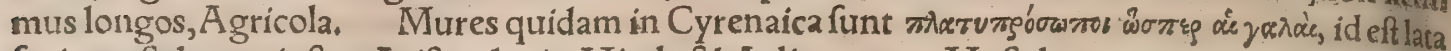
facie muftelarum inftar, Ariftoteles in Mirab, \& Aelianus, Muftelæ cor magnum, Ariftot,máa ximum proportione, ut $\&$ reliquis timidis aut propter metum maleficis animalibus, Plinius, . Mus, ftela genitale offeum eft, Ariftoteles $\&$ Plinius. Vide infra in Viuerra, Penis canibus $\&$ muftelis offe conftat, Vefalius, Vulpibus etiam offeum effe Ariftoteles ait, Muftela habet caudambres uem, Agricola,

Cauernaș terræ $\&$ petrarum fiffuras inhabitat, $A$ Albertus. Et rurfus, libro 12. In cauernis ha: bitat gali, $\&$ ad meridiem $\&$ ad aquilonem hoftia parat, ut undecunq ${ }_{3}$ uentus ueniat fit tuta contra uentum, (co fcilicet foramine obftructo.)Idem ferè de fciuris Plinius fcribit. Septentrionem urerfus fourea fux ingreffum facit, ut uento fibi contrario non fatigetur, Ifidorus, Incolit faxa, for amina; $\&$ interdum foenilia ubi foenum \& ftramentum reconditur, Stumpfius, A pud nos circa domos fere \& ftabula habitat muftela, unde \& domeftica dicitur:armelini uero in regionibus ad Septenrionem

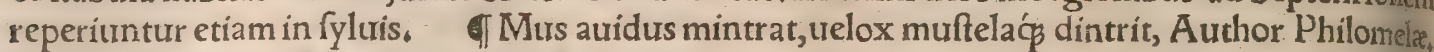
Germani ex fono uocis quam xdit uifelam nominant, A gricola. Audio uocem eis acutam efle, \& ferpentium fibilo feré fímilem. đMuftela diutiffimè dormit, Liber de nat, rerum. Gliribus fe nium finitur hyberna quiete. conditi enim $\&$ hi cubant:rurfus 2 ftate iuuenefcunt, fimili $\&$ muftelis quiete, Plinius, Muftelas hyeme cubare, aftate expergifi Ariftoteles fcribit, ut Perottus citat. (ego hoc nufquam apud Ariftotelem reperio:ftatim enim poft glires, mures Ponticos albos id facere fcribit, non muftelas ut Perottus citat.) Hoc muftelis accidere(inquit Perottus) compertum eft, quid ipfi quoç coëmptis in hunc ufum utriuf $\sigma_{5}$ generis muftelis, aliquando experti fumus, Muftaf noftrę domi uiuit, etfi habet furas cauernas, non diu ac multum fe condit; fi ruri, hyberno tempore in fpecubus later, Agricola. Hac dum fcriberem per mediam hyemem muftelam albam in horto exe

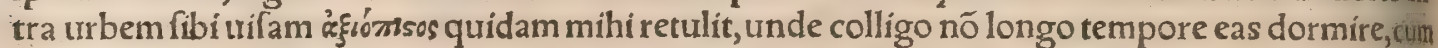
illa ne media quidem hyeme fomno indulferit. Rurfus alius quidam mihi affirmauit uidiffe fe mufte lam Limagum urbis noftra flumen fuperantem continuatis faltibus, ita ut nunquam demerfa tiata: ret, fed fubinde per fuperficiem faliret, quod propter leuitatem $\&$ agilitatem huius animalculi non difficulter credo, đMurfela rufticis noftris non eft ingrata, deurorat enim omnia genera murium, domefticos, tum minores tum maiores quos rattos uocant, item agreftes mures \& talpas. Cauernas etiam fubire poffunt ob corporis fui gracilitatem:itaç mures multò plures abfumunt quàm cati. Ita fit ut in Heluretia muftelæ ferè abundent, quod à rufticis $\&$ alpinis hominibus amentur, Stumpfius, Gale muribus uefcitur, \& ideo cum ferpentibus qui effdem uefcuntur, pugnat, Albertus ex Arifto: tele.Idem libro octauro galen hoc facere fcribens uulpem interpretatur. Muftela gallinis infefta eft.oua earum abforbet $\&$ ipfas interficit, Albertus. Ego à rufticis audio oua tantum ab eis rapi, tuel exorberi,gallinis uerò non noceriłquod \& Stumpfius fcribit. Sylueftres ueró muftelas, martes \& îla tiffos à nobis dífos, gallinas iugulare certum eft. Terreftris muftela fera beftia atque infidiofifth ma, in defunctos homines inuadit, \& nífi arceatur, eorum oculos diripit $\&$ exorbet, Ä elianus licet modo quo gallinarum oura. .. Prouidendum ne ad anferum cellas accedere poffint muffelx, alixue beftix qux noceant, $V$ arro. In anferum ftruendis cellis feruanda funt eadem, qux in ali generibus pullorum:ne coluber, ne uipera, felesćs aut etiam mưfela poffit afpírare: quæ ferè perni: cies ad internecionem profternunt teneros, Columella. TAmyntas ait mygalen, id eft muremara neum ex mure \& gale, id eft muftela nafci, ut refert Scholiaftes Nicandri : quod fané ridiculum eft, cum muftela omne murium genus maximè oderit ac deuroret. Muftela auribus concipit qua ore parturiat:quare efu eius interdictum eft Iudxis, ut hoc fymbolo infinuaretur perniciofiffimum effe hominibus morem, ut qua ipfi auribus acceperint, eadem uerbis exaggerantes maioribus malis in: uoluant, Arifteas, Aegyptī inter cætera oblcura fua fymbola galen habent, id eft muftelam: quä. auribus concumbere ferunt, ore parere, qua imago natales fermonis oftendit, Calcagninus ex He: roglyph. Muftelam ore concipere $\&$ aure parere, Clemens papa dicit, Liber de natur, rerum. Galen id eft muftelam ore parere fabulantur, ut pifcem quoque galeon, id eft muftelum, Horts, 5

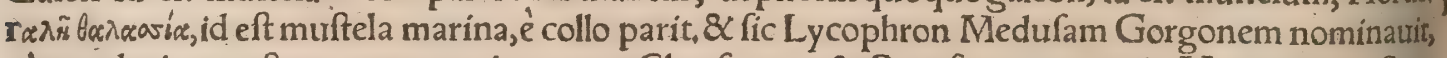
eô quód etiam poft amputatum eius capur Chryfaorem \& Pegafurm pepererit, Varinus. . Sunt qui coruos $\&$ ibin ore coire opinentur:inter quadrupedes etiam muftelam ore parere. atqui mufte. lam modo cxterarum quadrupedum uuluam habere certum eft. ex qua quonam pacto foetus ad os. deureniat $\because$ fed quia muftela paruos admodum parit, ut $\&$ cæteræ fidipedes, \& $\&$ æpe catulos fitos ore fufceptos transfert, fecit ut ita opinarentur, Ariftoteles de generat, anim,3.6. TOmne muftelarum, genus ira incitatum graue quiddam olet, fed maximè id quod Germani iltiffum appellant, Agricola \& Albertus, Omnis muftelæftercus aliquantum redolet mufcum, Idem. Muftela fugiens peffimé pedit, Vide infra inter prouerbia.

Muftelæ quanquam exiguro corpore, prudentes, animof $\&$ feroces funt, Matthæolus : quare \& animalia fe maiora, per aftutiam $\&$ agilitatem corporis uincunt, Obfcurus, Timidiffima eft $\&$ 


\section{DeMuftela. D.E. Lib. I. 855}

Tatebris gaudet, Textor. Muftela, mus $\$<$ lacerta, in Lege prohibita ne quis edat, clandeftinas infidias $\& \mathrm{f}$ furta denotant, ob naturx ipforum timiditatem, qux uel ad quemuis ftrepitum expauefcit ${ }_{3}$ Procopius Gazęus. Animal eft fubdolum, Obfcurus. Rapax:unde natum prouerbitum, Mufte. la rapacior. Facile cícuratur, Albertus. Cicurare autem folent aliqui propter auium pullos pre. cipué ènidis auferendos, ut in E. dicam. Muftelx $8 \times$ fciuri allio dentibus tentato in pofférum mor. dere uix audent, cicuresḉs hoc modo fiunt, Cardanus.

I Catulos nuper natos, quia ab hominibus $8 \mathrm{C}$ nonnullis alips animantibus, eis periculum meturit; fingulis diebus aliò transfert, Agricola. Magna cura \& induftria foetum nutrit : \& frpius de loco ad locum transfert ne inueniantur, Albertus. Muftelæomnes hoc commune habent ut foetus furos ideloco in locum ore transferant. fed hoc etiam canes aliquando faciû́t,Perottus. Muftelæe etiam, ut muress, domum ruituram prafentientes, paulò ante migrant, ut retuli ex A eliano in Mure D. Circa foureas fuas quàm fint induftrix, paulò poft initium præcedentis capitis dixi, TGaleos (id eft mu: ftelus pifcis) perfequitur $\mathcal{Q}$ alios quidem pifces, fed paftinacas præcipué,quibus nihil in mari uene: natius:ficut in terra ferpentes muftela, Plinius. Muftela ferpentem quoç impugnat, eum pracie pué qui mures uenatur, uidelicet ea caufa, quia ipfa etiam mures perfequitur, Ariftoteles. Et rurfus, Muftelx ferpens aduerfarius eft, quoòd eadem in domo uerfantur: uiçus enim ex eifdem appetatur neceffe eft. Murfela uifa eft frequenter cum ferpente pugnare, Perottus. Damulam odêre ferpen tes $\&$ fugiunt, \& eius anhelitum fuftinere non poffunt, A uicenna puto. Sed uidetur corruptus is lo cus uel mutrilatus:non enim ipfius, fed rutz quam comederit odorem ferpentes fugere alif fide di: - gniores fcripferunt.Muftela quoties dimicatura cum ferpente eft, rutam comedit: odor etenim eius herba infeftus ferpentibus eft, Ariftoteles. Ruta contra ferpentium icius datur in potu uel in cibo:u tpote cum muftela dimicaturæe cum his, rutam pritrs edendo fe muniant, Plinius thac fumpta fi dentí animo ad pugnam procedunt.oderunt enim huius herbxe odorem ferpentes, Aeliantus. Atqui muffelanı etiam ruta fugàri apud Auicennam legimus, lib. 3, fen, 6, tract, 3, cap.13. (Vide in Cato E.) quod mireris cum tot authores eandem ab ipfa edi fcribant, fiue ante pugnam cum ferpentibus ine: undam, fiue(utrecentiores quidam malunt)iam peractam. Muftela ferpentem aggreffura:agrefts ruta fe munit:Proinde omnem medicorum artem ruta fuperare dicitur:ita ut fi mortuos foetus fuos inueniat, per herbam naturaliter notam rédiuitos faciat, Liber de nat.rerum. Albertus etiam agre ftem rutam à muffela fumi ait:cum ueteres fimpliciter rutam dixerint: $\mathcal{X}$ poteft fanéfatiua uti, cum 3o circa domos uérfarí foleat. Gale muribus uefcitur, \& ferpentes eifdem uefcentes impugnat: quos cum uiicérit, deirorat, $\&$ poftéa rutam comedit pro antidoto ueneni, Albertus $\&$ Ifidorus. Muffela trires refoulet ruta $a_{j}$ in murium tuenatu, cum ijs dimicatione conferta, Plinius, Bafilifco ferpentium uenenatiffimô muftelàrum uirus exitio eft:A deò natura nihil placuit effe fine pari. Inịciunt eas ca uernis, facile cognitis fola tabe. Necant illi fimul odore, moriuntur'ć, \& naturæ pugnam con= ficiunt,Pliniuis $\&$ Soliniss. Omne iumentum muftelam reformidat, Aelianus. Muftela pruden=. ter caperè aures irideturr. iugulat enim quas ceperít, ut lupus ouem, Ariftotel. Gallinaceos muftela terret, Philes $\&$ Äelianus. Mures omnis generis à muftela maximè fibi metuunt: nam cauernas $e_{.}$ tiam fubiens eos apprehendit, ut in c. dixi. Mưftelæ $\&$ fues diffident, Plinitus:item muftela \& cor: nix, Idem. Muftela cornicứm nidos fape diripit, Perottus'. Muftelam aiunt dolofè colludere lepo ri, quem lưdo defatigatum gutture apprehendat, et firmiter a dhęrens comprimat, ne currentem qui dem relinquens, donec laffum tandem enecet ac dèuoret, Albertus. Mihi rufticus quidam affirmaz uit uifam fibi muftelam quả leporem auré tenerét. Cati,ut audio, muftelas aliquando inuadunt, fed cediunt eis, \& fortiter fe defendentes relinquiunt. TQuibus in locis muftelæ non fint, natura quodammodo aduerfante, fuperius in $c_{0}$ dixi。

Ê.

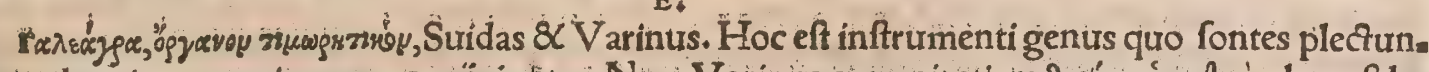
tur:uel potius cauea in quam conijciutitur. Nam Varinüs exponit etiam 9 seíwy v́roobxisy, hoc eft lo. cum feu uas potius, curi fera includuntur. Pollixi inter oxớn, hoc eft uaforum genera numerat ga: leagran, 8 hac uoce ufum fcribit Demofthenem in oratione ad Ariftogitone. Videtur quídem pro=

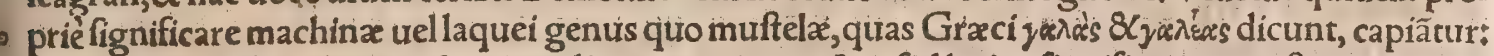
ut myagra, mufcipulam:podagra, pedicam ceruorum, $8 \mathrm{c}$. fed huius fignificationis teftimonium ex

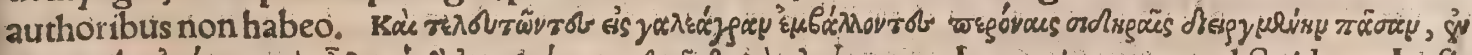

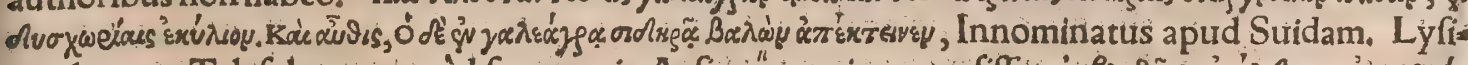

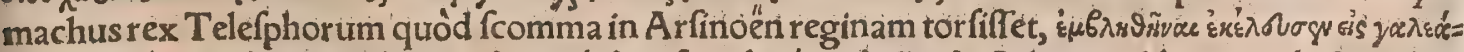

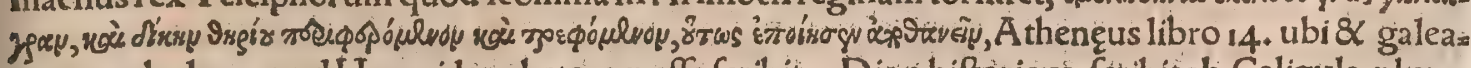
gra uocabulum apud Hyperiden rhetorem effe fcribit. Dion hiftoricus fcribit ab Caligula plures in galeagram conieços necatosq́, ut Cat Calius citat, Liưius alicubi genứ quoddam tưrris galeagram nominat. TSal Ammoniacũ frumentữ ḉ̧ hưmore aliquơ diluếs, circa loca quia frequentant mufte

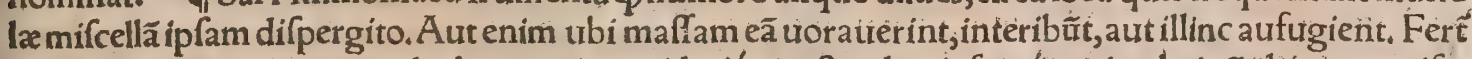

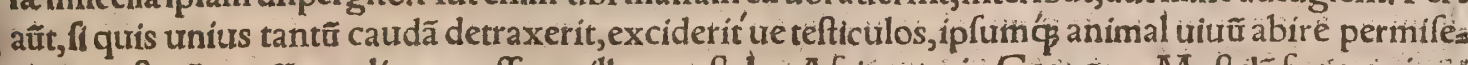

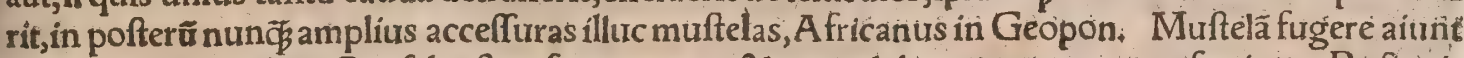
odorem rutz, Auicen. Cati fylueftres fumum rutæ $\mathcal{Q}$ amyggdalarum athararum refugiunt, $R$ afis?cis 
cures qurog ruta fylueftrifugantur, ut foripfi in Cato E. Chamaleontis felle in aquam conictio, muftelas contrahi, magi fcribunt, Plinius. Felffellionum tritũ in aqua muftelas congregare dicitur, Idem. In Iralia quibuldam locis muftelis domeficis, ut audio, utuntur; ut extrahant columbas èco lumbarifs, 8 alias aues ex nidis quas in parietibus habent, ut pafferes, fturnos. Aues capiuntur in foraminibus columbarips cum muftela cicurata in foramen immiffa, Crefentienfis, Muftelam Me us audio Gallicé uocari baccalłbanc funiculo alligatam uafculo fupra perticâ imponunt, eleuantóg ad auium in arboribus nidos, unde pullos extrahunt. Muftela mare auium pullos in nidis uenan. tur, Albertus 3.2. Ictis etiam fiue fylueftris muftela, autes captat, urt in eius hiftoria dicetur, A mu* frelis tuta fient columba, fi inter eas frutex uirgofus fine folins afper, uel uetus fpartea prohiciatur, qua animalia calciantur, ut eam fecretò non uidentibus alïs unus attulerit, Palladius, "Nuftela cinis fi detur in offa gallinaceis pullis 8 columbinis, tutos effe à muftelis aiunt, Plinius. Et rurfus, Gallinaceos non attingi à uulpibus, qui iecur animalis eius aridum ederint:uel fi pellicula ex eocol. lo inducta, galli inierint: Similia in felle muftelælegimus. Cafeos, fi cerebrum muftela coaguload, datur, negant corrumpi uetuftate, autà muribus atcingi,Plinius. Mures abiguntur cineremuftela urel felis diluto \& femine fparfo, uel decoctarum aqua.Sed redolet uirus animaliũ eorum, etra in par ne + ob id felle bubulo femina attingi utilius putant,Plinitus. Muftela $\&$ mures ftridentes, uehemen tem prafagiunt tempeftatem, Aelianus.

Muftela quondã Iudxis in cibo uetita fuit: eft enim animal (inquit Arifteas)ad deturpandum os mnia immundã: auribus praterea concipit (quod fupra in C.refutatumus) quax oreparturiat, gul a mos hominibus perniciofiffimus eft, cum qux ipfi auribus accipiunt, eadem uerbis exaggerantet, maioribus malis inuoluunt, Alin, ut Procopius, efur cius interdicto, infidiofum, rapax \& timidũ inge nium fymbolicè damnari putant. Sacerdotes muftelã non efitant, ut Aelianus ait, quòd ore pariat, Gyrald. Corpora qux natura funt ficca, falis confperfu exarefacta, cibo fiunt inepta:quidameninin leporê falire aggreffus, muftelis exiccatis fimilem reddidit, Galenus de ali,facult, 3 , Exiccantur aure muftela, non ad cibum, fed ad medicamenta, ut in G.dicam.

G.

Muftela febrim curat, Vrfinus, Acopon ad podagrã \& articularem morbü mirabile; facit \& ad diuturnum capitis dolorem, materiã ad fuperficiem dưcens, $\&$ ad fronte ac finciput:Caniculam par

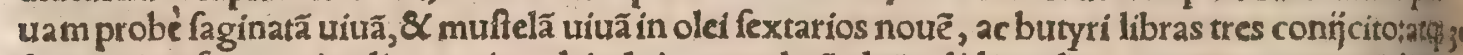
'donec uieta fiant animalia coquito: deinde in percolatû oleũ calidũ pedes aut manus per totă diem imponito, Äëtius 12.43. Aliqui terram fubfternuntlacertæ uiridi excacata, 82 unà in uitreo traf́ annulos includunt é ferro folido uel auro:cum recepiffe uifum lacertam apparuerit per uitrum, en miffa ea, annulis contra lippitudinem utuntur. Muftelax etiam oculis punctu erutis alunt uifum re - verti,eademíg qux in lacertis $\&$ annulis faciunt, Plinius. Aurcenna quadam attribuit dannnta, id eft, muftela carni fimpliciter, qua magis clafficiauthores cineri muftela adfcribunt ; qualia fint, arthriticis doloribus imponi : ex uino contra comitialẽ uel capitis dolorê bibi. Morfui fcorpionis utiliter imponitur, Albertus. Venenis refiftit caro dannula fumpta, Auticenna. In cibo fumptas2 pite \& pedibus abiectis, \& fanguine illito, ad comitales \& frumas laudatur, Vide infra inter reme dia ex fanguine. Exulceratis ftrumis muftela fanguis rectè inlinitur, uel ip fa in uino decocta falubri 4 ter imponitur, Marcel. Plinius paulò aliter, Strumis exulceratis muftela fanguis, uel ipfa decocia in ưno, non tamen fectis admouetur:aiunt 8 in cibo fumptã idem efficere. GMufela domeftica ad diuerfa remedia amburi folet, \& exenterata fale inueterari, \& in umbra ficcari, ut Diofcorides \& ta

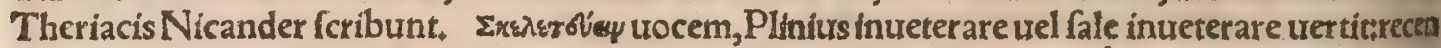
tiores quidã exiccare uel arefacere, quidã ineptius falire fimpliciter propriè autem ad animalia inte. gra qua fic reponuntur induranturọ́ ficcata pertinet, Corpora qua natura funt ficca, falis confpese

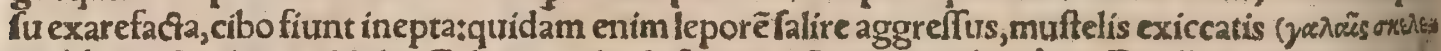

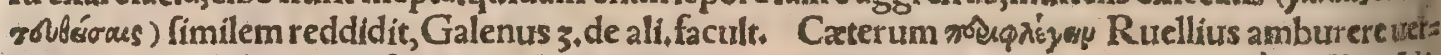
tit,Marcellus Verg.fignificantius, flammis amburere:Hermolaus Barbarus non rectè inaffare. Nis

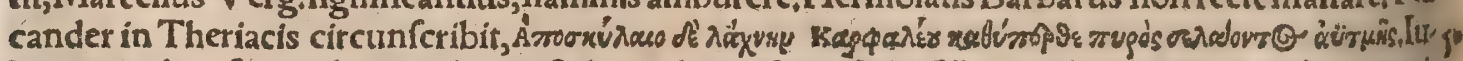
bet autem hoc fieri uel in catulis muftela, uel in ipfa muftela. Hoc quidem etiam in auibus, inquit Marcellus, mox mox coquendis coqui agunt, flammis enim quas non potuerunt manibus ucllere minutiffimas amburunt plumas, Vult fané Diofcorides, non inaffari,fed integram cum fura pelle, pis

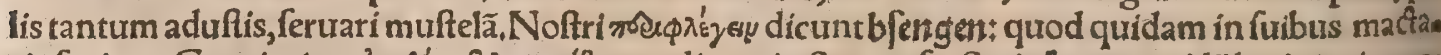

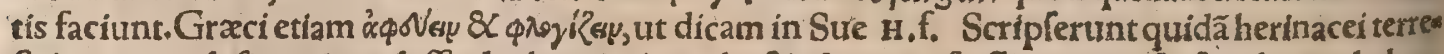
Itris carnem deficcatã prodeffe elephantiacis, cachectis, \&C. qua fi efficere potelt, facultatem habue rít ualenter fimul digerentem deficcantem 3. Exiccata è uino pota urenenis aduerfatur, Auicenna. Contra toxica muftela uulgaris inuetera. ta binis drachmis pota ualet, Plinius, Praparata(ut diximus) binis drachmis cum uino pota, aduera fus omnia ferpentium urenena præentaneo eft remedio toxico fimili modo fumpta refiftit, Diofcori 6 des lib.2.8 Auicenna inter remedia ad fagittas A.rmenias. Muftelæ catulus praparatus, ut dixi= mus (fale fcilicet inueterata)contra omnia mala medicamenta ualec, Plinius, Muftela fale inueterata 


\section{DeMurtela: G. Lib. I. 857}

inter auxiliaria morfutum, quos inflixêre ferpentes, medicamenta eft. Bibitur auten binis drachmis ex uino, prxparata ut fupra dictum eft, Diofcorides lib,6. Muftelam arefactam aliqui planè omnis feræ alexipharmacum effe referunt, $8 \mathrm{~L}$ maximé eius uentrem, Galenus de fimpl, 11.35 . Muftel $x_{\text {; } q u x}$ in domibus noftris oberrat, inueterate fale denarí) pondús in cyathis tribus (uini) datur percufis (à rerpentibus, )aut uentriculus coriâdro fartus inueteratusḉ $\mathcal{Q}$ in uino potus: $\mathcal{\alpha}$ catulus muftelę etia efficacius, Plinius, Caro muftelæa arida fi bibatur cum ruta(uino porius ) contra morfum omnium animalium, Albertus. Contra phalangï morfum utiles funt muftela catuli, ut diximuts (id eft inue terati fale \& è uino poti,)Plinius, Et rurfus, Muris aranei morfus fanatur muftelæ catulo, ut in feri pentibus dictum eft. Muftelæ caro arefacta ualenter fimul digerit $\&$ deficcat, qua utios ui comitia. 10. límorbo affliços iuuat epota, Galenus de fimplic, $11+3$. (8 A Auicenna.) Etrurfus, Arefactam ac potä legimus prodeffe comitialibus ui fcilicet digerente, 11.35 . Dioficorides fanguini eius hanc uim attri= buere uidetur, (Marcellus quidem interpres exprefle ad fanguinem refertremediũ ad comitiales a. pud Diofcor, Ruellius ueró fimpliciter uertit, ut Græca habent, Comitialibus etiam prodelt, ut quo referas dubites)ut alij alijs muftelæ partibus aliqui integræ muftelæ cineri, ut mox dicetur.

I De muttela cinere multa legimus remediałatqui Galenus nunquam fe hoc animal combuffif fe frribit, ut quid praftaret experiretur. Muftelx fanguis $\&$ cinis ad elephantiafin utiliter illinitur, Plinius, Sextus, Aefculapius. Elephanti morbo aduerfus eritcedri de cortice fuccus, Mufteláue cínis, uel fufus fanguis ab illa, Serenus. Muftelæ exuftæ cinis \& elephantis fanguis, immixtus \& il litus elephanticis corporibus medetur, Marcel. Aduerfus anginas, funt qui cuiufcun q, hirundinis pullum edendum cenfent, ne toto anno metuatur id malum. Strangulatos (pullos hirund.) cum fan. guine comburunt in uafe, \& cinerem cum pane aut potu dant.Quidam $\&$ muftelæ cineres pari mo do admifcent; fic $\&$ ad ftrum $æ$ remedia dant, \& comitialibus quotidie in potu, Plinius . Ad comitia lem, Aptus muftelæ cinis eft, $\mathcal{Q}$ hirundinis unà; Serenus. Plinius alibi muftelæ cinerem etiã per fecommendat aduerfus comitiales morbos. Auicenna fimpliciter muftelam è urino bibendam pra fcribit ad epilepfiam \& capitis dolorem. Muftelx cinis illitus capitis doloribus remedio eft,Plinius. Cinerem muftelà(inquit idem) phrenetico dare potui ex aqua aliqui prodeffe tradiderunt + fed quis ad hoc cogere poffet furtentem etiam fi certa fit medicina? Muftela cinis oculorum fuffufionibus confert, Plin. Ad reumaticos (fiue catarrhum in fauces) efficax remedium fic:Muftela die louis Lu na uetere capta, uiua in olla rudi ita excoquitur ut teri poffit, $\&$ in pultuerem redigi, qui puluis col $=$ olectus ex melle $\& \subset$ bene contemperatus, ieiuno reumatico ad diem per cochleare dabitur, fed inius ligula mènfura, mirè proderit, Marcel. De remedio ex hoc cinere ad anginas paulò fuperius dixi. Ad Itrumas, Cineri muftelæ farmentis combufte mifcetur axungia,Plin. Humeri doloribus tritus

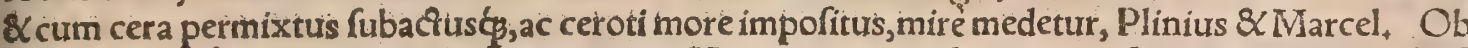
fcocnos fi ponè locos noua uulnera carpant, Horrentum manfa curantur fronde ruborum. Et fi iam ueteri fuccedit fiftula morbo, Muftelx cínere immifo purgabitur ulcus Sanguine cum ricini, quem bos geftauerit ante, Serenus. Muftela in fictili cremata podagricis confert, cinere ex ace= to illito, Diofcor. Cinerem eius cum aceto illitum podagricos arthriticoş̧́ iuuare, tanquam uehe. menter ualeat digerere (porós aperire, Albertus) quidam tradiderunt, Galenus. Muftelę uiuæ com buftx cinis cum oleo rólaceo $\&$ aceto penna illitus podagricis prodeft, Marcel. \& 2 Plinius: qui addit, uel fi cera \& rofaceum admifceatur. Muftelæc cinis aut cochlearüm cum amylo nel tragacantho, ar ticulorum doloribus illinitur, Plinius, Auicenna muftela carnem fimpliciter emplaftri more dolen tibus articulis applicarifcribit.

ब Comitialibus prodeft $\&$ cerebrum muftelęinueteratum, potumç, Plinius:ficcum potum cum aceto, $R$ afis، Cameli cerebrum ficcatum $\&$ cum aceto potium, epilepticos fanat, \& muftel fimili= ter, Galenus ad Pifonem cap.12. Facilius enituntur qux ex utriculo muftelino per genitale efflu entes aquas forbuêre, Plin. Equus fi inciderit morbum (fubitum ferè \& perniciofum ) quem noftri

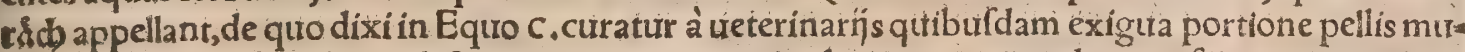
ftelinæ(quanta eft coronati dicti nummi aurei magnitudo)intra corpus data, nefcio an in potione per cornu, aut cum pabulo iricifa, Alī hermelini, id eft muftel albx caudam, qux dimidia parte alba 8 altera nigra eft, minutatim incifam equis fic affectis in pa bulo offerint, ut apud recentiores hippia tros Germanicè legimus: Botrèm fi ferpens aut animal uenenofum laeferit, muffelæ pelle locum fau cium demuiceto, Innominatus in libro Germanico manuifcripto. Idem feré fieri iubent aduerfus mor fus quos equis inflixerit:infricant enim uulneri pellem donec incale $f c^{2}$, $8 \mathrm{f}$ fimul antidotum aliquod intra corpus exhibent. Ego fi res fuccefferit, aut uulnus partim noxium fuife dix erim, aut antidoto liberatum animal, aut frictione uulneris ad calorem ufq. quid enim pellis arida iutret I fum animal potius diffectum $\&$ calidum appofitum proderit, quod \& ín mure arańeo \& alijs multis fit : fiure $q$ fimile trahitur fimili, fiue ipfa caliditas ad fe trahit:nam $\&$ alia qưodam animalia fi uiua diffectạ́ ap plicentur iuuant. TSanguis muftela fillinatur apoftenati poft atirem prodeft, $R$ afis. Archige nes ad parotidas muftelæ fanguinis illinendi meminit. At uero talia(inquit Galenus) tanquam curio 6o fa \& fuperuacanea, \& quæ magnam rei medicamentariæ egeftatem indicent, fi per alia auxilia, citra fanguinis muftelæa adhibitionem, parotidas curare nequeat, neç in uffim adfumpfi, nę̧; corum ex: perimentum habeo:fed neç ex amicis noftris quifpiam alius uti tentauit. Muftelat fanguine per 
unctre ftruma fanantur, Diofcorides:Mox autem fubijcit, Comitialibus etiam prodef, quod Mtarce lus Verg,ad fanguinem retulit, fed quoniam aliorum nemo idem remedium fanguini attribuit, ad iplam potius muftelam fiue uftam, fiuc inueteratam fale, retulerim, utrocs cnim modo ad comitialss facere authores habemus. Muftela tamen in cibo, pediburs capitéç abiectis, ad comitialemá nonnula lis datur, \& fanguis illinitur, aduerfus eplepfiam : eodem ç modo aduerfus ftrumas adhibetur, Ga. lenus Parab.2.3. Muf, fanguis ftrumis exulceratis recié inlinitur, Plinius \& Marcellus. Ad fa cium mala, Miuftela fanguris inungatur $\&$ fanat, Sextus. Elephantiacis prodeft, ut fupra diximus in Cinere muftela. Podagras lenit cum plantagine illitus, Plinius. Nertros contracios remollit, $\&$

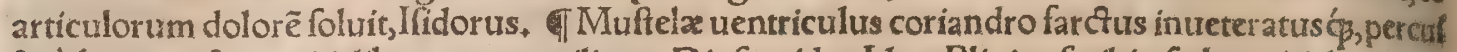
fis à ferpence 8 comitialibus potu auxiliatur, Diofcorides. Idem Plinius fcribit, fed comitialibus me deri,omittit, librariorum opinor culpa:Alibi enim, Prodeft, inquit, ad comitiales muftela uentrict: Ius inueteratus rum coriandro, ut diximus, Muftelam arefactam in potu comitialibus prodeffe: \& quidam planè omnis feræe alexipharmacum effe, fcribunt: $\&$ maximé eius uentrem, Galenus.

- Ad comitiales prodeft \& cerebrum muftelæ inueteratum potumíg, \& iecur eius, Plinius, Ept lepticis muftela iecur aridum ex aqua propinato.id facies autem cum agrotus mox eft cafurus, $\mathrm{Ga}$ : lenus de Parab.1.3. Fel leporis fimul \& iocinora muftela commife ad drachmas tres, caftorel drachmam unam, myrrha drachmas quatuor, cum aceti drachma ex melle aut paffo bibant qui uet tiginem patiuntur, fanabuntur, Sextus. Muftelze iecur lethargicis utile putant, Vide mox in Tefticu lis. TMuffelæ fel duntaxat contra afpidas eft efficax, cæetera funt uenenum, Perottus Plinim citans, fed perperam, uide infra in Muftelis fylueftribus, Fel eius potum interimit nifi temedia at mature adhibeantur, Rafis. Pro fellemuftela, (mygales, id eft muris aranei Grace legitur apud A eginetam, inter Galeni uerò opera y $x \lambda \hat{s}$, id eft muftel $x$, quod probo)fel cameli fubftitui poteft, Au thor Succidaneorum. बVirga damula ficcata tríta $8 \times$ pota, morfis à ferpentibus medetur, ut etra cerui uirga, Hali:Hic fi quis damulam non pro muftela, fed pro dama fiue ceruini fiue caprarun fylo ueftrium generis accipere malit, non repugno, Muftela ruftic fiuc uiuerra coles ad fir anguriatin 8 calculum celebratur, ut in ipfius hiftoria dicetur. बMuftela tefticuli $\&$ unulua ad comirioles tar lere creduntur, Plinius. Ex iftis (magicis puto)confeffa aut certe uerifmilia ponemus, ficut \&uisa thargum olfactorijs excitari + inter ea fortaflis muftelæ tefticulis inueteratis, aut iocinere ufto, Plis nius. Tefticuli muft, mulierialligati partus continent, Textor. Muftela tefticulus finifter in pelle mular ligatus, \& potus a tocion eft, Kiranides. Vel tefticulos eius abfcinde interlurin̈ temporc; 30

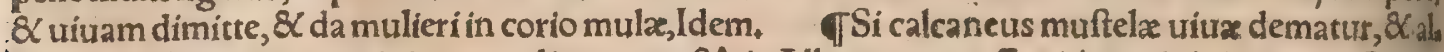
ligetur mulieri, non concipiet quandiu eum geftârit, Albertus, TCapitis canini cinis excrefcentia omnia erodit ac perfanat fpodí uiceł item muftela fimi cinis, Plinius. Pro mufcerda, muftele $x^{\circ}$ qualepondus, in Succidaneis Aegineta: fed legendum mufcarum aquale pondus, (ad alopecians opinor pracipué.)

TMorfus muftela uenenofus eft,Stumpfius. In rabie non minus quàm canis rabidus ladth, Bertrutius. Vulpes etiam \& muftela rabidx fiunt, Auricenna, Furo \& muftela urulnere magis quàm ueneno ladunt, Arnoldus. Venenatum aliquid ineffe muftelis, uel ipfa odoris grauita arguit, qux in omni muftelarum genere tum pracipué fe prodit quurm irafcuntur, Mures abiguntar cinere muftela uel felis diluto, \& femine fparfo, uel decoctarum aqua: fed redolet uirus animalium 4 corum etiã in pane,Plinius. Ariftides Locrus à Tartefia muftela morfus, iam moribundus, muitô libentius f́ moriturum fuiffe dixit, fî ấleone aut panthera potius quảm tam ignobili animante mor fus fuiffet, A elianus in Varüs lib.14. Muftela morfưm(inquit Auricenna 4.6.5.14.) celeres doloa res inferre aiunt, \& colore fufcum aut liuidum effe, (quod \& $R$ afis frribit.) Curatur autem cum cepis $\&$ allins (ut ftellionis etiam morfus) tum foris adhibitis, tum in cibo fumptis, merum fuperbibendo. Profunt $\&$ ficus immarura cum farina erui. Theriaca etiam utiliter emplaftri modo imponitur, $u t \&$ canis rabidi morfui, ficut in libro de theriaca legitur. Allia cum folijs ficulneis \& cymino trita im. ponuntur, Rafis. Liquor lacteus è ficu cum eruo impofitus, ut Aggregator ex Auicenna citat. item eruca in cibo fi uinum odoratum fuperbibatur, Auicenna libro 2. Vefpertilionis fel, non admu ftelx, ut Aggregator ex Plinio citat, fed ad muris aranei morfum à Plinio commendatur. Fit alla ja quando ut muftela iumentum morfu fauciet, cuius dentes inficiunt animal, \& moritur nifi fubuenia tur. Remedio eft fi uulnus oleo perungatur, in quo muftela fuffocata computruerit, expreffo ualidi. ufculè per linteolum. Fricatur \& locusi faucius arida pelle muftelax, ut incalefcat, \& datur iumento antidotus theriaca, Camerarius. Vide fupra inter remedia expelle muftela, Vaccasà mufter lis demorfas, ruftici aliqui incantationibus fanari fuperftitiofe credunt. Vbera uaccarum mor, det muftela, qux quàm primum in tumore furerint, muftelina pelle perfricata fanantur, Georgius Agricola,

H.

a. Muftelam per I. fimplex potius quàm duplex fripferim, nam $\&$ alia eiufdem terminationis Latina uocabula fic fribuntur, ut nitela, tutela, cautela, candela, cicindela. Cuftodelam dicebant ans tiqui, quam nunc dicimus cuftodiam, Feftus. Non enim probo quod Carolus Figulus feribit mu.

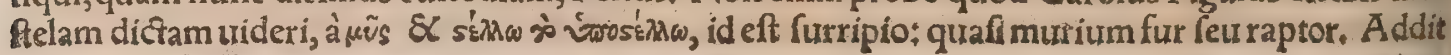




\section{DeMuftela. H.a. Lib. I. 859}

etiam fitlen uocen Germanicam ( fed ffellen potius fcribendum eft) quæ furari fignificat, à Grac

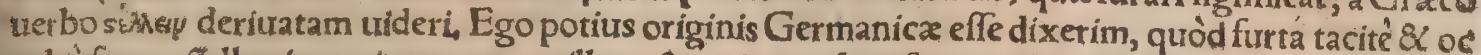
culló frunt, ftull enim tacitum, tranquillum, \& quietum fignificat: inde verftolen, quod occulto fas citi ablatúmue eff. St, apud Terentium, uox eft filentium indicentisłqua ip fa aut fimili Germani $e_{\text {. }}$

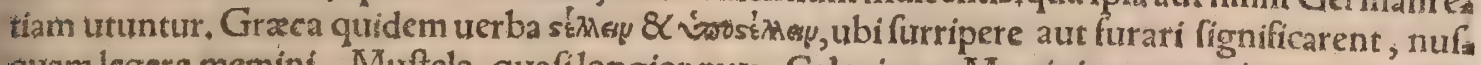
quam legere memini. Muftela, quafilongior mus, Calepinus, Memini grammaticum quendam deriuare à mus $\& \tau \tilde{\kappa} \lambda \xi$, quod eft longe, fed nugaces iftæe deritrationes non placent. ra $\lambda$ 's cxytonum

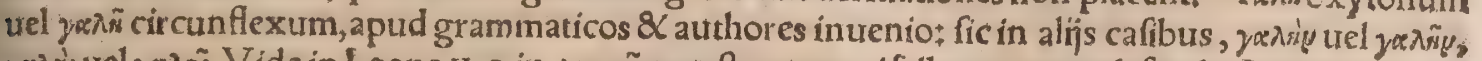

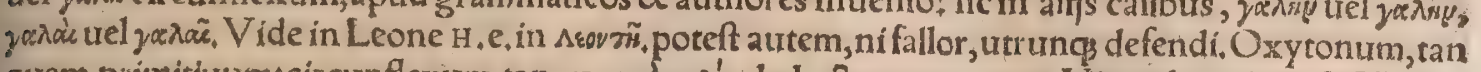
10 quam piunituum; circunflexum, tanquam à yexís deductum, qua troce Nicander utitur: \& Home.

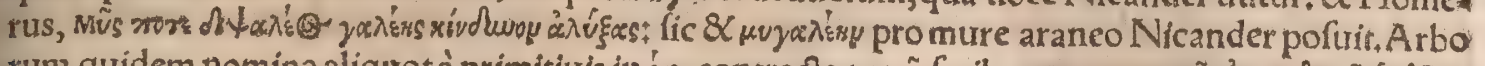

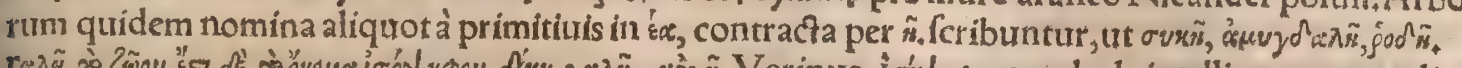

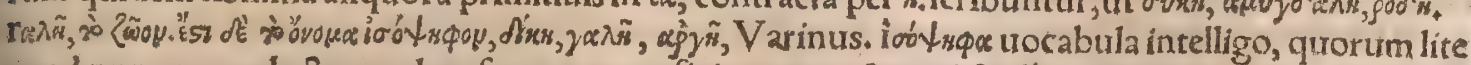
ra ad numeros redact $x$ eandem fummam perficiunt, nam $\&$ yoxin $\&$ dixx computatis literis conftitur.

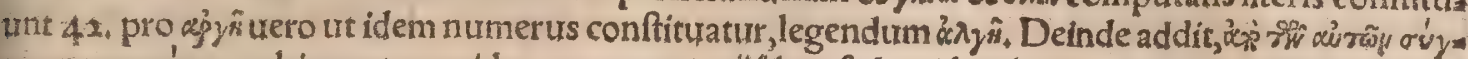

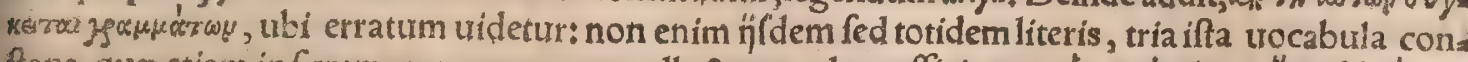

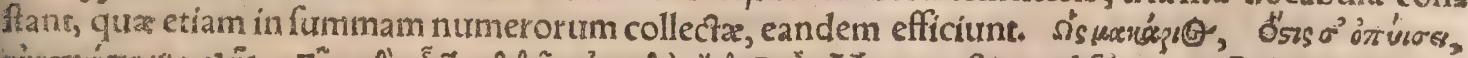

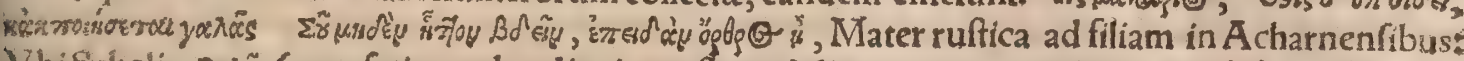
Vhischolia, rà̃äs (accufatiuus pluralis circunflexus) dixit prater expectationem à 20 \%vróras. Folent autem homines tempore matutino frequentius pedere, peracta iam concoctione. Mu Prela quidem ut $\&$ felis flatus alui a certimus $\&$ putidiffimus eft, unde $\&$ prouerbiũ natum, quod in

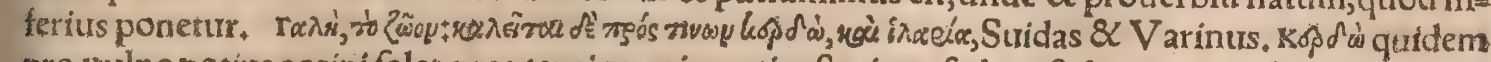
pro tulpe potius accipi folet, propter eius animantis aftutiam $;$ fed muftelam quoçaftutam effe do cuimus, i $\lambda$ ceia urocabulum alibinufquam reperio: 8 uulgare nomen recentioris Græcix effe pui

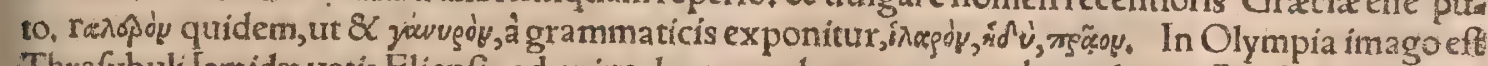
Thrafybuli Iamidæ uatis Elienfis, ad cuius dexterum humerum jochéwris adrepit, Paufanias Eliaco= rum 2.Calius 15.35. galeoten ex hoc loco muftelam aut felem uertit : egoftellionem effe docebo in Stellionis hiftoria:ks $x, y e \lambda \tilde{x}$, Hefychius $\&$ V arinus. Albertus galen alibi uulpem, alibihordum in terpretatur, utrung ineptiffime; item alibi adhuc abfurdius fpeciem milui. Animal quod uocant: 50 trabeninum, foueas habet in campis, \& pugnando uenatur animal dicfum pelagoz, quod Auicen. na uidetur nominare murem cacum quem nos talpam dicimus $+\&$ quodeuno aliud uicerit det: rat, Albertus in Ariftotelis hiftoriam o. 1 . ubi nihil omnino rale apud Ariftotelem reperio : conício autem habeninum illum Alberti, urel A uicennx potius, non aliud animal ffe quàm muftelam.

TEpitheta. Pauida, Introrepens, apud Textorem. Velox Author Philomelx, rad son, ident uelox, apudNicandrum.

- In Apulcio(inquit Calius) muftelatos legimus peplos, de muftelini coloris fimilitudine, qui fubliuidus eft aclentigin ofus, cuiufmodi in ureftibus comparet cruore commaculatis. Sed \& nos ci us color is fericum, ut uulgó iam loquimur, rafum diftrahl paffim fcimus, Scoppa muffellinum co lorem Italice interpretatur, lentiniofo, roffaccio. Hic eft uetus, uietus, ueternofus, fenex, colore to muftelino, Terentius Eunucho. ráriesstr equi dicuntur, quorum color eft òvoso's's, id eft afintinus, Etymologus. Quibus dum adhuc infantes funt profunda ac fubmerfa fuppurationes circa bra chị caputfiunt, omnes galcancones efficiuntur, Hippocrates in libro de articulis. Galenus in Glof fis, ranicy ycavob (inquit) dicuntur, qui paruum \& macilentum (atrophon) brachium habent, partes autem circa cubiti flexuram fiue gibbum tumidiores, quemadmodum etiam muftela. oi fo $\varphi^{\prime}$ conov*

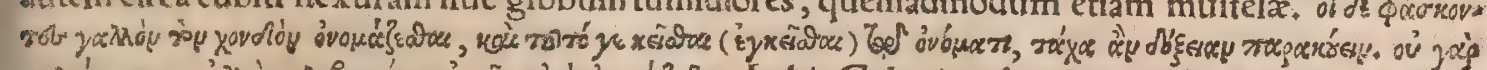

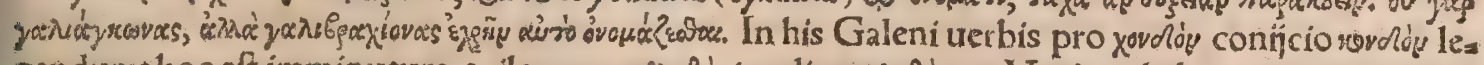
gendum; hoc eft imminutum, exile. nam romobos ( melius ronobis, ur V arinus habet qui tamen cate. ra Hefychin uerba recitans, prowowlós habet waracios, quod non probo) apud Hefychium exponi:

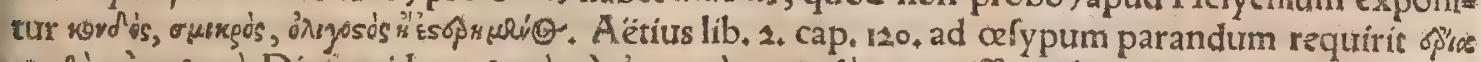
jo

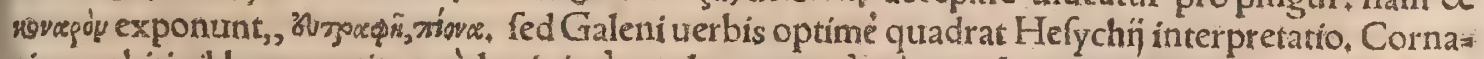
rius cubirigibbum ucrtit, quòd minimè quadrat, cum x́y quam ullum uocabulum ex durobus idem fignificantibus recté componatur. Gyraldus fyntagma. te g, de dịs, præcedentia Galeni uerba interpretatus, hac tanquam obfcura non attingit. Varinus

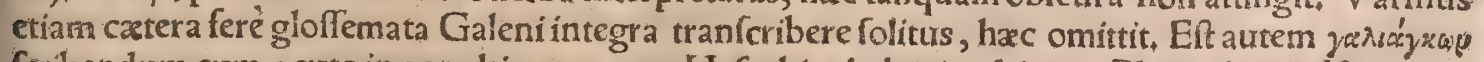
fcribendum cum acuto in penultima, non ut Hefychius habet in tultima. Plutarchus in Ifi \& Of,

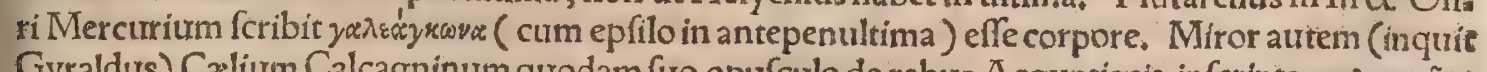
Gyraldus) Calium Calcagninum quodam fuo opufculo de rebus Aegyptiacis infcrip to yaenexy épusy expofuiffe albicubitum. Grammatici nonnulli galiancôna ínterpretantur quí iufo bretrio bo rem habeat cubitum, (fed hic ancurs Latinè dicitur, Galiancon quidem ab Etymologo exponitur

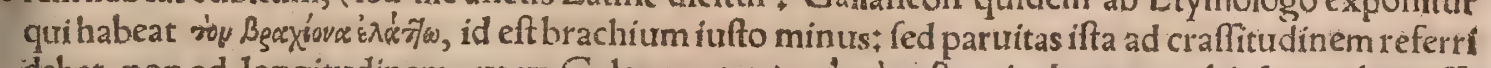
debet, non ad longitudinem, utex Galeno patet, ) Ánxày eft articulus totus ubi duo cubiti offä 


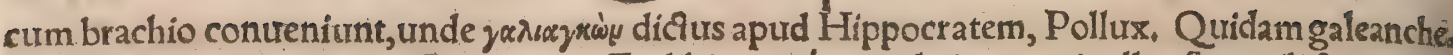

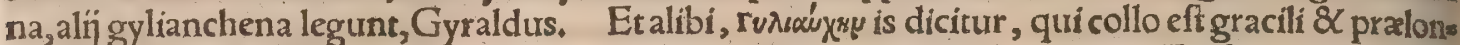
go. Carcini poêtra filios Ariftophanes gyliauchenas $\&$ gyliotrachelos(non ut Erafmus legit glycya

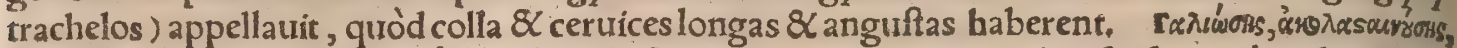

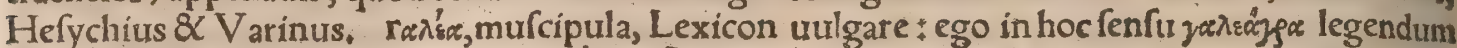

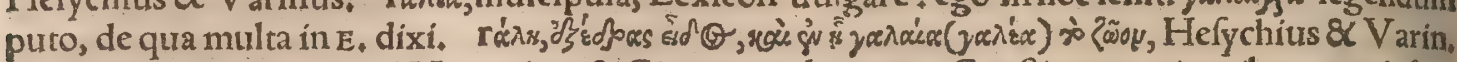
Exedræu uocabulum apud Vitruuium \& Ciceronem legimus, Confituantur in tribus porticibus (inquit Vitruuius) exedræ fpatiof $x$, habentes fedes, in quibus philofophi, rhetoresćs ac reliqui qui fudịs delectantur, fedentes difputare poffint. Dicta autem exedra uidetur, quod extra uel inxta porticum, aut ad latus eius extrueretur * ut hodie in perifylijs canonicorum aut monachorum, id eft clauftris(uulgò Capitula dicunt)fieri folent, rexiso'(uel galeotæ) diçi quidam uates in Sicilia ha bitarunt, ut in Stellione dicam.

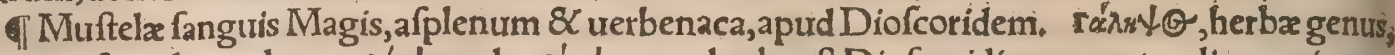

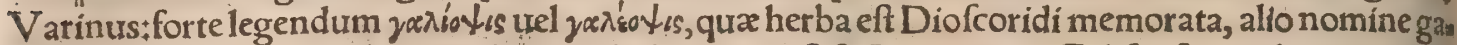
leobdolon. rexs tos quidem Stephano, urbs Thracia eft $\&$ Paonum. Galifopfis, pulegium, apud Diofcoridem.

TCarolus Figulus in dialogo de muftelis meminit auis cuiufdam qux mures uenetur, Germàt nicè $\mathbf{D e i c t e r}$ dicta, Latiné muftela fed qualis ea fit non defcribit. Latinum quidem muftelæ no: men confiçum ab eo uidetur, à fimili uenatu murium. Muftela pifcis eft, qui hodie ứlgò lampes tra uocatur, ut Maffario uidetur:aut, ut mihi, triffia (trüf $b$ ) noftris \& Italis botetriffia uulgò dicta, 1 Lugduni lota, in lacu Sabaudix iuxta Iuerdunum muftela etiamnum. Muftela breuis pif́cis nul, lam cum muftelo pifce (inquit Aelianus) communitatem habet. $\mathrm{Nam}$ hic quidem chartilagineus eft, \& pelagius, \& magnitudine præftans, fimul \& canis fpeciem fimilitudinemó gerit. Muftelam uero diceres effe iecorinum, $\& \mathrm{c}$, algas depafcitur, $\&$ faxatilis eft, atø̧ fimiliter ut terrena omnium

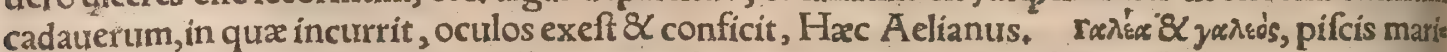
nus, Suid, \&V arin. Sed forte ita differunt hi pifces, ut de muftela \& muftelo ex A eliano iã recitaui, $r$

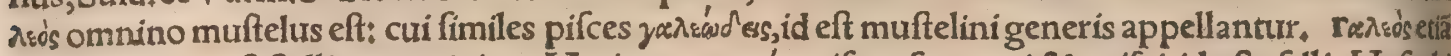
pro galeota,id eft ftellione accipitur, Varinus. raxice pifces funt qui \& onif́ci,id eft afelli, Hefychi

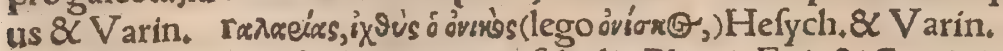

ब1 Muftelaria infcribitur una ex fabulis Plauti. Fuit \& Carcini poétx fabula myes, ubi muftela 30 ftrangulat nocfurnos mures . Murinitini, facellum fuit aduerfum murum muftelinum, Feftus. Galanthis ancilla Alcmenæ, partum dominx mira aftutia à Lucina eum impediente obtinuiffe, ideóç in galen, id eft muftelam mutata fertur à Lucina, addita pona ut ore quo pracipué peccauté rat, perpetuò pareret: feruare propterea muftelam colorem ancilla priftinum, cui flaui fuerant cri nes +8 in domibus nobifcum, ut ante, uerfarl, eadem ftrenuitate præditam, ut Perottus refert ex $O$ uidị Metamorph.nono. Vide Onomaft,noftrum. Alĭ ab ipfa gale quadrupede accurrente Alcme* næ partum facilê redditũ fcribunt: Vide inferius inter religiofa, rènsonoy, nomen loci, $\&$ mons prope Ephefum,Suridas \& V Varin,Stephanus Gallefium per I duplex, Ephefi urbem facit.

a) b. Mus quem zifelum uocant in Auftria, \& c cmagnitudine eft muftela, Albertus, Leanas aiưt informes minimaść carnes parere, qua magnitưdine muftelarum fint initio, Plinius. IMus a 4 raneus colore muftelx fimilis eft, magnitudine muris $¥ q u a r e ~ a b$ utro $\$$ animante compofito nomine

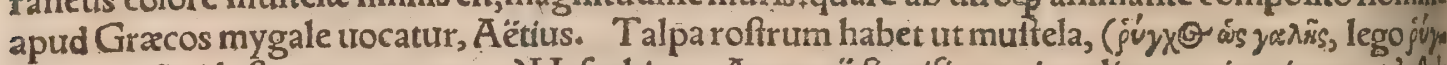

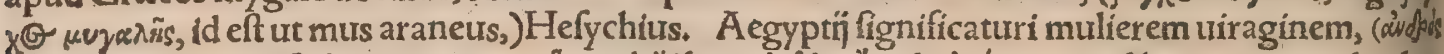

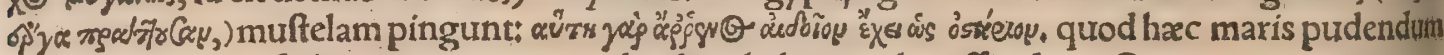
habeat(quod mas fcilicet in eo genere pudendum habeat) uelut officulum, Orus,

Ic. Muftelæ catuli, oxúruersu- Nicandro, communi ferè ad hurufmodi animalium digitatorum foetus uocabulo. Lycophron Medufam joêñ̄ uocat, quoniam poft defecturm caput Chryfaorem \&

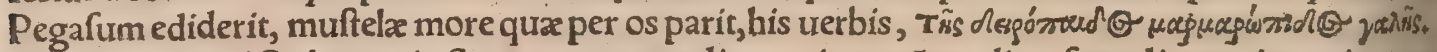
Simonides apud Stobxum in Sermone quo mulieres uituperãtur, díerfa mulierum ingenia recens fens, fingulas ex ṇs quæ moribus referunt animalibus nafci fingit: $\&$ inter cætera, miferum ac trifte illud mulierum genus effe fcribit, quod è muftela creatur. Huic enim(inquit) nihil prorfus amabile, pulchrum, uel iucundum adeft. Sed cum aliena fit(muftelarum fcilicet $\&$ felium modo) à Venereo complexu, matitum faftidiet, \& furando uicinis nocebit, $\&$ hoftias fape nondum confectatas uorabit.

T. Non allatrat canis caudam muftela, qua abfciffa dimiffa fit, habentes, Plinius $\&$ A elianus, Talifiniftri hyęna cinere decocto cum fanguine muftela, perunctos omnibus odio uenire, magi prodiderunt:idem fieri oculo decocto, Plin. Si in pelle muftele maris elaborata litera exarentur, \&fic alligetur damoniacis uel incantatis, confert, Albert.

Th. Polemarchum quendam periurum qui claffem Corinthiorum euaferat, quoties nocfu dor miret muftelarum morfibus infeftatum fabulantur, 8 in defperatione tandem fibi ipfi manum in. 6 tuliffe, Heraclides in Politijs. Heliogabalus iubebat fibi decem milia murium exhiberi, mille mufte las,mille forices, Lampridius, TMuftel laudem $\&$ epicedion carmine condidit $T$. Vefpafianus 


\section{DeMuftela. H.h: Lib. I. 861}

Stroża, fexto Eroticôn. बMuftela quoque, ficut picus, à finiftra reniens infaufti ominis eft, Ale. $x$ ander $a b$ Alexandro. Alciatus in Emblematis fub titulo Bonis aufpicïjs incipiendum; Aufpicipa res coepta malis bene cedere nefcit. Felici qux funt omine facta, iuuant. Quicquid agis, muftela tibi fioccurrat,omitte. Signa mala hac fortis beftia praua gerit. Vide mox in prouerbio Mufte. lam habes. đA Aelianus tradit magos affirmare muftelam ab Hecate nutritam effe, quòd hac dea amatorijs adhibeatur: nam cius uifcera his funt apta, Volaterranus. Thebani apud Gracos mufte lam religiofé uenerantur, \& dicunt, Cum Herculem Alcmena parturiret, \& parere non poffer, hanc accurriffe, \& parturiendi uincula diffoluiffe: unde Hercules in lucem expeditius exieric, Aelianus. Alij non à gale quadrupede, fed a Galanthide ancilla hoc factum dicunt, ut fuperius dixi. A egyptî colunt muiftelam, quòd ea, ut multi adhuc putant ac dicunt, aure concipiat \& ore pariat, quood fymbo lum eft nafentis fermonis, Plutarchus in libro de lfide.

P R O V E B I A.

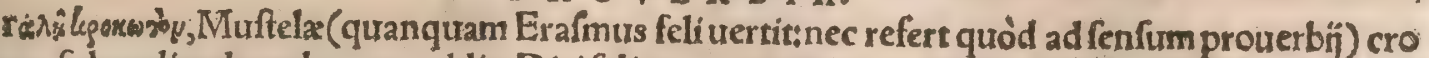
cotum, fubaudiendum das, aut addis. Dici folitum quoties honor additur indignis , \& quos haud: quaquam decet. Aut cum datur quippiam ñs, qui munere non norunt uti: ueluti fi quis à Mufis alie nifimo bellifimum donaret librum, Crocoton ueftis genus eft rotundxac fimbriatx, qua diuites utebantur matronx. Apud Nonium in dictione Richa, refertur inter ueftes delicatas 8 crocoton. Síc cnim arbitror legendum, Mollicinam crocotam, chirodotam richam. Ac tefte Plutarcho quidam Herchlem pingebant logew ropógov, Omphalx feruientem. Sumptum adagium ab apologo Stratidis,

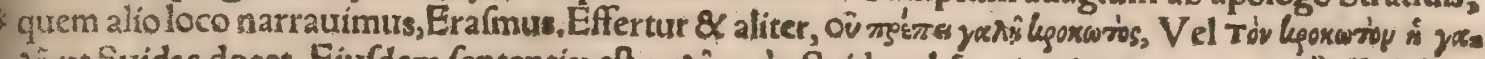

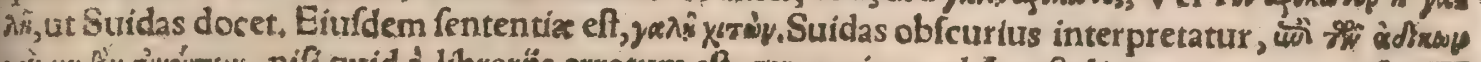

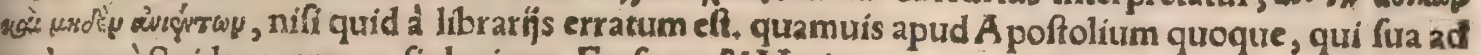
uerbum à Suida muruatur, fic legimus. Erafmus, \& Varinus quog,omiferunt. Erafmus crocoton non reçè neutro genere ufurpat. Gracis enim kgoxaros mafculinum nomen eft adiectiuum: accipio

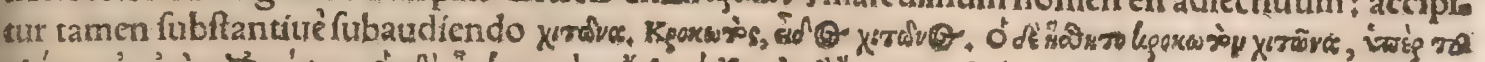

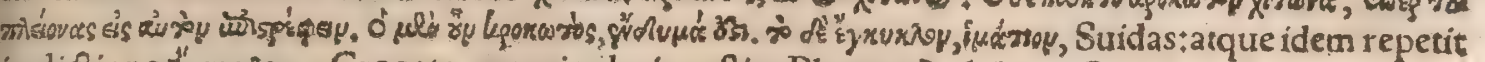

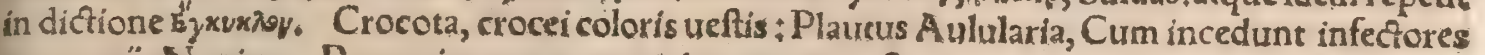
crocotarï, Nonius, Recentiores grammatici crocotam ueftem muliebrem crocei coloris interpre

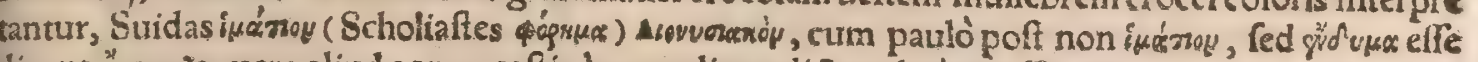
dicant, k้ kux 'rafmus, ut crocoton ueftem rotundam diceret, Crocotôs, tunica qua Bacchus utebatur, Poilux. Plư

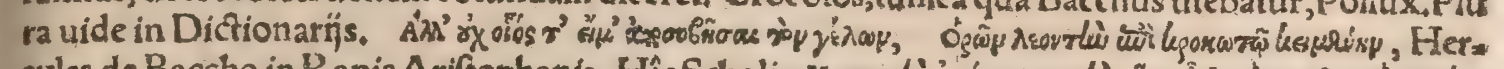

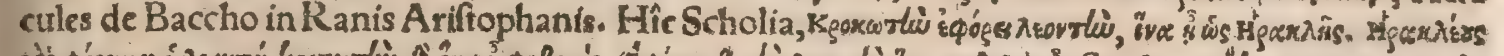

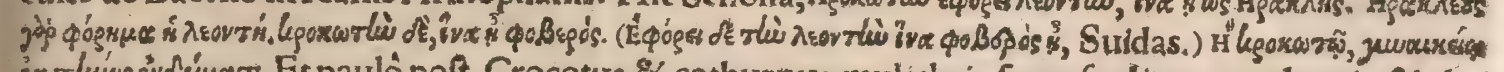

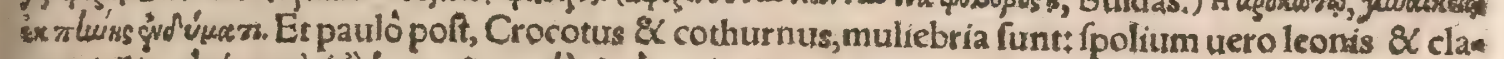

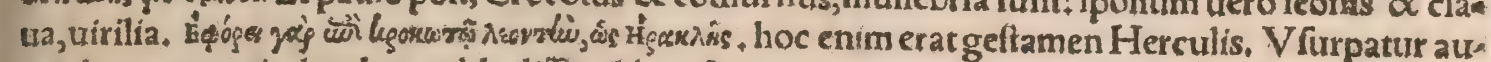
tem hxс parcmia de rebus ualde diffimilibus. Leonis exuuium fuper crocoton, prourerbium apurd Erafnum, quod nos etiam in Leone pofuimus. Ariftophanes in Ecclefiazufis legonarnop forma dia

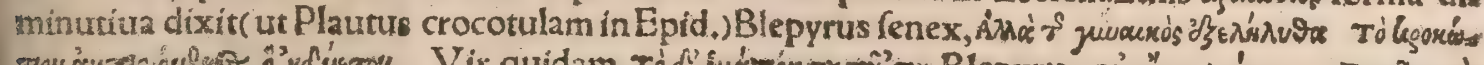

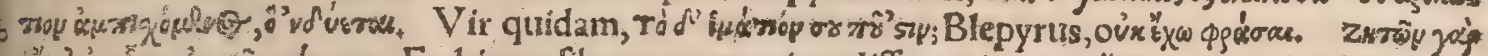

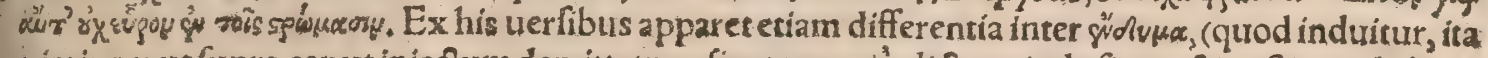
nimirum ur fupra caput iniec?um denuittatur, ficut proprie dicfum indufium, \& ueftis muliebris, quam fupra indufium mulieres fumunt: \& ipol'zsop, quod eft exterius, nec induitur, fed circunĭci. tur. Aliquando tamen indifferenter poni uidẽrur. Caterum Blepyrus cum à lecto furgens indufi. um fuum non reperiret, crocotula uxoris fure forte reperta abufus eft, non induendo fallicet, fed

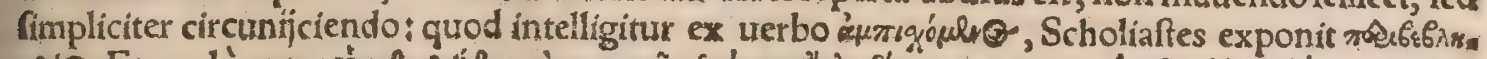

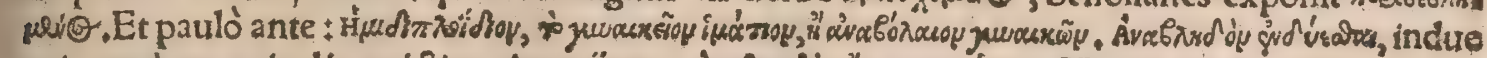

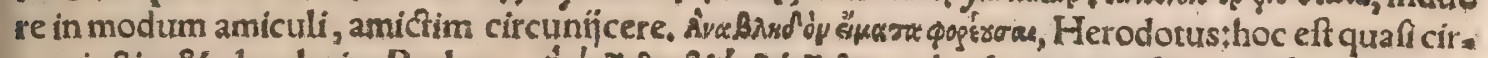

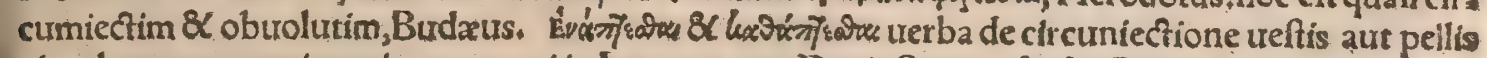
circa humeros pertinentia, enarraui in Leone $H, e_{4}$ Duris Samius fcribit Polyfperchontem uirum

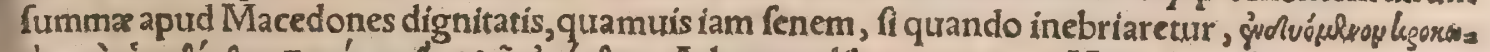

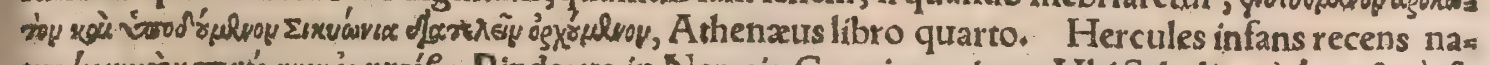

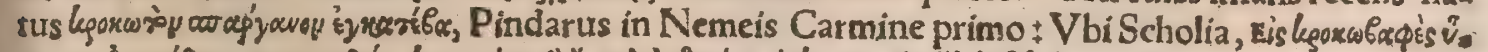

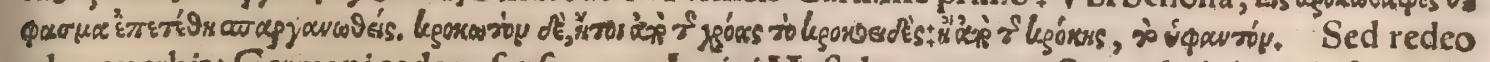
ad prourerbia: Germani eodem fenfu, quo Latini Muftela crocoton, Suem diphthera induere di=

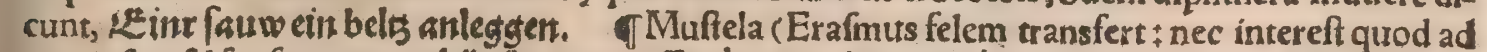

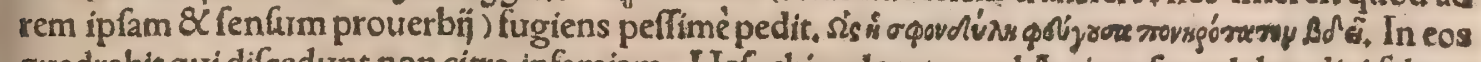
quadrabit qui difcedunt non citra infamiam. Hefychius docet apud A tticos fpondylen dici felem,

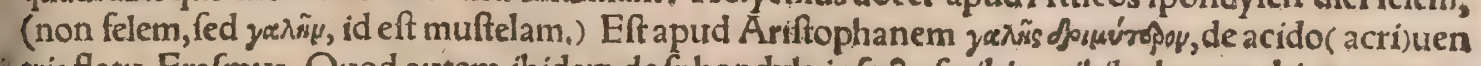
tris flatu, Erafmus, Quod autem ibidem de fphondyla infecfo feribit, nibil ad prouerbium : nec e. nim infectum ullum pedit; hoc etiam errat quod ibidem pro infecto ferpentem dicit: I Muftelam

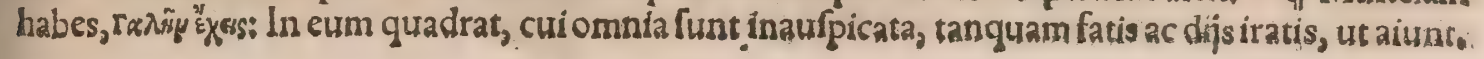


Olim creditum eft hoc animal inaưficatum infauftum ç̧ effe ijs, qui haberent domiç alerent, ut noti admodum diffideat ab illis equum habet Seianum, $\&$ aurum habet Tolofanum. Vnde nunc etiam apud quafdam gentes, nominatim apud Britannos, infelix omen habetur, ficum paratur uenatio, ali quis muftelam nominet, cuius etiam occurfus uulgò nunc habetur inaufpicatus. Adagium refertur à Diogeniano, Erafmus.Muftelam effe inaufpicatam, fupra etiam ex Alexandro ab Alex, \& Alciato

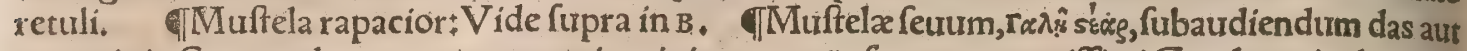
committis. Cum ea dantur, quiorum qui accipiunt natura funt appetentiffimi. Gaudet enim hoc ani: mal pracipué feuo: Veluti fi quis laudaret laudis auidiflimum:aut ad bibendum prouocaret natura

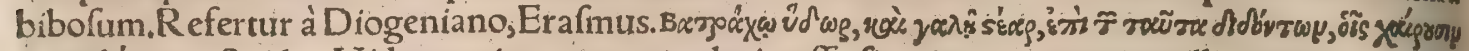

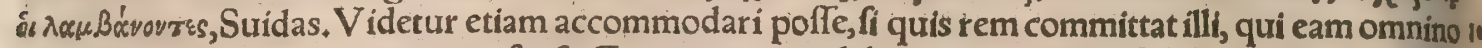
perditurus fit, urlupo ouem; quo fenfu Germanicum celebraturt adagium, Feli lardum aut cafeum committere. बMuftela Tartefia:Vide fupra in $B$.

DE MVSTELIS SYLVESTRI bus diuerfis; $\alpha$ primum de MVSTELA fyl= ueftrifeu ruftica in genere, mox de VIVERRA, FVRO= NE, ICTIDE.

A C T E N V S de muftela domeftica, \& fimul ijs qux omni muftelarum generi communia haben= tur. Venio ad reliquas, nempe fylueftres. Sunt enim plura earum genera, $\&$ quadam ueteribus. ignota. Quanquam enim ut Graci ueteres ictidem \& ga len agrian, pro uno animali acceperüt:fic Latini pro eodem aliâs uiuerram, aliâs muftelam fylueftrẽ uel rufticam dixêre: \& furonem uulgò dictum docti pleriog ueterum uiuerram effe confentiant, (cũ \& nomen ferè conueniat, \& ufus idem ad uenatum cuniculorum: $\propto$ ij fdem locis aliquot ubi Grace ictidas legimus, furones barbari interpretes reddant, ) $\mathrm{Ta}=$ men ego ne quicquam confundere cuiquam uideri poffem, de fingulis iftis nominibus feorfim agam, Diftincta enim, fi cui libebit,cóitungere:quâm confufa difiungere, multò pro= cliuius erit.

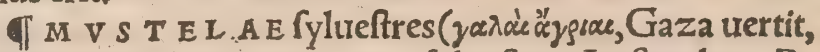
catifylueftres) urenantur mures fylueftres, Ariftoteles, $\mathrm{Pa}$ piliolucernarû luminibus aduolans inter mala medicamen= ta numeratur, huic contrarium eft iecur caprinum, ficut fel (caprinum) ueneficís ex muftela ruftica factis, Plinius. Mur ftelarum duo generataiterum in domibus noftris oberrat, al terum fylueftre. Diftant magnitudine, Graci uocant ictidas (uide plura de ictide infra ${ }^{\text {) }}$ Harum fel contra afpides dici= tur efficax, cæterò uenenum, Plinius, Perottus hæc uerba non rectè de muftelis fimpliciter legít $¥ \&$ pro caterò uene= num, quod de felle tantum intelligitur, legit, Catera funt ue nenum, quafi muftela toræ uenenatæ effent. Iocinerum do. loribus medetur muftela fylueftris in cibo fumpta, uel ioci= nera eius + item uipera porcelli modo inaffata, Plinius. Mar. cellum Empiricum in his Plinin uerbis non uiperam, fed ui= uerram legiffe uideo, fic enim fcribit, Viuerra tofta porcelli lactentis modo inaffata, \& cibo data ieiuno, miro modo iocinerofo fuccurrit. Sylueftris muftela tota in cibo furmpto aduerfus comitiales efficax eft,Plinius.

T Theodorus Gaza ex Ariftotele v I V E R R A M uel muftelam rufticam pro ictide Graca uoce reddere folet. ICtis genus muftela rufticæ, quod uiuerram interpretor, ma gnitudine eft, quàm Melitenfis catellus minor, fed pilo, for. ma, albedine partis inferioris, \& morum aftutia muftelę fimi lis. manfuefcit maiorem in modum, officit aluearibus:mellis enim auida eft, aures etiam petit, ut felis. genitale eius offeum eft, ut anté dixi, \& medicamento urinar ftillationibus effe pu tatur, datur per ramenta ex uino, Ariftot, interprete Gaza.

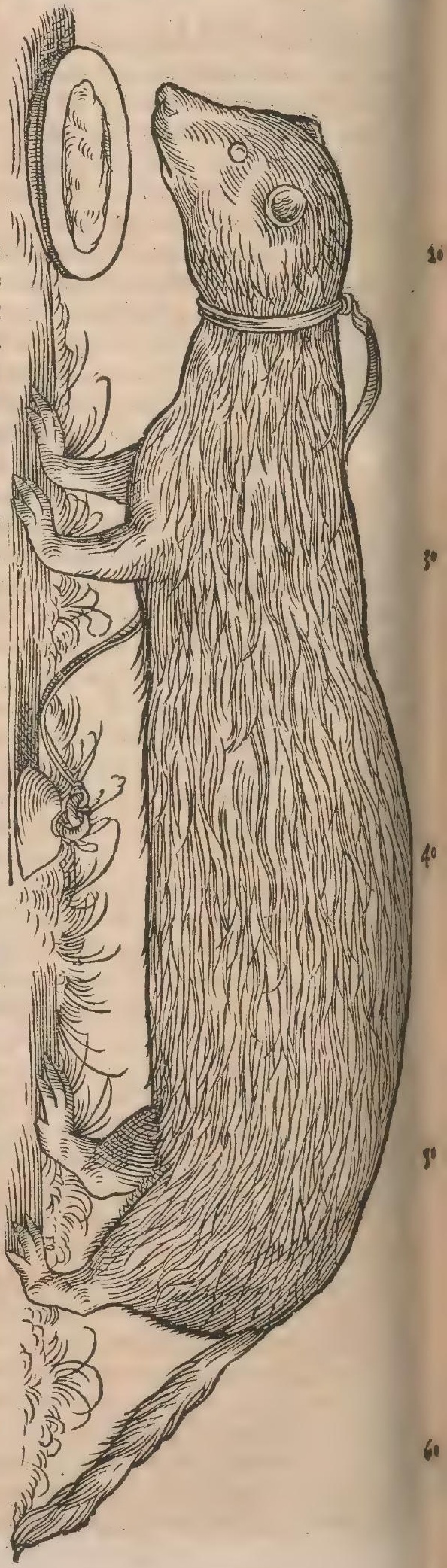




\section{Demuftelisdiuerfis. Lib. I. 863}

Alibi etiam muftela fimpliciter genitale offeũ effe fcribit. Genitalia offea funt lüpis, urulpibus, mu ftelis, uiuerris, unde etiam calculo humano remedia præcipua, Plinius. Canibus etiam offea funt; Vefalius: 2 fibris, quod ipfe obferuatri. Nemo autem arbitretur(inquit Albercus $2,1.4$. ) quòd quît dicimus offeam aut cartilagineam effe uirgam, intelligamus ueram cartilagínis effentiam, fed potitus fubftantiam cuius durities proportionem habeat ad os $\&$ cartilaginem $\& \&$ quxcunc; eft fubftantia uirgx, oporteat quód habeat medium in tactu ut delectationis fenfuiconuenit. Arqui fibri genitale, quod uidi, totum uno offe plané offex fubftantix conftat; fenfus uerò uoluptatis, neça ad of la neque ad cartilagines pertinet, fed ad neruos, ac mufculos uel tunicas quibus illi inferuntur ; ut Albertus prorfus ineptè hac de re locutus fit. Rafis interpres pro ictide furonem uertit. Furonis, inquit, pria = pus perutilis eft dolenti ueficx, \& Atillicidio ac difficultati ueficę. Mifcetur autem contrita inde drach ma una cum modico caryophyllorum $\&$ bibitur. ICAidis genitale aiunt diffimile effe natur $x$ cxter.o rum animalium, ut quod toum offis inftar folidum fit, ( $\&$ femper rigeat, ) quomodocunģ affectum fít ipfum animal. Idem aduerfus ftranguriam pracipuum effe pharmacum aiunt, \& propinari eitis

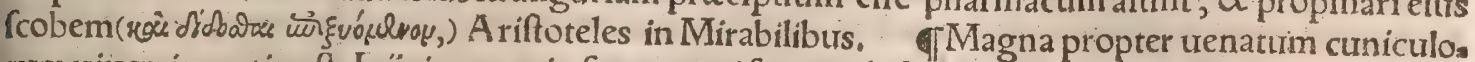
rum uiuerris gratia eft. Inịciunt eas in fpecus, qui funt multifores in terra, unde 8 nomen animali: atģ ita ciectos fuperné capiunt, Plinius, Idem hodie fit in hoc genere muftellarum quas utulgò furo: nes uocitant, Quare 8 hanc $\&$ alias ob caufas, ut paulò fuperius dixi, uiuerram à furone dif́crepare non puto. Viuerras, hoc eft imuftelas rufticas Strabo importatas ait ex A frica. Sunt qui eas Grace

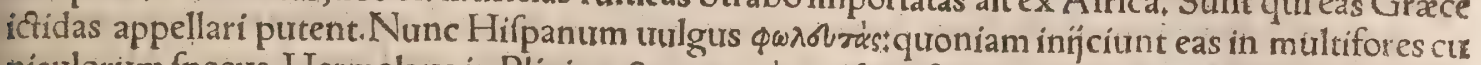
nículorum fpecus, Hermolaus in Plinium 8.15 . $\$$ wiso's quidem, fpeluncam, luftrum uel latibulam fi.

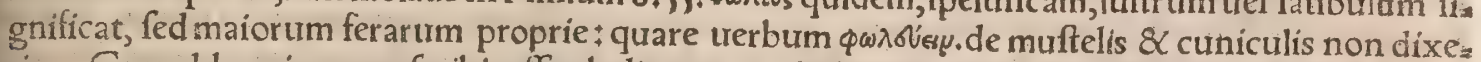
rim. Grapaldus uiuerram fcribit effe pholitam; ego pholectam ipfum fcripfiffe puto ex Hermolac, corrupiffe autem librarios. Mihi quidem furonis uox originem Arabicam aut alterius lingux barba ram habere uideturt nam $\&$ apud Albertum furo, \& alibi furioz pro fele legitur, etfi Albertus ipfe hoc non animaduertit. Syluatico helutos (corrupte ut conïcio pro aluros)furo uel furunculus expo nitur. GViuerra (apud Plinium uipera legitur, ut paulò ante recítaui in Muftela fylue frri)porcelli lactentis modo inaffata, $\&$ cibo data ieiuno, miro modo iocinerofo fuccurrit, Marcellus.

IF V R O N I $S$, ut hodie uocant, pictura eft, quam ab initio huius capitis uides. De hoc quredã in pracedentibus(Muftela fylueftri, \& V Viuerra) dixithîc reliqua addam. Furo quanquam inter oylueftres muftelas è nobis numeratur:in Anglia enim hoc genus fylueftre reperiri audio: tamen fa. cillimé cicuratur, \& domi in capfis quibufdam ligneis alitur, ubi magnam atatis partem fomno cona fumit; funt enim muftela omnes fomniculof $x$ fed quia temperamento funt calido(quod apparet $e x$ corum agilitate, \& facili exafperatione ad íram, \& excrementis odoratis, $\& \mathrm{c}_{0}$ ) citius concoquunt ali= mentum, unde experrecti aliud quarunt, tum die, fi nihil prohibeat, tum nocte magis propter timo= rem. Italia, Gallia \& Germania hoc animal fylueftre non habent, fed peregrinum \& 2 duectum. Et in Gallia quidem, pracipué Narbonenfi, à nobilibus feré alitur, qui cuniculorum uerationi dant $0=$ peram. Vidi primurm Nemaufi, ubi unam huius generis beftiolam, fi bene menini, coronato uęnire aiebant:qua fólicet ad capiendos cuniculos bene effet inftituta. In Anglia, ut audio, fylueftres ca= piuntur aut occiduntur, ne deurorando cunículos inopiam eorum faciant. Miror fané illic reperiri, 4o cum ex Africa primum, ut Strabo fcribit, aduecta fint ictides, quas uituerras \& furones docfi inter pretantur. Galli uocant furon uel furet, aliqui male proferunt furon $\&$ fufet. Hifpani hurón, uel fur ram, Angli feret, uel ferrette, Germani inferiores frett. qua uoce uoracem fignificari aliqui putant. ego à Gallica uoce furet uel Änglica feret, per fyncopen fret cfferri puto. Superioribus Germanis i= gnotum eft hoc animal:rariftime enim ad eos adfertur. Ge. Agricola Germanicé interpretatur fut. rette:aliqui puto frettel urocant. Frettæ inter galàs ponuntur:funt autem opinor illa animalia, que Galli furones uocant, Latini uituerras. Vtuntur eis pueri ad extrahendas de parietum nidis auicu. las; immittuntur $\mathcal{Q}$ in caua arborum, $\mathbb{X}$ inde auiculas unguibus referunt, Carolus Figulus, Angli e, tiam, ut audio, in hunc ufum furones adhibent, non muftelas. Non dubito tamen quin $\&$ mufta idem faciant, ut in ipfarum hiftoria fcripfi. Vide in Ictide ex Nicấdro. Ex recentioribus Latinis, aut potius Barbaris, alị furum, alï furonem, alị furunculum, alï furectum nomínant. Furus à furuo dictus eft, unde $\&$ fur ‘tenebrofos enim $\&$ occultos cuniculos effodit, (fubit) \& éncit pradam quam inuenerit,Ifidorus. Viuerra qua cuniculos ex fpecubus exturbat, paulò maior eft muftela dome. fica: Color ei in albo buxeus. Audax hoc animal $\&$ truculentum, ac omni ferè animantium generi

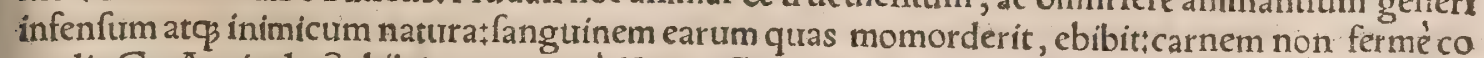
medit, Ge, Agricola.Subijcit autem quòd bamefiter etiam, quem uulgò cricetum nominant, iftius fit generis qurem ego cur muribus potius quàm muftelis adnumerârim, in ipfius hiftoria dixi. Cus: niculi capiuntur hoc modo, (ut fcribit Petrus Crefcentienfis $10+35$.) Venator magno frepitu excita. to cuniculos parrentes fugat ad fuos cauros:quó cum fe receperunt ad fingulos reticula extendit: 86 per unum immittit furectum (uide an legi debeat furettum) quem cicurem habet, propritum inimi cum cuniculorum, ore eius occlufo quodam frenello, (paruo capiftro, ) ita ne os aperire ac cuniculos mordere aut comedere poffit, fed propellere tantum. At illi omnes expulfi reticulis obcioluuntur. Plura uide in Cuniculis E, ubi tum alia quadam, tum Strabonis eadem de re uerba recitauimus, qui 
galàs agrias iftas uenatrices ex Africa aduehí fribit:quamobrem non inepté muftelas Africanas à liquis appellauerit.Sed de Africanis muftelis nonnihil etiam fupra dixi in Muftela domeftica capi. te fecundo. Furunculus putoriæ(fic Galli uocant iltiffum noftrum) ualde confimilis eft paulo am plior quàm muftela. Color ei inter album \& buxeum. Animal eft animofum ac ferox. Coire dicuntur

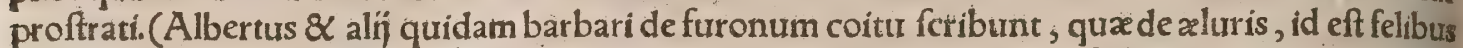
coéuntibus Ariftoteles prodiderat. Ego non proftratos uel catos uel muftelas coire puto: fed ita in

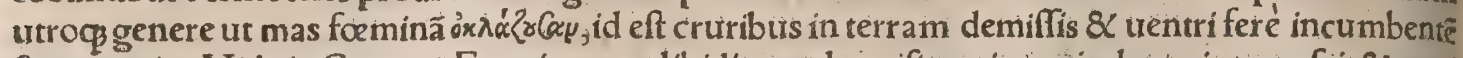
fuperueniat, Vide in Cato $c$.) Foemina cum libidine ardet, nifi maris copia detür, intumefét $\&$ mori tur. Partu focunda eft \#nam feptem tiel ocfo foetus fimul perficit .Vterum geftat diebus quadragin ta. Catuli recens nati, diebus triginta caci funt. A tempore trero quo uifum accipiunt, intra quadra. gefimum ferè diem uenari incipiunt, Author libri de nat,rerum. Quos ego uidi furones, circiter duos dodrantes longi erant, colore albotfed uenter, fi bene memini, in mare prafertim, pallidus erat, nimirum ab urina tincfus, ut in hermelinis quogg. Oculi planè rubebant, cruträ erant humilia. foemi. na grauida perquàm fomniculofa erat, $n$ K, oach, Hebraicam uocem, aliqui furonem uel furunculï interpretantur $+a l i j$ martem + alh cephum uel cercopithecum, ut pluribus in IMuftela domeftica dixi capite primo. đSi caput lupi in columbario fufpendatur, non accedet catus; uel furo, uel aliud con lumbis noxium animal, $R$ afis \& Albertus. TCatus, mus, furo \& muftela, ladunt plus uulnerc quàm ureneno, Ārnoldus.

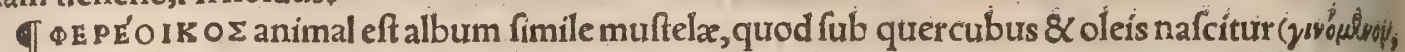
uel uerfatur potius, ) \& glandibus uefcitur, ab Arcadibus fic appellatum, Etymologus \& Hefychitss, 1 Hoc animal nifi muftelarum generis fuerit, quas etiam corpore refert, ignotum mihi fateor $\phi \phi p_{0}^{\prime}$ ros ròे $\phi \sigma \hat{p}^{\prime}$ ut 8 Cicero alicubi cochleam:) Varinus: Vel animal maius uefpa, Hefychius $8<$ Suidas

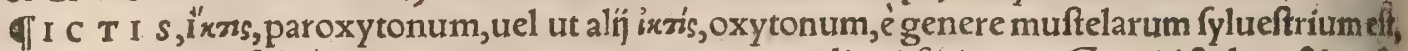
quarum qui unum folum genus cognouerunt, ut ueteres aliqui fcriptores Graci,ictidem $\&$ mufte lam fylueftrem, omnino idem effe putant;cum plures muftela fylueftres fint, ut in fequentibus ape parebit. Gaza pro ictide reddit uiuerram:de qua, 8 obiter etiam de ictide nonnulla, in pracedent bus dixi. Georgius Agricola ictidem effe putat, muftelam illam qux Germanis iltis uocatur; nam uocabula ictis \& iltris pulchrè colludunt, una tantum litera uariante. Niphus ictidem, marturü̉ irel marturellũ interpretaț. In Acharnenfib. Ariftophanis quidã dicit fe adferre omnia bona Bocotorử,

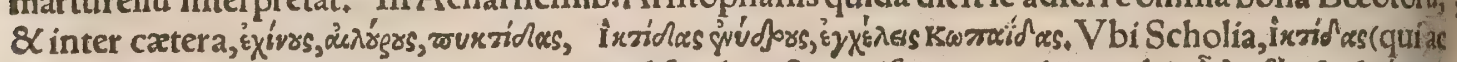

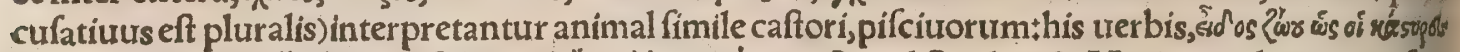

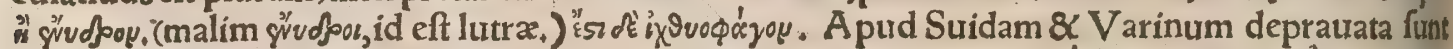
hæc uerba,Caterum in uerbis Ariftophanis fi diftinguas poft ixzides, g'víders fubftantiuè pro lutris accipies quod magis placet, fin minus, epitheton erit ictidum, tanquam illæe etiam in aquis uiuant, de quo mihi non conftat. Pifcibus tamen omne muftelarum genus uefci,non minus quảm feles, non dubito.Sed feles cum pifcibus delectentur, ab aqua tamen abhorrent. Iltiffos quidem noftros, de quil businferius, Ge.Agricola, iuxta aquas interdum habitare \& pifces tuenari fribit. Ego à rufticis no ftris ranas ab eis captari audio, (Fieri poteft ut ictis etiam dicta fit quafi ichthis, à pifcibus uorandis.)

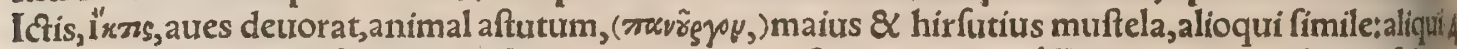

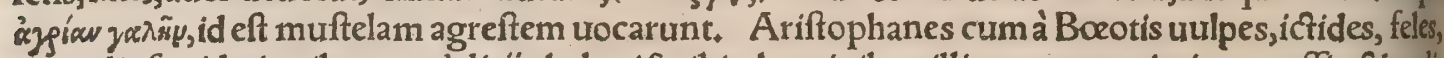
animalia foctida, in ciborum delicrijs haberifcribit, hominibus illis tanquam nimium craffis $\&$ rudi. bus(unde $\&$ prouerbia aliquot nata)illudere uidetur. Io.Tzetzes Variorum 5. 8. ictinum, id eft miluum aurem à multis cum ictide terreftri quadrupede confundi fribit:quod ut meritò reprehens dit, ita inepté ictidem interpretatur alurum, id eft catum, Albertus in Ariftotelis hiftoriam 9,6.pro ictide habet ankatinos, quod Auicenna(inquit) katy $z$ appellat: $\&$ eft apud nos animal pullos (gallis nas)comedens, quod Galli fiffau(uox corrupta uidetur) Germani illibezzum(lego iltizzum, uel po tius iltiffum) uocant:cuíus pars fub gula $8<$ uentre prafert ruborem, fed in dor fo eft fubnigrum, gal linas infeftat $8 X$ interimít non edit autem, nifi prius omnes aut multas iugulauerit. Alph quidam ob fcuri authores ex Ariftotele pro ictide habent ankacinor, cui tribuunt magnitudinem catuli canis le $\$$ porarij, (fic enim legendum ex Alber to:) \& prudentiam maiorem in minore atate quâm prouectio: re. Cuius quidem rei nec rationem nec teftem adferunt. T ikzo 'se, pellis æluri(id eft catti,) Stridas,

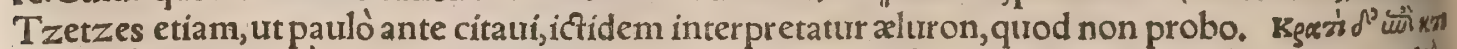
dísy kuv'sp, (pileum è pelle uiuerra factum,) Homerus Iliados k.de Dolone. Vbi Scholia monent alias

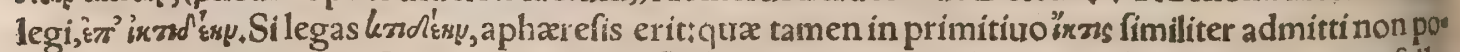
teft; fieret enim $x z r s$. qux fyllaba neç circunflecti poreft, cum producta non fit; nec acui, monofyllat bum enim acutum zis tantum reperitur. ए एक

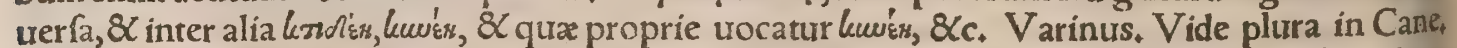

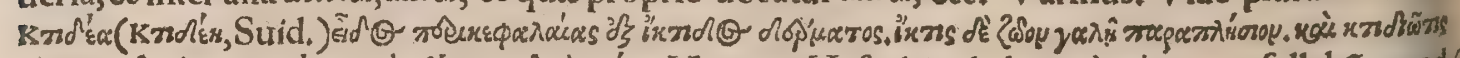

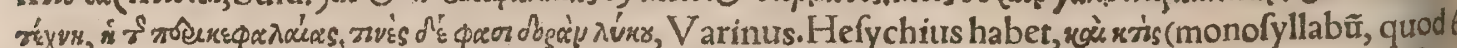

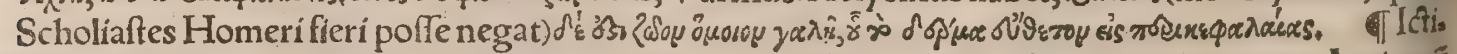
dis genitale commendari ad ftranguriam, fuperius in Viuerra dixi. Eadem enim uiuerra Latinor 


\section{Demurtelisdiuerfis. Lib.I. 865}

uidetur, qux Gracorum ictis eft. - flocufta cum ferpente pugnat, Áriftoteles o.6.de hiftor, anim, Locufta Gracéécxeis eft: Niphus dubitat an hoc in loco ixrzs potius legendum fit, quanquam in fuo codice çuw is habeatur. Ego uero óxe's, id eft locufta recté legi puto, qui fciam ophiomachum genus quoddam locuftę effe ab impugnandis ferpẽtibus nominatum. đI modo uenareleporem, nunc ityn tenes, uerfus prouerbialis apud Plautum; Erafmus legendum putatictin, quod ego in lepore $\mathrm{h}_{\text {; }}$ reprobaui,

\section{E M A R T E}

Martis figuram bis pofuimus, quonism duo genera nobis oogniss funt, que colore tantum differunt.

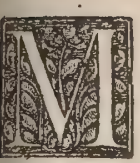

A R T E s muftelarum fylueftrium generis eft; hoc nomen hodie pluri. ma nationes Europx commune ha bent, Itali, Galli, Hifpani, Germani, Angli, terminationibus tantum differentes, \& qui Latiné fcriplerunt barbari quidam recen= tiores, martam (márta Hifpanicum eft, ) marta. rum, marturum uel marturellum nominare fo lent. Ex ueteribus hoc nomine folus opinor Martialis ufus eft, hoc uerfu: Venator capta marte fuperbus adeft:quod carmen V claterra nus memoria lapfus, aut error librariortum Horatio triburit, Eft autem generis foeminini, ut feles \& $\&$ meles eiufdem terminationis anima lia. Cxterum martem dictam conijcio, quod Martia, id eft pugnax $\&$ ferox beftia fit + iugux lat eniin mures, gallinas $\&$ aues cæteras, ut in30 fra dicèmus.sed cum plura eius genera fint, re centiores pleriog nion fatis diftinxerunt, nec apta ex uérnaculis linguỉs impofuêre uocabula. Carolus Figulus ictidem commuthi uocabulo muftelam fylueftrem facit, qutod fpécies fub fe comprehendat martam $\&$ putoriam. Sed mar tam in alias fpecies non diftinguít. Eft $\&$ hoc muftela genus fylueftrè, quood Martialis mar= tem, Germani martarum nóminant. In faxorồ rimis \& cauernis cubat. Domós ingreditur fí 40 militer ut ictis, (putoriam fíc uocat ${ }^{\prime}$ ) necat gallinas earumćs fanguinem exuguit, $\&$ oura $e x$ orbet; Ge. Agricola. Hoc genus noftri ud= cant tabmarder / bufnnardet/fetiniatber/ birbintarser: hoc eft, martem téctortim, uel fa xorum, uel domefticam, trei fagorum. Verfa. tur enim frequentius in magnis ędificñ s ac tent plis, precipuè fub tectis, (nec non in fyluis cirz ca fagos) \& gallinas $\&$ oua rapit, Stumpifiùs. Martes ifte domeftica, paffiun opinot ín omní yo bưs aut plerifó Europęregionib, habêtur:mar tes uero propriè dicta, quæ fylueftres funt, $\&$ quibus captis meritò uenator fuperbire queat propter pellium pretium, in fyluofis tantum re gionibus, Sed de fylueftribus infra priuatim di cam: nunc de domeftica agã, \& quxda mi com . munia martium generi interferani, $\mathbb{T}$ Galli igitur \& Itali martem domefticam noftram foi nam, uel ut alị fcribunt, fouinam nominant: aln̄ foinum aut fouinum mafculinè proferunt. Ët laqueo ưulpes, \& decipe caffe foinas, Calentits. 6. Sunt qui fouinum \& marturellum pro eodem animali accipere uideantur, utroq enim nomine fele interpretantur, ut pluribus dixi in Cato capite primo:ubi \& felem omnino catum effe oftendi . Ni phus cum alibi confudiffet, rurfus alibi ( $\&$ recte quidem, meo iudicio) diftinguit bis $_{3}$ uerbis:Felis eft 


\section{6

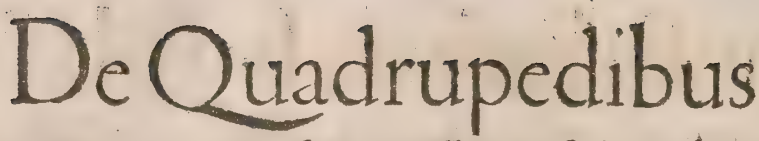

qua uulgò dicitur fouinatictis, marturus uxl marturellus:muftela ueró donila. Martẽ Germăni \& Angli uocãt marboer trel matter. Itali marta, uel martore, uel martorello. Galli mardre. II!rrỉ \& Polo nikuna. Eraf. Stella à Brufîs(qui Sarmatiæ puto adnumerãtur, ut $\&$ Poloni)gaynum uo qua uox accedit ad kuna. funt enim g, \& $\mathrm{k}$, literæ uicina. Sed bæ nomenclatur $x$, ut dixi, ad fylueftres potitus martes pertinent.

ه Oach urocẽ Hebraicã Efaix 13, aliqui mar" tem interpretantur, alij cephum uel cercopithe cum. Vide in Mufiela fupra.Item zịm Hebrai cam uoce, , martes, aut tiuerras (ut fupra dixi, aut cercopithecos, TSatyrium quadrupe. dem amphibiam apud Ariftotelem aliqui ( ut Niphus)marturum effe putãt, uel foinam qua magis aquas petit. Videfupra in Satyrio mox poft Lutram. Satherium, apud Auicennam kacheobeon uel kachyneon, Alberto uridetur effe martarus, animal fuluum, in gutture albû, magnitudine felis. Idem fafto $z$ uel faftor $A$ : uicennx, qui Ariftoteli caftor eft, ineptiffimè genus martari facit, minus et nigrius prędicto. Anglia, ut audio, nullum genus martis habet: fed muftelas, furones \& putorias . Marti ma* gnitudo felis eft, fed paulò longior, crura uerò habet breuiora, itemós breuiores ungues, To= tum eius corpus pilis in fuluo fubnigris vefti= tur, excepto gurture quod candidum eft, $\mathrm{Ge}_{\text {* }}$ Agticola. In dorfo fulua eft, uentre $\&$ gutture alba ficut muftela, Albertus. Hac cum fori berem cranium martis domefticx infpexi, den tes in eo precipuéadmiratus, $i j$ funt peralbi, in. xquales, $\&$ afperi: Canini infra fupraç̧ oblōgi eminêt: inter quos trāfurerfi linea reça fex par: si inciforiorum loco habẽtur, quorum illiper: exigui funt quos inferior mandibula continet, Molares ferrati, \& quidã ex eis trianguli funt, ocfoni infra, $\&$ totidem fupra. Eortum ultimi in fupcriore parte oris, finguli utrings multò cæe teris interius funt, nempe in ipfo palato. Den. tes in fumma, triginta duo. Setę nigricantes à fu periore mandibula retrorfum fpectant.

बMartis \& muftelarum genera uix un. quam quicfrunt, etiam cum domi cicures alun tur, Albertus. Ego martem prorfus cicurem aliquando haburi, canis quo cum nutriebatur amantiffimum. quem in itinere etiam faciendo fequi fo'ebat. Soluta uinculo, circa $x$ des $\&$ te. ça uícinorum 8 lógius quandogs uagabatur, Cemper reuerti folita. Morficatim fape cum caz ne 8 hominibus ludebat, et unguiculis fupina, ut cati folent, nec ladebat aut minimum. Sed quoniam facillimè exafperantur, ut morfum

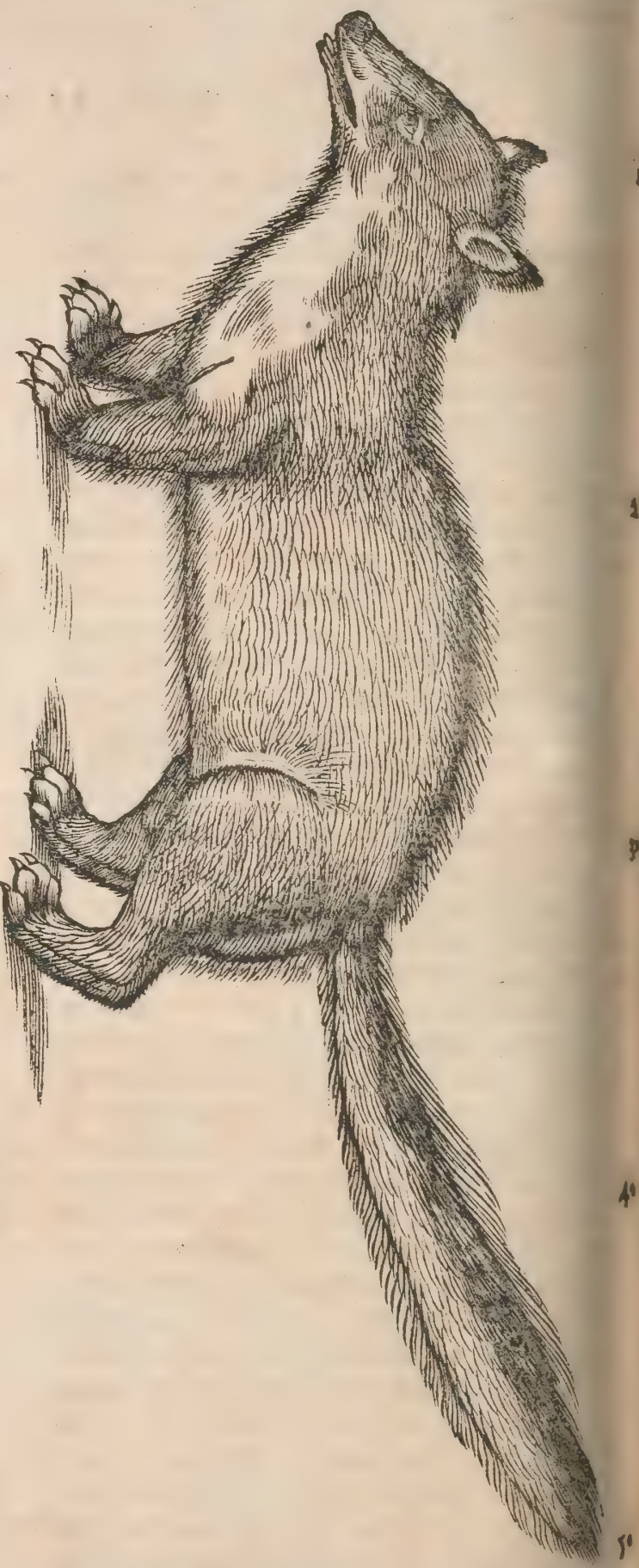
grauilfimé infligant, dentes, pręlertim caninos forcipe eis frangere quidam folent. Feles fylueftres (martes potius: fed felem uidetur pro fouina accipere, ut Beroaldus $\&$ Niphus, ) \& mures, reddunt interdum molchi odore recrementum, ut fape in dirutis agrorum ædificips uidimus, fed id acceptum ferendum eft odoratis fruticum cibis, quibus aluntur, Ruellius: Ego hæc animalia, martes pracipuè, herbis aut fruticibus uefci negauerim. Ale xander Aphrodifienfis problematum 1.29. caufam inquirens cur ferorum animalium, ut damarum ( $\pi$ goxw Quoniam ferè(inquir) cibo ficciori fimplicioriós uefcuntur, laborantọ́ uehementer, (unde $\alpha$ difflan tur magis, 8 calore abundantia plenius concoquunt.) TMuftelarum omne genus,à pellionibus paratur ad ueftitum. Martes pracipué fylueftres laudantur, ut paulò poft dicam, Sunt qui martium 6 $\&$ uulpium pelles podagricis infalubres effe dicant. Pileos ueró ex pellibus martis albz, id eft album guttur habentis, capiti falubres, ॠMartorella,id eft Valeriana usel berba cati, Syluaticus, Vide 


\section{Demuftelisdiuerfis. Lib. İ. 867}

in Cato. Ruta capraria à quiburdam taurina dicitur \& martanicà, ab alịjs herba nefa, ùel foenò. gracum fylueftre, Monachi in Mefuen. Manardus in Italia à quibufdam gyarcham uocari foribit; Brafautola giargam. Et forte eadem fuerit quam Marcellus Empiricus cicharbam uocat, mifcês eam alips quibứdam medicamentis ad capur porriginofüm \& ulcerofum. Martanica uerò an à marte quà drupede dicatur uel aliam ob caufam, incertus fum. Vide nonnulla fuper hac herba etiam in Ca= pra a.

هMartem fylueftrem Germani uocant, felomarber/wilomarber aliqui en im fimpliciter hor gẻ nus in domefticum 8 fylueftre diuidunt. Aliud eft muftel $x$ genus fylueftre (inquit Ge. A gricola; interpretatur autem Germanice baummatber, id eft martem arborum)quod in arboribus uitam ui - uit, qưod etiam uocabulo martis appellatur. Ea muftela fyluas infolenter $\&$ rarò deferit, atç in hoc differt à fuperioré, (domeftica marte:) $8 \times$ infuper quòd guttur eius lutei fit coloris, \& quòd reliqui corporis pilus magis fit obfcurè fuluus. Huius duo genera quidam effe cenfent : unum quod in fa. geis fyluis ucrfatur, (noftri uocant büc)matber; ) alterum quod in abiegnis, (tbannmatber uel fiectmarber:)atç id fané eft afpectu pulchrius, Hæc ille, fed martes à fagis cognominata, nec luteũ guttur habet, nec fylueftris tantum eft, fed circa domos etiam \& faxa uerfatur, unde eandem aliqui teçorum alin faxorũ martem in Germania uocant, ut fupra dixi:duo enim folum martis genera pelli fices noftri agnofcữt. Genus illud quod in abietibus nidum ftruit, multò eft pulchrius quàm quod in fagis : fed mifcentur inter fe hæc genera : \& martes fagi ferè fequitur martem abietum, tanquam nobiliorem, ut fotum ex ea nobiliorem acquirat,)Albertus, Vtraque martis genera apud $\mathrm{Hel}$. - uetios habentur, 8 in regionibus quidem ac uallibus alpinis praftantiores quàm alibi. In Gal. lia audio martes abietum non haberi. Fagorum martes habitant in cauis fagis. Sed illarum quibus abietis cognomen addimus, multò meliores $\&$ pretiofiores funt pelles. (Multę capiuntur apudR bę tos circa Curiam.) Animal ipfum exiguum eft, uulpina ferè forma, nigro fciuro non multó maius: (ego tam paruum nunquam uidi.) Pellibus eius nobiles $\&$ principes ueftiuntur, Stumpfius. Rufti= cus quidam narrauit mihi fe hoc anno initio Aprilis in præalta abiete martem cepiffe cum quatuor catulis $\neq$ folere enim hoc genus in abietibus fourorum inftar nidificare. Quoduis genus martis, à te. nero präecipué,cum homine nutritum, plané cicur fit $\&$ colludendo etiam familiare.Idem. Fagor \&abietum martes, ut \& zobelli, bonitate cæteris omnibus eó magis praftant, quó plures pili candi= di cum fuluis permifti fuerint, Ge. Agricola ${ }_{i}$ Sunt apud Brulfos hodie dictos nemora plena an ia malcúlortm, qux ïndigenæ gaynos, Germani matter appellant, Erafmus Stella.

TH Hec fcriplerẩ quum in officina pellionis curitufdam martium pelles aliquot infpexi. Vifa funt autem mihi illæ qua à fagis denominantur, Gallis foin $x$ ( quod nomen fimiliter for te à fago factum eft, quam arborem fau Galli appellant, )magis fofcæ maiórẹ́́s cauda \& nigriore quàm martes abie. tum, quas aliqui fimpliciter martes uocant. Magnitudo utrif́ç eadem feré. Sunt quidem pelles alię a= lís latiores maioresćp, aliż anguftiores, pro xtatis nimirum \& fexús differentia. Longitudo utrif plerunç ad duos dodrantes cum duobus tiel tribus digitis infuper. Cauda martis, dodrantis cum palmo menfurram æquat: foinæ paulô löngior $\&$ amplior eft. Abietum martes etiam exPolonia ali= quando afferuntur, fed fufco feré colore diluto, qui non probatur putriceo \& fufco coloremixtis infignes; (bâunledt).)Placet enim hic color in dorfo pracipué pelliữ, quiarum praftantia ex hoc ipfo,non gutturís colore magis minus ue flauo aftimatur. Fagorum dicta martes frequentiores funt in alpium noftrarum lateribus qux meridiem 8 Italiam fpectant, abie tum rara:in oppofitis partibus, qua uerfus noftras regiones $\&$ feptentrionem funt, res contra fe ha= bet;perpaucx enim albo, plures flautro gutture intrèniuntur. Egregia pellis è marte flaua, id eft abie turm, emitur apud nos fere coronato, hoc eft drachmis argenteis fere duodenis, quædam octonis: al. bæ trero martis pretium triplo aut quadruplo minus eft: plerunç enim ternæ uel quaternæ drach= mis octo aut pauló minoris ureneunt. I Lanzerucca fyluta eft scandinauix longitudine ad octoz ginta miliaria, in qua martes \& zobelli, \&c.abuindant, Olatis Magnits, Mardures \& $s$ c is $M$ I fic dicta animalia apud Mofchouritas abundant, Matthias à Michout. Populi quidam Sarmatix Euro pex ex fabellis, (zobellis) fcifmis \& alịs animalibus pelles confuiunt, Idem. Hungarix Scythic prope Tanais ortum incola, duci Mofcourix fabellorum fcifmorứćs pelles pro tributo pendunt, Io. Boémus. Circa initium lacus Poda micioppidum eft Brigantium, (25igenţ) cui fylua adiacer Bri gantina, in qua martes reperiri audio nocfu lucentes, liedtmarder, uel jiinomar der: fed noftri pel. liones nihil certi de rijs habent. बDerofurella Martis genere dixi fupra in Muftela $B$. De zobela lo inferius dicam, poft putoriums. 


\section{8 \\ DeQuadrupedibus}

\section{DE P V TOR I O.}
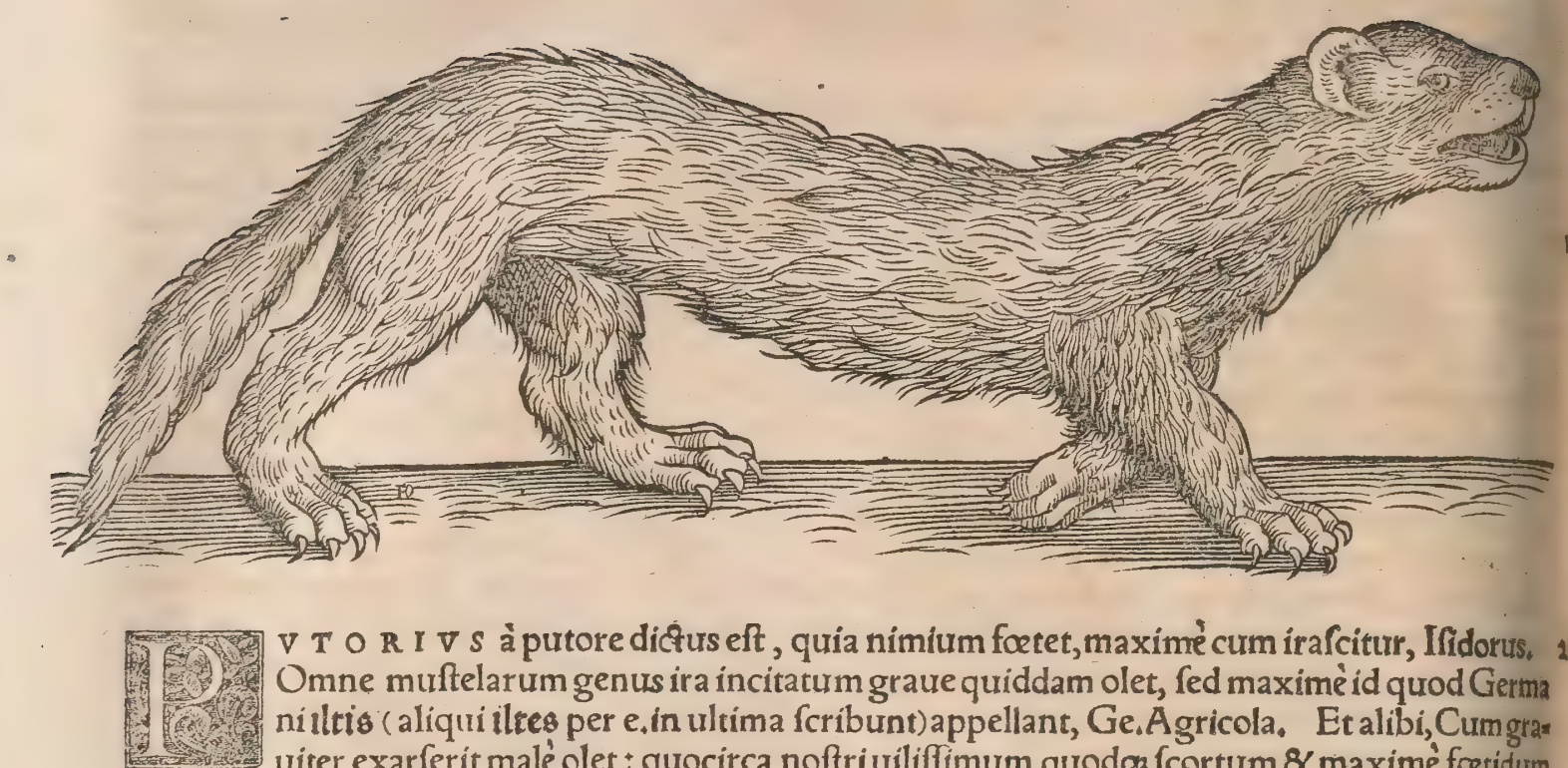

V T O R I V $S$ à putore diçus eft, quia nimium foctet, maximé cum irafcitur, Ifidorus, Omne muftelarum genus ira incitatum graure quiddam olet, fed maximè id quod Germa niltris (aliqui iltes per e, in ultima fcribunt)appellant, Ge.Agricola, Et alibi, Cum grat uiter exarferit malè olet ₹ quocirca noftri uiliffimum quodos fcortum \& 2 maximè føeridum pellem ictidos folent nominare, Exiftimat enim muftelam hanc fylueftrem Gracorum ictidem efle, quòd ictis Gracè, Germanicè iltis, una tantum litera differãt. In eadem fententia eft etiã Carol.Figư lus. Ego ictidemuel commune nomen effe puto ad muftelas fylueftres:uel fi ad unam fpeciem cons trahatur, uiuerram, id eft furonem uulgò dictum fignificare, ut in Furone dicium eft, Putorius anis mal eft non fecundum fpeciem, fed fecundum genus determinatum, fic dicfum quia foetet maxime cu m irafcitur: $\&$ hoc eft quod uocamus martarum fecundum omnem fui diuer fitatem : $\&$ mufela eft eiufdem generis, Albertus. Videtur autem putorium nomen generis facere, quod fpecies diuer: fas includat, ut prorfus fit idem quod martarus, hoc eft quacunq fpecies martis : qua in re omnino cum errare dixerim:quamuis enim omnia muftelarum genera, ut fape dixi,cum irafcuntur focteầ putorio tamen fic per excellentiam dicto id maximè accidit. Galli fane idem animal quod noftrittis fua lingua putois(alij feribunt poytois)nominant, ut ex pluribus Gallis audiui \& apud Carolum Fi gulum legi:Sabaudi pouttet:Angli fitche, uel ut noftri pronunciãt fitfch:lllyrij uelBohemi, tchorz: Poloni uindra,

- Iltiflus nofter(inquit Ge. Agricola)aliquanto maior eft muftela domeftica, minor marte fylute ftri,(Stumpfius marte corpulentiorẽ effe fcribit.)Pilos habet inæquales, \& nó unius coloristetenim breues fubfului funt:longi, nigri. qui fic ex multis corporis partibus eminent, ut pellis diftincta nis gris maculis effe uideatur:circa os tamen candidus eft, Agricola. Pellis iltiffi, ut tractando obferua 4 ui, denfiufcula eft, ideoó̧̧ durabilis cum ueftes ea fulciuntur, fed quoniam feré pinguiufcula eft, $\$$ grauius olet, minimi in genere muftelarum pretị habetur, minoris etiam quầm uulpes. Plurimis $0_{2}$ dore furo caput offendit, Pellifices dicunt hyeme captas tum putorias tum martes meliores haberl, minusćp urirofas odore, circa uer autem cum libidine pruriunt olere grauiffime. Cauda iltiffo bre: uior eft quàm martibus, utpote duorum palmorum. Reliquo corpore longitudinen martium ęquat, uel parum excedit:circa collum n̈fdem anguftior, amplior $\&$ latior circa imum uentrem. Cauda in fuper, pectore \& cruribus nigrior eft quámı martes, ad latera flauior: deniç multò foetidior. Putori us ficut $\&$ taxus, crura finiftrilateris breuiora quàm dextri habet, (hoc ego in pelle iltifil falfum des prehendi.) Ardua domorum \& penetralia habitat,gallinarum ac pullorum cupidiffimus. Vtprimú autem gallinam aut pullum ceperit, caput initio petit, Ifidorus. Iltiffus habitat in riparym cauernis $\varphi^{\circ}$ ubilutræ $\&$ fibri more pifces captos comedit: $\&$ uerfatur in fyluis, ubi prehendit aues $:$ in domibus ubi gallinas, (quare Plinius eam effe domefticam dicit,) quarum fanguinem exugit. fed ne clamare poffint, earum capita primò mordicus aufert:ato̧̧ etiam earum oua, quæ furarifolet ac multa in unû́ congerere, exorbet, Agricola. Ego apud Plinium ictidèm (hanc ením iltiffum Agricola facit) dome: fticam dici nufquam reperio. Vhus tantum quod fciam locus eft, ubi mox poft memoratam ictidem, domeftic muftelæ mencio fit, fed ita ut diftingui clarum fit. Putorï $\&$ martari omnes, muribusin fefti funt $\&$ gallinis, quibus primò caput $\&$ cerebrum auferunt ne clamare poffint, Albertus. Hac mihi fcribenti rufticus quidam narrauit fape plurimas ranas inueniri in cauis arboribus, quas ins teremptas îtriffi illuc congefferint. Sæpe uerfantur circa foenilia, ftabula $\&$ alia æedificia: gallinas \& oua rapiunt, abundant in regionibus alpinis, Stumpfius. Videntur mediæe effe naturæ inter feras 60 8 placidas animantes. Furunculus putorio fimilis ef, $\mathrm{Ob}$ fcurus. 


\section{Demuftelis divierfis. Lib. I. 869}

\section{DE MVSTELA SOBELLA, ET}

\section{ALIIS QVIBVSDA.}

V S T EL L A R V M genus omnium pulcherrimum \& nobilifimum eft, quod Germà ni zobelam (sobel) uocant, Ge.Agricola. Illyrij \& Poloni fobol, uel ut alí fcribunt fo: ból. Eruditus quidam amicus nofter murem Scythicum appellat ; ego martem Scythicã potius uel muftelam uel ictidem Scythicam dixerim. Galli, ut audio, corrupta uroce mars es foublines nominant. Aliqui, prafertim Itali, in prima fyllaba non o, fed e. uel i. fcribunt, aliz qui a.quod non probo. Confonantem quogs initialem non z, feriplerim, ut pleriç, fed $\mathrm{f}$. Nam Polos ni, quortm regio uicina eft locis illis unde ad nos mittuntur hxe pelles, fobol, ut dixi,nominant, Zo bela in fyluis ut martes degit:ea paulo minor, tota tamen obfcurè fulua, præter guttur, quod habet cinereum, Ge.Agricola. Zobela martem refert, minor quidem ea, 8 cruribus breuior, fed omnino martium generi adnumeranda. Pili eius quocung manu agantur, planum $\& \&$ aquabilem fitum obti nent, nec ut aliorum animalium pili in a duerfum acti rigent. Guttur medio ferè colore eft inter al. bum, quio martis domeftica, \& luteum quo fyluaticæ guttur infignitur, (fic en im legendum puto, lo ctis eft mutilus.) Catero nihil à martis colore differt, nifi quod elegantior eft, Michaell Herus, ê Ze bellinos leuium pilorum tenui canicie probatiffimos, quibus nunc principum ueftis fulcitur, $\mathcal{Q}^{\prime}$ de. licatà matronarum colla expreffa uiuæa animantis effigie conteguntur, Permin \& Pecerri prabent; to fed quos ipfi ab remotioribus etiam gentibus, quæ ad Oceanum pertinent, per manus tradítos accipiant, Paulus louius in libro de legatione Morchouitarum. Hungaria Scythica non longżà Tana= is ortu extat, \& Ihura hodie dicitur, duci Mofchouix tributaria. Pendunt enim cius incola pretio. fas animalium pelles, fabellorum fcifmorumág, Ioan. Boémus. Alba Ruffia fiue Mofrouia, qua parte Cronio mari accedit zebellinas armelinasós pelles nobilium ac matronarum delicias mittit, Authoris nomen excidit. Lituania ịs tantum mercatoribus aditur, qui pelles emunt zibillinas ab Italis appellatas; his loco pecunix qua carent(Lituani)omnia commutant, Volaterranus. Populi quidam Sarmatix Europææx, ex fabellis, frifmis, \& alijs animalibus pelles confuunt,Matthias Micha , uanus. Lanzerucca fylua eft Scandinauix cuius longitudo ad octoginta miliaria extenditur, in ea zobélli, martes $\&$ alia animalia capiuntur, Olaus Magnus، Zebellinæ pellium omnium longè pre tiofiores puilchiritudine $\&$ raritate thas mittunt fub extremis feptentrionibus Lapones, Cardanus. Regio quàdàn Tattariä eft ubi abundant parua quadam animalia, quæ delicatifimas fuppedi. tantpelles qứas ữulgò zebellinas uocant, Paulus Venetus 3 47. Et alibi,Ārmelinorum \& zebelli norum pelles apud Tàriàros adeò pretiofá funt, ut quandós uix pro duobus milibus Byzantio rưm aureorum pelles pró ửna tunica fúfficiant, $P$ aulus Vènetus; Pelles zobela ut pretiofifíma funt ita maximèdutrabiles exiftimantur; Michäél Heriss, Zobelinæ pelles pretï maioris funt quàm panni auro texti. Etentim comperi optimás quadraginta numero, tor enim ino fafciculo colligari $8<$ unà uendi folent, plùs quàm milibus nưmúm aưreorum iręniffe. Muftelæ quidem horum trium ge nerum (martés fagorum, martès abietưn, žcbela, ) bonitate cæaterís omnibus eò magis praftant, quo plures pili candidi cum fulúis permifti fuerint, Ge.A gricola. A pellificibus ipre audiuri pelles zobe - linàs mediocris pretri, qux pro una irefte fulcienda fufficiatit, imagna ex parte non minoris quàm mille aureis comparari: (aureum troco, pretium octó denariórúm uel drachmarum argenti ) à prín cipibus uero interdum multò pretiofiorés hàberi, Sarmaticum murem urocitant plerique zibels

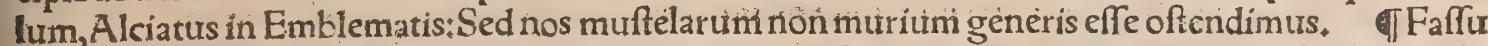
ron(fic peruerterunt Gracam uocem fatyrion, qux Ariftoteli animal quoddam amphibium fignifi cat, de quo mox poft Lutram diximus ) eft chebalius dictis Latiné, hirfutan \& nigram habens pel= lem pretiofam tialde, qua utuntur ante pallià uaria; Albertưs. Niphus Alberti urerbis negligentius ₹ftimatis, fatheriưm alterum animal amphibium apurd Ariftotelem, cebalum (chebalum, fic uocant zobelum ) ex eo facit, fatyrium uerò martarum. Ego ambos errare dixerim: \& fobélos non Ariftote li folum, fed foriptoribus ante Albertum, quorum ad nos libri peruenerunt, omnibus incognitos, cer tenon memoratos elfe.

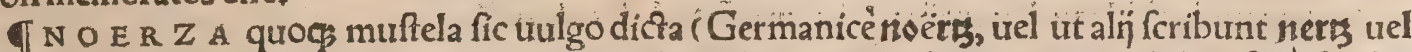
nơt ) in fyluis uerfatur, magnitudine martis. pilos habet æquales $8<$ breues, ato̧ colore fere fimiles lutræ pilisł:fed noerzæ pelles longèlutræ pellibus antecellưnt. atç ha etiam præeltant fi pili candidi cum reliquis fuerint mifti $R$ eperitur hoc animal in uaftis $\&$ denfis fyluis qux funt inter Sucuum $\&$ Vifulam,Ge. Agricola, Mihi pellifex quidam Francfordià narrauit noérżas ex Lituania ha= beri. Oblongæ funt, magis ruffe iltiflis, eadem feréodoris grauitate, toto corpore concolores. Qua draginta audio plerunque uendi feptem aureis Germanicis \& femiffe, hoc eft fexaginta denarijs ar $=$ genteis. Hanc aliqui latacem effe putant, quod urictum exaqua petat.

IV O R M E L A (Germanicé wormlein ) minor eft quàm uiuerra (id eft furo;) \& magis uaria; 6. Etenim prater uentrem, qui quidem niger elt, rotum corpus albis, fubluteis, rutilis, obfcure fuluis maculis decoratur. Cauda etiam qua longa fefquipalmum, habet pilos cinereos cum candidis per miftos, led extrema parte nigros, Ge,Agricola. 
TI Audiui à pellifice quodam inter per egrinas \& nobiles muftelas, effe etiam quandam nomitre S A L A M A D R A M. féd certi nil habeo, fi qux tamen huiufmodi reperiatur, nomen cifortafis à colorum uarietate impofium fuerit, qualis in falamandra lacerto flauis nigrisç maculis difincio fpectatur. f C H I V R C A M mittit India occidentalis émuftellino genere, qure ut fimituulpa, (de qua polt
fimias dicam) catulos fuos in crumena quadam fub uentre circunfert, Cardanus.

II A R D I R O N I figlires funt, ut in Glire mihi uideri dixi, non mutelarum generi, ut Cardas nus facit, fed murium potius adnumerari debent, librodixi.

I GE NE T H A cciam Cardano muftelarum generis uidetur, de qua in G. litera fupra hoc in

\section{NEADES, VEL NEIDES, VEL NAIDES.}

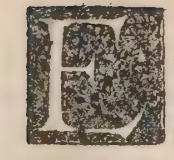

V P H O R IO $\mathrm{N}$ in commentarịs feriptum reliquit, Samum cum olim defertifimã fuffe, tum in ea beftias feras, maxima magnitudine, nomine Neades fuiffe, quarum fola uoce terra difcederet(abrumperetur, Volaterran.) Indéćs profectum effe id prouerbium, qurod uulgò Samñ dicunt,Maius in(forte, uii)Neadum. Idemćs affert, earum offa maxima uel fua ztate extitiffe, Aelianus interprete Gillio. Prouerbï huius mentionem alibi nufquam reperio, nã negg Erafmus meminit. Volaterranus hunc locum transferens, hac quidem uaftx magnitudinis ani malia prouerbio occafionem dediffe feribit, fed prouerbium ipfum non exprimit. Et Cxlius $21.40^{2}{ }^{20}$ prouerbï prorfus non meminit, pracedentia tantum reddens, his uerbis : Samum inirio fuifie defer tam aiunt, \& fuccreuiffe in ea ferarum uim, quarü audiretur intolerandus uelut barritus, qua: dice rentur Nwílis, hoc eft Neides. Quin \& Heraclides in Politijs, Samum infulam (inquit) olim de. fertam animalium guorundam qua ingentem æderent uocem copia habitaffe fertur, nomine Nuíd's.

\section{DE ORYGE.}

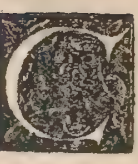

A P R A R V M fylueftrium generis funt \& oryges, foli quiburdam dicti contrario pilonte ftiri \& ad caput uerfo, Plinius. Atqui Aethiopico etiam tauro, alĭ quàm rhinoceroti, pia" lum in contrarium urerti legimus. Oryx quid fit non eft exploratum, Niphus. Idem in tertium Ariftotelis librum de partibus fcribens cap. 2. unicornem hodie diçum nô effe orygem aduerfus Albertum afferit. Domitius Calderinus apud Martiaiem, orygem pro hyfiricerh dicule exponit. $15 \pi$, theo, uocem Hebraicam Hieronymus \& Septuaginta Deut, cap. 14. ubt ine rer cibos puros numeratur, \& Efaix cap. 51. (Filin tui iacuerũt moerore affecti ficut oryx illaqueatus:) orygem interpretantur, ego potius bouem fylueftrem effe fentio, ut Dauid Kimhi exponit, \&c. Vide in Bubalo. Quarendum an difchon potius Hebrais orygem fignificet, pro qua uoce aliqui uni cornem, alń pygargum reponunt: Vide in Pygargo inter Capras feras. Orygem perpetuó fitien tem(aliâs fitientia, icilicet loca, quod magis placet, Afric $x$ generant, ) A frica generat, \& natura loci potu carentem, $8 \mathrm{C}$ mirabili modo ad remedia fitientium. Nanç Getuli latrones eo durant auxilio, $r e$ pervis in corpore corum faluberrimi liquoris hauftu(id eft potu)ueficis, Plinius, Et Getulus oryx, luuenalis Sat. II. Albertus $\&$ alij obfcuri authores, liquorem illum adipfon non intellecto Plinio, in uefica eius ( urinam continente ) ineffe putant, quum Plinius multítudinis numero ueficis dixt rit. Oryx beftia eft caprex magnitudinis, hirco ex parte fimilis, uillum habens fub mento, Author libri de nat, rerum. Caprex fimilis, magnitudine hirci, barbata fub mento:in eremo uerfatur, \& $\&$ facile decipitur laqueo, Albertus. Oryx(inquit Oppiamus libro 2. de uenatione interprete Gillio)in fyl uis uerfatur, feris infeftiffimus:colore eft lacteo, excepto ore nigro, ( folis in facie nigricantibus ges

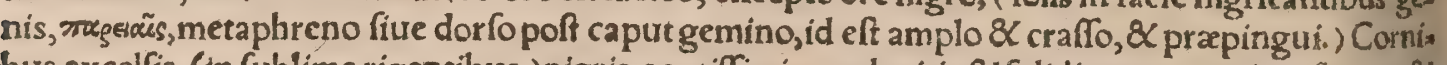
bus excelfis, (in fublime rigentibus, )nigris, acutiffimis, ea duritic $\&$ foliditate, ut ęs etiam, ferrum $\&$ faxum fuperent. (Eadem duritie monocerotis etiam $\&$ rhinocerotis cornua effe legimus.) Sed Grat"

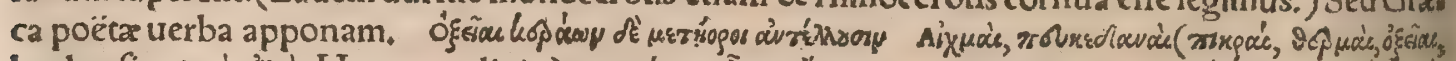

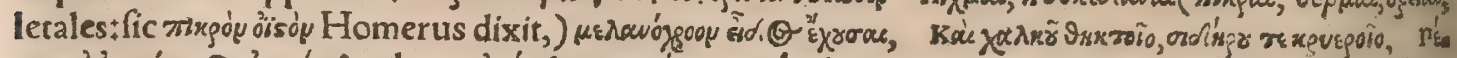

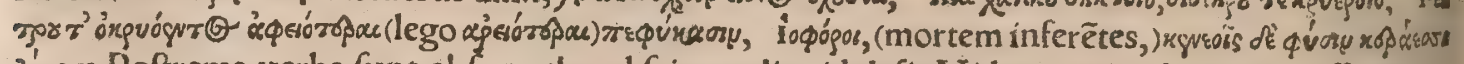
$\lambda \dot{k}$ ron. Poftrema uerba funt obfcura:haud fcio an aliquid defit. Videtur enim dicere uoluiffe prëta, cretera cornua quadrupedũ caua \& inania, orygis plena \& folida effe: ut cerui etiam, unicornium e: rhinocerotis, qua fimiliter eandem ob caufam æque duriffima ualidifïmá́g funt. Caterum animo oryx immani $\&$ crudeli eft: neç enim canis latratum timet, neç apri efferuefcentem feritarem, neq̧ tauri mugitum refugit, neç pantherarum triftem uocem, neक ipfius leonis uehementem rugitum horret: ne $\$$ item hominum robore mouetur, ac fape robuftum uenatorem orcidir. C um atiten ulel 6

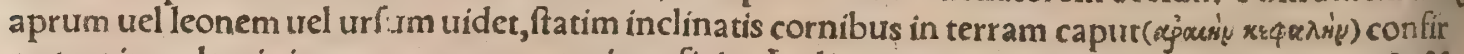
mat, ac inuadentis impe um manet, atç interficit, Inclinato enim capite oblique quodamnodo $\&$ 


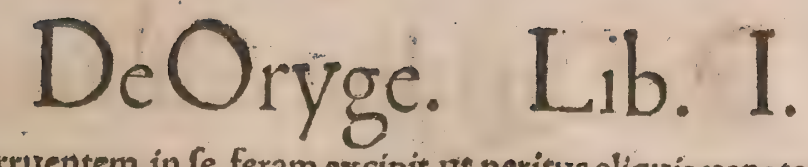

comu protenfo, fic illo irruentem in fe feram excipit, ut peritus aliquis uenator diuaricatis crurib, leonem uenabulo. Facile autem in ferarum pectora, cornua orygis (ineptè hac Gillius ) illabunttrr. unde illa ftatim cruentx fuum fanguinem manantem lambunt, (Interdum inter fe pugnan:; har in Grreco codice excufo non leguntur: quare Gillius aut malé uertit, aut uerba quadam legit in noftris exemplaribus defiderata:fed bene quadrant omnia, etiam fi non ad orygum inter fepugnam, fed orygis $8 x$ alterius ferx, ut leonis, uel urfi, referas.) Neq ubi femel pugna incospta eft, datur fugere. (Alterutrum neceffe eft uincere, aut mortuum iacere, Gillius:cum Gracé nihil tale habeatur, fed ira folum ut fubieci:) Perimunt autem fe inuicem mutuis cadibus. Sic ftrata cadauera amborun frepe: agreftes homines, paftores aut aratores, magna cum admiratione reperiunt, Hactenus Oppianus. Idem alibi rhinocerotem, non multo oryge maiorem effe fribit; cum alĭ rhinocerotem elephanto fe. réparem effe dicant. Et alibı à lyncibus oryges infeftari fcribit, nímirum maioribus: quod nō puguat cum ijs qua paulò ante recitauimus, nempeleones, pantheras aliasćs feras eum non refugerełquìn. uis enim non fugiat, mutua tamen ut dictum eft cade pereunt. Matutinarum non ultima prada fe. rarum Sxusus oryx, conftat qui mihi morte canum, Martialis libro 13. Oryx bifulcus \& unicor. nis eft, Ariftoreles \& Plinius. Audio in Tranfyluania capram fylueftrem unicornem reperiri, fed aliud praterea certi nibil habeo. Plinius quidem caprarum fylueftrium generis orygem facit, à quo Oppiani oryx diuerfus uidetur tum magnitudinetum animo:cum minime timidum eum faciat us reliqua caprarum ferarum genera funt, fed fortifimis etiam feris fe opponentem. Cornua etian Oppianus quot fint orygi non expreffit:uidetur autê fentire non unum, fed duo ci cornura effe: quro. niam femel atç iterum orygem in fingulari numero nominans, de cornibus eius in multitudinis rutr $\Rightarrow$

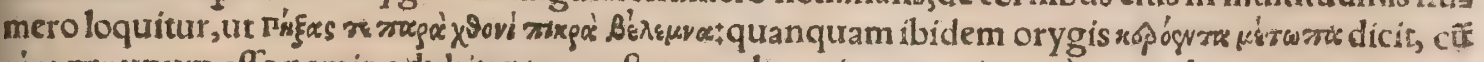

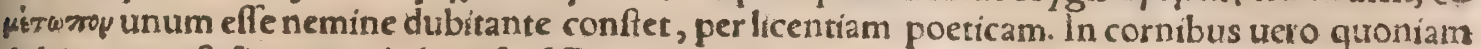
dubitari potef, fi unicum habere fenfiffet, omnino id exprimere oportebat:quud cum non faciat, ${ }_{2}$ cor nua nec plura nec pauciora quàm in cornutis antmalibus qux omnes nouerunt, ei triburffe trideri poteft. A elianum certe miror quí oryges quadricornes dixerit,fireciè tranftulit Gillius:fic cnim le ginus: Tigres domitas, cicures pantheras, 8 oryges quadricornes ad fuum regem lridi afferunt; fed forfitan in India tantum eiufmodi funt, Sic fieri poteft ut magnitudine etiam fecundum regior es plur. rimum differant. Symeon Sethi capream etiam qua mo!chum gerit, monocerotê effe fer ibit: quod fi uerum ef, aut eadem aut congener orygi fuerit: fed prater Symeonem aliorum nemo hoc tradit,

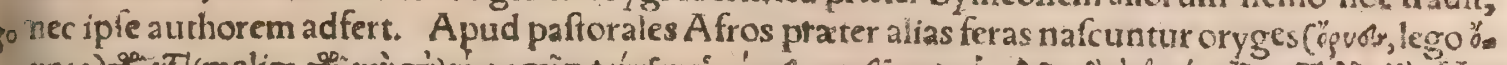

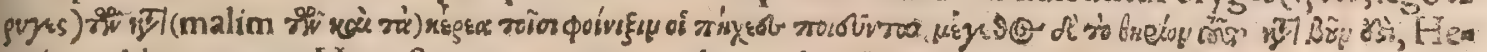
rodotus libro quarto. Hoc eft, ex quor um cornibus cubiti fiunt inftrumentis muficis qura phorices

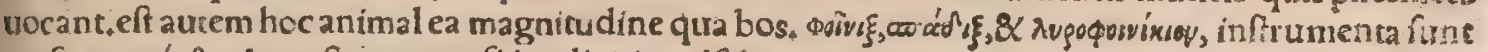
mufica seovoulere, hoc eft quorum fides digitis pul fabantur, ut cithara, chelys, \&e, Pollux libro 4. ini=

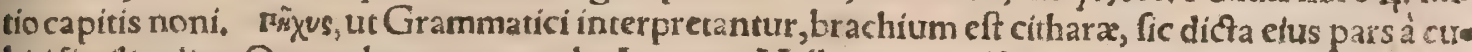
biti fimilitudine.Quamobrem non probo Laurenr. Vallarn qui ex Herodoto tranftulit, quibırs ulna les palmæ pro cornibus fiunr, 2 f fi ex orygum capite aliquid inftar phonicis fiue palma, ulna longi tudine enafceretur, ridiculo certe fenfu. Cum ftruthophagis Aethiopes qui Silli appellantir, Lel. lum gerunt, orygum cornibus pro armis utentes, Strabo. Hinc cornua ifta durifina \& mucronata effe conijcimus, de longitudine enim non conftat cum pilis ligneis prafigi potucrint. बEt Getut= lus oryx hebetilautifima (cœna)ferro Cxditur, Iumenal, Sar 11. TOryges apud Strabonem ali. qui uocari putant marinas orcas, ut Hermolaus foribic in Caftigat.in Plinium. TOrynx,"ogrvy a a nimal eft quadrupes dorcadi fimile colore, (Albertus etiam caprea fimile effe fcribit,) ) uel genus fca-

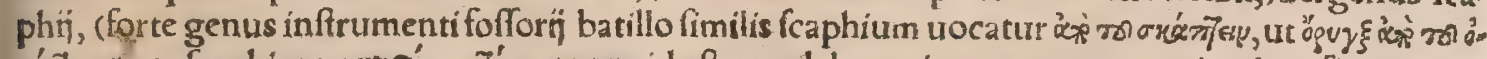

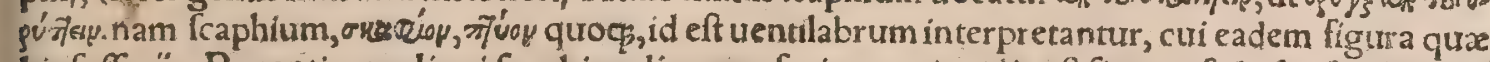
his fofforins $s_{4}$ Recentiores aliqui fcaphium ligonem faciunt, cuius alia eft figura, fed ufus fimiliter ad

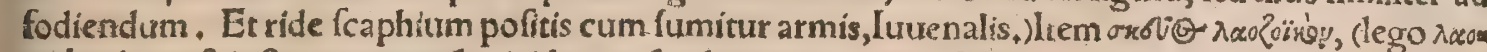
Foing,

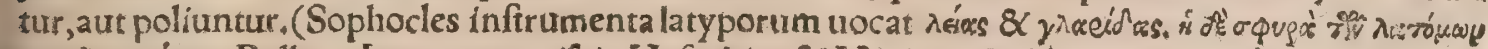

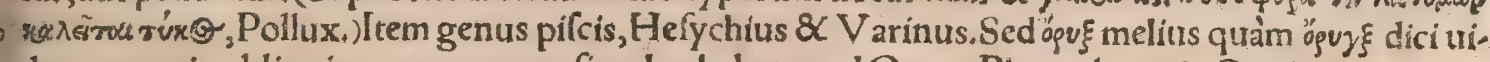
detur: nam in obliquis quoç gamma fimplex habet apud Orum, Plutarchum, \& Oppianum, ut $\otimes v$

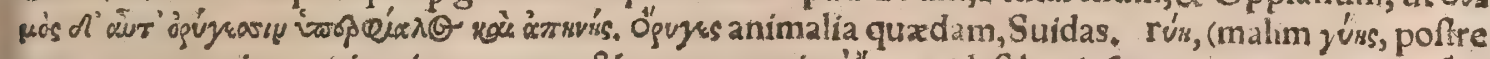
ma pars temonis, qux iam incuruatur, \& quam proxime \& $\lambda v u_{\ell} \alpha$, ideft buris fequitur, cui uomer inferi

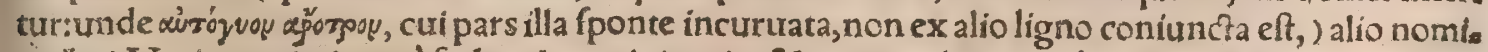

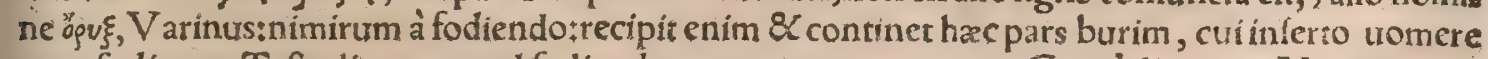
terra foditur. Teftudines qux ad fodiendum comparantur, oryges Græcé dicuntur, Viruuius 10. 21. Vbi Philander fcholiaftes, Suffolfuri turres, inquit, aut moenia urbis (Cxar agerecuniculos di. cit, quros minas uocamus) utebantur teftudine fronte triquetra, ut miffa tela dum in angulo confine re non poffunt, per latera laberentur \& reńcerentur:in ea machinatione comparati erant ad fodien 60 dum homines, unde nomen accepit, nam ógúw fodio fignificat. Trygem appellat A egyptus fe ram, quam in exortu Caniculæ contra ftare $\&$ contueri tradit, ac uelur adorare, cum fternuerit, Plini us. AfriAegyptios ob hoc rident, quòd orygem quo die horaç Canicula oritur uocem ædere fabu 
lenturłipforum quippe capras quoties cum Sole codem plané loco ftella hac oritur, in ortum omnes contrer fas eò refpicere, atç hoc fyderis eius reuolutionum argumentum certiffimum effe, cumćs de cretis aftronomicis prorfus congruere, Plutarchus in libro Vtra animalium, $\& c$. Eadem apud $A$ e, lianum paulò aliter leguntur, quare adfcribam: Aegyptif (inquit) dicunt orygem canicula exortum cognofcere: Libyci confidenter \& fortiter afferunt, fuum caprinum pecus finiliter eiufdem ftell exortum prafcire:itemó pluuias prafentire. Aegyptij impurum (inquit Orus interprete partim Gil lio partim Mercero) fceleftumós notantes animum,orygem pingunt:quoniam ad ortum accedente Luna, intentis in deam oculis fufpiciens, uociferatur: idḉs illius odio non amore eum facere ex eo lis quet, quòd prioribus pedibus terram effodit(hinc fieri poteft ut à fodiendo etiam nomen apud Gra, cos fortitus fit. Idem \& à lupi quodam genere, aureum uocant, factitari apud Oppianum legimusł)

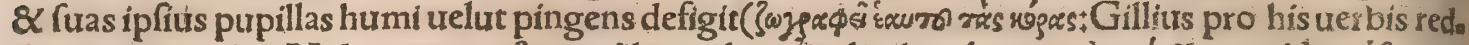

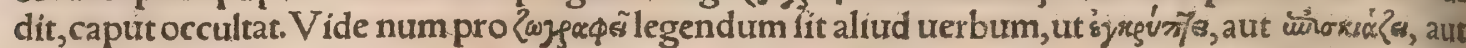
fimile) quafi indignabundus inuitus $\oint_{\beta}$ dex ortum afpiciens, Idem quoģ in exortu dei, Sol is inquam; efficit. (Sequentia tanquam obfcura Gillius omifit.) Qurapropter antiqui reges cum fibi ortum nun ciaret horarum obferuator, huic infidentes animali per medium ipfum uelut gnomones quofdam,

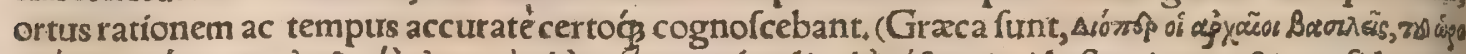

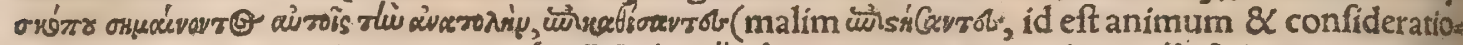

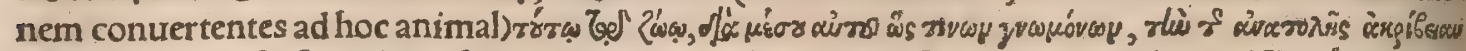
\&yvíe:?ov.) Vnde $\&<$ facerdotes folam hanc inter uolucres non fignatam comedunt: (

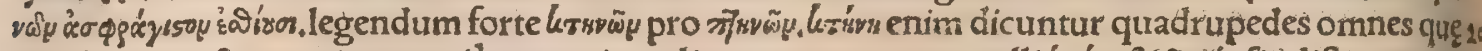

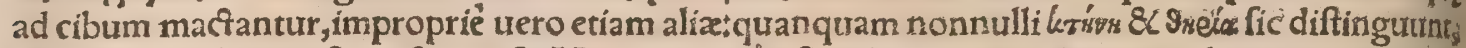
ut hac fera, illa manfueta fint, tefte Varino: ) quồd fimultatem quandam cum dea exercere uidea. tur. Etenim quemcunģ in deferto locum aquis fcatentem nactus fuerit, pofteaquam biberit, labris turbat, lutumó aqux commifeet, ac pedibus in eam puluerem conịcit, id̛́ć ut nulli alij animantia qua fit ad potum idonea, Et fane quum dea omnia qua toto orbe funt utilia gignat, augeat ac uegee tet, ingratus $\&$ impius in eam ory $x$ uideri deber, Hac Orus. Apud Aegyptios qui Serapidem $\mathrm{CO}_{*}$ lunt, ex eo orygem malè oderunt, quòd ad Solis exorum conuerfus, ficut A egyptỉ ferunt, aluum deijciat, \&c.A elianus. Oryx oriente cane mirabiliter exultat, quafi tunc conualefcat, Alber. Quũ oritur Canicula naturaliter tripudiare uridetur, corpore fcilicet eius manifeftò percipiente imbrem $\&$ frigus praterĭffe, \& inftare uapores ignei Solis, ut ueftiatur terra floribus, herbas ćs proferat\& $\xi_{0}$ fructus, Eft enim frigoris $\&$ niuium impatiens, Liber de nat.rerum fine authore. Feræ pecudes, ut capreoli damæọ́, nec minus orygum cer uorumćs genera, \& aprorum, modo latrtitrịs \& uoluptati: bus dominorum feruiunt, modo quxeftuí ac rediribus, Columella 9. 1. Et aliquanto poft, Nec uero patiendus eft oryx, aut aper, aliusue quis ferus ultra quadrimatum fenefcere: nam ufक̧ in hoc tem pus capiunt incrementa, poftea macefcunt fenectute:quare dum uiridis çtas pulchritudinem corpo ris conferuat, are mutandi funt. Orygern quidam ætatis noftra fcriptores, forminino genere non reçè efferunt:nam Plinius, Oppianus, Plutarchus, Orus, malculino tantum genere utuntur.

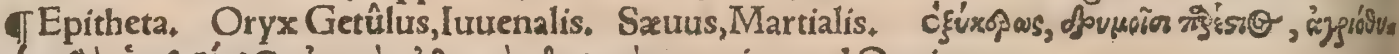

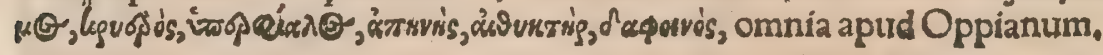

\section{E O V E.}

\section{A.}

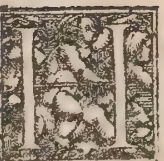

E B R A E I diuerfa habent nomina, quibus ourem \& genus ouillum fignificãt, ‘k*, zon, ouis, grex outum, indeclinabile, Genefeos zo. Inuenitur pro eodem nuy zoneh, P falmo 18.Scribitur etiam y7y zon. Dauid Kimhi(uide eundem 1.Reg.25.) in libro Radicum res çèinterpretatur pecus parưum agnorum \& caprarum, ut generis nomen ad minorape cora(id eft ouillum \& caprinum genus) fit, ficut $¥ p=$ bakar ad maiora. Septuaginta pro zon fape ${ }^{\circ}$ transferunt mgóbazra. Hieron, oues Amos 7. In principio Leuitici legimus oues \& capras pecorum

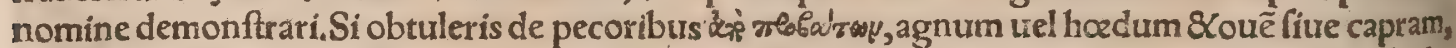
Genefeos 4. Chaldxus 1 עy transfert. Vertunt enim Syri aliquoties zade in ain, (Hinc 8 anabula,

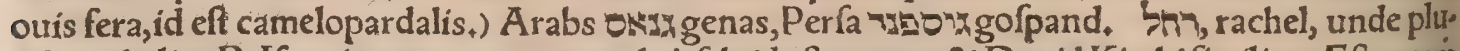
rale rechelim, R. Ifaac interpretatur nשz $\mathrm{kab}$ fah, id eft agnam, \& Dauid Kimhi fimiliter, Eft autem propriè ouris foemina, ut kebefch mas à quo tamen foemininum kibfah fit. Efaix 53. legimus, rahel nee

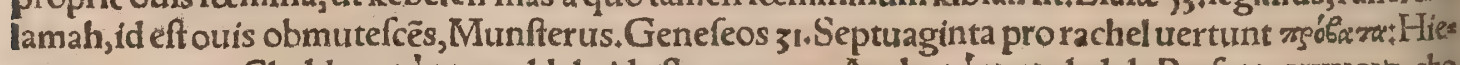

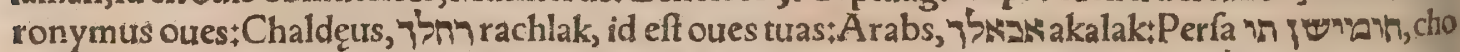
mefchan thu. egreffus dicitur $\zeta n k$ aipl uel eel, author Dauid Kimhi. A braham Efra etiam docet ail maiorem effe na 60 tu. Leuitici quarto kebes legitur foeminini generis, L XX. red dunt à $\mu v \alpha \dot{s}$. item Letritici duodecimo le girnus de immolando agno(kebes)anniculo: quare etiam alibi, licetnon expreffa unius anni ætate, 


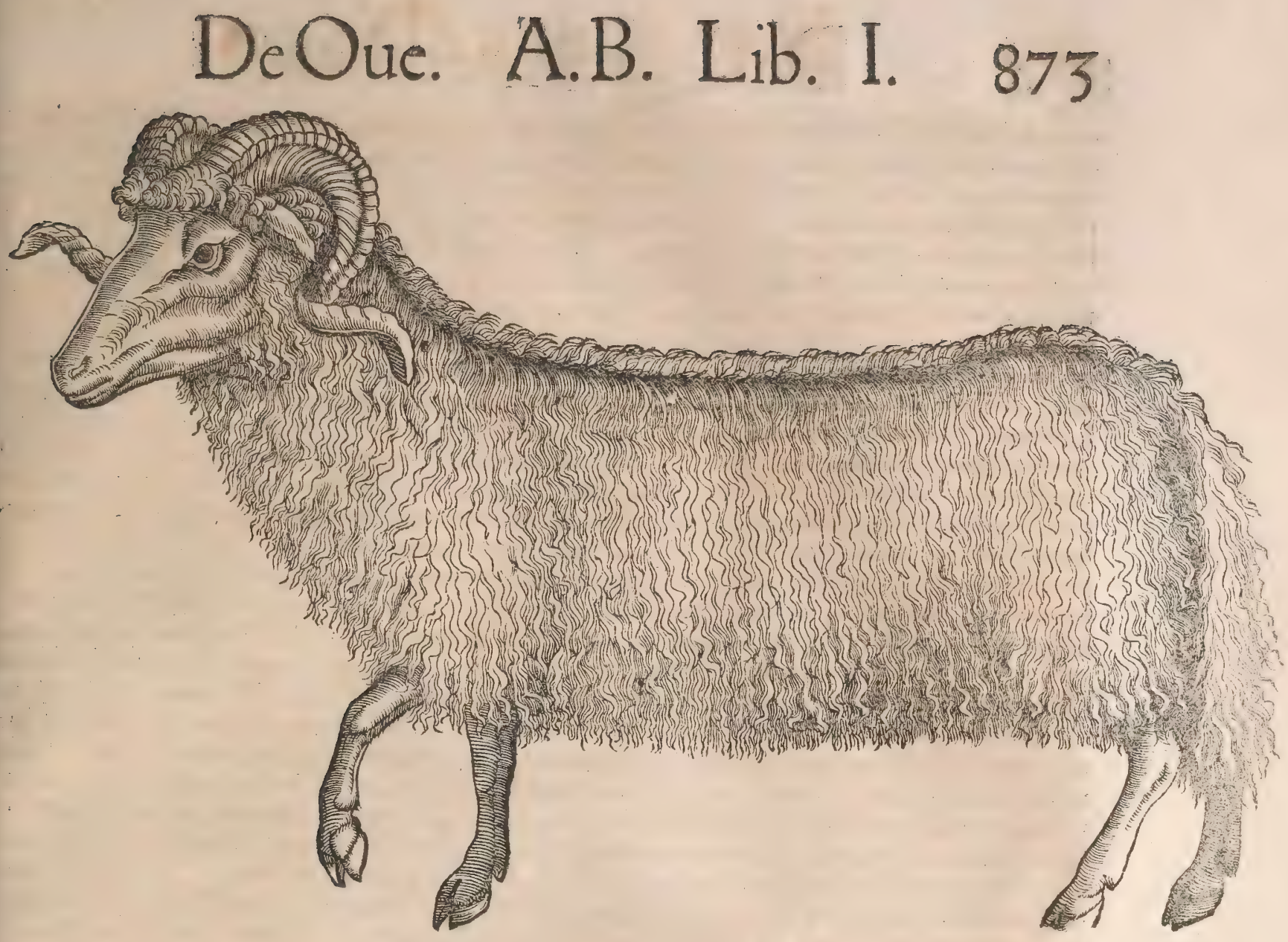

yo docti tamen eandem intelligunt. Leuitici 12.Chaldaus pro kebes uertit, thas, imar: Arabicus inter. pres $2 x y$, egl:Perficus na, barah. Kebes, inquit Munfterus, eft agnus $\&$ grex agnorum, Horeæ 4 . Vnde plurale kebafim Ezec. 46. Foemininum kabfa \& kibiah, outis, agna, 2. Reg 12: Plurale kebafoth Genef, 21. Eft $8 X$ בשב, kefeb, idem quod kebes, agnus, ouis. Plurale kefabim Genef, 30. (\& Deut, i4.

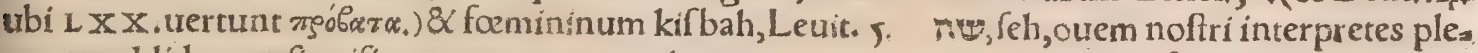
rung reddiderunt:fignificat autem pecora minora, nempe oues $\&$ capras, tum foeminas tum mares $\pi \in$, feh, inquit Mũfterus, eft pecus, grex, aries, agnus, ouis, generis communis ₹ accipitur autem pro agnis $\&$ hoedis.

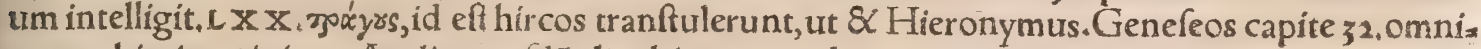
no pro hircis accipitur; Audio quofdã alicubi arietes uel totıım genus ouium interpretari (quod nó $4^{\circ}$ probo.) Vide in Hirco A. Chaldęus reddit teiafiah, Arabs teius, Perfa aftarha. Taifch (inquit Munfte rus)eft aries, uel fecundum alios hircus minor qui antecedit gregem ouium, \& facile afcendit rupes $\&$ loca alta, Prouerb, 30. Plurale eft teiafchim, hoedi, Genefis 30 . hל, thaleh uel theleh, (plurale the. laim, Efaix $4^{\circ}$ ) author concordantiarum kebes, id eft agnum exponit: Dauid Kimhi addit lactente $\tilde{e}_{\text {; }}$

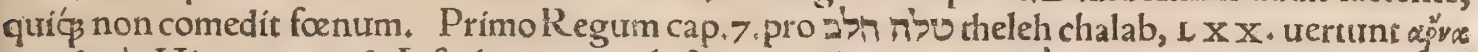

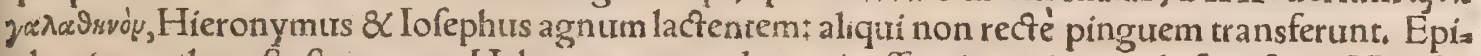
phanitus author eft aftronomos Hebræos ea uoce denominaffe arietem in circulo fignifero. Magiftri (inquit Munfterus) pro figno arietis cœleftis capiunt. השיק, kefithah, D.Kimhi \& R. Salomon in terpretantur ex fententia R. Akiba, qui teflatur fe profectũ in A rabiam, audiuifle quod ñyve meah numum uel potius denarium $\&$ ficlum uocarint kefithah. Onkelus autem Chaldxus interpres $\mathrm{Ge}=$

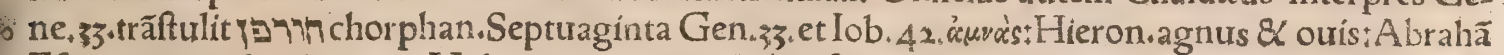
Efra, agnus uel ouis parua. Videntur autem doctia noftrx religionis hominibus agnam interpreta ri.Author concordantiarum, moneta quædam: Aug. Steuchus, denarius uel obolus: Nicolaus Lyra nus, obolus. $\pi \in$, feh, ouis urel capra, uide in Agno A. TAldan, id eft ouium, in utrogg fexu, Bellu nenfis, Videtur autem dan à Syr is dicium pro zon Hebraico, zade mutato in daleth. Oues hodie â Saracenis ganeme dicilegere memini. Garien, id eft pecora, Syluaticus. Hara garien, id eft fter cus pecortum, Idem. Alliat, id eft caudarum ouium, Bellunen fis, Ouis Gracis efl móobarop, \& o ois ue teribus: hodie unulgò mbbaziva, Vide in $\mathrm{H} .2$. Latiné etiam pecus pecudis per excellentiã pro oue fre quenter Plinius utitur:\& Italis hodiẹ́́p pecora dicitur. Gallicèbrebis,Hifpanis ouéia. Germanis, Thareff. Anglis, rheepe. Illyrins owcze uel rkop.

Pherecydes Gades Erythiam uidetur appellaffe ‘ubi tanta pabuli lectitia perhibetur, quròd pafcen tium ibi pecudum lac ferum non efficit, cafeumág multum immícentes aquam conficiunt $\ddagger$ tantum 
exuberat pingue. Tricefimo die animal fuffocatur, nifi aliquid cruoris exhaurriatur. Herba uerò quă pafcuntur oues, ficca quidem eft, fed incredibilem gígnit aruinam. Quibus ex rebus fabulam de Ge ryonis armentis confictam efle, cóiecturas faciunt, Strabo lib.3. TOues in Aegypto maiores quàm in Gracia fiunt,Ariftoteles. TOues Pyrrhicx in Epiro proueniunt, egregia magnitudine, a Pyrrho rege ita cognominatx, A riftoteles, Apud Indos Pfyllos (nam funt etiam alin in Africa) oues magnitudine non fuperant agnos noftros; Aelianus. Aefchylides in libris de agricultura fcripfit, minutiffimas effe oures in Chio pabuli inopia, cafeum tamen ex eis laudatiffimum, Volater, ranus ex Aeliano. Hifpania nigri uelleris pracipuas habet, Polentia iuxta alpes cani:Afia ru. tili, quas Erythræas uocant, item Bxtica: Canufium fului:Tarentum \& fux pulliginis, Iftria Libur. nix́́ pilo propior quàm lanæ, pexis aliena ueftibus, \& quam fola ars fcutulato textu commeñdatin Lufitania:Similis circa Pifcenas prouincix Narbonenfis :Similis \& in Aegypto, ex qua ueftis detri: ta ufu tingitur, rurfusćs æuo durat. Eft $\&$ hirtæ filo craffo in tapetis antlquiffima gratiałianti certe pri fcosịs ufos Homerus autor eft. Aliter hxc Galli pingunt, aliter Parthorum gentes, Plinius, Et rur: fus, Lana autem laudatiffima Apula, \& qux in Italia Graci pecoris appellatur, alibi Italica. Tertium locum Milefix oures obtinent. A pula breues uillo, nec nifi penulis celebres, Circa Tarentum Canu fiumós fummam nobilitatem habent. In Afia uero eodem genere Laodiceę. Allba circumpadanís nul la prafertur, nec libra centenos numos ad hoc aui exceflit ulla. Generis eximí Milefias, Calaz bras A pulasć noftri exiftimabant, earumó optimas Tarentinas. Nunc Gallicæ pretiofiores haben tur, eartımó præcipué Altinates,item qux circa Parmam \& Murinam macris ftabulantưr campis, Columella, Heluetia cum alibi tum in fummis etiam alpibus oues alit; idç altius qưàm capiras, 1, capræ enim frutices fequuntur, qui excelfis cacuminibus defunt. Oues quafdam ex inferior e Ger: mania noftri fle ruing nuncupant,id ef Flandricas, quæ mollem \& crifpam gerunt lanam; Oues pellitæ propter lanæ bonitatem, ut funt Tarentinæ \& Altinates, pellibus integuntur, nelana inquis netur, quo minus uel infici recté poffit, urel lauari, ac parari, Varro. Lana qua non mollis fed hirta fuerit, folox uocatur, ut $\&$ ipfum pecus, quod paffim pafcitur non tectum. Pafcali pecore, acmoni tano hirco atç foloce, Lucilius. Ego ab lana folocia ad puram data, Titinnius. Tarentinas oures \& nuces dicunt, qux funt terentinx, à tereno, quod eft Sabinorum lingua molle: unde Terentios

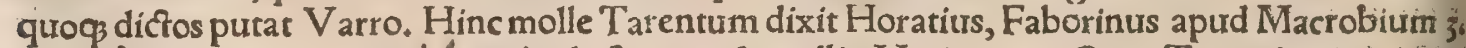

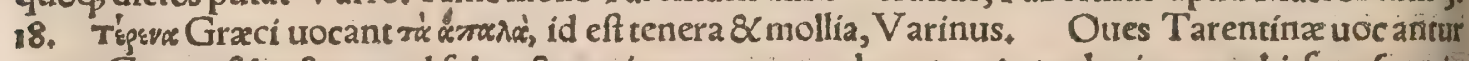
etiam Gracæ, \& tectæ, quod fub tecto maiore ex parte alerentur, ( ut colonicæ qua hirfuta funt, in, agro ) uel quod propter uelleris pretium pellibus integerentur : quare \& pellitx \& hirtæ Varroni dicuntur, item A fianæ, nam ut locis aut aliter etiam differant, mollitie tamen uelleris conueniunt, Ouium fumma genera duo, tecfum $\&$ colonicum. illud mollius, hoc in pafcuo delicatius, quippe cï tectum rubis uefcatur. Operimenta eis ex Arabicis præcipua, Plinius, De his plura dicam capite ex Columella, Athenæus libro 12, oures ex Mileto \& A ttica, tanquam præcipuas commendat, Gadilonetica regio uocatur poft Halyos oftia uf́p ad Armeniam, tota campeftris : oues habet mollis pellis \& lanx, quod in tota Cappadocia at $\$$ Ponto perrarum eft,Strabolibro 12. Ouillum pecus in Aethiopia lanæ inops, pilis camelorum hirfutum eft, Aelianus, Sed de lanarum differentia di. cetur pluribus in E.8 $e$. बA Abydenas oues nullas uideri albas, fed nigras omnes ferunt, Aelias nus. Et alibi, Ariftotelis filius Nicomachus in Budianorum regione ait albam ouem nullam nafci, to $^{\circ}$ fed nigras omnes effe. Videndum ne pro Budianilegendum fit Abydeni, uel contra. Oppianus 2. de trenatione, tradit, in Gortynide $\&$ rufas 8 quadricornes effe oues, Aelianus. TOues in Ponto fine felle effe dicuntur, in Naxo autem felle duplici: Vide infra ubi de felle, TOues Indix \& ca: pras ad maximorum magnitudinem afinorũ audio accedere. Quatuor foetus cum plerunç tres trerò cum minimum, nunquam minus tribus tum oues tum capra, Caudx ourilla longitudo ad pedes ufç pertinet.idcirco eas paftores ouibus matricibus abfcindunt, quod tum fic facilius inean tur, tum ex earum adipe oleum exprimatur. Arietum quo ĉio coniunctiffimé committitur, cicatricis ut ne tenue quidem ueftigium appareat, Aelianus, In Syria oues funt cauda lata ad cubiti menfuram, Ariftoteles 、Syriæ cubitales ourium caudæ, pluris mumćs in ea parte lanicí, Plinius.Ctefias ait apud Indos ouillæ caudæ latitudinem cubitalem effe, so A elianus. Præditas effe oues Arabix caudis infolitis \& diuerfis Herodotus fribit: earum fanéduo genera ponit, ( quæ nufquam alibi uifantur) unum dicit caudas maxima magnitudine habere, ut dimetienti non tribus breuiores fint cubitis, qux fi trahantur, omnino ad terram atteruntur, $8 \mathrm{cx}$ ulcerantur ${ }_{4}$ At paftores ad fabrilem artem inftituti, ploftella fabricant, ad qux quidem ipfa alligata caudæ nituntur $\&$ fuftinentur, quo fit, ut à uulneratione defendantur. Alterum caudarum genus di cit effecubitali latitudine, Aelianus ex Herodoti li.z. Quæ ad Oceanum pars refpicit fupra focii. cem Arábiam pofita, pecoribus, bubus, $\&$ ouibus magnas pinguesćs caudas habentibus abundar, Diodorus Siculus. Oures in calidis $\&$ ficcis regionibus caudas multò latiores habent, lanam uerò duriorem:in frigidis urerò \& falfis $\&$ humidis, lana eis mollior, cauda anguftior, Albertus . Idem alibi fcribit fe uidiffe plures oures, quarum caudæ latæ fuerint palmum (dodrantem) $\&$ amplius,

बA pud Garamantas ourillum pecus carne \& lacte alitur, A elianus. TDeouibus in Aegypto, Africa, \& Magnefia bis anno parientibus, \& in Vmbria ter, dicam in $c$. 


\section{De Oue. B. Lib. I.}

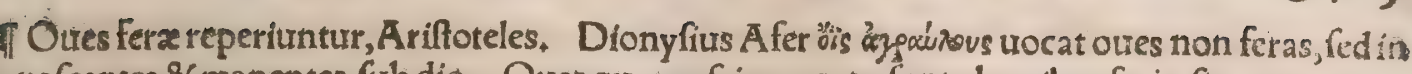
agris pafcentes \& manentes fub dio. Oues quas pafcimus orta funt ab ouibus feris, fic capra quas alimus à capris feris, Varro. Et alibi, Etiam nunc in locis mulcis genera pecudum ferarum funt al quot, ut in Phrygia ex ouibus, ubi greges uidentur complures. Cum in municipium Gaditanum ex uicino A frica miri coloris fylueftres ac fexi arietes, ficut aliæ beftix munerarịs deportarentur, pa. rtuts meus quofdam mercatus in agros tranftulit, 8 manfuefactos tectis ouibus admifit, Columella, Videntur, atte arietes ifti mufimones fuiffe, cum $\&$ feros $\&$ hirtos fuiffe, $\&$ coire cum oubus non de trectaffe legamus, qux tria etiam mufimoni conueniunt. Oues feræ non multo quidem noftris $\mathrm{c}_{a}$ uibus domefticis maiores, fed certè ad currendum uelociores, 8 ad pugnandum fortiores, tum re:

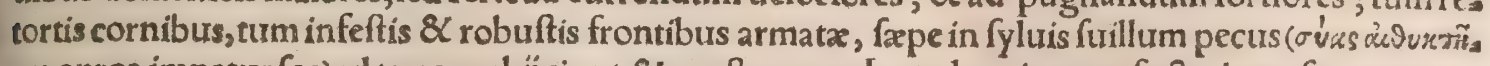
pas, apros impetuofos)ad terram abijciunt, $\&$ profternunt: Interdum impetu facto inter fe pugnant, Negs ubi femel pugna commiffa eft, fas putant fugere, imo frontibus confertis, alterutram eft necef fe aut uictoriam referre, aut ftratam iacere mortuam, Gillius ex Oppiano. Quintus Fulurius lepo; rarium dicitur habere in quo præter cætera animalia incluf $x$ funt oues fer $x$, Varro. Montes cfre aunt in intimis regionibus Indix, ubi qux apud nos beftix domeftic funt, feras aiunt effe, ut oues, capras, boures, A clianus. Ad arietes agreftes, prourerbium tuide fupra in prouerbio In capras feras.

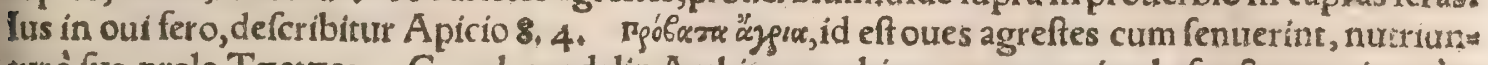
turà fua prole, Tzetzes. Camelopardalin Aethiopes nabim uocant, animal afpectu magis quàm feriate confpicuum quare etiam ouis feræ nomen inuenit, Plinius. A toce nabis Albertus 86 alif uidenzur anabula uocem detorfife, pro eodem animali*quanquam etiam defenderit aliquis, quon: am ana syy ourem fignificat, (Chaldaice ut reor, ) anabula poffe ouem feram fignificare, ut turebalah (Similiter Chaldaice') bouem ferũ. Alberto quidem ana longé aliud eft animal, de quo uerba eius fusa pra fratim pof hy $x$ na hiftoriam inter animantes hyænæ congenexes recitaui. Extat Gordiani fyl. us memorabilis, in qua picta etiam nunc continentur tum alia diuerfa animalia, tum oures feræ cen. tum:quax omnia populo rapienda concefferat die muneris quod fextum adebat, Iul. Capitolinus. बDe mufimone, qui genus ouis fylueftris eft, $\&$ ouibus Creticis, dicam infra mox poft Agnum. Vi

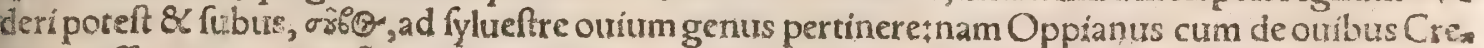
ticis egiffet, quas colore flauo uel purpurafcente effe frribit, quadricornes, non lana fed uillo feré caz prino tectas, fubiungic: Quinetiam fubus colore flauelcit fplendido, fed non aque uillis hírfutus eit, 30 8 duro antum ualida cornua fupra latam gerit frontem, Idem amphibius eft, \& pifces deciorat, qui quidem ipfum natantem miro quodam fiue odoris fiue alio defiderio allecí gregatim fequuntur. Eiufdem generis colon rónoy etiam dixerim, ut Strabo uocat, quadrupedem apud Scythas \& Sarma tas inter arietem \& ceruum, uelociorem, corpore albicante, \& c ut fupra in Coli hiforia dixi. Hodie inac(uel ut alij f cribunt frak uel fniatky) appellari puto apud Mofchouritas, candida eft \& fine lana: de quo hic adijciam uerba Macthia à Michou, qux in Coli hiftoría omifi, Apud Tartaros (inquit) ie pcriuntur cerui, dama, dorca, \& fnak. Id animal eft magnitudine ouis, in terris alips non urifrm, lana grifeum, duobus paruis cornibus praditum, curfu uelociffimum. Carnes eius fuauifimæ. Horum animalium grex cum alicubi inter gramina in campo confpicitur, imperator Tartarorum cum equ! tibus fuis eum circundat, in altifimis gramintbus delitef centem. Et cum equites tympana incipiunt - fonare, fnaccæ tanquam metu perculfar rapidifime huc illuc ab una parte circunftantium ad alteram procurrunt, idçs toties donec pr $æ$ laffitudine deficiant; $\mathcal{Q}$ ita ab irruentibus Tartaris cum clamore occiduntur, Hac ille. Attribuit autem ei lanam, improprie for taffisłlanis enim carere hoc animal au: dio, ut mufimones etiam \& oures Cretę, item colorem grifeum, ego candidum effe audiołfed fieri po teft ut inter utrungs medius fit:grifeus enim fiuc cinereus aut canus, ad album accedit. Caterum cas pi eas hoc modo, dum tympanis territę curfu fubinde reciproco laffantur, uerifimilius mihi fit, quàm ut quidam referunt, defatigari eas ad tympana faltando.

q Color albus in ouibus cum fit optimus, tum etiam eft utilifimus, quòd ex eo plurimi fis unt, neque hic ex alio. Sunt etiam fuapte natura pretio commendabiles pullus at $\phi$ fuffurs, quos

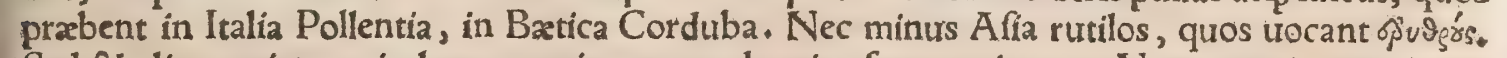
- Sed \& alias uarietates in hoc pecoris genere docuit ufus exprimere. Nam cum in municipi: um Gaditanum ex uicino Africæ miri coloris fylueftes ac feri arietes, ficut aliæ beftiæ munc= rarís deportarentur, patruus meus quofdam mercatus in agros tranftulit, $\&$ manfurefactos te ctis ouibus admifit. Ex primum hirtos, fed paterni coloris agnos ediderunt, qui deinde $\&$ ipf Tarentinis ouibus impofiti, tenuioris uelleris arietes progenerauerunt, Ex his rurfus quicquid conceptum eft, maternam molliciem, paternum $\&$ auitum retulit colorem. Hoc modo Colu $=$ mella dicebat, qualemcunø, fpeciem, quæ fuerit in beftijs, per nepotum gradus mitigata feritate, re: dịffe. Ad propofitum reuertar.Ergo duo genera funt ouilli pecoris, molle, \& hirfutum. Sed in utro que uel emendo plura communia, quadam tamen funt propria generofi, qua obferuari conueniat Communia in emendis gregibus ferè illa, fi candor lanæ maxime placet, nunquam candidifímos ma res legeris, quoniam ex albo fape fufcus editur partus: ex ery thræo uel pullo nunquam generatir albus, Columella. Oues intonfas mercaberis ti coloris, Idem. Oues nifl lanatas emi non oportebit quò melius unitas coloris appareat, Idem. 
Oues primum oportet bonas emere:quafita atate,fi neq uetula funt, neç mer agnx, quoò alterę iam nondum, alter ram non poffunt dare fructum + fed ea melior atas quam fequitur fpes, quàm ea quam mors. De forma, ouem effe oportet corpore amplo, qua lana multa fit, \& molli, uillis altis, \& denfis toto corpore, maxime circum ceruícem $\&$ collum; uentrem quoqg ut habeat pilofum: (Eade Florentinus fcribit in Geop.)itaç quæid non haberent, maiores noftri apicas (forte quafi ámókrs, à priuatione lanæ) appellabant, ac reifciebant:effe oportet crüribus humilibus, caudis obferuare, ut fint in Italia prolixis, in Syria breuibus, Varro \& Crefcentienfis. In ipfa oure fatis generofitatis often ditur breuitate crurum, uentris ueftitu:quibus nudus effet apicas uocabant damnabantó́ ; Plinius, Foemina poft bimatum maritari debet+iuuenis habetur quinquennis, fatifcit poft annum feptimum, Maiorem trima, dente minacem, fterilem repudiabis. Eliges bimam, uafti corporis, ceruice prolixa, prolixi uilli,nec afperi, lanofi $\&$ ampli uteritnam uitandus eft glaber $\&$ exigưus, Columella. $F \propto$ mina debet bima fubmitti, qux uf $q$ in quinquennium foeturæ neceffaria eft, anno feptimo deficit, (Sed de atate ouium, uide plura in $c_{*}$ ) Eligenda eft uafti corporis, 8 prolixi uelleris acmolliffimi, lanofi, \& magni uteri,Palladius. Lana fit multa, mollis, nec coloribus uaríjs diftinća:oculi magni, crura prolixa, $8 \mathrm{C}$ cauda fimiliter. Tales enim funt praftantiores ad agnorum educationem, Florenti nus. Oues nec uetula fint, nec meræ agnæ. Ea quidem atas melior eft quam fequitưr fpes, quàm ea quam mors. Probantur etiam ex progenie, fi agnos folent procreare formofos, Crefcentienfís, đSunt qua mollem quidem habeant pilum, fed minus tenuem, ut lepores contra quàm ouies, Árifto teles. Et rurfus, Oues frigidi tractus contra quàm homines afficiuntur. Scythre enim molli funt pilo; at oures Sauromaticæ duro. Timida animalia ferèmolles pilos habent, ut ceruus, lepus \& otres, Idẽ, 1 Optimæ oues funt qux tenuem fluidamós poffident lanam : qux enim incrifpantur lanugine, ex quidem natura languida habentur, Florentinus interprete Andrea à Lacuna. Gracé legitur, Äessu dèt

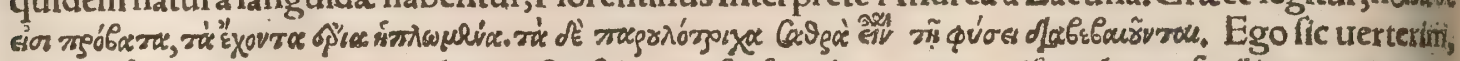
Maximé probantur oues, quibus rectæ \& extenfæ funt lanæ; nam crifpas (lanas) facilius natura cor rumpi affirmant, Si quis non lanas, fed oues ipfas quarum crifpa funt lanæe citius corrumpiafferat, huic non aliter refponderim, quàm expectare me fententiam opilionis, aut hominis quir oures poffe derit uel curârit. Sues hybernum pilum non amittunt, cum cæeteræ quadrupedes, ut canes $8 \mathrm{Cboa}$ ues amittere foleant. Nímirum quoniam catera quadrupedes magis obnoxiam frigori cưtim han bent, \& pilirefrigerati defluunt: fus uerò calidiffimus eft, $\&$ pilos habet pingui infixos, \&c, Ouese tiam ac homines propter fui pili tum denfitatem tum copiam, non ita affici pulfu frigoris poffunt non enim altius refrigerationi fubire licet, ut poffit uel humorem gelare, uel calorem concoquendo feuocare, Ariftoreles problem,10,23. Et fequenti problemate caufam quarit, Cur ouribus expilatis mollior pillus fubnafcatur, homini durior. Et deinceps, Cur ouium pili eo duriores fint quo prolixio res: hominum contra molliores quo prolixiores. De lanarum differentijs, fecundum regiones pra cipué,nonnulla attulifuperius، TInfirmiffimum pecori caput,Plínius. T Ouis cerebrum fqua lidius eft,id eft minus pingure, Arriftoreles. Cornua tenuiora foeminis plerunque funt, ut in pecore, multis ouium nulla, nec ceruarum, Plinius. In Africa arietes ftatim cornigeri generantur, nec fo, lum mares, ut Homerus fcribit, fed etiam foemina. Contrà in Ponto per prouinciam Scythicam nul lis cornua enafcuntur, Ariftoteles. Agni cur in Libya ftatim cornuti nafcantur, ut Homerus etiam Odyffex quarto teftatur, fupra in Boue $\mathrm{H}$, b. ex Herodoto rationem reddidimus A Albertus tefta 4 tur fe uidiffe arietem quatuor magna cornua in capite geftantem, \& duo longa in cruribus caprinis fimilia, Oues in Anglia cornuta funt prater morem aliarum regionum, Munfterus. Ego non alia ud differre Anglicarum ouium cornua a cateris audio, nifi quòd ferè magna funt, \& in una pecurde aliquando quaterna aut etiam fena reperiuntur. Oculi boum nigri funt, ouium aquini, Ariftot, de generat. 5.1. Cxteris animantibus cum careant manibus, defpiciant prorfus in latera neceffeeft: itaque plus eorum oculi diftant inter fefe, \& maximé ouium eó quòd maximé prono capite ingredi-

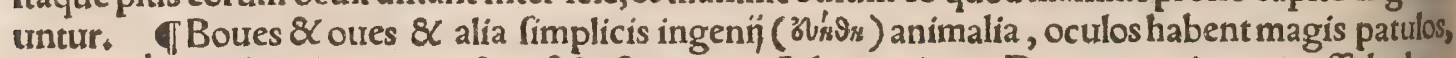

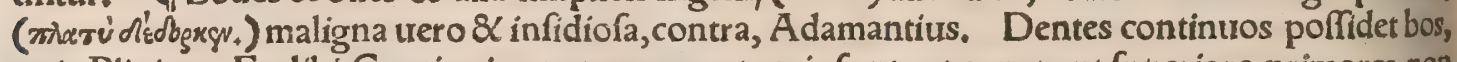
ouis,Plinius. Etalibi, Continui aut utraque parte oris funt, ut equo; aut fuperiore primores non funt, ut bubus, ouribus, omnibusḉ qux ruminant. Maribus plures quàm foeminis dentes in hos $s$ mine, pecude, caprísue. Oui pauciores funt dentes quàm arieti, Ariftoteles . Bidentes qui xftimant ob eam caufam oues à Vergilio dictas, quòd duos dentes habeant, peffimè ac uitiofè intelligüt, Nam nec duos dentes habent, $\&$ hoc quidem $\&$ genus monftri eft, \& melius intelligi poteft, fi bien nis dixerit authoritate Pomponij in Attellana. Mars tibi uoueo facturum, fi unquam redierit(redien ro, Macrobius, bidenti uerre. Laberius paupertate, Vifus hac nocte bidentes propter uiamfacere: \&Nigidius Figulus dicit bidental, quòd bimæe pecudes immolentur, Nonius Marcellus. Bidental dicebant quoddam templum, quód in eo bidentibus hoftịs facrificaretur, Feftus. Bidentes funs oures duos dentes longiores cateris habentes, Idem. Apud Macrobium etiam 7+9, ridetur grams maticus, qui oues bidentes dici docuerat, quòd duos tantum dentes haberẽt. A tqui hoc, inquit Aui enus, uel nunquam contingere: uel fi contingat, oftentum effe, \& $\mathrm{fac}$ (is piaculis procurandum, Tum Seruius citato Pomponĭ ex Attellanis uerfu, in quo uerrem bidentem legimus, oftendit, non proprium hoc epitheton effe ouxs, EtNigidius (inquit) in libro de extis, bidentes appellari ait non 


\section{DeOue. B.C. Lib. I.}

oures folas, fed omnes beftias bimas. Et in commentarñs ad ius pontificum pertinentibus, legi biden nes primó dictas, d. litera ex fuperfluo(ut fape affolet)interiecta, ficut pro reire, reamare, rearguere, dicitur redire, redamare, redarguere. Ergo bidennes primum dicta funt, quafi bieines, Quamuris Higinus qui ius pontificum non ignorauit, bidentes appellari fcripfithoftias, qua per $x$ tatem duos dentes altiores haberent, per quos ex minore in maiorem tranfcendiffe conftaret atatem, $\mathrm{Hac}_{\mathrm{Ca}}=$ crobius. Vide etiam Gellium lib, 16. Dentes ouium (inquit Petrus Crefcentienfis) mutantur poft annum unum $8<$ dimidium, nempe duo anteriores. \& poftea per fex menfes mutantur duro proximi; deinde cæteriłita quòd wribus annis uel ad fummum quatuor eijciantur(omnes.) Sunt autem iuni= oribus dentes inæequales: in ftatu, æquales: ætate prouectis, difcalcantur (fic loquitur, minutuntur \& corrumpuntur. Duidens hoftia, bidens, Feftus. Ambidens fiue bidens ouis appellabatur; qux fuperioribus $\&$ inferioribus eft dentibus, Idem. Ouis multiplicem uentrem habet, (ut catera ruminantia,) Ariftoteles 3, de partib.anim. A uentriculo lactes funt in homine 8 oure, per quas labitur cibus, in cæteris ile, à quibus capaciora inteltina ad aluum, Plinius. Teftes pecoriarmen. ró́, ad crura decidui, Idem. đ Ouibus mammæ inter femina binæ, papillaç̧ binæ, Ariftoteles. Oues capraç in feminibus mammas habent binas, Plinius. Ouium $\&$ caprarum pars maxima habet fel, \& quidem terris quibufdam adeò largé, ut exuperantia prodigḧ loco habeatur, ut in $\mathrm{Na}=$ xo. Sed alïs quiburdam locis omnino carent, ut apud Chalcidem Euboicam parte quadam agri, $\mathrm{A}$ riftoteles de partibus libro 4. cap. 2. In iecore eft fel, non omnibus datum animalibus:in Eubcex Chalcide nullum pecorit in Naxo pragrande geminum ${ }^{\prime}$, ut prodigij loco utrunque habeatur ad 10 uenis, Plinius 11. 37. Oues in Ponto line felle effe dicunt: contra in Naxo infula duplici felle praz ditas effe, Aelianus. Abfinthium Ponticum appellatur à Ponto, ubi pecora pinguefcunt illo, $8 \mathrm{ob}$ id fine felle reperiuntur, Plinius. In regionibus perfrigidis cum niue $\&$ hyeme uehementi anni tempus infeftum eft, fellis expers eft ouillum pecus: Intra enim ouilia compulfum, nouo pabulo non utitur. Deinde ineunte uere, cum ad paftiones proficifcitur, felle impletur, quod ipfum Scythi= cis ouibus ufu maxime euenire folere aiunt, Aelianus . Afix regio Scepfis appellatur, in qua lie. nes minimos effe pecori tradunt, $\&$ inde ad lienem inuenta remedia, Plinius ni fallor. GI Oujum cæterarumó̧ quadrupedum renes æquabiles funt, non ficut boum qui tanquam ex multis exiguis renibuts compofiti uidentur. Denfius item feuum circa renes nafcitur oubus quàm cæteris animali= bus; Ariftoteles. Caulis caudx uulpibus $\&$ lupis uillofus eft, ut ouibus quibus procerior, Plinius. - De latis \& longis ourium caudis in diuerfis regionibus iam fupra dixi. TOuis mirifice pinguis do nata eft regi Gallorum in oppido quodam Picardia anno is 47. cui altera ungula è duabus, nem. pe interior in utross péde, ad oc?o circiter digitos excréuerat, extrema parte furfum recurua inftar cornu rupicapra, itit oculatus quidam teftis mihí narrauit.

In quiburdam Heluetiorum montibus outes per fumma cacumina pafcuntur, cum capræ mo, rentur inferius, ubi reperiunt frutices, qui cacuminibus defunt. Oues etiam fomniane, Arifote= les. Prater hominem fomniare pecora, capras, \&c. Plinius. TBalare, factitium uerbum eft, pro= prium ouium. Oues dicimus balare, utiqueà fono ipfo uocis, Feltus. Exfacrificabat holtijs ba= lantibus, Cicero 1. de diuin. Iam ne balare quidem aut hinnire fortiter diceremus, nifi iudicio tretu of fatis niterentur, Quintilian. Tactá̧̧ fumanti puluere balet ouis, Ouidius 4. Faftor. Grex balan tum, Vergil.ı,Georg. Quoniam fatis balafti ò Fauftule nofter, Coffinius apud Varronem de re ruftic. Non inepte autem balaffe dicit Fauftulum, quí tracfauerat $\&$ docuerat de ouibus, quarum proprium eft balare. Agni balant, Aelius Spartanus. Balitare, frequentatiuum. Paftor harum dormit, quum ex eunt Sicà pècubalitantes, Qưfitus matri multis balatibus agnus, Vergil $\varphi_{*}$ Aeneid. Aegribalatiłs, Ouid.7. Metamorph. Tener balatus ibidem, id eft exíguus, qualis eft $\mathrm{a}=$ gni adhuc tenelli. Tremens, Stat,10. Thebaid. Pecorum balatu fonantripx, Vergil. 4. Georg. Guftatum à pecore capris ós pulegium, balatum concitat:unde quidam Græciliteras murantes ble=

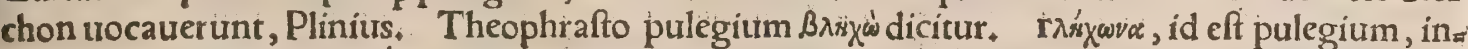

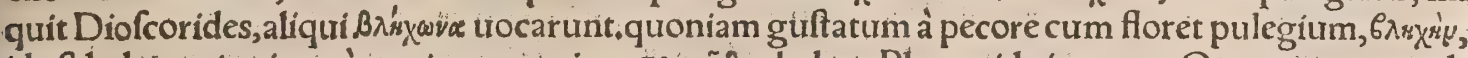

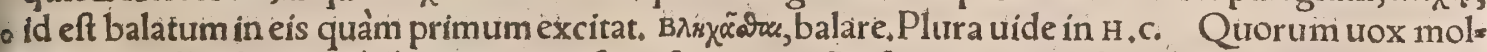

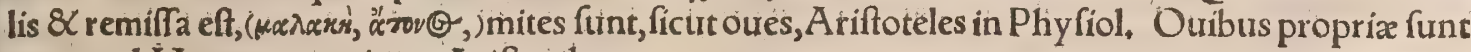
uoces ad Venereum coitum, Ariftoteles.

đNon multò aliter tuendum eft pecus caprinum in paftu atos ouillum, quod tamen habet fuà propria quadam, Varro. Oues radicitus herbas carpunt, $\&$ arbores deftruunt, $\&$ plurimis plan= tis morfus earum eft exitialis, Albertus. Pafcua ad Solis occafum fpectantia profunt, itinera \& la bores extenuant, Ariftoteles. Oues \& capräherba uefcuntur. pafcere oues fedula atç ftabiles folent. Capręloca crebrò permutant, fummaç tantưm contingưnt, Idem, Ouibus frondem uiiri: dem uffo dum habebis, præbeto. Vbi fementim facturus eris, ibioures delegato; $\&$ frondem ufas ad pabula matura dato, Cato cap. $3^{\circ}$. Decibo ouium uide etiam quadam in Ariete $c$. Oues licet 6o in pafcuis uberibus lanam acquirant molliorem fecundum rationem pafcuorum + tamen quia oures funt animalia humidi temperamenti, meliorem lanam \& molliorem faciunt ex pafcuis tenuibus $\&$ fallis quàm ex uberibus $\&$ dulcibus $; \&$ melius conualefcunt in falfis \& tentribus pafcuis, Albertus 
Locis aridis paftx melius conualefcunt, $\&$ in locis paluftribus morbida efficiũtur, Idem, De ges nere pabuli(inquit Columella) ut $\&$ ante diximus, $\&$ nunc corum, quar omiffa funt, meminerimus, iucundiffimas herbas effe, qua aratro profciffis aruis nafcantur, deinde qua pratis uligine carentio bus, paluftres, fylueftresćs minime idoneas haberiłnec tamen ulla funt tam blanda pabula,aut etiam pafcua, quorum gratia non exolefcat ufu continuo, nifi pecudum faftidio paftor orcurrerit prabito fale, quod uclut ad pabulicondimentum per ęfatem canalibus ligneis impofitum cum è paftu redie rint oưes, lambunt, atç co fapore cupidinem bibendi, pafcendiộ, concipiunt: at contra penuriz hye mis fuccurritur obiectis intra tectum per prafepia cibis : aluntur autem commodiffime repoftis ul meis, uel ex fraxino frondibus, uel autumnall foeno, quod cordum uocatur: nam id mollius, $8<$ ob hoc ícundius eft, quàm maturum:cytifo quoģ \& fatiua uicia pulcherrimé pafcuntur: neceffariz ta 1 men, ubi cætera defecerunt, etiam exleguminibus palex:nam per fe ordeum, uel frefa cum fuis uala uulis faba, uel cicercula fumptuofior eft, quàm ut fuburbanis exiguo pretio poffit praberi: fed fi uti,

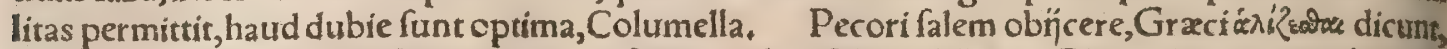
Gaza ex Ariftotele uertit falire. Quare paftores ouibus falem objiciant, Plutar chus quartit de caufig nat.problemate 3. Sal etiam coitum mouret, debetós eis dari ante \& poft coitum, ut inferius dice tur. Vide nonnihil de fale etiam in E. Cogitaliquot corbulas uuarum, $\&$ frondem iucundiffi mam miniftrat ourbus, Nonius Marc, ex Varronis de re ruft. lib.ı. Opimat pecus olea, oleafter, aphaca, palea, herba:qux omnia efficaciora funt ex falfugine refperfa. pinguefcunt $8 \alpha$ hac plenius prxfatigata inedia triduo, A riftot. Aphace propter oues feritur, Athenaus libr, *. Alexander Myndius dicit oues in Ponto amariffimo abfinchio pingues fieri, Aelianus. Abfinthium Pontia cum appellatur å Ponto, ubi pecora pinguéfuntillo, \& ob id fine felle reperiuntur, Plinius, $A$ ba finthium marinum impinguat pecudes, Serapio fecundum Diofcoridem, fed noftri Difcoridis codi ces nihil eiufmodi habent. Ouibus faba largius datz, copiam efficiunt lactis, Ariftoteles: Vide inferius ubi de lacte dicetur, hoc in capire. Fabx filiqua cauleş̧́ gratifimi funt pabulo pecort́, Plinius, Cytifum in agro effe quàm plurimum refert:quod bubus $\&$ omni generi pecudum utiliffmus eft.quod ex eocito pinguefcit, $\&$ lactis plurimum prabet ourbus, Columella. Frurex eff cyeifus (de quo plura leges in Boue c.) ab Ariftomacho A thenienfi miris laudibus pracicatus pan bulo ouium, aridus uero etiam fuum, Plinius. Omnia pecora cytifum depafta lac multum habes bunt, \& fimul embryon enutrient, A fricanus. Luxuria fegettrm caftigatur dente pecoris in berba duntaxat, $\&$ depaftæ quidem uel fapius nullam in fpica iniuriam fentiunt, Retonfarum ueró eniam femel, omnino certum eft granum longius fieri, fed inane caffum ch, ac fatum non nafci. Babylone ramen bis fecant, tertio depafcrtr, alioqui folia tantum fierent, Plinius. Eralibi, Sunt genera terra quarum ubertas pectinarifegetem in herba cogat, Eadem nihilominus $\&$ depafcuntur. Quę depatta funt, farculo iterum excitari neceffarium. Oues pellita ( qurx propter lana bonitatem fub trefo feréaluntur) quacun $q$ iubentur uefcunturłur folia ficulnea, \& palea, \& uinacea, furfures obïciuni rur modice, ne parum aut nimitum faturentur, utrun p enim ad corpus alendum inimicum.at maxin mé amicum cytifum \& medica, nam \& pingues facit facillimé, \& gignit lac, Varro. Si ex caprarum uel ouium grege quapiam eryngium herbam ore fumplerit, illam primo dicunt, ac mox reliquum gregem, tandiu à progrediendo fubfiftere, quoad de cius ore herbam paftor detraxerit, ut retuli in Capra C. Lafer pitium $\&$ circunfodífolitum prodidêre. nec purgari pecora, fed $x$ gra fanari, aut 4 protinus mori, quod in paucis accidere. Perfico filphio prior opinio congruit, Plinius. Etrurfus, Laferpitio uefci pecora folita, primó́ purgari, mox pinguefecre, carne nirabilem in modum iucus da. Et alibi,Lafer mulris iam annis in Cyrenaica prouincia non inuenitur, quoniam pubicant, qui pafcua conducunt, maius ita lucrum fentientes, depopulantur pecorum pabulo. Si quando inci dit pecus in fpem nafeentis, hoc deprehenditur figno:oue cum comederit dormiente protinus, can prafternutante. In India, 8 maxime in Prafiorum regione, liquido melle pluit: quod in herbas, ac paluftrium arundinum comas decidens, mirificas paftiones ouillo \& $\mathrm{Cubulo}$ pecori praftat:quod quidem ipfum à paftoribus eò, ubi dulcis plus roris de cœlo delapfum eft, agitur: \& fíc illis paftionis bus tanquam epulis iucunde accipitur, paftoresćg uicifím prolixo epulo compenfat:nam ex pecore fuauiffimum lac exprimût, neç ficut Graeci faciunt, mel mifcere \& temperare habent neceffe, Aelia gr nus. In noftris regionibus, mel iftud aêr eum (quod Graci aëromeli \& drofomeli uocant, Hebrał mannam, noftri bimmelbung) bubus fi forte in herbis comederint menfe Maio, ualde noxium eft. Ad Garamantas ouillum pecus carne $\&$ lacte alitur, A elianus. In locis quibufdam A fricæ, præfern tim Aethiopia uicinis, oues carne $\&$ lacte nutriuntur, Strabo. A pollonium circa Indiam artigife ferunt etiam Pegadem Oritarum regionem;ubi pecudes fint pifciuora, ea comedentes qua minime naturæ fux conueniunt. Paftores enim pifcibus illas alere confueuerunt, ficut in Caria ficubus cafo dem pafcunt. Indi enim Carmani cognominati, mirè pifcofum mare accolunt, Philoftratus. Circa Calimos uicum India maritimum, Nearchus refert ouium carnes pifcem refipere, ut atrium marina rum:pifcibus enim uefcuntur, quód regio gramen non ferat, Arrianus in Indicis. Errurfus non

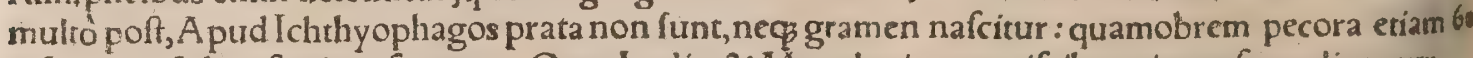
ipfortm pifcibus ficcis uefcuntur. Oues Lydix $\&$ Macedonic $x$ ex pifcibus pinguefere dicuntur, Aelianus. Ennius cum dicic,Propter fragna ubilanigerum genus pifcibus pafcirux, efle paludem 
demonftrat, in qua nafcuntur pilces fimiles ranunculis, quios oures confectatx edint, Fef: In pros uncia Aden, equi, boues, cameli, \& oues uefcuntur pifcibus; quorum ingens illic copia, \& libentius quidem ficcis quàm récentibuș nam propter immenfum calorem herbis $\&$ frugibus carent, $\mathrm{P}$ au. lus Venet. Deplantis qux in cibofumptæ noxia aut uenenofx funt oubus, dicam infra ubi de morbis earum: Er quadam de cibis earum, etiam capite quinto. Arabes dicunt ouium greges apud fe mufica plus fané quàm cibo pinguefcere, Aelian. Muficis fonis delectata melius pafcuntur, $A \mathrm{Al}$ bert. đOues ruminant, ut qua fuperiore dentium ordine careant, Ariftot. Prouidendum eft in hoc gènere ưt pabuli ubertate faturentur, $\&$ longé pafcantur à fentibus qux etiam la nam diminuũ 86 corpus incidunt, Crefcentien. Pinguefcit potifimum ouis ex potu $\neq$ quamobrem æiftate falem da ré diè quinto foliti funt, fingulis centenis fingulos modios; fic enim pecus incolume, aţ̧ pinguius redditur. Frequens igitur falis ufus eó pertinet, quando $\&$ paleis copiam falis admifcent, ut fitibun. dx plus aque hauriant: 8 autumno cucurbitam fale contactam afferunt:quod lac etiam auget: $\&$ a* gitatæ quoqg meridie, plus poftmeri dianis bibunt; foctis (poft partum, $A$ lbert, )diftenta ubera pendêt; quibus falis abunde eft, A riftot, Rafis \& Albert. A pud Rafim tamen locus mutilus eft.

At cui lactis amor cytífum lotosó̧̧ frequentes Ipfemanu, falfaṣ́́ ferat prafepibus herbas.

Hinc $\&$ amant fluuios magis: \& magis ubera tendunt. Et falis occultum referunt in lacte faporem, Vergil. Pecus potu pinguefcit, ideo fal illis aptiffimus, Plin. Oues fale delectantur, quòd is in cibo potionis defyderitum moueat, Aelian. Aqua ouibus autumno commodior aquilonia quàm auftris na eft, Ariftot. Aquam multam $\&$ turbulentam bibentes obefiores plerun $\$$ fiunt, Albert. Ex An 10 glo quodam accepi non fitire ouem nifi uiderit aquam : ea autem uifa etiam non fiticntem bibere: hoc an in Anglia (qua ourbus abundat)magis quàm alibi accidat, nondum exploraui. In Hifpania audio uellera ouium eo nobiliora fieri, quo minus biberint oures. Rore coeli in Anglia fitim fedant greges, ab omni alio potu arcentur, quód aqua ibi ouibus fint exitiales, Cardan. Sui per aftatem fitis maximé eft infefta:quare non ut capellam, uel ouem, fic \& hoc animal bis ad aquam duci praci. pimus, 8cc. Columella. Plura de potu ourum quare infra in $\mathrm{E}$. In Cephalenia infula, cum omnia ubiç pecora hauftu aqux quotidie recreentur, in ea pecudes maiore ex parte anni ore aperto ex al. to uentos recipientes, fitim fuam fedant, Valerius Max.1.6. बTheophraftus tradit, in Macedonia qui candida fibi nafci pecora uelint, ad Aliacmonem ducere: qui nigra aut fufca, ad Axium, Plin. Confluentem candidicoloris efficientem Crathis fl.emittit. Nam ouillum 8 bubulum pecus, 8 om. - his grex quadrupes, ficut Theophraftus ait, ex co bibens, de nigro rufóure albus fit, Aelian. Eudicus in Heftiaotide (Vetus lectio, Heftia, qua uox nufquan reperitur. Hermolaus Heltiaam ma= uuit legere, quxa pars fưit Theffalia, Ptolemæo, Straboni, cæeteris. Homero autem \& Thucydidi oppi dum in Eubcea. Stephanis $\&$ in Acarnania urbem hutius nominis tradit)fontes duos traditeffe, Ceronem, ex quo bibentes outes nigräs fièri:Mellan, ex quo albas: ex utrog autem uarias. Theophra fus in Thurins Crathim candorem facere, Sybarim nigritiam bobus ac pecoribus, Plin. De Crathide 8 Sybari fluuins; uide Prompttiarium noftrum, 8 Hermolatim in Plinium 31.2. Oues flauas red. dere Scamander amnis creditur quamobrem Xanthum pro Scamandro nuncupatum ab Homero autumant. Ex in Antẩdria quooģ duo funt fluuíi, qưorum alter candorem, alter nigritiam pecoribus facit, A riftotel. Ad diuerfam potionem colorum mutationem oues faciunt, quod quidem ipfum ex - uti $Q$ natura amnium ufu eis eutenire eo anini tempore, cum ineuntur, folet : Itacg ex albis commuta= tio in nigras fit, contráq ex nigris in albas conuertuntưr. Hacc autem cum ad Antandrum amnem accidunt, tum ad Thracix fluuium, cuius nomen Thraces accolæ tibi dicent, tum uero ad Troiam Scamander ex aqua fua potantes oures fuluas efficit ex eo factum eft, ut huic qui initio Scamander nominaretur, deinde aliud nomen aduentitius ouium color Xanthumimpofuerit, Aelian. Varro opinatur duo in Bocotia effe flumina, natura licet fépari, miraculo tamen non difcrépante: qurorum alterum fi ouillum pecus debibat, pullum fieri coloris, quem induterit, (uidetur locus corruptus:legi poteft, pullum fieri colorem uellerum, ) Alterius hauftu quacun $\phi$ uellerum fúfa funt, in candidu uerti, Solin,cap. 13. Poturs etiäm facit, ut mares äut fơminæ gignantur, ut infra dicemus. Nota eft hiftoria Iacobi nepotis A brahamitqui cum impetraffet à focero fuo Labano, tit pecora omnia traria \& maculofa ouilli caprigeniós generis fibi haberèt, tutirgás populi, coryli \& caftanex, decorticatas, ut Müfterus uertit: (non quòd cortices omnino eis detraxerit, fed ita ut pàrs aliquia corum delibrarêt, al tera relicta, quò appareret colorum uariètás, Munftèrus:) in aquas 8 canales, unde pecori bibendu erat impofuit, ita ut inter bibendum eas afpicerent, quio facto mox maribus admiffis, foettis maculo. fi concipiebantur. Hos in lucem æditos, feparatis omnibus qui maculofi non effent, in confpectum ouium matricum fub conceptum agebat, unde illę fimiliter ís quios ante fe confpexiffent maculofos adebant foetus.

đCapris 8 ouribus cur plurimum fit lactis proportione fui corporis, ínquirit Àrifoteles Proble. matum 10. 6. uidein Capra C. Inter omnia animalia ouis diu lac prabet ( refpectu fux magnitudi. nis, Albertus.) habet enim lac per octo menfes, Ariftotelés $\&$ Albertis, uide infra in E. Suillium $\&$ O - uillum lac fero reddendo inepra funt, Ariftot, Salis ufu lac augeri, $\&$ autumno efu cucurbitż fale contacta, fupra dixi in mentione potus ouium+item cytifo, cum de cibis earum dicerem. Ouibus fabæ largius datæ copiam efficiunt lactis, Ariftoteles interprete Gaza. fed Gracé fic legitur : 


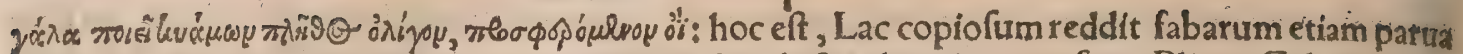
copia in pabulo. Herba lanaria ouibus ieiuna data, lactis abundantiam facit, Plin. Galariade (le. go, Galactite) lapide trito cum fale mifta aqua, oliux(outum) circunfpergantur ubera, Albert.Cum fale miftus aqua oriente Sole purgato ouili a fpergantur oures, \& turgebunt lacte, Obfcur. Oues craffiorem reddunt urinam quàm fui fexus mares, Ariftotel. TMenfes oui $\& 6$ capr temporecoé. undi indicantur:quod idem poft coitum etiam fit ad tempus, mox defiftit, donec parturiant: tum denuó indicatur + quare paftores proximum effe partum intelligunt. A partuautem purgario fequi. tur abunde: primum leuiter cruenta, poftmodum ualde, Ariftot.

ब1 Oues \& capr $x$ anniculæ coëunt, atç uterum ferunt; fed capræ potius.mares quorg in generibus eodem illo tempore ineunt, fed proles differt, quatenus præftantior ea eft, quam ienelcen, 10 res mares $\&$ focmin $x$ procrearint, Ariftot. Quis debet bima fubmitti, qux uf $q \beta$ ad quinquennium forturæ neceffaria eft, anno feptimo defícit, Crefcentienf. Arietes \& oues fot lem probari debent cum in tertio anno confiftunt, Florentin . Curandum eft, ne minori quadrima, néue ei qua exceffit annos octo, proles fubmittatur:neutra enim xtas ad educandum eff idonea: (ü

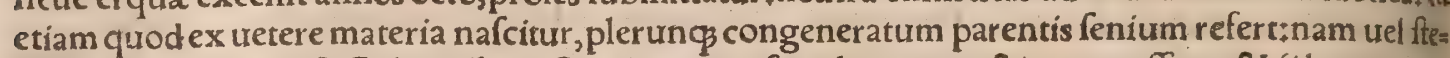
rile uel imbecillum eft, Columella. Oues parere ufq̧ ad annum octauum poffunt: $\&$ fi bene curen tur, uel in undecimum facultas pariendi protrahitur, (quod tempus ut plurimum ferè eft tota urita $0=$ uis:in quibufdam tamen terris marinis, ubi ficca \& falfa habent pafcua, uiuunt per uiginti annos \& pariunt, Albert.)\& quidem fieri poteft, ut etiam per totam feré uitam coéant, tam mares quàm fornis næ, Ariftotel. Et rurfus, Coëunt tam oures quâm capræ, quandiu uiuunt. Oues $\&$ capræ terno aut 10 quaterno coitu implentur, Ariftot, intra quartum coitum, Plin. Ouis decem uel duodecim annis uiuit, \& parit ocfo annis, Albert. Generatio bimis utrinç (ouibus 8 arietib.) ad nouenos annos; quibufdam 8 ad denos. Primiparis minores foetus. Coitus omnibus ad Axcturi occafum, quod ef 2̀ tertio idus Maias ad A quila occafum, id eft xiip,calend, Augufti, Plin. Ouili pecori äb Arciuri os

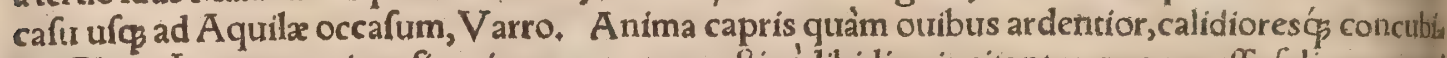
tus, Plin. In grege ouium fi maiores natu tempeltiuè libidine incitantur, annum effe felicem gregi paftores confirmant; fed fi minores, infelicem, Ariftot. Si minores natu pritus coierint, peftemant no illo futuram portendunt, fin maiores natu tardius ad coitum moueantur, idem præfagiunt; $A$ l= bert. Quæ aquam falfưfculam bibunt, maturius coéunt: nec folum ante coitum, fed eriam à coitu faliendum eft(fal eis prabendus:)atç etiam uerno tempore, Ariftot. Capra oul fimilis eft multis nominibustinitur quippe r̈fdem temporibus. Quinçs menfiburs ingrauefcit foeru, perinde ut outes, (idem Plinius fcribit.) Geminos etiam parit ut plurimum, Florentin. Ouis \& capra uentrem ferü: quinq̧ menfes, Varro \& Florentin. Ouis prægnans eft diebus centum quinquaginta: itaç fit para tus exitu autumnali, cum aër eft modice temperatus, ac primitus oritur herba imbribus primoribus euocata, Quamdiu admiffura fit eadem aqua uti oportet, quòd commutatio \& lanam facit uarian, \& uterum corrumpit. Cum omnes conceperunt,rurfus arietes fecernendi. Ita factis pragnantibus, quod funt molefti, obfunt:neos pati oportet minores, quâm trimas faliri, quod neque natum ex his idoneum eft, nec non ipfa fiunt etiam deteriores. Minores, quàm trimæ, deterrent à faliendo fifcellis éiunco, aliáue qua re, quam alligantad naturam,Commodius feruantur, fi fecretas pafcunt, Varro Pinguedo nimia impedit quò minus concipiant oues, Albert. Suntin equorum itemós ouiumge 4 nere qua nullam faciant prolem:\{ed multorum genus totum fterile eft, Ariftot. De ouium concer ptu nonnihil etiam dicetur in Ariete c. Cur oures ad Agenoris lucum abigentes A rgiui, ut ibidem ineantur efficiunt ? An quia Agenor uir fumma induftria in ouibus tractandis fuit, $\&$ pra cæeris regibus plurimos poffedit greges, Plutarchus in Gracanic. TArietis dextro tefte praligato oures (focminas)tantum gigni quidam fcripferunt, Plin. Non procul à Patrenfium ciuitate fluuius eft Milichus, $\&$ poft illum alius nomine Charadrus + ex hoc pecora tempore ueris bibentia, ut plurimum mares parere aiunt. Quamobcaufam paftores in diuerfam à flumine partem ea abigunt, (pecora ca tera, ut oures $\&$ capras, ) bubus tantum exceptis:tauri enim eis ad facrificia \& labores uaccis urilio res funt. Inter reliqua uero pecora foeminæ maribus præferuntur, Paufanias in Achaicis. Mares aut forminæ generantur ui, tum aquarum, tum admiffariorum. Nam $\&$ aqux faciunt, ut formin $x$ mares' ue concipiantur. ad hæc, aquilonis flatu mares potius concipiuntur, auftri forminx. Vis tan ta eft aquilonis, ut uel ea qux non nifi forminas pariant, immutet ad prolis mafcula procreationem, Spectrare ad a quilonem oportet cum coëunt foemina: qua mane iniri folent, marem, fi ferò diei admi feris, non patiuntur, Ariftotel. Aquilonis flatu mares concipi dicunt, auftri foeminas, Plin. Arifo teles uir callidiffimus rerum naturæ, pracipit admiffuræ tempore obferuare ficcis diebus halitus fea ptentrionales, ut contra trentum gregem pafcamus, \& eum fpectans admittatur pecus $\ddagger$ at fi foeminiz generandx funt, auftrinos flatus captare, ut eadem ratione matrices ineantur, (Idem ex Columella Palladius repetit, nec aliter Aelianus.) Nam illud quod priore libro docuimus, ut admiffarín dexter, uel etiam finifter uinculo tefticulus obligetur, in magnis gregibus operofum eft, Columella. $\quad$ \& à coitu imber acceffit, abortum infert, A riftoteles. Oues figrauida glandem copiofius ederint, $a b=6$ ortum faciunt, ut fues etiam. Ouibus tamen conftantius hoc glandibus efitatis accidit, Ariftot, Do cent paftores fuas oues gregari, facto ftrepitu:nam fi cum tonuerit aliqua relinquatur, quæ non con. 
currerit; abortum, fi eft grauida, facit, unde fit, ut fi quem domiftrepitum moureris, omnes concur. rant, propter confuetudinem, Idem. Tonitrus folitarijs ouibus abortus inferunt:remedium eft con gregare eas ut coetu iutuentur, Plinius \& Albert. Candidi, nigri' ue efficiuntur ! etus, fi fub lingua arieti uenæe nigræaut candidæ babentur:cuius enim coloris funt uenæ, eiufdem \& uellus eft : trari um etiam, fi plures uenarum colores funt, Ariftot, \& $\mathrm{Albert}$. Ouis aperto ore fi inueneris nigrican tem linguam, nigrum emittet foetum* fin albam, candidum: fi difinctam coloribus, partus fimiliter uariabit, Democrit. Fer unt quinq menfibus tun oues tum capræ. Vnde fit ut locis nonnullis, qui:= bus coli clementia \& pabuli copia eft, bis pariant, Ariftot, Gerunt partum diebus centum quinqua ginta, poftea concepti ínualidi.Cordos trocabant antiqui poft id tempus natos. Arietes primum ue tuftiores foeminas ineunt: nouellas enim minus perfequuntur . Pariunt, ut dixi, iuniores pauciora quàm uetuftiores, Ariftot. Pariunt maxima ex parte fingulos, fed aliquando $\&$ binos, $\&$ ternos, $\&$ quaternos, Idem. Pariunt geminos, tum pabuli beneficio, tum fi pater aut mater uim eam geminan di per naturam obtineat, A riftot. Oues in Magnefia 8 A frica pariunt bis, Ariftot. Problematum.

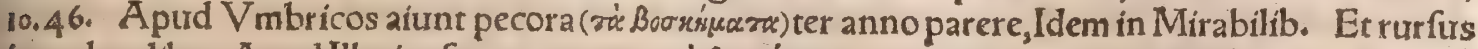

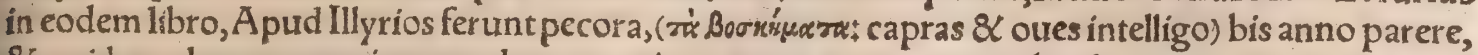
\& quidem plerunçg geminos: multa uero eciam ternos aut quaternos hoedos parere ‘ quandoø̧ etiẩ quinos $\mathbb{S}$ plures:item lactis féquicongium in diem ab eis emulgeri. Alegyptus tam abunde herbida eft, ut bis anno oures ex féfe pariant, biśç tondeantur, A elianus. In terris calidis $\alpha$ humidis bis con cipiunt, ficur in Mefopotamia, Albert. Oues nimium obefa difficulter pariunt, quxdam in ipfo partu moriuncur antequam abfoluant. Canes, ut reliqux parua quadrupedes monftra pariunt fre quentius quâm maiores, Ariftot.problematum 10.60. Et alibi, Capræ $\&$ oues, (ut \& reliqua forcun diora $\&$ multipara aninzalia) parturs interdum monftrofos ędunt. Ouis à partu cur non fauiat, Ari ftoteles inquirit problem, 10.37. TMufimonum (funt autem ueluti oues quxdam fylueftres, de quibus priuatim dicam poft Agnum)é genere 8 outbus natos prifí Vmbros uocauerunt,Plinius Mufmo ex capra $\&$ arietenafcitur, $\mathcal{X}$ cinirus ex oue $\&$ hirco, Albert, li,22, in dichione Ibrida. Apud Rhæetos Heluetips confoederatos locis alpinis, audio aliquando nafei capras pofteriore parte, anterius oues uel arietes; fed uiuere non poffe, $\&$ pauló poft partum moriłarietes enim cum fenefcût tualidos \& libidinofos fieri, \& capras aliquando fuperuenire. Ex orribus et arietum ferorum coitu foetũ con ceptum paternum colorem retuliffe, eumó̧ fimiliter dưraffe per fobolem $\&$ nepotes deinceps : Ianã 3o uero in primò quidem foctu hirtam, fed in nepotibus $\&$ deinceps mollem furffe, in B, retuli ex Colur mella. Oues à partu ( $m b$ ç rór tempore dari contrenit:) fale fruentes, ubera magis lacte diftenta demittunt, Ariftot. Partus uero incipientis pecoris non fecus quàm obftetricum more cuftodiri debet, neç enim aliter hos animal,

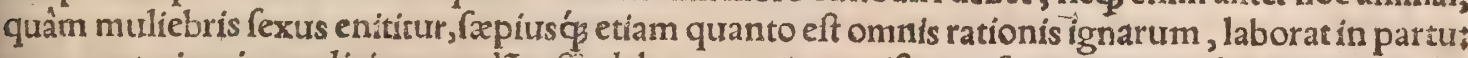
quare ueterinariæ medicinæ prudēs efie debet pecoris magifter, ut fires exigat, uel integrum conce ptum, cum traffuerfus haret locis genitalibus, extrahat:trel ferro diuifum citra matris perniciem par

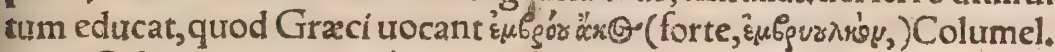

- Tubant oues capráç uniuerfa per cognationem, Ariftot. Etrurfurs, Cubãt difficilius oues, quàm capr $¥$ †magis enim capræ quiefcunt, accedunt ́́ ad hominem familiarius. Ouium femen (id eft genus) tardius eft, quo ha funt placidiores:contrà caprile mobilius, Varro. đI Vita ouribus ad denos annos, fed magna ex parte ad pauciores, Ariftor. Oues Aethiopica uel ad duodecim \& tre decim annos uitam agunt: capræe etiam ad decem $\&$ undecim, A riftor, Plinius capras tantum in Ae. thiopia uffs ad annos undecim uiuere fcribit, nulla ouium mentione. Alia quadam de ouitum uita $\&$ atate, $\mathcal{Q}$ in qua fint eligendx, dixi fuperius in $B$. In quibufdam terris marinis, in quibus ficca et falfa habent pafcua, uiuunt per uiginti annos $\&$ pariunt, Albertus fine aurhore : nifi forte tale quid apud Auicennam legitur. De mutatione dentium, \& atatis per eam cognitione, dictum eft in $B$. Oues in bono ftatu manent uf $q 3$ ad octo annos, \& quadam ufg; ad decem, fi copiofé pafcantur, fed quæ famem patiuntur, neceffariò cíto fenefcunt, Crefcent.

TDefanitate funt multa, fed ea in libro fcripta magifter pecoris habet, $\&$ qux opurs ad medendü - fecum portat, Varro. Quod ad cibum \& potum pertinet, tưm aliâs tum ad fanitatem, fuperius dictum eft. Mox etiam inferius uenena earum enumerabo. Equi muli 8 oures in Scythia, fape pra frigore moriuntur, Dionyf.Afer. Capr frigoris impatientiores funt quàm oues, Ariftotel. Porró inter ipfas oures frigoris patientiores funt, quibus cauda amplior, quàm quibus porrectior, \& glabræ exutiores, quàm ueftitiores:crifpx etiam algoris impatientes funt, Idem. Et alibi, Iudicant paftores ouem ualidiorem, cum hybernis temporibus pruinam, quam fufceperit, feruat, nam qubus uirium minus, parum prę fua imbecillitate conftantes, dífcutiunt fuo motu quantum fufceperint. Albertus longè aliter fiue uertit,fiue peruertit, his uerbisł Oues excutientes à caudis glaciem, ferociores funt, $\&$ melius ac diutius durant, non excutientes autem cito moriuntur. Valent melius oues quàm ca* præ:fed robuftiores capræ quàm oues funt, Ariftot. Sanitas $\&$ infirmitas ouium (inquit Crefcent.) 60 certis fignis cognof fitur:nam fi a periantur earũ oculi, \& uenæ fint rubicundx \& fubtiles, fanę funt: Sin alba uel rubicunda $\&$ craffa apparuerint, infirmæ. Item fi manu apprehenfa in fchina prope anchas (in fpina dorfi prope coxendices)comprimuntur, nec flectuntur, fana $\&$ ualidx funt : fi uero 
flectuntur, infirmx. Itẽ fi capite in pelle colli $\&$ ante tractx uix trahi poffunt, funt fanx $\&$ robufta: facile fequunt $\tilde{t}$, infirmæ. Itẽ fan $x$ per uiã animofius incedưt:imbecilles moleftius, $\&$ capite inclinato.

TOues nefcabræ fiant, nec ricinis infeftentur, \& lanx plus ut habeant, quid agendũ,docebo in fra in fcabiei ipfarum mentione. Maro fciens lauariouem, aut lanæe purgandx, aut fcabiei curane dæe gratia, pronunciauit tunc ouem per ferias licere merfari, fí hoc remedị caufa fieret. Balantưm gregem fluuio merfare falubri. Adñciendo enim falubri, oftendit auertendi morbi gratia tantume modo, non etiam ob lucrum purgand $x$ lan $x$ caufa fieri conceffum, Macrobius Saturn, 1,16, Ouil= lum pecus quamuis molliffimum fit, ut ait prudentiffimè Celfus, ualetudinis tutiffimæeft, miniméc peftilentia laborat, Columella. In Anglia cum æeftates pluuia funt, \& cum pafcuntur in locis uli. ginofis, \& cum lingunt mane rorem (non omnis ros, fed certo quodam tempore, Maio pracipue pecori noxius eft. rorẽ in Anglia ouibus $p$ potu effe fupra dixi)putref cũt et cötabefcunt eis uifcera, ut audio, बAlyffon fi circa ftabula plantetur, gregibus ouium \& caprarum falubre effe perhi, bent,Plutarchus 3.Sympofiacôn. De alyffo uide fupra in Cane G.inter medicamenta intra corpưs fumenda ab ḧs quros canis rabidus momordit. De uentriculo ciconize uel arietis, ouibus falubri, lege inferius in pefte ouium. Paftores $\&$ opiliones ablinthï flores aridos contritos, cum falc oule bus ac bubus prabent, quotidiana experientia edocti, omne genus interiores morbos abfinthio cus rari, dolores fedari, \& excrementa purgati, Tragus. Medetur ourium morbis decocf $x$ radicis cen. taurex fuccus, Plinius, Cani nonnunquam offeres decocturm heder $¥$ quo exhibito faltem per feptem dies, feruabis canis incolumitatem, nam ouem quogs paftus hederæ feruat, Blondus, Hy, phear ad faginanda pecora uifco utilius. Vitia modo purgat primo, dein ea pinguefacit, qux fuffere 1 re purgationi. Quibus fit aliqua tabes intur, negant durare. Ea medendi ratio xftatis quadragenis diebus, Plinius. Ilex frucfus aliquando quaternos habet, binos proprios, glandem $\&$ gtanum quoddam puniceum $\$ \&$ binos alienos, uifcum atos hyphear, hoc à meridie, illud à feptentrione. Ali qui uifcum,ftelin $\&$ hyphear non aliter differre putant, nifi quod in diuerfis arboribus nafcuntur, alí uerò fpecie differre aiunt,cum $\&$ fructus $æ$ dant diuerfos, $\&$ in eadem arbore aliquãdo pars un. felin, altera uifcum uel hyphear proferat, Idem de caufis 2.33. Stelis uocabulum eft Euboënfium, hyphear Arcadum, uifcum commune,Ibidem. Ouibus utile adiantưm circa ouilia earum feritur, Diofcorides, Pecori utiliffimos effe aiunt adianti ramulos in cibo, Plinius. Afplenos herba confix. mit fplenem pecorum, ut copiofé dictum eft in Boue. Caprino pecori eadem remedia conueniunt qux ouillo, Columella . Nunc quemadmodum uitīs, aut morbo laborantibus fubueniendumfit $z^{\circ}$ pracipiemus, quanquam pars hac exordí penè tota iam exhaufta fit,cum de medicina maioris pe. coris priore libro difputaremus, quia cum fit feré eadem corporum natura minorum, maioruḿ̧́ qua drupedum, paucx parux́ćs morborum \& remediorum differentix poffunt inueniri:quętamen quantulacunç fint, non obmittentur à nobis, Idem.

TVendere oportet armenta rejicula, (i. duplici in fecunda fyllaba) oures rẹjculas, Cato, Reicu, las Nonius (i,fimplici) interpretatur atate aut morbo graues, citans illud Varronis ex libro de libe ris educ. Et ut in grege opilio oues minus idoneas remouere folet, quas reiculas appellat, Cinis lanæouis paffionibus pecudum medetur, Plinius ut Aggregator citat. बFebres accidunt out bus, qux cognofci $\&$ curari poffunt, ut dictum eft de febribus in tractatu boum, Crefcentienfis, Quin etiam ima dolor balantum lapfus ad offa Cum furit, atç artus depafcitur arida febris: Profuic incenfos æeftus auertere: $\mathbb{Q}$ inter Ima ferire pedis falientem fanguine uenam, Vergilius in Geor. ( Prudenter Vergilius, inquit Columella, ouibus febricitantibus confulit de talo uel inter duas ungulas fanguinem emitti oportere. Nos etiam fub oculis $\&$ de auribus fanguinem detrahimus.) Et mox,

Quam procul aut molli fuccedere fæpius umbræ Videris, aut fumas carpentẽ ignauius herbas, Extremamḉ fequi,aut medio procumbere campo Pafentem, \& fer folam decedere nocti, Continuó ferro culpam compefce:prius quàm Dira per incautum ferpant contagia uulgus, Ägni febricitantes quomodo fint curandi, in Āgni hiftoria profequar. Ouibus ægris \& gregario aliquo morbo infectis, lac caprinum aqua permixtum bibendum dabis, Obfcurus. Videtur autem hic potus in febribus tum alij s tum peftilentibus conuenire.nam $8 X$ agnis febrientibus lac maternî́ 50 pari menfura coleftis aqua mifcerur, aut caprinum per corniculum infunditur, tefte Columella Nec capræ nec oues pefte inficientur, fi ex ciconiæu uentriculo aqua intrito, fingulis cochleare unum infuderis, Quintilin. Aduerfus morbum ouibus letalem, Ventrem arietis cum uino coques \&

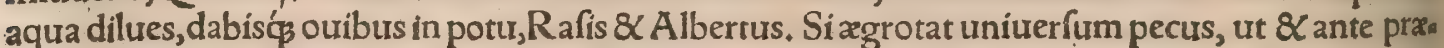
cepimus, \& nunc (quod remur effe maxime falutare) iterum adfeueramus in hoc cafu, quod eft res medium præfentiffimum:pabula mutemus, $\&$ aquationes totius regionis, \& aliũ quaramus ftatum

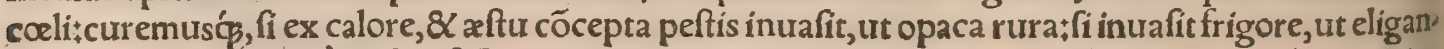
tur aprica, fed modicè ac fine feftinatione perfequi pecus oportebit, ne imbecillitas eitus longis itine ribus aggrauetur, nec tamen in totum pigre ac fegniter agere. Nam quemadmodum feffas morbo pe cudes uehementer agitare, \& extendere non conuenit, ita conducitmediocriter exercere, \& quaff 6 torpentes excitare, nec pati ueterno confenefcere, ates extingui. Cum deinde grex ad locum fuerit perductus in lacinias colonis diftribuatur, nam particulatim facilius quàm uniuerfus conualefcit, 
fiue quia ipflus morbi halitus minor eft in exiguo numero, feu quia expeditius cura maiori adhibe: tur paucioribus, Columella. Profpicere maximé in ipfo principio conuenit, ne in morbum pefti= lentem incidant oures. Vere igitur aduentante, elelifphacum montanum prafiumós hẹbas contundes, $\&$ per dies quattrordecim in potu eis temperabis:idem $\&$ autumno diebus totidem faciendum, Quod fi iam eas occupatuerit morbus, eifdem remedịs uti conueniet : iuuat etiam ex cytifo pabulü, arundinis ćs duriffim $x$ radices tener $æ$ madefactæ, at $q \xi$ in affectam partem admotæ, (ut Ând. à Lacu= na uertitł fed melius Cornarius, arudinis duriffima radices tenerrimæe in potu maceratæ. Græcé e. nim non rinoy fed roioy legendum.) Oportet autem infecfas in aliam regionem transferre, ne conta= gione fua fanas etiam uitient:quín $\&$ ipfa dum alia aqua fpiritúq̧́ alio frumtur, roborantur $\&$ con - ualefcunt, Africanus in Geoponicis Gracis, Balatu pecorum, \& crebris mugitibus amnes, Arentesć́s fonant ripa colleş̧́́ fupini. Iamó̧́ cateruatim dat ftragem:atçs aggerat ipfis In ftabulis, turpi dilapfa cadauera tabo, Donec humo tegere, ac foueis abicondere difcunt, Nam neç erat corijs ufus;nec uifcera quifö́, Aut undis abolere poteft, aut uincere flamma. Nec tondere quidem morbo,illutuiećg perefa Vellera, nec telas poffunt attingere putres. Verum etiam inuifos fiquis tentârat amiçurs, Ardentes papulæa, atç̧ immundus olentia fưdor Membra fequebat̃ $n$ nec longo deinde moranti Tempore, contactos artus facer ignis edebat, Vergil.in Georg. Seneca ab initio libri fexti Naturalium quaftionum, Pompeios celebrem Cam. panix urbem Regulo \& Verginio confulibus, defediffe terramotu, \& quidem diebus hybernis, fri bit, \&c. Et in eodem libro cap. 27. Aiunt(inquit) fexcentarum ouium gregem exanimatum in Pom= 10 peianæregionis motu. Nec eft quare hoc putes ouibus illis timore accidiffe. Diximus folere poft ma gnos terrarum motus peftilentiâ fieri.Multa enim mortifera(tum aér, tum aquæ) in alto latent. Qux cum extra fuperficiem terræe erumpunt furo halitu \& uapore, facilius pecora fentiunt, in que peftilen tia incurrere folet, quo auidiora funt, $\&$ aperto colo plurimum utuntur, \& aquis, quarum maxima in peftilentia culpa eft. Oues uero mollioris natura quo propiora terris ferunt capita, corruptas effe non miror, cum afflatum diri aéris circa ipfam humum exceperint. Nocuiffet ille $\&$ hominibus, fi ma ior exíffet, fed illum copia aëris fynceri extinxit, antequam ut ab homine poffet trahi furgeret, Hacc Seneca. TOues fiab ardente Sole labefactentur, cadantọ́ affiduè nec edant, agreftis betę lapathi nimirũ)fuccus eis infundi debet:cogendæ funt etiam ipfas betas comedere, Anatol, I siob pa* ftum infalubriorem uenter eis tumear, fangtuinis detractione curabis illas, tundẽs fcilicet eas uenas, 3o qua fupra labrum, \& quę fub cauda circa fedem funt. Infundere etiam conuenit fefquiheminam hu mani lorij. Quód fi uermes( $\sigma$ xúnswas) unà cum herbis uorauerint, idem faciendum eft, Anatolius. Idem aut fimilis morbus eft, quorut Gallus quidam non indoctus hæc mihi fcribenti retulit) oues di. cuntur trenenum in paftu cum hëbis fumpfiffe : quod fieri aiunt cum aër craffus, lentus, $\&$ noxius cum rore concretus in herbas decumbit, qualis etiam plantis $S$ arboribus fxpe exitialis eft. Ouibus inde ftatim ualde inflatis, paftores fummas auriculas ab cind unt ut fanguis emaner, 8 baculis percu tiunt latera. Alij aqux permifcent inulam, \& ori aperto infundunt: aut, fi defit aqua, urinæ permi= fcent, quam in uas aliqưod aut etiam calceum emiferint. Sic oures ftatim melius habere aiunt. $\mathbb{M}$ Mi les quidam narrauit nobis uifam fibi effe outem qux in rabiem inciderat cum uacca rabiofa cornu eam impetïffet, Rufius. TSi oues aftuantes biberint, \& fic refrigeratę fuerint, tum aliâs tum cir= ca omentum pracipué, ut lanij noftri referunt, auricula eis dimidia feré parte abfcinduntur: quod i fanguis è uulner e manet, bene habet:fin minus, mactantur. बBilis aftiuo tempore non minima pernicies, potione depellitur humanæu ueteris urina, qux ipfa remedio eft etiam pecori arcuato, Co. lumella. - TSi hirudinem hauferint, acetư acre $\&$ calidum, aut oleum eft infundendum, Ânatolius. Si uermes ( $\sigma x$ únsres) cum herbis deglutiuerint, quomodo curandx fint pauló fuperius dictum eft. I Si qua reptilium beftiarum momorderit percufferitue, melanthium ex uino illi offerendum eft: ac breuiter ea omnia facienda adhibendaćs funt, quarcunç̧ in hiftoria horum aliorumós animalium tradidimus, Anatolius. TVere moriuntur pafta rore melleo(de quo fupra etiam dixi, noxium ef fe ouribus, ut bubus quog.) Autumno autem fi ariftis nimium impleantur, \& poftea ftatim bibant, diruptis uifceribus(inteftinis)moriuntur, Albert. . A A conito neos pecus (ouris) neq ullum animal pafcitur, Theophraft. Oures necat nerion (id eft rhododendrum, Diofcorid.Pecus \& capra fi aquã biberint, in qua folia rhododendri maduerint, mori dicuntur, Plini. Oues $\&$ capras perdunt eurony mus \& conyza, uide in Capra c. Sabina capris \& ouibus tienenum ef, Plin.lib,16. Eft eriam gra uis pernicies herbx fanguinariæ, quam fi pafta eft ouis, toto uentre diftenditur contrahiturós, \& $\mathrm{fpu}$ mam quandam tenuem tetri odoris expuit. Celeriter fanguinem mitti oportet fub cauda, in ea parte qux proxima eft clunibus, nec minus in labrofuperiore uena foluenda eft, Columella. Eafdem tre. nas folui iubet Anatolius, fi ob paftum infalubriorem uentèr eis tumeat $\$ \&$ uerifimile eft ipfum $\mathrm{ex}$ Columella tranftuliffe, qua uerò fanguinaria effet herba non cegnouiffe, ac ideo quod de ea priua tim dictum erat communius protuliffe. Ego fanguinariam herbam dici nullam noui, prater polyges num Gracorum, cur tamen uim uenenatam nemo attribuit. Sed ouibus uenenum effe potef, non item alijs animalibus, aftriça nimirum aluo intumefcenté. (Atqui in Geoponicis Gracis polygonó herbam arietibus dari legimus, ut ualentiores fiant ad coitum.) Qua fola facultate alia etiam aftrin. gens herbula binis \& rotundis ferè numi inftar folips humi reptans, pulegio non diffimilis, locis opa a 
cis, ut circa fxpes $\&$ alibi, prafertim humidis, Fuchfius numulariam uocat (expreffa uoce Germanis ca fennig trut, A ngli codem fenfu dicunt penigras)ouibus exitio effe creditur. Itaq à Gallis per cir cunfcriptionem uocatur herba oues necans, l'herbe qui tue les brebis. A thom ni innoxia, \&L perfaz pe falutaris eft. Ego teneram uerno fape ex aceto fale $\&$ oleo comedi. Herba inodora eft, fios pallidus grauiter odoratus, ranunculi feré floris effigie: noftri ferpentinam (natertutut) nominant, quòd fer: pentes uulnerati aut etiam aliqua parte diffecti, hac herba fibi mederi ut partes feparatæcoalefcant, à uulgo fertur. Mirum quòd anagallidem forminam pecora uitant:atfi decepta fimilitudine, (fomi næa ad marem anagallidem, ) deguftauêre, ftatim eam qux afyla uocatur, in remedio quẹrunt:ea à no Ptris ferus oculus nuncupatur, Plín. Anagallis quidem herbula nitrofo, acri \& infuaui fapore eft, $\mathrm{fe}_{\text {: }}$ rè quo betæ radix cruda: $f$ d cum codem tum mas tum foemina fapore $\&$ facultate fit, cur illum gu: ftent hanc auerfentur, equidem miror. Cęterum afylę herba hoc uno in loco, quod friam, Plinius me minit, nec uel iple alibi, uel aliorum quifquam. Duua (ut mihi hac frribenti Gallus quidam di̊tå uit) herba uocatur Gallis, in Normannia pracipuè, fimilis lapatho (uel gentianæ maiori) fed angü ftioribus folịs \& femper erectis, neruo medio feré rubente, caufticis; nafcitur iuxta aquas. Hanc comederint ours, innafcuntur eis in iecore animalia quædã parua, nigra, qua fimiliter dưx tocantur: $\&$ morbus itidem duua, incurabilis; ita $c \beta$ mox macianda $\&$ comedenda funt animalia. Herba quoniam hyems erat demonftrari mihi non potuit:quarent diligentiores num aliqua hydrolaparti Species fit, aut potius plantago aquatica, cui folia femper eriguntur:quamuis neutra caufica fit, \& forfitan qui hae mihi dictauit hanc ei facultatem effe falfó credidit. Lanï noftri mihi affirmant fepe in iecore ouium hirudines reperiri, folliculis quibufdam inclufas, longitudine fefquidigiti, latitud. ${ }_{10}$ ne ad longitudinem ferè dimidia, prætenues; id uitium contrahi potu aqux paluftris : in uentriculo nunquam ullas hirudines reperiri. Nafcitur inter frumenta herba alba panico fimilis, occupans ar

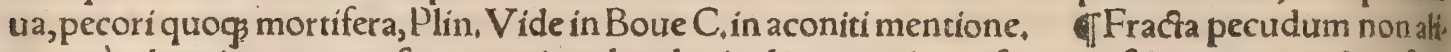
ter quàm hominum crura fanantur, inuoluta lanis oleo atç uino infuccatis, 8 mox circundatis feru lis conligata, Columella. ISi pediculi riciniue moleftent ouem, radix fphendamni (id eft aceris) cundêda $\&$ in aqua elixanda eft. Vbiautem à capite uf̧́ a d extremã fpinę partem, lanã totonderis, (a'vakg'vys, Cornarius reddit diuulferis, )tepidam ipfam aquam infundito, donsec penetret uniuerfun

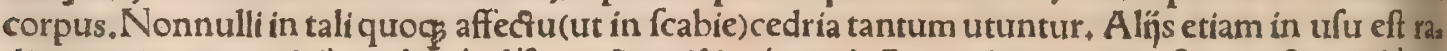

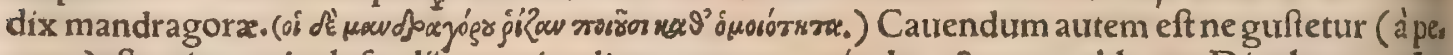
core. )eft enim periculofa.alín cyperi radices coquunt,eó́ decocto oues abluunt, Diophanes, $A t=3^{\circ}$ qui Plinius pediculos in ouribus gigni negat, his uerbis; In ouibus $\&$ in capris ricini folum gignun, cur, pediculi $\&$ pulices nulli. Et alibi,Pilos habentium afinum tantum immunem pediculis credût, \& oues. Gigni quidem pediculos in lanis interemptarum à lupis ouium, dicemus in $D$. I Scaa biem ouium contagiofam Galli uocant le rac. Oues ne fcabra fiant, Amurcam puram, \& aquam ubi lupinus deferbuerit, $\&$ fecem de uino bono inter fe pariter omnia fumito, \& bene commilceto. Poftea cum detondexis oures, unguito totas; finito bidaum aut triduum confudent: deinde in marila uito, fi aquam marinam non babebis, facito aquam falfam, ea lauito. Si hac fic feceris, non fcabra fi= ent, \& lanæ plus, \& meliorem habebunt, \& ricini non erunt molefti. Eodem modo in omnes quadru pedes utitor fif cabræerunt, Cato cap. 96 . Oues frequentius quàm ullum aliud animal infeftantur fcabie, quam facit macies, ut maciem exiguitas cibi. Huic morbo nifi occurratur, unica totum pecur 49 coinquinabit. Nam oures contagione uexantur, Textor. Præ frigore oues aliquando in fcabiem $\&$ podagram incidunt, tefte Vergilio. De tonfura ouium primum animaduerto antequam incipiam facere, num fcabiem aut ulcera habeant, ut, fi opus eft, antè curentur quàm tondeantur, Varro, Os ues lauari folent uel lanx purgandx, uel fcabiei curandx caufa, ut fuperius ex Macrobio recitaui. Qux inter tondendum excitantur uulnera, pice liquida inungere conuenit, at uniuerfum corpus 0 . leo cum uino, aut coctorum fucco lupinorum amarorum. Sed multò praftantius fuerit ex uini amut cæó portionibus paribus, aut ex oleo $\&$ uino albo ceræ $\&$ adipi(sñes, feuo)miftis, inungere. Hoc fi

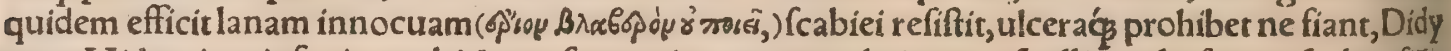
mus. Vide etiam infra in $\mathrm{E}$, ubi de tonfura ouium, quomodo iam tonf $x$ illinend $x$ fint ne fcabrafiât, ex Columella praciptrè. Scabie igitur oues nunquam infeftabuntur, fi eis qua prædicta funt, quif= $\rho^{\circ}$ piam oues tonfas inunxerit + Sin autem ob negligentiam tuam, fcabie tux foedentur oues, eas curabis hoc modo: A murcx fine fale, aquæ in qua amari lupini maduerint, fecisá uini albi,fingulorũ ęquas portiones in uafe aliquo mifcens, \& calefaciens, ouem inde perungito, eamó̧ fic in unam $\&$ alteram diem relinquito. Tertia uero die, marina aqua, aut muria calida lauanda eft:ac poft id, aqua porabili, Quidam cupreffi fphærulas aqua maceratas affundunt. Alij ex fulfure, cypero, cerufa atç butyro miftis, fcabras oures inungunt. Sunt qui ex luto orto ab urina quam afirus in uia excreuit, illinant oues. Nonnulli autem rectius facientes, non prius admouent aliquod remediorum dicforum, quàm totonderint partem fcabidam, eamó lotio antiquo perfuderint. In Arabia porrò uel fola cedrix in= unctione fcabiem difcutiunt, ut in camelis \& elephantis quoq. Scablem ouium compefces, fi lotio praluens, fulfure at $\$$ oleo inunxeris, Diophanes. Oues(inquit Columella)frequentius, quàm ul= 60 lum aliud animal infeftantur fcabie, qua ferè nafcitur, ficut nofter memorat poëra: Cum frigidus im ber Altius ad uiuum perfedit, \& horrida cano Brumagelu. Vel poft confuram, fi remedium. 


\section{DeOue. C. Lib.I. 885}

pradicti medicaminis non adhibeas, fixftiurm fudorem mari, ud flumine non abluas, fi tonfum gre gem patiaris fylueftribus rubis, ac fpinis fauciari: fi ftabulo utaris, in quo mula, aut equi, aut afin iteterunt: pracipuè tamen exiguitas cibi maciem, macies autem frabiem facit. Hæc ubi copic irre pere, fic intelligitur; uitiofum locum pecudes, aut morfu fcalpunt, aut cornu, uel ungula turdunt, aut arbori adfricāt, parietibúsue detergent, quod ubi aliquam facientem uideris, compreheriere $0=$ portebit, \& lanam diducere: nam fubeft afpera cutis, \& uelut quedam prurigo,cui primo quo pore occurrendum eft, ne totam progeniem coinquinet, \& quidem celeriter, cum \& alia pecora, 趾 pracipué oues contagione uexentur. Sunt autem complura medicamina, qux idcia co eruumerabia mus, non quia cunctis uti neceffe fit, fed quoniam nonnullis regionibus quędam reperiri nequeunt, yo ex pluribus aliquod inuentum remedio fit, Facit autem commodè primum ea compofitio, giuarn pau lo ante demonftraumus, fi ad fecem, \& amurcam, fuccumó $\$$ decocti lupini mifceas portione æąua detritum album elleborum, poteft etiam frabriciem tollere fuccus uiridis cicutæ: qux uerno :empo re, cum iam caulem nec adhuc femina facit, decifa contunditur, atque expreffus humor eius fichi: li uafe reconditur, duabus urnis liquoris, admifto falis torridi femodio:quod ubi factum eff, oblitum uas in fterquilinio defoditur, ac toto anno fimi uapore concoctum, mox promitur:tepefactumç me dicamentum linitur fcabra parti, qua prius afpera tefta, uel pumice defricta redulceratur. Eidern re medio eft amurca duabus partibus decoffa, item uctus hominis urina teftis candentibus inufta: qui: dam tamen hanc ipfam fubiectis ignibus quinta parte minuunt, admifcentóp pari menfura fuccum uiridis cicutæ. Deinde figularibus tritis, \& picis liquidæ, \& fricti falis fingulos fextarios infundunt. Facit etiam fulfuris triti, \& picis liquidæ modus æqualis igne lento coactus. Sed Georgicum camen affirmat, nullam effe praftantiorem medicinam, Quàm fi quis ferro potuit refcindere fun mum Vlceris os, alitur uritium, urưitćs teggendo. Itaçreferandum eft, \& ulcera medicamentis curandum, Hæc omnia Columel, Sed Vergilij etiam ex Georgicis eadem de re uerfus apponam omnes: Turpis oues tentat frabies, ubi frigidus hymber. Altius ad uiuum perfedit, \& horrida cano Bruma gelutuel cum tonfís illotus adhafit Sudor, $8 \times$ hirfuti fecurerunt corpora uepres. Dulcibus idcircofluüjs pecus omne magiftri Perfundunt, udisç aries in gurgite unlis Merfatur, miffuśç fecundo défluit amni. Aut tonfum trifticontingunt corpus amurca: Et foumas mifcent argenti, uiua ọ́ fulphura, Idxasḉs pices, \& pingureis unguine cems, Scilláós, helleborosćs graues, nigrumó̧ bitumen. Non tamé ulla magis prafens fortuna laborũ eft, $3^{\circ}$ Quàm fi quis ferro potuit refcindere fummum Vlceris ostalitur uitium, uiuitá̧, tegendo,

Dĩmedicas adhibere manus ad uulnera paftor Abnegat, $8 \mathrm{C}$ meliora deos fedet omnia pofcens.

Medentur pecorilupini cum chamaleonte herba decocti, aqua in potum collata. Sanant etiã fca $_{1}$ biem quadrupedum omnium in amurca decocti, uel utrogs licuore poftea mixro, Plin. Lupinicum chamaleontis nigri radicibus decocti, quadrupedum ( tepido decocto illo abluuntur, Diofcorid. Tragus (ex hoc opinor loco) quadrupedum \& ourium fca: biem fanari fcribit lupinis cum radicibus carlinx uulgó dictx ( $\$$ bermurz) decoctis in uino quod à dolịs dưm hauritur deftillãs uafculis excipitur, uel etiam in aqua. Halimo fylueltri effectus maio. res in fananda hominum ac pecorum fcabie, Plin. Herodotus maroravía dixit(malim omicron ía antepen.koräxy enim inungere eft, quoniam oures pice illinebantur, Hefych. $8 \mathrm{C}$ V arin, nimirum ada

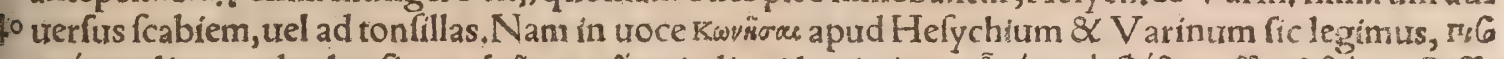
novíx(malim per duplex figma) fphaltos eft mixta bitumini pice, naturaliter ex Apolloniatarî̃ agro.Quidam ipfi mifcent, pręcipu ad fcabiem pecorum remedium, aut fi foetus mammas laferit, Plin. Pecorum fcabiem fanãt, lanas sć̣ emolliunt pifcina maris. Mediterrannei marinam aquā imitabuntur, quàm falfifimãa, fi quatuor fe= xtarị̂s aquæ, unum falis addiderint:nam fi quis amplius addere conetur, uinci aquã, falemág nonli= quari aiunt:moderatiffimã fièi putãt, fi aqux fextarís quatuor ocfonos falis cyathos mifceãt, Plin. 31.6. Sunt qui dicãt illam demum aquam falfam refpondere marinæ in qua ourum futitet nec fubfidat: quod cum ego experirer eiufdem ponderis aquam $\&$ falem effe oportere comperi ut outum innata ret. Duo falis fextarn̄ in quatuor aqua fextarios miffi, temperatiflimam marini liquoris copiam fa= go ciunt, Plinius Secundus apud Marcellum. If Si abfceffus corporis fuperficiem obfideat, aperiun. dus eft, uulnerió̧ torrefactus fal ato̧s tenuiffimus ex liquida pice imponendus, Anatol. बi Eft etiã infanabilis facer ignis, quã pufulam uocãt paftores:ea nifi compefcitur intra primam pecudem, qux tali malo correpta eft, uni:terfum gregem contayione profternit:fic quidem quod nec medicamento rum, nec ferri remedia patitur. Nam penè ad omnem tacfum excandefcít: fola tamen ea fomenta nó afpernatur lactis caprini, quod infufum tantum ualet, ut $\&$ blandiatur igneam fauitiá, differens ma gis occidionem gregis, quàm prohibens. Sed Aegyptiæ gentis autor memorabilis Dolus Mendefius,

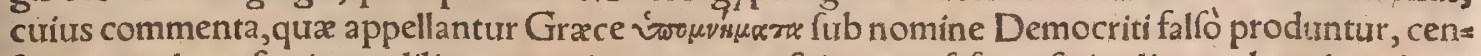
fet propter hanc fapius a diligenter ouitum terga perfpicere: ut fi forte fit in aliqua tale uitium depre henfum, confeftim frobem defodiamus in limine ftabuli, \& uiuam pecudem, quax futerít pufulofa, 60 refupinam obruamus, patiamuró̧ fuper obrutam meier e totu m gregem, quod eo facto, morbus pro pulfetur, Columella, बClaui quo $\beta$ dupliciter infeftant ourem, fiue cum fublurues, atç intertrigo in ipfo difcrimine ungulæ nafcitur, feu cum idem locus tuberculum habet, (ruftici noftri hes uitium 
in pecore uulgò herinaceum urocant)cuius media ferè parte canino fimilis extat pilus, elọ́ fubeft uer miculus, Subluuies, $\&$ intertrigo pice per fe liquida, uel alumine $\&$ fulfure, atç acetomiftis rite eruentur: uel tenero punico malo, prius quàm grana faciat, cum alumine pinfíto, fuperfúfó, aceto, uel aris ęrugine infriata, uel combufta galla cum auftero uino lęuigata, \& fuperpofita:tuberculum, cui fubelt uermiculus, ferro quàm cautiflime circüfecari oportet, ne dum amputatur etiam quod in: fra eft animal uulneremus:id enim cum fauciatur, uenenatam faniem mittit, qua refperfum uulnus ita infanabile facit, ut totus pes amputandus fit: \& cum tuberculum diligenter circuncideris, candẽ feuum uulneri per ardentem tadam inftillato, Hac omnia Columel \$De mentigine fiuc oftigi ne mortifera lactentibus agnis, lege in A gno C.

In morbo comitiali cerebrum nimis humidum eft. cognouerit autem hoc ipfum quis maxime ex ouibus, \& prafertim capris. ha enim frequentiffimè corripiũtur. quod fi caput ipfarum diffecué, ris, reperies cerebrum humidum \& fudore refertum ac male olens, Hippocrates in libro de morbo facro, Chamelæam quoquo modo collectam iumentorum pecorumós oculis falutarem effe aiunt, Plinius, Papaueris cornuti folium argema in ouibus tollere feripfit Theophraftus: Diofco rides inunctum argema $\&$ nubeculas $к \tau s v \tilde{y}$, (id eft pecudum $\&$ iumentorum,)emendare. đisi mo lefta pituita eft, cunila bubula, uel nepetx fylueftris furcull lana inuoluti naribus inferuntur, uetfan turḉ̧ donec fternuat ouis, Columella. Veratrum nigrum pecorum \& iumentorum pitưitas $f_{\beta_{3}}$ nat, furculo per aurem traiecto, \& 2 poftero die eadem hora exempto, Plinius. I Ād tonfillas pix liquida illinitur, ut fupra dixi inter remedia contra frabiem. WNafitur ouibus goflum fub gula ex fluxu humorum â capire defcendentium : \& perforata ibi pelle humor aquets paulatim extillat, is curantur'śs, Crefcentienfis. Noftri hoc uitium uocant trópff, id eft ftrumas, \& de ouibus fic affectis dicere folent, fy Eeldbent. contingit autem aliquandocum uitæ periculo, oboritur pręcipué initio ué ris: $\&$ poftea cum iam gramine pafcuntur inclinatis capitibus, currantur. Sunt qui fic affectarum pas bulo, uel fali potius, medicamenta mifceant, ut quidam apud nos iuniperi baccas 8 lingux cerưtinę folia trita. TOpiliones afari radicis pollinem fali mixtum oubus lingendum prabent,ad pulmo: nis præcipué uitia $\&$ tuffim, Tragus. Oues fi tuffient, amygdalærepurgatæ contufxéć cum tribus uini cyathis diftem peratx, per nares infundidebent, Anatolius. Paftores noftri ouibus xgris,in tuffi prafertim pfeudochamadry medentur, unde etiam noftri herbam ourum ([ $b a n$ ftrut) appela lant. Similis eft chamædryi, fed fatua \& inodora, floribus coeruleis fpicatim per adnatos ramulos di geftis, in medij caulis cacumine nunquam fe aperientibus. Plura de hac planta dixi in Boue C. Sue 30 fpiriofélaborantibus, auriculæ ferro refcindendx, mutandxq̧́ regiones, quod in omnibus morbis ac peftibus fieri debere cenfemus, Columella. Si laborent dyfpnoea, ferro illis aures rísuv $\{v$, id eft, amputare (forare uertit Andreas ấ Lacuna: Cornarius incidere, ego fummas auricularum partes re fecandas intelligo, )oportet, ipfasćģ oues aliò traducere, Anatolius. Radix herbæconfiligínis, fuum quidem \& pecoris omnis remedium prafens eft pulmonum uitio, uel traiecta tantum in auricula Bibi debet ex aqua, haberiç in ore affiduè fub lingua, Plinius, Ouem pulmonariam fimiliter ut fuem curari conuenit, inferta per auriculam, quam ueterinarí confiliginem trocant. de ea iam dixis mus, cum maioris pecoris medicinam tradidimus, fed is morbus aftate plerungs concipitur, fi defuit aqua, propter quod uaporibus omni quadrupedilargius bibendi poteftas danda eft. Celío placet,fi eft in pulmonibus uítium, acris aceti tantum dare, quantum ouis fuftinere poflit, uel humana uetes ris urinæ tepefactæ trium heminarum inftar per finiftram narem corniculo infundere, atcs axungle fextantem faucibus inferere, Columella đCauda ouis quàm arctiffimé praligata, euulfa indela na, pra faftidio qua non pafcebatur ouis, ftatim uefcitur: traduntí̧ quod extra nodum fit écauda præmori,Plinius, 『Bilis aftiuo tempore non minima pernicies potione depellitur humanx ue teris urina, qua ipfa remedio eft etiam pecori arcuato, Columella. De uermibus feu hirudinibus iecoris, fupra dixi inter morbos ouis toti corpori perículofos. TTormentilla uulgò dicta dyfente. riam $\&$ alia urentris profluuia fiftit. quare opiliones etiam ea utuntur ouibus curandis, Tragus, In noftra regione ut uenter ourbus fiftatur, falem prabent, $\&$ fic excitata fiti uinum nigrum, Albertus,

TMeatus etiam alimenti ficci coaluit aliquibus beftịs, fcilicet ouibus 8 quibufdam alịs. Arifo.

Tlen ouibus aliquando craffis humoribus impletur inflatur'q́, idł̣́ fępius mêfe Maio \& Aprili præ copia craffi lentióp fanguinis:unde fape fubitò moriuntur. Prodeft eis fetum, ut uulgò uocant, duorum digitorum poni inter nares, $\&$ operam dare ut multum detrahatur fanguinis . Qurdame. nim fic liberantur, alix nihilominus moriuntur, Crefcentienfis, đAnimalia in renibus pinguiffimałoures quidem letaliter circum eos concreto pingui, Plinius. Oues in renibus opimandis luxur

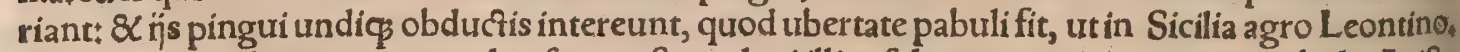
Quocirca fero dici agere oures ad pafcua paftores loci illius folent, quo minus capiant pabull, Arifto teles. Ouibus folis animalium renes totos obefos habere letale eft. quo fir ut quanquam pingures. admodum fint, tamen aliquid defit, \& fi non utri , dextro quidem, caufa cur hoc folis, aut maxime ouibus accidat, quod ins qua adipe pinguefcere folent, pingue humidum eft, itaç, non xque flatus interclufi dolorem faciunt, quod caufa fyderationis ef, Arift.de par.libro 3. cap.9. 8 rurfus, Copia etiam feur genus ouium longe excedit. omnium enim animalium oues celeri renũ obefitate opplens uur,itaç humore flatuóg interclulo celeriter pra fyderatione intereunt. nam per uenam aortam \& 


\section{DeOuc. D.E. Lib. I. 887}

moiorem fatim uitium ad cordis fedem tranfuchitur. . TOues pra nimio frigore aliciuando in fcabiem uel podagram incidunt, tefte Vergilio, GOuem, equum, 8 hominem eifdem fere totis demíg morbis tentari periti tradunt, Ariftoteles.

D.

Oues quadrupedum mitiffim funt, Textor:manfuetx $S C$ innocentes, Albertus, Ouis de do, mo uix eịcitur, \& electa recurrit, Obfcurus, Maximé narura quietæ funt, \& a ptiffimæa ad uitam hominum:quare $\&$ propter utilitatem $\&$ propter placiditatem nutriendx ab homine affumptę funt, Varro. Genus ouile amens, $\&$ moribus, ut dici folet, filtiffimis eft, quippe quod omnium quadru pedum ineptiffimum fit repit in deferta fine caufa, hyeme obfante ipfum fape egreditur ftabulo oc cupatum à niue, nifi paftor compulerit, abire non uult, fed perit defiftens, nifi mar es à paftore ducan. tur:ita enim reliquus grex confequitur, A riftot. Quàm ftulífima animalia lanata quà timuếre in. gredi, unum cornu rapto fequuntur, Plin. In ours ingenio fe prodit ro o ${ }^{\prime \prime} \& 806$, (id elt fimplicitas uel ftultitia,)Adamantius. Ouis $\&$ afinus ineptiffimis funt moribus \& degeneribus animis, Aelian. Ouium $\&$ boum duces conftituuntur, Ariftor. Omnium maximé animalium oues ad parendum faciles funt:Etenim ad uerba paftoribus obediunt, \& canibus obtemperant, $\&$ capras fequuntur, $f$ mil \& inter fe amant, A elian. Docent paftores fuas oues gregarifacto ftrepitt, ut fupra in c. retuli, ubi de partu et abortu ouiũ dixi. Pili molles hominem timidum defignant: nam 8 inter bruta hu= iufmodi funt quibus molliffimus pilus, ut otris, lepus, Ariftot. Oues fe inuicem amant, \& una con* dolet alteriłnam fana fi alteram uiderit imbecillam, Soli pro ea fe obijcit, \& umbram ei obtendit, $A=$ bertus. Mater agnum odore pofteriorum nofcit, Albert.

TCum capris oues amicitia coniuncex funt, Aelian. Luporum infidpis oives minus idcirco pa= tent, quòd non ita feparatim à reliquis errant quemadmodum fingula capra à gregalibus fuis fegre gantur, A elian. Lupum grauiore pedis fonitu ouis ftulta uocat, Plutarch. Vide in Lupo D. $\Lambda \in \lambda u$

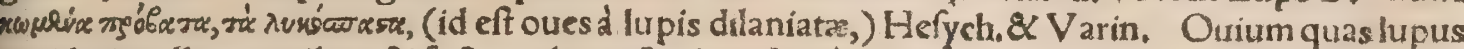
occiderit pelles ac uellera, \& facta ex his ueftis, longẻ quảm catera a pciora funt ad pediculos procre andos, Arrftot. Vide in Lupo D .ubi etiam expofitum eft, rur oues àlupis dilaniata carnem quidem frauiorem, lanam autem tabidam flaccidamç̧ habeant. Haud mirum uideri deber ouis pellem à lit po dilaniata pruxitum mouere, nam ob uehementem metum, tum etiam ob contraviam naturam ma lè afficitur: etfi mors enim ulrimum fit fupplicium, magis tamen afficitur corpus in uno quàm alio genere. Metuit homo magis in mari fluctuans quàm coram hofibus, Cardan. Mirum eft, inquit idem, \& tamen uerum, fidibus lupi agninas male obftrepere; quanquam hoc idem contingat neruis ferme omnibus diuer for um animalium, ut ranis $\&$ agni. Manifeftius hoc contingit eriam in tympa. nis:nam ouina coram lupinis penè obmutefcunt, fridentç. Oues etiam mortię mortuum lupurm extimefcunt, Oppianus:cum proximé dixiffet fi tympanum ex pelle lupina pulietur inter alia qua ouillis pellibus conftât, hæc obmutefcere, illud unum grauiter refonare. Si tendatur chorda lupi= na cum chordis ouillis, hæ rumpentur, uel omnem harmoniam(fonum) amittent. Quód fipelles eti am ouis \& lupi coniungantur, ouilla lanam amittet, ut \& alí fribunt \& Albertus, qui tamen hoc fe expertum negat.(Plura de his omnibus leges in Lupo D.) Ego ea qua dechordis \& tympanis dia cuntur fuperftitiofa effe puto. Quanquam enim lupina pellís cum durior folidioróg fit ouillis, fonum $4^{\circ}$ proculdubio in tympanis longé clariorem adat, ut fonus reliquórum longè inferior minus animad. uertatur, ut lux candelx iuxta ignem magnum pofitx: (eaden $\&$ in chordis ratio fuerit.) rumpi ta men uel prorfus obmutefcere quis credat? Caterum pellem oullam lupina coniunctam abfumi ct tius non mirum eft, ut neq anferis pennas prius quàm aquila, fi coniunxeris, Sicciorum enim anima lium partes etiam ficciores minusóp excrementitia funt, \& eandem ob caufam diuturniores. Sunt au tem fylueftria manfuetis ficciora, tum exercití tum pabuli rarione: nam \& exercentur amplius, \& pabulo tum ficciore tum minus copiofo frutuntur. Et anferis quidem pennas plures ab una aquilina adiecta confumptas, expertum fe profitetur Albertus, Sed fi natura citius pereunt anferina, non ue rènec propriè ab aquilinis confumi dicentur. Experiri poterunt curiofi, fepofitis anferinis pennis alịs per fe, alh̆s cum aquilina adiuncta, ut uideant pariter ne, an hæuel illæ priores intereant, Idem cum ouilla $\&$ lupina pellibus experiri licebit, I A pibus inimic $\&$ oures, difficile fe à lanis earum explicantibus, Plinius,

E.

Quadrupedum fylueftrium quas utilitatis caufa deprehenfas homines incluferunt, ut manfue fcerent, primas non fine caufa purant oues affumptas, $\&$ propter utilitatem $\&$ propter placiditatem. maxime enim hæ natura quietæ, \& aptifimæad uiram hominum. Ad cibum enim lac, $\mathcal{X}$ cafeum adhibitam, ad corpus ueftitum \& pelles attulerunt, Varro. V tilis cft cuis lana, corio, lacie; carne, uifceribus, (inteftinis)fimo in quo quiefcit, Albert. Noftri uulgò quofdam uerfus recitant, quorum fenfus eft, illum qui oures $\&$ apes poffideat uel mediocri diligentia adhibita, facile ditefere. Sab $_{4}$

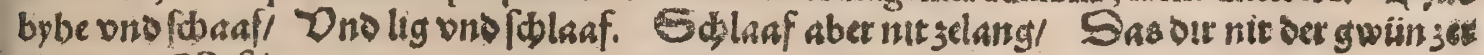
gang. TPaftio.

Ergo omniftudio glaciem, uentosćs niuales, Auertestuictumćc feres, \& uírgea lizus

Quo minus eft illis curæe mortalis egeftas, Pabulałnec tota claudes fonilia bruma: 
At uero Zephyris cum lata uocantibus aftas, pafcua mittes.

Carpamust dum mane noư̂̉, dũ gramina canêt:

Inde, ubi quarta fitim coli collegerit hora,

Ad puteos, aut alta greges ad ftagna iubeto

Aeftibus at medījs umbrofam exquirere uallẽ,

Ingentes tendat ramos:aut ficubi nigrum

Tum tenues dare rurfus aquas: $\&$ pafcere rurfus

Temperat: \& faltus reficit íam rofcida luna:

Vergil.3.Georg. (Vergilius libro 3. Georgicort
prouincia:nam in aliquibus locis morbum contr

Erouincia:

Lappaéć tribuliç̧ abfint:fuge pabula lxta,

( $\&$ arierê tum corpore, tum lingua (idua palatóg candidum.) Primum prouidendum, ut totum annus recte palcantur intus $\&$ foris, Varro. Pafcua ouillogeneri utilia funt, qux uel in noualibus, uel in pratis ficcioribus excitantur. Paluftria uerò noxia funt, fylueftria damnofa lanatis; Pallad. Seque, ris autem noualia non folum herbida, fed qux plerunç uidua funt fpinis, utamuró frepius authori tate diuini carminis: Si tibi lanititum curx eft, primum afpera fylua, Lappxóc tribuliós abfint, Quoniam ea res, ut ait idem, fcabras oues reddit, cum tonfis illotus adhafit Sudor: 8 hirfuti fecties runt corpora uepres $¥ t u m$ etiam quotidie minuitur lana, qua quanto prolixior in pecore concrefcit, 1 tanto magis obnoxia eft rubis, quibus uelut hamis inuncata à pafcentium tergoris auellitur molle uero pecus etiam uelamen, quo protegitur, amitrit, atç id non paruo fumptu reparatur, Columella Hoc pecus quamuis mollifimum, ualetudinis tutifimx eft, miniméğ peftilentia laborat. Verum ia men eligendum eft ad naturam loci:quod femper obferuarinon folum in hoc, fed etiam in tota ruris difciplina Vergilius præcipit, cum ait: Nec uero terræ ferre omnes omnia poffunt. Pinguis, \& cam peftris fitus proceras oures tolerat, gracilis $\&$ collinus quadratas: fylueftris $\&$ montofus exiguas:pra tis planiś́g noualibus tectum pecưs commodiffime pafcitur. Idóg non folum generibus, fed etiam coloribus plurimum referc, Idem. Aeftate oues fub dio nutriuntur ftabulanturó, Caterum inuale frente Sole in umbram funt fubducenda :alioqui nequaquam. Maximéfiquidem laduntur frigore, Florentin. Per totam aftatem (inquit Crefcentien, )aurora furgente feftinanter mulgeantur, ne $\mathrm{for}_{3}$ litum paftum perdant: \& cum dies incaluerit, fic ducantur, ut calor Solis aut uentus urens non pof, fit eis nocere. Cæterum uefperi tandiu foris fint, donec recuperent paftum quem perdiderunt in die. Cum redierint, femper curandum ne fint calidx cum in oulia includuntur. Quód fi magnusfes uor fuerit, eant in proxima pafcua, ne fi longius abierint non poffint recurrere ad umbracula : nec paftores finant eas importunè aggregari cum colum feruet : quin femper moderaté difpergant. Cü adducunt́t calidx, nó mulgeantur, (donec refrigerent̂́ mediocriter.) Cũ aurora apparuerit, mox agni culi ducãtur ex umbraculis, ubi folicitè cuftodiant. Cũ uiderint mane telas aranearû oneratas aqua, non permittant pafcere. Si feruor fuerit $\&$ pluuia ceciderit, non finantur iacere, fed ad altiora ducan tur, ubi expofita fint uento, femperćs moueantur. Cauendæa autem funt ab herbis, quibus permixta eft arena.Menfibus A prili,Maio, Lunio \&C Iulio non funt permittenda multum pafci, ut peritus quís dam paftor monet, ne nimium impinguentur. fed menfe Septembri, Octobri \& Nouembri poft ms diam tertiam funt tota die dimittenda in pafcuis, ut impinguentur quantum poterunt, $\mathrm{Hucuf} g \mathrm{Cr}$ fentien. Non eadem loca xftiua \& hyberna idonea omnibus ad pafcendum. Itaçgreges ouium longe abiguntur ex A pulia in Samniữ æeftiuatum, atç̧ ad publicanũ profitentur, ne li infcriptü ph cus pauerint, lege cenforia committant mulietos, \& i campeffri, æftate exigûtur in Gurgures altos montes, Varro. Et rurfus, Greges in A pulia(in folitudine $\&$. faltibus pafcentes, hybernis $\&$ ęftiuis pafcuis longé(eparatis) aftate prima luce exeũt in paftum,propterea quòd tunc herba rofcida meri dianam, qua eft aridior, iucũditate praftat. Sole exorto puro propellint, ut redintegrantes rurfus ad paftũ alacriores faciant. Circiter meridianos aftus, dũ deferuefcưt, fub umbriferas rupes $\&$ arbores patulas fubịciūt, quoad refrigerato aére uefpertino, rurfus pafcant ad Solis occafum. Ita pafcere pe cus oporter, ut aduerfo(auerfo)Sole agat:caput enim ouis molle maximé eft. (Infirmiffimũ pecori cas put:quamobrẽ auerfum à Sole pafci cogendĩ, Plin. ) Ab occafu paruo interuallo interpofito ad bi= bendũ appellũt, $\&$ rurfus pafcũt quoad contenebrauit : iterũ enim tunc iuctuditas in herba redinte: grauit. hæc ab Vergiliarũ exortu ad æquinoctiũ autũnale maxime obferuẫt, Quibus in locis meffes funt fact $x$, intereft utile (teneant in ftipulis, \&qd eft utile, $\&$ c. Crefcent, ) duplici de caufa, $\Phi \&$ caduca

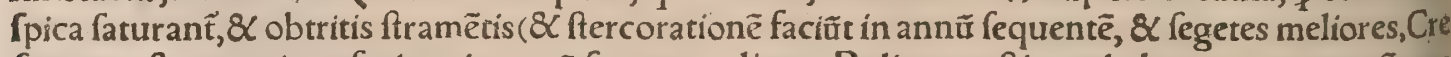
fcent $t_{*}$ et ftercoratione faciunt in annũ fegetes meliores. Reliquę paftiones hyberno ac uerno têpore

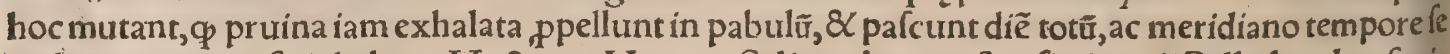
mel agere potum fatis habent, Hactenus Varro, Salis crebra confperfio, inquit Pallad, uel pafcuis mifta, uel canalibus frequenter oblata, debet pecoris leuare faftidiû. (De falis ufu fupra etiam dixi in 6 $C$.in cibiac potus ouiũ mentione, $\mathscr{Q}$ inter tuendx fanitatis præcepta.) Nam per hyemem, fi penuria eff, foenư, (fi penuria eft foeni uel paleę, uicia uel facilior uictus, \&c, Crefcent,) urel palea, uel uicia, uel 


\section{DeOue E. Lib. I. 889}

facilior uictus ulmi feruatis frondibus prabeatur, atut fraxini. Aeftuis menfibus pafcantur fub lucis initio, cum graminis teneri fuatritatem rotis miftura commendat, Quarta hora calefcente potus pun ri fluminis, aut putei prabeatur, aut fontis. Medios folis calores uallis, aut arbor umbrofa declinet. Deinde ubiflexo iam die ardor infringitur, 8 folum primo imbre uefpertini ror is humefcit, gregem reuocemus ad pafcua. Sed canicularibus $\&$ aftius diebus ita pafcenda funt oues, ut capita gregis femper auertantur à folis obiectu. Hyeme autem uel uere, nifi refolutis gelicidips ad pafcua prodire non debent:nam pruinofa herba huic generi morbos creabit:ac tunc (al tantum) femel adaquare fuf ficiet. De temporibus pafcendi \& ad aquam ducendi per æftatem non aliter fentio, quàm ut prodi dit Maro, Luciferi primocum fydere, ( $\mathcal{C}_{\mathrm{c}}$ ut fuperius recitaui.) Deinde circa quartam diei horam \& cum aftus uiget, ad puteos, ftagna, ualles aut aliam umbram perducemus greges. Rurfus deinde iam mitigato uapore compellantur ad aquam, etiam per aftatem id faciendum, \& irerum ad páfua producendum ad occafum Solis. Sed obferuandum eft fydus aftatis per emerfum canicula, ut ante meridiem grex in occidentem fpectans agatur, 8 in eam partem progrediatur, poft meridiem in or entem:fiquidem plurimum refert, ut pafcentium capita fint (auerfa) obuerfa foli, qui plerunq̧ nocet anímalibus oriente prædicto fydere. Hyeme $\&$ uere matutinis temporibus intra fepta contineãtur, dum dies aruis gelicidia detrahat:nam pruinofa ịs diebus herba pecudi grauedinem creat, uentrẽ qu proluit: quare etiam frigidis, humidiş̧́ temporibus anni femel tantum ei poteftas aquę facienda eft, Columella. Omni pecudi larga prabenda funt alimenta. Nam uel exigutus numerus, cum pabulo fatiatur,plus domino reddit, quàm maximus grex, fi fenferit penuriam, Idem. De cibis \& paftione ourium dixi etiam nonnulla Capite tertio, primum in mentione cibiac potus earû, deinde inter prae ceptatuendx fanitatis. Oues nutrire conuenit ex cytifo, herba Medica, aut foenogræco, aut bromo (id eft auena,)nec non ex culmis (achyris, id eft paleis, qui funt folliculi granorum ) leguminum atg hordei.Quae quidem multó praftantiora redduntur, fi in area ipfa refpergantur falfugine. Ex ficu

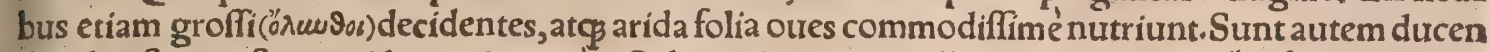

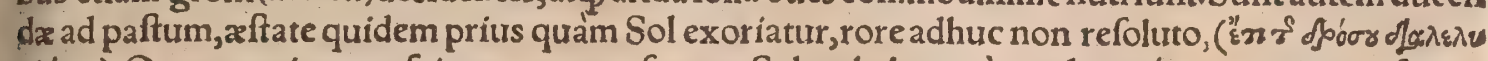
plims.) Oportet etiam profpicere ut oures femper Solem habeant à cauda : utćs earum impar fit nu. merus, ceu quod habeat quandam uim naturalem ad incoltumitatem atque falutem gregis, Floren tinus, Caprea, oues $\&$ iuuencæ fapibus arceri debent à uitibus, quibus plurimum nocent pafcen do 8 mordendo, tefte Vergilio. A pibus ftatio quarenda eft, quo neģ fit uentis aditus, neque oures hoedióp petulci Floribus infultent, Idem. Matrices oues poftquam pepererint quomodo fint tra= ctandx, tride in agno $\mathrm{E}$.

đGræcas oues, ficut Afianas, uel Tarentinas moris eft potius ftabulo nutrire, quàm campo, \& pertufis tabulis, folum, in quo claudentur, infternere ut fic tuta cubilia, propter iniuriã pretiofi uelle ris, humor red dat elabens, Sed tribus, per annum totum, diebus aprico die lotas oures ungere oleo $\mathrm{O}_{3}$ portebit, \& urino. Propter ferpentes, qui plerunos fub prafepibus latent, cedrum, uel galbanum, uel mulieris capillos, aut ceruina cornua, frequenter uramus, Palladius \& Crefcent. Græcum pecus, ín quit Columella, quod pleriç Tarentinum uocant, nifi cum domini pręfentia eft, uix expedit haberi: fiquidem \& curam $\&$ cibum maiorem defyderat:nam cum fit uniuerfum genus lanigerum cateris pecudibus mollius, tum ex omnibus Tarentinum ef mollifimum, quod nullam domini aut magi. ftrorum inertiă fưftinet, multoós minus auaritiã, nec æftus nec frigoris patiens. Raro foris, plerunç domi alitur, \& eft auidiffimû cibi, cui fi detrahitur fraude uillici, clades fequitur gregê. Singula capi ta per hyemem recie pafcuntur ad præfepia tribus ordei, uel fref $x$ cum fuis ualuulis fabx, aut cicer. culæ quatuor fextarỉs, ita ut $\&$ aridam frondem præbeat, aut ficcam uel uiridem medicẩ, cytifúmue, tum etiam cordi foeni feptena pondo, aut leguminum paleas adfatim. Minimus agnis uendundis in hac pecude, nec ullus lactis reditus haberi poteft; nam $\mathcal{X}$ qui fummoueri debent, pauciffimos poft dies quàm editi funt, immaturi ferè niactantur, orbæćç natis fuis matres alienæ foboli prabent ube= ra:quippe finguli agni binis nutricibus fummittuntur, nec quicquam fubtrahi fummiffis expedit, quo faturior lactis agnus celeriter confirmetur, \& parta nutrici confociata minus laboret in educa= tione foetus fui:quam ob caufam diligenti cura feruãdum eft, ut $\&$ fuis quotidie matribus, $\&$ alienis non amantibus, agni fubrumentur. Plures autem in eiufmodi gregibus, quàm in hirtis mafculos $e_{=}$ nutrire oportet:nam prius quàm foeminas inire poffint mares caftrati, curm bimatum expleuerint, $\mathrm{e}$ : necantur $\$ \&$ pelles eorum propter pulchritudinem lanæ maiore pretio, quàm alia uelleta mercantib. traduntur, Liberis autem campis, 8 omni furculo, rubó́ç uacantibus ouem Gracam pafcere memi nerimus, ne, ut fupra dixi, $\&$ lana carpatur $\&$ tegumen non quotidie procedit in pafcua, fed maiorem domefticam poftulat:nam fapius detergenda, \& refri geranda eft: fxpius eius lana diducenda, uinoćp \& oleo infuccanda nonnunquam $\&$ tota eft eluen= da, fi diei permittit apricitas:idós ter anno fieri fat eft. ftabula uero frequenter eurerenda 8 purgan= da, humorø̧ omnis urinæ deuerrendus eft, qui commodiffimè ficcatur perforatis tabulis, quiburs oul lia confternuntur, ut grex fupercubet:nec tantum cœno, aut ftercore, fed exitiofis quoç ferpentib. tecta liberantur, quod ut fiat, Galbaneó̧́ agitare graues nidore chelydros. Vipera delituit, colựćs exterrita fugit,

Difce $\&$ odoratam ftabulis incendere cedrum, Sxpe fub immotis prafepibus aut mala tactu

Aut tecto affuetus coluber. 
Quare, ut idê iubet: Cape faxa manu, cape robora partor. Tollentéós minas, \& fibila colla tưmentê Déjce. Vel ne iftud cum periculo facere neceffe fit, muliebres capillos, aut ceruina fapits ure cor nua:quorum odor maximé non patitur ftabulis pradictam peftem confiftere, $\mathrm{H}_{2}$ cienus Columella, Ne beftix nocentes prorepant ad oues, fuffitum in ftabulis moliri conuenit:nempe ex capillis mu lierum, aut galbano, a ut cornu ceruino, aut caprillis unguibus, aut pilis, bitumine $\&<$ cafia, aut cony, za, aut alio deniç graueolentium, fiue perfe, fiue cum alins pluribus contufo. Ad gregis autem ftra. tum, utendum eft calamintha, af phodeló́ aut pulegio, aut polio, aut conyza, aut abrotono: hac fí quidem fugant beftias, Florentin.

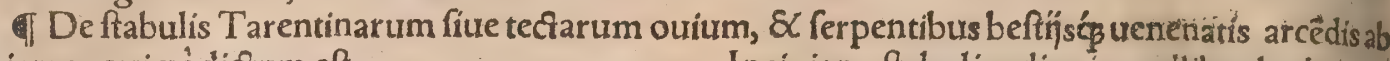
eis iam proximé dictum eft. Incipiens, ftabulis edico in mollibus herbam Carpere oureis, dum mox frondofa reducitur æftas: Et multa duram ftipula, filicumóp maniplis

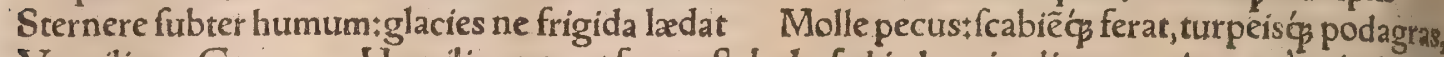
Vergilius 3. Georg. Humilia oportet facere ftabula, fed in longicudinem potius, quàm in latitus dinem porrecia, ut fimul hyeme calidx fint, nec anguftix foetus oblidant, ea poni debent contra mea dium diem: nanģ̧id pecus, quamuis ex omnibus animalibus uetuftiffimum, (lego, ueftitifimum,) frigoris tamen impatientiffimum eft, nec minus aftiui uaporis. itaç cohors claufa fublimi macerie praponi ueftibulo deber, ut fit in eam tutus exitus æeftiuandi:detur ut femper quàm aridiffimis filicibus, uel culmis ftabula conftrata fint, quo purius 8 mollius incus bent foer , fint quala mundiffima, ne qua earum ualetudo, qux præcipue cuftodienda eft, infeftetw uligine, Columella. Stabula idoneo loco ut fint,ne uentofa, qua fpectentmagis ad orientē, quàm ad meridianum tempus, ubi ftent, folum oportet effe eruderatum, (uirgultis aut paleis aur alinjs fra minibus ftratum, Crefcentienfis, ) \& procliuum, ut euerri facile poffit, ac fieri purum: non enim fos lum ea úligo lanam corrumpit ouium, fed etiam ungulas, ac eas frabras fieri cogit. Cumć aliquoł dies ita fteterint, fubijcere oportet uirgulta, (alia uirgulta uel paleas, Crefcent.) \& alia, quo molliuste quíefcant, puriores ć fint:łibentius enim ita pafcưntur. Faciendum quoç̧ fepta fecreta ab alịs, quo enitentes fecludere poffis, item quo corpore ægro: hæe magis ad uillaticos greges animaduertenda, Contra illę, in faltibus qux pafcuntur $\&$ à tectís abfunt longe, (nam in his qux pafcûtur in falcibus, cuftódes fecum portant crates, \& c.Crefcent, ) portãt fecum crates, aut retia, quibus cohortes in foll, tudine faciant, cæeterá̧́ utenfilia. Longé enim $\&$ laté in diuerfis locís pafci folent, ut multa milia ab, fint fape hybernx paftiones ab aftiuis, Ego uero fio, inquam:nam mihi greges in A pulia hybernaa $3^{\circ}$ bant, qui in Reatinis montibus æittuabant. Cum inter bac bina loca, ut iugum continet feirpiculos, fic colles publica diftantes paftiones, Varro. Otrium ftabula fatis ampla \& lata effe debent, ( rouis oporter decliure fit, lapidibusḉp ftratum \& complanatum. Ad partem eius accliuiorem prafepia funt collocanda, fupra qux etiam pertica ( krikeckes) infigendæ funt, ut oures dum pafcuntur fuperfilire prohibeantur, Florentinus.

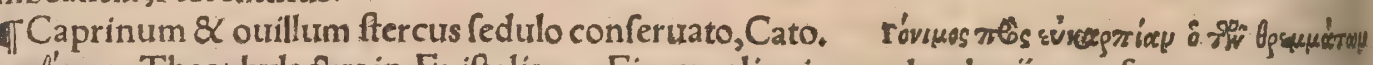
"ovdos ret'ssme, Theophylactus in Epiftolis. Fimumaliqui ex columbarïs praferunt. proximum deinde caprarum eft, ab hoc ouium, deinde boum, nouifimum iumentorum, Plinius. Caffiusfe cundum poft columbinum ftercus, fcribit effe hominis:tertio caprinum, \& ouillum $\&$ afininû, \&ci, $4^{\circ}$ Varro. Accrrimus hominis fimus eft, \& optimus fecundum aliquos, deinde fuum, caprarum, ouinum, boum, poftremò afinorum, ("ovwy, Gaza uertit iumentorum, ) Theophraftus, Ouillum quidam caprino præferunt, omnibus uerò afininum, Idem. Stercus afinorum primum elt maxis mèhortis, dcinde ouillum \& caprinum, \& iumentorum, Pallad. Ȧd cultum hortorum optimum freicus eft afini, quia minimum herbarum creat:proximum uel armenti, uel ourum, fi fit anno mace ratum, Columella libro 11. Iuftum eft fingulas uehes fimi denario ire, in fingulas pecudes mino: res:in maiores, denas: nifi cótingat hoc, malê fubftrauiffe pecori colonưm appareat, Sunt qui optimé ftercorari putent, fub dio retibus inclufa pecorum manfione, Plinius. Ouillo fimo ad afparagos uti Cato (capire 161 , )nominatim iubet, quoniam aliud herbafceret, (herbas crearet, ) Idem, Efes

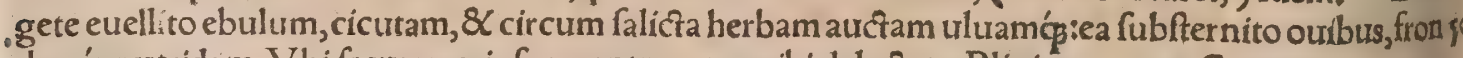
demq̧́ putridam. Vbi faturus eris frumentum, oues ibi delectato, Plinius 17.9, ex Catone.

- In emptionibus iure utimur eo, quod lex prafcripfit : in ea enim alij plura, alī pauciora excir piunt quidam enim pretio facto in fingulas oues, ut agni chordi duo pro una oue annumerentur, efficui uetuftate dentes abfunt, item binx pro fingulis, ut prodant ‘ de reliquo antiqua fere formula utuntur, cum emptor dixit: Tanti funt mihi empta? $\&$ ille refpondet, Sunt: $\&$ exprompfit numos, Emptor ftipulatur prifa formula:Sic illafre oures, qua de re agitur, fanas recte effe, uti pecus ouillit, quod recte fanum eft exrra lufcam, furdam, minam, id eft uẽtre glabro: neģ de pecore morbofo effe, haberéćs rectelicere: hac fi recte fierifpondes nec cum id façum eft, tamen grex dominum non mu tat, nifilit æs adnumeratum. Nec non emptor poteft ex empto uenditorem damnare, fi non tradat, cum is non foluert numos:ut ille emptorem fimili iudicio, fi non reddidit presium, Varro. Errur fus, Relinquitur de numero, quem faciunt alị maiorem, alị minorem:nulli enim nutuius moduli natu raies. lllud ferè omnes in Epeiro facimus, ne minus habeamus in centenas oues hirtas fingulos hom 
nes, in pellitas binos. De numero paftorum alij anguftius, alip laxius conftituere folent. Ego in ocfogenas hirtas oures fingulos paftores conftitui, Atticus in centenas, In gregibus cuium, fed ma: gnos quos miliarios faciunt quidam, facilius de fumma hominum detrahere poffunt, quàm de mino ribus, ut funt Attici. Tremellius. Septingenarij enim mei, ut opinor, tur octingenarios habuifti. Nec tamen non ut nos arietum decimam partem, Varro. Qui fequitur gregem circunfpectus, ac uigi lans(id quod omnibus, \& omnium quadrupedum cuftodibus præcipitur)magna clementia modere tur: Idemó̧ duci propior quàm domino, 8 in cogendís, recipiendiş́́ ouibus adclama tione, ac bacu. lo minetur: nec unquam telum emittat in eas:neq ab his longius recedat;nec aut recuber, aut confin dat:nam nifi procedit, ftare debet:quoniam grex quidem cuftodis officium, fublimem celfiffimamúp oculorum ueluti fpeculam, defyderat, ut neq tardiores $\$$ grauidas, dum cunctantur, neç agiles $\$$ foetas, dum procurrunt, feparari à cæeteris finat, ne fur aut beftia hallucinantem paftorem decipiat, Columel. Numerus caprini gregis min or effe debet quàm ouilli, quòd capra lafciux $\&$ qux difper gunt fe: contra quòd oues fe congregant, \& condenfant in locum unum. Itaç in agro Gallico gre. ges plures potius faciunt, quàm magnos, quòd in magnis citò exifunt peftilentix, Varro. Et alibi, Canis ita cuftos eft pecoris, ut eius quod eo comite indiget ad fe defendendum: in quo genere funt maximé oures, deinde capræ. Has enim lupus captare folet, cui opponimus canes defenfores. Ouri um, caprarum \& equorum paftores, genitalia earum tempore coitus, delibutis multo fali \& nitro manibus, 'perfricant: unde î́s uehementior coitus appetitio exoritur, $8 \times$ mares fuftinẽr, Alị alị̂s mor dicantibus pharmacis ea perungunt, ut pipere trel nitro, uel urticæ fructu, Aelian. Poft foturam longinquæ regionis pafcua petiturus opilio ferè omnem fobolem paftioni referuet fuburbanæ, uillicus enim teneros agnos, dum adhuc herba funt expertes lanio tradit, quoniam 8 paruo fumptu de. uehuntur, ,ijs fummotis, frucius lactis ex matribus non minor percipitur. Summitti tamen etiam in uicinia urbis quandoops oportebit. Nam uernaculum pecus peregrino longe eft utilius. Nec commit ti debet, ut rotus grex effotus feneciute dominum deftituat:cum prafertim boni paftoris uel prima cura fit annis omnibus in demortuarum uitiofarumḉ ouium locum totidem, uel etiam plura capita fubftituere, quoniam fape frigorum atq hyemis fęuitia paftorem decipit, \& eas oures interimit, quas ille tempore autumniratus adhuc effe tolerabiles, non fummouerat:quo magis etiam propter hos ca fus, nifi ualidifima, qua non comprehendatur hyeme, nouaç̧ progenie repleatur numerus, Colus: mella. Curandum eft ut mortuarum uel uitiofarum numerus nouella fobole reparetur. Autumno debiles quaç pretio mutentur, ne eas imbecillas hybernü frigus abfumat, Pallad. Oues ut fequan tur,earum aures lana obturato, Florentin. Antiphanes in Aceftria apud Athenæum quendã pra auaritia illas tantum oues mactare fcribit, ex quibus nullus amplius fructus, uellerum, cafei, agno. rum,ad eum perueniret.

TTonfura uocatur cum oures 8 capras detondent aut uellunt, Varro. Aegyptus tam abunde herbida eft, ut bis anno oures ex fefe pariant, biśg tondeantur, Aelian. Menfe A prili locis calidis tondeantur oures, Pallad, Locis temperatis menie Maio celebranda eft ouium tonfura, Idẽ. Et ali bi, Iunio menfe oues in frigida regione tondemus. Tondendarum ouium tempus eft in Iulio, $\mathrm{Te}_{\mathrm{z}}$ xtor. Tonfuræ certum tempus anni per omnes regiones feruari non potef, quonia nec ubiç tarde nec celeriter aftas ingruit: \& eft modus optimus confyderare tempeltates, quibus ouis, neç frigus,

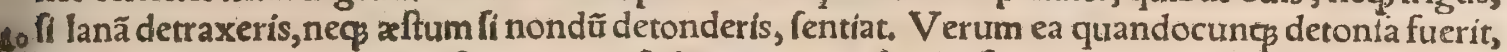
ungi debet tali medicamine:furccus excocti lupini, ueterisç̧ uini fex, et amurca pari mëfurra mifcent, eợ liquamine tonfa ouis imbuitur, a tఢ̧̣ ubi per triduû delibuto tergore medicamina perbiberit, quarto die fieft in uicinia maris, ad littus deducta merfatur:fi minus elt, coeleftis aqua fub dio falib. in hunc ufum durata paulü decoquitur: (aqua coleftis cum fale paululũ decocia fub dio debebit pe. rorum tonfa $\&$ uncta membra diluere, Pallad,) eaćp grex perluitur : hoc modo curatũ pecus anno fcabrum fieri non poffe Celfus affirmat:nec dubiư eft, quinetiã ob eam rem lana quoç mollior atq̧ prolixior renafcatur, Columella \& Pallad. Vide etiam fupra de inungendis ouibus tonfis ex Didy mo, Capite tertio in mentione fcabiei ouium: fic enim cauetur quo minus fcabra fiant. De tonfura ouium primum animaduerto ante quàm incipiant facere, num fcabië, aut uicera habeant, ut, fi opus eft, ante curentur quàm tondeantur. Tonfura tempus inter xquinoctiū uernum, 8 folltitiư cum fu dare coeperint oues:à quo furdore recens lana tonfa furcida eft appellata. Tonfas recentes eodem die. perungunt oleo $\& x$ uino, non nemo admifta cera alba, 8 adipe fuillo. Et fi ea tecra folet effe, quam ha buit pellem iniectã, eam intrinfecus eadẽ re perungunt $\&$ tegunt rurfus, Siqua in tonfura plagam ac cepit, eum locũ obliniunt pice liquida. Oues hirtas tondent circiter ordeaceâ meffem, in alị̂s locis ante foenificia. Quidam has in anno bis tondent, ut in Hifpania citeriore, ac femeftres faciunt ton. furas:duplicem impendũt operam, quòd fic plus putant fieri lanx, quo nomine quidam bis fecant prata. Diligentiores tegeticulis fubiectis oues tondere folent ne flocci intereant. Dies ad eam rem fu: muntur fereni, \& $\not$ ịs id faciût ferè à quarta ad decimã horam, quoniam fole calidioretonfa, ex fudore eius lana fit mollior, \& ponderofior, er colore meliore. Quam demptä \& conglobatam alí uellera, alij bo uelumina appellant:ex quorũ uocabulo animaduerti licet, prius lanæuulfuram quàm tonfuram ine uentam. (Oues non ubiqg tondentur: durat quibufdam in locis uellendi mos, Plin.) Quri etiam nunc uellunt, ante triduo ieiunas habent, quòd languidæ minus radices lanæretinent. Omnino tonfores. 
in Italia primum ueniffe ex Sicilia dicuntur poft Romam conditam anno quadringentefimo quin quagefimoquarto, ut friptum in publico Ardex in literis extat, eośç adduxiffe Publum Ticinitī Menã. Olim tonfores non fuiffe adfignificant antiquorum ftatua, quod pleræo habent capillum, $\&$ barbã magnam, Varro, Nec frigidoadhuc, nec iam x ttiuo tempore, fed medio uere oues tonden dæl funt. Currandum autẽ eft ut poft horam diei primã abfterfæo oues, exiccató̧́ uapore illo quem no ctulana contraxerat, pracipue ad Solem tondeantur, $N$ am quum ouis qua tondetur tunc fudet, $f_{a}$

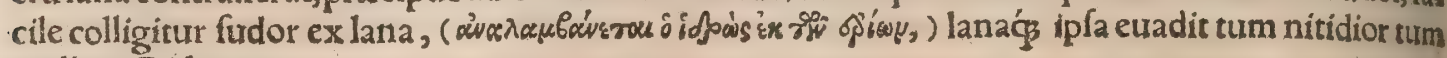
mollior, Didymus.

đFructum ouris èlana ad ueftimentũ miniftrat, Var, Quadrupedibus pili fenectute craffef(cũt, lanáćs rarefcunt,Plin. Lanæ molles $\&$ crifpa præferuntur, Albert. Arietis lanam fequitur quič quid ex eo generatur, Idem. De ariete eligendo, infra dicetur in hiftorize eius cap. 2. De Tarentino fiuc teço pecore, quod lanart̃ tantum gratia nutritur, fuperius hoc in capite dicium eft. Quibus pafcuis lana melior mollioróp fiat, explicaurimus fupra partim hoc ipfo in capite, partim tertio, Cur ouium expilatis mollior pilus fubnafcitur, homini durior? A riftot.Problem.10.24. Cur ouium pill cò duriores funt quo prolixiores, hominum contra! Ibidem fequentiftatim Problemate, Pabulafte rilia fubtilitatem lanx augent, Cardanusłideoćs Anglica lana(inquit)nunc, ut olim Milefia, celebran tur. Nec mirum, cum nulium animal uenenatû mittat Anglia, \& fineluporum metu, (nulli enim in Anglia hodie lupi reperiuntur, )pecus uagetur, Rore coli fitim fedant greges, ab omni alio potu ar: centur, quòd aqux ibi ouibus fint exitiales. Cur uellus ouis à lupo laceratæ tabidum \& pediculo. fum fit, uide fupra in D. 8 in Lupo.D. Lanas Hifpania nigri uelleris pracipuas habet, Pollentiaiti a xta Alpes: Vnde apud Martialem lanæ Pollentinæ. Non tantum pullo lugentes uellere lanas. Cantra fium rurili, quas ery thras uocant. Canufinæ ruffæ dictæà Martiale: Ronia magis furcis, ueftitur Gal lia ruffis. Er Canufinatum Syrum dicit, pro Canufina uefte ornato, ut Canufinatus noftro Syrus afo fere fudet.Fuluas habet Tarentũ, \& fux pulliginis. Hiftria Liburnix́ćs, pilo propior quàm lanæ, pes xis aliena ueftibus, \& quam fola ars fcutulato textu commendat in Lufitania. Scutulatĩ uerò texcum eiufmodi feré eft, quale cernitur in aranearum telis. Quanta arte celant pedicas, fcutulato rete, ad ca piendas mufcas circa graffantes, Plinitus 11.23 . Idem libro 17 . de emplaftratione arborum loquensfiu tulam uocat corticem ad effigiem parui fcuti eximendũ ab arbore, in cuius locum cortex alius cựit germine reponitur. At uero mollis erat lana in agro Mutinenfi, cuius meminit Strabo in quinto: La nam mollê (inquit)Mutinenfis ager, eaç̧ regio qua ad flutuium Scutanã pertinet, fert omnium lona $3^{\circ}$

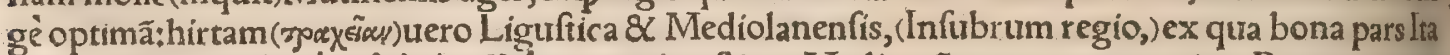
lia feruitiorum ( qua pretiofiffima tapeta $\&$ gaufapinx fiunt, Eft $\&$ hirta pilo craffu, in tapetis antiquiffima gratia, $\&$ hoc ftragula ueftis genus utring uillos eminentes habet, uel faltẽ ex altera parte, ) Bayfius. Feltrias ut hodie à Feltro urbe merca torum uulgus appellat, antiquis non defuiffe exiftimo:ueftes fcilicet nó textas, non confurtas, fed lana igne adacta compactas, quales nunc ad pilea $\&$ penulas in ufu habe,

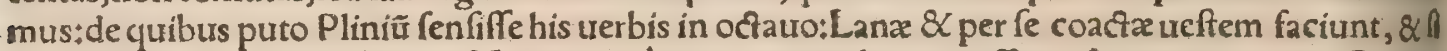
addatur acetum, etiam ferro refiftunt immò uêro etiã ignibus nouifímo fui purgamento. Quippe ahenis coquentium extractx indumentis ufu ueniunt, (Aliâs, Quippe ahenis polientium extracta in tomenti ufum ueniunt, Galliarum, ut arbitror, inuento:certe Gallicis hodie nominibus difcernü.4. tur: Nec facile dixerim, qua id atate cœperit, Calius Calcagninus epiftolicarum quętionum 3 , Sed addit Plinius, Antiquis enim torus è ftramento erat, qualis nunc etiam in caftris gaufape. Patris meimemoria copere amphimalla noftra, ficut uillofa etiam uentralia. Nam tunica laticlaui in mos dum gaufape texi nunc primum incopit. De lana feltria $\&$ pilotarîs artificibus qui pileos $\&$ ure. fes inde conficiunt, pluribus docui in Tauro capite 7. inter remedia aduerfus fanguinem taurinum. Lanæ Baticæ: Catullus timens naufragium eiecturus erat ueftes, quarum generofi graminis ipfum Infecit natura pecus: fed \& egregius fons Viribus occultis, \& Baticus adiuuat aér, Iuuenalis Sat, 12. Oues quas pelliones noftri Flandricas ( flentming) uocant, à molli \& crifpa lana laudantur. Sed de lanarum differentịjs, fecundum regiones pracipue, in B.etiam nonnihil diximus. đColoreslas narum. Bxticis ouribus, ut iam dixi, color fuus ex pabulo, potu $\&$ aére natura fit, non arte. Hæica præ)quoç non cura nobis leuiore tuenda: Nec minor ufus erit:quamuis Milefia magno Velleta mutentur, Tyrios incocra rubores, Vergil. Coloffinus color (inquit Hermolaus, qualem Plinius in flore cyclamini effe fribit)à Coloffis urbe Troadis uocari coppit. Strabo uolumine duodecimo, Lao

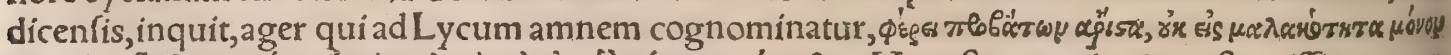

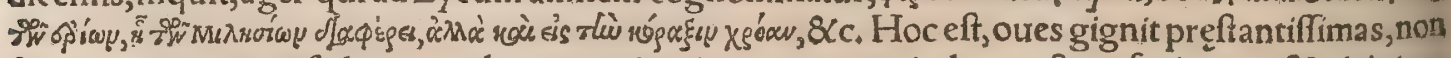
folum molitic lana, fed etiam colore coracino:ita $\$$ magnum inde quaftum faciunt, ut $\&$ uicini co rum Coloffini à cognomine eis colore. In Hifpania quoqs tradit coracino lanitium colore nafci. Vin truuius, In agris Clazomeniorum, Erethriaorum \& Laodicenfium pecora(inquit)procreantur, alins locis leucophæa, alījs pulla, alị́s coracino colore. De Laodicenfi uellere Plinius quo ̧̧ octauolibro; ubi 8 pulliginem coloris genus facit, Hæc Hermolaus. Ex Turditania Hifpaniæ frequens olim 6 ueftitus ueniebat, nune ucro Coraxorum amplius lanitium omnium pulcherrimum, unde ad. miffarijarietes talento emuntur. Telarum exuperans tenuitas atç copia, quas Salciata conftruunt: 


\section{DeOue. E. Lib. I. 893}

Strabo libro. 3. Lanarum funt $\&$ à coloribus quos bibunt difcrimina:cymatiles, à fluctibursł gerano chroểs à gruibus, Iam ab amethyfto, ab ferenitate, â croco, à rofa, à myrto, à glandibus, ab amygdalis, à cera, à cortro coraxicæ, à purrpura coloffin æ: Et hæec partim ex Plauto, partim ex Ouidio ín Artib. \& Strabone, Hermol. Coraxi quidem Colchidis populifunt, \& iuxta eos pars Tauri montis Coraxis uel Coraxicus appellatur. Lanam tingunt+alga Cretica, lactuca quadam fpecies, loti radix, nucum cortex, rubea, fideritis, ut A ggregator ex Plinio citat. Item fabę decoctio, Ifaac $\&$ Serapio fecundum Diofcor. Molliorem uero \& pulchram lanam reddit códifi, id eft ftruthium, Idem; Aqua maris, Plin. Colorum plura genera quippe cum defint etiam nomina eis, quas natiuas appellant, aliquot modis, Plínius. Lanarum colores natui memorantur quatuor pracipui, etiamfi Plinius dicat ucl natiuis nomina deeffe aliquot modis. Albus in Apulia nobilis, ut ait Martialis. Velleribus primis Apulia, Parma fecundis Nobilis, Altinum tertia laudat ouis. Niger in Hifpania \& Pollentía, ut dixímus.

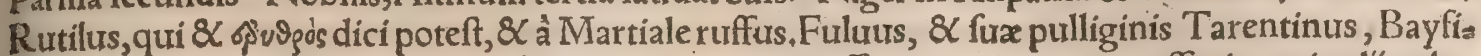
us: Mox autem ex Gellio fubricit, fuluum colorem ex ruffo $8 x$ uiridi mixtum efle, ita ut in alins plus uiridis, in alịs plus ruffi habeat, $\& c$, Lanarum nigræ nullum colorem bibunt; de reliquarum infe: ctu fuís locis dicemus in conchylīs marinis, aut herbarum natura, Plin. De coloffino 8 coracino coloribus pauló fuperius dixiłuide etiam in $\mathrm{B}_{+}$quædam de colore lanæ. Prætextæ apud Hetrufcos originem inueni. Trabeis ufos accipio reges: Pictas ureftes iam apud Homerum fuiffe, unde trium. phales natx. Acu facere id Phryges inuenerunt, Ideoç Phrygiones appellatifunt. Aurum intexere in eadem A fia inurenit A ttalus rex, unde nomen Attalicis, Colores diuerfos pictura intexere Baby= - lon maxime celebrauit, \& nomen impofuit.Plurimis uerolicís texere, qua polymita appellant, Ale xandria inftituit+fcutulis diuridere, Gallia.Metellus Scipio triclinaria Babylonica Teftertiü octingẽtis millibus uęniffe iã tunc pofuit in capitalibus criminib, qux Neroni principi quadragies feftertio nu. per ftetêre. Ser. Tullĭ prætextæ; quibus fignum Fortưnæab co dicatæ coopertum erat,durauêre ad Seiani exitum:mirumó furit nec defluxiffe eas, nec teredinum iniurias fenfiffe annis $\mathrm{d}+\mathrm{Ix}$. Vidimus iam \& uiuentium uellera, purpura, $\operatorname{cocc}_{0}$, conchylio, fefquilibris infecta, uelut illa fic nafci cogente luxuria, Plinius. Et rurfus, Lanam $\&$ colo $\&$ fufo Tanaquilis, qua eadem Caia Cacilia uocata eft, in templo Sangi duraffe, prodente fe, author eft $M$. Varro: factamḉs ab ea togam regiam undulatam xde Fortune, qua Ser. Tullius fuerat ufus. Inde factum ut nubentes uirgines comitaretur colus com pta, \& fufus cum ftamine, Ea prima texuitrectam tunicam, qua fimul cum toga pura tyrones indur. untur nouxás nuptx. Vndulata ueftis primo ể lautiffinis fuit, inde foricula ta defluxit. Togas rafas Phrygianas $\not_{\beta}$, diui Augufti nouifimis temporibus cœpiffe, fcribit Feneftella. Crebræ papauerat antiquiorem habent originem, iam fub Lucilio poéta in Torquato notata, Hucufque Plinius. Rica eft ueftimentum quadratum, fimbriatum, purpureum, quo flaminicx pro palliolo utebantur, Alij dicunt quôd ex lana fiat fuccida alba, quod conficiunt uirgines ingenuæ patrimæ matrimæ ci ues, $\&$ inficiatur coruleo colore, Feftus. Vide Ricæ, apud eundem alibi. Ex pilis ouium (inquit Crefcentienfis) fiunt indumenta neceffaria $\&$ iucunda hominibus + qui quanto funt fubtiliores, tan = to meliores $\&$ maioris pretị. Q Qui ouillam lanam pexerit, at $q$ s ex ea ueftem confecerit, fcabiem, ut ferunt, procreabit ei, qui ea uéftietur, Âelian. Reliqua de lanis uride in Philologia e.

TPelles qux cum furis pilis ad ueftitum parantur apud nos, agninæ omnes non ouillę funt:quam obrem in A gno de eis dicam. Ouium uero pelles quæ pilis detractis parantur à cerdonibus, colore aliquo infectx, ad calceos, ocreas, thoraces, chirothecas, marfupia 8 huiufmodi paranda adhiben $=$ tur. Ex pellibus ouium (agnorum potius) cum pilis fiunt pellicex pannorum temporefrigido com modx. Exiffdem depilatis fiunt calceamenta, Crefcentienfis. Ex ouillis pellibus audio etiam mem branas fieri, maceratis in aqua cum calce, $\&$ poftea extenfis. Harum tenuiores mollioreśǵ pro char ta infcribantur idonex funt, iam $\&$ libros in membranis excufos uidimurs. Craffiores pugillari. bus feruiunt, pigmento quodam illitæ candido aut luteo, Literæ ftyli ænei uel argentei mucrone obtufo infcribuntur, , pongia lintéute humido infricta delentur. Hinc $\&$ libri colligati ueftiuntur, \& alín diuerfi ufus habentur. TSeuo ouillo cerdones etiam uel futores illinunt ac molliunt coria. G Offa manubrís cultellorum idonea funt. GV rina ourium apud $R$ hætos, ut audio, nitri fiçitị materia eft. TVt pili nigri equorum mutentur in albos* In lacte pecudum bullientelinteum mas defactumloco impone, idós toties donec cum fricatione modica digitorum pili cadant $\ddagger$ deinde aliud linteum purum madefactum in lacte recentifrigido, (melius forte calido urel tepido, ) duces per lo. cum depilatum ubi pilos(pro nigris albos)renafci uolueristhor facies per tres dies uel pluries, donec pili incipiant crefcere, diebus fingulis ter ut minimum, $R$ ufius.

T Sues, oues \& capra cum libidinofiores funt, $\&$ mares paffa, mox ipfę etiam eos confcendunt,

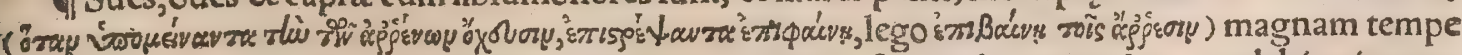

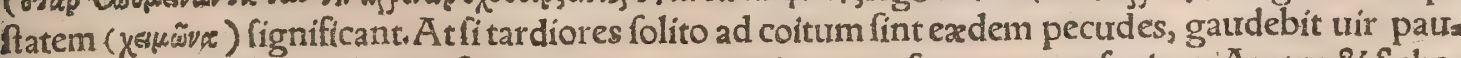
per quod ei ueftibus indigenti, fatis temperatum anni tempus futurum prafagiant, A ratus $8 \mathrm{Scho}$ liaftes. Et rurfus, Si boures $\&$ pecora ( $\mu$ sinex, id eft oues, Scholiaft.) declinãte iam auturmno terram (pedibus, Aelianus) foderint, 8 capita urerfus boream protenderint, magna $8 \mathrm{r}$ rigida hyems circa oc cafum Pleiadưm expectáda eft+eoćs maior, quo pecudes illa magis foderint. fequetur enim nix mul ta frugibus 8 plantís noxia. Hoc quidem de ouibus Aelianus etiam ex Árato repetit. Pecora 
exultantia, \&indecora lafciuia ludentia, (tempeftatem, præfertim pluuiam ) fignificant, Plinitro: Aelianus contra, Agni 8 hoedilafcitrientes $\&$ inter fe faltantes, latos dies promittunt, Agniad. pabula feftinantius pergentes, tempus frigidum ( $\chi$ erusvoce ) indicant, Item arietes 8 agni cum in uia fe inuicem cornibus petunt colludendo: tel faltantibus fimiles pedibus exiliunt, agni quidem, ceu le= uiores, quaternis, arietes uerò binis tantum anterioribus, item (eadem pecora) cum uefperia â paftor $i_{-}$ bus ad ftabula uix reduci, $\&$ ab herbis depafcendis uix lapidibus etiam abigi poffunt, Aratus.

IFructuum ex pecore fpecies funt duæ: una eft tonfura:altera, qux laxius patet, de lacte $\&<\mathrm{ca}_{3}$ feo,quam fcriptores Graci feparatim rvponoita Varro. Ouibus omnium maximè quadrupedum lac diu edurat:quippequibus mulçra menfium octo fpacio continuetur, Ariftoteles. Fructum ouium (inquit Cato cap. I 50.) hac lege uenire opors 10 tet. In fingulas cafei pondo $\mathrm{X} v$. dimidium aridum, lacte ferịs quod mulferit dimidium, \& præterea lachis urnam unam. Hifce legibus agnus diem $\&$ nociem qui uixerit, in fructum, \& Calend. Ianuar, emptor fructu decedat, Si intercalatum erit Calend. Maijs agnos triginta, ne amplius promittat, Oues, qux non pepererint, binx profingulis in fructu cedent. Die lanam $\&<$ agnos uendat. Menfes $\mathrm{X}$. ab coactore releget porcos fectarios. In oures denas fingulos pafcat, Conductor I I.menfes paftios rem prabeat, donec domino fatisfecerit, aut foluerit, pignori efto, Hac Cato. TButyrum etiam ex ourillo lacte habetur, uide infra in $\mathrm{F}$. E lacte pinguiffimo probatum fit butyrum; quale ouillum eft,Diofcorides. Otrillum lac caprinumóśs, mox bubulum, commodum eft ad conficiendumrepo, nendumq̧́ cafeum, Ariftoteles، Ouillo mifcere caprinum lac Siculi, \& quibuscunq̧ copia eftca. prini, folent,Idem. IVIq̧ ad feftum fancti Michaêlis (inquit Crefcentienfis) bis quotidie mulgen: tur oures, \& poftea femel lac elici poteft. Ne nimis pingues cum arietibus mittantur, ne importuno tempore foetus emittant, fed poft coniunctionem arietum ut pinguefcant cuftodiantur, ut horis op= portunis ducantur ad pafcua, $\mathcal{Q}$ cuffodiantur per totam xetatem. Feftinanter mulgeantur aurora furgente, ut tempeftiue educantur ad pafcua. Dum mulgentur, quorquot adfunt filentium praffêt, excepto magiftroqui tantum necelfaria loquatur. Cafeum coagulamus fyncero lacfe, coagulis aghi uel hoedi, ac pellicula quæ folet pullor um uentribus adharere, uel agreftis cardui floribus, uelladte ficulneo, cui ferum debet omne deduci, \& ponderibus premi. Vbi coeperit folidari, opaco loco pon natur, aut frigido: \& preffus fubinde adiectis pro acquifita foliditate ponderibus trito $\&$ torrefacto fale debet afpergi,iam durior, uehementius premi poteft. Poft aliquos dies folidatæ iam formula fal tuantur, ita per crates ne inuicem fe unaquaeq contingat, fit autem loco claufo $\&$ à uentis remoto, ut teneritudinem et pinguedinem feruet. Vitia cafei funt, fi aut ficcus aut fiftulofiss eft. quod euenit, fi aut parum prematur, aut nimium falis accipiat, aut calore folis utatur, (uratur.)Recenti cafeo con ficiendo aliqui uirides nucleos pineos terunt, atç fic lacte mix to congelant, aliqui cyminum tritum frequenter colatum congelant, qualemcunq̧ etiam fapore uelis efficere, poteris adiecto quod eleges ris condimento, uel pipere alióue pigmento id præftare, Hacienus Crefcentienfis.

$$
\text { F. }
$$

Caro cuiuf(q quadrupedis deterior eft, cum locis paluftribus quàm editioribus pafcit, Ariffote les. Caro leporum fanguinem quidem gignit craffiorem, fed melioris fucci quàm bubula \& oulle la, Galenus libr.3.de aliment,facult, Agni carnem habent humidiffimam ac pituitofam:ouium uerò magis excrementitia eft ac fucci deterioris, Ibidem. Et rurfus, Animalia qua humili $\propto$ tenui herba nutriri queunt,ea primo ac medio uere funt præftantiora, ut oues:xitate autem prima ac mes dia capra, cum fruticum germina uigent. Bubula caro fic cum ouilla comparetur, frígida eff, frne guinemó̧ melancholicum gignit, Symeon Sethi. Ouilla caro (

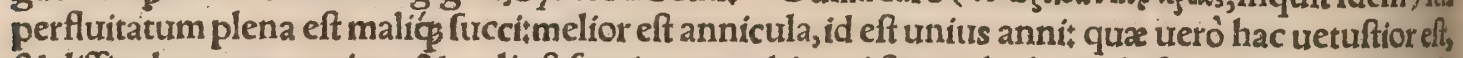
$\&$ difficulter concoquitur, $\&$ mali eft fucci, nocens his qui ftomacho humido funt, $\&$ pituitofis . Si mulieris uterus fuerit ulceratus, $\& \times c$, ferum coctum bibendum prabeto per dies quin $q_{3}$ aut lac afinis num coçum per dies 3 , aut 4 .P oft lactis autem potum cum aquís ipfam reficito, $\mathcal{Q}$ cum cibis com modis, carnibus ouillis teneris recentibus $\&$ uducrium, Hippocrates libro I, de morbis muliebrir bus. Caro ouium fapore eft ingrato, 8 nimium humida, negg conueniens niff forte rufticis affuetis, qui continuis laboribus exercentur, Crefcentienfis, Ouem arietem dentibus ne attingas, non mo, o do enim eius caro non prodeft, uerum etiam uehementer obeft, Platina. Carnes pecorum prohis bentur, quia malum fanguinem generant. Agni quidem prabent nutrimentum multum, calidum $\&$ humidum, fed pituitam gignunt. (Vide in Agno $\mathrm{F}_{*}$ ) Arietes anniculi melius temperati funt quàm natu minores. Hæa carnes uerno magis quàm alio tempore conueniunt. His qui opus habent refrigerari, prapparantur cum aceto: illis uero qui defcenfione indigent, cum muri. Salubriter autem fuperbibitur uinum album fubtile, deinde accipitur calche facharinum, Elluchafem in Tacuinis ex Oribafio, Magiftratus nofter ne oues poft ditui Iacobi diem, id eft uicefimum quintum Iulij ab alings regionibus mactandx adducantur, lanîs interdicit ₹ quamuis enim pingurores aliquando poft id tempus oures fiant: infalubriores tamen habentur earum carnes, 8 minus placent palato, tenacio resç̧ firnt, præafertim adductarü aliunde. Ouilla caro à quibufdam (Anglis præcipué) falitur, \& $\mathrm{in}, 6$ fumatur, ut audio, uno die tantum cum fale relicta in uafis. - I I Ius in oui fero fertreast: Piper, ligufti cum $_{2}$ cuminum, mêtham ficcam, thymum, filphium; fuffundes uinum:adịcies damaícena macerata: 


\section{DeOuc. F.G. Lib.I. 895}

mel, trinum, liquamen, acetum, paffum ad colorem,oleum + agitabis faficiculo origani 8 menta ficcx. Et rurfus, Ius frigidum in oui fero:Piper, ligufticum, thymum, cuminum frictum, nucleos toftos: mel, acetum, liquamen \& oleum:piper afpergis, A picius 8.4. Braffic fclia uel cymæ fi coquantur cum ouilla carne pingui ius optimum reddi aiunt. Cur oures à lupis dilaniata carnem quídem fua uiorem, lanam autem tabidam flaccidam ç habeant, dicium eft in Lupo D .ex Plutarcho, Armum $0=$ uillum elixum \& refrigeratum aliqui hoc iure perfundunt * Petrofelinum (fic uulgò apium urocant) minutatim incifum contundunt in pila $\&$ aceto affufo per horam relinquunt, exprimunt per linte um, zingibere \& pipere condiunt:fic perfufum armum frigidum apponunt. Ex ouis pulmone mi nutal fit, non item aliarum pecudum, apud noftros to circunuoluti, additis $\&$ herbis odoratis aliquando, uerubus ligneis transfixi in craticula affantur. Sunt qui in fartagine frigunt: nam apud Athenxum libo 3 . legimus rky lu

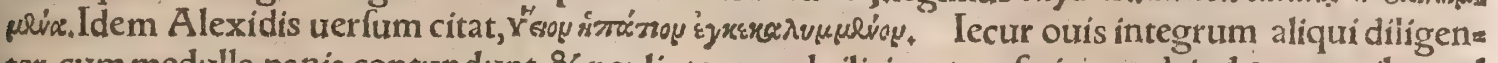
ter cum medulla panis contundunt, \& per linteum uel cilicium tranfmittunt, deinde aromatibus ad faporem coloremć, commendandum infperfis, modicè feruefaciunt, et turdos in iure carnium elixos

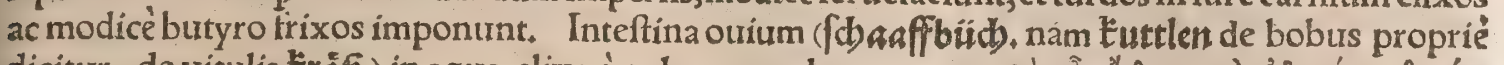

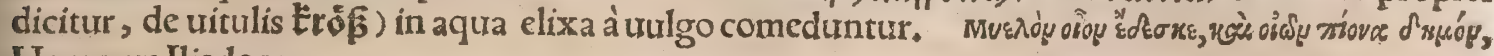
Homerus Iliados $x$.

đEx ouillo pecore cafei laçisḉ abundantia non folum agreftes faturat, fed etiam elegantium menfas iucundis \& numerofis dapibus exornat, Quibufdam ueró nationibus frumenti expertibus

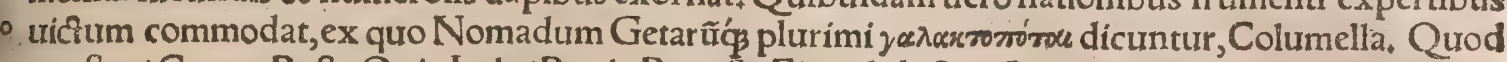
praftat Capra, Poft? Ouis, Inde?'Bouis, Baptifta Fiera de lacte, Lac nigrarũ ouium melius eft, in capris uero contra, Albertus. Lac ouillum nutrimentum eft fatis falubre: có melius, quó recentius fuerit: \& eó plus nutriens, quò fpiffius, Crefcentien. Et rurfus, Lac $\&$ cafeus ex uaccis non tam con ueniunt efui humano quàm ex ouibus, Ouium lac dulce craffum ( $\pi x x_{\dagger}$ †quadam exemplaria non reçé habent soæxu') \& prępingue eft, non uf́ç adeò(ut caprinum) utile ftomacho, Diofcorid. Idem lac bubulum afinium \& equinum magis aluum emollire fribit quàm ouillum, quod hoc craffius fit. Pinguifimum lac elt bubulum:ouillum uerò ac caprinum, habent quidem \& ipla pinguedinis quip piam, fed multò minus, afininum uero huius fucci minimé particeps eft, Gale. Caprino lacte craffi us ouinum eft, fed eius frequens ufus cuti uitiliyines albas inducit, Authoris nomen excidit. Lac $3^{\circ}$ muliebre temperatiffimum eft, mox caprillum, hinc afininum ouillự̧̧, poftremó uaccinum, Aegine= ta. Lac omnium rerum, quas cibi caufa capimus, liquentium maximé alibile, \& id ouillum, inde ca prinum, Varro. Stomacho accommodatiffimum caprinum, quoniam fronde magis quàm herba uie fcuntur:bubulum medicatius : ourillum dulcius 8 magis alit, ftomacho minus utile, quoniam eft pin guius, Plin. Erythea infula eft uel eadem qua Gades, trel proxima freto unius ftadij dífcernente, Ea pabuli ubertate ita glifcit,ut ouium lac in ea ferum non habeat, et infuper ad conficiendum cafeũ multam aquã admifceri oporteat propter pinguitudine,$Q$ uin $\&$ intra dies triginta fuffocari illic pe, cus dicunt, nifi aliquid fanguinis detrahatur, Euftathius in Dionyfium Afrum (ex Strabonis tertio.) I E lacte pinguiffimo probatum fit butyrum, quale ouillum eft, Diofcorides. Pinguiffimum eft lac bubulum; ouillum uerò ac caprinum, habent quidem \& ipfa pinguedinis quippiam, fed multò mi= 4. nus, Galen. Butyrum à boue nominatur, è cuius lacie copiofiffimum confit, ut miretur Diofcoridē Galenus, quòd ex caprino \& ouillo confici lacte dixerit: ex caprino tamen fieri folere teftis eft Plini= us, Hermolaus. Butyrum pluximum fit è bubulo lacte, $\&$ inde nomen : pinguifímum ex ouibus, Plin. Cafeus numerofior eft A pennino. Cebanum hic è Liguria mittit,ou:um maximèlactis, Plinis us. Cafei bubuli maximi cibi funt, \& qui difficillimè tranfeant fumpti. Secundò ouilli : minimi cibi, 8 qui facillime dẹ̄ciantur, caprini, Varro, Cafeus Siculus fit ouillo $\$ \&$ caprino laçe permixto, \&c. ut in Capra capite quinto. Cafeus ouillus eò melior quo recentior fuerit:tanto peior, quo uetuftior . $\&$ durior, Improbatur etiam nimis falfus, \& qui uel nimium uifcofus uel aridus \& friabilis eft, ut ait $R$ afis, laudatur inter utrunç medius, Crefcentien. Et rurfus, Lac $\&$ cafeus ex uaccis non tam con= ueniunt efui humano quàm ex ouibus. Cafei aridi ouilli proximi anni frufta ampla facito, $\mathcal{Q}$ in pis $5^{\circ}$ cato uafe componito tum optimi generis mufto adimpleto, ita ut fuperueniat, \& fit ius aliquanto co piofius quàm cafeus, Nam cafeus combibit, \& fit uitiofus, nifi muftum femper fupernatet. Vas aute, cum impleueris, ftatim gyp fabis: deinde poft dies uiginti licebit aperiri, \& uti qua uoles adhibita con ditura, eft autem etiam per fe non iniucundus, Columella 12,42.

G.

Verberum uulnera atç uibices pellibus ouium recentibus impofitis obliterantur, Plin. Pellis ouina recens detracta(adhuc calens) circîpofita p̉s qui quocunq̧ modo fuerint uerberati, omnium luculentiffimè adiưrat, adeò ut die ac noçe una illos curet: concoquit enim $\&$ digerit quæ fub cute fanguinem habent, (uibices, liurores, fugillata, Galenus de fimplicib, 11.16. Rafis, Albert. Vide in a= riete $G . a b$ initio. Cutis pedum $\&$ roftrorü bouis $\&$ ouris igni lento diu coquuntur, donec ueluti cos 60 agulü remittat:id exemptum ficcat đ̣́ in aére perflatili, ad hernias commendatur, Syluius. De re, medĭs ex pilis, lanis feu urelleribus ouium, uide infra, poft Oefypum, बAd comitiales morbos ma gníficé laudatur $\&$ fanguis pecudum potus, Plinius. đI Si uteros purgare uoles, primun quidem 


\section{DeQuadrupedibus}

ordeum olco imbutum in pruinis fuffire oportet. Poftridie uero carnem ouillam coquere, ciี ordel decocto fub dio per nocfem expofito. Sit autem decoctum ordei congï menfura, \& ualde ipfas co. quito. Vbi uerò cocta fuerint, leuiter tepidas edat, \& iufculum forbeat.Poftridie autem thus $\&$ pu legium tritum, melle fubaçũ \& lana exceptum ad triduũ fubdito, Hippocrates de nat.mul, Carnes pecudis combuftx ex aqua cxteris uerendorum uitijs (de formicationibus $\&$ uerrucis eorum prius dixerat)medentur, Plin. Si(inflicto alicui morfu uel ictu uenenato)neq qui exugat, neq cucurbitu la eft, forbere oportet ius anferinû, uel ouillum, uel uitulinũ, \& uromere, Cell. Seuũ ouillữ qưomodo curet̃ , in hircino ex Diofcoride prafcripfi. Nominatur aût feuũ ouiư,aliquando fimpliciter, de quo priore loco agemus $+a$ liquãdo exrenibus, uel omento. Seuo ouillo ad igñ̂̃ liquato linteuี intinge, \& partl adufta impone, curabit, Innomin. Cicatrices ad colorẽ reducit pecudũ pulmo, pracipué ex $a=10$ riete, feuũ ex nitro,Plin. Paniculas aperit feuũ pecudis cum fale tofto poficũ,Marcel. Seuũ ouiữ tretus cũ cinere è capillis mulierü furunculis mederi diciț,Plin. Cantharides illitas licheni prodefle

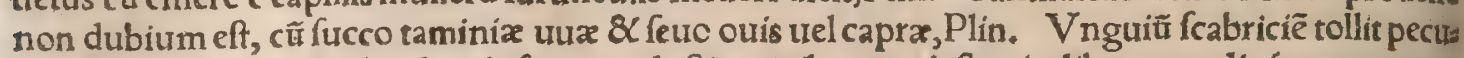
dum feuum,Idem. Malandrix $\&$ frigore aduftis partibus prodeft cuiuslibet pecudis feum cum ia lumine tritum uel excoctum, 8 ceroti modo impofitum, Marcel. Pernionibus quog imponitur fe. uum pecudum cum alumine, Plin. Articulis luxatis præfentaneum eft \& feuum pecudis (cuiufcũa que, Marcel.)cum cinere è capillo mulierum, Plin. Ad oculorum uaria uitia, caprínum,ouillumúue adipem calida aqua madentem imponito, Galenus Euporift.3.12. Seuum ouium decocium 8 cum vino auftero depotum, tuffi medetur, Marcel. Abfyrtus hippiatrus in tuffi equorum etiâ utitur, ur in ceruino ferro diximus. Dyfentericos recreat feuum ouiü decoctum in uino auftero: hoc \& ileosi medetur, \& tuffi ueteri, Plin. Seuum ouillữ decoctum in uino auftero, \& calidũ potui coliaco da. tum, manifefto remedio erit, Marcel. Hircinus adeps, ut qui ualidiffimé dífcutiat, podagricis auxi. liatur, cum fimo capr $\&$ croco impofitus: huic proportione refpondet ouillus, Diofcor. Pinguitu. dinem exteriorem (inter carnem $\&$ cutim) inter pofteriora crura, priuatim ad morbos quofdam rea quiri audio, Seuum pecudis à renibus uulfum, admixto pumicis cinere $\&$ fale, rectiffimé dolentie bus $\&$ tumentibus ueretris imponitur, Marcell. Seutum ex omento pecudis, pracipuéả renibus, aब mixto cinere pumicis $\&$ fale, cæteris uerendorum uirijs (de formicationibus $\&$ uerrucis prius dix rat)medetur, Plin. Seuum ex omento pecudum illitum, fanguinem narium fiftit, Plinius $\&$ Mar cellus. T Oulla medulla quinto loco poft ceruinam, uitulinam, taurinam $\&$ caprinam laudatur, Diof corid. Iecur ouium nychalopas fanat; decocto quoq̧ eius oculos abluere fuadent, \& medulla dolores tumoresçillinunt, Plin.

T Ouicula aut capra cornu tufum, \& ordeum toftum ac frefum, oleo fubigito ac fuffito, Hippo. crates de mor bis mulieb, in capite quod continet medicamenta qua fecundas educunt $\&$ menfes ds trahunt, $8 \mathrm{c}$. बCerebro ouis inuncti oculi aquam patientes iuuantur, Rafis $\&$ Albert. Ad den. titionem cerebrum pecoris utiliffimum eft, Plinius $\div 8 \mathrm{C}$ Galenus in libro de theriaca ad Pifonem $c_{2} .12$ : fed mel iubet adijci, ita uehementer profuturum dentien tibus pueris. Ad dentitionem, Magnifice iuuat \& ouis cerebrum gingiuis illitum, Plin. TCicatrices ad colorem reducit pecudum pulmo, pracipué ex ariete, Plin, Liuentia \& fuggillata pulmones arietum pecudumós in tenues confecti membranas, calidi impofiti extenuant, Idem. Pulmo ouillus quàm recentiffimus, protinus dum adhuc tepet, appofitus, continuó difcutit \& expurgatliuores, Marcell. Ebrietatem arcec pecudum \& affus pulmo præfumptus, Plin. Phreneticis prodeffe uidetur pulmo pecudũ calidus circa caputala ligatus, Idem. Conuenit hîc calidis pecudum pulmonibus aptê Tempora languentis medica redir mire corona, Serenus ad phrenefin. Lethargicis pulmonem pecudis calidum circa caput adalli gari putant utile, Plin. Pulmo pecudis, id eft ouis, dy fentericos recreat, decoctus cum lini femine, ita ut \& caro manducetur $\&$ aqua illa potetur, Marcel. Podagras leniunt pecudum, Plin. Pulmoa nes pecudis calidi recentes podagras leniunt, Marcell. Tlecur ouriũ nyctalopas fanat, efficacius quidem fulux ouis, decocto quoç eius oculos abluere fuadent, Plin. Iecur orrillum, id eft ouis candi dx difcoctû,cum aqua madefactum contritumć \& oculis fuperpofitum, nyçalopas purgat, Mara cel. Si pariens inflata fuerit, hepar ouillữ aut caprinã calido cinere obrutum, edendum dato meraci us, ad dies quaturor: 8 uinũ bibat uetus, Hippocrates de nat.mul, q Ouillo felli Diofcorides tauri num prafert. Domefticarum fuũ bile utuntur quidam ad ulcera aurium, medicamento utig non reprobo, ( $\&$ tu quo $\$$, ubí compofitorum nihil adfuerit, utitor:funt enim innumera.) fed pro affectus magnitudine alia eciam at $q$ alia alterius animalis bilis poteft congruere, Nam ubi ulcus diuturnum fuerit, multamćs faniem pusós contineat, etiam ficciorem bilem pręferes, puta ouium, qux paulo êß acrior fuilla, Gälen. Aures purgat fel pecudis cum melle, Plin. Fel ouillum mulfo mixtum fi cly: fterio addideris, $\&$ inde auriculas inrigaueris, expurgatis ulceribus certiffimam fanitatem confe: queris. I dem fel cum lacte mulieris inftillatum, etiam ruptas interius auriculas certifimè fanat, Marcel. Ruptis, conuulfis fel ouiũ cum lacte mulierum prodeffe dicunt, Plin. Cancer uel carnis corro foo fi inungatur felle ouis, manifefté iuuat, $R$ afis $8 \times$ Albert. Porrigines, (prurigines, Marcel.)tollun tur felle ouillo cum creta cimolia illira capiti donec inarefcat, Plin.mirum eft, Marcel. Fel pecudum 6 cum melle, pracipuéagninum, ad comitiales morbos laudatur, Plin. TPecudis lien recens magicis praceptis fuper dolentem lienem extenditur, dicente eo qui medeatur, lieni fe remedium facere. 
Poft hat iubent eum in pariete dormitorï eius tectóure includi, $8 \mathrm{C}$ obfignari annulo, terós nouís cax men dici, Plin. Lien pecudis toftus $\&$ in uino tritus, (potusć, )ileo refiftit,Idem, Etalibi, Tormina fanat lien ouium toftus, atç̧ é uino potus. बArticulorum trachuris cinis feminum(femorum, Mar cel.) pecudis peculiariter medetur + efficacius cum cera, Plinius \& Marcel.Idem medicamentum fit ex maxillis fimul uftis, cornúq̧́ ceruino \& cera mollita rofaceo, Plin. Dyfentericos recreant femina pe cudum decocta cum lini femine aqua pota, Idem, बf Pro equo ob uiam $\&$ laffitudinem 2 ftuante Seuum caprinum, acronaria ouilla, cum coriandro $\&$ anetho uetere, $\&$ coriandro recenti diligenter trito, in ptifana cremorem admifcebis, \& percolatum dabis per triduum, Hierocles in Hippiatricis 64. TAd dealbandos dentes aliáç corum uitia fananda ouillo talo ufto utitor, Galenus Eupori. fton 2.12. T Veficam caprinam aur ouillam uftam ex pofca bibendam prabeto his qui fe in fom. no permingunt, Galenus de comp.fec.loc. IIn muliebribus malis membranx à partu ouium pro ficiunt, ficut in capris retulimus, Plin. TContra uenena omnia ualet lac ouium calidum prater ijs qui bupreftin aut aconitum biberint, Plin. Alica peculiariter longo morbo ad habitudine reda: ctis fubuenit, ternis eius cyathis in fextarium aqua fenfim decoctis, donec omnis aqua confumatur. Poftea fextario lactis oulli aut capriniaddito per continuos dies, mox adiecto melle. Talis forbitio: nis genere emendantur fyntexes, Plin. Contra quartanas quidam deuorari iubent hirundinum fi. mi drachmam unã in lactis caprini uel ouilli uel pafficyathis tribus ante acceffiones, Plin. Tonfil las $\&$ fauces lactis ouilli gargarizatio adiuuat, Idem. Lac caprinum uel bubulum uel ouillum, re: cens mulfum dum calet, uel etiam calefactum gargarizatum, tonfillarum dolores \& tumores citò fa so nat,Marcel. Medicamenta quadam ad phthifin ex lacte bubulo uel ouillo propinantur. Ouilli la ctis fextario fi quis adijciat cnici purgati denarios quattor, $\&$ dif́cocum ita ebibat; molliet urentrem, Marcel. Aron interaneis exulceratis ex lacfe ouillo bibendum datur $¥$ Ad tuffim in cinere coctum ex oleo:Alij coxêre in lacte ut decoctum biberetur, Plin. Alui exulceratos furores $\&$ tenermos, $0=$ uillum bubulúmue aut caprinum lac fiftit, ignitis calculis decofum, Diofcorides. Lac ouile, qurod candentibus glarex lapidibus in ipfum lac demerfis excoquatur, dy fonterico potui cum ipfis lapidi bus datum efficaciter prodeft,Marcel. Si torminofi uel coeliaci propter frequentes defurrectiones uiribus deficientur, dandum erit eis lac caprinum aut ouillum tepidum per fe, uel etiam decoctum cum butyro, Idem. Infunditur quo $q$ lac contra rofiones à medicamentis factas, $\&$ fi urat dyfente. ria, decoctum cum marinis lapillis, aut cum ptifana hordeacea : item ad rofiones inteftinorum, bu* - bulum aut ouillum utilius, Plin. Afininum lac intefrinotum ulceribus $\&$ tenémo prodeft, ut $\& 0=$ uium lac, fed minus, Obfcurus, Satyrï duo genera, \&c. prioris radix in lacte ouis colonica data, neruos intendit: eadem exaqua, remittit, Plinius. TSerum lactis ouilli uentrem mouet $\$$ bilem expurgat, Crefcentienfis. TReduuias \& qua in digitis nafcuntur pterygia, tollunt canini capi* tis cinis, aut uulua decocta in oleo, fuperillito butyro ouillo cum melle, Plinitus. Inula in oleo dif. corta $\&$ contrita, $\&$ cum butyro ouillo $\&$ melle impofita $\$$ Eadem ratione curantur $\&$ tubera, fed hoc uitif emplaftri panno inlini debet, Marcel. Vlula auis cocta in oleo, cui liquato mifcetur butyrum ouillum \& mel, ad ulcera fananda ualet, Plinius, TCafeus ourllus uetus dyfentericos recreat, Pli nius. Cafeus ouillus uetuftus in cibo fumptus, uel rafus $\&$ cum uino potus, coliaco medetur, Marcellus.

TMedicus quidam medicamentorum peritus in Myfia Hellefponti, ouium utebatur ftercore ad acrochordonas \& myrmecias \& thymos \& furunculos duros, quos clauros nominant, aceto uidelicet diluens, $Q$ uin $\&$ ulcerum ambufta ad cicatricem illo ducebat, nempe ftercus hoc cerato rofaceo có= mifcens. Sed \& caprino ftercore ambuftos fimiliter curabat, parum eius cerato (rofaceo) longè copio fiori admifcens, Galenus, Fimum ouillum exaceto illitum fanat epinycidas, clauos, penfiles uer= rucas, thymos, \& ambufta igni, rofaceo cerato exceptum, Diofcorides: $\&$ eadem ferè Rafis $\& A$ bertus: cum aceto(inquiunt) illitum, uerrucas tollit, $\&$ uariolas qua nominantur affar $x_{*}^{+} \&$ cum ce $=$ rato rofaceo, ambufta. Stercus ouis cum melle impofitum medetur uerrucis leuibus (aliâs, lentis bus uerrucis) \& carnem excref́centem (qua dicitur acturo, Rafis: forte acrochordon) abolet : item formicam, Rafis \& Albertus. Fimus ouillus recens manibus fủbacius $\&$ emplaftri more adpofi tus, deterget uerrucas, Marcellus . Ambuftis medetur fim urm ouium cum cera commixtum, Plini= us. Clauos pedum fanat fimum ouium impofitum, Idem $8 \times$ Marcellus, Item uerrucas omnium ge nerum, Plinius. Fimum pecudum incipientibus carbunculis occurrit, Plin. Ex oleo tritum inftar cataplafmatis impones ad"uulnera recentia gladio aut ligno illata, Galenus Euporift, 1 ib, 2, $8 I_{*}$ Aut fi conclufum feruauit tibia uulnus, Stercus ouis placidxiunges, adipeséç, uretuftos, Pandere qua poterunt hulcurs, patulọ́g mederi,Serenus cap.43,cum proximè de luxatis fcripfiftet, Eumelus fi detorta fit iumenti ceruix, fimum ouillum cum uino uetere \& oleo nififerl iubet, eọ̧́́ ca lido fape perfricari ceruicem, In Hippiatricis cap. 15. Contra omnium phalangiorum morfus re: medio eft pecudum fimi cinis illitus ex aceto, Plinius. Et alibi, Aducrfus ferpentium ictus efficax

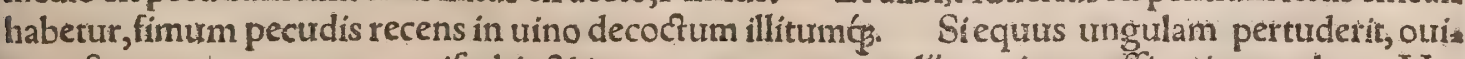
6o num ftercus cum aceto permifcebis $\&$ impones quanquam al'i caprinum efficacius credant, Vea getius. Magna uis $\&$ in cinere pecudum fimi ad carcinomata addito nitro, aut cinere ex offibus feminum agninorum, pracipuè in his ulceribus qua cicatricem non trahunt. Fimo quoģ ip fo ouitu 
fub tefta calefacto \& fubacto turmor uxulnerum fedatur, fifulx purgantur fananturós; item epiny: Eides, Plinius. Alopecias replet fimi pecudum cinis cum oleo cyprino \& melle, Idem. Expleri alopecias non caprino tantum fed etiam ouillo fimo, Graci quidam feripferunt, ut Paulus Aegineta lib.2. Abfceffui(tardo, $R$ afis)oborto in radice auris prodeft emplaftrum de ftercore ouis cum pin. guedine anferis aut gallinæ, Rafis \& Albertus, Tumidis mulierum uberibus fimum ouillum $\mathrm{C}_{2 \pi}$ lidum impone, Obfcurus. Stercus ouis potum pondere drachmx (duarum unciarum, Albertus) cum decocto caprifolif ( cum decoctione uel cum oxymelite, $R$ a fis) ualet contra icterum. Ad coli dolorem remedium phyficum fic: Stercus ouis montanæ menfe Septembri deficiente Luna pridie inclufx mane excipies, \& Sole durabis at $\$$ in puluerem rediges, $\&$ habebis in uafe uitreo fiue fta. gneo (fanneo) cum ufus exegerit cocleare plenum colico ex aqua calida, fi febricitauerit: fi fynce, 10 rus erit, cum tuino per triduum dabis, Marcellus. Si fplen exterius inungatur ftercore ouillo ufto (Albertus addit,ex aceto)imminuitur eius incrementum, $R$ afis. Ad calculum:Ibifcilibram unam, ftercoris ourilli recentis P.I I. axungia ueteris P. I I, hac omnia contrita pariter milcebis, \& in lana fuccida renibus adpones emplaftrimodo, ftatim proderit,Marcellus. Podagras lenit fimum pecu. dum quod liquidum reddunt, Plinius. In muliebribus malis membranxà partu ouium proficiunt; fimum quogs pecudum eordem ufus habet, Plinius. TVrina ours rubex aut nigra perutilis eft hy; dropi, (hydropi carnofo, Rafis:)prodeft etiam mixta cum melle hydropi, Albertus $\ddagger$ Sed $R$ afis aliter, Stercus etiam potum cum melle confert hydropi. TMorbo refiftunt regio fordes auriü aut mama marum pecudis denarị pondere cum myrrhæ momento, $\&$ uini cyathis duobus; Plinitus ${ }_{4}$ Furuns culis mederi dicuntur fordes ex pecudum auriculis, Idem, oVt mulier fterilis concipiat Aut ouis in ftabulis fractas cum ruminat herbas, Pendentem fpumam molli deducet ab ore, At $q$ illam memini mifto potare falerno, Serenus. का Sudor equi calefactus cum aceto conuentt epilepfix, \& exhibetur aduerfus morfus uenenofos: $\&$ ad hoc ualet fudor ouium, Syluaticus capite 330, ex Serapione.

- Tondentur oures quo tempore inter equinoctium uernum \& folftitium fudare coeperint:à quo fudore recens lana tonfa fuccida eft appellata, Varro, Lanam fuccidam Graci rhyparan, Ionia

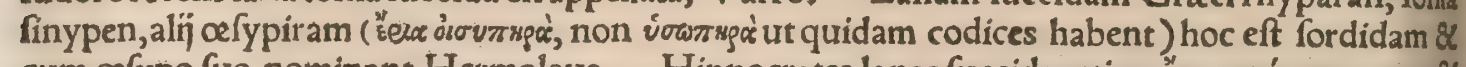
cum œfypo fuo nominant, Hermolaus. Hippocrates lanas fuccidas etiam seix muvógure. uocat, \&

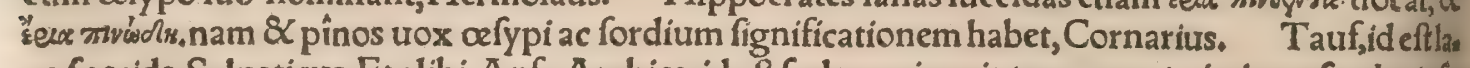
na fuccida, Syluaticus. Et alibi, Aufa Arabica, id eft fudor ouium inter coxas, ( nimirum fordes ipfa 30 lanarum \& cefypus, Laudatiffima omnis è collo:natione uerò Galatica, Tarentina, Attica, Mia lefia,Plinius. Noftrilana fordida ex nigris pracipué ouibus utuntur. Lanis fuccidis omnibus ufus medicatus, Plinius, Idem de ouis collo adtonfam laudat in epiftola apud Marcellum empir。 Succidx lanx, molles \& é collo feminibusḉ laudatiflim $x$ habentur. Subueniunt inter inicia uulne: ribus, percuffis, defquammatis, (thlafmata $\&$ apofyrmata uocat Diofcorides ) liuidis, offibus fractis, aceto, oleo aut uino imbuta, fiquidem facile fuccos combibunt quibus immerguntur: (Embregmat: \& embrochas Graci uocant, cum lintea, fupæ aut lanæ aliquoliquore fuccóue madidx imponun: tur.) Et ob pecudum fordem, fic enim ofypum uocant, emolliunt, Capitis, ftomachi, aliarumq́s par: tium doloribus, cum aceto $\&$ rofaceo efficaciter imponuntur, Diofcorides. Vinum quod fuccida nollet Lana pati, Aquinas in Satyra, Lana fuccida apté excipit irrigationes, (embrochas, ) qua adhibentur contufis aut quomodocunç percuffis, ut qux utilitatem ex illis proficifcentem promo: ueat, idós propter œfypon:Lota uerò nec amplius œfypon habens, materia tantum eft idonea excin

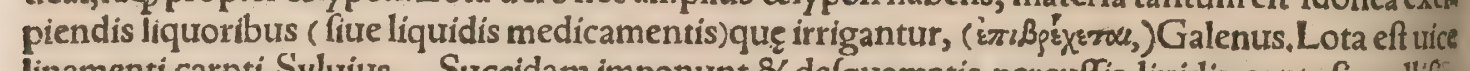
linamenti carpti,Syluius. Succidam imponunt $\&$ delquamatis, percuffis, liuidis, contufis, collifis,

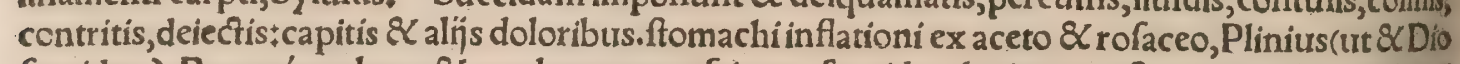
fcorides,) Præterćs cultum \& tutelam contra frigora, fuccidæ plurima præftant remedia ex oleotil nọ́́ aut aceto, prout quxq̧ mulceri morderíg opus fit, $\&$ aftringi laxariue, luxatis membris, dolen tibusós neruis impofitx, \& crebro fuffufx, Quidam etiam falem admifcent luxatis. Alị cum lanaru: tam tritam adipem q̧́ imponunt. Item contufis tưmentibusćs, Plinius, Et rurfus, At canis rabioff morfibus inculcata lana fucc, poft diem feptimum foluitur. Reduuias fanat ex aqua frigida. Ex q oleo calidohumidis adpofita medetur, Marcellus, Quin \& ulceribus uetuftis imponitur cum melle: Vulnera ex uino, uel aceto, uel aqua frigida 8 oleo fanat, Plinius. Diofcorides uulneribus inter initia fubuenire fribit, Vulneribus quibufeun $\phi_{3}$, Succida cum tepido nectetur lana Lyæo, Serenus. Offibus fractis, Conueniet cerebrum blandi canis addere fractis, Lintea deinde fur. perç̧ inductas nectere lanas, Idem; Intelligo autem lanas fucc, quas fractis offibus auxiliari Diofco rides quoģ docet. Medicinas ex uelleribus arietis, in hiftoria eius priuatim recêfebo. Lana fucc, uenas uerticis uel temporum Poni paftorales in quadrimis filijs inurunt, ut in Hircini lotị remen dijs docui ex Herodoto. Si talum aut ungulā bouis unomer laeferit, picem duram \& axungiam cum fulfure, \& lana fuccida inuolutam candente ferro fupra uulnus inurito, Columel. Lana fuccida prodeft phreneticis fuffitu, Plinius. Ād phrenefin, calidi pecudis pulmones circunponâtur, Illotis 60 etiam lanis fuffire memento, Serenus, Columbx, \&c. prafertim mafculæ fanguis ex uena fub ala oculis cruore fuffulis eximie prodeft, Superimponioportet fplenium émelle decoctum, lanamíg 
fuccidam ex oleo aut trino, Plin. Lanæ habent $8 \mathrm{cum}$ ouris focietatem fimul frontl impofitę contra epiphoras, non opus eft eas in hoc ufu radicula effe curatas: ncos aliud quàm candidum ex ouro in. fundi ac pollinem thuris,Plin. Lanam fuccidam in aceto feruetacias,exprimitoć $\beta$ humorem in au. rem, deinde foramen fummum lana fuccida integito, Galenus Euporift.2. 4. ad dolores aurium pat: latim ingruentes. Sanguinem in naribus fiftis cum oleo rofaceo, $\&$ alfo modo indita auribus obtu ratis fpiffius, Plinius. Lana fuccida conijcitur in nares cum oleo rofaceo, $8 \mathrm{C}$ auricula de lana fucci. da obturantur, \& íta fanguis profiuens continetur, Marcel. Ad fanguinem è naribus fiftendum, Lana madens oleo fed nondum lauta rofato, Hac datur in nares uel claudit denfius aures, Seren, Lana fuccida ex oue formina decerpta atọ̧ intorta, madefactạ́́ rofa liquida, fanguinis abundantia am reprimit, Marcel. Lana fuccida ex ariete fanguinem fiftit, articulos extremitatum praligans, Plin. Halitus oris gratiores facere traditur, confricatis dentibus atq gingiuis admixto melle, Plin. Lana fuccida melle illita dentes perfricti miro modo candorem maximum confequuntur, Marcel. Lanam fuccidam linteolo illigatam torreto, adiecta deinde tertia falis portione, terito omnia fimul, \& perfricato hoc puluere dentes +2 dolore praferuat, Galen. Euporift, 1.65. Lana fuccida nitro, ful fure, oleo, aceto, pice liquida feruentibus tincta, quàm calidifima impofita bis die, lumborum dolo= res fedat, Plínius. Ouis ftercus $\&$ alia quædam cum lana fuccida admourentur aduerfus calculum, ut fupra dictum eft in remedịs ex ftercore. Verendorũ cateris uitrïs (de formicationibus \& uerru cis prius dixerat)medetur lana fuc, ex aquı frigida, Plin. Lanam cuillam nigram tefticulis tumen= tibus prodeffe uulgo ferunt. Mulierum purgationem adiuuat fel taurinum lana fuccida appoficû: - Olympias Thebana addidit hyffopum (lege œfypum) \& nitrum,Plin。 Succida lana malos remoras turr fubdita curfus(id eft menfes nimium fuentes.) Mortua quineriam producit corpora partu, Se renus. Succida lana impofita fubditaç̧ mortuos partus eurocat: Siftit etiam profluuia mulierum, Plin. II Iam uerò pura uellera aut per fe impofita cacis doloribus, aut accepro fulfure, medentur: Tantumćs pollent, ut medicamentis quoç fuperponantur, Plin. Vellera cum uluo fuffiri fulfure prodeft, Serenus in regio morbo. Hibifci radicem ante Solis ortum erutam inuroluunt lana colo= ris quem natiưum uocant, praterea outis qux forminam peperit, ftrumisćs uel fuppuratis alligant, Plinius, Per fe conchylio infecta lana auribus magnopere prodeft: quidam acero 8 nitro madefa $=$ ciunt, Idem. GCrematarum lanarum cinis cruftas obducit, excrefcentias in carne cohibet, $\&^{\prime}$ ulce ra ad cicatricem perducit: (Eadem feré Plinius de ofypo feribit, ut inferius recirabo.) Mund $x$ autem 50 \& carpta, in fictili crudo, cęterorum more, uruntur. Nec fecus fimbriati marinarum purpurarum flocculi cremari folent. Aliqui cum fordibus lanas carpunt, 8 melle irrigant, eodemć modo urunt.

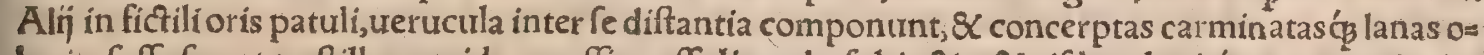
leo ita fuffufas, ut ne fillare quidem poffint, affulis txda fubiectis, \& eifdem lanisćs permùtatim ina terftratis, leuiter fuccendunt, \& uftas tollunt:quod fiè tæeda pix, pínguitudóure ullą profluxit, colle: cta reconditur. Laùatur ad oculorum medicamenta + cinerem in labellis, aqua addita, manibus confri cant, \& confidere patiuntur:iḑ́́s fapius, mutantes aquam donec linguam adftringat, nec mcrdear, Diofcorides. Lana ufta uím habet acrem pariter $\&$ calidam, unà cum partium tènuitate.Itaç mol les nimiumç humidas ulcerum carnes celerrimé eliquat. Inditur $\&$ in medicamenta deficcatoria Vrito eam tançalia plurima, ollam implens nouam, quam tegat operculum multis foraminibus per tufum, Galen. Cinis lanx fuccidx illinitur attritis, uulneratis, ambuftis: \& in oculorum medicamen ta additur.item in fiftulas auresḉ̧ fuppuratas. Ad hac detonfam eam, alij uero euulfam decifís fum mis partibus ficcant, carpuntós, $\&$ in fictili crudo componunt, ac melle perfundunt utrun ${ }^{\prime}$. Ali ha fulis tæda fubiectis \& fubinde interftratis, oleo afperfam accendunt+cineremós in labellis aqua ad = dita confricant manu, \& confidere patiuntur, idọ̧ (x pius mutantes aquã donec linguam afringat leniter, nec mordeat. Tum cinerem reponunt. Vis eius feptica (fmectica potius) eft, efficaciffimég genas purgat, Plin. Vulneribus quibufcunq̧; Succida cum tepido nectetur lana Lyæo, Ambus ftréue cinis complebit uulneris ora, Serenus, Combuftis igni $A$ ut tu fuccofa cinerem perducito la næ, Idem. Lanam ourculæ de inter femora uelles 8 combures, $\&$ in aceto intingues, \& fitper tem. pora caput dolentis ligabis, Marcel. Ad fpirandi difficultatem, Ouium pilos qui circa anum funt uftos ac tritos in dulci uino propinato, Galenus Euporift.2.23. Vellerum cinis genitalium uitrīs medetur, Plinius. Cinis lanæe ouis, paffionibus pecudurm medetur, Idem ut Aggregator citat.

f Sordes lanis inbxrentes dici afypum, cum Diofcoride Plinius fribit, uelut oios fúnou. Apud

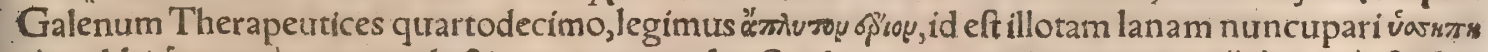

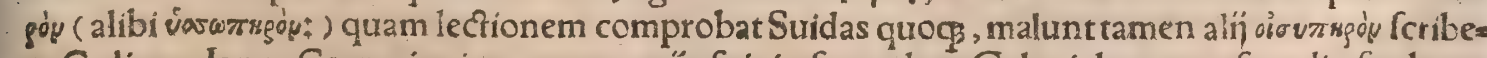
re, Cælius, Ianus Cornarius in commentarịs fuis in fecundum Galeni de compof.medic, fec.locos multís ueterum Græcorum Latinorum's locis recitatis, hyffopum pro cefypo paffim legi oftendit: qui error ita inualuit, ut iam aliquot feculis recentiores, 8 indocti hodiég, pro ofypo hyffopum hur. midam frribant, diftinguendi gratia ab herba hyffopo. Oefypus $\&$ clypum neutro genere ui Plini us dixit, funt fordes fudor'́ feminum $\&$ alarum adhærentes lanis, quæ lanæ fuccida propterea ap o pellantur, quòd fudoris fordibus $\&$ furcco fint imbutæ, Cornarius. Enneapharmacum emplaftrum conftat nouem rebus, \& inter catera hyffopo(lege, œfypo, Celfus $5.1 \%$. Sordes qua lanis ouium inharet \& adnafcitur, ex qua $\propto$ fypon, quod uocant, conficitur, concoquendi uim habet fimilem bu 
tyro, \& fimul parum digerentis factultatis, Galenus in fine libri decimi de fimplic, item Aeetrius, In medicamento quodam Andromachi ad ani uitia, aefypus cateris adiungitur:Heras uero(inquit $G_{2}$ lenus)pro oefypo adipem anferinum pari pondere coniecit. Pro ofypo medulla uitulina fubftituri-

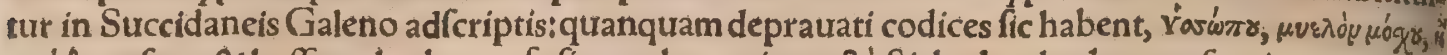

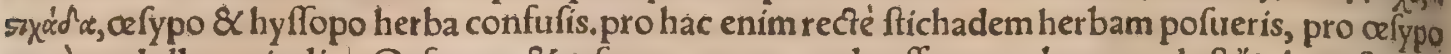
uerò medullam uituli.' Oefypum 8 oefypus utroq modo effertur, a b eo quod eft ö̌s, hoc eft ouis, Gracimafculino ferè utuntur, Latini frequentius neutro. Hippocrates caprinam è clunibus fordem urocauit offpen ( quibufdam.Quidam hoc à Galeno hyffopum dici putant, errore uulgi: \& quidem à Græcis orto, qui non afypum quandog, fed hyffopum fcribant: ut fiue prudentes, fiue imprudentes, non cefypü fims is pliciter(fed)hyffopon hygron (ut Alegineta aliquoties) \& hyffopum pharmacum fx piffimé coynomi nent, quafi ab hyffopo herba diftinguere uoluer int, ut $\mathrm{Paulus}$ in compofitione quam à ruta zsyyaus gàu appellãt, utilem pleuriticis, Hermolaus Corollario 284, ubi tamen hy fopus femper per $f_{0}$ fimplex

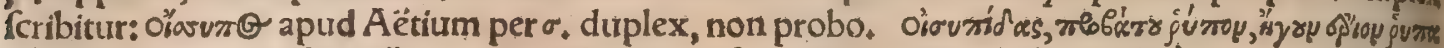

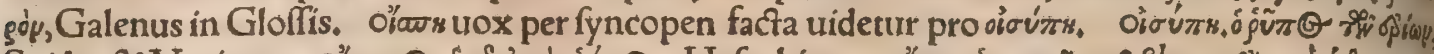
Suidas \& V arinus, D"

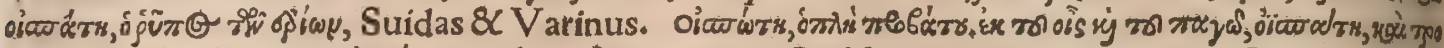

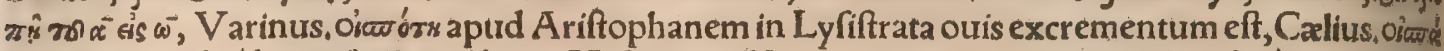

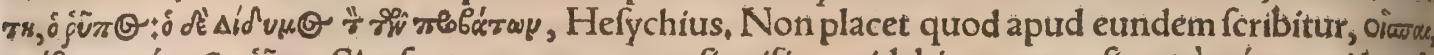

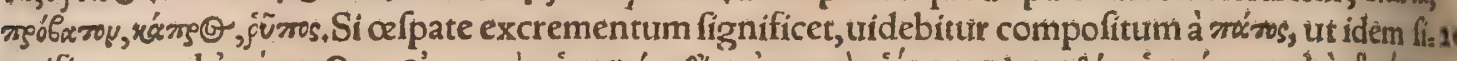

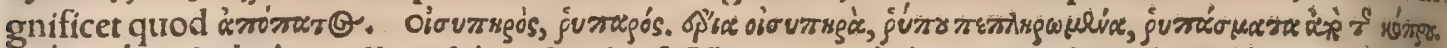
oi

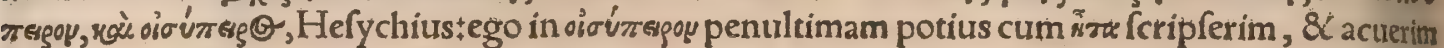
ultimam, ut Diofcorides 8 alĭ faciunt. Apud Ariftophanem in A charnenfibus cum quidam uuls

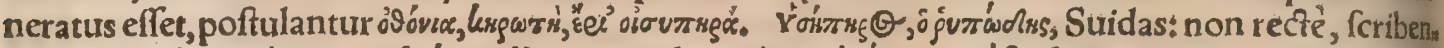

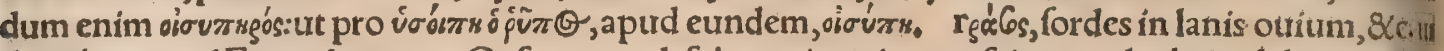
de récoup apud Etymologum. Oefypo quod fub armis ouium nafcitur, palpebris glabris medent, tur, 8c.Marcel. Oefypo in Atticis ouibus genito palma, Plinius. Atticum hyffopum (lege, celya pum)cataplafmati \& cerotis mifcere confultum fuerit, Galenus 13. Methodi. Alibi etiam eodem inli bro Atticum œfypum omnibus prafert. Oefypa quid redolent quamuis mittãtur Athen is : Ouidi us. Oefypum(inquit Diofcorides) rocant Graci, fuccidarum lanarum pinguitudinem. Cuius pa: randi ratio hæc eft: Succidæ molles, radicula non curatæ, calida aqua lauantur, \& quibufcungs fordi bus expreffis, 8 in labellum oris ampli conieçis, aqua infunditur, magnó́s impetu ligula, uti refpir met agitatur: aut lignea rude ualidiufculè conturbatur, quò largius fordida fpuma colligi poffit,dein de marina refpergitur, \& confidente pingui quod fupernatabat, ( colleçoćs in altero fiçili uafe, denuro aqua in labellum fufa agitatur:fpuma iterũ mari perfunditur, $\&$ demum eximitur thoc tantifper fieri folet, dum confumpta pinguitudine nihil prorfus fpuma ex. tet:collecium cefypum manibus emollitur : $\&$ fi qua infedit fpurcitia, confeftim demitur: exclufáp Tenfim omni aqua, recentiós affufa, manibus mifceatur, donec admotum lingux ofypum, adftin,

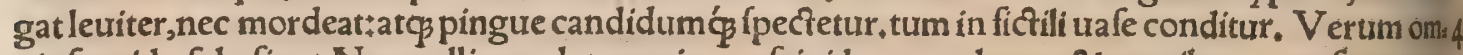
nia feruido fole fiant. Nonnulli excolatum pingue frigida aqua eluunt, $8 \mathrm{C}$ manibus, non fecus atg ceratũ mulieres, confricant+ita enim candidius redditur. Alín elotis lanis $\&$ fordibus quibufcứç ex. emptis, ac lento igni in ęneo uafe ex aqua decoctis, pingue q̊d fupernatat colleçu, aqua, ut diximus, lauant: colatumó̧ in fictile patellam, qux calidam aquam contineat, linteo operiunt, atque foli man dant, donec candidum fiat, \& fatis craffum. Alï bidui fpatio aquam effundunt, nouamọ́ adĭ ciunt, Melius eft laxue, radicula non curatum, quod fuccidarum uirus oleat, \& fi manu in concha fricetur cĩ aqua frigida, albefcat, nibil in fe duri aut concreti habens: ueluti quod cerato aut adipe adultera tur, Hacfenus Diofcorides libro 1. capite 66.interprete Ruellio. Cęterum ab initio ftatim, ubi legitur,

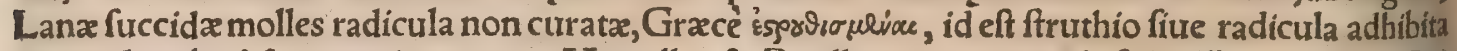

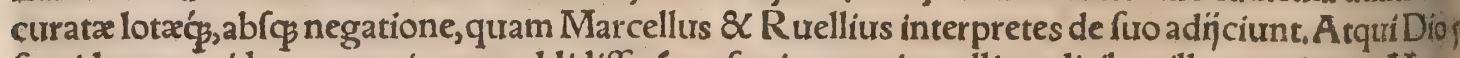
fcorides non uidetur negationem addidiffe, (præfertim cum in nullis codicibus illa reperiatur, Mar= cello etiam tefte:) fed eo modo quo à quibufdam fieri folebat ofypum defcripfiffe: quamobrem pos ftea monet meliorem effe aftruthifton, hoc eft lana non curata ftruthio, fed fimpliciter lota cum aqua calida, (ne fcilicet nimia caliditas aut acrimonia à ftruthio ei accedat, cum concoquendi tantum, quod moderato calore fit, uim habere debeat; ad quiofdam tamen affectus ftruthï uim etiam condis cere ei non negârim.) Sed adiungam Aëtrỉ quoģ uerba 2, 118. quoniam Diofcoridis uerba fe recifa re profeffus, non parum ab eo uariat. Sordidas lanas (inquit) fub axillis ourium repertas, denfas ac

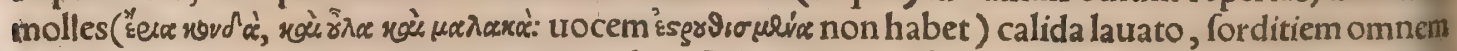
exprimendo, quarum loturam in uas ampli orificí coniectam feruenti aqua fuperinfufa agitato, a quam poculo excipiens aut alio inftrumento, $\&$ ab fublimi pracipitans, donec(tota) fpume $f_{c a t}^{*} t$ tum 6 marina aqua fi affuerit, fi non affuerit frigida infpergito, finitoós ut confiftat:ubi refrixerit, qurod flut tabit, tudicula eximito, atç in aliud uas conj̄cito, inde modica aqua frigida iniecta manibus uer $\mathrm{Ctato}_{2}$ 


\section{DeOue. G. Lib.I.}

mox aqua illa effufa nơvà feruentê infundito: idemఢ̧́ ominino repetito, quiod iam docuímits, donec candidus pinguisḉ cefypus reddatur, nihil amplius impuri continens, tum in fictili conditũ per alî̉ quot dies infolato, \& feruato. Sunt autem hęc omnia fub calido Sole facienda:ita enim efficacior can

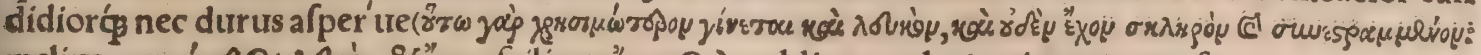

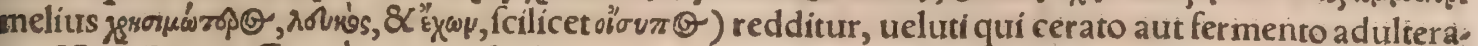

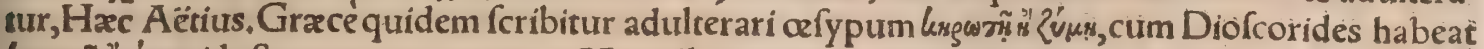
kxpwnin iै s'

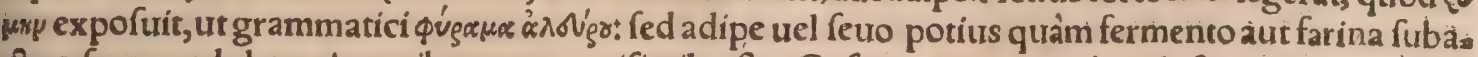
efa cefypum adulterari omnibus puto uerifimile eft. Oefypus (inquit author de fimplicibus ad $\mathrm{Pa}_{2}$ o ternianum hac ratione colligitur: Lanas fuccidas fordidiffimas $\&$ iam mox detonfas mittimus in ua fe quod habeat calidam aquam: $\&$ aquam fuccendimus ut aliquantulum ferueat, deinde refrigera. mus, \& quod fupernatat in modum pinguaminis, abradimus manu, $\&$ in uafe ftanneo abftergimus \& fic ipfum uas aqua pluuali implemus, \& opertum tenui linteo in Sole ponimus, \& rurfus delim. pidamus: \& tunc afypum reponimus, Vires enim habet cum aliqua acrimonia mollientes $\&$ rela xantes.Sed adulteratur ex pinguedine \& ceroto molli, Sed ftatim deprehenditur eo quòd fyncerus ofypus referuat fuccidum lanx, (fuccidalanx odorem feruat, Diofcor.) \& fi manibus fricetur, fim: lis cerufa efficitur, Hacille. Quin ipfafordes pecudum fudorć feminum 8 alarum adhærentes lanis(œfypum uocant)innumeros propéufus habêt. In Atticis ouibus genito palma. Fit plurib. mo, dis. Sed probatifimum, lana ab his partibus recenti concerpta, aut quibufcung fordibus fuccidis - primum collectis, ac lento igni in æneo uafe fubferuefactis $8 \times$ refrigeratis, pinguiç̧ quod fupernatet; collecto in fict:li uale,iterumó̧ decocta priori materia:qux pinguitudo utraç frigida aqua lauatur; $\&$ in linteo ficcatur, ac fole torretur, donec candida fiat ac translucida. Tum in ftannea pyxíde con= ditúr, Probatio atitem ut fordium uirus oleat, 8 manu fricante ex aqua non liquetur, fed albefcat ut cerufa. Oculis utiliffimum contra inflammationes genarumó callum.Quidam in tefta torrent, doa nec pinguedinem amittat, utilius tale exiftimantes erofis $\&$ duris genis, angulis fcabiofis $\&$ lachry mantibus, Plinius. Vide inferius inter remedia œfypi uel fuliginis eius ad oculos. Oefypus hodie corrupto nomine uocatur hyfopus humida, fed non bene praparatus habetur in pharmacopolijs, Euricius Cordus. Excefypo phar macum compofitum fit, quod Graci medici aliquando o'r

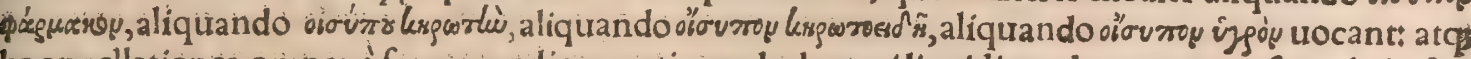
hę appellationes omnes à forma medicamenti, quod ad cerati liquidi modum paratur, funt deducte. Componendi autem modum docet Paulus libro 7. Sed tum in hoc $\mathrm{Pauli} l 0 c 0$, tum in alijs plerif́c $\mathrm{O} O$

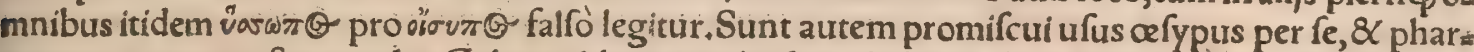
macum ex eo conftans, uelut Galenus lib. 14, methodi tradit his uerbis: Ex œfypo cerotum, notum omnibus pharmacum eft, quo plurimi ad inflammationes in hypochon drijs utuntur. Hoc etiam pro œefypo utilicebit, fi abfit ille, \& eundem finem confequeris. Quin $\&$ hodie in aliquibus pharmacopo Ins hyffopus humida habetur pyxidibus infcripta, $\&$ humidam ad differentiam hyffopi herbx arida dictam uolunt, qui forte de re ipfa nihil fciunt, quum non hyffopus humida ea res, hoc eft lanarum fordes fit appellanda, fed $\propto$ fypus liquidus (id eft ex œfypo cum alijs pharmacis cerotũ,) Cornar. Oe fyptis feruetur purus, ex ouibus integris, non fcabiofis, Syluius. Oefypi praparatione in fecundo - libro optimam defcripfimus: fed ubi hoc haberi non poterit, accipe quod pigmentarï hoc modo con ficiunt:Mel:loti unc. 4. cardamomi, hyffopi herbx, fing. unc. 2, fuccidx lanæex ouium axillis unc. 4. \&c.Aétius 15.25. \& A Aegineta libro 7.nönihil ab Aêtio uariãs. Inter cerata Nicolai Myrepfi qurod numero tertium eft, $\propto$ fypum recipit, $\&$ facit ad dolentes articulos ac podagras: $\&$ omnen phlegmo nem, doloremç mediarum corporis partium(hypochondria dixit Galenus)ac duritiem. Author li bri de dynamidijs Galeno adfcripti, œefypum appellat ius lanæ, id eff fuccum lanæ. Verba eius funt hac: Oefypi cerotum fic fac.ceram, axungiam fine fale, colophoniam, ius lana, uetus oleum, ana lia bram i,iuris fornogręci unc. vii, àdipis anferini \& pullini ana unc,i.Coque oleum cum iure lanæ $\&$ foe nograci diligentifíme, donec ad menfuram olei ueniattiterum pone ad focum, additis fuprafcriptis Tpeciebus, lus uero delana fic fac: Lanam fuccidam in aquam multam pone ut molliatur, diebus - fex:feptima uerò die coque, \& ipfam pinguedinem defuper collige fupra fcripto penfo, \& exinde confice cerorum, Hac ille. TOefypum excalfacit, explet ulcera \& emollit, præfertim fédis ac uul uæ(uide inferius ex Plinio)cum meliloto \& butyro, Diofcorides. Hyflopum(lege, offypum) ad ul cera manantia prodeft,Plinius 26.14 . Vulneribus medetur $\propto$ fypum cum hordei cinere $\&$ artigia ne æquis partibus. ad carcinomata quog; ac ferpentia ualet. Erodit $\&$ ulcerum margines : carnes $q$ excrefcentes ad requalitatem wedigit: explet quoq $\&$ ad cicatricem perducit, Idem. Eadem ferè Dio. fcorides de cinere lanæ cremarx limpliciter tradit. Igni facro medetur œfypum cum pömpholyge 8 rofaceo, Plinius. Somnos allicit cum myrrhæ momento in uini cyathis duobus dilutum, (eodem modo comitialibus medetur, ut mox recitabo, ) uel cum adipe anferino \& uino myrtite, Idem. Ma. culas in facie, ofypum cum melle Corfico, quod afperrimum habetur, extenuat:item fcobem cutis in Go facie cum rofaceo impofitum uellere. Quidam $\&$ butyrum addunt. Si uero uitiligines fint, fel cantiz num prius acu compunctas, Plinius, Sed aliter legit Marcellus, cuius hac funt uerba Oefyptum cum melle Corficano tritum $\&$ appofitum abolet de facie omnes maculas, quidam $\&$ butyrum addunt 
fi uerò \& uituli fimus \& fel caninum mifceatur, medicamen utilius erit, ita ut paritèr teniperata on nia decoquantur. Oefypum ex oleo tritum $3<$ inftillatum capiti, pityriafi medetur, Marcel. Comis. tialibus morbis utile tradunt afypum cum myrrhæ momento $\&$ uini cyathis duobus dilutum $\left(\mathrm{eO}_{2}\right.$ dem modo fomnos allicit, ut paulo ante dicium eft) magnitudine nucis auellanæa à balneo potum, $\mathrm{Pll}$ nius. Oefypum oculis utiliffimum eft contra inflammationes, genarum callum, Plin. Contra ero

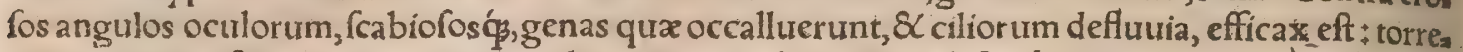
tur autem in telta noura (nempe ad medicamenta oculorum iam diça. Interpretes ineptè transferũt) donec redactum in cinerem pinguitudinem amittat. Ex co etiam fuligo colligitur, uti demonftraui, mus, reo nimirũ modo quem in butyro dixerat, quan $\not$ illic nulla œefypi mentio, nec alibi apud eum cefypi fuliginis quod fciam;) quæ in oculorum medicamẽta commodè addi folet, Hæc omnia Diofcon rid. Quidam œfypum in tefta torrent, (urunt,Diofcorides \& Aếtius)utilius tale exiftimantes erofis \& duris genis, angulis feabiofis \& lachrymantibus, Plinius. Butyri quidem fuligo fimiles fere effe. ctus habet. Diofcorides ofypo fimpliciter attribuit, quxe fuligini eius Aëtius ex Diofcoride mus tuari fe profeffus. Aëtij uerba haec funt: Oefypus crematus utililfimam fuliginem reddit, ad anguts los oculorum erofos f́cabiofosćs, \& ad palpebrarum callos, earundem ̧́́ depilationem. Crematur interdum etiam in noua tefta, donec exuftus ( $\pi v \rho \omega \theta_{\xi}^{\prime}$, , Diofcorides habet $\pi \phi \rho \omega \theta_{\varepsilon}^{\prime} y$. malim utrunq in mafculino genere, cum œefypus Gracis femper mafculini fit generis ) pinguedinem omnem amife rit. Ponatur tefta fuper carbonibus, deinde quod uftum eft colligatur, feruatumós ad ufum teratur. Mihi quidem tum oefypum ipfum uftum, tum fuliginem eius, eandem habere facultatem, ad oculo: rum pracipué medicamenta, Diofcorides \& Aétius fentire uidentur. Diofcorides cum ofypi uires za

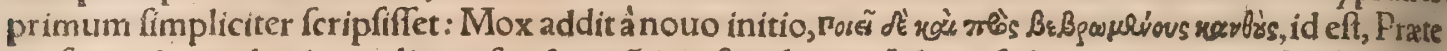

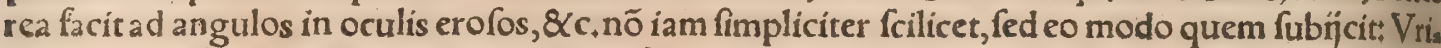
tur autem (inquit, nimirum ad prædictos ufus)in tefta noua, $8 \mathrm{c}$. Hoc interpretes non animaduerte runt. Palpebras gignere dicitur œefypum cum myrrha calidum penicillo illitum, Plinius. Glabris pàlpebris pilos induces, fi cfypo quod fub armis ouium nafcitur, adieça myrrha, pariteríg in mora tario trita, fpicillo calido loca pilis nuda perduxeris, Marcellus. Contufis oculis medentur, felana ferinum, fanguis anatum, ita ut poftea hylfopo(lege, oefypo) 8 melle inungantur, Plinits 29.6. Des. fypum ulcera non oculorum (aurium, Diofcor, ) modo fanat, fed oris etiam $\&$ geniralium cuman. ferino adipe,Plinius. Mifcetur œfypum cerato imponendo aduerfus phthifin apud Aécium: item epithematis ad pleuritidem, reiectionis maxime tempore, apud eundem. Oefypum menfes \& par tus etrocat, Diof́cor.VIcera genitalium fanat cum anferino adipe, Idem \& Plinius. Medetur \& uulux inflammationibus, $\&$ redis rhagadņs $\&$ condylomatis cum meliloto ac butyro,Plinius, Sea dis uitïs efficaciffimum eft cefypum:quidam adj̄ciunt pompholygem 8 rofaceum, Idem. Carbun culo in uerendis, cxterisç̧ ibi unulneribus occurritè melle oefypum cum plumbi fquamis, Pliniss, Podagras lenit ofypum cum lacte mulieris $\&$ ceruffa, Idem: apud Marcellum pro ceruffa legitur cea ra. Medicorum aliqui axungia ad podagras uti iubent, admixto anferis adipe, taurorumq́a feuo \& œiypo,Plinius. Mulierum purgationes adiuuat fel taurinum lana fuccida appofitum: Olympias Thebana addidit hyffopum(lege, œfypum) $\&$ nitrum, Plinius. Vuluæ uitiṕs $\&$ ulceribus $\propto$ fypum. mederi, fuperius ex Diofcoride retuli. Foetus $\&$ menfes in lana appofitum extrahit, Idem.

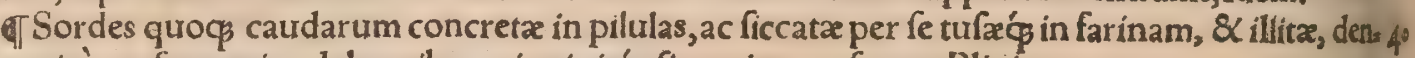
tibus mirè profunt, etiam labantibus, gingiuisḉ fi carcinoma fer pat, Plinius ,

बHydropicis orfypum ex uino addita myrrha modicé potui datur, nucis auellanę magnitudine, aliqui addunt $\&$ anferinum adipem, $\&$ oleum myrteum. Sordes $a b$ uberibus ouium eundem effen. ctum habent, Plinius,

H.

a. Ouem mafculino genere dixerunt, ut ouibus duobus, non duabus, Feftus. Otres generis. forminini ut plerung, ma fculini V arroni rerum humanarum lib, 27. Vt etiam putantibus, qui oues duos, non duas dicunt, Homerum fecutos, qui ait, Mñ $\lambda^{\prime}$ 'ö̈s $\pi$. Idem Terentio; Quando citarus neq. refpondir neq excitatus (lege, excufatus)eft, tum ego(is erat prætor) unum ouem mulctam dico, No nius. Vide plura infra in e.ubi de mulda ex ouribus. Ouis à Graco öts, interpofita u.litera pros $\gamma^{\circ}$ pter hiatum, fignificat pecudem. Ouis à Graco öss.ita enim antiqui dicebant, non ut nunc mgén Barø, Varro. Ouicula, diminutiuum. Lanata $\&$ bidens, epitheta ouium, fre abfoluce pro oure capiuntur. Quanquam ftultiffima animalia lanata, Plinius. Interea dum lanatas, toruumç̧ iu. uencum Cadit,Iuuenalis, Qui pecus pafcimus lanare, Varro. Pecudem Plinius frpiffime pro. oue ponit, ut fupra patet ex teftimonïs Plinianis in G. Pulmo pecudis, id eft ours, Marcellus. Elea phanti tanta narratur clementia contra minus ualio'a, ut in grege pecudum(id eft ouium)occurren* tia manu dimouear, Plinius;qui $\&$ ipfum elephantum alibi pecudem nominat, Eft enim pecus, (pes cudis, form. gen, ) omne animal quod fub imperio, pabulo terræ pafcitur, ut funt boues, afini, equi, ca meli, ours, capræ, authore Valla.imò, ut alin fcribunt, quoduis animal præter hominem. Exempla authorum quare in Dictionarijis. Dicitur $\&$ pecu gen, neutro, indeclinabile in fingulari, pecua in 6 plurali, eadem fignificatione $\&$ fimiliter pro ouibus aliquando abfolute. Paftorharum dormit, quum ha eunt Sic à pecu balitantes, Plautus Bacchid. Pallimós prada pecua balabant agris, Acu 


\section{DeOue. H.a. Lib. I. 903}

cius, Idem \& pecus, pecoris, neut, genere. Ef \& in Hifpania nó maximé abfimile pecori(ideft oui) genus mufimonum, caprino uillo quàm pecoris uelleri propius, Plinius. Sape quidem indifferen ter pro quouis præter hominem animali ufurpatur, aliquando contrahitur ad ea quæ ab homine aluntur, $\&$ diftinguitur in maius, ut funt boures, afini, equi: \& minus, ut ouis, capra, fus, apud Varro nem. Et fecundum pofteriorem acceptionem pro oure per excellentiam ponitur.

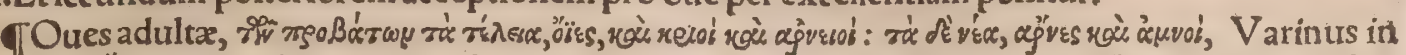

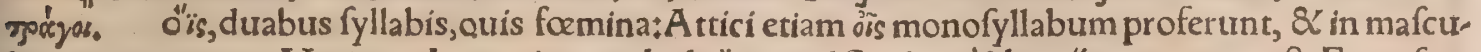
lino quoç genere, Varinus, Locus in uocabuloóis apud Suidam à librarịs corruptus eft. Et rurfus ö"is; ơsios, fine diphthongo poéticum eft : ốis uerò contractum, commune; cuius genitiuus óbòs ultimam , acuit, ur differat ab ö́os, id eft folus. A pud Homerum quidem nunquam reperias oüs monofyllabum in recto cafu, fed ois biffyllabum:in obliquis etiam, nifi carmen impediat; diphthongum non facit, ut

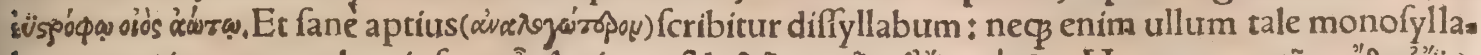

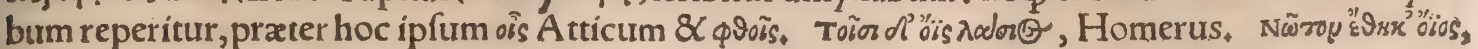

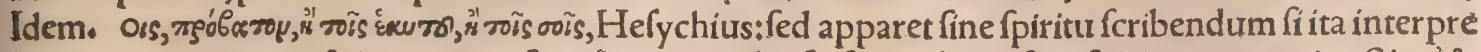
teris.nam cum tenui fpiritu, ouem fignificat; cum denfo, fuis uel tuis:fine fpiritu, utrumuis. Sic orofy

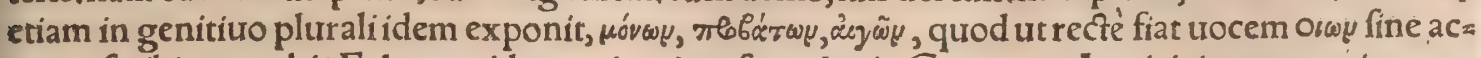
centu fribi oportebit. Et hoc quidem animadtrerfo multæ in Gręcorum Lexicis interpretationes a. lioqui inepta excufabuntur. fic apud Hebræos fine punctis fcripta diuerfis exponuntur modis.

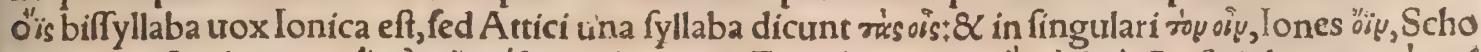

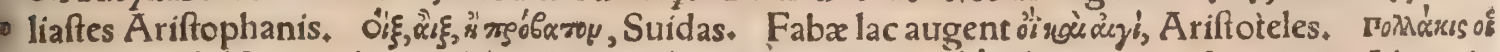

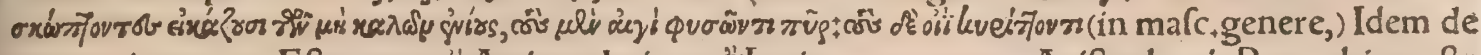
generatione 4.3. Eft autem oil Atticus datiuus, öilonicus, ut patet ex Arifophanis Pace, ubi profta tua $P$ acis confecranda oure(ö) facra faciunt. Et cum Trygxus admoneret hanc uocem effe lonicam,

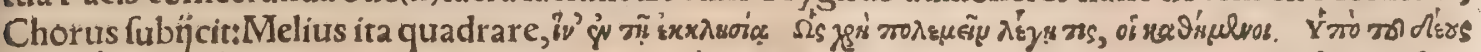

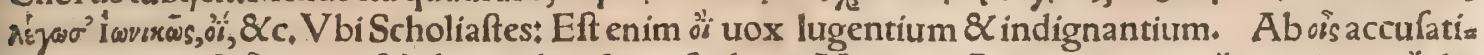

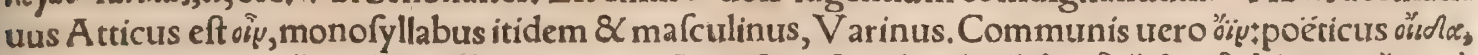

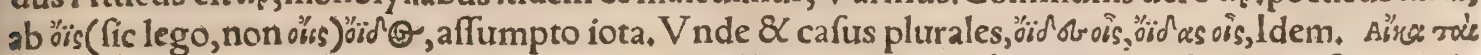

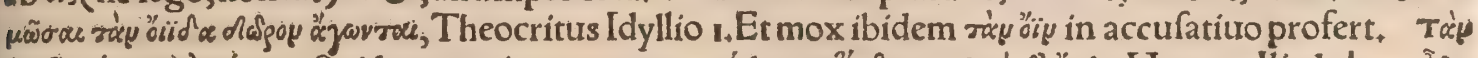

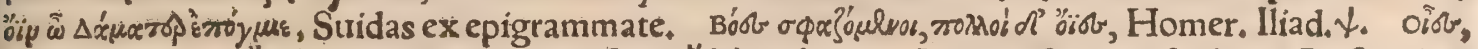

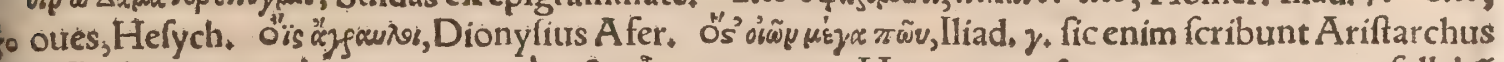
8 Ptolemæuts, ut ák ywy,tanquam à recto ois: cum tamen Homerus rectum nunquam monofyllabũ faciat, fed ne in obliquís quidem diphthongum nifi poftulante carmine, (ut fupra quogs dixi*) proin de melius öíwy fcribetur, Varinus, fed oißy biffyllabum etiam Odyffex primo legimus. o"karıy, ouib.

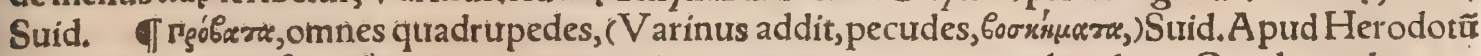
quidẽ probaton ufurpat̃ pro omni pecore, ita ut etiam uaccas comprehendat. Quadrupedes om.

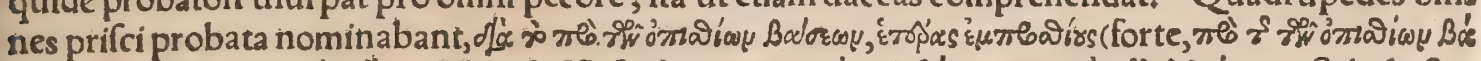

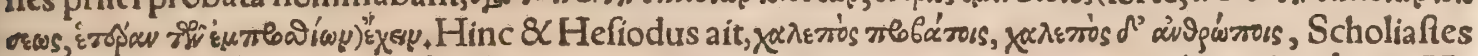

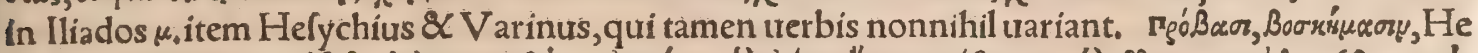

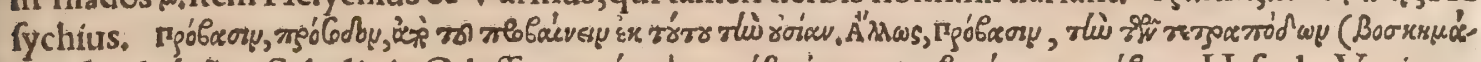

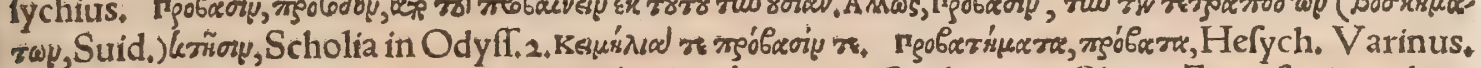

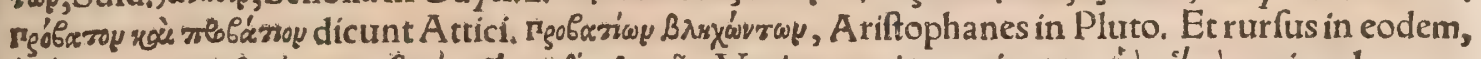

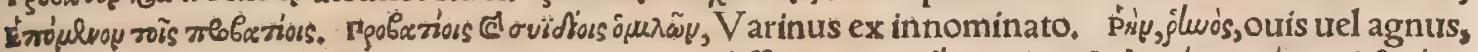

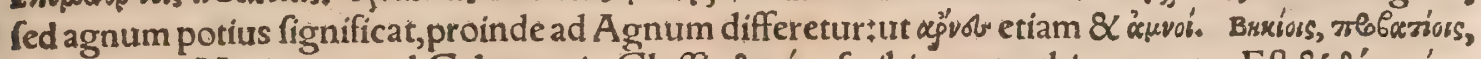

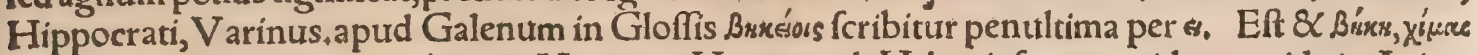
ex, id eft capella, Varino. Kà

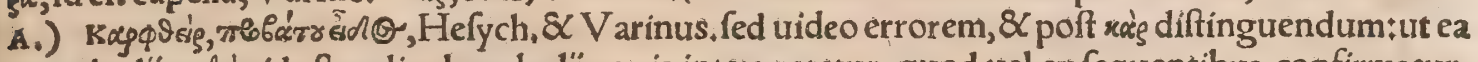
uox ab alins $\phi$ foij, id eft pediculus, ab alips ouis interpretetur, quod uel ex fequentibus confirmatur.

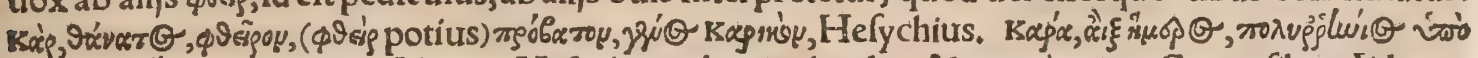

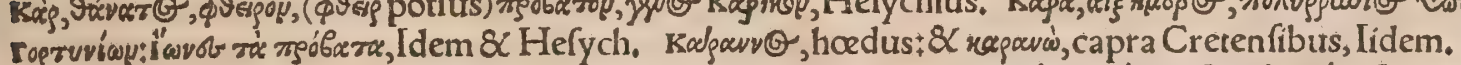

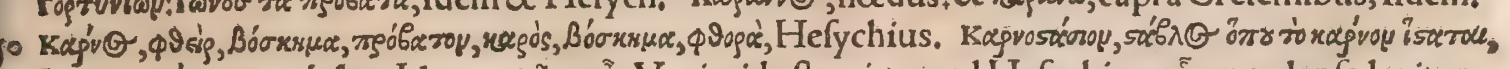

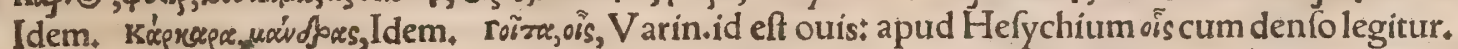

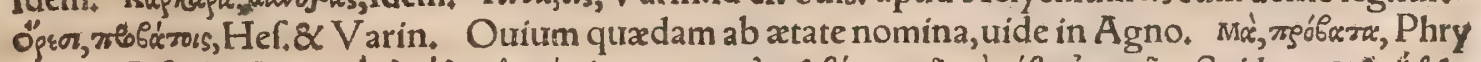

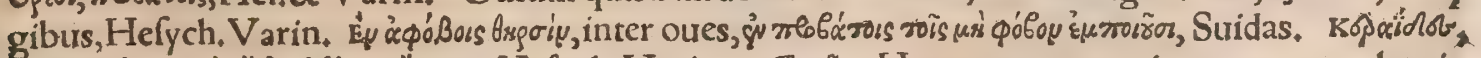

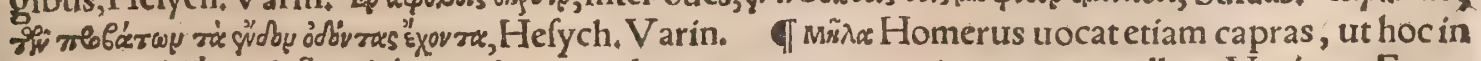

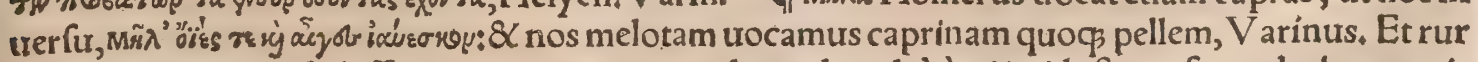

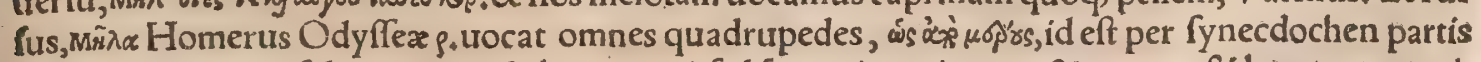
pro toto:non enim folas oues mactabant proci, fed fues etiam pingties, \& capras, \& boures armentí

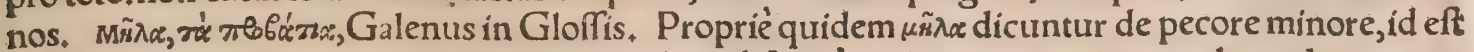
ouibus \& capris, per excellẽtiam uero de ouibus abfolutè. Mĩnx communiter quadrupedes omnes,

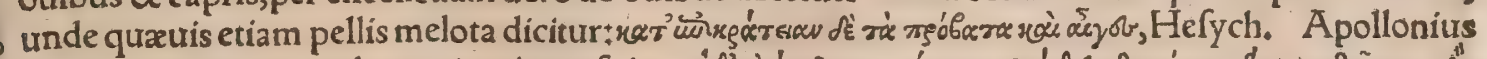

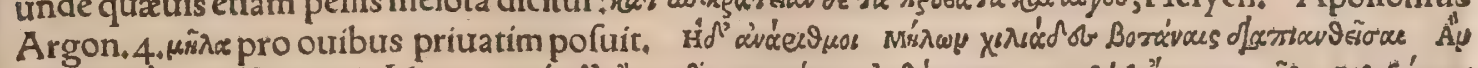

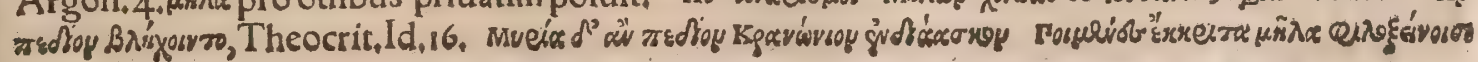




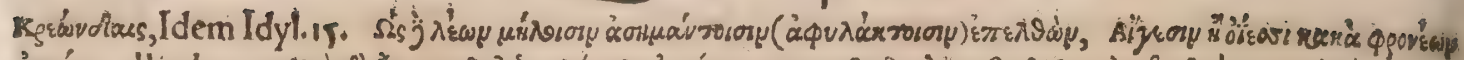

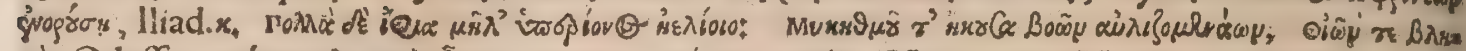

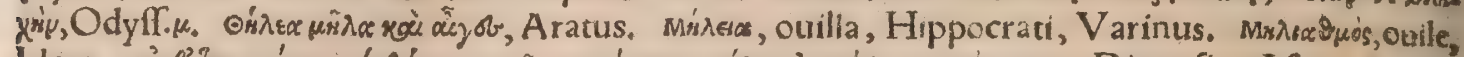

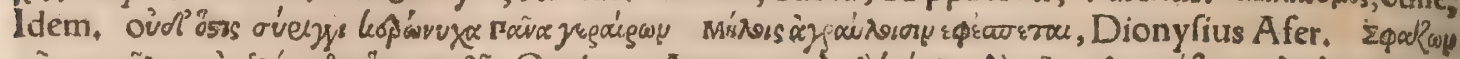

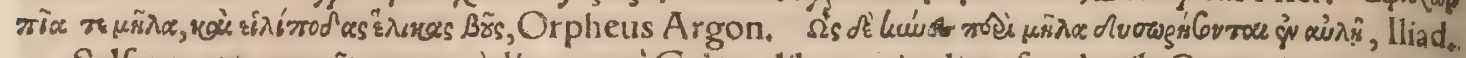

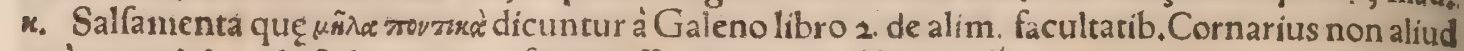
quàm cordylas, id eft thunnorum foetus elle putat. Msioboroy redroy, campus in quo oues benepa.

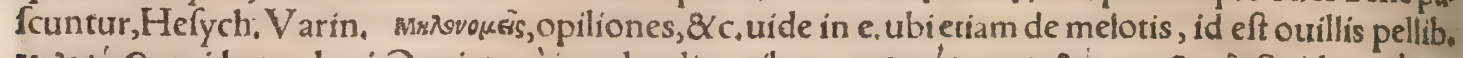

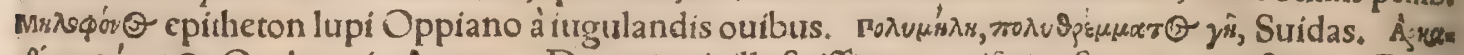

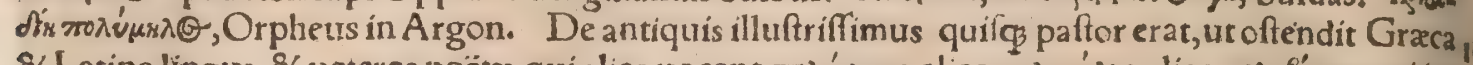

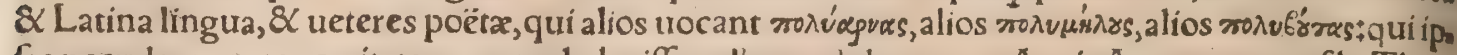
fas pecudes propter caritatem aureas habuiffe pelies tradiderunt, ut Argis Atreus, quam fibi Thye. Aten fubduxiffe queritur :ut in Colchide Oéta (A eetes, ad cuius arietis pellem profecti regio genere dicuntur Argonauta, ut in Libya ad Hefperidas, unde aurea mala, id eft fecundum antiquam cōfue tu dinem capras, \& oues, quas Hercules ex Africa in Graciam exportauit. Ea enim fua uoce Graci appellarunt $\mu \tilde{n} \lambda \alpha$. Nec multo fecus noftri ab eadem uoce, fed ab alia litera bela uocarunt. Non enim me (mee) fed bee fonare uidentur otres uocem efferentes, à quo polt belare dicunt, extrita e. litera, ut fit in multis, Varro. Athenaus libro 3.malorum fructuum genera enumerans, Hefperidum quo $\$$ mala commemorat:Sic enim (inquit) uocari mala quadam Timachidas ait* 8 in Lacedamone dips

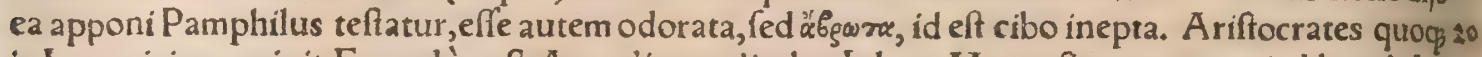
in Laconicis meminit. Et pauló poft, Aemylianus dicebar Iubam Maurufiorum regem in libro de Lis bya, fribere citrum apud Libyes uocari malum Hefpericum;ato inde etiam Herculem in Graciam träftulifie, ubi aurea à colore dicta fint. Afclepiades in Aegyptiacis radit emififfe hos fructus Tellu rem in nuptijs louis \& Iunonis. Vide Onomafticon noftrum in dictione Hefperides, $\&$ Calium. 18. ubi Helperidas interpretatur nocfurnas horas, \& mala aurea frellas: \& Scholiaften in quartum

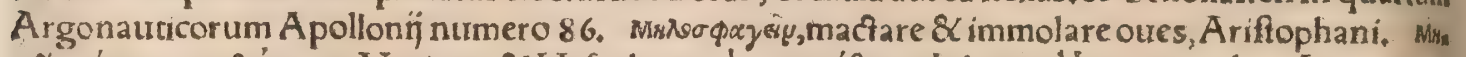

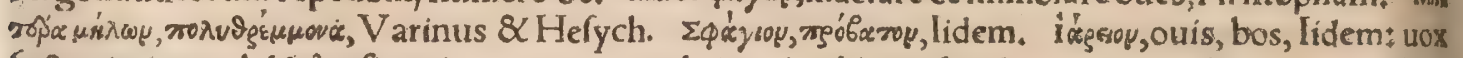
facta nimirum ab iop sop: fic enim uocatur quoduis animal immolandum, per excellentiam uero bos:

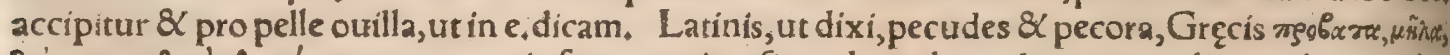
จ tím poëtis:) fiue ad eas tantum qua ab homine aluntur, pracipué cibi ex eis capiendi caufa : fiue ad

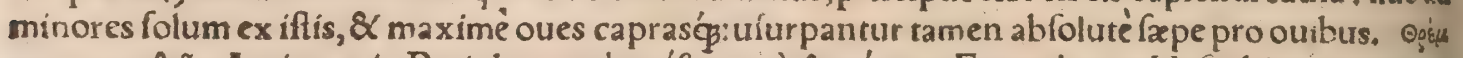

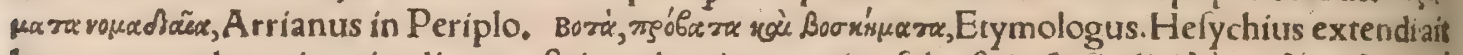
hoc nomen a domnia animalia, terreftria, Holucria, a quatica, fylueftria, 8 fic dici àx mo Bórxravos, rí

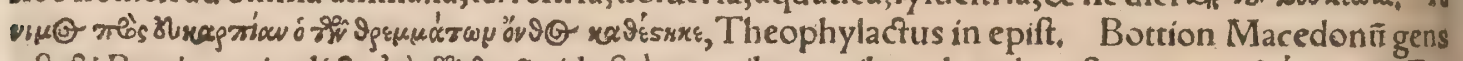
eft, \& Bottia regio, dicta ảs on Borw

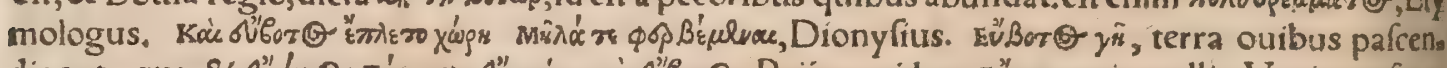

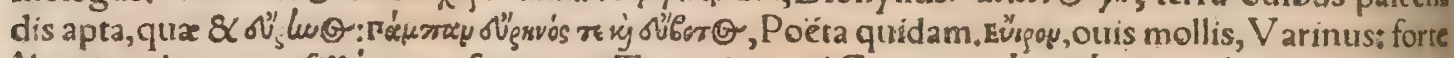

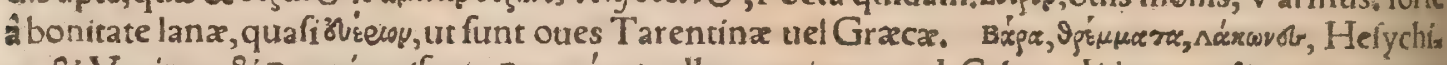
us \& Varinus. \& ' Brgaxx́xau (forte, Bagaváxau)pelles caprinx apud Celtas, Iidem. roü, grex

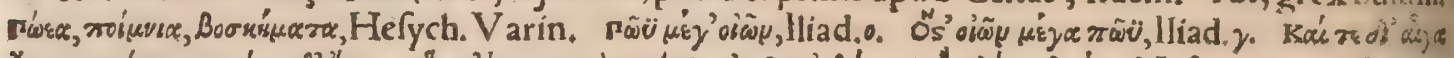

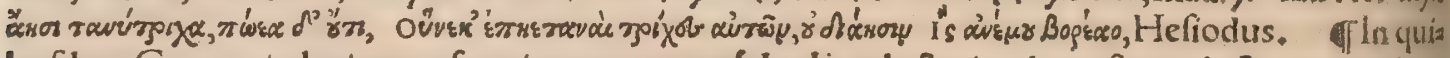
bufdam Germanix locis oues fominas uocant modberling. lactarias, hoc eft quae lactis gratia alum. tur, trfple, in Sueuia \& fominam qua agnos \& reliquas oues ad pafcua ducit ein ouw, cuius plura lecuto.

đEpitheta. Balantes.Pecudem fpondere facello Balantem, Iturenalis. Ponitur \& abfolurèa pud Vergilum pro ouibus:ut Bidentes quoç, de qua uoce plura feripli in B. Amathufiacasćs bla dentes, Ouid.9. Metam. Interea dum lanatas toruumág iucuencum More Numa cædit, luuenalis Sat.8. Lanigeros agitaregreges, Verg. Lanigeræ pecudes, Lucret.lib.2. Pecoriş́́ maritus La nigeri, Martial. Pafcalis, id eft qux paffim pafcitur, à pafco uel pafcuis, quafi pafcualis, Feft. Pafcali yo pecore, ac montano hirco atģ, foloce, Lucilius, uidêtur autem fic appellari colonica, atog hirta oues: ur contra pellitæ, (Horatio 2.Carm.) quæ non paffim pafcuntur, \& propter uelleris pretium pellib, integuntur. Pinguis, Verg.6.A egl. Placida, Ouidius iz.Metam. Stercus ouis placid $x_{2}$, Serents, Item a pud Textorem, Blanda, Canufina, Cornigera, Gracilis, Hirfuta, Imbe:lis, Immunda, Infirma,

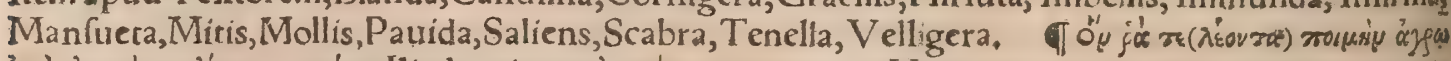

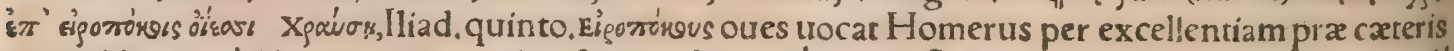

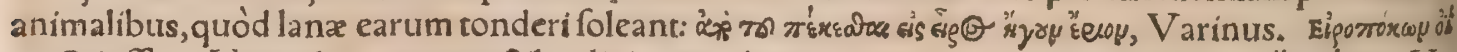

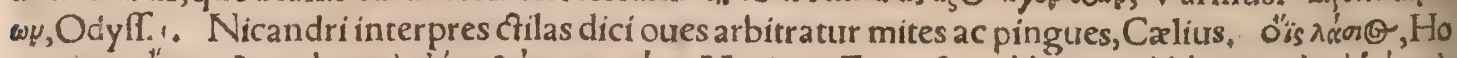

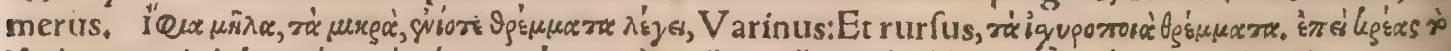

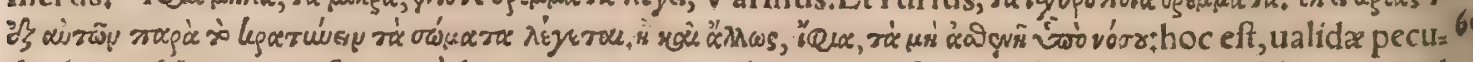
des(apud Homerum, fiue quód carnes earum in cibo ualidos $8 \mathrm{C}$ robuftos homines reddunr, ( quod de caprinis priuatim legitur:)fiue ipf $x$ ualida ad fui corporis modum $\alpha$ obefar, Varinus, I'eux Hefy 


\section{DeOue. H.a.b. Lib. I. 905}

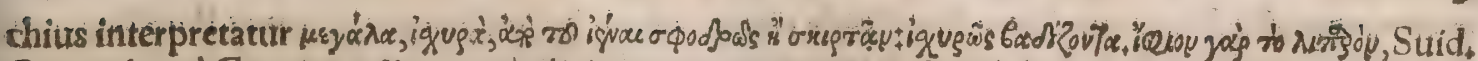

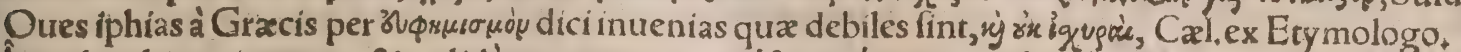

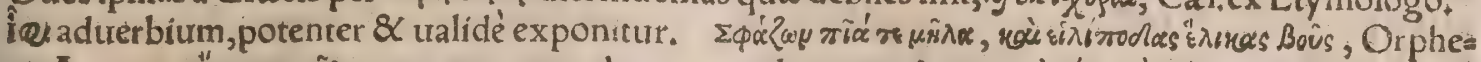

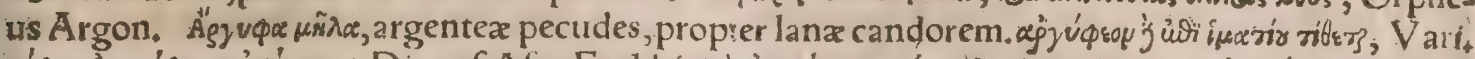

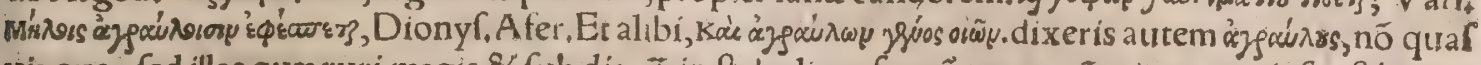

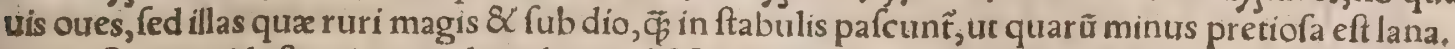

TOuiaria, id eft ouium multitudo a pud Varrone, ut pecuaria. Hinc ouiaricus poffeffiutu, apud Columel.Quoniam de ouiarico pecore fatis dictum eft, \& $c$, Oullus adiectiuũ in frequenti ufu eft; pręfertim Plinio, ouinus rarũ. Ex fuillo, ouillo,caprino grege, Liu.2, bel.Pun. Prurigines capitis dí fcutit fel ouinum, Marcellusłapud Plinium legitur, Porrigines capitis difcutit fel oullum. Ouilis apud Varronem (8 Marcellum Empiricum :) Vt fuillo pecorià fattonio ad aquinoctum uernum putant aptũ, (admittẽdo:) fic ouili ab arçuri occafu ufo̧s ad aquilę occafum, Et alıbi grex ouilis apud eundem, ut \& femen caprile. Molleftras dicebant pelles ouiles, quibus galeas extergebant, Feftus

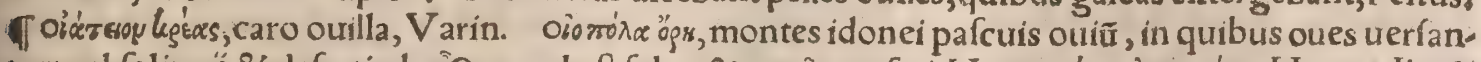

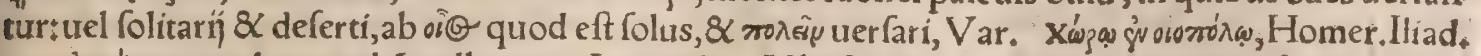

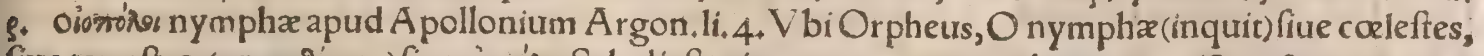

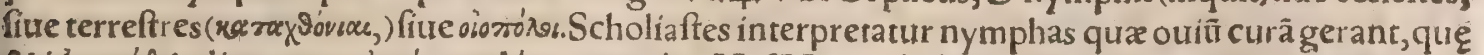

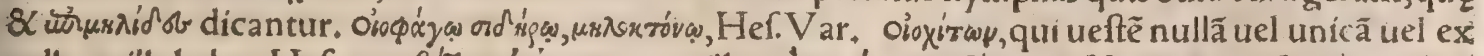

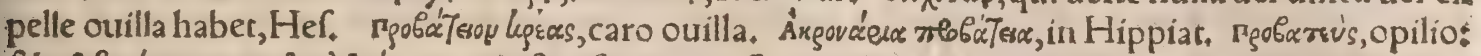

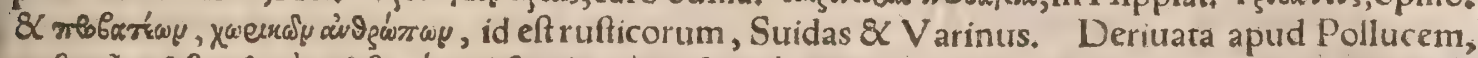

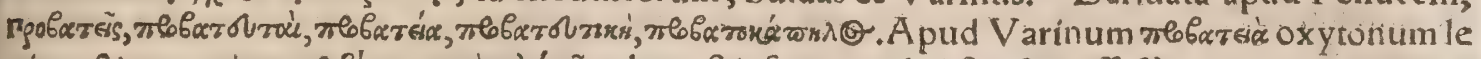

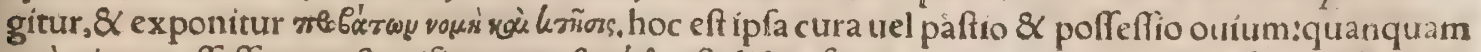

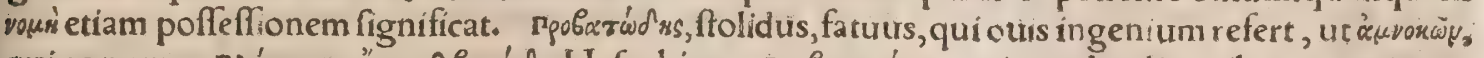

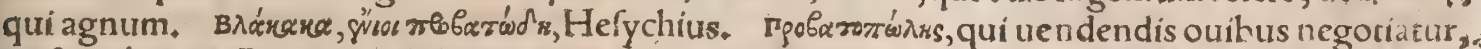

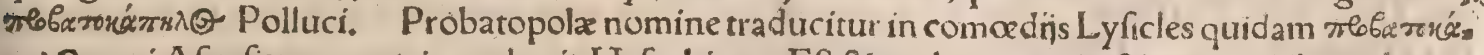

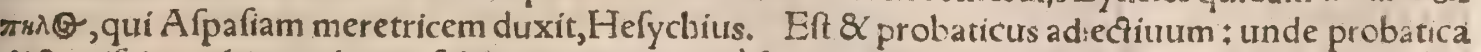
dicta pifcina, ubi oues lauari folebant, antequam à facerdotibus lirarentur, Psobaroyvónue qui den= tès ætatis indices iam amifit, qui \& $\lambda \epsilon \pi \%$ y

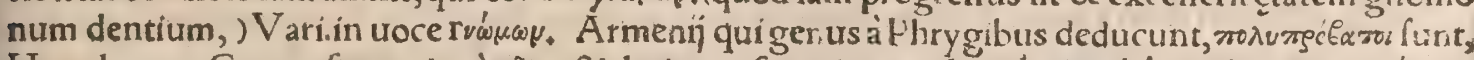

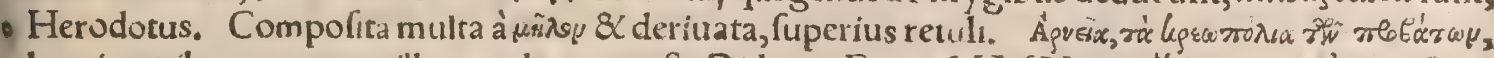
loca in quibus carnes ouilla uenduntur, refte Didymo, Etymol, Hef. Var. p'lüot propriè agni funt,

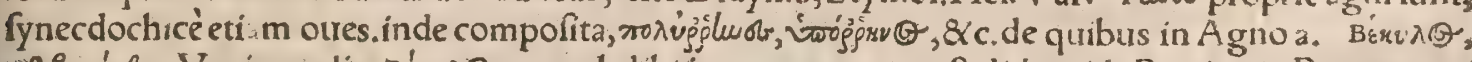

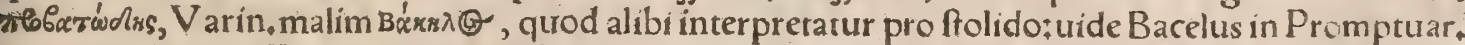

TAes antiquifimum quod conflatum, pecore eft notaium, Varro. Seruius rex, ouum boũás effigie primus æs fignauit, Plin. In uetuftifimis nummis, bouis aut pecudis aut fuis fignũ incrum apparet,Plutarch, in Public. Mandrabulus inuento thefauro ouẽ aureã primü confecrauic lunoni,

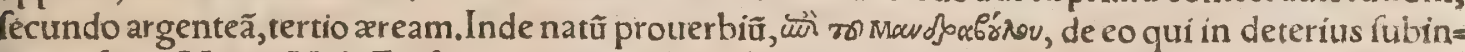
de proficiat, Varin. Vide Erafmum in prouerbio, Mandrabuli more res fuccedit.

đProbataa,ocimaftrum: \& probation, plantago, Nomenclaturæ apud Diofcoridem. Plantago to minor folijs eft lingux pecorum fimillimis, Plin. Hinc \& ajuó jawasop quafi agninam linguam appella riconftat. Arnophyllon uerò cytifus eft, herba fruticofa, Her. Varin.

TCatoblepx feu gorgones, ut quidã fcribunt, ouribus aut uitulis fimiles funt, ut inter Botres feros diçum eft. Oues etiam inter cete funt Äeliano. Exeunt $\&$ pecorifimiles belua ibiad Cadaram ru bri maris peninfulam) in terram, paftaćg radices fruticum, remeant, Plin.

T Troglodytæ pecorum nomina filns indunt, ut tauri, arieris, ouis, quòd ab n̈s nónà parentib. alantur. A minore pecore nomina habemus, Porcius, Ouinius, Caprilius, Varro, Ouinius Camil lus fenator antiqux familix, A el. Lampridius.Setuerus Ouinium inuitaut ut pedes iter faceret, $\&$ c.

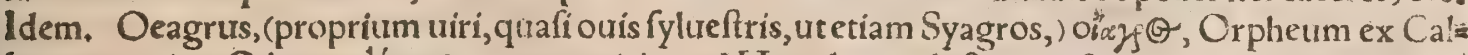

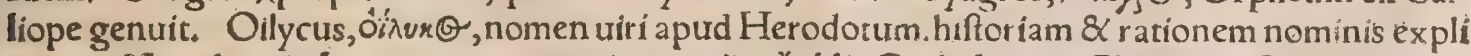
caui ex Heroduto in Lupo a, inter propria uirorữ, okn, filia Cephali, uxor Charhippi, Suid, in oiñoş. Rhene,

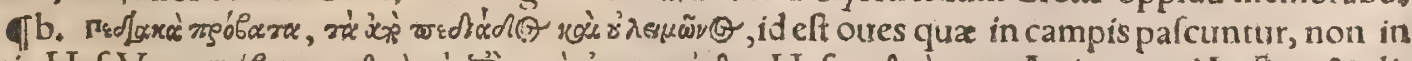
pratis, Hef.Var. ז

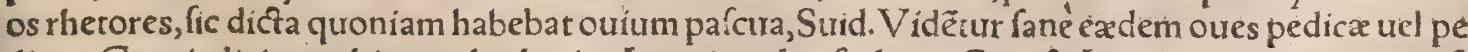
diacæ Græcis dici, quæ hirtæ uel colonic $x$ Latinis:uel pafcales, ut Cato \& Lucilius nominant, quafi pafcuales, quòd paffim pafcantur: \& foloces etiam dici poffunt, ut lana folox qux afperior eft, mon. tanum hircum atç folocem Lucilius dixit. Molliores trero oues ut Tarentínæ mollius pafri tracta. riç̧ defyderant. Oues Pyrrbicæe de regis Pyrrhi nomine dicuntur, ficut et Boures, ut in ipforữ hifto ria pluribus expofui. Ouem pellam in Theocrito nigram interpretantur, Calius. A pica ouis dt 6o citur quęuentrem glabrû̉ habet, Feff. eadem Varroni mina. Quadrupedũ interanea Græci quãdo: que chordas uocãt, fed \& ouium craffius inteftinum:unde eft apud Alexim chordarium., Athenæo referente, forma deminuta, Calius, Áxgov'seta mblérex legimus in Hippiatricis cap. 64, intelligo 


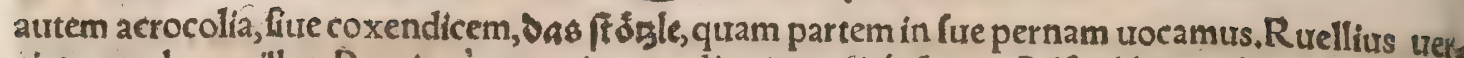
tit trunculos ouillos. Praccipuè tamen in ungulis trunculiş̧̧ fuum, Celfus libro 2 ubi quidam dubi

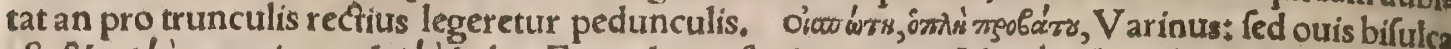

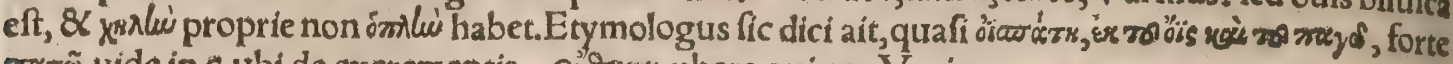

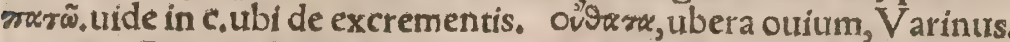

đc. Blaterat hinc aries, \& pia balat ouis, Author Philomela. Palatium mons Romx appel. latus eft, quod ibi pecus pafcens balare confueuerit, uel quod palare, id eft errare ibi pecudes fole. rent, Feltus. Bela oues nominauerunt antiqui Latini, unde belare, ( per onomatopoian à bee uoce

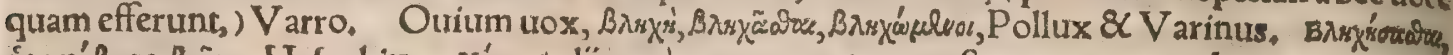

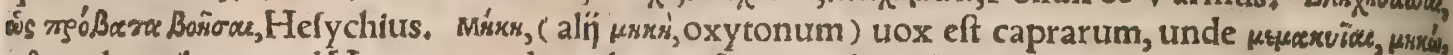

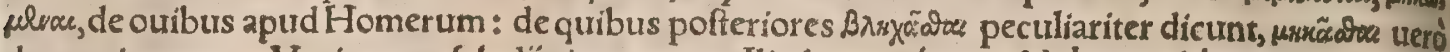

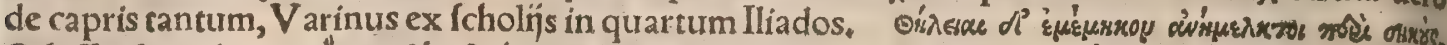

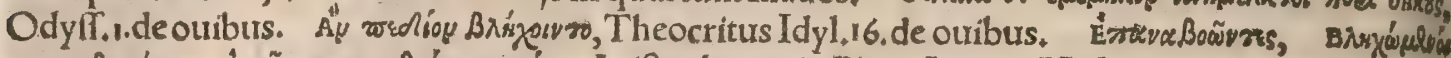

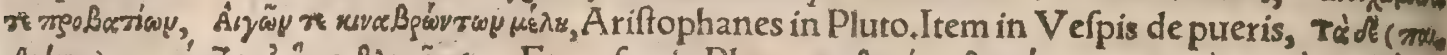

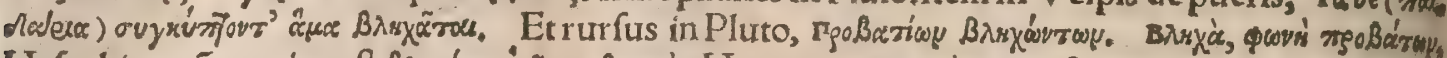

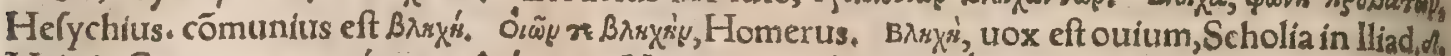

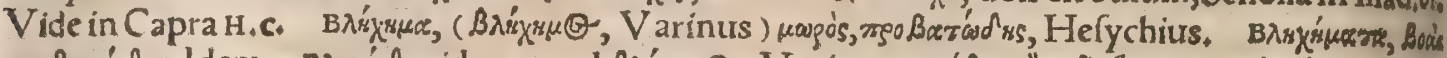

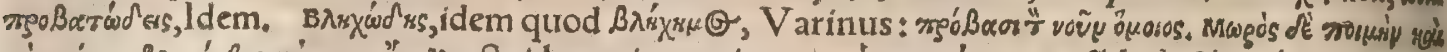

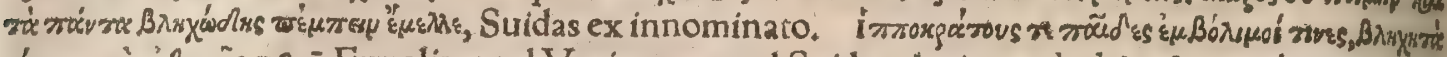

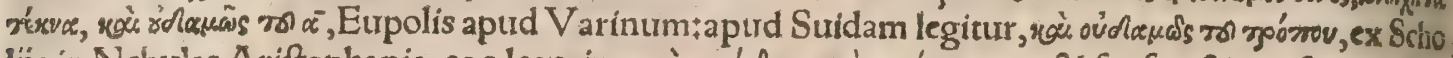

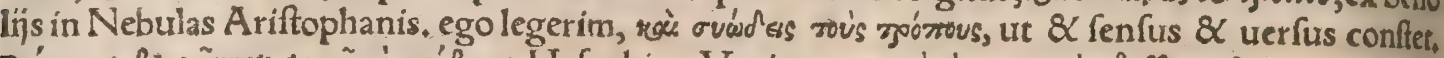

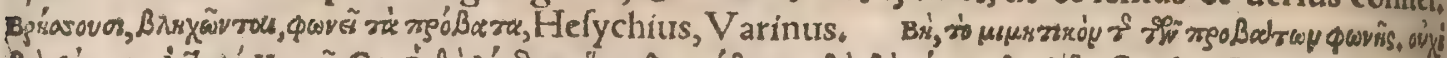

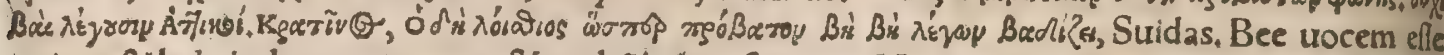

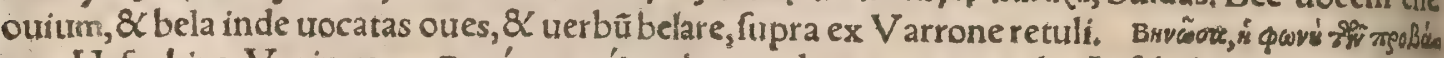

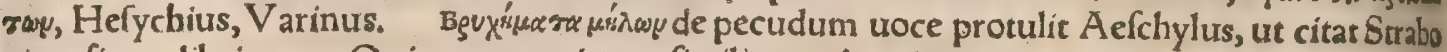
circa finem libri 14. Qui uocem emittunt fimiliter ouibus, ingenio quoģ oues referre iudicabun

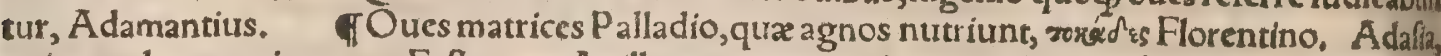
ouis uetula recentis partus, Feftus. Auillas, agnas recentis partus dicimus, Idem. TOuiumuef

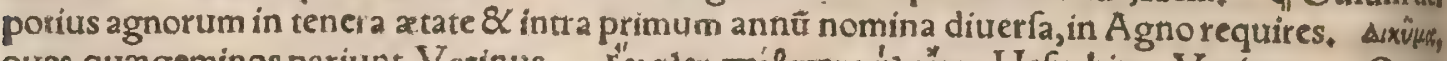

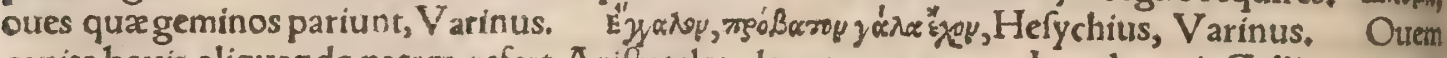
capite bouis aliquando natam refert Ariftoteles de generat, 43. In aula regis Galliarum anno 1549. monftrum fuiffe audio, anteriore parte afini, pofteriore ouis fpecie, ex Italia miffum. Neg

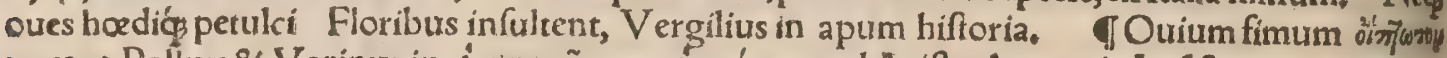

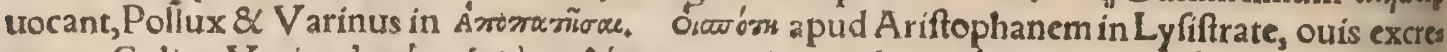

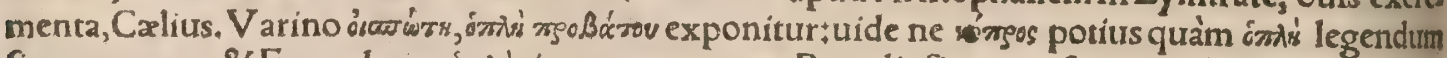
fit, quanquam \& Erymologus óntsip interpretatur. Pecudis fimum cépoten uel oipoten uocant, Ariftophanes eciam finypen, Hermolaus fi recté legitur. ego quidem non oipoten, fed oiptotonlege rim, nec finypen fed afypen. öoúzxp enim excrementum ouium fignificare fupra in $G$. dictum eft

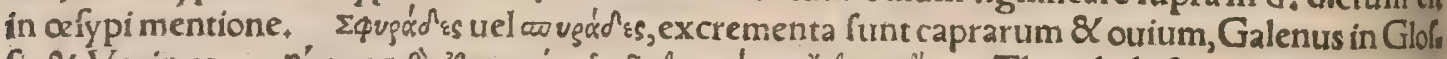

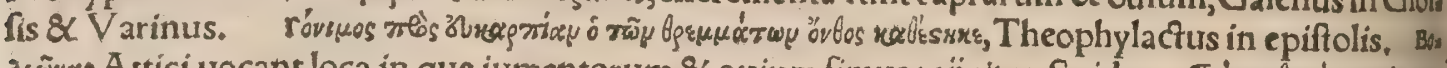

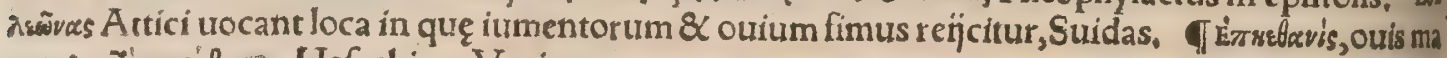

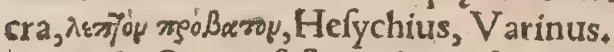

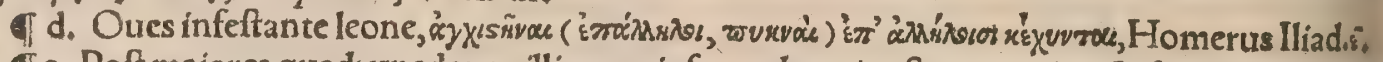

đe. Poft maiores quadrupedes ouilli pecoris fecunda ratio eft, quax prima fit fi ad utilitatis ma, gnitudinem referas. Nam id pràcipué nos contra frigoris uiolentiam protegit, corporibuş́́ noftris liberaliora prabet uelamina, Columella. Magna pecori gratia in ufu uellerum. Vt boues uifum hominum excolunt, ita corporum tutela pecori debetur, Plinius. Ouium uillis confectis atç con textis homines ueftiuntur, Ëeroy, id eft lana, fit à primitiuo sjgos, Varinus. Niuem veteres ap.

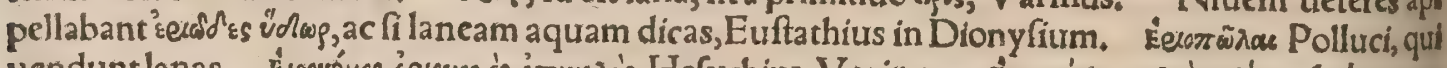

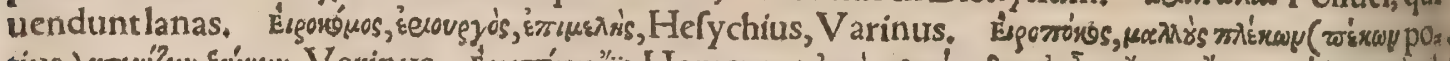

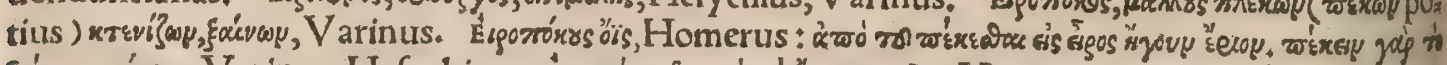

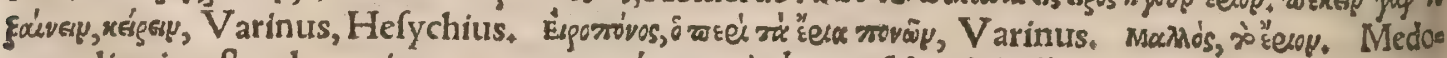

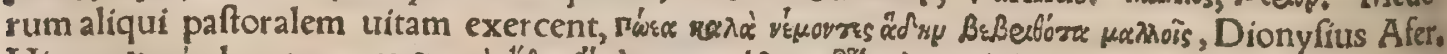

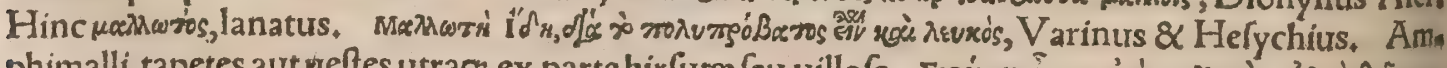

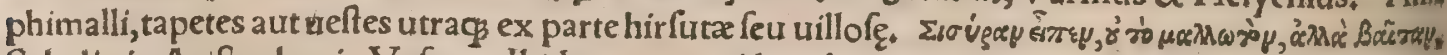
Scbolia in Ariftophanis Vefpas. Ibidem cum quidam de caunace barbarica uefte dixiffet, in qutram

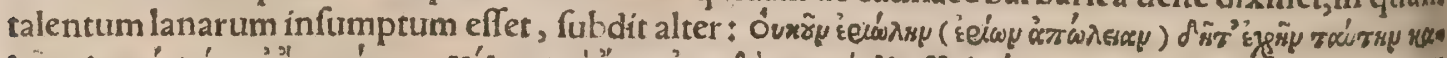

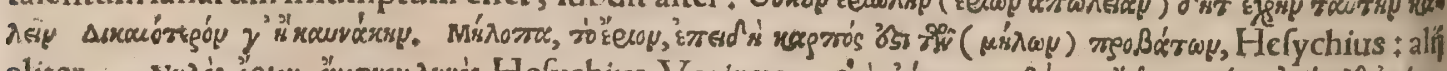

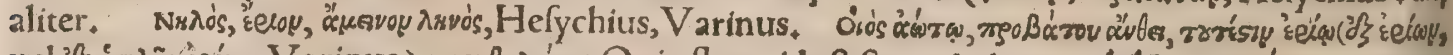

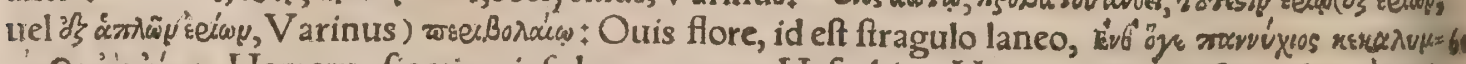

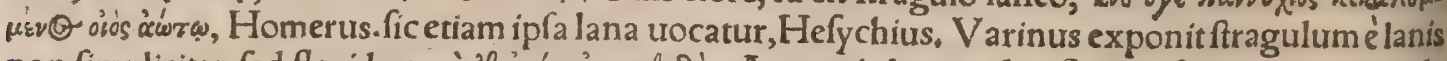

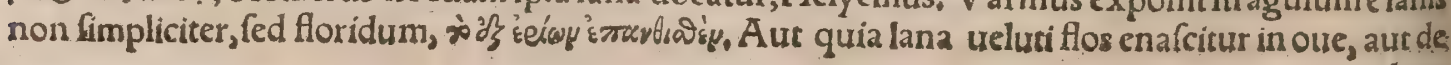




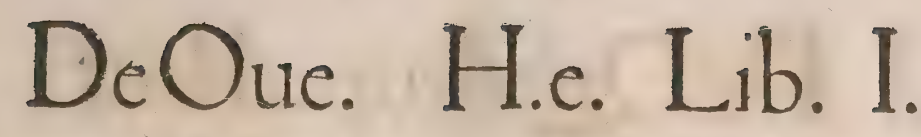

lana praftantiore tantum \& felecta accipitur, (utflorem farinæ dicimus,) Plura uide apud Vari-

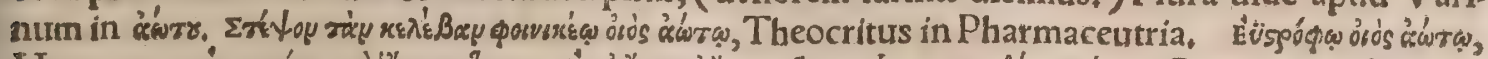

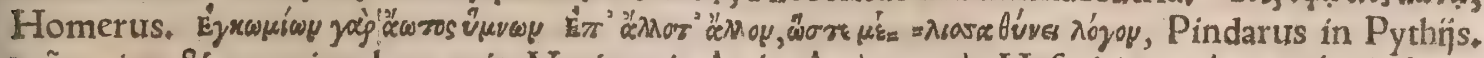

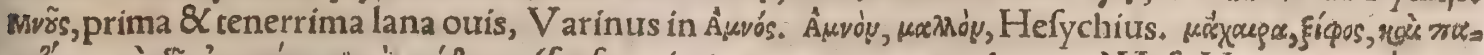

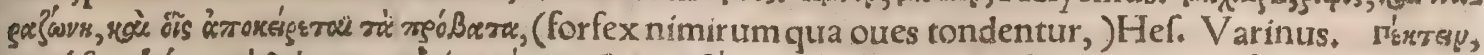

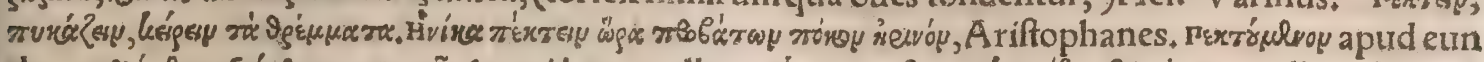

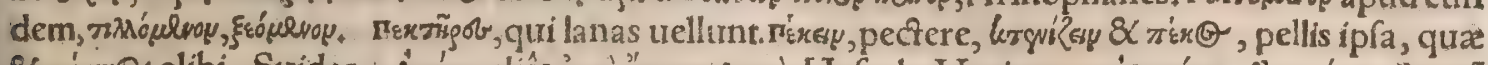

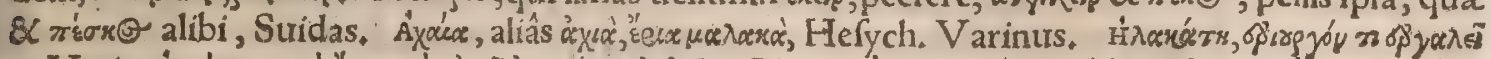

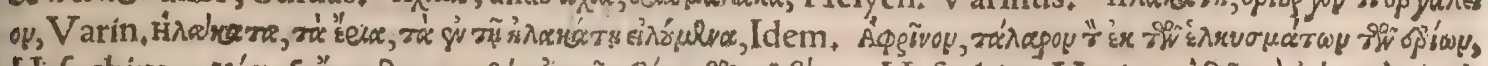

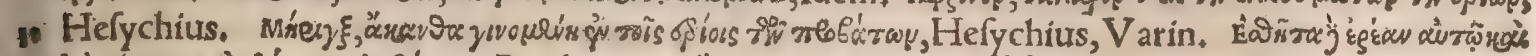

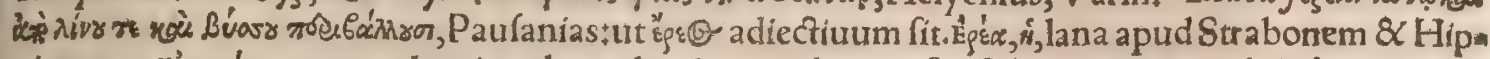
piatros. Eig̨óáns, ramus oleaginus lana obuolutus, arborum fructibus circumpendentibus, \&c. uri. de Lexicon Gracolatinum, Lanis authoritatem ueteres Romani etiam religiofam habuere, poftes à nubentibus attingi iubentes, Plinius, Lanicí plutimum in caudis, Plinius. Nec pinguia Gallicis Crefcunt uellera pafcuis, Horat.Carm+3.16. Vellus elutriare dixit Plinius. Elutriare lintea ex Las berio apud Gellium pro lauare pofitum uidetur, Calius. Ouium lana mollior \& fubtilior redde. tur, (i depafcantur agros uel nouales antequam aretur $₫ \&$ relicfos frumenti culmos ftatimà melfe: quod non folum lanam reddit meliorẽ, fed eadem opera agri fimo ouium ftercoraturur: 8 hoc praci pué in Anglia à diligentioribus obferuatur. Solox, lana craffa: \& pecus quod paffin pafcitur non 10 tectum. Titinnius, ego ab lana folocia ad puram(purpuram legit Perottus)data. Lucilius, Pafcali pe: core, ac montano hirco, atque foloce. Adulteros, ut Aelianus tradit, in Gortyna Cretæ deprehen fos, lana coronabant, mollitix probro, atque ita per ciuitatem ad magiftratus traducere moris erat, Hermolaus. Naccæ fullones dicti, ut quidam aiunt, quód omnia feré opera ex lana naccæ dicana

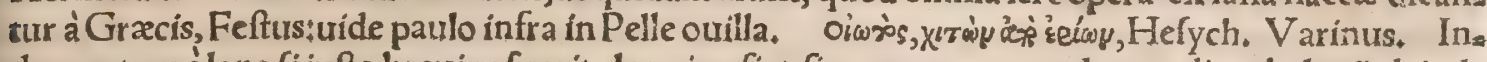
dumentum è lana fi iufto breuius furerit, longius fiet, fi roretur aqua unde egreditur balneũ, deinde illinatur melle, A ggregator. TLaneos pedes uulgò deis attribuunt, quod pedetentim \& abfque ftrepituad ulcifcẽ das malorum iniurias procedant:quo exemplo pictor deo laneos calceos induxit, Cxlius Calcagninus. Hinc $\&$ Saturnus per annum laneo uinculo alligabatur, ut apud Macrobi. um legitur.

3o $\quad$ Hyænæ dentes illighatos pecoris aut capri pelle, ftomachi cruciatibus prodeffe aiunt magt, Pli nius, Molleftras dicebant pelles ouiles, quibus galeas extergebant, Feftus. Rheno, ueftis pellis cea, pracipué ferina ad ufum humanum redacta, dicta quòd calidos teneat renes, fiue quia fivós pel= lis dicitur, fiue quòd R henani populi ea peculiariter utantur. Cafar fexto belli Gallici fcribit, Ger=

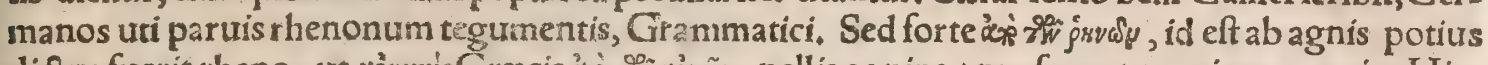

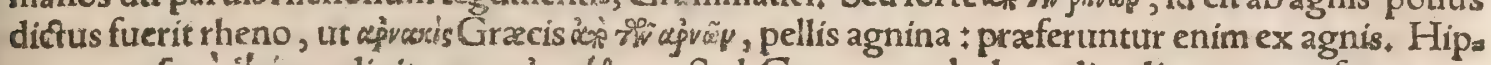

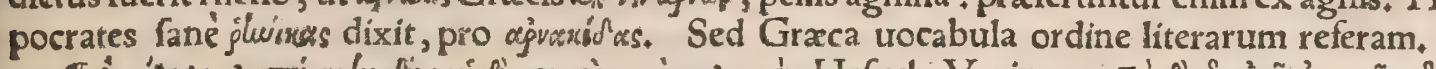

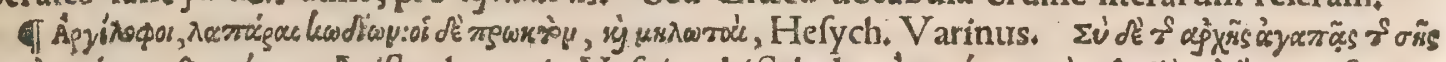

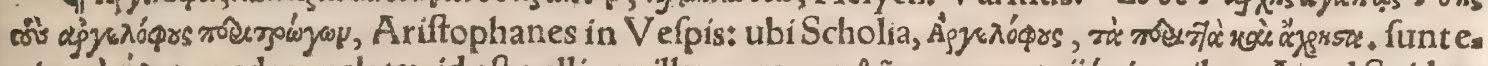

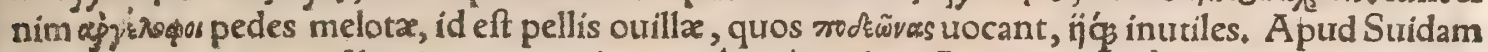
40 quoque legitur per epfilon in antepenultima. Agveris, uide in Agno. बी Bóctsy Varinus exponit

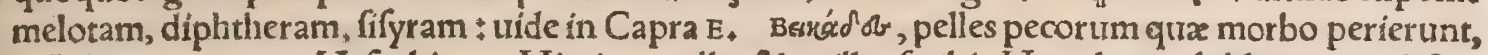
ut Lacones uocant, Hefychius. Hircinas pelles 8 ouillas fribit Herodotus, biblos etiam dictos ueteribus, quòd papyri uicem impleuerint quandoque, Calius: Hinc nimirum \& codicellus, lewot: $n \varepsilon \lambda A G$, pellis ouilla exponitur Varino. GDiphthera, pellis caprina propriè +uidetur etiam de 0.

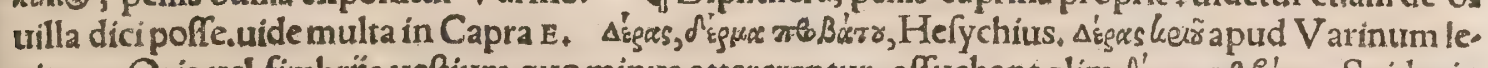

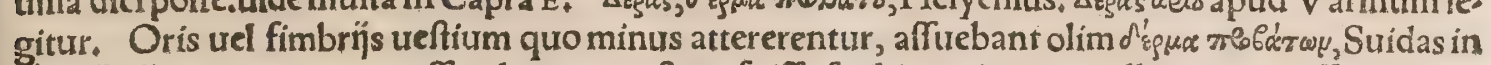
If: $x_{0}$. Pollux catonacam craflam laneam ueftem fuiffe fcribit, cuius ora pellis caprina affueretur.

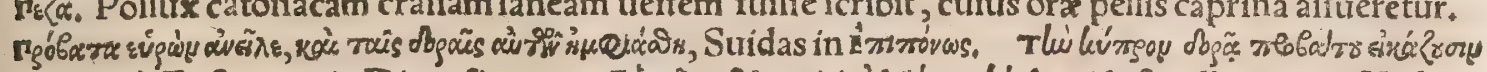

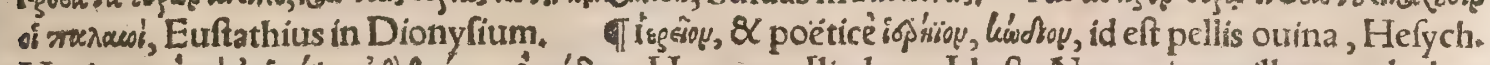

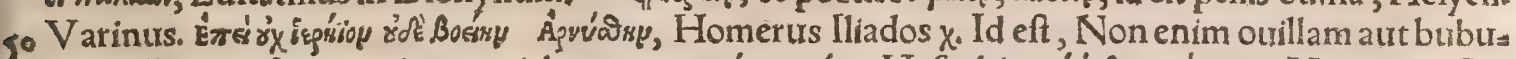

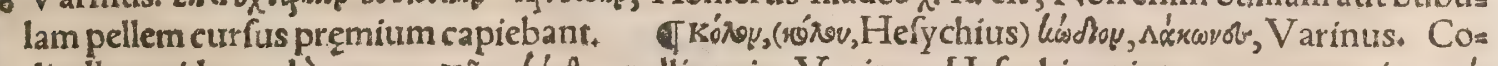

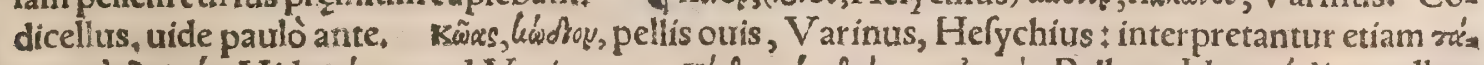

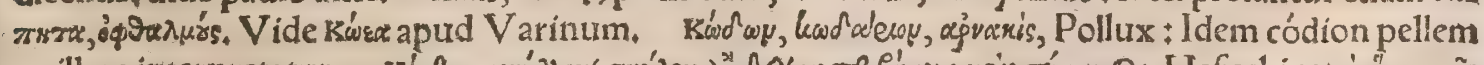

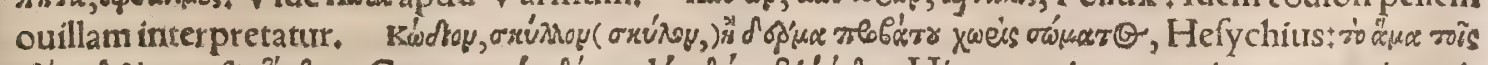

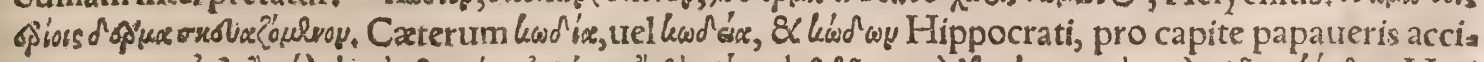

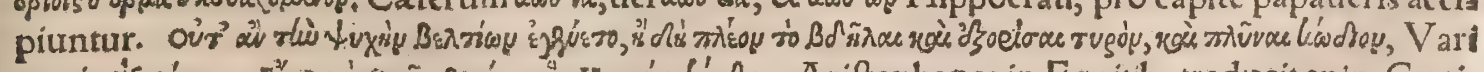

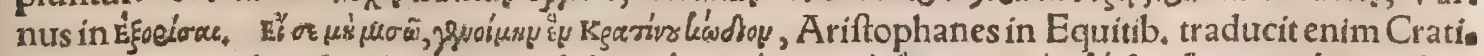

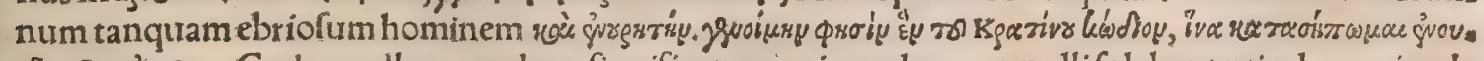

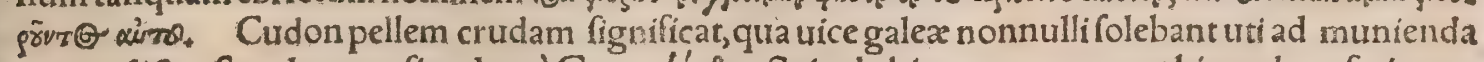
60 capita: dicta eff cudon quafi codon, à Græco k'wdov. Spicula bina gerunt: caput his cudone ferino Statcautum, Silius libro 8. Scipio contorquens haftam, cudone comantes Dífiecitcrines, Idem

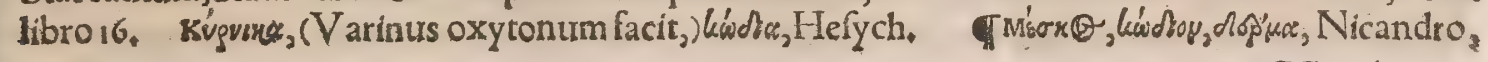




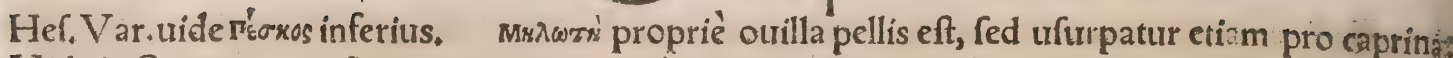
Vide in Capra E. Mũ $\lambda$ ce communiter quadrupedes omnes, unde quatris etiam pellis melota dici.

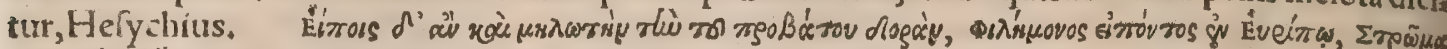

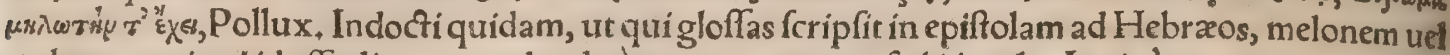
melotum animal id effe dicunt quod unigo taxus uocetur, (fed id meles Latinè nuncupatur, ut fes les: ) cuius pellis ualde hifpida, melota nominetur : unde de fancris quibufdam prifcis legatur, Cir *

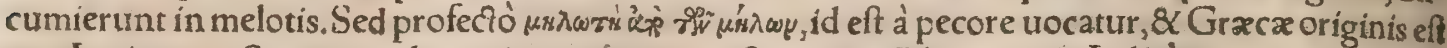
non Latinx. Scoppa melotam interpretatur ueftem ex pellibus ouinis, Italicèzamara, ciamarra,

T) Nacca fullones dicti, ut quidam aiunt, quod omnia feré opera ex lana nacca dicantur à Gra: cis, Fefturs. Nános uel vósx, pellis, \& proprie caprina, hinc varbrix roe dicti, quí lanas ouium tondent 10

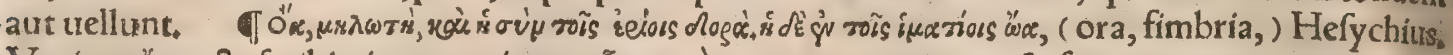
Varinus oै recte fcribi ait per omicron: wax uero cum 0 . magno per ecta fin, utrungs pro melota fitue

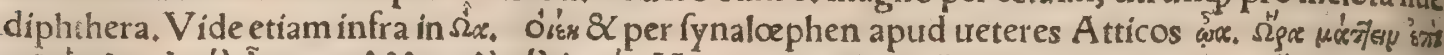

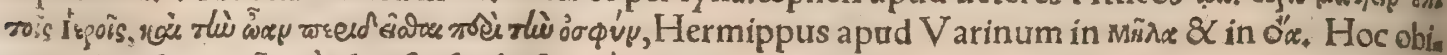
tcr animaduerti, way à plerifọs fcribi fine iôta, quod tamen or thographia fubfribendum monet.legi

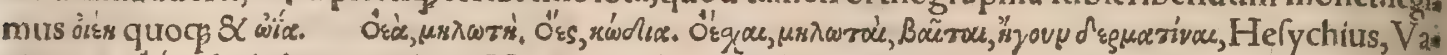

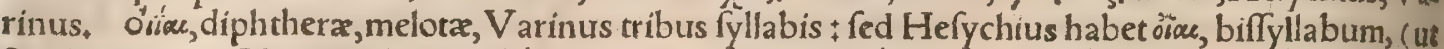

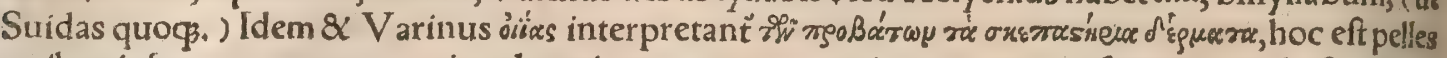
quibus ipfa oues propter pretium lanæ integuntur, ut puriorem eam conferuent, unde $\&$ pellitæ

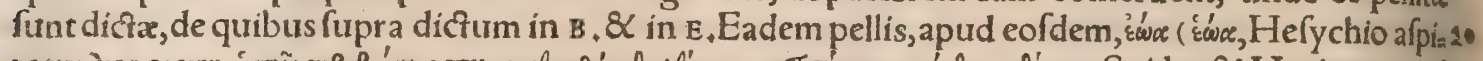

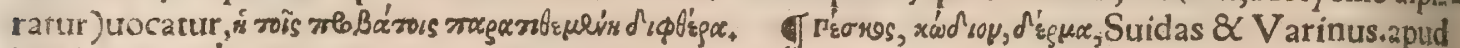
Hefychium rtorow legitur, quod minus placet. Sed $\mu t \sigma r o s$ etiam apud Hefychium \& Varinum, non resie pro wtoros fribi uidetur. Pefcia in Saliari carmine. Aelitrs Stilo dicit ait, capita ex pellibus agninis facta, quod Græci trocent pelles pefce (

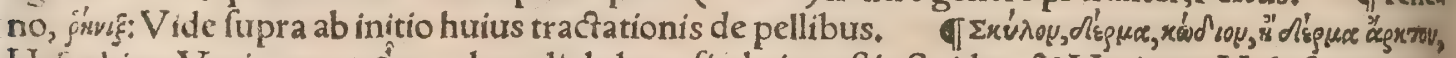
Hefychius, Varinus. $\hat{\Omega}_{x,}$, melota, diphthera, fimbria ueftis, Suidas, \& Varinus. Vide fuperiusin

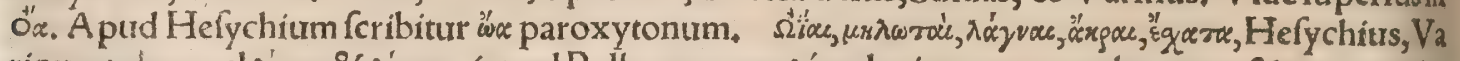

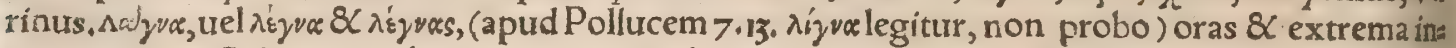
terpretor. Pellem qua fuccingerentur mulieres in balneis, uel qui illas abluebant, tocatam ine uenio oam lutrida, nurnc ueró oam per fe, fic uerò dicebatur melota, hoc eft pellis ouilla: unde flu=

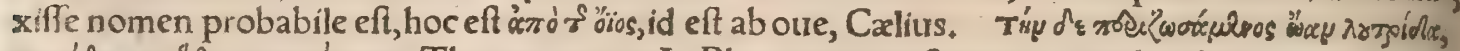

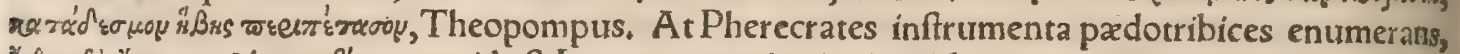
" $d^{\prime} n$ w fed etiam uiros in balneis oas pudendis adhibuiffe appareat.) Defumpfit hac Cælius ex Polluce 7. 13. \& 10.47. Caterum militibus, inquít ibidem Pollux, o2 etiam pro mactra feruit: quod Hermips

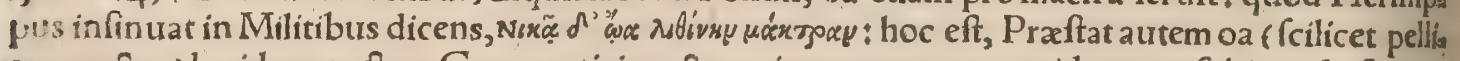
cea macira ) lapidex mactræ. Grammatici mactram interpretantur uas idoneum fubigenda farinæ;

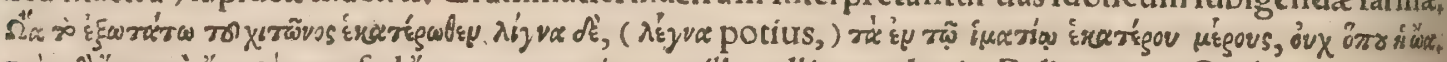

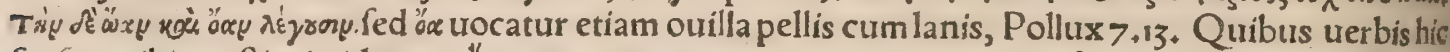

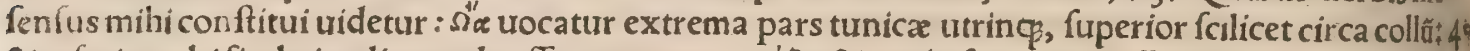

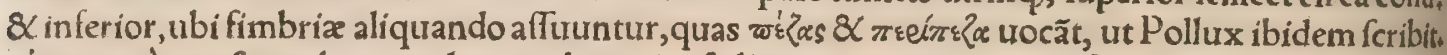

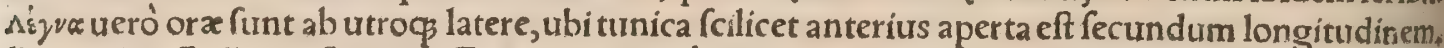

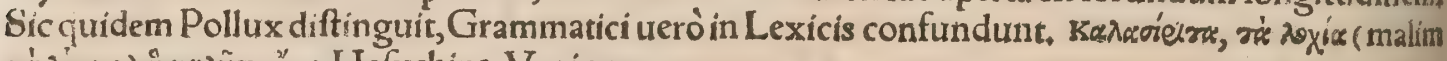

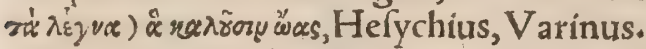

T) Opilio, quafi ouilio qui oues cuftodit, Etiam opilio qui pafcit inter alienas oues, Aliquam ha Let peculiarem, qui fpem foletur fuam. Sunt qui upilio fcribant authoritate Prifciani, qui dicit o. bres uem in hoc nomine effe conuerfam in $u$. longam ex literarum affinitate. Vtuntur uoce opilio, $\mathrm{Co}_{2}$ lumella libro 7. de re ruft. \& Cato cap.56. Venit \& upilio, Vergilius Aegl, 10. Armentarï \& opiliones, $V$ arro. Et alibi, Alius enim opilio, $\mathcal{X}$ alius arator. Tria tantum genera funt paftorum quidi gnitatem in Bucolicis habeant, bucolici, opiliones, \& omnium minimi xpoli, id eft caprarï, ut Ael, so Donatus feribit. Opuncalo, quod opilionis genus cantus imitatur, Feftus, roussiu, paftor ourum,

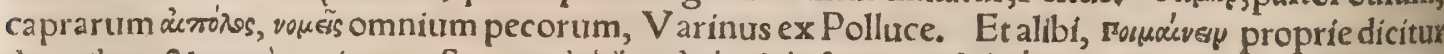

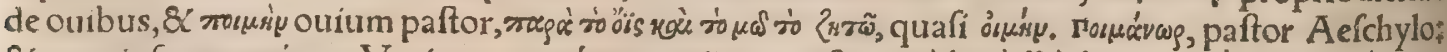

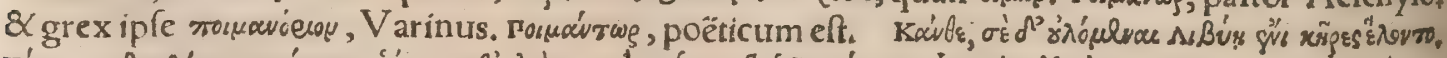

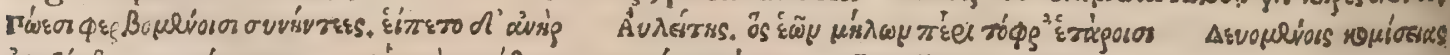

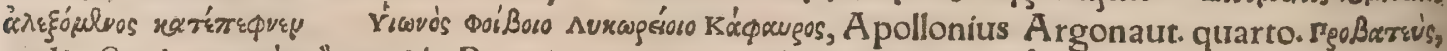

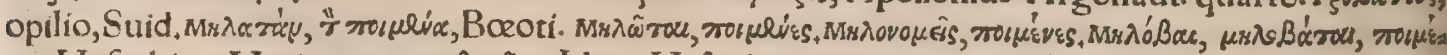

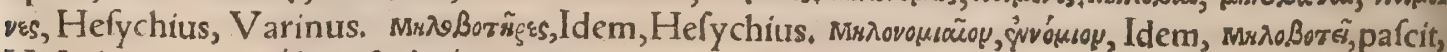

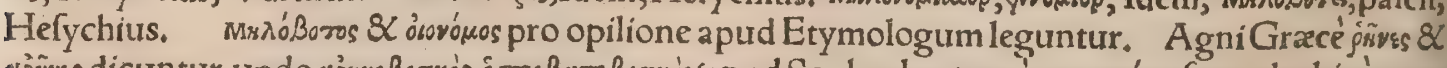

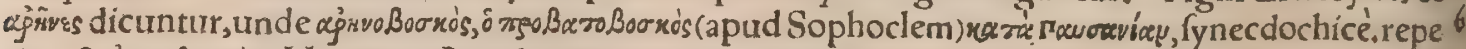

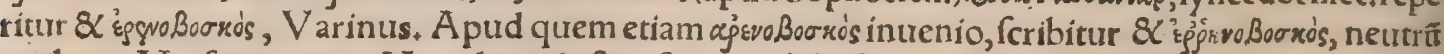
probo. Verfemus oues, Vergilius, id eft pafcamus. Verfantur enim modo in banc partem, modo 


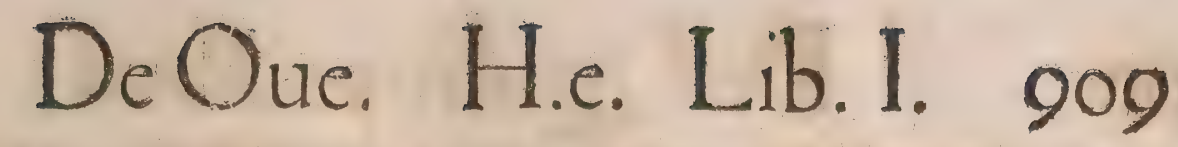

In dilam, ubliatiara pabula fefe oftentant. Sic errare apud eundem pro pafct, quia id errando fít.

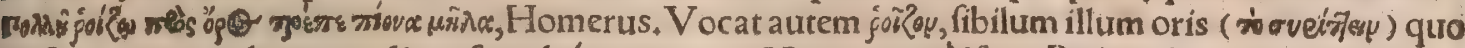
paftores in gregibus agendis pafrendis ue utuntur, Varinus in poî̉ov. Peđum, baculum incuruum quo paftores utuntur ad comprehendendas oures aut capras pedibusłcuius etiam meminit Verg, in Bucolicis cum ait,At tu fume pedum, rounvirou lúvor, canes ouium cultodes; Pollux.

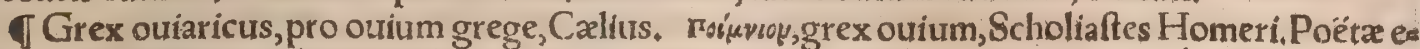

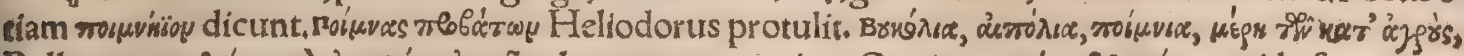

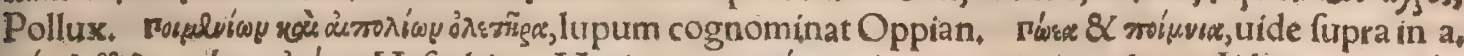

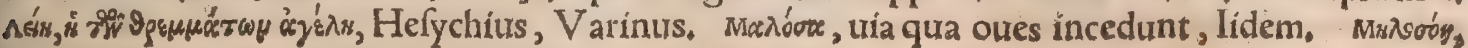
Idem.

TOuile, locus in quem oures fe recipiunt. Datum fecretò in ouili cum his colloquendi tempus, Liuius. Tepidis in ourlibus agni, Ouid.13. Metam. Incuftoditum captat ouile lupus, 1. Trift. .. Eleg. Non lupus infidias explorat ouilia circum, Vergil.Albent plenis \& ouilia mulctris, Nemefianus. Magica uanitatis uideri poteft quæ tradunt $\&$ de uefpertilione, fi ter circumlatus domui uíuus, per feneftram inuerfo capite infigatur, anuletum effe:priuatimćç ouilibus circumlatum toties, \& pedia bus fufpenfum furfum in fuperliminari,Plinius. Si feuo leonis liquefacto circuitus ouium inunga tur(diftilletur, nunquam accedent ad eum lupi, nec alia rapacia, $R$ afis, Albert. In incendịs , fi fimi äliquid egeratur è ftabulis, facilius extrahi traditur, nec recurrere oues bouresćs, Plin. Caula à ca uo dictre, antiquitus enim ante ufum tectorum oues in antris claudebantur, Feft. Ac ueluti pleno lupus infidiatus ouili, Quum fremit ad caulas, Verg.9. Aen, ubi Sercrius, Caulas, munimenta \& fe pta ouium:eft enim Gracum nomen,c. detracto.nam Graci aulas uocant animalium receptacula. Lucretius palati caulas dixit, id eft meatus $\&$ foramina. Et rurfum, Difpergũ tanimas per caulas cor

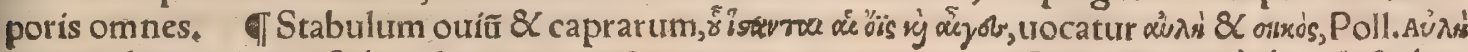
tamen aliquando prof fabulo boum etiam $\&$ equorum capitur, utin Boue dixi. Aй $\lambda \dot{\varepsilon}$

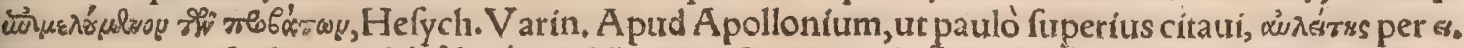

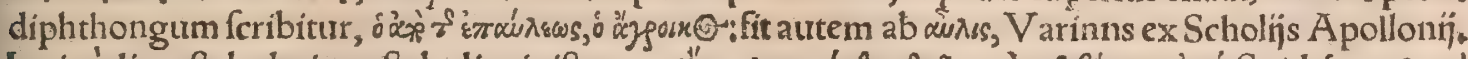

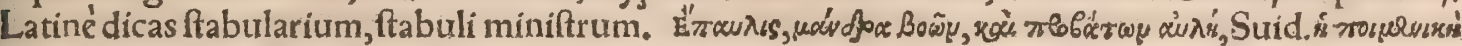

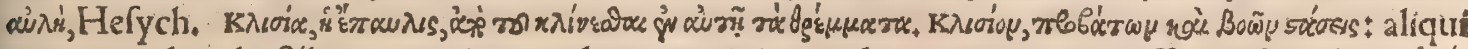
maiores ualuas hoftij interpretãtur, quibus apertis iugum boum intromitti pollit, Hefych. Dion lìi= oroy ourile interpretatur. Plurra lege apud Varinum in kivoia, bis. Aliâs quidem ea uox cafam fignifi $\Rightarrow$

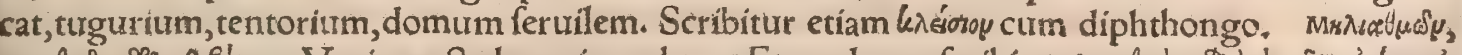

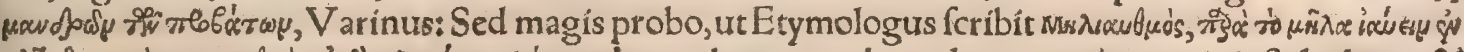

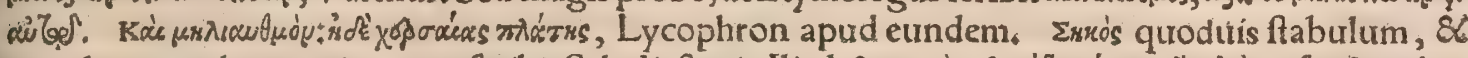

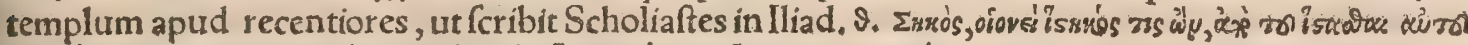

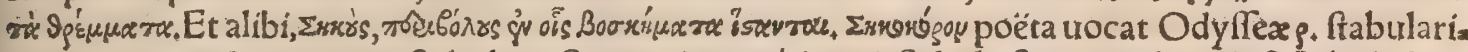
um, qui uerrit \& expurgat ftabulum. Sunt enim onwi(inquit Scholiaftes)mandræ, id eff ftabula \& lo

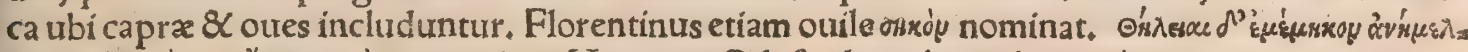

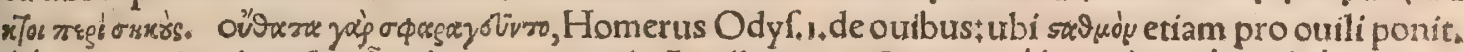

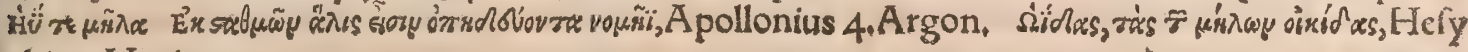
chius, Varinus.

ब Publicola in ea lege qua animadurertit in eos químinus confulibus partiriffent, adeó populas rís fuit, ut pro plebe mayis quàm pro patritịs lata uideretur $\$$ quinq enim boum $S \mathcal{C}$ duarum ouium pretium mulcta fuxt:erat uero pretium ouis oboli dècem, bouis autem centum. Cum enim nondum nummorum ufus ad Romanos per id temporis frequens effet,pecudibus \& iumentis plectebantur fontes, Ex quo inualuit ut patrimonia à pecudibus ufg in hanc diem peculia dicanturtin uetuftifi. mis quogs nummis bouis aut pecudis aut fuis fignum uncifum appareat, Plutarch, in Public. Muls tatio olim non nifi ourum boumós impendio dicebatur: non omittenda prifcarum legũ beneurolen. tia.Cautum quippe eft, ne botiem priufquam ouem nominaret qui indiceret multam, Plin. Mula cीa qua fuprema appellatur (inquit Gel.11.1.) utpote qua nulla maior inftituta fuit, in fingulos dies duorum ouium, triginta boum:pro copia fcilicet boum, proç ouium penuria. Sed quuin eiúmodi mulcta pecoris armentićs à magiftratibus dicta erat,adigebantur boues ouesćs aliàs pretri parui,aliz às maioris : eaç res faciebat inæqualem mulctx punitionem. Iccireo poftea lege Áteria conftitutl funt in oues fingulos æris deni, in boues aris centeni, minima autem mulcta eft ouis unius. Nune quo quãdo à magiftr atibus pop. Romani more maiorum mulcta dicitur, uel minima trel fuprema, obferuari folet ut oues genere uirili appellentur; ac nifi in eo genere dicer etur, negauerunt iuftam uideri mulctam. Varronis uerba quibus minima mulcta dicebatur à pratore funthæc: Quando citatus neq̧ refpondit neģ excufatus eft, ego ei unum ourem mulctam dico. Ouibus duabus muls tabantur apud antiquos (inquit Feft.)minoribus criminibus:in maioribus autem bubus, nec ultra hunc numerum excedebat multatio: qua pofteaquam are fignato uti ciuitas cópit, pecoraćs multi: tia aut incuria corrumpebantur, unde etiam peculatus crimen ufurparicoptum eft, facta eft afti matio pecoralis multæ, $\&$ boues centenis affibus, oues denis æeftimatx. Inde fuprema multa, id ef maxima, appellatur, tria millia aris:item viceffis minoribus delictis, Etrurfus, Peculatus furtum 
publicum dici coeptum eft à pecore, quia ab eo initium eius fraudis effe cocpit. Siquidem ante aes aut argentum fignatum, ob delicta peena grauiffima er at duarum ourum $Q X$ triginta boum. Ea lege fan, xêre T.Menenius Lanatus \& P. Septius Capitolinus confules, Qux pecudes poftquam xre fignato uti coepit pop. Romanus Tarpeia lege cautum eft, ut bos centuffis, ouis decuffis aftimarentur, Huc, uIfģ Feftus, Multa etiam nuncex uetere inftituto bobus 8 ouibus dicitur, Varro, Apud Lus, fitanos, tefte Polybio, ut citat A thenæus initio libri 8. ouis quondã duabus drachmis uannibat, Tro: glody tis uxores communes funt, nifi quæe tyrannorum funt. nam qui tyranni uxorẽ corruperit, oue mulçatur,Strabo. Cappadoces Perfis quotannis pendunt præter cætera, ouium quinquaginta millia, Medi duplum feré, Strabo.

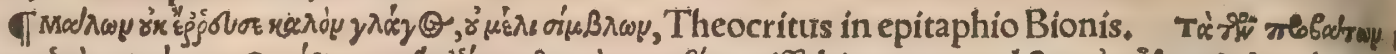

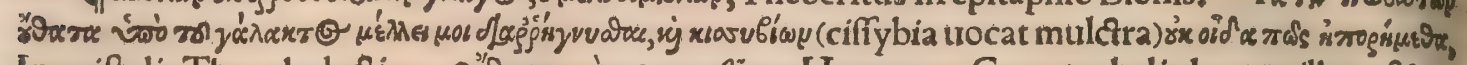

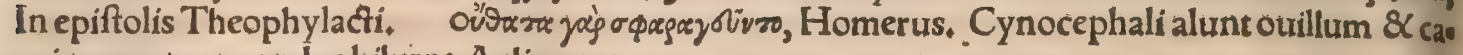
prinum pecus, arģ lac bibunt, A elianus.

I Blattæ ( erucæ potius, ) quas prafocurides quafi porricidas Graci uocant, ut Diophanes ferin ptum reliquit, hortis folent nocere, ergo uentriculum ouis ftatim occifæ nô elotum, fed fordibus fuis plenum, fpatio quo abundant, non alte fed fuperficie tenus debebis operire. Poft biduum reperies animalia ipfa congefta uentrem hunc replere, hoc cum iterum uel tertio feceris, genus omne quod nocebit excingues, Ruellius. Hirundo ex ouium tergis floccos lanarum euellit, indé́ģ fris pullis nidum quàm molliffimé fubfternit, Aelianus.

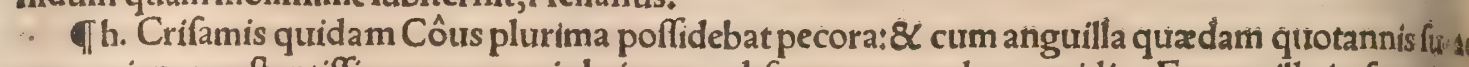
perueniens praftantiffimam ouem ei abriperet, obferuatam tandem occidit. Et cum illa in fomnio apparens Crifamidem ut ab eo fepeliretur moneret, re neglecta cum tota familia perĭt, Hefychitus, \& Suidas apud quem Criffamis per f,duplex fcribitur. IPan munere niueo lanze captam te Lith na fefellit, Vergilius. Mutat fabulam, inquit Seruius. nam non $P$ an fed Endymion amaffe dicitur Lu nam qui fpretus pauit pecora candidiffima, \& fic eam in fuos illexit amplexus. Pan Mercuriffio lius (inquit Probus) quum Lunam concupiffet, \& $C$ haberet optimum pecus, pofcente ea partem peco ris pro concubitu, dicitur pollicitus, \& duas partes feciffe gregum, quarum alteram candidiorem fed lanæ craffioris, Lunam deceptam candidiore, deteritus pecus abduxiffe, ut poéta fignifícat。

IDe oue in Co infula quar leonem peperit, dictumeft in Leone $\mathrm{H}, \mathrm{C}$. Feftis diebus oues purs gandæ lanæ gratia lauari non licet, licet autem ficuratione fcabies abluenda fit:quamobrem Vergi, s" lius non fimpliciter feftis diebus oures fluuio merfare conceffum fcripfit, fed fluuio falubri, Macron bius. Paftores ouilia, oures $\&$ pecudes purgabant fưmo ex fulphure, rofmarinumós a herbam fa binam $\&$ laurum cremabant, Gyraldus. Etalibi,Syntagmate 17.Si oues, inquit, luftrarentur, alia à fupradictis ratio fuit,nam paftor fummo diltuculo aqua oures infpergebat, \&C fulphure herbáç fabir na \& lauro igne fuccenfis, circumcirca ouilia fuffibat, cum'́s facro carmine milio et libo cum lacte \& fapa Pali deæ facra faciebat. Hoc fuffimento pecora piari, $Q$ morbos depelli $\&$ tabẽ putabant. Ver: gilius ( in Bucolicis ) cum loqueretur de filio Pollionis, id qưod ad principem fuum fpectaret, adies cit:Ipfe fed in pratis aries iam fuaue rubenti Murrice, iam croceo mutabit uellera luto. Traditur autem in libro Hetrufcorum, fi hoc animal infolito colore fuerit indutum, portendi imperatori retü omnium felicitatem. Eft fuper hoc liber Tarqquinij tranferiptus ex oftentario Thufco, ibi reperitur, 4 Purpureo aureóue colore ouis ariésue fi afpergetur, principi ordinis \& generis fumma cum felicio tate largitatem auget, genus propaginemó̧ propagat in claritate, læatioremọ́ efficit. Huiufmodi igis tur ftatum imperatori in tranfitu uaticinatur, Macrobius. De oue qualupum occidit, uide in Lupoh.

đMagna \& pecori gratia, uel in placamentis deorum, uel in ufu uellerum, Plinius, Victima antiquis frequentes fuere, ouris, fus, bos, \&cc. Gyraldus. Hecatombe, inquit Iul, Capitolinus, talefa crificium eft:centum arz uno in loco cefpititix extrtuntur, $\mathcal{Q}$ ad eas centum fues, centum oues ma çantur. Perfina boum, equorum ouiumḉ̧ greges, \& aliorum omne genus animalium in locum

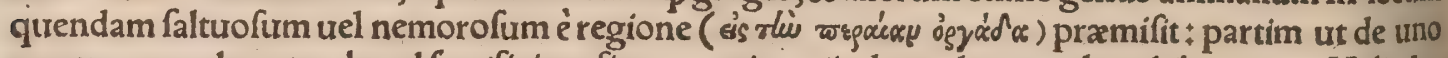
quoqs genere hecatombe ad facrificium fieret, partim ut inde epulx populo exhiberentur, Heliodos s" rus lib, 10. Exfacrificat hoftïs balantibus, Cicero I,de diuin. Pecudem fponderefacello Balane tem, Iutrenalis Sat.8. Iofias rex immolauit boum chiliades X I I. \& ouium chiliades X XX VIIIt Stuidas. Oues $\&$ arietes Aegyptï non immolant, fed capras, alij contra, uide in Capra $\mathrm{H}, \mathrm{h}$, Vis ctimæ antiquis hæ frequentes fuere, ouris, fus, bos, capra, gallina \& anfer:quas cum immolabant, niff puræ integræás $;$ fuiffent, $\mathcal{Q}$ lectæa ad rem diuinam, minus proficere putabant, Fuit quidem prifcis opi nio, ut ex hoedis potius $\&$ agnis hoftix fierent, quàm ex cæateris. quia hæ mites $\&$ cicures effent, ideo etiam ouilli pecoris hoftiam maximam, non ab amplitudine, fed quia animi effe placidioris uiderent,

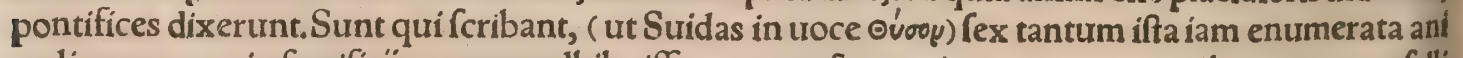
malium genera in facrificijs ueteres adhibuiffe: quorum fententiam nos nec approbamus, nec refelli mus.nam apud auciores plura inuenimus, fed uarins in locis $\&$ ritibus, Gyraldus. Ambigux oues 60 in facris quar dicerentur, Bebius Macer, qui Faftos dierum fcripfit, oftendit. ait enim, Iunoni eas quę geminas parerent, oues facrificari cum duobus agnis altrinfecus alligatis: $\mathcal{Q}$ has ambiguas uocatas, 


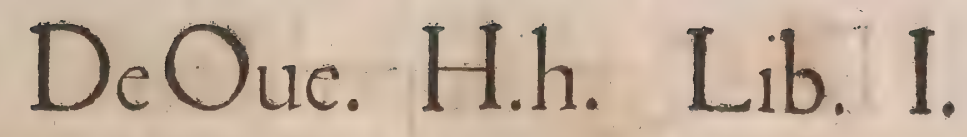

911

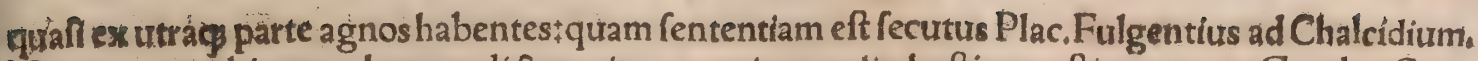
Varro tamen abigenam botrem dictam ait, quam circum alix hoftix conftituerentur, Gyral, Oues lecta dicuntur, qua ad facrificandum exceptæ funt, ur porci eximij, \& botres egregi uel eximiij. Ma

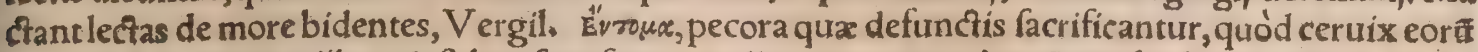

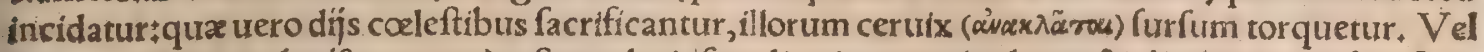

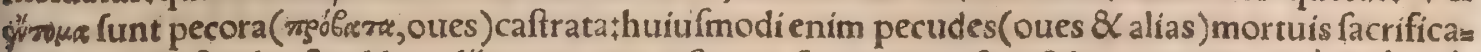

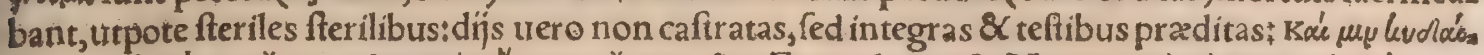

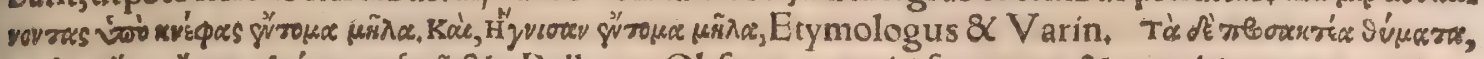

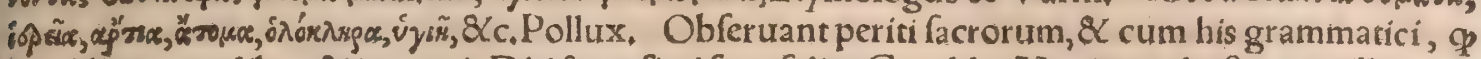
forilibus pecudibus 8 iuuencis Diti facra fieri funt folita, Gyrald. Maximam hoftiam ouilli peco: ris appellabant, non ab amplitudine corporis, fed ab animo placidiore, Feft. Ceruaria ouis dicitur qux pro cerua immolabatur, Idem. In hoftịs eam dicebant aruigem, qux cornua habeat:quoniam is cui oui mari tefticuli dempti, \& ideò ut natura terfa ueruex declinatur, Gyrald, Syntagmate 17.

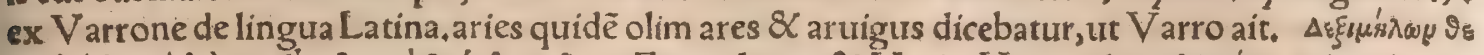

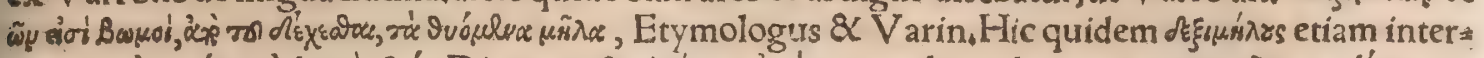

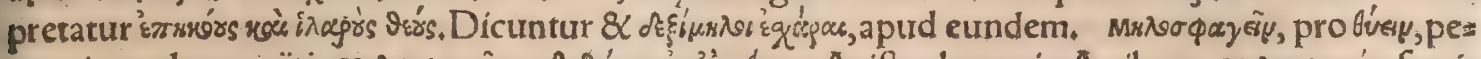

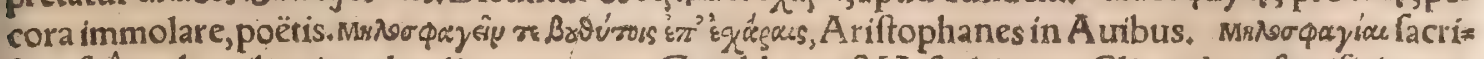
ficia fuêre ab ouribus iugulandis nuncirpata, Gyraldus poft Hefychium. Clitus dum facrificia pera geret, à rege uocatus, omiffis îs regem adnit. Tres illum oues ex immolandis hofin̈s confequuntur. - Quod prodigium confpicatus Alexander, accitis ariolis Ariftandro 8 Cleomanti Spartano aperit. His dira portendi affirmantibus, illicet pro Clito inftaurari facrificium iuffit, \&c. Plutarchus in Alez. xandro:fubijcit autem hiftoriam Clici ab Alexandro occificum ftatim poft facrificium non perlitaa tum, uino largius haufto multa in Alexandrũ nimis licêter dixiffet. Paufanias in Arcadicis Cleom broto Lacedxmonior um regi in Leuciris Bozoth̆s fignum huiufmodiaccidiffe foribit:Solebant Lace dæmoniorum reges pecora fecum educere in bellum, urt dijs ante pralia litarent: præibant autem ca præ ducesitineris ante oues:quas (capras) paftores catęades (ncroukeflas) appellant. Lupi tunc impetü. in gregem facto, illafis ouibus in folas capras graffati funt. Ouem aliqui, alifi bourem uictoria potití immolare confueuerunt, Valturitus 12.2. Interea dưm lanatas, toruumó̧́́ iutuencum More Numat cxdir Iouis ante altaria, Iturenalis Sat,8. Kal.Febr, Iout Tonantibidens uichima fiebatt idibus uero 30 Ianuarí, ueruex. Legi etiam qui flaminis uxorem feribat, omnibus nundinis Ioui arietem maslaffe, Gyrald.Bidentes oues quæ dicerentur, uide fupra in B. Idulis otis dicebatur, qux omnibus idibus loui mactabatur, Feft. Sunt qui exiftiment idus ab oure iduli diças, quam hoc nomine uocant Thu= $\mathrm{fci}, \mathbb{Q}$ omnibus idibus ouris immolatur à flamine, Macrob. Idibus alba lout grandior agna cadit, $\mathrm{O}$ ui dius. I Cum Samijs aurum furt to fublatum ouris inueniffet, Mandrabulus Samius Iunoniouem confecrautit, ut A ellanus fcribit, Gyrald. Niueam Reginz durcimus agnam, Iutenal. Apud Thuf, fas in Aegypto, ubi Venus cornuta colebatur, uacca illi immolabatur, \& in Nitriotica pi afeciurra os uis, Gyraid. Plutoni de nigra pecude rem dituinam faciebant, Gyrald. Interea nigras pecudes proz mitrite Diti, Tibullus. Velleris atri agnam, Verg. Et z.Aen. Nigram hyemi pecudem, Zephyr is fe licibus albam. Et 4. Georg. Et nigram mactabis ourem, defuncta Eurydicat. Et r. Aen. Huccad cam= - pum Elyfium)cafta Sibylla Nigrarum multo pecuderm te fangurine ducet, Et 6. Aen. de expiando infepulto, Duc nigras pecudes, ea prima piacula funto. Et in carmine deuotionis urbium \& exerci= tuum,legimus: Ouibus atris tribus. Nigrum pecus Plutoni immolabatur per fimilitudinem, ut a lix quadam uicima alins dińs uel per fimilitudinem, trel per contrarietatem, Seruitus. Vacca fieri,

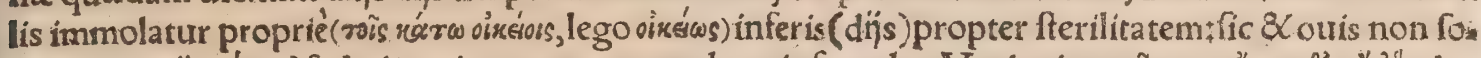

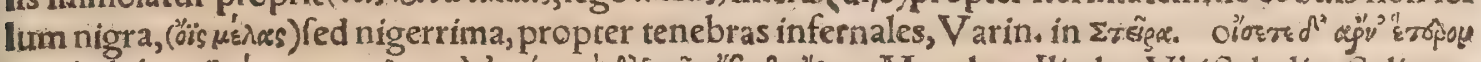

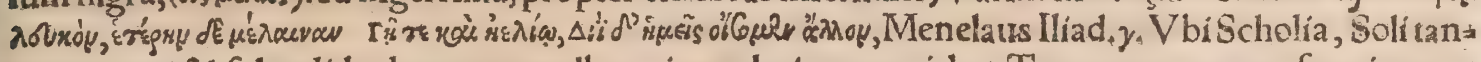
quam mari $\&$ fplendido deo, agnum album immolari conueniebat. Terræ uero, agnam fceminam et nigram. Nos uero, inquit Menelaus, alium agnum immolabimus Ioui, (nimirum xenio) cum $\&$ ipfi in Troia peregrini effent. Meminit etiam Varinus in Ägvs, Neftor Iliados $x_{+}$exploratori adituro

50. Troianorum caftra, promittit à fingulis optimatibus Gracis fingula dona danda, nempe ourem ni.

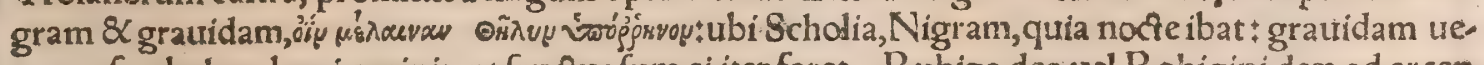
ro per fymbolum boni ominis, ut fructuofum ei iter foret, Rubigo deo uel Robigini deæ, ad arcen dam ex fegetibus rubiginem, ueteres menfe A prili extis canis $\&$ ouris facrificabant, ut Ouidius in $\mathrm{Fä}$ fris fcribir, Gyrald. Paci Ariftophanes uictimam facit ex oure, ut fuperius in a, retuli, ĖziBotov ap: pellabant facrifichn genus, ubi poft bouem Minerua facrificatư, Pand ryfo ouis facrificabatur, ut fcria pfi in Boue h. Börngegor, genus facrificí ex centum ouribus $\&$ boure uno:uide plura ibidem. Luftra ri exercitum, nifi fue, oue $\&$ tauris, qui puri effent, non erat fas, \& $c_{\text {. }}$ Vide in Sue h. in facrificio Mar tis ex fue. De folitaurrilib. ubi immolabantur, taurus, uerres $\&$ ouís uel potius aries, dicam in Ariez te. Apollonix, qua in finu lonico eft, facras Solioues fuiffe, Gracif fribunt, quax interdiu fecun dum flutum pafcerentur. Nociu uero ftabulantes in antro quodam, ab urbenon procul cuftodit

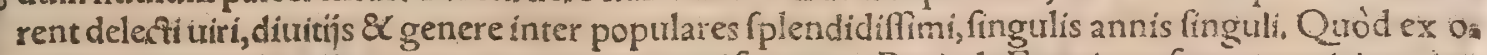
raculo quiedam A polloniataoues eas permagni facer znc, Proinde Eusnio (ut fertur) uaticino uigig 
lias èdormiente, contrutcidatis ouium plerifque(fexaginta, Herodotus) lupis graffantibus, publico A polloniatarum decreto, quum fe is minus tueri quiuifet, eft exoculatus, Calius ex Herodoti no no, ubi hac hiftoria copiofius defcribitur. Solis oues in Sicilia pafcebat Phaëthufa iunior filia Solis, boues uero Lampetie, ut canit Apollonius libro quarto Argon. Mala aurea Hefperidum, oures'ne an poma fuerint, require fupra in $a$. Samï ouem uenerantur : quoniam aurum eis furto fublatum ouis inuenit:quare Mandrabulus Samius Itrnoni ourem confecrauit, Aelian, Saitæ \& Thebaniouē colunt, Strabo libro 17. Deus animalia quxdam, qua colit $\&$ ureneratur Aegyptus, ut boues $\& 0=$ ues, in cibo Iudxis permifit, ut fuperftitionem iftam contemnere difcerent : Et rurfus interdixit jis, quibus A egyptīs nimium gulofétefcuntur, ut carne fuilla, Procopius. Aegyptī bouem $\&$ ouem propter utilitatem \& fructum coluerunt, Plutarch. in libro de Ifide. Lanatis animalibus abftinet $o_{\text {a }}$ mnis Menfa, Iutrenalis Sat.15, de Aegypto. Soli Aegyptiorum Lycopolitzo ouem edunt, quód à lupo etiam, quem deum exiftimant, deuoretur, Plutarch, in libro de Ifide

$$
\text { P R O V E R B I A . }
$$

Diogenes Cynicus opulentum quendam, caterum indoctum, ourem aurreo urellere dixit, rzgóbestoj

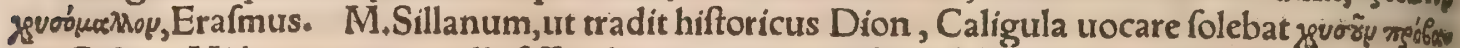
rov, Calius. Videntur autem allufiffe ad arietem quo uectus eft Phrixus, cuius uellus aureum far ctum fabulantur. Extat huius argumenti etiam Alciati emblema,infcriptum, Diues indoctus: Tranat aquas refidẽs pretiofo in uellere Phrixus, Et flatram impauidus per mare fandit ourem. Ecquid id eft! Vir fenfu hebeti, fed diuite gaza, Coniugis aut ferui quem regit arbitrium.

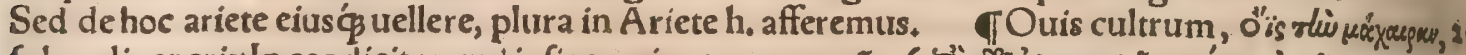

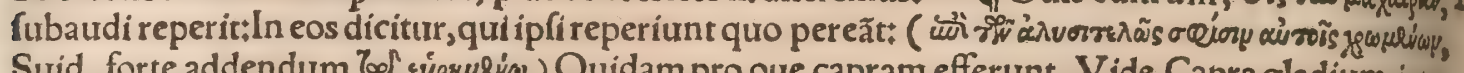

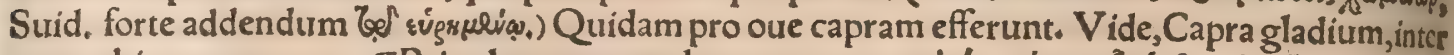

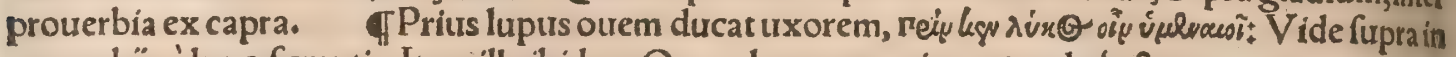
prourerbijs à lupo fumptis. Item illa ibidem, Ouem lupo committere(unde factum nomen propritum Diónux(6.) Ouem lupis relinquere: Nunc 8 oues ultro fugiatlupus. Cuftos ourum praclarus,

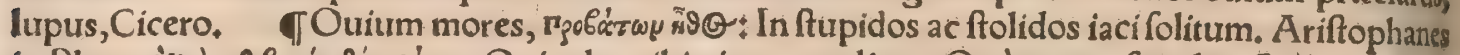

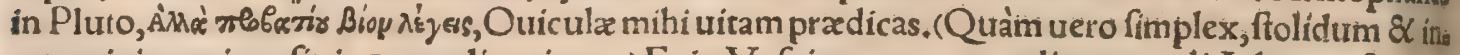
ers ours ingenium fit, in D. explicauimus, ) Et in Vefpis taxans uecordiam populi Athenienfis, outes

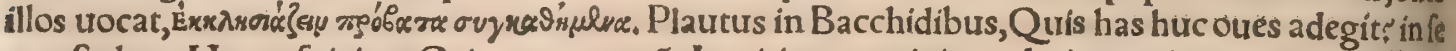
nes ftultos. Huc refpiciens Origenes enarrãs Leuiticum, ouis immolationem interpretatur affectư

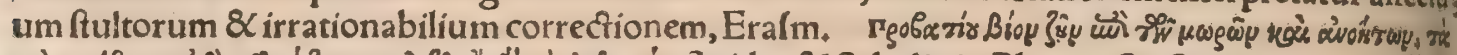

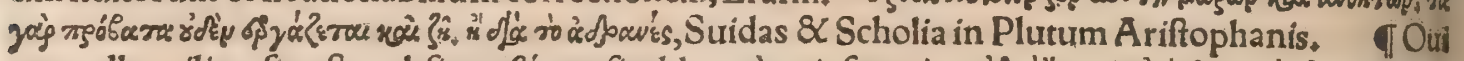

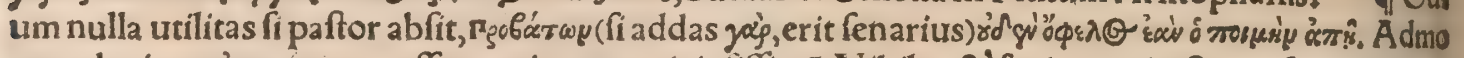
net adagium àvegxiou rem effe omnium perniciofiffimă. Nihil rectè faciunt miniftri, nifiadfit hertus, Inutiles difcipuli, quoties abeft præceptor. Inutilis populus, nifi principis authorita te gubernetur; Erafmus. Huc fpectat illud in Sacris, Terra commourebitur, eritós tanquam dama agitata, \& ouis quam nemo colligit, Efaix 13. TI Intrabunt ad uos lupi rapaces in ourum ueftitu, Acforum 10, Vide fupra in Lupo poft prouerbia profana. Videt lupum uenientem, $\&$ defertis ouribus fugit, lus pus autem rapit ac difpergit oues, Ioannis 10. TGermanorum prouerbia : Sie nacht find alle f baaf fow wart, Oues noctu nigræ funt omnes:Sublata lucerna nihil intereft inter mulieres. Ser 4 wolf if audb wolein gesellt foaaf, Lupus ouem quamuis numeratam deuorat: Non curat nut merum lupus.

TA A pologi. Ouis alens catulum lupi: Vide in Lupo prourerbium, Lupi catulos ale. Lupus cum paftores in tugurio ouem edentes uidiffet, propius accedens dixit: Atqui ego fi idem facerem, quant? tum cieretis tumultum ? A efopus in Sympofio Plutarchi,in Pittacum qui quamuis legem tuliffetad uerfus ebrios, ebrietatis tamen uitium iple non declinabat.

\section{E A R I E T E.}

A.

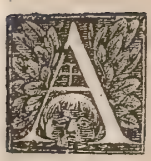

R I E S. duxx eft ouium, non caftratus:nam cui ademptifunt tefticuli, ueruex urocatur, de quo dicemus mox poft Arietem. Ifidorus $\&$ aln̈ recentiores ueruecem cum ariete impea rité confundunt. $5 \times$ ail \& eel, fcribitur etiam ל\$ eel fine iod, Genefeos is. ubi Septua: ginta uertunt keros, Chaldxus ץา

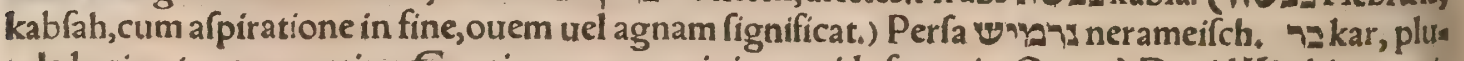
rale karim, (qux uox etiam Græcis pro oue accipitur : uide fupra in Oue a.) Dauid Kimhi exponit kebes, id eft agnum:item eelim $\&$ athudim, id eft arietes $\&$ hircos, Tropo etiam arietes dicuntur ma* chinæ bellicæ Pfalm.37.ubi Hieronymus monocerotes reddit, Septuaginta vं $\Psi_{\text {w }}$ iñva, A braham qui 6 dam agnos, quidam ualles. Deuteronomï 32 .A rabs uertit $n \geq \Sigma \equiv$ baraph, (Leuitici undecimo Perfis

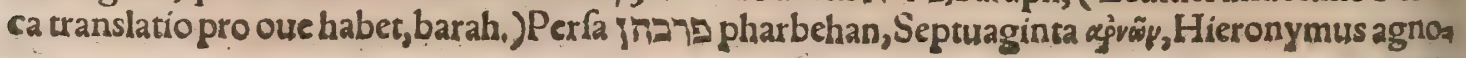




\section{DeAriete. A.B.C. Lib. I. 913}

rum. Plura uide fupra in Oue A. Lefan alhamel,id eft lingira arietis, $\&$ eft plantago, Ändr. Bellits. nen. Vetus quidã gloffographus habet, Afel alkame pro lingua arietis, corruptis opinor uocibus. Maraches, id eft fel ueruecis, Syluat. Aries Italicè nominatur montone uel ariete: Gallicè belier, uel ran: (Illyrï quidem ueruecem uocant beran) Hifpanicè carnéro:Germanicé wider, etfiquidam bä mell interpretantur, nos bammel uocamus ueruecem. (Bellunenfis lefan alhamel interpretarur lin guam arietis apud Äuicennam.) Sed uocabulum wioer à multis communiter ufurpatur pro ove ma re fiue caftrato fiue non caftrato, quamobrem differentix caufa aliqui non caftratum nuncupant bodenwioet:caftratum uero beilwioer. In Heluetia quidam arietem ramben, ueruecem wioer. Anglicéram, uel tup.

B.

De arietibus Tarentinis uide fupra ubi de oubus Tarentinis dicfum eft capite quinto. Oues \&arietes magni funt apud Indos:horum caud is amputatis oleum exprimunt, ut dixi in Oue B. Int Tartarix regione Camandu(in Scythia, Gillius)arietes non minores afinis funt, cauda tam longa $\&$ lata, ut triginta librarum pondus aquent: pulcherrimi, pingues, $\&$ in cibo optimi, $P$ aulus $V$ enetus i. 22. Vartomannus 2.j. fcribit in ædibus regis A rabum fuiffe prapinguem ueruecem, cuius cauda adeò obefa fuerit ut libras quadraginta appenderet. Et eiufdem libri cap. .. Prope Reame(inquit) urbem Arabix felicis, ueruecum genera reperiuntur quorum caudam animaduerti pondo effe lia brarum quadraginta quatuor. Carent cornibus, adeọ̧́ funt obefi ac pingues, ut uix incedere pof fint. Et capite penultimo, Circa Zeilam urbem Aethiopix uerueces nonnulli ponderofifimas tra hunt caudas, utpote pondo fedecim librarum. His caput ac collum nigricant, cætera albi funt. Sunt item uerueces prorfus albicantes, quorum cauda cubitalis eft longitudinis, modo elaboratæ uitis: pa learia ut bubus à mento pendent, qua humum propé uerrunt. Et 6.7.Circa Tarnafari urbem Indię tanta eft pecudum copia, ut duodeni uerueces fingulo aureo uaneant. Confpiciuntur illic rurfus uerueces alị, cornua haud abfimilia damis habentes, noftris longé maiores ferocioresḉs. Caudæ̇ ureruecum in peregrinis quibufdam regionibus tantæ funt, quantus nullus apud nos ueruex, Con= tingit hoc, quia humidiffimum eft hoc animal, \& inter quadrupedia frigidum. Cumćç cætera offa ex tendi nequeant, ne pingtiedine propria obruatur animal totum humorem in caudam tranfmittit; fitós carne \& pinguredine immenfa extenfis etiam offibus ac neruis non parum, qux humida natura uelut $\&$ pifces femper incremento apta funt, Cardanus. Allie eft cauda arietum prapinguis, ita 30 ut quandoģ circiter denas libras appendat,Bellunenfis. Coraxorum lanitium omnium pulcherri mum ef, unde admiffarn̈ arietes talento emuntur, Strabolibro lib.3. Tóneíbes, aries fylueftris,

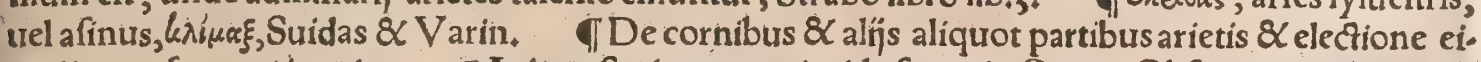
us dicetur fequenti capite. बArietes ftatim cornuti:uide fupra in Oue B. Obfurus quidam citat tanquam ex A riftotele hæc uerba In Libya citò apparent cornua in capitibus arietum: \& fecundum Homerum, arietum etiam fómina cornutæ funt. Sed apparet pro ceruis falfó interpretem tranftus: liffe arietes, ex Hebraica fcilicet uel Arabica lingtua: nam eel uel ail arietem fignificat, aial ceruum. fcribitur utra $\varphi_{\beta}$ uox îfdem literis bnk, ut nifi puncta accefferint non fit difcernere praterquam ex fenfur. In Septentrione alicubi arietes mutili funt, Obfcurus, Arieti cornua in modum circuli repli cata,Idem. Conuoluta in anfractum cornua arietum generi ceu ceftus natura dedit, Plin. Apud - Rhæros (ut ex amíci cuiufdam literis nuper àccepi)arietes prouectx ætatis, puta fex aut ocio anno= rum, ad priora cornua producunt alià trelutí adnata parua, bina uel terna uel ctiam plura. Idem fori bit in Italia genus quoddam arietum effe, quod natura $\&$ ab ineunte atate quaterna aut fena ali: quando gerat: $f e d$ hos imbelles effe, tenui ac infirmo corpore, lana inutili, $R$ haticis uero, quos dixi, minora illa cornua non ante quintum aut fexttrm annum adnafci, primis interim femper proficien. tibus robore \& craffitie: eofdem robuftos ac feroces effe, $\&$ à paftoribus aliquando ad pugnam ho. ftiliter concurrentes inequitari. Verueces quatuor cornibus infignes uidimus, Cardan.

C.

Blaterat hinc aries, 8 pia balat cuis, Äuthor Philomela. Emiflarius equits, aries, 8 hurufmodi, quiemiffus fit in folitudinem, uel qui ad generandam fobolem: emittitur, Valla in Raudenfem. Lea fo gitur hæc uox in Biblins: (ed Latinius admiffarium dixeris, pro co qui ad fobolem generandam for. minis admittitur. Quos arietes fubmittere uolunt, potiffimum eligunt ex matribus, quęgeminos parere folent, Varro. Et rurfus, In primis uidendum, ut boni feminis pecus habeas, id feré ex dua bus rebus poteft animaduerti, ex forma, \& ex progenie. Ex forma, fiarietes fint fronte lana ueftiti bene, intortis cornibus pronis ad roftrum, rauis oculis, lana opertis, auribus amplis, pectore $\&$ fca. pulis $\&$ clunibus latis, cauda lata, $\&$ longa, animaduertendum quoq̧ lingua në nigra, aut uaria fit quod ferè qui talem habent, nigros, aut uarios procreant agnos. Ex progenie autem animaduerti tur, fi agnos procreant formofos. Non folum ea ratio eft, inquit Columella, probandi arietis, fi uel. lere candido ueftitur, fed etiam fi palatum, atç lingua concolor lanæ eft. Nam cum hæ corporis par= tes nigræa autmaculof $x$ funt, pulla urel etiam uaria nafcitur proles : idóg inter cæetera eximie talibus Go numeris fignificauit;idemós, qui fupra.

Illum autem, quamuis aries fit candidus iple, Réjce,ne maculis infufcet uellera pullis

Nigra fubeft udo tanturm cui lingua palato,

Nafcentum, Vna eademóg ratio eft in Erýa 
thrais, \& nigris arietibus, quorum fimiliter ( ut iam dixi) neutra pars effe debet difcolor lanx, mul. tóç minus ipfa uniurerfitas tergoris maculis uariet:ideo nifi lanatas oues emi non oportet, quoo me lius unitas coloris appareat ; qua nifi præcipua eft in arietibus, paternæ nota plerunç natis inha. rent. Habitus autem maxime probatur, cum eft altus atç procerus, tuentre promiffo, atç lanato, cauda longiffima ( \& lata, Crefcentien.) denfí̧́ uelleris, tronte lata, teftibus amplis, intortis corni. bus, ( curtis cornibus, pronis ad roftrum, lana opertis auribus, amplo pectore, feapulis $\&$ clunibus latis, uelleris depreffi ) non quia magis hic fit utilis (nam eft melior mutilus aries) fed quia minime nocent. Intorta potius quàm furrecta \& patula cornua quibufdam tamen regionibus, ubi coliftaa tus uuidus, uentofuş́́ eft, capros, \& arietes optauerimus uel ampliffimis cornibus, quod ea porre. ća, alta ́́ maximam partem capitis à tempeftate defendant. Itaç fi plerunç eft atrocior hyems, hoc genus eligemus:fi clementior, mutilum probabimus marem, quoniam eft illud incómodum in cor. nuto, quod cum fentiat fe uelut quodam natura loco capitis armatum, frequenter in pugnam proe currit, \& fit in foeminas quoq procacior. Nam riualem (quamuis folus admiffuræ non fufficit) urio lentifime perfequitur. Nec ab alio tempeftiuum patitur iniri gregem, nifi cum eft fatigatus libidine: mutilus autem,cum fe tanquam exarmatum intelligat, nec ad rixam promptus eft, $\&$ in Veneremi tior, $\mathrm{Hac}$ Columella.Sed quomodo arietis petulci fauitiam paftores repellant, dicam in D. Menfe Iulio, inquit $P$ alladius, arietes candidiffimi eligendi $\&$ admittendi funt, mollibus lanis: in quibus non folum corporis candor confiderandus eft, fed etiam lingua, quæ fi maculis fufcabitur, uarietatem reddit in fobole. De albo plerunç nafcitur coloris alterius: de fufcis nunquam ( ficut Columella di= cit) poteft albus creari. Eligemus arietem altum, ( $\&$ c ut Columella, ) uentre promiffo $\&$ lanis candile 10 dis recto: 2 tatis primæ, qui tamen uf̧́ in octo annos poteft utiliter inire. Arietes (inquit Floren, tinus) effe debent bene compacti, afpectu pulchri, fplendicantes ( $x$ esorrs's, uide in Leone B qualis hic color fit)oculis, fronte hirfuta, uenuftis cornibus fed exiguis armati, auribus lana denfa intectis, lato dorfo, tefticulis magnis, colore undiquaq, uno. Pro diuerfitate coloris uenarum fub arietis lingua, agnos etiam colore uariare aiunt † ali ad colores uenarum fub lingua ouis hoc referunt, ut dixi in Oue c. Arietis lanam fequitur tota generatio ipfius, Albertus. Arietum maximé fpecfantur ora: quía cuius coloris fub lingua habuêre urenas, eius 8 lanitium eft in foetu, uarium q̧́ fi plures fuêre; \& mutatio aquarum potuş̧́́ uariat, Pliniưs. Hinc eft nimirum quod Didymus feribit, Volunt arien tes perpetuo aqua eadem uti, non peregrina $\&$ aliena.

- Aries per dimidium annum dicitur dormire fuper latere uno, \& per dimidium fuper altero, $\mathrm{Al}_{30}$ bertus. Sex hybernos menfes in lauum latus iacens quietem capit; contrá́g ab zquinoctio uerno in dextrum incumbit.fic ad utrunqs xquinoctium cubandi rationem mutat, Aelianus, Idem fcrie bit Macrobius, arietem Soli conferens ut in h, recitabo. Sed falfum hoc uidetur lanijs noftris cum ab utrogs latere maculati arietes, 8 ex incubitu for didati nunquam non fint.

a A rietes, tauri \& hirci per libidinem efferantiur. qui enim fuperiore tempore focí iugi concor. dia paferentur, coitus tempore diffident, $\&$ alter alterum libidinis rabic inuadit, Ariftot. Arietes quibus fis ufurus ad foturam, bimeftri tempore ante fecernendum, $\&$ largius pabulo explendum, Varro \& Didymus. Aliqui duobus ante menfibus arietes à coitu reuocant ut facem libidi. nis augeat dilatio uoluptatis, Quidam coire fine difcretione permittût, ut hoc eis genere per annum totum foetura non defit, Palladius. Sunt qui toto anno lac $8 \times$ agnos habere ftudentes, coéundi tem: 4 pus in fingulas anni partes digerunt multifariam. Commodiffima ad coitum in arietibus ætas, à̀e. cundo anno uf $\not \beta$ ad octauum, in ouibusćs fimiliter, Didymus. Vide in Oue c. Ante admiffuram diebus triginta arietibus ac tauris datur plus cibi, ut uires habeant, Varro. Cum redierint (arieres admittendi) ad ftabula è paftu, ordeum fi eft datum, fiunt firmiores ad laborem fuftínendum, Varro, Auiditas coitus putatur ex cibis fieri, ficut uiro eruca, pecori cepa, Plinius. Arietes reddentur ua, lidi ad coitum, fi cepæe corum nutrimento mifceantur, nec non polyphoros \& polygonos herba, que quidem pecora catera ad Venerem etiam excitant, Didymus, Polyfpori herba alibi in Geoponir cis in capite de pifcina mentio fit, his uerbis: Vbigg autem plures habebis pifces, fi polyfporum, poly. gono fimilem herbam, contufam aquis nutrientibus pifces inieceris. Andreas à Lacuna polyfporum \& polyphorum, eandem effe herbam putat, qua uero fit non explicat. Polyfpermos etiam \& qux $y$ polygonus uocatur herba, animalia ipfa reddent multis modis foecundiora, Quintilin in Geopon, 17.4. de tauris. Polygonos quidem altera mas eft; qux uulgó centumnodia uocatur, altera foemina caudx equinæ fimilis. Galenus marem nonnihil aftringere ait, pracellere urero in eo aqueam frigidi. tatem, ita ut in fecundo gradu uel principio tertị refrigeret. A d eadem facere foeminam, fed ignauis us, qua forfitan ratione etiam formina in hoc genere dicitur, non qua alix plantæ fexu diftinguưtur. Polygoni uero nomen utraç habet à frequentibus geniculis: quanquam gonos etiam femen figni. ficat, quo plurimum abundat mas. Caterum quomodo herba adeó refrigerans $\&$ aftringens nonni hil, mouere coitum poffit non uideo:contrarium enim ratio oftendit. Videtur fanè uulgus fuperfitis tiofum arrepto omine urocis, quafi polygonos ab augenda genitura foturá ue diceretur, frolidam iftam de eius facultate opinionem propagaffe. Ego polygonato potius, qurod uulgò figillum Salomo 6 nis uocant, uim libidinem citandi tribuerim, polygonis uero fiftendi. Polycriton, aut polycarpon(ut aliâs legitur ) Hippocrates uocat, quod Diof́corides cratzogonon, cui ad conciliandam in homine 


\section{DeAriete. C.D.E.F. Lib.I. 915}

foecunditatem mares etiam generandi uim effe alij etiam authores literis mandauerunt; Satyrï ge nus erythraicon arietibus quoç $\&$ hircis ad Venerem fegnioribus in potu datur, Plin. Arietes $\&$ capri, fícut $\&$ catera propriam habent uocem tempore libidinis, qua uocant $\&$ alliciunt fominas: quod fi aquam falfam biberint, cirius ad coitum mouentur, Ifaac in diatis particularibus. Arieti na curale agnas faftidire, fenectam ouium confectari, 8 ipfe fenecta melior, illis quoç utilior, Plin. A= rieti xtas confert, Albert. A pud eundem corruptélegitur, naturale effe arieti agnas 8 prouectiores diligere:legendum, non agnas fed prouectiores. Perfequuntur oues feniores, utpote coéuntes cith. us, iuniores uere poft illas, Didymus. De coitu arietum tride nonnulla etiam in Oue c. Inter auto res ferè conftat, primum effeadmiffura tempus uernum Parilibus fi fit ouis matura : fin uero focta, circa lulium menfem. Prius tamen haud dubie probabilius, ut meffem uindemia, fructum deinde uineaticum foetura pecoris excipiat, $\&$ totius autumni pabulo fatiatus agnus ante moftitiam frigor $\tilde{\text { ü, }}$ atф̧ hyemis ieiunium cófirmetur. Nam melior eft autumnalis uerno, ficut ait ueriffime Celfuts, quía magis ad rempertinet, ut ante aftiuum quàm hybernum folftitium conualefcat‡folusḉs ex omnibus animalibus bruma commode nafcitur:ac fi res exigit, ut plurimi mares progenerandi fint, Columel. Admittendi funt menfe Iulio, ut natiante hyemem conualefcant, $\mathrm{Pallad}$. Serotini foetus menfe $A_{\text {: }}$ prili fignentur. Nunc etiam prima eft admiffura, qua excellit, arietum, ut agnos iam maturos hyber num tempus inueniat, Idem. Tempus optimum ad admittendum, ab Arcturi occafu ad Aquila oc cafum:q qua poftea concipiunt, fiunt uegrandes atç imbecillę, Varr. Admiffura prima fit menfe Aprili(ut dictum eft:)aut etiam Iulio: fecunda poft medium Ociobris, ut pariant circa principium ueris nafcentibus herbis, Crefcentien. Tardius ne coëant, nocet enim. Dextro arietis tefticulo praligato, (uel excifo, Albert.) foeminas generãt, læuo mares, Plinius, Et alibi,Ar.dextro teftic. pra= ligato oues tantum gigni quidam feripferunt. Idem de tauris fertur, tefte Didymo. Si quis mafcu= lum malit nafci quàm foeminam, arietes admittat, dum contra flatus Septentrionales, die exiftente tranquilla, grex pafcitur:fin uero foeminam, contra Auftrum, (Gręcé tamen legitur, Auftro fpirante

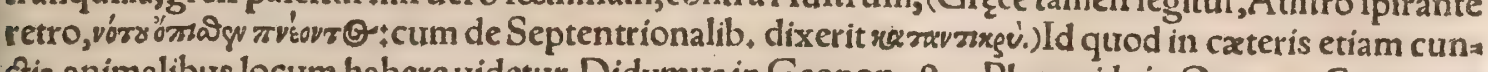
ctis animalibus locum habere uidetur, Didymus in Geopon,18.3. Plura uide in Oue c*Cum ours conceperunt, rurfus arietes fecernendi funt, Varro. $\int$ De ueruece, id eft ariete caftrato, mox poft Arietem dicam, \& deinceps de Ägno \& Mufmone, quem Albertus ex capra \& ariete generari frri= bit. Thibidinis tempore pugnat aries pro ouibus, \& aduerfarios cornibus impetit; ut uerò com= modius $\&$ fortius id faciat, retrocedens ac refiliens impetu renouato in hoftē fertur, Obfcur. Germa ni forte ab impetu ifto feriendi fubinde repetito, arietem wiber appellarunt : fignificat enim ea vox repetitionem. Veruexà uriribus dictus eft, quòd cateris ouib. fit fortior, uel quòd fit uir, id eft mas (confundit enim ueruecem cum ariete:) uel quòd uermes in capite habeat, (fed hoc falfum effe fris bit Albertus, )quorum pruritu ad pugnam $\&$ impetum feriendi excitetur, Ifidorus. Veruex, id eft dux gregis, fortiffimè cornibus percutit, \& duriflima eft frontis, Albert. Ex Rhato quodam nuper accepi, paftores aliquando uirgam colurnam arietibus concurrentibus manu tenentes intermittere, quam illi fecundo ftatim concurfu minutatim collidant. TArietis ætas ad progenerandum opti: ma eft trima:nec tamen inhabilis ufg; in annos ocio, Columella $\&$ Pallad. Duces pecoris ad quin. denos interdum annos protrahunt uitam, Ariftot, Vide in Oue c.plura de ętate $\&$ uita corum. O. to uium $\&$ boum duces plus temporis quàm cæteri uiuunt, ufu exercitî $\&$ copia pabuli,Ariftot.

D.

Singulis ouilibus finguli duces conftituuntur, qui quroties fuo nomine à paftore urocantur, antecedunt:quod ab ineunte atate facere affuefcunt, Ariftoteles. Sectarius ueruex, qui gregem agno. rum pracedens ducit,Feft. đA Aries naturali feritate dextro pede terram percutit, quando irafci. tur, aut ftupet uel timet: $\&$ hoc maxime libidinis tempore, Obfcurus. Capri uel arietis petulci faul tiam paftores hac aftutia repellunt, menfura pedalis robuftam tabulam configunt aculeis, $\&$ aduer fam fronti cornibus religant:ea res ferum prohibet à rixa, cum ftimulatum fuo ictu ipfum fe fauciat. Epicharmus autem Syracufanus, qui pecudum medicinas diligentiffiméconfcripfit, affirmat pugna cem arietem mitigari terebra fecundum auriculas foratis cornibus, quà curuantur in flexu, Colua mella. Ferocia eius cohibetur, cornu iuxta aurem terebrato, Plinius \& Albert. Ne incurrat aries proximéad aures ipfas cornua eius pertundito, Florentin. Pecora minimé inuadet lupus, fi ductori dicro fquillam appenderis, Anatolius. Āries lupum fugit etiamfi nunquam ante uiderit, Albert. Si elephantus feritate effertur, ftatim ad arietis confpectum manfuefcit, (impetum $\&$ furorem remic tit, Plutarchus, A efculapius 8 alï: Plura uide in Elephanto D.

E.

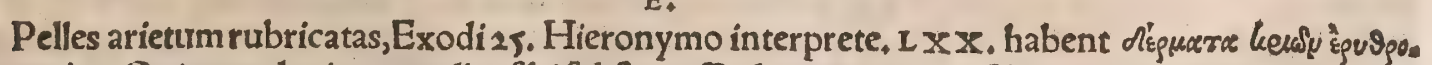
favcuslix. Ouium uel arietum pelles fibi fubftrauiffe dormientes quofdam, ut per quietem oraculis fuc fomnīs inftruerẽtur, dixi in Capra $\mathrm{E}$. Arietes inter fe cornibus decertantes tempelfatem aut fri gus minantur, ut in Oue E, ex Arato retuli.

De carne arietum uride quadam in Oure. Hircorum caro tum ad coquendum, tum ad fuccum bonum generandum, eft deterrima:hanc fequitur arietum, poft taurorum, Porrò in p̈s omnibus car: 


\section{De Quadrupedibus}

nes caftratorum funt praftantiores:fenum autem peffim $x$, Galenus libro 3 , de alim, facult, Hæedo: rum caro minus excrementitia eft quàm arietina, (forte agnina, ) A uicenna. Arietina ualidior eft $\&$ minus humida quàm ouilla, $\&$ concoćtu difficilior. Iuniores minus humidi minuséş uifcofi funt: \& caro eorum agninæ ac ouillæ prafertur:nam fi bene concoquantur laudabile \& multurm fanguia nem generât, maximè caftratorum:eft enim calıda $\&$ humida temperaté, $\mathcal{Q}$ eandem ob caufam bo: ni faporis. Improbatur in fenecta, (tum aliâs, tum caftratorum ferè magis.) Nam cum atas ipfa pro: uectior corporis habitum refrigeret, multò magis refrigeraturr in caftratis. Anniculi laudantur â mo derata temperie, minus humida fcilicet quàm lactentium, \& ficciore quàm iuuenum, itaq̧ caro eos

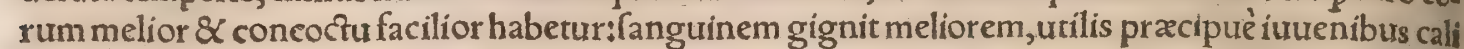
di.ac ficci temperamenti, \& ijs qui calidas ficcasós regiones habitant, Ifaac. Eubulus apud A thenæe um in Fabula quadam inter cateros delicatiores cibos, nominat ker.̌ogxes, id eft arietis tefticulos, No ftri etiam in quatuor partes difciffis teftibus fingulis, binas earum in fingula ligno uerucula infi. gunt, $\&$ in craticula torrent: funt qui omento etiam inuoluant, per fe, uel cum faluia, ut fit in iecino ribus ouium aut arietum. Sale conditi arietis pulmo, maximè uetufti, difficulter \& grauiter à uen, tre exuperatur, Aëtius 9. 30.

I) Medulla arietis non caftrati inter uenena numeratur, humanæ naturæa adeó contraria, ut me: morix functionem aboleat, refiftunt ei carnes phafiani, Arnoldus in libro de dofib, theriacal,

G.

Cur pelles recenter detracta, maximéç̧ arietum, uerberum uulneribus $\&$ uibicibus admotz, $\&$ oua fuper confracta, prohibent ulcera ne confiftant, inquirit Ariftoteles problematum 9.1. Vide fus 1 pra in Oue G.ab initio. Emplaftrum de pelle arietis ad hernias fiue enterocelas àrecentioribus qui bufdam medicis commendatur, $\&$ defcribitur, prafertim ab A rnoldo de Villa noua : $\&$ in aliquo: pharmacopolarum officinis paratum reperitur. Inhiberi Venerem pugnatoris galli tefticulis anfe rino adipe illitis, adalligatisç̧ pelle arietina tradunt, Pliniuss. Etalíbi,Gallinacei dexter teftis arieti. na pelle adalligatus partus continet. TArietis uellera lota frigida ex oleo madefacta, in muliebrit bus malis inflammationes uulux fedant: $\&$ fi procidant, fuffitu reprimunt,Plinius. Lana ariet, nigra intincta in aqua, deinde in oleo, $\&$ fuppofita locis dolorem tollit: \& fuffumigata, ante prolapfam uuluam reprimit, Sextus. Pugnacis arietis è medio cornuum lanas fuffitas, impone loco dolenti in hemicranio, dolorem fedat, Nicolaus Myrepfus; Alij cinerem huius lana ex aceto ponunt, ut mox dicetur. Lais \& Salpe canum rabioforum morfus leniriaiunt, \& tertianas quartanas ḉ tebres, menftruo in lana arietis nigri, argenteo brachiali inclufo, Plin. Et alibi, Partus adiuuari putant, fi in arietis lana alligatum cucumeris fylueftris femen infcientis lumbis fuerit, ita ut protinus ab exitu. (f́ilicet foetus)rapiatur extra domum. Lanam arietis de fronte uelles $8 \times$ combures in operculo ola la nouo, $\&$ in mortario confricabis, at $\not 3$ ex aceto fronti inlines ad capitis dolorem, Marcellus. Arie tinorum uellerum cinis cum aqua mixtus 8 appofitus, incommodis ueretri repugnat, Idem. Ves rendorum formicationibus uerrucisḉs medetur arietini pulmonis inaffati fanies:cærteris uitrijs uelle rum eius uel fordidorum cinis ex aqua, Plinius. Arietis de capite lanam, à coxis $\&$ à tefticulis, pafa fim fufpendas, perfeçè difcutit tertianas, Sextus. Sanguinem fiftit ex ariete fuccida, articulos ex tremitatum:(id eft manuum \& pedum hominis) praligans, Plini. Arietis quàm pinguiffimi lana, plena fuis fordibus combufta $\&$ in puluer em redacta, prodeft plurimum fi eo cinere ex aqua locî ins 4 guinum perfricaueris, Marcellus. TCaulis ius ex carne arietum priuatim aduerfus cantharidas ualet, Plinius. Caroarietis adufta utiliter illinitur morphea $\&$ impetigini. Confert etiam morfibus ferpentum \& fcorpionum, $\&$ algerarat, $\&$ cum uino canis rabiofi. Cinis eiufdem medetur albugini oculi, Auicenna. TAdeps ueruecinus fimilem fuillo uim habet:hyftericas aut ani caufas utiliter curat, \& ambuftis auxiliatur, Obfcurus Diofcoridem citans. Sepo arietis frabiem unge admixta fandaracha, \& fubinde rade: hoc $\&$ ad perniones facit, fed cum alumine mixtum, Sextus. Furun culis mederi dicitur feuum arietis cum cinere pumicis $\&$ falis pari pondere, Plinius. Cicatrices ad colorem reducit pecudurm pulmo, præcipure ex ariete, feưum ex nitro, Idem. Fel arietis cum leuo, podagras lenit, Plinius \& Marcellus, \Cornum arietis uratur, ciniş̧́́ eius cum oleo conteratur, atque inde derafum caput frequenter ungatur ad crifpandum capillum, Marcellus. FAd mentis alienationem \& defipientiam uitio cerebri obortam in manufcripto quodam codice Germanico tas le medicamentum reperi:Caput arietis nondum experti Venerem, uno icqu amputatum, cornibus tantum demptis integrum cum pelle $\& \mathcal{C}$ lana in aqua bene elixabis, tum aperto cerebum eximes, $\&$ addes aromata, cinnamomi, zinziberis, nucis mofchata, macis, caryophyllorum ana unciam femis. Horum pollinem cerebro admifcebis in patella ad prunam non magnam diligenter agitando ne au duratur, quod facile fierer. Curabis autem ne nimium deficcetur, fed ita coquatur ne ficcius fiat uia tulino cerebro ad cibum parato, Sat coctum fuerit, ubibene commifcueris ad prunam. Sic condis tum feruabis, \& per triduum ægro quotidie ieiuno dabis, ita ut horis poft duabus cibo portụ́ abftis neat. Sumi poreft cum pane, uel in ouo, urel ex iure, utcuncs, modo deuoretur ab agro. Danda intex rim opera, ne loco lucido ager fit, \& ut ad quatuordecim dies eodem uicqu utarur, quo uti folent qui 6 bus detractur eft fanguis: $\mathcal{X}$ uino caput tentante abftineant. Sunt qui breui tempore iuuencur, alis qui fex demum uel octo feptimanis à fumpto medicamento, Confultum autem fuerit medicamentü 


\section{DeAriete. G.H.a. Lib. I. 917}

Ittribus menfibus repeti, $\Phi$ Magna uis \& pulmonibus arietum, excrefcentes carnes in ulceribus ad requalitatem efficaciffimé reducunt, Plinius, Pulmo ariet, calidus adpofitus carnes excrefcen= tes in uulneribus exæquat $\&$ reprimit, Marcellus. Cicatrices ad colorem reducit pecudum pulmo, pracipué ex ariete, Plinius ،iuentia \& fuggillata pulmones arietum pecudumćç in tenues confecti membranas, calidi impofiti, emendant, Idem. Liuores $\&$ fuggillationes pulmo arietís concifus mi. nutatim \& impofitus, ftatim fanat, \& nigras cicatrices ad candorem perducit, \& à calciamentis lafos pedes fanat,Sextus. Attritus calciamentorum fanat agninus pulmo,(de quo idem Diofcorid, fcris bit,) $\&$ arietis, Plinius. Pernionibus $\&$ ruptis pedibus pulmo ariet, impofitus, omni afperitate $l{ }^{\prime}:$ uigata moleftiam tollit,Marcellus. Liquoris arietis, quem de pulmone concoques, ftilla fuperpofi: ta clauiculos, qui in manibus nafcuntur aut in ueretro, illita tollit, Sextus, Verendorum formicationibus uerruciş́́ medetur arietini pulmonis inaffati fanies, Plinius. Árietini pulmonis dum in craticula affatur fuccus exceptus, myrmecias qux in ueretro nafci folent, unctione fua purgat $\&$ di: fcutit, Marcellus. Arietis liquor qui à pulmone decocfo deftillat, tertianas 8 renum morbum in eis natum fanat, Aefculapius. Pulmo agninus uel ariet. uritur, \& cinis eius cum oleo imponitur, urel ipfe crudus admotus pernionum ulceribus utiliter alligatur, Marcellus. TContra peftilen. tem morbum ouium : Ventrem arietis cum uíno coques, 8 aqua admixta ouibus in potudabis, Albertus, TArietis fel aurium dolori, qui eft ex frigiditate medecur, Hali. Fel arietis cum feuo (fuo) podagras lenir, Plinius $\&$ Marcellus. Fel ueruecinum lanis adhibitum $\&$ in umbilico pofitum, uentrem foltrit infantium, Obfcurus Diofcoridem citans. TComitialibus morbis utiles tra dunt tefticulos arietinos inueteratos, tritos q́ dimidio denarn̈ pondere in aqua uel lactis afinini he= mina. Interdicitur uini potus quinis diebus ante $\&$ poftea, Plinius, Arietis tefticuli oboli tres potati cum aqua, caducis medentur, Sextus . Cinis feminum arietis cum lacte muliebri diligenter pri us elutís linteolis, ulcera caccéthe fanat, Plinius. đ Vngula ariet, cínis cum melle, muris aranei morfum fanat, Plinius : Valerianus imponendum exprimit, बSomno afcifcendo, in febri pra: fertim, Dilue præ̊terea glomeramina(pilulas fimi) qưæ gerit intus Claufa aries inter geminæ co xendicis umbras, Inde foporati ducentur gutture potus, Serenus. Fimus ueruecinus cum aceto ut cataplafma impofítus, maculas nigras emendat, nafcentes clauos corporibus tollit. Ignem facrum impofitus curat, ambuftis medetur, Obfcurus Diofcoridem citans, बChiron Centaurus ei as nimali (iumento) quod profluuio attico (uox corrupta) coperit laborare, ita ut uiridis ei uel palli= dus per nares humor erumpat, ex lotio humano aut arietino duas cotylas cum uino $\&$ cyatho ole rofacei putat effe mifcendas, $\&$ per nares, qua humorem funeftum egerunt, digerendas, Quam cu= rationem $\$$ pulmoni fanitatem, \& naribus ficcitatem praftare confirmat, Vegetius I. i7. $A_{\text {. }}$ rietis fordes quas inter femora habet, cum ariftolochia $\&$ myrrha æquis partibus pota to, ad regium morbum optimè facit, Sextus. Plinius fordes aurium $\&$ mammarum pecudis denarï pondere cum myrrhæ momento \& uini cyathis duobus morbo regio refiftere fcribit.

H.

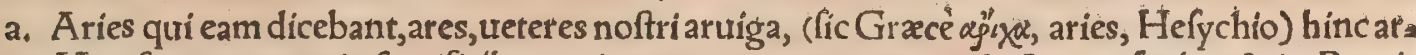
uigus. Hæc funt quorum in facrificins exta ín ueru coquuntur, quas $\&$ Accius fcribit, $\&$ in Ponti= ficins libris uidemus, in hoftịs eam dicunt aruigem, qux cornua habeat: quoniam is , cui oui mari tefticuli demptí, \& ideo ut natura uerfa ueruex declinatum, Varro de lingua Latina. Víderur au= tem locus depratratus. Aries dicitur ab aris: quòd hoc pecus primum in aris gentiles immolarint;

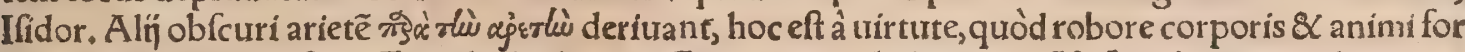
titudine ouribus præetet. Ega ab ápvesis uoce Gręca potius deduxerim. Nefrendes arietes dixerunt, quòd dentibus frendere non poffint, Feftus:Sed forte arietes nõ caftrati fignificantur, ad ueruecum differentiam; nam, ut idem fcribit, funt qui nefrendes tefticulos dici putent, quos Lanuuini appel lant nebrundines, Græci veфģ่s, Præneftini nefrones. Aut forte arietes adhuc teneri: nefrendes enim infantes funt nondum frendentes, id eft frangentes. Varro \& Fulgentius porcos propriè ne: frendes uocari aiunt, qui non amplius lactent, necdum tamen fabam frendere poffunt. Pecoris maritus lanigeri, portitor Helles, Phrixæus maritus, apud Martialem pro ariete quouis leguntur. Coniunx ouis lanigeræ, Ouidio $\$ \&$ laniger abfolute proariete, Eidem Metam.7. Ouem ueteres ge $=$

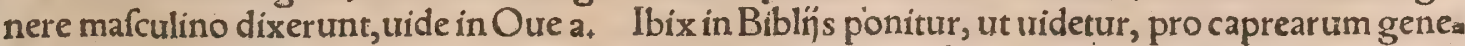
nere uel ariete, Obfcurus. Nos ueram ibicis hiftoriam dedimus fupra inter Capras fylueftres: nec $\mathrm{e}_{\text {. }}$ nim alius eft ibix uel ibex, quàm qui uulgò capricornus dicitur. Ipfe aries etiam nunc uellera ficcat, Vergil.in Buc.

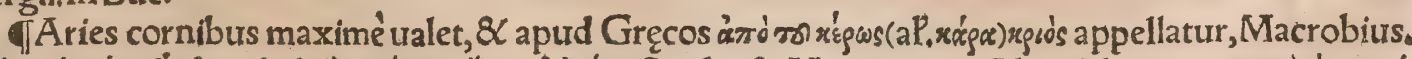

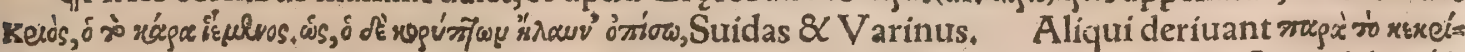

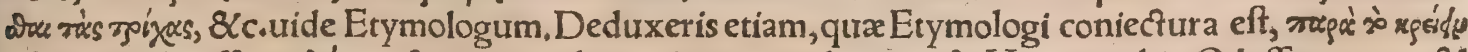
xàs ize

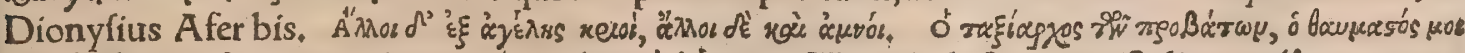

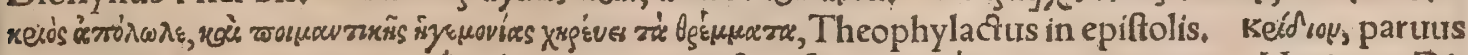
aries, Hefychius, Varinus. Ávveís ourem marem fignificat, ut zoózos capram marem, Varinus. Dia dymus quidem in Geoponicis 18 , ag avesov's ponit pro agnis; fed doctiores hoc reprehendunt. Iftrus 


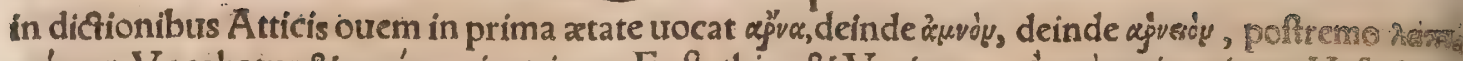

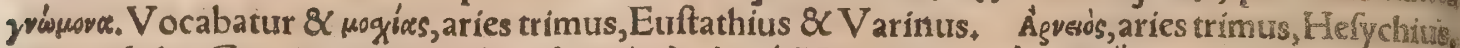

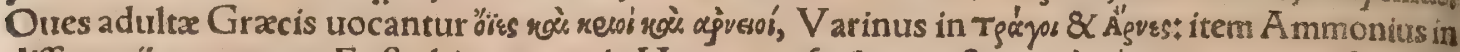
differentïs uocum. Euftathius quoç in Homerum fcribens teftatur xgivesòy non agnum, fed arie, tem effe. Agysiós non eft ag̉víoy, id eft agnus, (inquit Varinus) red prouectx iam atatis aries : ut cons ftat ex ariete quo feruatus eft Vlyffes, qui cum adultus $\&$ matura atate effet, à poëta indifferentę:

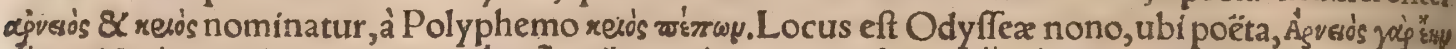

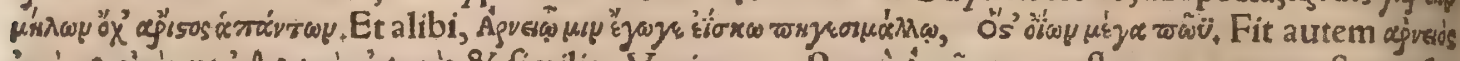

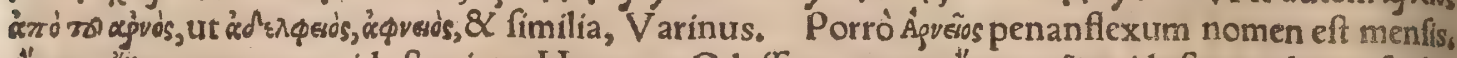

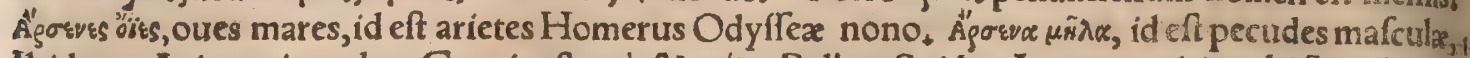
Ibidem. Aries ourum dux, Grxcis eft rero's $\&$ xritos, Pollux, Suidas, Leonem uiri multi flagellis do,

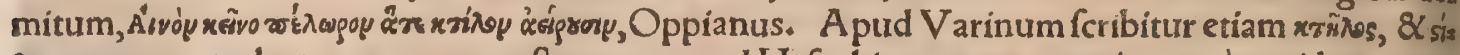
2os, neutrum probo: quanquam poftremum apud Hefychium quogg reperio, Keiós quidem, ut ego iudico, arietem fimpliciter fignificat, «rines uerò femper gregis ducem. Hinc etiam adiectiuè capitur,

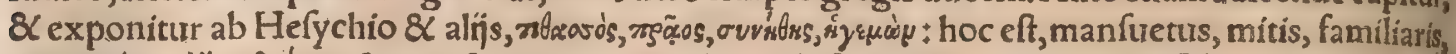
dux. Krihar $r^{\prime 2}$ we Bgúxwy, \& manfueta oura comedens, id eft manfuretarum auium, Nicander in Theria

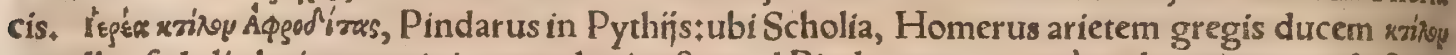
appellat, fed alia huius nominis etymologia eft apud Pindarum, nempe à uerbo kriou, quod eft nus

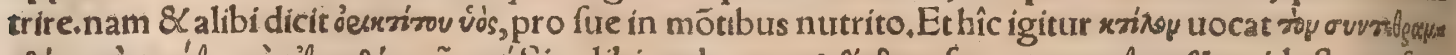

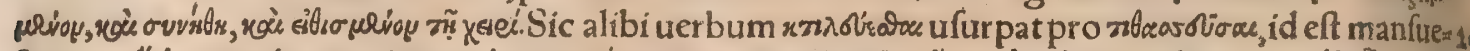

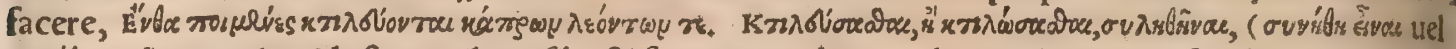

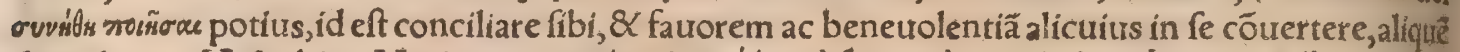

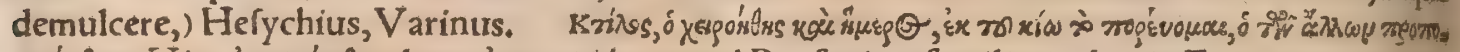

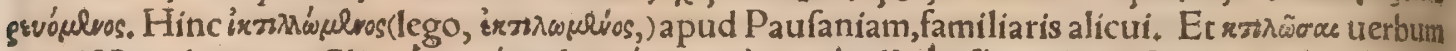

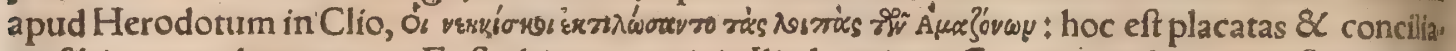
tas fibi uxores duxerunt, ut Euftathius exponit in Lliad.tertium. Cxterum Krìnos penanfiexum pro

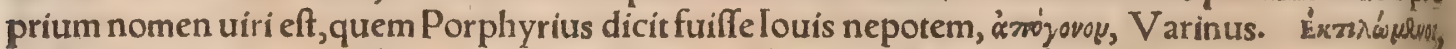

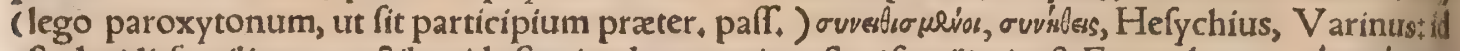
eft placidi, familiares, ut ctilos, id eft aries dux gregis paftori familiaris eft, Ety mologus. Ėxztrúvouyst

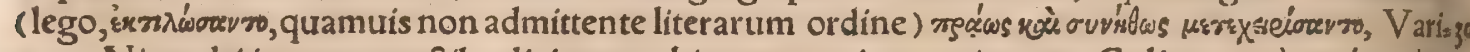

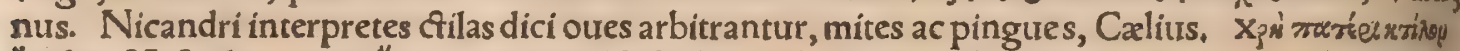
s.

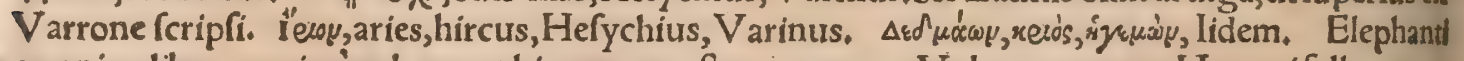
ex animalibus maximé exhorrent hircum, ceraften, porcum, Volaterranus ex Horo ni fallor. cera: Iten equidem non alium quàm ariecem intelligo: qui ab elephanto uifus etiam furente, mitẽ $8 \mathrm{x}$ man fuetum eum reddere fertur. Nec ineptum ei fuerit nomen ceraftes, id eft cornutus : quod cornibus maximé ualeat, unde 8 uerbum arietare Latinis factum, ab hac potius animante quàm alijs cornur ris quanquam longè ualidioribus. Noftri arietem uocãthermannum, id eft gregis maritum: Vfurn patur etiam pro uiri nomine proprio, per baptifmum imponendo.

TI Epitheta. Aries corniger, perulcus, pugnax, trux (apud Claudianum in Epithal. Honorif: $)_{4}$ tortus, celer, laniger, perfultans, praceps, bellator, Nepheleius: uillofus, petulans, Textor. Laberius poéta uocabat arietes reciprocicornes $\&$ lanicutes, quod reciproca habeant cornua, \& cutem lana

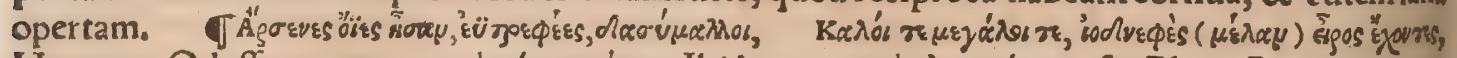

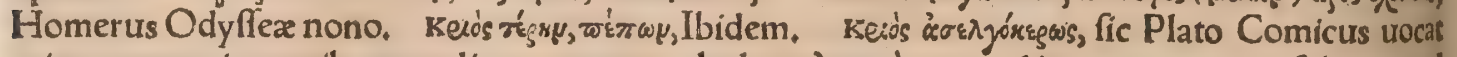

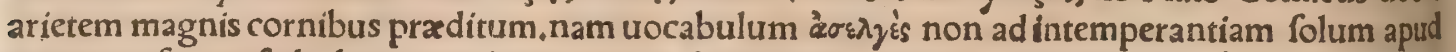

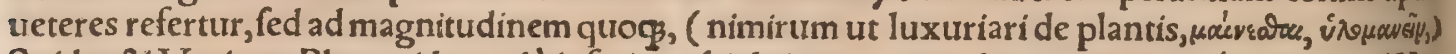

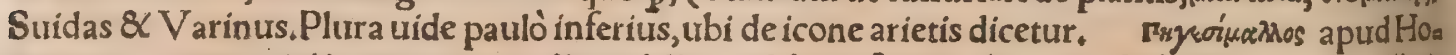
merum : grammatici interpretantur, ow gro uellere ueftitum, alij albo, Hefychius \& Varinus, apud quem plura, fi libet.

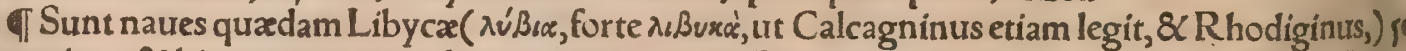
quas arietes $\&$ hircos tocant: unde taurum etiam qui Europam auexit tale nauigium fuiffe conípio mus, Pollux. Aliqui Phrixum non in ariete per mare uectum aiunt, fed in naui cuius prora arietis

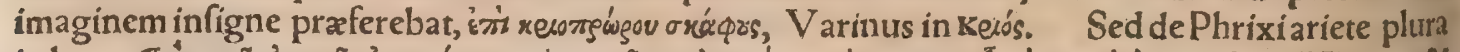

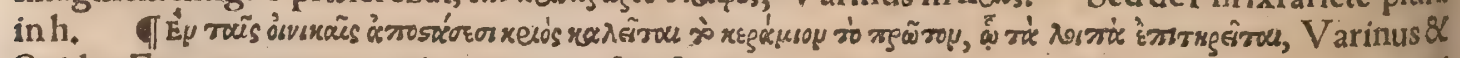
Suidas. Erant aurem ceramia, uinaria uafa teftacea qua nimirum certa ad diuerfas menfuras magn! tudine fiebant,aut capacitatis fur notis quibufdam $\mathcal{X}$ ueluti punctis interius fignabantur per inter ualla, quęéxesávess dixerim. In hoc forfan genere uas, quod femel iufta magnitudine \& iuftis interual lis paratum ueluti regula $\&$ archetypum aliorum obferuabatur, kees dicebatur, quòd primarium \&

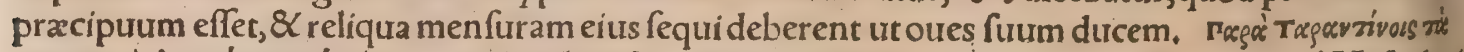

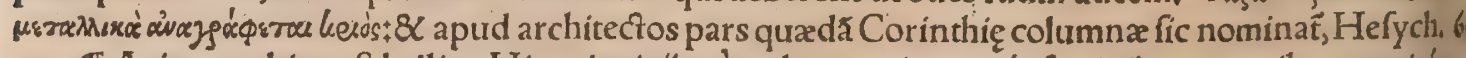

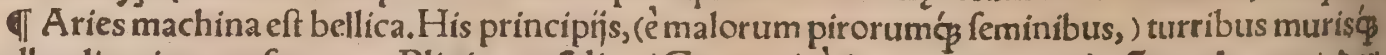
impellendis arietes nafcuntur, Plinius. Aliqui Germanice interpretantur, ein futmbaum/ovet 


\section{De Ariete. H.a. Lib. I. 919}

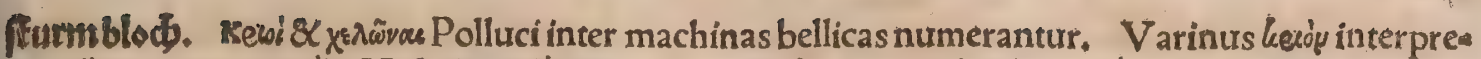

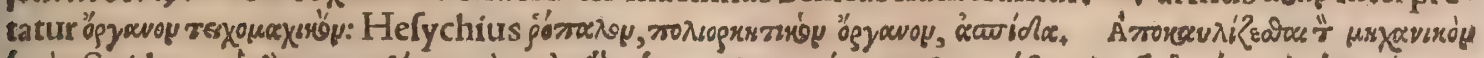

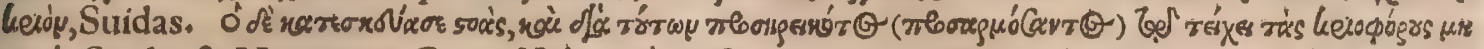
xaurós, Suidas \& Varinus. Carim Hebraicé,id eft arietes dicuntur machinæ bellicæ, ut Ezechielis 4.821.quamuis Kimhi illic malit intelligere duces fiue imperatores exercituum, Munfter. Qurod ab incendio lapis, $8 \mathrm{C}$ ab ariete materia defendit,Cafar 7.bel,Gall. Quamuis murum aries percuffe: rit, Cicero I. Offic, Cum effractis portis ftratísue ariete muris, Lituius I, ab Vibe. Labat ariete crè bro lanua, Vergil,2.Aeneid.id eft crebris ictibus arietis. Primum ad oppugnationes aries fic in. urentus memoratur effe(inquit Vitruuius 10.19.) Carthaginenfes ad Gades oppugnandas caftra po - fuerunt. Cum autem caftellum ante copiffent, id demoliri funt conati. Pofteaquam non habuerunt ad demolitionem ferramenta, fumpferưnt tignum, idó̧ manibus fuftinentes, capitéç eius fummum murum continenter pulfantes, fummos lapidum ordines denjciebant, $8<$ ita gradatim ex ordine to= tam communitionem diffipauerunt.Poltea quidam faber Tyrius nomine Pephafmenos, malo(tigno uel trabe inftar mali)ftatuto ex eo alterum tranfirerfum uti trutinam fufpendit, $\&$ in reducendo $\&$ impellendo uehementibus playis deiecit Gaditanorum murum. Cetras autem Chalcedonius de ma. teria primum bafim fubiectis rotis fecit, fupraćs compegit arrectarïs $\&$ iugis uaras, \& in his fufpen dit arietem, corịsćs bubulis texit, utit tutiores effent qui in ea machinatione ad pulfandum murum effent collocati. Id autem quòd tardos conatus habuerat, teftudinem arietariam appellare coepit, His tunc primis gradibus pofitis ad id genus machinationis, poftea cum Philippus Amynta fritus Byzantium oppugnaret, Polydus Theffalus pluribus generibus \& facilioribus explicauit, \&C. Dein de expofita ratione turris ambulatoria extruenda, fubdit:Conftituebatur autem in ea arietaria ma. china, qux Græcéleciodox dicitur, in quo collocabatur torus perfectus in torno: in quo infuper con. fitutus aries, rudentium ductionibus \& reductionibus, efficiebat magnos operis effectus, Hac Vis trutrius: A diecta eft \& figura per lo. Iocundum, Arietis eft figura Romæ in arcu Lucī Septimï Se: ueri in radicibus Capitolin, \& Colchide columna Traiani, Philander. De ariete fribit etiam $R$ ober tus Valturius libro 10. De materia ac tabulatis (inquit Vegetius 4.14.) teftudo contexitur, quæ ne exuratur incendio, corijs uel cilicijs centonibusç ueftitur. Hac intrinfecus accipit trabem, qux ad= unco prafigitur ferro, quod falx uocatur ab eo quòd incurtrata eft, ut de muro extrahat lapides. Aut certè ipfius caput ueftitur ferro, \& $\alpha$ appellatur aries : uel quòd habet durifimam fronten, qua fub= ruat muros, uel quód more arietum retrocedit, ut cum impetu uehementius feriat. Teftudo autem à fimilitudine ueræ teftudinis uocabulum fumpfit, quia ficut illa modo reducit, modo profert caput: ita machinamentum interdum reducit trabem, interdum exerit, ut fortius cædat. Perfæ(in oppido Bezabde, inquit Ammianus libro 20.) machina ingentis (arietis) horrore perculfi, quam minores quo $g$ fequebantur, omnes exurere ui maxima nitebantur $\$ Q$ affiduè malleolos atçs incendiaria te. la torquentes laborabant incaffum:ea re quòd humectis fortis $\&$ centonibus erant operta materię plures, alix uncta alumine diligenter, ut ignis per eas laberetur innoxius, \&c. Et cum iam difcuffu= rus turrim oppofitam aries maximus aduentaret, prominentem eius ferream frontem, qux reuera formam effingit arietis, arte fubtili illaqueatam altrinfecus lacinị́s retinuêre longis, ne retrogradiens refumeret uires, néue ferire muros affultibus denfis contemplabiliter poffet, $8 c_{c}$. Et rurfus libro 23. arietem his uerbis defcribit: Eligitur abies uel ornus excelfa, cuius fummitas duro ferro concludis tur $\&$ prolixo, arietis efficiens prominulam fpeciem, quæ forma huic machinamento uocabulum in didit: $\mathcal{Q}$ fic fufpenfa utrinç tranfuerfis afferibus $\&$ ferratis, quafi ex lance uinculis trabis alterius continetur:eamćs quantum menfurze ratio patitur multitudo retro repellens, rurfus ad obuia quęq\$ rumpenda protrudit ictibus ualidinimis, inftar adfurgentis \& cedentis armati.Qua crebritate uelut reciproci fulminis impetu ædificïs friffis in rimas, concidunt ftructuræ laxatæ murorum. Hoc gene re operis, fi fuerit exerto uigore difcuffum, nudato uallo defenforib, folutisḉ obfidịs ciuitates muni tiffima recluduntur. Pro his arietum machinamentis iam crebritate defpectis, conditur machina he lepolis dicta, 8c. Aries (inquit Iolephus de bel. Iud.3.9.) eft immenfa materia (trabes) malo nauis af.

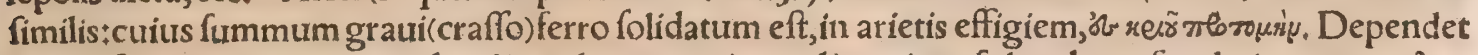

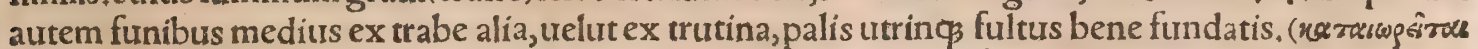

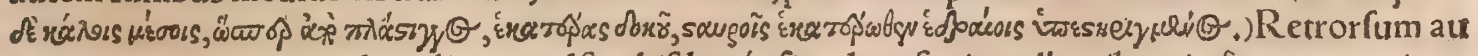
tem magna uirorum multitudine repulfus, hifdemćs fimul rurfus impellentibus, in fronte prominen re ferro mœnia percutit nec eft ulla tam ualida turris, aut murorum ambitus adeólatus, ut etfi prio= res ictus fortiter fuftinuerit, affiduos uncat. His fubiungit qua induftria ludxi faccos paleis confertos è muris demiferint, qua femper impetum arietis ferri uridebant:Romani uero proceris contis fal catis faccos abfciderint, poftremò Iudaus quidam faxo ingenti in machinam illifo caput eius abru= perit. Graca Iofephi uerba de arietis forma $\&$ ufu, recitat etiam Suid,in uoce Keiós. Et infuper, A ri es, inquit, machinamentum eft obfidionale, fic dictum quòd cum impetu muros feriat, \& mox retro cedat, idós continué tanquam impugnando. Eft autem trabs (kopácox) magna, arietis fpecie parte extre

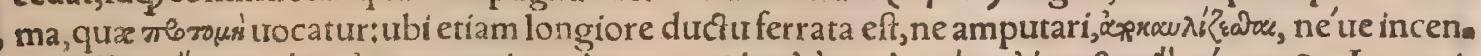

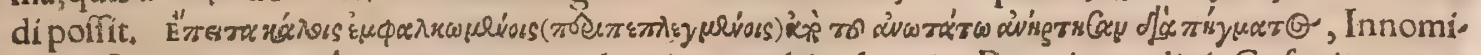

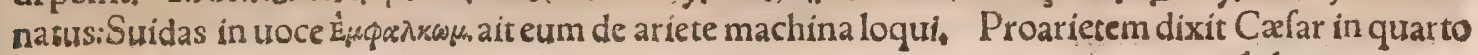


Commentariorum pro eo inftrumento quo uice arietis utimur ad adigendam materiam, his tuerbis: Et ad inferiorem partem fluminis obliqux a digebantur, qux proariete fubactx, \& communi opere coniunctx, uim fluminis exciperent. Quo loco obliqux fubftantiué pofitum credo, Bayfius in libro de uafculis. Ego non obliquæ fed fublicælegerim: fic enim uocãtur tum ab alịs tum ab ipfo Cæfare alibi pali ingentes in aquam adacti, fitre aliam ob caufam, fiue ad pontem fuftinendum, unde pons diĉus fublicius. Hæe quưm machinationibus immiffa in flumen defixerat, fiftucisćs adegerat, non fublicæ modo direxerat, \& c. Cxfar 3 . de bel.Gall.Eft autem fiftuca machina, qua etiam patritores us tuntur, uulgò(Gallis)pilotium, utrinç anfata:qua pali magna uí in terram adiguntur. Eadem, meo quidem iudicio, recté proaries etiam ex Cæfarenominabitur. Equum qui nunc aries appellatur, in muralibus machinis primum reperiffe aiunt Epeum ad Troiam, Plinius. Vide in Equo Troiano in=

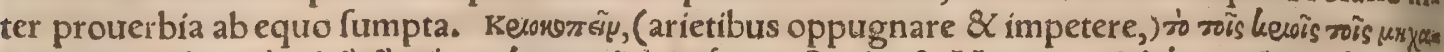

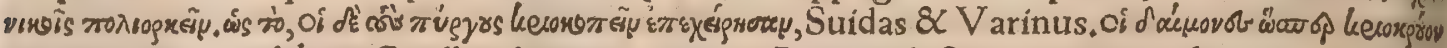

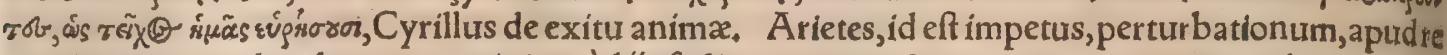
centiorem quendam legere memini:quòd ijs feilicet tentetur \& commoueatur animus humanus. Aduerfum icqus arietum quæ remedia opponantur, ut culcitræ, laquei, lupi ferrum in modum forfi, cis dentatum, \& bafes columnarum ex alto iniectx, docet Vegetius de re militari $4 \cdot 23$. If cholatus curm in Drye oppugnaretur à Chabria, uolente arietes admouere, prior iple muri partem deiecit: trunç fecum reputans, ut fui milites fortius pugnarent, cum munitionem moeniorum non haberêt; $8 Z$ hoftes exiftimarent, fuas machinas oppugnatorias effe contemptas. Certè hoftes fponte ab obfefz fis deftructa monia metuentes, ingredi in urbem non audebant,Polyænus libro 2.

IVniuerfa figna zodiaci ad naturam Solis iure referuntur: $\&$ ut ab ariete incipiam, magna ilit concordia eft. Nam $\&$ is per fex menfes hybernales finiftro incubat lateri, ab aquinoctio uerno fue per dextrum latus ₹ ficut $\&$ Sol, ab eodemós tempore dextrum hæmifphærium, reliquo ambit finia ftrum. Ideo \& A Ammonem(quem deum Solem occidentem Libyes exiftimant)arietinis cornibus fin gunt, quibus maximè id animal ualet, ficut radịs Sol,Macrobius. Et alibi(in fom,Scip.1.21.)Quan quam, inquit, nihil in fphæra primum, nihilás poltremum fit, primum tamẽ ex duodecim fignis atie. tem dici A egyptï uoluerunt. Aiunt enim incipiente die illo qui primus omnium luxit,id eft, quo in hunc fulgorem coliti et elementa purgata funt, qui ideo mundi natalis iure uocitatur, arietem in me dio coslo furiffe. Et quia medium coelum quafi mundi uertex eft, arietem propterea primum inter o. mnes habitum. Mox fubÿcit caufam cur aries Marti, 8 reliqua zodiaci figna alia alijs planetis attria go buantur. Etrurfus, A ries æquinoctiale fignum eft, $\&$ pares horas fomni $\&$ diei facit. Cur primus locus arieti inter duodecím figna tribuatur, plura lege apud Cęlium 1.9. Criòn, id eft arietem in cœe 10 dici autumant, quía quum in eo fuerit Sol inter diem ac noctem quodammodo iudicat, quod leí: v๘u nuncupant: \& quòd in eo figno inter hyemem pofitus ac æftatem ipfe rurfum iudicetur, Cælitus, Singula zodiaci fydera quamuis uni alicui planetæ confecrata, aliæ tamen eorum partes alís atças lijs planetis adfcribuntur, ut pluribus de arietis partibus præf́cribit Calius 30.10 . Arietem cœleftêt gnum(inquit Sipuntinus)aliqui putant effe illum quo uectus eft Phrixus, (de quo dicendum infra in $h_{\text {, }}$ ) Alin uero hunc effe arietem dicunt, qui Libero patri per deferta Libyxexercitum ducenti $\&$ fia ti laboranti apparuit, fontemós amœniffimum oftendit, ut fuperius diximus: quapropter Liber pater templum Ioui A mmoni co in loco conftituit, \& fimulachrum cum arietinis cornibus fecit, arietem 4 inter fydera figurauit:ita ut cum Sol in eo figno foret, omnia nafcentia recrearentur, quod ueris tem pore fit, ea maximè ratione, quod per eum Liber fiti pereuntem exercitum liberauerat. Duodecim præterea fignorum principem tradunt hunc effe uoluiffe, quòd optimus exercitus fui ductor fuifa fer. Sunt etiam qui fcribant, quo tempore Bacchus A egyptum tenebat; $A$ mmonem quendam ex $A_{1}$ frica ueniffe, \& pecudum multitudinem ad Liberum duxiffe, quo facilius $\&$ illius gratiam fibi conci liaret, \& ipfe aliquid inueniffe diceretur, Itaq̧ pro eo beneficio agrum ei à Baccho datum, qui eftcó tra Thebas Aegyptias \& $\&$ qui fimulachra eius fecerunt, cornuto capite ea figuraffe, ut homines mea moria tenerent, hunc primum pecus oftendiffe, Bacchum uero memoriæ gratia arietem in coelum tranftuliffe, Hre Sipuntinus ex. Higino. Paufanias in Corinthiacis ait, Cranion cuprefforum neo mus ante urbem fuiffe, in quo Bellerophontis lucus, \& Veneris Melænidos templum, ac Laidis mo. 5 numentũ, infculpta leæna, quæ prioribus pedib, arietẽ complecteretur:qua de re etiã Alciati emble, ma recitaui in Leone a. Mandrobulus(aliâs Mandrabulus) cum in Samo inueniffet ró yra qávou (hoc

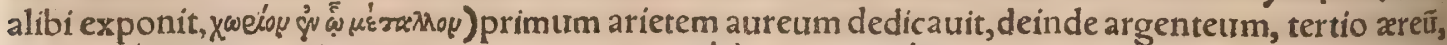

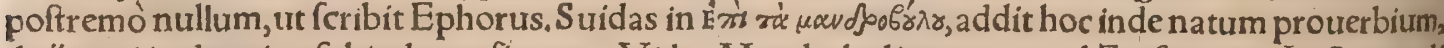
de ijs qui in deterius fubinde proficerent. Vide, Mandrabuli more, apud Erafmum. In Acropoli (Athenis)magnus aries areus confecratus erat, quem propter magnitudinem Plato Comicus ảathó z:opwe cognominat, \& equum Durium, (cuius fimiliter imago ibidem confecrata erat:aliqui unam 8 eandem imaginem unius muralis machinæ illic confecratæ, fuiffe putant, quam alĭ arietem alï ea

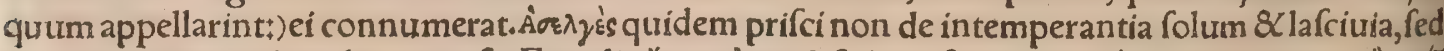

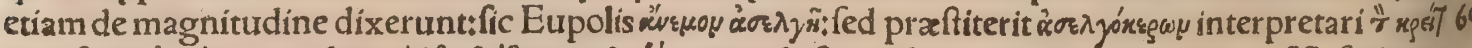

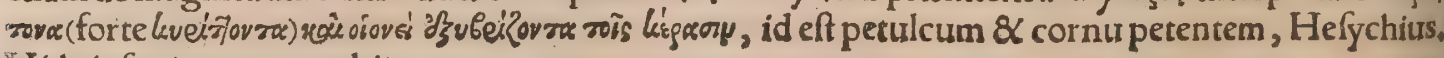
Vide infra inter prouerbia. 


\section{DeAricte. H.a. Lib.I.}

Arietinus, quod eft ex ariete, ut arietinum iecur, Plinitus, Cicer arietinum, quod arietino capi tifimile eft,Plinius، Arietarius, quod ad arietem pertinet, ut arietaria machina, Vitruuxius, IA $A=$ rietare, dicitur de arietè, quum capite $\&$ cornibus aliquem impetit. Accius in Bruto, apud Cicero= nem I. de diuinatione, Deinde eius germanum cornibus connitier, In me arietare, eoćs içu me ad cafum dari. Per translationem, Macedo gladium coeperat ftringere:quem occupatum comple. xu pedibus repente fubductis, Dioxippus arietautit in terram, id eft pracipitauit, Curtius libro\%. Arietat in primos, obrjcitç̧ immania membra, Silius libro 4. Quis illic eft, qui tam proterué nos ftras ades arietat $\%$ id eft, tam uehementer pulfat, Plautus Trucul. Arietat in portas, \& $\alpha$ duros obï. ce poftes, Vergil,iz. Aeneid, Vbi Seruius, In claufas portas more arietis ruebat, id eft bellici machi io namenti. Reperitur \& neutrum, pro labafcere.Quæ cafus incitat, fape turbari, \& cito arietare, Se = neca de prouident. Idem de uita beata, Nihil praui, nihil fubiti fuperef, nihil in quo arietet aut la= bet, Arietare inter fe dicuntur, qua concutiuntur mutuo ictu. Magno ímperatori antequam acies inter fe arietarent, cor exiluit, Seneca de ira. Sic dentes inter fe arietatos dicit, libro 3 , de ira. Ins noxium, \& quum concurrentia tecfa contrario ictu arietant, quoniam alter motus alteri renititur, Plinius libro 2, de motibus. Arietatio, percuffio \& frequens ictus, Sipuntinus. Cornibus impe:

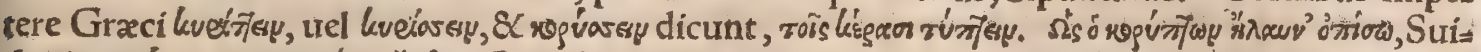

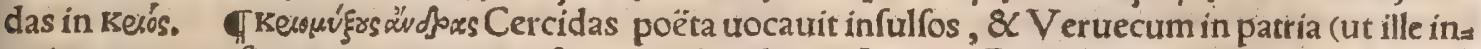
quit)natos, quafi qui arietino muco fcateant, Quidam in Lexico Gracolatino. Galenus methodi

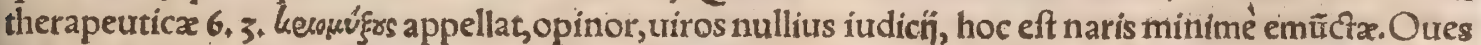
10. enim femper mucorem habent in naribus, Erafmus. Pituita $\&$ muco plena efle outium cerebra, in

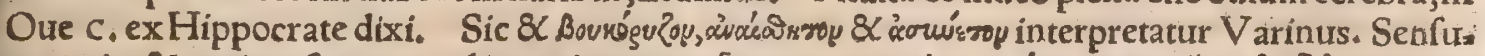

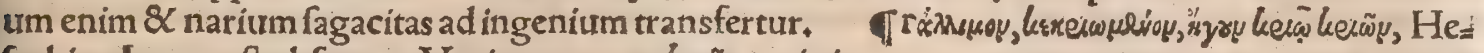
fychius:Locus eft obfcurus. Varinus uocem keiñy omittic.

TAmmoniacum, alíf Ammoniacum thymiama dicunt, in Libya deftillat ex ferula quadam ad Ammonis louis templum + qux agafyllis trocatur, ab alijps criotheos, ut habent nomenclaruræ apud

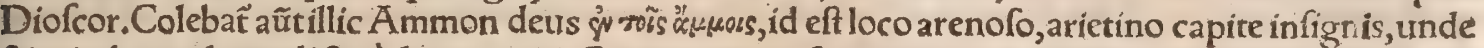
8 criotheos planta dicfa à deo ariete. Ciceris genus eft arietino capiti fimile, unde ita appellatur, album nigrumós, Plinius $8 \times$ Columella. Graci etiam keiò sop'tb Aireneios, radix fic dicza, Hefychius + nihil quod friam cum ariete commurne habet. Vide in Cato $a_{\text {. }}$

T Graffatur aries ut latro, Plinius de pifce cetaceo, qui à cornuum fimilitudine cognominis tert reftri factus eft. Athenienfes conchas afperas, (nimirum murices $\&$ purpuras, in quarum teftis mu crones tanfuam cornicula eminent, ) kerors nominant, Hefych.

đTroglodytx pecorum nomina filḧs indunt, ut tauri, arietis, ouris, quod ab ịs non à parentibus alantur. Keĩo penanflexum, nomen uiri:oxytonum uerò aries, Cyrillus, Sed inuenio apud autho: res hanc uocem oxytonam quoç \& paroxytonam prouiri nomine fcribi. Kéc's uir Aegíneta ftren nuus \& celeberrimus luctator (athleta) erat, à quo eiectus infula Lacedęmoniorum rex Cleomenes, ut perterrefaceret dixiffe fertur fcitum illud:Nunc, inquit, præpila tibi aries cornua, Hermolaus ex

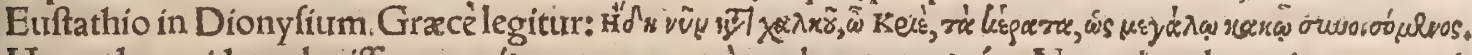

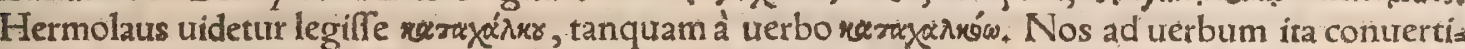
- mus, Nunc aduerfus as cornuta o aries, magno hominem malo intricandum fignificans, Vt cornia bus as aut ferrum, (fubaudi, impetere,) eodem feré lenfur dicatur, quo illud, Coiftra ftimullum calci= trare. Tale enim eft à priuato expelli regem. Cxterum arietis nomen ualido \& robufto athletx, pul chrèconuenit, Luctatorum enim eft obarietare inter fe. Idem puto eft Crius Aegineta Polycriti fi= lius, cuius meminit Herodotus libro fexto. Dionyfius in Argonauticis refert keion, aliâs keciòn, no= minatum ưrum, cui alumnus fuerit Phrixus, 8 nauigafie eum cum Phrixo ad Colchos, Varinus.

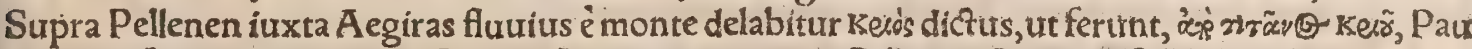
fanias in fine Achaicorum. Idem in Laconicis meminit Crij uatis Spartani fili Theoclis.

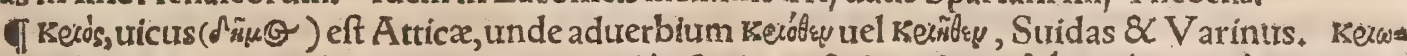

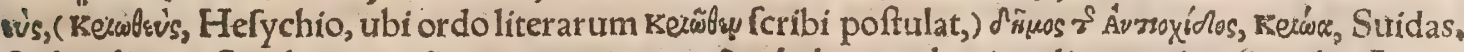
- Sed malim exStephano, Kesĩ̃e, (quanquam kesw̄yc habent uulgati codices, ) uicus in tribu Antio=

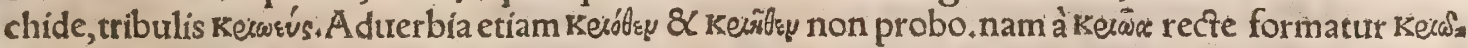

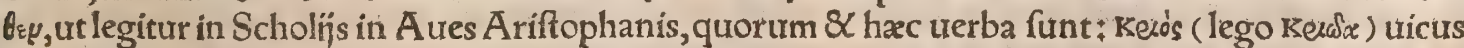
eft tribus Antiochidis à Crio quodam nominata. Scribitur autem aliâs oexĩfle tanquam à uíco tribus Oeneidis, oeín uel oeiw uricus eft tribus Oeneidis, Stephanus. Verfus Ariftophanis in uulgatis codi=

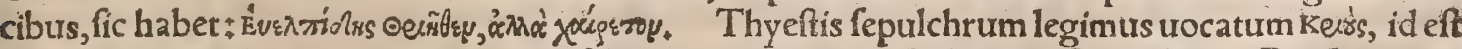
Arietes, in agro Argiuo, prope quod uifebatur regio Myfia, Calius ex Corinthiacis Paufanix. In agro Argiuo (inquit Paufanias) Thyeftis fepulchro appofitus fpectatur lapideus aries. Thyeftes enim incefto curm fratris uxore commiffo agnam auream habuit. Criû metopon promontorium eft in Taurica, aduerfum Carambico Afix promontorio, per medium Euxinum procurrens clxx: $6 . I M$. paffữ interuallo, quæ maximè ratio Scythici arcus formam efficit, Plinius. Etrurfurs 10. 22 grưes Pontum tranfurolare fcribit inter duo promontoria Criû metopon $8 \mathrm{C}$ Carambin. Diftant inter fe mi libus \& quingentis ftadips, Marcellinus lib.22. Ef \& Creta ad occidentem promontorium $C_{y}$ ren 

nas uerfus eodem nomine Plinio. Hoc nomen habere à fpecie qua caput arietis refert Dionyfits
A fer canit: Euftathius addit é longinquo confpectum huiufmodi apparere: 8 eandem ob caufam promontorium alterum ad Pontum Euxinum fic nominari. Et poftea in ïfdem commentarijs plura de duobus hifce promontorijs feribit, qua hic pratereo.

Tb. In Delo infula aiunt f́pectari facrata cornua, ex locis circa mare rubrum aduecta, arietis bi. cubitale $\&$ octo digitorum, pondo librarum uiginti fex, hirci autem bicubitale cum dodrante, eiufa dem ponderis, Euftathius in Homerum $\&$ V arinus in $K_{\text {'spa }}^{\prime} \pi x$. Arietis caput monoccrotis, id eft cornu unius, Pericli ex agris effe allatum legimus, (apud Plutarchum in uita eius:) quod intuitus Lampon uates, robuftum \& folidum in frontis meditullio fitum, refpondit, Ex duabus qua in urbe uigerent factionibus, fore ut altera obfcurata ad unum Periclem, apud quem uifum foret porten! !" tum, recideret ciuitatis potentia,Calius, Puerum aliquando natum capite arietis fertur, Ariftor,

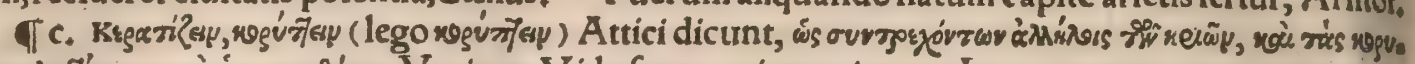

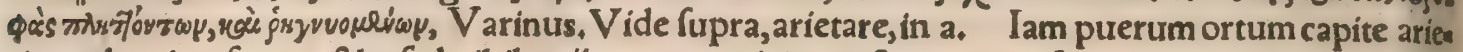
tis aut bouis referunt, \& $x$. fed nihil ex ịs qua nominant, eft, quamuis fimilitudo quadam geratur: quod euenit etiam non in monftrum peruerfis. quamobrem fxpenumero per conuricium nonnullif

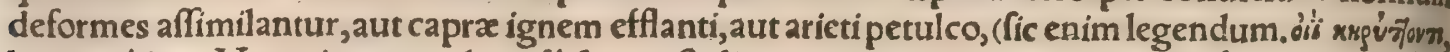
lego nveízovm. Vetus interpres legit $i$, \& tranftulit porco præconizanti, ineptilfimé, ) Arifoteles de

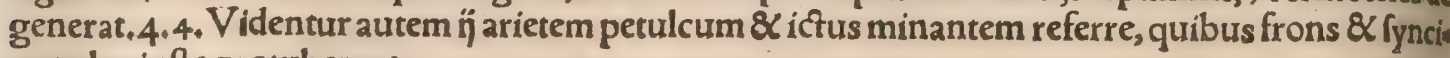
put plus iufto protuberant.

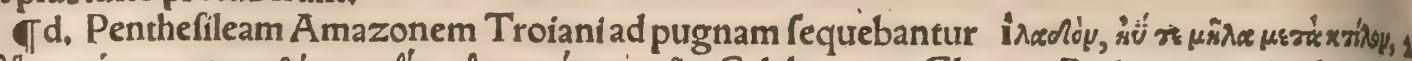

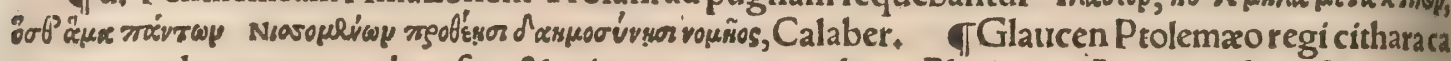
nentem,eodem tempore ab anfere $\&$ ariete amatam proditur, Plinius. Aries quidam A egyptius cithariftriam Glauciam deperibat,Plutarchus. Nihil mirum in Chio Glaucen citharœedam ho, mines, cum ea effet pulchritudine eximia, adamaffe fiquidem ab ariete $\&$ anfere etiam eandem alto dio amatam fuiffe, Gillius ex Aeliano. Aliqui non ab anfere, fed à cane eam amatam fcribunt. Gręce quidem xíva pro $x$ ñra, $\&$ in alips itidem cafibus, unum pro altero feribere procliue eft. I Deleo. nis $\&$ arietis concordia extat egregium Martialis epigramma, quod recitaui in Leone $H, d$.

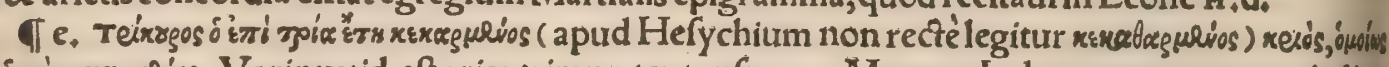

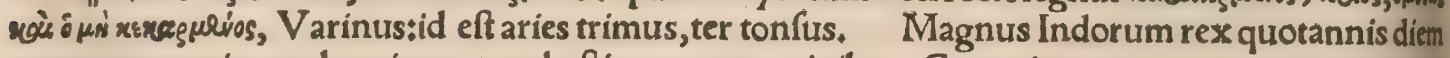
unum proponit tum hominum tum beftiar um certaminibus. Committuntur autem pugnaturaille ter fe beftiz, feri tauri, arietes manfueti, Aelianus, TA pud maiores homicidij poenam noxiusas rietis damno luebat, quod in regum legibus legitur, Seruius. T Afparagum inuenio nafci $\&$ arit tis cornibus tufis atç defolfis, Plinius. Arietis cornu in afparagos uerti fi fepeliatur ac putrefcat, tametfi non fum expertus, multorum tamen teftimonio concredam, putredo enim mater eft multa, rum rerum, Cardanus, TSi cornua (cornu, $R$ afis in fingulari) arietis fepeliantur ad radicemfici arboris, fructus in ea citius maturefcent, $A$ lbertus. T Scortes ( aliqui legunt, fcortum ) id eft pel, les teftium arietinorum, ab eifdem pellibus dicti, Feftus. Medico(digito)tefticulos arietinos tenen tem, Ciceroad Herennium. Politianus in Mifcell, cap. 62, receptacula nummûm intelligit, qux $\mathrm{F}_{\text {t }}$ fus (hunc locum citans ) fcortes nominârit. Sed enim Pedianus, inquit, fportas, $\{$ portulas, fportellas, nummûm effe ait receptacula. Vt nihil fit dubium quiné digito eo quị fit minimo proximus furpen: fas haberi uelit fcorteas, hoc eft èteftibus arietinis pelliceas crumenas. Suffifcus folliculus teftium arietinorum quo utebantur pro marfupio, à fifci fimilitudine dictus, Feftus,

Th. Portenta arietis monocerctis, \& pueri capite arietis nati,retuli paulò fuperius in $b$. Ouls aut aries purpureo colore natus miram felicitatem portendit, uide fupra in Oue h. Ouidius feptis mo Metamorphofeos canit quomodo Medea iugulatum arietem, \& in zreo uale medicamẽtis quio bufdam immerfum, pro uetulo $\&$ efforto agnum reddiderit.

đPhrixus (recentiores multi primam per yplilon fcribunt, ego Gracè femper iôta reperio,pra: terquam apud Scholiaften in Nebulas Ariftophanis, qui Phrygiam quog ab eo dictam teftatur, fie lius fuit Athamantis \& Nepheles, qui unà cum forore Helle, quum defuncta matre Inûs nourca infidias timeret, confentiente patre, confcenfo aurei uelleris ariete:quem antea à matre, ut quidam uolunt, ut alï, à patre acceperat, pontum ea parte qua anguftior eft, iransfretare copit. Sed Helle un darum ftrepitu in pontum decidit, \& fubmerfa eft, à qua deinde pars illa maris Hellefpontus dicta eft. Phrixus uero incolumis in Colchos ad Aeetem regem peruenit ( ut etiam docet Iuftinus lib, 42, ) ubi arietem loui, (Ioui Phyxio, ut aries ipfe iufferat humana toce locutus, Apollonius \& Scholia: ftes:Marti uelMercurio, Scholia Ariftoph.) uel ut alị́s placet, Marti immolauit, uellusḉ illud aureü in templo fufpendit, quod poftea Ia fon Medex ope adiutus abftulit. Aries uerò inter fy dera locatus, priftinam effigiem tenuit:qui à Phrixo Phrixęus appellatur. Dumó̧ adeunt regem, Phrixæá̧̧́ uelle ra pofcunt, Ouid.7.Metam. Sipuntinus \& Onomafticon. Quód fabulofa tradit hiftoria, (inquit Calius ex Palxphato) de Phrixo \& Helle, \&c. quidam interpretantur fuiffe paratam fugiendi na, uem, cuius infigne aries foret. Palxphatus uero affirmat, A rietem uocatum nutritorem, cuius fit o. 6 pera $\&$ confilio liberatus. Non defunt qui prodant, arietinis chartis fuiffe librum, qui auri confici. endi ac argenti rationem (arte chymiftica, ut \& Varinus fcribit in $\triangle$ śpess) contineret. Phrixi imago 


\section{DeAriete. H.h. Lib. I. 923}

rernitur A thenis in arce, qui immolans arietem quo uectus erat, fiue alteri cuidam deorum, fiue (ut conijcinius)Laphyftio(uide Gyraldum in Aphlyftio Ioue, ubi de Phrixo etiam nonnulla) apud Ore chomenios dicto, femora pro more Græcorum excifa uri fpectat, Paufanias in Atricis, In Colchide auriferi torrentes funt, ut inquit Strabo, unde $\&$ Chryforrhoas fl.dicius, hinc fabulis occafio de uel. lere apud Colchos aureo, Hermol. Supra Colchos habitare aiunt Thcânes homines auri ditiflimos

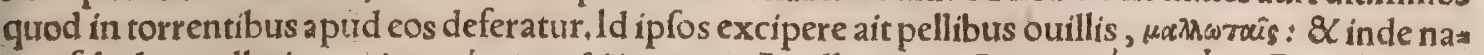

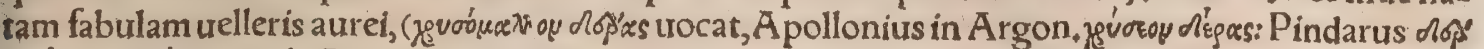

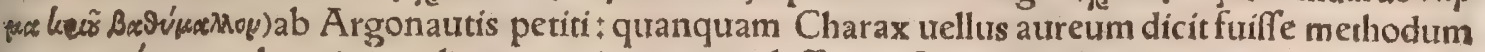
zuoogfarérs membranis inuolutam, cuius gratia claffem inftuxerint Argonauta, Euftathius in Diony $f_{0}$ A frum. Oues aurei coloris alicubi ferre lanam, Rheginus authorem citat Hefigonû, $T z e_{z}$ tzes 1. 18. Cum Atreus in Peloponnefo regnaret, uourit aliquando, quicquid pulcherrimum in pe. core fuo nafceretur, immolaturum fe Dianæ. Nata eft agna aurea, quam ille neglecto uoto in arcam inclufit. Deinde cum ea de re gloriaretur publicè, fratrem eius Thyeften inuidiffe aiunt: $\&$ fimulato in Aëropen Atrei uxorem amore, agnam auream ab ea accepiffe: $8 \alpha$ poltea contradixiffe Atreo, ut qui immerito de agna aurea gloriaretur: oportere autem, inquiebat coram populo, qui agnam aureã polfideret, regnum etiam obtinere.Quód cum A treus quoç concederet, Iupiter Mercurium ad ip.

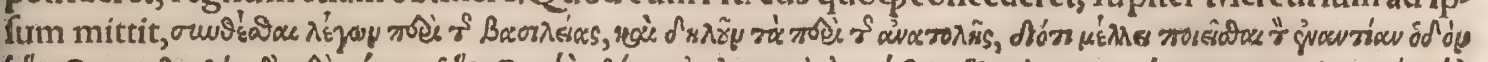

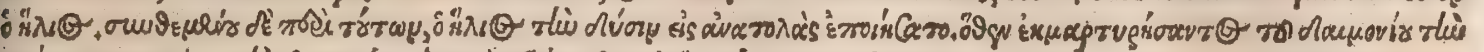

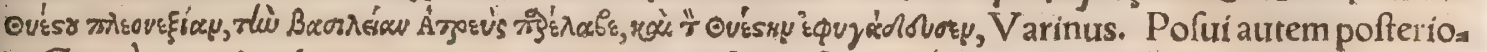
ra Gracè, quoniam locus non omnino integer uidetur, \& aliter ab alins hæc hiforia narratur. (Vide Onomafticon noftrum in A treo.) Idem in Xgúresou d'egas, Fertur (inquit) arietis pellem Mercurị̂ có

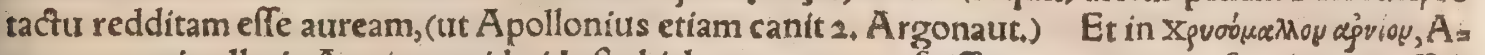
gnum aurei uelleris Atrei argyrida, id eft phialam argenteam fuiffe aiunt, in cuius fundo agni effigi es inaurata fuerit, $R$ ara autem $\&$ exquifita poffelfio olim non auri tantum, fed etiam argenti fuit, ex Athenzi fexto. Pellem arietis A pollonius \& alï multi auream fuiffe dixerunt, Simonides alicubi purpuream. Dionyfius autem Mitylenaus Crión uirum fuiffeait Phrixi pædagogum, Varinus in $\Delta$ op'es. Item in Kelou, Dionyfius in Argonauticis,inquit, Crium dicit nutritorem Phrixi fuiffe, qui intellectis Inûs noureræinfidn̈s, ut fuga fibi caureret eum monuerit. Herodorus A thamantis $\&$ The $=$ miftûs filios fuiffe tradit, Schoeneum, Erythrium, Leuconem, Pœum $8 \mathrm{C}$ minimos natu Phrixum ac - Hellen, qui propter Inûs infidias regionem reliquerint, \& Hellen in uia (iuxta Paciyam) mortuam effe, Etrurfus ibidem, Arietem dum Phrixum ueheret locutum effe Hecatæus refert. Alï in natí, quæ arietem in prora infigne haberet eum è patria naugaffe aiunt. Dionyfius uero libro 2 . Crium eitus nutritorem fuiffe, $\&$ naugationis in Colchos focium, $\&$ inde natam fabulam de arietis illic facri ficio, Hæc Varinus ex Scholijs in Argonautica Apollonị \& alijs. Plura lege in Scholins in Nebulas Ariftophanis, 8 in Pythia Pindari Carmine quarto in Arcefilaum Cyrenenfem, \& apud Higinum in Ariete fydere: \& Diodorum Siculum de fabulolis antiqurorum geftis libro5. Aurea agna Arrei, Solis deliquia \& regum mutationes effecit, \& plurimas occupauit tragœdias, (id eft argumentum tragicis poëtis fuppedirauit,) A thenæurs. Mollia Phryxæi fecuifti colla mariti, Hoc meruit, tuni. cam qui tibi frepe dedit. Martialis in caput arietinum. De dracone uel ferpente uelleris aurrei cufto - de, fcribunt Orpheus in Argonauc. Pindarus in Pythīs Carm, 4.8 alij. Aurata ouis, Ouid.6, epift. ouis Phryxi, Idem 2.Amor.eleg.11. Confpicuam fuluo urellere uexit ouem. M. Sillanum, ut tradit hí.

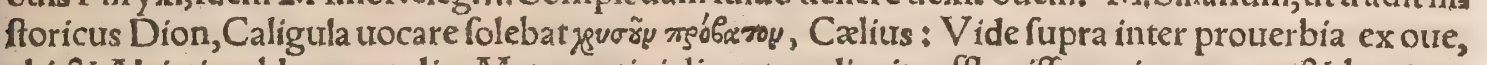
ubi \& Alciati emblema retuli. Metapontini dicuntur olim ita affluxiffe copia annonæ \& bonis a.

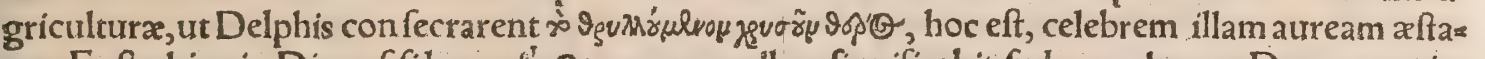
tem, Euftathius in Dionyfrilegas olkge, auream pellem fignificabit, fed non placet, De aureo ariea te dedicato à Mandrabulo fupra in a, inter icones dixi.

TVeteres per iocum aliquando iurabant per arietem $\&$ anferem, đ.Neptunus in arietem $m t$ tatus Bifalpida uírginem fefellit, Ouidius 6.Metam. De Ioue in arietem conuerfo dicam pauló poft in mentione Ammonis dei. TAries, inquit Ifídorus, ab aris dicitur:quòd hoc pecus à gentilibus primum mactatum $\&$ in aris immolatum fit. Aries in lege Mofaica animal fuit purum, facrificijs pro peccatis $\&$ cibo idoneum. Naucydes ftatuarius Mercurio \& Difcobolo, \& immolante arietem cenfetur, Plinius. Aries qui eam dicebant, ares (legendum forte, quia adducebatur aris:)ueteres no ftri aruiga, hinc aruigus. Hac funt quorum in facrificijs exta in ueru coquuntur: quas \& Accius fori bit, $\&$ in Pontifichips libris uidemus in hoftịs, eam dicunt aruigen qux cornua habeat, Varro, Dies agonales, per quos rex ín regia arietem immolat, dictiab agon', eó quód interrogatur à principe ciui tatis, \& princeps gregis immolatur, Varro. De hoc immolanda hoftix ritu \& uerbo hoc agon', quo facerdos minifter utebatur, fit mentio apud Senecam: ad quod allufit \& Ouidius illo uerfu, Semper agat'ne rogat, nec nifi iuffus agit.Quod mirum Politianum apurd hunc non animaduertiffe, cum di cat aptrd unum duntaxat Senecam eius factam mentionem, Bentinus. Iano quoqs A gonalia quia dam attribuerunt, quo die Iano aries mactabatur, Gyraldus. Ita rex placare facrorum Numina la nigeræe coniuge deber ours, Ouid. Subingere arietem, Antiftius elfe air dare arietem quí pro fe aga tur caedatur' ue, Feftus, Acgyptï cur non immolent oues $\&$ arietes, fed capras, alij contra, uide in 


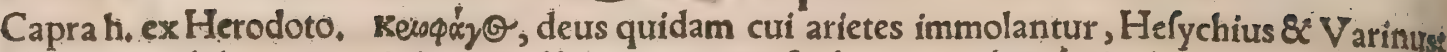

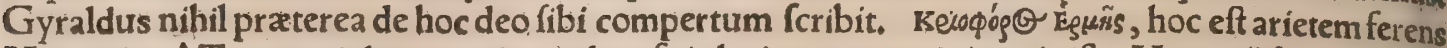
Mercurius, à Tanagrais hoc nomine cultus fuit: huius cognominis ratio ifta. Mercurî fimulachrum erat, arietem in humeris ferens, quod Calamis antiquus artifex effecerat. Tradunt enim, quód cir ca urbis muros Mercurius arietem geftans, Tanagraos peftilentia liberârit : qua geftandi arietis confuetudo in eius celebritate feruabatur. Nam formofiffimus iuuenis circum urbis monia gnum humeris ferebat, ut Paufanias (in Bocoticis) aucior eft, Gyraldus. I Kalendis Februar. loui Tonanti bidens uictima fiebat: idibus uero Ianuarï, ueruex. Legi \& qui flaminis uxorem fcribat, omnibus nundinis Ioui arietem mactaffe, Gyraldus. Cinnamomum in Aethiopia gin gnitur, nec metitur nifi permiferit deus: Iouem hunc intelligunt aliqui, Affabinum (aliâs Sa. 10 bin) illi tocant, quadraginta quatuor boum caprarumq́, $\&$ arietum extis impetratur uenia ca. dendi,Plin. Populus Romanus cum! luftratur Solitaurilibus, circumaguntur uerres, aries, taurts, Varro. Solitaurilia hoftiarum trium diuerfi generis immolationem fignificant, tauri, arietis, uer: ris:quòd omnes ex folidi integriç fint corporis, contra Accius*uerbices (forte, contra quàm fintuer ureces,)maiales. Atq harum hoftiarum omnium immolati funt tauri, quæ pars fcilicet cæeditur in cas ftratione.Sunt quidem qui portent(putent) ex tribus hoftịs pracipue nomen inclufum cum folido tauri, qua ampliffima fit earum.Quidam dixerunt omnium trium uocabula confufa, fuis, otris, tali ri, id quod uno modo appellarentur uniuerfa: quod fi à folo \& $\&$ tauris ear um hoftiarum ductum eft no men, antiqua confuetudinis per unum l. enunciari non eft mirum tera in fcribendo:quam confuetudinem Ennius mutaffe fertur, utpote Gracus Græco more ufus, 20 quòd illi aque fcribentes ac legentes duplicabant mutas, Feftus. Vide plura in Tauro h. Tauro, uerre, ariete Ioui immolari non licet, Atteius Capito. Vlyffes Neptuno ariete, apro \& tauro litauit, Heroibus tauro, capro $\&$ ariete litabant, Gyraldus. Athenis octauo die cuiufós menfis Neptuno fa

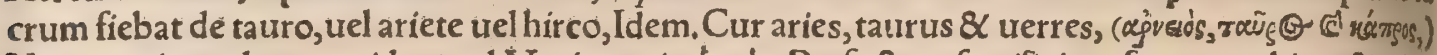
Neptuno immolentur, uide apud Varinum in İed. Perfectum facrificium fue, tauro, birco \& articte

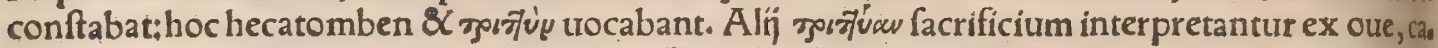
pra, boue: uel ex hirco, ariete, tauro: Vide in Boue h. A pollini aliqui arietem immolarunt, Gyrald, Corinthi in uia qua rectà ad Lechxum nauale deducit, aneum Mercurium fedentem fpectabis, chif aries aftat. Quoniam præeter reliquos deos Mercurius maximè uidetur curare $\&$ atigere greges, quta

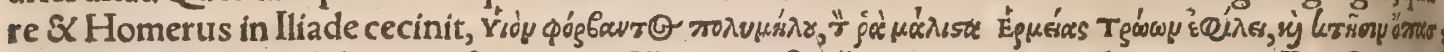
๙.Quæ præterea de Mercurio \& ariete in Matris myfterĭs narrantur, prudens omitto, $\mathrm{P}$ aufanias in Corinthiacis. Circa Bocotiam (inquit Pollux lib. 1.) Herculi $\mu \tilde{\lambda} \lambda$ facrificant, $\mu \tilde{n} \lambda \varkappa$ dico, non pecora uoce poética, red mala \& poma arborum, hanc ob caufam. Feftum huius dei $\&$ facrificandi tempus inftabat.hoftia erat aries, hanc qui adducebant inuiti morabantur, propter Afopum fluuium fubito auctum, Interim pueri ludentes ritus facrificin peregerant. Malo enim egregio feftucas quatuor pro pedibus infixerunt, $\&$ binas fuperné cornuum loco, ita fe $\mu \tilde{\lambda} \lambda s$, id eft ouẽ poéticè, immolare dictitan tes. Hoc facrificio oblectatum aiunt Herculem, eundemćs facrificandi ritum etiamnum durare: Et

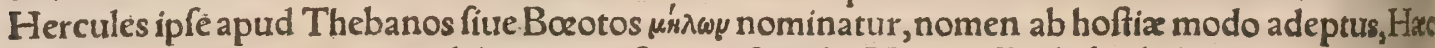
Pollux. Fluunjs arietes immolabant, ut teftantur Scholia Homeri Iliad. $\psi$, ubi hoc carmen legitur,

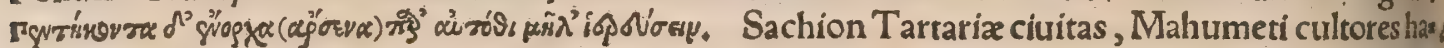
bet;item idololatras: $\&$ cum illorum alicui filius nafcitur, ftatim commendat eum idolo alicui, in cur ius honorem anno illo domi fua nutrit arietem, quem anno à natiuitate filij reuoluto, proximo illius idoli fefto unà cum filio offert cum multis ceremonijs. Poftea coquuntur carnes arietis, \& idolo dea nuo offeruntur, dimittunturós ante idolum tandiu fufpenfx, donec completx fuerint nephandx ora tiones. Imprimis autem rogat pater idolum, ut filium fibi commendatum conferuet. Deinde immola tas carnes ad locum alium deferunt, \& confanguinei omnes congregati, carnes illas magna cumre ligione comedunt, offa uero in uafe quodam conferuant, $\mathrm{Paulus}$ Venet,16 45. Aries Neptuno ima

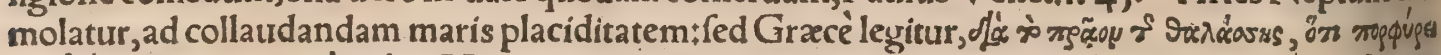
yoenturıp, Varinus in Âpvesós. Veterum gentilium quidam humana cum brutis iungebant, \& qua in natura diffimilia erant, ut ait $D$. Athanafius, deos fuos fecerunt + cynocephalos, criocephalos, \& $\alpha$ Gyraldus. Ammonem(quem deum Solem occidentem Libyes exiftimant) arietinis cornibus fin. gunt, quibus maximè id animal ualet, ficut radịs Sol, Macrobius. Effe uero \& alia arietiSolíç coma munia, dixi ina. Cum Gigantes bellum dịs inferrent, territi dị alī alias animalium formas ina duerunt, Iupiter arietis, unde recuruis Nunc quog, formatis Libys eft cum cornibus Ammon, 0 . uidius 5. Metam. Herodotus de Ammone libro fecundo fríibit, quòd Iupiter cum nollet ab Hercu le cerni, ab eo tandem exoratus, id commentus eft, ut amputato arietis capite, pelléç uillofa quam il li detraxerat induta, fefe ita Herculi oftenderet, $8 \mathrm{c}, \mathrm{ob}$ hanc rem arietes non mactantur à Thebanis, fed eis facrofancti funt, præterquam uno die quotannis in fefto Iouis (ut pluriburs retuli in Capra h.) $\overline{A b}$ alins Ammon traditur, quód in bellis ufus fit galea ${ }_{2}$ cuius infigne caput fuerit arietis. Fuere quit Ammonem arietem Phrixi $\&$. Helles putarent, ut Pherecydes pdidit. Serurius grammaticus ideo a. rietino capite ait confingi, quòd eius effent inuoluta refponfa: quin ea nutu $\&$ renutu alịs dabantur, quod $\&$ Strabo \& Euftathius prodidere. Plura uide apud Gyraldum in loue A mmone, 


\section{De Veruece. Lib. I. 925}

Syntagmate 2. De uertieceo loure qui in draconem mutatus grauidam fecit Proferpinam Arnobị Q. Eufebij uerba recitaui in Tauro h.

P R O V E R I A.

Ad arietes agreftes, uide fupra in prouerbio $A$ d capras feras. Arries cornibus lafciuiens, Kends ¿erengóxzesos: Diogenianus oftendit conuenire in magnos ac lafciuos. Pruriunt cornua arietibus bene paftis, quod idem accidit bubus. Mihi uidetur adagium conurenire $8 C$ in folidos prater merítum $e_{a}$ uectos ad dignitatem, Erafmus, Originem prouerbi lege fupra in a.inter epitheta arietis, $\mathcal{Q}$ in iconi

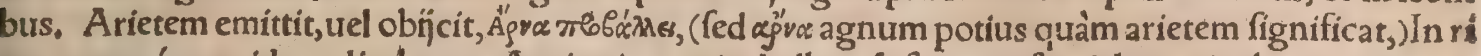
xæ pugnáģ́ cupidum dicebatur. Antiquitus enim bellum fufcepturi foecialem mittebant, qui arie10 tem adductum in hoftium fines immitteret; hoc fignificans pacto ciuitatem $\&$ agros illorum hoftibus compafcuos fore, Autor Diogenianus, Erafmus. Suidas fcribit legem fuiffe A thenis ne pritus ini

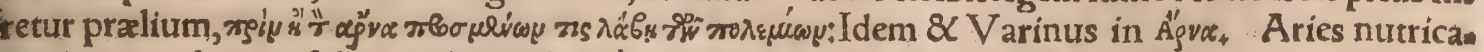
tionis mercedem perfoluit, Keiòs zooф çis maleficium reponit. Allegoria fumpta eft ab eo, quòd aries cornibus impetat(eos à quibus nutrí tus eft:)att uas (præfepe)in quo pabulum apponitur, ipfosóg quorum opera nutritus eft, aut etiam nutritur, cornibus inceffit. Effertur $\&$ ad hunc modum prouerbium, letö dgavovíc, id eft, A rietis mint? fterium, pro officio collato in ingratum, qui beneficium iniuria penfet, Erafmus in Chiliad, (Memi* nerunt Hef, $\&$ Suid.) Et alibi, A rietis minifterium, Keĩ dlarovi $\alpha$, Suidas $\&$ Zenodotus (inquit) fic referunt, quafi dici folitum de officio in ingratos collato: fiquidem aries cornibus ferit pafcentem. - Hefychius ita refert, quafi congruat in eos qui fpe cuiufuis pramioli inferuiũt indignis.Quurm pue, ros inuitamus ad minifterium, pollicemurr aliquid, puta talos aut nuces. ltidem in apologo guopiam,

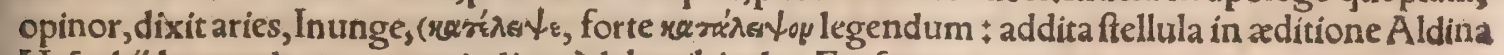
Hefychị locum deprauatum indicat, )dabo tibi talos, Erafmus.

\section{E V E R E C E.}

A.

E R V E X dicitur à natura urer $\{$, cut otri mari tefticuli dempti funt, Varro. Hinc alin, Ver uex mas eft inter oures cui inuerfi uel adempti funt tefticuli. Ifidorus tamen $\&$ alii recen: tiores ueruecem pro ariete etiam, id eft oue non caftrato ufurpant, ( $\&$ dictum nugantur à uiribus, quòd cateris ouribus fit fortior, uel quòd fit uir, id eft mafculus ; uel quòd uermes (n capite habeat, quorum pruritu excitetur ad pugnä, quod fallum effe Albertus afferit, $)$ Quamob rem quadam ab illis de ueruece fcripta, paffim in A rietis hiforiam inferui : hîc illa adiecturus quae propriê ad arietem caftratum pertinent. Graci uccem unam non habent, fed keiòn solúxw, id eft arietẽ caftratum dicunt. Sectarius ueruex, qui gregem agnorum pracedens ducit, Feftus: tanquam fcili cet uertreces agnis ducendis praficiantur, ut capi aliquando pullos ducunt:arietes uero ouibus, cum agnos fpernant. A pparet autem fectarium dici, quòd eurm fequantur agni. Apud Catonem cap. Iso. porcos quogs fectarios legimus. Aries ueruex'ue, crios $8 \mathrm{r}$ ctilos, præcipué fectarius, Hermolaus: fed cillon Gracis fimpliciter arietem gregis ducem fignificare, docui in A riete a. Veruex, aries ca\# ftratus, qui fubinde fectarius eft, Vuillichits. Idem arietem Germanicé interpretatur bamell, at noftri bammel ueruecem uocant. Videriautem poteft tox origine Arabica, nam lefan alhamel, Bel lunenfis uertit linguam arietis. In quibufdam Heluetixa locis circa alpes, ueruecem nominât frị̂ ch ling, (qua uox quibufdam porcellum fylueftrem fignificat:)circa Sabaudiam, bogner:alif wi $\mathbf{D e r}$. Vi de fupra in Ariete A. Scoppa ueruecem Italicé uocat caftrone, (qua uoce etiam Germani quidam utuntur,) caftrato \& montone: forte quafi mutilum propter teftes ademptos $\$$ nam $8<$ Galli mouton uocitant: (quamuis apud eofdem uox brebis, qua ouem fignificant, à ueruece detorta uideri poffit.) Illyrị beram. (A qua uoce opinor Galli quidam arietem non caftratum ran nominant, Angli ram.) Angli, a wether Shepe. Maraches, id eft fel ueruecis, Syluaticus.

IT Verres, iuvencos, arietes, hoedos decrefcente Luna caftrato, Pliníus. Quros in nume. rum ueruecum referri uolunt, eofdem non minores quinq, menfitum caftrare oporter, Platina. Aa

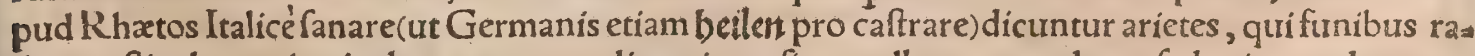
dices tefticulorum in eis abrumpunt, aut ligno impofitas malleo contundunt: fed prior modus prase ftat. Pofteriore modo caftratos Germanicé uocant Eniit $\int d$ er , id eft contufos: horum tefticuli cum machantur, ceu fuggillati $\&$ parui abínciuntur. Vitulos etiam fiffa ferula compreffis $\&$ paulatim con fractis tefticulis caftrari,docuimus in Vitulo E. Similis quædam olim hominibus ut eunuchi fierent

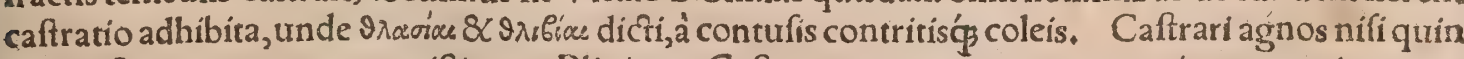
quemeftres, præmaturum exiftimant,Plinius. Caftrare oportet agnum non minorem quinģ, men 6o fium, neçs ante quàm calores aut frigora fe exegerint, Varro. Caftrationis ratio iam dicta eltit: ne. que enim alia in agnis, quàm in maiore pecude fertratur, Columella. Sed qura de uitulis caftrandis copiofé fcripfizal rijs etiam quadrupedibus accommodari poffecpinor. 
B.

A deps inter cutem $\&$ carnem abundat, in porcis maxime, lardum urocant, fed in arietibus qutrog caftratis in Syria, Bellunenfis. Homines ita commutantur, ut etiam cateror um animantium qua: cunç caftrata. Nam \& tauri \& uerueces fura cornua è contrario gerunt: quod foeminę quç corum contra 萿mares armantur cornibus. Itaç illi maiora excifi gerunt, hi minora, Ariftoteles problem: 10.38. In Aegypto circa urbem Damiatam uerueces amplis $\&$ rotundis caudis fpectantur, tant? interdum ponderis ut uix eas fuftineant, Italus quidam de itinere ex Venetijs Hierofolyma,Sed de magnis ueruecum caudis plura leges in Ariete B.

E.

Prafocuridas Græci uocant animalia, qux folent hortis nocere:ergo uentriculü ueruecis (ouis, 10 Ruellius ex Diophane)(tatim occifi plenum fordibus fuis fpatio, quo abundant, leuiter debebis ope rire.Polt biduũ reperies ibi animalia ipfa congefta. Hoc cum bis uel tertio feceris, genus omne, quod nocebit, extingures, $\mathrm{Palladius.}$

r.

Agnorum qui iam à lacte remoti funt caro fatis eft laudabilis, fed optima caftratorum, prafertitn anniculorum, Auicenna tefte: fed furpra illam xtatem deterior fit, Crefcentienfis. Plura uide in Arie te F. Anniculus placeat, uel fi fine teftibus agnus. Pinguior eft hcedo. quum calet olla, wores, Hunc amo fi duri per pafcua montis anhelat. Maluerofi auri uellere diues erit, Bapt. Fiera, Vera trecum caro falubris eft, $\&$ melior agnina. calida enim $\&$ humida habetur, ad temperamentum ten. denstilla uero plus humiditatis quàm caliditatis habet, Platina. Et alibi, Totum de ueruecenon iniuria elixabis, licet ex fpatula \& coxis bona fiat affatura, Platina. Si uoles duas patinas eitus pul menti quod uulgò gelatinã uocamus, quadraginta pedes uerueceos excoriatos exoffatosós,in aqua recenti per tres aut quatuor horas finito: lotos, in cacabum, ubi aceti acerrimi albi metreta una, tini aibi altera, aqux duę infint, impones, tantum falis addendo quantum fat eft. Facito deinde efferueat lento igne, Defpumare etiam diligenter memento, ubi femicoctifuerint, piperis rotundi, piperis obs longi, cinnami, fpicænardi, quantum fatis erit, infringito potius ̧̧uàm cõteras, In cacabumós indito, ut unà tam diu efferueant, donec ad tertias deuenerint, pedes tum eximito, iusćs efferuere iterum lits nito, decem ouorum albamenta tudicula tamdiu agitato, donec uẹfa in fpumam uideătur. Ebullire fimul rantifper hac debent, quoad femel aut bis cochleari inuolueris. Exempra ex cacabo, ftatimfac co lineo bis aur ter colato. Tale ius in patinas, ubi pulli aut hoedi, aut capi bene cocti $\&$ fruftatim di $\xi^{\circ}$

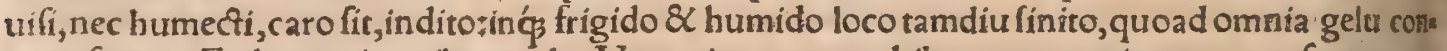
creta fuerint. Ex hac patina nil comedat Voconius meus, ne bilem qua exagitatur, cum fuo magno malo augeat, Platina 6.24. Paftilli, ut uocant, ex carne ueruecina fiunt, hoc modo: Caro minuta tim concifa, \& modicéferuefaça in aqua, fale, zinzibere, uuis paffis aut cepis, \& pauco buryro con ditur, \& intecta duas aut amplius horas coquitur, Balthafar Stendel. In conuiuio apud Antiphar nem in Cyclope inter catera apponitur xeiós ropices, ut Athenæus recitat.

G.

Remedia qux dam ex ueruece retuli in Ariete G. Ad fpafmum, Capite caftratino cum pedi. bus fiue trunculis $\&$ inteftinis, $\&$ hordeo, in a qua decoctis balneum parabis, cui infideat $\approx g e x$, pint guia enim \& humectantia omnia profunt, Leonellus Fauentinus,

H.

A pud Feftum in Solitaurilium mentione uerbices pro uerueces corruptèlegi conịcio.Semima ris ouis uifcera, Ouid. ı. Faft. Ëbe's, aries caftratus, rouias reiós, (fic enim legendum, ) Hefychirs, Varinus. I Veruecem hominem amentem uocauit Plautus in Merc. Ego ex hac ftarua ueruecea wolo Erogitare, meo minore quid fir factum filio, Plautus Capt.id eft, ex feruo, qui ureluti imago ueruecis eft, hoc eft fine ratione $8 \mathrm{C}$ prudentia non aliter quàm ueruex. Aut bouem, aut ourem, att ueruecem habet fignum, Varro de pop. Rom.uita apud Nonium, đKal, Febr, Ioui Tonantibis dens uictima fiebat:idibus uerò lanuarn̈, ueruex, Gyraldus. A mbegni bos $\&$ ueruex appellaban. tur, cum ad corum utraç latera agni in facrificium ducebantur, Feftus, Quod genus facrificium

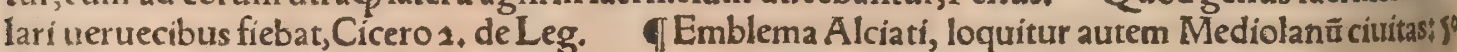
Bituricis ueruex, Heduis dat fucula fignum. His populis patrix debita origo mex eft. Quam Mediolanum facram dixêre puella Terram: nam uetus hoc Gallica lingua fonat, Cuita Minerua fuit, nunc eft ubi numine Tecla Mutato matris uirginis ante domum, Laniger huic fignum fus eft, animalç biforme, Acribus hinc fetis,lanitio indeleui. 


\section{DeAgno. A.B.C. Lib. I. 927}

D E A G N O.

A.

1.

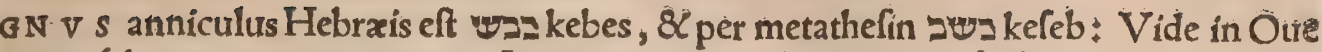

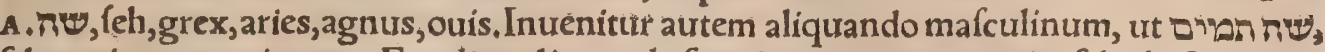
feh tamim, agnus integer, Exodi i2.aliquando formininum, ut nרוז difperfus Hieremix y .Significat autem agnum ouinum, \& caprinum, (id eft hœdum,) Munfterus, Noftri interpretes pro feh plerunç reddunt ouem:fignificat aũt pecus paruum, ut oue

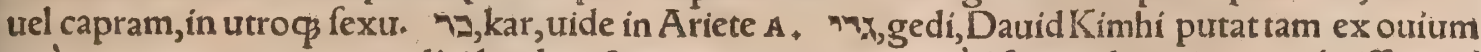
quàm ex caprarum genere dici hoedum $\&$ agnum, propterea quòd fape adiungitur trox haifim , id eft caprarum. R. Abraham folis capris nomen attribuit, ut folet etiam A rabica lingua:uide in Hoedo A. Geneleos 31.pro eo quod nos pofuimus, (inquit Hieronymus,) mutatuit mercedem meam decể uicibus, $\mathrm{L}$ XX. interpretes pofuerunt decem agnis, nefcio qua opinione duchi, quum uerbum He. braicum mónim, numerum magis quàm agnos fonet. A tquí ego conịicio in translatione L XX. inter

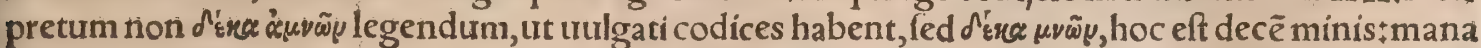
enimi, unde plurale manim, minam uel libram Hebræis fignificat. Græci agnum aǵvíopuocant, \&C

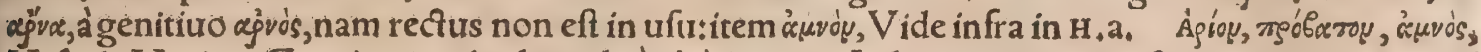
Hefych. Varin. Graecis etiam hodie uulgó ágoi dicitur. Italis agna $8 \mathrm{C}$ agno, $8 x$ diminutiuum agnel lo. Hifpanis cordero. Gallis agneau, diminutiuum agnelet. Germanislamb/lふ̊mblin. Anglis primo anno a lambe, fecundo a hogg.

B.

In Africa arietes ftatim cornigeri generantur, nec folum mares, ut Homerus foribit, fed etiam fo mina, Ariftot. Huius rei rationem reddidimus in Boue H.b.ex.Herodoto. Vide etiam in Oue $B$. Lactes dicuntur inteftina. Titinnius Pfaltria, Ferticula, cerebellum, lactes agninas, Nonius: Citatur etiam à Prifciano, Canem fugitiưum agninis lactibus alligare, uide infra inter prouerbia.

c.

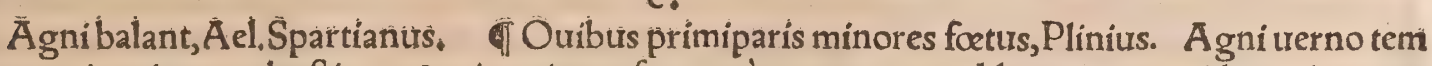
pore nati,maiores, robuftiores, \& pinguiores funt quàm auturmno uel hyeme, ut quidam citant ex Ariftotele \& Auicenna. Coéunt oues à tertio idus Maias, ad xiin̈. calendas Auguftí, Gerunt partũ diebus $\mathrm{CL}$. Poftea concepti ínualidi.Cordos uocabant antiqui poft id tempus (forte fimpliciter, poft tempus, legendum, ut etiam Varro habet)natos. Multi hybernos agnos praferunt uernis; quoniam magis interfit ante folftitium quàm ante brưmam firmos effe, folum ḉ hoc animal utiliter bruma na= fri,Plinius. Agnus qưo tempore anní commodiflimè nafcatur, plura diximus in Oue c. Qur na ta funt matura \& chorda, ut purè $\&$ molliter ftent, uidendum, \& ne obterantur. Dicuntur agni chor di,qui poft tempus nafcuntur, $\&$ remanferunt in uoluis intimis: (quas) uocant xeéoy, à quo chordi appellati, Varro. Agnus(inquit Columella)cum eft editus, erigi debet, atç3 uberibus admoueri, tum etiam eius diductum os preflis humectari papillis, ut condifcat maternum trahere alimentum . fed prius quàm hoc fiat, exiguum emulgendum eft, quod paftores coloftram uocant; ea nifi aliquatenus emittitur, nocet agno:quí biduo quo natus eft, cum matre clauditur, ut $\mathcal{Q}$ ea partum fuum foueat, $\&$ ille matrem agnofcere condifar, Mox deinde quandiu non lafciuit, obfcuro \& calido fepto cufto, diatur; poftea luxuriantem uirgea cum comparibus area claudioportebic, ne uelut puerili nimia ex. ultatione macefcat:cauendumç eft, ut tenerior feparetur à ualidioribus, quia robuftius angit imbecillum: (Ita feclufo paruulorum grege, matrices mittantur in pafcua, Pallad.) fatisćs eft mane prius ¿ grex procedat in pafcua:deinde etiã crepufculo redeuntibus faturis oubus admifcere agnos:qui cû firmi elfe coperint, pafcendi funt intra ftabulũ cytifo, ucl Medica, tum etiã furfuribus, aut fi per mittit annona, farina ordei uel erui deinde ubi conualuerint, circa meridiem pratis, aut noualibus uilla contiguis matres admouenda funt, \& à fepto emittendi agni, ut condifcant foris pafci, Hac ille \& Palladius. Menfe nourembri agnorum prima generatio eft, Palladius, Plura uide mox in E. ex Varrone. De paftu agnorum dixi etiam nonnihil in Oue e.ex Crefcentienfi. Ad conficienduns caleũ aliqui addunt pro coagulo de fici ramo lac $\&$ acetum. Quã ob caufam apurd diuę R umiæ facel lum à paftoribus fatam ficum non negârim:ibi enim folent facrificare lacte pro uino, \& pro lactentia bus:mammæe enim rumis, fiuce rumæ, ut ante dicebant, à rumi: $\mathcal{Q}$ inde dicuntur fubrumi (fengerling) agni lactentes, à laçe, Varro. Dicuntur 8 hœedi fubrumari,cum ad mammam admouentur, \&r. apud Feftum. Ferè ad quatuor menfes à mamma non difiunguntur agni, Varro. Agni Tarentini quorum delicata \& pretiofa lana eft, quomodo nutriendi, uide in Oue E. đI De caftratione agnil le ge fupra in Veruece. TAgni morbo non laborabunt, fi hederam in paftu appones curriculo $e_{e}$ ptem dierum, Democritus. Agnis quoģ fuccurrendum eft uel febricitantibus, uel ęgritudine alia affectis:qui ubi morbo laborant, admitti ad matres non debent, ne in eas perniciem transferant, Itae que feparatim mulgend $x$ funt oues, $\&$ coleftis aquá pari menfura lacti mifcenda eft, atcs ea potio febricitantibus danda; multilacte caprino ïf́dem medentur, quod per corniculum infunditur faucia 
bus, Columella. Etrurfus, Eft etiam mentigo, quam paftores oftiginem uocant, mortifera lactentia bus. Ea plerun $q$ fit, fi per imprudentiam paftoris emiffi agni, uel etiam hoedi rofcidas herbas depaute rint, quod minime committi oportet. Sed rum id factum eff, uelut ignis facer os atç labra foedis uice ribus obfidet. Remedio funt hyffopus, \& fal aquis ponderibus contrita. Nam ea miftura palatumat que linguam totumćs os perfricatur. Mox ulcera lauantur aceto, $\&$ tunc pice liquida, cum adipe fuil lo perlinuntur, Quibufdam placet æruginis tertiam partem duabus ueteris axungiæ portionibus commífere,tepefacró̧ uti medicamine. Nonnulli folia cupreffi trita mifcent aqua, \& ita per ulce, ra, atç̧ palatum. Mentigo in agnis $\&$ hoedis id fermè malum effe uidetur, quod in hominibus men. tagram appellant, V triuf́ç trocabuli etymon à mento: quoniam ab ea parte ferè oriebatur $¥$ focdisó ulceribus mentum, os, labra, obfidebat, Phil.Beroaldus. Videtur fané ut mentigo menti malum, fic oris oftigo dictum. Agnos pediculis aliquando infeftari fcribit Crefcentien.

D.

Agni fimul ut funt in lucem fufcepti, circum matres ftatim erratico faltu concurfare, $\&$ domefin cum incipiunt ab alieno internofcere + cum homo parentes fuos ferò admodum agnolcere incipiat, Aelianus. Præterea teneri tremulis in uocibus hoedi Corniferas norunt matres, agniçs petulei, Lucretius. Agnus fimpliciffimus, cum à matre quandoç aberrat, frequenter eam balatu abfentem excitat, multisó̧ licet uerfetur in millibus ouium, recognof cit uocem parentis, \& feftinat ad eam. Nam quamuis cibi $\&$ potus defiderio teneatur, tranfcurrit tamen aliena ubera licet humore lactis grauida exundent; foliusq̧ materni lactis fontes requirit, Ambrofius. Latini agnum ab agnofcen: do putant diçum:eò quòd præ cæteris animalibus matrem fuam nof cat, adeó quód fi in magno gre $=2$ ge errauit, ftatim balatu uocem nofcat parentis, Ifidorus $\&$ Albert. Ouis agnum fuum odore pofte riorum nofcit, $\&$ cum lactet agnus caudam uelociffimé agitat, Albertus. đMirum eft $\&$ tamenue rum, fidibus lupi agninas male obftrepere: quanquam hoc idem contingat neruis fermè omnibus din uerforum animalium, ut canis $\&$ agni, Cardan. Vide fupra in Oue $D$.

\author{
E.
}

In nutricatu cum parere cœperint:inj̣ciüt in ea ftabula, qua habent ad eam rem feclura: ibiọng ta recentia ad ignem prope ponunt: \& quoad conualuerint, biduum aut triduum retinent, dum au gnof́ant matrem agni, \& pabulo fe faturent. Deinde dum matres cum grege in paftum prodeun, retinent agnos:qui cum reductx funt ad uefperum, aluntur lacte $\$ 2$ rurfus difcernuntur, ne nochu à matribus conculcentur. Hoc idem faciunt mane ante quàm matres in pabulum exeant, ut agnifa 3 turi fiant lacte. Circiter decem dies cum præterierunt, palos affigunt, \& ad cos alligant libro, aut qua alia re leui diftantes, ne toto die curfantes inter fe teneri delibent aliquid membrorum. Si ad matris mammam non accedit, admourere oportet, \& labra agni ungere butyro, aut adipe fuillo, \& olfacere labra lacie. Diebus poft paucis obỉcere his uíciam mollitam, aut herbam teneram antequàm exeant in paftum, 8 cum reuerterunt. Et fic nutricantur, quoad facii funt quadrimeftres. Interea matres corum his temporibus non mulgent quidam (per duos menfes, ex Didymo, qui melius omnino per peturo, quòd \& lanæ plus ferunt, \& agnos plures. Cum depulfi funt agni à matribus, adhibendadilie gentia elt, ne defyderio fenefcant;itaç deliniendum in nutricatu pabuli bonitate, $\&$ à frigore $\&$ ętu ne quid laborent,curandum, Cum obliuione iam lactis non defyderant matrem, tum deniq 5 compel lendum in gregem ouium, Varro 8 mutuatus ab eo Crefcent. Plura uide fupra in c. 8 quadam 4 de agnis laciandis in Oue E. Partus ipfos ubi lacte fuerint expleti, feparatim feruare oportet, Cons culcantur enim unà reliçi cum matribus. Ante duos mêfes lac emulgendum non eft: melius autem erit finunquam, Sic quippe agni corpulentiores euadent. Caterum foetus ex primiparis ouibus nu trire operapretium eft, cum fint infirmiores quàm ut durent diutius, Didymus. Agnis aditis fingu la feptimana per menfem fal dari debet, $\&$ in pofterum decimoquinto femper die.Quando autemfex parantur à matribus, mox tondentur propter pediculos, (oures quidem pediculis carere Ariftot, 8 Plinius prodiderunt:)uel quia melius crefcunt, \& unaquaç hebdomade fal eis objucitur. Circa natis uritatem Domini iunguntur cum matribus, ut de agnis Palladius frribit, Crefcentien. TSeciarius ueruex, qui gregem agnorum pracedens ducit, Feft. Vide in Veruece A. Quod ad fructumexa= gnis percipiendum, leges quadam ex Catone in Oue E. Bini agni unius ouis (cum urenduntur) numerum obtinent, Varro. đR heno proprié ouium pellis eft, uel agnina potius, ut dixi in Capra E. Pelles 8 lanæ agnorum funt optimæ, atç ad operimentum humani corporis aptiores quàm ma. trum, Crefcent. Indumentum ex pellibus agninis corroborat corpora iuuenum, Filius Zor apud R.Mofen. Plura uide infra in G. Agninæ pelles, quas pellifices noftri ad ueftimenta parant, magna ex parte defumpte funt ab ouibus qua uel in partu uel proximis poft diebus moriuntur. Namintra paucos dies lanæ eis molliores fiunt \& ineptæ pellificibus. Pelles qua ex foetu fumuntur, cum oues

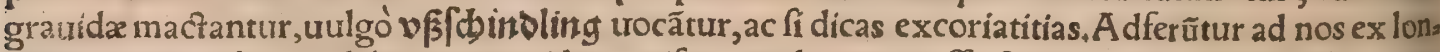
ginquis regionibus: pulcherrim $x$ quidem, crifpa, pralo compreffæ $\&$ maioris pretï ex Italiæ parte ultra Romam, A pulia præfertim. Elegantes \& nigra pelles ex Prouincia feu Narbonenfi Gallia \& Hifpania (ubi $\&$ monopolia haberi audio, ita ut certi quidam loci futum habeant mercatorem, cui fo: 6 li pelles uendi omnes oporteat)ferè mittuntur, iam ad ufum parat $x$; funt autem pinguiufcula. Can. dida uero apud nos parantur, \& ex noftris regionibus habentur. TLactis cuobus congijs addût 


\section{DeAgno. E.F.G. Lib. I. 929}

roagulum magnitudine olea, ut coěat:quod melius leporinum \& hoedinum quàm agninum, Var. Maio menfe cafeum coagulabimus fyncero lacie, coagulis uel agni uel hordi, Palladius. IT Tem. peftatis futurx prognofticon ab agnis, uide in Oue $\mathrm{E}$.

F.

Agnorum caro fatis-eft contreniens, cun de lacte remoti fuerint, Crefcentienfis, Agnina humia ditatis plus habet quàm caliditatis:ueruecina uerò temperata eft, Platina. Ex pedefribus animanti bus fuilla caro probatiffimus cibus eft, deinde hoedina, mox uitulina:agnina uero humida, tum letn. corem mucoremós in fe habere cenfetur, Galenus in lib. de cibis boni \& mali fucci. Agnicarnem habent humidiffimam ac pituitofam; ouium uero excrementofior eft ac fucci deterioris, Idem $\xi$. de a* lim, facult. Et in libro de attenuante uictus ratione, Agnorum efus propter infignem humiditatem eft fugiendus. Carnes quadrupedum recens in lucem æditarum, omnes mucola habentur, ac pra cipué qua fuapte natura humidiore funt carne, trt agni \& fues, Galen, in lib, de mali $\&$ boni fucci ci bis. Vide quadam fuperius in Oue $\&$ in Ariete F" Agnorum carnes modicé calida funt, humi. dam $\not$ habent fuperfuitatem;atq̧ ideo ab ijs laduntur qui humídioris funt temperatura : qui uero ficcioris, iưan tur: quãtò autem iunior agnus fuerit, tantó difficilius eius caro concoquitur, magiṣ́ humida eft quantó uero maior, tantó melius concoquitur, \& có minus eft humida. Sic $\&$ in cæer is animalibus contingit, quo iuniora funt, eó bumidior quàm maiorum eft eorum caro, Symeon Se. thi. Agnus lactens fimiliter ferè uifcofus eft ut porci fylueftres, (porci lactentes potius,)quòd nuper ab utero prodierit, \& ex lacte quo aluntur humiditatem fequatur:quamobrem caro eius non lauda tur, ut qux concoctu difficilis fit, \& lubricitate fua de uentriculo(cito) defcendat. Anniculi uero (uide fupra in Veruece F.ex Bapt. Fiera)mediocrem habent temperiem inter lactentium humiditatem, $\&$ iutuenum ficcitatem:quamobrem praferuntur, quòd faciliores concoçu fint, \& fanguinem gignã meliorem, Ifaac in diatis particularib. Agnina robuftis $\&$ fanis hominibus in cibo utilis eft, infirmis inutilis:quia etfi à uentriculo facile defcendat, uifcofo tamen quem gignit humore, partibus nimis tenaciter inhæret, Liber de nat.rerum. Suill $\&$ agnin $x$ carnes difficiliores concoctu funt, \& facile corrumpuntur propter pinguitudinem, caprina non item, Athenæuš. Priamus apud Homerum filips fuis exprobrat, (tanquam nimium gulofis, quòd in cibo agnos $\&$ hodos illicite \& præter mo.

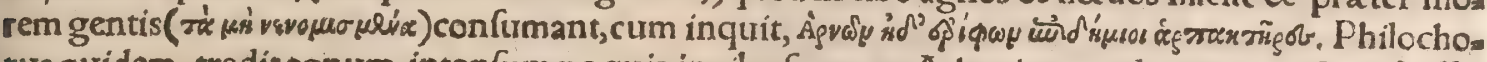
rus quidem tradit agnum intonfum ne quis in cibofumeret Athenis quondam interdicium fuiffe, cum ouium penuria futura metueretur, A thenaus libro primo. Et libro nono, Antiqua lex erat, ut

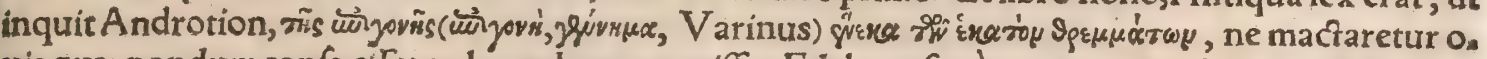
uis qua nondum tonfa eíret, uel nondum peperifiet. Edebant fanè ueteres animalia iam adulta, pro.

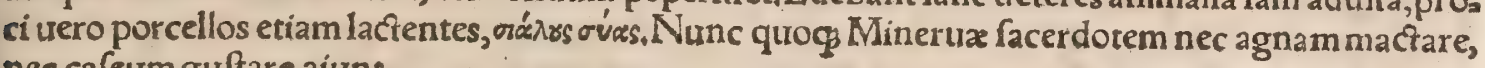
nec cafeum guftare aiunt.

THodi utrumlibet cocti, (affi aut elixi,) fuaues \& falubres funt:coxæ tamen affx meliores haben tur. Eadern $\&$ de agni coctura, Platina. In agnum uel hœdum uarios apparatus ex A picio recita: ui in Hodo $\mathbf{P}$,item in iecinora eorum, \& pulmones, \& copadia, Ibidem. Veteres aliquando in mas gnificis conuiứ, tum alia animalia integra affabant, tum boues, ceruos, agnos, A thenæus lib 4.4 . $A=$

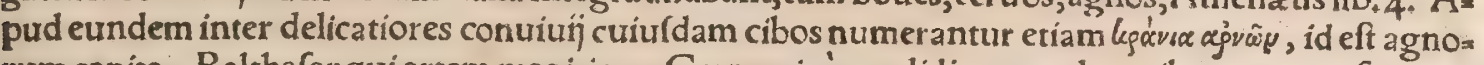
rum capita. Balthafar qui artem magiricam Germanicé condidit, ex pulmonibus agninis farcimi, na uel ifitia parat, hunc ferè in modum: Pulmonibus iam cráfítufculè concifis omentum addit, $8 \mathrm{mi}$ nutius concidit:oua admifcet, \& modicum cremælactis, \& fangurinis agnini modicum, \& pro condi

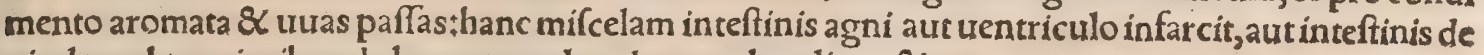
uitulo, uel tenuioribus de boue, nec admodum replet, elixat, $\& c_{*}$

$G_{\text {. }}$

Ad morfus uenenatos, optimè auxiliatur, fiftatim poft cucurbitas plagæ imponantur animalia parua difcerpta $\&$ adhuc intus calentia, uelut funt gallinæ, hœedi, agni, porcelli. Venenum enim exu gunt, \& dolores leniunt, Aëtius, Idem ferè Celfus fcribit, ut recitaui in Hoedo, initio capitis 7 . Expe rieris uerum remedium fi agnum candidifimi capitis decoxeris:atç inde caput eius, quem canum effe nolís, ungi pręceperis, Marcellus. Sanguínis hoedini recentis antequam coaguletur uncia cum aceto mixta \& triduo pota, uomitui fanguinis confert: \& fimiliter fanguis agni, Auícenna. Galenus de fimplicib. lib, so, de hoedino tantum fanguine hoc remedium à Xenocrate fcriptum refert. Ibi. dem, Agninum fanguinem (inquit) aliqui epilepfiam curare prodiderunt, quod mihi experiri non placuit. Quod fi quis perículúm facere uroluerit, fat fcio reprehenfum íri ab eo qui talia feripferunt. Omnia enim remedia qux in poru epilepticos iưant, urim incidendi habent, qux agnino fanguint nulla ineft. Sanguis agni cum uino epilepfiam fanat, Auicenna. Vt mulier concipiat, Dorcadis, hoedi, leporis coagulum $\&$ fel, cum agnino fanguine $\mathcal{X}$ adipe, medullaç ceruina, nardino $\&$ rofa ceo oleo commifce, \& polt purgationem fubdito, (utero prius purgato,) Aérius.

I Igni facro medetur fenectus ferpentium ex aqua illita à balineo cum bitumine $\&$ feuo agnino, 6o Plinius. De fuillo \& agnino (Ruellius apud Diofcoridem non ag'vesou, id eft agninum, legit:fed $x g^{\prime \prime}=$ кresoy, id eft urfinum, quod magis probo ) adipe curando Diofcoridis uerba in Sue recitabo. qMedụlla agni ad ignem liquefacta, cum oleo nucum \& fachare albo, deftillata fuper fabathum(zambac 
purum, $R$ afis ) \& fic epota, diffoluir calculum uefica, $\&$ confert mingenti fangurinem; ( $R$ afis addit, crematione uirgæ, $\&$ ad dolores uirgx, uefic $x$, renum, Albertus. \Dyfenterico fi frigoris fenfus adfit, pellem agninam leuem liquida pice imbutito,calefactamós aluo imponito, Aëtius, Veftis ex pellibus agninis corroborat corpora iutuenum, Filius Zor apud R.Molen. Pelles agnorum magis calefaciunt quàm hoedinæ, magis q́ conferunt dorfo \& renibus, Elluchafem in Tacuinis, Officun lo quod fit in dextro latere ranæ rubetæ, adalligato in pellicula agnina recenti, quartanas aliasćg fea bres fanari aiunt,Plinitus, Cinis ex offibus agnorum reée adhibetur ulceribus, qux non tras hunt cicatricem, Marcellus, Magna uis $\&$ in cinere pecudum fimi ad carcinomata addito nitro, aut cinere ex offibus feminum agninorum, pracipue in his ulceribus qux cicatricem non trahunt; Plinius. Attritus calciamentorum agni pulmo fanare creditur, Galenus \& Plinius: Impofitus Io contracfos à calciamentis attritus ab inflammatione tuetur, Diofcorides. Agninus pulmo vel arie. tinus uritur, \& cinis eius cum oleo imponitur, uel ipfecrudus admotus pernionum ulceribus utili, ter alligatur,Marcellus, đCoagulum agninũ aduerfus omnía mala medicamenta pollet, Plinius, Contra uenena omnia ualet coagulum pecoris, Idem. Hoedi,agni, hinnuli, \&c, coagula fimiles naturas fortiuntur.contra aconiti potum in trino, $\&$ concretum lac in aceto, conuenienter affumun tur, Diofcorides. A uenenofis morfibus omnibus fanat, A uicenna, Contra paftinacam, 8 om nium marinorum ictus uel morfus coagulum leporis, uel hoedi, uel agni drachmæ pondere ex uino fumitur, Plinius. Muris aranei morfus fanatur coagulo agnino in uino poto, Idem. Infantibus quilacte concreto uexantur, prafidio eft agninum coagulum ex aqua potum: Aut fi uitium coa. gulato lacte acciderit, difcutitur coagulo ex aceto dato, Plinius, Sanguinem fiftit in naribus coas do gulum ex aqua maximé agninum fubditum uel infufum, etiam fi alia non profint, Plinius. Ex aqua fubactum $\alpha$ infufum naribus fluentibus mire prodeft, Marcellus. Vide nonnulla fupra in Hoedo G. ubi de hoedino coagulo. TComitialibus morbis utile tradunt fel pecudum cum melle, pracipuè agninum, Plinius \& Samonicus, Si felle agnino inungantur loca cancro affecta, maa nifefte prodeft, Albertus. TSi quis agnum recens natum confeftim manibus diuellat, lienemíg eius ubi extraxerit calidum fuper lienem dolentis imponat, ac fafcia liget, $\&$ dicat adfiduè remedio lienis facio:poftero die fublatum de corpore cius parieti cubiculi in quolienofus dormire folitus eft, luto prius inlito ut harere poffit imponat, at $\$$ ipfum lutum uiginti feptem fignaculis fignet ad fin gula dicens lieni remedium facio: hoc tale remedium fi ter fecerit, in omne tempus lienofum quam: uis infirmum $\&$ periclitantem fanabit, Marcellus. I Vtlanugo tardior fit pubefentium, mango, nes illinunt fanguinem è tefticulis agnorum qui caftrantur : qui euulfis pilis illitus \& contra uirus proficit,Plinits. FIn ueficx doloribus ( ftranguriofis, Marcellus) decoctum agninorum pedum bibiffe prodeft,Plinius. TVux \& faucium dolori fimus agnorum, priufquam herbam guftentin umbra arefacius \& confrictus, atqg emplaftri more adpofitus medetur, Marcellus.

H.

a. Agnus, à nonnullis cum afpiratione fcribitur, hagnus: $\{e d$ ufus iam obtinuit, ut priore modo fcribatur. Agnus diciturrà Graeco áyuós, (melius áyvós cum a firatione : unde nimirum etiam Lao tinè aliqui agnum afpirant, )quod fignificat caftum, eò quod fit hoftia pura \& immolationi apta, $\mathrm{F}_{\mathrm{r}}$ ftus. Sed alibi apud eundem fic legitur, Agnus ex Grxco ákı ós deducitur, quod nomen apud mar iores communis erat generis. Varro agnum dictum putat, quod agnatus fit pecori ouillo. Agnus 4 à Graco uocabulo dicitur quafi pius, (čxyóv pium interpretatur, cum potius caftum fignificet, )nam inter omnia terræ animantia maximè inuenitur innocens 8 manfuetus, nullum enim lædit dente, aut cornur,aut ungue, Ifidorus. Et alibi, Latini agnum putant dictum, quod agnof cat matrem fuẩ præ cæeteris animalibus, a deo ut etfi in magno grege errauerit, ftatim balatu uocem nof cat parentis: Vide fupra in D. Auillas agnas recentis partus dicimus, Feftus, forte quafi ouillas, forma dimis nutiua. Belluam indifferenter pofuit authoritas ueterum. Quo quidem agno, fat fcio, magis nuff quam curiofam effe ullam belluam, Plautus Aulul,citante Nonio. Dic igitur me tuum paffercur lum, gallinam, coturnicem, Agnellum, hoedillum, Plautus in Afin.

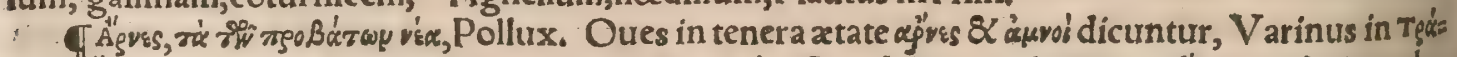

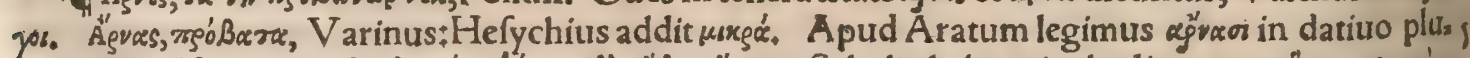

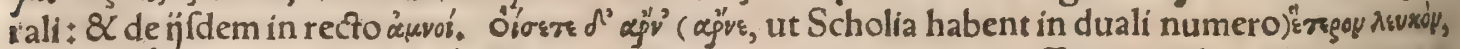

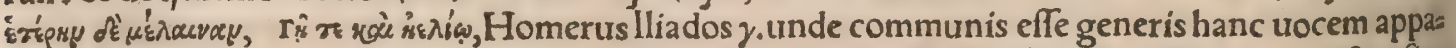
ret. A uoce ag̉in, ag̀ñvos (de qua paulo inferius, ) cafus eius obliqui fiunt,per fyncopen, rectus fin-

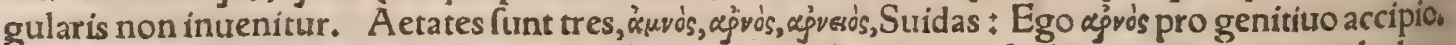
rectus enim (ut dixi) non eft in ufu. Ifter in dictionibus A tricis fcribit primæ æratis uocabulum

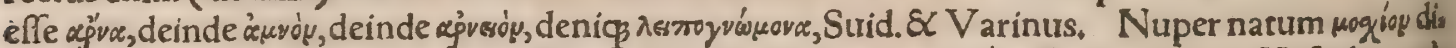

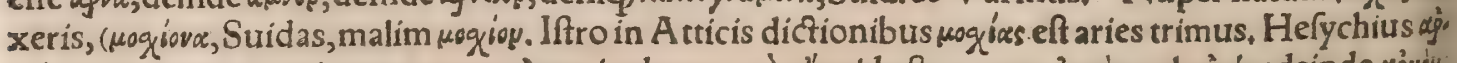

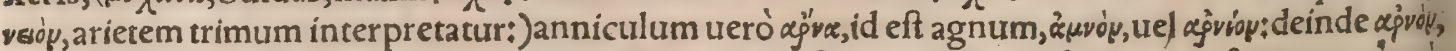

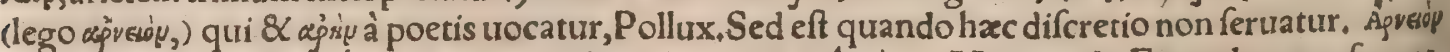

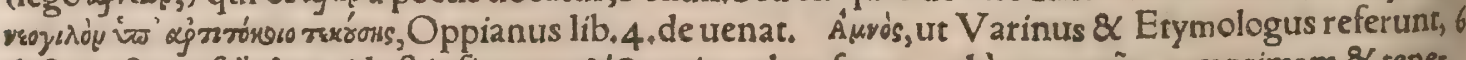
dićus eft quafí "

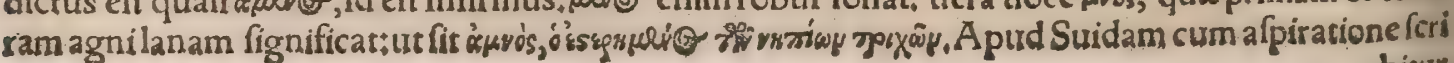




\section{DeAgno. H.a. Lib. I. 931}

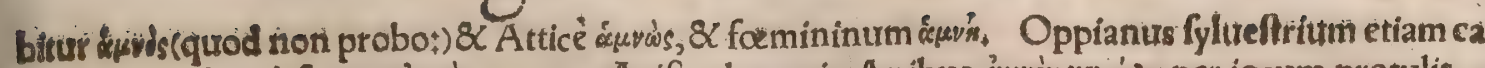

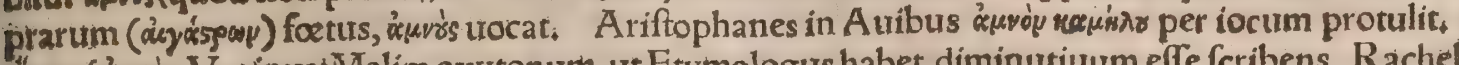

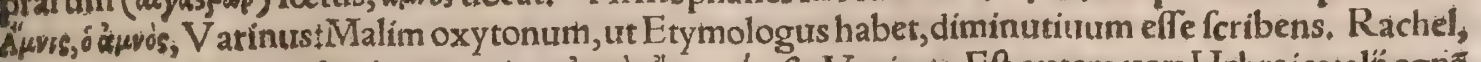

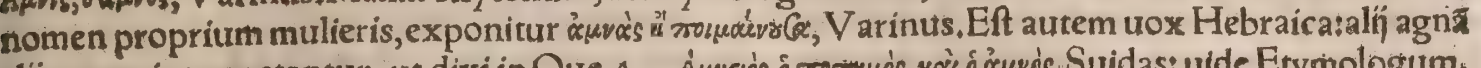
alij ourem interpretantur, ut dixi in Oue A.Àuveís, Agverios quidem aries eft, non agnus:quanquam pro agno Didymus pofuerit: Vide in Ariete a. Ari.

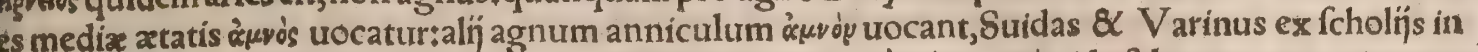

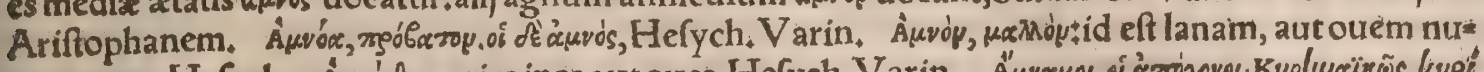

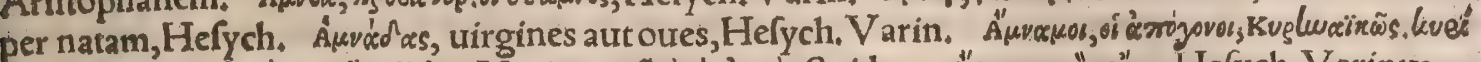

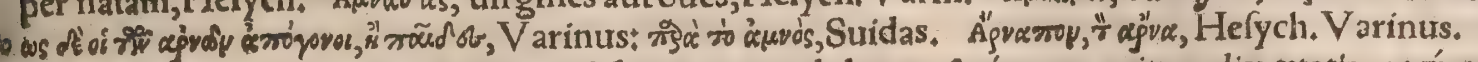

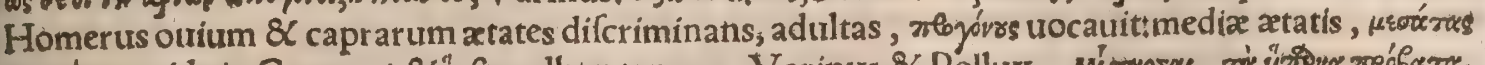

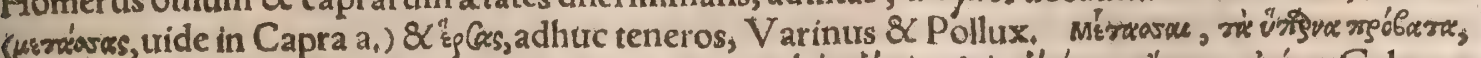

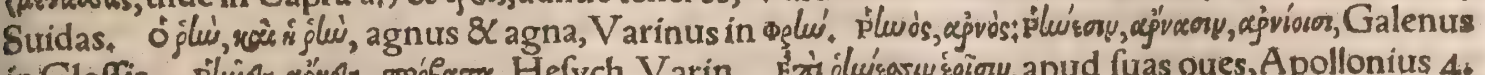

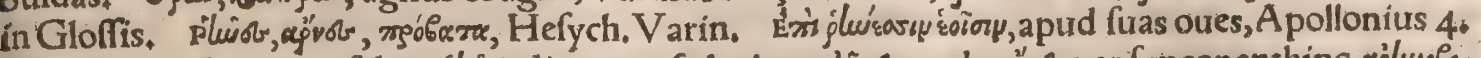

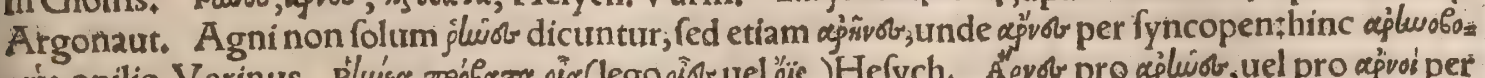

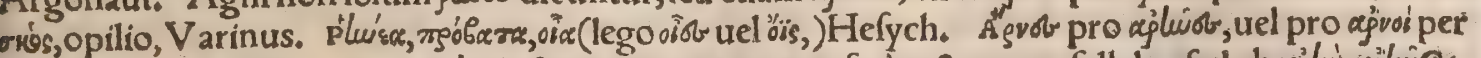

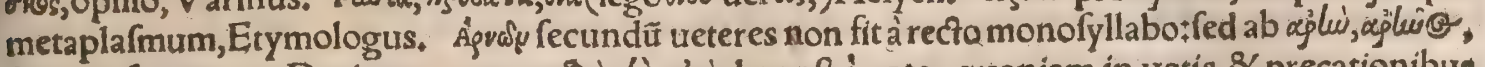

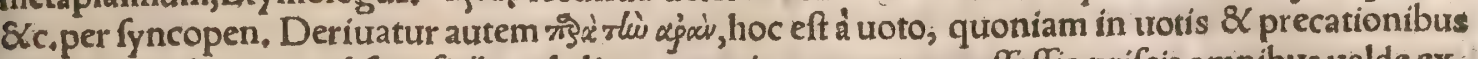
adhibebatur hoc animal facrificrifs:uel aliter, quoniam pecorum poffeffio prifcis omnibus ualde ex:

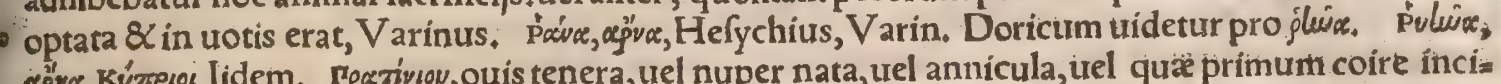

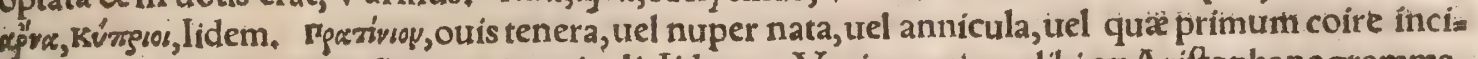
pit, Hefych, Varin. 1 tico, caprilli pecoris nomina pro atate diuerfa enumerans" '́arlus etiam, inquit, in atate quadam di.

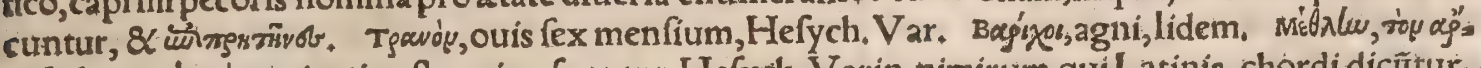
ve, lidem. ógool, agni qui poftremi nafcuntur, Hefych. Varin, nimirum qui Latinis chordi dicûtur nóweot, agni, lidem. \$adyıtoy agnum effe dicit Ariftoteles, Plutarch. problem, Grac. 14. A pud Hefy=

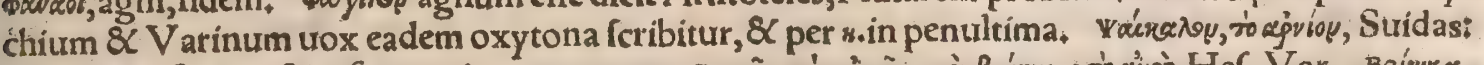

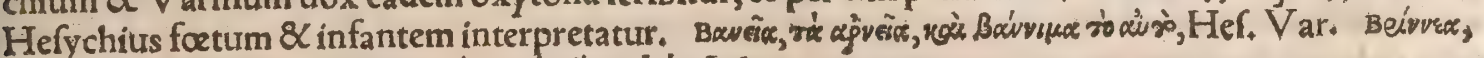
(apưd Var.penultima eft per iôta) rre coğvese kpésec, lidem.

TEpitheta. Hirtus, Columella 7. Hornus,ideft huius anni, Propertius 4. Eleg. Imbecillus \& immaturus, Columel. lib.7. Lactens, Ouid,4.de Ponto, Lacteoli, Prudentius. Mollis, Martia lis 5. Petulci,Lucretius lib.2. Pingures, Vergil.ı.Aeneid. Saturior lactis,Columel.2. Subrumi, hoc eft lactentes, Ibidem. Et præterea apud Textorem, Alacer, balans, blandus : Campiuagus,cor= niger,cornipeta:Imbellis, incuriofus:Lanicutis, laniger, lafciuus:Mitis, molliculus:Pauidus. TA * gnæepitheta. Muta,Horat, 2. Carm. Niuea, Iturenalis Sat,12. Nitida,Horat, 2,Serm. Nouella, Ouidius deArte. Pauens, 6.Metam. Pulla, id eft nigra,Horat.1.Serm. Tenera,Statius 8. Theb.

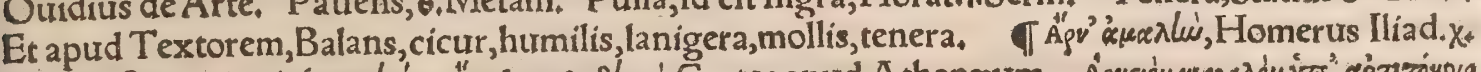

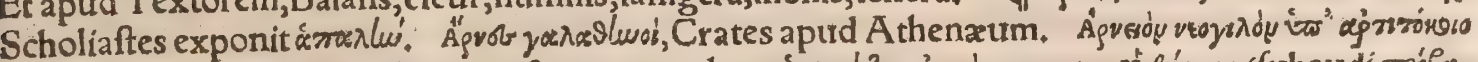

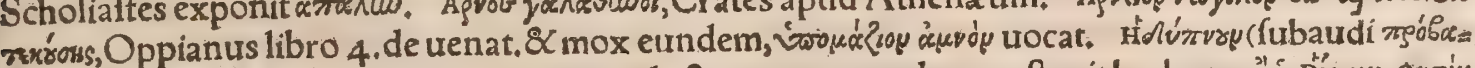

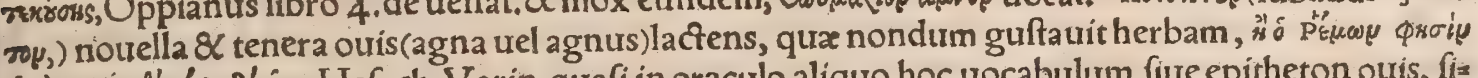

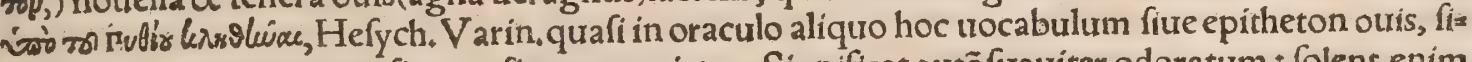
ue pro oure per antonomafiam pofitum reperiatur. Significat autê fuautiter odoratum : folent enim nuper editi foctus pecortum prafertim, fuatuem quendam, uitalem \& lacteum, ut ita dicam, odorem fpirare, Ef \& herba hedypnois apud Plinium, à fuauitate odoris dicta, eadem opinor qua hieracium

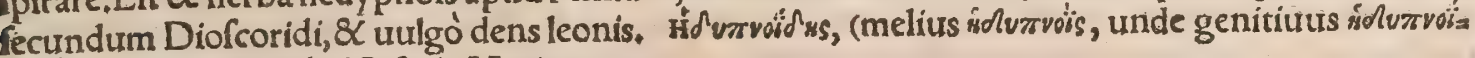

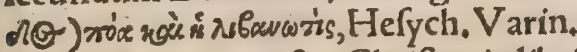

Dominus nofter Chriftus in libris facris agnus nominatur, quód innocens $\&$ placidiffima pro peccatis noftris hoftia futurus effet. Quid enim agno caftius, innocentius, patientius?" Agna, men* fura genus in agrorum dimenfione. A ctus quadratus undiqg finitur pedibus $\mathrm{c} \times \mathrm{x}$. hoc duplicatum so facit iugerum, hunc actum prouinciæ Baticx ruftici agnam uocant, Columella libro 5. Agninus, quod ad agnum pertinet, ut agnina pellis uel caro. Rogito pifces, indicat caros, agninam caram; Plautus:fubaudi carnem.

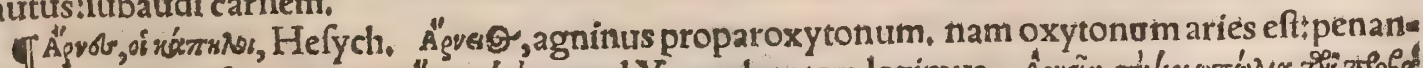

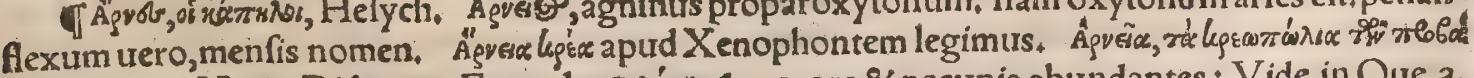

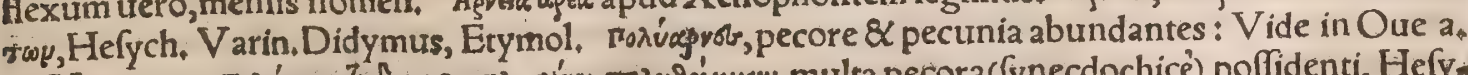

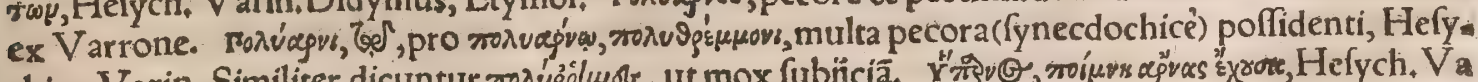

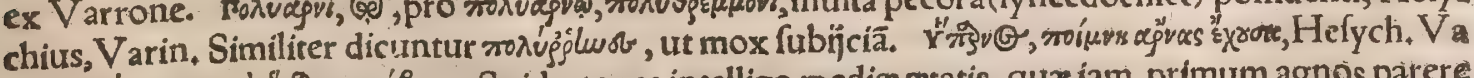

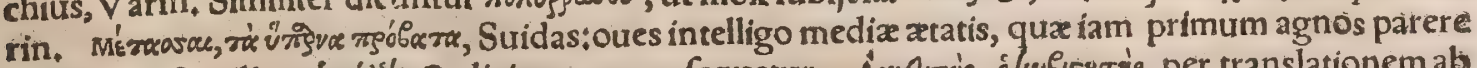

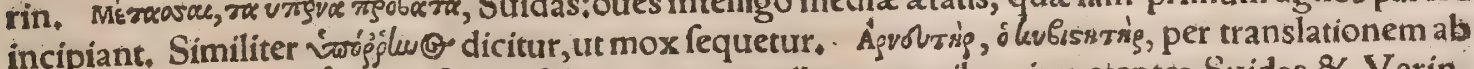
60 agnis qui in caput ferè proni faltare folent, tanquam aêrem cornibus impetentes, Suidas $\&$ Varin*

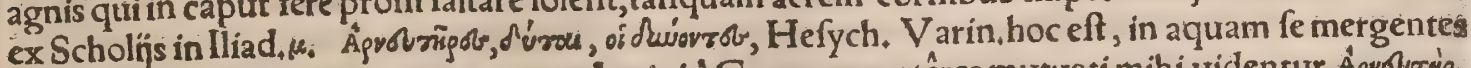
prauio capite, urinatores 
qui capite pramiffo in mare fe mergit, ab agnis qui dum prioribus faltant pediburs, caput terra ad; mouent:quamobrem hippurun quoç pilcem, quòd continuó exiliat ajvourtù aliqui uocabant, ut

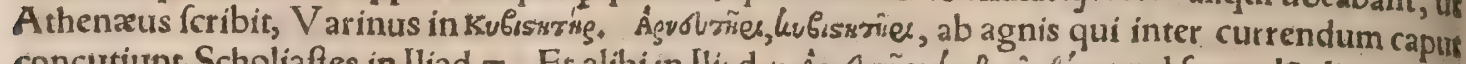

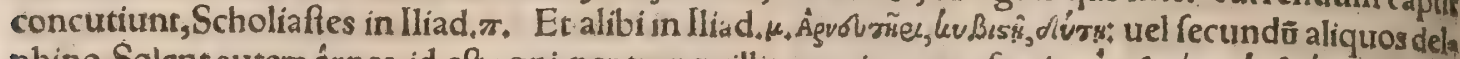
phino. Solent autem árnes, id eft agni, per tr anquillitatem in caput ferri. Ägvou z'́reic, lev bis'serex, Hefy,

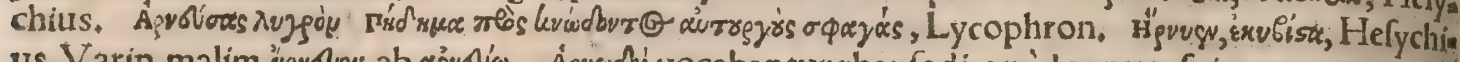

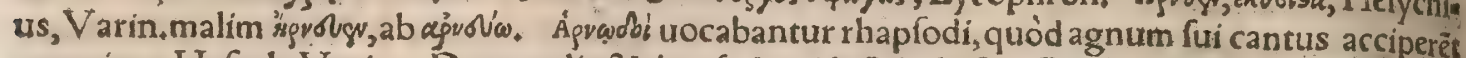
pramium, Hefych. Varin. De arnodis 8 rhapfodis uide Scholiaften Pindari in Nemea, à principio Carminis fecundi. Aproфrey jẹt eft $A$ thenis religiofiffimum \& fummum iudicium haberi, in quio fena cus \& populus unà coibant: quo rempore à triginta tyrānis penè in extremum difcrimẽ adacti funt. I

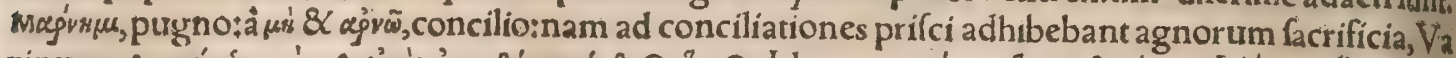

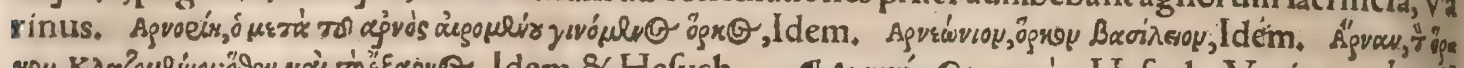

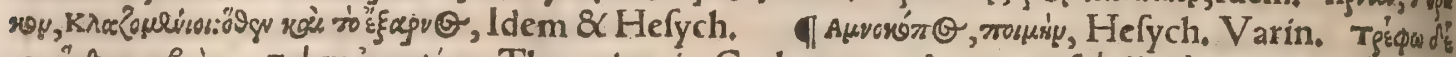

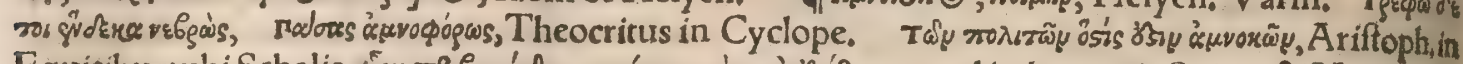

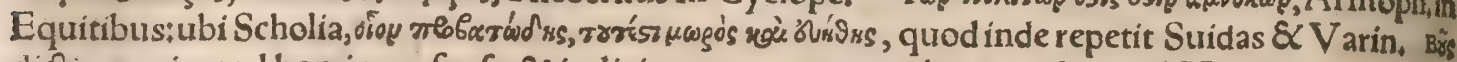
dictio pertinet ad hominem fenfu $S X$ iudicio carentem notandum, unde apud Menandrum boíns,

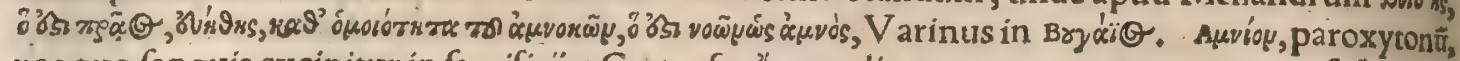

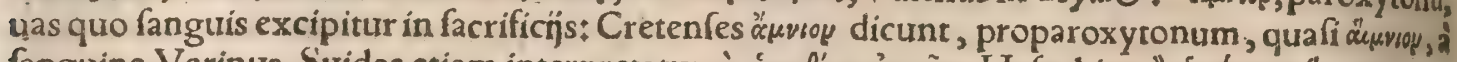

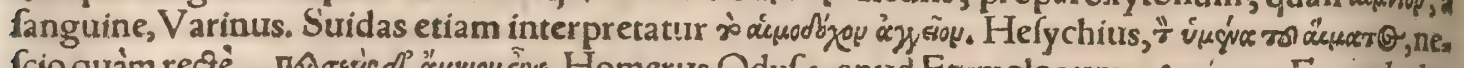

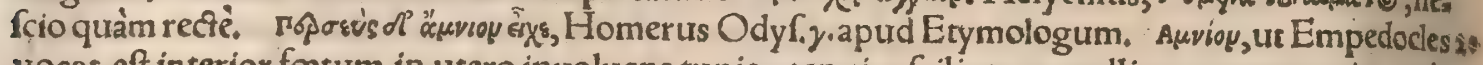
uocar, eft interior foetum in utero inuoluens tunica, tenuior fcilicer ac mollior $\$$ nam exterior yeíp uocatur, Pollux. Galeni interpretes membranam fiue pelliculam agninam transferunt ; alba acte nuiffima eft, \& foctum totum proximé amplectitur, ut fribit Galenus de uteri diffectione capite no.

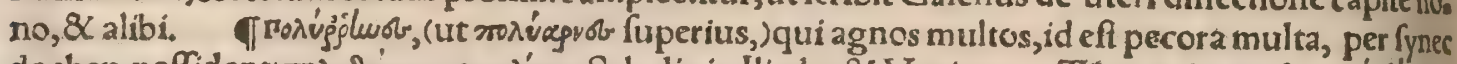

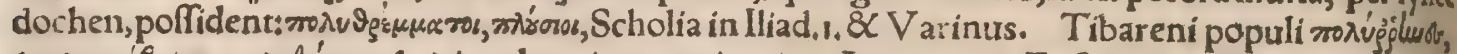

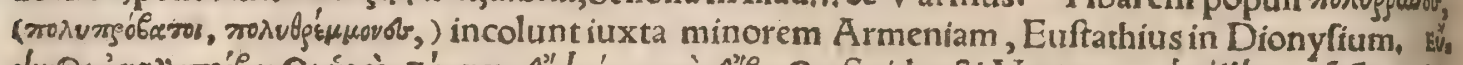

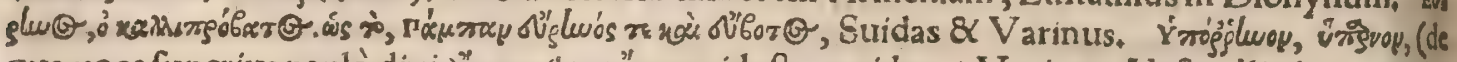

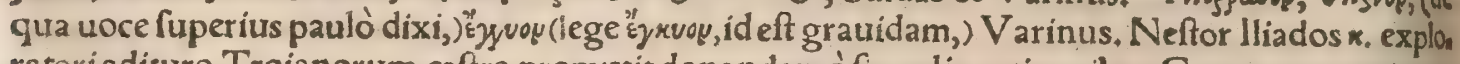
ratoriadicuro Troianorum caftra promittit donandam a fingulis optimatibus Gracis ouem nigram

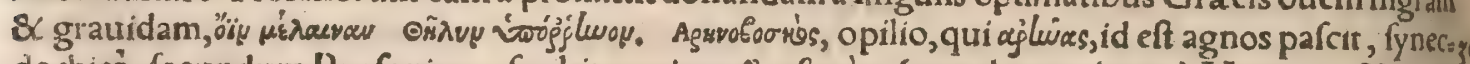
dochicè, fecundum Paufaniam . fcribitur etiam op ģuboorios, (quod non placer, ) Varinus: Vide in Oue e.

I Plantago minor folijs eft lingux pecorum fimillimis, Plinius: quare Graci arnogloffum qua: fi agninam linguam uocant;item arnion, ut habetur in nomenclaturis apud Diofcoridem. Arnos pyrites, pyretrum,Ibidem. Arnophyllon, cytífus, eft autem herba fruticola, Hefych. Varin. Folia quidem eius fatis tenera $\&$ mollia funt, \& fuauem prabent fuccum malua inftar, ut agnis in cibo a prus $\mathbb{X}$ gratus uideatur.

बf Agvolus's, pifcis quidam qui \& hippuros, frequenter exiliens caprarum modo, Euftath.Iliad,w. ex Athenzo:alij delphinum exponunt, ut pauló fuperius ciraui ex Scholijs in Homerum.

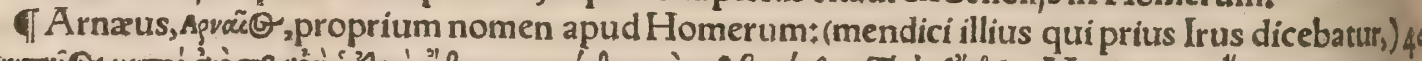

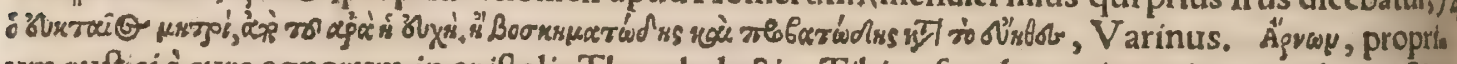
um ruftici à cura agnorum, in epiftolis Theophylacti. Tibia ufum hyagnim primum uolunt, \&c, Calius 9.3. Hydarnus, uiri nomen in Laconicis Paufania. đArne nympha fuit, nutrix Neptus

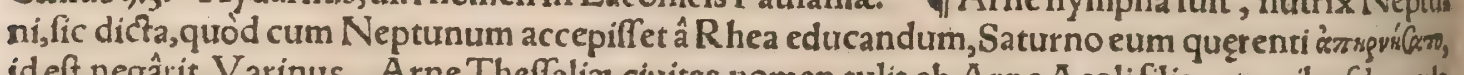
id eft negârit, Varinus, Arne Theffalix ciuitas nomen tulit,ab Arne Acoli filia, ut quibufdam pla cet,Etymol.ex Paufaniæ Bocoticis, Bceoti nominati funt à quodam Bocoto, quem Arne mater clam

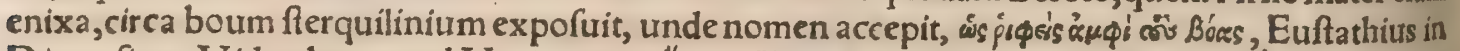

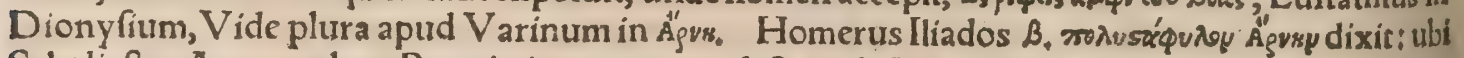
Scholiaftes Arnen urbem Bocotia interpretatur, dictam ab Arne, qua ex Neptuno Bœotum pepe: rerit. Alij uero negantes Arnen urbem tempore bell Troiani extitiffe, Tojolu fribunt:Zenodotus uero (ut Varinus refert) ÁF rigida $\&$ hyemalis uituperetur, Aiunt autem Homericam illam Arnen, fimul $\&$ Mideam ciuitatem à Copaide lacu abforptas effe. Penelope primum Arnea, Asv'se, dicta fertur, 8 cum à parentibus in mare proiectam aues quadam penelopes dictarurfus in continentem expofuiffent, parentes rece ptam nutriuerunt, uocaueruntçs Penelopen, atç ita deinceps furit binominis, Scholia in Pindari Olympiorum Carmen 9. Rhene, p'luis, ex Oileo filium fufcepit nothum, Homerus lliad. $B$. Ayvà, nomen nymphx, ut meminit Gyraldus.

T. Arne ciuitas eft iuxta finum Maliacum, Plinius. Etalia Theffalix, ab Arne Áeoli fic dicta: uel(ut Crates uult)ab agnis: quod pecori nutriendo apta fit, Etymol. Arne, urbs Bocotix, (Lebaden fium urbs olim Arne dicebarur, ab Arne filia Aeoli, ut 8 Theffalica Arne, Paufanias in Boeot.) 82 a. 60 lia Thetfaliæ âBoeotis deducta, qua Cierium uocatur:tertia Mefopotamiæ, quarta Erafiniorum ius xta Thraciam, Stephanus. Scythonis puella Arnen nefcio quam infulam prodidit. Scholia in 


\section{DeAgno. H.a.b.c.d.e.f.h. Lib. I. 933}

Ihad, s. \& Hefychius quocs fcribunt A rnen urbem effe Bocotix, (de qua pauló ante etiam inter pro. pria mulierum dixi, ) \& alteram Theffalix, Phthiota Dorida accolunt:eorum oppida celebria, La. mia,Phthia, Arne, Plinius 4.7. Campus quem Argum urocant in Arcadia, decem ftadiorum eft: $\&$ paulò pofteum alius, in quo fons Ârne fpectatur, cui hoc nomen contigit, ut Arcades ferunt: Quoniã Rhea illic Neptunum expofuerit inter gregem agnorũ: $\&$ fontem inde diçưm, $q$ agni circa eum pafcerentur:Saturnum uero perfuafum pullum equi tanquam à $R$ hea aditum deuoraffe, $P a u$

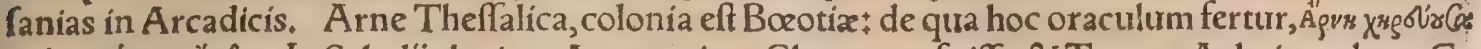

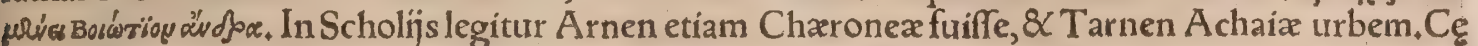
terum Leontarne uicus circa Heliconem fuit:aut fons, ita dictus, quòd immolante illic Adrafto leo

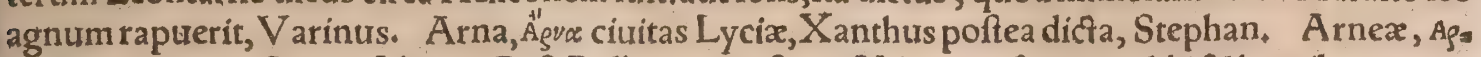
vrà, parua ciuitas Lycix, Idem. Poft Bolbiricum oftium Nili,arenofum quoddã $\&$ humile promon

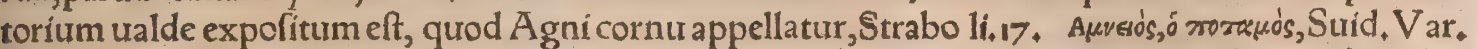
fluxius circa Themifcyrum, Etymologus. Amnitx, Auvirou, populi paruas infulas Oceani Britanni ci habitant, quorum mulieres facra Baccho celebrant, Dionyfius A fer. Inter oppida Cretæinfignia

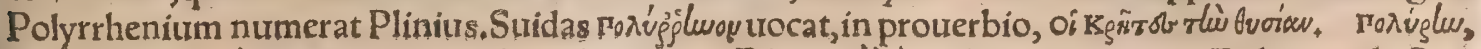
urbs Creta, quòd multas oues habeat, Stephan. Rhene, plew, infula parua prope Delum, uide Ono mafticon. Achai commune confilium una in curia cogebant, quod Arnarion uocabant, Strabo libro octauo,

đb. V anus \& Euganea quantumuis mollior agna, luuenalis Sat,8. Ärne, agni caput,Feftus,

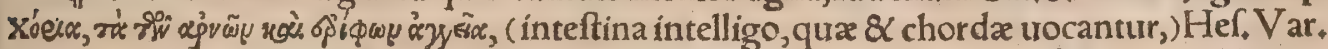

Ic. Claudian, lib, I 6. A gnigrundibant, dixit, cum grundire propriè futum fit, Nonius. Agnus curio apud Plautum in $A$ ul.exponitur beftia curiofa, uel macra \& curis confecta.

đd. Vt pauet acreis Agna lupos, caprexḉ̧ leones, Horat.2.Epod. Lupis $\&$ agnis quanta for titò obtigit, Tecum mihi difcordia eft, Idem Epodon 4. Quafitum aut matri multis balatibus a*

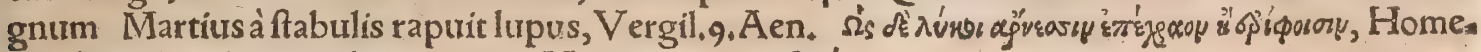
rus de audace $\&$ impudente rapina, Varinus in Iropaborín.

Te. Pefcia Ael,Stilo dici ait capitia ex pellibus agninis facta, quòd Græci pelles uocent pef́ce, $r \dot{x}$, Vide in Oue e, Rheno proprié ouitum pellis eft, uel agnina potius, ex Graca uoce jluirg, ut con

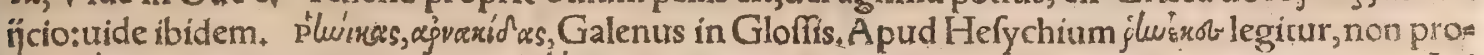

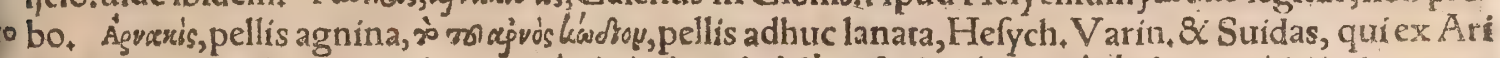

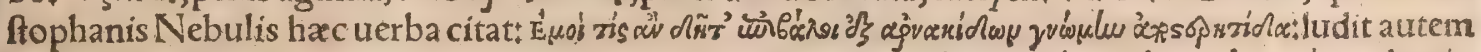

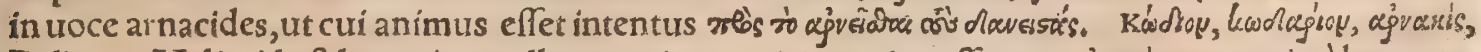
Pollux. Melio, id eft loro, círca collum canis uenatici interius affuatur cỏveris, ne ceruix à loro atte:=

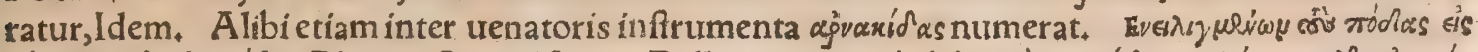

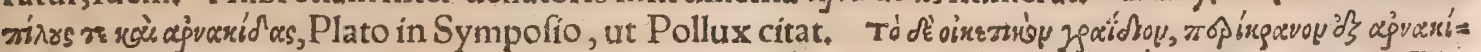

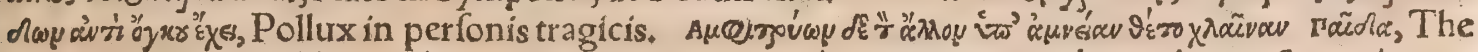

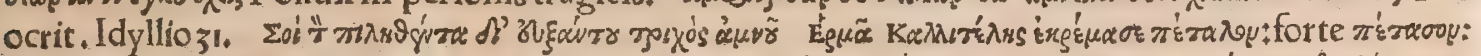

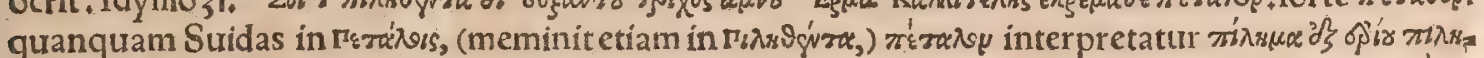
$\vartheta$ ğ́. TMurs, lana molliffima, prima agnorum \& pullorum lanugo, \& pluma tenuiffima, proprie an

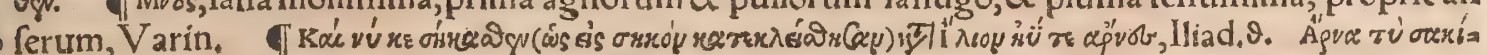

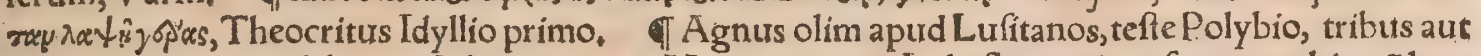
quatuor obolis uendebatur, A thenæurs. GVermem qui in Indo fl, reperitur, feptem cubitorĩ lon. gitudine, capturi, agnum aut hodum in hamum implicant, Aelian.

If. Patinas coenabat omafi Vilis \& agnini, tribus urfis quod fatis effet, Horat, 1.epift. Crofus in lebete coxit teftudinem cum carnibus agninis, quod ab eo factum ex oraculo etiam Delphico aus diuit, unde A pollinem quafi omnifcium ueneratus eft, Herodotus lib. I. Oraculi uerba fune, or usi o?

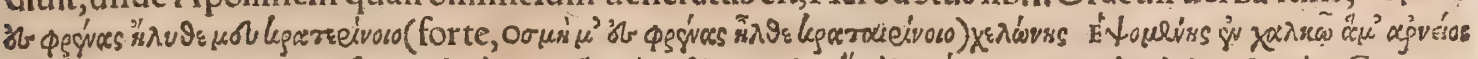

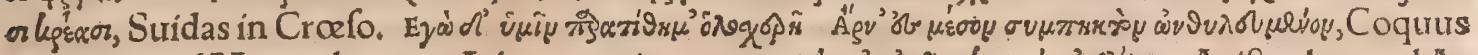

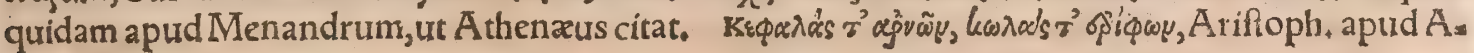
go thenæum.

Th. Agna aurea Phrixi, uide fupra in ariete aureo, In Plutarchi Vitis alicubi legimus agnum qui gemellos utrin ç corymbos haberet natum, nec iam occurrit locus. Scalpere terram Vngui. bus, \& pullam diuellere mordicus agnam Coperunt, Horat.ı.Serm. Sat.8. de mulieribus ueneficis * Veteres Graci hoedorum, agnorum, uitulorumós infpeçis inteftinis futura pradicabant , Paufan. Coronata agna aliquid luftrare fiure expiare, Iuuễ. Sat.13. Agnus dicitur à Græco ỏy vòs, quod figni ficat caftum,eò quód fit hoftia pura \& immolationi apta, Feftus. Pecoris foctus non ante ocfauum diem facrificio purus eft, Plin. Fuit quidem prifcis opinio, ut ex hoedis potius $\&$ agnis hoftix fierêt, quia hx mites \& cicures effent, Gyrald. Angna humilis, Horat.2,Carm. ubi Acron, Non humilem agnam, fed humilium oblationi aptam. Agricola de boure rem diuinam facit, opilio de agno, eppolus

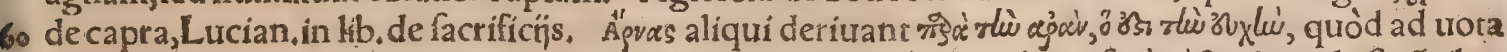

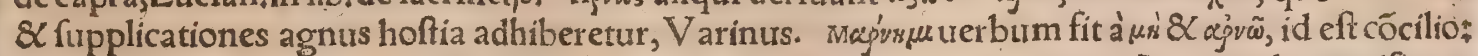
ad reconciliandum enim prif́ci hoftijs utebantur agnis, Idem. An quum in Aequimelium mifimus 


\section{4 De Quadrupedibus.}

qui afferat agnum quem immolemus, is mihi agnus affertur, qui habet exta rebus accommodata, $\&$

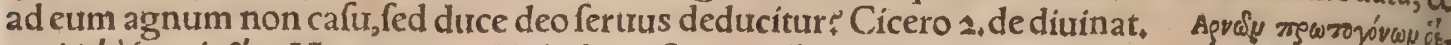
Esw ioplú irarórblu, Homerus, Idulis hoc eft agna alba, idibus (inde nimirum idulis dicta) à flami ne loui credebatur, Feftus. Idibus alba Iouigrandior agna cadit, Ouidius, Ouidius Termino deo gnam \& porcam in fecundo Faftorum immolari prodidit * item Horatius, cum cecinit, Vel agna fe itis carfa Terminalibus. Vbi Àcron, Terminaliorum inquit diem inftitutum, ut per epularum fefti: uitatem cæris agnis fines feruari faceret. Numa tamen fanxiffe fertur, ne Termino ex re a nimata fa. crưm fieret, Gyraldus. De porco, agno uitulọ́ immolandis in folitaurilibus, nugas quafdam, $\mathbb{R}$ libet, lege apud Catonem de re ruft.cap. 14I. Ambegni bos $\&$ ueruex appellabantur, cum ad eo

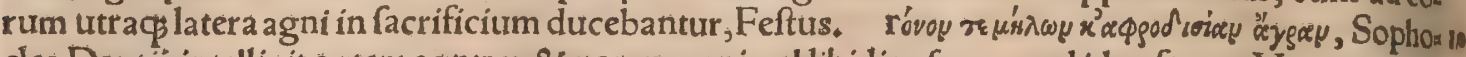
cles Danáé,intelligit autem agnum, \& porcum animal libidinofum, quod ideo feram Veneream uo cat, his enim duabus hoftins ad expiandum utebantur. Poteft etiam caprarum foboles accipi, quod

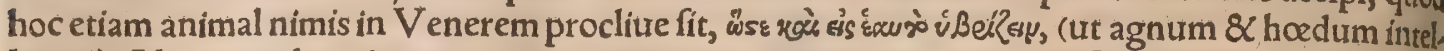
ligas.1) Aliqui perdices interpretantur, tanquam expiationi aptas, qux foemina in laqueo propo fita illici capiós folent, ut inde Veneream agran, id eftuenationem dixerit poëta. fed hoc non probat

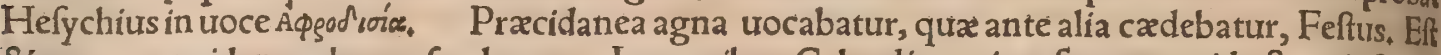
\& porca præcidanea, de qua fuoloco. In omnibus Calendis regina facrorum, id eft regis facro. rum uxor, porcam uel agnam Iunoni immolabar, Gyraldus. Tubiluftrio, id eft ultimo die Quin. quatriorum, quo tubx luftrabantur, de agna res diuina Minerua fiebat, Lege Varronem, \& alios, Niueam reginæ durcimus (aliâs,cædimus) agnam, Par uellus dabitur pugnanti Gorgone Maura, to Iurenalis Sat, 12, id eft Palladi, qux Mauritana Gorgone, capite Medufæ ufa à poétis fingitur. Athex nienfes annua folennia Minerux tauris $\&$ agnis celebrare folebant, ut ait $A$ lexander, Gyraldus,

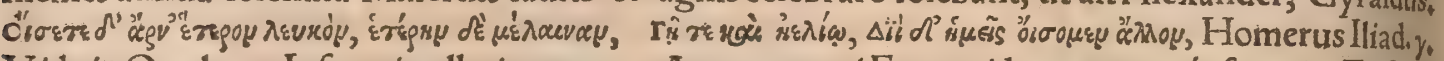
Vide in Oue h. Ipfe atri uelleris agnam Aeneas matri Eumenidum, magnæćś forori Enfe fe, rit, Vergilius Aen.6. (Vide in Oue.) Ventum uiolentum \& impetuofum Græci rvфळ'y appella,

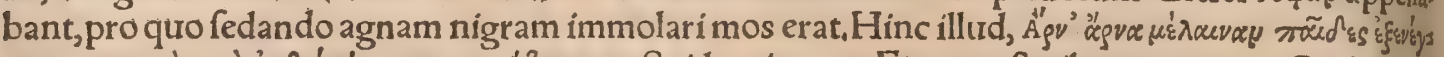

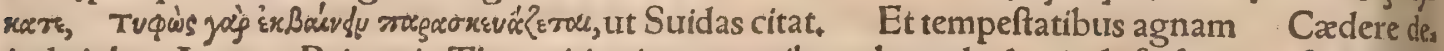
inde iubet, Aen. ). Priapo in Theocriti epigrammatibus, ab apolo de uitula fit facrum, $\&$ de hiriv to hirco, \& faginato agno, Gyraldus

P R O V E R B I A.

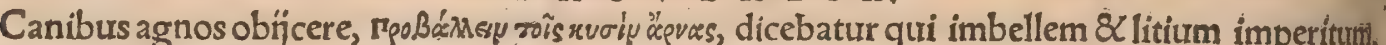
calumniatoribus \& exercitatis exponeret, quod id animal omnium maximè fit imbelle. Refertur Diogeniano, hemiftichium eft heroicum, ex oraculo quopiam, ut conịcio, decerptum, Erafmus, Mee minit \& Suidas in reoßaróvrts. Agnínis lactibus alligare canem $\div$ Plautus in Pfeudolo, Ballioni le: noni uerba affingit hæc, Quia pol qua opera credam tibi, una opera alligem fugitiuum canem agnis nis lactibus. Qui canem alligat inteftinis agninis, is non modo canem amittit, trerum \& prædamuh. tro dederit fugitiuo, Sic qui credit homini malę fidei, \& rem perdit, \& fruftra obligatum habet eum, qui non eft foltendo. lactes enim dicuntur inteftina molliora, Erafmus, Agnus tibilocutus eft,

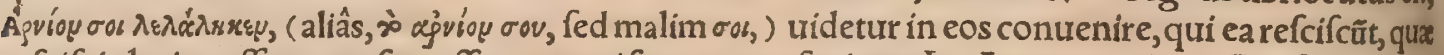
refcifci ab eis poffe nemo fperaffet, aut qui futura præfagiunt. In Aegypto enim (Apoftolius non 4 recté habet, A egina) aiunt agnum humana uoce ufum + in cuius capite uifus fuerit regalis ferpens

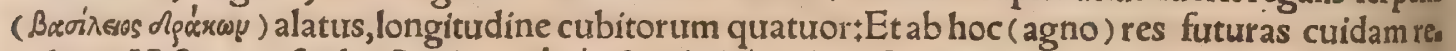
uelatas, Hiftoriam fcribit Suidas in Ágvioy \& Tó açvioy ; fed ufum prouerbï non explicat, SubBoc choro dynafta $A$ egyptiorum, qui iura eis conftituit, agnum loquutum tradunt, ijs ferè temporibus, quibus apud Albam æditi funt Romulus \& Remus, Calius, De ariete Phrixi etiam legimus, quodPhrixum humana uoce fit allocutus. TLupo agnum eripere, Vt lupus agnum amat, uide

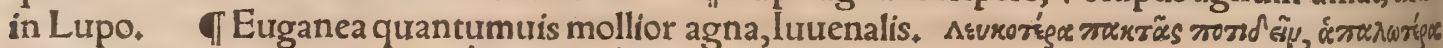

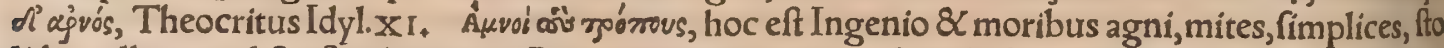
lidi, molles:apud Arriftophanem in Pace, ut interpretantur, Scholiaftes, Hefychius, Varinus. Vocas

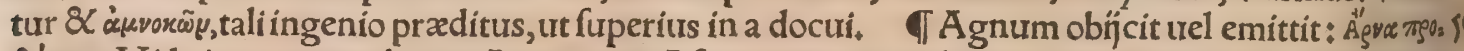

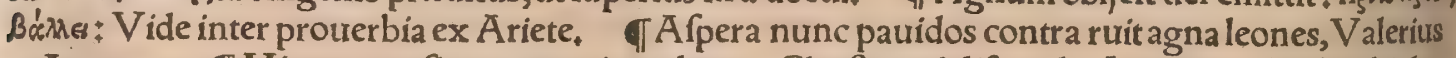
3. Argon. T Mittam uos ficut agnos inter lupos, Chriftus ad difcipulos Lucæ 10. Habitabit lis pus cum agno, Efaix 11. Lupus \& agnus pafcentur fimul,Efaix 65. Vide in Lupoh.

\section{DE M V S M O E.}

$\mathrm{T}$ in Hifpania, fed maximè Corfica, non maximè abfimile pecori (id eft ouiburs) gentrs mufimonum, caprino uillo quàm pecoris uelleri propius, quorum è genere \& ouibus na: tos prifi umbros uocauerunt, Plinius. Strabo quidem Græcè, ut paulò poft citabo, muls 60 mo, $\mu$ r $\sigma \mu \omega \mu$, duabus fyllabis fcribit, non tribus ut Latini. Afinum, aut mufimonem, aut arietem, Cato Deletorio ut Nonius citat. Mufimonis figuram pictam exhibuit Munfterus in des foriptione 
alị canarium, ut Theodorus \& Niphus ex Ariftotele uertunt, quem Græci etiamnum pantherent uulgò appellant, Arabes lupum Armenium, Turcæ cicalum, animal uile, minus lupo, \& cætera lom gé degenerans, \&c.idem animal pantherion, \& lycopătheros nominatur, ut copiofé fcripfi fupra in. rer teras lupo congeneres. TPanthera etiam uaria nominatur Latiné, nimirum propter pellem maculofam. Nunc uarias, \& pardos, qui mares funt, appellant in eo omni genere, creberrimo in Africa Syriaćp.Quidam ab p̈s pantheras folo candore dilcernunt, nec adhucaliam differentlam in ueni, Plinius 8.17. Pantheræ, qux $\&$ uariæ feu Africanæ dicuntur Suetonio in Gordianis, Egnati, us. Varias quidem à macularum uarietate dici manifeftum eff. Senatufconfultum fuit uetus, ne liceret Africanas in Italiam aduehere, Plinius:proximè autem de pantheris dixerat, Et mox fubiun. git:Primus autem Scaurus ædilitate fura uarias cl, uniuerfas mifit, \&c. Si à Libya Lucæ boues dicie effent fortaffe, pantheræ quoģ; 8 leones non Africanz beftix dicerentur, fed Lucx, Varro. Hę. molaus etiam in Plinium 8.19. ex Oppiano quædam de thôe transferens pardum $\&$ pantheram pro codem accipit. Philoftratus lexnam ex pardali mare concipere fcribit, Plinius $8 \mathrm{C}$ alì ex pardo: vide plura in c.inferius. Qui Græca hactenus tranftulerunt tum facra tum profana, pleriç pardalin, pardum redduntego de mare tantum fic uerterim : pro foemina pantheram, $8<$ fimiliter ubi fexus non exprimitur. Sed neq accufem eum qui Gracam uocem pardalin relinquat, uitandx fcilicetho monymix caufa. Pardus quidem Græcé nufquam legitur:nec apud Latinum puto uetuftiorem Lu cano \& Plinio. Leopardus etiam recentius eft uocabulum. Ip fe quidem his omnibus uocabulis aio nimal unum fignificari puto. Nam fi fexus tantum differentia fit inter pardum \& pantheram,auteti am coloris, quod tamen incertum eft, $8 \alpha$ dubitabat etiam Plinius: genere fiue fpecie differre exiftima: ri non debent. Oppianus pantheram in maiorem 8 minorem differnit, ut dicam in $\mathbf{B}$. Leopardus quidem propriè dici debebat animal ex leonis leanęue cum panthera pardótue coitu natum, ut infra capite tertio profequar:fed obtinuit confuetudo, ut leopardus fimpliciter pro panther a ponaturi un de $\&$ uulgares lingux fua mutuantur nomina, peregrinum animal omnes uno feré perégrino nomt ne uocitantes. Itali leonpardo, Galli leopard uel lyopard. Germani fimiliter, uel leppats tuel lefrat: (nam quod quidam fribunt pantbertbier, à recenticribus quibufdam fictum puto, eundem pant theræ leopardum effe nefcientibus,) Hifpani,león pardál, uel leonpardo potius, ut Itali quog;. An,

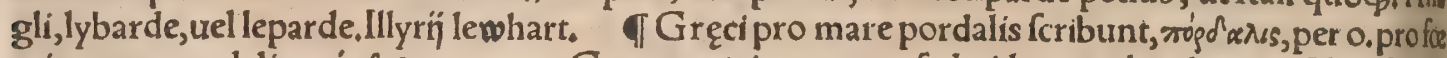
mina uero pardalis, rxíg olexhs, per a. ut Grammatici annotant:fed uideo apud authores, (Philoftratü, Oppianum, hanc differentiam non obferuari, nifi quis culpam in librarios reiecerit. I Pardalin Hebrai namer uocant, רas. \& fic ubiģ uertere folent $L$ X X. Hieronymus pardum. Tribuit autem facra friptura huic animali celeritatem, fer ociam fingularem $\&$ maculasł qux omnia probè conues niunt pantherx. Auicenna etiam aliquoties in aconiti mentione nemer protulit, ubi Graci pardas lin habent, uetus interpres leopardum reddit: ut non fit dubitandum quin recié fic transferatur in facris literis. Accedit quòd grammatici Hebracrum beftiam maculofam effe fcribunt. Habitabit lupus cum agno, $\&$ pardus cum hoedoaccubabit, Efaix 11, ubi Chaldzus interpres pro namer habet kา um. Sic $\&$ d. loannes Apocalypfens iz. uidit beftiam de mariafcendentem decem cornibus infignem, fimilem ॠरे $\dot{\alpha} \lambda$, Erafmus uertit pardo. Pardus(namer) uigilat fuper ciuitatem eorum, ut omnem inde egredientem difcerpat, Hieremix s. Letriores pardis(nemerim) equi eius, A bacuc I. Factus fum eis ficut leo, \& ficut pardus qui directus eft ad uiam, (Hieronymus uertit in uia Afyria, ) Ofee 13. Hîc proleone Hebraicè legitur fchachal, (Hieronymus \& alï leænam interpretantur.Septuagina

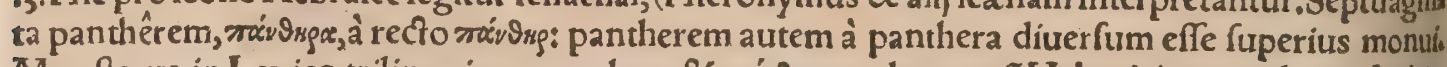

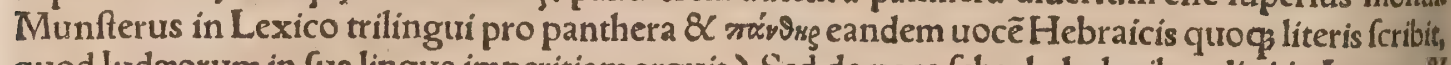
quod ludæorum in fua lingua imperitiam arguit.) Sed de uoce fchachal pluribus dixi in Leone, $\mathbb{Z}$ inter catera non effe, ut cuidam uidetur, leopardum:pro pardo autem(Ofee 13.) Hebraicélegitur na mer (quamuis libri quidam excufi perperam named, habent;) in Græca translatione pardalis, if mutare poteft A ethiops pellem fuam, aut pardus maculas fuas, \& uos poteritis benefacere cum didi ceritis malum, Hierem. 13. Coronaberis de uertice Sanir \& Hermon, de cubilibus leonum, de mon tibus pardorum, Canticorum 4. (Mons leopardorum diftat à Tripoli per duas leucas, rotundus $\&$ al $0^{\circ}$ tus, una leuca à Libano diftans, Brocardus in defcriptione Terræ fanctę). Immittetur in illos quafi leo, \& quafi pardus ladet eos, Ecclefiaftici 28. đAlpheth, uel alpheil, (ut Rafis habet:ut Albertus, alphec:ut Auicenna, alfhed,) generatur ex leone $\&$ leopardo(id eft panthera, uel pardali, ) ut mulus ex equa $\&$ afino. Cicuratur autem aliquando, $\mathcal{X}$ uenationi adfuefcit ut canis. Cum autem errat in uenatione, (aberrat, fruftratur, \& non affequitur pradam,) retrogreditur iratus, $R$ afis. Aliquando cicuratum hoc animal, ducitur ad uenandum, $\&$ nifi admodum blandiatur ei uenator, retrocedit $\&$ occidit homines \& canes,lupos etiam libenter interficit, Albertus. Bellunenfis alf hed leopardum in terpretatur, \& minorem effe ait quàm alnemer, ut fit pardalis minor; uide in $\mathrm{B}$. Leopardos quidem etiam hodie in aulis principum, alios maiores, alios minores haberi audio. Aconitum pardalianches interimit alf hed \& alnemer, Auicenna: Vetus interpres tranftulit leopardos \& lynces. Leopardü 60 quidem hodie uulgò dictum, in principum $\&$ regum aulis, fimiliter ad uenationes inftitui, \& nifi in tra paucos faltus feram affequatur à uenatore dimiffus, uehementer iracundum redire legimus. 
Pardus fit quidem cicur, fed nunquam prorfus fuam feritatem exuit. Nam cum à urenatore dimittía tur, nifi quarto aut quinto faltu feram affequatur, ferociter iratus fubfiftit: $\&$ nifi ftatim furenti trena tor beftiam aliquam obtulerit, cuius fanguine placetur, in ipfum urenatorem uel in quoslibet obui: os irruit. Aliter enim quàm fang trine placari non poteft. Quamobrem uenatores curant ut femper agnos uel alia animalia fécum habeant, Liber de nat. rerum. Alphec animal eft perquan ferox $\&$ noxium;multi in Italia, Gallia \& Germania leunzam(unziam)uocant, Albertus, V N C I A (inquit Ifidorus)eft animal fæuiffimum, non altius cane, fed longius corpore, canibus ualde infenfum, præa dam non edit, nifi in fublimi: $\&$ fape cum ad arborem uenit, à fummo ramo fufpenfam uorat. Cum. libidine feruens aliquem fauciauerit, mures ad faucium conueniunt, \& permingunt, ille moritur. 10 Vnde quidam ab ea uulneratus, nauigio in mare uectus eft, ne infeftaretur à muribus : qui homine quarentes cum ad littus maris ueniffent, fubftiterunt. Fel eius mortiferum eft, (hoc alin de leopardi feu pantherx felle fribunt, folius opinor inter quadrupedes; quamuris inter catera etiam animalia, nullis quàm ferpentibus fel uenenatum effelegere memini : muftela fylueftris tantum fel uenenatũ effe apud Plinium legimus, $H_{a c}$ ille. Addunt alh̆, nafci hoc animal in A frica interiore. Italicé lonza fcribitur. Aliqui(noftra atate)leanam interpretâtur, alĭ pardum, alij pantheram, tefte Fr. Arlunno. Ef \& L A V Z A N V M apud recentiores animal, uicini faltem nominis occafione hic memoran: dum. Hoc crudeliffimum effe fribunt, nullam ab eo tutam effe beftiam, leones quoç terrere: fuo tan tum generi parcere, in catera graffari, illa præcipue qua fortiora funt $\&$ uím alịs inferunt, homine imprimis odiffe, Liber de nat,rerum, \& A Abertus, quietiam Solinum citat, apud quem ego nihil tale 20 reperio. TDe morfuleopardi, (alnemer $\&$ alf hed, )ex genere leonis, $\&$ uulnere unguium corum, Auicenna 4.6.4.10, TSed ut magis fatisfaciam omnibus, neqs res diuerfas confundere cuiquam uidear, priuatim primum qux de pardo feripta reperio, referam omnia:deinde quæ de leopardo: nifi ubi ex Graco pardalis, uel Hebraico aut Arabico namer, aliqui pardum aut leopardum tranfulerunt:ea enim ad pantheram feu pardalin pertinere certiffimum eft.

I P A R D V M Plinius à panthera, ut fuperius recitaui, fexu tantum differre putat, fed dubitat. Supra dixeram pardi nomen Latinis tantum? ufitatum effe, Gracis non item:fed nunc in come

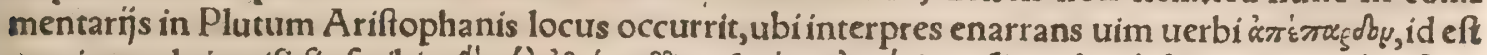

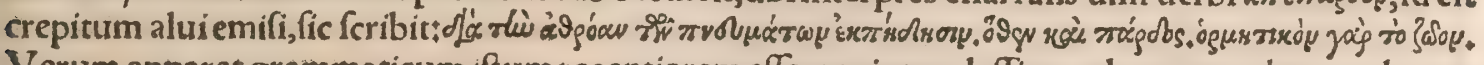
Verum apparet grammaticum iftum recentiorem effe, nec inter clafficos adnumerandum authores.

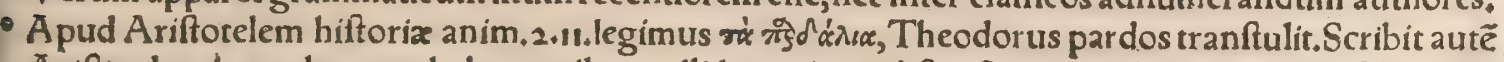
Ariftoteles chamæleonem habere pellem pallidam nigris diftinctam maculis ut pardalia. Nec alibi ufquam hac uox uel apud ipfum, trel alios quod fciam reperitur: nec Gaza pardum alibi conuertit. Heliogabalus ebrios amicos plerun $q$ claudebat, \& fubitó nocte leones, \& leopardos, \& urfos, exar: matos immittebat, ita ut expergefacti in cubiculo eodem, leones, urfos, pardos cum luce, trel quod eft grauius nocte inuenirent, ex quo pleriqg exanimati funt, Lampridius. Videri autem poteft eor dem pofteriore loco pardos dicere, quos prius leopardos dixerat. In his fylueftribus (locis Hyrca= nix) 8 pardi funt, fecundum à pantheris genus, noti fatis, nec latius exequendi : quorum adulterinis coitibus degenerantur partus lexnarum, 8 leones quidem procreant, fed ignobiles, Solinus. Par* dus fecundum poft pantheram eft genus, uarium ac uelociffimum, $\&$ præceps ad fanguinem : faltu $4^{\circ} \mathrm{enim}$ ad mortem ruit. Exadulterio pardi $\&$ lexnæ leopardus nafcitur, \& tertiam originem efficit, Ifidorus. Leones quos creant pardi in plebe remanent, iubarum inopes, Solinus \& Plinius. Par. dus eft beftia torua, \& acuto nimis impetu, corpus ́q moribus auium conueniens habet: colore uarium, faltu potius quàm curfu pradam infequitur. In Africa propter inopiam aqua congregan= tur diuerf $x$ feræ ad amnes, ibićs leænæ beftís uarijs (id eft pantheris)mifcentur : $\&$ inde pardi pro= creari dicuntur, Bafilius ut citatur in libro de nat, rerum. Odore pardi coitü fentit in adultera leo, totáç ui confurgit in pœnam. Idcircoaut flumine abluitur, aut longius comitatur, Plinius. Philo

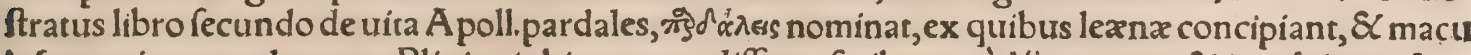
lofos pariant catulos:cum Plinius iubis tantum differre fcribat, quod ijs careant, \& ignobiliores fint. Sed quarendum eft, an ut lexna ex pardo concipit, \& corpore fibi fimilem gignit, animo diffimile: fic etiam pardalis feu panthera ex leone concipiat, 8 maculofum gignat foetum. Vt duorum fint ge nerum leopardi : Sicut $\&$ mulus alius ex afino \& equa nafcitur, alius ex equo $\&$ afina qui hin= nus uocatur. Omnia fanébigenera plus à matre accipere uidentur, præefertim quod ad magnitudi= nem $\&$ formam corporis. Grammaticus quidam in Promptuario leopardum interpretatur animal ex leone $\&$ panthera natum, uel ex pardo $\&$ lexna, nigris maculis leoninam pellem diftinguenti. bus, fine iuba:fed authorem non adfert. Vide in Leone c. Pardi, ut quidam dicunt, ex pantheris aliquoties $\&$ canibus procreantur, Albert. Leporarios magnos, quos ueltres quídam uocant,aliqui nafciaiunt ex coitu leopardi cum cane, Albert. Avжrán\$spop quidam in Lexico Gracolat. interpre tatur animal ex pardo \& lupo natum. TLeonibus ac pardis, omnibusḉ generis eius, etiã felibuss, imbricatæ afperitatis lingua eft, ac limæ fimilis : atten uansćs lambendo cutem hominis. Quæ caufa bo etiam manfuefacfa, ubiad uicinum fanguinem peruenit faliua, inuitat ad rabiem, Plin. Etalibi, Mis rum pardos, pantheras, leones, $\&$ fimilia condito in corporis uaginas unguium mucrone ne refrin gatur hebeterúrue ingredi, auer fisḉ̧ falculis currere, nec nưfi appetendo protēdere. Pardi in Africa 
condenfa arborum infidũt, occultatiḉ earum ramis, in prætereuntia infiliunt, atç è tolucrum fede (carde, codices minus emendati,)graffantur, Plinius, Scribit fané de pardali quioģ Orus,eam prorz fus infidiofam effe, celeritatem fuam abfcondere, $\mathcal{X}$ ex abdito inuadere animalia. Aliquoties inter frondes \& fruteta latens in aures graffatur, fure uelocitati confidens, Albertus, Pompeï Magni primum ludioftenderunt chaum, effigie lupi,pardorum maculis, Galli rhaphium uocabãt, Plinitus, Panther caurit amans, pardus hiando felit, A uthor Philomela. $\quad$ e Pardi fel uenenofum effe $\mathrm{Car}$. danus fcribit, alij omnes leopardi ; fed A rabicè nemer legitur, quare ad pantheram differo, Pardi epi theta, celer, fulmineus, fublimis, tuiridis, apud Lucanum, Claudianum, Iutuenalem. fHippardium fera quadam cornuta ab equo nominata, iubata, apud Arifophanem, nihil quod memoretur cum pardo commune habet. बPicfo quod iuga delicata collo Pardus fuftinet, Martialis. बHac funt 10 qua de pardo priuatim fcripta reperio : uidentur autem eadem omnia de panthera etiam ueré dici poffe. quamobrem in illa etiam pleraç repetentur, fed pardi nomine expreffo.

बI De L E O P A R D O nonnihil in pracedentibus iam dixi. Volui autem hoc loco de coetiam pritratim agere,quoniam apud recentiores tantum hoc nomen reperio, nec apud ullum qui uixerit ante Iulifi Capitolini, aut Ael,Spartiani feculum. Recentiores quidam, ut Bellunenfis, minorem tan tum pantheram leopardum uocant, ut in B.referam+alĭ maiorem.quidam non pantherã, fed ex pare do \& leæna natum animal, ef Pardalis, id eft leopardus, Syluaticus. Leopardo Italicè, pardus Latinè,Arlunnus, Et alibi, Pardo Italis, (forte apud poétas Italicos tantum, )Latinè pardus uelleopar dus. Leopardum quidam putant eandem effe beftiam cum pardo, Albertus Catos fylueftres etfi Angli quoç habent, ut nos, tamen leopardum etiam catum montanum uocant, ut audio. Leo: pardus ex leana $\&$ pardo natus colore eft fubrufo, maculis per totum corpus nigris, foemina mare fortior eft, Albertus \& Liber de nat,rerum, Leop. fimilis eft leoni capite 8 membrorum forma, minor tamen, nec adeó robuftus, Phyfiologus * Pellis leopardi nuper à me confyderata huiufmoa di erat; Longitudo pellis fimul $\&$ cauda, quanta hominis mediocris cum fefquidodrante: Caudæ per fe, dodrantes tres cum dimidio. Pellis latitudo circa medium, dodrantes tres, Color ferè flaturs di lutus, maculis rotundis nigris diftinctus. Pili breues $\&$ lanuginofi. Pretium unius, coronati, id eft denarÿ aurei quuinȩ aut fex, plus minus, pro pellium differentia, \& regionũ longinquitate. TLeon pardi rictant, A el, Spartianus. Animal eft uehementer iracundum: $\&$ cum morbo laborat, fangui. nem capri fylueftris requirit:aliquando $\&$ fímum hominis pro remedio. Camphora gaudet, $\&$ arbo rem eius cuítodit ne quis inuadat, $A$ lbertus, $P$ antheram fane $\&$ ipfam odoratam effe, $\&$ aromatibus 30 oblectari Philoftratus \& ali fcribunt. Quamobrem non mirum eft fi allium deteftetur, ut Cæalius ex Ambrofio repetit + Nam ficubi parietes, inquit, litu allip infeceris, exilit protinus nec refiftit, Vide infra in $\mathrm{D}$.ad finem. @Leop.ita cicuratur, ut tanquam canis uenatori inferuiat, $\mathrm{Phyfiologus,Quod}$ fi dimilfus non tertio quartóue faltu præda potiatur, indignatur adeó ut nifi fanguíne placetur, alls quando in uenatorem infiliat, Albertus. Audio principes quofdam $\&$ reges cum uenatum exea unt, leopardum à tergo fecum in equo uehere, $\&$ in ceruum aut aliam qua fe obtulerit feram immits tere. Eadem fupra de pardo $\&$ alfhed fcripfimus. Magnus Cham Tartarorum uenationi fape on peram dat, $\&$ equo infidẽs ducit fecum leopardum domefticum, quem in ceruos $\delta$ damas provocat, Paulus Venetus 1.65 . Et alibi, Rex Tartarorum habet cicures leopardos, qui mirum in modum ue nationi inferuíunt, multasó́ capiunt beftias.

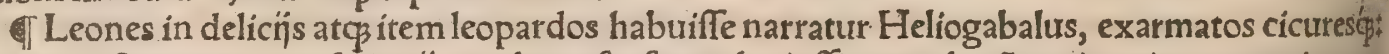
quos ita inftituerant manfuetarï, ut ad menfas fecundas iuffi accumberêt ex inopinato, nemine con frio exarmatas effe feras, Cælius ex Lampridio, cuius uerba in Pardo iam recitaui, of Fuerunt fub Gordiano Romæ camelopardali decem, leopardimanfueti triginta, \&c. Iul. Capitolinus. Giraffa, leones, leopardi, in prouincia Abafix nafcuntur, Paulus Venetus 3.45. In regno circa Melacha urıs bemè regione Sumatra infula, permultí leopardi reperiuntur, Vartomannus . TA Syria Ros mam ufq̧ cum beftís depugno per terram $\&$ mare die ac nocte uinctus cum decem leopardis, hoc eft cum militari cuftodia, qui ex beneficís peiores fiunt, Ignatius in epiftola ad Romanos.

बा L E F R A T dicta beftia in Scandinauia, deurorat animalcula muribus fimilia, qux lemmer to cant, \& eo cibo pinguefcit, pellis eius aliquanto laxior fit humana menfura, Zieglerus in Schondia, go ut pluribus recitaui fupra in Muribus diuerfis. Videtur autem hac beftia, uel leopardus effe, nomi ne detorto, nam $\&$ Germanilepart proferunt; uel prorfus ei congener.

B.

Pantheræ in Afia funt, in Europa autem nulla, Ariftoteles. Pantheræ in A frica Syriaçabun dant, Pliníus. Si lucam bouem Latini fic appellaffent à Libya, fortaffe pantheræ quoģ \& leones, non A fricanæ beftiæ dicerentur, fed lucæ, Varro de ling,Lat, Mauritania alit leones, pardales, \& alias feras diuerfas, Strabo . Vltra Catadupa Nili procedens A pollonius 8 comites, uideruntleo: nes $\&$ pantheras, Philoftratus. Vltimum extremæ Arabix promontorium à Dira ufó ad Auftri

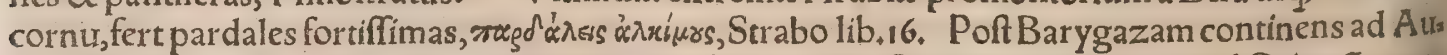
ftrum pertingens Dachinabades ưocatur $+q u x$ fupra hanc eft mediterranea regío ad Oriente, mon= 60 res magnos continet, \& omnigena ferarum genera, pardales, tigres, \&c. Arrianus in Periplo rubri maris. In parte Syria contermina, leones \& pardales multo plures maioresćs reperiuntur, quàm 


\section{DePanthera. B. Lib. I. 939}

in Libya, Diodorus. Pantherx capiuntur in Pamphylia parte qux aromata profert, Philoftratus in uita Apoll. Lycix \& Carix pardalis, nec animora eft, neqs ualde ualet faltu, nifi cum eft uulnerata: tum fpiculis refiftit, neq̧ ferro facilecedit, Gyllius ex A eliano. Eundem locum multò aliter transfert Volaterranus, his uerbis : In Caria $\&$ Libya (lego Lycia) pralongi admodum pardifunt, ac animo imbelles, minimum faltu agiles, pelle adeò dura ut ferro non cedat. Vter uero melius, iudicabunt qui Graca uiderint. Panthera numerofa funt in Hyrcania, Solinus, In itinere quod dextra Gan gen, finiftra uero Hyphafin fluuios habet, defcendenti Apollonio leones ac pantheræoccurrerunt, Philoftratus. Pantheras cicures ad fuum regem Indi afferunt, A elian.

đ Alnemer eft animal minus lynce, id eft lupo cerwario, leopardo fimile figura \& colorè, fed ali quanto maitus, pedibus quoģ $\&$ unguibus maioribus $\&$ acutioribus $\neq$ oculis obfcuris $\&$ terribilibus ut ipfe uidi.Idem leopardo fortius, ferocius $\&$ audacius eft. Inuadit enim $\&$ dilaniat homines, Cate. rum leopardus Arabicè nominatur alfhed, Bellunenfis. Hinc coniecturam facio alnemer panthe. ram Oppiani maiorem effe, alf hed autem minorem : quanquam Nicander de aconito in Theriacis

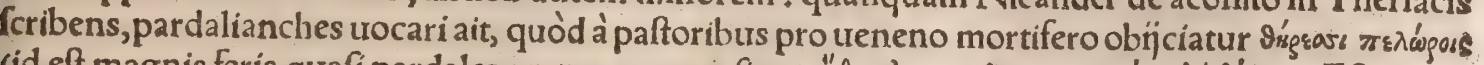

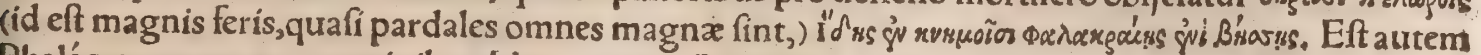
Phalácra unum ex cacuminibus Idæ montis. Pardalium duplex genus eft, inquit Oppianus ? funt enim alix maiores $\&$ dorfo ampliores:alix uero minores, fed robore $\left(\mu u^{\prime}(-)\right)$ non inferiores. Eandem coloris uarï \& figuræ corporis fpeciem fimilitudinem ́́; ambæ, præter caudam, gerunt. nam maior bus minor eft cauda, minoribus uero maior. Vtrif̧̧ folida funt femora, corpus oblongũ, oculi fplen. didi:quorum pupillæ fub glaucis fulgent palpebris, glauc $x$ etiam ip $\{\mathbb{X}$ interius rubicund $\mathfrak{x}$, ar dentibus fimiles, ignita:dentes pallidi, ioriro, id eft uenenofi: pellis uaria, color fplendidus, aéreus, crebris oculis(id eft maculis)nigricantibus, Hæc Oppianus. Ante annos aliquot Francfordix me mini ttidere uenales quafdam pelles peregrinas, maculofas, anguiftas, quinç; aut fex digitos latas, be ne longas tcauda ferémagnitudine $\&$ figura ut felium, circulis nigris diftincta. pelles fingulas quin que drachmis argenteis indicabant:coniungebantur autem uiginti in fafcem unum. Animal ipfum leppart uocabant, hoc eft leopardum. In hoc genere (pardorum) eft qui cognominatur bitis, haud alys abfimilis, pręterquam quòd cauda carere dicitur: is fià muliere afpiciatur, extemplo eam in mor bum deducit, Volaterranus ex Aeliano. II Inter omnia animalia(inquit Ariftoteles in Plyyfiogno micis) leo perfectifimam maris ideam prafe fert, $\& \mathrm{c}, \mathrm{P}$ ardalis uero inter ea qua fortia effe uidẽur,

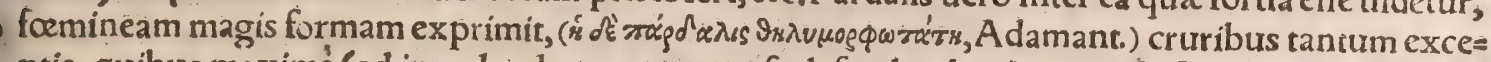
ptis, quibus maximé (ad inuadendum catera aut fe defendendum) utitur, $\&$ fortiter agit. Habet e.

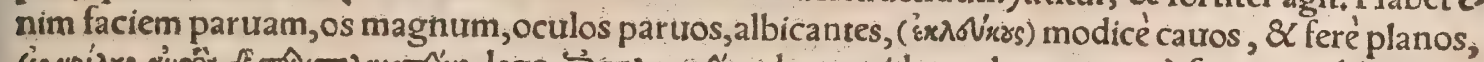

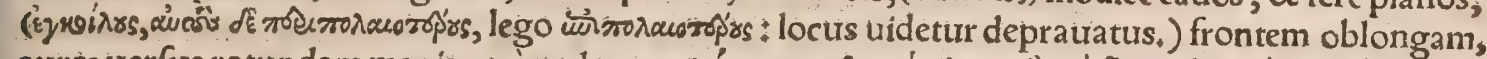

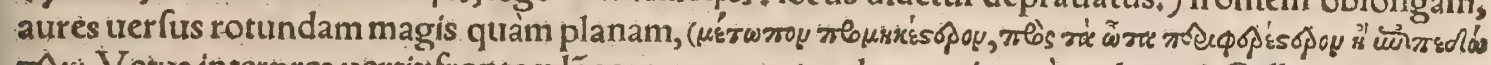
ropoj. Vetus interpres uertic:frontem lógam, aures rotundas magis quàm planas.) Collum ualde lon

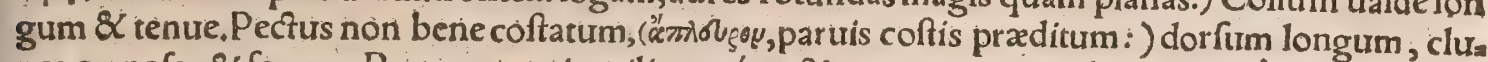

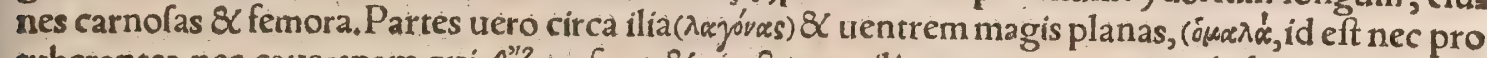
tuberantes, nec cauas:nam qui ov"(w)os funt, 8 cinctu gracili, eam partem cauam habent.) Colorem uatium. Corpus uero totum inarticulatum, \& afymmetrum, Hæc Ariftoteles. Omnia fermé faua - animalia felífimilia funt, panthere, lyncei, parditcommune enim eft unguium magnitudo $\&$ robur, pellis diftincta, uèrficolor ac pulchra:caput rotundum, facies breuis, cauda prolixa, agilitas cor poris, feritas, \& cibus qui uenatione acquíritur, Cardanus. Animalia quædam colore uaria funt, idós dipliciter:aut enim genere, ut panthera, pauo: aut non genere toto, fed parte, ut boues \& capræ in terdum uariæ generantur, Ariftoteles. Panthera \& tigris macularum uarietate propéfolæ beftiarũ fpectantur, cæteris unus ac fuus cuiufक̧ generis color eft, Plinius. Et alibi, Pantheris in candidobre ues macularum oculi. Etrurfus, Quidam à pardis pantheras folo candore difcernunt. Numero. Ix funt in Hyrcania, minutis orbiculis fuperpicix, ita ut oculatis ex fuluo circulis, uel corrulea, uel alba diftinguatur tergi fupellex, Solinus. Pardi uirides, Claud.z. Paneg. Picto quòd iuga delicata

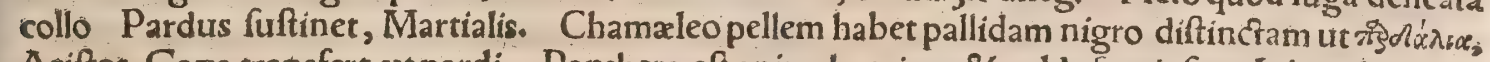
Ariftot. Gaza transfert, ut pardi. Panthera eft animal uarium $8 \mathrm{C}$ ualde fpeciofum, Liber de nat, re rum. Simutare poteft Aethiops pellem fuam, aut pardus (namer)maculas fuas, $\&$ uos poteritis be. ne facere cum didiceritis malum, Hierem.13. Panthera undequaque uaria eft (quare etiam uaria Latinè uocatur)maculis orbiculatis ad modum oculorum ex fuluo colore interdum ad album inter. dum ad caruleurm uergentibus, Albertus. Equi orynges dicti,(fiue à montibus, fiue ab impetu ad libidinem, ) alin pellem maculis oblongis uariam habent, tigridum inftar, alï uero rotundis ut pan.

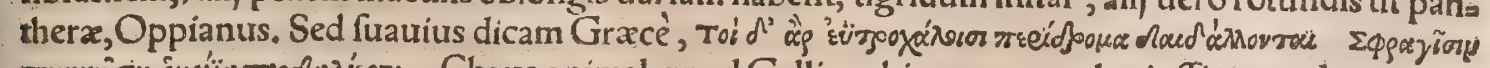

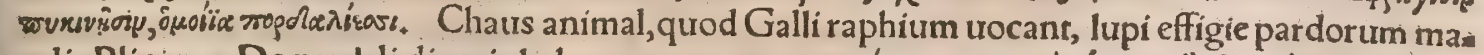

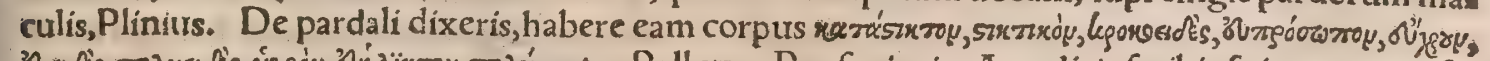

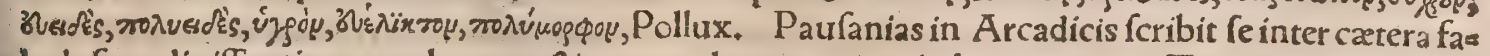
bulofa audiuiffe etiam gryphes punctis ut pantheras uarium habere corpus. Terram Eremborum

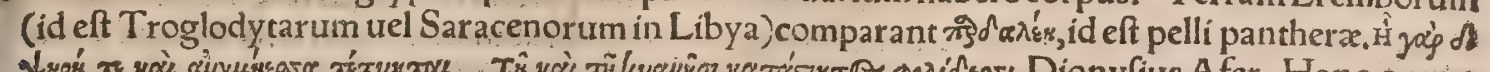

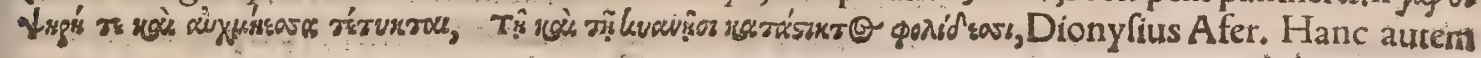




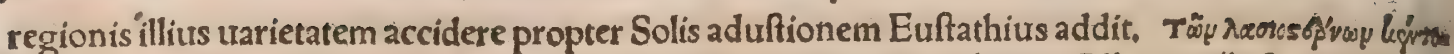

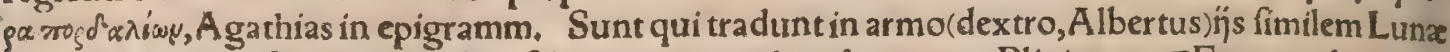
effe maculam, crefcentem in orbes, $\&$ cauantem pari modo cornua,Plinius. If Feruntodore earü mirè folicicari quadrupedes cunctas, fed capitis toruitate terreri : quamobrem occulrato co, reliqua dulcedine inutitatas corripiunt, Plinius. Tradunt Perficum fmaragdi genus uifum implere, quem non admittant, felium pantherarumós oculis fimiles; nan $q \mathcal{Q} \&$ illos radiare, nec perfpici : eofdem in fole hebetari, umbris refulgere, $\&$ longius quàm cæeteros nitêre, $I d e m$. Panthera dentes habet fer.

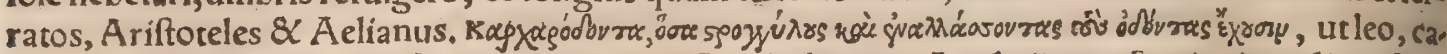
nis, pardalis, Scholia in Ariftophanis equites. Pardis lingua eft imbricatæafperitatis, ac limæ fimi. lis, ut fuperius in Pardo (cripfi, Pantheræ quaternas mammas uentre mediogerunt, Ariftotel, \& 8 Plinius. Panther $æ$ cor maximum eft proportione, ut $\&$ reliquis timidis, aut propter metum male. ficis, lidem. Multiplici pedum fiffura eft, Ariftot. Pedes priores quinis diftinctos digitis habet, po, fteriores quaternis:parua quidem inter quadrupedes digitatas, pofteriores etiam quin $q$ digitos obu nent, Idem. Condito panther $\&$ \& fimilia, in corporis uaginas unguium mucrone, ne refringatur he beterúrue, ingrediuntur, auerfiśḉ falculis currunt, nec nifi appetendo protendunt, Plin. Cauda leo ni infima parre fetofa elt, ut bubus \& forici:pantheris non item, Idem. đOs amplum \& refciffum habent, leo, canis $\&$ feher, quem nos dicimus leopardum, Albertus de animal. 2.1. 4 . Ego pro feher legerim fhed:fic enim leopardum Arabice uocari, ex Bellunenfi fuperius docui: al quidem fyllaba præfixa, articuli tantum uicem obtinet. đFomina crebrius inuenitur, Volaterranus:nimirum ${ }^{3}$ non fibi tantum, fed etiam catulis de uicqu profpiciens, latius uagatur.

c.

Panther caurit amans, pardus hiando felit, Author Philomelæ. Leopardi rićant, Âel.Spartiaa

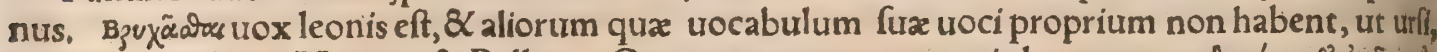

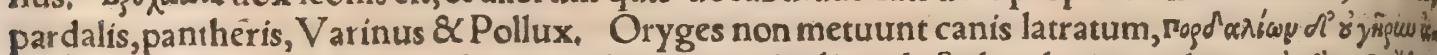

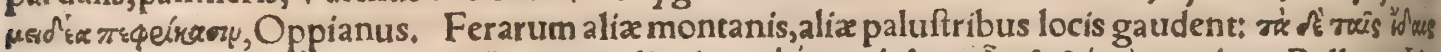

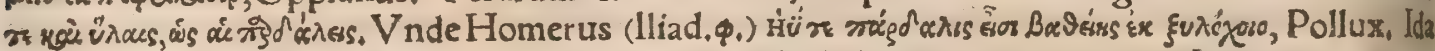
mons Troix eft, $\mathbb{Q}$ accipitur pro quouis monte, ut Achelous pro quauis aqua. lones uero nemus feu fyluam, idam uocitant, $\mathscr{Q}$ interdum Attici quoq, Varinus, zúrox@, locus montanus eft, fic dio ćus quòd ligna habeat:uel fimpliciter locus fruticibus $\&$ arboribus cóferctus. Fedecz (lego fhed, aurfhedos uel thedor numero plurali) qui funt leopardi, manent plerung apud flutios in locis con 30 fitis arboribus, $\&$ maximé iuxta arbores camphor $x$, Albertus lib.8. TPardales uino delectantur, Oppiano tefte:unde forfan poëtæ fabulantur eas olim mulieres Bacchi nutrices fuiffe. Vide infrain h. Quamobrem uino inebriatæ etiam capiuntur, ut dicam in E. TPanthera aliquando nimitumle replet cibo, ut $\&$ alia acutor um unguium quòd acrius efuriant: fic repleta in latibulum fe recipiens dit dormit, Albert. Veneno aconito carnibus infperfo à uenatoribus extinguitur, nifi ftercis hu manum inuenerit, quo deurorato fibi medetur, ut pluribus referam capite quinto. Leopardus cum zgrotat, fanguinem capri fylueftris requirit, \& flercore hominis pro remedio utitur, Albert, $\mathbb{f}^{\mathrm{P}}$ ars, di in A frica infidunt condenfa arborum, occultatiç earum ramis in pratereuntia defiliunt, atç'séto lucrum fede graffantur, Plinius. Pardalis curfus celeritate cum alia plerą̧, tum maximé fímias af́ lequitur, A clianus. At alibi non celeritate, fed aftu mox recitando, fimiam ab ea comprehendiatt 4 Philes fimpliciter fimiam ab ea captari fcribit, Plutarchus odore illectam fponte accedere $\&$ capi, Quamobrem in Mauritania pardales(inquít Aelianus) cum roborefint \& uiribus præftantes, non curfu quo maxime ualent, fímias perfequi aggrediuntur: caufa eft, quoniam non longe ante hanc excurrentes fefe tradunt: fed \& ut mox eam uiderunt, in fugam fe conferentes, in arbores altas alcen dunt, $\&$ illius impetum declinantes, illic confident. Veruntamen pardalis ad hanc rationem fimia dolofior, infidias molitur, $\&$ dolos nectit. Vbi enim fimiarum multitudo manet, eó profecta, ad terr ram fe fub arbore abpicit, \& uentre proiecto humi, fic iacet, tibias ut admodum remifte porrigat, ocu los claudat, fpiritu compreffo fefe ab anhelando contineat, \& uero mortua uideatur. Illæ ueroho: ftem ex alto defpicientes, mortuam fufpicantur, \& facillime credunt id quod uehementer optant, nondum tamen defcendere audent. At experimenti caufa unam ex ipfis, quam audaciorem putant, $s$ ad examinandum pardalis affectum præmittunt, hæc quidem non omnino fibi præfidens defcendit, fed timide $\&$ pederentim primo decurrit, poft metu repreffa reuertitur. Tum vero iterum defcendit, $\&$ cum proxime ad pardalim acceffit, regreditur rurfus. Tum tertio defcendit, $\&$ illius oculos fpecus latur, fpıritum ducat nécne periclitatur. Illa autem immotam fe fortiflime præftans, paulatimhuic animos addir. Etiam cum hanc permanere conftanter fine damno circum illam fublimiores ex fupe rioriloco fmiæ fpeculantur, fiduciam, \& fpiritum colligentes, ex arboribus frequentiffimæ decura runt, \& circum eam concurlantes, faltant, fimul \& fupra ipfam gradientes infultant: \& in illius con tumeliam faltationem fimicam faltantes, multifariam ei illudunt, $\&$ gaudium quod de hac ipfa tanç norrua immortaliter pergaudêt, teftant̂́. Illa aũt omnia fuftinens, fimul ac illa ipfas infultando, \& illit dendo defatigatas effe intelligit, ex inopinato exfiliens, earum partem unguibus lacerat, partẽ denti, 6 bus diftrahit, atç opimum, \& adipale ex hoftibus prandium fibi abunde comparat: \& tanquã Vlyf fes ancillarum contumelias \& procorum, fic diu mulcumós harum infultationes perpetitur, ut ho 


\section{DePanthera. C. Lib. I. 941}

fites ulcifci queat, Hactentis Áelianus, Vide etiam infra in prourerbio, Pardi mortem adfimulat. TCaucafus mons (inquit Philoftratus lib.2. de uita A pol.)principium eft Tatri, qui per Armeniam, Ciliciam \& Pamphyliam uf̧̣ \& Mycalen procedit, \&c.Quód autem noftra ex parte appellatus Tau rus per Armeniam protendatur, quod quodam tempore creditum non eft, teftantur panther $x_{\text {; }}$ quas in Pamphylix parte qux aromata profert, captas effe comperimus. Tales enim feræ aromatibus gau dent, \& ex longinquo odorem fequentes trahuntur, $\&$ ex Armenia per montes profectæ ad ftoracis lachrymam feruntur, quotiens uenti ab ea parte flant, $\&$ arbores liquore turgent. Accepi etiam in Pamphylia pantheram captam fuiffe, aureum torquem circa collum habẽtem Armenịs literis huiuf modi inferiptum, Rex Arfaces deo Nifaro. (Gracicodices non habent infcriptionem nec Armeni: cam nec Gracam.) Regnabat autem temporibus illis in Armenia Arfaces. Is ut opinor feram ui. dens eximia pra cateris magnitudine, eam Baccho facrauit. Bacchus enim Nifæus à Nifa quà in In dia eft nuncupatur, non ab Indis folum, fed abomnibus gentibus qua Orientem fpectant, Illa uero quam dixi fera, aliquandiu cum hominibus eft urerfata, attreçari demulceríç manibus patiens. Ad. ueniente autem uere, ubi Veneris eam cupido ftimulauit, maris defyderio tracta in montes feceffit; codem quod gerebat ornamento infignis. Et poftea capta eft in inferiore Tauri parte, aromatum o, dore, ut diximus, allecta, Hæc Philoftratus, Leopardi amant arbores camphora, $\mathbb{Q}$ ne quis eas in. uadat cuftodiunt, Albertus, Admirabilem quandam(inquit Aelianus)odoris fuauitatem olet par dalis, quam bene olendi praftantiam diuino munere donatam, cum fibi propriam planè tenet, tum uero catera animalia hanc eius uim præclare fentiunt. Hac autem hoc modo uenationem capit: Cum horum qux ad uictum opus funt eget, fefe uel in loca arboribus confita, uel folijs ueftita, ita oc cultat, ut inuentu difficilis tantum refpiret, hinnuli, dorcades, capræ fylueftres, atç alia eiufmodi a. nimalfá quadam fuauis odoris illecebra attrahuntur, \& proximéaccedunt. Illa tum quàm mox de la tebra exiliens, ad pradâ fe rumpit, atç eam comprehendit, (ex latebris profilit atç inuolat, Vola= terrantss.) Pantheram fe abfcondentem uenari ferunt, propterea quòd fuo odore belluas delectari Intelligat:propius enim ita accedunt, quas corripiat, Ariftot. Tradunt odore pantherarum $\&$ con= templatione armenta mirè affici, atq̧ ubi eas perfentifcant, properató conuenire, nec terreri nifi fola oris toruitate, quamobcaufam pantheræ abfconditis capitibus, quę corporis reliqua funt, fpectanda præbent, ut pectuarios grèges ftupidos in obtutu populentur fecura uaftatione, Solinus. Ferunt odorè (apud Volaterratum non reciè legitur colore) earum mirè folicitari quadrupedes cuncias, fed - capitis toruitate terreri. Quamobrem occultato eo, reliqua dulcedine inuitatas corripiunt, Plinius. Ad pardalim pleraç uel fponte adcurrere, odore allecta, fimiam cumprimis, narrant, Plutarchus. Hinc aliqui pantheram dictam uolunt, quód omne genus ferarum alliciat 8 captet. Ifidorus tamen alia quadam nugatur. Panther(inquit:pantherem cum panthera confundens) diçus eft, fiue quòd omnium animaliitm fit amictis(imo inimicus)excepto dracone, fiue quia fui generis focietare gau= $\operatorname{det}_{*} \&$ ad eandem fimilitudinem quicquid accipit $\&$ reddit: pân enim omne dicitur, Hac ille tum ridiculè tum obfcurè. Anímalium nullum odoratum, nifi fi de pantheris quod dictum eft credimus, Plinitts. Ariftotelès problematum 13.4. caufam quarit cur animantium nullum fuauiter oleat, ex cepta pantherałqua etiam ípa ,inquit, non nifi beftís ita olet; ferunt enim fuauem illis olentiam ab hac refpirari.Sed nihil adfert aliud quod ad pantheræ hiftoriam pertineat. Pardalim cxteris anima - libus fuauiter olere quidam affirmant: \& uenari in fenecta nimirum beftias alliciendo gratia fui odo risłat nobis nullam odoris affert fuatuitatem: forte quôd olfactum homines habeant omnium ferme deterrimum. Itaç multi odores fuauitates ḉ eorưm, uel grautitates, nimirum latere hominē poffunt, 8cc. Theophraftus de caufis 6.5. Et rurfus 6.26. Animal nullum penitus odoratum eft, nifi quis par dalim dixerit fenfui belluarum bene olere. Allbertus falfum effe putat cæetera animalia pantheræ odore delectaritquoniam in opere philofophi de fenfu \& fènfili legatur catera (pręter hominem)ani malia odoribus nec fuauiter nec molefté affici. Odores quidem certos animalia quadam fectari aut fugere, conftat:fed fortaffis hoc circa cibum folum, cum ex odore quid ipforum natura conueniat aut aduerfetur percipiant: ut ea fortaffis tantum bene oleant eis; \& longe etiam ad eà pelliciantur, qux in cibum eis uenire poffant, non ut meram odoris gratiam captent. Sed in prafentia hac de re nihil ftatuo. बMares in omni genere fortiores, (magis animofi, Ärifot.) praterquam in pantheris \&urfis, Plinius, Semiramis Âffyria non fi quando leonem cepiffet autt pardalim fimilémue feram

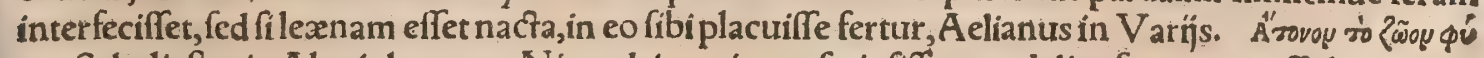
๘s, Scholiaftes in Alexipharmaca Nicandri : qui cum fcripfiffet pardalim frequenti affultu excre: mentû hominis in arbore fufpenfum (id enim pro remedio petit aconito cũ carnibus deưorato, ) pete re, fubỉcit, hoc animal natura infirmum effe: hoc efi citò fatigari $8 \mathrm{~L}$ exhauriri:nimirum $q$ in primos impetus quantumcunq $\$$ uirium habet $\&$ omnem fui roboris contentioné infumat. $\sigma$ Pardus ce= ler,Lucanus libro 6. Leuiores(id eft celeriores)pardis(nemerim)equi eius, Abacuc primo. Suem

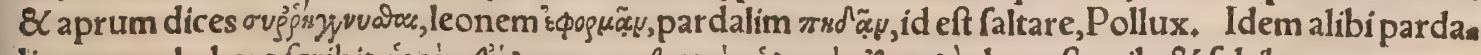

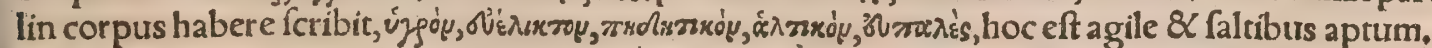

đCxcos gignunt canes, lupi, pantheræ, thôes, Plinius. Author libri de nat,rerum, pantheram femel tantum parere fcribic. Nam cum in utero matris, inquít, coaluêre catuli, maturiş̣́ ad nafcendum ui. ribus pollent,oderunt temporis moras. Itaç oneratam fortibus utuluam, tanquam obftantem partui, 


\section{De Quadrupedibus}

unguibus lacerant. Vnde illa partum effundit, feu potius dimittit, dolore cogerite, Ita poftea corriti: ptis $\&$ cicatricofis fedibus, genitale femen infufum non haret acceptum, fed irritum refilit. Nam, fefte Plinio, animalia quorum acuti funt ungues, frequenter parere nequeunt, uitiantur enim intrinfe cus fe mourentibus catulis, Hac ille. Lexnam quoq eandem ob caufam femel tantum parere, uul. gi quondam opinio fuit, quam refellimus in Leone $c$. Pantheram dicunt parui effe partus, \& paum ci $\&$ difficilis, propter ungues longos \& acutos, quibus catuli frequenter uterum matris ladunt; $A \mathrm{kl}$ bertus. Panthera tempore libidinis admodum uocalis eft, $\&$ ad uocem eius alia eiufdem aut uicini generis animalia conueniunt, Albertus. Leænas cum pardis coire, unde leones gignantur ignobi:les, nec iubati, (aut, ut Philoftratus refert, foetus maculoli,) pluribus dixi fupra in Leopardi mentio, ne priuatim: $\mathcal{Q}$ in Leone c.ex Philoftrato $\&$ alijs. Pardus in A frica abundat, ubi propter aqu nuriam multa animalia conueniunt ad amnes, $\&$ ibilean $x$ à pardis adulteratæ generant leones, fed ignobiles, Alberturs. Eft quandolupi cum pantheris coéunt, unde gignuntur thôes bigenere ani. mal, quod pelle(filicet maculofa)pantheram refert, facie attem patrem, Oppianus 3 , de uenatione, Sed de thôe uarias authorum fententias in hiftoria eius ftatim poft lupum exhibui.

D.

Leopardi gregatim conuerfari folent, Albertus. Panther(abutitur hoc nomine pro panthera)fit generis focietate gaudet, Ifidorus. Pardalis inter animalia illa qua fortitudine pradita uidentur, magis ingenium muliebre refert, ut corpore etiam formam muliebrem, ut in B, dixi ex Ariftotele, Leo contra, uiri,tum ingenium tum corporis fpeciem. Animo fanè pardalis eft pufillo, (usx góv, nifile,

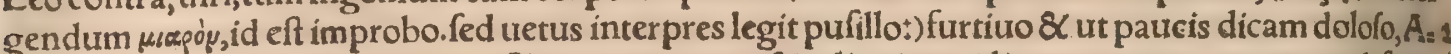
riftot. Panthera cor maximum eft proportione, ut $\&$ reliquis timidis aut propter metum maleficis,

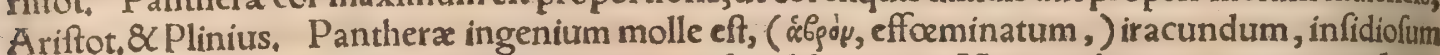
$\&$ fraudulentum ( refpondet, Adamantius. Namer, id eft, pardalis in facris libris tanquam ferociffimum $\&$ crudelifli mum animal cum lupo ac leone memoratur, ut citaui in A. Fulminei pardi, Claudianus 8. Paneg, बI Sapientes Aegyptiorum defignaturi hominem qui fceleftum fưum ac malignũ occultet animum, ne à fuis nofcatur, pardalin pingunt. Hac fiquidem clanculum alia perfequitur animantia, necfinit

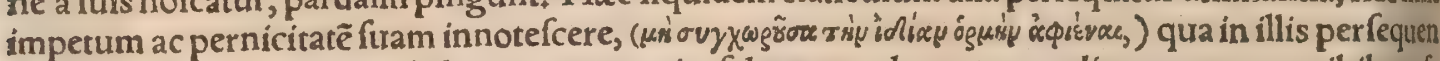
dis utitur, Orus, Quomodolatitans, aut capite faltem occultato, (cum reliquum corpus nihil prafe terribile ferat, )allectas ad fe propius fui odoris fuauitate feras deuoret, iam fupra capite tertio docui; 3 Et ibidem quàm mirabili aftutia fe mortuam fimulans, fimias captet, qua de re uide etiam infrà ptos uerbium, Pardi mortẽ adfimulat. đPanthera perpetuò fera eft, Ariftoteles. Atqui Albertus \&alî̉ recentiores facile cicurari fcribunt, prafertim ad uenationis ufum, ut fupra in Leopardi mentione dixicapite primo: $\&$ infra capite quinto pluribus dicetur. Sed utcunq cicur, nunquam prorfus den ponit feritatem, \& frepe ad ingenium redit. Leonibus ac pardis, omnibusḉ generis eius, etiamfeli bus, imbricatx afperitatis lingua eft, ac limæ fimilis, attenuans ́́ lambendo cutem hominis, Qux call fa etiam manfuefacta, ubi ad uicinum fanguinem pertenit faliua, inuitat ad rabiem, Plinius. Piço quod iuga delicata collo Pardus fuftinet, Martialis, TLeones, panther $8<$ tigrides, foetus ftros uehementer amant, \& pro ipfis contra uenatores pugnando, quauis tela $8<$ mortem quogs contem nunt, Oppianus lib.z. de uenatione, ubi etiam de ïfdẽ ac lyncibus feribit, quod cum ad latibula fua 4 reuerfac catulos fibi ablatos reperiunt, magno 8 miferabili eos ululatu plangant. TDe panthera tradit Demetrius phyficus, iacentem in media uia hominis defiderio, repente apparuiffe patri cuiuf dam Philini affectatoris fapientix+illum pauore cœpiffe egredi, feram uero circưuolutari non dubię blandientem, fefe conflictantem morore, qui etiam in panthera intelligi poffet, Fota erat, catulis pro cul in fouream delapfis. Primum ergo miferationis fuit non expauefcere, proximum ei curam inten

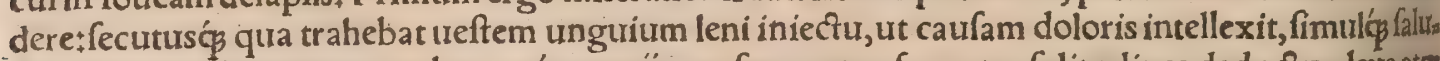

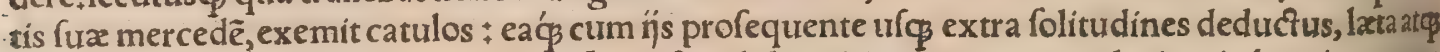
geftiente: ut facile appareret gratiam referre, $8 \mathrm{~K}$ nihil inuicẽ imputare, quod etiam in homine rarum eft,Plinius. Similia quadam leoninæ etiam manfuetudinis exempla, in Leone recitaui. Pardalim audio, cum eam à paruula cum hominibus uenator uerfari adfuefeciffet, atque adeò manfuefeciffet, camćs fané tanquã amafiã adamaret, \& magna cura aleret, ob eamọ́ rem hoedũ huic, quễ fimul cum ipfa aluiffet, eam hoedi efu oblectare cupiens, comedendum dediffet:edere illum, etfi occifus erat, re: cufaffe, Cum enim primo die is ad paftũ obiectus femel fuiffet, ab eo ipfo edendo fe fuftinuifle, quia propter cibi expletionem inedia uti neceffe haberet. Secundo iterum die hœedus huic allatus eft, ab cofimiliter, quoniam adhuc fame non premeretur, fe continuiffe. Tertio die quamuis efuriret quip dem, \& folito figno cibum requireret, non hodum tamen fuum contubernalem attingere uoluife, fed illo relicto, alterum fumpfiffe. Homines aute fuos intimos $\&$ perneceffarios non modo produnt, fed frepe etiã in fratres $\&$ parentes multa perfidiofe faciunt $\&$ improbe $\&$ malitiofe, Aelianus. An: droclis ferui hiftoriam, qui fugitiuus in A frica à leone nutritus fertur toto triennio, deinde captus $\alpha$ feris Roma obiectus, inter quas for tuitò idem leo captus erat, ab eodem agnitus $\&$ contra panthe ram defenfus eft, in Leone retuli cap, quarto.

G Panther (abuticur boc nomine pro panthera) omnium animaliü amicus eft, excepto dracone, 
Ifidorus abf $\$$ a athore. Ego pantheram omnibus inimicam dixerim. Panthera dicitur infefta effe draconi, $\&$ draconem ea uifa ad cauernas refugere, Albertus. Alfhed(id eft leopardus minor)lupos libenter interficit, Albertus. Ante paucos annos ftatim poft mortem Galliarum regis Francifci leo: pardos audio, marem $\&$ foeminã, fiue dimiffos negligentia aut malignitate cuftodis, fiue per uim é ca uea egreffos, in fyluas aufugiffe, \& circa Aureliã plurimos homines laniaffe, \& fponfam alíquãdo ad nuptias ducendã in tico rapuiffe, \& inuenta mulierum cadauera quarum illi mamillas tantum deuo raffent. ॠHyæna pardalim odit, Aelianus. Hyænæ pantheris præcipuè terrori effe traduntur, ut ne conentur quidem refiftere $\$ Q X$ aliquid de corio earum habentem non appeti : mirumós dictu, fi pelles utriufq contrariæ fufpendantur, decidere pilos panthera, Plinitus, Superiorem ab inferiore uictum fignificare uolentes Aegyptị, duas pelles pingunt, hyænæ unam, alteram pardalis: ha enim pelles fi fimul ponantur, pardalis quidem pilos abijcit, hyænæuero non, Orus, Mygale, id eft mus araneus, pantheras terret, Philes. Gallinaceo iure perunctos pantheræ leoneş́́ non attingunt, prę cipué fi $\&$ allium fuerit incoctum, Plinius. Leopardus uifo hominis craneo, fugit, A efculapius,

E.

Leopardus cicuratus $8 \times$ ad uenationem dimiffus, nifî tertio quartóne faltu præada potiatur, fuc: cenfet adeò ut nifi fanguine placetur, in urenatorem infiliat, Albertus, Plura uide fupra in A . in Par do, Leopardo \& Alfhed. Ego dum hac fcriberem accepi à quodam oculato tefte, in aula regis Gal: liarum, leopardos duorum generum ali, magnitudine tantum differentes $¥$ maiores trituli corpulen= tia effe, humiliores, oblongiores:alteros minores, ad canis molem accedere Et unum ex minorib, ali: - quando ad fpectaculum regi exhibendum à beftiario aut ienatore equo infidente à tergo fuper ftra gulo aut puluino uehi alligatum catena: \&lepore obiecto dimitti, quem ille faltibus aliquot bene magnis affequutus iugulet. Venator leopardum recepturus, accedit auerfus $\&$ fruftum carnis retro inter crura protenfum porrigit, ne fi faciem obuerteret ab eo inuadereț: et rurfus loro alligatum ma nu demulcet ac reducit ad equum; ille in fedem fuam facile refilit. Idem narrauit, tauro aliquando \& leone fimul emiffis, leonem placidiorem nihil in taurum fuiffe molitum, ac fponte ad caueam furam regreffum:deinde duos leopardos eductos, ftatim uifo tatro in eum infilíffe: quem $\&$ iugulaffent, nifi beftiarï funibus alligatis ad catenas eorum, quibus teneri folent, eos retraxiffent. Senatufconfultum fuit uetus ne liceret Africanas (pấtheras intelligo, de quibus $\&$ proximè dixerat. Vide in A .) in Italiam aduchere. Centra hoc tulit ad populum $\mathrm{Cn}$. Aufidius tribunus plebis, permifitćs Circenfi

$3^{\circ}$ um gratia importare. Primus autem Scaurus ædilitate fua uarias cl, uniuerfas mifit, deinde Pompei us Magnus quadringentas decem, diuus Auguftus quadringentas uiginti, Plinius, Picfo quòd ius ga delicata collo Pardus fuftinet, Martialis.

TÁconitum primum alio nomine pardalianches â firangulandis pantherís uocatur, ut Diofcori des, $P$ linius $\&$ alin tradiderunt. De herba ipfa copiole differui in Lupo a. $\&$ eam effe oftendi, qua ho die pauciffimis locis cognita, in montibus Sabaudix \& Galliæ Italiam uerfus tora uocatur, \& $x$. Hîc plura adjuciam, non ad herbx hiftoriam, fed panthera qua radice eius trita $\&$ in carnibus obiecta ex tinguitur quod fues etiam, \& lupi \& beftix omnes Diofcoride tefte patiuntur. Tangunt (id eft as fpergunt) carnes aconito, necantós guftatu earum pantheras; nifi hoc fieret repleturas illos fitus. $\mathrm{Ob}$ id quidam pardalianches appellauêre. At illas ftatim liberari morte, excremêtorum hominis guftu - demonftraturm, Plinius. Panthera cum uenenum pardalianches ederit, quo leones etiam intereũt, ftercus hominis quarit ; co enim ipfo iuuatur, quocirca uenatores ftercus ibi propinquum fufpen= dunt ex arbore aliqua in uafe, ne procul bellua abeat, petens fuum medicamentum+ ita q $_{\text {infiliens ibi }}$ dem, \& fpecapiendi perfeuerans, in fe efferenda emoritur, Anriftot. Pantheras perfricata carne aco nito(polline eius, nimirum) barbari uenantur. Occupat ilico fauces earum angor, quare pardalian. ches id uenenum appellauêre quidam. At fera contra hæc excrementis hominis fibi medeturi: $\&$ ali âs tam auida eorum, ut à paftoribus ex induftria in aliquo urafe fufpenfa altius, quàm ur queat faltu contingere, iaculando fe appetendó́ ut eiectis interaneis diu pugnet,Plinius. Hyrcani pantheras frequentius ueneno, quàm ferro ne: cant. A conito carnes illinunt, at $\$$ ita per compita fpargunt femitarum. Qua ubi efa funt, fauces ea. so rum angina obfidentur, ( $\&$ c.ut Plínius, ) Solinus. Auditum eft pantheras qux in Barbaria uene. nata carne caperentur, remedium quoddam (excrementum hominis forte nominare noluit) habere, quo ut effent ufa, non morerentur, Cicero 2, de nat, deorum. Panthera \& pardus (Árabicé legi pux to, alnemer $\&$ alfhed, hoc eft leopardus maior $8 \mathrm{C}$ minor:fic enim in aconiti mentione apud Auicen: namin Bellunenfis æditione legiffe memini)deurorato ueneno, ftercus hominis quærunt, quo gu. Ptato euadunt, Auicenna. Pardalin(inquit Pollux)tum alijs modis capiunt, tum aconito pharmaco cibis (ortious. Diofcorides $\&$ alin melius, carnibus)admix to:unde fera uentris profluuio exhauritur, 8 fęp uiua capitur. Pardalis intelligens aconitum fibi uenenum effe:non prius deguftat quàm excre mentum hominis, utpote antipharmacum prope fe uiderit : quamobrem paftores excrementum in arborem ea altitudine fufpendunt, ad quam pardalis peruenire faltu non poffit. Hoc uifo fera tan. quam prafente remedio, aconitum edit : deinde medicamentum petens, crebris tandem affultibus defeffa, aut moritur, aut à paftoribus interimitur, Scholiaftes Nicandri. Sed ridiculus eft aconitum à panthera edif cribens, non carnes aconito imbutas; $\&$ cum plurimum rationis ei tribuat, ut qua $\&$ 
uenenum $\&$ remedium fưum agnof cat, rurfus omnem ei rationem aufert, qux urenenum fciens ac prudens deuoret. Leones, lynces, pardales, pantheres, urfi, capiuntur aconitico ueneno ad eum admix to cibum quo quod 9 corum delectatur, $\& \mathrm{C}$, aut foueis, ut pluribus retuli ex Xenophonte in Leone E. Ariftoteles in Mirabilibus non pardalianches, fed pardalion( $(\pi)^{\circ} \delta / \lambda$ esoy)hoc uenenum no minat, cuilus uerba recitaui ín Lupo a, TEft $\&$ apocynon uenenofa herba, quam fimiliter pardalis anches appellari in nomenclaturis apud Diofcoridem legitur. Necantur apocynocanes, lupi, uula pes, panthera, $\&$ omnes quadrupedes: Vide in Cane $c$. Herba qux leopardi herba dicitur, leopar, dus terretur $\&$ herba quæ leopardum ftrangulans dicitur, interficitur, $R$ afis ut quidam citat:Eft au tem pofterior herba, non alia quàm aconitum primum: prior quæ fit, non facile dixerim! nam prater allium herbam qux ei aduerfetur non legimus, TPifces quidã nigri uenenati in Armenia reperi, untur ¿quós contritos in ouium aut caprarum difciffum latus abdunt:quod cum pardalis, leo aùt lus pus guftârit, continuò moritur, Â elianus. Si uenatori res fit cum alia fera quàm apro, uenabulum tenere opörtet pedibus non tantum diuaricatis, quantum in pugna aduerfus aprum: nam fera quę, dam, ut pantheræ $\&$ leones, curfu ad uenatorem ufp delatæ, cum propéfunt, infiliunt. Dirigendus eft autem ictus ad pectus $\&$ cor, tanquam tulnere in illis eo in loco maximèletali futuro, Pollux.

TVbi proficifcentis ad aquam ex fpelunca pardalis, uenatores tritam uiam obferuarunt, ibidem ro tundam \& altam frobem (minorem multó quàm pro leone capiendo)faciunt, in cuíus médio colum nam lígneam(nct lapideam ut pró leone) defigunt: ex ea catellum (non agnum ut pro leone, aut hoe dum) furpendunt, curus tefticulos tenuibus uinculis conftringunt. Is uinculorum dolore preffus ge: mit, \& latrans fuo fono pardalim ad fe commouret. Hac non mediocri uoluptate geftiens, illuc fe ma 10 gnis faltibus incitat, \& nullum dolum effe exiftimans, in pofitas infidias incidit, Oppianus libro 4. de uenatione, Eundem capiendi modum libro $\%$ de pif́ibus defcribit, pro fimilitudine adhibens, $\$$ admones etiam dicti pifces fimiliter capiantur in naffas illecti, in quibus paruos pífciculos natantes uiderint, \&c.Sed uerfus poët a adfcribam, ut res tota clarior fiat,

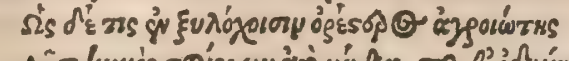

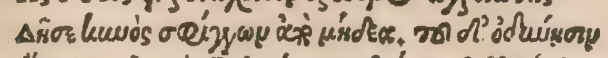

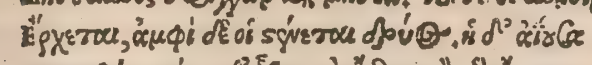

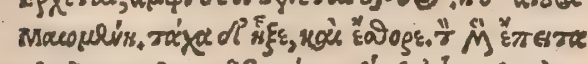

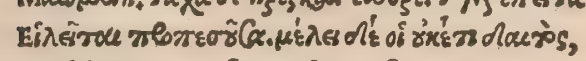

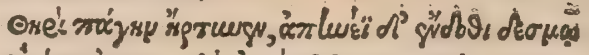

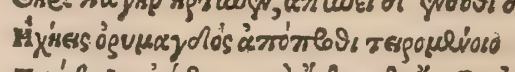

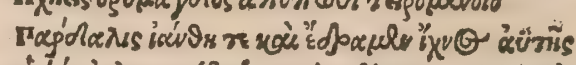

$$
\begin{aligned}
& \text { Y' '. } \sigma^{\prime} \text { 'a }
\end{aligned}
$$

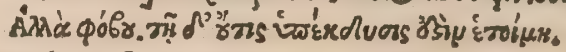

Idem alibi contra feras diuerfas, equos etiam colore diuerfos uenatori eligendos confulit: contra uli,

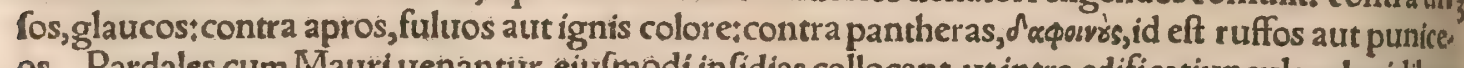
os. Pardales cum Mauri uenantur, eiufmodi infidias collocant, ut intra ędificatiunculam lapidibus quam primoftruxerint, putrefcentis iam carnis fruftum ex longiore funiculo appendant; deindeex arundinibus íanuam rara fructura imponant, per eas ut fotidæ carnis odor emanet, \& longelatég uagetur. Hunc inclufum foctorem feræ beftix fentiunt:nam quodammodo tetris odoribus delectan tur. Itaç huius cibi appetitione, huc illuc circunferuntur, \& tanquam quadam amatoria illecebra attacix, $\&$ incidunt in laqueos, \& infelici efca confrictx tenentur, Aelianus interprete Gillio. Vo laterranus eundem locum paulo aliter $\&$ breuius uertit, hoc modo: Capiuntur pardales in Maurita nia loco lapide fubftrato, laqueis praxparatis, carnéǵg appofita: ad cuius odorem per conualles fubie cfas delatum flatibus uentorum feflinantes, in infidias incidunt. TLeopardus diligit uinum \& in, 4 ebriatus capitur, Rafis $\&$ Albertus. Oppianus modum etiam quo inebrientur elegantiffimè defcri bit: Vbi primum(inquit) ın Libya paruum fontem animaduerterunt, nó copiofum nec longius ema nantem, fed intra fe confiftentem, \& fub arenam fubeuntem, unde pardales prima luce bibere fole ant, eò uenatores noctu amphoras permultas (uiginti)fuauis uini plenas afferunt, quod iam undet cim annos in dolins bene conditum conftitit. Ac nimirum pofteaquam hoc idem in fontem infudes runt, inde non procul fedent ftragulis tecti, nam nulla alia re fe occultare poffunt, neqs enim fanela pidum, neq arborum tegmenta inueniuntur : ibi enim fola terrarum ab arboribus nuda ex omni parte ad uidendum patent. Ex autem ardenter fitientes $\&$ grauem fitim depellere cupientes, ad ni. grum iam fontem accedunt, $\&$ fimul ut uini, cuius ftudiof $æ$ funt, potione fitim expleuerunt; fratim primo faltatione ludunt, deinde fenfim obdormientes humi fternuntur, Itac $\$$ arcfe $\&$ grauiter dor" mitantes, nullo negotio comprehenduntur.

TLeopardorum pelles ad nos etiam adferuntur, quanquam rarius: frequentius in Galliam.Pels lem uidi uenalem tribus uel quatuor aureis Gallicisł funt qui praftantiores aureis fex uel feptem in dicent, Maurorum pedites leonum $\&$ pardalium pelles induunt, $\&$ dormituri fubfternunt, Stra. bo. Paftorales homines quí loca inter Caucafưm montem $\&$ fluurum Cophêna tenent, Apollonio cum focijs tranfeuntileonum ac pantherarum carnes, $\&$ earundem ferarum pelles à carnibus nuper rimè direptas donabant, Philoftratus. Plura de pantherinis pellibus, uide infra in $e_{\text {。 }}$

Agriophagi populi in Aethiopia(occidentem uerfus, Solinus)pantherarum \& leonum carnibus vefcuntur, Plinius 6.30. Inde nimirum $\&$ nominati funt, quòd beftias edant agrias, id eft feras. Pan 6 theris uefci uidentur etiam qui inter Caucafum montem \& fluuium Cophêna habitant:lege Philo frati uerba in fine pracedentis capitis. Pardales 8 pantheres eduntaliqui, Galenus déalimentorû 


\section{DePanthera. G.H.a. Lib. I. 945}

facultate $\% \cdot 1$, cum proxime dixiffet aliquos etiam afinis $\&$ camelis uefei, homines feilicet tum animo

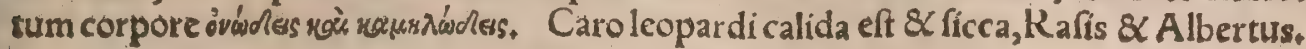

G.

Tradiderunt aliqui, fi corium leopardi(altamur, lego alnemer) fubfternatur, non accedere ferpen res, aut fi ftragulum inde fiat: fed eitis qui hoc retulit nulla eft authoritas, A uicenna, đQuomodo pantherarum \&leonum pinguia curari oporteat, ex Diofcoride \& Plinio prafcripfimus in Tauro. Leoninus adeps calidiffimus $\&$ ficciffimus eft, $8 \mathrm{C}$, proximus ei pardinus, pardino urfinus, Syluius ex fecundo Galeni ad Glauconem. Pinguedo leopardi craffa eft \& acris; fubtilltas eits apparet in his qui patiuntur pulfum temporum $\&$ reuolutionem capitis (uertiginem,) fi odor eitus inter affan* dum recipiatur, $R$ afis. Albertus aliter: V tilis eft paralycicis, \& pulfum cordis patientibus, $\&$ reutolu. tionem, fi odor eius inter affandum recipiatur. Seutum leopardi miftum cum oleo laurino, fi cum eo inungatur fcabiofus, cuius fcabies fcindit cutem, (qua nominatur artrath, $R$ a fis. Impetigines in. telligo, quas Galli dartres appellant,) confert, Albertus, TSanguís leop.utilis eft tumori uenar (uenarum crurium, $\mathrm{Raf}$, urarices puto intelligens,) fi eo calido confricentur, Idem, TCaro leop,ca lida \&ificca eft, lidem. TCerebrum eius miftum cum aqua erucx 8 modico zambac, potum miri gat dolorem uteri, Rafis, Albertus aliter: Cerebrum,eius cum fucco eruca, genitalibus uiri illitum, confirmat coitus facultatem:medulla uero pota uteri dolores tollit.

TLeopardi fel potum(intra corpus fumptum) eurftigio interficit, Bertrutius $\ddagger$ qui etiam de leonis felle idem feribit, nelcio quàm uere, cum authorem non habeat. Plinius etiam muftelx fylueftris fel uenenofum effe fcribit. Leopardi quidem felli(aut etiam pardi, ut Cardanus fcribit)uim iftam letas lem Árabes tantum attribuunt. Recentiores quidam obfediri idem de felle uncix fribunt: ego unci. am, ut fupra dixi, pantheram fiue leop.effe conjicio. Qui biberit felleop. (alnemer) eutomic bilem ui ridem aut pallidam, \& naribus percipic odorem aloës ( $\&$ ore faporem aloés, Matthrol,) $\&$ incidit in icterum maximo periculo mortis: quòd fi tres horas fuperauerit, melius fperatur. Procurandus igi tur maturé eft uomitưs, tum danda antidotus ei peculiaris, quæ recipit, 'T'erræ Lemnia, baccarum. Iatriana partem i.coagulicapreoli partes iiij, feminis rutæ $\&$ myrrhæ, ana partern femistexcipiantur melle. dofis eft magnitudo nucis, \& mox iterun euomat, \& fiat balneum ex aqua in qua res ociora ta fint decoct $x$, Auicenna 4.6.2.15. Inducit hoc uenenum omnia fymptomata qua napellus $8 \mathrm{C}$ mor fus uiperæ, \& $\not$ ifdem remedijs curatur, Matthæolus ex Aponenfi. Leopardus animal eft calidiffi. mum, quod uel ex maculis nigris \& uelociffimo eius motu eft conïcere* itaģ fel etiam eius fuo calo re urit humores, $\mathbb{X}$ intra fex horas interficit. Adharendo mufculis uentriculi facit fpafmum. Scythre fagittas eo inficiunt ut celexius interficiant, Ferdinandus à Ponzetto. Idem antidorưm ean dem quả A uicenna prafcribit: Mihi tamen, inquit, uidetur, potius effe propinanda antipharmaca frigida cor: roborantia, $\&$ utenđum balneo aqux odorifer $x$, deniç eodem modo curandum quo uenenum na. pelli. Lapis quem linguam ferpentis uocant, fudore fuo arguit felleopardi, uiperam, napellum, Mat thaolus ex Aponenfi. Leopardi fel recens fumptum, letiferum eft uenenun, ficcatum uero uehe: mentiam illam amittit, (Albertus hac deprauauit.) aurei pondere fumptum, necat eodem die. Nu. per cum rex cuidam ex fui regni principibus huius fellis recentis drachma (uncia, Albertus : non recié) pondus propinaffet ex uino pu. (puro,)poftridie cum dormire coepiffet mortuus eft, $R$ afis ci 4. tans Ariftotelem, apud quem nihil tale legicertum eif. Idem fel pondere dauic (paruo pondere, Ala bertus: Bellunenfis danich fribit, quę fit fexta pars drachmæ) fumptum cum cypho aqux decoctio nis caryophyllorum, (cum aqua fimpliciter, Albertus,) prohibet generationem $\&$ inducit fterilita: tem, Rafis.

T Tefticulus leop. dexter â muliere etiam prouectæ æatis fumpturs, menftruam purgationem de. fitam ei reftituit: \& fi pergat edere, fapius purgabitur : quod fi libeat fiftere, propinabis ei femen plyllï recentis, $R$ afis 8 Albertus.

TRemedia ad morfusleonum, pantherarum $\&$ urforum, ex Aëtï 13.3, uide in Leone G. Beftia rapaces, ut leopardus (alnemer, ) leo, \& alfhed, non tam innoxix funt morfu quàm canes $\&$ homí. nes: fed dentes eorum \& ungues non prorfus uacant ueneno:quare danda eft opera ut curentur im primis cum atcractione, quanquam leui: deinde uulnus fanetur, Auicenna.

H.

a. Ferarum uocabula quxedam peregrina funt, ut panthera, leo, utraqg Graca, Varro, rógd cex rs

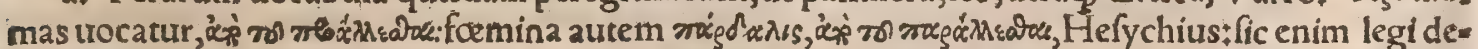
bet, ex Euftathio in Iliados $\rho$. Hinc natum puto errorem qui apud innominatum in eundem librum

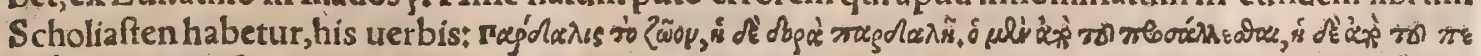

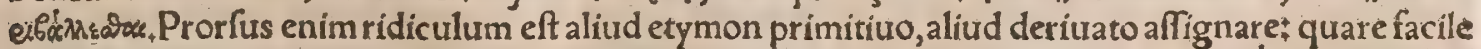
conïcio grammaticum aut librarium aliquẽ, qui Euftathỉ aut alterius uerba aut malẹ legerit aut nó fit alfecutus, tam ineptéferipfiffe. Suidas quocs pordalin marẽ, pardalin formină facit. Pordalin, in

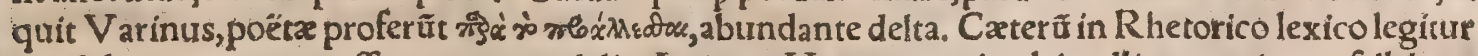
pordalin communem effe uocem, pardalin Atticam. Homerus animal Intelligens primam fyllabam per omicron fribit; pellem uerò, per al pha, Hæc ille. Sed fciendum eft apud Homerum pro animall utrog modo fcriptum reperiri:pro pelle uero, femper quidem per alpha in prima fyllaba, non míga 


\section{6

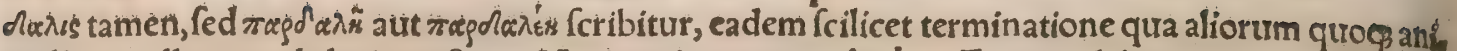

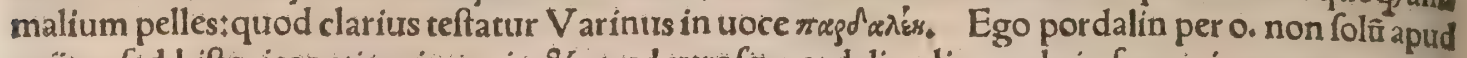
poétas, fed hiftoricos etiann inuenio: 8 apud utrof çs pordalin aliquando in foeminino genere, parda. lin in mafculino, contrà quàm grammatici obferuarint, fiue ita fcripferunt authores, fiue librarï de prauarunt. Mihi aliquando in mentem uenit, fieri poffe ut pardalis uox origine fit Hebraica, à par, des, id eft, horto quòd macularum oculis tanquam floribus pẹlis eius pulcherrime ornetur : fic $c_{t}$ pus etiam fimiarum generis à color is elegantia nomen adeptus uidetur, ut $x \hat{n \pi} G$, id eft, hortus dice,

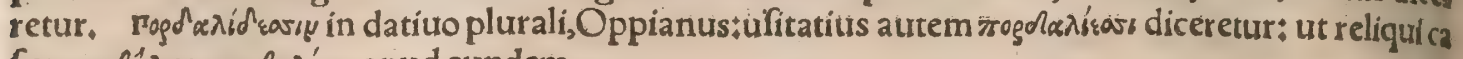

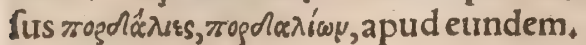

ब Epitheta. Panthera picta, ferox, multicolor, Textor. Pi\&farum fera corporà pantherarum, 10 Ouid.z.Meram. đPardus celer,Lucanus lib.6. Fulminei,Claud. S.Paneg, Sublimis, Iuuenal,

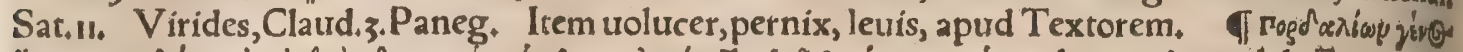

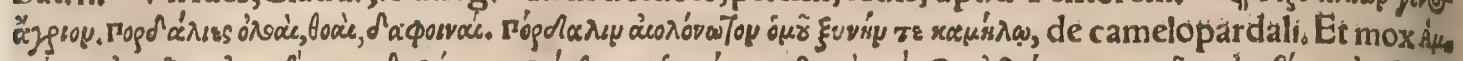

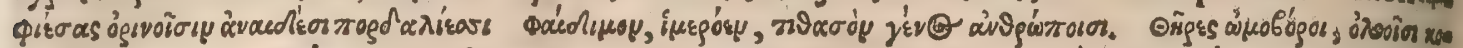

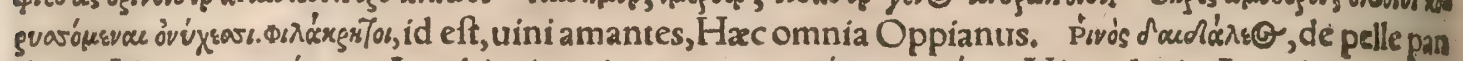

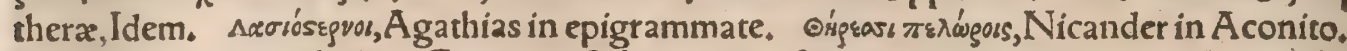

4) Panthera uocabulum Gracum eft, à quo etiam \& rete quoddam panther, Varro. Pantheron fiue pantherum retis genus eft, ex co nomen habens, quòd omnes aures uenetur $\&$ concludat, eadê feré ratione qua panagron, quod rete pifcatorium eft. 9 üge uenatum fignificat, $\&$ ad aucupium quog contrahitur, unde ögr $\vartheta_{0} 9$ ispas, id eft, auceps. Hoc rere humi exporrectum, $8 \mathrm{in}$ oblongam tenuitatem 10 contractum, tegitur quifquilijs, ne ab auribus prouideri poffit. Deinde quum opus eft adducto ma. gna ui fune, repente expanditur, inefcatasḉ aliquot diebưs auiculas uno icłu unituerfas contegit, (noftri uocant juckgarn, Galli retz faillant,) Veluti quum futurum iactî̀ retis à pif́catore emimus, aut indaginem plagis pofitis à uenatore, uel pantheram ab aucupe.nam etiamfi nihil capit, nihilomin nus emptor pretium praftare neceffe habebit, Vlpianus de Actio.empti. \& uendit. Obferutuathac Budaus. Scoppa Pollucem citat qui retia quædam pardales nominet, quod ego apud Pollucẽnon inueniri puto. De pantherze retis ufu ad capiendas anates lege Crefentienfem 10.17. \Panthen rinum, pantheræ fimile $\&$ uarium, ut pantherina pellis Plinio. Caprigenum hominum non place mihi, neç pantherinum genus, Plautus Epid. Menfis ex cedro pracipua dos in uena crifpis, ud in uertice uarịjs. Illud oblongo euenit difcurfu, ideoós tigrina appellantur: hoc intor to, \& ideo tales 3 pantherinæ uocantur, Plinius 13. 15. Hîc ubilegitur in uertice uarins, uetus lectio erat, in uertice par uis, Vbi Hermolaus, Legendum quidam putant peruins, aut certé, uarịs.quoniam pantherinæ dican tur. pantheras autem non modo uarias effe conftar, fed \& uocari. Fiebant $\&$ menfarum pedes ebo, rei,pardorum aut pantherarum effigie. Olim ex quauis arbore menfa fiebat: At nunc diuitibus coe nandi nulla uoluptas, \&c.nifi fuftinet orbes Grande ebur, \& magno fublimis pardus hiatu Dent. tibus ex illis quos mittit porta Syenes, \&c. Iam nimios, capitić (cum fcilicet menfæ portantur capite, id eft, orbe uel tabula pedibus impofita,)graues, luuenalis Sat.Ir. A Ariftophanes alicubi mereul

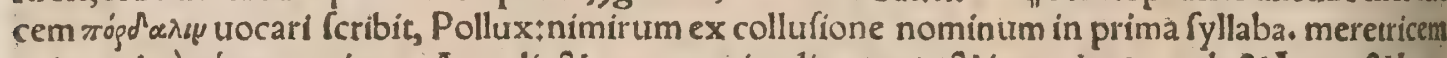

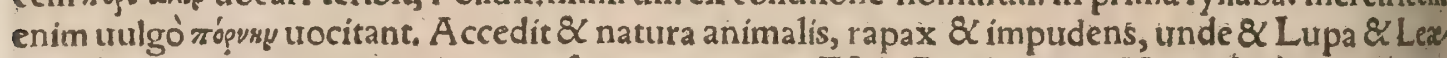
na $\&$ Leontium meretricum nomina fuerunt propria. Eft \& Pantheris, ut Varro fcribit, muliercis 4 Ix nomen, pulchre conueniens fcorto, quod omnes fine difcrimine ad fe alliciat \& captet. If

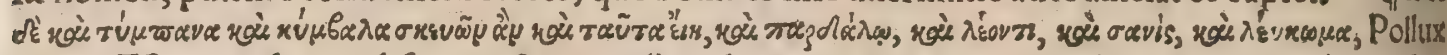
10. 42. Eft autem locus obfcurus, \& ut conịcio deprauatus. neqsenim uel ex pracedentibus uel $x$

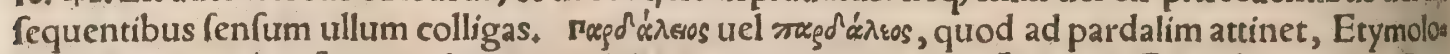

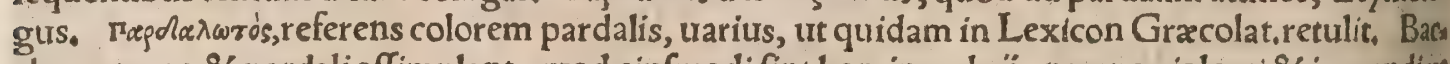
chum tauro \& pardali affimulant, quod eiufmodi fint homines ebrï, nempe uiolenti $\&$ iracundiut

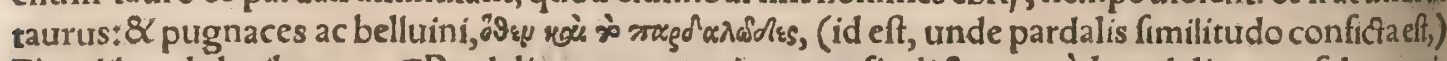
Platolib.1.delegibus. बPardalium, unguenti nomen, fic dictum quòd pardalis, qux fola ex anit

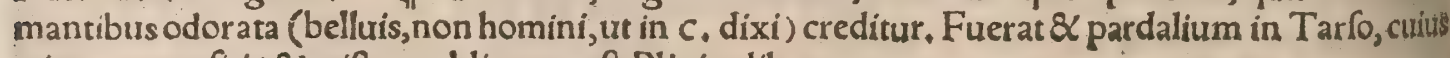
etiam compofitio 8 miftura obliterata eft, Plinius lib.13.

II Icon. Pardus eburneús, menfre pes: Vide paulò ante in menfis pantherinis.

T) Sunt $\&$ à leonis pelle \& pantheræ nominatæ gemma, leontios, pardalios, Plin. Et alibi, Tra. dunt Perficum fmaragdi genus uifum implere qưem non admittant, felium pantherarumç oculis fimiles, nanç \& illos radiare, nec perfpici; eofdẽ in Sole hebetari, umbris refulgere, \& longius quàm cateros nitere. Lapis pantherus, fecundum Albertum, multos habet colores, nigrum, uiridem, ru beum, $\&$ alios plures. Inienitur autem pallidus, purpureus $\&$ rofeus. Affertur plerungs ex India, A geftante infpici debet mane oriente Sole. fic efficacem fieri aiunt: haberc autẽ totidem facultates quor colores habet, ut Euax etiam fcribit, Syluaticus.

-1 Pardale herba, qux alio nomine leontopetalon uocaturtuide in Leone $a_{*}$. Pardalianches, aco, nitum primum, uel a pocynon; de quibus in $\mathrm{E}$. dictum eft.

đ Camelopardalis fera, uulgó giraffa, capite, oculis, colore, pilis, \& cauda, Diodoro tefte, parda lim refert; ungula fiffura camelum, \&c, ex qua $\&$ pardali nafci creditur. $\mid \mathrm{P}$ Pardalus auicula qua 


\section{DePanth. H.a.b.c.d.e.h. Lib. I. 947}

dam perhibetur, qua magna ex parte gregatim uolat, colore tota cinereo, \&c, Ariftoteles. Hefychio

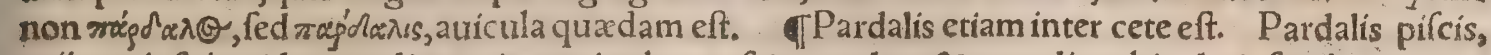
ut ij qui Ipfum uiderunt, dicunt, in mari rubro nafcitur, colore $\&$ maculis orbiculatis fimilis terrenz pardali, Aelianus.

T Mare circa Taprobanam infinitos pifces procreare ferunt, habentes capita leonum, pantheras rum,arietum aliorumós animalium, Aelianus.

TPantheris nomen muliercula, V arrołpaulò fuperius dixi nomen hoc effe meretrici aptum.

q Mons leopardorum diftat à Tripoli duabus leucis, uide fupra in A.

qb. Non crederes leones \& pantheras effe, quum tibi quales effent dicerentur ¿ Cicero i, de Nat. Gryphum corpori maculas ut pantherartum ineffe aiunt, Paufanias in Arcadicis. Extrema regio A rabix cepos fert, qui faciem leonis habent, corpus reliquum pantherís (rx́v 9 ro@) habent, ma gnitudinem caprex, Strabo + fed alius à panthera panther eft, de quo poft lupum diximus. Oneficri tus formicarum India fribit fe uidiffe pelles pantherinis fimiles, Gillius ex Arriani opinor Indicis.

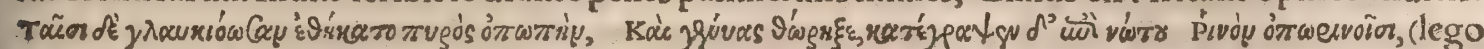

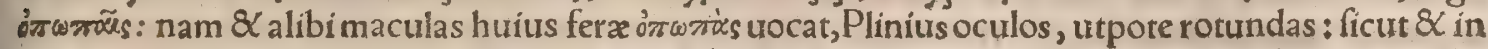

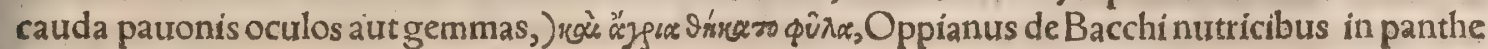
ras mutatis.

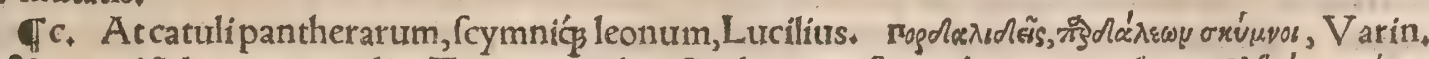

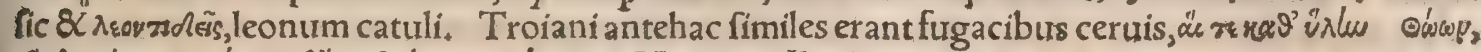

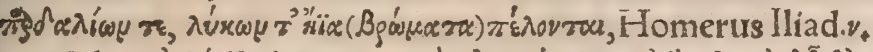

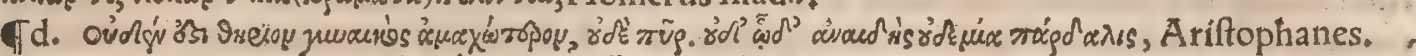

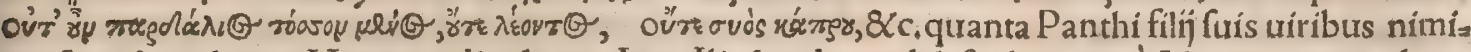
um freti fuperbiunt, Homerus lliados $\varrho$. Item lliad. $\phi$.de pardalifcribit, eam è fylua uenatori obuiã prodire, nec metuere canes, \& fi uulnerauerit eam uenator, ferro etiam transfixam non remittere

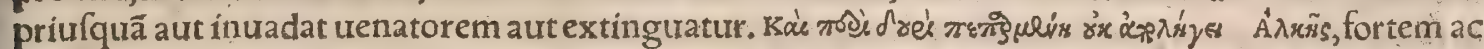

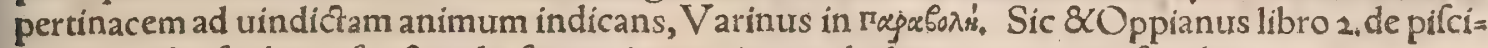
bus, pardalin fcribit in fpectaculis fponte irruere in uenabulưm opponentis fe ei hominis:

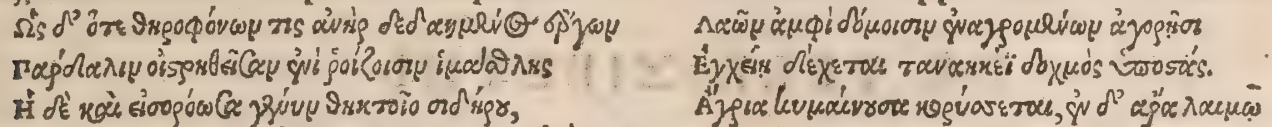

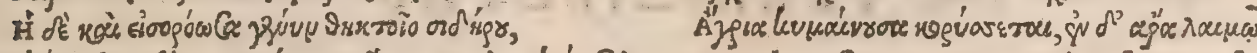

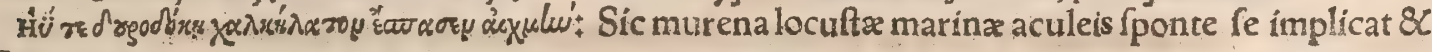
infigit.

बe. Venatio data leonum 8 pantherarum, Liuius 9.belliMaced. Vide fcripta ex Oppiano in fine pracedentis partis proxime. Linei thoraces in pugna ferrum uiolenter adactum tranfmittunt:

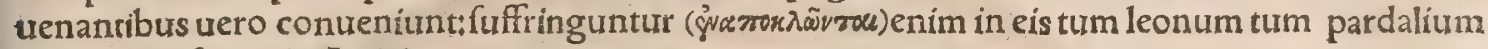
dentes, Paufanias in Atticis.

Antiphilus pinxit nobilifimum Satyrum cưm pelle pantherina, quem A pofcoponta appellãt,

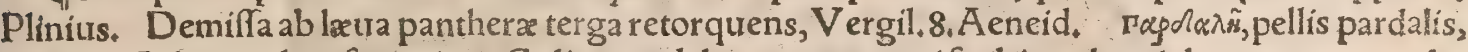
Pollux. Vide quadam fupra in a. Calius pardaleanı nuncuparifcribit, ut leonis leonteam. Iragolac=

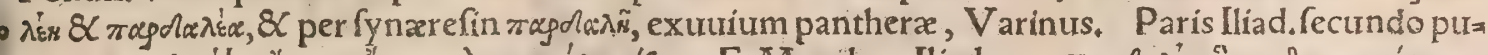

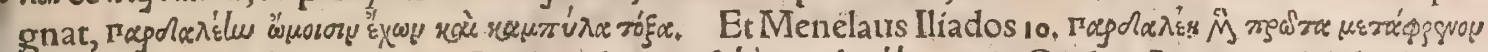

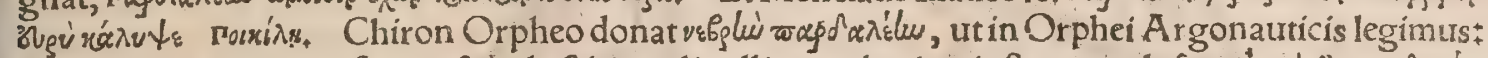

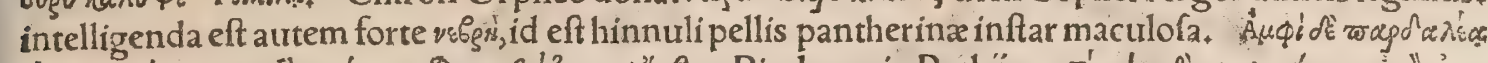

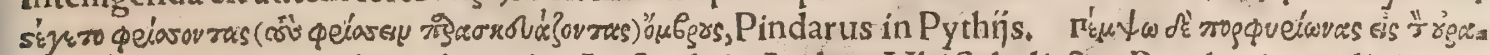

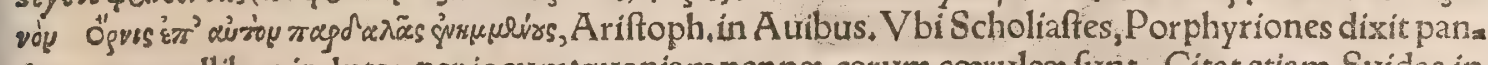
therarum pellibus indutas, per iocum:quoniam pennæe earum corulea funt. Citat etiam Suidas in

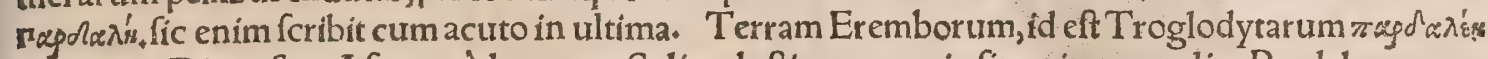
comparat Dionyfius Afer:quòd propter Solis aduftionem uaria fit, ut in B .retuli, Pardalea conue - ftitus dicitur, qui eft moribus uarius, \& uelut monústkros, id eft multis interpunctus notis, Calius \& Varinus in ropolac $\lambda \dot{s} \%$

Th. Apud Chaones adolefcens quidam nobilis Anthippen amauit: 8 cum allquando in fylua quadam fimul effent, tum forte fortuna regis filius Cichyrus pardalin fugientem in eam ufque fyls uam perfequens, iaculum in eam intentat, aberransós puellam ferit. Opinatus autem fe feram elfe iaculatum, equum propius adigit $\$ \&$ quum uideret adolefcentem in uulnere puella manus haben= tem amens factus, ac uertigine affectus, ab equo in praruptum ac petrofum locum delapfus eft, ubi fanè interít. Chaenes autem in honorem regis eundem locum muro cinxerunt, \& ciuritatem Cichy . rum appellarunt, Parthenius in Eroticis. T Bacchum tauro affimilât $\&$ pardali, quòd homines e. brï belluarum iftarum ingenia referant, $\&$ omnia uiolenter agãt, quidã enim iracundi fiunt tauror $\tilde{u}$

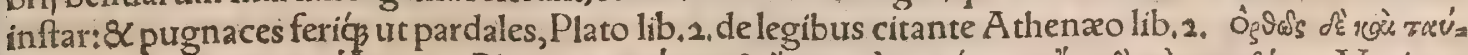

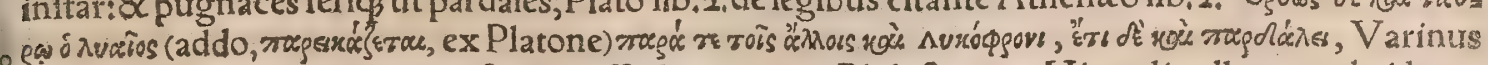
in suoúos. Pantheram Baccho facram effe dixi in c. ex Philoftrato. Hinnuli pellem, (nebridem, Bacchi more (Atowvoskwis)geftare dixeris hominem timidum, ebrium, uarium, inconftantem; propter 
uarias nebridum maculas, Varinus in ragela $\lambda \dot{\varepsilon}$ : Videtur autem eandem ob eaufam \& nebris \& pantherina pellis Baccho attributa: cum utra $\phi_{\beta}$ fimiliter maculofa fit: proinde hominem quoç uarif \& inconftantis ingení pardaleam geftare prouerbialiter dixeris. Bacchumà iugo pardalium uehi, $\&$ in comitatu eius pardales effe fingunt, fiue propter uarietatem coloris (uxuarum: Vide in Nebride in Ceruo H. $e_{+}$) ficuti $\&$ nebridem geftare fertur tum ipfe tum Baccha: fiue quòd utcun $;$ fera inge, nia moderata uini potione manfuefcant, Phurnutus. Eadem feilicet rationelynces etiam Baccho facra funt: Vide in Lynce h,item axis, quam Ctefias in India nafci fcribit, hinnuli pelle, pluribus candidioribusćp maculis. Bacchus aliquando effictus eft in curru pampineo $\mathcal{Z}$ triumplians, quí pantheris modo, modo tigribus ( $\&$ ipfis maculofis)ac lyncibus trahebatur, Gyraldus. Nutrices Bac chi mulieres in pantheras mutate deuorarunt Pentheum mutatum in taurum propter contumelias quibus Bacchum affecerat, ut prolixè fabulatur Oppianus de uenatione libro 3 .

$$
\text { P R O VER B I A. }
$$

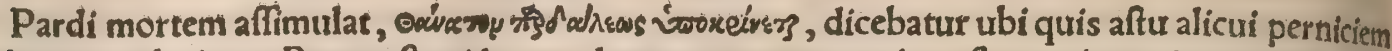
moliretur, ueluti cum Brutus ftupidum ac dementem ageret, ut in pofterum imperio poriretur. Id ac dagium ad quendam apologum referunt. In Maurufia fimiarum ingens copia, \&c. Erafm. Refertau tem apologum ex Apoftolio Byżantio non alium, quàm nos fupra capite tertio tanquam uram hi, ftoriam ex A eliano recitauimus, de pardali inquam qua mitabili aftutia fe mortuam fingens fimias captet. TPardaleam geftare prouerbio dici poteft uir uarius, animo inconftans $\&$ fraudulentus, (Vide paulò ante in $e_{\text {. }}$ ) Varinus. đT Si mutare poteft Àthiops pellem fuam,aut pardus (namer)ma culas fuas, 8 uos poteritis benefacere cum didiceritis malum, Hieremiz iz. ब1 Habitabit lupus 10 cum agno, \& pardus cum hoedo accubabit, Efaiz 11. đA pologus qui refertur à Plutarcho in Mo ralibus, interprete Erafmo in prouerbio, Multa noưt ưulpes, uerum echinuss unum magnum: Cum aliquando pardus uulpem prafe contemneret, quòd ipfe pellem haberet omnigenis colorum macts lisuariegatam:refpondit uulpes, fibi id decoris in animo effe, quod illi effet in cute. Neģ uerò paus. lò fatius effe, ingenio praditum effe uafro, quàm cute uerficolore.

\section{DE FELE ZIBETHI.}

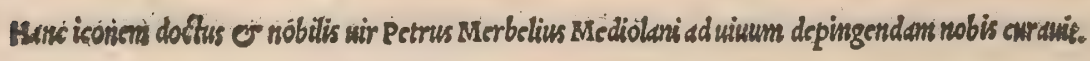
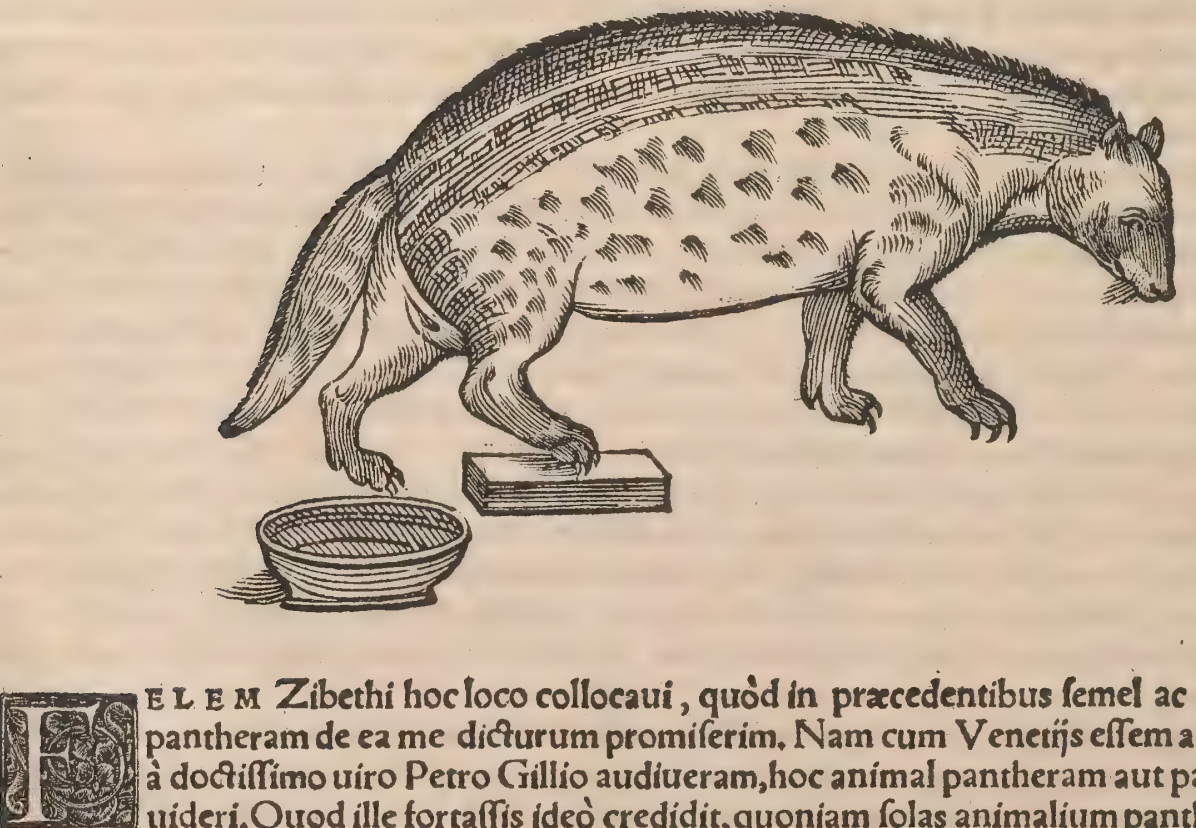

E L E M Zibethi hocloco collocaui, quod in pracedentibus femel ac iterum ftatim pof pantheram de ea me dicturum promiferim. Nam cum Venetins effem ante annos aliquot, à doctifimo uiro Petro Gillio audiueram, hoc animal pantheram aut panther $x$ genus fibi uideri.Quod ille fortaffis ideo credidit, quoniam folas animalium pantheras odoratas effe apud ueteres legiturł nec alia ferè hodie odorata reperiuntur prater zibethi \& mofchi animalia: fed quod mofchum fert, capreolum effe conftat. A tqui de pantheris ueteres docent, non fimpliciter, nec homini eas bene olere, ut zibethi feles olet: fed a nimalibus cateris, quanquam illud etiam dubitan. dum mihi uidetur, nec uno modo. Primum enim utrum omne animalium genus ad fe alliciant, ut uulgò ferebatur olim, non conftat:deinde, ut alliciant, odoris'ne an alia quapiam gratia id contingat, meritò dubitatur. Iam corporis quog figura, nihil ad pantheras: nec amplius puto cum illis commu ne habet, quàm feles aut nocqua cum Minerua:pellis forfitan maculas, fed diuerfo modo, 82 ungues 60 acuros qui uaginis conduntur. Sui igitur generis hoc animal efto : quo autem loco collocetur non admodum refert:necs enim anxié aut exquíitè de ordinis ratione cuiquam refponderim. Egohoc 


\section{Defelezibethi. Lib. I.}

animal Venetijs uidi apud quendam qui odoramenti ex eo colligendi gratia id alebat:fed defcribere corporis formam neglexi:quamobrem alienis tantum uerbis mihi utendum erit. TNatura zibe. thum finxit feli perfimilem, fed maiorem, animal quod Hifpania mittit, dentibus armatum \& ferum ualde, quod nulla temporis longitudine mitefcat, pilo afperiore, ore oblongo, ut taxo animali in huius tam mafculi quàm forminæ genitalibus folliculum genuit, e quo femen argenteo cochleari ex cipitur, adeòodoris fragrantis, utuel grana tria,pondus librarum plurium cuíufés arboris odora= tiffimæ uincant, Cardanus. Longitudo huius animalis, (ut oculatus quidam teft is ad me fcripfit,) a fronte ufq ad initium caudæe, brachium integrum hominis æquat. Crurum altitudo ufó ad pedes, trientem brachị. Magnitudo ferè uulpem excedit. Color ferè lurpinus eft, maculis paffim nigris inter ceptus, per fummum dorfum obfuré fuluo colore mixtus. Maxilla inferius albæ funt, $\&$ pili barbæ albi,Pedes nigri funt. Latera uentrem uerfus albicant, ita ut color albus eò fyncerior fit, quo uentr imo propior, Hac ille. Vir quidam bonus \& eruditus hoc animal certo anni tempore incalefcere, \& feipfum corrumpere, (inire, )atç ita liquorem illum, ceu genitale excrementum emittere, mihi nat rauit. Zibethi animal quod equidem fciam non nouit antiquitas: id in felium genere habetur, lin. gua tamen non afpera ut cæter is felibus feli feré fimile, pilo duriore, etiam odoratołbarbas habet, \& oculos noctu lucentes. Odoramentum ex eo colligitur, foeminæ intra genitale $\&$ aluum, mari intra genitale membrứm \& teftes, oriculario ueluti inftrumêto offeo. Eft autem excrementitius quidã len tor, primo butyri colore, qui mox liuidus redditur, fingulis diebus drachmæ pondere, Carnibus dun

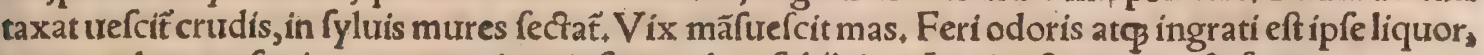
- ex quo plus (prafertim cum propíus) iufto naribus fubícitur. Leui taçu manus $\&$ faciem matrona rum odore commendat, cornu afferuatur. Vncia ocfonis aureis permutatur, nec ulla res in maiori atate noftra pretio fuit. A dulteratur felle bubulo acftyrace liquida elota, uel melle Cretico, Alexan. der Benedictus de curandis fingillatim morbis, 13.26. Idem in libro de pefte, Vnguentis ætas noftra non utitur, alioqui in omni genere luxuriæ antiquitatis amula qua zibetum animalis cati magnitu dine excrementitium ex naturalibus habet humorem, ac mofchum fuauius fpirantem, Illud ex pro: ximo nares acrius ferit, \& ex quo plus eft(lego, \& quó propius eft, eó fcilicet acrius $\&$ minus grato odore nares ferit.) Mufcho tamen charius comparatur:etenim odorem qui gerit ipfe non fentit: (hoc idem alibi de mofcho fcripferat.)A $\mathrm{b}$ ị $\mathrm{s}$ qui impendio non parcunt, additur etiam pilis fiure pomis uu! gò dictis, qux odoris gratia geftantur. Et alibi, Succinum orientale(id eft ambra) confuetudine odo ris fui gratiam acquirit, cum zibethum $\&$ molchus faftidium pariant. Etrurfus, Mofchus Vene tis matronis non placet, quibus nec zibethi fordes. If Feram quandam animantem zibettum re. centiores Græcinominant peregrino fermone. Ea autem feli, qui ueteribus ædificiorum ruinis ober rat, non abfimilis eft:è cuius natura fordes manat odoratiffima, qua folet pracipué purgari, quurm pars ea hac fcatet uligine, tum uafe uitreo uel alio recipitur. Si cauernulæ umbilici admoureatur, tras dunt conurerfum in alterutram partem uterum in fuam refilire fedem opprimat, fubdito eo deuocari:tam amans huius odoramenti uulua, ut ad id undecunç admodum irrepat. Nonnulli è recentioribus Gracis hoc animalis genus zapetion appellant: uulgus noftrum hodie fiuettam nominat. Quanquam celebratum Gracis recentioribus medicamentum, quod ex a= nimalis mofcho, agallocho, $\&$ ambare conftet, officinæ galiam mofchatam malunt appellare, barba. ri fonc mofchatum, Ruellius de ftirpibus 1,27.ex quo Matthæolus etiam in Italicis fuis in Diofcori. dem commentarïs mutuatus eft. Algalia compofitio eft molchata, de qua in Morchi caprea dixi,ca. pite quinto:eam nonnulli Gallicè ciuettam nominant. Peregrini murris pellicula, nominatur ab Hie ronymo ad Demetriadem+quis autem peregrinus ifte mus fit (inquit Hermolaus in Diofcor,) non uideo, nifi quis animal hoc intelligat ex quo zibettum, fiue (ut recentiores Græci uocant) zapetion excipitur.quanquam $\&$ compofitionis quoddam genus eft zapetion ex animalis mufco, agallocho \& orientali fuecino: hrc ipfa compofitio etiam net uocari folet à Gracis quibufdam, fed uox eft A. rabica. Io. Agricola Ammonius fcribit Othonem Henricum Bauarix ducem, gazellam habuiffe, quam matgnis impenfis affecutus faccharo potiffimum aluerit, neq cornutam neq dentibus promic nentibus, pauló maiorem cato, nigro $\$<$ albo ferè colore undiq̧ infignem : atqui gazella capreolus eft, cui nihil cum zibethi fele:impoluit ei puto, quòd utrunģ animal ( capreolus inquam morchi $\&$ feles zibethi)peregrinum eft, $\&$ odoribus nobile. TIn Pego urbe Indix inueniuntur feles, qui un guentum illud fragrantiffimum gignunt, quòd uulgó zibellum(zibettum) dicitur. Veneunt autem feles terni aut quaterni fingulo aureo, Ludouicus Romanus. Alibi etiam has feles reperiri fribic circa Tarnafari urbem Indix. Idem regem loghæ peregrinantem per Indiam religionis caufa, in. cer alia animalia gibellos (catos zibethi) fecum ducere feribit. Paulus Venetus 1.62, animal mof hi

haberi fcribit, pulchrum, magnitudine cati, \&c. fed hæc magnitudo feræ zibethi con. uenit : quanquam maior eft cato, aut etiam uulpe:nam mof chi animal

capreolus eft, cuius magnitudinem omnes norunt. 9 Am

bram factitiam quæ mofchum uel cibetum redole. at, defcripfi in Mofchi caprea $\mathrm{E}$. 


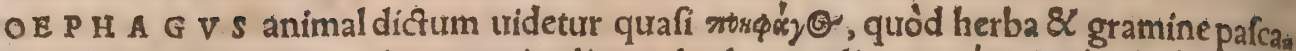

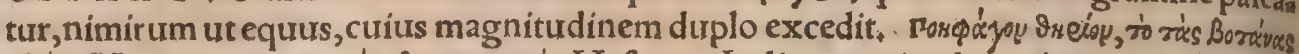

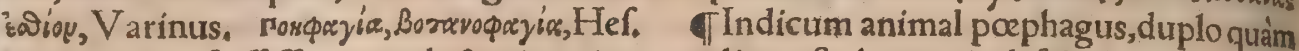
equus maior, fpiffiffima cauda $\&$ nigerrima praditus eft : humani pili fubrilitatem eius fen tæ uincunt, Permagni eas idcirco Indiæ mulieres $æ f t$ timant, quòd eis ipfis crines fuos pulcherrime implicent $\&$ deuinciant. Ad bina cubita fingulæ ipfius fetæ longitudine procedunt:ex una radicetri ginta fimul exoriuntur. Omnium animalium timidiffimus eft, nam fi à quopiam fe infpectim fentit, euteftigio quanta potelt maxima celeritate fefe in fugam properat conijcere, in quam magis ftudiofe quàm celeriter fe impellit.Quod fi quum infequentibus canibus 8 equis ad currendum promptiffi mis urgetur, intelligat fe appropinquare ut comprehendatur, prius occultata cauda contra ftans, ue natores intuetur, fimul \& ex magno timore colligit $f e, \&$ quadam fiducia nititur, neq̧ enim iam cau da abdita fe ullius precĭ putat amplits uifum iri: quòd praclare fcit in caufa caudam effe quamobrể tantopere appetatur, Veruntamen interea quifpiam preftanti telo illum ferit, \& ab occifo caudam præmium prædæa abfindit $\$ \&$ pelle, qux utilis eft, ex toto corpore detracta, cadâuer abícit, quòd ciufmodi carnium ufum nullum Indi habent, A elianus, Volaterranus aliter tranftulit, Animal,ina quit, timidum eft, $\&$ obuios quofç animi magis anxietate quàm pedum celeritate fugiens, pracifaf bi fponte cauda, ob quam fe peti præfagire uidetur. Nicolaus Venetus comes, extremæ Afrix pro it: uinciam quandam Macinum nominat, inter Indix montes $\&$ Cathaium fitam, (Sericam intelligere uidetur.) in hac regione qua ad Cathaium uergit, boues albos nigrosós gigni fcribit, equina cauda, fed pilofiore, ad pedes ufóp protenfa:pilos caudae fubtiliffimos, in modum plumx uolatilis, magno in pretio effe, quos equites in cacumine lancearum fufpendentes egregix nobilitatis infigne ducunt, Aeneas Syluius capite decimo de Afia. Hac bellua aut ipfe pœphagus eft, aut certe cum eius hifto ria coniungi meretur.

\section{DE RANGIFERO.}

Figuram hane qualemeung; ex tabula Septentrionalium regionum olai Magni mutuatifunus. Comu feor im pof iti figut ram depinximus ex uetuftifimis quibufdam cornibus, que in urbe noftra ciuis qquidam afferuat, rangiferi ne, an alterius animalis, nefcio.

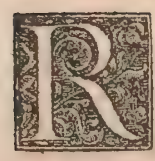

A N G I F E R animal, ut Albertus Magnus \& alï quidam eum fecuti uocant, in remotiffimis ad Septentrionem Scandinatiix regionibus inueni= tur, præfertim aptrd Lappos populos quorum lin gua reen uocatur; unde facta Germanis uocabula, alijs ali. ter fribentibus, rein/reyner/rainger/ren/dbieron. Gallis, rangier, uel ranglier. Latinis recentioribus, rangifer, rain= gus. Hanc ueteres Graci \& Latini an cognouerint incertum eft.A micus quidam nofter Plíní machlin effe conícit: fed machlin $\&$ alcen eandem mihi uideri, in Alces hiftoria oftendi. Fieriautem poteft ut Plinius diuerfas exiftimârit, quòd nomina fortè diuerfa à peregrinis hominibus audiuif fet. Ge. Agricola uir doctrina \& iudicio fummus, tarandum, reen interpretatur. Ego qux ueteres de tarando fcri= prerunt in Boum fylueftrium hiftoria recitaui tubi et meam de eodem fententiã, aut dubitationes potius attuli. đLap pi fiue Lappones equorum loco utuntur animalibus, qux raingi fuo fermone urocant. quibus magnitudo \& color afi ni, (pilus propè afini, hirfutus, Munfterus) ungula bifidx, forma atç cornua ceruorü. fed cornua lanugine quadam cooperiuntur, eadẽ humiliora (tenuriora $\&$ longiora, Mun= fterus ) \& ramis rarioribus quàm certiina funt, ut ipfi uidi=

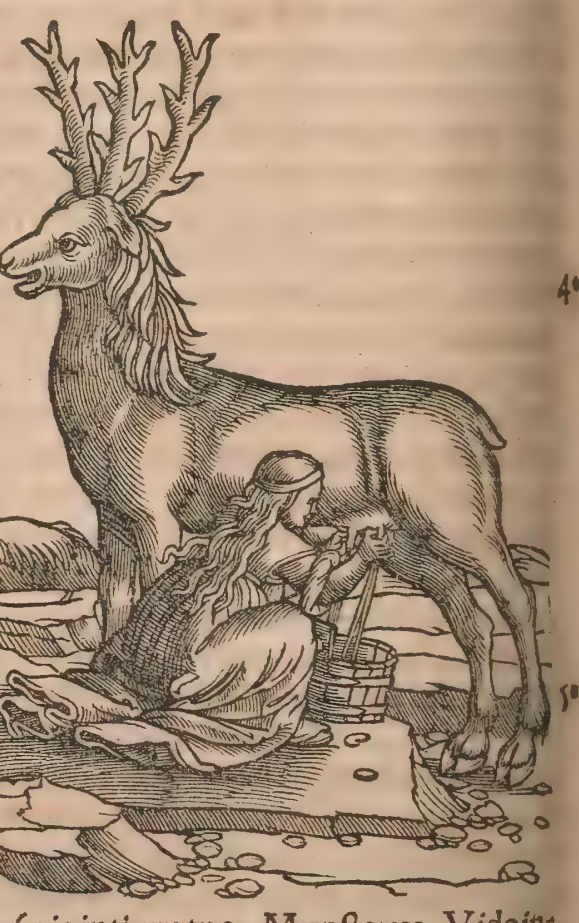
mus. A nimalia ipfa tantæ funt uelocitatis, ut fpatio duodecim(uigintiquaturor,Munfterus. Vide ints fra circa finem huius animalis hiftoriæ) horarũ, uehiculum C L, millia paffưm, id eft triginta milias ria Germanica proripiant. In progreffu eorum lento uel celeri, ex tibiarum articulorum agitatione ad inftar nucum collifionis crepitus auditur, Damianus à Gö́s. iores funt ceruis, \& gregatim pafcuntur, Olaus Magnus.

TRangifer in Septentrione uerfus polum Arcticum generatur, 8 in regionibus Noruegieac Suecix, \& alips quæ funt minoris latítudinis, Dicitur autem rangifer, quafi ramifer. Speciem enim 


\section{DeRangifero. Lib. I. 951}

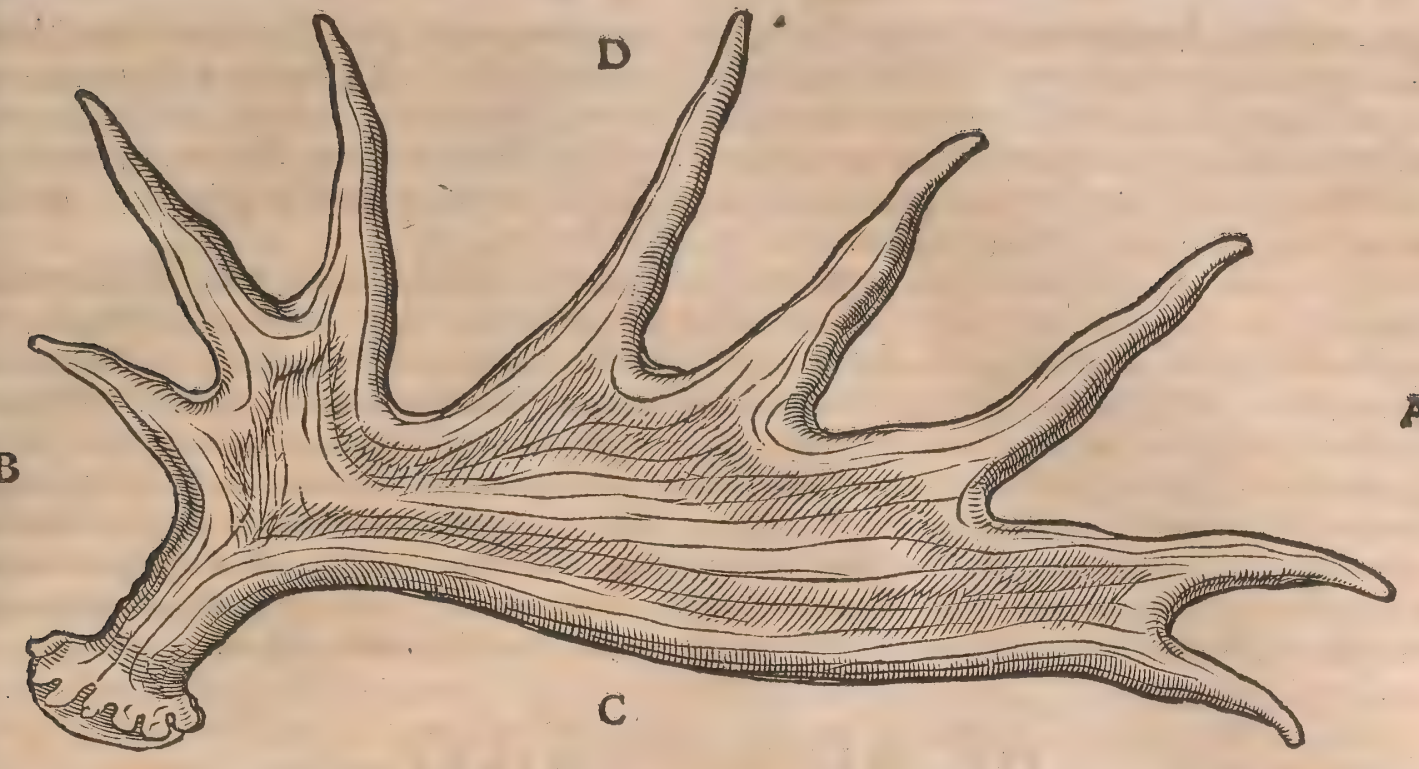

- cerui prafentat, fed maior eft corpore, robore infignis, $\&$ ad fugam celerrimus. Tres ordines cornutis um gerit in capite, ita ut in fingulis bína fint cornua, $\& \mathcal{X}$ caput eius uirgultis (aliâs, uirgulis) circumpo fitum uideatur. Ex his duo cæeteris maiora funt, in loco cornuum cerui, qua ad perfectam magnitu dinem augentur, adeò ut quinç cubitorum menfuram aliquando attingant, \& ramis confpiciantur uiginti quinç, (idem de ramorum numero huius feræ, Rob. Stephanus fcribit in Obferuationibus fuis uenaticis circa finem Diçionarij Gallicolatini. ) Duo etiam in medio capitis, lata ut damarum habentur, mutilis $\&$ breuibus ramis mucronata.Deniqg alia in fronte, antrorfum uerfa, offibus fimin liora, quibus in pugna potiffimum utitur, Allbertus:nimirum ut cerui fuis adminiculis, id eft infimis ramis, IEft in Polonia uaftiffimis faltibus celebre animal, renfchieron ab incolis appellatum, nufquam a bullo authore defcriptum, quod magnitudine exæequat ceruum, cornibus præarduis ar" - matum, quorum utrung in faftigio tridentem, hoc eft triplicem uerticem oftentat. Huiufmodi fera pro fplendido munere Saxoniz, Turingix $\&$ Mifnix principi Georgio miffa eft: anno Salutis trige* fimo primo fupra fefquímillefimüm, Io, Agricola Ämmonius. De rangifero etiam accipiendum pur to, quod Ia. Boëmus fcribit, in Polonia equum fylueftrem ceruino cornu reperiri. Et fane poffet hip. pelaphus dici, non minus quàm alcen Albertus fic uocat. fed alius Solini hippelaphus eft, ut in Alce docui. Animalis huius hiftoriam, inquit Zieglerus, putấrim ueteres quoqg agnouiffe, fed obfcura \& dubia quafi fama exceptam:fiquidem aiunt Scythas quofdam equitare ceruos. In Scythia natio quadam ferorum hominum eft, qua ex feritate ceruos in eam manfuetudinem traduxit, ut in cicus. ribus illis tanquam equis infideat, Anelianus. Vltra Catadupa Nili procedens A pollonius \& 6 focĭ, re pererunt feras quafdam ex boue $\&$ ceruo compofitas, Philoftratus. In Orientalibus A fix prouincriss(Scythiam $\&$ Tartariam uerfus)Medita habitant, homines fylueftres, qui carnibus animalium quæ uenando ceperint uefcuntur, maximè ceruorum, quorum magnam habent copiam, $\&$ adeò cicures faciunt, ut illis tanquam equis trel afinis infideant, M. Paulus Venetus 1. 61. Alibi etiam legimus ceruos cicures equitari in Ocdor regione Afiæ ad Oceanum Septentrionalem. Quòd fi quis rangiferum etiam, ceruum Scythicum appellârit, meo quidem iudicio non ineptè faciet. Eft bos in Hercynia fylua cerưi figura, cuius à media fronte inter aures unum cornu exiftit excelfius, magiṣ́́g dirêtum his, qua nobis nota funt cornibus dem eft fơminæ mariś́́, natura , eadem forma magnitudoó́s cornuum, Cææfar lib. 6. de bello Gallia co: Gillius hoc loco non rectè legit, Eft bifon in Hercynia fylua, \&c, Ego plane rangiferum à Cæare defcriptum puto, qui cum cerui quídem cornua gerat, fed corpulentia excedat, boui ab eo compara di potuit:accedit quòd etiam cicuratus mulgetur. Sed $\&$ Solinus, Tarando (quem rangiferum nofrum effe cum Ge. Agricola libenter credimus, inquit, magnitudo quęboui, caput maius certuino, nec abfimile; cornua ramofa, ungula bifida, $8 \mathrm{cc}$. Sunt autem rangiferi quoç cornua lata, 8 ex laritu dine in mucrones aliquot tanquam digitata.Illud quidem cornu quod depistum dedimus feorfim, $\mathbb{R}$ ue tarandi aut rangiferi, fitue alterius animalis, ab uno principio oritur, deinde in duas partes tan. quam manius aut alas in diuerfum abeuntes bifurcatur $¥$ quarum altera duplò ferè maior, ramulos fetr mucrones quinģ emittit: altera, tres, Latitudo cornu, qua latiffimum eff, à $\mathrm{C}$. ad D. digitorum eff duodecim, mucro longiffimus, quatuor palmor um: breuiffimus, fefquipalmi. Longitudo fecundum latitudinem accepta, hoc eft ab $A$. ad $B$. quatuor dodrantum, ut ipfe manibus tractando menfuraui. Sunt fanè alcis etiam cornua lata, ut damarum uel caprearum potius quas platycerotas uocant, $8 \mathrm{Q}$ in digitos aliquot finduntur:fed rangiferi cornua melius comparaueris ceruinís, ut Albertus $\&$ ali fe $f_{a}$ cerunt.Quamobrem certios etiam palmatos, ut Capitolinus nominat, eofdem rangiferis effe fufpie cor, ut pluribus dixi in Ceruo B, effillilic dubitârim, poffet'ne dorcas platyceros, yquam uulgò damam 
uocant, cerui palmati nomine intelligig. Illudetiam ceruorum genus, quod aliqui urocãt bsan\$bitน Ge. Agricola tragelaphum interpretatur, cornua in fummo latiufcula \& tanquam è pa!mis digitata habet. Rangifer, inquit Bellunenfis, cornua duo extrema habet ut ceruus, fed maiora \& Iongiora, utpote cubitorum quinģ, ramos augens ad numer um quando ç quindecim. Alia duo in medio cas pitis habet, ferè ut cornua dama lata, ramis exiguis \& breuibus circundantibus, pręter hac alia duo frontem fpectant, non cornibus, fedoffibus fcapularum fimilia.

Rangiferi equis celerius per niuem currunt in locis quiburdam Scandinauia : ubi \& metallis prafecti quadringentos aut quingentos rangiferos alere folent, ad uehicula, currus, traheas, \& equi tandi ufum. Quinetiam mulgentur, \& omne genus lactarïjoperis ex ipforum lacte conficitur, Ola. us magnus. Tengillus Scricfinnorum in Scandinauia rex equitatum habet rangiferis infidentem, 8 uincit tamen (aliquando) Helfinglandia regem Argrimum, cuius equites equis utuntur, Idem. Quamobrem miror quod Munfterus fcribit:Hoc animal equitem dorfo non fert, fed antilena impo fita iungitur uehiculo. Rangiferi circiter triginta miliaria uno die emetiuntur, trahentes etiam tra heas ualde onuftas, Olaus. $P$ ar fermé etiam alcis celeritas pradicatur. Sed dies $æ$ ftiui in regionibus ilo lis longiffimi funt, ita ut circa folftitium nulla propemodum nox fit, TRangiferorum neruis utun tur ad arcus, \& alicubi ubi clauris carent ad naurum tabulas compingendas, Olaus,

\section{DE RHINOCEROTE.}

PiCtura hac Alberti Dureri efl, qua clarißimus ille pictor (cuius etiam libri de pictura extant) Rbinocerotem Em manueli Lufitania regi anno falutis 2515 i è Cambaia India regione Vlyfbonam allatum, perpulchre expreßit. Rhi nocerotis, id cft naricornis, nuper pictam uidimus imaginem, referentem ex hoc genere animal, quod per has tempora LH fitano regi ex Indid allatum eft, Aug. Iuftinianus hanc ipfam indubie, quam hic damus, imaginem iutelligens.

\section{A.}

H I N O C E R O S elephanto fimilis eft, cornu in nare habet, unde nomen, Dion. Emi net enim ei unicũ de fummo nafo cornu, ut in progreffu pluribus dicemus, Quamuisau tem $\&$ alia quadam fingulis animalia cornibus confpiciantur, ut ory $x$, onager fureafia $3^{\circ}$ nus Indicus:cæeter is tamen à media fronte, huic uni ènaribus prominet. Et cum unicore nium maximus hic fit, monocerotis, id eft unicornis nomen, a pud recentiores prafertim $8<$ imperia tos, per excellentiam aliquando fortitur. Etfi urero reprehendi non potelt, qui pro rhinocerote unit. cornem dixerit, ut qui fpeciei nomen generis tribuit ₹ quanquam id aliquando ignorantix figntm eft, aliquando errandi caufa alijs: omnino tamen reprehendendus eft, qui pro monoceroterhinoce, rotem dixerit; fiue monocerotem utgenus accipias, qurod fieri quidem poteft, ufitatum tamen non ef: fitue certam animantis fpeciem, quam in monocerote defcripfimus, Quamobrem errant $\&$ alih mulri recentiores, Ifidorus, Albertus, \& eos fecuti, \& noftro feculo eruditi quidam medici, Carda nus $\&$ aln̈: qui $\&$ nomina confundunt, $\&$ medicas uires rhinocerotis cornu adfcribunt, qua monos ccrotis fiue afini Indici propria funt. Vide plura fupra in Monocerote A . Paufanias in Bocoticis, 4 tauros effe fcribit in Aethiopia, qui rhinocerotes uocentur, à nafo cornuto. In Eliacis quo ç de ele phanto feribens, tauros Aethiopicos in nafo cornu habere teftatur.Quamobrem non probo Angeli Politiani iudicium, qui ut Domitium reprehenderet Martialis interpretem, nomen quídem commu ne, animalia diuerfa facit, Sed tauros A ethiopicos $\mathrm{P}$ aufania ueros rhinocerotes effe, à Plinị ac Aelia ni tauris Aethiopicis diuerfos, contra Politianum in bubus feris oftendi. Elephantes nafcuntur, ut Iphicrates fcribit, apud Hefperios Aethiopes: et qui rhizes (oi $\rho$ í iss) urocantur, forma tauris perfimiles: uita uerò, magnitudine, \& pugnandi uiribus elephantos referunt, Strab. Aethiopici quidem ifti tats ri,alí quàm rhinocerotes uidentur. Rhinocerotem quidam effe aiunt bouem A egyptium, (lego, Acthiopicum,)Feftus. IIndorum lingua hoc animal fandabenamet uocat, okin reem, uocem Hebraicam in Biblị̂s interpretes aliâs unicornem, aliâs rhínocerotem transferunt. Apud Munfer rum etiam rimna legitur, in Lexico trilingui, Chaldaicé.Idem wp karas uel karafch, (qux uox in Biblijs non reperitur:alludit autem àd cartazonum, hoc eft monocerotem, ut Aelianus appellat)uni cornem interpretatur. Quòd fi uoces reem uel rimna $8 \mathrm{kar}$ as coniunxeris, uox fiet fimilis Graca rhinoceros, ut fufpicem ur uel Gracos Hebraicas uoces duas cópofưiffe, uel Hebræos Græcam inẩ in duas fecuiffe. Sed de Hebraicis iftis trocabulis plura leges fupra in Monocerote $A$, ubi etiam con ḧcere me dixi utroç cortum monocerotem potius quàm rhínocerotem fignificaritrem tamen in mes dio reliqui. Afinus Indicus ungulam unam 8 folidam habet, cornu quoo $\$$ unum; hic à quiburdä uocatur rhinoceros fiue unicornis: fed potius eft animal quod quidam Arabicé uocant archa, \&Left rhinoceros, cornu in nare unico, ungula ficut bouis bifulca, \& habet duo chahab in pedibus ficutcæ tera bifulca, Albertus de animalibus 2, 1.3. Et rurfus libro 12. A finus Indicus, inquit, habet unicum 69 cornu: $\&$ animal quod quidam ueterum archos, quafi principem, uocauerunt, nos unicornem Lafine, rhinocerota Graci uocant, Huius cornu maximum eft, \& folidumificut ceruinum : quod pedes 


\section{DeRhinocerote. A. Lib.I. 953}

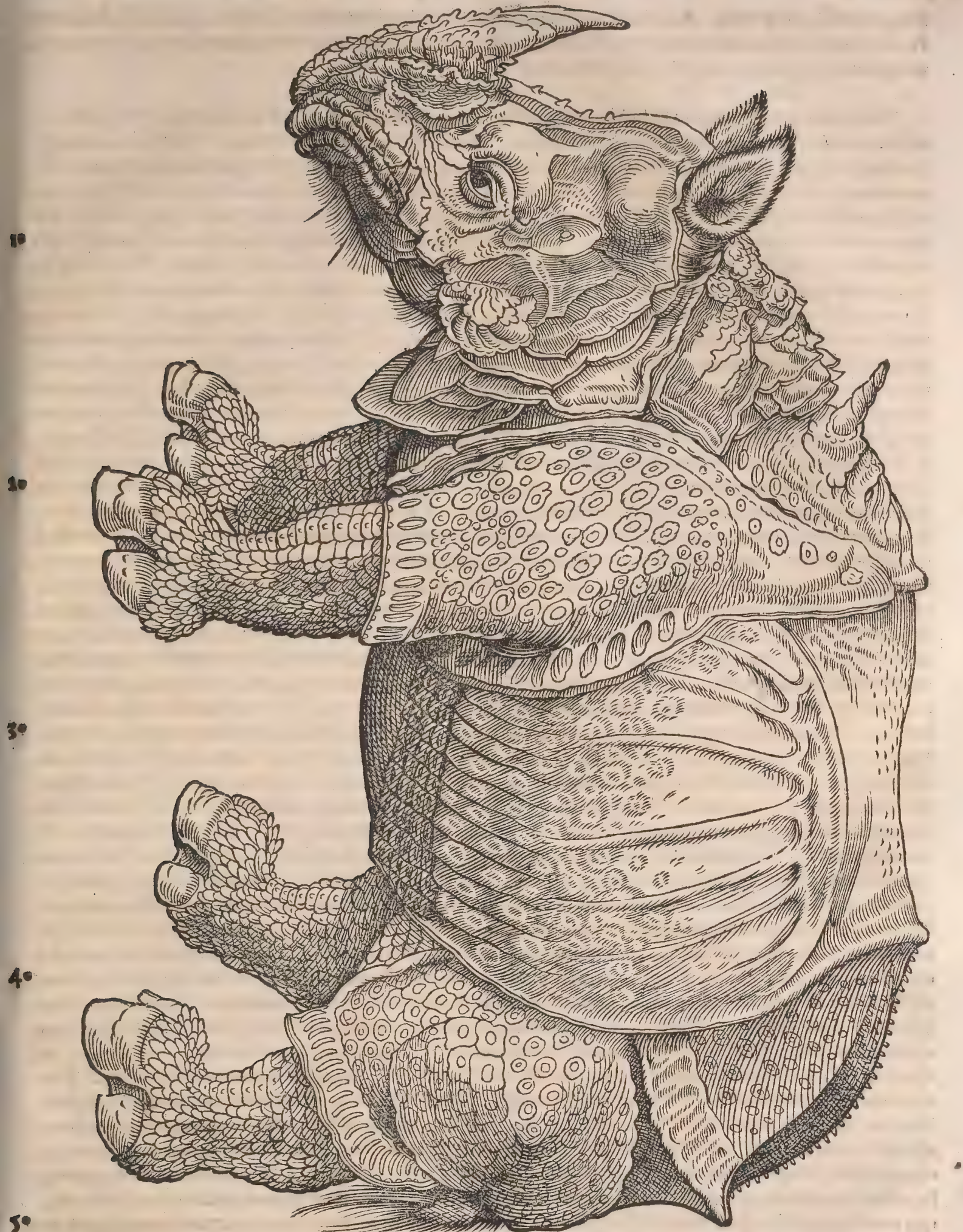

decem, ut ipfe menfuraui, longitudine excedit: $\&$ diameter eius in radice fefquipalmum, (Fefquido drantem intelligo, ) (uperabat, $H$ æc ille, Ineptè autem facit, primum quòd afinum Indicum ex Ariftos= tele fribens folipedem effe, mox rhinocerotem animal bifulcum interpretatur \$deinde, quòd rhino cerotem $\&$ unicornem confundit: tertio, quòd archa uel archos Arabicum nomen faciens libro fè, cundo, (corruptum forte à uoce karas, )duodecimo principem interpretatur ac fi Gracca effet. Sed et proteritas ifta cornu, decem pedes excedens, rhinoceroti puto non conuenit, fed monoceroticarta= zono,nam Oppianus rhinocerotis cornu paruum (hoc eft breue, Gillius quog; paruum transfert)

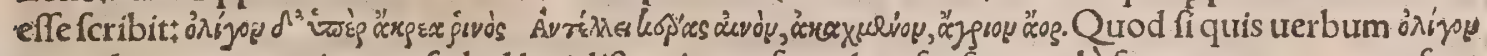
6o non ad cornu quantitatem, fed ad loci diftantiam referat, hoc fenfu : paulò fupra extremum nafum crudele $\mathcal{Q}$ acutifimum cornu oritur : nos tamen ex ipfa picturæe quam ad uiuum dedimus, propor tione, cornu breure effe conuincemus: nam cum fupra nares incipiat, $\mathcal{Q}$ multò infra aures definat, 


\section{4

longum effe non poteft. Ariftotelem nufquam huius animalis meminiffe miror, quod fi ipfi notum fuiffet, omnino hiftoriam eius orygi $\&$ afino Indico iungere debebat, ubi unicornium naturam con. templatur lib.3, cap, 1, de partibus animalium.

B.

Rhinoceros non multó oryge maior eft, Opplanus. Elephanto parê longitudine Plinius facit: alij uel parem uel pauló longiorem, humiliorem tamen, \& breuioribus cruribus. Elephantis longi. tudine propé par eft, breuior cruribus, Plin.\& Solinus Aelianus pugnare quidem ipfum aduerfus elephantem fcribit, fiducia cornu fui.cxtera non ei paria cum elephanto. nam hic (inquit) \& proce. rillimus elt, \& fortifimus, Sed Strabonis ex libro 16. defcriptionẽ recitabo. Haecregio, (inquit, In. dis puto contermina) rhinocerotes fert, qui (ut Artemidorus ait) longitudine parum ab elephantis exceduntur, quod Alexandrix uidiffe affirmat fe, ferè etiam quantum ad altitudinem. (Gracé ficle.

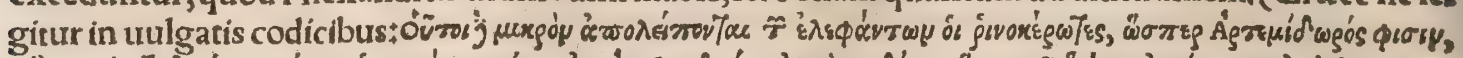

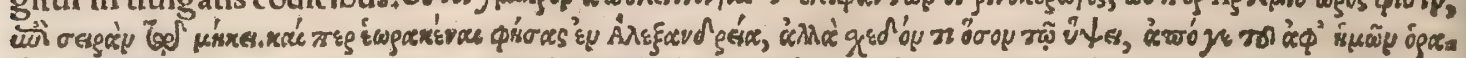

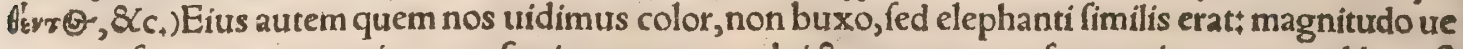
ro tauri,forma apro proxima, prafertim quantum ad rictum, prxter nafum, qui cornu quoddam eft

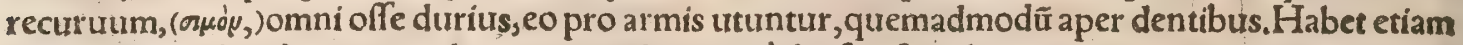
duo cingula (rúnous) tanquam draconum uolumina, à dorfo ufos ad uentrem circumeuntia, alterum

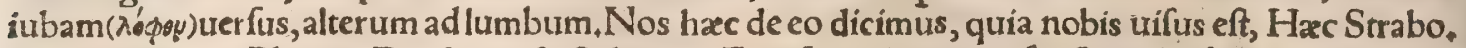
Color ei buxeus, Plinius, Diodorus, \& $\alpha$ Solinus. Eius frons leuiter rufa eft, \& dorfum maculis pur.

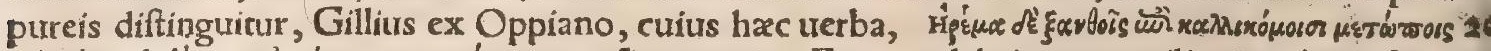

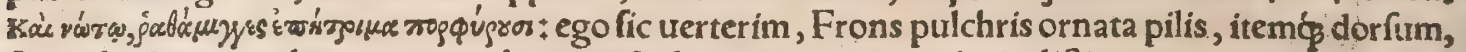
flauo fpectantur colore, quem crebra puncta leuiter purpurei coloris diftinguunt.quanquam illud

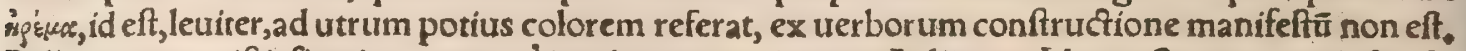
Pellis eius ea exiftit firmitate, ut xgrè iaculo penetrari queat, $A$ elianus. Idem teltantur qui noftro fxe culo belluam in Lufitania uiderunt: pellem enim habere prædenfam aiunt, ceu cruftis quibufdam fquamatím compactam, colore $\&$ figura teftam referre teftudinis. Plinius buxeum colorem, alif mu rinum, uel qualis in buxi cortice eft, ei attribuunt. IIn ludis Pompeị Magni exhibitus eft rhino ceros, unius in nare cornu, qualis frepe uifus, Plinius. In naribus cornu unicum \& repandum, (id eft, modicè reflexum, ) Solinus. Breue id effe, fuperius in A. docui. Ácutũ eft enfis inftar, $\&$ a deò uralidum, ut quicquid impetierit aut uentilet aut perforet, \& ferrum etiam \& faxa tranfigat, Oppias $\xi^{3}$ nus, A elianus. Simũ eft forma, durumóć inftar ferri, Diodorus Siculus. Tertullianus in libro ad uerfus Praxeam tertio uerba illa enarrans de uetere inftrumento, (Deuteronomï 33.) Tauri decor eius: cornua unicornis (reem, rhinocerotis Munfterus) cornua cius:in eis nationes ventilabit ad fum mum ufq, terræ: Non utiģ, inquit, rhinoceros deftinabatur unicornis, nec Minotaurus bicornis, \& quæ fequuntur. Non placet Eucherius, qui rhinocerota terribilem feram gemina in naribus cors nua geftare fcribit. Quanquam enim gemina in hac animante cornua fpectentur, unum in nare, ut diximus, quod grandius: alterũ fuperius, paruum admodum, $\&$ inutile, cum eo uti bellua non pof fit, ut in pictura apparet, quare uix cornu etiam nominatur \$ ut non fitreprehendendus, qui ab alte. ro mediocriter magno $\&$ utili unicornem hane belkam effe dixerit. Rhinoceroti in fummo nafo cornu fingulare eft, 8 aliud fupra ipfum non magnum, (aliqui hac citantes, de fuo addunt, fed uali= 4 diffimum, nam Græci codices non habent) in capite nullum unquam, Paufanias in Bocoticis. Hos Martialis uerfus libro I. Nanq̧ grauem cornu gemino fic extulit urfum, Iactat ut impofitas taus rus in aftra pilas, Domitius ita enarrat. Gemino(inquit)cornu, forti \& uehementi. Vergilius, Gea mino dentalia dorfo. uel quoniã rhinoceros habet duo cornua, ut apud Paufaniam folum legi. Taa xat hanc interpretationem Politianus, qux mihi fane proba uidetur, $\&$ pictur $x$, quam dedimus, con fentanea $\&$ Paufanix authoritate nititur $¥$ ip $f e$ Politianus aliam coactam, \& ineptam, ut ego iudico, affert. Vrfum (inquit) uidelicet à rhinocerote cornu illo unico elatum, eieçatumç, fentit grauem ge mino cornu, hoc eft grauem tauro futurum, cuifunt cornua gemina. Conueniebant fanè gemina huic belluæ cornua, cum bifulcum fit. Solipeda enim omnia cornibus carent prater afinũ Indicum, qui unicum tantum geri, Ariftotele tefte. Itaqg Eucherium dicemus, non in numero erraffe, fed in $\mathrm{j}^{\circ}$ loco, quòd in naribus utrunç haberifcribat.

c.

Coitus auerfus elephantis, camelis, rhinoceroti,leoni, \&c.quibus auerfa genitalia,Plinius \& So. linus. Sexus diffrimen rhinocerotes non habent, fed omnes eius generis mares apparent, foeminze nunquam, neq conftat de generatione ipforum, Oppianus.

Contra elephantum pugnaturus cornu faxis exacuit $\&$ limat $\$$ mox eo cufpidato elephanticrura toto rictu fubiens, aluum petit, quam fcit effe molliorem \& fuis ictibus peruiam, eamós difcerpir, Pli nius, Solinus, Aelianus, \& Diodorus Sic. Vincitur $\&$ fanguine fufo exanguis procumbit elephas. Pugna eis pro paftionibus, quibus tuendis multi mori dicuntur. Quod fi uentrem non pracoccupâ. 60 rit rhinoceros, fed in aliam elephanti partem aberrârit, probofcide feritur ac dentibus laniatur:quo. rum uis utcunģ firmiffimam illius cutim $\&$ uel iaculo difficilem penetrat, Aelianus. Veram hane 


\section{De Rhinoc.E.G.H.a.b.e.h.Lib. I. 955}

inter hafce belluas difcordiam effe, com pertum eft etiam Vlysbonx, cum elephas rhinocerotem il. lum, cuius hac pictura eft, productum fugit, ut mercatores teftantur, qui etiam ingenio callidum, am lacre, uelox \& agile hoc animal effe aiunt.

Ifidorus author eft, quordam qui de animalibus fcriplerint(quorum nomina exprimit) non alio modo capi rhinocerotem afferere, quàm puella uírgine propofita, \&cc, ut in Monocerote E, retuli, Sed ille hoc animal cum monocerote confundit; ut alij etiam ex recentioribus, qui rhinoceroti cor: nu è media fronte prominere, captumḉ eum præ indignatione $\&$ furore mori falfiffimè fribunt. Monoceroti enim ifta omnia, non rhinoceroci, attributunur à Græcis authoribus, quanquam illis e: tiam recentibus, Sub Gordiano Romæ monocerotem unum fuiffe lulius Capicolinus Icripfit,

G.

Recentiores quidam tum medici tum alï, rhinocerotis cornu ad medicamenta non recté requis runt decepti nimirum ab Ifidoro, Alberto, ac fimilibus, qui rhinocerotem cum monocerote confun dunt, ut dixi in $\mathrm{A}$. Veterum quidem nemo ex rhinocerote quicquam inter remedia ponit; monoce: rotis uero uel afini onagriue Indici cornu, contra uenena \& alios quofdam affectus miram habere fa cultatem Gracirecentiores prodiderunt, ut in Monocerote docui.

H.

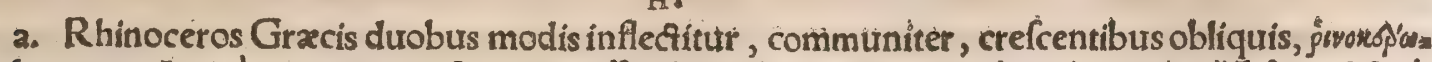

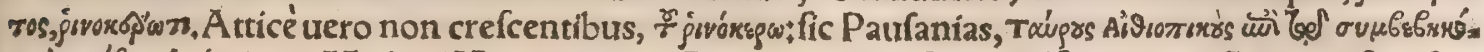

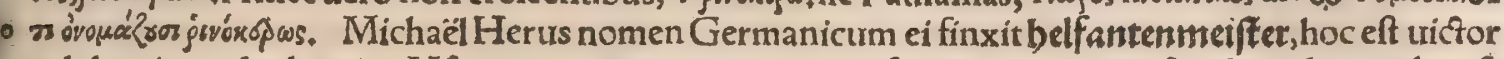
uel dominus elephanti. V furpatur etiam pro genere uafis oleum guttatim fundente lauantibus fe in balineo. Martialis lib,14. de gutto corneo: Geftauit modo fronte me iuuencus, Verum rhi. nocereta me putabis. Et mox ibidem fubRhinocerotis infcriptione, inter uafa: Nuper in Aufo: nia domini fpectatus arena Hic erit ille tibi,cui pila tatrus erat. Iuuenalis Sat, 14. Exitus hic eft Tongilli, magnocum rhinocerote lauari Qui folet. A pparet fanè uafi nomen à figura impolítum, à qua Lucilius etiam in Satyris thinocerotem uocauit hominem cui dentes prominebant, furfum fci licet ut apro. Brunci(aliâs Bronci, uide in Cane celere)funt producto ore dentibus prominẽtibus. Bruncus (broncus) nouit lanius dente aduerfo(Hermolaus uocem, aduerfo, reliquit)eminulo, hic eft rhinoceros, Lucilius apud Nonium. I Suntqui rhinocerotis nomine in Aethiopia proprị gene= ris aures intelligant, Calius ex Hefychio $\&$ Varino. Rhinocerotia cornua grammatici quidam di. xere nefcio quo authore freti.

Tb. In Rhaptis emporio iuxta mare rubrum, plurimum eft ebur, item rhinoceros, Arrianus in Periplo. Intelligit autem forte cornu tantum rhinocerotis nomine, ut $\&$ elephantem pro ebore Grę ci dicunt per fynecdochen. Dic mihi qux fuperis fint acceptiffima dona. Principium nafi rhino. cerotis amant, Aenigma Francifci Nigri noftri。 Heliogabalus rhinocerotem Roma habuit, Lam. pridius.

đe. Rhinocerotem Pompeius Magnus in fpectaculis Roma primus oftendit, Plinius, Solinus, Seneca. Atqui Dion hiftoricus, Augufto de Cleopatra triumphante, hippopotamum \& rhinocero. ta primum uifos Romæ fcribit, Calius. Edita munera in quibus tigrides $\&$ rhinocerotes, \&c.ex. hibuit, Capitolinus in Antonino Pio. Rhinoceros apud Martialem lib. in fpectaculis Domitiani Cafaris exhibitus, taurum cornu fuo in aéra fublimem reiecit, 8 rurfus etiam urfum. O quàm ter: ribilis exarfit pronus in iram, Quantus erat cornu, ${ }_{5}$ cui pila taurus erat. Hunc locum expofiti in

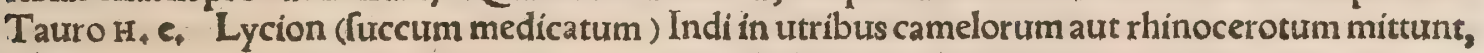
Plinius,

đ h. Nafutos homines, $8 x$ qui docté nouerint alios irridere, Martialis libro I. rhinocerotis nas fum habere dicit, his uerfibus: Maiores nufquam rhonchi, iuuenesḉ fenesćs Et pueri nafum rhi nocerotis habent. Nafus enim per fe quoç fubdolx irrifioni dicatus eft:fed hanc partem rhinoce: ros $\&$ maximam habet, $\&$ cornu repando infignem, quare ab eo potius quàm ullo alio animali, ad prouerbialem hunc fenfum affumpta eft. Nafo lufpendis adunco, Horatius in Serm. Rides aic \&nimis uncis Naribus indulges, Perfius.

R H I N O C E P H A I V S ceruicem habet equinam cum uniuerfo corpore: flammas ore eru. cqat,quibus homines pereunt, Phyfiologus author obfcurus.

\section{DE S C I V R O.}

\section{A.}

C I $\nabla$ R $\vee s$ Gracum nomen eft animalculo datum à cauda, qua fupra dorfum reflexa fe tegit $\&$ inumbrat, ita ut quum fub dio eft cauda illi pro tecfo fit, ut pedes hominibus illis quos fciapodes fabulofé nominant. Graci ueteres nufquam eius meminerunt, fed primus quod fciam Oppianus qui Antonini Cæraris tempore uixit, fciurũ nominauit. Latini no. men non habent, fed Graco utuntur, à quo aliarum etiam gentium aliquot deducta funt nomina, 


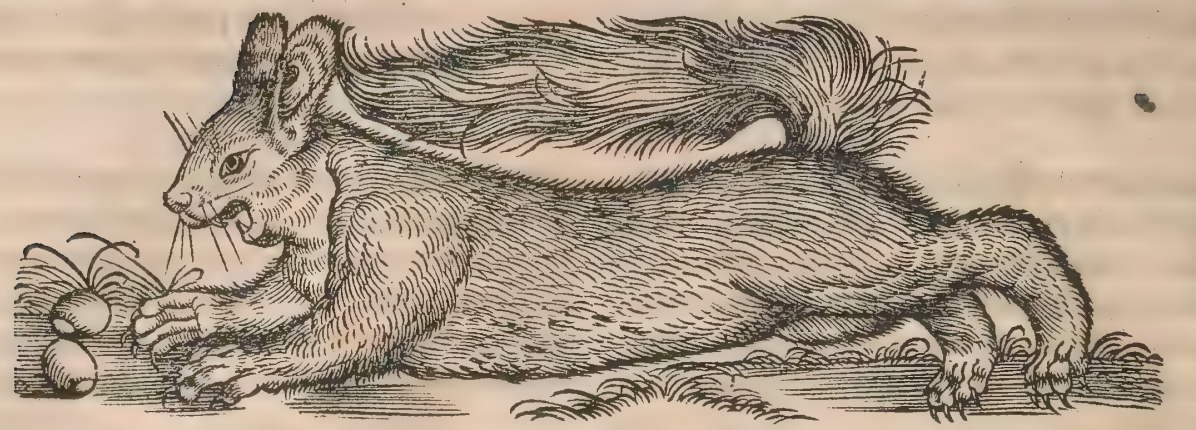

etfi quadam admodum detorta fint, ut originem uix agnofcas, Gallicum eft efcurieu uel efcureau (folent enim \& aliâs Latinis quibufdam e. literam præponere, ut efperit, pro fpiritu.) Germanicum à Gallico factum, eidborn/ uel eydbart. alips eydborn/cidbermlin, ac fi hermelinum, id eft muftelam quercuum uel arborum dicerent, nos mafculino genere proferimus, aliqui neutro $a s e y$ bort. An glicum, fquyrrell. Italicum fchiriuolo. Sciuri in murium genere, fchirati uulgò dicti, Maffarius Ve netus. Hifpanicum, hárda uel efquílo:aliqui non recté comadreia interpretantur, quax uox proprié muftelam fignificat. Illyricum wewerka:Poloni quidam fcribunt wïew fciurum ab eis fub uariorum nomine comprehendi. V arios enim(id eft Ponticos mures, ut ego inter pretor) Germanicè etiam werct nonnulli appellant, alij veeb, aut fed : ex quibus nomínibus quaft 20 compofitum uidetur wewerka. Recentiores quidam qui Latiné ineptius fcripferunt, pirolum \& fpiriolum(forté quafi fpiurum pro fciuro) uocitant. Ineptè Belluacenfís, Scurulus à currendo diêus eft. Pirolus, inquit Albertus, â uario non differt praterquam regione in qua nafcitur , uariantefer cundum eam colore + nam qui in Germania rubet cum adoleuit, intra primum autem xtatis annum niger eft:in Polonia grifeum (id eft cinereum)rutilo admixtum habet, in/Tufcia uero(Ruffia) totus d nereus redditur.Quod ad corporis lineamenta, magnitudinem, mores $\&$ uiçû, nihil plané pirolus à uario differt, Albertus \& Ge.Agricola. Quamobrem qui uoluerit uarín hiftoriam inter muresâ nobis defcriptã, cum hac coniunget:nos qux illic dicta funt hic non repetemus, बSciurus, animal

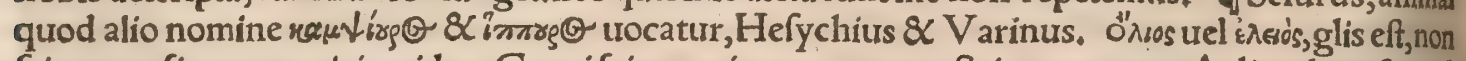
fciurus, etfi grammatici quidam Graci fciurum interpretentur. Sciurum autem à glire diuerfum efago

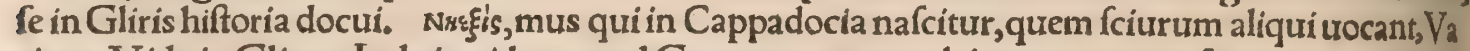
rinus:Vide in Glire. Iudxi quidam apud Germanos nב coach interpretantur fciurum.

B.

Pirolus paulò maior eft uel corpulentior quàm muftela, non tamen longior, Albertus, Colorel rutilus, fed uenter candidus, Obfcurus. Rutili \& nigri plurimi funt in Heluetia, \& abunde capiun tur, autumno pracipuè, Stumpfius. Albertus quidem, ut præcedenti capite dixi, intra primum atatis annum nigros effe putat, deinde rutilos fieri. Pilo funt nigro \&interim ferrugineo, Maffarius. Speriolus primò in dorfo niger eft, poftea proceffu xtatis rubefcit, $\&$ tandem quidam eorum feréca ni redduntur iam prouecta atate, Albertus 3.2.2. Nigros feiuros in Franconia ruffis frequentio= res effe aiunt. Pirolis, ut reliquis etiam muribus, duo inferiores dentes longifunt, Albertus $\propto$ Agri $4^{\circ}$ cola. Villofior eis cauda pro umbra \& tegmento eft, Plinius \& Mafrarius. Cauda eis uillofa, lon, ga, \& propéad reliqui corporis magnitudinem. Veras glires \& f fiuros cæcum inteftinum tantum habere fcimus, ut magnitudini uentriculi corum facile refpondeat; atģ idem in fectione fecibus tur. gidum reperitur, Vefalius. Genitale offeum habent, ut audio.

c.

Animalium quxdam ut manibus utuntur priorum minifterio pedum, fedentç̧ ad os illis admo. uentia cibos, ut f́itri,Plinius, Quum uefcuntur pedibus anterioribus, ficur cętera quoç murium genera, cibum quafi manibus capiunt \& ori imponunt, Albertus \& Ge. Agricola. Pofterioribus clunibus infident, Edunt autem nuces, poma, \& huiufmodi,Albertus: Vide in Mure Pontico. Vi uit nucibus, \& dulcibus cibis (fructibus)delectatur, Obfcurus. Aeftate cibum congerit, undeper so hyemem uiuat, Idem. Somnus eis pro cibo cum hyberno tempore latent, Ge. Agricola. Plinius qui dem cum de fciuris fcripfiffet, mox fubdit, non de fciuris, fed in uniuerfum: Alijs igitur prouifum in hyemem pabulum, alins pro cibo fomnus. Inquieti funt ualde, Albertus: 8 mira agilitatis.In arbo: ribus habitant, nidificant $\&$ foetum fouent. Facile autem tranfiliunt de ramo ad ramum, $\&$ aliquan do de arbore ad arborem, cauda feré tanquam ala utentes, (caudam interim mouentes, ac fí ea fe gu bernent, Albertus, ) Obfcurus. Cauda fua confpecfa ad faltum incitantur,Idem. Cum mouentur, (gradiuntur, ) caudam demiffam poft fe trahunt; cum uero fedent, fuper dorfum erigunt, Albertus, D.

Nidum in arboribus conftruunt, Albertus. Prauident tempeftatem : obturatisç qua fpiratus rus eft uentus cauernis, ex alia parte aperiunt fores, Plinius. Albertus idem feré de gale, id eft mus 60 ftela fcribit: In cauernis (inquit)habitat, ad meridiem pariter $\&$ ad aquilonem apertis, ut undecunq uentus ueniat, tuta ab co fit, Si quando gratia paftus aquam tranfire cupit fciurus, lignum(uel cor. 


\section{DeSimia. A. Lib.I. 957}

Vicem)leulffmum aqua imponir, eiģ infidens cauda ereça urelificans flante uento tranfurehitur, $\bar{A}$ ut thor lib, de nat, rerum. Flutum trahcit utens affere uel cortice pro naue \& cauda pro uelo, Vina cen.Belluac. Olaus Magnus idem teftatur in defcriptione Scandinatrix, tanquam illic peculiariter id faciant fciuri. Quidam fic eos tran̈cere aiunt geftantes interim cibum etiam ore, ut conum abie: tis. TSciurus ea eft folertia, ut in maximis Solis feruoribus ad frangendum calorem erecta cauda \& patula fefe ita opacet, quemadmodum pationes erecta fe cauda adumbrant, Gillius ex Oppiano. T. Domeftice aliquando aluntur, \& ita cicurantur ut hominem non refugiant, fed fponte accedant; $\mathcal{\alpha}$ à pedibus ad caput afcendant, $\&$ qua poffunt in ueftimenta perrepant tra domum fubinde redeant. Non proprie tamen cicures appellari poffunt, fed femiferi, ut $\&$ cunicu - li,femper funt. Muftelæ \& fciuri allio dentibus tentato, in pofterum mordere uíx audent, cicuresć hoc modo fiunt, Cardanus $\quad$ TPelles eius in nullo feré ufu, nifi quòd pellifíces aliquando cum pel. libus pedum uulpinorum eas confarcinant. Fertur tamen eas multò magis calefacere corpus homi nis quàmicateras pelles. Cauda utilis eft ad penicillos.

F.

Caro fciuri dulcis $\&$ bona ef, Alberturs. Suauris \& falubris eft,ægrotis etiam $\&$ imbecillibus:fed nigri rutilis praferuntur, Stumpfius, Videtur fanè hodorum aut cuniculorum carni rectè compa rari poffe, quood fimiliter tenera $\&$ fuauis fit.

H.

a. Epitheta. Cui comparatus indecens erat pauo, Inamabilis fciurus \& frequens phonix,

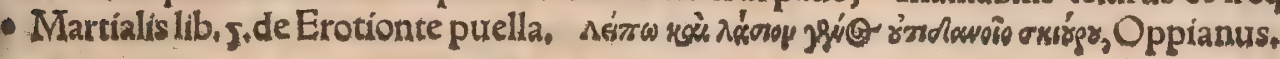

\section{E S I M I A.}

A.

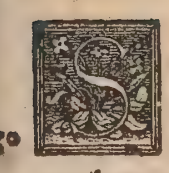

I M I AE dicuntur, ut grammatician notant, quòd fima fint $\&$ naribus de. preffis, uel quafi mimx $\&$ imitatrices. Simia nomen Gracum, id eft preffis naribus:unde fimias dicimus eò quòd huriứmo difint, $8<$ facie foeda, lfidorus. Gręcè rzistsk dicitur, non fimia:fimus uero adiectiuum, pro depreffo, (peculiariter autem de naribus dici: tur, )uocabulum eft Gracum, osu's. Legitur e. tiam fimius mafculino genere, fed apud poëtas, Horatium, Martialem, Claudianum : quamuis fimiolus diminutiuum apud Ciceronem habe. tur. Hebreifimiam koph nip, appellant, ut Da $4^{\circ}$ urid Kimhi $\&$ alî̉ eruditi exponunt:unde plura le kophim 3, Reg, 10. Chaldzus kophin reddit, Septuaginta monr $n$, , Hieronymus fimias, Hinc forte Graci cepi uel cephi, quæ fimia caudata eft, nomen mutuati funt. Semamit nyare, Prouerbiorum 3o+ ut D. Kimhi annotauit, ex fententia Rabi lonx, Ârabicè uocatur hkos

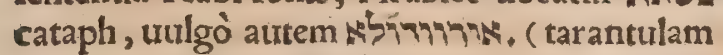
puto intelligens, id ef phalangium . nam $\&$ ipfe Dauid Kimhi kng xid eft araneam effe pu

$g^{\circ}$ tat, pro qua in Thalmud etiam ufurpatur.) Chaldxus uertit aps akmata. Iudxi multi araneam intelligunt, \& inter creteros $\mathrm{R}$. Leui. Alị uero กละ id eft fimiam, ut A braham \& R. Emmanuel. Commentarius etiam kaburenaki, fimiam poti. us quàm araneam accipiendam putat. Rabilfa. ac reptile uolans interpretatur : aliqui uermem pluuialem, (lumbricum.) Hieronymus ftellio.

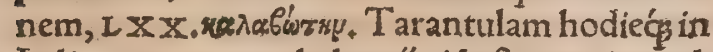

6. Italia urocant tum phalangij, id eft aranei quoddam genus uenenofum, tum fellionem lacerto fimi: lem, quem Grreciafcalabotem urocant . Samada, id eft fimia,Syluaticus. Maionio, id eft fimia, Id $\vec{e}_{*}$ cercopithecum Itali hodie gatto maimone uocant. Simia quidem apud Gracos recentiores $\mu$ udy 
uocatur, ab imitatione fcilicet. Hifpanis hodie móna, uel ximio. Itali nomen feruant, aliquibertuce ciam uocant, Galli,finge. Germani, aff. Flandri,fiñe uel føernited. Angli,ape, Illyrï,opicze,

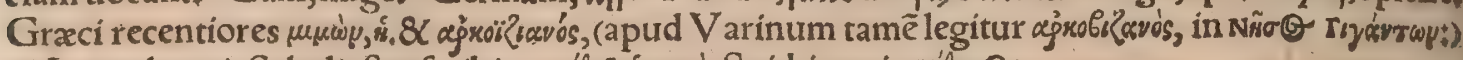

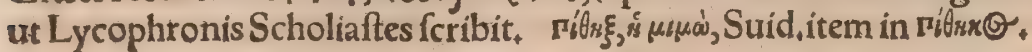

B.

Simias fert Libya, Strabo libro 17 + exPofidonio, Alibi etiam Mauritaniam fimias alere fcribit, Apud Zygantes Africa populos paftoralibus uicinos fimiæ affatim in montibus degunt, Herodotus. Omne latifundium quod inter Aegyptum, Aethiopiam Libyamós diffunditur, quacung lü cis opacum eft, urarium impleuit fimiarum genus, Solinus. Refert Pofidonius, fe cum ex Gadibus in Italiam nauigaret, in Libyæ oram delatum effe, ac fyluam quandam fecus mare uidiffe fimij ple to nam, quarum aliz fuper arboribus, aliæ in terra federent, nonnull catulos haberent, $\&$ ubera de: pendentiałrififfe itaq 3 cum eas uberibus graues cerneret, nonnullas etiam caluas, nonnullas hernio fas, 8 alia quædã huiufmodi detrimenta præfe ferentes, Strabo lib, 17. Caucafi pars quæ̃ in rubrum mare porrigitur fimís abundat, qua piper colligunt, ut in D. referam ex Philoftrato. Apud Indos pulchræ $\&$ magnæa admodum fimiæ funt, Arrianus, In India, Clitarchus tradit, fimiarum genus ua rium \& multiplex oriri, tantamç̧ earum in montibus multitudinem effe, ut uel Alexandrum magnis copijs feptum ex frequentes perterrefecerint, quòd arbitraretur fe fibi infidiantem exércitim uide: re. Nam cum Alexandro fe oftenderunt cafu, excelfo $\&$ recto corpore erant, Aeliantus. Bafman regnum(in Tartaria) abundat diuerfis fimijs, magnis $\&$ paruis, hominibus fimillimis, M. Paul. Ve netus. Plinius in India feribit Orfeos uenari fimias (toto corpore) candentes. Strabo Prafios, non ${ }_{21}$ Orfeos, effe tradit, qui cercopithecos albos capiant. Orfeos tamen fiue Orfios in India uridetur Plie nius agnofcere:fi modiò recté caftigatus eft à nobis locus libro 6.cap.20. Hermolaus. Indi adregem fuum afferunt fimias nonnullas albas, alias nigras. nam rufas ideo in urbem non adducunt, quod Veneris libidine inflammentur in muliebrem fexum, A elianus.

Timia homini forinfecus quidem fimilis eft, in nullo autem interiorum, \& minus quidẽ quàmi ulla beftia, Albertus $\&$ eum fecuti. A tqui Galenus uifcera etiam $\&$ interiora cæetera fimiam homini fimillima habere fcribit, ut inferius recitabo ${ }^{\ddagger}$ item Plinius. Nutrimentum magis mouretur antror: fum quàm retrorfum, propter calorem cordis 8 hepatis, quamobrem in equis multis motus nutrh menti eleuatiorem partem anteriorem quàm pofteriorem facit* $\&$ animal feraph Arabice dictũ, mul tò altius eft ante quàm retro, ita ut feré erectæ ftatura effe uideatur, In his autem fimijs qua exprela fius referunt hominem, tantum potelt hic nutrimenti motus, ut aliquando hominis inftar erigantur, Albertus, Simia condenfa eft uillo,Obfcurus \& Simia (inquit Arift.)tam parte fui corporis pro na pilofa eft, utpote quadrupes, quàm fupina, ut fpeciem gerens hominisłqui contrà, atç quadrupe des, obtinet pilum, ut diçũ iam eft ${ }_{+}$Sed craffiore pilo fimia ueftiuntur, longé $\beta$ hirtiores parte utraq̧ funt. Conueniunt cum homine plurimum fua facie, quippe qux nares, autes, dentes, tam primo: res, quàm maxillares hominis more habeant. Cilium etiẫ cum cæeteræ quadrupedes non in utraq palpebra habeant, fimix habent, quanquam pratenue ac prolixius, potilfimum in inferiore. Cates ra enim quadrupedes inferioribus carent cilings. Habent fimiæ in pectore binas mammarum papil las:\& brachia hominis modo, fed hirtiufcula, qux \& ipfa, \& pedes ut homo inflectunt, hoc eft, ita ut

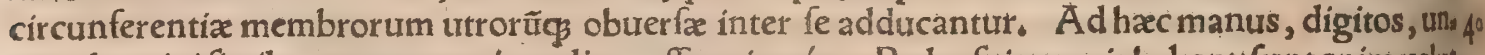
gues homini fimiles, uerum omnia rudiora, efferatioraç. Pedes fui generis habent: funt enim uelut manus maiufcula, \& digitis ut manus conftant medio longiore. Veftigium etiam manui fimileeft, nifi quod in longum fe porrigat, \& uolam referens tendat ad poftrema, Callofius hoc altera fui parte extrema eft, $\&$ calcem inepte atç exiliter imitatur. Pedum officium duplex eft $:$ ins enim $\&$ ut pedi bus, \& ut manibus utuntur, inflectuntó̧ cordẽ perinde ac manus. Lacertos \& femora habent bre uia proportione cubitorum $\&$ tibiarum, V mbilicum qui emineat, nullum habent; fed durum quid dam continetur loco umbilici. Partem corporis fuperiorem multo maiorem habent, quàm inferio: rem, uidelicet more quadrupedum: quinarỉ enim feré ad ternarium ratione conftant. Degenerant ergo,tum ea de caufa, tum etiam quod pedes manibus habeant fimiles, \& quafi ex manu pedé́ con fitutos, Calcis enim poftremum ad pedem, reliqux autem particula ad manum facile referuntur* digiti nanç uolæ fpeciem gerunt. Degunt plus temporis pronæ quadrupedum more, quàm ere cfax. Carent natibus, utpote quadrupedes. Priuatx cauda funt, utpote bipedes, Exigua enim om. nino cauda ineft, quatenus nota folum habeatur. Genitale enim foeminæ mulieris eft: mari potius canis, $\widetilde{\not}$ hominis, Hæc Ariftoteles, \& Albertus ferè eadẽ omnia de animalibus $2_{+} 1 \cdot 4$. Simia quòd forma ambigua fit, ut $\&$ in neutro $\&$ in utro $\$$ genere fit conftituenda, ideo nec caudam habet, neq nates. uidelicet, ut bipes, cauda uacat:ut quadrupes, natibus, Ariftotel, de partibus $4+10$. Aliter Al. bertus, Simia habet nates latas, 8 locum in eis quafi paratum ad fedendum. Pilofa eft, in facie tamẽ minus, Idem. Politianus in epiftolis aduerfus folius Ciceronis imitatores fcribens, Mihi (inquit). longè honeftior tauri facies, aut item leonis, quàm fimia uidetur, qua tamen homini fimilior eft. Sis miarum genera perfectam hominis fimulationem continent, facie, naribus, auribus, palpebris, quas 64 fola quadrupedum $\&$ in inferiore habent gena, iam mammas in pectore, \& brachia, \& crura in con trarium fimiliter flexa:in manibus ungures, digitos, longioremç̧ medium. Pedibus paulum differứt: 


\section{DeSimia. B. Lib. I. 959}

Sunt enim ut manus prælongi,fed ueftigium palmæ fimile faciunt, Pollex quogs his \& articuli ut ho minitac prater genitale tantum, 8 hoc in maribus, uifcera etiam interiora omnia ad exemplar, Plin,

đNatura fimię ridiculo animali, $\&$ animã habenti ridiculā, corporis quoģ conftructionẽ ridicu lam dedit, Galen. Simia inter uniuerfa animantiũ genera, tum uifceribus, tum mufculis, tum arte: rijs, tum neruis (quoniam \& offum forma, homini eft fimillima. Nam ob illorum naturam binis cru ribus incedit, prioribusćs artubus ut manibus utitur. Et pectoris os omnium quadrupedum latifliz mum babet, clauiculas humanis fimiles, faciem rotundã, collum longũ, Galẽ, de anatom. admin.1+2* Pręftat ut exercitaturus fe in corporum diffectionibus, fimiarum homini ö fimillimarum artus diffé cec; fin ea non detur, aliquam ei proximam deligat: aut fi nulla omnino fimia reperitur, cynocepha* lum, uel fatyrum, uel lyncem, In eodem opere. Et librif xti capite prime, Simia(inquit)homini fi: millima eft illa, cui necg facies oblonga neç canini dentes magni, (cui nee oblonga maxilla, nec ca= nini dentes magni, In eodem opere 1.2.) Etenim hac pariter aut augefcunt aur minuuntur (id eft, ut eò fimilior homini fit fimia, quo minus longam habuerit faciem, minuş̣́́ magnos dentes caninos, 8 . contra.) quemadmodum rectus inceffus, curfus uelocitas, magnus in manu digitus, temporum mu= fulus $\& \mathcal{X}$ pilorum iuxta duritiem mollitiemćs, longitudinem $\&$ breuitatem differentia. Verum ex his enumeratis quodlibet contemplatus, alia quoqs poteris cognofcere:quippe unituerfa hxc fimul tum increfcunt tưm minuuntur. Si quandoo fimiam confpexeris erectam currentem, ftatim ex longinquo hanc fimilem homini exiftere cogno ${ }_{\text {ces }}$ ac poteris omnia in ea effe $e_{2}$ qua ante paulum $e_{3}$ numeraui, pładicere: faciem rotundam, dentes caninos exiguros, maiorem manus digitom non a= deò exiguum ut in alịs fimpips, rurfus pedis digitos minores quàm quos reliqua fimix obtinent, tem porum mufculos exiguos, ficut etiam eos qui ex femore ad tibiam pertinent, haud in longum proce dentesład hac os coccygis appellati, minutum‡minimég hirfuram effe hanc fimiam, 82 pilos habere haud admodum duros uel prolixos. Ita fi quid ex relatis fecus habeat, alia quoç differenr. Iam non: nullæex ipfis proximè cynocephalos fpecie accedunt, adeò ut etiam lati ofis mucronem (coccyga

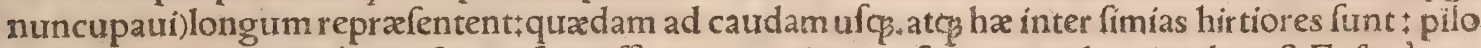
ueftiuntur duro rectóq $\$ \&$ a fpeçu funt efferatiore. ar in uera fimia etiam hic tímidus eft. Et fanè tem poralis mufculus in ueris fimís plurimum attollitur: ibi autem ceffat, ubi futura coronalis habetur, ut in hominibus eft cernere. Simili modo dentes magni quidem omnes, fed canini magis confpicuit. quemadmodum \& maxilla longa $+\&$ pollicem in manu omnes fimix qux cynocephalos imitantur o exiguum admodum babent. Tales múfculos quoģ qui ex femore in tibiam defendunt, longifine expanfos obtinent:atç ideo colligatum, ut ita dixerim, totum poplitent: cuius caufa crura perfectè extendere, ac probe ijs côfiftere nequeunt:quare nec erecta incedere uel currere uelociter poffunt. Neçs igitur maiorem in pede digitum habêt grandem, hominum modo: neç alios exiguos, fed om: nes ex æquo magnostis minor cæteris eft quem homo habet maximum. Porrò caudx initium quod dam ipfis ineft: Et huiufmodi fimia to to corpore cynocephalos referunt, Hæc Galenus. Et rurfus libro „.cap.2.Simix (inquit)qua cynocephalos imitantur, roftro longiore funt, $\&$ dentes caninos ha bent prominentiores. Hæe etiam uix binis cruribus confiftunt erecta, tantum abeft ut ambulare uel currere poffint. Itaq, fimix uel maximè homini fimiles, exiguo aliquo interuallo perfectam illits re ctitudinem non affequuntur. $\mathrm{Nam} \&$ femoris caput obliquius quodammodo cum acetabulo coxa - committitur $\$ 2$ quidam ex mulculis qui in tibiam defcendunt, ulterius progrediuntur, qua ambo rectitudinem impediunt, offenduntós quemadmodum $\$ \times$ pedes ipfis calce magis angufta conftant: digitis autem infigni fpatio inuicem diferetis: fed hæc parua funt, eóq̧́ fimia paululum à reçitudine difcedit qua uero cynocephalos referunt, quoniam amplius hæi, idós manifeftò iam ab humana fpe. cie degenerant, euidentem quogs offum difimílitudinem fortita funt, Hac omnia Galenus in Ope

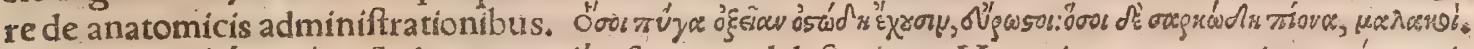

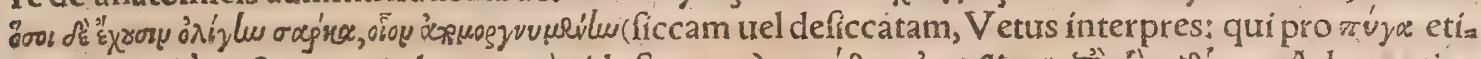

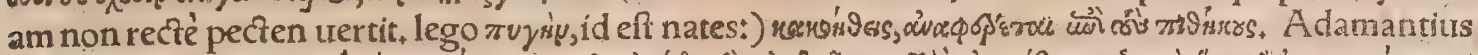

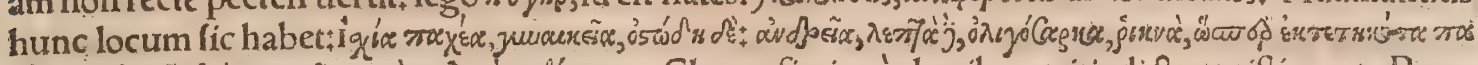

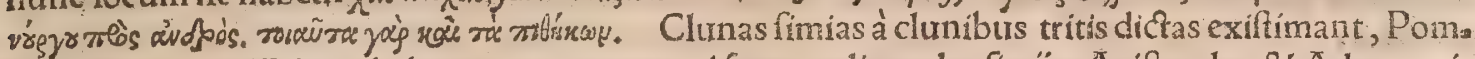
go peius lib. ฐ. đMaligni habentur quorum caui funt oculi, quales fimịjs, Ariftoteles \& Adamantí

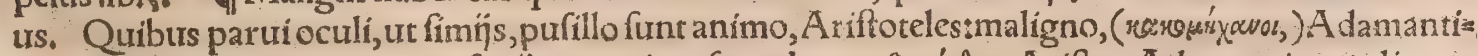

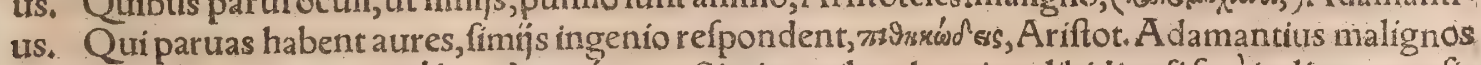

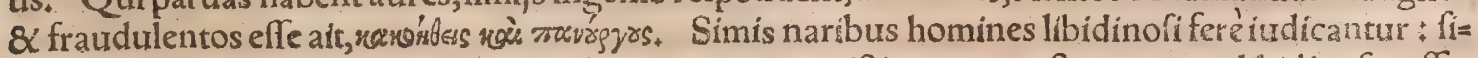
mæ autem etiam fimiæ funt, unde quidam nominatas exiftimant ; conftat uero cas libidinoŕas effe, $\&$ quafdam adeò ut mulieres etiam appetant. Quibus labra funt craffa, \& fuperius ultra inferius eminet, ftulti iudicantur, à fimili afinorum $\&$ fimiarũ fpecie, Ariftot. đlam uifum eftcor fimì ma ris, habens duo acumina, quod pro miraculo uel móftro babendũ eft, Albert. T Simia manillas ut mulier in pectore habet:eós manus dedit ei natura, quibus ad pectus poteft eleuare partú ficut mu lierł catera autem animalia inferíus habent mamillas, ut à fuis foetibus attingi poffint, Albertus.

Dorfum paruum, quale eft felis $\&$ fimix, hominem pufillanimem arguit, Ariftoteles. Adamantius quogs dorfum latum $\&$ folidum, tiri fortis $\&$ animoli fignum effe ait:contrarium uerò, contra. q Simị ungues imbricati, Plinius. Simia $\&$ quadrupedes affuete uinum bibere unguibus carent, 
ur dicam in c. TQux animal generant, genua antefe fleĉunt, \& fuffraginum artus in auertum. Homini genua \& cubita contraria:item urfis \& fimiarum generi, ob id minimé pernicibus ; Plinjus, 1 Caudæ prater hominem ac fimias omnibus feré animalibus, Plinius, GSimia calcaneum habe: in pedibus, 8 proptet hoc erigitur ut homo, ftat, \& currit quandoç, fed hoc non poteft nifi modice, Author de nat, rerum.

TV Venarum in brachịs diurifio in finijs non fecus quàm in homine per omnia apparet, Galenty in libro de uenarum $\&$ art.diffect.cap+4. Pollicem fimix etiam habent, fed breurem, gracilem, cur. uum, 8 omnino ridiculum. Sed $\&$ tota manus fimię humanam ridiculè $\&$ inepté imitatur, Galen, de ufu partium 2.12. TMufculi qui ex pofterioribus partibus cruris proureniunt, ad medium fere tis bie, aut paulò fupra id in fimijs implantati, mufculis anterioribus colum(crus)extendẽtibus reniten is tes, \&i crus retrorfum contrahentes, genu exacié extendi non permittunt, Galenus in eodem opere circa finem libri 3 . Et mox, Omnium enim offium crurum fyntaxim eiufmodi cum habeat fimia, qua eam recté ftare non permittat, maximé ridiculos retrorfum mufculos conftructioni aduerfantes fortita eft. Atq̧ igitur puerorum ludicro uelut claudo fubfultans, neqs exactè, neq teft. Sed ut homo deridens $\&$ fubfannans alium hominem claudum, ftat, $\&$ ambulat, $\&$ currit claudl cans:ita $\&$ fimia utitur cruribus. Simia pes(inquit idem de anatom,adminiftrat.2,15.) hac parteab humano difcrepat, (tendine quodam qui ad tarfum reflectitur ex fuperioribus partibus ad inferio, res productus) quòd ctiam natura digitorum huic animali diffimilis fit humanis. Illi fiquidem multó minores, quàm qui in manu exiftunt hi uero maiores etiam ijs in quos manus eft difcreta quales re pentibus quog, animantibus plurimum fiffi, tum inuicem diftantes adfunt, quorum beneficio ex $f_{2} 1$ cili fublimia confcendit fimia:quemadmodum muftel $x$, mures, uiuerr $x, \&$ id genus alia. Hunc igitur tendinem, ut dixi, in pede humano haud eft reperire, \&c. De mufculo etiã reperto fub axilla fimię fcribit quadam I. 5.de anatom, adminift.

TSimias ab homine in pluribus differre quàm putauit Galenus, Andr. Vefalius docet in Volus mine fuo de fabrica corporis humani:nempe in mufculis thoracis $\&$ brachiũ mouentibus: item in qui cubitum \& femur agunt ab eo differre, \& manus interna fabrica In mufculis pedis digitorum motoribus, $\&$ pedes mouentibus $\&$ fcapulas: In tendine pedi fubnato: Item colo $\&$ mefenterio: $\&$ pulmonis lobo quinto uenam cauam fuftinente, quo homines carent. Paffim etiam demonftrat fif miarum fectionis peritiorem fuiffe Galenum quâm hominum $: \&$ fimiarum fectione delufum, alio: rum Anatomicorum placita uera fape eurertere aggreffum. Defimiarum offe facro $\&$ coccygis; Omentum earum inter homines $\alpha$ canes mediam rationem fortiri, Quxere apud Vefaliư ex Indice,

c.

Simix in montium cauernis $\&$ foraminibus habitant, Philoftratus. In rupibus urel arboribus, Albertus, $\quad$ Nucibus $\&$ pomis in cibo delectantur:fed reperto in eis amaro cortice, totum abijch unt, Obfcurus. Vermes(pediculos) in capitibus \& ueftibus colligunt $\&$ comedunt, Albertus, I Vinum etiam bibunt, \& inebriatæa aliquando capiuntur, ut Athenæus refert. Simias quadrupen desćp quibus digiti funt, negant crefcere affuetas meri potu, Plinius. Hưius rei caufam inquirit $\mathrm{C}_{2}$ lius Calcagninus Epiftolicarum quęettionum lib.1.ad Thomam Calcag, nepotem, đOmnis foem na inter quadrupedes urinam retrò reddit, nifi forte erecta incedat aliqua duobus pedibus, ut Auria cenna dicit de quodam genere fimiarum: quarum foeminas cum erecta aut fedentes urinamemita tunt, certum eft antrorfum ab eis emitti ut à mulieribus, Albertus. Aegyptï hominem fua dedecos ra occultantem infinuantes, fimiam mingentem pingunt : hæc enim urinam à fe redditam occulit, Orus. Indi fimias rufas in urbes non adducunt, quòd Veneris libidine inflammat 2 , in multï brem fexum furentes fint \$ ac fi quando deprehendunt, eas tanquam adulteros odio perfequentes interficiunt,A Alianus. TCatulos pariunt geminos, quorum alterum amant, alterum oderunt, ut dicam in $\mathrm{D}$. Pariunt quandog in domibus ubi aluntur, \& partus fuos oftendunt hominibus quafi pulchros, Albertus ex Plinio. Simia animal mobile $\&$ inquietum eft, morfu ferox, \& præ cxteris an nimalibus exquifito ualer guftu, Obfcurus. De inceffu eius erecta \& curfu, diximus quadamfü pra in $B$.

\section{D.}

Simiarum generi præcipua erga foetum affectio. Geftant catulos : quos manfuefacta intra do: mos peperere, omnibus demonftrant, tractariç gaudent, fimiles gratulationem intelligentis. Itą̧ magna ex parte complećendo necant, Plinius \& Albertus. Immoderaté foetus amant, adeó ut cas tulos facilius amittant quos impendio diligunt $\&$ ante fe geftant, quoniam neglecti poné(id eft poft, à tergo matris)matrem (emper hærent, Solinus. Duos foetus plerunç parit:ex quibus chariorem magis complectitur et geftat:minus charus dorfo matris infidet, Albertus. Ex geminis catulis alte.

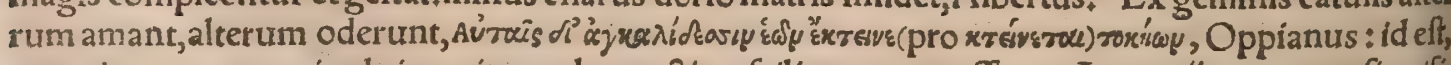
propriæ autem matris ulnis perit catulus, arctius fcilicet compreffus, Aegyptij ut patrem fignificent qui inuifo filio hareditatem reliquit, fimiam cum catulo eius retro(in tergo) pingunt: parit enim fimia geminos:unum amore, alcerum odio profequitur. Quem igitur amat ante fe geftans interimit; 60

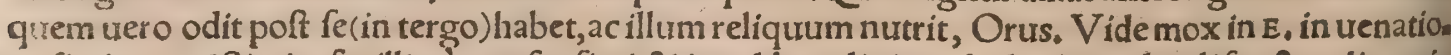
ne fimix, TSimias facillimemanfuefieri, $\&$ in adibus diuitum ludicri ac ridiculifpectaculigratia 
catenis alligatas nutriri, notum eft omnibus,

TLuna caua triftes effe, quibus in eo genere cauda fit, nouam exultatione adorare, (nanciz defè ctum fyderum \& cæteræ pauent quadrupedes, ) Mutianus tradit,Plinius , Solínus tamen de limijs; non caudatis, fed fimpliciter, Exultant (inquit)noua Luna, triftes funt cornuto \& cauo fydere. of $S$ i mix facies turpiter hominem affimulat, triftis, fraudulenta, Gillius. Diuitibus in delicijs funt, omni um ferè rerum imitatrices. đPufillicas animi effe, malignas, ftolidas, \& eodem ingenio praditos cenferi homines; qui oculos, aures, labra aut dorfum eis fimilia habent, ex Ariftotele \& A damantio in $\mathrm{B}$, diximus, Simia quemuis ludum docetur, natum ad imitationem animal:fed mala potius quàm bona in homine imitatur. Ferocitatem quídem obliuifcitur, fed nunquam adeó manfuef́cit, quinin faci - le femper fiat rabida, (ad impetuofam iram prona.) Delectatur ludendo cum pueris $\&$ canibus $₫$ fed puèros(infantes) non cuftoditos aliquando ftrangulat, uel ab alto præcipitat, Author de nat,rerum;

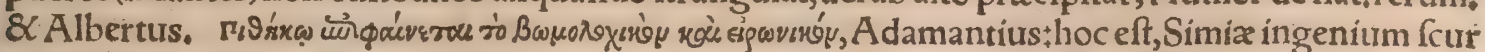
rile \& fimulatione infigne eft. Simia cicur dominum furm agnoficit etiam poft multos annos reuer tentem, Alexander. Iniuria longo tempore meminit, 8 fimultatem diu exercet in eum à quo læra fuerit, Albertus $\&$ alij. TNatura fimiz ridiculo animali $\&$ animam habenti ridiculam, corporis quog conftructionem ridiculam dedit, Galenus. Simia maximè delectatur ludis, unde factum à

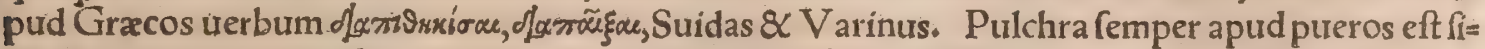
mia, ut ait ueterum quidam, nos admonens hudicrum effe ridiculium puerorum hoc animal illudena tium. Omnes enim humanos actus imitari dum fatagit, \& fruftratur in ipfis, \& ridiculum fe exhibet: An non tridifti fimiam fiftula canere, faltare, fcribere, $\&$ alia agere uniuerfa conant $\tilde{e}$, qua homo pulchre perficit?'Galen, de ufu part,2.22. Simia actuofum animal, $\&$ ad omnia imitanda habile, omnè quod corpore agitur, fi doceatur, praclare dífit, \& idipfum actione repraefentat : ac fi faltare docea= tur, faltationem affequitur; fi ad tibiam cancre, canit, Ego aturiga munus obire uidi, habenas nimi= rum uel abducendi, uel remittendi, \& flagello fimul tutendi:breui, fi quis ad alia quxpiam inftituat; non fallit docentem:a deó uarium natura animal eft, $\&$ multiplex, ut ad omnem actionem fefe uerfer, Aelianus. Et rurfus, Cum cæeteris in rebus omnium beftiarum fimia peruerfiffima eft, tum peruer= fior in ips,in quibus hominem imitari conatur. Cum enim nutricem ex eminenti loco perfpexiffet puerum infantem in pelui lauare, $\&$ fafcias in orbem contrahere, $\&$ in arcium ad aqux expreffione $\tilde{e}$ contorquerè, at ̧̧ quo reliquiffet loco puerum obferuaffet, fimul \& circa eum ipfumà cufodibus - magnam introfpexiffet folitudinem + feneftella quax turm pateres in domum intrauit ad puerum, quem fímiliter ut factitari à nutrice uiderat, ex lecto fublattum integumentis nudauit, \& aquam, fuc cenfis carbonibus, calefcentem, in mifer ìm infantem infưdít, atç interfecit. Mutianus \& latruncu lis lufiffe fictis cera finias tradit, nucés ưifu diftingưère, Pli. Callidus emiffas eludere fimius haftas, Martial. Caucafi pars(inquit Philoftratus de urita A pol. lib. $3_{*}$ ) qua in rubrum mare porrigitur, tum alia aromata, tưm piperis arbores profert. Nafcuntur illæ̀ in extremis praruptisḉs locis, homini inac

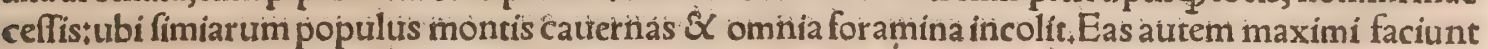
Indi, quoniam piperis (ut fic dicam) tuindemiatrices funt $\$$ quapropter $\&$ armis $\&$ canibus leones $\&$ cæteras feras ab ipfis arcent. Infidiatur autem fimia leo ägrotus, medicinæc caufa, (uide paulò poft;) $\&$ cum iam fenex feras affequi alias non poteft, paltus cibió̧ gratia. Sed Indi fimias non negligunt, \& fé beneficia ab ipfis cäpere arbitrantes leones arcent. Quod autèm ad piperís collectionem atti. net, fic fe habet. A ccedentés Indi ad arbores qua in parte montis infima nafcuntur, frućtusḉ ab illis decerpentes, paruas quafdam fub arboribus arèas faciunt, ubi piper congerunt, quafi cafu illic ip. fum prö́cientes, ceu rem neglectam $\&$ minimi ab hominibus exiftimatam in auijs abdita fimix, talia defuper afpicientes ubi nox aduenit, Indórum opus imitata auulfos ar borum ramulos, (Bosgúyoss, )in areas quas diximus conferunt. Indi autem ubi dies illuxit piperis acera uos afportant, quos nihil laborantes fed dormientes acquifierunt, Hac Philoftratus.

Trleo inter beftias terreftres, fic in mari delphinus imperat, Ambo fenectute tabefcunt: : 2 cû funt in ægritudine, illi terreftris fimia, huic marina medètur, Aeliañ. Aegroto leoni nulla poteft alia médicina adhiberi: fed fi comederit fimiam,id ei morbi remedium eft, Idem in Varijs. Hoc $\&$ Philoftratùs fcribit, ut paulò anté retuli, Cum fưpra quà̀m fèrre quteat cibo fé compleưitleo, aut

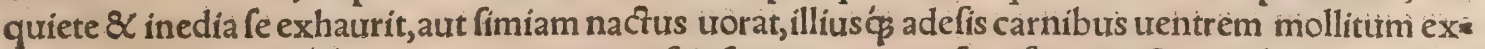
tenuat, Aelianus, Hominem agrotum ac feipfum curantem fignificantes Aegyptïl leonem pin: gunt fimiam uorantem + hic enim febricitans uorata fimia contualefrit, Orus dỉ tantum fentitleo, in qua medetur ei contumelia, in rabiem agente annexaritm lafciuia finiarum: Guftatus deinde fanguis (fimià, non canis ut Phyfiologus habet)in remedio eft, Plinitis ، mirabili aftutia pardalis fe mortuam fingèns, fimias captet, uide in Pardali capite ž. ex Aelianołunde 8 prouerbium natum, Pardi mortem adfimulat, Ad pardum plerac tiel fponte adcurrere, odore alleça, fimiã comprimis, narrant, Plutarch. at Aelianus pardalin curfus celeritate fimías affequí fori bit. TCati etiam in A egypto fimias uenantur, ut in Cato dixi ad finem capitis quarti. Inter mamo netum (id eft cercopithecum ) \& fimiam odium eft implacabile, bellumóg frequens \$ \& licet uiribus impares fint mamoneti, aftutia tamen $\&$ animofitate pugnandi fimịs præferuntur, Ifidorus, Epho rinus in Colloguijs Erafmi in dialogo de amicitia, poftquam multa de animalium inter fe riatưrall 
uel confenfu uel pugna dixiffet, fubdit:Addam quod non legi, fed his oculis confpexi. Simitus fupra modum horret teftudinem. Huius rei quidam dedit nobis fpecimen Romx. Pueroftro in trerticem impofuit teftudinem, $\&$ pilco contexit, dein producit ad fimium. Ilico fimius gaudens infilït in hu, meros pueri uenaturus pediculos, fublato pileo reperit tefudinem.Mirum erat fpectaculum quan: to cum horrore refilierit beftia, quàm expauerit, quàm timide refpexerit an fequeretur teftudo. Ad, ditum eft aliud fpecimen : alligauimus teftudinê catenæa à qua reuinctus erat fímius, ut effugerenon poffet, quin faltem afpiceret, incredibile dictu quantopere fuerit difcruciatus : tantum non metu exa nimabatur, interdum auerfus pofterioribus pedibus depellere tentauit hærentem beftiam. Tandem quicquid erat in aluo aut uefica oneris, reiecic. Sequuta eft ex pauore febris, ut nobis fuerit foluen: dus à catena, 8 aqua ưino temperata refocillandus, Hac ille. Ego trero fimiam non teftudines, fedlik It maces, metuere audio:quæ fi circumponantur ei, comprimere fe, \& præ metu contingere non aude rełut errârít Erafmus uulgari hodie multis errore teftudinem pro límace dicentibus. Et paulò poft in eodem dialogo + Thomas Morus (inquit loannes interloquutor) in Ānglia alebat domi fimium pragrandem, tum fortè, quò reualefceret à uulnere folutus obambulare finebatur. In extremo horti erant inclufi cuniculi , quiburs infidiabatur muftella. Id fimius procul quietus \& ociofus fpectabat, donec uideret cuniculis nihil effe periculi. Cæterum pofteaquam muftella labefactaffet carream àmir ro reuulfam, iamćs periculum effet, ne cuniculi à tergo nudati prædæeffent hofti, accurrit fimius, \& confcenfa trabe quadam, caueam retraxit in locum priftinum, tanta arte, ut homo non poffet dexte rius. Ex quo perfpicuum, hoc animantium genus fimijs effe charum. Ipfi cuniculi non intelligebant fuum periculum, fed hoftem fuum per cancellos of culabantur. Simius opitulatus eft periclitanti fim 20 plicitati.Tum Ephorinus, Omnibus (inquit) catulis minoribus delectantur fimị, gaudentọ́ forere finu $\&$ complecti; fed pius ille fimius dignus erat aliquo pietatis pramio.

Simia \& elephas uino inebriantur, illæ quidem etiam inebriatæ capiuntur, Athenæus lib, 10, Mira folertia uifco inungi, laqueiśç çalceari imitatione uenantium traduntur, Plínius, ut Romana exemplaria habent. Hermolaus magis probat Veneta, in quibus legitur, Vifco inungi laqueos, cal cearićs uenantium imitatione.Scio $\&$ intingere fibi oculos (inquit)folere fimias, atçs inde capi facile, ut inquit Strabo : fed illud non tam folertiæ quàm fultitix tribuendum erat, Hac ille, EgoRomaträ lectionem malim : nam quod in Venetis legitur, apud nullum alium authorem reperitur. Vulgus fimiarum palim uidemus non fine ingenio zmulandi, şuò facilíts in manus ueniunt. Nam dum 3 auidè renantium geftus affectant, relicta confultò uifci unguilla, quod mendacio factum uídent, 0 . culos fuos oblinunt. Ita uifu obducto pronum eft eas corripi, Solinus. In montana regione India genus fimiarum frequens $\&$ pragrande reperitur, (inquit Diodorus Siculus lib. 17.) qua cum uaa lido corpore $\&$ animi fagacitate præftent, haud facile per uim comprehendi poffunt, Igitur éuenaa torum turba quifpiam melle fibi oculos perungit, alius (belluis hac omnia uidentibus) calciamenta fibi induit, alin fpecula capitibus applicant. Calciamentis innectuntur laquei, atç ita ea difcedentes

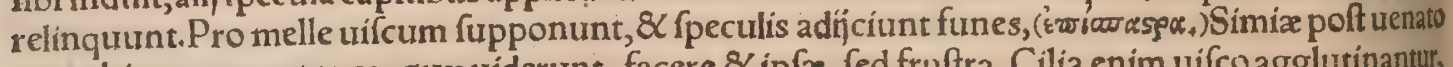
rum abitum conantur ea, qux uiderunt, facere \& ipfa, fed fruftra. Cilia enim uifco agglutinantur, pedesí́s laqueis impediti, \& corpora uincta remanent, Hac Diodorus. Inter Hydalpen \& Aceli. nen in India fylua eft prope Emodos montes, in qua maximam ingentium cercopithecorum mults 4 tudinem effe dícunt, a deo ut cum Macedones aliquando multos in collibus quiburdam apertis uí

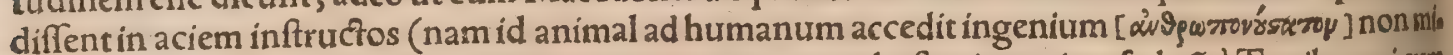
nus quàm elephantes, ) caftra putarint, 8 in eos tanquam hoftes irruerint Alexandro erat, rem agnouiffent, ceffarût. Hoc animal duobus capitur modis, nam cum imitationis fudiofum fit, \& in arbores fugiat, uenatores cum eos in arboribus infidere animaduertũt, catinum aqua plenum in confpectu ponunt, oculos fibi ex ea abluentes, poftea uifco pro aqua pofito abeunt, ex longinquo infidiantes. Cum animal ex arbore defenderit, \& fefe uifco illeuerit, \& conniurenti palpebræ implicitæ fuerint, accedentes uiuum capiunt. Atq̧ hic unus eft modus. Alter eft, poftquá

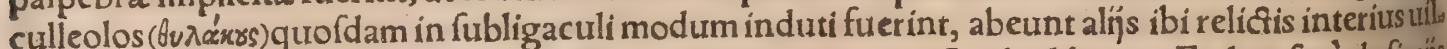
lofis $\&$ uifco illitis. Simix in hos ingredientes facile capiuntur, Strabolib+15. Eadem ferè de fimijs uifco aut calciamẽtis propolitís, capiendis, Author libri de nat, rerum \& Albertus fribunt. Nonca piuntur retibus, neque fagacium canum uenandi folertia praditorum: fed cum fit animalfaltationis auidurm, faltare cupit: fi item quempiam uiderit calceos induentem, imitatur $\$ \&$ fi quem uiderit ocu los pingentem, aut lauantem, hoc idem facere futdet: itaque pro his ex plumbo factos graues calceos proponunt, \& laqueos fubíciunt, ut pes quidem ingredi poffit, \& interim firmo uinculo retineri, Itemćs uif́co decipiuntur, nam illis uidentibus Indus pelues aqua plenas in earum confpectu ponit, ex eać oculos oblinit, ac mox uifcum pro aqua reponit:illa afpicientes (ut funt ad omnia imitanda aptæ) continuò defcendunt, oculosás \& ora ipfi fimiliter uifco oblinunt, itaç poftea facillimé capiun rur, Aelianus. Otides etiam autes imitatoria, uifco fimiliter capiuntur. Catulos ferè geminos pas rit:ex quibus chariorem magis complectitur, \& geftat(ulnis.) qui minus diligitur, dorfo matris infte det:\& cum aliquando à uenatore agitatur, neceffitate adaça fortum quem ulnis geftat, abïcit, ut fü gere poffit, dorfo autem adharens excuti nó potelt, $\&$ fi forte cum illo euaferit, diligere incipir quem 


\section{DeSimia E.F.G.H.a. Lib. I. 963}

ante minus dilexit, Albertus. Piper quomodoex arboribus colligant fimix, dictum eft fupra in D. Regio Bafman magno Cham Tartarorum regi fubiecta, abundat diuerfis fimpis magnis $8<$ partris, hominibus fimillimis. Has capiunt uenatores, $\mathcal{Q}$ occifas totas depilant, pilis in barba tantum $\&$ ano relictis $\& \mathcal{Q}$ aromatibus conditas deficcant, $\mathcal{\&}$ mercatoribus urendunt, qui in diuerfas orbis partes cor pora illa deferentes, hominibus perfuadent tales homunciones in maris infulis repgriri, $M$. Paulus Venetus 3.15. TSimix in leporario rarenter tenentur: fed catenula in qualibet fere adium parte li gantur, ut confpici poffint atq̧ delectent, Grapaldus. Imponitur aliquando equo partio, \& cani= bus in equum irritatis, cum defilire non audeat, metuens fibi à canibus, miros interim geffus ædit.

T) Serpens, canis, fimia $\&$ gallus gallinaceus, culeo parricidx in mare pracipitando fimul inferun tur. Vt enim fimia homo non eft, attamen uidetur ₹ fic qui preprium occiderit patrem. Serpens in fidijs ànteit, inimiciffimus humano generi non fecus ac parricida. Canes omnes odiffe videntur, fo= lumç̧ hoc animal nulli penitus parcit, neģ proprio generi.Gallus infons huius culpa, forfan ob gẽ tis fimilitudinem adijcitur, quam maximéRomani oderunt, uel quod fuperbifimus fir. Præcipita= tur in mare, uelut omni indignus elemento, \& cuius focietate aer, terra aquaḉs inficerentur †ob id cư leo infuitur uirgis fanguineis prius uerberatus, Cardanus,

F.

Zygantes A fricæ populi fimpis uefcuntur, quarum affatim gignitur ịs qui in montibus degunt; Herodotus, Simia frigida $\&$ auftera eft, $\&$ humorem generat peffimum, $R$ afis .

G.

Cor fimix affum $\&$ aridum potum drachmæ pondere cũ melicrato uetere, roborat cor, $\&$ acri. moniam eius audaciamḉ auget, pufillanimitatem $\&$ cordis pulfum depellit,acuit intellectũ, $\mathcal{X}$ con. tra caducum morbum ualet, $R$ afis.

đSiue homo, feu fimilis turpiffima beftia nobis, Vulnera dente dedit, uirus fimul intulit atrû, Betonicam ex duro (aliâs puro) prodeft affumere Baccho, Nec non \& raphani cortex decocta me: detur, Si trita admorfis fuerit circumlita membris, Serenus, Fel tauri illitum fuper morfum fimia, perfanat,Sextus. Simix morfus (inquit Auicenna)aliquando uenenofus eft, cui applicari opor tet ea quæ uenenum extrahant: quale eft cataplafma cum cinere, aceto, cepa $\&$ melle +aut cum amy gdalis amaris $\&$ ficubus, præfertim immaturis. Conuenit etiam lithargyrus cum fale, $\mathcal{\alpha}$ radix foni: culi.A poltema eius fedatur lithargyro liquefacto in aqua: $\&$ cooperiat(aliâs aperiatur) ipfum curm nigella \& melle, \& eruo \& melle:Aliâs, Affumat in potu nigeilã tritam \& mel \& porrũ: aut orobum $\&$ mel. Arnoldus de Villanoua in Breuiariofic legit, Nigella $\&$ mel cum farina orobimixta $\&$ fu perpolita, mirèualent. Ferdinandus Ponzettus penultimo capite operis fui de uenenis, cum in: dicaffet remedia contra morfum cati, fubiungit: Similiter curatur morfus muris fylueftris $\&$ fimix, $\&$ aliquorum, fuper quos ueteres ponebant fabas mafticatas. Et quidam putant quod betonica \& plantago fumptx cum uino ueteri conferant ad omnes* $\& \propto$ fimus caprarum decoctus in aceto, $\&$ ulceri illitus fanet.

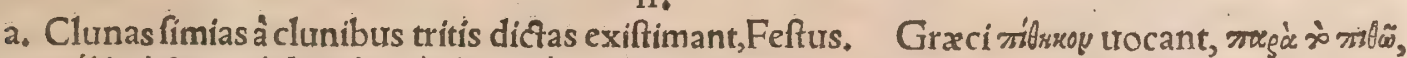

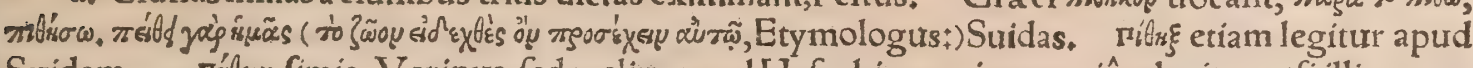
- Suidam, ríboun, fimia, Varinus, fed melius apud Hefychium prima per iôta legitur, etfi illic quoç

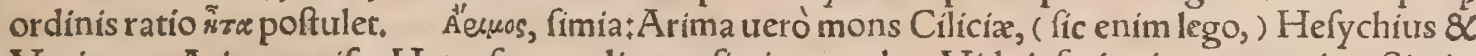
Varinus, Arimos prifca Hetrufcorum lingua fimias tocabat: Vide inferius inter propria, Simiæ

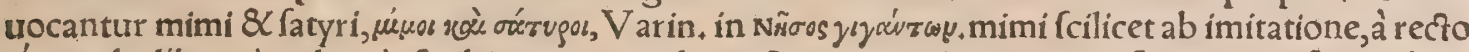

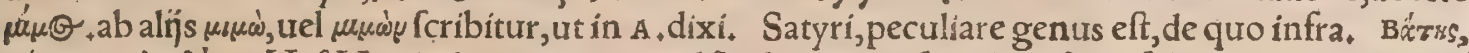

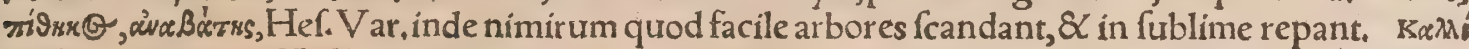
«, fimia, Lacones, Hef, Var. Galenus in commentarn̈s chirurgiæ Hippocratis notat ynuréicu à Græ cis uocari fuem, uel porcum in facrificio, blanda fcilicet uooce, ut quocs fimiam rankérav, eadem ratio=

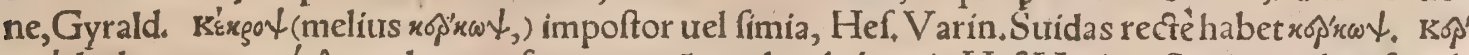
«c) citer \& proprie dicta, caudata non eft, fed cepus fiue cercopithecus:cercos enim Gracis cauda eft, un de $\&$ cercops deriuatur, ut eo nomine caudata fimia potius quàm fimia fimpliciter intelligenda uia deatur.Suidas cercopem non fimiam, fed genus fimiæ interpretatur. Kop $x \omega \pi j i \epsilon y$, irridere, illudere ficut fimix: quod uerbum etiam prouer bialiter ufurpatur, per translationem, ut Chryfippus inquit, ab animalibus qux cercon, id eft caudam motitantes adulantur. Cercopes, aftuti, dolofi, impoftores, adulatores, qui(ficut uulpes canes urenaticos decipit cauda huc illuc translata, Varin.) homines fim.

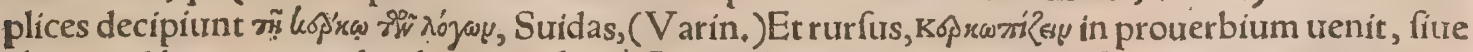
ab animalibus quæ cauda adulantur:fiue à Cercopibus, quos in Lydia uerfatos aiunt, magnos impo

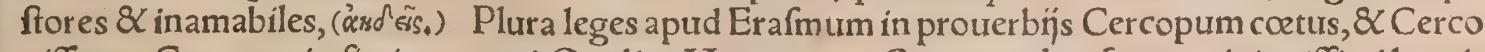
piffare. Cercopes in fimias mutati, Ouidius IMetam. I4. Cercopes duo fratres, iniquiffimi homi= - nes $\&$ ab ipfa improbitate fic dicii, alter Paffalos, alter Acmon. Quod cum animaduerteret mater eo rum Memnonis, monuit ne in melampygum inciderent, hoc eft Herculẽ. Hos Xenagoras propter malignitatem in fimias transformatas ait, \& $\mathcal{X}$ Pithecufas infulas ab eis dictas. Nomina corum, Candu 


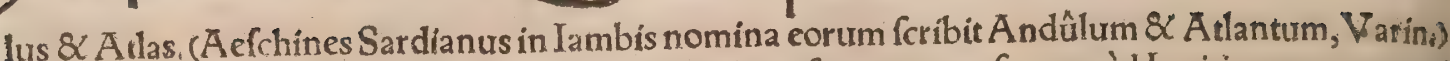
Alin ex Thea (éx ๑sics) \& Oceano eos natos aiunt, \& in faxa conuerfos, quòd loui imponere conati effent. Et mox, Cercopes aî̃it fuiffe mendaces, fuperbos, deceptores, qui per multas uagati terras, ubiç deceperint homines. Cercopes olim uocabantur Cyclopes, quare improbos $8 \%$ malos homi-

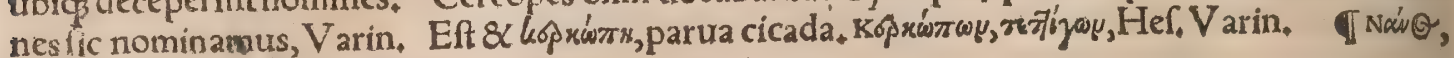
nanus 8 Cimia,Etymologus.

ब1 Epitheta. Simius, infamis, proteruus, calidus, fimulator, parafitus, turpis, apud Textor. Si=

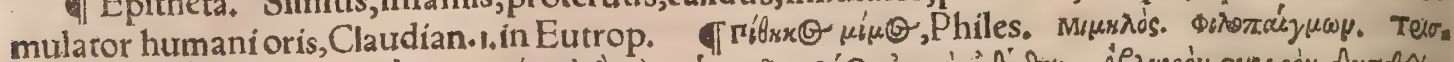

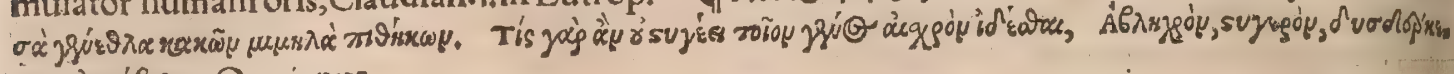
rou, áco íbrasy; Oppianus.

ब Simia, per translationem, qui alium imitatur. In quo Rufticum infecfatur, atø̧ etiam Stolcorî fimiam appellat, Plinius epift. Quos neç pulcher Hermogenes unquam legit, neç fimius ifte, \&c. Horatius 1.Serm. Simiolus diminutiuum, qui utcun $\varsigma_{\beta}$ alterum imitatur. Hic fimiolus animi caufa, me, in quem inueheretur, delegerat, Cic. adMarium lib. 7. epift. Tatianus orator fimiz co. gnomentum indeptus eft, quód omnia ingeniofius imitando exprimeret, Cælius. Maximinus iunin or oratore ufus eft Tatiano filio Tatiani fenioris, qui dictus eft fimia temporis fui, quòd cuncta imi tatus effet, Capitolinus in Maximino luniore. Ariftophanes in A uibus quendam traducens $x^{\prime} \hat{h}_{\text {ha }}$ rov uocat, fiue tanquam deformem, fiue tanquam panûrgon, id eft improbum $\&$ aftutum. In homin nem deformem \& nigrum, qui liberos etiam deformes habebat, iocofum epigramma authoris incer.

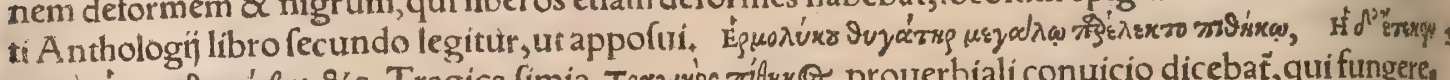
monix́s É tur honoribus, opibuśç polleret, alioquin indignus. Simiam appellant homuncionem, uix homine, feo fímulachrum hominis magis. Tragicam addunt, propter fortunæ ftrepitum $\&$ perfonam addi tam. Demofthenes in oratione pro Ctefiphonte, Aefchinem tragicam fimiam appellat, quódquum effet nequiffimus, fplendidis uerbis probum ciuem ageret. Curius prouerbij meminit Philoftratus in A riftide. D. Hieronymus in epiftolis oftendit hoc fcomma iaci folere uulgò in Chriftianos, fed ab im.

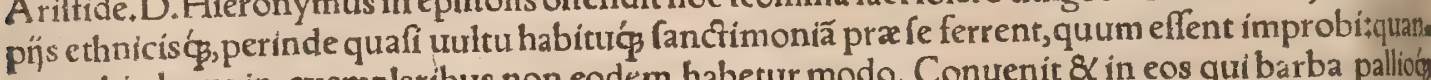
quam hic locus in exemplaribus non eodem habetur modo. Conurenit $\&$ in eos qui barba palliog

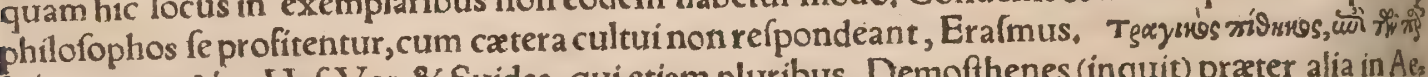

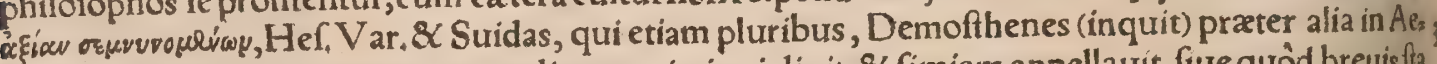
rchinen fcommata, poétarum tragœedias eum imitari dixit, \& fimiam appellauit, fuue quòd breuis fta turz bomo in fcenam intraret:fiue quòd fimia animal eft ad imitationem factum, \& A efchines quo que rragodiarum hiftriones imitaretur. Videtur \& Tragica fimia dici poffe in hominem curiofu us \& pretiofius ueftitum, ut Calius innuit. Eleganter \& aptèCallippides Mynifcum hiftrionẽ trą gicum fimiam uocabat:nam fimias ueteres appellabant imitatores, qui geftu omnia exprimere $0_{4}$ nantur, Robortellus. Simile huic eft aliqua ex parte, Simia purpurata, de quo uide infra inter pros

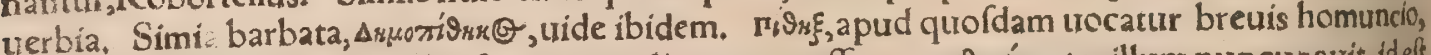

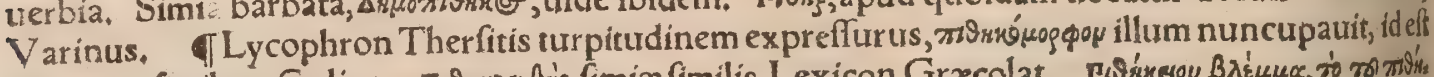
fimix confimilem, Calius, ए内

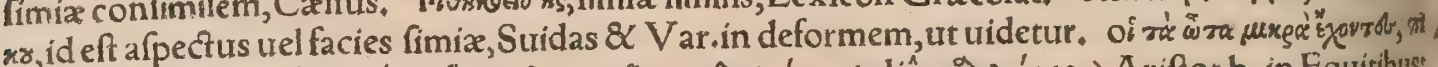

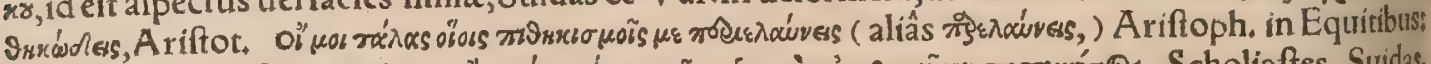

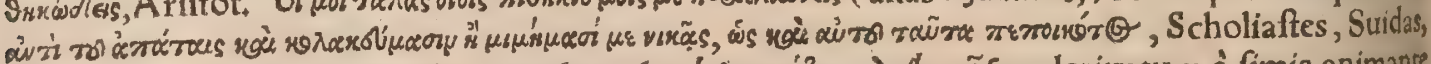

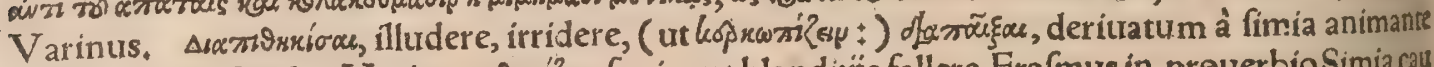

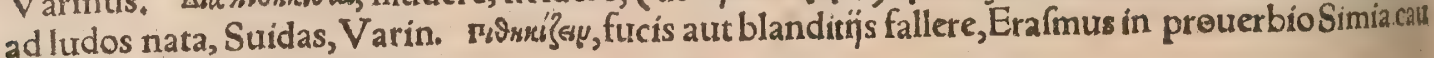
data:fed authorem non citat.

II Ef $\&$ fimia in mari rubro, non pifcis quidem, fed beftia cartilaginea, colore terreftrifimilis, \& reliqua etiam fpecie aliqua ex parte, fimiliter quoogs refima, \&c. Âelianus,

TPithecium, mulieris nomen Plauto, Hermolaus.

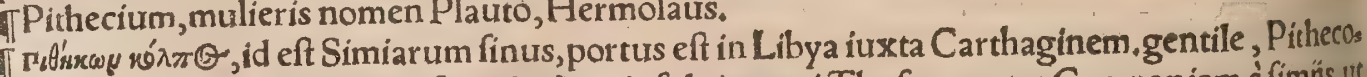

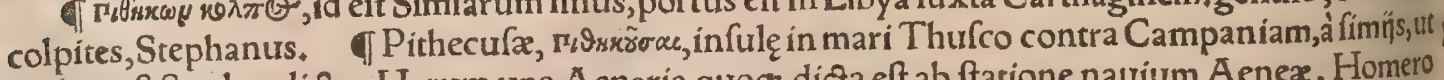
author eft Strabo, dictæ. Harum una Aenaria quoç dicta elt ab ftatione nauium Aenex, Homero Inarime: hodie If chia ab oppido cui coxendicis fimilitudo, ut Hermolaus in Caftigat. fuis in Plinium docet. Plinius uero à figlinis doliariorum nomen factum putat, qua ibi ex Creta fiebant. Dolium enim Graci pithon, fimiam pithecon wocant. In harum fummitate oppidum fuit, quod plurali nth mero Pithecuf $x$ dicebatur. Meminit Plinius 3.6. \& Ptolemæus 3. 1. Inarimen Prochytenćs legit, fie riliós locatas Colle Pithecufas, habitantum nomine dicras, Ouidius. Incolæ, Pithecufai, Srephia nus. Prochytam $\&$ Pithecufam à Mifeno abruptam Strabo in primo author eft, quã tamen idemin quinto à Pithecufis ipfis quondam diuulfam tradit. Pofteriorem fententiam Plinius fequitur \& Ser' uius. Vnde $\&$ fecundum hos à profufione nomen Prochyta traxit, quod etiamnum feruat. At Dion nyfius libro I. fcribit à nutrice Ánex eiufdem nominis dicfam. Pithecufam autem $\&$ Pithecufas nu mero multıtudinis dicimus alteram infulam, qua Inarime primum Vergilio diça eft, Nic, Erythre: us in Indice Vergiliano, ubi plura leges in uoce Inarime. Arimum Hetrufci olim fimiam uocabāi. 
Vide etiam Inarime in Onomaft, noftro: \& quædam Strabonis loca, \& Hermolai in Plinium, ex In. dicibus. Iouem deuicis Gigantibus aliqui Damafcum, alij Siciliam, trophæum ftatuiffe aiunt:ali uerò Gigantum infulas, Pithecos ( $\mathrm{F}_{6} \mathrm{P}_{\mathrm{H}}^{\prime}$ rrs $)$ accipiunt, qui iuxta Italiam funt; Aefchioni memorati. In his olim Gigantes habitabant, poftea uerò Iupiter domitis eis infulas fuperimpofuit, \& fimias in de=

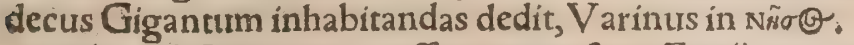

đb. M. Cicero antiquiffimum uerfum (Ennī puto) refert de fimia, Simia quàm fimilis turpiffi ma beftia nobis.

【 $c$. Simonides apud Stobęum in fermone quo mulieres uituperãtur, pro diuerfís ingenị s alias ex alijs animalibus natas fingens: Ea uero, inquit, qua ex fimia nafcitur, omnium peffima eft : turpl facie, omnibus ridicula, breui ceruice, natibus depreffis. Ingenio quoç fimiam refert, à læctitia $8 \mathrm{x}$ rifu aliena tin neminem benefica : hoc unum meditatur, quomodo infigne aliquod malum facinus edat

đd. Epictetus dixit, Adulatoris minas \& fimix iras eodem loco habendas: aut fi Græcé mauris

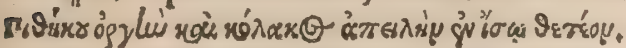

$\Phi e$ Si fupponatur capiti dormientis cor fimiz, uridebit in fomnijs res terribiles, $R$ afis

Th. Cafarem cum peregrinos quofdam Roma locupletes homines canum $\&$ fímiarum catulos cirçunferentes gremio, eisós deditos intueretur, inter rogaffe ferunt, nunquíd apud illos mulieres li. beros parerent, Plutarchus ab initio uita Periclis. T Simia quam rex Molofforum in delicijs habe bat, \& fortes ipfas, \& cæetera quæerant ad fortem parata difturbauit, \& aliud aliò diffipauit, Cicero 1. de diuin. đCercopes in fimias mutati, Ouidius Metam+14. Vide fupra in a, TSimia Minerue - olim facra erat, Fr. Arlunnus fine authore. DianæColoénæ templum fuit in Sardiana regione pro= pe Coloén lacum, in cuius celebritate fímix faltare ferebantur, qua in re fuam non uult fidem Straa bo aftringere, Gyraldus. Nero Claudius aliquando fomniauit afturconem, quo maximé latabas tur, pofteriore corporis parte in fimix fpeciem transfiguratum, ac tantum capite integro hinnitus adere canoros, Suetonius.

P R O VER B I A

A finus inter fimias, ubiftolidus aliquis incidit in homines nafutos $\&$ contumeliofos. Simile eft

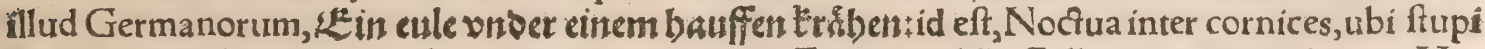
dior aliquis in homines petulantes ac dicaces incidit, Extatapud A. Gellium 2. 23. apud quem $\mathrm{Me}_{z}$

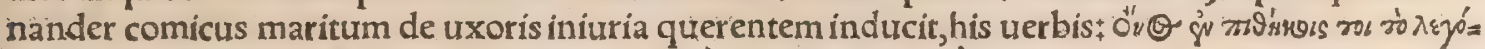

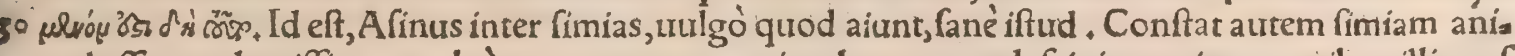
mal effe petulantiffimum, adeò ut non uereatur etiam leonem per laf́iuiam agitare, natibus illius af fixa,Erafmus. Simia barbata, (nó placet quód addit Eralmus, fetr caưdata.) Ariftophanes in Achar

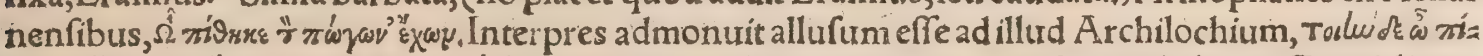

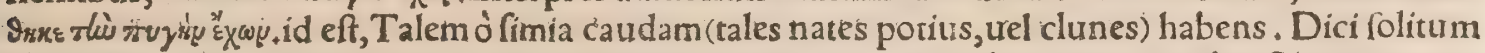
de ridiculis. Regulus $R$ ufticum Stoicorum fímium dixit, contumelix gratia, ut refert Plinius in epi= ftolis, opinor quòd barba \& pallio Stoicum ageret uerius quàm morib, Idem Ariftophanes alio quo

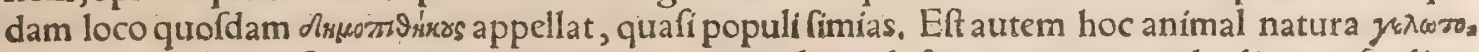
roió, nec in alium ufum uidetur natum, quum nec ualeat ad efum ut oues, nec ad adium cuftodiam ut canes, nec ad onera geftanda ut equi. Athenæus libro 14, narrat A nacharfim philofophum gene: - re Scytham, quum in conuiuium inducerentur homines ad rifum mouendum edocti, folum omniũ non rififfe. Tandem quum inducerentur fimiæ, cœ pit ridere. Rogatus caufam $+\mathrm{H} x$ (inquic)natura

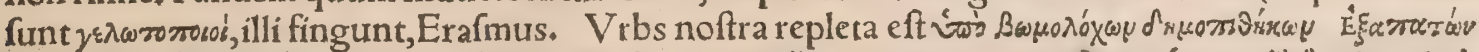

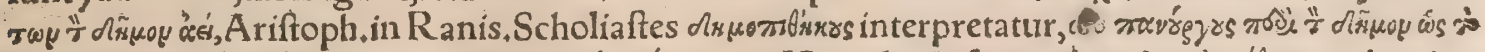

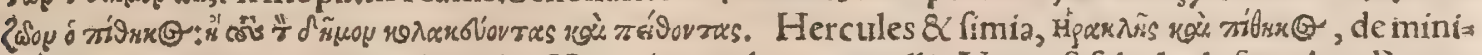
mé congruentibus. Simia dolis ualet, Hercules uiribus antecellit, Nota eft fabula de fratribus Perpe: rís, quos Hercules comprehenfos à claura fufpendit: eos ferunt uerfos in fimjos, Erafmus, Quos e go non pluris facio quàm, ut dici folet, fimias, Dion Prufenfis in libro de Troía non capta. Eft enim fimia plané ridiculum $\&$ uulgó contemptũ animal, Eraf. Simiarum pulcherrima deformis elt, T்̃̆

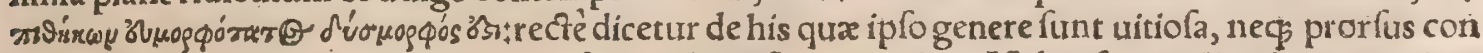
ferenda cum uel extremis eorum quæ funt in honeftorum ordine. Velutifi quis dicat lenonem inte gerrimum effe periurum, aut honeftiffimum hiftrionem infamem, aut optimum Meuñ carmen ma: lum effe. Citatur â Platone, $\mathbb{Q}$ ad Heraclitum authorem refertur, Erafmus. Simia in pelle leonisł.

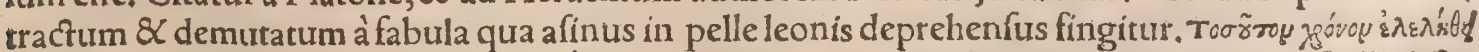

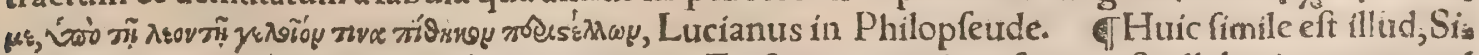

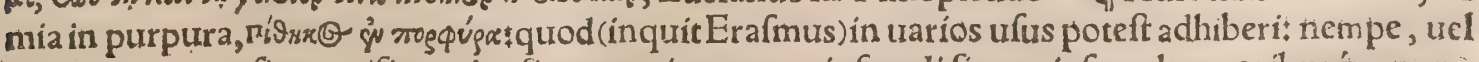
in hos, qui tametfi magnifico cultu fint ornati, tamen cuiúmodi fintex ipfo uultu moribusó́ cogno fcitur: trel in hos quibus dignitas indecora addiťtuel quoties rei per fe foedx, afcititia peregrinaçó or namenta indecenter admouentur. Quid enim tam ridiculum quàm fimia ueftita purpurea irefte? Atç id tamen non rarò fieri uidemus a pud iftos qui fimias habent in delicís, ut quàm maximè pof 6o funt, ad humanum morem ornent ac uefiant, aliquoties $\&$ purpura : quò parum attentos aut impe ritos fallant, próç homine falutetur fimia, aut fi deprehenfus fuerit fucus, res magis fit ridicula Quàm multos id genus fímios uidere eftin principum aulis, quibus fi purpuram; fi torquem, fi 


\section{6}

\section{De Quadrupedibus}

gemmas detrahas, meros cerdones deprehendes. Lepidius erit fi longius tranfferatur, uelut in 00 qui barba pallió́s fimulant fanctimoniam, Hatc Erafmus. Memínit adagï Suidas. Iulianum impe ratorem, loquacem talpam, \& purpuratam fimiam quidam appellabant, Ammi.Marcellinus.

- Simia furcata, (uel potius ceruffata, id eft ceruffa illita candoris comparandi gratia, \& rugas ac formæ uítia occultandi, quæ ucx apud Martialem $\&$ Ciceronem legitur) de deformi anu, fucata ta.

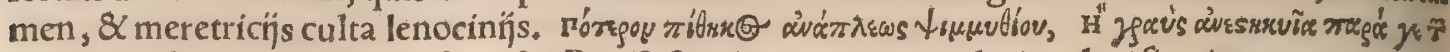

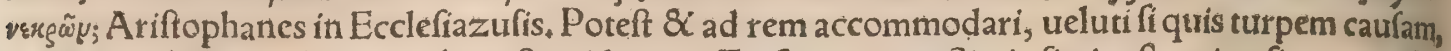
orationis phaleris adornet, ut honefta uideatur, Erafmus. TSimia fimia eft, etiamfi aurea geftet

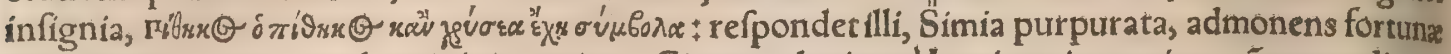
ornamenta non mutare hominis ingenium. Citatur adagium à Luciano in oratione cótra erưditum, 10 Natum uidetur à fimins illis Aegyptís faltationem humanam imitantibus, Lucianus refert apoløgin in hunc modum : Rex quidam A egyptius fimias aliquot inftituit, ut faltandi rationem perdifcerent, Quam illæ protinus edocta, faltare coperunt, infignibus indutæ purpuris ac perfonatæ, Multoó iam tempore maiorem in modum placebat fpectaculum, donec è fpectatoribus facetus quif́piam, nus ces, quas clanculum in finu geftabat, in medium abiecit. Ibi fimia, fimul at $\$$ s nuces uidiffent,oblita chorea, id elle coeperunt quod ante fuerant: cótritiş̧́ perfonis, dilaceratis ueftibưs, pro nucibưs in ter fe depugnabant, non fine maximo fpectatorum rifu, Erafmus. Eundem apologum paulóaliter recitat $T$ zetzes Chiliade 4. hiftoria I. In eandem fententiam Germani, Su fuw iff ein fuw/ ons

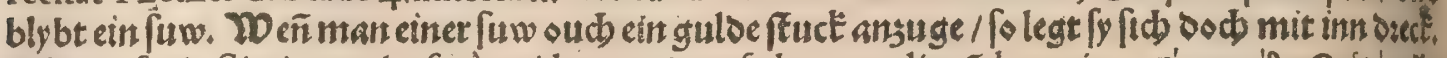

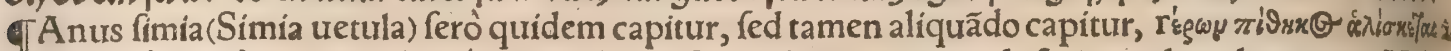

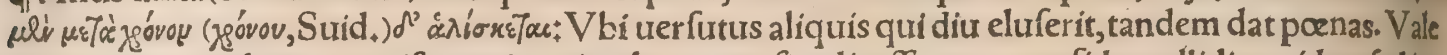
bit ad exhortandum, ut quifog ueris rationibus agat, fi uelit effe tutus, ne fidat callidis quidem fed in

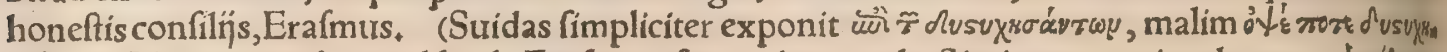

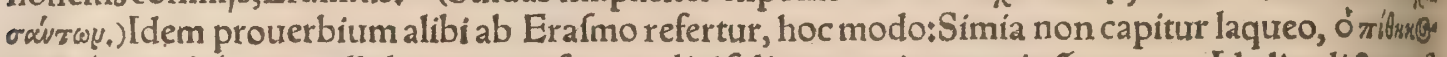

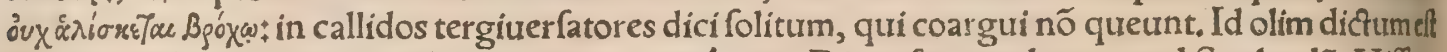
in Heraclidẽ, qui per imprudentiã perperam citârat ex Dionyfio quod erat apud Sophoclẽ. Miffum eft exemplar, ut ibi cốpecto carmine agnofceret fuum errorem. Hîc quoçs tergiuerfanti, nec lapfum agnofcenti, dicẽriç̧ cafu fieri poffe ut in diurerfis poëtis uerfus confentiant, fcripfit quifpiam fimiam

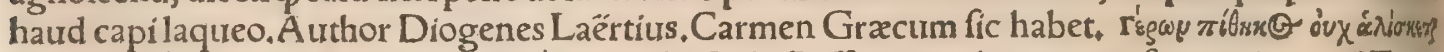

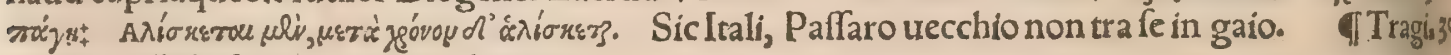
ca fimia: $V$ ide fupra in a,inter deriuata.

T Simix cum turpifima beftix uocentur ab Ennio, credunt tamen furos catulos effe omnium for mofifîmos, id quod plerifģ noftrum qui fcribimus euenit, Grapaldus, đI Simiâ in naufragio con fpicatus quifpiam periclitantem, 8 hominem effe ratus, manu data feruauit è mari. Cum uerointera rogaret cuias effet, fimia Athenienfem fe refpondit. Ille iterum, An Piræeum noffet. (eft autem Pirz: eus portus in Attica.)Simia, optime fe noffe dixit, \& filios eius omnes, coniugem atç amicos. Tum ille indignatus, magis impulit eam ut fuffocarerur, Tzetzes Chiliade 4.hiftoria แ. Ka

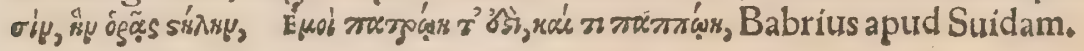

\section{DE SIMIIS DIVERSIS.}

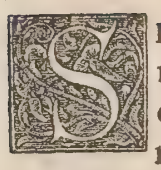

I I I A R V gुenus omnino multiplex eft, hoc quidem omnibus cómune, humani corpo ris fpeciem aliquo modo referre, pofterioribus cruribus erigi, ad omnia dociles $\&$ imitatrl ces effe. Differunt autem inter $f e$, cauda $\&$ barba, quod aliæ habeãt, aliæ careant. (Simlan rum genera hominis figuræ proxima, caudis inter fe diftinguuntur, Plinius, ) Deinde mat gnitudine, colore. Item faciei figura, qua uel hominem, uel canem, uel porcurm reprafentant, Prima fimpliciter fimia dicuntur, alteræ cynocephali, tertia CH O E R O P I T HE CI, id eft fimix porcaria, IIt Gaza apud Ariftotelem uertir: Qui uno tantum in loco hoc animal nominat, chamæleontê fcribens roftrum ei fimillimum habere. Differunt autem inter fe fimix, non folum ut nominibus diftincta i funt, ut fimpliciter dictæ fimiæ, de quibus iam fcripfimus : cercopitheci, cepi, callitriches, cynoces phali,fatyri, fphinges, de quibus deinceps fcribam. fed etiam qua unius funt generis $8 \times$ nomen com mune habent, non omnes funt fimiles, nam ex fimpliciter dictis fimpis, aliæ fua facie hominem, aliz canem magis referunt, \& c, ut fupra ex Galeno expofui in Simia B. Sunt \& cynocephalorum diuer. fa genera, nec unum genus caudatarum, Recentiores fimiarum generi animalia quadam nonie: cte adfcribunt, ut Allbertus chimaram, quæ non reuera animal, fed poëtarum figmëtum eft, de quo pluribus egi in Capra a. Idem de animalibus 7.1.6. P Y GM AEOS genus quoddam fimiarumeffe putat, non homines, fed homini figura tantum \& ftatura erecta fimiles, \& actionibus tum alijs tum pugna aduerfus grues, quafi ex deliberatione, ut Niphus inquit. Circa paludes fupra Aegyptur unde Nilus profluit, Pygmæi pugnare dicuntur cum gruibus, non enim id fabula eft. fed certe ge nus tum hominum, tum etiam equorum pufillum, ut dicitur, eft, deguntés in cauernis, Ārifot, de hift.anim. S, 12. Vbi Niphus, Pygmai(inquit)homines non funt:Primò quia non habent rationis us 


\section{Defimijs diuerfis. Lib. I. 967}

fum perfectum: deinde quia nec urerecundiam, nec honeftatem, nec iuftitiam reipub, exercent. Sed quia in multis imitantur homínes, adeò ut loqui poffint, ideo creduntur homines $\$$ non funt autem, quia locutionem imperfectam habent. Ad hac non uidentur homines effe, cum careant religione: eft enim religio, ut Platoni placet, propria homini, \& foli \& omnihomini conueniens, Hac ille. Sunt quidem in genere fimiarum nonnulla canina fpecie \& paruis hominibus fimiles, ut dicam in cynocephalis $\mathrm{H}$. funt $\&$ fatyri, $\&$ a lia fimiarum genera, humana ferè forma. Vitæ etiam longitudo, an ni circiter octo, ut Älbertus refert, $\mathcal{Q}$ corporis proceritas, pygmæos fimijs potius quàm hominibus coniungit. Sed ueterum nullus aliter de pygmais fcripfit, quàm homunciones effe, \&c. neç recen. tiores quicquam aliud præterquam ex ueterum fcriptis de eis cognouerunt. Pygmæorum \& pu. 10 gnx ipforum cum gruibus meminit Homerus lliados tertio:cuius uerfus Strabo etiam citat libro is Pygmzeos meridianam oram Oceani incolere fcribens. Idem libro 2. afferit fcriptores rerum India carum, præfertim Deimachum $\&$ Megafthenem tum alia falfa prodidiffe, tum qux de Pygmais an te ipfos Homerus fabulatus erat. Et libro 15, ex Oneficrito; Homines in India(inquit)quofdam tri. um, quofdam quing dodrantum effe ait, quorum nonnulli nafo careant, folis fpirandi foraminibus facie fupra os infigni. Cum illis quorum proceritas trium dodrantum eft, grues pugnare, item perdi= ces anferum magnitudine. Illos gruum oua legere atç abolere:nam ibi nidificare grues, nec alibi ea rum oua nidosćs reperiri. Sape etiam gruem cadere quæ æneum fpiculum habeat, quo fcilicet ín pugna uulnerata fuit. Item libro 17 . In locis quibufdam, ubicalor (aut frigus) excedit, pecora par= ua funt:ut oures, capræ, $\&$ boures. Canes quoqs pufilli, afperi tamen $\&$ pugnaces . Et fortaffis $a b$ ani=

10 malium iftorum paruitate, homines quo $\$$ Pygmai conficti funt : nę enim fide dignus quifquam ceu teftis oculatus eorum meminit. Pygmzorum \& latrantium (ìnexrźrvwethos alí cynocephalos

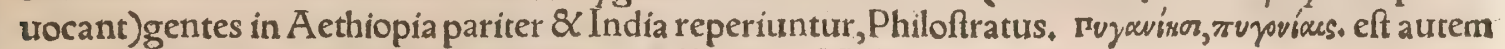
gens ante A egyptum pufillor um hominum, V arinus. Vide rvyни̃̈o apud eundem.

ब) Raphaêl Volaterranus mantichoram quoç \& crocutam fimiarum genera effe putat, nullo authore, nullis argumentis : quanquam Albertus quoq alicubi maricomorion(corrupto uocabulo mantichoræ) fimiarum generis effe fcribit, Ego fententiam meam de duabus iftis beftís, ftatim poft Hyanam fupra expofui.

DE C E R C O P I T H E C O.

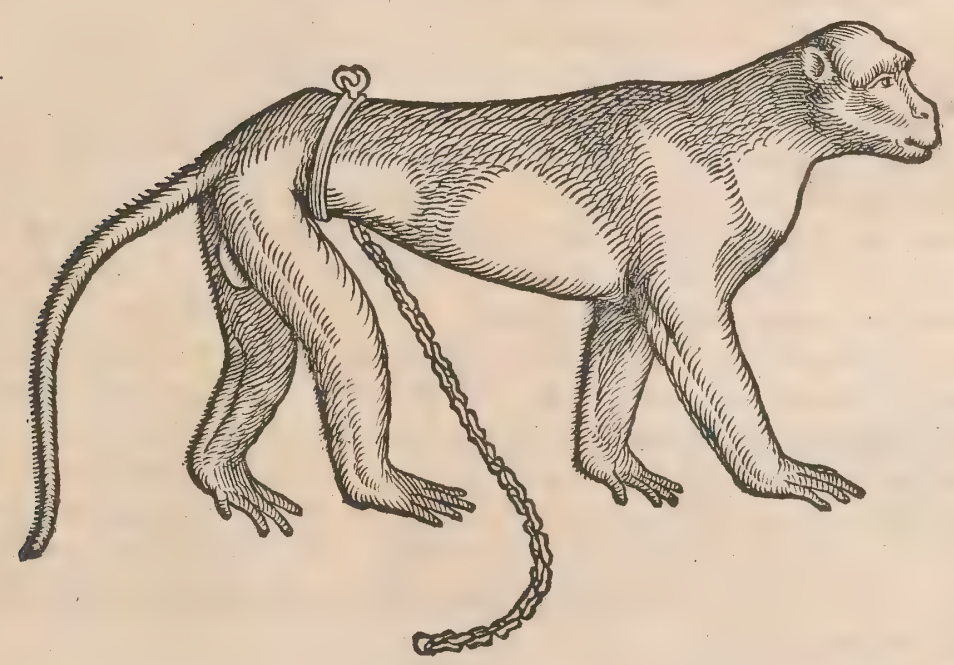

A.

S E R C Ó P I T H E C V s uocabulum Gracum, Latinè ad uerbum fimiam caudatam fo nat:cercos enim caudam fignificat. Callidus emiffas eludere fimius haftas, Simihi cauda foret cercopithecus eram, Martialis. Quamuis autem \& alia quadam caudata lint, prater eam cuitus iconem pofuimus: huic tamen priuatim hoc nomẽ contigit, qurod

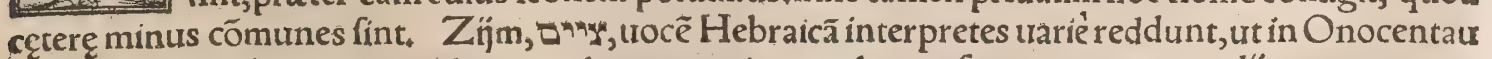
ri hiftoria dixi:aliqui cercopithecos, uel catos marinos, uel catos feros exponunt, (alíj martes aut ui. uerras, \&c.) Ibidem dixi de Hebraica uoce rjm, quam fimiliter aliqui catos fylueftes interpretantur.

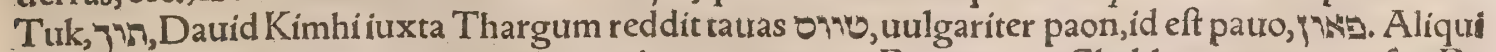

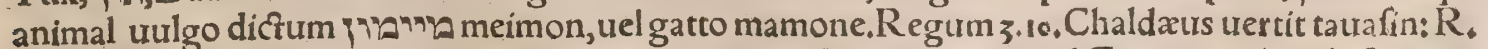
Salomon \& Leui $\&$ Hieronymus paui. (tauas quidem Chaldaica uox ad Gracam zacis, id eft pauto,

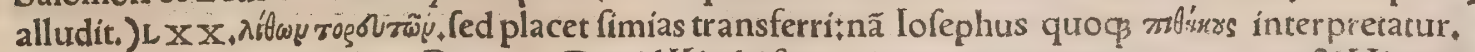

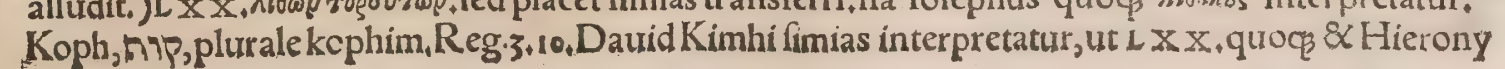




\section{DèQuadrupedibus}

mus.Chaldxus Hebraicam uocem relinquit. Graciquidem cepum peculiare genus fimiz nomia nant, (de quo poft cercopithecum ftatim dicam, ) mutuati forte id nomen ab Hebræis. Sunt qui oach, mink, cercopithecum uel cephum effe putent, (Babel fubuertetur, \& cubabunt ibi beftix horren $\mathrm{dx},[\mathrm{z}$ ijm: $] \&$ implebunt domos eorum cercopitheci, [ochim, $]$ Efaiæ 13.interprete Munftero;) Alij alis ter. Vide fupra in Muftela. Maionio, id eft fimia, Syluaticus + uidetur autem uox corrupta ; \& mamonus uel marmonus aut fimile quid legendum:fic enim ferè hodie cercopithecum tali uecant;

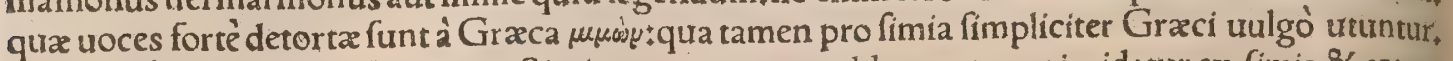
De uoce lop'rw $\downarrow$, dixi in Simía A. Simiarum genus quoddam componi uidetur ex fimia $\&$ cato as grefti, fimix admodum fimile, duabus nigris maculis in maxillis infigne : fed caudam habet oblon. gam grifei coloris, $\mathcal{X}$ in extremo nigram thoc aliqui fphingem appellant, alï cy thoficam, Albertus, 10 A pparet autem de cercopithecoloqui, unde $\&$ corruptum cythoficæ nomen conício. Defphinge, diuerfo genere, dicam infra. Idem Albertus de anim, 2, 1. 4. bis aut ter kybor uocari fcribitfimia genus cauda præditum, eft autem id quod Ariftoteles cebum uocat, alij cepum, caudatum quis $\mathrm{dem}$, fed à cercopitheco (cuius Ariftoteles nufquam meminit) diuerfum. ब/ Cercopithecus Ita lis eft gatto maimone, Gallis marmot, forte quafi marmona, id eft maris fimia : móna enim Hifpanis fimiam fonat, (at marmontana Italis mus alpinus eft.) Germanis meertats, id eft catus marinus:ma rína enim uel tranfmarina feré uocamus, quæcunģ nobis peregrina funt. lilyrïs fimiliter; morka koczka. Anglis marmofet. Cati quidem nomen adiectum puto à cauda, quà fimia fimpliciter dis c̊x carent. Mammonetus (aliâs Mamonetus per m. fimplex. ) eft animal fimia minus, Italífpinga (fphingem) uocant:quod in noftris etiam regionibus haberi $\&$ ali poteft, Ifidorus $\&$ Albertus, Ceri, copithecos Celta uocant ábáivas, Hefych. Varin.

Aethiopia generat cercopithecos nigris capitibus, pilo afinino, \& diffimiles cateris uoce, Plini us. De Prafianis uide inferius ad finem hiftoria de Cercopicheco. Indix fylua fupra Emodos mon tes abundat ingentibus cercopithecis, Strabo lib, 15. Et alibi; Oneficritus foribit in India cercopio thecos effe, qui per pracipitia uadentes, petras contra infequentes deuoluant, Strabo. Ex quik bufdam regionibus Noui Orbis cercopitheci pulcherrimi aduehuntur, ut Perrus Martyr fcribit; Non procul ab Aden urbe Arabix editiffimus mons eft qui cercopithecis abundat, Ludouicus Ró. 2.13. Et alibi, Rex logæ in India cum peregrinatur religionis gratia, cercopithecos complufulos fecum ducit. Et 5.21. Regio Calechut mittit cercopithecos, uendunturóp fingulis folidis, id eft qua: ternis caffis:tot enim folidum efficiunt, funt autem cercopitheci ift cultoribus, inopibus prafertim, magno oneri:quippe qui iuglandium(palmarum genus effe puto, Gillius arborum nomen omitti) arbores confcendunt, 8 liquorem illum, unde uinum exprimi diximus, effundunt, euer tuntég uafa quibus liquor excipitur. Angli cercopithecum, ut dixi, marmofet uocant:eft autem alius maior, alius minor. Et rurfus munkai ijdem appellant, aliud cercopithecorum genus barbatum, mia nus priore: id'ćs fímiliter in maius $\&$ minus diuiditur : ita ut quatuor cercopithecorum genera fint, magnitudine differentia:quorum minim um inftar fciuri feré eft. Et quoniam miris gefticulatio nibus, \& uocis ut audio mutationibus diuer fis cercopitheci,pręertim minores utuntur, monachum uel alium hiftrionice concionantem Angli uulgo munkay cognominant. TCercopithecicaudas habent: hac fola difcretio eft inter prius dictas, Solinus. Simias caudatas ab hominibus differre in $\phi^{\circ}$ neruorum ferie: De lumborum uertebris in eis 8 procelfibus earundem : Irem quiòd careant tertio mufculo digitos manus mourentium, $A$ nd. Vefalius in Fabrica corp.hum, Locos ex Indice requires Mamonerus minor eft fimia, in dorfo fufcus, in uentre candidus:caudam babet longam \& uillofam, collum aque craffum ac caput:quamobrem ilibus (uentre)non collo alligatur, ne laqueus poffit ela bi. Caput habet rotundum, \& faciem prorfus humana fimilem habet, nigram \& fine pilis a collouf que fupra frontem. Nafus ei non continuus ori ut in fimia, fed certo interuallo difcretus, ut in bomis ne, Ifidorus \& Albertus.

c.

Aethiopia generat cercopithecos, diffimiles cæateris uoce, \&c.Plinius. Cercopithecos defiderio carnis comedendx correptos, caudam fibi prærodere uidemus. Animal eft corpore prorfus agili, \{ D.

Ludicrum \& actionum hominis amulum, Mich. Herus. Induftrix \& fagaciratis inter bruta quidam primas partes canibus tributunt, alï elephantis, alï cercopithecis, Cardanus. Quibus in fis miarum genere cauda fit, Luna caura triftes effe aiunt, nouram exultatione adorare, Plinius, Intex mamonetos $\&$ fimias odium eft implacabile bellum ç frequens tamen $\&$ animofitate bellandi fimís præferuntur, lifidorus $\&$ Albertus. Cercopitheci crocodilos intueri tantopere perhorrent, ut ne longinquum quidem crocodilinæ pellis confpectum ferre of fint:ac nimirum potius per ignes $\&$ aquas effugiant. Quod quidem ipfum cum experirer, $8<$ ex ala tiffima feneftella conditum crocodilum his longo interuallo diftantibus' oftenderem, cum clamo: re, $\&$ alui deiectione, $\&$ tremore, \& fi uinculis conftricti tenebantur, per obiectos ignes $\&$ aquas eua dere furenter conabantur, Gillius, 


\section{Defimijs diuerfis. Lib. I. 969}

E.

Cercopitheeiquomodo capiantur, in Simia E. ex Strabone retull. Calecuthenfibus nocent, 1t: quore ex quo uinum illi conficitnt in arboribus effufo, $\mathcal{Q}$ uafis euerfis, ut in $\mathrm{A}$, dixi. Pelles mino: ribus cercopithecis detractas fpačiceo colore, fi bene memini, à pellionibus ad ueftimenta parari audiui.

H.

Quid dubitatis utrum nunc fitis cercopitheci, An colubra, an belluar Varro Eudamonibus citante Nonio. ICercopithecum Panerotem foeneratorem, $\mathbb{Q}$ urbanis rufticisć̨̣ prædins locuplea tatum, Cl. Nero Carar propè regio extulit funere, Suetonius, 『Effigies facri nitet aurrea cercopio 10 theci, Iuuenalis Sat, I , de animalib, qux in Aegypto coluntur.

\section{E C E P O.}

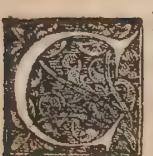

E P V S,Kñ̃t $\Theta$,genus fimix caudatx nomen tulit à colorum uarietate, (à corporis \& atatis decore, Diodorus Sic.)qua fimiliter infignis fpectatur, ut hortus floribus diuerfis confitus, ut inferius ex Aeliano recitabo. Apud Ariftotelem liño per B. fcribitur, Gaza cabum transfert:aliqui etiam cæepum per a. diphthongum fcribunt, alip cephum;alij etiam inepti=

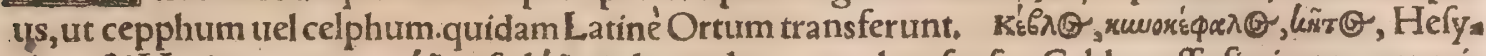

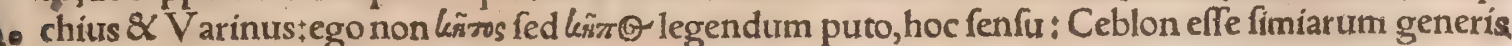
fiue cynocephalum fiue cepum:nam inter cete, id eft belluas marinas, ceblon nufquam legimus. Hebræi quidem fimiam koph appellant, ut dixi in cercopitheco A aa qua uoce Gracos cepum uel ce: burm denominaffe aliquis coníciat.

đCêbus fimia gerens caudam êt, Ariftotel. (Albertus, uel Aurcenna potius, procebo transfert kybor.) Et rurfus, Cebi omnes caudam habent, Partes uero interiores humanis fimiles, genera hęc (fimiarum) omnia continent. Et alibi, Sunt quæ natura ancipite partim hominem, partim quadrus= pedem imitentur, uelut fimix, cebi, cynocephali, Ex his Ariftotelis uerbis cebum à cercopitheco dicto, id eft fimpliciter caudata fimia non eft diftinguere, præfertim cum neç cebi alibi meminerit: cercopitheci uero nufquam.Strabo, Aelianus, \& Plinius diftinguunt, ut uerbis eorum iam recitan. 30 dis apparebit.

đPompeñ Magni primum ludi oftenderunt chaum: lidem ex Aethiopia, quos uocant cephos, quorum pedes pofteriores pedibus humanis $\&$ cruribus: priores manibus fuêre fimiles, hoc animal poftea Roma non uidit, Plinius، Idē ferè ex eo Solinus repetit, apud quèn non cephus fed celphus feribitur.Seneca etiam cephum à Pompeio Magno in fpectaculis Roma primum oftenfum refert.

ब Cepus faciem habet fatyro fimilem, cæetera inter canem atque urfum, in Aethiopia nafcitur, Strabolibro 17. Et rurfus, Cepum colunt Babylonĭ qui funt iuxta Memphim. Sunt \& Prafianæe fimiæ caudatæ $\&$ facie fatyris fimiles, de quibus infra ex Aliano: ut congeneres exiftimari poffint.

In extrema Arabia cepus reperitur, cui facies leonis, corpus reliqurum panther , magnitus dodorcadis, id eft caprex, Strabo libro 16. $\&$ Diodorus Siculus: qui tamen non in Arabia, fed in 4. Aethiopia cepum reperiri fcribit. Terrenum quoddam animal $P$ ythagoras fcribit fecundum mas re rubrum procreari, \& cepum, hoc eft hortum, appofité iccirco nominari, quòd tanquam hortus uarïs coloribus diftinguatur. Cum eft confirmata æetate, pari magnitudine eft cum Erythrienfibus canibus. Iam porrò huius colorum uarietatem, ficut ille fribit, animus nobis eft explicare. Eius caput $\&$ pofticæ partes ad caudam ufque prorfus ualde igneo colore funt, tum aurei quidam pili diffemtnati fpectantur, turm album roftrum, inde ad collum aurex uitræ pertinent; Colli inferio= res partes ad pectus, $\mathcal{Q}$ anteriores pedes omnino albi $¥$ mammæ duæ manum implentes cæruleo colore uifuntur : uenter candidus : pedes pofteriores nigri funt, roftri forma cynocephalo recie comparari poteft, Aelianus. Textor nefcio quo interprete eundem locum multò aliter, (ineptè $0=$ pinor. Graca enim non uidi) translatum recitat: Ortus (inquit) reperitur circa Erythræum mare, co go lore uario, magnitudine canis, \&c. De caneErythrienfe non memini alibi quícquam legere.

đ Chephrenem Aegyptiorum regem Herodotus lib,2, memorat, Diodorus Cephum uocat.

\section{DE CALLITRICHE SIMIA CAV=} DATA BARBATAQVE。

6

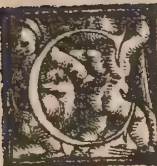

A I I I R I C H E S toto penēafpectu differunt(à cateris fimn̈s:) barba eft in facie,

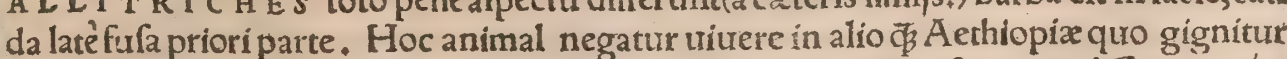
coelo, Plinius. Callitriches, inquit Hermolaus, à barbitio dicta funt, quod Graci moix uocant. Callitriches toto pené afpectu à cæteris fimijs differunt. In facie barba eft, lata cauca: has capere non eft arduum, fed proferre rarum:neç enim uiuunt in altero quàm in Aethiopi co hoc eft fuo folo, Solinus. Sunt \& Indic 2 (fimix) toto corpore candida, barbata, caudis latis, quas 
fagittis uenantur Indi. \& cum cicurãturr in omnem luddũ funt habiles, ac fi non nifi ad ludũ fint crea tæ, Albertus. Et alibi, Sunt \& aliæ fimiæ facie ualde gratæ \& blandæ, \& cæterís fimís diffimiles: barbatæ, caudis longis, quæ A ethiopicæ dicuntur, \& extra Aethiopiam delatæ parũ uiuunt, Alber: tus. Aduehuntur in Germaniam aliquando cercopitheci parui (teinte meeten anen). barba caput to tum ambiente, callitriches for tè aut congeneres. Chartolipis (fi recie legitur) genus fimix, qux ulti, mam partẽ caudxu uillofam habet, Feftus. Vide ne eadem callithrix fit (fic enim proferendữ in reço cafu fingulari cum $t$. afpirato, in obliquis nó item)cuius caudam priori parte, id eft ultima Plinius la

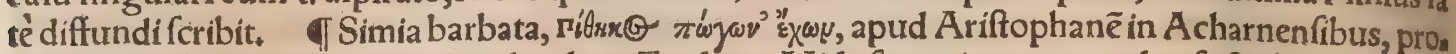
uerbialiter dictum in hominem ridiculum, Erafmus, Videfupra inter prouerbia facta à fimia.

\section{DE SIMIIS SIVE CERCOPITHECIS}

PRASIANIS ET ALIIS MAGNIS.

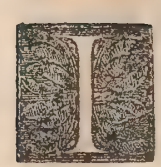

NPrafiana Indortum regione Megafthenes fimias fcribit, maximis canibus non inferiores effe magnitudine, quínç cubitorü (fic $\&$ Volaterranus tranftulit $\&$ præterea comameis humanam effe) caudam habere, tum ex earũ fronte comas propendere, ealdemćç barbam. promittere $\ddagger$ tum facie alba effe, $8<$ uero corpus nigrum fpectari, neque malitia cateris fi. mịs ingenita, fed manfuetudine $\&$ humanitate imbutas effe, A elianus. Sed audiamus Strabonepr quo $\beta_{3}$, à quo ille mutuatus uidetur, intereft enim nonnihil. Megafthenes author eft(inquit Strabo libro 15.)apud Prafios gigni cercopithecos maximis canibus maiores, $\&$ totos albos præter faciem, quæ nigra eft, apud alios tuero econtra: caudx longitudine fupra duos cubitos, præterea mitiffimos,

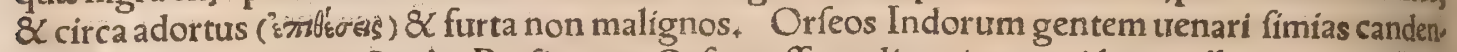
tes apud Plinitu legitür: Strabo Prafios non Orfeos effe tradit qui cercopithecos albos capiant, Her: molaus. Rurfus eafdem finias Aelianus his uerbis defcribit:In Prafijs Indis fimiartum genus effefe runt, humanis fenfibus, \& magnitudine Hyrcanorum canum: tum earum comam etfi naturalem,ar tificio tamen ueritatis imperito elaboratam trideri, tum barbam ipfarum fpeciem fatyricæ fimilitud nemó gerere, caudamḉ leoninæ fimilem fpećari: reliquo corpore albas, capite \& extrema cauda flauas effe. Neç uero quòd uiuendi ratione $\&$ genere ipfo fylueftres fint (montanis enim rebus \& agreftibus pafcuntur) propterea feras effełimo natura cicures, ad fuburbium Latagis urbis frequen tes proficifcuntur, quibus coctam oryzam rex comedendam obijcit,ac quotidie cibaria eis proinciun turłexplétæ in domefticas fedes curm magna moderatione redire, neç obuium quicquam lædere dit: cuntur, Hac Aelianus. Nos fupra cépum quogs caudatumi effe retulimus, \& faciem fatyrofimilem habere: quare eundê Prafianis fimịs affinem effe probabile fuerit. Huc pertinet etiam ille cercos pithecus, quem Pet. Martyr libro quarto Oceanea decadis tertia his uerbis defcribit. Animalia nutriri in ora Cariai eadem qua alibi diximus : fed unum reperêre natúræ longé diffonæ. Ideft grandi cercopitheco par, caùda longiore proce.

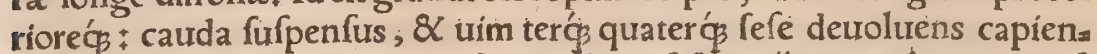
do, ex ramo infilitin ramum, $\&$ ex arbore fefepronjcit in arborem, acfi uolitaret.A rcuarius è noftris unum fagitta confixit. Vulneratus fefe dénj= cit cercopithecus, hoftem uulneratorem rabidus adoritur. Stricto enfe agit in pecus uenator: lacertum cercopitheco abfidit, cepitḉs mancum ferociter renitentem. Ad claffem perductus, manfueurit inter homines $\mathrm{pa}$, rumper. Dum fic ferreis uninctum catenis feruarent, èlittoris trahunt pa: ludibus aprum uenatores alip. Cercopitheco aper 8 ipfe fefox oftenditur: fetas excutit uterç, in aprum cercopithecus furibundus falit, cauda cir. cumligat a prum; cum feruato à uenatore uicfore fuo lacerto, guttur apro prehendit, 8 reluctantem fuffocauit, Hac ille.

T Eft $\&$ formæraræ cercopithecus, magnitudine $\&$ forma hominis: cruribus fiquidem, uirili membro, facie, dicas hominẽ agreftem, quia totus eft pilo obfitus, nullum animal perfeuerat plus ftandoillo, homine folo excepto, amat pueros 8 mulieres, non fecus ac homines fur regionis, $\mathrm{CO}=$ naturç cum uincula effugerit palàm cum his concumbere, quod nos ui= dimus. Cæterum animal tamen ferum eft, fed talis induftriæ, ut homines aliquos minus ingenio ualere dicas, non quidem è noftris fed barbaris, qui inclementes coli regiones habitant, uelut Aethiopes Numidæćs qui= dam \& Lapones, Cardanus: Nos infra fatyrorum etiam $\&$ quos pilofos uocantrecentiores, fimilem tum formam tum libidinem commemorabix mus. Eiufdem generis fuerit fimia ifta cuius imaginem hîc adiecimus, exGermanico quodam libro defcriptionis Terra fancta mutuati.

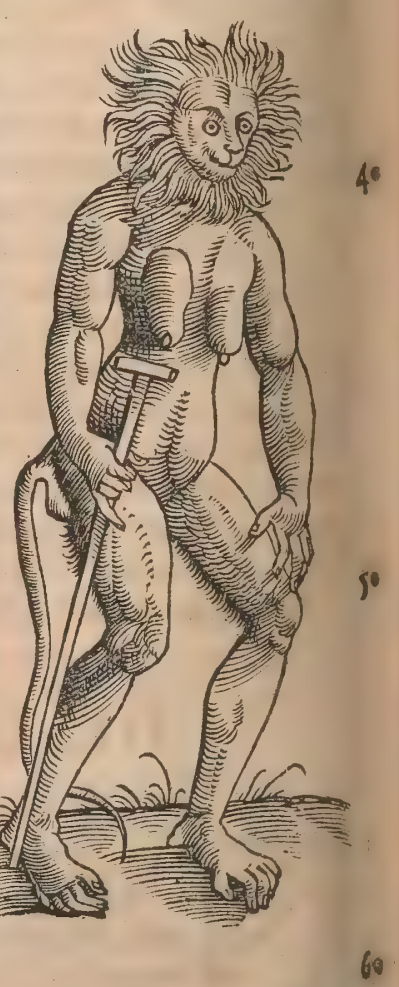




\section{Defimijsdiuerfis Lib, I. 971}

\section{DE CYNOCEPHALO.}

A.

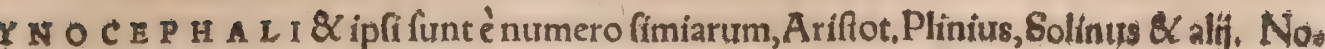
men ex co trahunt quòd canino praediti funt capite, cxtera membra humana habent, Aeli anus. Gaza apud Ariftotelem canicipites tranftulit, Quidam Gallicè, Germanicé, \& Illyricè interpretantur babion. Babuino(Italicé)rpecies fimix, fed minor, (Ariftoteles cy nocephalum fimia maiorem effe fcribit, fed dici poteft, multa cynocephalorum genera effe, Arriano tefte, Arlunnus, Anglicé babons.

Regio quam Aratores in Libya occidentem uerfus habitant, montana ualdeacnemorofa eft. It que reperiuntur in ea tum alia fera tum cynocephali, tum acephali, Herodotus lib. 4. Vide in $\mathrm{H}, \mathrm{a}_{\text {, }}$ Cynocephali in Aethiopix partibus frequentiffimi funt, Solinus. Circa folitudinem reperitur ani: mal corpore hominis; capite canino, pifcationis peritiffimum ; toto enim die immoratum aqua fun: do, tandem cum magna pifcium copia emergit, Prefto loannes (ut uulgò uocant, id eft Rex Aethio. pum, in epiftola Hebraica ad pontificem Romanum. Atqui Orus in Hieroglyph.cynocephalum à pífcibus abhorrere fcribit:fed diuerfa cynocephalorum genera funt. Extrema Arabia regio à Di. ra uf́g ad Auftri cornu, ín ulcimo fui promontorio, prater cæeteras feras producit fphinges, cynoce. phalos, cepos, Strabo lib.16. Poft Barygazam continens ad Auftrum pertingens Dachinabades uo catur: fupra quam mediterraneá regio ad Orientem montes magnos continet, \& plurimas feras, ti gres, crocutas, \& cynocephalorum plurima genera, Arrianus in Periplo rubri maris.

I Cynocephali capite funt canino, catera membra hominis habent, Aelianus, Galenus in Ana tomicis adminiftrationibus, Præftat (inquit) fimiarum homini quàm fimillimarum artus diffecare, cum te in exemplo exercere inftitures: fin ea non detur, aliquam ei proximam deligito: aut fi nulla 0. mnino fimia reperiatur, cynocephalum, uel fatyrum, uel lyncem. Apollonius inter Gangen \& $\mathrm{Hy}$ phafim fluuios ad mare defcendẽs, cum alias feras tum fimiarum genus uidit, longe diuerfum ab his quas apud piperis arbores uiderat, (de quibus dixi fupra in Simia D. fimpliciter enim fimias effe fori bit Philoftratus.) Erant enim nigræuillo\{xó, fpecie canina, paruis hominibus fimiles, Philoftratus. 5. Sunt quę natura ancipite, partim hominem, partim quadrupedem imitentur, uelut fimix, cebi, cyno cephali, Ariftoteles. Et rurfurs, Cynocephalus(Caniceps, Gaza)eadem forma qua fimia eft, fed maior, (Babuino fpecies fimix, fed minor, Arlunnus) ualidior $\$$ \& $\&$ facie caninæ fimilior, unde $\&$ nomê accepit, $2 \mathrm{~d}$ hxc moribus ferocioribus eft, $\&$ dente robuftiore caninó́s propiore. Facie fimilis eft ca ni, fed totum reliquum corpus canino maius $\&$ ualidius habet:dentes etiam ut canis habet, fed for= tiores $\&$ longiores, Albertus, Corporis forma hominiperfimilis eft, Diodorus Sic. Cepus roftrum habet cynocephalo fímile, A elianus: atqui Strabo \& Diodorus faciem leonis cepo tribuunt, qua cy nocephalo 8 cani non conuenit. Sed Strabo alibi faciem eius fatyro fimilem effe ait, qua melius con uenit. Cynocephali fupercilip̧s afpectúç horrido ac truci funt, Diodorus Sic. Circuncifigignun. tur, Orus. Foeminis fua natura accidir, ut palàm expofitam extra corpus uuluam per omnem uitam 4. ferant, Diodorus Sic. Plura de quibufdam cynocephali partibus ex Galenorecitaui fupra in Si: mia B.

In xquinoctins duedecies per diem, femel frilicet fingulis horis, tum mingunt, tum latrant, (kgá? my,) Orus. Vocem imitantur humanam, Diodorus Sic. In dicum fermonem intelligunt; nihil tame loquuntur, fed ululant, Aelianus. ISi efculenta teftaceis inuolucris claufa reperiant, curiofmodi funt amygdala, glandes, nuces, excernunt präclarè, intelligentes intima quidem efculenta effe, exti= ma uero réjci oportere. Vini item potione uti non recufant: atop etiam carnibus uel elixis uel aftis exfaturantur, \& his quidem recte $\&$ fuauiter apparatis, magna delectatione afficiuntur † Contrà ex non accurate elixis ualde offenduntur, A elianus. Et rurfus, Ferina uefcuntur, quam quidem quia so uelociffimi fint, ideo facile comprehendunt, \& captas beitias interficiunt, non tamen eas igne, fed ad affatulum folem membratim concifas coquunt. Alunt etiam ouillum \& caprinum pecus, atç lac bi. bunt. Alegyptiorum fapientes facrificum defignaturi, cynocephalum pingunt: quood is natura ab

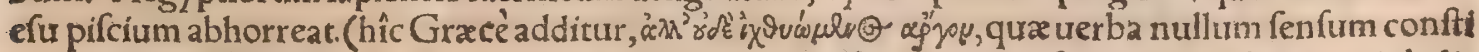
tuunt. Mercerus uertit;quem tamerfi pifcibus interim uefci contingat, fegne tamen $\&$ torpori dedi* tum animal non eft, ficut $\&$ externi [extra Aegyptum] facerdotes. Sed fi natura abhorrer, quomodo

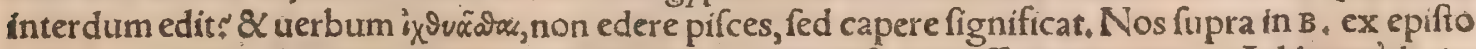
Ia Hebraica regis Aethiopum, cynocephalos pifcatores infignes effe recitauimus, ) Adde quòd cir = cuncifus gignitur, quam quidem circuncifionem fummo curant ac peragunt ftudio facerdotes, $O_{\text {. }}$ rus. Eundem fedentem pingunt æquinoctia fignificantes. Durobus enim anni æquinoctijs, duo, decies in die per fingulas nimirum horas urinam reddit, idemģ́ \& noctu facit. Vnde non immerito fuis hydrologíns Aegyptri cynocephalum fedentem infcujpunt, è cuius membroaqua defluat : idó propterea quod duodecim, ut ianz dixi, in quas aguinociij tempore dies ac noctes ex aquo diuidun 


\section{DeQuadrupedibus}

tur, horas fignificat. Cäterum ne foramen illud, per quod in horologium aqua profluit $\&$ excernis tur, atrt latius fit, aut rurfum arctius hoc enim modo tardius aqua profunderetur, illo celerius quàm

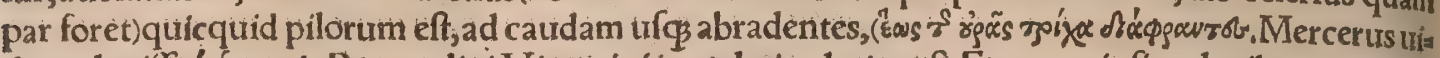
detur legiffe léfgeve ob. Bernardini Vicentini translatio clarior eft, Extrema ipfius depilata cauda, ad huius craffitudinem ferream fiftulam in hunc ufum parant. Notandum autem róaiv hic pro membro

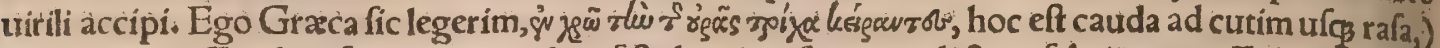
pro huius craffitudine ferream quandam fiftulam in ufum iam dictum fabricantur. Et hoc quidem non temere faciunt, tum quòd urinam reddit, ur dictum eft $\ddagger$ tum quòd folus etiàm ex omnibus ani,

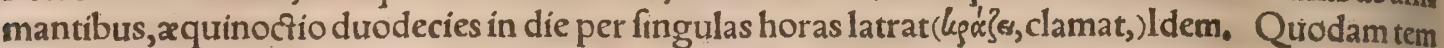
pore Trifmegiftus cum effet in Aegypto, facrum quoddam animal Serapi dedicatum, qưod in toto 10 die duodecies urinam feciffet, pari femper interpofito tempore, per duodecim horas diem dímenfím effe coniecit, \& exinde hic horarum numerus cuftoditur, Victorinus in Rhetoricos Ciceronis. $\mathrm{Li}$ bidinoficynocephali, ut hirciad res uenereas ardent, hos enim cum mulieribus uenereo complexu iungi ferunt:illos libidinis furore in uirgines infanire, \& uim inferre, Aelian. Violentiad faltum, ferimorfu, $\mathrm{S}_{3}$ linus. Cynocephali pictura Aegyptijs natationem quoque fignificat: quoniam $\mathrm{c}_{3}$ tera animalia natatione ufa, fordibus inquinantur, (nimirum per terram fe uolutando aquam egrefu fa.) folus autem cynocephalus nando peruenit quo libuerit, nec ullis fordibus confpurcatur, Orus. Eodem picto terrarum orbem intelligunt, quoniam feptuaginta duas inquiunt iam olim habitatior bis regiones (climata) fuiffe, Caterum cynocephali fi diligenter in facris nutriantur $\&$ curentur, non ficut cæetera animalia uno die emoriuntur, fic $\&$ ípfos emori aiunt: fed eorum partem aliquamse fingulis diebus emorientem ac tabefcentem à facerdotibus bumari, reliquo interim corpore in fua natura perfiftente, idós per feptuaginta duos dies, quibus demum expletis prorfus intereat, Idem;

D.

Efferatior(quàm fimnjs) cynocephalis natura eft,Plinius \& Albertus. Feri funt morfu,nunguami ita manfueti ut non fint magis rabidi, Solinus. Et fi facie canes referant, mores tamen eorum funt ualdegraues $\&$ duri, eò quòd feroces funt $\&$ mordaces, Albertus Cynoceph. animal omninofe rum eft atque indomitum, ratione carens, Diodorus Siculus, Supra quàm catera animantia irar cundus eft, \& ad indignationem procliuis: quare Aegyptí, cynocephalo picto iram defignant, 0 rus. Aemulifunt humani geftus, \& fi infanti admoueris, ubera ei mulgenda prabent, Volaterrat nus ex Aeliano: Sed Gillius aliter tranftulit, hoc modo: Si corum catulos etiam nunc perparunlos ad mulieris ubera admoueas, tanquam pueruli lac exfugunt. Alunt ouillum $\&$ caprinum pecus ats que lac bibunt, Aelianus, Vefte indui mirifice gaudent, Idem. Et rurfus, Ferarum pellibus ith duuntur, \& iuftitia retinentes, laxdunt neminem ${ }_{+}$cumćç Indici fermonis intelligentes fint, tamen nihil loquuntur, fed ululant. Ad humanum accedunt ingenium, non minus quàm elephantes, Strabolibro 15. Cynocephali picqura Aegyptñs literas denotat. Eft enim apud Aegyptios genus

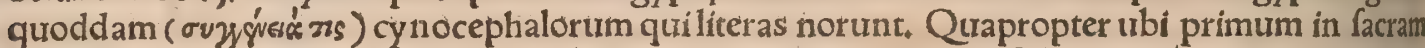

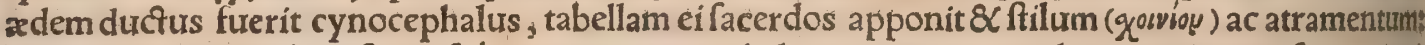
nimirum ut periculum faciat fit'ne ex eo cynocephalorum genere qui literarum ynari funt: pingit itaque in ea tabella literas. Praterea hoc animal Mercurio dicatum eft, qui literarum omnium pars ticeps eft, Orus. Bene fanè animalia difcère ita percepi $\leqslant$ Regnantibus Ptolemais cynocephalos 4 Aegyptỉ literas legere, \& faltare, (talia ferè etiam de fimijs fcripfi ex Galeno in Simia D. ) \& ad th biâm canere, \& pulfare citharam docebant. Tưm uero unưqưifpiam cynocephalorưm mercedem horum nomine fic fcitè tanquam periti pecuniarum coactores exigebat, \& id quod dabatur in mar. rypium, (in phaciolion quod capitis geftamen eft, Calius hac cadem transferens $25+28$ ) quod fere, bat appenfum, congerebat, Âelianus, Aegyprí pro Luna cynocèphialum pingunt : propterea quód animal hoc confenfum quendam quo ad Luna cum Sole coitum afficitur habet. Vbienim all quanto tempore Luna cum Sole congrediens expers luminis permanet, tum mas quidem cynoce phalus nec quoquam inturetur, nec uefcitur: fed demiffo in terram uultu, Lunæ tanquam rapta ula cem dolere \& indignè ferre uridetur. Foemina uero praterquam quòd nufquain oculos contorquet,

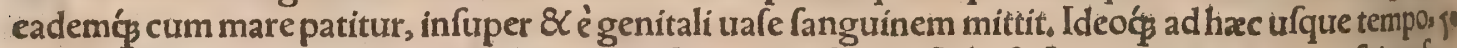
ra in facris cynocephali nutriuntur, ut ex ipfis coniunctionis Solis \& Lunæ ternpuš cognofci pofa fit, Orus. Et pauló poft, Lunam autem orientem indicare uolentes, cynocephalum pingunt ftant tem, manusís in coelum tollentem, ac regium infigne capite geftantem. Hanc autem figuram ufura pant, quód hoc habitu uideatur cynocephalus dea congratulari, quòd ambo(Sol \& Luna)luminis participes fint.

Nomades ex Âethiopum numero, cynocephalorum lacte uiuunt, Plinius \& Solinus. $\mathrm{H}$.

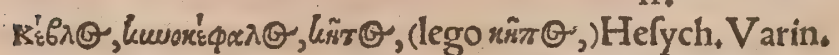

ब Cynocephalus adiectiuum, canino capite praditus. Cleon apud Ariftophanem in Equitit: 6

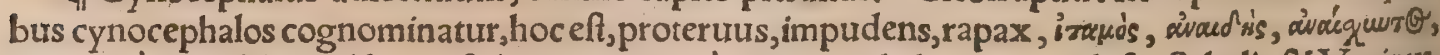
ḱgradrzztwós: quod animal (canis fcilicet potius quàm cynocephalus) etiam talefit, Scholia $\&$ Varinus. 


\section{Defimijs diuerfis. Lib. I. 973}

Cynocephali cognomeneum, quod quum alins tum uero Pericli adhafiffelegimus, non ferè aliud quàm impudentiam \& rapacitatem fignat, Calius, fed Pericles fchonocephalus potius quàm cyno. cephalus dictus eft, \&c, uide fupra in Canea.

đIcon. Aegyprij cynocephalum pinguntad dituerfas res fignificandas, ut paffim fupra tertio $\&$ quarto capiribus expofui. mus.

T Cynocephali genitura aut capilli Magis, anethum, ut inter Diofcoridis nomenclaturas legis

TCynocephali funt qui in Mappa mundi canini homines uocantur, Albertus. Pygmæorum

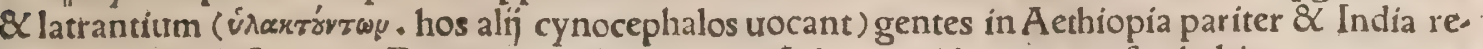
periuntur, Philoftratus. Regio quam Aratores in Libya occidentem uerfus habitant, montana tualde ac nemorofa eft. itac reperiuntur in ea tum aliæ feræ, tum cynocephali, id eft capita canina habentes, tum acephali, id eft non habentes capita, fed in pectoribus oculos, ut ab A fris memoratur, nec non uiri foeminxós agreftes, Herodotus libro 4. quafi uero cynocepliali etiam homines qui= dam fint, nec potius fimiarum genurs, quod quroniam erigi facile poteft, erectum etiã, ut hodie in tabu lis Geographorum, fic olim etiam pictores pinxiffe uerifimile eft, atog inde in uulgus imperitum, tan quam tales quidam homines uiuerent, opinionem fluxiffe: In qua \& Aelianus fuiffe uidetur, nam cum cynocephalos fimias alibi defcripfiffet, rurfus de cynoprofopis hominibus, id eft canina facie praditis, fic fcribit: Poft uaftam A egypti folitudinem, quam omnem feptem diebus tranfiri ferunt, fecun dum uiam qua ad Aethiopiam pertinet, Cynoprofepi homines habitantes, ex uenatu dorcas dum $\&$ bubalorum uiuunt: nigro afpec $\{u$, capite $\&$ dentibus caninis præditi funt, quæ corum fi militudo cum canibus effecit, uthic ipforum mentionem interpofuerim. Vocis quidem expertes funt, fed ftrident acutè infra barbam mentum poflident, fic promiffum, ut ferpentium fimile id effe uideatur:(circa labra more draconis pubefcentes, Volaterranus :) corum manus robuftis ungui, bus, $\&$ acutis armantur, fimiliterćs toto pecfore, ut capite ipfo hirfuti habentur, atģ etiam pedum celeritate $\&$ ualent: $\&$ captu difficilia non ignorant loca ea effe ubi aqua exiftant, (petitiad aquas confugiunt, propterea uenatu difficiles, Volaterranus:)Hac Aelianus. Philes non cynoprofopos red cynocephalos homines uocat, fribens de eis tum horum quadam, ex Aeliano iam recitata : tum alia qua fupra de cynocephalis fimijs fcripfimus; unde apparet non aliud animal cynocephalum fi= miam, aliud cynocephalum feu cynoprofopum hominem eum exiftimaffe, fed uñ̃ omnino, quæ no fra etiam fenteritia eft. Noui quoddam(inquit) canina fpecie hominum genus, quod non loquitur,

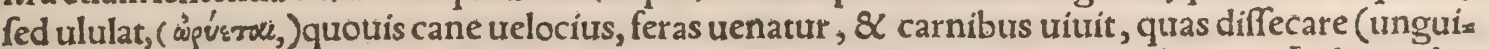
bus) $\&$ ad Solem torrere folet. Pellibus uero detractis ueftitur. Hominum nulli nocet, Indorum lin guram intelligit, \& boues lactis caufa manfuetè pafcit. In multis(Indiæ)montibus genus hominum capitibus caninis, ferarum pellibus uelari, pro troce latratum ædere, unguibus armatum uenatu $\&$ aucupio uefci. Horum fupra $\mathrm{CXX}$.M. fuiffe prodente fe, Ctefias fcribit, Llinius 7.2. Et paulo poft, Choromandarum gentem uocat Tauron fylueftem, fine uoce, Pridoris horrendi, hirtis corpori= bus, oculis glaucis, dentibus caninis, Plura de cynocephalis hominibus uide in Canea, inter pro pria locorum \& pop.

T NOS T R A rtate(inquit author libri de nat.rerum) allata elt regi Francia beftia, ad magnis tudinem canis. Caput quidem non multum diftabat à capite canis» catera corporis membra, ut ho. mo prorfus habebat. Crura quidem nuda, ut homo, manusćs \& brachia, collum album ac nudum habebat. Carnibus coctis uefcebatur. Ita decenter $\&$ modefte manibus capiebat cibum, \& ori fuo inferebat, ut nullus dubitaret quin humanum modum in talibus haberet. Erectum ut homo ftabat, fedebat ut homo. Puellis $\&$ fominis libentiffimè iungebatur. Et in fexu uiri \& fominæ difcretio: nem habebat. Genitale membrum ultra quàm corporis quantitas exigebat habebat magnum. Fu. rijs agitatum hoc animal crudeliffime mouebatur, $\&$ in homines fxuiebat, Cæterum cum placatum efet inftar hominis mitiffime \& decentiffime fe gerebat, \& mulcebatur alloquís, \& colludentibus applaudebat, Hæc ille.

TCynocephalorum aquatio, locus in extrema Arabia Auftrum uerfus, Strabo.

TCynocephali cur in facris (in templis) nutriantur, leges in D. Hermopolitani cynocepha. lum colunt, Strabo. Cynocephalum Mercurio facrum effe, dixi in D. item Serapidi, in C. Ter. tullianus \& diuus Auguftinus, uidentur cynocephalum pro Anubi deo ponere, quòd fcilicet capite fit canino: non enim pro cynocephalo fero an nimali $\&$ indomito, ab ipfis defumitur,

Gyraldus. 


\section{4 De Quadrupedibus. \\ DE SATYRO.}

A.

V E M A D M O D V M cynocephali fimix occafionem fabula dederunt, ut homines quit dam tales putarenturt fic fatyri rarius etiam $\&$ maioris admirationis fimiarum genus, da: mones quidam crediti funt ( $a b$ aliquibus etiam homines, ut dicam in $\mathrm{B}_{\text {. }}$ ) quibus poétra \& fimí corum pictores, plaftæó caprinos pedes $\&$ cor nua affinxerunt, ut admirationem ac fuperftitionem augerent.nam in fatyris fimijs nihil tale fpectatur. Quanquam fieri poteft, ut dxmo:

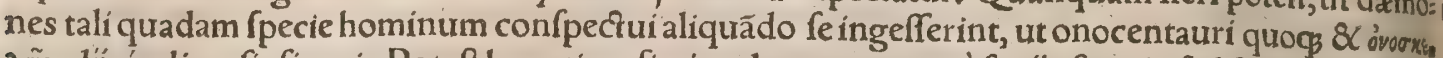

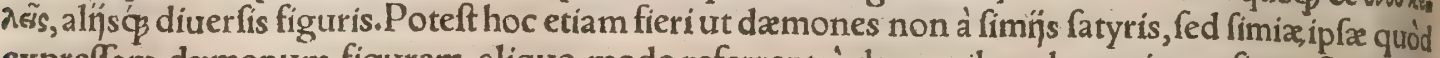
expreffam dæmonum figuram aliquo modo referrent à dæmonibus denominatæ fint. Sunt fanè nonnulla tum fatyris fimins, tum damonibus fatyris communia, forma fimilis humanæe, corpus erez cum, pilis hirtum, uerfari in locis defertis, \& libido in mulieres, qua aliz etiam fimix capiuntur, fed

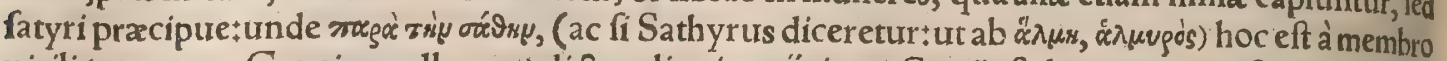
utirili (ut ueteres Græci appellarunt) diços aliqui coníciunt. Certũ eft dæmones præffigiofam fuam libidinem, aut libidinis potius imaginationem in homines aliquando exercere, unde faunorum ge. nus incubi $\&$ fuccubi dicti. Sed fortè ab Hebrais potius fatyri nomen defcenderit, nam in uetere Teftamento $79 y$, fair, legimus, ut Efaix $34.8 \mathrm{x}$ multitudinis numero feirim, Efaix 13. Hebraimons Ifra quædam deferti interpretantur, noftri pilofos aut faúnos pilofos. Nominantur autẽ fimul etiam

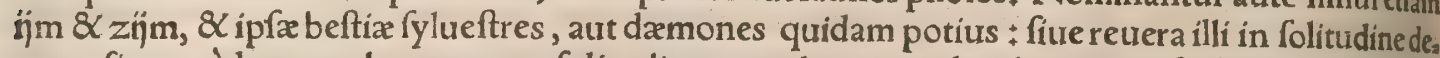
gant, fiue quòd mentes humanæ per folitudines accedente quodam horrore ipfæ fibi talia finxerint, ut melancholici \& fomniantes terrificis fape fpectrís ludificantur. Seir Hebraica uxox, hirfurum etiam feu pilofum adiectiue fignificat: $\&$ hircum, cum additur iffim, id eft caprarum. Leuitici it, Chaldxus pro feirim reddit fchedin, id eft malos damones, Arabs, lefeiathin, id eft fatanis, Perfa, de

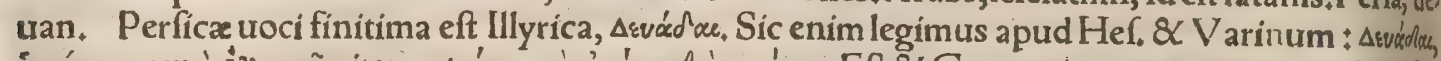

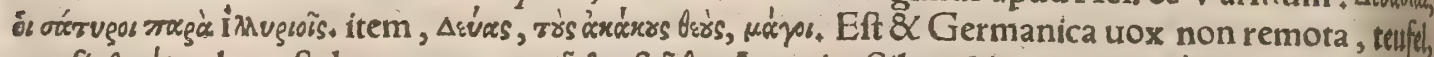

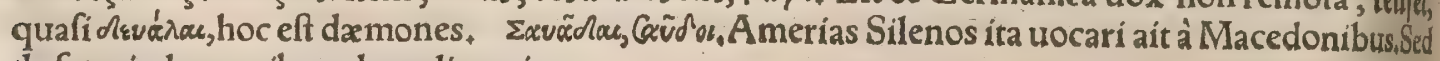
de fatyris dæmonibus plura dicam in $\mathrm{H}$,

Satyri de hominibus nihil aliud praferunt quàm figuram, Solinus cap.34. de intimis gentibus Li byę agens. Satyri habitant Satyridas dicfas Oceani infulas, quibus iuxta coxas enafcuntur caurdx, non multo minores equinis, ut ait Euphemus Car, qui fe in Italiam nauigantem ui tempeftatum in

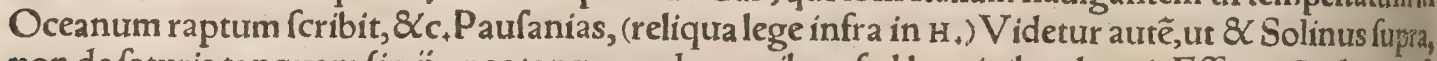
non de fatyris tanquam fiminjs, nec tanquam dæmonibus, fed hominibus loqui. Effe autẽ tales quoofra dam homines credere, puerorum 8 anicularum eft. Sic etiam Plinius 7.2 , de monftrofis homini. bus loquens: Sunt $\&$ Satyri fubfolanis Indorum montibus (Cartadulorum dicitur regio) pernicififi mum animal, tum quadrupedes, tum recte currentes humana effigie, propter uelocitatem nififenes aut ægri non capiuntur. Sunt $\&$ quas uocant fatyros (inter fimias) facie admodum grata, gefticus $4^{\circ}$ latis motibus inquietæ, Solinus. Cepus faciem habet fatyro fimilem, cætera inter cañ atç urfum, in Aethiopia nafcitur, Strabo lib.17. Simiarum genus in Prafís Indis effe ferunt, barba faryrorum inftar, $8<$ cauda leonis infignes, $\& c_{*}$. Aelianus. Præeftat fimiarum homini quàm fimillimarum artus diffecare, cum te in exemplo exercere inftitures. fin ea non decur, aliquam ei proximam deligito, autf fi nulla omnino fimia reperiatur, cynocephalum, uel fatyrû̃, uel lyncem, Galenus in anatom, admin, Plinitus, ut iam recitabo, fatyrorum manus appellat.

Condit in thefauros maxillarum cibum fphingiorum $\&$ fatyrorum genus : mox inde fenfim ad mandendum manibus expromit: $\mathbb{Q}$ quod formicis in annum folêne eft, his in dies uel horas, Plinius. IS Satyri inter fimias gefticulatis motibus inquieti funt, Solinus.

D.

Efferatior(quàm fimings)cynocephalis natura, ficut mitiffima fatyris $\&$ (phingibus, Plinius. Suz fponte prudentia, non aliena inftitutione apud Indos ualent, elephas, pfittacus, fphinges, \& nuncus pati fatyri, Aelianus.

H.

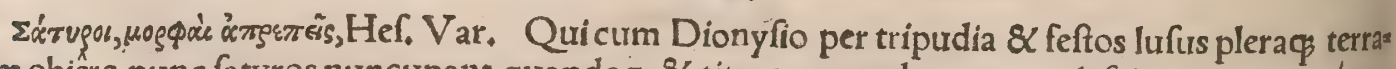

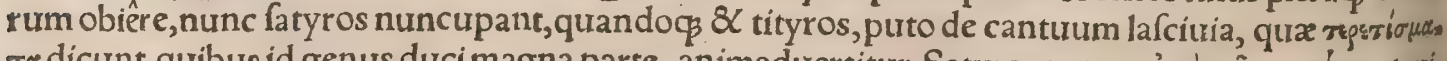

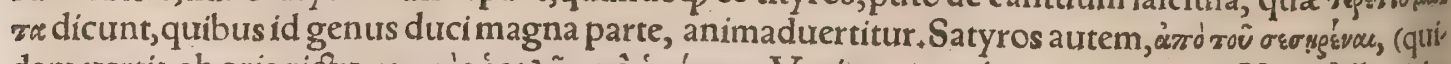

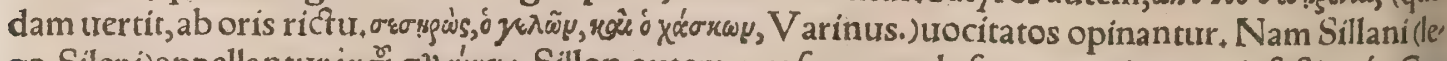

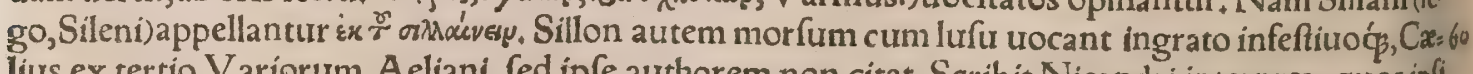
lius ex tertio Variorum Aeliani, fed ipfe authorem non citat. Scribit Nicandri interpres, quos ipfi

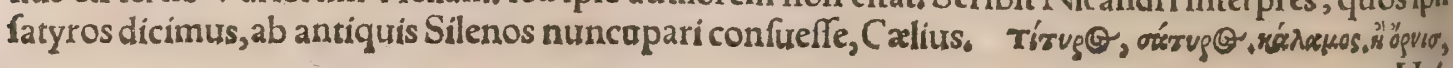




\section{Defimijs diuerfis. Lib.I. 975}

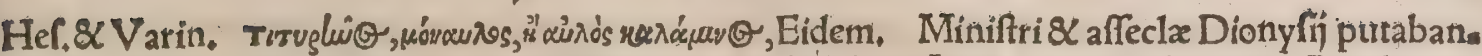
tur,Sileni,Satyri,Baccha, Nymphx, Tityri, \&c, Strabo lib, 10. Itaç pingitur aliquando Bacchus in curru pampineo, \&c.quem propter Silentus aftat afello uecius, \& Baccha \& Satyri thyrfos ac feru. las uibrantes, Gyraldus, Satyri etiam Tragi, id eft hirci uocabantur, inde quòd aures haberent hir= cinas, Hefych. Varin. Terreftres dị fuêre, Satyri,Satyrifci,(Panifcum \& Satyrifcum, Pầna \& Saty rum paruos, Cicero primo Diuin, nominat)Syluani, Sileni, Ephialta, et Hyphialta, hoc eft Incubi \& Succubi, publica hos perfuafio, ut Macrobius ait, opinatur quiefcentes inuadere, 8 pondere fuo preffos ac fentientes grauare. Mediciuero morbum effe aiunt, qui quiefcentes inuadit $\&$ premit.

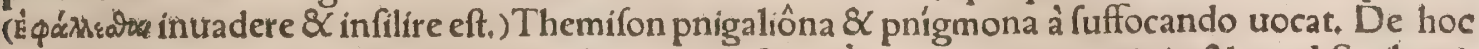
morbo plura leges apud Cælium A urelianum, qui Latinè incubonem uocari ait: \& apud Scriboni. um, Gyraldus. Noltri hunc morbum uocant fbzettele; quo in fomnis affecti uehementer quidem \& fupra quàm dici poffit, angi $8<$ comprimi fibi uidentur, clamare uero 8 opem implorare non por: fe. Feré autem accidit cum redundans caput infeftat euaporatio, ex uoracitate \& cruditate: $\&$ injs fa pius quibus comitialis morbus adelt, aut adfuturus eft $+i t a c \beta$ naturales caufas hoc malum habet, $\&$ quibuslibet hominibus incubus ifte accidit, (Saxones alp uocitant; $\mathcal{Q}$ belemniten lapide, compofito ex ephialte \& fagitta uocabulo, alpfeff fuppreffiones ualere dicunt, ut Ge. Agricola prodidit.) Alị uero incubi funt mulieribus, fuccub! uiris, non morbi, fed drmones, qui uel corpus aliquod fibi affumpferunt, uel miferorum mentes in: anibus fpeciris ludificantur. Hoc non patiuntur, nifi homines plané impï, qui Deo opt.max, relicto - fpretó́, dæmonibus fe addicunt $\&$ deuouent. Satyri dicti funt, utMacrobius docet, ueluti Sathư ni, (fathuri uel fathyri, ut in A. fcripfi) quòd fint in libidinem proni, rọgà rlù ox́slus, quod membrum uirile declarat. Hos petulcos(inquit Gyraldus) in libidinem fuiffe, etiam D. Hieronymus in Pauli Thebæi uita teftatur, \& Eufebius in 3, præpar. Euang. cos omnem ueneream uirtutem oftendere

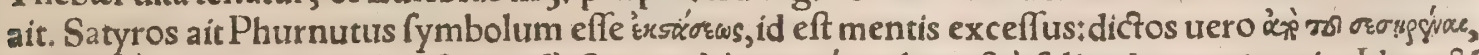

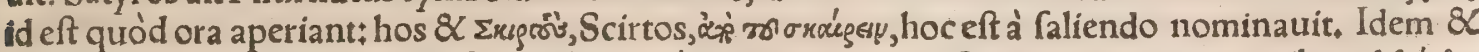

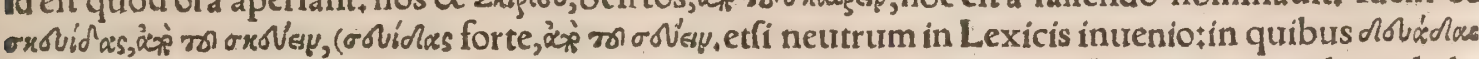
oxuã au legitur: uide fupra in A.) quod eft furere $\&$ fauire, appellauit:unde $\&$ fæuus apud nos dedu

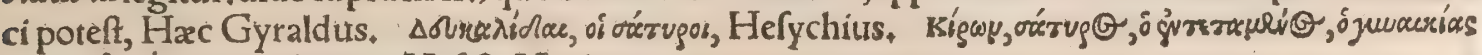

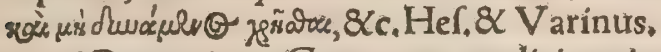

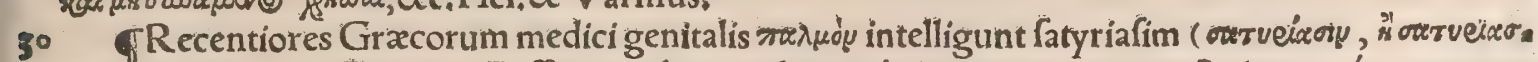
$\mu \dot{d}(y)$ qưod malum, Galeno in Diffinitionibus tradente, obtingit, mutone arrecto intentoǵ , nec non particulis adiacentibus, cum feminis quando $q$ uoluptaria profufione, quandoç uero $\&$ mentis confternatione ac diftentione nertrorum, Calius. Et alibi, Satyriafis à Paulo effe traditur ảesirran= $\mu \Theta$, id eft pudendorum fubfultatio, qux uaforum fpermaticorum confequatur inflammationem.

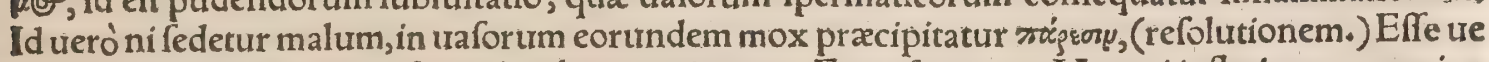
roaffectionem raram qua $\&$ mulieribus contingat. Et rurfus 30.14 . Veretri inflationem nomine cuiurfam dęmonis fponfarũ depicti nuncupauerunt, id eft fatyriafin, ut interpretantur nonnulli: a $_{2}$ tyrifmum \& priapifmum enuntiat Galen!Is. Satyrifmos tubercula intelligit Hippocrates pralon=

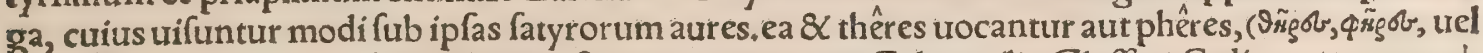

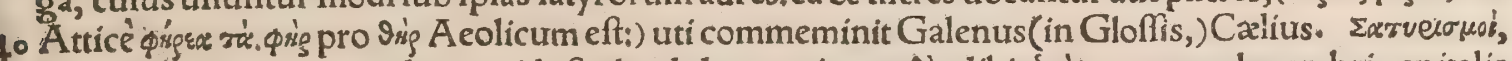
oblongæ prominentiæ adenum, id eft glandularum circa ( $\approx 00$, alibi vio aures: uel membri genitalis intentiones, Ibidem. Satyria morbus eft, in quo præabundantia fluxionis aut flatus crudi in par: tes. faciei decumbentis, facies animalis diuerfi $\&$ fatyri apparet, Ariftoteles de generat. $4 \cdot 3$. Ele $=$ phantiafis à quibufdam fatyriafis dicitur, propterea quòd malæ faciei fic affectis cum rubore attol= luntur, 8 mufculis maxillaribus ueluti conuulfionem patientibus, mentum ipfum dilatatur, quem= admodum etiam ridentibus euenire folet, fimilitudine quadam ad picturas fatyrorum : quin \& ala critas uehemens ad coitum ipfis adelt, quemadmodum $\&$ de fatyris fertur, Aétius 13:120. Elephan tem morbum, cum incipit, fatyriafmon uocant:quoniam fatyris fimiles fiunt uultu: aliqui urero qua in temporibus funt offex eminentia, fic urocant: in alís partibus quoq 3 tales offium fiunt eminen= tiæ , easç trocant aliqui exoftofes: ut naturales quoque pudendorum diftentiones non defiftentes fatyriafmum aliqui trocant, aliqui uero priapifmum, Galenus de tumoribus præter naturam, cap. 15. TA Satyris (inquit Gyraldus) poématis genus uarium $\&$ maledicum, \& petulans denominatum eft, archęæ comodix charactere compofitum. Olim hac ex uarijs poématibus conftabat:quo gene= re apud Latinos fcripferunt, Pacuuius, Ennius, \& V arro Menippeas. Nonnunquam interpofita foluta oratione, ut funt fragmenta quæ extantPetronï Arbitri. Lucilius uero uerfu hexametro ali. ud genus induxit, \& eum fecuti Horatius, Perfius $\&$ Iturenalis. Dic eft autem(ut quidam putant) fatyra non à Satyris, fed à fatyra lance, qua referta uarịs multisḉ̧ primitíjs, deís inferebatur : cuitus Iancis Vergilius meminerit; fiue dicta à quodam genere farciminis; ut ait Varro \& Diomedes. alij àlege Satyra, (uide plura in Promptuario, in uoce Satyra) cuius legis Lucilius meminit, Per faty: 60 ram $x$ dilem factum quilegibus foluat. Plura Diomedes $\&$ Feftus grammatici, 82 demum ( in pro: uerbio) Per (atyram Erafmus, 8 ipfe in fexto de poëtarum hiftoria dialogo tradidi, Hac Gyraldus. Scena fatyrica ornatur arboribus, fpeluncis, montibus, rebus agreftibus alijs, in topiarï operis fpe. 


\section{6

ciem, Calius:nimirum quòd in talibus locis uerfari Satyri fingantur. Enzveí, genus edulf ex her,

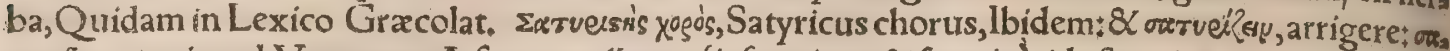
Tueiäe, prurire ad Venerem. A fatyra poémate fir fatyricus $\$ \&$ fatyrice, id eft acriter, cum conuicio.

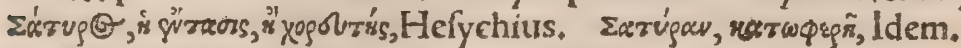

4) Satyrion(herba) concitatricẽ uim habec, Duo eius genera. Vna longioribus folips quàm olę, \&c. radice gemina ad formam hominis teftium, alternis annis intumefcente ac refidente. Altera $\mathrm{fa}_{z}$ tyrion orchis cognominatur, 8 formina effe creditur. Er aliud genus fatyrí erythraicon appellant, 8c. Plinius. Et mox, In totum quidem Graci cum concitationem hanc uolunt fignificare fatyri, on appellant, fic $\&$ cratægin cognominantes, \& thelygonon quarum femen teftium fimile eft. Pro= digiofa funt qux circa hoc tradidit Theophraftus, author alioqui grauis, feptuageno coitu durare 10 libidinem contaçu herbæ cuiufdam, cuius nomen fpeciemós non pofuit, Hæe Plinius. Herbam il, lam Theophrafto allatam ex India, cuius contactu libidinem dur are feptuagefimo coitu meminit, fat, tyrion Indam appellauerim. Habent hodiéç Syri herbam fimili effectu, bucheiden'́s nominant $\&$ Indicam fatyrion, fortaffe cum ea, cuius mentionem Theophraftum feciffe diximus, eandem:radice candida $\&$ dura, commendatiore quó craffior $\&$ rugofior, $\&$ albior, podagris utili, Sed $\&$ ariftolo, chia genus unum, quod polyrrhizon cognominant, fatyrion ex facto uocari cenfeo, Hermolaus, Tefticulos Cacerdotis Galli fatyrion uel cynoforchin hodie uocant: Itali uero chelidonium minus, Satureix etiam herbx ufus marcefcentes coitus ftimulat ; quare à Satyris nomen eam traxiffe com minifcuntur(grammatici, Ruellius.

बDe Satherio \& Satyrio amphibijs animalibus dixifurpra in Lutra . L. Florus in Valern̈ Cora 16 uini hiftoria coruum fatyram auem dixit; fiue à peculiari libidine, quoniam ore coire $\&$ parereuul gò olim credebatur: fiue à Satura palude Pontina rcribunt, oblectantur autem aquis cornix ac coruus, Calius. TL.Cornelius Sylla à Dyrrhachio Brundufium cum claffe tran̈cere parabat. Proxima eft A pollonia, iuxta quam eft Nymphrum fas cer locus, è uirenti colle ac pratis ignis fontes effundens affiduè per fparfos riuulos defluentes. Hoc in loco memorix proditum eft, fomno preffum Satyrum fuiffe captum, qualem poétx ac pictores (plafta) effingunt. Is perduçus ad Syllam complures per interpretes quifnam effet interrogatus, nihil quod polfet intelligi uix uociferatus eft: at uocem afperam equi prafertim hinnitu $\&$ hircibas

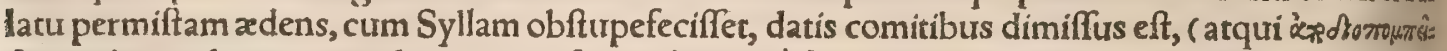
a ox uerbum, deprecari malum omen, \& prodigium à fe depellere \& expiare potius fignificat : unde $\xi_{0}$

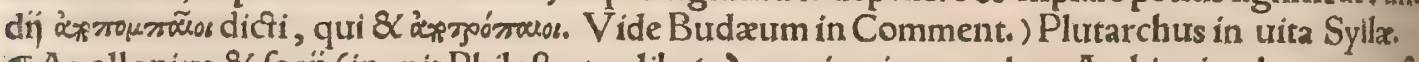
TA pollonius \& focij (inquit Philoftratus lib.6.) cum in uico quodam Aethiopia ultra cataractas Nili cœnantes quiefcerent, ecce fubitus clamor in uico auditus eft, mulierum fefe inuicem cohor: tantium, quarum alix capere, alix perfequi clamitabant, uiros quogs ad eiuldem operis communi. cationem cohortantes: illi uerò fuftibus, aut faxis, $\&$ quicquid in manus ueniffet arreptis, exclama, bant fe iniuria erga uxores affici. Venerat autem in uicum illum decimo iam menfe antè Satyrifpe: ctrum'furens erga mulieres, iamćs duas interfeciffe ferebatur, quas amare maximé uifus furerat。 Hæc audientes Apolloní comites perterrebantur : Et Nilus, (unus è comitibus,)Certe per louem, in quit, ne $\beta$ nos nudi hunc iam diutius infultantem auertere potuinus unquam, quó minus more fuo lafciuiret. Eft tamen, inquit A pollonius, aduerfus infultatores huiufmodi remedium aliquod, $4^{\circ}$ quo ufum fuiffe Midam perhibent. Ipfe enim Midas Satyrorum genus participauit, quod ipfits alta res manifeftant. Satyrus igitur quidam propter affinitatem ipfum illudebat, in Mida aures calum. nias iactans, nec uoce folum, uerum etia m tibrijs in ipfum carmina decantabat. Ille ueró cum ex ma tre (ut opinor) audiffet, Satyros uino demulceri, adeò ut cum epoto uino dormitauerint, mutato ingenio modefti ac temperantes euradant:(uel, modeftiores fiant $\&$ quibus infefti erant reconcili

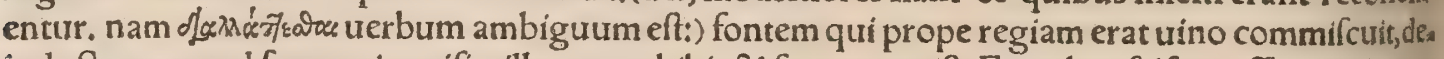
inde Satyrum ad fontem immifit, ille autem bibit \& fuperatus eft. Et ne hoc falfum effe putetis qua ramus à uici huius prefecto num aliquid loci huius habitatores habeant, $\&$ illud Satyro prabeas mus: fic enim non amplius moleftiam afferet. Cum ita fieri cunctis placuiffet, amphoras quatuor Aegyptias uino plenas in magnum uas ( $\lambda x$ vò̀ , lacum qui torculari fubícitur) impofuêre, ubi eius go uici pecora bibere confueuerant. Hoc peracto A pollonius Satyrum inuocauit, occultè etiam aliqua minatus. Ille autem quafi adhuc uinum non uidiffet, eius tamen odore pené ac fi bibiffet correptus acceffit. Poftquam uerò bibit, Libemus inquit Satyro Apollonius : iam enim dormit. Ea cum dixif, fer, omnes uici habitatores ad Nympharum antra deduxit, qux́ iugeris fpatio à uico diftabant : ibíg dormientem illum oftendens, Verberibus, inquit, 8 maledictis parcite, neque illum ullatenus laces. fite. iam enim moleftiam uobis afferre definet. Cæaterum effe Satyros, eosḉs ad amandum procliues negandum non eft. Egoenim in Lemno quondam audiui æequalem meum, qui ad matrem fuam ues nire folitum Satyrum quendam narrabat:eiusq́s talem defignabat habitum $¥$ nebride humeros amis ciri dicebat, cuius anteriores pedes collum circumplectentes in pectore nectebantur, Hæc Philo. Pratus.

TD. Hieronymus in Pauli Eremitæ uita, cum Hippocentaurum Antonio apparuiffe fcripfif fet, qualem poétæeffe perhibent, moxaddit: Nec mora, inter faxofam conuallem haud grandem 


\section{Defimijs diuerfis. Lib. I.}

culum uidet, aduncis naribus, fronte cornibus afperata, cuius extrema pars corporis in caprarum pedes definebat. Infraciusḉ $\&$ hoc Antonius fpeçaculo, futum fidei $\&<$ loricam fpei, ut bonis pra liator arripuit. Nibilominus memoratum animal palmarum fructus, eidem ad uiaticum quafi pacis obfides afferebat. Quo cognito gradum preffit Antonius, \& quis'nam effet interrogans, hoc ab eo refponfum accepit:Mortalis ego fum, \& unus ex accolis eremi, ques uario delufa errore gentilitas Faunos Satyrosć $\&$ Incubos uocans colit, Legatione fungor gregis mei † Precamur, ut pro nobis communê Deum depreceris, quem pro falute mundi ureniffe cognouimus. Et paulo pòft, Necdum uerba compleuerat, \& quafi pennigero uolatu petulcum animal aufugit. Hoc ne curiquam ob incre dulitatem frupulum moureat, fub rege Conftantino, uniuerfo mundo tefte defenditur. Nam Ale, - xandriam iftufmodi homo uiuus perductus, magnum populo fpectaculum praburit $\&$ poftea cada: uer exanime, ne calore aftatis diffiparetur, fale infufo Antiochiam, ut ab Imperatore uideretur, als latum eft. Hac fi uera funt, (inquit Floridus Sabinus Succif. lect. 2,6*) haud uera ufgqquaç ftrerit Lucretif ratio, qui libro qu into de rerum nat, afferit, nec; Centauros, ne $\$$ s alia animalia duplici natti$r a, \&$ corpore bino ex alienigenis membris compacte, confiftere poffe. TPaufanias in Atticis pi. cturas $\&$ ftatuas qua Athenis in arce fpectantur, defcribens, Lapis (inquit) eo in locoeft, non ma* gnus, fed tantus, quantus homo paruæ ftaturæ fedens:in quo, cum Bacchus Atticam ingrederetur; Silenum quieuiffe aiunt. Satyros enim qui ætatis funt adultioris, Silenos appellant, Caterum de Sa=. tyris quí nam fint, cum plura quàm alî́ fcire laborarem, cum multis ea de re furm colloquuturs. Dixit autem Euphemus Car, fe quum in Italiam nauigaret, curfur effe excuffum ui uentorum, $8 \mathrm{C}$ ad mare extimum, quod nauigari non item foleat, perlatum. Infulas autem ibi multas effe ac defertas, $\&$ à ui ris agreftibus incoli. Ad alias urero aiebat nautas deflectere recufaffe, quòd antea quoç cò appulli, incolarum inhumanitatem effent experti. Tempeftatis deniç uiolentia cò perueniffe. Infulas eas à nautis uocari dicebat Satyrias. Incolas inefferubicundos, \& caudas in imo dorfo habere, equinis non multò minores. Hos, ubi fenferunt, ad nauigium accurriffe, nullamó̧ uocem edidiffe, fed muli: eribus naui unà aduectis manus inieciffe. Nautas uero timore correptos, barbaram mulierem in in. fulam tandem proieciffe. Eam Satyros non folum qua parte cófuetudo permittat, uerum etiam toto corpore libidinofè uiolalle, referebat, Hac Paufanias. Idem Eliacorum fecundo, Silenos mortales effe ex fepulchris conïci poffe fcribit. fuiffe enim in Hebraorum etiam regione Sileni monumentũ.

THac loca capripedes Satyros Nymphasóp tenere, Lucretius lib, 4. Satyros nonnulli uocan - Aegipanas, Grapaldus. Similes quidem uidentur, utriq̧ caprínis cruribus, hirti, cornutit fed Pli= nius diftinguit.Plura lege in Capra $h$, unde quadam hic repetemus. Aegipani populi ad ripas $\mathrm{Ni}$ li habitant, Plinius 6.30. Et in fine eiufdem capitis, Iuxta Hefperios Aethiopes (inquit) quidam mo= dicos colles amœena opacitate ueftitos Aegipanum Satyrorumós produnt. Item Y. I. Atlantem no: cibus micare crebris ignibus, Aegipanum Satyrorumó la lciuia impleri tibiarum ac fiftulæ cantu, cympanorumós \& cymbalorum fonitu ftrepere. Etrurfus cap.8, inter Aethiopix populos numerat Aegipanas femiferos, \& Satyros . Satyris, inquit, præter figuram nihil moris humani effe traditur: Āegipanis, qualis uulgò fingitur forma. Pomponius Mela ultra Atlantem Mauritanix montem fcribit noctu perfape uifa lumina, \& crepitus cymbalorum ac fiftularum cantus auditos: nec die re= pertum quenquam, idcirco pro conftanti habitum hos Faunos effe ac Satyros. Vide Melam libro 3. 40 in defcriptione Aethiopiz. In Parnaffo alternis annis Bacchanalia, id eft Trieterica agebantur,ubi Satyrorum frequens cernebatur cotus, \& frequentius uoces exaudiebantur, \& cymbalorum cre $=$ pitus, id quod $8 \times$ Macrobius poft Paufaniam annotauit, Gyraldus, TCordax faltatio fuit Comia ca: Arrianus in Commentario Indico Satyricam putat, \& à Libero patre in India inftitutá. Sicinnis

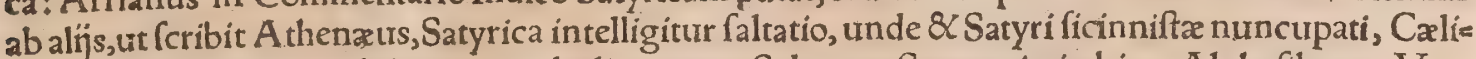
us 5.4 , ubi plura etiam de huius uocabuli etymo. Saltantes Satyros imitabitur Alphefiboeus, Ver=

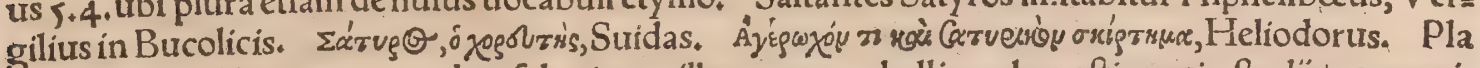
to de legibus libro7. non probat faltationes illas qux nec belli nechoneftis pacis ftudijs conueni= unt, ut in quibus faltantes imitantur Nymphas, Panas, Silenos, \& Satyros inebriatos, (qualis apud nos faltatio quadam eft, Der fblfffer tant, hoc eft dormiturientium faltatio, ) qux in facris quibuf, so dam ceremonïs exercebantur. đExrat Orphei hymnus in Satyrum. Coluerunt enim ueteres hurufmodi monftra pro femideis fiue fylueftribus dijs: Faunos ac Satyros nemorum deos effe dicen-

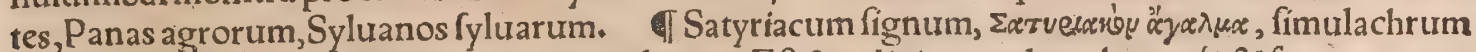
Priapi, quod in hortis apud antiquos poncbatur. Eft \& religio quædam, hortosćp \& 2 fores tantum, contra inuidentium fafcinationes dicari uidemus:in remedium Satyriaca figna, Plinius libro 19. Antiphilus pinxir nobiliffimum Satyrum, cum pelle pantherina, quem A polcoponta appellant, Plis nius. Ariftidis Thebani pictoris eft Satyrus cum fcypho coronatus, Idem. Myron fecit Satyrum admirantem tibias, Idem. Et rurfus, Myron fecit nobilem Satyrum quem periboëton cognomi. nant. Hunc Satyrum(inquit Hermolaus in Caftigationibus) A thenis fuiffe tradunt, uia qua Tripo: des appellabatur, miratumós in eo fe Praxitelem + adeò ut petenti Phrynæ, quod ex operibus fuis. to praftantiffimum exiftimaret, daturum fe quidem receperit, (amabat enim) fed iudicare quodnam eiufmodi effet noluerit. fed fubornato uernula, qui comcfianti apud fe trepido curfu nunciarer, ab. fumptam fubito inçendio maiorem operum eius partem, attonitum $\&$ accurrere parantem excla 
maffe, falura effe omnia fi Satyrus $\&$ Cupido fupereffent. ita cófeffione iudicij dolo expreffa, foemina Cupidinem optanti non Satyrum dediffe, \& $c$. Hre ille ex Atticis Paufanix. Protogenes Rhodius pinxit Satyrû quem Anapauómenon uocant, tibias tenentem, Plinius. Celebratur \& Stratonicus, qui Satyrum in phiala grauatum fomno collocauiffe uerius, 苑 calaffe dicius eft, Idem. Timanthes pinxit Cyclopem dormiente in partuula tabella, atç̧ irrxta Satyros thyrfo pollicẽ eius metientes, Idẽe,

If Satyri cuiufdam adulatoris utriufç Bionyfj meminit Timæus, Athenæus. Satyri architecti mentio apud Plinium 36.9. Satyrus Eleus, Lyfianactis fil, ex genere Iamidarum, quinquies in $\mathrm{Ne}=$ mea pugiles uicit, in Pythỉs bis, bis infuper in Olympia, ftatuă eitus fecit Silanion Athenienfis, $\mathrm{P}_{a u_{3}}$ fanias in Eliacis. Gorgippus filius Satyri tyranni Bofpori, Pelyzenus lib. 8. Strateg. Satyrus qui.

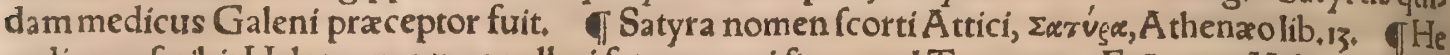
rodianus fcribit Helotas quoo̧ appellari fatyros, qui fint apud Tænarum. Erãt trero Helotæ publici

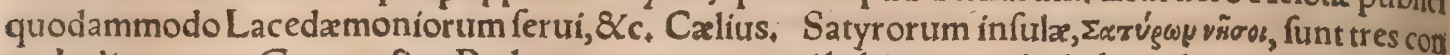
tra Indiam, extra Gangen fitz, Ptolemæo 2. 7. quas qui habitant caudas habere dicuntur, quales $S_{a z}$ tyris pinguntur.Paufanias has infulas Satyrias uocat, (Calius Satyrides transfert, )cuius uerba fupe rius hac ipfa in parte retuli. Satyrion, regio prope Tarentum, gentile Satyrinus, Stephanus, Sattre ra feu Saryra palus Pontina eft, uigintiquatuor urbium olim locus capax. Qua Saturæ iacet atra paa luss,gelidusḉ̧̧ per imas Quærit iter ualles, atç̧ in mare conditur V fens, Vergil.7. Aen.Calius.Me minit hurius paludis etiam Plinitus 3. 6. Satyrus fluuius in Aquitania, cuius meminit Lucanus lib, i. Tunc rura Nemetis Qui tenet, 8 ripas Satyri qua littore curua.

बi Finitimos Indix montes tranfmittenti, ad intimum latus denfiffimas conualles uideri aitunt, $\alpha$ is Cor udam locum nominari, ubi beftiæ fatyrorum fimilitudinem formam $\hat{q}_{\text {g gerentes, }} \propto \mathrm{\alpha}$ toro corpore hirfutæ, uerfantur : atqure equina cauda præditæ dicuntur. Eæ cum non à uenatoribus agitantur, in opacis \& fpiffis fyluis folent uiuere. Cum autem uenantium ftrepitum fentiunt, \& canum latratus exaudiunt, in montium uertices incredibili celeritate recurrunt $\$$ nam per montes iter conficere afs fuetæ funt, Contra eos qui fe infequuntur pugnant, de fummis montibus faxa decioluentes. Exĭf nonnullæ, fed ægerrime tandem, aut ægrotantes, aut grauidæ comprehenduntur. Illæ quidempros prer morbum; ha uero ob grauiditatem, A elianus. Sed feras toto corpore hirtas effe, caudis equinis, \& propter celeritatem non nifi morbo aut fenecta graues capi, alij authores fatyris ipfis attribuerüt,

Monftri buius defcriptio proxima pagina fequetus:

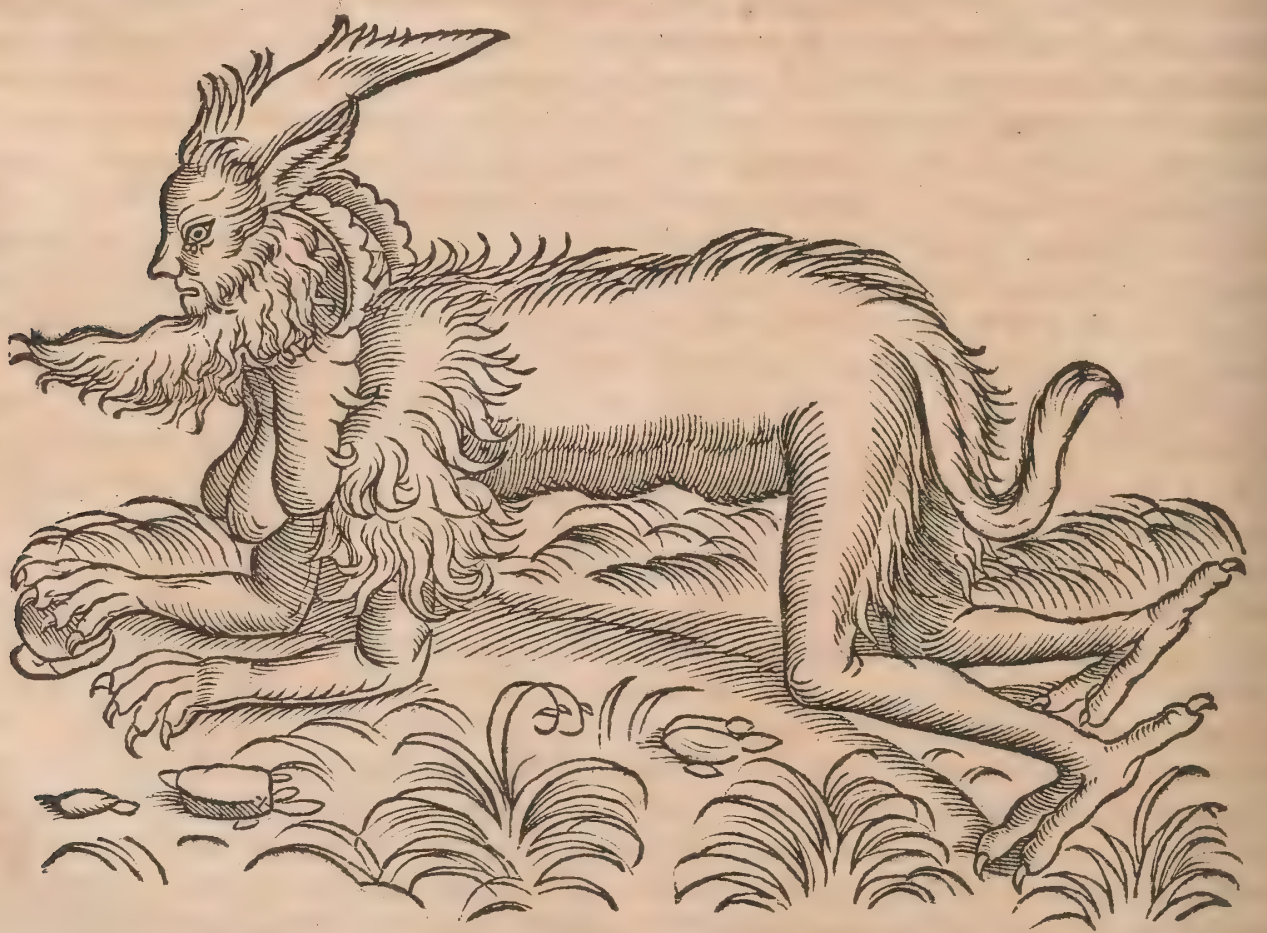

TIn Syluis Saxoniæ uerfus Daciam, in deferto murice(nemore) curiufdã, capta funt parum ante hæx tempora duo monftra pilofa, ferè in omnibus habentia figuram hominis: \& føemina quidẽ mor. tua fuir morfibus canum \& uulneribus uenatorum. Mafculus autem captus eft domefticus, $\&$ didis cit ire fuper pedes erectus: $\&$ didicit loqui imperfecte ualde $\&$ non multa uerba, $\&$ habuit uocẽ exis lem ficut capreolus, \& rationem nullam habuit, de feceffu $\&$ egeftione $\&$ alĭs talibus uerecundaba tur, multum autem appetint coire cum mulieribus. 8 has publice qualefcunç effent tempore libidi. 60 nis opprimere tentauit, Albertus. Et rurfus libro 22, in Catalogo quadrupedum, de Confufa bes ftia fcribens, citatis Solini uerbis; qua apud Solinum non de Confufa (corruptum enim hoc nomen 


\section{De fimijs diucris. Lib. I. 979}

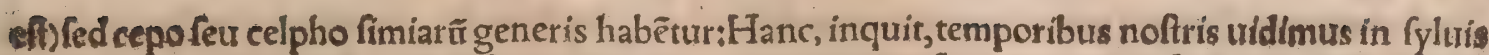
Sclauix (fupra legitur Saxonix, forte pro Sclauonix) depreherifam, marem \& foemină , ut in prace. dentibus diximus, (locum iam recitatum intelligens;) \& procedente tempore uoces quafdam expref fit. Eft aũt hoc animal de genere finiarum. Rurfus eodem libro, Pilofus, inquit, animal eft compo: fitum ex homine fuperius, $\mathcal{X}$ capra inferius, cornutũ in fronte. fimiarü generis, fed ualde monftro. fumtaliquoties ereêtu incedit $\&$ manfuefcit, In defertis Aethiopix habitare ferunt: \& aliquando caz ptuี $\&$ mortuum fale conditû Alexandriã miffum, inde Conftantinopolim delatum. Ex quibus uere bis omnino apparet pilofum Alber to \& recentioribus, nihil aliud quàm fatyrum efte.

Satyrorum hiftoriæ fubijciendum duxi monftrum iftud, cuius effigiem appofui, quam eximix $e_{a}$ ruditionis $\&$ humanitatis uir Georgius Fabricius ex Mifnia Germanix ad nos mifit, \& fimul de. fcriptionem, his uerbis : Quadrupes illud captum eft in ditione epifcopi Salceburgenfis, in faltu quem Hanefbergium uocant, Colore fuít giluo in flauum declinante, Feritatis infolira. hominum enim afpeçum fugit, fẹ́ in tenebras, ubi potuit, abdidit. Tandem cum ad cibum capiendum neç cogi neqgallici poffet, paucos poft dies eft extinctum. Pedes pofteriores prioribus diffimiles, \& mul tò longiores furerunt, Reliqua facile ex. icone intelliguntur, Captum eft anno falutis tricefimo pris mo fupra mille quingentos.

\section{DE SPHINGE SIMIAR VM GENERIS.}

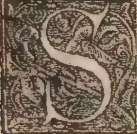

P H I N G A s fufco pilo, mãmis in pectore geminis, Acthiopia generat, multaç̣ alia mon ftro fimilia, Plin. Inter fimias habentur $\&$ f phinges, uillof comis, mammis prominulis ac profundis, dociles ad feritatis obliuionê, Solin. In promontorio quodã extremæ Arabia quod fitũ eft inter Dirā \& Auftri cornu, leones formicx dicti reperiuntur, \& fphinges \& alix fere, ut fcribit Strab.li, I6. Efferatior (quàm fiminjs) cynocephalis natura, ficut mitifima fatyris ex fphingibus, Plin. Condit in thefauros maxillarum cibum fphingiorum \& fatyrorum genus, mox inde fenfím ad mandendum manibus expromit; $\&$ quod formicis in annum folenne eft, his in dies uel horas, Idem. Sphinges \& apud 'Troglodytas, Aethiopesás nafcuntur, forma haud ei diffimill qua pinguntur, fed paulo pinguriores. Naturam habent manfuecam, pluribus exercitijs difciplinisç aptam, Diodorus Sic.lib. 4 . de fabulofis antiquorum geftis. Sphinges(inquit Albertus)nec ita funt te ræ ut domari non poffint; nec ita manfuetae ur nocentibus non noreant; nou laduntenim illos à quí: bus non laduntur. Cercopithecum fimiam idem à quiburdamifphingem appellarifcribit; fed inepte. Sua fponte prudentia ualent in India, elephantus, pfitțacus, fphinges, \& nuncupati fatyri, A elian.

\section{De Sphinge fabulofa.}

Simulachra quadam funt rerum in natura non extantium, ut Tritones, Sphinges, Centauri, Sui das: Hydra peperit Chimaram, Chimara Sphingem ex Ortho, \& Nemeaum leonem, Hefiodus in Theogon. Sphinga fabulantur filiam Chimara ac Orthi, qui fuit Geryonis canis, ut in Theogonia cecinit Hefiodus, Cxlius. Recentior quidam Grammaticus Sphingis patrem facit, non Orthum, fed Orcum. Tradunt $\&$ de his fabulx, Sphinga triforme monftrum, cuitus pars una uolucris, altera 4o leonis, tuirginis tertia, ut quidam citat ex Plinio. Terruit Aoniam uolucris, leo, uirgo, trifornis Sphinx uolucris pennis, pedibus fera, fronte puella, Aufonius in gripho Ternarij. Sphín, mon frum apud Thebas, cuius caput $\&$ manus puella, corpus canis, ala auis, uox hominis, ungues leo. nis, cauda draconis, Grammaticus quidam. Aegyptï biformem tantum finxerunt ex urrgine \& leone corpore compofito, A eliano tefte. Biras, Sphingas, Hefych.Varin. Sphinx, animal monftro

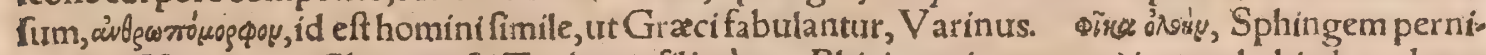
ciofam. Elt autem ea Chimeræ \& Typhonis filia:à qua Phicion etiam(mons) in quo habitabat, deno

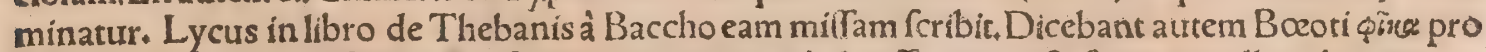
Sphinge, Varinus. Sphingem ferunt corpus canis habuifle, caput $\&$ faciem puella, alas uero a= uium, atç hominis uocem: Er in Sphincio monte fedentem ænigma unicuique ex ciubus propofuif yo fe.foluere nefcientem interemiffe: cum urero id Oedipus foluiffet, fefe ipfam ex monte deieciffe. Sed treritas fic fe habet. Cadmus cum mulierem Amazonida cui Sphinx erat nomen, fecum haberet, Thebas peruenit, cumḉ Draconem interfeciffet, huius ipfius regnum occupautit. Poft bęc $\&$ Draco nis fororẽ, cui Harmonia erat nomen, cepit. Intelligens aũt Sphinx $q$ Cadmus aliã duxiffet uxorẽ, ac fibi perfuadens multos ciues fe abeunte fecuturos effe, 苑 plurimas diuitias rapiens, fecuméç cele. rem canem ducens quem Cadmus habebat, cum his omniburs in Sphincium montem nuncupatum peruenit, \& exinde Cadmo bellum inferebat: $\&$ incurfionibus quotidie factis plures homines interimebat. Vocant autem Thebani incurfiones ipfas ænigmata. Hoc ciues paffim diuulgabant, in hunc modum dicentes: Argiua Sphinx nos ænigma quoddam proponens diripit. Quonam atl tem modo anigma faciat, inuenire nemo noftrum poteft. Publico itaque edićo nunciari Cada 6o mus iuffit, Sphingem interficienti cuicunç ditiffimum pramium effe propofitư. A d quam cum Oe dipus Corinthius acceffrfet, cũ equo ueloci, quem fecum habebat unà cum Thebanis quibufdã no: c̊tuno tempore montẽ uerfus accedens, Sphingẽ de medio iuftulit, Hęc Palaphatus. Oedipus Laif 
Thebarum regis filius in monte quodam expofitus, \& a Melobo ruftico inuentus ac educatus, cum iam adoleuiffet, latrocinn̈s operam dabat, quo tempore Sphinx etiam deformis $\&$ belluinæ natur mulier latrocinando uiuebat. Viro enim amiffo manum collegit pradonum, \& locum natura muni tum occurpauit, ubi tranfeuntes occidebat. Huic Oedipus audaci confilio tanquam focius prad fe coniungit,\& opportuno tempore obferuato, ipfam ac focios hafta interimit. Quo intellecto The: bani regem ipfum appellant: \& Laium regem bello eos adorientem occidunt. Regina Iocafte Oed po,quem filium fuum effe nefciebat, nubit, $\alpha_{c}$.Suidas. Vide Sophoclis Tragcediam qux Oedipur Tyrannus infcribitur. A Thebano agro (inquit $P$ aufanias in Bocoticis) Sphingem aiunt progredt folitam, quum, ut homines à fe raptos perderet, quaftiones eis proponebat obfeuras. Dicunt nonnu li nauali eam potentia inftrućam latrocinin exercendi caufa oberraffe, $\&$ ad mare circa A n thedonên appuliffe. Hoc autem monte occupato, rapinis fuiffe intentam, donec Oedipus eam confecerit ( $\dot{y}_{\xi}$ igw)obrutam exercitus multitudine, quem Corintho eduxerat. Dicitur item Laif fuiffe notha fillia 8 edocta à Laio per beneuolentiam, quod Cadmo datum erat oraculum Delphicum. Priufquamau

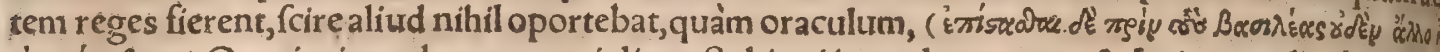

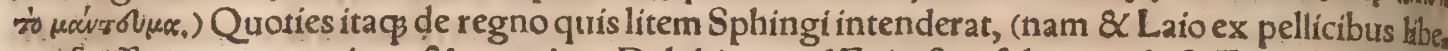
ros fuilfe procreatos aiunt, $\&$ oraculum Delphicum ad Epicaften folummodo $\&$ Epicaftx filios fpe ctabat: hac Sphingem aiunt aduerfus fratres ufam effe fraude, ut ex Laị ftirpe fi effent procreati, quod datum fuerat Cadmo oraculum, proferrent. Qui refpondere non poterant, eos morte multa bat, uxt qui immerito $\&$ de genere difceptarent $\&$ imperio. Oedipus uero in fomnis oraculum edo: ctus, Sphingem acceffit, Hactenus Paulanias, Loefchero fere interprete. Sphingis fpeciem fuiffe al: unt, anterius leoninam, à tergo humanam:unguibus gryphis, alis aquilæ, \& alijs modis monftrofam, Reuera autem mulier hæc prædo ( $\lambda$ sşis) fuit ad Moaben regionem Africæ, \& Phicion montem, quiæ pratereuntes occidebat, nifi quis propofitum ab ea ænigma folueret, quod erat huiufinodi. Ḣsidi.

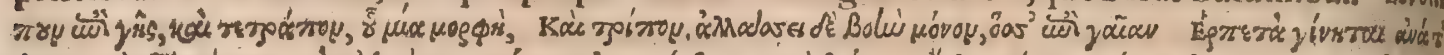

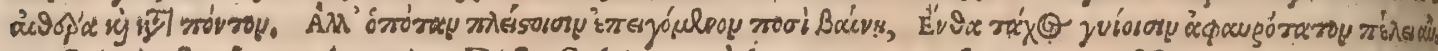
mon,Scholiaftes Lycophronis. Dicta Sphinx quòd cogeret tranfeuntes confrftere, quibus æenigma proponebat, quidnam id effet in orbe terrarum quod quaternis primum pedibus inambularet, inde duobus, poftremó tribus, quod nefcientes foluere, fublatos in rupem agebat pracipites. Oedipusil lac iter habens ænigma diluit, hominem effe dicens, qui in infantia manibus $\&$ pedibus nitens qua drupes, in iuuentute pedibus tantũ $\&$ bipes, in fenectute uero baculo utens tripes eft. Turic Sphinx fe de faxo pracipitem dedit.Inde origo huius adagí apud Terentium, Dauus fum, non Oedipus:id. eft, (eruili officio, non quaftionibus foluendis aptus fum, (uide plura apud Erafmum in protrerbits, ) Grammaticus quidam. Eos qui propofitum à fe ænigma foluere non poffent, alis $\&$ unguiburs ad fe in rupem trahebat, \&c. Lactantius in primum Thebaid. Michaël P fellus Sphingem fuperiore

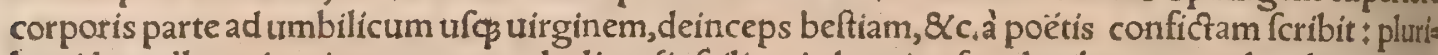
bus idem allegoriam interpretatur, de diuerfis fcilicet in homine facultatibus, ex quibus homo coms ponitur, mente, ratione, opinione, phantàlia \& fenfibus utens, inter rationale $\&$ rationis expersas

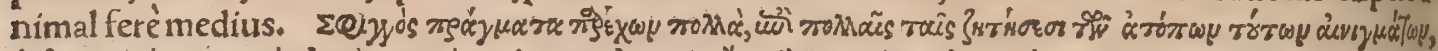

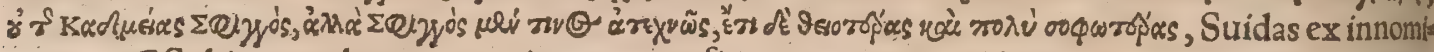
nato. TSphingem alatam tum pingunt tum fingunt omnes qui in ea arte, qux acfionem manus to um habet cum actione(fcientia uel contemplatione) coniunctam, operam ponunt, Aelianus, In Li bya funt feræ facie muliebri, ima parte ferpentes, alas non habent quemadmodum Sphinges, neq loquuntur ut illæ, Dion in hiftoria Libyca, ut in Lamia hiftoria retuli. Sphingis pedes leoninie. rant, Scholiaftes in Ariftoph. Picati appellantur quidam qutorum pedes formati funt in Ipeciem fphingum, quod eas Dorij Sphincas (eirrs urel Biress, ut coníiciou)uocant, Feftus. Sphinx cum hos mini offertur, fi illum(illam)præfentiat, feruatur: fi uero befía prius hominem fenferit, perditur ho, mo, Quidam in Onomaftico fine authore.

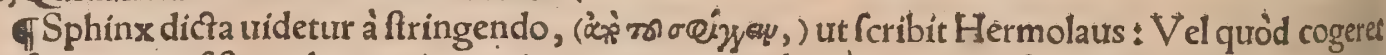
tranfeuntes confiftere, dum anigma eis proponeret + uel quod homines fuis quartionibus ita ftrin. geret, ut fe expedire non poffent:uel quafi omnlum mentes fuis propofitionibus ligaret, Recentio s

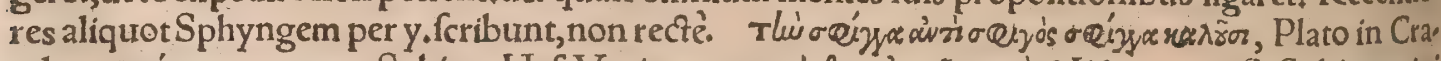

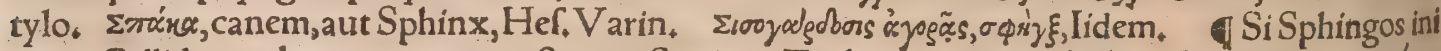

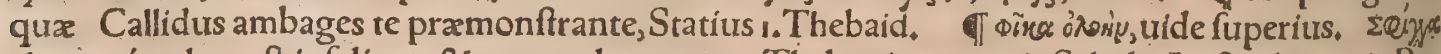
oivoriuséav, (hoc eft infelicem \& qux malo tempore Thebanis apparuit, Schol.) Ariftophanes in $R_{2}$

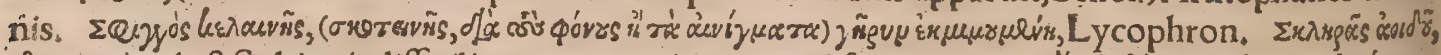

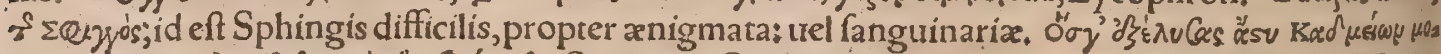

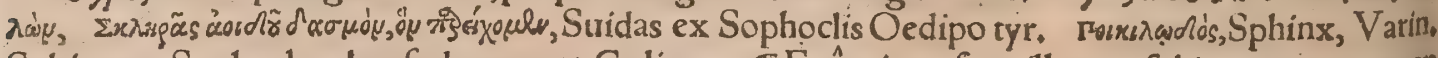
Sphingem Sophocles rhapfodon uocat, Cælius. TI Fuêre item fcortilla quæ fphinges nuncuparen tur: nam 8 molles ( $\sigma$ Qúx rou, cinædi, molles, Her.Varin, ) fphinctæ appellantur, quod prodit Suidas,

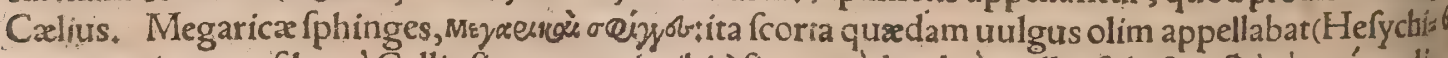

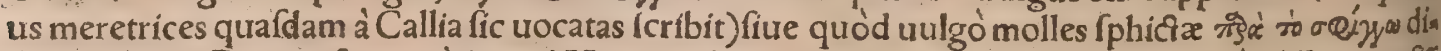
cunur apud Gracos:fiue quòd apud Megarenfes nutrix fphinx appelletur, fiue quòd Megarenfiú 


\section{Defimijsdiuerfis. Lib. I. 98I}

mores improbifictiq́s, \& populari notitia, quondam notati fuerint. Vnde Ariftophanes in Vefpis rifum Megaricum, de quo dictum eft alibi, taxat. Suridas refert $\&$ hunc uerficulum, fed tacito ( ut fo.

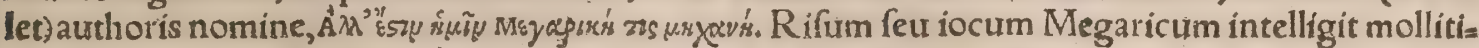
em Megarenfium. Refertur à Diogeniano (\& Suida, ) Erafmus. Megaricæ fphinges, meretrices:

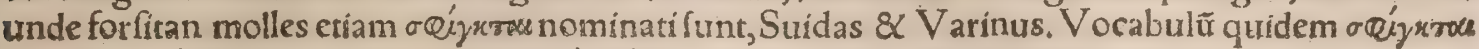
magis probârim cum gamma fribi quàm fine eo:utroģ enim modo reperitur, ut iam citaui.

IIcon. Sphingem A egyptĭ qui fcalpturam exercent, $\&$ Thebanæ fabulæ, biformem nobis re= prafentant, ex corpore uirginis $\&$ leonis cum grauitate $S$ compofitione ipfam architectantes, Aelia anus. Scyles Scytharum rex in Boryfthenitarum urbe æedes magnificas habebat, circum quas èla. pide candido fphinges $\&$ grypes ftabant, Herodotus libro 4. Athenis in arce, in templo quod Par thenôna uocant, tum alia quxdam de generatione Minerux effigies habentur, tum Neptuni cum Minerua contentio de terra. Simulachrum ipfum (Minerux) ex ebore $\&$ auro factum eft, $\&$ in medio galex Sphingis imago expreffa, Paufanias. Pyramides tres funt inter Memphím \& Del ca oppida, uico appofito quem uocant Bufirin. Ante has eft [phinx, uel magis miranda, qua fyl. ueftria funt accolentium. Amafin regem putant in ea conditum, \& uolunt inuectam uideri, Eft au tem faxo naturali elaborata, \& lubrica. Capitis monftri ambitus per frontem centum duos pedes colligit,longitudo pedum CX $L$ II $I_{+}$eft, altitudo à uentre ad fummum apicem in capite $L$ X. Ir.Plinius 36.12. Per totam longitudinem(templi Heliopolitani in A egypto) protinus ex utraque latitudinis parte funt pofiræ lapidex fphinges, uigenis cubitis, uel paulo pluribus inter fe diftãtes: 8 alter fphin gum ordo eft à dextra, alter à finiftra. Poft fphinges eft ueftibulum ingens, procedenti ulterius aliz ud ueftibulum, poftea aliud: 8 neq̧ ueftibulorum, negs fphingum diffinitus eft numerus, Strabo liz bro 17. A egyptī ante templa (in propylax is ) Sphingem aftituebant, quo argumento indicarent, theologicam ipforum fapientiam obfcuriorem, fabulisćs ita fxpe conuelatã, ut ueritatis ueftigia uix interlucerent, Calius R hodig, \& Calcagninus ex Plutarcho de Ifide. Amafis rex Aegypti ueftibu. lum Mineruæ fecit in Sai, opus admirandum, ubi etiam ingentes coloffos $\&$ immanes androfphin. gas pofuit, Herodotus lib.2. Signis qua uocantur Corinthia, plerique in tantum capiuntur, ut fe= cum circumferant, ficut Hortenfius orator fphingem Verri reo ablatam. Propter quam Cicero illo iudicio in altercatione neganti ei fe ænigmata intelligere, refpondit debere, quoniam fphingem do= mihaberet, Plinius, Octauius Auguftus in diplomatibus libellisḉs \& epiftolis fignandis, initio 30 fphinge ufus eft, mox imagine Magni Alexandri, nouiffimè fua, Suretonius,

TAlciati emblema in fubmourendam ignorantiam, per dialogifmum.

Qurod monftrũ id?'Sphinx eft. Cur cãdida uirginis ora, Et uolucrum pennas, crura leonis habet? Hanc faciē affump fit rerũ ignorantia:tanti Scilicet eft triplex caufa \& origo mali. Sunt quos ingeniũ leue, funt quos blãda troluptas, Sunt $\&$ quos faciunt corda fuperba rudes, At quibus eft notũ, quid Delphica litera poffit, Præcipitis monftriguttura dira fecant.

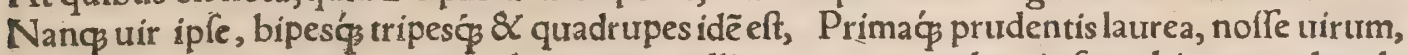
Hxcille per uirgineam partem uoluptatem intelligens $\$$ per crura leonis, fuperbiam:per alas, leuita* tem. đEft \& Sphinx fabula ueteris cuiufdam poétæ, Aefchyli ni fallor.

\section{DE SIMIVVLPA. SIC ENIM FINGO \\ NOMEN, NE SIT ANONYMOS HAEC BESTIA: cuius imaginem addidi, qualis in tabulis Geographis cis depingi folet.}

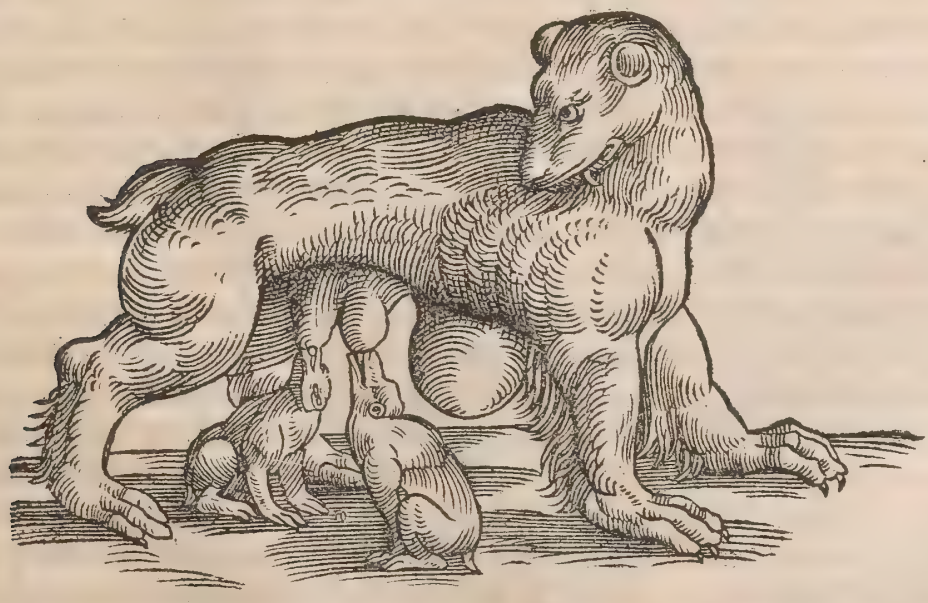
dem, ex anteriore parte uulpem, ex pofteriore fimiam: praterquàm quòd humanis pedi. bus fit, $\&$ nocीux auribus: $\&$ fubter communem uentrem, inftar marfupij alium uentrem 
gerat, in quem tam diu eius catuli occultantur, dum tuto exire, \& fine parentis turitione cibaria incut rere poffunt:ac nimirum non ex eo receptaculo prodeuht, nifi cum lac fugunt, Gillius: Tranferipfit autem, ut apparet, ex Vincentiani Pinzoni Nauigatione. Portentofum hoc animal, ut in eadem le, gimus, cum catulis tribus Sibiliam delatum eft, $\&$ ex Sibilia Illiberim, id eft Granatam, in gratiam re gum. Catuli licet in itinere perierint, confpećt tamen funt à cóplurriburs qui huius rei teftes fuerunt Petrus Martyr etiam Oceanex Decadis primæ libro 9. Arbores ibi (in Pariana regione, inquit) tan. tas effe aiunt, ut pleræc fedecim hominum manu iunc?oru in gyrum uix lacertis concludi quirent, Inter eas arbores monftrofum illud animal uulpino roftro, cercopitheci cauda, uefpertilionis auri, bus, manibus humanis, pedibus fimiam amulans ₹ quod natos iam filios alio geftat, quocun $\$$ profls cifcatur, utero exteriore in modum magnx crumenæ, repertum eft. Id animal licet morturum ipfe uridi,conuolui, crumenamóp illam noưm uterum, noưm naturæ remedium, quó à urenatoribus aut aliâs à càterís uiolentis $\&$ rapacibus animalibus natos liberet, illos fecũ afportando, admiratus fum. Experimento effe compertum aiunt, eo femper utero crumenali animal catulos fecum portare, nec illos inde unquam emittere, nifi aut recreandi aut lactandi gratia, donec fibi uicturm per fe quaritare didicerint. Cum catulis animal ipfum deprehenderant: fed in nauibus catuli intra paucos dies pea rierunt, mater per aliquot menfes fuperfurit, fed $\&$ ipfa tandem tantam aêris $\&$ ciborữ mutationem ferre nequiuit, Hae ille.

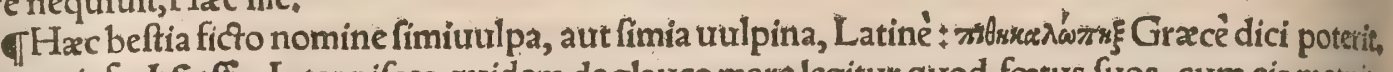
Germanis fuळ 6 aff. Inter pifces quidem de glauco mare legitur quod foetus fuos, cum eis metuit, deuroret ac rurfus incolumes emittat, ut Āelianus refert.

\section{DE S VBO.}

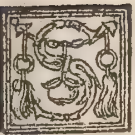

V B V $s(\Sigma \tilde{x}$ in mari natat, eum permultus pifcium grex confequens of culatur, quôd ex illius cốpeçu fumma uoluptate afficiatur ₹ fed pracipuo quodam ftudio circum ipfum uerfantur pagti, oculatæ, acus, mulli, aftaci: Denics omne pifciü genus circa fubum uerfari gaudet, atque ordineiter faciens, à tergo dextra \& finiftra eidem comitatur : fed fceleftus ille externã amicitiam contemnens, marinos focios exedit $\&$ conficit. Hi uero tametfi,ob oculos uerfantem mortem uident, tamen inter fectorem furm neque oderunt, neq, relinquunt. Sed fcelerate fube \& fraudulente, non impune in: nocenteis pifces occideris, nam ipfi tibi perniciem pifcatores molientur, Gillius ex Oppiani de uenaa tione fecundo. Videriautem poreft ad fylueftre ouium genus hoc animal referri poffe, nam ftatim ante hiftoriam eius Oppianus de ouibus feris Creticis egit, quas colore flauro uel purpurafente effe fcribit, quadricornes, non lana, fed uillo ferè caprino tectas. Et mox addit, Quinetiam fubus colore flauefcit fplendido, fed non aqué uillis hirfutus eft, \& duo tantum ualida cornua fupra latam gerit front $\tilde{e}$. Quod finon congeneres beftias iftas exiftimaffet, conferre inter featç diftinguere opurs non fuiffet, Sed coniectura hæe nuda eft. nam certi nihil habeo, cum nullus omnium excepto Oppiano, (quod fciam)authorum huius animantis meminerit,

\section{DE S VE.}

\section{A.}

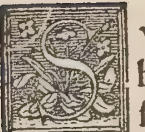

V I I I V M genus uarium, \& uaria fortitur nomina pro atate, fexu, caftratione, \& 2 c ut hoc in capite, \& in Philologia apparebit. Varro differentias omnes cóprehendens pecus fuillum nominat. In fuillo pecore(inquit) funt qua fe uindicent (aduerfus lupos) fues, uer: res, maiales, fcrofæe. propé enim hæc apris, qui in fyluis fxpe dentibus canes occiderunt, Sus genea ris communis fecundum prifcos, porcum \& porcam fignificat, telte Prifciano. Sus foemina, apud Columellam legitur, Suis fomin cerebrum contra carbunculos proficit, Plinius , Suis nomine apud Ariftotelem Michaël Ephefius generatim intelligit tam urbanum quàm ferum, Niphus, Gas za quidem ex Ariftotele urbanum reddere folet, pro cicure ( alicubi tamen etiam fues cicures rede dit) uel domeftico, quod fero aut fylueftriopponitur, ut boues \& fues urbanos:quod non admodum probo, manfuretum enim potius dixerim:(Idem Gaza apud Ariftotelem problem.10 4 6. fuem agre»

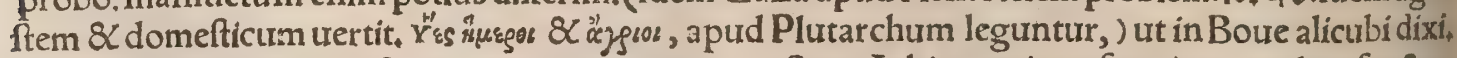
Eft quando fus fine adiectione pro apro ponitur, ut: Sues A thi montis ne foeminas quidem fpectare mares fitus inferioris audent, A riftoteles interprete Gaza. Sed frequentius fylureftris aut feri feraue differentia adýcitur, ut idem transferre folet.nam 8 mafculino genere furem ferum dicit, utrunģ $\int_{e}$ xum comprehendens $\$ \&$ forminino fuem feram, quod Atticum uidetur, pro utrouis fexu: $V t$, Sues fylueftres animofx, peruicaces, $\&$ brutæomnino funt. Nanq̧ fagacius unus odoror, Polypus an grauis hirfutis cubet hircus in alis, Quàm canis acer ubi lateat fus, (id eft aper,) Horatius, đ Pris ufquam porcam foeminam immolabis, Cato cap.134. Vetus exemplar habet porcurm forminam $\$ 26$ ibidem paulò antè, porco foemina, quam puto urerã lectionem. fi enim porca dixiffet, quíd opus erat addere fomina? Porca, fus forta, Palladio. Porcum pro porcello Varro protulit, item Cicero \& 


\section{De Sue.}

Columella,uide infra in $a$, I Scrofa, (uel ut alij feribunt fcropha, per ph, ut Graci etiam

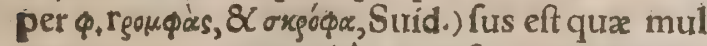
tos peperit porcos, (aliâs, qux frepius peperiț tamen etiam pro porca ipfa peculiariter fumi= tur. Eorum fi cuiufquam frofam ín publico confpexero, Plautus Capt. Scrof $x$ probantur longiffimíftatus, \& c c Columella, fic Plín ius lib. 28. ut quidam in Promptuario annotauit.

10 TVerres dicitur porcus non caftratus, man. fuetus, nam ferus, aper eft. Marcellus tamen Empiricus uerrem fyluaticum dixit pro apro: \& Suetonius aprum ferum nominat, quafi $\&$ cicures rectè nominentur apri, ut differentia caufa fi ferum intelligamus id exprimere opor teat. Dentes exerti nulli, quibus ferrati : rarò forminx, \& tamen fine ufu* itaç cum apri ( ui= detur tum manfuetos tum feros intelligere)per cutiant, forminæe fues mordent, Plinius, Et ali-

20 bi de apris, Pilus areo fimilis agreftibus, cateris niger. đIn fuibus maiales (barg) funt, por ci feu uerres caftratitut in equis canterÿ, in gal lis gallinaceis capi, Varro. Plura uide in E.

THybridas antiqui uocabant fues femiferos, hoc eft ex fero $\&$ domeftico progenitos, ut Plinius refert lib. 8. fic $\&$ canis hybris uocatur, imparibus parentibus natus, hoc eft ex uenati co \& gregario,Porphyrio.

I 7 nh chafir, fus aper, (id eft uerres, ) ma. 30 fculini generis:ut chafir thame, id eft mus im= mundus, Leuit, II. A pud Rabinos fœmininum legitur חา⿻ chaferah, Munfterus. Deuterono mí i 4. pro chafir Hebraico, Chaldaus reddit

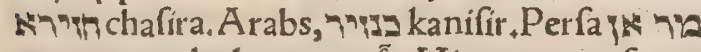

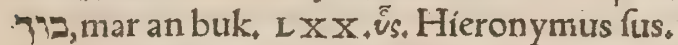
Hazir,id eft porcus, Syluaticus, Marchangir, id eft fel porci, Idem. Acanthil, id eft porcurs, Idem. Achira, fcrofa, Syluatic, corruptum à Graco yeípo uocabulum. Xicreon, id eft 4o porcina caro, Idem: Videtur autem hoc quoos eGracis depraututum.

TGrace $\sigma \tilde{u} s$ dicitur de porco, ũs de porca; fed multi indifferenter utuntur, Scholiaftes $\bar{A}_{\text {* }}$ riftophanis $\&$ Suidas, Apud Ariftotelem frpe ró vis legimus, in Phyfiognom. A thenæus eti= am mafculino genere $\frac{\|}{v} \widetilde{v}_{p}$ dicit. Alibi tamen Ariftoreles $\tilde{\tilde{u}}_{\nu}$ foeminino genere profert de utro $\phi_{\beta}$ fexu, more fcilicet Attico:quem in hoc Gaza Lat

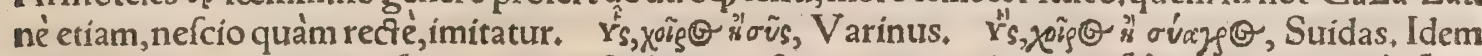
docet rectum fingularem vis cum acuto fcribi, accufatitum uero pluralem vis circumflecti, rixs is $\&$

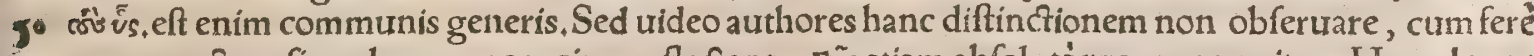
omnes reçum fingularem quogs circumfleçant. ¿ũs etiam abfoluté pro apro ponitur. Hercules ue

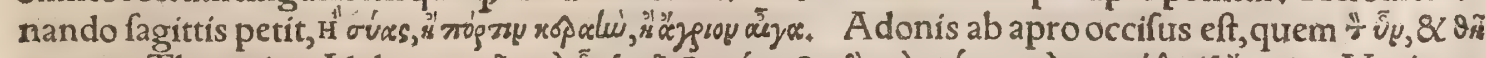

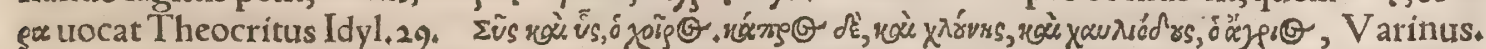
Homerus, Pindarus, Plutarchus $8 \mathrm{r}$ alï, fuem ferum rómbe nominant. Apridicuntur à locis afpe ris, aut forte à Græco rómbs, Varro. In Geoponicis Græcis tamen cápron legimus ubi uerrem Lati

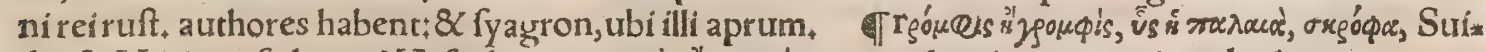

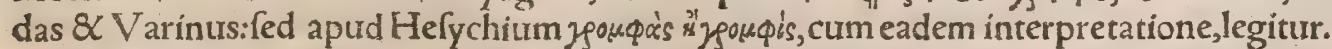

बI Sus, Italis porco:Florentinis peculiariter cíacco, Arlunnus, Scrofa, nomen etiam Italicé feruat: aliâs troiata, uel porca fattrice, (id eft porca matrix aut focta potius, )Idem. Troiam uulgò nunc $R$ ha 60 uennates appellant fropham, ea puto ratione qua quodam tempore(aliqui) Troianum porcum no= minabant, qui quafi inclufis animalibus pragnans, ut ille Troianus equus grauidus armatis fuit, in menfam inferri folitus fit, Nic. Erythraus. Maialis, lo porco caftrato, lo maiaie, Scoppa, - I Sus 
Gallis porceau. Surs formina, truye, coche. Verres, uerrat. Porcellus, cochon,porcelet, \&Lug duni caion. Maialis, pore chaftrè,id eft porcus caftratus per periphrafin. ब Sus Hifpanis, puér. co. T Sus Germanis, faw uel fuw//u//du wyn uel fob wein. Sus foemina, moz uel loo/stproprié ta.

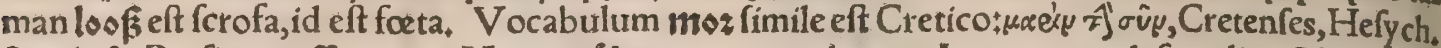
Simile $\&$ Perficum effe puto. Verres, sbet:quae trox ab apro Latinorum defcendit. Maialis, id eft uerres caftratus, barg. Porca caftrata, galos. Porcellus, fírle/[euwle:\& laciens adhuc, [panfít. le. TSus Anglis, fu uel fowe, foem. generis ut Germanis : in plurali fwyne. Verres, pork uel bor aliâs boore, urel hog aliâs hogge (ouis etiam annicula hog ab eis trocatur,)Maialis, libdhog, uel baro. we hogge. Porca caftrata, libdfu, trel geldid fu, eft enim eis geldid, quod nobis ghellet, id eft caftra, tum, Porcellus, pygge. đI Sus Illyrijs, fwinie uel prafe.

B.

Athenzus libro 12, fues ex Sicilia tanquam pracipuas ad cibum probat. Agatharfides ait fues in Aethiopia cornua habere, A elianus + Plinius apros Indorum cornutos effe prodidit. Arabes Sce nitæ carnibus fuillis prorfus abftinent: fanè hoc animalis genus fi inuectum illò fuerit, moritur illi, co, Solinus ni fallor. Suem nec ferum nec manfuetum India habet, tefte Ctefia, quanquam non fi, de digno, Ariftoteles:Idem Aelianus ex eo repetit, 8 addit fuilli generis efum Indos à fe deteftari, In Arabia fuillum genus non uiutit,Plinius. Germania fuibus abundat, maximè inferior, Ad nos ex Bauaria macilentæ feré, ex Bargundia pinguiores adiguntur. Sues Belgici fercces admodum funt, ut dicam in $D$.

Electio. Sues procero corpore, capitibus fint paruis, Varro, Et alibi, Qui fuum gregem uults habere idoneum, eligere oportet primum bona atate, fecundo bona forma. Ea eft, cum excellit am: plitudine membrorum, praterquam pedibus, \& capite, unius coloris potius quàm uarï. Cumbac eadem ut habeant uerres uidendum, tum utiog fint ceruicibus amplis, boni feminis. Stres enim ani. maduertuntur à facie, \& progenie, \& regione coeli. A facie, fi formofi fint uerres $\&$ fcrofa. A progea nie, fi multos porcos pariunt. A regione, fi potius ex his locis, ubi nafcuntur ampli,quàm exiles. In omni genere quadrupedum (inquit Columella)fpecies maris diligenter eligitur, quoniam frequenter patrifimilior eft pregenies quàm matri.Quare etiam in fuillo pecore probandi funt, totius quidem corporis amplitudine eximin, \& qui quadrati potius, quàm qui longi, aut rotundi funt, (rotundi poti us quàm longi, $\mathrm{Pallad}$.) uentre promiffo, clunibus uaftis, nec perinde cruribus aut ungulis proceris,

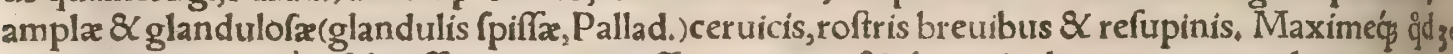
ad rem pertinet, quàm falaciffimos oportet effe mares, qui $\& \mathrm{ab}$ annicula xtate commode progene: rant, dum quadrimatum agant, poffunt tamen etiam femeftres implere forminam. Scrofa proban. tur longiffimi ftatus, $\&$ ut fint reliquis membris fimiles defcriptis uerribus. Si regio frigida $\&$ pruin nofa eft, quàm duriflim $x$ denf $x$ ćp \& nigræ fetæ grex eligendus eft : Si temperata, 2 tç aprica, glabrî pecus, uel etiam piftrinale album poteft pafci. Scrofas (inquit Palladius) longi lateris debemus elia gere, \& quibus ad fuftinendum forturæ onus magnus fe venter effundat, cærera uerribus fimiles, Sed in regionibus frigidis denfi $\mathbb{Q}$ nigri pili, in tepidis qualefcung prouenerint. Eadem ferè de th troos fexu eligendo Florentinus in Geoponicis Gracis prafcribit. Et infuper, Verres (inquit) para

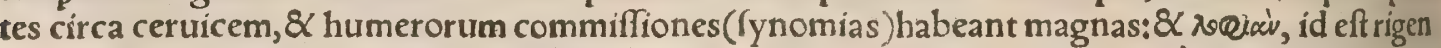
tes in ceruice fetas, condenfam : multum ro rearicoón.

T) Nullum corpus animalis compofitione $\&$ numero, $\&$ c. interiorum partium, tam refpondere humano fertur quàm porcinum. Quamobrem Phyfici interior a humani corporis inueftigantes, por cos diffectos quafi quoddam exemplar infpiciunt, Obfcurus quidam. De porci interiorum ina fpectione Cophonis cuiufdam obfcuri authoris fcriptum extat. Bruta quadam, ut fimia, hominem partibus externis referunt, internis uero nullum animal homini tam fimile quàm porcus, quamob. rem anatomen in eo inftituimus, Author libelli Galeno adfcripti de anatome parua. Prima anato. mes exercitia fieri debent in fue macra, ut uafa omnia melius appareant.

đS Suillis offibus parum medulla ineft, Ariftot, बT Tergus fuis eft quo tegitur, Varro deling. Lat. TSuum pili craffiores funt quàm bubus $\&$ elephantis, quamuis tenuiorem quàm boues \& 5

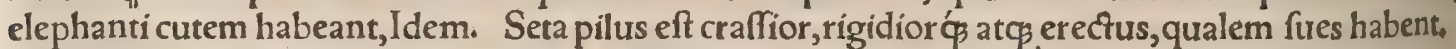
Pilus æreo fimilis agreftibus, cæteris niger,Plinius. A pud nos ruffi feré funt, in Gallia \& Italia nigri, De lardo $\&$ alijs quiburdam partibus, dicam in $\mathrm{F}$. Aruina durum pingue inter cutem $\&$ uifcus, fes cundum Suetonium in libro de Vitrijs corporal, commune(puto)urocabulum ad pinguedinem hur ius loci in fure $\&$ alịs animalibus. Et fpicula lucida tergent Aruina pingui, Vergil.7.Aeneid. Ar* billa, aruina, id eft pinguedo corporis, Feftur. Saham Arabicè, eft adeps concretus circa renes $\&$ o. menturm. Semen uero Arabicé eft pinguedo collecta fub cute $\mathcal{Q}$ inter mufculos, ut apparet in porcis $\$$ arietibus caftratis in Syria: Veneti pinguedinem illam uulgò nominant lardo, Andreas Bellun, Vocant fanélardum Latiné etiam, fed imperitè, recentiores quidam, non in fue folum, fed alịs etiam pinguibus animalibus, ut mele, mure alpino, homine, $\& c_{\text {. Axungia adeps fuillus inueteratus aut }}{ }^{6}$ cum fale, aut fyncerus: Vide plura in $\mathrm{G}$.

TI Agtharfides ait fues in Aethiopia cornutos effe, apud A elianum : Plinius apros in India, 


\section{DeSue. B. Lib. I. 985}

Suis cerebrum pinguiufculum ef, Ariftot. Decrefcente Luna magis eis minuitur quàm ulli anie manti,Obfcurus. đOculifuibus caui profundićp funt, ut fine uritæ periculo eximi non poffint: quare uel alsero tantum priuati, extinguuntur, Obfcurus: Vide inter morbos in c. TQuibus fus percilia nafum uerfus deorfum nutant, ad tempora ueroretrahuntur, ftolidi funt, argumento fuum,

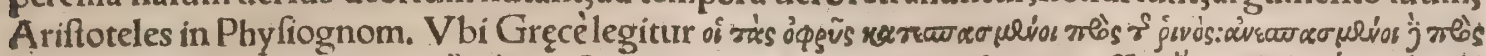
* le

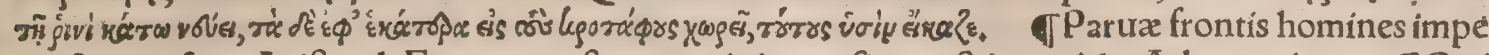
riti funt, ut fues, Ariftotel. Frons angufta non minimum fignũ eft imperitiæ, Adamantius, TQưl

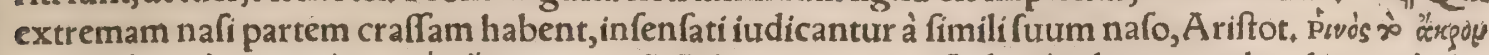

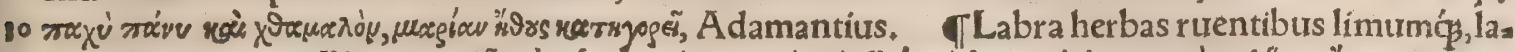

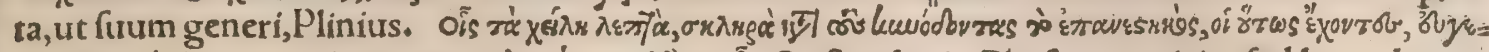

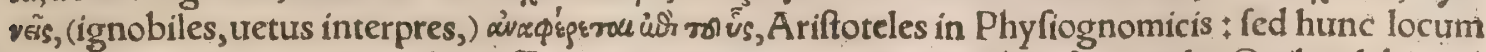
tum deprauatum tum mutilum effe ex Adamantio apparet, curius hac funt uerba:Quibus labia iu:

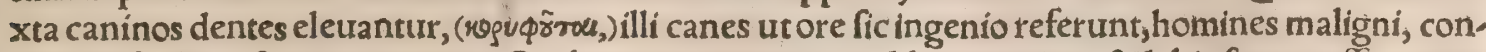
tumeliofi, clamofi, conuriciatores. Quibus uero os totum ualde porrigitur, \& labia funt craffa, rotun da $\&$ foras uerfa, fuis illi mores $\&$ ingenium referunt. $\dot{p} v_{y \chi}^{\prime} \odot$, id eft roftrum Graci de caníbus $\&$ fuibus dicunt. Suis roftrum latum eft, ut facilius infodiat: nam radicum appetens eft, Ariftotel, de partibus. Quxdam roftri latitudo eft apta ad fodienda mollia:nam porci propter radices quas effo diunt, habent os latum anterius:in cuius medio inter nares eft additamentum quafi acutum habens 10 angulum, quo terram fodit \& cauat, Albert. T Dentes exertiapro, hippopotamo, elephanto, Pli= nius. Hippopotamis fuibusá̧ ex inferiore mala dentes prorumpunt exerti, quos yourióobvorus appel lant, Calius: non tamen dentes ipfi fic appellantur:fed ipfa animalia, quibus huiufmodi funt dentes; yeuriódbr za recté dixeris. Aper dentes habet exertos, quibus fures foeminæcarent, Ariftot. Et alibi, Suibus dentes exerti ad auxilium $\&$ robur dati funt, fues autem fominæ mordent, ut qua careant dente exerto, Quemadmodum duobus dentibus apri, fic elephanti armantur, fed fitu contrario: il= lis enim in fublime feruntur, his deorfum retorquentur, Gillius. Exertos apri dentes, Plinius denti um ficas nominat. Suibus foeminis pauciores funt dentes quàm maribus, Ariftot. Suibus dentes nunquam decidunt, Plin. Sus dentes non amittit, A riftot, \& Albert.nullum prorfus amittit, Ariftot . T) soeuav uocamus fetas in ceruice rigentes, Florentin. soQux de fue proprie dicitur, ut iuba de equo - 8 leone, Varin. TQui collo funt nimium craffo, iracundi, improbi $\&$ imperiti habentur, à fuum

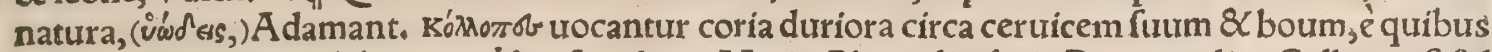
nunc etiam dictos collabos, (wanábrs, ) faciebant, Varín. Plura alicubi in Botre attuli. Collops eft q̊d

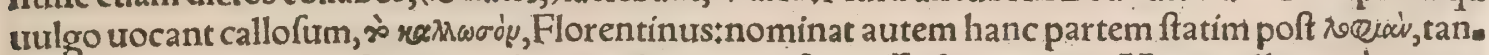
quam proximam: $\&$ in fue eligenda, ut multa(magna $\&$ craffa )fit requirit. Magis calleo quàm aprut gnum callum callet, Plautus Perfa. Grammatici callum interpretantur cutem labore uel opere denfiorem factam, cuiufmodi fit in fuis roltro, ceruice bouis, animalium plantis pedum. TSues quo= niam hebetiore fenfu funt, inarticulatiora corda habent, A. riftot.3.4.de partib. T Genus quoddã ceruorum fel in auribus habere exiftimatur. In auriculis etiam fuis inuenitur humor quidam felli fi: milis, minus tamen liquidus, fed proximus denfitate fua humori fplenis. ब Petimina in humeris

$4^{\circ}$ iumentorum ulcera $\&$ uulgus appellat, $\&$ Lucilius meminit, cum ait: Vt petimen nafo aut lumbos ceruicibus tangat, Eo nomine 8 inter duos armos fuis quod elt, aut pecius appellari folitum teftatur Næurus in defcriptione fuillæ, cum ait:Petimine pifcino qui meruerat, Feft. đPetafo,perna,glan. dium, fumen, abdomen, finciput, clidium, 8 alię quædam fuis partes in cibo commendata, dicentur in F. T Suillus uenter (urentriculus)amplior eft flexuofusćs, ut diutius concoquat, habent autem omnia ferè utrinģ̧ dentata uentriculum aut fuillo aux canino fimilem, Ariftor. Et rurfus, Sui urentri culurs eft amplus, cum paucioribus $8<$ lauibus cruftis. Noftri uentrem ruminantium uocãt budb: fuis uero $8 \mathrm{C}$ aliorum non ruminantium, magen. GIn iocineribus aprorum inueniuntur lapilli, aut duritie lapillis fimiles, candidi, ficuti in uulgari fue,Plin \Spectile, caro quadam exos infra umbilicum:tride in $\mathrm{F}$. TQua numerofo foecunda partu, $\&$ quibus digiti in pedibus, hæc plures so habent mammas toto uentre duplici ordine, ut fues: generofa duodenas, uulgares binis minus: fimi: liter canes, Plinius $\&$ Ariftot. TA A pro teftes non abfoluti funt, Ariftot. Sues habent teftes adne= xos, Plin. \& ad fedem feffiles, Arriftot. Caftorem Softratus fcribit inueniri in defertis Scyt: $*, \&$ te, fticulos habere latos apri inftar, wis rérngr, Scholiaftes Nicandri. Polimenta tefticuli porcorum dicun tur cum caftrantur:à politione ueftimentorum, quòd fimiliter ut illa curantur, Feft. Polimenta porci na Plautus dixit. G Sus foemina, genitale ea continet parte, qua pecoris ubera habentur : \& cum per libidinem turget, ac prurit ad coitum, furfum tantifper hoc retrahit, uertitćp foras, ut inde mari coitus fit facilior+refcifum id longe productius, \& dehifcens amplius eft, Ariftot. Et alibi, Apria(re

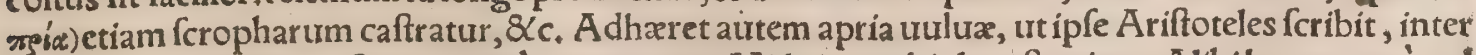
femina, quà maribus teftes maximè continentur. Vide in $\mathrm{E}, \mathrm{ubi}$ de caftratione. Alibi humorem è uul o ua deftillantem poft conceptum, apriam nominat, ut in c.referam. ब Acro 8 longano porci, nomi

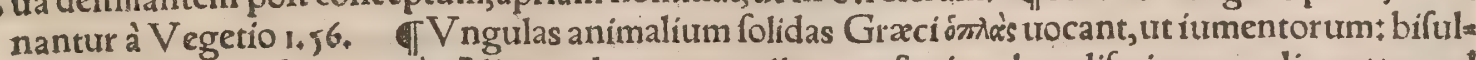

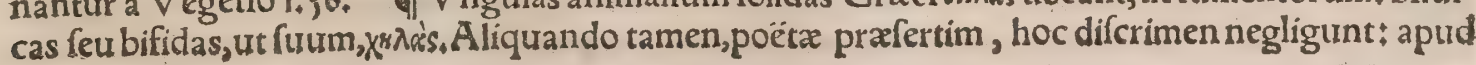




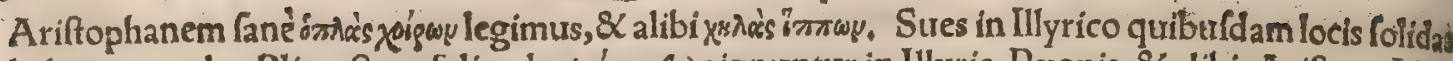

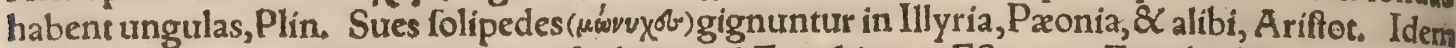
in Mirabilibus, fues folipedes reperiri frribit apud Emathiotas. Eft autem Emathia Macedonia, uel pars eius. Mihi etiam amicus quidam narrauit fues folipedes fua memoria in Anglia repertos. Al bertus eitufmodi in maritimis locis Flandrix reperiri teftatur. TSus talo caret probiore, cum inter folipedes $\&$ bifulcos ambiguus fit, Ariftot. Sues ex utrog genere (folip. \& bifulc.) exiftimãtur: ided foedi corum tali,Plinius. đ Stres intorquent caudam, Plinius. Et alibi, Cauda nudx funt hirtis, ut apris.

c.

If Sus omne unguentum (odoratum, prafertim amaracinum, ) tanquam trenenum fugit $\&$ timet, nam omne unguentư, tefte Lucretio, fetiger ís fubus acre uenenum eft. \& Plurimum dormit, pra, cipue aftate, quum humiditas eius calore refoluitur, Albertus. IVox. Porcelli grunniunt, Ael, Spartianus. Et cum remigibus grunniffe Elpenora porcis, Iutrenalis Sat. 15. Aut grunnitũ, quum itgulatur, furs, Cicero 5. Tufc. Et pifcis qui aper uocatur in Acheloo amne grunnitum habet, Pll nius. Grunnientem afpexi fcrofam, Laberius Sedigito, ut Nonius citat;ficut 8 illud Varronis A. boriginibus, Grunnit lepido laçe fatur mola mactatus porcus, fi recte fic legitur. Veteres aliqui, progrunnire pofverunt uerbum grundire, fi modò proba hxec lectio eft apud Nonium. Grundire (inquit)proprium eft furm, ut Laberius dicit: Grundientem afpexi fcropham. (fed alibi in eodem La berin teftimonio, ut iam recitaui, grunnientem, legitur,) Et Claud.lib.16. Agni grundibant dixit, 8 ;

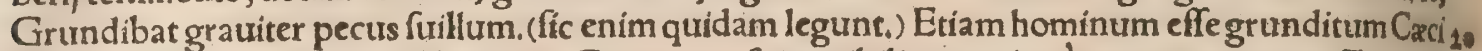
lius Ebrïs defignauit, Hæe Nonius. Grunnitus fui terribilis, præcipuè autem uno percuffocateri grunniunt, 8 quafi condolentes concurrunt, fed ftatim obliti fui plancius, ad lutum uel ad cibumrex deunn, Obfcurus, Grxea uocabula fuper fuis uoce ad Philologiam differo. In Macedonia aprl (fues A elianus) muti effe traduntur, Plinius. Cur fues, cum furfurm uidere coguntur, filent? Quon niam genus id animantium unum femper pronum in terram eft, cibi auidum $\&$ rebus gatudens fers dis ac fordidis, idcirco fubita mutatione confpectus ftupefcit, lucisóg copia perculfum uocem emits rere nullam poteft. Sunt tamen qui afperam huius animalis arteriam comprimi per anguftiam tre: line,cum in fublime erigitur, A phrodifienfis problematum $1+14^{\circ}$. TSus animal eft calidi tempe ramenti, Theophraftus. Cur fues hybernum pilum amittere non folent, cum cateræe quadrus pedes (ut canes $\&$ botres) foleant? An quod furs calidiffimus omnium eft, partíǵ calenti corporis cius $3^{\circ}$ pili adhærent, quippe cum pingue tale effe neceffe fit. Cxteris itaq, uel quia humor refrigefcit, pili defluunt, uel quia furus calor alimentum concoquere non poteft, uel quia bene alimentum conco, quitur, nam etfi quando caufa cur defluant fit, tamen pinguedo uetare poteft, Ariftoteles problem, 10. 23. I Scrofa lac craffiffimum eft, A riftoteles: \& fero reddendo ineptum, ut ouillum quoque, Pinguiffimum eff omnium, ut ad concretionem coagulo non indigeat, ac perquàm modicum feriex. cernat, decoctumćs ocyffime coaguletur. Ideo neç facile feced it, neç uentriculo congrtit, fed natus feam guftantibus excitat, Aếtius 1.8 ;. Scrofx prapingues, penuriam lactis fentiunt.

9 Vichus. Sus minime herbæe frugứmtre appetens eft, fed radicum maxime ex omnibus anima libus, quoniam riciu aptiffimo ad id negocí eff, Axiftoteles. Et alibi, Suis roftrum latum eft ut facis lius infodiat, nam radicum appetens eft. Labra herbas ruentibus limumóǵ lata, ut fuum generi, Plit to nius, Vide fupra in B. TPafcere gregatim pro xtate uelle uidentur, Arift. IGlandes fuautiter quidem à furbus comeduntur, fed carnem humidam faciunt fi folx dantur. \& fi grauida glandem co piofius ederint, abortum faciunt, ut oues:quibus conftantius hoc glandibus efitatis accidit, Ariftor, Nouembri menfe glandis legend a a feruand $x$ cura nos excitet, gitod opus formineis ac puerilibus operis celebrabitur facile more baccarum, Palladius. Italix nemora tantum habent glandium, ut educandis hinc porcorum gregibus maxima ex parte Romanus alatur populus, Authoris nomen non memini. Glans fagea fuem hilarem facit, carnem coetibilem ac leuem $\mathcal{Q}$ utilem ftomacho: illt. gna fuem anguftam, nitidam, ftrigofam, ponderofam:querna diffufam $\&$ grauiffimam, \& ipfa glan: dium $x$ quẻ dulciffima. Proximam huic cerream tradit Nigidius, nec ex alia folidiorem carnem, fed duram. lligna tentari fues, nifi paulatim detur. hanc nouifimam cadere, fung ofam carnem fieri efcu, lo, robore, fubere, Plinius. Et rurfus, Haliphloco inter glandiferas rarò glans, \& cum tulit amara, quam præeter fues nullum attingat animal, ac ne ex quidem fi aliud pabulum habeant. Et alibicum præftantiora quadam caftanearum genera recenfuiffet, fubdit: Cateræe futum pabulo gignũtur, fcrth pulofx corticis intra nucleos quog, ruminatione, (ruminationem hic improprie dixit: neģ enim rus minant fues.) Palmarum frucius hi demum feruantur, qui nafcuntur in falfis atq̧ fabulofis, ut in lus dxa \& Cyrenaica Africa. Nõ item in A egypto, Cypro, Syria, \& Seleucia Affyriax.Quamobrem fues $\&$ religqua animalia ex his faginantur, Plin. Aluntur fues omni cibatu $\&$ radicibus, Plinius. Omnê porrò fitum ruris(inquir Columella) pecus hoc ufurpat, nam $\&$ montibus, \& campis commode pas fcitur, melius tamen paluffribus agris, quàm fitientibus. Nemora funt conuenientiffima, qux ueftib untur quercu, fubere, fago, cerris, ilicibus, oleaftris, tamaricibus, corylis, pomiferisćs sylueftribus, ut to

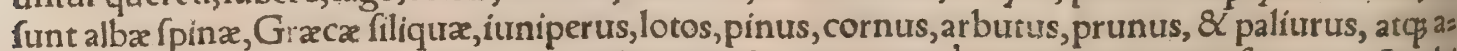
chrades pyri, Hæec enim ditterfis temporibus mitefcunt, ac penè toto anno gregem faturant. At ubi 


\section{DeSuc. C. Lib. I:}

penuria eft arborum, terrenum pabulum confectabimur, \& ficcolimofum praferemus, ut paludem rimentur, effodiantóp lumbricos, atç in luto uolutentur, quod eft huic pecori gratiffimû, quín etiam ut aquis abuti poffint, nang $\&$ id teciffe maxime per $x$ ftatem profuit, $\&$ dulceis eruiffe radiculas aquatilis fylux, tanquam fcirpi iunciớ, \& degeneris arundinis, quam uulgus cannã uocat, nam quidem cultus ager opimas reddit fues, cum eft graminofus, \& pluribus generibus pomorum confitus, ut per anni diuerfa tempora,mala, pruna, pyrum, multiformes nuces, ac ficum prabeat, nec tamen propter hac parcetur horreis : nam fape de manu dandum eft, cum foris deficit pabulum, propter quod plurima glans uel cifternis in aquam, uel fumo tabulatis recondenda eft. Faba quoc;, $\&$ fimi: lium leguminum, cum uilitas permittit, facienda eft poteftas: Et utiq̧̧ uere, dum adhuc lactant (1aa cient, Pallad.) Viridia pabula fuibus plerung nocent: itaç mane priufquam procedant in pafcua, conditiuis cibis fuftinend $x$ funt, ne immaturis herbis citetur aluusł eoćs uitio pecus emacietur, $\mathrm{Ha}_{2}$ ctenus Columella. Genus hoc omnibus locis haberi poteft, melius tamen agris paluftribus quàm ficcis, præcipuè ubi arborum fruçuofarum fylua fuppetit, quæ fubinde maturis fructibus alterna per annum mutatione fuccurrat. Maxime locis graminofis, \& cannarum uel iunci radice nutriuntur. Sed deficientibus alimentis per hyemem, nonnunquam prabenda funt pabula glandis, caftaneę, uel frugum uilia excrementa caterarum, uerno magis cum lactent(uidetur addendum, 8 in cibofu munt, tiel tale quid: Vide paulò ante in fine uerborum Columella) nouella uirentia, qux porcis fo. lent nocere, Pallad. In paftu locus huic pecoriaptus uliginofus, quód delectatur non folum aqua,

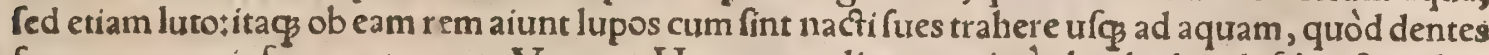
- feruorem carnis ferre nequeant, Varro. Hoc pecus alitur maximè glande, deinde faba, 8 ordeo, \& catero frumento: Qux res non modo pinguitudinem efficiunt, fed etiam carnis iucundum fapo. rem, Varro. Si fundus miniftrat, dari folent uinacea ac fcapi ex uuis, Idem. Fraxini fructu fues pinguefcunt, canes uero dolorem uertebræ coxarum inde fibi contrahunt, Aelian, hoc enim fentire uidetur Gillius interpres cuius obfcura hoc in loco translatio eft. Frutex cytifus ab Ariftomacho Athenienfi miris laudibus prædicatus eft pabulo ouium, aridus uero etiam fuum, Plin. In Salamine fi fus fegetem herbefcentem fuerit depaftus, eius dentes lege Salaminiorum exteruntur, A elian. Tipha grandines tollit, 8 in cibatu utilis eft, A riftot. (Tipham Tragus 2,20, ex coniecfura inter preta tur welf ben weyffen/oder wey/fen Eolben, hoc eft triticum peregrinum, \&c.) Ordeum crudum uer ri coéunti dandum eft:foetis autem fcrofis elixum, Ariftot. Bulbi quoddam genus in Bauaria fuil. - lum uocant, quoniam à fuibus appetitur, flore rubente uel purpureo, fimili floribus lilï conuallium uulgò dicti.defcribitur ab Hier. Trago Tomo 2,ca,79. Appetunt 8 alias radices diuerfas, (ut quas Itali dulcichinos uocant, uicia fylueltris genus quoddam:quod Fuchfius \& Tragus non recté apion Diofcoridis faciunt. Germani appellant eronu ș \& fübzot, hoc eft nucem terræ, \& panem porcinư. quamuis recentiores quidam cyclaminum quog Latine panem porcinum nuncupant, temere ut $p u$ to. licet enim à figura panis dici polfit, à fuibus tamen minimé a ppeti crediderim, quòd nimium medi camentofo \& ingrato fapore, \& animalibus quibufdam uenenum fit.) $\&$ inter alias radicem rapi uel ut uulgó uocant rapunculi fyluatici, quod uiolarum fere folia habet, acutiora, radicem candidam, dulcem, non fine lacte: noftri uocant büd fpick, quòd in nemoribus fagorum ferè nafcacur. Afple:

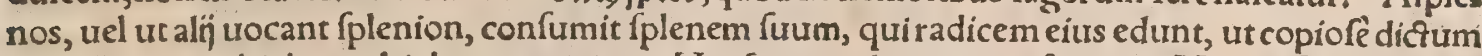
40 eft in Boure c.ubi de morbis boum egimus. Hyolcyamo deuorato infaniunt: Vide infra in Morbis corum. Edit porcus ferè omnes cibos quibus reliqua animalia utuntur, ita quòd ne porci quidem carnibus abttineat, licet non interficiat eum: $Q$ hoc expertus fum, quòd porciauidiffimé ederunt baccones(lardum) \& alias carnes porcinas, Albertus, Scio fues(domefticos) occiforum à latroni. bus hominum cadauera in fyluis relicta aliquando vorare. Suillum pecus tantopere explendo ab: domini deditum eft, ut ne proprijs quidem fuis fortibus parcat, neq helluationem fuam ab humano corpore abftineat, Aelianus. Sues comeffe foetus non eft prodigium, Plin. Illud autem, quod per, tinet ad religionem patrisfamiliâs, non reticendum putaui: funt quadam fcrof $x$, quæ mandunt fox: tus fuos:quod cum fit, non habetur prodigium:nam fues ex omnibus pecudibus impatientiffimæ fa mis funt, ita ut aliquando fi indigeant pabuli, non tanturm alienam(filiceat) robolem, fed etiam fuam 5o confumant, Columella. Audio fané fcrofas quafdam natura fua tam improbas effe, ut fuos ipfę por cellos deuorare foleant, non aliter quàm gallinæ quædam qux pepererint oua. Sues torant lima= ces, Ariftot. Sui ferpens aduerfatur, quia deuoratur ab ea, Idem. Talis $\&$ tanta uis ueneni(falaman dra)à fuibus manditur, Plin. Et alibi, A pros in Pamphylia \& Cilicię monturofis, falamandra ab his de uorata, qui edêre moriuntur:nec eft intellectus ullus in odore uel fapore. Si quando falamandrã CO. mederit fus,ipfe extra periculum eft Cum cicutam homo biberit, ei fanguis quafi conglaciat, \& eatenus concretione fpiffus fit, ut inde moriatur. Suillum uero pecus, huius faturitate fe licet compleuerit, tantum abeft eius ueneno tolla. tur, hac ut maxime pinguefcat, A elian,Sturnos etiam cicuta nutririlegimus. Circa Scytharum $\&$ Medorum dicf $m$ Thraciæ regionem, locus eft uiginti ferè ftadiorum fpacio, qui hordeum producit 6. quo homines uefcuntur, equi uero $\&$ boues \& cætera animalia abftinent: imó fues etiam $\&$ canes excrementa hominum qui mazam aut panem ex hordeo illo comederint, aurerfantur, tanquam mor tis periculo, Ariftoteles in Mirabilib. Solent noftri carnem quam fumo indurare uoluerint, dies 
aliquot copiofo fale afperfam in uafe aliquo relinquere: in ctius fundo partim liquefcente fale, par. tim Taniem remittente carne, ius colligitur, cuius guftu gallinaceum genus mori putant aliqui: fuib, etiam nocere, fi copiofius cis detur, quamobrem modicum ad reliquam potionem affundêt. crebrò potum defyderat, aftate potiffimum, Florentin. Scrofa bis die ut bibant, curant, lactis caufa, Varro. Cum omni quadrupedi per $x$ ftatem fitis fit infefta, tum fuillo maxime eft inimica, quare non ut capellam,uel ouem, fic $\&$ hoc animal bis ad aquam duci pracipimus; fed, fi fieri poreft, iuxta flumen, aut ftagnum per ortum canicula detineri, quia cum fit aftuofiflimum, non eft contentum potione aqua, nifi obefam illutiem, atç, diftentam pabulis aluum demerferit ac refrigerarit:nec ul, la remagis gaudet, quàm riuis atog coenofo lacu uolutari. Quod fi locorum fitus repugnat, ne ita fie ri poffit, puteis extracta $\&$ large canalibus immiffa præbenda funt pocula, quibus nifiaffatim fatien I tur, pulmonarix fiunt, Columella. Suillum pecus in luto fe uolutans \& aquam turbidam bibens pinguefcere audio, Aclian. Sues inebriantur uinaceis faturati, A thenæus. Item fæce uini in colluui em eorum mixta. T Plerif $\beta$ animalium eft pinguitudo fine fenfu quam caufam fues fpirantes a muribus tradunt arrofas, Quin et L. A proní confularis uiri filio detracłos adipes, leuatumós corpus immobili onere,Plin. Vere fus uf $\not \beta$ adeo pinguítudine crefcere folet, ut fe ipfa ftans fuftinere non poffit, necs progredi ufquam:itaç eas fiquis quò traïcere uelit, in ploftrum imponit. In Hifpania ul teriore in Lufitania cum fus effet occifus, A ttilius Hifpanienfis minime mẽdax, \& multarum rerum perítus in doctrina dicebat, Lucio Volumnio fenatori miffam offulam cum duabus coltis quæ pen: deret III.\& XX.pondo, eiusḉ fuis à cute ad os pedem $\$ \&$ III.digitos fuiffe. Cur ego:Non minus res admiranda, quàm qux nunc eft dicta, in Ârcadia fcio effe fpectatam fuem, quax pra pinguitudine 10 carnis non modofurgere non poffet, fed etiam ut in eius corpore forex exefa carne nidum fecifet, 8 peperiffet mures, Hoc etiam in iutuenca factum accepi, Varro. Crefcentienfis ex eodem fic ha. bet, In Lufitania fertur fus effe occifus, qui fuit xiij. pondo, id eft quingentis feptuaginta quing lis brisieiusć fuis à cute ad os pedem $\&$ tres digitos fuiffe, id eft lardum cum carne uno pede $\&$ tribus digitis craffum. Audio etiam noftra memoria Bafilex porcum ab oleario (fic uoco illum qui oleum Riuglandibus exprimit) faginatum, pinguitudine tantum profeciffe, ut excauata à múribus foramlis na in corpore eius reperta fint. Pinguefcunt fexaginta diebus, fed magis tridui inedia faginationê orfa, Plin. Sex diebus fenfibiliter pinguefcit, Albert. legendum fexaginta, non fex, cum Plinio \& Ariftotele. Nam $\&$ noftri tribus ferè menfibus ful faginando opus effe aiunt. Angli aliquandoper integrum annum faginant porcum, curius pingue folidius \& lautius fieri uoluerint, ut dicam in $F_{0}, 3^{\circ}$ Sus facillime omnium ad quoduis pabulum affuefcit, \& celerrime quoç in pinguedinem proficit, profui corporis magnitudine: fexaginta enim diebus pinguefcit:quantû autem profecerit, î̉ cogno: fcunt, quibus ea res curæe eft, ubi ieiunium ad faginam conftituerint . pinguefcit fame prafatigatus triduo. \& catera quo $\not 3$ omnia ferè melius prafatigata fame pinguefcunt; faginant à triduo iam qư fues obefant. Thraces per faginam, cum primo die potum prabuerint, poft interpofito uno dic pra: bent, tum duobus, deinde triduo, atç ita fubinde augendo numerum ufos in feptimum, curant, Ari frot. Noftri haccirca potum non ita obferuant; fed poft cibos quofdam, ut fabas \& pifa, potum eis tha tilem effe putant:poft auenam non item, ne liquidior reddita mox per aluum dilabatur. Pinguefcit hoc animal hordeo, milio, ficu, glande, piro, cucumere. Sed maxime tum hoc, tum cętera, quibus uen ter calidus eft, quiete, immotioné́ $\$$ pinguefcunt: caterum fues pinguiores redduntur, etiam cum in $4^{\circ}$ luto fe uolutant, Ariftot. Et rurfus, Sed pracipuéalunt $\&$ opimant ficus $\&$ cicer : cibus deniq non fimplex, fed uarius fagina optima eft.gaudent enim fues pabuli mutatione, quemadmodum \& cate ra animalia:tum etiam fieri aiunt cibi uarietate, ut partim infletur, partim impleatur carne, partim os pimetur. Intelligo fuillum pecus fefe in luto uolutans, ac turbidam aquam bibens, cum pingue eua, dere,tum cibis qui uehementer inflent $\&$ expleant, delectaritum etiam quietem $\&$ fuile tenebris oppletum appetere, A elian. Porcos aliqui farina éfabis faginant, ut in Elfatia Germanix : multum enim et citó inde proficit pecus;al'í(puto)farina hordeacea cum lacte à quo butyrum extractum eft. Sures in alpibus qui fero lactis faginantur, carnem meliorem $\&$ albiorem habent ut audio, quàm qui glandibus pafcuntur. Sed eft quando nimium repleti fero, $\&<$ uentre diftenti periclitantur, nifi mox aluus fluat, î prafertim porci qui ita pafci non fuerint affueti. Nutritur hoc animal præciptue glans yo dibus, faginaturós triticeo furfure, areaćs reiectamentis, ac deniç ipfo frumento: hordeum autem prater hoc quod pinguefacit, etiam ut partus facilis fit ipfum animal reddit optimé perfpirabile, Flo

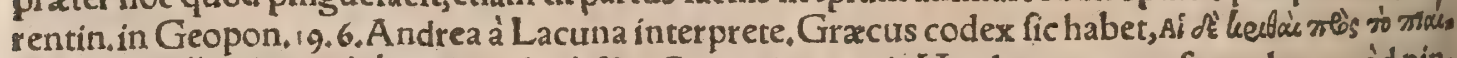

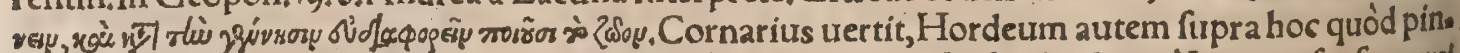
guefacit, etiam ad generationem indifferens animal facit,nullo fenfu. Andreas à Lacuna fenfum quil dem aliquem exprimic, fed ineptum:neqz enim faginantur fues ut facilius pariant, cum contrarium potius accidat, 2 lactis etiam penuria laborent qua pinguiores funt, Ego pro grirrouy lego zoliay, hoc eft guftum \& faporem: hoc fenfu, Saginatos hordeo fues, non folum pingues, fed etiam melioris faa

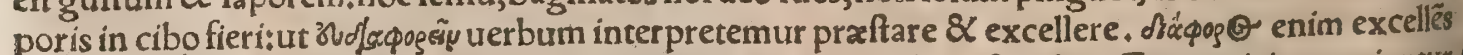
eft:nec refert non ufitatum effe hoc uerbum, cum non pauca huiufmodi in Geoponicis reperiantur 6 urpote à recentioribus Græcis confcripta aut certe collecta. Confirmat fententiam noftram Varro, his uerbis: Hoc pecus alitur maximé glande, deinde faba $\&$ ordeo, $\&$ cxtero frumento: qux res non 


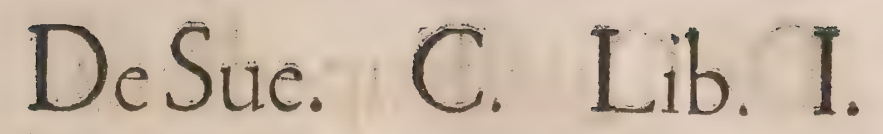

modo pinguitudinem efficiunt, fed etiam carnis iucundum faporem, In régioniburs qửe cèreưfín bibunt, hordeo pro cereuifia coquenda macerato in aqua, optimé faginantur. Noftri auenam, fecale; 8 glandes eis obijciunt. Piftores ac molitores furfure pafcunt. Tum piftores fcrofipafci qui alût fur fure fues, Plaut. Capt, Olearị reliquïjs fuglandium expreffo ab eis oleo maximé pingues reddunt.

Non aliunde magis quàm loti paluftris radice fues craffefcunt, Plin. Et alibi, Filicis utriufas radice fues pinguefcunt, Reliqui ad faginationem pertinentes cibi, dicti funt fuperius inter cibos fimplis citer. Scrofa nimium pinguis parum lactis habet, $\&$ porcellos alere non potelt. Tam futes, quàm catera animalia omnia folent, cum lactantur, extenuari, Ariftot. Sexta pars ponderis quantü pon; derârít uiuus(fus faginatus) abfurmitur occifo in pilos, fanguinem, \& reliqua id genus, (excremêta,) - Ariftot. M.Varro principatum dat ad agros latificandos turdorum fimo ex auiarís:quod etiam pa bulo boum fưmós magnificat, neq̧ alio cibo celerius pinguefcere affeuerat,Plin. Sus in regionib. calidis propter uifcofi motum humidi, maior 8 obefior euadit quàm in frigidis, Albert. Frifí qui maritimam Germanix oram habitant, boues \& porcos uno eodem prafepe ligato hordeum cum fuis folliculis fiue glumis prabent.id bos dentibus non comminuens, deglutit; \& ex molliore tantum eius parte, qux emolliri in uentriculo eius potuit, nutrimentum ca= pit'reliquum cum ftercore reddit.Porcus igitur caudx bouis alligatus, ut aiunt, hordei grana cum ftercore emiffa mandit atक̧ pinguefcit, Albert. Sues utriufo̧̧ fexus caftrati, celerius pinguefcunt, De caftratione uero eorum cap.quinto dicam.

IIn litto uolutatio fuillo generígrata,Plin. Hac corum requies eft, ut lauatio homini, Varro. Sus nulla re mágis gaudet quàm riuis at taui ex Colum. Volutatione in luto pinguefcit, Arift. Ephefius Heraclitus ait fues cœno, cohorta les aues puluere uel cinere lauari, Columel. Cur ftercoribus fures gaudeant + Medici rationem red= dunr, quòd iecur habeant maximum, qux quidem fedes cupiditatis fiue libidinis eft. Ariftoteles ue= ro quoniam naribus craffis interceptisćs fint, idcirco uim hebetem olfaciendi habere, itaç, foctorem

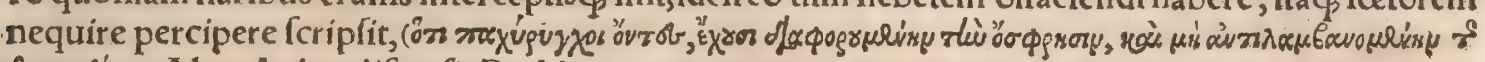
ofvoadias, Alex. Aphrodifienfis Problem, 1, 36 .

\$Mares non ultra trimatum generant,Plin. A pro ad triennium probitaś coéundi edurat:uetư fioribus proles deterior gignitur:nullus enim praterea profectus ei accedit, nulla uirium recreatio: folet inire pabulo fatiatus, \& cum alteram non fubegerit, uel initus breuior agitur, \& foètus corpore - minore creatur, Arift. Verres octo menfium incipit faltre, permanetóg ut id recrè facere polfit, uf́ç ad quartum annum, deinde caftratur, faginaturéc quoad perueniat ad lanium, Varro. Ad foeturã uerres duobus menfibus ante fecernendi. Prodeft apro coéunti hordeum apponere pabulo: quod idem $\&$ frofx foet commodum eft, fed elixum, Arrfor. Verres unicus fufficit uel decem fuibus implendis, Florentin. Verrem fubantis audita uoce, nifi admirtatur, cibum non capere aiunt, ufos in maciem, Plin. Homerus non ignorans ut fus uidens foeminam fefe extenuet, 8 carnes atterat, fa cit mares feparatim à foeminis cubarè, A elian. Locus Homeri eft Odyf.̧.circa initium. Verres pro pter copiofum humorem multum ac diu coit, quoniam calidus non ef, Alber. Maribus in coitir plu rima eft afperitas:tunc inter fe dimicant indurantes attritu arborum coftas, Text. de fuibus fimplici ter : cum Plinij de feris tantum fuibus hæc uerba fint. Equos \& canes \& fues initum matutinũ ap= - petere, foeminas autem poft meridiem blandiri, diligentiores tradunt, Plin. Mas fi pinguet, inire $0=$ mnibus anni temporiburs potef, nec folum interdiu, fed etiam nocfu, aut certe matutino potiffimum tempore:fenefcens autem minus fubinde agit, ut dichum eft:fæpe qui uel per ætatem, uel per infirmi tatem fua naturæ nequeant expedite coire, quum fomina impotens fuftinendi maris feffa clunes de mittat, cubantes unà cum focmina coêunt, A riftot. Fominæ fenectute feffær cubantes coéunt; Plin. Alegyptĭ fuem ( Plutarch,in lib, de lfide. Sues fæpius coéunt pariuntós propter teporem $\&$ pabuli ubertatem, ut alia etiam animalia quæ cum homine uiuunt, $A$ rif. Sues agreftes femel(anno)ccéunt, domeftici fæpe: nimirum propter pabulum, calorem atç laborem:quippe cum Venus comes fatietatis fit, etc. Arift. problem,10.46. Plutarchus etiam caufarum naturalium quaftione 21, inquirit cur fcropha fiue do mefticæ porcæ, \& fæpius, \& alīs atç alịjs anni partibus fœtæ fint, cum fues feræ omnes $\&$ femel tan tum quotannis, $\&$ propè circa idem tempus, nimirum cum æeftas appropinquat, pariant: Vnde apud

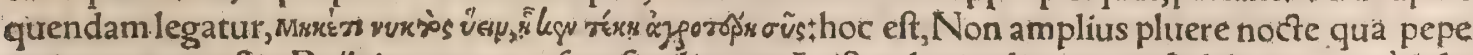
rerit porca agreftis, Reịcit autem caufam fimiliter ut Ariftoteles in alimentum \& laborem. quòd do mefticis alimentum abunde femper fuppetat, nec ut feræ id inquirere, ac fape fibi metuer e cogătur: red neç adeó laborent, cum à fubulcis parum feparentur:agreftes uero paffim per montes uagêtur, unde nutrimentum omne in corpus confumitur. A ut forte, inquit, domeftici cum fubinde contrer Ientur $\$$ gregatim degant, ex ipfa confuetudine magis ad libidinem ferũturłagreftes uero cum mas res à foeminis feparentur, tardos $\&$ hebetes ad uenerem motus habent. Aut urerum etiam illud elt quod Ariftoteles dicit, chlunen ab Homero nominari fuem monorchin, id elt unius tefticuli, quoniä pleríf, ex affrictu ad truncos, teftes atterantur, Sus animal cur fit multiparum, in fequentibus ex. plicabo. Sues turm mares, tum formina coire incipiunt menfe fuæ ætatis octauo : quanquam mas antequam fit anniculus, prolem generat uitiofam:formina annicula parit: fic enim tempus gerendi 
uteri exigit, Sed non omnibus locis eadem $x$ tatis ratio eft, ut dixi:iam enim fues, nonnufquam temi mares quàm foeminæ quarto coéunt menfe $₫$ fexto tamen ita, ut uel progenerare $\&$ educare poffint: nonnufquam apri menfe decimo inire incipiunt. Valent ris admiffura à fauonio ad zequinociumuernum, Plinius $\&$ Varro:hoc eft, à calendis Februarijs ad duodecimum diem Martï, Crefcentienfis. Ita enim contingit, ut feropha xftate pariat : quatuo: enim menfes eft prxgnans: $8 \alpha$ tunc parit, cum pabulo abundat terra, Varro \& Florentin, Vbi au tem fues concepiffe apparet, feparant ab eis uerres, ut qui eas inuadentes $\&$ deturbantes, abortireco gant, Florentin. Aetatis oclato menfe(porca) coëunt: quibufdam in locis etiam à quarto ad fepth mum annum, Plin. Februario menfe uerres maximé foeminas debent inire, Pallad. Foeminafus habetur ad partus ædendos idonea feré ufqs in annos feptem, qux quanto focundior eft celerius fe nefcit. Annicula non improbè concipit, fed iniri debet menfe Februario, Columella $\&$ Pallad. Non minores admitcendx quàm annicula. Melius uiginti menfes expecfare, ut bimæ pariant. Cum expe rint, id facere dicuntur uf $\beta$ a d feptimum annum recté. Ad dmiffuras cum faciunt, prodigunt in luto fos limites ac luftra, ut uolutentur in luto, quod eft illarum requies, ut lauatio homini. Cum omnes conceperunt, rurfus fegregant uerres, Varro. Audio fcrofas apud nos per annos circiter ocio pare re. Sus ubi quintumdecimum annum nacia eft, non praterea generat, fed efferatur. Si pinguet, $\infty$ cyus $\&$ iuuenis $\&$ fenefcens mouetur ad coitum, Ariftoteles. Scrofa poft quindecim annos non pariet, nifi admodum carnofa $\&$ bene nutrita fuerit, Albertus,

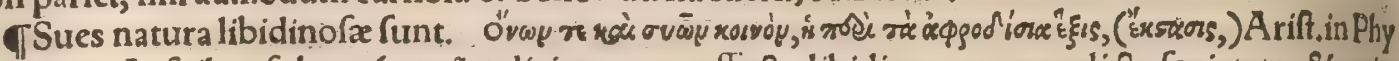

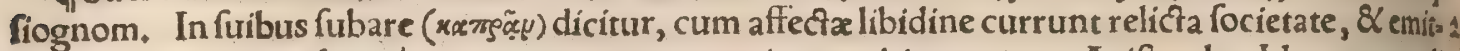
tunt id quod a priam (xosjgixu) uocant, ut equar nominatum hippomanes, Ariftoteles. Idem tamen ali

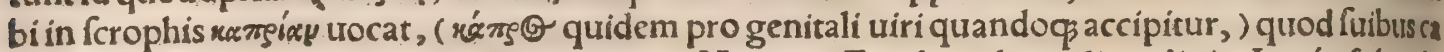
frandis excinditur, ut pluribus dicam in $\mathrm{E}$. Horatius Epod.12, de muliere dixit, Iamó fubando Tenta cubilia, tećtá̧́ rumpit. Hinc $\&$ fubatio nomen apud Plinium. Suum libido ardentifima,ita ut opprobrium mulieribus inde tractum fit cum fubare \& fubire dicuntur, Feftus. Sic de equabis,

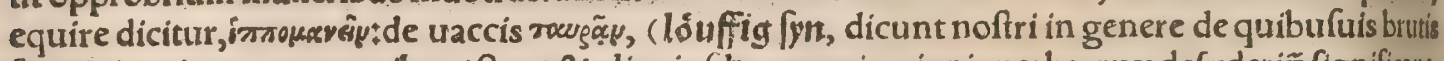
farminis coitum appetentibus.) Sunt $\&$ alia ciufdem terminationis uerba quæ defyderiũ fignificant,

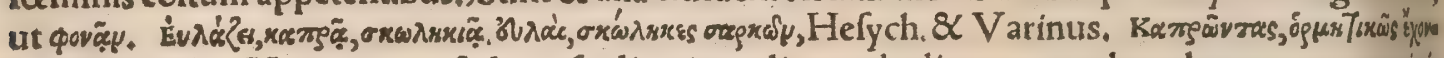
Tes $\pi$ b's ouwroixp, Varinus, quafi de mafculis etiam aliquando dicatur, quod ego legere non memini: \& fi fortè de maribus reperiatur, accipietur certé improprie. xamgãe proprie dicitur de porca terrẽ 3

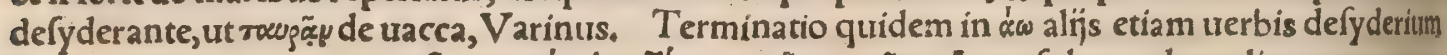

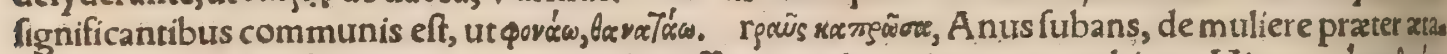
tem libidinofa. Erafmus non recte uertic hirciffans, ut docui inter prouerbia ex Hirco. Á $q$ pod inizy

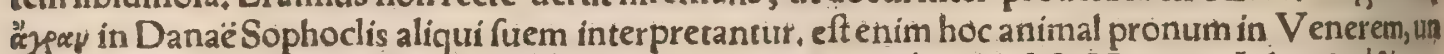

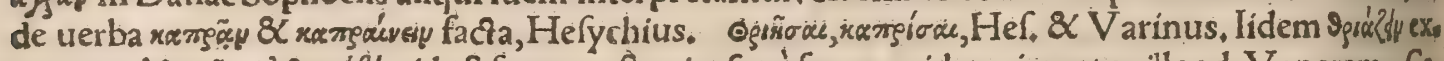

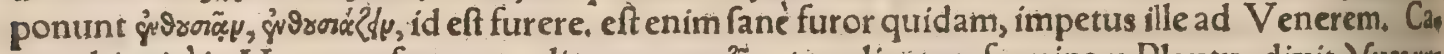

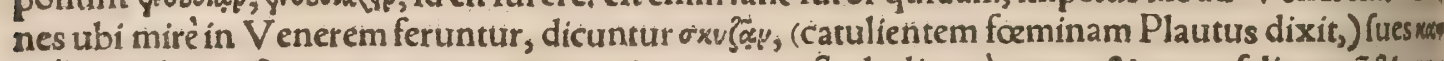
mgíl\{u, Calius. Si mas propter ætatem coire non poteít, declínat à porca, \& porca falit marē $\&$ pro: uocat eum, Albertus. Sues foemina cum libidine excitantur, quod fubare dicitur, uel homines aga grediuntur, Ariftoteles. Fœminas fubantes in tantum efferari aiunt, ut hominem lacerent, candi 49 da maximè uefte indutum, rabies ea aceto mitigatur natura afperfo, Plinius. Quadrupedum pran gnantes Venerem arcent, prater equam \& fuem, Plinius. Ariftoteles uero, Sola animalium muliex \& equa grauida coitum patiuntur. IImplentur fues uno coitu, qui geminatur propter facilita tem abortiendi (Eadem feré paulò poft ex. A riftotele recitabo:) remedium, ne prima fubatione, nę ante flaccidas aures coitus fiat, Plinitus. Cauendum ne prima fubatione ante aures flaccidas coitur fiat, fruftra etenim fuerit. At fí plena iam auiditate ac defiderio libidinis turgido admiffura fiat, unus (ut modo dixi) initus fatis fit, A riftot. Etrurfus, Concipit pracipue fus, cum pra libidine geftiente pruriens auriculas flaccidas demittit : aliter femen à uulua refpuitur, relapfumós euanefcit, Sunte frofis aliæ ftatim prolis foecund $x$ laudabilis, aliæ increfcentes melius generẳ, Idem. Sues tantum coitu fpumam ore fundere diligentiores tradãt, Plinius. Suibus propria funt uocès ad Veneretum coitum, Ariftot. Scrofa nifi conceperit, iterum \& íterum coire quarrit, Albertus, Sues cicures uic xum feruntmenfes quatuor, Ariftoteles, Plinius, Varro, \& alij. Iniri debet menfe Febrtuario, Quaı tuor quo $\$$ menfibus fota, quinto parere, cum iam herbæ folidiores funt, ut $\&$ firma lactis maturita porcis contingat, \& cum defierint uberibus ali, ftipula paf́cantur, cateris $\not$ leg luminum caducis frú gibus. Hoc autem fit longinquis regionibus, ubi nihil nifi fubmittere expedit. Nam fuburbanis lai ćtens porcus are mutandus eft: fic enim mater non educando, labori fubtrahitur, celeritusćs iterum conceptũ partû edet. Id’á̧ bis anno faciet, Columel. Quarto exempto mêfe pariunt, ubi quintus incia piet. Incipiunt autem, ficut dixi, menfe Februario, ut folidioribus herbis nati, \& ftipula fuccedente pafcantur, Palladius, Partus bis anno,Plinius. Fomina in partu afperiores, Textor: fed Plinits deferis tantum fuibus hoc feribit. Natura diuifus eft fcrof $x$ annus bifariam, quôd bis parit in ans 6 no:quaternis menfibus fert uentrem, binis nutricat, Varro. Bifulca, pauca generant, praterquam fues, Ariftot, Senefcentes etiam pariunt quidem fimili modo, fed tardius coëunt, implentur uno coî 


\section{DeSue. C. Lib. I.}

tu. fapius tamen fuperuentum patiuntur, ea de caufa, quod pof coitum humorem, quam apriam nonnulli appellant, emittunt; quod quidem commune omnibus incidit, fed aliqux unà cum loc fe. men etiam admiffum eijciunt, Ariftot. Ex omnibus qua perféctos fortus, fues tantum $8 \mathrm{x}$ numero. fos adunt: item plures, contra naturam folidipedum aut bifulcorum, Plin. Sola inter multipara ifus parit perfectos, eaćs una euariat, generat enim multos more multifidi generis, cum $\&$ bifulcum \& folipes fit, funt enim locis quibufdam fures folida ungula, partu igitur numerola eft : quioniam ali. mentum quod in corporis magnitudinem abfumeretur, in excrementum feminale decedit. Id enim ut folipes magnitudine caret, (id eft, ipfa fcropha, quamuis folipes fit, magnitudine caret, \& fic non indiget multo alimento, Niphus.) quin \& potius quafi ambigens cum natura folipedum 3 bifulcum

to eft. hac igitur caufa $\&$ unum parit, $\&$ duos, $\&$ quod plurimum, multos, enutrit uerò ufa̧ in fine qua peperit, propter fui corporis alimoniam probam, habet enint ut folum pingue fuis ftirpibus: fic fcrofa filịs alimentum copiofum $\&$ commodum, Ariftot, de generat,anim.4. 6. Et alibi, Numerus partus plurimum ad uicenos.fi tamen multos pepererint, educare omnes non queunt. Numerus forcunditatis ad uicenos: fed educare tam multos nequeunt, Plinius. A pud nos ut plurimum circiter fedé ; cim parere audio, fed rarò, fape octonos uel denos. Sue quòd ad uefcendum hominibus àpta fit, ni hil genuit natura fœcundius, Gillius. Sus ad foturam quàm fit foccunda, animaduertunt ferè ex primo partu, quod non multum in reliquis mutat, Varro. Pauciftima fus adit prima partione, uii. get fecunda, nec fenefcens copia foetus deficitur, quanquam lentius coit, Ariftot. Penuriam lactis prapingues fentiunt, \& primo foctu minus funt numerofx, Plin. Parere tot oportet porcos quot 20 mammas habeat, (habent quidem denas pleræç, ad fummum duodenas;) fi minus pariat, fructuari am idoneam non effe:fi plures pariat, effe portentum, (exiftimandum eft.) In quo illud antiquifi: mum fuiffe fcribitur, quòd fus Aenea Lauini triginta porcos peperit albos: itaç quod portenderit factũ, triginta annis ut Lauinienfes conderent oppidũ Albâ, Var. Sola ex omni calidorû̉ genere ca nis $\&$ fus, partu numerofo notantur, Theophraftus de cauf, 1.27. Cur quouis anni tempore $\&$ feppius fues manfueta coëant, ac pariant non certo tempore, (bis anno, agreftes uero femel tantum 8 f fta to tempore, ex Plutarcho \& Ariftotele in pracedentibus docui. Sus, canis, lepus, partu funt numero fo:nimirum quòd uuluas fiue uteros continent multos, totidemćs formandi loculamenta, Ariftotel. Problem.10.16. Cur fus \& canis fint tam foecunda $\&$ multipar $x$, Democritus caufam affert, quòd multiplicem uuluam \& feminis cellas receptatrices multas habeant;eas omnes femen non uno ini: - tu explet, (Atqui Ariftoteles \& Plinius tum canes tum fues uno coitu impleri fcribunt: ) fed iterum \& fapius ea profeminantur, ut frequentia feminis receptacula impleantur, Aelian. Scropha foe= cundior alba, luuenal. Citatur ab Erafmo in prouerbio Regia uaccula, quod olim de prodigiofa fo. cunditate ferebatur: quòd atate Ptolemai iunioris uacca quædam codem partu fex adidiflet uitu. los. Cur parua quadam quadrupedes, ut canes, fues, capra, oues monftra frequentius pariunt quàm grandes? An quòd parux longè foecundiores funt: monftra autem tum confici folent, cum plura femina inter fefe cohærefcunt $\&$ confunduntur, \&c. Ariftot, Problem, 10.60. बf Fotus qui in uterolafus minutusó̧ fuerit, metachorum dicitur(quafi pofthumum uoces, inquit Gaza : mihi non placet.) quod in parte qualibet uulux accidere poteft, Ariftotel. Focundioribus (multiparis) animalibus, atç etiam magis multifídis, (ut canibus,) frpius accidit monftra parere : nam cum alio. - qui feré imperfectos ædant, (ut canis cæcos:) facilius ad monttrificam partionem delabuntur, (ut ca: præe etiam $\&$ oues:) $\&$ in ijs potiffimum etiam qux metachœra appellantur confiftunt: qux aliquate nus labe monftrifica funt affeça:nam deeffe aut fupereffe quicquam monftrofum $\&$ prater naturã eft, Ariftot de generat, anim. 4.4. Videri autem poffet hoc ex loco Ariftoleles metachocon uocare fotum, non fuis tantum, fed cuíuf̧̧ animantis in utero lafum minutumós: quoniam nulla hic fuis mentio. Ego locum hunc mutilum effe crediderim, $\&$ fuis mentionem addendam : quemadmodum in problematibus etiam 10.60, ubi eiufdem argumenti quaftio tractatur, $\&$ eadem a nimalia multipa ra nominantur, (canis, ouis, capra,) fus quoq̧ nominatur, quamuis fine metachori mentione. Certe uocabulum ipfum, à chœero, id eft porco compofitum, de eo tantum, non item alịs animalibus, recte accipi indicio eft, Et Ariftotelis uerba qua fuperius recitaui ex hiftor anim. 6.18, ita pofita funt, ut de so fue priuatim in pracedentibus fimul $\&$ fequentibus agatur. Et eiufdem libri cap. 24. Ginni, inquit, ex equa prodeunt, cum in gerendo utero agrotauit, more pumilionum in ordine hominum, aut por

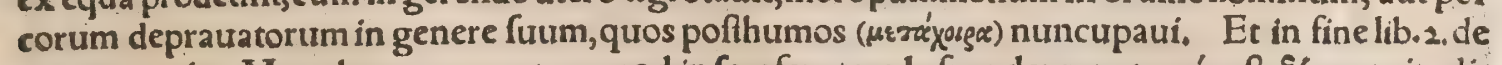
generat, anim. Metachœrum uocatur, quod in fcrof xutero lafum deprauatumóg, eft, \& magnitudi: ne imminutum, quafi aporcellum dixerisłidóp cuilibet fcrofá accidere poteft: fic à mulis ginni gene rantur. Vertit autem Gaza aporcellum, nimirum quòd a. priuatiuum apud Græcos aliquando mi.

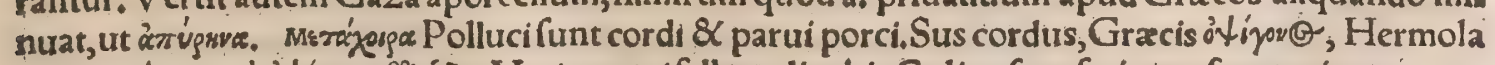

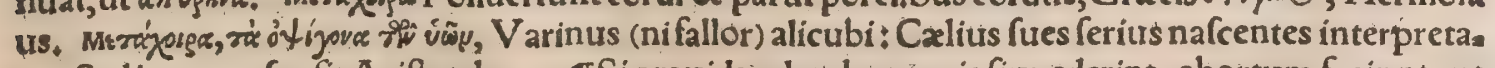
tur.Sed hoc non fenfit Ariftoteles. đSi grauida glandem copiofius ederint, abortum faciunt, us oues: quibus conftantius hoc glandibus efitatis accidit, Ariftot. Si grauida admodum pinguefcat,

6. efficitur, ut foeta minus habeat lactis. Proles, quod ad atatem attinet, optima eft, cum uigent paren= tes:quod ad tempora, praftantior quæ hyemis initio gignitur : deterrima, quæ æeftate: quippe qua parua, exilis, \& perhumida fit, Ariftoteles, \& Albertus, Porciqui nati funt hyeme, fiunt exiles 
propter frigorà, \& quòd matres eos afpernantur, propter exiguitatem lacfis, \& quòd dentiburs fati-

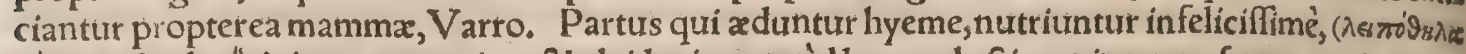
jivยrou, $) \&<$ ob aéris intemperantiam, $\&$ ob id etiam, quòd largam lactis copiam non fugant, nimirum matrìibus ipfis cos tunc abigentibus, quòd mamma laborantes penuria lactis, attrita inter dentes ex ulcerentur, Florentin. Noftri praferunt porcellos Martio natos, (Poctgling, ) aut falten uno uel altero menfe prius. In calidis regionibus melior eft foetus porcæ hyemalis quàm aftiuus, in frigidis autem contra, Liber de nat,rerum, Diebus decem circa brumam ftatim dentatos nafci, Nigidius tradit, Plin. Sues $\&$ canes poft partum fauire folent;nimirum quia extenuantur, ratione inedix, $\&$ integra eis materia fecernitur ${ }^{*}$ non excrementa folum ut oubus $\&$ mulieribus, Ariftot.problem, 10. 37. Cum ferofa peperit, primam mammam porco qui primus in lucem prodït, prabet, Ariftot. Et io rurfus, Porcis æditis primis, mammas præbent primas. hę enim mammæ plurimum lactis obtinent. Primis genitis in quo $\$$ partu fues, primas prabent mammas. Ex funt faucibus proxima:tamen(ali. âs ut, forte, \&) fuam quifíg nouit in foetu quo genitus eft ordine, (quod lo. Tzetzes quọs frribit:) ea ́́s alitur, nec alia, detracto illa alumno fuo, fterilefcit ilico ac refilit. Vno uero ex omni turba relis cfo, fola munifex, qua genito fuerat attributa, defcendit, Plin. De fanitate furum unum modo exem pli caufa dicam: Porcis lactentibus fi frofælac non poteft fuppeditare, triticum frictum dare opor: tet, (crudum enim foluit aluum, )uel crdcum obíci ex aqua, quoad fiant trimeftres, Varro. Scrofam in fua quanç hara fuos alere oportet porcos: Vide infra cap.quinto, Curabit autem ut foctus pro. prios cum unaquaqs procludat. Plus uero quàm ocfo(ficut Columella dicit)nutrire non debet.Mihi trero utilius probatur exper to, porcam cui pabula fuppetunt, ut plurimum fex nutrire debere, quia 10 licet plures poffit educare, tamen frequentiore numero fucta deficiet, Pallad. Nutricare ocionos porcos paruulos primó poffunt, incremento facto à peritis dimidia pars remoueri folet quód nequie mater fola poteft fufferre lac, neqs congenerati alefcendo roborari, Varro. Porcl à mamma menfes cuos non difiunguntur, I dem. Etrurfus, In nutricatu, quam porculationem appellabant, binis mea

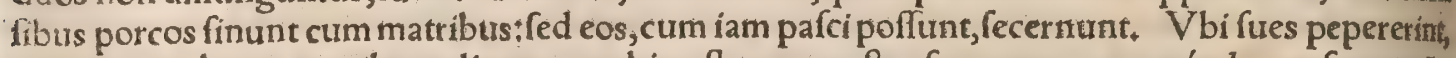
porcellos unà cum matribus relinquentes bimeftre, eos poftea fecernunt, matresćg denuo fupponứt, uit $\mathrm{ex}$ toto anno, ocfo quidem menfes digerantur in ipfam impregnationem, quatuor uero, in educe tionem emifforum in lucem, Florentin. Vbi facultas eft tranfigendi, uenditis qui fubinde natifunt, celerior matribus foctura reparatur, Pallad, ब Hybridam ex fue domeftica \& apro natum fuem appellant aliqui.

Gorbi faum. Aconitum enecat pantheras, fues, lupos, beftiasç̧ omnes in carnibus obieciú, Diofcorides:fed apparet eum de fuibus feris loqui,feris enim tantum a conitum $\&$ alia urenena obin. ciunt uenatores:quanquam domefticis quoq, ut quibufcunq alijs animalibus letale eft aconitum,

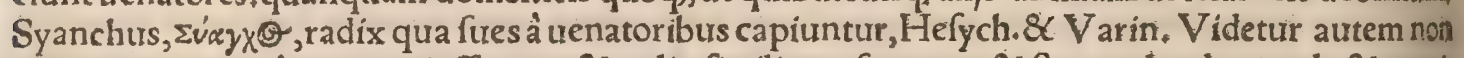
alia hæc radix quàm aconiti effe, cum $\&$ radix fimiliter ufurpetur, \& ftrangulando, (unde $\&$ aconir to pardalianchi cognomen, ) fimiliter quod ex uocabuli compofitione apparet, mortem inferat, Sues necat chamaleon albus, radice fcilicet cum polenta $\&$ hydrelæo fubacta, Diofcor, uide in Cane $c$. Succus radicis chamaleonis candidi occidit canes fuesćp in polenta : addita aqua 8 oleo contrahit in fe mures ac necat, ni protinus aquam forbeant, Plinius. Elleboro nigro equi, boures, fues necans tur:ita $\$$ catrent id, cum candido uefcantur, Plinius. Sues cum imprudentes hyof cyamum comes qo $^{\circ}$ derint, etfi agerrime afficiuntur, (refoluuntur $\&$ conuelluntur, Hermolaus)tamen reptantes fefe ad aquas trahunt: quo profecti, cancros legunt, \& deuorant, eorum'ş cibo ad incolumitatem reftituun tur, Aelianus. Hyof yamo poto fues infaniunt, unde vooxudea vro infanire $\&$ delirare, Phere:

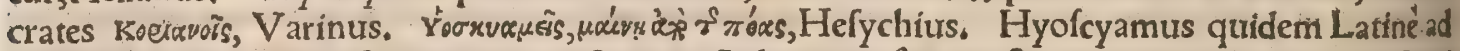
uerbum fabam fuillam fonat, quoniam fues, ut Aelianus refert, paftu eius conuellantur prafenti mortis periculo, nifi copiofa aqua ftatim fe foris $\&$ intus proluerint, Marcellus Vergilius. Sed nos alia de hyof cyamo A cliani uerba, interprete Gillio, proxime recitaurimus:qux magis probo, quoniá

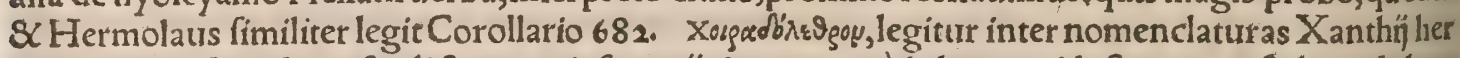
bæa apud Diofcoridem, fic dictum, ut ipfe conïcio, non quòd chœros, id eft porcos, fed quod cltce rados fiue frophulos tollat: nam \& contra tumores, Diofcoride tefte, utiliter emplaftri modo impo: so nitur. Herba quam noftri anferinum pedem à foliorum figura nominant, quam Hieronymus Tra gus Tomi primi de plantis ca, 101. inter folana defcribit, ( $\&$ à Germanis nonnullis à furum pernicie foweinftrost/ \& feuwplag appellari fcribit, fuibus fi forte ederint uenenofa effe creditur, idç non raris experimentis conftare ait, Eadem forte chenopus Plinï fuerit, cuius ille femel tantum me minit 11.8 . quoniam $\&$ nomen conuenit, \& uis forfitan uenenata: huius enim $\&$ rumicis flores apes non attingunt, ut Plin. fcribit:quamuis inde nô fequitur uel homini uel fui uenenatam effe, ut nẹ; rumex eft. Egoconiectur am tantum affero, Quin $\&$ fcrophularia maior, fortida herba, urticx feréfo lins, etc. (noftri uocant bzunwurt, id eft herbam fpadiceam, à colore*tuel fob wartsenadbt fbatt, id eft folanum nigrum, improprie tamen) fuillo generi exítio effe fertur. Eupatorio aquatico, (ut pharma copola quidam trocant, Ruellits hydropiper, noftri ceruinum trifolium, $8\left(c_{\text {c }}\right.$ )hirundinaria, quam 60 aliqui afclepiadem putant; $\mathbb{X}$ arcio, id eft perfonata feu lappa maiore, tum fues tum pecudes om. nes abltinere audio. 
deri in pracedentibus dictum eft. Druidx Gallorum famolum herbam nominauêre nafcentem in

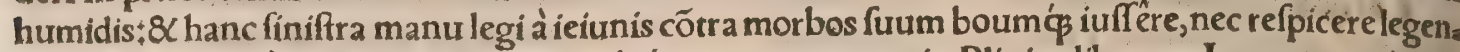
tem, nec alibi quàm in canali deponere, ibiọ́ conterere poturis, Plinius lib. 24. Lappa canaria me. detur fuibus effoffa fine ferro, $\&$ addita in colluuiem poturis, uel ex lacte $\&$ uino. Quidam adjiciunt $\&$ fodientem dicere oportere:Hac eft herba argemon, Quam Minerua reperit, Suibus his remediü, Qui de illa guftauerint,Plinius. Hæc an eadem fit cum argemone Ruellius dubitat. Paftores quí. dam hodie trichomane utuntur pro fuibus agris, \& mirifice pradicant, Hier. Tragus. Vtuntur \& carduo benedicto, ut uulgò nominant, $\&$ radice generis illius gentianæ quam noftri cruciatam a foraminum aut fectionum fponte nafcentium in ea fitu appellant: \& radice herba quam uulgócer. uinam nigram uocitant, eft autem genus fefelis ut conijcio.

TSolec etiá(inquit Columella) uniuerfum pecus æarotare ita, ut emacietur, nec cibos capiat, pro. ductumás in pafcua medio campo procumbat, \& quodam ueterno preffum fomnos aftiuo fub fole captet, quod cum facit, totus grex tecto clauditur ftabulo, at $\not \xi$ uno die abftinetur potione, \& pabulo: poftridie radix anguinei cucumeris trita, \& commifta cum aqua datur fitientibus quam cum pecuo des biberunt, naufea correptæ uomitant, atq̧ expurgantur, omní̧́ bile depulfa cicercula, uel faba, dura muria confperfa, deinde (ficut hominibus)aqua calida potanda permitritur, Sues fi affligantur incerto morbo, tota die \&i nocte includere oportet, nihilós interim nec cibi nec potus apponere, fed radices agreftis cucumeris comminutas, per diem ac noctem aquæ infundentes, aquam ipfam in po tu eis poltridie offeremus: Ex qua quidem bibentes largius morbi caufam paulò poft uomitu red. dunt,Didymus. Apud nos aliqui nefcio ad quos morbos, forté ipfis etiam incognitos, prafertimfü bitos, porcorũ uel aures uulnerant, uel caudas abfcindunt, nam uena fectione in hoc pecore noftri, quod fciam, non utuntur. Canes, boues, fues, capræ, ferpentes $\&$ beftix alix cum impendentem peftem, tum uerò terræ motum, \& coeli falubritatem, \& frugum fertilitatem præfentiunt, A elianus, Democritus phyficus afphodeli radicis parũ maceratze fingulis fuibus nutrimento iubet mifceri tres minas, fic fiquidem ante dies feptem fanitatis firmitudinem ait fues recuperaturos, Didymus, Sues peftilenti affectu non corripientur, aut correpti reftituentur facile, fi afphodeli radices in eam qutram bibuntaquam inieceris, aut etiam ubi crebro lauantur, Florentinus. Audio fuibus in peftilentiafo fectione, multos circa collum duros tumores(tubercula)oboriri. Quatit ægros Tuffis anhela fues, ac faucibus angit obefis, (tempore peftis, ) Vergilius. Polypodium aliqui fuim cibo contra peftic lentem luem admifcent, Hieron. Tragus. Idem folanigenus fyluaticum baccis nigris cerafi magnis tudine (aliqui Germanorum uocant porcorum herbam, alij baccas fomni, fïwtrut/ foblaaffberte) aduerfus periculofos (contagiolos)fubitos $\&$ calidos futum morbos, quales per medios aftatis feruon res accidunt, plurimum commendari ait, folīs fcilicet in cibo datis : eamó̧ ob caufam ubi fponte nan fcens haberi non poteft, à plerifó̧ in hortis plantari. quód uero idem fatiuum folanum effe affirmat, non affentior. Si peftis in fuillum gregem inuaferit, limacum fpolia (cremata, ut aliqui uolunt trita) in potu dabis, ut etiam bubus. Vel Saracenicam herbam (betonifd) wundtrut : fic noftri pleriģ uow cant, quam Galli $\&$ Itali, coftum hortenfem, reliqui uero Germani , chirurgi præfertim uirgamatu ream Italorum)aridam tritam in cibo. Aut lactucam (lattid, malim atticb, id eft ebulum ) fortidam in aqua elixam $\&$ minutatim incifam, ac rurfus cum decoefo fuo iniectam, in colluuiem porcorum admifcebis, Hac reperi in manufcripto quodam libro Germanico. Cauendum eft ne ad pralepis 4 boum fus aut gallina perrepat, nam hoc quod decidit immiftũ pabulo, bubus affert necem: 8 id pras cipue quod egerit fus agra peftilentiam facere ualet, Columella \$ \Sues parari $\&$ emi folent fic* Illafce fues fanas effe, haberé́s recte licere, noxịsós praftare, neq̧ de pecore morbolo effe, fpon désne?Quidam adịciunt perfunctas effe à febri, 8 a foria, Varro. Febricitantium figna funt, cum obftipa fues tranfuerfa capita ferunt, ac per pafcua fubito cum paululum procurrerunt, confiftunt, $\&$ uertigine correptæc concidunt. Earum notanda funt capita, quam in partem proclinentur, utex aduerfa parte de auricula fanguinem mittamus. Item fub cauda duobus digitis à clunibus intermifa fis uenam feriamus, qua eft in eo loco fatis ampla, eamọ́, farmento prius oportet uerberari, deinde $a b$ ictu uirgx tumentem ferro refcindi, detractó́p fanguine colligari faligneolibro, tuel etiả ulmeo, Quod cum fecerimus, uno aut altero die fub tecto pecudem continebimus, $\&$ aquã modicé calidam quantam uolent, farinæćç ordeacea fingulos fextarios prabebimus, Columella. Febrientibusex cauda fanguis eft detrahendus, Idem, Cum à magno feruore in frigidam incübunt, prafertim fi non ftatim cogantur pergere in uia, fed alicubi confiftere aut quiefcere permittantur, membris on

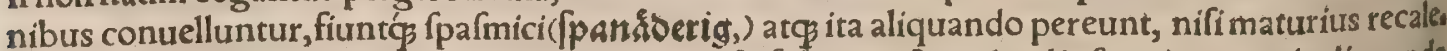
f cant. Vituli quidem fíc affecti non euadunt. If Infeftantur $\&$ pediculis fues, ita ut cutis aliquando plurimum erodatur, tolluntur locis illitis crema lactis, butyro, \& fale multo, fimul ad ungentí modî decoctis alin partes lotas purgataś̨́ face unini liquida inungunt. TSus multum dormit, pracipure aftate, \& tunc nifi frequenter excitetur, lethargo captus moritur, Albertus. TAccidit eis etiá dolor

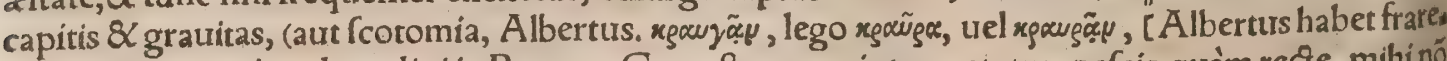
$\mathrm{tyn}_{\text {, }}$ ] de quo morbo plura dixi in Boue $\mathrm{c}$. Gaza ftrumam interpretatur, nefcio quàm recte, mihi nó 6 placet:nam \& alui profluuium in fuibus eodem uocabulo fignificatur, ut infra dicam: ) quo plurimi laborare folent, remedium eft, uino adhibito naribus, eóg ipfo dilutis, fed difficulter co quós peri. 


\section{DeSue. C. Lib. I. 995}

culo fubtrahituribidio enim aut quatriduo interitus obuenit, Ariftot. Albertus hunc ex Ȧriftotele locum reddens, Hoc morbo, inquit, moritur maior pars fuum, propter collectos multos humores fri gidos in capite. fed remedium quod apud Ariftotelem huic morbo adfribitur, perperam refert ad profluuium alui. In hoc morbo ut in brancho quon;, auricula fuum flaccida 8 deiecta funt, Idem.

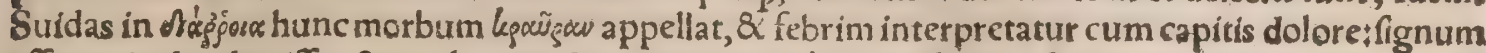

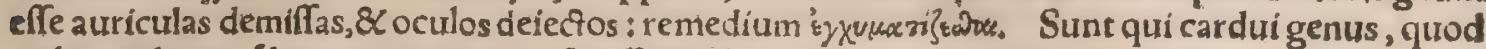

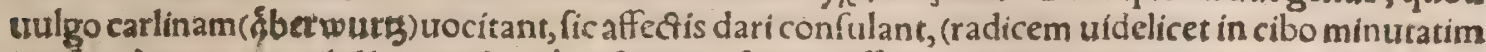
incifam, )tanquam nihil hic morbus à peftilentia furm differat. TStrem altero oculo amiffo breul extingui mayna ex parte nonnulli exiftimant, Ariftoreles 8 Plin. ब Quadrupedum fues tribus

10 morbi gencribus laborant, quorum unum raucedo vocatur, quo maximè fauces maxillxós inflam. mantur, (ibi quidem proprie mihi uidetur branchus uocari, alips in locis impropriè, phlegmone poti. us in genere dicenda:) fed idem malum, uel qualibet alia corporis parte contrahi poteft. Iam enim ple runç in pedem, aliâs in aurem decumbic. Putrefcit protinus membrư, $\&$ ulcus ferpit, donec ad pul monem deueniat, quo tacto mors fequitur, crefcic hoc uitium celeriter, nec poteft fus quicquam ede

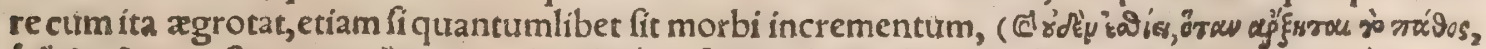

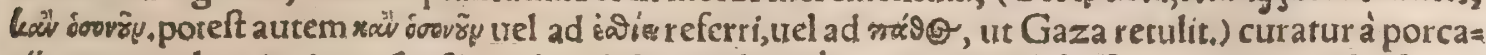
rijs, cum malum incipere fenferint, haud alio modo quàm tota parte abfcifra qua coeperit, Ariftotel.

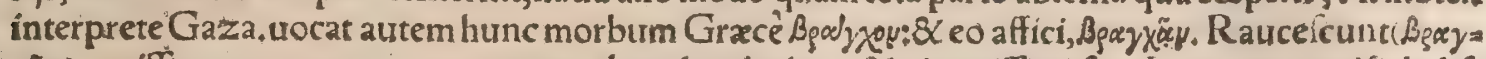
xwios) potiffimum eo anno, quo montes abunde tulerint, $\&$ pinguiffimi fint. Iutrat mora celfi dedifs - fe in cibatu(qux $\&$ homini contra anginam profunt, ut in medicamento diamoron, Niphus) \& bals neum multum $\&$ calidum, $\&$ uren fub lingua fitx cultello adacto fanguinem detraxiffe, Ariftotel.

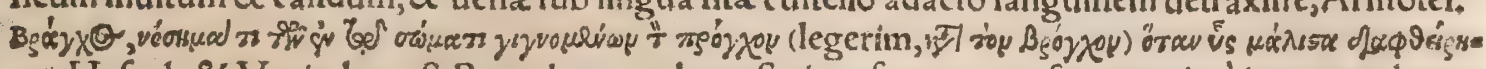
roci, Hefych.\& Varin. hoc eft, Branchus morbus eft circa fauces quo fues maximé intereunt. bron*

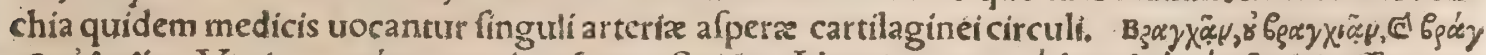

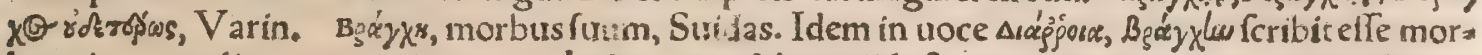
bum in parte aliqua corporis purcini, legeupav uero febrim (id eft totius corporis) cum capitis dolore. Branchus aliquando dilatatur fub gutture, $\&$ incidunt in fynanchen: $\&$ tunc multum mourent pe: des, 8 moriuntur intra tres dies, A ibertus: \&ic. urt Ariftoteles. Strumofis fublingua fanguis mittendus eft, qui cum profluxerit, fale trito cum farina triticea confricari totum es conueniet. Quidã

30 prafentius putant efle remedium, cum per cornu fingulis ternos cyathos gari demittunt: deit de fif Ias taleas ferularum lineo funiculo religant: \& ira collo fufpendunt, ut ftruma ferulis contingantur, Columella. Non facile autem dixerim, craurám ne an branchon Ariftorelis, frumam appellet in fui bus. Crauram enim ftrumam Gaza interpretatur : fed remedium fangtrinis fub lingua detrahendi brancho conuenit, quód fi quis neutrum horum ftrumam effe contendat, doceat meliora. Authos ritate Plinij nonnulli afferunt ftrumam effe ferophulam, in qua concretæ quædam \& puræ (forte, purulenta) \& fanguinex quafiglandula oriuntur, Niphus, f Suillum genus morbis obnoxium. eft, anginx maximè \& frumæ, Plin. Gutur bomini tantum \& fuibus intumefcit, aquarum qua po tantur plerung uitio, Idem. Angina fub faucibus apoftema eft, quod firibus maximé accidit, Syl= uaticus. Noftrifideritin illam qux eft lattfimo folio lcopas tegias trocant: medetur anginis fuum, 4. Plin. Herba impia uocatur incana, rorifmarini afpeciu, \&c. Aliqui fic appellatam, quód nullum a= nimal eam attingat, exiftimatếre. haec inter duos lapides trita feruet, præcipuo aduerfus anginas fuc co, lacte \& uino admixto:mirumós trâ ditur, nunquam ab eo morbo tentari qui guftauerint, itags \& fuibus dari:quaćs medicamentum id noluerint haurire, co morbo interimi, Plinius 8 Hermolaus Corollario 767 . ubi antipatrem uulgò dis am herbam (filium ante patrem, uel Chriftophorianam, $\&$ oculum confulis, )ab impia Pliní̉ diuerfam effe doret, nec aliud. Herba trinitatis uulgò dicta, (à uri. plici florum colore, qui uiolas Martias reliqua fpecie omnino referunt, freiffant Erut) utilis eft fúbus angina, id eft calido gutturis abfcelfu laborantibus. Habet fanê hæc herba utolæ Martia uires, quad ex guftu faporećs conijcio, quamuis odore caret.commendantur autem etiam uiolæ flores, aut quod in eis purpureum eft, ad anginas á Diofcoride. ब Tonfillx in homine, in fue glandula, Plin. Si $5^{\circ}$ tonfillis (parifthmins)infeltentur fues, fanguis ex humeris detrahatur, Didymus. Tubercula qua. dam faucibus \& gutturi porcorum innafcuntur, qua Angli (ut audio) fua lingua kyrnel nominant, quod malum ad anginam referendum puto. Nam qua extrinfecus in collo nafcuntur tubercula, \& matura pus aut faniem emittunt, cum uel à fue attrita, uel à porcario fecta fuerint, periculo uacant, \& choerades uel frophula, ni fallor, appellari poffunt. TMorbus quem noftri rangen appellant, Itali quidam (ut audio) fidor, non contagiofus quidem, fed admodum periculofus eft fuibus. mors e. nim ferè intra biduum fequitur: quare uulgus imprecando etiā homini huius morbi nomen ufurpat, cũ nihil quod friam fimile in hominẽ cadat. Nafcitur hoc malum in inferiore oris fuilli parte, in ipfa (puto)maxilla co fpatio quod inter anteriores $\&$ pofteriores dentes eft:indurat enim pars illa cornts

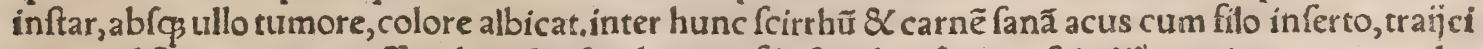
6o tur ore diftento per immiffum baculũ: fic eleuatus filo fcirrhus ferro refcinditî, at ç ita curantur ples riqg. nifi ferò forte fectio adhibeatur. Sunt qui radicem gentiana illius generis quod à diffecta radi. cis figura cruciatam noftri wocirant, (ut fupra dixi, $\&$ pluribus in Boue $c_{\text {) }}$ ) aduerfus hunc morbum 
pabulo aut potioni admixtam prabeant, quare $\&$ à morbi illius auxilio rangenterut appellant noth nulli. Sed noftri ferè omnes, prafertim periti laní,fectione potius tanquam certiore prafidio utun, tur. Accidere hoc eis aiunt fi colluuries nimis calida detur : quòd \& aliâs noxium effe audio, arteria afpera (noftrates uocant ben weyfel berffrupft)inde aftricta, \& exulceratis nonnunquam uel aliter lafis inteftinis. Sus quirangam (ut Germanico nomini terminationem Latinam addam) patitur, cis

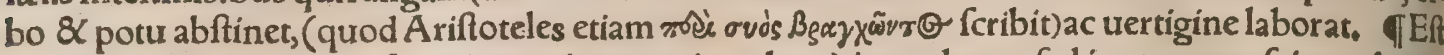
praterea malum quod in fuperiore oris parte (in palato) intra dentes fed iuxta eos nafcitur, duritly es quadam qua fpatium non maius ungue humano occupat, hanc ferro refoluunt lanî, \& ut pof, funt refecant:uocant autem die fêf(en. Eiufdem nominis morbus, re tamen ut puto diuerfus nonni, hil, in equi etiam palato nafcitur, ut inter equorum morbos fcripfi, of Hinc (tempore peftis)cani, bus blandis rabies uenit, $\mathcal{Q}$ quatit $æ g r o s \quad T u f f i s$ anhela fues, ac faucibus angit obefis, Vergilius, qRadix herba confiliginis, quam nuper inuentam diximus, fuum quidem \& pecoris omnis reme, dium prafens eft pulmonum uitio, uel traiecła tantum in auricula, Bibi debet ex aqua, haberiǵs in ore affidué fub lingua, fuperficies eius herbx an fit in aliquo ufu, adhuc incertum eft, Plinitus. Sues nifi potu affatim fatientur, pulmonaria fiunt:isóş morbus optimé fanatur auriculis inferta confiligí ne(quod in ouibus etiam pulmonar î̉s fieri iubet:) de qua radicula diligenter ac frepius iam locutifiu mus, Columella. Idem facit radix hellebori nigri per auriculam bouis aut fuis traiecta, itemóǵ ad alib os ufus, faltem extra corpus, Intra corpus enim confiliginem dare non aufim, quamuis medicus non indoctus ætatis noftræ pulmonarís etiam hominibus intra corpus fumendam confulit, nec tamen uel authoritate uel experimento ullo id confirmat.Sed plura de hac herba frripfi in Boue c. S in Lut po a. in aconiti mentione. ब Lanij noftri rarum effe furem aiunt, qui non aliquo uel hepatis uel pul monis uel alio uritio laboret; reperiri enim in pulmone aliquando alba quædam tubercula, magnitu dine dimidiatæ iuglandis: $\mathcal{Q}$ pulmonem aliquando coftis fiue membranæ fuccingenti adhęrere(çd bubus etiam accidere audio, uulgò uocant angbefft.) In hepate uero ueficas quardam aqua plenas (Édarid'as, waffergallen/wafferblatetn, confpici. INaufeantibus falutaris habetur eburneafco bis fali fricto $\&$ fabæ minutz frefre commifta, ieiunis'şs prius quàm in pafcua prodeant obiecta, Collu mella. Animal hoc uoracifimum natura exiffit, quare potiffimum fplene laborat.danda eftalt,

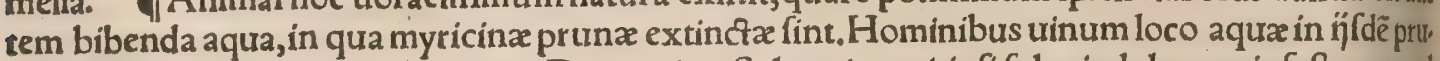
nis infufurm opitulatur, Didymus ex Democrito. Solet etiam uitiofi fplenis dolor eas infeftare, quod accidit,cum ficcitas magna prouenit, \& ut Bucolicon loquitur poếma, Strata iacent paffim fua 3" quxq, fub arbore poma. Nam pecus infatiabile eft, fues enim, dum dulcedinem pabuli confectan, cur, fupra modum æftate fplenis incremento laborant. Cui fuccurritur, fi fabricentur canales ex tar maricibus, \& rufco, repleanturớ $\not$ a qua: $\&$ deinde fitientibus admoureantur. Quippe ligni fuccus mer dicabilis, epotus inteftinum tumorem compefcit, Columella. A deò mirabilem myricæa antipathiam contra lienem faciunt, ut affirment, fi ex ea alueis factis bibant fues, fine liene inueniri: \& ideo homi ni quogs fplenetico cibum potumóç dant in uafis ex ea factis, Plinitus $8 \alpha$ Conftantinus monachus. Fs pud nos tam parua crefcit myrica, ut rarò ftipes eius ad digitum craffitudine duplus fit * quamobs rem nec aluei inde fieri poffunt fuibus, nec uafa hominit pocula tamen ex pluribus paruis taleis has rente adhuc cortice, ambiente fupra infraćs ligneo circulo parantur, ut uegetes feu uafa uinaria ex pluribus ligneis afferibus fieri folent. A d furm uero medicinam, decochum eius in potu datur. Tath maricis radicem uel folia trita ex aceto bibat, qui de fplene laborat, cuius ufum fi experiri uolueris, da porco edendam per dies nouem, cum eum occides fine fplene inuenies, Marcel. Afplenos etiam herba confumit fplenem fuum: Vide in Boue $c$. TA Alui profluuium (quod fimiliter ut capitis don

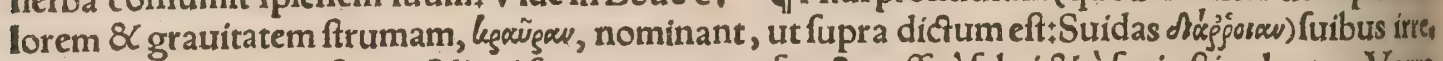
mediabile incidit, A riftot. Aliqui fues empturi perfunctas effe à febri $\&$ à foria ftipulantur, Varto. Verno tempore herbæ nouellæ $\&$ immaturæ porcis aluum citant, unde emaciantur, Columella. Porci quidam in alpibus fero lactis non affueti,fi nimium biberint, rumpi aliquando periclitantur, nifi aluus maturè fluat 、 đSui dyfuria uel ifchuria laboranti quidam grana lathyridis aliquotpras: bent, ut audio.

, Plurimis uita ad annos quindecim:aliquibus etiam propè ad uicenos, Ariftot, Vita ad quin decim annos, quiburdam \& uicenos:uerum efferantur, Plin.

$$
\text { D. }
$$

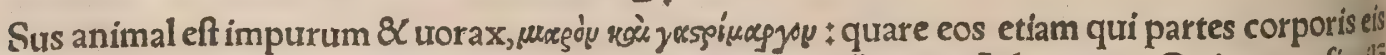
fimiles habent, naturam quog; eis non diffimilem habere conificimus, A damant. Qui porco fimili habent frontem, fupercilia, labra, os, uel collum, homines iudicantur inepti, ftolidi, improbi, iracundi,

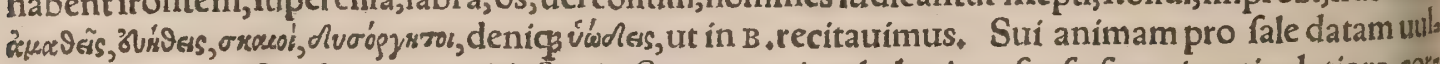
gò fertur:uide infra ab initio capitis fexti. Sues quoniam hebetiore fenfu funt, inarticulatiora cols da habent, Ariftot.3.4.de part,anim. Sunt qui fubtilitatem animi conftare non tenuitate fanguinlis putent, fed cute operimentiş́ corporum magis aut minus bruta effe, ut oftrea $\&$ teftudines : boutum tergora, fetas fuurm obftare tenuitati immeantis Ipiritus, nec purum liquidumóg tranfmitti, Plinitss. Animalium hoc maxime brutum, animamús ei pro fale datam non illepide exiftimabatur. Coms pertum agnita uoce fuarí furto abactis, merfo nauigio inclinatione lateris unitus remeaffe, Quin 


\section{DeSue. D.E. Lib. I.}

8 duces in urbe forum nundinariữ domosç petere difcunt, Plin. Porculatoris uocem fuillum pè. cus fic agnofcit, ut etiam fi ab eo procul feductum fuerit, appellantem intelligat, cur quidam reí teftis monio eft id quod proxime fequitur. Cum maris pradones ad Tyrrhenam terram piraticam natuem appuliffent, ex bara permultos fues furto abactos impofuerunt in nauim, quam foluentes ad naui. gandum incubuerunt. Subulci prafentibus piratis filentium tenebant, fuesćs eatenus abduci quie. fcebant, quoad ex portu latrones fe eripuifent, $\&$ à terra foluiffent. Tum uoce fuibus audiri folita fuarí quàm maxime poterant exclamantes, eos retro uerfus ad fe reuocabant. Porci primum uit fub latum clamorem paftorum exaudierunt, ftatim fe in alterum nauis latus compellentes, eam euerte. runtłmalefici piratæ naufragio quàm mox funditus perierunt, fues ad fưos enatarunt, Aelianus.

Sus animal ímpurum, cœno, \& lacunis maximé gaudet:ut tam craffi \& hebetes ei fenfus quàm in= genium exiftimetur. Primus fcrofæ foetus prima ubera lactet, $\&$ deinceps cæteri fuo quif̧́ gradu \& ordine, Io, Tzetzes, \& alï, ut in C, recitaui.ubi hoc etiam diximus à fcrofis nonnullis furos porcel. los deutorari. Pafcere gregatim proxtate uelle uidentur, Ariftoteles. Sui grunnitus terribilis. pra cipuè autem uno percuffo cæteri grunniunt, 8 quafi condolentes accurrunt: $f e d$ mox obliti fui plan ctus ad conum cibum'ue redeunt, Obfcurus. Noftrific concurfantes inter fe fues, ut uiribuis con= iunctis mutua ferant auxilia, ad uim uel arcendam uel inferendam homini aut alteri animanti, dis cuntrïblen, alij rewlent. Verres unus in grege porcorum alins pugna deuictis imperat, \& gregem fibi deditum habet. Hoc diffidin \& pugnæ tempore, uel aliter etiam libidine ardentibus non tutum eft accedere: neq̧ enim homini, neq̧ pecoribus parcunt:præcipué uero albis ueftibus indutos infe= 2. ftant,Mich.Herus. Sues Belgici proceritate, robore $\&$ celeritate præftant, a deò ut infueto cuipiam accedenti, non minus $\widetilde{\not}$ luporum periculorum ingruat, Strabo. Sui \& crocodilo natura eam con. ciliauit a micitiam, ut impune fues circa Nili ripas obuerfentur, neçà à crocodilis offenfam ullam pa. tiantur, Calcagnin. Sui ferpens aduerfatur, quia deuoratur ab ea, Ariftot. Muftelæ \& fures diffia dent,Plin. Sus(id eft fues aliquot coniuncti, Ephefius) etiam lupo obfiftere repugnaréç poteft, Ariftot. Lupos aiunt cum fint nacti fues, trahere uf $\beta$ ad aquam, quòd dentes feruorem carnis fer: re nequeant, Varrołintelligendum fures à lupis deuorari, non contra. Minimo fuis ftridore terren. tur elephantes,Plin. Elephas exhorrefcit porcelli recens nati uocem, Zoroaftres in Geopon. Ele phanti ex animalibuts maxime exhorrent hircum, ceraften, (arietem intelligo, \& $\&$ porcum $\%$ quibus fa nèmachinamentis Romani elephantos Pyrrhi regis primum urertentes, uictoria funt potiti, Volater 5o ran. Vide plura in Elephanto D. Iam uifus eft leo, qui cum fuem aggrederetur, ut fetis horrentem afpexit, fugeret, Ariftot. Lupus aliquando capram aut fuem auricula mordicus apprehendit $\& 2=$ liquo fecum deducit, ubi commodè $8<$ fecurè deuroret, trt pluribus retuli in Lupo D. TPorcos fex qui cos à quibus cereburnt corui acceperint in offa, quidam feriplerunt, Plinius \& Sextus, ut Aggre gator citat, Idem facit iecur muris datum in ficu, quod 8 in homine fimiliter ualere dicunt, Aggre gator citans Plinij librum 29. Nigidius fugere tota die canes confpectum eius qui è fue ricinum e: uellerit, fcriptum reliquit, Plin,

Subulcus debet confuefacere, omnia ut faciant ad buccinam, Primo cum inclufer unt, cum bue: cinattrm eft, aperiunt, ut exire poffint in eum locum, ubi ordeum fufum in longitudine fit. Sic enim 40 minus deperit, quàn fi id in acertos pofitum eft, \& plures facilius accedunt dicuntur, (ideó̧́ ad buccinam conurenire dicuntur, Crefcent.) )ut fylueftri loco difperfi ne difpere. ant, Varro. Cuftos porcorum (in quit Columella)fit uigilans, impiger, induftrius, nautus, Omnium, quas pafcit, et matricum, $\&$ iuniorum meminiffe debet, ut uniufcuiuf(̧̧ partum confideret. Semper obferuet enitentem:claudató̧ ut in hara foxtum edat. Tum denotet protinus quotós $\&$ quales fint nati, \& curet maxime nequis fub nutrice aliena educetur:nam facilime porci, fie euaferint haram ${ }_{j} \mathrm{mi}_{\text {- }}$ fcent fe, \& fcrofa cum decubuit, aque alieno ac fuo prabet ubera, Itaq porculatotis maximum of: ficium eft, ut unamquan $\$$ cum fura prole claudat, qui fi memoria deficitur, quo minus agnofcat cut. iuffo progeniem, pice liquida eandem notam fcrofæ \& porcis imponat, \& fitue per literas, fitre per a: lias formas unumqueng fortum cum matre diftinguat:nam in maiore numero diuerfis notis opus eft, ne confundatur memoria cuftodis. Attamen quia id facere gregibus amplis uidetur operofum, commodiffimum eft haras ita fabricare, ut limen earum in tantam altitudinem confurgat, quantum poffit nutrix euadere, lactens autem fupergredi non poffit. Sic nec alienus irrèpit, $\&$ in cubili fuam quifos matrem nidus expectat, quit tamen non debet ofto capitum numerum excedere. Non quiti ignorem focunditatem frofarum maioris effe numeri, fed quia celerrime fatifcit, qux plures édu. cat. A tos ex quibus partus fummittitur, cocto funt ordeo fuftinenda, ne ad máciem fummam perdut cantur, \& ex ea ad aliquam perniciem. Diligens autem porculator frequenter fuile conuerrat, \& faze pius harasłnam quamuis prædiçum animal in pabulationem fpurcè uerfetur, mundiffimum tame̋ cubile defiderat. Hic feré cultus eft fuilli pecoris recte ualentis. Ex rurfus, Nec ut cæeteri greges uni: uerfi claudi debent, fed per porticus haræ faciendar funt, quibus aut à partu, aut etiam pragnantes - includantur: nam pracipue fues cateruatim atç incondita, cum fint pariter inclufa, fuper alias alize cubant \& foetus elidunt. Quare, ut dixi, iunctę parietibus harx conftruend $x$ funt in altitudinê ped quatuor, ne fus tranfilire fepta queat.nã contegi non debet, utà fuperiore parte cuftos numerû̃ port. 
corum recenfeat, $\&$ fi quem decumbens mater opprefferit, cubanti fubtrahat, Hac Columella: Neç gregatim claudendx funt porcæ more aliarum pecudun, fed haras fub porticibus faciemus, quibus mater unaquax $\$$ claudatur, $\mathcal{Q}$ alumnum gregem tutior ipfa defendat à frigore. $Q$ ua harxâ fuperiori parte detectx fint, ut libere numerum paftor exploret, \& oppreffis à matre foetibus fape fubueniar fubtrahendo, $P$ alladius. Scrofam in fua quanque hara fuos ut alat oportet porcos, quo. niam alienos afpernatur, \& ideo fi conturbati funt in foetura, fit deterius, Varro. Singula ex para turientibus fuibus peculiari in hara funt includenda, ne fcilicet diuerfi partus mutuò inter fe mifce. antur, fed matres agnofcant prolem, porcelliç fimiliter affuefcant fuis matribur. quippe fi confuns dantur, haud amplius eos ipf $x$ ferof $x$ difcernent. Commodius autem eft fi fingula proprios fortus enutriant, Florentinus. Haram facere oportet circiter trium pedum altam, \& la tam amplius pauló, ea altitudine abs terra, ne dum exilire uelit pragnans, abortet. Altitudinis modus fit, ut fubulcus fa cile defpicere poffit, nequis porcellus à matre opprimatur, \& ut facile purgare poffit cubile. In haris oftium effe oportet, \& limen inferius altum palmipedale (id eft, pede \& palmo, Crefcent.)ne porciex hara, cum mater prodit, tranfilire poffint. Quotielcunģ haras fubulcus purgat, toties in fingulas are nam inijcere oporter, aut quíd aliud, quod exugat humorem, $V$ arro. Cum pepererit, largiore ribaa tu fuftentare oportet, quo facilius lac fuppeditare poffit $;$ in quibus hordei circiter binas libras aqua madefactas dare folent, \& hoc quoq conduplicant, ut fít mane, $\&$ uefperi, fi alia, qua objijciant, non haburerint, Idem. Et rurfus, A partu decem diebus proximis nó producunt ex haris matrem pras terquam potum. Prateritis decem diebus finunt exire paftum in propinquum locum uillæ, ut cre bro reditu lacte alere poffit porcos. Cum creuerunt, cupiunt fequi matrê, tum domi fecernunt àmas à tribus, ac feorfum pafcunt, ut defyderium ferre poffint parentis, quod decem diebus affequuntur, Paftum exigunt aftate mane, $\&$ ante quàm æftus incipiat, fubigunt in umbrofum locum, maxime ubi aqua fit.Poft meridiem rurfus lenito feruore pafcunt. Hyberno tempore non prius exigunt paa ftum, quâm pruina euanuít ac colliquefaça eft glacies, (quod 8 Florentinus feribit.) De numero in centum fues, decem uerres fatis effe putant. Quidã etiam hinc demunt. Greges maiores inaqua biles habent.Sed ego modicum puto centenarium. Aliquot maiores faciût, ita ut ter quinquagenos habeant porcos in grege, alị duplicant, alị etiam maiorem faciunt. Minor grex, quàm maior minus fumptuofus, quod comites fubulcus pauciores quarit. Itags gregis numerum paftor ab fua utilitate conftituit, non ut quot uerres habeat, id enim à natura fumendum + hac hic, Hac omnia Varro, Agriculturæab initio fui ftudiofus, nec de pecore fuillo mihi minor cura eft, quàm uobis magnis pe cuarins, Cui enim ea res non eft communis? Quis enim noftrum fundum colit, quin fues habeat: $Q$ qui non audierit patres noftros dicere, ignauum, $\&$ fumptuofum effe, qui fuccidiam in carnario lis fpenderit potius ab laniario, quàm ex domeftico fundo? Tremellius Scrofa apud Varronem.

TSues terram roftro fodiunt, (noftri dicunt mitlent,) $\&$ fic fodiendo propter radices multum no: cent agris. srïbórtege $\sigma \tilde{u}$, fus alienam fegetem depafcens, cui domini agri dentes elidebant, fecundï Cypriam legem ut aiunt. quam ponam etiam Vlyffi Irus apud Homerum minatur, tanquam obfie mile delictum, ut qui meffem fuam ex epulis procorũ ei depafceretur, Varinus, Axïboris apud eun. dem fus fylueftris exponitur. Sues admittunt agricolæ in agros $\&$ fegetem, ut latibula effodiant, Ariftoteles. In porcis etiam illud eft commodum, quòd immiffi uineis necdum turgentibus, uel exacta uindemia gramine perfecuto diligentiam fofforis imitantur, $\mathrm{Palladius:gramen} \mathrm{perfequendo} \mathrm{f}$ uertunt folum, poftea relicta(reliqua)fofforis diligentia mutantur, Crefcentienfis. Vulgo credeba tur à Nili in Aegypto euagantis deceffu ferere folitos, mox fues impellere ueftigís femina deprimen tes $¥ \mathcal{Q}$ in madido folo credo antiquitus factitatum, Plinius. Eudoxus ideo inquit Alegyptios ab im* molandis fuibus fe fuftinere, quòd pofteaquam fementem fecerunt, eorum greges ad proterendam \& conculcandam frumentorum fationem atq depellendam in altiorem terram \& humidiorem indus cere foleant, ut hac quali occatione terra obducta ne ab auibus femina exhauriantur, Aelianus, Sed aliter Calcagninus in Aegyptiacis, Poftquam Nilus (inquit) reftagnare defierit, 8 in aluû fueritre uocatus, fuum opera ad profcindendos fubigendosćs agros utuntur, in quos femina iaciantur. đQuomodoMegarenfes in pralio aduerfus Antipatrum, fuibus pice oblitis incenfisć in elephans tos eius immifis eos perturbarint, \&c, dixi in Elephanto D.

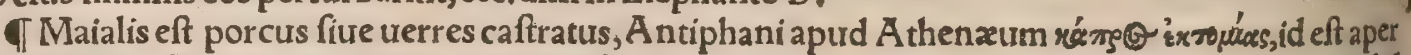
fiue uerres caftratus, qua quidem periphrafi reliqux etiam lingux mihi cognitx omnes utuntur, $\mathrm{fed}$ Germani proprium habent ein barg uel bóts. Porcaftrus, id eft porcus caftus, Syluaticus:maialem intelligo. Porci nefrendes uel nephrendes uocabantur caftrati, quafi fine renibus, Fulgentius ad Chalcidium. Graci quidem renes veфpós uocant, fed $V$ arro porcos nefrendes uocari ait, qui non am. plius lachent, necdum tamen fabam frendere poffunt. Feftus arietes nefrendes dicit, qui dentibus frendere nondum poffunt. A per (Verres) iracundus $\&$ rudis eft, nec difciplinam ullam admirtic, $\&$ quamuis caftretur nihilo melior euadit, Ifidorus. Verres, iutrencos, arietes, hødos defcrefcente Luna caftrato, Plinius. atqui Hefiodus in Diebus ocfauo diemenfis Lunaris uerrem $\&$ bouem ca. ftrari iubet. Aper qua ætate caftretur non refert; catera nifi nouella caftrentur, intereunt, Ariftot, 60 Caftrationis in hoc pecore duo tempora feruantur, uer is, $\&$ autumni: $\&$ Ceius adminiftrandx duplex ratio. Prima illa quam iam tradidimus : cum durobus uulneribus impreffis per unamquang plagam 


\section{DeSue. E. Lib. I.}

finguli exprimuntur tefticuli.Altera eft fpeciofior, fed magis periculofa, quam tamen non omittam: cum uirilen partem unam ferro refectam detraxeris; per impreffum uulnus fcalpellum inferito, $\&$ mediam quafi cutem, qux interuenit duobus membris genitalibus, refcinditołatç uncis digitis alte. rum quoos tefticulum educito, fic fiet una cicatrix adhibitis cæeteris remedijs, qux prius docuimus, Columella. Et rurfus, Mares uel cum primum ineunt femeftres, aut cum frepius progenerauerunt, trimi aut quadrimi caftrantur, ut poffint pinguefcere. Caftrantur uerres commodiffime anniculi, utiçs ne minores, quàm femeftres, quo facto nemen mutant, atçs è uerribus dicuntur maiales, Varr Etrurfus, Verres rectè inire poteft uf̧́ ad quartum annum, deinde caftratur, faginatur'suoad perueniat ad lanium. Polimenta tefticuli porcorum dicuntur, cum caftrantur \$a politione uefti= - mentorum, quòd fimiliter ut illa curantur, Feftus. \Caftratur \& foemina fus, etiam qux fxpitis iam peperit, \& à noftris tocatur ein galt5. Fominis quogs truluæ ferro exulcerantur, \& cicatrici bus clauduntur, ne fint genitales. Quod facile(facere) non intelligo quae ratio compellat, nifi penu: ria cibi:nam ubi eft ubertas pabuli, fubmittere prolem femper expedit, Columella. Apria etiam fcrophæ caftratur, ne praterea coitum appetat, fed breui tempore obefetur. Caftratur autem cum biduo ieiunarit, fufpenfa pernis prioribus, recifa cute inter femina, quà maribus teftes maximè conti nentur: hac enim parte adhæret uuluis apria dicta, cuius exigua parte abfciffa, confarcinant, Arifto seles. Lanï noftri porcis foeminis iunioribus uuluam totam ( Die gantse burbe) excindunt: uetulis

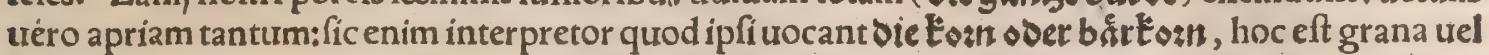
genitalia grana, qua plura fimul coniuncta effe aiunt, humore genitali grauida : quamuis non eo: 。 dem loco quo apriam Ariftoteles fita effe ferunt, fed in dextrolatere os facrü uerfus. Caftrantur foe minæ fic quog uti cameli, poft bidui inediam, fufpenfa pernis prioribus, uulua recifa, celerius ita pinguefcunt,Plin.

TPhorine, фoeirn, dicitur fuilla pellis thac optima eft pro calciamentis, Crefcentienfis. Noftri fut. tores, ut audio, non utuntur, quòd breui mollis $\&$ flaccida fiat, $8 \mathrm{~h}$ humorem trälmittat, (Iy wirt bal feifdig on১ blutt.) Ephippiarn̈ puto lora inde conficiunt, $\&$ helcịs fuperinducunt, Hinc \& libris operimenta adduntur, multò diuturniora quàm ouilla aut uitulina: firmior enim fuperficies eft, nec ita facile deteritur. Ex corn̈ fegmentis decoctis glutinum fit, quod quidam taurocollæ praferunt: ad cuius uocis fimilitudinem chorocollam dixeris Adeps fuillus optimus eft pro calciamentis conferuandis, Crefcentien. Noftri umbilicum cum fua pinguitudine pro calceis inungendis fer: 30 uant. Succinum rude primum nafcitur $\&$ corticofum, deinde incoctum adipe lactentis fuis expoli tur ad quem uidemus nitorem, Solinus cap. 13. Deaxungix ufibus fctibetur in G. Sanguinem fuillum aliqui mifcent medicamentis qux inịciuntur in aquam pro pifcibus capiendis. Venato. res quidam ut lupos aut uulpes captent, ex iecore fuillo affo $\&$ in frufta diffecto qux melle tingan= tur, efcam parant, \& calceos pinguti fuilla tofta illinunt, felem mortuam poft fe trahentes, \& $\&$ c uide in Cato E* Acerrimus hominis fimus eft, ut \& Chartodras omnium optimum eum effe affeuerat, fecundum fuillum, tertium caprarum, \&c. Theophraftus. Aliqui(adftercorandum) praferunt ho minum fimum, \&c.proximé fpurcitias futum laudant, Columella folus damnat: alij cuiufcunq qua drupedis ex cytifo, Plinius. Et alibi, Vrituineas fuillum fimum, nifi quinquennio interpofito, pra terquam fi riguis diluratur. Stercus afinorum primum eft, maximè hortisł̇deinde ouillum, \& capri 40 num, 8 iumentorum;porcinum uero peffimum, cineres optimi, Pallad. Laciucarum amplitudine quidam augent, recifis cum adfenipedem excreuerint, fimǫ̧́ fuillo recenti illitis, Plin. In arborum genere ftercoribus nonnullis ex ualidiorum numero uti confueuerunt, potiffimò cum fructus emol lire, immutaré́́ uolunt, ceu fuillo, quo punicæ dulcefcant $\&$ nucleo uacuæ reddantur, \& amygda la ex amaris in dulces tranfeant, Theophraftus de hift,3.12. Simala punica acida nafcantur, abla= queatis radicibus fimum fuillum adhibent: lum punicum fiacidum aut minus dulcem fruçum feret, ftercore fuillo $\&$ humano urináç uetere radices rigato. Ea res $\&$ fertilem arborem reddet, $\&$ primis annis fructum tinofum, \& poft quin. quennium dulcem $\&$ apyrenum facit. Ego ab homine non indocto foeniculum dulce futurum aut diui, fi terra circa radicem effoffa fimum bubulum reponatur. Columbino ac fuillo fimo pla. go gis quoo arborum medentur, Plinius. TAdlatas oliuas qua fructum non afferunt: Sed \& fine ablaqueatione adiuuanda elt amurca infulfa cum fuilla uel noftra urina uetere, Columella 5.9.

बIn quo quidem loco fues ftabulabunt, eodem equos nequaquam deducemus, nę̧ propè confifte= re patiemur. Inimica enim omnia fuilla equino generi, grunnitus, foetor, halitus, Camerarius. Quod egerit fus ægra, fi in prafepia boum inciderit, peftilentiam facere tualet, Columella, Sed plura in Bo. uis \& Equi hiftoria diximus quàm noxium eis hoc excrementum fit. Cauendum ne anferes hoedis nos porcinósue pilos deuorențexoluunt enim eos fi uorauerint, Anatolius. TQQuomodo foueís capiantur tum alix feræ, tum canes ac porci inträtes $\&$ diffipãtes uineas, Crefcentienfís docet 10.43.

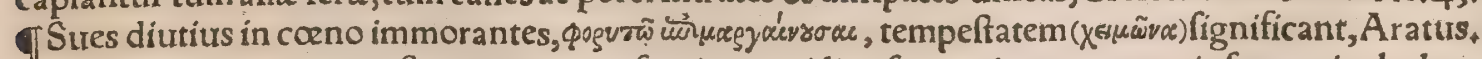
Imminentem enim tempeftatem cum præfentiant, auidius faturari quarunt priufquam includan: 60 tur, Scholiaftes qui фogu zoy conum interpretatur; uide paulo polt. Sues \& capræ præter morem li bidinofx, ( $\&$ maturius, )tempeftatem magnam futurã fignificant: fin tardiores fuerint ad coitu, fatis moderatum anni tempus futurum expectatur, Aratus urt retuli in Oue cap,quinto. Porci alienos 
fibi manipulos foeni lacerantes, tempeftatem, prafertim pluuiam fignificant, Plinius: uidetur autem ex Arato uel alio Greco anthore фogutoy uocem foeni manipulos reddidiffe. Et fanè Hefychi . us фogvìy interpretatur farmenta, paleas, quifquilias, et foeni manipulum quem uentus circa terram

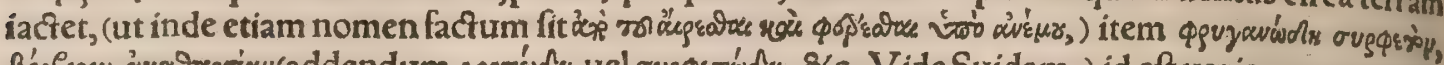

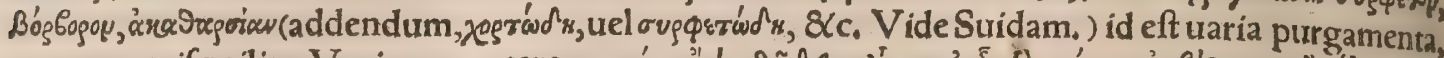

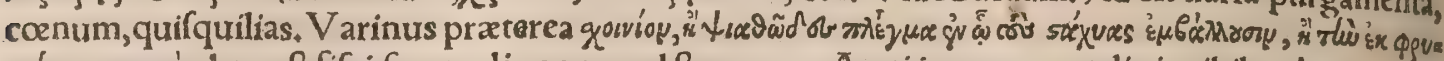

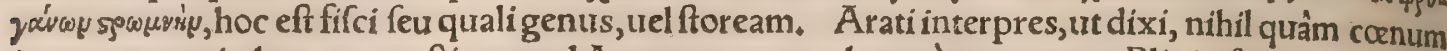
interpretatur in hoc prognoftico apud Aratum uocem phorytòn, ego cum Plinio foeni manipulos

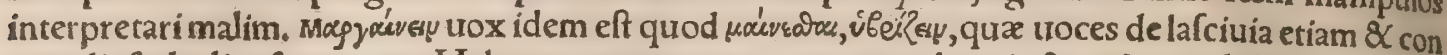
tumeliofis ludis ufurpantur. Habent autem pecora quo $\$$ exultantia $\&$ indecora lafciuia ludentia 1 eandem fignificationem, ut Plinius eodem in loco fcribit. A tqui fues ita lafciuire, \& obuium quod roftro arripere interdum, iactare, uulgò notum eft. Accedit quod apud Aelianum interprete Gillio fic legimus: Sues iactatis manipulis infanientes, uentum aut imbrem imminere fignificare, Democritus ait,

Sui animam pro fale datam non illepidè exiltimabattrr, Plin, Sus, inquit Cicero, quidhabetprę ter efcam:cui quidem ne putrefceret, animam ipfam pro fale datam dicit effe Chryfippus; qua pecus de, quòd erat ad uefcendum hominibus apta, nihil genuit natura forcundius, Gillius. Etenim omni um rerum quas $\&$ creat natura $\&$ turetur, qux aut fine animo funt, aut non multo fecus earum furma mum bonum in corpore eft, ut non infcite illud dictum uideatur in fuem, animum illi pecudi datum 20 pro fale, ne putrefceret. Sunt autem beftix, in quibus ineft aliquid fimile uirtutis, ut in leonibus, ut in canibus, ut in equis, in quibus non corporum folum ut in fuibus, fed etiam animorum aliqua ex parte motus aliquos uidemus, Cicero libro 5 . de finibus, Greci porcum à natura donar tum dicunt ad epulandum, itaq̧; fuibus animam datam pro fale, qui feruaret carnem, Varro. fIn lege Mofis Leuit, 11 \& $\&$ Deuter, 14 . fuilla prohibetur:quia nec ruminat fus $\&$ uiçu impuriffimus eff, Animalia quædam quæ diuino cultu profequebatur Aegyptus, ut ouem 8 bourem, Dets pura in cibo haberi uolurit, ut contemnere ea difcerent Iudxi i illa uero qua Aegyptif autidius lurcabantur, prohibuit, ut fuillam, quam in folitudine etiam defyderabant Iudaxi, Procopius. Comedentes cars nem fuillam $\&$ ius (animalium)abominabilium habentes in uafis fuis ; qui dicunt, mane apud te, \& ne accefferis ad me, quoniam fanctior te fum: illi (fufcitant) fumum in furore meo, Efaiz 95 . Munfe 30 ro interprete. Dominus iudicabit, \& c cedentes fuillam, $\mathcal{Q}$ abominationem atç murem, Efa, 66, Ea leazarus unus ex principibus fcribarum, iam nonagenarius aperto ore hians compellebatur carnê porcinam manducare:fed ille mori potius quàm hoc exemplum uiolata legis in fe committere, funfin nuit,Machab.2.6. Contigit autem feptem fratres unà cum matre apprehenfos compellià rege(An. tiocho Epiphane)edere carnes porcinas flagris $\&$ taureis cruciatos, \&c, Ibid, 2.7. Heliogabalis abftinebat fubus, ut mos eft Phơnicibus, Herodianus. Mulieres Barcęæx in Africa non modogufus uaccinæ carnis, fed etiam furille abftinent, Herodotus lib. 4. Aegyptí quoq̧ fuem non guftant, Ibia $\mathbf{d e m}$. Vide plurra infra in $\mathrm{h}$. Arabes Scenitze carnibus fuillis prorfus abftinent, fane hoc animalis genus fi inurectum illò furerit, moritur illico, Solin.ni fallor. Arabas nouimus camelorum lacie uefdi, à̀ carnibus fuillis uero abftinere imprimis, copix uel raritatis utrungs ratione, Calius. A pud Indos $4{ }^{\circ}$ nullum furem neqģ ferum neq̧ cicurem nafci Ctefias Cnidius ait, 8c fuilligeneris ufum Indosấfede teftari, \& tantopere ab eo uefcendo, quàm ab humanis carnibus abhorrere, A elian.

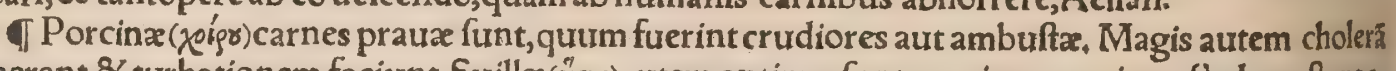

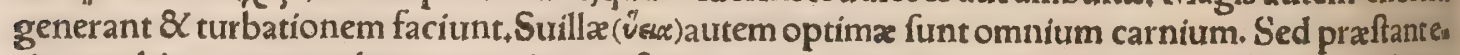

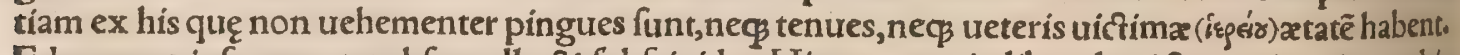
Edere uero ipfas oportet abfog pelle, \& fubfrigidas, Hippocrates in libro de uictus ratione in morbis acutis. Vbi Galenus in commentarńs: Porcum (yeîgov, inquit)priuattm nominabát ueteres, ualde part

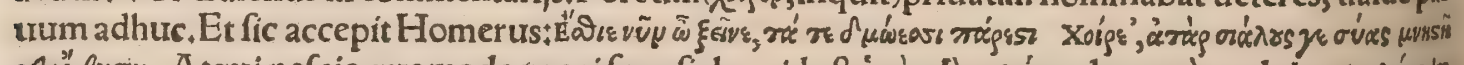

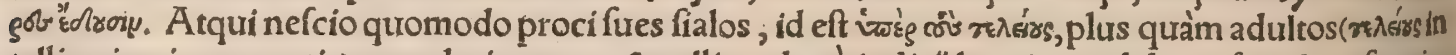
telligo in uigore ætatis)comederint, tanquã nullius plané iudicí̉ homines ad dignofcendum fuauio so ra $\&$ concochu faciliora cibaria:quod fimiliter de uentribus caprinis dixerim, quos fanguine $\&$ adia pe repletos edebant, quo uix difficiliorem concoctu cibum reperias. Facillima fanè concoctu $\& x$ fuaa uiffima caro eft fuis atate medĭ, qux fanguinem quog, probum generat, peffima uero tum uetuli ni mium, tum nuperrimè nati. Siquidem fus omnium fere terreftrium animalium, qux in hominis cis bum ueniunt, humidiffima carne eft: quamobrem nuper geniti porcelli caro immodicè humida cum fit,plurimam pituitam gignit:idós multò magis fi crudiuffula(non fatis cocta ad ignem)fuerit, Ean* dem ob caufam Hippocrates fuis carnem nimium pinguem magis improbat quàm mediocriter cor. pulentæx fuis, humiditatem eíus non probans:propter quam omnis fanè pinguedo minus bene tum concoquetur tum nutriet quàm de eodem animante caro. Sed ambuftre quiogs(porcinę carnes)inter affandum, ad concocionem $\&$ boni fucci generationem non idoneæ funt, $\&$ proprex acquifitam as 6 crimoniam choleram fiue bilem procreant.Commune enim hoc uitium bilioforum cibariorum eft, cum humida $\&$ acria fuerint, Corrumpuntur enim hac (omnia) fimiliter, $\&$ cum acredine fua uaforü 


\section{DeSuc. F. Lib. I, roor}

ad uentriculum pertingentium ora mordicent, ut humores ex toto corpore in uentrem deriuentur, efficiunt, Caterum pellem non ediubet, quód carne concoctu difficilior fit, utpote frigidior. Porró cum fuillas etiam (ut caprinas ante) frigidiufculas edi uult, carnem nullam calidam probare uidetur,

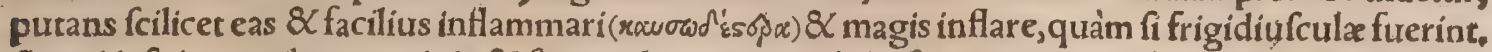
Atqui ipfe in carnibus caprinis, \& fi qua alize natura calid $x$ funt, rationem iftam admitto:in illis ue ro qux calefaciendo $\&$ refrigerando temperatx funt, fimpliciter $\&$ abfí $\beta$ diftinctione alteras alteris praferri non approbo, Hucufq̧ Galen. Xö̈g porcus eft adhuc tener, delphax uero adultus, alí, contra uolunt, Hermol. Omnium ciborum (inquit Galen. de alim, fac.3.1.) fuum caro potentifime nutrit. Cuius rei athletæ certiffimum tibi præbent indicium. Si enim paribus exercitationibus parẽ 10 molem alterius cibi pridie totum diem comederint, poftero die ftatim fentient fefe redditos imbecila liores. Quòd fi pluribus deinceps diebus id fecerint, non imbecilliores modo, uerum etiam alimenti penuria macilentiores palàm confpiciuntur.Idem etiam de eo quod dicimus, potes in pueris, qui in palaftra fefe exercent, experiri, $\mathcal{X}$ in alij s, qui quamlibet actionem fortem ac uehementem (cuiufmo di eft fodientium)obeunt. Et mox, Cæterum quantum carnes bubulæ totius fuæ fubftantię crafitie fuillam fuperant, tanto fuill $x$ bubulas lentore antecedunt. Cxterum ex fữ carnibus, hominibus quii dem ætate florentibus, fortibus $\&$ qui fe multum exercent, fuũ atate florentium carnes ad coquen. dum funt praftantiores:alịs uero fuum adhuc increfcentium. Porrò quemadmodum ex fuibus qui xtate funt florenti, ịs iuuenibus qui bono corporis funt habitu, conueniunt: fic $\&$ boum, qui nond $\tilde{u}$ florentem xtatem attigerunt. Bos enim temperamento eft quàm fus multò ficciore.quemadmodũ $\&$

20 uir æatate florens quàm puer. Et paulò poft, Capra temperamento minus quàm bos eft ficca, $f i$ tam $\widetilde{\varepsilon}$ homini \& fui comparetur, multum fuperat. Suilla autem carnis fimilitudine cum humana ex eo po teris intelligere, quòd quidã carnes humanas pro fuillis fine ulla in guftu uel olfaçu fưfpicione come derunt.id enim ab improbis hofpitibus $\&$ alijs quibufdam factũ furfe iam compertum eft. Merito igitur porcelli alimentâ nobis prabent, tanto magis fuibus excrementofius, quanto ipfis funt humi: diores:meritò minus etiam nutriunt. Nam alimentum humidius, ut diftribuitur, ita etiam difcutitur celerius. Et rurfus, Sures quanc̈̈ temperamento funt humidi, cum tamen iam fenuerint, carnem ham

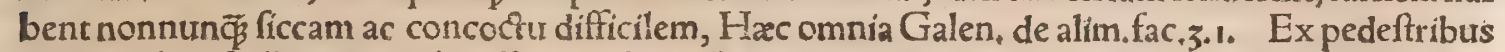
animantibus fuilla caro probatifimus cibus eft, deinde hoedina, mox uitulina, Galen, in lib, de cibis boni \& mali fucci. Alica, ficuti \& fuilla caro, fí exactê in uentriculo concoquantur: tum in fangui= 50 nem à iocinore conuertantur, probatifimos humores gignunt, fed glutinofi aliquid in fe habent, ob idćs in ńs iecur obftruunt, \& renes, quiburs hac â natura aciftrictos meatus habent, \&c. Ibidem. Â pri fuibus domefticis in cibo funt anteponendi, ut omnia qua exercentur jus qua funt otio $\{\neq \&$ qua $c i=$ bis ficcioribus, ïjs qua humidioribus utuntur. deniq qua purũ ac tenuem aérem inf́pirant, ñs qua contrarium funt praferenda. Suum quidem domelticorum caro, omnium aliorum ciborum firmif: fimè nutrit:multũ enim in feipfa habet lentorem, tum propter uítã defidiofam, tum propter cibi hur= midioris affluentiam. Verũ ab his prorfus abfinebit, cui propofitũ erit uictur extenuante uti. Quod uero ad reliquas carnes attinet, non quibufuis fimpliciter uéfetur, fed fi multum fefe exerceat, lice. bit ei $\&$ auribus $\&$ roftris, $\&$ pedibus fuillis uefci, uentre præterea $\&$ matrice, fi modo ea elixa belle fuerint, Galen. de attenuante uictu 6 . Etrurfus ca, 10, Qui attenuante uictu uti uolet, poterit nónun 40 quam etiam prædictis(ut cetaceis pífcib.) craffioris fucci cibarijs uefci, fi ex aceto aut oxymelite fue rint praparata,tum alijs etiam plurimis corum qua fucco omni exhauriri queunt, Quin \& furilla ip fa exurca tutò uefcetur, qux utiọ alioquii effet uitanda, ut qux fuccum craffum ac lentum generet, Omnium quas nouimus ciborum maximé nutriens fuilla caro eft, fed non aque ut pradicta (pifces

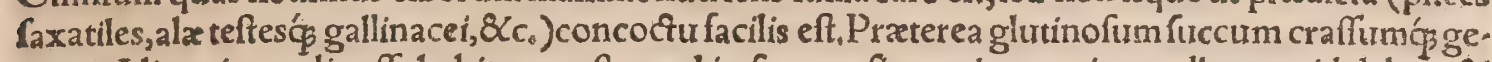
nerat. Alioqui nec alio effe habitu poteft quod in fummo fit nutriens:quippe adharere id deber, $\&$ firmiter affigi, non autem pratenuitate diffluere, Galen.7. Wethodi medendi. Carnes fuillar, $Q^{\prime}$ que cunqu lentos ac craffos humores habent, longo tempore faciunt ex toto corpore tranfpiratione. Ole ra uero $\&$ pifces faxatiles, \& quacun $\phi$ tenuem habent humorem diftribuendum, celerius quidem di ftribuuntur \& apponuntur, ftabilem uero naturã non habent, fed facile difflantur, Galen, aphorif́m.

$5^{\circ}$ 2.18. Extremas quadrupedum partes edunt homines, pedes, roftra, auriculas + quas magna ex parte aqua elixas cum aceto \& garo, interdü $\&$ cum finapi, aliqui uero etiã cum oleo $\&$ garo, uino qurọ affufo, comedunt: quidã cum oleribus fiue aqua elixas, fiure in ollis conditas, Porcini quidem pedes, ptifanæ inter coquendum inieçi, tum illam meliorẽ reddunt, tum ipfi molliores fiunt, eó̧́ aptiores tum ore mandi tum concoqui in uentriculo, Galen de facult. alim.3.3. Et pauló inferius, Præeftane fuilli pedes roftro, illud auribus, aures enim fola cartilagine $\&$ cute conftant, quare perparum alût, Inter domefticas quadrupedes (inquit Celfus) leuifima fuilla eft $\&$ ex eodem fure ungula, roftrum aures, cerebellum, aliquantò quàm cxtera membra leuiora funt, adeò ut in media materia poni pof, fint:\& eadem cum trunculis uuluisóng inter res leues, boni fucci \& ftomacho idoneas numerat. Suil Ia tam recens quàm falita, etfi guftu titillat, perniciofa tamen omnino eft ac mali fucci, ut aic Celfus, 6. Platina. Porcellorum carnes mucofas $\&$ nimis humidas effe, in Vitulo etiam ab initiocapitis fext ex Galeno recitaui. Caro fuis tum cicuris tum domeftici, ut fertur, cito concoquitur \& defcendit, multum alic, fed fuccum gignit craftum $\&$ uifcofum, Auicenna, Caro apri fecundum Chriftianos 
inter ferinas optima eft:nempeleuior quàm fuis cicuris, \& ualidi multiọ nutrimenti.citó concoqui tur, pręcipuè autem hyeme conuenit, Idem. Porcellorum caro parum nutrit, quód facile refoluatur \& adinodum humida fit, Idem. Galen, lib, 8, de fanitatis ratione, fuillam carnem cateris laudabilio rem facit. Auricenna capite de fanguine, humanum fuillumó̧ fanguinem, in omnibus exactam ha, bere fimilitudinem foribit: \& fimiliter carnem:adeó ut impuratiores quidam pro fuilla humanam dı ftrahere aufi fint: quod facinus diu perrexit impunitum, donec digiti hominis intermixti forte con. fpecti, ad fupplicij diritatem, etiamfi feram, auctores protraxêre:id quod decimo(cap.2.) Simplicis medicinæaffatim expofuit Galenus. A urerrois quinto Colliget, ex Auicennx placitis porcinam cat. nem cæteris præferendam omnibus ftatuit, ueluti hominibus natura cognatiore $\tilde{e}_{\text {. quod (inquit) effe }}$ ita experimento planè difcimus, Calius. Suum qui delphaces, hoc eft porculi nuper nati, qui \& hu 11

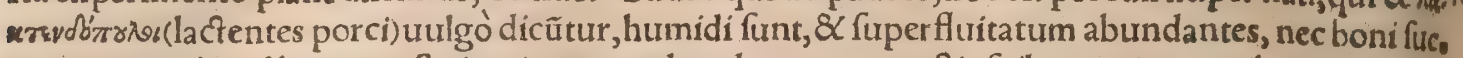
ci, qua ex re haud bonum eft eis uti : quemadmodum nec uetuftis fuibus, quippe quibus malus infit fưccus. A prorum uero caro melior eft quàm fuũ domefticorum, quod tantarũ non fint fuperfluitatü

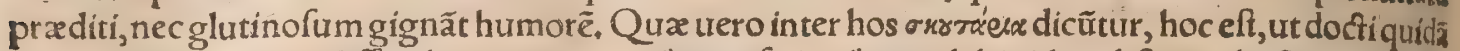
putant, calli a prugni, difficulter concoquunte et perficiunt, atक̧ ab his ideo abftinendû, Symeó Sethi, Et alibi, Suilla caro boni fucci eft $\&$ facilis concoctionis cum porcus annalis eft, propter fimilitudinë quã curm hưmano corpore habet. Quidam enim famis neceffitate carnes humanas guftauêre, quas fuilla fimiles guftu effe prodiderunt. Alit uero magis omnibus alīs cibarís. Quęrent fortaffealiqui, quonam pacfo fuilla magis alat, \& præalijs temperata uel mediocris fit, cum hoc femper animal in coeno $\&$ fordibus uolutetur \& nutriatur : quam dubitationem quidam foluentes, aiunt, quód nifia ualde bene temperatum foret fuis corpus, nunquam malum nutrimentum in bonam carnem uerte. ret. Quemadmodum enim in hominibus qui corpore bene temperato funt $\delta<$ fano, rebus mali fucci 8 alimentis non multum lxduntur: quoniam natura cum tempore quod noxium eft in bonum fuc cum uertit, fic $\&$ in noxijs animalibus. Qui ergo humidi funt uentriculi, fuillam non bene concos quunt, fed obfrpiuntur, fuperuacaneãós, \& fuperfluam humiditatẽ, glutinofumç̧ humorẽ actutum gignunt. At fi probe concoquantur, bonum \& boni fucci alimentum facit, præfertim fi poreus caris ciș alatur:ut enim aiunt, is apprimé fuauis $\&$ boni fucci alimentum facit, Hactenus Symeon Sethi, Suem fuauiores (habere) carnes iamdudum creditum eft, Aelianus. Suillam carnem quoquomo: do coxeris, infalubrem inuenies, Platina. Suilla $\&$ agninx carnes cum in corporibus incoctamax nent facillima corrumpuntur propter pingứtudinem:caprinæ non item, Athenæus, Sulla nifiui ${ }^{30}$ num bibatur deterior eft ouilla, addito autem uno alimenti fimul \& medicamenti rationem habet, (humectando corpus, )ut legitur in Carmine Salernitano: ubi Arnoldus, Hoc maximè intelligendû̉ eft de porcellis affis, uel apr is optimè praparatis. nam fuilla falfa, uel Sole fumoúce exiccata, fiue cum uino fiue $a b f c ̧$ uino fumatur, minime debet praferri ouilla. In eodem Carmine legitur, llia porco, rum bona funt, mala funt reliquorũ. Arnoldus ilia interpretatur omafa fiue inteftina, Sed pauca ins teftina (inquit) comedimus, nifi quæ replentur fanguine, uel quæ funt animalium pr æainguium, ut porcina. Solus autem porcorum fanguis, propter fimilitudinem eius cum temperamento humano inteftinis immitti folet ad cibum \$ \& porci facilius obefantur quàm ullum aliud animal. quamobrem fuis potius quàm alia inteftina eliguntur.

Sus tibi coenofo fit cona domefticus ore,

Ille licet currat de uertice montis, a quofa

Húc feritas fyluæç domant, \& inania faxa, Poft melius pofita rufticitate fapit, Baptifta Fiera. Bianti pugili cum natura uorax effet, contigit ut in affectiones cholericas, bilis furfum ac deorfum exeuntis, delaberetur, ex carnis efur.maxime uero ex porcinis carnibus crudioribus, $\&$ ex ebrietate uini odorati, \&c. Hippocrates 5. Epidemiorum. Scropha cum peperit macilentior fit, \& carnẽ mas gis lentam minusćs fapidam habet. Aliqui talpa caput præcidưnt, \& cum terra à talpis excitata uto fum digerunt in paftillos pyxide ftannea, \& utuntur ad omnia qux intumefcunt, \& qux apoftemata

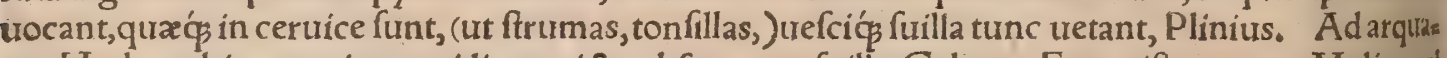
tos: Herba rubia utere in quotidiano uictu abfq carne fuilia, Galenus Euporifton 2. 39. Mulier cul ulceratus eft uterus, abftineat carnibus, porcinis, bubulis, $8 \mathrm{C}$ caprinis, edat autem panes, Hippocrat, de morbis mulieb. Suilla uentrem uifcofo humore fuo humectat, $\&$ urinam mouet, Ifaac, Mihi qui dem cum lentum craffumóp fuccum reddat, urinæ mouendæ nequaquam idonea uidetur. Porcelli lactentes(inquit Ifaac apud Vincentiü Bell,) facile in malos humores uertuntur, $\mathcal{Q}$ in putredinem, pracipue in uentriculo prauis humoribus imbuto, fortibus uerò uentriculis utiles funt, cũ bene con coquuntur.fecus enim phlegma uifcofum gignunt, \& naícentes inde morbos, podagram, ilium dolo rem, calculos renum, paralyfin, \& fimiles pro temperamentis $\&$ naturis edentium. Adulti fues, me liores funt, præfertim caftrati, uetuli uerò peffimi, utpote frigidi, \& carnis duræ, lignex, infipidax, qui bus affueti incidunt in melancholiam $\&$ diuturnas febres, ut quartanam. Raró utendum domeftico fue.præferentur autem partes extremæ, ut pedes, \& pernæ, qux femper mouentur. Qui ederint, poft cibum exercitari debent. quietè autem uituentibus cauenda funt fylueftria multò magis quàm dome 60 ftica,Hæc ille. Suilla omnis tum cicuris tum ferífuis, æftate damnatur; nec probatur donec magnú frigus ingruat, circa brumam, id eft, folftitium hyemale, Per aftatem enim immodicé fomno deditum 


\section{DeSuc. F. Lib. I. Iooz}

eft hoc animal, Mich. Herus, Sus nimium fomno obnoxius per aftatem, nifi frequenter excitetur, lethargum incurrit \& moritur aliquando. quare tum temporis, caro eius infalubris eft, propter hu= miditatem a calore refolutam, Albertus \& Liber de nat.rerum. Idem aprugnam difficiliorem con= cociu effe fcribit quàm domeftici fuis, eamós ob caufam otiofis hominibus minus conuenire: quod ego non probârim. Aliquí in cibo noxiam elfe aiunt porcam, fi mactetur mox poftquam cum uer recoierit. De grandinofis fuibus, quos aliqui edunt cum non omnino abundant, fupra capite ter. tio dixi.

T) Aurelianus porcinam carnem populo Rom,diftribuit, qua hodiéǵs diuiditur, Vopífus. Ifte tibi faciet bona Saturnalia porcus, Inter f pumantes ilice paftus apros, Martialis lib.14. Heliogaba

- lus habuit iftam confuetudinem, ut una die non nifi de phafianis tantum ederet:item alia die de pul. lis, alia deporcis, Lampridius, Athenaus lib, 12, fues ex Sicilia tanquam pracipuas laudat. Idem

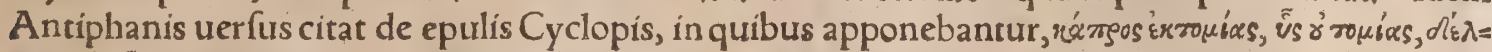
$\Phi x \xi$, id eft, maialis, fus non caftratus, $\&$ porcellus. TCarnem fuis nondum uetuli minutatim concifam, cum lardo teffellatim incifo, \& columbis, perdicibus aut alís, $8 \mathrm{c}$, aliqui paftillo uulgo dicto ine clufam coquunt. बP Porcus Troianus; Gula ueteres architecti(inquit Erafmus in Chiliad.) \& hoc commenti funt, ut bos a ut camelus totus apponeretur, differtus intus uarïs animantium generibus. Hinc \& porcus Troianus uenit in populi fabulam, cui hoc nomen inditura eft, quód ita uarias ani= mantium fpecies utero tegeret, quemadmodum Durius equus texit armatos uiros. Macrobius libro Saturnalium tertio $(c a$, ; .) refert Cincium in oratione qua fuafit legem Fanniã de moderandis fum,

10 pribus, obieciffe fuo feculo, quòd porcum Troianum menfis inferrent. Conueniet in opipara conui uia, aut in hominem uarís delicins expletum, Erafm. Callum aprugnum \& porcus Troianus fum= ptuarı lege prohibebantur, Volaterranus, Poft hæc infertur difcus (rivą) argenteus, non modica craffitudine inauratus, tantus ut porcum affum eumós pragrandem caperet, qui fupinus in eo pofí tus erat, eminente uentre urarijs bonis refer to. Inerant enim fimul affa, turdi, uulux, ficedulæ pluria mx, oua fuperinfura, oftrea, pectines: qux adhuc feruida fingulis conuiuis unà cum orbibus diftri buebantur, Hippolochus in epiftola ad Lynceum de Carani conuiuic a pud Athenæum lib. 4. Idem Athenæus lib.9. in Dipnolophiftarum conuiuio, Allatus eft nobis(inquit)etiam porcus(delphax) di

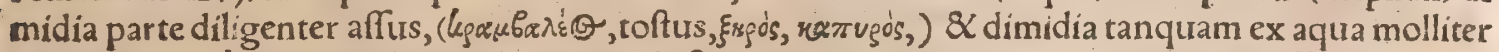

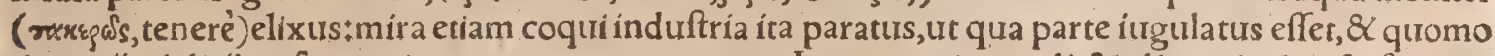
o do uarị́s delicịs r efertus eius uenter, non appareret. Inerant enim turdi, $\&$ aliæ auiculæ, \& fuminü

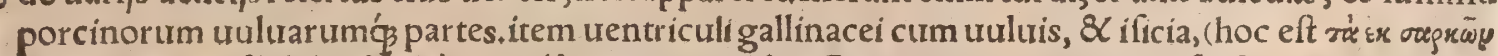

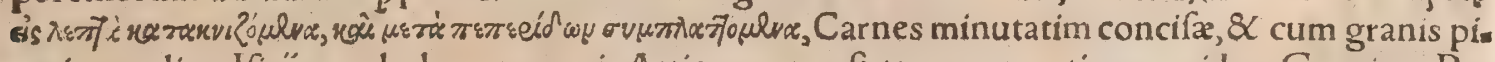
peris condita. Ificĭ uocabulum quamuis Atticum non eft, tamen recentiores quidam Graci, ut $\mathrm{P}_{2}=$

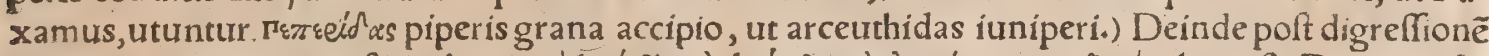

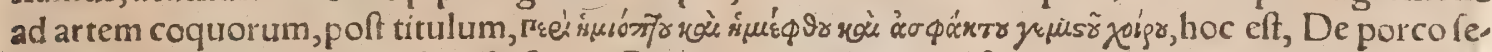
miaffo, femielixo, non iugulato \& farcfo:Porcus(inquit coquus) fub humero paruo uulnere macta tus eft: deinde copiofo fanguine euacuato, inteftina omnia unà cum apharefí(quam \& exærefin uo= cant, ut Dionyfius Comicus) exemi(hoc uerbum Athenæus non haber, fed addendum uidetur;) $8 C$ poftquam uino fapius ac diligenter collui, à pedibus fufpendi, \& rurfus uino perfurum elixauri cum 40 multo pipere, tum prædictas delitias ( $\chi \propto \omega \mu \alpha \operatorname{crc}$, nempe auiculas, fumen, uitellos) per os uentri intru. fas,copiofo \& optimo iure per fudi, \& dimidiam porci partem multa polenta(farina ex hordeo) uino

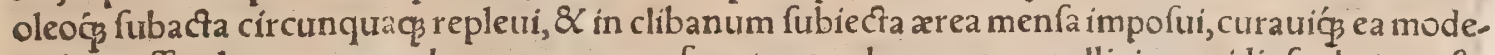
ratione affandam, ut negs adureretur, nec auferretur cruda. nam cum pellis iam aridiufcula (

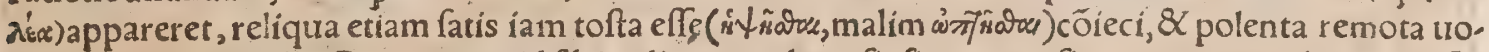
bis appofui, Hac ille. Cærerum quid fibi uelit uox aphærefís fiue exærefis, non reperio, hoc manife= ftum eft, aliquid in trentre porci, quod unà cum inteftinis eximebatur, unde nomen inditum, fic di= ctum fuiffe, omentum fortaffis, aut mefenterium. Quanquam \& inde dici potuit, quòd lanij forte has partes ceu parandi exenterandiós mercedem fibi auferrẽt $\&$ exciperent, ut pifcatores apud nos in pifcibus praparandis faciunt. Sic $\&$ aphæremata dicuntur, partes quas à uictimis auferebant (fa so cerdotes qui eas mactabãt, ut in Sacris literis legimus, )pectus, brachium dextrum $8<$ fibra iecinoris, ut Varinus fcribic. Cum hoc porcello Athenæi communia quadam habet porcellus hortulanus A picï, qui inferius inter cateros A picin porcellos defcribetur. đIn Lufitania, ut Polybius lib. 34. author eft, fua ætate tanta rerum uilitas erat, ut $\&$ cætera minimo plané pretio uęnirẽr, \& ũs díris vay, centum librarum pondere, quinç drachmis, $A$ thenæus ab initio libri 8.ubi illud obferuandum, uo:

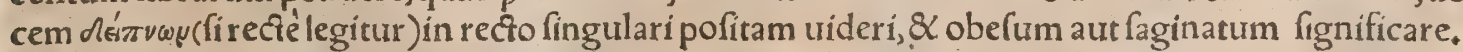

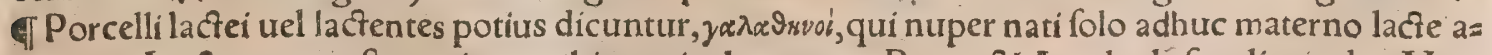
luntur. Laçemero paftum pigræ mihi matris alumnum Ponat, \& Aetolo dé fue diuesedat, Mar: tialis. Et alibi, Nondumćs uicta (concocta) lacteum faba porcum, libro quinto in epigrammate ad

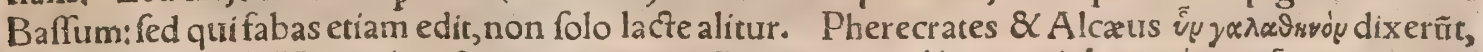

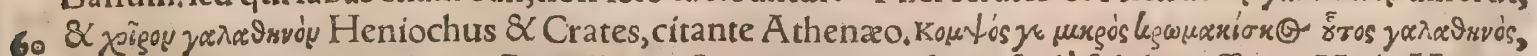
Antiphanes apud eundem. Porcellus noftro etiam auo fapiufculé folidus affatur, Mich. Humel. bergius, Vipera(uiuerra,IMarcellus)porcelli modo inaffata,tocinerum doloribus medetur, Plin, 
đI In porcellum(trerba funt Apicii 8.7 .) farfilem duobus generibus, (qui duobus modis ato locig farcitur † (cilicet fub cute $\&$ in uentre, ficut $\&$ pulli noftro $æ u$ farcíri folent, Humelbergíus.) Curäs, à gutture exenteras, à ceruice ornas antequam pradures, fubaperies auriculam fub cutem, mittes im penfam Tarentunam in ueficam bubulam, \& fiftulam auicularñ (quí auiario præeft)roftro(collo) ure ficæ alligabis, per quam exprimes in aurem quantum ceperit, poftea charta pracludes \& infiblabis: \& praparabis aliam impenfam,fic facies. Teres piper, ligufticum, origanum, laferis radicem modia cum:fuffundes liquamen: adịcies cerebella cocta, oua crưda, alicã coctam, ius de fư fibi,ferueat: cî̉ ferbuerit, auicellas, nucleos, piper integrum: liquamine temperas:imples porcellum, charta obturas \& fiblas, mittes in furnũ:cum coctus fuerit, exornas, perunges, \& inferes, Aliter porcellum, falem, cuminum, lafer. Porcellus liquaminatus:De porcello ëjcis ưriculum,(uentriculum, ita nealiquę pulpzin eo remaneant, Teres piper, ligufticum, origanum:fuffundes liquamen:adícies unum cere bellum, oua duo mifces in fe, porcellum praduratum imples, fiblabis, in fportella feruentiolla fub. mitris,corto fiblas tolles, ut ius ex ipfo manare poffit, pipere afperfum inferes. In porcellü elixum farfilem:De porcello utriculum eijcies, præduras. Teres piper, ligufticum, origanum : fuffundes li quame ; cerebella cocta quod fatis fit, fimiliter oua diffolues: liquamine temperabis: farcimina cocia integra pracides, fed ante porcellum præduratum liquamine delauas, deinde imples, infiblas, in fpor tella fer uenti olla fubmittes, coctum fpongizas, fine piperé inferes. Porcellus affus tracfomelitus: Porcellum curatum à gutture exenteras, ficcas. Teres piperis unciam, mel, uinum: impones utfer. ueat, tractam ficcatam confringes, \& partibus cacabo permifces $:$ agitabis furculo lauri uiridis; tandiu coques donec lenis fiat $\mathbb{X}$ impinguet; hac impenfa porcellum imples, furclas, obturas charta, infur. 14 num mittes, exornas, \& inferes. In porcellum lacte paftum elixum calidum fiue frigidum iure cru do A piciano: Adịcies in mortarium piper, ligulticum, coriandri femen, mentham, rutam, fricabis: fuffundes liquamen+adincies mel, uinum: 3 liquamine porcellum elixum feruentem fabano müdo ficcatum profundes $\&$ inferes. Porcellus Vitellianus:Porcellum ornas quafi aprum: fale afperges: in furno affas:adijcies in mortarium piper, ligufticü :fuffundes liquamen : uino \& paffo temperabis: in cacabo cum oleo pufillum ferueat, $\alpha$ porcellum affum iure alperges ita ut fub cute ius recipiat, Porcellus Flaccianus:Porcellum ornas in modum apri, fale afperges, 8 in furnum mittes: dumcoa quitur, adịcies in mortarium piper, ligufticum, careum, apị femen, laferis radicem, rutam uiridem, fricabis: fuffundes liquamę; uino \& paffo temperabis + in cacabo cum oleo modicum ferueat, amylo obligas, porcellum coctum ab offibus tanges + apï femen teres ita ut fiat puluis, afperges $\&$ inferes, 30 Porcellus laureatus: Porcellum exoffas quafi onogaratum, ornas, praduras, laurum uiridem in me: dio franges, fatis in furno affas: 8 mittes in mortarium piper, ligufticum, careum, apī femen, laferis radicem, baccas lauri, fricabis; fuffundes líquamen $\div$ uino $\&$ paffo temperabis; adỉ cies in cacabü olet modicum ut ferueat, obligas, porcellum lauro eximes, $\mathcal{Q}$ ius ab offe tanges, $\mathcal{Q}$ inferes. Porcellus Frontonianus + Porcellum exoffas, praduras, ornas ; adịcies in cacabum liquamen, uinum: obligas fafciculum porri, anethi: media coctura mittes defrutum ; coctũ lauas $\&$ ficcum mittes:piper afper ges, \& inferes. Porcellus œnogaratus: Porcellũ praduras, ornas, adijcies in cacabum oleum, liquaa men, uinum, aquam:obligas fafciculum porri, coriandritmedia coctura colorabis defruto: adjicies in mortarium piper, ligufticum, careum, origanum, apü femen, laferis radicem, fricabis ₹ fuffundes liqua men, ius de furo fibi : uino \& paffo temperabis: exinanies in cacabum: facias ut ferueat:cum ferbue, 40 rit, amylo obligas:porcellum compofitum in patina perfundes:piper afperges, $\&$ inferes. Porcellus Celfinianus: Ornas, infundes pipere, ruta, cepa, fatureia, fucco fuo: \& oua infundes per auriculam: $8<$ ex pipere, liquamine, uino modico in acetabulum temperas \& fumes, In porcellum affum: $\mathrm{Te}$ res piper, rutam, fatureiam, cepam, ouorum cocforum media : liquamen, uinum, oleum, condimen: tum;bulliat conditura:porcellum in boletari perfundes $\&$ inferes. In porcellum hortulanum, (hoc eft, oleribus fartum, Humelbergius. Meo quidem iudicio non falletur qui pro hortulano Troianum dixerit ${ }_{\ddagger}$ ) Porcellus hortulanus exoffatur per gulam in modum utris, mittitur in co pullus ificiatus particulatim concifus, turdi, ficedula, ificia de pulpa fua, (forte fuis, ) lucanicx, dactyli exoffati, fat briles bulbi, cochlex exemptæ, maluæ, betæ, porri, apium, coliculi elixi, coriandrum, piper integtü, nuclei: oua quindecim fuperinfunduntur:liquamen, piperatum, oua mittantur tria \& confuitur, \& $p$ praduratur, in furno affatur. Deinde à dorfo f cinditur, \& iure hoc perfunditur † piper teritur, ruta: liquamen, paffum, mel, oleum modicum, cum bullierit, amylum mittitur : (Haber quxdam cum hora tulano ifto Apichi porcello communia, ille Athenai quem Dipnofophiftis appofitum fupra recitaui in Porci Troiani mentione.) Ius frigidum in porcellum elixum ita facies: Teres piper, careum, ane thum, origanum modice, nucleos pineos: fuffundes acetum, liquamen, carænum, mel, finape factum: fuperftillabis oleum: piper afperges \&inferes. Porcellum traganum fic facies: Exoffas porcellum, $\&$ aptabis ficut œnogaratum, $\&$ ad fumum fufpendas $\&$ appendeas, $\&$ quantum appẽdeas tantum falis in ollam mittes, \& elixas ut coquatur, $\&$ ficcum in lance inferes, falfo recente. In porcello lat ctente: Piperis unciam, uini heminam, olei optimi acetabulum maius, liquaminis minus, Hucufque Apicius.

đDe porcello affo. Porcellum adhuc lacientem (inquit Platina 6,15.) iugulato, uillosćç cultro omnino acuto abradito, $\mathrm{Per}$ fpinam deinde fcindito, eximitó́p quicquid in uentre habet: lecufcula 


\section{DeSue. F. Lib. I. 1005}

cius cum larido, allio, cum'ç odoriferis herbis minurim concidito tritư cafeum, our agitata, tunfum piper,crocum in puluerem redacfum, cum fuperioribus bene mifceto : in porcellumóp omníno ita inuerfum, ut quod intus erat, foris fit, indito: ac claudito, ne excidat. Coqui in ueru, aut fuper crati. culam lento igne non incommodé poteft, ut omnia pariter efui bona fint. Dum coquitur, aceto, ple pere,croco, fimul mixtis cum faluiæ aut rofmarini aut lauri ramufculis fape afpergenda eft. Idem $e_{\text {: }}$ tiam fieri ex anfere, anate, grue, capo, pullaftra, poteft. Malè hoc 8 parum alit, tarde concoquitur: fto macho, capiti; oculis atç, hepati nocet. Obfructiones facit, calculum creat, pituitam auget. TEu

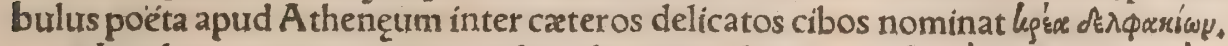

- Lardum, ut grammatici quidam deriuant, dicitur quafi latè aridum, (largè arídum, Hermola= - us ex Macrobio, )eft autem caro fuilla quoquo modo falfa, fiue(ut alips placet)id pingue quod eft in fue. Pinguia cur illis guftantur larda calendis ? Ouidius 6. Faft. Plinius dixit, lardum pingue hoc unctum, quafi \& macrum dici poffit, Et pallens faba cum rubente lardo, Martialis lib, 5. Graue lar.

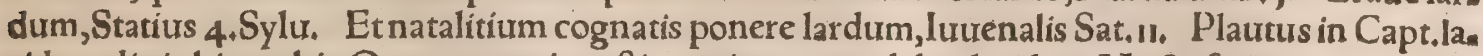
ridum dixit, his uerbis + Quanta pernis peftis ueniet, quanta labes larido? Vncta fatis pingui ponen tur olufcula lardo, Horat.Serm.2.6. Vtlurcaretur lardum $\&$ carnaria furtim,Lucilius. Lardum lurcabat lubens, Pomponius Syris apud Nonium. Lardus porcorum optimus eft in condiendis omnibus cibis, Crefcentienfis. Noftri lardo olerum ferèminutalia $8 \times$ rapa condiunt, fiue decoquen do fimul lardi offas, fiue in minimas teffelas incifum infpergendo. Turundx etiam, ut fic uocem, oblongx, exiles quadratæ, in acum ligneam(ex fruticis quem fufariam uocant, aliqui euonymon pu 2. tant, pracipuéligno)decuffatim feçam à pofteriori parte inferuntur, ut ea per carnes quafuis traie: cta, lardum in eịs relinç urat, idóg fimul affetur: quod cum aliâs faporem carnium, commen dat, tum in parum pinguibus præfertim auibus ferèneceffariú uidetur. Adipem fuis carne multo infalubrio rem effe, fuprà uerbis Galeni recitauimus. Ius lardarium apud Scoppam Italum Grammaticum le gi. Habent \& Germani in ufu panis offas in aqua coctas cum lardo copiofo diffecto \& cepis, $\{$ pect. fuppert. Inferiores Germani lardum coctum fer unant, $\&$ frigidum edunt, quidam etiam crudum. TLiquamen eft pinguedo animalium ad ignem liquefacta ${ }_{2} \&$ in ufum coquinarium feruata ad con diendos cibos. Liquamen ex adipe porci atģ anferum hoc modo fit:Concifum minutim ad carbo: nes ignitos in cacabo pones, ne fi ad flammam fufpenderis, fumum concipiat: tantumćs falis indes, quantum fatis effe putabis. Liquefactum, antequam refrixit, in ollam repofitoriam colabis : repo= 5o neş́́ ad ufum, ut ubi uoles, eo uti liceat, Fit item liquamen ex anferino \& gallinaceo adipe, Platina 2.21. Et præcedenti capite, Colliguntur multa ad pulmentaria ex porco nuper cæfo, ut adeps. Pau peres apud nos ex adipe abdominis fuilli (f quamen faciunt, quo olei aut butyri loco utuntur * Pernas $\&$ lardum conficimus, non folum decem bri menfe, fed omnibus quos hyemalis algor aftringit, $\mathrm{Palladius.} \mathrm{Laridi} \mathrm{cocfura:Tectum} \mathrm{aqua} \mathrm{cum}$ multo anetho coques, olei modicum diftillabis $\&$ modicum falis, Apicius. Angli brân appellant lardum non quoduis, fed è uerre faginato ferè per anni fpacium; quo toto tempore; non molliter, nec in ftramentis, fed tantum in tabulis ligneis cubare ei permittitur, ut lardum induretur, \& folidefcat: huius mactati lardum feruant in aceto ex cereuifia facro:poteft autem diu feruari. menfis apponũt cum iure in quo coctum eft, condito agreftium pomorum fucco(loco omphací) \& pauco fale: ciburs 4. habetur nobilis \& pretiofus, quem locupletes tantum inter fe dono mittunt.

I Suilla caro ita aliquando paratur, ut fuis feri uideatur, ut diçum eft fupra inter A picíp porcel los $\$ Q$ dicetur infra in prouerbio Suilla caro eft. Surllarum carnium ius decocium opitulatur con. tra bupreftín, Galenus lib.2, de antidotis. De fuxe partes quadam ferè affantur à lautioribus, ut fpa

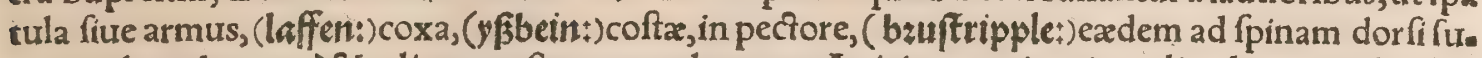
perius, (rambzaten:) \& reliqux coft $x$, nempe laterum. Apicius 4.3 . in minutalia aliquot addi iubet fpatulam porcinam coctam \& telfellatim concifam. Varro fcribit L. Volumnio fenatori miffam of fulam fuillá cum duabus coftis, qua penderet xxin̈.pondo. Offula ab offa minima fuillasab eo $q$ in. fecta caro, ut in carmine Saliorum eft, quod in extis dicitur nunc iffitia, Varro de ling, Lat. Penem antiqui codam uocabant,à qua antiquitate etiam nunc offa porcina cum cauda in conis puris offa so penita uocatur, Feft. Etrurfus, Penitam offam Nauius appellat abfegmen carnis curm coda \$antiquí enim offam uocant abfciffum globi forma, ut manu glomeratam pultem. Noftri ex cauda cum a. Iís partibus extremis gelu in patina, ut uocant, parare folent. Caryophyllatx feu benedict $x$ uulgò dicra fucco trunculos fuillos macerant, \& ad ufum aliquod tempus feruant, Ruellius. Quornodo carofuilla fruftatím concifa, in aqua falfa feu muria multo tempore recens feruari poffit, Baltafar Cellarius in libro fuo de arte coquinaria docet:Primum, adornatum fuem in menfa poni pracipit, co piofa niue undiquaç circundatum, donec caro duriufcula $\&$ folida appareat, quod feréper noçem unam fit: deinde carnem in tomos oblongos diffectam in uas larignum cum multò fale alternis com poni iubet per dies octo, tabella impofito lapide oneraram: poftea aquam fontanã cum multo fale no uis fcopis diu agitatam donec lentefcat, fuperinfundi, ut duobus digitis aqua excedat, $\&$ oneratam

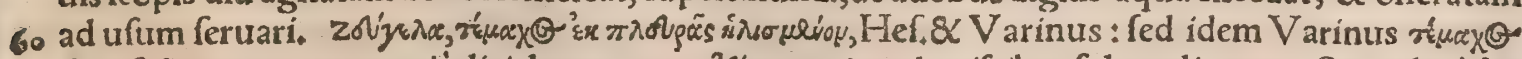
de pifcibus tantum propriè dici docet:quare ₹ơyeno etiam de pifcibus folum dicetur. Stccidia à fue nominatur cuius caro eff, Hermolaus, Succidia, (inquit grammaticus quidam recentior) eft tergũ, 
fiue maffa carnis porcina falita, qua quoties opus eft fucciditur, continet autem pernam, petafo, nem 8 lardum. Nonius fuccidiam pro lardo exponit. Varrolib,4.de ling. Latin, non à fuccidendo, fed à fuibus cadendis (fiue edendis, quod non placet, nec eft in noftris codicibus Varronis) dictam purtat: nam id pecus primum occidere coeperunt domini, \& ut id feruarent, falire, lam hortum ipfi agricola fuccidiam alteram appellant, id eft, ut ait Nonius, fucceffionem neceffariam. Patres nofri dixerunt ignauum $\&$ fumptuofum effe, qui fuccidiam in carnario fufpenderit potius ablaniario, quàm ex domeftico fundo, Varro. Succidias Galli optimas $\&$ maximas facere confueuerunt. Optio marum fignum, quod etiam nunc quotannis è Gallia apportantur Romam pernæ, tomacinæ, \& tas niaca, \& petafiones(malim petafones. Vocabula tomacin $\&$ taniacæ alibi nufquam reperio: de to, maculis inferius dicam.) De magnitudine Gallicarum fuccidiarum Cato fcribit his uerbis : In Italia in fcrobes terna at $\$$ quaterna millia aulia fuccidia, Idem. Porcos fuccidaneos apud Apicium legia mus. Suum obeforum ac $x$ tate florentium carnes, ad faliendum funt appofita, ut qux utriufç ex, ceffus fint expertes, annoforum uidelicet ficcitatis, \& nouellorum porcellorum immodica humidi: tatis.Quemadmodũ enim corpora ficca, falita, corịs euadunt fimilia:fic contra qux immodica humi ditate diffluũr, falis commercio contabefcunt, Galenus de alimentorum facultatib. 3.40, Ad annü ubi uenerit porcus, falituræ non incongruit. pridie quàm occidatur potione prohibere oportet, quo fit eius caro ficcior: dein de diligenter falire, ne fracefcat, \& uitium fapiat, néue tinea \& uermibus la. datur. Dum falfuram facis, in fundo dolí aut feria falem fternito : frufta deinde ponito, eutis deor: fum fpectet. Tam diu caro in dolins remaneat, quoad falem conceperit : (noftri feré quatuordecim dies relinquunt, 8 his amplius fi fues annofi fuerint, uf $\$$ a a uiginti.) In carnario deinde, quo fumus 10 penetret, fufpendatur. Hinc fumes laridum pro tempore, hinc pernam, hinc petafonem, hinc fumen, hinc glandium, Platina. Omne pecus(inquit Columella) $\&$ præcipue fuem pridie quàm occidatur, potione prohiberi oportet, quo fit caro ficcior. Nam fi biberit, plus humoris falfura habebit, Ergo fi, tientem cum occideris, bene exoffato. Nam ea res minus uitiofam, 8 magis durabilem falfuram fas cit:deindecum exoffaueris, cocto fale, nec nimium minuto, fed fufpenfa mola infracto diligenter fa lito, \& maxime in eas partes, quibus offa reliça funt, largum falem infarcito, compolitiśç fupra tă bulatum tergoribus, aut fruftis uafta pondera imponito, ut exanietur. Tertio die pondera remotreto 8 manibus diligenter falfuram fricato, eamó cum uoles reponere, minuto $\&$ trito fale afpergito, at, que ita reponito:nec defieris eius quotidie falfuram fricare, donec matura fit, Quod fi ferenitas fues rit ijs diebus, quibus perfricatur caro, patieris eam fale confperfam effe nouem diebus: at fi nubilum $3^{\circ}$ aut pluuiæ, undecima uel duodecima die ad lacum falfuram deferri oportebit, \& falem prius excuti, deinde aqua dulci diligenter perluínecubi fal inhereat, 8 paululum afficcatam in carnario fufpen. di,quo modicus fumus perueniat, qui fi quid humoris adhuc continetur, ficcare eum poffit. Hac fals fura luna decrefcente maxime per brumam, fed etiam menfe Februario ante Idus commode fiet. ERt \& alia falfura, qux etiam locis calidis omni tempore anni poteft ufurpari,qux talis eft: Cum ab aqua pridie fues prohibiti funt, poltero die mactantur, $8 \times$ uel aqua candente, uel ex tenuibus lignis flam mula facta glabrantur(nam utroç modo pili detrahuntur) caro in libraria frufta conciditur ; deinde in feriam fubfternitur fal coctum, fed modicé(ut fupra diximus) infractum: deinde offula carnis fpif fé componuntur, \& alternis fal ingeritur: $\{$ ed cum ad fauces ferix peruentum eft, fale reliqua pars res pletur, $\&$ impofitis ponderibus in uas comprimitur ‘eáģ caro femper confer uatur, $\&$ tanquam falla $4^{\circ}$ mentum in muria fua permanet, Hactenus Columel, Carnem falitam larido intertextam, in teffel. las concides: concifam, in fartagine non admodum friges:frictam, aceto, faccharo, cinnamo, petrofe: lino minutatim concifo afperges. Idem etiam fieri de perna ac fumine poteft. Sed hac fucco citriuel malarancí fuffundi amant. Clamat in hanc opinionem Bibulus, \& fine acredine, (intincium acetoa fum intelligo, quo uehementior excitetur fitis, hæc deuoranda affirmat, Platina. Et alibi, Non fits mem admodum pingue, fed rubeum coquatur eo modo quo perna, (cuius coctio inferius recitabi.

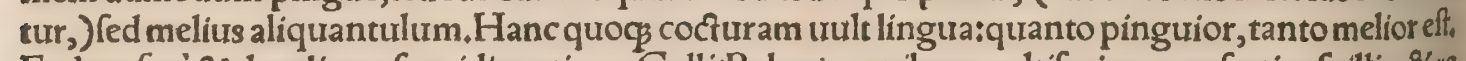
Eadem fere $\&$ de reliqua fuccidia ratio. Galli(Belgæ) carnibus multifariam, præfertim fuillis, \&re centibus \& falitis utunț,Strab. Venter fuis falifcus uocatur, Volaterran.Non lucanica, non grates falifci, Martialis. Et alibi,Et lucanica uentre cum falifco. Lucanicam dicunt, quòd milites à Lucanis qo didicerunt, ut quod à Falerịs falifcum uentrem, Varro de ling. Latin. Filia Pícenæuenio Lucanica porca, Pultibus hinc niueis grata corona datur, Martialis. Grammatici farciminis genus inter* pretantur, à Lucanis primum inuentum, (bzatwiitft.) Si uoles bonas lucanicas, carnem macram fi= mul \& pinguem ex fue concídito, ablatis omnibus fibris ac neruis. Quòd fi caro decem librarum fue rit, falis libram unam, foeniculi bene mundi uncias duas, totidem piperis femitunfi admifceto, cone fricatóg per diem hac in menfula finito:Sequenti, in inteftinum bene mundum iñ̈́cito, \& fic adfu mum fufpendito, Platina. De lucanicis parandis legeetiam Apicium 2. 4. Qui uenit botulus me: dia tibi tempore bruma, Saturni feptē ueneratante dies, Martialis, Botulus autếfiue botellus di minutiuum farciminis genus eft è carne fuilla, â bolis, id eft fruftulis carnis, ut quidam putant, appel latus, (propter connexionem à bolis, Feftus.) Fiebat ex oui uitellis coctis, nucleis pineis concifis, ce= pa, porro, iture crudo, concifis, addebatur piper $\&$ liquamen $\&$ uinum, fić̣́ farĉum inteftinum co: quebatur, Apicius 2.z.idç farciminis genus in Saturnalibus præcipué celebrabatur, Et pultemni。 


\section{DeSue. F. Lib. I. 1007}

ucam premens botellus, Martialis lib. 5. Inteftina fanguine farcta nofri uocantro 3 wiirft / blit. wiffit. ex his quod craffius eft, $\&$ apicem quendam adharentem habet, (unde $\mathcal{Q}$ apexabo Latinè uo catur, Varrone tefte) prater fanguinem, cerebro etiam $\&$ lardo concifo farcitur, \& aromaribus quan doç conditur, wecterling. Ventriculus etiam fuis uel in oblongas particulas fectus, uel minutatim concifus, unà cum carne fimiliter feça concifá ue craffioribus inteftinis infarcitur, cum fale, careo, Q pipere, foübling uel magenwiarf. Ificium, farciminis genus, Volaterranus. Scoppa Italice to: macellam interpretatur, ut $\&$ tomaculum, de quo infra dicemus in iecoris mentione. Videtur $f_{a n d}$

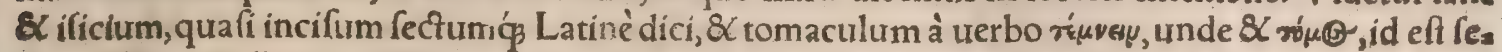
ctio. De porcello tenero ificia quintum locum poft ifícía de paưo obtinêt, apud Āpicium 2. 2. Idem - ificiorum uaria genera per totum librum fecundum defcribit. Vbi Humelbergius in annotationi: bus fuis, Ificia, inquit, cibaria funt ex carne concifa \& infectałquæ nunc per $f_{e}$, nunc reticulo $\&$ o. mento circundata in fartagine, alpips etiam iunctis rebus, $\&$ aromatibus aliquando, cum adipe aut oleo butyrótre friguntur. Alio nomine tomacula fiue per fyncopen tomacla \& tomactnx ali =

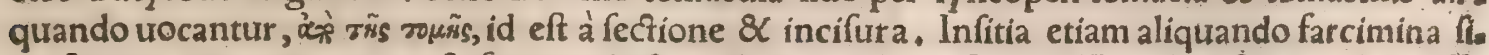
gnificant, qua carne concifa fartis, id eft impletis inteftinis fiunt, Hæc ille: fed quod potiff. mum ad ifici rationem pertinet, omifit. Nam minutatim concidi alịs quogs eduliorum generi. bus commune eft, minutalibus, lucanicis, botellis, \&c.ificium uero non concíditur folum, fed etiam in mortario, ut ificium fiat, pulpa cuiufuis animantis tunditur, teritur, fricatur: his enim uocabulis A picius utitur, $\&$ pulpam tritam in ificia plaffari, id eft formari iubet; contrita enim $\mathcal{Q}$ in unum re.

- dacta corpus, facile manibus in quam uolueris formam, rotundam, teretem aliámue, formantur. Ede. bantur autem uel recentia, uel in fumum fufpendebantur, ut ex A picio patet. quanquam idem luca nicis quogs admifceri iubet pulpam bene tunfam, quod apud nos non obferuatur, fed fimpliciter $m i$ nutiffimè concifa inditur. Sed lucanic $x$, botelli, $8 x$ alia farcimina propriẻ dicta, femper inteftinis im. mittuntur:ificia non item:nam quod Humelbergius ificia pro farciminibus aliquando accipi fcrio bit, deceptus eft fortaffis â Volaterrano, ego apud nullum idoneum authorem reperi. Quòd uero in mortario femper tererentur ificia, fiue ificiorum pulpa, Macrobij \& A phrodifienfis etiam authorita te conftat. Hic enim problematum 1.22. inquirens cur agrè id genus carnis concoquatur quod ificium, iox $\Theta$, nominatur: Quoniam(inquit) fua leuritate fluitat in uentriculo per cibi humidi medium, nec eius corpus attingit, quo taciu fieri concoctio poteft + ed iuxta gulam redundat, quinetiam for is

$3^{\circ}$ aquæ iniectum non fubfidet, fed innatat; quoniam dum carnes teruntur, fpiritus admittítur pralea uis, qui corpus eleuet, $\mathbb{Q}$ in humore fluitare aptiffimum reddat. Dicas quaefo (inquit Furius Albi. nus ad Difarium, apud Macrobium Satur.7.8.) qua caufa difficile digeftu facit ifitium, quod ab in. fectione infitium dicfum:amiffione n.liter, poftea, quod nunc habet nomen obtinuit:cum multum in eo digeftionem futuram iuuerit tritura tam diligens, \& quicquid graue erat carnis affumplerit, confummationemós eius multa ex parte confecerit. Et Difariust Leuitas quam tritura praftitit, facit ut innatet udo cibo quem in medio uentris inuenerit, nec adhreat cutiuentris, de cuius calore dix geftio promouetur+fic $\&$ mox tritum atç firmatum, cum in aquam conṕcitur natat. Ex quio intelli= gitur quòd idem faciens in uentris humore fubducit fe digeftionis neceffitati: $\&$ tam ferò illic coqui: tur, quàm tardius conficiuntur qux uapore aqua quàm quæ igne foluuntur. Porcellus femitoftus

$4^{\circ}$ \& femielixus apud Athenęum libro g. farctus erat tum alịs delicijs, tum ïs qua ificia uocant! quan. quam hoc uocabulo uix uti fe audere coquus inquit, prafente VIpiano qui Attica tantum $\&$ urete ribus Græcis ufitata probabat:ificium uero apud recentiores tantum legitur, $\mathrm{Paxamum}_{3}(\&$ alios.)

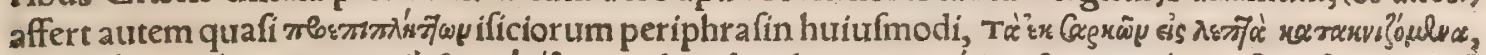

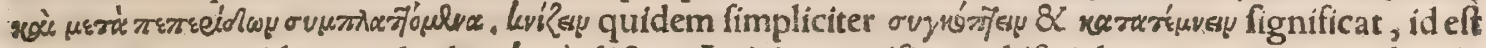
minutatim concidere, unde olera kvisè dića. Apicius 4.3.ificia urel ificiola minuta in minutalia aliquot addi iubet, Ventrem porcinum bene exinanies, aceto $\&$ fale, poftea aqua lauas, \& fic hac im. penfa imples. Pulpam porcinam tunfam tritam ita ut eneruata commifceas cerebella tria, 8 oua cru da, cui nucleos infundis, $\&$ piper integrum mittis, $\&$ hoc iure temperas. Teres piper, ligufticum, fil phium, anifum, zingiber, rut $x$ modicum, liquamen optimum $\&$ olei modicum, reples aqualicum (a* 50 qualiculum) fic ur laxamentum habeat, ne diffiliat in coctura, furclas, amylas $\&$ in ollam bullientem fubmittis, leuas, \& pungis acu ne crepet:cum ad dimidias coctus fuerit, leuas $\&$ ad fumum fufpen. dis, ut coloretur, $\&$ denuo eum perlaxabis ut coqui poflit deinde líquamine, mero, oleo modico $\$ \&$ cultello aperies, \& cum liquamine $\&$ liguftico apponis, Apicius 7.7 . Ventrem ut toftum facias In cantabro inuolue, poftea in muriam mittis, \& fic coques, Ibidem. TNon alio ex animali nume: rofior materia ganea, quinquaginta prope fapores, cum cæeteris finguli. Hinc cenforiarum legum paginx, interdictáģ conis abdomina, glandia, tefticuli, uuluæ, fyncipita uer rina, ut tamen Publị mi morum poëtx coena, poftquam feruitutem exuerat, nulla memoretur fine abdomine, eciam uocabu lo fuminis ab co impofito, Plinius. đGlandium pars quadam inteftinorum eft, ut inguit Prifia nus. Alij uolunt effe partem apri iuxta ceruicem, uel ipfam ceruicem: in hac enim glandulx pofitas 60 funt. Arripuir gladium, prætruncauit tribus tergoribus glandia, Plautus Capt. Pernam, abdomen fuis, glandium, Idem Curcu. Hinc Cenforiarum legum pagina, interdictáç conis abdomina, glan dia, tefticuli, \&c. Plinius 8.51. Quibufdam funt tubera, ficut in carne glandia, Idem lib,16. Eff gui dam terreadeps ac uelut glandia in corporibus, Idem lib,17.de marga, Glandula, ut ícribit Gram 
maticus quidam, caro glandulofa in fue, qua ab antiquis boni faporis putabatur. Glandulam fullo lam,laridum, pernam itidem, Plautus Menah. Partitur apri glandulas palaftritis, Martialis; Ter

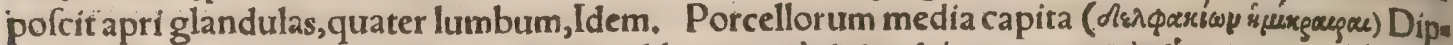

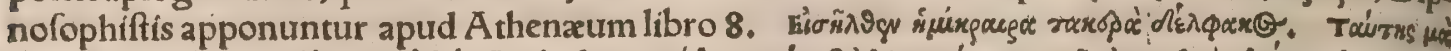

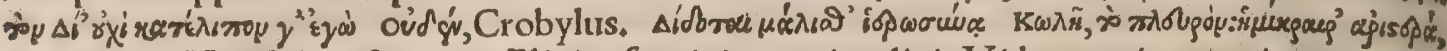
Amipfias. Hac fcilicet funt qua Plinius fyncipita uerrina dixit. Videtur enim anterior pars pofte: riore lautior effe.Caterum in A mipfix uerbis ubi finiftram hemicraram, id eft dimidiam capitis par tem facerdotibus relinqui fcribit, aliter accipiendum eft, nempe ut caput non in occiput et fynciput,

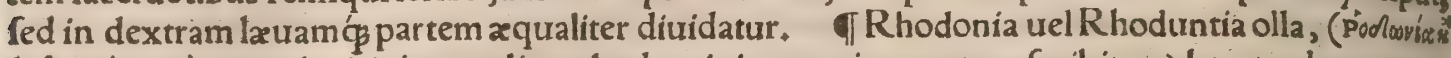
podbuvrix $\lambda$ rides. ego rhodoniam malim, rhoduntia in margine tantum (cribitur,) hoc modo paratur, in ut coquus quidam apud Athenxum libro 9 . docet:Rofis(inquit) odoratiffimis in pila contufis, cere.

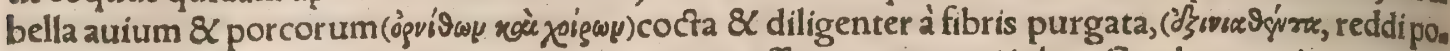
teft eneruata $\div$ nam $\&$ A picius 2.1. iecur porcinum affatum eneruari iubet. Cerebrum etiam enertaa tum apud eundem additur uentriculo porcino, ut paulo fuperius mox poft ificia recitaui) $\&$ ousa rum uitellos adieci:deinde oleum, garum, piper, uinum, hxc diligenter trita in ollam nouam iniec, igne molli $\&$ continuo fubiecto. Hæe dicens fimul ollam aperiebat, unde fuauiffimus odor in totum fympofium diffluxit, Hæc ille:qux \& Calius 7. 10, tranfulit, fed parum diligenter, Pod wrsc oxyto, num, locum rofis confitum fignificat : hic uero adiectiué paroxytonum jod covios nories feribitur. बSanguiculum aliqui hoedi aut fuis fanguinem exponunt in cibum formatum, ut in Hodo dixi in F. Sanguis fuillus humidus eft, \& minus calidus, humano maxime temperie fimilis : fiquidem \& 20 carnes fuum humanis funt fimiles, Galenus. Plura de fanguine fuis fupra diximus in Carnium eius mentione. Clidium uocatur quod inter iugulum eft, Volaterranus?tuel potius os in fummis coftis,

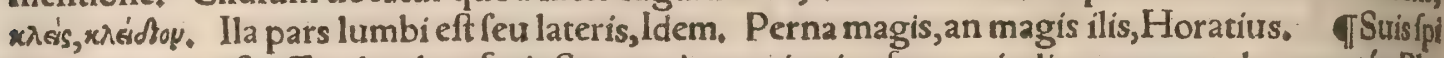
na ubi recens eft, affa ad gulam facit. Sunt qui cepas in eitus feruenti adipe coquant, deurorentó,, $\mathrm{Pla}$ tina. Spectile uocatur infra (aliâs iuxta) umbilicum fuis caro quadam proprn̈ habitus, exos, quae: tiam antiqui per fe utebantur.Plautus enumerandis uilibus obfonịs in Carbonaria: Sic ego pernä, fumen, fue, fpectile, callum, glandia, Feftus. Vulua electo partu melior quàm adito:Eiectitia uoca: tur illa, hæc porcaria:primiparæ fuis optima, contra effoetis:à partu, praterquam eodem die fuis ocs cif $x$, liuida a macra. Nec nouellarum fuum, praterquam primipararum probatur, potiusíg uetea rum, necdum effortarum, $\&$ biduo ante partum, aut poft partum, aut quo eiecerint die. Proxima eie 30 ctitix eft occifx uno die poft partum. hurius $\&$ fumen optimum, fi modo foetus non hauferit: eiectitie deterrimum, Plinius. Verba Pliní (inquit Hermolaus in Caftigationibus) de uulua fuis, multum obfcuritatis habent, fi pracedentia fequentibus conferas:illud meminero, Plinium priore loco dee, iectitia loqui ụ̧́ ad eum finem, quo eiecerint die, ut eiectitiam intelligat partu eiecto feu enecio, porcariam edito:quicquid literatores hac parte fentiant. Delphaces propriè uocantur fues foenite næ, quæ delphînas, id eft uteros feu uuluas habent, A thenæus. Idem libro 3. Alexis, inquit, Callime dontem rhetorem tanquam gulofum ( $\&$ inter alias delicias uuluarum appetentem)traducens, fcribit:

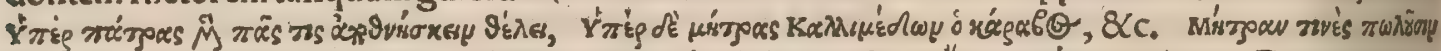

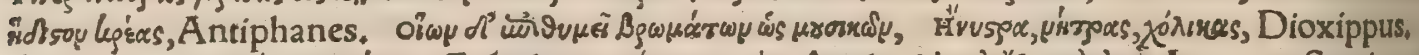

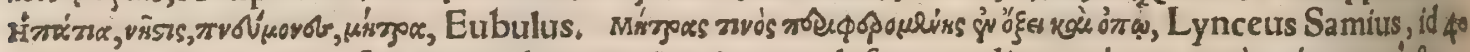

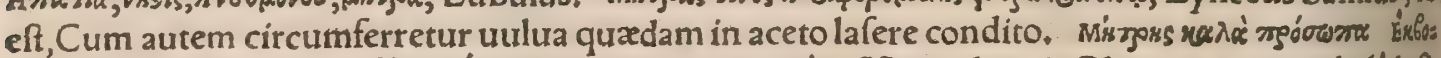

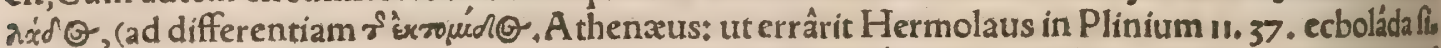
mul et ecfomida eiechitiam interpretatus:porcariam uero v́fiow, quam uocem ego generalem putoad

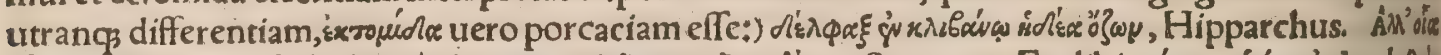

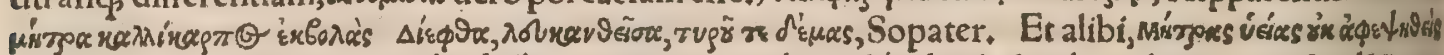

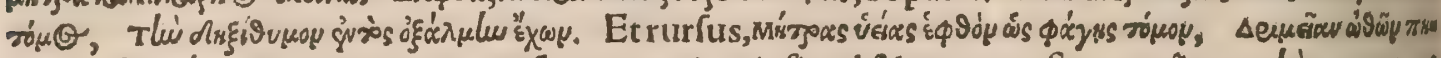

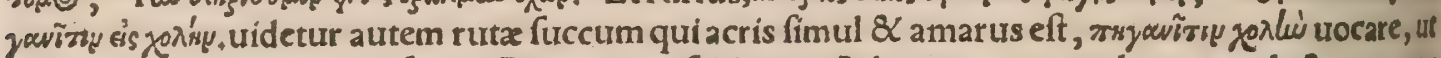
ufus eius pro embammate fuerit.Cxterum prifci,inquit Athenaus, neqs uuluas, neg lactucas, nec aliud huriufmodi ante cœnas proferebant ut nunc fit. ( ed poft cœnãa, hinc Martialis de lactuca, Clau dere qua cœnas lacfuca folebatauorum, Dic mihi cur noftras incipit illa dapes?) Quare poft coe so

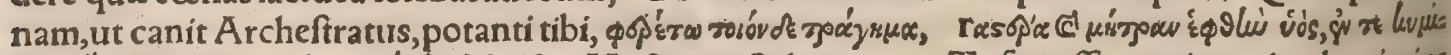

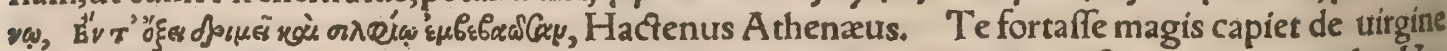
porca, Me materna graui de fue uulua capit, Martialis, Apicius uuluam fterilem commendat, Het molaus. Curius aliquando edebatolera, qux nuncetiam fqualidus foffor faftidit, Quimeminit calida fapiat quid uulua popinæ, Iuuenal.Sat.II. Vultua nil pulchrius ampla,Horat.ı.epift, Lanif noftri mactatis porcis hanc partem femper abj̈ciunt, nec quifquam apud nos, quod fciam, uuluam in cibo appetit. đPublij mimoruu poétæa, poftquam feruitutem exuit, cœna nulla memoratur fis ne abdomine, exiam uocabulo fuminis ab eo impofito, Plinius. Et rurfus, Occifx uno die poft pars tum fumen optimum, fi modo foctus non hauferit: eiectitiz deterrimum. Antiqui abdomen uocas bant, priufquam callerer id, fcientes occidere non affueti. Scribendum arbitror (inquit Hermolaus) prius callere id finentes, occidere non affueti. (Pauciora mutabis, fi legas, priufquam calleret, id finen tes. Vtabdomen uocatum fit,fimpliciter:cum callebat uero, fumen, quod magis probo.) Plautusin 


\section{DeSue. F. Lib. I.}

Ponulo ad hanc confuretudinem ferè alludens: Vide fis, inquit, calleas: cui refpondens conferuus, Callum aprugnum(inquit) callere aquè non finam. Eft autem fenfus, Id quod modo fumen(inquit) dicitur: hoc eft, fuillas cum lacte fuo mammas, ueteres abdomen uocabant, ab lacte opinor iam abdi to $\&$ fugato, utpote qui antequam ubera callefcerent thoc eft, ficcato lacte durefcerent, fuem occide $=$ re non folerent, Hac Hermolaus. Effe putes nondum fumen, fic ubere largo Effluit, \&uiuo la. cfe papilla tumet, Martialis. Sumen propriè à futgendo dictum:nam mulieris mammam, fumen ue reres dici uolunt. Quòd fi nulla poteft mulier tam corpore duro Effe, tamen tenero moureat fuccuf fa lacerto, Atque manus uberi lactanti in fumine fidat, Lucilius a pud Nonium. Sumen (ut gram matici quidam exponunt)fit ex papillis fuillis uno die poft partum fectis ac falitis. Quanta labes la - rido, quanta fumini abfumendo, Plautus Capt. Alij putant effe lac fuis extractum ac denfatum fue occifatuel quafi rumen, id eft mammam. Cafar Vopifcus campos Rofex, Italix dixit effe fumen, in quo relicta pertica poftridie non appareret propter herbam, Varro. Abitomen porc $x$, Iutuenal. Sat.2. Heliogabalus exhibuit fumina aprugna per dies decem, tricena quotidie cum fuis bulbis; Lampridius. Sumen quomodo parandum ex Platina fuperius in Succidia dictum eft. Abdo: men quod Graci laparan uocant, uentris pars illa eft, qua ab umbilico ad inguina inter cartilagi: nem $\&$ pellem ducitur. Pingue id quidem eft, Satyrico tefte: Montani quo $q$ s uenter adeft abdomíne tardus. Erit igitur abdomen, ex quo fumen fit, quod idem uulua appellatur, (in hoc fallitur. omni. no enim alia pars fuis abdomen eft, alia uulua, )nec obftat, id etiam turgentibus porca papillis fieri, cum circa abdomen mammx fint, Platina. Efitium ex carne: Pro decem conuiuís(inquít idem) li-

20 bram abdominis porcini aut tritulini bene elixato:coctam ac concifam, cum felibra cafei ueteris, pait co etiam \& pingui addito, cumḉ herbis odorifer is bene concifis, pipere, gingibere, caryophyllo mifce to. Sunt etiam qui pectus capi tunfi non incommodéaddant. Hac omnia farina bene fubacta, ac in cenuiftimum folium redacta, ad caftanea magnitudinem inuoluito inuoluta in iure pingui ac cro. co colorata decoquito. Parum cocfura requirunt. In patinas traducta, cafeo trito $\&$ aromatibus dulcioribus afpergito. Fieri \& hoc edulium ex pecfore phafiani, perdicis, aliarúmue altilium potelt. In cœna Lentuli flaminis Martialis inaugurati, inter alia, appofita funt fumina, patina fuminis, \& $c_{*}$ Macrobius.

Tlecur. Ificia omentata ita fiunt: Affas íecur porcinưm, $\&$ tum eneruas: ante tamen teras pi: per,rutam, liquamen, \& fic fuperimmittis iecur \& teres, \& mifces, ficut affolet pulpa, in omentum, 30 \& fingula introlutantur folia lauri, $\&$ ad fumum furpenduntur quandiu troles, Cum manducare uoa lueris, tolles de fumo, \& denuo affas, \& ficcum adícies in mortarium, piper, ligufticum, origanum: fricabis:fuffundes liquanien:adịcies cerebella cocta, teres diligenter ne affulas habeat: adijcies oua quinç $\&$ diffolues diligenter ut unum corpus efficias:liqua mine temperas, \& in patella ęnea exitia. nies, coques $;$ cum coctum fuerit, uerfas in tảbula munda. Teffellas concides, adîcies in mortariumi piper, ligufticum, origanum ; fricabis in fe:commifces in caccabum: facias ut ferueat \$ cum ferbuerit; tracta confringes + obligas, coagitabis, \& exinanies in boletaritpiper afperges, $\&$ appones, A picius Iecufcula aut fuilla, aut ex quouris animali, ad magnitưdinem nucis aperta, infperfáćs fale, foeniculo $\&$ aromatibus dulcibus ac bene tritis, omento uitulino attr hơdino feparatim ínuolues: ad focum q́a non nimium decoques, ac cocta ftatim comedes,Platina. Etrurfús, lecinora porcina uel qurorum= to uis animalium, paululum elixa, terito eo modo quo cafeum foles. Porcinum deinde tuentrem condi: to ad quantitatem iecinoris, tantumćs cafei ueteris, amaraci, petrofelini, paffularum, aromaturm coti tritorum, cum duobus ourorum uitellis admifceto, quantum fatis effe putauerís. Ex his in unum re: dactis, ad magnitudinem nucis pilas facítołomentóć inutoluitołacubícules, in fartagine cum lari: do frigito. Lentam \& partuam cocturam requirunt. Tomacula hæc utulgus appellat, qur fortaffe melius omacula, cum inuoluta omento fiant, dicerentur? uel tomada, ut Martiali placet. De tomá: culis nonnihil fupra etiam dixi in ificiorum mentione: ificium enim aliquiltalice tomacellam interpretantur, \& idem Latinè tomaculum dici putant, Vt tamen \& pofcas aliquid, touteasớç facellis Exta, \& candiduli diuina tomacula porci, Iturenalis Sat. 10. Iecur fuillum omento intectum in farta

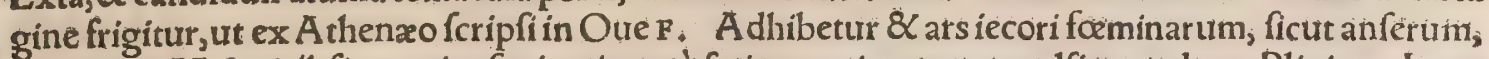
so inuentum M. A picij, fico carica faginatis, ac (a) fatiè necatis repente mulfi potu dato, Plinius. Iécur fuillum prafertur omnibus Aëtio, fi quis, inquit, animal id arida fico pauerit, quod genus Graci fy cotón appellant:unde ortum puto ut imperitum uulgus (in Italia)omnia iecinora trocare ficata coc perit. Sanè ut meminit âriftoteles, fuem pracipué alunt \& opimant ficus \& cicer, Hermolatus. Quemadmodum in fuibus dum adhuc uiuunt hepar ex caricarum paftu ficatum ( $\sigma$ vxwroy) ad uo. luptatem praparatur+ita in anferibus uideo eorum alimenta lacte imbui: ut non modo eorum iecur fit iucundiffimum, fed potenter etiam nutriat, ac optimi fit fucci, \&c. Galenus de aliment. facult، 20. Anthologï libro fecundo, titulo In munera, extat Pallada tetraftichon, huiufmodi:

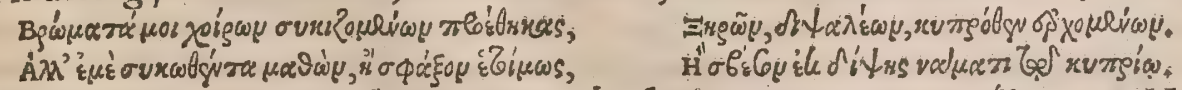

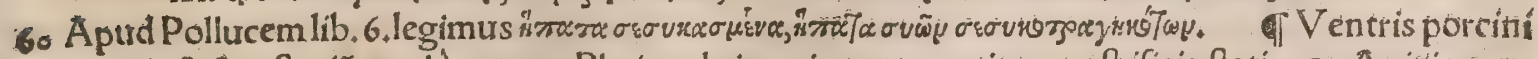
mentio facta eft etiã pauló ante ex Platina de iecoris apparatưitem poft ificia ftatim ex A picio 7.7 . quomodo pulpa tunfa \& cerebellis impleri debeat, Vide ctiam infra in Pedum mentione, Sartutil 


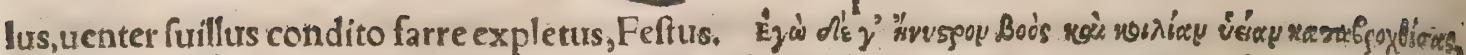
Varinus in H'yvsooy ; funt autem Ariftophanis in Equitibus uerba, ut citat etiam Atheriaus lib, $3_{0}$ of

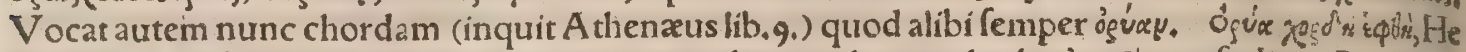

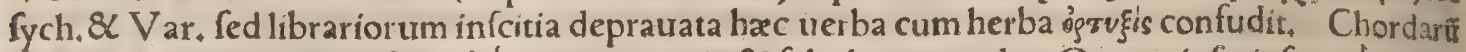

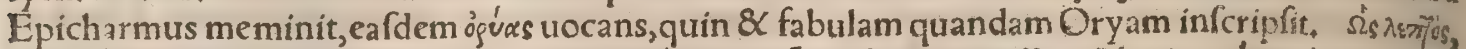

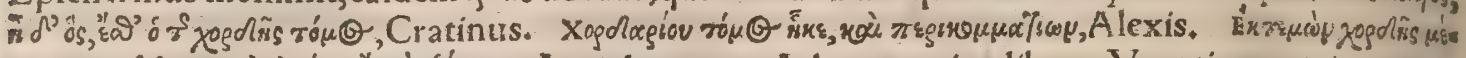

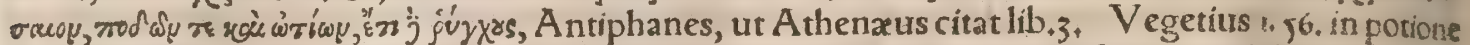
equi prophylactica utitur acrone falfo porci pinguis, uel longanone: uel fi percina defuerint, capire hodino depila to cum pedibus fuis \& cordulis inteftinorum mundis. Mimarcis proprie eft chorda 10 leporina, fiue edulium quoddam é uentre $\&$ inteftinis leporis, aut ex fanguine leporíno $\&$ inteltinis: fed ufurpatur etiam de fue:plura de hac uoce attulimus in Lepore F. Xors 9. Xónıxas Varinus uentres aut craffa inteftina interpretatur. Liquamen: Omentũ fuis dum recens eft, minutim concifum ad caftanez magnitudinê, fale multo afperges ac contundes: contufum, per diem in tabulato fines, fequenti, in aheno ad ignem, fi centum librarum erit, cum duabus aqua me, tretis decoques, lento igne efferueat, neceffe eft, donec bene liquerit. Colo deinceps colabis, capiesć, quod in aqua natabit. Inditum liquamen in feriam, loco fubterraneo per annum conferuabis, Plati. na. Omento porcino uel uitulino teffellatim incifo inuoluendum edulium ex Platina 6. 20. fcripf in Vitulo $\mathrm{F}$.

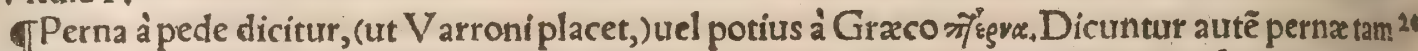
priores quàm pofteriores coxæ porcinæ falitæ cum toto pede, quos Martialis petafones appellat, Pernam atç ophthalmiam, Horæum, frombrum, \&c.Plautus Capt. Quanta pernis peftis uenies, quanta labes larido?lbidem. Caftrantur foeminæ fic quogs uti cameli, fufpenfæe pernis prioribus, uulua recifa, Plinius, Item offa ex acetabulis pernarum, Idem lib.28. Debilis perna, Sat.4.Sylu, Fumofa, Horat.2.Serm. A b huius fimilitudine perna etiam dicitur conchx genus, quod margaria tam fert, de quo Plinius:Stant uelut fuillo crure longo in barena defixa. Perna etiam in asboribus dicitur Plinio lib. 17. A uulfisćs arboribus ftolones uexếre : quo in genere \& cum perna fúa auellun. tur. Noftripernam fuis uocant bẫ uel bam̃en:aliqui, ni fallor, fhincken. ef autem os illud per fe, ab articulo furpra genu fito incipiens 8 coxam comprebendens. Petafo (ut grammatici docent) caro porcina quam alij coxam, alij (inter quos Sipont, )eam partem fuis dicunt, qua ab alis incipit, $\& 3^{\circ}$ coftas comprehendit, quibufdam ueluti uirgulis pinguibus diftincta. Mufteus eft, (de mufteo peta. rone uerba A picin recitabo inferius)propera, charos nec differ amicos. Nam mihi cum uetulo fitpen rafone nihil, Martialis lib.13. Siccus petafunculus, $\&$ uas Pelamydum, Iuuenal, Sat. 7. Apud

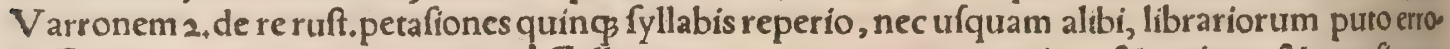

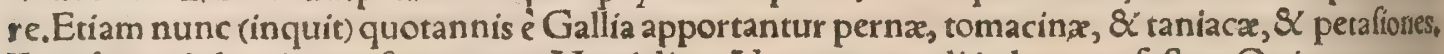
Et pulpam dubio de petafone uoras, Martialis. Non temere edi in luce profefta Quicquam pras ter olus fumofa cum pede pern $x$, Horatius Serm.2. 2. Pernas 8 lardum conficimus, non folum Decembrimenfe, fed omnibus quos hyemalis algor aftringit, Palladius. Ceretana( $x \in \rho j \rho$ s bo urocar populos, uide paulò poft) mihi fiet, uel maffa licebit DeMenapis, lauti de petafone uos rent, Martialis lib.14.fub lem̃ate Perna. Pafcholas appellant Græci quas uulgus pernas uocat, $\mathrm{Fe} 4$

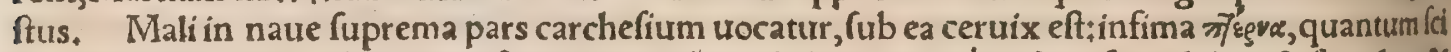

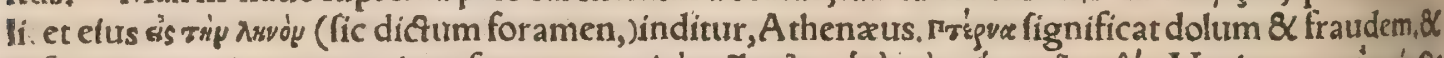

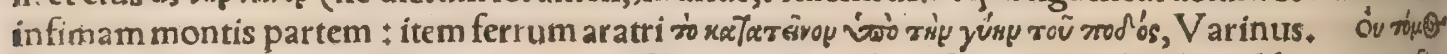

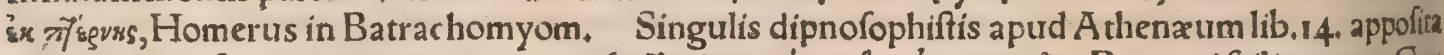

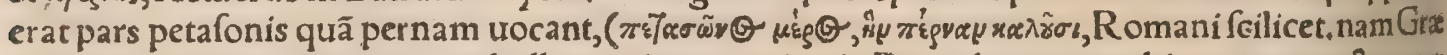
ciuereres pternam dixerunt, unde illa murium nomina in Batrachomyomachia, pternotroctes, ptet noglyphus, \&c.) Sunt autem pernarũ præftantiffim $x$ Gallic $x$, nec inferiores eis quas Cibyra Afia tica, \& quas Lycia mittit. Meminit autem earum Strabolib. 3. his uerbis: Pompelon Hifpanix prope Aquitaniam urbs eft, in qua pernæ eximix habentur, qux cum Curicis (Kreisräs, apud Achenæum.

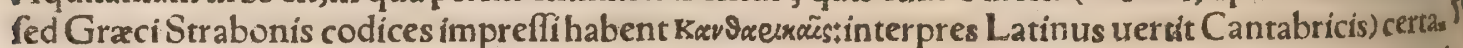
re poffunt, Hxc A thenzus. Sed nos apud Strabonem lib. 3. fic legimus: Cerretani medias Pyrenad montis conualles tenent, apud quos pernæ fiunt egregiæ, Cantabricis perfimiles, unde prouentus non mediocris ad incolas peruenit. Pernas fic falire oportet, in dolio, aut in feria. Cum pernas eme ris, ungulas earum præcidito. Salis Romanienfis moliti in fingulas femodius. In fundo dolï, aut fen rix falem fternito. Deinde pernam ponito. Cutis deorfum fpectet. Sale obruito totam. Deinde per nam alteram infuper ponito. Eodem modo obruito. Caueto, ne caro carnem tangat. Ita nmnes obruit to, ubi iam omnes compofueris, fale eas infuper obrue, 8 ne caro appareat, æqualem facito. Vbiam dies $v$, in fale fuerint, eximito omnes cum fuo fale. Qux tum fumma fuerint, imas facito. Eodem'́ modo obruito, 8 componito. Poft diem omnino duodecimum pernas eximito, \& falem omnem des tergeto, \& fufpenditoin uento biduû. Die tertio extergeto fpongia bene, perungito oleo. Sufpendis 6 ! to in fumo biduum. Tertio die demittito. Perungito oleo \& aceto commifto, \& fufpendiro in carna, rio:nec tinea, nec uermes tangent, Cato de re ruft, cap, ultimo. Pernas à cute liberatas, $\&$ (ur decet) 
paratas incifasç tribus diebus cum fale relinques: polfea per tres uel quatuor feptimanas in fumo ficcabis, fic optimx erunt: coquuntur integrx, \& frigidx per dies circiter octo menfis infertuntur; Balthafar Cellarius. Etrurfus, Menfe Martio(inquit)pernas diligenter falitas, 8 cum exemptx funt bene ablutas in aqua pura fluente, $\alpha$ cultro purgatas ne quid falis refideat, funiculis in fumum fufpendes, baccarum iuniperi polline afperfas: caue ne nimium infumes: fic rofeo colore $\&$ grato fapore placebunt. Pernam(inquít A picius 7.9.) ubi eam cum caricís plurimis elixaueris, 8 tribus lauri folins, detracta cute teffellatim incidis $\&$ melle complebis:deinde farinam deo fubactam conteres $\&$ ei corium reddis, $\&$ cum farina cocta fuerit seximas furno; $\&$ inferes. Aliter $¥$ Perna cocturam ex aqua cum caricis cocta fimpliciter ut folet in lance cum buccellis, caræno uel condito - melius. Muftei petafones: Ex mufteis petafonem elixas cum bilibri ordei, \& caricis Xxv, cum elixa tus fuerit, decarnas, 8 armillam illius candentibatillo uris $\&$ melle contingis: tiel quod melius eft; miffum in furnum melle obligas: cum colorauerit, mittis in cacabum paffum, piper, fafciculum ru= $t x$, merum, temperas + cum furerit temperatum, dimidium in petafonem profundis: $\&$ alia parte pipe rati buccellas mufteorum fractas perfundistcum forbuerit, quod muftei recufauerint, petafoni re: fundis. Mufteus dicitur, inqurit Humelbergius, qui nouus \& recens eft + qui quidem longè prapo= nitur: nam uetus ob pinguedinem facile rancefcit. Celfus pernas, ut puto, trunculorum nomine in telligit, Idem. Figito cultrum in mediam pernam, olfactụ́ fi bene olebit, bona erit perna: fin fecus, reñcienda eft. Bonam in uino albo aut aceto decoquito. Sunt qui tantundem aqux addendum di. cant, maximé uero Publius, qui uinum non bibit. hi certe falluntur. Suauior eft in uino tantum, uel 2. aceto, \& diutius durat. Non eft coquenda perna, nec eft iure eximenda, nifi ubi refrixerit, Platina.

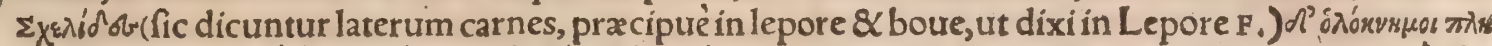

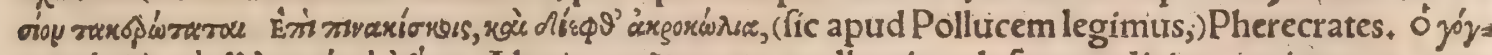

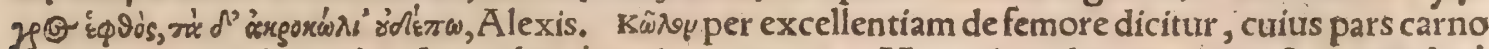

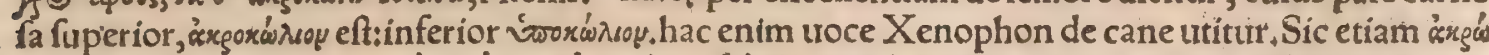

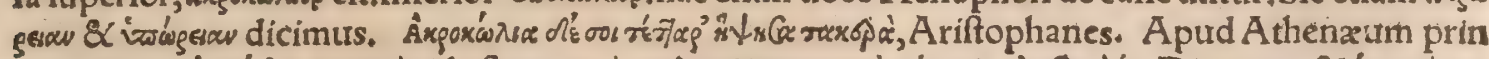

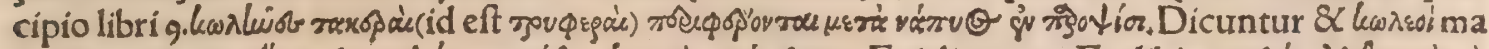

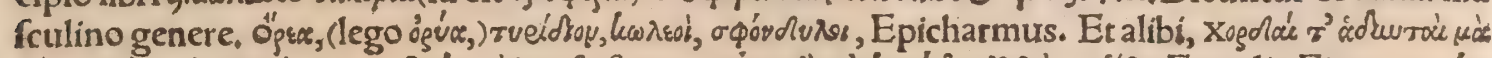

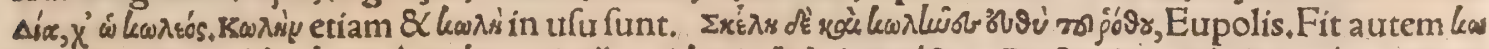

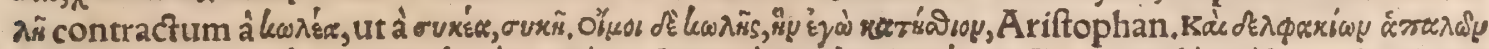

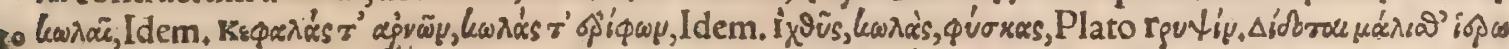

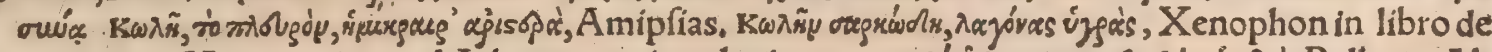

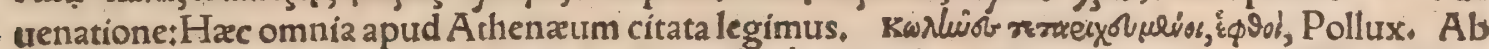

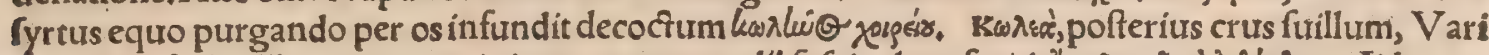

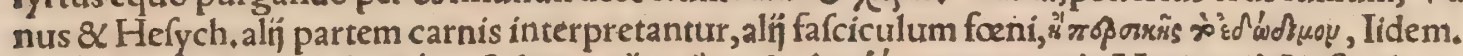

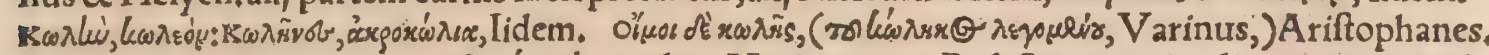

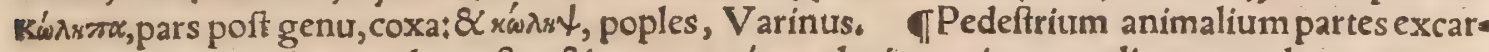
nes homines mandunt, pedes, roftra, \& aures $+e a s(\$$ ut plutimum in aqua elixas mandunt cum ace. to $\&$ garo, uinum affundentes: fun qui cum oleribus aut in aqua elixis, aut in patinis conditis. Por: cellorum autem pedes ptifanæe elixæ iniecti, aptiffimi funt, tum ut illam meliorem efficiant, tum $4 \circ$ ut ipfi molliores réddantur, $\&$ ob id ad elaborationem, qux in ore fit ac utentriculo, meliores, Galenus libro tertio de aliment . faculta. Noftri extremas ferè fuillas partes, pedes, caudas, auriculas, roftra, \& fummi dorficarnes, ufurpant ad genus illud cibarñ quod quidam gelu in pa tina uocant. Porcipedes utiles funt, boniós fucci:bene enim concoquuntur.quapropter fe ex mor bo reficientibus idoneifunt,Symeon Sethi. Porci pedes refrigerant $\&$ humectant, conualefcenti. bus utiles, Syluaticus. Vindicianus comes Arrchiatrorum in epiftola ad Valentinianum imperato rem, defcribens hiftoriam laborantis ardente febri $\&$ ficcitate uifcerum à fe curati, Præcepi etiam ei (inquit) efcam fieri de minutalibus porcinis, id eft podocylins $\&$ uentriculo:in quem uentriculum a* cetum cyminatum modico adiecto lafere mitti mandaui, ut omnino excocta carc etiam offium duri. tiam emolliret, ut foluta eorum medulla cum iure ipfo abforberetur. Galenus lib.1. ad Glauconem - de curanda febri tertiana exquifita fcribens, inter alios cibos commendat furm pedes \& cerebra.

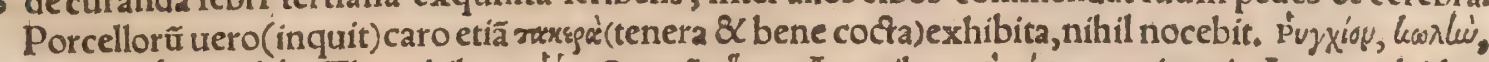

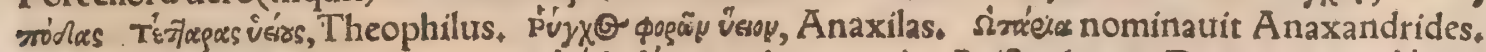

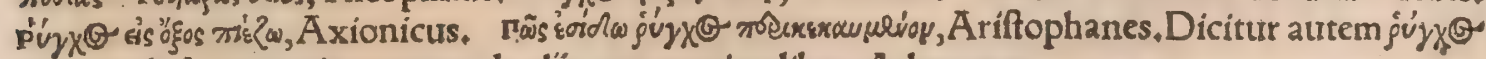
proprie de fure, reperitur tamen de alịs quo ơ animalibus, A thenaus.

Strillum lac pinguiffimum (craffiffimum) eft omnium, ut ad concretionem coagulo not ind geat, ac perquam modicum feri excernat, decoctum'ş ocyflimé coaguletur. ideo neq facile fecedit, neç uentriculo congruit, fed naufeam guftantibus excitat, Aétius. Eorum qui lac fuillum bibe. rint, corporaleprofa $\&$ fcabiofa fieri putant. hanc $\&$ alias ob caufas Aegyptij fuem animal profa, num exiftimant, Plutarchus in libro de Ifide. Manethonem porrò Aegyptium fumma fapientia ui rum accepi dicere, eum qui fuillo lacte uefcatur, uitiliginibus \& lepra oppletum iri, quos quidem morbos A fiani omnes peffime oderunt, Aelianus. Nos apud Aétium de oulllolactelegimus frequen ti eius ufu cuti uitiligines albas induci. 
G.

Remedia ex porcello, fimpliciter, uel lactente, Ad morfus uenenatos, optimé auxiliantur fiftas tim poft cucurbitas plagx imponantur animalia parua difcerpta, \& adhuc intus calentia, uelut funt gallinx, hodi, agni, porcelli, Venenum enim exugunt $\&$ dolores leniunt, $A$ étius, Idem ferè Celfus fribit de hodo, Aétius de agno: Vide in Hoedo $\mathrm{G}$, ab initio. Ad equos uulfos feu pneumonicos, Porcellum lacientem macta iuxta equum affectum, utfanguinem feruentem ftatim in fauces eius infundas, Pelagonius. Porcelli laçêtis uentriculo, id eft aqualiculo exempto, quod in interiore cu reluteum adhæret lanæ coniunges, madefảctá̧ ea illum humorem auriculæ inferes, cuius è diuer. fa parte dens dolebit, certiflimo remedio ftatim fubuenies, Marcellus. Porcelli fanguris, uide inferius in fanguine fuis.

T Remedia ex fue, uerre, fcropha: \& obiter quadam ex A P R O, maiufculis liter is fripto femper eius nomine, ut Lector ab apro huc remiffus facilius inueniret. Suillarum carnium ius decoctum opitulatur contra bupreftin, Galenus lib.2, de antidotis. Pharmacum Galeni ad podagram, quod omnibus ferè corporibus congruit: Cafeus bubulus uetutiffimus, adeò ut ob acrimoniä edi non pof fit, cum porcin carnis inueteratæ ac falf $x$ decocło teritur, $\&$ probé emollitus ad durities artuũ impo nitur, $A^{\prime \prime} t, 12,43$. ( 8 pluribus li, 2, ca.100.) Vbi etiam alia duo medicamenta ad podagram fatim fubs ไ̊cit, quorum primũ præter alia pernam porcinã recipit, alterũ uero pernę ueteris porcinę iufculum, Indi elephan torü quos ceperint uulnera, aqua primũ tepida colluũtt:deinde fi profunda fint, butyro ungunt:poftea inflammationê leniunt, fuillā carnem recenti fanguine madentê \& calidã admouren tes, A elia. Vulneribus elephantũ butyrũ auxiliat̃, ferrũ enim extrahit:ulcera fuillis carnibus fouêt,

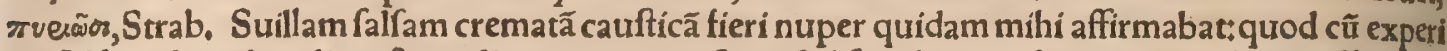
rer falfum deprehendi, guftu indicante non caufticã, fed fimpliciter ad exiccandũ idoneã effe iracre matam. T Sanguis fuillus humidus eft, \& minus calidus, humano maximè tẽperie fimilis (ut diĉi

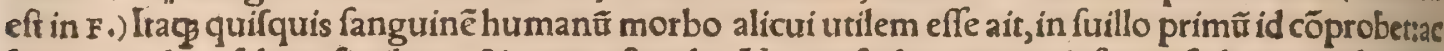
fi non eandem, faltem fimilem actionem oftendat. Nam etfi aliquatenus inferior fit humano fanguia ne(hoc \& Auicenna ex Galen, repetit)faltem affimile quippiã efficiet, quo cognito ab humano ple: niorem fore utilitatẽ 'fperabimus. Nam fi ne paulü quidem promiffis refpondeat, non erit cur in hu mano experiri oporteat, Galenus de fimplo10,2. Eumelus equo refrigerato fanguinem porcinum calidum cum uino infundi iubet. In libro quodam Germaniço manuficripto medicamentũ inuen huiufmodi: Verrem caßtratũ pilis omnibus ruffis præditũ \& optimæ ualetudinis iugulato:fanguinē olla recens exceptum, bacillo de iunipero rubra diu agitato, $\&$ agitando colleçû fanguinis grumî̉ ej̃cito. Tum ramenta eiufdem iuniperi inj̣cies, \& baccas de iunipero rubra fimiliter circiter uiginti quing. His addes parû agrimonix, (id eft eurpatorỉ ueterũ,) item rutæ, phu, fcabiofę, ueronicx uulgò dictze, pimpinellx, cichorî, pulegî, fingulorum manipulum. Quod fi fanguinis menfura fextarios tres excedit, adjicies theriaca uncias duas, fin minor fuerit, pro portione fanguinis theriacx modum minues. (Sed omnia praparata effe debent, ut fanguini adhucà fue calenti imponantur.) Permia xtis omnibus, liquorem ftillatitium elicito, quem diligenter feruatum in uitreo uafe dies octo infolas bis, quod femel quotannis facies, durat enim circiter uiginti annos. Hunc liquorem experientia con ftat egregie prodeffe aduerfus peftem, apoftemata capitis \& laterum feu coftarum, iecoris \& pulmo nis morbos, lienis inflationem, fanguinem corruptum, febrim, tumores, cordis tremorem, hydropem, do calores prater naturam, malos humores, $\&$ imprimis uenena $\&$ peftilentem febrim. Bibet autem $\&$ ger quocunç ex prædictis morbis correptus, ligulx menfuram, uel quatuor aut quinq̧ guttas, \& $\mathrm{Qut}$ infuper fuder curabit. Aliquil liquore ui ignis extrafto ex fanguine melis aduerfus peftem utun. tur. Cum porcus iugulabitur, is qui uerrucas habebit, fanguinem eius fubiecta ea corporis parte fus fcipiat, dum adhuc calidus exilit, $\&$ mox ubi ficcatus fuerit,ftatim abluat:citum remedium experie tur. Mulier fanè remedium de fcrof $x$ fanguine faciat, Marcellus. Verendorum carbunculis ceres brum A P R I uel fuis, fanguisóp medetur, Plinius. Vbera circunlita fanguine foeminæ fuis, mir nus crefcent, Plinius. Porcellum diffecans crurore mammas obline, amplius non augefcent, Gale nus Euporift.2.29.

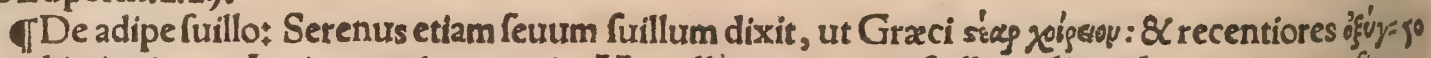
yrop ad imitationem Latinæ uocis axungix. Marcellius axungiam fuillam aliquãdo nominat, ac fi $a_{\bullet}$ liorũ quọ̧ animaliũ axungia dicatur, quod apud ueteres non reperio: nam noftro feculo qui minus Latiné fcribunt, axungiã uocant pingue quod inter cutẽ \& carnē folidius cōcrefcit, in fue, homine, mele, glire, mure montano, \&c. Lardum uel laridũ Latini carnem fuillam appellant, non folam, fed unà cum pinguifuo, inde lardum pingue apud Plinium $\&$ alios legimus: $\& C$ lardum cum pingui fuo, apud Marcellum.aliquando pro pingui folo, unde Marcellus, lardư quod inter cutê \& carnem macrâ eft.Plura de lardo dixi in F. Sed quia uidentur foriptores lardum \& axungiam, fiue adipem fuils Ium, interdum indifferēter accipere, aut faltem eafdem uires tribuere, nos quoq non diftinguemus $10 c 0$, recitando de eis autorũ uerba:hunc folum ordinẽ fecuturi, ut primò agamus de remedris corû́ quum foris applicantur, fecundo loco quum intra corpus fumuntur. Adipem \& feuum $\&$ pingtre 6 medici ferẻ confundunt, cum ueteres, tưm noui. Sed feưum propriè rưminantia habêt, cętera adipê. Vtrunç in fine carnis eft, utrự̧ concrefcit ac gelafcit, \& fragile eft fi refrixerit : pingue inter carne 


\section{DeSue. G. Lib. I. IoIz}

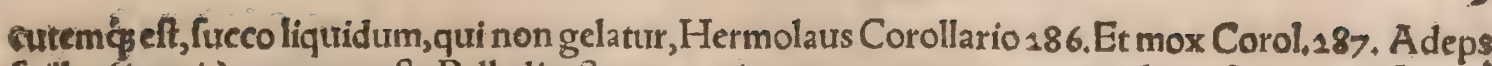
fuillus (inquit) unguen, tefte Palladio (Serenus etiam unguren pro axungia dixit) $\&$ axungia Latine dicitur: \& Græci quoq̧ ufurpant, fed oxyngon ferè appellant, tracta origine ab axibus curruum per ungendis.quanquam eft ubi Plinius aceti fecem oxyngion interpretatus effe uideatur. Er nos fortaf fe quibufdam locis autoritatem fummi uiri noftro iudicio pratulimus. Alioqui Paulus Aegineta o. xyngion pro axungia clariffimè uidetur intellexiffe, in emplaftro cui Phœnicite nomen eft. A xun. gięnomen ad alia quoģ pinguia transferri, fed rarò comperi, Hactenus Hermolaus. A butyro pro xima in communibus adipis laus eft, fed maxime fuilli, apud antiquos etiam religiofi. Certe noua nupte intrantes etiamnum folenne habent poftes eo attingere. Inueteratur duobus modis, aut cum 80 fale, aut fyncerus: tanto utilior quanto fituetuftior. A xungiam etiam Graci appellauere in uolumis nibus fuis, Neq̧ eft occulta uirium caufa, quoniam id animal herbarum radicibus uefcitur. Itaç eti. am fimo innumeri ufus. Q uamobrem non de alia loquimur fue, multò efficaciore foemina, \& qua non peperit. Multo uero praftantior in A.PRIS eft, Plin. Noftri pharmacopola ad ungenta qua: dam paranda, porcellum mafculum lactentem caftrant, eiusç̧ pinguedinem auferunt, illam maximé qux in uentre intra carnem circa peritonxum habetur, plerig tem axungiam uulgò fobmơr, Galli oing quafi unguen. Colligebatur etiam à renibus, utinfra dicä, Alapis, id eft axungia porcina, Syluaticus, Antiqui axungia maximè axibus uehiculorum perun. gendis ad faciliorem circumactum rotarum utebantur, unde nomen, Plinius. Noftrates pro axun. gia feutum, butyrum, præfertim quod inutile alioqui $\&$ rancidum fuerit, $\&$ butyri fecem ac refinam

10. abietis aut piniad ufum rotarum permifcent, quę quidem compofitio illita fcabiem quoç in homine \& ferpiginem emendat. Synceram axungiam Plinius uocat, Serenus fimplicem, quar non eff falfa: de qua femper intelligendum puro, ubialiud non exprimitur. Salfe ufus non eft, nifi ad ea qua

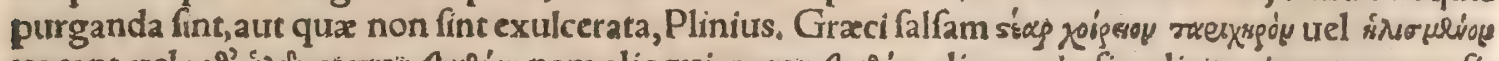

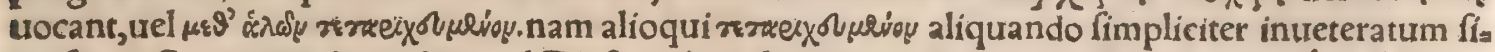
gnificare Cornarius docet: 8 apud Diofcoridem ab initio capitis de adipibus inurenio, ség dixe \& $x \bar{n}$

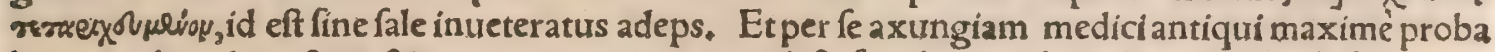
bant renibus detractam, \& exemptis uenis aqua colefti fricabant crebro, decoquebantí̧ fićtili no: vo fapius, tum demum afferuantes, Plinius, Suillus adeps $\&$ urfinus (ag’reG $\mathcal{G}^{\prime}$, ut Ruellius legit: meus Diofcorides Gracus ap̧ve(6) habet,id eft agninus, ut Marcellus etiam \&. Hermolaus uerterunt:

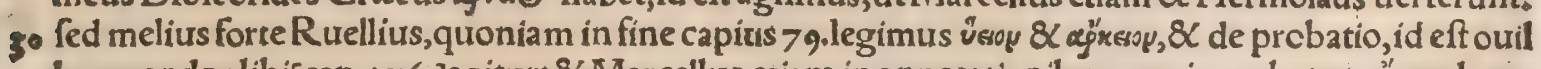
lo curando alibi[cap.276.]agitur:\& Marcellus eriam in annotationibus magis probatut aǵxerop lega. tur) hoc curantur modo: Recens, prapinguis, renibus potiflimum detracnus, in largiore aqua coele Iti $\&$ quàm frigidiffima, exemptis tunicis, diligentiftime manibus confricatur, \& exprimendo fermè ficcatur, fubindeḉ́ noura aqua abluítur.cæeterum fictili capacitatis duplæ inditus, in aquam demergi cur, \& fubditis leuibus, prunis fpatha mouetur ₹eliquatusó, , colo transfunditur in aquam : ubi uero refrixit, \& guttatim aquam omnem éxclufit, in pralotum fictile demittitur, \& infura aqua leniter eli= quari debet, \& manu deprimi, quó facilius fæculentum uirus peffun eat, poftea in pilam fpongia madefactam transfunditur. Vbi coire cœpit, refidens in imo fordes eximitur: tertio citra aquam eli. quatur, repurgatuság, fictili bene operculato, perquàm frigidis locis reponitur, Diofcorides interpre so te Ruellio. Caprinus adeps fuillo calidior eft. Hoc femper meminiffe oporter, pro animalium tem peratura femper exiftere differentias eius qua in illis eft pinguedinis, aut adipis, Igitur cum fus om= nibus propé quadrupedibus in caliditate acficcitate inferior fit, pinguedinem quog minus habet ca lidam, magiṣ́́ humidam, Galenus de fimplic, 11.4. Etmox, Pinguedo fuis ut ad nos quidem largius humectare poteft, fed non aqué excalfacere ut oleum : uerum pinguedinis fuum talis eft caliditas, qualis fpectatur in nobis. Porrò taurorum adeps fuillo multò calidior eft \& ficcior. Quód Diofcori des non recté dixerit caprinum adipem adfrringentiorem effe fuillo, in caprino iam reprehendi Gale ni uerbis ufus, Vfus axungix eft ad mollienda, excalfacienda, difcutienda, purgandaç, Plinius. Et rurfus, Conuenit falfam magis emollire, excalfacere, difcutere, utilioremç̧ effe uino lotam. E fue ue tuftiffimus quifoģ a deps fale conditus excalfacit, \& emollit, elotus uíno pleuriticis prodeft.cinere aut - calce exceptus, inflammationibus, fiftulis ac tumoribus fuccurrit, Diofcor. Adipis fuilli $\&$ uulpin eandem effe facultatem in Succidaneis A egineta legitur; ego fape quidem indifferenter ufurpari poffe concefferim, femper $\&$ abfolure non item, uulpinus enim tum calidior fuillo eft, tum minus hu

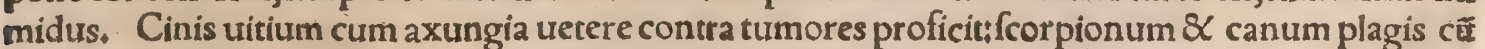
oleo perfanat, Plin. Caftor marrubium, prafertim candidum, tunfum cum axungia ueteri uulneri: bus à cane factis illini iubet, Idem. Spuma nitri canum morfibus ex afinino aut fuillo adipe mede. cur,Diofcorid.lib. গ. fed hîc adeps fuillus materiæ potiffimum uicem explere uidetur $;$ ut in omnibus illis unguentis qua argento uino axungix mixto, \&c.aduerfus Gallicum morbum paulò ante no: fram memoriam parari coperunt. Defenderit tamen aliquis, peculiarem quandam axungix etiam per fe aduerfus hane luem ineffe facultatem, qua fcilicet, ut Plinius fcribit, genibus etiam adalligata c. reddit ori faporem, ut expui uideatur. In rigore ceruicis poplites axungia illini Serenus iubet. Nico laus Myrepfus etiam inter unguenta duobus ultimis ad feabiem inferiptis argentum uitum addit, ul timo \& antepenultimo esiam fuillum a dipê, Item fectione 47. qua tota eft de medicamẽtis aduerfus 
fcabiem, Vnguêto ultimo mifcet adipem porcinum, hydrargyrum, oleum laurinũ \& fuccũ fumarię hoc palmas mantum $\&$ plantas ualidè perfricari iubet ter die, fic malum per urinam abiturum, Vn: de apparet unctiones uulgó ufitatas contra Gallicum morbũ antiquiores effe quàm pleríç putant. Lardum coctum cum pingui fuo appofitumóp, potenter omnia expellit, qua corpori inhaferint, ff illic alligetur, Marcellus. Ad uulnus incurabile in quauis corporis parte : Bugloffon herbam euel. lito, \& fuccifas radices curiofé lotas in pila conterito, fuillã axungiam a dịcito, ac bene emolliens uul neri imponito, Galenus Euporift.3.160. Neruis uulneratis prodeft, Terræ lumbricos indere tritos, Queis uetus $\&$ ranis fociari axungia deber, Serenus. Fracta off lardum elixum ato̧ circunligatü mira celeritate folidat, Plinius. Si cui forté la pis teneros uiolauerit artus, Nece adipes uetulos, \& tritam chamæciffon, Serenus; uidetur autem fuis adipem intelligere, nam \& ftercus lutex porcæ ad idem prodeffe mox fubiungit. Axungia panis illinitur cum calce : item furunculis duritiáç mam, marum.R upta, \& conuulfa, \& fpafmata, \& luxata fanat. Clauos $\&$ rimas callićs uitia, cum elleboro albo, Plinius. Vtilifimum contra inflammationes ulcerum adipe uerrino (axungiam) confici, \& inungi putant utile; ịs ć̣ qux ferpant illinire cum refina, Idem. Axungia è fue qua non peperit ap tiffime utuntur ad cutem mulieres, contra fcabiem uerò admixto iumentorum feuo pro parte tertia, $\&$ pice, pariterćs fubferuefactis, Plinius. Cicatrices concolores facit cerufa admixta, uel argenti fpuma. at cum fulphure unguium fcabricias emendat, Idem. Glans intrita duritias quas cacoêthes uocant, cum falfa axungia fanat, Idem. Lac ficulnum cum axungia uerrucas tollit, Plinius. Rutis emendat uitiligines, ftrumas $\&$ fimilia cum ftrychno $\&$ adipe fuillo ac taurino feuro, Idem. Parotidas fanat axungia, ammixta farina falfamentarix teft : quo genere proficit $\&$ ad ftrumas, pruritus $\& 1 \&$ papulas in balneo perunctis tollit, Idem. Parthenium illinitur ftrumis cum axungia inueterata, Pli nius. Idem alibi lapathum fylueftre ad ftrumas cum axungia efficaciffimum effe tradit, Suillus adeps ambuftis igne medetur, Diofcor,abfceffibus $\&$ ambuftis, Auicenna. Syncera axungiamer detur ambuftis uel niue; pernionibus autem cum hordei cinere $\&$ galla pari modo, Plinius, Et ali: bi,Vlceribus ex ambufto cum candido ouorum tofum hordeũ \& fuillo adipe, mire prodeft. Com buftis igni, Ordea uel franges (forte, friges) atç our candida iunges, Adfit adeps porca, (mira eft nam forma medela,) Iunge chelidonias, ac fic line uulnera fuccis. Quodés recens uffit glacies, axungia fimplex Mulcet, $\&$ ex facili grata eft medicamine cura, Serenus. Syncera axungia pro* deft cốfricatis membristitinerumó̧ laffitudines \& fatigationes leurat,Plinius. Cinere de capillis mu liebribus in tefta crematis, addito adipe fuillo, emendari aiunt facrum ignem, fanguinem fifti illico, ${ }^{\circ}$ \& formicationes corporû, Idem. Perniones fa:cit, A P R Inum uel furillum fel: cum adipe pulmoim pofitus, Plinius. Virides brafficarum caules unà cum radicibus fuis cremati, lateris diutinos dolor res impofiti fanant, Diofcorides, IIn pecorum etiam remedips multiplex axungix ufus eft. Pra fractis cornibus boum linteola fale ato̧̧ aceto \& olco imbuta fuperponuntur, ligatisós per tridıũe ea dem infunduntur.quarto demum axungia pari pondere cũ pice liquida, \& çortice pineoleuigató imponitur, \&c. Columella. Si talum aut ungulam bouis uomer laferit, picem duram $\&$ axunglam cum fulfure $\&$ lana fuccida inuolutam candente ferro fupra unlnus inurito, Idem. Boum attriis ungulis cornua ungendo aruina, medentur agricolæ, Plinius. Canum aures à mufcis exulceran: tur:in qux ulcera coctam picem liquidam cum fuillo adipe ftillari conueniet, hoc eodem medicamis ne contactiricini decidunt, Columella. Ad mentiginem in agnis uel hœdis, quiburdam placet 21 tra ginis tertiam partem duabus ueteris axungix portionibus commifcere, tepefactoóp uti medicamine, Idem. Ad fcabiem equi hyemalem, $\&$ in cruribus, rappas uocant: Axungiam igne liquatam infun des in frigidam: 8 rurfus exemptx fubactaćs, admifcebis fulfur quàm tenuiffime derafum, \&iterum fubiges, \& inunges, tertio die cruftulas fcabiei perfricando aperies, \& quotidie inungere perges, Manufcriptus quidam liber Germanicus. Quidam cum fuppurationẽ in bubus inufferunt, urina uetere eluunt, atç̧ ita æquis ponderibus incocta pice liquida cum tretere axungia linunt, Columella, Sanguis demiffus in pedes boum, nifi emittatur, faniem creabit. Locus primo ferro circũcifus \& ex purgatus, deinde pannis aceto $\&$ rale $\&$ oleo madentibus inculcatis, mox axungia uetere \& feuo hir cino pari pondere decoctis, ad fanitatem perducitur, ldem. Hxc de brutorû remedị́s per axungiam, TFabalium filiquarum cinis ad coxendices, $\&$ ad neruorum ueteres dolores, cum adipis fuilli uetus st ftate prodeft, Plinius. Medicorum aliqui axungia admixto anferis adipe taurorû́ó feuo $\&$ œfypo ad podagras uti iubent.fi uerò permanet dolor, cũ cera, myrto, refina, pice, Idem. Et rurfus, Axun gia podagricis prodeft mixto oleo uetere, contrito unà farcophago lapide, \& quinquefolio tufo in uino. uel cum calce, uel cum cinere. Facit $\&$ peculiare emplaftrum 85 . pondo. C. fpuma argenteęmi xtis.(quod ita ferè eft, ut axungix ponderis fint partes fex, lithargyrï feptẽ.) A deps fuilla cum aqua $\&$ cumino fubacta, podagricis opitulatur,Sym. Sethi. Medetur axungia \& capillo fluenti : \& ulce: ribus in capite mulierum, cum galla parte quarta $\&$ infumata pilis oculorum, Plinitus。Axungía porcina infulfa ápud A eginetam medicamentis ad alopeciam mifcetur. Ruborum rofa alopecias cum axungia emendat, Plinius. Lingua ( aliâs Lingulaca) herba, nafcitur circa fontes " radix eius combulta \& trita cum adipe fuis, adịciunt ut nigra fit \& fterilis (aliâs, ut nigra fit \& nunquam pepes rerit,) alopecias emendat ungentium in Sole, Idem. Alopecias replet hippocampinus cinis nitro \& adipe fuillo mixtus, aut fyncerus exaceto, Idem. Scrofina adipe recenti fi quis contritos (contrita) 


\section{DeSue. G. Lib. I.}

angulos oculorum, interius exterituśg inunxerit, uermículos qui noxỉ funt oculls potenter educit, Marcellus, Axungia infumata (in fumo furpenfa) pilis oculorum (defluentibus nimirü, ut $\&$ alo. peci $x_{\text {, }}$ medetur, Plinius. Ad aurium dolorem qux pus emittent, laridum uetuftiffimum teres in mortario, 8 fuccum illum lana delicata collectum in auriculam immittes, \& fubinde aqua calida fo. uebis, \& iterum fuccum illum infundes, mira uelocitate fanabis, Marcellus. Si maior fit dolor aut grauitas aurium, lardum pingue inftillant, Plinius. Ad acerbos dolores aurium; Subactum oleo a. dipem(śą, cum afterifco appofito, qui locum deprauatum uel mutilum indicat, deeft enim anima. lis nomen, fuis ut puto, aut uulpis;) infundito: $\&$ (pongia locum occludito: bene facit $\&$ ad neruoruี morbos ex uulpino adipe atç fuillo ("ir, uox corrupta, pro qua interpres legit vér) xqua portione mí 80 xtis remedium, Galenus Parabilium 2,4. Pingue laridi(laridum)quod inter cutem \& carnem ma= cram eft,fi parotidibus adponatur, \& illic ligetur, cito fanabuntur, Marcellus. Axungia(uetus, Mar cel.) (anat parotidas ammixta farina falfamentariæ teftæ, (cum tefta uafi falfamentarï,) fubacta $\&$ ad pofita, Plinius $\&$ Marcellus. Sideritis cum axungia ueteri parotidas fanat,Plinius. Si quod tuber culum in collo nafcatur, uinum \& lardum fimul in olla calefacies, \& fubinde gargarizabis, Obfcur. In rigore ceruicis, Geminus mulcebitur unguine poples. Hinc longum pariter neruos medicina fequetur, Serenus. Vnguen axungiam fignificare fupra diximus. Penetrare autem huius illitionis uim ad ceruicem minus mirum, cum Plinius fcribat axungiam genibus adalligatam reddere ori fa porem, \& expui uideri : cuius uero rei gratia id fiat non expreffit. alibi quidem axungiam genibus dolentibus cum genifta imponi prodidit. Efure uetuftus uino elotus adeps pleuriticis prodelt, Dio

20 fcorid. Ruta adeò peculiaris in teftibus effectus eft, ut fylueftri ruta cum axungia ueceri illitos ra= mices fanari prodant, Plinius. Axungia antiqui maxime axibus uehiculorum perungendis ad faci liorem circumactum rotarum utebantur, unde $\&$ nomen; fic quogg utili medicina cum illa ferrugi: ne rotarum ad fedis uitia uirilitatisç, Idem. Genifta tufa cum axungia genua dolentia fanat, Plini: us. Suillus adeps contra uulua $8<$ fedis uitia idoneus eft, Diofcor. Syncera(id eft non falfa:adipes enim falfi utero non conueniunt, Diofcoride tefte) axungia partus in abortum uergentes nutrit, collyrij modo fubdita, Idem. Periftereon appofita in adipe fuillo recenti, frangulatum à uuluis menfi. ưmó difficultatem emendat, Plinius. Si dolor $\&$ ulcera in matrice fint, fpongia aut molli lana in ca lidam intincta locos expurgabis, $\& c$, poftea refina $\&$ adipe fuillo mixtis fimul illinito fape interdiu ac noctu, Hippocrates lib.ı.de morbis muliebribus. Et paulò poft, Si uero uehementer exulcerati 3o fuerint loci, \&c. collutis eis purgatiśç̧refinam ac mel \& pinguedinem fuillam illinito. In libro eti= am de natura muliebri ad nefcio quos uteri affectus, (neç enim fatis exprimitur ¥) capra cornu, \& gallam, $\&$ adipem fuillum ac cedriam fuffiri iubet. TVinum falfum cum adipe fuillo recente con tra hyof cyamum bibitur, Diofcorid. Lardum eiusḉ decocti potum his qui bupreftin hauferint au. xiliatur, Plinius. Iis qui argentum uiuum biberint lardum remedio eft, Idem. Phthificis medetur macræ fuis foemina herbis paftx lardum, Plinius. Ad phthifin, Proderit $\&$ ueteris fetri pila fumpta fuilli, Serenus, Axungix fuilla uetufta uncia tres ex uini uetuftifimi cotyla una decocta, porui phthificis datæ potenter remediantur, Marcellus. Axungia datur etiam phthificis unciatím, cum ui ni ueteris hemina decocta, donec tres unciæ è toto refidant:alij $\&$ mellis exigurum adíciunt, Plinius, Et rurfus, Axungia uetus etiam phthifin in pilulis fumpta fanat, qux fine fale inueterata eft. Omni= 40 no enim non nifi ad ea qua purganda fint, aut qua non fint exulcerata, falfa petitur. Quidam qua* drantes axungix \& mulfi in uini cyathis tribus decoquunt contra phthifes, quintóg die picem liquidam in owo fumi iubent, circumligatis lateribus, \& pectoribus, \& f capulis eorum qui phthifin fentiunt. Tantaćg eft uis, ut genibus etiam adalligata, redeat in os fapor, eamó̧ expuere uideantur. Et alibi, Ad tuflim ueterem recens axungia decoquitur quadrantis pondere in uini cyathis tribus addito melle. Coeliacis dantur lutea ouorum trium(cum)lardi ueteris $\&$ mellis quadrantibus, uini ueteris cyathis tribus, trita ad craffitudinem mellis, $\&$ cum opus fit auellanæ nucis magnitudine ex aqua pota,Plinius. Equo tuffienti offas éfuillo adipe butyro \& melle illitas, per os infere, Hippocra tes in Hippiatri. Offx de adipe fuillo ueteri uino uetere madefactas equo ob uram aut curfum ex. aftuanti (caufonem patienti) per os dabis, Hierocles. Axungix pars una tribus partibus hyffopi - permifta, in fauces uitulorum demiffa, lumbricos pellit, Columel.

T Si lingua \& fauces morbo epidemio nigrefcant, (quem noftrià colore uocant die baine, lin. guã faluberrimè perfricari pollicentư interiore parte pellis laridi,fic extrahi nimiun calorem. Eam pellem fi poftea canis obiectam deuorauerit, agrotabit aut forte morietur, fi ualde infectus fuerit ho mo cuius defricata eft lingua. Si opus uidebitur, duabus aut pluribus huiufmodi pelliculis deinceps linguam ægri perfricandam curabimus, Obfcurus.

đLupino adipe uel medulla fuum fricari oculos contra lippitudines pracipiunt, Plin. Coitus ftimulant medulla fuum haufta, I dem.

II In ambuftis prodeft fetarum ex fuibus é penicillis tectorïs cinis cum adipe triturs, Plin. Penim culi cinis fiftit fanguinem usulneris nimium fluentem, Serenus. Ad procidentem fedem: Sedi uino 60 prius abluta picem aridam tritam, uel fetas porcinas uftas 8 tritas apponito, Aétius 14.6.

Fractis oflibus prafentaneus maxillarum A PR I cinis uel fuis, Plinius. Vlcera(in tibís cruri busç̧) qux ferpuntmaxillarum A P R I uel fuum cinis fanat, Idem. Offa ex maxillis A P R I uel 
Suis domeftici uruntur, ulcerá̧̧ perniciofa crurum illo cinere afperguntur, Marcel,

बf Contra ferpentes laudatur A P R I acjeps cum melle refinág: fimili modo uerrinü iecur exem ptis duntaxat fibris quatuor obolorum pondere, uel cerebrum in uino potum, Plin. Contra carbun culos fuis foeminx cercbrum toftum illitumóp proficit, Idem. Verendorum carbunculis cerebrum A P R I uel fuis fanguisć́ medetur, Idem. Verris cer ebrum cocium \& cum melle adpofitum carbun culos in ueretroefficaciter fanat, Marcellus. Aut teneris cerebrum gingiuis illine porci,Serenus ad infantes dentientes. TOfficula in capite porci duo naturaliter forata inueniuntur, id eft unum in dextra parte, \& aliud in finiftra, qux reperta \& repofita, \& cum opus fuerit licio fufpenfa, medelam capiti prout inuenta fint præftant:id eft dextrum dexteræ parti, \& finiftrum finiftra: fed præter te $\&$ agrum officula tertius non contingat, qux ad hane neceffitatem colligi diligenter \& feruari de bent,Marcellus. I Aurcula porcina os perforatum collo alligatum à tuffi futura cuftodit, Gale: nus Euporift, 2.43.

In fuillo uentre gobius recens decoquitur ad alui deiectionem: Vide in Gobio ex Diofcoride,

बi Ebrietatem arcet pulmo A P RI aut fuis affus, ieiuni cibo fumptus, eo die, Plinius. Suillus \& agninus pulmo impofitu attritus à calciamentis contractos, ab inflammatione tuêtur, Diofcorid.cal ciamentorum attritus fanare creduntur, Galenus,Sym. Sethi \& Hali. Clauos 8 rimas callíğ uitia pulmo A R IN v s aut fuillus fanat, Plinius. Perniones urfinus adeps rimasḉ̧ pedum omnes fara cit, \&c,item A P R I N v M uel fuillum fel;cum adipe pulmo impofitus, Idem.

đI Sús iecur cum uino fumptum uenenatorum morfibus medetur, Symeon Sethi, Contra fer: pentes auxiliatur uerrinum iecur(inueteratum cum ruta potum ex uino, ut A P R I quo $\$$ ) exemptis is duntaxat fibris quaturor obolorum pondere, Plinius. Vitia qua in uerendis ferpunt, iecur fuis utel A PR I combuftum maximé iuniperi ligno \& arrhenico lanat, Plinius. Aluum fiftit fullum iecur af fum:uel A PRIN V M ex uino potum citra falem recensć, Idem. Iecur uerrinum recens combuftum contritumó̧ ad fummam leutitatem, cum uino, fed fine fale potul datum, efficaciter fupprimit nimi. am deiectionem,Marcel. TDe lapillis qui in iecorefuis reperiuntur, uide in Apro G.

qDiofcorides ubi de felle in genere tractat, taurinum fuillo efficacius effe fribit. Suillumfil (inquit Galenus de fimplic, 10.12.)minimè uehemens eft, ita ut ulceribus etiam non intolerabile fit: \& fanè magis aquofum quàm ullum aliud uidetur, praterquam fylueftrium fuum $\&$ montanorum: quorum ut caro tota calidior ficcior'ç ef, (quàm uulgarium, fic etiam fel. Pro felle fuillo, fel perdie cis, Antiballomena apud Aeginetam. Infirmius(humidius, Hali)eft cateris, Auicenna, IMaturat 30 \& uenenofis morfib, prodef, \& prauss humores foluit, Hali. Articulorum attritis fel A P R orum uel fuum linteo calefacto impofitum prodeft,Plinius. Vetuftam porriginem miréadimes, fi herba cyclaminis fucco fulphuris aliquantum mifcueris $\&$ fel frophinum, atģ inde caput in balneo bene perfricabis, Marcellus. Ad euulfos palpebrarum pilos, ne renafcantur:Suis mafculi fel $\&$ adipem ciufdem, in fictile nouum denfiffimum leuigatıfimumó̧ conịcito, atç aceti acerrimi $\&$ olei alini (2o mygdalinum interpretantur) utriuf $\$$ trientem infundito, denfioriḉ linteo circunligato, \& finito uf: que ad dies feptem, deinde effundens in mortarium tundito, 8 habebis tanquam aurum, quod etis am toti corpori conferet, (pro plilorhro, trel ne pili euulfi renafcantur, Aétius 7.67. Panos \&apoo ftemata in quacuncs parte difcutit fel urfinum fiue uerrinum, Plinius. Ad agilopas, Fel porcinum ficca $\&$ appone, Galenus Euporift.2.106. Suillum fel contra aurium ulcera, reliquaćs omnia, mas 40 gno ufu affumitur, Diofcorid. Suillo felle aliqui utuntur ad ulcera aurium non improbandoremea dio, quo tu quoç utêris ubi nullum compofitum adfuerit. funt enim innumera. Cæeterum proaffes ćtionis magnitudine aliud etiam alterius animantis fel contrenire poterit. Nam cum ulcus $\&$ ditu turnum fuerit, \& faniem ac pus multum habuerit, aliud etiam magis exiccans fel tolerabit, quale eft ouium paulo acrius fuillo, eoć magis caprinum, cui feré fimile eft urfinum $\&$ bubulum, Galenus de fimplic,10,12. Aurium dolori \& uitís medetur fel A P I uel fuis, uel bubulum cum oleo cicino \& rofaceo $¥$ quis portionibus, Plinius. Ad aures qua grauiter dolent $\&$ uetera uulner 2 intrinfecusha bent, meilis optimi unam partem, aceti acerrımi duas partes confufas decoques ferúoribus tribus, $\&$ longius ea ab igne remouebis, donec commotus fertor conquiefeat: tum nitrum addes co ufg do: nec ex uapore cognofcas nitrum refediffe, $\&$ iterum leni igne recoques, ne efferueat: tunc addes fel so hircinum, uel aprugnum, uel uerrinum aut porcinum, dummodo non de fcrofa, \& commouebis \& iterum concoques, ac tepefacies, $\&$ inde quantum fatis eft auribus infunde, Marcellus. Verrinum fel in mali punici cure ficca tepefactum, infúfumć, purulentas auriculas expurgat, Marcellus, Suris manfueti fel pari mellis ad carbones cocti portione admiftum tepidum infunde, Galenus Euporif, 33. Porcæ fel quæ nondum peperit cum mellis aquo pondere ad aurium uitia laudatur, Alexan. der Benedictus. Lienem fedat fel A.PR I uel fuis potum, Plinius, Fel fuis arefactum marifcis feu

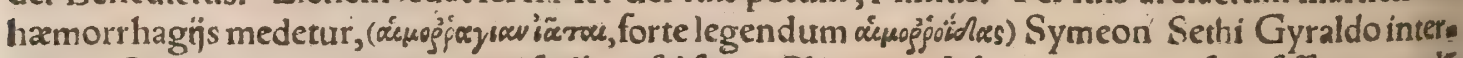
prete. Perniones A P R I N v uelfuillum fel fanat, Plinius. Ad grappas, qua funt fiffura quadă in pedibus equorum, aliqui fel maialis cum tribus ouorum uitellis mifcent \& fuperilligant, malum fic una nocte pellendum promittentes.

4 Ciet urinam uefica fuis, fi terram non attigerit, impofita pubi, Plinius. Veffica uerrina cocta uel ufta comedenda aut bibenda efficaciter datur ei qui urinam fuam non poteft continere, Marcel, 
Alï adidem \& PR I ueficam commendant, ut pluribus in cius hiftoria dicetur. Adulcera manan. cia capitis, qua uulgó tíneas uocant, noftri bert grind: Veficam maialis cum urina fua accipies, 8 in. ijcies in eam axungiam minutatim concifam, \& falis multumªddes, donec ferèalbefcat. Poftea uefí cam diligenter ligatam in horto defoffam fub terra ad cubiti feré profunditatẽ quadraginta aut quin quaginta dies relinques donec bene computruerit coagulata in ea materia. Hanc poftea in patellall quabis, $\&$ redditum inde unguentum feruabis. Oportet autem caput fic exulceratum, primumlixio vio abluere, $\&$ cum bene ficcatum fuerit inungere, idḉ per hebdomadem tertiò repetendum eft . Sic breui tempore corrupti capilli defluent $\&$ fubnafcentur noui, Caterum lixiuium initio quidem me. rum adhibeatur latrando capiti, poftea uero dilutum, ne nimia acrimonia ladat. Capiti interim à fria 6- gore cauendum, Germanicus liber manufcriptus, Si cornu perfractum hiet, (Si thlafma in ungula equi apertum fit,) poft cætera remedia, $8 \mathrm{c}$, ubi calor conquieuerit fuilla uefica dehifcentem locum indues, \& ubi non amplius claudicârit, refolues, Pelagonius in Hippiatr.101.

Contra comitialem morbum dantur fuum tefticuli inueterati tritiós in fuis lacte, pracedente uí. ni abftinentia $\&$ fequente continuis diebus, Plinius. Tefticulos uerris Bartolemaus Montagnana mifcet medicamento cuidam melle excipiendo, ad coitum in uiro $\&$ conceptum in muliere promo. uendum. Ad urina incontinentiam:Magi uerrini genitalis cinere poto ex uino dulci demonftrant urinam facere in canis cubili, ac uerba adijcere, ne ipfe urinam faciat, ut canis in fuo cubili, Plinius, 8. fimiliter Marcel. fed fuperftitionem de mingendo in canis cubile omittit. Eandem(urina incon. tinentiam) uefica foeminæ fuis cumbufta ac pota cohiber, Plinius. Memini audire quofdam è uul. 20 gò pueris contra hoc uitium uuluam fcrof $x$ diutiffimè coctam in cibo dare. Contra dolores aurium, uirus uerrinum è fcrofa exceptum, priufquam terram attingat, prodeft, Plinius, Verris cum fcro. fam faliet, priufquam in terram deftillet de uerendis eius, uirus exceptum tepefactumó \& cum aquę modico auricula inditum, quamuis moleftos dolores releuat:quod etiam circa auriculam inlitum, plurimum prodeft,Marcel.

Sicca lippitudo lumbulis fuum toftis atqg contritis $\&$ impofitis tollitur, Plin.

đAd tuffientes adfidué:Pernam contundens $\mathbb{X}$ inftar farina in locum affectum fpargens, iuurat. hoc idem $\&$ fanguinis ex ore eiectioni fuccurrit egregié, Galenus Euporift.2.21. Perna porcina e* lus ú iufculum, mifcetur medicamentis ad podagram imponendis apud Áétiũ 12,43. Emplaftrum diapternes, hoc eft ex perna, quod tofos foluit:Pernæ fuillæ ueteris pinguis, guttæammoniaca, cafei 30 ueteris uacciniaut caprilli, feui taurini, apochymatis qua eft nauis rafura, fingulorum libra:medul. Ix ceruinæ uncia viī. œfypi cerati unciæ tres, cyprini olei unciæ fex, uini Aegyptij quod fatis eft, $A$ e gineta lib.7.cap.17.de emplaftris, Offa ex acetabulis pernarum circa qux coxendices uertuntur, dentifricî ufum prabent. Lifdem fanari dimiflis in fauces iumentorum uerminationes notum eft: fed $\&$ combuftis dentes confirmari, Plinius. Perna fcrofinæ os quod eft amplifimum combuftum tri: cứćs optimum $\&$ falubre dentifricium praftat. gingiuas enim ficcat, $\&$ adftringit, dentesí̧ ab hu*

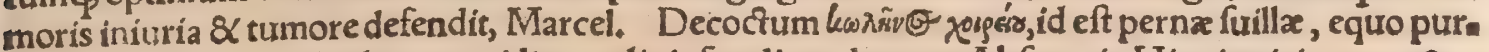
gando per triduum duabus quotidie cotylis infunditur, docente Abfyr to in Hippiatricis cap. 128. Si equus malide humida laboret fuccum pernæ fuill $x$ cum pedibus decocfæ per os infundes, menfur. ra duarum cotylarum, percolatum \& melle mixtum, ac ouis fímul agitatis, Idem utiliter per finiftram 40 narem infunditur, Hierocles in Hippiat, cap.2. Vegetius 1,56.in potione equi prophylactica adhi. bet acronem falfum porci pinguis, uel longanonem. In perna fuis articulos effe diximus, quorum decoctum ius facit urinæ utile, Plin.

TSuis talus comburitur, dum é nigro albelcat:qui triturs \& potus inflationibus coli, longisḉp tor minibus medetur, Diofcorides; mederi fer tur, Galenus. Talum furillum uftum $\&$ tritum, totum ex aqua bibendum prabe, $A$ étius 9.31.inter remedia ad colicam. Talus fuis uftus difcutit qua in uen: triculo fiunt inflationes, \& cephalalgiam, id eft capitis dolorem diffoluit, Symeon Sethi. Talorum fuis uel A P R I cinis, clauos \& rimas callị́ uitia fanat, Plin. Eft etiam proditum,quod fi os(ỏsz̄y)fu. fpenfum furerit quartana affectis, eos melius habituros, Idem:[ed de quo offe loquatur, incertum:pro ximé enim ante adipem tali meminerat.

TOfa ex ungulis furm combufta, dentifrici ufum prabent ; item offa ex acetabulis pernarum circa quæ coxendices uertuntur+ïfdem combuftis dentes confirmari notum eft, Plinius, Offium ex ungulis porcinis combuftorum cinis, pro dentifricio habitus, plurimum confirmandis dentibus prodeft, Marcel. \& Auricen. Dentifricium fit ex cinere cornu ceruini aut ungula porca torrida, Se renus. Porci ungularum offa combufta tritáç \& cribrata, adieço nardo $\&$ folio, frictione frequen ti dentes candidiffimos præftant, Marcel. Vrina incontinentiam cohibet ungularum APR I uel fuis cinis potioni infperfus, Plinius: A P R I ungula ufta ex uino, Galenus Euporifton, 3. 257. Vn. gula porcina combufta ad cinerem, poftera die ex uino haufta, mirabiliter dyfenterico prodef, Mar. cel. Aluo foluend $x$ mercurialis decoquitur quantum manus capiat, in duobus fextarís aqua ad di midias, bibitur fale $\&$ melle admixto, nec non cum ungula furis, aut gallinaceo decoctum falubrius, 60 Plinius.

Lacte fuis poto cum mulfo adiutuantur partus mulierum:per fe uero potum, deficientia ubera puerperarum replet, , linius. Suillum lac ex melle potum partus accelerat, Galenus Euporift, 2, 88. 
utiliffimum eft tenefmo, dyfenterix, nec non phthificis, hoc $\&$ mulieri faluberrimum qui dicerene fuerunt, Plinius. Contra comitialem morbum dantur fuum tefticuli inueterati tritíç in fuis lacte pracedente uini abftinentia, \& fequente continuis diebus, Idem. Chamæleontis feminis finiftri uel pedis cinerifi mifceatur lac fuillum, podagricos fieri illitis pedibus magi fcriplerunt, Plinius,

TNon eft occulta uirium axungix caufa, quoniam id animal herbarum radicibus uefcitur, itag etiam fimo innumeri ufus, Plin. Ad morfus uenenatos fuillum recrementum aceto cocfum utill. ter imponitur, Aêtius. Pro hyęnæ ftercore fubftitui licet porcinum, Aétius in emplaftro quodam contra crocodili morfum. Stercus fuis impone aduerfus ictum fcorpï aut alterius reptilis, Anato, lius in Hippiatricis, Sibouem aut aliam quadrupedem ferpens momorderit, melanthñ acetabulü, \& quod medici uocant fmyrnium, conterito in uini ueteris hemina, id per nares indito, $\&$ ad ipfum 1 mor furm ftercus fuillum apponito. Idem homini facito, fi ufus errenerit, Cato. Stercus fuillē recens \& mel Atticum nonnulli cum uino mifcent, \& calefactum quafi cataplafma inducunt, addentes uri nam humanam, ad ictus uirulentos, Vegetius 3, 77. Stercus fuillư iumentis propinatur contra ure. nenofos morfus, Ibidem. Vide inferitis inter remedia ex hoc fimo intra corpus fumpto, Fimus fuil lus in tefta arefactus $\&$ tritus, $\&$ cum oleo impofitus, mirè fanat liuores, Marcellus. Luxatis recens fimum A P R IN V M uel fuillum medetur, Plinius:Diofcorides fuis fylueftris fimum cum cerato rofan ceoluxatis mederi fcribit. Fimum recens fuum, uel inueterati farina illinitur uulneribus ferro fa. -chis, Plinius. Ad uulnus dulce, Suillum fimum cum oleo $\&$ acri aceto mifceto, $\&$ locum prius feta. ceopanno excoriatũ inungito, Galenus Euporift. 3.190. In ambuftis prodeft A P R IN V M aut furits lum fimum inueteratum, Plin. Prurigini, papulis $\&$ fcabiei arcendis, Stercoris ex porco cinerem 10 confundito lymphis. Sic pauidum corpus dextra parcente foureto, Serenus. Puftulis fuilli fimici nis aqua illitus medetur, Plinius. Fimum fuillum in tefta calefactum, tritumós cum oleo, duritias corporum omnes tollis optime, Plinius. Clauos $\&$ rimas calliç uitia, fimum A P R I uel fuis recens illitum, actertio die folutum fanat,Idem. Fimus A P R I uel fuis domeftici recens impofitus, \& poft tertium diem folutus, efficaciter clauros, uerrucas $\&$ callos aufert, Marcellus, Stercus fcrofinum uis no immixtum cum rofa liquida, id eft, rof fucco, lendes pedunculosíg difcruciat, Marcellus. Suil lum fimum comburito, \& cinerem melli admifceto, capurtós rafum inungito, ac fuper braffic $x$ foliz dato, Galenus Euporift, 3. 285. Si cui fortè lapis teneros uiolauerit artus, Non pudeat lutexfter, cus perducere porca, Serenus . Si fanguis profluat iumentis, fuillư fimum ex uino infundendum, Plinius. Adhamorrhagiam ex uulnere, Fungus quem crepitum lupi uocant, cum ftercore porci 30 gramina pafcentis tritus $\&$ calidus appofitus plagx, fanguinem fiftit, fed intra triduum remouri non debet, Rufius hippiatros، Ad cynanchen, id eft, anginam equorũ, Stercus fuillum melle per, mixtum illine. fit autem mellis tantum ut ftercus occultetur, Hierocles. Stercus porcinum ficcum inligatum phœnicio \& collo fufpenfum, tuffem moleftitimam fedat, Marcellus. Mulierifi mamma inflentur à partu, fuillum ftercus cum aqua tritum inunge, Nicol.Myrepfus. Cum oleo perfrictum $\mathcal{Q}$ in tefta calefactum, 8 inguinibus impofitum plurimum prodeft, Marcellus, Vitia qua in ueren dis ferpunt, fuilli fimi cinis fanat, Plinius. Inflationi uuluæ fimû̃ A PR IN V M fuillúmue cumoleo illini prodeft,Idem. Vlcera fanat in tibrijs cruribusḉ adeps urfinus cum rubrica : qua uerồ ferpû́t, fimum furum illitum ficcum, Idem. Spafnata \& percuffu uitiata,fimo A P R IN O curant uere colles cto \& arefacio. Sic \& quadrigis agendis tractos, rotáue uulneratos $\$ \&$ quoquo modo fanguine cons $4^{\circ}$ tufo, uel fi recens illinatur. Sunt qui incoxiffe aceto utilitus putent, Quin $\&$ in potu farinam eam rua ptis conuulneratiş́́ \& euer fis, ex aceto falutarem promittunt. Reuerentiores cinerem eius ex aqua bibunt.Feruntós $\&$ Neronem principem hac potione recreari folitum, cum fic quoç fe trigario ap. probare uellet. Proximã fuillo fimo uim putant, Plinius, बRemedia ex fuccerda in corpus fuma pta. Farinam eius in potu ex aceto falutarem effe ruptis, conuulneratisḉ \& eurerfis promittunt, ut iam proximé ex Plinio recitaui, Iumentis propinatur contra uenenofos morfus, Vegetius 3.77 . Forinfecus quidem trenenofis morfibus $\&$ ictibus falubriter imponi in pracedentibus dicium eft Equo $\&$ boui fape exitialem effe fuis fimum fi fortè comederint, in ipforum hiftoria diximus, quam obrem miretur aliquis idem inter remedia recenferi. atqui non fimpliciter fuis, fed ægræ fuis fimum noxium effe fi deuoretur intelligendũ eft, quod Columella expreffit, Vegetius non item. Idem Ve g getius 3.9. ftercus fuis bibendum prabet iumento cui natura excidit. Colo medetur fuilli fimi fan rina addito cumino in aqua rutæ decocta, Plinius. Meminietiam alibi uel legere uel audire ftercus fuillum aduerfus colicam ualere experimento cognitum effe. Sed contra hunic affectưm alị etiá alia excrementa prabent, botris, equi, gallinx. Dyfentericis $\&$ coliacis auxiliatur A P R INI uel fuilli uelleporini fimi cinis infperfirs potioni tepidx uini,Plinius. Sunt qui phthificis furm fimi cinerem profuiffe fcripferint in paffo,Idem. Lumborum dolores, \& quacungs alia mollire opus fit, urfino adipe perfricari conuenit; cinerem A P R INI aut fuilli fimi inueterati afpergi potione uini, Plinius, Ad ftranguriam equi, Stercoris fuilli uncias quatuor cum uini fextario permífe, \& colatum in po tur dato, ftatim pellet urinam, Hierocles. Inflationi uuluæ fimum A P R I N V M fuillumue cum oleo illini prodeft. efficacius fiftit farina aridi, ut afpergatur potioni, uel fi grauida aut puerpera torques 6 antur,Plinius.

Aduerfus panos 8 apoftemata in quacung parte, urina fuum in lana impofita medetur, Plin 


\section{DeSue. G. H.a. Lib. I. Iorg}

Remedium ad achôras, id eft, ulcera manantia capitis ex uefica maialis ctrm urina fúa, fuperius in: ter remedia ex uefica expofui, Vrina terris in fumo arefacta ex aceto mulfo pota bene facit ad co mitialem morbum, efto autem urinx portio ad A egyptię fabx magnitudinem, fed optima eft A P R I, Galenus Euporift, 2. 3. Lotium porcorum prodeft albedini oculorum, fed eius proprietas eft ut cal culos frangat, \&c. Hali. Vrina porci frangit lapidem in renibus 8 uefica, \& prouocando educit ex ambobus, Auicenna. Lotio fuillo locum inguinum dolentem adfidue perungue, aut cumeo la. nam fuccidam adpone, ftatim medebere, Marcel.

IVerris fpuma recens cum aceto luxatis illinitur, $\mathrm{Plin}$.

9) Virus feu femen genitale uerris; uide fupra in Genitalibus 


\section{0}

\section{De Quadrupedibus.}

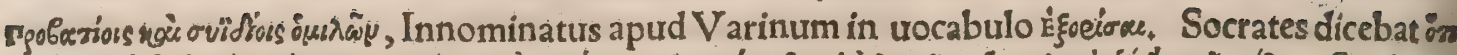

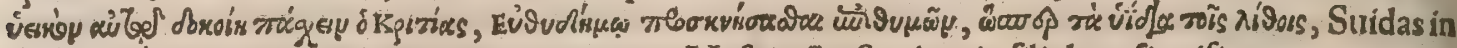
verió, viósoy cum diphthongo in prima in Verpis Ariftophanis filiolum fignificat, quamuis in

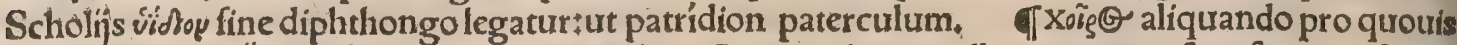

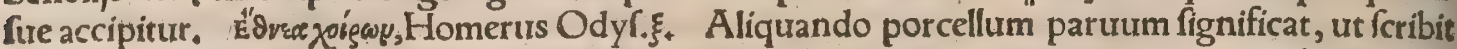
Galenus in Hippocratem de uictur in morbis acutis: Xoîgoy (inquit)priuatim ueteres uocabant roy $\mu_{0}$

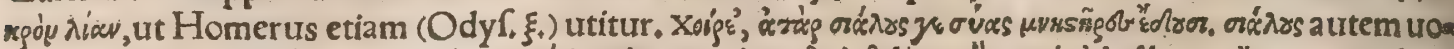

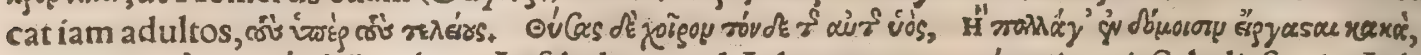

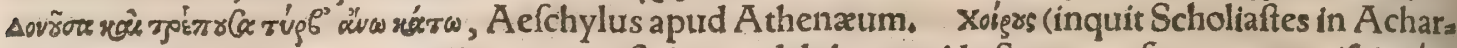
nenfes Ariftophanis) uocat poéta, quos noftri nunc delphacas, id eft paruos fues, quos prifci yéprs. 10

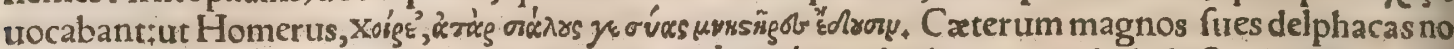

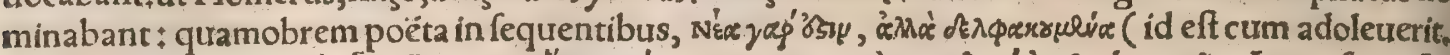

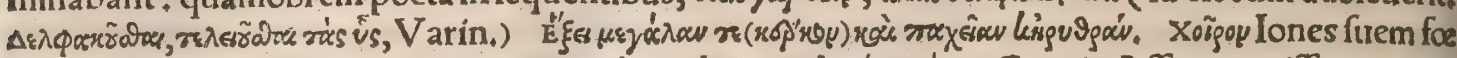

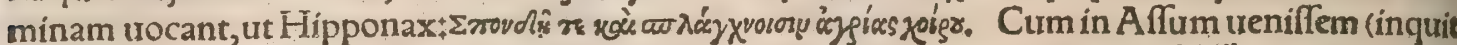

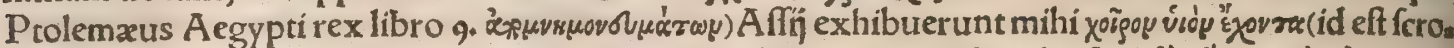

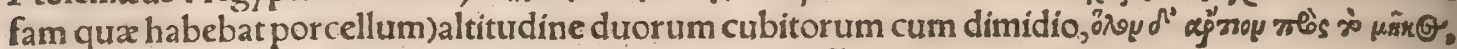
colore niueum, $\&$ dicebat Eumenem regem talia ftudiof $a$ ab eis emere, expendentem pro uno qua:

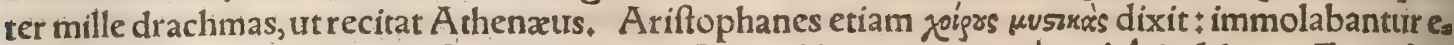

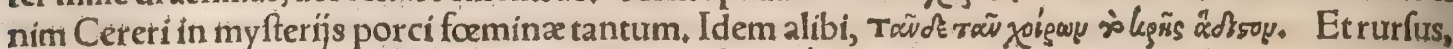

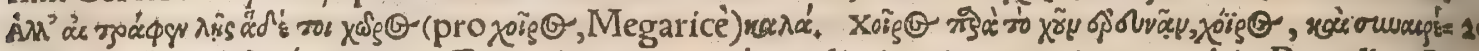

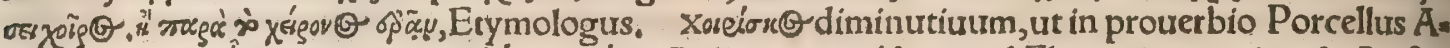
carnanicus. Yंsu, $\sigma \tilde{v} \sigma, x$, for

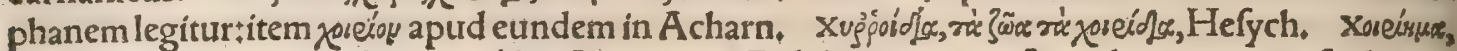

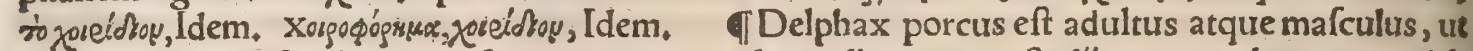

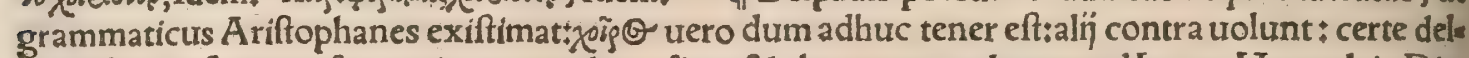
phax \& pro foemina fure capitur quando ${ }_{3}$, ficut \& chœros quando $\$$ apud lones, Hermol, in Dio fcorid. Délphax, porcus lactens uel paruus, fecundum alios magnus, Suidas, Varinus: \& Scholia=

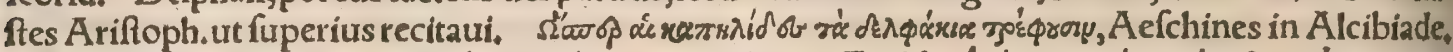

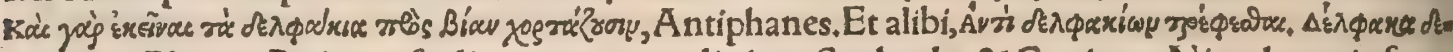

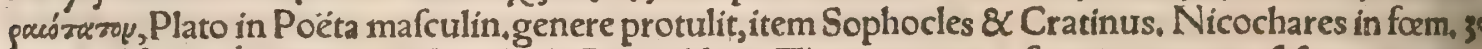

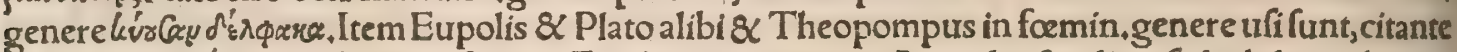
Athenæo. Délphaca fuem mafculum Epicharmus uocauit, Anaxilas fimiliter fed adultum, his uer

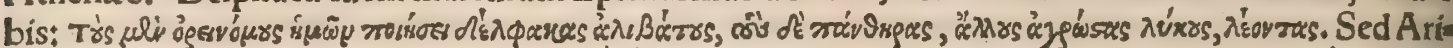

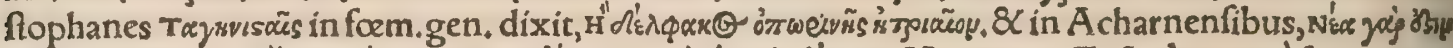

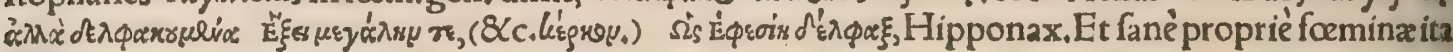
dicerentur, quę delphînas (Calius legit delphyas, quod placet : unde, inquir, adelphi, id eft fratre: uterini nuncupantur, ut qui eodem prognati funt patre ac matre autadelphi) id eft uteros habent,

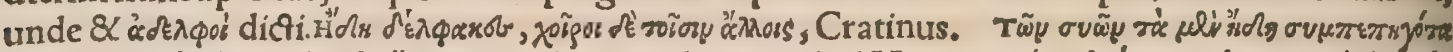

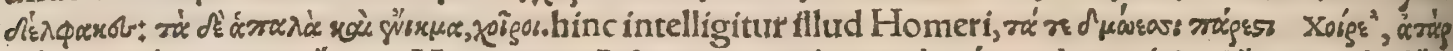

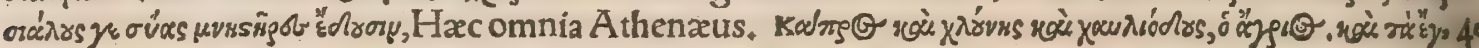

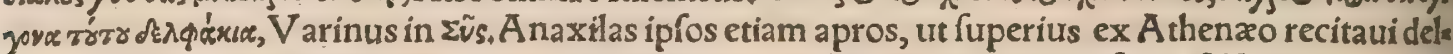
phacas nominat. Delphacium etiam de pudendo muliebridicitur $\div$ uide infra poft Epitheta, Del. phacium funt qui uulgò temporalem diçum fuem intelligant, Calius. TLactentem porcellum, qui \& fubgrumus (lego fubrumus) eft, Græci orthragorifcon uocant, quia matutinis uenas

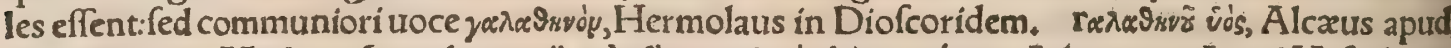

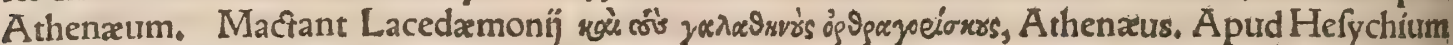

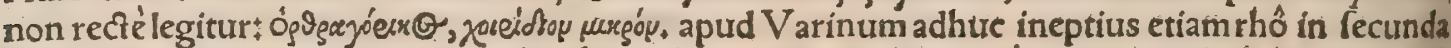

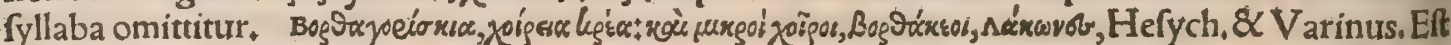
\& inter pifces orthragorifcus idem qui porctis, trocalis, \& $c_{*}$ Hermolatrs. Gelenius in Lexicolym.

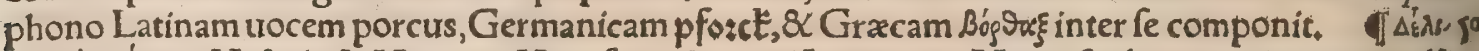

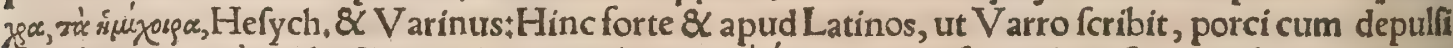

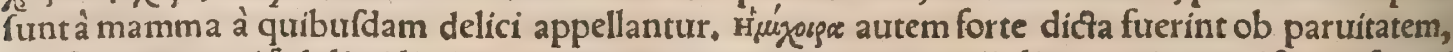
quafi non integrifed dimidiati porci, per ætatem nimirum:nam qui aliquo uitio parui $\delta$ quafi nani

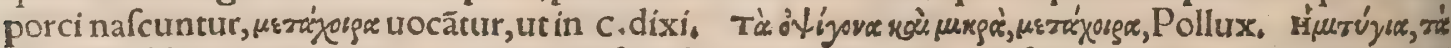

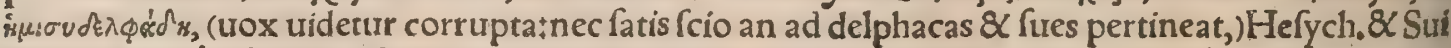

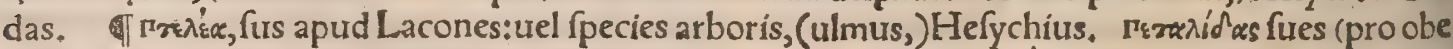

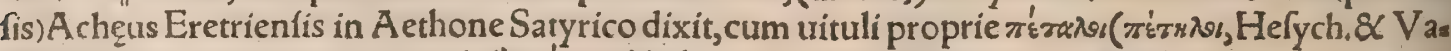

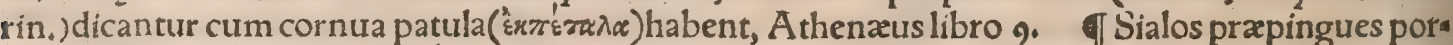

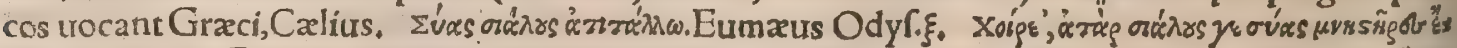
drom,Ibidem. Galenus in Hippocratem de uictu in morbis acutis citans hunc locum Homeri, fues 60

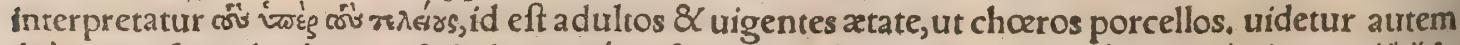

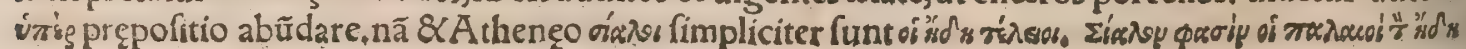




\section{DeSue. H.a. Lib. I.}

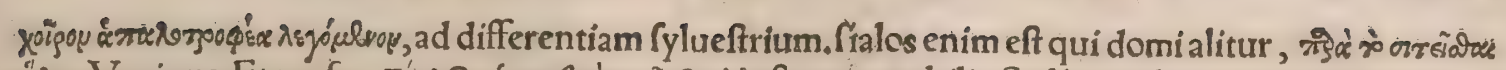

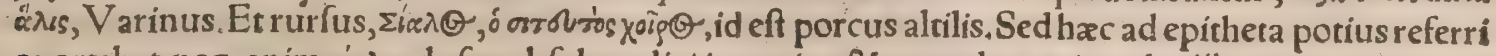
oportebat. ne $q$ enim óx

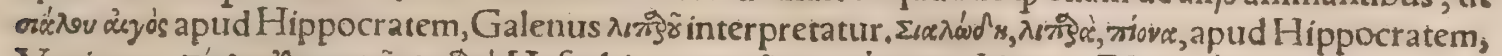

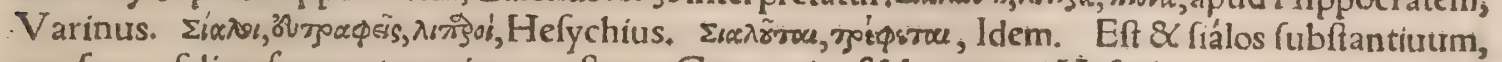
pro fputo, faliua, fpuma, (propinqua eft uox Germaníca folym) apud Hefychium: atque inde adie: ciumm pro pingui obefọ̧́́ fieri uidetur:talia enim humidiora \& quafi faliuæ fucciós plena funt, \& uefcentes etiam pinguibus cibis, faliux $\&$ humoris amplitus colligunt. Dicitur atutem faliua non fo lum de oris fputo, fed alijs etiam humoribus. Saliua lachrymationum, Plinius libro 1 . Siue eft coeli to fudor, fiue quardam fyderum faliua, İbidem. Sui cuiqg uino faliua innocentifima, Idem libro $2 j$. Hinc $8 \mathrm{blennus}$ pifcis wenis ab Achais uocatur, quòd mucofo humore abundet, nimirtum ut tinca noftra.

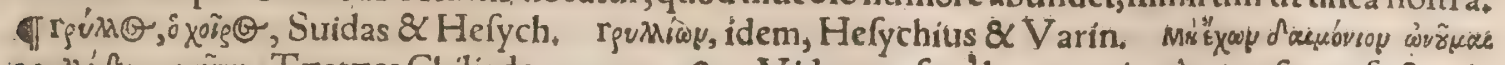

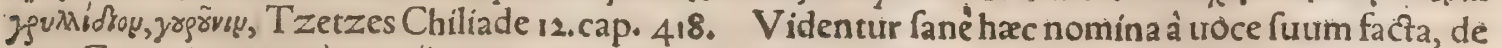

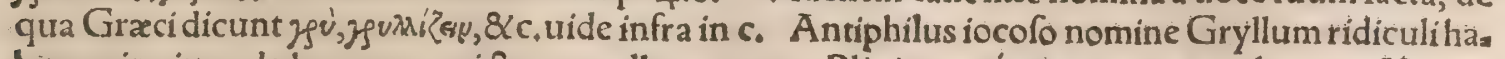
bitus pinxic +unde hoc genus piçura gryllus uocatur, Plinius. rúdı, porcus, aut leo, aut Hercu= les, Varinus \& Etymologus:fed Gyllius pro Hercule apud Hefychium per 1.duplex frribitur. Vide in Cuniculo A, ubi de charogryllo uel chcerogylio dixi. T reiowy, ¿xoîg $\sigma$, Varinus, revó̀ coxy 'tonum a pud eundem, \& circunhlexum apud Hefychium) $\varepsilon_{\text {s. }}$ A riftophani uero nomen curfor is qui

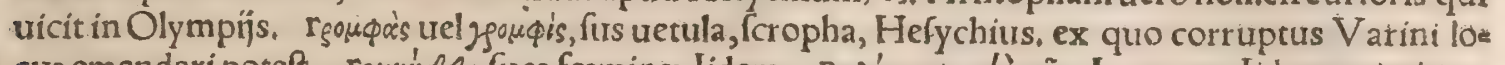

10 cus emendari potelt. r quòd glebas $\&$ terram roftro fodiat. Dionyfius Siculus porcum iacchum nuncupabat, Calius (ex

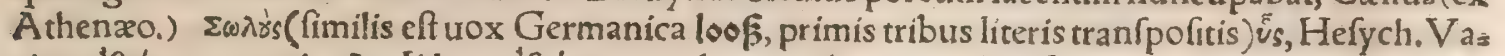

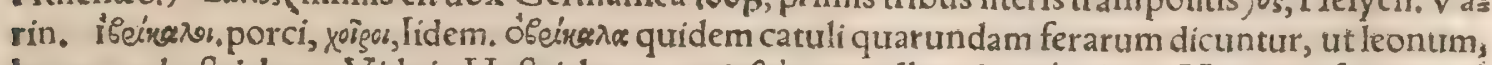

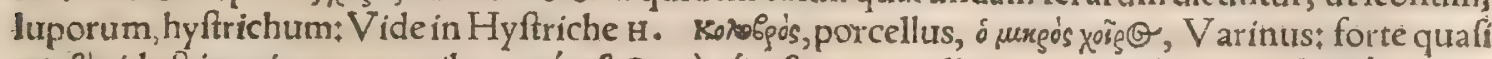

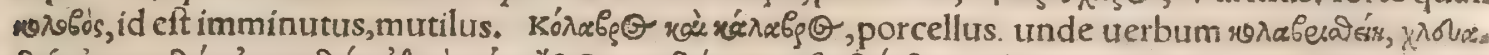

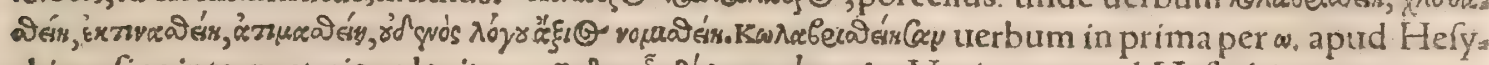

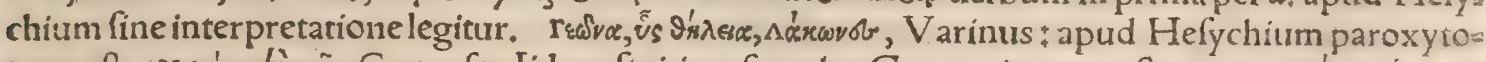

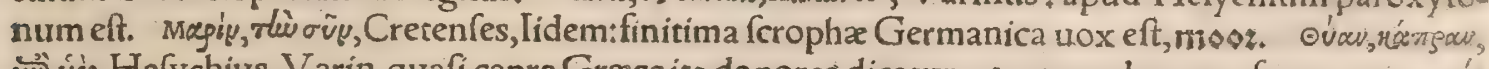

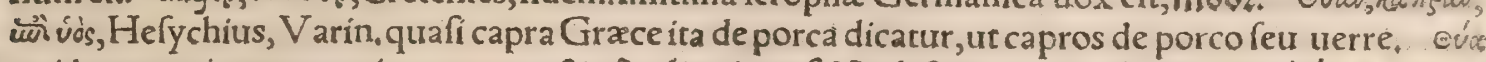
3० quidem nominatur non inepte: nam $\& \sigma \tilde{y} y$ aliquí quafi $\vartheta_{\tilde{y}}$ dicfum putant, $\&$ Varro gúzlu uocatum

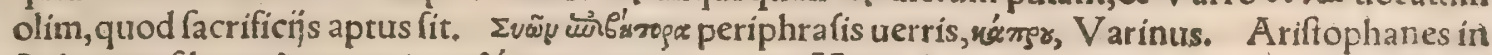
Acharnenfibus yoígou nominat Bórкruax, quam uocem Xenophon etiam de equis pofuit, Scholiaftes

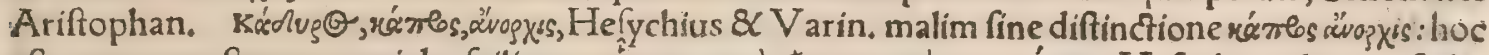

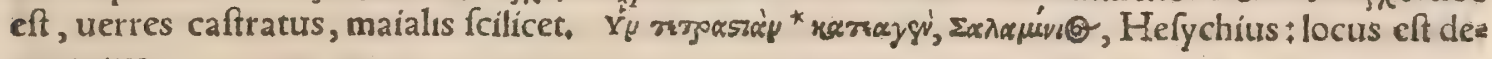
prauatus.

GEpitheta. Suís uelporci. Amica luto fus, Horatius i. epift. Bifulcus. Brutis. Clamo rus. Glandilegus. Hifpidus. Horrens, Lucretius lib. y. Aeneas focijs ad littora mittit Vigintí tauros, magnorum horrentia centum Terga futum, Verg.1.Aen. Horridus, Idem 4.Georg. Igna vus. Immundi fues, Verg. I. Aen. Impatiensfamis. Ingens, Verg. 3. Aen. Lætus glande, 3* 40 Georg. Lutofus. Lutulenta, Horatius 2.epif. Obfccnus. Saginatus, Segnis, Setiger \& fe. tofus apris potius attribuuntur. Spurcus. Turpes, Plinius, Vdus, Vulniticus 8. Metam. ad aprum potius pertinet. TPorca. Aurida,Horat.3. Carm. Ouidius 1. Faft. Laciens 2. Faft. Mul= tipara. Pracidanea, non reçe inter epitheta numeratur. fic enim dicebatur quã Cereri immolabât porcam, uide in h. Sordida, Author Philomela, Porcellus lactens. Lacte mero paftum pigra mihi matris alumnum Ponat, 8 Aetolo de fue diues edat, Martialis, Bimeftris porcus, Horatius

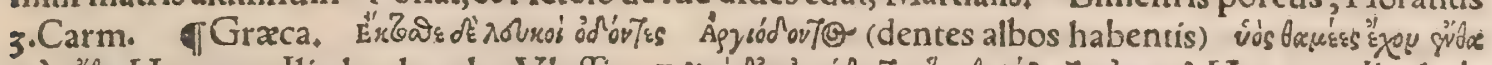

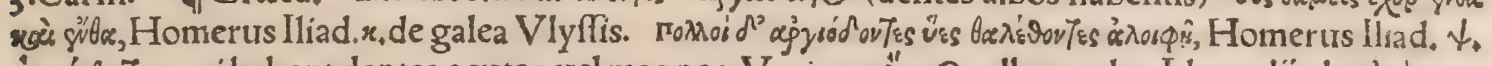

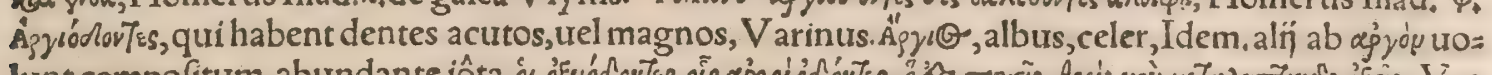

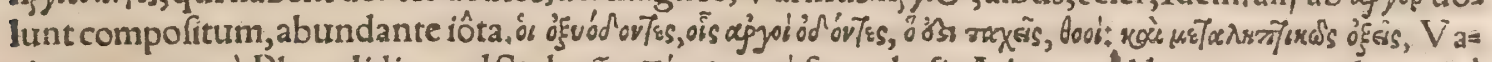

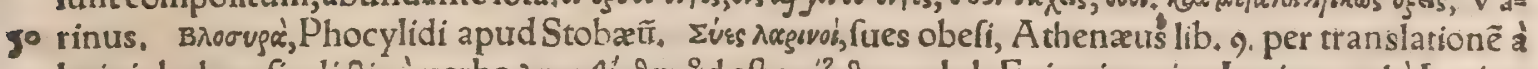

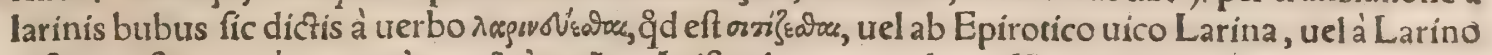

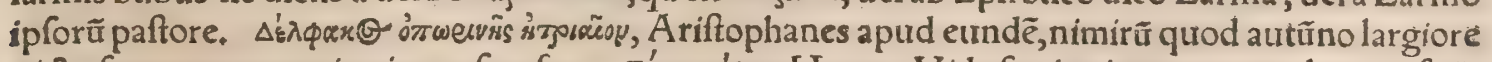

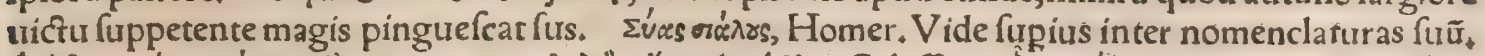

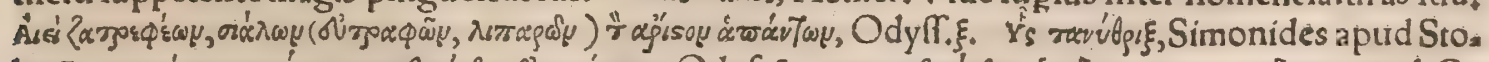

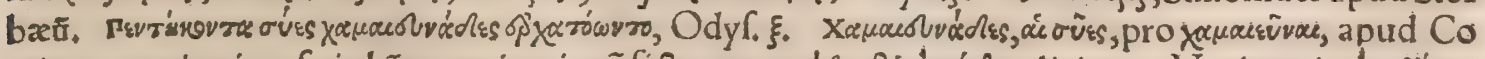

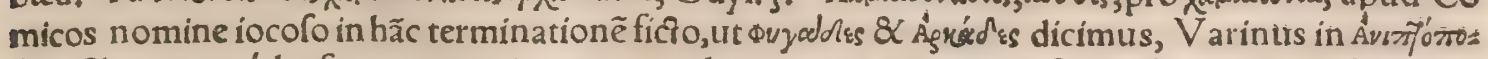
frs. Chamzeunádes fues cognominantur, quod corpore in terram proftrato dormiant. multre enim

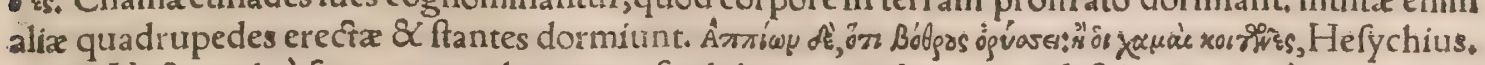

of Noftri uulgò fuem uocant hominem fordidum, inciuilem, immodeftü, qui impudentia intem=

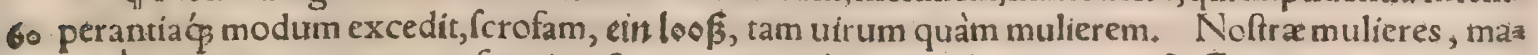

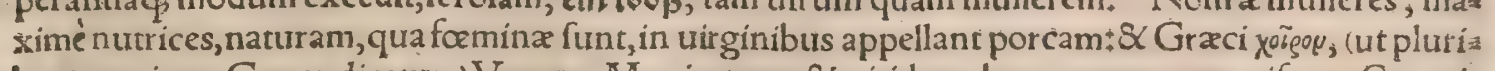
bus mox inter Graca dicetur, ) Varro. Me pinguem $Q$ nitidum bene curatacute uifes, Cum rí, 
dere uoles Epicuri de grege porcum, Horat.epift. I. 4. Sucula (inquit Budaus) machina eft tractorin generis, conftat autem tereti ligno, duobus aut pluribus uectibus traiecto, utrinqs æqua extantibus longitudine, hac dum uerfatur, funis qui ducfarius dicitur circa eam obuoluitur. Meminit eius Vir truuius lib, 10. Noftri uocant ein b a p pel. uide in Afino a. Stipites craffi pedes duos, alti cum cardink bus pedes decem : fucula prater cardines pedes nouem, Cato cap. 18. de rorcularï conftructione. Catera diuidito quàm rectiffime, porculum in media fucula facito. inter arbores medium quod erit, id ad medium collibrato, ubi porculum figere oportebit, uti in medio pralum recte fitum fiet, Idem.

cap.19. Sucula genus intimæueftis, author Promptuarï. ego pro uefte fubuculam legendam pu. to, non fuculam+ ${ }_{+}$multó minus ficulam, fic enim legitur in teftimonio ex Rudente Plauti quod ci. tat. Sunt etiam affimilanter dicta hæc, canatim, fuatim, (id eft, ad fimilitudinem fuis, ) bouatim, No nius. Porca in agro dicitur terra elata. Porcæ appellantur rari fulci, qui ducuntur aqux deri, uandæ gratia, dicfæ quod porceant, id eft prohibeant aquam frumentis nocere.nam crebriores fulci, limi uocãtur.Porcas qua in agris (alibi addit, inter duos fulcos) fiunt, ait Varro díci, quod porrigant frumentum, Feftus. Qua aratrum uomere lacunam fecit, fulcus uocatur, quod eft inter duos ful. cos elata terra, dícitur porca, quod ea feges frumentum porrigit, $V$ arro de re ruft, 1. 29, ut citat $\mathrm{No}$, nitus. Bene profciffas coffigerare ordine porcas, bidenti ferro, rectas deruere, Accius, Porca funt figna fulcorum, qux ultra fe iaci femina prohibêt. porcere enim pro prohibere (porrò arcere) fxpius legimus, Nonius. Porculeta(fic enim legendum potius quàm proculeta uidetur) Plinio 17. 22.à por' ca, ut à limis limeta, Hermolauss. Semé(poft arationem) protinus injíciunt, cratesć́ dentatas fuper. trahunt. Nec farrienda funt hoc modo fata, fed porcellís binis ternisç fic arant, Plinius 18. 18. Her. 10 molaus (in fecundis caftigationibus) fcribendum, inquit, arbitror procellis, à quibus fuperiore libro proculeta:etiamfi porculeta legebatur. Porca in agro eft, quam (ut Columella tradit) liræ fimilem in fationibus campeltribus ruftici faciunt, ut uliginem uitent, Idem author 2. libro, Liras (inquit) ruftici uocant, eafdem porcas: cum fic aratum eft; ut inter duos latius diftantes fulcos medius curmulus fic: cam fedem frumentis prabeat. Porcæ, porculeta, porcula, porcella, lib.18. cap. 18. urraç editione Campani hodie porcas uocant puluinos fiuc hortulos, in quibus ueluti fulcatim faa cuiufig generis olera feruntur,id genus $\&$ arex dicuntur multis locis, apud Columellam quog, Hermolaus in glof fematis in Plinium. Quemadmodum os reiectum terræ obtegatur, qux́s in porca confracta iura fint, quo tempore incipiat fepulchrum effe $\&$ religione teneatur, Cicero, 2 de Legibus, Non uides in pub. nocie te tabernas, qua populus ambulando perinde, $u$ t in aratro porcas reddit $\div V$ arro $T \alpha \phi 30$ Mivímr apud Nonium. Ruftici ueteres non liras tanturm, ut iam recitaui Columella uerbis ; fed \& triginta pedum latitudinem, $\mathrm{c} \times \mathrm{x}$ v. longitudinem, porcam uocabant, Columella lib.5. Porca (in. quit Robertus Cenalis ) apud Columellam longifima dimenfione centum uiginti pedes habet, latitudine uero triginta, qui numerus ductus in alterum, profert pedes quadratos ter mille fexcentos, Eft ergo porca octaua pars iugeri : \& quarta pars actus. Imporcitor, qui porcas in agro facit arando, Feltus. Hincimporcatum femen eleganter dicfum per porcas ingeftum. A pud Plinium legimus etiam porcellas uocabulo diminutionis, Beroaldus. Quod aratri uomer fuftollit, fulcusł quo ea ter ra iacta,id eft proiecta,porca, Varro. Eft $\&$ fcamnum terra altior inter duos fulcos, fed differt à por $\mathrm{ca}$, qurod uitio agricolarum nonnunquam relinquatur, crưda uidelicet $\&$ immota, hoc eft aratro non

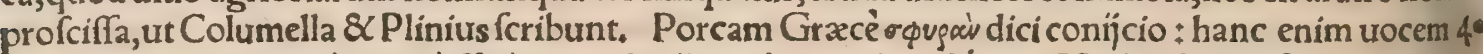

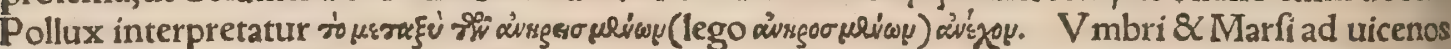
pedes intermittunt(inter binos uitium ordines)arationis gratia in his qux uocant porculeta, Plinius lib.17. Suile, ftabulum fuum. Diligens porculator frequenter fuile conuerrat, \& fxpius haras, $\mathrm{CO}_{1}$ lumella . Strumas femidoctum uulgus ferophulas uocat, quoniam eas Graci ab ciufmodibruto yos p'x $\delta^{2} \alpha$ a ppellaurerint: eft enim in fue morbus ftruma, fed ab hoc diuerfus omnino, Cælius. Plura quę res inferius inter Graca in uoce Chorades.

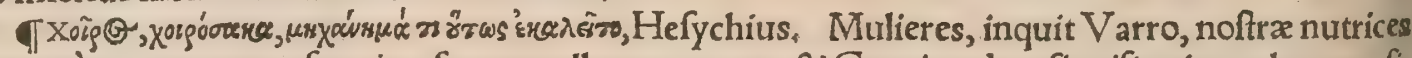
maximè, naturam qua forminæ funt appellant porcum : $\&$ Græci eadem fignificatione choron, fis ue(ut Athenæus inquit)delphaca, Hermclaus in Diofcoridem, Delphacion uocabant etiam mus liebre pudendum, Varinus, Xoîjo Corinthịs pudendum muliebre fignificat: unde prouerbium,

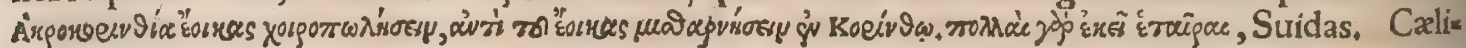
us meminit uirile membrum capron dici: quare non mirum muliebre yỗgoy appellari. Pauper quidam Megarenfis apud Ariftophanem in Acharnenfibus, filias quas alere non poterat perfuafas ut uendi potius quàm efurire uellent, cum porcina roftra capitibus $\&$ ungulas pedibus earum appo fuiffet, $\&$ in faccum indidiffet, grunnire iuffas pro porcellis uenales habuit $\div \&$ cum mercator quis dam alterius eleuatæ pudendum infpiciens yoîgop effe negaret, Megarenfis yoïgou effe affirmat. (quo. niam Græci etiam pudendum muliebre fic uocant. ) tum grunnitum ædente illa, mercator inquit,

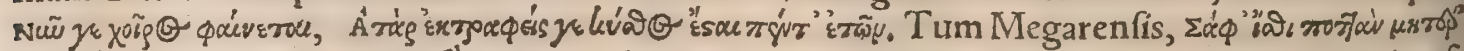
eirag

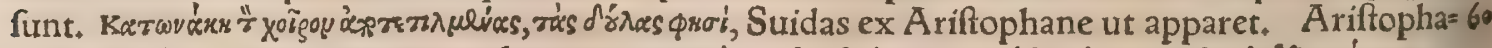

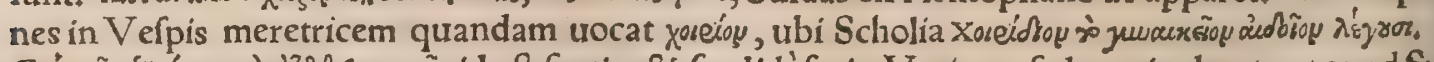

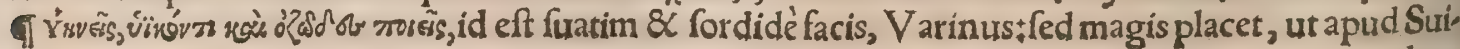




\section{DeSue. H.a. Lib. I.}

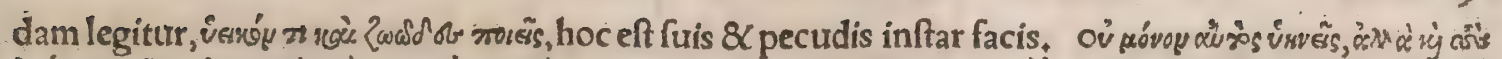

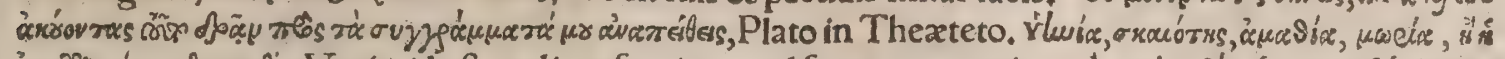

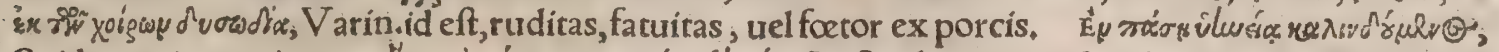

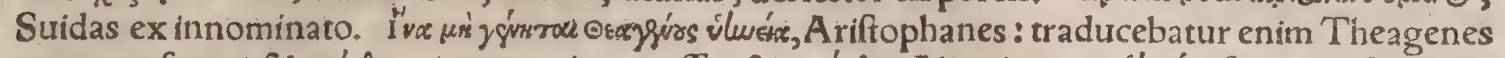

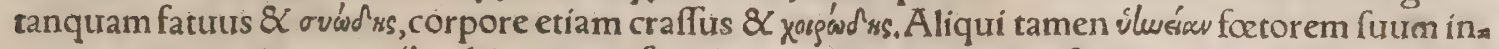
rerpretantur, qui cum uarịs cibis utantur foetida reddunt excrementa, 8 in coeno uolutantur, ( $d v=$

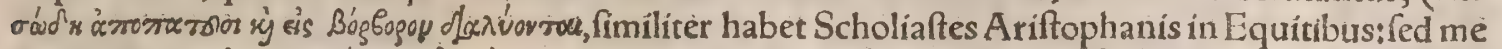

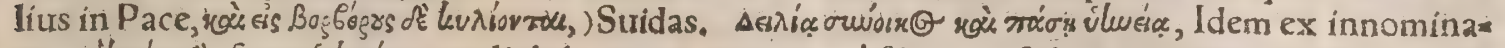

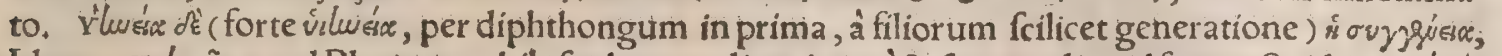

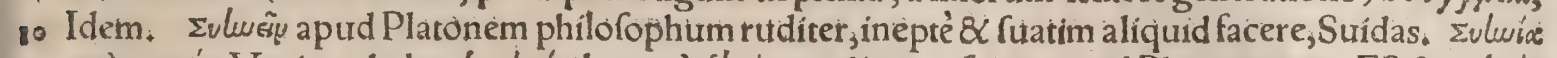

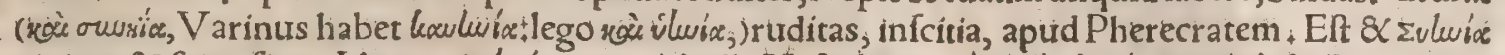

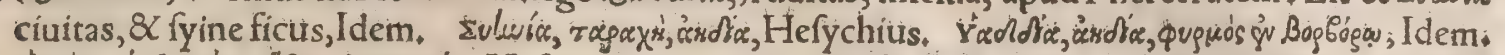

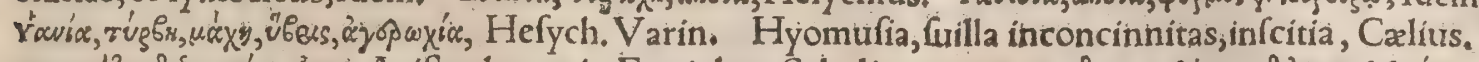

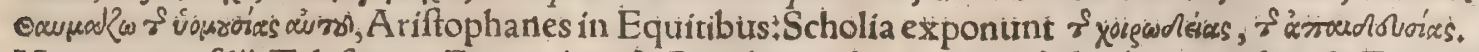

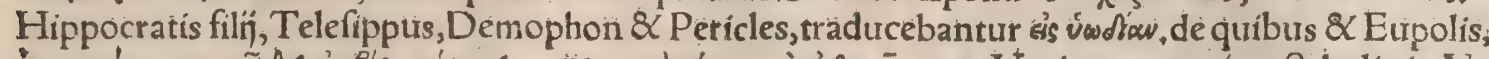

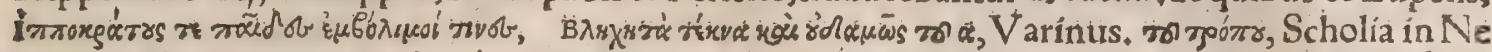

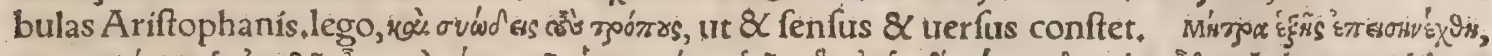

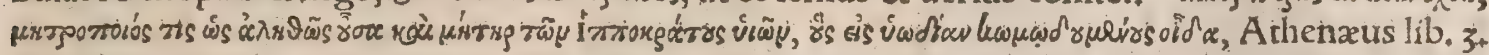
de ưulua porcæ loquens, qua nimirum ampla erat.(Vulua nil pulchrius ampla, Horàtiưs.) unde io so candi occafionem fumpfit, quafi diceret fatis amplam effe illam fuis iuluam, 3 qux trel Hippocratis

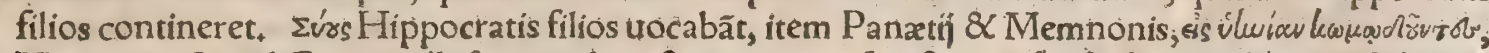

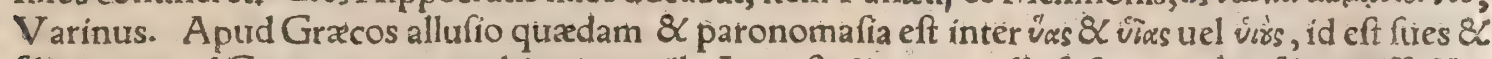
filios, ut apud Germanos quogh. híne iocus ille Augufti dicentis malle fe fuem quàm filium effe He.

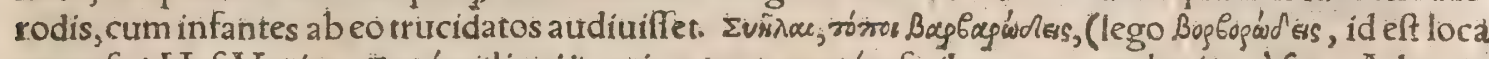
conofa, ) Her.Vatin. Eıxjóve aliqui in prima per v. ovxyóva frribunt per analogiamà fue, Athenx:

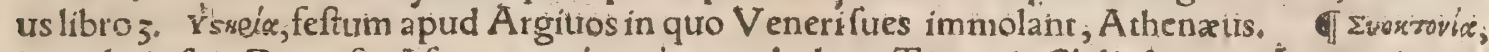

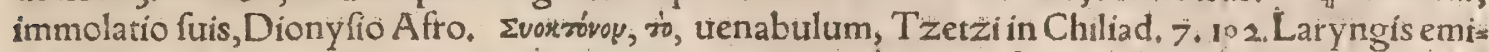
nentiffimæ parti præponitur os multiplex, quod nonnulli à liter $v$. figura vi $\downarrow$ thesd's, alī fuccinctíus voes des appellant: qua uoce diffectionum rudes delufi, in Galeño os fuem referens uerterunt, Vefaliz 3o us. Syrbe, uox qua fues allectant fubulci, Caelius. Suidas \& Varinus fyrben, oúpblew, rárachon, id

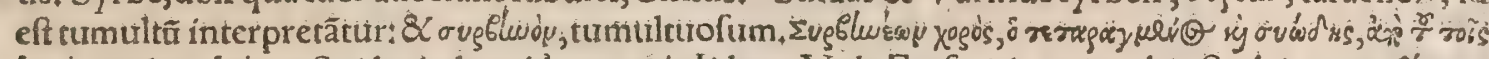

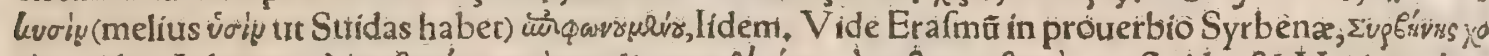

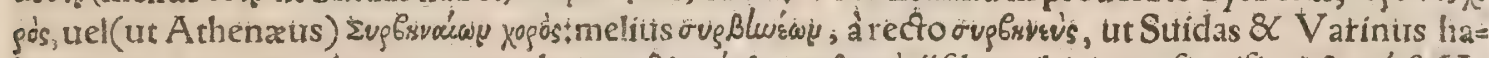

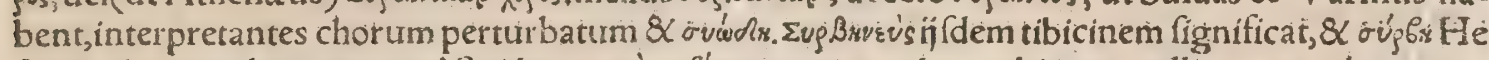
fychio thecam tibiarum. apud Suidam uerò $\sigma$ efry exponitur theca tibiarum pellicea, aut pharetra.

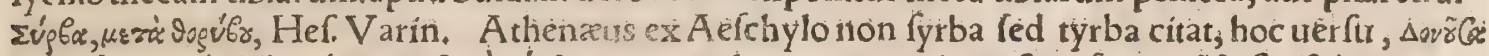

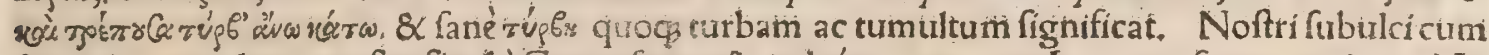
fues educunt, clamitant fig/fig: (à Graco forte vús; trel ónk, quta uoce Lacones fuem nominant:) In

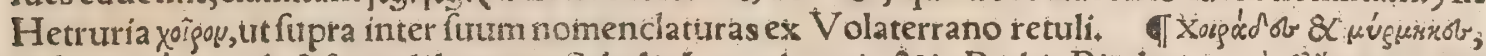
40 ó ú

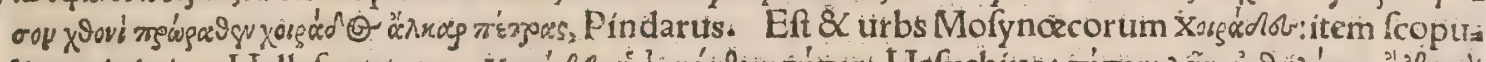

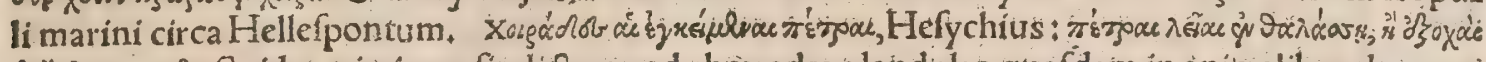

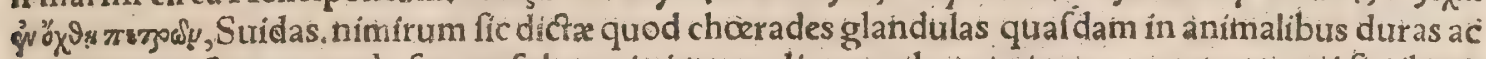

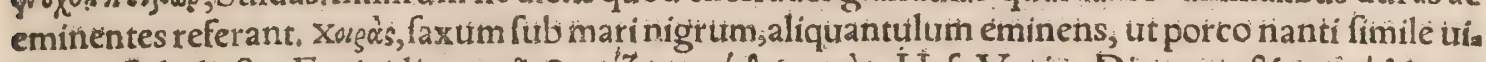

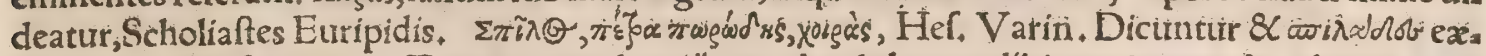
dem petra, Hefychius. Tumores quildam ("oyror; glandula) medí inter carnem $\&$ adipem con. fiftunt circa inguina, alas, maxillas $\&$ méfenterium : circa quos (tumores) etiam choerades fiunt, Pollux. Quidam parum Latine ad imitationem Gracorum forophulas uocant, frumas melius di.

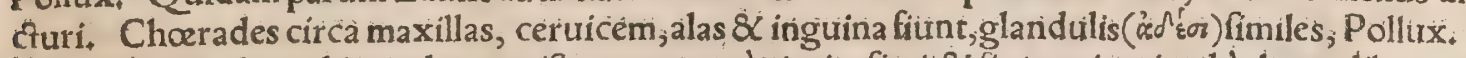

so. Eadem Manardus, addir, indura tos îtos tumores à pituita fieri: $\alpha$ fic nominari, tuel à chioradibuis pe. tris per marinas aquas tranfparentibus, uel à fuibus miltiparis animalibuis, \& eo morbo frequenter

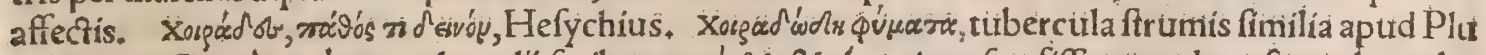

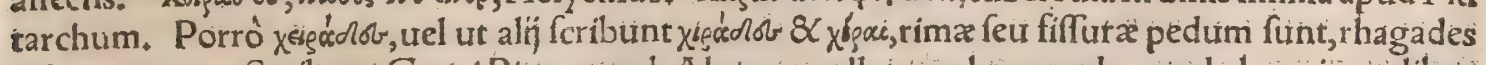
calcaneorum. Scribunt Graci Pittacum ab Alcro appellatum chorapoda, quod ulcera in pedibuis

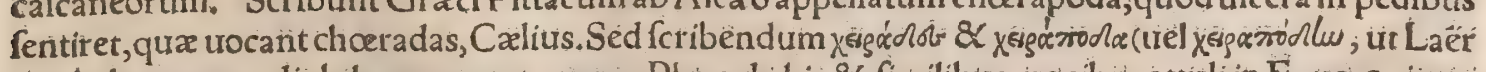

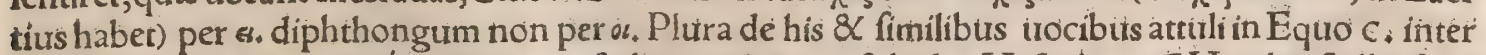

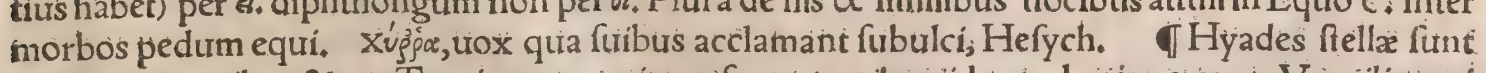
fepteni in cornibus \& ore Tauri, quax quoties nafcuntur uel occidunt, plutias creant. Vergilitis eti am (ut feribit Nic. Erythræus) Hyadas pluuias cognominans, per epitheton Hyadum criginem ả ă

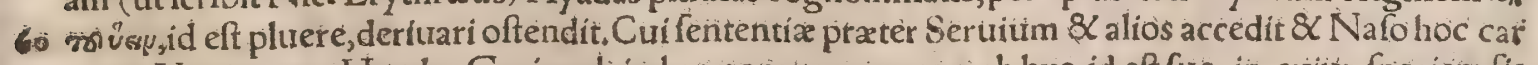
mine, Nauita quas Hyadas Graius ab imbre trocat: non autem ab hye, id eft fue, in cuius fpeciem fi gurentur, ut etiam pofteriore fententia refert Seruiustaut à fratre Hyade, quem à leana interfectum 
uenando luxerunt. Veteres Romani ob imperitiam Grac lingux, fimilitudine nominis derepit, quòd Græcihyas fues uocant, Suculas appellarunt. Quanquam Gellius ab Hyadibus Sucularum nomen fua ratione detorquet. Sertrius quidem à fucco Succulas appellare uidetur, quia fucculenta puro, propter pluuias, Hæc ille. Plura leges in Onomaftico \& Higino,\&c. Suculas noftri à fimi lítudine cognominis Graci propter fues impolitum arbitrantes, imperitia appellatêre Suculas, P/s

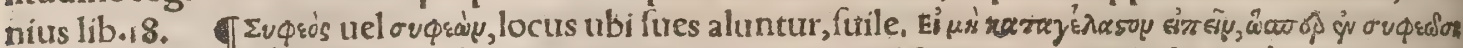

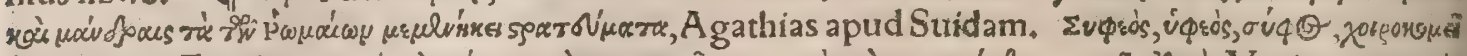

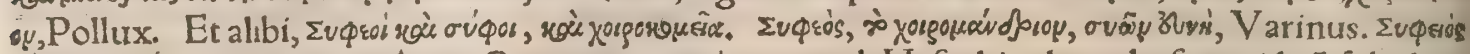
poëricum eft abundante iôta. Cxterum ovфquós per a, ab Hefychio chœrobofcus, id eft fubulcus

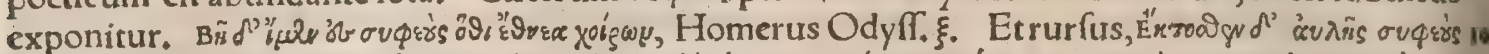

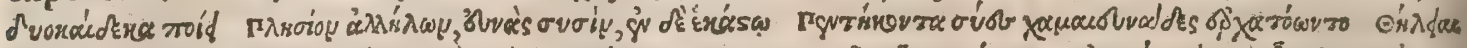

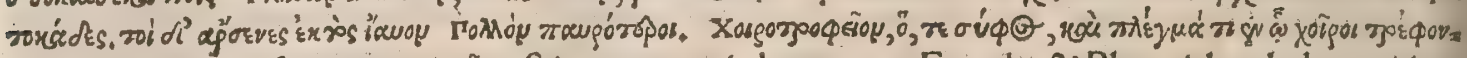
rou, Pollux. Etrurfus, Xoigorpoфsion eft in quo porcialuntur, ut Eupolis $\&$ Phrynichus habent, idem

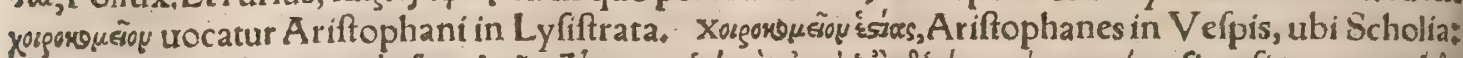

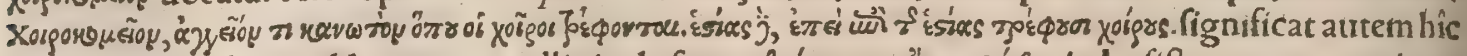

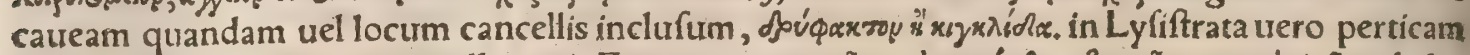

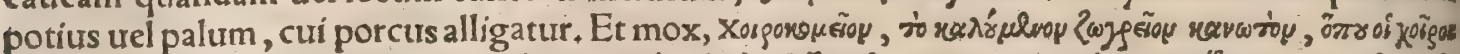

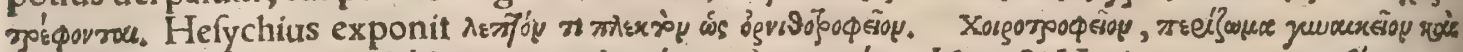

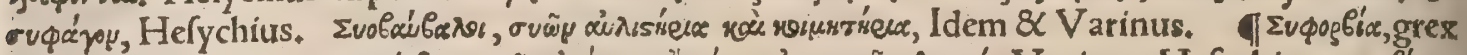

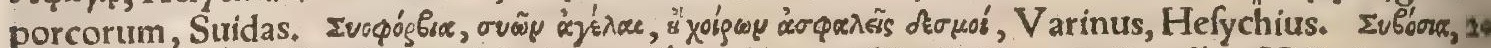

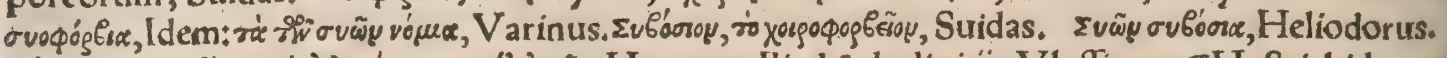

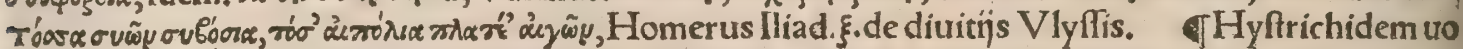
cant affectum cum in cauda equorum pili rigent feris fimiles fuillis, Hippiat. 59 . Hy ftrix, flagellum à fure dictum, non ab hyltriche animante: (Vide in Hyftriche $a_{\text {, ) }}$ lorum cum ip fis pilis è pelle fuilla Eiufdem fignificationis eft ṽas $\lambda \mu \xi$ uel ṽ cipitur etiam pro ftumulo boum, \& pro carceribus certaminum: Vide in Hyftriche a \& in Equoe, Tŕs, ö̌rosфay, Bźs, Hefych. Varin, nefcio quàm recté.

đ Suillus, adiectiuũ, quafi diminutiuum à fuinus. Hic enim conciliator fuinæ ( uetus exemplar habet fuilla) carnis datur populo, Varro lib, 2. Ego fuinum non dixerim, ut neog bouinum \& oui= num:fed fuillum, bubulum, ouillum. Plinius fuillum pecus dixit, fuillum gregem Liuius. Suari $3^{\circ}$ us, adiectiuum:ut fuarius negotiator, Plinius libro 7 . Interdum fine adiecio pro fubulco: Com $\mathrm{cr}$. tum agnitam uocem fuarï furto abactis, \&c. Idem libro 8. Scipio, Suario cognominabatur, pro, pter fimilitudinem fuarï cuiufdam negociatoris, Plinius. Hermolaus legendum conịcit, Scipio Sci riatico cognominabatur, propter fimilitudinem ferui cuiufdam negociatoris. TPorcinus, quod eft ex porco, Plautus Capt. Porcarius, idem quod porcinus, ut porcaria uulua apud Plinium lib. 11. Porcarius uero fubftantiuum, porcorum cuftos Firmico $\&$ Gazx. Porcinarius, qui carnes por cinas uendit. Quanta lanijs laflitudo, quanta porcinar uocabulo laniũ uocat cum alibi, tum his uerbis, Lanius conciliator fuilla carnis datur populo. Por: culator Columella 7.9. qui porcos nutrit ut pinguefrant: Beroaldus interpretatur eum qui curat porcellos lactentes, Scoppa Italicè,lo porcaro, id eft, fubulcumः Galli porchier. Porculatoris uerò 40 \& fubulci diuerfa profeffio, diuerfa paftiones, Columella. A pparet fanè porculatorẽ dicfurm, quod porculos, id eft, porcellos, non fues aut porcos adulros curer. In nutricatu, quam porculationem appellabant, binis menfibus porcos finunt cum matribus, Varro. Sic pullatio, pullorum nutricatio dicitur. Scrofipafcus, qui pafcit fcrofas. Tum piftores fcrofipafci qui alunt furfure fues, Plau. cus Capt.

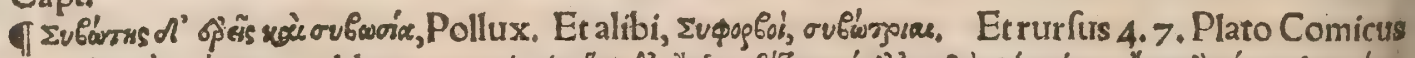

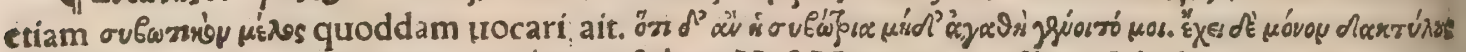

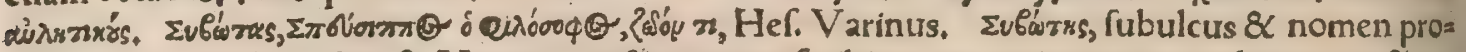

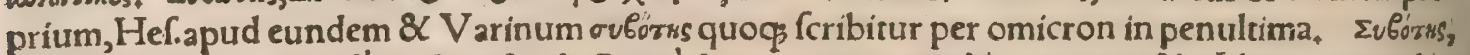

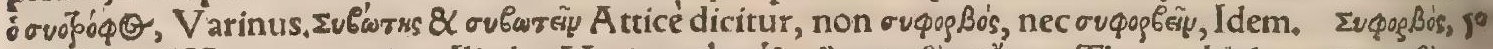

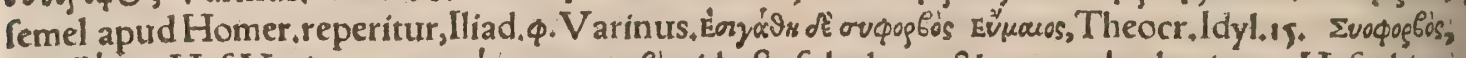

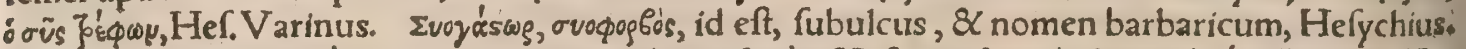

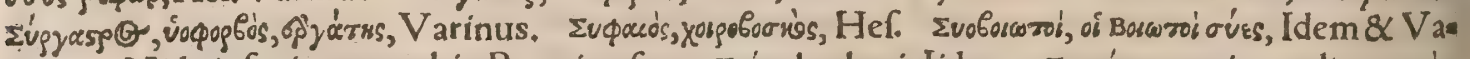
rinus: Vide infra in prouerbio Bocotica furs. Evooce, barbari, Iidem. Eunvís, turpis, rudis, orou's,

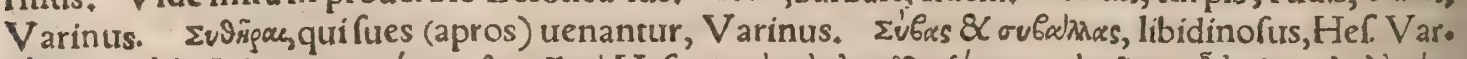

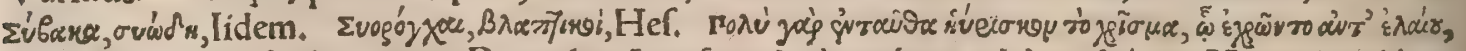

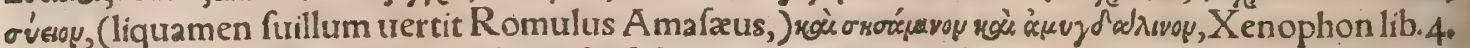
de Cyríminoris exped. Syinon oleum \& fefaminum, quo ungebantur qui militabant cum Cyro, Suidas: Calius Suidam citans, idem oleum fefaminum $\&$ fyinon ab eo uocari ait : quafi legerit non

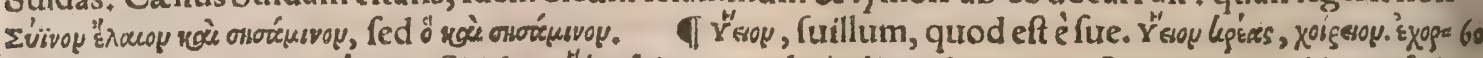
Tंकेष reprehenditur, dictiones enim quæ partem corporis fignificant, omnes in ov purum exeunt, nulla in 


\section{DeSue. H. a. Lib. I. กิ025}

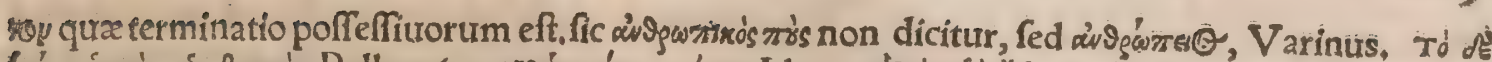

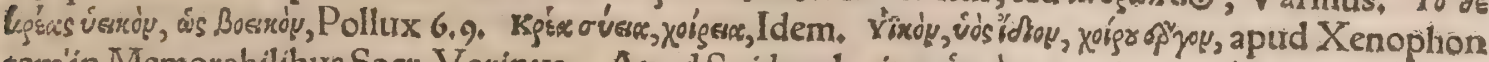

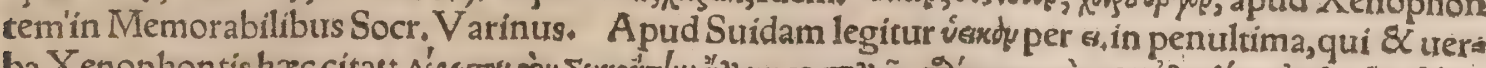

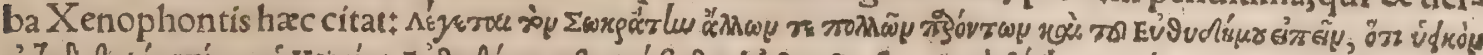

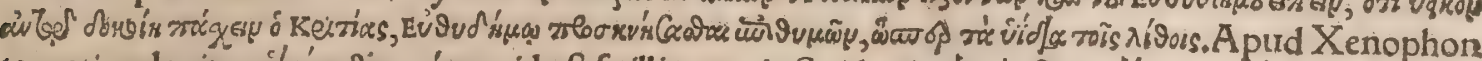

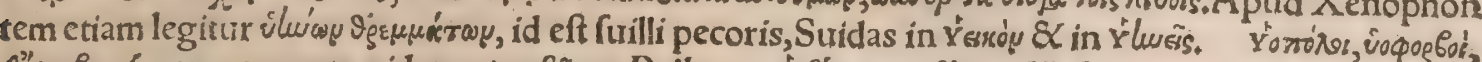

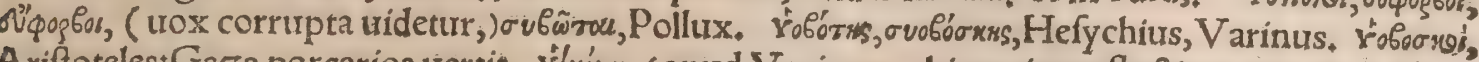

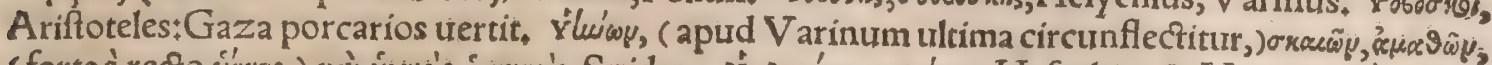
(forte à recto ú'

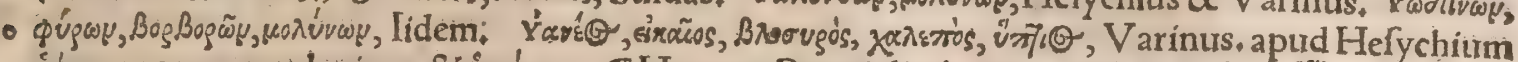

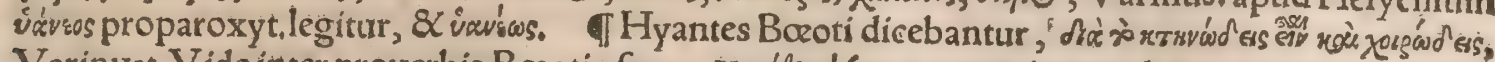
Varinus: Vide inter prouerbia Bocotia fus. Xocgódx 4 (cum acuto in penultima, quamuis in Scho lịs habeatur in ultima ) apud Ariftophanem in Vefpis exponitur, qui pudendum muliebre (quod

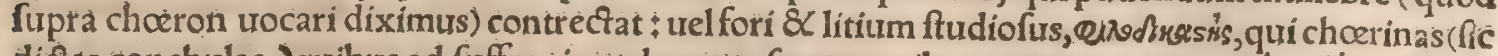
dicias conchulas, )quibus ad fuffragia utebantur, frepe manibus premat, Xorgooфá yos, túrns. Hefÿ chits : qui fues mactat, laníus, porcinarius, Xosgortwiss, qui fues uendit, (negotiator fuarius Pli= nio, ) apud Ariftophanem in Acharnenfibus: Pollux citat ex Horis Ariftophanis. Nutrices na: turam muliebrem choerum id eft porcum uocabant, ex quo facetiffimé quibufdam concinnatư uer: bum yoigortwinein, quod fignat porcum uendere, id eft capturas corpore quærere, Calius,

20 II Icones. Sus Aeneæ Lauini ( ut fcribit Varro) tríginta porcos peperit albos, itaqs quod por. tenderit factum fcribitur, triginta annis ut Lauinienfes conderent eppidum Albam. Huits fuis ac porcorum etiam nunc ueftigia apparent. Iam ne fimulacra eorum ænea etiam nunc in publico po. fita, \& corpus matris ab facerdotibus, quod in falfura fuerit demonftratur? Porci (apri, Plinius: uide in Apro a. ) effigies inter militaria figna quintum locum obrinebat, quia confecto bello, intei

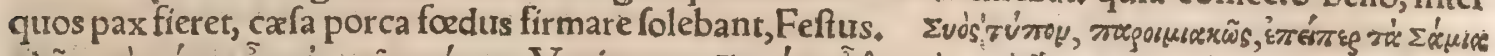

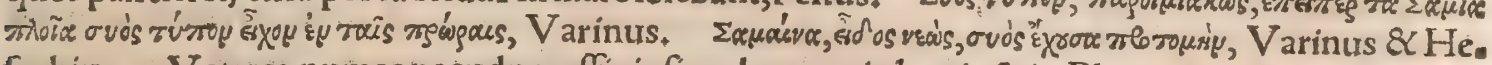
fychius, Veteres numos pecudum effigie fignabant, ouis, bouris, fuis, Plutarchus in uita Publico, 1a. Bituricis uertrex, Heduis dat fucula fignum, \&c, uide in Veruece H, ex Alciato. Porcam aus. ream $\&$ argenteam dici ait Capito Atteius, qua etfi numero hoftiarum non fit, nomen tamẽ earum

50 habere, alteram ex auro, alteram ex argento factam adhiberi factificio Cereali, Feltus.

1. Planta, Fungorum tertium genus fuilli, uenenis accommodatiffimum, familias nuper inter: emêre $\&$ tota conuiuia, Plinius. Et rurfus, Siccantur pendentes fuilli iunco transfixi, quales è Bie thynia ureniunt, canum morfibus ex aqua illinuntur. Et alibi, Robora boletos quoq̧̧ fuillosí̧̧ ferũt, gula nouiffima irritamenta, qua circa radices gignuntur ; quercus probatiffimos : robur autem $\&$ cypreflus \& pintis, noxios, Hoc genus forte eft, quod Germani tocant moscbelett, qui menfe Aprili ad Maium uf. reperiuntur $\&$ appetuntur in cibo, colore ex pallido fuf $c i$, pilei oblongi $\&$ in conum fe colligentis forma, in medio protuberantes, fpecie fauis fimiles, uocant autem noftri quock forminam fuem mos, ut moscbelet fuillos fignificare uideatur, etfi quid cum fue commune habeat non fatis uideam.conício tamen trel delectari eis in cibo fues: uel fuperiorem eorum partem circa 40 conum, roftri fuilli formam aliquarenus referre. Defcribuntur ab Hieronymo Trago ab initio tertij de ftir pibus Tomi, fed non recté Latinè tübera ab èo uocantur.nam longé diuerfum ruberum genus eft, totum infra folum, fuperficie nulla aliqui Germanicè grebling uocant, id eft folfilia, quod èterra fodiantur. Hypochoris herba in cibo tuulgaris apud Aegyptios, Plinius : Vide pluta in Equo a. ubide plantis ab equo dictis egi, ftatim ab initio. Hyofiris intubo fimilis, fed minor \& tactu afpe: rior:urinneribus contufa praclarè medetur, Plinius. Noftri fiibiftel, id eft fuarium carduưm, genus fonchi fpinofum uocant, quod aliqui puto in Italia 82 Gallia cicerbitam, referunt autem florum caly ces antequam a periantur, ut $\&$ hieracij, , quandam roftri porcini figuram, ut inde forfan hyofiris (quafi viós $\rho$ is, hoc eft fuis nafus) uel potius hyoferis, hoc eft feris uel intubus porcinus appellata uide. ri poffit, Ruellius roftrum porcinum ab aliquibus eandem herbam uocari ait, quam alif dentem leo

$5^{\circ}$ nis nominant, hoc eft cichorï fylueftre genus, luteo flore, hedypnoida Plinï, aliqui apud Italos den. tem canis uocant, \& alij pifcia al letto, ut Matthxolus feribir: noftri wyenfob wans, uel füblimen, id eft flores porcinos. Videri autem poteft eadem Diofcoridis hieracíum minus. Defcribitur à Syluaz

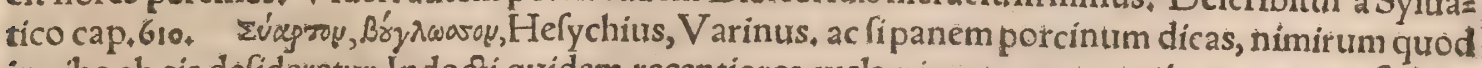
in cibo ab eis defideretur. Indocti quidem recentiores cyclamium panem porcinum uocant, fed in: epté. quamuis enim radice rotunda panem referat, nibil tamen ad fues. haber enim propemodũ trim urenenofam. Melius ruftici in multis Germanię locis, fylueftris quoddam leguminis aut uitia genus,

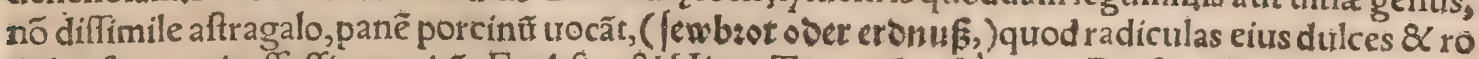
tữdas, fures agris effolfis requirăt. Fuchfius \& Hiero. Trag, nō recié apion Diofcoridis interpretätur. Capria, capparis, ut legitur in nomenclaturis apud Diofcoridem. Frutex fpinofus quem Graci 60 coccum uocãt, de quo plura dicam in libro de Infectis(nafcitur enim in fructu uermiculus, qui cum erumpit, culici fimilis uolat)â Galatis quifuper Phrygiam incolunt lingua uernacula ì s nominatur,

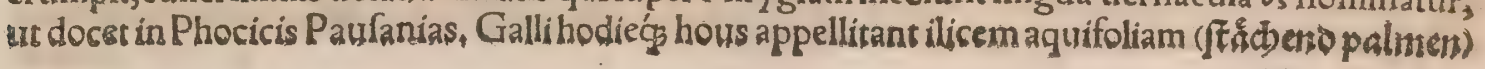




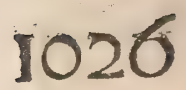

\section{De Quadrupedibus.}

à qua coccus ferè rion aliud differt, nifi quod per omnia miner \& femper pumilus eft, unde conn̈cio mus ueterem linguam Gallicam alia quogs Galatarum uocabula pleraç habuiffe, pro quibus pau latim imperantibus Romanis Latina fuccefferint. Scini, id eft pira porcina, \& funt fylueftria, Syls uaticus. Aftragabos, (Afragalos forte, ) id eft pes porcinus, Idem. Adiantum fiue capillum Ve. neris, aliqui capillum porcinum uocant, Idem \& Vetus Auicennæ gloffographus : nimirum quod coliculos inftar fetarum proferat. Milium Solis, id eft cauda porcina, Syluaticus. Idem alibi caus dam porcinam, peucedanum interpretatur : inde puto quod radicis caput multis ceu fetis rigeat, quod in omnibus etiam fefelis generibus apparet. Scrophularia Syluatico herba eft qua alio no. mine millemorbia \& caftrangula \& urtica mortua (propter foliorum fimilitudinem) ab eo uocatur. hxc eft qua guftata necari fues, ut quidam affirmant, in C. diximus. Scrophulis, id eff frumis medea 10 ricreditur, quarum fpeciem etiam multi radicum eius protuberantes nodi referunt, tanquam ufum demonftrante natura. Eandem ob caufam chelidonium minus, multi fcrophulariam nominant : 82 aliqui fabam inuerfam uulgò dictam, quam multi telephium effe putant. Hyofcyamum Hieron. Tragus interpretatur Germanis ad uerbum füwbonen, id eft fuillam fabam. quod nomen ab eo ad Graci imitationem facium eft:Germani aliud proprium habent bülfen uel bullett. Sed de hyofcya: mo, fyancho, chenopode quã Germani fđwynstos \& füwplag uocant, \& alins fuillogeneri noxịs plantis plura diximus fupra capite tertio : item de folani genere fyluatico quod baccas nigras cerafi uel halicaccabi fructus magnitudine fert, fed fine folliculo, noftri uocant füwtrut, hoc efl porcorũ herbam:quod calidis $8 \mathrm{C}$ fubitis fuum morbis medeatur.

Animalia. Chœrogylius, uel ut alij feribunt chœerogryllus, alins erinaceus alins cuniculus effe

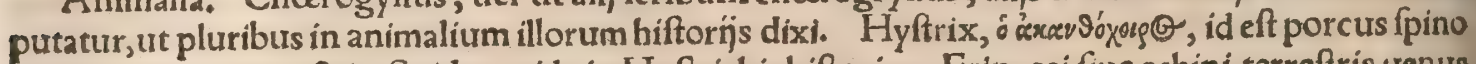
fus, uel echinus terreftris, Surdas, uide in Hyftrichis hiftoria. Erinacei fiuc echini terreftris yenus unum noftri uulgó caninum uocant, quod canis inftar digitatum fit:alterum fuillum qưod ungulas ut fues bifulcas habear:alij etiam roftri figuram in altero canis, in altero firis effe aiunt. Eafdem melis

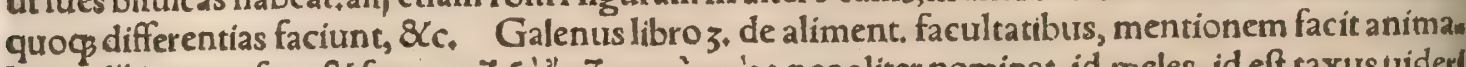

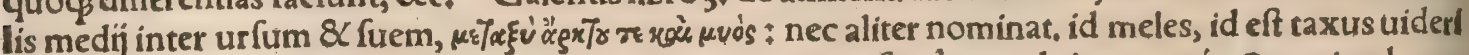

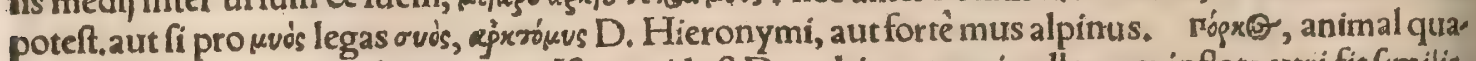
drupes, fluuiatile, amphibium, iuxta Iftrum, id eft Danubium, tenui pelle, quæ inflata utri fit fimilis,

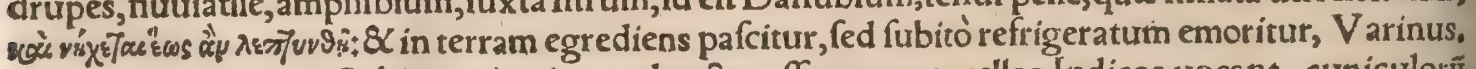
Audio nuper ex noui Orbis nauigatione aduectos effe quos porcellos Indicos uocant, cuniculorü ferèmagnitudine, paulò minores, albos, fine caudis, fingulis menfiburs cuniculorum inftar foecun: dos, uoce $8 \times$ natura porcorum. Hos effe puto quos utias uocant, qui de nouro Orbe fcripferunt. Iuvodusoy, genus pifcis, Suridas, A pri pifcis meminit Plinius II. Ji. etficodices quidam caprum haa beant corrupte: qui uocem ut grunnitum habet, qux uox aprorũ fưmó̧ propria eft, accedit quod in Eurota quog, $\mathrm{f}$. Laconicx, pifcis orthragorifcus uocalis eft, trt lib.32. (Plin̈̈)dicitur. Eft autem or: thragorifcus ide, qui \& porcus, A thenzo tefte. In Danubio mario extrahitur, porculo marino fimil limus $\$ \&$ in Borythene memoratur præcipua magnitudo, nullis offibus fpinis ue interfitis, carne pradulci, Plinius. Eft autem mario, quem uulgo hufonem uocant, buf quafi hys uel hyfca, id eft por cus uel porculus. Mario uox forfitan originis eft Germanic Cretenfes uxéín. Caterum porculus marinus Plinio dichus proculdubio non alius eft quàm fturio, $4^{\circ}$ (ftă $)$ uulgo nominatus. cui hufonem perfimilem effe fcio, porculi autem nomen à corporis pinguis tudine meretur, \& hodie in Italia fturiones adhuc parui, porcellæ uocantur. Hyccam (ròy vilenxy) pifcem aliqui facrum uocant. putant autem hunc aliqui erythrinum effe, alin iulida (ex A thenxi fe. ptimo:)ex noftris aliqui(inquit Calius 12, 12.8 Hermolaus in Coroll.)fturionem.Et mox, Hyccam fiue hyfcam Latiné interpretantur porculum. Hyæna pifcis nomen eft apud $A$ thenæû, qui $\&$ hyæ. nida ex Epicharmo nominat, uidetur autem idem pifcis quem $\&$ hyn illic (lib. $7_{0}$ ) nominat, \& dubi. tat an idem fit qui capros, id eft, aper uocatur, ut pluribus fcripfi in Hyæna quadrupede capite primo, Sed de pif́cibus quibus à fue nomen contigit propter pinguitudinem, uel uocem, uel corporis formam, in Libro de pifcibus copiofe agam. Syænam pifcem Graci recentiores choerillam inter. pretantur, hoc eft porculum, Hermolaus in Plin. Diphilus(apud Athenaum) pifcem quendamca go prifcum dici fignificat, qui $\&$ mys uocetur. nifi quis non myn, id eft, murem, fed hyn, id eft, fuemlex gendum potius exiftimet, Hermolaus. Gryllus $\&$ fuem fignificat, ut fupra diximus: $\&$ pifcis genus anguilla fimile A thenæo lib.8. quod libro feptimo congrum interpretatur. Oppianus lib.3. de ues natione mullos pifces fuibus terrenis comparat duplici nomine: primum quod admodum uroraces fint, ut qui fœetida etiam quauis, \& naufragorum cadautrera detrorent: deinde quòd ad lautitiam cibi ita praferantur reliquis pifcibus, ut pecoribus fues. Marinum animal quoddam informe eft, corio quafi fuillo, pedibus loraceis, fine dentibus, paruis oculis, fub uentre duo foramina habet iuxta cau. dam. cauda pralonga, brachî menfura latiore, quam menfuram longitudine \& latitudine implent fingula auricula:corio craffiore quàm digitus fit, forfan è polyporum genere, Cardanus, Xougivar. conchæ quædam marinæ funt, labris ut ita dicam denticulatis, læues admodum $\&$ fplendid $x$, à qua $=60$ dam oris fuilli opinor fpecie, quam parte fui dehifcente quodammodo referunt, fic appellate, has ho diéğ porcellanas uocant, funt autem diuerfa, magnitudine fcilicet $\&$ colore differentes. Hefychius chœria 


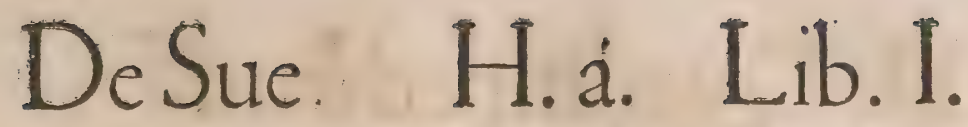

1027

choerinas non recie interpretatur calculos marinos, neç enim calculi funt, fed calculorum ứccm in fuffragïs implebant, minimum \& album earum genus noftri inepte uocant müterfein, id eit la pil los matrici utiles. nam quod figura matricem quodammodo referant, fuperftitiofx quædam muliers cula corporiappenfas uteri morbis falutares mentiuntur. Eft \& gemma porcellana hodie uulgo ab Italis diça, forfan à fimili nitore lauoréǵs porcellanæ conchæ. Scoppa murrham gểmam, agatham uulgò dictam uel porcellanam interpretatur. Georgius Ágricola murrhinam non murrbam urocat, $\&$ interpretatur Chalcedonium, ut $\mathbb{Q}$ onychẽ. his enim duobus nominibus rem eandem Plinio defi: gnari, onyx quidem etiamnĩ nomen apud multos retinet, onyd)el. Cardanus libro quinto de fub: tilitate, myrrhina uafa ea effe affirmat, quę hodie porcellanæ dicantur, ex Oriente mitti, nec gemmas 10 fed figlina elTe, ex argilla tenuiffima, denfa, leui ac pingui, cuiufmodi in Italia quoqs fiant, fed nullo odore $\&$ pallidiora quàm qux Oriens mittit ; folins ac imaginibus placere : purpuræ color em abelie,

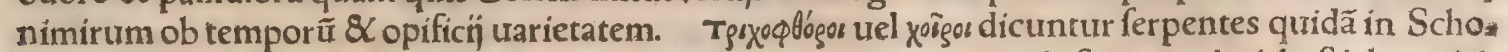
lijs Nicandri, à quorum morfu feilicet capilli defluunt. Altamuga, id eft porcus luti, beftiola multi: peda acuti ueneni, Syluaticus: Videtur non alia quàm fcolopendra effe, fortè quod pilis ceu fetis ría geat, ut erucx maiores. Afelli eriam infectorum generis à colore dicti, ab al ís muítipedx, uel muls tipedes afelli,à nonnullis hodie porcelli nominantur, ni fallor, à corporis fcilicet figura,

đPropriahominum. Scipio Suario cognominabatur propter fimilitudiñ fuarí cuíurdam ne gotiatoris, Plinius. Hermolaus legendum conïcit, Scipio Sciriatio cognominabatur propter fimili* tudinem ferui cuiufdam negotiatoris. Auus meus(inquit Tremellius scrofa apud Varronem) pri 20 mum appellatus eft Scrofa, qui quaftor cum effer, Lícinio Nerua pratore, in Macedonia prouincia relictus, qui praeffet exercitui, dum prator rediret, hoftes arbitrati occafionem fe habere uicioria, impreffionem facere caperunt in caftra. Aurus, cum hortaretur milites, ut caperent arma, ac exirế contra, dixit celeriter fe illos (ut ferofa porcos)difiecturum, id ş fecit, nam eo pralio hoftes ita fudit ac fugaurit, ut eò Nerua prætor imperator fit appellatus, \& auus cognomẽ inuenerit, ut diceretur Scro* 2a. Sed aliter Macrobius Saturnaliorum libro r, circa finem cap, fexti Tremellius, inquit, cum familia atop liberis in uilla erat: ferui eius cum de uicino fcropha erraret, furreptam conficiunt. Vicinus aduocatis teftibus omnia circưmuenit, ne quà hac efferri poffit, isḉ ad dominum appellat reftituíi: bi pecudem. Tremellius qui ex uillico rem comperiffet, frophæ cadauer fub centonibus collocat, fut per quos uxor cubabat.Quæftionem uícino permittit. Cum uentum eft ad cubiculum trerba iuratio o nis concipit, nullam effe in uilla fua fropham, nifi illam, in quit, qua in centonibus iacet, lectulum monftrat. Ea facetiffima iuratio, Tremellio Scrophx cognornen dedit. Sergius, qui pritus Os porct uocabatur, ex pontificibus primus fuit qui propritum demutauit nomen: quod mox obferuatum ad nos uf́c perdurat, Calius. Porcelli grammatici in fuaforijs orationibus Seneca meminit. Idem eft puto qui aliquando ad Tiberium Cæefarem uerbo haud Latino ulum dixit: Tu Romanorum homi $\Rightarrow$ nibus, ô Cáar, mo^rtécy dare potes, uerbis non potes. Porcellius poéta Neapolitanus faripfit res. Frederici ducis Vrbini. A minore pecore nomina hahemus, Porcius, Ouinius, Capriliu's, Varro. Suillus, Porcius, Bubulcus, Caprarius, nomina fuerunt ueterum Romanorum, Plutarchus in uira Publicola. Porcius cognomen fuit Catonis Cenforiai. Porcia lex, ut Cicero in quadam oratione innuit: $\&$ leges item aliæ fuerunt, quibus exilium damnatis permittebatur, Cælius ${ }_{3,}$ Latro Portius grauis fuit orator, ut ex Seneca refert Calius, 11. 1. \& 11. 13. TVerres nomen uiri Romani prato* ris in Sicilia, contra quem repetundarum reum à Siculis Cicero orationes habuic qua Verrinæap= pellantur. TChoerilus, xoiento, A thenienfis Tragicus poëta, 8 alius Samius:uíde Suidam. Athe naus libro 8. Chorilũ poétam inter helluones $\&$ gulofos homines numerat. Syadra Spartaniftatuarin meminit Paúanias in Eliacis, \& Sybotæ fil'n' Dotadx in Meffeniacis. Tibia ufum Hyagnim primum uolunt, SXc.Calius 9. 3. Hyas, filius Atlantis \& Aethræ, cuius meminit Ouidius Y. Fafto: rum, à quo Hyades forores aliqui dictas putant. A thenienfis quidam è Melite uico (tribus Oené-

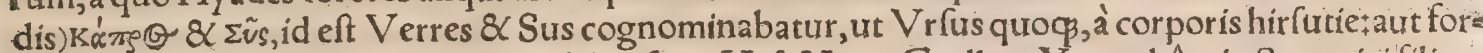
té quod molas poffideret, in quibus alebat fues, Hef. Var. Gryllus, Xenophôntis Socratici filius, Suidas. Germani etiam nomen uiri ab apro fecerüt, Zleberbart, ac fi Caprofthenẽ dicas, aprumz autem uocant non ferum modo, fed frequentius cicurem, id eft, uerrem. đPorcia nomen mulieris Romanæ, furerũt autem dux, maior 8 minor. Porcia minor cum laudaretur apud eam quądan be. ne morata, qux fecundum habebat uirum, refpondit: Felix \& pudica matrona nunquam prater $\mathrm{fe}=$ mel nupfit. Bouinia Porcilla auia Pï (imperatoris puto.) ब/ Chorile dicta fuit uxor Euripidis,

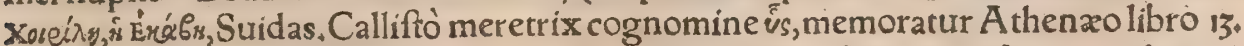

- Populorum \& locorum. Clifthenes tribus Dorienfium diuerfis nominibus notauit, nam praz ter tribum fuam, cui A rchæ nomẽ erat, reliquas ludibrio habitas ex brutis appellauit. Quíppe Hyà tas, id eft, Suales:aliquibus Oneatas, hoc eft Afinales : reliquis Choreatas, hoc eft Porcales nomina indidit, Alexander ab Alex. Hyæa, Ýác, urbs Locrorum Ozolorum, gentile Ḧyæus, Srephanus: ex Thucyd.lib.3. Hyamea, urbs Mefenes, una ex quing, Idem. Hyamion, urbs Troiana, Idem. co Hyampolis, urbs Phocidis, Stephanus. Et ualles Lebadea tuas, \&. Hyampolin acri Sum̃iffam fro pulo, Statius lib.7.Theb. Meminit Herodotus, Homerus, \& Plinius lib. 4.cap. 7. bis. Vbi relicto Abis oppido uiam rectam Opûntem uerfurs fueris ingreflus, Hyampolis te excipiet, Ipfum aurem bo 
minum nomen arguit, qua nam origine hi fint orti, autunde egreffi in hanc regionem peruenerint, Qui enim Cadmum eiussás exercitum Thebis fugiebant, Hyantes in hünc fe locum contulerũt. Ve: terum memoria Hyantum ciuitas à finitimis uocabatur.temporis autem progreffu ufus obtinurit, ur Hyampolis diceretur, \&c. Paufanias in Phocicis, Hyantum meminit Plinius 4.7. Exul Hyan tros intrenit regna per agros, Statius. Compellat Hyantius ore, Ouidius lib,3.Metam.nominat atr tem Actæonem, iutrenem Hyantium, Etalibi,Hyantæa Aganippe. A pollonius libro 5. Onche, ftrm trrbem Neptuno in Bocotia dicatam, ut apud Homerum legitur \& Plinium, Hyantiam uo caurit.nam \& Boeoti fues ab illiberalitate morum dicuntur, unde nomen Hyantibus, ( Vide plura infra in prouerbio Bocotia fus. Varinus. Hyampolin triplicem memorat, Hermolaus, Hyantes populi circa Alalcomeniam, dicuntur etiam Hyantí \& Hyantini,Stephanus. Sunt qui Hyantes Bocotix populos faciant, quorum urbs Hyantia dicatur, incolx Hyantix. Hyantia Stephano urbs

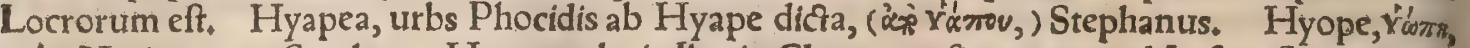
urbs Matienorum,Stephan: Hyops, urbs in Iberia Cherronnefi non procul Lefyro fluuio, Idem. Oafis, ciuitas Aegypti, qux \& Hyafis, Steplanus. Hyi Afix populi pratenduntur fupra Elymai, da, quam Perfidi in ora iunximus, Plinius. Hyfia uel Hyfix, urbs Bcotia, (apud Suidam quoq, ) colonia Hyreorum, cuius meminic Thucyd.lib.3.Et alia regia fedes Parthorum. Item uicus Argit uus Thucydidi,Characi uerò ciuitas. \& Arcadizurbs, Stephanus, Hyfiæ nominantur locamul, tr, in Bocotia, Arcadia, \& alibi, ex Thucydide, Pherecyde, Artemidoro, In Argolide autem funt hx quas hîc (apud Plinium 4. 5.) legímus, ex Paufania, \& Strabone: qui Hyfias celebrem Argolicælo. cum facit, Hermolaus. Hy fix ciuitatis meminit Paufanias in Arcadicis. Syrbota, (aliâs Sybotæ)po 10 puli fecundum flumen Aftacum ad Septentrionem uergentes, Plinius 6.30, collocat autem eos in A ethiopia, \& octonûm cubitorum ftaturam eis tribui fcribit. Sybota, infula quadam \& portus, Ste phanus. Sus fluuius fiue torrens eft circa Olympum,Paufanias in Bocoticis. Hyóeffa fons qui. dam apud Sophoclem nominatur: de quo uide plura in Tauro $\mathrm{H}$, inter propria, in Tauri fluuñ mens rione. Hyomemnia, feftum quoddam Argis, Hefychius \& Varinus, TCaprialacus A proн inter propria. TChorades, urbs Mofynoecorum, gentile Xoipadivis, Stephanus. Legimus \& f copulos quofdam marinos circa Hellefpontum fic nominari, fed fupra inter deriuata quofuis foo pulos marinos, qui uel latent, uel paululum eminent, fic appellari docuimus. Infulas in Älexandria Aegypti Pharon \& Chorades appellatas fciunt omnes, Hermolaus in Plinium 32,11 .

Tb. Chalaftra urbs $\&$ lacus eft Macedonix, unde Chalaftręi fues dicti, \& Chalaftræum nitrum, Hefychius. Circa Hierofolyma funt porci mira magnitudinis, dentibus cubitalibus, Phyfiologus,

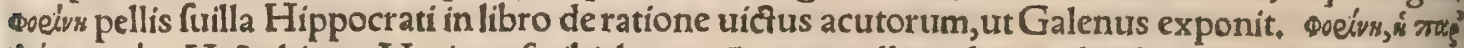

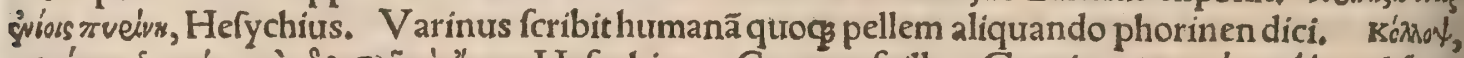

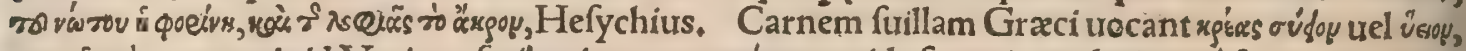

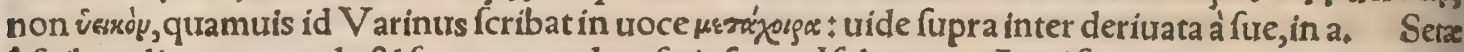
â furibus dicuntur, unde \& futores qurod ex fetis fuant, Ifidorus, A ciei frontem in anguftum defi: nentem, caput porci fimplicitas militaris appellat, Ammianus Marcellinus. Cuneus dicitur muls titudo peditum, qux iuncta cum acie primo anguftior deinde latior procedit, $Q$ adurerfariorum or. dines rumpit, quaia à pluribus in unum locum tela mittuntur: quam rem milites nominất caput por cinum, Vegetius 3.19. Oculi porci naturale figmentum habêt, ita ut in terram neceffitate femper in $=40$ tendant, Phyfiologus, Elephantorum promufcis intus cócaua, fuilli labri fimilitudinem quandam gerir, A elianus. Delphinis lingua breuis atç lata, haud differens fuillx, Plinius, Mars tibiu, ueo fachurum, fi unquam redierit, bidenti uerre, Pomponius in Attellana citante Fefto * Bidentes non oues folum, fed omnes beftias bimas olim appellabant, quia neç maiores aut minores licebat hoftias dare, Macrobius: de bidenti pecore, \& quod de ouibus ferè lemper dicatur, uide in Boure $H_{*}$ ubi de facrificïs ex eo. Nefrendes, adhuc lactentes porculi, quod nondum aliquid frendant, id eft comminuant dentibus. hinc $\&$ faba frefa qux molita eft, Ifidorus. Plura de hac uoce diximus fupra in E. Chamalconti eminet roltrum, ut in paruo, haud abfimile fuillo, Plinius. Roftrum fuis proa prie Graci jóvyxos uocant, unde diminutiuum jugxioy in Acharnenfibus Ariftophanis. Pihaoreb, (alias algorab, ) =רופ, id eft roftrum porcinum, Arabice uocatur os acromij, id eft fummus hus so merus, quẽ fcapulæ procelfum Galenus rẹa fonat. ita $\phi_{\beta}$ roftrum coruinum, non porcinum ab eo uerti oportebat, ut Galenus etiam Gracèà corui fimilitudine nomen indidit. Aluus in homine infima parte fimilis eft fuillæ,Plinius. Ventres ele phanto quatuor, cxtera fuibus fimilia, Idem. Exta elephanto fuillis proxima, fed majora, Ariftot,

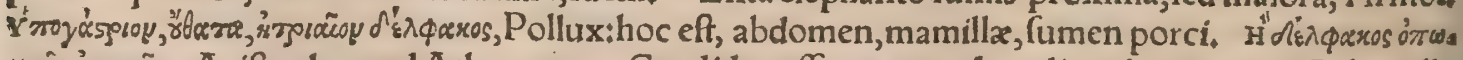

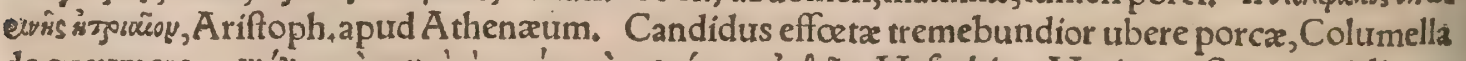

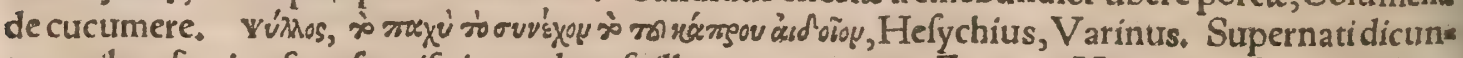
tur quibus femina funt fuccifa in modum fuillarum pernarum. Ennius, His pernas fuccidit iniqua ruperbia Poni,Feftus * Talis furum difcordiam quandam ineffe traditur, Plinius ni fallor * ónda's

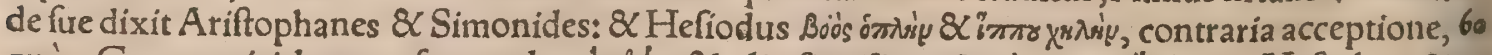

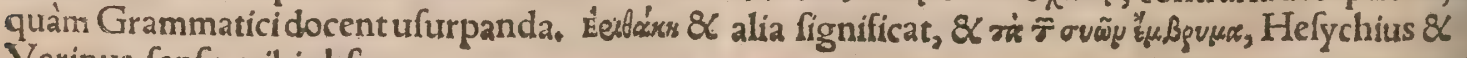
Varinus, fenfu mihi obfcuro.

Germani 


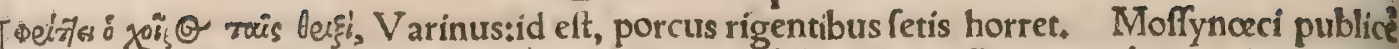

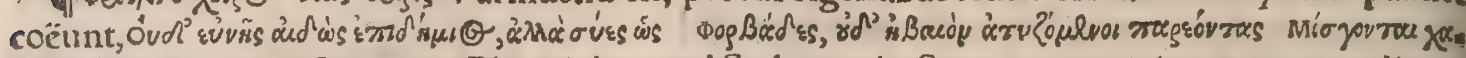

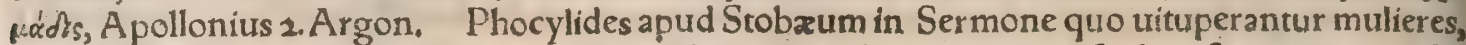
promorum $\&$ ingenï diuerfitate, alias ex alijs animantibus prognatas fcribit, $\&$ eam qux ex fue nata fuerit, nec bonam nec malam effe. Simonides uero è fue natam omnia domi inpura fine ordine $\&$ ornatu uel humi iacentia negligere ait $\div$ atque ipfam illotam cum ueftibus immundis in ftercore fedentem pinguefcere. Calchas uates oraculum accepit, tunc fe moriturũ quum in uatem fe me: liorem incidiffet. Capto igitur llio Colophonem uenit ad Mopfum A pollinis filium, à quo interroa gauit quot groffos (ónúvbrs, id eft ficos immaturas, non de fylueftri fed urbana ficu ) ficus ferret. cui Mopfus refpódit, $\mu$ eirs id eft decies mille, $8 \mathrm{C}$ medimnum, $8 \mathrm{infuper}$ groffum unum. quod ita inuen 10 tum eft. Mopfus uerò Calchantem de fue partui uicina rogauit, quot foetus utero gereret $\&$ quando pareret.quo tacente, ipfe dixit, numero decem effe porcellos, $\&$ unum marem, parituram ueró poftridie. Quod cum ita contigiffet, Calchas memor oraculi præ mœroreobït, uel ( ut alih uolunt) uim fibi intulit, Scholiaftes Lycuphronis. Deterix porcx, id eft macilentx, Feftus. Dedithaccon tagio labem, Et dabit in plures : ficut grex, totus in agris Vnius fcabie cádit, \& porrigine porci, Iutuenalis Sat.2.

I d. Aiunt Pyrrhonem deprehenfum tempeftate, alijs omnibus confternatis periculi magnitu.

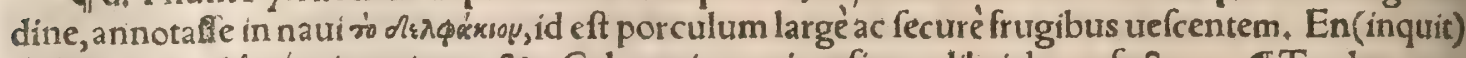
uobis ueram outurias imaginem, \&c. Calcagninus circa finem libri de profectu. IT Traduntmas gici iocinere muris dato porcis in fico, fequi dantem id animal, in homine quoopfimiliter ualere, fed 2 refolui cyatho olei poto, Plinius.

T e. Tria tantum genera funt paforum, qui dignitatem in Bucolicis habeant, bucolici, opilio. nes, \& omnium minimi xpoli,id eft caprarï, ut Âl. Donatus fcribit. Subulcorum ueró nulla nec apud Vergilium necs Theocritum mentio fit. Errorem enim Seruin \& aliorum, qui Aegl ${ }_{110}$. legunt, Tardi uenérefubulci, fupra in Boue reprehendimus. Subulcorum epitheta apud Textorem, Tardi, Hircofi, Duri. Aurké ह̇y Plura de fubulcorum uarn̈s appellationibus require fupra prima parte huius cap. inter deriuata: item alia nomina quæ ad greges porcorum, ftabuláue $\&$ haras pertinêt ab iplis deriuata, ut $\sigma u B_{\text {óoroy, }}$

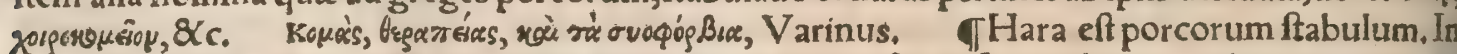
tenebris ac fuilla ( forte fuili, id eft ftabulo fuum ) uiuunt, nifi non forum, hara atç, homines qui nũc ${ }^{39}$ pleriç fues funt exiftimandi, Varro Prometheo. Ex hara producte, non fchola, Cicero in Pifone, ut citat Nonius. Hara ftabulum dicitur tam de porcis, quàm de auibus, Varro de re ruft.3.10, ur Ge. Alexandrinus intrerpretatur. Varro quidem \& Columella 8.14, haras anferum uocant, fepta eis extructa in quibus pariant. Hara in qua pecora includuntur, Donatus. Te Iupiter dí́ omnes per dant, cboluifi allium, Germana illuuies, rufticus, hircus, hara fuis, Plautus Muftell. Tertius im. mundx cura fidelis har $x$, Ouidius in epift. Penelopes. Villam adificandam fi locabis nouam ab folo, faber hac faciat, oportet, limina, poftes, cellas familia, haras decem, \& $c_{4}$ Cato. Diligens autem porculator frequenter fuile conuerrat, 8 fxpius haras, Columella lib. 7. đ X'vecou, uínculum quo

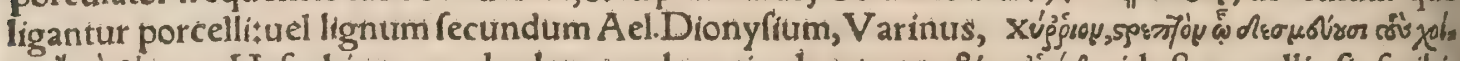

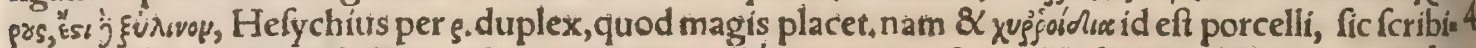

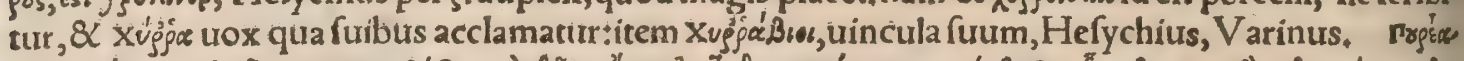

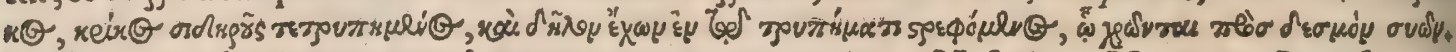
mrsárus, ut Arrftophanes ait in Laconicorum interpretatione, Hefychius, Varinus, Pontifex min nor è ftramentis napuras nectito, id elt funiculos facito, quibus fues adnectantur, in Commentario

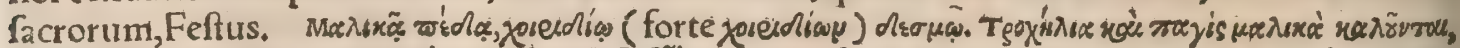

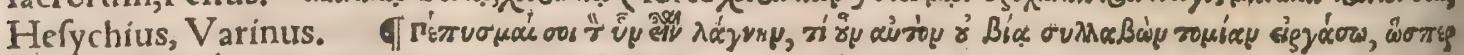

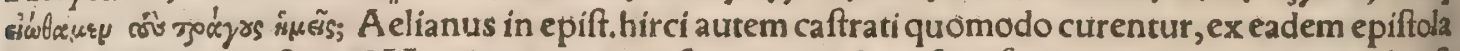
in Hirco dictum eft. ब Hominem perniciofum cum uolunt fignificare porcum pingunt, talis eft enim porci natura, Orus in Hieroglyph. TAd lithoftrota conficienda, ( qualia uulgò Mufaica uocant opera, ) ex fruftulis lapidum diuer forum colorum glutino tenaci inuicem iutinetis, fit maltha ${ }^{\circ}$ (glutinum, lithocolla ) perpetua ex calce $\&$ fuillo adipe, uel pice \& oui candido, Cardanus. ó gaj

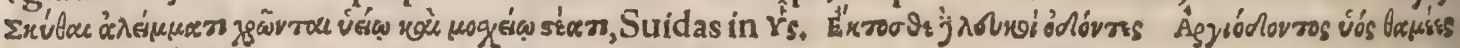

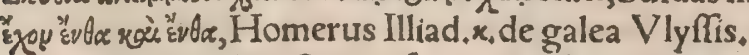

If. Plutarchus Sympofiacorum libro 4. problemate r. Probabile uidetur, inquit, Iudxos fuem colere ( $\&$ colentes potius quàm faftidientes abftinere) utpote feminandi $\&$ arandi magiftrum, ut afinum quoos colunt quòd aqux fontem eis aperuerit. Scythr fues pro nibilo putant, quos nec alere omnino in fua regione uolunt, Herodotus libro quarto. TSues mactatos noftri in labro aqua feruid $x$, addita etiam in fundum labri $\&$ alia fuibus impofita réfina, depilant : aliqui fiammis

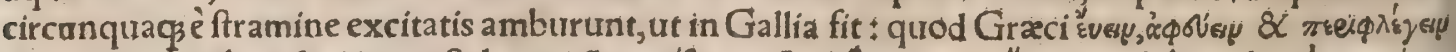

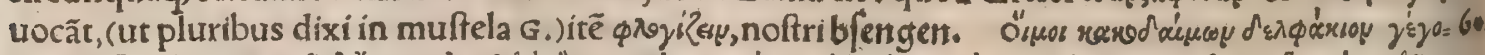

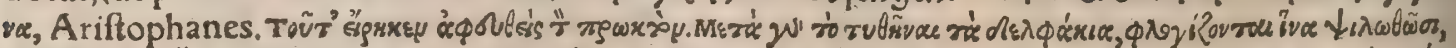

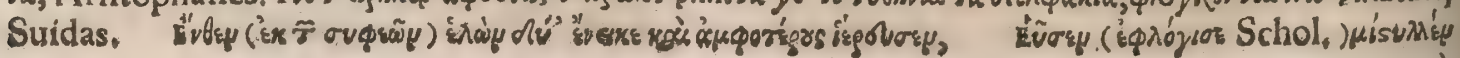


cratis. Vlyffes fibibiffet pocula Circes cum focijs, Vixiffet canis immundus, uel amica luto fus,

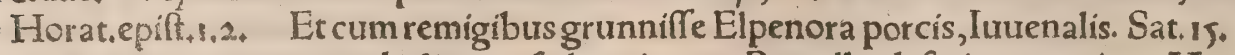

4] T E S T A mentum ludicrum fed antiquum Porcelli, defcriptum primo Moguntixà Ioanne Alexandro Brafícano, \& à Georgio Fabricio poftea correctum locis aliquot ex antiquiffimo exem plari, inuẽro Memmelebij in Turingia ad Vniftum. M. Grunnius Corocotta Porcellus teftamen tum feci, gutod quioniam manu mea fcribere nó potui, fcribendum diçaui. Magirus cocus ( proco quus ) dixit, ureni huc euerfor domi, (prodomus, ) foliuerfor fugitiue Porcelle, ego hodie tibi uitam adimo. Corocotta Porcellus dixit, fi qua feci, fi qua peccaui, fi qua uafcula pedibus meis confregi, rogo domine coce, ueniam peto, roganti concede. Magirus cocus dixit, Tranfi puer, adfer mihi de culina cultrum, ut hunc Porcellum faciam cruentum, Porcellus comprehenditur à famulis, ductus to fub die x v1. Cal. Lucerninas ubi habundant ( pro abundant) cyma, Clibanato \& Piperato Coff, $\&$ ut uidit fe moriturû effe, hor $x$ fpatium petịt, cocum rogauit, ut teftamentum facere poffet. Incla mauit ad fefures parentes, ut de cibarñs fuis aliquid dimitteret eis, qui ait: Patri meo Verrino Lardi.

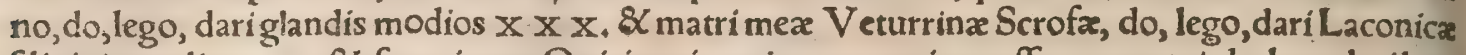
filiginis modios X L. \& forori mex Quirinæ, in cuius uotum intereffe non potui, do, lego dari hor: dei modlos $\mathrm{x}$ X X. \& de meis uifceribus dabo, donabo futoribus fetas, rixatoribus capitinas, furdis auriculas, caufidicis $\&$ uerbofis linguam, bubularịs inteftina, eficiarijs femora, mulieribus lumbur los, pueris ueficam, puellis caudam, cinædis mufculos, curforibus $\&$ uenatoribus talos, latronibus ungulos, \& nec nominando coco do, lego, ac dimitto popam \& piftillum, quæ mecum detuleramà querceto ufs ad haram, liget fibi collum de refte. Volo mihi fieri monumentum ex litteris(pro lite=20 ris ) aureis fcriptum. M. Grunnius Corocotta Porcellus uixit annos D. C c C C.X C V I I I I.quod fi femis uixiffer, mille annos impleffet. Optimi amatores mei uel confules uita, rogo uos ut corpori meo bene faciatis, bene condiatis, de bonis condimentis nuclei, piperis, \& 2 mellis, ut nomen meum in fempiternum nominetur. Mei domini \& confobrini mei, qui huic meo teftamento interfuiftis, iubere fignari.
Lucanicus fignauit.
Lardio fign.
Tergillus fign.
Offellicus fign.
Nuptialicus fign.
Cymatus fign.
Celfanus fign.

D. Hieronymus in procemio octaui libri in Efaiam, inquit: Teftamentum Grunnï Corococt Pors

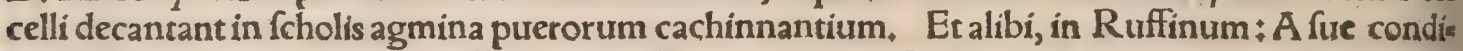
tum teftamentum, cachinno Befforum membra concutit, ut Calius citat.

THiforiam de dæmonibus, quibus è duobus uiris (Lucas unius tantum meminit) quos occu, pauerant Chrifti imperio expulfis in regione Gergefenorum, (Gadarenorum, Lucas ) permiffum eft demigrare in gregem porcorum, unde is mox per pręceps in mare delatus perịt, Matthæus $\&<\mathrm{Lu}$ cas etrangelifta, uterç octauo libri fui capite, defcribunt.

I Sus fi plures (quàm mammas habet) porcos pariat, portentum eft ; in quo illud antiquifli: mum fuiffe fcribitur, quod fus Aenex Lauini triginta porcos peperit albos, itaq quod portenderit façũ, triginta annis, ut Lauinienfes conderentoppidum Albam. Huius fuis ac porcorum etiam nực ueftigia apparent. Iam ne fimulachra eorum ænea etiam nunc in publico pofita, \& corpus matris ab facerdotibus, quod in falfura fuerit demonftratur? 'Varro.

Cum tibi follicito fecreti ad fluminis undam, Littoreis ingens inuenta fub ilicibus fus, Triginta capitum foetus enixa iacebit, Alba folo recubans, albi circum ubera nat;: Is locus urbis erit, requies ea certa laborum, Helenus ad Aeneam A eneid,3, de urbe in Italia con. denda. Eoldem uerfus Aeneas octauo Aeneid. nis urbem redeuntibus annis, Âfcanius clari condet cognominis Albam. Et luuenalis Sat, duo. decima, Confpicitur fublimis apex (id eft mons Albanus, ubi A fcanius condidit Albam ) cui can= dida nomen Scropha dedit latis Phrygibus mirabile fumen, Et nunquam uifis triginta clara mas millis. Dionyfio tyranno cum bellum aduerfus Dionem effet, fues in lucem nuper æditi, cum relis quis manci partibus non effent, nullas habebant aures, Plutarchus in uita Dionis. Cypriorum in. uentum eft ex fuibus ( ex fuillis extis, Alexander ab Alex. Gyraldus addit \& inteftinis) etiam uaticinari,Paufanias in Eliacis, Sus alatus Clazomeniorum agros uaftauit, uide in A proh. A doles so fcentes (

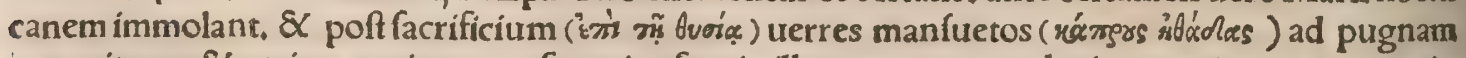
committunt: $\mathbb{Q}$ utrius partis uerres fuperior fuerit, illam quoque ut plurimum uincere contingit, Paufanias in Laconicis.

I Sus apud A egyptios ut impurum, deteftabile $\&$ uoraciffimum animal in fummo odio habe. tur: contra autem mitiores beftix natur $\&$ mifericordis $\&$ pix, præcipuo quodam honore afficiun tur, Aelianus. Et alibi, Aegyptīs (inquit) perfuafiffimum eft fues Soli $\&$ Lunæ inimiciffimos effe. itaç femel tantum eos fíngulis annis Lunx facrificant, ut inferius referam. Eudoxus inquit Aegy ptios ideo ab immolandis fuibus fe fuftinere, quod pofteaquam fementem fecerunt, eorum greges ad proterendam $\&$ conculcandam frumentorum fationem, atç depellendam in altiorem terram $\& 6$ humidiorem inducere foleant, ut hac quafi occatione terra obducta ne ab auibus femina exhaurian. tur, Aelianus. Sic \&Plutarchus in Sympofiacis 4. 5. Iudxos à fuibus abftinere putat, nan quidem 


\section{DeSue. H, h. Lib. I. I0z3}

faftidientes, red colentes magis eas, ut arandi magiftras, quam eius opinionem falfifimam $\&$ itoli= diffimam effe nemo non noftræeligionis non imperitus agnofcit. Suem Aegyptí fpurcan be Iuam arbitrantur: quam fi quis uel tranfeundo contigerit, abüt lotum fefe cum ipfis uefimentis ad flumen. Eoós, foli omnium fubulci in Aegyp̀to, etfi indigenx, tamẽ null î ingrediuntur in remplum: nemó́s aut filiam cuipiam corum nuptum dare uult, aut cuiufpiam eorum filiam in matrimonium ducere. Ipfi inter fe fubulci dant, accipiuntćs filias, Herodotus lib, 2. L unæ \& Baccho tantuin $A e=$ gyptij fues immolant, ut inferius eodem ex loco Herodoti recitabo. Aegypiij fuem animal profa=

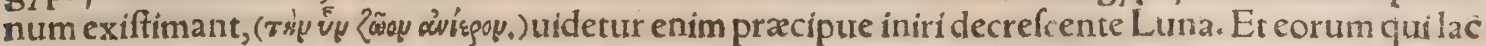
fuillum biberint corpora, lepra \& f cabic exafperantur. Caterum fermoni quen proferunt, cum fe= mel in plenilunio furem facrificant \& edunt, nempe quod Typhon aliquádo fuem in plenilunio per fequens, arcam ligneam in qua corpus Oriridis conditum erat iruenerit, \& difiecerit, non om nes fi= dem adhibent, Plutarchus in libro de Ifide, $\mathcal{K}$ Calcagninus in libro de rebus Aegyptiacis, qui addit: Alij melius exiftimauêre ueteres ita oftendiffe, uoracitati delicrijsć \& gulæ inuitamentís nuncium mitti oportere. Aegyptijs quibufdam nullam pecudem fas eft immolare prater fues, praterç bo= rves mares $\&$ uitulos, dummodo mũdos, $\&$ anferes, Herodottis lib.2. Aegyptī fuem non guftant, Idem lib.4. Mulieres Barcææ non modo guftu uaccinæ carnis, fed etiam fuill abfinent, Ibidem. Vide plura fupra in $\mathrm{F}$. A Ariftophanes in fabulis fuum plerunq $\&$ porcorum facrificium com

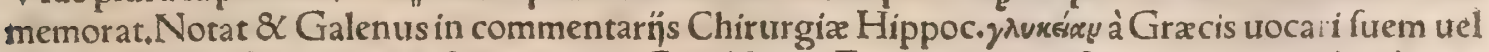
porcum in facrificio, blanda fcilicet uoce, Gyraldus, Fuit quidem prifcis opinio, ut ex hoedis po. tius $\&$ agnis hoftix fierent; quia hæ mites $\&$ cicures effent, nam gallinacei, fues $\&$ tauri animo ma: gis abundare uidentur, Gyraldus. Sex facrificia ex animalibus peragebantur, oue, fue, boue, ca

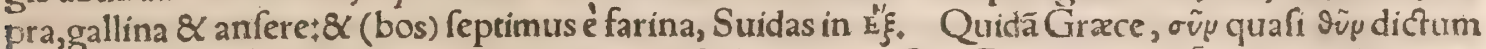

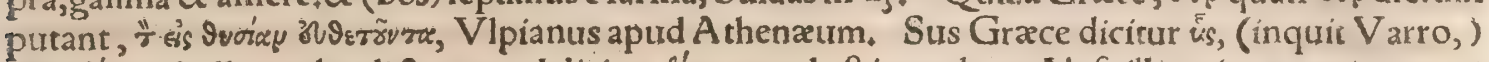
olim túrss ab illo uerbo dictus, quod dicitur b'vey, quod eft immolare. Ab fuillo enim pecoris genere immolandi initium primum furmptum uidetur, cuius ueftigia quòd initijs Cereris porci immolan. tur, \& quòd initịs pacis foedus cum feritur, porcus occiditur, \& quòd nuptiarum initio antiqui re= ges, ac fublimes uiri in Hetruria in coniunctione nuptiali, noura nupta $\&$ nouus maritus (uide infra

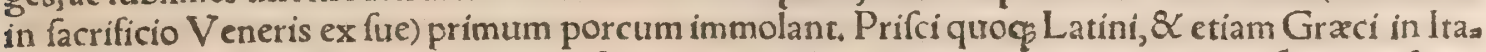
lia idem factitaffe uidentur. Nam $\&$ noftræ mulieres maxime nutrices naturam, qua focmina funt; 30 in uirginibus appellant porcam; \& Græci xếpoy, fignificantes effe dignum id fignữ nuptiarum, Нæc Varro de re ruftica 2.4. Sus prima holtia fuit: uide infra in facrificio Cererisex Sue. Forcü ims mola, prouerbum apud Erafmum. Plautus in Menachmis(inquit)porcum fyncerum \& facrum in molare iubet eum, quem mente captum fignificat. A dolefcens, quibus hîc preinjs porci uraneunt Sacres, fynceri. nummum unum en à me accipe. Iube te piari de mea pecunia: Nam ego quiciem infanum effc te certò fcio.Opinor quod ueterum ufu, qui cuiufpiam irati numinis intemperijs age: retur, hoc piaculo fe foleat purgare. I dem paulò poft in eadem fabula : Nam tu quidem hercle certò non fanus fatis Menæchme, qui nunc ipfus maledicas tibi, Iube fi fapias porculum afferri tibi. Horatius in Sermonibus, Immolet aquis Hic porcum laribus. loquitur de eo qui iam ab in fania re. fipuiffe uideretur, Hæc Eraímus. Porci qui à partu decimo die habentur puri, ab eo appellantur $4^{\circ} \mathrm{ab}$ antiquis facres, quod tum ad facrificia idonei dicuntur primum. (Suis factus facrificio die quinto purus eft, Plinitus.) Iraç apud Plautum in Menæchmis, cum infanum quem putat, ut pietur in oppi* do Epidamno, interrogat, Quanti hic porcifunt facres? Varro de re ruft. Gyraldus hunc locum fic legit, eum infanum purat, qui ut pietur, 8 c.). Et alibi, Porci qui puri funt ad factificium ut immo. lentur, olim appellati facres', quos appellat Plautus cum ait, Quanti funt porci facres?. Porci effi. gies inter militaria figna quintum locum obtinebat: quia confecto bello, inter quos pax fieret cara porca fordus firmare folebant, Fefus. Stabant $\&$ cafa iungebant foedera porca, Vergil.8. Aeneid. Fabius Quintilianus lib 8. ubi de ornatu loquitur, Quadam (inquit) non ram ratione, quàm fenfú iudicantur, ut illud: Cáa iungebãt foedera porca: fecit elegans, fictio nominis. quod fi fuiffet porco, uile erat, Hac Fabius. Porrò quòd porco cæro (inquit Nic. Erythraus) foedus percutifolenne cffet, so ex Liuio, Varronéç difcimus legimus tamen apud Pompeium Feftum lib, 14. (cuitus iam tuerba re citaui,) porcam cadi confueuifle. Seruius hunc locum enarrans, Foedera(inquit)ut diximus fupra, dicta funt à porca foeda \& crudeliter occifa, cuius mors oprahatur ei, quià pace refilinffet. Falló autể ait porca. nam ad hoc genus facrificij porcus adbibebatur. Ergo aur ufurpatrit genus pro genere, ut Timidi uenient ad pocula damx. Aut certè illud oftendit, quia in omnibus facris, formininígeneris plus ualent uictima. Deniç fi per marem litare non poflent, fuccidanea dabatur foemina fi autẽ per forminam non litaffent, fuccidanea (uicima) adhiberi non poterat, Hacille. Et in eundem locum Chriftophorus Landinus, A pud Romanos(inquit)foecialis hoftiũ regem de foedere rogat. Hic poft multa uerba ait: Audi lupizer, audi pater patrix populi Albanitaudi tu populus Albanus. Deinde expreffis foederis conditionibus, fubiunxit: lupiter porrò fic ferito, ut ego hunc porcum ferio, ran» 60 tóç magis ferito, quanto magis potes polleśq̧, inceligebat autem fi non feruaretur pax. Is' ubi dixit, porcum filice percuffit, Foedus hinc dicitur ictum, quia non fine ictu fancitur. Intorra cauda, id 
etiam notatum, facilius litare in dexterum quàm laxum detorta, Pliníus. Confceta firs dicebatưr, qua cum omni foctu adhibebatur ad facrificium, Pompeius lib. $z_{*}$ Eximia pecora dícuntur qua a grege excepta funt ad ufus dominorum fuorum ut uberius pafcantur, fed propriè eximij funt porci maiores, qui ad facrificandum excepti, liberius pafcuntur, Gyraldus, yourkvio, feftum quoddam Argis, Hefychius $\&$ Varinus, Propuditatporcus, dictus eft, ut ait Capito Atteius, qutod facrificio gentis Claudix uelut palmentum, \& exfolutio ominis contractæ religionis eft parum, (forre, por: cus. ) Caius fe uidere pronunciat magiftratus, cum de confulis fententia capitis quem condemiatu rus eft, Feftus. Hecatombe (inquit lulius Capitol.)tale facrificium eft: centum aræ uno in loco ce

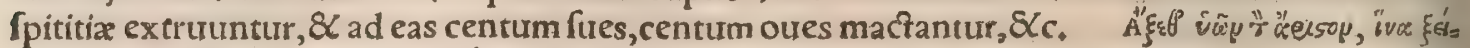

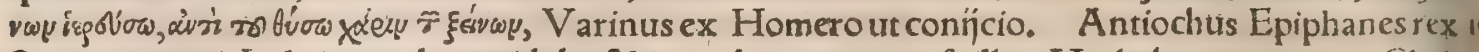
Syrix pracepit Iudxis ut colerent idola, $\&$ immolarent carnes fuillas, Machabxorum I,l. Chri. ftiani iuffi micam falis, iecur aut fuis litare, apud Prudentium in paffione Cypriani. Qui offerr ob= lationem (in templo Domini,) fimilis eft offerenti fanguinem fuillum, Er ias 66, de ludroorum perz uerfitate, qui licet Deo uni facrificarent, nihilò tamen meliores erant gentilibus. 'Lucum collucare (inquit Cato cap. 139.) Romano more fic oportet. Porco piaculo faciro. Sic uerba concipito.Si deus, fi dea, cuius illud facrum eft, uti tibi ius fiet porco piaculo facere, illiufce facri coërcendi ergô, $\& c_{*}$

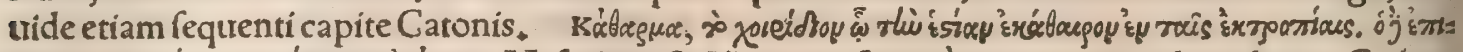

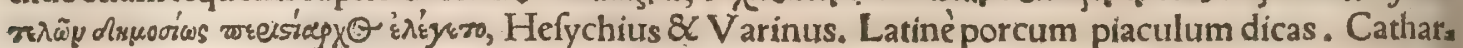
mata dicebantur $\&$ homines quidam uiles $\&$ obfuri Athenis, piaculares Latinè dici polfunt, qui in hoc alebantur, ut peftis aut alterius calamitatis tempore immolarentur pro falute publica: Quimos 2 Romæe etiam receptus fuit, Varinus, Porco uel agno ad expiationem utuntur, Hefychius in Áф̧o。 Soik. Solitaurilia hoftiarum trium diuerfi generis immolationem fignificant, tauri, arietis, uerris: quod omnes ex folidi integriós fint corporis, (non caftrati, ut uerueces, maiales.) Quidam dixerunt omnium trium uocabula confufa, fris, ouis, tauri, ita ut uno modo(una uoce) appellarentur uniuer, $\mathfrak{x}$, Feftus. Plura de hoc facrificio, \& eodem aut fimili quod Græci trittyn uel triada uocant, leges in Boure, in Tauro, in Ariete. Populus Romanus cum luftratur, Solitaurslibus circumaguntur uerres, aries, taurus, Initiandi confueuerunt immolare porcum:uide infra in prouerbio, Ad pors cellum da mihi mutuo tres drachmas, Sus in fponfalibus facrificabatur:hinc ciarior effe poteft fen fus prourerbï, Á dicendum: \& primo loco quibus dís, quibus deabus fecundo. In Creta facrum creditur animal 30 hoc fuillum, quoniam nafcenti loui fus mammam fubmiferit, ac gryfmo, id eft grunnitu, pueri uagia tum audiri uetuerit, Calius ex Arhenxi nono:qui pluribus, Quamobrem, inquit, omnes fuem co. lunt, \& carnibus abftinent. Pręij uero(Præffus, per f,duplex, aut etiam fimplex, urbs Cretæ, Stepha

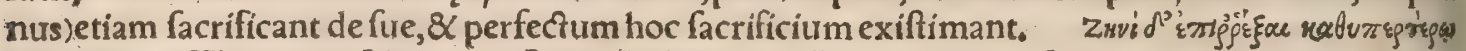

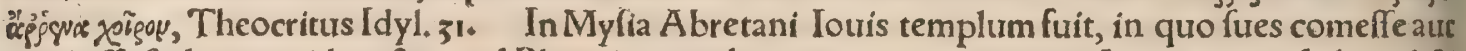
mactaffe fcelus erat,idem \& apud Phonicas, quibus per omne tempus, ut ludęis etiam, fubus abfit nere per leges cautum fuerar, Gyraldus. Reges Spartanorum cum primum in eam affumpti funt dignitatem, prituilegio honoris præcipui, Iouis coleftis \& Lacedæmoni facerdotio funguntur: quia bus ex omni frofarum foctu porcus debebatur, ut fi dịs immolare uellent, nunquam uictima deefs fet, Alexander ab Alex. Ioui de tauro non immolabatur, nifi cum triumphi nomine de fue uel 4 cauro fiebat:ubi non tantũ loui, fed aln̆s etiam deis qui bello præerant facrificabatur, Seruius. Tatr. ro, uerre, ariete Ioui immolari non licet, Atteius Capito. Vocabant autem Solitaurilia facrificium

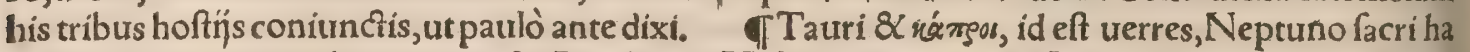
bentur, utpote animalia impetuofa, Proclus in Hefiodi Dies. 7 Galli Cifalpini uerrem Marti dicabant, Gyraldus. Mars tibi uoueo faciurum, fi unquam rediero, bidenti uerre, Pomponius in Attellana apud Macrobium \& Nonium. Diophantus Lacedæmonius qui de facris deorum fri. pfit, ait apud A thenas Marti folere facrificari facrum quod érerouфóvoukex appellabatur. fi quis enim centum hoftes interfeciffer, Marti de homine facrificabat apud infulam Lemnum, quod facrificati eft à duobus Cretenfibus, \& uno Locro, fed pofteaquam hoc Äthenienfibus difplicuit, coperunt af ferre porcum caftratum, quem nephrendem uocabant, quafi fine renibus, Fulgentius ad Chalci, dium. Luftrari exercitum nifi fue, oue $\&$ tauris, qui puri effent non erat fas:qui poftquam ter cir cum inftructas acies ducti erant, pracedente pompa \& greffu compofito, Marti immolabatur, Ale. xander ab Alex. Hoc genus facrificin Solitaurilia dixeris, de quo fuperius, đPorciBaccho immo. labantur:uide infra in Lunæ facrificio ex fure. II Immolet æquis Hic porcum laribus, Horatius Sermonum 2.5. loquitur de eo qui iam ab infania refipuiffe uideretur. Diximus attem fuperius por cum contra infaniam immolari folitum: unde prouerbium, Immola porcum, in hominem infanum, Cædere Syluano porcum, quadrante lauari, Iuuenalis. Tellurem porco,Syluanum lacte piabant, Horatius. đObferuatum eft, Numam regem ftatuiffe, ne ex re animata res facra Termino fierer: id quod pluribus Plutarchus fcribit, \& ante eum Dionyfius Halicarn. Ouidius tamẽ illi agnam \& porcam in fecundo Faftorum immolari prodidit, Gyraldus. IInitïs(initiationibus, Gyraldus)Ce 6 reris porci immolantur, Varro. Porci Cereri \& Baccho immolabantur, utpote deorum illorum mu neribus noxij, Scholia in Ranas Ariftophanis, Eandem ob caufam caper etiam priuatim Baccho 


\section{DeSue. H.h. Lib. I. iozs}

maçatur. Athenienfes in myfterỉs iưre optimo fues immolät, propter pernicien quam fegètibùs moliuntur. Nam ex fpicis fape alias exinaniunt, alias quæ nondum ad maturitatem peruenerũt ua ftant, alias effodiunt, Aclianus. Prima Ceres aưida gauifa eft fanguine porca, Vlta fuas merita cædenocentis opes. Nam rata uere nouo teneris lactentia fuccis Eruta fetigeræ comperit ore fuis, Ouidius ı. Faftorum. Et alibi, Prima putatur Holtia fus meruiffé mori, (aliâs necem, quià femina pando Eruerit roftro, fpemç interceperit anni. Menfe Aprili cum lampadibus $\&$ tædis accenfis, facerdotes in ueftibus albis mactata porca facrum Cereri peragebant. Sanè porcirm uilem admodum apud Platonem Socrates uictimam facere uidetur, in libro de Legibus, (imòlibro 1. dẻ repub.) In arcanís, inquit, audiendæe funt eiufmodi fabulæà quàm pauciflimis, qui quidem hon por:

- cum, fed pretiofam quandam rarāmḉ uictimam facrificauerint. Idem \& Proclus repetit, Gyraldus, Phurnutus fcribit Cereri facrificiũ de fue prægnante facium, proprer terræ fertilitatem conceptũó

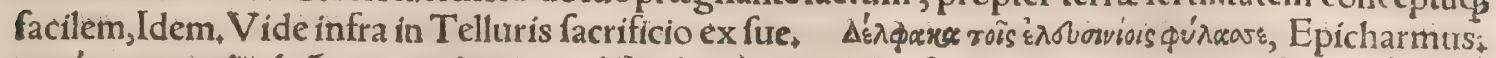

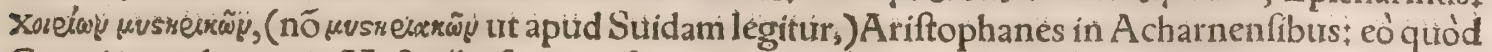
Cereri immolentur in Myfteríps, fic enim facra eitus uocabant. Quod fi fus fómina, \& ea fecundư Phurnutum etiam prægnans Cèreri immolabatưr, míretur aliquis cur yeı́́x, id eft, porcellos Arifo= phanes dixerit. fed eo in loco poéta iocatur, partim de fuibus, partim de puellis cuitufdam pauperis

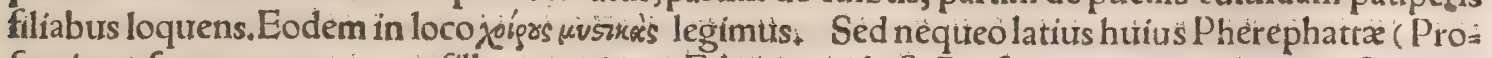
ferpinx) facra enarrare, quafillum, rapinam Edonex, (id eft, Proferpinæ, ) terræ hiatủm; fues Eux bolei,(Eubulĭ, Plutonis,) quas eodem hiatu fimul $\&$ duas deas abforptas fuiffe aitunt $\ddagger$ unde Mega10 renfes in Thefmophorijs fues immittunt, Eufebius citantè Gyraldo. Porcã auream \& argenteam dici ait Capito Atteius, qux etfi numero hoftiarum non fit; nomen tamen earum habere, alteran ex auro, alteram ex àrgento façam adhibèri facrifício Céreali, Féftus. Præcidatieam porcam dicebãt; quam immolare erant foliti antea, quàm nouam frìgem inciderent, Feftus. Pracidanea agna uro: cabatur, quæ ante alia cæedebatur, item pórca, quæ Cereri mactabatur ab eo, qui thortuo iufta non fe ciffet, id eft glebam non obieciffet. quia mos erat èis id facére prius quàm nouas fruges guftarent, $\mathrm{Fe}$ ftus. Præcidaneum eft præcidendum, Varro de uita pop, Ro. lib. + . Quòd humatus (inquit) non fit, hrededi porca pracidanea fuf́cipienda, Telluri \& Cereri, aliter familia pura non eft, Nonius. Porca pracidanea quomodo fiat Cereri priufquả méflem facias, Cátó cap. 134. A mbaruale facrừn nifi de porca foecunda \& grauida, aut uitula, fieri thon confuevit. Eft autem facrum ambaruale, cum 30 arua \& fegetes folenni uictima luftrantur : eam trictimam maturis frugibus ter circum arua ducere

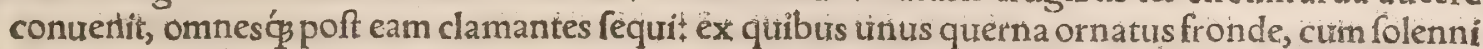
faltatu compolito carmine Cereri decantabat laudesłac poftquam lacte, uino \& fatro libaffent, ante: quam fruges meterént, porcam Cereri mmoolabant, qua pracidanea dicta eft, Àlexander ab Alex. Prefa(Prę̧a)porca dicitur, ut ait Veranius, qua familix purgandx caufa Cereri ímmolabatur, quòd pars quadam eius facrificin fit in confpectu mortui eius, cuius funus inftituitur, Feftus fi recte legis tur Præfa(potius quàm Præcidanea)nam Gyraldus quoqs dubitat, qui Syntagmate 77 . de dịs, plưrà de Pracidaneis hoftijs fcribit. TProferpinæ fterilis uictima attributa fuit, quia nec ipfa unquam peparit. Macrob, ex fententia Cor,porca. Quidam fuper hoc \& illud Martialis in fexto interpretan= tur, Exoluit uotis hac te fibi uirgine porca. Vergilius tamén \& Prudentiús fterili uracca éam placari 40 cecinerunt, Gyraldus. I Iunoni porcam uel agnain in ominibus Kal.regina facroritım; id eft regis facrorum uxor immolabat, Gyraldus. TAegyptij, quibus perfuafiffimum eft, fues Soli \& Lunæ inimiciffimos effe, femel tantût cum fefros dies agitant, eos Lunæ fingulis annis; aliấs trero nuinquam; nec huic ipfi, nec cưipiam alij deorum facrificant id çs propterea faciunt, quia execrandos \& detefta. biles ducunt, Aelianus. Alp̉s dịs immolare fues (inquit Herodotus lib. 2, ) ius A égyptís non eft; praterquàm Lunæ tantum $\&$ Liberołnifi per tempüs plenilunï, quo fues immolant; ac fuilla carne uefcuntur. Ideóg alips diebus feftis fues reformidant, cum in ifto mactent: Cuius rei ab Aegyptijs ra tio redditur, fed eandem intellectam milii magis decorum eft non referre. Sacrificium autem de fui= bus Lunæ hunc in modum fit Immolata fuxe, extremam eius caudam, \&lienê, \& omenta fimul com ponunt, $\&$ adipe qui circa aluum pécudis exiftat, ea operiunt, ac deinde igni admouentireliqua car. tre pleniluñ die uefcuntur, quo die facra faciunt:alio die non amplius gultarent. Quífunt ex eis in: opes propter tenuitatem facultatum, affimula tos quioldã fues coquunt, quos imtiolent Baccho quo. que iri êus fefto. Singuli in conam porcum pro foribus mactant, redduntós fubulco qửillum traz dit, Hac ille. PorciCereri \& Baccho immolabantur, ut qui deorum iftorum muneribus noceant; Scholia in Ranàs Ariftoph. hoc nomine caper etiam Baccho pritatim tiichima fit. Maiæ; qux Mercurn̈mater fuiffe perhibetur, Romani menfe Maio fuem pragnantem immolabant, Gyraldis; THoratius fecundo Epint. Tellurẽ porco placari folitam caniț quo loco Porphyrion ait porcum pro

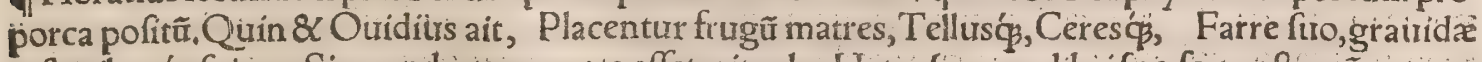
uifceribuş̧́́ fuis. Si quando terra mota effet, rituales Hetrufcorum librifue fóta oftentũ prociz= rare folebant. \& Arnobius ridens facrificia, ita fcribit in feprimo: Telluri, inquiunt, matri fcrophia in 60 gens immolatur foeta. Quod humatus non fit, hæredi porca præcidanea fufcipienda, Telluri \& Cé reri, aliter familia pura non eft, Varro de uita pop.Rom. apud Nonium. Deorum matri nuillitm fa crum nifi de por ca fieri permiffum quidam prodidêre. In facris dex Plirygix; quæ Matuta \& matè 
deûm dicta eft,curi Galli execti membra fecabant, cymbala pulfantes : porcam tanquam impuram

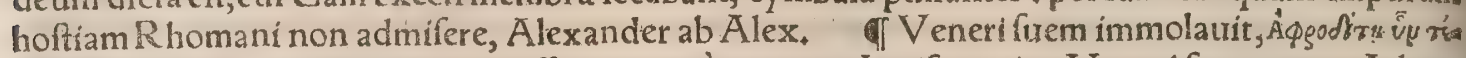
Өvrę, dici folitum ubi quis munus offert minimè gratum. Inuifus enim Veneri fus propter Adoni. dem illius amafium apri dente peremptum. Aut contra, cum quis alium in gratiam alterius lædit, quemadmodum çaper mactatur Libero, non quia gratur, fed quia nocuir, Erafnus. Proditum eft in Theffalia Veneris (Caftnienfís, ut addit Alexander ab Alex.) fanum fuiffe, $8<$ aliud in Sida Pam phylix, \& in Afpendo, \& Argis, in celebritate qux Hyfteria dicebatur, in quibus prater inftituta

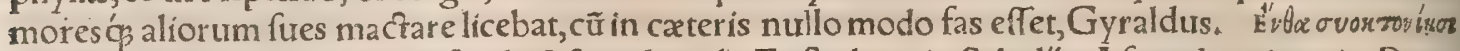

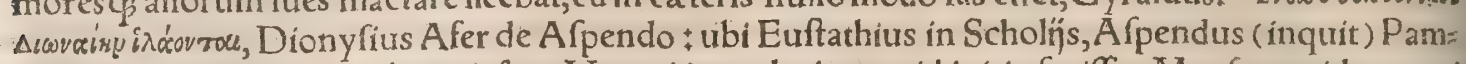
phylia urbs eft, ubi mos obtinuit fues Veneri immolari, curm id initio feciffer Mopfus quidam :qui $1 *$ animal quoduis primo in regione obuium immolaturum fe cum uouifet, fuem cepit \& immolauit, Quamuis fus inuifus Veneri dicitur, fues tamen legimus etiam apud Græcos Veneri immolatos, uteft apud A thenæum comprobatumi ex Antiphanis, Callimachi uel Zenodoti fcriptis. Idem pra: terea A thenxus ait, ab A rgiuis fuem Veneri facrificari,cuius facrificĭ celebritas à fuibus úsmeíx nun

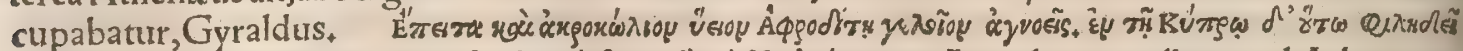

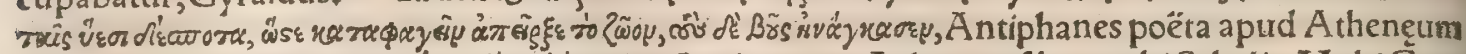

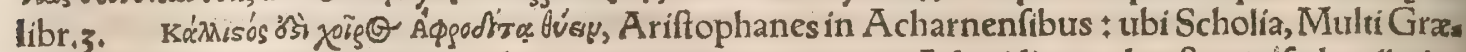
corum Veneri porcos non immolant, ut qua propter necem Adonidis eos deteftetur. Fed poëta lu. dit per feísoy intelligens pudendum puella qux pro porcello à patre paupere uendebatur, ut dixi. mus ftrpra in a,uidetur autem pars Venerea fuem, à qua denominatur, quodammodo aptam Ve 20

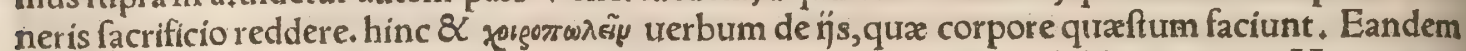
forte ob caufam, nuptiarum initio (ut Varro fcribit) antiqui reges, ac fublimes uiri in Hetruria in coniunctione nuptiali, noua nupta $\&$ nouus maritus primum porcum immolant. Prifei quogs La tini (inquit ) \& etiam Græci in Italia idem factitaffe uidentur. Suillũ genus inuifum Veneri pro* diderunt poëtę,, $\mathrm{b}$ interfectum $\mathrm{ab}$ apro Adonim, quem diligebat dea ₹ quidam autem quod immun. diffimi funt fues ex omni manfueto pecore, $\&$ ardentiffimæ libidinis, ita ut opprobrium mulieribus inde tractum dicatur, cum fubare $\&$ fubire dicuntur, Feftus,

P R O V E R B A.

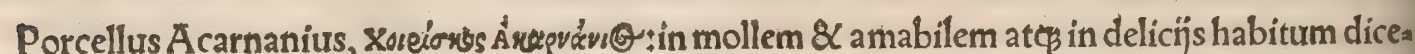

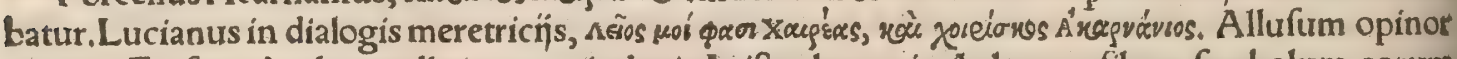
(inquit Erafmus) ad porcellam quem inducit Ariftophanes in Ä charnenfibus, fymbolum eorum membrorum, quibus obfccenæuoluptates peraguntur. Sus acinos dependes, Árorioes yeíg yí. yoşra: Lues quod admififti, reddes quod abftulifti, non fine focnore, Quadrabit, ubi pufillum com* modi magno dependitur malo. Natum apparet à ruftico quopiam, qui uerbis hifce comminatus fit fui pafcenti racemos, Erafmus. Tappius huic prouerbio adiungit eiufdem fententix Germanicum, Su wirft eo nod mit ber baut bejalen. Scropha foecundior alba, Iutrenalis; de prodigiofa foes cunditate: uide fupra in c. Nihil cum amaracino fui, Aul. Gellius lib, ultimo, hoc eft ftolidis uel optima putent difplicentóg. Erat autem amaracinum unguentum nobile $\&$ imprimis odoratum. At 4 fue cum nihil immundius fit, nihil fordium amantius : (Quamobrem dixit Vergilius, Immundi me. minere fures. Præterea Flaccus, Vel amica luto fus, Et, Lutulenta ruit fus.) nihil profecto minus con. urenit roftro fuillo, quàm deliciæ unguentarix, quippe cui id demum dulce olet, quod cœnum olet. Maximé ueró inter unguenta, peculiari quadam naturæ proprietate amaracinum inimicum elt fuil lo generi, ita ut illis ueneni inftar fit, fiquidem credimus Lucretio, cuius in fextolibr.hifunt uerfus: Deniç amaracinum fugitat fus, \& timet omne Vnguentum:nam fetigeris fubus acre uenenũ eft, Ad hoc adagium allufiffe uidetur M. Tullius cum ait:llli alabaftrus unguẽti plena putet.id eft,optis ma propeffimis difplicent, ( Scarabeo etiam, ut fuo loco dicemus, inuifum eft unguentum, ftercus gratum, ) Erafmus. Imperitis craffioréǵs obuolutis ignorantia, pro fale animam effe datam pro= nunciamus, quod à fuibus propagatum eft, Càelius. Vide fupra ab initio capitis fexti. đBoootica fus, Hै Bow

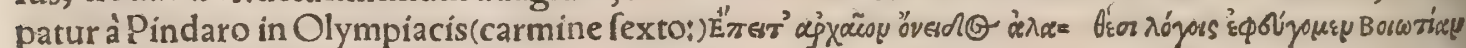
غ้y,admonet Aeneam chorodidafcalum, ita curet canendum hymnum, ut uetus illud probrum ueris rationibus oftendat ip fos (homines fcilicet Boeotos) effugere, quod in amufos dici confureuerit, Bosw zite

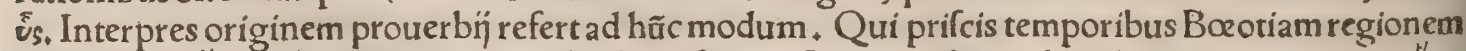

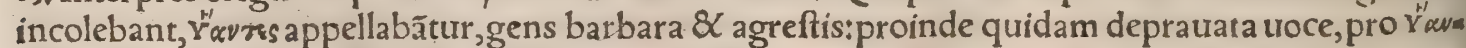
oxs, vैas, id eft fues appellabant. Id ç̧ fcomma ceffit in prouerbium, ut primum in Bocotos diceretur:

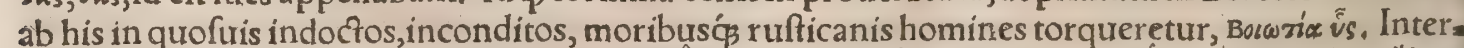

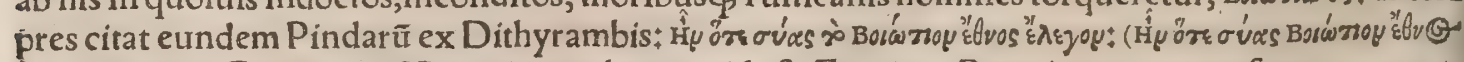
Everoy, ut citat Galenus in Hortatione ad artes: )id eft, Erat cum Bocoticam gentem fues trocarent, 6

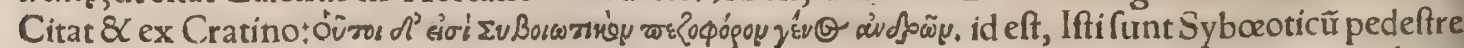

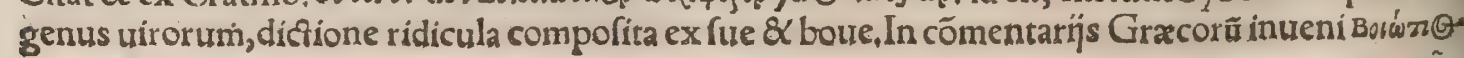




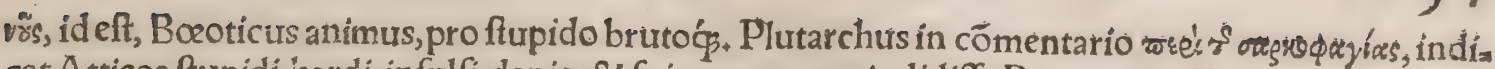
cat Atticos ftupidi, bardi, infulfi, deniç \& fuis cognomen indidiffe Bocotis, potifimũ ob edacitatem.

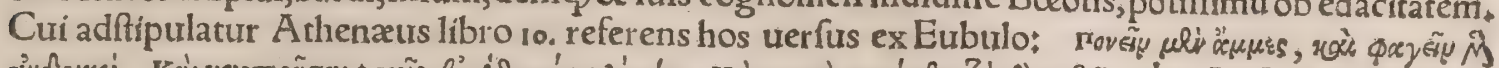

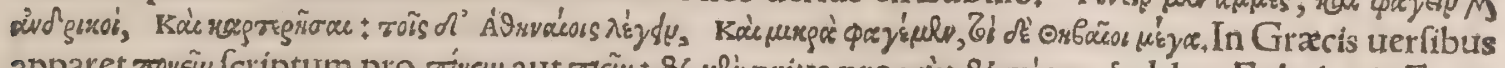

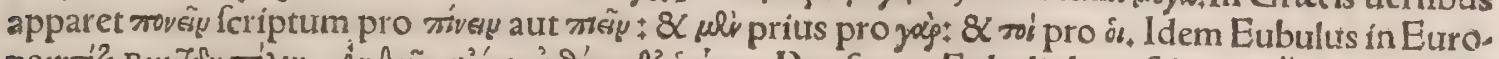

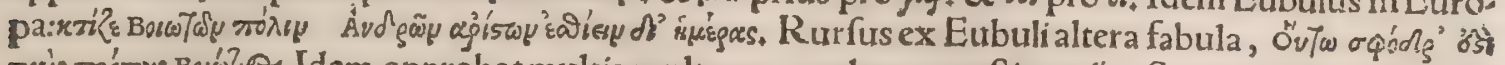

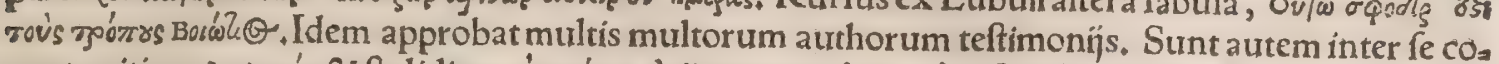

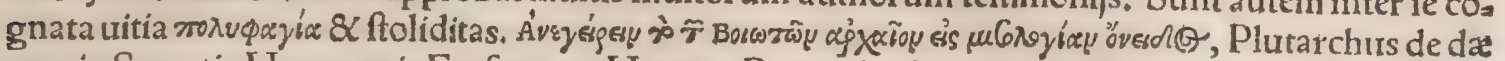
monio Socratis, Hac omnia Erafmus, Hyantes Bocoti dicebantur, quod pecoribus \& porcis fimi.

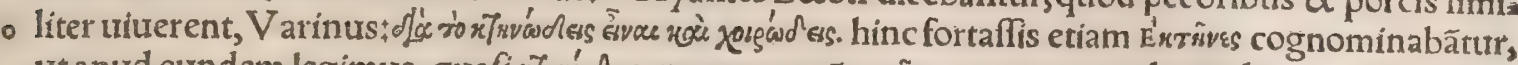

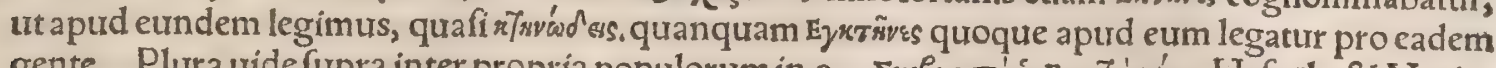

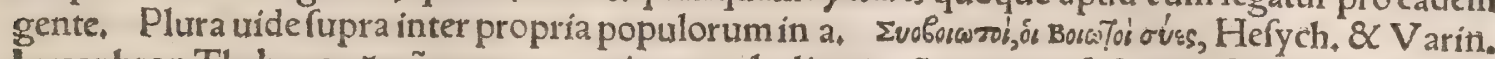

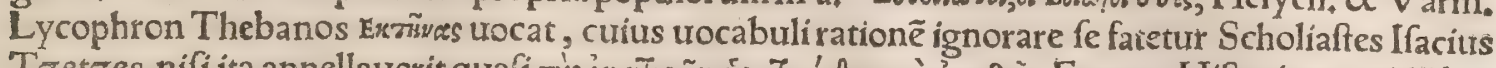

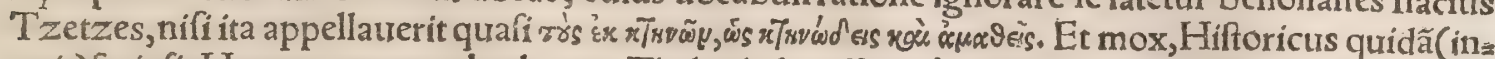
quit) rcripfit Hyantes gentem barbaram Thebis habitaffe $\&$ à rudi plebe aliquo illorum demonftra

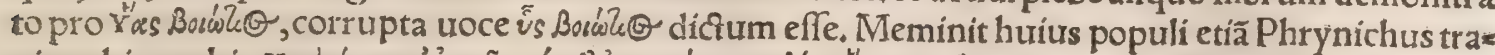

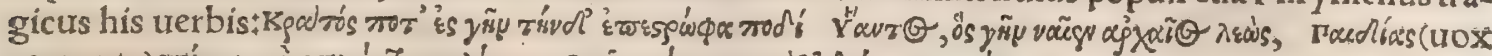
corrupta) móv

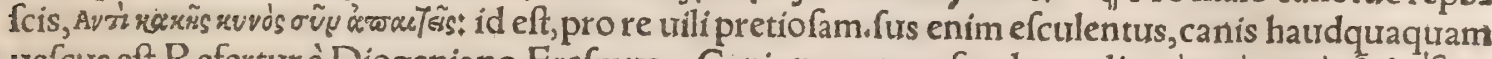

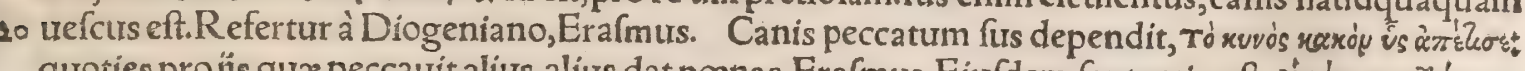

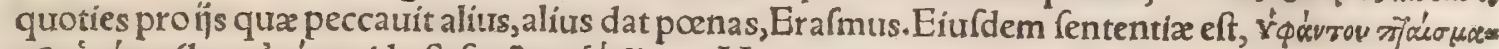

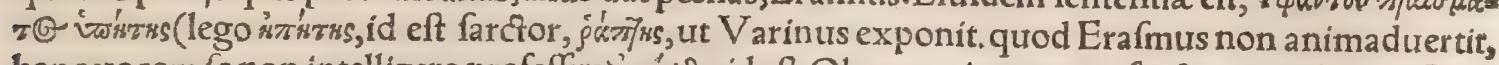

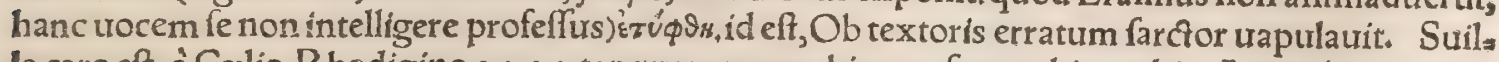
la caro eft, à Calio Rhodigino 25. 25. tanquam prouerbium refertur, his uerbis: Antiocho rege nu. merofo exercitu in Graciam irrumpente, T. Quintius Romanorum imperator ita ad Achæos uer: ba feciffe memoratur, dum peditum equitum $\alpha^{\beta}$ nubes iactari audiffet à rege, qui \& claffibus conftra turum fe maria interminabatur † Eft (inquit) res fimillima cœnæ Chalcidenfis hofpitis mei, hominis $\&$ boni $\&$ fciti conuiuatoris apud quem folftitiali tempore comiter accepti, quum miraremur, unde illi eo tempore anni tam uaria \& multa uenatio: homo non (quàm ifti funt) gloriofus renidens, Con

30 dimentis ait, uarietatem illam \& fpeciem ferina carnis, ex manfueto fue factam. Hoc perinde in re. gis copias, quaiactentur promi poffe. Varia enim genera armorum, 8 multa nomina gentium in. auditarum, Dacos \& Medos, Cadufios, Elymæos, homines tamen effe, haud multò quàm mancipio: rum melius, propter feruilia ingenia, militum genus. Ex hiftoria urerò huiufmodi, cuius aucior T.Li uius eft, commoneor, fcitum elici adagium poffe: A tqui fuilla caro eft, de ñs quæ re quidẽ ipfa parui fanè aut nullius omnino momẽti funt, apparatu tamen ac fuco, \& (ut ille ait) nugis peregrinis pra: cellere uidentur plurimum. Sus comeffatur aut faltauit, $x_{s}^{*} \varepsilon^{2} u_{u \mu x} \sigma \mathrm{g}:$ Diogenianus oftendit dici fo. litum de ỉjs, qui præter decorum quippiam facerent, quiós rerum fucceffu præter meritum obieço,

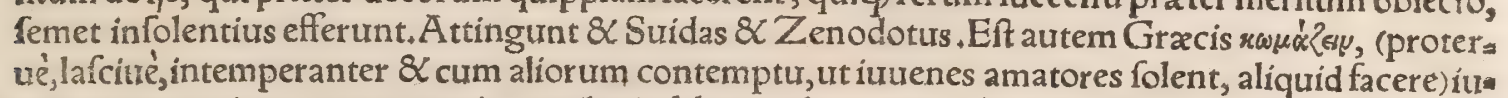
40 urenurm amantium more coronis, cantilenis, faltationibus, cæeteris ćp̧ iuuenilibus nugis lafciuire, $\&$ in

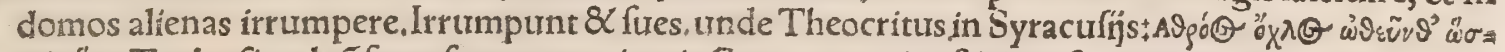

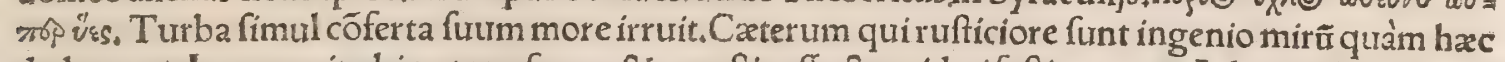
dedeceant, Locus erit ubi natura fauus \& agreftis affectat uideri feftiuus. F Ad porcellû da mihi muturo tres drachmas: dicebatur ab eo qui mori decreuiffet, aut qui uellet initiari. nã initiandi con.

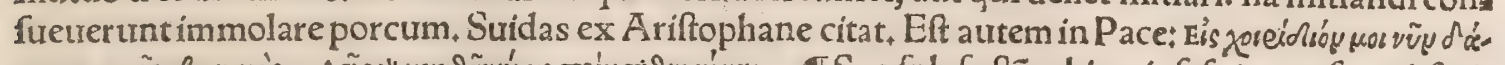

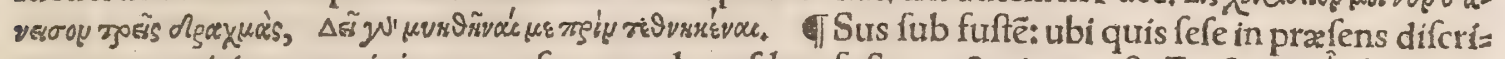

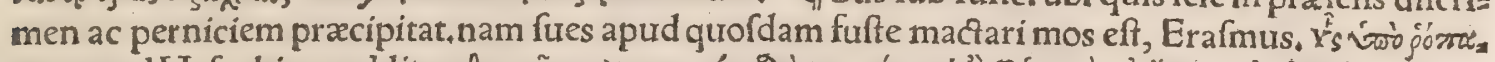

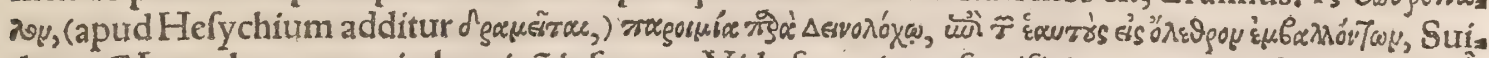
das. Immola porcum, in homine infanum $+V i d e$ fupra inter facrificia ex porco. Suem iritat, $x_{y}$ go ỏive: Vide inter prouerbia in A pri hiftoria. TAlia Menecles, alia porcellus loquitur:ubi quis mul. tum uerborum effutit, qua nihil ad rem pertineant. Mihi (inquit Erafmus) fubeffe prourerbium uide tur, tametfi nondum fatis liquet unde natum fit. Alludit ad illud Lucillius in Epigrammate Græco, arguto \& eleganti+quod Erafmus Latinefic reddidit:

Sucula,bos, \& capra mihi, periêreMenecles, Acmerces horum nomine penfa tibi eft.

Nec mihi cũ Othryade quicquã eft úe fuitu ue negoci, Nec furres ullos hurc cito Thermopylis.

Sed côtra Eutychidẽ nobis lis, pinde quid hic mi Aut Xerxes facit, aut quid Lacedæmonij:

Ob pactũ \& de me loquere, aut clamaurero clare, Multò aliud dicit fus, aliud Menecles.

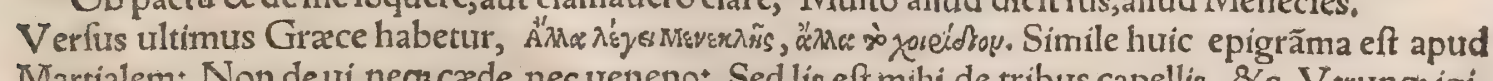
Martialem: Non de ui, neqg cade, nec ueneno: Sed lis eft mihi de tribus capellis, $8 \mathrm{cc}$. V trunç igi. 60 tur in eum recte dicetur, qui qua extra caufam funt, $\&$ ad rem nihil attinent, dicit: Aliud fus, aliud

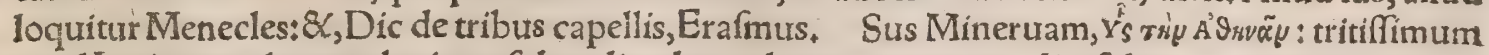
apud Latinos authores adagium, fubaudiendum, docet, aut moner, dici folitum, quoties indoctus 
quífpiam atque infulfus eũ docere conatur, à quo fit ipfe magis docendus+ aut, ut Fefti Pompeỉ uèr bis utar, cũ quis id docet alterũ, cuius ipfe eft infcius. propterea quod Minerux artium \& ingeniorû turtela triburitur à poëtis. Porrò fue nulfum aliud animal magis brutum, magisás fordidurm:ut quod ftercoribus impenfé gaudeat, uel ob iecoris magnitudinem, qua fedes eft concupifcentix ac libidi nis:uel ob narium craffitudinem $\&$ olfactum hebetem. unde fit ut non offendatur fotore, \& $c$. Vnde nunc quoos uulgò homines infipidos, \& quafi uentri atक̧abdomini natos, fues appellare confueuimus. Quin \& Suetonius in catalogo illuftrium grammaticorum, refert $\mathrm{Pal}$ amonern arrogantia tan ta furife, ut M. Varronem porcum appellaret, fecum \& natas $\&$ morituras literas, Præterea fi quid indoctum atque illiteratum fignificare uolumus, id exhara profectum dicimus, quemadmodum M. Tullius in Pifonem: Ex hara producta, non fchola.L.Cæfar apud Ciceronem libr, de Oratore 2, 10 Sic ego, inquit, Craffo atediente, primum lequar de facetris, \& docebofus, ut aiunt, oratorem eum, quem cum Catulus nuper audiffet, foenum alios aiebat effe oportere. Idem Cicerolibro 1, de Acam dem, quaftionibus, Nam etfi non fus Mineruam, ut aiunt, tamen inepté quíquis Mineruam docet. Hieronymus in Rufinum, Prætermitto Gracos quorum tu iactas fententiam, \& dum peregrina fe ciaris, pené turi fermonis oblitus es, ne uetere prouerbio fus Mineruam docere uideatur. M. Varro $\&$ Euemerus adagium ad fabulas retulerunt, id quod ex Pompen̈ uerbís licet conijcere. Quam rem (inquit)in medio, quod aiunt, pofitam, ineptis mythis inuoluere maluerunt, quàm fimpliciter refer: re. Celebratur à multis Demofthenis fcomma, qui cum Demades uociferaretur in eum: $\Delta$ suoấwis

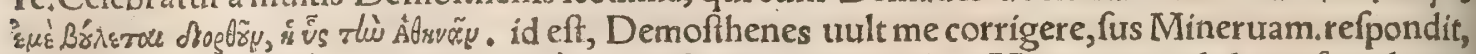

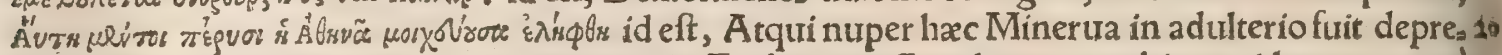
henfa. Dicium allufit ad Mineruam uirginem, Erafmus, Cum hoc proưerbio aut idem, aut certé

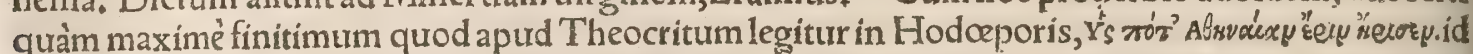
eft, Sus cum Minerua certamen fufcepit: Quoties indocti ftolidiç, \& depugnare parati, non ueren tur fummos in omni doctrina uiros in certamẽ literarium prouocare. Theocriti cnarrator fic efferri

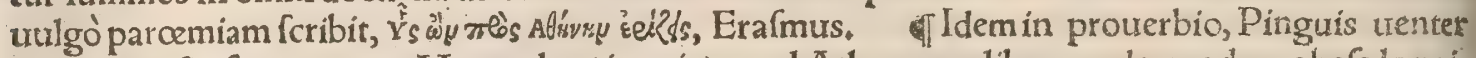
non gignit fenfum tenuem, Menander (inquit) apud A thenzum libro 12. de quodam obefoloqui:

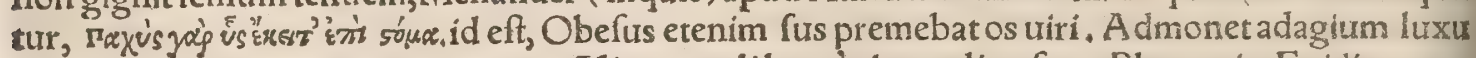
corporis hebetefcere mentís aciem. Aliter catuli longè olent, aliter fues, Plautus in Epidico, quuo dicto fignificat, nó uefte dignof ci hominem ab homine, urerum ineffe natiurm quiddam, genuinum ac proprium in unoquoqs, quod in ipfo uultu oculiśás eluceat, quo hominum ingenia difcernas, $3^{\circ}$

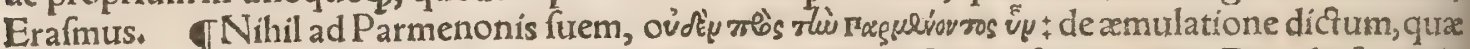
longo interuallo abeffet ab eo quod imitaretur. Plutarchus in Sympofiacis quintæ Decadis fecundo problemate, quo pacto natum fit adagium narrat ad hanc fermé fententiam. Parmeno quifpiam ua rias animantium $\&$ hominum uoces fcitè imitabatur ac repręfentabat ₹ quem cum reliqui conarens

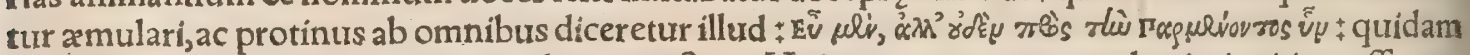
prodịt, ueram fuculam fub alis occultatam geftans. Huius tocem cum populus imitatitiam effe crea

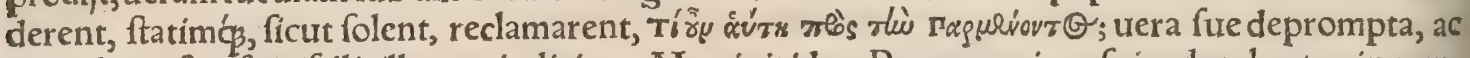
propalam oftenfa, refellit illorum iudicium. Meminit idem Parmenonis ac fuis adumbrata, in com= mentarïs De audiendis poëtis. Nec intempeftiuiter utemur hoc adagio, quoties aliquis opinione

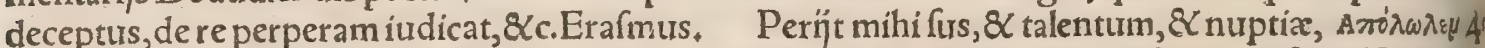

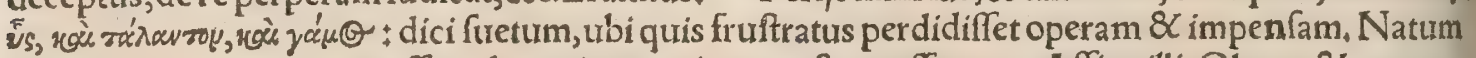
â quodam, qui cum apparaffet ad nưptias omnia, non eft eas affecurtus. Affine illi, Oleum \& operam perdidi, Erafmus. Suem in fponfalibus immolari folitũ author eft Varro, ut fupra recitaui. बHip.

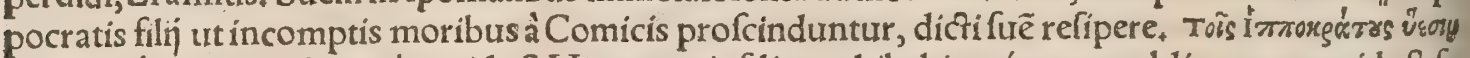

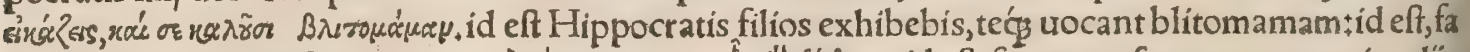

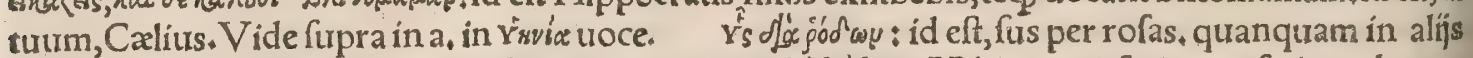
exemplaribus (inquit Erafmus ) fcriptum inuenio do jois cou. Mihi neutra foriptura fatis probatur:

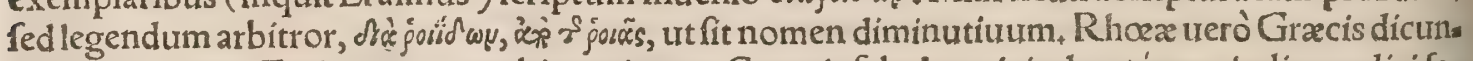
tur mala punica. Eudemus prouerbium citat ex Cratetis fabula,cui titulus réroves, indicans dici fo, lere de agreftibus $\&$ intractabilibus, quemadmodurm fus per mala commodé duci non poteft, Hac ${ }^{\circ}$

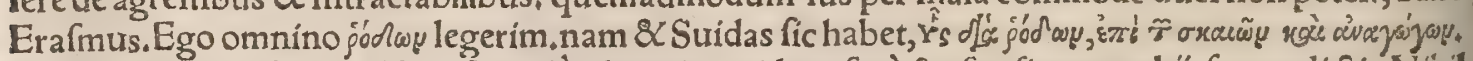
hoc eft, de hominibus rudibus $\&$ malè educatis, utidem ferè fenfus fit prourerbì fupra dicti, Nihil

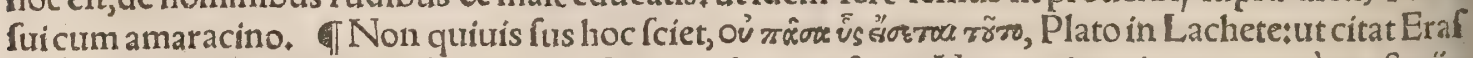
mus in prouerbio, eiufdem fententix, Nemomalus hoc fciet. Natum, inquit, apparet à myfterijs

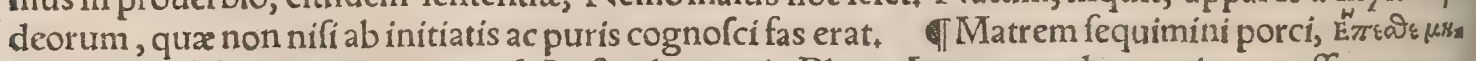

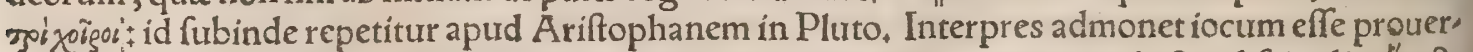
bialem in ftupidos 8 indoctos. Veluti fi quis diceret indocti præceptoris indoctis difcipulis, Ekta

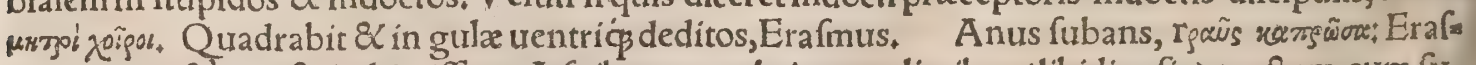
mus non recté tranfulit hirciffans. A fuibus opprobrium mulieribus (libidinofis) tractum, cum fus bare $\&$ fubire dicuntur, Feftus. Afinus afino, \& fus fui pulcher : conueniet (inquit Erafmus) ubi 60 inter (parum) honeftos fimilitudo morum $\&$ inftituti conciliat beneuolentiam . Alcimus apud Dio genem Laërtiữ inter multa quęcollegit ex Platonis philofophi $\&$ Epicharmi Comici friptis, quibus 


\section{DeSue. H.h. Lib. I. 1039}

perfuadere conatur philolophum à comicis multa fuiffe fuffuratum, \& hos refert fenarios:

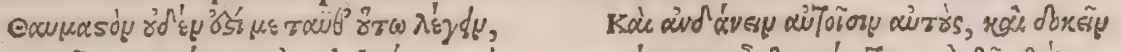

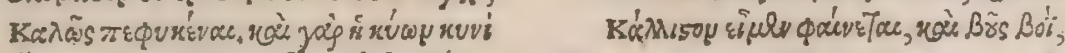

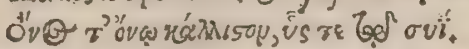

T) Sus tubam audiuit: in eos quadrabit, qui res quident egregias audiunt, ucrum eas neque intelligunt, neç mirantur. aut in cos, qui tis qua audiunt, ne $\$$ gaudent, neque cómourentur. Equi tubarum clangore concitantur ad bellum : fuem abigat citius,

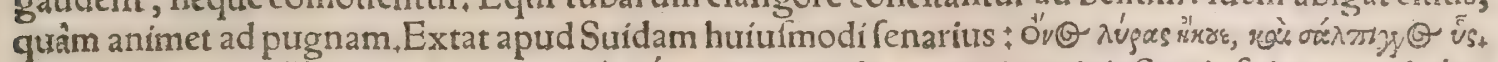

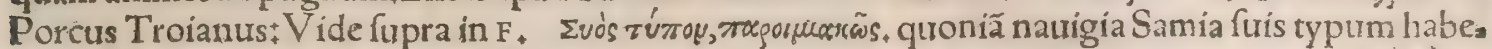
bant in proris, Varinus in $\Sigma \tilde{y}_{4}$ Cómodè fortaffis hominem obfconum aut turpem uerbis füctis'

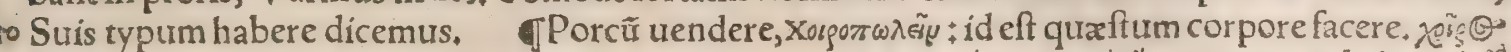
Corinthijs purdendum muliebre fignificat, unde prouerbium : Ák, orteus

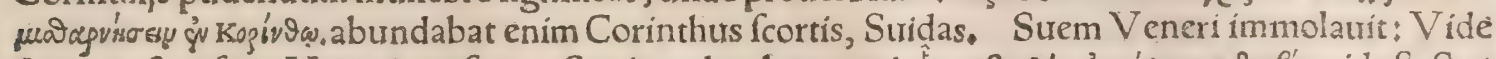

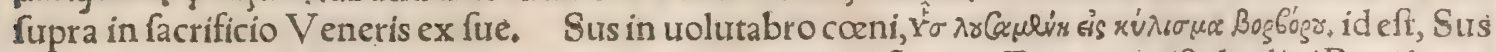
lota redït ad uolutabrum luti,cum quis iterat iam expiata flagitia. Extat in epiftolis diui Petri $(2,1$. Huic affine eft quod habent prouerbia Sirach, Qui lauatur à mortuo, \& iterum tangit mortum, quid prodeft lotio illius ? Erafmus, GGermanorum prouerbia à fuedeductas Suemrhenone

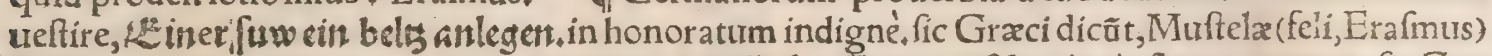

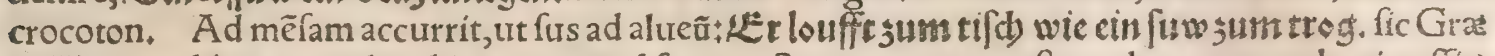
ci, lllotis pedibus ingredi uel irrumpere ad facra . Suem non opus eft tondere, cum amburi poffit

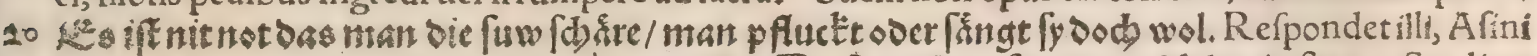
caput ne laues nitro. Sus perpetuò manet fus: Siefuw iff ein fuw/ ons blybt cin faw. Sus licet auro urefita, in coeno fe uolutabit: Dann man einer fuw oud cin guloin ftuct anjuge/ folegt fy

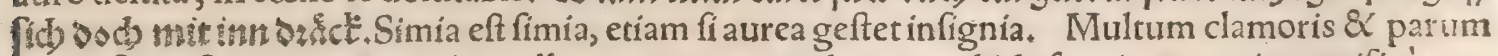
ana: Dil gef $\phi$ zeys wro wentig wullen * natum ex apologo quodã de fue, in cos qui magnifice pro= mittunt, nihil praftituri.in quos \& illud Horatij ex Arte poëtica conueniet, Quid dignum tanto fes ret hic promiffor hiatu? Et ex eadem, Parturiunt montes, Et illud, Aureos montes polliceri. Reil= giofum aliquid de fue dicere, 2 twa geiflid) o von einer fuw. in eum qui res fordidas, triles, ridi* culas, aut etiam turpes, uultu tanquã in uera narratione compofito, dicendo illuftrare \& ornare co natur. Noftri uulgo hoc prouerbio utûtur in imperandimodo, cum ridiculı̃aliquid $\&$ facetum ad

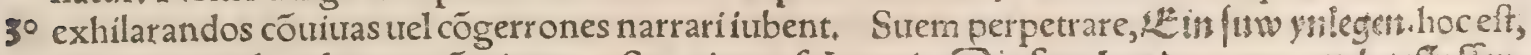
aliquid inciule uel turpe cómittere. Sus uinum fubuertit, Sic fuw bat sent wyn vmbgefteflert.

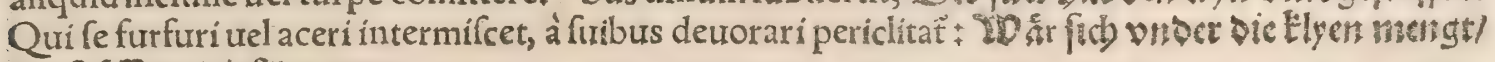
Sen fretrlens dic füw gern.

IMonile aureum in naribus porci, eft mulier formofa, qua deftituitur iudicio rationis, Prouer biorum Salomonis cap. II.Munftero interprete. Nolite canibus facrum uel fuibus margaritas obij= cere, Matthæi 7. Fabula quadam Phrygia ab Aefopo Phryge profecta, Suem ait, fi quis eam teti= gerit, clamarełidós merito. Nec enim uellera fus haber, neque lac, neque aliud prater carnes. Statim igitur fomniare mortem, cum fciat quibus ufibus praftandis ufurpari polfit. Sunt autem A efopica fui fimiles tyranni, qui omnia fufpicantur $\&$ metuuns, friunt enim quod ficuti fues, ita $\&$ ipfi uitam $4^{\circ}$ omnibus debeant, A elianus apud Stobrum.

- Alciati emblema, fub lemmate, Indies meliora.

Roftra nouro mihifetigeri fuis obtulit anno, Hxcós cliens uentrix x́nia, dixit,habe.

Progredicur femper, necretro refpicit unquam, Gramina cum pando proruit ore uorax.

Cura uiris eadẽ eft,ne fpes fublapfa retrorfum Cedat; $\&$ ut melius fit, quod $\&$ ulterius.

\section{DE APRO.}

A.

50 $1<1$ oN in furibus tantum,'fed in omnibus quoq̧ animalibus cuiufcunģ generis ullum eft plà cidum, eiufdem inuenitur \& ferum, Plinius. A per de feris dicitur, ut quidam annotautit, cum fus tam de feris quàm de domefticis dicatur. At Sextus aprum agreftẽ nominat, quafi uerres etiam, id eft fus cicur mas, codem nomine nuncupari poffit, Er Plinius, Pilus (inquit)arco fi= milis agreftibus apris, cateris (manfuetis fcilicet) niger. Græci quidem rámbl, de utriufç generis (manfueti \& feri)mare ufurpant.Pö́ra femper, ni fallor, ró thores fapius uerrem. Albertus Ariftetelis uerba de hift, anim. 5. 14. enarrans, multa triburit apro fero, qua uerris domeftici funt. A pris maribus non nifi anniculis generatio, Plinius, uidetur aus. tem pleonafmus quod addit maribus. neģ enim aprum foeminam quifquam dixit: fed fuem feram tum ipfe tum alï. Nempefues fyluaticos in montibus fectaris uenabulo, Varro apud Nonium. 60 Suem etiam fimpliciter pro apro poni tum Grace tum Latine, \& alia quadam de apri nominibus, docui in Stre A. marem. Deuaftat eam ( uitem tuam, id efigentem Ifraeliticam) aper (chafir) de fylua, \& fera (p) f fis 
uelziz, quod eft nomen commune de omni fera beftia ) agri depaf́citur eã, Pfal. mo 80. Munftero interprete. Hierony= mus aliter, Exterminauit eam aper de fyl ua, 8cingularis ferus depaftus eft eam.

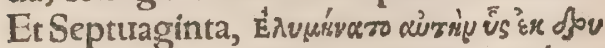

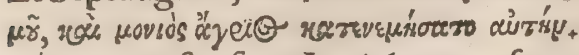
súxzpoy pro fue fero Antiphanes ufurpa= uit, \& Dionyfius Tyrannus in Adonide, 8. alip, Athenxus: Vide plura in a. $\bar{A}=$ prum Graci capron uocant \& fyagron poérę itẽ chlunin, ut in TruculêtoPlauti cluinum pecus legendum cenfeam, chlu ninum, nam \& Ariftoteles fuem ferum chlunin uocat, Hermolaus, Sciendum eft (inquit Calius) chlunem dici ab Gra

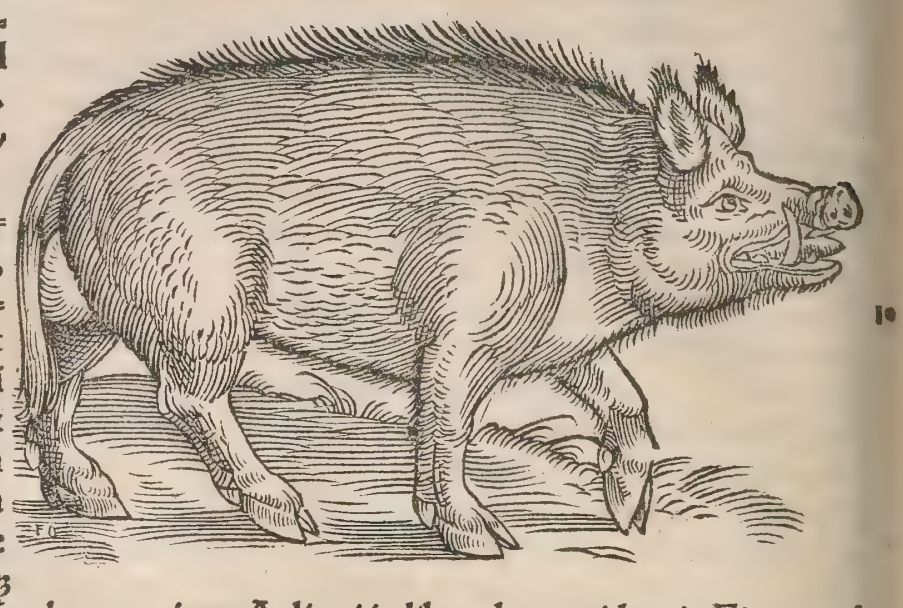
aprum. Id quod A Aefchyli doctrina comprobat, atç item Aeliani in libro de prouidentia. Fiunt kerò eunuchi attritis arbori aut faxotefticulis, infeftante uf $\not$ ad affectionem pruritu. Sunt qui chlunem

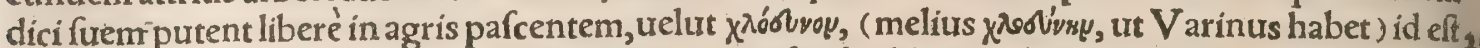
in herbis foenóue dormientem. Alị magnitudine uifenda chlunem accipiunt. Ariftophanes grama maticus in libro de atatum nomenclatura $\div$ Sunt ex fuibus, inquit, qui dicuntur monÿ, quibus limi= lis forfan fuerit, quem uocant chlunem, fauitia \& uiribus. Monium funt qui monolycon interpre tentur + alỉ fuem ferum, qui cum alïs minimè aggregetur. Cyrillus in Oream prophetam afínum eo nomine intelligit. Thomas magifter in Atticis elegantīs, chlunem ac monion \& chauliodonta effe putat poéticas uoces, ( Varinus hæec tria fimiliter fuem ferum fignificare ait, ) Hacomnia Cælitus,

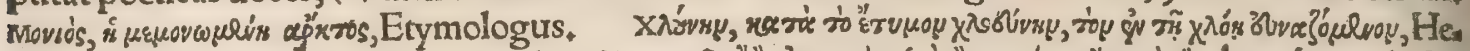

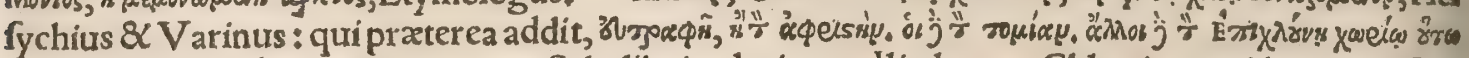

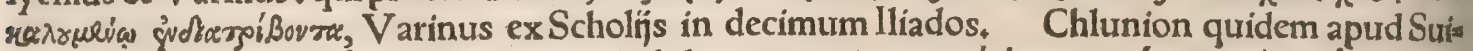

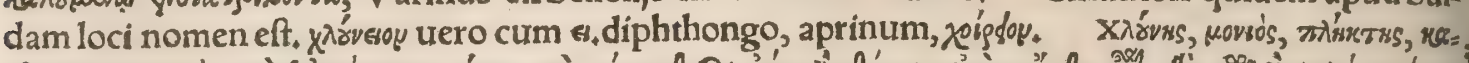

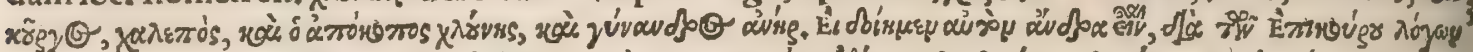

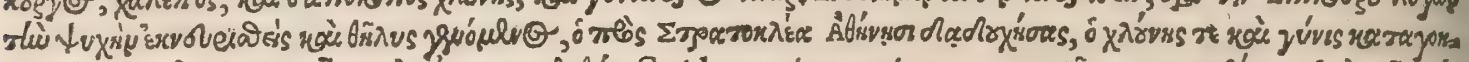

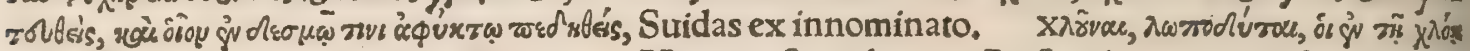
suva ?ókelvor, Idem, Hefychius 8 .V Varinus, Mares caftrati (inquit Ariftoteles) maiores ferocioresćs euadunt, ut fcitè Homerus fingit, cum dicat: Nutrít exectum fyluis horrentibus aprum, Inftar non bruti,fed dorfi montis opaci, Caftrantur, quod recentibus adhuc morbus pruriens incumbitin teftes, quò atterentes eam partem ad arbores, teftes extinguunt. Græci uerfus Homerici hi funt:

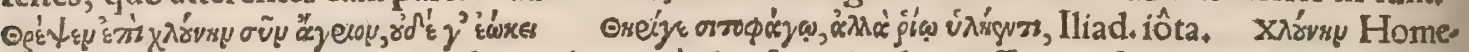

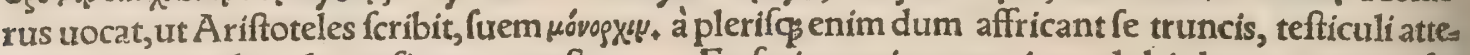
runtur, Plutarchus de canfis nat, quxft, 2I. Ex feris capris mares iam adulti dum uenatores fü

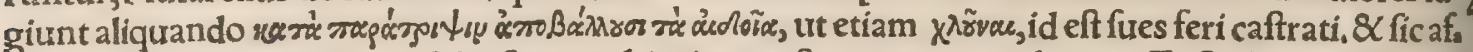
fectos tum apros tum hircos fylueftres multi etiam noftro tempore uiderunt, Euftathius in Homes

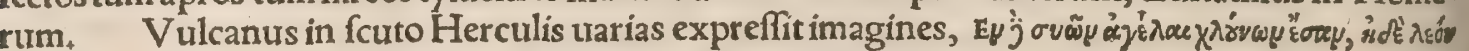
тw, \&c. Hefiodus. बA per ab Italis cinghiale \& cinghiare uocatur, \& porco fyluatico, A Gal lis fanglier, uel porc fanglier, corrupta fcilicet uoce ut Italica etiam à Latina fingulari, qua uoced. Hieronymus utitur in translatione P falmi 80. Aper fylueftris à nonnullis fingularis ferus appella turr, Albertus, nimirum quod folitarius ferè degat, unde $\&$ uovıò recentiores Graci uocitant, aliqui ineptè cingularem fribunt. Hifpanis, puérco filueftre; uel puérco montés, uel iauali. Germanis, wilofकweit. Anglis, bore. Illyrís weprz.

Mirabile in Creta apros non effe, Plinius, A Apri ( fires, Aelianus) in Macedonia muti funt, Idê. Sues Äthi montis ne forminas quidem fpectare mares fitus inferioris audent, Ariftot. Hifpani in quadam parte noui Orbis apros inuenerunt noftris minores, caudis breuiffimis, adeò ut abfciflas fuiffe arbitrarentur : pedibus etiam noftris diffimiles. pofteriores quippe aiũt pedes in his apris uno digito non ungulato conftare, (hoc eft, pofterius folipedes effe, anterius bifulcos $s_{+}$) Carnibus multo quâm noftrorum tum fuatioribus tum falubrioribus. nec mirum cum palmeta propelittus effent, inter qux $\&$ paluftres uluas aprorum multitudo libera uagabatur, ut fcribit Petrus Martyr Oceas nea decadis 1.2. Olaus Magnus in quibufdam Scandinauia locis apros duodecim pedum lon. gitudine reperiri prodidit. In Heluetia multi funt, prafertim in regionibus iuxta alpes fitis. quo niam ex arboribus abundant diuerfis, qux pabula apris fundunt+effentóc plures, nifi fubinde à ple ${ }_{3} 60$ be efriam caperentur, permittente magiftratuñ quorum agris molefti funt. A per nullus eft in $A=$ frica, Ariftoteles $_{2}$ Herodotus, Plinius, A elianus \& Euftathius in Dionyfium In Aegypto(in Nilo) 


\section{DeApro. B. C. Lib. 1.}

infulix permagn coagmentantur, ut $\&$ fures permulti in eis nafcantutr; quos incola tranfeuntès ue nari confueuerunt, Theophrafus 4 . 15. de hift. Suem nec manfuerum nec ferum India habet, te fte Ctefia, quanquã non fide digno, Ariftoteles \& Aelianus, addit Aelianus, fuilli generis ufum In dos à fe deteflari, \& tantopere ab eo uefcendo, quàm ab humanis carnibus abhorrere. quamobrê mí nus mirum eft fues, faltem manfuetos, apud eos non reperiri. Sed huic aliqua ex parte aduerfatur quod apud Plinium legimus, Indicis apris cubitales effe dentium flexus geminos ex roftro: \& toti dem à fronte ceu uituli cornua exire. Lycotas rufticus in Bucolicis Calphurnin, refert fe uidiffe Ro: mæ in fpectaculis, niucos lepores, \& non fine cornibus apros. Agatharfides ait fues in Aethiopia

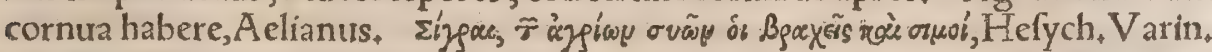

10 Deglandio (qux pars eft apri iuxta ceruicem, uel ipfa ceruíx) \& glandula \& alijs quiburdant partibus apri, dixifupra in Sue F. Vide non nihil etiam infra in F. Apri feré colore funt nigro, uel fpadiceo nigricante. Pilus æreo fimilis agreftibus, cateris niger, Plinius. Sues feros albos fe ui= diffe Paufanias feribit in Arcadicis. Leo \& aper fortiffima animalia, pilum gerunt duriffimum, $A$. riftot.in Phyliog. Sanguis aprorum non fpiffatur,Plin. fibris refertus eft, Ariftot, innati caloris ui nigricans eft $\&$ afper, Plutarch.in cauf.nat. Oculi iracundis fimiles $\&$ apertis palpebris patuli, ut in lupis 8 apris, omnium peffimi, Adamantius, TDe apri dentibus $\&$ cauda, uide quram in Sue B. Ágyiodrs, epttheton apri apud Homerum, quod dentes habeat albos, uel acutos, uel magnos, Varinus. Cum ad terrã procubuit aper, canibus $\&$ multis haftis debellatıs, dentẽ illius infämato anhelitu tantopere ignefcere aiunt, ut fi quis de ceruice fetam detractã $\delta$ ad eiufdẽ etiamnũ fpiran

20 tis dentem admouerit, candens in orbem cötrahatur ac aduratur $¥$ ac fi eo dente canes infecfantes at tigerít, ftatim ignita ueftigia pelli ipforum imprimantur, Gillius ex Oppiani tertio de urenatione. Ea. dem Xenophon feribit in libro de trenatione, \& Pollux his uerbis $¥$ Si dentibus obliquè attingat ca: nes, pilos eorum adurit. quod fi à morte (ftatím) denti eius éxerto pilum admoueris, cótrahetur tan.

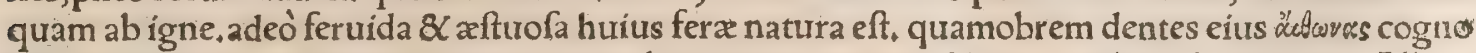
minat Oppianus. Arma dentium apri, culmi (non tamen apud bonos authores) uocantur, Albertus: (à noftris, baw incidunt dum in uituo funt animali, \& ideo magna infligit uulnera. Dentes habet magnos $\$<$ recur tos, ad incidendum aptoșin quibus hoc mirabile eft, quòd uiuente beftia poflunt idem quod ferrü: mortux uero detracti, uim incifionis amififfe probantur, Liber de nat,rerum. Audio exertos apri

so dentes aliquando ita excrefcere, ut circulum fere abfoluant, toti in fe reflexi. In India cubitales den tium flexus gemini ex roftro, Plínius: fed Albertus pro cubitales legit monopedales, quod non pro= bo. Culmos (inquit) in India aper habet monopedales longitudine, cum alibi uix perueniant ad f $e_{\text {s }}$ mipedem:qua longitudine aliquando apud nos inueniuntur. Apri fel non habent,Plinius. $\mathrm{Ha}=$ bent os ad modum fcuti, quod urenabulis 8 machara opponunt, Liber de nat. rerum. A A pud Gallos qui fcirè $8 \times$ uenatoriè de apris loquuntur, propria quadam uocabula ufurpant. nam dentes exertos, tocant armes aut limes, aut defenfes, 8 oppofitos eis fuperiores, quorum ufus tanturm eft ad acuendum exertos, grecz, pectus, le bourbelier.ueftigiñ fitie folum, la fole du pied, excrementa; laifes. Iidem urfi,apri, \& aliarum mordacium beftiarum caput hure nominant.

\section{C.}

40. Ferarum aliæ montanæ ut plurimum funt, ut leones:aliæ paluftres(id eft, circa paludes, )ut fues; Pollux. Scythis \& Sarmatis uenationes funt, intra paludes quidem ceruorum aproruméç, in cam: pis autem onagrorum $\&$ caprearü, Strabo. Lulitra fignificant lamas (lama, aquæ collectio elt, Idem

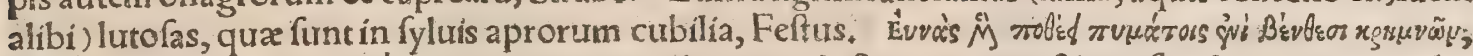

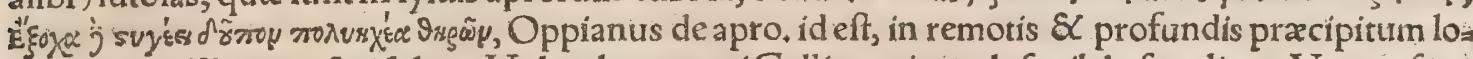
corum receffibus uerfari folet. Volutabrum apri Galli nominant le fueil du fanglier. Vocemfues feræ fimilem manfuetis ædunt: fed foemina uocalior eft, mas raro trocem emittit, Ariftot. Frendet agreftis aper, Author Philomelæ. A per frendens, Ouidius de Arte am. Silius leonem frendentem dixit. Nos aper auditu; lynx uifu, fimiaguftu, Vultur odoratu pracellit, aranea tacfu, Incertus; proprium aprorum generi eft, quod \& porcorum effe dicitur, concitari ad rabiem uno ftridente, $\mathrm{Al}$

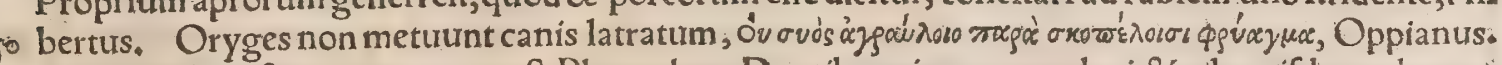
T A per calidæ \& igneæ naturæeft, Plutarchus. Dentibus eius canes aduri, \& pilos eifdem admotos (dum recens interfecta fera adhuc fpirat)contrahi tanquam ab igne, in $B$, dictum eft. Aper cun cras beftias præcedit auditua dextris, Liber denatirerum. - ब A per domefticus magis immoraturir foctidis quàm fylueftris, Albertus. A pri inueniuntur aliquando inter filicum folia, qua ipfi fibi col legerint $\&$ fortefubftrauerint, ut audio. Galli fangliers afouchies uocitant apros; cum fcrobes fo: diunt, \& filicum afparagorumç radices in terra rimantur. Genus quoddam farris, qưo noftrín aqua cocto leguminum modo uefcuntur, acutis $\&$ afperis hordei inftar armatum ariftis, ruftici acco $1 x$ fyluarum in Germania ferunt, quod huic generi minus quàm cæeteris propter acutas ariftas apri noceant, ut annotatit Tragus Tomo 2, hiftorix plantatum cap. 20. Apros in Pamphylia \& Cilicia 6. montuofis, falamandra ab his deuorata, qui edêre moriuntur, nec eft intellectus ullus in odore uel fà pore, Plinius: Videfupra in Sure C. Aper fyluaticus gregatim incedit, nec alios quàm de fua proge nie porcos fecum uef ci patitur, Albertus, Lumbricis fiue inteltinis terra roftro effolfis uefcuntur 
apri, quod Galli dicunt uermeiller. Tidem maniuxes appellant loca ubi fagorum \& quer curm glan: dibus pafcunture. TS Spuma tenax in currentibus equis uel ira percitis apris circa os generatur: in his propter calorem, in illis tum eandem ob caufam, tum propter motus uehementiam, Galenus in aphorifmos Hippocratis 2.43, Suum agreftium lachryma cur dulcis, ceruorum autem falfa 8 improba fit, fcripfi in Ceruo c.ex Plutarchi de caufis naturalibus problemate 20, unde Calius etiam tranftulit 12.5. Ipfi apro tam gratis fua urina eft, ut nifi egefta fuga non fufficiat, ac uelut de. uinctus opprimatur.exuri illa tradunt eos, Plinius* đApri circa Cal. Decembris fubantes fues fectari folent, indéç callum obducere urenabulo quoç refractarium,Budæus. Sues agreftes femel anno coeunt, domeftici fxpe, Ariftoteles: Vide fupra in Sue manfueto c. Sues feræ principio hye. mis coéunt, uere pariunt, petêtes maxime inura, prarupta, angufta, \& opaca. mas cum foeminis con uerfari dies triginta magna ex parte folet. Numerus partus, \& tempus ferendi idem, ató in urbanis fubus eft, Ariftot. Sues fera femel anno gignunt. Maribus in coitu plurima afperitas. Tunc inter fe dimicant, indurantes attritu arborum coftas, lutoḉ fe tergorantes. foeminæ in partu afperiores, $\&$ feréfimiliter in omni genere beftiarum. A pris maribus non nifi anniculis generatio,Plinitus. Tem pore libidinis fues feri acerrime fauiunt, quanquam per id tempus imbecilles ex coitu reddantur. dimicant inter fe mirum in modum armãtes fefe; $\&$ cutem quàm craffiffimam pręparantes, induran tesḉ attritu arborum. fxpe etiam luto obducto, ac reficcato, tergus inuictum contra ictus efficiunt, pugnant adeó acti certamine, grege relicto, ut fæpenumero mortem uterç̧ aduerfarius obeat, Aria ftoteles. Per fyluas tum fruus aper, tum peffimà tígris, Vetgilius in Georg, de uri amoris. Et mox, Ipfe ruit, dentesćs Sabellicus exacuit fusł Et pedibus fubigit terram, fricat arbore coftas: $A_{t=10}$ que hinc atç illinc humeros ad uulnera durat. Ad Veneris libidinem inflammatiffimus eft, cerui. cis fetis fic inhorref cit, ut crift galearum effe uideantur + fpumas fündit ab ore, magno ftridore dena tium concrepat, efferuefcentem fpiritum anhelat, coëundi furore ardet, quod fi formina eum fic libia dine furentem patiêter manet,omnem illius bilem extinxit, \& libidinem fedauit? Sin autem coitum refugit, is coffeftim feruidis ftimulis incitatus, aut ipfam ui expugnatam init, aut mortuam in terram dentibus abj̄cit, Gillius ex Oppiano. Quxex feris mitigentur, non concipere tradunt, ut anferes: apros uérô tardé, \& ceruos:nec nifi ab infantia educatos, In nullo genere æque ( ac in fuillo) fa cilis miftura cum fero:qualiter natos antiqui hybridas uocabant, ceu femiferos, ad homines quog, ut in $\mathrm{C}_{+}$Antonium Ciceronis in confulatu collegam, appellatione translata, Plinius. Themafini Epicadi ex gente Parthica hybridx, Stretonius in A trg. Hybrida quo pacio fit Perfius uitus, opi, z० nor, Horatius 1. Serm. Hybris etiam canis uocatur, qui imparibus parentibus natis eft inquit Por phyrio, hoc eft ex uenatico $\&$ gregario. Inflexionem apparet effe duplicem, nempe hybris hybridis,

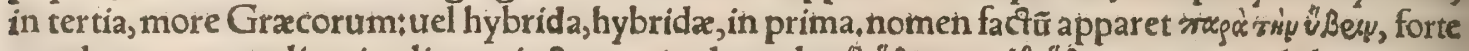

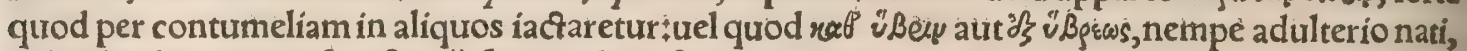
hybrides dicerentur, fiue fpurí, fiue ex diuerfartum gentium parentibus hominesła aut alię ferę, ex pa rentibus feu fpecie feu genere differentibus:fpecie dico, ut fus ex manfueto $\&<$ ferołgenere, ut canis ex cane \& leone, \&c. Cicur fus, ex apro \& fcropha domeftica, Feftus. Nilli dentés exerti, qui bus ferrati:rarò foemin $¥, \mathbb{Q}$ tamen fine ufułita $\not \mathcal{S}$ cum apri percutiant, foeminæ fués mordent.

I Aconitum \& fyanchi radix fues feros occidunt:uide in Sue $c$, ab initio de morbís eorư. Cum per imprudentiam hyof cyamum comederunt, ftatim attrahunt pofteriora, dimiffe ita fefé gerentes, $4^{\circ}$ Deinde licet contracti tamen ad aquas perueniunt, èt ibi collectós cancros epulahtur promptifimé, qui morbi remedium eis praftant, A elianus. Edera apri in morbis fibi medentur, \& cancros ue. fcendo maximé mari eiectos, Plinius. đNec ueró patiendus eft oryx, aut aper, aliúsue quis ferus ultra quadrimatum (in uiuario) renefcere.nam ufo in hoc tempus capiunt incrementa, poftea ma. cefcunt fenecture, quare dum uiridis atas pulchritudinem corporis conferuat ære mutandi funt, Columella,

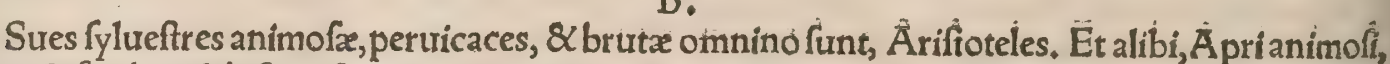

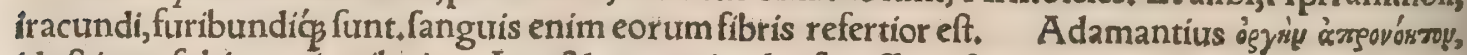
id eft iram fubitam eis tribuit. Leo \& aper animalia fortiffima funt \& pilum gerunt duriffimum, $\varsigma^{\circ}$ Ariftoteles in Phyfiogn. Aper nullius difciplinæ capax eft, femper ferus ac ferox, Liber de nat. rerum. Apri \& Cerui quomodo mufica illecti capiantur, uide in Ceruo E. A pud Varronem 14. legimus in leporario quodam Varronis in Thufculano, ad buccinam inflatam certo tempore $a^{=}$ pros \& capreas conueniffe ad pabulum, Paret purpureis aper capiftris, Martialis libro it,in fpecta. culi cuiufdam defcriptione. Sues feri fapiunt ueftigia palude confundere, urina fugam leurare, Plinius: Vide etiam fuperius in C, de urina, Aper fylueftris hoc proprium habet quod ad pabu= lurm fecum non admittit porcos qui ex eo nati non funt: fed fi iungantur cum eo contendit cum eis; ut obferuaui in apro quem cicuraui, Albertus. Mas tempore libidinis fauit, foemina à partu, ut $\&$ catera ferè omnia animalia, ut in $\mathrm{C}$, dictum eft. Nec enim latêre te debet, (inquit Cyaxares ad Cy: rum libro 4, de inftitutione Cyri apud Xenophontem, )non maiorem tibi effe cupiditatem hoftium 60 uxores atç liberos capiundi, quàm illis feruandi. Cogitandum praterea tibi eft, fues, fimulta etiam fint, fugere, ubi uideãt uenatorem, unà cum natis. Sed ubi quis uenetur quenquam ex earum natis, 
non amplius furgere, ne fi una fit quidem, fed ruere aduer fus capere molientem. Propritim apro rum generi eft, quod $\&$ porcorum effe dicitur, concitari ad rabiem uno fridente: $\&$ tunc pericuio fum eft incidere in gregem eorum, præcipue candida uefte indutum, \& maximé fi foeminælibidine ardeant, (uel potius, fi mares libidine ftimulentur, aut focminæ pepererint,) Albertus, Inter fecon certantes apri,cum uiderint lupos, quafi confoederati fe iuuant mutuo, \& concurrunt ad uocem cla mantis quotquot audierint: \& hoc conurenit multis animalibus, Idem. Lupus quiomodo rapuerit eE uorârit aprum paruum, uide in Lupo D. ex Alberto. A Apridentes acuunt ad luçẵ, Plutarchus Lapidibus dentes exacuunt Homero tefte, Aelianus, Etalibi, A prum priufquam in aliquem inua dit, dentes exacuere ferunt:cui rei teftimonio eft Homerus cum ait, Album acuens dentem. In ar: - boribus exacuunt limantós cornura elephanti, $\&$ faxo rhinocerotes, $\&$ utró̧ apri dentium ficas, Pli nius. Sues feros urfus aggreditur, fi clam repenté́ potuerit agere, Ariftoteles. Vulcanus in f́cú to Herculis uarias expreffit imagines, ut canit Hefiodust $\&$ inter catera apros leonesćs acriter $\$ C$ for titer utrinq $\$$ pugnantes, ita ut neutra pars cederet, $\&$ caderent utrinç mortui, cateri tamen magis ad pugnam excitabantur. đSiuelis ne in te aper graffetur, cancrorum brachia illa denticulata tecum appenfa circunfer, Didymus.

A pri apud nos feré maiorum inftituro, Budxus, nis colore. Cerui $\&$ a priquomodons in uenatione aduer fus apros, equis uti iubet fuluis fitueignis colore. Cerui \& a priquomodo capiantur podagra inftrumento in Ceruo docui ex' Polluce 10 Fouea capitur multitudo aprorum (inquit Petrus Crefcent, 10, 33.) hoc modo. In loco ubi multi uer= fantur apri,agellus conferitur melica, quam aliqui faginam uocant, circa agellum cöftruitur ualida $\&$ alra fapes ex uiminibus arborum $\$ \&$ una in parte relinquitur apertus introitus, è regione fapis depreffax, extra quam fouea fit fatis profunda. Melica iam matura multi apri per locum apertum in = trabunt. Tum uenator accedat quandocũ $\beta$ uolet, etiam inermis: 8 in loco introitus ftando clanet, $\&$ quouis modo tumultum \& ftrepitum excitet. Sic apri perterriti, cum uia euadendi nulla patear, nifi per locum fapis depreffum, inde profiliunt omnes foras, $\&$ in fouream incidunt. Circa Romanos agros $\&$ in fyluis fuburbanis, infidiatores iaculis, noctu, fiue machina ferrea ignicrepitante transfigunt tam capreas, quàm ceruos, urfos $\&$ apros lucente Luna,Blondus. Pifces quidã nigri uenenati in Armenia reperiuntur: horum farina ficus confpergunt, quas in ea loca qua maxime 3- abundant feris, diffeminant. Beftiæ primum ur eas attigerû́, ftatim moriuntur. atçs ea fraude apri, fe ræ capræ, cerui, \& urfi necantur, utpote animalia ficuum \& farinarum auidifima. Aconito, \& $f_{y=}$ ancho dicfo ureneno tum manfueti tum feri fues pereunt, ut dixi in Sue $c$. Apros non folum natu* ra obdurata pelle pilisḉs hirfutis ueftiuit, uerum etiam ipfiluto fe quodammodoloricant, ne telis fa. cile ladi poffint unde euenit aliquando, ut nifi letale uulnus acceperit aper, uenatorem conculcet fi ipfum ferire nequiuerit. At fi foemina fuerit, cum careat dentibus exertis, conculcatum uenatorem proftratumq́g lacerar, Belifarius. Vide plura fupra in $c$. Aper in lanceam feu uenabulum fponte incurrit, \& nifi letaliter uulneretur, uenatorem profternit, nifi in terram humi cadens iaceat, uel ree tro arborem uel fuperius in arborem fe recipiens euadat, quía culmis recur uis furfum tantû fecare, deorfum non poteff, fed iacentem humo conculcat, foemina uero culmos non habens, dentibus la: 40 cerat, Albertus. Sus ferus (ut fribit author libri de nat. rerum) fi mane antequam reddat onus ure ficæ,à uenatoribus petatur, facile fatigatur. Sin autê uel ante, uel in ipfa uenatione reddat urinam; difficilis erit captu. Sed quamuis laffus non cedit; fed in pofterioribus fubfiftic, \& atrocitare rigida laffitudinem diffimulat, duellum offerens uenatori. non ferire tamen nec inuaderefolet homine, niff prius ab eo uulneratus, Caterum uenatori cauendum eft; nam nifi primo ictu letale uulnus inter ar mum \& laterum coltas adegerit, de uita periclitabitur : nifi fortè aut proximam arborem confcendè rit, aut in humiliori loco foli planiciem amplexus totis membris fe premat, non poterit enim fera re. curuis dentibus fuis nifi elatum $\&$ erectum attingere. Suftinebit tamen pedum eius conculcation donec fic iacenti focíj opem ferant, Hac ille. Ipfi apro tam grauis fua urina eft, ut nifi egefta furga non fufficiat, ac uelut deuinctus opprimatur.exuri illa tradunt eos, Plinius. Solet aper quum éfyl so ua egreditur, uentum ab omni parte excipere \& odorari, num quid ei aduerfum feu expectandum fit, quod Galli dicunt prendre le uent de toutes pars. Nempe fues fyluaticos in montibus fectaris uenabulo, aut ceruos, Varro in Afino ad lyram apud Nonium. Eft autem uenabulum telum uena=

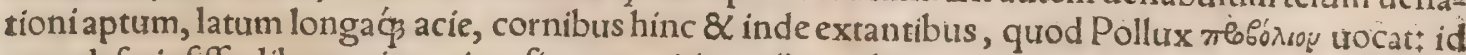
cum defcripfiffer libro quinto circa finem capitis tertij, quale contra cateras fer as qua cominus pute gnant parari oporteret: fequenti mox capite, Aduerfus apros uerò (inquir) circa fínem colli ( $\alpha^{\prime} \lambda \lambda \dot{\gamma}$. fic

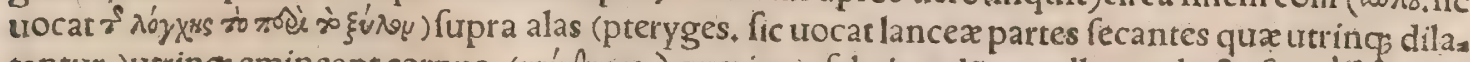
tantur, )utrinq̧emineant cornua, (xv'écburts,) qux inter fabricandũ ex collo producta fint, éferro fó lido: ne dum aper præ íracundia in trenatorem magna ui fertur, per ipfurm haftile ad eum perieniat; red obfaculis illis prohibeatur. Caterumuenabulo hunc in modum utetur uenator: Pedé finiftrum 6o pratendet", dextrum fifter pofterius, eo ferè interuallo quo uriluctantes folent. Latus quod promï net ( finiftrum ) pedem uerfus antrorfum protendat: Manus finiftra medio uenabulo fubijciatur, ut ic่ũ dirigat:dextra uero pofterius contrario fitu uenabulo fortiter apprehenfo içũ quàm ualidifini 


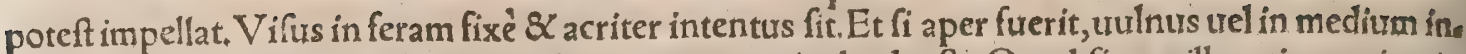
ter fupercilia locum, uel in armum adigat, utrunç enim letale eft, Quod fi maxillas etiam attigerit, efficiet quo minus uti poffit dentibus exertis, Sue infliente, retrocedet $\&$ fimul enfem diftringer. $\|_{*}$ lud catrendum, ne fus uiolento capitis motu, \& uehementi in lanceam impulfu, \& impetu faltus ues nabulum elidat, $\&$ uenatorem comminus inuadat, quo facte, in terram ille pronus incumbat opor tet, $\&$ ad folum fe comprimens ftirpes aut cefpites tenaciter apprehendar: fic enim fito corpori nibil fuis dentibus fera nocere, nec infra ipfum fubïcere poteft. fed ambiens calcat, foemina eriam mor det, Hucufqu Pollux. बCanibus capiuntur apri aclupi, fed cum auxilio uenatorum, nam raro folieos aggredi audent, nifi maftini fortiffimi $\&$ audaces fuerint. Sed procapiendis apris requirun: tur pilifortes(uenabula ualida) circa ferrum prominentibus crucis inftar(hoc eft, tranfuerfis) obfta= in culis, (ea quidam ridiculé nominant, fufficit: quod ferrum eoufqg in corpus adigi fatis fit, cum non poffit ulterius.) Hos uena tores quum aprum uident indignabundum accedere, in terram obfirmãt, \& cum accefferit uulnerant, probibentibus ne in ipfos irruat obftaculis. Paruus interim catuilus ad hoc inftructus per uiam it, \& fic à canibus $\&$ foch̆s uenationis occiditur, Crefcentienfis 10. 29. Ro. bufti canes uenatici tum contra alias feras tum contra apros immittuีtur, ut in Canum hiftoria pro

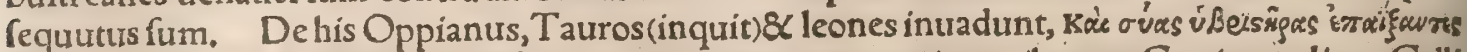
"Drecsou. Aetoli canes celeres \& fagaces, uenantur apros, ut in canibus ex Gratio retuli. Galli fub nomine leporariorum, fuarios etiam lupariosćp canes comprehendunt,Budaus. C Canes mas fini, quos Galli uocant Alans uautrez, id eft Alanos ueltros, ut recentiores aliqui uocant, (ut Fr. $A=$ luñus), capitibus \& auriculis magnis, labris craffis, aduerfus urfos et apros emittũtur. A pri in fyl 10 uis fape dentibus canes occiderunt, V arro. Aper cum exit è cubili uel luftro fuo canibus uifis to cem aduerfus eos emittit, quod Galli dicunt rendreles abbais. TApri \& cerui apud Tyrrhenos cum retibus $\&$ canibus muficæ adiumento capiuntur, ut in Ceruo recitaui ex. Aeliano. IVena tor(inquit Xenophon)in apros canes comparet Indicas, Cretenfés, Locrenfes, Lacanas: fagenas, ia

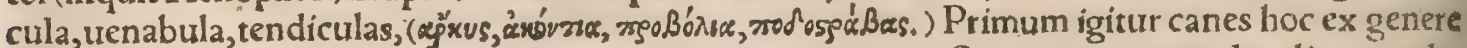
effe oportet, minimé uulgares, ut paratæ fint cum fera pugnare. Sagenas autem eodem lino quo le, porum, (iufferat autem fupra leporum fagenas ex tenuifimolino Phafianouel Carthaginenfi confici, filis nouem) filis quincs $\&$ quadraginta, $\&$ chordulis tribus:ita ut unaquac chordula (rivo) fi-

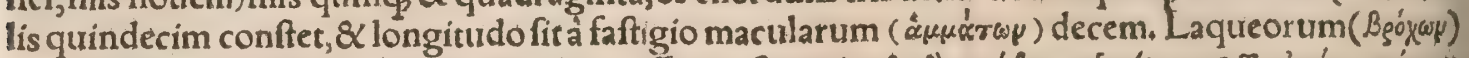

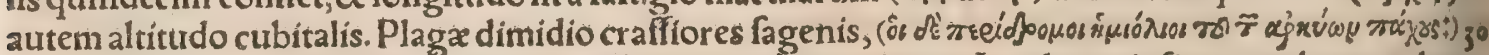
extremás earum per annulos exeant. fufficient uerơ quindecim. Iacula uaria fint, qua lanceas has

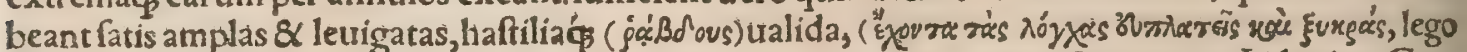
ईv'

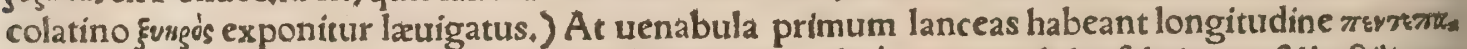

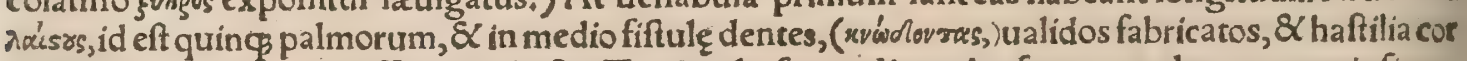
nea(ex corno arbore) craffitudine haftx. Tendicula feu pedicx tales funto, quales pro ceruis fiunt, Sed uenationis comites adfint. fera enim à multis uix capi poteft. Quomodo autem fingulis quibuf cunce uti conueniat, oftendam. Primum igitur cum ad locum uenerint, ubi aprum effe conịciunt, canum gregem fubducere oportet, 8 foluta una ex Lacænis, reprimens alias cum cane circumeat. Cum ueftigia deprehenderint indagando, fequatur deinceps quo tenor duxerit. Sed uenatoribus $4^{\circ}$ eciam multa indicia aprum prodent, in mollibus locis ueftigia, in fyluofis ramorum fragmenta, ubi arbores fuerint dentium uulnera. Canis uerò ut plurimum ad fyluofa indagando perueniet, quod in his locis fera plerunç recumbit, nam hyeme minus frigida funt, minus calida $æ$ frate. Cum ad cubile peruenerit, latrat:ille uerò ut plurimum furgere non folet. Sumat Igitur canem, \& ipfam cum alĭs omnino procul à cubili religet, \& fagenas ad diuortia (öprs, d'vo

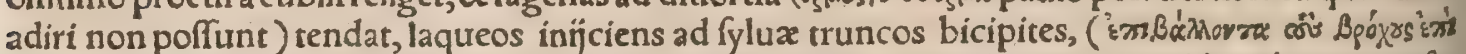

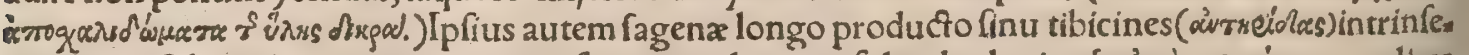

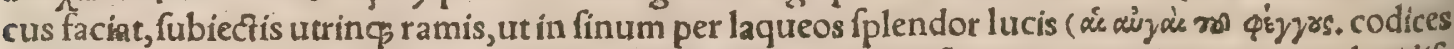
quidam corrupte habent, $\left.\alpha_{c} \alpha_{c}^{u} z \alpha c\right)$ prorfus infiftat, $\&$ accurrenti feræ pars interior perquam lucidif

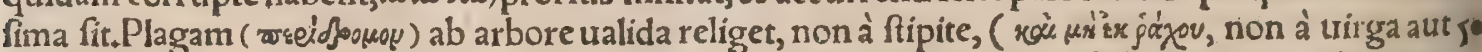
frutice, jayei funt fafciculi lignorum, aut uirgx tamaricis;uel planta fpinofa fępibus apta, [rhamnus

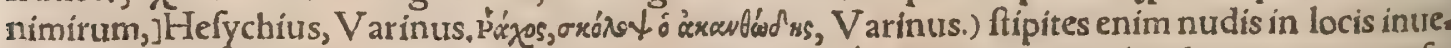

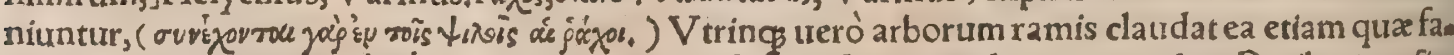

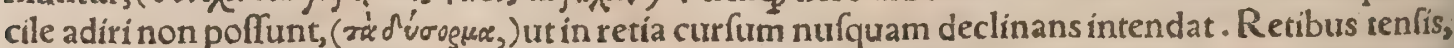
ad canes redeant, omnesḉ foluant, \& iaculis uenabulis óg fumptis procedant. Canes aliquis hortetur qui peritifimus fit, reliqui deinceps ordine fequantur, magnis interuallis alius $\mathrm{ab}$ alio diftantes, ut fe ræ difcur fus laté fatis pateat. Nam fi aper in confertos inciderit, periculum eft ne faucientur, nam in quencunģ irruerit, per iracundiam ladit. Porrò canes cum iam cubili propius fuerint, incítentur $\&$ immittantur à uenatore, excitatus ille confurget, 8 quarcunc canis à fronte fe illi oppofuerit, eam

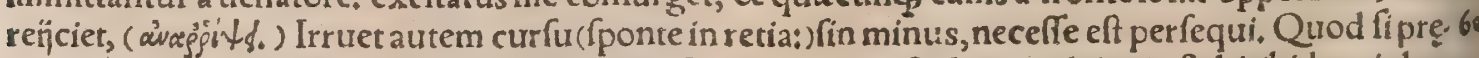
ceps fuerit locus, in quo eum fagenæ detinent, ftatim exurget:fi planus, ab initio ftabit ibidem inhæ: rens:incumbent tum ueró canes, Simul etiam uenatores oportet intêtos in eũ (cauté, ne canes feriẫt) 


\section{DeApro. E. Lib. I. 1045}

tela conjicere, $\&$ circumuenientes à tergo $\&$ eminus lapides mittere, donec retibus fe ingerens pla= gam eorum intenderit. Tum eorum qui adfunt peritiffimus $\&$ robuftiflimus, uenabulo progreffus à fronte percutiat. Quòd fi petitus ífusćs telis, non fatis fe retibus ingefferit, fed in accedentem fe con

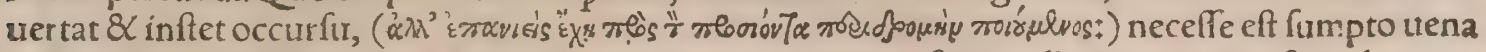
bulo accedere, Id tenendum eft manu læua anterius, dextra pofterius, illa enim dirigit iftum, hæc ur= get 8 impellit. Pedes autem manus fequantur, læuus læuam, dexter dexteram, Itaç accedens uena=

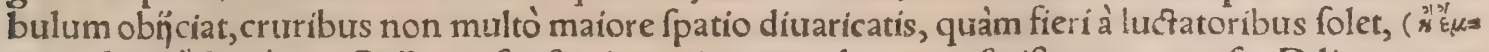

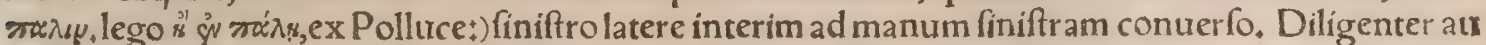
tem feræ oculos infpiciat, capitis illius motum obferuans, $\&$ uenabulum porrigat prouidus, ne aper capite rotato de manibus ei excutiat. Venabulo enim interdum cum impetu elifo in uenatorem pergit. Hoc fi cui contigerit, pronus in ora cadat oportet, 8 uirgulta interiora (

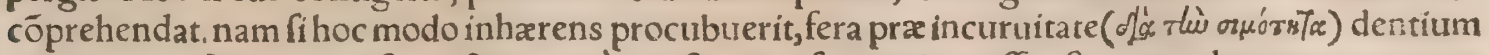
corpus adipifín non poteft, erectum uerò aut ftantem fauciari neceffe eft. quamobrem aper uenato ris corpus attollere tentat q quod fi nequiuerit, obambulans proterit. Huius autem rei liberatio una tantum fupereft : cum in hac anguftia deprebenfus fuerit, tum ex comiubus aliquis cum uenabulo accedens, fuem irritet, immiffuro limilis, non tamen immittet ne iacentem feriat, Hoc aper ubiani. maduerterit, omiffo eo quem premebat, contra irritantem pra ira $\&$ furore contsertitur. Tum ille celeriter exiliat, memor cum uenabulo exurgendum effe; nam nifi uincenti falus honefta non eft. \&

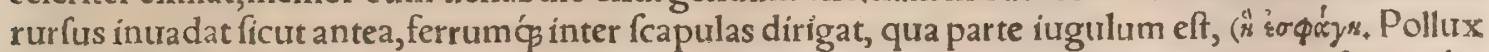
20 uidetur legiffe, $" \mu \varepsilon 6 \varphi_{\rho} v_{0}$, quod placet. hocfenfu, ferrum inter fcapulas, aut medio inter fupercilia loco adigat:) 8 obnixus uenabulo acriter incumbat. Saucius aper furens progreditur, \& nifi lance dentalia ( $x v^{\prime} \omega^{\prime} b v / \xi s$ ) prohiberent, per haftile fe trudens ad e!rm ueniret qui uenabulum tener. Eft enim fera adeò feruida, ut canũ pilos quos dentibus forte perftrinxerit, amburat; \& pili recens occifi den. tibus admoti contrahantur, (ut in B. diximus, ) Caterum fi formina in retia inciderit, cauebit uenator ne impulfus cadat:quod fi contigerit, proteratur neceffe eft ac mordeatur. Non eft igitur fponte ca= dendum, fi quis uerò inuitus ceciderit, ei non aliter furgendũ eft quàm fub mafculo. Cum uerò furs rexit, uenabulo percutiat oporet, quoad eam occiderit. Porrò capiuntur hoc etiam modo: Retia illis

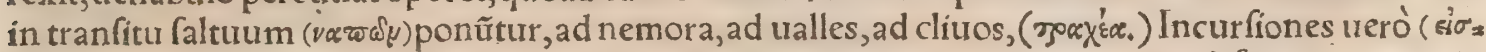
Corai, uenatorum fcilicet in hac loca cum tumultu irruentium, ut fuem excitent, ) fiunt in agros, in $3 \circ$ paludes, in aquas. Qui iuffus eft, retia cum uenabulo feruat, alị canes agunt, optima quar locorum fcrutantes: \& cumprimum inuentus fuerit, agitatur. Vbi iam in caffes inciderit, retium cuftos acce= dat fumpto uenabulo, \& utatur quemadmodum diximus. fi non inciderit, infequi oportet. Capitur etiam dum medio aftu premitur canibus. Nam licet uíribus prafter, pra nimio tamen anhelitu fatif cit.Pereunt autem multæ in eiufmodi uenatione canes: quinetiam uenatores ipfi periclitantur. Cæ terum ubi curfu fatigatum petere coguntur, fiue in aqua, fiue in rupis feceffu fuerit, fite ex opaco exire noluerit; ubi nec rete illum, nec aliud quicquam prohibet cominus cum appropinquantecon= gredi: nihilominus adire oportet, ut magnitudo animi cuius gratia hi labores fufcipiưtur, declaretur. Vtendum eft aût uenabulo, \& corpore ita compolito, ut dictũ eft nam ita etiamfí quid aduerfi accide

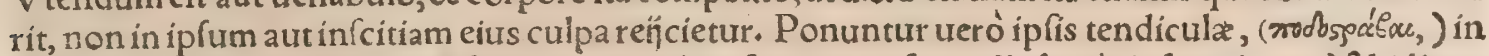

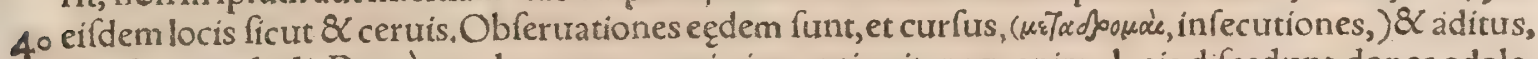
$\&$ ufus uenabuli. Porrò catulos earum capi uix contingit. neq enim ab eis difcedunt, donec adole. uerint, \& cum eos canes inuenerint, uel aliquid ipfi præfenferint, ftatim fe abdunt in fyluas, \& $f_{e}$ quuntur eos ubicunç fuerint parentes utriq̧ ; quo tempore fatiores funt, \& pro illis acrius quàm pro feipfis pugnant: Hac omnia Xenophon in libro de uenatione, ex OmniboniLeoniceni inter* pretatione per nos emendata. बGermani circa aprorum uenationem propria quxdam uocabu= la 8 locutiones proprias habent; ut funt, 62 an mabt ein bag. binder feiler an. fellt garn vĩ weers

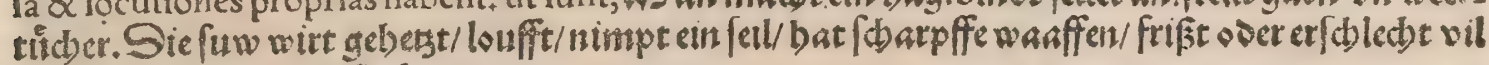
bün oser lititwirt geftodent.

đViuaria aprorum cæterorumós fylueftrum, primus togatigeneris inuenit Fuluius Hirpinus, go qui in Tarquinienfi feras pafcere inftituit, nec diu imitatores defuêre L. Lucullus \& Q. Hortenfius, Plinius, In leporario pater tuus Axi praterquam lepufculum è uenatione uidit nunquam, neç enim erat magnum id feptum, quod nunc ut habeant multos apros ac capras, (capreas, ) complura iugera macerị̧s concludunt. Non tum(inquit) cum emifti fundum Thufculanum à M. Pifone in le: porario apri fuerunt multi, Varro. Et alibi, Leporarï fpecies dua funt, in altera eft aper, caprea, le= pustin altera apes, coclea, glires. Et rurfus, Apros quidẽ habere poffe in leporario, nec magno ne. gotio tibi eft, captiuos, \& cicures qui ibi nati fint, \& pingues folere fieri, fcis inquam Axi. Nam quem tundum (in fundo, quem) in Thufculano emit hic Varro à M. Pifone, uidifti ad buccinam inflatam certo tempore apros \& capreas conuenire ad pabulum, cum è fuperiore loco è palxetra effundere: tur apris glans, \&c.ut in Lepore fcripfi. बा Extar Gordiani fylua memorabilis picta in domo roftra 60 ta Cn. Pompen̈, in qua picła etiam nunc continentur, apri i 50. ibices 100. $8 \mathrm{c}$; haxc autem omnia po pulo rapienda conceflit die muneris quod fextum adebat, Capitolinus in Gordiano \%.

I Plutarchus in Commentario de caufis naturalibus, uerfum hunc ceu prouerbio iaçatî́ citat, 


\section{6}

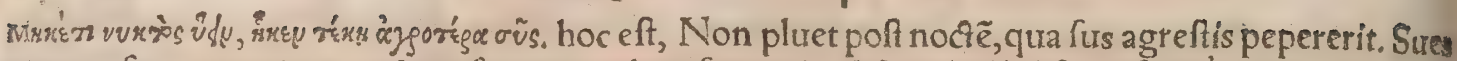

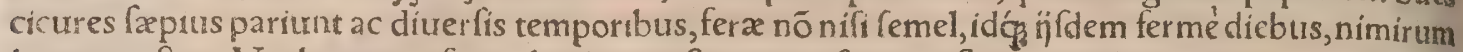
ineunte $æ$ ftate. Vnde negant fore pluxuam pofteaquam fus agreftis pepererit, nimirum exactis iam menfibus pluuins. Periocum ufurpari poterit, fi dicamus, res fore tranquilisores pofteaquam moro fus ac rixofus quifpiam animo fuo morem geffit, Erafmus.

Suís caro uifcofa eft \& frigida, \& maximé cum uicinior eft lactiłferi tamẽ minus quàm manfueti. Caro porci tum feri tum cicuris, facile concoquitur \& cito defcendit, multũ nutrit, et fuccum gignit craffum ac uifcofum, Aucenna. Plura leges in Sue F.non procul initio ex Galęno \& alijs. Caro aprina leuís concoctionis, melioró̧ domeftica:item ualentiffimi generis $\&$ plurimi alimêri, authore Celfo. Hippocrates ait, Caro fuis fyluatici ficcat, corroborat, $\&$ mouet. of Primus Romanorum P.Serulius Rullus, pater eius Rulli, qui confulatu Ciceronis legem agrariam promulgauit, a prum folidum epulis appofuit, (ut mox ex Plinio recitabo. ) Ad quod refpiciens Iuuenalis, \& fua notans tempora, exclamat:Quanta eft gula, qua fibi totos Ponit apros, anímal propter conuiuia natum, Grapaldus. Num pluris nunc tu e ullla illic natos uerres lanio uendis, quàm hîc apros milliarios (alin miliarios fcribunt per l. fimplex)emis? Varro. Apri milliarij dicebantur mille librarum, quos rolebant in conis apponere Romani, Ge. Alexandrinus \& Crinitus. Apud Athenæum aper Dis pnofophiftis apponitur. Menfæapud Indos imponuntur integri leones, \& caprex, \& apri, Philo= Itratus lib.2. Rancidum aprum antiquilaudabant, non quia nafus Illis nullus erat. fed credo, hac mente, quod hofpes Tardius adueniens, uitiatum commodius, quàm Integrum edax domi=10 nus confumeret, Horatius 2. Serm. Rancorem grammatici odoris grauitatem interpretantur, quæ ex uetuftate ac corruptione nafcitur $+\&$ rancidum, quod rancore putidum eft.

THis addemus qux de apri apparatu Apicius fcripfit ab inirio libri octaui, his urerbis. Aper ita conditur $\div$ Spongiatur, \& fic afpergitur ei fal,cuminum trirum \& \& fic manet. Alia die mitritur in fur num:cum coctus furerit, perfunditur piper tritum . Condimentum aprinum:Mel, liquamen, care num \& paffum. Aliter in aprum: Aqua marina cum ramulis lauri aprum elixas quoufoc made: fcat, (id eft mollefcat, tenerefcat, \& coquatur:) corium ei tolles: cum fale, finape, aceto inferes. Aliter in apro: Teres piper, ligufticum, origanum, baccas myrthæe exenteratas, coriandrum, cepas: fuffun des mel, uinum, liquamen, oleum modic + calefacies, amylo obligas, a prum in furno cocrum perfun= des. Hoc \& in omne genus carnis ferina facies. In aprum aflum iura feruentia facies fic: Piper, 3 cuminum frictũ, apị femen, mentham, thymum, fatureiam, cnici(aliâs anethi) flores, nucleos toltos, amygdala tofta tiałPiper, ligufticum, ap p̈ femen, mentham, thymum, nucleos toftos modice., Cum ius fimplex bullierit, tunc trituræ globum mittes: $\&$ agitas cepa \& rutæ fafciculo. Si uolueris pingue ius facere, obligas ius albo ouorum liquido, moues paulatim, afpergis piper tritum, 8 inferes. Ius in aprum elixum:Piper, ligufticum, cuminum, filphium, origanum, nucleos, caz ryotam‡mel, finape, acetum, liquamen \& oleum. Ius frigidum in aprum elixum:Piper, careum, li= gufticum, coriandri femen frictum, anethi femen, apï femen, thymum, origanum, cepullam, mel, ace tum, finape,liquamen, oleum. Aliter ius frigidum in aprum elixum:Piper, ligufticum, cuminum, anethi femen, thymum, origanum, filphium medicum, er urcæ femẽ plufculum:fuffundes merñ: con: 4 dimenta uiridia modica, cepam, pontica, uel amygdala fricta, dactylum, mel, acetum, merum modi= cum:coloras defruto:liquamen,oleum. Aliter in apro: Teres piper, ligufticum, origanum, apï femen, laferis radicem, cuminum, forniculi femen, rutam:liquame $\tilde{e}$, uinum, paffum : facies ut feruear: cum ferbuerit, amylo obligas intro foras, $\&$ inferes, Perna aprina ita impletur recens: Per articua lum pernx palum mittes, ita ut cutem à carne fepares, ut poffit códimentum accipere per cornulum, ut uniuerfa impleatur. Teres piper, baccam lauri, rutam; fi uolueris, la fer adïcies, liquamen optimû, carænum, \& olei uiridis guttas. Cum impleta fuerit, conftringitur illa pars quæ impleta eft ex lino: $\&$ mitritur in zymam, elixatur in aqua marina cum lauri turionibus $\&$ anerho, Hucufos A picitus 8 . 1. \& rurfus 7.4. Ofella aprugnex (inquit) ex oleo, liquamine coquuntur, \& mittitur eis condimen: turm. Cum cocix fuerint, fupera dijcitur his, cum in foco funt, conditura, Piper tritum: condimẽtum, mel, liquamen, amylum: $\&$ denuo bulliunt ${ }_{+}^{+}$cum iam bullierunt, fine liquamine $\&$ oleo, elixas $\&$ fic cas, pipere afperfo inferes.

T Antequam piper reperiretur myrti bacca illam obtinebat uicem, quodam etiam generofi obfo.

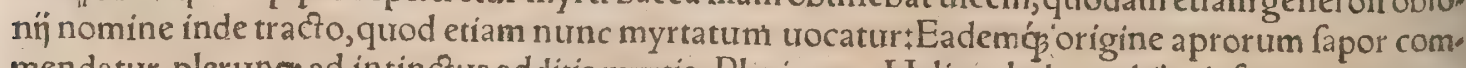
mendatur, plerunq̧ ad intinctus additis myrtis, Plinius. Heliogabalus exhibuit fumina aprugna per dies decem tricena quotidie cum fuis bulbis, Lampridius. Placuêre \& feri fues. Iam Catonis cen foris orationes aprinum exprobrant callum, in tres tamen partes diuifo, media ponebatur lumbus aprugnus appellata. Solidum aprum Romanorum primus in epulis appofuit $P$. Seruilius $R$ ullus, $p a$ ter eius Rulli, qui Ciceronis confulatu legem agrariam promulgauit. Tam propinqua origo nunc quotidianæe rei eft. Et hoc annales notarunt, horum fcilicet ad emendationem morum : quibus no=60 tata quidem cœna, fed in principio, bini ternićp pariter mandantur (aliâs, mandebantur ) apri, Pli, nius. Callum aprugnum $\&$ porcus Troianus fumptuaria lege prohibebantur, Volaterranus ex 


\section{DeApro. G. Lib. I. I047}

Macrobio. Magis calleo quàm aprugnum callum callet, feftiue quidam apud Plautum lưdens ho. monymia huius dictionis calleo, qux \& fcire, $\&$ callofum elte fignificat. Quo die Lentulus flames Martialis inauguratus eft, in cœna fueruntlumbi aprugni, fumina, finciput aprugnum, Macrobius,

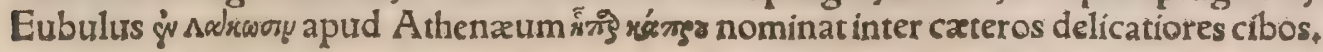

G.

Millia remediorum ex capra demonftrantur dem ratio circa remedia ex fure manfueto $\&$ fero fuerit, nec non alịs omnibus manfuetis $\&$ feris; uídelicet ut îjdem aut fimiles utrorum $\$$ effectus fint, recundum magis $\&$ minus tantum differentes. quoniam animantium ferarum partes exdem minus humidx minusç̧ frigidæ, îfdem ex manfuetis 10 animantibus funt. A prosf fui cicuri communia remedia in alliquot eorum partibus, nempe fana guine, cerebro, maxillis, pulmone, iccore, fëlle, talis, ungulis, fimo \& urina, in Stre iam recitata nó eft quod hîc repetamus, A pri cerebrum contra ferpentes laudatur cum fanguine, Plinius, Et alíbi, - Vetendorum carbunculis cerebrum apri fanguisç̧ fuccurrit. Vide in fanguine fuis $\dot{G}$. Axungia praftantior eft in apris, ut in Sue G, ex Plinio retuli, Lardum apri elixum ato circumligatim mi. ra celeritate folidat fracta, Plinius ut citat Obfcurus quidam. Adeps apri cum mellerefina óp cỗtra ferpentes laudatur, Pliniuss. Cum adipe pulmo aprinus impofitus, fi pedes fubtriti fint contufíte of fenfione, prodelt, Idem. A pri \& equi adipes quomodo curentur in Tauro dixi ex Diofcoride* quanquam eius interpretes horum animaliũ nomina omittunt. Epinyctidas adipe aprino cum ro: faceo inungi prodeft,Plinius. đA pri cerebrum cótra ferpentes laudatur cum fangurine, Pliníus.

10 Apri cerebrum ad ferpentium morfum ualet, Sextus. Verendorum carbunculis cerebrum apri fanguiş̧́ fuccurrit, Plinius, Ad carbunculos $\&$ dolores ueretri: A pri cerebrũ coctum contritum ex melle, \& impofitum, mirè fanat, Sextus, Cerebrum apri cocfum $\&$ potatum cum uino, onnes dolores fedat, Idem. Plura de remedijs ex cerebro, in Sue diça funt, TCinis maxillarum apri fanat ulcera quæ ferpunt:Idem quoç confert fractis, Plinius, Vide in Sure, TDentis fume fcobes diram pleuritida foluent, Nec quatiet pectus tuffis anhela tuum, Io. Vrfinus. Potus in pleuritia de expertus: Exhibeatur femilibra, fi grauior morbus eft: fin minus, uncia duntaxat una aut altera oleilinini puri, calidi, cum fcobe dentis aprini, quanta fuper Marcellinum numum exaggerari po: tef, Io, Kufnerus. THoedi, agni, dorci, apri, cerui, \&c, coagula fimiles naturas fortiuntur, contia aconiti potum in uino, $\mathbb{Q}$ concretum lac in aceto, conuenienter alfumuntur, Diofcorides.

$5^{\circ}$ pulmonem cum melle commixtum, ut malagma fuperpone pedibus à calciamentis lafis \& exulcera tis, fanabuntur, Sextus, Diofcorides alios quoç pulmones, fuillum, agninum, urfinum ad idem re: medium commendat, nempe quod impofitis eis excitandx in pedibus calceorum attrifu inflamma tiones arceantur. Cum adipe pulmo apri impofitus, fi pedes fubtriti fint contufiú offenflone (uel ctiam ad perniones, ut ulíf citant, ) prodef, Plinius, Ebrietatem arcer, Vide in Sute. Glecur apri

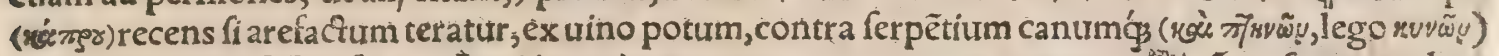
morfus auxilio eft, Diofcor. À pri iecur intreteratum cum ruta potum ex uiño, cótra ferpenies lau datur, Plinius. Iecoris apri fibra, illa potiffimum qua prope fel $\&$ iecoris portas eft, ex aceto urel po: tius uino pota contra ferpentes auxiliatur, Nicander. Lethargicos excitat iecur aprinum $\div$ itaç $\&$ ueternolis datur, Plinitus. Apri iecur auribus purulentis inftillatũ proficit, Sextus. Aluum fiftic 40 iecur aprinum ex uino potum citra falem, recens क́ , Plinius : recens ex uino potatü, uentris fluxum mirêreftringit, Sexturs. In iecore apri inueniuntur lapilli, ficuti in ưulgari fue, aut duritie lapillis fimiles, candidi, quibus contritis $\&$ in uino potis, calculos pelli aiunt, Plinius. Plura de remedís ex iecore apri leges in Sue. $\quad$ Strumas difcutit fel aprinum uel bubulum tepidum illitum, Plinius. fed Marcellus empiricus pro aprino caprinum legit, his uerbis; Fel bubulum uel caprinum ad incia pientes ftrumas optimè facere experimenta docuerunt.nam penitus crefcerè non finentur, fi co ad: fiduè tangantur. Vlcera quæ ferpunt fanat fel aprinum cum refina 8 cerufa, Plinius. Fel aprug= num $\&$ oleum amygdalinum pari menfura permifce, tepidum'́́ laboranti auriculæ inftilla, Marcel lus، Lienẽ quoç fedat potum, ut quidam ex Plinio círant. Coitus ftimulat fel aprinum illitum, Plinius. Fel apri cum feuro quolibet pofitum,optimé placat podagram in prafens, Marceilus, In - Sue etiam nónulla de remedís ex felle apri diximus. G Comitiali morbo teftes urfinos edifle pros deft, trel a prinos bibiffe ex lacte equino, aut ex aqua, dantur \& fữ teficuli, inueterati tritió̧ ex fuís lacie pracedente uini abftinentia, SC fequente continuis diebus, Plinius, Ad caducos: Tefticulos apri ex uino uel aqua potato, 8 curaberis, Sextus. Remedia ex uefica requires inferius in lotio. बRemedia ex talis apri, uide in Sue. đVngularum aprugnarum exuftarũ cinis potioni infper:. fus, plurimum urinæ difficultates iuruat, Marcellus. Vngues aprugni exufti tritiç in potione fum: pti, efficaciter fubmeiulis profunt, Idem. Ad inuoluntarium urinæexitum in fratis: A pricuel fuis, Plin.) ungulas uftas ex uino potui dato, Galenus Euporif. 3.257 . Vide plura in Sue. ff Fimum ruis fylueltris aridum, in a qua aut uino potum, reiectiones fanguinis fiftir. uetuftum lateris dolorem mulcet.ad rupta $\&$ conuulfa ex aceto bibitur. Iuxatis cum cerato rofaceo medetur, Diofcorides : ex 6. quo partem etiam Auicenna tranferipfit. Fimi aprini uim ad membra fpafmo uel percuffu uitiata aut quadrigis agẽdis rotaue uulnerata, foris illiti, tum in poru fumptiad ruptos, uulneratos $\$$ cuct Ios, expolui in Sue G. Fimus apri recens, \& calidus, pracipuum eft remedium contra fluxum fath 


\section{IO 48}

\section{De Quadrupedibus.}

guinis è naribus, Liber de nat.rertrm. Stercus aprugnum ex uino fubactum, \&cemplaftri more im pofitum, quicquid inhæefer it corporiceleriter extrahit \& fanat, Marcellus. Et alibi, Tufum cribra. tumć, \&L cum melie deteriore coctum \& fubaçum, articulis impofitum medetur. VIcera cætera

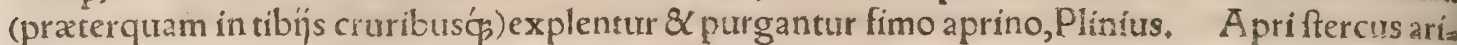
dum contritum $\&$ potioni infperfum dolores lateris fanat mira potentia, Marcellus. Et alibi, Siccif contritum ex uino potui datum, pulchrènon folum fplenis, fed 8 renum dolori medetur. L Luma bortum dolores $\&$ quæcunç a lia mollire opus fit, cinerem aprini fimi inueterati afpergi potione uind conuenit,"Plinitus. Luxatis recens fimum apri, illinitur, Idem. Stercus agreftis apri $\&$ fulphur colatum, $\&($ ex $)$ hemina uini picati potata, coxendices emendat, Sextus, Fimus aprugnus uino remiffus tepefactus colatusq́ą, $\&$ duorum cyathorum menfura potui datus, ifchiadicis faluberrimé medetur, Marcellus. In aceto decoçus, \& cum melle fubacius, impofinuś́, plantis uel talis, miti= gat eorum dolores, Idem. Aprini fimi cinis infperfus potioni tepidi uini dyfentericis medecur, Pli. nius ut quidam citant. Reliqua de remedís ex fimo apri, quares in Sue.

TRemedia ex uefica 8 lotio apri, tum fimul, tum feorfim. Ad caducos; Lotium apri cum oxy. melite bíbat, $\&$ remedium capiet, Plinius. Comitiali morbo prodeft aprinam urinambibiffe ex aceto mulfo, efficacius que inaruerit in uefica fua, Plinius, (Idem alibi de fibri urina fcribit,adferuari eam optimé in uefica fua.) Aurium dolori \& uirị̄s medetur urina apri in uitro feruata, Pinin. Ad aurres minus audiêtes: Aprilotium in uitrec repofitum tepefactum auribus inffillatum perfećtéme. detur,Sextus. Vrina apri feruatur in uitro, fed melius in uefica ipfius, quo(qua)modo ei fublata fuerit.hæc tepens infufa auribus (dolentibus puto \& purulentis) unicè prodeft,Marcellus. . Apri 20 lotium infufum auriculçualde medetur:quod quia uetuftum magis prodeft, collecium feruari debet in uafe uitreo, ut fit ad remedia praparatum, Idem. Et alibi, Apri lotium in fumo ficcatum, \& melle liquefactum auri infunditur, \& remediat furdiginem uel dolorem. Porri fectiui fuccum, \& lon. tium apri, $\&$ oleum cyprinum pari pondere cóiunges, $\mathcal{Q}$ tepefaçum auribus inftillabis, Marcellus. A prina urína uíribus eifdem prædita eft ( proxime autem dixerat taurinam cum myrrha inftillatam aurium dolores lenire) priuatim comminuit ueficæ calculos, $\alpha$ potu expellit,Diofcorides. Vrinx incontinentiam cohibet uefica aprina, fi affa mandatur, Plinius $\&<$ Sextus. Veficam affam (addia. derim apriłaut uerris, nam $\&$ uerris ueficæ eandem uim tribuit Marcelluss)efui dato per triduũ mina gentibus in ftragulis, Galenus Euporifton 3.176. Qui urinam tenere non poterit capræuefican comburat, \& cinerem eius ex aqua cum uini potione bibat. Marcellus + ego non capr 2 , fed aprí lege= 3 xim.quoniam cæteri etiam authores apri urinæ hanc facultatem attributunt, caprinæ nullus quod fciam. Veficæx calculorumó́ cruciatibus auxiliatur urina apri, \& ipfa uefica pro cibo funıpta: Effis cacius, fi prius fumo maceratur utrunģ. Veficam clixam mandi oportet, $\&$ à muliere foeminæ fuis, Plinius. Veffica apri recté aduerfum uefficæ dolores in cibo fumitur, ita ut mulier foemina, uir mafculi fumat, Marcellus. Ad ftranguriam \& ueficæ dolorem: Vefica apri cum lotio infufo fi fur fpenfa \& paffa fuerit donec aquaticus humor effluat, \& difcocłam dederis mãducare his qui patiun zur, miré fanantur, Sextus. Verris fyluatici lotium cum fua ueflica in fumo furpenfum \& adferuaa tum, firanguriofis cum potione mixtum potui datum, efficaciffimè prodeft, Marcellus. Hydropi= cis auxiliatur a pri urina, uel etiam uefica, paulatim in potu data, Plinitrs ut quidam citant. Vide etiam in Sue deremedins ex urina apri.

T Ad uomitum \& fomnum:Spuma apricum adipe in heminis tribus ad tertias excocta \& data Tanabit, Sextus,

TQ Quandoquidem uerò $\&$ in uenationibus à fylueftribus fuibus læduntur quidam, operapres tium ẹt $\mathcal{Q}$ de his facere mentionem. Vulnera itaq̧ ab ipfis incuffa gratria funt, propterea quiod non folum profunda, fed $\&$ magna exiftant. Adglutinatorio autem medicationis ductu ea curare impofs fibile eft. Nam unà cum contufione labia uulnerum difcindunt, $\&$ adurunt. Mutuo enim dentüum inter fe attritu, ac ueluti ad cotem affriçu utuntur, ad uindicfam eorum qui eis obueniunt currêres. Adufta itaç corpora cruftam quandam iuxra uulneruml labia inducunt. Quare fuppuratorium 86 non adglutinatorium curationis modum in eis adhibere cportet, Aëtius 13.4. Vlceribus rheus maticis, id eft fluidis non calida fed frigida tam æftate quam hyeme adhiberi debet. Facile enim inter so uenandũ equus ab apro interno poplitis finu, aut interiori crure uulnus accipit. quod in ulcus rheu maticum degener at, ac tumor fequitur, huic frigida adhibenda eft, $\&$ curatio inftituenda inungendo medicamentum quod atramento futorio conftar, diachalcanthes uocant. Aut canis caput exempta

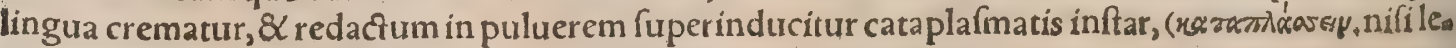

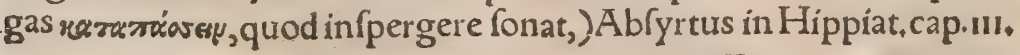

H.

a. Aper dicitur quod in afperis locis, fenticetis $\&$ montibus intonfis uerfatur, ut refert Varro lia bro quarto de lingua Lat. nifià Græcis quod hi róxtroo . Sed forte à dentium eriam aut animi afperi. tate fic dici potuit. A pris maribus, inquit Plinius, in coitu afperitas plurima. Ego tamen à Græeca troce capros potius per aphærefin primæl literæe fic dictum reor. A per à ferocitate uocatus eft: $\mathrm{ab}$. 60 lata f.litera \& $\mathrm{p}$ p.fubrogata. unde $\&$ apud Græcos fragros (lego, fyagros) id eft fertus, dicitur. omne enim quod ferum eft \& immite, abufiue agrefte uocamus, Ifidorus. Setiger epitheton, à Marriali 


\section{DeApro. H.a. Lib. I.}

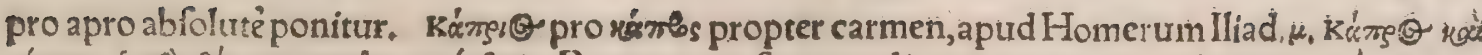

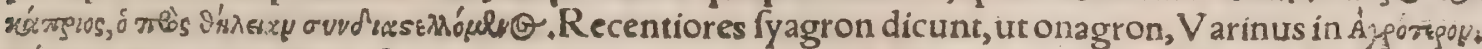

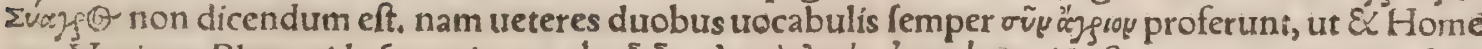
rus, Varinus. Plura uide fupra in A. Ép ois ñy «

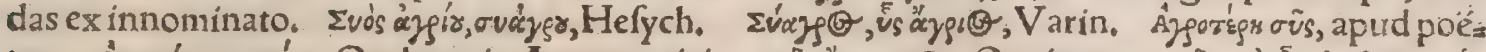

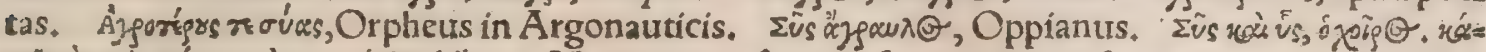

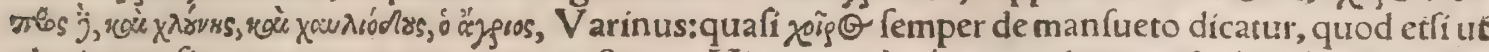

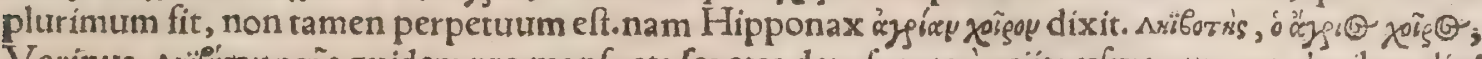
Varinus, Axibb́trega oũs quidem pro manfueta legetes depafcente à poéta ufurpatur, ut pluribus dixi 10 in Sue E. Agriophiros (lego agriochiros, )id eft porcus fylueftris, Syluaticus. Sic \& delphax cum plerung \& $\&$ propriè de fue manfueto dicatur, Anaxilas tamen poéta de fylueftri dixit, his uerbis: $T \Varangle \dot{s}$

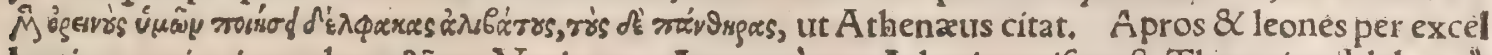
lentiam antiqui urocabant $\$ \tilde{\mu} \rho \alpha s$, Varinus. A prum à quo Adonis occifus eft; Theocritus Idyl. 19. *: ซ๊ \& \& Anga nominat. Movıós, fus ferus, qui folitarius eft, \& non degit gregatim. Diutus Cyrillus in proz phetam Ofeam feribens, afinum interpretatur, aliqui magnam feram, quę propter ferociam (15) ámó. voseep) (olitaria pafcatur, Hefych, \& V arinus. Sunt qui monolycum interpretantur, \&c. Caliusłuide

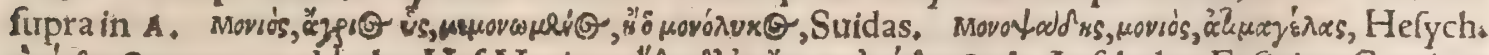

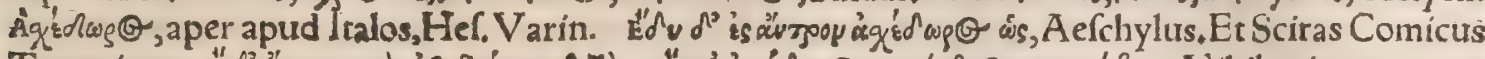

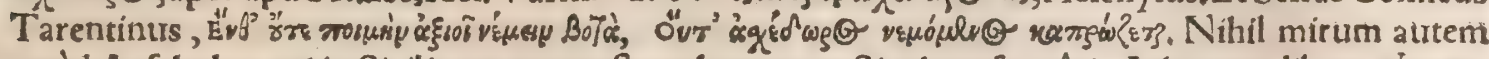
20 quòd A efchylus qui in Sicilia moratus eft, multas uoces Siculas ufurpârit, A thenæus lib.q. $K_{\varepsilon}^{\top} \lambda r(G)$,

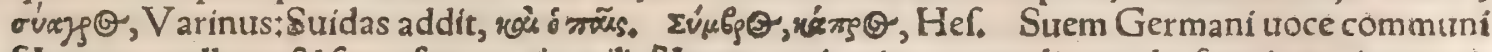
fbwyn appellant: $8<$ fuem ferum, cin wils /owyn : priuatim tamen aliquando foeminam ita nomis

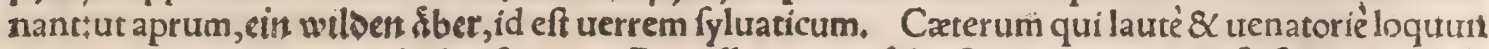
tur propria quadam tocabula ufurpant, Porcellum enim fylueftrem uocitant ein frifoling. (Hel= uetij quidam ueruecen ita nominant. ) iam bimum, cin becter, adultum aut uetulum, etn bonens fowyn, hoc eft fuem fecantem, quòd grandes gerat dentium ficas ad fecandum aptas.Scrophã fy]* - ueftrem, fiure porcorum fylueftrium matrem, ein leen ober bad.

Epitheta, quorum ea qua fine authoris nomine funt, apud Textorem inuenimus. Acer, Ver= gil.A eg. 10. Agreftis. Arcas. Arcadius. Atalantzus. Conturbator, Martialis, Cruentus, 3o Claudianus. Dentatus, Durus, Properc.lib.2. Erymanthaus uel Erymanthius. Ferox. Feruidus, Ferus, Fortis, Frendens, Ouid.ı, de Arte. Fulmineus, Statius 2, Achil. Fulmineófpu mantis aprifum dente perempta, Martialias de cane Lydia, Fuluus, Horatius 2. de Arte, Furens, Glandilegus. Thufea glandis aper populator, \& ilice multa Impiger, A erola fama fecunda fera, Martial. Hirfutus. Hirtus, Ouidius 1. de Arte. Horridus, Hifpidus, Seneca in Agam. Mr: nalius, Marfus, Meleagraus, Minax, Nemoriuagus, Catullus in Aty. Quadrupes, Den= tesọ́ Sabellícus exacuitfus, Verg.in Ge. Sxúlens, Sæuus, Verg.z.Georg. Sanguineus. Quí Diomedeis metuendus fetiger agris, Martialis. Vulnera feciffent, nifi fetiger inter opacas Nec iaculis iffet, nec equo loca peruia fyluas, Otrid, 8. Metamorph. Setofus, Vergil.7. Aegl. Spu= mans Vergil, 1. Aeneid. Martial, lib. 14. Fulmineo fpumantis apri fum dente perempta, Mar* 4. tial. Spumeus. Spumiger. Strictus, Syluiugus, Sordidus. Tegeaus Terribilis, Thu* fcus, Martialis, Et alibi, Thufcre glandis aper populator. Timendus dente, Ouidius 4. epift Toruus, Ouid.2. de Arte. Truculentus. Trux, Ouid.11. Metamor, Vaftator, 9. Metam. Vio= lentus, 8.Metam. Vmber, Horatius. Vulnificus, Ouid.8. Metam. TÁgyiórrs, Homero, uide

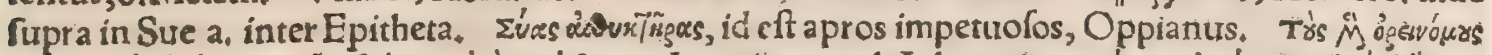

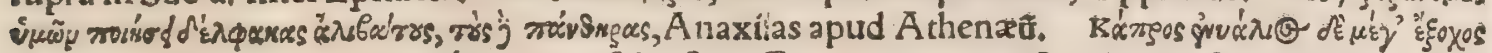

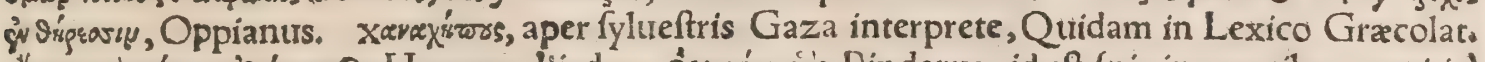

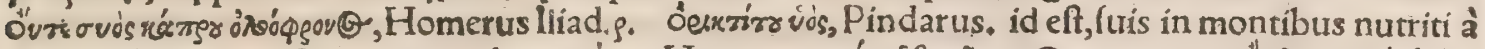

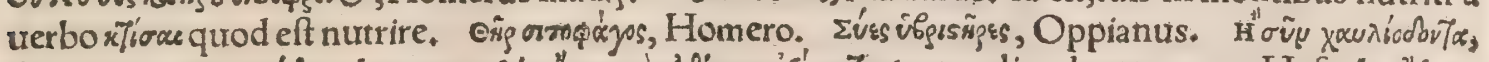

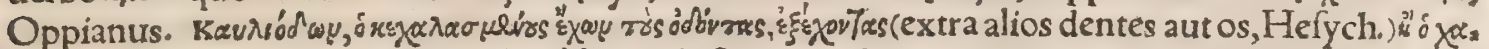

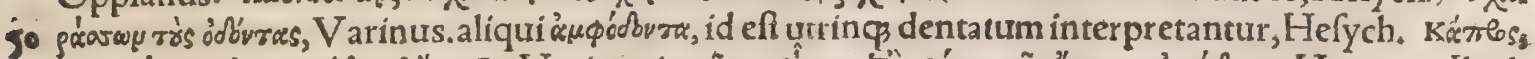

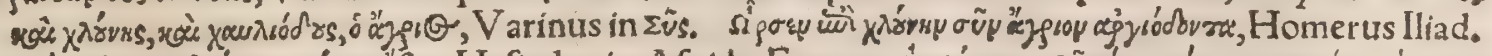

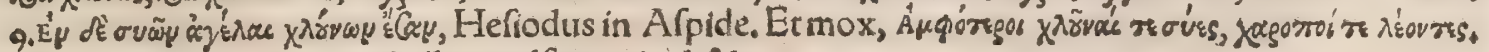
Plura epitheta Graca ex Polluce adferam in d. \& e.

TAprinus, adieciuum, fic dici debet fecundum analogiam, ut a caper trel capra caprinus, anti. quí tamen', ut apparet ex uetuftís codiciburs, per quintã uocalem in fecunda, \& per g. in tertia ferï bunt aprugnus:quo utitur Plinius, callum a prugnum $\$ C$ lumbum aprugnum dicendo. Qux dixi ut nunciares, fatin' ea tenes? so. Magis calleo quàm aprugnum callum callet, Plautus Perf. Feftiue fic refpondet, ludens homonymia huius dictionis calleo, qua \& fcire \& callofum effe fignificat.

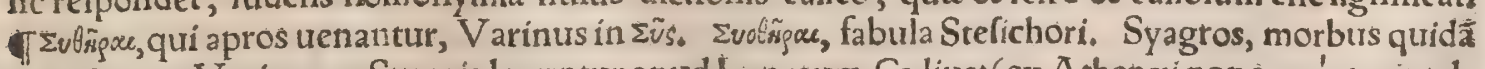
so apicularum, Varinus. Syagria leguntur apud Lynceum, Calius:(ex Athenai nono, ovóxpla, intels

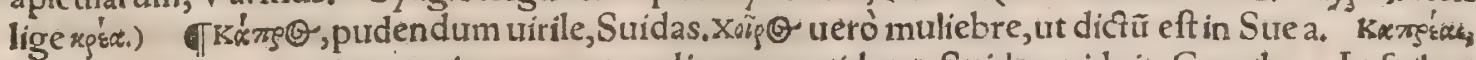
carnes quxdam prominentes in natura cameli quas excidunt, Suidas, uide in Camelo E. In fuibus 


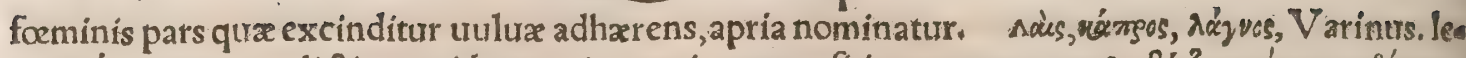

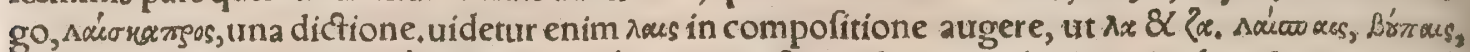

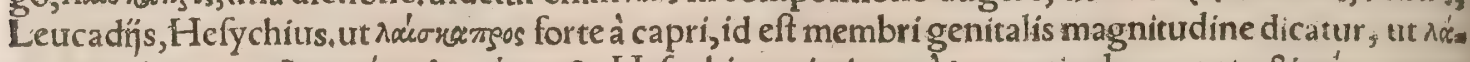

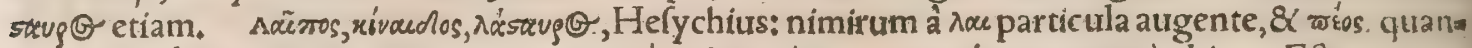

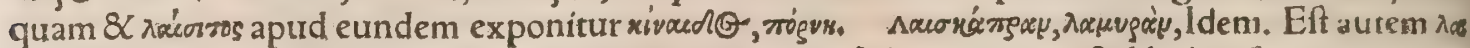
$\mu \nu \rho \dot{s}$, elegans, iucundus, facetus, temerarius, loquax: qux filicet amatori \& libidinofo conuenuint,

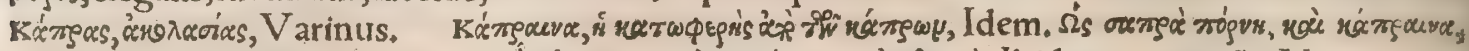

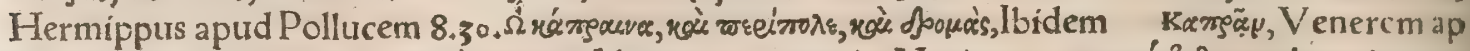

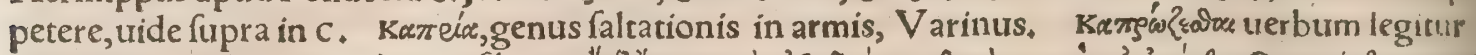

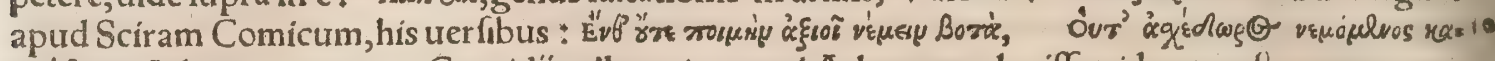

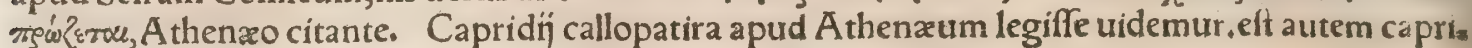
diưm, â capro deminutumin, quo nomine aprum intelligimus, Cxlius.

IIcones. A quilam Romanis legionibus C. Marius in fecundo confulatu fuo proprié dicauit. Erat $\&$ antea prima cum quaturor alịsł lupi, Minotauri, equi, aprí̧́ fingulos ordines anterbant. Pau cis ante annis fola in aciem portari copta erat, reliqua in caftris relinquebantur. Marius in totum ea abdicauit, Plinius. Feftus non aprum, fed porcum fimpliciter fuiffe fcribit, his uerbis: Porci effigies inter militaria figna quintum locum obtine bat, quia confecto bello, inter quos pax fieret, cafa porca foedus firmare folcbant. Vulcanus in fcuto Herculis uarias expreffit imagines, É jovãy àyenace

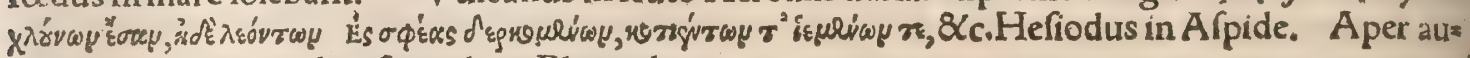
reus ore humano, uide infra in h.ex Plutarcho.

If Plantæ. Chlunion, eryngiũ, ut legitur inter nomenclaturas Diofcoridi adfcriptas:fortequod apri radicibus eius utpote dulcibus delectentur. Eftenim genus eryngî, quod frequens in Galiia Narbonenfis littore deprehendimus, dulci $8<$ odorata radice, odore faporéç paftinacx. In meridiano orbe præcipuam obtinent nobilitatem palmæ fyagri, proximamós margarides. Vna eaium ar bor in Chora effe traditur, una \& fyagrorum.mirum de ea accepimus, cum Phœnice aue, qux pil. tatur ex huius palma argumento nomen accepiffe, iterum mori ac renafci ex feipfa : erató cum liac proderem fertilis. Ipfum pomum grande, durum, horridum, \& à cateris generibus diftans fapor e fe rino, quem fermè in apris nouimus, euidentiffiméćs caufa eft nominis, Plinitus.

1 A nimalia. Eft $\&$ pifcis capros, id eft aper, $8 \times$ caprifcus:uide in Sue a. Capron aliqui phagr

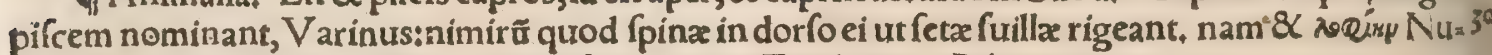
menius cognominat. Syagrides, pifces quidam Epicharmo, Athenæus.

T Propria. Diocletiani dictum fertur, Ego apros occido, fed pulpamento alter uefcitur.quod inde eft natum. Agenti in Gallia Diocletiano dicebat Dryas (Dryas mulier uetula, Pomponius La tus: tridetur autem Dryas de foemina facerdote uel faga dici, ut Druida de uiro;) Nimium Diocleta= ne aurus, nimium parcus es. Cui per locum is, Tunc ero largus, quum imperator furere. At Dryas: Noli Diocletiane iocari:nam imperator eris, quum aprum occideris, Ex eo uenationibus deditus a. pros forte oblatos enixius occidebat, dicti euentum expectans : quo eft fruftratus, donec prafectum pratorï Aprum (Arium Aprum ) peremit, Cxlius. Eft \& Syagros uiri nomen, ut c'ıryo.

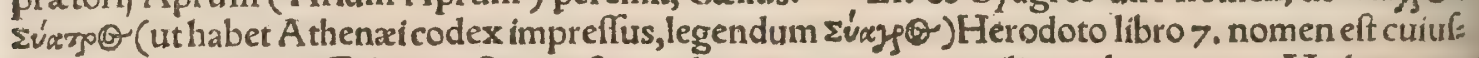
dam Laconis, qui ad Gelonem Syracufanum legatus uenit,ut auxilium ab eo contra Medos pete. $4^{\circ}$ ret. Fuititem Syagros Aetolorum dux. Syagros apud Sophoclem in A matoribus A chillis, nomē

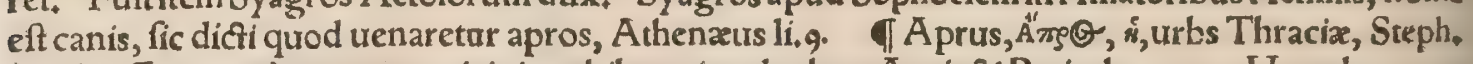
Scythia (Europaa) prater municipia urbibus niter duabus, A pris \& Perintho, quam Heracleam po fteritar dixit. Rhodopa huic annexa, \&c. Marcellinus libro 27. Apros colonia à Philippis abeft clxxxviii. M. paff. Plinius 4.11, in Thracix defcriptione. Vallis quadam in Liguria uulgò Por. cifera dicitur, nimirum ab apris feu porcis feris. Syagra regio Cilicix prope Adum $\&$ Laërtem, gêrile Eveygov's, Stephanus. Syagros, promontorium totius orbis maximum, in Arabia thurifera, Arrianus. Meflenñ \& Lacedamoní tertiam pugnam ad A pri fepulchrum inftituunt. Locus hic (Apri fimulachrum) ad Stenyclerum Meffenix fitus eft. Herculem enim ibiad diffectum aprum liberis Nelei iufiurandum dediffe, 8 accepiffe ab eis perhibent, Paufanias in Meffenicis. Capreta ${ }^{50}$ populi, ubi A pamia condita eft à Seleuco rege, interierunt, Ifidoro tefte apud Plinium. Caprex, uél Capriæ, uel Capriene, Koetrgetírs, infula Italiæ, ultra Surrentum Campanię urbem circiter octo mil lia paffurm, proxima Neapoli, Tiberï principis arce nobilis, \& coturnicum multitudine. Caper fluuius Laodiceam Carix urbem cum Lyco 8 A fopo amnibus alluit, Strabo lib. 12. \&Plinius y. 29. In ora octaux regionis Italix, Ariminum colonia, cum amnibus Arimino \& Aprufa, Plinius 3. 15. Capria, lacus ingens in Pamphylia, ut meminit Strabolib.14.

I b. rágurs mons Atticus aprorum $\&$ urforum uenationem prabet, $P_{a}$ aufanias. Hippopota.

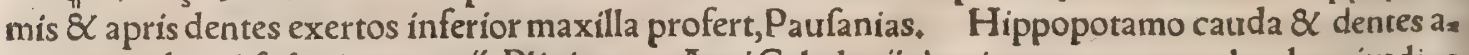
prorum, adunci,fed minus noxï, Plinius. ApriCalydonï dentium exertorum alter longitudine

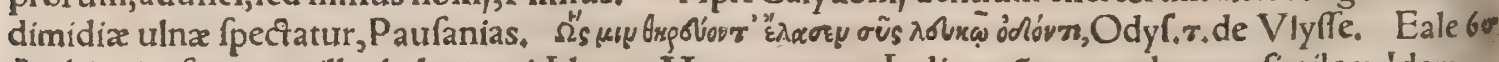
Aethiopica fera, maxillas habet apri,Idem. Monocerotem Indi uenãtur, cauda apro fimilem, Idem \& Aelianus. IA prorum pernas noftri uocant, leuff oder bammen. 


\section{DeApro. H.c.d.e. Lib. I. I051}

7. c. Aprorum luftra, Budæus Gracè gúnsyob, Ex thynnis pifcibus maximi, fimiliter ut fures foli $\&$ feparatim natant: alij more luporum bini proficifcuntur, alij ut capræ gregatim, A elianus

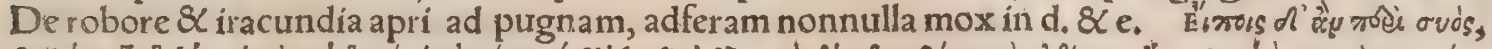

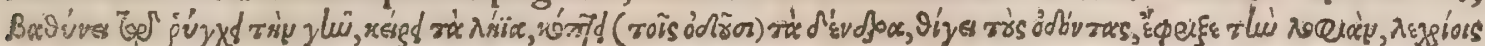

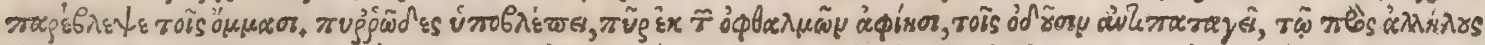

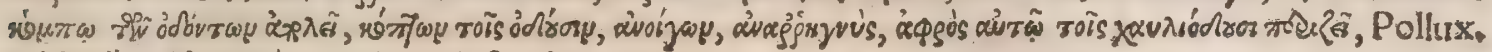

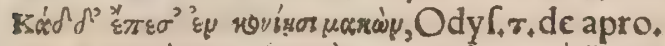

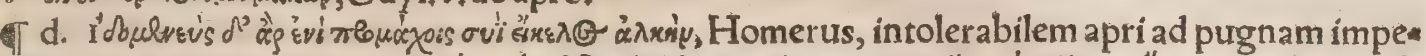

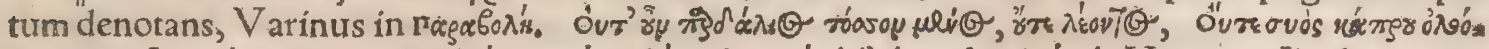

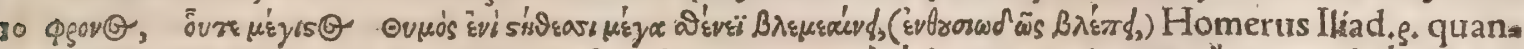

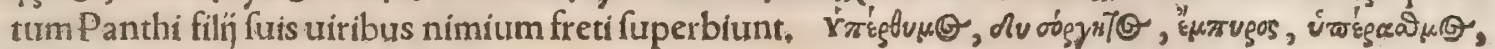
Pollux de apro.Plura leges in $e$.

T e. Spumantem aprum ex equolaceffere, irruentemó ultro eundem mucrone conficere, $\mathrm{Bu}$ s dæus. Aut fpumantis apri curfum clamore prementem, Verg.1,Aen. Thufcæ glandis aper poput lator, \& ilice multa Impiger, Aetola fama fecurida feræ, Quem meus intrauit fplendenti cufpide culter, Præda iaces noftris inuidiofa focis, Martialis lib. 7. Fulmineo fpumantis apri fum dente perempta, Quantus erat Calydon, aut Erymanthe tuus. Idem libron. in epitaphio canis Lydia, Site delectant animofa pericula, Thufcis (Tutior eft uirtus) infidiemur apris, Idem libro 12, ad Pris fcum in leporum urenatu equo nimis pracipite periclitantem. Nang fagacius unus odoror, Po= 1. lypus an grauis hirfutis cubet hircus in alis, Quàm canis acer ubi lateat fus, Horatius 12,Epodon. Sxpe uolutabris pulfos fylueftribus apros Latratu turbabis agens, Vergilius in Georg. Ceruũ, aprum, urfum dimiffos, canis Indicus Alexandro donatus tanquam fe indignos contempfit: in folü uerò leonem infurrexit, ut in Cane robufto dixi ex Aeliano. Actus aper fetis iram denunciat hir tis: . Et ruit oppofiti nitens in uulnera ferri, Preffus $8 \mathrm{~L}$ emiffo moritur per uifcera telo, Ouid. in Halieut, Lepolemus quidã (ut fcribit A puleius lib.8. de afino aureo)cum uenaretur affumpto Thra fyllo cuius uxorem amabat, ut in urenatione eum occideret, 8 a fera occifum mentiretur; ad feruidos diffonośç canum latratus, aper immanis atç̧ inufitatus exurgit, tor is callofa cutis obefus, pilis in= horrentibus, corio fqualidus, fetis infurgentibus fpinæ hifpidus, dentibus attritu fonanti fpumeus: oculis flammeus, afpectu minaci, impetu fxuo, feruentis oris, totus fulmineus; $\&$ primum quidem - ranum procaciores, qui comminus côtulerant ueftigium, genis hac illac iaçatis, confectos in terficit. deinde calcata retiola, qua primos impetus reduxerat, tranfabint, \& c. Et mox, Beftia genuini uigoris non oblita,retorquet impetum, $\&$ incendio feritatis ardefcens, dentium cópulfu, quem primum in: filiat contabunda rimatur, $\& c$. Thrafyllum aper furens inuadit iacentem : ac primo lacinias eius,

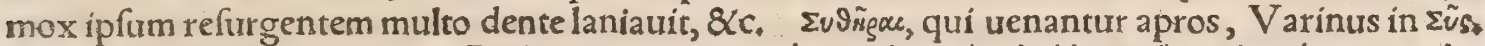

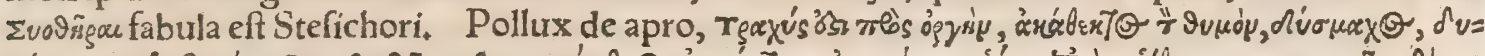

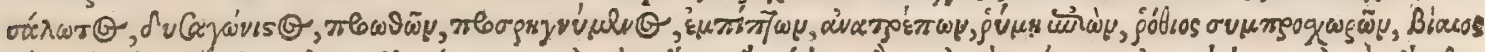

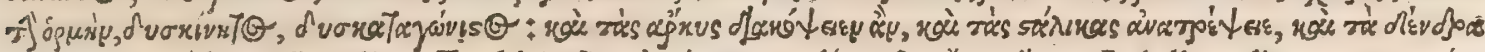

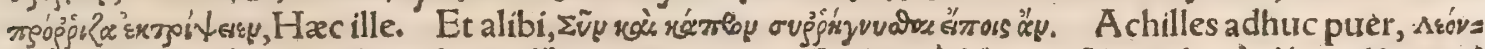

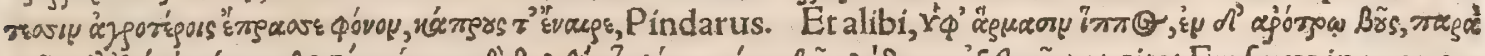

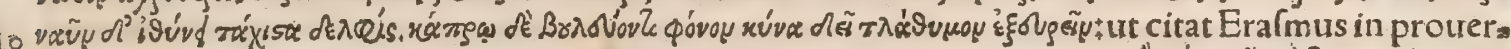

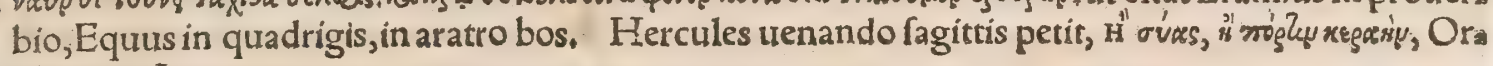
pheus in Argon.

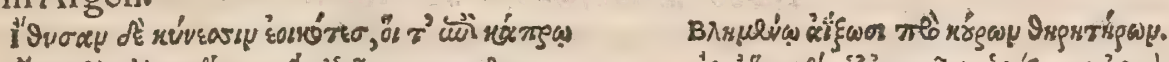

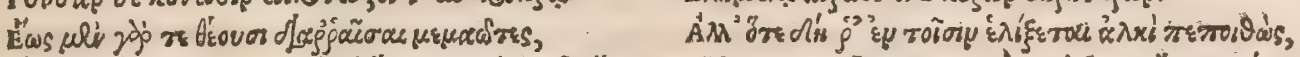

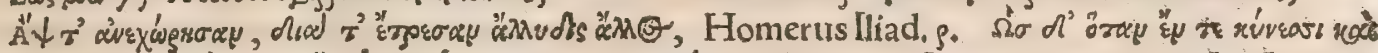

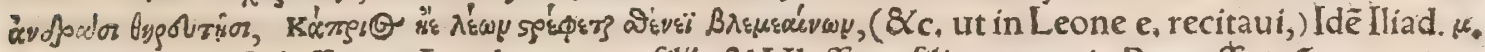
A pud eundem Odyffex r. Autolycus cum filins \& Vlyffe ex filia nepote in Parnaffo móte uenatur

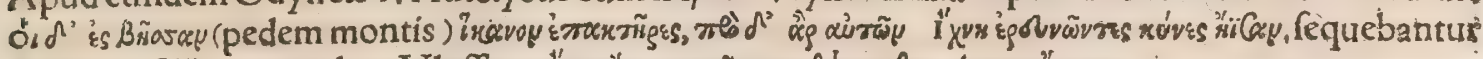

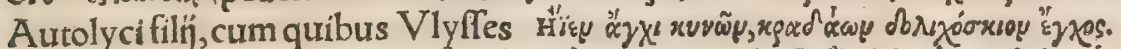

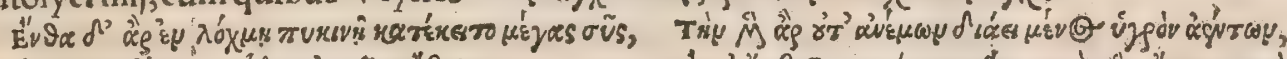

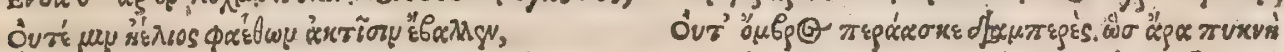
से

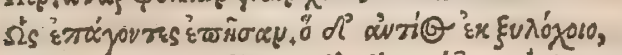

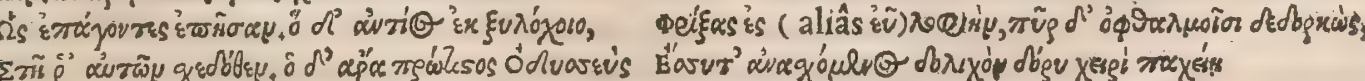
¿ning a

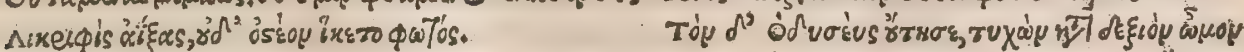

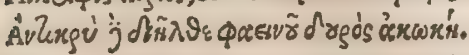

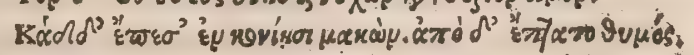

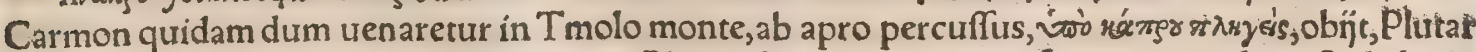
chus de flutinjs in Pactolo. Apri quidem, ut Plinius fcribit, percutiunt, foeminæ mordent. Sed plures

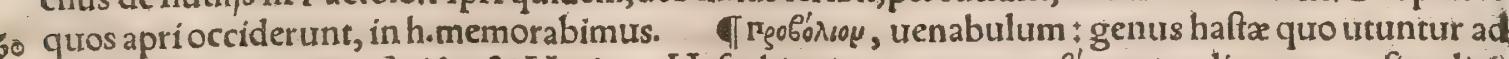
uenationem aprorum, Suidas $\&$ Varin. Hefychius interpretatur obvyvsy (malim cum $\mathrm{n}$. fimplici)

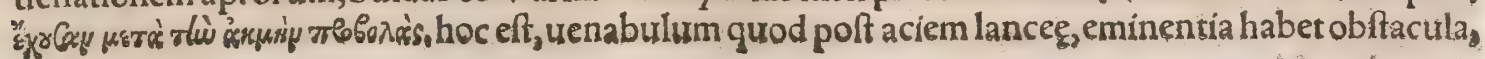




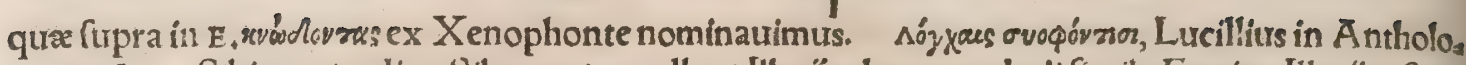
gio 1.28. Stbinam (melius, Sibynam) appellant Illyrï telum uenabulifimile. Ennius, Illyrïr reftant

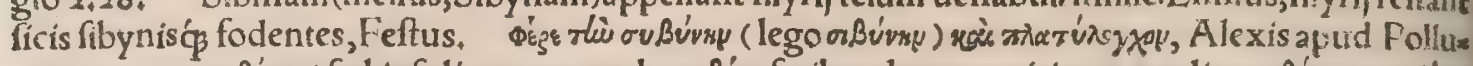

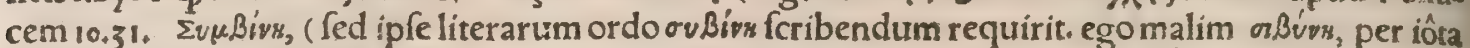

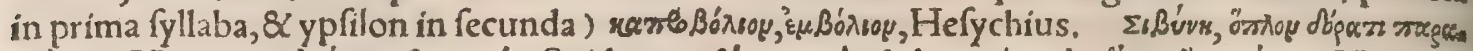

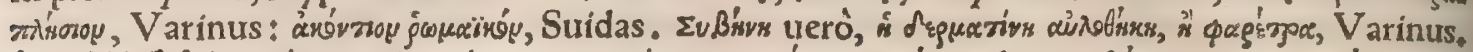

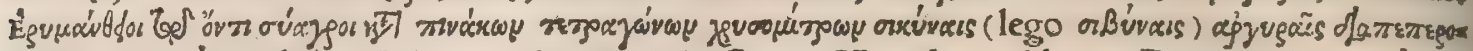

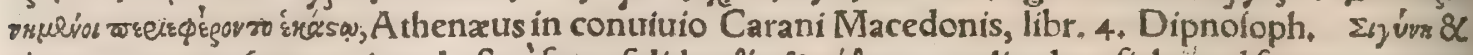

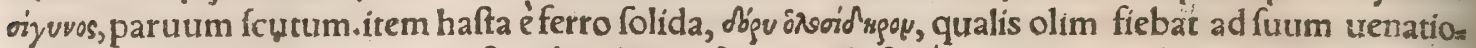

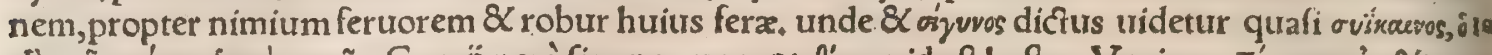

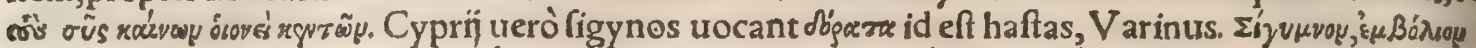

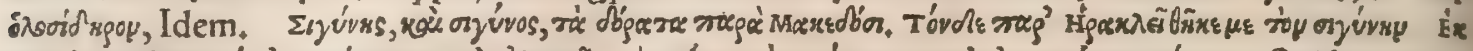

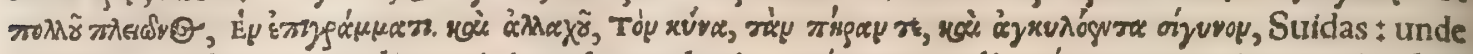
apparet penultimam modo corripi, modo produci. Eígyvos ( melius ójyuvos, requirente etiam lite.

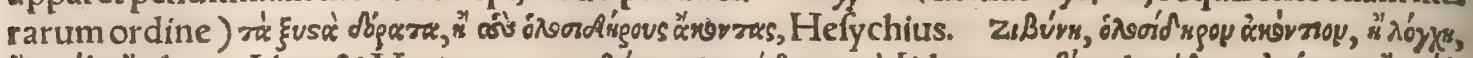

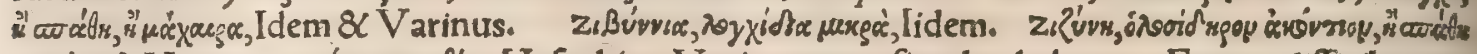

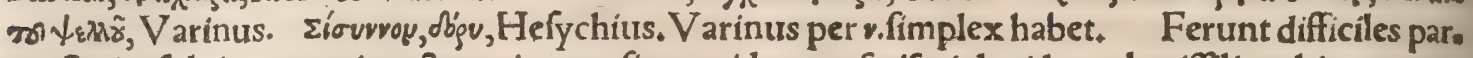
tus ftatim folui, cum quis tectum, in quo fit grauida, tranfmiferit lapide, uel miffili ex his, qux tria animalia fingulis ictibus interfecerint, hominem, aprum, urfam,Plinius. Galli quod ex capto apro et maçato canibus obỉcitur pafcendis, ceu merces laboris, vernacula lingua uocấtla fouraille dung 20 fanglier, (quod fiat fur le foeu, id eft ạd ignem, )quidam Latinè uifcerationem interpretãtur. candem fi de ceruo fiat, curee nuncupant. Taifalorum gentem turpem ac obfconæ uitæ flagitijs ita acce: pimus merfam, ut apud cos nefandi concubitus foedere copulentur maribus puberes. Horum fi qui iam adultus aprum exceperit folus, uel interemerit urfum immanê, colluuione liberatur incefi;, Marcellinus librozı.

T Adraftus oraculo iuffus filias coniungere apro \& leoni : cum uenirent ad eum Tydeus apri, \& Polynices leonis pelle induti,illis elocauit, Varinus in Óıfïrs. TApud Calphurnium Aegl, 6. ceruus quidam monile gerit, in quo pendulus apri Dens fedet. Noftri etiam hos dentes argento claufes puerorum collis appendunt, ut $\&$ offa palmularum, ut dentium emiffio iuuetur, dum iftis mandendis exercentur gingiux.

If. In niue Lucana dormis ocreatus, ut aprum Coenem ego, Horatius Serm.2.3. Vmber \& ${ }^{3}$ Iigna nutritus glande rotundas Curuet aper lances, carnem uitantis inerte, Idem 2.Serm. Quame uis Puret aper, rhombusq̧̧ recens, mala copia quando Aegrum follicitat ftomacbum, Ibidem 2. Sumine cum magno lepus, atक̧ aper, atç pygargus, Iutuenalis Sat, II. Quanta eft gula qux fibi to: tos Ponit apros, animal propter conuiuia natum, Idem.

Pinguefcant madidi laxto nidore penates,

Sed coquus ingentem piperis confumet aceruum, A d dominum redeas, nofter te non capit ignis Conturbator aper:uilius efurio,

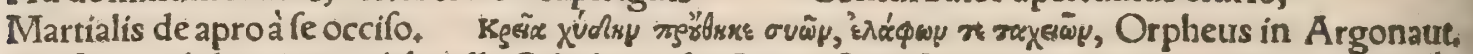
Sus ferus nihilo minor celebri illo Calydonio fure Dipnofophiftis apponitur apud A thenaum. Ive $4^{\circ}$

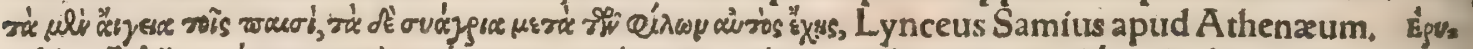

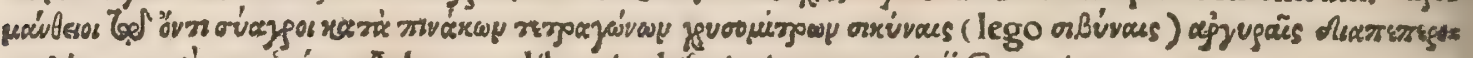

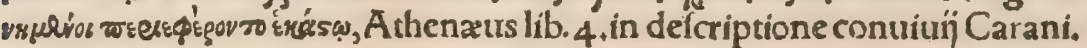

Th. In portentis numerantur tres apri:Erymantheus, Calydonius, \& tertius in Olympo Myfix, Grapaldus, nos defingulis ordine dicemus. Erymanthus mons eft Arcadix, in quo aprê agro. rum uaftatorem Hercules domuit, uiuumó fuper humeros ad Euryftheum detulit: quo confpecto Euryfheus in areo uafe fe abfcondit. Aut Erymanthi Placârit fyluam, \& Lernam tremefeceric arcu, Vergil. Eft \& fylua \& fluuius hoc nomine in Alpheum defluens, ut oftendit Plinius libro 4. Beluam Erymanthiam uaftificam legimus apud Ciceronem libro 2. Tuf́. Arcades habitant fub Erymantho monte, in quo multi funtapri, Euftathius in Dionyfium A frum. Dryopes gentem im jo probam circa Pythonem Hercules eiecit, ( $\mu \varepsilon r^{\prime} \omega_{1}$

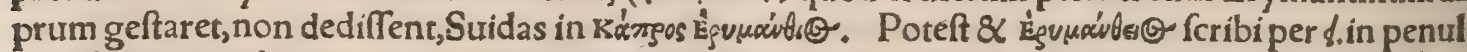
tima.Poëtæe eundem Arcadium, Mænalium \& Tegexum nominant. Fulmineo fpurmãtis aprifum dente perempta; Quantus erat Calydon, aut Erymanthe tuus, Martialis de cane Lydia, TMe. leagri \& Calydonï apri hiftoriam multis profequitur Homerus lliados nono. nos Scholiaftę uerba, qui rem paucis complectitur, conuerfa apponemus. Oeneus (inquit) Aetolia princeps, cum primi tias anni fruçuum dịs immolaret, folam Dianam neglexit, Quamobrem irata illa, aprũ immanem Aetolis immifit, quitum regionem tum incolas perdebat. Ad duerfus hunc in uenationem prodierũt Calydonï \& Pleuronï:primus autem feram uulnerauit Meleager Oenei filius, \& pellem eius cum sapite, quod uir tutis pramium acceperat, Atalantę uirgini A rcadi filix Iafi uenationis focix, cuius 60 amore captus erat, donauit. quod ægre ferentes filij Theftị, qui auunculi erant Meleagri, hoc eft fra tres Althæex matris eius, infidiabantur ei: $(\alpha$, ut al'n fcribunt, donum illud A talantz abftulerunt.) 


\section{DeApro. H. h. Lib. I. 1053}

Ipfere cognita alios interfecit, alios fugauit. Quam ob caufam Pleuronï Calydonịs bellum interle: runt in cuius initio Meleager matri iratus, patrix opem non tulit. Cum uerò ciuitas iam uafaretur, à Cleoparra uxore perfuafus, in pugnam progreffis, hoftes partim occidit, partim fugatos in prbecipis tia egit. Caterum Althæa filio fuccenfens, datam fibià Parcis tædam(titionem, id eft ftipitem femitr. ftum)concremat. hac enim exufta fatalis erat mors Meleagro, quo defuncto, ponitudine ducta ma

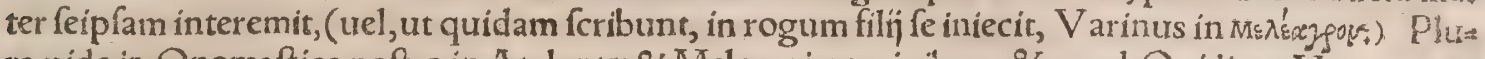
ra uide in Onomafticonoftro in A talanta \& Meleagri nominibus, \& apud Ouidium Meramor.8. Bus Calydonius primo circa Oetam fuit, ( quare à Lycophrone ó،txies sóvz̧ nominatur, ) deinde in Aetoliam à Diana immiffus eft, pern̈t autem in eius uenatione Ancaus A gapenoris pater, Ścholia. 10 ftes Lycophronis. Ancxus Lycurgi Arcadis filius, cum lafone ad Colchos nauigaciit, \& pofea ab apro Calydonio occifus eft, $\mathrm{Paufanias}$ in Arcadicis. Dentes habuit plus quàm cubitales, memine: runt eius Homerus, Soterichus (in Calydonijs, ut Scholiaftes Lycoph. fcribit) 82 alin in numeri, Io.

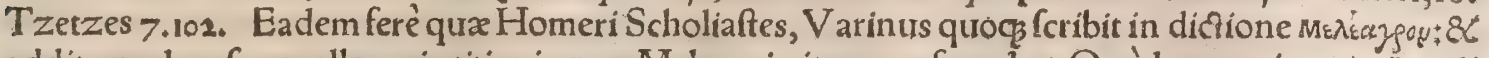
addit quadam fuper allegoria titionis qua Meleagri uitam conferuabat, Quòd autem, inquit, A etolí $\&$ Calydoní propter apri caput pugnarint, ut Homerus canit, mirum non ef, cum hodiȩ́́ multis in locis, \& maximé in Lycia, uenatori qui primus ceruum, capram aut aprum attigerit, quamuis in utili etiam icłu, feræ caput pro præmio offeratur. Cæterum Geographus fribit, quòd uerifimile fic Curêtas \& Aetolos proparte aliqua regionis pugnaffe, \&c, Varinus. Crommyon terræ quiden nunc eft Corinthix, antea uerò Megarenfis, ubiCromm yoniam uerfatam fuiffe fuem, refertur in fa 20 bulis, ex qua Calydonium natum fuife aprum memorant;interćs præclara Thefei certamina unum illud prodiderunt, hanc illius manibus occifam, Strabolib,8. Sus Calydonius albo colore $\&$ focmi na fuit, ut Cleomenes R heginus prodidit, Athenxus lib. 9. Feræo olim hominibus multò magis (quàm noftro freculo)metuend $x$ furerunt, ut Nemeaus \& Parnafius leo, \& Calydonius ac Eryman thius fus, \& (alius)in Crommyone terræ Corinthixłita ut diceretur, alias é terra prognatas, alias dịs facras fuiffe, alias in ultionem hominum immiflas, Paufanias in Atticis. Qui Diomedeis metuen= dus fetiger agris, Aetola cecidit cufpide, talis erat, Martialis in Xenís fub lemmate, Aper. Et rura fus fub lemmate, Porcellus lactens: Lacte mero paftum pigræ mihi matris alumnum Ponat, \& Aex tolo de fue diues edat. Poétæhunc aprum Meleagreum \& A talanteum cognominant. A talan* tx canis Aura nomine fuit, quam cum Calydonia peremiffet, bruto fepulchrum indigen $x$ ftruxêre,

30 Calius. Ariftophôn pinxit Ancæum uulneratum ab apro, cum focia doloris Aftypale, Plinius. His adfcribam qux in Paufanix Arcadicls de hoc a pro leguntur. Ancaus (inquit) Lycurgi filius Calydonium aprum fuftinuit, licet uulneratus, Et paulò pof ₹ Atalanta prima in a prum incidit, \& fagittis eum petijt. Harum rerum gratia caput ei $\&$ pellis aprl, pramia fortitudinis funt data. Etmox, In aquilis (id eft pinnis templi Tegeatarum) parte priori uenatio apri Calydonij eft ex. preffa. In medio potiffimum aprihi funt depicti, una parte Atalanta, Meleager, Thefeus, Telamon, Peleus, Pollux, \& Iolaus Herculis ærumnarum maxima ex parte focius, Theftì isem filij, fratres autem Althææ Prothus \& Cometes. Altera parte apri Ancæum uulneratum iam $\&$ uenabulum $(\pi \varepsilon \lambda \varepsilon x v y$, fecurim ) emittentem fuftinet Epochus. Iuxta eum Caftor \& Amphiaraus Oiclei filius. poft hos Hippothus Cercyonis F. Agamedis F. StympheliF. Poftremus Pirithous eft. Caterum 40 dentes apri Calydoní Romanorum imperator Auguftus abfulit, pofquam A ntonium bello fupe: rauit, Et pauló poft, Alterum autem ex dentibus apri retineri aiunt rerum mirabilium(illic)cuftoz des, reliquus in hortis imperatoris in Bacchi templo eft fufpenfus, lögitudine dímidiam omnino ul nam a drequans, ( tarum donaria præftantifima funt, pellis apri Calydonï, quæ temporis diuturnitate computruic, $\&$ pilis omnino eft nudata, \&c. Hæc omnia Paufanias.

ब. Adraftus natione Phryx, regïgenerís, quum fratrem imprudens interemiffet, Sardis ad Crot fum confugit, \& expiatus cum co habitauit, Per hocidem tempus apud Olympum Myfix, aper exin

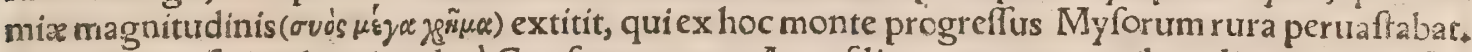
Ad hunc conficiendum incola à Croefo petunt ut Atyn filium cum uenatoribus aliquot mittat, Ille so quòd in fomnis uidiffet filium ferrea cufpide periturum, metuens ei mitter e noluit, fed alios uenatc res abfq eo. Perfuafus tamen, mittit: $\&$ falutem eius $A$ drafto commendat. Vbi igiturad feram per: uentum eft, Adraftus uibrato in aprum iaculo, non illum, fed Crofi filium uulneratum imprudens occidit.qua re tantum indoluit, ut quamuis re cognita ignofceret ei Crofus, fefe fuper buftum filí eius transfoderit, ut copiofê fcribit Herodotus lib. I. Scribitur autem Ärvs per $\tau$. fimplex. nam alius fuit Ä7fss Phryx ab a pro occifus, ut inferius referam, Bspérvoou nomen eft ciuitatis, nam cum apud Noricos populos aper dituinitus immiffus regionem uaftaret, $\$$ omnes eum perempturi nihil pro. ficerent, unus quidam fuem inuerfum in humeros affumplit, ut poétæe etiam de Calydonia fue fa. bulanutr. (nempe quòd à Diana ímmiffus agros uaftauerit, nó quòd aliquis eum in humeros affuma pferit, Quod uidentes Norici acclamarunt uernacula lingua, Brģ́rrs, (Vir unus, Latinæ uoces funt,

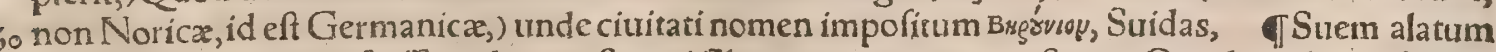
Clazomenis exortum fuiffe auditum eft, quiClazomenios agros uaftarer. Quod quidem ipfum in Clazomeniorum finibus Artemon confirmauir accidiffe; unde illic locus decantatus, Sus alatus no* 
minatur. Id quod fi cuipiam fabula uideatur, $\&$ ego hoc idem non ignorem,tamẽ de animali dî? facile patior, Aelianus, Inter Cafarex difcrimina fæua Dianæ, Fixiffet grauidam cum leuis hafta fuem, Exilÿt partus mifera de uulnere matris. OLucina ferox, hoc peperiffe fuit? Mar= rialis in libro Spectaculorum.

ब. Ancaus Agapenoris pater ab apro Calydonio interfectus eft, ut fupra in buius apri mẽtione retuli. Carmon quidam cum in Tmolo monte uenaretur, ab apro percuffus interijt, Plutarchus de fluxips in Pactolo. Attæ duo fuerunt, alter Syrus, alter Arcas, quorum uterq̧ ab apro interemptus traditur, Plutarchus ab initio uitæ Sertorï. Attes (Ä7ins) quidam Phryx cum pafceret pecora, \& ma trem deorum fiue $R$ heam hymnis celebraret, amatus eft $a b$ ea, $\&$ in honore habitus cum frequenter ei appareret. Quod aggre ferens Iupiter, Atten interfecit, non palàm ob reuerentiam matris, fed apro ra immiffo. Rhea poft luctum, cadauer fepelijt, \& Phryges eundem quotannis treno tempore lugent, Scholiaftes Nicandri. Plura de hoc Atte in Achaicis fcribit Paufanias. Idmonem Argonautam aper occidit, Orpheus, Sus Veneri inuifus eft propter Adonin ab apro occifum:uide in Sue h.in fa crificio Veneris ex fue. A per ob Addonidis caedem uinctus ab Amoribus Veneri adducitur apud Theocritum Idyllio 29. Macrobius libro ı. Saturnaliorum Adonin non alium quàm Solem effe docens, $\mathrm{Ab}$ apro autem (inquit)tradunt interemptum Adonin, hyemis imaginem in loc animali fin gentes:quod aper hifpidus $\&$ afper gaudet locis humidis $\&$ lutofis, pruinaḉç cótectis, propriég hye mali fructur pafcitur glande. Ergo hyems ueluti unulnus eft Solis, qua \& lucem eius nobis minuit \& calorem, quod utrunq animantibus accidit morte.

1 Caico Myfix flutuio mons Teuthras adiacet, à Teuthrante Myforum rege dictus. Hic cum ali; 20 quando uenationis gratia Thrafyllum montem confcendiffet, aprum ingentem repertum cum $f_{2}=$ tellitibus perfecutus eft. Aper ceu fupplex in Orthofix Dianx templum confugit. Et cum uenatores quroos ingrederentur, alta \& humana uoce exclamauit, Parceô rex pecudi deæ. fed Teuthras nihi commotus, eum interemir. Hanc regis improbitatem déa iniquè ferens, apro uitã reftituit: $8<$ regem impetigine atģ infania affecit, cuius ille mali pudore in montium iugis remanfit. Hac re cognita Ly fippe mater, in fyluã ad ipfum progreffa eft cum Polyido tuate Cyrani filio, à quo inftructa deam bor facrificins (Brbvoitus) placautitunde cum filium fanæ menti reftitutum recepilfet, Dianæ Orthofia fa

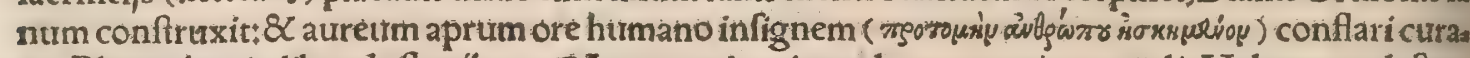

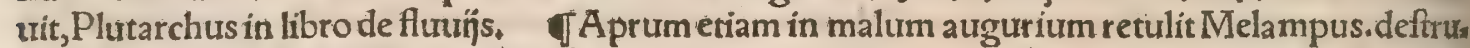
ctionem enim eorum, qua agenda inftiturit aliquis iter faciens, cum obuius furerit, præfagit, $\mathrm{Niphus}_{\text {, }}$

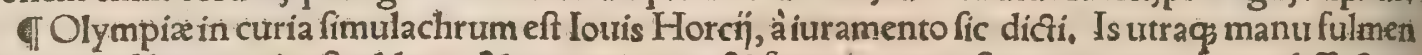
tenet. A pud hû́c moris eft athletas, \& patres eorum $\&$ fratres, gymnaftas item, per aprum diffecium

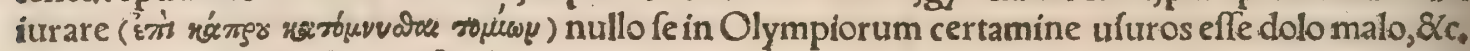
Caterum in quem ufum poft athletarum iuramentum conuertant aprum, non in mentem uenit in. terrogare.Quoniam antiquióribus feculis ufitatum fuit in facrifiç̄s, ut quacunç in iureiurãdo ad. hibuerant homines, eorum prorfus efu abftinerent. Id quod Homerus uel potiffimum fignificat: $A_{\text {a }}$ prum certè, per cuius diffectas carnes A gamemnon iurauit, rem fe cum Brifeide non habuiffe, per

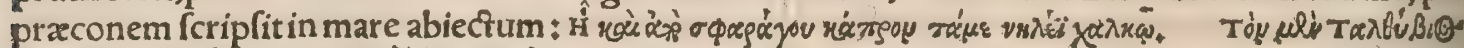

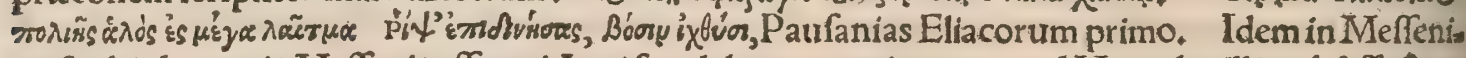
cis fribit, locum in Meffenia effe qui A pri fepulchrum nominetur, quod Hercules illic ad diffectum 4 aprum liberis Nelei iufiurandum dediffe, $\mathcal{Q}$ accepiffe ab eis perhibeatur. Galatæ qui Pefinûntem incolunt a prorum contactu abftinent, nimirum quod Attes, quem colunt, ab apro occifus feratur: quanquam ipfi aliam de co fabulam narrent, Paufanias in Achaicis, Karjoorúgr, wreuréstogers, Vari

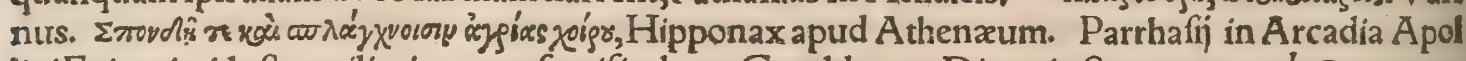
lini Epicurio, id eft auxiliari, aprum facrificabant, Gyraldus, Diana in Samo rempoф áz (G) cogno.

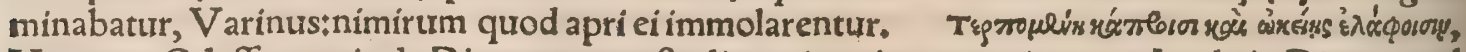
Homerus Odyffex tertio de Diana, propter ftudium eius circa uenationem, Laphriæ Dianæapud Patrêfes magno in ara igne excitato, a pros, ceruos, \& alias feras uiuas in̄̋ciứt, Paufan. in Achaicis, P R O V E.R B I A.

In faltu uno duros apros capere, eft eadem in re duos pariter deprehẽdere. Plautus in Cafina, Iam yo ego uno in faltu lepidé apros capiam duos, Erafmus, Dubium non eft; (inquit idem Chiliadis ter tię centuria $f$ exta, quin ad prouerbiorum claffem pertineat quod eft apud Maronem in carmine Bư colico: Eheu quid uolui mifero mihi, iloribus aufrum Perditus, \& liquidis immifi fontibus apros: $\checkmark$ bi quis optat nocitura.nam uentus floribus inimiciflimus, præcipué aufter, ob uiolentiam. Ec rurfus Chiliadis quartæ centuria 1,idem repetens, in eum qua drare ait, qui fibi accerfit optátue per. niciem allatura. Siquidem apri ( inquit) non tantum bibunt è fonte impreflis pedibus, uerum etiam nolutant fefe. Suem iritar, ru óeivd, in auidum rixarum dicebatur. Sus enim agreftis protrocatus re ĉ̀̀ petit eum,à quo prouocatus eft. Sic enim narrant uenandi periti: fi quís fuê lancea protenfa pro. uocârit, etiam fi iam ille fequebatur alium quempiam, ilico uertere curfum, $\&$ in prouocatorem ten dere, ne cufpide quidem uitata, Erafmus. Sus agreftis ubi pepererit non pluet: Vide fupra circa fio 60 nem capitis quinti, Del phinum fyluis appingit, fluctibus aprum, Qui uariare cupitrem pron digialiter unam, Horatius de Arte, 


\section{DeTalpa. A. Lib. I. To5s}

TEmblema Alciati, quod infcripfit, Ex damno alterius, alterius utilitas,

Dum fruis ruerent in mirtua uulnera telis, Vngueleæna ferox, dente timendus aper. Accurrit uultur fpectatum, \& prandia captat. Gloria uictoris, prada futura fua eft

\section{DE TALPA.}

\section{A.}

I0

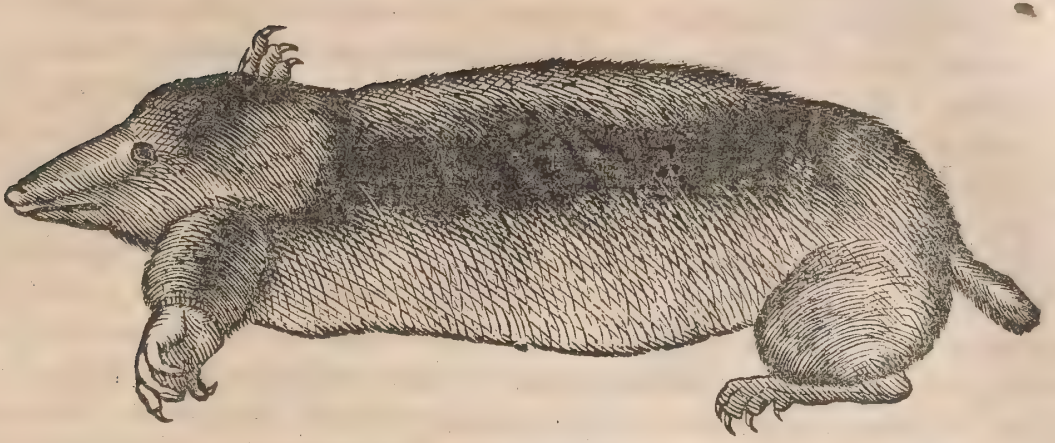

A I P A. M aliqui murrium generi adnumerant, quod iple non probo.neçenim aliud mur ribus fimile habet prater magnitudinem. qua $\&$ ipfa tamen in muribus uariat. Murium fané genus omne, anteriores binos dentes oblongos $\&$ cururos habet, talpæ non item. Als bertus talpam aliter murem terrenum uel cacum appellari fcribit. Sed mures terreni, qui fruges $\&$ herbarũ radices in aruis $\&$ hortis populantur, alï diuerforum funt generum, ut homony $=$ - miæ cauendæ caufa, idem nomen talpis communicari non placeat. Cæcus uerò mus, idem qui ara=

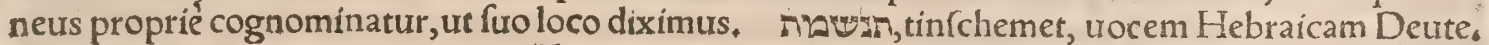
14. alif aliter interpretantur: Dauid Kimhi auem, qua cæteras furo confpeciu obftupefaciat, R. Salo-

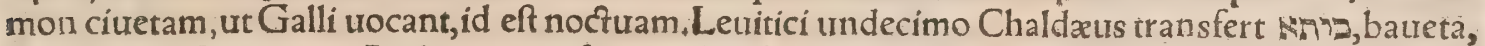

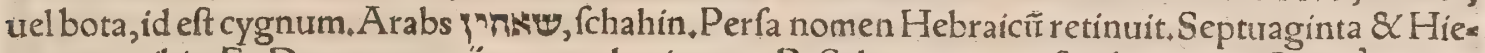
ronymus ibin, Et Deuteronomij 14 .porphyrionem, R. Salomon auem fimilem mưri, Gallicè dictam chaulue fouris, id eft uefpertilionem. Et rurfus Leuítici I. (ubi legitur $\div$ Stellio, lacerta \& talpa, hæc omnia immunda, Munftero interprete, ) Dauid Kimhi reptile interpretatur, R. Salomon $\$ \$ 50$, tal

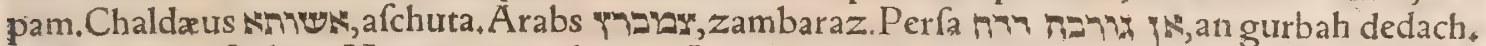
Septuaginta afpalacẽ, Hieronymus talpam. In die illa pröjciet homo aureos $\&$ argenteos deos, in 40 foffuras talparum $8<$ uefpertilionum, Efaiæ 2. Munftero interprete. Hieronymus utertit, Proj̉ciet ho

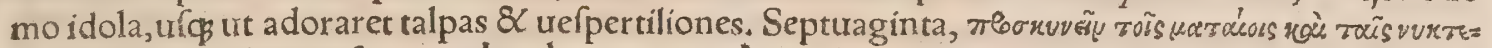

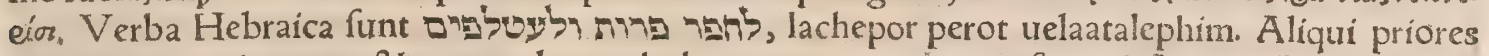
duas uoces coniungunt $\&$ pro una legunt lacheporperot, ceu compofitam dictionem. Dauid Kimhi in libro Radicum \& in Cómentarịs quoç, docet quo /dam exiftimare fic dici auem qua fodiat phiroth, id eft foureas ₹ quordam reptile â fodiendo dictum. Ipfe troces duas effe putat, 8 interpreta= tur, ad fodiendum foffas, ut in Thalmud aliquando facit, cheporperot, qua fignificetur auis noctu uolans, interdiu fe occultans, ut uefper tilio, uel, ut alij dicunt, auis qua noctua uocatur. Clialdæus transfert abominationes aut idola, (fecutus nimirum Septuaginta, ut fape facit, qui u'croex uerterunt: ) unde ludxi quidam fufpicantur idøla forma illarit 5o aurim aut reptilium eos adorauiffe.Symmachus infructuofa, A quila öpuas, (quam uocem uidetur pro folfis accipere. nam uerbum óviz żu fodere eft.) Theodotion Hebraicam reliquit. Docti hodie om nino talpas effe putant, à fodiendo fic dictas. Syluaticus barbaras uoces irbea \& lagocecos, pro tal pa interpretatur, utguzden Vetur gloffographus A uricennæ. Animal uocatum habenium foucas in campis habet, \& pugnando uenatur animal dictum pelagoz, quod Auicenna uidetur uocare mu. rem cacum, quem nos talpam nominamus. Vtrumlibet uicerit, deuorat alterum, Albertus in Aria

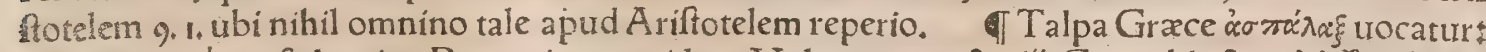

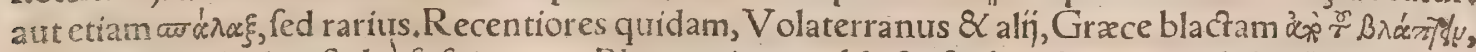
id eft ànocendo dici,fulté fufpicantur. Blatta enim non blacta feribendum: qux dictio Latina, non Græca, infecti quoddam genus, non talpam fignificat. Ex codem errore natü puto quod fcribit Vo: 60 laterranus, talpas frumentum in area populari, quod blatta ac gurguliones, infector um fcarabeo. rumós genera faciunt Ineptifime etiam Albertus tal pam Græé colry, uel (ut alibi legitur) koky ap. pellari lcribir,quam uocẽ eum ab Auicenna fumpfiffe puto, ut forté Perfica fit, Talpa apud Italos 


\section{6}

\section{De Quadrupédibus.}

nomen Latinuro retinuit. Hípanicè, tópo, qua uoce Itali murem nuncupãt. Gallicè,taulpe. Gere manicèmulwerf, uel ut Saxones fcribunt molwurff, quòd terram roftro fodiat $\&$ réjciat. Heluetí

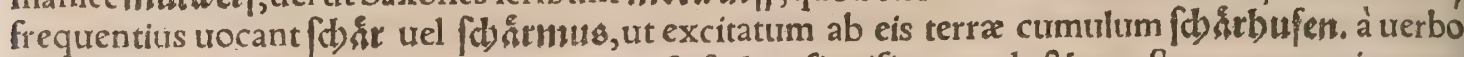
cotarten, quod manibus aut pedibus radere $\&$ fodere fignificat, unde $\&$ agreftes mures qui terram fodiunt ut radices deuorent, $[$ Chozrmü $\beta 3$ appellantur. Flandri $\&$ Hollandi talpam uocant mol uel molmu活 + Angli molle, prima fyllaba tantum Germanicx uocis mulwerf uel molwurf, ut uidecur, ufurpata.Sed Anglietiam want appellant. Illyrï krticze.

Terræ Bocotiæ in Orchomenio agro talpæ habentur multæ: at in Lebadico uicino (in Coronea, ut legimus in Mirabilibus Ariftot, ) nullæ funt, neç fi aliunde portatæcò fuerint, uolunt infodere, 10 Ariftoteles \& Aelianus, quanquam hurits interpres Gillius fic uertit, Bœotiæ terræ folum ralpis ca: ret, \&c. In Bocotia Lebadia illatæ folum ipfum fugiunt, qux iuxta in Orchomeno tota arua fubs ruunt talpæ, Plinius. TTalpæ coloris funt nigri, (cinerei, Cardanus) pili mollis, breuis $\&$ denfi, Albertus. Pilos habent nigrore fplendido infignes, qui catulis earum funt albi, Georg. Agricola,

ब Aegyptí ut hominem cæcum fignificent, talpam pingunt. hæc enim neç oculos habet, neque aliter uidet, Orus. Aut oculis capti fodêre cubilia talpa, Vergil. ı. Georg, ubi Seruius, Oculis ca= pti, id eft oculis debiles, quum enim cæræ nafcantur, quomodo capti oculis ? Quid talpam, num de: fyderarelumen putas? Cicero 4. Acad. Talpa priuata eft uifu, (Hefychius oculis,) Suidas. Ocu

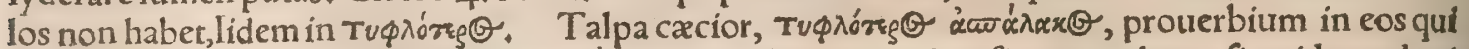
fupra modum cæcutiunt, aut qui minimé iudicant, Nam iocundior fiet metaphora, fi quidem ad ani is mum transferatur, Erafmus. Meminerunt prouerbï Suidas $\&$ Hefychius. Stefimbrotus ait eas à Terra excacatas effe quoniam fruges perdãt, Suidas. Talpam modo quedam oculos habere dixe rim, cum tamen omnino habere negem. quippe cum omnino quidem nec uideat, nec perfpicuos ha* beat oculos. Verum fi quis prætentam membranam detrahit, locus oculorum apparet, $\&$ pars nigra cor undem + fitus deni $\$$, \& defcriptio eadem, quam legitimam confpicui oculi obtinent, utpote cum obciucta cute oculi preffi, confufi, oblæefíç effent, dum crearentur, A riftoteles, Et alibi, Generi tals parum uifus deeft, non enim oculos in aperto id habet: cute tamen detracta, qua craffitufcula obren ta fedem luminum opacat, oculi intus laceffiti imperfectiḉ̧ uifuntur, fed ita, ut partes eafdem habeãt omnes, quibus oculi integri conftant. Habẽt enim nigricantem illum orbiculum, \& quod intra eum continetur, quam uocant pupillam, atç̧ etiam portionis albidx ambitionem * fed non tam liquidò, $z^{\circ}$ quàm oculi confpecti $\&$ eminentes.nec in partem exteriorem apparere hæc poffunt, propter curis obduct $x$ corpulentiam, utpote cum natura inter generandum lædatur, atç ita opus inchoatum re. linquatur, pertinent enim à cerebro, qua cum neruo cóiungitur, meatus duo neruofi ualidi ad ipfas oculorum fedes, qui in dentes fuperiores finiunt, $\mathrm{Hæc}$ Ariftoteles, Quadrupedum talpis uifus nó eft. Oculorum effigies ineft, fi quis prætentam detrahat membranam, Plinius. Talpa dicta eft, eò quod perpetua cæcitate tenebris damnata fit, eft enim ab/क oculis, Ifidorus. Talpa loca oculorum habet, non oculos.nam pellem in loco oculorum non habet pilofam, Albertus. Etrurfus 1. 2.3. Talpa (inquit) priuata eft oculis, ut uidetur. nihil enim omnino uidet, \& errat incedens quum de terra egreditur.fed hoc ex perimẽto cognoui, quod pellis in loco oculorum plana eft, $\&$ tenuis, alba, fine pilis, $\&$ prorfus folida, ut ne ueftigium quidem diuifionis appareat. hanc cum cautè incidiffem, 40 nibilomnino inueni nigredinis aut materiæ oculorum, fed carnem deprehendi illic humidiorem quàm alibi, erat autem recens capta talpa, $\&$ adhuc palpitabat. Sed nil mirum talpam oculis carere, quam extra terram nec uictum quarere nec aliter uerfari foleat. tuenatur enim in terra lumbricos, ubioculiei forent inutiles. Pellem uerò oculorum loco, tenuem, planam \& glabram obtinet, ut tenui ad eam luminis reflexione facta, hoc faltem percipiat fub terráne an fupra eam fit. Nam fupra terrã nifi ad unam alterámue ad fummum horam uiuere nequit, Hac ille. Mihi quidem aliquoties in: f picienti, tal parum ocelli liquidò a pparuerunt. prominent enim extra cutim ueluti puncta nigra, ma gnitudine feminis milij uel papaueris, nerto affixa. Hæc cum digito chartæ apprimerem, nigro hus: more eam infecerunt. Quin \& eruditus quidam amicus nofter, in talpa grauida diffecta foetus ali= quot fe reperiffe mihi narrauit, maiufculis capitibus, in quibus iam etiam oculi apparerent. $\llbracket A_{u=} \varsigma^{\circ}$

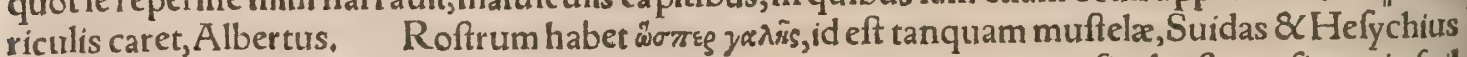

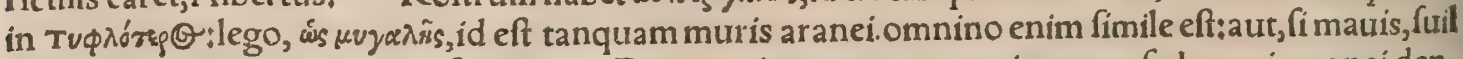
lo roftro, ut magnis parua conferantur. Dentes etiam non ut cæteri mures, fed muris aranei den. tibus feré fimiles habet, prafertim inferiores, binos enim anterius coniunctos $\&$ oblongos non ha= bet.fed ut canes uel muftelæ utrinç ad latera fingulos habet eminentes, non in utraç tamen ut illi, fed fuperiore tantum maxilla, pofteriores fiue interiores multis cufpidibus ut in mure araneo exaa

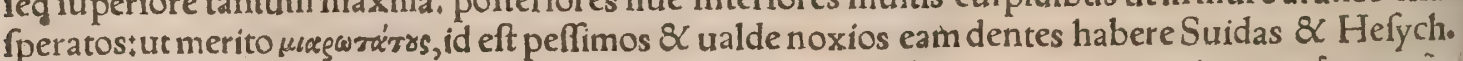

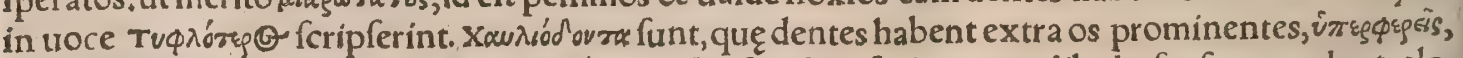
ut elephas, fus, talpa, $V$ arinus in Kapyogé ov rx. fed fui ab inferiore mandibula furfum tendunt, ele= phanto \& talpx à fuperiore deorfum. Lingua eft tanta, quantam inferior oris meatus capere po= 6 teft. Collum inter crura anteriora breuiffimum, \& propénullum. Pulmcnes multæ funt fibræ feparatx, qux nullo communi inter fe principio cohxrent, Sitifunt illi cum corde quod amples 


\section{DeTalpa B. C.D.E. Lib. I. 1057}

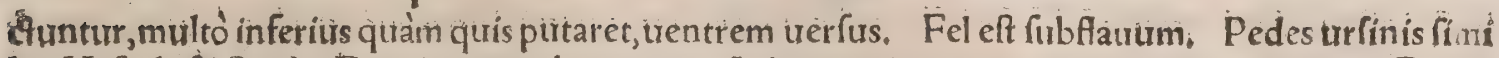
les, Hefych, \& Suid. Digiti eius quibus terram fodit, omnino acutis unguiculis a mantir, Ge. A.

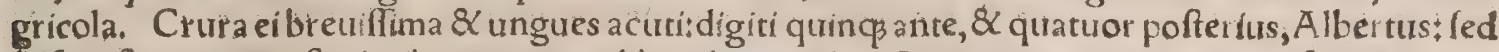
talfus eft, nawi in pofterioribus quoq̧ pedibus digiti quinç funt, quorum minimus ita fpectat intror fum, ut negligentius infpicientem lateat. Vola feu palmá anteriorum pedum bene lata eft, $8 \mathrm{ma}=$ numm refert, ratio etiam per mediuni relicto fi modice cöprimatur. Vngues in eifdem robufti, \& ma= iores longiores latioreş́́ quàm in ulla animante pro fui corporis modo. Hoc etiam eifdem cruribus peculiare, quod anteriorem duntaxat partem habeant, offibus conftantê geminis, qua fratim in ar= mum fiue os humeri inferuntur, fic enim fortius fodit. (ad quod illud etiam facit, quod pedes eorũós

10 digiti non deorfum fed ad latera fpectant,) Pofteriora uero crura, utranç partem, ut murium crura habent. fed pars qux infra genu eft, offe uno conftat, quod pauló infra genu bifurcatur. Cauda brè uis $\&$ hirfuta eft.

C.

Decæcitate talpæ, præcedenti capite diximus, đLiquidius (quàm homo) audiunt talpæobrù̉ tx terra, tam denfo atç furdo naturæ elemento. Præterea uoce omnium in fublime tendente, fermo:

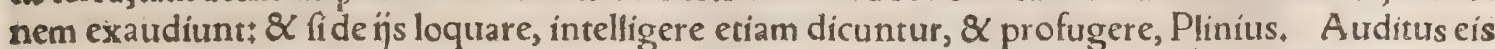
acriór fub terra, quàm fupra, Mich. Herus. Talpa acri audítu eft. 8 ideo longè in terra trahẽtes (fe mouentes) uermes audit. Verum hoc non ex auditus praftantia contingit, fed potius ex conmotx terra continuitate. Nam fi oblógus meatus fub terra excauetur, in quem aliquis uocem emitrat, aut 1. loquatur, longéauditur:ficut \& ille qui loquens"per haftas \& ligna caua quãmuis longa aùditur. Et hanc ob caufam talpa undiç circa fe oblongos meatus fodit. THomo nullius iudicij, fed tamen impendio uerbofus, loquax talpa dichus eft populari conuitio. Quod primum dicfum eft in Iulianũ Capellam, pofteaquam uenerat in publicû̃ odium. Nam talpæ noftri ut cæecifunt, ita funt æqué muti. Rerfert Ammianus libro 17. Erafmus. TCrura habet breuia, quare tardè graditur. Cum iníu=

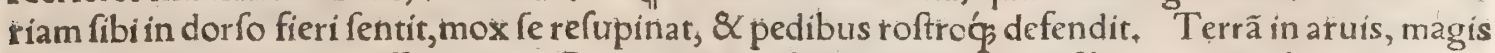
uerò in pratis $\&$ hortis paffim egerit, Ge. Agricola. Talpa domicilium fibi parat, Arifot. Terram pedibus effodere, roftro rëjcere uidetur, unde nomen Germanicum tuttilwetff. Adeò aurem hoc opus celeriter $\&$ amplè explet, ut qui uiderintprimò defoffam (à) ralpa humũ, multum admirentur; Cardanus. Nullum animal fanguine præditum ( $\&$ uiuiparum, fub terra perpetuồ uiuens præter 30 talpam eft inuentum, Cardanus. Audio talpas omnes menfe lunio apud nos latibulis fuis aliquan

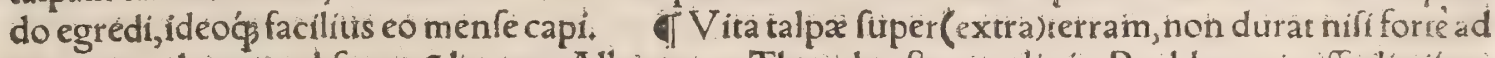
unam aut alteram ad fummũ horam, Albèrtus, Theophraftus tradic in Paphlagunia effodi pifces gratiffimos cibis, \&c. quicquid eft; hoc certe minis admir abile talparum facir trita fubterranei ani. malis, Plinius. Talpæ cum terram per caúernulas fubèant, fub terra fpirandi facultas eis nō adimitur: Et forfan cuniculorum fuorum aditus terra obrutos, idcirco rurfus aperiunt, ne refpiratio necefa faria eis intercipiatur, quanquẫ aliquando in fecundum aut tertium diem id facere differunt. Ifrn cibolumbricus appetunt. quamobrem amant loca ftercoràa, \& fterquilinijs hor torímó areis pro, xima. Agunt autem cunicülos fưos multò altius quàm fubterianei mures. Lumbrici cuin ralpas fibi imminere fenferint, ad folifuperficiem fugiünt. Vermibus uiuunt, in fame etiam terra, A uthor li $=$ 40 bri dé nat,rerum. Albertus lumbricis eas uefci fcribit, $\&$ in fame radicibus herbarũ, pracipué frua

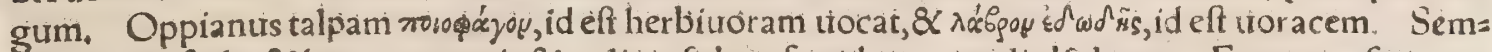
per terram fodit, $\&$ humum egerit, \& radices fubter frugibus comedit; Ifidorus. Experrus fum ( in: quit Albert.) quòd talpa delectatur bufonibus \& ranis in cibo. Et aliquando deprehendi bufone $\mathrm{ma}$ gnum, quem talpa fub terra pede mordicus apprehenfum retinebat: \& bufo fugiens iam toro corpo: re extra cuniculum educto, altam uocem ædebat propter morfum talpæi. Sed ranas etiam biufonesća talpam mortuam edere expertus fum. GCreatur talpa ex terra finul ac pluuia, Rodolphus qui.

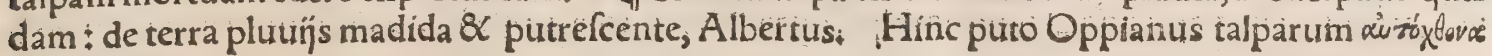
фǜre dixit.

D.

50 Muftela ín agris $\bar{\alpha}$ pratis mures $\&$ tal pas capit: quás in cuniculos etiam pérfequititir $\bar{\alpha}$ celeriter conficit. Feles quoģ capiunt quidem talpas \& perimunt, fed non edunt; ut audio. Voce omnutú in fublime tendente, talpæ tamen fub terra fermonẽ exaudiunt: $\&$ fi de his loquare, intelligére etiani dicuntur \& profugere, Plinius. Cum talpa quixdam in uas incidiffer, équio euadéré no n porerät áltera terram inijciendo ei opem tulit, ut referam féquenti capite, uerbis Gillï.

E:

Talpx omnes mènfe lunio latibulis fuis aliquando egredi dicuntür, ideoç̧ facilius eo mènfe ca pi. Quidubitant talpa ne an mus fubterraneus cunicttlos foderit, terra eos obruint. quod fifta. tim rưrfus aperti inueniantur, murem effé intelligũt. quiaminis enim talpa quoç̧ cos ruirfus aperiat; aliquando tamen in fecundum aut tertium diem differt. Vtriç fimiliter capiuntur, obferuatur ènim 6o quando ad aperiendum accédani, deprehenfíģ ligone ftatim poft ipfos in terram adacto eficiuntiur: Sunt qui decipulas quafdam firniliter ad utrof p̧ parent: machinis quibufdam, quorum ferréi mucro

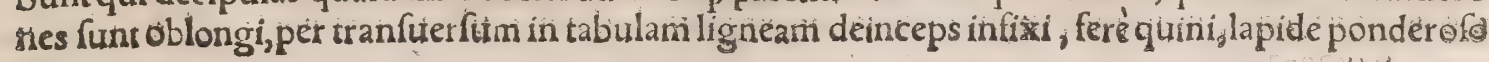


oneratis, ita inftructis, ut cum mus ad aperiendum cuniculum accefferit, \& impofitum illic paruum lignum attigerit, machina ruens dentibus fuis talpam perforet. aliqui filum ferreum mucronatum baculo infigunt, quem terra infertum flectunt, $\mathcal{X}$ ira inftrunt, ut cum ta!pa in aditum fui caui ue nerit, filo feriente trajjciatur. Talpas Graci hoc genere perfequuntur + Nucem perforari iubent, uel aliquod pomigenus foliditatis eiufdem. Ibi paleas, \& ceram(cedriam, Paxamus)cum fulfure fuf ficienter includi. Tunc omnes paruulos aditus, \& reliqua fpiramenta talpartim diigenter obftrui, unum foramen, quod amplum fit referuari, in cuius aditu nucem intus incenfam, fic pon $i_{\text {, }} u t$ ab una parte latus poffit accipere, quos ab alia parte diffundat, fic impletis fumo cuniculis ta! pas uel fugere protinus, uel necari, Palladius, Eadem omnino Grace leguntur in Geoponicis, authore Paxamo:

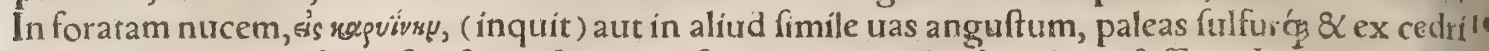
lachryma quantum fatis eft inferito, \&c, ut ita fumus omnis illaplus talpam fuffecet. In hëc modum

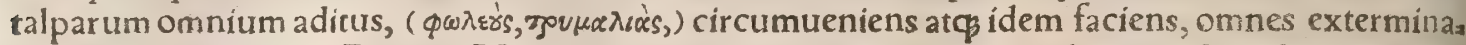
bis. Aliud eiufdem Paxami, Veratrum album $\&$ corticem cynocrambes trita $\&$ cribrata, cum fa rina \& ours ex lacte fubigens, in offas ( $\mu \alpha^{\prime}$ 2as) rediges, quas cuniculis talparum impones. Multi $\&$ formicas $\&$ talpas amurca necant, Plinius. Cum ad comprehendendas talpas tictile uas angu ftis faucibus in frobem de induftria factum demififfem, earumç una in hec ipfum incidiffet, $8 \mathrm{C}$ exi tus non ei pateret, quod furfum uerfus propter decliuitatem adrepere nó poffet, altera ei opẽ et falu tê tulit, terrãá̧̧ effoffam in uas tandiu côiecit, quoad exaggeratione faça, altera exire potuerit, Gill.

TE pellibus talparum cubicularia uidimus ftragula. adeó ne religio quidem à portentis fummo: uet delicias, Plinius. Ex earum pellibus etiam pileolos fieri Ge. Agricola fribit. Ego crumenas ali ${ }^{20}$ quando ex eifdem confutas uidi, oblectat enim denfa pilorum mollicies, \& color ex atro fplendens, quo fericum uillofum refertur. TCumulos à talpis excitatos in pratis hortisćg dificere oporter, idós potiffimum defcendente Luna, à cancro fcilicet ad capricornum, pręértim cum in aliquo figno ficco fuerit. Sunt qui cò utilius hoc fieri putant, quò minor Luna fuerit, non pluuio, fed ficco coelo, Obfcurus. Superftitiofum $¥$ Si falcem, qua foenum fecatur, in natali Domini in prato acuas, talpa omnes quotquor fonum audierint, è prato diffugient, Obfcurus. đM.Varro author eftà cunicu lis fuffoffum in Hifpania oppidum,à talpis in Theffalia, Plinius.

G.

Magi de talpis multa urana prodiderunt ‘ nec quicquã probabilius inuenietur quảm muris ara. nei morfibus aduerfari eas, quoniam et terra, ut diximus, orbitis depreffa aduerfatur, Plinius. Mor $3^{\circ}$ fui muris aranei talpa cifcerpta imponitur, Plinius Valerianus. Sorices magni, id eft talpæ, fi ima ponantur ictui fcorpï, fanant, Hali, Talpam fuper glandulas ligato, deftruit, Sexturs . Pilulas ex talpis cum melle fubactas, (diebus nouem deuoratas,) Arnoldus à bocio \& fcrophulis liberare putat, Oliuarius. Vtpili defluant, nec renafcantur: Talpam in aqua tandiu macerari relinques donec pi lis nudetur: hac aqua locum pilofum illines: ( $\&$ poftea ablues lixiuio, \& linteo perfricabis. \& fi pilire dituri uideantur, bis aut ter reperas.) hoc aliqui fe expertos fribunt, Andr. Furnerius, Vt pili in equis renafcantur \$ Talpa coquatur in oleo donec diffoluatur $\&$ confumatur caro. boc oleo locum pluries inunges, bis faltem die, Rufius. Vt piliequorum nigri mutentur in albos: $T$ alpam in aqua falfa uel lixiuso per triduum coques: \& cum aqua uel lixiuium confumptum fuerit, nouam aquam uel lixiuium addes : quo facto, aqua illa aliquantulum calida locum madefacito. Pili nigri mox des $4^{\circ}$ fluent, $\&$ fubnafcentur albi, Rufius. Aliter, Talpam in olla noua difcoques diutiffime, \& fuperna. tante pinguedine collecta locum in equo illines, Obfcurus. Aliter, Talpam in aqua coques do. nec diffoluatur: $\&$ fic triduo relinques. deinde illines locum, in quo pilos albos nafci uolueris, prius derafum, Obfcurus. Nugantur quidam, fiquis talpam manu dextra teneat donec expiret, fingu larem in illa manu facultatem futuram fedandis mammarum muliebrium doloribus. बTalpa ufte cinis cum albumine oui loco leprofo illitus, plurimum ualere dicitur, Albertus $\&$ alius obfcurus, Talpa cinis ex oleo uel melle illitus, cutim leprofam emendat, lacobus Oliuarius. Strumis talpæ cine rem ex melle illinire fuadent, Plinius \& Marcellus. Fertur etiam quod cinis talpæ contra fiftulam. ualeat, nempe ad eius putredinem confumendam, Obfurus apud Vincentium. Ad dentes mo= biles; Talpa cinerem mixtum cum melle fuperfricato, dentes confirmat, Sexturs, बSanguis talpx ${ }^{\circ}$ orcifa capiti glabro illitus, pilos reftituit, Albertus $\&$ alius quidam obfcurus. Ad paronychiam: Talpæ fanguinem chartæ inftillatum fuperilligato, Innominatus. Magi tradunt lymphatos fan: guinis talpæa afperfu refipifcere, Plinius. बAd ftrumas: Aliqui talpæ caput præcifum, 8 cum ter ra à talpis excitata tufum digerunt in paftillos pyxide ftannea, \& utuntur ad omnia qua intume: fcunt, \& quæ apoftemata uocant, quxós in ceruice funt, uefriós fuilla tunc uetant, Plinius. Tals parum capita recifa cum terra fua contunduntur, $\&$ pro em pla tro adponũtur frumis, utaliter proz funt, ob id quod paftilli inde facti in pyxide ftannea reponi debent, ut praffo fint cum opus eff, Mar cellus. TDente talpæu uiux exempto, fanari dentium dolores adalliga to magi affirmant, Plinius.

If Arnoldus putat cor talpæ nouem dies comeftum, liberare à bocio \& fcrophulis, Iacobus Oli uarius. đAd ftrumas:Aliqui iecur talpæ contritum inter manus illinunt, \& triduo non abiuũ̃, 60 Plinius. Iecur eius inter manus tritum adpofitum, plurimum prodeft, Marcellus, ब Dextrum quo. que pedem eius remedio effeftrumis affirmant, Plinius. 


\section{DeTalpa. H.ac.e.h. Lib. I. 1059 \\ $\mathrm{H}$.}

a. Talpæ octilis capti, Vergil.1, Georg, ubi Seruius, Mutauit(inquit) genus, nam hac talpa dicí tur.ficut $\&$ de damis fecir. Fiunt $\&$ circa genus figuræ in nominibus. nam $\&$ oculis capti talpæx, $\&$ timidi damæe dicuntur à Virgilio. fed fubeft ratio, quia fexus uter ç altero fignificatur tam enim ma. res effe talpas damasćç, quàm forminas, certum eft, Quintilianus 9.3. Talpa dicta eft, eò quód per petua crecitate tenebrís damnata fit:quam Graci afflata (lege, afpalaca) uocant, Ifidorus. Afpialis,

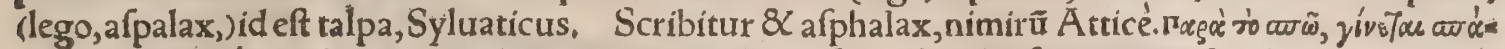
$\lambda \alpha \xi$, unde afphálax, abundante alpha, \& tenui in oppofitam fibi denfam conuer $\lceil a, V$ arinus, Ari= ftophanes in Acharnenfibus Bocotos ceur rudes ađamodum homines notans, Bocotum quendam in- ducit in foro uendentê lepores, uulpes, fcalopes, onedrowos, (Scholiaftes mures interpretatur qui alio

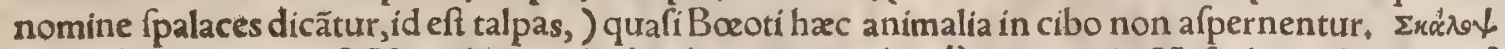

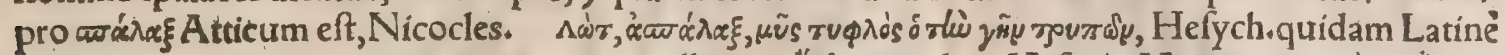

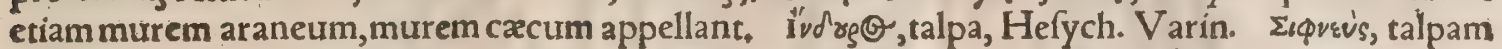

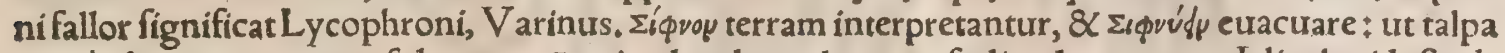
oqvevंs dicatur, tanquam fubterraneũ animal, uel quod terram fodiendo uacuet. Irliocha,id eft tal pa,syluaticus. Orthoponticos, id eft, talpa, Idem. TEpitheta:Oculis captus, obrutus, captus lux

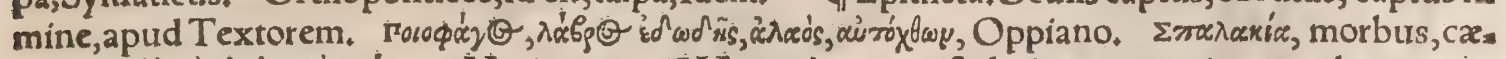

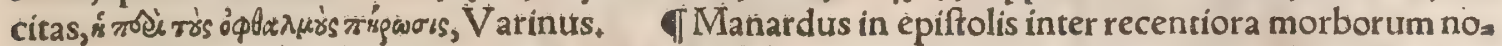
mina, teftudinem $\&$ talpam (tumores, nimirum ab horum animalium craffo, lato $\&$ informi corpore

20. fic dictos)ponit. Teftudinem (inquit) uocant tumorem mollem, uel non ualde durũ, fatis autem ma= gnưm, ín quo pinguis materia, tunica quadam obtecta continetur, qux caluarix ita haret, ut ipfam

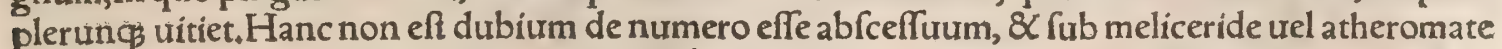
contineri. uidetur autem meliceris potius quàm atharoma. Cæterum talpæab iftis non magnopere diftant, nifi quòd quum albã materiam contineant, ad atharomata potius quàm melicerides referun. tur, Hæc Manardus. Sed uidetur etiam author libri tertị de Parabilibus, (qui Galeno adfcribitur,)

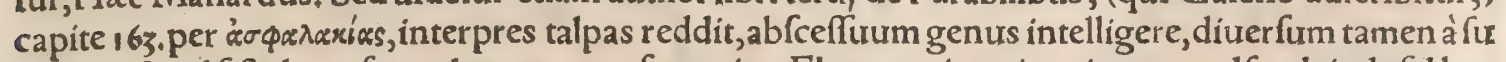
periore, $\&$ ad fiftulas referendum propter foramina. Elues eas(inquit)primum mulfo, deinde fel bus bulum inṅcito, \& leporis fimum, aut quod ex fapone confectum eft : aut rutæ fuccum in foramina inftillato, aut ariftolochiam tritam cum aceto fubigens, in foramina infarcito. đEft \& herba fpa= 5o.lax, uel ut Gaza reddit afpalax:de qua Theophraftus I. II. hiftoria plantarum, Herbaceorum etiam

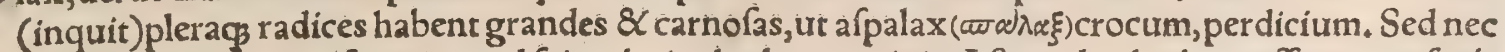
ipfe alibi, nec alius quifquam quod fciam huius herba meminit. Aftragalus herba craffos carnofoś́ aliquot nodos in radicibus habet, \& quarendum an ita melius quàm âfpalax legatur.

T) c. Formic Indic, quemadmodum talpx, fic ad cauernarum fauces terram exaggerant, Aeliantus.

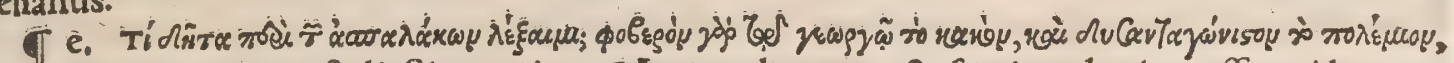
Rufticus quidam in epiftolis Simocati. đArmo talpæcontacta femina uberiora effe quidam pu= tant, Pliniưs.

h. Phineum excacatum $\&$ in talpam mutatum, Oppianus canit circa finem lib,2, de uenatio. 40 ne. Ouidius tamen in Metamorphofi ipfum $\&$ focios in faxa conuerfos fribic. Talparum è pelli= bus cubicularia uidimus ftragula, adeò ne religio quidem à portentis fummouet delicias, Nam re ligionis capax dicitur animal, Plinius. Et alibi,Peculiare uanitatis Magorum fit argumentũ, quód animalium cunctorum tal pas maximé mirantur, tot modis à rerum natura damnatas cacitatis per. petuæ, tenebris etiamnum alịjs defoffas, fepulcisḉp fimiles. Nullis æquè credunt extis. Nullum reli= gionis capacius iudicant animal: ut fi quis cor eiưs recens palpitansḉ̧ deuorârit, diuinationis \& re= rum efficiendarum euentus promittant. Veteribus monumentis traditur, gallinaceorum fibras maximé dịs gratas uideri, ficut talparum(ưifcera)Magi ueriffima dicunt, illiśç̧ haud fecus quàm fo lenni uictima pulcherrimè litari, hæc enim funt exta argutiffima, in quibus diuina mens ineffe credi tur, Alexander ab Alex.5.25. Et paulò poft, A pud Magos talparum exta \& ranarum, eurentus fortu=

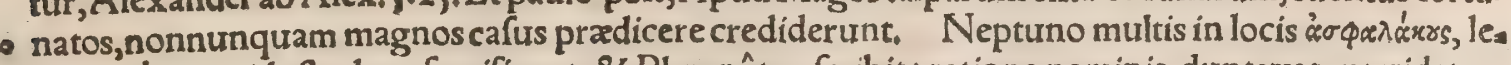

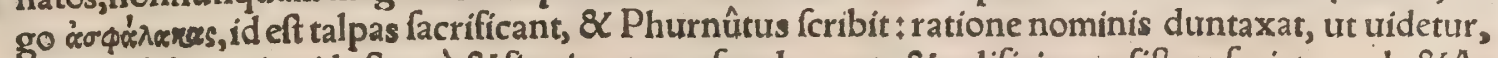

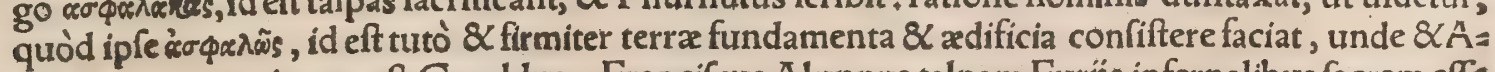
fphalius cognominatus eft, Gyraldus. Francifcus Alunnus talpam Furïs infernalibus facram effe fribit:authorem uerò non adfert.

đProuerbia, Talpa cæcior; 8 T Talpa loquax, explicata funt fupra capite tertio. 
Ic60 De Quadrupedibus.

D E T I G R I D

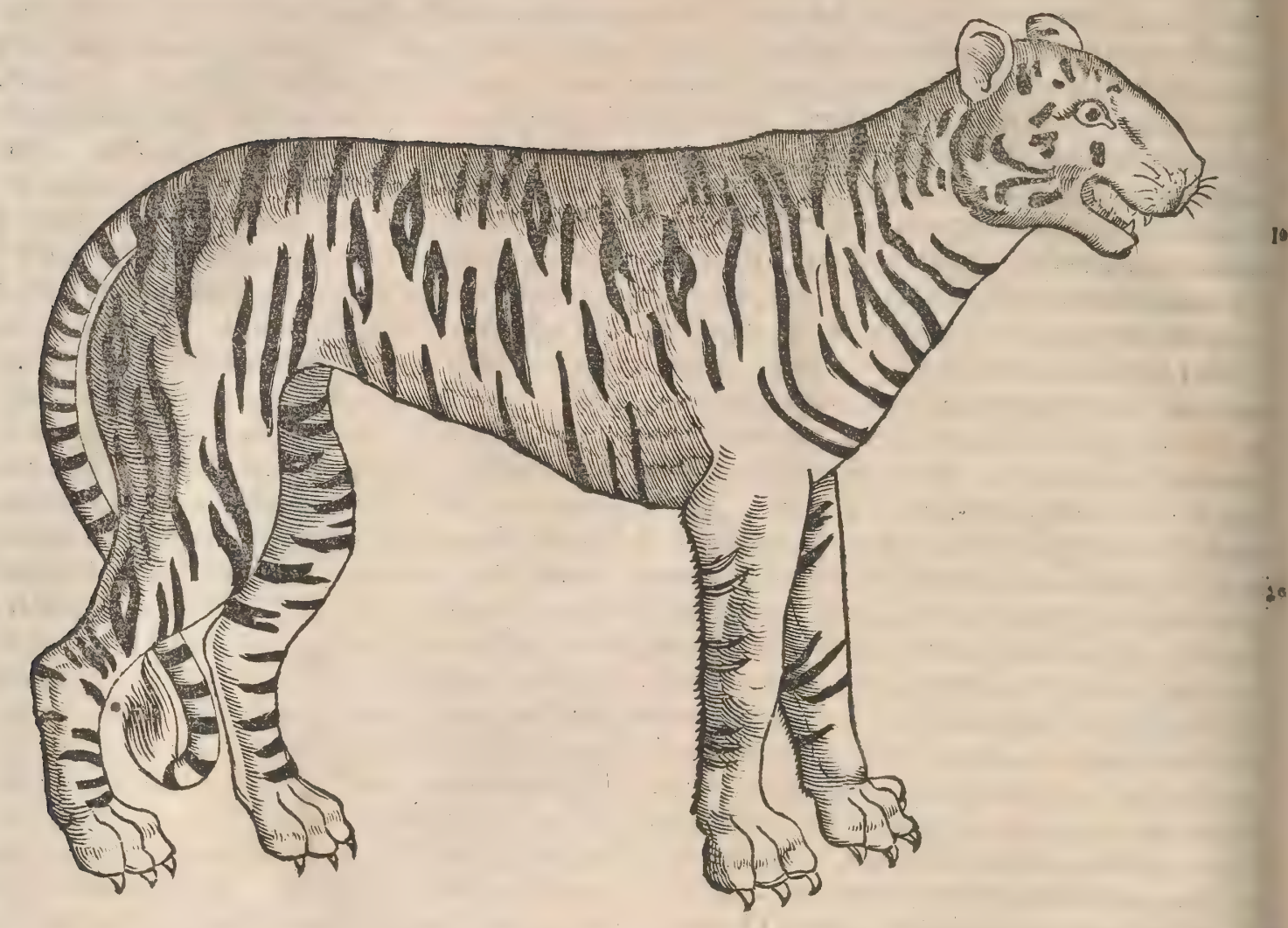

A.

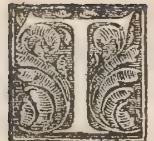

I G R I S uocabulum eft lingure Ârmenix.nam ibi \& fagitta, 8 quod uehementifimum flumen, dicitur Tigris, $V$ arro de ling.Lat. Tigris uocata eft propter uolucrem fugam. fic enim nominant Perix $\&$ Indi fagittam, Ifidorus. Medi tigrin fagittam appellanr, Pe oe tus, \& Euftathius in Dionyfium. Munfterus in Diçionario furo trilinguiuocem ๆ"มgir, 8 girera, fagittam interpretatur. In eodem opere hanc feram Hebraicis literis eiufdem foni, quis

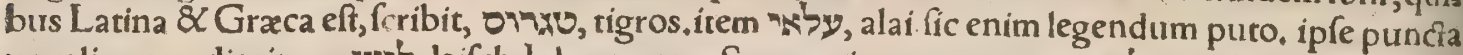

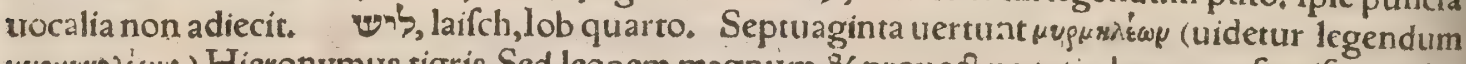

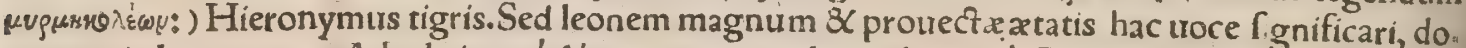
cuimus in Leone A. A ludæis qogḱold uocatur a nimal, quod tigris à Græcis, Hefychius, Varinus, Hoc animál quia Europæ peregrinum eft, omnes in ea populi tum barbari, tum Latini Gracióg, uno 8 codem nomine peregrino u ữtur. A b Italis tigre uel tigra in recio fingulari fcribitur. $A$ Gals lis mafculino genere ung tigre, à nobis neutro, tigertbier, hoc eft, tigris animal. Tigres uulgò dia ćas non ueré tigres, fed thôas maiores effe aliqui putant, ut dicam in B.ex Arriano. Mantichoram Paufanias in Bocoticis, tigrin effe conijcit:ego leucrocutam potius, ut inter animalia hyxnæ conge. nera declaraui,

\section{B.}

Leones $\&$ tigrides in regionibus ad Orientem $\&$. Auftrum nafcuntur; quod maiorem caloris copiam hæc animalia defyderent, Calius. Tigres in India funt 8 iuxta rubrum mare, Philoftra= $5^{\circ}$ nus. Afanga Indix populi (ultra Gangen)tigri fera fcatent, Plinius.Prolemaus Befingos Perimus leis ultra Gangen uícinos tigribus infeftari plurimis fcribit, Megafthenes in Prafrńs tigres gigni leonibus feré duplò maiores tradit, Strabo. In Taprobane tigrides \& elephanti capiuntur, Solinus. Inter tigrium epitheta apud poëtas, Armenias \& Hyrcanas legimus. Tigrin Hyrcani $\&$ Indi ferunt, Plinius. Tigridum millia multa apud Hyrcanos cernuntur, Ammianus Marcellin. Hyrcania foeta eft tigribus, Solinus. Apollonius (inquit Philoftratus libr.3.) dextra quidem Gan gem, finiftra uerò Hyphafin flutrium habens, ad mare defcenditcum focijs. Defcendentibus autem multæ feræ, Q inter cateras tigres occurrerunt. In parte Syriæ contermina reperiuntur leones $\&$ pardales, \& qui Babylonï uocantur tigres, Diodorus. Poft Barygazam continens ad Auftum pertingens Dachinabades uocatur:qux fupra hanc eft mediterranea regio ad Orientem, mötes ma $=$ to gnos continet, \& omnigena ferarum genera, pardales, rigres, \&c. Arrianus in Periplo rubri maris. Colonus Hifpanus ex Hifpania foluens ab Oriente in Occidentem diebus 26. Hifpaniolam infu* 


\section{DeTigride. B. C. Lib. I. 1061}

lam attigit, inde Occidentem rectà fecutus in Guanaffam infulam peruenit : unde pergens, ad mila liaria decem Ciambam regionem inuenit, qua leones $\&$ tigrides nutrit, Perrus Martyr.

Indi tigrim elephanto robuftiorem muliò exiftimant. huius ferx pellem fe uidiffe Nearchus frribut, animal uerò ipfum nó ucitle: Indos uerò referre, tígrim effe naximi equi magniudine, ue= locitate $\&$ uiribus beftias omnes fupcrat e:elephantum rriam, infileniem in capur eius, facile fufio care. Illas uero quas nos uidemus $\&$ tigres uoramus, thoas uarios effe, \& maiores quam cateri thoes fint, Arrianus in Indicis. Strabo lib.15.teftatur Megaf.henem feribere, iggres : $n$ Ir dia apud Ptatros populos, magnitudine duplos ferè ad leonem, adeò ualentes effe, ut unus $\mathrm{cx}$ manfuetis à quatuor ho minibus ducius fi mulum pofteriore pede apprehenderit, ad fe trahat. Tigris ad magnitudinem 10 leporarij canis, (Anglici, Obfcurus, Hyrcani, Arnoldus de Villanoua) \& amplius excrefcit, Alber=

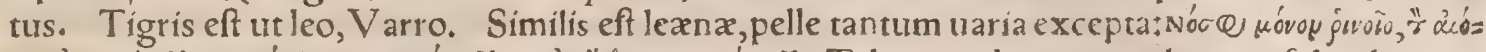

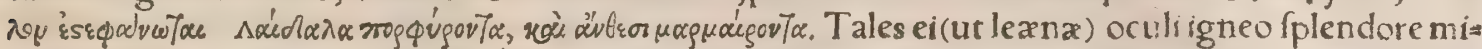
cant, \& reliquum corpus fímile eft, nempe ualidum \& bene carnofum, (¿u Geprov, ) \& cauda fimuliter prolixa. Tale os, facies, ac fimilis in ima fronte laxa pellis (epifcynion, de qua uece plura dixi in Leo=

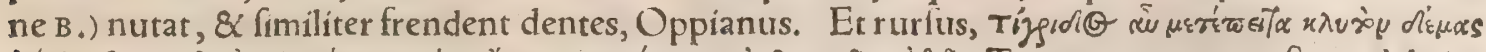

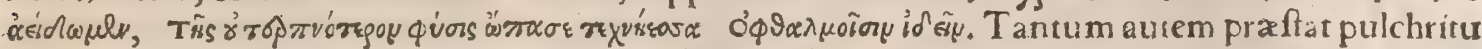
dine tigris inter alias feras, quantum inter uolucres pauo. Idem libro primo de uenatione, in men tione equorum quos orynges uocat.horum alĭ, inquit, floridis decorantur máculis multis (

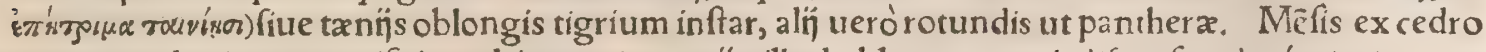

20 pracipua dos in uena crifpis, uel in uertice uarïs.illud oblongo euenit difcurfu, ideoćs tigrinæ ap= pellantur thoc intorto, $\&$ ideo tales pantherinæ uocantur, (plura fuper hoc loco dixi in Panthera a. inter deriuata,) Plinius. Panthera \& tigris macularum uarietate propé folæ beftiarum (pectan= tur, cæteris unus ac fuus cuiufá, generis color eft, Plinius. Tigres beftias infignes maculis notæ \& pernicitas memorabiles reddiderunt. fuluo nitent. hoc fuluum nigrantibus fegmentis interunda. tum, uarietate apprime decer, Solinus. Albertus Solini uerba non reciè inuertit, nigri coicris efie fcribens, fuluis uirgulis quafi undatim intercepti. Tibi dant uaria pecfora tigres, Seneca in Hip. polyto. Tigris atra, Vergilio 4. Georg. Maculora, Ouidio ı. Metamor. Vngues haber adun. cos, dentes acutos, pedem multifidum, Albertus. Omnia fermé animalia frua feli fimilia funt, pan= theræ, lynces, pardi, \& forfan etiam tigrides, commune enim eft unguium magnitudo \& robur, pel $3^{\circ}$ lis diftincta, uerficolor ac pulchra, caput rotundũ, facies breuis, ( hæc duo tigridi non conueniunt:) cauda prolixa, agilitas corporis, feritas, \& cibus qui uenatione acquiritur, Cardanus. Natura leoni bus, ficut $\&$ urfis $\&$ tigribus anguftiora (breuiora intelligo) creauit colla. quia in terra ceruicem $\&$ ora non déj̧ciunt pafcendi gratia, fed aut ceruum inuadunt, aut bouem ouem ̧̧́ difcerpunt, Ambro fius. Falló creditur omne genus tigrium foemineum effe, nec coire cum ullo mare, fed ex uento concipere. capitur enim nonnunquam mas, etfi rarius, Oppianus.

c.

Tigrides indomitærancant,rugiuntć leones, Author Philomelæ. Si uenatores raptis eius ca.

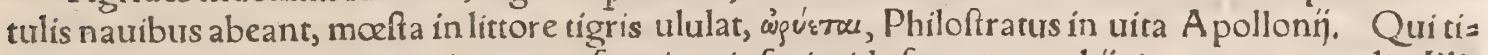
gridis catulum rapuit, appropinquante fremitu, (ipfa tigride fremente, ) abịcit unum ex catulis, Pli= 40 nius. Oppianus tigrin $\&$ catera leænæ fimilia habere fcribit, fi pellem maculofam excipias, \& fimi

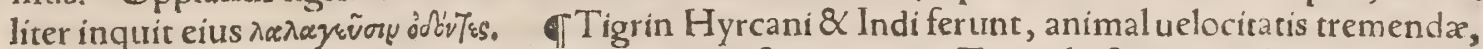
8 maximè cognit $x$ dum capitur, Plinius. Vide inferius in E. Tigres beftias macularum notæ \& pernicitas, memorabiles reddiderunt, Solinus. Etrurfus, Pedum tigridis motum nefcio an uelocitas an peruicacia magis adiuuet, nihil tam longum eft quod non breui penetret, nihil adeòantece: dit, quod non illico affequatur. Cætera(præter pellem uariam)fimilis eft leænæ: fed multó celerior tum hac, tum quibufuis uelocibus feris, curfu enim fimilis eft Zephyro genirori. nam à ciento eas concipere falfó creditur, Oppianus. Huic fabula forfan nimia earum uelocitas occafionem dedit, uc 8 equos quoldã uelociffimos è uentis prognatos ueteres fabulati funt, ut equos Dardani ex Borea. In Lufitania etiam equas ex uento concipere, in Equo c. ex Varrone retuli, Præter tigridem nul= go lum animal fermè rapax, pernix eft, Cardanus. Ocyor \& coeli flammis \& tigride, Lucanus lib. s. बI Indi tigrim elephanto robuftiorem multo exiftimant.aiunt autem eam maximi equi magnitudine effe, uelocitate $\&$ uiribus tantis, ut nullum ei animal conferri poffic. nam fi quando cum elephanto pugnat, infilire in eius caput, $\&$ facile fuffocare. Quas ueró nos uidemus $\&$ appellamus tigres, Near chus fcribit thôas uarios 8 maiores effe, Arrianus in Indicis. Megafthenes prodidir, in Prafís tí. gres gignileonibus duplò ferè maiores, eo robore ut fì de manfuetis unus à quatuor hominibus dus

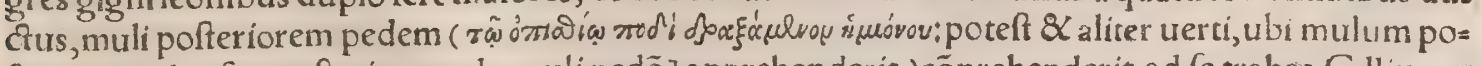
freriore pede [ fuo pofteriore pede, muli pedẽ] a pprehenderit,) cöprehenderit, ad fe trahat, Gillitus $\mathbf{e x}$ Strabone. De tigride cicure qua ferum leonem lacerauit, Martialis carmen extat in libro Specia culorum, epigrammate 18. बTigres in Hyrcania urgente inedia Oxum \& Maxeram amnes alí. to quoties nataru fuperantes, improuifa finitima populantur, Am.Marcellinus. TCibicaufa onne a nimalium genus, quadrupedes prafertim maiufculas, inuadit, Elephantum ab ea facilefuperari, \& mulum uel pede apprehenfum trahi, (à maiore fcilicet $\&$ propriè dicta tigni, ) paulójante rcciraú. 


\section{2

Ceruos, boues \& oures inuadit, Ambrofius. Tigris cicur obieço hoedo, quo cum familiariter dius uerfata erat, biduum totum abftinuit;tertio die cum efuriens aliud poftularet, felem datum difcers pfit, Plutarchus in libro Vtra aninalium, \&c. T Per fyluas tum (tempcre libidinis) fruus aper, tum peffima tigris, Heu malè tum Libyx fulis erratur in agris, Vergil,in Georg, Coitus auer= fus elephantis, camelis, tigribus, \&c.quibus auerfa genitalia, Plinius $\&$ Solinus. Tigris multos pa rit catulos, Albertus. Tigris curfu eft fimilis Zephyro genitori; etfi fabulofum uideatur feris uen tum mifceri, falfò enim creditur omne tigrium genus foemineum effe, nec coire cum ullo mare,capla tur enim nonnunquam mas, etfi rarius, ut qui uifis uenatoribus catulos deferere, $\&$ fuga fibi confus lere foleat, manente cum eis matre, Oppianus. Ex tigride $\&$ cane Indicos canes gigni confirmâr: uerum non ftatim, fed tertio coitu, primo enim belluinos adhuc catulos procreari aiunt, alligantur canes locis defertis, $8 \mathrm{x}$ nifi bellua incenfa libidine fit, fæpe lacerantur, A riftoteles. Idem alibica=

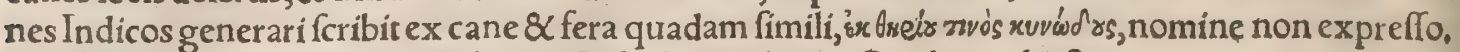
Plinius Hyrcanos canes ex tigribus nafci fcribit, ut dixi in Canibus robuftis.

D.

Tigris bellua eft afpera, fxua, indomita, rabida, his enim epithetis eam poëtx cognominant. Ti gres leones ó $\$$ nunquam feritatem exuunt, aliquando fubmittunt, \& cum minimè expeçaueris, ex: afperatur toruitas mitigata, Seneca in epiftolis. Leonibus manus magifter inferit, of culatur tigrim furus cuftos, Ibidem citante Crinito. Indi ad fuum regem afferunt tigres domitos, cicures panthe, ras, \& c.Aelianus. Plutarchus(in libro V tra animalium \& c.) fcribithœdum quo cum tigridi ui= uendi confuetudo fuiffet, cum deuorandum huic quidam obieciffent, eiufmodi feram, quamuis alte zo rius cibi nulla facultas effer, ab edendo non modò fe fuftẽtaffe toto biduo, uerũ etiam ut aliũ cibũ pe tere intelligeretur, caueam (galeagram) qua contineretur, diftraxiffe, \& dirupiffe. Eandem hiftoriá de pardali, qua hoedum fecum nutritum attingere noluerit, ex A eliano retuli in Panthera $D$. Tigris animal eft fæuiffimum, \& incomparabili rabie fæuiens, præcipué quando raptis catulis infequitur uenatores, Phyfiologus. Leones, pantheræ $\&$ tigrides, foetus fuos uehementer amant, $\&$ pro ipfis contra uenatores pugnando, quxuis tela $\&$ mortem quo $\$$ contemnunt, Oppianus libr, 3 . de uena: tione. Deñfdem \& lyncibus ibidem fcribit, quod cum ad latibula fua reuerfæe catulos fibi ablatos nó reperiunt, magno \& miferabili eos ululatu plangant. Tigris mas rarò capitur, nam uifis uenato. ribus relictis catulis in fugam fe conijcit, fomina uerò cum catulis manet, \& animo mofta à latis ue natoribus irretita capitur, Oppianus. Plura adferemus mox fequenti capite. Tigris etiam ( $\mathrm{fi}_{3} 3^{\circ}$ milia proximè de elephanto dixerat) feris cateris truculenta, ato̧̧ ipfa elephanti quoo $\phi_{s}$ (pernens uefti gia, homine uifo transferre dicitur protinus catulos, Plinius. QQuæanimalia tigris inuadat, la niet, aut fuffocet, præcedenti capite dixi.uidetur enim cibi duntaxat gratia, quæcunç confequi po= teft, interimere. T Tigrem dicunt fi tympanorum fono cbftrepatur, infanire atç̧ furere, $f^{\prime} f_{e} e_{\beta}$ di= ferpere \&lacerare, Aelianus,

E.

Tigris uiuus capi adhuc non potuit, Varro de lingua Lat. Iuxta Gangen Indix flưuium bua gloffo fimilis herba nafcitur, cuius fuccum expreffum Indi feruant, 8 intempefta nocte latibulis ti=

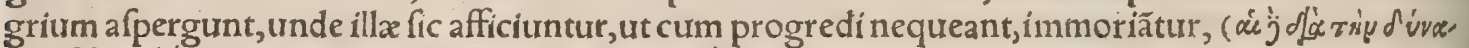

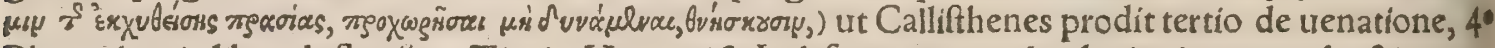
Plutarchus in libro defluuns. Tigrin Hyrcani \& Indi ferunt, animal uelocitatis tremendx, \& ma. xime cognite dum capitur. Totus enim foctus, qui femper numerofus eft, $\mathrm{ab}$ infidiante rapitur equo quàm maxime pernici, at ${ }^{3}$ in recentem fubinde transfertur. At ubi uacuum cubile reperit forta $(\mathrm{ma}$ ribus enim cura non eft fobolis)fertur praceps, odore ueftigans. Raptor appropinquante fremitu, abïcit unum ex catulis. Tollit illa morfu, \& pondere etiam ocyor acta remeat, iterumọ́ confequitur 8 fubinde, donec in nauem egreffo irrita feritas fruit in littore, Plinius、 Tigrium potentia(uelo citas)maximè probatur, cum maternis curis incitantur, cum catulorum infiftunt raptoribus. Succe, dant fibi equites licet, 8 aftu quantolibet amoliri prædam uelint, nifi in prafidio maria fuerint, frus. ftra eft aufum omne. Notantur frequentiffimè, fi quando latrones (uenatores) fuis afportatis catulis renauigantes uident, in littore irrita rabie fe dare præcipites, uelut propriam tarditatê uoluntaria ca so ftigantes ruina:quanquam de fotu uniuerfo uix unus queat fubtrahi, Solinus. Ad naues ufque procedere tigrim ferunt catulorum repetundorum gratia, illiş̧̧́ receptis cum gaudio abire. quod fi ablatis catulis abeuntes naues afpiciat, moftam in littore ululare, (uide etiam fupra in $D$.) quandog: etiam ob doloris magnitudinem mori, Philoftrat.lib.2. de uita A pollonï. Mas raro capitur. nam ue natoribus confpectis, catulos deferit $\&$ fugit. foemina uerò cum eis manens, irretita à uenatoribus ca pitur, Oppianus. Venatores quidam fphæras uitreas catulorum quos rapuerint infequentibus ma tribus ob̆́ciunt, quas illæ intuentes, imagine quam ipfa reddunt decipiuntur, ut catulos fubeffe pu tent, idćs eo magis, quod fphæra moueatur, ceu uiuum in fe animal continens. Sed cum tigris fphæ: ram pedibus confringit, ut catulo potiatur, delufam fe uidens pergit infequi. Illialias fubinde fplia: ras obriciunt, deluduntó̧, donec ad ciuitates uel naues euadant, Albertus. TDarienen infulam 60 noui Orbis in Oceano Occidentali, qua octo feré dierum nauigatione ab Hifpaniola diftat, infefta= tam anno fuperiore (circa annum Domini isi4, )aiunt, ita ut integro femeftri tempore, nox nulla ins 
demnis abierit, quin uel iuuenca aut equa, canis aut porcus, in tra uici ipfius uias interimeretur. Ar. menta gregesḉ iam affequuntur.ínò $\&$ minimé tutò referunt, domo exiffe quenquam co tempore, quando pracipue catulos alebat. tunc nanç adoriebatur $\&$ homines, fame urgente catulorum, fi ho mines prius occurriffent quàm brutum animal. Neceffitate cogente tandem ars inuenta eft, qua tanti fanguinis poenas lueret, exploratís anguftịs femitarum, quibus è cauernarum latebris ad prax: dam noctu prodire folebat, iter feiffum eft. Excauatam frobem cratibus \& egefta terra, parte fuper uacua difperfa, ftrauerunt. Veniens incautus, mas quidem erat, tigris decidit in foueam, \& fudibu's acutis in fcrobis fundo fixis inhæefit. Rancatu fuo uniuerfam obtundebat uiciniã, \& montes illo ftri. dore reboabant. Saxis ingentibus è foff $x$ fupercilins in eum fudibus infixum deiectis, peremptus eft. - In mille affulas $\&$ mille fruftula, fixa dextra, directas haftas $8 \mathrm{ab}$ alto iaculatas dirumpebat. Semia nimis \& exanguis formidine replebat intuentes. Ioannes quidam Ledefma Hifpalenfís, de tigride il lo fe comediffe faffus eft, bouina carne nihilò deteriorem effe mihi retulit. Vnde tigridem effe dicât interrogati, qui nunquam tigridem uiderunt alijs ab authoribus datis tigrim arbitrari. Cum \& pardos $\&$ pantheras maculatos ex ipfis plariç le uidiffe prædicent. Tigride mare perempto, montes uerfus ueftigia illius fecuti, antrum coniugale ipfius domicilium adeunt, duos, abfente genitrice, catulos uberibus adhuc matris indigos auferunt Mutato confilio, quo grandiufculos effectos in Hifpaniam poft hæc mitterêt, ferreis catenis diligen: ter in colla compofitis, ad maternum antrum paruulos reportant lactandos. Poft paucos inde dies regreffi ad peluncam, catenis nil fuo loco mutatis, uacuam reperêre fpeluncam. Putant à matre in 2o frufta præ rabie dilaceratos, ablatosíg ne quifquam eis frueretur. Affeuerant nanq̧ folur ẻ catenis nullo pacto poturiffe uiuos. Pellis perempti tigridis ad Hifpaniolam, ficcis herbis $\&$ culmo farcta, mif fa eft ad Almir antum $\&$ primores. Qui à tigride incommoda paffi funt, \& qui pellem eius tractarũt, hæc mihi differuerunt, qua dant accipimus, Petrus Martyr Oceanex Decadis 3. libro 2. $\$$ Diutus Auguftus Q. Tuberone, Fabio Maximo coss, quarto nonas Maй, theatri Marcelli dedicatióe, tigrin. primus omnium Romæe oftendit in cauea manfuefectam : diuus uerò Claudius fimul quaturor, Pli. nius. Inter munera Augufto miffa ab Indıs, tigres Roma uifa fuêre primo, ut author eft Dion, Ca lius. Fuerunt fub Gordiano Roma tigres decem, leones manfueti fexaginta, \&c. Iul, Capitolinus . Heliogabalus portentofi ingenī imperator, leones $\&$ tigres ad currum iunxit, Cybelem $\mathrm{fe} \& \mathrm{~L}$ Liberü patrem uocitans, Textor ex Lampridio. Meminit etiam Crinitus 16, 10. Picto quòd iuga delicata o collo Pardus fuftinet, improbxẹ́ tigres Indulgent parientiam flagello, Martialis in libro Specta= culorum epigrammate i48. Romæ in triumpho Aureliani fuerunt tigrides quatuor, camelopar= dali, alces, Vopifcus. Edita munera in quibus prater alia diuerfa ex toto orbe terrarum, tigrides exhiburit, Capitolinus in Ântonino Pio.

F.

Menfæapud Indos imponuntur leones, apri, \& tigrium clunes, Cateris enim animalis huius partibus uefci Indi prohibentur, Philoftratus lib. 2. de uita Apollon. Qui in Dariene infula tigria nam carnem guftauit, bubula nibilò deteriorem effe retulit, ut præcedenti capite recitaui.

$\mathrm{H}+\mathrm{a}$.

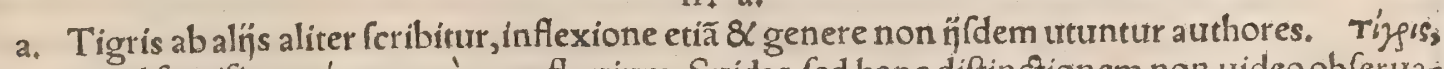
$40 \mathrm{cum}$ animal fignificat: riggss uerò, cum fluuium, Suidas. fed hanc diftinctionem non uideo obferua:

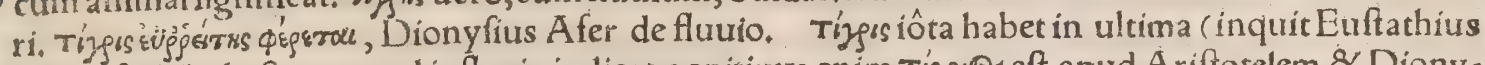

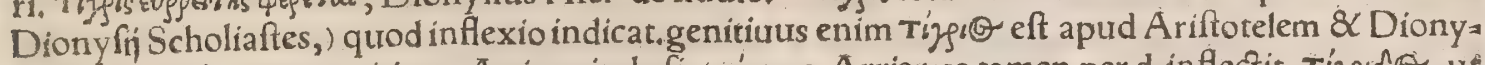

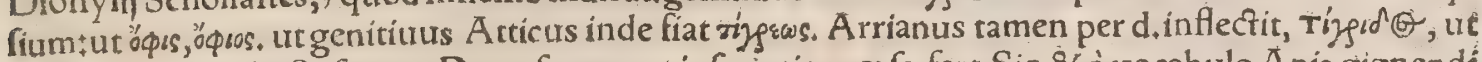
etiã author fabula Sufannæ, Damafcenus ut infcriptio præfe fert. Sic \& à uocabulo Apis gignendi

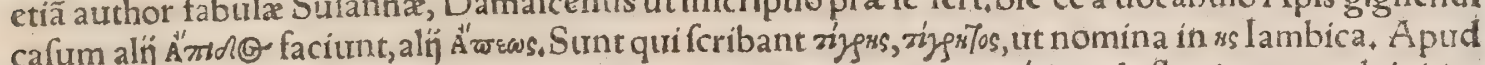
Iulianum quidem $\&$ Arrianũ de geftis Alexandri, reperitur etiam ríggs, de flutio, per p. ab initio,

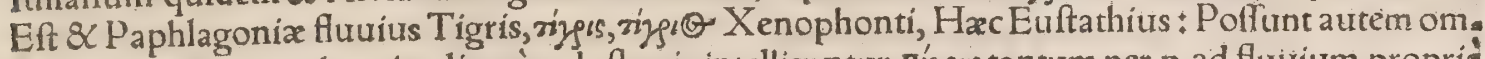
nia fic accipi, ut tam de animali quàm de fluuio intelligantur, niggss tantum per p.ad fluirium propriè

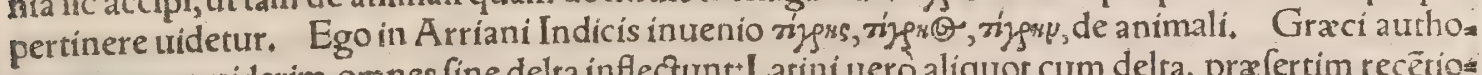
- res, quos ego tiderim, omnes fine delta inflectunt: Latini uero aliquor cum delta, prafertim recêtio res. Tíurides enim legimus apud Solinum, Capitolinum, $\&$ authorem Philomela: Tigridum, a pud A.m. Marcellinum $\div$ Tigridibus, apud Capitolinum. Ocyor tigride, Lucanus lib. 5. Tigrin, tigrim, $\&$ tigrem, apud ueteres Latinos reperio, omnia in accufandi cafu. Legimus $\&$ in plurrali numero apud clafficos aurhores, Plinium, Senecã, \&c,tigres, tigrium, tigribus. Tu (alloquitur teftudinem inftrumentum muficum) potes tigreis, comitesćs fyluas Ducere, Horatius Carminum 3. 11. Iden in libro de Arte, primam huius uocis corripuit, Diçus ob hoc lenire tigres, rapidosḉ̧ leones, de Or. pheo. Tigris qui eft ut leo, qui uiuus capi adhuc non potuir, Varro genere mafculino. Plinius \& aln̈ Latini omnes, ni fallor, foeminino genere efferunt. Graci uerò pleriç in mafculino, Paufanias,

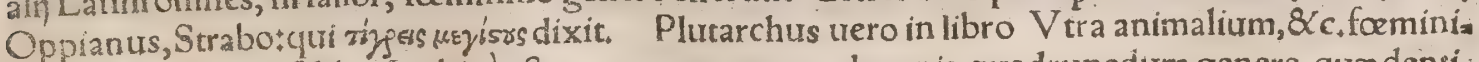
60 num fecit. Alfebha Arabicè eft nomen commune ad omnia quadrupedum genera, quxe denti: bus $\&$ unguibus fuis aggrediuntur homines mordendo $\&$ lacerando, \& quandoç mortem inferen. do, utleo, lupus, tigris, $\&$ fimilia , Bellunenfis. Vetus A uicenna interpres lupos uertere folet. A 


\section{4

fluxio dicor, fluruius uel dicitur ex me, Iunctá̧̧ fum uento, uento uelocior ipfo, Et mihi dat uen rus natos, nec quaro maritos, Camerarius in Exercitīs rhetoricis.eft autem ænigma de tigri.

(1) Epitheta. Armeniz tigres, Vergilius 5. Aegloga, Atqui non ego te tigris ut afpera, Ge= tulúsue leo frangere perfequor, Horatius I. Carm. Atra, Vergil.4.Georg. Hyrcanxás admos runt ubera tigres, Idem 4 . A eneid, in fxum 81 crudelem. Improbx, Mar tialis. Indomitx, Au= thor Philomelæ. Maculofa, Ouidius I, Metamorphofeos. At rabidxtigres abfunt, 8 faur leo= num Semina, Vergilius de Iralia * Quis fcit an hæc fruas infula tigres habet? Ouidius epifto. 10, Tibi dantuariæ pectora tigres, Seneca in Hippolyto, Virgatæ, lbidem. Et præterea apud Te* xtorem, Tigres acerbx, A fræ, afperæ, auidx, capiftratæ, Cafpix, carchefix, Caucafex, concita, den= tat $x$, effer $x$, fer $x$, furibund $x$, Gangetic $x$, immanes, Ind $x$, Martiæ, Parthic $x$, pedeftrenux, rabio $x$, 10 rapidx, rigidx, farax, truces, fpumantes, ualidx, uiolentæ. T Tígeres áconóvwrot, Oppianus, Ti=

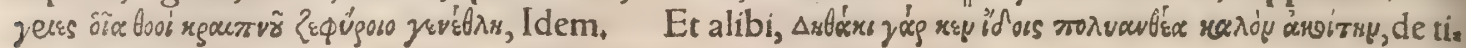
gride mare.

TTigrinus, adiectiuum. Menfæ tigrinæ Plinio dicuntur, ut fupra retuli : quæ oblonge uena, rum difcurfu funt. tales apud nos ex acere $\&$ fraxino fiunt, $\&$ ut refplendeant flauo pigmento (uer nicem uulgus uocat) illinuntur. T Tigris nomen eft nauis Maffici apud Vergilium libro decix moAeneidos. THippotigrin animal celebratum inuenias in Antonino Caracalla ex Dionis $\mathrm{Ni}$ cæi hiftoria, Calius,

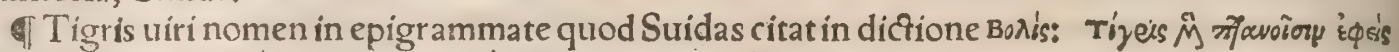

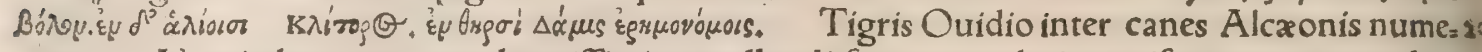
ratur. Nominibus canes non longiffimis appellandi funt, quo celerius quifo 3 uocatus exaudiat, rec tamen breuioribus quàm qua duabus fyllabis enuncientur, ut funt Scylax, Ferox:aut foemina, Lupa,Cerua, Tigris, V arro. Tigranes rex fuit Armenix maioris, quem primò Lucullus, deinde Pompeius Magnus uicit. Eft \& fluuñ nomen. T Tigris appellatur ingens fluuius, propter uelo. citatem, qui inftar beftix nimia pernicitate decurrit. Hic de paradifo exiens, iuxta Scripturę fidem, pergens ${ }_{S}$ contra Affyrios, poft multos circuitus (Iofepho tefte) in mare rubrum defluit. Plura leges in Onomaftico. De fcriptione $\&$ inflexione huius uocabuli attuli quædam fuperius ab initio herius capitis،Q Quaćscaput rapido tollit cum Tigride magnus Euphrates,Lucanus. Tígers, fluuius

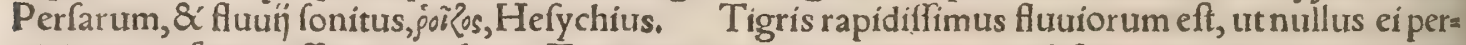
nícitate conferri poffit:quamobrem Tigris uocatur, quod iaculum uel fagittam uelocitate æquet, Medi enim fagittam tigrin uocãt. Sic \& Acis Sicilix fluuius apud Theocritum diçus uidetur, quod áxíd, id eft fpiculo uel telo celeritas eius comparetur. Aliqui tamen malunt à tigri fera nominatum

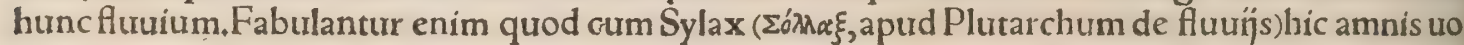

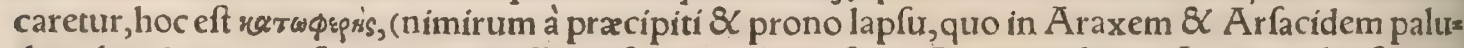
dem deuoluitur, poftea tigris appellatus fit, hanc ob caufam. Bacchus ab irata Iunone ad infaniam redactus cum paffim temere uagaretur ad hoc flumen peruenit, \& cum de traieciu anxius hareret, miferatus eum pater Iupiter, tigrin feram mittit, qua uecfus ille traiecit, unde fluuio nomen impo= fitum. Sed etiam citra fabulam à feræhuius fumma $\&$ incomparabili pernicitate nomen ei apté ima poni potuit. Hic fiutuius intelligitur etiam in dolofo illo oraculo quod luliano redditum eft, promit=

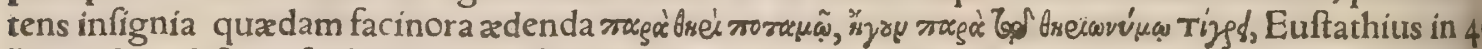
Dionyfium Afrum fribens. Addit $\&$ Arriani ex opere de geftis Alexandri uerba : Euphrates $\&$ Ti gres, ( Tíggrs, aliâs ríggss) fluuï, mediam inter fe Affyriam includunt. Vnde \& Mefopotamia ab in= colis Tigres uocatur ( ipfa potius regiofic uocatur, ut \& Dionyfius poéta canit, ) \& humilior eft Eu phrate. Sed aliam cur Tigris fic dict us fir fabulam Hermefianax affert : Dionyfius (inquit) ad a morem fuum nec donis nec precibus pellicere poffet, in tigrin feram mutatus, metu confternatam per fluuium tranfuexit, \& Medum filium ex ea genuit, quiriam adultus in rei memoriam fluuium appellauit Tigrin, Plutarchus in libro de fluuñs. Tigrin aiunt prope hoftia quibus in mare fe exs onerat, $\mathrm{Pafitigrin}$ uocari, quafi non amplius fimplicem fed mavroín Tiyeiw, propter multos in fe rece ptos amnes, Euftathius in Dionyfium. Defle Arabicé eft fluuius in Mefopotamia, iuxta quem erac ciuitas Niniue, \& a pud Latinos Tigr is nominatur, \&c. Bellunenfis in gloffis in Auicennam. Tigris yo minor \& Delas fluun̈, A pameam Mefenorum ciuitatem circundant, Stephanus, Tigris Xeno= phonti Paphlagonix flutuius eft triplethros, hoc eft trium inger um latitudine. Herodotus etiam fori bit non unum folum effe tigrin, fed alterum etiam $\&$ tertium, qui nec idem fint, nec ex eodem fluãt, fed nomen tantum commune habeant, Euftathius. Tigrana Ptolenæa 2.6. oppidum elt Medix

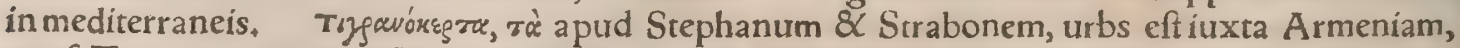
quafi Tigrani ciuitas.nam $P$ arthis certa ciuitas eft. Inhabitauit autem eam Tigranes Armenix rex.

T b. In rubri maris infula effe fruticem baculis tantum idonea craffitudinis, uarium tigrium maculis, ponderofum, \& cum in fpiffiora decidit uitri modo fragilem, Alexandri Magni comites prodiderunt, Plinius.

Tc. Cum Maximinus omnia in uiriburs fuis ita poneret, quafi non poffet occidi, quidam in 60 theatro prafente illo dicítur uerfus Gracos dixiffe, quorum hac erat Latina fententia: Qui ab uno nó poteft occidi, à multis occiditur. Tigris for cis eft \& occiditur, \&c.Iulius Capitolinus, Turrigeros 


\section{DeVrfo. A. B. Lib. I. 1065}

elephantorũ miramur humeros, tigrium rapinas, $8 \mathrm{c}_{4}$ Plinius. Tigris ut audítis diuerfa ualle duo= rum Extimulata fame mugitibus armentorû,, Nefcit utro potius ruat, \& ruere ardet utroqs. Sic dubius Perfeus dextra læuáue feratur, Ouidius 5. Metam.

ब. Hoc ego fi patiar, tum me de tigride natam, Tum ferrum $\&$ fcopulos geftare in corde fa tebor, Medea apud Ouidium 7. Metam. Sylueftres homines Cadibus \& uicfu fodo deterruit Or. pheus, Dictus ob hoc lenire tigres, rapidosḉ leones, Horatius de Arte.

-4 h. Bacchus in curru, quem fummum texerat uuis, Tigribus adiunctis aurea lora dabat, Oui dius 1, de Arie. Haçuirtute te merentem Bacche pater tuæ Vexêre tigres, indociliugum Collo trahentes; Horatius Carm. 3.3 . Sed de tigribus alijśç feris maculofis Baccho facris, plura dixi in 10 Panthera h. Heliogabalus tigres iunxit, Liberum feté tocans, Lampridius, ब Poétis quidẽ om. nia licent, fed cum aliqua uerifimilitudine, non ut Serpentes auibus geminentur, tigribus agni, Ho ratius de Arte. TProtei conformatio in dituerfa corpora, imaginum falfarum rationem continet quibus deludimur. Eft qui expleffe iram, crudelitatis cöceptaculum, inter opta ta maximé opinatur, tunc in tigridem demutatio recognofcitur, \&c,Cælius,

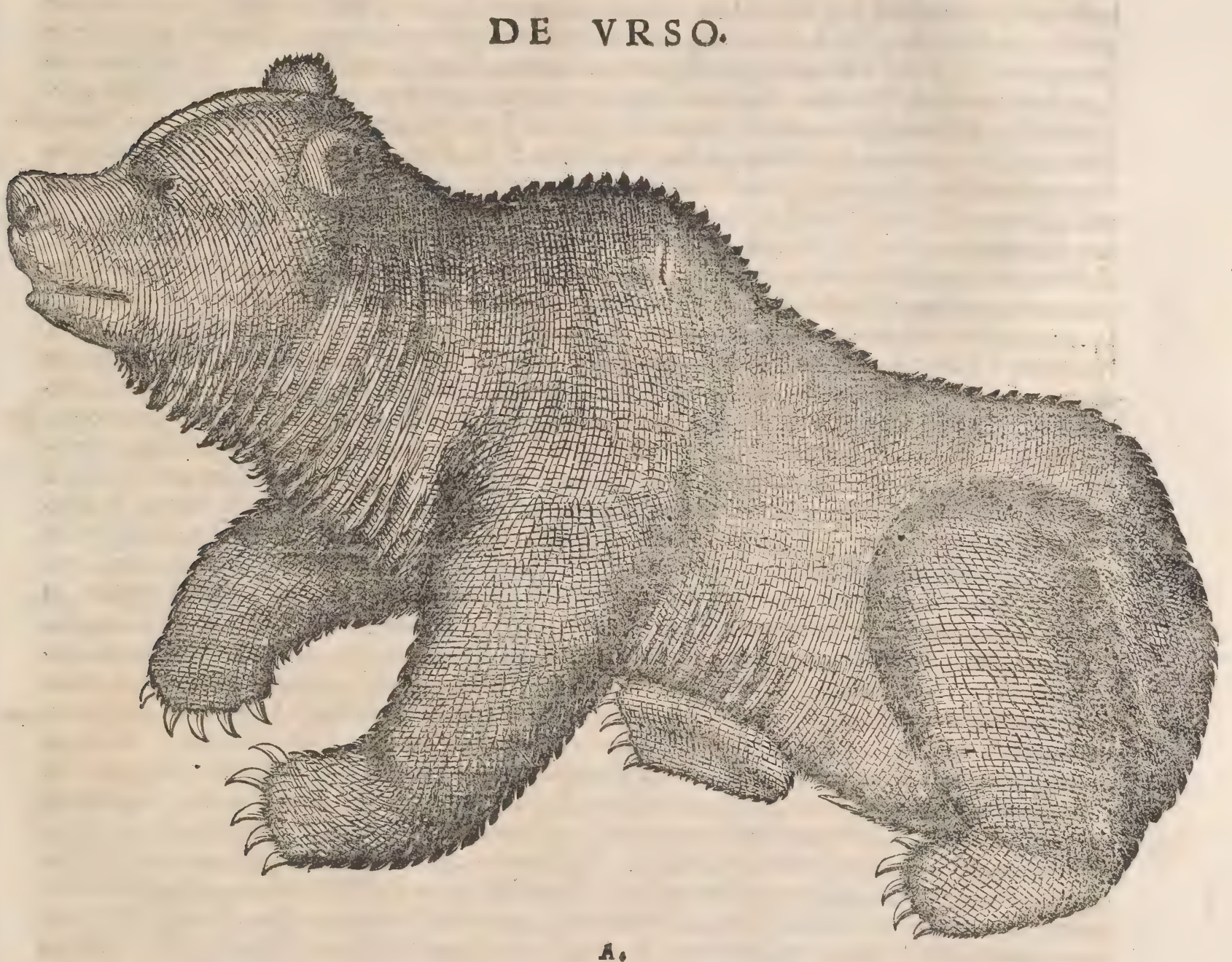

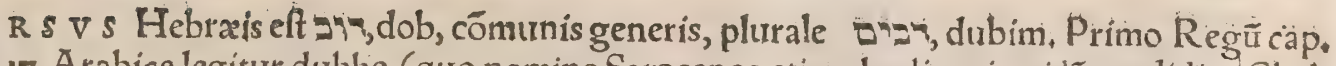
17. Arabice legitur dubbe, (quo nomine Saracenos etiam hodie uti quidã prodidit, ) Chala

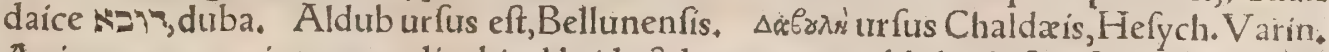
Aurcennæuetus interpres alicubi adib, id elt, lupum cum aldub, id eft urfo confundit: Vi de in Lupo A. Adraces, id eft tefticuliurfi, Syluaticus. Maractis, id eft fel urfi, Idem.uidetur au* tem nomen ineptè compofitum, ex diuerfis linguris.nempe à marah quod fel Hebræis, \& arctos, a ğ́x ros, quod Gracis urfum fonat. Irali hoc animal uocant orfo : Galli, ours. Hifpani fimiliter ltalis orfo:alh̆ tamen fine r. ofo uel offo proferunt. Germani bsitr, uel (ut alij fribunt) beer. Anglifimilis ter beet uel beate. Illyrica lingua uariat, nam Boheminedwed appeliant:Poloni wewer, per anadia plofin(ut apparet) Germanici uocabuli.

\section{B.}

60. Vrfos multos regiones frigidæa gignunt, 8 quidem fufcos aut nigros, quorum duo funt genera: magni \& parui, hi facilius arbores fcandunt, $\&$ in tantam magnitudinem, in quantam illi nurnquam crefcunt, Ge.Agricola, Paruum urforimg genus audio ab Helueing noftris uocari fentoficm, id 
eft faxatiles aut faxorum incolas urfos, Maiores, in quibufdam Germaniz locis, bauptbaten, quaff capitales urfos, Vrfus alius uulgò notus eft, $8 \mathrm{C}$ alius aquaticus colore albo, qui fub aqua uenatur ut littra $\&$ caftor, $A$ lbertus. Sunt quadam genera urfortum alborum $\&$ canum $\&$ luporum, $\&$ fimilium quorundam animalium amphibia, qux tam in aqua quàm in terra uerfantur, Idem. In Oceani infulis ad Septentrionem, diuerfis locis, Iflandix præcipue, magni \& $\alpha$ faui urfi albi reperitun tur, qui manibus fuis glaciem frangunt, \& è foraminibus extractos pifces deuorant, ut Olaus $\mathrm{Ma}$ gnus annotauit. Sed de urfis albis plurra adferam paulò poft. A bundant urfi in alpinis Heluetiz re. gionibus, magni, ualidi, \& præ cxteris animofi, ita ut robuftos etiam equos $\&$ boues lanient. quam, obrem ab incolis magno ftudio capiuntur, Stumpfius * Formicx nimium abundant in occiden talis Indix partibus nonnullis. Ibi gignitur animal quod uocãt V R S V F OR M I C A R I V M, 10 quod lingua eas rapiat depafcaturç - atç fic regionis iacturæ prouifum eft, cum ad nullum alium ufum hoc animal paratum uideatur, neç enim ferum eft, nec mordax: dictumós potius urfus à fimis litudine corporis, quàm à robore uel feritate, hoc lingux humore difcutit ac dilincit folidifimas for micarum domos.inde etiam his difiectis lingux harentes ad fe trahit ac deuorat, Cardanus.

Elephanti fià Libya dicti effent Lucę boues fortaffe, panthera quoģ \& leones non Africana beftix dicerentur, fed Lucæ. Sin ab Lucanis, urfi cur potius Lucani quàm Luci dichị Varro de line gua Latina. Et rurfus, Vrfi Lucana origo, uel unde illi noftri ab ipfius uoce: (fed locus mihi corru ptus uidetur.) VrfiPerficiultra omnem rabiem fauiunt, Marcellinus libr.24. Quod freno Li: bycidomantur urfi, Martialis. Numidici urfi forma cateris præftant, rabie duntaxat, $\&$ uillis pro. fundioribus, Solinus. Seruatum eft (inquit Crinitus ) in Romanis Annalibus relatum, urfos Numi- 1o dicos in Circo Romano ab adilibus æditos M. Pifone \&M. Meffala coss.quam rem C.Plinius mi rarife plurimum refert, quod etiam Numidicos additum fit, cum in ipfa (ut inquit) Africa minimé urfi gignantur. Ego etfi ä Plinị authoritate non cenfeam penitus diffidendum, non tamen prętermit tam quo minus ea de urfis Numidicis afcribam, quæ cum publica Annaliũ authoritate conueniant, Poft hac recitatis Solini uerbis, tum illis qua nos iam attulimus : tum illis quibus Annalium uerba continentur, ut apudPlinium quo $\$$, addit:Herodotus quoos Halicarnaffeus idem fenfit de urfis $L$ bycis:ut poëtas noftros mittamus qui apertè probant fuiffe Numidas urfos maximè celeres, nam $\&$ Numidas $\&$ Libycos paffim appellitant, cuiufmodi illud, Profuit ergo nibil mifero, quod comminus urfos Figebat Numidas Albana nudus arena, Hac ille. Mirabile in Africa, nec apros, nec cer, uos, nec urfos effe, Plinius 8.36 . A tqui Herodotus lib +4 .cerurum \& aprum duntaxat in Africa repe $3^{\circ}$ riri negat, \& A riftot, de hilt.anim.8.28, ceruum,aprum, \& capram fylueftrem, uel, utPlinius trans= fert, capream:urfum uerô de fúo addit. lapfus, ut puto, memoria, cưm Cretę non Africæx urfos deeffe dicere debuiffet, nam proximé ante Cretæ meminerat, his uerbis, Mirabile in Crétà certios, prater quam in Cydoniatarum regione, non effe:item apros $\&$ attagenas, herinaceos, Vrfos uerò Cretam non alere hoc loco non meminit, quod tamen alibi afferit: In Olympo (inquiens) Macedonia monte non funt lupi, nec in Creta infula, ibi quidem non ưulpes urfiue. Et Áriftoteles in Mirabilibus, In Creta (inquit) lupos, urfos, uiperas, $\propto$ his fimiles feras nafci negant, eò quod Itipiter in ea natus fic, Angliam quoģ urfis carere audio, In extrema Arabiæ regioneà Dira ufós ad Auftrí corriư cír. ca ultimum promontorium, urfi reperiuntur carniuori, qui noftros $\&$ magnitudine $\&$ celeritate lon

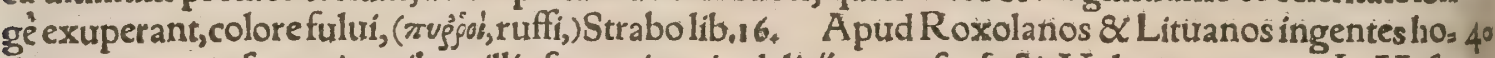
die uenantur urfos, qui regibus illis funt etiam in delicips manfuefacti, Volaterranus. In Myfia aiunt genus effe urforum alborum, qui cưm à uenatoribus urgentur, talem halitum æedant, qui canũ carnes putrefaciat, \& aliorum quoq a nimalium cibo ineptas efficiat. Quod fí quis inftet $\&$ propius accedat, phlegma copiofum ore emittunt, quo canum ora afflat, $\&$ fimiliter hominum, ita ut uel fuf focet uel excacet, Ariftoteles in Mirabilibus. Myfia albos urfos gignit, qui pifces ut lutra \& fiber capiunt, Ge.Agricola, fed quarendum an Myfji illi urfi albi, quorum Ariftoteles meminit, terreftres tantum non amphibij fint. Paufanias in Arcadicis meminit uidiffe fe apros albos, \& urfos Thracios albos, quos homines priuati poffederint. Aethiopix rex in epiftola quam Hebraice ad Pontificem Romanum fcripfit, camelos $\&$ urfos albos in regno fuo reperiri teftatur. Iam perdix uifa eft alba, \& coruus, \& paffer, \& urfa, Ariftoteles in libello de coloribus, Rutellio interprete, uide in Ceruo B. 5o

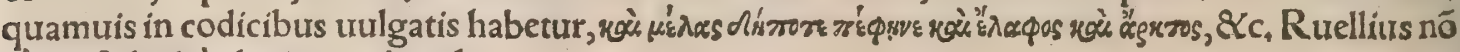
$\mu=\lambda a s$, fed rouros legit, quod probo.

đVrfus animal eft humidum ualde $\&$ informe, Alberturs. Vergilitus urfos informes, Ouidius turpes dixit, Quid nifi pódus iners, ftolidxá̧ ferocia mẽtis? Ouidius in Halieut, de urfo. Corpus ei craftum \& uix'mobile, Albertus. Vrfos multos regiones frigidæ gignunt, \& quidem fufcos aut nigros, Ge، Ägricola.Sunt qui urfum femper cref́cere affirment: $\&$ fane inueniuntur aliquando urf longitudine quindecim ( quinç) cubitorum. Sunt autem apud nos nigri, fufci, $\&$ albi, Albertus. Forte pellem urfinam dum hac commentabar, Viennæuidi ex Lituania allatam, longitudinis cubi. torum quinq̧, latitudinis tãtæ ut quodlibet uel bouris tergus uinceret:quæ Cæfari Maximiliano tum in Thermis Badenfibus lauanti oblata, fumma admirationi fuit, Vadianus in Melam.Vrfi pellis 6 fpiffa \& uillofa eft, Albertus. Numidicis urfis uilli profundiores, Solinus, Illis quiad diffectio= nem partiũ humani corporis prxparari uolunt, fi defint fimię aut fimiles eis animantesialias deligent 


\section{DeVrfo. B. C. Lib. I. 1067}

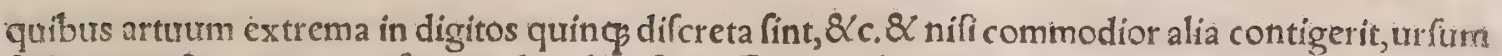
\& leonem, \& omnia qux ferratis dentibus funt, Galenus de anatomicis admin. Credit Theophra ftus per id tempus (cum latitant hyeme) coctas quoç urforum carnes, fi afferuentur, crefcere, Plit! 8 Albertus. Vide pauló mox in Adipe. Eodem tempore (cum latitant) ranguinis exiguas circa cor tantum guttas, reliquo corpori nihil ineffe Theophraftus credit; Idem. Vrfis nulla eft medulla, Pli nius, Axungia $\&$ laridum funt in animalibus non cornigeris, quorum quatuor dentes ut plurim pminent, ut funt, porcus, glis, felis, canis, urfus, \&c. Monachi in Mefuen. Valde mirabile eit quod circa adipem urfi contingit, qui eo tempore quo latitant urfi, in uafis attollitur \& replet ea, Theo: phraftus in libro de odoribus. (Idem paulo ante de carnibus urfi ex Plinio diximus, Theophraftum

to citante. In Mirabilibus etiam Ariftotelis legimus urfinum adipem latente hoc animali augeri in ua fis eaćs excedere. His adịciam Oppiani uerfus de urfi corpore $8 \alpha$ aliquot eius partibus:

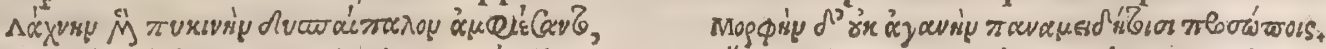

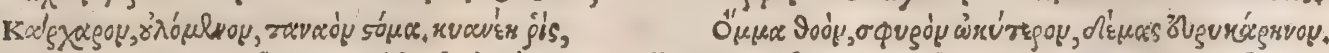

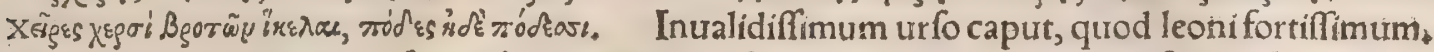
ideo urgente ui pracipitaturife ex aliqua rupe, manibus eo operto iaciuntur, ac fape in harena co. lapho infracto exanimantur, Plinius. Inualidũ urfis caput, Solinus †ed pracipué fynciput, Ȧlbera tus. Capitis offa infirmiffima effe urfis, duriffima prittacis, fuo diximus loco, Plinius. Os fiue ro: ftrum urfi oblongum eft, inftar fermèfuilli, Mich. Herus. Os longum urfo, Gillius ex Oppiano, $V$ trings dentatus eft. Dentibus exertis armatus, Gillius ex Oppiano:qui tamẽ non javicódby $7 x_{\text {, hoc }}$ 20 eft dẽtibus exertis urfurm effe fcribit: fed os eius rágxaegoy effe, hoc eft ferratis dentibus, ur canes funt. Vrfus idcirco dentibus retia non lacerat, quod ijs bene penitus reconditis, ea ipfa propter labrorum craffitudinem affequi non poffit, Gillius(exPlutarcho de caufis naturalibus.) Natura leonibus, $f i=$ cut \& urfis \& tigribus anguftiora(breuiora)creauit colla.quia in terra certuicem \& ora nó deịciun pafcendi gratia:fed aut ceruum inuadunt, aut bouem ouemóp difcerpunt, Ambrofius. Vrfo ven* triculus eft amplus, Ariftot, Venter ci unus, ac poft uentrem inteftinum, ficut \& lupo. elt autern in aliquibus animalibus uenter maior, ut in porco $\&$ urfo, ut quidam obfcuri ex Arifotele citant. Vrfæ mammas habent quaternas, Ariftor. \& Plinius. Genitale urfi,fimul ut expirauterit, cornefce. reaiunt, Plinius. Homini genua $\&$ cubita contraria: item urfis $\&$ fimiarum generi, ob id ninime pernicibus, Plinius. Vrfa pedes habet manibus fimiles, Ariftoteles. Extrema fimilia habet houri 30 ni, Albertus. Manus earum fimiles humaris manibus, $8 r$ pedes pedibus, Oppianus. Vrfis uis maxima in brachịs $\& \mathcal{L}$ lumbis; unde interdũ pofticis pedibus infiftunt, Solinus + Cameli pes imus ueftigio carnofo eft, ut urfi. qua de caufa in longiore itinere fatifunt, Plinius. Noftri manus, id eft anteriores pedes urfiuocant \$asen uel taapen. Armati unguibus urfi, Ouidius 10. Metam, Vr= fis natura caudam diminuit, quód reliquum corpus admodum pilofum fir, Ariftot. Caudx paruae funt uillofis animalibus, uturfis, Plinius.

C.

Vrfus animal eft humidum ualde $\&$ informe, Albertus. Valde frigidum \& pituitolum, ut cortftat ex corpore eius quod admodum craffum \& uix mobile eft, pedes lati, pellis denfa, Idem. Ex eo quod hyeme latitant urfi, $\&$ abfo cibo multum temporis degunt, pituitofo eos temperamento effè 40 conijcio, Antonino Geta familiare fuit has quaftiones grammaticis proponere, ut dicerent fin. gula animalia quomodo uocem emitterent, uelut, agni balant, urfi fauiunt, \&c, ut refert $\AA$ el. Spar= tianus. Atq3 in prafepibus urfi Sauire, Vergilius de uocibus animalium auditis in domo Circes Vefpertinus circungemit urfus ourle, Horatius Epodo. Vrfus ferus uncat, Author Philomelax.

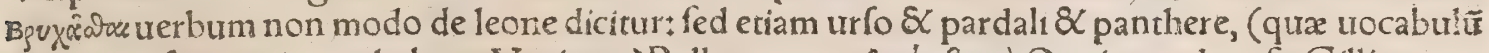

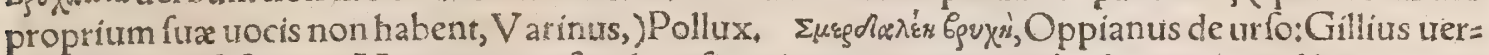
tirrugitum infeftum. Venatores noftri de urfi irati uoce utuntur urerbo b:ommen uel bsumment aliqui etiam bílent. Vrfus latitans cum murnure quodam pedes fugit, Alexander. Ingredi. untur urfi $\&$ bipedes, Plinius, Ingredi uel duobus innitens pedibus erectus aliquandiu poteft, Ariftot.fed non diu, Albertus. Inter ingrediendum pedes primum anterius leuiter in terram ponũ

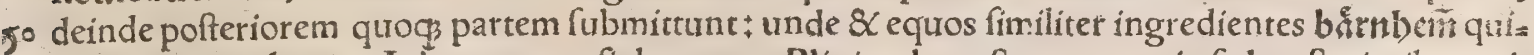
dam uocari uolunt. Arborem auerfi derepunt, Plinius, hoc eft, non proni, fed pofterioribus pri* mum pedibus, anterioribus interim molem corporis fuftentantes, ne ruant $\$ \&$ in hoc quoque ho= minem imitantur præter morem quadrupedum. Vrfiparui, (quibus noftri à faxis nomen po, firerunt, ) facilius arbores fcandunt, Georg, Agricola. Homini genua \& cubita contraria: item

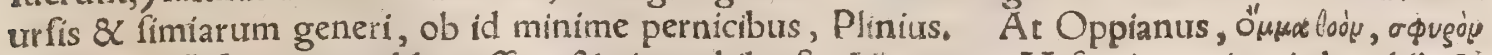
ẇsúzepoy. Vrfí corpus ualde craffum $\&$ uix mobile eft, Albertus. Vrfo uis maxima in brachijs \& lumbis: unde interdum pofticis pedibus infifunt, Solinus. Brachịs quidem $\&$ manibus tantum ualent, ut retia n̈s potius quàm dentibus difcerpant. Vrfis brachịs ad multa opera utitur. hís ali. quando ligna fortè inuenta in canes prọ̈cit, \& frangit oliueta \& aluearia a pum, \& in fublime fcan 6it, Albertus. IV Vrfus animal uorax eft, Erafmus. Vifus aninal omniuorum eft $\div$ quippe quỉ $\&$ fructus arborum quas confcendit corpore lubrico edat, \& legumina, \& a pes perfringens alueos, \& cancros, \& formicas. carne etiam uef́citur, uiribus enim fuis confidens, inuadit quadrupedes dia 


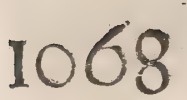

\section{DeQuadrupedibus.}

ueifas, (ut in D.referam,) A riftoteles. Carnes omnes pramaceratas, \& propemodum putres cơ medit, Idem. Quibus uerbis Mich. Ephefius afferit Arifrotẹlem intellexiffe, urfum non ucrare care nes alicuius animalis, nifi pené putridas : cuius contrarium docer obferuatio, nam deuictis fue $\&$ tauro, ftatim uorat. unde conftat eum recentes carnes uorare. Melius igitur exponas, ut difưneft, quod urfurs uroret etiam cadauera quorumcunç anímaliũ quæ uincit ac in pugna fuperat, Niphus. Vrfi \& fruge, fronde, uindemia, pomis uiuunt: $\&$ a pibus, cancris etia $m \&$ formicis, $P$ linius. Vrfus alius eft aquaticus a!bus, qui urenatur fub aqua, ur lutra \& $\mathrm{caffor}$ :alius terreftris tantum, qui comedic carnes, herbas, mel, 8 fructus arborum, Albertus. Vtrique comedunt carnes, mel, frucius arba rum, herbas, Ge. Agricola. Vefpertinus circungemit urfus ouile, Horatius Epodo. Infidiantur aluearibus apum, maximé fauros appetunt, nec auidius aliud quàm mella captant, Solinus. Huius 10 gratia arbores fcandunt, ubi examen a pum fylueftrium animaduerterint ${ }_{+}^{\ddagger} \alpha$ clatræ mucronatæà ra: mo dependentis, $\mathcal{Q}$ aditum examinis obtegentis, dum manibus indignantes reïciunt, fubinde reci. procis ictibus intereunt, ut pluribus dicetur capite quinto. Aliquando in mellarias foueas illapfi, in eis fuffocantur. Oculi eorum hebetantur crebrò:qua maximé caufa fauos expetune, ut conuulne ratum $a b$ apibus os leuet fanguine grauedinem illam, Plinius. Vrficum extra latibula fua palcun. tur, circa arbores fruçiferas feré capiuntur, Pollux. Herbam arum comedere folent cum prímum èlatibulo egrediuntur, ut inteftinum laxetur 8 hiet, A riftoteles. (Vide etiam inferius ubi de latitas tione eius dicetur.) Matthxolus Senenfis arbuftum quoddam fpinofum, (quod Galli, ut mihit uts detur, fpinam albã uocant, noftri mđlbeere) folinjs ferè ut apị diuifis, flore albo, baccis rubẽtibus, \&c. in montibus circa Tridentum panem urfi uulgò uocari author eft. Ego hanc Plinī fpinam appendi 10 cem effe conipcio:ipfe Grxcorum oxyacantham facit, \& diuerfam ab ea uuam crifpinam Italorum fiue berberim uulgarem. Idem alibi fcribit urfos delectari fpecie illa rubi, quæ mora fert odorata \& rubicunda, noftri quod hinnulis ceruorum grata lint bin๖beete appellitant، Galenuslibro 7. cap. 4. de compof. fecundũ locos, plantæ cuiurdã meminit, quæ uua urfi nominetur, folp̈s arbuti, \&c. hanc quidam ribes noftrum uulgò dicfum effe conïciunt, fed falluntur, cum non arbuti fed opuli feré folia habeat. Cætera animalia fana qux carnibus uiuunt, herbas non comedunt, præeter homi nem \& urfum, Albertus.

TVrfi bibendo nec lambunt nec forbent, ut cæteræ animantes, fed aquam quoque morfu uoi rant,Plinius \& Ariftoteles. đT Cum deguftauêre mandragoræ mala, formicas lambunt, Plinius, Cum gưfauếre mandragorę mala, moriuntur. fed eunt obuiam, ne malum in perniciem cóualefcat, 3 \& formicas deuorant ad recuperandam fanitatem, Solinus, Conftat urfos ægros deuoratis for. micis fanari, Plinius. (Vide nonnihil etiam infra, circa finem eorum quiæ de latitatione urfiafferens tur.) Vrfus cum naufea laborat, myrmeciam adit jaffidens ćs linguam humore dulci fưentem exer tam leuiter tandiu tener, dum fcatêre formicis uideat, eas deglurit poftea, \& plurimum iuruatur, Plus tarchus in libro Vtra animalium, \&c. Saturitatioccurric uomitione, quam fibí excitat comman. ducatis formicis, Textor fine authore. Vrfus iulneratus herbis ficci temperamentí uulnera fa nare tentat, Albertus. Oculi eorum hebetantur crebro ; qua maximè caufa fauos expeturit, ut conuulneratum ab apibus os leuet fanguine grauedinem illam, Plinius, A latitatione egreffa in diem liberum urf $x$, tantam patiưtur infolentiam lucis, ut putes obfitas cæcitate, Solinus, Dicunt aliqui urfum femper crefcere, Albertus. बA nima lecnis uirus graue, urfi peftilens. contacta has $4^{\circ}$ litu eius attingit nulla fera,citiusćs putrefcunt afflata relíquis, Plinius. Vide in Leoné c. In Myfia aiunt genus effe urforum alborum, qui cum à uenatoribus urgentur, talem halitưm ædant, quít cà num carnes putrefaciat, \&c.utin B.retuli. I Vrfæ Veneris libidine flagrant, \& noctes diesçáad coitũ inflammatiffimæ maritos appetunt. Et quoniam fera grauidæ maribus non mifcentur, præter lyncem \& leporem, urf ne diutius maritis careane, ut ad Venerem maturius redire poffint, priuf: quam certum pariendi tempus ueneriț,uentrem elidunt, \& partû̉ uiolenter edunt:ac mox à recentí partu fimul $\&$ alend $x$ proli, \& explenda libidini, (ut cuniculi quo $\phi_{s}$ ) dant opéram, Oppianus ; ex quo Gillius perperam tranftulit urfas etiam grauidas coire. Tempore non alio( quàm libidínís) catulorum oblita leana Sæuior errauit campisłnec funera uulgo $T$ am multa informes urfiftra geḿç dedêre, Vergilius. Vrfi,lupi,leones acrius libidinis tempore in eos qui accefferint, faruintit, yo inter fe tamen minus hac dimicant.uidelicet ob eam rem, quia nullum ex ịs gregale eft, A riftoteles, De Philippo Coffeo Conftantienfium facris præfecto, ingenuarũ artium perfudiofo, qui hoe ipfum fe ex bono authore cognitum habere, mihi ualde affirmauit : urfum accepi ex mötibus Allobrogum puellam in fpeluncam rapuiffe, eandem $\beta_{3}$ uenereo complexu \& ofculatione profecutum fưffe:atç ex pomis agreftibus, qux permulta quotidie in fpeluncam inferret maturiora, fudiofe delegiffe, eis demás edenda amatoriè dediffe, ac nimirum cum ad cibi inquifitionem proficifceretur, ingenti faxo fpeluncam, ne puella exire poffer, occlufiffe. Cum autem poftlongam inquifitionem parentes urfis num laribulum præterirent, fuam peradolefcentem animaduertiffe, faxó́s æogre depulfo, eam rece: piffe, Gillius. Vrforum coitus hyemis initio, Plinius. Defyderium Veneris hyems fufcitat, So: linus. Coiturfa menfe Februario, parit eo tempore quolatet, Ariftot. Vrficoëunt, non fuper: 6 uenientes, fed humi ftrati, Ariftot. Coëunt non itidem (eodem modo) quo quadrupedes, fed apti amplexibus mutuis, uelut humanis coniugationibus copulătur, Solinus:ambo cubätes complexį̧́s 


\section{DeVrfo. C. Lib. I.}

1069

Plinius: $\&$ alibi, humanitus ftrati, Quadrupedum urf $x$ demiffis cruribus, quemadmodumin cęteră, qua pedibus innitendo exercent $V$ enerem, admota parte maris fupina ad dorfum foeminx coéunt, Ariftot. Coéunt urfi ut homines, ficut $\&$ fimia, Albertus. Secreti honore reuerentur mares gra, uidas, Solinus. Grauidam capi ur fam difficile eft, Äriftot, grauida enim ( ut mox dicetur) latent. Fert uterum dies triginta, Ariftoteles $\$$ Solinus . Volaterranus non reciè tranftulit ex A eliano ur fam poft menfem tertium parere, nç̧ enim tandiu uterum geftat: fed tanto tempore exacio, èlatibut: lo in quo peperit plerunq $\beta$ prodire folet, ut inferius quoque dicetur. Coéunt hyemis initio, deinde fe cedunt in fpecus ubi pariunt tricefimo die, Plin. Parit tum unum, tum etiam duos, fed complurímum quinq̧, Ariftor. Cxcos parit catulos, $I$ dem. quod $\&$ uenatores noftri affírmant. Pariunt plu.

so rimum quaternos, Plinius: Idem alibi ut plurimum quinos eas parereait. Quæadam catulos inarti= culatos propemodum pariunt, ut uulpes, urfa, leæna, \& alia nonnullałfed omnia feré cæcos, Ariftot. Quadrupedum pleraç perfectos ædunt partus, pauca inchoatos, ut leænæ, urf $\&$ uulpes. In formia etiam magis quàm fupradicta urfæ pariunt, rarumćs eft uidere parientes. Poftea lambendo calefa ciunt foetus omnia ea \& figurant, Plinius. Vrfa foetum minimum pro ful corporis magnitudine adit:quippe quæ minorem catto, maiorem mure parere foleat, nudum item, $\&$ cæcum, \& cruribus propemodum membrisćç alịs plurimis indifcretum \& rudem, coitmenfe Februario, parit eo tempo re quolatet, Ariftot. Lucinæ illis pperatius tempus eft. quippe uterû trigefimus dies liberat: unde euenit, ut præcipitata foccunditas, informes creet partus. Carnes patrxillulas ædũ̃t, quibus color can didus, oculi nulli, nulli pili, $\&$ de feftina immaturitate tantum rudis fanies, exceptis unguium linea: 2. mentis. Has lambendo fenfim figurât, 8 interdum ad pectora fouent, ut adfiduo incubatu calfactre animalem trahant fpiritum, Solinus $\&$ Plinius.Vrfa partum ab initio prorfus informem effe, ut ne agnof ci quidem poffit, deinde à matre lingua fingi, \& finu gremiọ́́ fouer $i$, A elianus quoç anno tauit. Nec catulus partu quem reddidit urfa recenti, Sed malè uiua caro eft. lambendo mater in.

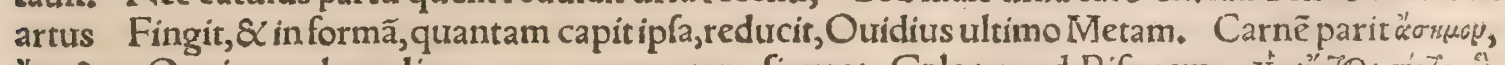

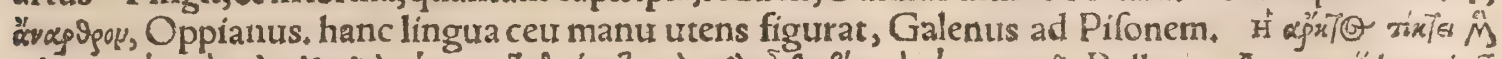

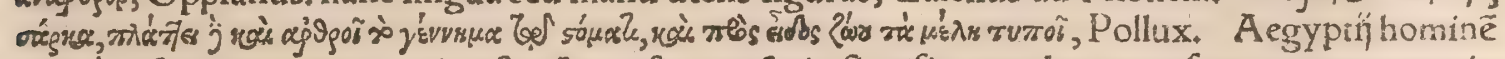
primò deformem natum, qui poftea formofior euaferit, fignificare uolentes, urfam prægnantem pin gunt, hæc nanç fanguinem primum condenfatum $\mathbb{X}$ concretum parit, hunc poftea proprin's fouens femoribus efformat, linguá̧ lambens perficit, Orus. Vrfurs dicitur quafi or fus, fcilicet in uentre,

5० 8 extra completus, quoniam pramaturum partum matar lingendo informat, Liber de nat, rerum. Non quicquam rarius homines quàm parientem uidere urfam, Plin. Fotuum urfa membra ui. dentur imperfecfa propter immodicum humorem:quamobrem urfa eos diu lambit $\&$ fouet, Aiber= tus. Idem de animalib.7 3. 3. Animalia quadam (inquit)in antris circa finem quietis fux pariunt: propter quod eriam ignoratur locus partus urforum. Concipiens enim urfa ex coitu, propter frigidi catem temperamenti, $\&$ pituitofi humoris copiam, non poffet femen in utero formare perfecte, nifi expectaret abftinentix tempus $\ddagger$ pracipué cum eadem frigiditate $\&$ humoris copia, adeò cóftringan tur meatus per quos parere debet, quơd illo tempore uix poffet, itacs tempore latibuli fui emittit, (pa rit,) quum recens expergifcitur. Et quanquam hoc tempus expectấrit, adhuc tamen informem ferẻ partum xdit, ita ut aliqui poétarum putauerint, nihil quàm carnis fruftum ab ea pari, idóg poltea \{pi. $4^{\circ}$ ritu SClingua eius formari in animalis figuram, quod tamen minime uerũ eft, Hæc Albertus, Vr= fxà fuis catulis uehemêter ferociunt, ut canes à catellis, Ariftot. of Hyftrix hybernis fe menfibus condit, quæ natura multis, $\&$ ante omnia urfis, Plinius $\&$ Ariftot. fed utrum propter frigus an alia de caufa condantur, ambigitur, Arift. Hyeme tempore frigido \& humido later urfa, \& tunc par it propter caloris in ea augmentum, Albertus. Hyberno tempore (inquit Aelianus) parit, cum pepe. rit, latibulis fe tegit, nam frigoris uim reformidat, \& ueris aduentum manet, nec ante treis menies ca tulos in lucem profert. Cum autem fe habitu corporis opimo fentit, (hoc enim ipfum morbiloco dua cít,)latibulum, quod Græci $\phi \omega \lambda \varepsilon \dot{y}$ appellant, expetit. (Vnde affectus quo latendi tenetur defiderio, фìíx Grace nominatur.) In antrum non recto motu fur corporis, fed fupina ingreditur, \& dorfi fui tractu repit, uenatoribus ut ueftigia fua obliteret:Ibíģ poftquam eft ingreffa, fe quieti dans, habitut go corporis extenuat per quadraginta dies $\grave{e}$ quibus quidem quatuordecim immobilis manet, reliquis alins mouetur: tantum folo lingendo dextero pede fe fuftentat, eiç̧ inteftínum eatenus adducitur, uic propemodum cohreat. Quod quidem ipfum ea fentiens, aron herbam agreftem edit, (ut pluribus dicam pauló poft, ) Hac Aelianus : Cuius ex hoc loco uerba Graca recitat Calius 25. 27. Apud

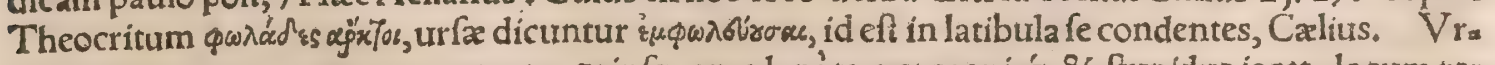
fus ueterno quem uocant appetente, priufquam planè torpet grauisćs \& ftupidus iacet, locum tea purgat antea : ac fubiturus fpecum, per reliqua quidem greffu quantum id fieri poteft fufpenfo ma. xime \& leui, fummis tantum nixus ueftigijs incedit : poftremò per terga uolutatus promouet cor* pus agitó̧ in luftrum, Plutarchus in libro Vtra animalium, \&c. Mares (inquit Plinius) quadrage: nis diebus latent, formin $x$ quaternis menfibus. Specus fi non habuere, ramorum fruticumćs conge: 6o rie adificanr, impenetrabiles imbribus, molliç fronde cöfratos. Primis diebus bis feptenis tam gra. ui fomno premuntur, ut ne tulneribus quiden excitari queant, (quod \& Solinus ex Plinio repetit.) Tunc mirun in modũ ueterno pinguefcunt, lli funt adipes medicaminibus apti, cötrał̧̧ defluuium 
capilli tenaces, $\bar{A}$ b j̆s dicbus refidunt, ac priorum pedum fuçu uiuunt. Foetus rigêtes apprimend pectori fouent, non alio incubitu quàm oua uolucres. Mirum diciu, credit Theophraftus per id tem pus coctas quoç urforum carnes, fi afferuentur, increfcere: cibi tunc nulla argumenta, nec nifibu moris minimum in aluo inueniri : fanguinis exiguas circa corda tantư guttas, reliquo corpori nihil ineffe. Proced unt uere, fed mares prapingues: cuius reicaufa non prompta eft : quippe nee fomno quidem faginatis prater quatuordecim dies, ut diximus, Hac Plinius, Cum condiri funt, pingure fcunt urfi per id tempus, tum mares, tum forminx uehementer, (hoc $\&$ alibi ab co repetitur, )ut ni $0=$ uere fefe facile nequeant.paric etiam foemina eo tempore, et tandiu later quoad tempus fit urt fuos ca tulos in apertum producat, quod uerno tempore menfe à bruma tertio facit. Sed quod minimit, dies circiter quadraginta latet:ex quibus bis feptem ita fopitur, ut fe nihilo moueat : reliquis poftea plus ribus latetquidem, fed mouetur, \& furgit, Ariftoteles, Et alibi, Cum prolem enutrierit, exut à menfe iam ueris tertio:hoc eft, (inquit Albertus,) poft initium Man̈, qui eft tertius menfis ueris. Ex latibu= lis rurfus prodeunt uere, mares ualde pingues, foeminx non item, quod pepererint eo tem pore, Ge, Agricola. Secreti honore reuerentur mares grauidas, $\&$ in $\ddot{n j f d e m ~ l i c e t ~ f o u e i s, ~ p a r t i t i s ~ t a m e ̃ ~ p e r ~ f c r o=~}$ bes fecubationibus diuiduntur, Solinus, Etrurfus, Interea cibus nullus. Timent hyemem \& fri gus urfi utcunç hirfuti, \& abdunt fe in fatis amplum fpecum: nec ullo interea cibo utentes, manus pedeş̧́ lambunt ac uelưti fugunt, ut per hyemem fub fcopulis latitantes polypi furos cirros arrodũt, Oppianus lib.2.de pifcat. Vrfus non fine murmure pedes fugit, tanquam alimenti quipplam inde percipiat,Alexander, Vrfi quidem manum in cibo etiam homini fuauifimam effe, dicemus infra capite fexto. Enixæ quaternis latent menfibus, mox egreffa in diem liberum, tantam $\mathrm{pa}_{2} 20$ tiuntur infolentiam lucis, ut pures obfitas cæcitate, Solinus. Fotu grauida urfa, uel à nemine, uel à pauciffimis capra eft, tempore fui latibuli hoc animal nihil edere certum eft excat, \& captum uentre inteftinoós inani uideatur. Narrant eius inteftinum per inediam ita connis uere, ut adduçum propé cohæreat. Itą̧ urfum latebram egreffum primum herbã arum diçã deə guftare, ut inteftinum laxetur $\&$ hiet, Ariftoteles. Exeuntes herbam quandam aron nominela xandis inteftinis alioquin concretis deuorant, circa furculos cum dentiunt prædomantes ora, Plin. Solent aron herbam comedere cum è latibulo egrediuntur, ut dictum eft: ligna etiam manducant, quafi dentiant, Ariftoteles. Alberturs hunc locum inepte tranftulit, his uerbis:Cum æurotant, herbas edunt, pracipué dracontium ad acuendos dentes. Ari herba natura uentofa inteftinum urforum diducit \& dilatat, eidemóp facultatem receptandi affert. Cum autem cibis fefe rurfus refecerit, formi 3 cas exedens facile exinanitur, Aelianus. Vrfus poft incubatum diutinum luftro exiens, fylueftri aro uefcitur, aluũ cóftriçam haçenus acrimonia eius ciente. Idem, cum cœpit naúfea, myrmeciam adiens, afTidenść linguam humore dulcifluentem exertam leuiter tandiu tenet, dưm fcatere formi: cis uideat, eas deglutit poftea, uehementeró̧̧ iuuatur, Plutarchus, Vide fuperius inter morbos urfi. Cum animalia de antris, ubi latuerant, egrediuntur, prxcipué requirunt ad cibum ea, qux aliquam habent acredinem, ut appetitum cibi excitent, qual is eft herba cuculi quam quidam alleluia uccant, $\&$ alluf $\&$ iarus pes, (aron, quæ uulgò pes uituli, )has enim herbas egrediens comedit urfus, Alber= tus 7.3. 2. Eft autem herba quam primo loco nominat, oxys Plinï, ternis folïs, fapore acido:altera, dracunculus, calidiffima \& acerrima planta: \& eiufdem omnino facultatis tertia, nempe aron. In alpibus Helueticis aiunt quendam uaccarium, (fiue lactarium appellare mauis, qui in alpibus ęftate 4 uaccas mulget, \& opera lactaria conficit,) à monte defcendentem, $\&$ amplam cucumam, (in qua lac ad cafeos decoquunt, ) geftantem, eminus uidiffe urfum, qui radicem quandam fua manu effortam edebar: Er cum eius difreffum expectaffet, adj̈ffe locum $\&$ ipfum etiam de radice illa guftafie, atque inde tanto fomni defiderio affectum, ut continere fenon potuerit quin ibidem in uia cubans fomno frueretur, ca pite cucuma intecto ut effet tutior à frigore. erat enim initium hyemis.atç ita tctam hye mem dormiendo exegiffe illafum, proximo demum uere experrectum. Hoc $\&$ li fabulofum, ut appa ret, quoniam tamen uulgò fertur, omittere nolui,

Oppianus urforum appellat dorepou récep, $\mathrm{D}$. ciofos perfidos \& fraudulentos effe follius urfos aftutos, cædis auridos, perni= (Maligni certe natura funt adeó, ut ne longo quidem yo

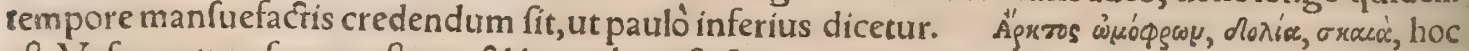
eft, Vrfus natura fauus, aftutus $\mathcal{X}$ improbus eft, Adamantius. Feritate cæteras belluas fuperant, Philoftratus,Quamobrem tyranni morte inulctatos homines urfis, ut pantheris \& leonibus dilani: andos obịciunt, ut in E, referemus. Poëtæurfos fæuos $\&$ truces cognominant, Incertamini= bus fpectacuiorum urfi mappa proritantur, ut Seneca refert in libro de ira. Vrfi Perfici ultra om nem rabiem fæuiunt, Ammianus Marcellinus. Numidici urfi forma cæteris præfant, rabie dunta xat, \& uillis profundioribus, Solinus. Quid nifi pondus iners, ftolidæḉ̧̧ ferocia mentıs: Ouidius. in Halieut, de urfo. Fœmina omnes in uniuerfo animantium genere minus quàm mares funt ani. mofa, excepta panthera $\mathcal{\alpha}$ urfa, Ariftoteles. Quàm cautè in latibulum, fufpenfis primum ucftigïs accedens, refupinata irrepat, ut fallat uenatores, pracedenti capite dixi. Vrficadauera fui genex bo ris fepeliunt, Tzetzes. TApudRhoxolanos inueniuntur pleriģ manfuefacti, Textor. Qnód freno Libyci domantur urfi,Martialis, Capti aliquando manfuefcunt, \& uarÿs ludis ac gefticulas 


\section{DeVrfo. D.E. Lib. I. io}

tionibus fe exercent. fed facile concitantur, \& commoti fxuiunt ac perimunt homines. Aliquando circumeundo uoluuntrotas, \&C fic aquas é puteis trahunt, aut faxa per trochleas fupra altos muros, quod frepe obferuatum à nobis eft, Albertus. Dum ludis indulgent, mirificos adunt geftus, $\&$ in. terdum pedes manibus a pprehendunt fupini, atç ita alternis in latera fe motant, ut nutrices folent infantes in cunis. Prouerbĭ fpeciem habet illud apud Martialé, Rabido nec perditus ore Fuman tem nafum uíui tentaueris urfi. Sit placidus licet, \& lambat digitosḉ manusćs: Si dolor $8<$ bilis; fi iufta coëgerit ira, Vrfus erit, uacura dentes in pelle fatiges. Admonet(inquit Erafmus)nõ effe ten tandos qui poffint nocere. Confimili modo Synefius in Encomio caluitij fcripfit, Canem naribus prendere + proeo quod eft proutocare mordacem \& nociturum. Hac parte(nafo) corporis icta potiffi. - mum urfos iritari docent beftiarí. Vrfoutcunģ manfuefacto, quòd ualde malignum $\&$ fraudut. lentum fit animal, \& fubinde ad ingeniũ redeat, minimè credendũ effe, miferabiles fæèe cafus often: derunt. Infidiofam certe $\&$ malignam huius beftix naturam etiam ipfe expertus fum áliquàndo. nam cum Bernx, qux Heluetix ciuitas eft, iuxta caueam in qua publicé urfos alere folent, aftarem; \& manum in clatris tenerem, nihil fufpicans, quòd urfus, quem contemplabar, uideretur profun= diore effe loco quàm ut facile læderet : ille fubito erecturs manũ fuã clatrís iniecit ita ut quàm mini: mum abeffet quin meam apprehenderet. Apud Britannos complures alunt greges urforum ad fal tationem, animal uorax \& maleficum, Erafmus Rot. Suidrigal(Sindrigal, Volaterranus)Lituaniæ princeps urfam nutriuit, qux fueta ex manibus eius panem accipere fape in fyluas uagabatur. $\mathrm{Re}_{\mathbf{z}}$ deunti, uf $\$ 3$ ad thalamum principis, oftia quaç patebant. Ibi confricare ac pulfare pedibus oftium;

20 cum fames urgebat, confueuit, cui princeps aperiens cibum prabuit, Confpirauêrenobiles aliquot a dolefcentes aduerfus principem, at $\$$ urfa modũ fecuti, fumptis armis cubiculi principalis ianuam.

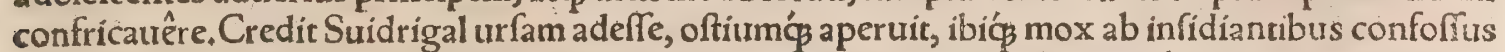
interït, Aeneas Syluius, \& Volaterranus lib.7. Geographix. Sed Mathias à Michou de Sarmatía Europ. 2, 2, hunc principem fic occifum nominat Sigifmundum de Starodup. De urfo qui per libi. dinem puellam rapuit, \& luftro futo obuoluto faxo inclufam amatoriè tractauit, allatis ei fubinde po mis, \&́c.fuperiori capite dictum eft. De urfa quam Pythagoras è fera mitern reddidit, \& dimifirurus ne quod animal deinceps læderet obftrinxit, dicã infra in $h$. Vrfæe cum fugiunt, furos catulos pros pellunt, fufceptosís portant, cum ab infectante iam occupantur, arbores fcandunt, Ariftot, Vide plura fequenti capite, ubi de trenatione urforum agitur. Vrficum feritate cateras belluas fupe: 50 rent, pro catulis tamen omnia faciunt, Apollonius apud Philoftratum. Occurram eis quafiurfus (dob, Hebraice."egere, Lxx.) orbatus, Ofee 13. Vrfus nuper Bernæ, ut audio, ubi publice urfialun; tur, fortum coniugis enixx ftatim occidit.

đVrfus in animalia qux impugnat, infilit: $\dot{\&}$ fi fint cornuta, cornuta eorum manibus apprehe dit; \& profternit ea.Cum homine ueró non facile praliatur: à quo uulneratus, frequẽter quali frendens ungues lambir, Albertus. Vrfus uiribus fuis confidens inuadit non folum ceruos, fed etiam fues feros, fi clàm repentéç potuerí ageré, taurum apertō Marte aggreditur, conferta iam pugna, fernit fe refupinü, dumó taurus ferire conatur ${ }_{j}$ iple fuis brachịs amplectitur cornua, ore morfun armis

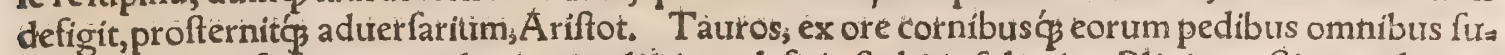
fpenfi, pondere fatigant.nec alteri animalit in maleficio ftultitia folertior, Plinius. Si quando taus $4^{\circ}$ ros adoriuntur, fciunt quiburs potiffimutum partibus immorentur, nèc aliud quàm cornua auc nares petunt, cornua, ut pondere defatigent:nares, ut acrier dolor fít in loco teneriore, Solinus. Vrfus famelicus incidens in taurum non aperto Marte pugnan cómittit, féd obliquo impetu, palearia inua dit, premendó́ lancinat, donec conficiat, Volaterranus \& Gillius ex Aeliano, Pugnant lupus, (Albertus hoc loco non recte urfum reddit, ) affinưs, taurus, Ariftot.\%. i. Si calcaurerit equus ueftigium lupi, (interpres non recfe tranftulit urfiłtuidè in Equo D.) torpore eius pédes corripiuntur, Aes fculapius. Rhinoceros urfum in Circo Romano cornu exceptim reiecit, ut inter fpectacula à $\mathrm{M}_{21}$ tialidefcripta legimus. Vrfa qua leonumi catulos in latibulocum patentes abeffent difcerpferat, $\&$ cum ab ĭs reuerfis fugaretur in arborem confugerat:quomodo fabro materiario éfylua per leone âdducto, qui arborèm fuccideret, leana interim iuxta arborem expectante, pónas eis dederit, hillo= so riàm mirabilem ex. Aeliano recitaui in Lèné capite quarto. Ibidem ex eodem authore leges hifto riam leonis ulti canem contubernälem fuưm, quem uirfa itidèm contubernalis inter colludendum ir ritata lantiârat. Equo animali obfequäh̆s hominum hato, capítale diffidium eft cum ưrfo homini nos

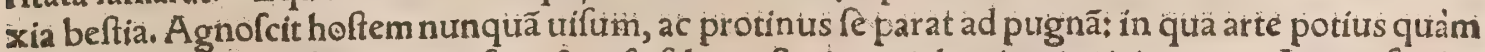
uiribus utitứ. Tranfilit enim urfum, \& ipfo faltu pofteriores calces impingit in caput. Atç urfus in terim unguibus fcalpit equini uentris mollia, Erafmus in diälogo de amicitia. Phocam etiam in ter ra metuunt urfi, \& fi ad pugnam congrediantur, unincuntur, Oppiänus. Mortuos odiffe exiftiman

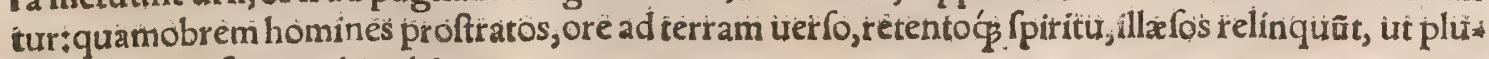
ribus dicetur fequenti capitè.

6o Leones, pardi, urfi, $\&$ aliz eiufmodi fera quomodo capiantur, partim in montibus ueneno pròptér alperitatem regionis, partim in planitie noctu équis $\&$ armis introclufi, partim foucis circuina Cepti, fuprâ quarum medium capra fub noctem fufpenfa fit, ex Xenophonte récítaui in Leone t: 
Quicirca Tigrin \& A rmeniam habitant, (ut canit Oppianus lib 4 , de uenatione, ) ur fos hoc modo uenantur: Frequentes exeunt ad fyluas cum canibus: $\&$ cum tandem cubile urfi deprehenfum fue, rit, canis fagacis ductur,mox canis â loro procurrere geftiens, latrat, fed reprimens eum uenator ad focios redit. Tum mox retia per longurios extendunt, \& fagenas ( $"$ gevers) circundant, ad utrunca retis terminum fingulos retium cuftodes locant, deinde ab uno latere à reti oblongum tendunt fu= nem tænĭs uerficoloribus $\&$ pennis auium fplendidis, ut uulturum, cygnorum, ciconiarum reple* tum, quæ uento flante micant, uibrantur, \& ftrepitum ædunt. (De pennis retibus affigêdis, diximus nonnihil etiam in ceruorum uenatione.) extendunt autem ea altitudine fupra terram, ut ad hominis umbilicum perueniat. Ad alterum uerolatus quatuor é uiridibus frondibus tuguria contexunc, in quibus uiri totidem latitẽt, in fingulis finguli, frondibus toto corpore ueftiti. Sic omnibus inftructis, 10 tuba inflatur, cuius uehementi fonitu excitatus urfurs é cubili fauiens \& igneum tuens progreditur, Tum iuuenes frequentes utrin a durfum feftinant:ille rećtà qua amplam $8 \alpha$ patentem uiderit pla niciem fugit, fed fune cum pennis $\&$ tranjis(à retium cuftodibus)concuffo, agitantibus etiam uertis $8 \times$ fibilum mouentibus, $\&$ fimul clamore, tuba, fonitu, $\&$ uiris territus $\&$ anxius $\&$ inops confilin, in retia fertur. Tum fubitò retium cuftodes aliud fupra ipfum rete expandunt, $\&$ pluribus intricatum retibus implicant.Quod fi nimium fruientes, ut folent irretiti, retia dentibus $\&$ manibus dilanient, ( fic enim aliquãdo euadunt:)robuftus aliquis uenator dexteram eius manum iniecfo uinculo impe dit, \& ad aliquem truncum alligat, Huxcufog Oppianus: ex quo Belifarius etiam tranftulit in libro de uenatione, fed pleraç ineptè. Vrfi capiuntur hoc modo: Homo armatus ferreis armis, capiteac undiç coopertus, cum folo cultello acuto ad latus:ad urfum, ubicungs fuerit, accedit. Vrfuserigitur 10 \& hominem amplectitur. qui ftatim euaginato gladio locum cordis urfi perforat, \& fic eum occi:

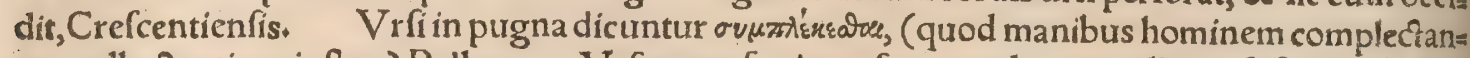
tur, colluctantium inftar,) Pollux. Vrfacum fugiunt, fuos catulos propellunt, fufceptośs pors tant, cum ab infectante iam occupantur, arbores fcandunt, Ariftoteles. Vrfa fi infequentibus ur getur, eatenus fuos quoad poteft catulos propellit: cũ autem fe iam intelligit laffitudine deficere, $\&$ ut comprehendatur uicinam effe, tum alterum dor $f 0$, alterum ore geftans, in arborem afcendit, eo: rum alter unguibus ad dor fum urfæa adhærefcit, alter dêtibus eiufdem retinetur, A elianus. (Simiam quoç fugientem fimiliter feréfuos geftare catulos, dictum eft in hiftoria eius,) Vrfus cum honits ne non facile pugnat; à quo uulneratus quafi frendens ungues lambit, Albertus. Vrf $x$ poftea quam urenatores, qui non humi modo fe fternunt, fed $\&$ os ad terram abípciunt, \& fpiritû continent, $3^{\circ}$ odorati fuerint, tanquam mortuos relinquunt, eiufmodi enim animalium genus exiftimatur mor tuos odiffe, Aelianus. hinc eft forte quod mortuos etiam urfos urfi fepeliunt, fi urerum eft quod Tze: tzes fribit. Fortem \& robuftum admodum, qui fe urfo opponat, uenatorem effe oportet, inquit Blondus, nam nifi ualidis retibus impediatur, aggredi folet uenantem, et fi poteft ftrictis amplexibus colluctariłquo genere pugnæ plerung uincit, rariffimè uincitur. Nos quidem uidimus hominem ex hac lucta fraça referentem crura, atç̧ idem nífi fubito ex prærupta rupe fe deieciffet, nequaquã cuafiffet uiuus. Porrô cum quis infidias molitur urfo, poft retia cautius latitabitł $\&$ cum in recia à ca nibus agitatam inuolutam $q$ uiderit belluam, acuto uenabulo impetet, ictu maximé per os $\&$ gulam adacto:id quod fortiter \& magno animo faciendumeft, Hæc ille. Germani circa urfum \& eius uenationem propria quędam uocabula ufurpant, qualia funt: Ser b \&r bsompt/gebet/frifit/wirot 4 gejagt/ertructer vnd frifst vilbünจ: wir dt geftoden.hoc eft, Vrfus fauit, (de uoce eius:) procedit, uorat, agitatur, comprimit $8<$ deuorat multos canes:uenabulo figitur. Quamobrem urfus retia mi nus quàm cæteræ feræ, ut lupi \& uulpes, dentibus laniet, inquirens Plutarchus in libro de caufis na turalibus: Forte, inquit, hoc non facit, quia cum dentes interius fitos habeat, magnis \& craffis labris impedientibus, retia eis attingere fatis non poteft. aut potius quòd plurimum ualeat manibus, retia his iniectis lacerat, aut pariter manibus $\&$ ore utitur:illis, ad laniandum rete:hoc, ut à uenatoribus fe defendat. Cæaterum ut euadat, plurimum fxpe urolutationibus adiuuatur, itac dum per caput fe uos

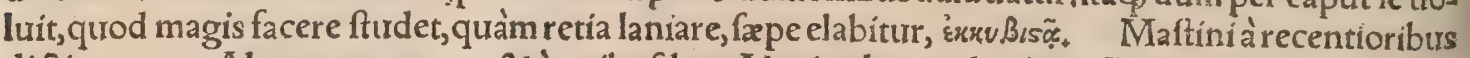
dicti canes, ex Alanorum genere, \& à quibufdam Alani ueltres uel ueltri, (Alans uautrez, Gallicé,) magnis leporarïs fimiles, fed capite $\&$ auriculis magnis, labïs craffis, in urfos $\mathcal{Q}$ apros immittuntur, $\delta$ Rob.Stephanus. Nourimus circa Romanos agros, inç̧ fyluis fuburbanis, infidiatores iaculis aut machina ferrea igni crepitante capreas, ceruos, urfos atç apros figere, noctu filicet ad lumen Lunx, Blondus. Capitur urfus laqueis $\&$ falcibus, Platina. Audiuimus nuper à SigifmundiPolo nix regis legato, Sarmatas quodam uenandi genere ad urfos uiuos capiendos utí . Nam tribus aut quatuor hominum millibus nemus (ubi urfos refidere compertum eft) circundatur, ita ut non maios ribus quàm cubiti diftent interuallis. Quo peracto, à uenatorum magiftris eodem temporis momen to, ubi cornua tubaḉ cecinêre, arboribus ac lignis eodem impetu ftatim fecuribus incifis atọ ita di: fpofitis raptimós contextis, ut quafi murus eleuatus circum effe uideatur, uenatores reliqui qui fur cas quafdam manibus detinent, cum urfis appropinquarint intrentis, alï caput, alï brachia, alï pe: des urfí furcillis ipfis impediunt:adeò ut ligari os, manus, urfusọ́ totus tutifímè polfít, quem ad re. 60 gem ut canibus armisç homines interficiant, ligatum deferunt, uel fi deferre nequiuerint, trahunt, Belifarius. Tale uenationis genus per furcas ligneas depictum dedit nuper author Geographicæ 


\section{DeVrfo. E. Lib. I.}

tabulæ Mofchouix in eadem tabula. Rhxti decipulas quardam ad lupos \& urfos rapièndos fruunt, quas magnis trabibus confertis erigunt, \& trabem delapfuram ut obruat feram, cum efcam fune dependentem attigerit, ualde onerant, eft quando urfus pede tantum oppreffo, re: liço eotandem euadit. Ad alias atque alias feras equi etiam colore diuerfi requiruntur. Oppia* nus in uenatione urforum probat glaucos: aprorum, fuluos uel ignei coloris, \&c. In Helue. ticis circa alpes regionibus, ficubi urfum animaduetterint incolæ , frequentiffimi ad eius uenatios nem conueniunt, ut pecoribus fuis, qua per aftatem fub dio abfque paftoribus ( prater eos qui ma ne $\&$ uefperi mulgenda cogunt) dies noctesćp relinquunt, periculum auertant. Quòd fi quis per fe urfum urel bombarda uel aliter occiderit, quibufdam in locis magna pecunia donatur. Vrfo capto so detractam pellem, ftramento farciunt, ita ut uiuentis urfi effigiem reddat, \& loco aliquo publico fui= fpendunt, Stumpfius, Vrfi in Sarmatix fyluis arbores fcandunt ut fauos deuorent. perimunture autem clauæ oblongæ mucronatæ repercuffu, cuius pars craffior foraminis aditum operit. hanc ur fus mant repellit, \& repercutienti iratus maiore ui rej̣cit. illa quò ualidius repellitur, eò uehemen. tius urfum reuerberat; donec faucius tandẽ in palos acutos fub arbore fixos decidit. Quòd fi nulla arbor apum aut uefparum examen habuerit eo in loco ubi urfus moratur, uenatores aliquod in ar: bore foramen inuentum, aut recens ab eis excifum, interius melle perlinunt: fic breui examen ali= quod illic colligitur, ad quod urfus afcêdens, perimitur ur diçum eft. In Noruegia pali multi acue ti circa arborem figuntur, in qua nimirum fit fauus aut aliud quod appetit urfus:arbor ipfa fuperius ferra fecatur, ita ut parum adhuc hæreat. eó cum peruenit urfus, unà cum parte refecta in palos des

20 lapfus capitur. Sunt qui in trabe aliqua uel trunco arboris foramen excauent, ad magnitudinemi urnæ, quà aqua é puteis hauritur.in huius fundo mel ponunt, adduntur aliquot unci ferrei, qui urfi caput inferendum ut mel deuoret, facile admittunt $\div$ retrahi uero $\&$ eximi non pariuntur, Alligatur autem truncus arbori. Sic retentùs urfus, 8 plurimum dum caput extrahere nititur defeffus, facile occiditur, quod fi etiam euadere ipfum contingat, innoxius tamen eft obuijs, utpote captus oculis, $\&$ dentibus lafis in contentione illa capitis extrahendi, Mich. Herus. Capitur urfus retibus, $\&$ pu= gna, $\&$ foueis quibufdam, quas uenatores fub arboribus fructifer is fodiunt, $\&$ fragilibuis lignis fipu liśç infternunt, ingefta infuper terra immota, (hoc elt non effolfa, fed alibi è fuperficie fumpta:) \& herbis iniectis, (quales pro lupis etiam fiunt.) Vrfus igitur cum ad arbore feftinat, ut ad fructus für:

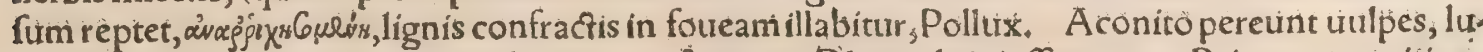

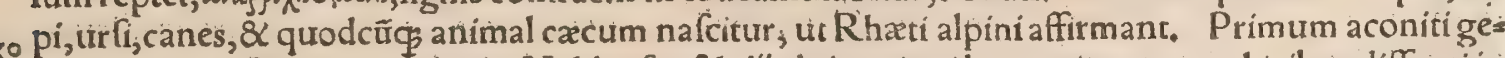
nus cyclamini folio, toram hodie Valdenfes $\mathcal{Q}$ aln̆ alpium incolæa nominant, ut plutribus díferui in Lupo. Hîc quæ fuper eadem herba, \& occifo fagitta inde infècta ur fo amicus quidam nuper àd mẻ fcripfit, adijciam, his uerbis $\div$ Valdenfis quidam mihi affirmauit toram herbam quandam à fuis uoca ri, ex cuius radice aliquandiu feruata loco humicto $\&$ contưfa furccus exprimitur, quo fagittæx tingün tur. Quàm uerò promptum $\&$ prafens uénenum herba illi infít, ex eo cognofces qưod mihi narra uit, Quum (inquir) aliquando aưunculus meus procul fagitta huiufrinodi fucco infecta lèuiter uras

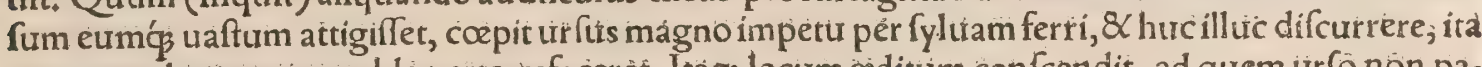
ut autunculum meưm ualde perterrefaceret. Itá $\beta_{3}$ locum àditum confcendit, ad quem ưrón nón pas tebat uia. hinc qutum illum fpeçaret, uidit tändem longis decurfis fpatịs concidentem $\&$ uítam ex: halantem. quium nimirum uenenum illud pérutafífet cor; quod ita effé occifo iam urfo deprehendie. 40 Faba lupina feu marcillium datum in adipe necat canes, lupos, uulpes 8 urros; A rnoldus de Villa noua. uidetur autem translatưs hic locús ex Diofcoride, qui apocynon fribit in adipe occidere ca= nes, lupos, uulpes $\&$ pantheras. Séd marcillium non aliud quam cêfiliginen effe putó, quam hodie Sabaudi marfieure uocant:quæ longéalia quiàm apocynon eft, cui Diofcorides folia hederæ tribuit, 8c. Pifces quidam nigri uenenati in Armenia reperiuntur:borum farina ficus confpèrgunt, quas ea in loca quæ maximé abundant feris diffeminant, beftiæ primum ut eas attigerunt, ftatim moriun tur, atç ea fraude apri, cerui, urfi, \&c.necantiti; A elianus.

T Spectacula. Annalibus notatưm eft M. Pifone, (M. Pifonis nomén Solints omittit, Méfiala tàntum cos. hoc factum memorans) M. Meffala coss. ad 14. Calend. Octob. Domitium Aeñobarbut so æalem curulem urfos Numidicos centum, \& totidem tuenatores Aethiopas in Círco dédiffe, Plin, miratur autem adiectum Numidicos fuiffe, cum in $A$ frica(inquit) urfos non gight confter. qua de re plurafcripfifupra in B. Nuper inuentum turfortim in harena $\&$ leonum ora afpergere chalcati. tho, tantáç eft uis in aftringendo, ut non queant mordere, Plinius. Taurum color rubicuindus ex. citat, urfos lèoneśćs mappa proritat, Seneca lib.z. de irä.

Praceps fangtuinea dum fe rotat itrus arena Implicitam ưifco pèrdidit ille futgam.

Splendida iam tecfo cefferit uenabula ferro, Nec uolet excuffa lancea torta manit.

Deprendat uacuo trenator in aére prædam, Si captare feras auctipis arte placer, Martíalis in libro Spectaculorum. Canis Indicus Alexandro donatus, cerưu, a prum \& urfum diniffos, tafl, quam fe indignos contempfit: in folum uero léonem infurrexit, it in Cane robufo dixí ex A éliano: 60 Intralidiffimum urfo caput: ideo fxpe in harena colapho inflicto exanimantur, Plinius, Caffiodo. rus Variarum libro s. edira circa belluas foectacula defcribens: Primus (inquit) fragilli ligno confifus curtit ad ora belluarum, \& illud quod cupit essadere, nagno impetu uidetur oppetè , (appeteré, ) 


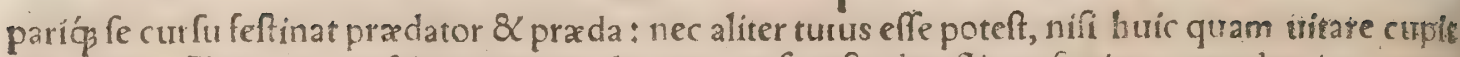
occurrerit. Tunc in aére faltu corporis elcuato, quafieftes leuifima, fupinata membra iucurtur, \& quidam arcus co:poreus fupra belluam libratus, dum moras difcedendi facit, fob uplu uelocitus ferina difcedir. Sic accidit, ut ille magis poffit mitior uideri, qui probatur illudi. Alier anguis an yuas drifaria mundi diftributione compofitis, rotabili uelocitate pręfumens, nondifredendo ingır, non le longius faciendo difredit, fequitur infequentem, poplitibus fe reddens proximum, ut ora uirer urio rum, \&c. ut cirat Gul.Philander Vituuium illuftrans. TA pros \& urfos n vituario quodā prope Crefiphontem in A fia fuiffe, quos milites Romaniuenatorïs lanceis \& miffium multrudıne con. foderint, A mmianus Marcellinus fcribit. TValentinianus imperator cũ duas haberet urfas ho= minum ambefirices, Micam auream \& Innocentiam, cura agebat enixa ut earum caueas prope cu= 10 biculum fuum locaret, cuftodeş́́ adderet fidos uifuros follicité ne quo ea fuperarum debetur(locus eft obfcurus, deprauatus ut conịcio)luctificus calor. Innocentiam deníp poft mult s quas elus la. niatu cadauerum uiderat fepulcuras, ut bene meritam in fyluas abire dimifir ir noxiam, Am. Mar. cellin, lib.29. IV Volucra(uoluox)animal tenercs adhuc pampinos prarodit \& uuas : quod ne fiat, falces, quibus uineam putaueris, peracta puratione fanguine urfino linito, Columella iibro de arboa ribus, \& fimiliter Plinıtis, Contra grandinem multa dicuntur : Noctua pennis patentibus extenfa f fffigitur: uel ferramenta fepo unguntur urfino. Aliqui urfiadipem cum o'eo tufum relertiant, \& falces hec, cum putaturifunt, ungunt. Sed hoc in orculto delet effe remedium, ut nulius putator intelligat cuius uis tanta effe perhibetur, ut ne $\$$ gelu, neqs nebula, neç alio malo poffit noceri. ina tereft etiam ut res profanata non ualeat, Palladius. Si fanguis uel pinguedo urfi in f́crobe uel uafe 10

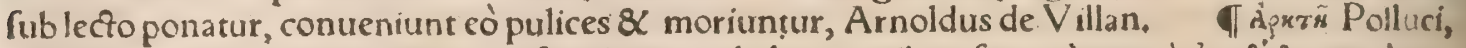

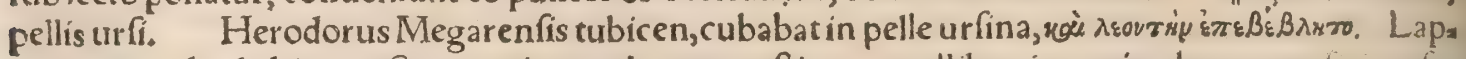
pones populiadultimum Septentrionem, hyeme ueftiuntur pellibus inregris phocarum rue urfoz rum artificiofé elaboratis, easćs aftringunt fupra caput, folićs oculi patent, corpóre relijuo to i cona tecti funt, \& quafi in culeum infuti. hinc fortaffis creditum quod fint corpore hi futo bruturum ina ftar, Munfterus; Maurorum pedites leonum $\&$ pardalium $\&$ urforum pelles induunt, $\&$ dormien tes fubfternunt,Strabo.

F.

Sunt qui $\&$ urfis, 8 ịs adhuc deterioribus, leonibus ac pardis urefcantur, femel aut bis elixantes, Galenus de alim. fac.3.ı. Carourfi frigida eft,mucofa, difficilis concoct!l, illaudata, Rafis. Ifaac ze perquàm uifcofam effe fcribir, concoctu difficilem, peffimi nutrimenti : medicinæ magis quàm nu= tritioni apram. Tardè concoquitur, Ipleni arog hepati oheft:mulra recrement generat, apperena tiam tollit ac faftidio edentes afficit,Platina. Sunt qui urfinam carnem ex paliillo comedant, Idem. Carourfi cocta, tempore quo latitant urfi, in uafis ubi afferuatur crefcit, ut Theophraftus credic, Pli, nius, uide fupra in $\mathrm{B}$.in mentione adipis urfi. Vrfi manus, id eft pedes anteriores inter efitandum effe pradulces infignióg fuatitate traditur:quoniam (ut Plutarcho placet) partes bene concoquen= tes, carnem reddant fuauiorem. concoquit autem pracipué omne quod difflat. id uerò eft quod mo. uetur, quod'̧̣ exercetur: ficuti urfus partem hãc agitat plurimum, tum inceffus ratione, tum appre: henfionis, Calius ex Plutarcho de caufis nat, quaeftione 22. Vrfina quanquam infalubris, hodie ta= men apud Germanos in pretio habeturtfed manus pracipué, quas uel principes uiri a ppetût, Mich. Herus. Vrfipedes anteriores falfos 8 in camino ficcatos qui ederunt, optimum \& fuauiffimum effe cibum mihi retulerunt, nec amplius fe mirari quod eos per hyemem inter latendum fugant.

G.

Panos \& apoftemata in quacunç parte fanguis urfinus difcutit Pliniur . Galeni fententiam de caprini, hircini, $\mathcal{Q}$ urfini fanguinis ad abfceffus concoquendos curiofo ufu, in taurino fupra reci. taui. Sanguis urfi prodeft pilis qui in oculis nafcuntur, cum loco depilato illinitur, Rafis.

q Vrfus cum per hyemem latet ualde pinguefcit, illi funt adipes apti med caminibus, Plinius, Conditum in uafa hunc adipem, eodem tempore quo latitant urfi,crefcere, fupra in B .retuli. Pro adipe uulpis, adipe urfi utemur, ut legimus in Succidaneis Aleginetæadfriptis. Adeps urfinus quomodo curetur ex Diofcoride recitaui in Sue G.quamuis Gracus euulgatus codex nofter Dio= fcoridis, non aǵnesoy, id eft urfinum, fed xýveson, id eft agninum habet, quod non placer. nam \& Ruel. lius ur finum uertit: $\&$ pauló poft eodem in libro apud Diofcoridẽ in fine capitis de adipe odoribus

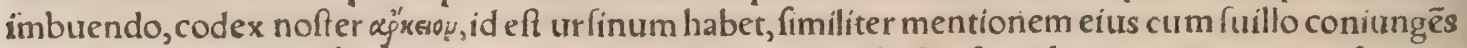
ut 8 fupra. Adde quòd eo in loco de adipe agnino curando Diofcoridem agere non opus fit, cum fequenti mox capite de ouillo agat, fub quo agninus continetur. Leoninus adeps calidiffimus $\&$ ficciffimus eft, 8Xc. Pardinus ei proximus, pardino urfinus, taurinus urfino uicinus, lacob. Sy'uius. Recentiores quid m medici, urfi adipem alịs quibufdam mifcent medicamentis, ad inungendum loca conuulfa uel refoluta. Mifretur $\&$ acopoex uulpe in oleo deccéta apud Nicolaum. Vrfi adeps liuores \& maculas eximit,Marcellus. Ambuftis prodeft urfinus adepscum lilin radicibirs, Plinius, Idem alibi, Aduftis, uel combuftis aqua feruenti ( inquit ) adipe urfi cum cera utendum 60 putant. Obfcurus quidam fcriptor hocadipe duros tumores molliri, \& ad liuppurationem qux opus eft duci, putat. Lumborum dolores, \& quacunque alia mollire opus fit, urfino adipe perfricari 


\section{DeVrfo. G. Lib. I. ' 1075}

conuenic, Plinitis. Igni facro illinitur urf.adeps, maximè qui eft ad renes, Plinius. Vrfinus maxi: méaut uulpinus a deps, uel fi ifti haberi non poffint, taurinus cum farmétitio cinere emollitus, et cuni lixiuio cocfus probe attenuat eminentes tumores. hoc enim modo etiam fapo præaparatur, quem in ufum conuertere oportet, fi urfinus aut uulpinus adeps non adfit, Archigenes apud Aétium in cu= ratione elephantis. Vlcera fanat in tib̆̉s cruribusćs adeps urfinus admixta rubrica, Pliníus. Sed aliter Marcellus empiricus: Vlceribus crurum 8 tibiarum medetur adeps urfi cum herba rubricata tunfa. cum hæc ergo in unum corpus fubacta coierint, impofita uelut emplaftrum, conligantur ut diumaneant. Vlceribus omnibus pedum in qualibet parte, adeps urfina addito alumine medecur; Idem. Perniones urfi adeps, rimasóş pedum omnes farcit, efficacius alumine addito, Plinius. Dio.

10 frorides quoque pernionibus eum fubuenire fribit. Splenis afinini leuiffimus puluis cum feuro urfino $\&$ oleo ad mellis craffitudinem redactus \& illitus, fupercilips pilos reftiturit, $R$ afis, Vrinium adipem conftat raptos uitio alopecia capillos reftituere, Diofcor, \& A uicenna. Hunc adipem alo; pecijs congruere quidam ante nos uere fcripferunt ₹ fed nos alia magis probata pharmaca contra hunc affectum habemus, Galenus. Leporis exuftum caput $\&$ cum adipe urfino aut aceto illia tum, alopeciarum inanitatibus medetur, Diofcorides $\&$ Auícenna, Galenus lib. 11. de finipl medicum quendam innominatum eodem hoc pharmaco ufum fcribit. Murem uftum $\&$ tritum, cum adipe urfino $\&$ melle fubiges, $\&$ alopecias inunges, Galenus Euporift. 2. 86 . Et paulơ mox, Cum foln̈s ficus frica diligenter, deinde unge cum adipe urfino. Apud Galenum fecun= dum loc, Cleopatræ quædam compofitio eft laudatifima, aduerfus alopecias \& profluuium cà 10 pillorum, cui adeps urfinus addicur: Item alia Heraclidx. Herinaceorum marinorum cinerem, ut ibidem docetur, alị aqua excipiunt, alin, quod melius eft, adipe urfino ad eundem affectum. Viz de fupra in Echino G. Vrfiadeps $\&$ fel cum modico pipere alopecińs illita, pilos inducunt, $R_{a}$ fis. Roboris pilula, ( quæ gallas fimilant, ) cum adipe urfino tritæ; alopecias emendant $\&$ capil lo replent, Plinius, Marcellus, \& Samonicus. Rofa fylueftris cum adipe urfinoalopecias mirifice emendat, Plinius. Calami radices uitas cum adipe urf, excipe atç impone, Crito apud Galenirm. Vitium capitis in quo funt alopecix, prius ra ditur, poft illic cxpa acerrima perfricatur. deinde hor: deum combuftum $\&$ in puluerem redactum cum urfina adipe permixtum, fuperimponitur, Mar cellus. A deps urfina cum fungis qui in lychno lucernæ cócrefcunt fubacta, (uide mox ex Plinio,) 8 alopecijs perunctione impofita, priftino decori capur reuocato crine reftituir, Idem, Vrfinus 30 adeps cum ladano $\&$ uino uetere mixtus, capillos fluentes continet $\&$ cörpiffat, Sextus. Ad capil, los decidentes confirmandos, adipem urf.cum ladano mifcebis, \& caput, uel loca defluentium capil lorum perunges, Marcellus, Capilli defluuia urf, adeps, admix to ladano $\&$ adianto continet, alo= peciaśç emendat, \& raritatem fuperciliorum cum fungis lucernarum, (uide paulò ante ex Marcel= $\mathrm{lo}$ ) ac fuligine qua eft in roftris earũ, porrigini cum uino prodeft, Plin. Lacerta ut docuimus com: bufta, cum radice recentis harundinis minutatim fiffa + ita myrteo oleo permix to cineres capillorumi defluuia cótinent. Efficacius uirides lacertæ omnia eadem præettant, etiamnum utilius admixto fale, $\$$ adipe urfino $\&$ cepa tufa,Plinius. Mifcetur $\&$ alịs medicamentis quæ uel continerecapillos, uel locis etiam caluis reftituere pollicentur, ut illi quod ex leporum uentrib.\&c. Andromachus compo= fuit, a pud Galenum de comp. fec.locos, lib.1. in fine capitis 2. Adeps urf. pari pondere cum feno 40 taurino \& cera permixta at $\not 3$ adpofita, parotidibus mirum remedium eft, Marceliusi comprimit pas rotidas, fed addunt quidam hypocifthidem, Plinius. Ad faucium dolorem:Præterea fauces extrini fecus ungere prodeft Vrfino \& taurifeuo, cerisçąremiffis, Omnia quæ geminis aquabis lan cibus ante, Serenus, Ceruicum dolores butyro aut ( $\&$, Marcel ) adipe urfino perfricătur, Plinitus. Vrfiadeps commendatur contra flatus quos phlegma crudum excitat, 8 in dorfi dolore, (ad lumi borum dolores, Plinius,) Rafis. Gladioli radix contufa cum fulfure uiuo \& adipe urf. lumbis do* lentibus impofita plurimum prodeft, Marcellus. Articularibus morbis $\&$ podagricis plurimi cuni oleo uetere urticæ femina, aut folia, cum urfino adipe trita imponunt, Plinius, Adeps urf.cu m lea uo taurino \& cera pari pondere decoquuntur, eóq̧ ceroto podagra contaêa lenitur, Marcellus, àds dunt quidam hypocifthidẽ \& gallam, Plinius.

so đHeraclides apud Galenum pilos urfi combyftos, $\&$ adipem urfi alp̈s quiburdamad inierera tas alopecias medicamentis nifcet. Eft $\&$ Sorani medicamentum apud eundem ad alopecias, huz iufmodi, Foliorü ac radicis calami uftorum, pilorum urfi, (addendum uidetur, uftorum)adianti, adiz pis urfini, picis liquida, pilorü caprarũ uftorum, cedria, omnium octo par pondus accipe, liquidáćs cum aridis cómitte, \& præfrictis adhibe, IVrfi pellis utiliter fubfternitur morfis à cané rabido, ut \& phocæ, Aétius، đVrforum cerebroueneficium effe Hifpaniæ credunt, occifortmós in fpeça culis capita cremant, teftato, quoniam potum in urfinam rabiem agat, Plinius. Rafis quidem $8<$ Albertus cerebrum leonis intra cor pus fumptum amentiam inducere tradiderunc. Cati cerebrum fimiliter uenenofum effe, fcripfi in Cato G. Tf Oculus urfi dexter ficcatus $\&$ appenfus puteris, amolitur ab eis timores quibus in fomnis uexantur, $\mathrm{R}$ afis. Oculos urfi erutos fi finiftro hominis adiutorio (brachio) alligaris, febrim eius quartanam mitigabis; Aefculapius. Thillus \& agnis nus urfinusćs pulmo impofitus, attrittus à calciamentis contractos ab inflammatione tưetur, Dio fcorides : fanare creditur, Galenus lib. 11, de fimpl, Sed Galenus fuilli tantum $\$$ agnini pulmonis 


\section{$1076^{\prime}$

mentionem facit, urfini nưllam, quamobrem conïcio apud Diofcoridem quoq illa fuperfluam effè. pottit autem in textum irrepere uerbum xp'resos, id eft urfinư, quod aliquis forte in margine tanquä diuerfam lectionem notaurerat facillimé enim pro ağvesos legitur ag’nesos, uel contra, ut fupra quoç di= ximus in principio medicaminum ex adipe urfi. Et fane ridiculum foret pro pede quem calceus Iæfiffer, tam longèremedium quarere $\mathrm{s}_{\mathrm{z}} \mathrm{b}$ urfo inquam, agninus uerò \& fuillus pulmo, quoties líbue rithaberi poffunt.

đFel urfinum cum uefica fua ab hepate feparatum, fufpendi \& ficcari debet.per duos annos fer uatur, Phyfiologus, Diofcorides urfino taurinum prafert. eadem enim fed inefficatius praftat. Caprino felli confimile ferè eft urfinum \& bubulum, efficacius eis taurinum, Galenus. Si frigore ita occupecur corpus, ut uix medicamentis cedat, fel urfinum tepefacta dilue lympha, Proderitio hoc potu, Serenus. Fellis urfi myftra duo cum aqux cyathis duobus, mơnfis à cane rabido quidam per triduum ieiunis offerunt, 8 in magna admiratione habent, Damocrates apird Galenum de ane tidotis libro 2. Fel urfinum fiue uerrinum panos $\&$ apoftemata in quacunio parte difcutit ${ }_{j} \mathrm{Pli}_{i}$ nius. Carcinomatis qua ferpunt circa ulcera fel urfinum bene adponitur, Marcellus Plinius, Carcinomata (inquit) curat coagulưm leporis, \&c.gangranas urfinum fel pennä illitứ. Fel urfinum leprofos admodum fanat, fi eo affidué perlinantur, Marcellus. Sepum \& fel urficum mo dico pipere, fi alopecia illinantur, pilos reftituunt, Rafis. Articulorum uitís (doloribus, Marcel. lus) fel urfinum utiliffimum effe tradunt, Plinius, Priuatim in eclegmate comitiales adiuuat, Dio. fcorides. Fel urfintrm cưm aqua calida fumptum caducos fanat, Sextus. Ab Arnoldo de Villan, etiam ad epilepfiam commendatur. Calidum eft \& ficcum, contra epilepfiam $\&$ paralyfim utile, 10 Phyfiologus. Felle urfino circunilini fuffufiones prodeft, Plinitus. Fel urfinum atg hyęnx cum melle optimo mixtum \& ditr coagitatum, caligines eximit, fi adfidue inde oculifuffundantur aut fux perlunantur, Marcellus. Ad exefos dentes: Fel urfi impofitum illico dolorem leuat : curatautem etiam quoquo modo illinatur, Galenus Euporift.2.12. Omnem oculorum obfcuritatem, incipien. temć fuffưfionem curat fel urfinum cum aqua duplo, Idem Euporift, 1.44. Ad fufpiriofos fanana dos fel urfinum aqua (calida, Sextus ) dilutum bibendum optimé datur.intra paucos enim dies po. tenter medetur, Marcellus. Fel urfinum ín aqua laxat meatus fpirandi,Plinius. Fel urfi potum pondere fex granorum danic cum melle $\&$ aqua calida, tralet contra afthma, $R$ afis. Tufim fanat urfinum fel admixto melle, Plinius. Antidotus ex felle urfino ad induratas hepatis affectiones,

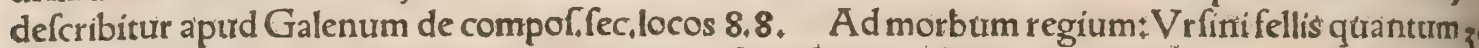
Grxcam fabam xquat exhibeto, deinde aquam fuperbibito, Gálenus Euporift, 2, 29. Peffus ad conceptum promouen dum: Leonis aut urfi aut hyæn $x$, uel faltiem tâuriní fellis ueficam eutacuato:

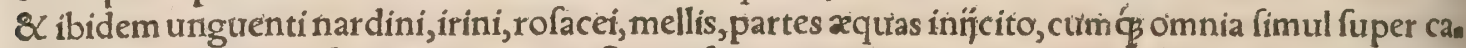
lido cinere uniưeris, feruato \& utere poft menfium purgatiơnem ante concúbitum, Aêtius 16.34. Qui ligârit fel urfi fuper femur dextrum, coibit quoties uoluerit; \& non nocebit ei, $R$ afis. Sedis ul. tijs præclare prodeft fel urfinum cum adipe:quidam adijciunt fumam argentiac thus, Plinitus. Fel urfi potum pondere fex granorum danic cum melle $\&$ aqua cálida, afthma $\&$ hæmorrfioides remon uet, Rafis.

GComitiali morbo teftes urfinos ediffe prodeft,Plinius. Suffimentữn ad epilepticos expertum, recipit hirci $\&$ urfi $\&$ lupi teftum, fanguinis hirundinis, \& lapidis in eiưs uentriculo reperti, afterï $4^{\circ}$ in mari inuenti, (ftellam marinam intelligo, )anethi, ana $3 . \not 1$. alliorum purgatorum, cornu ceruini $\&$ caprini, ana $3+1$, \& c. Eft autem ordine fecundum inter fuffimenta apud Nicolaũ Myrepfum。 đDo lor aurium fedatur canino lacie $\&$ urfino, fi recens inftilletur, Marcellus,

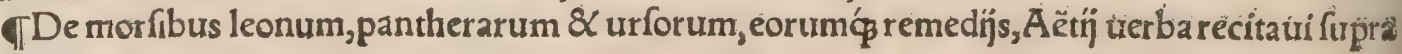
in Leone $\mathrm{G}$.

\section{H.}

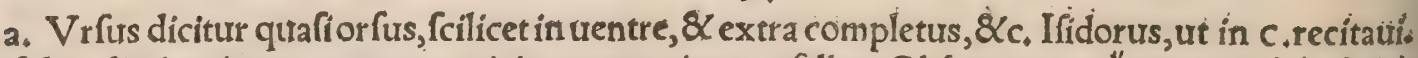
Vrfulus, diminutiuum, ut grammatici annotant.item urfelius, Obfcurus, Ä

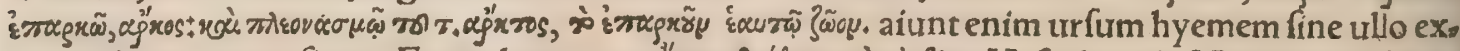

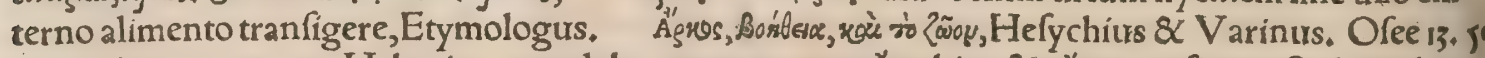

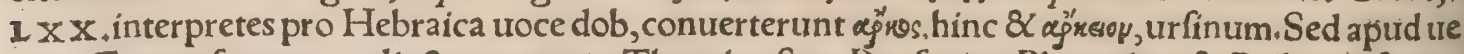
teres Gracos femper r.adiecium reperio. Theophraftus, $P_{\text {aufanias, }}$ Plutarchus $\&$ Pollux in fomi nino genere proferunt, non folum de foemina loquẽtes, fed de urfo fimpliciter $\&$ haud f́io an quif

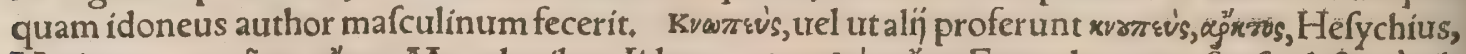

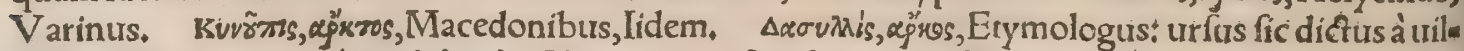

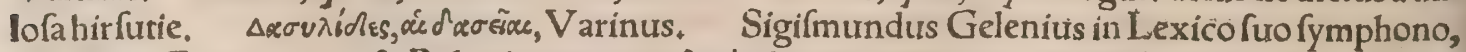
Græcam, Germanicam, \& Polonicamuoces, Besjós, ber, wewer, tanquatn eiufdem fignificationis cố iungit. Varinus Besgò interpretatur $\delta$ 'covi, id eft hirfutum. fubftanticie quidem pro urfo pofitum nuf quam reperio. Movsós, urfus folizarius, Etymologus : alị moniôn aprum, alí lupum folitarium in. terpretantur, alỉ afinum,ut dixi in Afino a. Árougẽ̃ss, urfa parua, Varinus:de fydere intelligo. retuli,

Valentinianus imperator duas habebat urfas, Micam auream, \& Innocentiam, ut fupra in E. 


\section{DeVrfo, H.a. Lib. I. 1077}

Epitheta. Tu licet Aemonios includas fentibus urfos, Gratius. Armati unguibus urff, $\mathrm{O}$ uirdius 10. Metam. Fœdus Lucanis prouoluitur urfus ab antris, Ouid.in Halieut, Informes, Verg; 3.Georg. Sauris inter fe conuenit urfis, Iuruenalis Sat, 15. Truces, Valerius 2. Argon, Turpes, Ouid, 3. Trift. Statius 6. Theb. Vefpertinus circumgemit urfus ouile, Horat, Epodo Villofaca: tulos in fummis montibus urfa, Ouid, 13.Metam. Sunt $\&$ alia apud Textorem, nempe; Atrox, auí. dus, Calydonius, crudus, deformis, Erymanthius, ferox, grauis, Libycus, (uide in B .) minax, Numiz

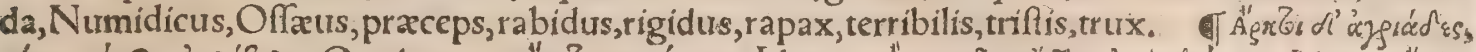

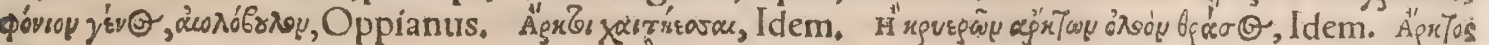

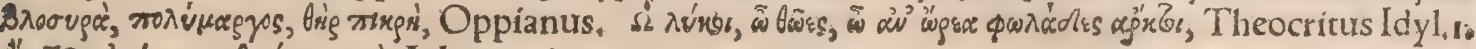

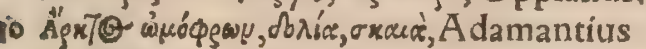

IV Vrfa uocatur fydus coelefte, figura \& fitu ftellarum feptem plauftro fimile, quatuor enim ex eis rotarum, tres equor um locofunt.unde antiqui Grxcorum hámaxan, hoc eft plauftrum dixerũ $t_{\text {, }}$ ut $\&$ Germani hodie. Latini Septentriones appellant; à feptem ftellis à quibus quafi iuncti triones. hoc eft boues, figurantur. Sunt autem dua urf $x$, maior $\&$ minor, quas Graci rejrizs nominant. Vr fam maiorem (inquit Higinus) Hefiodus ait effe Califto (melius per duplex lambda, ur Graci fria

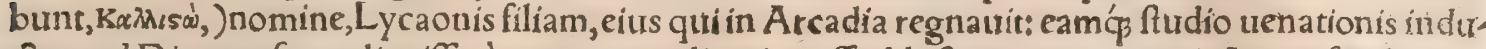
ctam ad Dianam fe applicuiffe: à qua non mediocriter effe dilectam, propter utriufas confimilem na turam: Poftea autem a b loure compreffam, ueritam Diana furm dicere eurentum, qquod diutius ca lare non potuit. Nam iam utero ingrauefcente, prope diem partus in flumine corpus exerciratione

20 defeffum cum recrearet, à Diana cognita eft non obferuaffe uirginitatem:quamobrem à dea in urfa fpeciem conuerfa eft In ea figura corporis Arcada procreauit. Sed ut ait Amphis comcediarum fori ptor, Iupiter fimulatus effigiem Dianæ, cum uirginem uenantem ut adiutans perfequercurr, amo. tam à confpectu caterarum compreffit: qux rogata à Diana quid ei accidiliet quód tam grandi ute, ro uideretur, id illius peccato eueniffe dixic. Itaç propter eius refponfum in urfam eam Diana con= uertit. Qux cum in fylua ut fera uagaretur, à quibufdam Aetolorum capta, ad Lycaonem pro mus nere in Arcadiam cum filio eft deducha. Ibi igitur infcia legis in Iouis Lycxi templum fe coniecit: quã confeftim eft filius fecutus, Iraç cum eos Arcades infecuri interficere conarentur, Iupiter me mor peccati, ereptam Califto cum filio inter fidera collocauit, eam'́s Arctum, filiț autem Archophy laca nominauit, Nonnulli etiam dixerunr, (ut Scholiaftes Homeri etiam refert Iliad, figma ex Calli= 30 macho)cum Califto ab loue effet compreffa, lunonem indignatam in urfam eam conuertiffe: quam Dianæuenanti obuiam factam, ab ea interfectam, \& poftea cognitam inter fidera locatam, \&c, Hæc Higinus. Hanc Callifûs metamorphofın in urfam Ouid.lib. 2, Metam.defcribit. Callifo Lycaonis filia fuit, quam (ut Graci referunt) lupiter compreffit. Iuno deprehenfam mutauit in urfam : \& Dia* na in Iunonis gratiam fagittis confecir. Iupiter uerò miffo Mercurio filium quem utero geftabat Cal lifto feruari fibi iuffit. I pfam uero Callifto in fydus, quod Vría maior uocatur, conuertit : cuius etiam

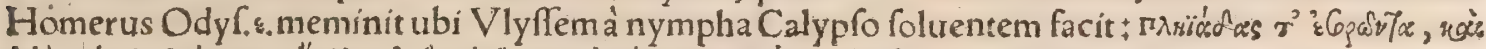

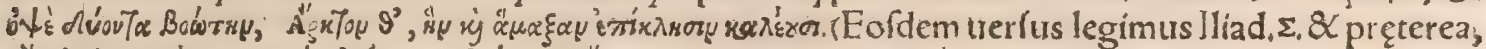
H" $\tau^{\prime \prime}$ aì lud hoc nomen in honorem tantum Calliftûs acceperit : nam fepulchrum eitus Arcades oftendunt, 4. Paufanias in Arcadicis. Arcas(ur Iftrus inqutit)natus eft ex loue \& Themifte(lego, Callifto, ) fic di ctus propter matris mutationem in arcton, id eft urfam. quo tempore etiam fydus coelefte, quod Há maxa prius dicebatur, Vrfa dici cœpit, Stephanus in Arcas. eft autem locus corruptus. Sed de Ly caonis filia Callifto in urfam conuerfa, plura fcripfi in Lupo a. inter propria uirorum. Fabulam de Callifûs mutatione Palaphatus inde natam conịcit, quód hæc montes habitans ab urfa fortè in uénationeconfumpta fit: $\&$ qui in trenatione cum ea erant, non illam amplius ex urfac cubili egredien: tèm, fed folä urfam uidentes, quód Callifto puella urfa facta effet dictitarint. Ef $\&$ alcerum fydus fuperiori proximum, figura confirnile, V rfam minorem uocant:de qua plura leges apud Higinum; ubi etiam de maiore $\mathrm{Vr}$ a, quomodo ab alins plauftri nomen acceperic a feptem ftellis, ab alijs $\mathrm{Vr}$. rx pluribus ftellis ad unam effigiem computatis, copiofus fcribit, \&c. Item de Arctophylace fiue so Boote apud eundem. Nos de Cynofura, id eft, minore Vrfa nonnihil attulimus in Cane a. Helice (fic quoque maiorem Vrfam uocant) \& Cynoftura, in coslo dicuntur geminæ Vrfa: quarum alteram (Cynofuram) louis nutricem fuiffe perhibent, alí ambas. Sunt quiCynoftram eius nutricem, He licen uerò amores eius faciant, Follux. Cynofura,id eft Vxfa minor, fic nominatur, quòd caudam inftar canis reflexam habeat: cuius Homerus non meminit utpote pofterius inuenta à Thalete Mi. lefio, Scholiaftes Homeri. Nicander in Alexipharmacis arefon omphalóeffan uocauit: interpres Tooфúd r exponit, ueluti dicas nurritiam. funt qui Crecicam exponant. nam Omphalòs Creta locus eft, Calius. Sed fortéfic dicirur quód eo fitu in colo fit Vrfa fydus, quo umbilicus in animante, uide=

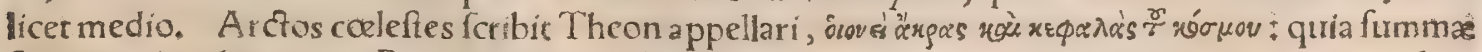
fint, ac coeli uelut capita. Peculiarius autẽ Cynofurấdici ex caudæ imagine, quoniam canis caudam 6o habeat. Helicen uer ò dà to Eriarearxi, quia inuoluta fir cauda ; uel per exochen quandam quòd à coclo

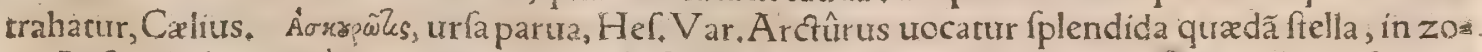
na Arctophylacis; quòd iuxta caudam urfa fita fit fic appellata, unde integrunileciam fydus Bootes 


\section{8}

\section{De Quadrupedibus.}

codem nominè appellatur,Suidas \& Varinus, Ápróos rórrs, locus Septentrionalis, in quo feptemi ftella uifuntur, Varinus. Hinc $\&$ circulus Arcticus dicitur, \& qui ab ea coli plaga exoritur uen. tưs ärtęrios, Pollux. Varinus tamen in toce Ä

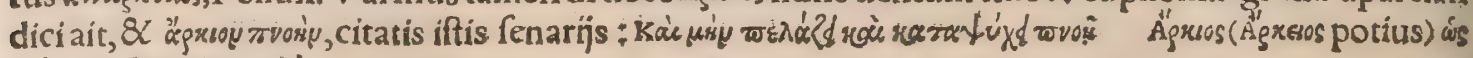

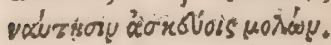

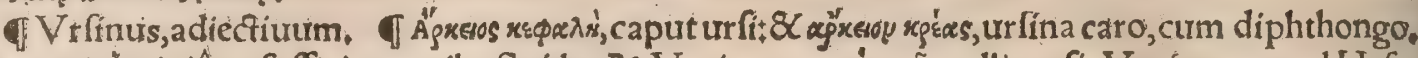

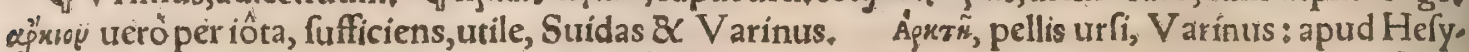
chium acuitur ultima、 TVirgines ag̉ntovizarce (decimari inter pretatur Gyraldus) Athenienfis po pulus dicebat, Pollux. Id uerbum fignat, (inquit Cxlius, ) Dianx prius quàm tem pus appetat nuptia rum, uirgines confecrari initiaríue. Quod Lyfias fcribit in oratione pro Fhrynichi filia, fitamen ex is eitus illa prodint officina. Decreto nangs fancitum Aithenienfitum erat, ne qua uiro puella traderetur,

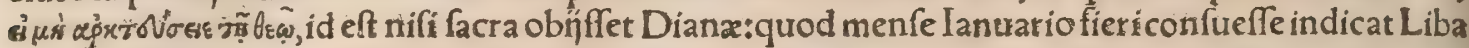
nius in oratione quam de Diana laudibus dixit . Induebantur autem uefte quam crocotam nomie nant, nee décimo étatis anno grandiores, nec quinto inferiores. Iis autem placari credebatur Diana, quæ caufa eiufmodi indignationem concepiffe uidebatur. Ferunt quandoç urfam feram in A trica

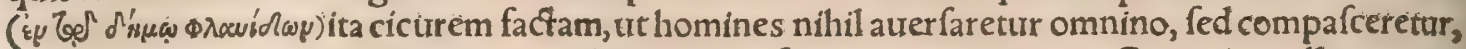
multaćs licentia huc illuc, nemine impedimentum inferente, peruagaretur. Contigit puellam quane dam lafciuiufculè cum bellua colludere:qua iritata, puellam facto impetu profcidit. At fratres rem intuiti, ac commoti acrius, urfam iaculis impetitam necarunt. Ex qua caufa peftilens morbus latius per regionem gtaffari coepit.Confultis oraculis, refpondit deus, mali non defuturum finem, fi uirgi. 10

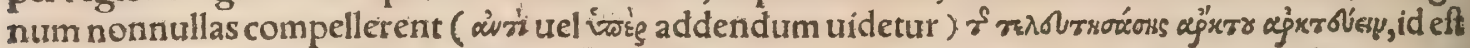
urfa perempta honori Dianx dicari. (Gyraldus exponit, fi uirgines aliquas Dianæ mactarent pro urfa.) Nã \& puellæ fic irocabantur arcti, id eft urfá, quod perfpicué docuit Euripides in fabula Hyp

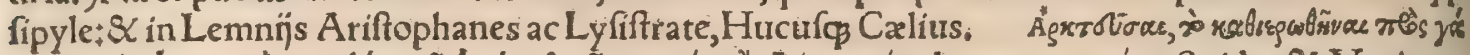

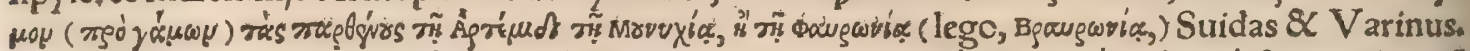

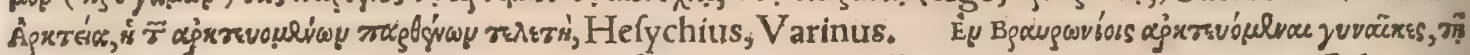
A

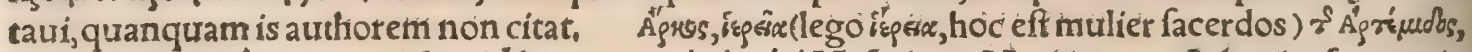

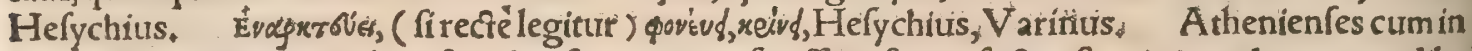
Dianæ Munychiæ templo urfam deæ facram interfeciffent, fames facta eft. qua tum demum eos libe 3 ratum iri prædixitoraculum, cum eorum quifpiam deæ filiam facrificaffet, id quod Embarus ea con ditione pollicitus eft, fi facerdotium in fua familia perpetuó perntanfiffet, \& gentilitium fieret. quod cum annuiffent, exornatam filiam immolaurit:qua ex re factum in eos eft prouerbium, qui infani ac uecordes funt, Ë $\mu$ ßacés siju, id eft, Embarus fum. plura in prouerbins Erafmus, A b hoc facto, fcribit Harpocration, mos inoleuit, ut inde uirgines Dianæ Munychię \& Brauronię confecràrêturur ante nu

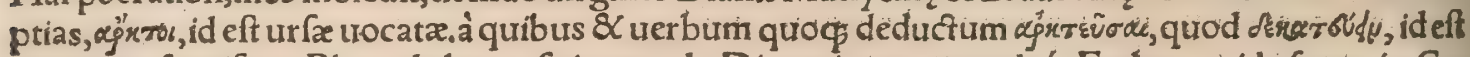
decimare fignificat,Plura de hac urfa in templo Diahx interempta, déćs Embaro, uide fupra in $\mathrm{C}_{2}$

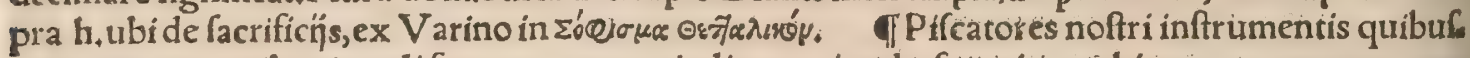
dam utuntur, retibus in coli formam contextis, ligneo circtulo fiperius ambiente os apertum : qua nefcio qua de caufa urfos appellant, b\&ren. funt autem diuerfa, alia ftozb\$์ren, quibus turbatos in $r i=4$ pis pifciculos aut cancros excipiunt: alia naffis uimineis fimilia in profundum demittuntur, fesb ren, fergattr.

G Berna Heluetia clariffima ciurtas urlos publice alit. eoldem pro infignio habet, quatuor pedis bus infiftentes, $\&$ nomen quoog ciuitatis ab urfo factum uidetur etymo Germanico. Caterum San gallenfes \& Abbatifcellenfes Heluetix populi urfo erecto pro infigni utuntur.

TEf \& fylueftreallium, quod urfinum uocant, odoremolli, capite pratènui, foln̈s grandibus, Plinius. Arcfûrus, genus herbx, Hefychius, Varinus. Arction uel arctûrus herba memoratur â Plinio 27. 5. \& à Diofcoride, creditur autem effe qua uulgò lappà mínờ (quiamuís xanthion etiam à quiburdam lappa minor exponitur ) uocatur. Maior uerò lappa fiue bardana uulgò dicta, arcion fitue profopion, id eft perfonata Diofcoridis exiftimatur:Plinius ( ut ipfe deprehendi) lappam boa. $\$$ riam nuncupat. Arcophthalmus, chryfogonum*arcopus, catanance:arciu dendron, fambucus, ut inter nomenclaturas apud Diofcoridem legimus. De pane urfi, \& uua urf, friptum eft fupra in $c$. Branca urfina uulgò appellata apud Gallos \& Italos, (de qưa lege Syluaticum cap.87.) uieterü acan. thus eft. Ea uerò quam Germani quidam medici, Fuchfius $\&$ alĭ, byancã urfinam tiocant, omnino fphondylion fuerit. Alia eft etiam quam Germani uulgo brancham ưfiñ̆ uocitant bi̊rentapen,

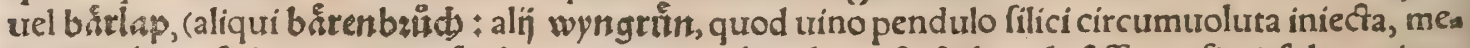
deri credatur.fed uinum cum fecibus prius perturbandum eft, $\&$ baculo fiffo, ut fieri folet, agitan= dum:) quod hirfutiem urfinam quodammodo referat, aut etiam pedis digitorum figuram extremis ramuiis ferèternis, repit circa faxa, quibus minimis fibris adhęret, folịs ferè abietis teneris, cöfercîis, 8c.uide Hieronymum Tragum Tomo 2,cap.189.

of Nafcitur apud Lucanos animal quoddam medium inter urfum \& fuem, Galenus : uide fupra

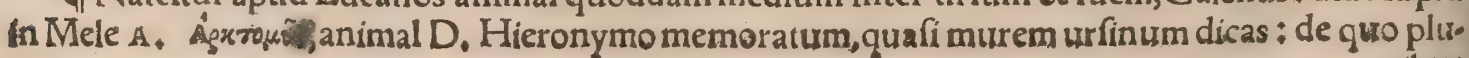




\section{DeVrlo. H.a.b.c.d.e. Lib. I.}

iribus f́ripfi in Criceto mure. Aldabha (id eft hyana) eft animal notum in Syria, colore turf, Andr. Belluneñ. Dalac, fera fimilis urfo, Syluaticus. Eft \& urfa marina, cancrorum generis, fine chelis, magno $\&$ informi corpore dicta, Ariftoteli \& Athenæo.

6. Vrfulus nomen proprium uiri apud Am. Marcellinum lib,16. \& Vrficinus apud eundem lib 15. Vrfus quidam ceu uir fançus apud Heluetios Solodorenfes colitur. Vrfinus monachus feripfit opus infigne de non rebaptizandis hæreticis, $8 \mathrm{c}$. Gennadius. In fancforum catalogis legimus etiam Vrficini cuiufdam, \& Vrfatij confefforis nomen. Nobilis quædam familia apud Gallos ori ginem fuam à nefcio guo Vrfone deriuat, quem in folitudine urfa quadã annis aliquot nutriuerit.

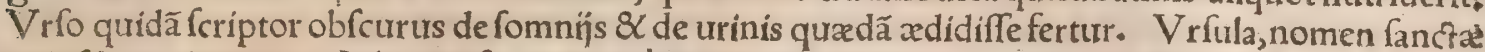
yo cuiufdam uirginis. Athenienfis quidam éMelite uico(tribus Oeneidis) rámlos uel oṽs, id eft fus, \&C. arctos, id eft urfus cognominabatur, propter corporis hirfutiem, Hèr. Var, in Medirev́s. Arcefiades,

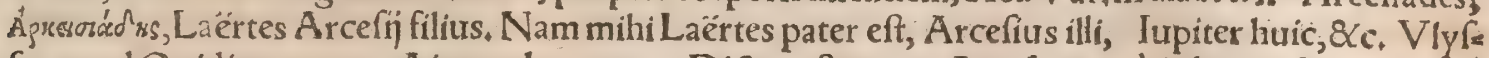
fes apud Ouidium contra Aiacem loquens. Dictus eft autem Arcefius quòd ab arco fiuce arcto, id eft,urfa lactatus fit, ut fabulantur. Vera autem hiftoria refert, Cephalũ Deionei uel Deionis filium ex Arcio uxore Arcefium genuiffe, Varinus. Cephalo de liberis quarenti, deus refponfum reddi= diffe fertur, ut cuicung, primum obuiam factus effet, ei mifceretur, Illum uerò cum in Arcon mulie= rem incidiffet, filitrm ex ea fuftuliffe, qui deriuato à matre nomine Arcefius dicius fit; Heraclides in

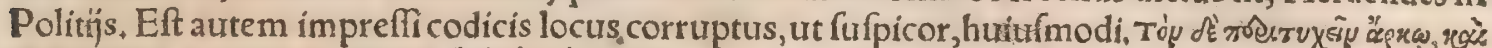

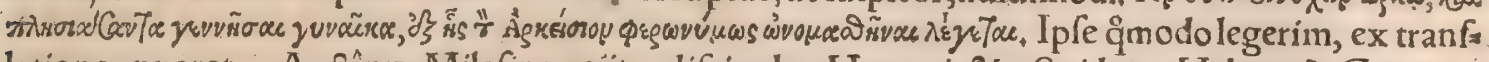
20 latione apparet. Arcfînus Milefius poëta, difcipulus Homeri, \&c. Suidas, Habent \& German uiri proprium nomen ab urfo fumptum, 2 ernbart, ac fi Arctofthenem dicas. đArciûrus, flu= uius Scythia Phafis poftea dictus, Plutarchus in libro de fluurijs. Vrfa, fluuius apud Heluetios,

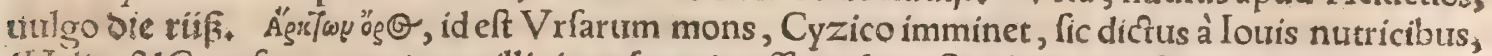
(Helice \& Cynofura puto, quas illic in urfas migraffe tradunt, Stephanus (ni fallor) alicubi. Vrfa: rum mons nominatus eft, à nutricibus Bacchillic in urfas cóuerfis: Vel quod locus uenationi aptas feras contineat, ab urfa fera: Vel propter altitudinem, quód uertice fuo ad Arctos fydera appropin=

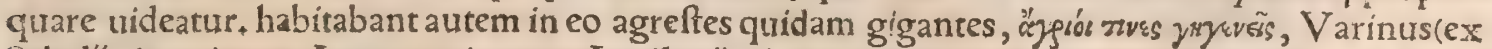
Scholins in primum Argonauticorum A pollonĭ ad numerum 35. ubi additur hunc montem fitum effe iuxta Cherronnefum in Propontide. legitur autem "espow per o. paruum, apud Varinum, A pol= 5o lonium \& Scholiaften, perperam apud omnes, In Propontide eft infula Cyzicus cum urbe, cuius

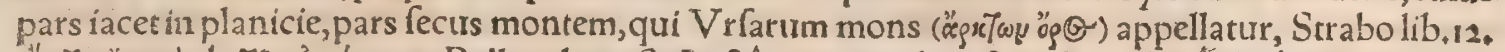

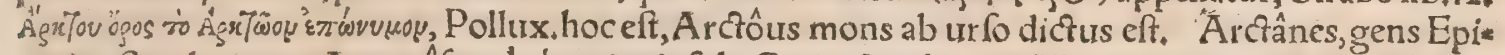

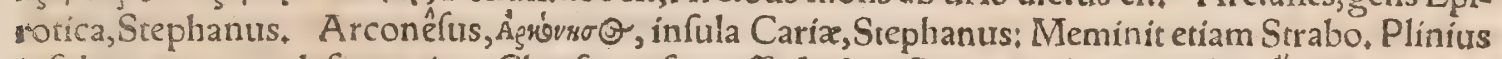

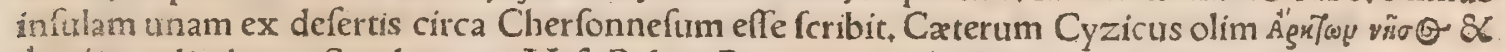

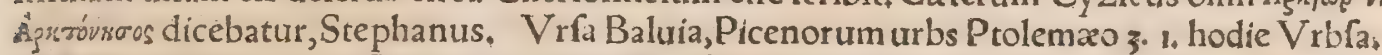

ब) b. Parnes mons Atticus aprorum \& urforum uenationem prabet, Paufan. Apud Aratores Afros ad Occidentem reperiuntur leones, urfi, elephantes, Herodotus lib.2. बr Cepus faciem ha bet fatyro fimilem, cxtera inter canem atqu urfum, Strabo. Tarando uillus magnitudine ur forum,

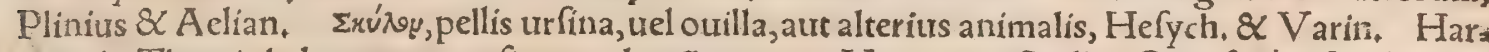
40 pyiz in Thracia habent aures urfinas, uulturũ corpora, Varinus in Scylla. Os urfi, sóvec \& yó cat Plutarchus, \& pedes anteriores yejeres, id eft manus. Talpa pedes habet urfi,Suidas \& Hef. Be ftia quam uidi fimilis erat pardo, \& pedes fimiles urfi, Ioannis A pocalyp. 13. Beftia alia fimilis urfo, Danielis 7. Galli caput urfi $\&$ aliarum mordacium ferarum hure nominant; $\&$ urfa mamillas poupes uel tettes:urfinum fimum, ut apri quog \& lupi, laiffes, Rob.Stephanus. @Pellem urfi, qui propriè apud nos loquuntur uocant cin but: \& eandem excoriari dicunt, gef fbun

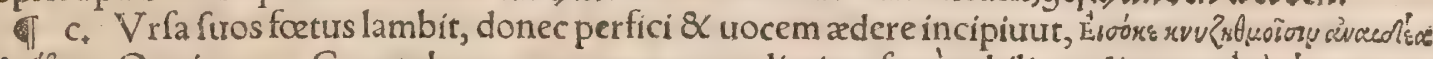

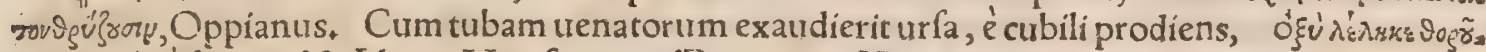

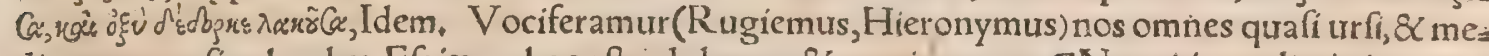
ditamur quafi columbæ, Efaix 59. hoc eft, ululamus \& gemimus. GNequitia nulieris immutar 50 faciem eius, $\&$ obcæcauit uultum furm tanquam urfus, Ecclefiaftici 25. Vrfis quidem oculos hebetari,cum recens è latibulo prodierint, in c.retuli. TPatinas cœnabat omafi Vilis \& agnini, tri bus urfis quod fatis effer, Horatius r. epift. IVrfa pragnans à Gallis peculiari \& uenatoria locura

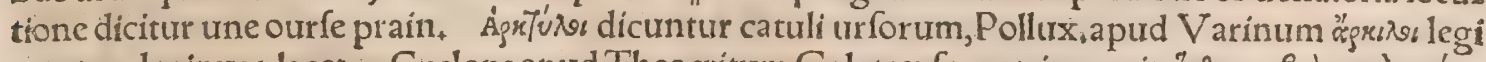

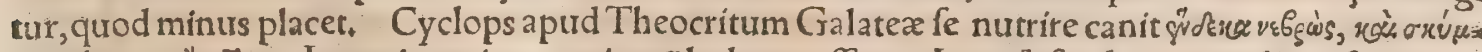

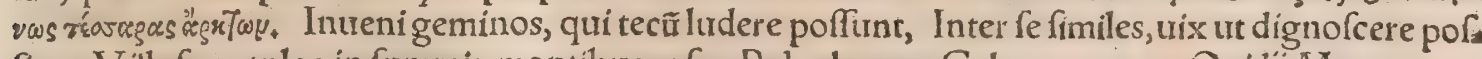
fis, Villofx catulos in fummis montibus urf $x$, Polyphemus Galatex canens Ouidin Metam, 15,

ब1 d. Occurram eis quafiurfus orbatus, \& lacerabo obftinatum cor eorum, Ofee 13. Praftat occurrere urfo orbato (raptis catulis ) quàm faturo (obftinato) in ftultitia fua, Prourerb, 17. Tu noft: patrem tuum $\&$ uiros qui cum co funt fortiffimos $\&$ amaro animo, uelutifi urfa raptis oculis in fal. 60 tu fæuiat, 1. Regum 17. Sunt autem uerba Chufal ad Abfalonem de Datride.

i e. Ferunt difficiles partus ftatim folui, cum quis teçum, in quo fit grauida, tranfmiferit lapide: uel miffili ex his, qua tria animalia fingulis ictibus interfererint, hominem, aprum, urfam, 
Plinius. Taifalorum gentem turpem ac obfconæ uitæ flagitrijs ita accepimus merfam,ut apưd co: nefandi concubitus foedere copulentur maribus puberes. Hor um fi quis iam adultus aprum exce. perit folus, uel interemerit urfum immanem, collutione liberatur incefti, Marcellinus libro tricefi moprimo. TCertéfurit, acuelut urfus Obiectos cauea ualuit fi frangere clathros, Horatius de Arte ad finem. Heliogabalus ebrios amicos pleruncs claudebat, 8 fubito noće leones, 81 leo. pardos, $\&$ urfos, exarmatos immittebat, ita ut expergefacii in cubiculo eodem, leones, urfos, pardos cum luce, uel quod eft grauius nocte inuenirent, ex quo plerigs exanimati funt, Lampridius, Vi* toldus Lituanix princeps fubditis fuis adeò metuendus fuit, ut iuffi laqueo fe fufpendere, parere potius quàm in eius indignationem incidere uoluerint. detreffantes imperium, infutos urfina pelle uiuentibus urfis (quos eam ob caufam nutriebat) dilaniandos obiectauit, crudelibus ḉ alips affecitı fupplicijs; A Aeneas Syltrius. đMaurileonum, pardorum $\&$ urforum tergoribus tuelantur, $\&$ dor

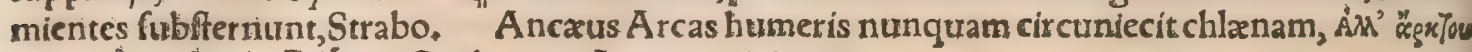

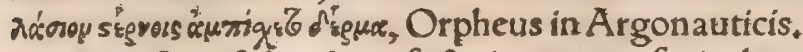

I g. Si urfi feuo liquefacto inungatur facies hominis, intelliget $\&$ difcernet quicquid audit ac legit, Rafis,

9h. Heliogabalus inter diuerfas fortes habuit $\&$ urfos decem, 8 decem gryllos, Lampridius, Perfeus rex capream \& urfum amabat, Tzetzes. Demetrius Morchouitarum legatus Romam miffus, multo auditorum rifu, ut erat ingenio comi $\&$ faceto, proximis annis uicinia fux agricolam, retulit, quarendi mellis caufa in prægrandem cauam arborem fupernè defilịffe, eumó̧ profundo meilis gurgite pecfore renus fuiffe hauftum, ac biduo taitam folo melle fuftinuiffe : quum uox opem 1 implorantis in ea fyluarum folitudine ad uiatorum aures penetrare nequiuiffet, ad extremum ueró defperata falute mirabili cafu, ingentis urfæ beneficio inde extractum euafiffe, quum forte cius bels luar,ad edenda mella morc humano fe demittentis, renes manibus comprehendifiet, \& eam fubito timore exterritam ad exiliendum tum tractatu ipfo, tum multo clamore concitaffet, Paulus louius. Pafcebam ( inquit Dauid I.Regum i7. ) patris mei gregem, \& ueniebat leo uel urfus, \& tellebat arie $\mathrm{tem}$ de medio gregis, \& perfequebar cos, \& percuticbam eruebam $\$$ ab ore corum, \& interficiebam ipfos. Dauid cumleonibus lufit quaficum agnis, 80 urfos fimiliter ut agnos traçauit, Ecclefra: ftici 47. Cum Helifrus propheta afcender et in Bethel, parui pueri de ciuitate egreffi, illudebant ei, dicentes : Afcende calure, afcẽde calue, Is uerómaledixit eis in nomine Domini:egreffị́̂́, funt duo urfi de faltu, \& lacerauerunt ex eis quadragintaduos pueros, Regum 4.2. Non enim non poterat omnipotens manus tua immittere illis multitudinem urforum, aut audaces leones, aut noui generis ira plenas \& ignotas beftias, Sapientia 11. Sanctus Florentius urfum habuit, Textor, Legímus fuiffe urfam quampiam feritate côfpicuam, magnitudine inufítata, quæ uifentibus modo horrorem incuteret.Ean ueró uir hic (Pythagoras) accerfitam demulctam'śs apud fealuit. Mox dimifiurus, ueluti conceptis uerbis, iureiurando(ut fic dicam)adegit, nulli animantium cunctarum damno ob. lafionúue futuram. Abiens illa in fyluras fe coniecit fuas, fummaćp fide, quod inter homines quoque perrarum eft,in quod adiurata recefferat; praftiti, Calius. Paris infans expofitus ab urfa laeia. tus fertur, Varinus, fic \& Arcefius Laërtis pater, ut feripfi fupra inter nomina uirorum ab unfo fum pra. Et ecce de proximo fpecu uaftum a ttollens caput funefta proferpit urfa, quam fimul confpe. xi, pauidus $\&$ repentina facie conterritus, totum corporis pondus in poftremos poplites recollo, ar $4^{\text {s }}$ dua ḉ ceruice fublimiter eleuata, lorum quo tenebar rumpo, mȩ́́ protinus pernicíftrgæ committo, fummo ftudio fugiens immanem urfam, Apuleius fub perfona afini aureí. TDeCalliftûs filiz Lycaonis in urfam mutatione, lege fupra in a.ubi de Vrfa fydere dictum eft. Iphigeniam immo. landam in ceruam, alij in taurum, alĭ in urfum mutatam ferunt, Varinus in Nєo $70^{\prime} \lambda \varepsilon_{\mu} O_{0}$, ut pluribus in Tauro retuli. Arcton oros, id eft Vrfarum mons, Cyzico imminet, fic dictus à Iouis nutricia bus ( Helice \& Cynofura puto) quas illic ín urfas migraffe tradunt, Periclymenus Nelei fuit fi. lius, frater Neftoris:cuià Neptuno auo conceffum ut poffet in quas uellet fe transformare figuras, ut in urfum, formicam, apem, \&c. uide Onomafticon noftrum, qV Vrfos qui facri, ut lupos quoa que, A egypin eo loci fepeliunt, ubi iacentes inueniunt, Herodotus libro fecundo. De interfecta urfa Dianæ Munychia facra, plura dixi in a.inter deriuata, in uerbo Ágxzkiłu. Laphria Dianæ. apud $P$ atrenfes magno in ara igne excitato, apros, ceruos, dorcades, aliqui luporumatut urforum cas tulos, tuiuentes inijciunt, Paufanias in Achaicis.

Ti P R O V E R B I A. Vrfus cum adfit ueftigia quxris, Ä qưi timiditate prafens negotiũ declinãt, atç ad alias nugas dilabuntur. Translatũ à formidolofis ure natoribus qui fe diffimulät fenfiffe urfum, \& ueftigia perfequí fingüt quo abfint à periculo, Eraf.Me

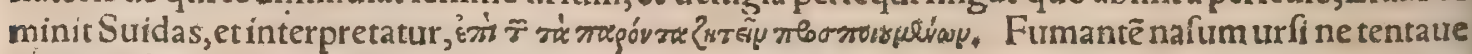
risłuide fuprain D. đExfacris. Leo rugiens $\&$ urfus(ad prædam) excurrẽs, eft princeps impius populo pauperi, Prouer, 18. Habitabit lupus cử agno, \& pardus cû høedo accubabit: Vitulus \& ur

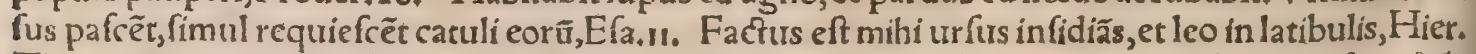
Thren.5. Quomodo fi fugiat uir à facie lecnis, \& occurrat ei urfus, Amos \%. đGermanifi quê de 6

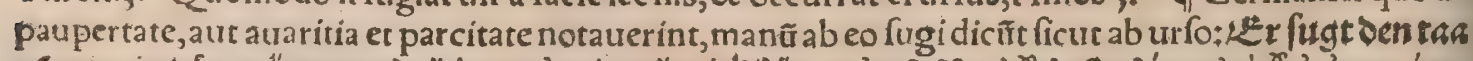

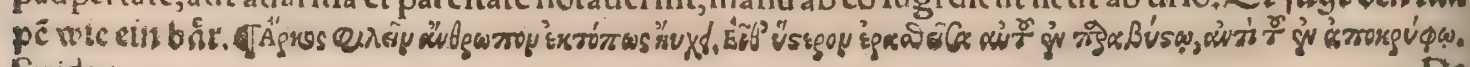
Suidas, 


\section{DeVulpe: A. B. Lib. İ. ios̊i}

DE VVLPE.

10

,

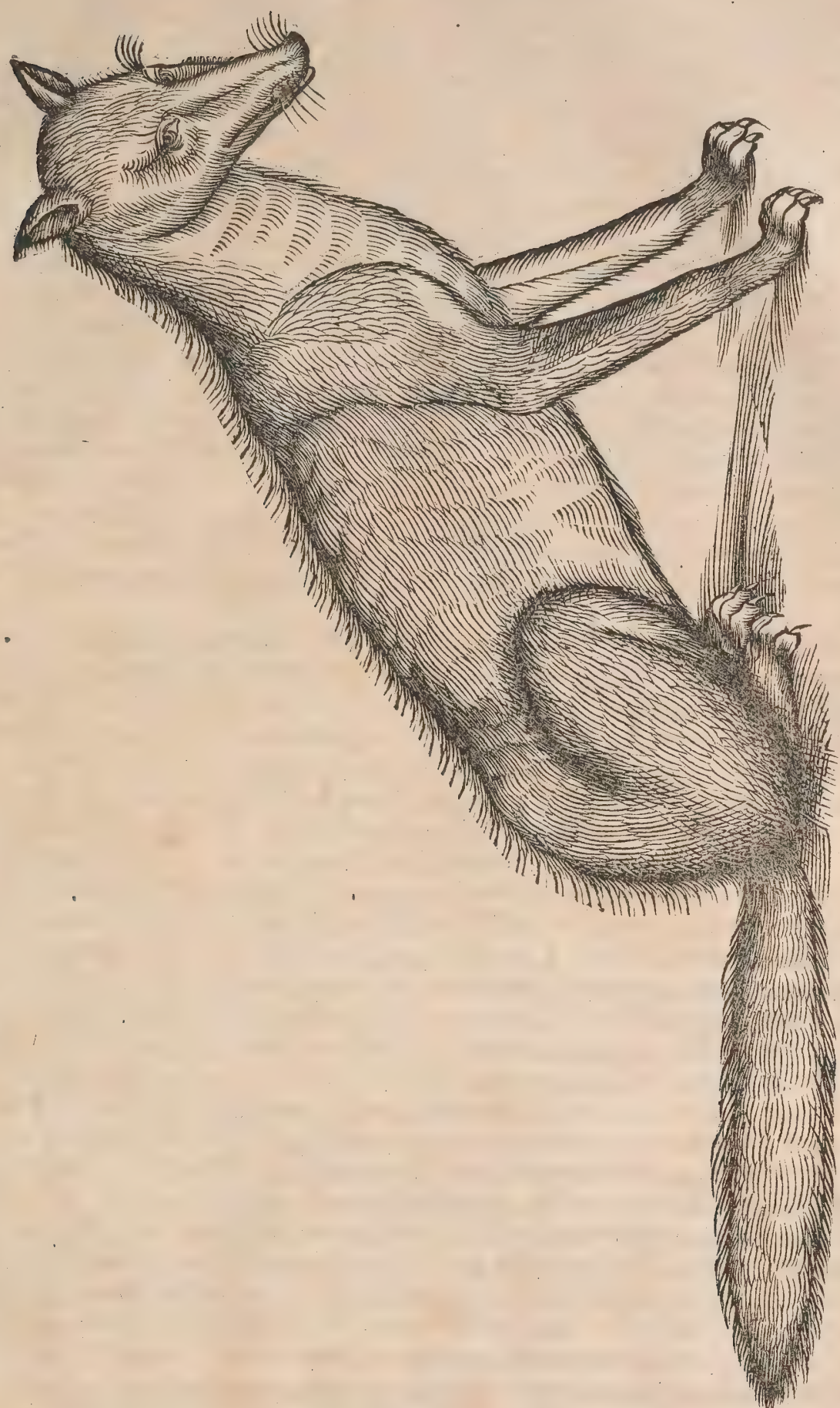

I.

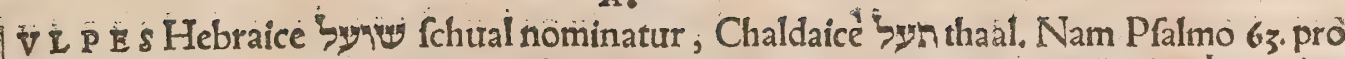
fchualim; id eft uulpes numero multitudinis, Chaldæus reddit thealàia. Arabs $=5 y s$, tha.

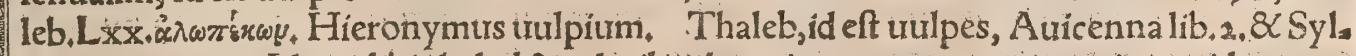
uaticuts cap.673. Idem alibi chabel $\&$ calcail tuulpem interpretatur, corruptis, itt uidetur; uro cibus pro thaleb. Chos alcalip, (lego althaleb) id eft tefticuli uulpis, fatyrion, Idem. Galcis, id eft

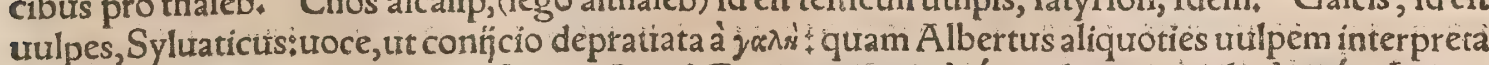

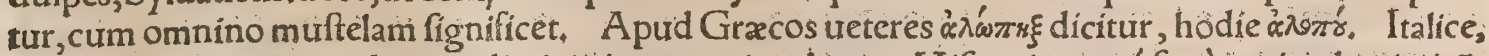

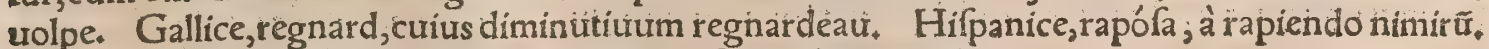
Germanice, futbos. Flandrice, uos. Anglice, foxe. Illyricè, lifska,

B.

6ò Alpinæ regiones Helutetiorum plưrimas habentưulpes: ubi mercatorès coêmptas ëarưm pêlles in allias regiones diuendunt, Stumpfius, Amyntas in Manfionibus, quas fic inferipfit, eam ait $\mathrm{Ca}_{a}$

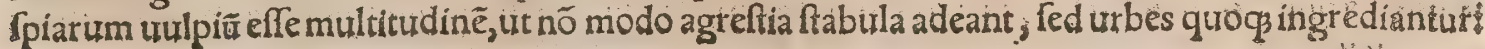


nihil tamen nocentes, neqg rapientes, , dita cicures $C$ afpüs tanquam canicula adulantur, Ả clianus: Vulpes in Sardinia noxiz funt, occidunt enim arietem etiam fortifimum, capram, \& vitulum ad: huc tenerum, Munfterus. Lupos, uulpes, aliaç̧ quadrupedum noxia, Creticus ager nứq quam educat, Solinus \& Plinius. Baffara,Bzarága, genus uulpis, Varinus, alí unlpcm fimpliciter inter. pretantur + uide in Philologia a. Vulpes in Acgypto minores quàm in Gracia fiunt, Ariftoteles, Vuipi magnitudo eadem qua cani mediocri domus cuftodi, Albertus. Villos habet uberes \& ala

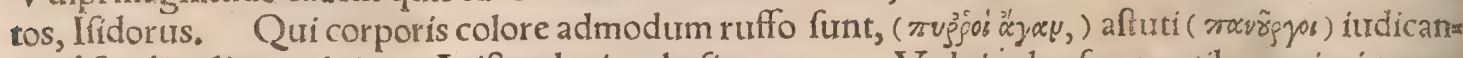
tur, à fimilitudine uulpium, Ariftoteles in phyfiognom. Vulpicolor fape rutilus, priori tamen parte canefcens, Ge. Agricola \& Albertustrarô candidus, rarius niger, Agricola. Vulpes audio in Hípania omnino albas reperiri, \& à mercatoribus. Francfordiam ad nundinas uelit, Vulpes 1 nigræ \& albæ in Mofchouia habétur titem in quibufdam Scandinauix locis, ut Olaus Magnus an= notauit. Germani uulpes qualdam uillo denfiore 8 nigricante, à colore bzanofüdbs nominant, ( ut ceruorum etiam genus denfioris ac nigrioris pili, bzandbirtbent, ) noftritolerle $₹$ funt autem mi noris pretï, \& magnitudine etiam ut plurimum minores. Circa montana Heluetia, ut audio, uulpes externis maiores ac meliores habentur. TSerpentes, fimix 8 uulpecula, \& quacunç mala

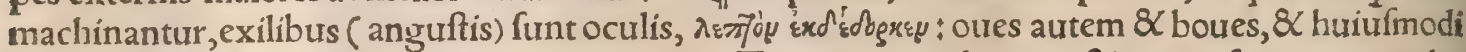
fimplicis ingenï, afpectu amplo, Adamantius. Teutones cum bonum $\&$ generofum equum des pingunt, diuerforum animantium uirtutes in eo coniungunt, \& ex alips quidem animalibus alias ei attribuunt, ex uulpe uerò aures breues, caudam longam, greffum lenem, alij, bonos oculos, \& cau= dam pilofam. बI Vulpi(mari)genitale offeum eft, Ariftoteles, Plinius, Albertus. Cauda magna 1 $\&$ uillof, Albertus, Boum caudis longiffimus caulis, \&c, uulpibus \& lupis uillofus, Plín.

C.

Vulpes animal eft calidum.nam $\&$ mortui pellis calefacit, Albertus, Mihi quidem dubium non eft, quin calidi temperamenti hoc animal fit, cum canum $\&$ muftelarum maiorum naturam referat, \&odorem graurem exhalet.adipem etiam eius calfacere conftat, \& oleum in quo uulpes tota deco cta fuerit. बGannire propriè de uioce uulpium dicitur, authore Donato:fed transfertur etiam ad homines, $\&$ ufurpatur pro eo quod eft obftrepere, $\&$ ueluti uapulantis uocem emittere. Quidille gannit?quid uult?Terentius Adel. Hinc gannitus. Nanq̧ hac (Nereis) in eodem fpectata littore eft, cuius morientis etiam gannitum triftem accolx audiuere longé: Gannit (Gannuit, codices im: preffi) odiofus omni toti familix, Plautus ut citat Varro de lingua Lat. Fallax uulpecula gannit, 30 Author Philomela. Putes ulularelupos,gannire fagaces Vulpeculas, Mantuanus, Latrando \& ululando uulpes canem imitatur, cum irafcitur aut dolet, aliâs uerò gannit, \& immurmurat blan: dè, ut cum petit aliquid, fi domi alatur. Latrat ut canes, (ut catuli canum, fecundum alios) $\&$ gan= nit in fame, Albertus. In fame pra anguftia latratus canum imitari dicitur, Conftantinus. De

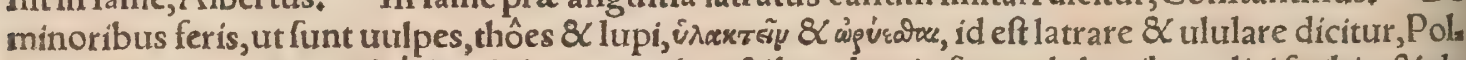
lux. Varinus tamen wjúrà de lupis, canibus \& leonibus in fame ululantibus, dici fcribit; \& de alịs qux proprium fux uocis uocabulum non habent. Noftri etiam uulpem latrare dicunt, Der fud s billt/trabt/rayet. Ceruum aiuntfibi timere à gannitu uulpium, Albertus. TVulpes ani. mal folerti auditu, in Thracia amnes gelatos lacusós non nifiad paftus itura redituráḉ tranfit,obfer uatum eam aure ad glaciem appofita coniectare craflitudinem gelu, Plinius. Nugantur quidam è urulgò tam acutéaudire uulpem, ut nefcio quam herbam crefcentem percipiat, IT Vulpes, lutra, melis fubeunt cauernas:fed egrediưtur ad paftum capeffendum, etiam hyberno tempore, Ge. Agris

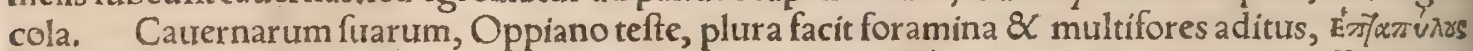

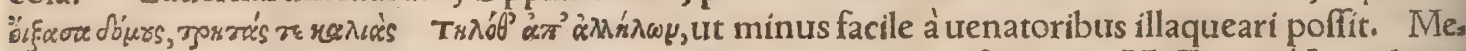
lis foueam occupat, aluo in eam exonerata, ut dicam in D. Ariftomenes Meffenitus à Lacedamo nińs captus, per cauernam latomiarum euafit, anguftos uulpium aditus fecutus, Plinius. Ego cum domi aliquando uulpem alerem, fxpius obferuaui iacentem in uentre pedibus pofterioribus rectà retro extenfis, ac fi homo in uentre iaceret, quod $\&$ cuniculi faciunt + facile autem eft conícere eas huic extenfioni apta crura ideo à natura accepiffe, ut facilius per anguftos $\&$ oblongos terræ meatus penetrare eis liceat. $\varangle$ Lepores 8 uulpes per aftatem noctu progrediuntur, Tardiuus, Vulpes $\&$ capreoli etiam nocte cibum quarunt, Cardanus, TVulpes animal feréomniuorum eft. Syl= ueftres mures uenatur, Ariftoteles: Sunt qui mures è cauis fpiritu à uulpibus extrahí \& deuorari af firment. Vulpes edit carnes, \& muribus ficut catus infidiatur ${ }_{*}$ cuniculos etiam \& lepores capit, ra pitḉ̧ gallinas, Albertus. Nec uulpes nec aliud animal gallinas continget, fi gallinis fub ala ruta fyl ueftris fufpendatur $¥ 8$ multò magis fi uulpis aut felis fel cibo admix rum exhibueris, ut etiam Demo critus confirmat, Cornarius in Geopon. libr.14. Andreas à Lacuna in Graco codice excufo, \& furo manufrripto, hæc legi negat:Inferius tamen capite de turturibus eadem ponit, "ogvidas eo in loco non gallinas, fed aues fimpliciter exponens. Gallinaceos aiunt non attingi à uulpibus, qui iecur uulpis

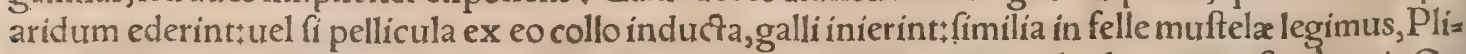
nius, Per hyemem efuriens, fi uuas in uitibus non inueniat, aues $\&$ catulos leporum aftute capit, Op 6 pianus. Vide plura mox in D.qua aftutia animalia quadam capiat. Pauonibus una cura debe, tur, ut incubantes per agrü fominas, qux hoc paffim faciunt, à uulpe cuftodias, Palladius, In Afia 


\section{DeVrfo. C. D. Lib. I. 1083}

multis locis uinum fine iugo minittrat uinea, qux fape uulpibus \& hominibus fit communis, Vare

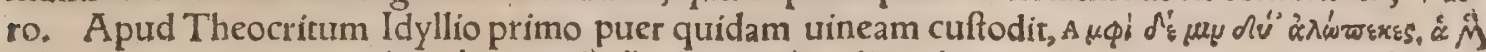

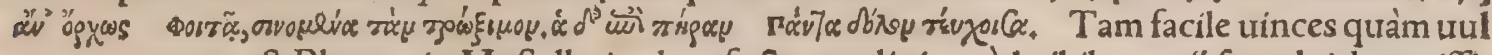
pes pyrum comeft, Plautus in Muftellaria, de re factu procliui, quòd nihil negorị fit uulpi dentatiffi mæ pyrirm edere, Erafmus. Vulpes necant amygdala amarx, item apocynon: Vide plura in E. T A nimal eft foetidum, \& etiam à pofteriori parte imminente mortis periculo, Liber de nat.rerum. Ore $\&$ ano foeter, Albertus. Hic olidam clamofus ages in retia uulpem, Martialis, IV Vulpes fuperueniens coit, Ariftoteles. Atqui recentiores aliqui obfcuri authores ex Ariftotele citant hac uerba, Vulpes coit ad terram proiecia, (in quibus uerbis uulpem eos pro fele feu cato po»

so fuiffe conịcio.) Vulpes coëunt in latera proiectæe, maremç̧ foemina amplexa, Plinius.

Quadrupedes (uiuiparæ) pleræo perfecfos ædunt partus, paucæ inchoatos:in quo funt genere leanx, urfa, \& uulpes, Plinius. Multifida qux pariunt imperfecta, omnes multipara funt, quo fit ut parturm adhuc recentem alere poffint, auctum iam adeptumóp magnitudinẽ nequeant, quaedam enim ex n̈s catulos inarticulatos propemodum pariunt, utuulpes, urfa, leana, \& alia nonnulla. fed omnia feré cæcosłut ea quæ modo dixi, atç etiam canis, lupus, thos, Ariftor. Etalibi, Vulpes, in. quit, parit cęcos, ut urfa, atģ etiam infirmiores. parturiens ita fecedit, ut rarograuida capiatur.Cum partum ædiderit, lingua lambendo refouet $\&$ concoquit. parit cum plurimos quatuor. Deleonis partufingulari, uulpis multiplici, apologum Aefopi in Leone c, recitaui ex Càlio. Vulpium ca. tulos fxperapiunt milui, uultures, aquila, Mich.Herus. đCoëunt animalia etiam, quorum ge 20 nus diuer fum quidem, fed natura non multum diftat, fi modo par magnitudo fit, \& tempora aquent grauiditatis, rarò id fit, fed tamen fieri $\&$ in canibus, $\&$ in uulpibus, $\&$ in lupis certum eft, A riftoc. Ex uulpe \& cane Laconici canes gignuntur, Idem. Et alibi, Ex uulpe \& cane primi foetus cömuni

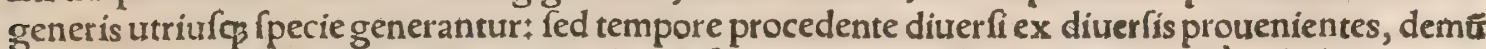
forma forminæ(fcilicet primæ genitricis fur)inftituti euadent. Laconicos canes è uulpibus \& cani bus primum natos $\&$ alopecidas dictos aiunt, Pollux. Vide in Canibus mixtis. Eoldem aliqui cyna $=$

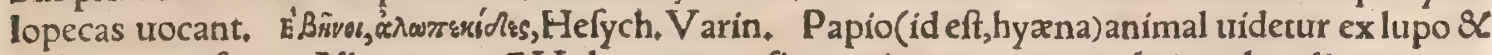
uulpe compofitum, Albertus. I Vulpes xgra refinam pineam uorat, unde \& ualetudinem recu= perat, \& uita fruitur longiore, Albertus \& Liber de nat.rerum. Vulpes \& muftelas rabiem incur rere dicunt, Auicenna. Catera(prater canem)animalia, ut lupi, uulpes, \&c, rabie afficiũtur æefta

$3^{\circ}$ te potius quàm hyeme, Ponzettưs. Vulpes rabiens eadem incōmoda infert qua canis rabidus, Al bertus, Quemadmodum quædam plantæ humoris proprij penuria tabefcunt, quadam alieno fuf focantur † ita \& capilli fuccorum paucitate corrumpi folent: ac humidi quidem paucitate caluicies, pratuitate uerò alopecix $\&$ ophiafes generantur, agritudines nihil fpecie, fed figura tantum ac noa mine differentes. ophiafis enim in parte quam obfidet capitis, formam ferpentis defcribit. alopecia autem fic appellantur, quòd id morbi genus in uulpibus frequentifimum effe tradatur, n̂étius Alopecia, uitium eft quo capitis $\&$ barbæ pili defluunt, per metaphoram à uulpe, quæ ubi minxerit, locum fterilem facit, ita ut herba illic nafcí non poffit, \& fi qua nata erat illam exiccat, Varin. A ${ }^{2} \lambda \omega_{\text {. }}$

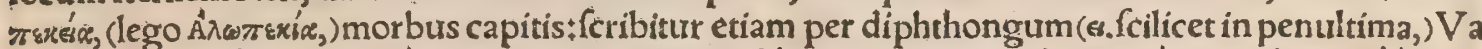

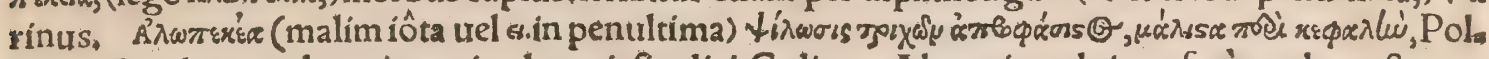
40 lux. Eundem morbum inuenio alopeciafin dici, Calius. Alopecia uulpinus ferèmorbus eft, quo ties in humano capite areas $\&$ glabreta capillus deciduts facit, Hermolaus. Vulpicaput (iecur, Mich. Heruss) aliqutuando nimium incalefcit, præfertim aftate, \& curatur fanguine ad fuperficiem fluente $\&$ ulcerante pellem: quare pili tum temporis defluunt, Albertus : \& pelles captarum aftate inutiles habentur, Mich.Herus. Alfefafes efr animal generis ceccartim (id eft ricinorum) quod ca= nibus, bobus \& uulpibus adharens fanguinem ab eis exugit, Andr, Belluneñ, 9 Vulpes fatis iu ftam ætatem confequitur, Stumpfius:

D.

Vulpes afturæ, malitiof $\&$ callidæ funt, Äriftor. Homines colore admodũ ruffo maligni ( orpyot) iudicantur, argumento utulpium, Idem in Phyfiognom. Adamantius uulpis ingenium doloz 5. fum \& infidiofum effe inquit. Animal eft odio dignum propter ra pinam, defpectum propter infir mitatem, incautum fux falutis dum infidiatur alienæ, Ambrofius in Hexaëmeron. Mihi quidem codem fermé ingenio uidentur præditæ ưulpes, \& muftel $x$, præfertim maiores, ut martes, ictis, \&c. Prouterbia aliquot à urulpis calliditate nata, Vulpe pellace benignior, Vulpes annofa haud capitur laqueo, Vulpes non iterum capitur laqueo, Vulpinari cum uulpe, Vulpina pellis affuenda fi leo

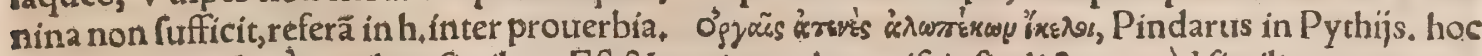
eft, Vulpium planè moribus fimiles. Eft 8 marina uulpes, pifcis fic dictus quòd fimiliter ut terrena fraudulentum $\&$ folers fit animal. Vulpinus, id eft aitutus animus ne quid moliatur mali, Plau* rus, Fraus quafi uulpeculæ, uis leonis uidetur, Cicero i. de Nat, Complures apologi ex uulpis cal liditate conficti, A efopi \& aliorum nomine leguntur. IAftutam uapido feruas fub pectore uulpem, - Perfius Sat.5. If Vulpes Cafpix tam numerofx funt, ut non modo agreftia ftabula adeant, fed ut bes quogs ingredianturłnihil tamen nocentes, neq̧ rapientes, fed ita cicures Cafpỉs tanquam cant culæa adulantur, Amyntas apud A elianum, Intimas cauernas, qua multos habeant exirue 


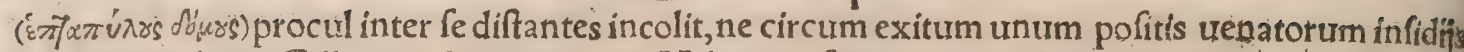
comprehendatur, Gillius ex Oppiano. Thabitat in foureis, quas ipfa tamen non parat, fed à taxo, id eft mele efforfas dolo occupat. Illo enim abfente, aditum furo excremento inquinat.Reuerfus ille, foedi odoris impatiens, foueam fuam deferit, quam mox unlpes inhabitat, Ifidorus. Sape in me lium cauternis uulpes effoffa comprehenditur, Alber. TLupus contactu feillæ conuellitur, unde etiam uulpes propter lupos latebris fuis fcillas apponunt, Zoroaftes in Geopon.lib.15. Gillius aliter uertit,nempe uulpes in luporû cubilia folia fquillæ imponere, quod non probo. non enim tam ftudiofa lupo nocendi, quàm fuos tuendi catulos uulpes eft, \& cum à lupo occidatur, non eft ueri. fimile eam fponte ad cubile cius accedere. Turtur in nido fưo ponic folia fquilla, ne lapus puls los eius incurfer, A mbrofius turturi hoc adfcribens, quod Zoroaftres uulpi, non recié ut uidetur, ${ }^{10}$ Iupum enim uulpibus infidiari conftat, turturi aut cateris aubus non item.

ब1 Vulpes pulicibus infeftata;fipulam (manipulum) foeni quod inuenerit molliffimum, aut pis los ore continens, paulatim à pofteriori parte in aquam fe mergit:cauda primum immiffa, deindere liquo corpore, ut pulices aquam fugientes ad caput afcendant, quod $\&$ ipfum poftremo paulatim immergit, ita ut pulices in ftipulam aut uillum quem ore tenet, colligantur $¥$ quo tandem in aquam proiecto fugit, Albertus authorem citans Iorach. In Thracia locis rigentibus $\&$ uulpes, animal alioquín folerti auditu, amnes gelatos lacusćs non nifi ad paftus ituræ rediturxćç tranfeunt. Obfer. uatum, eam aure ad glaciem appofita, coniectare craffitudinem gelu, Plinius, Thraces congela tum flumen molientes tranfmittere, uulpem, Plutarchi ( in libro Vtra animalium \&c. ) teftimonio, pramittunt, glaciei indicem, quantum firmitatis habeat. ea enim pedetentim $\&$ moderate gradiens, ${ }^{10}$ aurem admouet: ac fi ex ftrepitu confluentem non multo infra ferrifentit, ftatim cöiectura affequh tur, frigoribus flutium non bene penitus conglaciaffe, fed tenuem $\&$ infirmam glaciem exiftere, itaç regreditur: fin fubterlabens aqua non admurmurationem facit, confidenter tranfit. Quod qui. dem ipfum non acrem beftia fenfum dicimus effe: fed ex fenfu ratiocinationẽ. Sic enim uulpes col. ligit, ipfum ftrepere motu praditum eft, quòd autem motum habet non gelu conftringitur. Iteinú: Quod aqua non glaciat liquidum eft, quod autem liquidum, facile concedit, Gillius. Eadem albi Aelianus frribit, ut Gillitus uertit. Aure prius ad ripam humi adpofita, ferenitatem itineris explorat, Volaterranus ex codem. If Vulpes in omnes hoftes fuos infeltiflima eft neqs modó contra canes, fed $\&$ cum feris robuftioribus, $\&$ cum uenatoribus (canibus uenaticis, Oppianus)molitur pugnare. Neog folis beftips terrenis, fed etiam aquatilibus, \& uolatilibus mille infidias comparat, of $\mathrm{Vul}=3$ pem beftiam improbam poëtæ $\&$ fraudulentam appellare folêt. Sedet improbus erinaceus ter reftris $\mathcal{Q}$ infidiofus.nam ut uulpem is uel audiuerit, uel uiderit, os contrahit, pedeś́ comprimit, \& fe to tum in globofam formam concludit : llla autem cum hunc fic in arcfum conftrictum comprehẽdere non quit, in eius os urinảm reddit: hic uel ex contractrone, uel ex uulpis fraude fpiritu interclufo fuf focatur, Aelianus. Etalibi, Vulpes fraudulentum animal, infidias hoc pacto in erinaceos terrenos molitur, ut cum eos recfos, quod à morfu uulpinum impetũ fpinis prohibent, expugnare non queat; ipfos furmma cautione or is leniter \& caute primum euertens, fupinos conftituat, deinde $\$$ lacerét, $\&$ qui antea effent formidabiles, exedat, conficiatç. Vide plura fupra in Echino h, in protrerbio, Multa nouit uulpes, fed echinus unum magnum. of Vulpes cum dolofa fit, aliquando cum lepore ( uel cuniculo, Ge. Agricola) fe uelle ludere fimulat, $\&$ (incautum) apprehenfum deuorat.quamob 4 rem uulpem confpectam non minus quàm canem fugiunt, Albertus. Quemadmodum à uulpi. bus lepores noctu continua perfecutione defatigati, \& fubinde à quiete, quã ubi aliquantifper curfu: prauenêre a ppetunt, exturbati,tandem capiantur, ex Aeliano recitaui in Lepore D. Lepores fre. quentiores funt in infulis, quod ibi ut plurimum nec uulpes funt, à quibus ipfi cum catulis occidun tur; nee aquilæ, qua montes magnos fxpius quàm paruos frequentant. nam parui plerunc in infü: lis funt, Xenophon. TMures etiam in aruis $\&$ pratis à uulpibus aftutè capiuntur. TCum aurif greges fubuolantes uidet, humi ftrata iacet, fimul \& oculos claurdit, \& rofrum in terram deponit, $\&$ animam cótinet, \& prorfus uel dormientis, uel potius extinctæ fpeciem fimilitudinemó́ gerit. Cum autem eam fic ad terram abiectam aues defpiciunt, mortuam arbitrantes, gregatim delabuntur, in eaç̧ feffitantes tanquam illudunt: at uulpes eas ad roftrum appropinquantes ore hianie atç immi. 5 nente, deuorat, Gillius ex Oppiani de pifcibus libr,2. ubi ille ranam quog pif́catricem fimili ferè aftu pifciculos captare dixerat. In fame aliquando infidiof é mortuam fe fimulans fupina iacet, fpiritu compreffo exertaćç lingua : quo uifo aues tanquam ad cadauer accedunt, $\&$ incautæc corripiuntur, (fic $\&$ pardus fimias mortuum fe fingens, captat)Albertus, Conftantinus, Ge. Agricola * Eadem fcribit Mich. Herus, fed addit uulpem priufquam ita fe refupinet, in argilla rubra uolutari inquina: riç,ut uulnerata $\&$ fanguine cruenta appareat, \& quod ubi ita iacentem uiderint corui, cornices, et alix aues præfertim rapaces, gaudentes tanquam de hofte mortuo, aduolantes comprehendantur, una faltem ex eis. Muftela aues iugulat ut lupus oues, \& pugnat cum ferpente, illo præcipure quỉ mures uenatur, Ariftor. de hift. anim.9.6. Albertus imperité eo in loco galen inter pretatur uulpem, \& eadem de uulpe fcribit. Et rurfus alibi de muftela fylueftris genere, quod uulgò putorium, noftri 60 iltiffum uocant, fcribens: Non comedit (inquit) de gallinis, nifi prius omnes aut multas iugulaurerit, cuius ingenij etiam uulpes eft, $\&$ animal quod dicitur feyton, (id eft mustela.) Vulpes communis 


\section{DeVulpe. D.E. Lib. I. 1085}

eft holtis pauonum, columbarum, 8 omnium feréautium, Stumpfitus. In co maximé nocet homití. bus, quòd rapit anferes, anates, gallinas, in quo tamen eam parcere dicunt domui uicíniori iuxta quẩ uerfatur,Idem. Gallinas noctu clam ingreffa in cafas, prehendit $\&$ afportat, Ge. Agricola. In Pon to fic otidas uenatur, ut $\&$ fefe auertens, \& in terram abónciens, tanquam auis collum, fic caudam ex: tendat, ex autem hac infidiarum inftructione feduct $x$, ad illam, tanquam ad fuam gregalem acce: dunt, illa uero fé uertens nulló negotio capít, A elianus interprete Gillio. Sed aliter ex eodem Volà = terranus tranftulit, non rectè ut conn̈cio, adfcribam tamen. Otides(inquit)in fluminibus (mo/xuoís le=

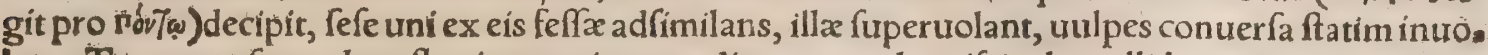
lat. Tum uero fecundum fluuiorum ripas gradiens, paruulos pifciculos callide exceptat, nam cau 10 dam in áquam deijeit, in quam n̈ innantes denfis pilis comprehenduntur, quod quidem ipfum uul= pes fentiens, caudam ex aqua remouet, $\alpha$ repente fe in aridum fubducens eam excutit, pif́ciculi ex. cidunt, ätç ab ea deuorantur, Aelianus interprete Gillio \& Volaterrano. Vulpes in exuperantiam infinitze tum malitix, tum fraudis progreditur, nihil ut non $\&$ malitiofe, $\&$ dolofe agat : Cum enim uéparium refertum effe animaduerterit, retrorfum eò accedit, atque tota à uefpeto auer $\mathrm{a}_{\mathrm{a}} \mathrm{ab} \mathrm{acu}$. leorum fanè uulneribus declinans, in cellas uefparias immiffa hírfuta cauda, eademós bene prolixa, uxefpas concutit. Cum autem uefparum circumueftitam fpiffis pilis caudam impetentiú referta eft, tum eam ipfam uel ad arborem, uel ad parietem ad maceriémue allidit: Itaque multa caudx attritione his extinctis, in reliquas inuadit, perindéç eas ut primas interimir : Iamóp reliquas cæteras ab acu. leis intelligens inopes effe, os in uefpariû abịciens, idipfum uorat, Aelianus interprete Gillio. Tran

20 ftulit eadem aliter Volaterranus his uerbis $+V$ efparum quandoç multitudine uexata, fefe in cauum condit, extante cauda circa quam ut illas certatim occupatas, uilloǵ denfo implicitas animaduertit, egreditur, atç̧ ad murum fiue arborem perfricãdo obterit, extinctasç̧ depafcitur. Q Quibus ue: ro aftutījs utatur cum in urenatione urgetur à caniburs, fequenti capite explicabimus.

đIuft magnitudinís accipitres 8 integr $æ$ tatis, cum uulpibus pugnaciter certare audio, Gil: lius. Vulpem inuadit circus accipiter, quia carne uiuit, Ariftotel. Vulpes hoftis eft circi, Philes. Vulpi inimicus eft æfalo. ferít enim pilosḉ eius euellit, occiditḉ catulos, uncis nanq̧ unguibus eft. Vulpi amicus coruus eft. pugnat enim cû̃ æralone:unde fit, ut huic cũ ab illo percutitur, auxilietur, Ariftoteles \& Aelianus. Aefalon uocatur parua auris, oua corui frangens, cuius pulli infeftantur à uulpibus. Inuicem hac catulos eius ipfamć uellit, quod ubi uiderint corui, contrà auxiliantur, ue.

30. lut aduerfus communem hoftem, Plinius, Quamuis autem diximus coruum effe amicum uulpis, $\&$ commorari eos, tamen hæc non eft uera amicitia.nam uulpes (aliquando) infidiatur prædx coruo rum:unde fabula illa A puleíj celebratur de uulpe blandiente coruo, $8 \mathrm{Z}$ ad cantum inuitante. ilio ue= ro canente, offam carnís ab ore eius elapfam uulpes rapuit. Auicenna etiam fcribit, fe uidiffe à rege Efceny de regione qux uocatur Vla, coruum \& uulpem inunam caucam coniuncfos forticer pug? nalfe + ita ut à uulpe morfum corui caput fanguinem emírerit $+\$$ coruus unguribus labia uulpis adeo

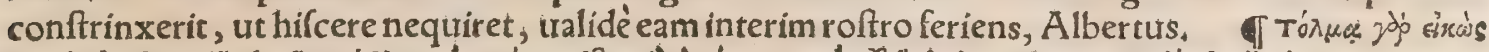

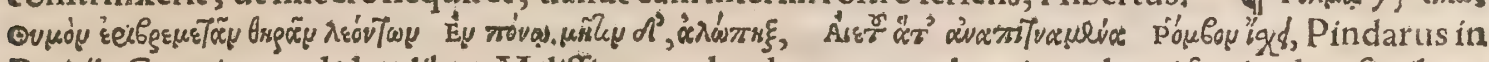
Pythịs Carmine 4. de lauddibus Meliffi, quem laudat tanquam hominem leoni fortitudine fimilem, calliditate uulpi: qux aquilæ etiam aduerfus fe impetum \& f trepitum aftute fe refupinans fapius ir 40 ritum fecit. Vel fic, Audacia Meliffum leoni, úafricie uulpi comparat \$ qua irruentem in fe aquilam fupina excipit, pedibus tum fe defendens tum illam qua poteft lanians. Videcur autem innuere ho* minis in lưcta fcientiam, qui iacens etiam $\&$ fupinus, uolutatione $\&$ agilitate aduerfariumi uicerit, Scholia, In regionibus quibufdã ad Septentrionem remotis aquila parit $\&$ incubat in pelle quam uulpi aut lepori detraxerit, ut fcribit Olaus Magnus. T Vulpes ardeolam nocte inuadit, Ariftot. Amici paurones $\&$ columba, turtures $\&$ pfittaci, merula $\&$ turdi, cornix $\&$ ardeol $\propto$, contra uulpiü genus communibus inimicitịs, Plinius, ब Vultur quoq̧ uulpem deprehendit, Obf́curus quidam Ariftotelem citans. 9 Vulpes inimici funt miluis, Textor, fortẻ quia utriq̨) rapiuht gallinas, Stum pfius. TVulpes $8 \times$ Nili angues diffident, Plinius. T Vulpes luptis inuadit, nutritur enim car nibus, Ariftot. q Vulpes etíam cum ferpente amicé uiuit ambo enim cauernis gaudent, Ariftot. so đQuid faciendum ut gallinacel à uulpibus non attingantur, in c.iam dictum eft,

$$
\text { E. }
$$

Canes non affuefcant agitare uulpes.id enim non mediocre uititum fuerit, \& cum oportet, nun: quàm prafto adfunt, fed in diuerfos faltus educito, ut \& canes uenandi, \& ipfe regionis peritus eura das, Xènophon,iudicat autem leporum capturam uenatico ftudio quàm uulpium digniorẽ. đHîc olidam clamofus ages in retia uulpem, Martialis. Lepus $\&$ uulpes canum metu exhorrefcunt, atq $;$ interdum uel fola canis latrantis denũ ciatione ex loco undiç fepto, uepribus $\&$ dumetis ueftito ex. citantur, Aelianus. Vulpes uf s $^{3}$ adeò uerfuta eft, ut nullis dolis, laqueis, aut retibus facile capiatur. fúa enim aftutia tum aliấs euadere, tum retia $\&$ laqueos morfư abfindere folet. Quamobrem canes in eam multi pariter immittendi funt : q̨uamuis ne illi quidem eam abfọs fanguine, utcunģ, validi, 60 domare poffint, Oppianus, Velocibus canibus capiuntur uulpes utcunģ in fuga fagaces, Crea fcentienlis. Animaduertend um eft fi uuipes à canibus agitentur, ut uentus à uenatoribus infpi ciaturtcuum uento (contravio) gुafis inpelli ad curfum ulpes uideantur, quo fiet ut nec calliditate 


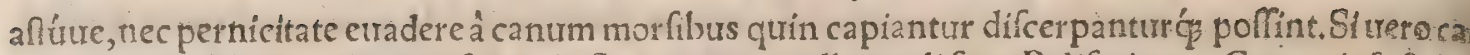
preæ ceruiç fuerint, ad uenti(fecundi)flatum canes collocandifunt, Belifarius, Canem infectans tem uulpes cauda hac $\&$ illac per ipfius rictum duefa, eludit, Albertus $\&$ Ge. Agricola. Hinc uer

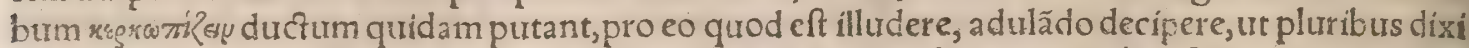
in Simia a. Vrgentibus à tergo canibus caudas fuas lotio perfundunt, hisç in fectantium propius canum ora diuer berant:qua moleftia affecti canes infequi defiftunt, Textor. Oppianus uulpem ceu beftiam bene dentatam, contra feras fe maiores 8 canes uenaticos etiam pugnare fcribit. Iu. cundum aliquando fui fpectaculum prabet in procera arbore deprehenfa. In ea enim (inquit Blon. dus) tanquam in arce oppugnarifolet.cum neç ignem timeat, nifi pars proxima ardeat : plerunque etiam acutas cufpides non fugiat, \& perfodi potius fuftineat quàm in turbam canum defcendere, 10 Tandem uerò defcendere coacta, impetu quodam inftar fulguris deijci folet in numerofam canum cohortem, ut fagacilfimos laniet, \& à praftantioribus dilaceretur, Hac ille. Circa uulpium uena. tionem fuis ac proprijs locutionibus uenatores noftri utuntur, quales funt : KE in gatn wirot ge:

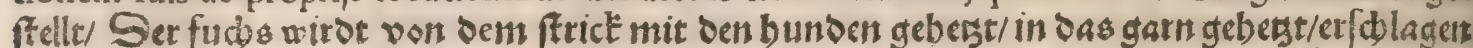
- ber ven ben bunten crwiirgt. Canes quidam exigui a pud nos locb biinole uocantur, id eft ca=. uernarum canicula. fubeunt enim uulpium ac melium cauernas, 8 morfibus ad exitum cogunt. Canis uulpem in locum fubterraneum fecuta, in Orchomenis Boeotix, cum latrando ingentem fo, nitum excitaffet, uenatores aditu effracto ingreffi, locum quendam per foramina illuftrari, $\&$ nefcio quæ intus latentia uiderunt, ac in urbem regreffi magiftratui nunciarunt, Ariftoteles in Mirabilis bus. Lupi $\&$ uulpes dentibus lacerant caffes, urfi non item, Plutarchus de caufis naturalibus 28. TEt laqueo uulpes, \& decipe caffe foinas, Calentius. Laqueis capiuntur uulpes 8 lepores cum per aliqua foramina introire folent in loca claufa, quod duobus fit modis. Vno, cum laqueus annes ĉtitur ad aliquam perticam plicatam, \& adeó ualidam ut feram collo captam in altum eleuet ac fus fpendat. Altero, cum prope laqueum eft fortis canolus ftringen laqueum ferè, caput impediens etiā ne ipfa laqueum rodere poffit, Crefcentienfis 10.31. Vulpes cauernæ fux complures facit aditus

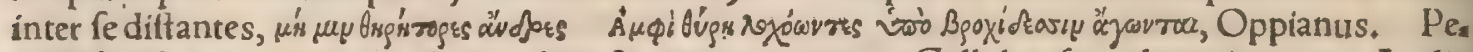
dicx fiue laqueigenus quo lupi uulpes $\&$ meles capiuntur, Galli haufepied nominant. Audio quafdam pedicis captas, crus irretitum aut ui extrahere, aut morfu fibi amputare, \& ita tripedes eua dere. Reti quod arolum uulgò uocant, capiuntur uulpes, fi gallina noctu ponatur in medio, debet auten ualidius fieri pro uulpibus \& aquilis, quàm alĭs auibus, Crefcentienfis 10.12. Sagaciores $3 \circ$ oportet effe uenatores in decipiendis uulpibus quàm cæteris animalibus. quoniam facillimè proria

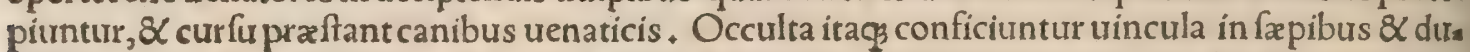
metis, qux tranfgredi folent uulpes, pracipue dum pullos gallinaceos requirunt. his enim detinen= tur: fed ip fa fe extricant, nifi uelox cuftos adfuerit, ut primum aliquam comprehenfam animaduer terit,Blondus. Parantur $\&$ decipulæ quædam aut machin $x$, aut inter cæateras genus quoddam arcus quod Germani appellant fudbsbogen oder felb/gefdjofo, hoc eft arcum automaton: qui à fera contactus, fagittam ei immittit. Decipulis aut foueis capta, fpiritum continet, $\&$ mortuam fe fimu lat, fi forte fic minus curata effugere poffit, Mich. Herus, Vulpes \& lupi præcipué capiuntur qua. dam taiola ferrea, quæ circa fe multos habet rampiones acutos: \& ipfi habent circa fe annulã prope re ubi annexi uoluuntur, ad quem annecitur fruftum carnis, \&c. Crefcentienfis 10.32. ut recitaui in 4 Lupo E. Et rurfus 10.35. Vulpes(inquit) in caueis(foueis)fuis capiuntur hoc modo. Venator ha= beat alureare apum, fed longius $\&$ angufturs, quod ab uno capite paucis filis ferreis claudatur, ab al tero habeat hoftiolum internum ex parte fuperiori praparatum, ut poffit intus eleuari fiperius ita ne foras exeat, hoftiolum hoc defcendens fuperius eleuatum, permanet cum uirgula parua. Hoc in frumentum ponitur in fourea uulpis, cum prafcitur ipfam in ea effe. Ponitur autem hoftioli pars in parte intrinfeca fouex, cxteri q̣ $_{3}$ aditus fouex, qui plures effe folent, diligenter clauduntur, Itaç uuls pes exitura, in alúeare intrat, non metuens filis exilibus fe impediendam : fiććs uirgulam fecum tra hit, $\&$ hoftiolum caden seam concludit : qux retro cedens magis claudit ac firmat. Venator autem quandocunç ueniens, ( quo poteft modo uel interficit fic captam uulpem: ) uel fi libuerit cum al, ueari fupra pureum aut uas aliquod profundum portans, aperto hoftiolo immittit, Hæc ille. Proja lupis, uulpibus, leporibus, $\&$ cæteris feris ac canibus, $\&$ porcis intrantibus $\&$ uaftantibus uineas, fo uea quomodo fiat pluribus defcribit Crefcentienfis 10.33. Lepores \& uulpes quomodo Indiue. nentur, lege in Aquila E, ex A eliano. Quomodolupi \& uulpes alliciantur à uenatore catum mor. tuum poft fe trahente, $X$ c.cum comite uenationis qui feram fi qux iam intra teli iactum accefferit, fe riat, dixi in Cato $\mathrm{E}$,item in Lupo. đVulpes aiunt fi ederint amygdalas amaras, nec contingat é ui. cino aquam lambere, morí,Plinius. Vulpes fi cum aliquo (cibo) a mygdalas am.ederint, enecans tur, Diofcorides $\&$ Auicenna, \& Serapio. Marcellus Vergilius hiftoriam fribit felis, qux poft ali. quot amygdalas am.detioratas, intra horam perierit. De muribus etiam fertur, poft arfenicum $\&$ alia quadam uenena, nifi fuperbiberint, certius morituras, alị negant : uide in Mure $E_{*}$ A non in adipe canes, lupos, uulpes $\&$ pantheras necat, Diofcorides. Videplura in Cane C. Fabaity. 60 pina feu marcillium datum in adipe, necat canes, lupos, uulpes $\&$ urfos, Arnoldus. apparet autem eum Diofcoridis de aposyno uerba mutuatum, (ut dixi in ur fo E, ) quamuis marcillium uideur ea 


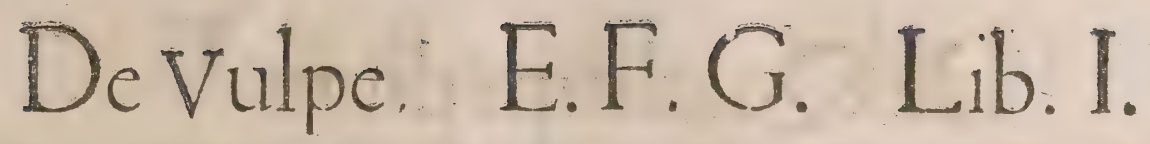

effe herba, qua à Sabaudis hodie marcieure nominatur, qua ueterum confiligo ef, alia quàn apos cynon, ipfa quoq̨ uenenata. de qua pluribus egi in Boue $c$. Huius herba femina aliquando uul. pi, quam domi alebam, cum carne \& cafeo mixta cledi, qux cum poft horam feré uomicu reieciffet, il lafa manfit. Aconitum luparium, quod noftri radicem lupi nuncupant, omne animal occidit, ut multis docuri in Lupo a, uel, ut $R$ hatus quidã mihi afferuit, feras illas peculiariter, qua cacæ nafcun tur, ut uulpes, lupos, urfos, canes, De catapotīs fiue piludis uenenatis, quibus lupi \& uulpes interi. muntur, copiofe fcripfi in Lupo a, aconitílycoctoni occafione.

TNec uulpes nec aliud animal gallinas cótinget, fi fub ala ruta fylueftris eis appendatur $\$ \&$ mul tò magis, fi uulpis aut felis fel cibo ammixtũ exhibueris, ut Democritus confirmat, Geoponica Græ*

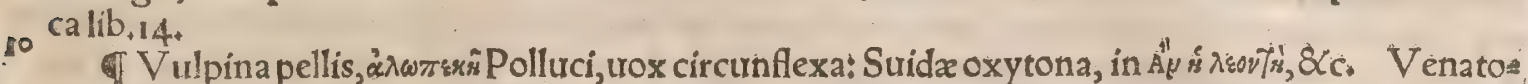
res uulpem expetunt propter pellem, non propter carnes qux funt inutiles, Ifidorus. Animal eft calidum: nam \& mortui pellis calefacit, Albertus. Calidior eft aliorum animalium pelliburs uulpi. na,Blondus(ex Auicenna, pilis enim munitur denfis, mollibus, \& oblongis. Praferri audio $\&$ ma ioris effe pretii, ex catulis uulpium in Gallia quod an uerum fit dubito.apud nos enim catuli $8 \mathrm{O}$ om nes minores natu uulpes, ut \& $x$ ftate captæ, ideo contemnuntur, quòd pili é pelliburs earum facilius defluant. Sunt enim eis pelles tenuiores, ita ut radices pilorũ ab interiori parte appareant, (quod ui= tium noftri uocant Durb b stig, ) unde pili facile excidunt. Dorfum quidem furos tenacius retinet Xenophon Anabafeos feptimo Thraces fribit, hyeme fauiore alopecidibus, id eft pellibus uulpi: 20 nis caput præmunire ac aures, Cælius, hinc eft forte quòd Grammaticis quiburdam alopecia (malim alopecis)pericephalixa, id eft pileus exponitur. Fiunt autem ex his pellibus pilei etiam apud noftra. tes, 8 quandoç ex difciffis fecundum longitudinem uulpium caudis, rurfusḉ̧ confutis.Ventris etiam \& laterum pelles duplo maioris pretị ferè habentur quàm è dorfo, quòd \& colore magis pla= ceant, \& molliores leuioreş̧́ fint, \& fi minus temporis durent. Vulpes per aftatê frequenter mor= bo ab eis nominato alopecia laborant, hoc eft pilorum defluuio. quamobrem pelles eo tempore ca: ptarum non folum inutiles, fed etiam noxix aliquando funt. Biffari(fibri)pelles multũ calefaciunt, fed uulpina magis, Elluchafem in Tacuinis, Vtiles exiftimantur arthritidi frigidx, podagrax, \& frigidis fluxionibus, quamobrem aliqui etiam tibialia fiue caligas inde parari curant podagricis, Mich. Herus. Scythiæ magna pars tergoribus uulpium $\&$ murium opertiincedunt, Alexander ab Alex. Ad podagrãः Phocæ, leonis, lupi aut uulpis corium fi quís elaboret, \& calceos geftet, pedes 30 non dolebit, Galenus Euporift. 3.248 . uide in $G$.

F.

Vulpem infequiturur uenatores propter pellem $\div$ non propter carnes, qua funt inutiles, Iffdorus. Sarmatis, Vandalis, ac innumeris alijs equorum \& uulpiũ carnes folatio funt; Calius, Canum \& ưulpium carnem nunquam equidem guftaui, nec fané guftare unquã fui a dad̂us, neç: in A fia, neọ in Gracia, necs in Italia :aiunt tamen hanc quoç mandi, coniectare autem poffum uim ei ineffe car: nileporum fimilem. Nam canis 8 uulpes, ut fummatim dicam, temperamento funt ficco, Galenus de attenuante uictu. Vulpium carnes autumni tempore etiam qui apud nos funt uenatores edunt.

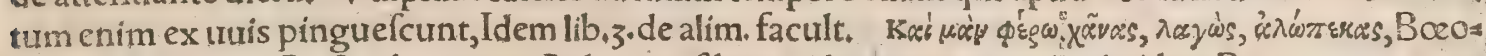
10. ths quidam a pud Ariftophanem in Acharnenfibus, uidetur autem poêta irridere Bocotos tanquam admodũ rudes homines, quí uulpes non minus quàm lepores $\&$ anferes in delicijs haberent. Mne= fimachus apud A thenæum lib,q, nominat carnes efculentas diuerforum animalium, anferis, porci,

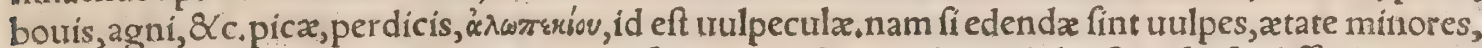
ceu teneriores \& minus graue olentes, praferentur. Caro uulpis calida eft, uifcofa, difficilis conco efu, prauifuccitmelior tamen eft autumno, (hoc eft minus mala, quod tum fructus arborum diuer: fos $\&$ uuas comedunt, unde pinguiores redduntur, $R$ afis. Aétius fcribit carnes uulpinas, leporio nas, \& ericij, naturæ humanæ effe diffimiles, \& alimenta efficere peffima + cuius argumentũ fit odor foedus, ut lo. Agricola Ammonius citat $\ddagger$ Atqui Antonius Gazius in Corona florida uerba hac de nutrimento leporin $\&$ uulpina carnis ex Ifaaco citat,

Podagris magnificant uulpem decoctam uiuam, donec ofla tantum reftent, Plinius, Vulpem ex aqua coquito donec mollefcat, \& ex aqua percolata pedes adfidué foureto, quo facto doloriburs fa cile careri hoc remedio quidam frequenter experti funt, Marcellus. Ad morbum articulor $\tilde{u}_{\mathrm{i}} \mathrm{Vul}$. pis uiua in amplo uafe decocta donec offa relinquat, mirè fanat, fi fxpius in aquamin uafe quis de fcenderit, Idem praftat oleum ubi decocta fuerit.Si quis hoc aut illo modo unult, utatur, Sextur, Cat terể de uulpibus (in quit Galenus de fimplicibus 11.47 .) qux toræ in oleo coquuntur, (nain fic quida curant arthriticos, partim uiuas uulpes in lebetē ingentem inïcientes, partim etiam mortuas, furfius

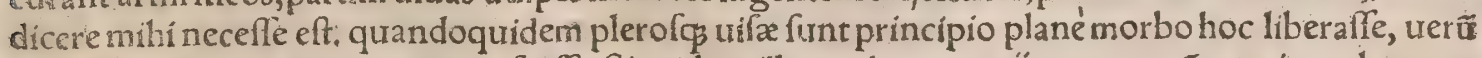
pof multum temporis non ita profuiffe. Siquidem illos malum repetịt, quanquã non ita urehemens 6o quàm antea. Sane oleum in quo cocta uulpes eft, non eft potentioris in digerêdo facultatis, quàm in quo hyæria:quæ fi fimiliter in oleo lixetur, redditur oleum longé porentiffima in digerendo faculta cis, Forrò frequenter diftum eft, talibus medicamentis ineffe potentiam eorum qua in al to continen 
tur corpore, in extimam cutem extrahendi, ac co nomine quando ${ }^{3}$ fedandi dolores, non enim per: petuò hoc ad ea fequitur, cum ij duntaxar dolores ab eiufinodi medicamentis fedentur, quorum caúfa eft humor in alto contentus, dolorem ciens aut fubftantize craffitie, aut refrigeratione, aut uehe menti acrimonia, aut etiam fpiritus flatuofus exitum non habens, Itaç qui ufi funt uulpibus, $\&$ ipf oleum digeftorium efficiebant; atque inde impletis co alureolis totos arthriticos in eos imponebant, multo ibi tempore immorari pracipientes, unde fiebat ut non tantum qui circa articulos funt tumo res euactrarentur, fed etiam uniuerfum corpus. Itaque cum corpus illis antea plenitudine affectum fuiffet, mirum non erat per euacuationem confecutum commodum, nempe cum $\&$ nihil amplius in affectas partes influeret, corpore uniuerfo iam euacuato, \& qui continebantur humores difcuteren tur. Cẹterum quemadmodum antea cum corpus noxa uacaret, praua uiçus ratio morbum inuexit; 10 eundem in modum, aut etiam amplius, à fimili diata par eft rurfum illos fimiliter afficiendos in ar. ticulis quibus iam laborauerunt, Hưcufq̧ Galenus, ex quo Aétius quoç repetīt 12.44. Si uuh pes coquantur in aqua, hoc decocto utilifimè embrochantur (fouentur immiffi) articuli dolentes. Similiter iutrat oleum, in quo uiua (aut etiam decollata) difcoquitur, quod \& efficacius eft. Eft au. tem aliquandiu immorandum, potifimum poft euacuationem fiue purgationem $;$ ne forte facultate fua attrahendi refoluendić, humores ad articulos attrahat. \& quando euacuatur corpus poft illud, nihil attrahitur ad articulos:quod fi redeat morbus, erit leuis, Auicenna. Oleum uulpis difcoctr, utile eft nodis $\&$ tumoribus arthriticis, $\mathrm{H}_{2}$ ly. Podagricis $\&$ neruis patientibus ob nimiam humin ditatem prodeft, $R_{2}$ fis. Infufum folio arthritidem recentem infidentis $\&$ balneantis in eo pellit, ueterem leuat \& mitigat, Idem, Vulpes decollata tota decoquatur in cacabo areo cum corio fuo 1. non fiffa, donec diffoluatur, huic decocto infideat cui nerui dolent aut artus ex pituita, Id $\tilde{e}_{\text {. Vulpi }}$ integræexenteratæ in cucuma affunde aqux fontanæ $\&$ aquæ marin $x$, utriufç fextarios duos (ato qui non poteft pręfcribicerta menfura tplus minus enim addetur, ut uulpes magna uel partra fuierit. annofa etiam cum diutius coquenda fit antequam diffoluatur, plus aqua fubinde affundi poftulat:) olei antiqui clari fextarios duos (aliâs libras tres, uncias nouem.). Decoque lento igne cum falis un cins tribus, donec aquæ confumantur. Deinde pone in uafe: \& adijce herbæa anethi \& alliafech (thya mum exponunt) ana libram 1.8 affunde a quam dulcem, in qua decocfx fint iam dicta herbx $x_{2} u t r i=$ ufque manipulus. Decoque ficut príus, uf $\$$ ad aqux confumptionem, 8 adminiftra, eft enim mira* bile.Aliquando etiam prater oleum difcoquitur (donec artưs omnes faxentur 8 diffoluantur) uul

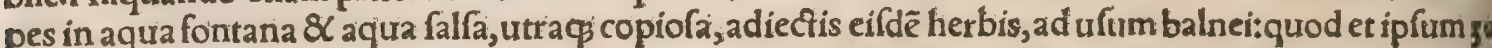
efficax eft,Mefue. Vulpes cum pelle, exenterata, in aliquot partes concidi poteft, ut melius in uafead decoquendum aptetur. \& antequam immittatur oleum, fi immittendum érit, diligêter prius auferenda eft fpuma, Monachi in Mefuen: Recentiores non ut Mefue fcribere uidetur, duas deco. ctiones faciunt, fed unam tantưm, in prima ftatim anethi $\&$ thymi ana librã. 1.2 dipcientes: $\&$ cum fa. $_{\text {. }}$ tis decocta fuerit uulpes, colant $\&$ fortiter exprimunt, uel aliấs, uel cum prælo. Leporis decoctî podagricis $\&$ arthriticis, fimiliter prodeffe ut uulpis, author eft Auicenna* Quin $\&$ herinacei ter. reftres uiui oleo incocti, ipfum difcufforium reddunt, Aëtius poft mentionem olei in qua uulpes dif cocfa eft. Vulpem exenteratam \& excoriatam fractis offibus, in aqua menfura qua fufficiat co. quíto denec caro ab offibus feparetur, hoc decocto embrochetur nucha $\&$ membrum paralyticum. hoc enim prodeffe medici omnes comprobant, Leonell us Fauentinus,

TVnguentum admodum bonum ad neruorư incontinëtiam, poda grícos, arthriticos, omnem neruorum affectum \& eorundem ficcitatem $:$ Accipe uulpem uiuam, \& conj̆ce cum ipfa in lebetem olei libras uiginti, \& adijce feminis anethi, ammeos, ftichadis,carnabadï, foenigræci, \& apï, fingtulo rum uncias duas. Hxc decoque in oleo cum uiua uulpe, donec uniuerfa eius caro fuerit diffolura, dein cola to oleum, in ́q́ aliud uas tran̈cito, \& de eo accipe libras quatuor, at $q$ in lebetem corifice, ad. ditis, cíninamomi uncia femis, fpicæexagḥ̂s durobus, \& iterum probè feruefacito, ac oleum quod res

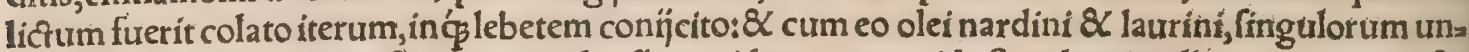
cias duas, Ádipis leonini, ftruthiocameli, af bi, ( uide ne taxum, id eft melem intelligat, ) anatis, anfea ris, tauri, urfi, fuis, gallina, fingulorum fefquunciá. Butyri ueteris unciàs tres. Terebinthina, fefquun ciam. Medullæ ceruinæ, drachmam unam.Galbani, uncias duas، Opopanacis, caftorï, ammonia ye ci, ftyracis calamitis, bdellin, fingullorum unciam, Calami odorati, uncias duas. Myrrhæ, exagia tria.

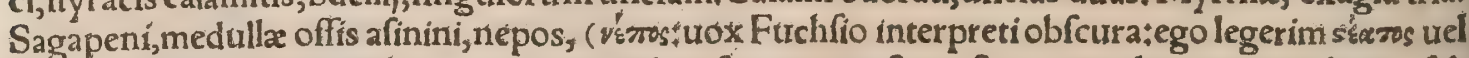
$\pi \mu \varepsilon \lambda \hat{n}$ s. alioqui enim quid de cato accipiendum fit, non conftat, eft autem adeps cati prafertim fyl. ueftris, in ufu ad pradictas affectiones, )cati, fingulorum fefquunciam. Dilytxa, (lutra fortaflis, un cias tres. 8 alios adipes quos inueneris, fingulorum unciam. Hi omnes cû prædicto oleo feruefiant, donec diffoluantur. dein amoue ab igne, $\&$ iufta (integra) hora quoad refrigerentur commotreto, ac repone in uafe:atop ubi ufus exigit, inunge tepidum nertuis incontinentibus, Nicolaus Myrepfus.

ब. Pellis utulpina membris pro ueftitu adpofita quos iuuet affectus, dixi iam fupra in E. Calidior eft cæteris. utilis humectatis (nimio humore aut fluxione laborantibus membris,) fua refoluen di(difcutiendi)facultate, Auicenna. De uulpina pelle interior pars calciamentorum fiat, 81 poda. 60 grici utantur, leuiorem inceffum habebunt, Sextus, Aliqui hodie martium \& uulpium pelles po: dagra noxias putant:quod intellexerim non de quauis fed calida podagra, fi horum animaliũ pelles 


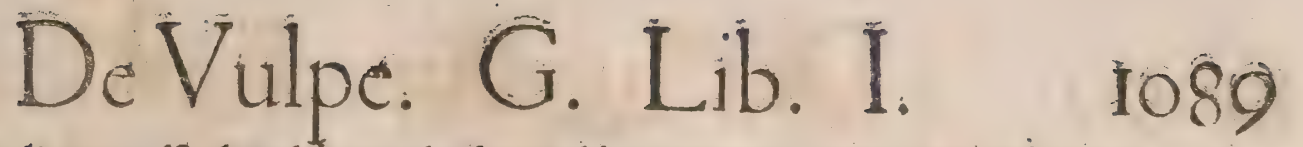

cum fuis pilis applicentur. (Sed ut aliâs inutiles fint; pedibus tamen fubiectæ præcipuè uulpine, mol liorem greffum efficient, propter denfam pilorum molliciem.) Ad podagram: Phocæ, leonis, lupi aut uulpis corium fi quis elaboret et calceos geftet, (nimirũ ex pellibus fine pilis, )pedes non dolebir Galenus Euporift.3.248. TCinis carniũ uulpis cũ uino potus afthmaticis conferre dicitur, Albert.

- Sanguinem tulpinum calidum è uena fecta potum, calculum frangere audio, Syluíus. Reme. dium nephriticum: Accipe uulpem uiuam, $8 \mathrm{macta,}$, confeftimćs prabeto fanguinem laborantibi: bendum feruidum, \& colem eius ac pudendum fanguine illo inunge, Nicolaus Myrepfus antidoto 199. Item antidoto 59. qux infribitur Antidotus nobilis ad calculofos: Accipe (inquit) uulpem uit uam, eamç̧ mactato, atç de recenti eius fanguine quantum dimidium exigui poculi capere poceft 0 bibendum prabeto. efficiet autem, ut ager eadem hora per urinam lapidem eñciat. Vulp. fanguis aridus tritus cum faccharo ex uino bibitur contra calculum, Obfeurus. Equo lethargico per nares infundatur oxycrati non acris cotyla, \& fanguine uulpino recenti caputillinatur, Ablyrtus in Hip = piat. 101. T Vulpini adipis facultas inter taurinum \& fuillum eft, Syluius, Aliquando plus at trahit quàm refoluat, Auicenna. Pro adipe uulpis fubftitui poteft adeps urfi, ut legitur in Succida. neis cum Aegineta excufis. Etrurfus, pro adipe fuillo, adeps uulpinus; Ibidem. Pinguedine uulpie na 8 lupina nonnulli ad fpafmum utuntur. Adeps uulp. membris tremulis \& fpafmicis prodeft, 8 nertrorum dolores mitigat, Mich. Hertrs. Vrfinus maximè aut uulpinusadeps, uel fi hi haber non poffint, taurinus, cum farmẽtitio.cinere emollitus, \& cum lixituo coçus probé attenuat eminen. tes tumores. hoc enim modo etia fapo praparatur, quem in ufum conuertere oportet, fi urfinus aut

20 uulpinus adeps non adfit, Aétius 13.123 , de cura elephantiafis ex Archigene. Adeps uulp.alope, cias fanat, Syluius $\&$ Mich. Herus. Capitis ulceribus laudatur uulpium adeps; fed pracipué fel \&: fimum cum finapi, pari modo, illitum, Plin. Adeps unlpiũ exulcerationibus tulluarum impofitus prodeft, Idem. V tilis eft auriũ doloribus, Diofcor,lib. 2. cap.67.8 cap.36. inftillatus atıriư dolores finit. debet autem prius remitti fiue liquariad ignem, $\&$ tepidus infillari. Idem foribunt, Sexus, Auicenna, \& Albertus. Rafis recentem adipem in hunc ufum præfert, quanquam etiam falfus(ii)= ueteratum intelligo, inquit, multũ prodelt. Medici quidã fcribunt adipem uulp.curare auriũ dolo, res, nec exprimunt quales nam illidolores fint. quamobrem tanquam ignorantes morborum difcri, mina non funt audiendi, Galenus de fimpl.11.4. Ad acerbos dolores aurium : Subactam oleo adi: pem, (animantis nomen deeft,) infundito, \& fpongia locum occludito ; bene facit $\&$ ad neruorum

30 morbos uulpino adipe atç fuillo xqua portione permiftus, Galenus Euporif. 2.4 . Ad auritum nocumenta ex aqua:Confert adeps tum anferinus, tum uruipinis, tum gallinaceus, Galen; Eupor. 1. 16. Ad fonitus aurium intra feipfas $\&$ acies dolores: Vulpis adeps eliquata infundatur; Ibid, 2, 4 ; A deps uulp. cum oleo fifami (interpres aut alius inepte addidit, id elt ireos. nifi fifami legendü non eft)liquefaçus, aurium dentiumç medecur doloribus, Haly. Auribus fractis glutinum è naturis

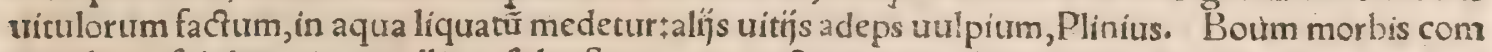
mendatur fulphur uiuum, allium fylueftre, ouum cocfum:omnia hac trita in uino danda, att uulpis adipem,Plinius. Si pili corrumpantur in extrema equi cauda, urina eam abftergere oporcet, \& fur. fures uino oleọ́ diligenter abluere. aliqui loco adipem.canis aut uulpis (aut firis, poftquam abftere ferint, Hierocles, illinunt, quod utilifimum eft, \& pilos reftituir, Ablyrtus $\&$ Theomneftus, of In

$44^{\circ}$ alopecia; ubi iam ulcera ad cicatricem uenerint, capur uulpecula urito, \& alcyonium, anchufáç ni. gra folia omnia contrita fuper inunctioni inducito, ut caput pilis contegatur, Alegineta. बCerea brum uulpis infantibus fape datum, facic ut nunquam fint caduci, Sextus, IV Ulpinam linguam habentes in armilla lippituros negant, Plinitus. Albugini oculorum detergende efficax remedium:

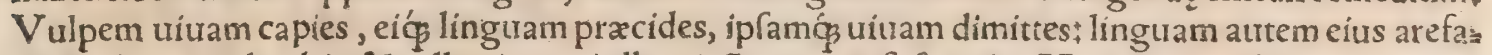
cfam, phœenicio ligabis, \& collo eius qui albugin $\tilde{e}$ patietur, fufpendes, Marcellus. Vulpis linguan quidam mihi retulit fpicula extrahere, fi imponatur : aridam etiam, fi prius maceretur (nimirum ex uino calido) impofitam idem facere: idç tam potenter, ut fi mucro lingua impofitæ infra aut fupra fpiculi foramen in cute ponatur, id uel per integram carnem ad fe trahat. of Vulpinus pulmo fi arefaçus bibatur, fufpiriofos adiutuat, Diofcor.\& Galenus, lecur uulpinum aut pulmo è uino ni= go gro laxat meatus fpirandi, Plinius lib.18. Vide nonnihil mox in iecore, ¿ Celfo. Profurit multis ad furs fpirium uel dyfpnoxam depellendam pulmo uulpis, uel iecur in olla fictili exuftum; atog ad cinerem redactum, $\mathcal{X}$ datum ad diem iciuno, menfura cochlearior ũ trium, cum aquæ cyathis tribus, fi febrici tabit:fi fyncerus erit, ex uinouetere, Marcellus. Pulmonis uulpis aridi drachma pota utilis eft afth= maticis, Paulus \& Auicenna : quidam citant ex Auicenna corpus prius purgandum effe. In cine: re affus $\&$ tritus ex uino nigro datus, fufpirium miré fanat, Sextus $\&$ Galenus Euporift. 2, 23. qui ta men non in cinere, fed fimpliciter ficcatum requirit. Rafis aridum tritum cribratumós, drachmae pondere cum aqua uuarũ paffarû, aut aqua frigida difficulter refpirantibus propinat. Pulmo uul= pis lauatur à fanguine, clibano ficcatur, reponitur, teritur, cum alịs mifceturutendi tempore, Syl. trius. Aliqui uino abluunt $\mathcal{Q}$ in olla ficcant in furrno, mox facchare cốdiunt. fic parato amicus quí:

60 dam nofter medicus egregius, in ægri cuiufdam inueterata tuffi annorum (ut aiebat) uiginti, feliciter ufus eft, propinabat autem quotidie cochlearia duo éuino. Pulmonem uulpis recentem, extractís ab eo arterijs afperis, lauabis uino odorato calido, \& mox olla impofitũ in furno tépído ficcabis jocd 
ficco repones, \& abfinthio, ne putrefcat,inuolues, Euricius Cordus, Quidam in umbra tantum ficcarl iubet, quod non placet, nifi umbra illa fit fub dio ęltate feruida. Aliqui recentiores aridi triti pollinem linteolo includunt, quod afthmaticorum poculis inijciunt. Loch,id eft eclegma de pula mone uulpis, medicamentum compofitum, uulgò ad úfus medicorum in pharmacopolijs paratur. $R$ afis \& Albertus lupinum quogs pulmonem è lacfe cum pipere bibi iubent à fufpiriofis, Galeni au thoritate freti, apud quem eyo hoc medicamentum legere non memini. Pulmonem uulpis phthia ficis maximé prodefie ob totius fubftantiæ familiaritatem, omnes propé practici inculcant, Syluius. Lienifedando pulmo uulpium prodeft, cinere ficcatus, atç, in aqua potus, Plinius $\&$ Sextus.

Arcbigenes apud Galenum de compof.fec.locos lib.9. Iplenicis iecur uulpis aridum ex oxy= melite im perat fimiliter potum Marcellus lienofis mirè mederi ait. Sextus affatum \& tritum îfdem fimpliciter bibendum confulit, lecur quoque uulpinum, aut pulmo, in uino nigro laxat meatus fipi. randi, Plinius. Item Celfus libro 4.Eft etiam non uana opinio, uulpium iecur ubificcum $\&$ aridum factum eft, contundi oportere, polentamćç ex eo potioni afpergi ₹ uel eiufdem pulmonem quàm re. centiffimum affum fed fine ferro coctum edendum effe. Iecur uulpinum aut pulmo èino nigro laxat meatus fpirandi,Plinius. Iecoris uulpini cinerem potum fuffiricfis prodeffe, ex Marcellore. tuli paulo ante in remedijs ex pulmone. IVulpium adeps capitis ulceribus laudatur, fed pracipue fel, \& fimum cum finapi pari modo illitum, Plinius, Ad aurium dolorem: Fel uulpis fi in aurem cum oleoftillatur, fanat, Sextus. Cum melle Attico commixtum $\&$ oculis inunctum, caliginem oculorum mirabiliter tollit,Idem. Fel fumptum pondere drachmæ mifceatur, \& portet in uulua mulier continué in lana triduo, deinde qutarta die uiro cum ea coëunte, concipiet mafculum, $R$ afis: 20 Verbum, mifceatur, fententiæ non quadrat $\$$ pro quo legi poterit, formetur in peffum, nifi quis $\&$ intra corpus fumendum, \& fimul peffum inde faciendum malit.

V ulpis lienis fuper locum(tumentem $\&$ durum)alligatus, lienofos morboliberat, Galenus Eu porift, 2.40. TTonfillis priuatim renes uưlpium aridi cum melle triti illitiós profunt, Plinius, Ad faucium tumorem: Rene uulpis in melle fxpius fauces tumentes confrica,Sextus، qVulpis man fcula genitale circunligatum capiti,fi credimus, dolores eius fedat, Plinius \& Sextus, Genitalia offea funt lupis, uulpibus, muftelis, uiuerris: unde etiam calculo humano remedia pręcipua, Plinius, Ad mulierum fuffocationem à locis: Articull membri uulpis in oleo ueteri unà cum bitumine cocti \& propeffo fuppofiti,fanant,Sextus. Simili modo ut fupra, illinito capiti, alopecias fanat, Idem. Vifupra inftillato in aures, dolorem tollit mirifice, Idem. TAd parotides profunt \& uulpium te- 3 ftes, Plinius. Tefticulo utulpis fapius parotidas confricáto, diffoluit eas; Sextus. Strumas di fcutiưt teftes uulpini, Pliniuss. Tefticulo uulpis fi frepius inguina confricaueris, cito fanat, Sextus, Ad erectionem pudendi: Tefticuli uul pis ficcibibe cochlear unum, Galenus Euporif, 2,142. Bare tolemaus Montagnana tefticulos uul pis mifcet in electuarium quoddam ad coitum in uir,$\&$, con. ceptum in muliere excitandum. Sedherbam quoģ fatyrion recentiores quidam medici tefticure Jum uulpis appellant:cuitus facultatés ad Venerem excitandam $\&$ aduerfus tetanum, obfcuri qui. dam aurhores unulpis quadrupedis tefticulo imperite adfcribunt. Mulier qua binos uulpis tefticu los tritos fumplerit, concipiet, Rafis. IVulpis caudam fummä ad brachium fufpenfam, irritamen tum effe ad concubitum dicimus, Sextus, TVulpis ftercus cum aceto tere, \& perunge lepram, cito fubuenies, Marcellus. Capitis ulceribus laudatur uulpium adeps, fed pracipuè fel, \& fimum 4 cum fina pi, pari modo illitum,Plinius, Stercore tulpis trito cum oleo rofarum fi inungatur uirga, coëundi urim auget, Rafis. Ad conceptum: Vulpinum ftercus in peffo apponatur, \&loci mus liebres fubliniantur, atç ita Venere utatur, Galenus Euporift, 2. 13. Aliud: Vulpis ftercus cum feuo bubulo mifce, \& mulieris uriç̧ genitalia inunge, Galenus Euporift, 3.234.

H.

a. Vulpes, a pud grammaticos etiam uolpes fcribitur:fic dicia, ut Ảelius dicebat quod uolat pe dibus, Varro, quafi uolipes, Albertus. Eft $\& 6$ uulpis per i.in ultima, apud recentiores quordam, quod non probo, Vulpecula, Cícero, Marcellus \& alij. Huius ưocis antepenultimã ueteres pros ducunt. Forte per anguftam tenuis uulpecula rímam, Horatius 2.epift. Fallax uulpecula gannit, Author Philomela. Mantuanus corripuit, Gannire fagaces Vulpeculas, grunnire fures. If Ve meriatim, id eft uulpis foemina parua cum eft in fourea, Syluaticus. đNomina apud Græcos com: plura inuenio, qux ordine literarum fubnectam. Á Áürs fomininum eft, fed reperitur ctiam ma

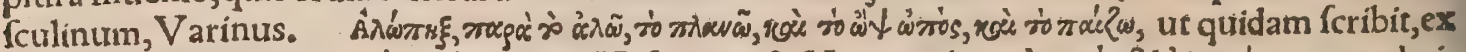

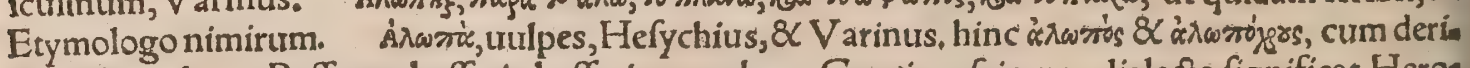
uatis dicenda. Baffarus, baffaris, baffarium, uulpem Gracis nefcio qua dialecto fignificat. Hero dotus libro 4, hyęnas $\&$ baffaria apud paftorales Afros gigni fcribit: Varinus uulpes interpretatur.

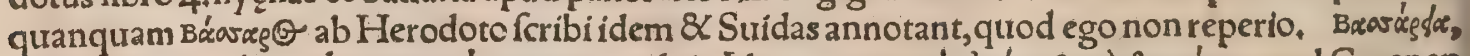

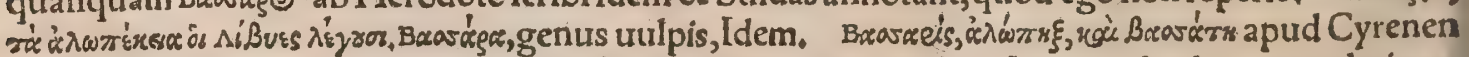

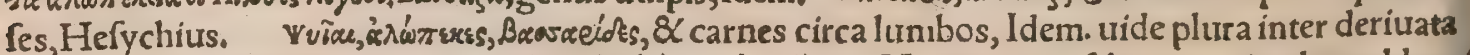

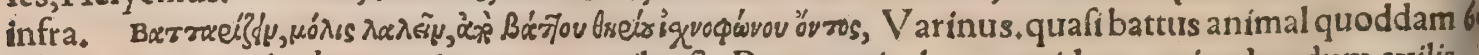
fit:fed legendum Aseácor, quod nomen gentile eft. Battus enim homo quidam uocis admodum exilis fuit, ut Suidas 8 Hefychius docent, Erafmus nó rectè legit $\theta_{n}$ Báuv, Thebanum interpretatus:apud 


\section{DeVulpe. H.a. Lib. I.}

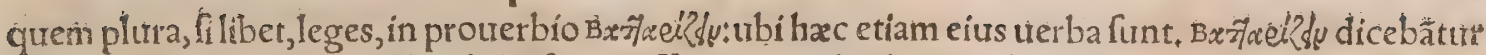
uulgo qui balbutirent, quibusç hxfitans efiet \& impedíta língua, \&c. Mibi magis apparet dieium

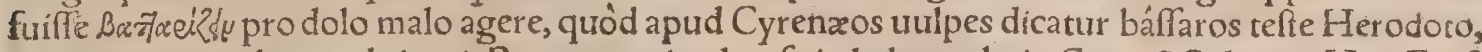
ut Latini quog dicũt uulpinari. Battarus enim dux fuit deducenda in Cyrené Colonia, Hac Eraf

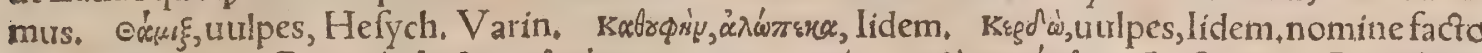

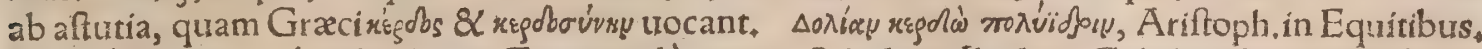
Kesdloxíos, prudens, à uulpe quam Graci cerdò uocant, Scholia in lliad.x. Gale(id eft muftela) à qui.

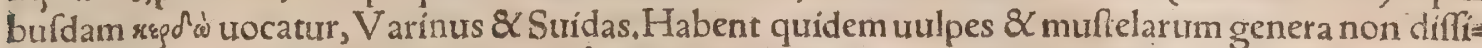
mile ingenium, cum aliâs tum pracipuè círca furta $\&$ rapinas aftutiam parem, ut non immerito com 10 mune nomen cerdò eis tríbuatur. Genere tamen differunt, $\&$ imperite Albertus gale pro uxulpe in

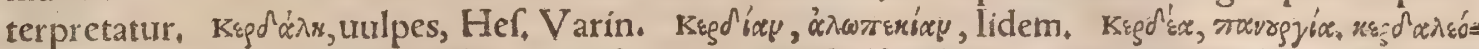

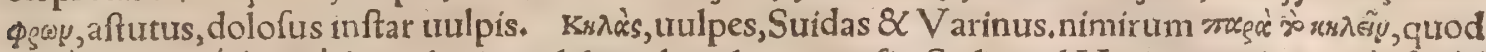

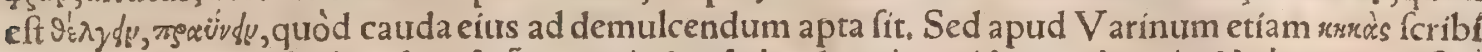

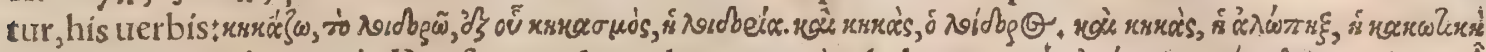

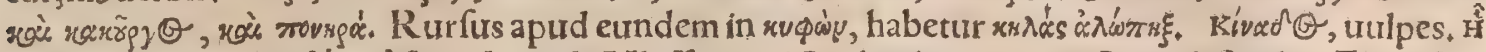

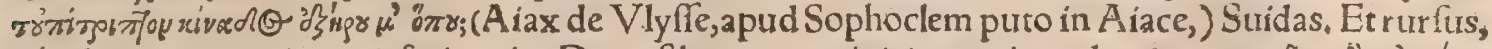

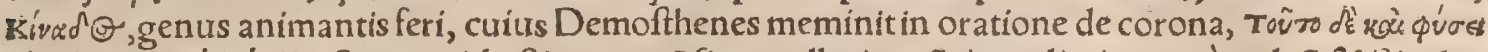

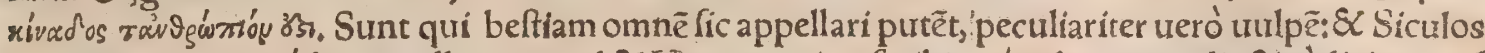
priuatim uulpẽ xıvádroy appellare, (quod $\&$. Farpocration fribic.) xivados etiam adiectiué dicitur, uul 10 pis inftar dolofus, Suidas \& V arinus. KivadO, inquit Theocriti interpres, uulpes nuncupatur à

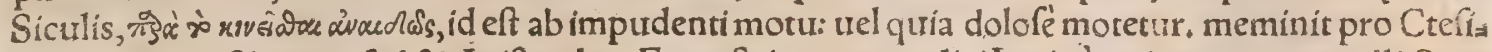
phon e Jemolthenes, fed \& Áriftoteles. Exnoftrís martem diciLatinè opinantur nonnulli. Strne qui co nomine intelligant paruum animal genitalia numc proferens, nunc retrudens: quod A rifto. phanij interpretes adnotarunt, ( $\&$ ex eis $V$ arinus,) Calius, In Auibus Ariftophanis cum Chorus

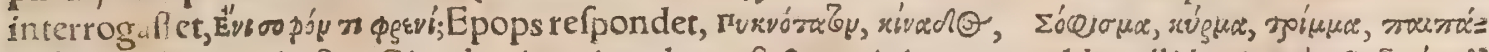

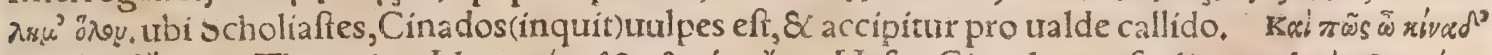

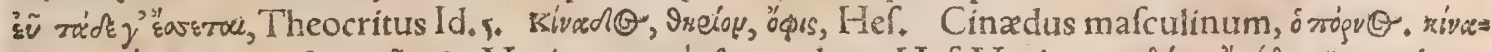

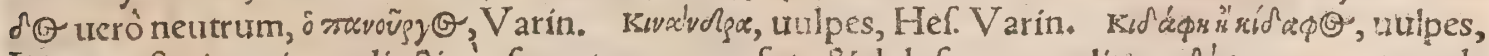
Iidem pofterius etiam adiectiue ufurpatur pro uerfuto $\&$ dolofo, quem aliter xio \&́ $\phi$ เo urocant, unde

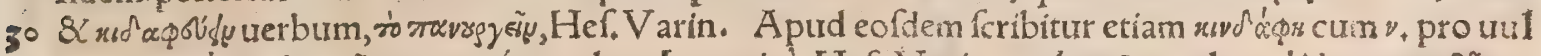

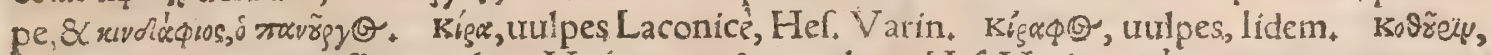

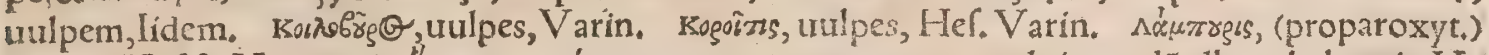

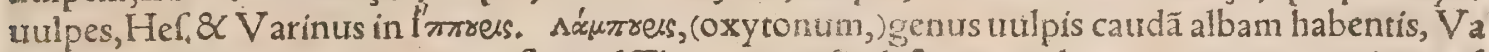
rinus. Lampurus nomen canis eft apud Theocritum, fic dicti, ut quidam exponunt, quoniam uul pi fit affimilis, quam lampuron uocant, Calius. saursove's, animalculum é ligno ('\&x $\left.\phi_{?} v y=2 \omega \omega\right)$ naz

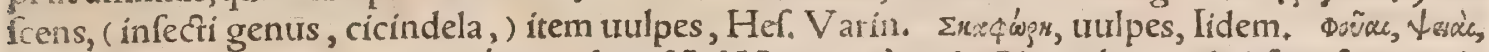

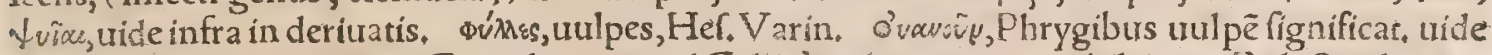
Azaniinfra inter propria. Goupil aut renard Gallice, uulpes quar in cubili iacet, Rob.Stephanus

GEitheta. Aftuta ingenuum uulpes imitata leone, H.ratus Serm 2.3. Aftutam uapido fer= 40 uas fub pectore uulpem, Perfius Sat, y. Cauta, Horatius s epift. Vulpẽ captare dolofarm, Gratius, Failax uulpecula gannit, Author Philomela. Foeta, Hurat, 3.Carm. Hic olidam clamofus ages in retia uulpem, Martialis. Sagaces uulpeculas, Mantuanus, Et apud Textorem, Infignis dolis, cau=

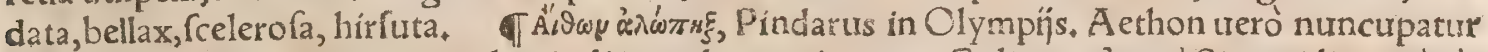

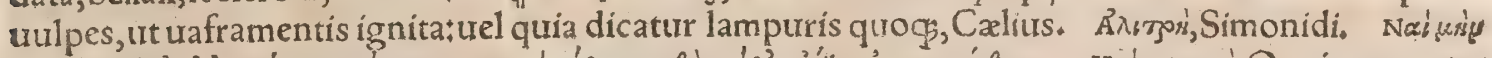

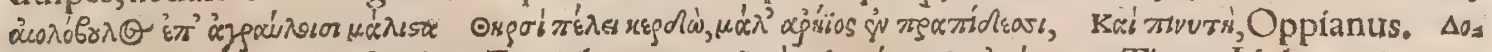

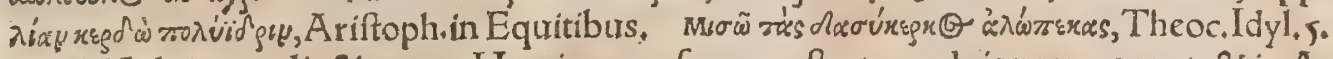

of Vulpinus, adiectiuum. Hominem uafrum noftrates urulpionem uocant, \& in A pologetico Apuleius, Calius. Vulpinari cum uulpe, uide infra inter prourerbia. Vulpinaris nomen adiectiuum pro aftuto, Scoppa fine authore.

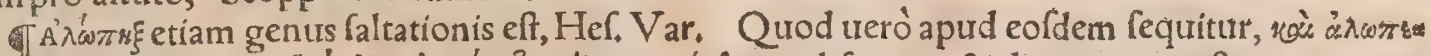

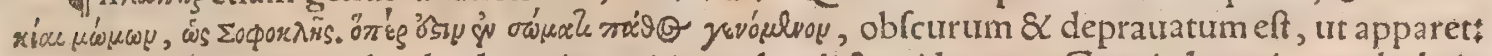
quamuis pofteriora uerba de alopecia capitis morbo dicta uideantur. Graci alopecis uocabulo in medicina quandoç intelligunt carũculas mufculares eas, qux utrinģ lumbos animalis quafiue, ftunt, quas Hippocrates pfyas, Ariftoteles prolumbis ipfis proas $\&$ plocas : Hieronymus pryas pro renibus accepit, alị neurometras uocant, Hermolaus. Nonus $\&$ decimus mufculus (inquit Vefa:

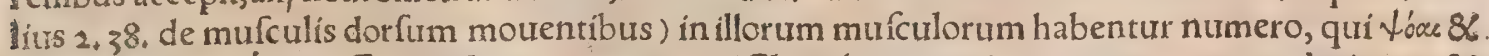

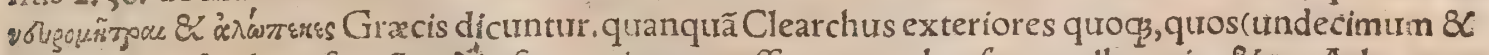
duodecimũ $\&$ duos fequẽtes ) in fermonis progreffu numerabo, fic appellauerir, \&c. Athenæus

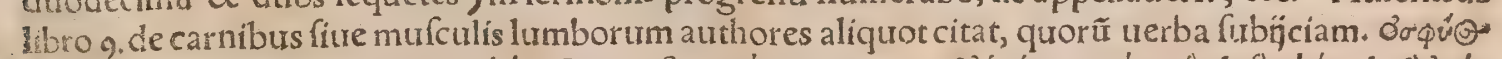

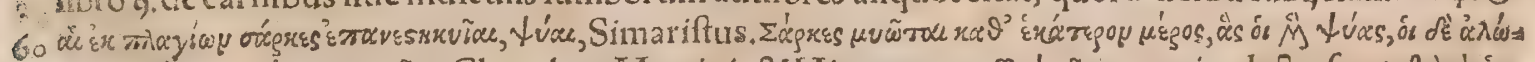
$\pi \varepsilon r s_{2}$,

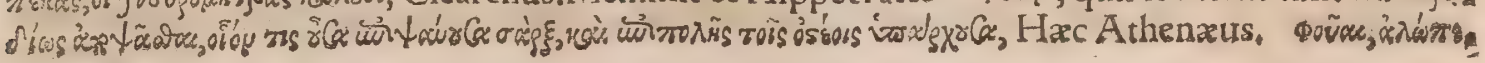


xes, Hcfychius $\& V$ Varitus, que nomine non aninalia, fed lumborum tantum mufculos intelliga,

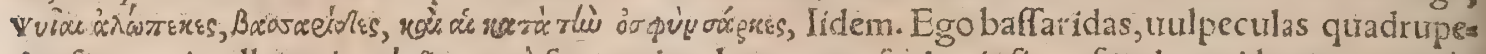
des femper intellexerim, tuáas ueró femper itumborum mafculos, ipfi confundere uidentur, Yerac,

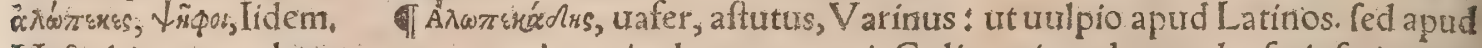
Hefychum penultima per $\omega$. ( quod magis placet, quamuis Calius etiam alopecades feripferit) non

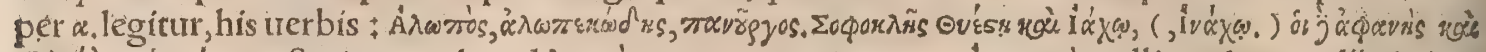

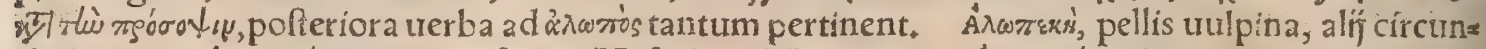

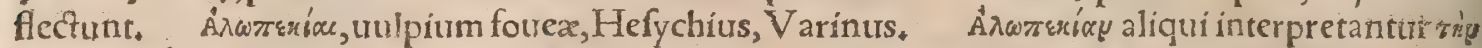

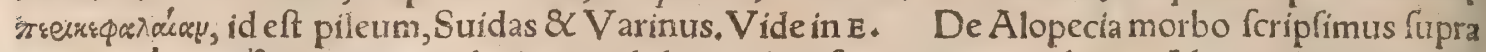

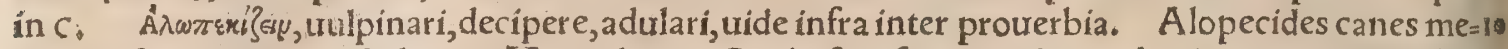
morauifuprain c. Calius ex Xenophontis A nabafeos feptimo alopecides interpretatur pelles uulpinas, År.

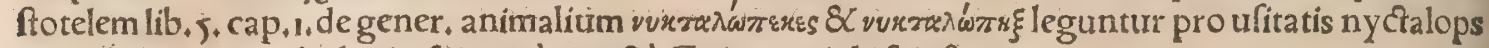
\& nyctalopies ưocabulis, nef́cio quàm rectè. Gaza uertit lựciofitatem.

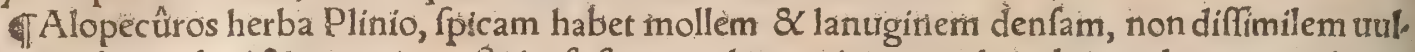
pium caudis, unde ei $\&$ nomen. Spicofa funt, oculus caninus, cauda utulpina, plantago, cuí quos

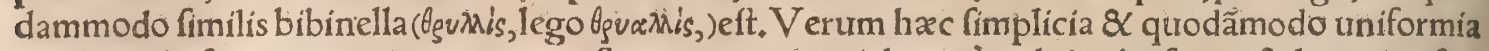
creantur, \& fpicam nec acutam nec ariftatam gerunt, cauda uerò uulpina hirfutior \& lantiginofior eft, qua mobrem fimilis uulpium caudis cernitur, unde $\&$ nomen accepit, huic plantago finitís cons Itat, nifi quod florem non quemadmodum illa particulatim æedit, fed per totam fpicam tritici modo, 10 ambabus tamen flofcutlus lanugineus exit, ficut etiam frumento. fimilis tota fpecie trítico eft, uerum folio la tiori, Theophraftưs de hiftoria plantarum 7.10. Cauda uulpis uulgó à quibufdam dicitur polygonos, id eft fanguinaria foèmina, Monachi in Mefuen. Denaphia calcail, id eft cauda uulpis, herba quęaliấs centumnodia fờmina dicitur, Syluaticus. Idem fribit cap.218. ex Serapione, cen tumnodiam foeminam, fcapo nodore, folińs pini \& c. urulgò caudam uxulpis nominari. Arabicè har fiarbai, quod nomen ibidem dipfaco quóós attribuit. Luparia (aconiti genus) iuxta Tridentum herba uulpis uocaturir, quod eas occidat, Matthrolus, Arbor uulpis, id eft liquiritia, Syluaticus, Chofahaltaleb, id eft tefticulus ưulpis; fatyrion eft, Vetus gloffographus Auicennæ: qui \& fucution \& fcutudans, nomina corrupta, ut uidetur, à fatyrio, tefticulum uulpis interpretatur. Plura leges in Satyrorum hiftoria inter fimias ، Tefticulus uulpis, id eft buzeidem, fatyrion eft, Idem, fed alibi pro zo buzeidem, bacidem feribit, Syluaticus biziden. Vua urulpina, id eft folanum, Bellunenfis \& ure. tus gloffographus Auicenna. Auicenna interpretilib, 4. fen 6.8C.utua uulpis omnino dorycnion

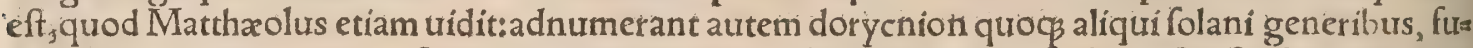
riofum cognominantes. Inter uuas dammantur, trifu cinerea, $\&$ rabufcula, $\&$ afinifca, minus ta. men caudas uulpium imitata alopecis, Pliniuss. Huius \& Columellam alicubi meminiffe puto.

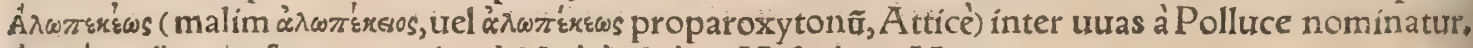

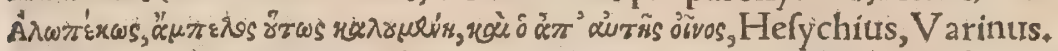

IA Animal quiod priore fui parte uxilpem, pofteriore fimiam refert, quod fimiuulpam uocauimus;

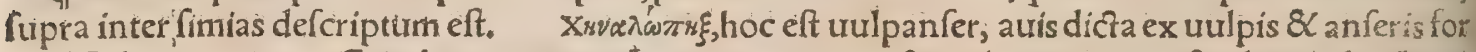
ma, Volaterranus. Cyñalopecés, canes Laconicæ ex cane $\&$ uulpe natæ, qua \& alopecídes dicin zur, ut in C.retuli. Ariftophanes cynalopecem uocat hominem impudentem firmul $\&$ aftutum. Vulpem Gracẻlampurim \& alopeca uocant, eft \& urolucre animal(auis) \& 2 pifcis hoc nomine, $H c r$ molaus. Vulpes pifcis muftelorum generis, ya nomen ei impofitum, Athenæus lib. 8. A elianus fimiliter fraudulentam $\&$ dolofam effe fcribit mari= nam urilpem, ut quadrupes eft. Genetha beftia eft paulo maior(minor)uilpecula; Ifidoruss. Rof. fomaca fiue gulo fera magnitudine canis eft, facie cati, corpore \& cauda tulpis. Eckutabne bes friola in fuperficie aqua, \& $<$. dicitur effe uulpis ab amatur, Syluaticus, tipulam intelligo.

ब $A \dot{\lambda} \omega \dot{\omega} \pi x \xi$, nomen proprium, Suidas. A pud Gracos legimuts, Limnaerim locum effe Orthix fa crum Dianæ, eius fimulachrum id effe memorant, quiod ex T aurica eft ab Orefte \& Iphigenia trala $=$ tum. Hoc qui primi compererunt Aftrabacus \& Alopecus, mox dilapfi in amentiam funt, \& $\&$. Ca $=$ s

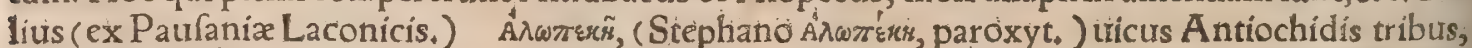

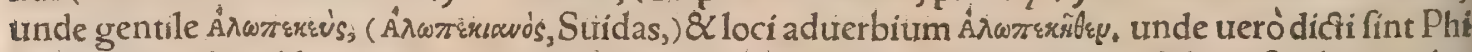
lochoruis explicat libro tertio, Suidas; Hefychiùs, Varinus. Archippa uxor Themiftoclis ex tribu Alopecia,Plutarchus. Extat in Alopecis Atticæ buffum Anchimolij, iuxta Hercilis templum quod eft in Cynofargi, Herodotus libro quinto, Azani urbs Phrygia eft, quain Hermogenes

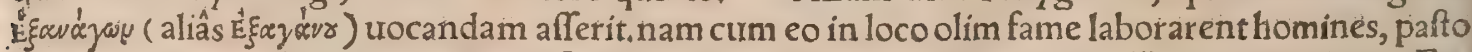
res conuenerunt, \& pro impetranda fertilitate facrum fecerunt . Sed cum dij tion exaudirent Eun phorbum ferunt rowr̃ $\&$ fecuta fertilitate, incola Euphorbum facerdotem $\&$ principem creauerunt, \& urbi nomen ab eo

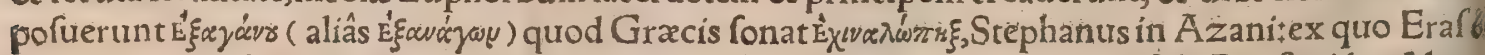
mus etiam tranftulit in prourerbio A zanæa mala I Iuxta Smyrnam funt infule, Perifterides, Alo= pece, Plinius 5.31. Et 4.12.Bolphorus Cimmerius infulam habet Alopecen, Ptolematrs, Poma 


\section{DeVulpe. H.a.b.c.d.e.f.h. Lib. İ. 1093}

ponius, Strabo \& alï, infulam hanc non Alopecen, fed Alopeciam, \& Tanain quoç urocant, Vene: torum olim coloniam.nunc Turcx potiuntur, ut alio quoç omni Ponto, Hermolatus in Plinị locü iam citatum fcribens. Ante Emporium urbem fic dictam ad Tanaim $\mathrm{fl}$. \& lacum, ínfula iacet no.

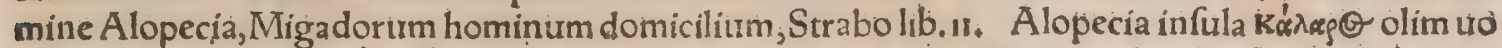

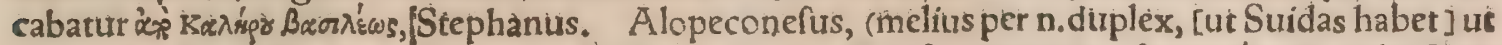
Peloponnefus $\&$ fimilia, quod probat Euftathius Dionyfij $A$ fri interpres, ) $A^{2} \lambda$ wøer fonnefi in Hellefponto, condita ex oraculo, quod urbem illic condendam (Athenienfibus) iufferat; ubi catuli uulpis confpec? i fuiffent. Sunt qui uulpem dum urbs conderetur, catulum aliunde allaturu (aliâs, catulos allatos) illuc depo fuiffe fcribãt, [Stephanus in Alopeconefo \& in Calaro. Aliquí A

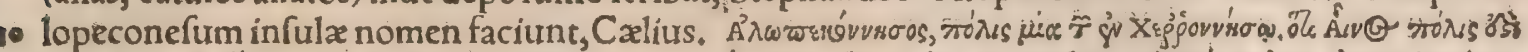

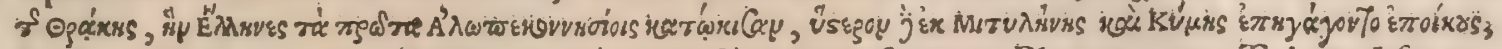
Suidas. Alopeconnefus haud procul à Càlo Cherronnefi portu; Plinius 4. 12. Tubera Afia no. biliffima,circa Lampfacum \& Alopeconnefüm,Idem $19.3^{\circ}$

T b. Canés non latrantes, uulpino roftro; alicubi in Nouro orbe reperitunturr. TQ Qui apud

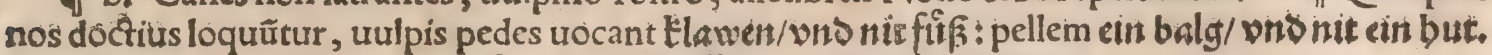
de eadem cum uulpi detrahitur, fy wirt geftreift/vno nit ge/dunoen.

(T c. Super montem Sion qui defolatus eft ambulauterunt tuilpes, Thrèni Hieremia s. Vulpes foureas habent, $\&$ uolucres coeli nidos, at filitts hominis non habet ubi caput reclinet, Matthæi $8 . \&$

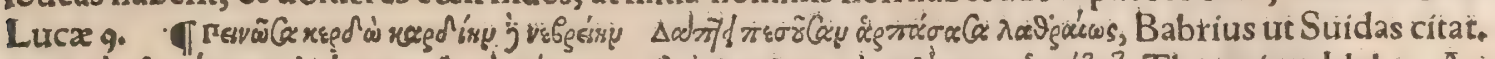

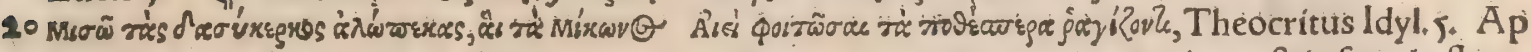
prebendite uobis uulpes, uulpés parưas, qux corrumpunt tuineas: uineæ̉ enim noftra funt in flore Canticorum 2. Dericiant eos in aciem gladij, ùt fiant pars tuulpium, P almo 63. Pràdicit autem illo. rum cafum(inquit Munfterưs) quód per holtes adigendi fint in gladiũ, \& cadatiera corum per utuls pes laceranda, đFiente, id eft fimưm; Gallicè, non de quibuislibet feris, fed proprié de foctentibiss

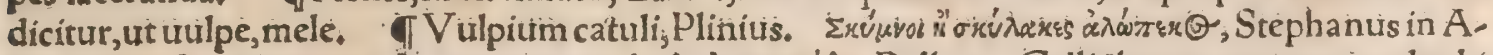

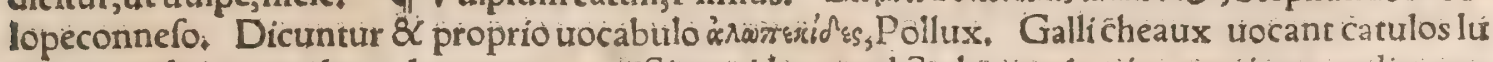
portum, uulpium, melium, lutrarum, fSimonides apud Stobaitm in uituperatione mulierum; alíà ex aln̆ sanimalibus, (fuè, càne, afino, equo, muftelà, $\& c_{*}$ ) pro ingèniorum diuerfitate natas com=

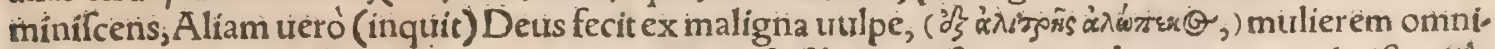

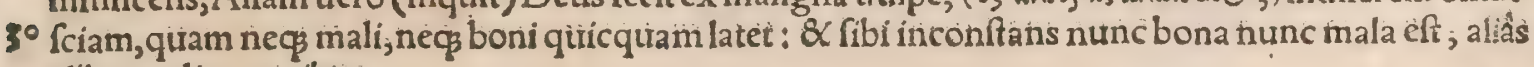
alins pradita moribus,

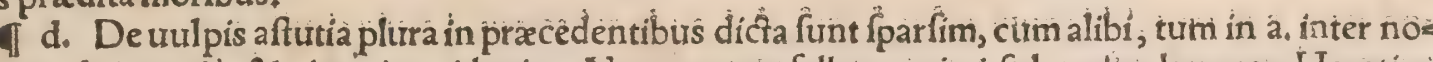
mina tuulpis, xegdì, \&c.item in epithetis. Nunquam te fallant animi fub uulpe latentes, Horatius de Arte. Solonis uerfus quofdam in A thenienfes aftutos quidem; fed qui blanditijs decipi fe päte:

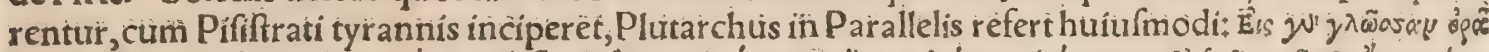

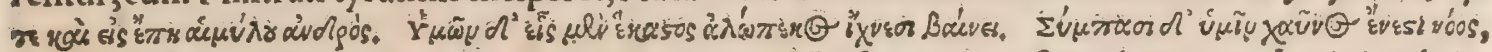
ex diuerfis (ut apparet) locis Blegiarum Solonis, Verfuturn $\&$ uafrum hominem Latini uiulpio:

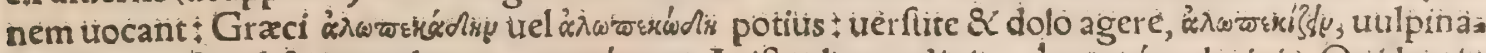

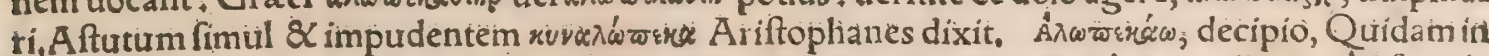
$4^{\circ}$ Lexico fine authore. Lyfander Lacedartionius, cum ei uitio uerterẻtur à nonnullis, quód fratrdè fubinde agere uidereturr, Quó(inquit)leonis peruenire pellis non poteft; uulpinam affuiffe haud de decuerit. Prouerbium uulpes non garrit, de ijs qui diligentiffime catrent ne quid temere loquan tur, Cälius Calcagnitius commêmorat, Dominus nofter Chriftus in Euangelio Lucæ cap, 13. He roden appellat ưulpem:

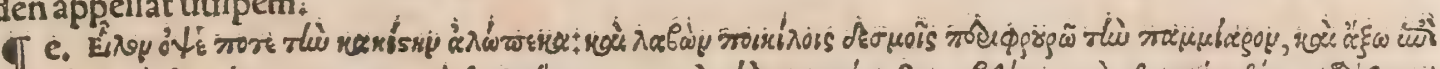

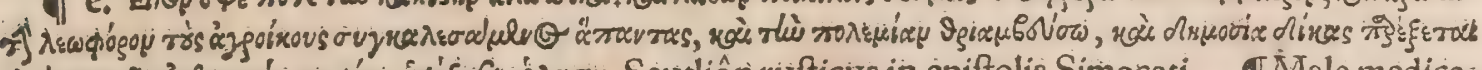

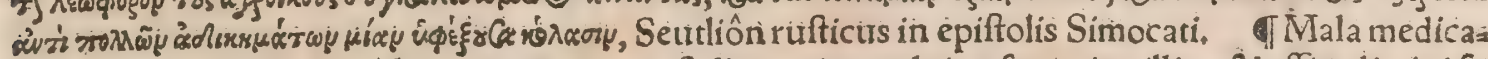
menta inferri negant poffe, aut cette nocere, ftella marina uulpino fanguine illita, $\&$ affixa limini fú periori, aut clauo areo ianux; Pliníus, I Baffareus Bacchus drcitur, \& Baffarides Bacchæ, fiue $5^{\circ}$ â gènere ueftis talaris, quain Thraces balfaram uocant, fiue à uulpibuis, quarũ pellibus Bacchaefuc: cingebantưr,ưt \& lyncum pantherarumó̧ pellibus.uulpes inde Thraces baffares dicũt, Gyraldus. In pelle quam lepori atit uulpi detraxerit genús quioddam aquila in locis quibufdam Scandinatia ad Septentriotiem rèmotis, ouja incubat.

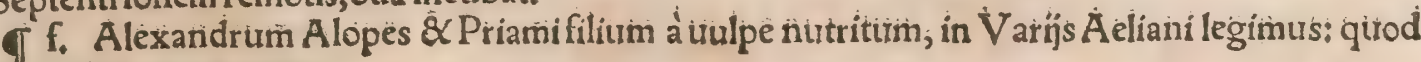
exi eo Calius etiam repëtit.

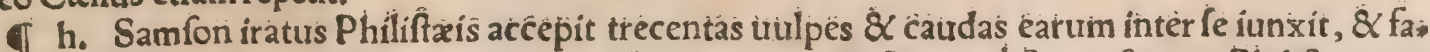
ces in medio ligauit, quas igne fuccendens difcurrere permifit. Illa uerò ftatiò fegetes Philifxarumì ingreffa funt: quibus fuccenfis \& comportata iam frirges; $\&$ adhuc ftantes in ftipula concremata funt; adé ut urineas quooģ \& oliureta flamma confumerer, ut legimus Iudicum ir. đAriftomenes

6o Meffenius à Lacedxmonís capturs, per ćairernam latomiarum euafit, anguftos uulpium adítis fecutus, Plinius. Sed latius in Meffenicis profequitut Patufanias. Lacedæmoníj(inquit) Ariftome

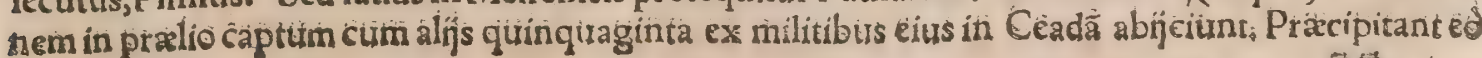




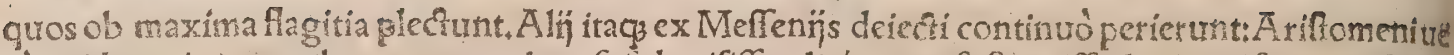
rò guxidam aúun aquilam auem uolatu fe lubmifife, alisçs eum fuftinerife donec ad finem deferre, tur illafus. Hic tertio die frepitu percepto, uulpem cadautera arrodere a nimaduertit, $\&$ currentem fecutus, cum in loca effet uentum tranfitur ualde difficilia, ab ea eft auulfus. ferò autem cautrnam quandam deprehendit, wulpecula ad fuffugiendum aptam, \& per eam luminis folendorem uidit, ac uia manibus latiore reddita euafit. Hanc hiftoriam paulò aliter Polyanus defcribit Strategematum 1ib. I. 9Procridis fiue Cephalicanis, fuit eius natura, ut uitari non poffet, ubi infequeretur: ficut

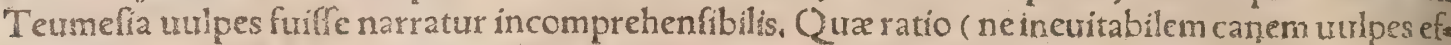
fugeret, aut ulpem incomprehenfibilem canis caperet) utrunç deformaurit in lapidem: Lege plura in Canis celeris hiftoria circa finem. Vulpeculam Teumefiam, ut damnum inferret The banis, à Bacchocx indignatione effe educatã narrant $\&$ capiẽda cum iam cffet à cane, quem Procridi Erech thei filia Diana dono dederat, in lapidem unà cum cane tranfmutatam, Paufanias in Bceoticis.

ब. Vulpes forta occurrens in uia infortunatum iter præfagit, Alexander ab Alex. Impios parre recinentis omen Ducat, \& pragnans canis, aut ab agro Raua decurrens lupa Lanuuino, Foe. taç uulpes, Horatius Carm.3.27. TEquitia fingulis annis duodecimo (decimo quarto, Gyral. dus)calend. Maias in Círco maximo celebrarunt, qui dies Cerealibus incurrebat, in quibus poft equos, uulpes fipulis alligatæ, accenfa flamma, curfitabant, Alexander ab Alex. Ouidius quarto Faftorum die quarto poft Idus Ap prilis Hyades oriri fribit, \& tertio poft Hyades remotas die Equi. tia celebrari, \& eodem die uulpis pellem aduri: fabulam addit, fuiffe in rure Peligno pauperis colo= nifilium annorum duodecim, qui uulpem ceperit qua multas gallinas abftulerat: Captiuam fti. 1 pula fornó́pinuroluit, \& ignes Admouet, urentes effugitilla manus. Qua fugit, incendit urea Pitos meffibus agros, Damnofis uires ignibus aura dabat. Facium abrït, monimenta manent. nam dicere certam Nunc quoog lex uulpem Carfeolana uetat. Vtó́sluat poenas genus hoc $\mathrm{Ce}$ realibus ardet, Quoós modo fegetes perdidit, illa perit. QQuòd fí animantium cruore affici. untur fuperi, cur non maciatis illis mulos, canes, uulpes, \&c. Arnobius contra gentes.

$$
\text { P R O VER B I A. }
$$

Archilochi urulpes, de ualde aftuto \& malitiam fuam egregie diffimulante, ut funt $Q$ ui Curios fis mulant, \& Bacchanalia uiuunt, prouerbialiter dici poffe uidetur. Nam apud Platonem libro de re pub. fecundo in perfona Glauconis fic legimus: Ea qux dicta funt de iniuftitix apud homines com modis, \& facili peccatorum apud deos expiatione) mihi quidem, fi iuftus fim, non tamen appaream, 3 nihil prodeffe dicunt, labores autem \& poenas certas effe: Iniufto uerò opinionem iuftitia affequu= to, urita diuma adeffe dicitur. Nónne igitur poftquam exiftimatio harc iuftitix, ut fapientes tradunt, ueritatem cogit ac uiolat, \& ad beatitudinem eft pracipua, (hoc eft beatiores efficit apud homines, quàm uera iuftitia qux non appareat ) ad eam omnino tendendum eft? Induere itą̧ imaginẽ opor= tet iufitix, \& quandam præ fe ferre uirtutis adumbrationem, à tergo verò illam fapientis Archilochi

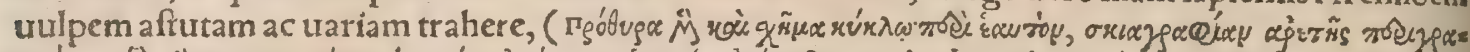

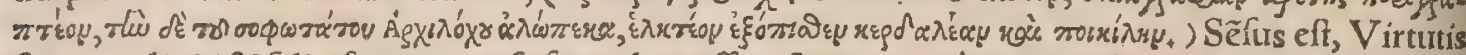
fpeciem diuiti \& felici futuro pra fe ferendam effe, afturiam uerò $\&$ improbitatem pofterius occul tandam, Erafmus in protrer bio, Benignior pellace uulpe, Platonis uerba imperitécốuertit, nos Mar filị trăslationem pofuimus. Archilochi uulpeculam commemorat \& diuus Bafilius, cum aliâs, tưm 40 in libello ad nepotes fuos, \& Philoftratus in Imaginibus. Multi funt apologi de uulpis aftutia, ex his quis fit Arrchilochi non fatis liquet, Erafmus. Huc certe facit apologus ille, quem noftri pictores aliz quando reprafentane, de uulpe hominis religiofi habitu fumpto concionante, $\&$ collectos ad concio

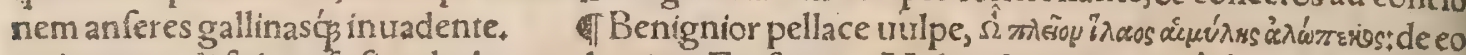

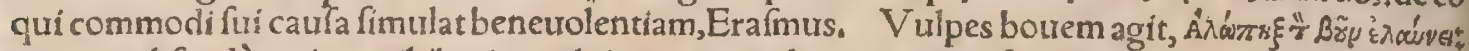
cumres abfurdè geritur, nilil enim uulpi cum agricolatione. uelutí fí quis poëta de reburs facris con cionetur, aut leno tractet rempublicam. Licebit $\&$ ad eum torquere, qui non ex animo, fed aliò fpea

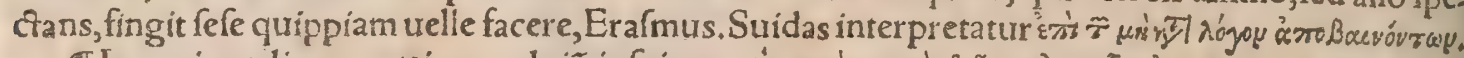

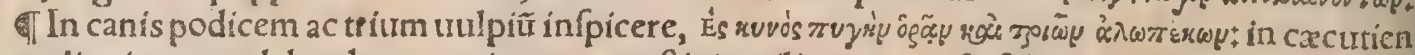
tes aut lippientes:uel de rebus paruis atç anguftis inutiliter anxios \& folicitos: Vide in prouerbĭjs ${ }^{\circ}$

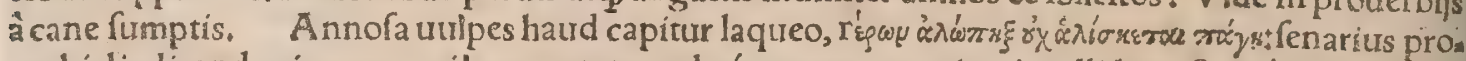
uerbialis dicendus in eum, qui longa atate multá̧̧̧ rerum experientia callidior eft, quàm ut arte do

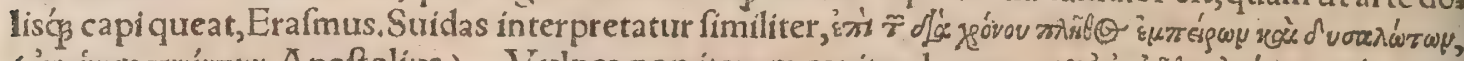

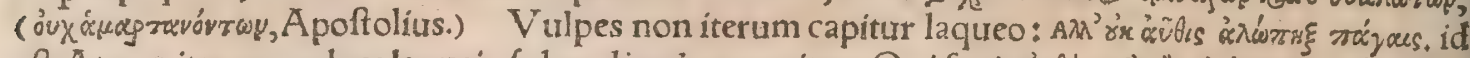

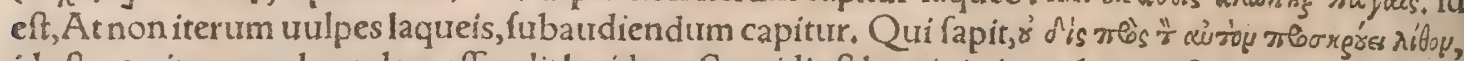
id eft, non iterum ad eundem offendit lapidem. Stupidi eft hominis, in malum guftaturm iterum incl

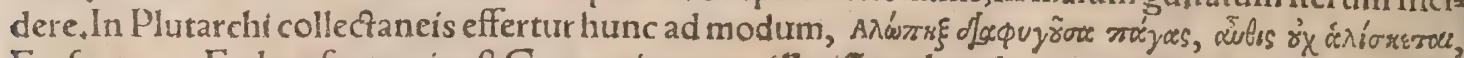
Erafmus. Eadem fententia eft Germanicorum, LE $r$ if wol mebr voz bes? gern geneft. KE bat ons gern gerodben. Vulpes haud corrumpitur muneribus. Suidas huius adagij Cratinum citat autorem. De callidis ac uerfutis, quos haud facile fit obiecto munufculo, aut affentatiuncula, 60 pollicitísue fallere. Larus enim $\&$ alia qua dam aues efca capiuntur, uulpes non item, Erafmus. $L O=$

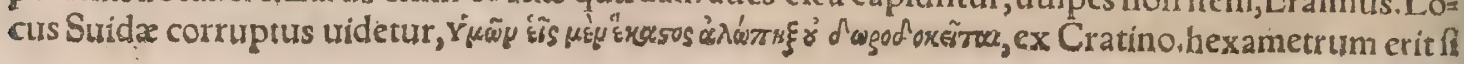




\section{Devulpe. H.h. Lib. I. 1095}

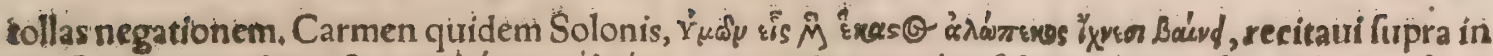

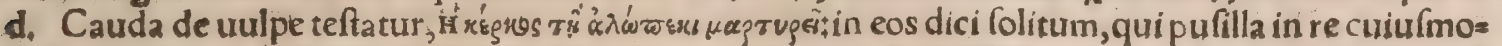
difint declarant. Êf autem uulpi cauda pro corpore maior ac pilofior, ut non fit facile celare: alioqui canis uideri poftit. Vnde quadrabit de exitu declarante cuiufmodi fuerint reliqua. Quidam primo aggreffu agni, in euentu uulpes comperiuntur, Erafmus. Vbi quem.admiffa noxa mulctari leuius animaduertimus, uulpis cauda correptum fuiffe dictitare confueuimus, Calius. Eft \& Germanis

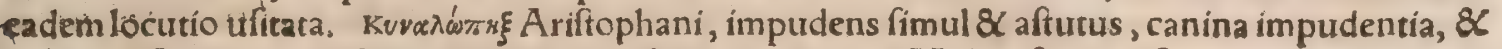
uulpina afturia coniunctis, ut in Cane alicubi diximus. TVulpi efurienti fomnus obrepit, एesvw.

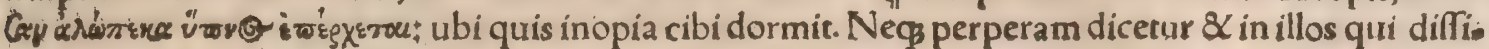
5 mulant, conniuentóp ad quadam, ut per occafionem aliquid commodi ferant. fiquidem uulpes ur gènte fame fomnum adfimulat, ut illeças aues capiat deuoretó $\beta$. Fit autem hoc phyfica quadam ra: tione, ut famem ac fitim extinguat fomnus. Adagium recenfuit Diogenianus, Erafmus. TDe

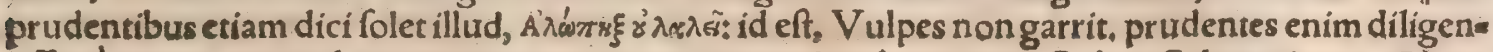
tiflimé cauent, ne quíd prater rem att parum commodum loquantur,Calius Calcagninus. If lun=

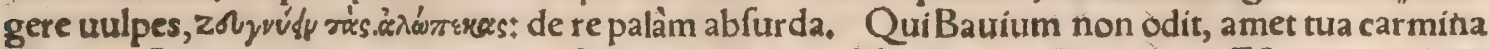
Maui, Atque idem iungat uulpes, \& mulgeat hircos, Vergilius in Palamone. Eft enitn uulpes animal ab aratro uehementer alienum, Erafmus.

đCongregare cum leonibus uulpes, a pud Martialê, eft res impares diffimilesćs permífcere. Vula pes dolis nititur, leo uiribus fidit, Erafmus. Vbileonis pellis deficit, uulpina infuenda eft, Sueto* 20 nius. Lyfander Lacedamoniưs cưm ei uítio uerterecur à nonnullis, quòd fraude fubinde agere ui deretur:Quô (inquit) leonis peruenire pellis non poteft, uulpinam affuiffe haud dedecuerit, Calius *

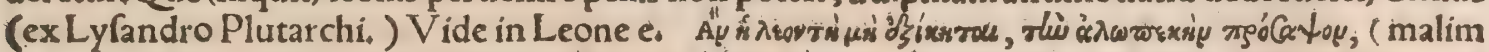
rgórgex oy, fecundum Suidam \& A poftolium; 'Zenodotus. Huius affine eft(inquit Erafmus)quod apud Plutarchum in uita Syllx Carbo dixiffe memoratur: Quum enim Sylla non folư aperto Mars

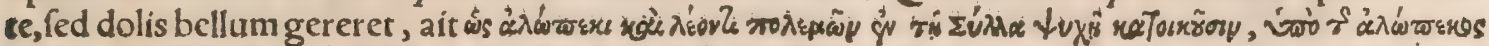

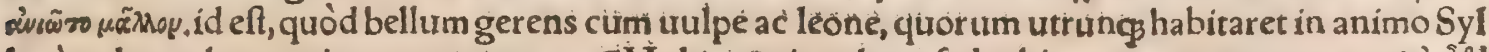

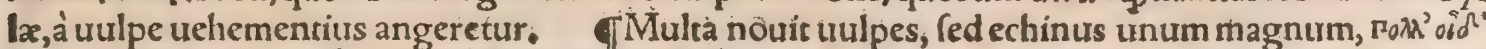
'̇ं le uinces quàm uulpes pyrum comeft, Plautus in Muftellarią de re factu procliui. quòd nihil nego= 30 tị fit uulpi dentatifima pyrum edere, Erafmus. Domil leones, in pugna uulpes: A pud Ariftophaz

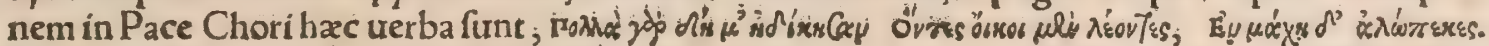
Eft autem fcomma in Lacones. Scholiaftes monet parờmiam effe, contortam primum in Lacones

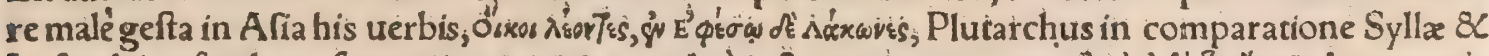
Lyfandri, refert hanc fententiam tanqư

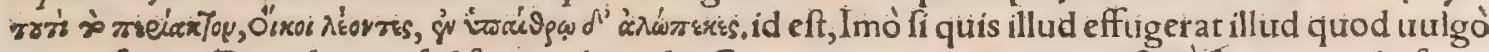
circunfertur, Domi leones, fed for is ưulpecula. Conuetiiet in eos qui prapofterè re gerunt : ibi fero= ceś, ubi nihil erat opus:ibi furgaces; ubí res pofcebat tuirum, aut qui in fưos faùi, non itidem audent aduerfus inimicos:quod Ciceroni obijcit Saluftius, uidelicèt quiòd cótumeliofus in amicos, fupplex inimicis. Aut in illos, qui fimulata manfuetudine peruèniunt ad tyrannidem, Erafinus. Pulchè fal

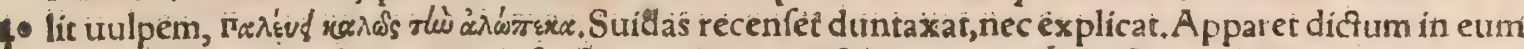
qui dolis captaret aftutum, cuićs fruftra tenduntur infidià, nam mox

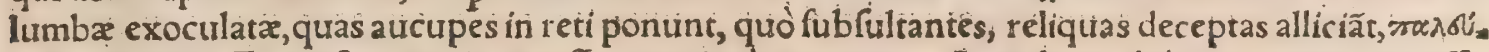

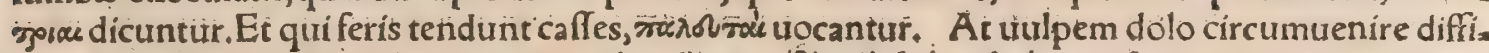

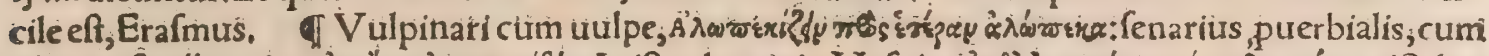

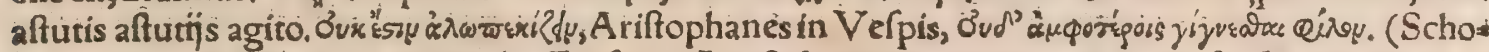

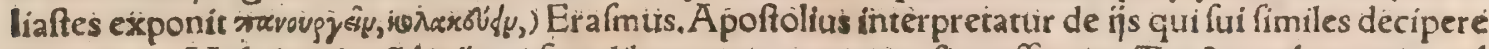
conantur. Vulpinari, mẽdacís ac fraudibus uera peruertere fiue effugere. Tractum ab intor to uul pium curfu. Varro Myfterijs, Vulpinare modò, \& concurfa, qualiber erras, Ex Nonio. Varro qui=

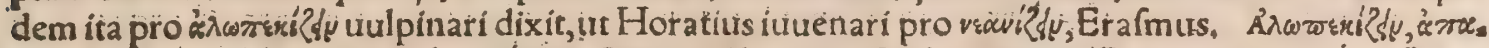

to ră

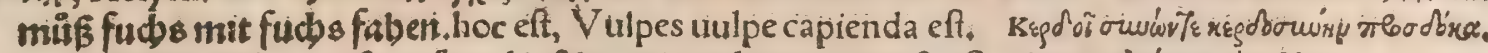

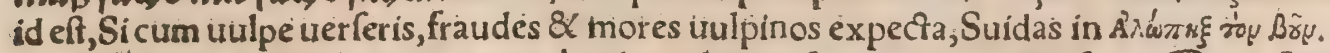

fGernanis peculiaria quædam à inulpe adagia ufurpantur, qualia funt: Su initif fubs ons baAs fyri: Vulpem fimul ac leporem effé oporter, hoc eft pro re riata mitandum ingenium, Polypi

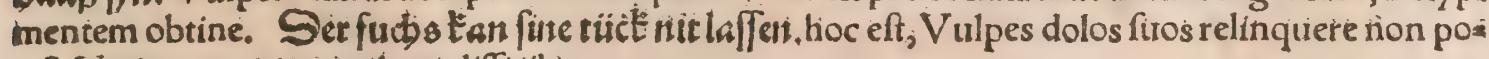
teft, Natiuos mores occultrare difficilè.

đQuafi uulpes in defertis(bacharaboth)fuerunt prophetre tui ô Ifraẻl, Ezechielis 13. Vbi Munfertis, Comparantur (inquit) falfi proplietxuulpibus fubdolis, quæ per laceratas fæpes intrant in ui: heas aut agros; ut utuas \& fegetes depafcant. \& intelligunitur hîc per charaboth; loca fxpium difru: 60 pta,per qux beftips pater locis intrandi. Si afcenderit uulpes, tranfiliet murumi eorum lapideum; Neemia4. de ludais moenia Hierofolymorum reparantibus,

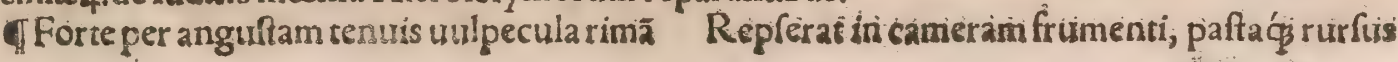


* 1096 De Quadrupedibus.

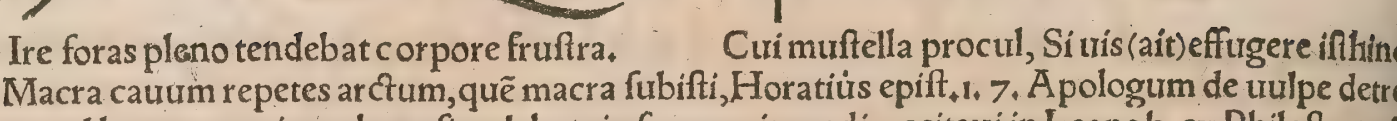
cante ad leonem, qui morbum fimulabat, in fpecum ingredi, recitaui in Leone h. ex Philpeftrato
Horatio. Item alium de leonis, afini $\&$ uul pis focietate, in eodem in prouerbio Leonina focietas.

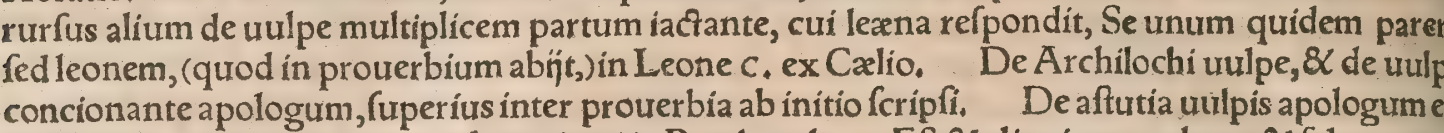

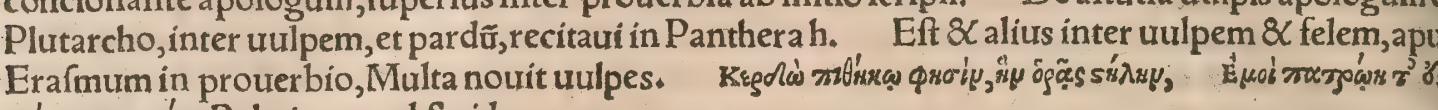

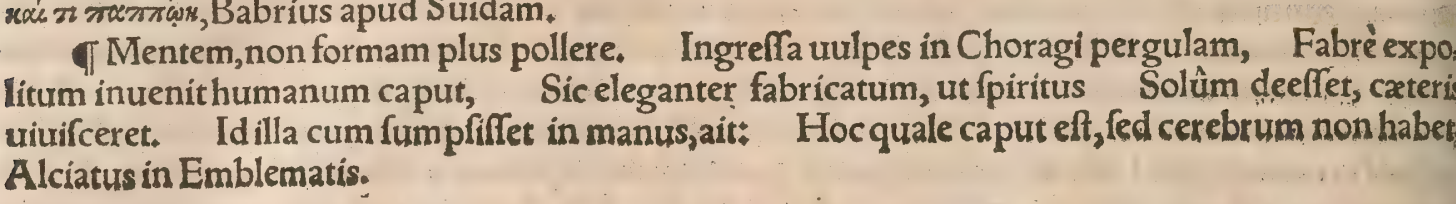
$\operatorname{INI.~}$ 


\section{Paralipomena. PARALIPOMENA.}

I C E S figuram nuper doctiffimus uir Seb.Munfterus ad nos mifit, ad uiutum(ut ait)píçam, qua à noftra nihil differt, nifi quòd iubata nó eit: \& fanè puto non recté huic quadrư pedi iubam addi. Eadem cornuta eft geminis cornibus, ( talibus quale nos unum fepara: tim dedimus, )tergum uerfus reclinatis, ita ut pars in mucrones diuifa frontem fpectet, op pofita tergum. B Boruffia(inquit Erafmus Stella ) gignit $\&$ alces, quos falfó fylueftres afinos qui $=$ dam autumant, quum hos Afia tantum \& A frica procreet: fpecie media inter ceruinam \& iumenti, nifi quantum aurium proceritas ipfaçsceruix diftinguit, magnitudine inter camelum \& cerurum. Maribus in fupercilins cornua nafcuntur, quæ quotannis amittunt, latiora quàm ceruinis, ramofa tà men, \& per totum concreta ac folida. Vngula bifida coloréǵ ceruum imitatur. Venatorem è longin quo fentit.animal certe fimplex, \& quod plus latebris quàm fugæ fidat, Siui canum urgetur, magis in canes fe calce quàm cornibus tuetur. In locis paluftribus fefe plurimum condit, illic $\&$ partus ædit fuos. Formidinis eius argumentum effe aiunt, quòd rarenter folitarium, in armento multum ap= pareat. Vngulis eius comitialem morbum etiam fpumantem abigi creditum eft, fi cute attingitur. Hallucinati funt qui hanc feram nullo fuffraginum flexu dixerunt, Hæc ille. o Nuper etiam a peregrino quodam accepi, alcen à uenatoribus agitatã ad aquas confugere, atçs in î̉s ftant $\tilde{e}$, aquam ore hauftam in canes feruidam eruciare.

V R I quoģ effigiem ante paucos dies, ad uiữ expreffam Seb,Munfterus nobis cómunicauit à noftra(quam ex tabula Mofcouix Antonij V uied mutuati fumus)nonnihil diuerfam, Cor pus uri, quem picfura illa repræentat, perquàm craffum eft, tergo fummo ferè gibbofo, lógitudo ei à capite ad caudam breuior quàm proceritas $\& \mathcal{X}$ uentris laterumás $\&$ dorfi craffitudo poftulet. Cornua den $=$ fa, nigra, breuia, oculi uerfus exteriorem canthum rubicundi, os lattrm, craffus \& fimus nafus. Craffum \& amplum caput, facies (ut fic uocem) lata Tempora uillofa, mentum barbatum, fed breuibus uillis, nigris. Color fere niger, maximè in temporibus, mento, collo \&c.in facie, lateribus, cruribus, cauda, ad puniceum uergit, TQui fe uenatione urorum exercent, fí plurimos interfecere, relatis in publicum cornibus, quar teftimonio funt, magnam laudem adipifcũtur. Soliti erant antiquitus caz ueis ad hoc ex opera (foureis ad hoc in terra)fachis eos capere, captosḉ̧ iugulare: forté quòd ea tempe ftate ferro caruêre (Boruffi.) Pofterioribus uero, lectis ad hoc pracipux unitutis \& audacix iutueni= bus, canibus cos infequi placuit, uenabuliṣ́́ cominus ac eminus petere, arboribus fefe robuftioris bus femper condendo, ne à fera impetantur, qua cornibus arbori infertis, uindicta auida inhæret, donec infequentium telis faucia concidat. Sub mento uillos longiufculos habet in ar unci fpeciem; cæeteris tauro perfímilis, Erafmus Stella.

DE CAPRIS INDICIS. Jndianif geiffen.

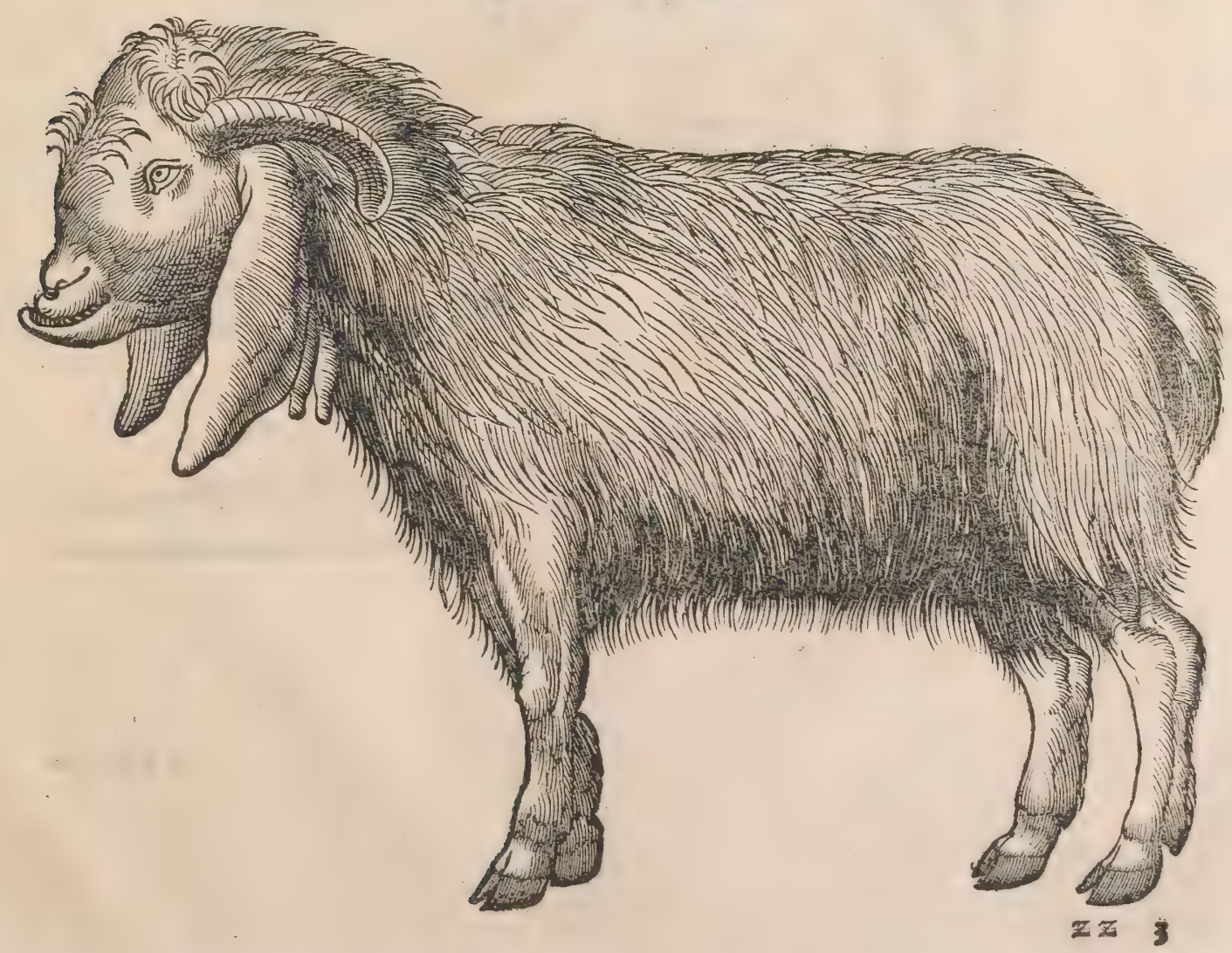




\section{8}

\section{Paralipomena.}

C A P R A M Indicam, aurt Mambrinam aut Syriacam potius, ante annos aliquot Ferra= riæ in Iralia uidi, ex qua urbe figuran etiã ma= iorem clariffimus illuftriffimi principis Hercu lis Eftenfis medicus Antonius Mufa Brafauro= lus ad nos mifit, minorem, qux geminas habet - capras, ex Germanico quodã libro defcríptio= nis Terræ fanctæolim mutuatus fum. Pluriz bus autem de hoc caprarum genere fcripfi in Capra B.

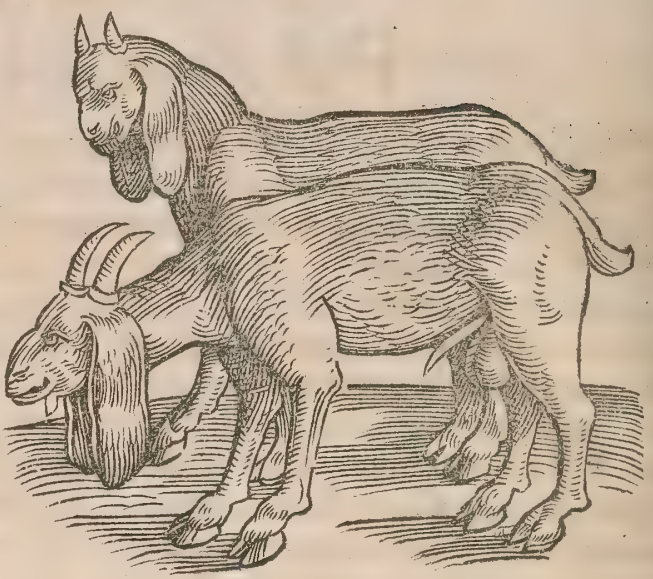

C A P R E O I I maris figura, quam curm hiftoria ipfius nimis anguftam dede: ramus. Formina quidem cornibus caret. 2ieed.

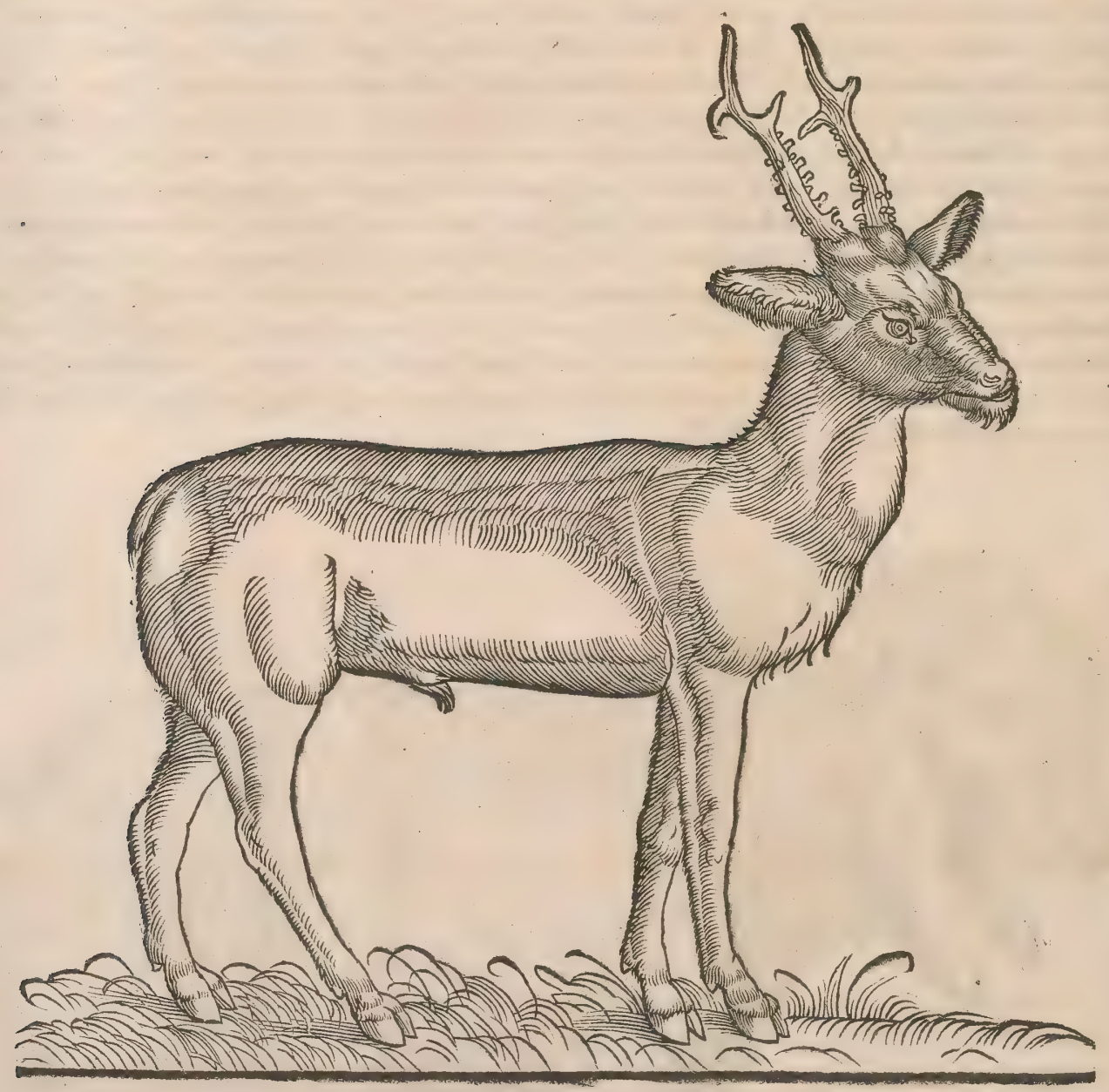

C A P R I 


\section{Paralipomena.}

C A P R I C O R N I trel potius ibicis maris figura, quam fimiliter cum eius hiftoria anguftiorem polueramus. Etcinboct.

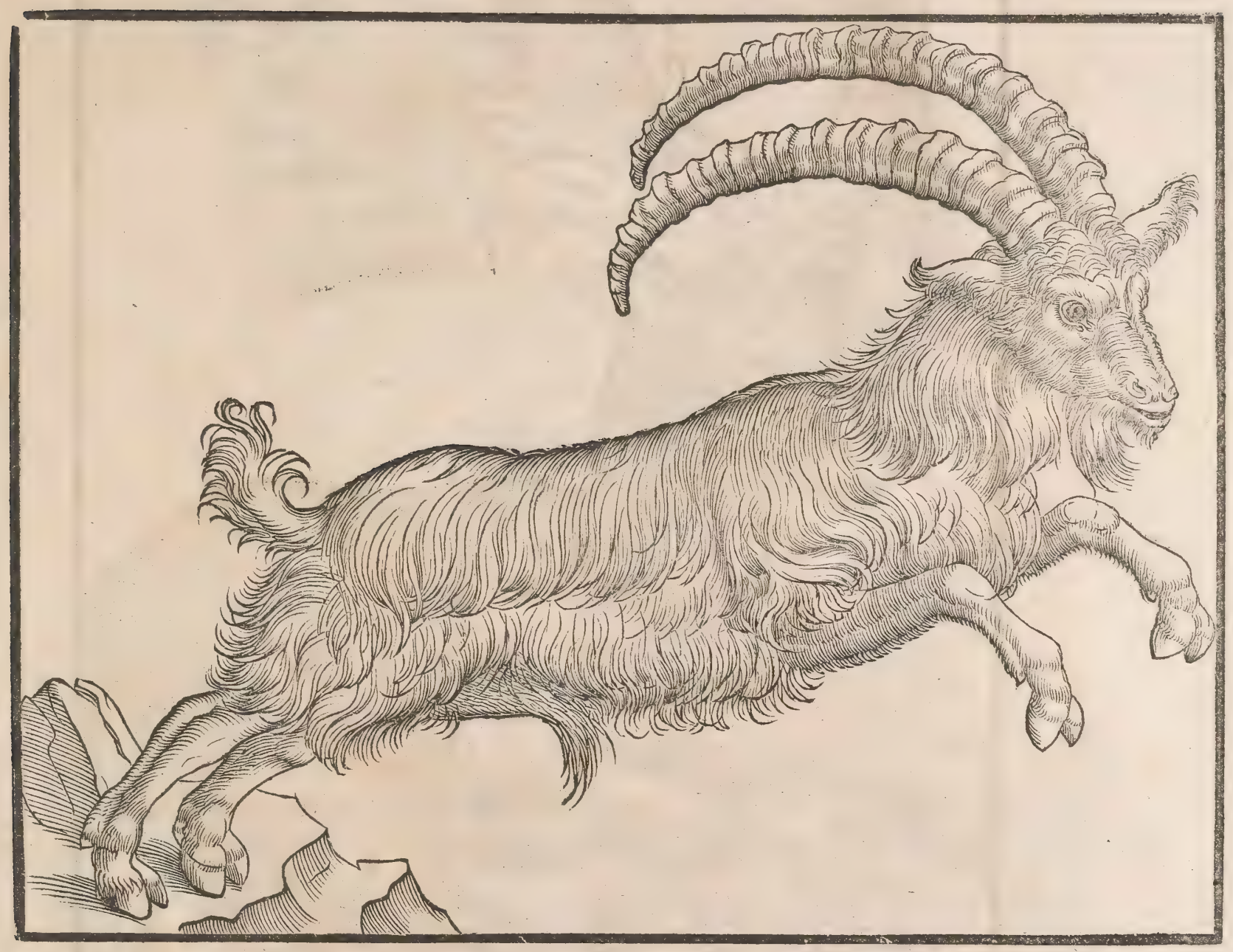


D A A A fure caprex platycerotis figura, in hifforia eius; inter capras fylueftres, omiffa.

Sambirs/osimle.

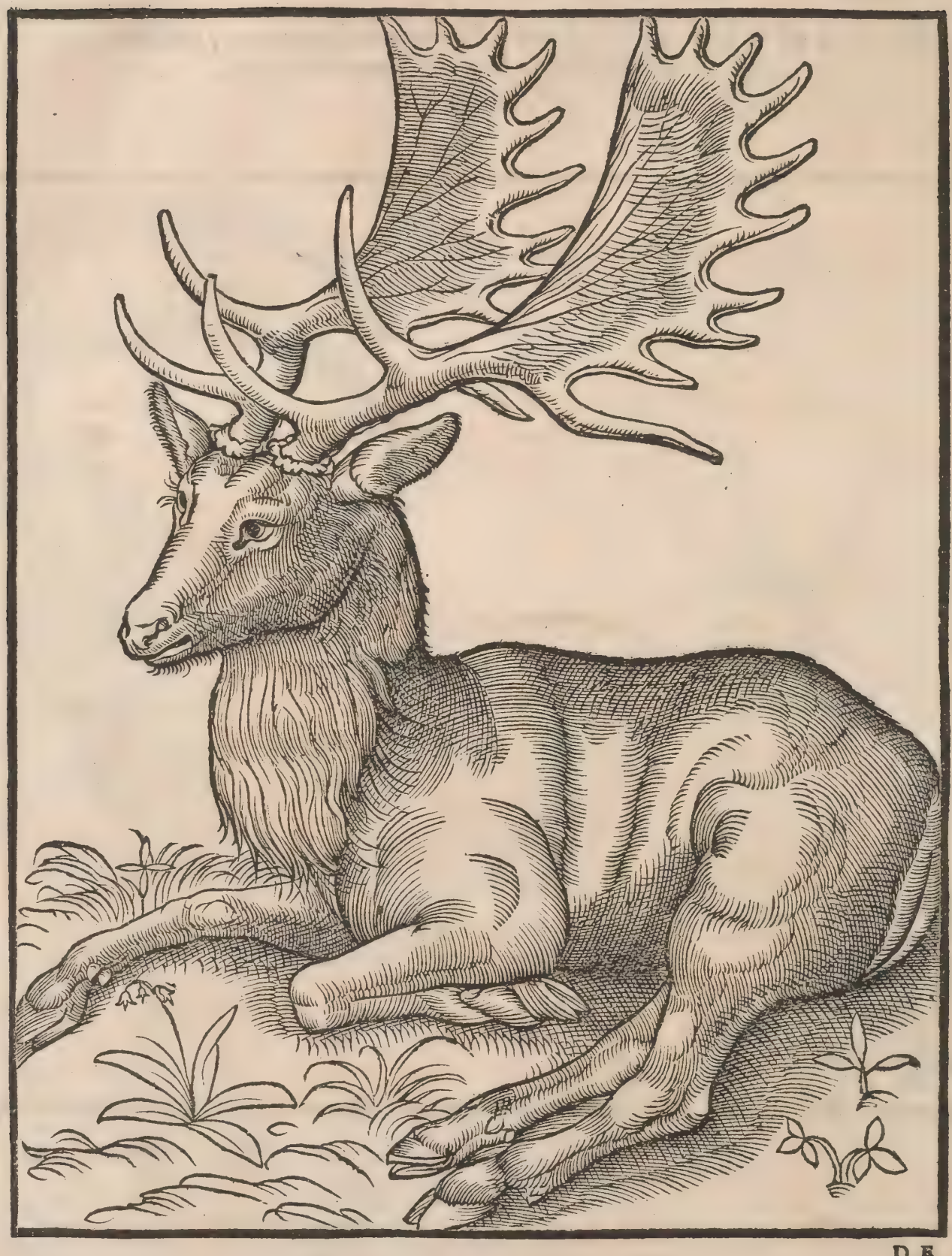




\section{Paralipomenâ:}

DE TRA GE L A P H O, id eft Hircocertro; 23zanbbirts.

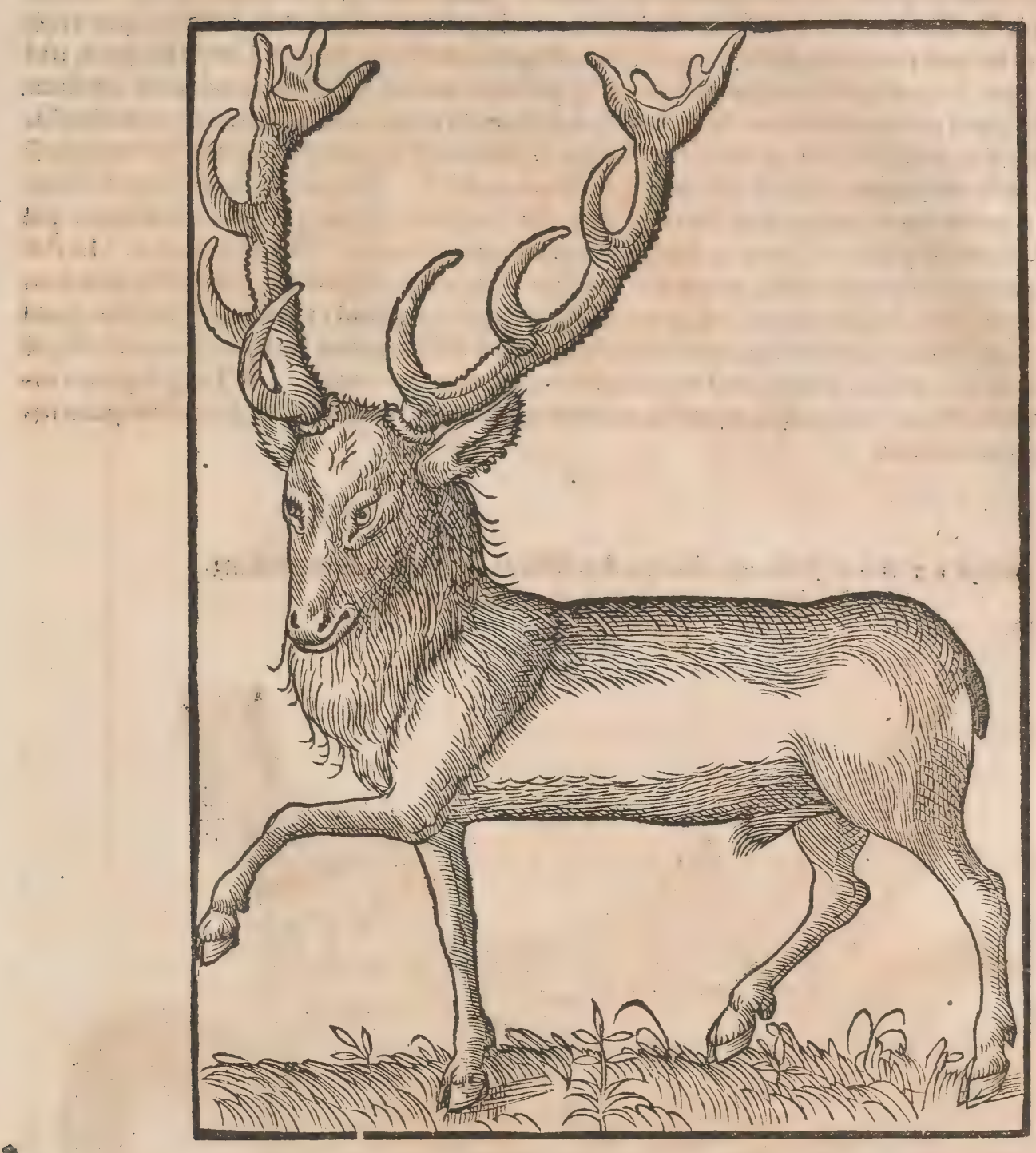

I I \& V R A M hanc ad uiuum expreffam uir undequaç doctiffimus \& egregius poètra Gècora gius Fabricius nobis tranfmifit ex Mifena Germanix, unà cum literis, quibus hæcicontinentur : De ceruorum generibus, (inquit,) qux ex uenatoribus didici, quamuis infirma auctoritate, uulyi fcili. cet nituntur, tamen ut tuæ uroluntati uidear fatisfeciffè, adfcribam. Tria igitur dicunt efle ceruo= rum genera, non fingulari quidem naturæ difcrimine, fed aliquo tamen nominis, formæ, uirium. Pri mum illud notum omnibus, quod diligenter Ariftoteles \& Plinius defcripferunt. Alterum igno, tius, quod Græco nomine tragelaphus dicitur, priore maius, pinguius, tum pilo dêfius, $\&$ colore ni grius:unde Germanis, à femiufti ligni colore, 23 and bir nominatur. Hoc in Torantinis 8 Konig ftenianis Mifenæ faltibus, Boêmię uicinis capitur. Vulgus uenatorũ ait nomẽ reperiffe àlocis, in quï bus carbones fiunt, quòd ea frequentet, et hèrbis ibidẽ renafcentibus, libẽter pafcatur. Hoc uerũ fit, an ex eríore ac opinione propter nomen fabella nata, in medio relinquo:certe uulpes etiam uilli den fioris \& nigricantis, à colore eodem modo $\mathbf{3}$ zan $\triangleright$ fudb) fe nominantur, quos in areis illis carbonarnjs uerfari non eft uerofimile. Tertium genus, quod reliquorum ceruorum more non amitrit cornua, hoc caftratis accidere ait Plinius: fed $\&$ uicio accidere affirmant, qui feras apud nos confectanturs

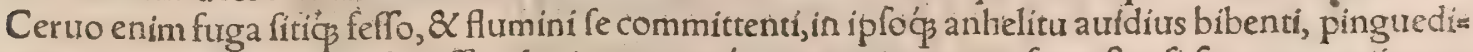
nem qua abundat refolui $\&$ diffundi aiunt:ex eoç aut mori eum, aut fuperftes fi fit, cornua ei nuns quam decidere.id'śsfieri eo maximè tem pore, cum ardentifime forminam a ppetit. Hoc genus cerui proprio nomine, etn TiR ummeter appellant, Hæc Ge. Fabricius, qui fimul etiam praftãtiffimi \& eru

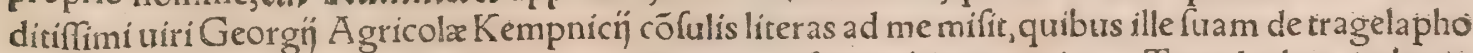
fententiam, quam meo nomine Fabricius periuerat, hifce uerbis exponit. Tragelaphus ex hirco 8 ceruo nomen inuenit, nam hirci quidem inftar uidetur effe barbatus, quod ei uilli nigri fint in gut sure $Q$ in armis longi; cerui uero ge: it fpeciem, eo tamen multo eft craffior $\mathcal{Q}$ robuftior, ceruinus 
etiam ipficolor infidet, fed nonnihil nigrefcens : unde noinen Germanicum traxit, ueruntamen fur prema dorfi pars cinerea eff, uentris fubnigra, non ut cerui candida, atç illius uilli circa genitalia ni gerrimi funt, cateris non differunt, uterq̧eft in noftris fyluis:quanquã plures tragela phi in his qux finirima funt Boëmicis quàm in alīs seperiuntur. quare Plinius haud recié fcripfit tragelaphum nõ alibi quàm iuxta Phafim amnem nafci, Hxc Agricola. Ego huius animantis cornua, qux ciuis quidam noftre ciuitatis tanquam ualderara afferuat, diligenter infpexi, cum de Ceruo fcriberê, ubi in Philologia capite fecunde, defcriptionem eorum appofui his uerbis: Obferuaui etiam in confum mati cerui (nam quod genus cerui hoc effet adhuc ignorabam) cornibus mucrones fiue ramulos fu. premos, quibini aliogui plerunģ aur terni fpecfantur, feptenos: \& eodem in loco ftipitis latitudinê fex digitorun. inferius autem erant $\&$ alin bini rami, $\&$ adminicula. Inquírent ftudiofi an hoc cer: uorum genus à fpecie cornuum, qux in fuprema fui parte tanquam palma in digitos finduntur, pal matum Latinè dici rectè poffit.nâ ceruos palmatos Capitolinus memorat: Vide in Ceruo B. In An \$lia ceruos nigricantes reperiri audio, qui an ïdẽ fint cum illo cuius effigiem hîc poluimus, non fum adhuc certus. Ariftoteles in libro de coloribus ceruum aliquando nigrum ( albû legit Ruellius, quod - probo)effe captum fcribit, ut urfum quog:non tamen generis differentiam facir, fed propter aliquê corporis affectum id accidere putat, quod tragelapho noftro non contenit. TTragelaphus (in. quit Plinius) eadem eft qua ceruus fpecie, barba tantum et armorum uillo diftans, non alibi quàm ix xca Phafin amnem nafcens.

C E ET H A pellis;qualis apud pellifices fpectatur, Denetblab Scripfimus autem de hoc animali,ftatim polt Equum.

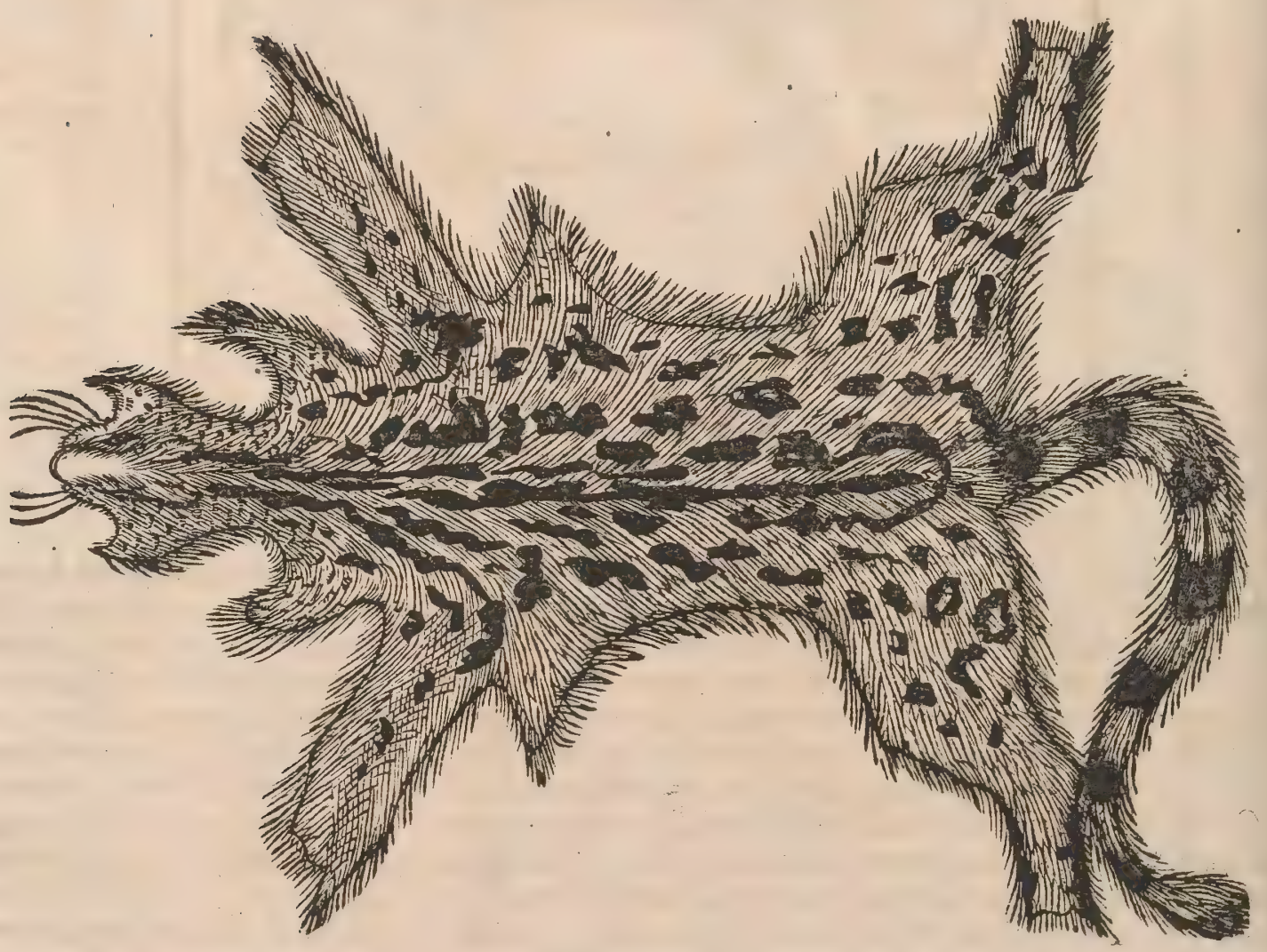

2. I N C Is figura quam dedimus uera effer, fi caput \& facies (ut fic appellem) catum referrent: \& ungues anguftiores effenc. 


\section{Paralipomena.}

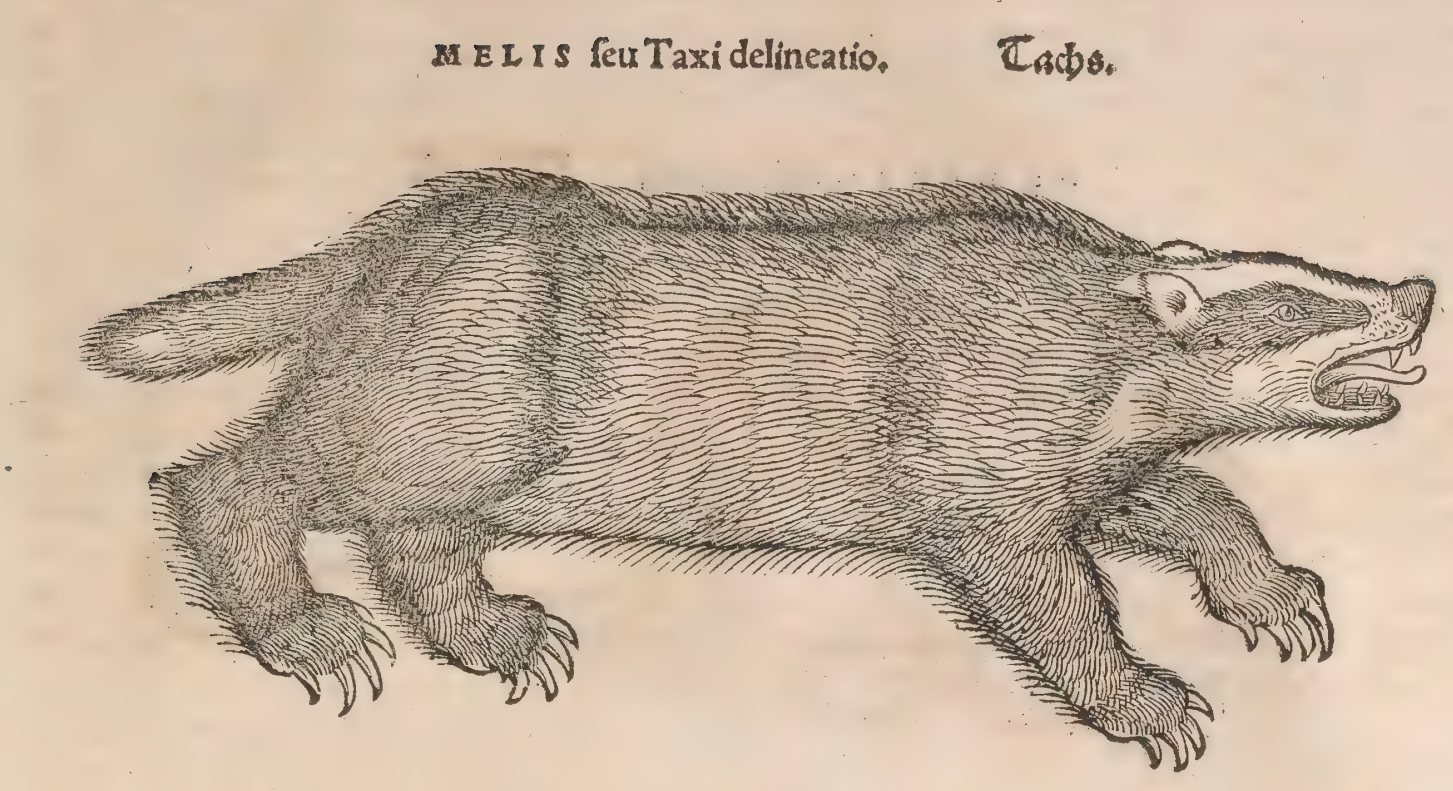

DE MONOCEROTE.

C V M mondcerotis hiftoriã exararem, ab incomparabili docfrina \& uirtute uiro Nicolao Ger belio, quem equidem parris ac praceptoris loco $\&$ amo $\&$ ueneror, per literas petï, ut defeription aliquam cornu illius, quod pro monocerotis cornu Argentorati in fumma ecclefia thefauro fer. uari audieram, ad me daret. Sed cum refponfum eius ferò mihi redditum effet, malui inter Paralie pomena collocare, quàm prorfus omittere. Cornu igitur (inquit) quod inter archana fummi templi habentheroes illi, fepiffime uidi, manibusó̧ meis atcrectaui. Ea elt longitudine hominis proceri, fi $\rightarrow$ quidem aciem illi addideris, fuit enim inter illos impius quidam, qui à nefcio quo didicerat aciem feu cacumen illius cornu contra uenena contraçs peftem remedium effe prafentiffimum. Quam ob rem quadrifur ille fuperiorem partem ad tres aut quatuor träfuerfos digitos à reliquo corpore auul= fit. Ob quod facinus, \& ipfe eiectus è côfortio illo, er ne quifquã unquam poftea hưưs familia in hoc fodalitium recipiatur, grauiter \& maturé fancitum. Hac cacuminis aurulfo, notabilem deformitaz rem pulcherrimo muneri attulit. Totũ cornu ab ea parte qua fronti animalis adhæret, ufog ad fum. mann aciem folidum eft;nullis pundtis, rimis, aut fciffuris hians. Paulò ampliore craflitie quàm late: ris ferè noftri. Sapius enim manu dextra complexus cornu, propé totum comprehendi $i_{\text {. A radice }}$ ufque ad cacumen, paruis lineolis, ut folent S. Blafị candelæ incuruari, elegantiffime faftigiatur dia fcriminaturćs. Pondus cornu, fur praquàm quis credere aufit, infolitum + ut fape multos mirari uide. rimà tantillo animali tantưm onus, tamọ́ longam molem geftari poffe. Nullum ego prorfus odorem animaduerti, Color fimilis inueterato ebori, medius inter aibum $\&$ croceum. Verum nufquam me lius hunc deprehendes, quàm ex fegmentis qux in myropolị̂s uaneunt. Illis enim noftri cornu co. Ior fimilis eft. A quo uero huic templo donatum fit, incompertum mihi, Hucur quidam amicus meus uir fide dignus, afferuit mibife Luterix apud Cancellarium D. à Prato uidiffe monocerotis cornu partem cubitalem, fpiris contortam, craffitudine baculi (mediocris, cuius dia. meter circiter fefquidigitum extendatur)luteo colore intus forisós, fubftantia folida: cuius fragmen ta in uino ebullierint, quamuis ufta non effent, odore nullo. 


\section{IIo4 Paralipomena.}

DE M $\vee$ E agreftimaiore. Titlmuf.

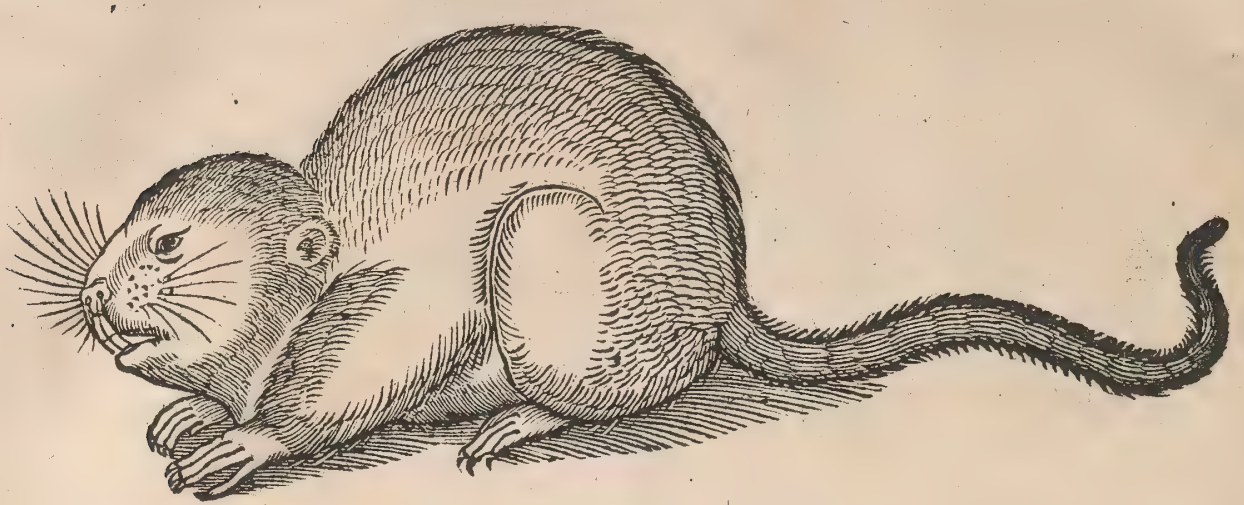

A I I y $\$$ minor hoc eft agreftis mus fubrubeuss, quem in agris frumentarins ali. quando abundare, terra fcilicet putredine in mures conuer $f_{j}$ exiftimo : non illum cuius hic effigiem damus. 


\section{ALIAE ADDITIONES ET}

CASTIGATIONES, PLERAEQVE OMNES CIRCA PHI.

lologiam tantũ, cuitus fines tam latẻ patent, ut nunquam non aliquid adrici poffit.

fed hxe omnia praterire poreft, cui Philologia cordi non eft, cum ad ipfam ani. malium hiftoriam $\&$ naturam neceflitas eorum nulla fit. Prior numerus

paginam, pofterior uerfum indicat. Annotauimus autem

fapius nó quid depratratum, aut omiffum fit, fed

fimpliciter quomodo legendum.

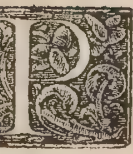

A GIN A 2. uerfu 8. diftinguat, (quo. niam aures $\&$ ceruicem breuiores ha bet alce quàm iumentum, ) iumento fi milem.

3. 17, bouinam) bubulam.

3. 37 . bufonem) glirem.

9.33. detractam cutem, Plin, \& Marcellus.

12. 53. Afinaftra Macrobio inter ficorum ge= 13. 29. dicatur.

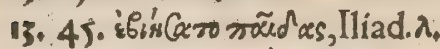

(nera.

13. 17. mulum ferè femper.

18. 58, uentre, Varro.

18. 61. Varro.)abundat hactrox.

19.20. pofthumos $\left(\mu \varepsilon z x^{\prime} x\right.$ erpa $)$ uocant.

19. 50. Septuaginta, Iofephus, \& Hieronym.

20. 12. fatis amplum, altum, latum.

23. 41. catos marinos, id eft cercopithecos,

23. 51 . 19'ל 'ax, gamaleon, uocetur. ( fed chas malcon quadrupes eft ouipara, non auis ut fom niant ludæi. hunc Plinius etiam aére uictitare putauit, Quidam deniģ, \& 8 .

26. 20. aut bos in genere) abüdant hac uerba. 26. 21. Anglice oxe.

27. 48. cornua (id eft ipfas ungulas, fed Pli. nius homonymia fortè deceptus non ita accepifa fe uidetur. uide infra in $\mathrm{H} . \mathrm{b}$.)

18. 20. Aelianus $\&$ Oppianus.

28. 22. Aelianus $\&$ Oppianus.

28. 30 . Ärmenís dưo cornua.

28. 31. A elianus:item Oppianus, qui cum uni: co cornu Aonios defcripfifítet, fubdit de Arme. nïs, gemina eis effe cornua. Circa Bocotix ura bem Poemandriam, $Q c$.

28.37.in Scythicis.) Cyprios boues ftercore humanouefci ut medeantur torminibus, apud Pliniñ legimus: Vide inter prouerbia ex boue.

In Boeotia etiam Ariftophanis interpres vorroo ó: gous boues effe fcribit.

29. 5. tricornes, Solinus,

29. 28. folus (atqui Ariftoteles etiam meminit de partibus anim, 2,16.) opinor, 82 .

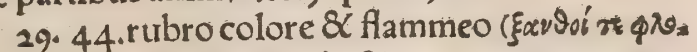
zegoi $\pi$, Oppianus,)altá́s, \&c.

29. 54. A elian. \& Oppianus, qui \& Pellaos hos trocat:apud quem uide plura.

23.14, nemo tradidit. Similis error eft Plinï circa ęran etiam, id eft lolium, \& feftucam, de qui bus 18.17 , hac eius uerba funt: Triticum, ara: hordeum, feftuca quæ uocatur ægilops, circum. ligando fe 8 complexu necat.

$34 \cdot 56$. author eft. Sed uidetur ille perperam de melega, quẩ nos forgi urocamus, intellexiffe, ut etiam Hermolaus. A laffeft, $8 \mathrm{c}$.

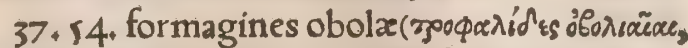
id eft, cafei obolares, uel quorũ finguli obolo ux: nirent) undeuiginti, $\& \mathrm{C}_{\text {. }}$

38. 16. Aelianus ex Horo Apolline: qui ad= dit, hanc ob caufam Aegyptios ut audicum de. fignent tauri auriculam pingere.

41. 22.tam fimplicia.

44. 12. mortifera. Theophraftus aconitũ (res cundum Diofcoridis ) frune to comparat, quod ad genicula fcilicet, propter caules geniculatos: ficut $\$<$ primũ gramini. Hieronym. Tragus, \&c.

44. 60. In aruis ( utferibit Sotion in Geopo. nicis 2.40.$)$ non prodibit.

45. 23. in radice tantum haberi, Ruellius ex Theophrafto, qui tamen non aconitum, fed fror pium hanc ftirpem uocatef autem primum acos nitũ Diofcoridis. Boures, oues, iumenta, omnȩ̃́ quadrupedem necat,eodem die, figenítalibus ra dicula uel folium imponatur, Theophraftus de aconito fimpliciter. eft autem alterum genus aco niti apud Diolcoridem, recentiores confundunt. Ego in montibus, \&c.

47.34. De oeftro quo boues, \&c.ufg, ad tra çabimus‡) hæc tanquã nõ hưius loci deleantur. 49. 43. Veget, fed fumma cutis cultello prius recidenda eft, Pelagonius)refecare, $8 \mathrm{X} c$.

49. 45. creta figulari (gypro, Pelagonius) circundari.

55. 49. eiufdem nominis, (Angli uocant fals uiam Hierofolymitanam, )folins, \& c.

56. 56. fi pulmones coltis adhaferint, (quod fuibus etiam accidere fertur, uulgò uocant ang= beff $t$; uel omentum, $8 \mathrm{c}$.

58. 20. fibi mederi ferunt, Plin. ut inter prouer bia etiam dicemus.

60. 45. cû̃opts erit illines. Aliqui lauant cos decocto fabinæ, cui alumen etiam infpergunt.

đSiquid noxij, \&c.

61. 33. manfuefcet, Rafis. A elianus taurü man

fuefcerefcribit,fí dextrum iplius genu fafcia de. Iigetur.

64. 54. Atanneis, Qux eo in loco de uitulis ca ftrandis fcribuntur, melius omnia referrêtur ad Vitulum E.

65. 17. Machid, aliàs mathid, traccinum, \&c.

67.16. percoquunt, Plin. Quinetiam ipfos bo ues $\&$ tauros caprifico alligatos mäfuefcere, tum Plinius alibi, tum alij authores fribunt.

7i.28. applicetur, \& praterea panni calidi: 


\section{Additiones \&}

Moxlac caprinum prius feruefactum in ueficã bubulam infundes, (uel fpongia excipies, $\&$ pa. ropfide lignea operies ne diftillet $¥) \&$ umbiliz $72,53$. Dorice \& poétice.

(co \&c.

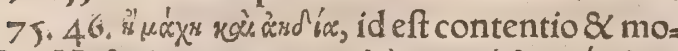

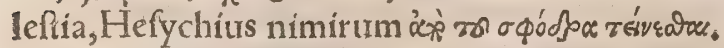

76. ab initio uerfus decimib. litera fignetur, $\&$ eadem deleatur initio uerfus decimiquinti。

$77+33$. Sichæo.

$78+13+q u x$ hic $\&$ deinceps de fimo bouris fcri, buntur, debuerãt ad c,referri, \& qua de Bceotia, ad propria à boure deriuata, qux in h,reperies, ali bi femper tamen propria in ultima parte $a_{4}$ colk locaui.

79.41.epiftolam is. Vide in Tauro etiam in $\mathrm{E}_{\text {. }}$ exHoro.

80. 2.mugientes, cum Perfeum perfequeren tur, caput Gorgonis eo in loco reuocarint: Vide Mycale \& Mycaleffus apud Etymologum.

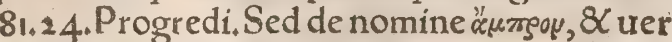

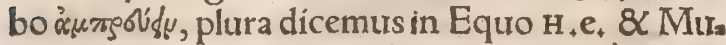

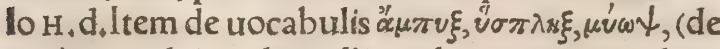
quibus eodem in loco illic in boue agitur, ) plura fimiliter in Equo $\mathrm{H}, \mathrm{e}$.

82,21 .Gergittius per $t$, duplex

82,27 . Boocóos uel Boowinos.

83.62, continere fribit: Vide infra in Bonafo. 84,12. cenfione) cafione.

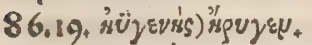

86.45 . (ö is $\mu^{\prime} \varepsilon \lambda \alpha s$, id eft aries niger.)

90. 58. fummoto lictorum) Vetus lectio \& Gy raldus addunt, ftrepitu. fieri poteft ut Plinitus aut ante eum alius éGraco tranftulerit, \& pro f'sur, id eft populi, legerit $\delta$ sum, id eft licforum.

97.62.Melãpodion+ Plura uide in Capra $\mathrm{H}, \mathrm{h}$.

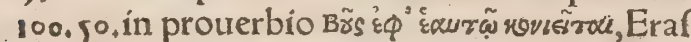

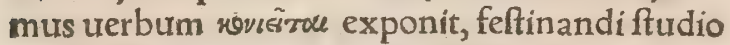
ciere puluere $\tilde{e}_{+}$ego ex Plinio \& Plutarcho potius reddiderim, puluere $\&$ arena fe confpergere, ut athletx ante luctam folent. \& fic forte alius, quã qui ab Erafmo affertur, prouerbĭ fenfus fuerit.

T104. 53, Aethiopici tauri Paufania, rhinoce= rotes funt.

105.24 . caudam (ré̀) accipitur autem hoc loco progenitali)ceruinam $\& \mathrm{c}$.

106.13, dextrorfum. His fimilia, uel eadem po= tius, de equis etiam fribunt authores, quantum attinet inquam ad curandum ut mas uel foemina procreetur, uel uter fexus conceptus fit difcerna. tur, ut in Equo referemus cap. 3 .

109.9. fed tremulos, fed rectélegi poteft tormix nofos, nam \& uaccarum \& uitulor ũ medulla dy= rentericos fanat, $R$ afis ad neruorum contractio= nes ea utitur, $\& \mathbf{c}$.

$114 \cdot 36$. uulgo filk, de qua dicã etiã in Oue E. 116.5 . Preira (inquit) Hippocrates uocat $\frac{1}{7} \pi \mathrm{e}$ veop.

121,52, conftabat ex uerre, (quẽ Graci capron uocant, ariete $\&$ tauro.

121. 60, Gyraldus: Plura uide in Ariete.

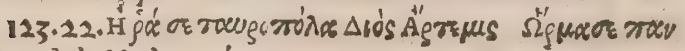

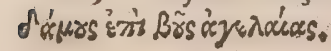

131. 27. Marcellus. Idem locus apud Plinium fic legitur, Maculas in facie, cefypum cum melle Corfico, quod afperrimum habetur, extenuat;ite fcobem cutis in facie cum rofaceo impofitũ uel. lere, Quidam \& butyr um addunt. Si uerò uitiligì nes fint (hîc uituli fimum Marcellus habet) fel ca ninum prius acu compunctas.

131.33. (uitulinum forte, quod \&c.

131.35. legitur. fed malim de caprino accipere, quod Plinius alibi etiã cum aceto ulcera ferpen. tia curare fcribit, ut in capra dicam: prodeffe $8 i c$.

140, 29. Kutz cohit aut potius buz cohifice. nim etiam Deuter. 14. Perfica translatio habet, pro difchon Hebraica uoce, quam pygargum in. terpretantur.)

140.47. A fricanum.

140. 49. Ariftophanes grammaticus (inquit

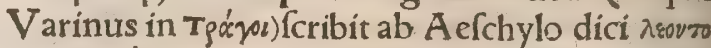

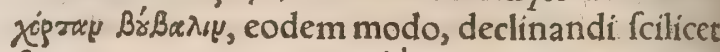
$\&$ accentus ratione, quo o $\alpha_{\alpha}^{\prime} \mu x \lambda \ell$ dicimus, nam $a=$ lioqui cómunior uox eft $B r \beta a \lambda i$ is, oxytona, in $a c=$

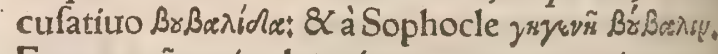

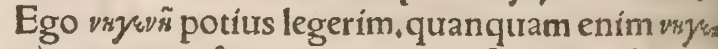
vis uocem nufquam reperiam in Lexicis, dici ta= men poffe exiftimo (ut poétæ multa huiuf́modi uocabula pręfertim compofita $\&$ epitheta fingũt)

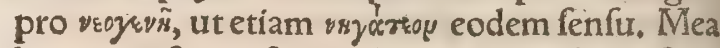
hac coniectura eft, qui aliter cur zryevris, id eft ter rigena dicatur bubalis, nô urideo:niff forte quod ex terra $\&$ herbis alatur, quod nimis latè patet. In

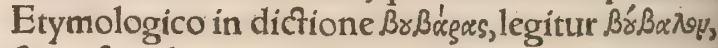
\&c.ufकs ad, тxis minkyais. Hæc fic emendata com= modius referentur ad philologiam de bubalo dor cadum, id eft caprearum generis,

145.24.capreís)rupicaprís.

147.21. Cum ifta foriberem, nondum inuenes ram quantam menfuram Ariftoteles per $x \lambda$ irsy intelligeret: $\&$ dum inquirerem apud authores, quacunq $\$$ obiter de clines, tricliní, \& fimilium vocũ ufu \& fignificatione $\&$ difcumbendi more ueterum fe offerebant, annotabam. Poftea uero deprehendi in Mechanicis Ariftotelis problema te 25 . clines, id eft lectil longitudinem effe pedum fex, \& pauló plus: latitudinem uero pedum trítĩ.

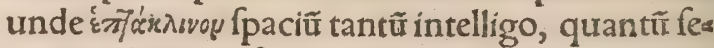
ptem lectis inter fe contiguis occupatur.quomo. do uerò inter fe coniungen di fint lecti, non facile dixerim. nam fi omnes uno ordine ponas, maior quã deceat lógitudo, latítudo anguitior erit. $\mathrm{Hoc}$ faltem conftat, quoniam leçus, ut dixi, pedes fex longus, tres latus eft, unius lecti fuperficiem totã octodecim pedes cörinere. qui lepties repetiti pe des conftituữtcentü uiginti fex, ex quibus quot longitudini, guor irem latitudini tribuas, côñicien dum eft ex proportione longitudinis ad latitudi= nem corij de boue uulgari.

I52, 27. cum hre nomina potius ad tarandum pertineant, de quo paulo poft agemus.) hac urera ba obelifco induci debent.

161. 18, à quiburdam.

161.33, interprete Pogio.fed Grecum exemplar infpiciendum eft, Quod ad caudam, \&c. 
161.37.Camelopardalis.

$166.48 . \&$ Plinio:Vide etiam in Equo D.

166. 17. equorum uelocitati. quamuis Pollux

(cribit Bactrins camelos effe equis uelociores) fed fua cuics $8 \mathrm{C}$.

167. 3. Calius. Strabo libro 15, de elephantis,

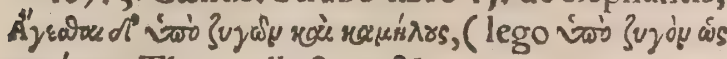
ren'mirs.) Thus collectum $8 \mathrm{c}$.

168. 24, fơtarum ambulantium, aliâs Arabi= carum quod magis placet)prodeft 8 c.

170.10 .8 pileum latum contra imbrẽ. IIcon. Romę in domo loãn is Zampolini iuxta plateam ludxorum eft imago cameli, hanc habens infcri, ptionem, Salius Auguftus Folix Leonides $*$ ut le= gimus in antiquis infriptionibus à Petro Apia= no \& Bart. Amantio collectis, ubietiam imago expreffa eft.

174.38. A riftoteles de partib, anim.4.12, unde Plinius etiam tranftulit 11.43 , fed locus. Plinğ cor= ruptus eft, ut docebo in Lupo $B$. Rapacibus un. ci \&c.

$8 \mathrm{mel}$.

180, 7. falem amarum, (forte ammoniacum,

180. 56.aêre, \&c, Vide etiam in Mulo H,c.

185. 37. Qui paruam $\&$ planam babent fron. tem, \&c.

185. 51. diuerfa ratione. Catera ad phyfiogno= moniam à cane fumpta, uide infra in $\mathrm{H}$.d. đGlaut cam $8<$.

185. 53. Aelianus, ex quo Calius defcripfit 13. 12. A tqui Plinius non à cane, fed $\mathrm{ab}$ anfere $\mathrm{amo}=$ tam frribit Glaucen Ptolemęo regi cithara canen tem:quam eodem têpore, inquit, \& aries amafte proditur:Item ab anfere amatum Argis puerum Olenum, facile quidem kuvo's pro yivos foriptum eft, uel contra.uide in Ariete d.

186.8. Plutarchus in lib, V trà animalítum \&́c. fcribit.

186.16. excitandi)furgendi

189.38. Aefculap. Fel herinacei pfilothrum eft, utiç mix to cerebro uefpertilionis \& lacfe capri no, (lege canino,) Plin. De lacte can. \&c.

190.22. linguam in boue occupat.

192.33. Adianton, Author obfcurus: $\mathrm{fed} \mathrm{Ag}=$

grégator ex A uicenna citat, etiâ ad rabidicanis morfum imponi.

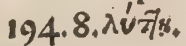

198. 58. mox inter medicamenta intra corpus fumenda:licet hoc etiam foris alligetur, tefte Pli= nio.

100. 61. Trito allio defricto rabiof $x$ canis uel lupi morfus in boue curatur, Columella.

201. 19. Auicenna : fed bibendam potius intel ligere uidetur, licet non exprimatur.

201. 9. fecundum Galenum apưd Serapio= nem ( meminit Galenus de fimpl, 9. 2.) illita ex acri aceto ( $\&$ pota ex uino diluto) fuperpofitis aliquibus folins : quorum pracipua funt fcordin folia, poft centaurí minoris, \& $\mathrm{Cc}_{4}$

202, 36. licio) forté lineo brachiali, ut proxí= mè ante argenteo brachiali dixit.nifi legas, ac uel liciof.i. filo, ueftis ita infectx) brachiali inferto,
102. 5o.Poft tituium ftatim quí incipit, Antín doti, \&c, hic uerfus fubijciatur: Potiones omnes quas contra uiperarum morfus feripfi, Damocra tes apud Galenum lib.2.de antid.

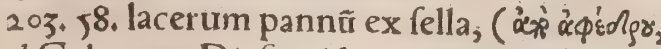
apud Galenum. Diofcorides in capite de lepore,

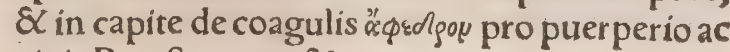
cipit.Poteft autem, \&c.

206. 31. Alyffon folio (flore potius, nã Aêtius «vtos rogфugízov Alyffo tribuit, ut paulò fupra di= xi) (uppurpureo, \&c.

208. 26. Plinius) hac uox abundat.

209. 25. in hift.plant.9.9. Atqui non poffunt flocci illi in oculos inuolare, cum in uafculo fuo femper inclufi maneant, etiam arido, fi tamen in. grederêtur oculos, ( quod uafculo per hominem aper to fieri poffet à uento)omnino læderent. Ve rü nec iple Theophraftus fímpliciter hoc appro= bat:fed ab herbarïs dici aut fieri foribit quadam huiufmodi, partim forfitã recté, partim quo rem fuam oftentent ac pradicent.

210.35 . mihi uidetur. Eadem ferè Plinius de cacto, \& caulem pternicē uocari ait, fed pro afca. leron habet afcalia.

$210: 42,8 \mathrm{~V}$ arinus, hoc nimirũ fuerit genus illud lilí montanum apud nos, quod recentiores nonnulli nô recté afphodeli genus faciunt, flore rofeo, cuius folia reflexa maculis afperguntur, quales \& hyacintho tribuũtur.noftri à radicis co lore radicem auream uocãt. Itali martagon, fortè corrupta à uulgo uoce pro cynorhodon.

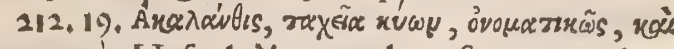

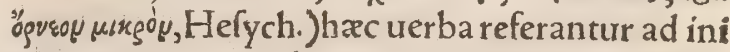
tium paginæ 218. ubi propria canum nomina re= cêfentur. Òouxzzrâs inter pretor, nomine proprio.

212, 46. Odorifequus, in hymno Liun $\mathrm{An}_{\mathrm{n}}$

113. 10. Kuvíntss, (dronici.

217. 11, ni fallor ( $\&$ eadem forfitan Diofcori= dis delphinium fuerit, uide in $\mathrm{Lupo} H_{+} \mathrm{a}_{\text {. }}$ ) Aut hac, \&C.

217. 19. Idem. Aconitum etiam fecundũ, ali. qui cynoctonon cognominant, uide in Lupo $\mathrm{H}$. a.Cynogloffus, \&c.

2:8. Aglaodos. Hylax in limine latrat, Ver gilius, Hyleus, $8 \mathrm{C}_{4}$

218. 31. Arcas, O. Orthus Geryonis, Pame phagurs, \&c.

219. 41. promifcutus fit, Grammaticus quidã, fed inepte, nam Plinitus 5. 1, ita fcribit:Qui proxi. mos (Nigro A fricx fluuio ultra A tlantem mon: tem) inhabitent faltus refertos elephantorum fe= rarumq̧́ \& ferpentum omni genere; Canarios appellari,Suetonius Paulinus prodidit. Quippe uictum (id eft cibũ) eius animalis pmifcutum his effe, 8 diuidura ferarũ uifcera. Hemicynes, $\mathcal{Q}_{\mathrm{c}}$.

219. 56. Gelliũ. Solinus cynocephalos in $A e_{\text {a }}$ thiopia effe fcribit, uiolentos ad faltum, inorfu fe ros:fed feras ita dictas fimtarum generis, non ho mines intelligens. Vide in Cynocephalo $\mathrm{H}$, in ter fimias. Meminit etiam; \&c.

221. 39. Catulire) $\mathrm{Ab}$ hoc uerbo initiñ eft ter. tix partis Philologix, nempe c quod apponi de* 


\section{Additiones \&}

buerat, $\&$ initium fierià nouo urerfur.

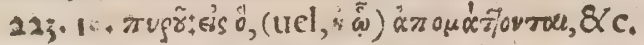

13 . 35. dicam in Canibus diuer lis cap primo.

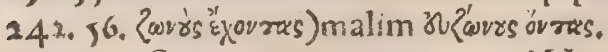

$247.4 \%$. Syagrus uiri nomen apud Herodo= tum lib.7. legitur.

249,14 . \& fera quadam fimili ( $\varepsilon$ oreiov movós xurós'rs)non exp. \&c.

149,49 , maluiffet:Indus uidens, \& $8 c_{\text {, }}$

$250,54 . \Xi 6 \phi \omega$.

25!. 10. idem hos canes plaudos appellat, ex

Fefto frilicet qui plaudos canes flaccidis $\&$ latis auribus interpretatur. Noftrates, $8 \mathrm{c}$.

251, $25 . \mu \varepsilon \tau \pi \theta$ (ivoc) fic habent codices Pollucis wulgati,lege $\mu \varepsilon z$ zatsiu.

254.8.retuli \& dicam etiam inferius in Cane ueloce. TBritannici, \&c.

259. 15. Blondus, Paufanix de his uerba refe= ram in Vulpeh. canes.

259. 45. bigeneri (bigeneres, bigenx, infititï)

268. 24. cuftodibus: ( quanquam de cuftode prinatarum ædium inferius etiam fimul cum In= utili cane quxdam afferemus, )E( primum, \&'c.

272.12.1 dem. Capræefanguinem non coa= gulari, in Plínio alicubi malè legitur pro caprex. 272. Verfus 35. totus abundat.

278. 4. Caprino fanguine macula contacta abluuntur, Marcell, hac uerba hoc loco abun= dant, obelifco ndurenda.

279. 49. petiuit, Plura de melota, uide in

Oueн.е.

280. 12. fuerit. (Vide $\pi\{\dot{\alpha} \alpha$ in Suida. ) Sicyo. nị s, \&c.

168. 9. capra (apri potius, uide in Apro G.) ueficam $8 \mathrm{c}$.

286. 26. caprino, (legendum, canino:) irem 293.34 . qua) abundat.

(per fe, \&c.

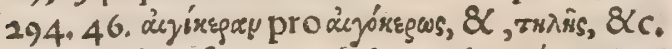
294. 13. depafci aiunt. fed ut uideo xúrapa legi debet apudHefychium.cynarã enim Athenaus cy nosbatum effe conijcit, ut in Cane dixi. Phil= l) ream, \&c.

196. 33.0 óculvos. Vide in Equo н.c. Mrxn, \&c. 300.25 . nam ad id accommodat Erafmus)hęc uerba parenthefi inclufa, abundant.

ब3ㅇ. 47. teiafhia, \& fimiliter uerfu s5.

301. 49. iffim. Perfx pro fheir ponunt kabale (aliâs kalahei)proiffím uerò bufan.

301.5), interpretantur, (quod non placet.)

301. 58. adbehan) lege pharbehan, ut in $A_{\text {. }}$ riete fcripfi.

3०4. 3. pellibus hircinis, (Strabo idem fieri fcri bitcum tragopogone, de qua agemus infra in 2. inter plantás,)fuffiuntós \&c.

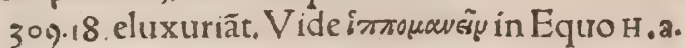
311. \{2.qux quidem mihi hactenus ignota eft.) hæc uerba inducantur. nam effigiem fimul $\& \mathrm{hi}$. ftoriam tragelaphi in Paralipomenis damus.

312. 53. de equo. Vide in Equo H.c. Évó, \& cr.

314. Y5. kahale(aliâs calahei)bulan, ponunt au tem Perfakahale profheir Hebraico, \& bufan pro ifim, bus quidem capram eis fignificat. $S e$ pruaginta \&c.

3:6. G. impofita.Idem ferè Aêtrius uide in $A_{0}$ gno G. I Alioquí \&́c.

318. 37. ad unum extuatx (lego, ad imum exte. nuara, ut in luparia reftra corulea. uide in Lu po a.ubi de aconito:)habetó̧ \& $c$.

320, 23. Varirus. Euftarlisus in quartum li a

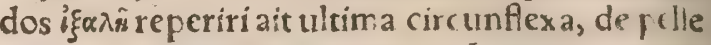
caprina, $\leftarrow$ t $\lambda \varepsilon 0 y \tau \tilde{x}$ delconina, in Lexico qुuodam thetorico.

322. 61. Caterum als hac faculiate diciamno

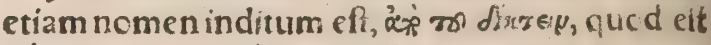

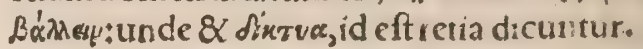

324. 15. Capræin plurimas fimilitudines trans figurantur:funt caprex, funt rupica pr $x_{\text {, }} \&$ c.Pli $_{\text {. }}$ nius, fcribens manfueta omnia etiam tera repe. riri, quafi in illa transfigurentur.

327.11. Strabo. đ Caprz fanguinem non coas gulari apud Plinium non recté legi pro caprex, uel inde conftat, quod medici hoedino fanguini bibendo, antequam coaguletur, acetum milceri iubent ne coagulari polfit. Poft hac lequitur $c_{\text {. }}$ id eft caput tertium.

334.14.ibici feræ accommodari poffunt:quan quam ueteres omnes, quod fciam, de fydere tan. tum protulerint.

335. 26. Noftra uerò dama etíam in Europa ca pirur, cum alibi, tum circa Oreánum Gern:anis cum, ut audio. Germani uulgò uocant sam, \& c,

336. Ic. ut apud Syluancum legimus.fed decea pit illum nominis ticiniras. nam ranis pontuc us, caftor eft:canis potamios ueró lutra, urin Lutra hiftoria demonftrabo. Italis, \&'c.

336. 43. interpretatur: ( $Q$ in lit ro 21.eadem, ut apparet, uoce deceptus, la mix quadam antrs buit, quęomnino caftoris funt:) fed lamyak:z pro latace habet A uicennz translatic, pro caftore au tem faftoz, Caftoreum tefticulus eft $\& \mathbf{c}$,

338. 49. ab infectantibus.

34!. 38. filphium.

342. 16, eliminat.

342. 33. mourent caftorum teftes.

346. 59. furiomorum, (aliâs fur onum uide in Furone, )inquit, $8 \mathrm{c}$.

347.34. Hanc autem urolupt.

350,44 . Felis aurea, Plin.6 29.

3 50. 62. apud Suidam ; addit autem Suidas,

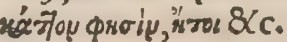

351. 1. domefticam intelligit: non quidem fpa talen dicens effe felem, ut aliquis putaret, cum тоoфisu, id eft cibum pau'ò antéinterpretatus fir: fed infinuans, ut uidetur, hac uerba pertinere ad apologum quendam de muribus $\&$ fele confi: ctum. Catum marem \&c.

351.28 . Porrò catí non unguib.

352. 5. exponitur: Idem rurfus Heluros ferie bitcum a!pir.

313.32. faltant cibo tuo arrepto, Author inno minarus apud Suidam in Spatale: tanquam in $a^{\circ}$ pologo aliquis ita adfelem de muribus dixerit, Videtur fané \&c. 
554. 18. fugere legitur apud Auricennam.

355. 20.iam apparent: \& fubulones non ante biennij atatem dicuntur, cum tubera ifta annicu lis fe promant.

355. Poft uerfum 35. (patiñ uacare debet, cui B. litera fecundi capitis nota infcribatur.

356. 21. palmata toga grammaticis.

357. 52, ramorum numero. Ceruum binun no Itri uocant $\{$ pifirbirt, trimum gabler, quadrimú fimpliciter ceruum, birts. Proætate, \&c.

358. 10. habeant + fed quarendum an ea ran= giferi fint, non cerul.

359.3. tradidit. proindelegendûfufpicor ele. phantos, quos id facere conftat, non elaphos, id eft ceruos.

363. 50, meretur, nam $\&$ qui ceruorum uiua= ria apud nos curant, omnino mates hinnulis nihil nocere aiưt, nec occuli à ma trib. Cerux, $\&$ c.

372.21 , coniecerit. Arfenicurm quidẽ Hebrats cæoriginis uox uidetur. fimiles enim ucces pro ueneno fimpliciter in Lexico Munfteri trilingui inuenio. Mify xenicón apud Aeginetam \& Ga $a=$ lenum de comp. $\{e c$, locos, inter pretes aliquando relinquunt, aliquando peregrinum uertunt.

372. 40. putrefaciédi uel exedẽdi, omnib. $8 c_{*}$ $381+49$, ex cleo,

381.48. liburerit, non cum illx mollirileniriç opus habebunt ut in dentitione, Aétius, $8 c_{\text {. }}$.

383. 31. nota fextarí fic erat pingenda, 8 .id eft S.litera maiuf́cula, principio eitus $\&$ fine obli. qua linea coniunctis.

$386+52$, cicuta (aconiti potius, ex Diofcor,) 8 fungorum.

$39^{\circ} .12$, exiftimatur, (ut recentiores quidam grammatici in Dictionarís annotant; $f e d$ à nullo idoneo authore id proditum memini. ego à colo= re potius autmaculís diçum putârím ceruariur, aut quòd ceruos infeltet, $)$ de quo, \& $\mathrm{c}$.

391. 12. Ob(eruaui etiam, \& $2 c_{1}$ ) hac cornua non uulgaris funt cerui, fed illius quem Germas ni uocitant branobirts. quem Ge. Agricola tra= gelaphum facit, de quo in Paralipomenis.

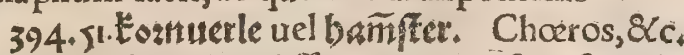

395.33. deprehendiffe, quod \& ipfe poltea ob.

rertaui, fltieronymus, $\& c_{6}$

395. 42. reddit Nive, thap pa. Pfalmo quogs 104.pro fephanim, \&c.

396. J. hoc eft ad.

396. 46. $\&$ aui (propter pedes totos plumis indutos)de qura, \&C.

397.34. pariunt non cxcos, (hoc falfum effe pauló poft declarabo. quare legerím, pariunt aus= tem (xcos,) Plinius, \&c.

399.7. fidentes, (findētes potius $)_{3}$ Feftus, $8 C_{\text {. }}$

ब1 401, 16. uiuerra, (quod non placet. in nulla enim lingua hodie uulgare id nomẽ eft.) Septua. ginta, $8 \mathrm{Cc}$.

401, 27. à Gracis hyftricem uocarifcribit, ex Suida. Áróvotroy, $8 \times C$.

402. 54 , uerifimile fit: de uulpe uero, quám echini hoftem effe conftat, hoc dici non foretab= rurdum. Vulpes quibus dolis conglobatum echinum tractet, ut explicâtem fe deuoret, Lege in uulpe $D .82$ mox in puerbio, Multa nouit riul pes, fed echinus unum magnum.

406. obfidet: Cuius uitij Columella in ouium morbis meminit, fubluuiem uel intertriginẽ uel tuberculum in ipfo difcrimine ungula nafci fcri bens.

407.53 . annis fingulos fingulis ædiderat,

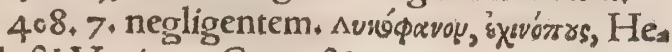
fych. \& V Varin. Ceras, 8 c.

4.08. 9. factum nomen. Quanquam herbam quandã fuibus uenenofam Germani uulgo che=

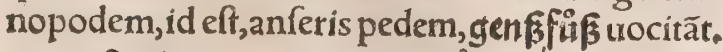

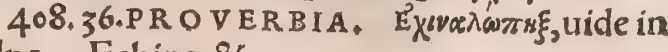
uulpe. Echino, $8 \mathrm{Cc}$.

409. 10. Fcribit, (uide in Vulpe D, ) urulpẽ, $8 \mathrm{C}_{*}$

411. 43 , in ea infula) abundant hae uerba.

417.62, dicuntur, \& Plinius foctus corû ui. tulos uocat)meti, $8 \mathrm{c}$.

423. 52. quàm mas fit: Et, \&c. Numerus paginæ 424 - malè notatur 428 .

428. 1. def(ribens) abundat,

431.2 . fed eorum quí,

433. 37. Palibotra.

435. 23. pallefcant. Ebur etiam uerum, cum in terram cadit, facilius frangitur, catera offa te. naciora funt, Ex arbore, $8 \mathrm{c}$.

438. 44. De eburneo Pelopis humero, uide Leonicenum in Varäs, \& c $_{\text {, }}$ ) hxc abundant hoc loco.

446. 35. moliuntur. Vide infra capite tertio in Cofmeticis.

$447.17 .8 \%, 8$.ni fallor)abundat.

447.36. fubterfpatulas (forté fubterfpondy. los, ut \& paulò ante fpatulępro fpondylis legun tur) trigintaduas,

447.59. Vegetius 4.7. Sanguinem mitte de uena organica equi qux eft in collo, Rufius. Recentiores, $8 \mathrm{c}$.

448. 8. fy felader, (uel potius felfelaser, loco fic dicto, ut conijcio, quod iumentis illic numetla inijciantur, id quod nos feflen dicimus,

448. 22. Grãmatici noftri (ut Seruius) glau. $\cos , 8 \mathrm{c}$.

449.5. Hierocles. Vide in H. a. ubi de ima. ginibus equortum.

449. 49. Ruellius pro coccyge catagrapho, trertit prominentiam litura difinctam, \& $\mathrm{c}, \mathrm{Ab}=$ fyrrus quidem expreffé dicit coccygê effe, \&c.

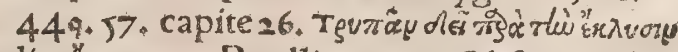

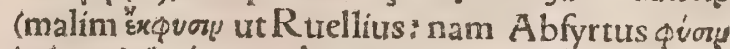

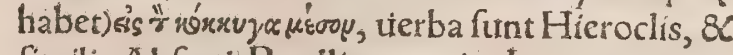
fimilia Abfyrti. Ruellius uertit, luxta exortum armi in mediam prominentiam perforare tergus oportet,

449. 6e. xevesra. Eadem ex Xenophonte mu= tuatus eft Pollux.

$450.2 .70 \tilde{\text { in }}$.

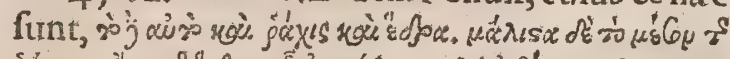

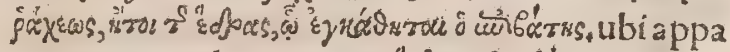
ret eum eandem partem sodou $\&$ jáxy uocare* pracipue ueró sdopofy dici mediam f́pina partersys 


\section{Additiones \&}

curi infidet eques : ut forte legendum fit, Mćsisa $j$

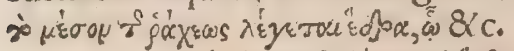

454.6 , ro jow rim, \& fimiliter reliqua fpina, \& $q$ quæ inter clus neseft; ) maximé uerò illa (pinæ pars cui infide= tur, bac omnia obelifco notentur.

454. 11. mufculofo. fed Abfyrtus quoç pro.

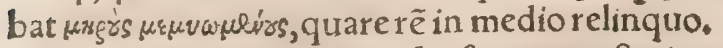
454. 15. Omnia, Crura feu femora pofteriora

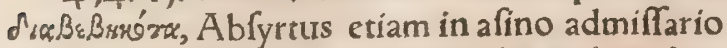

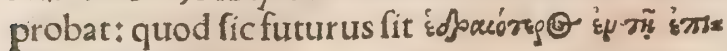
Báxoses. Femur \&c.

454. 57. $\mu v^{\prime}$ d $^{2} \varepsilon s$, , (Pollux ivód'ses, \&ce, ut pau. lò fuperius monui:) áurix \& $\&$.

455. 1. dicetur, Quò acrior equưs eft, eò am plius in bibêdo nares mergit, Plin. đEmptio \& $\mathrm{C}$.

455. 6. Varro. Quales fint eligenda equa ex quibus muli procreêtur, in A fino fcripfimus. Forma \&c.

457.25. iquos, rézrquos, $\lambda$ errókgress.

457.17. Xenophontem. Cenfores P.Scipio

Nafica, \& M. Pompilius cum equitum cenfum agerẽt equum nimis ftrigofum $\&$ male habitum, fed equitem eius uberrimum $\&$ habitiffimum ui derunt : Verbafunt Mafurï citance Nonio, \& Gellio 4.20.

457.90. uitri caufa. Vide infra in C, de morbis toti corpori communibus, initio ftatim.

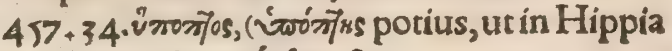
tricis legitur, )dvowrź́rulvos, $8<c$.

461. 39. depender,Strabo.Oppiani \&c. 463. 48, nato equo. Admeti equa praftan. tiffim apud Homerum lliad, $B$. Theffalic $x$ fue= runt, Acarnanum \&c.

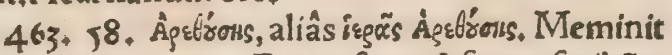
rurfus Euftathius in Dionyfium Afrum fcribẽs, \& Arethufam, cuius hicmentio, Eubox fontem facir.

466.19. \& Varinus. Calpe in Olympịs cur

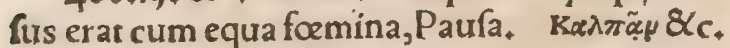
466. 39. anhelę(anheli potius) Prouduât, \& $\mathrm{c}$. 467. 40. Ego celetem equum non iuncium,

\& curfui idoneum dixerim, fiue fratus is, fiue in ftratus fit.) abundant.

$467 \cdot 47 \cdot$ unicum femper \& fingularem figni ficet $8 \mathrm{c}$.

468. 8. equitibus, De celeribus equis dice mus etiam in b. \& $\mathrm{H}$.e. inter certamina. 468. 31. cap.14. fed áuo dicuntur, uerû qui poff: dẽt equos: Vide in $\mathrm{H} . \mathrm{b}$.

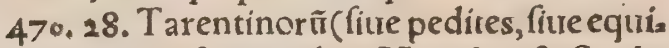
tes potius, ut ex fequentibus Herodoti $\&$ Suidx verbis inter fe collatis colligitur) ob ex dlbad. 473.15.uetera(ueterina)animalia 473. 43. templa. Vineæ qux pedaminibus. 474. 33 . Idem in Mirabilibus, \& qua fequun

tur ufģ ad, Alpes.) abundant. 477.33 .8 nos forte referemus in $\dot{\gamma}_{\text {y }}$ (สvoîs.) abundant. H.C.

481. 52. [pringbengff, Vide etiam in $\mathrm{H}, \mathrm{a}, 8 \mathrm{C}$ 483. 48, uel mafculus.
485. 54. qua impulfi minores natu, qui fam nas falierint, per fequuti caftrant.

487.20 , totidem pariunt quot.

488. 44. manucalci, (corrupta puto uoce, pro uulgari illa, marefcalci, )mulomedici $\& c$.

489,36 . forte)abundat.

498. 21. inflantis, cum aliqua $8 \mathrm{C}$.

499.10. locis deprehendi. Opus eft $8<$.

IT 5o 4. 6. Ėrópulvos: $\&$ morbus ab Alberto fre nes dictus, de quo leges infra in morbis renum $\&$ lumborum.

508. 3. De ueratro \& $x$ golethro in cibo.

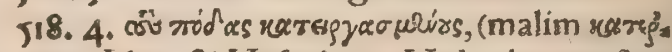
joyplirs.) Idem \& Hefychius. Vide plura in Sue a.inter deriuata.

519. 36 .dulcedines uocãt. glycea ulcera etiam apud Galenum kgimus)habentó̧ $\& c$.

\$20.1. difcedit à feipfo, ita ut fpacium in medio cauum $\&$ inane relinquatur, (prafertim $\& c$.

521. 24. equarum. $\&$ in Mulo $c$. ubi de afino admiffario, Equi $\alpha c$.

132. 4. felfio (uel potius tãquam in fella.nam

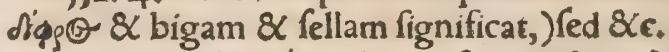

532. 41. ( a'vrrúrros, lapidoros intelligo, ) anguftos.

335. 4. Calabrum leyi, qui $8 \times c$.

540,62 . abunde; quod filicer affatim pafca tur ex prafepi; uel femper redundans aliquid ex prafepi, dumiumentũ pafcitur, delabatur.A pud Varinum $\& c_{*}$

542, 3. Omnes) Vtriqs.

542. 47. Podagrus, (Podargus, in Scholins, qux ex his duo tantum propria faciunt, $8 \times \mathrm{Xan}$ thus, \& $c_{*}$

542.14, ibidem, (Vide nonnihil etiam infra in e,polt mentionem fitmulorum.) Coppa 8(c,

54?. 33. Pauor, (fic V alerius lib.3.Argon,ina terpretatur, Martis \& $c_{*}$

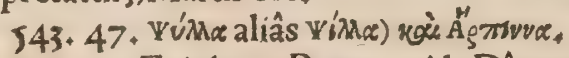

\$43. 57. Eripha. Pawor, uideDímos, Pe. dafus, $\& c_{*}$

$544 \cdot 3^{6}$. Brigliadorum (hoc eft freno aureo infignem) \& Vegiantinum,

545. II. Epift,uide etiã paulò inferius: $\& 2$ rur* fus in e,ubidecentris, TEquum \&c.

\$45. 21, fibi(fui)copiam.

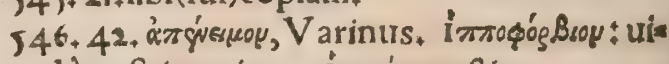
de pauló pofi:item in e, ir rójorou, \&c.

547.51. Hermol. Atqui Scholiaftx in Aues.

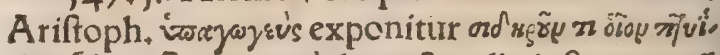

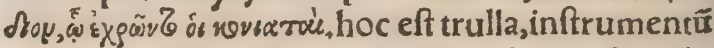
camentarï pro illinendo muris tectorio, $8 \times$ indu cendo gypfo: unde uerbũ trullifạre cin p fleffrer.

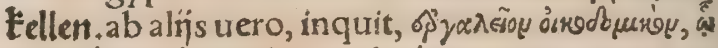

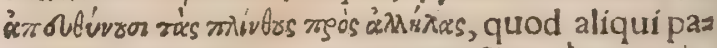

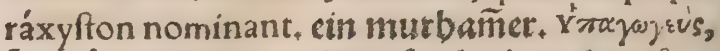

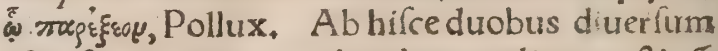
eft inftrumentum quo lapides expoliuntur \& có planantur, тúxos dictum(à quo túros alibi í $\sigma \phi u g a \dot{~}$

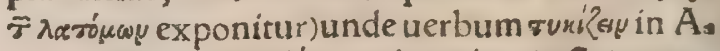

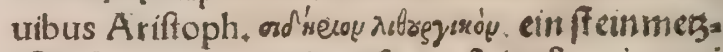
y fen. funt autem ea diuerfa, ein fpisyfen/ein 3 wei 
fpis/cinfoblagnfen/cin feinay.

550:37. Fine fquamis uel fpinis. Citat, $8 c_{4}$

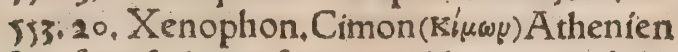

fis, \&c, fcripfit hippofcopicum librum mirabile, Suid.in K, litera, Ibidem uerfu 21, dele hacuer ba, (lego Simonis ${ }_{*}$ )

513. 56. Ab equo uidentur; ) hac uerba in. choent nouum uerfum, cum lemmate: Propria.

55. 18. "şwos. Vide infra in prouerbio, Hippo mene iniuftior.

558. 23. Trito(Tritoni)propinquior,

560. 39. de equis, Hefiodus in Afpide, im. चबise, $8 \mathrm{c}$.

562.15 . Theb, Vide plura infra in $c$, ubide uroce Equi.

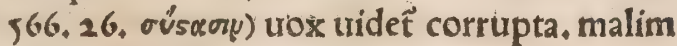

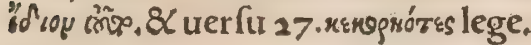

567. 11. frementes, Plura fuper hoc uerbo le. ges fuperius in b.ubi de equo animofo,

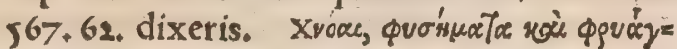

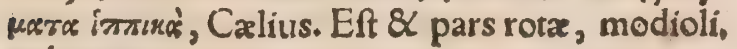
Xpór, \&cc.

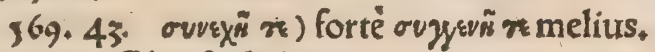

$, 69,31$. Plin. 8 Solinus.

57०. 58. conftabit. quanquam $\&$ apud Pollu

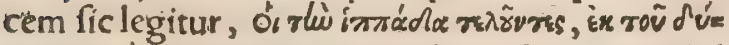

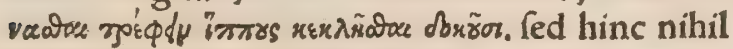
certi, unúsne plures an fingulos equos alueric.) 51.34 . interpres de fuo addic.

\$72.60. fufpicemur, fed mardives potius cor= ruptum fuerit. $\quad \boldsymbol{K}_{\alpha}^{\prime} v \delta$ ivs, \&C.

573.35: utuntur. Erant $\&$ anabatx, equis maribus ad curfum utentes in Olympins, à quí= bus prope finê curriculi defiliebãt, $\&$ apprehen= fis frenis fimul cum equís pedibus currebant, quod in calpe etiam fiebat, fed calpe equam foe: ininam habebat, $\&$ alios terminos curriculi. ब. Olympia, Sc.

$\$ 74.1$. ubi plura de curribus dicentur, $p$ his uerbis fubftitue,polt carcerũ $\&$ metæ mentionẽ.

574.2 . iungebat, (ex Commentarís in $\mathrm{Py}$ thia Pindari.)

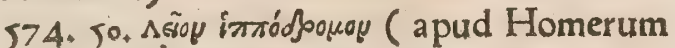

Iliad.ф.) $\lambda \dot{\varepsilon} \gamma r \sigma$.

575.47 . Ego, ut res clarior fiar, Græca app. uerba,

\76.45. uide an melius raygí $\lambda \omega \mu$.) delenda hẹc

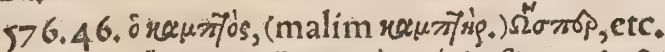

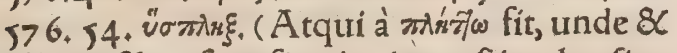

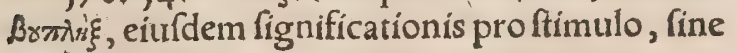
$\left.\gamma_{+}\right)$ó d̂े, $\& c_{\text {. }}$

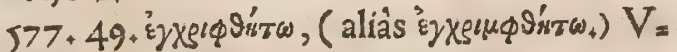
furp, $8 c$,

$5>8,2$, nefcio quàm proprié, $)$ dele hac uerba

378,32, uetus inuentum eft.

58. 55 + uel contrà, apud Varinum, ut paulo

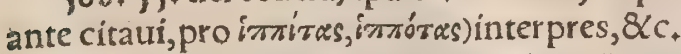

$589+11$. interpretatur, ego equitiariũ potius dixerim, quinç fyllabis, qui equitio praeft uel cu rat, ut $\&$ Calius habet.

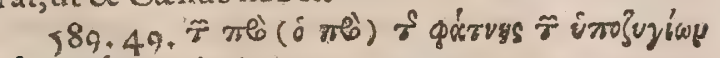

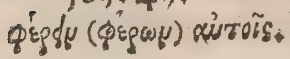

592. 9; folet, Vide in Lupo $\mathrm{H}_{*} a_{4}$ Tempo. $\mathrm{re}, \boldsymbol{Q} \mathrm{c}$.

593, 41, exponi, (Aut pro utrogg forfan re* cte accipi poteft, cum acetabuli nomen laté pa. teat, ita ut coxa etiam acetabulum, fed Latiné, Gracè cotyla, dicatur, ) Mutuatius, \& c :

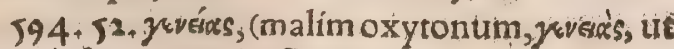

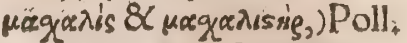

396,18, mafculinum apind treteres fuife di $\left.x i_{,}\right)<c_{*}$

$600+32$. (hanc uocem fine figma in Gracis Lexicis non reperi,)delenda hac uerba.

600,60 . Pollux. fed per excellentiam de mut

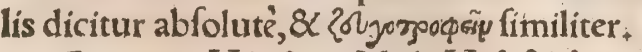

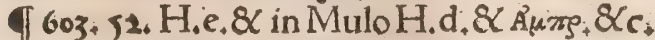

607. 61. Fribunt, (ego tamen Cimonis ma: $\lim _{3}$ ) ut dict, \&c.

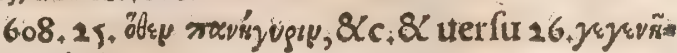
Qrese $\phi x{ }^{\prime}, V$ arinus;

$618+37+$ uaftauerunt, Varinus ex authore inis nominato: apud Diçyn quidem \& Daretem ni. hil tale inuenio

$619+6$, praftatis in pigna $\&$ alacris con. fert, $8 c_{\text {. }}$

619, 18. Albert, \& rectè) urulpecula, \&c.

$620+12$, interpretantur, quod \& ipfe probo, li cet non nulli pro glire accipiant. Hieronymus Lè uitici II. murem uertir $\ddagger$ item Elaia 66: quem nos (inquit) glirem uocamus, \&c. Et uerfu 14, pir trel phir,

621, 48, fczurek, (quidam rattum uulgò dia çum, Polonicé fcurcz interpretatur, ) qux, \&c.

623. Initium Philologia hoc fit: Gliris pro glis in nominandi cafu apud Marcellũ Empiricum: item apud Plinium fi recté legitur. $\Phi$ Epithe ta, $8<c_{+}$

626.11. Plinius; hoc Aelianus etiam de lupo fcribit, Hyænæ; \& $c_{\text {, }}$

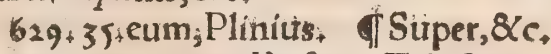

629) 48. cæteris Rafis, Tali, $8 c_{\text {c. }}$

$629+52+1 d e m$ : Super quibus uerbis fenten tiam meam explicabo in Lupo $a_{+}$in mentione aconiti.

$63^{\circ}+3+$ lupü, ( Sed chaus omnino idem eft qui lupus ceruarius, ein luchs.) $\mathrm{De}, 8 \mathrm{c}_{4}$

631. Verfus quartus hic fit $\ddagger L$ v P v S Catus; uel L V P V $S$ Indicus ; uide in fine Operis in Ca: ftigationibus fuper pagina 770 .

$638+19.820$. pro cicadarum, cicadam, cica. dx, repone locuftarum, locuftam, locufta.

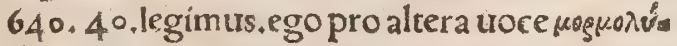
xsoy legerim) pro, $8 \mathrm{C}_{4}$

640.22. Calium 15, 8. nos etiam de colore charopo $\&$ rauo plura afferemus infra in $b$.

$65^{\circ}+12$, Gellius. (Idem feré aliqui de panthe: ra ferunt, uide in hiftoria eius cap.z.) Quod, $\mathcal{X}_{\mathbf{c}_{*}}$ 672.49. Venetus. De tigride cicure qua: ferum leonem lacerauit, Martialis in lib ${ }_{4}$ Spectad culorum epigrammate 18 . ftela.

174. 48. Vide plura inter prouerbia ex mut

274. 55 . Apoftol.plura leges in Vulpe $G_{4}$

a 24 


\section{Additiones \&}

$677+17$. ex A chille defumpferis, qui \& $c_{*}$ 678,34 , adorant)abundat.

$683+13$. Lepores albi rarò Romam perferun= tur, Hermolaus, )abundant.

$693+52$, fundum (Nam in fundo quem) in Thufe,

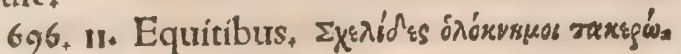
zurou, Pherecrates defue.

T705. 15. epimedio, (Theophraftus epime. tron uocat, )quod S.C.

7.9 .17$. quidam : Homerus forte.nam idem alicubi 77 बre $\lambda x$ ywò dixit.

717.36. Phocicis, \& Munfterus.

717. 38. Mirabilibus. Atqui Lycaftum Cretx urbem Stephanus dictam ait à Luporum multitu dine, quxibi effe crederetur.

717.44 , ni fallor. Nulli in Anglia hodielux pi reperiuntur, Munfterus, If Sunt $8 \mathrm{C}$.

713. 21, Movortéges. Hefychius interpretature

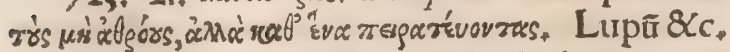

726. 62. fribunt, $8<$ aliqui hodie huius quo. que corticem luparia radici admícent in globus los, quibus deuroratis lupi moriuntur, ut dicam in aconito infra in $a_{+}$) ac inter $8 c_{\text {. }}$

$742+32$, etiam habet ¿xios. Et uerfu 54 Staphifagria fanè non.

742 . 4. placent $₹ \&$ uideo deceptum Eufta. thium quod cicutæ attribuendû erat, frigido ue. neno ut conftat, (hanc enim curm uino potam irremediabilem effe Plinitus feribit ${ }_{y}$ ) aconito ads fcripfiffe.

742. 21. Paternianum, Celfus uim exedents di corpora cicutæ tribuit, quę certé non huius fed aconiti eft, Mífcetur \&C. fed forte ruta legen. dum, ut $\&$ inter ea qux rodunt paulò ante apud eundem nó cicutæ fed rutæ femen, id ením inter anaftomotica prius numerauerat.

742,21 . dixerim. Sed fieri poteft, ut cicuta uires aconito Diofcorides adfcripferit, mífcetur enim illa collyrís, \& oculorum medicamentis ad epiphoras, \& dolores fedandos refrigerando $\&$ accerfendo fomnum, ut apud Plinium \& Diofco ridem legimus. Confundunt enim aconiti $\& \mathrm{ci}=$ cutæ uires inter $f e$, pracipué Latini aliquot $\& A$. rabes, fed \& Graciut Aétius.

743. 27. Auricenna : à qua plurimum differt Græcorum thapfia, qua tamen \& ip $\{a, \&$ gummi eius à recentioribus quibufdã (Arnoldo \& aln̈s) inter uenena numeratur, 8 fuccus eitus à Dio= fcoride, Albis, 8c.

247. 13. non probat. alnemer enim non lynx eft, fed panthera uel leopardus maior:)

$750.51 \cdot$ prabet. De imagine area eiufidem uide infra in d.

75r. Varinus, Argiuorum numus lupi ima gine infignis fuit, quod A pollini facrum credere. tur id animal, Scholia in Electram Sophoclis.

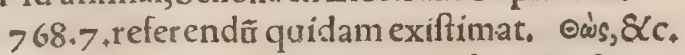

768,42, nudi. Thos corpore longior $\&$ cau da porrectior eft, (quàm lupus, ut Plinius accipit Ariftotelis uerba.ego cani potius thôem ab eo có ferri puto. nam de cane propius dixerat, lupos etiam et pantheres ei comparans:) fed proceritate breuior. celeritate æque praftat, quamuis crura habeat breuiora, mollis enim $\&$ agilis eft, profi, líréç longius ob eam rem poteft, A riftor, 6.35.de

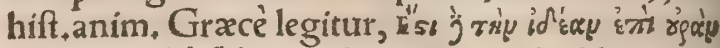

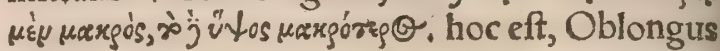
eft à capite ad caudam uel extremum corpus, al, titudine uerò breuior, nã \& Plinius ita ferè tran ftulit, nulla cauda mentione facta. Idem proceri. tatem de longitudine à capite uerfus caudam ac. cepit, non ut Gaza pro altitudine crurum $\&$ re. liqui corporis, Sic inter uocabula rei militaris $\mu \varepsilon_{3}$

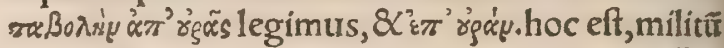
conuerfione $\tilde{e}$ ab extremo agmine, uel contra, Lu pi ceruarỉ certè noftri cauda perbreuis eft, quod meminiffe deburerat Gaza, cum pro thôe lupum ceruarium uerteret. Thos interno, $8 \mathrm{c}$.

768,49 . Varinus \& Ariftot, ut recitaui in B. Quadrupedum \& $c$.

770.56 . Alunno tefte. Egoante annos ocio Tridenti in arce epifcopi feram quandam uidi quam Italicé uocabant, loup chatt, id eft lupum catum, catum enim feu felem quodammodo facie refert, $\&$ unguibus fimiliter acutis $\&$ maleficis pradita eft, hanc tum temporis luchfam noftram id eft lupum ceruarium effe putabam* fed poftea cum pelles luchf noftr $x$ infpicerem, (nondum enim uiuam uidere contigit, ) deceptum me ani= maduerti: \& lupum catum illum hyænam effe fu fpicari cœpi, colore enim fi recté memini, nigri. cans \& maculofa erat, \& à nonnullis etiam lupus Indicus nominabatur. Talem autem effe hyænã, etiam amicus quidam uir doctus in Gallia fibi ui fam mihi affirmauit, cum ab agyrta quodam, $\&$ hyænæ quidem nomine circunduceretur. Sed hæc alieno hic loco.in hyæna enim fcribi debue: rant. Lupos ceruarios in quiburdam Heluetix locis, \& circa Seduntum, \&c.

771. 12. Textor *atqui hoc fphingum non lyncum eft.

778,21 ، amphibium iuxta Iftrum, Varinus, 785 . 21, fignum effe aiunt, cum \& $\mathrm{c}$.

788.40 . uel fuos anima aut $\& C$.

792. 27. red infirmiorem, $\mathrm{nt} \& \mathrm{C}$.

824.23. Myûnta condidit, Strabo.

816. 21. fementem feciffent, infructuofas red didiffent:cumós Del phicas deus de hacre conful tus effet, refpondiffe: Oportere facrificare Smin thio Apollini. Eos quibus datum effet oraculum, refponfum fecutos, ab hoc murium impetu libe: ratos fuiffe, $\&$ frumentũ eis ad ílitas meffes per. ueniffe. Strabouerò $\& c$.

816,19 , utenfilium(clypeorum lora \& arcuñ neruos Aelian, )ex corio \& c. Et eodem loco, apa pellaffe( $\&$ Sminthio A pollini templum excitaffe, Aelian.) Heraclides \& $c$.

728. 51. hic urerfus cum dimidio fequente, nö hîc fed infra ponendus eft, fub Titulo, De muris bus fecundum regiones, ubi de Aegyptīs.

831. 26. in fine B, adijciantur hac: Amicus quidam nofter medicus perquàm eruditus, com. plures ex putredine natos in aruis mures diffe. 


\section{Caftigationes.}

cutit, acin omnibus inteftinum unicum rectum \& fimplex, non ut aliorum conuolutum fe depre hendiffe mihi narrauit:fum plerat autem occafio nem ex Baffiani Landilib.2, de humana hiftoría, ubi ille muribus ex putri materia genitis intefti. na recta effe fcribic.

ब37. io.propter nomẽ Germanicum à mu. re ei facium $3 y$ felmuf, )delenda hxc.

844. 48. fed graciliore, \& (ut Aétius fcribit) breuiore: nec eadem, $8 \mathrm{c}$.

847.29 . potus, appenfus, ut in fequent. $8 \mathrm{c}$.

8 8.38. conuenire. $₫$ Ne mus araneus ani mal mordeat, ipfum a nimal (ipfe mus ar,) uiuum de creta circundabitur, qua cum induruerit, fu= fpenditur in collum, \& non contingetur à mor= fu, certiffimum eft, Vegetius.

853. 45. Tartefus (ego femper potius $r_{6}$ dupli ci fcripferim)urbs, $8<$.

$860+2$, gylianchena ( fed utrobiç praftiterit tertiam fyllabam per au, diphthongum fcribi) les gint, $8<c$.

863. 34. experrecta

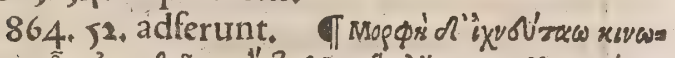

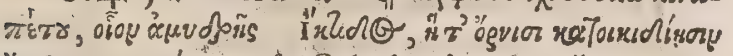

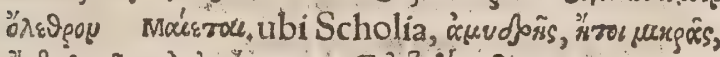

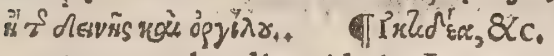

873+37+ hordis; tide in Agno A. Ibidem

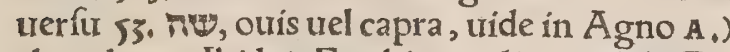
abundant. Ibid. 6J. Erythiam (aliqui infulã Ga= dibus proximam faciunt, freto unius ftadî di= fcernente) uidetur, \&c, Et 62, multam. frum.

874. 3. lib.3. \& Euftathius in Dionyfium $A_{\text {. }}$

875.31 . fequuntur : ut copiofiurs referã infra ftatim poft Simias.

880,54 . Plin. Acfires exigit ut plurimi ma res progenerandi fint, Ariftoteles, \&c.

893. 37. lanam (nimirum ouis à lupo laniata, ut alibi diximus, pexerit, \&c. Ibid. 42. (agno, rum potius)dele. Ibid,49. idonea funt. GDe ufur uentriculi ouis aut ueruecis contra erucas, fcribemus in Veruece. If Vrina, \&c.

$896+45$. Pecudum pulmones (calidirecentes,

Marcell, )podagras leniunt, Plin * I Iecur, \&c. 9c0, 18. Es $\omega$, ólaw $\omega \tau \%$, Varinus,

ब903.27. fic lego non öus) dele hæc uerba.

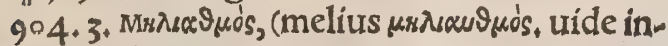

fra in $e_{\text {, }}$ ourile, $8 \mathrm{c}$.

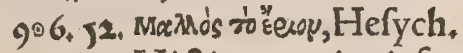

910. 45. Victim $x$ antiquis frequentes fuêre, ouis, fus, bos, 8c. Gyraldus.) abundant.

914. 1. Erythrais (erythris, id eft rutilis, ut ipfe exponit 7.2.) Et ibid. lanæ (difcolor lana potius, uel difcoloris lanæ, ) multoós, \& $\&$.
915. 14. ac fi res exigit, ut plurimi mares pro. generandi fint, )abundant hac uerba.

917.55. ab initio uerfus legendum, o"is apud ueteres in mafculino genere, uide mox inter Epi theta, Áries, $8 \mathrm{C}_{\mathrm{r}}$

927. 19. Ágrion.

932,2 quòd frequenter exiliat.

937.14 . lonza (quod nomen fortaffis àlynce factum fuerit $\$ \&$ inde per aphærefim, uncia, ab imperitis) rcribitur.

944. 10, qua leopardo aduerfetur.

955 . 52, author obfcurus. Ipfa quidem compo fitio uocabuli perabfurda eft, quafi nafus pro ca* pite ulli fit animantium. ego hoc animal fimile au thori qui de eo prodidit effe puto, hoc eft omni: bus obfcurum \& ignotum, quôd in rerum natur. ra non extet.

957.30. Simia (Simus, potius)nomen, $8 \mathrm{Cc}$ 968, 11. A pparet autem eum de cerc

98 5. 22. Calius: Vbi notandû̃ quòd frequen tius animalia quibus huiurmodi dentes funt you

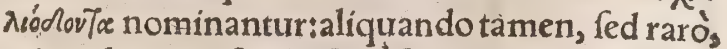
etiam dentes ipfi adiectiue fic dicuntur, nam $\mathrm{He}_{2}$ rodotus crocodilum habere fcribit ódivfos $\mu \varepsilon y$ yed rs rä XuvióobvTas, Calius tamë de dentibus fubftan tiuépofuit. Aperdentes habet, \&c.

990.27 . Sunt $\&$ alia eiufdem terminationis uerba, quæ defyderiũ fignificant, ut фovợ, ) abun dant.

991. 21. exiftimandum eft.)abundat. . 997.11 . ubera fugit, \& deinceps, \&c. 997.34 , ut Aggregator citat. Vide infra in H, d. Nigidius, \&c.

1002,13 . quód tanta non fint fuperfluitate praediti,

91007.7. mentione. Idem alibi tuccetum,to macellam interpretatur. ego apud Arnobiư tus cetum lego, lib +7+contra gentes, ubi ille: Tucetî̉ (inquir) in exiguas aruina eft miculas, \& 1 ilia mi= nutim infecta de more.

1021.25. prabeat. Plinius porcæ, porcule. ta, porcula, porcella, lib.18.cap. 18. utraq̧ editio* ne, (Veneta \& Romana,)Campani, \&c. be, $\&$ c

1034. 6. (fortè, porcus, ) Feftus, Hecatoma

$1051_{4} 6 . \dot{\alpha} \pi \epsilon \lambda \tilde{\epsilon}_{*}$

1054 12. Paufanias, Hunc tamê Catullus non Atten, fed Atyn uocat, prima breui, 8 in fecuns da perypfilon.

$1057+21$, fodit,Albertus, THomo, \&c.

1064. 44. Dionyfius (inquit) cum ad Alphe. fibcam nympham ad amorem fuum, $\&_{c}$,

IIN $\mathrm{s}$, 


\section{ËPPÍKOY

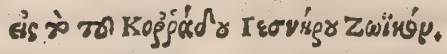

$\sum$

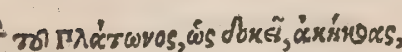

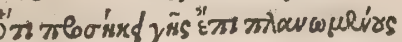
Tr̈ roîs yoveñ

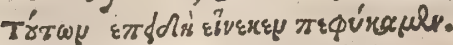

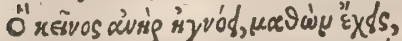

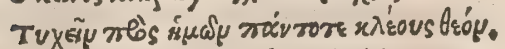

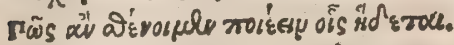

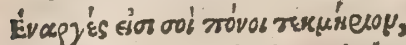

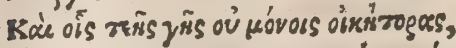

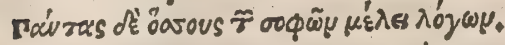

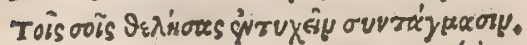

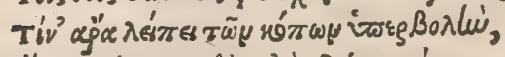

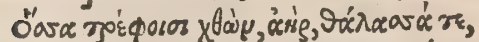

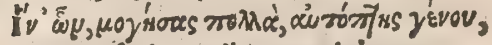

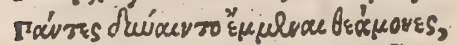
Êt oîs á

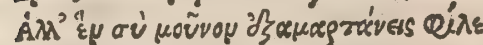

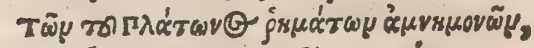

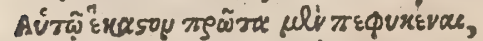

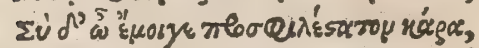

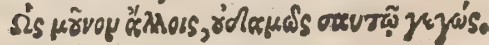

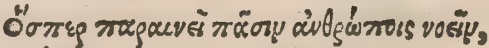
Toúrou ye vuxzis घ́soyx́a

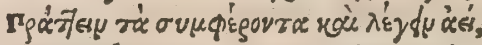

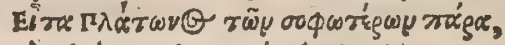

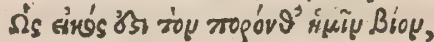

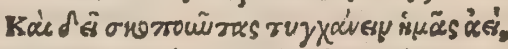

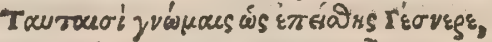

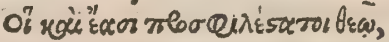

هỉous $\tau$ в ห่

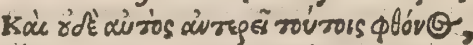

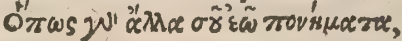

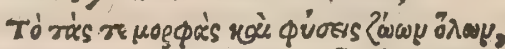

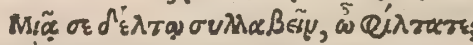

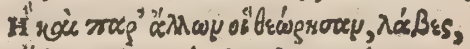

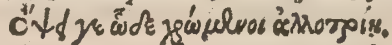

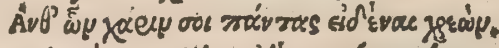

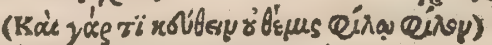

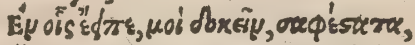

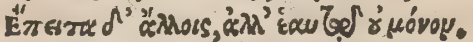

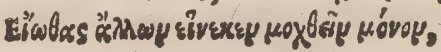


IAVS ET GLORIA OMNIS DEBETVR DEO OP T。 max, ex quo, ut phyficus Empedocles feripfit,

एवंध

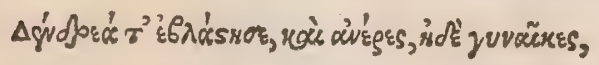

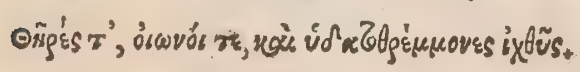

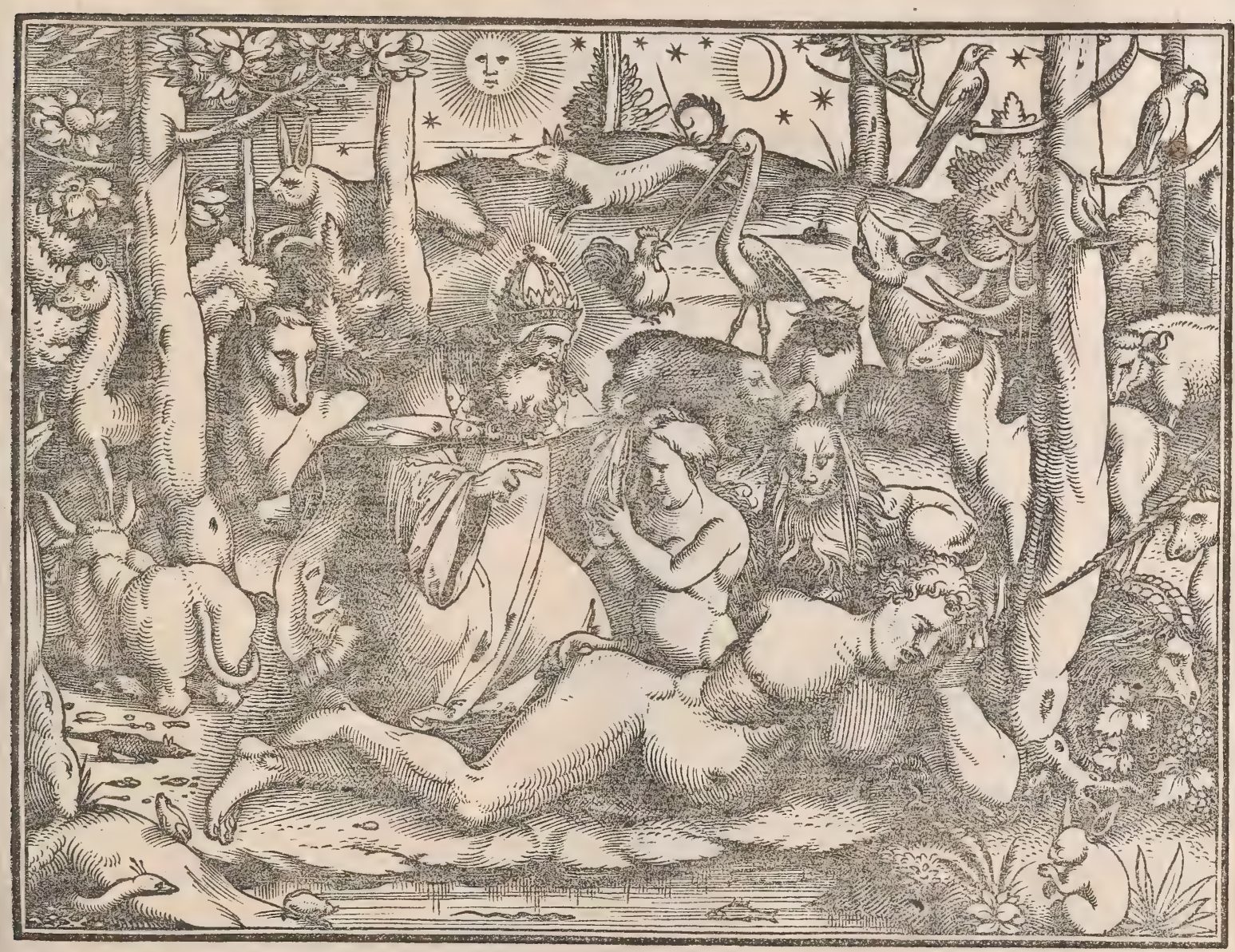





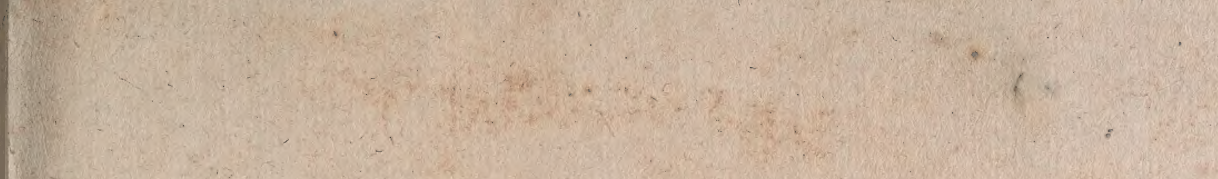





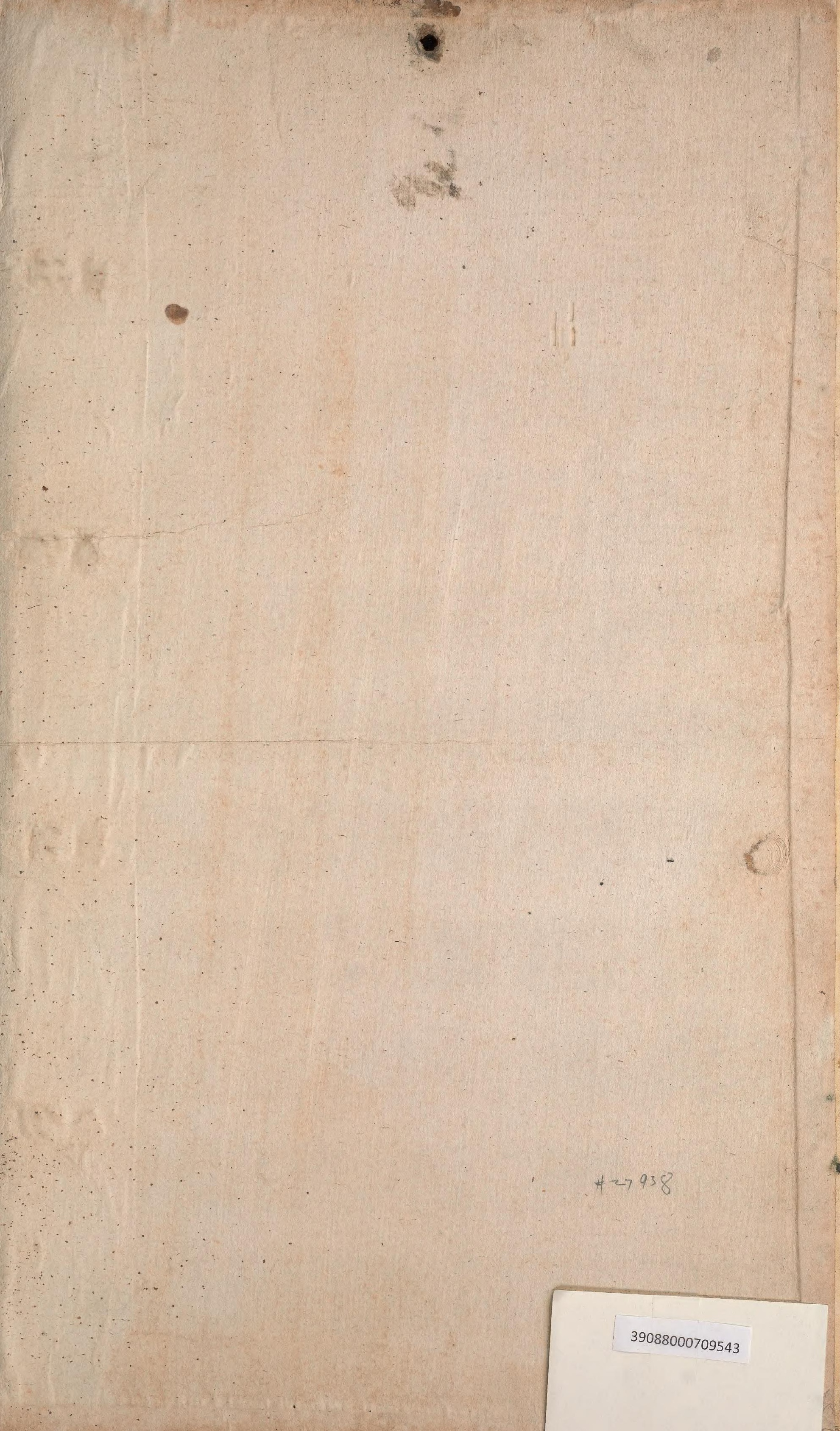




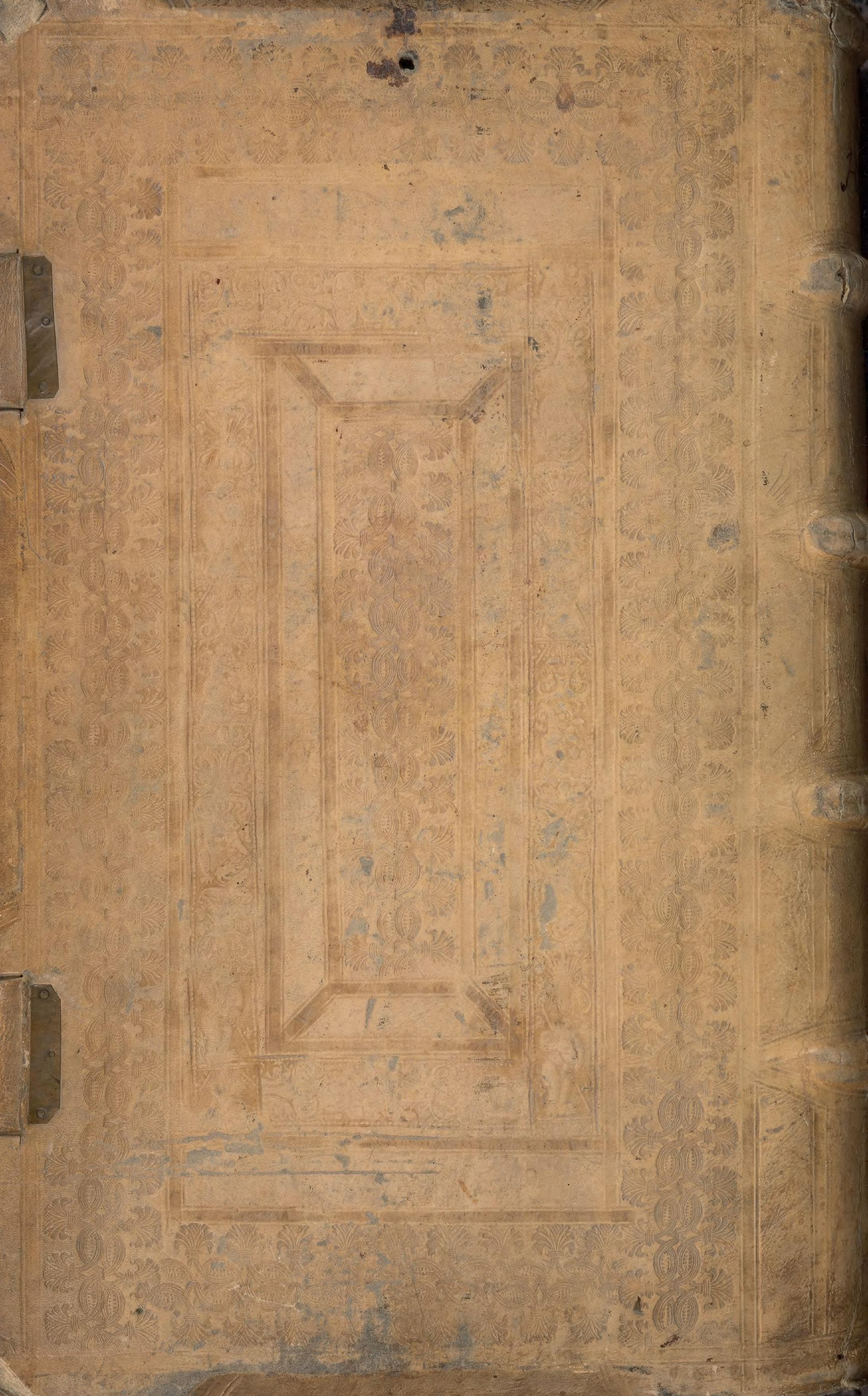

